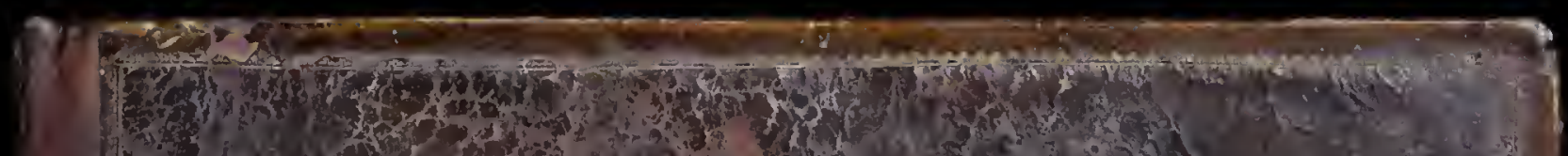

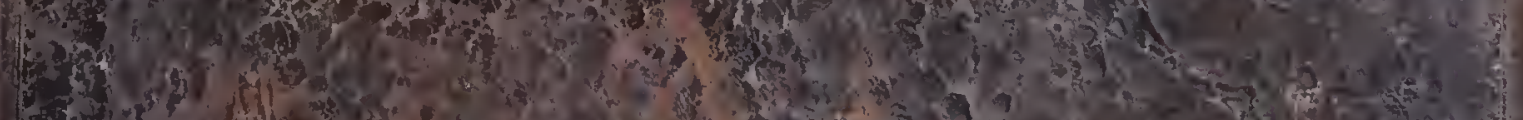

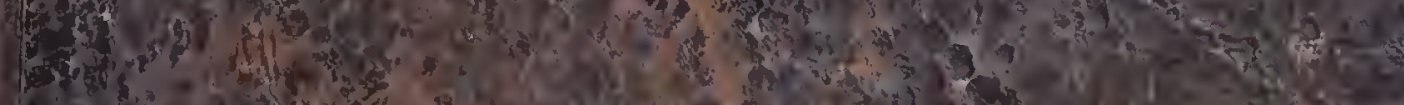

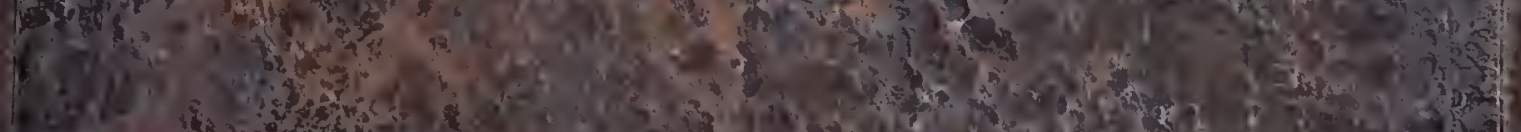

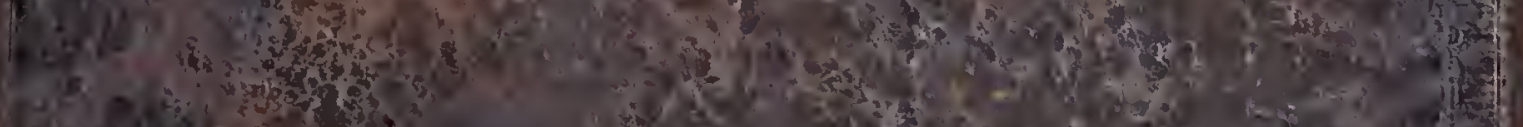

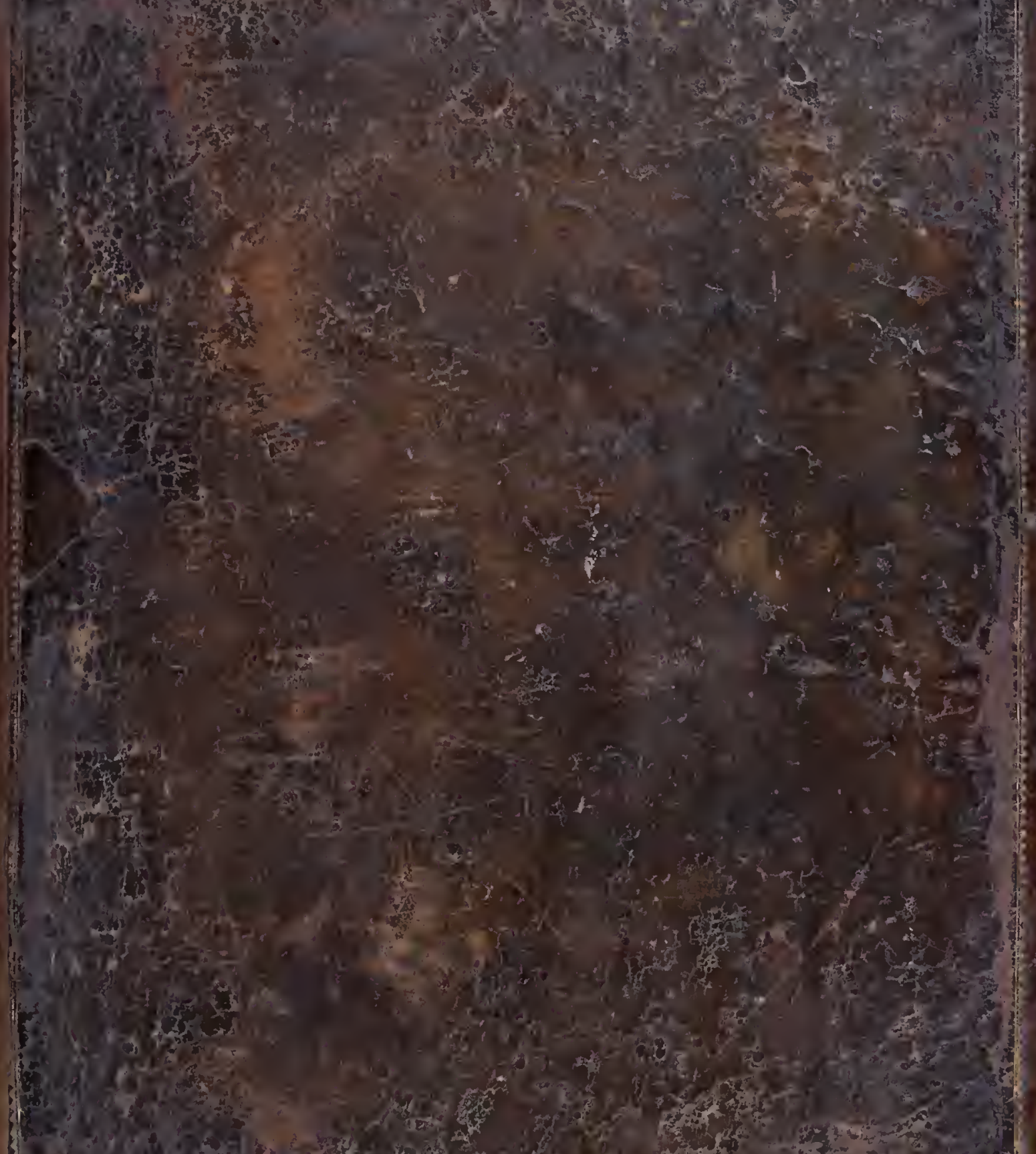

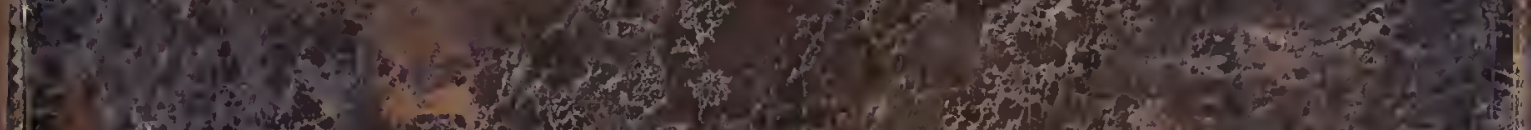
3 (1)

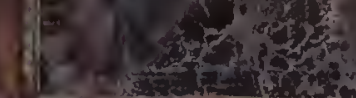


- gesery y y y

S J J

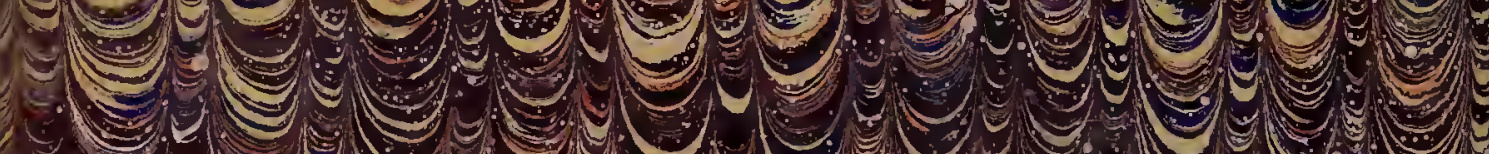

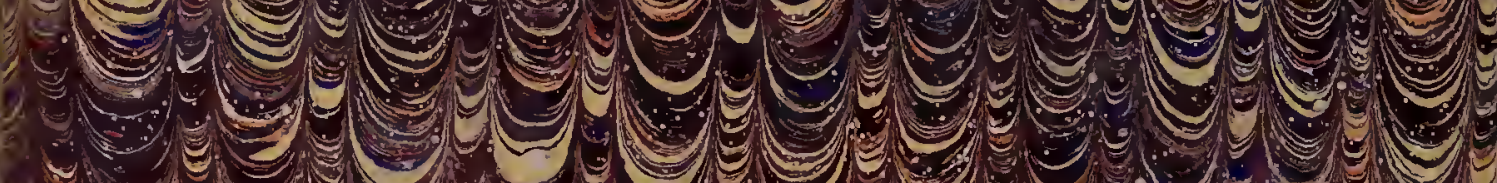
(1)

g-

3_,

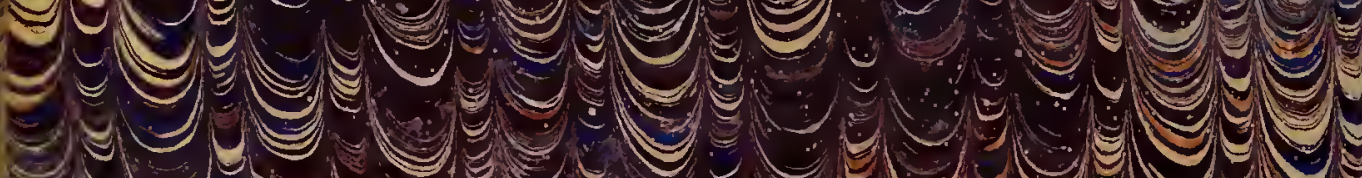

SI

Y्रg.

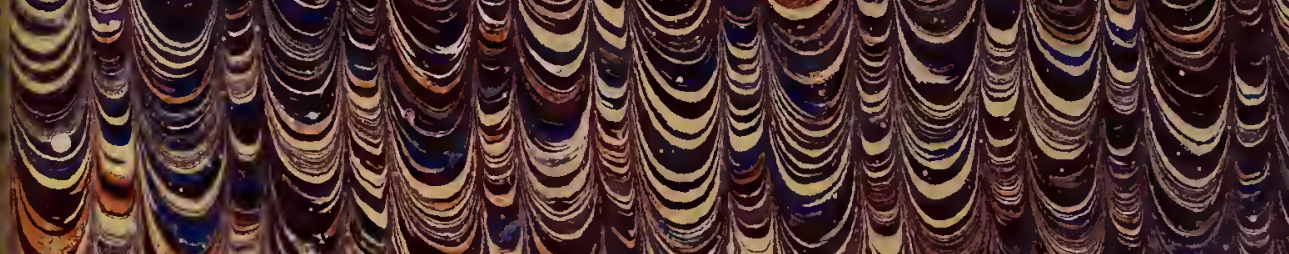

\section{Sy}

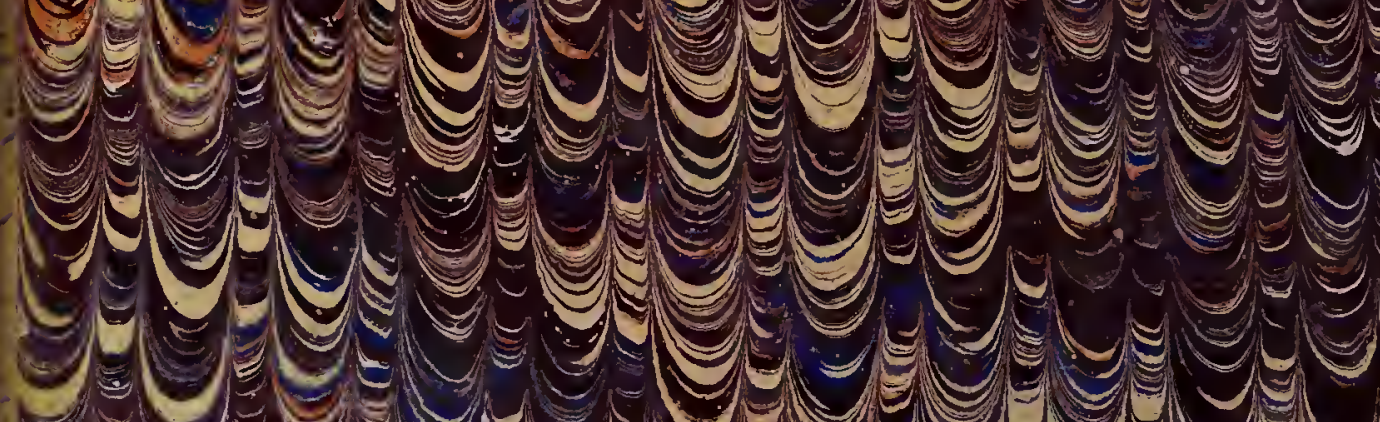


38

3

1

48

MU $-4,3=$

40403
$y(3), 0$ 3 U.
yes

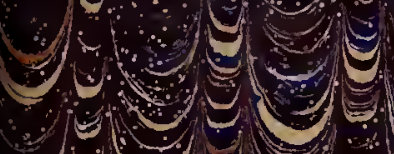

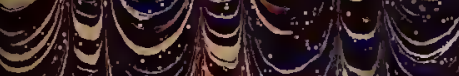

13

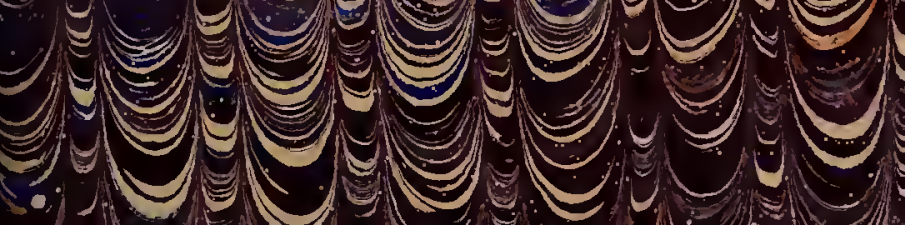

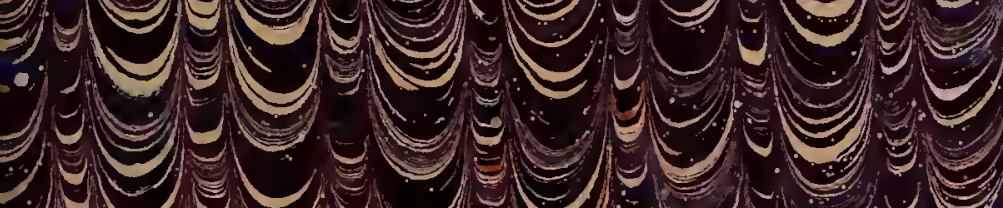

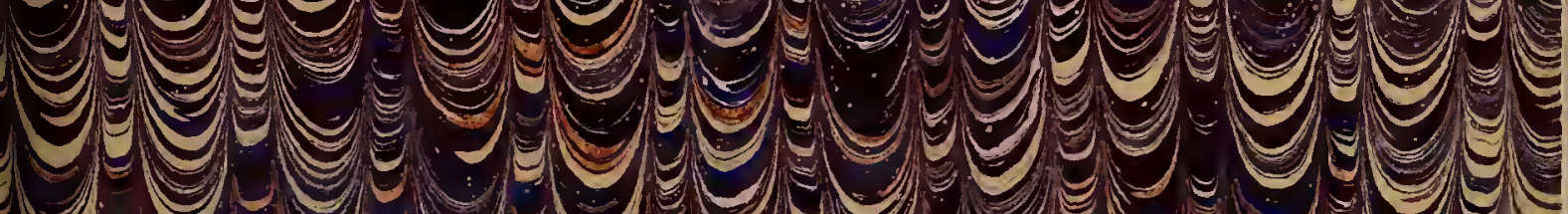
C 20.30

- $=3$ $19(y-3)$

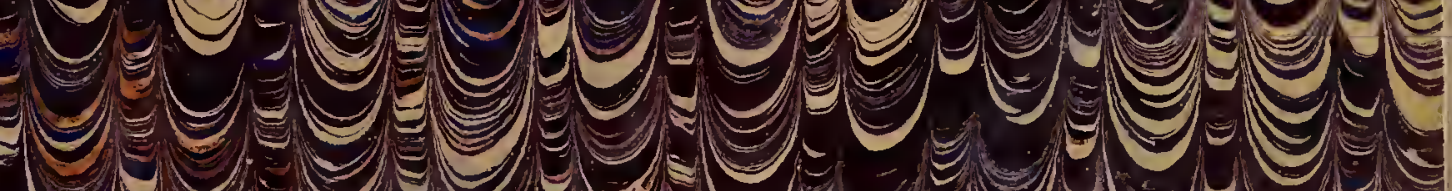
y. -

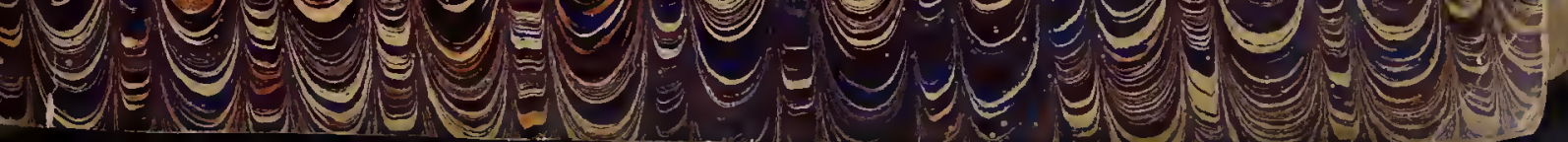




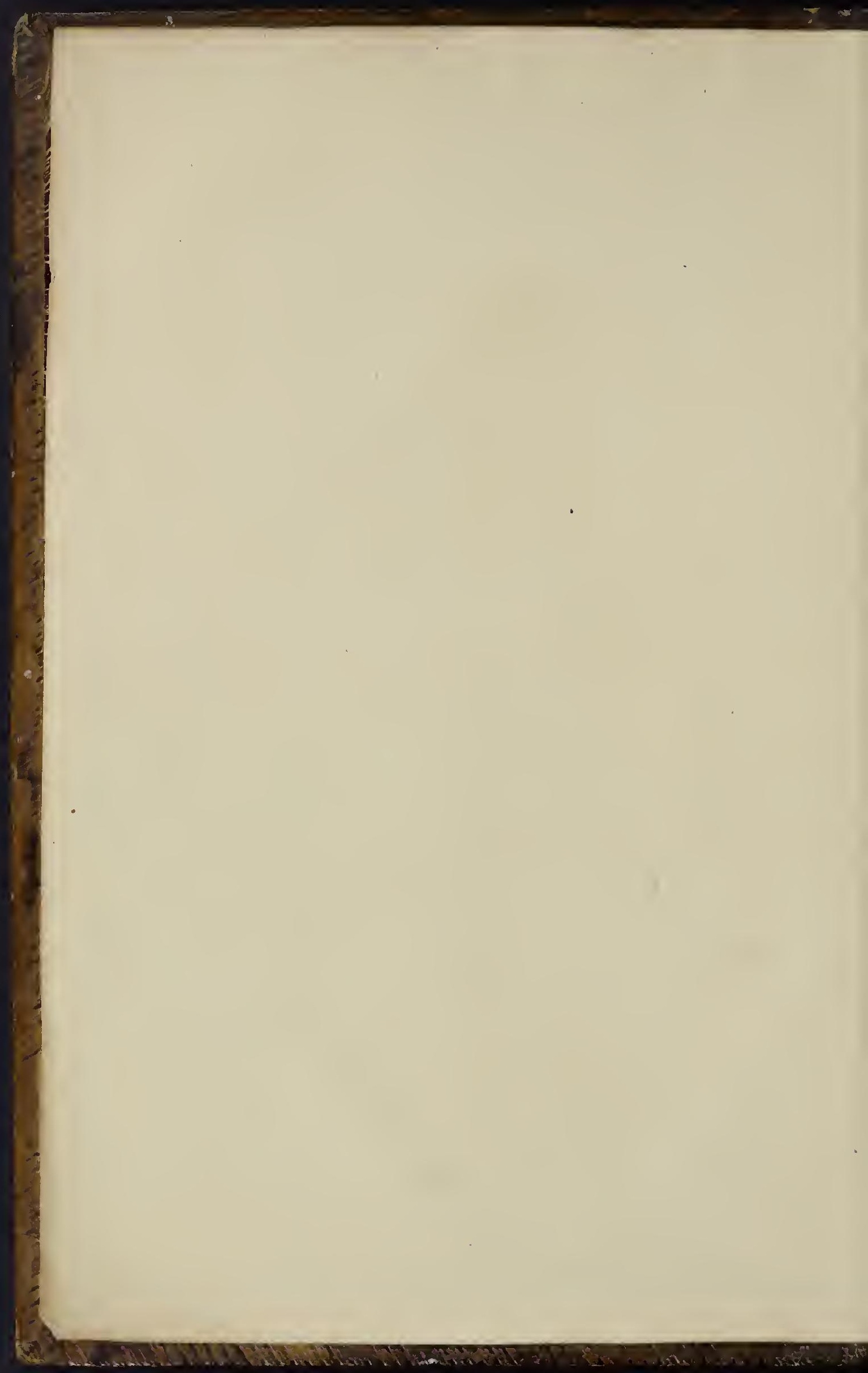




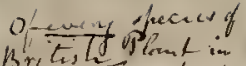

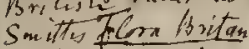

$$
\begin{aligned}
& \text {-nize not wowich } \\
& \text { syprom sal has bear } \\
& \text { made to Corrads } \\
& \text { Tter bal bo the } \\
& \text { adotern ffer Em, } \\
& \text { the name las bear } \\
& \text { wortter in any } \\
& 3.8 .61 \text {. }
\end{aligned}
$$




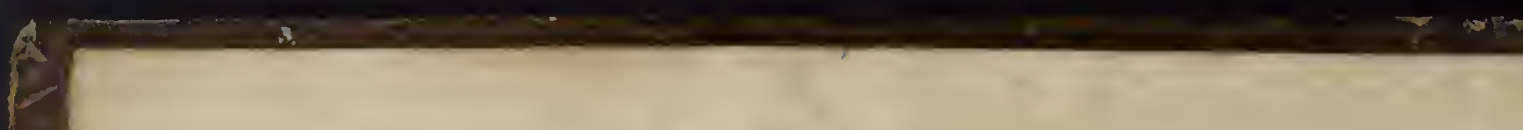




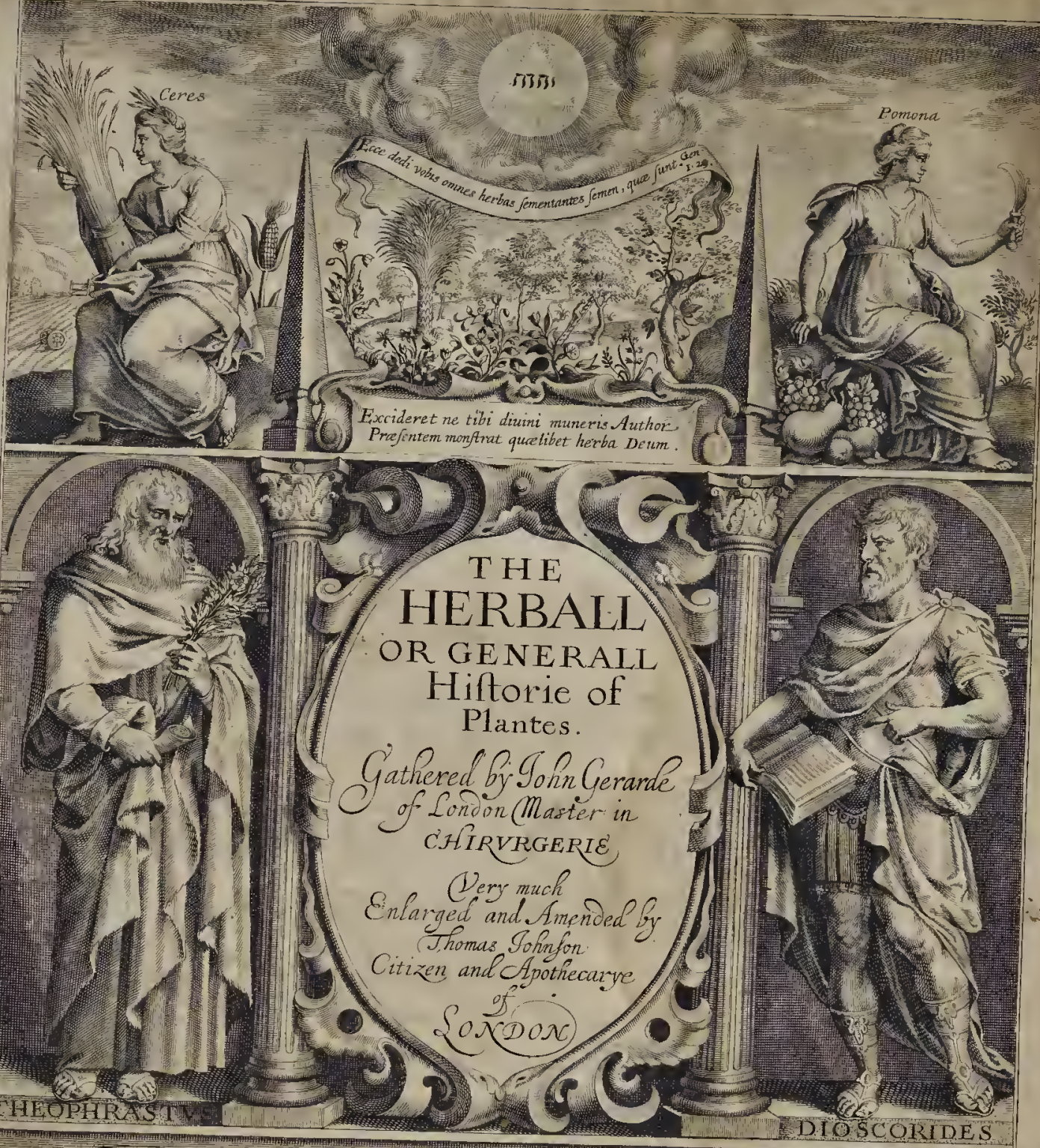

$7 \times$ :

$=-3$ anctit Nestio $2 x^{2}=$ Nor

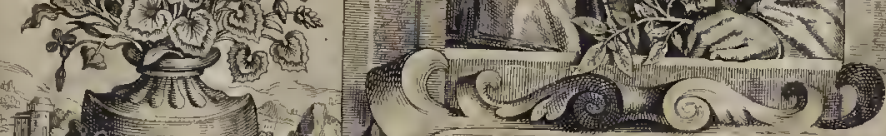
4 (E) $x$ ( London Puntal hy

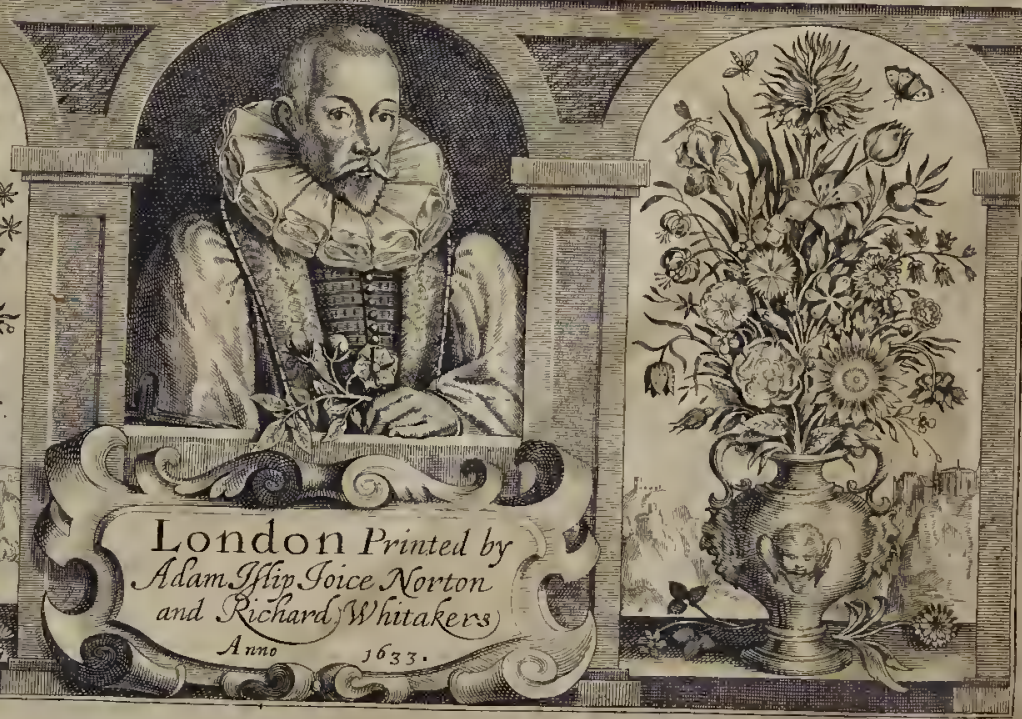




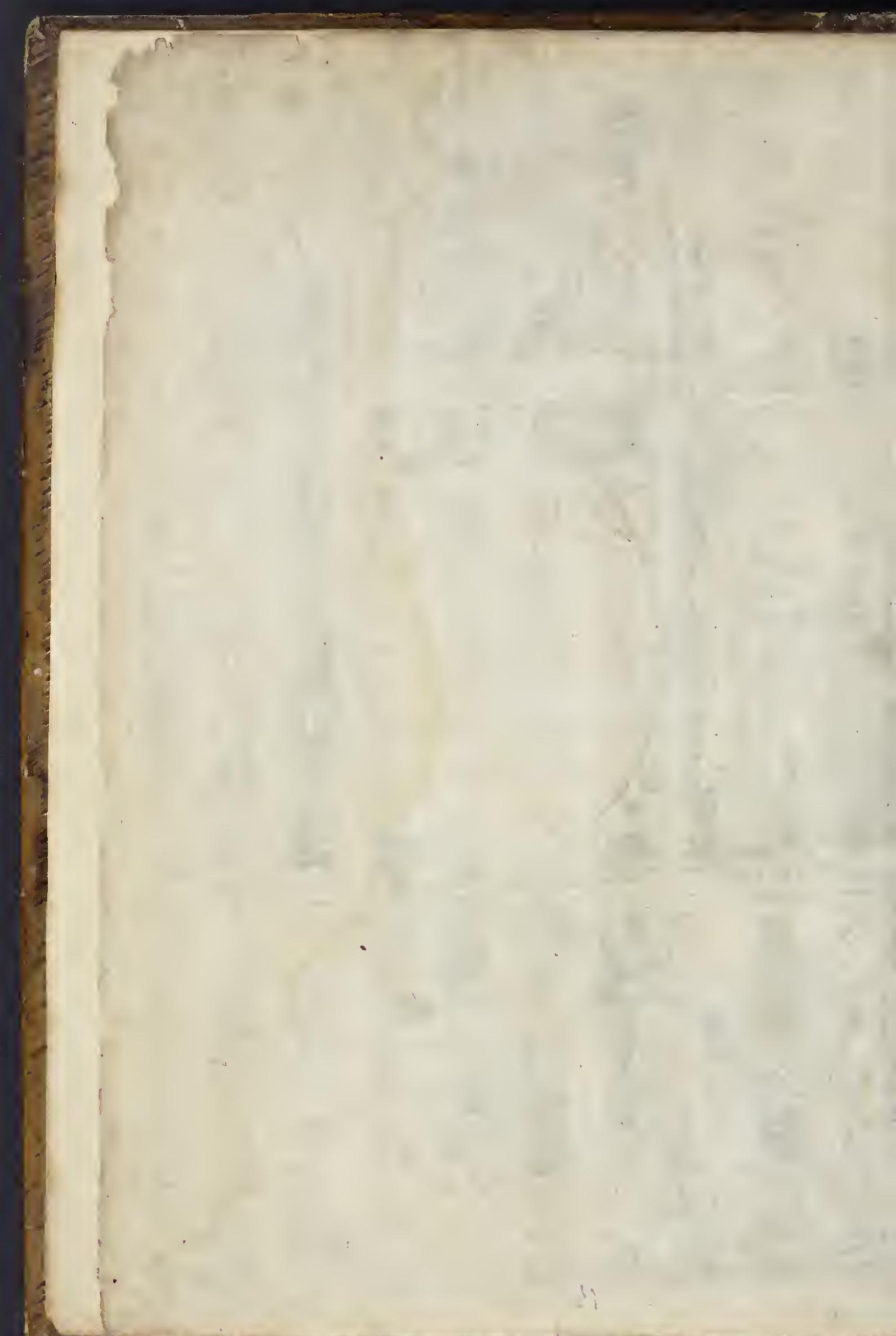




\section{VIR IS}

PRVDENTIA, VIRTVTE, ARTE, RERVMQVEVSV SPECTATISSIMIS,

D I G N I S IM I S

\section{RICHARDO EDVVARDS}

RECTORI, SIVE MAGISTRO;

EDWARDO COOKE, LEONARDO $S T O N E: G V A R D I A N I S$,

CAETERISQVE CLARISS. SOCIET. PHARMACEVT. LOND. SOCIIS,

\section{HOS SVOS IN EMA-} C VLANDO, AVGENDOQVE H A N ${ }^{*}$ C P L A N TAR VM H. IS T ORIA M,

L A B ORES, STVDIORVM BOTANICORVM SPECIMEN, AMORIS SYMBOLVM, EX ANIMO

D. D.

VESTRÆ, PVBLIC̋QVE VTILI. TATIS STVDIOSISSIMVS

THOM. I O H $30 \mathrm{~N}$.

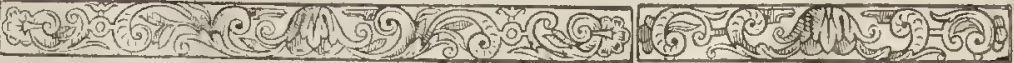




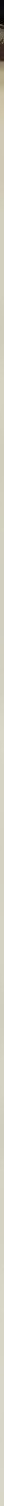



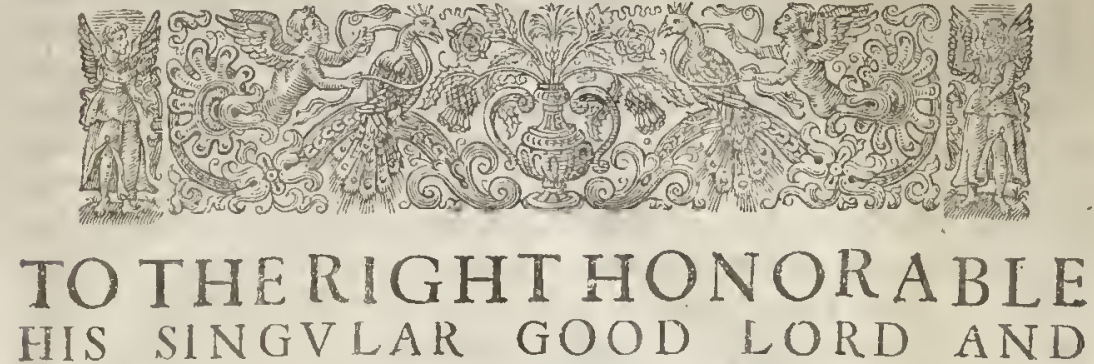

MASTER, SIR WI Li a C éil KNIGHT, BARON OF

Burghley, Mafter of the Court of Wards and Liueries, Chancellor of the

Vniucrfitie of Cambridge, Knight of the molt noble Order of the Garter, - one of the Lords of her Maieft ies moft honorable Priuy Councell, and Lord high Treafurer of England.

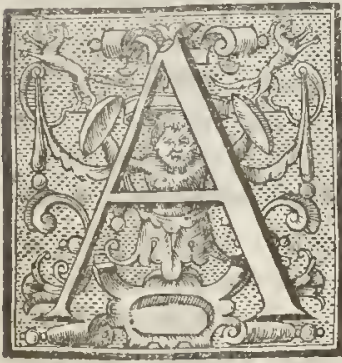

Mong the manifold creatures of God (right Honorable, and mv fingular good Lord) that haue all in all ages diuerfly entertained many excellent wits, and drawne the on to the contemplation of the diuine wifdome, none haue prouoked mens ftudies more, or fatisfied their defires fo much as Plants haue done, and that vpon iuft and worthy caules: For ifdelight may prouoke mens labor, what greater delight is there than to behold the earth apparelled with plants, as with a robe of embroidered worke, fet with Orient pearles, and garnifhed with great diuesfitie of rare and coftly iewels? It this varietie and perfection of colours may affect the eye, it is fuch in herbs and foures, that no Apelles, no Zeuxis eucr could by any art expreffe the like : if odours or if tafte may worke fatisfaction, they are both fo foueraigne in plants, aud fo comfortable, that no confection of the pothecaries can equall their excellent vertue. But thefe delights are in the outward fences: the principall delight is in the minde, fingularly enriched with the kndy?edge of thefe vifible things, fetting forth to vs the inuifible wifedome and adatirable workmanthip of almighty God. The delight is great, but the vle greater, and ioyned often with necefitity. In the firt ages of the world they were the ordinarie meate of men, and haue continued euer fince of neceliaric ve both for meates to maintaine life, and for medicine to recouter health. The hidden vertue of them is fuch, that (as Pliny 11oteth) the very bruite Pti.li.8.ca.27. beafts haue found it our:'and (which is another vfe that he oblerues) from thence the Dyars tooke the beginning of their Art.

Furthermore, the neceflary ve of thele fruits of the eartli doth plainly appeare by the great charge and care of almo ft all men in planting and maintaining of gardens, not as ornaments onely, but as a neceftarie prouifion alfo to their houfes. And here befide the fruit, to peake againe in a word of delight, gardens, efpecially fuch as your Honor hath, furnithed with many rare Simples, do fingularly de. light, when in them a man doth behold a flourithing thew of Sommer beauties in the midf of $W$ inters force, and a goodly fpring of floures, when abroad a leafe is not to be feene. Befides thefe and other caules, there are many examples of thofe that haue honored this fcience : for to paffe by a multitude of the Philofophers, ic may pleafe your Honor to call to remembrance that which you know of fome noble Princes, that haue ioyned this ftudy with their moft important mat- 


\title{
The Epifle Dedicatorie.
}

Plut. de Dife. Rdul sx amic. Plin.lib 25 . cap. 2,

ters of ftate: Mitbridates the great was famotis for his knowledge herein, as Plutarcb noteth. Euax alfo King of Arabia, the happy garden of the world for principall Simples, wrot of this argument, as Pliny fhewerh. Diocletian like wire, might haue had his praife, had he notdrowned all his honour in the bloud of his perfecution. To conclude this point, the example of Solomnn is before the reft, and greater, whole wifedume and knowledge was fuch, that hee was able to fet out the nature of all plants from the highelt Cedar to the loweft Moffe. But my very good Lord, that which fometime was the ftudy of great Philofophers and mightie Princes, is now neglected, except it be of fome few, whole fpirit and wildome hath carrier them among other parts of wifedome and counfell, to a care and ftudie of fpeciall herbes, both for the furnifhing of their gardens, and fur therance of their knowledge: among whom I may iuttly affirme and publifn your Honor to be one, being my felfe one of your feruants, and a long time witnefle thereof: for rnder your Lordhip I have lerued, and that way emploved my principall tudy and almott all my time, now by the fpace of twenty yeares. To the large and fingular furniture of this noble In and I have added from forreine places all the varietie of herbes and floures that I might any way obtaine, I lawe laboured with the foile to make it fit for plants, and with the plants, that they might delight in the foile, that fo they might liue and profper vnder our clymat, as in their natiue and proper countrey: what my fuccefle hath beene, and what my furniture is, I leaue to the report of them that haue leene your Lordhips gardens, and the little plot of myne owne efpeciall care and husbandry. But becaufe gardens are priuat, and many times finding an ignoranr or a negligent fucceffor, come foone to ruine, there be that haue follicited me, fint by my pen, and after by the Prefse" to make my Labors conmon, and to free then from the danger whereunto a garden is fubiect: wherein when I was ouercome, and had brought this Hiftory or report of the nature of Plants to a iuft volume, and had made it (as the Reader may by comparifon (ee) richer than former Herbals, I found it no queftion vnto whom I might dedicate my Labors; for confidering your good Lordhip, I found mone of whole fauor and goodnelse I might fooner prefurrieffeeing I haue found you euer my very good Lord and Mafter. Again, confidering my dury and your Honors merits, to whom may I better recommend my Labors, than to him viato whom I owe my felfe, and all that I am able in any feruice or deuotion to performe? Therefore vnder hope of your Honorable and accuftomed fauor I prefent this Herball to your Lordhips protection; and not as an exquifie Worke (for I know my meanneffe) but as the greateft gift and chiefeft argument of duty that my labour and feruice can affoord': wher of if there be no other fruit,yet this is of fome vfe, that I haue miniftred Matter for Men of riper wits and deeper iudgements to polith, and to adde to my large additions where any thing is defectiue, that in tume the Worke may be perfect. Thus I bumbly take my leaue, befeeching God to grant you yet many dayes to liue to his glory, to the fupport of this State vnder her Maieftie our dread Soueraigne, and that with great encreafe of honor in this world, and all fulnefse of glory in the world to come.

\section{Your Lord/hips moft bumble}

\author{
and obedient Seruant,
}

IOHN GERARD. 


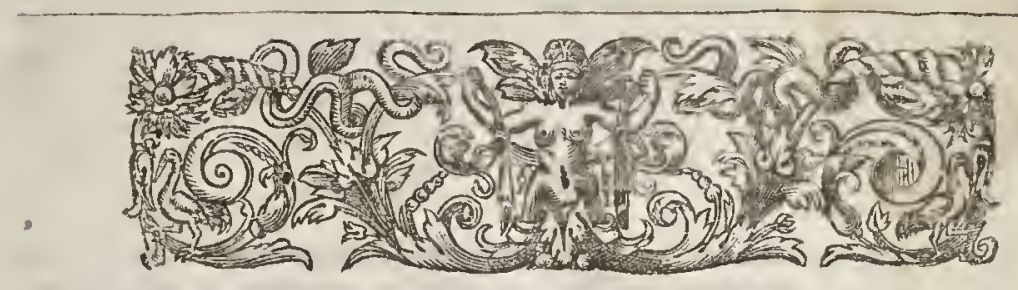

\section{LANCELOTVS BRVNIVS MEDICVS REGINEVS IohAN I GER R D Cbirurgoperitisimo, do rei Herbaric callentißimo S.P. D.}

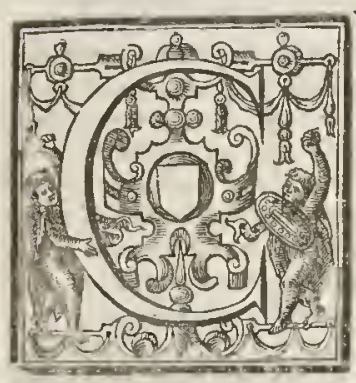

V M fingularum medicinæ partium cognitio atque intelligentia libero homine digna confenda elt; ; tum carum nulla vel antiquitate, vel dignitate, vel vtilitate, vel denique iucunditate, cum ftirpium cognitione iure comparari debet. Antiquiffimam eam effe ex co liquer, quòd quum ceteræ medicinæ partes (ficut reliqu $x$ ctiam artes) ab ipfis hominibus (prout cos dura preffit neceffitas) primum excogitata: \&. inuentæ fuerunt: fola herbarum arborumque cognitio ante hominem formatum condita, eidemque nò $x$ creato $a b$ ipfo mundi archetecto donata videri poteft. Cuius tanta apud antiqua fecula exiftimatio ac dignitas erat, vt \& ipffus inuentionem fapientiffmo Deorum Apollini veteres tribuer int, \& reges cclebetrimi in ftirpium viribus indagandis ftudium laboremque futn confumere, fummx fibi apud pofteros laudi honorique futurumeenfuerint. Iam verò plantarum v tilitas, at $q_{\text {; }}$ etiam neceffitas, adeò latè patet,vt eius iminenfitatem nullius vel acutiffimi hominis animus capere,nedum meus calamus exprimere queat. Stirpium enim complurima nobis in cibos, alimentumque ccdunt : innumer $x$ aduetfus morbos remedia fuppeditant : ex alijs domos, naues, inftrumenta tam bellica quam ruftica fabricamus: aliquor etianr carum veftes noftris corporibus fubminiftrant. In quibus fingulis recenfendis diutiùs perfiftere, hominis effet intemperantèt abutentis \& otio \& litetis. Quantas auten, \& quam varias voluptates ex ftitpium fute amœnitate ocul is capiamus, fue fragrantia naribus lauriamus, fine fumma inearum conditotem impictate inficiari non polumus. Adè vt ab que ftirpium ope $\&$ fubfidio vita nobis ne vitalis quidem habet $i$ debeat.

Qum igitur res plantaria reliquis omnibus medicinæ pattibus anti quitate antecedat; dignitate, nulli cedat;vtilitate infuper oblectationeque cateras longè fuperet, quis fututus eft, adco, aut infenfatus vt non exploratum habeat, 'aut ingratus, ut non ingenuè agnofcat, quanra vnituer fis Anglis commoda, quantafque voluptates tuus mi Gerarde in ft irpium inueftigatione \& cultu labor indefeffus, ftudium inexhauftum, immenfique fumptus loc de ftirpibus el ito libro allaturi funt. Macte itaque ifta tua virtute, iftoque de republicabenè merendi fudio, \& quod infigni tua cum laude ingreffus cs virtutis glorixque currieulum, eidem infifte animosè \& gnauitèr, neq; à re plantaria promouenda prius defifte,quam eam à te ad umbilicum iam fermè productam ipfe plenè ab foluas atque perficias. Sic enim \& ribiadhù fuperftiti gloriam paries immortalem, \& poft obitum tantum tui nominis celebritatem relinques, vt tuatum laudum poftetos noftros nulla vnquam captuta fit obliuio. Benc vale. " Ex Aula Reginea Weftm. ipfis Cal. Decemb. I597. 


\section{MATTHIAS DE L:OBEL IOHANNI GERARDO felicitatem.}

Aurhoris ncceflitia diligentia in ftirpium liue $\mathrm{Ma}$ corıx Uedica engnitione sommendat

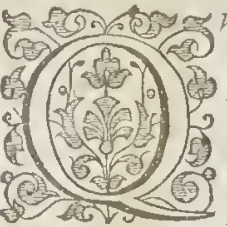

Ywm Londinem appuli, in finu ganif fus fum Gerarde amicißSime, dum typogra pho formis excudenda plaktartmo collectanea tua commifa vidi, de quibus furrmas, nulla die perituras laudes Anglia tibi Rei-herbarie familiam uni-

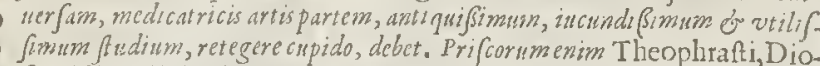
Af 25 fontes; Notericorwm autcm, feu rivulos, Brunfelfi, Fuchfi, Tragi, $R u$ elli, Matthioli, Dodonai, Tumeri, Clufij, Dalefcampij, Camerarij, Tabernxmontani, Penx, noftramque nowam met hodum or ordinem, it Gramine o notioribus ad Triticca, generatim O. peciatim, matcrno idiomatc, Anglica zenta tue cultifime, Rerpublice valuptabili commodo, re-

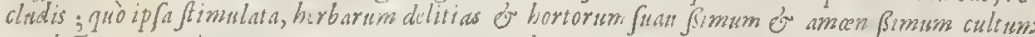
wnplectetur, maximorum Imperatorum, Regum \& Herasm tam priformm quam nupcrorum ex emplo. Nec fatis boctibi fuit. fid mulio migis infuper preftufti, quo l copiam multarum elegan. tifumarum plantarum in Anglia ponte naficntium ab alys bactenus pratemifarum, biftoriam deficripefli, maga a hoc fudio captorum vilitale oblectamento: Singulas enim regiones pecu lia. resqualdam plantus, quasinalys non facili reperias, gignerc certum. Nequemagni tibi fut hec

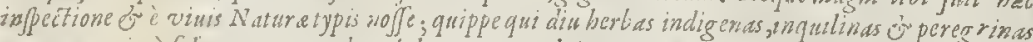
cum nuperrimè folo crumpentes ch pulul, intes, tum adultas, femineque pragnantes, bortulo iuo fub.

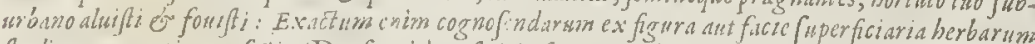

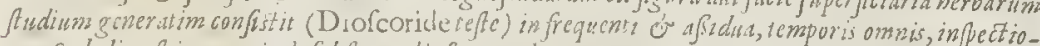

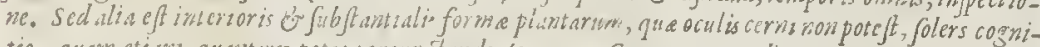
tio; quam etiam, quintum potis percunet ando, fen, orum Gracormm Medicurum more, aperire cona. $r$ is. Solcbant autem antique jurwin utedicaminum experinenta, in Reipublice vilitatem, forip. tis tabellis dire, quibes apud Ephefos tenulifyluatice Dian aparetes veficbantur. Compcrtwin etiam eft Hippocratcm difcendi cupidsm, pernultis region; bus peragratu, idem praftutife, of is me

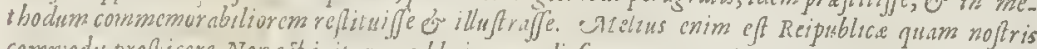

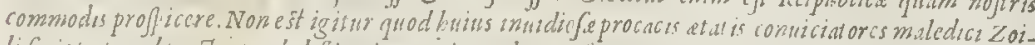

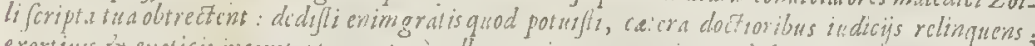

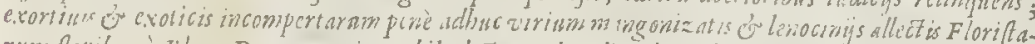

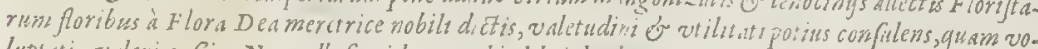
lupiati, valeri infis. Nonwull figuidem ex alys lbis berbarum tranforplores rapfodi, ignot is fibi vivis plantis ad medendum maxme ncceforÿs, afsignant mectis, dubys o fuppofituys firpibus (unum crim (.tpi fimplex compofitionem ineftan reddit perscrit aut dipranat) quibus nec tutö nuc tencrec credendum; mulioque tiam minus mulus berbirum experiment is allacibus quibus eti.

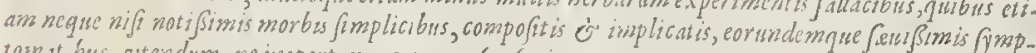

Prreftigiofas populaium mcdicaftint fallacias detcgimus se inue teratos depu. limus ertort

Initio prolog Pharmacipra. parand.

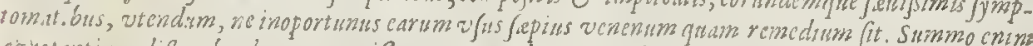
agrolantium difpendio du excrcitatißsmorum Miducorum tadio periclitatores procaces, contempt is o neglect is artis inflitutionibus, Hippocratis of Galcni preceptis, per falutis difcrimind o bo-

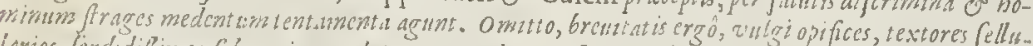
Larios, Jordidifinzos fauros, interpolattores, ctrculatores forcnfis of veterutores foutica dignos, qui

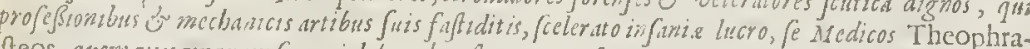

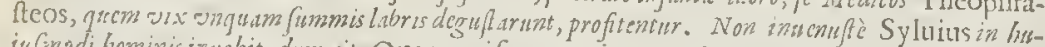
m. inodi hominis inuchit, dum ait, Quam quif que nouit artem, hanc exerceat vnam, at que excolat, \& totus in ea verfetur, \&c. Et fub finem prafationis rurfus ait, Faxit Deus ve quifque quam cxercet Artem, pernof́cat, \& Medicus nihil corun quæ ad morbos citò \& $\dot{x}$ tutò curandos vtilia vel neceffaria effe confueucrunt, ignoret. Præualet Medicus vbi Pharmacopoci fides fufpecta ef, qui ipfe fimplicia \& compofita pernofcit ; imò quam infamia notam imprudens inurit, dum ignarus horun fimpliciun medicamentorum, tanquam a fin nus quidam id onnia Pharmacopœi rogata, auribus motis, velut annut : quid quod illi fxpectiann volens Pharmacopous illudit. Abfurdiffmus eft ac fapè ridiculus qui medicinam facit, harusu rerum ignarus; \& Pharmacopœo ignorantis fufpectum meritò fe reddit. Pisrafi quis requre apud Syluium, ibidern loci. 
Medico quam plurima porforst anda, vt fat is fuperd; ad artem medicatricem perdiscendism, annos pascos baudguaquam fufficere, teftaratur ipfius experzenti fimi \&o Diuini fenis verba whi inquit; Ego enim ad finem Medicinæ non perueni,etiamfi iam fenex fim. Et ftatim per initia $A_{-}$Epit.ad Dephorifmorum vitambrouem of artens longam pronunciauit. 2uomodo ergo tuto medebuntur mul. mocritum. tilaruati CMedici aut Medicaftri tam repente creati, malla Medicina parte, Medicamentorumve fa cultatibus perpectis? Huinf modi adulatores, ajfentatores, dubitatores, rixatores, periclitatores of Gnathonicos parafiftratos hiffrionibus qui in tragadijs introducuntur fimilimos fecit Hippocrates. Quenadmodum enim illi(inquit) figuram quidem \& habitum ac perfonam corum quos referunt habent, illi ipfi autem vere non funt:Sic \& Medici fama quidem \& nomine mul $\mathrm{ti}$, "re autem \& opere valde pauci. It aque cum panlo wate Medicinam omnizm artiumpre- " Multi ma* clariffim am effe dixerit : Verum propter ignorantiam eorum qui eam exercent, \& ob vul- lunterideri gi ruditatem, qui tales pro Medicis iudicat \& babet, iam eo res detteniffe, vt omnium ar - quam effe. tium longe viliffima cenfeatur. At vero hoc peccatum ob hanc potiffimum caufam committi videtur ; foli namque Medicinæ nulla pæna in rebus-publicis ftatuta eft, præterquam ignominix. Ne animam ó famam ledert, aut illi infignis ignominia isureretur ob buinfmodi ardua of noxia dif crimina, bonus ille of fyncerus Dodonerus (quamvis multas berbas ex . . . lis of Fuchfiotranf cripferit, cui us methodo vfus eft, quemque inchoauerat, wt ipfenet mihi retulit, veracula Germanicanferiori lingua vertere) vulgatiffimis, notiffimis ij (que paucis ex tot berba. rum millibus, quinquagenis aut feptuggenis herbis quibus viebatur, potius contentus fuit, guam in. numeris fibi ignot is periclitari : melizus enim omnino medicamento carere, abfinere, o naturac com: mittere, quam abuti.Vtinam buius nostra atatis quamplares aufo potiti, medicinam factituntcs,eo ftudio, candore ó voto mederentur: Illis id for fit an nequaquam euenerit, quod Philo fophis (Hippocrate defun fto) difctpalis fuis inexpertis \& parum adbuc exercitat is medendo, id eft necando (vt me. moria traditume eft) contingit: quamobrem ars Medica 1 thenis, Rsma ò per vniwerfam Gracian centum of (eptraginta anms, interdict a et exul fuit. CMerito igitur caute et tute agendum: Opiat is et Diagrediat is, Colocynt bide, Tithymalis, E fula, Lathyride, Esercurio, Stibiv, \& fimilibus molefitfimis fimplicibres cum cautione vtendum : optimis ducibus \& experientiffimes fonioribus preceptoribus adharendum, quoris fub vexill is fidipinae of tutiffime rara o preclara, ob barbariem fere extincta, pat rum of auorum remedia, maximo et priffino art is ornamento et proximi vt litatere-

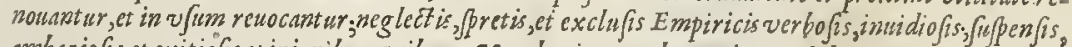
ambagiofis et exitiofis opinionibus, quibus caundus immundus regitur et labitnr ; qui cum decipi velat, decipiatur:in cuius fallacias perappofite finxit et cecinit olim hos verficulos eruditifimus collega D.Iacobus Paradifus nobilis Gandauenfis alludens ad nomen tanti werfutifimi herois Noftram dami Saloneinfis Gatlo-prouincic,

20 Qf ra-damus, cum verba damus, quia fallere nostrum; Et cum verba damus, nil mifi Noftra-damus.

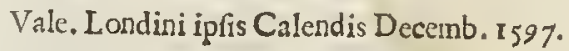


7 Limas ccee Gerardus : at edit an optimus berbas?

2nidni? non not as fed dedit ille novas.

Ergo ne inuideas, videas cum nomen o omen quтrár, mirum eft ardila quastagerit. Q

sic liber eft promus, condus wt hortus erat.

yaitu apoun celum gue folumg; fubegit.

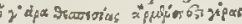

ANTONIVS HVNTONVS. Medicina candidatus.

\section{Ad Iohannem Gerardum Chirurgum Herbari. umq; peritisimum.}

Vila oculos hominum fpecies magis allicit illa,

Quan praftante manu duxit generolus A pelles.

Nulla aures animo? que rragis facundia, quam quax

Se fufam loquitur Ciceronis ab ore diferti:

Hxc eadem hunc librum commendat caufa, Gerarde,

Cui pro laude fatis tali natum effe parente,

Artifices cui inter dextras pro numine, nomen

Nobilius reliquis herbz,plantreq;magiftris.

Illi etenim Europx fuccos, Afįque liquores

Quxeque arentefolo fitiens parit Afriea, tractant:

Tu veccrun inuentis nous conluis omnia, fiqua

Indus verque dedie noftram forura falutem,

Sive aliunde vehit noftr as mercator adoras,

Hocipfo veilius.Quia qux funt credita feriptis,

Illa manu expereus medico, \& bene diues ab horto

Explorata diu multumq; emitcis in auras,

Qure curenthominum languencia corpora, multi

Prattantefq; viri docuere fideliter artem.

Sed fifuftuleris plantas, quem verba iuvabunt

Sic anitoo,fic fronte minax. In pralia miles

Profilit,at ftricto cedit victoria ferro

Qux tibi pro tanto cedit victoria ferro

Prxinia perfolues, Myrti lauriq; coronas?

Iftam nouic ed $1 \mathrm{x}$ mercedem abolere vecuft2s.

At tibi pro ftudio impenfif que la boribus iftis,

Queis hominum curas fertam tectamg; /alutem,

Ille opifex rerum, cuftof $q$; authorq; fal lutis

Ex terna ltatuit frontem redimire corona.

In bistornm plantarum, Io.Gerardi cinis of Chirurgi Londinenfis, M.Iacobi Ihontonij Scoti Balliscrife Regiy pagi portio-

$$
\text { nary Epigramma. }
$$

DEline,guar vaftis pomaria montibus Aclas Clauferat(Hefperij munera rara foli)

Auracis fol jijs auraros define ramos

Mirari,\& ramis pendula poma fuis

Singula cum Domino periere, \& Gorgone vifo

In montis riguit vefcera verfus $A$ tlas.

Alcinoi perijt qui, cedat penfilis hortus,

Quen ceiebrat prifcitemporis aurafugax:

$\checkmark$ na Gerardinifpecies durabilis horti

ticerno famx marmore fcul pta manet.

Hic quicquid Zephyrus produxit, quicquid \& Eurus, Antiques quicquid \& novus orbis haber,

Intulit in partram naturamq; exprimitarte:

Sic nullo cedic cerra Britanna folo.

$0 \mathrm{~s}$ 
Quod magiseft Graium \& Latiun concludit in vno Margine,\& Anglorumiam facit ore loqui : Sic erit xtenum hinc vt viuas, horte Gerardi, Cultoris ftudio nobilitate tui.

In Plantarum biftoriam, A folertißimo viro, Reiq; Herbarie peritifj $2 m o, D$. Iohanne Gerardo, Anglice edit atm

Epigramma.

Treyiam certè hudem, decusimmorrale refertis LTu, focigq; tu, magnum \& memorabile nomen (Illuftris DEV O R A X) raptoribus orbis I B ER IS

Deuiat is clafie Ánglorum; Tuque (Dicafta

Maxime E G E R T O N E) vererem fuperans Rhadamanthum,

H ER OVM merito im reñ, centendus in albo.

Nec laus veftra minor (facræ pietaris alunni)

Qui mentethominum diuina $\mathrm{p}_{2}$ fcitis efca.

Ornatss Patriam cuncti, nomeng; Britannum

Augetis, vobifq; viam munitis adaftra.

Quinagite, in partern faltem permittitehonoris

Phobei veniant Vates, qui pellere gnari

Aginina morborum, humanx infidiantia vitx.

Huius \& ingentes, fetena fronte labores

A NG L O-D I O S COR I D IS, Patrix, veftrag; faluti

Fxcipite exhauftos : paulum huc diuortite in $H O K$ I OS

Quns CH OR T EI A colit,quos Flora exornat, \& omnes

Nalades, \& Dryades, Charites,Nymphxq; Britannz.

Corporibus hicgratz falus, animisq; voluptas.

Hiclaxate animos: H A B ITA VI I NVMEN IN HORT IS.

Fran.Hering GMed.D.

Thomas Newtomus, Ceftrehyyrius, D. Io. Gerardo,amic conson vulgari, $S$.

DOft tot ab ingenuis confcripta volumina myltis, Herbartan vires qui referare docent,

Tu tandem prodis Spartamq; hanc gaauirer ortias,

Dum reliquis palmam praripuilteftudes.

Nec facis hoc, rutilo vt poltis ditarier auro,

Nec tibi ve accrefcar grandis acervus opum,

Sed prodeffe volens, veftiros gramine colles

Perluftras, \& agros, frondiferumq; luemus.

Indeg; Pxonias (apis inftar) colligis herbas,

Ing; tuim itirpes congeris slucolum.

Mille tibi fpecies plantarum, millec; nota;

Hortulus indicio el? , quem colis ipfe dorai.

Pampinex vites, redolens cedrus, innuba laurus, Nota ribi,nota eft pinguis oliua tibi.

Balfama, narcyltus, rhododaphne,nardus,amomum, Saluia,dictannus, galbana nora tibi.

Quid multis ? radix, ftirps, flos,cum corrice ramus: Spicaq; cum filiquis eft bene nota ribi.

Gratulor ergo tibi,cunctifq; (Gerarde) Britannis, Nampewicoq; tuo gratulor atg; meo.

Nam Ceitrelhyruj teac me genuere parentes, Tu meliore tamen fydere natus eras.

Macte animo,pergafq; precor,coeptumq; la borem Vrge etiam vlterius.Viuitur ingenio.

Aurtun habeant alij, gemmas, nitidolq; pyropos,

Planas qu\&flores feribe Gerarde, Vale.

Vere ex animoturs, Tho. Newton, Ilfordengs iepétxis. 


\section{To the well affected Reader and perufer of this Booke,St.Bredwell Phy jition, greesing.}

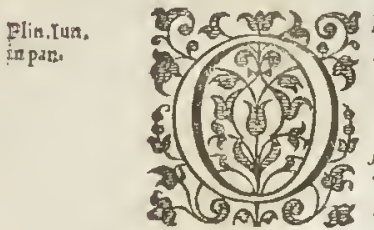

Pen is the campe of glorie aisd honour for all men, aith the younger Pliny: not onely men of great birth and dignitie, or men of office enducd witb publique charge and titles, are fene therein, and hatue the garland of praife and preferment waiting to crowne their merits, but euen the common foulder likenife: fo as he, whofe name and notewas erft all otf cure, maty by egregrous acts of valour obtaine a place anzong the noble. The feboole of frience kecpeth fembla. ble proportion: whofe amplitude, as not alwates, nor onely, men of great titles and degrees, labour to illuffrate; fo whofoeucr cioth, may confidently accowat of, at the leaft, his name to be immortall. What is be then that will denie his voice of gracious co m.

Turnerus. Turnerus. Pene. L Obclius. Tabernamon Eanus,

Leert, i.s.

cap.:.

Iuvenal, $\%$, Sat.

Simplic.

$\operatorname{com} n$.in Eprit?. mendation to the $A$ uthors of this Booke: to euery one, no doubt, there is due a condigne meafure. $T$ he firft gat herers out of the Antients, and aum mentors by sheir owne paines, hauc alreadie pread the odour of their good names, through all the Land's of learned habitations. D. Prief, for histran feation offomuch as Dodonizus, hat h thereby left a tombe for his bonorable fepulture. M. Gerard conming laft, but not the leaft, hath many waics accommodated the whole worke vrato our Englifo Nation: for this Hiftoric of Plants, as it is richly replenifhed by thofe fue mens labours laied to. Gether, fo yet could it full ill hauc wanted that new accefion he hath made vnto it. Many things bath be nourifhed in his garden, and obferued in our Englifh fields, that neuer came into their pennes to write of. Againe, the grcatef number of the e plants, hauing neuer been written of in the Englifh tongue, world bine wanted nawes for the wulgar fort to call them by : in which de feat he hath bin currouly carefull, touching bothold and new names to make fupply. And left the Reader Bould too often languilh with fruftrate defire, to finde fome plant be readet h, of rare vertue, he fpareth not to tell (if himfelfe haice feene ut in England) in what wood,pafture or ditch the fante may be fene and gat hired. Which when I think of and therewit all remember, with what checrefull alacritie, and refolute attendance be hath mary yeares tilled this ground, and now brought forth the fruit of it, whether I fould wore commend his grat diligence to attaine this skill, or his large benenolence in bcfowing it on bis countric, 1 cainnot eafily determine. T his bouke-birth thus browg hit forth by Geratd, as it is in forme and dipofotion farre and comely, cuery fpecies being referred to bis likelieft genus, of whofe flocke it cinze: Jo is it accomplifhed with furpaffing varictic, wnto fuch preading growth and firength of estcig lim, as that it may fecme fome beroicall Impe of illuftrious race, able to draw the cies aislexpectation of euty man visto it. Somen bat rare at will be bere for a man to moue a queftion of this nat ure, arad depart againe wit hout fome good fat is fation. Cli a nifold will be the ve both to the Phy (ition andothers: for eucry man dighteth in kizowledge naturally, whish as Ariltotle (ad) is in profperitu an ornament, in aducratie arcfure. But this booke aboue many others will frte with the moft, becarfe it boih plenteonfly miniftreth knowledge, which is the food of the minde, and doth it alfowith a familiar and pleafing taffe to eutry capacitie. Now as this com-

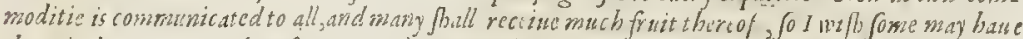

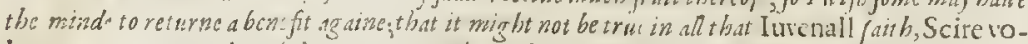
lunt onnes, mercedem folucie nemo: (i.) All cefire to know, none to yeeld reward. Let weve think, that the ferfections of this knowledge is the ligh adrancement of the health of nan that

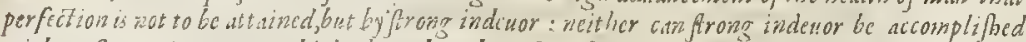
wit thout free maintenance. This hath not he, wh ho is forced to labour for his daily bread: Wut if hee, who from the phort houres of his daily and necefJarte trauell, stealing as it were fonte, for the publike bchoofe, and fetting at length thofepeccestogether, cam bring forth fo comely a garmut as the, meet

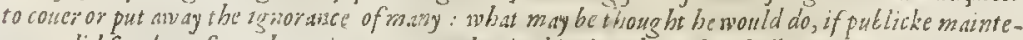
nance did free bu from that prinase care, and wnite bis thoug bts to be wholly intent to the generall

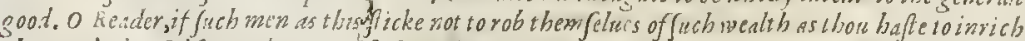
thec, with that fubftancethou wanteft, detract not to hare out of thine aboundance to merit and cn. courage theirpaines : that fo fluxible riches, and permarent fiences, may the one become a prop vizto the other. Alt hough praife and rewardioined as comparions to frut full endewors, are (in part) difireciof alimen, that vindertake lofes, labours, or dangers for the publigive behoofe : becaufe they an'le finewes (as it were) vnto reafon, and able her more and more to refine ber felfe: yet doe they

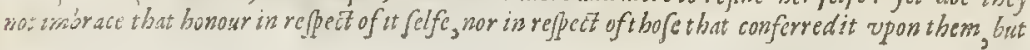


as having thereby an argument in themfelues, that there is Something in then worthy eftimation among men : which then doublet thew diligence to deferue if more abundantly. Admirable and for the imitation of princes, was that att of Alexander, who feting Ariftotle to compile com - Plain, lib.8. mentaries of the bruit creatures, allowed him for the better performance thereof, certain thou- cap.16. Sands of men, in all Afar and Greece, riot skillful ob eructs of $\int u c h$ things, to give him information touching all beasts, filses, fowles, serpents, and flies. What came of it? A bookewritten, where. in allicarned men in all ages fine do exercise them el tues principally, for the knowledge of the ocrea. turks. Great is the number of tho fe that of their on ne primate hate laboured in the fame matter, from bis age down to our present time, which all do not in comparison fatisfie vs. Whereas if in tho fe confusing ages there bad ripen fill new Alexanders, there (certainely) would not have wanted Ariftotles to batu made the cadence of tho fe things an hundred fold more cheered unto as, than now they be. Whereby you mas y perceive the unequal effects that follow tho fe unfutable canes of publike and private inatntenances vito labours and studies. Now that I might not dipnire in this my exhortation, I fee examples of this munificence in our age to gite me comfort : Ferdinand the Em. Gryllus in peron and Cofinus Medicos prince of $r_{n}$ fane are herein regiftred for furthering this science of orate de pere plants, in following of it them flues and becoming skill all therein : which course of the irs could gr.
nor be holden without the supporting and advancing of such as were furious to excel in this binder. Bellonius likewise (whom for honours cause I name) a man of big attempts in naturall faience, Bellow. de greatly cxtolletb bus $K$ ing liberalise, which endued bim with free leisure to follow the folie of neg!. Stirs. plants, seconded also herein by Montmoreneie the Confutable, the Cardinals Cafrilion and Lartaine, with Oliuerius the Chancellor; by who fe menes be was cabled to per forme tho fe bis notable peregrinations in Italy, Africa and Asia: the poet fruit whereof, as we bane received fond taste by his ob formations, fo ne Gould plenteously bane been filled with them, if violent death by most accursed robbers bad not cut him off. And as I find the fe examples of comfort in forreine nations, fo we are (I confe(jc) much $106 \mathrm{cthank}$ full to God, for the experience we base of the like things at home. If (neverthelef(c) unto that Ploy fiche lecture lately fo well erected, men who have this worlds goods Shall howe hearts also of that frit, to add forme ingenious labourer in the skill of finales, they foal mightily augment and adorn the whole faience of Phyficke. But if to that likewise they ioine a third, surely tho art of Chemical preparation; that out of thole good creatures which God hath give man for his bealth,pure jubfances may be procured for thole that be fiche, (I fear not to fay) it, though I fee how Momus cornet) this prefect generation would purchafemore to the perfects. on of Pbyficke, than all the generations past since Glens time baste done: that I fay, nothing of this one fruit that would grow thereof, to wit, the difcouering and abolifing of the fe pernicious impi. fares and fophifications, which mount promising Paracelfans ency where obtrude, through want of a true and conf ant light among vs to difcerne them by. In which behalf, remembering the

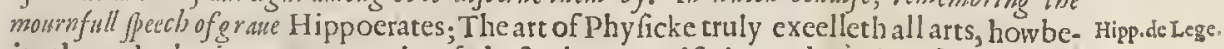
it, through the ignorance partly of thole that exereife it, and partly of thole that judge rathly of Pliyfitions, it is accounted of all arts the mol inferiour: I fin in like mannev, the art of Chimiftrie is in it fife the most noble infrument of natural l knowledge; but through the ignorance or impiety, parry of tho fe that mo ft audaciously profeffe it without skill, and partly of them that impudently condemn that they know not, it is of all others molt basely defied and corn. fully rejected. A principal remedy to remsue such contumelious disgrace from the fe two pure viz. gins of one locke and linage, is his bat I bane now in innate, even by erecting the laboratory of in indus trio us Climifo, by the fret garden of flourifbing fimples. The Phyficke reader by their means po all not only come furnifhed with authorities of the Ancients, and fencible probabilities for that he teacbeth, but with rall demonstrations al fo in anythings, which the reason of man without the light of the formate would newer bane reached unto. I base uttered my hearts define. for promoting first the perfection of my profeßrom, and next by necessary consequence, the bealibie lines of men. If God open mans hearts to provide for the former, it cannot be but that the happy fruit hall be gene in the later. Let the ingenious learned inge whether I bant reason on my fides: the partial addicted feet I four, as men that newer mene good to

pofteritie.

George 


\section{George Baker, one of her cMaiefties cbiefe Chirurgions in ordinarie, and $\mathrm{M}$. of the Chirurgions of the Citie of London, to the Reader.}

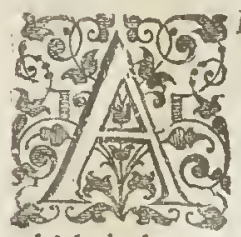

Riftotle, a Prince amongtt the Philofophers, writing in his Metaphyficks of the nature of mankind, faith, that man is naturally inclined and defirous offeience. The which fentence doth teach vs,that all creatures (being vertuoufly given) doe ftriue to attain to perfection, and draw neare in what they can to the Creator; and this knowledge is one of the principall parts which doth concerne the perfection of vnderftanding : for of the fame doth follow, that all fuch are generally inclined to know the meanes by the which they may conferue their life, health, and reputation. And although it be neceffarie for man to learne and know all fciences, yet neuerthelefte the knowledge of naturall philofophie ought to be preferred, as being the molt neceffarie ; and moreouer it doth bring with it a fingular pleafure and contentment. The firft inuentor of this knowledge was Cliron the Centaure, of great renowne, fonne to Saturne and Phillyre : and others fay that it was inuented of Apollo:\& others of Efculape his Ion; efteming that fo excellent a fcience could neuer proceed but from the gods immortall, and that it was impoffible for man to finde out the nature of Plants, if the great worker, which is God, had not firft inftructed and taught him. For, as Pliny faith, if any thinke that thefe things have bin inuented by man, he is vngratefull for the workes of God. The firft that we can learn of among the Greckes that haue diligently written of herbes, haue bin Orpheus, Mufeus, and Elefode, hauing bin taught by the Ægyptians : then Pytbagoras of great renowne for his wiledom, which did write bookes of the nature of Plants, and did acknowledge to learne the fame from Apollo and E/culape.Democrite alfo did compofe bookes of Plants, hauing firft trauelled ouer all Perfia,Arabia, Ethopia, and Egypt. Many other excellent firits haue taken grcatpleafure in this fcience, which to accomplifh haue hazarded thsir liues in paffing many viknowne regions, to learne the true knowledge of Ellebornis, and other Medicaments: of which number were Hippocrates, Crateun, Ariftotle, Theophraft, Diocles Cariftius, Pamplylits, Montius, ,Hieropbile, Diofrorides, Galcm, Pliny, and many others, which I leave to name, fearing to be too long. And if I may fpeake without partialitie of the A uthor of this book, his great paines, his no leffe expences in trauelling far and neere for the attaining of his skill haue bin extraordinarie. For he was neuer content with the knowledge of thofe fimples which grow in thofe pars, but vpon his propet colt and charges hath had out of all parts of the world all the rare fimples which by any means he could attaine vnto, 13ot onely to have them brought, but hath procured by his excellent knowledge to hatre then growing in his garden, which as the time of the yeare doth ferue may be feene: for there thall you fee all uanner ot ftrange trees, herbes, roots plants, floures, and other fuch rare things, that it would make a man wonder, how one of his degree, not hauing the puife of a number, could euer accomplinithe fame.I proteft vpon my cenfcience, I do not think for the knowledige of Plants, that he is inferiour to any: for I did once fee hum tried with one of the beft ftrangers that euer came into England, and was accounted in Paris the onely man, being recommended vnto me by that famous man Mafter Amb. 
Parcts $;$ and he being here was defirous to goe abroad with fome of our Herbarifts, for the which I was the meane to bring them together, and one whole day we fpent therein, fearching the rarelt Simples: but when it came to the triall,my French man did not know one to his foure. What doth this man deferue that hath talicn fo much paines for his countrey, in fetringout a booke, that to this day neuer any in what language foeuer did the like? Firf for correcting their faults in fo many hundred places, being falfly naned, miltaken the one for the orher; and then the piftures of a great number of plants now newly cut. If this man had taken this paines in Italy and Germany, where Matrbiollus did write, he Thould have fped as well as he did : For ( Gaith he)I had fo greac a defire euer to finith my Booke, that I neuer regarded any thing in refpect of che publique good; not fo much as to thinke how I hould finith fo greac a charge, which l had neuer carried ouc, bus that by Gods ftirring vp of the renowned Emperour Ferdinando of fanous memorie, and the excellent Princes had not helped mee with great fums of mone"; , fo chat the Common wealth may fay, That this bleffing doth rather proced of them than from me. There have been alfo other Princes of Almaine which hauc bin liberal in the preferring of this Book, and the moft excel. lent Elector of the Empire the Duke of Saxonie, which fent me by his Polt much mony toward my charges: the liberal irie of the which and the magnificence toward me I cannot commend fufficiently. They which followed in their-liberalitie were the excellent Fredericke Count Palatine of the Rhine, and the excellent Ioachim Marques of Brandeburg, which much fupplied my wants: and the like did the reuerend Cardinall and Prince of Trent, and the Excellent Archbilhop of Saltzperg, the Excellent Dukes of Bauare and Clenes, the duke of Megapolencis Prince of Vandalis, the State Republique of Noremberg, the liberalitie of whom ought to be celebrated for euer : and it doth much reioice tne that I had the helpe and reward of Emperors, Kings, Electors of the Ro:nan Empire, archdukes, Cardinalls, Bifhops, Dukes and Princes, for it giveth more credit to ous Labors than any thing that can be faid. Thus far Matchiolus his owne writing of the liberalitie of Princes towards him. What age do we liue in here that wil fuffer all vertue to go vnrewarded ? Maiter Gerard tath taken more pains than euer Mattbiolus did in his Commentaries, and hath corrected a number of faults that he pafted ouer; and I dare affirme(in reuerence be it fpoken to that Fxcellent man) that Mafter Gerard doth know a great number of Simples that were not knowne in his time:and yet I doubt whether he thall tatte of the liberalitie of either Princ, Duke, Earle, Bihop, or publique Eftate. Let a man excell neuer fo much in any excellent knowledge, neuertheles many times the is not fo much regarded as a Iefter, a Boatter, a Quackfaluer or Mountebanke : for fuch kinde of men can flatter, diffemble, make of trifles great matters, in praifing of this

sare fecret, or that excellent fpirit, or this Elixer or Quinteffence;

which when it thall come to the triall, nothing

thal be found bur boafting words.

$V A L E$. 


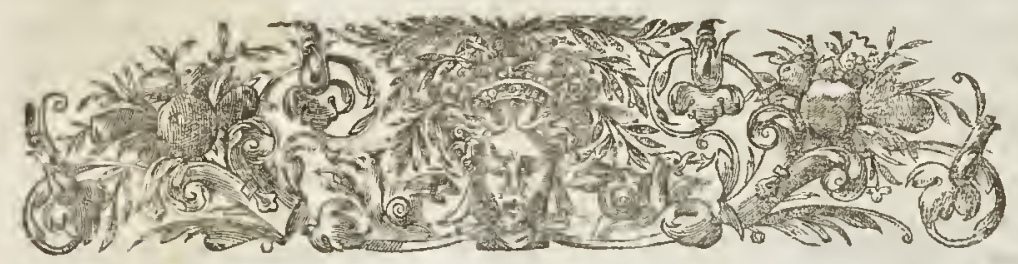

\section{To the courteous and well willing Readers.}

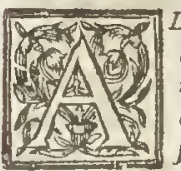

Lthough my paines haus not been ßpent (curtcous Reader) inthegracious difcoueric of golden Munes, nor in the tracing after filusr veines, whereby my natiue country might be enriched with fuch merchandife as it bath moft in requeft and admiration; yet hath my labour (Itruft) been ot herwife profitably employed, in deforying of fuch a harmlefe treafure of berbes, trces, and plants, as the earth frankely without violence offereth unto our moft neceffarie ves. Harmilefe I calltbenn, becaufe

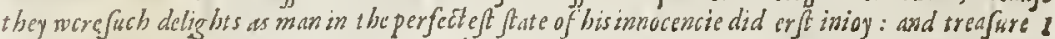
may well terme them, feeing both Kings and P rinces hawe efteemzed them as Iewels; fith wife nen baus made their whole life as a pilgrimage 10 at taine to the knowledge of them: by the which tbey have gained the hearts of all, and opened the mouthes of many, in commendation of thofe rare vertues which are contained in thefe terreft riall creatures. I confeffe blind Pluto is now adayes more fought after than quicke fighted Phoebus: and yes this dufty mettall, or excrement of the earth (which was finf deepely buried leaft it fhould be an eye-fore to grieus the corrupt beart of wanin) by forcsble ewtry made into the bowels of the earth, is rather fratched at of man to bis orvne deftruttion, than directly fent of God, to the coms fort of this life. And yet behold in the compassing of this worldly droffe, swhat care, what coft, what aduentures, what myfticallproofes, and chymicall trials are fet abroach; whers as notwithftanding the chiefeft end is but wncertnine wealth. Contrariwife, in the expert krowoledge of herbes, what pleafures ftall renewed with varietie? what fmall expence? what fecurity? and yet what an apt andordinary mesines to condust man to that iroft defired benefit of bealth ? Which as I denoutly wi h onto my natiue countrey, and to the carefull nurfing mother of the fame; fo bausing bent my labours to the benefiting offach as are fudioully practifed in the conferuation thcreof, I thought at a chiefe point of my duty, thus out of my poore ftore to offer tp thefe my fur feeched exps. riments, together with mine owne countrics wnknowne trenfure, combined in this comperadious Hey. ball (not wisprofit able thoug b rupolifhed) vinto your wife conftructions and courteous confiderations. The drift so hereof is a ready introduction to that excellent art of simpling, which is net ther fo base nor contemptible as per haps the Englifh name may feeme to inimate : but fuch st is ws altogesher bat hbeen a ftudy for the wiseft, ane exercife for the nobleft, a puftime for the beft. From whence there fpring flomres not onely to adorne the gar lands of the Mufes, to decke the bojomes of the beautifull, to paint the gardens of the curious, 10 garnifh the glorious crownes of $k$ ings; $b_{\text {at }}$ elfo fuch fruit aslearned Diofcorides long tranelled for ; and princely Mithridates referned as precious in his owne clofot : Mithridates I meane, better knowne by his fouc raigne cituthridate, that by bis fom. time peaking two and twenty langugyes. But wobat this famors Prince did ly tradition, Euax king of the 1 rabians did delizer in a dif courfe written of the vertucs of berles, and dedicated it vnto the Empersr Nero. Estery greene Herbarift can make mention of the herbe Ly fimachia, whofe vertues were found out by King Lyfimachus, and his wertues no leffe eternifed in the felft farase plane, thas the name of Pliydias, queintly beaten into the foield of Pallas, or the firft letters of $A$. jax or Hyacinthus (whether you pleafe) resiffred in that beloutd foure of A pollo. As for Ar-

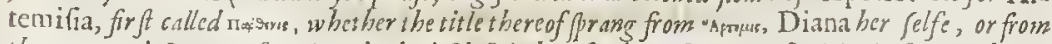
the renowned 2 uecene of Caria, which difilofed the vfe thereof unto pofferitie, it furwiseth as a monument to retutuc the memories of them both for eutr. What hould we peake of Gentiana, bean. ring ftill the cognifance of Gentils ? or of diucrsother herbes eaking their denominations of their princely Inuentors? What hould I fay of thofe royall per forages, Iuba, A tralus, Climenus, A. chilles, Cyrus, Mafyniffa, Semyramis, Dioclefian? but onely thus, to beßpeake their princely lones to Herbarifmc, and beir enterlafting honors (which neither old Plinius dead, nor youg Lipfius liuing will permit to die? ) Crefcent herb $x$, crefcetis amores : crefcent herb $\mathfrak{x}$, crefcetis honores. Eut had this sonted deultie wanted the authorifement of fuch a roy all companie, King Solomon, excelling all the reff for wifdome, of greater royaltie than tbey all (thoug th the Lillies of

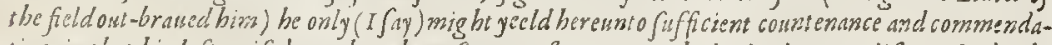

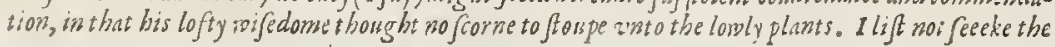




\section{To the Reader.}

common colours of antiguitic, when notwithf anding the world canbrag of no more anient CMonin. ment than Paradife and the garden of Eders: and the fruts of the earth maty contend for feigmioritse, fecing their mother was the firft Creature that conceined, and they themfelwes the firft frust the brought forth. Talke of perfect bappineffe or pleafure, und wisat place wes fo fit for that as the garden place where Adan was let to be the Herbarift? Whither did the Poets. hunt for their incere dolights, but into the gardens of Alcinous, of Adonis, and the orchurds of Hefperides? Where did bey dreame that Hculuen houldbe, but in the pleafant gardes of Ely fum ? Whither do all men w. Ilke for their honcft recreation, but thither whercthe carth hat hmoft bencficially paintcal ber face with flowrifhing colours? And what feafon of the yeare more longed for than the Spring, whojegentle Lreat henticet horth the kindely weets, and makes them yecld their fragrant mells? who weuld therefore looke dangeronly wp at Planets, that minht fafely looke downe at Plants? And if true he the old pronerbe, Qux fupra nos, nihilad nos; I fuppofe this new faying cannot be falle, Quxe infra nos, cu maximè ad nos. Eafie therefore is this treafure to be gained, and yet pretious. The fience is nobly fupported by wife and Kingly Faurites: the fubrect, he reof fo nece firy and delcetable, that asthing can be confcoted cither dclicate for the tafte, daintie for finell, pleafant for fight, wholeforme for body, conferwat ive or reftoratiue for healih, but it borrowet th the relifh of an her be, the fowour of a floure, the colour of a leate, the inice of a plant, or the decoction of a root. Andfuch is the treafure that this my Treatife is furnifhed withall, wherein though myne 4 rtbe not able to countersaile" Nature in her liuely portraitures; yct hanc I counter fcited likenes for life, fiapes and fo adowes

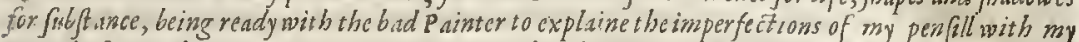
pen, chufing rather to fcore vpon my piztures fuch rude marks as way deforibe my meaning, than to let the bebolder to guiffe a randome and miffe. I hase here therefore fet downe not onely the names of findry Plants, but aljo their natures, thcir proportions and properties, their affects and effects, their increafe and decreafe, their flourifbing and fading, their diftinst varieties and lewerall qualizies, as well of thofe whach our owae Countrey yeldet h, as of others which I bauc fetched furt ber, or drawne out by perufing diuers Herbuls fet forth in ot her languages, wherein none of my country-men hath to my knowlc dectaken any paines, fince that excellent Worke of Mafter Doctor Tunner. After sphich time Mafter Lyte a Worfhipfull Gentleman iranglated Dodonæus ous of French into Englifh : and fince that, Doctor Prieft, one of our London Colledre, harh ( $I$ heard) tranlated the lajt gdition of Dodonxus, and meant to publifh the fame; but being preuented by death, hes tranflation likewifeperifhed. Lafty my felfe, one of the leaft among many, haue prefumed to fet forth unto the view of the morld, the firft fruts of thefe myne owne Labours, which if they be weh wa may con. tent the Reader, I foall thinkemy felfewell rewarded, ot herwife there is 10 man to bc blamed bat my felfe, being aworke I confeffe for greater Clerkes to vndertake: yet ma my blunt attempt feruc as a whetfone to fet an edge uponfome fharper wits, by whom I wifh this my courfe Difcourfe might be both fincd and refined. Faults I confeffe lsaue efcaped, fonse by the Printers onerfight, fome through defects in my felfic to performe 10 great a Worke, and fome by meanes of the greasne fe of the Labour, and that I was conft rained to feeke after my liwing, being void of friends to beare fome part of the burthen: The rather therefore accept this at my hands (louing Countrey-men) as a token of my good will; and I truft that the beft and well minded wil not rafhly cosdewne me, although fome thing hawe paffed worthy reprehenfion. But as for the flanderer or Enuious I paffe not for them, but rcturne vp. on themfelues any thing they fhall without caufe either murmute in corners, or iangle infecre. F arewell.

From my Houfe in Holborn within the Suburbs of London, this firft of December, $1597^{\circ}$

\section{Thy funcere and unfeigned Friend,}

IOHN GERARD: 


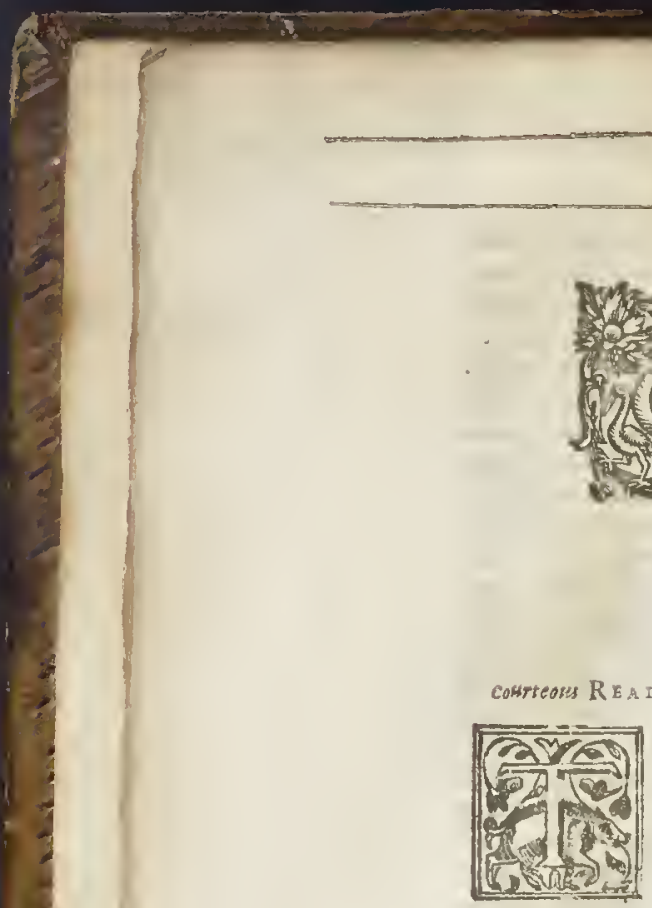

\section{TO THE READER.} large difcourfe to fet forth the ir many and great vfes and vertues : gitue me leaue onely to tell you, That God of his infinit goodneffe and bountie hath by the medum of Plants, beftowed almon all food, clothine, and medie ine vpon man. And to this off-fpring we a lfo owe (for the moft part) our boufes, thipping, and infinite orher things, though fome of them Proteus like hatic run through diters fhapes, as this paperwereon I write, that firft from feed became Flax; then after much vexation thred, then cloath, where it wascut and mangled to ferue the Fahions of the time: but afterwards rejected and caft afide, yet vawilling fo to forfake the leruice of man for which God had ereated it, againe it comes (as I may terme it) to the Hammer, from whenee it takes a more noble forme and aptitude tobe imployed to Sacred, Ciuill, Forreine and Domeflicke vfes. I will not fpeake of the many and various obiects of delight that thefe prefent to the fenfes, tor of fundry other things, which I eould plentifully in this kinde deliuer : but rather acquaint you from what Fountaines this Knowledge may bedrawne, by thew ing what Authours haue delituered to vs the Hiftorie of Plants, and after what manner they haue doneit; and this will be a meanes that many eontrouerfies may be the more cafily vaderttood by the leffe learned and judicious Reader.

Hewhofe name we firf finde v pon reeord(though doubtleffe fome had treated therof before) that largely writ of Plants, was the wifeft of men, etten King Solomon, whocertainely would not haue medled with this fubieet, if he in his wifedome bad not knowne it worthy himfelfe, and exceeding fitting: Firft for the honour of his Crcator, whofe gifts and bleffings there are : Secondly for the good of his Subiests, whereof without doubt, he in this worke liad a fpeeiall regard in the euring of their difeafes and infirmities. But this kingly worke being Inft, I will not infift vpon it,but come to fuch as are yet extant, of which (following the courfe of antiquitic) that of $\mathcal{T}$ beophraftas firf takes place.

Theophiofus. Now Thiophrafus fucceeded Ariftotle in the gournement of the Sehoole at A thens, about the 14 Olymp. which was fome 322 yeares beforc Chrif. He amnng many other things writ a Hiftorie of Plants in ten bookes, and of the caufes of them, cight bookes; of the former ten there are nine come to our times reafonable perfect; but there now remain but fix of the eight of the caufes of Plants. Some looking vpon the Catalogue of the bookes of $T$ heophraftus bis writing, fet forth in his life, written by Diogenes Laertius, may wonder that they finde no mention of thefe bookes of Plants, anongit thefe be reckons vp, and indeed I thought it fomewhat frange, and fo nuch the more, becaufe this his life

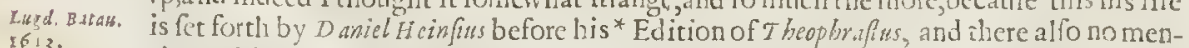
tion neither in the Greke nor Latine of thofe workes. Confidering this, I thinking to laure faid fomething therof, I found the doubt was long fince cleared by the learned Cau-

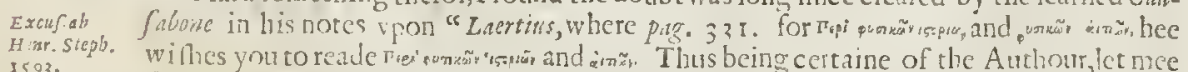
2593. fay fomewhat of the work, which though by the iniuric of time it hath futhered much, yet is it one of the chiefe picees of Antiquitie, from whence the knowledge of Plants is 
to be drawnc. Theophraftur as he followed Ariffotle in the Schoole, fo alfo in his manner of writing,foraccording as Ariffotle hath deliuered his Hifforia Animalium, fo hath hee fet forth this of Plants, not by. writing of each pecies in particular, but of thcir differerces and Theoph.Hille. mature, by their parts, affections, generations and life. Which how hard a thing it was, hec tells plus.ccap, as.

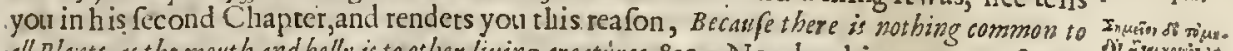

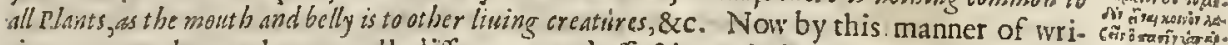
ting youmay learne the generall differences and affe tions of Plants, but cannot comie to $\%$, wat the particilar knowledgc of any without much labour : for you muit goe to many places to gather vp the defcription of one Plant: neither doth hee, (nor is it neceffarie for any writing in this manner)make mention of any gteat number, and of many it may bee but once. His workes being in Grecke were tranflated into Latine by Theodore $G a z a$, who did them but Grea fide, for he omitted fome things, otherwhiles rendicd them contraty to the mindc of the Author :but abouc all, he tooke to himfelfe too much libertie in giung of names in imitation of the Grecke, or of his owne inuention, when it had beene better by

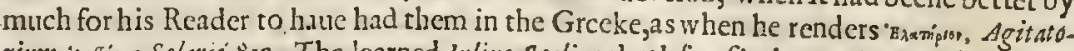

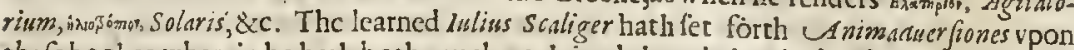
thefebookes, wherein he harh both nucli cxplained the mindc of $\tau$ beophraftus, and fhewcd, the ertours of $G_{a z a}$. Some fince his time hauc promifed to do fomething to this Author, as D sinicl Hem fuss,and Spigelims, but twentie yeares are paft fince, and I haue not yct heard of any thing done in this kinde by either of them. Thus much for Tbeoploraftus.

Let me not paffe oner s A riffotle in filence, though his bookes writ of this fub ic $A$ were srifoth but two, and thefe according to the conie dure of Iulizus Scaliger. (who hath made a large and curious ckamination of them' have either perifhed, or come to vs not as they were o: riginally written by Ariffotle, but as they haue becn by fome later man put into Greeke. Among t other things sicaliger hath the fe concerning thofe two bookes : Reor è textrina

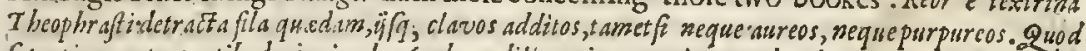
fi protiwus autorem tibs dari vis sd A rabsm diligentiam propius accedit: And afterwards thus : Attribuere viri docti, alius alij, at quidem qui aloorum vidercm nibil Planudem autorem facienti malim afjentiri, extant cnim "illins alijs in libris fimilis veftigiafemilatinietat is, \&c. Thus much for Ariftorle, whom as you fee I hauc placed after his Scholler, becaufe there is fuch doubt of thefe bookes carricd about in his name, and for that Sealiger as you fee thinks them sather taken out of $T$ beophraftus, than written by his Mafter.

The ncxt that orderly followes is Pedacius Diofcorides Anatarbeus, who lined (accor- Dioforidsio ding to Suidas) in the time of Cleopatra, which was fome few yeares before the birth of our Sauiour. Now Suidas hath confounded * Diofcordes AnaZarbcus with Diofcorides Phacas, but Anopowsur Aar by fome places in Galen youmay fee thcy werc different men: for our A niazarbean $D$ iofio. rides was of the Empericke fect, bur the other was a followet of Herophylus and of the $\mathrm{R}_{3}$. or Said. tionall fect. He writ not only of Plants, but de tota materia medica ; to which fudie hee was addieted cuen ftom his childe-hood, which made him ttauell much g tound, and lcade a militarie life, the betrer to accomplinh his cnds:and in this he attained to that petfection, that few or none fince his time hauc attained to, of the cxcellencie of his worke, which is as itwcre the foundation and ground-worke of all that hath been fince deliucred in th is Defimpl.med. naturc. Heare what $G$ alen one of the excellentcft of Phy fitions; and one who fpent no fmal facultalib.6. time in this ftudy, affirmes : But, faith he, the Anazarbean Diofcorides in fiue bookes hath written of the neceffarie matter of medicinc, not onely making mention of herbes, but alfo of trees, fruits, "liquours and iuices, as alfo of all mineralls, and of the parts of liking creatures : and in mine opinion be hath with the greateft perfe tion performed this worke of the matter of Medicine : for although many before him haue written well vpon this fub iect,yet none hame writ fo.well of all. Now Diofcorides followes not the method of Theopluraft us, but treats of each kinde of herbe in particular, firft giving the names, then the defcription, and then the place wherc they vfually grow, and lattly their vertues. Yet of fome, which then were as frequently knownc with them, as Sage, Rofemary, an Afh or Oke tree are with vs, he hach omitted the defcriptions, as not neccffarie, as indeed at that time when thcy were forulgarly knowne, they might feeme fo to be : but now wee know the leaft of thefe, and haue no certaintie, but fome probable conie ctures do direet is to the knowledgc of them. Hewas not curious about his words nor method, but plainely and truly dclituercd that whereof he had certaine and experimentall knowledge, concerning the defcription and nature of plants. But the generall method he obferued you may finde fet forth by Bastine in his Edition of Matthiolss, immediatly after the preface of the firft booke, whereto I refer the curious, being too long for me in this place to infift vpon. His workes 


\section{To.The Reader.}

workes that haue come to vs are fue bookes de materia cuedica. Ore de lotalulus ouncris, corumg; precautione et curatione : another de Came rabido, det; not is qua mor Jus salujve ammalium venenum relinguentium fegunnur: a third De corusn cur at:ase. Thefe eight bookes within thefe two laft eenturies ot yearcs haue beentranlated otit of Greeke into Latine, and eommented vpon by diucrs, as Hermolaus Barbarus, Iobannes Ruelliws, Marcellus Virgilius, \&cc. But of thele and the reft, as they offer themfelues, I thall fay fomewhat hereafter. There is alfo another worke whieh goes vnder his nane, and may well be his. It is r wa mopisw fiue de facile parabilibus, diuided into two bookes, tranflatcd and eonfirmed witl the eonfent of other Greeke Phyfitions, by the great labour of Iols eMoibane a Phyfition of Aufpurge, who liued not to finin it, but left it tobee perfected and fet forth by comrade Gejner.

Pling. The next that takes plaee is the laborious $C_{\text {ains }}$ pliniss frowdus, who liued in the time of $V$ efpafan, and was fuffocared by the fulphureous vapours that eame from mount Veluvius, falling at that time on fire; he through ouermueh euriofitie to fee and finde out the caufe thereof approehing too nigh, and this was 4 mo Domini, 79. He read and writ exceeding mueh, though by the iniurie of time wee hate no more of his than 37. books de Hiftoria surndi, whieh allo haue reeeiued fuch wQunds, as haue tried the beft skill of our Critickes, and yet in my opinion in fome places require medscas masus. From the ewelfth to the end of the twentie feuenth of thefe bookes he treats of Plants, more from what he found written in other Authors, than from any certaine nowledge of his owne, in many plaees following the method and gituing the words of Theopluraftus, and in other places thofe of Diofcorides, xhough he neuer make mention of the later of them s he alfo mentions, and no queftion followed many other Authors, whofe writings hane long finee perithed. Sometimes he is pretty large, and otherwhiles fo briefe, that fcaree any thing can thence be gathered. From the feuenteenth vnto the twentie feuenth be varioully han. dles them, what method you may quickly fee by his Eleschus, contained is his frft book; but in the rwenty feuenth hee handles tho fe whereof hee had madeno, or not fuificient mention, a fter an Alphab etieall order, beginning with Exhyopis, Ageratuas, CAloe, \&e. fo going on to the relt.

I muft not paffe ouer in filence, neither need I long infift vpon Gulen, Paulus a Eineta, and $A$ etius, for they haue only alphabetically named Plants and orber frople Medicines, briefely mentioning their temperature and faculties, without deferiptions (fome very few, and thofe briefe ones, exeepted) and other things pertinent to their hiforie.

suct. The next that prefent themfelues are two counterf its, who abufe the World vnder feined titles, and their names baue mueh more antiquitie than the works them felues: the firft goes vnder the ritle of asmilus Macer a famous Poet, of whom owidmakes mention in thefe ve:fes:

$$
\begin{aligned}
& \text { Sepe fuas wolucres legit mihigrandiar svo, } \\
& \text { 2ueg; nocet Serpens, que iunat berba Macer. }
\end{aligned}
$$

Pliny alfo makes mention of this CMacer : hee in his Poems imitated Nicander, but this worke that now is earried about vnder his name, is written in a rude, and fomewhat barbarous verfe, far different from the ftile of thofe tumes wherein Macer litued, and noway in the fubiect immitating Nicander. It feemes to natse beene written about 400 or 500 yeares agoe.

The other al fo is of an vnknowne Author, to whom the Printers haue giten the title of Apuleines Madaurenfis, and fome haue been fo abfurdly bold of late, as to put it vnto the workes of Apulciss; yet the vneurious file and method of the whole booke will eonuinee them of errour, if there were no other argumenr. I haue feene fome foure mantferipts of this Authour, and heard of a fifth, and all of them feeme to bee of good Antiquicie : the figures of them all for the moft part haue fome relemblanee eaeb of other : the firft of thefe I faw fome nine yeares agoe with that wortly louer and ftorer of Antiquities, Sir Robert Cotton : it was in a faire Saxon hand, and as I remember in the Saxon tongue; but what title it earried, I at that time was not curious to obferue. I faw alfo another after that, whieh feemed not to be of any fmall ftanding, but earelelly obferued not the title. But finee I being informed by my friend Mafter Goodyer (as you may finde in the Chapter of Saxifrage of the Antients) that his Manufeript which wasvery antient,acknowledged no fueh Author as Apuleius, I begunne a little to examine fome othet Manuferipts, fo I proeured a very faire one of my mueh honored friend $S^{r}$. Theod. Matyern: in the veriebeginning of this is wit, Is hoc sontinentur libri quatwor medicina Ypocrats, Platon is apolien/is vrbis de diner is berbis; Sextipapiri placitiex Animalibus, \&xc. A little after 


\section{Tothe Reader.}

In the fame page at the beginning of a table which is of the vertues, are thefe words; In primo libro funat berba deforipte, quas Apolienfis Plato defcriffat, ourc. and thus alfo he is named in the title of the Epifte or Proeme; but at the end of the worke is explicit liber Platonis de herbis mafculinis, Sic. "Nith this in all things agrees that of $\mathrm{M}^{\mathrm{x}}$. Goodyer, as he hath affir. med to me. Befides thefe, I found one with $M^{*}$. Tohn Tradefcant; which was written in $a$ more ignorant and barbarous time, as one may coniecture by the title, which is thus at the very beginning. Innomine domini inciput Herboralium Apulei Platonis guod accepit a Scolapio, fo Chirone Certanuro magif r.o. Then followes (as alfo in the former, and in the printed bookes) the tract afcribed to Antonius Mufa, de berba Betonica: after that are thefe words, Liber Medicine Platonis berbaticus explicit. By this it feemes the Author of this worke either was named, or elfecalled himfelfe Plalo, a thing not withour example in thefe times. This worke was firt printed at Bafill, 1528, a mongt fome other workes of Phylicke, and one Albanus Torinus fer ir forth by the helpe of many Mantiferipts, of whofe imperfe ations he much complaines, and l thinke not withont caufe : after this, Gabricl Humelbergius of Rauenfpurge in Germany fet it forth with a Comment vpon it, who alfo complaines o the imperfections of his copies, and thinkes the worke nor perfect : indeed borh the edition $s$ are faultic in many places : and by the help of thefe Manuferipts I haue feen they might be mended. (if any thought it worth their labour) in fome things, as I obferued in curforily looking ouer them. One thing I mueh maruel! at, which is, that I finde not this Authar mentioned in any Writer of the middle times, as Platearius, Bartbolomaus Unglus, 816. Now I coniecture this worke was originally written in Grecke, for thete realons: firf, becaufe it hatlu the Greeke names in fueh plenty, and many of them proper, fignificant, and in che firft place: Secondly fome are oncly named in Greeke, as Hiercbulbon, Artemifua Leptophyllos, and Artemifin tagantes, Batrachion, Gryas (which I iudge rather Grceke than Latine) \&xc. Befides in both the written bookes in very many places amongtt the names I finde this word omocos, bur dinerny written; for I coniecture the Greeke names were written in the Greke character, and imolas amongt them; and then alfo when the zeft of the worke was tranflated, which afterwards made the tranferibers who vnderftood it not to write it variounly, for in the one booke it is alwaies written Amocos, and in the other Omocos, and fomtimes Omeos, as in the Chapter of Brittanica, the one hath it thus, No. men herbe iftius Britanica, Amoeos dicunt eam Damafinium, \&cc. The other thus: Nomen berba Brittanica, O meos Damafinius, \& c. \& in the chap.of Althat the one hath it thus:Nowen buius horba Liltea 4 moeos vocant hanc herbam Moloche, \&c. The other Nomen herba Jbijcus omocos Moloce, \&zc. If it be certaine which Philip Ferrarius affirmes in his Lexicos Geographisum, that the citie Apoley is Conftantinople, then haue I tound Apolienfis wrber, of whieh 1 ean finde no mention in any antient or moderne Geographer befides; and then it is more than probable that this was written in Grceke, and it may be thought differently tranlated, which occafions fuch diuerfit ie in the copies, as you thall finde in fome plaees. Jow I conie ture this worke was written about fome 600. yeares agoe.

From thefe Antients haue fprung all, or the greateft part of the knowledge, that the middle or later times baue had of Plants; and all the contronerfics that of late hane fo ftuffed the bookes of fuch as haue writ of this fubie t, had their beginning by reafon that the earelefneffe of the middle times were fuch, that they knew little but what they tranferibed ont of theie Antients, neuer endeuouring to acquire any perfect knowledge of the things themfelues : fo that when as learning (after a long Winter) began to fpring vp againe, men began to be fomwhat more curious, and by the notes and deferiptions in the fe antient Authors they hate laboured to reftore this loft knowledge; making inquiric, firft whether it were knowne by Theophraf 1 us, Ditfcorides, or any of the Antients, then by what name. But to retume to my Autliors.

About An.Dom. 1 100.or a listle after, liued the Arabians Auicen, Auerrhoes, Me fue, Rba. The Arabiesto fis and Serapio; molt of the fe writ but briefely of this fubie t; neither haue we their works in the A rabicke wherein they were written, but barbarouly tranlated into Latine, and molt part of thefe workes were by them taken out of the Greekes, efpecially Diofcorides and $G$ alen; yet fo as they added fomewhat of their own, and otherwhiles confounded other things with thore mentioned by the Greekes, becaufe they did not well know the things whereof they writ. Amocen, Auerrboes, and Rhafis alphabetically and briefly foilow ing the method of $G$ alen) give the names, remperature, and vertues, of the chiefert fimple medi-suicen. cines. But Serapio after a particular tract of the temperature and qualitics of fimple medi- 4 suerrbees. cines in generall, comes to treat of them in particular, and therein followes chicfely $D i-$ R $_{-}$- serapio. sfcorides, Galen, and $P_{a u l}$ ses, and diuers Arabians that went before him. This is the chiefe worke in this kinde of the Arabians, which haue eome to vs; he himfelfe tells vs his me- 


\section{To The Reader.}

rhod in his preface, which is (when he comes to particulars) firft of medicines temperatc, then of thofe that are hot and dric in the firft degree; then rhofe cold and dric in the fane degree: after that, thofe hot and dry in the fecond degree, $8 x c$, and in each of thefe tracts he followes the order of rhe Arabicke Alphabet.

In or after the times of the Arabians vntill abont the yeare 1400. Therc were diuers obfcure and barbarous writers, whoby fight knew littlc whereof rhey writ, bur tooke out of the Greckes, Arabians, and one anorher, all rhat they writ, giuing commonly rude figures, feldome fetting downe any de?criprions : I will only name the chiefe of them that I haue feene,and as nearc as I can gueffe in that order that one of them fixcceded anorher. For rhe particular times of their lining is fomewhat difficult to be found out. One of rhe ancienteft of them feemes robe Ifidore; then Platearnus whofe worke is Alphabeti-

Ifodore. cal and intituled Circa inftans: the next Matthaus Syluaticus, who flourifhed about the yerc

Platcarius. 1319.his worke is called Pandecte : a little after him was Bartholomels Anglus, whofe workes (as that of ifodorc, and moft of the reft of thofe times) treat of dinets other things befides Plants, as Beafts, Birds, Fithes, \&c. His worke is called De troprietatibus rerum:the Authors name was Bartbolmew Glamull, who was defecnded of the Noble Family of the Earles of Suffolke; and he wrote this worke in Edward the thirds timc, about the yearc

Hortus fanitas. Of our Lord, 1397 . After all thefe, and much like them is the Hortus fanitatis whofe Author I know nos. Bitt to leaue thefe obfcure men and theit writings, let mereckon fome of later time, who with much more learning and indgement haue endeuoured to illufrat this part of Phy ficke.

About fome 200 yearc agoe learning againe beginning to flomith, diuers begunne to leatle and loath the confured and bar barous writings of the middle times, and to haue tecourfe to the Antienrs, from whence together with puritic of language, they might acquirc a more certaine knowledge of the things treated of, which was wanting in the o-

erermol, barb. ther. One of the firft that tooke paines in this kinde was Hermolaus Barbarus Patriatch of Aquilcia, who not onely tranflated Diofcorides, but wtit a Commentatie vpon him in fiue bookes, which he calls his Corollarium; in thiswotke hee hath fhewed himfelfe both iudicious and learned.

Matr.Virg. After him Marcellus Virgilizs Sccretarie to the Statc of Florence, a man of no leffe learning and indgement than the former, fet forrh Diofcorides in Greeke and Latinc with a Comment vpon him.

8obn, Ranllius: Much about their time alfo Iolm Rullius a French Phy fition, who fourithed in the yere 1480, tranflated Diofcortdes into Latine, whofe tranlation hath been the moft followed ofall the reft. Morconer he fet forth a large worke, De natura shirpium, diuided into three bookes, whercin he hath accurately garbered all things out of frndry writers, efpecially the Greekes and Latines; for firtt hauing (after the manner of Theophraftus) deliuered fome common precepts and Aduertifements pertaining to the forme, life, generation, ordering, and other fuch accidents of plants; he then comes to the parricular handling of each $/$ ecies.

Much about this time, the Germanes began to beautifie this fo neceffary part of
otho srumfel. Phy ficke; and amongft them Osho Brunfelfuus, a Phy fition of good account, writ of plants, and was the firt rhar gauc the lisely figures of them; but he treated nor in all of aboue 288 Plants. He comnonly obferues this method in his particular chapters : Firft the figuse (yet he gines not the figures of all he writes of) then the Grecke, Latine, and Germane names; after that, rhe defeription and hiftoric out of molt former Authors; then the temperarure and vertues and laftly, the Authours names thar had treated of them. His worke is in three parts or tomes, the firft was printed in $153^{\circ}$.the fecond in $153 \mathrm{I}$,and the third in 1536 .

Himetisugus. Next after him was Hieronymus Tragus a learned, ingeninus, and honeft writer, who fct forth his workes in the German tongue, which were fhortly after tranflated into Latine by $D$ awid $K i b c r$. If treats of moft of the Plants commonly growing in Germany, \& I can ob fertue no generall merhod he keepes, but his particular one is commonly th is ! hee firft giucs the figure with the Latine and high Dutch name; then commonly a good defcrip. tion; after rhar the names, then the temperature, and laftly the rereues, firft inwardly, then outwardly ved. He hath figured fome 567 , and defcribed fome 800 . his figures are good, (and fo are moft of rhe reft thar follow? ) His workes were fer forth in Latine, An. I5 5 .

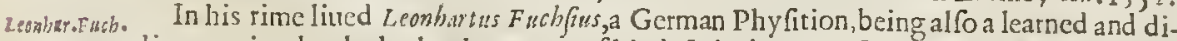
ligent writer, but he hath taken many of his defcriprions as alfo vertues word for word out of the Anrients, and to them larh put figures; his generall method is afrer the Greek Alphabct, and his particular one thus: Firft the names in Grecke and Latine, together of $_{\text {- }}$ 


\section{To the Reader.}

times with theit Etynologies, as al fo the Getman and Frencl names, then the kinds, after that the forme, the place, time, temperature, then the vertues : firft out of the Antients, as Diofrorides, Galen, Pliny, efc and fonetimes from the late Writers, whom lie doth not particularize, but expreffes in generall ex recentioribus. His worke was fet forth at Bafl, I 542 , in Fol.containing, 5 i 6 figures; alfo they were fet forth in oct.wo, the hiftorie firft, with all the figures by themfelues together at the end with the Latine and high Dutch names.

A bout this time, and a little after, flourifhed Conrade Gefner alfo a German Phy fition, conrade Grs who fet forth diuers things of this nature, but yet liued not to finith the great and general worke of Plants, which he for many yeres intended, and about which he had taken a great deale of paines, as may be gathered by his Epifiles. Hewas a very learned, painfull, tonelt and iudicious writer, as may appeare by his many \& great workes; wherof thofe of Plants were firft a briefe $\Lambda$ lphabericall Hifforic of planes without figures, gathered out of Diofcorides, Theophraftus, Pliny, $x_{0}$ w with the vertues briefely, and for the molt part taken out of Paulus efgineta, with their names in Greck and French put in the margent: this was printed at Venice, 154 , in a finall forme. He fet forth a catalogue of Plants, in Latin, Greeke, high-Dutch and French, printed at Zurich, 1542. Alfo another trait De. Limariss ó noctu tucentilus curm mont is fract i, five Pilati Lucernatum defcriptione, An. I 552.in quarto. He allo fet forth the foure Books of $V$ alerius Cordus (who died in his time) and his Sylua obferwationums at Stratsburgh, is 6 I.in fol. and to thefe he added a Catalogue of the Germane Gardens with an Append Ix and corollariunz to Cordus his Hiftorie. Allo another treatife of his $D e$ firpium collectione, was fet forth at Zurich by Wolphius, An. $15^{87}$, in Octarie.

At the fame time litued Adtm Loniccrus a Phyfition of Frankeford, whofe natutall hi. Loaicerus. ftoric was there printed, $A n_{1}, 155$, and the firnt part there of is of Plants and foure ycres af. ter headded another part thercto, treating alfo of Plants. I finde nngenetall method obferued by him, but his particulat method vfually is this: firf he gites the figure, then the names in Latine and Dutch, then the temperature, \&cc.as in Trasus, from whom $8 x$ Cordus, he botrows the moft part of his firft tome, as he doth the 2. from Matth. \& Ainat Luftamus.

In his timc the Italian Pliyfition Petrus Andreas Matthiolus fet forth his Commenta- P. wad. Mix * ries vpon Diofcorides, fitt in Italian with 957 latge and very faire figures, and then afterwards in Latine at Venice, with the fame figures, A2. 1568 . After this he fet fotth his Epitome in 2 uarto, with 921 fin aller figures. Now the fe his Commentaries are vety large; and he hath in them deliuered the liftorie of many Plants not mentioned by Diofcorides; but he is iuftly reprebended by tome, for that he euery whete taxes and notes other Writers, when as he himfelfe runs into many etrours, and fome of them wilfull ones, as when he gives figures framed by his owne fancie, as that of $D$ raconsium maiss, $R$ h.tburbarum, \&c. and falfified otherfome in part, the better to make them agree with Diefcori. his def́cription, as when he pictures Arbor Indew ith prickles, and giues it for the true A $A$ atiu: and he oft-times giues bare figures without defcription of his owne, but faith, it is that defcribed by Diofcorides, Nullis reclamantibus not is, for which the Authors of the Aduerfaria much declainte againft him. It had bin fit for him, or any one that takes fich a worke in hand, to hate thewed by defctibing the plant he gites, and conferting it with the defcription of his Author, that there is not any one note wanting in the defeription, vertues, ot other patticulars which his Author fets downe; and if hee can thew that his is fuch, thenwill the crntraty opinions of all others fall of themfelues, and need no confutation.

- Awatus Luftutus al fo about the fame time fet forth Commentaries vpon Diofcorides, auding the names in diuers Languages but without figures, at Strausbourgh, $A n$. 155 s. in ams (2) wo he diffented from Matthiolus in many things: whereupon Mattbiolus writ an Apologic agalnft bim. He hath performed no great matter in his Enarrations vpon Diofcorides, butwas an Author of the honefie of Mathisines, for as the one deceived the world with counterfeit figures, fo the other by feined cures to ftrengthen his opinion, as Crato iudges of his Curationes Medicinales (anothet worke of his) which hee thinkes, potius fieter, quam
fathe.

Rembertus Dodonerts a Phy fition borne at Mechlin in Brabant, about this tine begun to Remb. Dusu urite of Plants. Hee firf fet foorth a Hiftorie in Dutch, which by Clufus was turned itto French, with fome additions, Uaro Domini, 1560 . And this was tranlated out of French into Englin by Mafter Hcary Litc, and fet forch with figures, Snno Dom. I 57 S. and diters times fince printed, but without Figures. In the yeare $155^{2}$, Dodonacus fet forth in Latine his Frngum Hiftoria, and within a while after his Florum,purguntum, od deleteriomon Hiftoria. A frerwards liee put them all together, his former, and thofe his later Workes, and diuided them into thirtie Bookes, and fet them forth with 1305 figures, in fol. An. 158 . This edition was alfo tranllated into Englifh, which became the foundation 


\section{To the Reader.}

of this ptefent Wotke, as I thall thew hereaftet. It hath fince beene ptinted in Latine, with the addition of fome few new figutes: and of late in Dutch, Anno 1618 .with the addition of the fame figures; and moft of thefe in the Exoticks of Cluffirus, and great ftore of other additions. His generall method is this : fitt he diuides his Works into fix Pemptades or fiues: the fifth Pemptas or fiue bookes of thefe containe Plants in an Alphabeticall order, yet fo as that other Plants that haue affinitie with them are comprehended with then, though they fall not into the ordet of the Alphabet. The fecond Pempt.con-

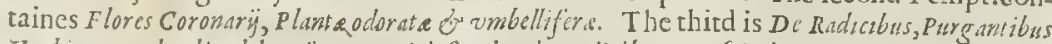
Herbir, convolvulis, deletcrijs acperniciogis Plant is, Filicibus, If uf is of Fungis. The fourth is De Frimentis, Leguminubus, paluffribus of aquatilibus. The fifth, $D_{c}$ olcribus o Cardwis. The fixrls, de Fruticibus of Arboribus. The patticulat metlod is the fame vfed by our Author.

Peter Tena.

In the yeare 1570, Peter Pena and Matthias Lebcldid bete at London fet forth a Worke, entituled Stirprum Aduryaria noura the chiefe end and intention whereof being to find out the Materis medica of the Antients. The generall method is the fame with that of our Author, which is, purting things togethet as they haue moft refemblance one with another in externall forme, beginning with Graffes, Cornes, \&c. They gine few figures, but fomerimes refer you to F fuchfius, Dodonaus, and Matthiolus : but where the figure was not ginen by formet Authors, then they commonly giue it ; yer molt part of thele figures ate very finall and unpetfea, by teafon (as I coniecture) they were take $\mathrm{n}$ from dried plants. In this Worke they infift litrle vpon the vertues of Plants, but fuccinctly handle controuerfies, and giue their opinions of Plants, together with therr defcriptions and names, which fometimes are in all thefe languages, Greeke,Latine, French, ligh and low Dutch, and Englifh : otherwhiles in but one ot two of then. Some W riters for this Work call them Doctifimi Angli; yet neither of them were botne here, for Pena (as I take it) was a French man, and Lobelwas botne at Ryffele in Flanders, yet liued molt patt of his later time in this Kingdome, and here alfo ended his dayes. In tlie yeare 1576 he fer forth his Obferuations, and ioyned them with the 4 diserfirta, by them two to make one entire Worke: for in his Obfertuations he giues moft part of the figures and vcrues belonging to thofe hetbes formerly defcribed onely in the Aducrfaria; and to thefe alfo adds fome mew ones not mentioned in the former Wotke. After which he fer fotth an Herball in Durch, wherein he comprehended all thofe Plants that werc in the two former Workes, and added diuers other to them, the Worke containing fome 2116 figures; which were printed aftetwards in a longinh forme, with the Latine names, and references to the Latine and Dutch bookes. Afrerall thefe, at London, Amo i 605 , he againe fet forth the 1 dwerfaria, together with the fecond part thereof, wherein is contained forne fourty figures, being moft of them of Graffes and Floures; but the defcriptions were of fome 100 plants, varieties and all. To this he added a Trearife of Balfam (whiehalfo was fet fotth alone in Quarto, Anno 1598.) and the Pharmacopec of Rondelctius, with Annotations vpon it. He intended another great Wotke, whore title fhould hauc beene Stivpitum Illuftrationes, but was prenented by death.

Garol.elufius. Some fix yeares after the Edition of the Aduerfaria, Anno 1576, that leatned, diligent, and laborious Herbarift Carol. Clufizs fet forth his Spanifh Obfertations, bauing to this purpofe tranelled oner a great patt of Spaine; and being aftetwards called to the Imperiall Court by Maximzilzan the fecond, he viewed Auftria and the adiacent ptouinces, and fet forth his there Obferuation, Anno 1583. He alfo tranflated ont of Spanin the Works of Garcias ab orta and Chriftopher Acofta, trcating of the fimple nedicines of the Eaft Indies, and Nicolas Monardus, whowrit of thofe of the Wett Indies. A feer this he put into one body both his Spanifh and Pannonicke Obferuations, with fome other, and thofe he comprehends in fix bookes, entituled Rariornm Plantarum Historis: whereto he alfo addes

Hanor.Bellus. an Appendix, a treatife of Murhtoms, fix Epiftles treating of Plants, from Honorins Bellus an Italian Phyfition liuing at Cydonia in Candy, as alfo the defcription of mount Baldus, being a Catalogue with the defeription and figures of fome rare and not beforewritten of Plants theregrowing, written by Ioha Pona an A pothecaric of Verona (This Defcription of Pona's was afterwards with fome new deferiptions and thirty fix figures fer forth alone in Quarto, $A n$ 1608.) This firf Volume of Clufus was printed in Antwerp, Anno 1601 , in Folio: and in the yeare 1605 healfo in Folio fet forth in anorher volume fix bookes of Exoticks containing various matter, as plants, or fome particles of them, as Fruits, Woods, Barks, \&rc. as alfo the forenamed tranflations of Gartins, Acofta, and $\mathrm{No}$. nardus: Thtee Tracts befides of the fame Monurdus; the firl, De lapide Be anar, \& Herba

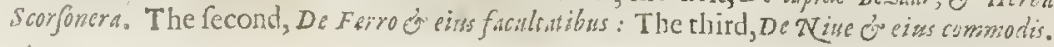


To thefe he alfo added Bellonius his Obferuations or Singularities, and a tract of the fame Author, Den:glecta Stirpium cultura, borh formerly tranflated out of French into Latine by him. Hewas borne at Atrcbas or Arras, the chiefe ciry of Artois, Anno 15 26. and died at Leyden, Am. 1609. A fter his death, by Euerard Vorftius, Peter Pam, or fome o. rhers, were fet forth forme add itions and emendations of his formet Works, together with his funerall Oration made by Vorstius, his Epitaph, \&xc. in Quarto, LAmo 101 I, by the name of his Cur e Poftcriores. .

In the yeare 1583 , Andreas Cefalpinus an Italian Phyfition, and Ptofeffor at Pifa, fet ardircafasis, forth an hiftorie of Plants, comprehended in fixteene bookes: his Worke is without fi. gures, and he oft times giues the Tufcane names for Latine; wherefore his worke is the more difficult to be vnderftood, vnleffe it be by fuch as haue been in Tu fcanie, or elfe are already well exercifed in this ftudy. He commonly in his ownewords diligently for the moft part defcribes cach Plant, and then makes enquirie whether they were knowne by the Ancients. He feldome fets downe their faculties, wnleffe of fome, to which former Writers haute put downe none. In the firft booke he treats of Plants in generall, accor: ding as Thcoplarafus dnth: but in the following bookes hee handles them in parcicular: the malseth the chiefe affinity of Plants to con fift in the fimilitude of their feeds and feed veffels.

Ioachimus Cameravius a Phy fition of Noremberg flotrithed about this time: Hee fet Ioash. Camer: forth the Epitome of CMatrbiolus, with fome additions and accurate figures, in Quarto, at Frankfort, 1986 : in the end of which Worke (as alfo in that fet forth by cMatthiolus himfelfe) is Iter Baldi, Or a journey from Verona to mount Baldus, written by Frances Cal- Fr.calcsolarius ceolarius an A pothecaric of Verona. A nother Worke of Camerarius was his Hortus CMe. dicns, being an Alphabeticall entmeration of Plants, wherein is fet forth many things coneerning tlie names, ordering, vertues, \&cc. of Plants. To this he anexed Hyrcinia Saxonothuringica lobamis $T$ baliy, or an alphabeticall Catalogue written by Tohn Thalius, of fuch rob.Thaliuso Plants as grew in Harkwald a part of Germanie betweene Saxony and Dutengen. This was printed allo at Frankfort in Quarto, An. 1588 .

In the yeare 1587 came forth the great Hiftorie of Plants printed at Lyons, which is therefore vulgarly termed Historia Lugdunenfis : it was begun by Dalechampius : but hec dying before the finiching thereof, one Iobn cMolinaus fet it forth, but put not his name thereto. It was intended to comprehend all that had written before, and fo it doth, but with a great deale of confurfon; which occafioned Barbine to write a treatife of the etrors committed therein, in which he thewes there are about foure hundted figures twice or thrice ouer. The whole number of the figures in this Worke are 2686 . This Hiftory is diuided into eighteene bookes, and the Plants in each booke are put together either by the places of their growings, as in Woods, coples, mountaines, waterie places, \&c. nt by their externall thape, as vmbelliferous, bulbous, \&c. ot by their qualities, as purging, poyfonous, \&cc. Herein are many places of $T$ heophriffus and other antient $W$ riters explained. He commonly in each chapter giues the names, place, forme, vertue, as molt other do. And at the end thereof there is an Appendix containing fome Indian plants,

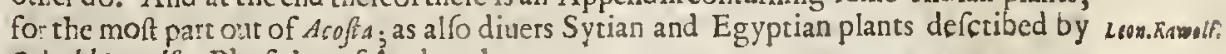
Reinold Rawols a Phyfition of Ausburgh.

At this time, towit Amo 588 , Iacobus Theodorus Taberamontanus fet forth an Hiftory gabernamous. of Plants in the Germane tongue, and fome twelue yeares aftet his Figures being in all 2087 , were fer forth in a long forme, with the Latine and high-Dutch names put vnto them; and with thefe fame Figures was this Worke of our A uthor formerly printed.

Proper Alpimur a Phyfition of Padua in Italy, in the yeare 1592 fet forth a Treatsfe of Profp.Apinus: fome Egyptian Plants, with large yet not very accurate figures: he there treats of fome 46 plants, and at the end thereof is a Dia logue or Treatife of Balfam. Some fix yeares agone, Anso 16:7, his Son fet forth two bookes of his fachers, De Plantis Exaticis, with the figures cut in Braffe : chis Worke containes fome i 36 Plants.

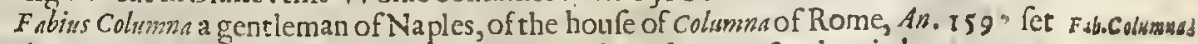
forth a Treatifecalled phytobs fanos, ot an Examination of Plants; for therein he exammes and afferts fome plants to be fich and fuch of the Antients : and in the end of th is worke he gitucs alfo the hiftorie of fome not formerly defcribed plants. Hee alfo fet forth two other bookes, De minus cosnitis, or of leffe knowne Plants : the firft of which was priated at Rome, Anno 1606 ; and the other I 616 . He in thefe works, which in all contain little abone two hundred thircy fix plants, fhewes himfelfe a man of an exquifit iudgment, and very learned and diligent, duely examining and weighing each circumetance in the writings of the Antients. 


\section{To the Reader.}

Cajp. \&ushime. Capar Baubine, a Phyfition and Profeffor of Bafil, befides his Anatomicall Works, fet forth diuters of Plants. Anno 1596 he fet forth his Phytopinax, or Index of Plants, wherein he followes the beft method that any yet found ; for according to Lobels method (which our Author followed) lue begins with Graffes, furhes, \&x. but then he briefcly giues the Etymologic of the name in Greeke and Latinc, if any fuch be, and tells you who of the Antients writ thereof, and in what part of their Works : and laftly (which I chiefly commend him for) he giues the Synonima's or feucrall names of each plant giuen by each la te Writer, and quoteth the pages. Now there is nothing more troubles fuel as newly enter into this fudy, than the diuerfitie of names, which fometimes for the fame plant are different in each Author; fome of them not knowing that the plant they mention was formerly written of, name it as a new thing; others knowing it writ of, yec not approuing of the name. In this Worke he went but through fome halfe of the hiftorie of Plants. After this, Amo I 598, he fet forth Mathiolus his. Commentaries vpon Diofiurides, adding to them 330 Figures, and the deferiptions of fifty new ones not formerly deferibed by any; together with the Synomimn's of all fueh as were deferibed in the Worke. He alfo Anno $161_{3}$ fet fortl Tabcrmanontanus in Dutch, with fome addition of hiftorie and figures. In Anno 1620 he fet forth the Prodromus, or fore-runner of his Thatrum Butanicum, wherein hegiues a hundred and forty new figures, and deferibes fome fix hundred plants, the moft not defcribed by others. After this, Amo I 623., he fet forth his pinax Theatri Botaxici, whofe method is the fame with his Plytopinax, but the quotations of the pages in the fetrerall Authors areomitted. This is indeed the Index and fummeyf his great and generall Worke, which fhould containe about fix thoufand plants, and was a Worke of forty yeares : but he is dead fome nine yeares agone, and yet this lis greatworke is not in the Preffe, that I ean heare of.

Bafl Befler an Apothecarie of Noremberg, Amo 16 i 3 fer forth the garden of the Bithop of Eyftet in Bauaria, the figures being very large, and all curiomly cut in braffe, and printed vpon the largeft paper : hc onely giùcs the Synomima's and deferiptions, and diuideth the worke firft into foure parts, according to the foure feafons of the yeare; and then againe he fubdiuides them, each into three, fo that they agree with the noneths, putting in each Claffis the plants that flourith at that time.

Thefe are the chiefe and greateft part of thofe that either in Grecke or Latine (whofe Works haue come to our hands) haue deliuered to vs the hiftory of Plants; yet there are fome who haue ved great diligence to helpe forward this knowledge, whofenames I wil aloyj.arguill. not paffe ouer in filence. The firft and antienteft of thefe was Aloyfius Anguillara a phyfition of Padua, and Prefident of the publique Garden there : his opinions of fome plants were fet forth in Italian at Venice, 1561 .

Melcbior Git- Melchior Grillandinus, who fucceeded Anguillara in the garden at Padua, writ an A polo: uadiws. gie againft CMatthiolus, fome Epirtes of plants, and a Commentarie vpon threc Chapters of Pliny, De Papyro.

rer. Imperaso. Ferantes Imperatus an A pothecary of Naples alfo fet forth a Naturall Hiftorie diuided into twenty eight bookes, printed at Naples Amo I 599. In this there is fomething of Plants : but I haue not yet feene the opinions of Anguillarn, nor this Naturall Hiftoric : yet you thall find frequent mention of both the fe in moft of the forementioned Authors that writ in their time, or fince, wherefore I could not on it them.

Let me now at laft looke home, and fee whowe haue had that hate taken pains in this will.Twiner. kinde. The firft that I finde worthy of mention is D. William Turner, the firft of whofe works that I laauc feene, was a little booke of the names of herbes, in Greeke, Latine, Englifh, Duteh, and French, \&c. printed at London Anno I 548 . In the yeare $155 \mathrm{I}$ he fet forth his Herbal or Hiftoric of Plants, where he giues the figures of $F u c h$ fius, for the moft part : he giues the Names in Latine, Greere, Duteh,and Freneh : he did not treat of many Plants; his method was aceording to the Latine alphabet. He was a man of good iudgment and learning, and wel performed what he tooke in hand.

Yex, yte. After this, Dodowets was tranflated into Englifh by $M^{\mathrm{r}}$. Lyte, as I formerly nentioned. And fome yeares after, our Author fet forth this Worke, whercof I will prefently treat, haung firft made mention of a Worke fet forth betweene that former Edition, and this Inow prefent youwithall.

Qob.rarkingon. M". Iohin Parkinfon an Apothecarie of this city (yct liuing and labouring for the com. mon good) in the yeare 1629 fet forth a Worke by the name of $P$ arad fus terref $r$ is, wherein he giues the figures of all fuch plants as are preferued in gardens, for the beauty of their floures, for vfe in meats or fauces; and alfo an Orchard of all trees bearing fruit, and fuch thrubs as for their raritic or beauty are kept in Orchards and gardens, with the ordering, planting, 
planting and preferuing of all thefe. In this Worke he hath not fuperficially liandled thefe things, but accurately defcended to the very varieties in each fpecics: wherefore I hate now and then referred my Reader addicted to thele delights, to this worke efpecially in floures and fruits, wherein I was loth to fpend too much time, efpecially feeing I could adde nothing to what he had done vpon that fubicat before. Healfo there promifed another worke, the which I thinke by this time is fit for the Preffe.

Now am I at length come to this prefent Worke, whereof I know you will expeet I thould fay fornewhat; and I will not fruftrate your expectation, bur labour to fatisfie you inall I may, beginning with the Author, then his worke, what it was, and lakly what it now is.

For the Author $\mathrm{M}^{\mathrm{T}}$. Iobn Gerard I can fay little, but what youalfo may gather out of robn Gerardi: this worke; which is, he was borne in the yeare 1545. in Chefhirc, at Namptwich, from whencc hee came to this city, and betookc himfelfe to Surgerie, wherein his endeatours were fuch, as he thcrein attained to be a Mafter of that worthy profeffion: he liued fome ten ycares after the publinhing of this workc, and died about the yeare I 607 . His chiefe commendation is, that he out of a propenfe good will to the publique aduancement of this knowledgc, endeauourcd to performc therein more than he could well accomplith; which was partly through want of fufficient learning, as (bcfides that which he himfelfe faith of himfelfe in the chapter of Water Docke) may be gathered by the tranflating of see the fore diters places out of the Aduer faria; as this for one in the defeription of * Affer Atticus, mer Edition Caules pedales terni aut quaterni : which is rendred, A ftalke foure or fiue foot long. He alfo herementio by the fame defeet called burnt Barley, ${ }^{*}$ Hordeum diftichon; and diuided the titles of ho. ned. nour from the name of the perfon whereto they did belong, making two names thereof, "pag.398. beginning one claufe with ${ }^{*}$ Iulius Alexandrimus faith, \&cc. and the next witl, Cefarius Ar- 8.147 . chiater faith. He alfo was very little conuerfant in the writings of the Antients, neither, as it may feeme by dituers paffages, could hee well diftingnioh betwcencthe antient and modcrne writers : for he in one place faith, $\left[{ }^{*}\right.$ Neither by Diofcorides, Fuchfius, or any other $p .918$. antient writer once remembred.] Diuers fuch thereare, which I had rather paffe ouer in filence, than here fet downe: neither fhould I willingly haue touched hereon; but that I haue met with fome that haue too much admired him, as the only learned and iudicious writer. But let none blame him for thefe defcets, feeing he was neither wanting in pains nor good will, to performe what he intended; and there are none fo fimple but know, that heauy burthens arc with molt paines vndergone by the wcakcf men : and although there were many faults in the worke, yet iudge well of the Author; for as a late writer

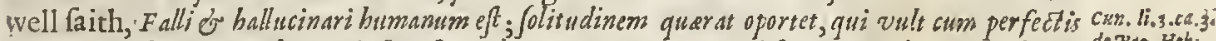

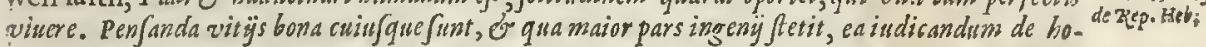
mine eft.

Now let meacquaint you how this Worke was made vp. Dodon.us his Pemptades comming forth Anno 158 , were fhortly after tranflated into Englith by D. Prieft a phy. fition of London, who died either immediately bcforc'or after the finiming of this tranflation. This I had firft by the relation of one who knew $\mathrm{D}^{r}$. Prieft and $\mathrm{M}^{2}$. Gerard: and it is a pparant by the worke it felfe, which you thall finde to containe the Pemptades of Dodona us tranflated, fo that ditiers chapters haue fcarce a word more or leffe than what is in him. But I cannot commend my Author for endeatouring to hide this thing from vs, cauilling (though comnonly vniuftly) with Dodoneus, wherefoetucr he names him, nuaking it a thing of hearc-fay, ${ }^{*}$ that $\mathrm{D}^{\mathrm{r}}$. Pricft tranlated Dodorials : when in the Epiftle of se: lis Epirfle his friend M*.Bredwell, prefixed before this workc, are thefe words: [The firft gatherers to the Reader. out of the Antients, and attgmenters by their owne paines, hauc already fpred the odour of their good names through all the lands of learned habitations : $D^{r}$. Prieft for tranflating fo much as Dodoneus, hath hereby left a tombe for his honorable fepulture. $\mathrm{M}^{\mathrm{r}}$. Gerard comming laft, but not the leaft, hath many waies accommodated the whole worke vnto our Englifh Nation, \&c.] But that which may ferue to cleare all doubts, if any can bc in a thing fo manifeft, is a place in Lobels Annotations vpon Rordeletius his Pbarmaco. peia, where pag.59. he findes fault with Dodloneus, for ving barbarouly the word Seta for Scricum : and with $\mathrm{D}^{\mathrm{r}}$. Prieft, who (faith he) at the charges of $\mathrm{M}^{\mathrm{x}}$. Norton tranflated Dodoneess, and deceiued by this word Seta, committed an abfurd errour in tranflating it a brif:le, when as it thould have bcen filke. This placc fo tranflated is to be feen in the chapter of the Skarlet Oke, at the letter F. And Lobal well knew that it was Dr. Prieft that committed this error, and therefore blames not $\mathrm{M}^{\mathrm{r}}$. Gerard, to whom hee made thew of friendhip, and who was yet liuing : but yet he couertly gaue vs to vnderftand, that the worke wherein that error w ascommitted, was a tranflation of Dodonsus, and that made by

$$
\text { वा था } \quad D^{r} \text {. Priefl }
$$




\section{To the Reader.}

$D^{1}$. Prieft, and fet forth by Mr. Norton. Now this tranlation became the ground-worke whereupen $\mathrm{M}^{x}$.Gerard built vp this Worke : but that it might not appeare a tranllation, he changes the generall method of Dodonsus, in to that of Lobel, and therein almoft all oter followes his Icones both in method and names, as you may plannly fee in the Graffes and orchides. To this tranlation he alfo added fome plants out of Clufius, and otherfome out of the $A$ ducrarit, and fome fourteene of his owne not before mentioned. Now to this hiftorie figures werew anting, which al fo $\mathrm{M}^{\mathrm{r}}$. Rerton procured from Frankforc, being the fame wherewith the Works of Tabernamont azus were printed in Durch: but this fell croffe for my Author, who (as it feemes) hating no great iudgemenr in them, frequently pur one for another : and befides, there were many plants in thofe Authors which he followed, which were not in $T$ abcrnamont anus, and diuers in him which they wanted, yet he put them all together, and one for anotber; and ofr times by this meanes fo confounded all, thatnone could poffibly hate fet them right, vnlefle they knew this cccafion of thefe errors. By this meanes, and after this manner was the Worke of my Author made ${ }_{\mathrm{P}}$, which was printed at the charges of $\mathrm{M}^{ }$. Norton, An. 1597 .

Now it remaines I acquaint you with what I haue performed in this Edition, which is either by mending what was amiffe, or by adding fuch as formerly were wanting: fome places I helped by purting out, as rhe Kindes in the Chapter of Stonc crop, where rhere was burone mentioned. I haue alfo put out the Kindes in diuers p!aces elfe where they were not very neceffarie, by this meanes to get more roome for things more neceffarie: as alfo diuers figures and defcriptions which were put in two or three places, I haue put them out in all butone, yet $\int 0$, as that I alwaies giue you notice where they were, and of what. Somewords or paffages are alfo put out here and there, which I thinke needleffe to mention. Sometimes I nended what was amiffe or defectiue, by altering or adding one or more words, as you may frequently obferue if you compare the former edition with this, in fome few chapters almoft in any place. But I thinke I thall beft fatisfic you if I briefely fpecific what is done in each particular, hauing firft acquainted you with what my generall intention was : I determined, as wel as the fhortneffe of my time would give me leaue, to retaine and fet forth whatfoeuer was formerly in the booke defcribed, ot figured without defcriptions (fome varieties that were not neceffarie excepted) and to thefe I intended to adde whatfoctier was figured by Lobcl, Dodonaus, or Cluffius, whofe figures we made vfe of; as alfo fuch plants as grow either wilde, or vfually in the gardens of this kingdome, which were not mentioned by any of the forenamed Authors; for I neither thoughr it fit nor requifite for me, ambitioully to aime at all that Bathine in his Pinax reckons vp, or thc Exotickes of Profper Alpinus containe, nor mentioned in the former. This was my generall intention. Now come I to particulars, and firt of figures : I hauc, as I faid, made vfe of thofe wherewith the Workes of Dodonems, Lobel, and Clu fuss were formerly printed, which, though fome of them be not fo fighrly, yer are they generally as truly expreft, and fometimes more. When figures not agreeable to the defcriptions were formerly in any place, I gitue you notice rhereof with a marke of alteration before the title, as alfo in the end of the Chapter, and if they were not formerly in the booke, then I giue you them with a marke of addition. Such as were formerly figured in the booke, though put for other things, and fo liauing no defcription therein, I haue caufed to be new cur and pur into their fit places, with defcriptions to them, and only a marke of alteration. The next are the defcriptions, which I haue in forme places lightly amended, without giuing any notice thereof, but when it is much altered, then gitie I you this marke $t$ at the beginning thereof; but if it were fuch as thar I could not helpe it but by writing a new one, then fhall you finde it with this marke $\neq$ at the beginning and end thereof, as alfowhat foeuer is added in the whole booke, either in defcriptionor orherwife. The next is the Place, which I hate feldome alrered, yet in fome places fupplied, and in others I haue put doubts, \& do fufpect otherfome to be falfe, which becaufe I had not yet viewed, I left as I found. The Time was a thing of no fuch moment, for any matter worth mentioning to be performed vpon, wherefore I will not in fift vpon it. Names are of great importance, and in them I fhould haue been a little more curious if I had had more time, as you may fee I at the firft hate beene; but finding it a troublefome worke, I hatre onely afterwards where I iudged it moft necdfull infifted vpon it: B aubinus his $p_{i_{-}}$ wax may fupply what you in this kinde finde wanting. In many places of rhis worke you thall firde large difcourfes and fometimes contiouerfies handled by our Authour in the names; thefeare for the moft part ont of Dodoneus, \& fome of them were fo abbreuiated, and by that meanes confounded, that I thought ir not worth my paines to mend them, fo I haue put them out in fome few places, and referred you to the places in Dodonems out of 


\section{To the Reader.}

which they wete taken,as in the chapter of Alehoofe : it may be they are not fo perfect as they. Thould be in fome very few other places, (for I could not compare all) but if you furpect any fuch thing, haue recourfe to that Author,and you thall finde full fatisfaction.

Now come I to the Iemper and Vertues. Thefe commonly were taken forth of the fore-mentioned Author, and here and there out of Lobels Obferuations, and Camerarius his Hortus medicus. To thefe he alfo adddedfone few Receipts of his owne: thefe I haue not altered, but hete and there fhewed to which they did moft properly belong; as alfo if I found them otherwife than they ought, I noted it; or if in vnfit places, I haue tranffetred them to the right place, and in dituet sthings whercof out Author hath bin filent, I haue fupplied that defect.

Fot iny additions I will here fay nothing, but refer you to the immediatc enfuing $\mathrm{Ca}$ talogue, which will enforme you what is added onely in figure, or defeription, or in both, by which, and thefe two formerly mentioned marks, you may fee what is much altered or added in the Work; for th is marke t put eithet to figure,or before any claufe, thews it to hate bin otherwife put before; ot that claufe whether it be in defcription, Place, Time, Names, or Vertues to be much altered. This other marke $\ddagger$ put to a figure fhewes it not to baxe been formerly in the worke, but now added; and put in any other place it thewes all is added vntill you come to another of the fame marks. But becaufe it is fomtimes omitied, I will therefore giue notice in the Errata where it thould be $\mu$ tt, in thofe places where I obferue either the fotmer or later of thern to be wanting.

l'urther, I muit acyuaint you how there were the defcriptions of a few plants here and there put in vnfitring places, which made me deferibe them as new added, as Saxifraga maior eAiattbioli, Perficaria filiquofa, of which in the chapter of Perficaria therewas an ill defeription, but a seafonablegood one in the chapter of Af trantis nigra.P apauter pinofum, was figured and defcribed among ft the $C$ ardui; now all thefe (as I faid) I added as new in the moft fitting places; yet found them aftetwards defcribed, but pur them out all, except the laft, whofe hiftorie I ftill tetaining, with a reference to the preceding figure and $\mathrm{Hi}$ frorie. Note alfo, wherefoeuer my Authot fotmerly montioned Clufuns, according to his Spaninh or Pannonicke Obfernations, I haue made it, according tolis Hiftorie, which containes them both with additions.

Alfo I muft eertifie you, (becaufe I know it is a thing that fome will thinke ftange, that the number of the pages in this booke do no morc exceed that of the former, confidering there is fuch a large acceffion of matter and figures) the caufe hereot is,each page containes dituers lines more than the former, the lines themfelues alin being longer; and by the omiffion of deferiprions and figutes put twice or thrice ouer, and the Kindes, vnneceffarily put in fome places, I gainked as much as conucniently I could, beeing defitous that it might be bound together in one volume.

Thus baue I thewed what I haue performed in this Worke,enttcating you to take this my Labor in good part; and if thete be any defeet there in (as needs there mult in all humane works) alcribe it in part to my hafte and many bufineffes, and in fone places to the wane of fufficient information, efpecially in Exoticke things; and in other fome, to the little conterfation I formerly had with this Author, before fuch time as (ouetcome by the importunitic of fome friends, and the generall want of fuch a Worke) I tooke this taske vpon me. Furthermore l defire, that none wo dld rafhly cenfure me for that which I haue bere done ; but they that know in what time I did it, and who themfelues are able to do as mueh as I hate here performed, for to fuch alone $i$ thali gitue free libertie,and will beas ready to yeeid further fatisfaction if they defire it, concerning any thing I haue here afferted, a: I thall be apt to neglect and fcorne the cenfitre of the Ignotant and Vnlearned, who I know are ftill forward to verifie our Englifh prouerbe *

I muft not in filenee paffe ouer thofe from whom I haue receitued any fauour or incouragement, whereby I might be the better enabled to performe this Taske. In the firft plaee let me remember the cnely Affifant I had in this Worke, which was $\mathrm{M}^{\mathrm{r}}$. $10 \mathrm{hn}$ Goodyer of Maple-Durham in Hampihire, from whom I receited many aceurate deferiptions, and fome orher obferuations concerning plants; the which (defirous to gite euery man his due) I have eaufed to be fo printed, as they may be diftinguined from the reft : and thus you thall know them; in the beginning is the name of the plant in Latine in a line by it felfe, and at the end his name is infetted; fo that the Readet may eafily finde thofe things that I had from him, and I hope together with me will be thank full co lim, that he would fo readily impart them for the further increafe of this knowiedge.

M*. George Bonles of Chiffelhurft in Kent muft not here be fotgot, for by his trauells and induhry I hauc had knowledge of diutets plants, wh hich wete not thought nor formerly 


\section{To the Reader.}

knowne to grow wilde in this kingdeme, as ycu thall finde by diuers places in this took. Yhosras Hiches My louing friends and fellow Ttanel lers in this ftudy, and of the fame rrofeffion, whofe willians Broad. companie I hate formerly enioyed in fearching oucr a great part of Kent, and whoare Job weale. . A ill ready to do the like in orher places, are here alfo to be remembred, and that the raner. rames clarke. neglected, efpecially by thofe towhom it did chiefely belong, and who ought to be afhamed of ignorance, efpecially in a thing fo abfolutely neceflatic to their profeffion. They fhould indeed know them as workemen do their tooles, that is readily to cal them by their names, know where to fetch, and whence to procure the beft of each kinde; and laftly, how to handle them.

I hate alrcady much exceeded the bounds of an Epifte, yet haue omitred many things of which I could further haue informed thee Reader, but I will leaue them vntill fuch

time as I finde a gratefull acceptance; or fome orher occafion that may againe inuite me to fet Pen to Paper; which, That at may be for my Countreyes good and Gods glory, thall cuer be the prayers and Endeatours of thy Well.

Wirher

Frows my houfcon Snow-hill, 0 tob.22.1633.

THOMAS IOHNSON: 


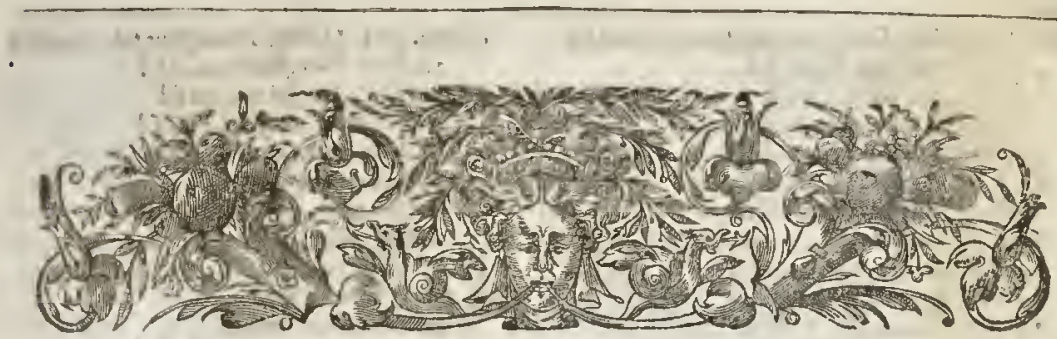

\section{A Catalogue of eAdditions.}

$\mathrm{B}$ Ecaufe the markes were not fo carefully and right put to thefe Figures, which were Bnot formerly in the booke, I haue thought good to giue you the names of all fuch as arc added, either in figure or defeription, or both : together with the booke, chapter, and number or place they hold in each chapter. $F$ ftands for figure, $D$ for Defcription, and where both are added,you thall finde both thefe letters; and where the letter $C$ is pur, the Hiftorie of the whole Chapter is added.

\section{B O OKE: I.}

Hap. 2. 3. Gram.min.rub. froe Xerampelinum, f. Chap.5: 3. Gram arundminus $D_{i f}$.

Chap. 6. Gram toment.arkndix.f. 2.Gram. pars, elegans d.

Chap. 8 3. Gram,typhoides fpica longifod.

Chap.13. 3.Gram. Tanic. ficic. fimp.d,

Chap.14. I Gram.pal.echin.t.

3. Gram capit glob.d. 4.Gram.mont.echin.d.

Chap. 16.8.Gram.oyper.pie.d.

Chap. 20,3.Gram.dactyloides. fod.

Chap.2 I. 1.Gram.Cyp.ang.msi.fd

2.Pferdocyperis, f.d.

C. 3.Cyperses long.inad.f.d.

4.Cyperis rot.snod. $\mathrm{fd}$ 5 Cyper.Gram.milf.d.

Chap. 22. I Gram,mont. asen.f.d. 2. Grammuror spic.long.f.d. 3.Gram.criftatum.f.d. 4. Gram fpice fecal.d. 5.Gram. fpoct. Eriza d. 6. Grem. lanatum d.

C. 7 Gram isno.lestcasth,d 8 Gram.Loliac.min.d. 9. Gram.lold.d. I 0.Gram. partesm min.d I i.Gram.alopecur. Sp.afpera.d. ( I2.Gram.foparsum. d.

Chap.24.3.Cyperus rotund. Syriacus.d. 4.Cyp.min, Cret.d. 5.Cyp.rotsnd,snodorus.f.d.

Chap.2 5. Cyp.efsulentit.d.C.

Chap.26.Galings maior.C. Galanga misor.C.

Chap.27. C)permindicu.C.

Chap.28.Zedoaria.C.

Chap.29. 5. Izsncus cap.Equif.f.d,

Chap.34.5.Spartisn nofopar.f.d. 6 Spart e Austriacsm.t.d.

Chap. 39.4 Phalinoinmanila.f.d. 5.Phalaso.Virgin.f d
Chap.42. 4. Tris Byzantina,d. 7.Iris flacerul.objolof-d. 8.Chamairis nimea, F.d. 9.Chansair olat florub.f.d. Io.Chameir.tur.f.d. Is Cham, variegar.t.d.

Chap.45. 3.Calamus aromat.f.d.

Chap.63.3.Panicum Americanum, $\mathrm{f}_{0} \mathrm{~d}$.

Chap.64.3.Thalar prat.alteraf f

Chap.65. 2. Alopecuros Anglica.pald.

Chap.68. 2 CMelasupyrumpurp. f d 3 Melampyr.cernilfd 4 Uselasopyr. Lwt.fd

Chap.70. 5 Asphodelus minimis, fd

Chap. 7 Y Aphod.Lanc.ver. Fd

Chap.74. I Iris bulbofa Lut.Fd 4 lri, bulb. virficol, $\mathrm{d}$ 6 Iris bulb.flo.cin,fd 7 Iris bulb.flo.alb.f d

Chap.75 2 Sifynrichium mintes, f

Chap. 64 Gladiolus lacestris ofd

Chap. 772 Hyacintbus ftel allbicons, ff 3 Hyacenthus 5tel.bifol.f d 6 Hyac.ftel.Byzant.f d 8 Hyacfiel. Som.fd o Hyac.felosft.mai.f d Io IIyac. fteloest min,fd I 2 Hyec. Perwo of d

Chap. 78 i Hyac.ffel.ver.d.

Chap.79 6 Hyac. Or.polyanth.f d 7 Hyac.Or.pesrp. Fd 8 Hyac.Or.alb.fd o Hyac. Brsmalus, fd Io Hyac.Or. anule foliofo, fd II Hyac. Or.Ao.pleno, fd 12 Ifyac. Or.flo.cerul.pleno. Fd 13 Hyac.Or. flo.cand plen, $\mathrm{fd}$ 17 Hjac. objolet.fla Hifp.fd 15 Hyac. zrin. Hifp. f d 36 Hyac.Indiuber.f d

Chap. 80 i Hyacinthuscom. Byzant.f 4 Hyacenth.com. ramofus.d 5 Hyacimh com rams eleg. fd

$$
\text { व } 913
$$




\section{Additions.}

Chap. 84.4 Natc If medio-croceres ferot.polyanthof d 5 Narc.medro parp.flo.plen.f d

II Nare. flore pleso albo, fd

I 2 Narc.flo.plen, mediolst, $\mathrm{Fd}$

13 Narc. flore plenamed.verfic. fd

x) Narc, inncifol.rofeolut. Fd

I\& Narc. inncifol.amplocal. fd

Io Nurc.iuncifol.reflex flo alb. fd

o Narc. isncifol.reflex.min.fd

20 Narc. suncifolmult. fd

$2 ;$. Narc.vernus prac. flam. $\mathrm{fd}$

Chap. 8 s.3 Pfendonarciffus Husp. f

4 Pesdonarc. mro.hsfpan. fd

5 P ewdonarc.albo flore td

CClnap.86.1 Narct.omvism maximus fd 2 Narct.onutt. Roburi. d

3 PSexdonarc. floopleno o d

4 Nartif.wilmos.d

C. Narc.Tradefcant.d

Narc.Parkinfondd

5 Narcif.Iacob. Indicus fd

6 Narcifousucifol,mont.min.f d

7 Narc, mont.issncifol fore fimbriato ofd

8 Narc,oninimm.mimomont.alb.f d

Chap. 87. Tsliparam fig.23.

Chap. 88.2 Lencoimm bolbofum precox Byzantofd 5 Lencosum 6ulb. Aur. miss.f d 6 Lers.bsolb.2ern.min.d

Chap. 80.3 Fritillariae Aquitar.min.flo.obfol. fd. Fritrallallopracex fd

Cum nominabus of notis nossem alsarkn wariesatum.

Chap.90.3 Crocus vernus flo.lut of

4 Crocus vern flo.albof

5 Crocus vern.flo.purp.f

6 Croc.mont. Antum.f

Croc.mon. Autum. flo maialbid carul fd

8 Cracies Autum.flo.all.f

9 Crocus vernus angustifol.flo.viol.f d

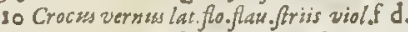

11 Croc.vern.Lat. Arrat. flo. dupl.d

Chap. 915 Colchecum montansm min, verfic.flo, fd ${ }_{2}$ Colchicsm lastrolisum. fd

Io Colchicsm verfic. florefd

II Colchicum.fo.pleno of d

12 Colchscem biflor fd

I 3 Colchicum vernum $\mathrm{fd}$

${ }_{4}$ Colchickm variegat. Chienfe fo d

is Hermodultyls offic. fd.

Chap.92. 4 Ornithogalum b: forn.miviu. fd 5 Ornithogalwm lutesm misw if 6 Bribus vinifolins fd

y Ormshogalum maiss Arabiewm fo

80 rnishogalwom fpicat un fd O Ornsthogalum Neapolicanumf

Chap.93.3 Cepatiefrasices oblonga fd 4 Afcalonitides ot d.

Chap. 4 I Serlla Herpanica vulg.fd 6 Narcrffus tertus Matbioli.f d

Chap.95 Porrum fectivsmast confile fd

Chap.g6 3 Ampeloprafor, five Porram fyltf d

Chap.97.2 Allium Jyl.rubent .nsl.f d

Chap.99.2 Scorodoprassm primums Clms. . 3 Scorodoprafum minus fd 4 Ophiofcorilon id

Chap. I00.6 Moly lat folikm flore flaws. fd. 7 Moly minus flo albo.fd
Chap. IOI. I Moly Narcifsinis foliss prim of d 2.C Moly Nare. foliis secund.f d 3 Moly Narc. fol tertium fd 4 Moly monr. latifol. I Clas.fd

C.5 SCMoly mont. fecund.Cluf.5d 6 Moly mont. 3 Clwf.fd 7 Moly mont 4 fpec.I Clisf.fd 8 Molymont.4 Jpec.2.Clus.fd - Moly mont 5 Clar.f.

Chap.I 03.2 Lilimm rsbrum, f ${ }_{4}$ Liliwm crsentum bulbif.f

5 Lil.cruent. fecundum carl.bulb.dor.f. 6 Lalism parparesm minus fd

Chap. $10_{5} 2$ Lilism Byzantinum flo.purpur. Sang of d 3 Lilimm By zant flo deluste rwbent. Fd ${ }_{4}$ Lilism Byzant.miniatrm polyansh, fd

Chap. 10G.I Lulism rubrum anguffiff fd 2 Liliums rubrsm precex.d

i Lilium mont.Flo. Flav.purtt. Fd

4 Lilimm mont flore flavo non prenti.f

Chap. I 10.5 Cynnforches minor. Pannon of d

Chap. 111.3 Cynoforches mmominor. fd

Chap.112.4 Tragorchis minor Batasicafd

Chap. I1, I, Oichestrifol.mixar.f d 16 Oiches anguff fol.d

Chap.I 19.3 Orches palmata Parror.8.Clufff d

Chap. 116.9 Serap!as Batrachites alteraf d a

Chap.I I 7. 5 Palma Chrtfis max.fd

Chap. I18.2 Nidus asis flore or casle violat.d

$$
\text { LI B } 2 .
$$

Hap.r. 2 Rapssaradiceoblongaf d Chap.2 .2 Rapifrums arveste als. fd

Chap. .1 Bunias,

2 Burias Syl.Lobelis f

Chap.5.I Raphanss fativus $\mathrm{f}$ 2 Radecula jat wrin.

Chap.7.3 Lepidimm annuим fd

Chap. 9. I Sirapifativwm, f

2 Sinapi valgared

3 Sinapifat.alt .f

4 Sinapralbsm, fd

5 Sinapifyl.minss $\mathrm{E}$

Chap. 10. I Eruca Jativa, f

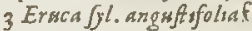

4 Ersca Nafturtia cognt tentifolef

5 Erwca noarina f

6 Eraca aquatica, d

Chap. I 5. 2 Eryfimsm alterum Iralic ums,

Chap, 17.2 Sinm maims anguffifol.d 3 Sum vmbellatum repens d

4 Sism altersm $O$ lufarri facie, fd 6Sism Mathbiol: of Italf d

Chap. I 8.3 Cardamine alicra flo.plero fd 7 Stam muns impatiens, $\mathrm{fd}$ 8 Cardamine pumila Bellidis fol,fd

Chap. I0.6 Thlospi amarsms d

Chap. 20 Thlaspi Cand.flo,alb. fd

Chap.21.8 Thlafpi perr entm minus, fd

Chap. 22 . 4 Th haspi ifrutico fum folio Lenc.mat of 5 Thlafpi hederacenm, fd

Chap.23.2 Turrtis mator f d

FChap. 24. I Draba Diofcoridiofd

2 Drabaprima repersifd

C. 3 Draba alterarepens $\int d$

24 Drabafive Arubis quorwndam.d

Chap.27.3 Erigeron tomentofum alteram, td 


\section{Additions.}

Chap.28.2 Iacobea angusfifolia, $\mathrm{fd}$. . 3 facobara latifolsa.td

Chap. 29.5 Cicborim Jping fom of d

Chap. 3 1. 3 Chondrilla lited,

4 Chondrilla Hipanica, $\mathrm{f}$

C Cichorium verrucarium of

Chap. 32.3 Densleonis bulbofus, fd

Chap. 33.2 Sonclisus apersor of

5 Sorchus lauis muralis, $\mathrm{fd}$

6 Sonchres lawis angulitef. d

9 Sonchns arborefcess alt.f

ro Sonchresfluaticus d

Chap. 34.9 Hicrscism falcatsm alterwm.f d

Chap. 35.5 Hieracisum porvum Creticum.fd 6 He racinm Dentis Leonis folio birft d

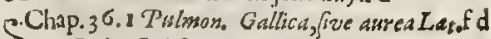

C.8) 2 Pulm.Gal.froe aur.anguftiff. C. 3 Hieracobost.lnteff d CChap. ${ }_{3} 8$. I Lactaca fylmai.f d

C.8 2 Latucugl, minor fol.integris.d \&. 3 Lattuca fyl.fol.diffect.fd

Chap.72.3 Betarubra Romanef

Chap. $4 j_{0}$ I Blarises mainus alb.f 3 Blirum minus alb.f 4 Blitum minus rubrum ff

Chap.44.5 Amaranthuspamicula incurvaboloferica:'td

Chap.45.3 Atriplex fyl.juse Polygermon.d s Airip.jl.vuloaris.f d

6 Astip.y laklera,t d

7 Arriposplasingultifol.fd

8 Atrip.baccifera.fd

Chap. 4.1 Atrip. Jllolatif.f 2 Atrup fylalatif.alt.fd

Chap.52.I Cyrocrambe of 3 phyllon sbelygon.d

Chap. 54.2 Scorpiozdes CMatth.f

Chap.55.2 Solanum fomniferum.fd

Chap.58.2 CKirwbiliaperwv. flo.alb.f

Chap.66.3 Hyofcyamus alb.min,f d 4 Hyojcyanus alb. Cret.fd 5 Hyofcyamres flo.rub.id

Chap. 883 Tabacum min.fd

Chap.7 5.2 Capjicum rotundior.filig.f cum 12. alisvarietatibus.

Chap. 72.3 Papaster cosniculat um phenic. glab. Id

Chap.73.3 Papauer findriatumalbum. id 5 Papaver fylfd

Chap. 76.7 Anemose lasifolia duplo flawo flore

CChay.77. Anemone latif. flo.cocciss, fd $\mathrm{fd}$
2 cAnem.latif.flo.mag.coccin. [d
3 Anemdatif. Byzant fo d
4 Anem.ten.flo.ampl.jang.f fd
C. 5 Anerntex.flo.Coccin.t 5
6 eAnem.ten.flo.dilute purp. fd
7 Anem.tenflo.exalb.t d
8 Anem.ten.flo.cerul.friat of d
2 Anem.zen.flo plen.coccin.f d
10 Anem.ten flo.atropkrp. fd

Chap.78. 3 Anem.nemorum.fo.pleno alb. 4 Anerinem fla.pleno. purp ofd

Chap. $79 \cdot 4$ Pulfatilla Floreminore.f d 5 Psilfatil.flo.lust.d

Chap.8 1.z. Lapathum.fyl.folminadcuso ofd

Cliap.82.5 Lapathum fat ivmm.jang.f.
Chap. 83.2 Rha capitat um angustif. $\mathrm{fd}$ $3 \mathrm{kba}$ versm antíg.t d.

Chap:87. 3 Ophris bifolia bulb.fd

Chap. 83.2 Opbiogloffon abortivem. $f$

Chap.8. 3 Lunaria mir.ramofa, fd

Chap.90. 2.Pyrala 2 tenerior. Cluf.t d 3 Tyrola 3 fruticans Cluf.td 4 Pyrola 4 mira.Cluf of d

Chap.92.3 Limeanium folio finuaro. ff 4 Limonio congeser Cluf.t d

Clip.93.2 Tripolium vulg.twin f

Chap.96. 2 P lansago aquat miror ftel. $\mathrm{fd}$

Chap.97.6 Plantago panricelis parfis.fd.

Chap.95: 4 Holosterm fine Leontopod, Cret.fd 5 Holuft. five Leonzod. Cresuale tid

Chap. 104 Herba Dorea Label,f

Herba Dorea alisera d

Chap.105. 2 Gentiana min.purpo.fd

Chap.107. I Gentianella verna maior of $d$

C. $\left\{\begin{array}{l}2 \text { Gent. Alpin.vern.d } \\ 3 \text { Gent.fus min.d }\end{array}\right.$

$\left\{\begin{array}{l}3 \text { Gent.funar min.d } \\ 4 \text { Gent.fngax maid. }\end{array}\right.$

Chap. 109.2 Spiculum Veneris ntinus $\mathrm{fd}$

Chap. I I .2 Calceolus Mariealter ofd

Chap.I I 4 - 3 Perficariapufolla riepess.f

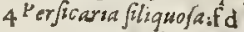

Chap. I 16.5 Trachelsum maizs petrinm $\mathrm{fd}$

Chap. I 17.7 Campanwla (jimbalarice foldd

Chap. II S, 4 Rap!enculies Alp.Corniculfd 5 Rapuncslus cornic.monifd 6 Rapunculus faxatulus, $\mathrm{fd}$...

Chap. IIg. 4 Leacoium fyl. d 5 Lese.luterm flo. ampl.d 6 Lescoinm Floolbo-d

Chap 120.2 Lencoinm flo.mulsiplifd 3. Lewcarmm fpinofum Cret.f d

Chap 121.2 Leucoium marinum purp.d

Chap. $122,2 V$ sola matronalis flore, multipl.d 3. 4 Viona Mat. Flo.obfol.five Lexcoism Melareholicum ofd

Chap. I 24.2, Aly fym Diofcoridisf

Chap 126.3 Lychus Caronaria mult.f d

Chap. 127.1 Lyclonis Syl.rub.Flo. ff

Chap.127.7 Lychnis caliculis friat is 2. Cluf.d 8 Lych.fylal6.9.Clus.d

Chap.128.1 Lychnisfyl multipl.purp ofd

2 Lychnis fyloalba mult .fd

C. 3 Lychnis abortiva fle.malt, virud.f d

${ }_{4}$ Lych. flolat. Clinf.f d

5 Lych.mont.repens fd

Chap. 129.2 Lyfimachra lutea min. $\mathrm{fd}$

3 Lyfrnachia lut. Flo.glob. fd

4 Ly frssacbia lust.virgin.f d

7 Chomenerion f

8 Chamenerion alt.angu/thf.fd

9 Ly frmachia coritea.f

Io Lyjimatbia galericulasa. $\mathrm{f}$

I Ly/muchia parpominor.fd

Chap.131. I Coniza masor.fd

C 2 Conizamin.f d

C) 3 Coniza media,d

C.IR 4 Coniza minim,d

c) 5 Coniza folys lacin. $\mathrm{fd}$

6 Coniza paluftris ferratifol.d

7 Coniza Auft.Clnffd 


\section{Additions.}

8 Coniza incasa, f.d.

9C oniza eAlpisa pilofisf. f.d.

10 Coniza carules acris, f.d.

Ch.1 32.2 After Izal.f.d. 5 After Conizoides Gefn.f. 6 Afer lme. Jup. Cluf. $\mathrm{F}$.

7 After lut. fol. fuccifa, $\mathrm{f}$.

8 After falicis folio, $\mathrm{E}$.

2. After Anftrsacus 5. Cliv. f.

10 After 6. Cluf.f.

11 After T. Cluf.f.

12 After Virgimas. finticof.d.

13 After fruiscofus minor, d

Ch. 133. Glastum fylueftre, f.

Ch. 135.2 Sefamoudes Salamantscams parvm, d. 3 Sefamoides parvessm Maxth.d.

Ch. 139.10 Tithymalus characias anguft folof.d. 11 Tithymalus eharacias ferratis ol.t.d. 12 Tithym.lines dendroides ex cod. Caf. fo 17 Efula exigusa Tragi,f.d.

23 Apios radice oblong a, t.d.

$\mathrm{Ch}_{1} 1+1.1$ Aloc vulgar is, $\mathrm{f}$.

Ch. I 4.2. 2 Sedum masus arborefcens, f. 5 Sedrma mains angufis fol. $f$.

Ch. $143 \cdot 3$ Sedum minses aftivam, fo 4 Sedum misus fio. amplo.f. 5 Sedum mediumsteretrfolism, fod. 6 Aizoon Seorpioides, f. Sedurm Porllandicum, f.

8 Sedum petressm, $\mathrm{f}$.

Ch. 144.1 Sedum mixus palustre, f.d.

\{ 2 Sedum Alpissm I Cluf.f.d.

C 3 Sedum Alptnsm 3 Cluf. f.d.

4 Sedum Alpensm 4 Clus. f.d. 5 Sedum petrenm Buplewri folio, fad.

Ch. I $47 \cdot 3$ Telephism legitimum Insperati, f.d.

Cha. 4 49. I Halimus bast folins, fo.

2 Halimus angufts fol.procumbens, fo

3. Halimus vulgaris, d.

4 Vermicularis frusex minor, $f$.

5 Vermicularis fitex major, $\mathrm{f}$

Ch.150. 5 Chamapizys puria alt. Dod.f. 6 Chamapitys Auftr. f.

Ch. 55 1. 2 Vmbelicus ver. fine Cotyloalo fo 3 mosliess ven. min.d.

4 Cotyledon min. mont, alt. f.d. 6 Cymbalaria lealica, f.d.

Ch. 155.2 Kali masus fem. cochleat o, f 3 Kali minus, $\mathrm{f}$.

Ch.1 57.2 Cerintbe aperior flore finno, f.d.

Ch.158. 3 Hjperienm tomentofism Lob.f.d. 4 Hyperiesm fupinum glabrum, f.d. 5 IYyericum pulehrum Trags,d.

Chap. 159.2 Afcyron supinum palustre, d.

Ch. 160.2 Androfemsm bypericosdes, f.d.

c. $\{\mathrm{Ch}, 161.1$ Coris Matth. f.d.

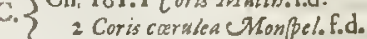

Ch. 162.2 Centaritism mains alt. $\mathrm{E}$

Ch. 164.5 Antirrhinum min. repens, $f_{1} d$.

Ch. $165 \cdot 3$ Limaria purp. als.f. ${ }_{4}$ Linaria Valentima Clmf.f. 7 Ofyris flassa Jyl.f $\mathrm{d}$.

$\$$ Linaris quadrifol. Jupina, d.

12 Paferina linaric folio, $f$.

13 Pafferina altera,d.

14 Linaria adsiterina,

Ch. 1 66. Linкаafativam,
Ch. 107.3 Linsm fyl.latifol.f.

5 Linum fol. catharticam, f.d. 6 Linum gl. latifol. 3 Clug.d. 7 Linkm marinum lut. f.d.

Ch.170. 3 Polygonsm marinum max.d.

Ch. I71.2 Ausbyllis Valentina Clwf.fo. 3 Polggonsm ferpillifolinm, f. d. 5 Sarifraga Anglicana alfonefolia, d. 6 Sa.vifrag a paluftris alfonefolua, f.d.

Chr.1 72.2 Millegrana minima, t.

Ch.173. 7 Serpillsm citratsm, f. 8 Serpillum hirfutum, f.d.

Ch. 175.4 Satureia Cretica, f.d.

Ch. 177.5 Hyfo pus parua anguft. folys, f.d.

Ch.1 78. 2 Gratrola augastifolia, f.d.

Ch.1 80. 4 Stachas fummis canlic, nudis, f.d.

Ch. 182. Caryophyll.jig. 4 .

Ch.18 . Caryophy Rl.plum, albus odorat. f.d. 8 Caryophyll. pumil. Alpinus, fid. 11 Caryophyll.prat.f.

13 Cary phyll. mont . hum. Lat. fo 14 Caryopbyll.mont alb.f.d.

I 7 Caryophyll.hum. flore cand ameno, f.d.

Ch.184. 5 Armeria prolifera, Lob.d.

Ch. I 85.3 a Armeria prat. Alo.pleno, f.

Ch.186. 3 Mufcupula anguffifol, f.d.

c. 5 Ch.188. I Saxifrag.mag. CMat. E.d.

. $\{2$ Saxifrag. antig. Lob.f.d.

Ch.18g. 4 Ptarmica Imperati, d.

Ch.I I. 3 Litholpermsios Anchuse fac f. 4 Anchufa degener, $f$.

Ch. 10211 Alline rotundifolia, f.d. 12 Alfone paluft. Serpillefol. f.d. I3 Alfine baccifera, f.d.

Ch. I94. 3 Anagallis tensifol. f.d.

Ch. 105.3 A Anagallis agrat. rotwndifol. f.d. 4 Anagallis agrat. 4 . Lob. fod. 5 Cepar, f.d.

Chi1g, I Antbyllis lentifolia, $f$ 2 Anehyllis matrina incana, fo 3 Antbylis alsera ltalorum, d.

Ch. Ing. 5 Veronac a frut icams ferpilifol. f.d. 7 Veron. picata lat.d.

8 Veronica Jupina, f.

Ch. I,8. 3 Nummularia flo.purp of.d.

Ch.205.8. Guaphalism Anmericarnom. f. 13 Graphaliam oblong o folio, f.d. $I_{4}$ Graphalisus minus lat. fol, f.d.

Ch. 207. I Staches citrina, f. 2 Amaranshus luteus latis old.

Ch.208. 3 Agerat um folys non ferratis, $f$ 4 Ageratum floribus albis, f.d.

Ch. 209.4 Tanacetum un odor, masins, f.d.

Ch. 2 10. 3 Matricaria Alpina Cluf. $\mathrm{f}$.

Ch.211. 5 Polism lasasdrlce folio, f.d.

Ch.213. 3 Teucrism maius Pann.f.d. 4T Teucrism petraum prmil. f.d.

Ch.215. Scorodonia,f.

Ch. 210. 3 Tragorigasum Cretenfe, f.d.

Ch. 221, I Pulegism reginm, f. 2 Psilegines mas, $\mathrm{f}$.

Ch. 222.4 Ocimum Indisam, f.d.

Ch.223. 3 Corchores, fo.

4 Acinos Anglisum Clinfij, d. 5 Clinopodimm Anftr.f.d. 6 Clsnopodism Alpinum, f.d. 7 Acinosodoratiff.d. 
Ch. 225.4 . Mextba cardisca, $\mathrm{f}$. Menthappicataslt. f.d.

Ch. 227.3 CMentaftrm, f.d. 4 Mentaftr. niv. Angl. f.d. 5 Ment aftrum minus, f.d. 6 Mentaftr. mont. I Clsh/. f.d. 7 Mentaftrum eriberof. rad. Clm. f.d.

Ch. 229.3 CMelis]a Fuch. flo.alb. o purp.f.2. 4 Herba Indaica Lob.f.

Ch. 2 1. 3 Stachys stinofa Cretica, f.d. 4 Stach is Lufitan. f.d. 5 Sideritis fcordioides, $f$. 6 Sideritis Alpina Hyfopifolia, $\mathrm{f}$. CCh.232.t Sideritis vulgaris, f.d. 2 Sideritis anguffifol.f.d.

${ }_{3}$ Siderit is procumb. ramoja, f.d.

C. 4 Siderit is procumbens non ramofa, $\mathrm{f} \cdot \mathrm{d}$. 5 Sidertis bamilis laso obrufo folio, $d$. 6 Saderisis latifolia glabra, f.d. (7. Sideritis arvenfis flo.rub.d.

Ch.233. Marrubium aguat.f.

Ch. 234.2 Marrubium nigrum longifol.f.d.

Ch. 235.2 Lanium Pannon. £. 5 Galeopjis vera, f.d. 6 Lamew Pannon. 3 Clis. F.d.

Ch.238. 2 Cansabis fam. $f$.

Ch.239.2 Cannabis puria alt. f. 3 Cannabis puria ters. F.

Ch. 240. 2 Empat. Cannabinum mas, $\mathrm{f}$.

Ch.245. 5 Scrophularia Ind. f. 3 Scropbularia flo o lus .f.d.

Ch.247. 2 Scabiofa rubra Anftr.d. 8 Scaboofa mont. alb. f. d. 13 Scabiofa min. Bellidis fol. f. d. 14 Scabiofa flo. pall.d. Is Scation a prolifera, f.d. 16 Scabioga rubra Indica, f.d. 17 Scabiofa aftivalis Cluf.f.d.

Ch.249. 7 Iacea Auftr.villofa, f.d. 8 Iacea capitulis birfut.d

Ch.250. 4 Stabe Rofmarinifol.f.d. 5 Stabe ex Cod.Cefar.f.d.

Ch.251.9 Cuarus repens latifol. F.d. Io Cyannes repens angustifol.f.d.

Ch.253.4 Viperaria angaffifol. elatior, $f$ 5 Viper.P annon.angugt.d.

Ch.256. I Chryjantbe mum fegetum, fo 3 Chryjanth. Alp. I Clisf. f.d. 4 Chryfanth. Alp. 2 Cluf. f.d. 5 Chryfanth. Cret. f.d. 6 Chrysanth. Balcum Bocly, d. 7 Chryfanth.tenuifol. Beer. Boel. d.

Ch. 260. Flos folis pyranidain, f.d.C.

Ch.262. 3. Lescantbersum Alpinsm Clwf.f.d.

Ch.264. 5 Doronicum angrift fol. Auftr.t.d. 6 Doronscum Stiriactim 10 o amp. F.d. 7 Duroxicum maximssm, f.d.

Ch.205.7 Salsia abfinthizes,d. 8 Saluta Cret.pomifera of nos pomif.f.2.d.

Ch.266. 2 Verbafcum anguft is faluia fol. F. 3 Pblonsos Lychnites Sjr. f.d.

Ch.267. 3 Colus loris, $f$.

Ch.268. 3 Horminum gyl. Iatifol.f.d.

4 Horminum Spl. flo.all. F.d. 5 Hormenum Syl.flo.rub.f.d.

Ch.271. 3 Blatsariaflo, viridi, $\mathrm{f}$. 4 Blatiaria flo ex vir. prapsurafe, $f$.
5 slattariafo. albo, f.d. G Biattariaflo. amplo, f.d. $>$ Blatraria flo.lut. f.d.

Ch.273.8 'Primusu veris Heskethi, f.

$\mathrm{Ch} 3.277 \cdot 3$ Drgitalis lutea, $\mathrm{f}$. 4 Digitalis ferrugraea $\mathrm{f}$. 5 Digital is ferrug. minor, d.

Ch.278. Bacchar. CMonpel.f.

Ch.283.3. Bugloffagyl.min.f.d.

Ch. 284.2 Anchris lurea, $\mathrm{f}$. 3 Anchufa minor, $\mathrm{f}$.

Ch. $28_{3} .2$ Echium valganesf 3 Eshrum pullo flore, t.d. 4 Echisem rubro fo. f.d!"

Ch.286. 2 Cynoglegfum Crat.t. Cynogloff. Cret.ale. f.d. Cynogloff. minus fol. virente,

$\mathrm{Ch}_{28} 8_{7} 3$ Symphytwistuberofus $\mathrm{f}$. 4 Symphytum par. Borag faci f.d. Ch.290. 2 Tinflatago Nipina, f.d.

C. $\left\{\begin{array}{c}\text { Ch.292.1 Cacalia incano folio, f.d. } \\ 2 \text { Cacalia follo glabro. Fod. }\end{array}\right.$

2 Cacalis follo glabro. fod. 3 Potamogetion 3 Dod.f.

4 Potamagenon long. acnt foligs, f.d.

Ch.298. 2 Tribsius agsat .mins. guer.flo. f.d. 3 Tribulus agsat mm. Mufcat flo.f.d.

$\mathrm{Ch}$.300.4 Miliefolum ronkifol, $\mathrm{f}$. 5 Millefol.palufer galeric, $\mathrm{f}$. 6 Myriophyllon agiat minss, d.

$\mathrm{Ch}_{1.302 .3}$ Stellarin aguatic $\mathrm{f}, \mathrm{f}$.

Ch.304.2 Arwm e Egytiacnm, f.

Ch. 307. 2 Soldanella Alp. m.zior.f. 3 Soldanella Alp. minor, f.d.

Ch. 308.2 Gramen Parnajfiflo, duspl. f.

Ch.309. Saxifratga alba petraa, t,d.

$\mathrm{Ch}_{3} 3$ ro. 3 Cjclamen vernsisn, $\mathrm{f}$. 4 Cyclamenvernism album, fod. 5 An Cyclaminos alt.f.

Ch.3I1.4 Arifolochin Saracenica, fo 5 Piffolochw, $\mathrm{f}$.

6 Pest. Cret. Frue Virginima, f.d.

Ch. 3 I 4.2 Hederajaxanlis, t.d.

Ch. $\mathbf{I}_{5} \cdot 3$ Hedera Virginiane, d.

Ch. 337.4 Corvoloulissargenters, d.

Ch. 318.2 Conuolvulus cer fol.rot.f.d. ; Corvolv.carkl.win.f.d.

Ch.3 19. 3 Scarnososium Monfpel.f.

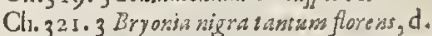

Ch.322. Ialapism, d.

Ch. 326.3 Clemat is cer flo.pleno, f.d.

Ch.327. Clemasis cruciata Alpina, F.d.

Ch. 330.2 Clematis Daphrooides maior, $\mathrm{f}$.

Ch.334. Apocynsus Syr. Cluf.f.

Ch. 336.2 Periploca latifolio, $\mathrm{f}$.

Ch.337. 6 Polygonat wm I trginianenz, $d$.

Ch. $34^{2}, 2$ Cetrullus minor, $t$.

Ch.345. Macocks Virginiani, d. Melones aquat edules, Virg.d.

Ch.352.5 Malua aftina Huparicr, f.d.

Ch. 353.5 Alcea frutuco fa cannab.t.

Ch.355.3 Alcea Egyps.f.d.

Ch. 356.2 Geranium colum, mains diffct. fol. d. 3 Geran. faxatile, d.

Ch.360. 2 Geranism batrachioides alt. F.d. 3 Geras. Basracbioides prillo Fl. fod. 4 Geran. batrach. long rad.f.d.

Ch. 362. 


\section{Additions.}

C. $\left\{\begin{array}{l}\text { Cb.363. I Geraniam bulb. Pen.f.d. } \\ 2 \text { Geran. nodofum Platean, f.d. } \\ 3 \text { Geran. argent. Alp.f d. } \\ 4 \text { Geras, barrach. flo.var.d. } \\ 5 \text { Geran. Ind.flo. maculato,d. }\end{array}\right.$

Ch. 367.13 Ranunculus lirgut. Alp.jlo alb.f.d.

$1_{4}$ Ran.mnnt .birfut.psirp.t.d.

Ch. 360. 2 Ranunculus esfrat. Flapler.min.f.d.

3 Rax. Afiat. Flo.plen. prolifero, fod.

5 Ran.grums. rad.ramofus, f.d.

6 Ran. grum.rad. Flo.alb.f.d.

7 Ram.eAfart.grum.rad.Fio.fav var.fid.

Cli.37 I I Ran.Cret.Larifol.f.d.

o Ran.folio plantef.d.

C) Ran.mont.Flo,nsin. E.d.

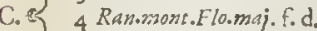

\&) 5 R.m.precox rut fol.f.d.

6 G Ram. precor Thalietriful.f.d. 7 Ran.parvus echinat.f.d.

$\mathrm{Cl} .376 .4$ Acositwm igcoct. ex cod.Cef.f.

5 Acom.lycol.hirfut.f.d.

6 Acon. Violacesm, fd.

7 Aconitum purp. Nomberg. F.d.

S efconitum max. Iridenberg. f.d.

9. Aconsmax .nutant.coma $\mathrm{fd}$.

Ch. 380.5 Pcosia promifcra, f. 6TRosia fàmina prmila, $\mathrm{f}$. 7 Pconia Byzant.f.d.

Cl. 38 1.5 Paoria Pentaphyll.alt.f.

Ch.382. 6 Festapbyllon fap. Torm.fac.d. o Restaphyll. incanum minus rep.d. 11 Quinguefol. Syl.minus f.d. 12 Quenquefol.min.flo. aur. f.d. 13 Pensaphyllsm fragif. f.d.

Ch. 385.4 Caryophyll, mont.parp.f.d. 5 Caryophyll.Alp.min.f.d.

Ch. 3 Se Eragaria fructu hifpids, d.

Ch. 387.3 Archangelica, $\mathrm{F}_{0}$

Ch. 39 1. Laferpitixm, f.

Ch. 395.2 Coriantrum alt.min.od. f.

Ch.396. 3 Apium, fise Petrofel. Virgind,

Ch.398. Oreofelinam, $\mathrm{F}$.

Cl.399. I Petrofelinam Macedos Fuch.fo

Ch.400. Selinum Si fol, f.d.C.

Ch.402. Apinm fyl. fine Theffelium Plin. f.

Ch. 403.2 Caucalis Apiy fol.t.

4 Cascalis maior, $\mathrm{fd}$.

5 Cancalisminor flo $\int$ c rub. $\mathrm{f}, \mathrm{d}$.

6 Cancalis nodo.echimat o fem. f.d.

Ch.407. 2 Pastinaca fatima atrorubens, $f$.

Ch. 414.2 Anifum Ind.fell.F.d.

$\mathrm{Ch}_{4} 4 \mathrm{I} 5.2$ Amm Cresicum, $\mathrm{f}$.

3 Ammi perpufsl. f.

Cl. 4 I 6.2 Cerefolinm fyl.d.

4 Myrrhis aleera parsa, f.d.

5 Myrrbis Etgricolor. noma, d.

6 Cicutaria albur, d.

$\mathrm{Cl}_{1.417 .2}$ Anthrefcres, f.d.

Ch.419.2 Barba Capri Tragi, d.

Ch.421. 3 Pimpinella fangut forba max. d.

Ch.422, I Saxisfraga eAng. fac. Fofeliprat.f. 2 Sarifraga Panmondid.

Chap 424. 2 Sefili Granc, mij. f.

3 Sefoli nontanum mains, $\mathrm{f}$.

4 Sefel Murfiliense, F.

$\mathrm{Cl} .425 .2$ Xetem alt. Iizl. f.

$$
2 \text { Ferulago, f. }
$$

Ch. 27.3 Parax Afclepism, fd.

Ch. 435.2 Chelidon mai. fol.mag. diffecto, f.d.

Ch. 440.6 Valeriana CMexicam. f. 8 Valersara annua Cluf. f.d. 9 Valer, Alp, Lat.f.d.

10 Valer. Alp.anguft. f.d.

Ch. 442,3 Confolidareg. Elo.dus, f.d. ${ }_{4}$ Confol reg. elat. Flo.plen.f.d.

Ch.443. 4 Melantbrum Dam.Flo.plex.f.d. 6 Nigella $H_{2} \beta$. Flo.amp. F. d.

$\mathrm{Ch} .447 \cdot 4$ Agrailegia var, f.d. 5 Aqusil. Flo.inserfo rubro, f.d. 6 Aquil. Flo, inuerfo albo, f.d. 7 Agwal. Flo.rof.f.d.

8 Aqull. degener, f.d.

Ch.457.6 Drypis, f.

Ch.460. 4 Rubia fpicasa Cretica, f.d. 5 Rnbiafynanchica, d. 6 Rubia minoma, f.d.

Ch.462. 2 Rubiacrusiata lesis, $\mathrm{f} . \mathrm{d}$.

Ch.463. 2 Afperula Flo.cersl.t. is Sigina jpergula, $f$.

4 Spergula marina, d. 5 Sperghlarabra, d.

Ch.565. Esticis maris wariet.f.d.

Ch.467.3 Polypodium Ind.f.d.

Ch. 468. Dryopieris Adu, f.d.

Ch.70. 3 Hexisonitis maior, fo. 4 Hem.minor,f.

5 Ilem, peregrina, $\mathrm{f}$.

Cli. $47^{2} .4$ Chamaflix war. Angl.f

Cl1.475.2 Acanthus fyl, acsleasus, $\mathrm{f}$.

Ch.478. 2 Carduns globof, acmt fo 3 Cardun glob.mosn.f.

s Cardwas glob. cap. latiore, $f$. $\sigma$ Cardsuss eriocephalus, $f$.

Chi, 81. I Carlina carlefcexs, f. 3 Carlma acanlosmin.Flo.purp.f.d.

Ch. 485.5 Eryngismpufils, pian. f.d.

Ch.4\$7. 3 Dipjacus minor,f.

Ch.488. I Carshamus, f.

Ch. 490. 2. Picnomos, d.

Ch.493. I Cirfinm max. Apbod. rad. f.d.

(5) 2 Cirfimm mai, aller. f.d.

C) ${ }_{3}$ Carfinn fol som birfut.f.d.

C. is 4 Cirf.mont.cap.parv.f.d.

c) 5 Cirf. mont. Angl.f. $3 . d_{0}$

6 o Carduns mollis fol. differt.f.d. 7 Card,moll,fol.Lapatbi, f.d.

Ch. 404.3 Trifol.mai.Flo.alb.f. 4 Trifol. misi. Flor purp. f. 5 Trifol. Ist.lupul. . 6 Trifol. lut.min.f.

Ch.496. G. Corosopres ex cod. Caf. F.d. 8 Trifol. lut.fil.corn.f.d.

Ch.497. I Lagopus max. f. 2 Lagop. mat. pica long.f.d. 3 Lagop. Ang:Jf. Hif .t.d.

Ch. 500 . Fonum-Gracmongly.f.

Ch.501. Lotus filiqua quad.f.d.

Ch. 502 Medica frudicuchleat. Jpinf.d. 4 e'at. sCh.506. I Trifol. filique lisn. E.d.

2 Trifol,ang. Alp.t.d.

C) 3 Trifol.pin.Cret.t.d.

C. 4 Trifol.frogif.t.d. 5 Trifol. fell. birfus.d.

a oTrif. fiell.glab.d.

Ch.507. 


\section{Additions.}

Ch.507. Faba vulgaris, d.

Ch. $508.5,6,7,8,9$, Phafeolor.pegrin.var. 9. cum fig. 3 ,d.9.

Ch.509. 4 Lupinus mai. flo. car.f.d.

Ch.5r5. IVicia, f.

2 Viciamato dumer. d.

3 Vicia fyl.fls. alb. f.d.

5 Viciafyl. fute Cracea min. f.d.

Ch.516. 1 Lathyrus mai.latifolof.

2 Lath. ang. flo.alb. f.

3 Lakb.enguff. flo.purp.f.d.

4 Lath. A 4 gypt. f.d.

s Lath. imn.fl. Orobi,f.d.

6 Latb. Jy', flo.lut.f.

Ch.5 18. 2 Hedjarum glycyrshizatum, fo

3 Hedyfar. naai. filigus artic of.

4 Securidace mon.pal. corrul.f.

5 Secur.mix.lut.f.d.

6 Secur. Al.plan.dent.E.d.

7 Hedyystr. clyp. f.

Ch.5ig. 2 Aftragalus fyl. f.d.

Ch. 520.3 Aftragalus CWath.f. 4 Afreagaloides, $\mathrm{f}$.

$\mathrm{Cl} .52 \mathrm{I} .3$ Ornirhopodism mai. $\mathrm{f}$, 4 Ornichopad. min. f.

g Scorpioides leguminofa, f.d.

Ch.526 I Orobus venet.f.d.

C. 2 Orobus gyl.vernus, f.d.

3 Orob.mont.flo.alb.f.d.

4Orob mont.anguft .fod.

Ch.527. I Ochrusfine Ersilia, f.d.

C. 2 Erнкт fylv, f,d.

C. 3 Aphaca, F.d.

4 Legumen mar .long .rad.d.

Ch. 528 . 3 Talidtrum mat. Hispan.d.

Ch.531. 6 Ruta canzn. F.d.

LI B. 3 .

H.2.6 Ro fa lut. multipl. f.d.

8 Rofa Cimnam. foo. fmpl.f.

Ch. 3 . 2 Rofa fyl, ador. flo. dxp. f.

Ch. 4.2 Kubus repens fructu eaf $10, \mathrm{~d}$.

Ch.5. 1 . Ciftus ann. flo. mac. f.d. 20 Ciftus folio farmpluch. f.d.

Ch.6. 7 Chansacifus Serpillifal, f.d. 8 Chamacistus Frt. f.d.

Ch.7. ${ }_{5}$ Ciftus Ledonfolijs Rofm.f.d.

Ch. 12. Glycyrrhiza vulg. f.

Ch.17. Orobanchestriplex var. $\mathrm{f}_{0} 3$.

$\mathrm{Ch}_{1.20 .} 5$ Genifta fprnofa bumilis, d.

Ch.25. 2 Tragacantha minoicon accur. 3 Poterion Lob. $\mathrm{f}$.

Ch.26. 1 Acacia Diofc.f.

Ch. 27.2 Lycium H.P.f.

Ch.28. I Rhammis flo.alb.f. Khimn alt fin.purp. f.d. 2 Rhamnus 2 Cluf. f.d. 3 Rhamnus 3 Cluf. d.

Ch.3०. I Rbamnus folue. f. 2 Rhamn. fol min. E.d.

3 Khatos. Fol.pismil.d.

Ch. 34 . Ilicis ramus flor of

Ch. 35 . Cerri minoris rano. cusm flo. $\mathrm{f}$.

Ch.37. 2 Gatta maior alt.f.d.

Ch.40. 2 Pecea prumila, $\mathrm{t}$.

Ch.42. 8 Pirafter Ausftr. f.d. ${ }_{2}$ Pinastermar. min. f.d.

Ch.43. 2 Abres mas, f.

Abict is ramus cums lulis, $\mathrm{f}$.
Ch.47. Taxus glandif. obaccif. d. Taxus tant. flor.d.

Ch. 48.3 Inniperus Alp, min. f.d.

Ch.49. 3 Cedruslycia alt.f.d.

Ch.50. 3 Sabina bacc.alt. f.d.

Ch.52. 3 Ericamai.floalb.d.

9 Erica bacififprocumbens, $\mathrm{f}$.

Io Erica baccif. ten.d.

II Ericapum. 3. Dod.f.d.

12 Erica tornes per intersalla ramis, f.d.

13 Erica peregrin. Lob. f.d.

14 Erica coris folio 7 Cluf. F.d.

Is Erica Coris fol.o Cluf. f.d.

Ch. 54. 2 Pitex lat. ferat. folio, f.d,

Ch. 55.8 Salix hum. repens, $f$.

Ch.61.3 Syringa Arabica,f.d.

Ch. 71.2 CMyrtus Eatica lat. $\mathrm{f}$. 3 Myrt.exot.f.

4 Myrt. frutalolo.f.

5 Mrytus mixu.f.

6 Myrt. Beticafyl.f.d.

Ch. 73.6 Vitis Idea fol. fubrotund. maid.

Ch.77.2 Sambucus fruttu albif.

$\mathrm{Cl}_{1} 89$. Auellana pum.Byz.f.d.

Ch.91. 3 Caftaned PorH. frutt.f.d.

Ch.94. 5 Perfica flo.pleno,d.

Ch. 98.2 Mepilusjatroalt .f.d. 4 Chameme $\beta$ ilus, $\mathrm{f}$.

Ch.113. 2 Alnus birfut.f.d.

Ch.I 16. I Vlmus valgat. fol dato fcabro,d.

2 Vlmus min. fol. angufto farbro, f.d.

3 Ulmus fol. latiff.jcab.f.d.

4 Vlmus ful. glab.d.

Ch.118. I Acermai. f.

Che 11 9. 5 Populus alba foligs minor, $\mathrm{f}$.

Ch.1 22. 2 Zizypha Cappadocica, $\mathrm{f}$.

Ch.124. Guaiachm Patan. anguft.d.

Ch.1 33 . 2 Chamaficus, $\mathrm{f}$.

Ch. I 36 Mufa fruitus exalt. icon, f.d.

Ch.145. 3 Balfamim Alp. f.d.

Ch. 146.2 Molle arboris adultaramus, $\mathrm{f}$.

Ch.153.5 Piper caudatum, $\mathrm{f}$.

C. 5 Ch.159. Frultus Indici of exoric quorken fig. ad.26.defcr.35.

Ch.162.6 CHufcus Pyxidatus, f. I 2 Mufc clesiat fol.Cypr.d. I4 Musc. parv.ftell.f.d.

Ch.164.3 Liches mar. rotssnd.f.d. 4 Q Hernss mar.var.f.d. 5 Quern.mar.fecusd.f.d. 6 Quern.mar .tortia,f.d. 7 Quern. mar. guarta,f.d. 8 Alga, f.d.

9 Fucus phafganoides er poly $\int_{2}$ f.d. Io Fucus pong. nod. f.d. I1 Conferua, f.d.

Ch.165. 7 Fucus ferul.f.d.

8 Fucus temifol.alt.f.d. g Muscus mar. Cluf.f.d.

Io Mufcus mar.tertius Dod.f.d.

II Abres mar.Belg.Cluff.d.

Ch.166. 5 Coralordes alb.f.d. 6 Coral.rub.f.d.

8 Spong. infundibnli farma, f.d. 9 Spongia ramosa, fd.

Ch. I67. Pungerwm fig. I4.

The Appendix costaines fig 46 . defcrip. 72 . 


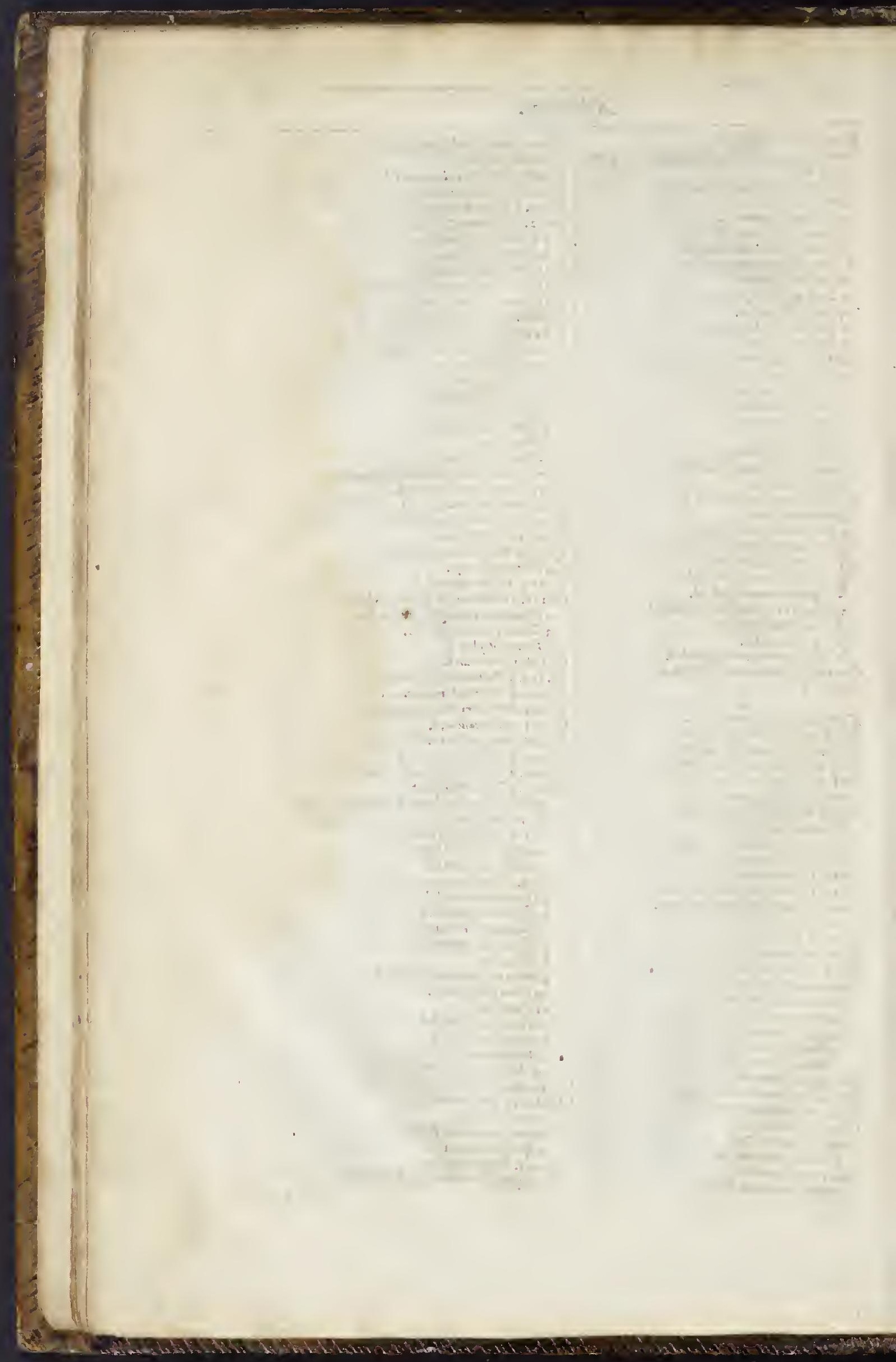




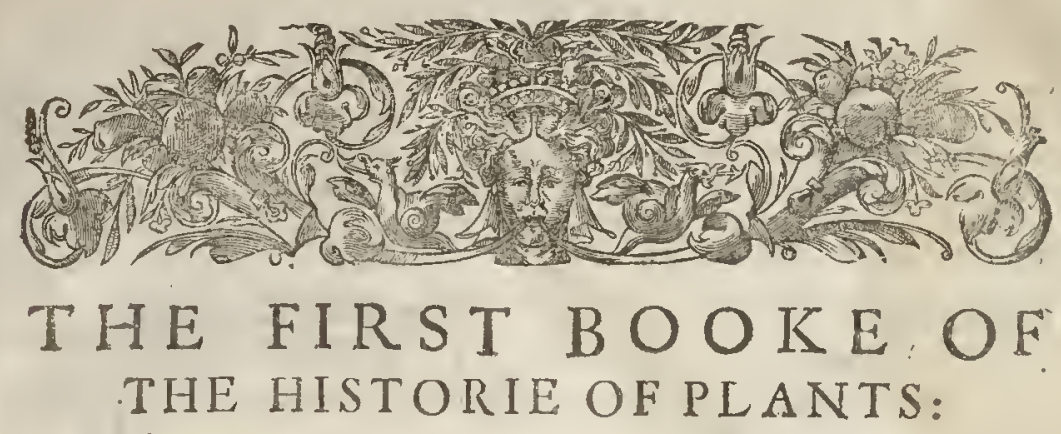

\section{Containing Graßes, Rufhes, Reeds, Corme, Flags, and Bulbous, or Onion-rooted Plants.}

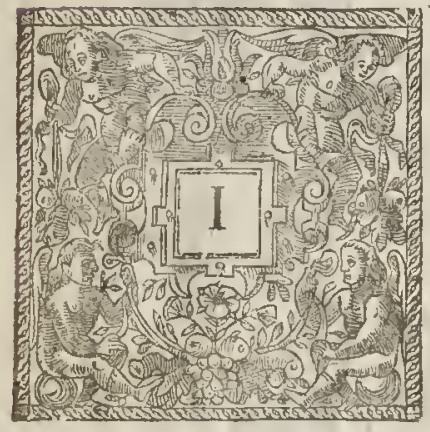

The firft booke hath Graffes, Ru/hes, Corne, Reeds, Flags, Bulbous or Onion-rooted Plants.

The fecond, moft forts of herbes vfed for meate, medicine, or fivect fmelling.

The third hath Trees, Shrubs, Burhes, Fruit-bearing Plants, Rofins, Gummes, Rofes, Heathes, Moffes, Munhtoms, Corall, and their feuerall kindes.

Each booke hath chapters, as for each herbea bed : and cuery Plant prefents thee with the Latine and Englioh name in the title, placed ouer the pioture of the Plant.

Then followes the kindes, defcription, place, time, names, natures, and verrues, agreeing with the beft receitued opinions.

Laft of all thou haft a generall Index, as well in Latine as Englinh, with a careftull fupply likewire of an Index bilinguis, of barbarous names.

And thus hauing gituen thee a generall view of this garden, now with our friendly labours wee will accompany thee, and leade thee through a Graffe-plot, little or nothing of many Hetbarits heretofore touched; and begin with the moft common or beft knowne Graffe, which is called in Latine, Gramen praterafc: and then by little and little conduct thee through moft pleafant gardens and other delight full places, where any leerbe or plant may be found fit for meateor nuedicine.

\section{Cна в. I. Of cMedow-Graffe.}

Tera - Here be fundry and infinite kindes of Graffes not mentioned by the Antients, either as vnneceffarie to be fet downe, or vnknowne to them: onely they make mention of fome fetw, whofe wants we meane to fupply, in fuch as haue come to our knowledge teferring the reft to the curions fearcher of Simples.

7) The Defoription.

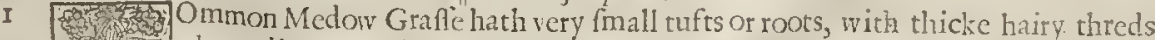

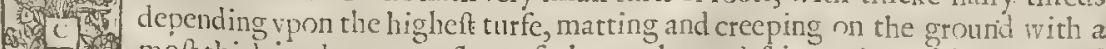
0.2. 3 moft thicke and apparant fhew of wheaten leates, lifting vp long thinne ioynted and light ftalks, a foot or a cubir high, growing fmall and tharpe at the top, with 2 loofecare hanginz downward, like the tuft or top of the common Reed. 
2 Small medow Grafe differeth from the former in vatictie of the foile; for as the firft kind groweth in medowes, fo dorh this fmall graffe clothe the hilly and more dry grounds vntilled,and barren by nature; a Graffe more fit for flicepe than for greater cattell. And becaufe the kindes of Grafie do diffet apparantly in root, tuft, ftalke, leafe, fheath, eare, or creft, we may affure our felues rhat they are endowed with fencrall vertues, formed by the Creatot for the ve of man, although they laue been by a common negligence hidden and vnknowne. And therefore in this our Labor we haue placed cach of them in their feuctall bed, where the diligent feateher of Nature may, if fo he pleafe, place his learned obferuations.

$$
\begin{aligned}
& \text { I Gransenpratenfe. } \\
& \text { Medow Gralfe. }
\end{aligned}
$$

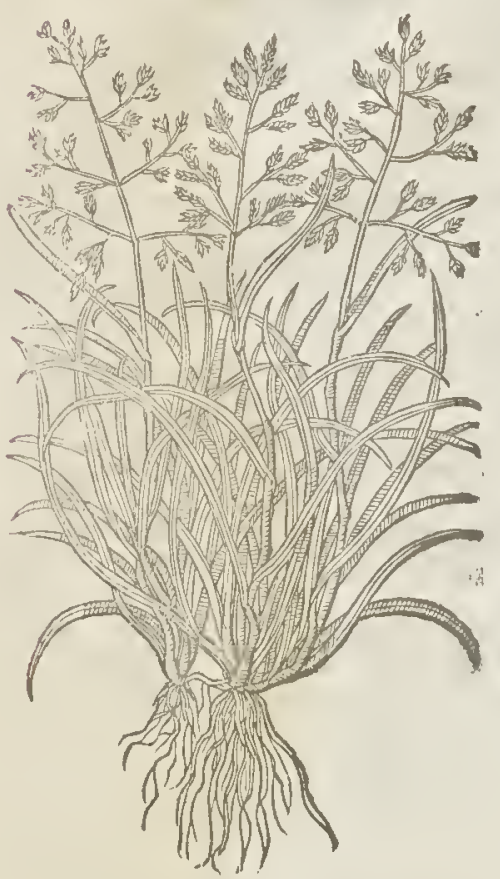

2 Grimenpratenfeminus. Small Medow-grafle.

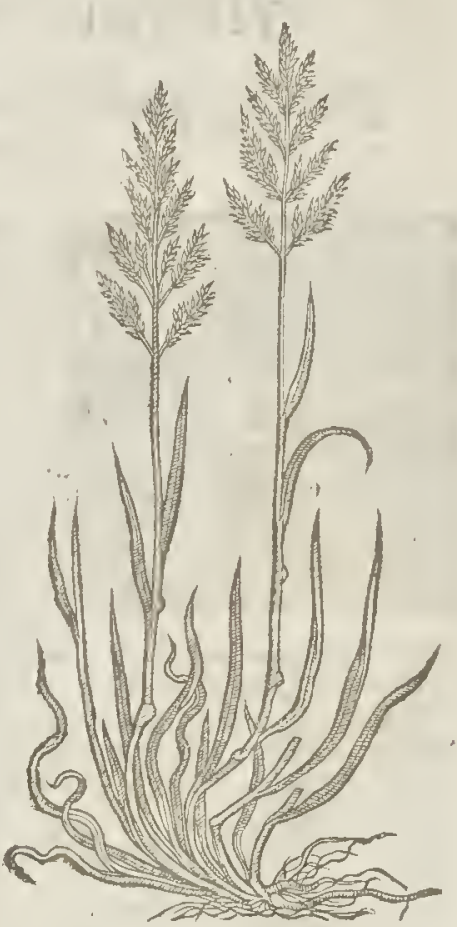

gi The Place.

Common Medow-graffe groweth of it felfe vnfet or vnfowen, eutery where, but rhe fmall medow grafte for the moft part groweth vpon dry and barren grounds, as partly wee haue touched in the defeription.

$$
\text { The Time. }
$$

Concerning the time when Graffe fpringeth and feedeth, I fuppofe there is nonc fo fimple but linoreth ir, and rhat it continucth all the whole yeare, feeding in Iune and Iuly. Neither neederh it any propagation or replanting by feed or otherwife; no not fo much as the watery Graffes, but that they recouer themfelues againe, alrhough rhey haue beene drowned in water all the Winter long, is may ap: we in the wilde fennes in Lincolnfhite and fuch likeplaces.

$$
\text { T) The Names. }
$$

Gtaffe is called in Grecke, azrys: in Latine, Gramen, as it is rhougltt, a gradicndo, quod geniculat is intirsodiys ferpat crelroque mones pas gat radices : for it growcrh, goeth, or fpreadeth it felfe vnfet or un fown, naturally ouct all ficlds or grounds, cloathing rlsem with a faire and petfert greene. It is vearily mowed, in fome places rivice, and in fome rare places thrice; then is it dricd and withered by the learc of the Sunne, with often tuming it ; and then is it called Fanum, nefio an d funore aus fut:. In Englifh, Hay: in Erench, Le herbe dupraiz.

$$
\text { T The Nature. }
$$

Tle toses and feeds of Graffe are of more $v e$ in plyficke than the lierbe, and are accounted of aj! Writers molerately to o enobltructions, and prouokerrine. 


\begin{tabular}{lll}
\hline L B. I. Of the Hiftory of Plants. & 3 \\
\hline
\end{tabular}

The decostion of Graffewith the roots of Parfley drunke, helpeth the diffurie, and pronoketh A vrine.

The roots of Grafe, according to Galen, doe glew and confolidate together new and bleeding $B$ wounds.

The iuyce of Grafe mixed with honey and the pouder of Sothernwood taken in drinke, killeth C wormes in children; but if the childe be young, or tender of nature, it thall fuffice to mixe the iuyce of Graffe, and the gall of an Oxe or Bull togethet, and therewith anoint the childes belly; and lay a clout wet therein vpon the naucll.

Fernelius faith, that graffe doth helpe the obftructions of the liuer, reines and kitnies and the D inflammation of the raines called Nephritis.

Hay fodden in water till it be tender, and applied hot to the chaps of beafts that be chap-fal- E, len, through long ftanding in pound or ftable without meate, is a prefent remedie.

\section{C н а . 2. Of Red Dwarfe-Griffe.}

\section{If The Defription.}

3 Warfe Graffe is one of the leaft of Graffes. The root confifts of many little bulbes, conered with a reddifh filme or skinne, with very many fmal hairy and white ftrings : the tuft or eare is of a reddifh colour, and not much differing from the graffe called rjchemon, though the eare be fofter, broader,and more beautifull.

t. Gramen minimum rubrum, fue Xerampelinum.

Red Dwarfè-graffe,

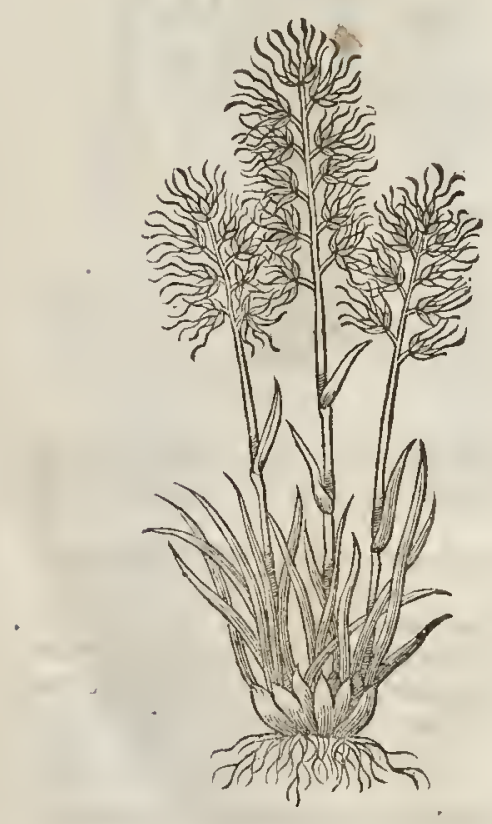

2 Gramerimikimum alkum:

White Dwarfe-graffe,

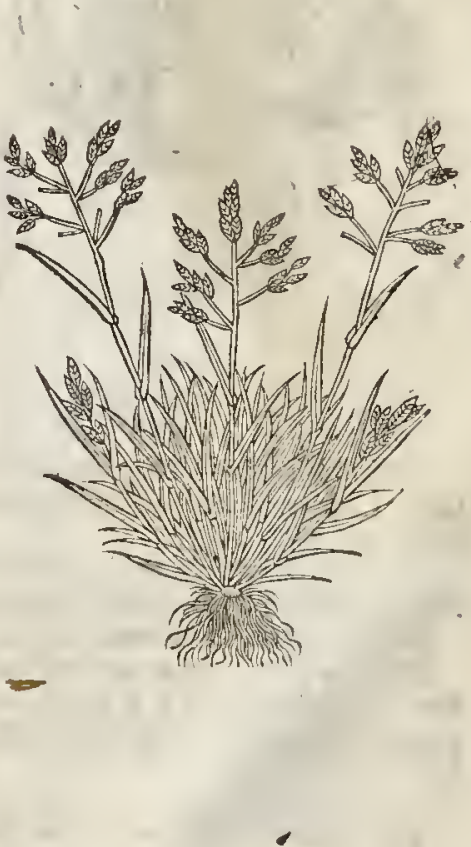

+ : Thiskinde of Graffe hath fmall hairy roots; the leaues are fmall and thort, as alfo the Italke, which on the top thereof beares a pannicle not much inlike the fmall medow Graffe, but leffe: the colour thereof is fometimes white, and otherwhiles reddifh; whence fome haue gituen two figures, which I thinking needleffe, haue oncly retained the later, and for the former giuen the figure of another Graffe, intended by our Author to be comprehended in this Chapter. 
3 Small hard Grafle hath fmall roots compact of little ftrings or threds, fiom which come forth many foure rufhy leates of the length of an inch and a halfe: the tuft or eate is compact of many pannicles orvery little eares, which to your feeling are vety hard or harfh. Tlis Grafe is vnpleafant, and no wholefone food for cattell.

4 Ruth-graffe is a fmall plant fome handfull high, hauing many fmiall ruthy leaues tough and pliant, as are the common Rufhes : whereupon do grow fmall fcaly or chafie huskes, in ftead of Houres, like thofe of Ruthes, but fmaller. The root is threddy like the former. $\neq$ There is a varietic of this to be found in bogs, with the feeds bigger, and the Icaues and whole plant lefet. $\neq$

3 Gramen minus duriuf culum. Snall hatd Grafic.

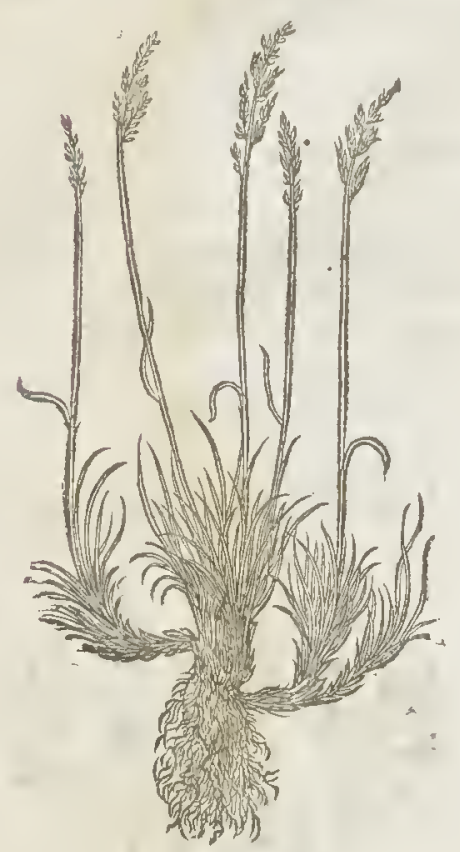

4 Gramen juncesm.

Rufh-graffe, or Toad-graffe.
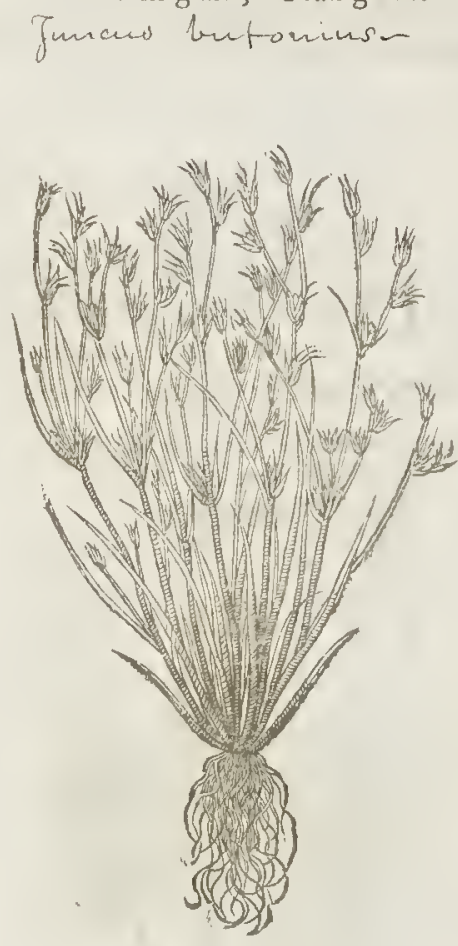

9T The Place.

The Dwarfe-grafle doth grow on heathy tough and dty barren grounds in moft places of Eng: land. F That which I haue giuen you 1 haue not as yet obferued growing in any part of England.

The white Diwarfe-grafte is not fo commonas the former, yet doth it gtow very plentifully among the Hop gardens in Effex and inany other places.

Small Hard-graffe groweth in moift frefh marifhe, and fuch like places.

Rufh-gtaffe groweth in falt marithes neere vnto the fea, where the marifhes haue beene outerflowne with falt water. $\neq$ It alfo groweth in manywetwoods, lanes, and fuch places, as in the lane going by Totenham Court towards Hampltead. The lefler varietie heteof growes on the bogges vpon Hamplead heath. $\ddagger$

I The Time.

'There kindes of Grafles do grow, floure, and flourith when the common Medow graffe doth.' T) The Numes.

It fufficeth what hath beene faid of the names in the defeription, as well in Englith as Latine : onely that fome hate lecmed White Dwarfe-graffe to be called Xerampelinum.

Ruth-grafic hath been taken for Holofeum Matthioli.

$$
\ddagger \text { I The Names in particular. }
$$

1 This 1 hetegiue you in the fitf place is the Gramen minimum Xerampelinum of Lobel: it is the 
Gramen of Matthiolus, and Gramen bulbofum of Dalefchampius. Our Authordid not vnderftand whet Yerampelinus fignified, when as he faid the white Dwarfe-graffe was fo termed ; for the word imports red, or murrey, fuch a colour as the withered leanes of Vines are of. 2. Tabern.calls this, Gramen pannicelatum minus. 3. Lobel calls this, Exile Gramen durius. 4. This by cxattholus was called Holoftum : by Thalsus, Gramen epigonatocaulor : by Tubernamontanus, Gra. Bufurasm, that is, Toad-graffe. $\neq$

$$
\text { T) The Nature and Veriues. }
$$

Thefe kindes of Graffes doe agree as it is thought with the common Medow-graffe, in nature and vertues, notwithftanding they haue not beene vfed in phy frcke as yet, that I can reade of.

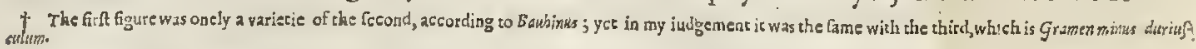

\section{C на в. 3. Of Corne-Grafe.}

it The Defoription.

I Orne-gtaffe hath many graffie leaues refembling thofe ofRie, or tather Otes, amongf the which commeth vp flender benty falkes, kneed or ioynted like thofe of cotne, whereupon groweth a faire tuft or pannicle not much vnlike to the feather-like tuft ofcommon Reed, but toundet compact togethet like vnto Millet. 'The toot is threddy like thofe of Otes.
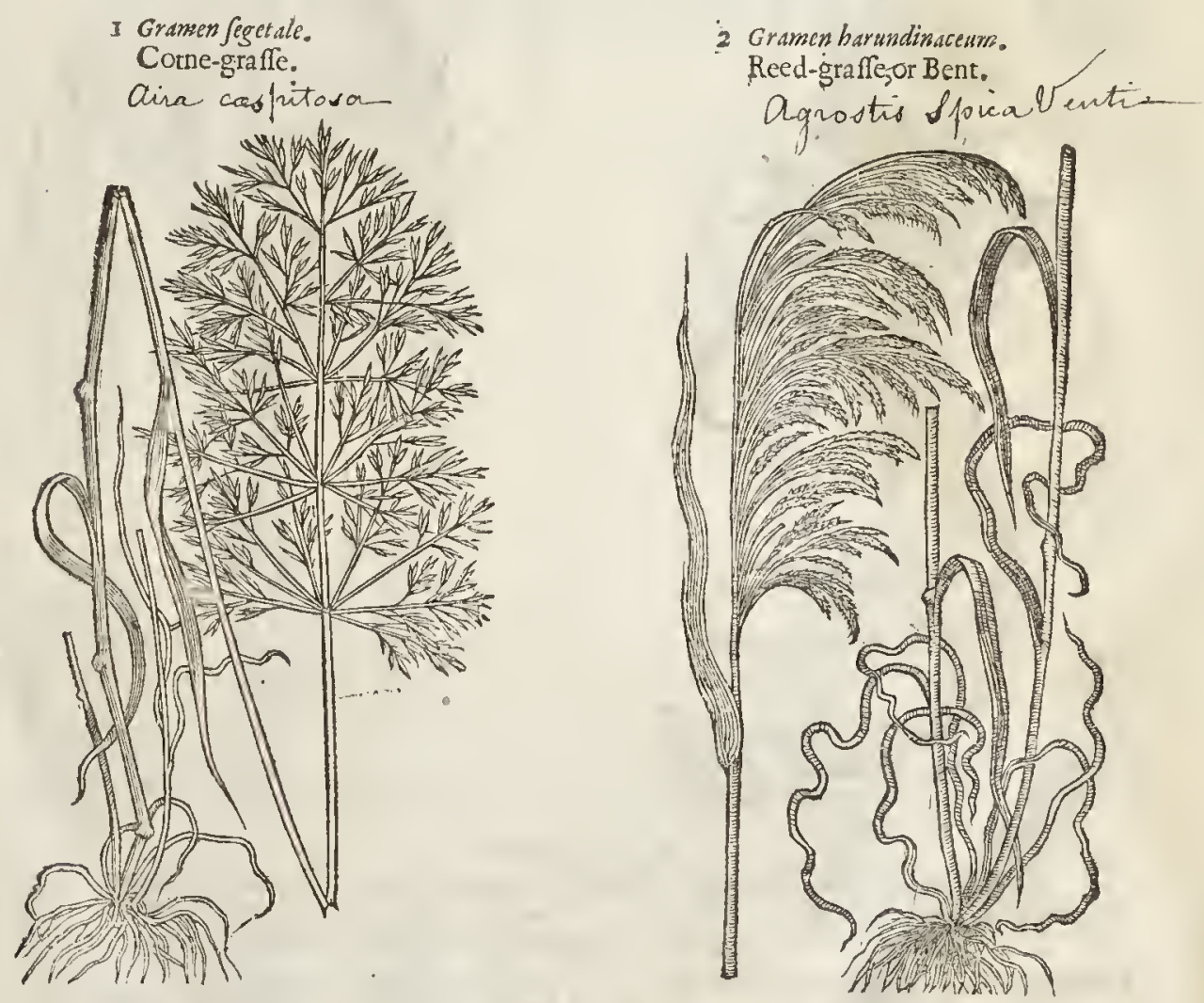

2 Reed-graffehath many thin gtaffe leaues like the former : the bufhy top, with his long fea ther-like pannicles dorefemble the common Reed, which is lightly fhaken with the winde, branched vpon a long flender reeden ftalke, kneed or ioynted like corne. The root is fmall aid fibrous, IT The Place and Time.

Thefe kindes of Graffes grow fot the moft part neere hedges, \& in fallow fields in moft places? Their time of fpringing, flouring, and fading may be teferred to the common Medow-grafe.

$$
\text { A } 3 \text { II } T \text { is }
$$




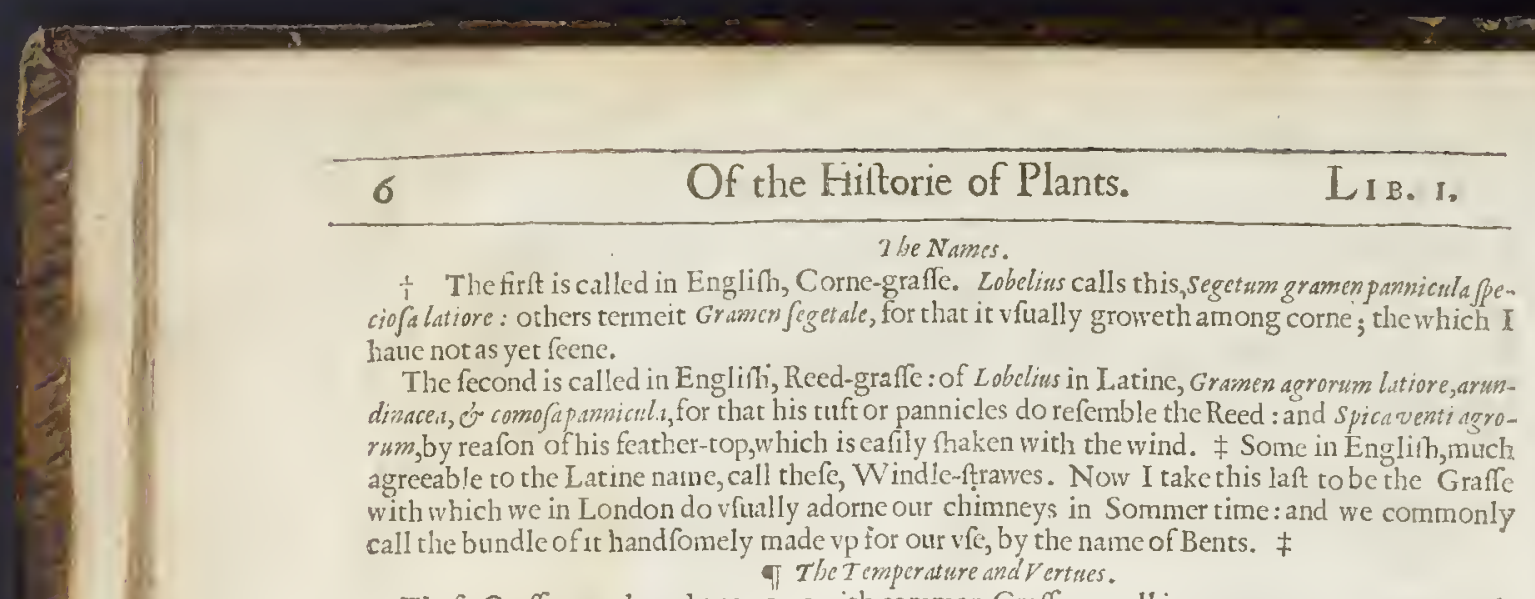

Thefe Graffes are thought to agree with common Graffe, as well in temperature as vertues, al= though not vfed in phyficke.

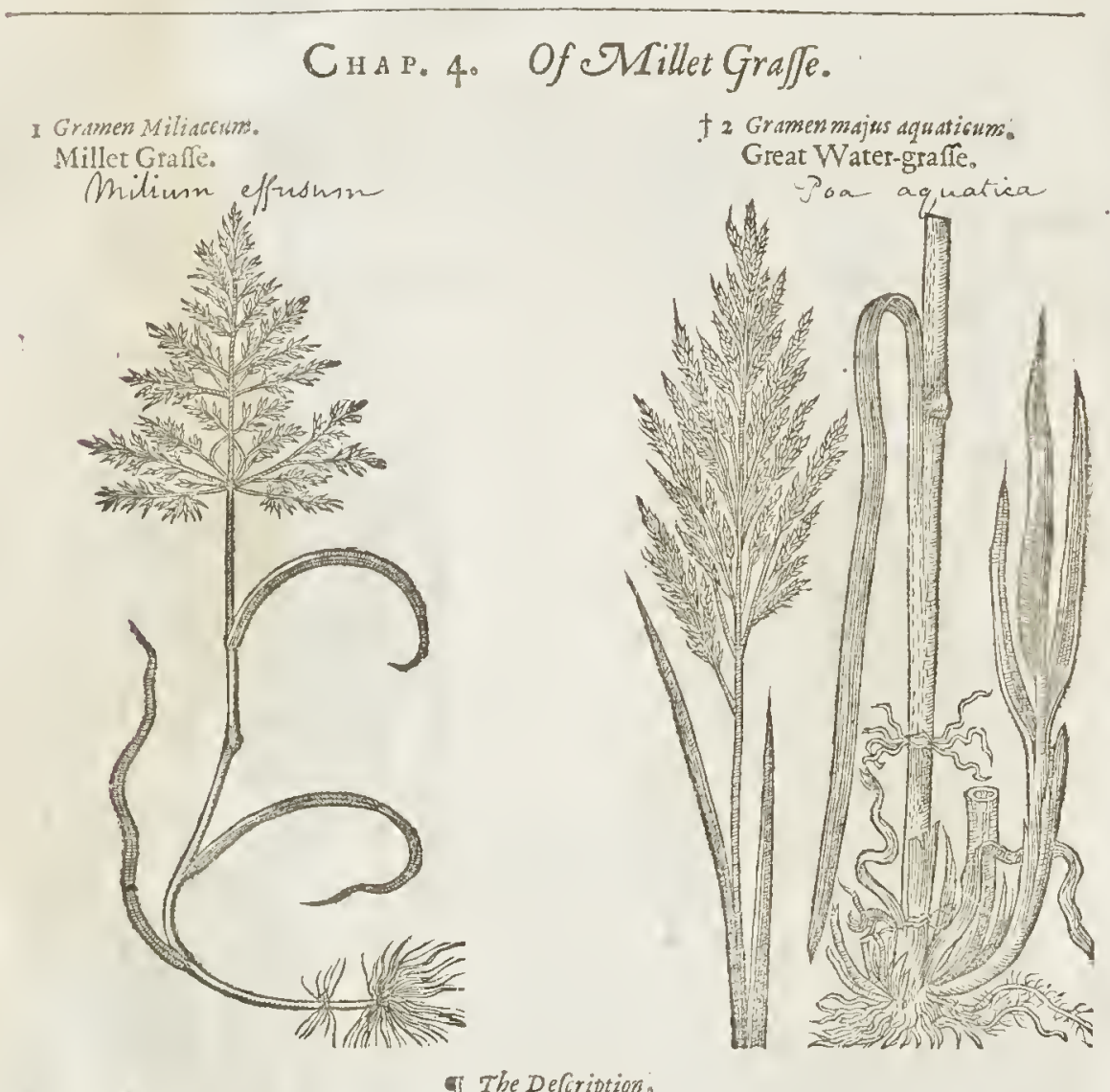

3 TIllet Graffe is but a flender Grafe, bearing a tuft or earelike vnto the common Me-

1 dow-grafle, but confifting of fmall feeds or chaffic heads like to crilium,or Millet, whcreof it tooke the name. The ftalke or leanes do refenble the Bent, wherewitl countrey people do trimme their houfes.

2 The great Water-graffe in root, leafe, tuft, and reeden ftalke doth very well refemble the Graffe called in Latine, Gramen fulcatum, or Piztzm, and by our Englifh women, Lady-laces, becaufe it is ftripe or furrowed with white and grcene ftreakes like filke laces; but yet differs from that, that this Water graffe doth get vnto it felfe fome new roots from the middle of the ftalks and ioynts, which the other doth not. $\neq$ This is a large Graffe, hauing falkes almoft as thicke as ones litrle finger, with the leates anfwerable vnto them, and a little rougi $\mathrm{i}$ : the tuft is fomew hat like a recd, bur leffe, and whitith coloured. : 


\begin{tabular}{ll}
\hline LI B. I. & Of the Hiftory of Plants. \\
\hline T The Place, Names, Nature, and Vertues.
\end{tabular}

The former growes in medowes, and about hedges, and the later is to be found in moft fenny and watery places, and hane their vertues and natures common with the other Graffes, for any thing that wee can finde in writing. The reafon of their names may be gathered out of the defcription.

t This which I giue you in the fecond place is nor of the fame plant that was figuredin the former edition 3 for that piotre was of Gramen aquaticurs barundins.

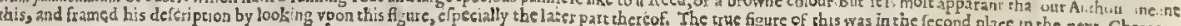

\section{CHAP. 5: OfDarnell Grajfe. \\ II The Defoription.}

I Arnell Graffe, or Gramen Sorg hinum, as $L$ obel hath very properly termed it, hath a brownith ftalke thicke and knotty, fet with long fharpe leanes like vnto the common Dogs Graffe: at the top whereof groweth a tuft or eare of a grayin eolour, fomwhat like Sorgbum, whereof it tooke his name.

3 Gramen Sorghinum: Damell Graffe.

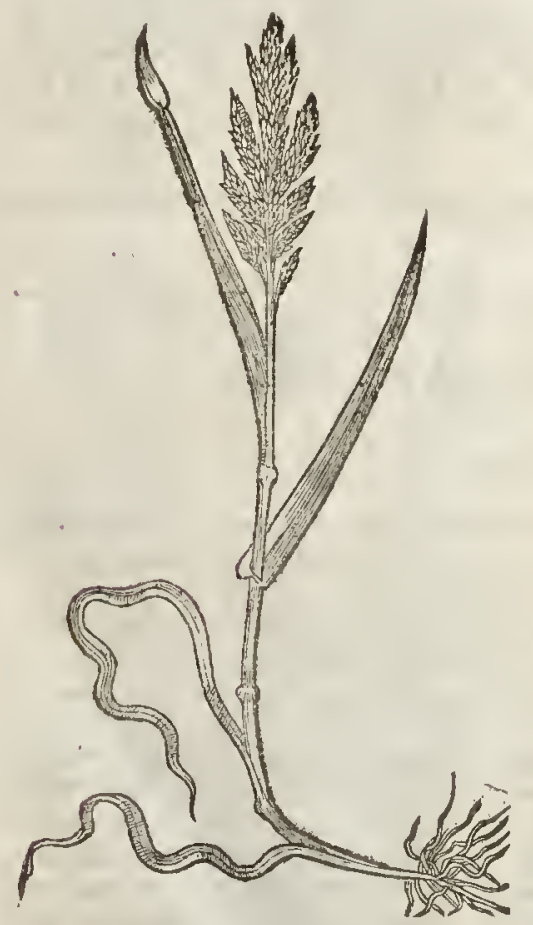

it 2 Gramen barandinacerm paniculatum. Wilde Reed.

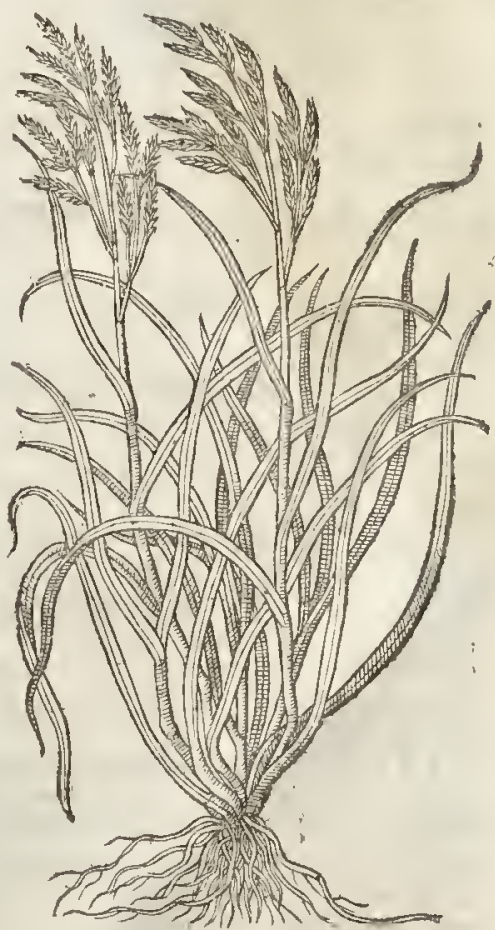

2 Wilde Reed, or Gramen harmdinaceum parniculatum, called alio Calamogroftit, is far bigget than Couch graffe, or Dogs graffe, and in ftalkes and leaues more rough, rugged, and cutring. It is bad food for eattell, though they want, or be very hungry ; and deadly to Sheepe, becaufe that, as the Husbandman faith, it is a caufe of leannefle in them, thirf, and confumption: it cutteth their 


\section{S}

Of the Hiftorie of Plants.

LIB: $I_{0}$ The leffer fieed-Grafte.

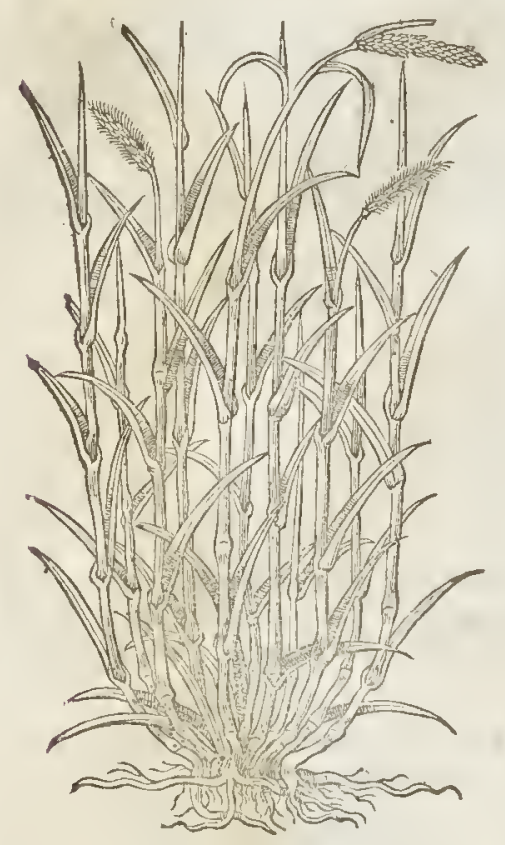

t 3 Grimenarudinaceum minu.

tongue, fraitneth the gullet or throat, and draweth downe bloud into the Ptomacke or nuw whereofenfueth inflammation, and dcarl: tor the mort part. And not onely this Calamorrofl is is hurtfull, butalfo all orher kindes of thearing leaued reeds, flagges, fedge, or the like, which haue as it were edges; and cut on bo:l lides like kniues as well mens fingers, as cattels mouthes. This lerbe is in a meane between reed' \& graffe. The root is white, creeping downwards very deepe. The fpike or care is like vito the reed, being foft and cotrony, fomewhat refermbling Pannicke.

\pm 3 This in root,ftalkes, and leaues is like to the laft defcribed, but that they are leffer: the top or head is a long fingle fpike or eare, not feuered or parted into many eares like the top of the precedent, and by this and the magnicude it may chiefely be difinguibed from it. This was in the ewelfth place in the fixteenth chapter, vnder thetitle of Gramen barkind nareum minus : and the Calumogroft is but now defcribed, was alfo there againe in the eleuenth place. $\neq$ ot The place.

The firt growes in fields and otchards almof etrery where; the other grow in fenny waterifh places.

$$
9 \text { The Names. }
$$

2 This in Lincolnchire is called Shecregraffe, or Henne: in orher parts of England, wild heed: in Latine, Calamogroftis ; out of the

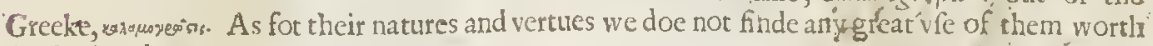
the fetring downe.

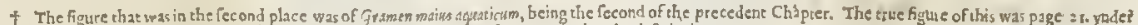

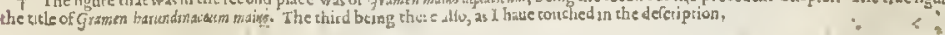

\section{Cin a. 6. Of Featber-top, Fernè, and Wood_-graffe. \\ IT The Defcription.}

+ 1 His might fitly hate beene put to thofe mentioned in the foregoing chapter; but that our Aurhor determined it for this, as may appeare by the mention made of it in the names, as alfo by the defcription hereof, framed from the figure we here gitue your. ₹ This Graffe is garnithed with chaffie and downie tufts, fet vpona long benty ftalke of two cubits high or fomew hat more, naked without any blades or leaues, for the moft part. His root is cough and hard. \& The top is commonly of a red or murrey colour, and the leaues foft and downy. $\ddagger$

\$ 2 This, whofe figutervas formerly by our Author giuen for the laft deferibed, thouglo verie much diffe"ent from it, is a very pretty and elegant grafle : it in roots and leaues is not vnlike to the vfuall medow Graffe, the ftalle rifeth to the height of a foot, and at the toprhereof it beareth a beautifull pannicle, (whence the French and Spanifh Nations call it Amourctes, that is, the Louely Graffe.) This head confifs of many littlecares, thaped much like thofe of the ordinaric Quaking Gmffe, longer and flatter, being compofed of more fcales, fo thar each of them fomewhat refembles the leafe of a fmall Ferne, whence I hane called it Ferne-Graffe. Thefe tops when they are ripe are white, and are gathered where they grow naturally to beautifie garlands : $\neq$

3 Wond-graffe hath many fmall and threddy roots, compact cogether in manner of a tuft; from which fpring immediately out of the eatth many grafly leaues, among thew hich are fundrie 


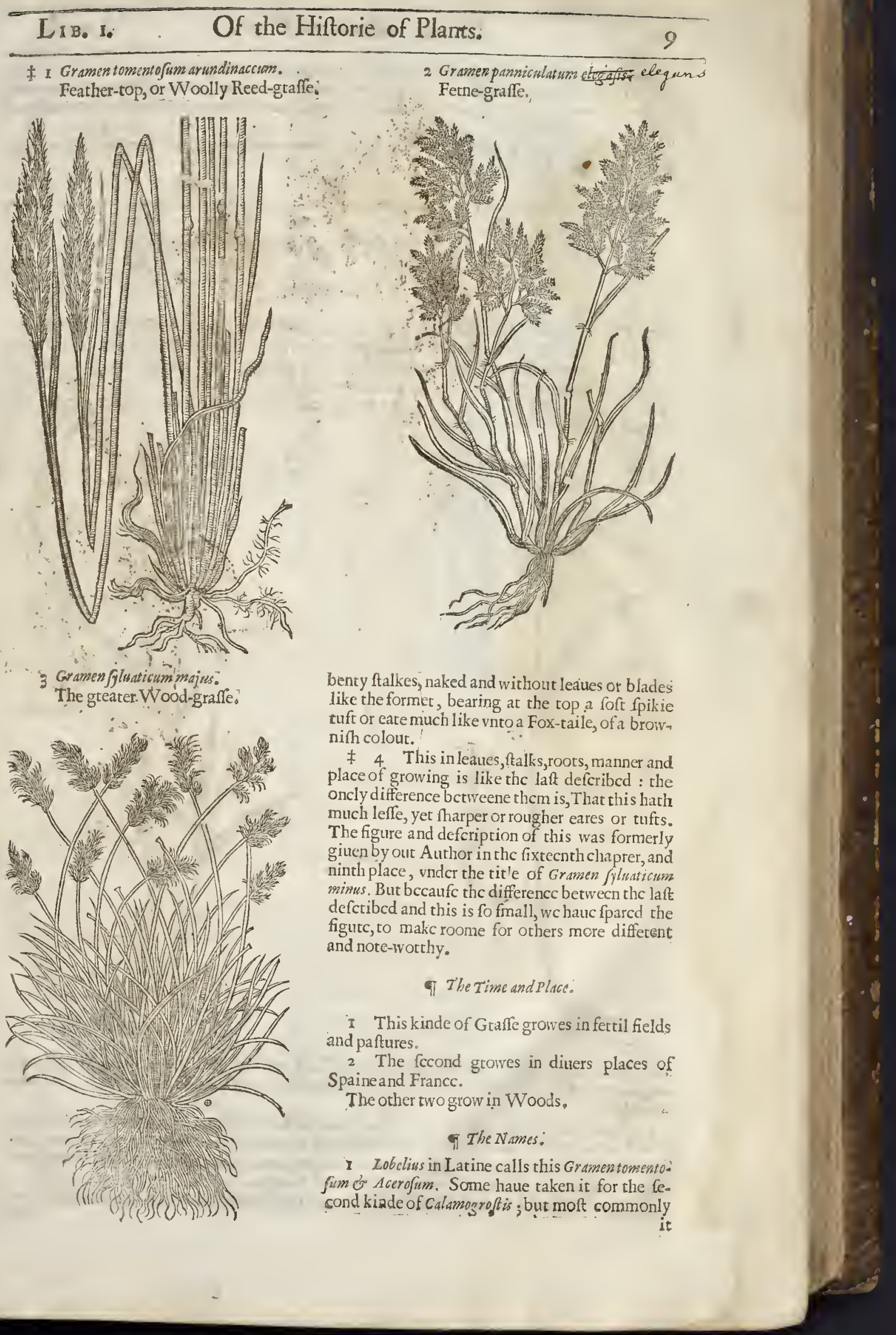


it is catled Gramen plumofum : and in Englih, a Bent, or Feather-top Graffe.

2 Gramen pamiculatum is called by fome Heragroftu in Greeke. Label calls this Gramen panisulofum phaluroides. And it is named in the Hifl. Lugd. Gramen filacem, (eupolyanthos : that is, Fenne, or maity-floured Graffe. †

3 Gramcn fyluaticum, or as it pleafeth others, Gramen nemorofum, is called in our tongue, wood Grafle, or hidow Grafle. 2

$$
\begin{gathered}
\text { Ch A Р.7. Ofgreat Fox-taile Grajfe: } \\
\text { II The Defcription. }
\end{gathered}
$$

I He great Fox-taile Graffe hath many threddy roots like the common Medow grafle;

1 and the ftalke rifeth immediatly from the root, in fafhion like vnto Barley, with two of three leaues or blades like Otes; but is nothing rough in handling, but foft and downie, and fomewhat hoarie, bearing one eare or tuft on the top, and neuer more; farhioned like a Fox-taile, whereof it tooke his name. At the approch of Winter it dieth, and recoureth it felfe the next yeare by falling of his feed.

I Gramen Alopecuroides majus: Great Fox-taile Graffe.

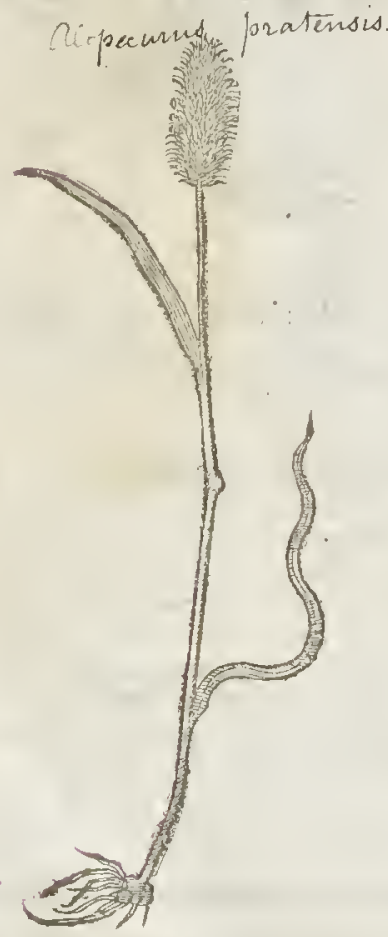

I 2 Gramen Alopecurgides minus. Small Fox-taile Graffe.

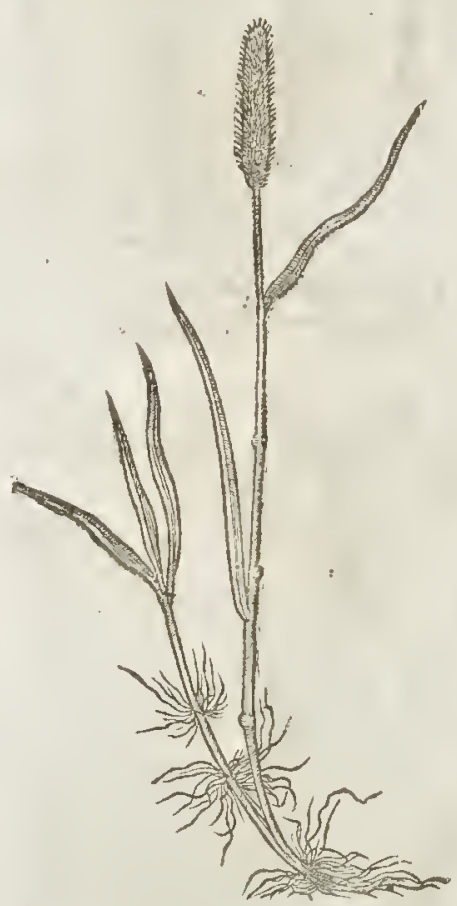

2 The leffer Fox-taile Grafe hath a tuffe and hard root compact of many fmall ftrings, yeelding a frawie ftalke like the forner, though fomwhat leffer, ivith the like top or cref, but of a whitifh colour.

3 Greatbaftard Fox-taile Graffe hath a frawie ftalke or ftemme, which rifeth to the he ight of a cubit and an halfe, hauing a finall root confiting of many fibres. His leafe is fmall and graffie, and hath on his top one tuft or fpite, or eare of a hard chaffe fubfance, fome three inches long, compofed of longith feeds, each hauing a little beard or awne.

4 Small baitard Fox-taile Graffe doth refemble the former, fauing that this kinde doth not 
- fend forth fuch làrge falkes and eares as the other, but fmaller, and not fo clofe packed together,

I 3 Gramen Alopecurimum majus. Great baftard Fox-taile Gtaffe.

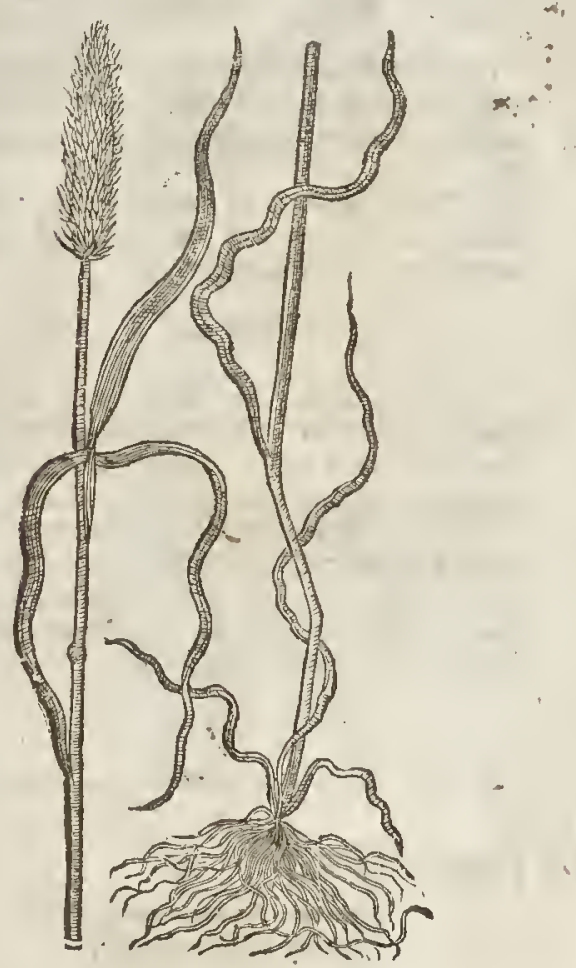

4 Gramen Alopecurinum minus. Small baftard" Foxrtaile Grafe,

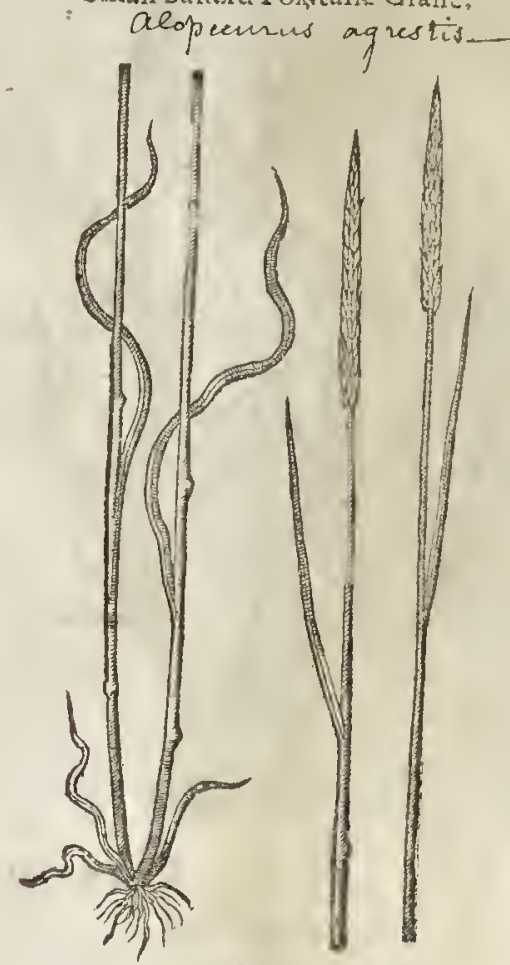

If The Place and Time? Thefe wilde baftard Fox-taile Graffes doe grow in the moift furrowes of fertile fields, towards
the later end of Sommer.

$$
\text { The Nambs. }
$$

\# The firt by Lobel and $\tau_{\text {abern. }}$ is called Gramenphalaroides. The other Lobel calleth 2 Gramere Alopecuroides. 3. minus. 4 . minus alterum.

\section{С н в. 8. Of Great Cats-taile Grafe. \\ 9f The Defcription.}

I

Reat Cats-taile Graffe hath very fmall roots, compact of many fmall skins or threds: which may eafily be taken from the whole root. The ftalke rifeth vp in the middeft? or thereabout; bearing at hat like vnto wilde Barley, kneed and ioynted like corne, of a foot high taile.

2 The fmail Cats-taile orafe is like vnto it. The root is thickeand cloued like thofe of Ruther, differing chiefely in that it is leffer than hairie threads annexed vnto it.

$\$ 3$ There is another that growes plentifully in many places about London, the which may fome two foot or better high, fet at each ioynt with long graffeleaues : the foike oreare is com- 
Gramen Typhinum minus.

Small Cats-talle Grafle.

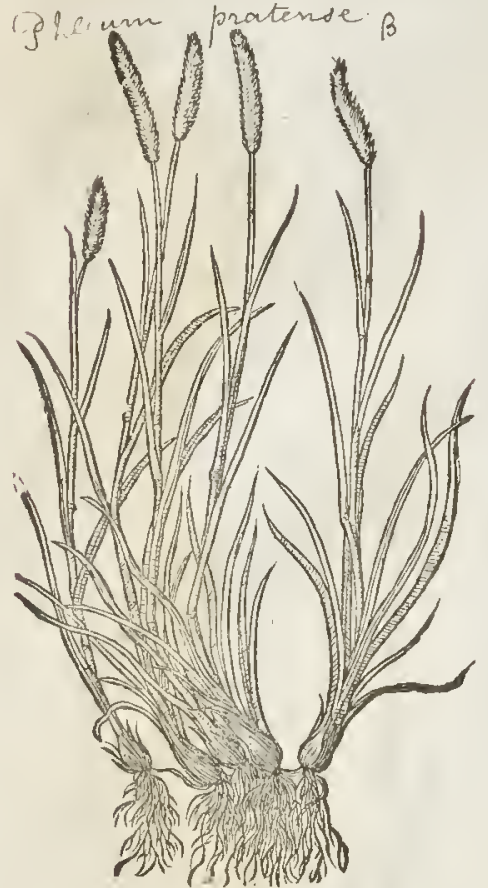

Cна в.9: Of Cyperus Graße.

I Gramen Cyperoides. Cyperus Graffe.

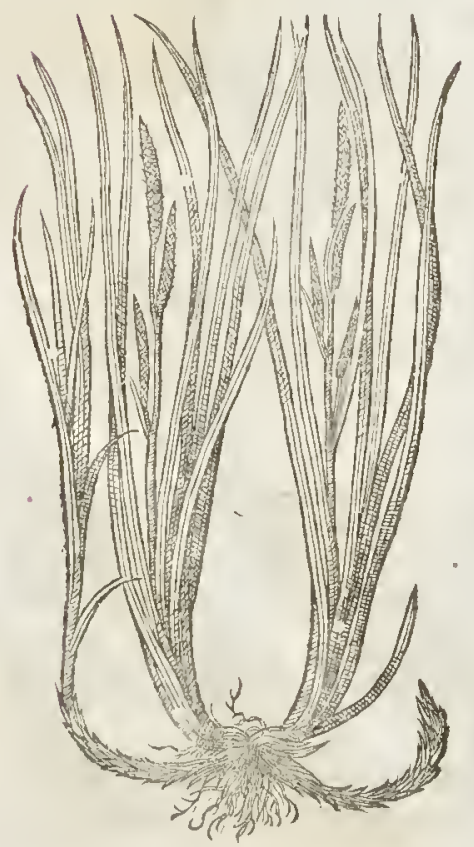

monly foure or fue inches long, elofely and handfomely made in the fathion of the preeedent, whieh in the thape it doth very much refemble. *

of The Place and Time.

Thefe kindes of Graffes do grow very well neere waterie places, as Gramen Cyperoides doth, and flourifh at the fame time that all the others doe.

\# The latter may be found by the bridge entring into Chelfey field, as one gocth from Saint Iames to little Chelfey. $\ddagger$

$$
\text { T) The Names. }
$$

The Latines borrow thefe names of the Greekes, and call it Gramen Typhinum, of Typha, a Cats taile : and it may in Englifh as wel be called round Bent-graffe, as Cats-taile Graffe.

* The laft deferibed is by Butbine, who firft gaue the figure and defeription thereof in his Prodomus, pag Io. ealled Gramen Typhoides maximurn picalongisima; that is, The largeft Foxetaile Graffe with a very long care. \pm
2 Gramen Tunceum aquaticum? Rulhy Water-Grafle.

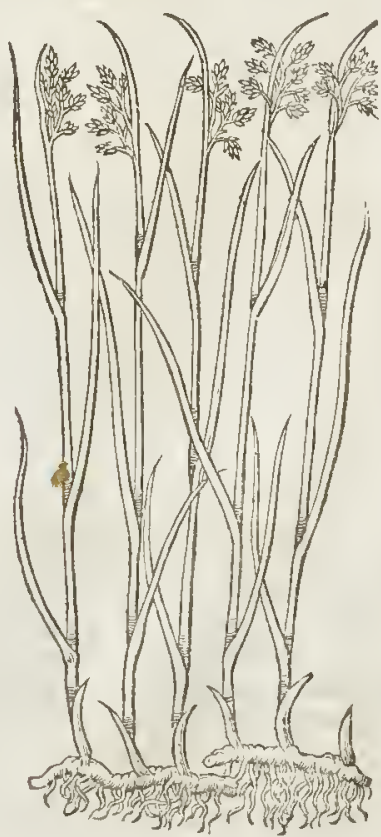




\begin{tabular}{lll}
\hline L I B. 1. Of the Hiltorie of Plants. & 13 \\
\hline The Defription.
\end{tabular}

I

Yperus Grafle hath roots fomerwhat like Cyperus, wheteof it tooke his rame: his leaues ate long and large like vnto the eommon reed : the ftalke doth grow to the height of a eubit in fome places; vpon which groweth little fealy knobs or eares, fpike fafhion, fomew hat like vnto Cats-taile, ot Reed-mace, very ehaffie, rough, and rugged.

2 Ruthy Water-graffe hath his toots like the former, with many fibres ot ftrings hanging at them; and creepeth along vpon the vppetmoft faee of the earth, or rather mud, whercin it gtoweth, bearing at each ioynt one flender benty ftalke, fet with a few fmall grafie blades or leaties. bringing forth at the top in little hoods, Inall feather-like tufts or eares. T) The Place, Time, and Names.

They grow, as I haue infinuated, in myrie and muddy grounds, in the fame fea fon that others do. And eoncerning their names there hath been faid enough in their titles.

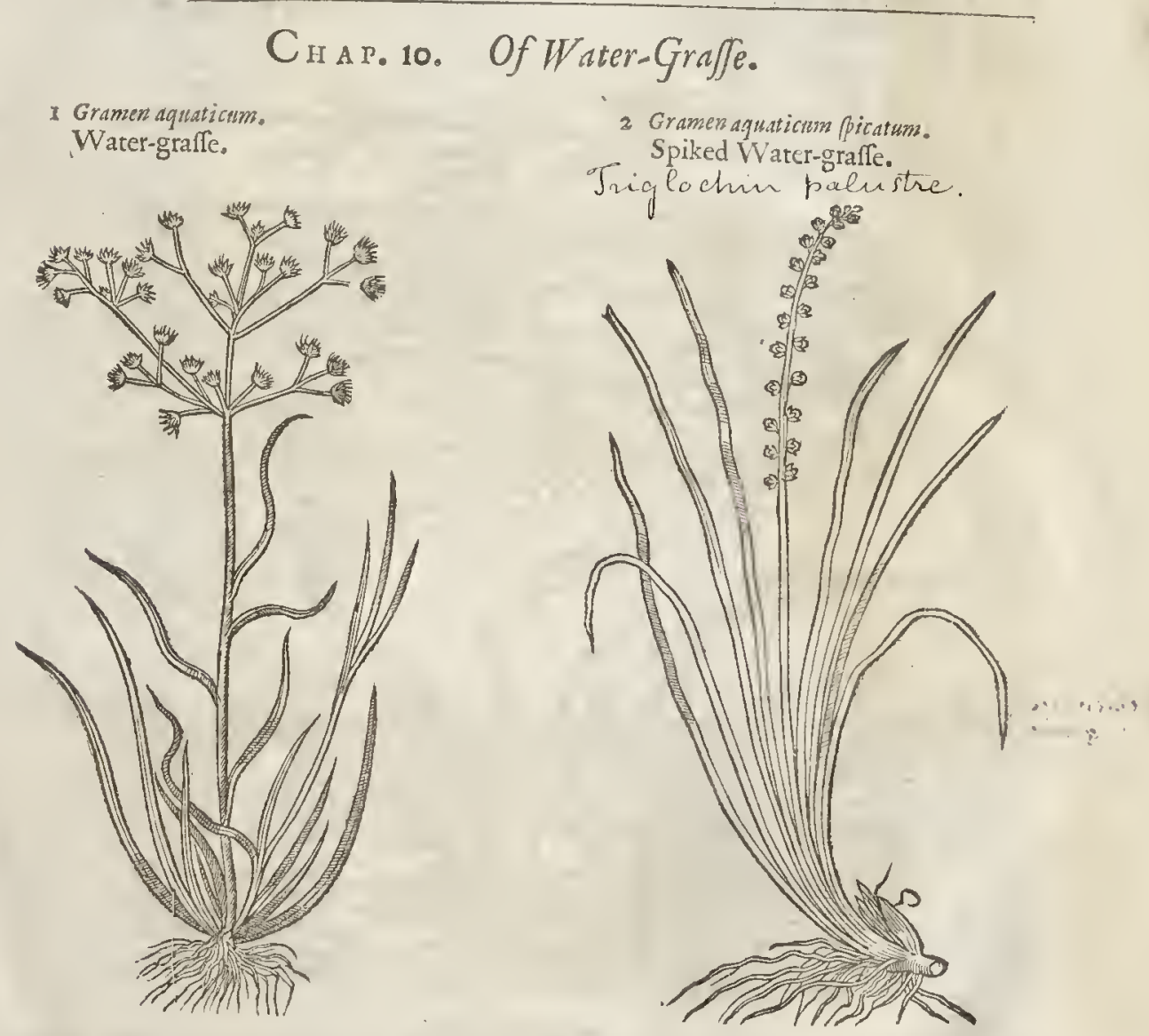

9) The Defoription.

I TJ.7 Atet-graffe, ot as we tetme it, Water Butre-graffe, hath a few long nartow flender and ioynted leaues: among which rifeth vp a falke of two foot high, bearing vpon his fmall and tender btanches eertaine little rough knobs, or brownith fharpe pointed feeds made vp into cornered heads : his root is fmall and threddy.

¥ The figure of this plant is not well expreft, for it thould haute had the leaues made narrowet, and ioynts expreft in them, like as you may fee in the Gramen jwaccum fyluaticum, whieh is the ninth in the fixtcenth ehapter; for that and this ate fo like, that I know no other difference berweene them, bur that this hath leaues longer and narrower than that, and the heads fmaller and whirer. There is a reafonable good figute of this in the Hiftoria Lugd.p.100I. vnder the name of W A rundo minima. 
2 Spiked Water-graffe lath long narrow lcates: the ftalke is fmall, frngle, and naked, without leaues or blades, bearing along ft the fame torvard the top an eare or $f$ pike made of eertaine fmall buttons, refembling the buttonic floures of Sea Worme-wood. His root is thiek \& tough, full of fibres or threds.

\section{The Place and Time.}

They differ not from the former kindes of Graffes in plaee and time : and their names are manifeft.

- The NatureandVertues.

Their nature and vertues are referred vnto Dogs Graffe, whereof we will fpeakc hereafter.

$$
\text { Cha r.ix. Of Flote-Grafje: }
$$

I Gramenfuviatile. Flote-grafie.
2 Gramen fuviatile picatwru. Spiked Flote-grafle.
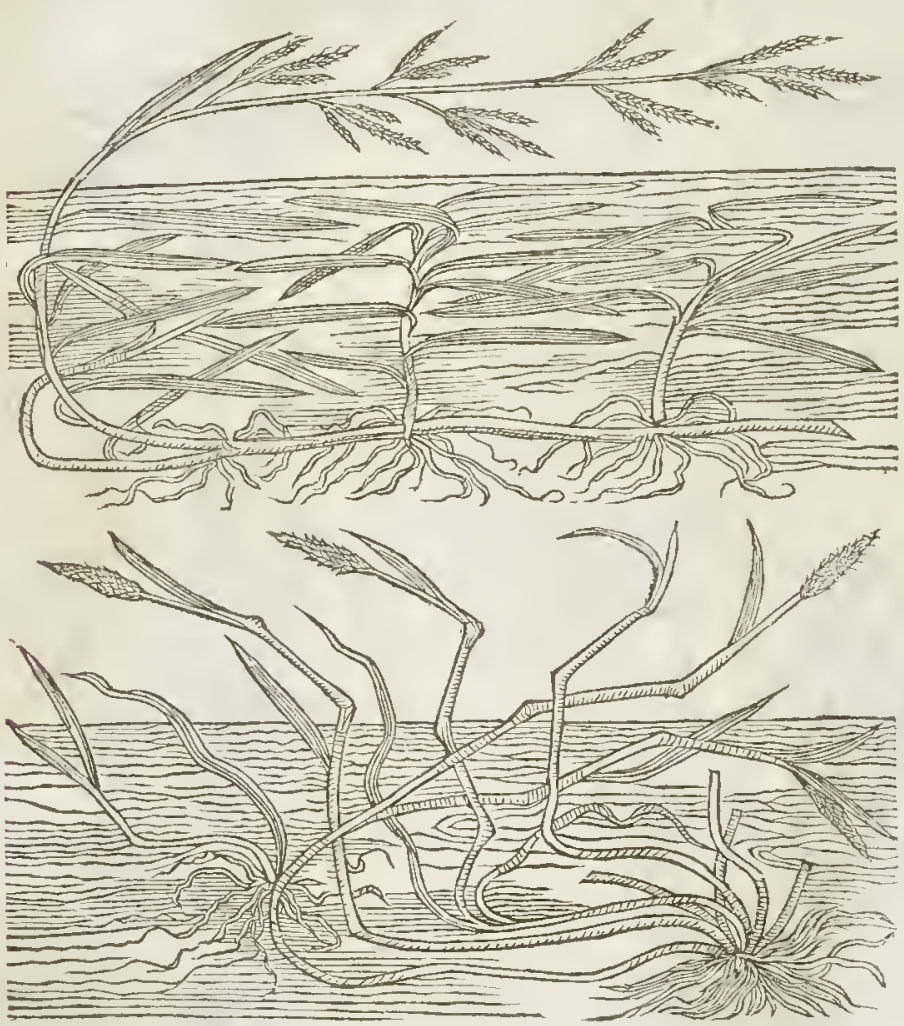

- The Defeription.

t I CLote-graffe hath a long and round root fomewhat thieke, likevnto Dogs-graffe, let $F$ on euen ioynts with fimall ftrings or threds; fro $n$ the which rife vp long and erooked ftalkes, eroffing,winding,and folding one within another with many flaggie leates, whieh horfes eate greedily of. At the top of thefe ftalks, and fomewhat lower, there come Fortl very many litt'c eares of a whitin colour, compofed of two ranks of little ehaffie feeds fet alternately, each of thefe fmall eares being almoft an ineh in length.

2 Spike Flote-Grafe, or fpiked Flote-graffe bearethat the top of each flender ereeping ftalkene fniked eare and no more, and the other many, which maketh a differenee betwixt them, otherwife they are one like the other. His root is eompac, tufted, and made of many thrummie threds.

$$
\text { T) The Place. }
$$

The firft of thefe growes euery where in waters. The fecond is harder to be found. 


\section{The Names.}

The firf is called Gramen fuviatile, and al fo Grancn aquis innatans : in Englifh, Flote-grafe. Tr. ous calls it,Gramen $A$ natrm, Ducks-grafe.

The feeond is called Gramen fuviatile picatum, and fuviatile album by 1 abcramontanus. Likewife in Englin it is ealled Flote-graffe, and Floter-graffe, becaufe they fivimme and Hote in the water.

\section{Cна т.12. Of Kneed-Grafje. \\ T) The Defcription.}

i T Need-graffe hath ftraight and vpright ftrawie ftalkes, with ioynts like to the ftraw of corne, and beareth fmall graffie leaues or blades fpiked at the top like vnto Pannick, with a rough eare of a darke browne colour. His roots are hairy and threddy, and the ioynts of the ftraw are very large and confpieuous.

I Gramengeniculatwr.

Kneed-graffe.

Panicum verticileatumi

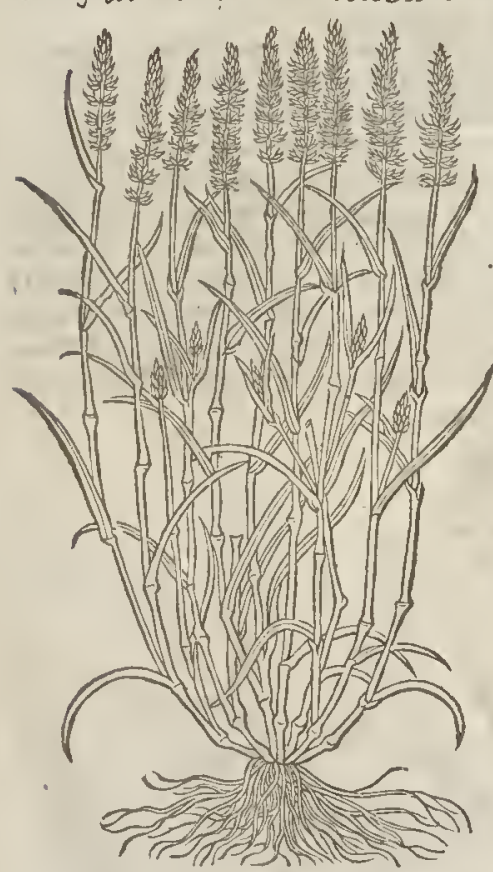

2 Gramengeniculatum aquaticum. Water Kneed-graffe.

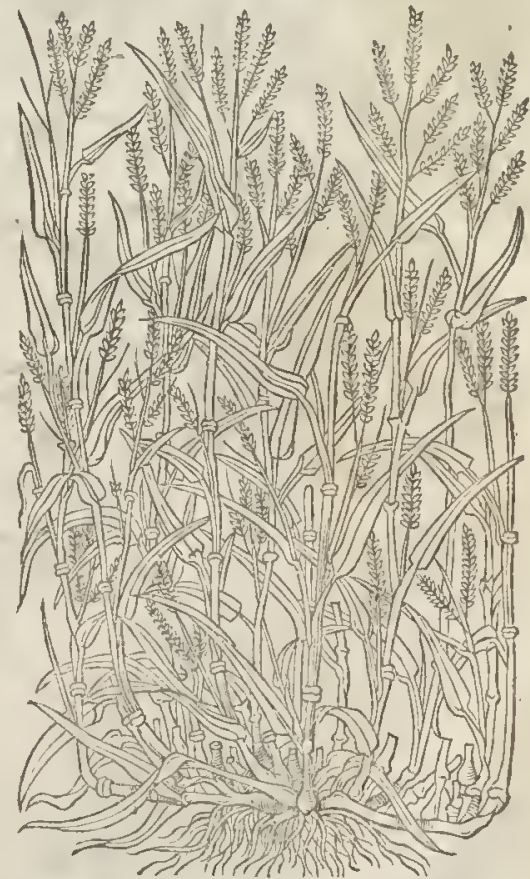

2 Water Kneed-graffe hath many long and flender ftemmes, ioynted with many knobby and gouty knees like vnto Reed, fet with broad flaggy leates fonctwhat fharpe pointed; bearing at the top a tuft or panniele diuided into fundry fuall branches, of a duskith colour. His root is threddie like the orher.

$$
\text { If The Place, Time, and Names. }
$$

Thefe Graffes do grow in fertile moift medowes; not differing in time from others. And they are called Geniculata, becaufe they haue large ioynts like as itwere knees.

We haue nothing deliuered vs of their nature and properties, 


\section{C н А Р. 13. Of Bearded Panicke Grafle.}

I Gramen Ianiceum.

Bearded Panick Graffe.

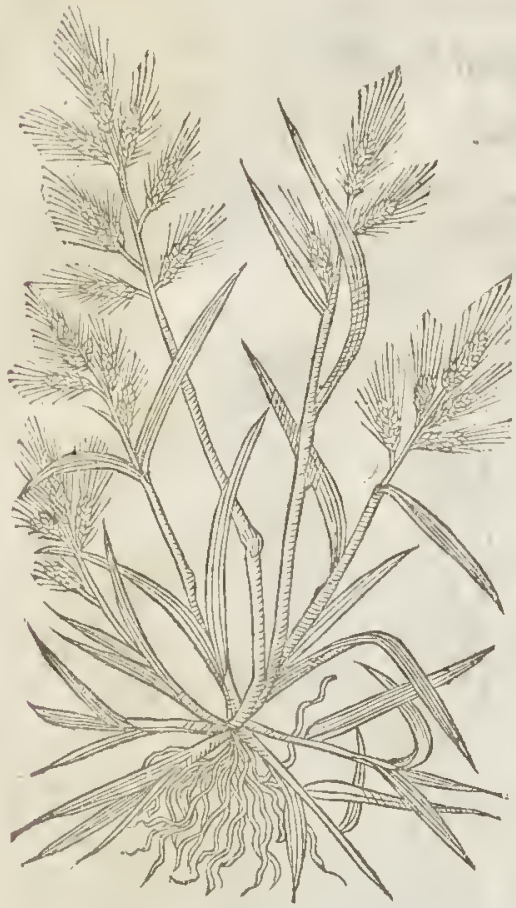

TI The Defription.

Rardel Panickegraffe hath broad and 1 large lcaues like batly, fomm lat hoürie, or bf an oner-worne rufler colour. The falkes hate twoor three iovnts at the mont, and many cates on the top, without order; vpon fome falkes more eares; on others fewer, much like vuto the eare of ilde Panicke, burthat this hath many beards or awnes, which the other wants.

2 Small Pannicke Grafic, as tobelims writeth, in roots, leaues, ioynts, and ftalkes is like the former, faung that the care is much lefle, confifting of ferrer romes of feed, contained in fimall chaffic blackifh hushes. This, as theformer, hath many eares ypon one ftat ${ }^{1} \mathrm{ke}$.

\# 3 This fmall Tanniche Grafe from a threddy root fendeth forth many little falkes, whereof fome are one hand full, other-fome lirtle more than an inch high, and each of thefe ftalkes on the top fuftaines one fingle eare, in fhape very like vnto the eare of wilde Pannicke, but about halfe the length. The Palkes of this are commonly crooked, and fet with grafic leanes likc to thereft of thiskinde. The figure hereof was vnfitly placed by our Author in the fixteenth place in the cighth chapter, vnder the title of Gramen $6 y$ : peroudes joicatum.

2 Gramenpariceumparvum.

Small Panicke Graffe.

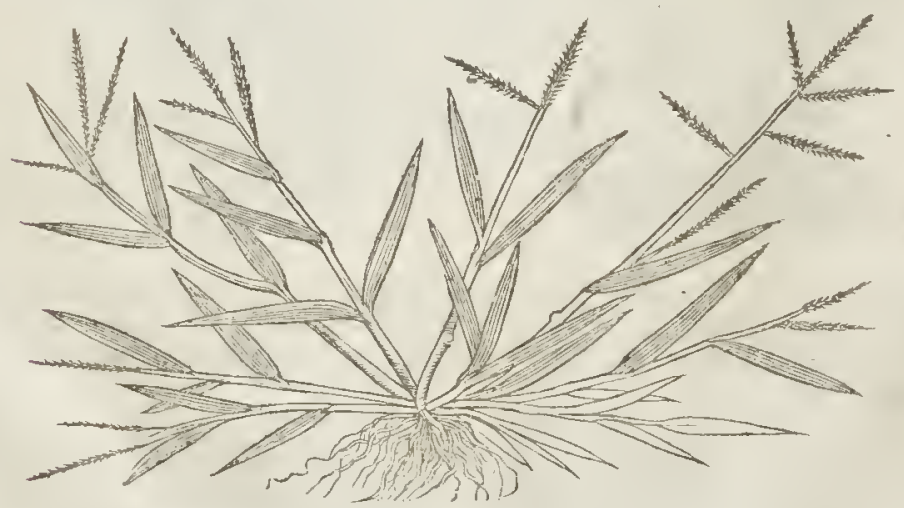

9) The Place and Time.

The firft of thefe two doth grow ncere vnto mud walls, or fuch like places not manured, yet fertile or fruitfull. 
The fecond groweth in thallow waterie plathes of paftures, and at the fame time with orhers. $\ddagger$ I haue not as yet obferued any of thefe three growing wilde. $\neq$

+ 3 Gramen Pannici effiriefpica fimplici. Single eared Pannicke Graffe.

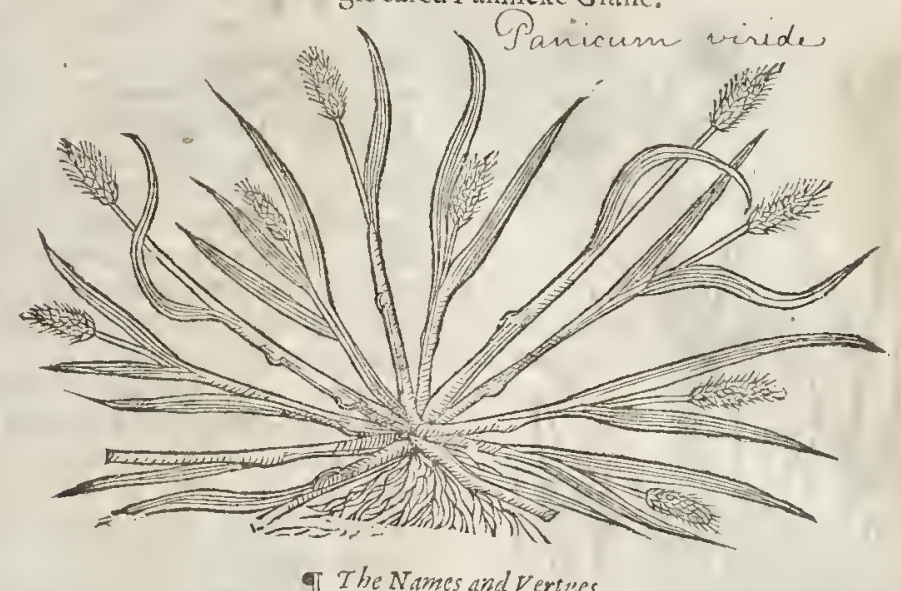

They are called Panicke Grafies, becaufe they are like the Italian corne called Panicke. Their nature and vertues are not knowne.

t I Gramenpaluflre Echinatum. Hedge-log Graffe.

Carex leava

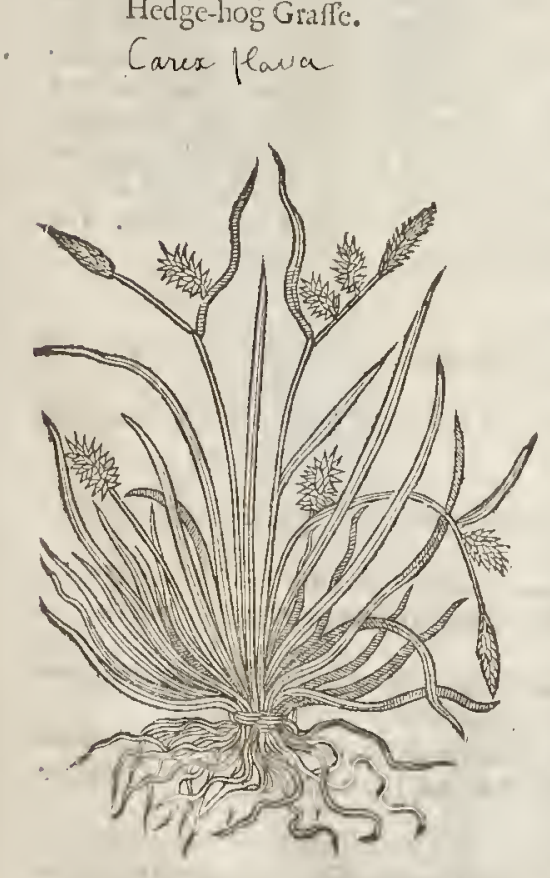

\section{HaP. 14. Of Hedge-hog Grafje.}
2 Grumen exile Hirfutum. Hairy-graftc, Jumcis campestris.

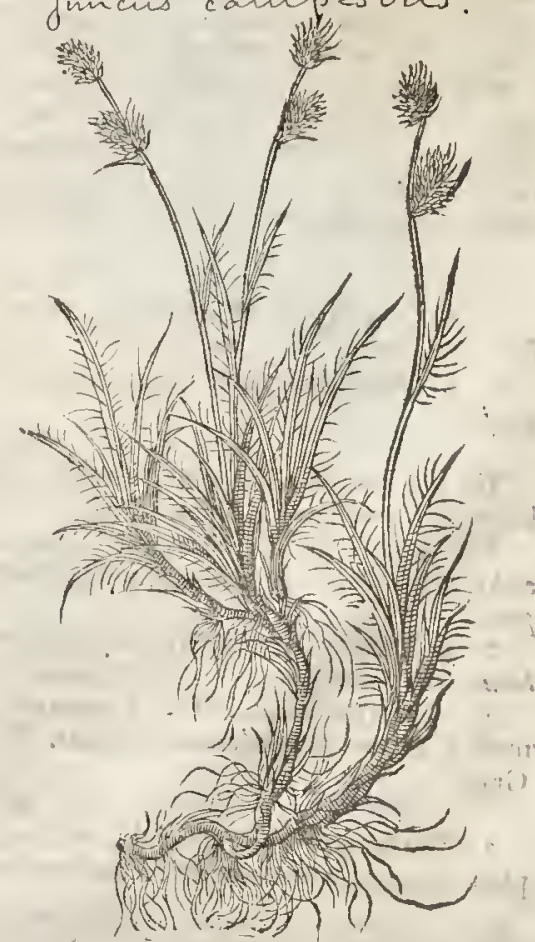


$\ddagger 3$ GramenCipitalis globofis.

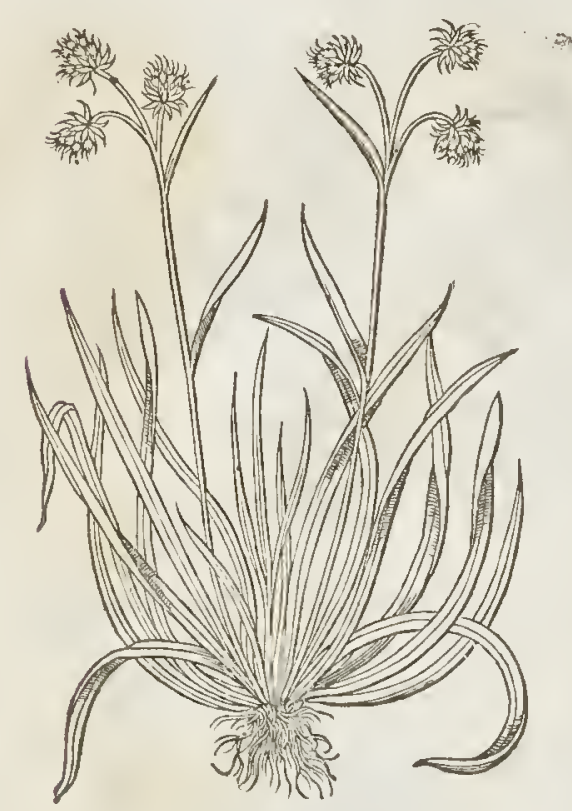

Round headed Siluer-grafle.

T) The Deferiftion.

I

1 Edge-hog Graffe hath long ftiffe fliggy leaues with diuers ttalkes proceeding from a thicke fpreading root; and at the top of cuery ftalke growe certaine round and pricking knobs faihioned like an hedge-hog.

$t \quad$ The fecond is rough and hairie: his roots do fpred and creep vnder the mud and myre as Cyperus dorh; and at the top of the italkes are certaine round foft heads, their coloul being browne, intermixed with yellow, fo that they looke prettuly when as they are in their prime.

$\ddagger 3$ This Grafe (whofe figure was formerly in the firft place in this Chapter) hath a fmall and fibroustoot, from which rife leates like thofe of Wheat, but with fone long white hairs vpon them like thofe of the lat vefcribed:at the tops of the ftalks (which are fone foot or better ligh) there grov two or threc round heads confifting of fo tand white downie threds. Thefe heads are frid to thine in the night, and therefore they in Italy call it (according to Cufalpi. nus) Lucrola, quia soct un lucet:

4 To this I may addeanother growing alfo in Italy, and firft deferibed by Fabitus columna. It hath fmall, creeping ioynted roots, out of which come fmall fibres, and leaues little and very narrow at the firf, but thofe that are vpon the ftalkes are as long againe, incompaffing, the ttalks, as in Wheat, Dogs-graffe, and tho like. Thefe leaues are crefted all along, and a little forked at the end : the ftraw or ftalke is very flender, at the top whereof growes a tharpe prickly round head, much after the manner of the laft defcribed : each of the feed-veffels whereof this head confins ends in a prickly ftalke hauing fute or feuen points, whercof the vppermolt that is in the middle is the longeft. The feed that is contained in thefe prickly vefels is little and tranfparent, like in colour to that of Cow-wheat. The floures (as in others of this kinde) hang trembling vpon yellowish fmall threds. $\ddagger$

ब The Place and Time.

+2 They grow in watery medows and fields, as you may fee in Saint Georges fields and fuch like places.

34 Both thefe grow in diuers mountainous places of Italy; the later whercof floures in May.

T 7 be Numes.

The firft is called Hedge-hog Graffe, and in Latine, Gramen Echinatum, by reafon of thofe pric: kles which are like vnto a hedge-hog.

The fecond hairy Grafe is called Gramen cxile hirfutum Cyperoides, becaufc it is fmall and littic, and rough or hairy like a Goat : and Cyperoides, becaufe his roots do fpring and creepe like the Cyperus.

‡ 3 This by Anouillsra is thought to be Combretum of Pliny; it is Gram. Incidum of Tabernamon. tanus; and Gramen birfu'wn capitulo globofo, of Bauhne, Pin.pag.7.

4 Fabius Column calls this, Gramen montanm Echinatum tribuloides capitatum : and Babine nameth it, Gramen pica Jabrotundaechinata. Wee may call it in Englifh, Round headed Caltrope Grafle.

$$
\text { बा The Vertucs. }
$$

3 The heade of this (which I haue thought good to call Siluer-graffe) is very good to be applied to greene wounds, and effectuall to ftay bleeding, Cafalp. $¥$

† It is cuident by the mane and defcription, that ont Author meant this which we here gitue you in the firf place; yet his figure was of another Graffe fomwhas

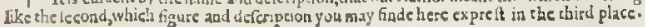

Cliap. 


\section{Cir A P. 15. Of Hairy Wood-Graße. \\ Tl The Defcription.}

I I Airy Wood-graffe hath broad rough leaues fomewhat like the precedent, but much 1 longer, and they proceed from a threddy root, which is very thicke, and ful of itrings; as the common Grafle, with frall ftalkes rifing vp from the fame roots; but the rop of thefe ftalkes is diuided into a number of little branches, and on the end of euery one of them ftandeth a little floure or huske like the rop of Allum Vrfinum, or common Ramfons, wherein the feed is contained when the floure is fallen.

2 Cyperus Wood-grafle hath many theary grafie leaues, proceeding from a root made of many hairy ftrings or threds : among which there rifeth vp fundry fraight and vpright ftalkes, on whofe tops are certaine fcaly and chaffie huskes, or rather fpikie blackifh eares, not much vnlike the catkins or tags which grow on Nut-trees, or Aller trees.

I Gramen birfutum nemorofium. Hairy Wood-grafle.

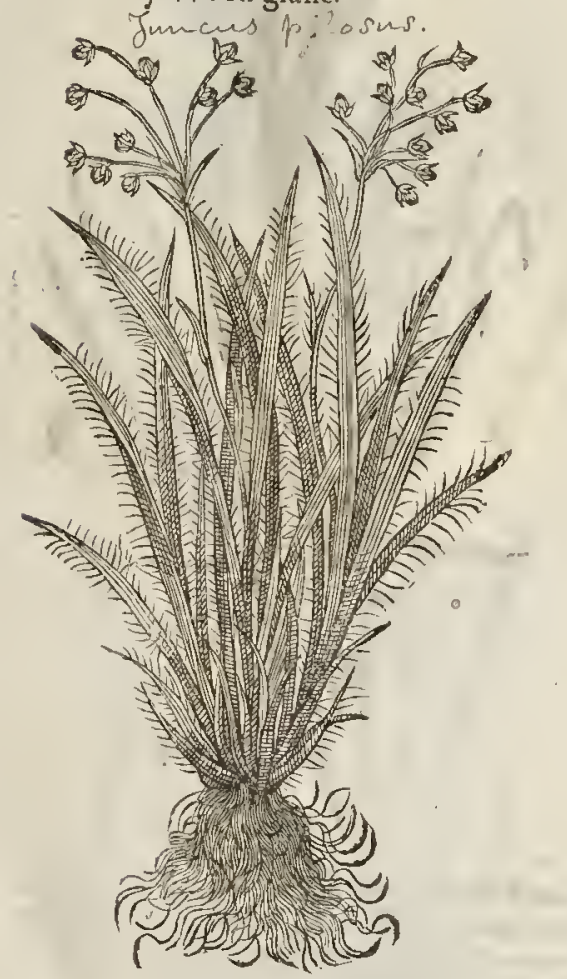

3. Gramen Cyperinum nemorofum. Cyperus Wood-grafe.

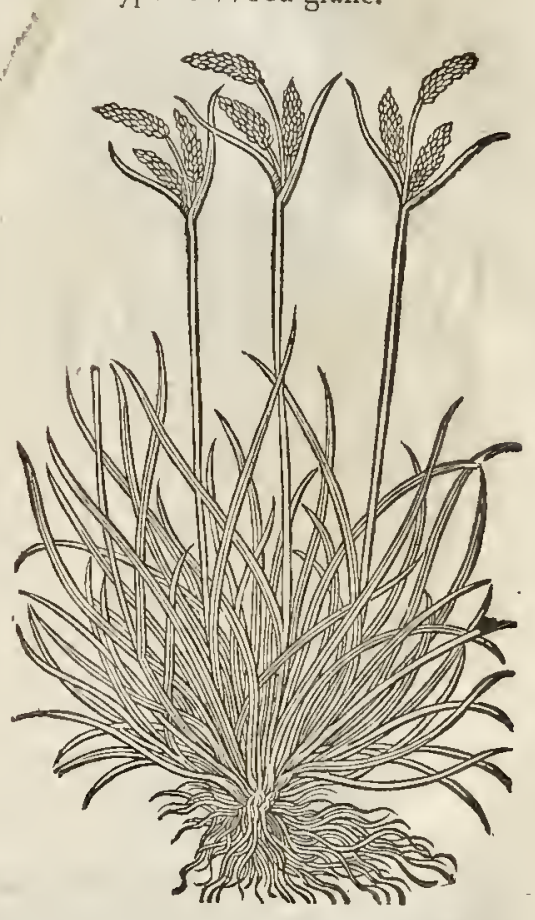

I The Place; Time, and 2 ames. Thefe two grow in woods or thadowie places, and may in Englifh be called Wood-graffes?
Their time is common with the reft;

\section{T. Their Nature and Veritues:} mer.

There is nothing to be faid of their nature and vertues, being as vnknowne as moft of the for? 


\section{Cин т. г 6: Of Sea Spike-Grafje: \\ I The Defription.}

† I Ea Spike-gtafie bath many fmall hollow round leates about fix inches long, rifing from a buthy thteddy white fibrous root, which are very foft and fmooth in handling. Among thefe leanes there doe fpring vp many fmall rufhy ftalkes; alopgft which are at the firft diuers fmall flouring round buttons; the fides wheteof falling away, the middle part gtowes into a longifh feed-veffell ftanding vptight.

1 Gramen marinum picatrm. Sea Spike-graffe.

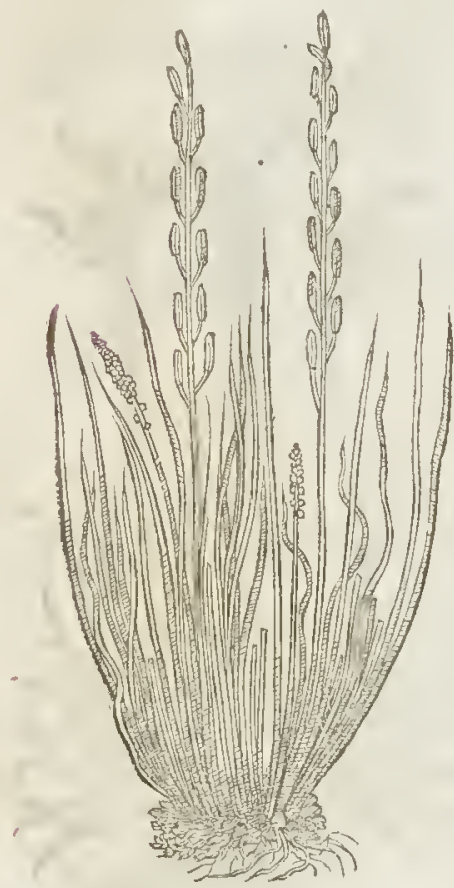

2 Gramen picatum alicrum.

Salt math Spike graffe.

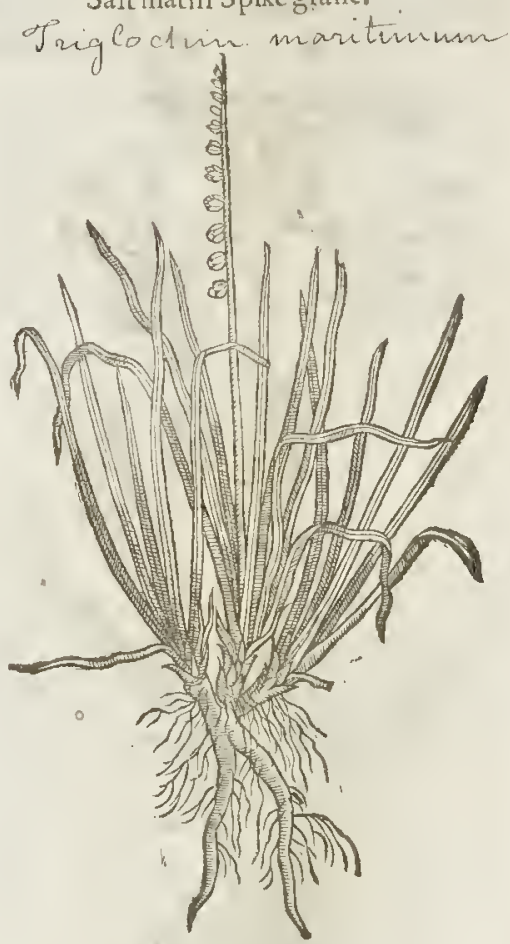

$\dagger=$ Salt-marnh Spike-gtaffe hath a woody tough thicke root with fome fmall hairy threds fanted thereunto; out of which arife long and thicke leaues very like thofe of that Sea-graffe we vilgarly call Thrift. And amongft thefe leaues grow vp flender naked rushy ftalkes which liauc on one fide fmall knobs ot buttons of a gteenifh colour hanging on them.

3 The third hath many rufhy leates tough and hard, of a browne colour, well refembling Ruthes: his root is compact of many fmall totgh and long ftrings. His falke is bare and naked of leates vnto the top, on which ir hath many fmall prctty chaffic butrons or heads.

4 The fourth is like the third, faring that it is larger; the ftalkc alfo is thicker and taller than that of the former, bearing at the top fuch huskes as are in Ruthes.

5 Great Cypreffe Graffe hath ditiers long three-fquare ftalkes proceeding from a toot compact of many long and tough ftrings or threds. The leaues are long and broad, like vnto the fedge called Carex. The fpike or eate of it is like the head of Plantaine, and very ptickly, and commonly of a yellowith greene colour.

6 Small Cypreffe Graffe is like vnto the other in root and leates, fauing that it is finaller. His falke is fmooth and plaine, bearing at the top certaine tufts or pannicles, like to the laft deferibed in roughnefie and colour. 


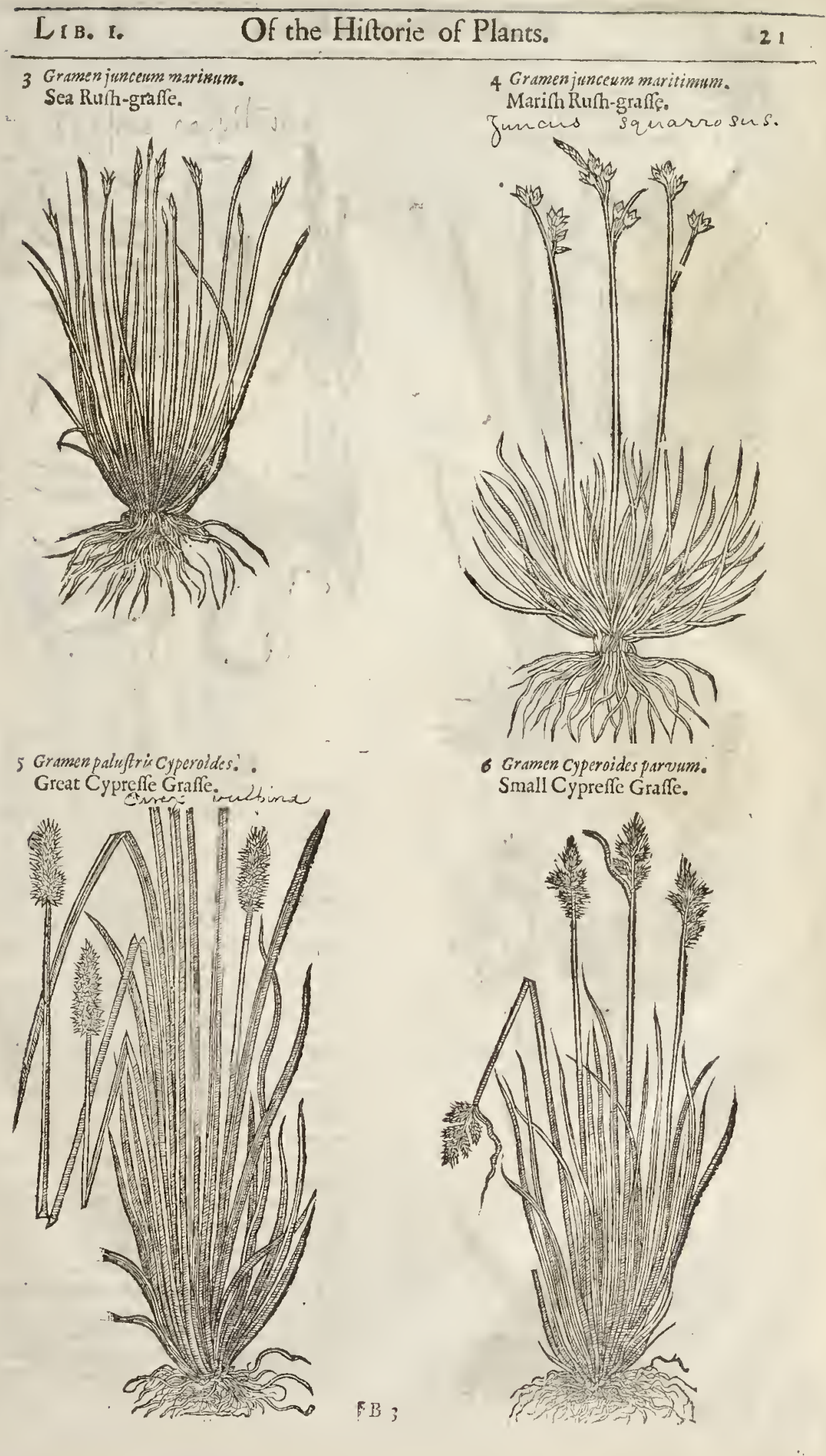


7 Gramen aquaticumi Cyperoides oulgatius. Water Cyprefle Graffe.
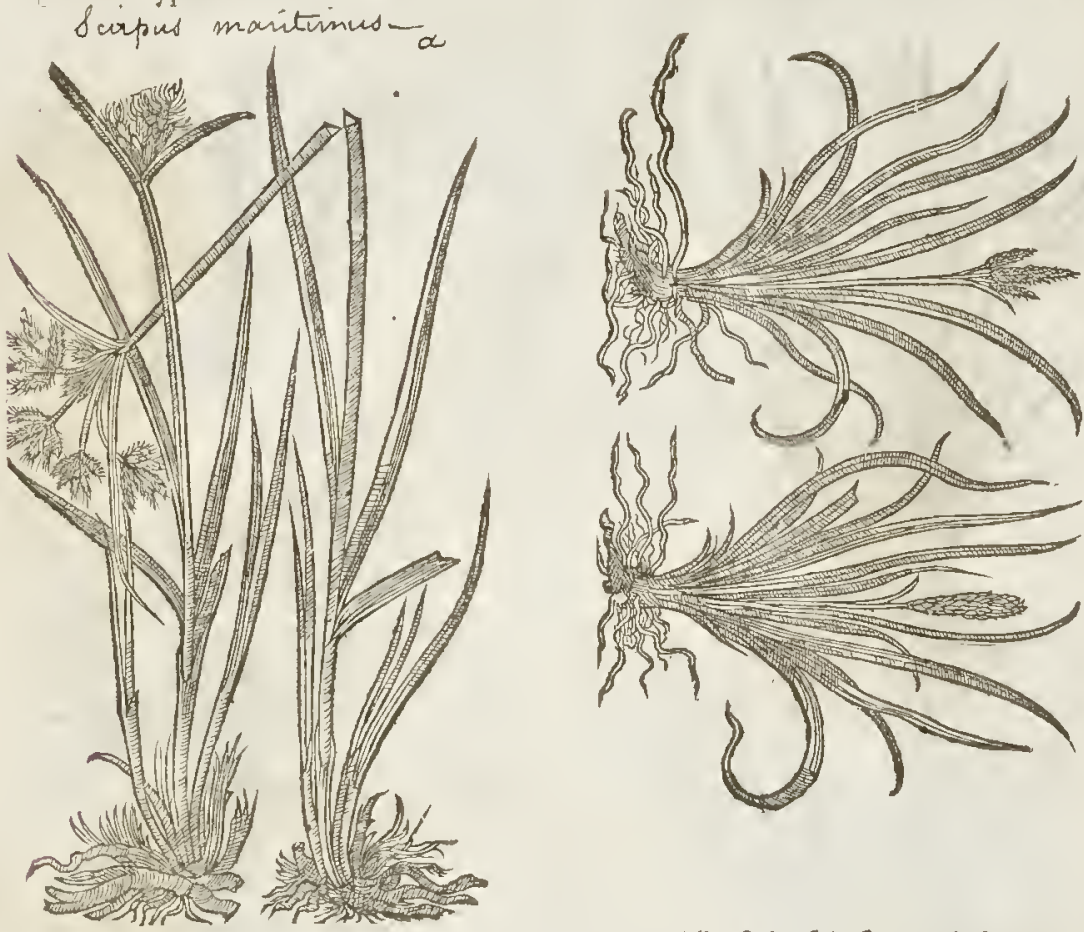

को

5)

$\therefore$ \&

$\rightarrow$

है

$\curvearrowleft$

बid

9 Gramenjunceun fyluaticum. Wood Rulhy-graffe.

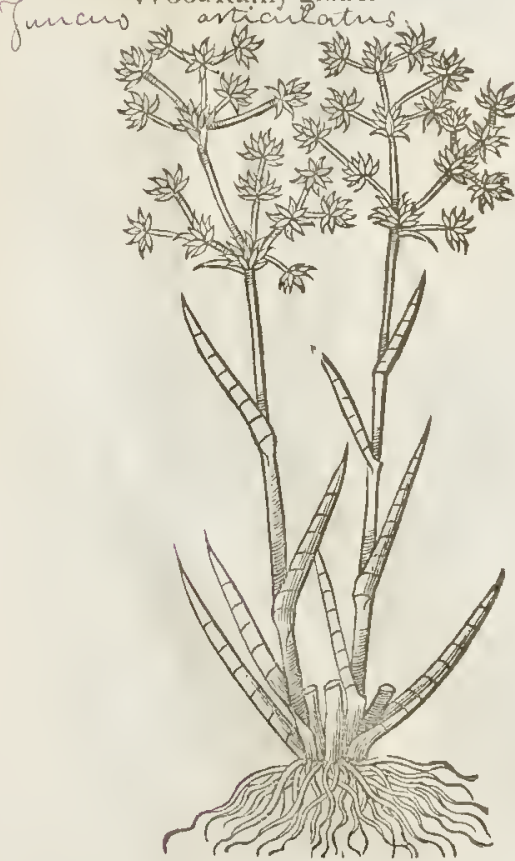

7 The firft of thefe two kindes hath many crooked and crambling roots of a woody fub. ftance, very like vnto the right Cyperus, differing from it onely in fmell, becaufe the right Cyperus roots hate a fragrant fmell,and thefe none at all. His leaues are long and broad, rongh, tharp or cutring at the edges like fedge. His ftalke is long, big, and three fquare, like to Cyperus, and on his rop a chaffie vmbelor tuft like vnto the true Cyperts.

¥ 8 The fecond hinde hath many broad leaues like vnto thore of Gillowers, but of a frefher greene: amongft the which rifeth vp a Thort falke fome handful or two high, bearing at the top three or foure thort eares of a reddith murrey colour, and thefe cares grow commonly together at the top of the falk, and not one vnder another. There is alfo another leffer fort hereof, with leaues and roots like the former, but the ftalke is commonly fhorter, and it hath but one fingle eare at the top theteof. You haue the figures of both thefe expreft in thefame rable or piece. This kinde of Graffe is the Gramen fpicatum foligs Vetonice of Lobel. +

9 This hath long tough and hairy ftrings growing deepe in the earth like a turfe, which make the root; from which rife many crooked tough and rufhy falks, hauing toward the top rcaly and chafie lnobs or buttons. ‡ This 

growes fome halfe yard high, with round brownifh heads, and the leaues are ioynted as you fec
them expreffed in the figure we here gine you. $\ddagger$

I The Place, Time, Names, Nature, and Vertues.

All the Graffes which we have defcribed in thischapter doe grow in marifh and watety places necre to the fea, or other fenny grounds, or by muddy and myrie ditches, at the fame time that the others do grow and fourifh. Their names are eafily gathered of the places they grow in, or by their Defcriptions, and are of no vertue nor ptopertie in medicine, or any other neceffatic vfe as yet knowne.

reftored to his dn the eighth place (but very ynfity) was the figure of Gramen panaicieffigic Bica fwaph. being the third in the thirteenth chapcer. The ninth allo is

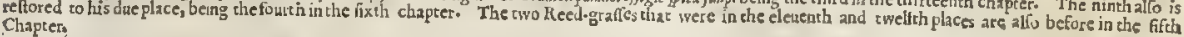

\section{C н а . 17. Of Couch-Grafje, or Dogs-graße.}

I Gramen Caninum.

Couch-graffe, or Dogs-graffe:

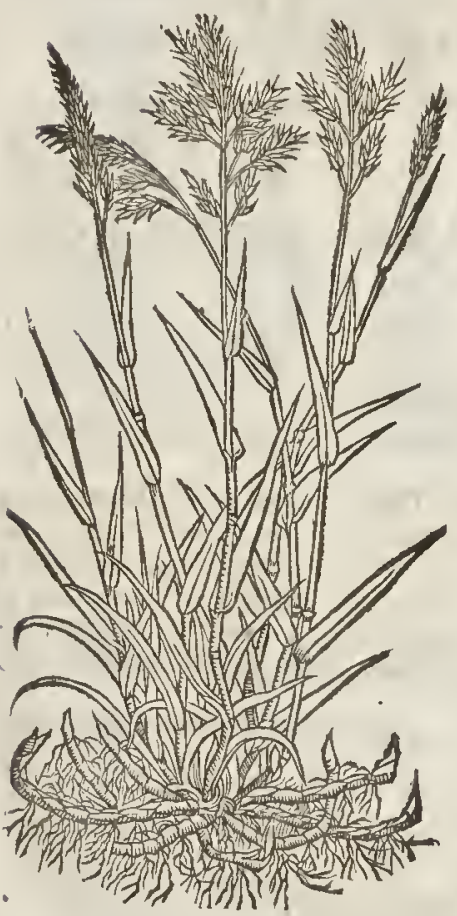

2 Gramen Caninum nodofurm. Knotty Dogs-graffe.

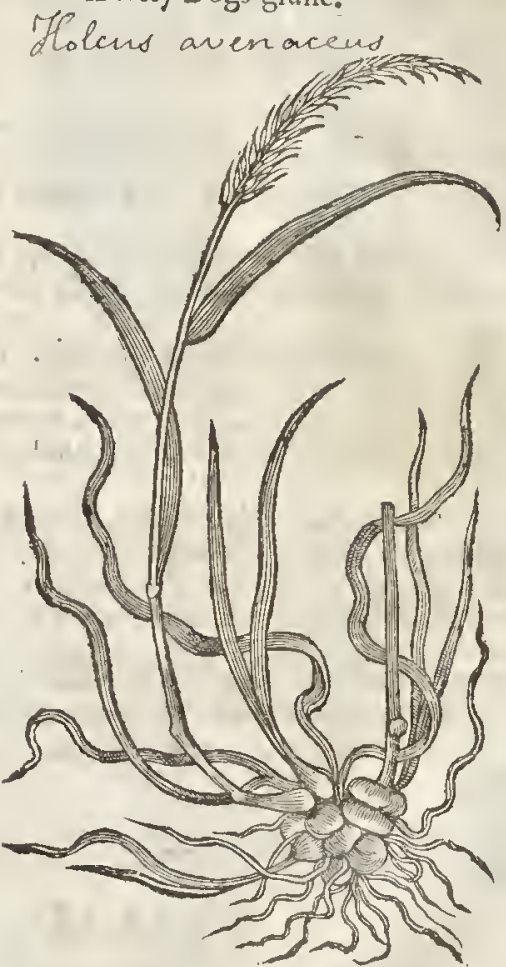

T) The Defcription.

-t I THe common or beft knowne Dogs-graffe, or Couch-graffe hath long leaues of a whitifh greene colour : the ftalke is a cubit and a halfe high, with ioynts or knees likewheaten ftraw, but thefe ioynts are couered witly a little fhott down or woollineffe. The plume or tuft is like the reed, but fmaller and more cliaffe, and of a grayifh colour: it creeperh in the ground hither and thitherwith long white roots, ioynted at certaine diftances, hauing a pleafant fweer tafte, and are platted or wrapped one witiilin anothet very intricately, infomuch as where it hapneth in gardens amongft pot-herbes, great labour muet be taken before it can be deftroyed, each piece being apt to grow, and cucry way to dilate it felfe.

$$
34
$$


2 Knotty Dogs graffe is like vnto the former in ftalke and leafe, but that they are of a decper colour; alfo the fpike ot eare is greener, and about fome two handfulls Iong, much in fhape refembling an Oate, yet far fuallet, and is much more difperfed than the figure prefents to you. The roots of this are fomewhat knotry and tuberous, but that is chiefely about the Spring of the yeare, for afterwards they become leffe and leffe vntill the end of Summer. And thefe buibes do grow confufedly together, not retaining auy certaine thape or number.

T The Place.

I The firft growes in gardens and arable lands, as an infirmitic or plague of the fields, nothing pleafing to Husbandmen; for after that the field is plowed, they are conftrained to gather the roots togetherw wh harrowes and rakes; and being fo gathered and laid vpon heapes, they fet them on fire left they hould grow againe.

2 The fecond growes in plowed fields and fuch like places, but not euery where as the other. I haue found of thefe in great plenty, botl growing, and plucked v pwith harrowes, as before is rehearfed, in the fields next to $S$.lames wall as ye go to Chelfey, and in the ficlds as ye go from the Tower-hill of London to Radcliffe.

T The time.

Thefe Graffes feldome come to thew their eare before Iuly.

The Names.

It is called Grumen Cuninum, ot Sanguinate, and Fniola. The Cointreymen of Btabant name it pecn : others, Leat geafle: of the Grecians, azess : of the Latines, by the conmon name, Gramen. It is of fome named a'zoo; : in Englin, Couch-grafe, Quitch-Gtaffe, and Dogs-grafte.

Gramen caninum bulbofim, or nodofmm, is called in Englifh, Knobby, or Knotty Couch-grafte. T The Nature.

The nature of Couch-graffe, efpecially the roots, agreeth with the nature of common Graffe: although that Couch-griffe be an vnwelcome gueft to ficlds and gardens, yet his phy fickevertues do recompence thofe hurts; for it openeth the ftoppings of the litter and reines, without any manifent beate.

The learned Phyfitions of the Colledge and Societic of London do hold this bulbous Couch grafle in temperature agreeing with the common Couch-graffe, but in vertucs mote cffectuall.

I The Vertues.

A Couch-graffe healeth greene wounds. The decoetion of the root is good for the kidneys and bladder : it prouloketh wine gently, and driueth forth grauell. Diofcorides and Galcs do agree, that the root famped and laid voon greene wounds doth heale them fpecdily.

B The decoetion thereof ferueth againft griping paines of the belly, and difficultic of making water.

C Marcellus an old Author maketh mention in his 26 chapter, That feuen and twenty knots of the herbe which is called Gramen, or Graffe, boiled sin wine till halfe be confumed, preffed forth, ftrained, and giuen to drinke to him that is troubled with the ftrangurie, hath fo great vertue, that after the Patient hath once begun to make waterwithout paine, it may not be gitien any more. But it muft be giuen with watet onely to fuch as haue a Feuer. By which words it appeareth, That this knottcal Graffewas taken for that which is properly called Gramem, or Agroftis; and hath bin alfo commended againft the ftone and difeafes of the bladder.

D The later Phyfitions doevfe the roots fometimes of this, and fometimes of the other indifferently.

\section{C н а т. 18. Of SeaDogs-Grafje.}

T) The Defription.

I IJe Sea Dogs-graffe is very like vnto the other before named: his leames are long and lender, and very thicke compact together, fet vpon a knotty ftalke fpiked at the top like the former. Alfothe root crambleth and creepeth hither and thither vnder the earth, occupying much ground by reafon of his great encreafe of roots.

₹ This Graffe(whereor Lobel gaue the firft figure and defeription, vnder the name of Gramen achiculatum Canmm swamm) I coniecture to be that which growes plentifully vpon the banks in the falt marithes by Durford in Kent, and moft other falt places by the fea; as alfo in many banks and orchards about London, and mot orher places furre from the fea. Now Lobels figure berng not good, and the defcriptionnot extant in any of his Latine Workes; I cannot certainly affrme any thing. Yet I thinke it fit to giue you an exact defeription of that I do probably iudge to be it; 
LIB. I.

Of the Hiftorie of Plants.

and not onely fo, but I iudge it to be the fame Graffe that Baubint in his Prodromis liath fet forth, pag. I7. vnder the name of Gramen latufoliumspicatriticen compacta. This is a very tall Grafte, for it fends forth a ftalke commonly in good ground to the height of a yard and an halfe: the leaues are large, ftiffe, and greene, almoft as big as thofe of white Wheat; the which it alfovery mueh refembles in the eare, which vfually is fome handfull and an halfelong, little fpokes fanding by coutfew ith their flat fides towards the ftraw. About the beginning of fuly it is hung with littie

I Grames Caninum marinum.

Sea Dogs-graffe.

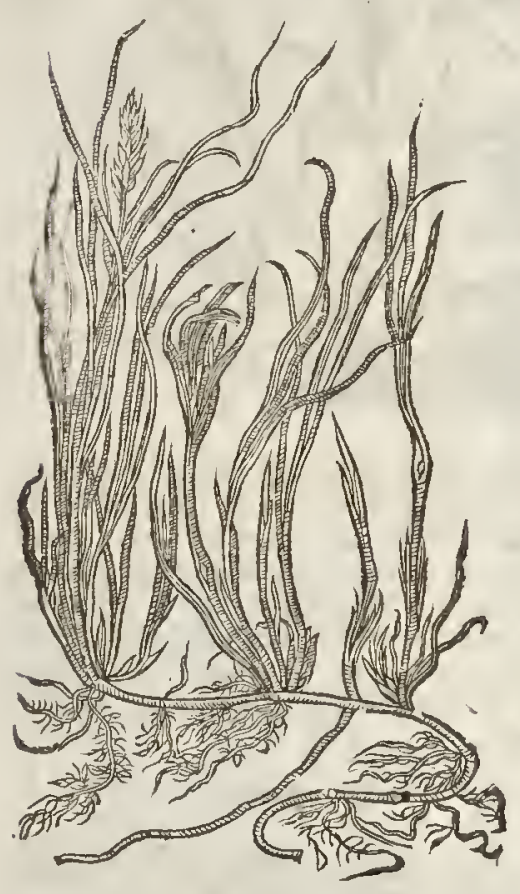

2 Gramen Caninum marinum alecrum. Sca Couch-grafic.

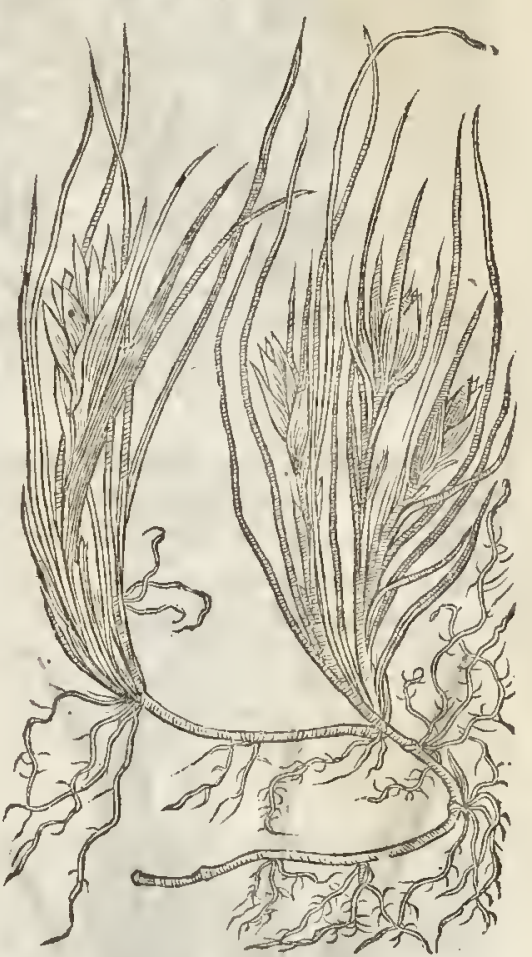

whitifh yellow foures fuch as Wheat hath. The toots of this ate like thofe of the firft defctibed: This fometimes varies in the largeneffe of the whole Plant, as alfo in the greatneffe, fparfedneffe, and compactneffe of the eare. $\neq$

2 The fecond Sea Dogs-graffe is accotding unto Lobel fomewhat like the formet : his roots are more fpreading and longer, difperfing themfeltes vnder the ground farther than any of the reft. The leaues are like the former, thickebuthed at the top, with a clufter or bufh of fhort thick leaues one folded within another. The ftalke and tuft is of a middle kinde, betweene 1 f chemon and the common Couch-graffe.

T) The Place, Time, Names, Nature, and Vertues.

They grow on the fea fhore at the fame time that o thers do; and are fin called becaufe they grow neete the fea fide. Their natute and vettues are to be teferred vnto Dogs-graffe.

\section{C на P.19. Of upright Dogs-Graße.}

I Ptight Dogs-grafe, or Quicl-grafe, by reafon of his long freading ioynted roots is like vnto the former, and hath at enery knot in the root fundry ftings of haizie fubftance, thooting into the ground at eurery ioint as it fpreadeth : the ftalks ly creeping, or rife but a little from the ground, and at their tops hate fpokie pannicles farre finaller tilan the 
eommon Couch-graffe. By which notes of difference it may eafily be difeerned from the orher kindes of Dogs-graffe.

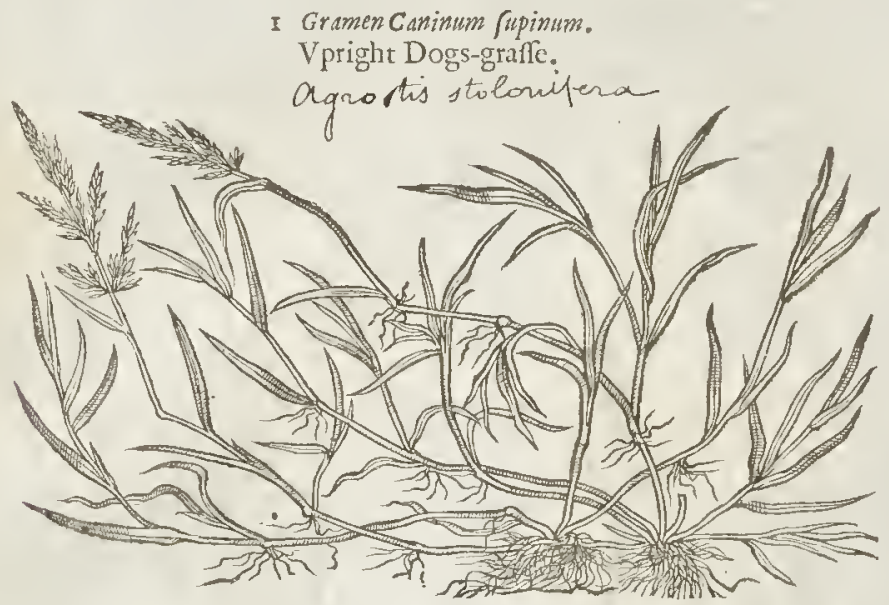

2 Ladies Laces hath leates like vnto Millet in fafhion, rough and tharpe pointed like to the Reed, with many whire vaines or ribs, and filuer ftreakes running along through the midit of the leaues, fithioning the famelike to laces or ribbons wouen of white and greene filke, very beauti-

2 Gramen friturm.

Lady-laee Graffe.

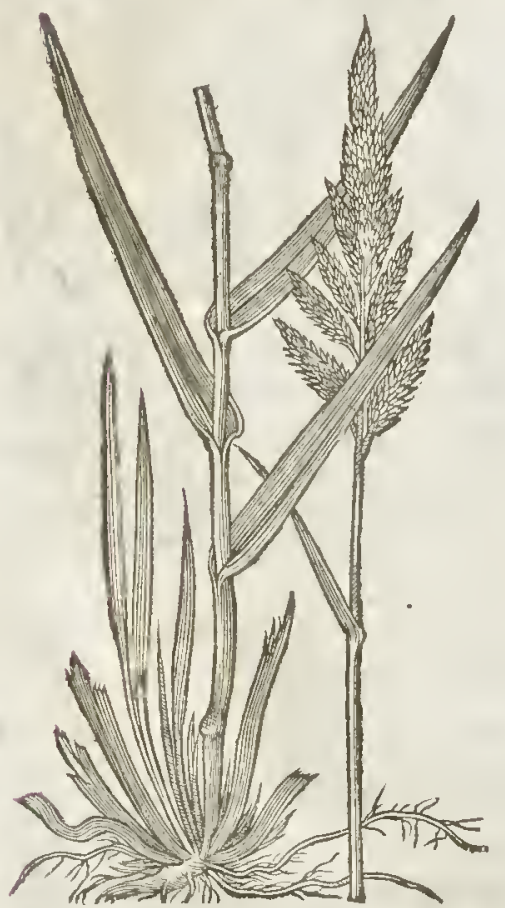
full and faire to behold: it groweth vnto the height of wilde Panuieke, with a fpoky top not very much vnlike, but niore compact, foft, white, and chaffic. The root is fmall and hairic, and white of eolour like vnto the Medowgrafle.

$$
\text { T) The Place. }
$$

I Vpright Dogs-graffe groweth in dunged grounds and fertile fields.

2 Lady-laces growes naturally in wondy and hilly places of Samoy, and anfwers eommon Graffe in his time of feeding.

$\mathrm{It}$ is keprand maintained in our Englifh gardens, rarher for pleafure rhan vertue, which is yet knowne.

II The Names.

Lobelius calleth the later, Gramen fulcatum, and friatum,or Gramen pidtum : in Englifh, the Furrowed Graffe, rhe white Chanclion Graffe, or ftreaked Grafle; and vfually of our Englifh women it is ealled Lady-laces, or painted Grafle : in French, Uigullettes d'armes.

9 The Nature and Vertues.

The vertues are referted vinto the Dogsgrafles. 


\section{Cha r. 20. Of Dew-Grajee. …}

T) The Defeription.

11 Ew-graffe hath very hard and tough roots long and fibrous : the ftalkes are great, of three or foure eubirs high, very rough and haury, ioynted and kneed like the eommon Reed : the leaues are large and broad like vnto curne. The tuft or care is dirnided mnto fundry branches, elaifie, and of a purple eolour; wherein is eontained feed like Milinm, wherewith the Germanes do make pottage and fuch like meat, as we in England do with Oteneale ; and it is fent into Middleborough and other townes of the Low-eountries, in great quantitie for thic fame purpore,as Lobel harh rold me.

2 The fecond kinde of Dew-graffe or If chemon is fomewhat like the firf kinde of Medowgraffe, tefembling one the other in leaues and ftalkes, fauing that the ereft or tuft is fpred or ftretched out abroad like a Coeks foot fer downe vpon the ground, 'w hereupon it was called Galli crus, by Apulizus. Thefe tops are eleere and vpright, of a glietering purple colour, or rather violer, and it is diuided into foure or fiue branehes like the former Dew-graffe. The root confints of a great many fmall fibres.

\# 3 'To thefe may firly be added another Graffe, which Clufius hath iudged to be the medicinall Graffe of the Antients : and Lobel referres it to the Dogs graffes, beeaufe ir harh a root iointed thicke, and ereeping like as the Dogs-graffes : the ftalkes are fome foor high, round, and of a purplifh colour : but the top is very like to that of the laft deferibed, of a darke purple colour.

I Granen Manne efoulentum. Dew-graffe.

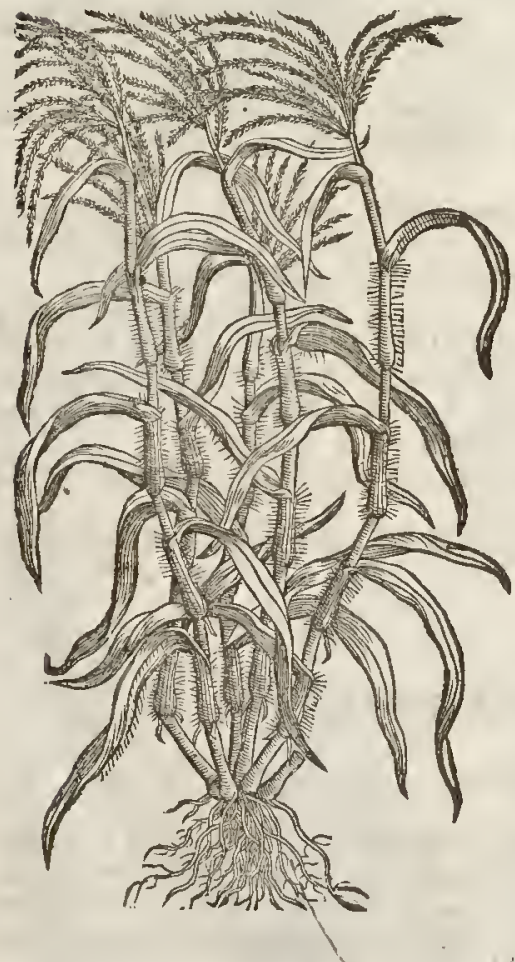

2 Ifchomonvulgare. Cocks-foot graffe.

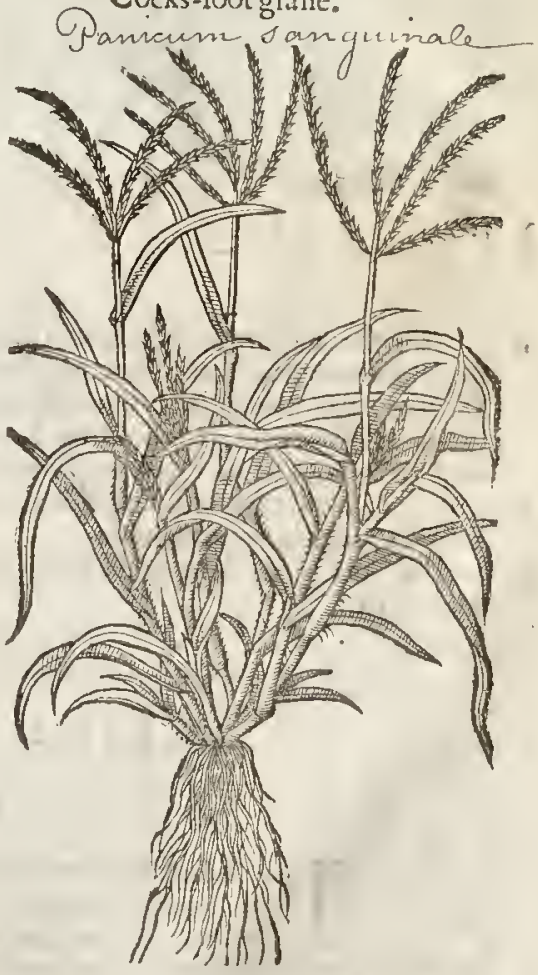

1) The Place and Time.

I The firft growerh naturally in Germanic, Bohemia, Italy, and in the territories of Goricia and Carinthia, as ckatthiolus reportèth.

2 The fecond groweth neere vnto rough bankes of fields, as I haure feene in the hilly bankes neere Greenhithe in Kent. It differeth not in time from thofewe haule fpoken of. 
+ 3. Gramen dactiloides radice repente.

Cocks-foot Graffewith creeping roots.

CJanicum dactylon

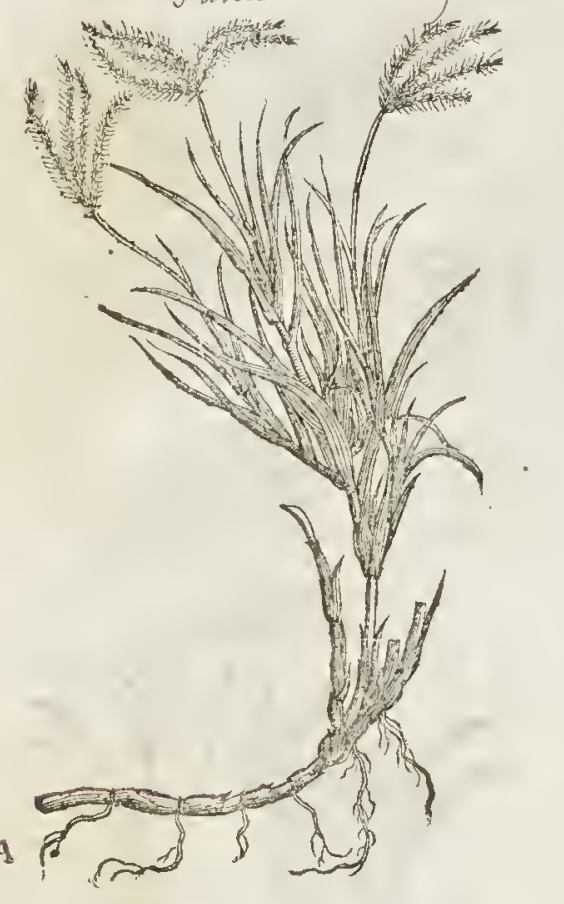

$\ddagger 3$ This groweth plentifully in moft parts of $S$ painc and France; and it is probable, that thiswas the graffe that our Author found necre Grenhithe in Kent.

$$
\text { 9) T be Narnos. }
$$

I The Germanes call it Himeidan: That is to fay, Calt ros; whercuton it was called Gra. men Manna: at feemeth tobe Miliy fylueftris fonrium quoddam gernas, a certaine wide or baftard kinde of Millct. Leonisenus and Rsellizes namo it Capriola, and Sangunaria : fome would haue

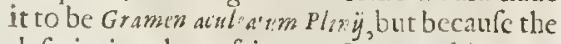
defcription thercof is scry n ort, nothing can be cerrainly affrmed. But they are far deceiued who thinhe it te r os uropus, as fome very learned have fet downe: but enery one in thefe dayes is able to contro'l that errour. Lolel calleth it Gramen Manne eforlintum, for that in Germany and ot ur rarts, as I ol emia and Italy, they ife tocate the fame as a kind of breadcorne, and a: fo mahe | ortage tlerewith as wee dowith Otcmeale; for tle which purpofe it is thire fowen as Conne, and fent into the Lowcountries, and tlere foid by the pound. In Englith it maybecal'cd Manna-grafe, or Dewgraffe; but more fitly Rice-graffe.

2 This is iudged tobe Ifchemon of Pliny; and Galli crus of Apuleins.

$$
\text { 9) The Natures }
$$

Thefe Grafes are aftringent and drying, in tafte frece like the common Dogs-graffe.

$$
\text { If The vicrues. }
$$

Apuleizes faith, if a plaifter be made of this Graffe, Hogs greare, and leuen of houfehold bread, it curcth the bitirg of mad dogs.

B As in the defcription I told yout, this plant in his tuft or cate is diuided into fundry branches, fome tuft into three, fome foure, and forne fuc clouen parts like Cocks tocs. Afulcizs reporteth, If ye take that care which is diuided oncly into three parts, it wonderfully te'peth the rumning or dropping of the eyes, and thofe that begin to be bleare cyed, being bout d atout the necke, and fo vfed for certaiue dayes together, it turneth the humors away from the weale part.

C $¥$ Manna Graffe, or Rice-graffe is faid to be very good to be put into fultu fles, to difcuffe hard fivellings in womens brefts.

D The Cocks-foot Dogs-grafic is very good in all cafes, as the other Logs-grafles are, and equally as effectuall. $\neq$

\section{\# С н а р. 21. Of diners Cyperus Greffcs.}

$$
\text { IT The Defcription. }
$$

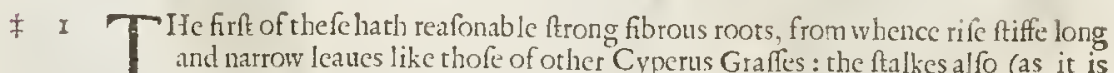
and narrow leaucs like thofe of other Cyperus Graffes : the ftalkes alfo (as it is
proper to all the plants of this kindred) are three fquare, bearing at their tops fome three brownin eares foft and chaffie like the reft of this kinde, and ftanding vpright, and not langing downe as fome others do.

2 This hath pretty thicke creeping blacke roots, from whence arife three fquare ftalkcs fet with leaues fhorter, yet broader than thofe of the laft defcribed; and from the top of the ftalke come forth three or foure foot-ftalkes, whercupon doe hang longifh rough fcaly and yellowith heads.

3 The roxts of this areblacke, without fnell, and fomewhat larger than thofe of the thet 
\# I Gramen Cyperoides angufifolinom majus. Grear natrow leated Cyperus Grafle.

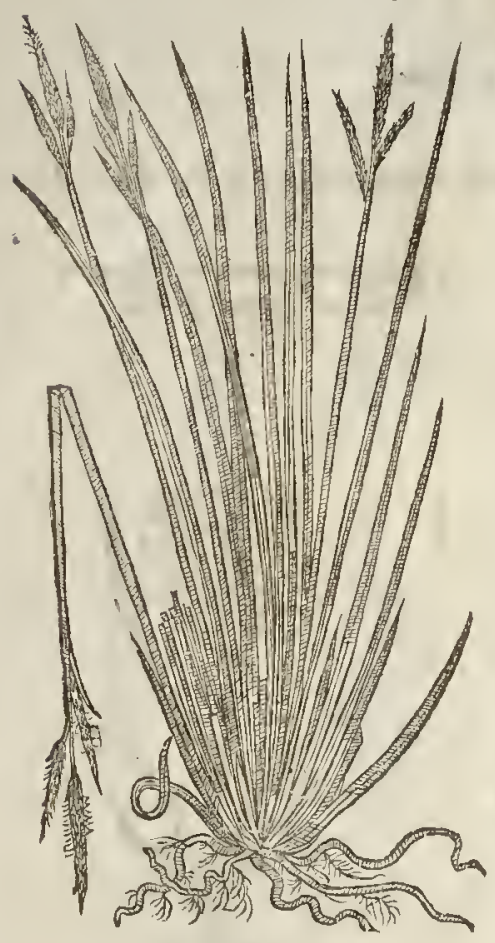

¥ 3 Cyperus longus inodorus fylueftris. Long Baftard Cyperus.

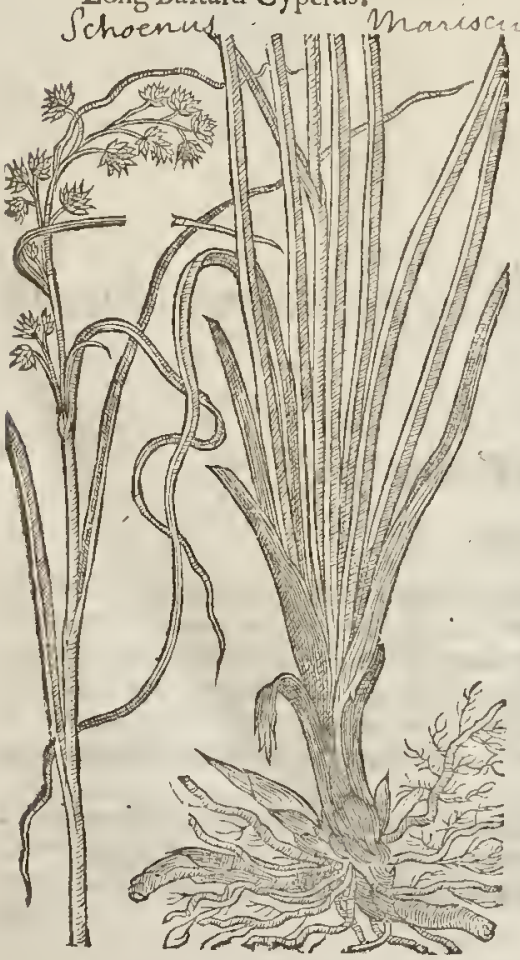

† 2 P feudocyperus. Baftard Cyperus;

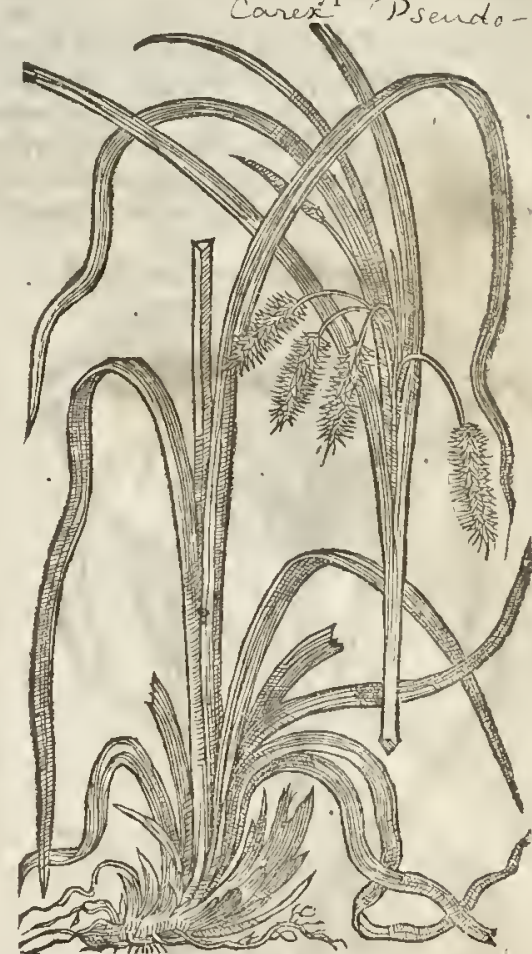

yperces.

deferibed: the 3 future Palkealfo is fome two eubits high, bearing at the top difperfedly round fealy heads fomewhat like thofe of the wood Ruth-graffe: the leates are fomewhat tharpe and triangular like thofe of the orher Cyperus.

4 This Cyperus hath ereening blacke roots, hauing liere and there knotty tuberous heads for the moft part, putting rp leaues like thofe of the laft deferibed, as alfo a falke bearing at the top long chaffy eares like to fome orhers of this kinde.

5 This Cyperus Grafle hath pretty thicke fibrous and blacke roots, from whence arifeth a ftalke fome eubit high, pretty ftiffe, triangular, ioynted, fet at each ioynt with a large greene leafewhich at the bottome ineompaffes the ftalke, which is omitted in the figure. At the top of the ftalke, as in the true Cyperus, eome forth two or three pretty large leaues, betweenc which rife vp many fmall foot-ftalkes very mueh branehed, and bearing many blacke feeds fomewhat like Millet or ruhes.

बा The Place and Timac.

All thefe grow in ditches and watcrie places $_{3}$ 
places, and are ro be found with their heads about the middle of Sommer, and fome of them fooner.

\section{The Names.}

The firf of thefe by Lobel is ealled Gramen paluftre majus.

2 This by Gefner, Lobel, and Dodonewis is ealled Pferdocyperus.

3 Lobel names this, Cyperus longus inodor us fy luefris.

4 He alfo calls this, Cyperus aquaticus feptentrionalis.

5 This is the Cyperus graminea mailiaced of Lobcl and Pena : the Iuncus latus in the Hiffor. Lugd. pagr. 988. and the Pleudocyperus polycarpos of Thaliws.

¥ Cyperus rotundus inodorus fylueftris. Round Baftard Cyperus.

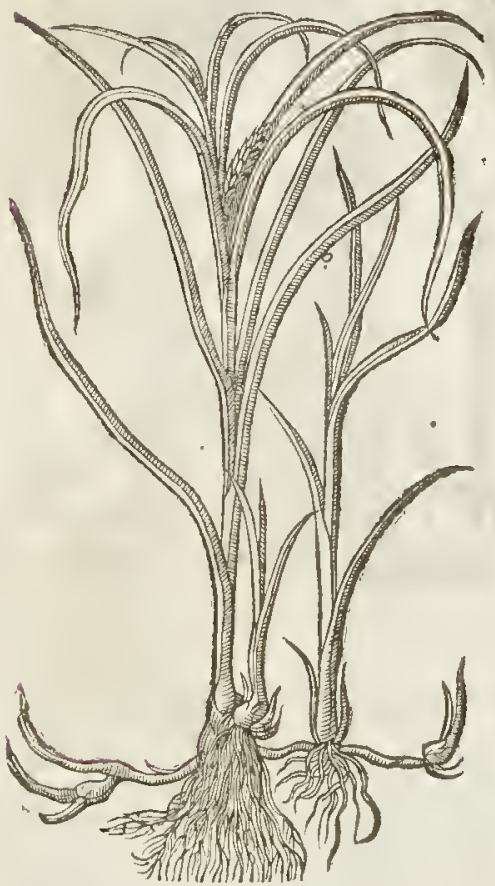

$¥ 5$ Cyperus gramincus miliaceus. Millet Cyperus grafte.

I] The Temper andVertue?

None of thefe are made vfe of in pliyfieke; but by their tafte they feeme to be of a cold and a: itringent qualitic. $\neq$

\section{¥. С н а P. 22. Of diners utber Graffes. \\ T) The Defcription.}

‡ I THis Ote or Hauer-grafe, deferibed by clufus, hath fmall ereeping roots : the ftalks 1 are fome enbit high, fender ioynted, and fet with thort narrow leaucs: at the top of the ftalke growes the care, long, ficnder, and bending, compofed of downy huskes containing a feed like to a naked Ote. The feed is ripe in Iuly. It growes in the mountainous and Thadowie woods of Hungary, Auftria, and Bohemia. Our Author miftaking himfelfe in the figure, and as much in the ritle, gauc the figure of this for Burnt Barley, with this title, Hordesm Diftichor. See the former edition, pag 66 .

2. I eannot omit this elegant Graffe, found by M. Goodyer vpon thewals of the antient ciry of Winehefter, and nor defcribed as yet by any that I know of. It hath a fibrous and ftringy roos, from which arife leaues long and narrow, which growing old become round as thofe of $S p$ artum or 
Mat-weed : amongft thefe graffie leaues there growes vp a flend $r$ ftalke fone two foot lon, , carfe ftanding vpright, but of t times hanging down the head or top of the eare: it hath fome two : oivts, and at each of thefe a pretty graffy leafe. The care is almoft a foot in length, eompored of many fmall and flender hairy tults, which when they eome to maturitic looke of a grayin or whitith eolour, and do very well refemble a Capons taile; whenee my friend, the firft obferuer thereor, gane

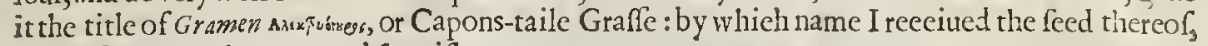
which fowen, tooke root, and flourifhes. •

I Gra.montanum avenaceum. Mountaine Hauer-graffe.

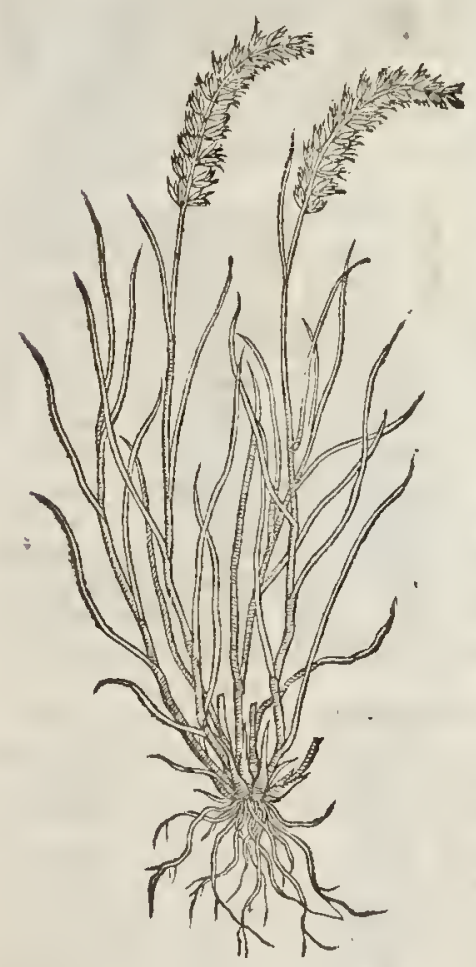

\# 2 Gromen murorum ficalongißimas Capon-taile Graffe.

Festuca myurnd

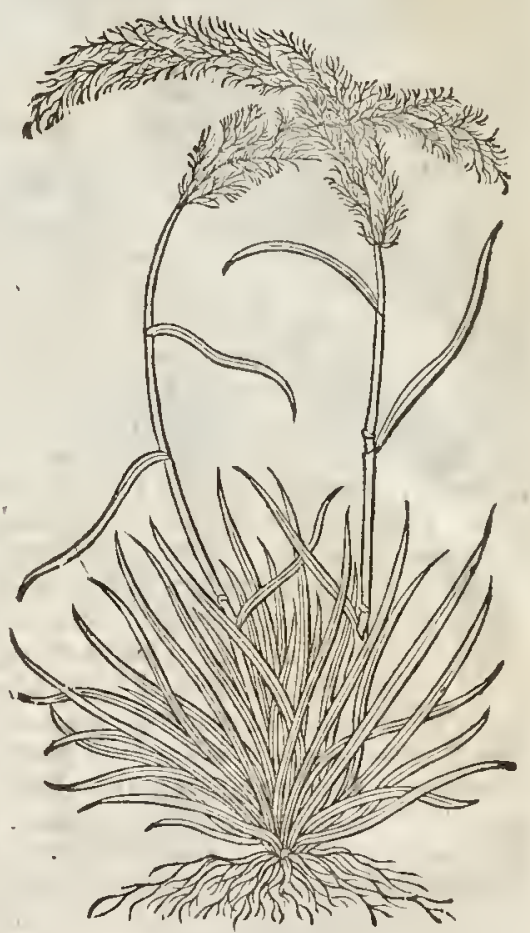

3 Next to this I thinke fit to place the Gramen Criftatum, or Coeks-combe graffe of Bubinuts. 'This Graffe hath for the root many white fibrous threds thieke paekt together, the leates are but fhort, about the bigneffe of the ordinarie medow graffe; the ftalks are fome eubit and halfe high, with fome two or three knots a piece: the leaues of the falke are fome foure or fiue inehes long: the eare is fmall, longith, of a pa'e greene eo'our, fomewhat bending, fo that in fome fort it refembles the eombe of a Coeke, or the feed-veffell of that plant which is ealled Caput Gallinaceum. This is ordinarily to be found in moft medowes about Mid-fummer.

4 There is alfo eommonly about the fame time in our medowes to be found a Graffe growing to fome eubit high, hauing a fmall falke, at the top whereof there growes an eare fome inely and an halfe, or two irehes long, confinting as it were of two rankes of eorne : it very mueh refembles Rieboth in thape and eolour, and in his thort bearded awnes, wherefore it may very fitly be termed Gramen fecalinum, or Rie-grafie. Yet is it not Gramen pica fecalinawhieh Baubine deforibes in the fifty feuenth place, in his Prodromus, pag .1 8. for that is mueh taller, and the eare mueh lasger than this of my defeription.

5 In diuers places about hedges, in Iuly and Auguft is to be found a fine large tall Graffe, which Baubine (who alfo firfteferibed it) hath vnder the name of Gramen pica Briza majus. This hath ftalkes as tall as Rie, but not fo thicke, neither are the leaues fo broad : at the top of the ftalk grow diuers pretty little flattifh eares confifting of two rankes of ehaffie huskes or feed-veffells, which laue yellowith litrle floures like to thofe of Whear.

6 There is alfo commonly to be found about May or the beginning of Iune, in medowes and 
fueh places that graffe which in the Hiftoria Lazdism, is fet forth vnder the name of Gramen Lamatum Dalcfchampiy; the ftalkes and lcates are much like the common medow graffe, but that they arc more whitifh and hairy; the head or paniclc is alfo foft and woolly, and it is commonly of a gray, orelfe a murric colour .

7 Therc is tobe found in fome bogs in Summer time about the end of Iuly a pretty ruthic graffe fome foote or better in height, the falke is hatd and ruhic, hauing fome three ioints, at cach whercof there comes forth aleafe as in other graffes,and out of the bolome of the two vppermoft of thefe leaues comes out a flender ftalke being fone 2 or 3 inches high, and at the top thereof growes as in a little vimble a prety white chaffie fourc; and at, or nigh to the top of the maine ftalke there grow three or foure fueh floures eluftering together vpon little fhort and flender fort falkes:the leaues are but finall, and fone hand full or better long; the roote I did not obferue. This feemes to haue fome alfinitie with the Gramenjunceum aluaticum, formerly deferibed in the nintli chapter. I neuer found this but once, and that was in the companic of M.Thomas Smish, and M.lumes Clarke, Apothecaries of London; we riding into Wind fore Foreft vpon the fearch of rare plants, and we found this vpon a bogge neere the high way fideat the corner of the great parke. I thinke it may very fitly becalled Grumen jun eum leucanthimum: White foured rufh-gr'fie.

\& The laft yeare at Margate in the Ifle of Tenet, ieere to the fea fide and by the chalky cliffe

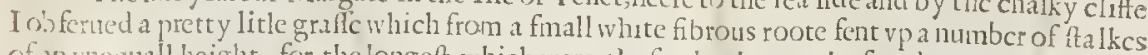
of an vinegull height, for the longet, which were thofe that lay partly fpred vpon the ground, were fone hand full high, the orher that grew ftraight vp were not fo much; and of this, one incli anci halferws taken vp in the fpike or eare; which was no thicket than the reft of the ftalke, and fecmed nothing elfe but a plaine fmooth ftalke, wnlcffe you looked vpon it carneftly, and then you might perceiue it to be like Darnell graffe:wherefore in the Ioumall that I wrot of this Sim-

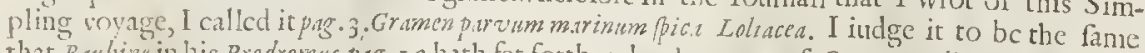
that Barbine in his Prodromus,p.13. I g hath fet fotth vnder the name of Gramen Loliaceum minus pi. cafimplaci. It may be callad in Englioh, Divarfe Darnell Grafte.

9. The Darnell graffe that I compared the cate of this laft defcribed vnto, is not the Gramer forhginum (which out Author called.Damel-grafe) but another graffegrowing in noft places with falkes about fome fpan high, but they felone ftand pright, the eare is made iut like that which hereafter chap. 5 .is callad Lolium rumrm, Red Darnell, of which I iudge this a variety, diffcring little therefrom but in finalineffe of growth.

ro Vpon Hampted heath I haue oftcn obferued a fmall gtaffewhofe longef leaues are feldotne aboue two or three inches high, and thefe leaucs are very greene, fmall, and perfectly round. like the sparturn Arfriacum, or Fcather-graffe: I could neuct finde any falke or care vpon it : wherefore I haue brought it into the Garden to ob ferue it better. In the forementioned Iournall, pag.33. you may finde it vnder the name of Gramen spartum capillaceo folio mamimum. It may be this is that graffe which Baubine fet forth in his Prodromus, pag. I 1 . vnder the title of Gramen par term Monfpeliacum capillacco folso minimum. I haue thought good in rhis place to explaine my meaning by thefe two names to fuch as are futious of plants, which may happen to light by chance (for tbey were not intended for publicke) vpon our Iournall, that they need not doubt of my
meaning.

II I muft not paffe ouer in filcnee two other Graffes, which for any thing that I know are ftrangers with vs, the one I hate feene whith M. Parkinfon, and it is fet forth by Barbize, pas. 30.0 of his Prodromus. The other by Lobell in the fecond part of his $\mathcal{A}$ dverfarit, pag. 468 . The firft which Babine fitly calls Gramen alopecurvodes pica apera, and thinkes it to be Grom. Echinatum D. alc foh ampï, defcribed Hist. Lugd. p.rg. 432.) hath a fibrous and white root, from which arifes a fiffe ftalke diuidat by many knots, or knees : the leaues are like to the other fox-taile graffes, but greener:the care is rough, of fome inch in length, and growes as it were von one fide of the ftalke:the care at firt is greene, and thewes ycllowilh little Howcrs in Auguft.

12. This other Grafe which Lobell in the quoted place figures and deferibes by the name of Gramen Scoparium If chemi pannicules G.allicum, hath rootes fome cubit long, Ilender, and very ftiffe, (Cor of thele arc made the head bruthes which are vulgarly vfed) the ftraw is flender, and fome cubit high, being heere and there ioynted like to other Graffes : the top hath foure or fue cares ftanding after the manner of Cocks foot $G$ raffe, whercof it is a kinde. It growes naturally abour Orleance, and may be called in Englifh, Prull-graffe. : 
L. B. I.

Of the Hiftory of Plants.

29

CH A P. 23。

Of Cotton Graffe:

T) The defcription.

I His ftange Cotton graffe, which L'obelius hath comprehended vnder the kindes of Rumes; notwithiftanding that it may paffe with the Rufhes, yet I finde in mine owne cxperienee, that it doth rather refemble graffe than ruines, and may indifferently be taken for cither, fot that it dorl patticipate of both. The falke is fmall and turhy, garnifhed with many graffy lcaues alongtt the fame,bearing at the top a burh or tuft of moft pleafant downe or cotton like vinto the moft fine and foft white filke. The root is vety tough, fmall and threddy.

2 This Water Gladiole, or gralfy Ruth, of all others is the faireft and moft pleafant to behold, and ferueth vety well for the decking and trimming vp of houfes, becaufe of the beauty and Braterie theteof : confifting of fundry fmall leaues, of a white colour mixed with carnation, growing at the top of a bate and naked ftalke, fiue or fix foot long, and fometime more. 'The leaues ate long and flaggy, not muels vnlike the common reed. The root is threddy, and not long.

I Gramen Tomentarium.

Eriophorum Cotton Gtaffe. angustifilium

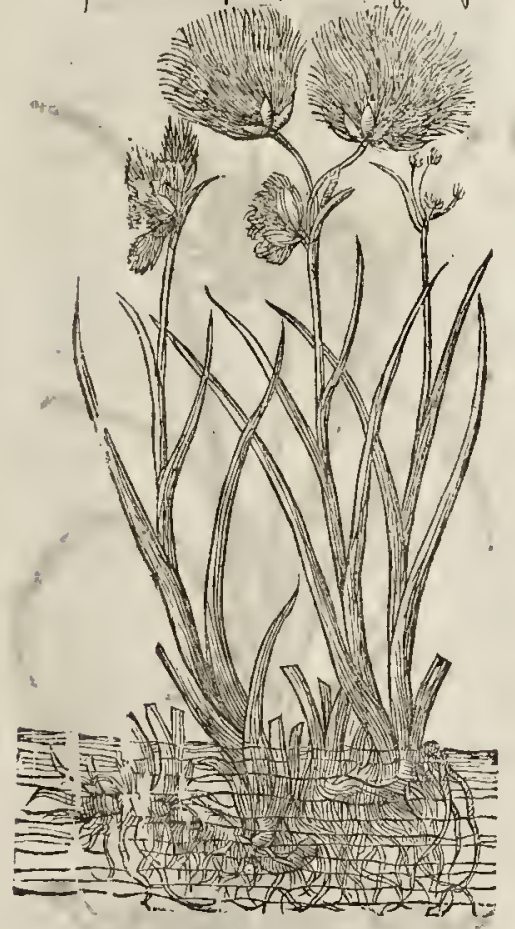

2 Glidiolys paluftris Cordi. Water Gladiole.

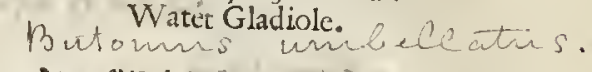

4 The place and time.

" Cotton gtafle groweth vpon bogs and fuch like moorith plaees, and it is to be feene vpon the bogs on Hampted heath. It groweth likewife in Highgate parkc neere London.

2 Water Gladiole groweth in ftanding pooles, motcs, and watcr ditches, I found it in great plenty being in company with a Worhipfull Gentleman Mafter Robert Wilbrabam, at a Village fifteene miles from London called Buhey. It groweth likewife neete Redtiffe by London, and many other places : the feafon anfwerethall othets.

Tf The naines.

I. Gramen Toment of phaliwm Hicronymi Bockï. In Englifh Cotton graffe. $:$.

¿ Wate: 
2 Water Gladiole is called of L' Obelius, Iuncus Cyperoides foridus paludo/us, Flowring Cy-

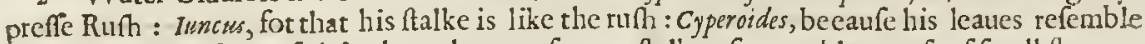
Cyperss : Floridus, becaufe it hath on the top of eucry ftalke a fine vmble or tuft of fmall flowers, in farhion of the Lilly of Mlexandtia, the which it is very like, and therefore I had rather call it Lilly grafte.

\section{The nature and vertues.}

A Cordses faith, That runces bombicinus fodden in wine, and fo taken, helpeth the throwes and gripings of the belly, that women haue in their childing.

There be alfo fundry kinds of Graffes wholly vnknowne, or at the leaft not temembred of the old Writers, whereof fome few are touched in name onely by the late and new Writers : now for as much as they have oncly named them, I will referte the better confideration of them to the induftrie and diligence of painefull fearehers of nature, and profeeute my purpoled labour, to vnfold the diuers forts and manifold kindes of Cyperes, Flags, and Ruthes : and becaufe that there is added vnto many of the Grafies before mentioned, this differenee, Cyperoides, that is to fay, refembling Cyperus, I thought it therefore expedient to ioyne next vnto the hiftory of gtefes, the difcourfe of cyperus, and his kindes, which are as follow.

\section{C н в. 24. Of Englifh Galingale.}

I Cyperus longus. Englith Galingale Cyperns longus

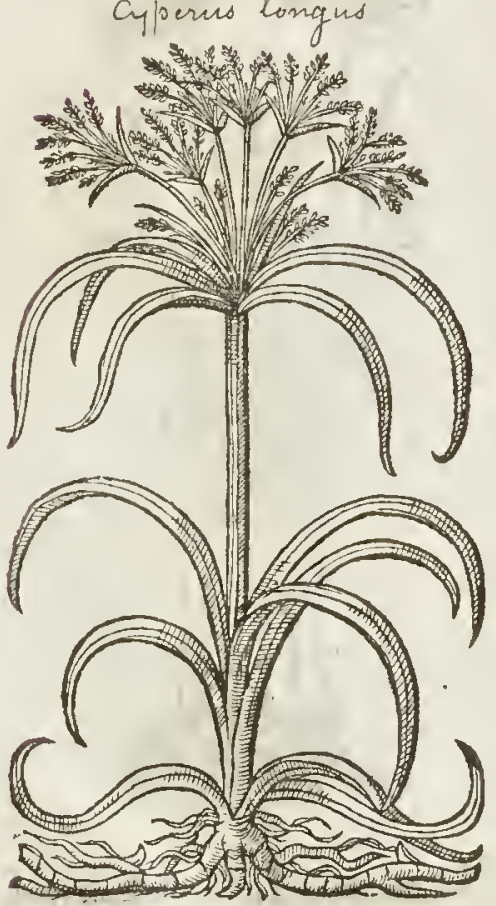

2 Cypcrus rotundus vulgaris. Round Galingale.

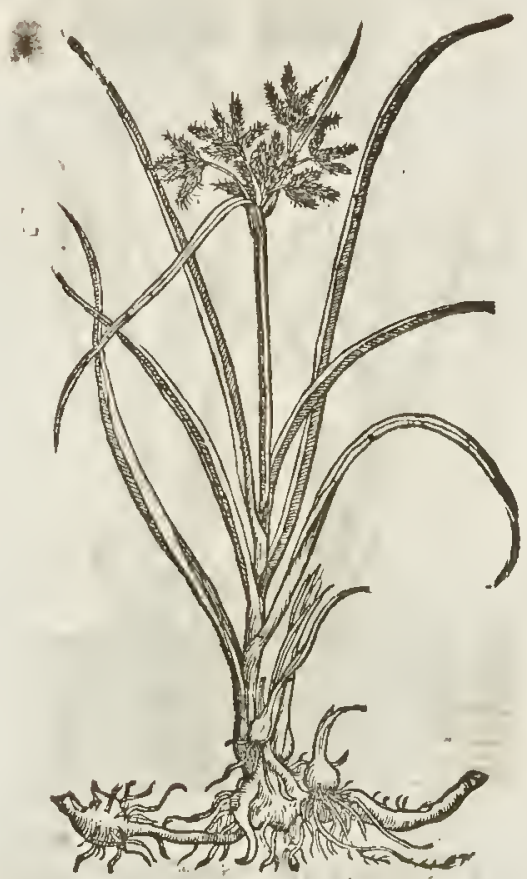

9) The defcription.

I

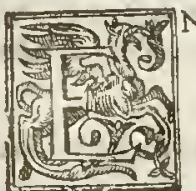

Nglin Gaingale hath leaues like vnto the common Reed, but leffer and fhorter. His Italke is three quare, two cubits high : vpon whofe top ftand fundry branches, eucry little branch bearing many fmall chaffy fpikes. The toot is blacke and very long, erceping hithet and thithet, oceupying much gtound by teafon of his fpreading : it is of a moft fweet and pleafant fmell when it is broken. 
2 The common round cyperus is like the formcr in lcaucs and tops, bur the roots are here and therc knotty and round, and not altogetlec fo wcll-finelling as the formcr.

$\ddagger 3$ There is alfo another Cyperus which growcs in Syria and Ægypr, whofe roors are round, blackith, and large, many hanging vpon onc ftring, and hauing a iquicke and aromaticke finell: the leaucs and fpokyn-rufts ricfomble thic fornicr.

4 There is faid to bc another kinde of this laft deferibed, which is Leffer, and the roots are blacker, and it growes in Creet, now called Candy.

5 There is alfo another round $C y p e r u s$ which growes about ditches and the bankes of Ritrers whoreas rhe falt watcr fometimes comes : the roors of this are hard and blacke without fmell, many hanging fometimcs vpon one ftring: rhic ftalkc and lcaues arc much like the formcr, but the heads vnlike, for they are rough and blachith, about the bigncffe of a filbert, and hang fome fix or feuenattic top of the ftalkc. It foures in Iuly and Auguit. $\ddagger$

$$
\text { IT The plate and time. }
$$

I 2 The firt and fecond of thefe grow naturally in fenny grounds, yct will they profper cxcecdingly in gardens, as cxperience hath taught vs.

34 The formcr of thefe growes naturally in Syria and $Æ g y p t$, the later in Candy.

5 This growcs plentifully in the Marifhes below Grauefend, in Shipcy, Tenct, and otlicr places.

$$
\text { The name in senerall. }
$$

Cyperus is called in Grecke, Kirenes, Or Rimes: of the Latines as wcll Cypirus as Cyyer us: of fome Iuncus quadrat us:

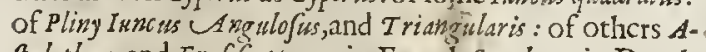
Bpalathum and Ergfiffceptron : in French Souchet : in Duteh Galgan: in Spanifh Iunco odorofa: By vs Cyperus and Englim Galangall.

\section{\# The rames inparticular.}

I This is called Cyperus longus, and Cyperus longus $O$. deratior : in Englin, Common Cyperus, and Englin Gallingall. 2 This is called cyperus rotundus volgaris, Round Englifh Galangall. 3 Cyperus rotundus (Cyriacus, or $E$ gyptiacus, Syrian or Egyptian round Cyperss. 4 Cyperus minor Creticus, Candy round cyperus. 5 Cyperus rotundus inodorus Litstoreus, Round Salt-marh Cyperus, or Galingalc. $¥$

\section{Thenature.}

Diofcorides faith, That Cyperus hath an heating qualitic. Galen faith, Theroots are molt cffectual in medicine, and are of an heating and drying qualitic : and fome doe reckon it to be hot and dry in rhe fccond degree.

\section{q The vertues.}

It maketh a moft profitabledrinke to breakc and expcll graucll, and helpctls rhe dropfic.

If it bc boylcd in wine, and drunke, it prouoketh vrine, dritietl forth the feone, and bringeth downe the naturall ficknefre of women.

"The fame taken as a forcfaid, is a remedie againft the ftinging and poyfon of Serpents. Fernelius fairh, The root of Cyperus vfed in Baths helpeth the coldneffe and fopping of the $\mathrm{C}$
matrix, and prowoketh the tcrmes.

Hcwriteth alfo, that it increafcth bloud by warning the body, and makcth good digction; E wondcrfully refrefhing the fpirits, and exhilarating the minde, comforting the fenfes, and cn-

The powder of $c_{y}$ perus doth nor oncly dry vp all moift vlecrs cither of the mouth, priuy members, and fundamenr, bur ftaycth the humor and hcileth then, though they be maligne and virulent,according to the iudgement of Fernelius.

5 Cyperus rotundus littoress. Round Salt-marih Cyperss. scifous maritimus $\beta$ $\beta$

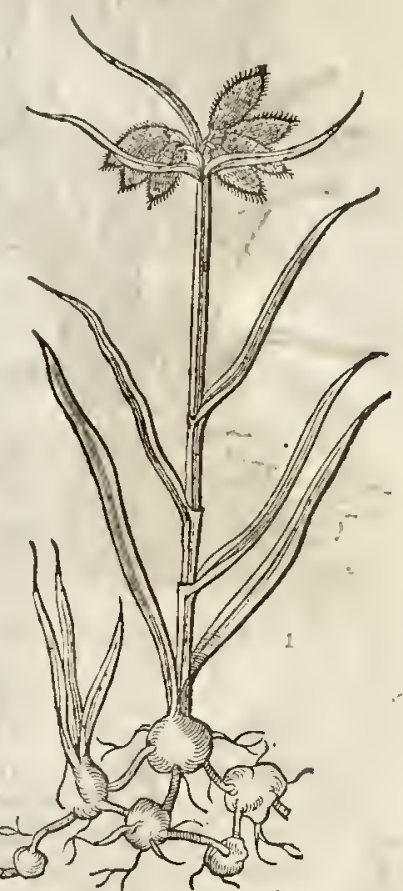
, . . 


\section{* С на Р.25. Of ftalian Trafe, or Spanifh Galingale.}

I Cypersus Efculentus fine Caute of flore. Italian Trafi, or Spanith Galingall, without ftalke and foure.

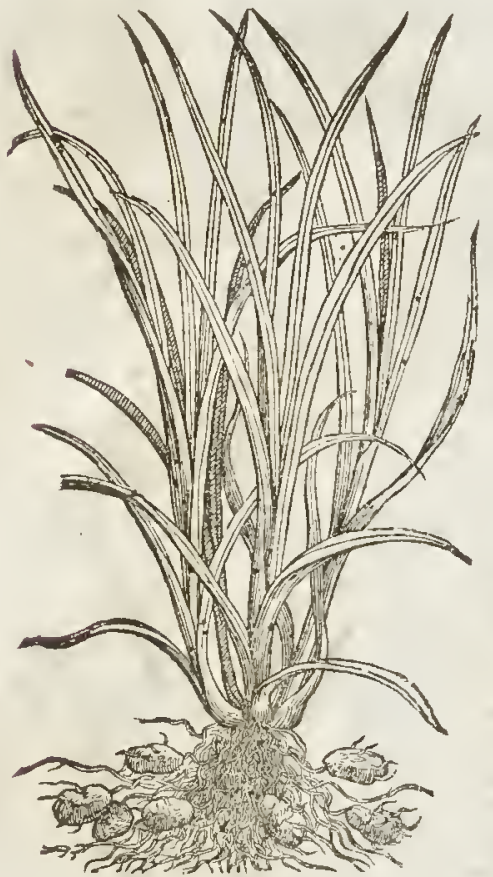

2 Cyperus Efculentus, fine Traft Italorum. Italian Trafi, or Spanith Galingall.

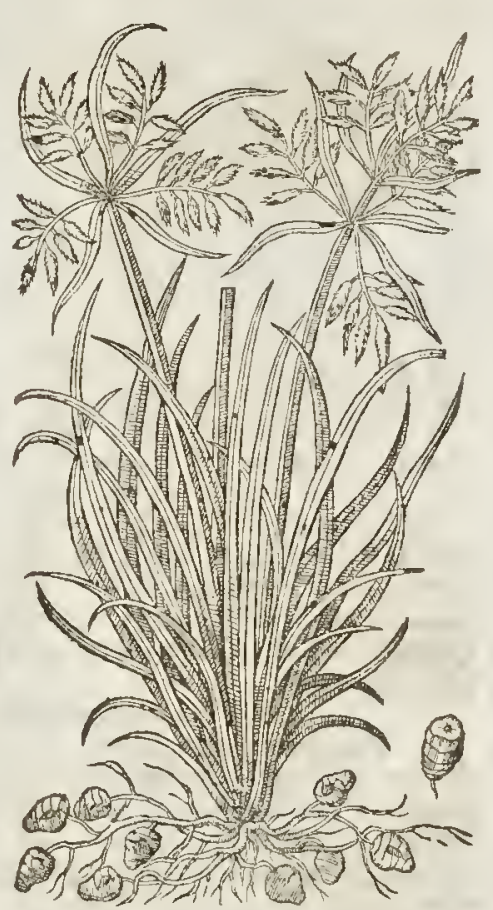

¥ $1 \mathrm{THe}$ Italian Trafi, which is here termed Spanifh Galingale, is a plant that hath many fmall roots, hanging at ftringy fibers like as our ordinary Dropwort roots do, but they are of the bignefie of a little Medlar, and baue one end flat and as it were crowned like as a Medlar, and it hath alfo fundry freakes or lines, feeming to diuide it into feueral parts : it is of a brownith colour without, and whitewithin; the tafte thereof is fweet almoft like a Chefnut. The leaues are very like thofe of the garden Cyperus, and neuer exeed a cubit in length. Stalkes, flowers, or feed it hath none, as Iobn Pona an Aporhecary of Verona, who diligently obferued it nigh to that city whereas it natmally growes, affirmes; but he faith there growes with it much wild cyperus, which as he judges hath giten oeealion of their error who gite it the falkes and flowers of $C y p e r$ s, or Englinh Galingale, as Matthioliw and others haue done. It is encreafed by fetring the roots firft fteeped in water, at the beginning of Nouember. I haue here giuen you the figure of it without the falke, aecording to Pona, and with the ftalke, according to Mathiolus and others.

$$
\text { 9. Thenames. }
$$

The Italian Trafi is called in Greeke by Theophrafius Meanasin, Hift.plant. 4. cap. Io. as Fabises Colwma hath proued at large : Pliny termes it Anthalium : the later writers Cyperus $E$ fculentus, and Dolcichinum: The Italians, Trafl, and Dolzolini, by which names in Italy they are cryed vp and downe the ftreets, as Oranges and Lemmons are here.

$$
\text { T Thetemper and vertues. }
$$

A . The inilke or creame of thefe Buibous rootes being drunke, mund ifies the breftand lungs, wherefore it is very good for fuch as are rroubled with; coughs. Now you muft beat thefe roors, and maerate then in brotl, and then preffe out the creame through a linnen eloath, which by fome late Writers is eommended al fo to be vfed in venereous potions.

B The fame creame is alfo good to bedrunke againft the heate and tharpnefle of the vrine, efpecially if you in making it doadde thereto the feeds of Pompions, Gourds, and Cucumbers. The Citifens of Verona eate them for dainties, but they are fomewhat windy. $\neq$ 


\section{* Cиа Р. 26. Of the true Galingale, the greater and the lefjer.}

I Galanga major.

The greater Galingalc. $\mp=$ Galanga minor. Theleffet Galingale.
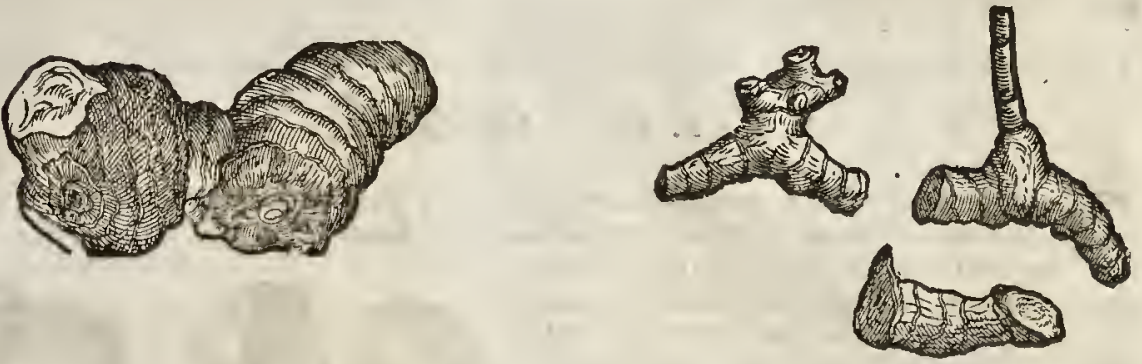

T

He affinitie of name and nature hath inducet me in this place to infett thefe two, the bigget and the leffer Galingale; firft therefore of the gteater.

The defcriprion.

I The great Galingale, whofe rootonely is in vfe, and brought to is ftom Iava in the Eaft Indies, hath flaggy leates fome two cubits high, like thefe of Catf-taile ot Reed-mace : the ront is thickeand knotry, refembling thofe of our ordinary flagges, but that they are of a more whitifh colour on the infide, and not fo large. Theit taft is very hot and biting, and they ate fomwhat reddith on the out fide.

2 The leffer growing in China, and commonly in thops called Galingale, without any addition, is a fmall root of a brownifh ted colout both within and without; the tafte is hot and biting, the fmell atomaticall, the leates (if we may beleeue Garcias ab Horto) ate like thofe of Myttles.

The rames.

I The firf iscalled by Matthiolws, Lobell, and othets, Galanga major. Some thinke it to be the Acorus of the Ancients : and Pena and Lobell in theit Stirp. Aduerf. queftion whithet it be not the Acorus Galaticus of Diofcorides. But howfoeuet, it is the LAcorus of the thops, and by many w fod in Mithridate in Atead of the true. The Indians call it Lancut?.

2 The leffer is called Galanga, and Galanga minor, to diftinguinh it from the precedent. The Chinois call it Laundon : the Indians Laneuaz : we in England tetme it Galingale, without any addition.

Tा Theirtemaper and rertue.

Thefe roots are hot and dry in the third degree, but the leffet are fornewhat the hotter.

They ftengthen the ftomacke, and mitigate the paines thereof arifing from cold and flatu- A lencies.

The finell, efpecially of the leffer, comforts the toocold braine; the fubftance thetcof being $B$ chewed fweetens the breath. It is good alfo againit the beating of the heatt.

They ate vfefull againft the Collicke proceeding of flatulencies, and the flatulent afferts of $\mathrm{C}$ the wombe; they conduce to venety, and heate the too cold teines. To coniclude, they ate good againft all cold difeafes. $\neq$

\section{: $\mathrm{CHAP}_{\text {HA. 27. Of Turmericke. }}$}

$\mathrm{T}$ His alfo challengeth the next place, as belonging to this Tribe, according to Diofcorides " yet the roor, which onely is brought vs, and in vie, doth more on the out fide refemble Gin ger, but that it is yellower, and not fo flat, but roundet. The infide thereof is of a Saffron colour, the tafte hot and bittetifh; it is faid to haue leanes larger than thofe of Millet,and a leafie ftalke. There is fome varictic of thefe roots, for fome are longer, and others rounder, and the later are the hotter, and they are brought ouer oft times together with Ginger.

It growes naturally in the Ean-Indies about Calecut, as alfo at Goa.

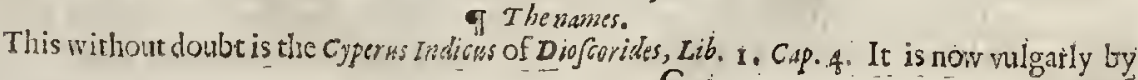
C 3 mort 
moft Writers, and in fhops, called by the name of $T$ erra merita, and curcuma : yet fome terme ir Crocus Indicus, and we in Englin call it Turmeriche.

$$
\text { 91 The temperature and vertuer. }
$$
vfed with good fucceffe in medicines againft the ycllow Iaundife, and againfthe cold diftem. pers of the liter and fplecne.

\section{H.AP. 28.}

Edoaric is alfo a root growing naturally in the woods of Malavar about Calecut and Citnanor in tic Indies; the lcaues thereof are larger than Ginger, and much like then; the root is alfo as la rge, but confifting of parts of different figures, fome long and finall, others round; their colour is white, and oft times brownith on the infide, and they liaue many fibers comming out of them, but they are taken away together with the outwatd rinde before they come to vs. Thefe roots hate a ftrong medicine-like fmell, and fomewhat an ingratefull tafte.

Some call the long parts of the fe roots $Z$ edoaria, and the round (whofe figure we here giuc you) Zerumbeth, and make them different, whenas indeed they are but parts of the fame root, as Lobell and others hauc wcll obferued. Somc make Zedoaria and Zerumbeth different,as $A$ utcen: othcrs confound then and make them one, as Rhafes and Serapro. Some thinke it to be 'Aprafu of Egine-

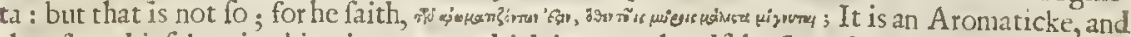
therefore chiefely mixcd in ointments : which is as much as if he thould hauc faid, That it was put into ointments for the fmells fake, which in this is no wayes gratefull, but rather the contrarie.

\section{The temperature and yertues.}

A It is hot and dry in the fecond degrec; it difcuffes flatulencies, and fattens by a cettaine hidden qualitie. It alfo diffipates and anends the vngratefull fimell which Garlicke, Onions, ortoo much winc infeet the breath withall, if it be eatenafterthem. It cures the bites and fings of venomous creatures, ftops laskes, refolues the Abfeffes of the wombe, ftayes vomiting, helpes the Collicke, as alfo the paine of the ftomacke.

BI It kills all forts of wormes, and is much vfed in Antidotes againt the plaguc, and fuch like contagious difeafes. $\neq$

\section{Снар. 29. Of Ru/hes.}

1 Do not here intend to trouble you with an accurate diftinction and enumeration of Fufhes I for if I hould, it would be tedious to you, laborious to ne, and beneficiall to neit her. Thercfore I will onely defcribe and rechon vp the chiefe and more note-worthy of them,beginning with the moft v fuall and common. I

\section{T) The defcription.}

I The roots of our common Ruthes are long and hairy, fpreading largely in the ground, from which, as from one cntire tuft, proceed a gieat company of fmall tathes; fo exceedingly well knownc, that I thall not necd to fpend much time about the defeription thercof.

2 There be fundry forts of Ruthes befides the former, whofe pictures are not here expreft, and the rather, for that the generall defcription of Rufhes, as alfo their common vf and feruice, are fufficient to leade vs to the knowledgc of them. This great Water-Graffc or Bul-Rufh, in ftead of leaucs bringeth forth many ftrait twiggie fhoots or fprings, which bc round, finooth, fharpe pointed, and without knots. Their tuft or flower breaket forth a littlc beneath the top, vpon the one fide of the Ruth, growing vpon little fhort ftems Jikc Grape clufters, wherein is contained the feed after the fafhion of a peares point. The roots be flender and full of ftrings. Pliny, and Theoplus aftus before him, affrme that the roots of the Ruth do die eucry yeare, and that

it groweth 
it growerh againe of the feed. And they afirme likewife that the male is baren, and growenls againe of the yong thoots; yet I could neuer obferue any fuch thing: $;$

$\neq 3$ There growes a Ruint to the thicknes of a Reed, and to fome tivo yards and an halfe threc yards high, in diuers fenny grounds in this kingdome, it is very porous and light, and hiey. whally make mats, and bottom chaires therevith. The fecds are contained.in reddith tufts, breaking out at the top thereof. The roots are large and ioynted, and it grows not uniefe in waters. "

4 Intress acutus, or the fharpe Ruh, is likewife common and well, knowne; tor much difte-

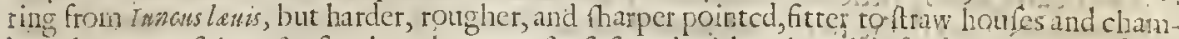
bers than any of the ren; for the others are fo foft and pithy, that they tirne to dunt and filth with nuch treading; where contrariw ife this turh is fo lard that it will laft found much longer.

$\ddagger 5$ There is alio another pretty frall kinde of Ruth growing to fone foos in heigth, hat uing finooth ttalkes whech end in a liead like to that of the ordinary Horfe-taile. This ruth hath alfo one fittle joynt towards the bottome thereor. It growes in watcry places, but not fo frequently as the former. $¥$

I Iuncuslicuis.

Common Ruthes.

\section{Iunchs actuts.}

Sharpe Rufh, or hard litulh

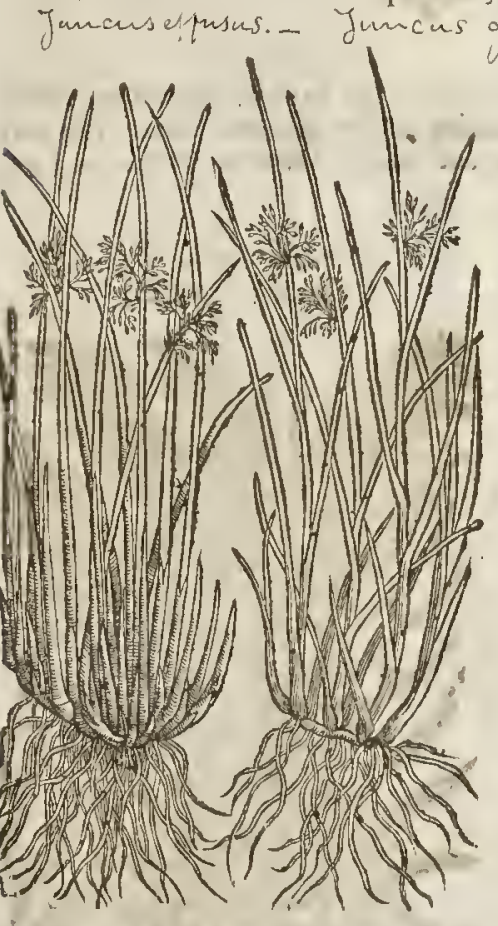

3 Iuncus nquaticus maximus.

Great Water-Rufh, or Bul-Rufh.

Sinpond

palustris

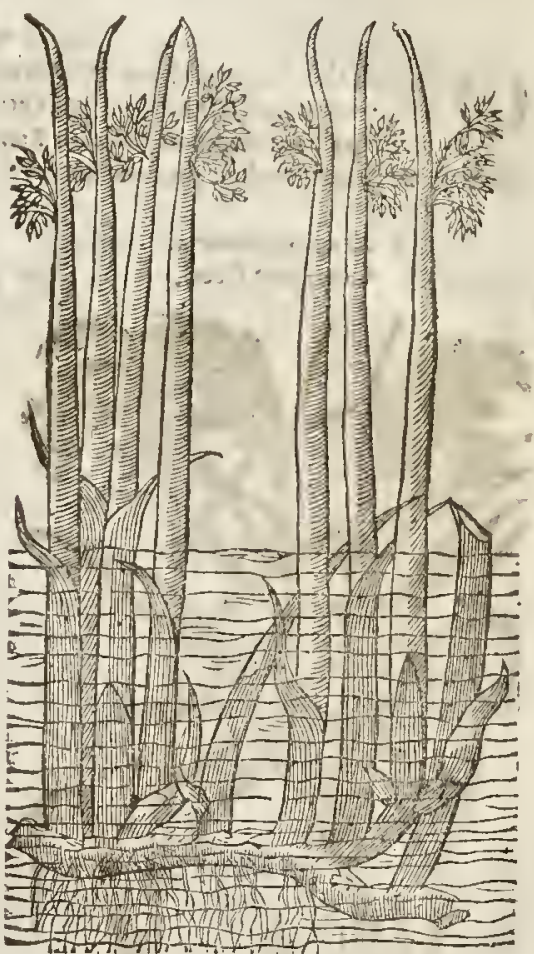

बा Theplace.

1 Yuncus latus growcth in fertile fields, and meadowes that are fomervint muift.

235 . Grow in ftanding pooles, and by riuers fides in fundry places.

4 Inncus acut us groweth vpon dry anidbarren grounds, efpecially neere the furrows of plowed land. I need not fpeake of their time of growing, they being fo common as they are.

The Ruth is called in Greeke I Thenames.

$$
\text { I Tlienames. }
$$

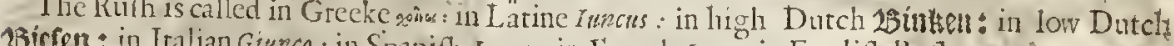

Bicfen: in Iralian Giunco: in Spanifh Iunco: in Fitench Ionc: in Engliph Rulhes.23 The Grecians hauc called the Bull-Rufh oxesonsen The greater are commonly in many
placcs terned Bumbles.

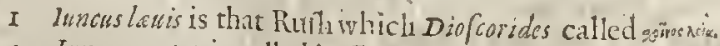

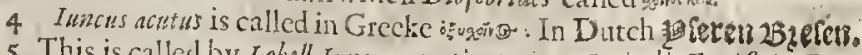

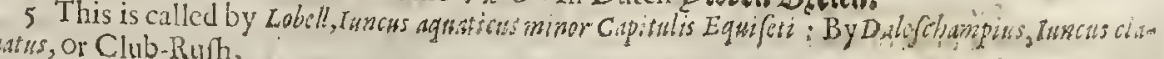


Thefe Ru fhes are of a dry nature.

\author{
If The nature and vertues.
}

A The feed of Rurhes dried at the fire, and drunke with wine alayed with water, tayeth the lashe and the ouermuch flowing of womens termes.

B Galen yeeldetl this reafon thereof, becaufe that their temperature confifeth of an earthy effence, moderately cold and watery, and meanly hot; and thercfore doth the more cafily drie vp the lower parts, and by little and little fend vp the cold humours to the head, whereby it pronoketh drow fineffe and defire to leepe, but caufeth the head-ache; whercof $G$ alen yeeldeth the reafon as before.

C The tender leatues that be next the root make a conuenient ointment againft the bitings of the Spider called Phalaigium.

D The feed of the Bull-Rurh is mon foporiferous, and therefore the greater care muft be had in thie adminiftration thereof, left in prouoking flecpe you induce a drow finefice or dead floepe.

$$
\text { Cна в. 3о. Of Reeds. }
$$

T $T$ he kindes.

F. Reeds the Ancients haute fet downe many forts. Theof braff $u$ s hath brougbt them all firft into two principall kindes, and thofe hath he diuided againe into moe forts. The two principall are thefe, Auletice, or Tibiales Arundines, and Arundo vallatoris. Of thefe and the reft we will fpeake in their proper places.

I Arundovallatoria.

Amido. Common Reed.

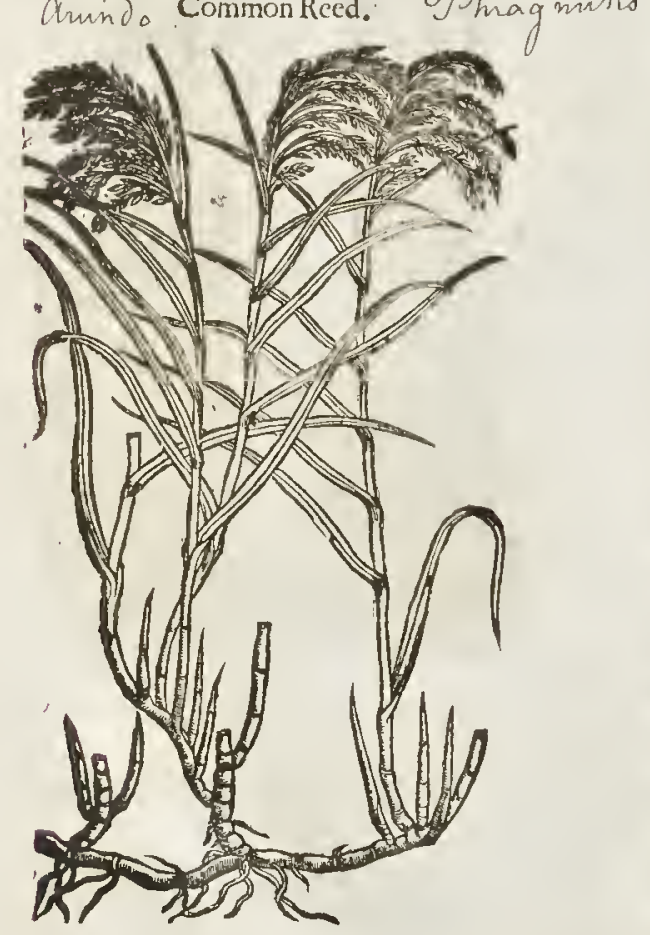

2 Arundo Cypria. Cypreffe Canes.

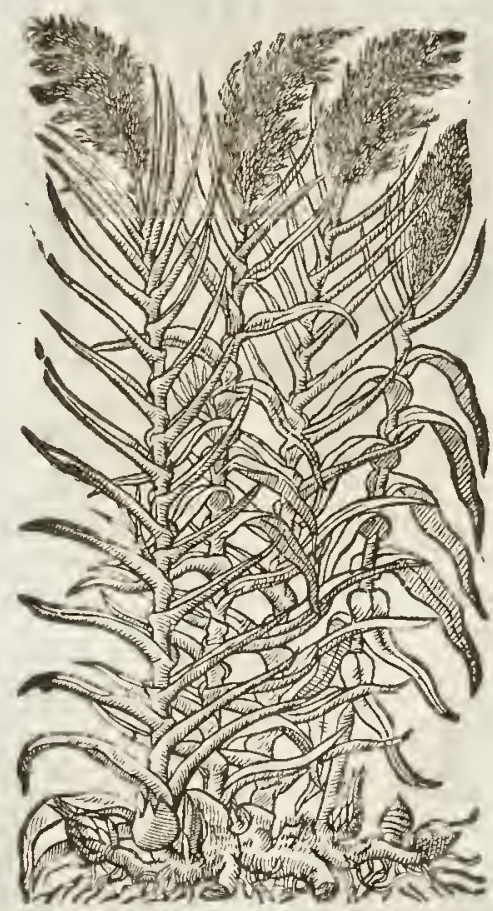

Tा The defcription.

x $\Gamma$ He common Reed hath long fraw ie falkes full of knotty joints or knees like unto corne, whereupon do grow very long rough flaggy leaues. The tuft or fpoky eare doth grow at the top of the ftalkes, browne of colour, barren and without feed, and doth refemble $a$ buth of feathers, which turneth into fine downe or cotton which is carried away with the winde. The root is thicke, long, and full of ftrings, difperfing themfelues farre abroad, whereby 
wherby it doth greatly increafe, $\ddagger$ Bathinus reports, That he receiued from D. Cargill at Sertith man a Reed whofe leaues were a cubit long, and two or three inehes broad, wirh fome nertes atrpatantly tunning alongft the leafe; thefe leates at the top were ditided into tre, thirec, oif frte points or parts; as yet I hate not obferued it. Baubine termes it Arundo Anglicu folys in funnmuste diffectis. $\neq$

I The Cypteffe Reed is a great Reed hauing ftalkes execeding long, fometimes twenty or thitty foot higl, of a woody fubftance, fet with very great leates lnke thofe of 'Tuky wherte. It carrieth at the top the like downie tuft that the former doth.

3 Arundo farita.

Stuffed Canes.

4 Calamus fagittalis Lobcliy.

Small ftuffed Reed.

5 Niffos Cluffi.

Turky walking ftanes. 6 Arundos criptoria.

Tutky writing Reeds.

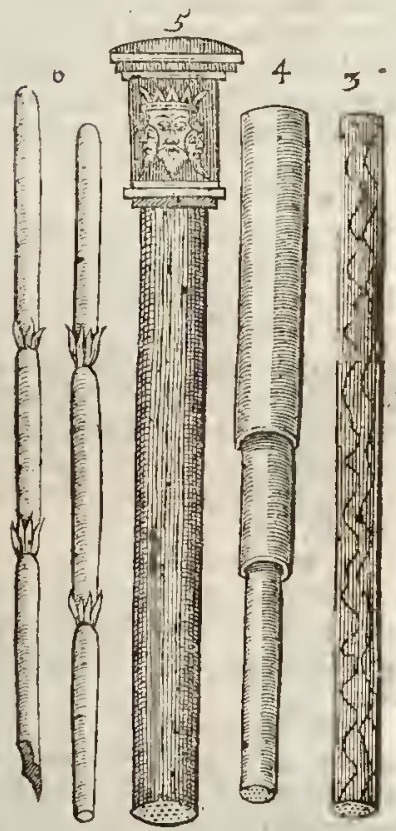

3 Thefe Reeds Lobdius hath fecne in the Lorr countries brouglit from Conftuntinople, whete as it is firi, the people of that cointrey haue procured then from the parts of the Adriaticke fea fide whete they do grow. They are full tafte with a fongeous fubftance, fo that there is no hollowneffe in the fame, as in Canes \& orler Reeds,except here and there certaine fmall pores or parfages of the bignefle of a pinnes point ; in manner fuch a pith as is to be found in the Bull-Rurh,but more firme and folid.

4. The fecondediffereth in fnulnefe, and that it will winde open in fleakes, otlerwife they are very like, and are ved for darts, arrower, and fuch like.

5 This great fort of Reeds or Canes hath no parriculat defeription to anfwer your expectation, for that as yet there is $110 t$ any man which hath written thereor, efpecially of the manner of growing of them, either of his owne knowledge or report from others: fo that it Thall futice that yee know that that great cane is wfed efpecially in Conitantinople and thereabour, of aged and wealthy Citifens, and alfo Noblemen and fuch great perfonages, to muke them walking ftaues of, caruing them at the top with fundry Sentchions, and presty toyes of imagerie for the beautifying of them; and fo they of the better fort do gamin them both with filuer and gold, as the figure doth molt liuely fet forth vnto you.

6. In like manner the fmallet fot hath not as yet becne fecne growing of any that hate beene curious in herbatime, whereby they night fer downe any certaintic thereof; onely it hath beene vfed in Confantinople and thereabout, euen to this day, to make irriting pens withall, for the which it doth very fitly ferue, as alfo to make pipes, and fucli like things of pleafure.

$$
\text { T) The place. }
$$

The conmon Reed groweth in ftanding waters and in the edges and borders of rituets almoff euery where: and the othet being the angling Cane for Fithers groweth in Spaine and thofe hot Regions.

\section{Thetime.}

-They floutish and flower from Aptil to the end of September, at what time they are cut doirn fot the vfe of man, as all do know.

$$
\text { T) The xames. }
$$

The common Reed is called Arundo and Harundo watlatorits: in Frencle Rofeau : in Dutch taiet : in Italian Canne a far frepo : of Diofc. Phragmit is : in Englip, Reed.

Arundo Cypria ; or after Lobelius, Arusdo Donax : in Frencl Canne : in Spanilh Cara : in Italian, Calnmi a far Comrochia: In Englinh, Pole reed, and Cane, or Canes.

$$
\text { q1 The maiure. }
$$

Reeds are hot and dry in the feeond degrec, as Galcir frith.

$$
\text { T The vertues. }
$$

The roots of teed ftamped final diaw forth thorns and fplinters fixed in any patt of mans body.
The fame ftamped with vineger eafe all lixations and members ont of ioynt.

And likewife ftamped they heale hot and. Tharpe inflammations. The afles of then mixed with wineger helpeth the fales and feurfe of the hear, and lelperh the falling of the liaice. 


\section{$3^{8}$ Of the Hiftorie of Plants. L 1 в. 1.}

$\mathrm{D}$ The great Reed or Cane is not vfed in phyficke, but is efteemed to make flears for Weaners, fundry fotts of pipes, as alfo to light candics that ftand before Ininges, and to makc hedges and pales, as we do of laths and fuch like; and alfo to make certaine diuifions in thips to diuide the fweet oranges from the fowre, the pomecitron and lemmons likewife in findes, and many other purpofes.

\section{C на р. 3r. Of Sugar Cane.}

बा The defeription.

I. Vgar Cane is a pleafant and profitable Reed, hauing long ftalkes fucn or cight foot $\checkmark$ high, ioynted or kneed like vinto the great Cane; the lcaucs come forth of eteric joynt on euery tide of the ftalke one, like vnto wings, long, 1aarrow, and thatpe pointed. The Cane ir felfe, or ftalke is not hollow as other Canes or Reeds are, but full, and ftuffed with a fpongcous fubftance in tafte cxceeding fivect. The root is grcat and long, creeping along within the vppercruft of the enrth, which is likewife fweet and pleafant, but leffe hard or woody than orher Canes or Reeds; from the which there doth thoot forth many yong fiens, which are cut away from the maine or mother plant, becaufe rlicy fhould not draw away the nourithment from the old ftocke, and fo get vnto thenifelucs a little moifture, or elfe fome fubitance not much worth, and caufe the ftocke to be barren, and themfelues little the better; which floots do ferue for plasts to fet abroad for encreafe.

Arundo Saccharins. Sugar Cane.

A

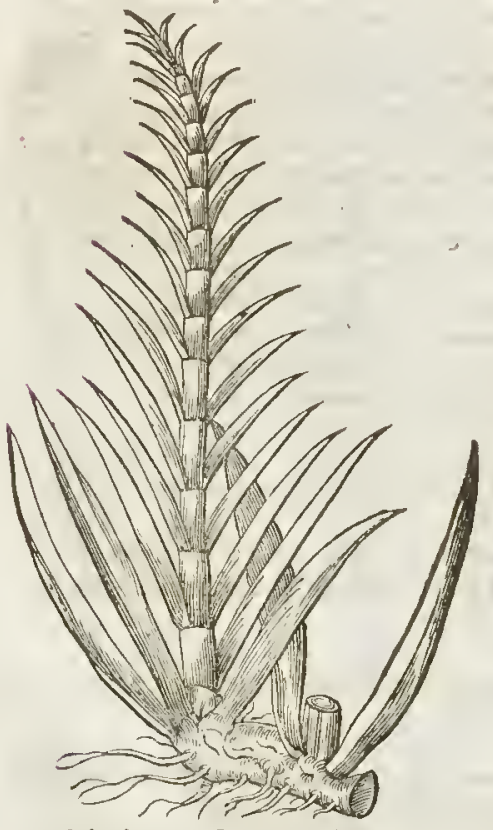

$$
\text { of The place. }
$$

The Sugar Cane groweth in many parts of Europe at this day, as in Spaine, Poitugal, Olbia, and in Pronence. It groweth alfo in Barbarie, gencrally almof eucty where in the Canaric Inlands, and in thofe of Madera, in the Eaft and Weft Indies, and many other places. My felfe did plant fome fhoors thereof in my garden, and fome in Flanders did the like: but the coldneffe of our clymate made an end of mine, and I thinke the Flemings will haue the like profit of their lábour.

$$
\text { \% Thetimse. }
$$

This Cane is planted at any time of the yeare in thofe hor countrics where it doth naturally grow, by reafon they feare no froits to hutr the yong thoots at rheir firft planring.

$$
\text { The names. }
$$

The Latines haue called thes plant Arundo Sacebarena, with this additament, Irdical, becaufe it ivas firfte knowne or brought from India. Of fome it is called Calamus Saccharatus : in Englin Sugar Cane : in Dutch Supictietriedt.

If Thenature andivertues.

The Sugar or juice of this Recd is of a temperate qualitic; it drieth and cleanfeth the Ptomacke, maketh fmooth the roughneffe of the breft and luness, clearcth the voice, and putteth aw ay hoarfeneffe, the cough, and all fourcneffe and bitternefle, as If sar faitl in Dittis.

T) Therfe.

Of the ilyce of this Reed is made tlie moft pleafant and profitable fweet, called Sugar, whereof is made infinite confe:tions, confectures, fyrups, and fuch like, as alfo preferuing and conferuing of fundry fruits, herbes, and flowers, as Rofes, Violets, Rofemary flowers, and fuch like, which ftill retaine with them the name of Sugar, as Sugar Rofet, Sugar violet, \&c. The which to write of would require a peculiar volume, and not perrinent vnto this hiftoric, for that it is not my purpofe to make of my booke a Confectionarie, a Sugar Bakets furnace, a Gentlewomans preferuing pan, nor yet an A pothecaries fhop or Difpenfatorie ; but oncly to rouch the chiefeft matter that I purpofed to handlc in the beginning, that is, the naturc, propertics, and defcriptions of plants. Notwithatanding I thinke it not amifie to thew vnto you the ordering of thefe reeds

wlien 
when they be new gathered, as I receiued it from the mouth of an Indian my feruant: he faith, They cut them in fmall pieces, and put them into a trough made of one whole tree, wherein they put a great ftone in manner of a mill-itone, whereunto they tie a horfe, buffe, or fome other beaft which draweth it round: in which trough they put tho fe pieces of Canes, and fo cruth and grind. themas we do the barkes of trees for Tanners, or apples for Cyder. But in fome places they ve a great wheele, wherein flaues do tread and walke as dogs do in turning the fpit : and fome others do feed as it were the bottome of the faid wheele, wherein are fome tharpe or hard things which do cut and cruth the Canes into powder. And fome likewife haue found the inuention to turne the wheele with water workes, as we do our iron mills. The Canes being thus brought into dufe or powder, they put them into great cauldrons with a little water, where they boyle vntill there be no more fweetneffeleft in the cruthed reeds. Then doe they ftraine them through mats and fuch like things, and put the liquor to boyle againe vnto the eonfiftence of honey, which being cold is like vnto fand both in fhew and handling, but fomewhat fofter; and fo afterward it is carried into all parts of Europe, where it is by the Sugar Bakers artificially purged and refined to that whiteneffe as we fec.

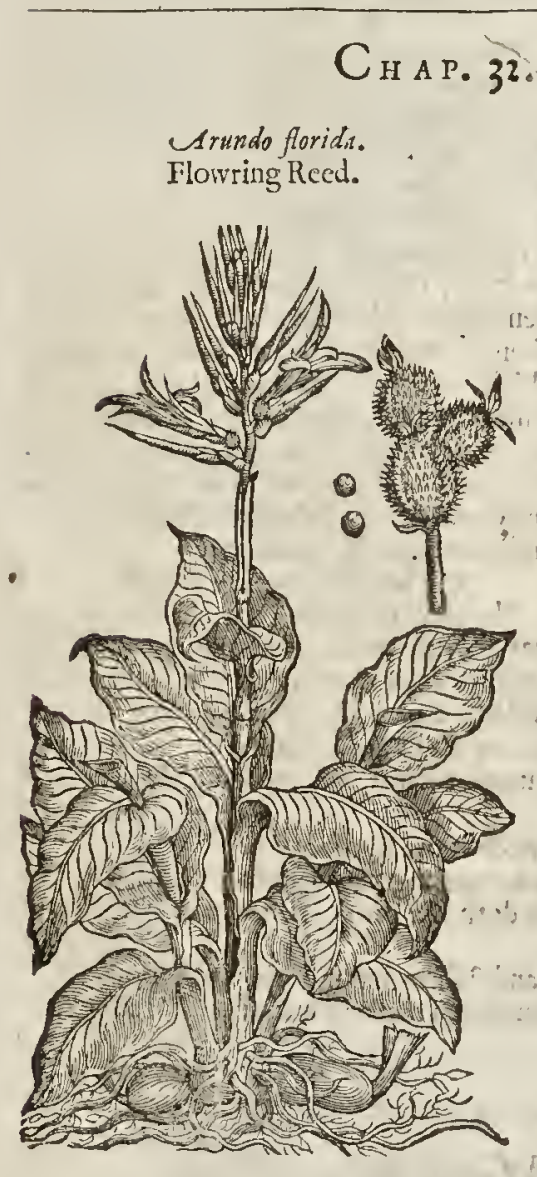
-1 Lourishing Reed hath a thicke and fat falke of
foure or fue foot high, great below necre the ground, and fmaller toward the top, taper-wife: whereupon do grow very faire broad leaucs ful of ribs or finewes like vnto Plantaine, in thape reprefenting the leates of white Hellebor, or the great Gentian, but mueh broader and larger enery way : at the top of which falkes do grow phantafticke flowers of a red or vernilion colour; which being faded, there follow round, rough, and prickly knobs, like thofe of Sparganinw, or water-Burre, of a browne colour, and from the middle of thofeknobs thrce fmall leaues. The feed contained in thofe knobs is exceeding black, of a ferfect roundneffe, of the bigneffe of the fmallen peafe. The root is thicke, knobby, and tuberous, with certain finall threds fixed thereto. $\neq$ There is a variety of this, hauing floures of a yellow or Saffron colour, with red fpots. $\neq$

It groweth in Italy in the garden of Padua, and many other plaees of thofe hot regions. My felfe hauc planted ir in my garden diuers times, but it nener came to flowing or feeding, for that it is very impatient to endure the injurie of our cold clymate. It is a natiue of the Vert Indies.

\section{T Thetime.}

It mut be fet or fowen in the beginning of Aprill, in a por with fine earth, or in a'bed made witl horfeding, and fome earth frawed thereon, in fich manner as Cueumbers and Muske-Melons are.

बा The names.

The name A rumdo Indica is diuer fly attributed to fundric of the Reeds, but prineipally vnto this, called of Lobelius, Cumbacurus . of others, Arundo florida, and Harundo florida: in Englinh, the Flowring Reed.

There is not any thing fettome as touching the temperature and vertues of this Flourifhing: Reed, either of the Ancients, or of the new or later Writers. 


\section{C на P. 33. Of Paper Reed.}

P A per Reed hath many large flaggie leaues fomcwhat triangular and fmooth, not much in. like thofe of Catf-taile, rifing immediatly from a tuft of roots compact of many ftrings, among ft the wbich it thooteth vp two or three naked falkes, fquare, and rifing fome fix or feuen cubits high aboue the water ; at the top whereof there ftands a ruft or bundle of chaffie threds fet in comely order, refembiing a tuft of flowers, but barren and void of feed.

Papyrus Nilotica. Paper Reed.

A

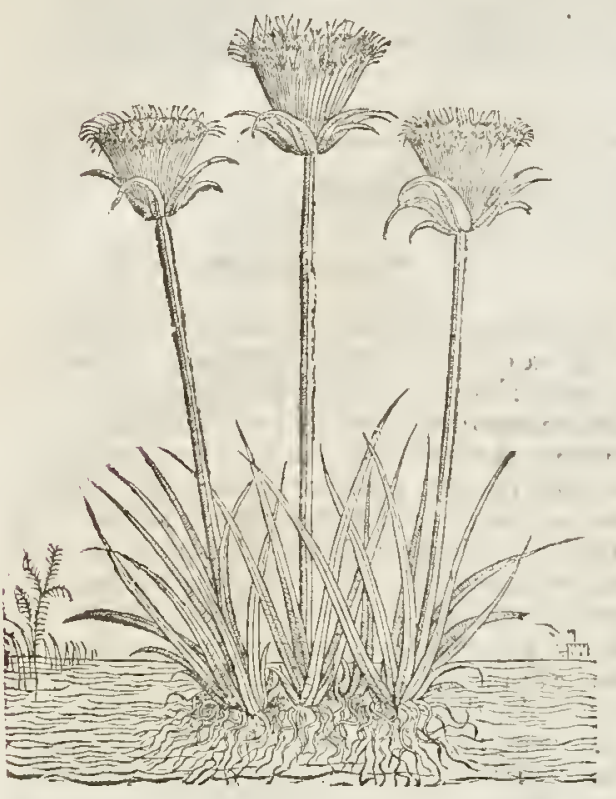

This kinde of Reed growes in rhe Riners about Babylon, and neere the city Alcaire, in rhe riuer Nilus, and fuch orber places of thofe countries.

$$
\text { of Thetime. }
$$

The time of fpringing and flourifhing anfwercth thar of the common Recd.

$$
\text { बT The names. }
$$

This kinde of Reed which I haue EngliThed Paper Reed, or Paper plant, is the fane (as I do readc) that Paper wats 11 ta de of in Egypt, before rhe inuention of papes made of linnen clouts was found nut. It is tlinught by men of great learning and underftanding in the Scriptures, and fer downe by them for truth, that this plant is the fame Reed mentioned in rhe fecond cluapter of Exodus ; whereof was made that basket or cradle, which was dawbed within and without witl flime of that countrey, called Bitumen Iudaicum, wherein Mofes was put being commitred to the water, when Pharauls gave commandement that all the male children of the Hebrewes thould be drowned.

$$
\text { T T he nature, vertues, and vee. }
$$

The roots of Paper Reed doe nourifh, as may appeare by the people of Ægypt,which do vfe to chew them in their mouthes, and fivallow downe the juice, finding therein great delight and comfort.

B Thearhes burned affivage and confume hard apofumes, tumors, and corrafiue vlcers in any part of rhe body, but chicfely in the moutl.

C The burnt paper made hercor doth performe thofe effects more forcibly,

D The falkes hercof haue a fingular vfe and priuiledge in opening the chancls or hollow paffages of a Fiftula, being put therein; for they do fwellas doth the pith of Elder, or a tent made of a fponge.

E The people about Nilus do vfe to burne the leaues and fralkes, but efpecially the roots.

F. The frailes wherein they pur Raifins and Figs are fometimes made hereof; but generally with the herbe Spartum, defcribed in the nexr Chapter.

\section{Снат. 34. Of Mat-Weed.}

Tा The kindes.

There bediuers kindes of Mat-Weeds, as thall be declared in their fenerall deferiptions.

$$
\text { T) The defcription. }
$$

$\neg$ He herbe spartum, as Pliny faith, growerh of it felfe, and fenderh forth from the root a multitude of llender minic leaues of a cubit high, or higher, tough and pliable, of a whitifl colour, which in rime drawerh narrow together, making the flat leafe to become round, as is the Rurh, The fub or falke thercofbeareth at the top ccrtaine feather-like tufts comming 
forth of a theath or huske, among the which ehaffic huskes is eontained the feed, long and chaffre. The root confifterh of many ftrings folding one within another, by meanes wheref it com-
meth to the forme of a turfe or hafloeke.

I. Spartum Plinë Clufio. plinies Mat-Weed.

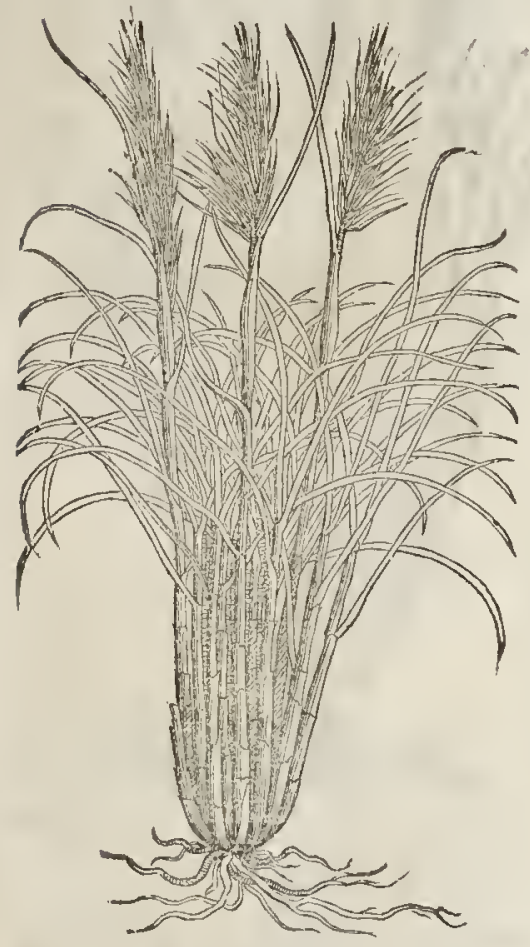

2 Spartum altcrum Plimi. Hooded Mat-Weed.

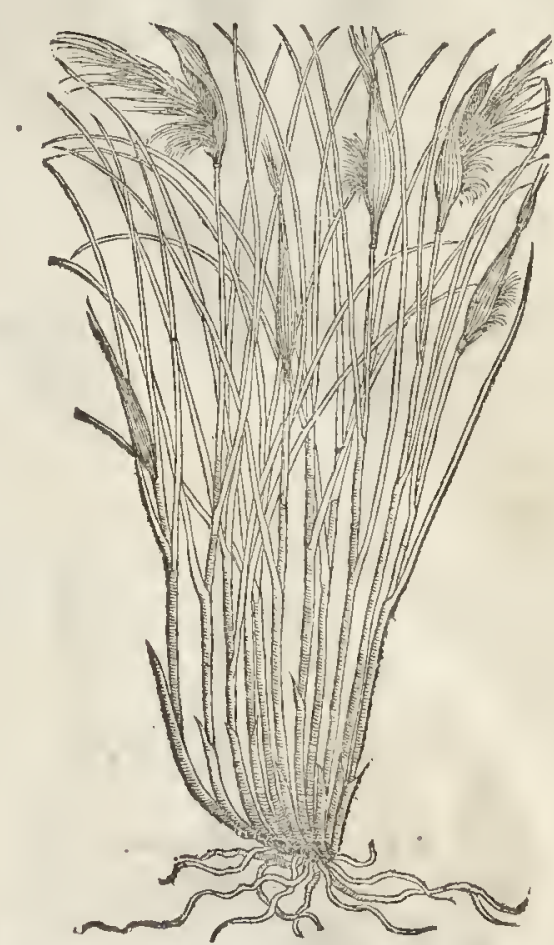

i The fecond likewife Pliny deferibeth to have along falke not mueh vnlike to Reed, but leffer, whercupon do grow many graffic leates, rough and pliant, hard in handling as are the Ruhes. A fpokic chaffie tuft groweth at the top of the ftallie, comming forth of a hood or finewie thearh, furch as eneloferh the flowers of Onions, Leckes, Nareiftus, and fueh like, before
they come to flowring, with feed and roots like the preeedent.

3 Englith Mar-weed hath a rufhie root, deepely creeping and growing in heapes of fand and graucll, from the which arife eftiffe and fharpe pointed leates a foot and a lialfe long, of a whitinh colour, very much refembling thofe of Camels hay. The ftalke growerh to the height of a cubit or more, whereupon doth grow a fpike $f$ or care of fome fute or fix inehes long, fonw hat refenfeed is bre; it is the thickneffe of a finger in the milit, and fmaller towards both the ends. The plant ncither Sheepe nor any orher Cat, but round, and fomerwhat tharpe at the one end $\neq$. Of this plant neither Sheepe nor any other Cattle will tafte or eate.

4 The other Englifh Mat-Weed is like vnto the former, fauing that the roots of this are the vpper eruft of the earth. The rufto not rluruft decpe into the ground, but ereepe onely vnder the vpper eruft of the earth. The tuft or eare is fhort: $\mathrm{s}$, and nore refembling the head of Canary
feed than that of $R$ ie.

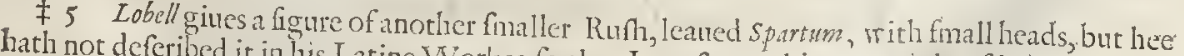
6 To this kindred mut beadde Workes, fo that I can fay nothing eertainly of it.

in place of grow th. Nory ir batded the Feathered Graffe, though not partaking with the former ted, not mueh in formevith ithath many fmall leaues of a foots length round, grecn, and tharp poinrife vp many fmall ftalkes not exeed deferibed Mat-weed, bur much leff: among ft thefe leaues foremany fmall ftalkes not execeding the lieight of the leates, whieli beare a fpike nnlike the forementioned Mat-weeds, haning 3 or foure feeds ending in, or fending vp very fine white Feathers, refenbling tlie fmaller fort of feathers of the wings of the Bird of Paradife. The root confits of many fmall grafic fibres. 
3 Spartum Anglicanum. Englirh Mat-Weed, or Helme. Arumdo Urenaria

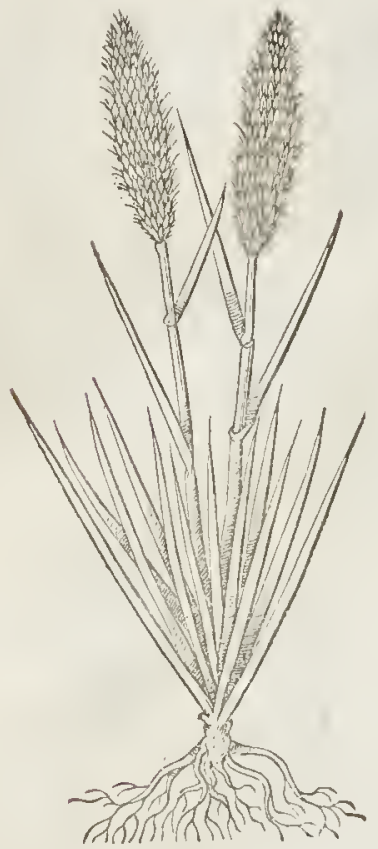

\section{\# 6 Spartuni Auftriacum.}

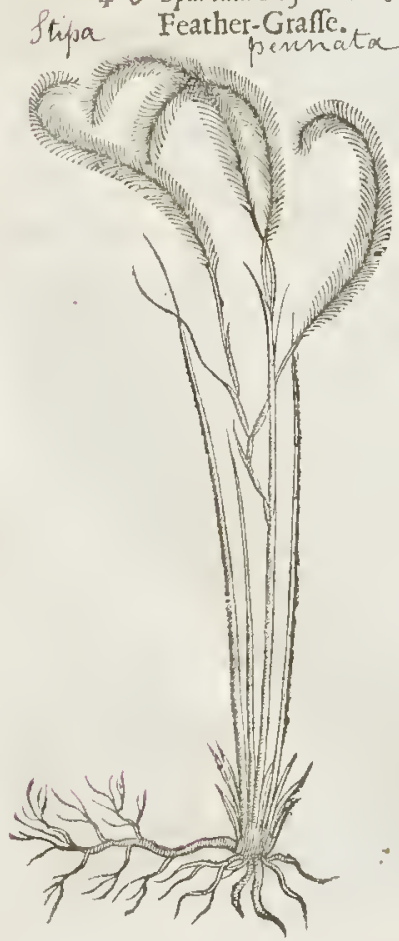

4 Spartum Anglicanmm altcrum. Small Englifh Mat-Weed, or Heline.

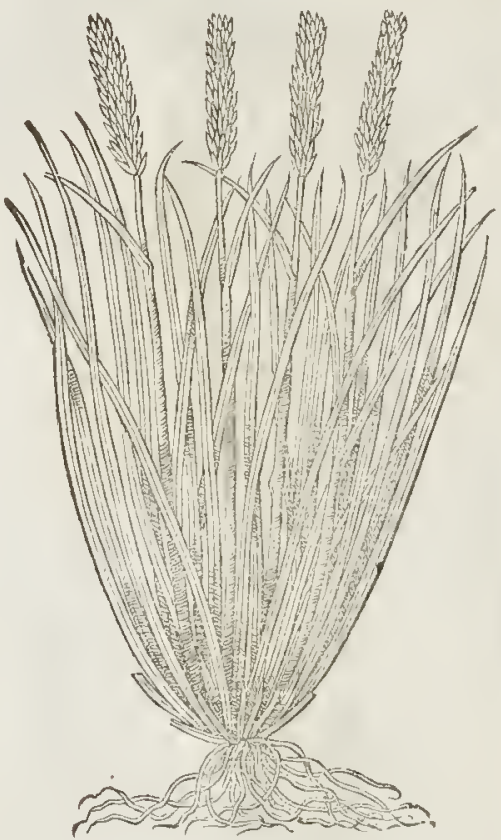

$$
\text { T The place. }
$$

I 2 Thefe two grow in diuers places of Spane. 3 I being in company with M. Tho. Hicks, William Broad, and threc other London Apothecaries befides, in Auguft, 1632 , to finde out rare plants in the Ifland of Tenet, found this bigger Englifh one in great plentic, as foone as we came to the fea fide, going betweenc Margate and Sandwich.

45 Thefe it may be grow alfo vponour Coafts; howeucr they grow neere the fea fide in diucrs parts of the Low-Countries.

6 This elcgant Plant Clufius firft obferted to grow naturally in the mountaines nigh to the Bathes of Baden in Germany, and in diuers places of Auftria and Hungaric. It is nourihed for the beautic in fundric of our Englioh gardens.

$$
\text { Tा Thetime. }
$$

Thefe beare their heads in the middle, and fome in the later end of Sommer.

$$
\text { 4. The names. }
$$

I This is called Spartum primum Pliniy; that is, the firf Mat-Wecd defcribed by pliny ; in Spaine they call it sparto: the French in Prouence terme it $O l p h o$.

2 This is Spartum alterum Plinï, Plinie his fecond Mat-Weed, or Hooded Mat-weed, it is called Albardin in Spaine.

3 This is Spartum tertium of Clufuns, and Gronch sparterm ferundum Schenanthinum of $T$ absr. Our Author 
gate Clufus his figure for his firt, and T thernumontanus figure for the fecond Spartum Anglicanm: but I will thinke then both of one plant (tiough Bubine diftinguifh them) wntll fome thall make the contrary manifeft. This the Dutch call alnue; and our Englifh in Tenet, Helne, Turner calls it Sea-Bent.

4 This is Spartum berba 4 Batarian of Clufus; Grumen Spartcum, or runci Spartiuna of T.tberm. and our Authorgatu Tabern. figure in the $2 ;$ Chapter of this Booke vnder the title of runcius ma. rinus gramincus; Lobell calls it sp.rivmnoftres altcrum.

5 Lobell calls this Spartuminoftras parunam.

6 Clufurs calls this Spartum Aufruacum; Dalefobmpius, Gramen pimatum; we in England call it Gramen plumofum, or Fcathered Grafle. $\neq$

$$
\text { Thetcomperature, serines, and vee. }
$$

Thefe kindes of graffe or rather ruthie Reed haue no vfe in phy ficlie, but ferue to make Mars, A and hangings for chambers, frailes, baskets, and fuch like. The people of the Countries where they grow do makebeds of them, ftraw their houfes and chambers in ftead of Rufhes, for which they do excell, as my felfe hauc feene. I urner affimeth, That they made hats of the Englith one in Northumberland in his tine.

They do likewife in fundry places of the Iflands of Madera, Canaria, Saint Thomas, and other $B$ of the Iflands in the rract vnto the Wett Indies, make of them their boots, flooes, Herd-mens Coats, fires, and lights. It is very hurtfull for cattell, as Shecre-grafe is.

The Feather-Graffe is worne by fundry Ladies and Gentlewomen in ftead of a Feather, the which it exquirtely refembles.

\section{Cнар. 35. Of Camels Hay.}

I Scananthwm

Camels Hay.

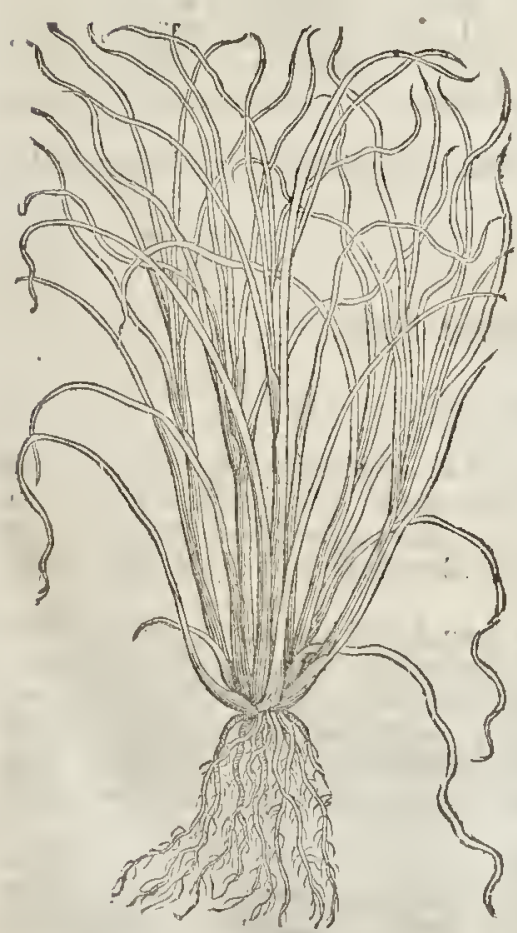

2 Sconantbum adulterinum. Baltard Camels Hay.

Tा The defription.

Amels Hay hath leaues very like vnto Mat-Weed or Hęlme; his roots are many, in quantitie meane, full of fmall haires or threds proceeding from rhe bigger Root deeply groming in the ground, hauing diuers long italkes like Cyperus Grafe, fet 
with fome fmaller leaties cucn vnto the top, where do grow many fmall chaffie tufts or pannicles like vnto thofe of the wilde Oats, of a reafonable good fmell and faum,when they arebroken, like vnto a fiofe, wicl a certaine biting and nipping of the tongue.

† 2 Francis Penny, of famous memory, good Phy fitian and skilfull Herbarift, gathered on the conft of the Mediterranean fea,between A igues Mortes and Pefcaire, this beatifull plant,whofe roots are creeping, and ttalkes and leaues refemble Squinanth. The flowers are foft, pappous, and thicke compan, and fome fue or fix inches in length, like to Fox-taile; they in colour refemble white filke or filuer. Thus much Lobell. Our Author defcribed this in the firf place, Ch.23.vnder Imucus Marinus Gramineus, for fo Lotell alfo calls it. $\dagger$

$$
9 \text { Thiplace. }
$$

I This growes in Africa, Nabathas, and Arabia, and is a franger in thefe Northerne Regions.

2 The place of the fecond is mentioned in the defeription.

Their time anfwereth the other Reeds and Flags.

$$
\text { Tl Thenames. }
$$

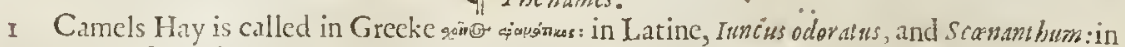
fhops Squmanthum, that is, Flos Iwnci: in French, Pafteur de Chammeam : in Engliph, Camels Hay, and Squinanth.

2 This Lobell calls Iuncus murinus gromineus, and $P$ fcudogchenuthum: We call it Baftard Squinanth, and Fox-taile Squinanti.

$$
\begin{aligned}
& \text { The temper. } \\
& \text { This plant is indifferently lot, and a little attrictiue. } \\
& \text { The vertues. }
\end{aligned}
$$

A Camels Hay prouokcth vrine, moueth the termes, and breaketh winde about the ftomacke.

B It caufeth aking and heauineffe of the head, Galen yeeldeth this reafon thereof, becaufe it lieateth moderately, and bindethwith tenuitic of parts.

C According to Diofcorides, it diffolues, digefts, and opens the paffages of the veines.

D The floures or chaffie tufts are profitable in drinke for them that piffe bloud ary wayes : It is giuen in medicines that areminiftred to cure the paines and griefes of the guts, ftomacke, lungs, liuer, and reines, the fulneffe, loathfomenefie, and other defects of the ftomacke, the droplie, conuulfions, or thrinking of finews, giuen in the quantitie of a dram, w ith a like quantitic of Pepper, for fome ferv diayes.

E The fame boyled in wine helpeth the inflammation of the matrix, if the woman do fit oner the fume thercof, and bathe her felíe often with it alfo.

\section{С на з 36. Of Burre-Reed.}

T The defeription.

I The firt of thefe plants hatl long leaues, which are double cdged, or tharpe on both fides, with a tharpe creft in the middle, in fuch manner raifed vp that it feemeth to be rriangle or three fquare. The ftalkes grow among the lcaues, and are two or three fort long, bcing diuided into many branches, garnifhed with many prickly huskes or knops of the bignefle of a nut. The root is full of hairy ftrings.

2 The great Water Burre differeth not in any thing from the firnt $k$ ind in roots or leaucs, fauce that the firt hath his leates rifing inmediately from the tuft or knop of the root; but this kinde hath a long ftalke comming fron the root, whereupon, a little aboue the root, the leates fhoot out round about the ftalke fucceffucly, fome leaues ftill growing aboue others, cuen to the top of the ftalke, and from the top thereof downeward by certaine diftances. It is garnifhed with many round wharles, or rough coronets, hauing here and there among the faid wharles one fingle thort leafe of a pale greene colour.

$$
\text { Theplace. }
$$

Both thefe are very common, and grow in moift medowes, and neere vnto water-courfes. They plentifully grow in the fenny grounds of Lincolnthire, and fuch like places; in the ditches about S. Georre his fields, and in the ditch right againft the place of execution, at the end of Southwark, called S. Thom w Waterings.

They bring forth their burry bullets or fecty knots in Auguft. 


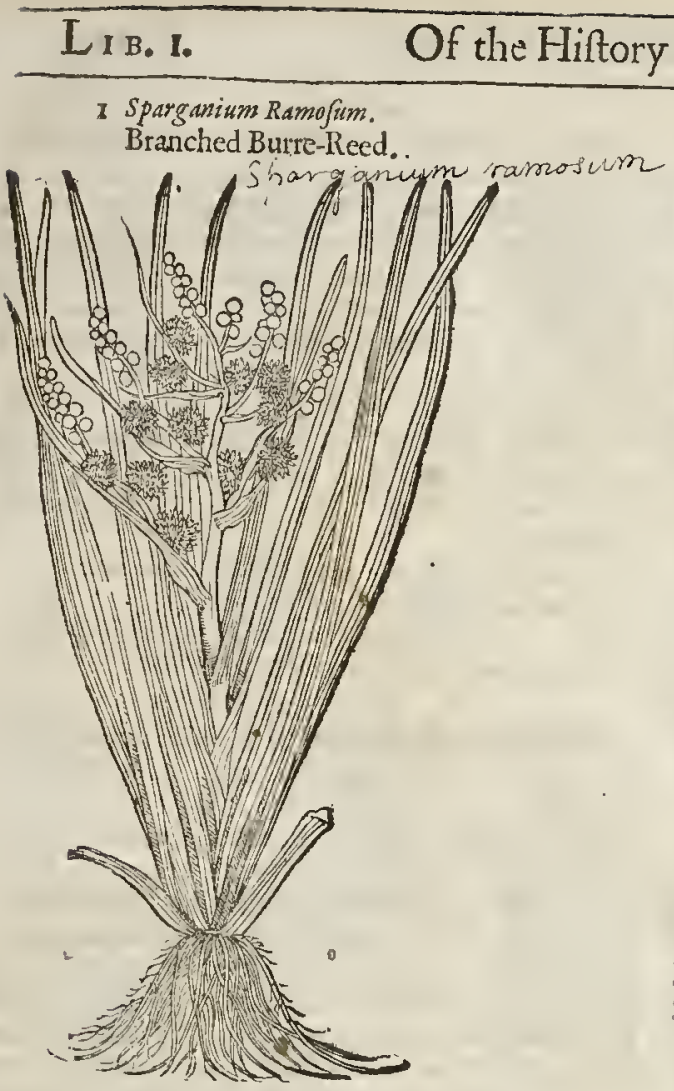

y of Plants.

2 Sparganiumilatifolium.

Great Water-Burte.
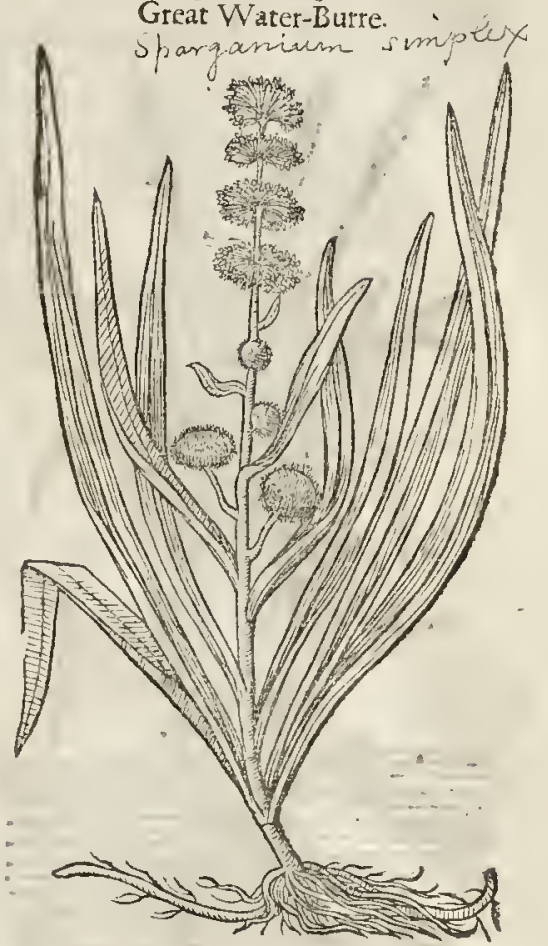

Thefe Plants of fome are Thenames.

Chapter calleth them Butomus : of firganium : Theophraftus in his fourth Booke and eighreenth tongue they are called $S a$ farbe Bamon firf Sparganium ramofum, or Branched branching Burre-Reed.

They are cold and dry of complexis The tomperature.

Tा The vertucs. Some write, that the knops or rough burres of thefe plants boyled in wine, are good againft
the bitings of venomous beafts, if either it be drunke, or thewound wafhed therewith.

\section{$\mathrm{C}_{\mathrm{HAP}}$ 37. Of Cats Taile.}

\section{T) The defoription.}

Ats Taile hath long and flaggy leaues, full of a fpongeous matter, or pith, among which leaues groweth vp a long fimooth naked ftalke, without knot, fahioned like a fpeare, of a firme or folid fubftane, hauing at the top a browne knop or eare, foft, thicke and fmooth,
feeming to be nothing elfe but a deale of floekes thicke fet and thruet together, which being ripe
turneth into a downe, and is carried away with the turneth into a downe, and is carried away with the winde. 'The Roots be hard, thicke, and white, full of ftrings, and good to burne, where there is plenty thereof to be had.

It groweth in pooles and fuch like The The place.

I haue found a fmaller fuch like ftanding waters, and fometimes in running ftreames.

Shepey, going from Sherland houre to Frowing in the ditches and marthie grounds in the Ifl s of

They the.

They floure and beare their mace or torch in Iuly and Augutt.
$\mathrm{D}_{3}$
a) The 
dayes the quantitie minifted euery day fafting for the fpace of thirtic fpecified doth not onely helpechildren and ftriplings, but growne men alfo, if in time of their cure they vic conuenient ligature or truffings, and fit confounding plaifters vpon the gricued place, according to art appointed for that purpofe in Chirurgerie.

C This Downe in fome places of the Iflc of Elie, and the low countries adioyning thereto, is gathered and well fold to make matreffes of, for plowmen and poore people.

D It hath beene alfo often proned to heale kibed or humbled heeles (as they are termed) being applied to chen, either before or after the skinne is broken.

\section{C на I. 38. Of Stitchwort. \\ T) The defription.}

1 Titchwort, or as kuellizs termeth it Holufterm, is of two kindes, and hath round tender ftalkes full of joints leaning toward the ground : at eucry ioynt grow two leaues one againft another. The flowers bewhite, confifting of many fnall leaues fet in the manner of a ftarte. The roors are fmall, jointed, and threddy. The feed is contained in fmall heads fomewhat long, and tharpe at the vpper end, and when it is ripe it is very fmall and browne.

2 The fecond is like the former in thape of leates and flowers, which are fet in forme of a ftarre; but the leaues are orderly placed, and in good proportion, by couples two together, being "of a whitifh colour. When the flowers bevaded then follow the feeds, which are inclofed in bullets like the feed of fiax, but not fo round. The chines or threds in the middle of the floure are fometimes of a reddith, or of a blackith colour. + There are more differences of this plant, or tather varicties, as differing litele but in the largenefle of the leaues, floures, or ftalkes. $f$

$$
\text { T The place. }
$$

They grow in the borders of fields vpon banke fides and hedges, almof eucry whete.

$$
\text { Thime. }
$$

They Gourift all the Sommer, efpecially in May and Iune. 


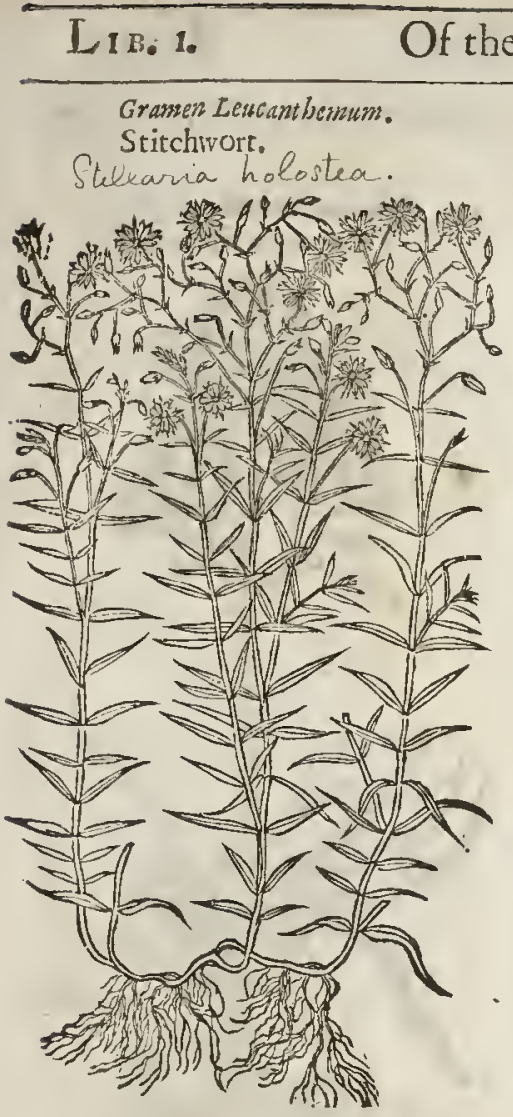

T) Thenames.

Some (as Ruellizs for one) lratre thought this to be the plant which the Grecians call oxison: in Latine, Tot offer : in Englifh, All-Bones; whereof I fec no reafon, except it beby the figure Antonoria; as when we fay in Englifh, He is an honeft man, our meaning is that he is a knaue:for this is a tender herbe hauing no fuch bony fubrtance. $\neq$ Dodoneus queftions, whether this plant be not Crateogonon; and he ealls it Gramen Ler.. canthemum, or White-floured Graffe. The qualitic here noted with B. is by Diofcorides giuen es Crateoro.

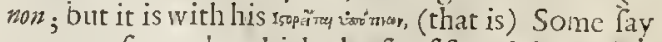
or report fo much : which phrafe of fpeceh hee often vetli when as hewrites faculties by heare-fay, and doubts himfelfe of the truth of them, $\ddagger$

$$
\text { II The nature. }
$$

The feed of Stitchwort, as Galen writeth, is Thatpe and biting to him that tarteth it; and to hin that veth it very like to Mill.

\section{- Thevertues.}

They are wont to drinke it in Wine with the pwo- A der of Aeornes, againft the paine in the fide, ftitehes, and fueh like.

Divers report, faith Diofcorides, That the Seed of $B$ Stitehwort being drunke caufeth a woman to bring forth a man ehilde, if after the purgation of her Siekneffe, before the conceiue, the do drinke it fafting thrice in a day, halfe a dram at a time, in three ounees of water many dayes together.

\section{C н Р. 39. Of Spiderwort. \\ T The defiription.}

17 Heobfeuredefeription which Diofcorides and $P l i n y$ haue fet downe for $P$ halungium, hath bred much contention among late Writcrs. This plant Phalungium hath leates much like Couch Grafie, but they are fomethat thickerand fatter, and of a more whitim greene colour. The ftalkes grow to the height of a eubit. The top of the falke is befer with fmall branehes, garni hed with many little white flowers, enmpact of fix little leaues. The threds or thrums in the midd le are whitih, mixed wirh a faire yellow, which being fallen, there follow blacke feeds, inelofed in fmall round knobs, whieh be three cornered. The roots are many, rough, and white of colour.

2 The feeond is like the firft, but that his falke is not branched as the firf, and floureth a moneth before the other.

3 The third kinde of Spidenwort, which Carolus Clufus nameth Afphodelus winor, hath a root of many threddy frings, from the whieh immediately rife vp grafle leaues, narrow and harpe pointed : among the which come forth diuers naked ftrait ftalkes diuided towards the top into fundry branches, garnilhed on euery fide with faire fture-like fowers, of colourwhite, with a purple veine diuiding cach leafe in the middeft : they haue alfocertaine cliues or threds in them. Tlie feed followeth inelofed in three foure heads like rnto the kindes of Afphodils.

$\$ 4$ This Spiderwort hath a root confinting of many thicke, long, and white fibers, not much vnlike the precedent, out of which it fends forth fome fiue or fix greene and firme leatres, fomewhat hollowed in the middle, and mutually inuolung cacli other at the root : among ft thefe there rifeth vp round greene ftalke, bearing at the top thereof fome nine or ten floures, more or leffe; thefe confift of fix leaues apicee, of colour white (the three innermoft leaues are the bro ader, and more curled, and the thre ontmont ate tipe with greene at the tops,) The whole flour much 


\section{8}

Of the Hiftorie of Plants.

L 1 в. I.

refembles a white Lilly, but much fmaller. Three fquare heads, containing a dusky and vnequall feed, follow after the Houre. vide Erata.

I Phalangium Ramofum.

Branched Spiderwort.

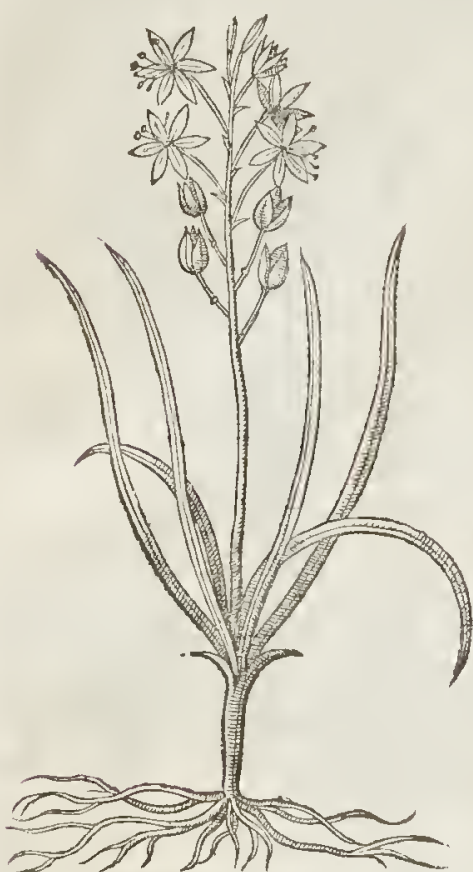

+ 3 Phalangium Crete."

Candy Spider wort.

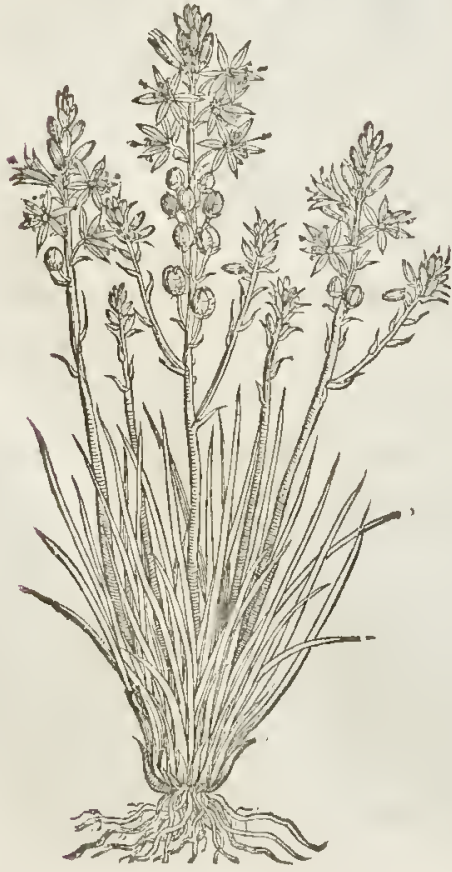

2 Phalangium atamofrm.

Vnbranched Spiderwort.

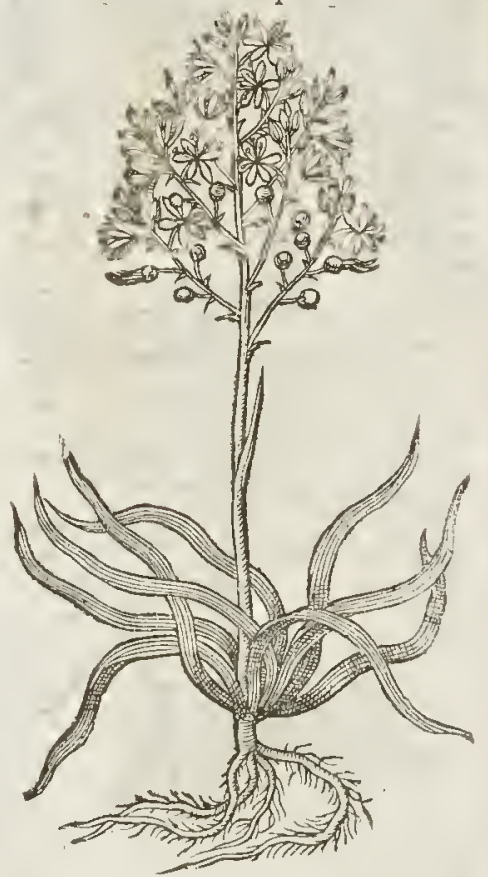

\# Phalangium Antiquorum.

The true Spiderwort of the Ancients?

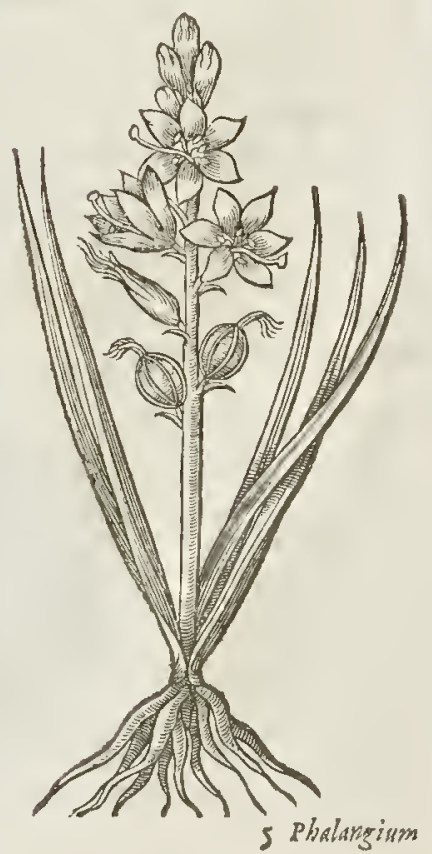




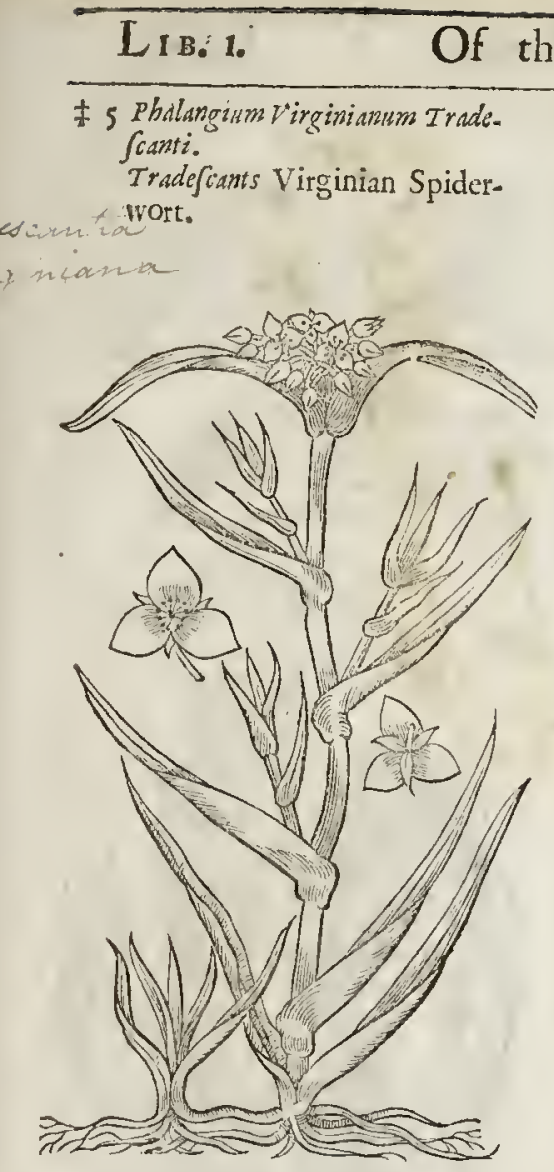

Tanes $\quad$ wort. $\therefore$ incoxsta

5 This plant in my iudgement cannot be fitler ranked with any than thefe laft deferibed therefore I haue here ginen him the fifth place, as the laft commer. This plant hath many creeping ftringy toots, which here and there put vp greene leaues, in thape refembling thore of the laft dercribed : amongft there there rifeth vp a pretty ftiffe ftalke jointed, and hauing at each joint one leafe incompunfing the ftalke, and out of whore bofome oft times little branclies arife: now the ftalke at the top vfually diuides it felfe into two leaues, much after the manner of cyperus : between which there come forth many foures confifing of three pretty large Jeaues a piece, of colour decpe biew, with reddith chines tipt with yellow ftanding in their middle. Thefe fading (as vfually they doethe fank day they fhew themfelues) there fucceed little heads couered wirh the three little leaues that fuftained the floure. In thefe heads there is contained a long blackim feed.

I. 2. 3. Thefe grow only in gardens with vs, and that very rarely. 4 This growes naturally in fome places of Sauoy. 5 This Virginian is in many of our Englifh gardens, as with M.P.trkinfon, M. Traden fcant, and others.

\section{9) The time.}

1.4.5. Thefe foure in Iune: the fecond about the beginning of May : and the third about Augut.

Therames.

The firft is called Phalangium ramofum, Branched Spiderwort. 2 Phalangium nor ramofum, Vnbranched Spiderwort. Cordus calls it Liliago. 3 This, Clufus calls Apphodelus minor: Lobell, Phalangium Cret a, Candy Spiderwort; 4 This is thought to be the Phalangizm of the Ancients, and that of Matthiolus : it is Phalangium Allobrogicum of Clufuzs, Sauoy Spidenwort. 5 This by M. Parkinfon (who firth hath in writing giuen the figure and defeription thereof) is aptly termed Phalangium Ephemerwm Virnz nianum, Soone-fading Spiderwort of Virginia, or Tradefcants Spiderwott, for that M. Tohn Vry fcant firft procured it from Virginia. Bashinc hath deferibed it at the end of his Pindix, and very vile fitly termed it Allium, fiuc Moly Virginianum. $\neq$

$$
\text { Galen fith Thenature. }
$$

Galen faith, Phalangium is of a drying qualitie, by reafon of the tenuitic of parts.

$$
\text { Thevertues. }
$$

Diofcorides faith, That the leaues, feed, and floures, or any of them drunke in Wine, preuaileth againt the bitings of Scorpions, and againft the ftinging and biting of the Spider called $P$ balargium, and all other venomous beafts.

The roots tunned vp in new ale, and drunke for a moneth together, expelleth poyfon, yea al- $B$ though it haue vniuerfally fpred it felfe through the body.

\section{Cна P. 40. Of the Floure de-luce.}

\section{T The kindes.}

$\mathrm{T}$

Here be many kindes of Iris or Floure de-luce, whereof fome are tall and great, fome lirtle, fmall, and low; fome fmell exceeding fweet in the root, fome hatue no finell at all : fome floures are fweet in fmell, and fome without, fome of one colour, fome of many colours mixed : vertues attributed to fome, others not remembred : fone haue tuberous or knobby roots, others bulbous or Onion roots, fome haue leates like flags, others like gtafe or ruthes. 


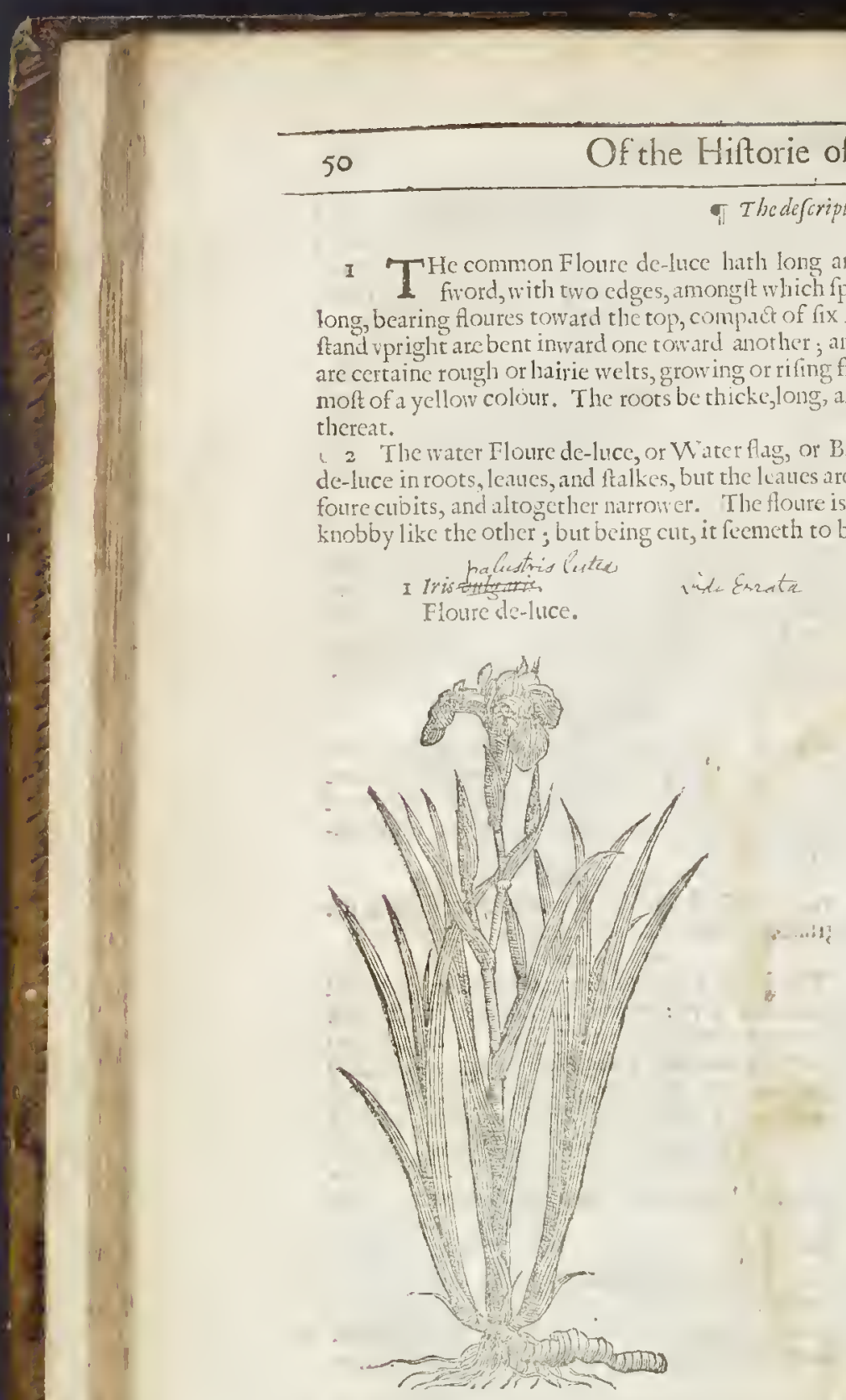

I THe common Floure de-luce hath long and large flaggy leatues like the blade of a of

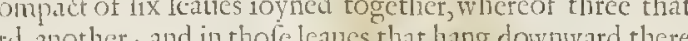
tand vprighe are bent inward one tonard another; and in thofe leates that hang clown ard there of thereat.

2 The water Floure de-luce, or Waterflag, or Baftard Acorus, is like vito the garden Floure de-luce in roots, leatues, and \{talkes, but the luates are nuch, longer, fometimes of the height of foure cuivits, and altosether narrower. The floure is of a perfe et. yellow colour, and the Roor knobby like the other; but being cut, it feemeth to be of the colour of raw fiesh.

I Iris

Floure de-luce.

$$
\text { me Garis }
$$

2 Iris tufini-luter.

Water-flag 5, or Tloure de-Luce.

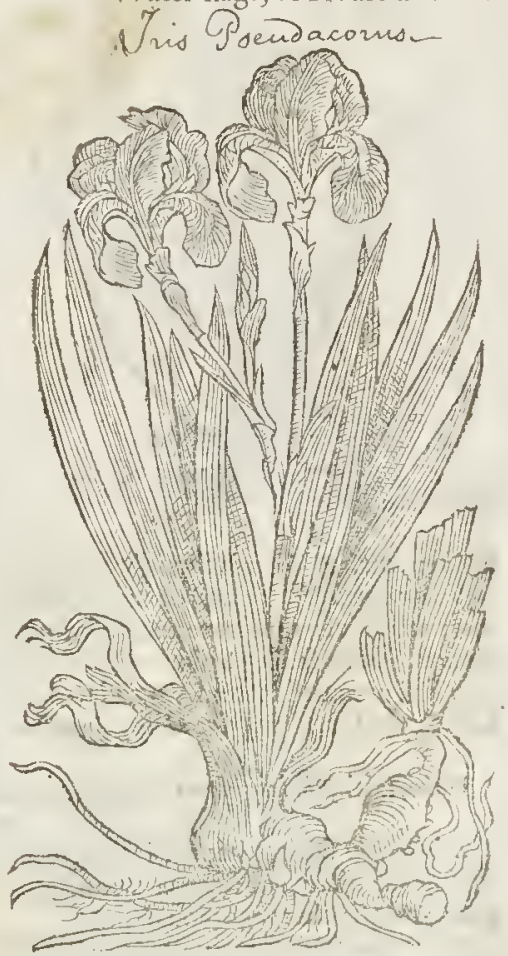

T) The place.

The Water Flomre de-luce or yellow flag profuereth well in moift nedows, and in the borders and brinks of riuers, ponds, and ftanding lakes. And although it be a water plant of nature, yet being planted in gardens it profpereth well

बT The numes.

Floure de-luce is called in Greeke iers: LAthenaus and Theophraftus readeirers:as though they thould fay, Confecratrix; by which name it is alfo called of the Latines Radix Marica, or rather Radix Naronica, of the riuer Naron, by which the beft and greateft fore do grow. Whereupon Nican. der in his Treacles conmendeth it thus :

Iradoriz quam aluit Drilon, ơ $\Lambda^{7}$ ironis rip.t.

Which may thus be Englifhed:

Iris, which Drilon water feeds,

And Narons bankes with other weeds.

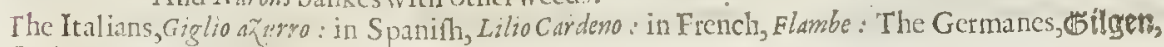
Sichwettel: in Dutch, Rirch.

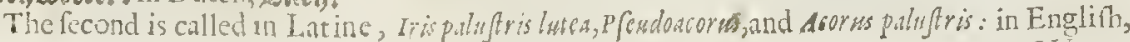


Waterflags, Battard Fbuse de-luee, or Water Floure de-luce : and in the North they call them Seggs.

Ti The nature.

I The roots of the Floure de-luce being as yet freeth and greene, and full of juyce, are hot alnoft in the fourth degree. The dried roots are hot and dry in the third degree, burning the thront and mouth of fuch as tafte them.

2 The baftard Floure de-liec his root is cold and dry in the third degree, and of an aftringent or binding facultic.

$$
\text { If The vortues. }
$$

The rout of the common Floure de-luce cleane wathed, and ftamped with a few drops of Rofe water, and laid plaifter-wife vpon the face of man or woman, doth in two dayes at the moft take away the blackneffe or blewnefle of any ftroke or brufe : fo that if the skinne of the fame woman or any other perfon be very tender and delicate, it fhall be needfull that ye lay a piece of filke, findall, or a piece of fune laune betweene the plaifter and the skinne; for otherwife in fuch tender bodies it often caufeth heate and inflammation.

The iuyce of the fame doth not onely mightily and vehemenrly draw forth choler, but moft $B$ efpecially watery humors, and is a fpeciall and fingular furgation for then that haue the Dropfie, if it be drunke in whay or fome orher licuor that may fonew hat temper and alay his heate.

The dry roots attenuate or make thiune thicke and tough humours, which are hardly and with $\mathrm{C}$ difficultic purged away.

They are good in a loch or licking medicine for fhortricfe of breath,an old cough, and all in- D firmities of the cheft which rife hereupon.

They remedic thofe that hate cuill fpleenes, and thofe that are troubled with convulfions or $\mathrm{E}$ cramps, biting of ferpents, and the running of the reines, beiny drunke with vinegre, as faith $D$ ioforides; and drunke with wine it bringeth downe the monethly courfes of women.

The decoction is good in womens baths, for it mollificth and openeth the matrix.

Being boylcd very foft, and laid to plaifter-svife it mollificth or foftneth the kings euil and out hard fivellings.

₹ The roots of our ordinary flags arc not (as before is deliuered) cold and dry in the third de- $H$ gree, nor yet in the fecond, as Dodona us affirmes; but hot and dry, and that at the lcast in the fecond degrec,as any that throughly taftes them will confeffe. Neither are the faculcies and vfe (as fome would perfuade vs) to be neglected; for as Pcna and Lobell affirme, though it haue no fmell, nor great heat, yet by reafon of other faculties it is much to be preferred before the Galanga major, or forreigne Acurus of fhops, in many difeafes; for it imparts morc heate and ftrength to the ftonacke and neighbouring parts than theother, which rather preyes vpon and diffipates the innate heate and implanted ftrength of thofe parts. It bindes, ftrengthens, and condenfes : it is good in bloudy flixes, and itayes the Courfes. $\neq$

\section{С на. 40. Of Floure de-luce of Florence.}

$$
\text { T) Thedefoription. }
$$

17 He Flourede-luce of Florence, whofe roots in thops and generally euery where are called Ircos, or orice (ivhereof fiveet waters, fweet pouders, and fuch like are made) is altogether like vnto the common Floure de-luce, fauing that the flowers of the Ireos is of a white colour, and the roots exceeding freet of fmell, and the other of mo fmell at all.

2 The white Floure de-luce is like vnto the Florentine Floure de-luce in roots, flaggy leaues, and ftalkes; but they differ in that, that this Iris hath his flower of a bleake white colour declining to yellowneffe; and the roots haue not any fmell at all; but the otter is very fweet, as we hauc faid.

3 The great Floure de-Iuce of Dalmatia hath leaues much broader, thicker,and more elofely compact together than any of the other, and fet in order like wings or the fins of a Whale fith, greene toward the top, and of a fhining purple colour toward the bottome, euen to the ground: amongft which rifeth wp a falke of foure foot high, as my felfe did meafure oft times in my garden : whereupon doth grow faire large floures of a light blew, or ats we terme it, a watchef colour. The foures do fmell excecting fiveet, much like the Orenge fioure. The feeds are contained in fquare cods, wherein are packed trogether many fiat feeds like the fornts. The root linth no fmell at all. 
LI B, I.

I Iris Florentina.

Flouste de-luce of Florence, Just Rorentina

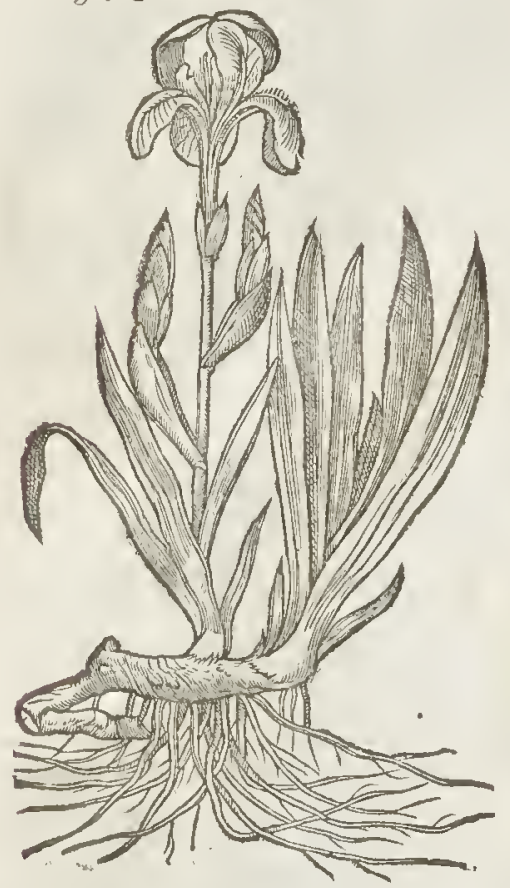

3 Iris Dalmatica major?

Great Flourede-luce of Dalmatia
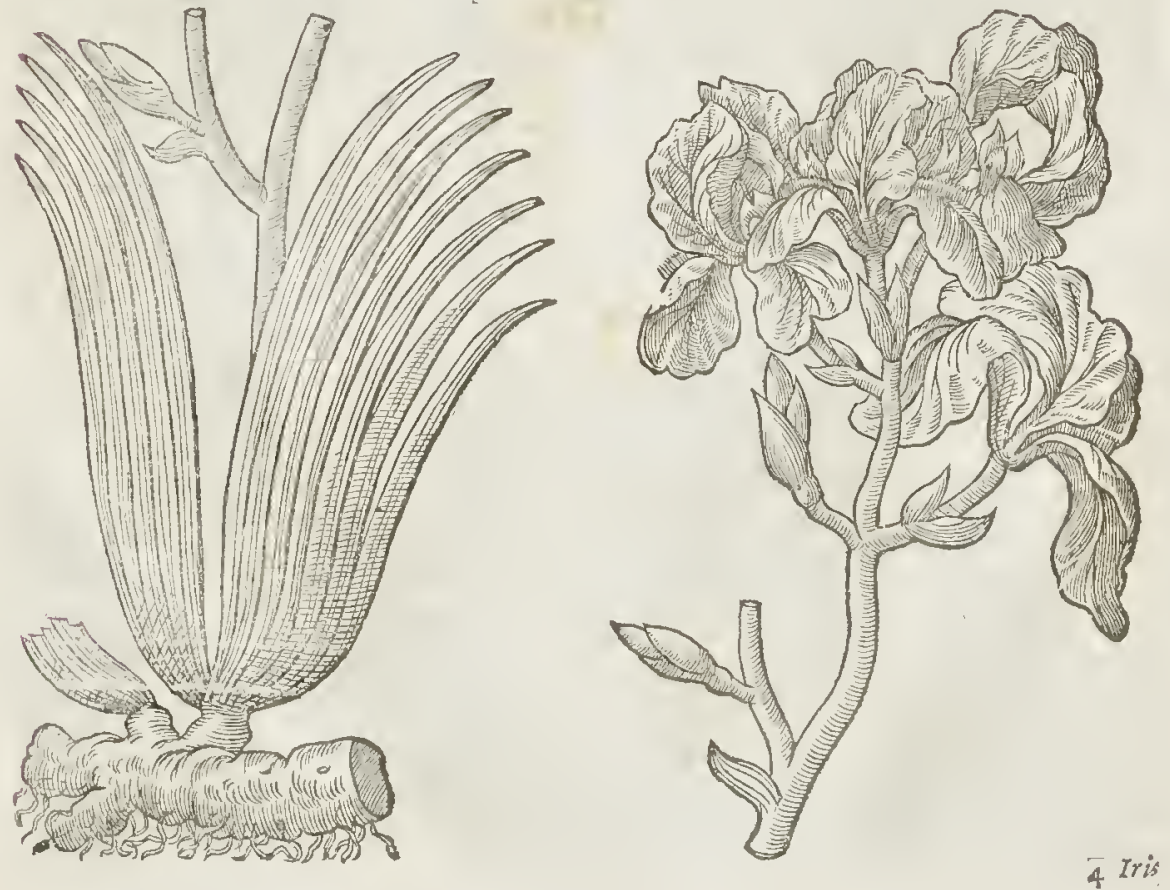

2 Tris alba.

6. White Floure de-luce.

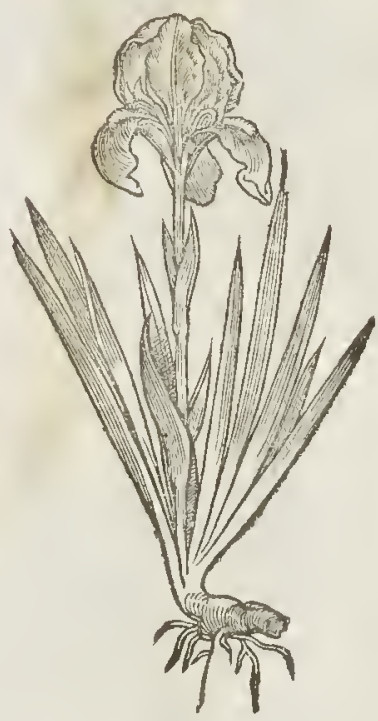


LI B. I. Of the Hiftory of Plants.

4 Iris Dalmatica minor.

Small Dalmatian Iris.
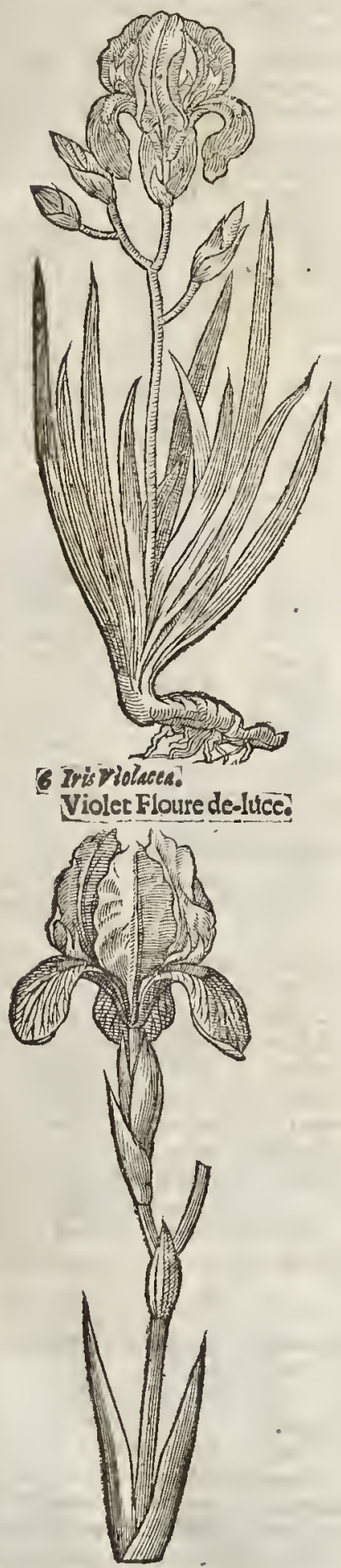

5 Iris Biflorit:

Twice-flouring Floure de-luce.

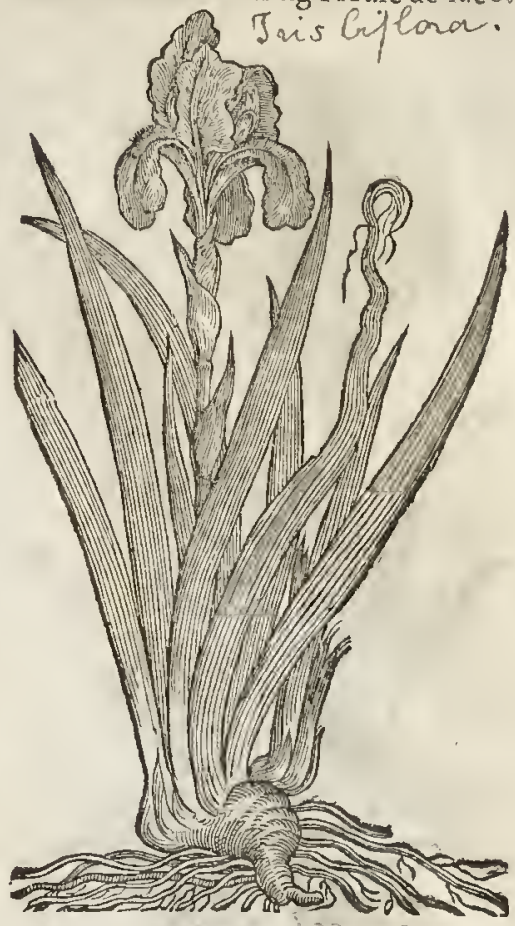

7 Ir is $P$ annonica.

Aufrian Floure deluce.

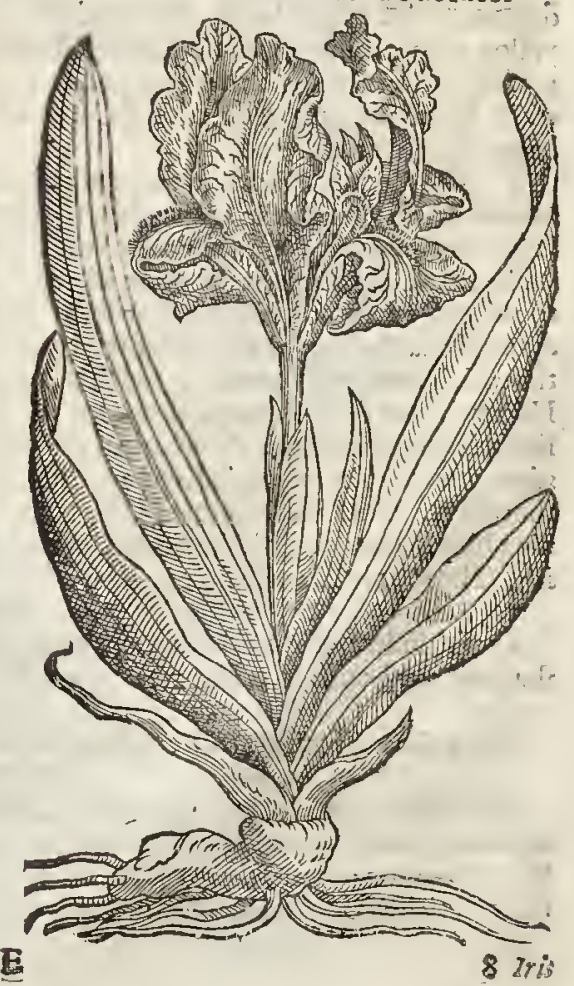


+8 Iris Camcrarï.

Germane Floure de-luce.

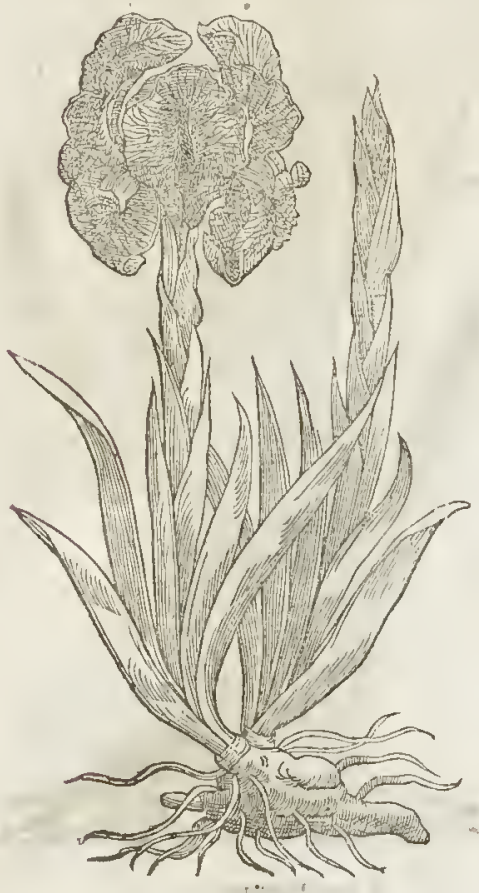

4 The fmall Floure de-luee of Daimatia is in therv like to the precedent, but rather refembling Iris bifora, being both of one furture, fmall and dwarfe plants in refpeet of the greater. The floures be of a more blew colour. They Hower likew ife in Muy as the others do. but beware that ye neuer cait any cold water vpon them prefently taken out of a Wel; for their tenderneffe is fuch, that they wither immediatly, and rot away,as I my felfe hauc proued:but thofe which Ileft vnwatred at the fame time lite and profper to this day.

5 This kinde of Floure de-luce came firft from Portugal tovs.It bringeth forth in the Spring time foures of a purple or violet colour, finelling like a violet, with a white hairy welt downe the middle. The root is thick and fhort, ftubborne or hard to breake. In leaues and fhew it is like to the leffer Floure de-luce of Dalmatia, but the leaues be more fpred abroad, and it commonly hath but one ftalke, which in Aurumne Roureth againe, and bringeth forth the likef floures; for which eaufe it was called Iris liflora.

6 Iris violace is like vnto the former, but much finaller, and the floure is o: a more deepe violet colour.

7 Carolus Clufin, that excellent and learncd Father of Herbarifts, hath fet forth in his Pannonicke Obferuations the pieture of this beatifull Floure de-luce, with great broad leaues, thicke and fat, of a purple colour neere vinto the ground, like the great Dalnatian Floure de-lue, whieh it doth very well refemble. The root is very fweet when it is dry, and ftriucth with the Florentine Ir is in fivectneffe. The floure is of all the other moft confufedly mixed with fundry colours, infomuch that my pen cannot fet downeiedery. lime or ftreake, as it deferueth. The three lcaues that ftand vpright do elafpe or embrace one another, and are of a yellow colour. The leaues that looke downward, about the edges are of a pale colour, the middle part of white, mixed with a line of purple, and hath many fmall purple lines fripped ouer the faid white floure, euen to the brim of the pale eoloured edge. It fmelleth like the Hauthome floures being lightly finclled vnto.

8 The Germane Floure de-lue, which Camerwius hath fet forth in bis Booke named Hortus Medicws, hath great thicke and knobby roots: the ftalke is thicke and full of iuyce: the leaues be very broad in refpe it of all the reft of the Floure de-luees. The floure groweth at the top of the ftalke, eonfifting of fix great leaues blew of colour, welted downe the middle, with white tending to yellow; at the bottome next the ftalke it is whitc of colour, with fome yellowneffe fringed about the faidwhite, as alfo about the brims or edges, which greatly fetteth forth his beatic ; the which Ionchimus Camerarius, the fonne of old Camerariss of Norenberg, had fent him out of Hungaric, and did conmunieate one of the plants thereof to clufus; whofe figure he hath mott liucly fet forth with this defeription, differing fornewhat from that which Ioachimus himfelfe did giue vnto me at his being in London. The leaues, faith he, are very large, twice fo broad as any of the others. The talke is fingle and fmooth; the floure groweth at the top, of a moft bright fhining blew eolour, the middle rib tending to whiteneffe, the three vpper leaues fomew hat yellowinh. The root is likewife fweet as Ireos.

$$
\text { of } T \text { be place. }
$$

Thefe kindes of Floure de-luces do grow w ilde in Dalmatia, Goritia, and Piedmont , notwithfanding our London gardens are very weli ftored witheuery one of them.

$$
\text { 9. Thetime. }
$$

Their time of flouring anfwereth the other Floure de-luces.

$$
\text { Tा The names. }
$$

The Dalmatian Floure de-luee is called in Greeke of At heneus and $T$ beoplor attes ines: it is named alfoivexis, of the heaucnly Bow or Rainbow : vpon the fame oeeafion soumassir or Admitable: for the Pocts fometime do call the Rainbow savsurias: in Latine Iris, and in Englion Floure de-luec.Their feuerall titkes do fufficiently diftinguifh then, whereby they may be knowne one from another.

II The 


\title{
II Thenature.
}

The nature of thefe Floure de-luees are anfwerable to thofe of the common linde; that is to fay, the dry toots are hot and dry in the latter end of the fecond degree.

$$
\text { Tा The vertues. }
$$

The iuyce of thefe Floure de-luees doth not oncly mightilyand vehemently draw forth choler, but moft efpecially waterie humors, and is a fingular good purgation for then that haue the Dropfie, if it be drunke in fiveet wort or wlay.

The fame are good for them that haue cuill fpleenes, or that are troubled with cramps or con: vulfions, and for fuch as are bit with Serpents. It profiteth alfo much thofe that haue the Gonorrhea, or running of the reines, being drunke with Vineger, as Diofc. faith; and drunke with Wine they bring downe the monethly termes.

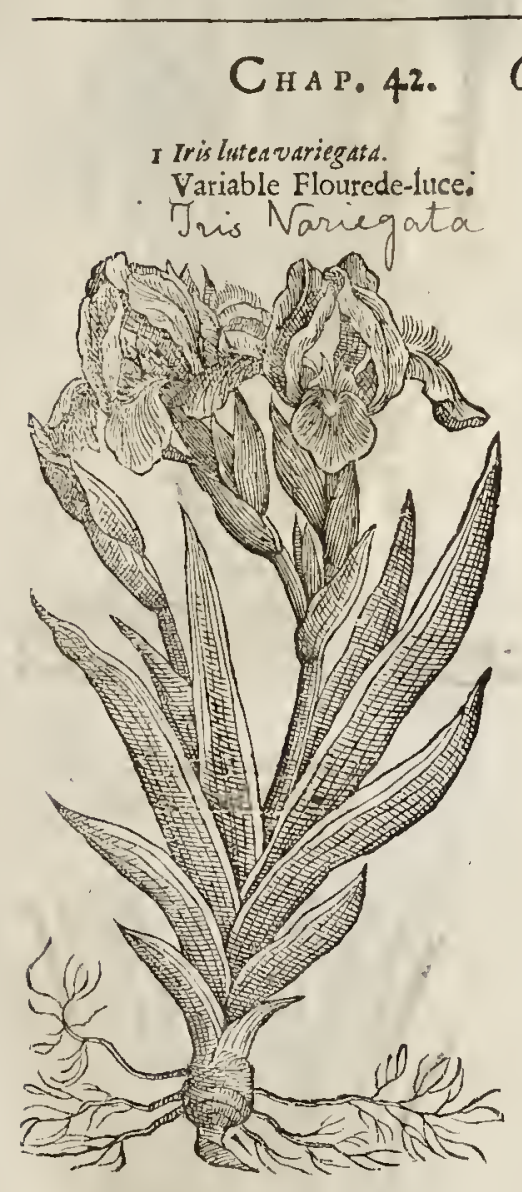

Of Uariable Floure de-luces.

\author{
I 2 Iris Cbalcedonica. \\ Turky Floure de-luce.
}

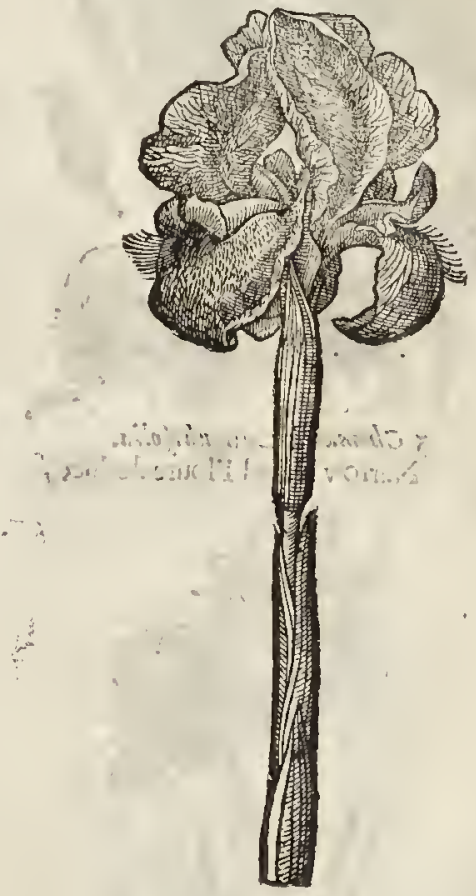

Tt The defcription?

x Hat which is called the Floure de-luce of many colours lofeth his leaues in Winter and in the Spring time recoueteth them dnew. I am not able to expreffe the fundrie colours and mixtures contained in this' floure: it is mixed with purple, yellow, blacke, white, and a fringe or blacke thrum downe the middle of the lower leaues, of a whirifh yellow, tipped or frized, and as it were a little raifed vp; of a deep purple colour neere the ground.

2 The fecond kinde hath long and narrow leames of a blackin greene, like the ftinking Gladdon; among which rife vp ftalkes two foot long, bearing at the top of cucry ftalke one floure compact of fix greatl caues : the three that ftand vpright are confufedly and very ftrangely ftripped, mixed with white and a duskinh blaeke colour. The three leaues that hang downeward are like a gaping hood, and are mixed in like manner, (but the white is nothing fo bright as of the oher) ard are as it were fhadowed ower with a darke purple coloul fomewhat hining : fo that 
cording to my iudgement the whole floure is of the colour of a Ginny hen : a rare and beautifull floure to behold.

* 3 Ir is maritima Narboncnfis. The Sea Floure de-luce.

4 Tris fylueftris Bifantina.
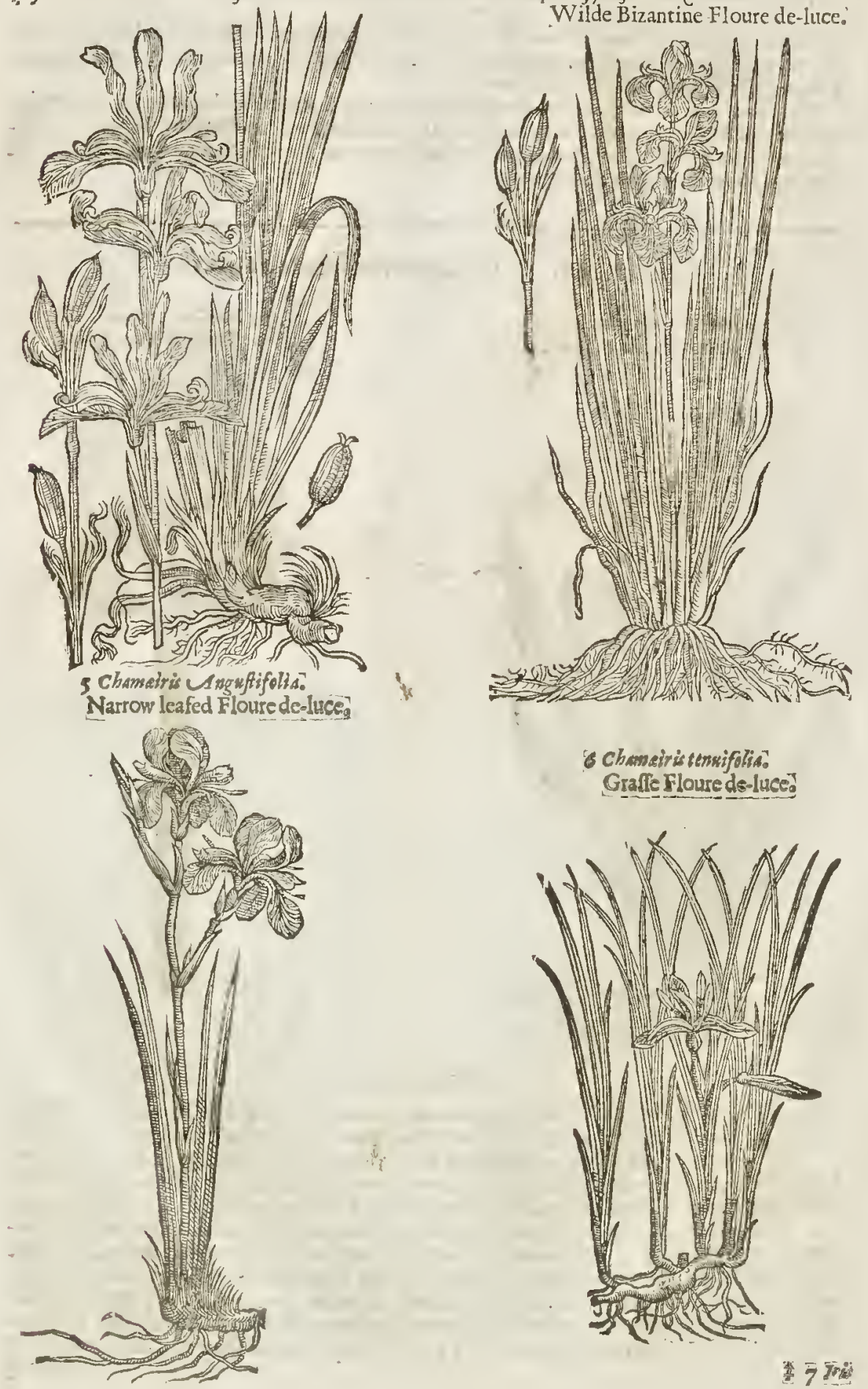

6 Chmairis tenrifolis.

Grafie Floure de-Iuce?

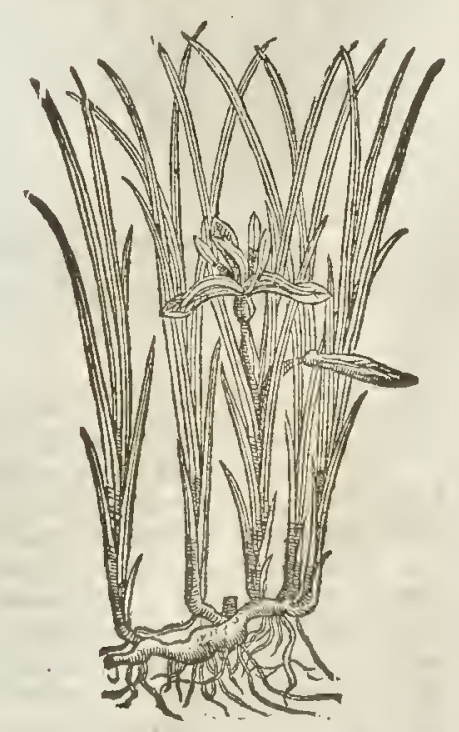


\$ Iris flore ceruleo obfoleto polyanthos.

Narrow-leafed many-floured Iris.
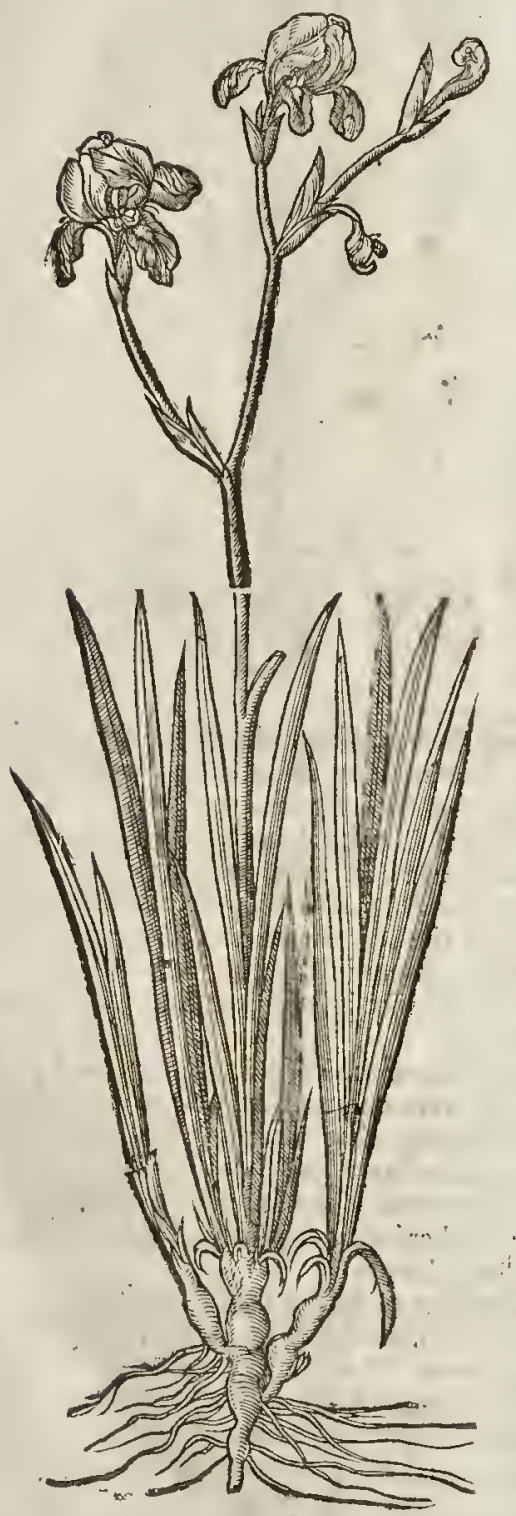

$\$ 8$ Chameiris nived aut Candids White Dwarfe Iris.
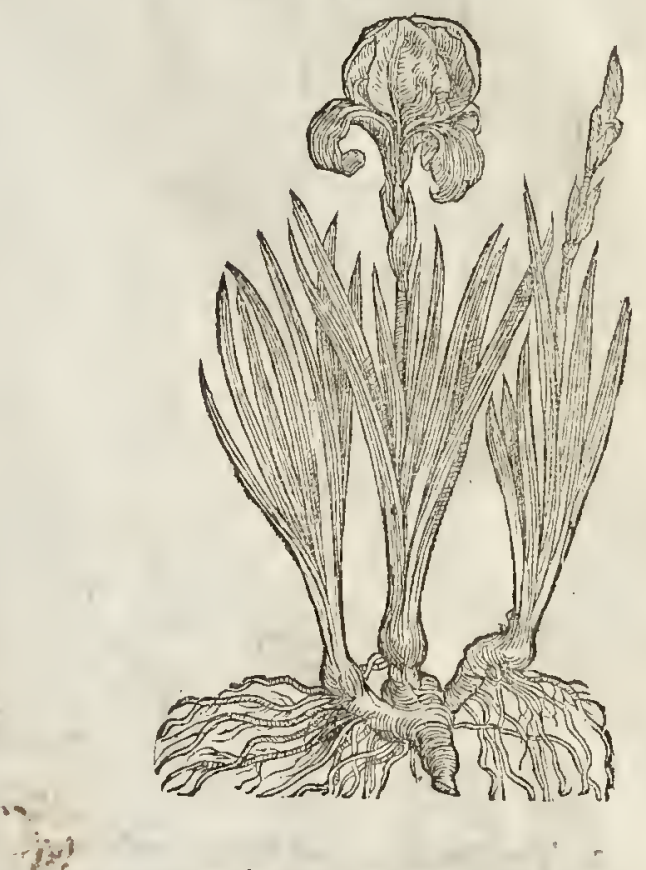

\# 9 Cham ciris latifolia flore ribello.'

Red floured Dwarfe Iris.

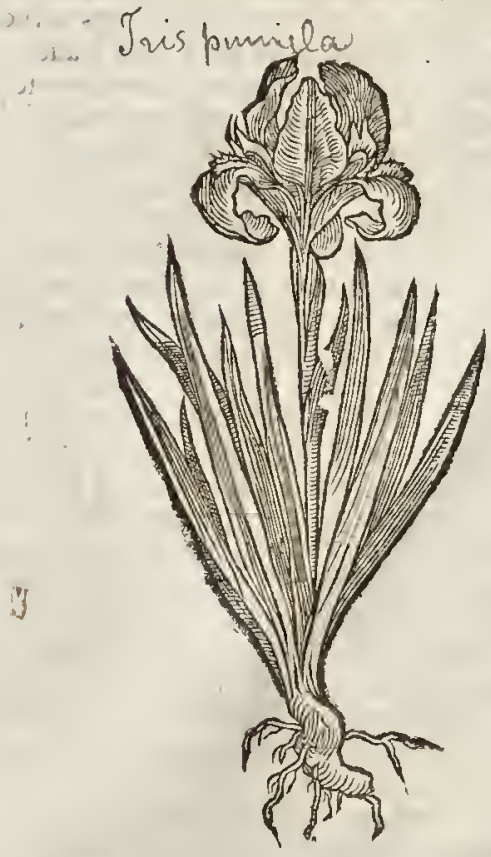

E 3

t) 30 cha- 

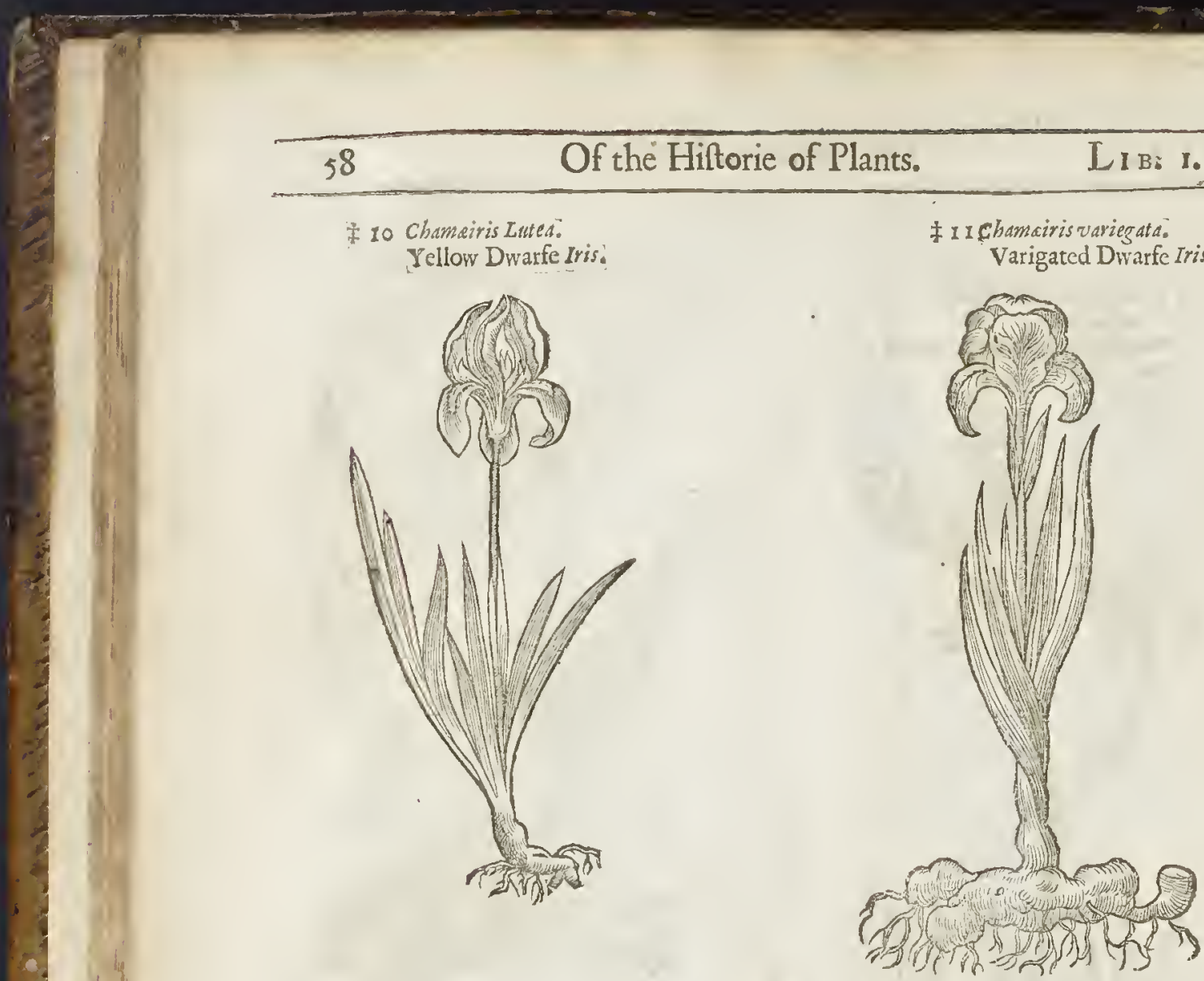

3 The French, or rather Sea Floure de-luce (whereof there is alfo another of the fame kinde altogether leffer) haue their roots without any fauour. In thew they differ little from the garden Floure de-luce, but that the leaues of thefe are altogether flenderer, and vnpleafant in fmell, growing plentifully in the rough crags of the rocks vnder the A lpes, and neere vinto the fea fide. The which Pena foind in the graffe grauclly grounds of the fea coaft neere to Montpellier. The learned Doctor Affatus a long time fuppofed it to be Medium Diofc.Mathiolus decciued Limf ' ${ }^{\circ} \mathrm{C}$ and others, in that he faid, That the root of this plant hath the fent of the peach : but my fe:te hame proued it to be without fautour at all. It yeeldeth his floures in Iune, which of at reft moft like vnto the graffe Floure de-luce. The tafte of his root is hot, bitter, and with mu h renuitic of parts, as hath been found by phyficall proofe.

+4 This Iris Bizantina hath long narrow leaues like thofe of the laftefcribed; very I ?n: tharpe pointed, linuing novngratefull fmell ; the falks are fome cubit and an halfe in lengtliand fom times more; at the top they are diuided into 2 or 3 branches that halle 2 or 3 floures a pie like in thape to the floures of the broad leafed variegated bulbous Iris; they haue alfo a good fmell : the ends of the hanging-downe leaules are of a darke colour; the other parts of then are va riegated with white, purple, or violet colour. The three other leaues that fand vp are of a decp. violet or purple colour. The root is blackifh, flender, hard, knotty. $¥$

5 Narrow leafed Floure de-fuce hath an infinite number of graffe leaues much like vin $x$ Reed, among which rife ip many ftalkes : on the ends of the fame fpring forth two, fometime three right fiveet and pleafint floures, compact of nine leaues. Thofe three that lang downward are greater than the ret, of a purple colour, fripped with white and yellow; but thore three fmul! leaues that appeare next,are of a purple colour without mixture:thofe three that fand vpright are of an horfe-feth colour, tipped with purple, and vnder each of thefe leaues appeare three fmali browne aglets like the rongue of a finall bird.

6 The fmall graffe Floure de-luce differeth from the former in finalneffe and in thinneffe of leauce, and in that the falkes are lower than the leaues, and the floures in thape and colour are like thofe of the ftuling Gladdon, but much leffe.

$\ddagger$ There are many other varieties of the broad leafed Floure de-luces befides thefe mentio ned by our Authour; as al fo of the narrow leafed, which here wee doe not intend to infiner po:

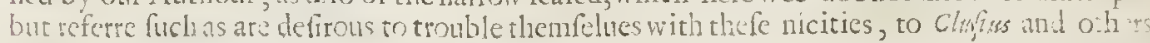


Notwithftanding I judge it not amife to giue the figures and briefe deferiptions of forne more of the Dwarfe Floure de-lices, as alfo of one of the narrower leafed.

7 This therefore which we giuc you in the feuenth place is Iris flore cerulco obfoleto, occ. Lobelij. The leaues of this are fmall and long like thofe of the wild Bizantine Floure de-luce; the roor (which is not very big) hath many ftrong threds or fibres comming out of it : the ftalke (which is fomewhat tall) diuides it felfe into two or rhree branches, whereon grow floures in thape like thofe of the other Floure de-luces, but their colour is of an ouer-worne blew; or A th colour.

8 Many are the differences of the Chamairides latifolic, or Brond leafed Dwarfe Floure deIuces, but their principall diftinetion is in their floures; for fome haue flowers of violet or purple colour, fome of white, other fome are variegated with yellow and purple, \&c. Therefore I will onely name the colour, and giue you their figure, becaufe their thapes differ little. This eighth there fore is Chamairis nivea ant Candida, White Dwarfe Iris: The ninth, Chameiris latifoliafore rubello, Red floured Dwarfe Iris: The tenth, Camairislutea, Yellow Dwarfe Tris: The eleuenth, Chro. mairis variegata, Variegated Dwarfe Iris. The leates and ftalkes of thefe plants are vfually about a foot high; the floures, for the bigneffe of the plants, large, and they floure berimes, as in A prij. And thus much I thinke nay fuffice for the names and defcriptions of thefe Dwarfe varicties of Floure de-luces. $\ddagger$

Thefe plants do grow in the gardens of London, amongft Herbarifts and other Loners of Plants.

$$
\text { Theplace. }
$$

If The nature.

They floure from the end of March to the beginning of May.
of The names.

The Turky Floure de-luce is called in the Turkifh tongue Alaia Sufari, with this additament from the Italians, Fiore Belle pintate; in Englifh, Floure de-ltce. The reft of the names haue bin touched in their titles and hiftorie.

Tा Their natures and vertues.

The faculticsand temperature of thefe rare and beautifull floures are referred to the other forts of Floure de-luces, whereunto they do very well accord.

There is an excellent oyle made of the floures and roots of Floure de-Juce, of each a like quan- A titic, called oleum Irinum, made after the fame manner that oyle of Rofes, Lillies, and fuch like be made : which oyle profiteth much to ftrengthen the finewes and joints, helpeth the cramp pro.
ceeding of repletion, and the difeafe called in Greeke Peripnewmonia.

The floures of French Floure de-luce diftilled with Diatrion fandaton, and Cinnamon, and the $B$ water drunke, preuaileth greatly againft the Dropfie, as Hollerius and Gefner teftifie.

\section{С н А. 43. Offinking Gladdon.}

T) The defcrittion.

Tinking Gladdon hath long narrow leaues like Iris, but fmaller, of a darke greene colour, and S being rubbed, of a ftinking finell very lothfome. The ftalkes are many in number,and round toward the top, out of which do grow floures like the Floure de-luce, of an oner-worne blew colour, or rather purple, with fome yellow and red ftreakes in the midft. After the floures be vaded there come great huskes or cods, wherein is contained a red berry or feed as bigge as a peafe, The root is long, and threddy vnderneath.

Tा The place. Gladdon groweth in many gardens : I haue feene it wilde in many places, as in woods and tha:
dowie places neere the fea.

The ftinking Gladdon of Thetinse.

The ftinking Gladdon floureth in Auguft, the feed whereof is ripe in September.

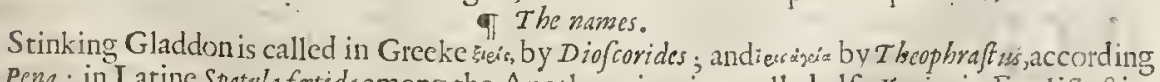
to Pena : in Latine Spatula fetida among the Apothecaries : it ts called allo Xyris: in Englith, ftinking Gladdon, and Spurgewort.

Gladdon is hot and dry in theture.

$$
\begin{aligned}
& \text { 9 The nature. } \\
& \text { Tा The vertuses. }
\end{aligned}
$$

Such is the facultic of the roots of all the Irides before named, that being pounding they pro- A woke firefing, and purge the head; generally all the kinds liate a heat ing \& extentiasing quivity. 
They are effectuall againt the cough ; they cafily digeft and eonfume the grofe humors which are hardly eoseofed : they purge choler and tough flegme: they procure flecpe, and helpe the gripings within the belly.

It helpeth the Kings Euill, and Buboes in the groine, as Pliny faith. It it be drunke in Wine it prouoketh the termes, and being put in Baths for women to fit ouer, it pronoketh the like effeets moft exquifitly. The root put in manner of a peffarie haftneth the birth. They eouer with fleth bones that be bare, being vfed in plaifters. The roors boyled foft, ind vfed plaifterwife, foften all old hard tumours, and the fwellings of the throat ealled Struma, that is, the Kings Euill; and emplaiftered with honcy it drawerh out broken bones.

The meale thereofhealeth all the rifts of the fundament, and the infirmitics thereof called Cordilomata; and openeth Hemorrhoides. The juice fniffed or drawne vp into the nofe, protioketh finec fing, and draweth downe by the nofe great fore of filthy excrements, whiehwould fall into other parts by feeret and hidden waies, and conucianees of the channels.

It profiteth being vfed in a peftarie, to pronoke the termes, and will eaufe abortion.

It preuaileth much againft all cuill affections of the brefe and lungs, being taken in a little fweet wine, with fome Spiknard; or in Whay with a littlc Mafticke.

The Root of xyris or Gladdon is of great foree againftwounds and fractures of the head, for it drawcth out all thornes, ftubs, prickes, and arrow-heads, without griefe; which qualitie it effecteth (as Galen faith) by reafon of his tenuitie of parts, and of his attracting, drying, and digenting facultie, which ehiefely confifterh in the feed or fruit, which mightily prouoketh vrine.

H The root giuen in Wine, called in phyfieke Paffwm, profiteth much againft Convulfions, Ruptures, the paine of the huekle bones, the ftrangury, and the flux of the belly. Where note, That whereas it is faid that the potion abone named faycth the flux of the belly, hauing a purging qualitic; it mutf be vnderftood that it worketh in that manner as $R$ habarbarum and $\mathcal{A}$ fartum do, in that they coneod and take away the cauf: of the laske; otherwife no doubt it noneth vnto the ftoole, as Rheubarb, $A$ farum, and the other Irides do. Hercof the Countrey people of Somerfetfhire hane good experience, who vfe to drinke the deeoction of this Root. Others do take the infufion thereof in ale or fuch like, wherewith they purge themfelues, and that vnto very good purpofe and effect.

I

The feed thercof mightily purgeth by wrine, as Galer faith, and the eountry people lidue found it true.

-

$$
\begin{aligned}
& \text { Cна Р. 44. Of Ginger. } \\
& \text { If The defcriplioio. }
\end{aligned}
$$

1 Inger is moft impatient of the coldneffe of thefe our Northerne Regions, as my felfe 7 haue found by proofe, for that there haue beene brought vato me at feucrall times fundry plants thercof, freth, greene, and full of juyce, as well from the Weit Indies, as from Barbary and other places; whieh haue fprouted and budded forth greene leaues in my garden in the heate of Sommer, but as foone as it hath been but touched with the frift tharp blaft of Winter, it hath prefently perifhed both blade and root. The true forme or picture hath not before this time beene fet forth by any that hath written; but the World hath beene deeciued by i counterfeit figure, which the reuerend and learned Herbarift Matt bias Lobell did fet forth in his Obferuations. The formewhereof notwithftanding I hate here exprefied, with the true and vndoubted 
doubted pisureal fo, twhich I reeeined from Lobeliws his orne hands at the impreffion hereof. Ild eaufe of whofe former errour, as alfo the meanes whereby hegot the knowledge of the true Ginger, may appeare by his owne words fent vnto me in Latine, whieh thaue here inferted. His words are thefe :

How hard and vneertaine it is to defcribe in words the true proportion of Phants, (hauing no other guide than skilfull,but yet deceitfull formes of them, fent from friends, or other meanes) they beft do know who haue deeplieft waded in this fea of Simples. About thirty yeares paft or more, an honeft and expert Apotheearie William Dries, to fatisfie my defire, fent me from Aniwerpe to London the pieture ef Ginger, whicls he held to be truly and liuely drawne : I my felfe gate him credit eafily, beeaufe I was not ignorant, that there had bin of ten Ginger toots brought greene, new, and full of juice, from the Indies to Antwerpe; and further, that the fame had budded and growne in the faid D ries Garden. But not many yeares after, $I$ perceiued that the picture whieh was fent me by my Friend was a eounterfeit, and before that time had been drawne and fet forth by an old Duteh Herbarift. Therefore not fuffering this error any furthet to fpred abroad, (whieli I difconered not many yeares paft at Fluthing in Zeeland, in the Garden of William of Naffau Prince of Orange, of famous memorie, through the means of a w orthy perfon, if my memorie faile me not, ealled $V$ ander $M$ ill ; at what time he opened, and loofed his firft young buds and thoots about the end of Sommer, refembling in leaues, and ftalkes of a foot high, the young and tender fhoots of the common Reed, ealled Harundo vallatorid) I thought it conuentient"to impart thus much vito Mafter Iohn Gerard, an expert Herbarift,and Mafter of happy fucceffe in Surgetie; to the end he might let pofteritie know thus much, in the painefull and long laboured trauels which now he hath in laand, to the great good and benefit of his Countrey. The plant it felfe brought me to Middleborrough, and fet in my Garden, perithed through the hardneffe of the Winter.

Thus much haue I fet downe, truly tranflated out of his owne words in Latine. though too fas uourably by him done to the commendation of my meane skill.

I Zineiberis ficta Icon.

The feigned figure of Ginger:
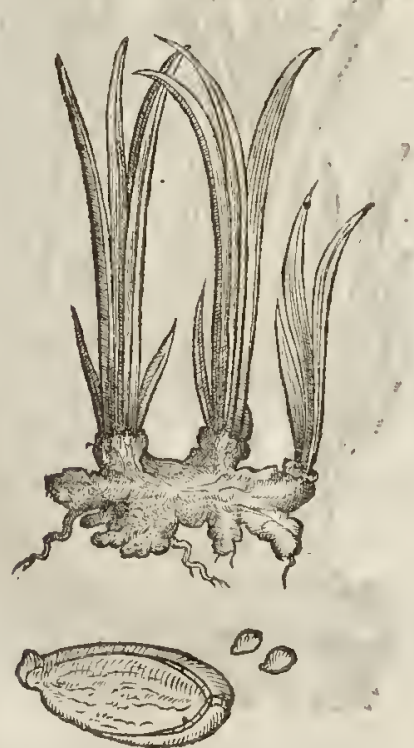

I Zinziberis verior Icon: The true figure of Ginges .

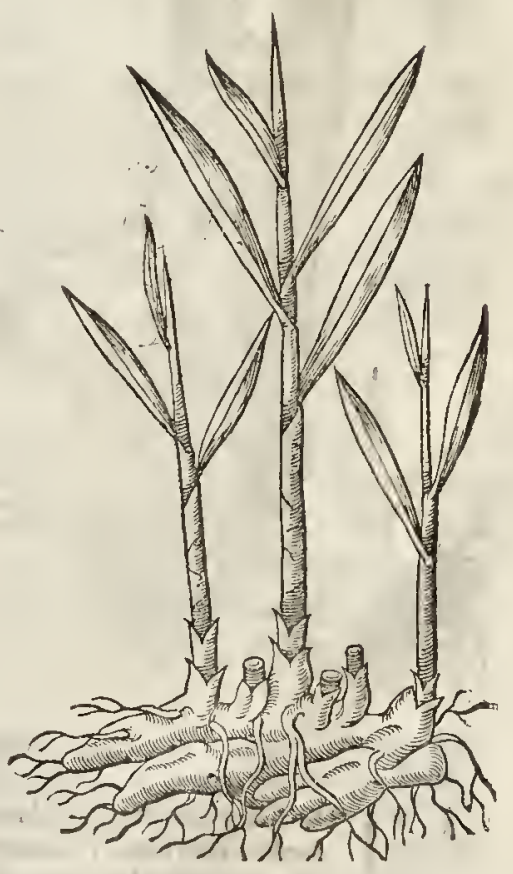

Ginger groweth in Spaine, Barbary, in The place. Barbary, in the Canary Iflands, and the Ázores. Our mea which acked Domingo in the Indies, digged it vp there in fundry places wilds. 
Ginger flouritheth in the hot time of Sommer, and loreth his leates in Winter,

Tा The time.

T) The vames.

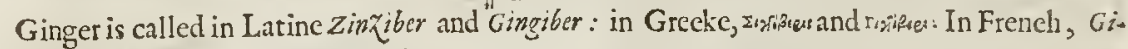
gembre.

Ginger heateth and drieth in the third degree.

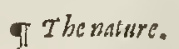

T The nature.

$$
\text { If The vertues. }
$$

A Ginger,as Diofcorides reporteth, is right good with meate in fauces, or otherwife in conditures: for it is of an heating and digefting qualitic; it gently loofeth the belly, and is profitable for the ftomaeke, and effectually oppofeth it felfeagainft all darkneffe of the fight; anfwering the qualities and effects of Pepper. It is to be confidered, That eanded, greene or eondited Ginger is hot and moift in qualitie, prowoking Venerie : and being dried, it heatcth and drieth in the third degree.

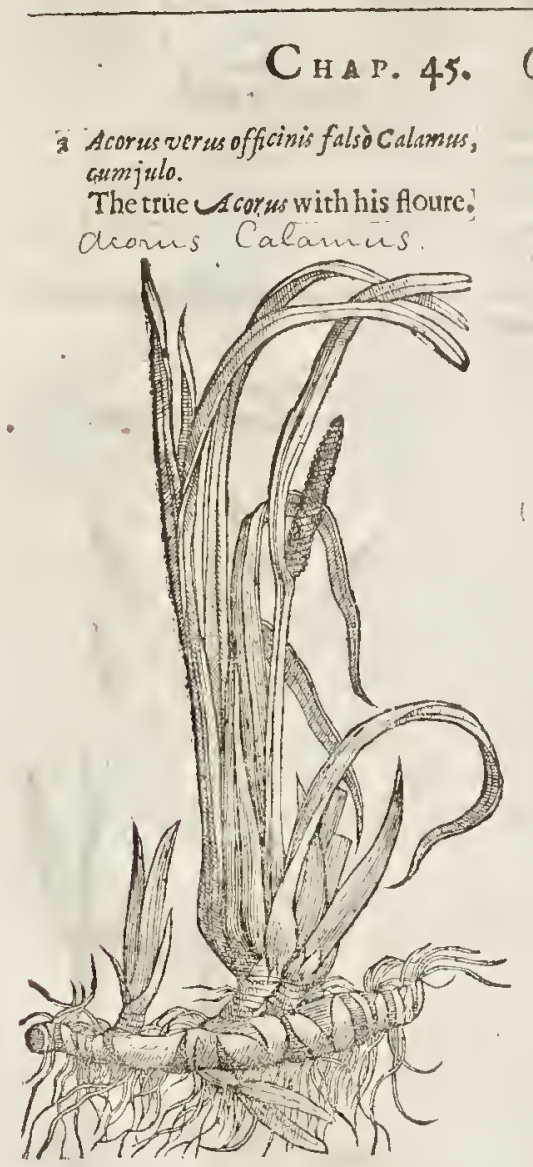

\section{Of Aromaticall Reeds.}

Acorws verus fine julo:

'The true 1 corms without the floure.

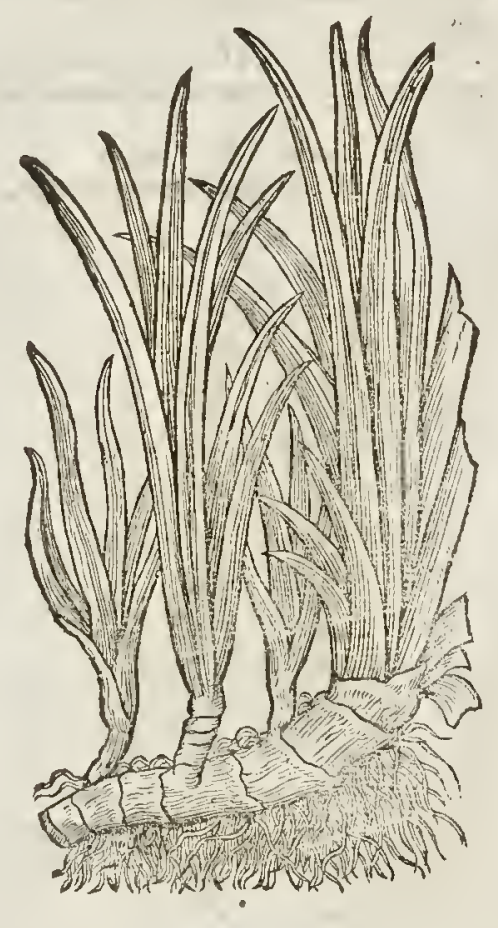

The Tefcription.

I THis fweet-fmelling Reed is of a darke dun colour, full of joints and knees, eafie to be broken into fmall fplinters, hollow, and full of a eertaine pith cobweb-wife, fomewhat gummy in eating, and hanging in the teeth, and of a tharpe bitret tafte. It is of the thickneffe of the little finger, as Lobelius affirmeth of fome which he had feene in Venice.

2 . Baftard Calamus hath flaggy leaue's like vnto the Water floure de-luce or flagge, but narrower, three foot long; of a freh greene colour, and aromaticke fmell, whieh they keepe a long time, al though they bedrisd. Now the falke which beares the floure or fruit is much like ano- 
ther leafe, but onely from the fruit downwards, whereas it is fomewliat chicker,and not fo broad. but almoft triangular. 'The floure is a long thing refembling the Catf-tailes which grow on Hafels; it is about the thickneffe of an ordinarie Reed, fome inch and halfe long, of a greenifh yelJow colour, curioully chequered, as if it were wrought with a needle with greene and yellow filke intermixt $\%$. I haue not as yet feene it beare his tuft in my garden, and haue read that it is barren. and by proofe haue feene it fo:yet for all that I belecue clufus, who faith hee hath feene it beare his floure in that place where it doth grow naturally, although in England it is alrogather barren. The root is fweet in finell, and bitter in tafte, and like vnto the common Flagge, but fmaller,
and not fo red.

3 Calamus Aromaticus Antiquorum.

The true Aromaticall Reed of the Antients.

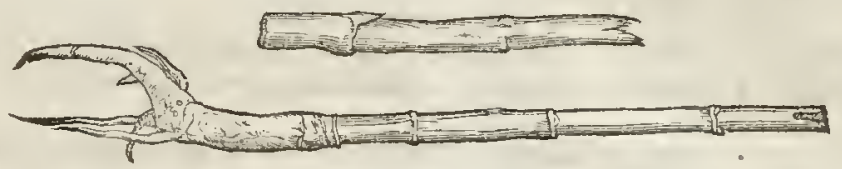

\$3 Ithinke it very fitting in this place to acquaint you with a Plant, which by the eonjeEture of the moft learned (and that not without good reafon) is itdged to be the true Calmus of the Ancients. Clufius giues vs the hiftorie thereof in his Notes vpon Garcias ab Horto, Lib. T. ca.32. in thefe words: When as (faith he) this Hiftoric was to be the third time printed, I very opportunely came to the knowledgc of the truc Calamss Aromaticus'; the whieh the learned Bernard $P_{a-}$ ludames the Frifian, returning from Syria and Egypt, freely beitowed vpon me, together with the fruit Habhel, and many other rare feeds, about the beginning of the yeare 1579 . Now wee haue caufed a figure to be exactly drawne by the fragments thereof (for that it feemes fo exquifitly to accord with Dioforides his defcription.) In myne opinion it is rather to be iudged an vmbellife'rous plant than a reedy; for it hath a ftraight ftalke parted with many knots or ioynts, otherwife fmooth, hollow within, and inuefted on the infide with a flender filme like as a Reed, and it breaketh into fhiuers or fplinters, as Diofcorides hath written: it hath a fmell fuffieiently ftrong, and the tafte is gratefull, yet bitter, and pettaking of fonce aftriction: The leaues, as by remaincs of them might appeare, feeme by couples at euery ioynt to engirt the ftalke: the root at the top is fomewhat tuberous, and then ends in fibres. Tiventy fiuc ycares after Paludanus gaue me this $C_{a-}$ lamus, the learned Anthony Colme the Apothecaric (wholateiy tranlated into French thefc Commentaries the fourth time fet forth, Anro 1593) fent ithe from Lyons pieces of the like Reed; certifying mewithall, That he had madevfethereofin his Compofition of Trcacle. Now thefe pieces, though in forme they refembled thofe I had from Paludanus, yet had they a morc bitter tafte than his, nether did they partake of any aftriction; which peraduenturc was to be attributed to the age of one of the two. Thus much chifus. $\neq$

$$
\text { Tा The place. }
$$

The true Calamus Aromaticus groweth in Arabia, and likewife in Syria, efpecially in the moo. rith grounds betweene the foot of Libanus $f$ and another little hill, not the mountainc Antilibanus, as fome haue thought, in a fmall valley neere to a lake, whofe plafhes are dry in Sommer.Pliny
I2. 22.

Baftard or falfe Calamus growes naturally at the foot of a hill necre to Prufa a ciry of Bithynia, not far from a great lake. It profpereth exceding well in my garden, but as yet it beareth neither floures nor ftalke. It groweth alfo in Candia, as Pliny reporteth : in Galatia likewife,and in nuany
other places.

They lore theirleaucs The time. of the yeare. Glym of Glyn $\neq$ In May this yeare 1632 , I recciued from the Worthipfull Gentleman M.T bomas Glyn of Glynnihivon in Carnaruanhire, my very good fricnd, the prettv tus, or floure of this plant ; which I could neuer fee here about London, though it groweth wit . s in many Gardens, and that ingreat plenty. $\ddagger$

+ The wame a The names.

\# The want of the true Caldmus being fupplica by Acorss as a fuccedanewn, was the caufe (as ing as it were probably coniecture) that of a fubftitute it tooke the prime place vpon it; and being as it were made a Vice-Roy; wouk needs be King. But the falfeneffe of the ritle was difco- 


\section{4}

Of the Hiftorie of Plants.

L I E. I.

uered by Matthiolus, and others, and fo it is fent backe to its due place againe; though notwithftanding it yet in flops retaines the title of Calamus.

I The figure that by our Author was giuen for this, is fuppofed, and that (as I thinke truly) to be but a counterfeit, of $M$ a thiolus his inuention; who therein hath beene followed (aceording to the euftome of theworld) by diucrs others. The defeription is of a fmall Reed ealled calams oderatus Libani, by Lobell in his Obferuations, and figured in his Irones, $p \cdot 54$.

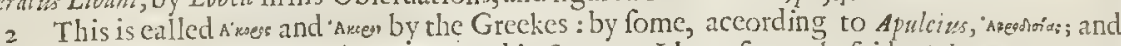
in Latine it is called Acorus and Acormm; and in thops, as I haue formetly faid, Calamis Aromati. cus : for they vfually take Galanga major, (defcribed by me, Chap. 26.) for Acorus. It maly befides the former names be fitly called in Englin, The fweet Garden Flag.

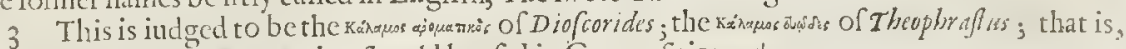
the true Calcmus Aromaticus that fhould bevfed in Compolitions. $\neq$

of Tlie natare of the truc Acorus, or our fweet garden Flag.

Dioforides faith, the roots haue an heating facultie : Galcn and Pliny do affirme, that they haue thin and fubtill parts, both hot and dry.

$$
\text { of The vertues of the fome. }
$$

A The decoetion of the root of Calumus drunke prouoketh vrine, helpeth the paine in the fide, liuer, fpleene, and breft; convulfions, gripings, and burftings; it eafeth and helpeth the piffing by drops.

B It is of great effect, being put in broth, or taken in fumes through a clofe ftoole, to prouoke womens naturall aceidents.

C The iuyee ftrained with a little honey, taketh away the dimnes of the eyes, and helpeth much againft poy fon, the hardnefle of the fplecne, and all infirmities of the bloud.

D The root boyled in wine, ftamped and applied plaifterwife vnto the eods, doth wonderfully abate the fwelling of the fame, and helpeth all hardneffe and collections of humors.

E The quantitic of two feruples and an halfe of the root drunke in foure ounces of Muskadel,helperh them that be bruifed with grienous beating, or falls.

F The root is with good fuccefle mixcd in conterpoyfons. In our age it is put into Eclegma's, that is, medieines for the lungs, and efpecially when the lungs and cheft are oppreft with raw and cold humors.

G $\quad ¥$ The root of this preferued is very pleafant to the tafte, and comfortable to the ftomacke and heart; fo that the Turks at Conftantinople take it fafting in the moming, againf the contagion of the cormpt aire. And the Tartars haue it in fuch efteeme, that they will not drinke Wates (which is their vfuall drinke) vnleffe they haue firt itceped fome of this root therein. $\neq$

$$
\text { Thechoice. }
$$

The beft Acorus, as Dioforides faith, is that which is fubftantiall, and well compact, white within, not rotten, full, and well fmelling.

Pliny writeth, That thofe which grow in Candia are better than thofe of Pontus, and yet thofe of Candia worfe than thofe of the Eafterne countries, or thofe of England, although we haue no great quantitic thereof.

\section{The faculties of the true Calums out of Diofcorides.}

H It being taken in drinke moueth vrine; wherefore boyled with the roots of graffe or SmalIage feeds, it helpeth fuch as are hydropick, nephritick, troubled with the ftranguric, or bruifed.

It moues the Courfes, either drunke or otherwife applicd. Alfo the fume thereof taken by the mouth in a pipe, either alone orwith dried Turpentine, helpes coughs.

KI It is boyled alfo in baths for women, and decoetions for Glylers; and it enters into plaifters and perfumes for the fmells fake.

\section{Cha P. 46. Of Corne.}

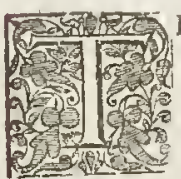

Hus farre haue I difeourfed vpon Grafies, Ruthes, Spartum, Flags, and Floure deluces : my next labour is to fet downe for your better inftuction, the hiftorie of Corne, and the kindes thereof, vnder the name of Graine; which the Latines call Corialia femina, or Bread-corne; the Grecians, maes and snumeia nuspera; of which wee purpofe to difeourfe. There belong to the hiftorie of Graine all fuch things as be made of Corne, as Far, Condrus, Alica, Tragus, Amylum, Ptifana, Polenta, CMatha, Byme or Malt, Zyt bum, and whatfoeuer are of that fort. There be alfo ioyned vnto them many feeds, which $T$ beophraftus in his cighth booke placeth among the graines; as Millet, Sorgum, Panicke, Indian wheat, and fuch like. Galen in his firt booke of the Faculties of nourifhments, reckoneth 
vp the difeafes of Graine, as well thofe that come of the graine it felfe degenerating, or that are changed into fome other kinde, and made worfe through the fault of the weather, or of the foile; as alfo fuch as be cumberfome by growing among them, doe likerife fitly fucceed the graines. And beginning with corne, we will firf fpeake of Wheat, and defcribe it in the firt place, becaufe it is preferred before all other corne.

I Triticum $\beta$ ica mutiea. White Wheate.

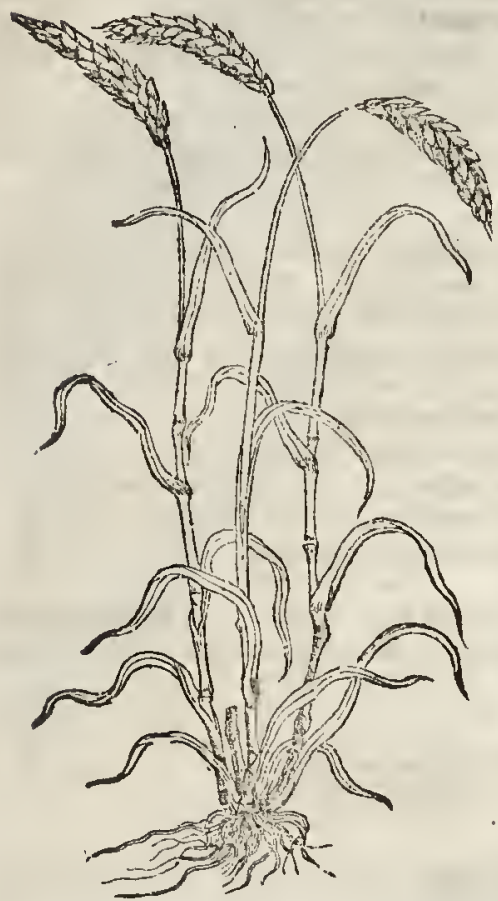

I) The defription.

I T His kinde of Wheate which Lobelizus; diftinguirhing it by the care, calleth spicat Mutica, is the moft principal of all other, whofe eares are altogether bare or naked, without arvnes or chaffie beards. The ftalke rifetl from a threddy root, compact of many ftrings, joynted or kneed at fundry diftances; fron whence thoor forth graffie blades and leaues like into Rie, but broader. The plant is fo well knowne to many, and fo profitable to all, that the meaneft and moft ignorant need no largerdefcription to know the fame by.

2 The fecond kinde of Wheat, in root, ftalkes, joints, and blades, is like the precedent, differing onely in eare, and number of graines, whereof this kinde doth abound, hauing an eare confifting of many ranks, which feemeth to make the eare double or fquare. The toot and graine is like the other, but not bare and naked, but brifted or bearded, with many finall and tharpe eiles or awnes, not vilike to thofe of Barley.

3 Flat Wheat is like nnto the other kindes of Wheat in leates, ftalkes, and roots, but is beatded and bordered with rough and tharpe ailes, wherein confifts the difference. $\neq I$ know not what our Author means by this flat Wheat; but I conjecture it to be the long rough eared Whear, which hath blewin eares when as it is ripe, in other things refembling the ordinary sed wheat. $\neq$

4 The fourth kinde is like the laft defcribed, and thus differeth from it, in that, that this kind hath many frnal cars comming forth of one great eare, $\$$ the beards hereof be fhorter than of the former $k$ ind.

5 Bright wheate is like the fecond before defcribed, and differeth from it in that, that this kind is foure fquare, fomewhat bright and thining, the other not.

\# I thinke it a very fit thing to adde in this place a rare obferuation, of the tranfmutation of one fpecies into another, in plants; which though it hauc beene obferued of ancient times, as by Theophraftus, de cauf. plant. lib.3. cap. 6. whereas a mongft others hee mentioneth the change of

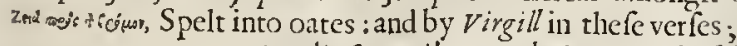

Grandia fepe quibus mandauimus Hordea fulcis,

Infelix Lolium, \& fteriles dominantur arens.

That is :

In furrowes where great Barley we did fow,

Nothing but Darnel and poore Oats do grow ;

yet none that I haue read haue obferued, that two feucrall graines, perfect in cacls refpeet, did grow at any time in one eare : the which I faw this yeare 1632 , in an eare of white Wheat, which was found by my very good Friend Mafter 10 ha Goodyer, a man fecond to none in his induftrie and fearching of plants, nor in his iudgement or knowledge of them. This eare of wheat was as large and faire as moft are, and about the middle thereofgrew three or foure perfect Oats in all refpeets: which being hard to be found, I held very worthy of fetting downe, for fome reafons not to be in. fifted vpon in this place. $\ddagger$

$$
\text { Theplace. }
$$

What groweth almoft in all the countries of the world that are inlabited and manumed, arid requireth a fruitfull and fat foile, and rather Sunny and drv, than watery grounds and thadowie: for in a dry ground (as Colmmella reporteth) it groweth harder and better compact: in a moitt and darke foile it degeneratetl fometime to be of anothe kinde. 


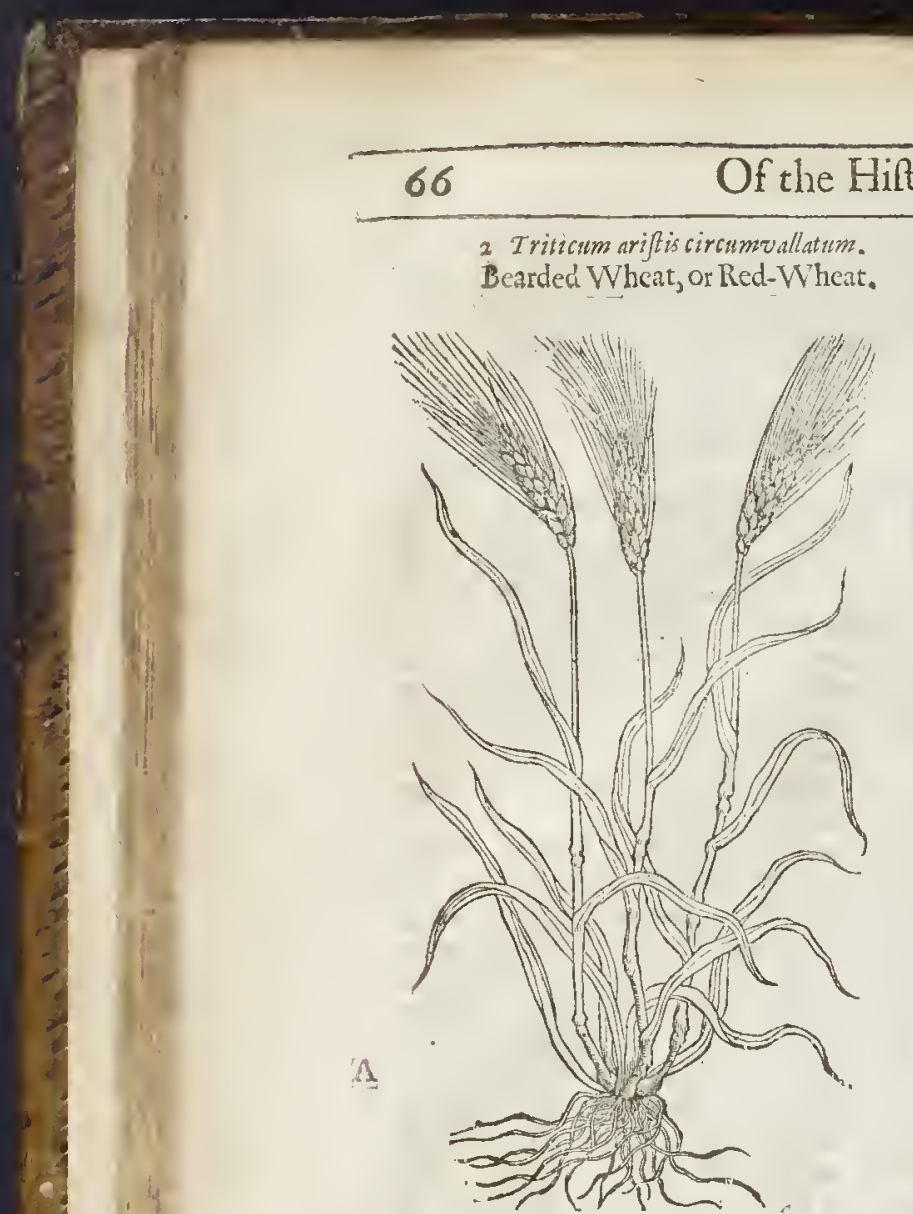

3 Triticum Typhinum; Flat Wheat.
T) Thetime.

They are mott commonly fowen in the fall of the leafe, or Autumne: fomtime in the Spring.

9ा The names.

Wheat is called of the Grecians tuej: of the Latines, Triticum, and the white Wheate Siligo. Trtincum doth generally fignifie any kinde of Corne which is threened out of the eares, and made clean by fanning or fuch ordinary meanes. The Germans call it menfen: in low Dutch, oferioe: in Italian, Grano: the Spaniards, Trigo : the French men, Bled, oif Fourment : in England we call the firt, WhiteWheat, and Flaxen Wheat. Triticum Lucidum is called Bright Wheat : Red Wheat is called in Kent, Duck-bill Wheate, and Normandy Whear. - Thenature.

Whear (faith Galen) is very much ved of men, and with greateft profit. Thofe Wheats do mulrith mott which be hard, and haue theirwhole fubfance foclofely compact as they can fearcely be bit afunder; for fuch doe nourith very much : and the contrary but little.

Wheat, as it is a medicine outwardly applied, is hot in the firft degree, yet can it not manifeftly cither dry or moiften. It hath alfo a certaine clam. mineffe and ftopping qualitic.

$$
\text { The vertues. }
$$

Rav Wheat, faith Diofcoridcs, being eaten, bree: dethwormes in the belly : being cluewed and ap. plied, it doth cure the biting of mad dogs.

\section{$4 \quad$ Triticum multiplicipica.} Double eared Wheat.

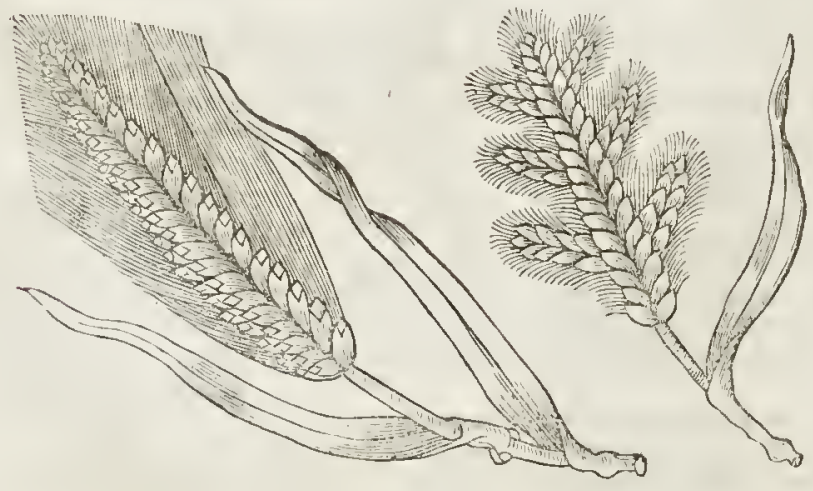

B

The floure of wheat being boyled with honey and water, or with oyle and water, taketh away all inflammations, or hot fwellings.

C The bran of Wheat boyled in ftrong Vineger, clenfeth away feurfe and dry feales, and diffolueth the beginning of all hot fwellings, if it be laid vnto them. And boyled with the decoction of Rue, it flaketh the fivellings inwomens brefts.

D The graines of white Wheat, as Pliny writcth in his two and twentieth booke, and feucnth chapter, being dried brown, but not burnt,and the pouder thercof mixed with white wine is good for watering cyes, if it be laid thereto.

E The dried pouder of red Wheat boyled with vineger, helpeth the fhrinking of finewes. 


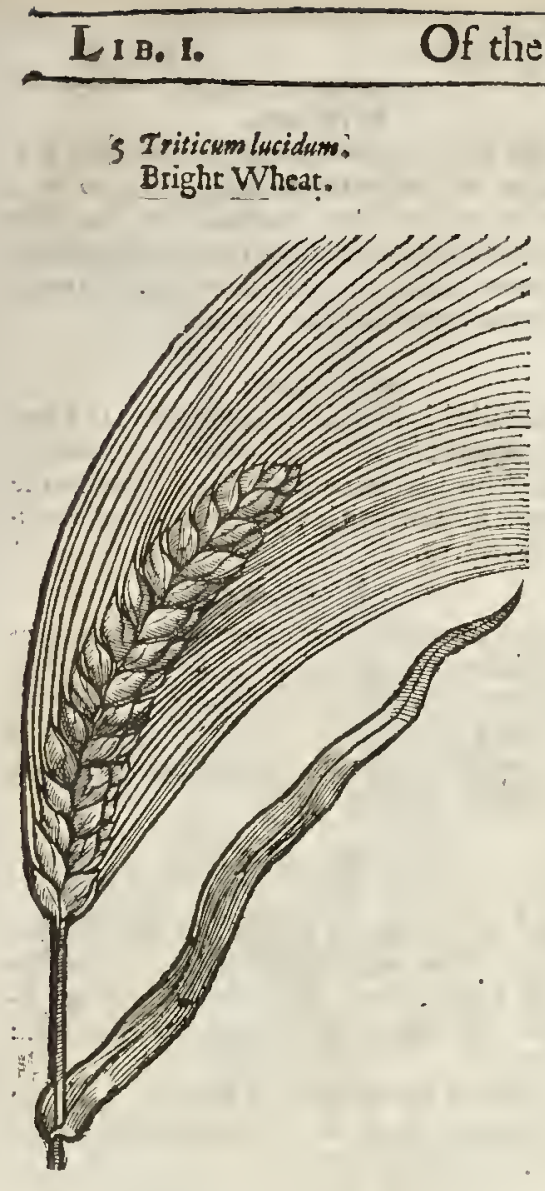

inflammations, as Ignis facer, or Saint Anthonics Fire, and fuch like, ftaying the fux of humors to the ioynts, which the Grecians call Rhesmatifmata. Paite made of fine meale, fuch as Booke-binders vfe, helpeth fuch as doe fpit bloud, taken warme one fpoonfull at once. The branof wheat boiled in tharpe vineger, and rubbed vpon them that be fcuruie and mangie, eafeth the party very much.

The leauen made of Wheat hath vertue to heate and draw outward, it refolueth, concocteth, and openeth all fwellings, bunches, tumors, and felons, being mixed with falt.

The fine floure nixed with the yolke of an $\mathrm{H}$ egge, honey, and a little fatfron, doth draw and heale byles and fuch like fores, in children and in old people,very well and quickely. Take crums of wheaten bread one pound and an halfe, barley meale $3 \mathrm{ij}$. Fennigreeke and Linefeed of each an ounce, the leaues of Mallowes, Violets, Dwale, Sengreene, and Cotyledon, ana one handfull: boyle them in water and oyle wntill they be tender : then ftampe then very fmall in a ftone morter, and adde theteto the yolks of three egges, oyle of Rores, and oyle of Violets, and $\tilde{3}$ ij. Ineorporate them altogether; but if the inflamnation grow to an Eryfipelas, then adde thereto the juice of Nighrihade, Plantaine, and Henbane, ana 3 ij. it eafethan Eryfipclas, or Saint Anthonies fire, and all inflammations very fpeedily.

Slices of fine white bread laid to infufe or neepe in Rofe water, and fo applied vnto fore eyes which haue many hot humors falling into them, doth eafily defend the hunour, and ceafe the paine.

The oyle of wheat preffed forth betweene two plates of hor iron, healeth the chaps and chinks $K$ of the hands, feet, and fundament, which come of cold, making frooth the hands, face, or any other
part of the body.

The fame vfed as a Balfame doth excellently heale wounds, and being put among falues or vngucnts, it caufeth them to worke more effectually, efpecially in old vlcers.

\section{Cна Р. 47. Of Ric. \\ If The defcription.}

$T$ He leafe of Rie when it firf commeth vp, is fomew hat reddith, afterward greene, as be the other graines. It groweth vp with many ftalks, flenderer than thofe of wheat, and longer, with knees or ioynts by certaine diftances like vnto Wheat : the eares are ordetly framed vp in rankes, and compaffed about with thort beards, not fharpe but blunt, which when it floureth ftandeth vpright, and when it is filled vp with feed it leaneth and hangeth downward. The feed is long, blackin, Aender, and naked, which eafily falleth out of the huskes of it felfe. The roots bemasty, flender, and full of ftrings.

Riegroweth very plentifully in the 7 Theplace.

heare great quantitie brought into England in times of dearth, and fearcitie of corne, as hapned in the yeare 1596, and at other times, when there was a generall want of come, by reafon of the aboundance of raine that fell the yeare before; whereby great penurie enfued, as well of cattell and ali other vietuals, as of all manner of graine. It groweth $l_{1}$ kewife very wel in mon places of England,
efpecially towards the North. 


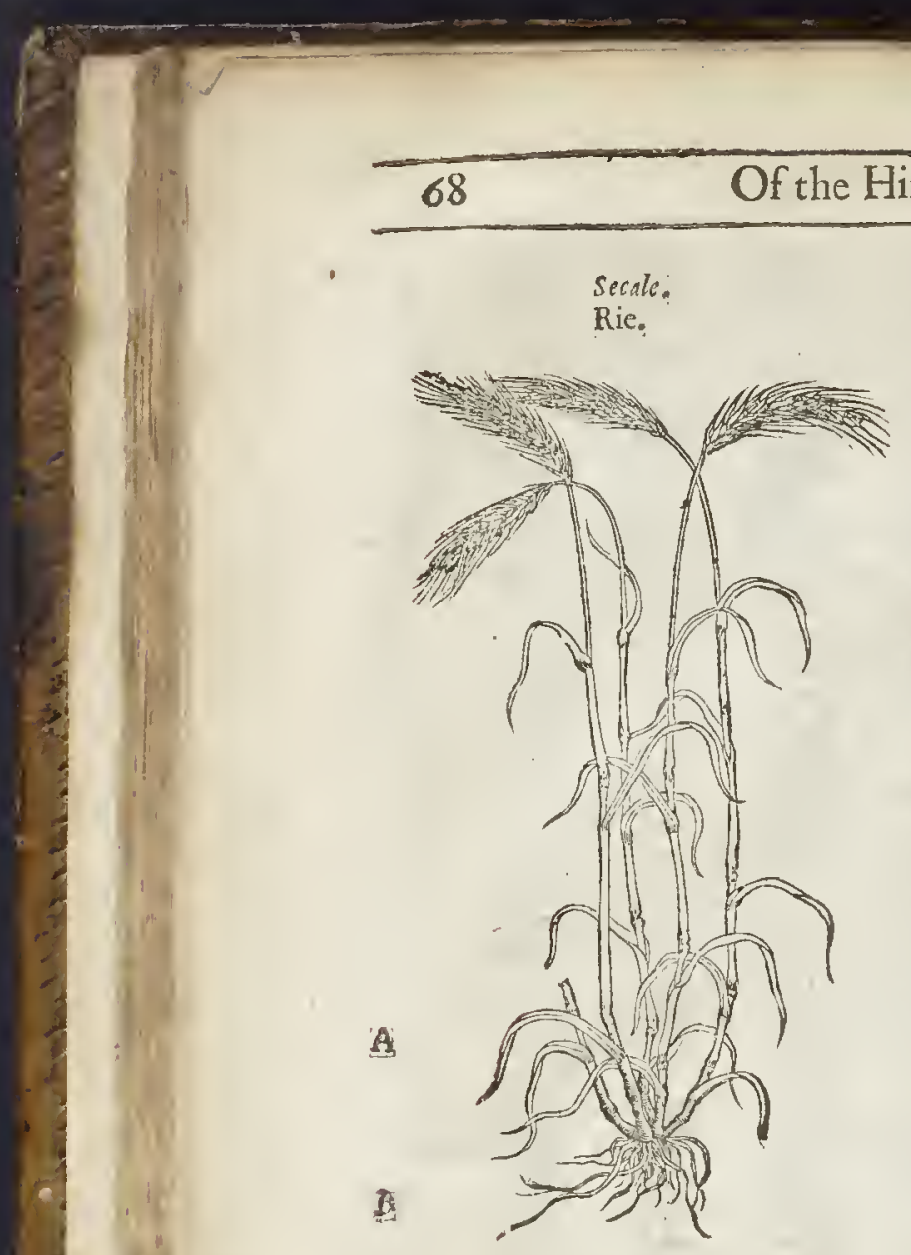

Pelt is like to Wheat in ftalkes and eare: it growe th vp with a multitude of ftalks which are kneed and joynted higher than thofe of Barley: it bringeth forth a difordered eare, for the mofk part without beards. The cornes be wrapped ineertaine dry huskes, from which they cannot eafily be purged, and are joyned together by couples in two chaffie huskes, out of which when they be taken they are like vnto wheat cornes: it hath alfo many roots as wheat hath, whereof it is a kinde.

It groweth in fat and fertile moift ground.

$$
\text { T) Theplace. }
$$

$$
\text { Tा The time. }
$$

It is altered and changed into Wheat it felfe, as degenerating from bad to better, contrary to all other that do alter or change; efpecially (as $T$ beophraftus faith) if it be clenfed, and fo fowen, but that not forthwith, but in the third yeare.

\section{- Thenames.}

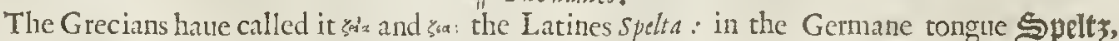
and Sintel: in low Dutch, Speite: in French, Epeature: of moft I talians, pirra, Farra; of the Tufcans, Biada: of the Millanois, Alga: in Englifh, Spelt Corne. Diofcorides maketh mention

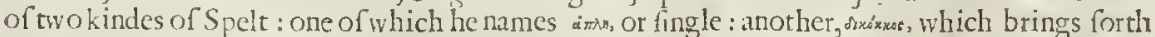
two cornes ioyned together in a couple of huskes, as before in the defcription is mentioned. That Spelt which Diofcorides calls Dicoccos, is the fame that Theophr.and Galendo nane Zea. The molt ancient Latines have called $Z e a$ or Spelta by the name of $F$ ar, as Diomy fur Halicarnaffers doth fufficicntly teftifie: The old Ronans (faith he) did call facred marriages by the word pakizara, becaufe 


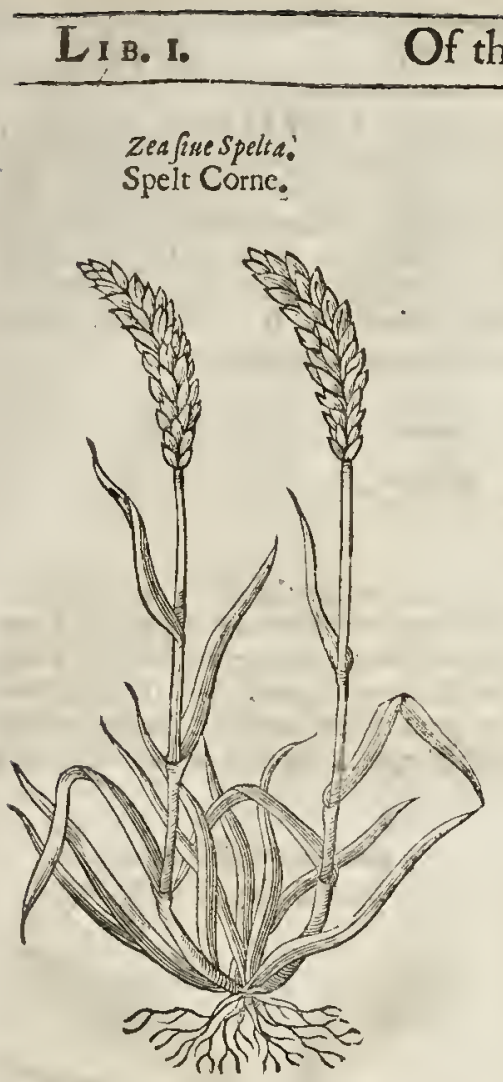

\section{C}

\section{Triticum Amyleurs:} Starch Corne.

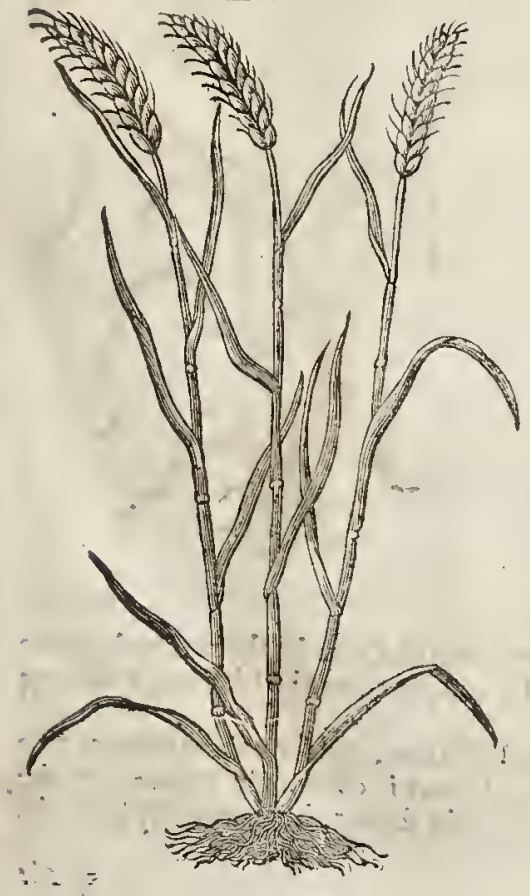

the Bride and Bridegroome did eate of that $F_{B^{n}}$ which the Grecians do call sia. The fame thing $A$ folepiades affirmeth in Galen, in his ninth Booke according to the places affected, writing thins; Farris quod Zea appellant : that is to faty ${ }_{j}$ Far ivhich is ca!led $Z e a, \& x$. And this' $F$ ar is allo named of the Latines, Ador, Adoreum, and Semen adoreum.

$$
\text { I The temper. }
$$

Spelt, as Diofcorides reporteth, nouritherh more than Barley. Galen writeth in his Bookes of the Fuculties of fimple Medicines, Spelt is in all his temperature in a meane betweene Wheat and Barley, and may in vertue bereferred to the kindes of Barley and Wheat, being indifferent to then both. IT The vertucs.

The floure or meale of Spelt corne boyled in A water with the pouder of red Saunders, and a little oyle ofRofes and Lillies, vnto the forme of a Pulteffe, and applied hor, taketh away the fwelling of the legs gotten by cold and long ftanding.

\# Spelt (faith Turner) is common aboui Weifen- B burgh in high Almanic, eight Dutch miles on this fide Strausbourgh : and there all men vfe it for wheat; for there groweth nowheat at all : yet I neuer faw fairer and pleafanzer bread in any place in all my life, than I haue caten there, made oncly of this Spelt. The Corne is much leffe than Whear, and fomewhat fhorter than Rie, but nothing fo blacke, $\neq$

\section{Of Starch Corne:}

\section{9ा The defription.}

7 His other kind of spelta or $Z$ ea is called of the Germane Herbarifts Amyleum Frumentum, or Starch corne; and is a kinde of grain fowen to that end, or a three moneths graine, and is very like vnto wheat in ftalke and feed; but the eare thereof is fet round about, and made vp with two ranks, with certaine beards, almoft after the manner of Barley, and the feed is clofed vp in chaftie huskes, and is fowen in the Spring.

$$
\text { Tा Theplace. }
$$

Amil corne, or Starch corne is fowen in Germanie, Polonia, Denmarke, and other thofe Eafterne Rcgions, as well to feed their catrel and pullen with, as alfo to make farch; for thewhich purpofe it doth very fitly ferue.

$$
\text { 9l The time. }
$$

It is forven in Autumne, or the fall of the leafe, and oftentimes in the Spring; and for that caure hat li beene called Trimeftre, or three months grain : it bringeth his feed to ripeneffe in the beginning of $A$ ugut, and is fowen in the Low-Countries in the Spring of the yeare.

$$
\text { T) The names. }
$$

Becaufe the Germanes haue great vfe of it to make farch with, they do call it almelcoun: Wee F. 3 thinke 
thinkegood to name it in Latine Amyleum frumentum : in Englifh it may be called Amclcornc, aftet the Germaneword; and may likewife be called Starch Connc. Tragus and Fuchfrus tuoke it to be Triticum trimeftre, or three monetls whcat; but it may rather be referred to the Farra: for Columella fpeakcth of a graine called $F$ ar Halicaftrum, which is fowcn in the Spring ; and for that caufc it is named Trimeftre, or three moneths $F$ ar. If any be defirous to leame the making of Srarch, let thcm rcade Dodoneus laft cdition, whcre they thall bc fully taught; my fclfc not willing to fpend timc about fo vaine a thing, and not pertinent to the ftory. It is vfed oncly to fced cattcll, pullen, and make ftarch, and is in nature fomewhat like to wheat or Barley.

\section{Сан. 50. Of Barley. \\ The defription.}

D Arley hath an helme or ftraw which is horter and more brittle than that of Wheat, and hath more joints; the lcautes are broader and roughcr; the eare is armed with long, rough, and prickly beards or ailes, and fet about with fundry rankes, fomctimes two, otherwhiles three, foute, or fix at the moft, according to Thcophraftus; but cight according to Tragus. The graine is includ cd in a long cliaffic huske : the roots be flender, and grow thicke together. Barley, as Pliny writcth, is of all graine the fofteft, and leaft fubiedt to cafualtie, yeelding fruit very quickely and profitably.

I Hordeum Difichon. Common Barley.

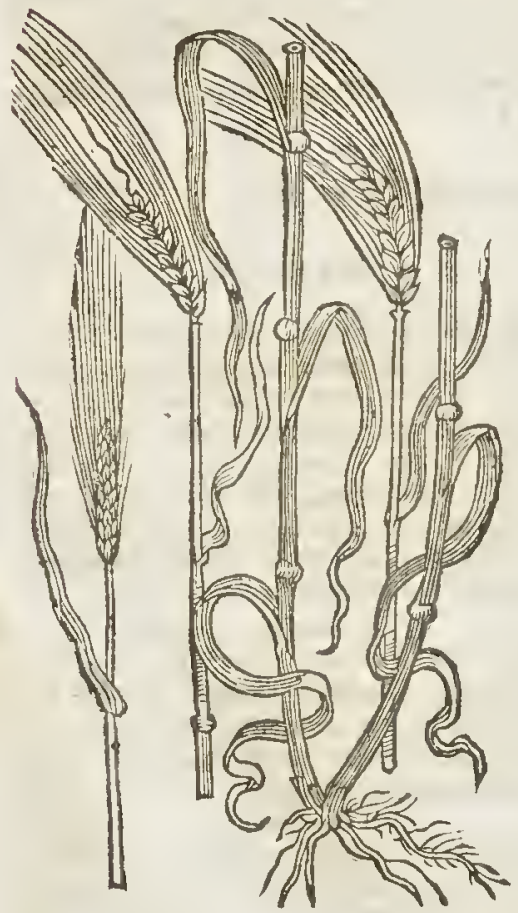

2 Hordeum Polyftichumvernum: Beate Barley, or Barley Big.

I The moft wull Barley is that which hath but two rowes of Cotne in the eate, each gtaine fct iuft oppofite to other, and hauing his long awne at his end, is couered with a huske ficking clofe thereto.

2 This which commonly hath foure rowes of cotne in the eate, and fomet imes more, as wee hauc formerly deliueted, is not fo vfually fowen with vs; the eate is commonly fhortet than the former, but the graine vety like; fo that none who knowes the former, but may eafily know the later at the firft fight. 
The place.

They are fowen, as Columella teacheth, in loofe and dry ground, and are well knowne ail Europe through. ham.

2 The fecond is fowen commonly in fome parts of Yorke frire ard the Bithopricke of Dur-

T) The names.

I The firt is called of the Grecians ais: in high Dutch, Gerften: in Low Dutch, Gett: in Italian, orzo: in Spanifl, Cicurdt: in French, orge : in Englifh, Barley.

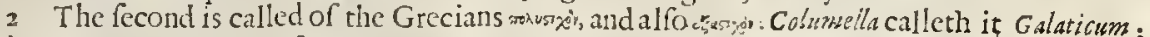

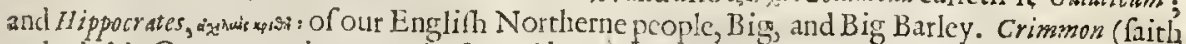
Galem in his Commentaries vpon the fecond booke. of tuippocraies his Prognofticks) is the groffer part of Barley meale being groffely ground. Malt is well knowne in England, in omuch that the word needeth no interpretation; notwithfanding becaufe thefe Workes may chance into the hands of Strangers, that neuce heard of fuch a word, or fuch a thing, by reafon it is not enerie whcre made; I thought good to lay downe a word of the making thereof. Firf, it is fteeped in water intill it firell; then is it taken from the water, and laid (as they terme it) in a Couch; that is, fpred vpon an euen floorc the thicknefle of fome foot and an halfe; and thus is it kept vntill it Come, that is, vntill it fend forth two or three litrle Atrings or fangs at the end of each Cone: then it is fpred vfually twice a day, each day thinner than other, for fome eight or ten daies fpace, sntill it be pretty dry, and then it is dricd wp with the heate of the fire, and fo vfed. It is called in high Dutch, 9 galt?: in low Dutch, $\$$ Bout : in Latine of later time, Maltum : which name is borrowed of the Germanes. Actins a Grecke Phyfitian nameth Barley thus prepared, zun, or Bine: The which Authorafirmeth, That a plaifter of the meale of Malt is profitably laid vpon the fwellings of the Dropfic. Zytbum, as Diotorus Siculus affirmetl, is not onely made in Egypt, but alfo in Galatia. The aire is fo cold (faith he, writing of Galatia) that the country bringeth forth neither swine nor oyle; and theteforc men are compelled to make a compound drinke of Barley, which they call $Z$ ythum. Diofcorides nameth one kinde of Barley drinke $Z$ zythum; another, $C_{u r m i}$. Simeon Zetbi a later Grecian calleth this kind of drinke by an A rabicke name, call it Becre and Ale which is made of Barlcy Malt.

\section{T The temperature.}

Barley, as Galezwriteth in his booke of the Faculties of nourinments, is not of the fame tem perature that Whear is; for Wheat doth manifenly heate, but contrariwife what medicine or bread foeuer is made of Barley, is found to haue a certaine force to coole and drye in the firft degree, according to $G$ alen in his booke of the facultics of Simples. It hath alfo a little abfterfuge or cleanfing qualitie, and doth dry fomewhat more than Beane meale.

\section{of The vertules.}

Barley, faith Diofcorides, doth cleanfe, protoke vrine, breedeth windineffe, and is an enemie to the ftomacke.

Barley neale boyled in an honied water with figges, taketh away inflamnations : with Pitch, Rofin, and Pigeons dung, it foftneth and ripeneth hard fwcllings.

With Melilot and Poppy fecds it taketh away the paine in the fides: it is a remedy againft windinefe in the guts, being applied witl Linefeed, Fonugreeke, and Rue : with tarrc,wax, oyle, and the vrinc of a yong boy, it doth digeft, foften, and ripe hard fivellings in the throat, called the Kings Euill.

Boylcd with wine, myrtles, the barke of the pomegranate, wilde peares, and the leares of brambles, it ftoppeth the laske.

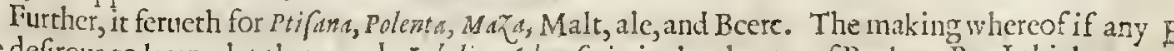
be defirous to learne, let them reade Lobolins Aduerfaria, in the chapter of Barley. But I thinke our London Becre-Brewers wiould feorne to learne to mitake beere of citlicr French or Dutch, much leffe of me that can fay nothing therein of mine owne experience more than by the Writings of others. But I ma deliter vito you a Confection made thereof (as Columell a did concerning fiveet wine fodden to the halfe) which is this; Boyle ftrong ale till it cone to the thickeneffe of hony, or the forme of an vnguent or falue, which applied to the paines of tbe finewes and joints (as hauing the propertic to abate aches and paines) may for want of better remedies bevfed for old and new fores, if it be made after this manner.

Take ftrong ale two pound, one Oxe gall, and boyle them to one poind with a foft firc, conti- F nually ftirring it; adding thereto of Vineger one pound, of olib.nmm one ounce, floures of Camomil and meli lot of each $\tilde{z} \mathrm{i}$.Ruc in fine pouder $\tilde{z}$ s. a little hony, and a fmall quantitic of the pouder of Comin feed, boyle them all together to the forme of an vnguent, and fo apply it. There be fundry forts of Confeitions made of B.rilcy, as Polenta, Ptifana, made of water and husked or hulled barlcy, and fich like. Polenta is the meate made of parched Barky, which the Grecians dos pro. 
perly call axostor. $M a z a$ is made of parched Barley tempered with water, after Hoppocrates and 5 cnophon: Cyrus hauing called his fouldiers together, exhorteth then ro drinke water wherein parched

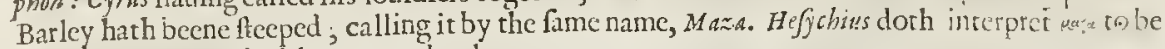
Barley meale mixed with water and oyle.

Barley meale boyled in water with garden Night fhade, the leates of garden Poppie, the pouder of Fonugrceke and Linefeed, and a little Hogs greafe, is good againt all hot and burning fwellings, and prewaileth againft the Dropfie, being applied vpon the belly.

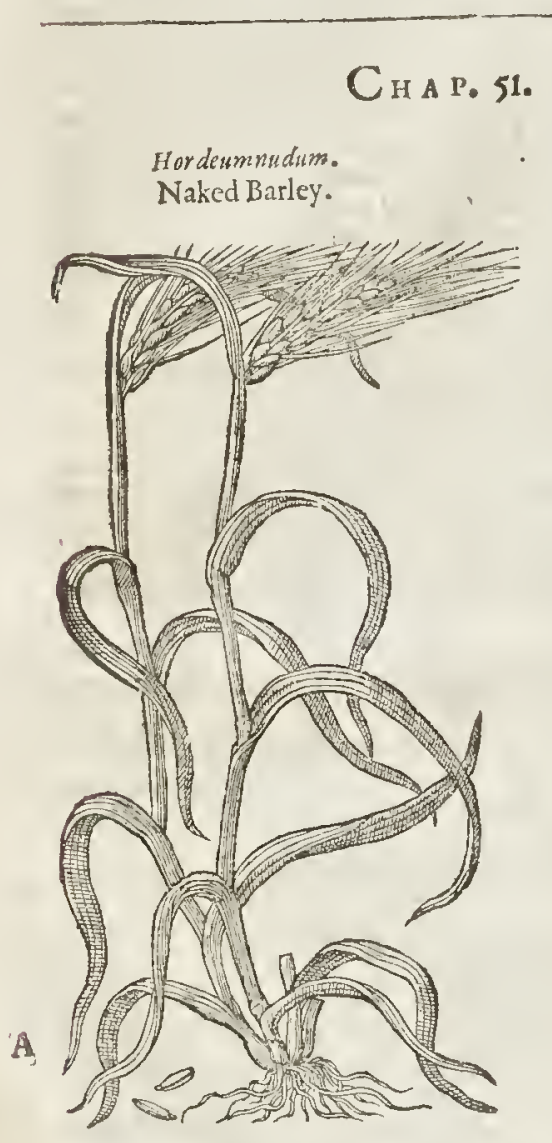

\section{of Naked Barley.}

$$
\text { Ti The defcription. }
$$

T Tordeumnudum is ealled $Z$ eopyrum, and Tri1 tico-speltum, beeaufe it is like to $Z e_{a}$, otherwife called spelta, and is like to that which is called Freneh Barley, whercof is made that noble drinke for ficke Folkes, called Ptifima. The plant is altogether like into Spelt, faung that the eares are rounder, the ciles or bents rougher and longer, and the feed or graine naked without huskes, like to wheat, the which in it's yellowifh eolour it fomewhat refembles.

$$
\text { 9T } T \text { beplace. }
$$

* It is fowne in fundry places of Germany' for the fame ves as Barley is.

\section{T) Thenames.}

It is called Hordeum Nudum, for that the Corne is without huske, and refembleth Barley. In Grecke it is called ziomugr, becaufe it participateth in fimilitude and nature with $Z c a$, that is, Spelt, and Puros, (that is) wheat. $\ddagger$

\section{The vertues.}

This Barley boyled in water cooleth vnnatu:rall and hot burning choler. In vehement feuts you may adde thereto the feeds of white Poppie and Lettufe, not oncly tocoole, but álfo to ptouoke flecpe.

B Againft the fhortnefle of the breath, and paines of the breft, may be added to all the forefaid, B figs, raifins of the Sunne, liquotice, and Annife feed.

Being boyled in the Whay of Milke, with the leaues of Sorrell, Matigolds, and Scabious, it

C quencheth thirft, and cooleth the heate of the inflamed Lituer, being drunke fitf in the morning, and laft to bedwatd. 


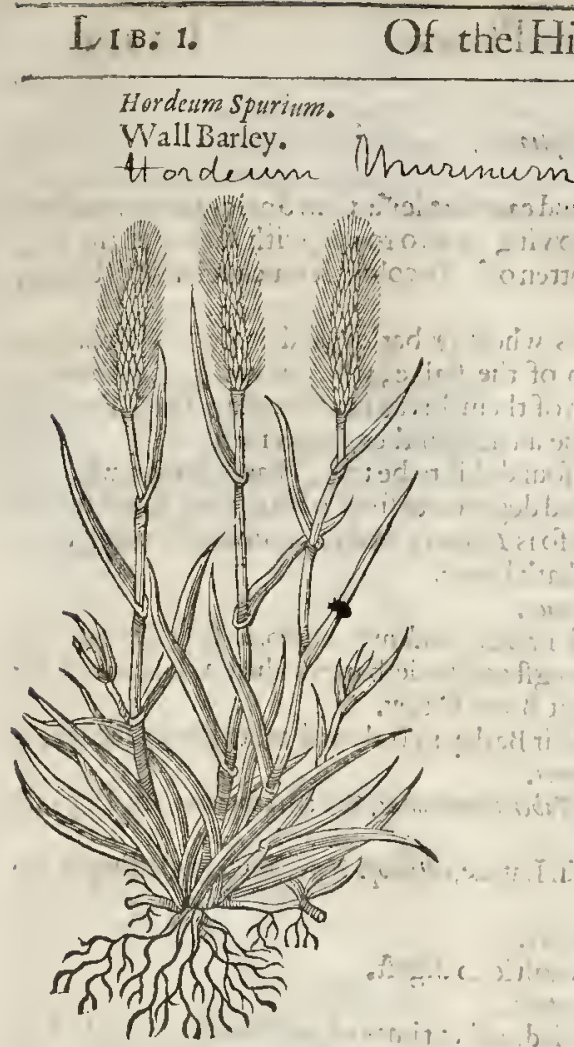

Hordeum Spurium.

WallBarley. Mnurinurin

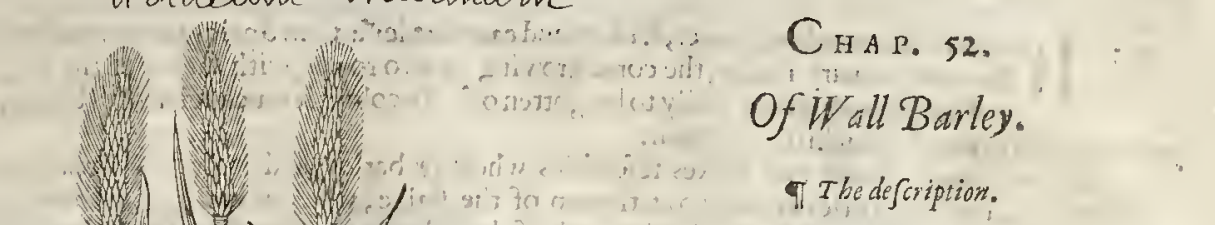

Ti The defription.

7 His kinde of wilde Barley, called of the La tines Hordcuin Spurium ; is called of Pliny, Holcus; in Englith, Wall Barley, Way Barley, or after old Englifh Writers, Way Bennet.' It groweth vpon mud walls and ftony places by the wayes fides : verywell refembling Selfe-fowed Barley, yet the blades are rather like graffe than Barley. $¥$ This groweth fome foot and better in height, with graffe leaues, the eare is very like that of Rie, and the corne both in colour and thape abfolutely refembles it ; fo that it cannot be fitlier named than by calling it wilde Ric, or Ric graffe.

This Baftard wilde Barley ftamped and applied unto places wanting haire, doth caure it to grow and come forth; whereupon in old time ic was called Biftida.

\section{$\mathrm{C}_{\text {HA I. 53. Of Saint }}$ Peters Corne:}

I Pritidnosodectos: S.Peters Corne.

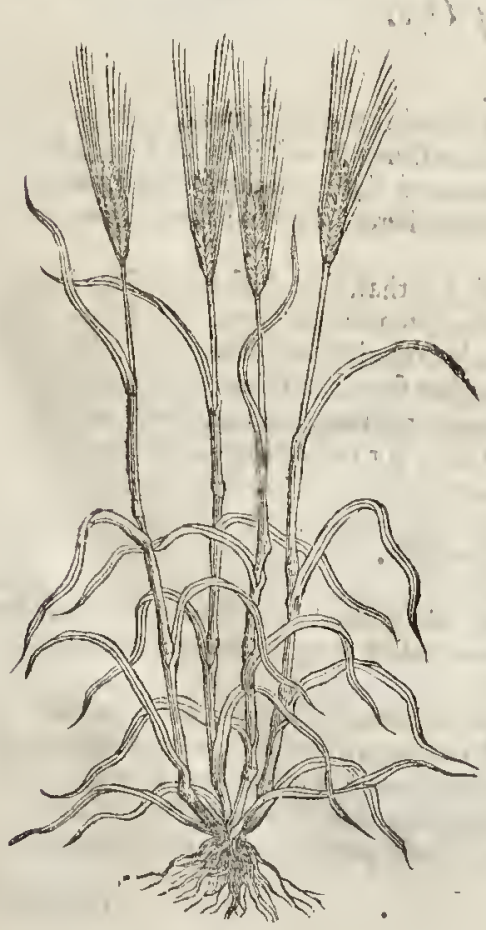

2. Feftuca Italica, Hauer Graffè

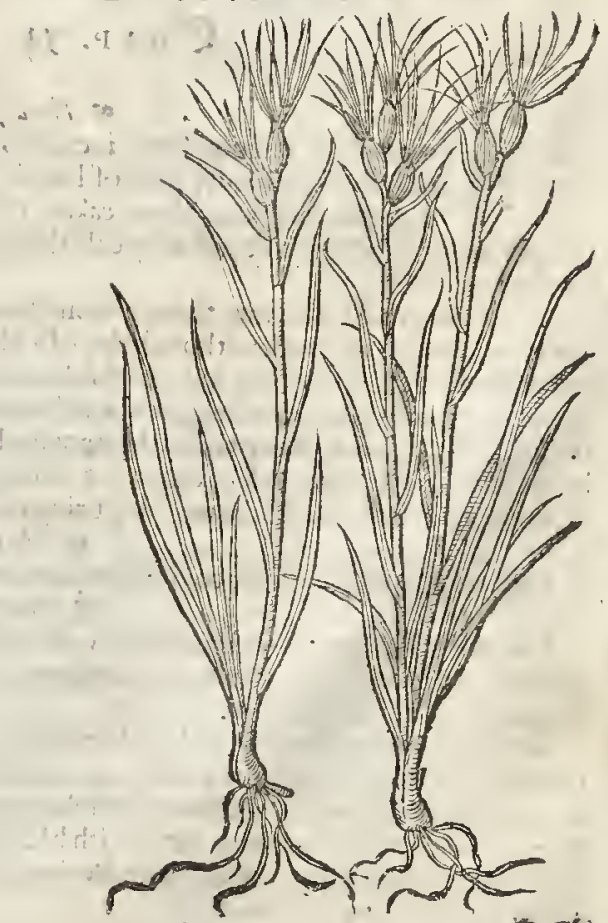

Ithe

\section{a}

\footnotetext{
$$
\text { . }
$$
}




\section{- If The defcription.}

+1 Riza is a Come whofc lcaues, ftalkes, and eares are leffe than Spelt; the eare refem1 bles our ordinary Barley, the cornc growing in two rowes, with awnes at the top, and huskes vpon it not eafily to be gotten off. In colour it much refembles barley; yet Tragus faith it is of a blackifh red colour.

2 This Egilops in leaues and ftalkes refembles whear or barley, and it growes fome two handfuls high, hating a little eare or two at the top of the ftalke, wherein are inclofed two or three feeds a little fmaller than Barley, haung each of them his awne at his cnd. Thefe feeds are wrapped in a crefed filme or shinne, out of which the awnes put themfelues forth.

Mathiolss faith, That he by his ownettiall hath found this ta betrue, That as Lolium, which is onr common Darnel, is certainly knowne to be a feed degenerate from wheat, being found for the mot part among wheat, or where wheat hat barley, and is found among Barley, or where barley hath beene.

$$
\text { I The place. }
$$

- Briza is fow en in fome parts of Germany and France; and my memorie deceitues me if I haue not often times found niany eares thereofamongft ordinaric barley, when as I liued in the further fidc of Lincolnefhirc, and they there called it Brant Barley.

2 This figilops growes commonly among? their Barley in Italy and other hot countries, $f$ The names.

I Brina Monococcos, after Lobelius, is called by Tabernamontanus, Zea CMonococcos: in Englifh, Saint Peters Cornc,or Btant Barley.

2 Fefuce of Narbone in France is called sigixat: in Lat inc, Gteeke :in Englifh, Hauer-graffe.

They ate of qualitie fonewhat tharpe, hauing facultie to digen.

I The vertues.

A The iuice of Feftuca mixed with Batley meale dried, and at times of need moiftned with Rofe water, applied plaiferwife, healeth the difeafe called Egilops, or Fifula in the corner of the eye: it mollifeth and difpetfeth latd lumps,aind afwageth the fwellings in the joynts.

\section{CHAP. 54. Of Otes.}

The defoription.

1 A VenaVefa, Common Otes, is called $r e f c a, \grave{a} V e f c e n d o$, becaufe it is vfed in many counA 1 tries to make fundry forts of bread, as in Lancafhire, where it is their chiefcef bread
corne for Iannocks, Hauer cakes, Tharffe cakes, and thofe which arc called generally Oten cakes; and for the molt patt they call the graine Hauer, whereof they do likew ife make drink for want of Barley.

2 Auena $N$ uda is like vnto the common Otcs; differing in that, that thefe nakcd Otes immediately as they be threfhed, withour helpe of a Mill become Otemeale fit for our vfe. In confideration where of in Nortlifolke and Southfolke they are called vnhulled and naked Otes. Some of thofe good houfe-wiues that delight not to have any thing but from hand to mouth, according ro our Englifh prouerbe, may (whiles theirpot doth feeth) go to the batne, and rub forth with their hands fufficient for that prefent time, not willing to prouide for to morrow, accotding as the Scripture fpeaketl, but let the next day bring with it.

$$
\text { of The nature. }
$$

Otes are dry and fomewhat cold of temperature, as Galce faith.

$$
\text { if The vertues. }
$$

A Common Otes put into a linnenbag, with a little bay falt quilted handfomely for the fame purpofe, and made hot in a frying pan, and applied very hot, eaferh the paine in the fide called the ftitcl, or collicke in the belly.

B If Otes be boyled in waret, and the hands or feet of fuch as haue the Serpigo or Impetigo, that is, certaine chaps, chinks, or rifts in the palmes of the hands or feet (a difeafe of great affinitie with the pocks) beholden cuer the fume or fmoke thereof in fome bowle or other veffell wherein the Otes are put, and the Paticnt concred with blankets to fweat, being firft annointed with that ointment or vnotion r fually applied contrs Morbam Gallicum: it doth petfectly cure the fame in fixe times foannointing and weating. 
L I B.: 1.

Of the Hiftorie, of Plants.

Otemeale is good for to make a faire and wel eoloured maid to looke like a cake of tallow, efpe- C cially if fhe take next her ftomacke a good draught of ftrong vineger after ic.

Otemcale vfed as a Cataplafixe dries and moderately difeufes, and that withont biting; for D it hath fomewhat a coole temper, with fome aftriction, fo that it is good againft fcourings.

I Aumavefa.

Common Otes,

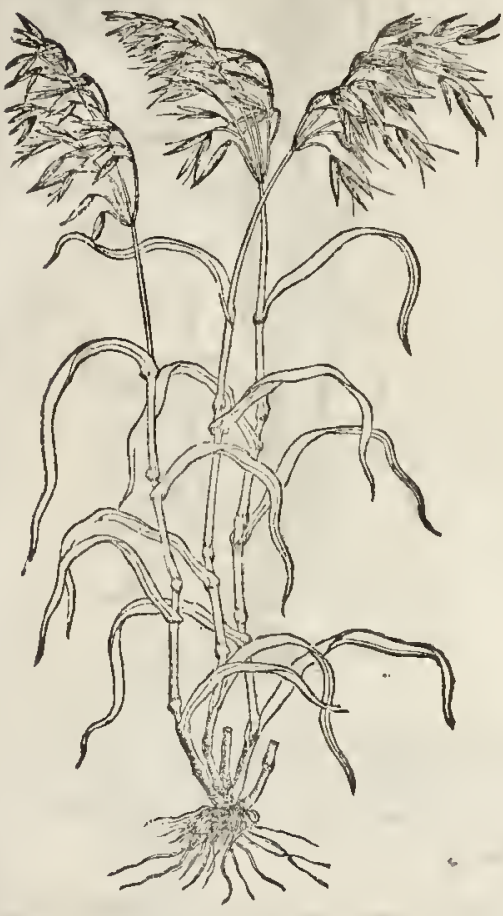

2 Auena Nuda: Naked Otes?

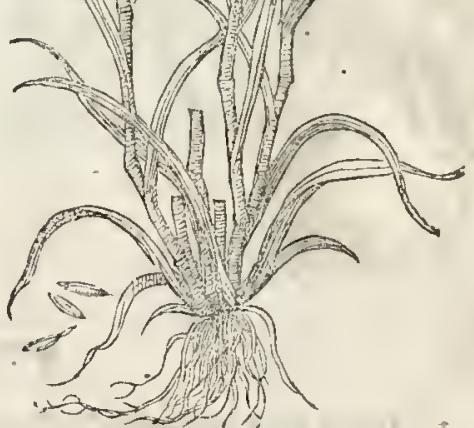

\section{Chap. 55. Of Wilde Otes.}

\section{The defcription.}

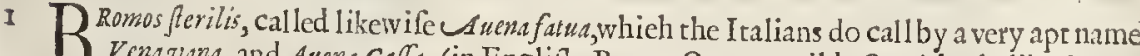
Venavana, and Auena Caffa, (in Englin, Barren Otes, or wilde Otes) hath like leaues and italkes as our Common Otes; but the heads are rougher, tharpe, many little fharpe huskes making caels eare.

$t_{2}$ There is alfo anorher kinde of Bromos or wilde Otes, which Dodonetus calleth Feftuca alte. $r a$, not differing from the former wilde Otes in ftalkes and leates, but the heads are thicker, and more compact, caeh particular eare (as I may terme it) confitting of two rowes of feed handfomly compact and ioyned together; being broader next the ftraw, and narower as it comes' to an
cnd.

\# The firf in Iuly and Augut $\neq$ T The time and place. great plenty in fonof Ric.

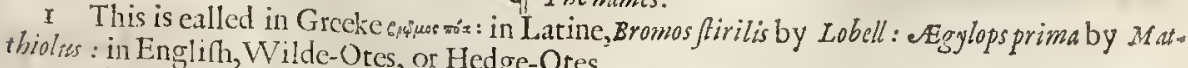
2 Lobell calls this vilde-Otes, or Hedge-Otes.

Dumich: in Eng!ifh, Drauke. 


\section{6}

Of the Hiftorie of Plants.

LIB. I.

¿ Bromosfterilis:

Wilde Otes.

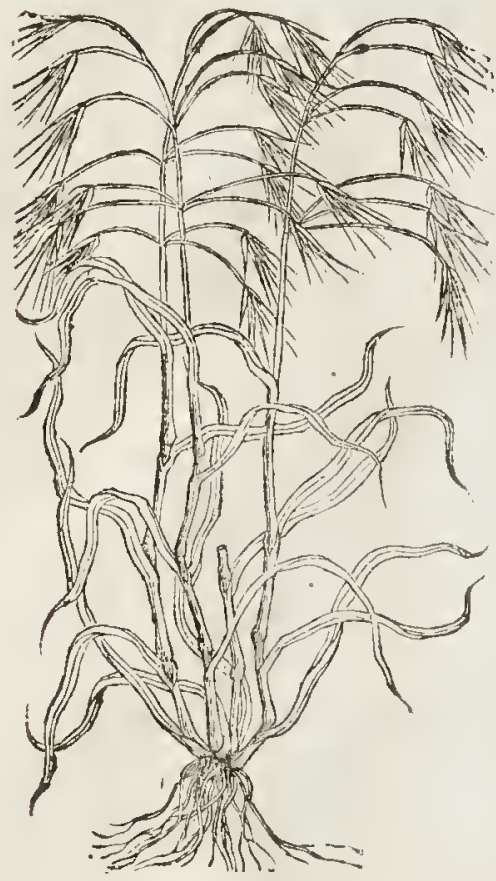

Bromos altera.

Drauke, or fmall wilde Otes?

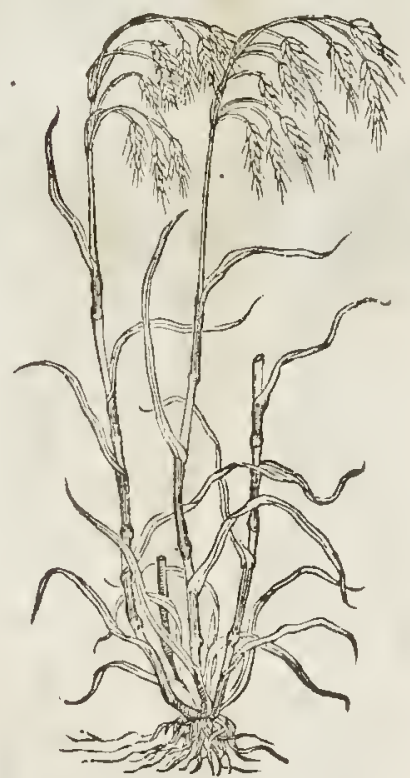

T) The nature and vertues?

A It hath a drying facultie (as Diofcorides faith.) Boile it in water together with the roots wntill two parts of three be confumed; then ftraine it out, and adde to the decoction a quantitie of honey equall thereto : fo boile it vntill it acquire the thickneffe of thin honey. This medicine is good againt the 0 zana and filthy vlcers of the nofe, dipping a linnen cloth therein,and putting it vp into the nofthrils; fome adde thereto Alocs finely poudred, and fovfe it.

B Alfo boiled in Wine with dried Rofe leaues, it is good againft a finking breath.

\section{Cина. 56. Of Bearded Wilde Otes. \\ T'T be defcription.}

在

Gylops Bromoides Belgarum is a Plant indifferently partaking of the pature of exilops and Bromos. It is in thew like to the naked Otes. The feed is Tharpe, hairy, and tomewhat long, and of a reddith colour, inclofed in yellowith chaffie huskes like as Otes, and may be Englifhed, Crefted or bearded Otes. I haue found it often among Barley and Rie in fundry grounds. This is likewife vnprofitable and hurtfull to Conne; whereof is no mention made by the Antients worthy the noting. 
Li в. r. Of the Miftory of Plants.

$\dagger$ Exilops Bromoides. Bearded Wilda Otes.

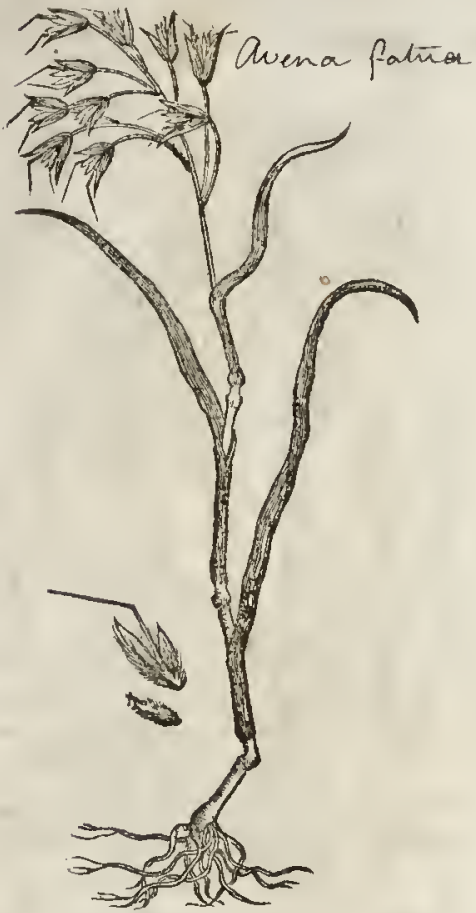

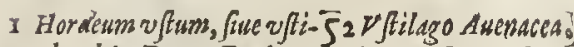
ngo hordei. Burnt Barley. $\{$ Burnt Otes,

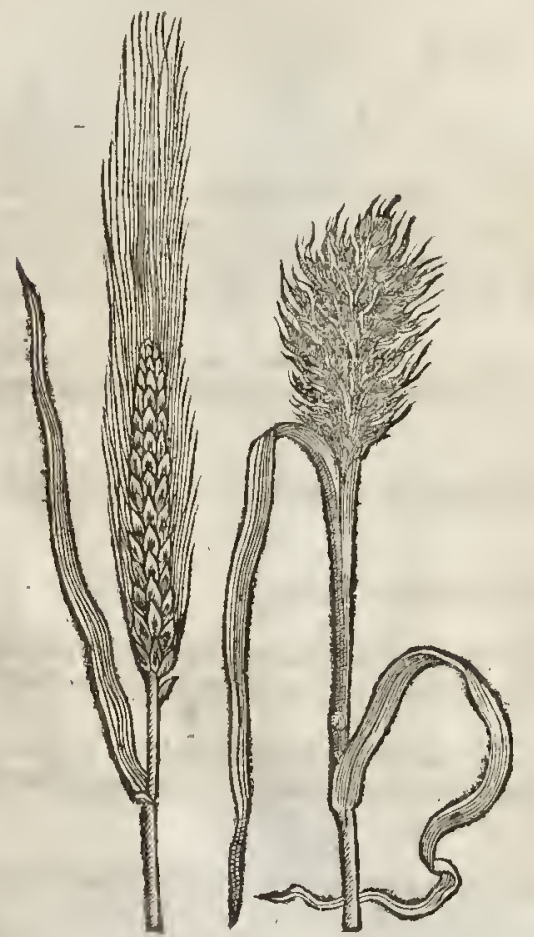

Chas. 57. Of Burnt Corne.

T) Thedefriplion. 1 Tordeum vftum, or $\begin{aligned} & \text { Iftugo Hordei, is that } \\ & \text { burnt or blated Barley which is alto- }\end{aligned}$ gethervnprofitable and good for nothing, an enemy vnto corne; for that in ficad of eare with eorne, there is nothing elfe but blacke duft,which fpoilkth bread, or whatioeuer is made thereof.

2 Burnt Otes, or Ffilago Auene, or Auenacen, is likewife an vnprofitable Plant, degeneratin from Otes, as the other from Barley, Fie, and Whicat. It were in vaine to make a long harueft of fuel euil! corne, confidering it is not poffer. i with one good qualitie. And thercfore thus nuch hali fuffee for the defeription.

3 Burnt Ric hath no one good property in fil: ficke, appropriate either to man, birds, or beat, and is a hurtfull maladie to all corie where it sroverh. hauing an eare in fhape like to eorne, but 11 ftead of graine it doth yeeld a blacke pouder or duft, which cauferh bread to looke blaeke, and to haue an euill tafte: and that corne where it is, is called fmotic corne, and the thing it felfe Burnt Conne, or blafted corne.

\section{Ffilago Secalind:} Burnt Rie.

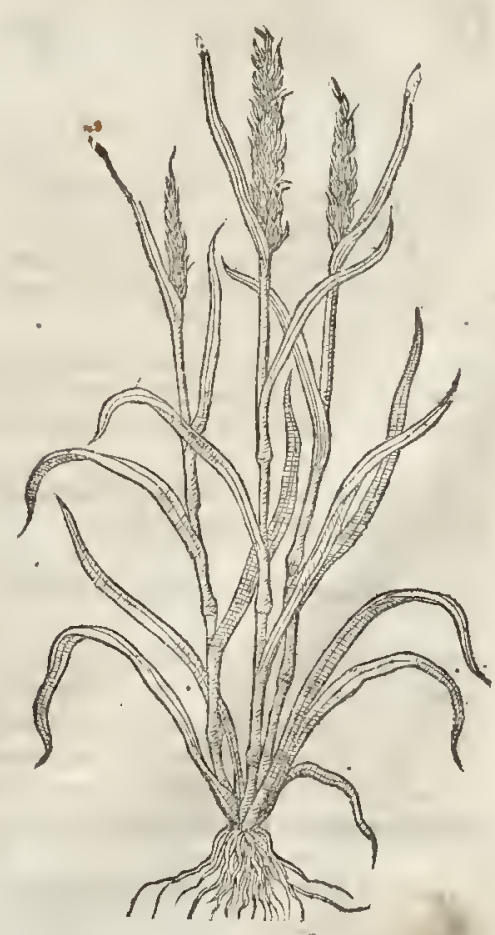

G Chaps. 


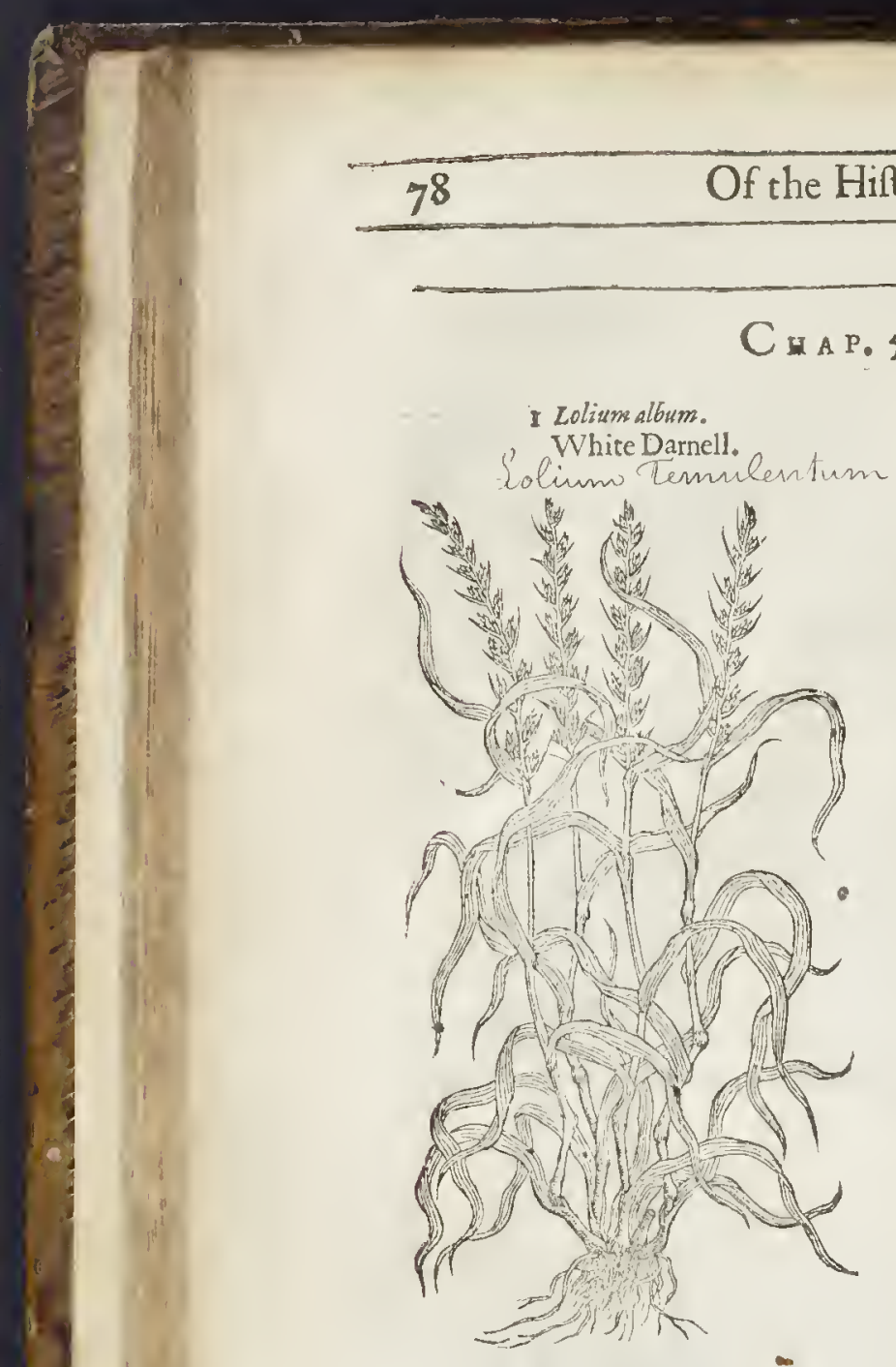

LI в. I.

Of Darnell.

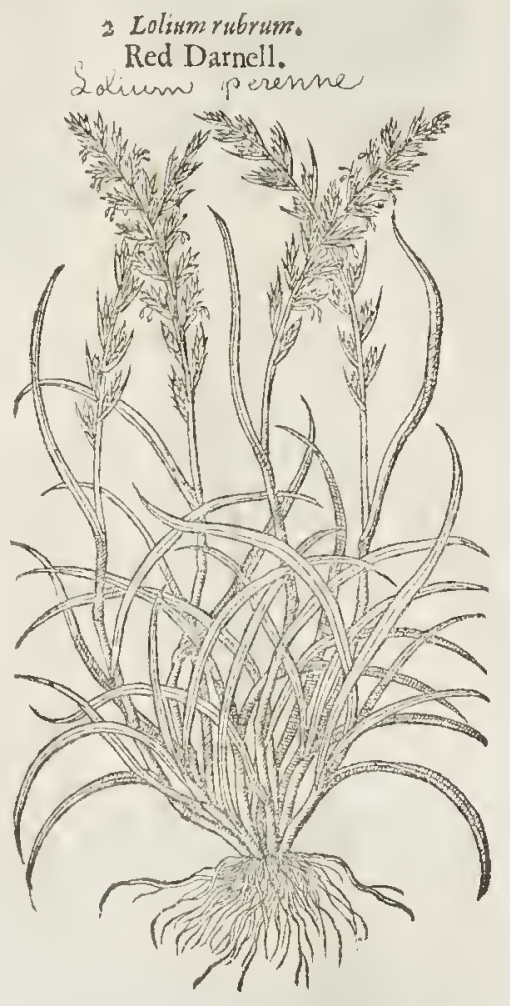

T) The defription.

1 Motig the hurtfull weeds Darnell is the firft. It bringeth forth leaues or ftalkes like thofe of wheat or barley, yer rougher, with a long eare made vp of many little ones, euery particular one whereof containeth two or three graines leffer than thofe of wheat, farcely any chaffic huske to couer them with; by reafon whereof they are cafily thaken out and feattered abroad.

2 Red Darnell is likewife an veprofitable corne or grafle, hauing leaues like barly. The joints of the ftraw or ftalke are fomerimes of a reddifh colour, bearing at the top a fmall and tender eare, fiat, and much in forme refembling the former.

$$
\text { Theplace. }
$$

They grow in fields among wheat and barley, of the corrupt and bad feed, as $G$ alen faith, efpecially in a moift and dankith foile.

$$
\text { 9ा The time. }
$$

They fpring and fourin with the corne, and in Auguft the feed is ripe.

$$
\text { T) The names. }
$$

I Darnell is called in Greeke, eipe: in the Arabian.Tongue, Zizania and Sceylen: In French, $\Upsilon_{\text {wray }}$ : in Italian, Loglio : in low Dutch, Zolick in Englifh, Darnell : of fome, Iutay, and Raye: and of fone of the Latines, Tritieum temulentum.

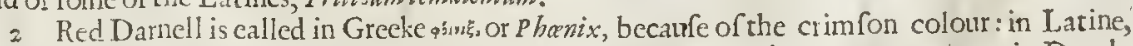
Lolium Rubrum, and Lolinm Muriwum : of fome, Horderm Murinum, and Triticum Murinum: in Dutch, 901upfe coten: in Englifh, Red Darnell, or great Darnell Grafle.

$$
\text { व) The temperature. }
$$

Danell is hot in the third degree, and dry in the fecond. Red Dannell drieth without fharpenefie, as Galer faith. 
- Thevertwes.

The feed of Damell, Pigenns dung, oile Oliue, and peuder of I.inefred, boiled to the forme of A a plaifter, confumewennes, hard lumpes, and fueh like excrefcenfes in any part of the body.

The new bread wherein Darnel is, eaten hot, caufeth drunkennelfe: ln like manner doth beere $B$ or ale wherein the feed is fallen, or put into the Malt

Damell taken with red wine ftayeth the fux of the belly, and the oternuch fowing of womens $\mathrm{C}$ termies.

Diofcorides faith, That Dancll meale doth fay and keepe backe eating fores, Gangrenes, and D putrified vleers; and being boyled with Radifh roots, lait, brimftone, and vineger, it eureth fpreading fcabs, and dangerous tetters, ealled in Greeke, noixns, and leprous or natighty fcurfe.

The feed of Durnell giuen in white or Rhenirh wine, prouoketh the flowers or menfes.

A fume made thereof with parehed barly meale, myrrh, faftron, and frankinfonee, made : E of a pulteffe, and app ied vpon the belly, heips coneeption, and caufeth eafie deliterance of ehild. bearing.

Red Darnell (as Diofiorideswriteth) being drunke in fowre or harth red Wine; ftoppeth the laske, and the ouermuch forwing of the flowers or menfes, and is a remedie for thofe that piffe in bed.

T The danger.

Darnell hurteth the eyes, and maketh them dim,if it happen in corne either for bread or drinke: which thing ouid in his firft booke Faftorsm hath mentioned, in this verfe:

Et careant lolys oculos vitiantibus agri.

And heretipon it feemeth that the old prouerbe came, That fuch as are dimme fighted fhould be faid, Lolio vidtitare.

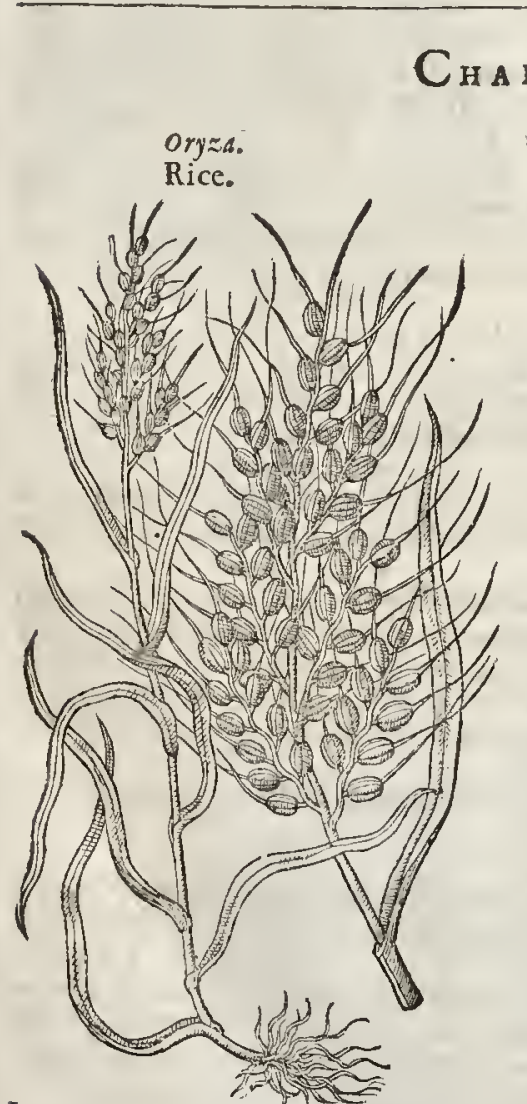

\section{Of Rice.}

\section{TI The defoription:}

D Ice is like vnto Darnell in thew, às Thcophra: ftus faith : it bringeth not forth an eare, like cone, but a certaine mane or plume, as Mil! or Millet, or rather like Panick. The leaues, as Pliny writeth, are fat and full of fubltanee, like to the blades of leeks, but broader: but(if neither the foile nor climate did alter the fame) the plants of Riee that did grow in my garden had leaues foft and graffie like barly. The floure did not thew it felfewith me, by reafon of the iniurie of our vnfeafonable yere 1 596. Theophraftus concludeth, that it hath a floure of a purple colour. But, faith my Author, Riec hath leaties like vnto Dogs graffe or Barley, a fmall ftraw or ftem full of ioynts like corne: at the top whereof groweth abufh or tuft farre inlike to barley or Darnell, gatnithed with round knobs like fmall goofeberries, wherein the feed or graine is contained : euery fuch round knob hach one fmall rougli aile, taile, or beard like vnto barley hanging thereat. Ariftobuliss, as Strabo reportetli, therveth, That Ricegrowes in water in Bactria, and neere Babylon, and is two yards high,and liath many eares, and bringeth forth plenty of feed. It is reaped at the ferting of the feucn ftarres, and purged as Spelt and Otenealc, or hulled as Freneh Barley.

$$
\text { T) Theplace. }
$$

It groweth in tise territories of the Bactrians, in It grometh in thofe dayes not onely in thofe combries, before named, but alfo in the fortunate Ifands, and in $S$ paine, from whence it is brought.vnto vs, puiged and prepared as twe fee, after the manner of French Barley. It prof pereth beit in fenny and waterith places,

$$
\begin{aligned}
& \mathrm{G}_{2} \\
& \text { बा? } \tau^{2}
\end{aligned}
$$


Thetime.

LI B. I.

The names.

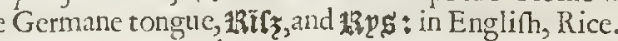

The temperature and vertses.

Geten faith, That all men vfe to flay the belly with this graine, being boiled after the fame maner that Chondrus is. In England we vfe to makewith milke and Ricc a certaine food or pottage, which doth both meanly binde the belly, and alfo nourith. Many other good kindes of food is made wirl this graine, as tliofe that are skilfull in cookerie can tcll.

It is cold in the firn degree, as Galen writeth, and dry in the third, or in tbe later end of the fecond, and is of a thinne fubftance.

T The vertues.

A The meale of Mill mixed with tarre is laid to the bitings of ferpents, and all venomous beafts.

B Tliere is a drinke made hercolbearing the name of Sirupres Ambrofij, or Ambrofe his fyrup, which procuretly freat, and quencheth thirt, vfed in the city of Milan in Tertian agues. The receit whereof Henricus Rastf somis in his booke of the gouernment of health ferteth downe in this manner: Take (faith he) of vnhusked Mill a fufficient quantitie, boile it till it be broken; then take fue ounces of the hot decoction, and adde theteto two ounces of the beft whitewine, and fo giuc it hot vnto the patient, being well couced with clothes, and then he will fweat throughly. This is likewife commended by Iohannes Heurneus, in his booke of Pratife.

C Millet parched, and fo put hot into a linnen bag, and applied, helpes the griping piines of the belly, or any other paine occifioned by cold.

Chap. 
L I B. I. Of the Hiftory of Plants.

Сан. бr. Of Turkie Corne.

I Frumentum Afraticum. Corne of Afia.

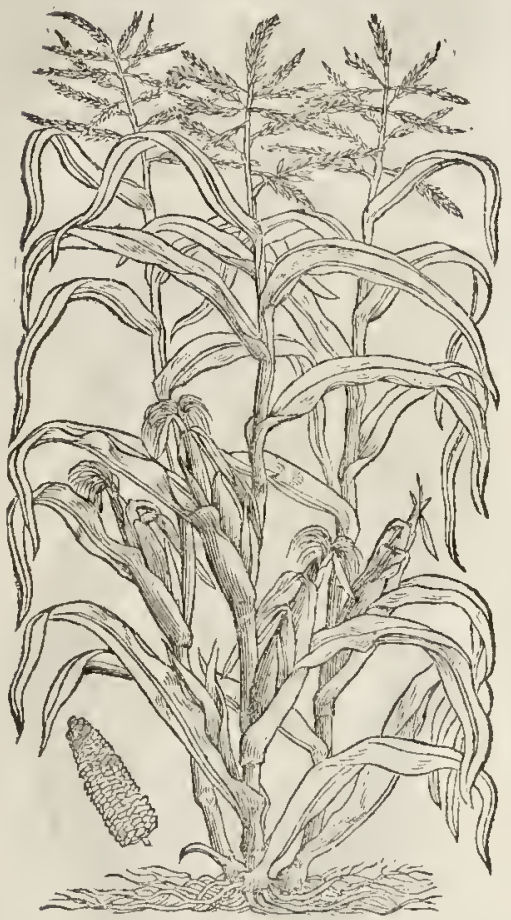

2 Frumestum Turcicum. Turikie Corne.

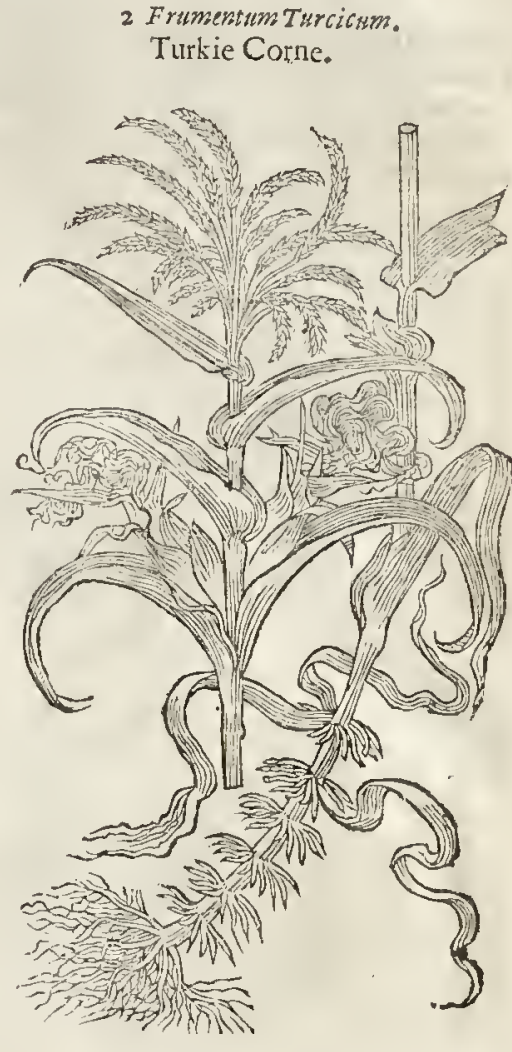

Tl The kindes.

F Turkie cornes there be dituers forts, notwithfeanding of one ftocke or kindred, confifting of fundry coloured graines, wherein the difference is eafie to be difeerned, and for the better explanation of the fame, I haue fet forth to your view certaine eares of different colours, in their full and perfeet ripeneffe, and fuch as they fhew themfelues to be when their skinne or filme doth open it felfe in the time of gathering.

The forme of the eares of Turky Whent.

3 Frumenti Indici fpica.

Turkiewheat in the huske, as alfo naked or bare:

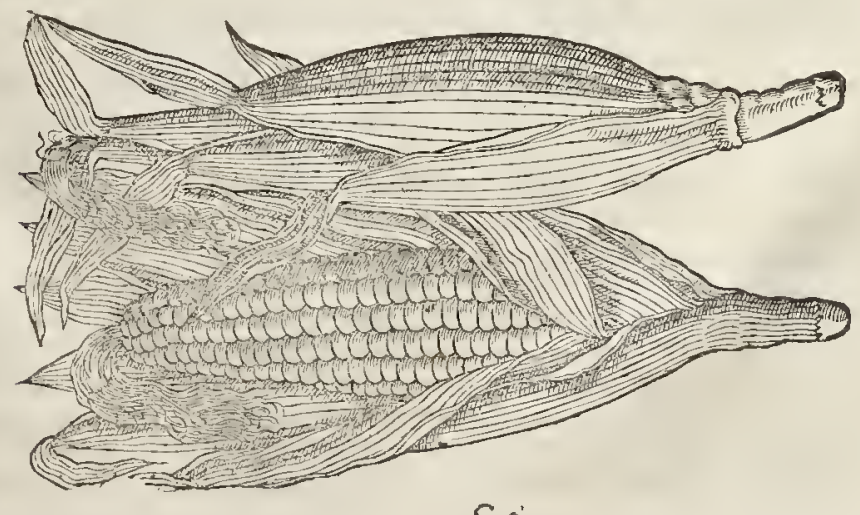

G 3 
$8 z \quad$ Of the Hiltorie of Plants.

T. The defcription.

I Orne of Afra bearcth a long great item or ftalke, couered with great leanes like the great Cane reed, but much broader, and of a darke brownifh colour tow ards the bottone: at the top of the ftalkes grow idle or barren tufts like the eommon Reed,fomtimes of one colour, and fomet imes of another. Thofe eares whieh are fruitfull do grow vpon the fides of the ftalkes, anmong the leaties, which are thicke and great, fo eouered with skins or filmes, that a man eannot fee them vntill ripeneffe haue difeouered them. The graine is of fundric eolours, fometines red, and fometimes whitc, and yellow, as my felfe haue feene in myne owne garden, where it hath eome to ripenefe.

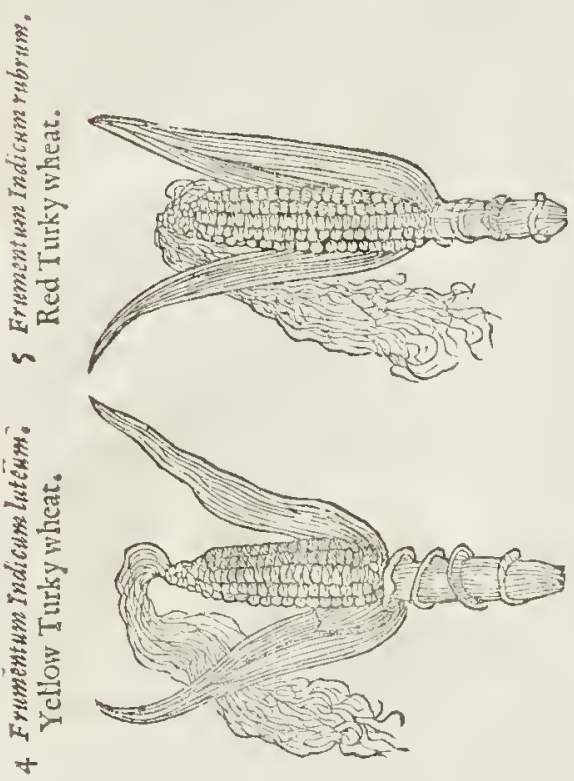

\section{Frumentums Indicum caruleum. Blew Turky wheat.}

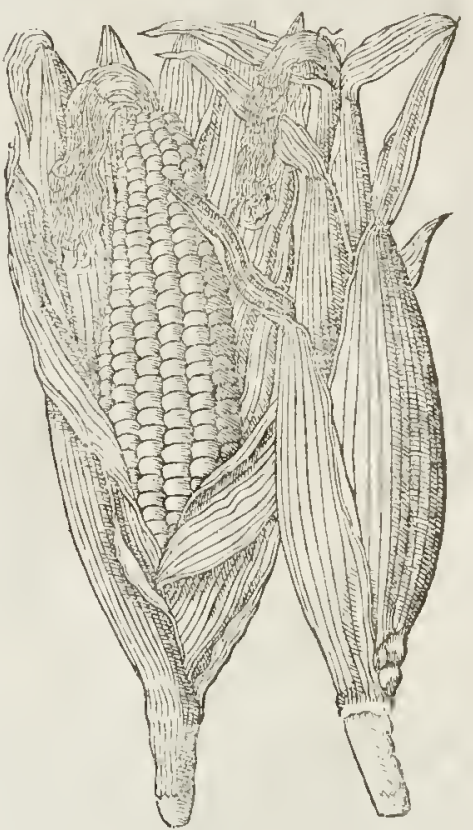

2 The ftalke of Turky Wheat is like that of the Reed, full of fpongie pith, fet with man ioynts, fue or fix foot high, bigge beneath,and now and then of a purple colour, and by little and little fimall aboue: the leaues are broad, long, fet with vaines like thofe of the Reed. The eares on the top of the ftalke be a fpanne long, like vito the feather top of the eommon Reed, diuided into many plumes hanging downw ard, empty and barren without feed, yet blooming as Rie doth. The floure is cither white, yellow, or purple, that is to fay, euen as the fruit will be. The Fruit is contained in very bigge eares, which grow out of the ioynts of the ftalke, three or foure from one ftalke, orderly placed one aboue another, conered with cotes or filmes like huskes and leates, as if it were a certaine fheath; out of which do ftand long and flender beards, foft and tender, like thofe laees that grow ipon Sauorie, but greater and longer, euery one faftned vpon his owne feed. The feeds are great, of the bigneffe of common peafon, connered in that part whereby they are faftned to the eare, and in the outward part round : being of colour fometimes white, now and then yellow, purple, or red; of tafte fiw ect.and pleafant, very elofely ioyned together in eight or tenne orders or rankes. This graine hath many roots, flong, and full of ftrings.

$$
\text { 4) Theplace. }
$$

Thefe kindes of grainewere firft brought into Spaine, and then into other prouinces of Elzrope : not (as tome fuppofe) out of Afia minor, which is the Turks Dominions, but out of Ameriea and the Inlands adinyning, as our of Florida and Virginia, or Norembega, where they vfe to fow or fet it, and to make bread of it, where it groweth mueh higher than in other countries. It is planted in the gardens of thefe Northerne regions, where it commeth to ripeneffe when the fommix falleth out to be faire and hot, as my felfe haue feene by proofe in myne owne garden. 
ef Thetime.

It is fowen in thefe countries in March and A priil, and the fruit is ripe in September.

$$
\text { T) The names. }
$$

t Turky wheat is called of fome Frumentum Turcicum, and Milium Indicum, as alfo $M$ ai ${ }^{2} u m$, and Maiz, or Mays. It in all probabilitie was vnknome to the antien both Greeke and Latine Authors. In Englifh it is called Turky corne, and Turky wheat. The Inhabitants of America and the Iflands adioyning, as alfo of the Eaft and Weft Indies, do call it Mais : the Virginians, Paga-
tom\%.

\section{T The temperature and wertucs.}

Turky whear doth nourith far leffe than either whear, rie, barley, or otes. The bread which is made thercof is meanly white, without bran : it is hard and dry as Bisket is, and harly in it no clarnmineffe at all, for which caufe it is of hard digeftion, and yeeldeth to the body littic or no nourilhment; it flowly defcendeth, and bindeth the belly, as that doth which is made of Mill or Panick. We haue as yet no certaine proofe or experience concennung the vertues of this kinde of Corne; although the barbarous Indians, which know no better, are conftrained to make a vertue of neceffitie, and thinke it a good food : whereas we may eafily iudge, that it nourifheth but little, and is of hard and euill digettion, a more conuenient food for fwine than for men.

\section{Cи а т. 62. Of Turkie Millet.}

Sorghum.

Turky Millet.

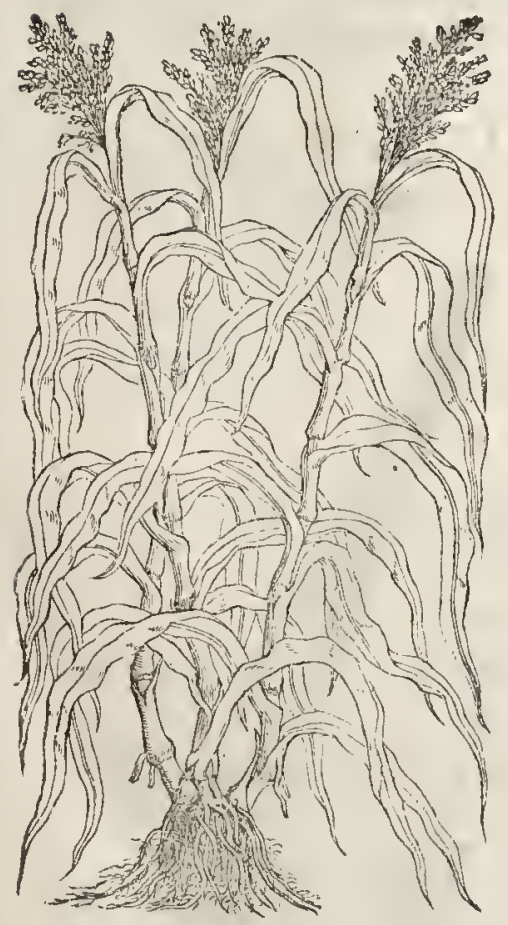

$$
\text { 9) The defcription. }
$$

$T$ Vrky Millet is a ftranger in England. It lath many high ftalkes, thicke, and jointed commonly with fome nine ioynts, befet wirh many long and broad leates like Turky Wheat: at the top whereof groweth a great and large tuft or eare like the great Reed. The feed is round and Tharpe pointed, of the bigneffe of a Lentill, fome. times red, and now and then of a fuller blacke colour. It is faftned with a multitude of ftrong flender roots like'vnto threds : the whole plant hath the forme of a Reed : the ftalkes and eares when the feed is ripe are red.

$$
\text { Tा The place. }
$$

It ioyeth in a fat and moift ground: it groweth in Italy, Spaine, and other hor regions.

$$
\text { I) The time. }
$$

This is one of the Sommer graines, and is ripe in Autumne.

$$
\text { T The nancs. }
$$

The Millanois and other people of Lombardy call it Melegua, and Melera : in Latine, Melica : in Hetruria, Saggina : in other places of Italy, Sorgho: in Portugal, Milium Saburrum : in Englifh, Tutky Mill, or Turky Hirfe.

$\ddagger$ This feemes to be the carilizm which was brought into Italy out of India, in the reigne of the Emperour Nero: the which is defcribed by Pliny, li6. I8.cap.7. $\neq$

$$
\text { T The temper ature and vertues. }
$$

The feed of Turky Mill is like vnto Panicke in tafte and temperature. The country Pcople fome-
ueth to fatten hens and pigeons with times make bread hereof, but it is bri
ucth to fatten hens and pigeons with. 
¥3 To thefe may be added another Weft-Indian Panicke, fent to Clufinus from M. Iames Ga. ret of London. The eare hereof was thicke, clofe, compact and made Taper-farhion, fmaller at the one end than at the other; the length thereof was more than a foor \& halfe. The fhape of the feed is much like the laft defcribed, but that many of them together are contained in one hairic huske, which is faftncd to a very fhort ftalkc, as you may fee reprefented apart by the fide of the figure $\neq$

4 Panicum vulgare:

Common or Gcrmanc Panicke.

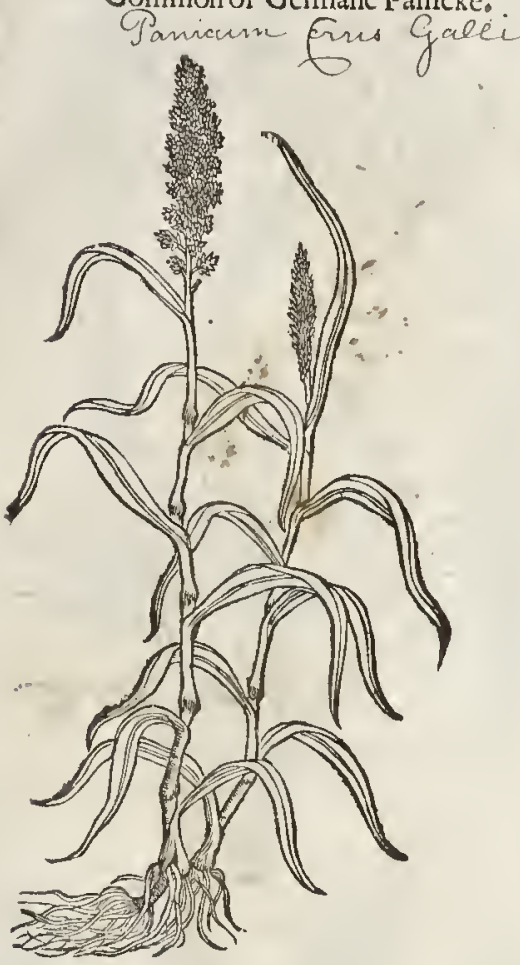

5 P.tnicum fylueftrè. Wild Panicke.

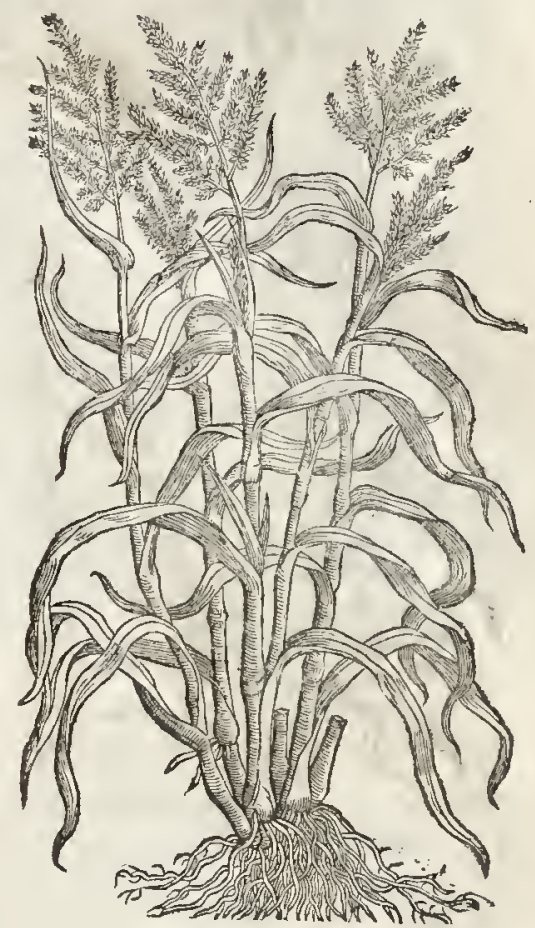

4 Germane Panicke hath many hairy roots growing thicke together like vnto wheat,as is all the reft of the plant, as well leaues or blades, as ftraw or falke. The eare groweth at the top fingle, not vnlike to Indian Panicke, but much leffer. The graines are contained in chaffie feales, red declining to tawny. ":

5 The wilde Panicke groweth vp with long reeden ftalkes, full of ioynts, fet with long leaues like thofe of Sorghum, or Indian Panicke : the tuft or feather-like top is like vnto the common reed, or the eare of the graffe called Ifchemon, or Manna graffe. The root is fmall and threddy.

$$
\text { T) The place and time. }
$$

The kindes of Panick are fowen in the Spring, and are ripe in the beginning of Augurt. They profper beft in hot and dry Regions, and wither for the moftpart with much watering, as doth Mif and Turky wheat : they quickly come to ripeneffe, and may be kept good a long time.

- Panick is called in Greeke thous, and whention Diocles the Phyfition nameth it Mel Frugum : the Spaniards, Paniz 0 : the Latines, P aricum, of Pannicula : in Englin, Indian Panicke, or Otemeale.

Panicks nourith little, and aredricts, as Galen faith.

$$
\text { of The temperature. }
$$

$$
\text { The vertues. }
$$

Panicke ftoppeth the laske, as Millet doth, being boyled (as pliny reporteth) in Goats milke, and drunke trice in a day. Outwardly in Pulteffes or otherwife, it dries and cooles.

Bread made of Panick nourifheth little, and is cold and dry, very brittle, hauing in it neither clammineffe nor fatneffe; and therefore it dricth a moift belly. 


\title{
С н в.64. Of Canary Jeed, or Pety Panicke.
}

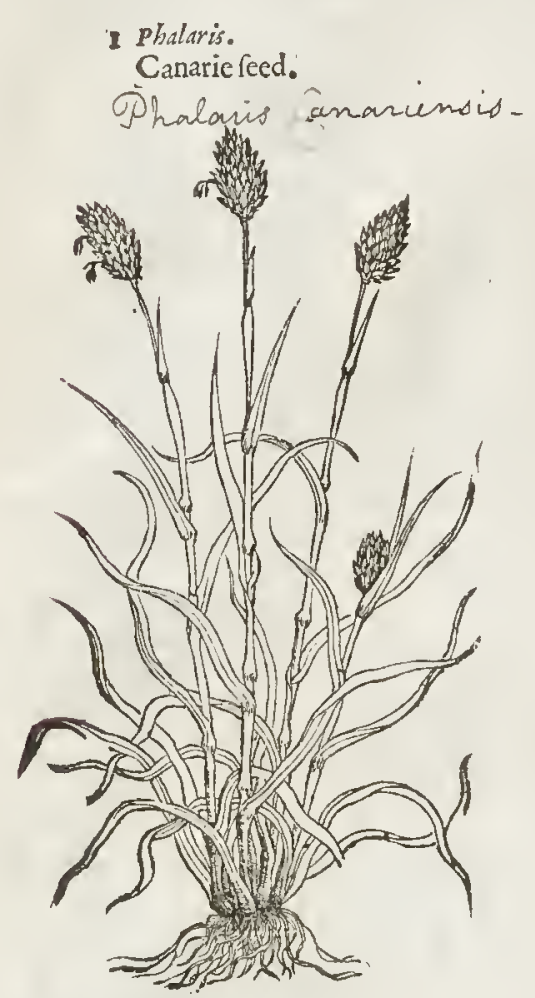

\author{
2 Phalaris pratenfis. \\ Quaking grafle. \\ Briza media
}

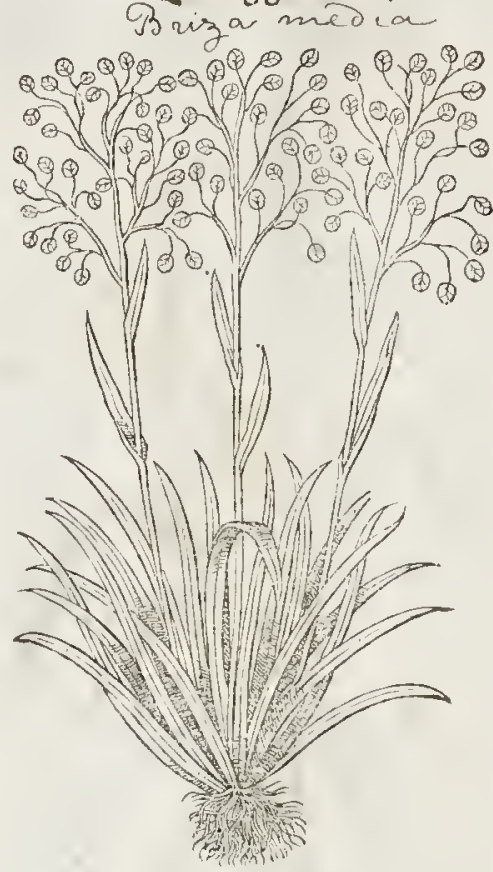

The defcription.

I Anarie feed, or Canarie grafle after fome, hath many fmall hairy roots, from which arife fmall frawie ftalkes ioynted like corne, whereupon do grow leaues like thofe of Barley, which the whole plant doth very well refemble. The fnall chaffic eare groweth at the top of rhe ftalke, wherein is contained fmall feeds like thofe of Panicke, of a yellowith colour, and fhining.

2 Shakers, or Quaking Graffe groweth to the height of halfe a foot, and fometimes higher, when it growerh in fertile medowes. The ftalke is very fmall and benty, fec with many grafle leaues like the common medow graffe, bearing at the topa buth or tuft of flat faly pouches, like thofe of Shepheards purfe, but thicket, of a browne colour, fet vpon the inoft fmall and weake hairy foot falkes thar may be found, whereupon thofe fmall pouches do hang : by meanes of which fnall hairy ftrings, the knaps which are the foures do continually tremble and thake, in fuch fort rhat is is not poffiblewith the moft fedfaft hand to hold ic from fhaking.

$\ddagger 3$ There is alfo another Graffie plant which may fitly be referred to thefe: the leaues and ftalkes refemble rhe lafteferibed, but the heads areabour the length and bredth of a fmall Hop, and hand fomely compact of light fcaly filmes much lite thereto; whence fome hate termed it Gramen Lupuli glumus. The colour of rhis pretty head when it commerh roripeneffe is white. $\ddagger$

$$
\text { If The place. }
$$

I Canarie feed groweth naturally in Spaine, and alfo in the Fortunate or Canary Iflands, and dorh grow in England or any other of thefe cold Regions, if it be fowen rherein. 
3 Phalaris pratenfis aliera. Pearle Graffe:

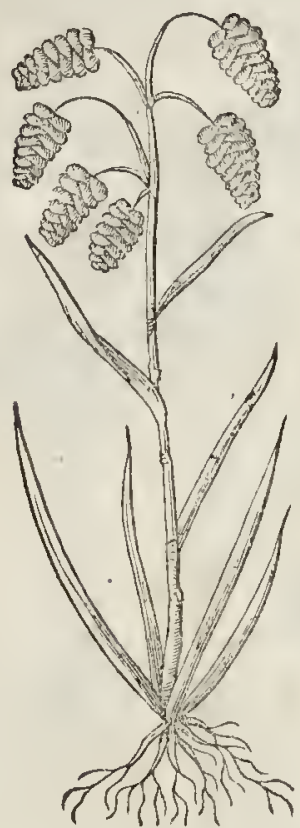

Vlopecuros:

Fox-taile.

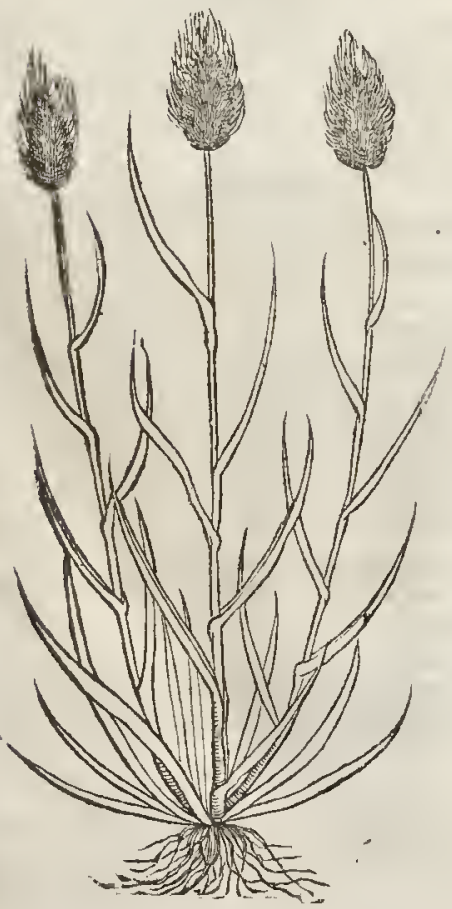

2 Quaking Phaldris groweth in fertile paftures, and in dry medowes.

3. This growes naturally in fome parts of Spaine, and it is fowen yearely in many of our London Gardens.

$$
\text { 9 Thetime. }
$$

I 3 Thefe Canarie feeds are fowen in May, and are tipe in Augurt.

$$
\text { 9) The names: }
$$

I Canary feed, or Canaric eorne is ealled of the Greeians, कaxaes: the Latines retaining the fame name Phalaris : in the Inlands of Canarie, Alpiffi: in Englin, Cana rie feed, and Canary graffe.

2 Phalaris pratcnis is called alfo Gramen tremulum in Chefhire about Nantwich, Q rakers and Shalers : is forme places, Cow-quakes.

3 This by fome is termed Phelaris alterd: Clufius calleth it Gramen Amourettes majus : Baubine, Gramentre. mulum maximsm: In Englifh they call it Pearle-Graffe; and Garden-Q: aakers.

$$
\text { T Thenature and vertues. }
$$

I finde not any thing fet downe as touching the rcmperatute of $P$ halaris, notwithitanding it is thought ro be of the nature of Millet.

The inyce and feed, as Gulen faith, are thought to be ptofitably drunke againt the paines of rhe bladder: Apothecaries for want of Millet doe vfe the fame with good fucceffe in fomentations ; for in dry fomentations it ferueth in ftead thereof, and is his fuccodancum, or quid proquo. We vee it in England alfo to feed the Canarie Bitds.

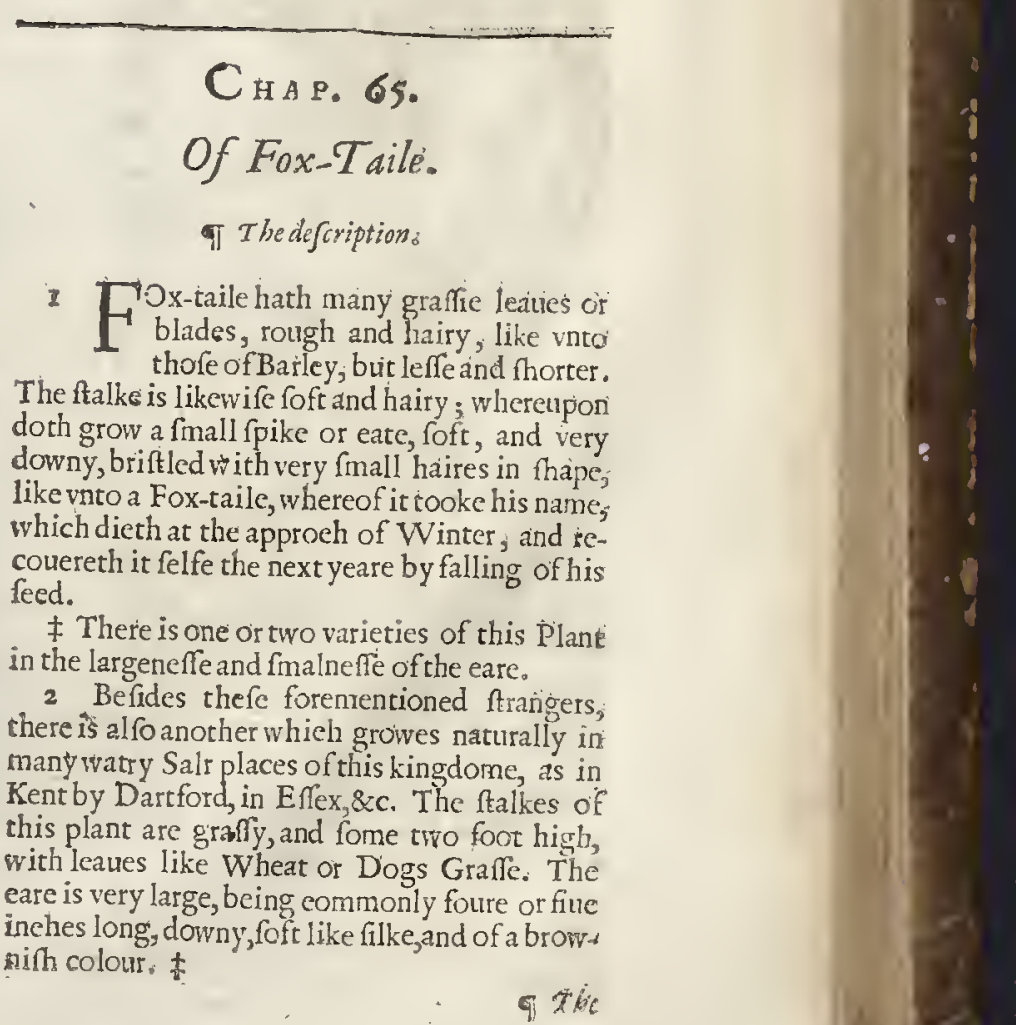




\section{T) The place.}

I This kinde of Fox-taile Grafle groweth in England, onely in gardens.

$$
\text { 9 The time. }
$$

I This fpringeth vp in May, of the feed that was featered the yere before, and beareth his taile with his feed in Iune.

2 This beares his head in Iuly.

ब. Thenames.

I There hath notbene more faid of the antient or later writers, as touching the name, than is fet downe, by which they called it in Greeke Alopecuros; that is in Latine, Candarn/pis : in En glifh, Fox-taile.

2 This by Lobdl is called Alopecuros abtera maxima Anglicapalsdofa; that is, The large Englin Marih Fox-taile.

$$
\text { of Thetcmperature and vertues. }
$$

I finde not any thing extant worthy the memorie, either of his nature or vertues.

\section{С на. 66. Of Jobs Teares.}

Lachrime Iob.

Iobs Teares.

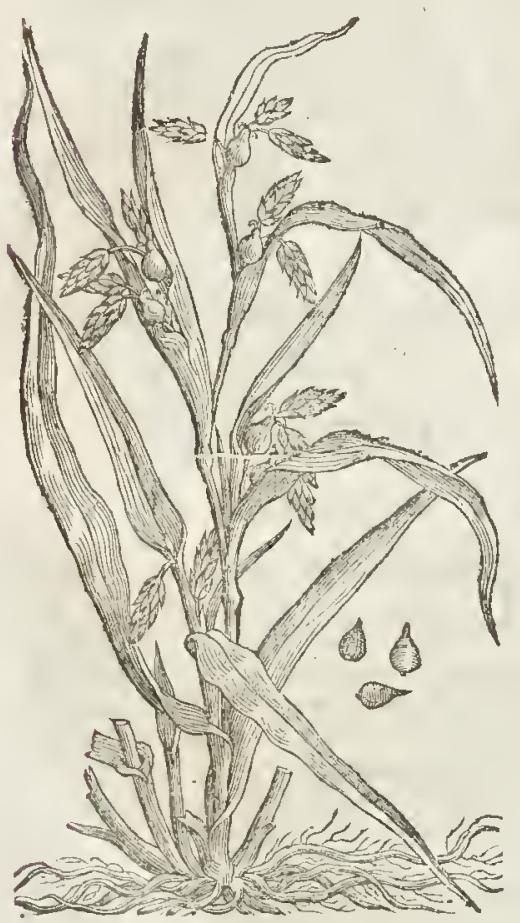

$$
\text { of The defeription. }
$$

Tobs Teares hath many knotty falks, proceeding 1 from a tuft of threddy roots, two foot high, fet with greatbread leaues like vnto thofe of reed, amongft which lcaues come forth many fmall branches like ftraw of cone : on the and whercof doth grow a gray thining feed or graine hard to breake, and like in thape to the feeds of Gromell, but greater, and of the fame colour, whereof I ho!d t a kinwe : enery of which grains are bored through the middentike bead, and out of the hole commeth a fmall idlc or barren chaffic care like vnto that of Dirnell.

$$
\text { T) The place. }
$$

It is brouglt from Italy and the countries adjoynins, into thefe comntrics, where it doth grow very wel!, bur fi-ldome commeth to ripeneffe; yet my felfe had ripe feed thereof in my garden, the Sommer being very hot.

$$
\text { iा Thetime: }
$$

It is fowen early in the Spring, or elfe thew intervill outertake it before it come to ripeneffe.

$$
\text { का The names. }
$$

Diucrs hauc thought it to be Lithoffermi fpecies, or a kinde of Gromell, which the feed doth very notably refemble, and cioth not much differ from Diofcorides his Gromell. Some thinke it Plinies Lithopermum, and therefore it may verie aptly be called in Latine, A indo Lithopermos, that is in Englifh, Gromell reed, as Gefner faith. It is generally called Lechrem iob, and Lachrima Iobi : of fome it is called Diopiros : in Englifh it is called lobs Teares, or 7obs Drops, for thateucry graine refembleth the drop or teare that falleth from the eye.

TI Thenature and veriues.

There is nomention made of this herbe for the vfe of phyficke : onely in France and thofe places (where it is plentifully growing) they do make beads, bracelets, and chaines thereof, as we do with pomander and fuch like. 


\begin{tabular}{lll}
\hline LI B. I. & Of the Hiftory of Plants. & ${ }^{3}$ \\
\hline
\end{tabular}

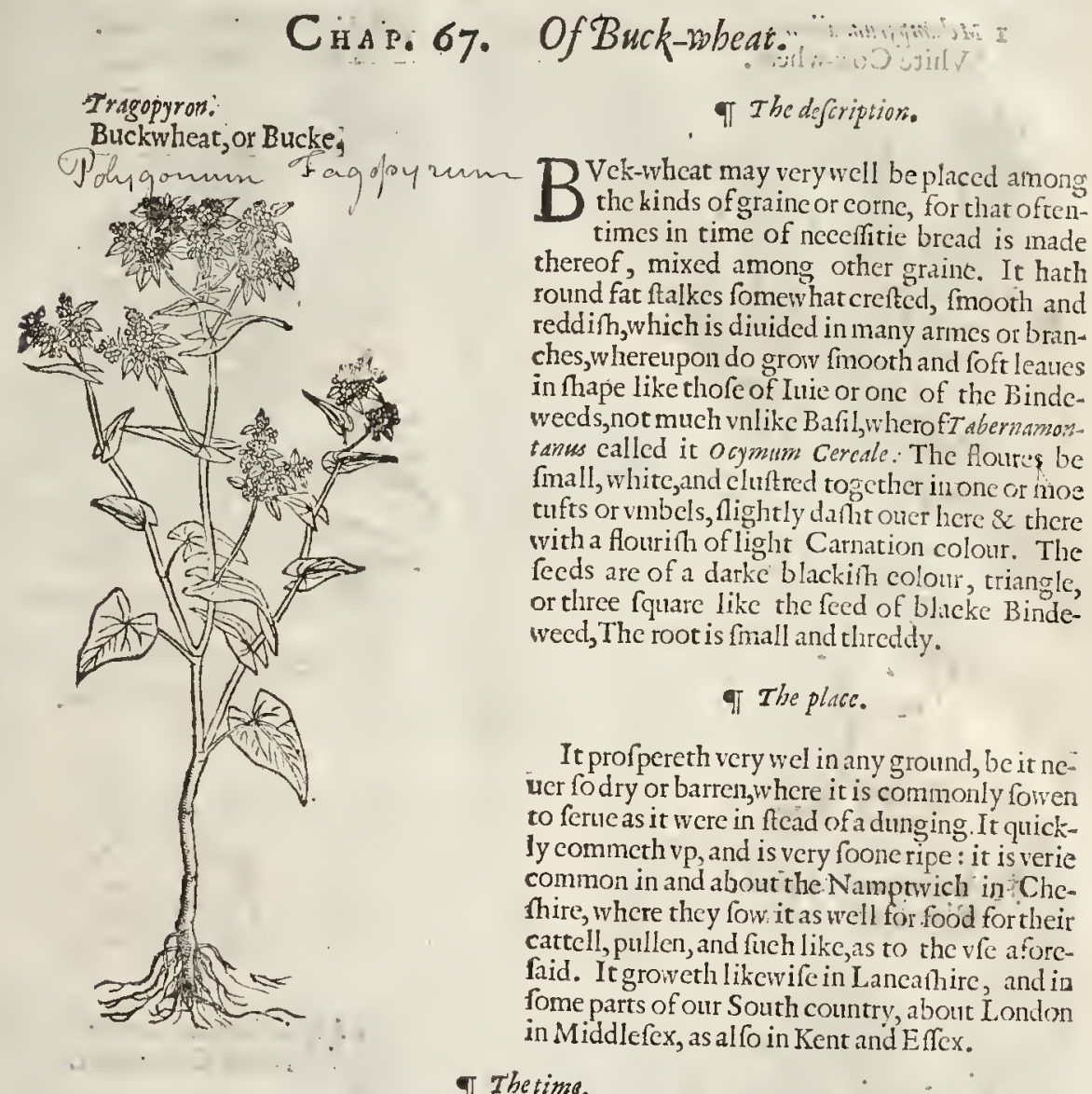

This bafe kinde of graine is fowen in Aprill and the beginning of May, and is ripe in the beginning of Auguft.

$$
\text { \T The names. }
$$

Buck-wheat is called of the high Alnaines, Hepdencoun : of the bafe Almaines, Buctict toneiot; that is to fay, Hircitriticum, or Goats wheat : of fome, Fugi triticum, Bech Wheat: In

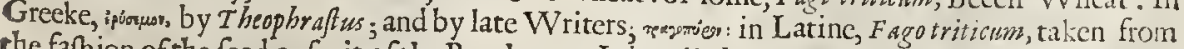
the fanhion of the feed or fruit of the Beceh tree. It is called alfo Fegopyrum, and Tragopyron: In Englirh, French wheat, Bullimong, and Buck-wheat; In French, Dragee aux cheucuru:

$$
\text { If The temper. }
$$

Buck-wheat nourifheth lefie than Wheat, Ric, Barley, or Otes; yct more thun either Mill or
Panicke. Panicke.

$$
\text { I) Therertucs. }
$$

Bread made of the meale of Buck-wheat is of eafie digention, and fpecdily paffeth through the belly, but yeeldeth little nourifhment. 


\section{Chas. 68. Of ConWheat.}

Melampyrum album. White Cow-wheat:

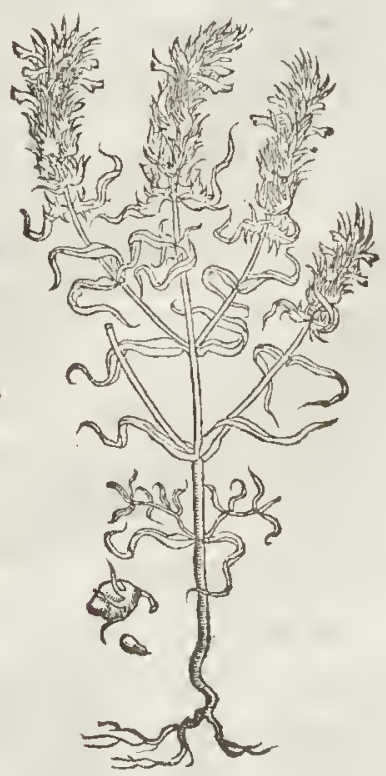

3 Melampyrums ceruleum? Blew Cow-whear.

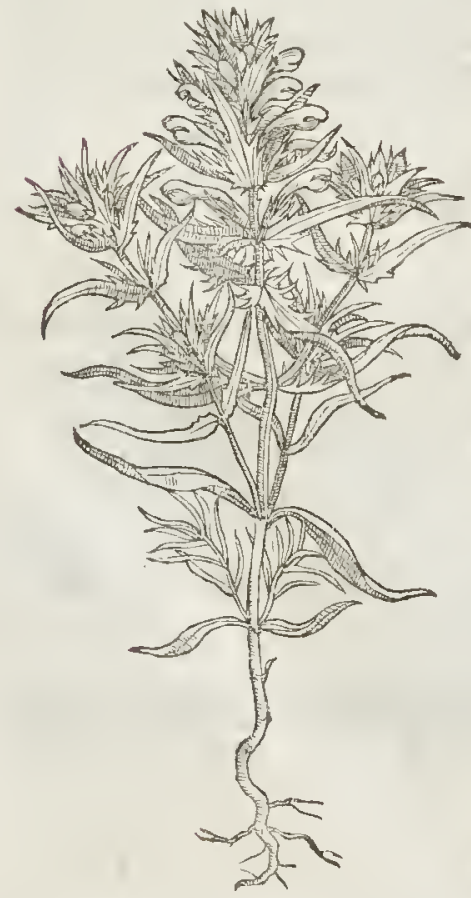

2 Melampyrum purpureum? Purple Cow-whear.

inclampusum arvense

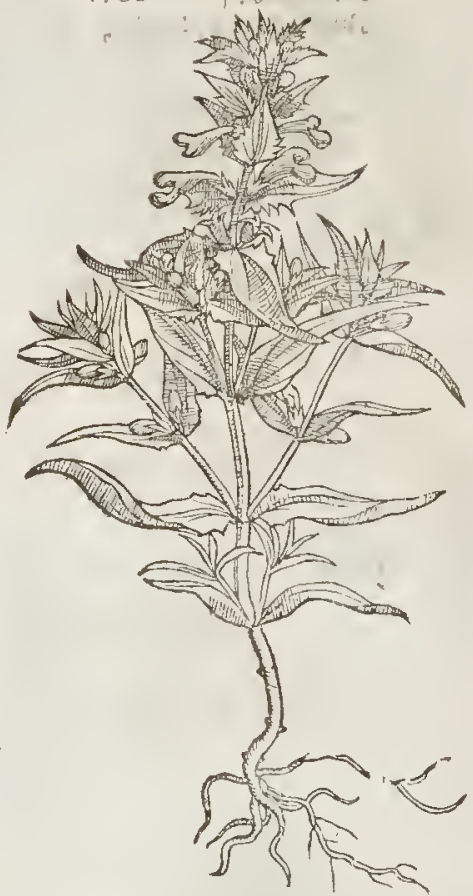

7 Melampyrzm luteum: Yellow Cow-wheat.

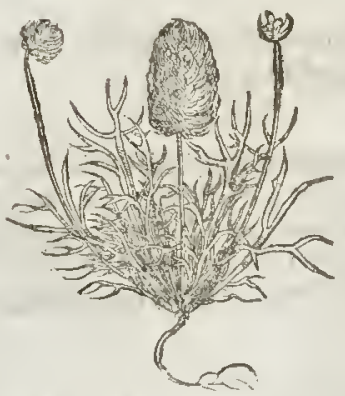

Thedefcription.

is 
eare beginncth to foure below, and fo ypward by little and little vnto the top: the friall leates before the opening of the floures, and likewife the buds of the floures, are white of colour. Then come vp broad husks, wherein are enelofed two feeds fomewhat like wheat, but fmaller and browner. The root is of a woody fubftance.

$\$ 23$ Thefe two are like the former in ftalkes and leates, but different in the colour of their floures, the which in theione are purple, and in the other blew. Clufius calls thefe, asiallo the Crat teogigonon treated of in the next Chapter, by the names of Parietaric fylveftres. $\neq$

4 Of thiskinde there is another ealled exclampyrum luteum, whiel growcth neere vnto the ground, with leaues not mich vnlike Harts horne, among whilel rifeth vp a fmall ftraw with an eare at the top like Alopecuros, the common Fox-taile, but of a yellow colour.

$$
\text { Tा The place. }
$$

I The firf groweth among corne, and in pafture ground that be fruitfull : it groweth plentifully in the paltures about London.

The reft are ftrangers in England.

They floure in Iune and Iuly.

$$
\begin{aligned}
& \text { I Thetime. } \\
& \text { T Thenames. }
\end{aligned}
$$

Melampyrum is called of fome Triticum vaccinium : in Englin. Cow-wheat, and Horfe-foure: in Greeke, minaptoen: The fourth is called Melampyrum luteum : in Englifh, Yellow Cow-wheat.

The feed of Cow Wheat raifeth vp fumes, and is hot and dry of nature, which being taken in meats and drinks in the manner of Darnell, troubleth the braine, cauling drunkenneffe and headache.

\section{Of Wilde Cow-Wheat.}

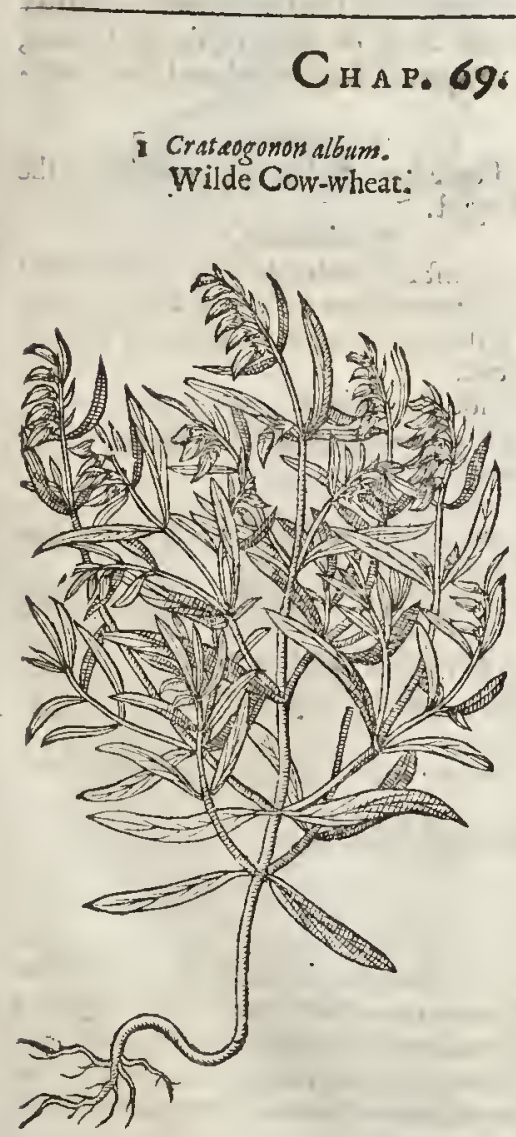

\section{T) The defcription.}

17 He firft kinde of wilde Cow-Wheat Clasfius in his Pannonick hiftory ealls Parietariafylueftris, orwilde Pellito. rie: which name, aceording to his owne words, if it do not fitly anfwer the Plant, hee knoweth not what to eal it, for that the Latines haue not given any name thereunto: yet becaufe fome haue fo called it, he retaineth the fame name. Notwithftanding he referreth it vnto the kindes of $u$ elam. pyrum, or Cow-wheat, or vnto Crataogonon, the wilde Cow-wheat, which it doth very wel anfwer in diuers points. It hath an hairy foure fquare ftalke, very tender, weake, and eafie to breake, not able to ftand vpright without the helpe of his neighbours that dwell abouthim, a foot high or more; whereupon do grow long thin leates, tharp pointed, and oftentimes lightly fnipt about the edges, of a darke purplifh eolour, fometimes greenifh, fet by couples one oppofite againit the other; among the which eome forth two floures at one ioynt, long and hollow, fomewhat gaping like the fioures of a dead netrle, at the firit of a pale yellow, and after of a bright golden colour; which do foure by degrees, firit a few, and then more, by meanes whereof it is long in flouring. Whichbeing pat, there fuceed fimall eups or feed veffels, wherein is contained browne feed not vnlike to wheat. The whole plant is hairy, not dif-

2 Red leafed wilde Cow-wheat is like vnto the former, fauing that the leatres be narrower, and the tuft of leaues more iagged. The ftalkes and leaues are of a reddifh horfe-fleth colour. The 
floures in forme are like the othet, but in eolour differing; for that the hollow part of the floure with the heele or fpurre is of a purple eolour, the reft of the floure yellow. The feed and veffels are like the precedent.

3 Crateogonon Euphrofine.

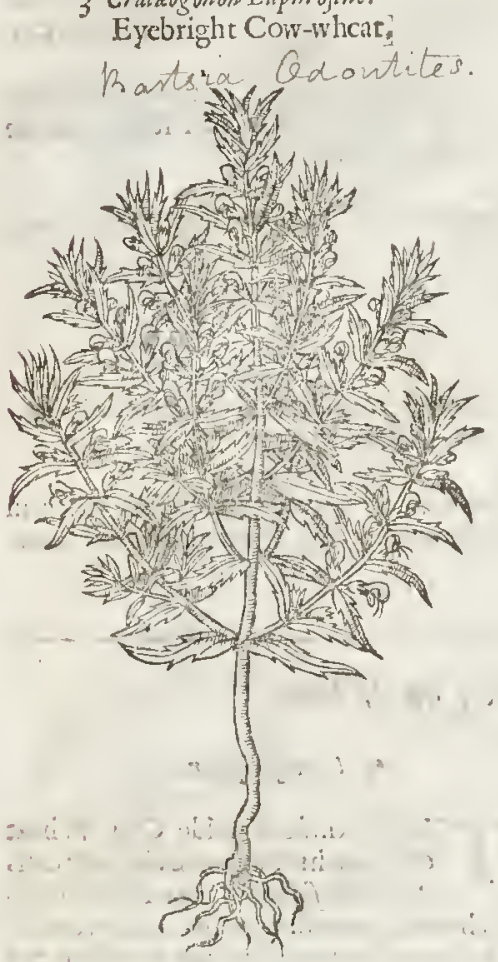

\section{-I The defcription.}

3 This kinde of wilde Cow-wheat Tabernamontamus hath fet forth vinder the title of odontites · others hatle taken it to be a kinde of Enphrge fin or Eyebright, beeaufe it doth in fone fort refermble it, efpecially in his toures. The ftalks of this plant are fnall, woody, rough, and fqure. The leaurs sare indented ibout the edges, tharpe pointed, and in moft points refenbling the former Cow-wheat ; fo that of necerfitie it muft be of the fame kinde, and not a kinde of Eyebright, as hath beene fet downe by fome. -

$$
\text { T. The place. }
$$

The fe wilde kindes of Cowv-wheat doe grow commonly in fertile parfures, and buthy Copfes, or low woods, and among bufhes tpon barren heaths and fuch like places.

The two firt doe grow vpon Hampted heath necre London, among the Iuniper bufhes and bilberry buthes in all the parts of the faid heath, and in eucty part of England where I haue trauclled.

$$
\text { बा The time. }
$$

They floure from the beginning of May, to the end of Augute.

$$
\text { Tlienames. }
$$

I The firt is ealled of Lobclius, Crateogonon: and of Tabernamout anus, Milium Syluaticum, or "Wood Millet, and Alfine fyluatica, or WoodChiekweed.

2 The fecond hath the fame titles: in Englin, Wilde Cow-wheat.

3 The lat is ealled by $\tau$ abernamontanus, Odonutes : of Dodonaus, Euphrafia altera, and Euplurofio ne. Hippocrates called the wilde Cow-wheat, Polycarpum, and Polycritum.

$$
\text { T T benature and veriues. }
$$

There is not much fet downe either of the nature or vertues of thefe plants : onely it is reported that the feeds do caufe giddineffe and drunkenneffe as Darnell doth.

The feed of Crat sog on on made in fine pouder,and ginen in broth or otherwife, mightily prouloketh Veneric.

Some write, that it will likewife caufe women to bring forth male children.

+ Seethe vertues attributed to Crat rogonon by Diofcorides beforc, Chap. $38 . B$.

\section{С н г. 70. Of White A $\mathrm{pl}$ bodill. \\ T The kindes.}

Tuting finifhed thekindes of corne, it followeth to fhew vnto you the fundry forts of Afpho1 dils, whereof fome hauc bulbous roots, other tuberous or knobby toots, fome of yellow colour, and fome of mixt eolours:notwithit anding Diofcorides maketh mention but of one Afphodill, but Pliny festeth downe two; which $D$ ionyfius confirmeth, faying, That there is the male and fenale Afphodil. The latter age hath obferued many more befides the bulbedone, of which $G a$ len maketh mention. 


\section{1 B. I. Of the Hiftory of Plants:}

I. Aphodelus non ramofus? White Afphodill.

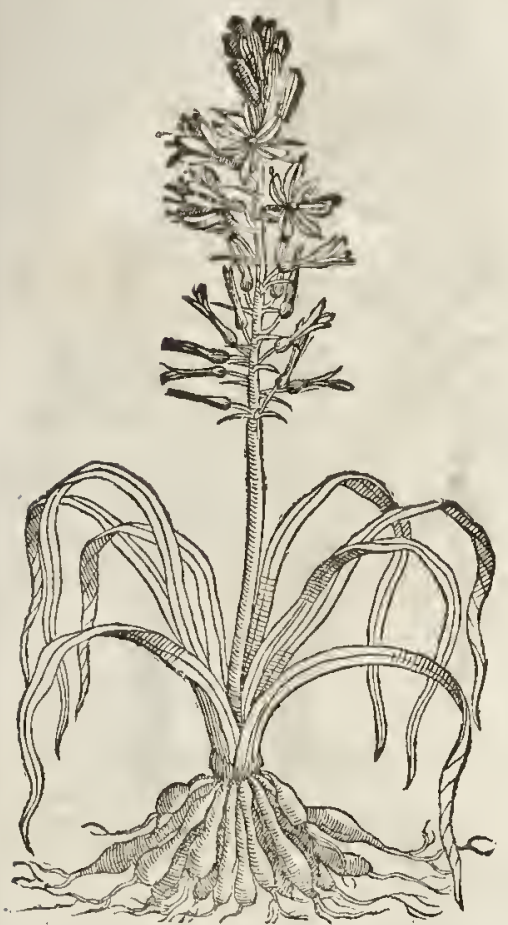

2 Aphodelus ramofes. Branched Afphodill.

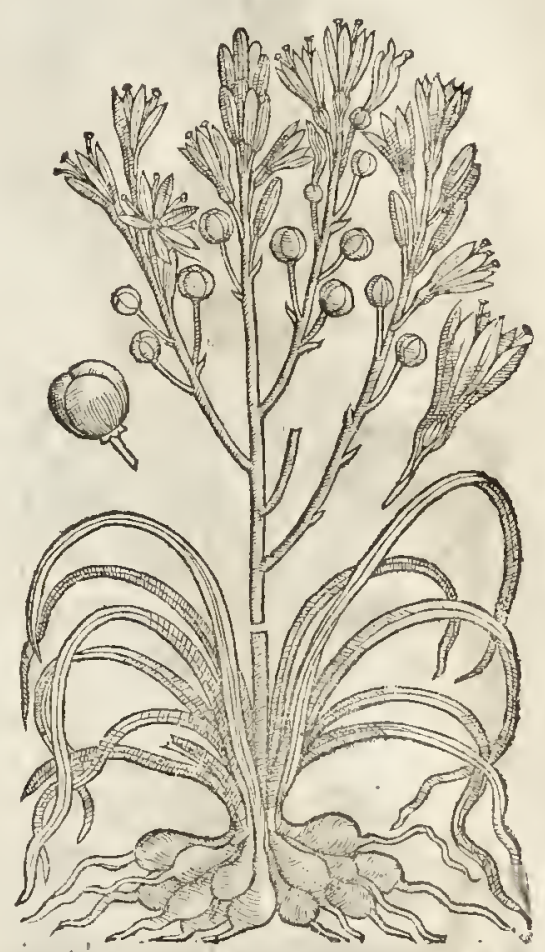

II The defcription.

THewhite Afphodill hath many long and narrow leaues like thofe of lecks, tharpe pointed. The ftalke is round, fmooth, nakcd, and withour leaues, two cubits high, garnifhed from the middle vpward with a number of Hourcs ftarre-farhion, made of fiuc leaues apiece; the colour white, with fome darke purplc freakes drawne downe the backe-fide. Wirhin the foures be certaine finall chines. The floures being paft, there fpring vp little round heads, wherein are contained hard, blacke, and 3 fquare feeds like thofc of Buck-wheat or Staucf-acre. The toot is compact of many knobby roots growing out of one head, like thofc of the Peonic, full of juyce, witha fmall bitterneffe and binding tafte.

2 Branched Afphodill agreeth well with the former defeription, fauing that this hath many branches or armes growing our of the ftalke, whereon the floures do grow, and the orher hath not any branch at all, wherein confifteth the difference.

3 A phodill with the reddifh foure groweth vp in roots, ftalkc, leafe, and manner of growing like the precedent, fauing that the floures of this be of a dark red color, \& the others white,which ferteth forth the difference, if therc be any fuch difference, or any fuch plant at all : for I haue conferred with many moft excellcnt men in the knowledge of plants, but none of them can giuc mee certaine knowledge of any fuch, but tell me they haue heard it rcported that fuch a onc there is, and fo haue I alfo; but certainly I cannot fet downe any thing of this plant vntill $I$ hearc more certaintie for as yct I gitte nocred it to my Authour, which for reuercnee of his perfon I forbeare
to name.

4 The yellow Afphodill hath many roots growing out of onc head, made of fundry tough; fat, and olcous yellow forigs, or groffe ftrings, from the which rife vp many graffy leates, thick and groffe, tending to fquarenefe; among the which commerh vp a frong thicke falke fet with the like lcaues enen to the floures, but leffe: vpon the which do grow ftarre-like yellow flotres, otherwife like the white Afphodill. 


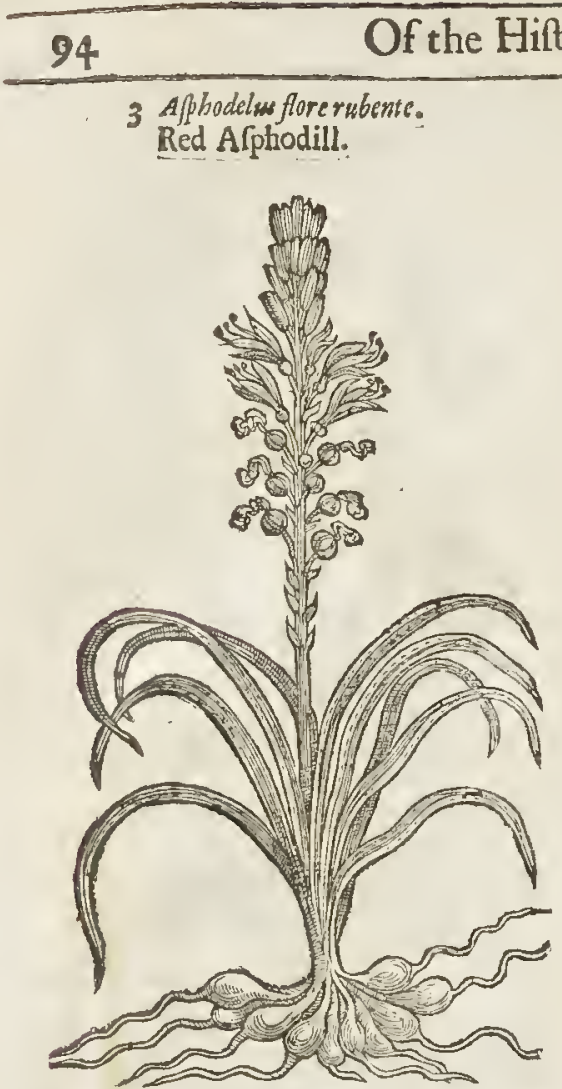

* A Aphodetus minimus. Dwarfe Afphodil:

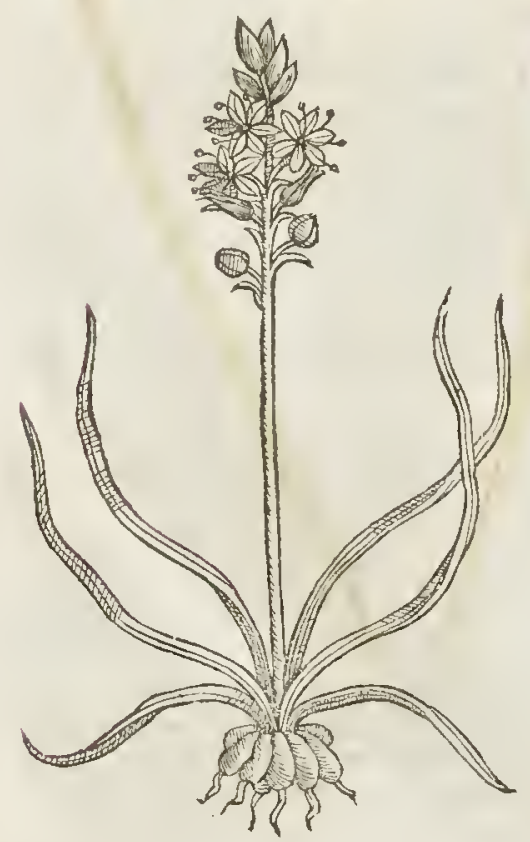

4 Aphodelus lutews.

Yellow Afphotill.

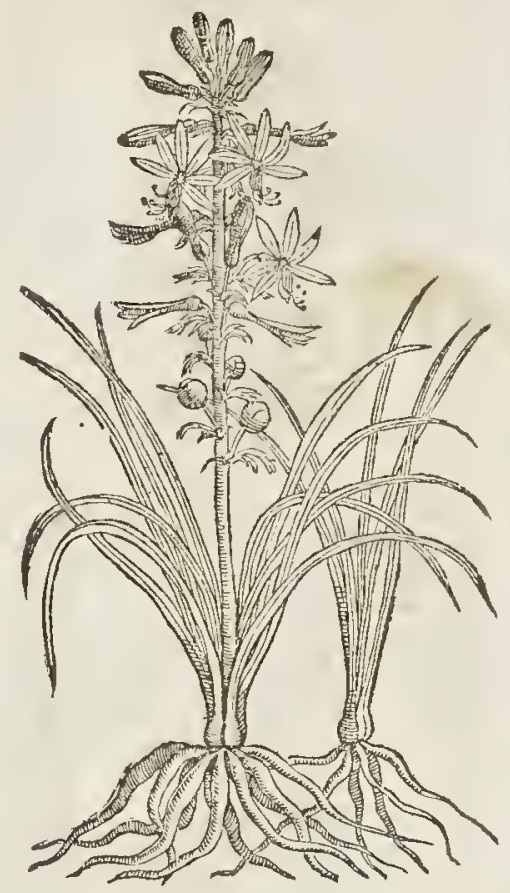

\# Befides thefe there is an Arphodill which clufus for the fmalneffe calls Apblodelus minimus. The roots thereof are knotty and tuberous, refembling thofe of the formerly defcribed, but leffe: from thefe arife fuse or fixe very narrow and long leaties; in the middeft of which growes ip a ftalk of the height of a fort, round and without branehes, bearing at the top thereof a fpoke of floures, eonfinting of fix white leaues a piece,each of which hath a ftreake running a longtt it, botl on the infide and out fide, like as the firft defcribed. It floures in the beginning of Iuly, when as the reft are paft their floures. It lofeth the leaues in Winter,and gets new ones againe in the beginning of Aprill. $\ddagger$

$$
\text { oा Thrtime andplace. }
$$

They floure in May and Iune, beginning below, and fo touring vpward: and they grow naturally in France, Italy, Spaine, and moft of them in our London Gardens.

$$
\text { Ti I be names. }
$$

Afphodill is ealled in Latine, Aphodelus, Albucum, albucus, and Hastula Regia. in Greeke, eopsidar: in Englifh, A fphodill, not Daffodil, for Daffodill is Narciffus, another plant differing from Afphodill. Pliny writeth, That the Atalke with the floures is called Anthericos; and the root, that is to fay, the bulbs Appodelus. 
Of this A f phodill Hefrot maketlimention in his Works, where he fath, thar fooles triow not bow much good there is in the Mallow and in the Aplio till, becaufe the roots of Afphodill are good to be eaten. Yer Galendoth not beleete that he meant of this 1 fphodill, but of that bulbed one, whereof we will make nention hereafer. And he himfelfe teftifieth, that the buibes thereof are nor to be caten w ithout very long feething; and therefore it is not lite that Hefrod hath commended any fuch : for he feemeth to underitand by the Mallow and the Afphodil, fuch kinde of food as is cafily prepared,and foone madeready.

$$
\text { -i The nature. }
$$

Thefekindes of $A$ fphodils be hot and dry almoft in the third degree.

$$
\text { 9 Tlevertues. }
$$

After the opinion of Diofcorides and Actius, the roots of Afphodill caten,prouoke vrine and the $A$ termes effertually, efpecially being famped and frained withwine, and drunke.

One dram thereof taken in wine in manner before rehearfed, helpeth the paine in the fides, rup- B tures, convulfions, and the old cough.

The roots boiled in dregs of wine cure foule earing vlcers, all inflammarions of the dugges or $C$ ftones, and caferli the felon, being put thereto as a pulteffe.

The inyce of the root boyled in old fwect Wine, together with a little myrrh and faffron, ma- D keth an excellent Collyric profitable for the eyes.

Galen faith, the roots burnt to athes, and mixed with the greafe of a ducke, helpeth the Alopecis, $\mathrm{E}$ and bringetl haite againe that was fallen by that difeafe.

The weight of a dram thereof taken with wine helpeth the drawing together of finews,cramps, F and burftings,

The like quantitie taken in broth prowoketh vomit,and helpeth thofe that are bitten with any $G$ venomous beafts.

The iuyce of the root cleanfeth and taketh away the white morphew, if the face be annointed $H$ therewith; but firft the place mult be chafed and wel rubbed with a courfe linnen cloath.

\section{$\mathrm{C}_{\text {H A P. 7r. Of the Kings Speare. }}$}

I Aphodelus luteus minor. The Kings Speare?

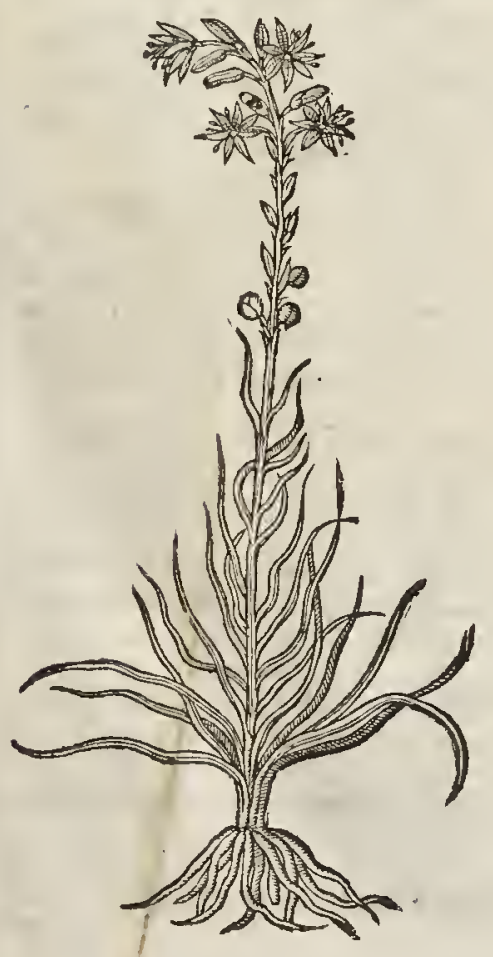

2. Aphodelus Lancaftrie.Lancafhire Afphedil!

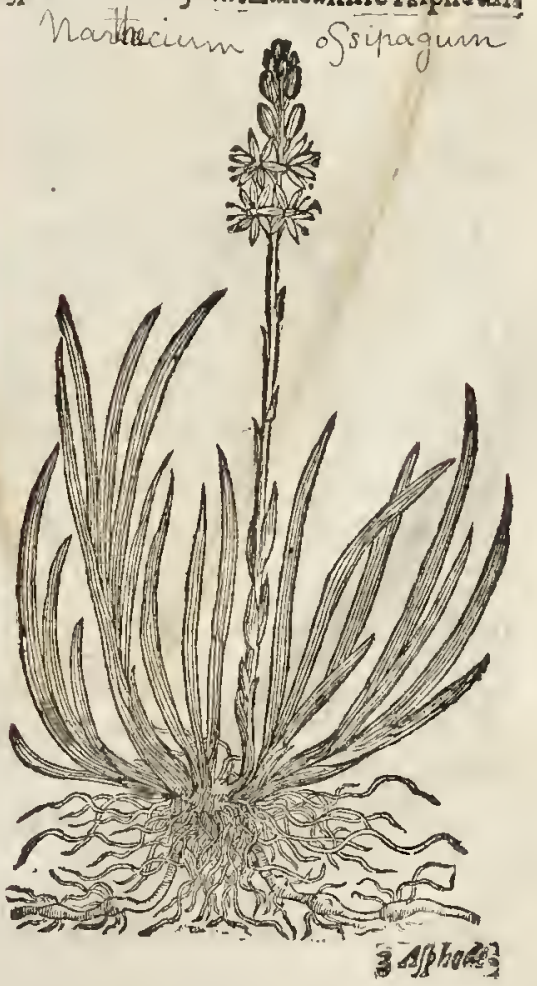


$\ddagger 3$ Aphodelus Lancaftrie verus. The true Lameanire Afphodil.

Gopicidia Palustirs \# fruttiv I T
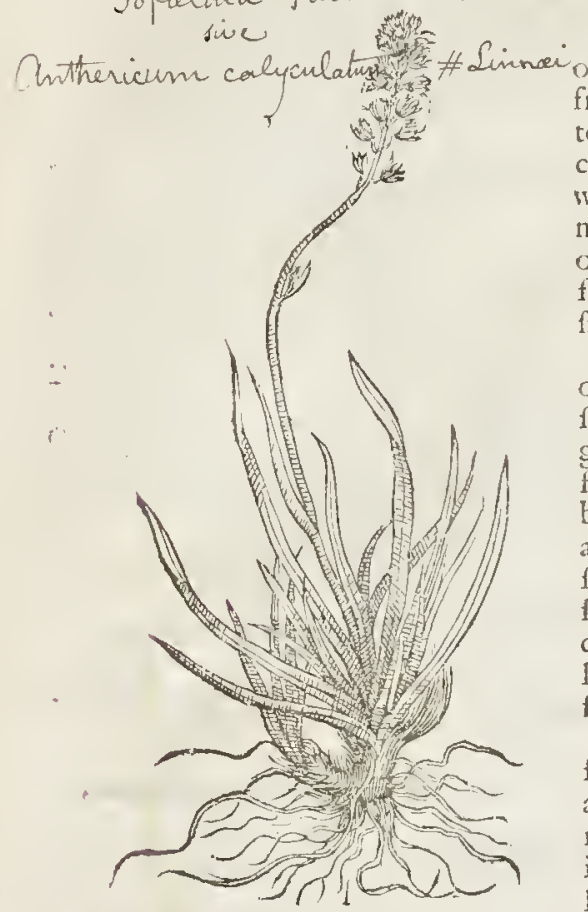
fmall ftrings.

The Tefription. narrow, and chamfored or furrowed, of a
blewih greenecolour. The ftall is round, f a eubit high. The floures which grow thereon from the middle to the top are very many, in thape like to the floures of the other; which being palt, there come in place thereof little round heads or feed-ieflels, wherein the feed is eontained. The roots in like manner are very many, long, and lender, fmaller than thofe of the other yellow fort. Vpon the fides whereof grow forth certaine ftrings, by which the plant it felfe is eafily encreafed and mulriplied.

2 There is found in thefe dayes a certaine waterie ormarifh Afphodill like vnto this laft defcribed, in ftalke and floures, without any diference at all. It bringeth forth lcaues of a beatifull greene fomw hat chamfered, like to thore of the Floure de-luce, or corne-flag, but narrower, not full a fpan long. The falke is frait, a foot high, whereupongrow the floures, confifting of fixe fmall leaues: in the middle whereof come forth fmall yellow chiues or threds. The feed is very fnall, contained in long tharpe pointed cods. The root is long, ioynted, and ereepeth as grafle doth, with many

¥3 Befides the lant defcribed (which our Authot I feare miftaking, termed A phodelus Lancaftric) there is another water Afphodill, whieli growes in many rotten moorifh grounds in this kingdome, and in Laneathire is ved by women to die their haire of a yellowith colour, and therefore by them it is termed Maiden-haire, if we may beleeue Lobell.) This plant hath leates of fome rwo inches and an life, or three inches long, being fomewhat broad at the bottome, and fo fharper towards their ends. The falke feldome attuines to the height of a foot, and it is finooth without any leaues thereon: the rop thereof is adorned with pretty yellow ftar-like floures, wherto fueced longifh little cods, vfually three, yet fometimes foure or fiue fquare, and in the fe there is contained a fimall red feed. The root confifts onely of a ferv fmall ftrings.

\section{IT The place.}

I The fmall yellow Afphodill groweth not of it felfewilde in thefe parts, notwithfanding we hate great plenty thereof in our London gardens.

2 The Lancathire Afphodill groweth in moift and marifh places neere vnto the Towne of Laneafter, in the moorifh grounds there, as alfo neere vnto Maudfley and Martom, two Villages not farre from thenee; where it was found by a Worthipfull and learned Gentleman, a diligent fearchet of fimples, and feruent louer of plants, M. T bomas Hesket, who brought the plants thereof vnto me for the encreafe of my garden.

I receined fome plants thereof likewife fron Mafter Thomas Edwards, A pothecarie in Excefter, learned and skilfull in his ptofefion, as alfo in the knowledge of plants. He found this A fphodill at the foot of a hill in the Welt part of England, ealled Baghot hill, neere vnto a village of the fame name.

* This Afphodill figured and deferibed out of Dodorsus, and ealled Aphodelus Lancafrix by our Author, growes in an heath fome two miles from Bruges in Flanders, and divers other places of the Low-countries; but whether it grow in Lancathire or no, I can fay nothing of certaintie: but I am certaine, that which I haue defcribed in the third place growes in many places of the Weft of England; and this yeare $16_{32}$, my kinde friend M. Gcorge Bowles fent mee fome plants thereof, which I keepe yet growing. Lobellalfoaffirmes this to be the Laneafhire Afphodill.

$$
\text { T Thetime. }
$$

They floure in May and Imne: molt of the leaues thereof remaine greene in the Winter, if it be not extreme cold.

of The names.
Some f the later Hetbatifts thin'se this yellow Aiphodill to be Iphyon of Theophraftus, and
pthers 
others iudge it to be Erizambac of the Arabians. In Latine it is called Aphodelus lutens : of fome it is called Haftuta Regia. We haue Englifhed it, the Speare for a King, or fimall yellow A foluo-
dill.

2 The Lancanhire Afphodill is callecd in Latine, $1 \beta$ hodelus Lanaforix : and may likewife be

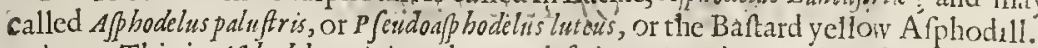

$\neq 3$ This is Appodelus minimus luteus paluffris Scoticus of L aracaflrienfis, of Lobell; and the $P f(u-$ doufphodelus pumilio folys Iridis, of clufurs, as farre as $\mathrm{F}$ can iudge; although Bauhine diftinguitheth them. $\neq$

\section{The temperature and verities.}

It is not yet found out what vfe there is of any of them in nourifhme nt or medicines.

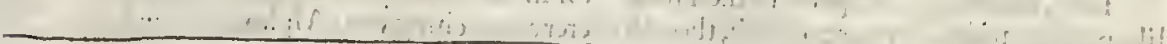

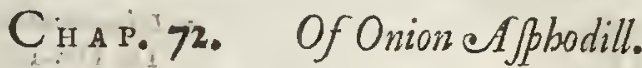

Aphodelus Bulbofus.

Onion A phodill.
Ginithogalum pyreriancum $T$

Tा Thedefription.

He bulbed Afphodill harh a round bulbus or Onion roor, with fome fibres hanging thereat ; from the which come vp many graffie leaues, very well refermbling rhe Leeke; among the which leaues there riferl vp a naked or fmooth fem,garnifhed toward the top with many ftar-like floures, of a whition greene on the infide, and wholly greene withour, confifting of fix little leatues fharpe pointed, with certainechines or threads in the middle. Afrer the floure is paft rhere fureceederh a fmall knop or head three fquare, wherein lieth the feed.

$$
\text { T The place. }
$$

It groweth in the gardens of Herbarifts in London, and not elfewhere thar I know of, for it is nor very common.

$$
\begin{aligned}
& \text { It The time. } \\
& \text { It floureth in Iune and Iuly, and fomerwhat after. } \\
& \text { I The names. }
\end{aligned}
$$

The falke and foures being like ro thofe of the Afphodill before menrioned, do thew ir to be $A$ Sphodel pecics, or a kinde of Afphodill, for which caufealio it feemerh to be that Afphodil of which Galen hath made menrion in his feeond book of rhe Faculties of nourifhments, in thefe words; The root of Afphodill is in a manner like ro the root of Squill, or Sea Onion, as well in thape as bitternes. Nowithitanding, faith Galen, my felfe hate known certaine counrrymen, who in rime of famine could not with many boilings and fteepings make it fit to be eaten. It is called of Dodoinens, Aphodelus farm. ma, and A phodelus Bulbofus, Hyacintho-Aphodelus, and Aphodelus Hyacinthinus by Liobell ; and that rightly; for that the root is like the Hyacinth,and the foures.like the Afphodill : and therefore as it doth participate of both kindes, fo likewife doth the name: in Englifh we may call it Bulbed Afphodill. clufurs calls it Ornithogalum majus, and that firly.

$$
\text { The Thature. }
$$

The round rooted Afphodil, according to Galen, harh the fame temperature and vertue that Aron, Arifarum, and Dracontium haue, namely anabiterfiue and cleanfing qualitic.

$$
\text { वा The rertues. }
$$

The yong fprouts or fprings thereof is a fingular medicine againft the yellow Iaundife, for that the root is of power to make rhin and open.

Galen faith, that the arhes of rhis Bube mixed with oile or hens grease cureth the falling of the haire in an Alopecis or fcalld head.

\section{A} B 


\title{
Сна в.73. Of Yellow Lillies.
}

\author{
of The kindes.
}

Ecaufe we thall hauc occafion hereafter to fpeake of certaine Cloued or Bulbed Lillies, wee will in this chapter entreat oncly of another kinde not bulbed, which likewife is of two forts, differing principally in their roots : for in floures they are Lillies, but in roots Afpho. dils, participating as itwere ofboth, though neerer approching vnto A fphodils than Lillies,

I Lilitwan non bulbofum. The yellow Lillie.

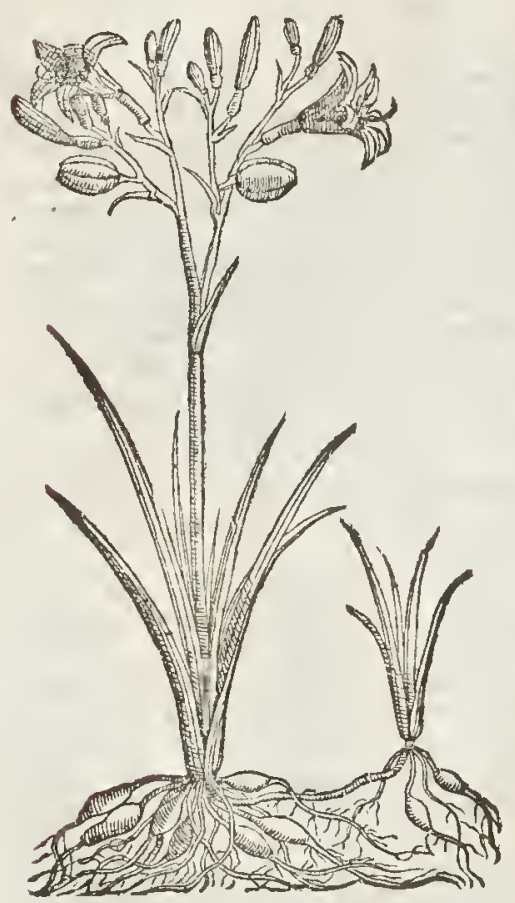

2 Lilium noribulbofum Phenicerm. The Day-Lillic.

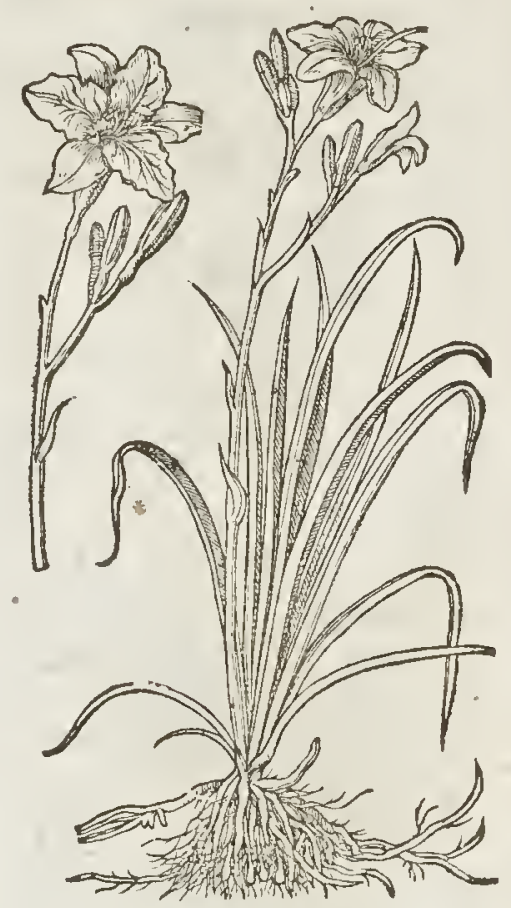

Th The deription.

17 Heyellow Lillie hath very long flaggic leanes, chamfered or chännelled, hollow in the middeft like a gutter; among the which rifeth vp a naked or bare ftalke, two eubits high, branched toward the top, with fundry brittle armes or branches, whereon do grow many goodly floures like vnto thofe of the common white Lillie in thape and proportion, of a fhining yellow colour; which being paft, there fueceed three cornered huskes or cods, full of blacke thining feeds like thofe of the Peonie. The root confiftet of many knobs or tuber rous clogs, proceeding from one head, like thofe of the white A fohodill or Peonic.

2 The Day-Lillie hath ftalkes and leaues like the former. The floures be like the white Lillie in thape, of an Orenge tawny colour : of which Houres much might be faid which I omit. But in briefe, this plant bringeth forth in the morning his bud, which at noone is full blowne, or fpred abroad, and the fame day in the euening it thuts it felfe, and in a thort time after beeomes as rotten and ftinking as if it had beene trodden in a dunghill a moneth together, in foule and rainie weather: which is the eaufe that the feed feldome followes, as in the other of his kinde, not bringing forth any at all that I could euer obferue; according to the old prouerbe, Soone ripe, foone totren. His roots are like the former. 
a Theplace.

Thefe Lillies do grow in my garden, as alfo in the gardens of Herbarifts, and louers of finc and rare plants; but not wilde in England, as in orher countries.

$$
\text { q Thetime. }
$$

Thefe Lillie's do floure fomewhat before the other Lillies, and the yellow Lillie the fooneft.

$$
\text { T) The names. }
$$

Diucrs do c all this kinde of Lillic, Lilialphodelus, Liliago, and alfo Liliaftrum, but moft commonly Lilium non 6 ulbofum: In Englifh, Liriconfancie, and yellow Lillic. The old Herbarifts name it Hemerocallis = for they have twokindes of Hemerocallis ; the one a fhrub or woody plant, as witneffeth T heopibraftus, in his fixth booke of the hiftorie of Plants. Pliny fetteth downe the fame fhrub among; thofe plants, the leauos whereof onely do ferue for garlands.

The orher Hemerocallis which they fet downe, is a Floure which perifherh at night, and budderh at the Sunne tifing, according to Atbrneus; and thetefore it is firly called imegraxts; that is, Fairc or beaurifull for a day : and fo we in Englinh may rightly terme it the Day-Lillie, or Lillie for a day.

The nature is rather refetred to the Afphodils than to Lillies.

$$
\text { If The vertues. }
$$

Diofcorides faith, That the root famped wirh honey, and a mother pefarie made thercof with $\mathrm{A}$ wooll, and put vp, bringeth forth water and bloud.

The leaues ftamped and applied do allay hot fivellings in the dugges, afrer womens trauell in $B$ childe-bearing, and likewife taketh away the inflammation of the eyes.

The roors and the leaues be laid witli good fucceffe vpon burnings and fealdings.

\section{Cнат. 73: Of Bulbed Floure de-Luce.}

¥ Iris Bulloga Latifolia.

Broad leaued Bulbous Floure de-Iuce;

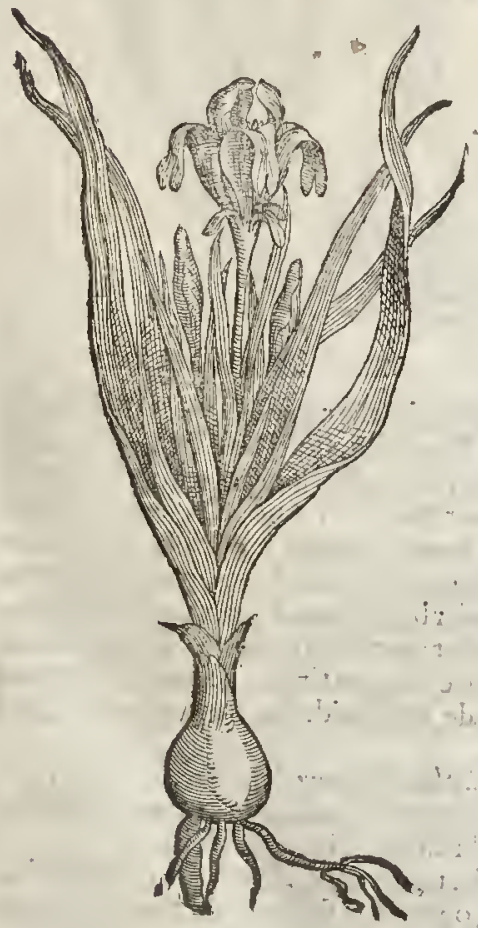

2 Iris Bulbofa Anglicis: Onion Floure de-Luce? Tris tiphioides.

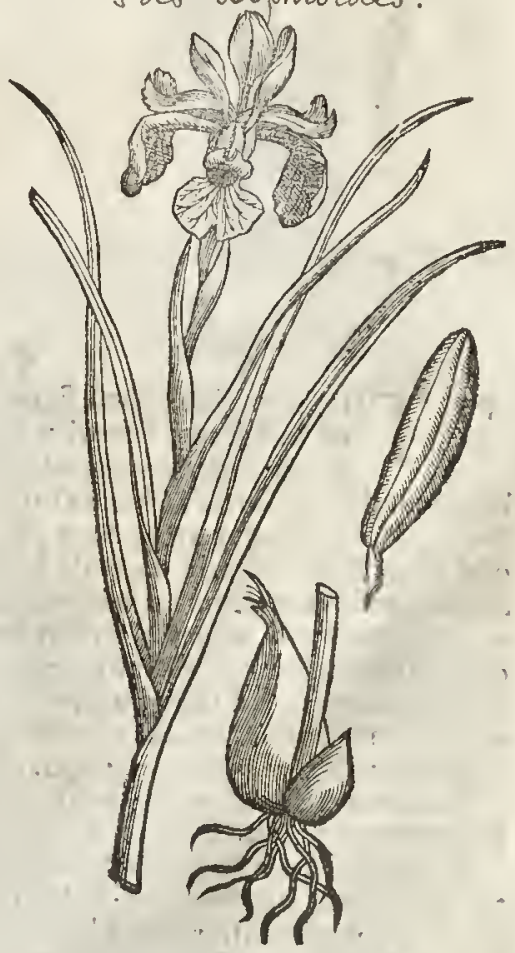




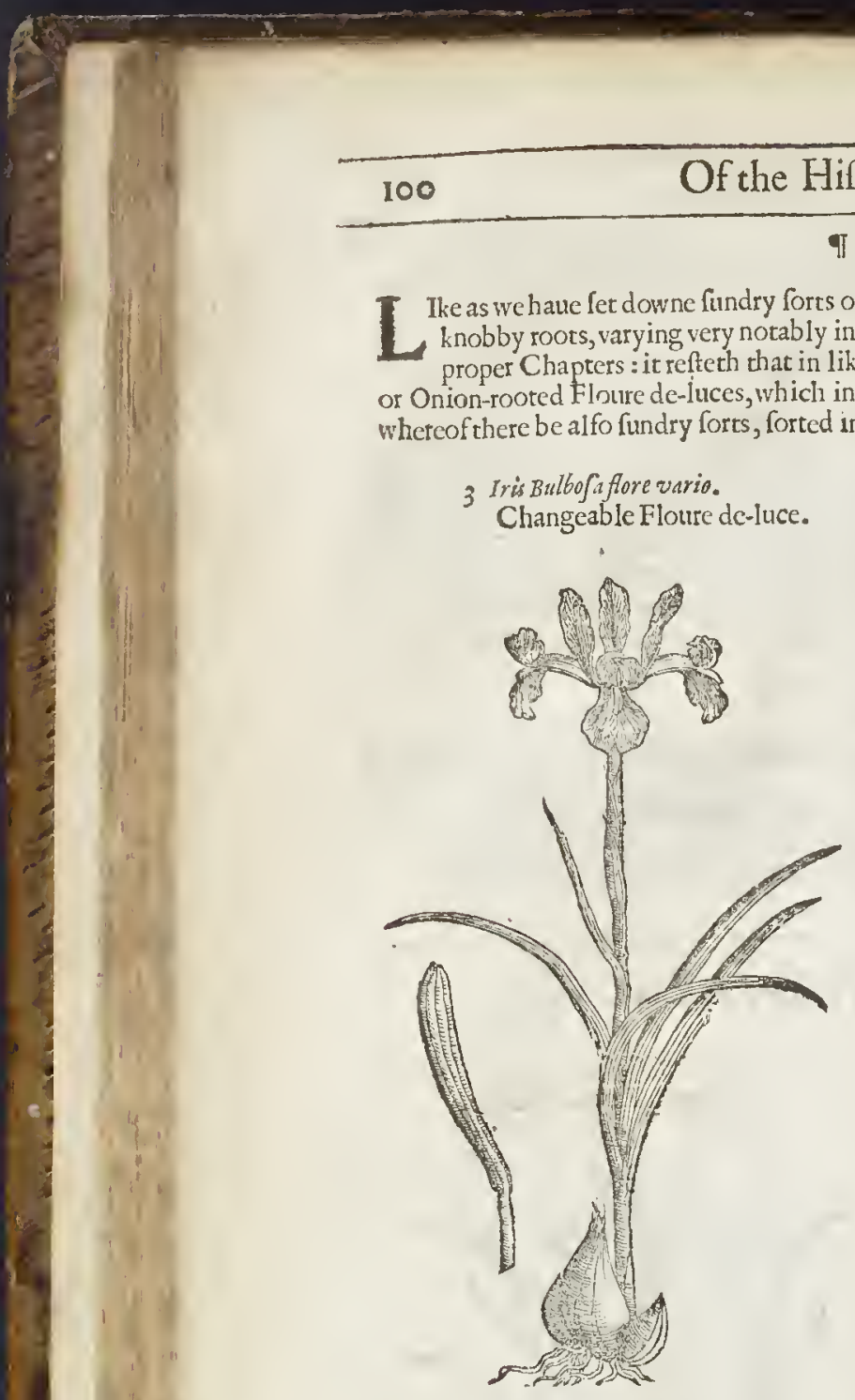

LIв. I.

ขा The kindes.

Tkeas we haule letdowne fundry forts of Floure de-luces, with flaggy leaues, and tuberous or knobby roors, varying very notably in fundry refpets, which we haue diftinguifhed in their proper Chapters : it refterh that in like manner we fet forth vnto your view certaine bulbous or Onion-rooted Floure de-luces, which in this place do offer themfelues vnto our confideration; whereof there be alfo fundry forts, forted into one chapter as followeth.

3 Iris Bulbofaflore vario.

orison
\# Iris Bulbofa verficolor Polyclonos. Many branched changcable Floure de-liuce.

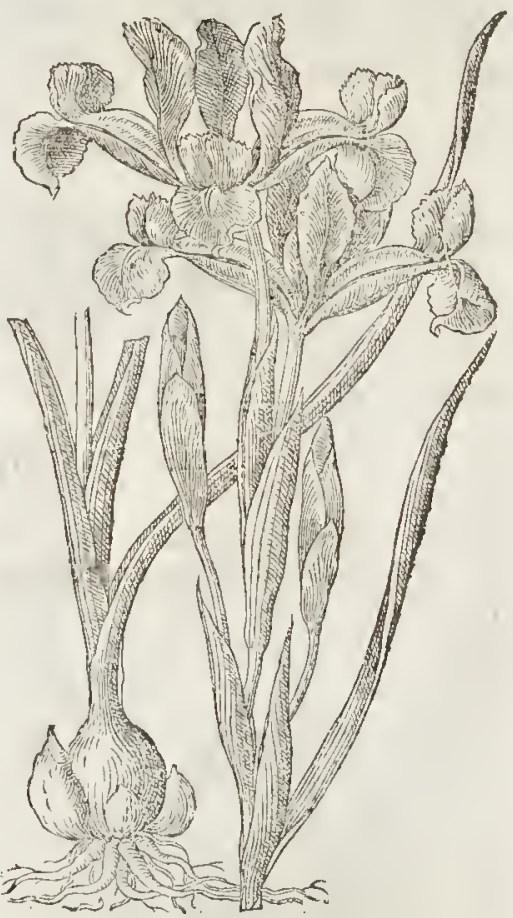

T The defcription:

I $\neg$ He firl of thefe, whofe figure here we giue youvnder the name of Iris Bulbofa LatifoLia, hath leaues fomewhat like thofe of the Day-Lillie, foft, and fomewhat palifh greene, with the vnder fides fomewhat whiter; amongft which there rifeth vp a ftalk bearing at the top thereof a Floure a little in thape different from the formerly defcribed Floure de-luces. The colour thereof is blew ; the number of the leaues whereof it confifts, nine : three of thefe are little, and come out at the botrome of the Floure as foone as it is opened three more are large, and being narrow attheir bottome, become broader by little and little, intill they come to turne downwards, whereas then they are thapen fomewhat roundifh or obtufe. In the middeft of thefe there runnes vp a yellow varieg ated line to the place whereas they bend backe. The three other leaues are arched like as in other Floures of this kinde, and ditided at their vpper end, and containe in them three threads of a whitifh blew colour.

This is called Iris Bulbofa Latifolia, by Clugius; and Hyacinebus Poctarum Latifolius, by Lobell.

Itfloures in Ianuarie and Fcbruarie, whereas it growes naturally, as it doth in diuers places of Portugall and Spaine. It is a tender plant, and feldome thriues well in our gardens. $¥$

2 Onion Floure de-luce hath long narrow blades or leaues, crefted, cham fered, or ftreaked on the backe fide as itwere welted ; below fomew hat round, opening it felfe toward the top, yet remaining as it were halfe round, whereby it refembleth an hollow trough or gutter. In the bottome of the hollownefie it tendeth to whitenefe; and among thefe leaues do tife vp a falke of a cubit high ; at the top whetcof groweth a fuire blew Floure, not differing in fhape from the com- 
mon Floure de-luce : the which being pat, thcre come in the place thereof long thicke cods or feed-veffels, wherein is eontained yellowifh fect of the bigneffe of a tare or fitch. The root is round like an Onion, eonered 'ouer with eertaine browne skinnes or filmes. Of this kind there are fome fiue or fix varieties, caufel by the various colours of the Floures.

$\because 3$ Iris Bulbofa Flore huteo cum flore of femine.

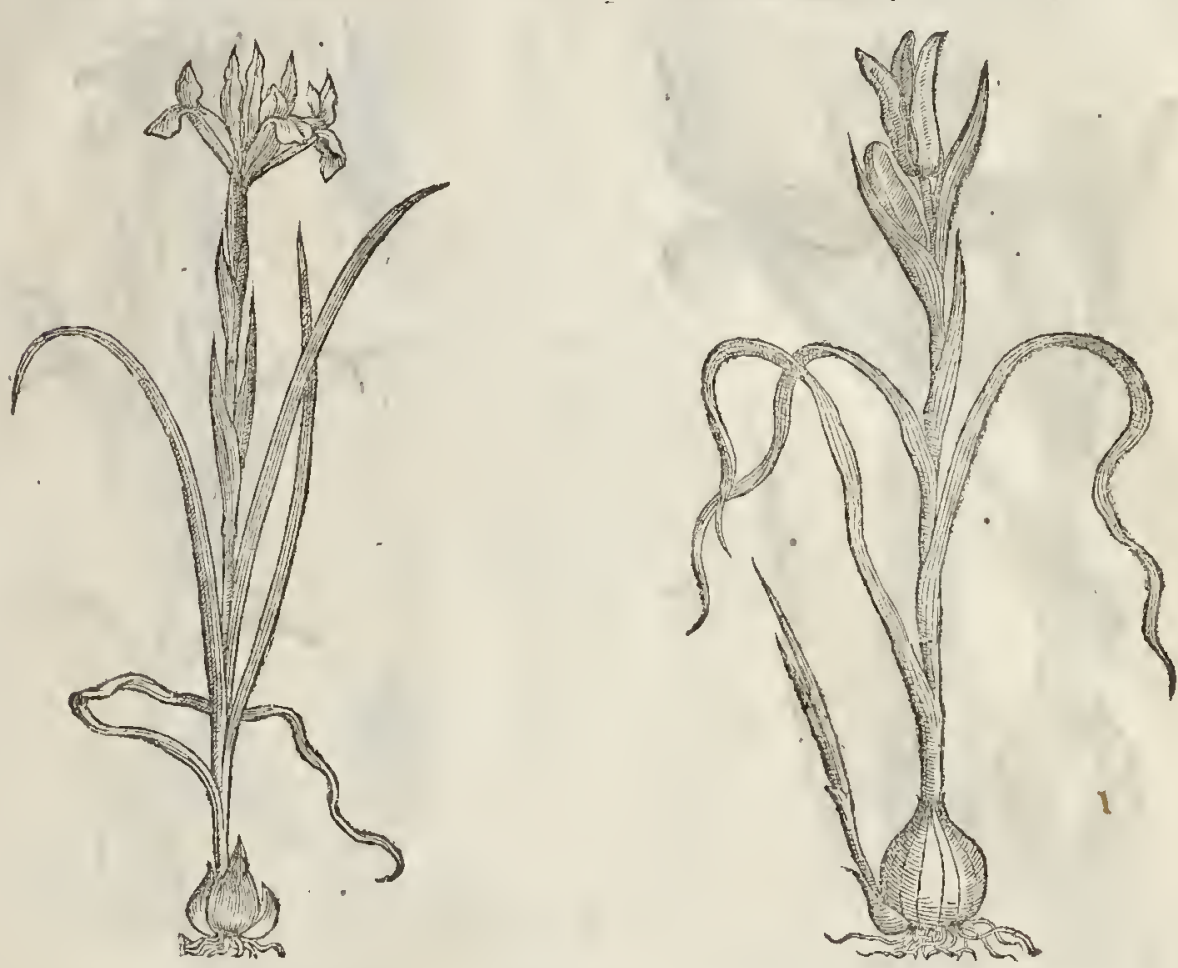

Yellow bulbed Floure de-luce in toure and feed.

3 Changeable Floure de-luce hath leaues, ftalkes, and Roots like the former, but leffer. The Floure hath likewife the forme of the Floure de-luec, that is to fay, it eonfifteth of fixe greater leaues, and three leffer; the greater leaucs fold baekward and hang downward, the leffer ftand vpright; and in the middle of the leates there rifeth vp a yellow wclt, white about the brimmes, and fhadowed all oucr with a wath of thinneblew tending to a Watchet colour. Toward the falke they are ftripped ouer with a light purple colour, and likewife among th thc hollow places of thofe that ftand vpright (which eannot be expreficd in the figure) there is the fame faire purple colour the fimell and fauour very fwect and pleafant. The root is Onion fathion, or bulbous like the
other.

¥4 There is alfo another varicgated Floure de-luee, mueh like this laft defcribed, in the co lour of the Floure ; but each plant produceth more branches and Floures, whenee it is termed Iri Bulbofa verfecolor polyclonos, Many-branched changeablc Floure dé-luce. $\ddagger$

5 Ofwhich kinde or fort there is another in my Garden, which I receiucd from my Brother Lames Garrat A potheearie, far morc bcautifull than the latt deferibed; thic which is darht ouer, in fweet, with bulbed rotchet colour, with a nolt plearant gold ycllow colour, of fmell excceding Get is the other fort.

6 It is reported,that therc is in the garden of the Prince Ele ofor the Lantgratic of Heffen, one of this fort or kinde, with white Floures, the which as yet I hawe not feenc.

$\neq$ Bcfides thefe forts mentiond by out Author, there are of the narrow leated bulbous Floure de luces, fome twenty foure or more varieties, which in thape of rooss, leanes, and Floures differ very little, or almoft nothing, at all; fo thar he which knows one of thefe nay prefently know the reft. Wherefore becuufe it is a thing no more pertinent to a generall hiftorie of Plants, to infift veon thefe accidentall wicities, than for him thut writes a hiftoric of Beilfs to defcribe all the coiours, and their mixtucs, in Horfes, Dogs, and the like; I refer fuch as arc defirous to infome 
themfelues of thofe varieties, to fuch as haue onely and purpofely treated of Floures and their dinerfities, as $D C-B r y$, Swcrts, and our Countreyman M. Parkingon, who in his $\boldsymbol{P}_{\text {aradifusterreftris, fet }}$ forth in Englifh, Anno I 629 . hath iudiciounly and exatly comprehended all that hath beene delinered by others in this nature. $\neq$

¥ 6 Iris Bulbogaflore cincrco. Afth-coloured Floure de-luce.

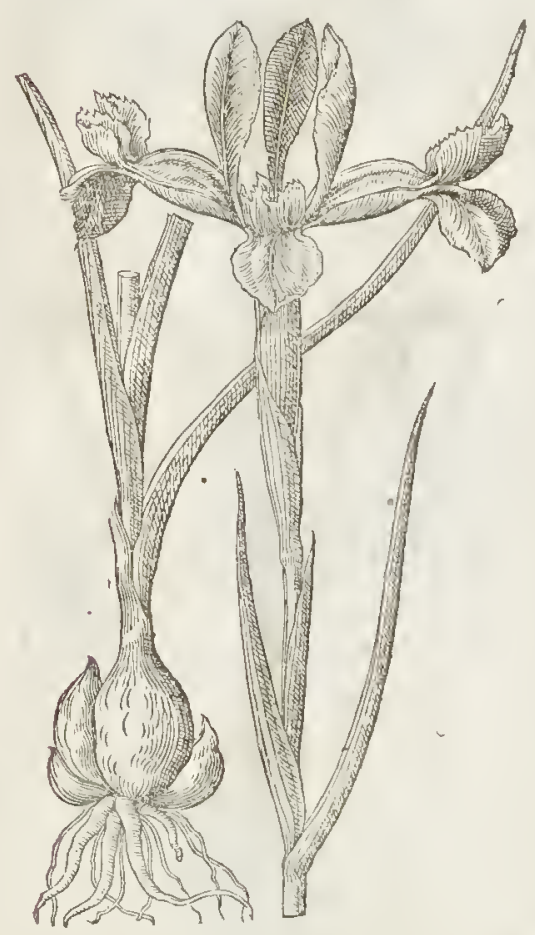

$\neq 7$ Iris Bulbofa fore albido - $n$ Whitinh Floure de-luce.

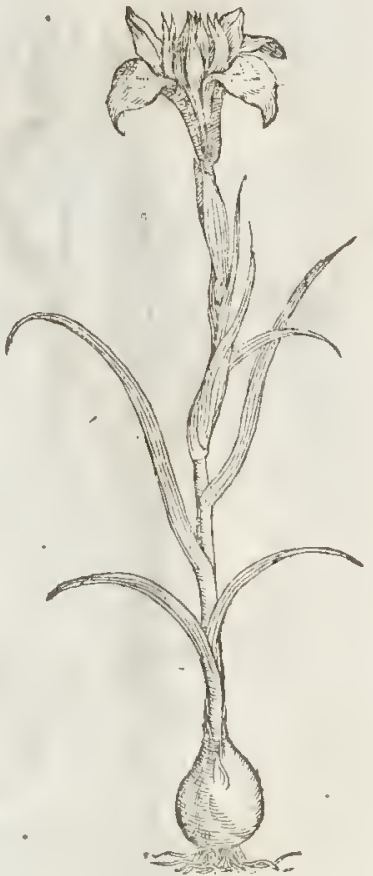

बा Theplace.

The fecond of thefe bulbed Flourede-luees growe walde, or of it felfe, in the come fieids of the $W$ cef parts of England, as ahout Bathe and $W^{\prime} l^{\prime}$, and thofe places adiaeent ; from whence they were firlt brought into London, where they be naruraifed, and encreafe in great plenty in our London gardens.

The other forts do grow naturally in Spaine and Italy wilde, from whenee we haue had Plants for our London gardens, whereof they do greatly abound.

$$
\text { of The time. }
$$

They foure in lune and Iuly, and feldome after.

$$
\text { T The names. }
$$

The Bulbed Floure de-luce is ealled of Lobelims, Iris Bulbofa, and alfo Hyacintbus fore Iridis: of fome, Hyacinthus Pocturum; and peraduenture it is the fane that Apuleins mentioneth in the one and twentietly Chupter, faying, That ris, named among the old W'riters Hieris, may alfo he called, and not unproperly, Hicrobulbus, or Hieribulbus : as though you fhouid fay, Iris Bulbofa, or Bulbed Iren; ;nleffe you would haue resepaneoc, called a greater or larger Bulbe: for it is eertaine, that great and huge things were ealled of the Antients, frex, or Sacra : in Englinh, Holy.

$$
\text { II The natture. }
$$

The nature of thefe Bulbed Floure de-luees are referred to the kindes of Afphodils.

$$
\text { ai The vertses. }
$$

Take, faitl apulcius, of the herive Hierobulbus fix $\tilde{3}$. Goats fuet as much, Oile of Aleanna one A pound, mix them together, being firft ftumped in a ftone morter, it taketh away the praine of the Gout.

Moreoner, if a woman dovfe to wath her facewith the decoction of the roct, mixed with the B meale of i.upine, it for thw ith clemfeth away the freckles \& morphew, and full like deformities. 


\section{С на : 75: Of Spanifh $\mathcal{X}$ (ut.}

\section{sifjurichium majus: Spanish Nut.}

Iris $S$ is ynichiom. a

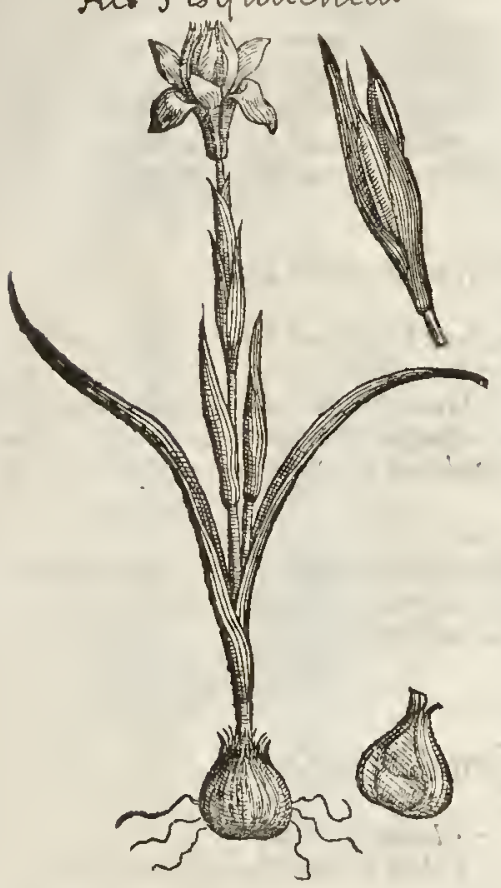

3 Iris Tuberofa! Veluet Floure de-luce:

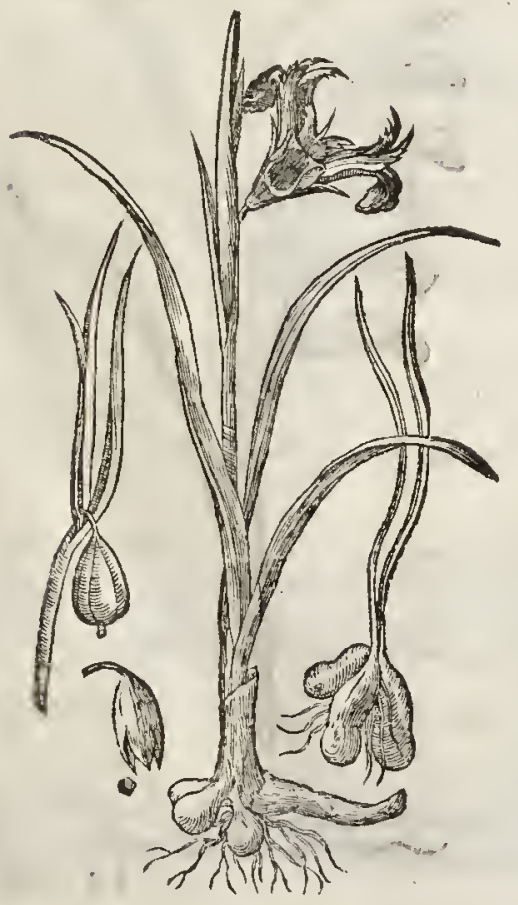

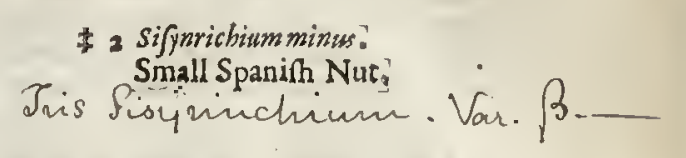

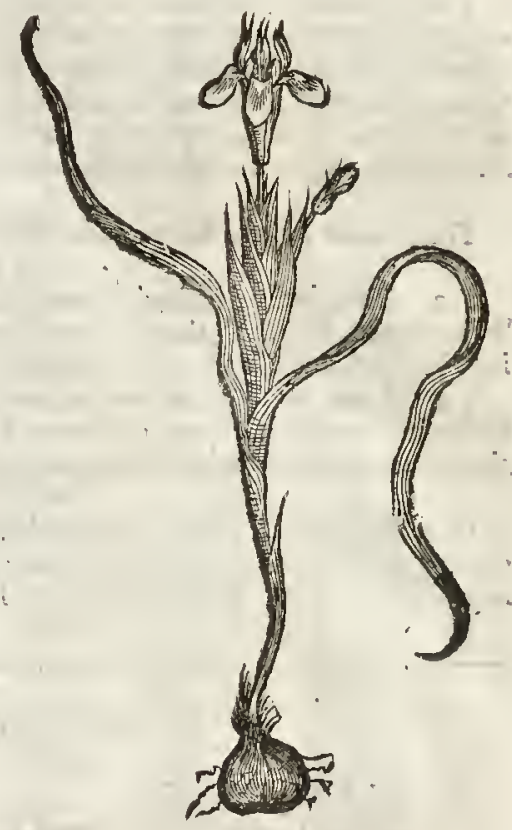

T) The defription.

I Panith Nut hath fmall graffie leaues like thofe of the Starres of Bethlem, or armithogalum; among which rifetir vp a fmall ftalke of halfe a foot high, garnithed with the like leaues, but fhorter. The Floures grow at the top, of a skie colour, in thape refembling the Floure de-luce, or common Iris; but the leaues that turne downe are each of them marked with a yellowifh fpot : they fade quicke$\mathrm{ly}$, and being paft, there fuceeed fmall cods with feeds as fmall as thofe of Turneps. The roor is round, compored of two bulbes, the one lying vpon the other as thofe of the Corne flag vitually do; and they are courered with a skinne or filme in thape like a Net. The Bulbe is fweet in tafte, and may be eaten before any other bulbed Root.

2 There is fet forth anothet of this kinde, fomewhat leffer, with Floures that fmell fiveeter than the former.

3 Veluet Floure de-luce hath many long fquare leaues, fpongeous or full of pith, trailing vpon the ground, in fhape like to the leaues of Ruhes : among which rifeth vp a ftalke of a foct I 2 high? 
high, bearing at the top a Floure like the Floure de-luce. The lower leaues that turne downwitd are of a perfect blacke colour, fott and fmooth as is blacke Veluct; the blackneffe is welted about with greenifh yellow, or as wee terme it a Goole-turd greene; ofwhich colour the rppermolt leaues do confift : which being pait, there followeth a great knob or crefted feed veffell of the bigneffe of a mans thumbe, wherein is contained round white feed as bigge as the Fetch or tare. The root confifteth of many knobby bunches like fingers.

$$
\text { 9 The place. }
$$

Thefe baftard kindes of Floure de-luces are ftrangers in England, except it be among fome few diligent Herbarifts in London, who hate them in their gardens, where they increafe exceedingly; efpecially the laft defcribed, which is faid to grow wilde about Conftantinople, Morea, and Greece: fromwhence it liath beene tranfported into Italy, where it hath beene taken for Hermodactylus, and by fome expreft or fet forth in writing vnder the title Hermoductylus; whercas in truth it hath no femblance at all with Hermodactylus.

$$
\text { of The time. }
$$

The wilde or Baftard Floure de-luees do floure from May to the end of Iune.

$$
\text { The names. }
$$

I 2 Thefe bulbed baftard Floure de-luces, which we haue Englifhed Spanifh Nuts, are cal: led in Spaine, Nozelhas; that is, little Nuts : the leffer fort Parua Nozelha, and Cracuca. wce take it tobe that kinde of nourihing Bulbe which is named in Greeke, areixzv : of Pliny, sifynrichium.

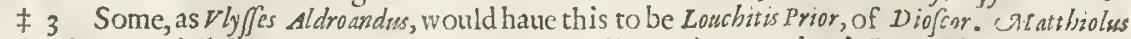
makes it Hermodactylus verus, or the true Hermodactill: Dodoncus and Lobell more fixly refer it to the Floure de-luces, and call it Irtstubcrofa.

$$
\text { T Thenatureand veriues. }
$$

Of thefe kindes of Floure de-luces there hath beene little or nothing at all left inwricing concerning their natures or vertues; only the Spanifh iut is caten at the tables of rich and delicious, nay vitious perfons, in fallads or otherwife, to procurc luft and leclueric.

\section{Снар.76. Of Corne-Flagge.}

I Gladiolus Narbonenfis.

French Corne-Flag, or Sword-Flag.

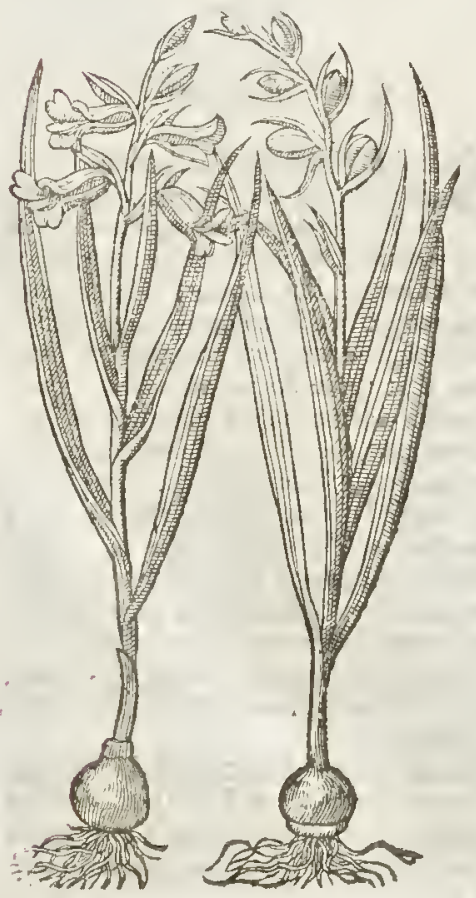

2 Gladiolus Italicus.

Italian Corne-Flag,or Sword-Flag.

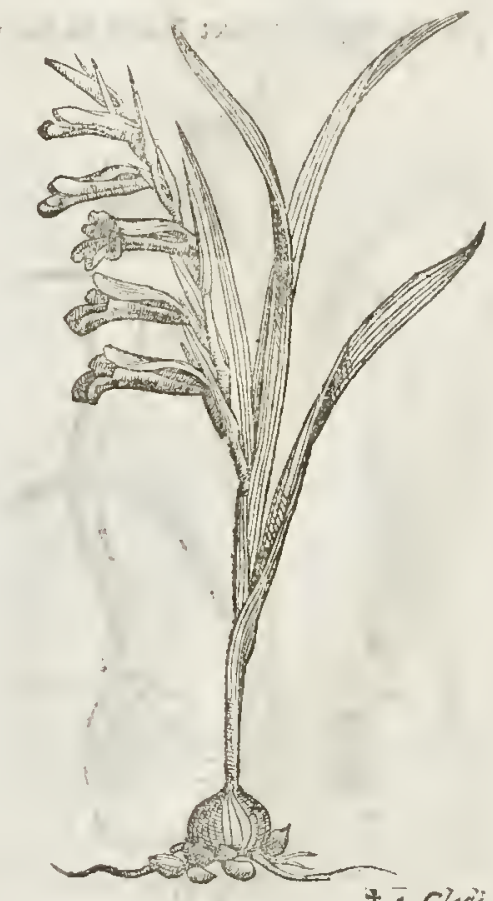


$\$ 4$ Gladiolus Lacuftris. S Water Sword-Flag.

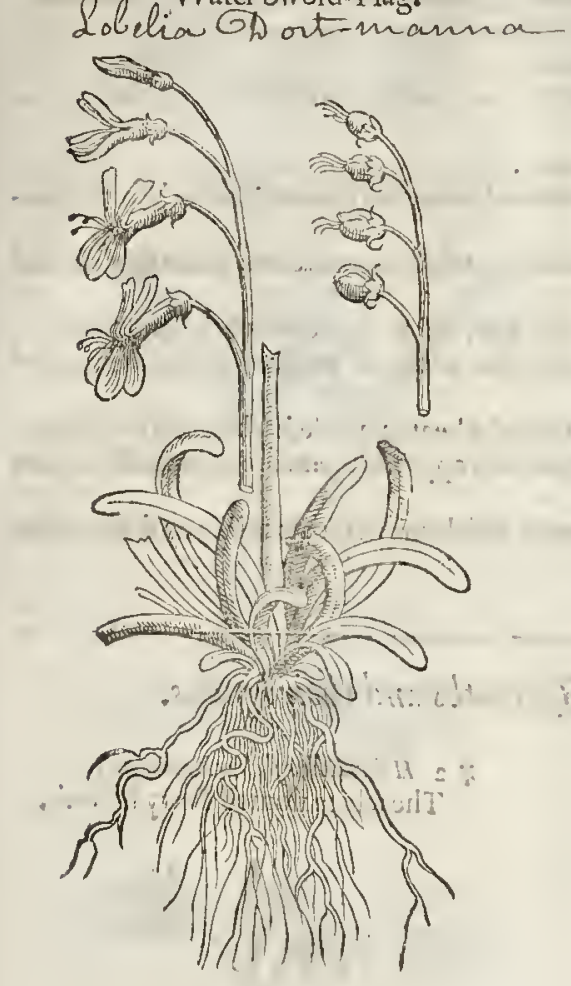

T The defcription.

1 Rench Corne-Flagge hath fmall ftiffe I leaues, ribbcd or chamfered with Iong nerues or finewes ruming through the fame, in thape like thofe of the finall Floure deluce, or the blade of a fword, tharpe pointed, of an outer-wornc greene colour, among the which ififeth vp a ftiffe brittle ftalke two cubits high, whereupon doe grow in comely order many faire purplc Floures, gaping like thole of Snapdragon, or not mueh differing from the Fox-Gloue, called in Latine Digitalis. After them come tound knobbic feed-veffels, full of chaffie feed, very light; of a browne reddith colour." The root confifterh of two Bulbes, one fet r pon the other; the vppermolt whereof in the beginning of the Spring is leffer, and more ful of juice; the lower greater but more loofe and lithie, which a little while after peri. nheth.

2 Italian Corn-Flag hath long narrow leaues with many ribbes or nerues running through the fame : the ffalke is ftiffe and brittle, iv hereupon do grow Floures orderly placed vpor one fide of the ftalke, whereas the precedent hath his floures placed on both the fides of the ftillke, in fhape and çolour like the former, as arealfo the roots, but feldome feene one abone another, as in the former.

3 There is a third fort of Corne-Flag which agreeth with the laft defcribed in euerie point, far uing that the Floures of this are of a pale colour, as it were betweene white, and that whieh we call Maidens Blufh.

\# 4. This Water Sword-Flag, defcribed by Clufuts in his Cur.Poft. hath leaues about a fpan long, thicke and hollow, with a partition in their middles, like as wee fee in the cods of StoekeGillouers, and the like : their colour is gteene, and tafte fweet, fo that they are an acceptable food to the wilde Ducks ducking downe to the bottome of the water; for they fometimes lie forne ells vnder water : whieh notwithftanding is ouer-topt by the ftalke, which fprings vp from among thefe leaues, and beares Floures of colour white, larger than thofe of Stock-Gillouers, but in that hollow part that is next the ftalke they are of a blewifh colour, almoft in fhape refembling the Floures of the Corne-Flag, yet not ab folutely like them. They confift of fue leaues, whereof the two vpermoft are reflected towards the ftalke; the three orher being broader hang downewards, After the floures there follow round pointed veffels filled with red feed. It foures at the end of
Iuly.

It was found in fome places of Weft-Frifeland, by tohn Dortman a leatned A pothecary of Gro. ningen. It growes inwaters whieh haue pure gratuell at the bottome, and that bring forda no plant befides.

Clus fus, and Dortman who fent it him, call it G ladiolus Lacuftris, or Stiggalis. f

Thefe kindes of The plate.

laces of Italy, as alfo in the parts of in medowes, and in earable grounds among eorne, in many places of raly, as alfo in the parts of France bordering thereunto. Neitherate the fields of Atlftria and Morauia without them, as Cordess writeth. We haue great plenty of thenz in our London Gardens, efpeeially for the garnifhing and decking them vp with their feenly Floures.

They floure from May to the end of Iuly.

$$
\text { बा The time. }
$$

eI Thenanes.

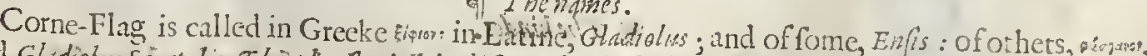

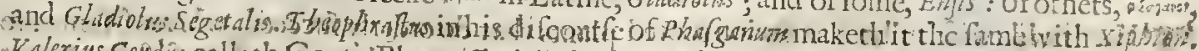

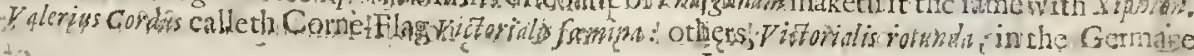


Tongue, Geiglouttz: yet we muft make a differenee betweene Gladiolus and Victorialis longa; for that is a kinde of Garlicke found vpon the higheft Alpith mountaines, which is likewife called of the Germanes Exigwoutz 2 . The Floutes of Cone-Flag are ealled of the Italians, Monacuccio: in Englih, Corne-Flag, Corne-Sedge, Sword-Flag, Corne Gladin : in Freneh, Glatis.

\section{T Thenature.}

The root of Corne-Flag, as Galen faith, is of forec to draw, wafte, or eonfume away, and dry, as alfo of a fubtill and digetting qualitic.

$$
\text { The vertues. }
$$

A The root ftamped with the pouder of Frankineenfe and wine, and applied, draweth forth fplinters and thomes that ftickefaft in the fleth.

B Being famped with the meale of Darnell and honied water, doth wafte and make fubtill hard lumps, nodes, and firellings, being emplaifted.

C Some affirme, that the vpper root pronoketh bodily luft, and the lower caufeth barrenneffe.

$D$ The vppet root drunke in water is ptofitable againft that kinde of butfing in children ealled Enteroccle.

E The root of Conne-Flag ftamped with hogs greafe and wheaten meale, hath been found by late Practitioners in phyfieke and Surgerie, to be a cettaine and approued remedie againft the Strume Scrophutu, and fuch like fwellings in the throat.

F The eods with the feed dried and beaten into pouder,and drunk in Goats milke or Affes milke, prefently taketh away the paine of the Collicke.

\section{С н Р. 77: Of Starry Hyacintbs and theirkindes.}

I Hyacinthus ftellatus Fuchfij: Starry Iacinth. Scilla cijocia -

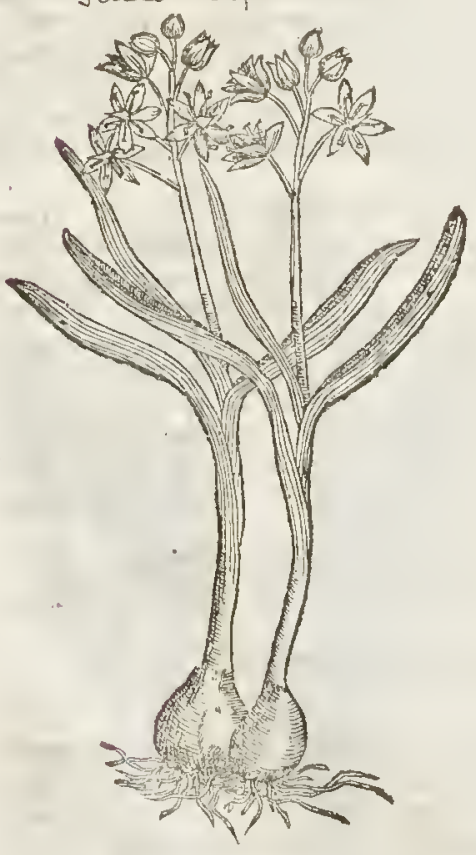

¥ Hyacinthus ftellaris albicans: The white flourcd farry Iacinth:

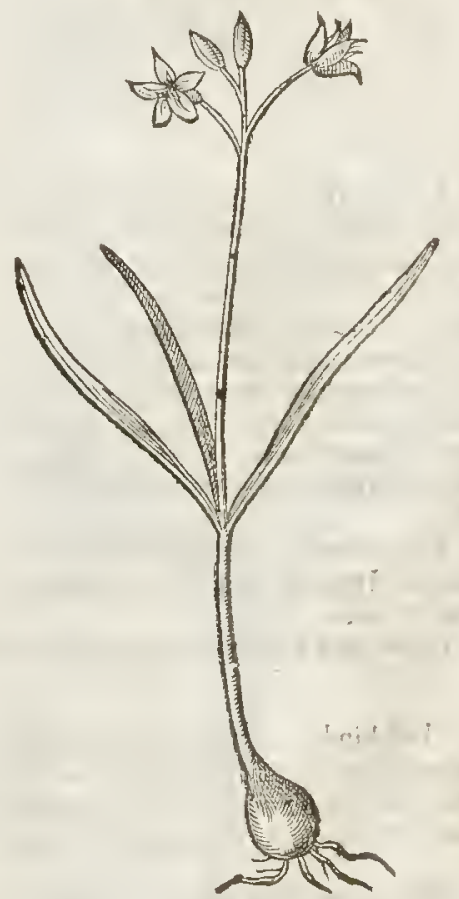

7) Thekindes.

7 Hete be likewife bulbous or Onion rooted plants that doorderly fucceed, whéreof fomé arø ro be caten, as Onions, Garlicke, Leekes, and Ciues, notwithlanding I am firft to entreat 
L1в. 1.

Of the Hiltorie of Plants.

107

of thofe bulbed roots, whofe faire and beattifull Floures are receined for their grace and ornament in gardens and garlands : the firft are the Hyacinths, whercof there is found at this day di. uers forts, differing very notably in many points, as thall be declared in their feucral deferiptions.

\$ 3 Hyacinthus fellatus bifolius. Two-leaued farry Iacinth.

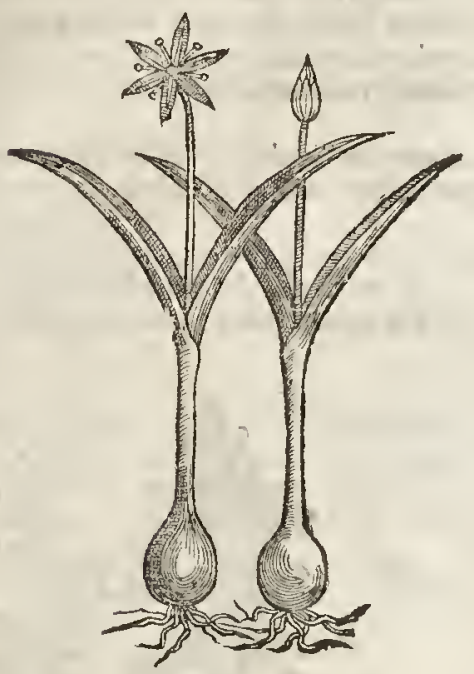

\$6 Eyacinthus ftellaris By zontisus! The farry Iacinth of Confantinople]

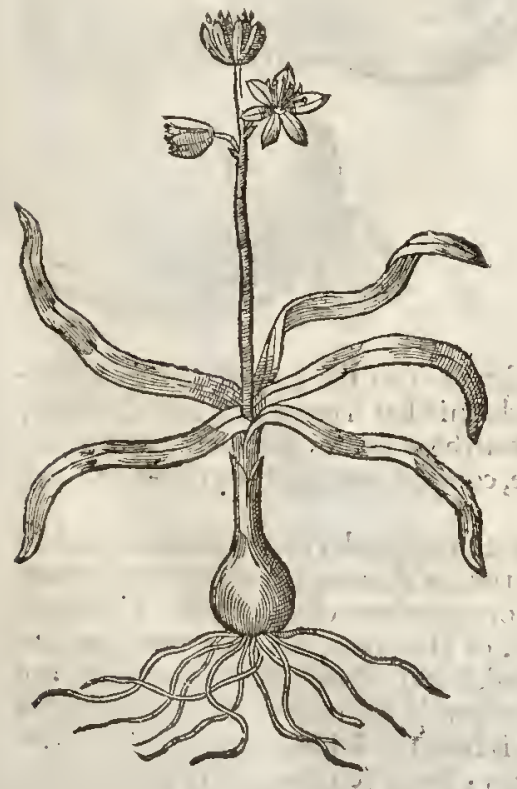

4 Ityacintbus fellatus Lilifolius cum flore of femixe. The Lilly leaued farry Iacinth in floure and feed.
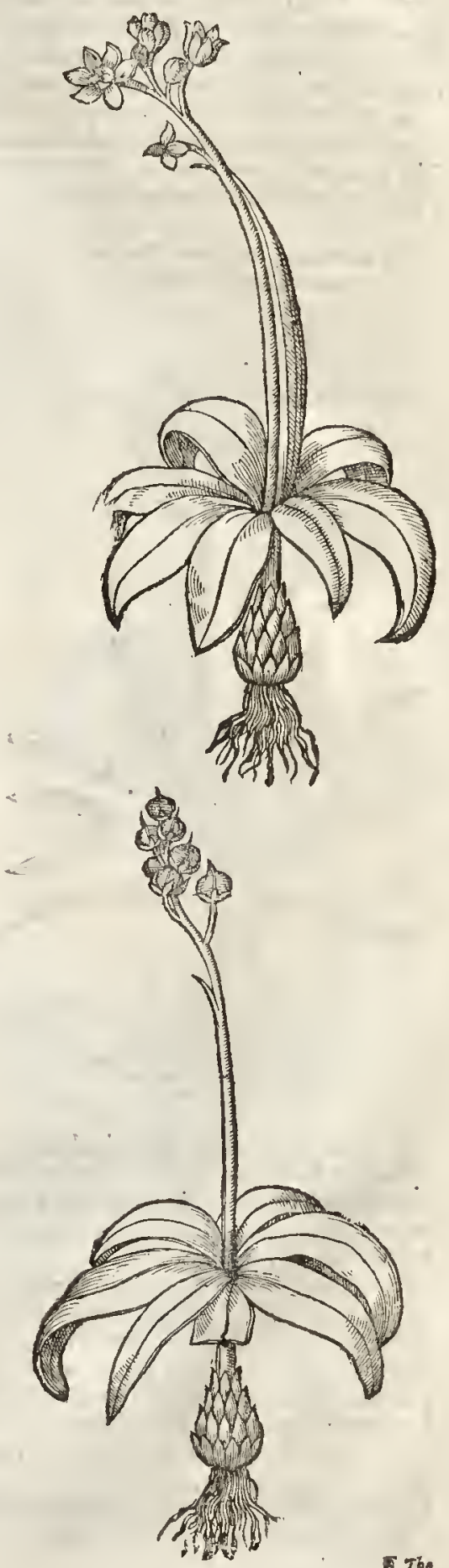


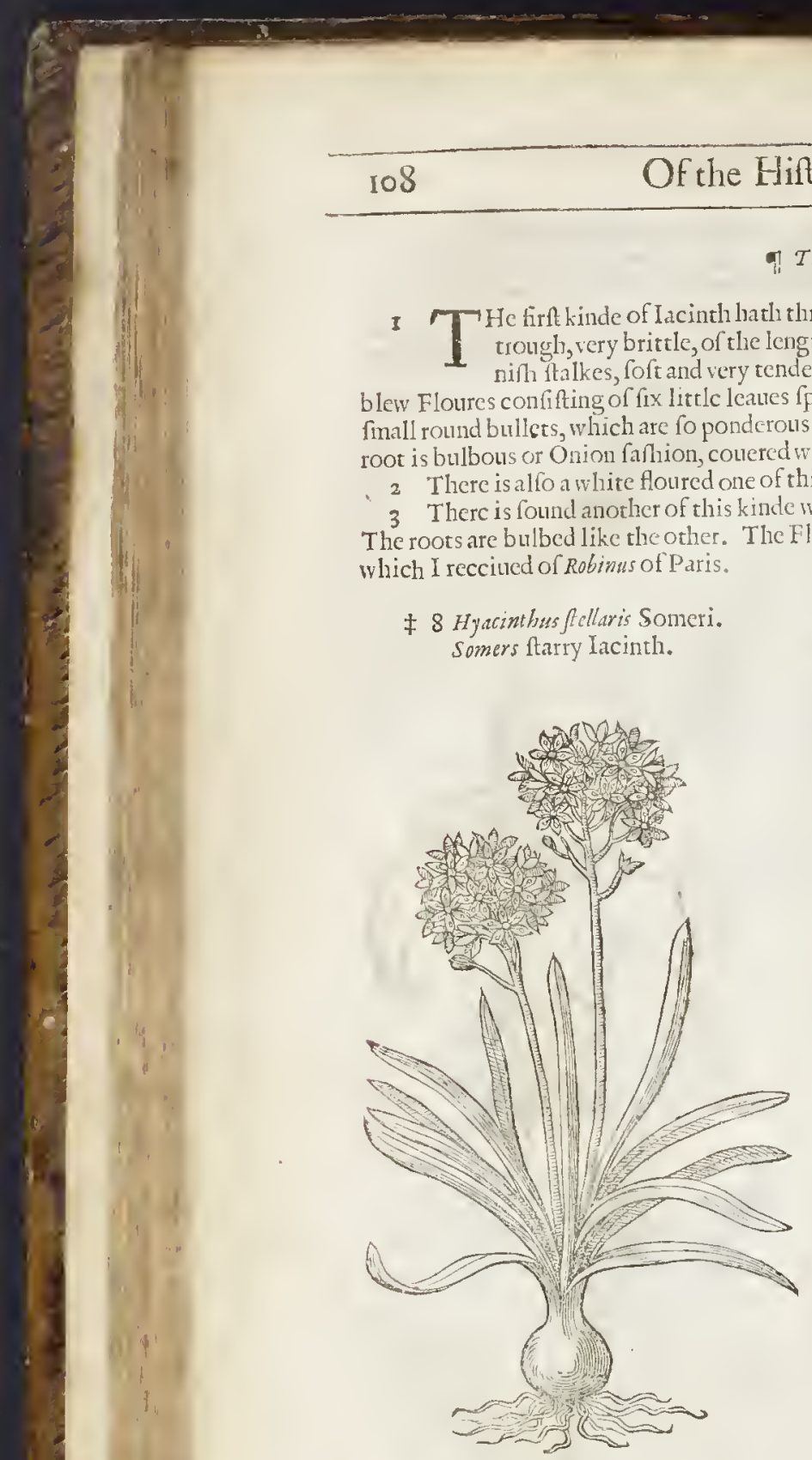

\section{The defiription.}

I MHc firf kinde of Iacinth hath three very fat thickebrowne leaues, hollow like a little trough, very brittle, of the length of a finger : among which thoot vp fat, thick brownifh thalkes, foft and very tender, and full of juyce; whereupon do grow many fmall blew Floures confifting of fix littlc leaues fpred abroad like a ftarre. The feed is contained in fimall round bullets, which are fo ponderous or heauy that they lie trailing ven the ground. The root is bulbous or Onion fafhion, couered with brownith fcales or filmes.

2 There is allo a white flourcd one of this kinde.

There is found another of this kinde which feldome or neuer hath morc than two leaues. The roots are bulbed like the other. The Floures be whitifh, ftarte-fathion,tending to blewnefle, which I recciued of Robinus of Paris.

¥ Hyacinthusftellaris Someri. Somers farry lacinth.

4 This kinde of Hyacinth hath many broad leaues fpread vpon the ground, like vnto tliofe of Garden Lilly, but thorter. The ftalkes do rife out of the middeft thereor bare, naked, and rery fmooth, an handfull high; at the top whereof dogrow fmall blew floures ftarre-fafhion, very like vnto the precedent. The toot is thicke and full of juyce, compact of many fcaly cloues of a yellow coloutr.

$\ddagger$ There are fome tenne or eleuen varicties of ftarry lacinths, befides thefe two mentioned by our Authour. They differ each from other either in the time of flouring (fome of them flouring in the Spring, other fome in Sommer) in their bigneffe, or the colours of the ir flourcs. The leaues of moft of them are much like to our ordinaric Iacinth, or Hare-bels, and lie fpread vpon the ground. Their Houres in thape refermble the laft defcribed, but are vfually more in number, and fomewhat larger. The colour of moft of them are blew or purple, one of them excepred, which is of an Afh colour, and is knowne by the name of Somers his Iacinth. I thinke it not amiffe to giue you their fuall names, torgetherwith fome of their figures; for fo you may cafly impofe them truly vpon the things themfelues whenfoeucr you thall fee them. 
5 Hyacint bus fellaris ByZantimus nigra radice, fore caruleo.

The blew ftarry Iacinth of Conftantinople, with the blacke root.

6 Hyacint bus fellatus ByZantinus major flore corwleo.

The greater blew ftarry Iacinth of Conftantiple.

7 Hyacinthus ftellatus By antinus alter flore borag inis.

The other blew ftarry Iacinth of Conftantinonople, with Floures fomewhat refembling Borage.

8 Hyacinthus fellaris aftivus, fue exoticus Someri flore cinereo.

Afh coloured ftarty Iacinth, or Somers Iacinth.

9 Hyacinthos ftellatus aftious major. The greater ftarry Sommer Iacinth. Io Hyatint bus fellatus aftious minor. The leffer ftarry Summer Iacindi. I I Hyacinthus fellaris Poreti flore caruleo friys purpureis.

Porets ftarry Iacinth with blew Floures, hauing purple ftreakes alongft their middles.

I2 Hyacinthus Hafpanions flellaris flore aturè ceru. leo.

The Spanith ftarry Iacinth with deepc blew flotures.

$r_{3}$ There is another ftarry Iacinth more large and beautifull than any of thefe before mentioned. The leaues are broad and not very long, fpread vpon the ground, and in the mide of them there rifeth vpa ltalkewhich at the top beareth a great fpoke of faire ftarry floures, which firft begin to open themfelues below, and fo thew themfelues by little and litrle to the top of the ftalke. The vfuall fort hercof hath tlew or purple floures. There is alfo a fort hercof which hath flerh-coloured floures, and another with white Floures: This is called Hyacinu bus fellatus Peruanus, The ftarry Iacinth of Pert.

ro Hyacint bus ftellatus aftious minor.

The leffer ftarry Summer Iacinth.

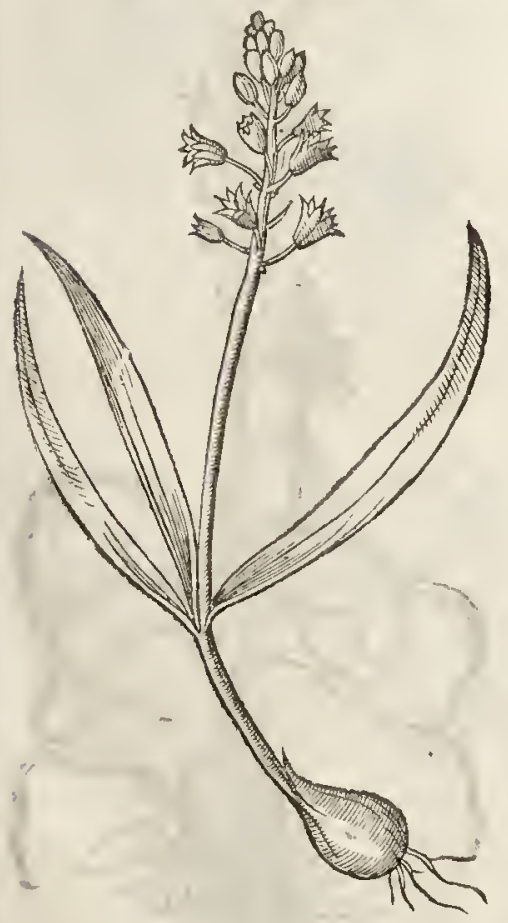

13 Hyacinthus Peruanus.

Hyacinth of Peru.

Scillapheriedicence

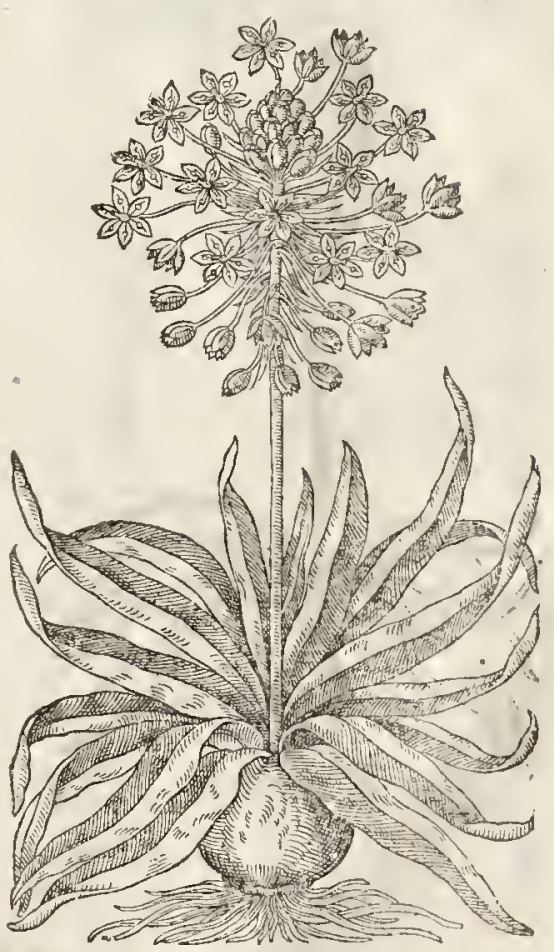

Thofe who are Itudious in varieties of Floures, and require larger defcriptions of thefe, may have recourfe to the Workes of the learned Carolus Clufus in Latine, or to M. Parkinfons Worke in Englifh, where theymay, haue full fatisfation. " $\neq$
JA.

The three firft mentioned Plants grow in many places of Germany in woods and mountaines, as Fuchjus and Gefner do teftifie : In Bohemia alfo vpon diuers bankes that are full of Herbes. In 
England we cherin moft of thefe mentioned in this place, in our gardens, onely for the beauty of their floures.

$$
\text { Thetime. }
$$

The three firt begin to floure in the midft of Ianuaric, and bring forth their feed in May. The other foures in the Spring.

T) The names.

I The firft of thefe Hyacinths is called Hyacinthus ftellatus, or Stellaris Fucb fij, of the ftarre-like

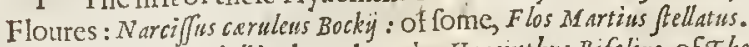

3 This by Lobell is thought to be Hyacinthus Bifolins, of Theophraftus: Tragus calls it Narciffus caruleus: and Fuchfius, Hyacinthus carsless minor mas. Wee may call it in Englin, The fmall two leaucd ftarric Iacinth.

4 The Lilly Hyacinth is ealled Hyacinthus Germanicus Liliflorus, or Germane Hyacinth, taken from the countrey where it naturally groweth wilde.

\section{$\neq$ T The vertues.}

* The faculties of the Itarry Hyaeinths are not written of by any. But the Iilly leaued Iacinth; (which growes naturally in a hill in Aquitaine ealled Hos, where the Herdmen call it Sarabug) is faid by them to caufe the heads of fuch eattell as feed thereon to fwell exceedingly, and then kils them: which fhewes it hath a maligne and poyfonous qualitic. cluf. ¥

\section{С на р. 78. Of A Atumne Hyacintbs:}

I Hvainthus Autumnalis minor. Small Autumne Iacinth.

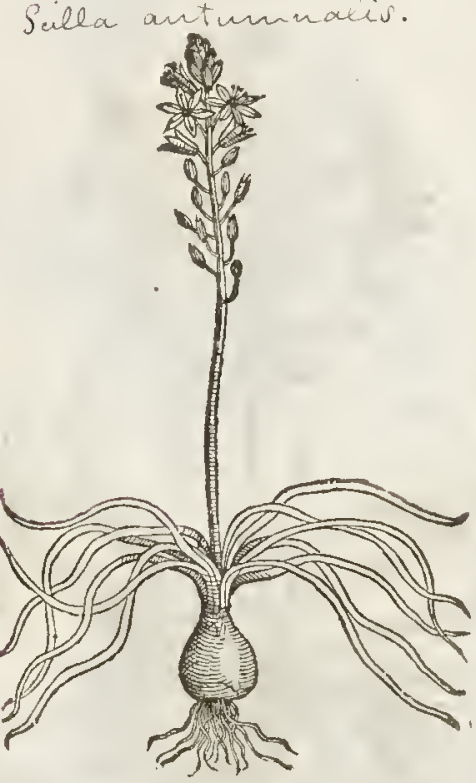

2 Hyacintbus Autumatis major. Great Autumne Iacinth,

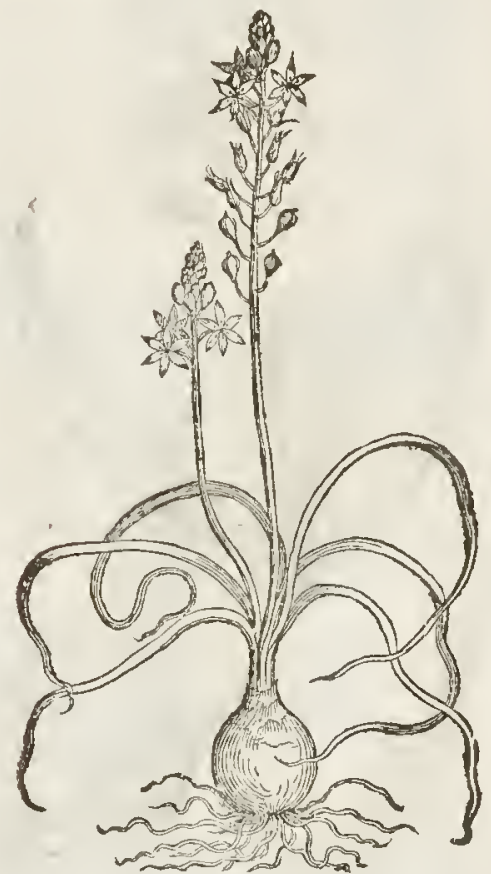

It Thedefriprion.

1 Vtumne Iacinth is the leat of all the Iacinths : it hath fmall narrow graffy leaues fpread abroad vpon the ground; in the middef whereof fpringeth vp a fmall naked ftalkean handfull high, fet from the middle to the top with many fmall farre-like blew floures, hauing certaine fmall loofechiues in the middle. The feed is blacke contained in fmall huskes : the root is bulbous. 
2 The great Winter Iaeinth is like nnto the precedent, in leaues, ftalkes, and foires, nor differing in any one point but in greatneffe.

*3 Tothefe I thinke it not amife to adde another finall Hyaeinth, more different from the fe last deferibed in the time of the flouring, than in thape. The root of it is lietle, fmall, white longinh, with a few fibres at the bottome; the leaues are fmall and long like the lant deferibed. The italke, which is fearee an handfull high, is adomed at the top with three or foure farry floures of ablewifh Ath eolour, eachtioure confifting of fix little lemes, with fix ehiues and their pointals, of a darke blew, and a peftill in the middeft. It floures in Aprill. $\neq$

$$
\text { बा The place. }
$$

+ The greater Autumne Iacinth growes not wilde in England, but it is to be found in fone gardens.

The firft or leffer growes wilde in diuers places of England, as vpon a banke by the Thames fide betweene Chelfey and London.

\section{Thetime.}

They floure in the end of Auguft, and in September, and fometimes after. 9) The names.

I The firft is ealled Hyacinthus Autumalis minor, or the leffer Autumne Iacintli, and Winter Iacinth.

2 The feeond, Hyacinthus Autumnalis major, the great Autumne Iacinth, or Winter lacinth.

3 This is called by Lobell, Hy winthus parvulus fellaris wernus, The finall ftarry Spring Iaeinth.

\section{С на . 79. Of the Englifh facinth, or Hare-Bels.}

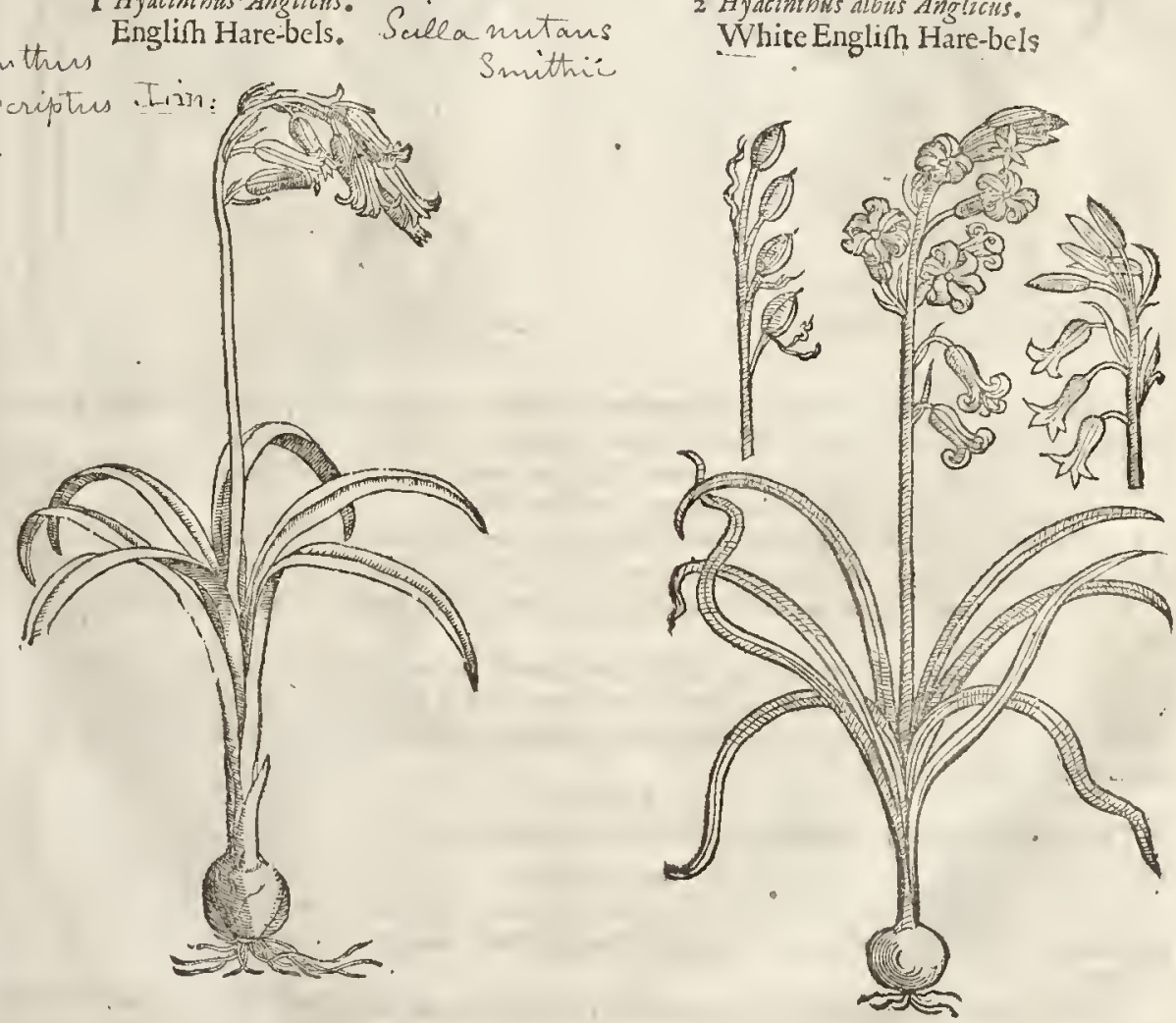

2 Hyacinthus albus Anglicus.

Hydinthus Anglicus. Sulla mutan
Englioh Hare-bels. Su

Smithic

T) The defcription?

1 Heblew Hare-bels or Englinh Iacinth is very common throughout all England. Ic hath long narrow leaues leaning towvards the ground, among the which fpring vp naked 
or bare ftalkes loden with many hollow blew Floures, of a ftrong fweet fmell, fomewhat ftuffing the head: after which come the coddes or round knobs, containing a great quantitie of fmall blacke thining feed. The root is bulbous, full of a limy glewith juyce, which wil ferue to fet feathers vpon arrowes in ftead of glew, or to pafte bookes with: whereof is made the beft farch next vnto that of Wake-robin roots.

4 Hyacinthus orientalis caruleus. The blew Orientall Iacinth.

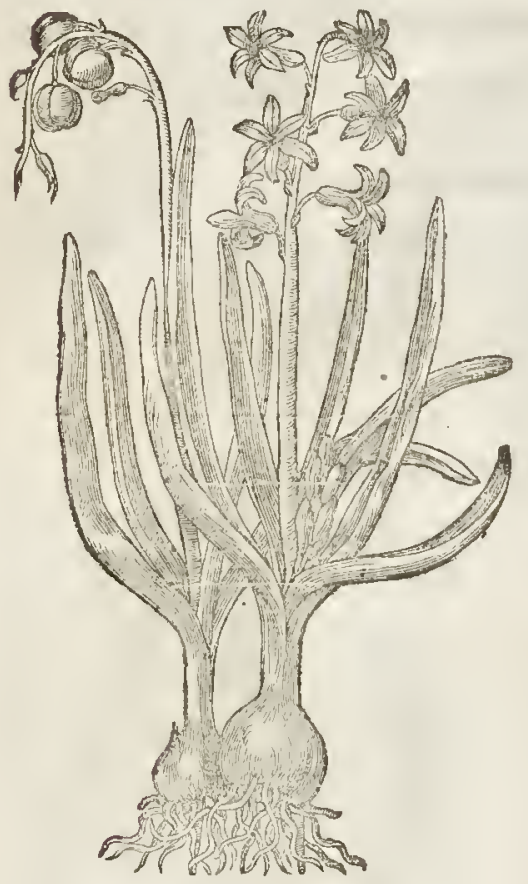

5 Hyarinthus orientalis Polyanthos. Many floured Orientall Iacinth.

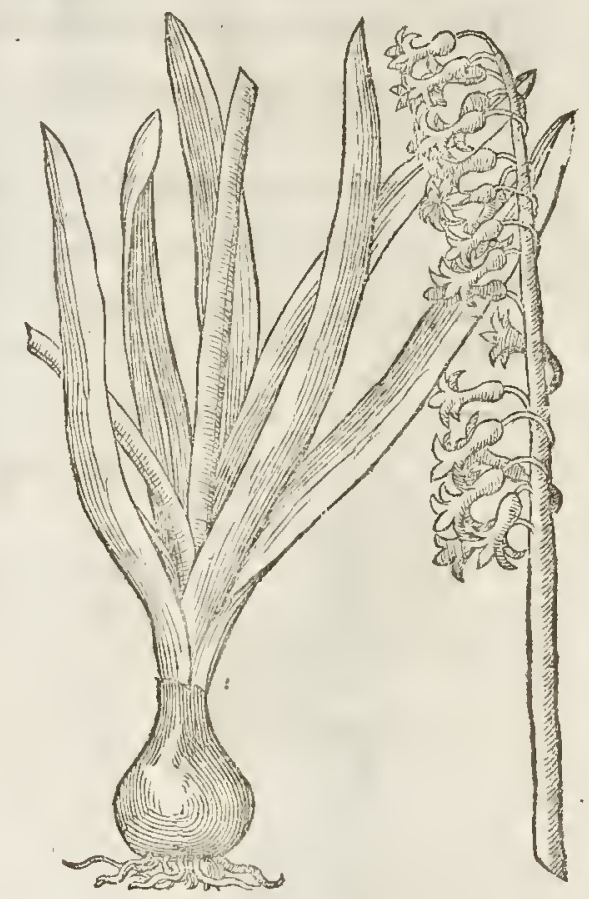

2 The white Engliph Iacinth is altogethet like vnto the precedent, fauing that the leaues hereof are fomewhat broader, the Floures more open, and very white of colour.

3 There is found wilde in many places of England, another fort, which hath Floures of a faire carnation colour, which maketh a difference from the other.

$\ddagger$ There are alfo fundry other varicties of this fort, but I thinke it vnneceffaric to infift vpon them, their difference is fo little, confifting not in their hape, but in the colour of the ir Floures. $¥$

The blew Hare-bels grow wilde in woods, copfes, and in the borders of fields enery where tho. row England.

The other two are not fo common, yet do they grow in the woods by Colchefter in Effex, in rhe fields and woods by South-fieet, neere vnto Graucs-end in Kent,as alfo in a picce of ground by Canturbury called the Clapper, in the fields by Bathe, about the woods by Warrington in Lancarhire, and other places.

They floure from the beginning of May vnto the end of Iune.

$$
\text { It The names. }
$$

I The firft of our Englin Hyacinths is called Hyacinthus Anglicus, for that it is thought to grow more plentifully in England than elfewhere; of Dodoneus, Hyacinthus non friptus, or the vhwritten Iacinth.

2 The fecond, Hyacintbus Belgicus candidus, or the Low-Countrey Hyacinth with white Floures.

$\neq 3$ This third is called Hyacinthus Anglicts, aut Bolgicus Florcincarnato, Carnation Harebels.

+6 Hyacimbus 


\section{I B. I. Of the Hittory of Plants.}

¥6 Hyacint bus oricntalis polvanthos alter.

The other many-Floured Oriental lacinth.

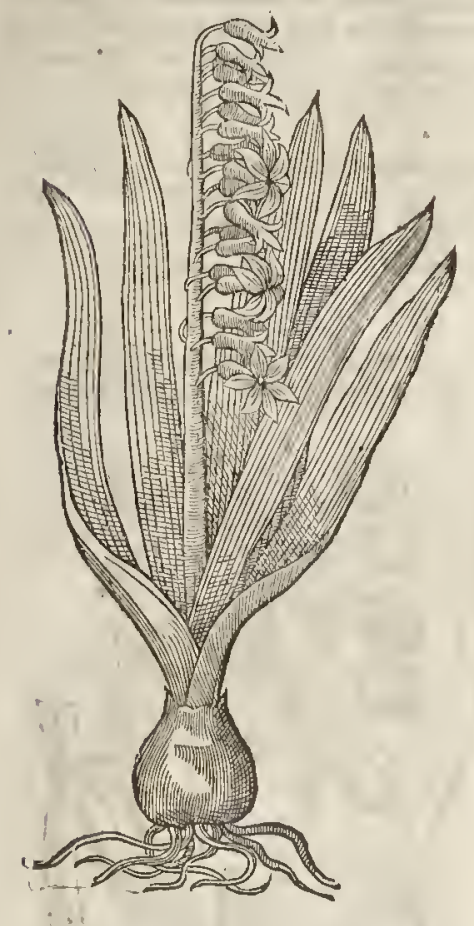

\# 8 Hyacinthus Orientalis albus, White Oriental Iacinth.

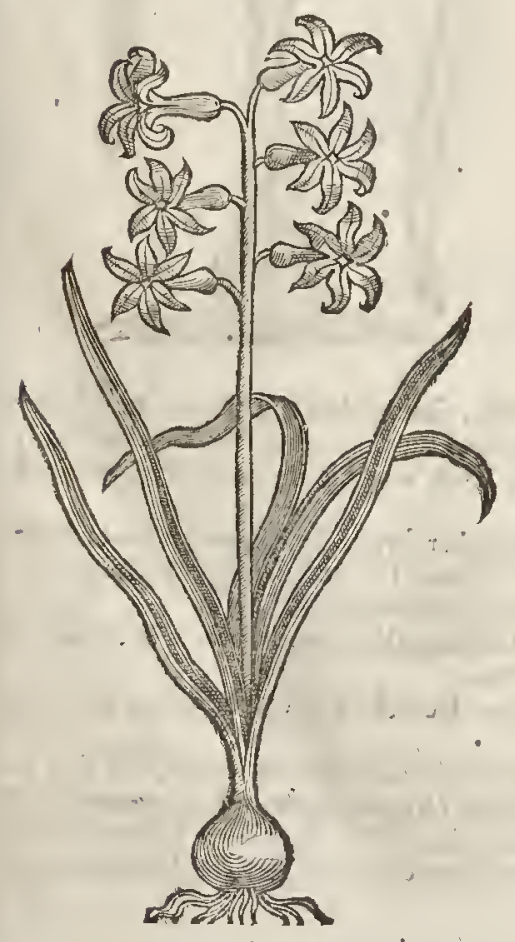

$\$ 7$ Ilyacinthus Oricntalis purpurorubens. Reddih purple Oriental Iacinth.

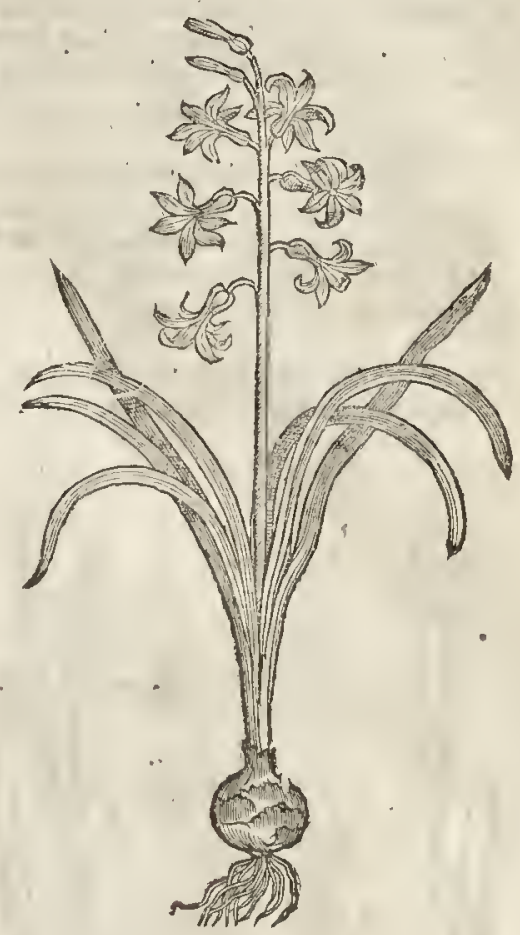

I Hyacinthis Brumalis。 Winter Iacinth.

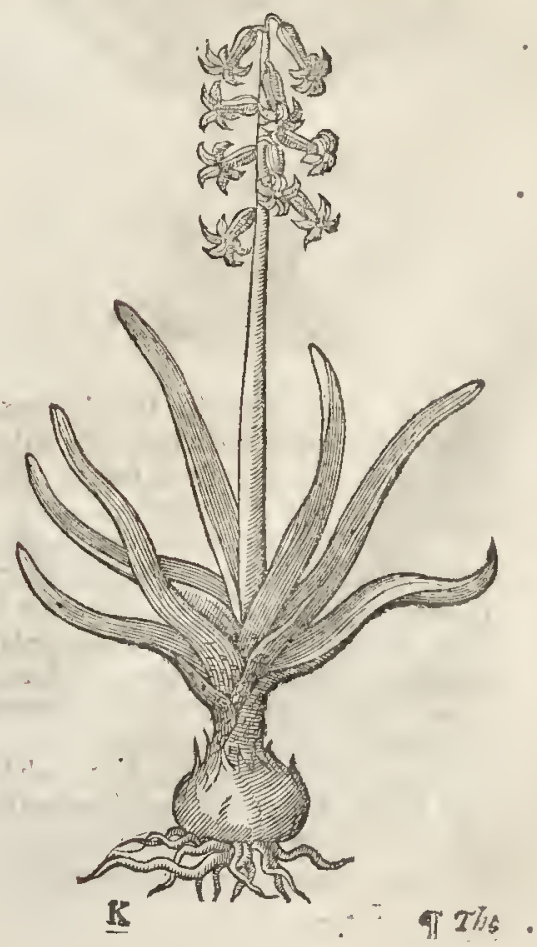




\section{T The Defription.}

4 The Orientall Iacinth hath great leaues, thicke, far, and full of juyce, deepely bollowed in the middle like a trough : from the middle of thofe leaues rifeth vp a talke two hands high, bare without leates, very fmooth, foft, and full of juice, loden coward the top with many faite blew Floures, hollow like a bell, greater than the Englifh Iacinth, but otherwife like them. The root is great, bulbous, or Onion fathion, eouered with many fealy reddifh filmes or pillings, fuch as coner Onions.

5 The Iacinth with many Floures (for fo doth the word Polyanthos import) hath very many large and broad leaues, thort and very thicke, fat, or full of nimy juyce: from the middle whereof rife vp ftrong thicke grofle ftalkes, bare and naked, fet from the middle to the top with many blew or skie coloured. Floures growing for the noft part vpon one fide of the ftalke. The root is great, thicke, and full of flimy juyee.

+ ro Hyacinthus o rientalis caule fritoso Orientall Iacinth with leaues on the ftalke.

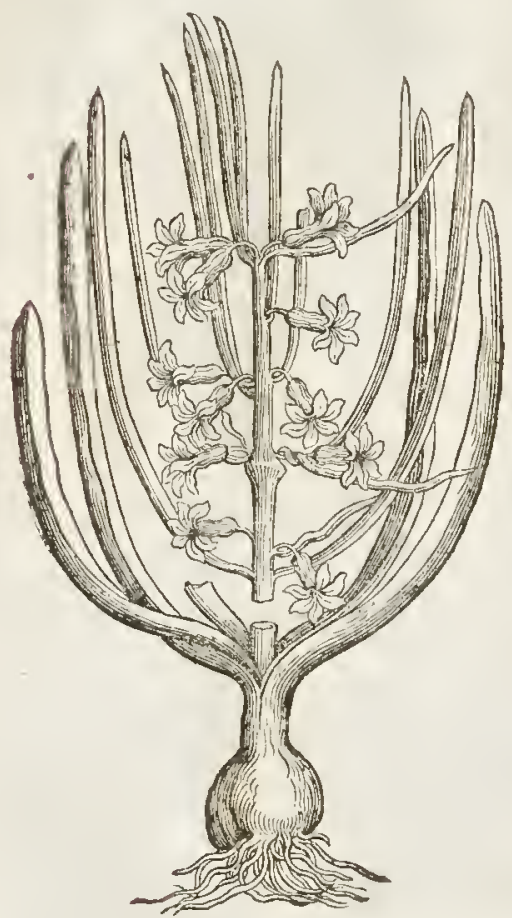

I I Hyacinthus oriental is fore pleno. The double floured Oriental Iaeinth.

$¥ \quad 6$ There is another like the forner in eaeh refped, fauing that the floures are wholly white on the infide, and white alfo on the outfide, but three of the out-leaues are of a pale whitili yellow. Thefe floures fmell fweet as the former, and the heads wherein the feeds are contained are of a lighter greenc colour. $\ddagger$

7 There is comevnto vs from beyond the feas diuers other forts, whofe figures are not extant with vs; of which there is one like vnto the firtt of thefe Oriental Iaeinths, fauing that the floures thereof are purple coloured; whenee it is termed Hyacinthus purpuro rubeus.

8 Likewife there is another ealled orientalis albus, differing alfo from the others in eolour of the floures, for that thefe are very white, and the others blew.

9 There is anothercalled Hyacinthus Brumal $\dot{B}_{3}$ or winter Iaeinth : it is like the others in thape, but differeth in the time of flouring.

‡ 10 There is another Hyacinth belonging rather to this place than any other, for that in root, leaues, foures, and feeds it refembles the firft deferibed Oriental Iacinth; but in one refpect it differs not onely frum them, but alfo from all other Iacinths : which is, it hath a leaule ftalke, hauing fometimes one, and otherwhiles two narrow long leaues comming forth at the bottome of 
I4 Hyacint bus ob foleto fore Hipanicus major. Thegreater dusky floured Spanifh Iacinth,

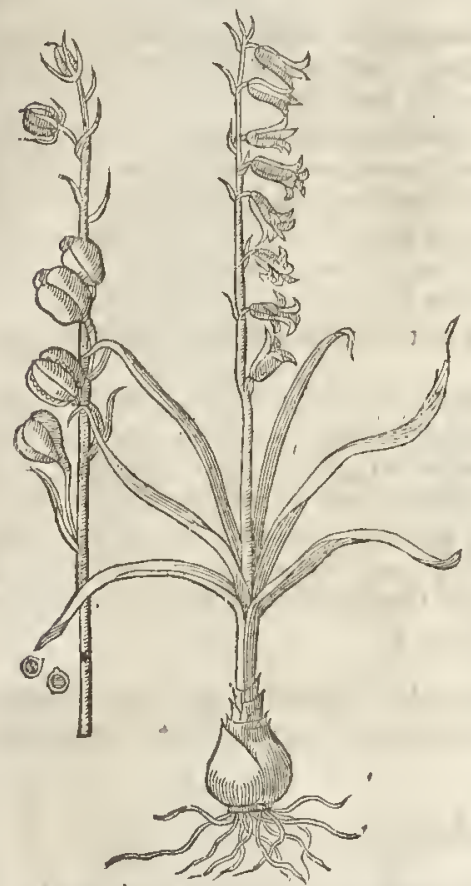

¥ 6 Hyacintbus Indicus tuberofus. The tuberous rooted Indian Iacintli.

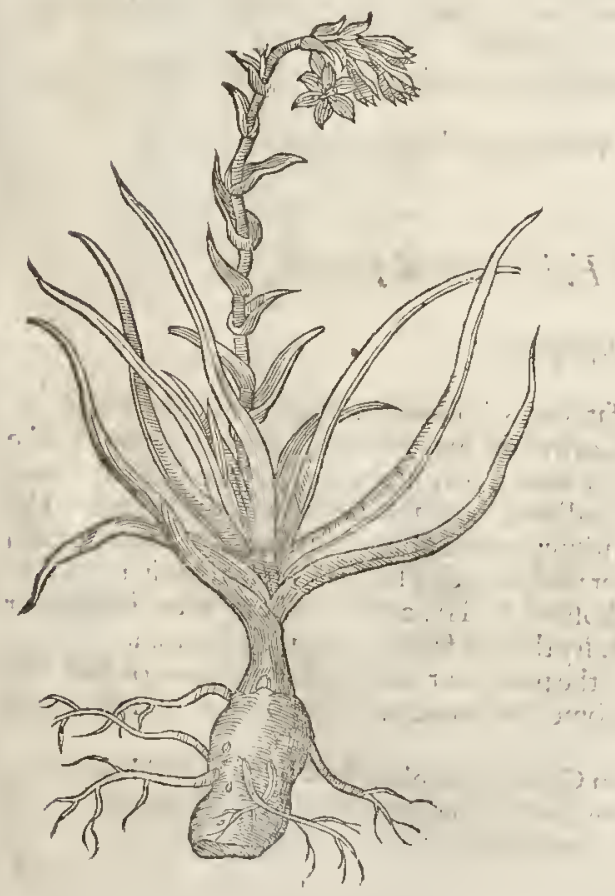

\# 5 Hyacintbus minor Hifpanicus. The leffer Spanifh Lacinth.

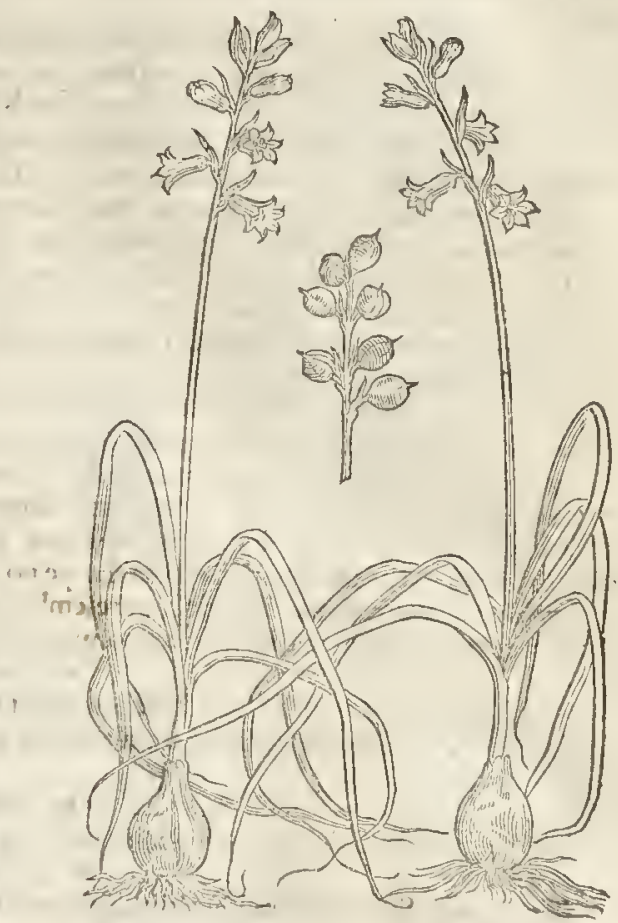

the fetting on of the floure. Whereupon Clttfuscalls it Hyaint bus orientalis culle foliofo: That is, the Oriental Hyacinth with leatues on the ftalke.

I of double floured orient al Hyacinths.

Of this kindred there are two or three more varicties, whereof I wil give you the defcription of the molt notable, and the names of the other two; which, with that I fhall deliwer of this, may ferue for fitficient defeription. The firft of thefe (which Clatizs calls Hyacint hurs O. rientalis frbbircfente flore, or, the greenith fioured double Orientall Iacinth) hath leates, roots,and feeds like vnto the formerly deferibed Oriental Iacinths; bur the floures (wherin thedifference confits) are at the firt, before they be onen, grecne, and then on the out fide next to the ftallie of a whiting blew; and they confilt of fix leaues whofe tios are whi. tifh,yet retaining fome manifeft greenes:ther out of the midf of the floure comes forth an. other floure confiting of threc leanes, ivitin on their inner fide, yet keeping the great veine or Atreake vpon the outer fide, each floure hiuing in the middle a ferv chicues with blackith pendants, It toures in Aprill.

$\mathrm{K} 2$ 
I 2 'This varietie of the laft deferibed is called $H$ yasint/ows orientalis flore carmleo pleno, The dou. bleblew Orientall Iacinth

I 3 This, Hyacinthus orientalis candidisimus flore pleno, The milke-white double Orientall Iacinth.

I4 This, whicl Clufus calls Hyacintbus obfoletior Hifpanicus, hath leaues fomewhat narrower, and more flexible than the $M u f c a r i$, with a white ve ine running along the infide of them : among thefe leates there rifeth vp a falke of fome foot high, bearing fome fiftecne or fixteene flourcs, more or leffe, in thape much like the ordinarie Englifh, confifting of fix leaues, threc ftanding much out. and the other three little or nothing. Thefe floures arc of a very dusky colour, as it were mixt with purple, yellow, and greene : they haue no fmell. The feed, which is contained in triangular heads, is frnooth, blacke, fcaly, and round. It floures in Iune.

I5 The leffer Spanith Hyacinth hath leaucs like the Grape-foure, and fmall foures thaped like the Orientall Iacinth, fone are of colour blew, and other fome white. The feeds arc contained in three cornered feed-ieffels. I haue giuen the figure of the white and blew together, with their feed-reffels.

I6 This Indian Iacinth with the tuberous root (faith clufus) hath many long narrow tharpe pointed leates f fread vpun the ground, being fomew hat like to thofe of Garlicke, ind in the mictdeft of the fe rife vp many round firme ftalkes of fome tw o cubits high, and of t ines higher, fometimes exceeding the thickneffe of ones little finger; which is the reafon that oftentimes, rnleffe they be bornevp by fomething, they lie along vpon the ground. Thefe ftaikes are at certaine fpaces ing irt with leaues which end in tharpe points. The tops of thefe ftalkes are adorned with many white foures, fomewhat in thape refembling thofe of the Orientall Iacinth. 2\%e roots are knotty or tuberous, with diuers fibres comming out of them. $\neq$

T. The place.

Thefe kindes of Iacinths haue beene brought from beyond the Seas, fome nut of one countrey, and fome out of others, efpecially from the Eaft countries, whereof they tooke their names orientalis.

The time.

They floure from the end of Ianuarie vnto the end of Aprill.

If The nature.

The Hyacinths mentioned in this Chapter do lightly cleanfe and binde; the feeds are dry in the third degree; but the roots are dry in the firft degree, and cold in the fecond.

\section{9] The vertues.}

A The Root of Hyacinth boyled in Wine and drunke, foppeth thebelly, protuoketh vrine, and heloeth againft the venomous bitings of the ficld $S$ pider.

B The feed is of the famevertue, and is of greater force in ftopping the laske and bloudy fix.Being drunke in wine it preunileth againft the falling ficknefic.

C The roots, after the opinion of D iof corides, being beaten and applied w ith white Wine, hinder or keepe backe tive grow th of haires.

D $\neq$ The feed gituen with Southerne-wood in Wine is good againft the Iaundice.

\section{C н а р. 80. Of Faire baired Jacinth. \\ T The Defcription.}

I He Faire haired Iacinth hath long fat leaues, hollowed along th the infide, trough fathion, as are moft of the Hyacinths, of a darke greene colour tending to redneffe. The ftalke rifeth out of the middeft of the leaues, bare and naked, foft and full of flimie juyce, which are befet round about with many fmall foures of an oucrworne purple colour : The top of the pipike confisteth of number of faire thining purple floures, in manner of a tuftor buth of haires, whereof it tooke his name comofus, or faire haired. The feed is contained in fmall bullets, of a hining blacke colour, as are moft of thofe of the Hyacintlss. The roors are bulbous or Onion fafhion, full of flimy juyce, with fome hairy threads faftned vnto rheir bottome.

${ }_{2}$ White haired Iacinth differeth not from the precedent in roots, ftalkes,leaues, or feed. The floures hereof are of a darke white colour,w ith fome blackneffe in the hollow part of them,which fetteth forth the difference.

3 Of this kinde I receiued another fort from Conftantinople, refembling the firt hairy Hyacinth very notably : but differeth in that, that this is altogether greater,as, well in leaues, roots, and Aoures, as aifo is of greater beaty without all comparifon. 
Of the Hiftory of Plants.

I. Hyacinthus comofus. Faire haired Iacinth:

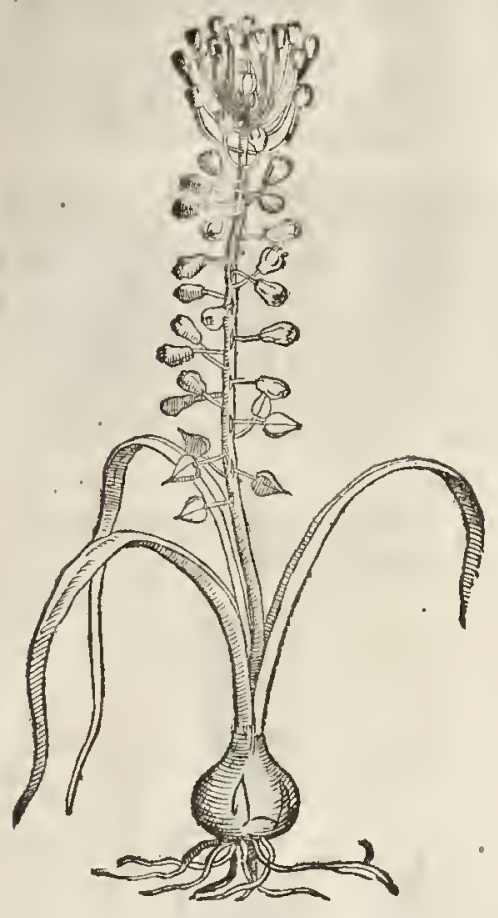

* 3 Hvacinthus comorus si 2 antinus. Faire-hairę Iacinth of Conftantinople?

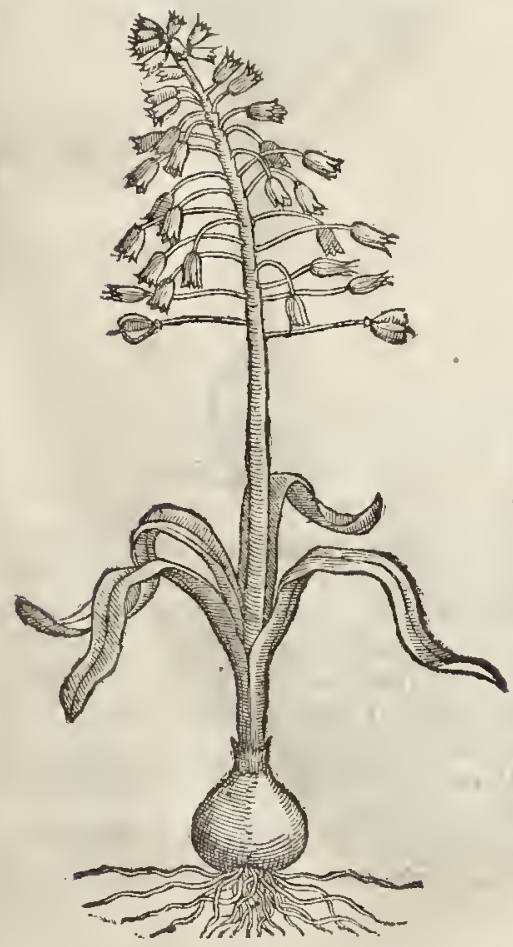

2 Hyacint hus comofus albus:

White haired Iacinth.

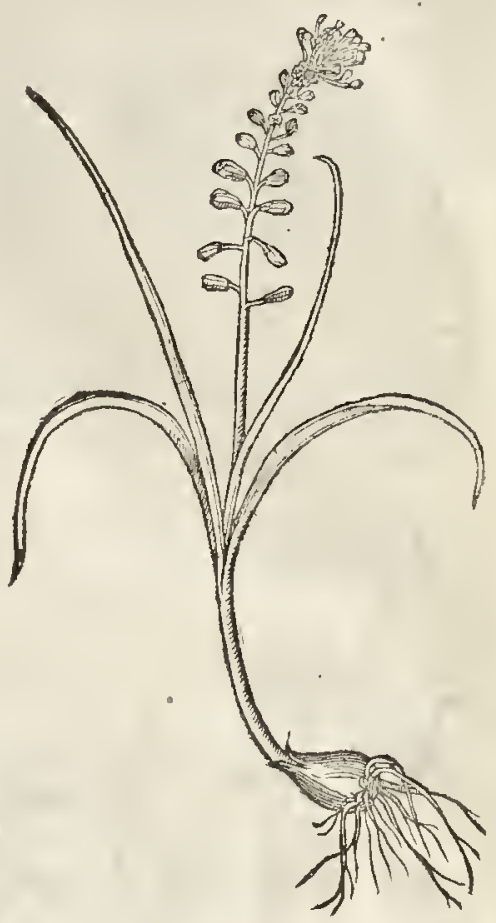

$\$ 5$ Hinacinthus comsofus ramofus elegantior? Faire curld-haired branched Iacinth.

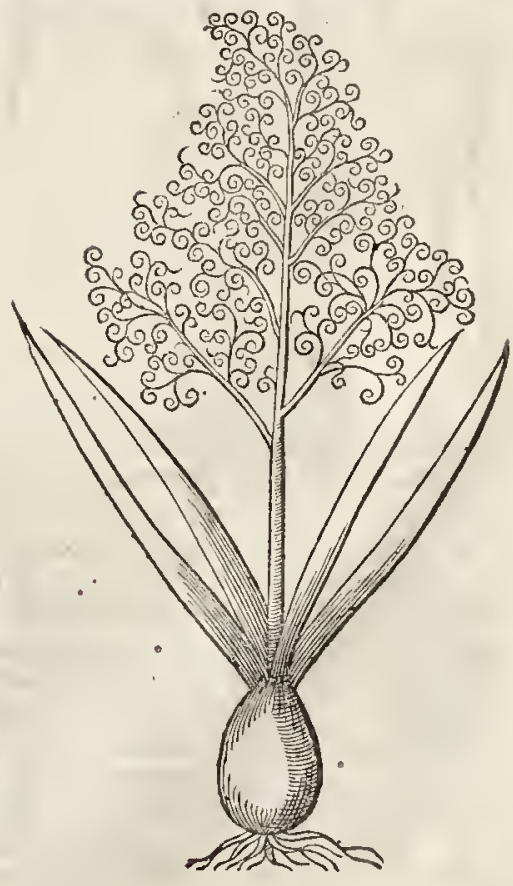

$\bar{K} \overrightarrow{3}$

$\$ 4$ There 
$\mp 4$ There are two other more beautifull haired Laeinths nourithed in the gardens of our prime Florifts. The firft of thefe hath roots and leaues refembling the latt deferibed : the ftalke commonly rifeth to the height of a foot, and it is diuided into many branehes on eucry fide, whieh are fmall and threddy, and then at the end as it were of rhefe threddy branehes there come forth many fmaller threds of a darke purple colour, and thefe fpread and diuarieate themfelues diuers wayes, mueh after the manner of the next defcribed; yet the threds are nether of fo pleafing a colour, neither fo many in number, nor fo finely eurled. This is ealled Hyacmothus comofus ramofus purpureas, The faire haired branehed Iaeinth.

5 This is a moft beautiful and clegant plant, and in his leaues and roots he differs little from the laft deferibed; but his ftalke, which is as high as the former, is diuided into very many flender branehes, whieh fubdiuided into great plenty of eurled threads varioufly fpread abroad, make a very pilcafunt thew. The colouralio is a light blew, and the floures vfually grow fo, that they are moft dilated at the bottome, and fo ftraiten by little and little after the manner of a Pyramide. Thefe floures keepe their beautic long, but are fueceded by no feeds that yet eould be obferned. This by Fabus Columna (who firft made mention herenf in writing) is ealled Hyacint hus Sannefius parniculo f coma: By others, Hyacinthus comofus ramofus elegatior, The faire curld-haire Iacinth.

Thefe floure in May. $\ddagger$

6 Hyacintlus botryoides caruleus. Blew Grape-floure.

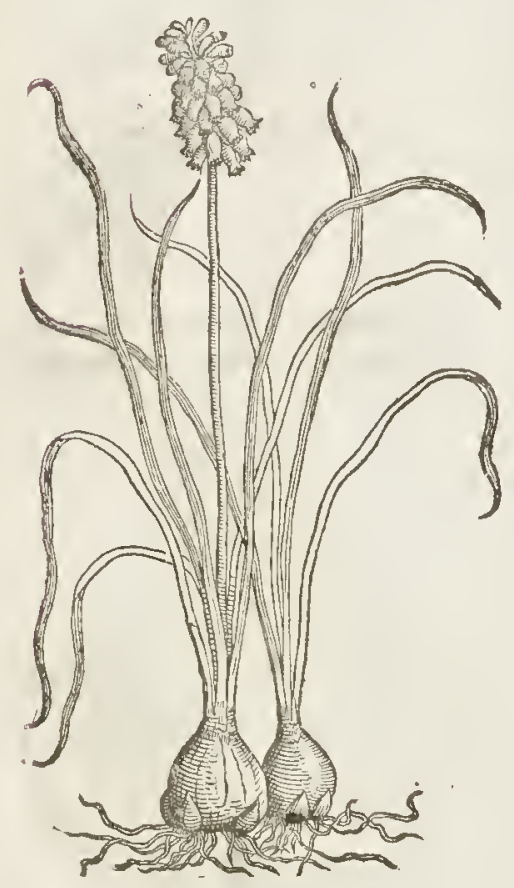

7 Hyacint hus botryoides cernlens major. Great Grape-Plourc.

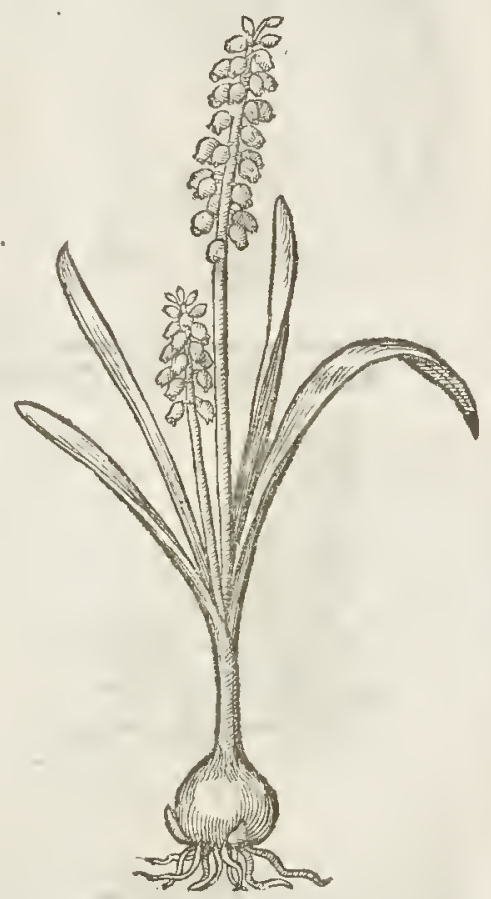

6 The fnall Grape floure hath many long fat and wcake leaues trailing vpon the ground, hollow in the middle like a little trough, full of llimic juyee like the other lacinths; amongft which come forth thieke fort fmooth and weake ftalkes, leaning this way and that way, as not able to fand vprighr by reafou it is fureharged with very heauy foures on his rop, eonfifting or many lit= tle bottle-likeblew floures, elofely thruft or paeked together like a buneh of grapes, of a ftrong fmell, yet not unpleafunt, fo new hat refembling the fauour of the Orange. The root is round and bulbous, fet about with infinite young eloues or roots, whereby it grcatly increafeth.

7. The great Grape-foure is very like vnto the fmaller of his kinde. The difference eonfifteth, it that this plant is al together greater, but the leaucs are not fo long.

8 Thesky-eoloured Grape-foure hath a few leanes in refpeet of the other Grape-floures, the which are thorter, fuller of juyee, ftiffe and vprighr, whereas the orhers traile vpon the ground. 
The floures grow at the top, thruft or packt together like a bunch of Grapes, of a pleafant bright sky eolour,euery little bottle-like floure fet about the hollow entrance with fimall white f pots not
eafie to be perceiued. The roots are like the former.

\section{Hyacinthus Botryoides caruleus major. Great Grape-floure.}

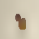

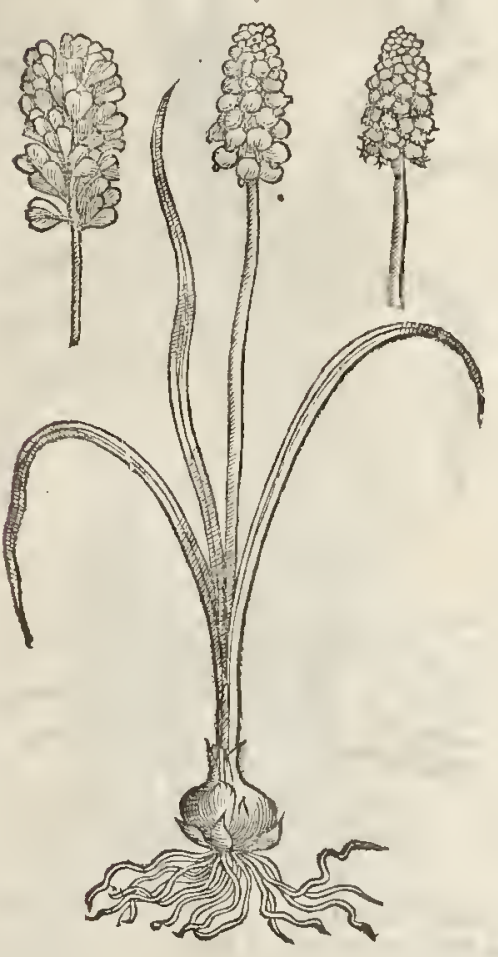

9 The white Grape-floure differeth not from the sky-coloured Iacinth, but in colour of the foure:for this Iacinth is of a pleafant white colour tending to yellownes, tipped about the hollow part with White, whiter than White it felfe; otherwife there is no difference.

$$
\text { 9) The Place. }
$$

Thefe plants are kept in gardens for the beautic of their floures, wherewith our London grardens do abound.

\section{a) The Time.} May.

They foure from Februaric to the end of 91 The Nitmis.

The Grape-flotire is called Hyacinthus Botry. oides, and Hyacinthus Neotucorum Dodonat: of fome, Bul' us Efculentus, Hyacinthus fylueftris cordi, Hyacintbus exiguus Tragi. Some iudge then to the Bulbi ie, of Pliny.

tThe faire baired lacinth defcribed in the forft place is the Hyacinchus of Diof corides and the Antients.t

$$
\text { IT The Nature and Vertues. }
$$

t Tle vertues fet downe in the precedent Chap. ter properly belong to that kinde of Hyacinth which is defcribed in the firft place in this Chaprer.

$\therefore$ Chap. 81.

$$
\begin{aligned}
& \text { Of OMuifari, or Musked Grape-floure. } \\
& \text { II The Defcription. }
\end{aligned}
$$

I 7 Ellow Mufcarie hath fiuc or fix long leaues fpread vpon the ground, thicke, fat, and full of limie juyce, turning and winding them felues crookedly this way \&z that way, hollowed alongft the middle like a trough, as ate thofe of faire haired Iacinth, which at the firft buddng or fpringing vp are of a purplinh colour; but being growne to perfection, become of adarke greene colour :ampng ft the which leaues rife vp naked, thicke, and fat ftalkes, infirme and weake in refpect of the thickneffe and greatnefie thercof, lying alfo vpon the ground as do the lcaues; fet from the middle to the top on euery fule with many yellow foures, eueric one made like a fmall pitcher or little box, w ith a marrow mouth, exceeding fweet of fincll like the fauor of muske, whereof it tonke the name Mugcari. The feed is inclofed in puffed or blowne vp cods, confufedly made w ithout order, fa a fat and fpongeous fub tance, wherein is contained round blacke feed. The rnot is bulbous or onion fanhion, whereunt? are annexed eertaine fat and thicke ftrings like thofe of Dogs grilfic.

2 Afh-coloured Mufcari or grape-flotre, liath large and fat leaues like the precedent, not differing in any point, fauing that thefe leates at their firt fpringing vp are o? a pale dusky co'o: it like arhes. The floures are likewife fivece, but of a pale bleake colour, wheren confiter h the dif-
ference, 
I Mufcari flavum.

Yellow musked Grape-Houre.

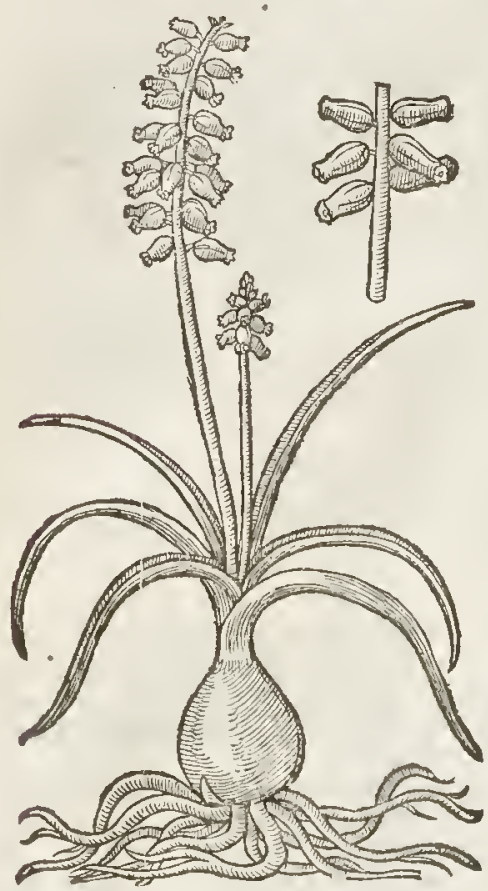

Mufcari caulis filiquis onufus.

The falke of Mufcari hanged with the feed-veffels.
2 Mufariclufij.

Afh-coloured Grape-floure.

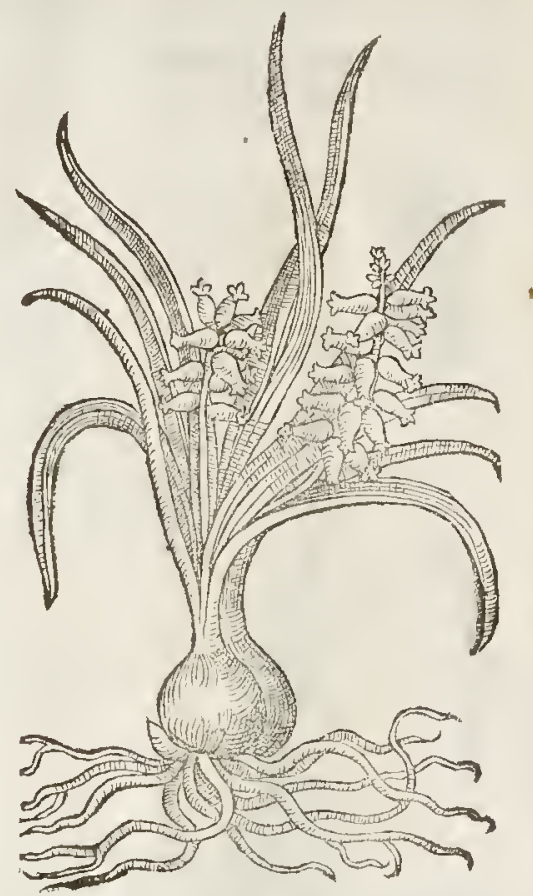

The Place.

Thefe Plants came from beyond the Thracian Bofphorts, out of Afia, and from about Conftantinople, and by the meanes of Fricnds hauc been brought into thefe parts of Europe, whereofour London gardens are poffeffed.

\section{The Time.}

They floure in March and Aprill,and fomezimes after.

$$
\text { T The Nancs. }
$$

They are called generally Mufcari: In the Turky Tongue, Mufchoromi, Mufurrimi, Tipcadi, and Dipcadi, of their pleafant fweet fmell: of Matthiolus, Bulbus Vomitorius. Thefe plants may be referred vnto the Iacinths, where of vndoubtedly they be kindes.

$$
\text { T The Nature and Vertues. }
$$

There hath not as yet any thing beene touched concerning the nature or vertucs of thefe Plants, onely they are kept and maintained in zardens for the pleafant fncll of their floures, fut not for their beauty, for that many ftinking field floures do in beautie farre furpaffe them. But it fhould feem that Matthiolus called then Vomitorius, in that he fuppofed they procurevomiting; which of other Authors lath not bin remembred.

Chap. 


\section{Cha p. 8z: Of Woolly Bulbus.}

Bulbus Eriophorus.

Woolly Iacinth.

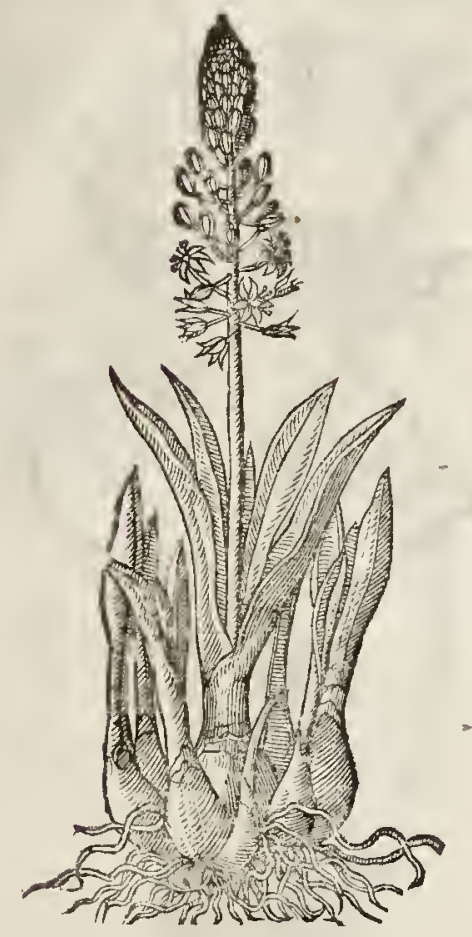

\section{T) The Defcription.}

7 Herc hath fallen out to be here inferted a bulbous plant confifting of many Bulbes. which hath paffed currant amongft all our late Writers. The which I am to fet forth to the view of our Nation, as others haue done in fintdry languages to theirs, as a kind of the Iacinths, which in roots and leaues it doth very wel refemble; called of the Grecians,"Eeupoes: in Latine, $L a-$ niferus, becaufe of his aboundance of "Wooll-re: fembling fubftance, wherewith the whole Plant is in eucry patt full fraught, as well roots, leaues, as ftalkes. The leatues are broad, thicke, fat full of juyce, and of a fpider-like web when they be broken. Among thefe leanes tifett vp a talke two cubits high, much like vito the ftalke of Squilla or Sea-OL:On; and from the midaje to the top it is befet round about with many fmall ftarre-like blew fourcs without (meli, vry like to the floures af Afphodill; beginning to floure at the bottome, and fo vpward by degrees, whercby it is long before it hath done flouring: which floures the learned Phyfitian of Vienna, Iobarnnes Aicholzius, defired long to fee; who brought it firft from Conftantinoplc, and planted it in his Garden,where he nourifhed it tegne yeares with great curiofitic: which time being cxpired, thinking it to be a barren plant, he fent it to Citrolus Clufins, with whom in fone ferw yeres it did beare fuch floures as before defcribed, but neuer fince to this day. This painefull Herbarift would gladly hate feene the feed that fhould fucced thefe floures; but they being of a nature quickly fubie $c t$ to priíh, decay, and fade, began prefently to pine away, leaung onely a few chaffic and idle ieed-veffels without fruit. My felfe hath beene poffeffed with this plant at the leaft tweluc yeares, whereof $I$ haue y carcly great cncreafe of new roots, but I did neuer fee any token of bud. ding or flouring to this day: notwithftanding I thall be content to fuffer it in fomc bafe place or other of my garden, to ftand as the cipher o at the end of the figures, to attend his time and lcifure, as thofe men of famous memorie have done. Of whofe temperature and vertues there hath not any thing beene faid, but kcpt in gardens to the end a forefaid.

\section{C нат.83. Of two feigned Plants. \\ T) The Defription.}

2 Taue thought it conuenient to conclude this hiftorie of the Hyacinths with thefe two bulbous Plants, receiued by tradition from others, though generally holden for feigned and adulterinc. Their pictures I eould willingly haue omitted in this hiftorie, if the eurious cye could elfewhere haue found them drawne and defcribed in our Englinh Tonguc: but becaufe I finde them in none, I will lay them downe here, to the end that it may ferue for excuic to others who thall come after, which lift not to defcribe them, being as I faid condenned for feined and adulterine, nakedly drawnc onely. And the firt of them is called Bulbus ienoser: by orhers, Bulbus Bombicinus Conmontitius. The defeription confifteth of thefe points, viz. The floures (fiitl the Author) areno leffe ftrange than wonderfull. The leaues and roots are like to thofe of Hyacinths, 
einths, which hath caufed it to oceupic this plaee. The floures refemble the Daffodils or Narciffus. The whole plant confifteth of a woolly or foekic matter : whieh defeription with the P1ourewas feut vuto Dodonens by Iohames Aucholiziss. It may be that Aicholzus reeeiued inftuctions from the Indies, of a plant ealled in Greeke res'sods, whieh groweth in India, whereor Theophrafiss and Aibenews do writc in this manner, faying, The floure is like the Noriffus, eonfifing of a fockic or woolly fubftance, which by him fcemcth to be the defctiption of our bombaft Iacinth.

I Bulbus Bombicinus Commentitius. Falfc bumbaltc Iacinth.

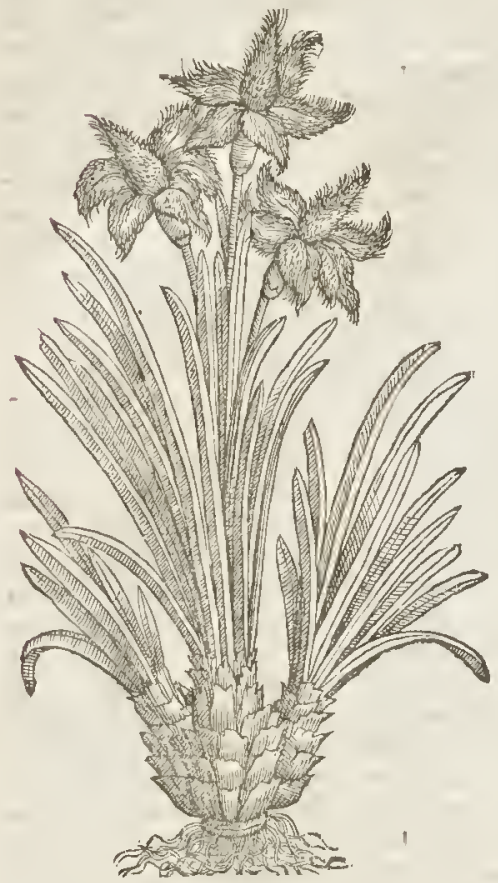

2 Tigridisflos. The floure of Tygris.

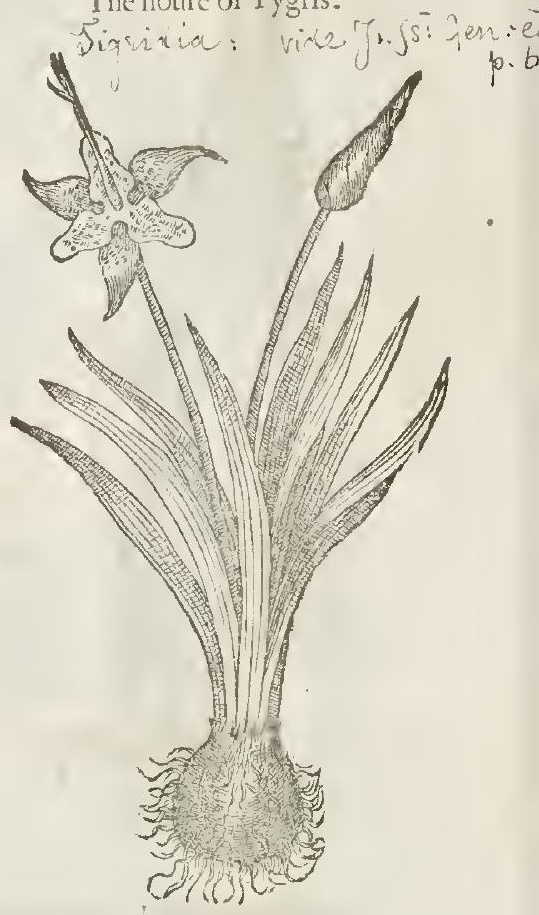

2 Thefecond feigned picturc hath becne taken of the Difconercr and othess oflater time, to bea kinde of Dragons not feene of any that hauc writen theteof; whieh hath moued them to thinke it a feigned picture likewife; now ithitanding you thall rceeiue the defeription thercof as it hath come to my hands. The root (faith my Author) is bulbous or Onion fantion, outwatdly blacke; from the which fpring vplong leaues, fharpe pointed, natrow, and of a freth greene colour : in the middet of whieh leaues rife vp naked or batc falkes, at the top whereof groweth a pleafant yellow Houte, ftained with many fmall red fpots here and thete eonfufedly eaft abroad: and in the middeft of the floure thrufteth forth a long red tongue or ftile, which in time grometh to be the cod ot feed-veffell,erooked or wreathed, wherein is the feed. The vertues and tempetature are not to be fpoken of, confidering that we affuredly perfuade our felues that there are no fuch plants, but meere fiotions and deuices, as we terme then, to giue his friend a gudgeon.

$\neq$ Though thefe wo laue beeng thought commentitious or feigned, yet Bawhinus feemeth to vindieate the latter, and Iohn Theodore de Bry in his Florilegium hath fet it forth. He gitues two Figures thereof, this which we here gite you being the one; but the other is farre more elegant, and better refcmbles a naturall plant. The leaues (as Baubine faith) are like the fword-flag, the root like a lecke, the floures (according to'De Bries Figure) grow fometimes two or three of a ftalke: the floure confits of tro leaues, and a long ftilc ot peftill : each of thefe leaues is diuided into three parts, the sttermot being btoad and large, and the innermoft much narrower and fharper: the tongue or ftile that eomes forth of the midit of the flourc is long, and at the end diuided into three crooked forked points. All that $D c$ Bry faith thetcol is this; Flos Tigridis rubet egregie circa medium tamen pallet, albuf gue eft or maculatus; ex Mexico a Caparo Babino. That is; Flos Tigridis is wondrous red, yet is it pale and whitifh about the middlc, and alfo fported; it came from about Mcxico, I lad it from Capar Bawhine. $\ddagger$

Chap. 


\section{Снар. 84. Of Daffodils.}

T The Kindes.

$\mathrm{D}$

Affodill, or Narcifus, according to Diofcorides, is of two forts : the floures of both are white, the one hauing in the middle a purple circle or coronet; the other with a yellow cup circle or coronet. Since whofe rime there harh been fundry others defcribed, as fhall be fet forth in their proper places.

I Narcifus medio purpurcus: Purple circled Daffodill. Sarigsus poetrciss.

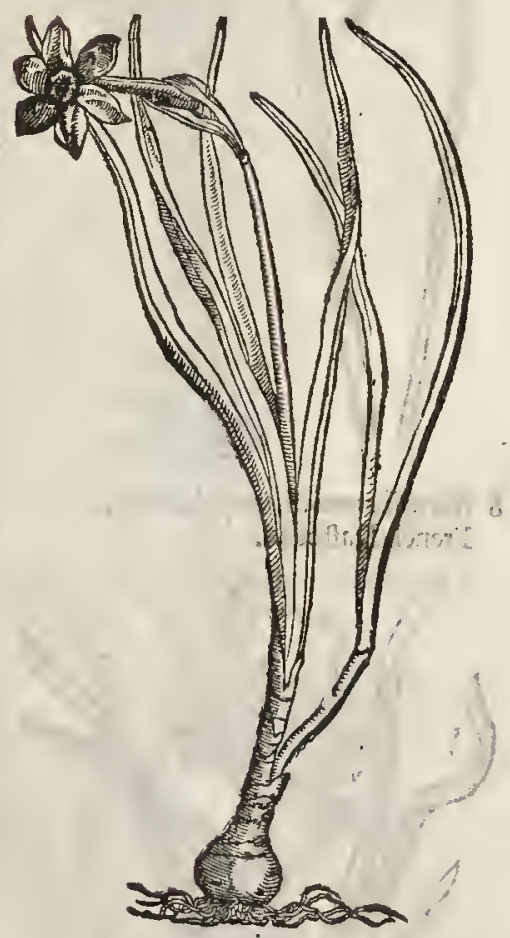

\# 4 Narciffus medio croceus fer otinus Polyant hos: The late many floured Daffodill with the Saf-

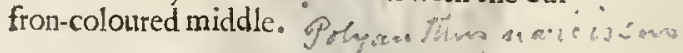

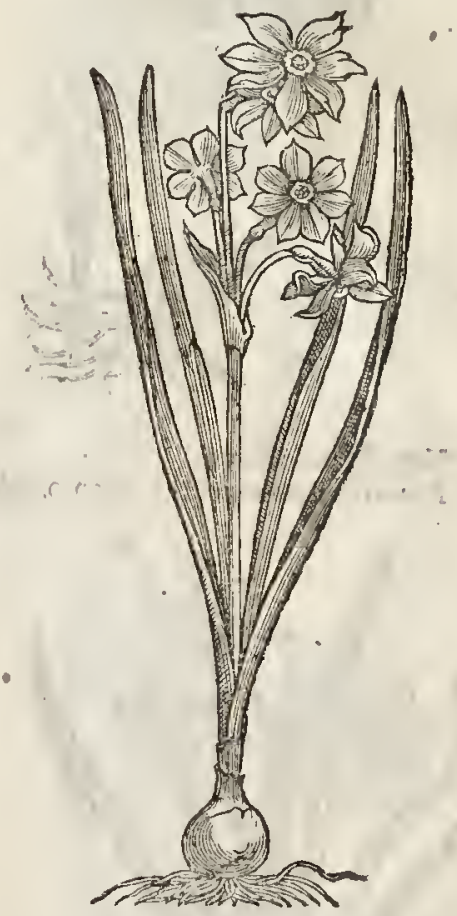

T The Defcription?

1 He firft of the Daffodils is thar with the purple crowne or circle', hauing fmall narrow leaues, thicke, fat, and full of flimie puyce; among the which riferh vp a naked ftalke, fmooth and hollow, of a foot high, bearing at the top a faire milk-whire tloure growing forth of a hood or thinne filme, fuch as the floures of onions are wrapped in : in the middeft of which flomre is a round circle or fmall coronet of a yellowifh colour, purfled or bordered about the edge of the faid ring or circle with a pleafant purple colour ; which beeing paft, there followeth a thicke knob or button, wherein is contained blacke round feed. The root is white, bulbous or Onion fafhion.

2 The fecond kinde of Daffodill agreeth with the precedent in enery refped, fauing that this Daffodill floureth in thebeginning of Februarie, and theother not vntill Aprill, and is fomew hat

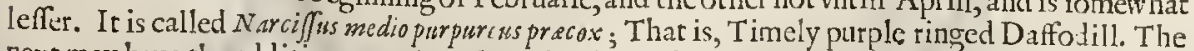
next may haue the addition precocior, More timely : and the laft in place, but firt in time, priccociffimus, Molt rimely, or very early flouring Daffodill. 


\section{Of the Hiftorie of Plants.}

¥ 5 Narcifus wedio-purpurens flore plesio.

Double Aoured purplecircled Daffodill.

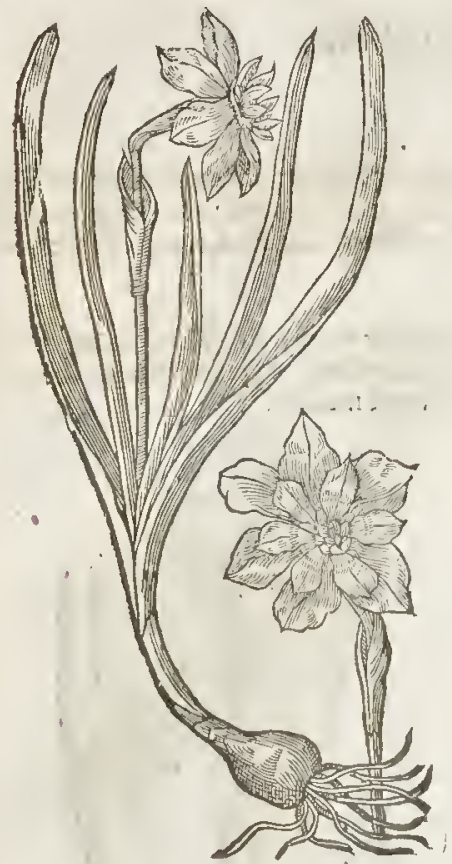

7 Narciffusmedioluteus.

Primrofe Pearles, or the common white Daffodill.

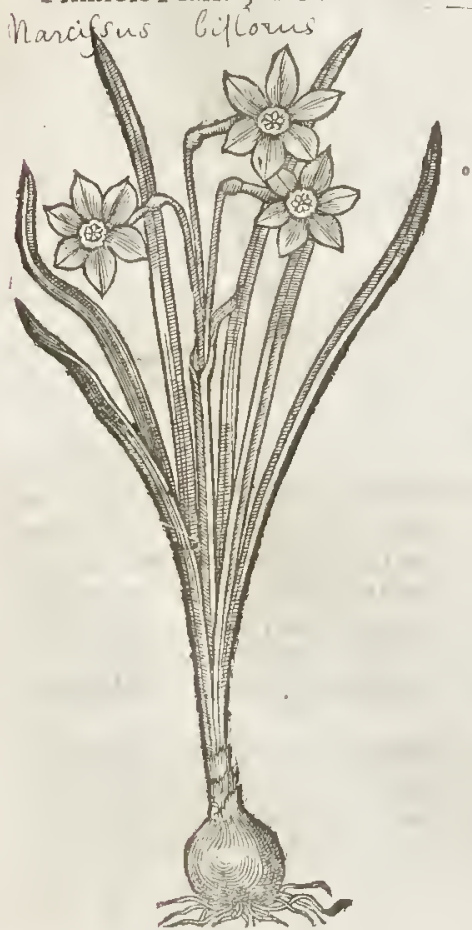

6 Narcifus minor ferotinus.

The late flouring fmall Daffodill.

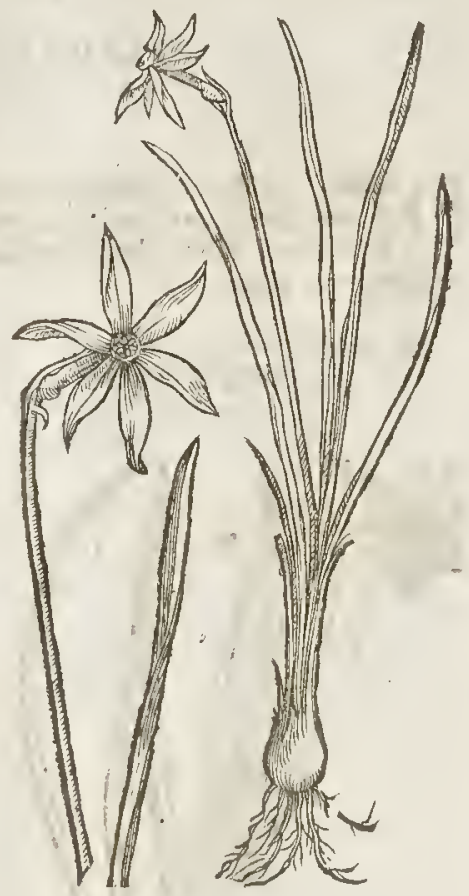

8 Narcifjus medioluteus polyanthos. French Daffodill.

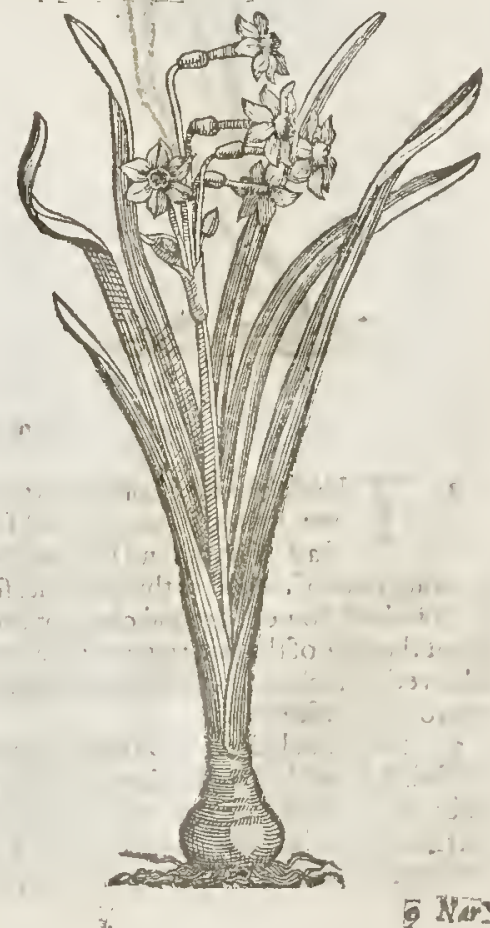




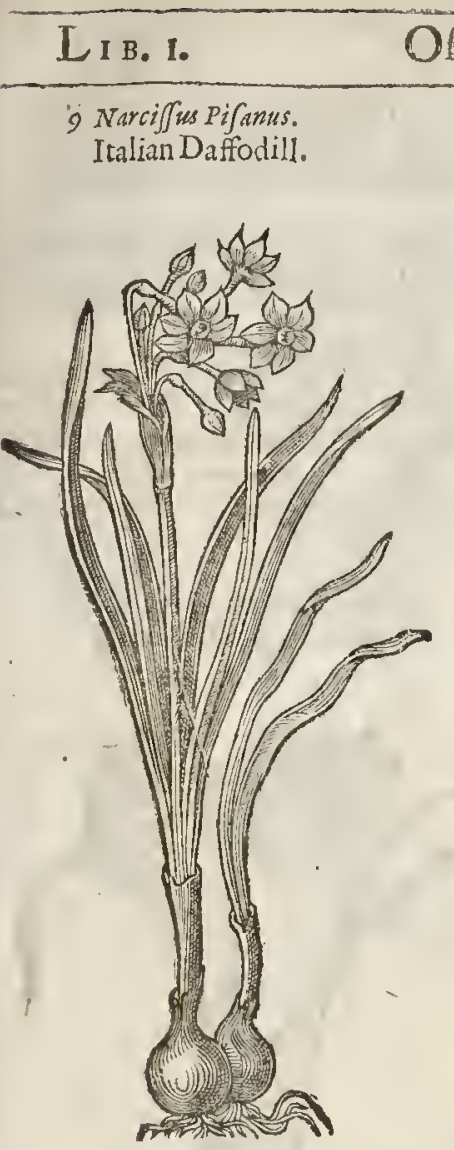

\# II Narciffus flore pleno albo:

'The other double white Daffodill.'

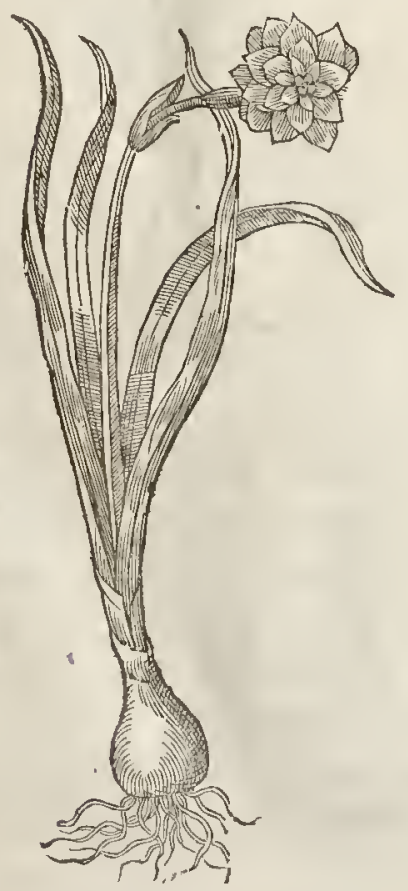

I0 Rarcifjus albus multiplex.

The double white Daffodill of Contantinople.

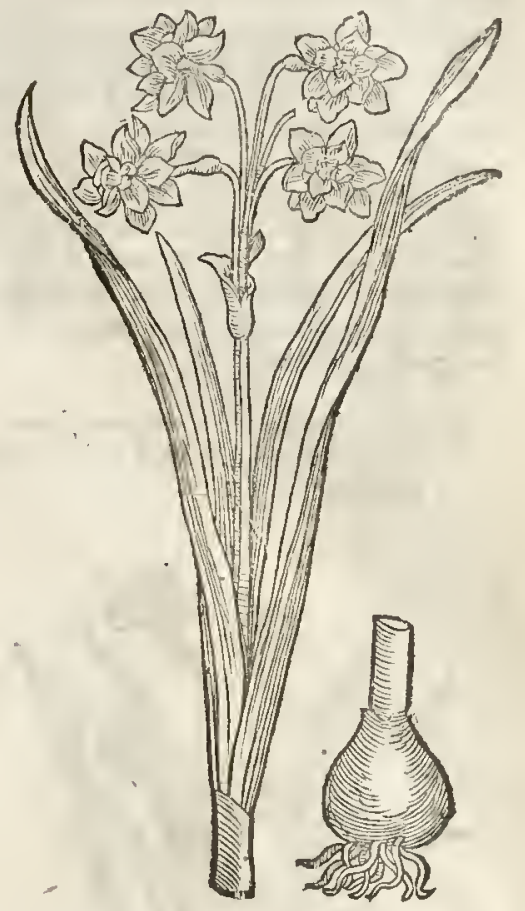

\# I Narciffes florepleno, medio luteo.

Double white Daffodil w ith the middle yellow.

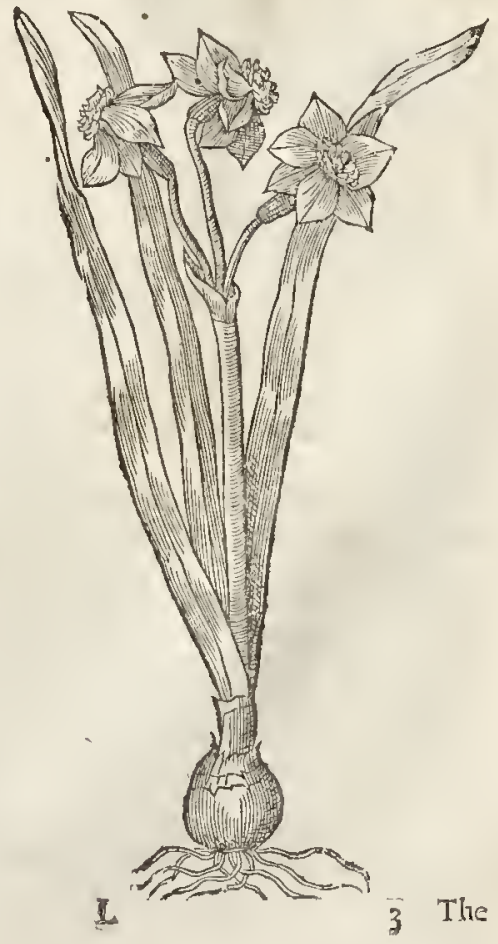


3 The third kind of Daffodil with the pnrple ring or circle in the middle, hath many fmall narrow leaues, very flat, crookedly bending toward the top; among which rifeth vp a flender bare falke, at whofe top doth grow a faire and pleafant flowre, like vnto thofe before defcribed, but leffer, and floureth fooner, wherein confifteth the difference.

$\mp$ There is al fo another fomewhat leffe, and fouring fomewhat carlier than the laft defcribed.

4 This in roots, leaues, and ftalkes differeth very little from the laft mentioned kindes; but it beares many floures vpon one falke, the out-leates being like the former, white, but the cup or ring in the middle of a fatfron colour, with diuers yellow threds contained therein.

5 To thefe may be added another mentioned by clufiss, which differs from thefe onely in the floures: for this hath foures confifting of fix large leaues fairely fpread abroad, within which are other fix leaues not fo large as the former, and then many other lit comming forth of the middle. Now there are purple welts which runae betweene the firft and fecond ranke of leaues, in the thoure, and fo in the reft. This foures in May; and it is Narcifus pleno flore quinius, of Clufuss. $\ddagger$

* 13 Narciffus florcpleno, medio verficolore.

Double Daffodill with a diuers coloured

I4 Narcifus totus albus. middle.
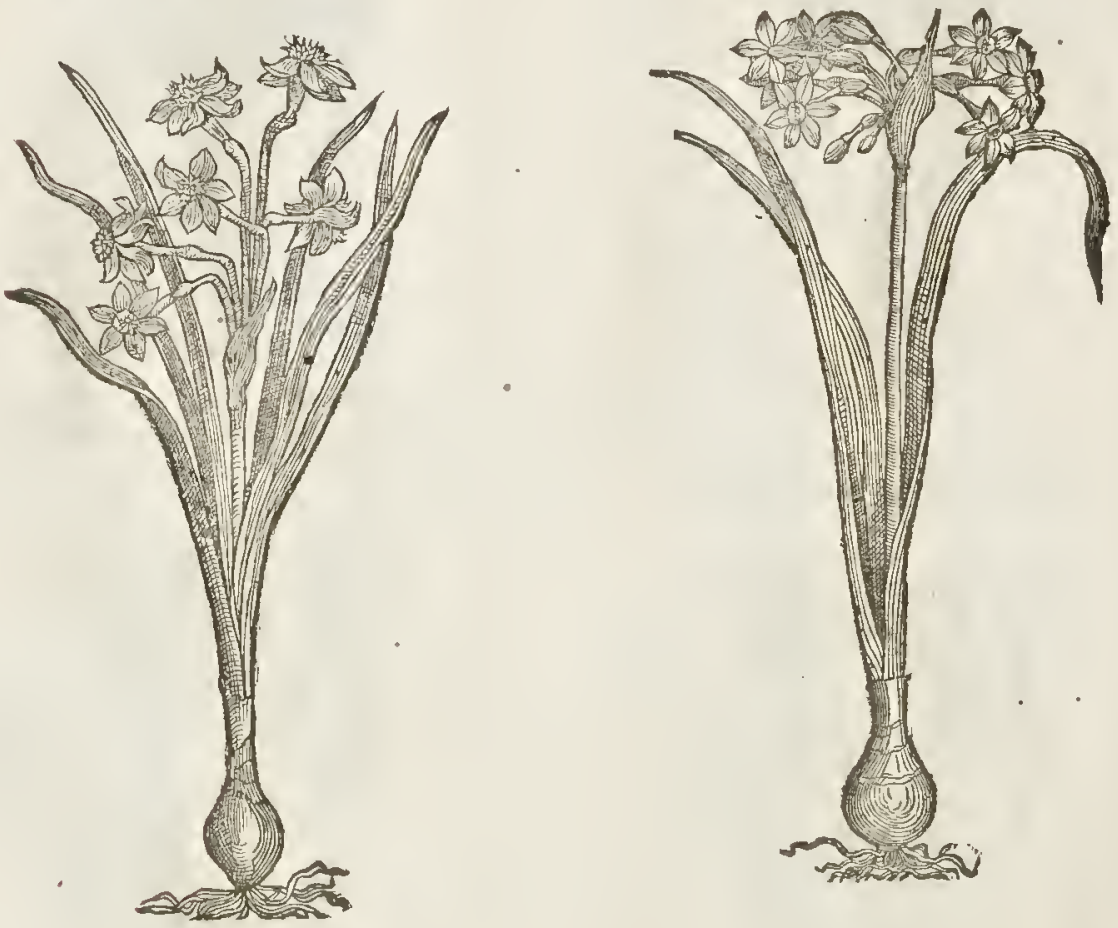

6 This late flouring Daffudill hath many fat thicke leanes, full of juice, among the which rifeth vp a naked falke, on the top whereof groweth a faire white flourc, hauing in the middle a ring or yellow circle. The feed groweth in knobby feed veffels. The root is bulbous or Onion fathion. It floureth later than the others before defcribed, that is to fay, in A prill and May.

7 The feuenth kinde of Daffodill is that fort of Narciffus or Primerofe peereleffe that is mof common in our countrey gardens, generally knowne ettery where. It hath long fat and thicke leaues, full of a fimie juice; among which rifeth vp a bare thicke ftalke, hollow within and full of juice. The foure groweth at the top, of a yellowith white colour, with a yellow crowne orcircle in the middle; and floureth in the moneth of A prill, and fometimes fooner. The root is bulbous fartion.

8 The eighth Daffodill hath manybroad and thicke leaues, fat and full of juice, hollow and fpongeous. The ftalkes, flotres, and roots are like the former, and differeth in that, that this plant bringeth 
bringeth forth nany floures vpon one ftalk, and the other fewer, and not of fo perfect a fweet fmel, but more offenfite and ftuffing the head. It hath this addition, Polyanthos, that is, of many Houres, wherein efpecially confifeth the difference.

$\therefore 9$ The Italian Daffodill is very like the former, the which to diftinguifh in words, that they may be knowne one from another, is impoffible. Their floures, leaues, and roots are like, fauing that the floures of this are fweeter and nore in number.

15 Narciffus Iuncifolius precox.

Rufh Daffodill, or Iunquilia.

Marcifsus fronguilea

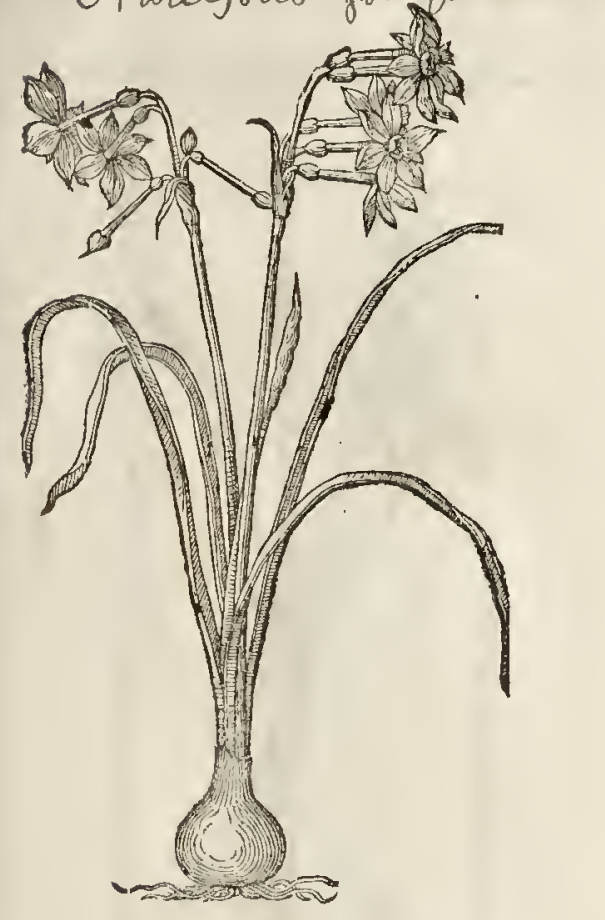

16 Narcifus Iuncifolius/erotinus. Late flouring Rurh Daffodill.

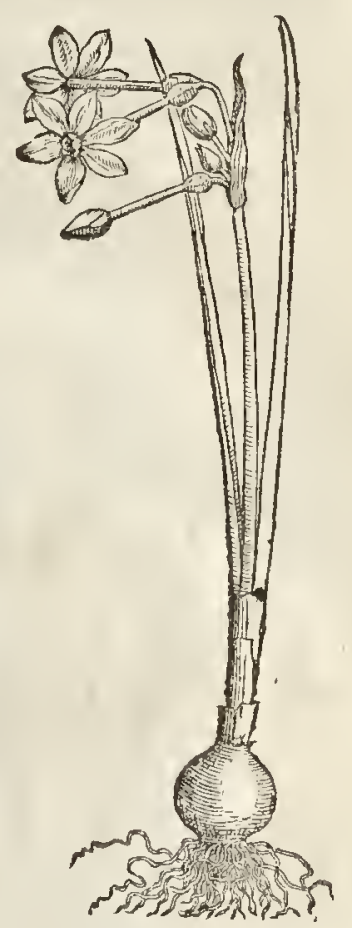

Io The double white Daffodill of Conftantinoplewas fenr into England vnto the right honourable the Lord Treafurer, anong other bulbed foures : whofe roots when they were planted in our London gardens, did bring forth beat full floures, very white and double, with fome yellow neffe mixed in the middle leaues, pleafantand fweet in fmell, but finee that time we neter conld by any induftrie or manuring bring them vnto flouring againe. So that it thould appeare, when they were difcharged of that birth or burthen which they had begorten in their owne cumstry, and not finding that matter, foile, or clymate to beger more floures, they remaine euer fince barren and frutleffe. Befides, we found by experience, that thore plants which in Autumne did thoot forth leaues, didbring forth no floures at all ; and the others that appeared not vntill the Spring, did flourith and beare their floures. The ftalks, leates, and roots are like vnto the other kindes of Daffodils. It is called of the Turks, Giul Cat amer lale; That is, Narciffus with double foures. Notwithftanding we hamereceiued from beyond the feas, as well from the Low Countries, as alfo from France, ancther fort of greater beautie, which from yeare to yeare doth yeeld forth mo ft pleafant double floures, and great encreafe of roots, very like as well in falkes as ather parts of the plant, vnto the other forts of Daffodils. It differeth onely in the foures, which are very doutble and thicke thruft together, as are the floures of out double Primrofe, hauing it the middle of the floure fome fer chiues or welts of a bright purple colour,and the other mixed with yellow as
aforefaid.

$\ddagger$ II This alfowith double white floures, which clufurs fets forth in the fixth place, is of the famekinde with the laft defcribed , but it beares but one or two floures vpon at ftalke, whereas
the other hath many.

I 3 This, which is clufus his Narciffus flore pleno 2, is in roots, leaties, and ftalkes very like the

$$
\text { L } 2
$$


precedent; but the floures are compored of fix large white out-leates; but the middle is filled with many faire yellow lit tle leaues much like to the double ycllow wall-Antre. They fned fireet like as the laft mentioned.

I 3 This differs from the laft mentioned oncly in that it is lefe, and that tlemiddle of the floure within the yellow cup is filled with longifn narow little leates, as it were crothing arch other. Their colour is white, but mixed with fome greene on the outfide, and yellow on the infide. $\neq$

I4 The milkewhite Daftodill differeth not from the common white Daffodill, or Primrofe pecreleffe, in leaues, ftalkes, roots, or foures, fuing that the foures of this plant hath not any other colour in the flourc but white, whereas all the others are mixect with one eolour or other.

I) Narciffusjuncifolites Rofeolntens. Rofe or round floured Innquilix.

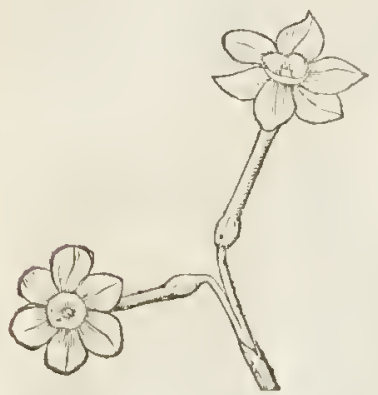

\# Ig Narciffus juncifolius refexus flore albe. The white reflex Iunquila.

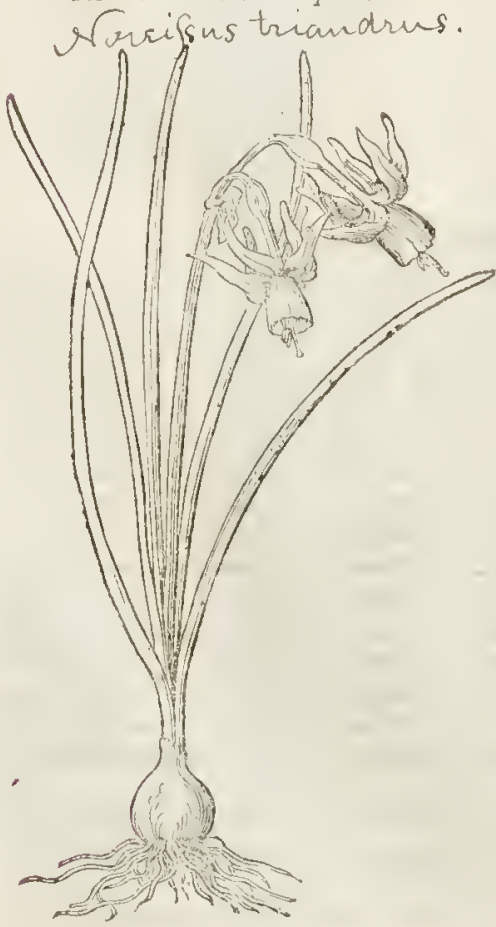

\pm i 8 Nirciffus juncifolius amplocalive. White Innquilia with the large cup.

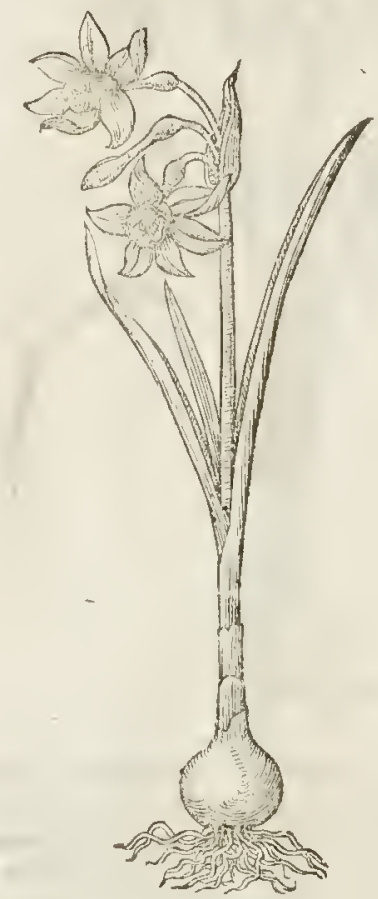

Is The Rufh Daffodill lath long, narrow; and thicke leaues, very fmooth and flexible, almoft round like Ruthes, whereof it tooke his fyrname Iuncifolins or Ruthie. It fpringeth vp in the beginning of lanuarie, at which tine alfo the floures doe fhoot forth their buds at the top of fmall rufhy ftalkes, fometines two, and often more vpon one ftalke, made of fix finall yellow leaues. The cup or erowne in the middle is likewife yellow, in mape refenbling the other Daffodills, but finaller, and of a frong fircet fincll. The root is bulbed, whitewithin, and cotrered with a blacke skin or filme.

I6 This Ruh D affodil is like voto the precedent in each refpeet, futing that it is altogether leffer, and longer before it come to flouring. There is alfo a white foired one of this kinde.

\& I7 There 
¥ I7 There is alfo another Rufh Daffodill or Iangwilia, with floures not fhaspe pointed, but round with a little cup in the middle: the colour is yellow or elfewhice. This is Lobels atarciffus juncifolius flore rotunde circinitat is $r$ ofeo.

18 There is alío another Innquilia whofe leaues and ftalkes are like thofe of the firft deferibed Runy Daffodill, but the eup in the middeft of the floure is much làger. The eolour of the floure is commonly white. Clufuus calls this $N$ arcifus a Iuncifolius amplo calice.

19 There are three or foure reflex Imnquilia's, whofe eups hang downe; and the fixe incompaf. fing leaues turne vp or backe, whenee they take their names. The floures of the firft are yellow ; thofe of the fecond all white, the eup of the third is yellow, and the reflex leaues white. The fourth hath a white cup, and yellow reflex leaues. This feemes to be Lobcls Narciffus mont anus minimus coronatus.

20 This is like to the ordinarie leffer Iunquilia, but that the floures are very double, eonfifting of many long and large leaues mixed togetlier; the thorter leaues are obtufe, as if they were elipt off. They are wholly yellow, $\ddagger$

\$ 19 Narciffus Inncifolius reflexus minor. The leffer reflex Iunquilia.

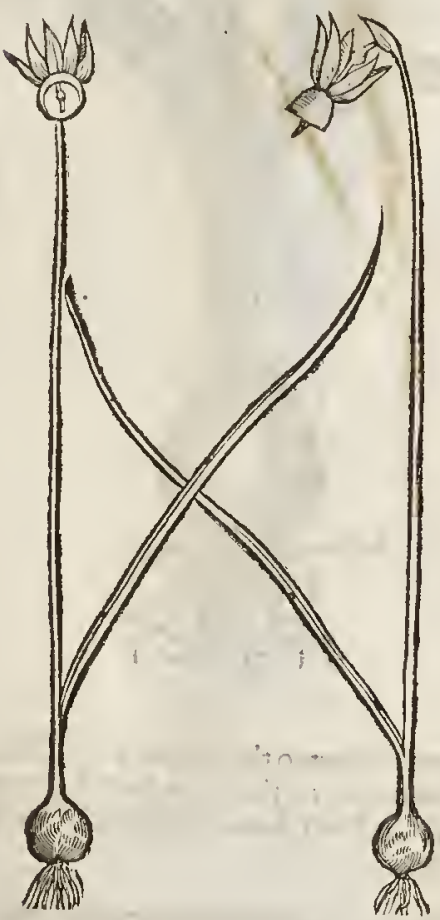

\pm 20 Narcifusjuncifolius multiplex. The double Irinquilia.

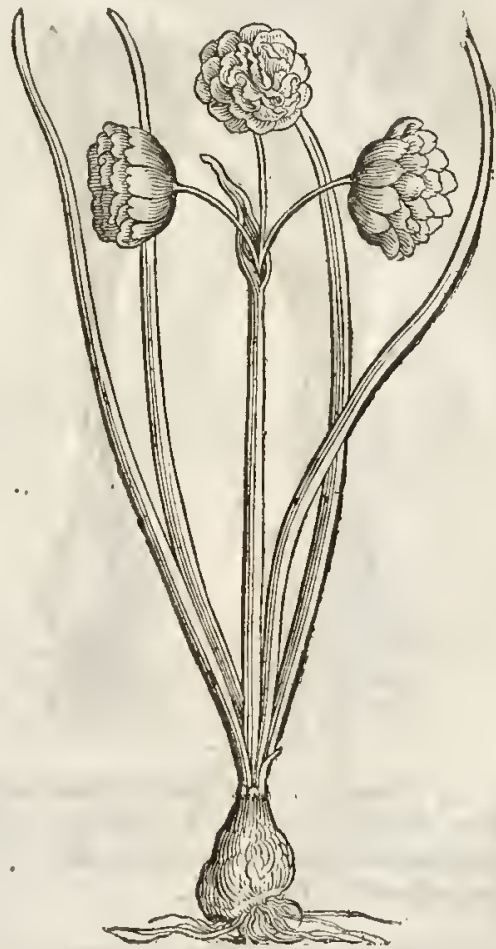

2 I The Perfian Daffodill hath no ftalke at all, but onely a fmall and tender foot ttalke of an inch high, fueh as the Saftron floure hath : vpon which thort and tender ftalk doth ftand a yellowifh floure confifting of fix fmall leaves; of whieh the three innermoft are narrower than thofe on the out fide. In the middle of the floure doth grow forth a Iong ftile or pointall, fet about with many fmall chiues or threds. The whole floure is of an vnpleafant fmel, mueh like to Poppy. The leaues rife vp a little before the floure, long, fmooth, and thining. The root is bulbed, thicke, and groffe, blackifh on the out fide, and pale within, with fome threds hanging at the lorver part.

22 The Autumnc Daffodill bringeth forth long fmooth, glittering leaues, of a dcepe greene colour : among whiel rifeth vp a fhort ftalke, bearing at the top one floure and no more, refemling the flourc of Mead Saffron or common Saffron, confifting of fix leaues of a bright thining yellow colour ; in the middle whereof ftand fix threds or chines, and alfo a peitell or clapper yellow likewife. The root is thicke and groffe like vnto the preedent.

\$23 To this laft maybeadioyned another which in thape fomewhat refernbles it. The L 3 
leaues are fmooth, greene, growing ftraight vp, and almoft a fingers breadth; anong whieh rifeth vp a f alke a little more than halfe a foot in height, at the top of which groweth forth a yellow foure normuch vnlike that of the laft deferibed Autumne Nareiffe: it eonfifteth of fixe leaues fome ineh and halfe in length, and fome halfe inch broad, fharpe pointed, the three inner leaues being fomewhat longer than the outer. There grow forth out of the middeft of the foure three whirifh ehiues, tipt with yellow, and a peftell in the midft of them longer than any of them: The root eonfifts of many coats, with fibres eomming forth of the bottome thereof like others of this kinde. It floures in Februarie.

2 I Narcifus Perficus.

The Perlian Datfodill.

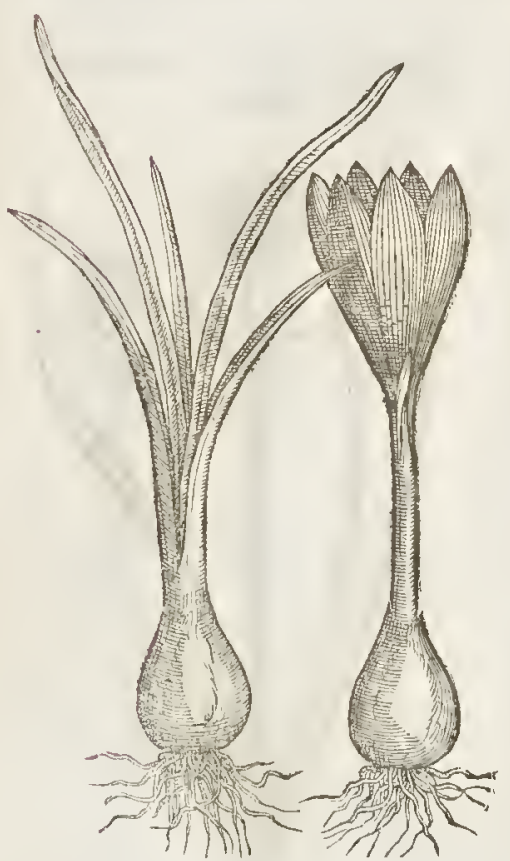<smiles>C1CCCC1</smiles>

.22 Narciffus Autumnalis major. The great Winter Daffodill.

24 Small Winter Daffodill hath abulbous root, much like vnto the root of $R$ um Daffodil, but leffer: from the which rifeth vp a naked ftalke without leaues, on the top whereof groweth a fmall white floure with a yellow eirele in the middle, fweet in fmell, fomething ituffing the head as do the other Daffodils.

$$
\text { T The Place. }
$$

The Daffodils with purple eoronets do grow wilde in fundry plaees of Franee, ehiefly in Bourgondie, and in Suitzerland in medowes.

The Rurh Daffodill groweth wilde in fundry plaees of Spaine, among graffe and other herbes. Diofcorides faith, That they be efpeeially found vpon mountaines. Theocritus affirmeth the Daffodils to grow in medowes, in his nineteenth Eidyl. Or twenticth, aceording to fome editions : where he writeth. That the faire Ladie Europa entring with her Nymphs into the medowes, did gather the fweet fmelling Daffodils; in thefe Verfes :

$$
\text { Asd", ination, sce. }
$$

Which we may Englin thus:

But when the Girles were come into

The medowes florring all in fight,

That Wench with the e, this ivenchwith thore

Trim flowres, themfclues did all delight:

she with the Nareiffe good in fent,

And hewith Hyacinths content. 


\section{L1B. 1. Of the Hiftorie of Plants.}

But it is not greatly to our purpofe particularly to fecke out their places of growing wilde, feeing that we haue them all and enery of them in our London gardens, in great aboundance. The common white Daffodill groweth wilde in fields and fides of Woods in the Weft parts of Eng-
land.

They floure for the mort part in the Spring, that is, from the beginning of Februarie vnto the end of Aprill.

The Perfan and Winter Daffodils do floure in September and Oetober.

$\$ 23$ Narciflus vernas pracocior flano flore.

The timely Spring yellow Daffodill.

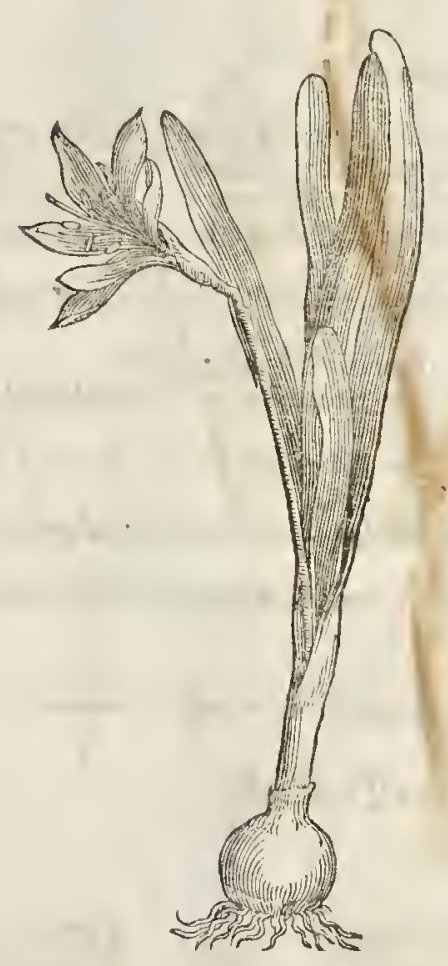

24 Narciffus Auturnnalis miner. Small Winter Daffodill, . Marcigsus serotinus.
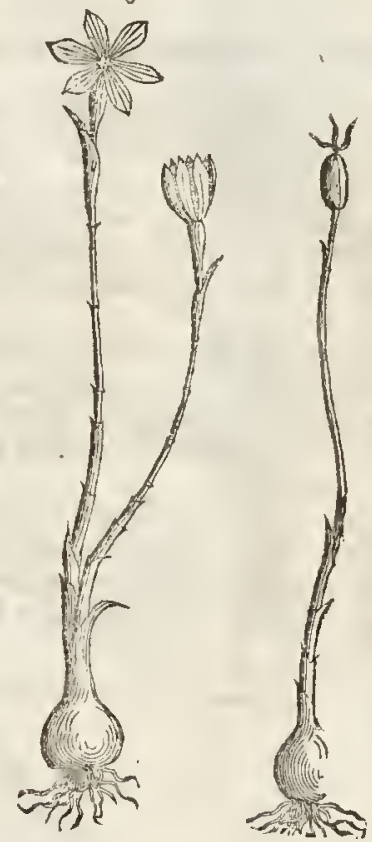

If The Names.

Although their names be fet forth in their feuerall titles, which may lerue for their appellations and diftinctions; notwith anding it fhall not be impertinent to adde a fupply of names, as
alfo the caufewhy they are fo called.

The Petfian Daffodill is called in the Sclauonian or Turkifh tongue, Zarcmeada Perfana, and Zaremcatta, as for the moft part all other forts of Daffodils are. Notwithitanding the double floured Daffodill they name Giul satamer lale: Which name they generally gine vnto all double
floures.

The common white Daffodil with the yellow circle they call Serin Cade, that is to fay, the kings Chalice; and Deue bohini, which is to fay, Camels necke, or as we do fay of a thing with long fin-
dle fhinnes, Long-haankes, vrging it from the long necke of the floure.

The Rum Daffodill is called of fome Ionguillias, of the fimilitude the leaues haue with furhes. of Dioforides, Bulbus Vomitorius, or Vomiting Bulbe, according to Dodonews.

Generally all the kindes are comprehended vnder this name Narcis fus, called of the Grecians

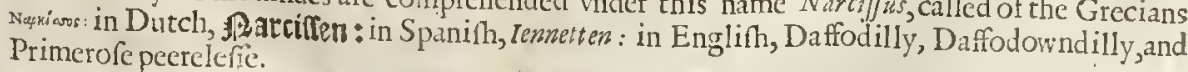

Sophocles nameth them the garland of the infernal gods, becaufe they that are departed and dulled with dearh, hhould worthily be crowned with a dulling floure.

Of the firf and fecond Dafodill owid hath made mention in the third booke of his cretsmor. 


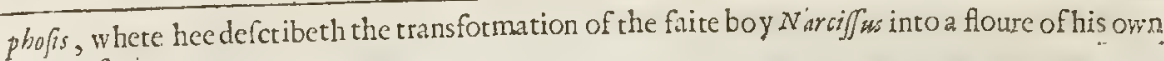
name; faying,

Nufquan corpus erat, croceum procorpore florem

Jineniun, folys medium cingentibus albis.

But as for body none temain'd, in ftead whereof they found

A yeliow floure, with milke whitc leaues ingirting of it round.

Pliny and Plutarch affime, as partly hath been touched before, that theit narcoticke quality was the very caufe of the nane Narcifus, that is, a cualitie caufing fleepineffe; which in Greekes is varess : or of the firt Torpedo, called in Greeke rofen, which benummes the hands of them that touch him, as being hurt full to the finewes; and btingeth dulnefle to the head, which propetly belongeth to the Natciffes, whofe fmell curfeth drowfineffe.

Th The Nature.
The roots of Narciffus ate hot and dry in the fecond degree.

\% The Fertues.

A

Galen faith, That the roots of Narcifus hate fuch wonderfull qualities in drying, that they confound and glew together very great wounds,yea and fuch gafhes or cuts as happen about the vcins, finewes, and tendons. They laue alfo a certaine cleanfing and attracting facultie.

b

The roots of $N$ arciffus ftamped with honey, and applied plaiftet-w ife, helpeth them that ate burned with fire, and ioynerh togethet finewes that are cut in funder.

C

Being vfed in manner afotefaid, it helpeth the great w tenclies of the ankles, the aches and pains of the ioynts.

D The fane applied with hony and nettle feed helpeth Sun burning and the motphew.

The fame ftaniped with barrowes greafe and leucn of tie bread, haltneth to matutation hatd im: poftumes, which are not eafily brought totipenefle.

$\mathrm{IF}$

Being ftamped with the meale of Datnell and honey, it draweth fotth thotnes and ftubs out of any part of the body.

The root, by the experiment of $A$ pulcius, ftamped and ftained, and giuen in dtinke, helpeth the $G$ cough and collicke, and thof that be entred into a ptificke.

The roots whether they be eaten or drunken, do moue vomit; and being mingled with Vineger and nettle feed, taketh away Icntiles and fpots in the face.

\section{С н Р. 85. Of the Baftard Daffodill.}

बi The Defcription.

I He double yellow Daffodill hath fmall finooth natrow leates, of a datke gteene colour; among which rifecth vp a naked hollow ftalke of tw o hands high, bearing at the top a faire and beatrifull yellow floure, of a pleafant fwect fnell: it theddeth his floure, but there followeth no feed at all, as it hapneth in many other doublc floures. The root is fmall, bulbous, or onion falhion, ilke vnto the other Daffodils, but much finaller.

2 The common yellow Daffodill or Daffodowndilly is fowell knowne to all that it needech no defcription.

3 We hate in out London gardens another fort of this common kind, which naturally gtoweth in Spaine,very like rnto our beft knowne Daffodill in thape and proportion, but altogether fairer, greater, and lafteth longer before the floure doth fall or fade.

\$ 4 This hath leaties and roots like the laft defcribed, but fomcwhat leffe; the floute alfo is in thape not vnlike that of the precedent, but leffe, growing vpon a weake flender gteene ftalke, of fome fingers length: the feed is contained in three cotneted,yet almoft round heads. The toot is fmall,bulbous, and blacke on the outfide.

5 This hath a longith bulbous root, fomw hat blacke on the out fide, from which rife vp leaues not fo long nor broad as thofe of the laftefcribed : in the midf of thefe leatres fprings vp a ftalk, flender, and lome halfe foot in height; at the top of which, forth of a whitifh filme, breakes forth a floure like in thape to the commun Datfodill, but leffe, and wholly whitc, with the brim of the cup welted about. It floures in Aprill,and tipens the feeds in Iunc.

q The Place.

The double yellow Daffodill I teceiued from Robimus of Paris, which he procuted by meanes of friends from Orleance and nthet parts of France. 
I Pfexdonarciffus luteus multipler. Double yellow Daffodill.

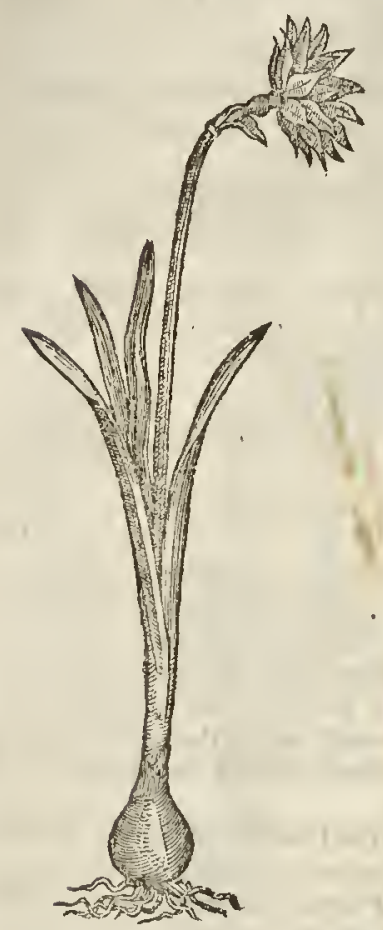

* 3 Pfeudonarcifus Hi parious? The Spanin yellow Daffodill. Marigs ys licolou

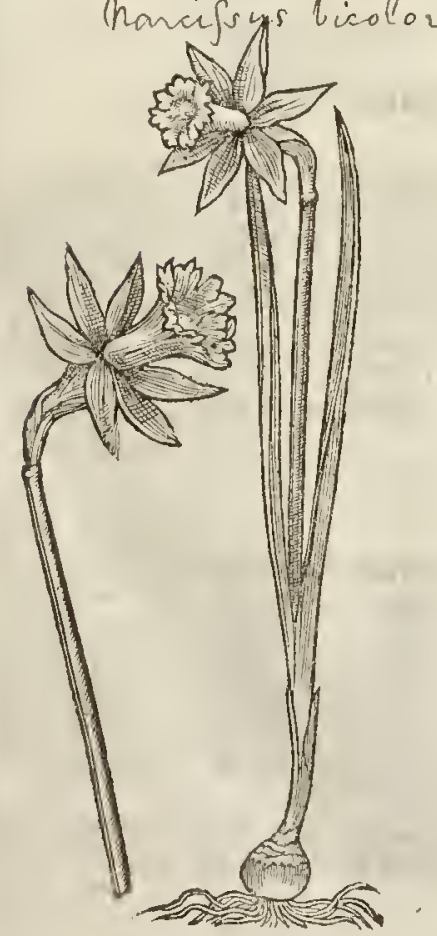

2 Pfoudonarciffus Anglicus.

Common yellow Daffodill. Narcissus of sendonaraigsus.

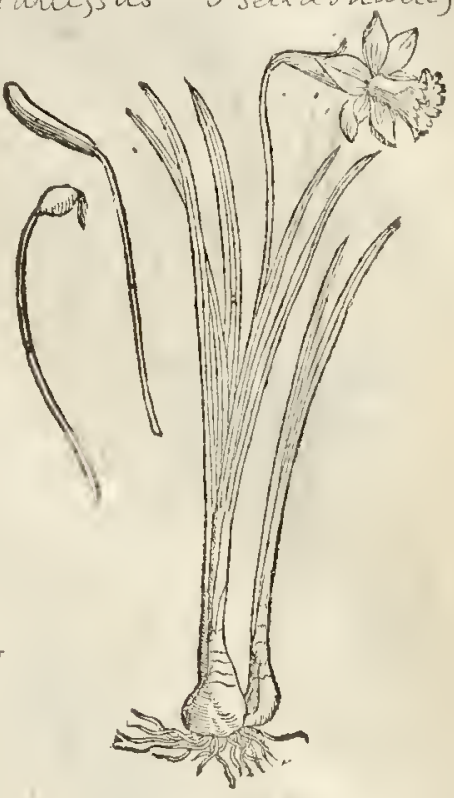

4 Pfcudonarcijfus minor Hijpanicas? The leffer Spanifh Daffodill.

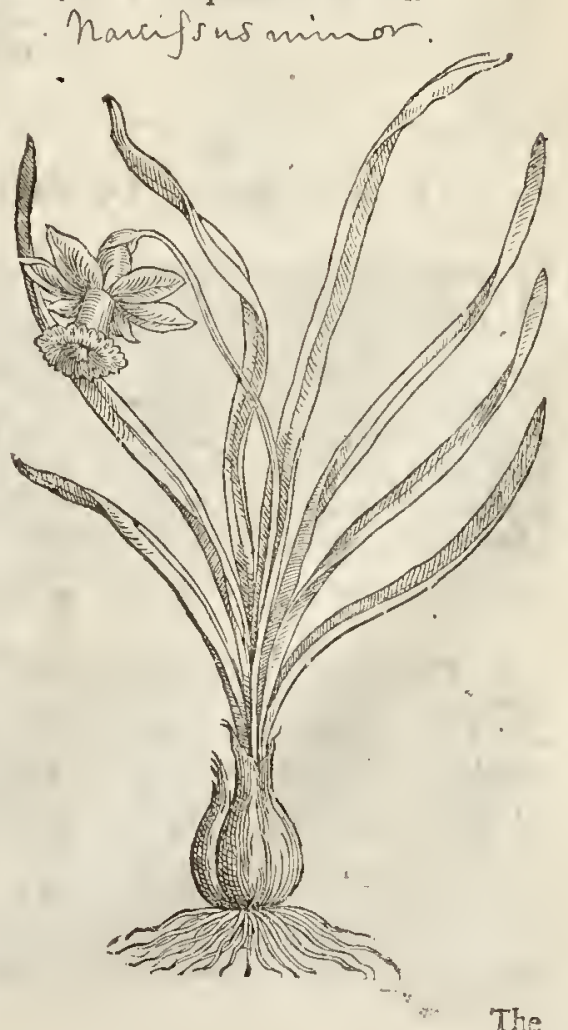


5 P Jendonarcif sus albo flore. White Baftard Daffodill.

A

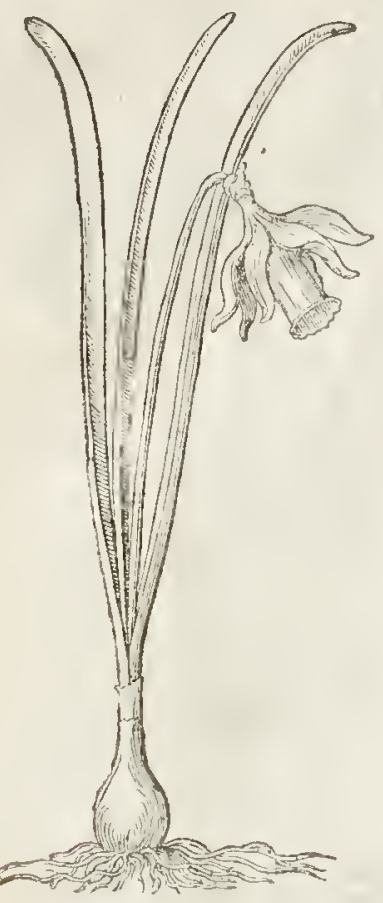

The yellow Englifh Daffodill groweth almoft eneric where through England. The yellow Spanim Daffodill doth likewife decke vp our London Gardens, where they increafe infinitely.

\section{- The time.}

The double Daffodill fendeth forth his leares in the beginning of Februaric, and his floures in A prill. - The Names.

The firft is called P feudonarcis fus multiplex, and $N_{a r}$. ciffus lutews Polyanthos: in Englith, the double yellow Daffodill, or Narcifus.

The common fort are ealled in Dutch, Beel Sporetel bloemen: in Englih, yellow Daffodill, Daffodilly, and Daffodowndilly.

\section{-1 The Temperature.}

The temperature is referred vato the lindes of $x \mathrm{dy}$ ciffors.

$$
\text { T The Vertues. }
$$

Touling tlie vermes hereof, it is found out by experinient of fome of the later Plyyftians, that the decontion of the roots of this yellow Duffodill do purge by ficge rough and flegmaticke humors, and alfo waterifh, and is good for them that are full of raw humors, efpecially if there be added thereto a little anife feed and ginger, which will eorreet the ehurlin bardneffe of the working.

The diftilled water of Daffodils doth cure the Palfie, if the Patient be bathed and rubbed with the fayd liquor by the firc. It harls becre proued by an efpeeiall and trufty Friend of myne, a nian learned, and a diligent fearehet of nature, M. Nicholas Belfon, fometimes of Kings Colledge in Canbridge.

\section{$\mathrm{C}_{\text {нат. }}$ 86. Of diuers otber $\mathcal{D}$ affodils or $\mathcal{N}$ arriffes.}

$\$ 7$ Here are befides the forementioned forts of Daffodils, fundry others, fome of which may be referred to them; other fome nor. I do not intend an exact enumctation of them, it being a thing nor fo fitting for a hiftorie of Plants, as, for a Florilegie, or booke of floures. Now thofe that require all thcir figures, and more exact deferiptions, may finde fatisfaction in the late Worke of my kinde friend M.lohe Parkinfon, which is intitled Paradifus terreftris : for in other Florilegies, as in that of De Bry, Swertz, Sic. you hauc barely the names and figures, but in this are both figures, and an exact hiftoric or declaration of them. Therefore I in this place will but onely briefely deferibe and name fome of the rareft that are preferued in our choice gardens, and a few others whereof yet they are not poffent.

$$
\text { I The Defcriptions. }
$$

1 The firt of thefe, which for the largeneffe is ealled Nompareille, hath long broad lcaucs and roots like rhe other Daffodils. The flourc ennfifts of fix very large leanes of a pale yellow colour, with a very large eup, but not very long : this eup is yellower than the incompafing leaues, narroweralfo at the buttome than at the top, and vncienly cut about the edges. This is called NarsifSus omnium maximzts, or Non purcille; the figure well exprefich the floure, but that it is fomewhat too lietle. There is a varietic of th is with the open leaues \& eup both yellow, which makes the differenee. There is alfoanother Non pareille, whofe floures are all white, and the fix leaues that ftand fpred abroad are vfually a little folded, or turned in at their cnds.

2 Befides thefe fomer there are foure or fure double ycllow Daffodils, which I cannot paffe

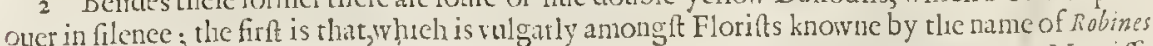


Narcife; and it may be was the fame our Author in the precedent chapter mentions he receined from Robine; but he giuing the figure of another, and a defcription not well fitting this, I can affirmenothing of certaintie. This double Narciffe of Robine growes with a falke fome foot in height, and the floure is very double, of a pale yellow colour, and it feemes commonly to dinide it felfe into forme fix partitions, the leaues of the floure lying one vpon another etren to the middle of the floure. This may be called Narciffus pallidus multiplex Robini, Robines double pale Narciffe.

I I Aarciffus omnium maximus. The Nomparcilke Daffodill. Kereant

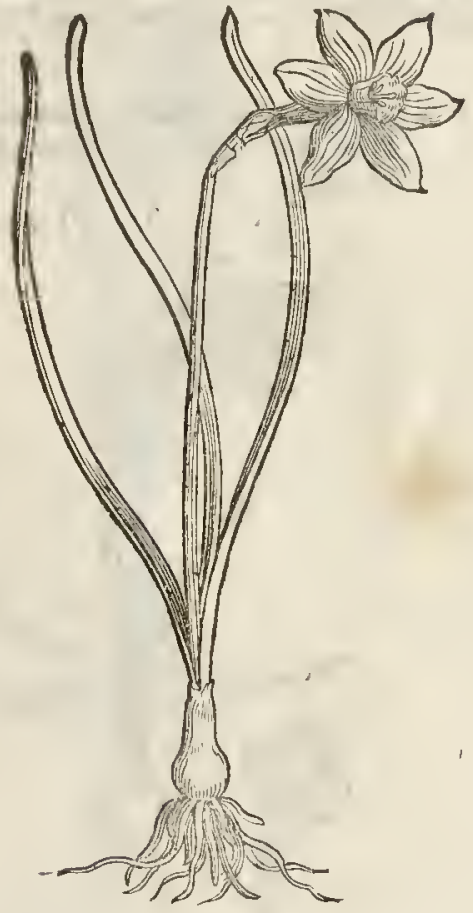

* 3 Pfesdonarciffus fore pleno.

The double yellow Daffo dill. He neeudontiarcums

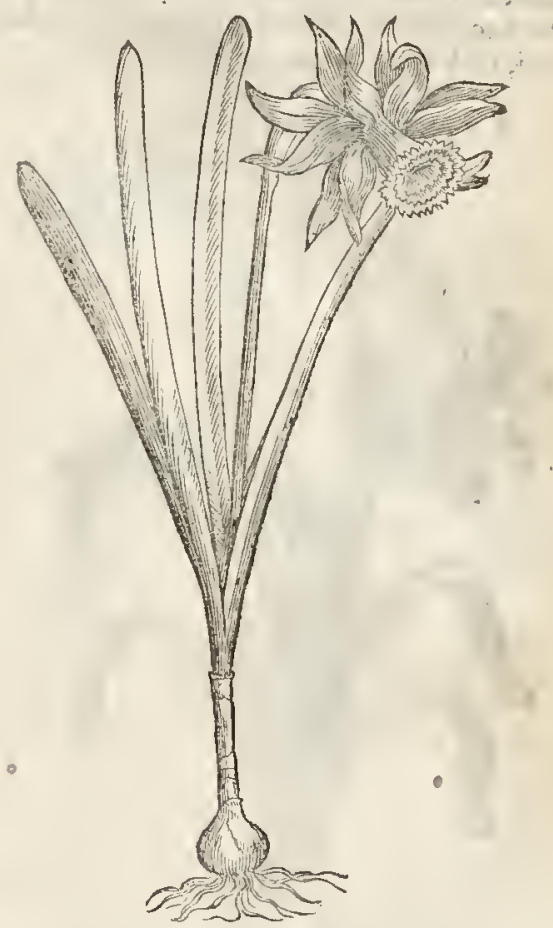
il fie

3 The next to this is that which from our Author, the firtt obferuer thereof, is vutgarly called Gerrards Narciffe : the leaues and root do not much differ from the ordinarie Daffodill; the ftalk is fearce a foot high, bearing at the top there of a foure very double; the fixe outmoft leaues are of the fame yellow colouras the ordinarieone is; thofe that are next are commonly as deepe as the tube or trunke of the fingle one, and a mong ft them are mixed al fo other paler coloured lcaues, with fome green ftripes here \& there among thofe leaues:thefe floures are fomtimes all contained in a trunk like that of the fingle one, the fixeout-leaues excepted: other whiles this inclofure is broke, and then the floure fands faire open like as that of the lafteferibed. Lobel in the fecond part of his Aduerfaria tells, That our Autlor Mafter Gerrard found this in Wilthire, growing in the garden of a poore old woman; in which place formerly a Cunning man (as they vulgarly terme
him) had dwelt.

This may be called in Latine, according to the Englinh, Narciffus multiplex Gerardi, Gerrards double Narciffe.

The figure we beregiuc you is expreffed fomcow bat too tall, and the floure is not altogetber fo double as it ought to be.

4 There are alfo two or three double yellow $\mathrm{D}$ affodils yet remaining. The firft of thefe is called Wilmots Narciffe, (from Mafter Wilmot, late of Bow) and this hath a very faire double \& large yellow floure compofed of deeper and paler yellow leaues orderly mixed.

The fecond (which is called Tradefcants Narciffe, from Mafter Iobn Tradefount of South-Lambeth) is the largeft and ftatelief of all the reft; in the largeneffe of the floures it exceeds Wilmots, which otherwife it nuch refumbles; fome of the leanes whereof the floure confifts ate tharp poin- 


\section{6}

Of the Hiftorie of Plants.

LIB.I.

ted, and thefe are of a paler colour; other fome are much more obtufe, and thefe are of a deeper and fairer yellow.

This may be called Norciffus Rofcus Tradefcanti, Tradefcants Rofe Daffodill.

The tlied M. Parkinfon challengeth to himfelfe; which is a floure to be refpected, not fo much for the beautic, as for the various compofure thereof, for fome of the leaucs are long and tharpe pointed, others obtufe and curled, a third fort long and narrow, and vfually fome few hollow, and in fhape refembling a horne; the vemoft leaues are commonly ftreaked, and of a yellowith green; the next to them fold themfelues vp ronnd, and are vfually yellow, yet fometimes they are edoed with greene. There is a deepe yellow peftill diu ided into three parts, vfually in the midft of this floure. It floures in the end of March. I vually (before M. Parkinfon fet forth his "Florilegie, or igarden of floures) called this floure $N$ arciffus mathoseses, by reafon of its various fhape and colour : but fince I thinke it fitter togine it to the Author, and terme it Narciffus multiplex varins Parkinfoni, Parkinfors varions double Narciffe.

* 5 Narciffus Incobers Indicus.

The Indian or Iacobxan Narcife.

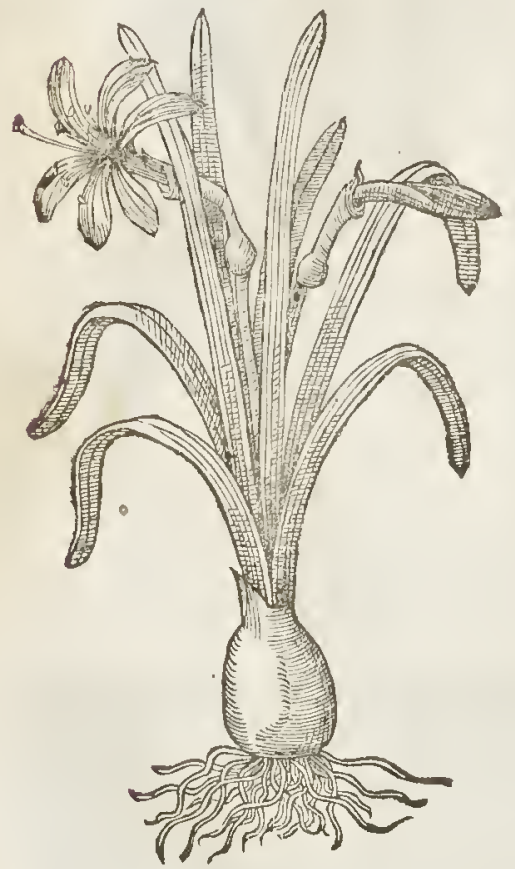

¥ 6 Narciffus juncifolius mortanus minimus. The leaft Runh-leaned Mountaine Narciffe. rarcissus Bullocodim

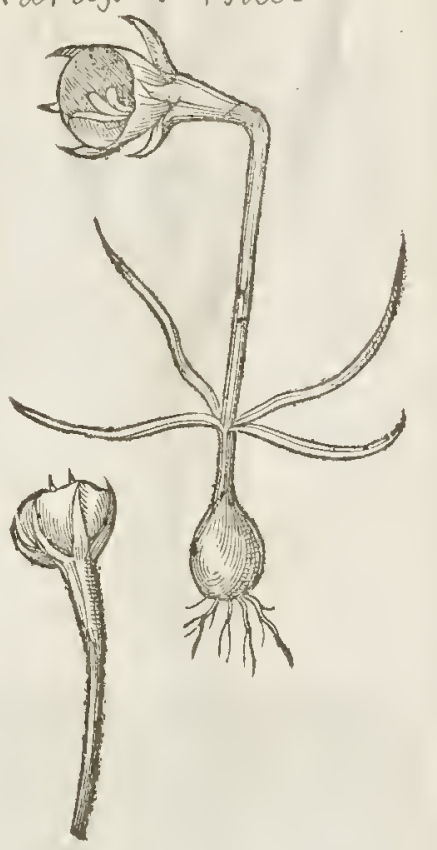

5 Now come I to treat of fome more rarely to be found in our gardens, if at all. That which takes the firt place is by Clufus called Nurcifus Iacobcus Ixdicus, the Indian or Iacobxan Narciffe. The root hereof is much like to an ordinarie onion, the lcaucs are broad like the other Narciffes, the ftalke is fnooth, round, hollow, and without knots, at the top whereof, out of a certaine skinny huske comes forth a faire red floure like that of the flouring Indian reed, but that theleaues of this are fomew hat larger, and it hath fix chiues or threds in the middle thereof of the fame cnlour as the floure, and they are adomed with brownith pendants; in the midte of thefe there ftands a little farther out than the reft, a three forked ftile, vnder which fucceeds a triangular head, after the falling of the floure.

This giues his foure in Iune or Inly.

6 This Lobell calls Narciffus nontunus juncifolitus minimus, The leaft fulh-leaued mountaine Narciffe. 'The leaues of this are like the runguilia; the Atalke is fhort, the floure yellow, with the fix winged leates fmall and paler coloured, the cup open and large to the bigneffe of the floure. 
7 This alfo is mueh like the former; but the fix incompaffing leaues are of a greenifh faine yellow colour; the eup is indented, or mequally curled about the edges, but yellow like the precedent. Lobell ealls this $N$ arciffus mont anus juncifoliws flore. fimbriato, The mountaine Ruih-leaued Nareiffe with an indented or curled eup.

\section{\$ Narcifus montanus jurcifolius flore fimbriato.}

The mountaine Rurh leaued Narciffe with an indented or curled cup:

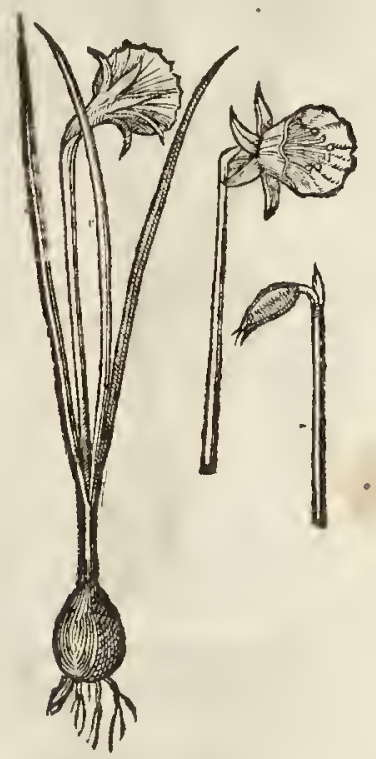

\section{\$ Narcifusomnium minimusmonta-} mus albus.

The leaf mountaine white Narciffe.

Nomoughethes

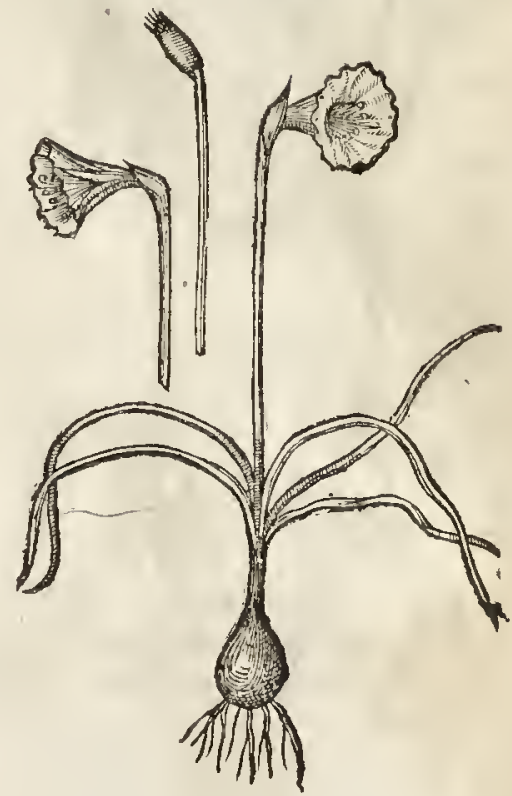

8 The leaues of this are as fmall as the Autumne Iaeinth, the ftalke fome handfull high, and the floure like the laft deferibed, but it is of a whitin colour. Lobell ealls this laft deferibed, $N$ ar si (fus omnium minimus mont anus albus, The leaft mountaine white Nareiffe. Thefe three laft vftally
floure in Februarie. $\neq$

\section{Cна Р. 87. Of Tulipa, or the Dalmatian Cap. \\ II The Kindes.}

$\mathrm{T}$ Vlipa, or the Dalmatian Cap is a frange and forreine fioure, one of the number of thebul bed floures, whereof there be fundry forrs, fome greater, fome leffer, with which all futdious of molt braue floures which it beareth. Of this there be rwo chiefc and generall kindes, viz. Precox and Serotina; the one doth beare his floures timely, the other later. To thefe two we will adde another fort called cMedia, fouring betweene both the others. And from thefe three forts, as from my louing friend $M$. Tames do proceed, which are almoft infinite in number. Norwithftanding, don, hath vndertaken to finde our, if it were poffler of Simples, and learned A pothecary of Lon- feeds, and by planin the forte feeds, and by planting thofe of his orre propagarion, and by others reeeiued from his Friends 


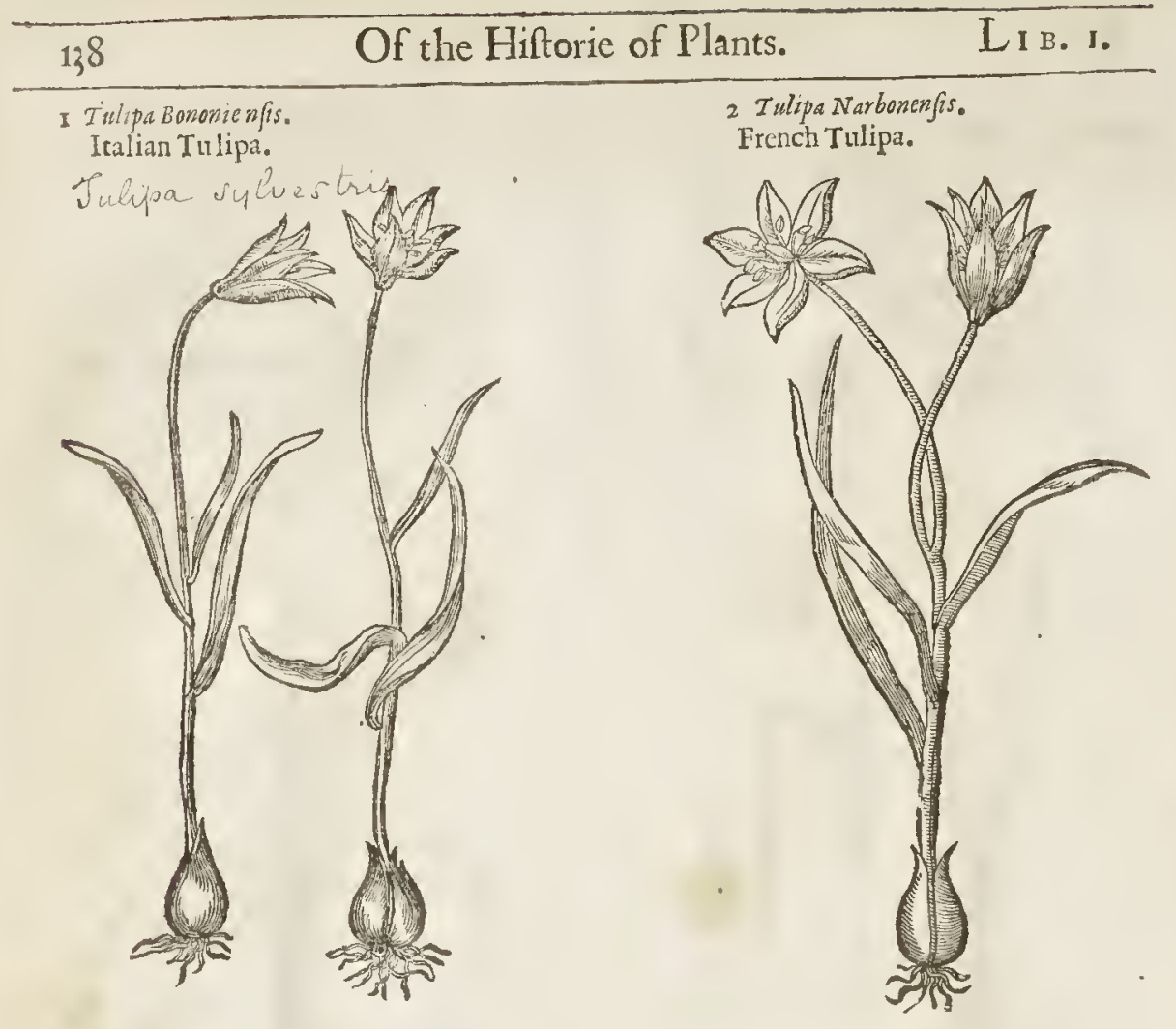

3 Tulipa precox totaluted. Timely flouring Tulipa:

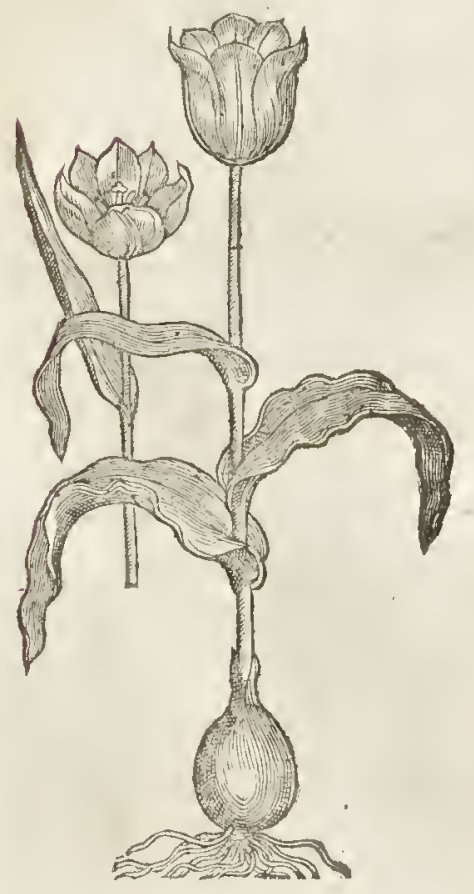

4 Tulipa Coccineaferotina? Late flouring Tulipa.

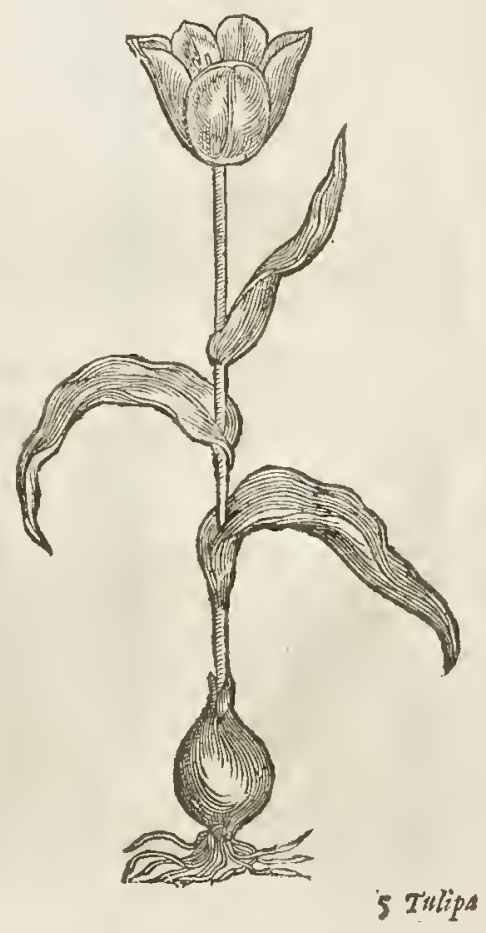




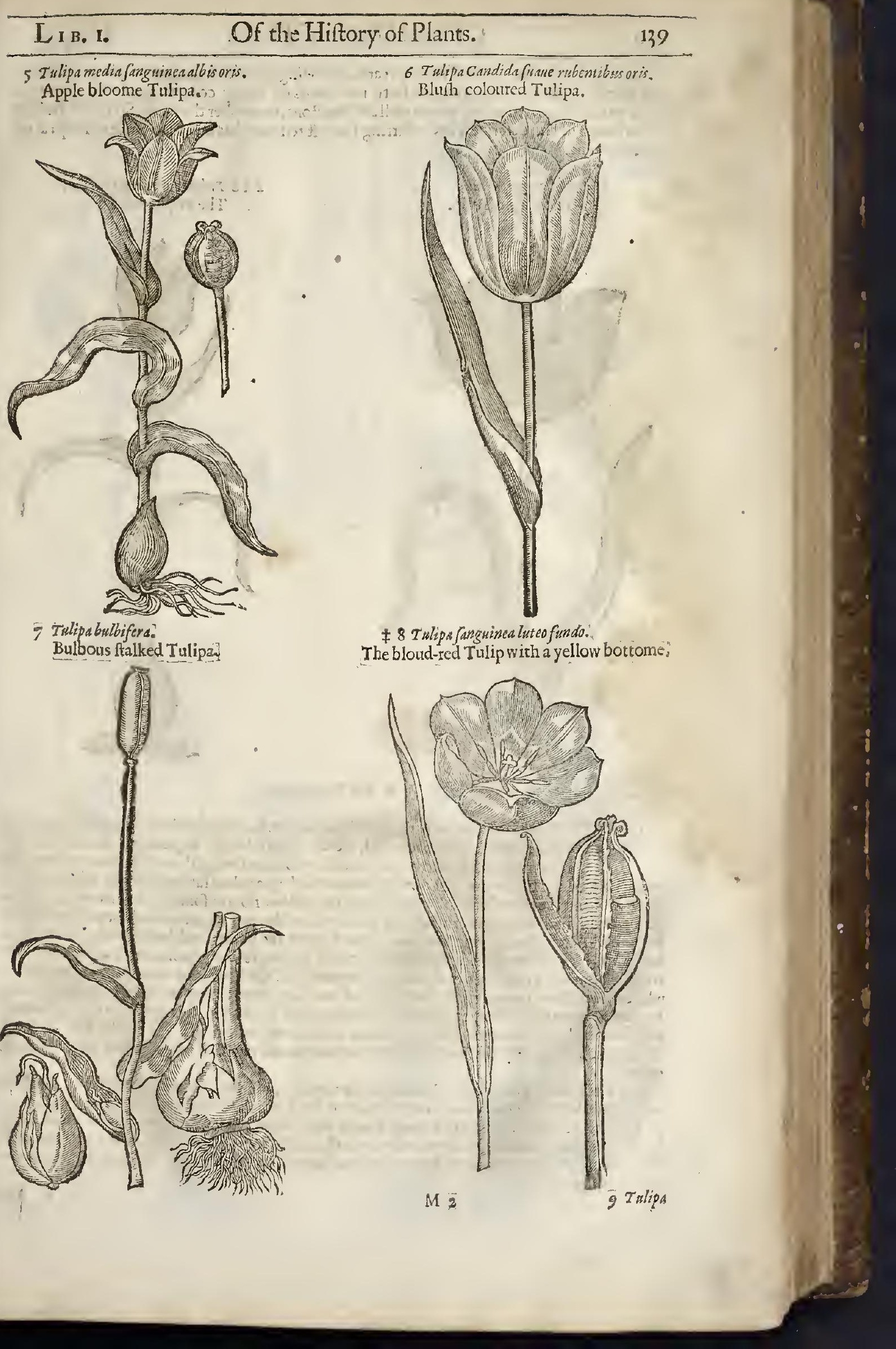


beyond the feas for the fpace of twenty yeares, not being yet able to attaine to the end of his trauell, for that each new yeare bringeth forth new plants of fundry colours, not before feene : all which ro deferibe particularly were to roll sifiphus ftone, or number the fands. So that it thall fuffiee to fpeake of and defetibe a few, referring the reft to fome that meane to write of $T$ ulipa a particular volume.

\section{$\ddagger 9$ Tulipa purpurca.} The purple Tulip.

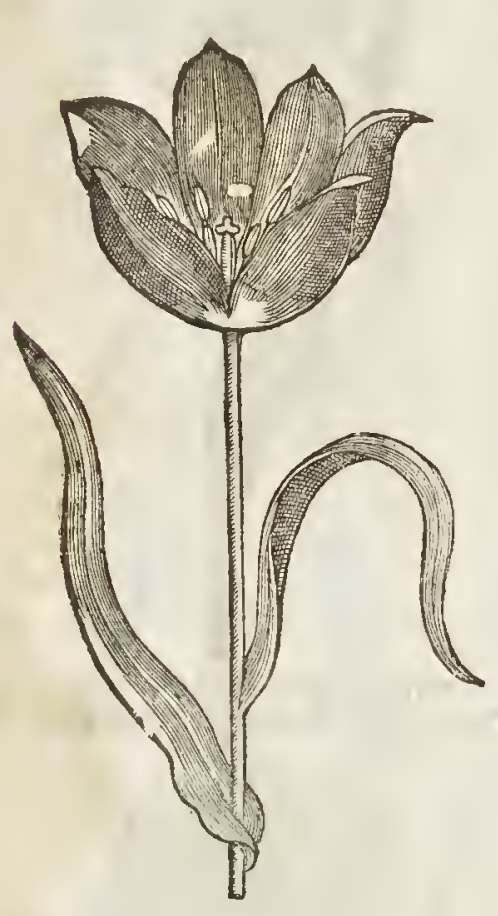

† Io Tuliparubra amethiftina. The bright red Tulip.

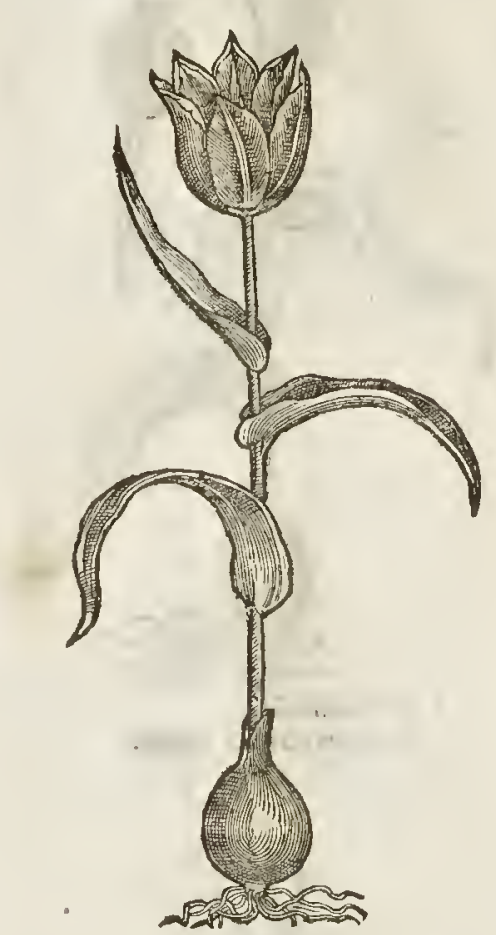

II The Defcription.

I THe Tulapa of Bolonia hath fat, thicke, and groffe leaues, hollow, furrowed or chanelled, bending a little backward, and as it were folded together: which at their firft comming vp feeme to be of a reddih eolour, and being throughly grow ne tume into a whitith greene. In the middeft of thofe leaues rifeth vp a naked fat ftalke a foot high, or fomething more, on rhe top where of ftandeth one or two yel low floures, fomerimes three or more, confifting of fix fmall leaues, after a fort like to a deepe wide open cup, narrow abouc, and wide in the bottome. After it hath beene fome few dayes floured, the points and brims of the floure turne backward, like a Dalmatian or Turkifh eap, called Tulipan, Tolepan, Turban, and $T$ urfan, whereof it rooke his name. The cliutes or threads in the middle of the floures be fometimes yellow, otherwhiles blackinh or purplin, but eommonly of one ouer-worne colour or other, Nature feeming to play more with this foure rlan with any other that $I$ do know. This fourc is of a reafonable pleafant fmell, and rhe other of his kinde hate little or no fmell at all. The feed is flat, fnooth, thining, and of a griftly fubftance. The root is bulbous, and very like to a common onion of Saint omers.

2 The French Tulipa agreeth with the former, except in the blacke bottome which this hath in rhe middle of the floure, and is not fo fwect of fmell, which fetteth forth the differenee.

3 The yellow Tulipa that floureth timely hath rhicke and groffe leaues full of iuyce, long, hollow, or gutter fanhion, fet about a tender ftalke, at the top whercof doth grow a faire and pleafant thining yellow floure, confifting of fix fmall leatues without fmell. The root is bulbous or like an onion. 


\section{I B. I.}

Of the Hiftory of Plants.

14 I

¥ ir Tulipa flore albo fr puris.

The whire Tulip with purple ftreakes.
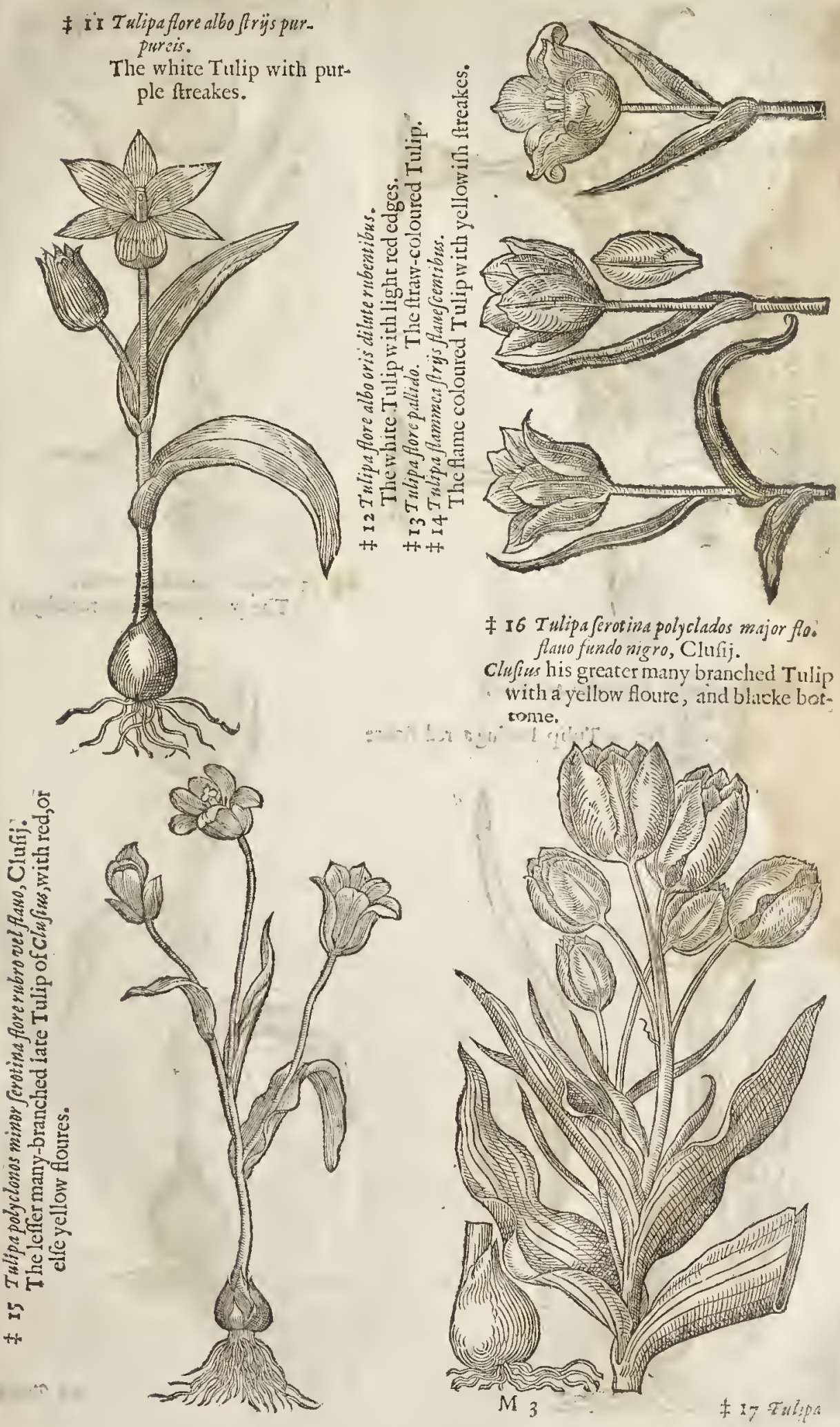

¥ I6 Tulipa ferotina polyclados major fo: flano fundo nigro, Clurij.

Cluffus his greater many branched Tulip with a yellow Houte, and blıcke bottonie.

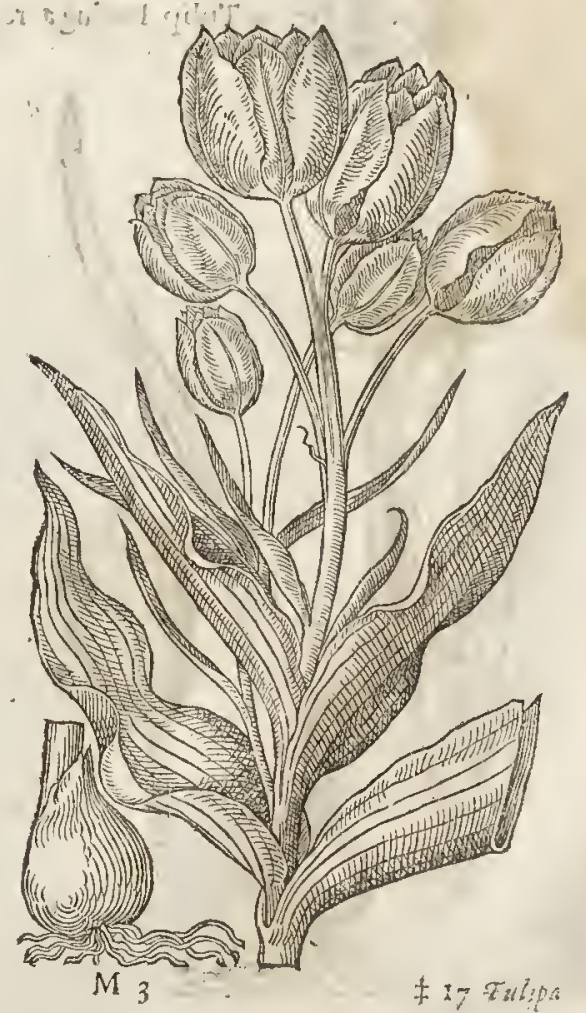




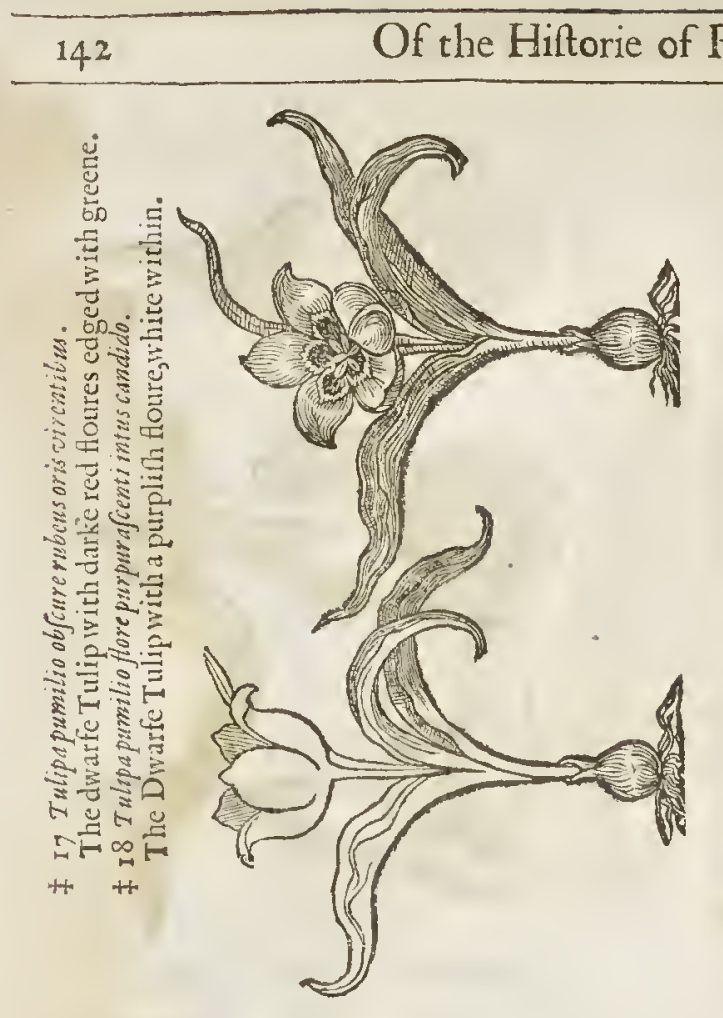

20 Tulipa Perficaflore rubro, oris albidls clegans.

The pretty Perfian Tulip hauing a red floure with whition edges.

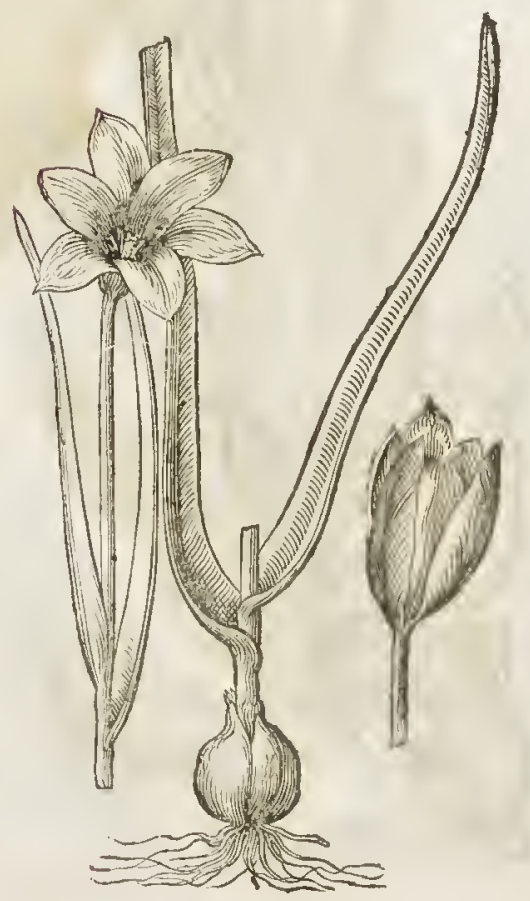

‡ g Tulipapumilio Lutea.

The yellow Dwarfe Tulip:

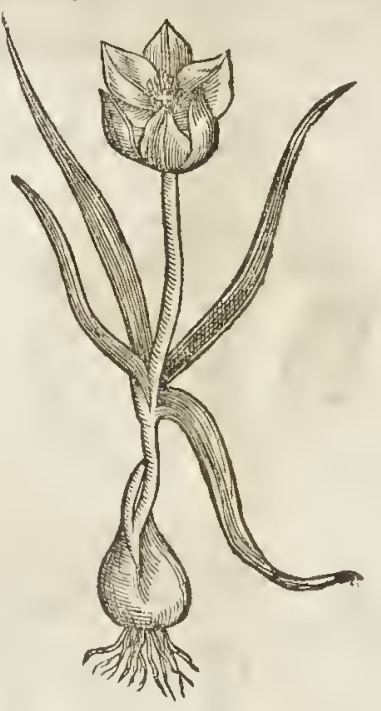

*21 Tulipa aurea oris rubentibas. The gold yellow with red edges:

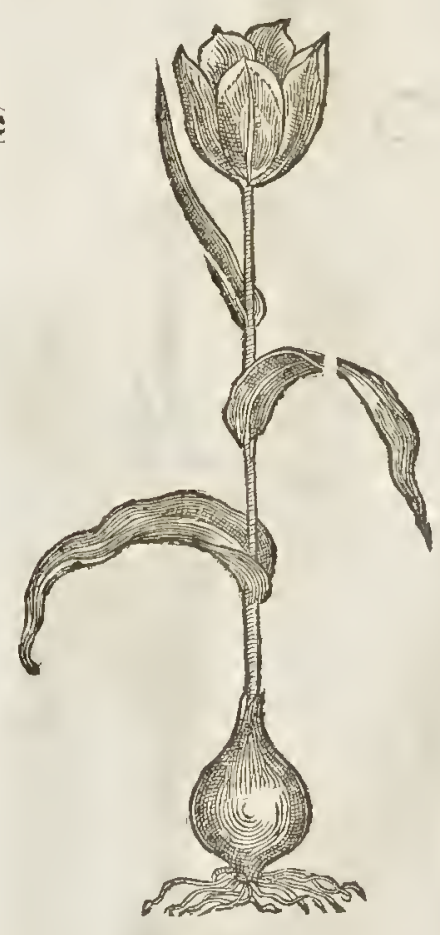


4 The fourth kinde of Tulipa, that floureth later, hath leanes, falks, and roots like vnto the precedent. The floures hereof be of a skarlet eolour, welted or bordered about the edges with red. The middle part is like vnto a hart tending to whiteneffe, fpotted in the fame whitenes with red fpeekles or fpots. The feed is contained in fquare cods, flat, tough, and finewie.

¥22 Tulipa miniata.

The Vermilion Tulip.

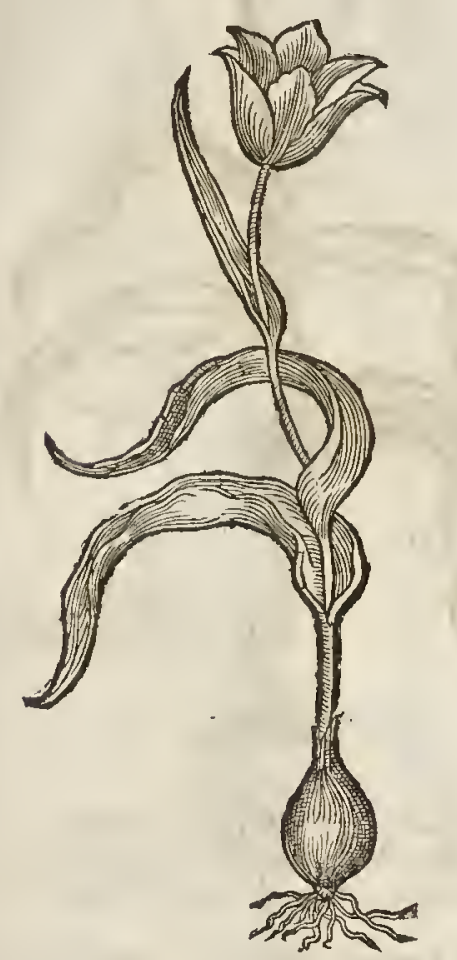

$\$ 23$ Tulipa albo \&o rubrofriatus. The white and red ftriped Tulip.

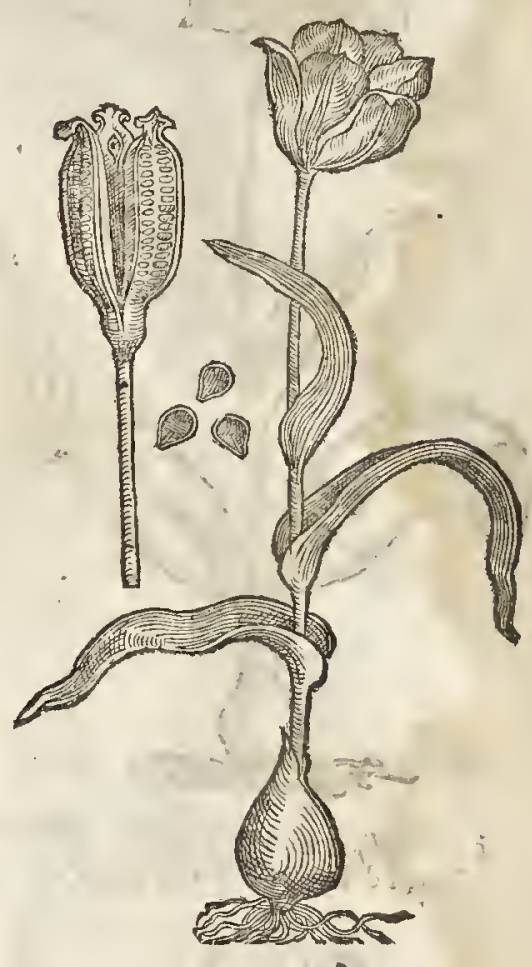

-

5 The fift fort of Tulipa, which is neither of the timely ones, nor of the later flouring fort, burone that buddeth forth his moft beattifull floures betweene both. It agreeth with the laft deferibed Tulipa, in leaues, falkes, roots, and feed, but differeth in floures. The floure confifteth of fix fmall leaues ioyned together at the bottome : the middle of which leates are of a pleafant bloudy eolour, the edges be bordered with white, and the bottome next vnto the ftalke is likewife white; the whole floure refembling in colour the bloffomes of an Apple tree.

6 The fixth hath leaues, roots, talkes, and feed like vnto the former, but mueh greater in euery point. The floures hereof are white, daiht about the brimmes or edges with a red or blum colour. The middle part is ftripped confuredly with the fame mixture, wherein is the differenee.

7 Carolus Clufius fetteth forth in his Pannonicke hiftorie a kinde of Tulipa that beareth faire red floures, blacke in the bottome, with a peftell in the middle of an oner-worne greenifh colour; of which fort there happeneth fome to haue yellow floures, agreeing with the others before touched : but this bringeth forth encreafe of root in the bofome of his loweft leafe next to the ftalke, contraric to all the otherkindes of Tulipa.

8 Lobelius in his learned Obferuations hatln fet forth many orher forts; one he calleth Tulipas Chalcedonica, or the Turky Tulipa, faying it is the leaft of the fraall kindes or Dwarfe Tulipa's, whofe floure is of a fanguine red eolour, vpon a yellow ground, agreeing with the others in roote, leafe, and fralke.

9 He liatl likewife fet forth another ; his floure is like the Lilly in proportion, but in colour of a fine purple.

ro We may alfo behold another fort altogether greater than any of the reft, whofe floure is in colour like the ftone ealled $A$ imet hift, not vnlike to the floures of P conie.

is We haue likewifeanother of greater beauty, and very much defired of all, with white foutres datht on the back fide, with a light wath of watehet colour. 
+ 24 Tulipa lutco or rubro friatus. The red and yellow Fooles coat.

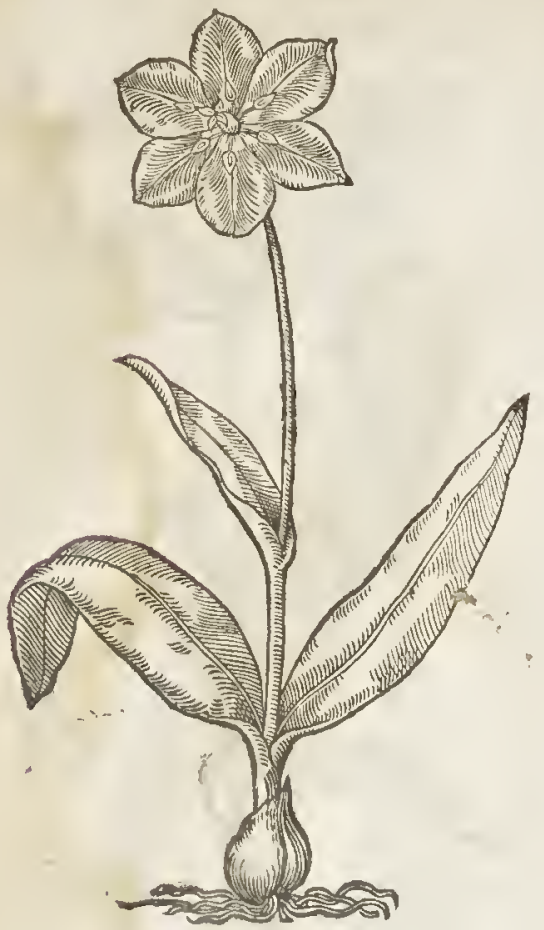

¥ 6 Tuliparubra or is pallidis. The red Tulip with pale edges.

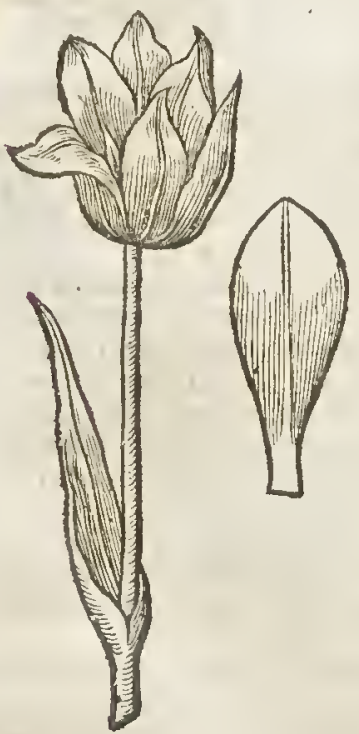

\$25 Tulipa fiore color is Mlpharei The fulphur-coloured Tulip.

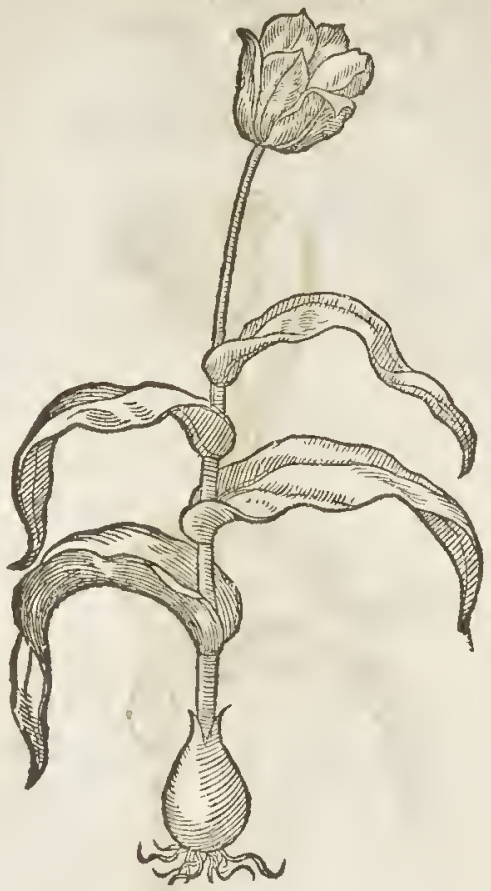

I2 There is another alfo in our London gar:dens, of a fnow white eolour the edges flightly watht ouer with a little of that we eall blufh colotir.

I3 We have another like the former, fauing that his floure is of a fraw eolour.

14 There is another to be feene with a floure mixe d with ftreaks of red and yellow, refembling a flame of fire, wherupon we hauc called it Flambant.

There be likewife fo many more differing fo notably in colour of their floures, although in leaucs, ftalke, and roots for the moft part one like another, that (as I faid before) to fpeake of them feucrally would require a peeuliar volume.

$\ddagger$ Therefore not to trouble you any furcher, $I$ haue giuen you onely the figures and names of the notableft differenees which are in thape; as, the dwarfe Tulipa's, and the branehed ones, togetherwith the eolour of their floures, entained in their titles, that you need not far to feeke it. $\ddagger$

Therebea fort greater than the reft, which in forme are like; the leaues whercof are thicke, long,broad, now and then fomewhat folded in the edges; in the middeft whereof doth rife vp a ftalk a foot high,or fomthing higher, vpon whieh fandeth onely one floure bolt vpright, eonfifting of fix leaues, after a fort like to a deepe wide cup of this forme, viz. the bottome turned vprards, w irh thicids 
threds or ehiues in the middle, of the colour of Saffron. The colour of the floure is fometimes yellow, fometimes whitc, now and then as it were of a light purple, and many times red; and in this there is no fmall varieties of colours, for the edges of the leaues, and oftentimes the nailes or lower part of the leaues are now \& then otherwife coloured than the leaues themfelus, and many times there doth runne all along thefe ftreakes fome other colours. They hate no finell at all that ean be perceited. The roots of thefe are likewife bulbed, or Onion faftion; euery of the which to fet forth feucrally would trouble the writer,and wearie the Reader, fo that, w hat hath bin faid thall fuffice touehing the defeription of Tulipa's. \# True it is that our A tithor here affrmes, The varieties of thefe floures are fo infinite, that it would both tyre the Writer and Reader to recount them. Yet for that fome are more in loue with floures than with Plants in gencrall, I haue thought good to direct them where they may finde fomewhat more at large of this Plant : Let fuch therefore as defire further fatisfaction hercin haue recuurfe to the Florilegies of $D e B r y$, Swerts, Robin, or to M. Parkinfon, who hath not onely largely treated of the floures in particular,
but alfo of the ordering of them. $\neq$

$¥ 27$ Tulipalutea ferotina. The late flouring yellow Tulip.

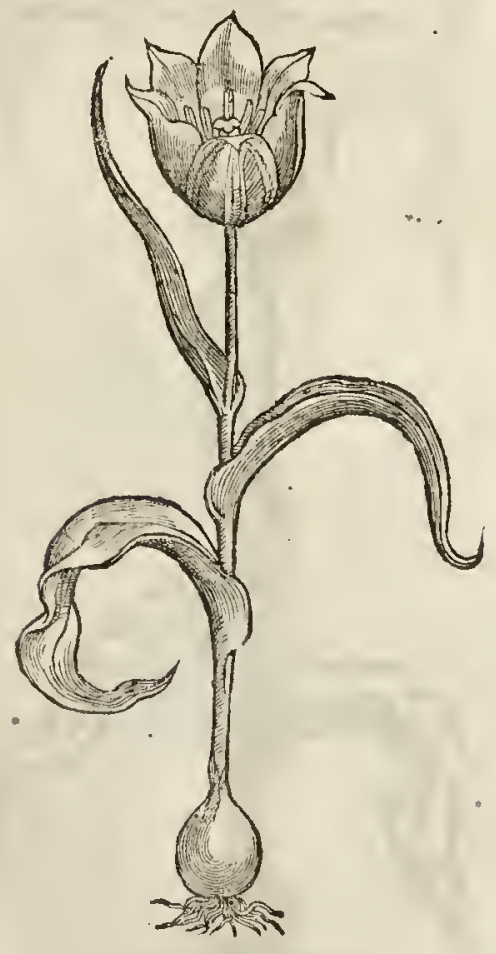

\section{\$28 Tulipa ferotinaluten guts is fanguine is fundonigro.}

The late Yellow with fanguine fpots and a blacke bottome.

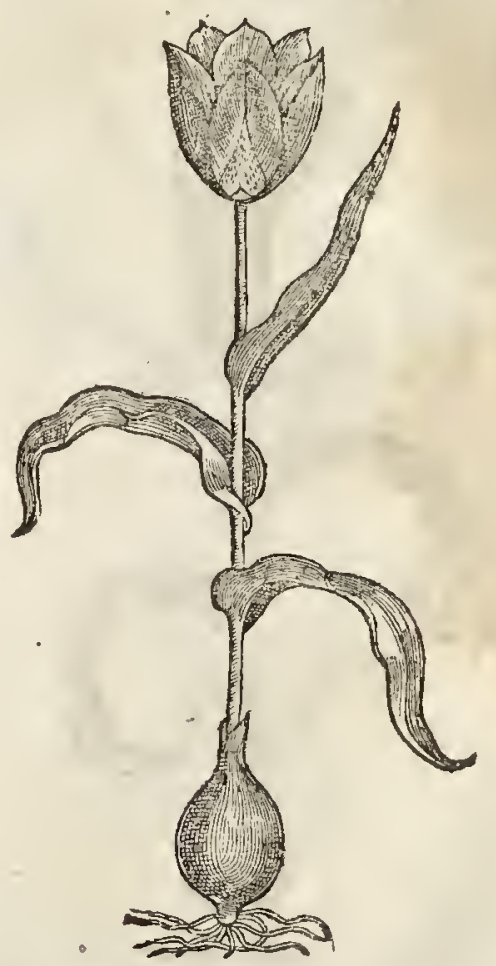

T) The Place.

Tulipa groweth wilde in Thracia, Cappadocia, and Italy; in Bizantia about Conftantinople, at Tripolis and Alepo in Syria. They are now common in all the gardens of fuch as affect floures,
all ouer England.

\section{T The Time.}

They floure from the end of Februaric vnto the beginning of May, and fomewhat after; although Augerius Busbequius in his journcy to Conftant nople, faw between Hadrianople and Conftantinople, great aboundance of them in floure euery where, euen in the middeft of Winter, in the moneth of Ianuarie, which that warme and temperate climate may feeme to performe. 


\section{The Names.}

The later Herbarifts by a Turkith and ftrange name call it Tulipa, of the Dalmatian Cap called Tulipa, rhe forme whereof, the floure when ir is open feemeth to reprefent.

It is ealled in Englion after the Turkîh name Tulipa, or it may be enlled Dalmatian Cap, or the Turkes Cap. What name the anticnt Writers gaue it is not cerrainly knowne. A man might fufpect it to be mod, if it were a Bulbe that mighit be earen, and were of force to make milke cruddy, for $T$ heophraftus reekoneth it among thofe Bulbes rhat may be earen: and it is an herbe, as $H$ clychius faith, wherewith milke is crudded. Corradus Gejnerus and diuers others haue raken Tulipa to be rhat Satyrinm which is fyrnamed Erythronism, beeaufe one kinde harh a red foure; or al together a eertainc kinde of Satyrium : with which it doth agree reafonable well, if in Diofcorides

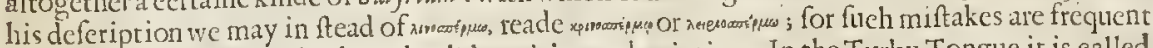
in antient and moderne Authors, borh in writing and printing. In the Turky Tonguc it is called Cafélalé, Cauálelalé, and likewife Turbasiand Turfan, of the Turks Cap fo called, as beforefaid of Lobelius.

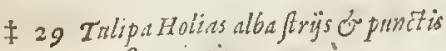
fanguincis.

The white Holias with fanguine fpors and ftreakes.

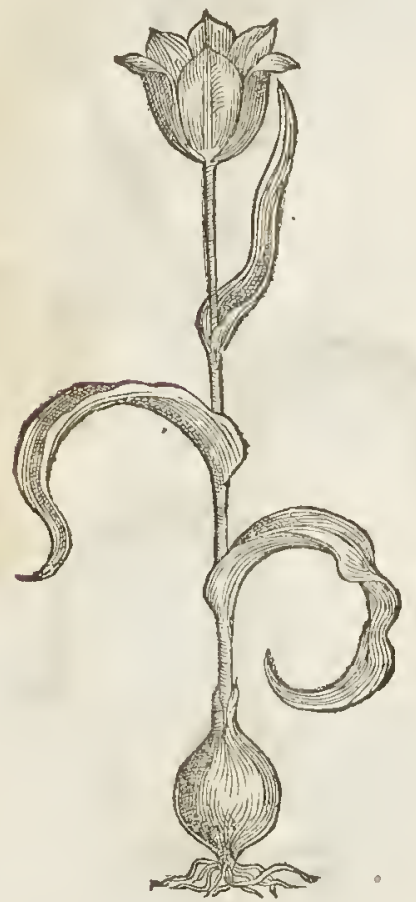

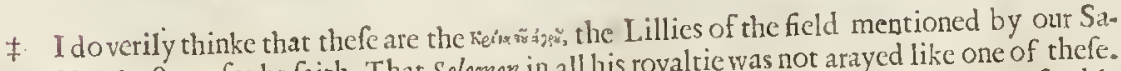
(1) faith, That Solomon in all his royaltie was not arayed like one of thefe. The Lillies, and in thefe plzees whereas our Sauiour was conuerfant they grow wilde in the fields. Secondly, the infinite varictic of colour, which is to be found more in this than any other fort of foure: and thirdly, the wondrous beautie and mixtures of thefe floures. This is my opinion, and thefe my reafons, which any may either approue of or gainfay as he fhall thinke good. $\ddagger$

\section{T) The Temperature and Fertues.}

ing fet downe of the antient or later $\mathrm{W}$ riters as touching the $\mathrm{Na}$ There hatl not beene any thing fet downe of the antient or later Wre
rure or Vertues of the Tulipa's, but they are efteemed efpecially for the beauty of their floures.
$\neq$ 'The 


\begin{tabular}{lll}
\hline L 1 1. & Of the Hiftorie of Plants. & 147 \\
\hline
\end{tabular}

\# The roots preferued with fugar, or otherwife dreffed, may be eaten, and are no vapleafant Af nor any way offenfiue mear, but rather good and nourinhing. $\neq$

\section{С нар.88. Of Bulbous Violets.}

\section{ขा The Kindes.}

7 Heophraftus hath mentioned one kinde of bulbous Letucoion, which Gaza tranflates Viola alba, or the white Violet. Of this Viola Theophrafti, or Theophraftus his Violet, we hate obferued three forts, whereof fome bring forth many floures and leaues, others fewer; fome flomre very early and uthers later,as fhall be declared.

I Letcoium bulbofum pracox minus. Timely flouring bulbous Violet. Galanthin moralis

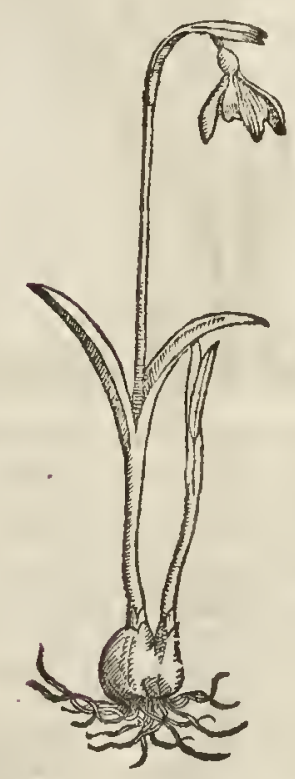

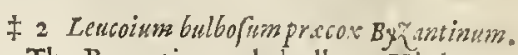
The Byzantine early bubous Violer.

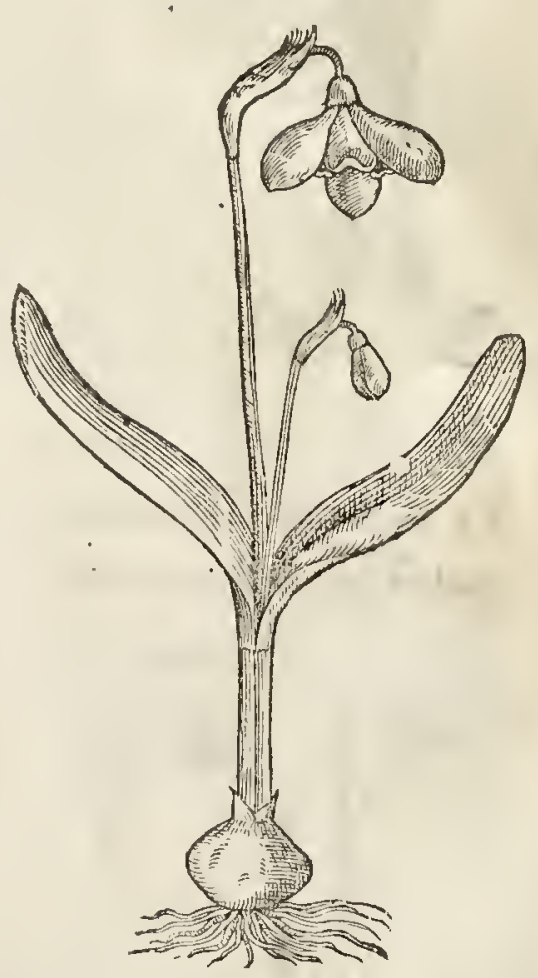

T) The Defeription.

I. THe firft of thefe bulbous Violers rifeth out nf the ground, with two fmall leaues flac and crefted, of an ourvorne greene colour, betweene the w bîch rifeth vp a fimall and tender ftalke of two hands ligh, at the top whereof eommeth forth of a skinny liood a fmall white floure of the bigneffe of a Violer, compact of fix leaues, threc bigger, and three leffer, tipped at the points with a light greene: the fmaller are fafhioned into the vulgar forme of a heart, and pretily edged about with greerie; the other three leates are longer,and harpe poinced. The whole floure hangeth downe his head, by reafon of the weake foot ftalke whereon it groweth. The root is fmall, white, and bulbous.

$\ddagger 2$ There are two varieties of this kind which differ little in thape, but the firft hath a floure as bigge againe as the ordinarie one, and Chufus ealls it Lencoium buibofum pracox Bysartinum, The greater carly Conftantinopolitan bulbous Violet. The other is mentioned by Lobcl, and differs onely in eolour of floures; wherefore he calls it Lescoimm triphyllimifore cerulco, The blew Houred bulbous Violet. 
3 Leucoium bulbofum ferotinum. Late fouring bulbous Violet.

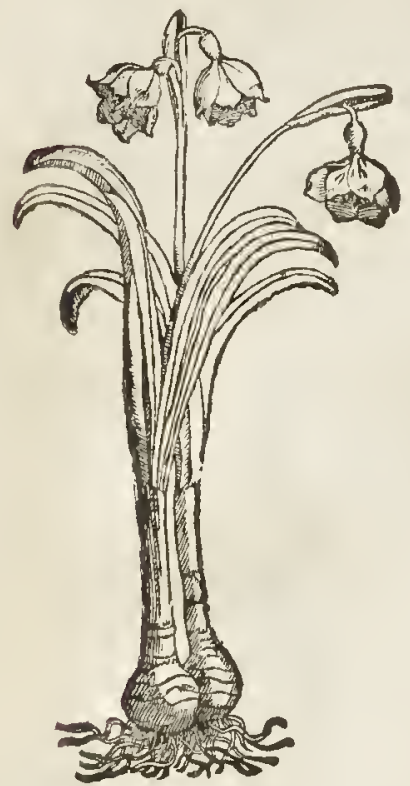

5 Leucoium 6ulbofum Autwrunale minimsim.

The leatt Autumne bulbous Violet.

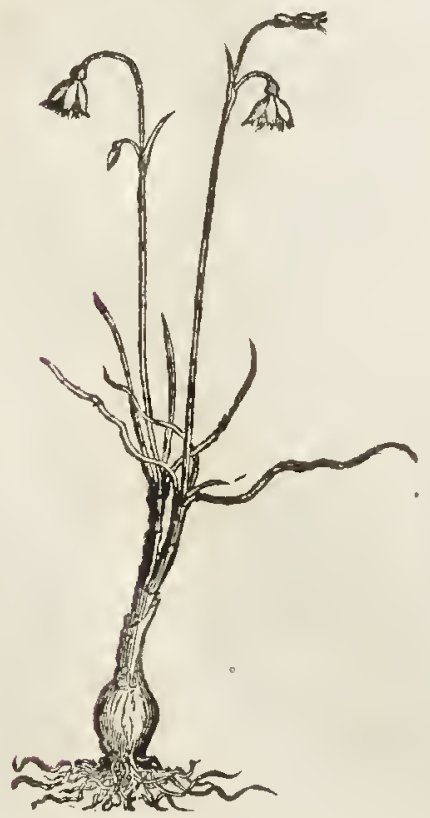

4. Leucoium bulborummajuspolyanthernum. The many floured great bulbous violet.

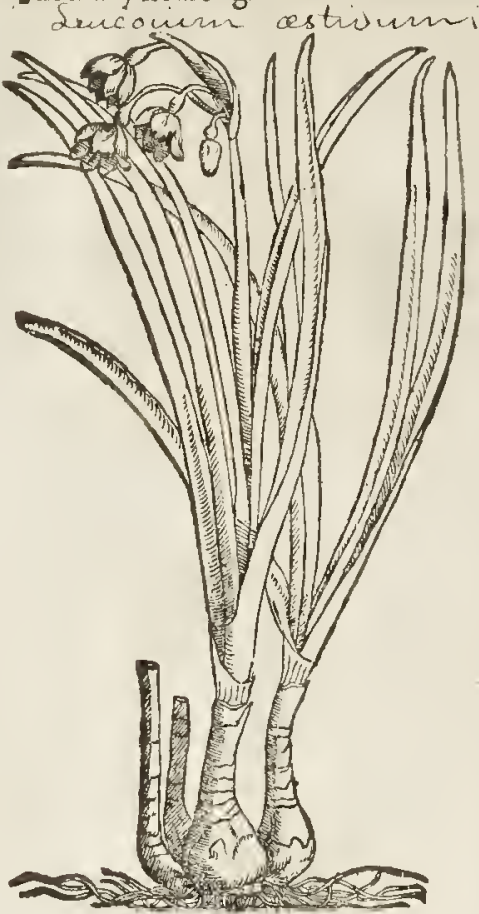

3 The third fort of bulbed Violers hath narrow leaues like thofe of the lecke, but leffer and fmoother, not vnlike to the leaues of the battard Daffodill. The ftalks be flender and naked, two hands high, whereupon doe grow faire white floures, tipped with a yellowing greene colour, with many fmall chiues or threds in the middeft of the floure. The feed is contained in fmal round buttons. The root is white and bulbous.

4 The great bulbed Violet is like vnto the third in ftalke and leaues, yet greater and higher. It bringeth fortl on euery ftalke not one floure onely, but fiue or fix, blowing or flouring one after another, altogether like the other foures in forme and bignefie.

$\ddagger 5$ This fmall bulbous plant may be annexed to the former, the root is fmall, compact of many coats : the leaues are alfo fmall,and the ftalke an handfull high, at the top whereof there hang downe one or two fmall white floures confinting of fix leaues a piece, much refembling the laf defcribed, but farre leffe. It floures in Autumne.

6 Bcfides thefe, Clufius makes mention of a fmall one much like this, and it floures in the Spring, and the floures are fomewhat reddifh nigh rhe ftalke, and fmell fwcer. Clufius cals this, ceucoium bulbofum veraum mimum, The fmalleft Spring bulbous Violet. + 


\begin{tabular}{ccc}
\hline L $_{\text {B. I. }}$ & Of the Hiftory of Plants. & 149 \\
\hline
\end{tabular}

Thefe plants do grow wilke in Italy and the places adiacent. Nowithftanding our London gardens haue taken pofferfion of noft of them many yeares pant.

$$
\text { ot The Tine. }
$$

The firf floureth in the beginning of Ianuary; the fecond in September; and the third in MLay; the reft at their feafons mentioned in their defcriptions.

$$
\text { T The Names. }
$$

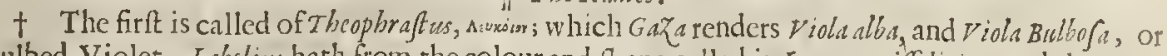
Bulbed Violet. Lobelins hath from the colour and Thape called it Letuconarciffolirion, and that very properly, confidering how it doth as ir were participate of two fundry plants, thiat is to fay, the root of the $N$ arciffus, the leaues of the fmall Lilly, and the white colour; taking the firft part $L$ cuco, of his whiteneffe; Narciffo, of the likeneffe the roors haue vnto Narciffes; and Lirium, of the leaues of Lillies, as aforefaid. In Englifh we may call it the bulbous Violet ; or after the Dutch name, Somet fottekcus; that is, Sonmer foles, and drops. This name Lcucoum, without his Epichite Bullofom, is taken for the Wall-floure, and ftock Gillohoure, by all moderne Writers.

\section{9) The Nature and Vertues.}

'Touching the faculties of thefe bulbous Violets we haue norhing to fay, feeing that norhing is fer downe hereof by the antient Writers, nor any thing obferued by the modderne; only they are maintained and cherifhed in gardens for the beautie and rareneffe of the floures, and fweetneffe of
their fmell.

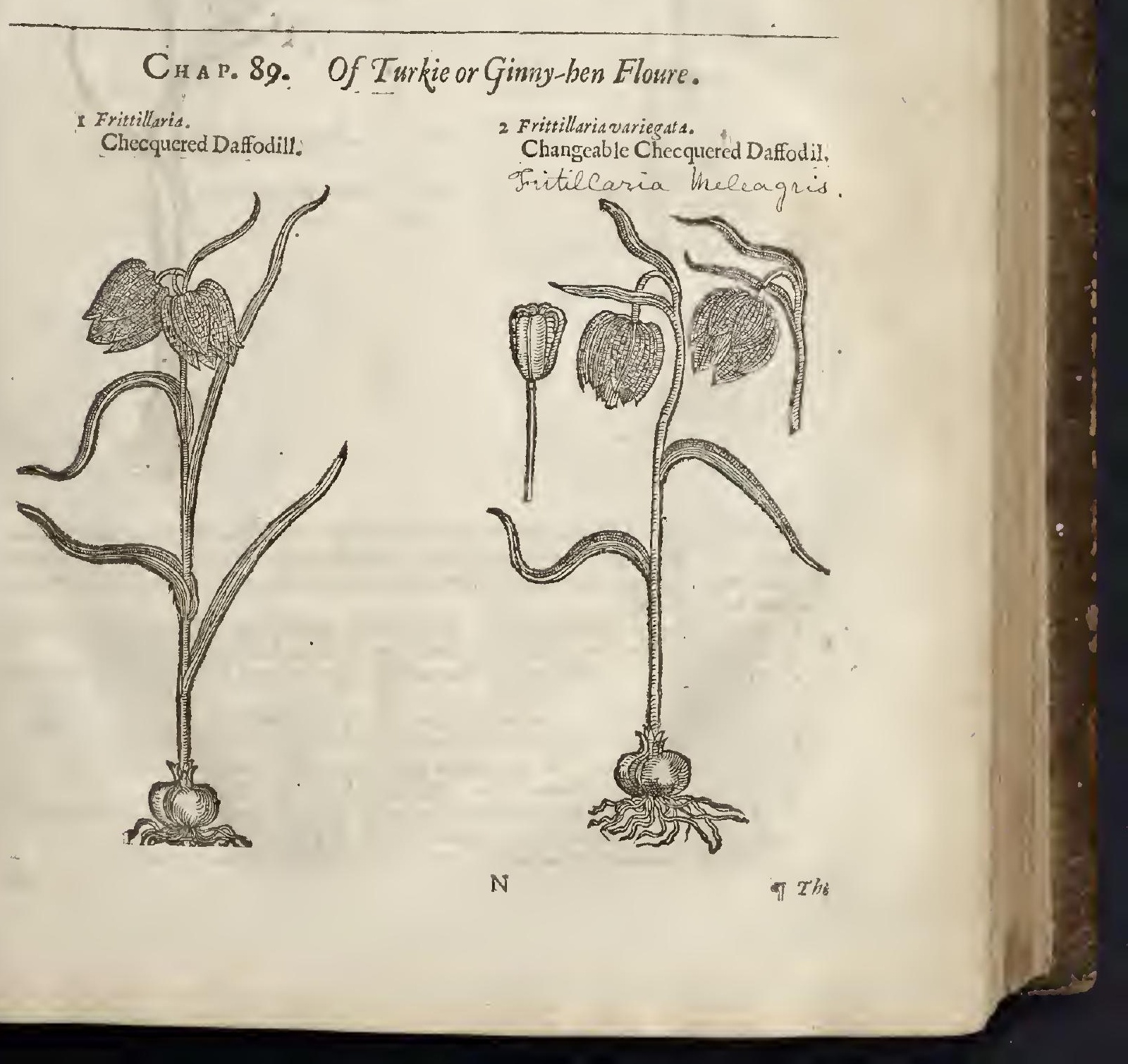




\section{-T The Defcription.}

r THe Checquered Daffodill, or Ginny-hen Floure, bath fmall narrow grafie leaues; among which there rifeth vp a ftalke three hands high, hauing at the top one or two floures, and fometimes three, which confifteth of fix fmall leaues checquered molt Atrangely: wherein Nature, or rather the Creator of all things, hath kept a very wonderfull order, furpafing (as in all other things) the curioufeft painting that Art can fet downe. One fquare is of a greenifh yellow colour, the other purple, kceping the fame order as well on the backfide of the ffoure, as on the infide, although they are black ih in one fquare, and of a Violer colour in an other ; infomuch that euery leafe feemeth to be the feather of a Ginny hen, whereof it tooke his namc. The root is fmall, white, and of the bigneffe of halfe a garden beane.

2 The fecond kinde of Checquered Daffodill is like vnto the former in each refpect, fauing that this hath his floure dafht onerwith a light purple, and is fomewhat greater than the other, wherein con fiftech the difference.

$\ddagger_{3}$ Frittillaria Aquitcnica minor flore lutcoolfoleto.

The leffer darke yellow Fritillaric.

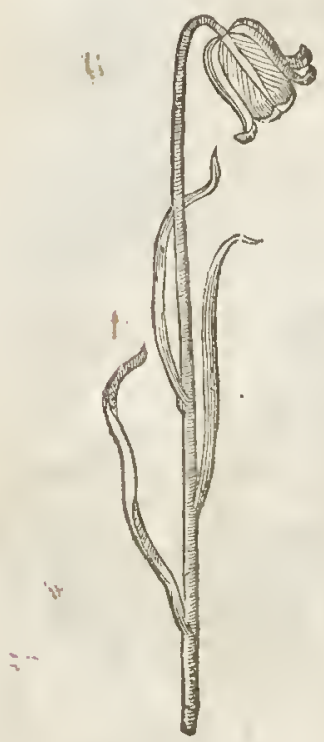

\$ Frittillaric albaprecos.

The early white Fritillarie.

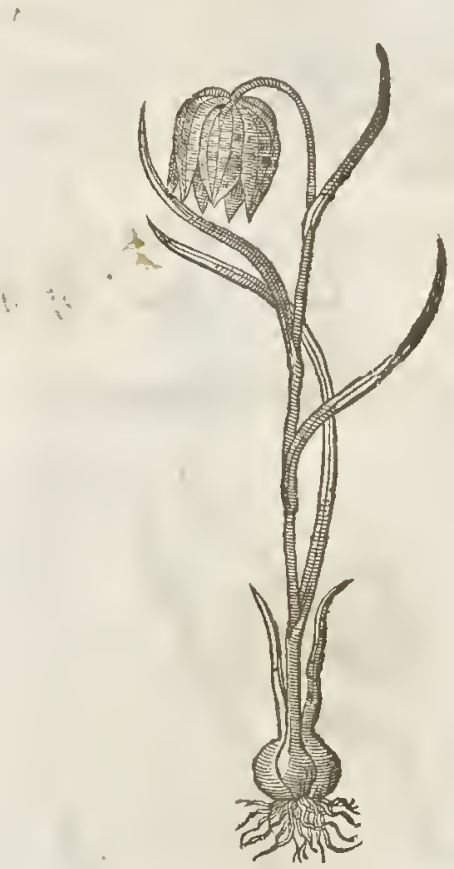

¥ There are fundry differences and varieties of this floure, taken from the colour, largenes, dou. bleneffe, earlinefe and latenes of flouring, as alfo from the many or fow branches bearing floures. Wewill onely fpecific their varieries by their names, feeing their forme differs little from thofe you haue here deferibed.

4 Fritillaria maxima ramofapurpurea. The greateft branched purple checquered Daffodill.

5 Fritillaria flore purpurio pleno. The double purple floured checquered Daffodill.

6 Fritillarin polyanthos flanowiridis. The yellow ifh greene many floured checquered Daffodill.

7 Fritillaria lutea Someri. Somers his yellow Checquered Daffodill.

8 Fritillaria alba purpureo tc fulata. The white Fritillarie checquered with purple.

9 Fritillarialla aprecox. The early white Fritillarie or Checquered Daffodilf.

Io Fritillariaminor fore luteo abfoleto. The leffer darke yellow Fritillaric.

II Fritillaria angugh folia lutea variegata paruo flore, \& altcra forc majore. Narrow leaued yellow waricgated Fritillarie with fmall floures; and another with a larger floure.

I2 Fritillariamianan phuribus floribus. The leaft Fritillarie with many foures. 
Fritillaria Hijpanica gmbellifera. The Spanifh Fritillarie with the foures ftanding as it were in an vmbell. $\neq$

$$
\text { \Thi } N_{\text {imes. }}
$$

The Ginny hen floure is called of Dadonass, Flos Meleagris : of Lobelius, Lilio-narciffes variegata, for that it hath the floure of a Lilly, and the root of $N_{\text {An }} r$ ciffats. it hath beene called Fritillaria, of the table or boord vpon which men play at Cheffe, which futare checkers the floure doth very nutch refermble; fome thinking that it was named Fritillus : whereof there is no certaintie; for crartialis feemeth to call Fritillus, Abacus, or the Tables whereat men play at Dice, in the fifth Booke of his Epigrams, writing to Galla. *

\section{Iam trift is, nutibus puer reliditis, Clamofo renocatur à magiftro: Et blandu male proditus Fritillo Arcanamodò raptusè popina etidem rogat vdus aleator. \&o.} The fad Boy now his nuts caft by, Call'd unto Schole by Mafters cry: And the drunke Dicer now betray'd By flattring Tables as he play'd,

Is from his fecret tipling houfe drawne out,

Although the Officer he mucil befought. \&xc.

In Englifh we may call it Turky-hen or Ginny-hen Floure, and alfo Checquered Daffodill, and Fritillarie, according to the Latine.

Of the facultic of thefe pleafant floures there is nothing fer downe in the antient or later Writer, but are greatly efteemed for the beaut 1fying of our gardens, and the bofoms of the beautifull.

\section{C н а р. 90. Of true Saffron, and the wilde or Spring Saffrons.}

Crocus florens of fine flore. Saffron with and without floure.
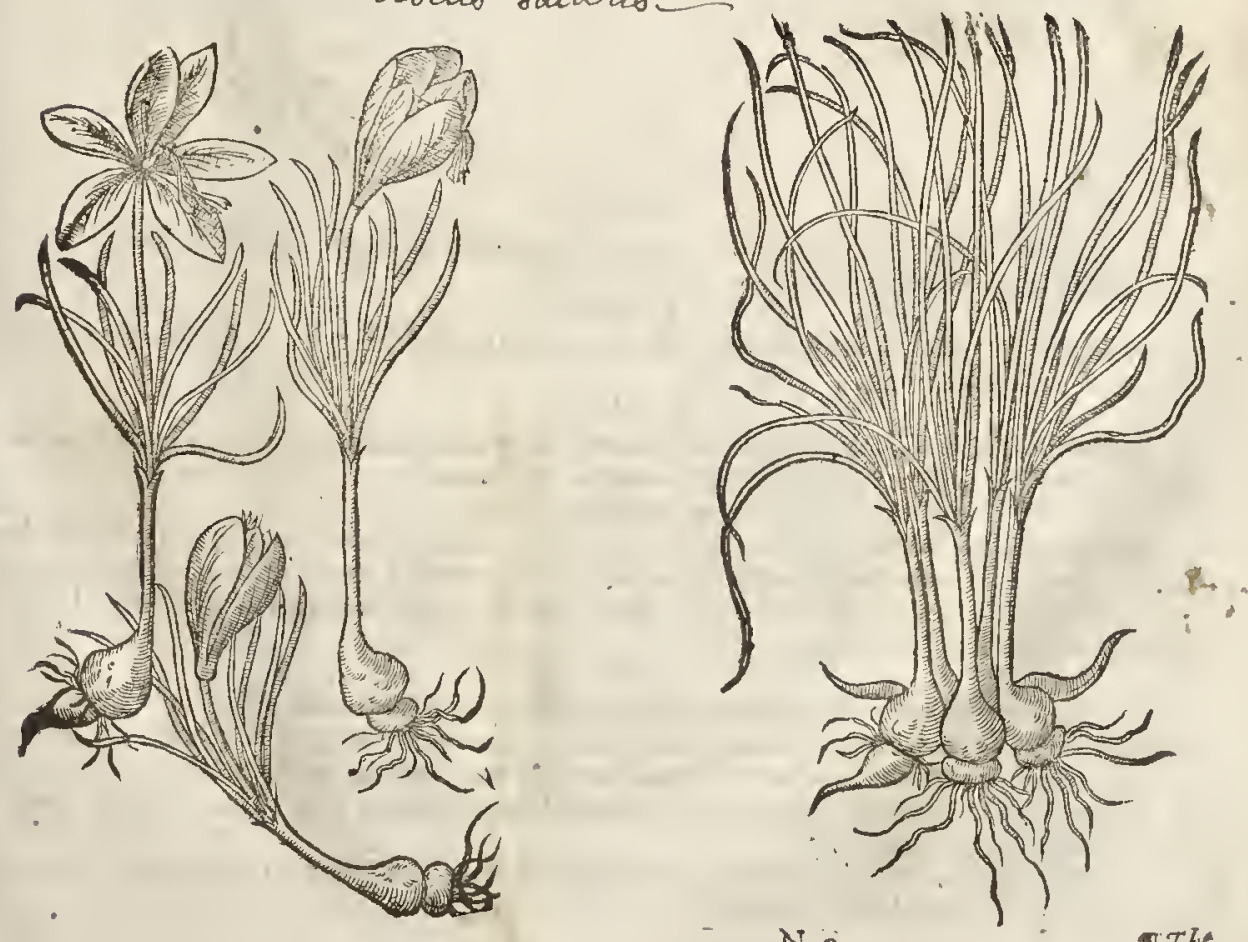
The Defeription.

Ithough I haue expreffed two pictures of Saftrons, as you fee, yet are you to vinderftand that thefe two do but fet forth one kinde of plant, which could not focafly be perceited by one picture as by two,becaufe his floure doth firft rife out of the ground nakedly in September, and his long fmal graffy leaues fhortly after the floure,neuer bearing floure and leafe at once. The which to exprefle, 1 thought it conuenient to fet downe two pietures before you, with this defeription, viz. The root is fmall, round, and bulbous. The flourc confifteth of fixc fmall blew leaues tending to purple, bauing in the middle many fmall yellow ftrings or threds; among which are two, threc, or more thick fat chiues of a fieric colour fonewhat reddifh, of a ftrong fmell whes they bedried, which doth fuffe and tromble the head. 'The firft pisture fetteth forth the Plant when it beareth floures, and the other expreffeth nothing but lcaues.

I Crocus vernus.

Early flouring wilde Saffion.

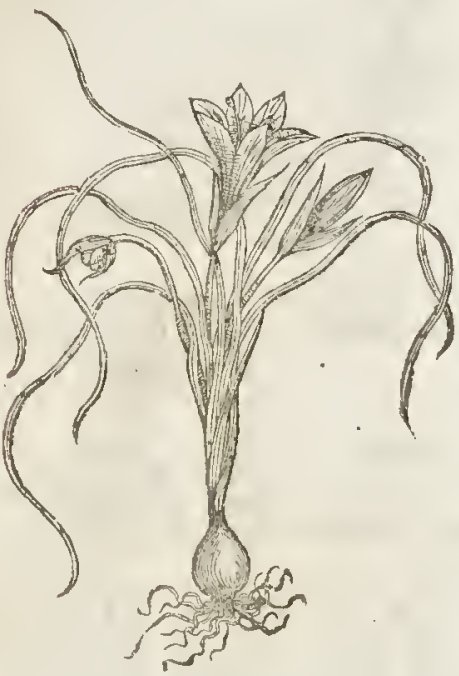

2 Crocus vernus minor. Small wilde Saffron.

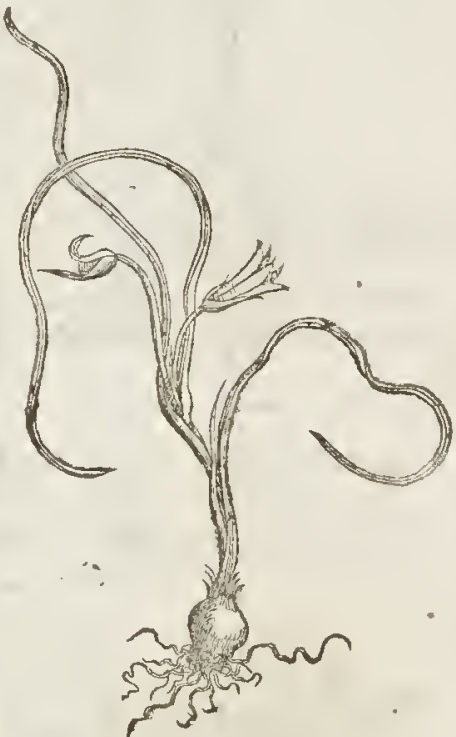

The Place.

Cummon, or the beit knowne Saffron groweth plentifully in Cambridge-Thire, Safiron-Walden, and otlier places thereabout, as corne in the fields.

TI The Time.

Saffron beginneth to floure in September, and prefently after fpring vp the leaues, and remaine greene all the Winter long.

Saffron is called in Greeke, kporos: in Latine, Crocus: in Mauritania, Safferan : in Spanifh, Açafron : in Englioh, Saffron : in the Arabicke tongue, Zabafar an.

T) The Temperature.

Saffron is a litcle attringent or binding, but his hot qualitie doth fo oucr-rule in it, that in the whole effence it is in the number of thofe herbes which are hot in the fecond degree, and drie in the firf: therefore it alfo hath a certaine force to concost, which is furthered by the fmall afriction that is in it, as Galen faith.

$$
\text { The Vertues. }
$$

A Asicen affrmeth cliat it caufeth head-ache, and is hurtfull to the braine, which it cannot do by taking it now and then, but by too much vfing of it : for too much ving of it cutteth off fleepe, through want whereof the head and fences are out of frame. But the moderate vfe of it is good for the head, and maketh the fences more quicke and liuely, thaketh off heauy and drowfie flecpe, and maketh a man merry.

B Alfo Saffron Itrengthneth the heart, concocteth crude and raw humors of the cheft, openeth the lungs, and remoucth obfuctions, 


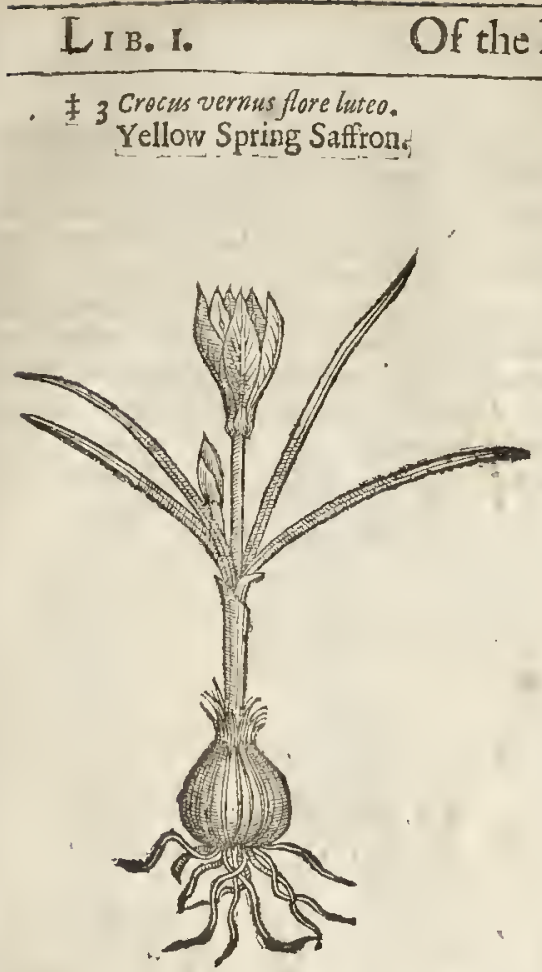

153

\$ 4 Crocus veraus flore albo.
White Spring Saffron.

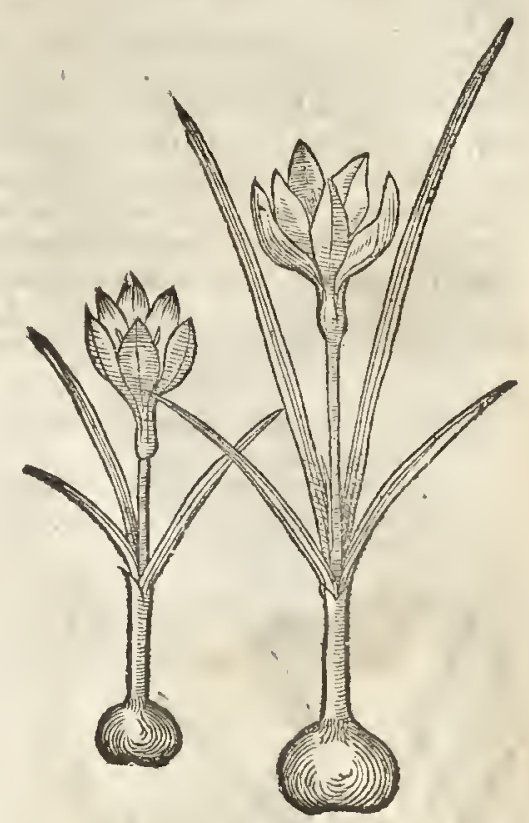

16 Crocus montasus Asturnnalis. Autumse mountaine Saffron: Crocus madiflorms

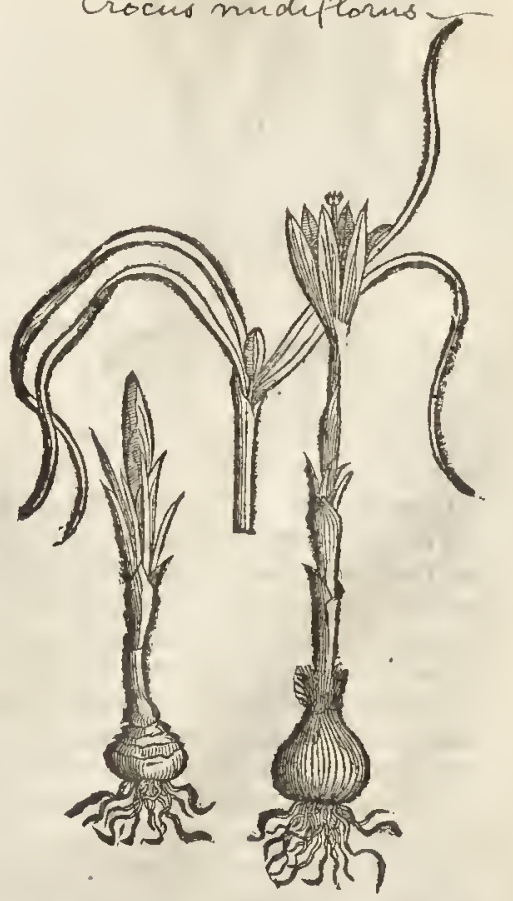

$N_{3}$

7 Crocks 
C. It is alfo fuch a fpeciall remedie for thofe that haue confumption of the lungs, and are, as wee terme it, at deaths doore, and a lmoft paft breathing, that it bringeth breath again, and prolongeth life for eertaine dayes, if ten, or twentic graines at the moft be giten with new or fweet Wine. For we haue found by often experience, that being taken in that fort, it prefently and in a monent remoueth aw ay difficultie of breathing, which moft dangeroufly and fuddenly bapneth.

D Diofcorides teacheth, That being giten in the fame fort it is alfo good againft a furfet.

E It is commended againft the ftoppings of the liuer and gall, and againft the ycliow Iaundife : And hereupon Diofcorides writeth, That it maketh a manwell eoloured. It is put into all drinkes tlat are made to helpe the difeafes of the intrailes, as the fame Authour affirmeth, and into thofe efpecially which bring downe the floures, the birth, and the after burthen. It protoketh vrine, fterreth feithly lutt, and is vfed in Catapla fines and pulteffes for the nuatrix and fundament, and alfo in plaifters and feare-eloaths whieh ferme for old fwellings and aches, and likewife for hot firellings that haue alfo in them S. Anthonies fire.

\section{$\$ 7$ Crocus montamus Lutumnal is flore majore albido carrleo.}

Autumne mountaine Saffron with al largew hitim blew floure.
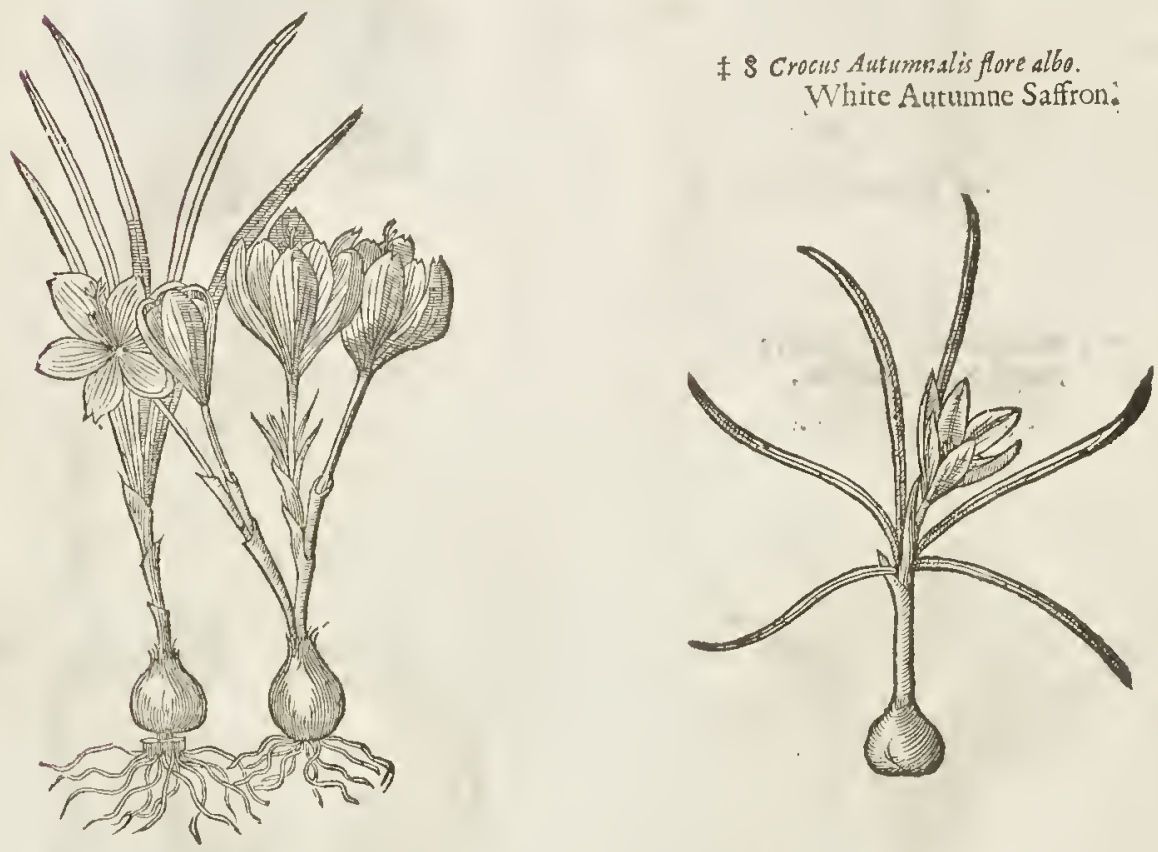

F It is with good fucceffe put into compofitions for infirnities of the eares.

$G$ The eyes being amointed with the fame diffolued in milke, or fennell or role water,are preferued from being liurt by the fmall pox and meafels, and are defended thereby from humours that would fall into them.

H The chiues fteeped in water, ferue to illumine or (as we fay) limne pictures and imagerie, as alfo to colour fundry meats and confections. It is with good fuceeffe giucn to proeure bodily luft. The confections called Crocomagna, Oxycroceum, and Diacarcuma, with diuers other emplaifers
and ele ettaries cannot be niade without this Saffron.

I The weight of tenne graines of Saffron, the kernels of Wall-nuts two ounces, Figges two ounces, Mithridate one dram, and a few fage leaues, ftamped together with a fufficient quantitie of Pimpernell water, and made into a maffe or lumpe, and kept in a glaffe for your ve, and thereof twelue graines giuen in the moraing fafting,preferueth from the Peftilence, and expelleth it from
thole that are infe ited. 
\$ Crocus vernas anguf tifolius fore violaceo. Narrow leaued Spring Saffron with a violet floute.

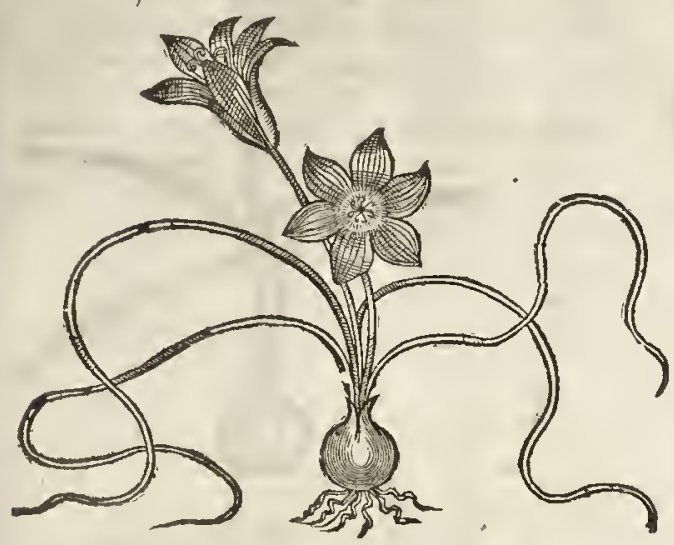

I I Crocus vernus latifolitu feriatus fore duplici.

Double floured ftreaked Spting Saffron.

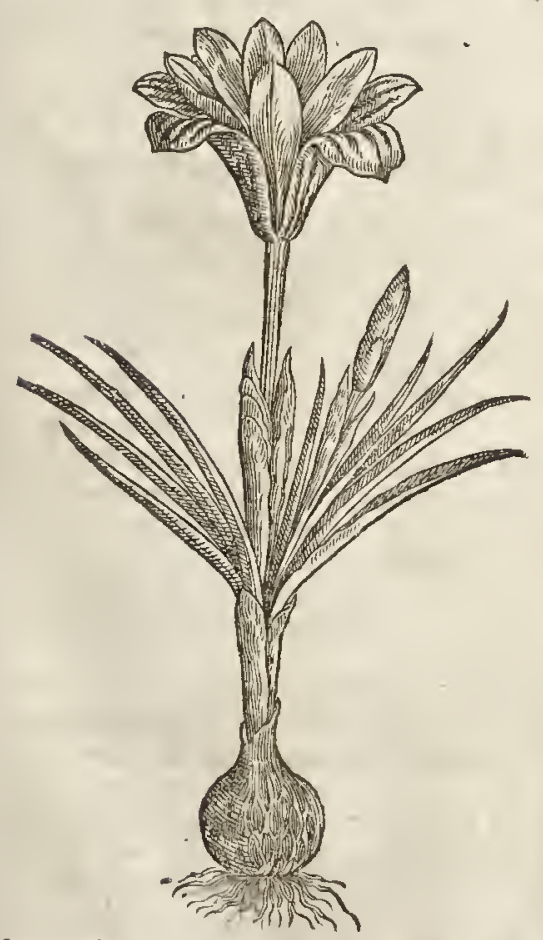

I
‡ 10 Crocus vernus lat ifolins fore fano früs violaceis.

Broad leated Spring Saffron with a yellow floure \& purple ftrcaks,

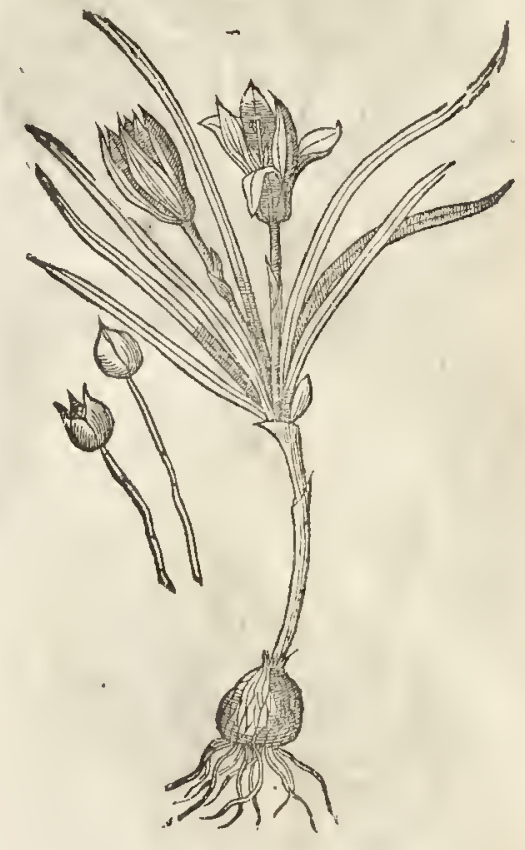

T The Kindes of Spring Saffror

F wilde Saffrons there be fundry forts, differing as well in the colour of the floures, as alfo in the time of their flouring. Of which, moft of the figures fhall be fet forth vnto you.

\section{Tा The Defoription of wilde Saffroin.}

$7 \begin{gathered}\text { He firft kind of wilde Siffrom liath } \\ \text { fmall fhort grafle leates, furtowed }\end{gathered}$ or chanelled downe the nidit ivith a white line or ftreake: among the leaues rife vp fmall floures in thape like vno the common Saffron, but differing in colour ; for this hath floures of mixt colours ; that is to fay, the ground of the floure is white, ftripped vpon the backe with purple, and dafht ouer on the infide with a bright fhining murrey colour ; the other not. In the middle of the floures come forth many yellowinh chities, withour any fmel of faffron at all. The root is fmall, round, and coucred with a browne skinne or filme like vnto the roots
of common Saffron.

2 The fecond wilde Saffron in leaues, roots, and floures is like vnto the precedent, but altogether leffer, and the floures of this are of a purple violet colour.

3 We haue likewife in our London gardens another fort, like vnto the other wille Siffrons 
屯 I 2 Crocus vermus latifolius flore purpureo. Broad leated Spring Saffton with the purple floure.

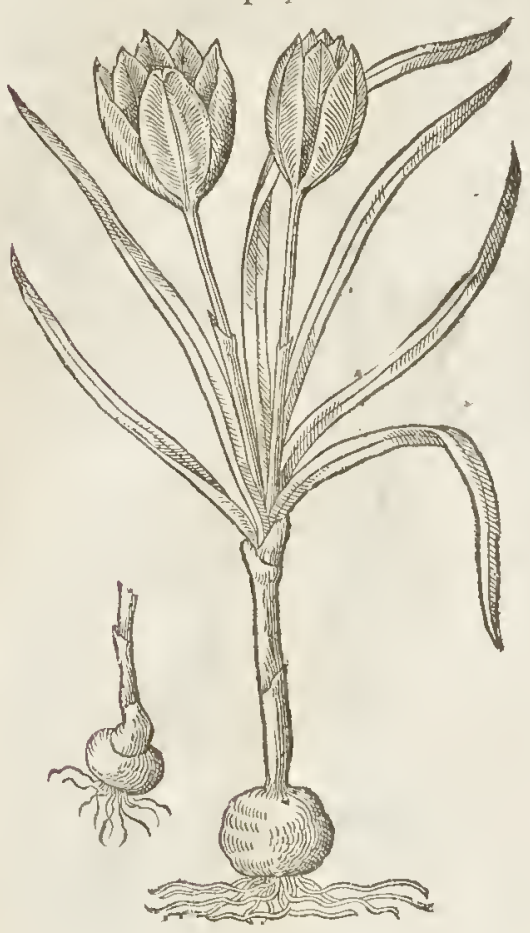

\# 4 Crocus vernus laifolius flore fauovario duplici.

Broadleaued Spring Saffron with a double floure yellow \& Atreaked.

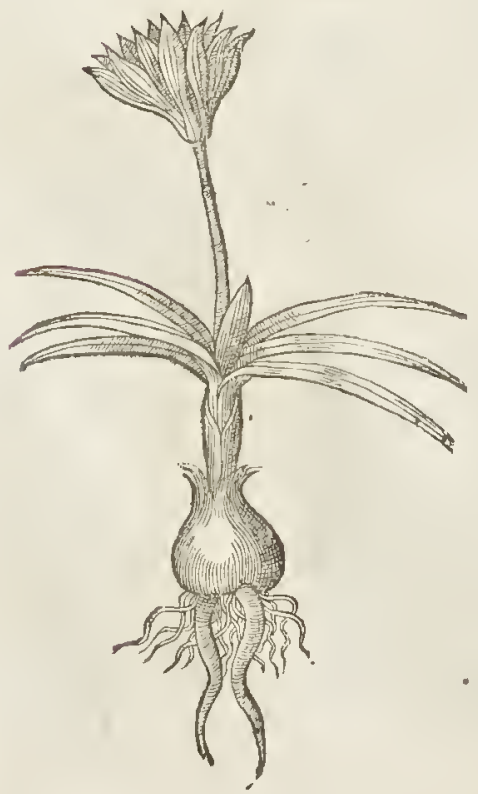

4 I 3 Crocus wermus fore cinerco friato. Spring Safiron with an Afh-co. loured fiteaked floute.

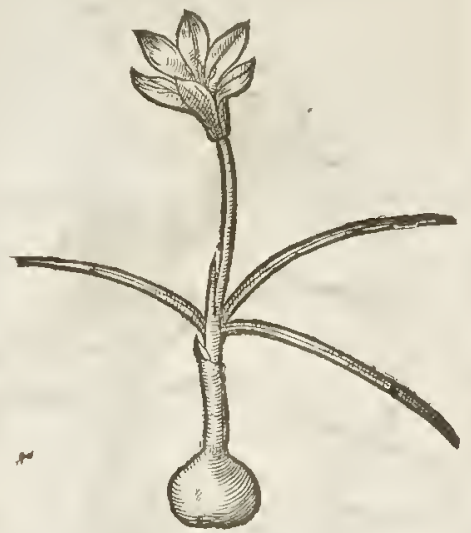

in euety point, fauing that this hath foutes of a molt petfect fhining yellow eolotr, feeming a far of to bea hot glowing cole of fire, which maketh the differenee.

4 There is found among Hetbarifts anothe fort, not differing from the others, fauing th st this hath white flomres, eontraric to all the reft.

5 Loucrs of Plants haue gotten into their gardensone fort heteof with purple ot Violet colouted floures, in other refpeets like vnto the other.

6. Of thefe we haue another that Houteth in the fall of the leafe, with floures like to the common Saffron, but deftitute of thofe chities which yeeld the colour, fmell, or talte that the right manuted Saffron hath.

¥ 7 And of this laft kinde there is anotherwith broader leaties, and the flotre alfo is latget, with the leaues thereof not fo thatpe pointed, but more round; the colour being at the firft whitifh, but afterwards intermixt with fome blewneffe. $\neq$

8 There is alfo another of Autumne wild Saffions with wlute floures, which fets fotth the diftinction.

Many forts there are in out gardens befides thofe before fpecified, which I thought needleffe to entreat of, beeaufe their ve is not great. * Thetefote I willonly giue the figures and names of fome of the chicfe of then, and refer fuch as delight to fee ot pleafe themfelues with the varieties ( for they are no fpecificke differences) of thefe plants, to the gardens and the bookes of Florifts, who are onely the preferuers and admirers of thefe varieties, not fought after for any ve but delight .

I The 
Lis. 1. Of the Hiftoric of Plants.

157

et The Place.

All the fe wilde Saffrons we have growing in our London Gardens. Thole which choc fore in Autumn do grow upon certain craggy rocks in Portugall, not far from the fer ide. The other have been font outer vito vs, forme out of Italy, and forme out of Spline, by the labour and diligence of that notable learned Herbarift Carolus Clufius; ont of whole Obfermations, and partly by feeing them in our own gardens, we have fer down their deferiptions.

That pleasant plant that bringeth forth yellow flies was font vito ne from Robinzus of Paris, that panful and mot curious searcher of Simples.

9) The Time.

They flour for the molt part in Ianuarie and Februaries; that of the mountain excepted, which fourth in September.

9T The Names.

All there Saffrons are unprofitable, and therefore they be truly fid to be Crock fjutuftres, or wild Saffrons: in English, Spring Saffrons, and venal Saffrons.

II The Temperature and Vertus.

Of the faculties of the fe we hate nothing to fer dow ne, for that as yet there is no known vie of them in Phys fiche.

CHA P. 91. Of Redon Saffrons.

9 The Kinds.

7 Here be foundry forts of Medow Saffrons differing very notably as well in the colour of their flours, as al fo in feature and Countrey, from whence they had their being, as thill be declare.

I Colchicum Anglican Purpureum.

Purple English Medow Saffron'

Colchicum antumerale
2 Colchicum Anglisum album.

White English Medow Saffron:

Colchicum aninumake
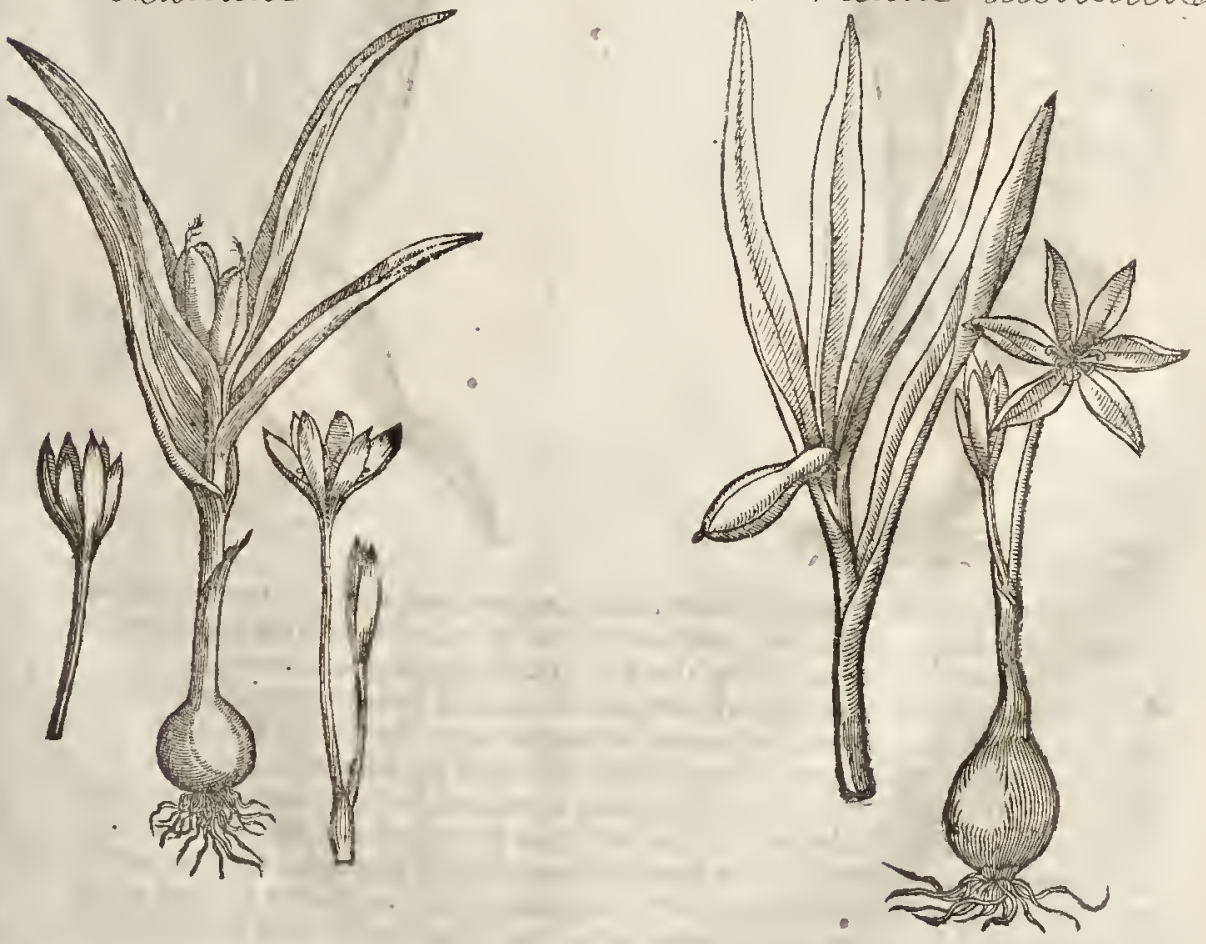

. $2 / 6$ 
đT The $\boldsymbol{D}$ cfoription. neffe of a fmall Wall-nut, ftanding vpon thort tender foot-ftalkes three fquare, and opening themfelues when they be ripe, full of feed fomething round, and of a blackin red colour : and when this feed is ripe, the leates together with the ftalkes doe fade and fall away. In Septembet the floures bud fortl, before any leates appeare, ftanding vpon thort tender and whitith ftemmes, like in forme and colour to the floutes of Saffron, hauing in the middle fmall chiues or threads of a pale yellow colour, al togethet vnfit for meat or medicine. The root is tound ot bulbous, thatper at the one end than at the othet, fiat on the one fide, hauing a deepe clift or furrow in the fame flat fide when it floureth, and not at any time elfe : it is couered with blackifh coats or filmes; it fendeth downe vnto the loweft part cettaine ftrings or theds. The root it felfe is full of a white fubftance, yeelding a juyce like milke, whileft it is gteene and newly digged out of the carth. It is in tafte fweet, with a little bitternefle following; which draweth water out of the mouth.

3 Colchicum Pannonicum florens or fine flore.

Hungary mede Saffron with and without Floute.
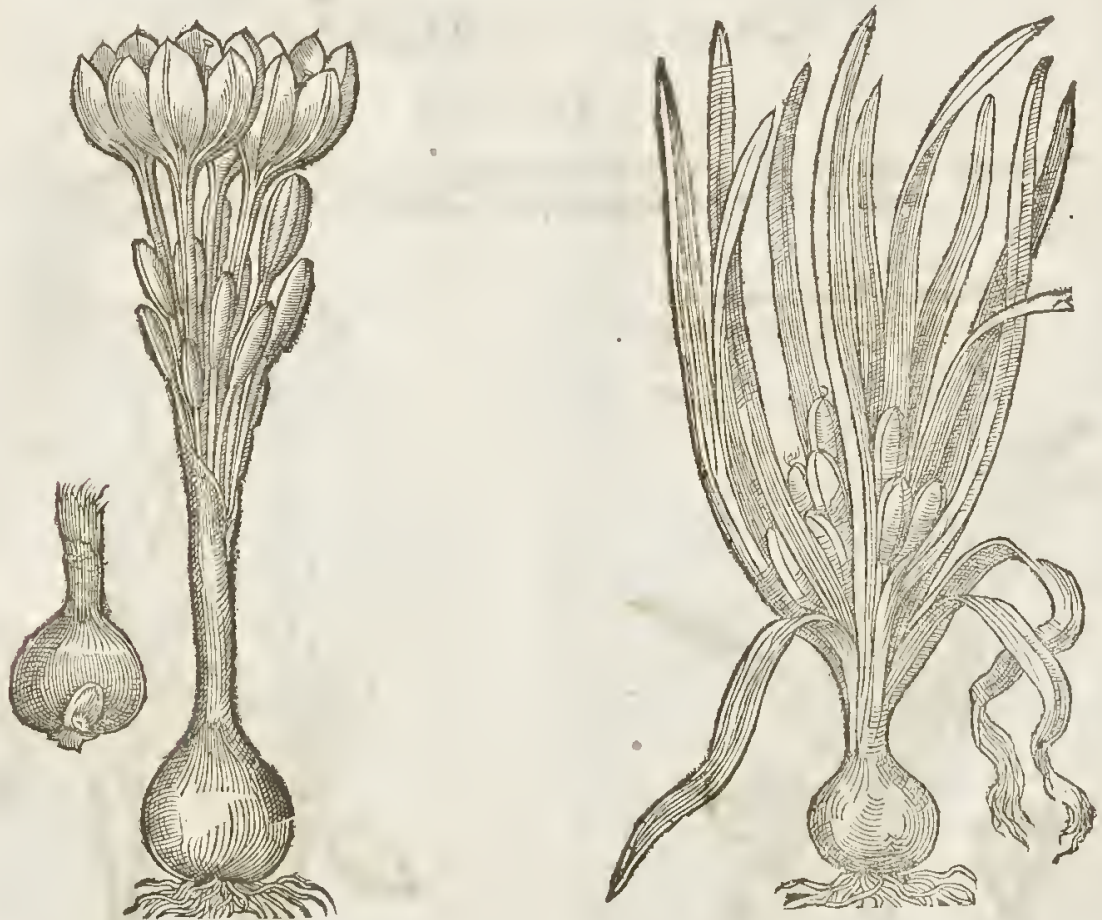

2 The feeond kinde of Mede Saffron is like the ptecedent, differing onely in the colout of the floures, for that this plant doth bring forth white leaues, which of fome hath beene taken for the ttue Hermodict lus : but in fo doing they haue committed the greater etrot.

3 Thefe two figures exprefle both but oneand the felfe fame plant, which is diftinguifhed becaufe it neuer beareth floutes and leaues both at one time. So that the firft figute fets it forth when it is in leaties and feed, and the other when it flouteth; and thetefore one defcription thall fuffice for them botl. In the Spring of the yeare it bringeth forth his leaues, thiche, fat, thining, and fmonth, not vnlike the leaties of Lillies, which do continue greene vnto the end of Iune; at which time the leaues do w ithet aw ay, but in the beginning of September there hooreth forth of lie ground naked milke white floutes w ithout any greene leafe at all: but fo fonne as the Plant luth done bearing of floutes, the root remaines in the gtound, not fending forth any thing vntill Febturic in the yeare following. 


\section{B. 1.}

Of the Hiftoric of Plants. $\neq$ It beares plentifull ftore of reddith feed in loofe triangular heads. The root hereof is big-
ger than that of the laft deferibed. $\neq$

t 4 The fmall medow Saffron hath three or foure thieke fat leaues narrower than any of the reft. The floure appeareth in the fall of the leafe, in fhape, colour;and manner of growing like the common mede Saffron, but of a more reddifh purple colour, and altogether leffer. The leaues in this, contrarie to the nature of thefe plants, prefently follow after the Houre, and fo continue all the Winter and Spring, euen vntill May or lune. The root is bulbous, and not great; it is couered with many blackifh red coats, and is white within.

¥5.This medow Saffron hath roots and leaues like to thofe of the laft deferibed, but the leaues of the floure are longer and narrower, and the colour of them is white on the infide, greene on the middle of the backe part, and the reft thereof of a eertaine flefh colour.

4 Colchicum montamum minus Hipanicum cum flore \& fernine. Small Spanifh medow Saffron in floure and feed.
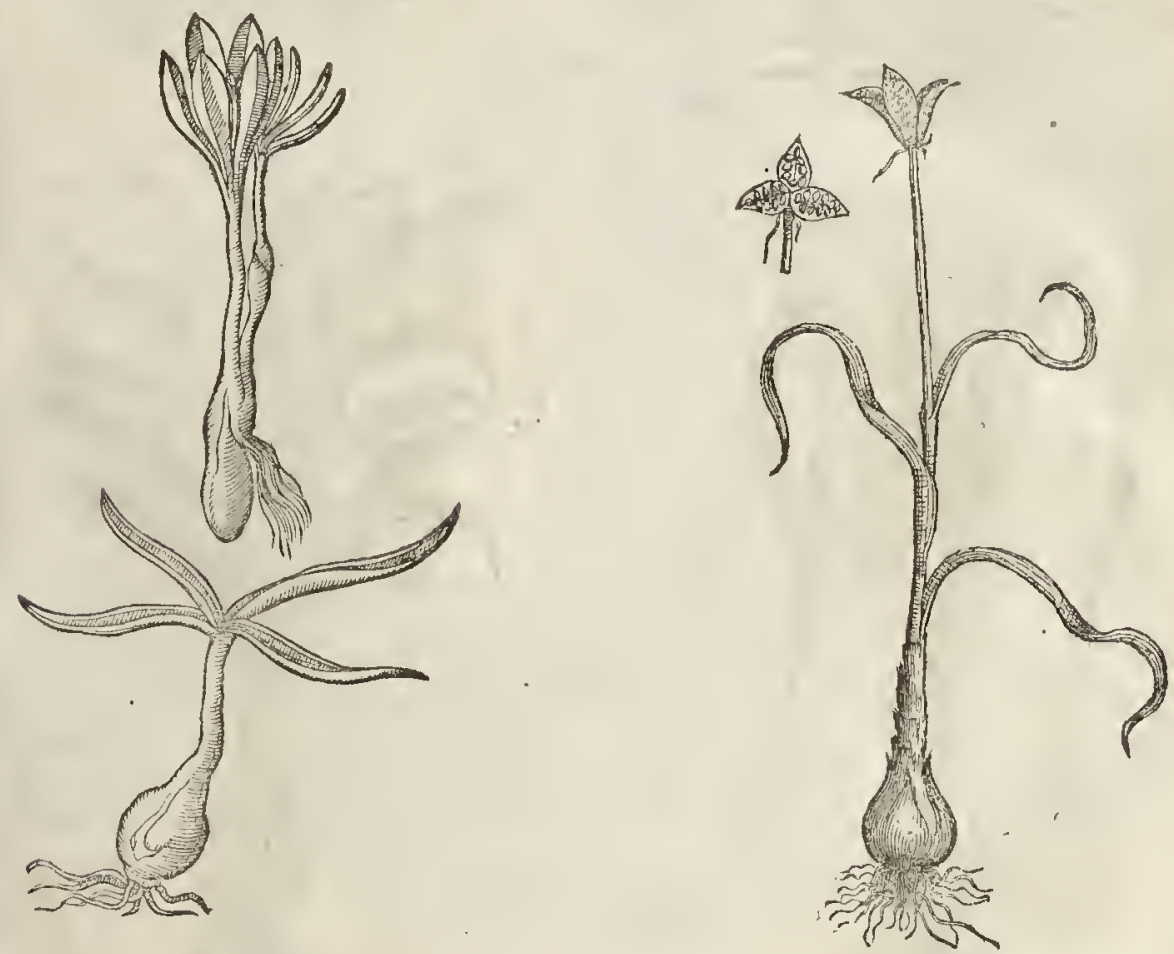

'6 The medow Saffron of Illyria hath a great thiekc and bulbous rost, full of fubrance:from which rifeth vp a fat, thieke, and groffe ftalke, fet about from the lower part to the top by equall
diftances, with long, thieke, and groffe leaues, tharpe pointed, not vnlike to the leates of leekes; among which leaues do grow yellowi h Aloures like vnto the Englifh medow Saffron, but finaller.

7 The Affyrian medow Saffron hath a bulbous root, made as it were of two pieces; from the middle eleft whereof rifeth vp a foft and tender ftalke fet with faire broad leaues from the middle to the top: anong which commeth forth one fingle floure like vnto the common medow Satfron, or the white Anemone of Matthiolus de feription.

8 The mountaine wilde Saffron is a bafe and low plant, but in thape altogether like the eommon medow Saffron, but much leffer. The floures are fmaller, and of a yellow eolour, which fetteth forth the difference. $\neq$ The leaues and roots (as Clufurus affirmes) are more like to the Nareiffes; and therefore he calls this I arciffus Autumnalis minor, The leffer Autumne Narciffe. $¥$

$\neq 9$ This, whofe figurewe here giue you, is by clufus ealled Colcbicum By antimum latifolium, The broad leaued Colchicam of Confantinople. The leaues of this are not in forme and magnitude mueh vnlike to thofe of the white Hellebor, neither leffe neruous, yet more greene. Ir beares many floures in Autumne, fo that the re come fometimes twenty fro'n one root. Their forme and eolour are much like the ordinarie fort, but that thefe are larger, and hate thieker falkes. They 
are of a lighter purple without, and of a decper on the infide, and they are marked with eertaine veines rumning alongt thefe leates. The roots and feeds of this plant are thrice as large as thofe of the common kinde.

to This hath roots and leaues like to the firft defcribed, but the floure is thorter, and growes voon a thorter ftalke, fo that it rifes but little aboue the earth: the three inner leatues are of a reddifh purple; the three out leates are either wholly white, or purplith on the middle in the infide, or ftreaked with faire purple veins, or fpotted with fuch coloured fpots : all the leatues of the floure are blunter and rounder than in the eommon kinde.

I This in leaues, ronts, manner and time of growing, as alfo in the eolour of the floures, differs not from the firft defcribed, but the floures, as you may pereeiue by the figure here expreffed, are very double, and con fift of many leaues.

\section{\& colchicum montaramminus verfico- lore flore.}

The leffer mount aine Saffron with a various coloured floure.
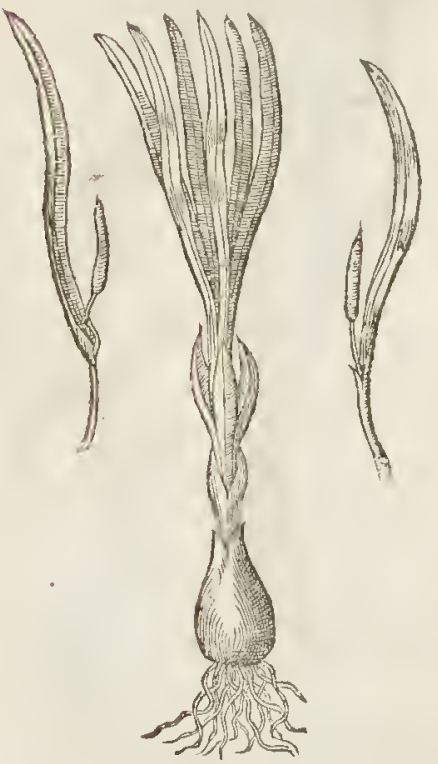

\section{Colchicum Illyricum.}

Greeke medow Saffron.

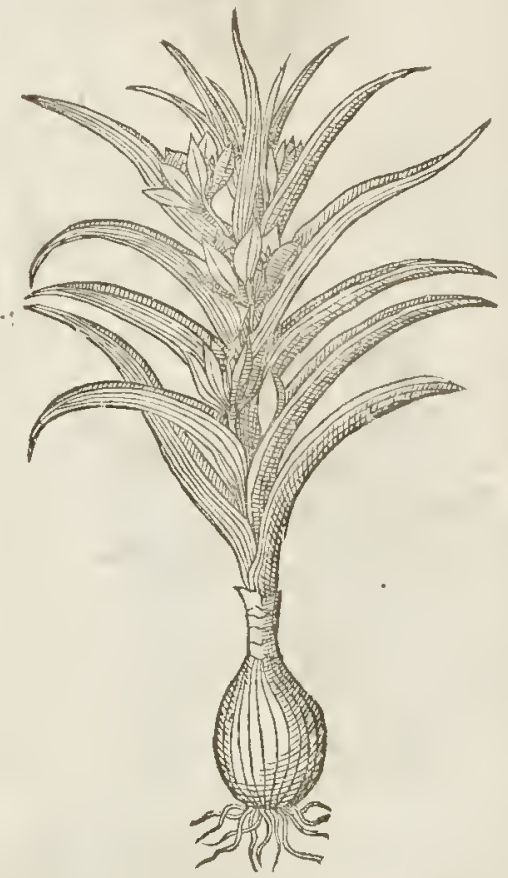

This Colchicum differs little fiom the furft ordinarie one, buthat the floures are fomew hat leffe, and the three out-leaucs are fomwhat bigger than the three inner leaues; the eolout is a lit te deeper alfo than that of the common one; but that wherein the prineipall difference eonfifts, is, That this floures twice in a yeare, to wit, in the Spring and Autumne: and henee clufus hath called it Colcbicm biflorum, Twice-flouring Mede Saffron.

I3 This alfo in the thape of the root and leaues is not mueh different from the ordinary, but the leaues of the floureare longer and narrower, the colour al fo when they begin to open and thew themfelues, is white, but thortly after they are changed into a light purple:each leafe of the Aoure hath a white thread tipt with yellow growing out of it, and in the middle ftands a white three forked one longer than the reft. The floure growes vp between three or foure leaues narrower than thofe of the ordinaric one, and broader than thofe of the fmall Spanifh kinde. Clufus, to whom rve are beholden for this, as alfo for moft of the reft, calls it Colchicum vernum, or Spring Mede-Saffron, beeaufe it then floures together w ith the Spring Saftrons and Dogs Tooth.

14. There are other Mede-Saffrons befides thefe I haue mentioned, but becaufethey may be referred 


LI B. I. Of the Hiltory of Plants. 161

7 Colcbiruns Syriacum Abexandrinums. Affrrian Mede Saffron.

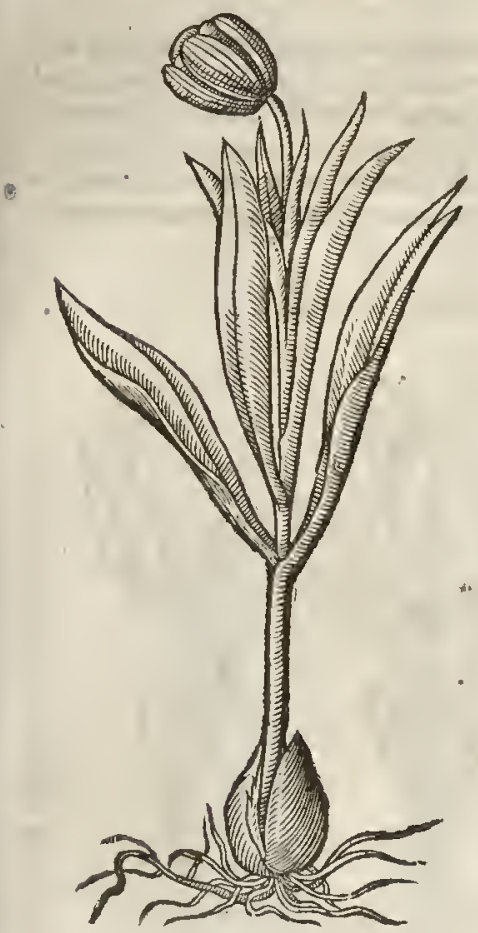

referred eafily to fome of thefe, for that the ir difference chiefely eonfifts either in the doubleneffe or colour of the floures, where of fome ate ftriped, fome fraided, others variegated, I will not.infif vpon them, but referre fuch as defire their further acquaintance to look into the gardens of our lorifts, as M. Parkinfons, M. Tusgies, do corelle into thebooke of floures fet forth not long fince by M. Parkinfor, where they thall findetherm largely treated of. Yet I caunot paffeouer in filcuce that curious Colchicum which is called by fome, Colchicum viriegram chichyfe. The floure thereof is very beautiful, confining of fix pretty broad and tharp pointed leaues, all eurioully checkered ouer with decpeblew or putple, the reft of the foure being of a light whitith colour : the lcaues, that rife vp in the Spring, are not very long, but fomewhat broad and tharpe pointed; the toot is like others of this kinde. I luaue giucn you an exact and large figute of this, as I tooke it from the growing floure fome three yeares agone, it being at that time amongft her Mitiefties floures kept at Edgcombe in Surry, in the garden of my much lonouted friend $S$ ir lobn Tunfiall, Gentleman Viher vito her Maiefic.

I5 I giue youllere in this place the true Hermodactill of the fhops, which probably by all is adiudged tò this Tribe, though none can certainly fay what Houres or leates it beares: the hoots are onclybrought to vs, and from what place I cannot tell ; yet I coniciture from fone part of Syria or the adiacent countries. No:y how hard it is to iudge of Plants by one part or patticle, I hall thew you more at large when I come to treat of Piftolochia, wherefore I will fay nothing thereof in this place. Thefe toots, which wanting the maligne qualitie of colchicum, either of their ow ne nature, or by drinefle,arecommonly about the bignefle of a Chefnut, fmooth, flatrin, and tharpe at the one end, but fomewhat full at the other, and on the one fide there is a little channell or hollowneffe, as is in the roots of Mede-Saffron whete the ftalke of the floure comes vp. Their colour is cither white, browne, ot blackifh on the outfide, and vety white within, but thofe are the beft that arewhite both without and within, and may eafily be made into a fine white meale or pouder. $\ddagger$

\section{Colchicumparvum mont anum lutemn. Yellow mountaine Saffron.}

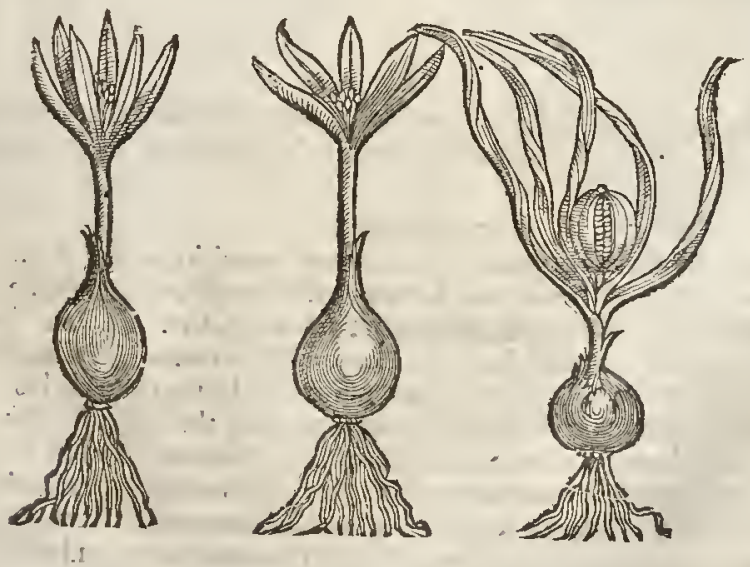

0 
Mcdow Saffron, or Colchicum, groweth in Meflinia, and in the Inle of Colchis, whereofit tooke his name. The ritles of the reft do fet forth their natiue countries; notwith tanding our London gardens are poffeffed with the moft part of them.

The two firft do grow in England in great aboundanee, in fat and fertile medowes, as abour Vilford and Bathe,as alfo in the medowes neere to a fmall village in the Weft part of England,called Shepton Mallet, in rhe meduwes abour Britoll, in King@roppemedow neere vnto a Water-mill as you go from Northampton to Holmeby Houfe, vpon the right hand of the way, and likewife in grear plenry in Nobortle wood two miles from the faid towne of Northampton, and many other plaees. $¥$ The reft for the moit part may be found in the gardens of the Florifts among vs. $\ddagger$

¥ colcbicum latifolium. Broad leaued Mede Saffron
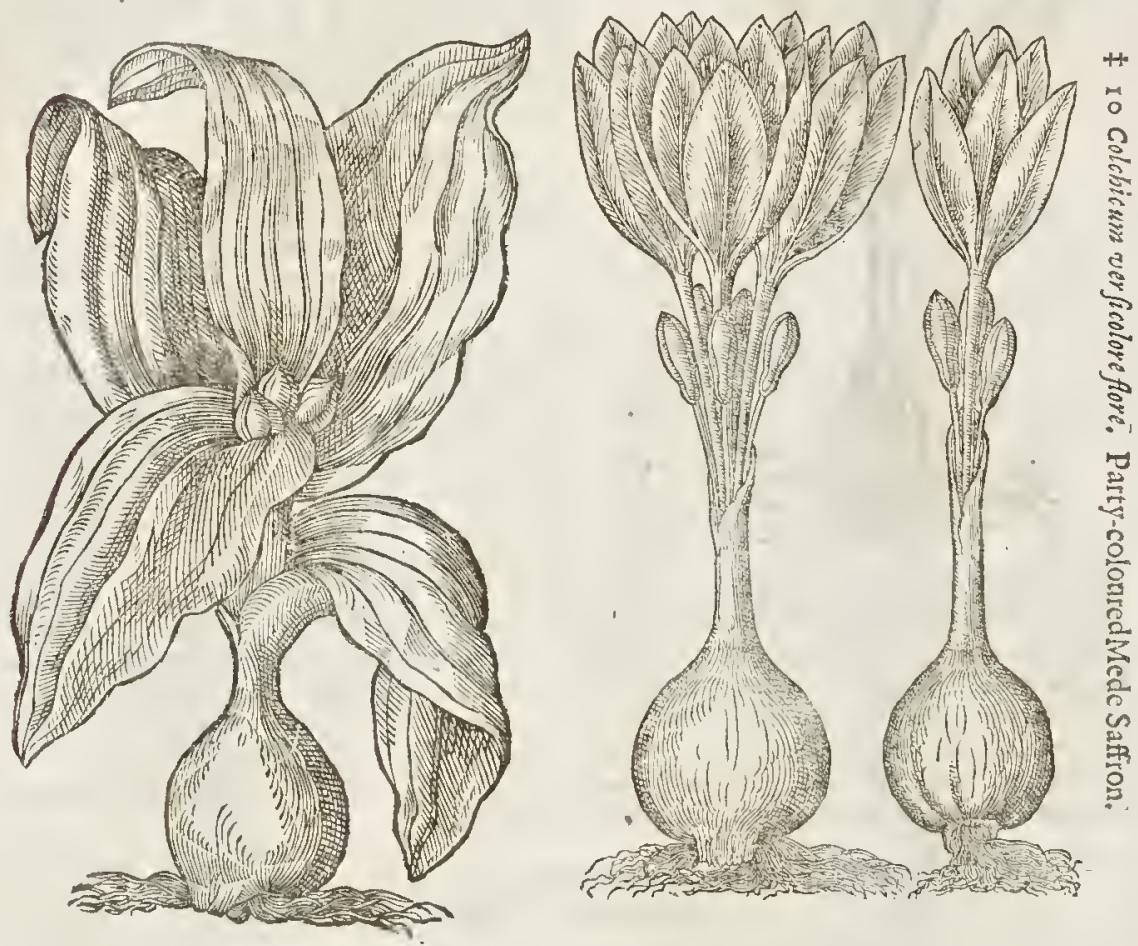

- The Time.

The leaues of all the kindes of Mede-Saffron do begin to thew themfelues in Februarie ; The fect is ripe in Iune. The leaues, ftalkes, and feed do perifh in Iuly, and their pleafant floures doe come forth of the ground in September.

\section{T The Names.}

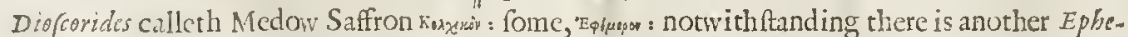
meron which is nor deadly. Diucrs name it in Latine Bulbus agreft is, or wild Bulbe : in high Dutch it is called Zsitloofen: in low Duteh, Oflteloofen: in French, Mort au Cbien. Some haue taken it to be the rrue Hermodactyl, yet falfely. Other fome eall it Filius ante Patrem, although there is a kinde of Lyfirmacbia or Loofe-ftrife fo called,beeaufe it firft bringeth forth his long cods wirh feed, and then rhe floure after, or at the fame time at the end of the faid cod. But in this MedeSaffion ir is fur otherwife, becaufe it bringeth forth leaues in Februarie, fced in May, and floures in Septemier, which is a thing cleane eontrarie to all other plants whatfoeter, for that they do firft Hourc, and after feed; bur rhis Saffron feedeth firt, and foure moneths after brings forth floures: and therefore fome haue thought this a fit name for it, Filizs ante Patrem: and we accordingly may 


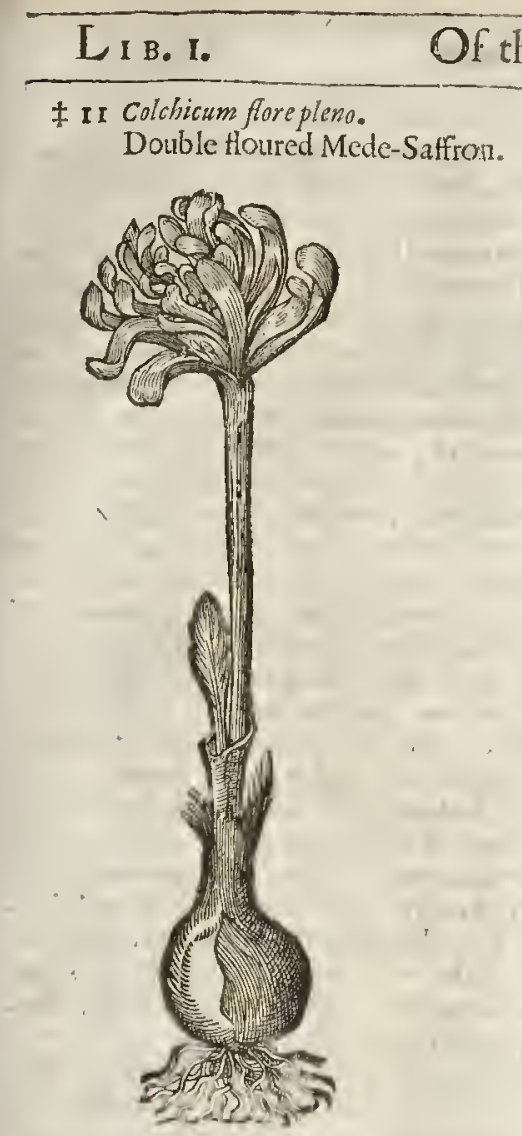

$\$ 13$ Colchicum vernum.

Spring Mede-Saffron:

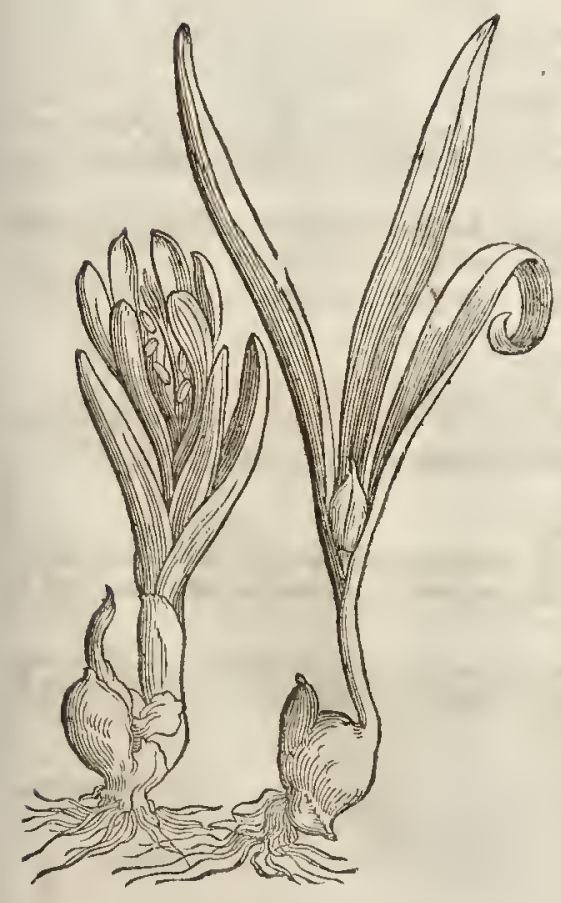

$\ddagger$ I 2 Colchicurn biforum.

Twice-flouring Mede-Saffon.

163

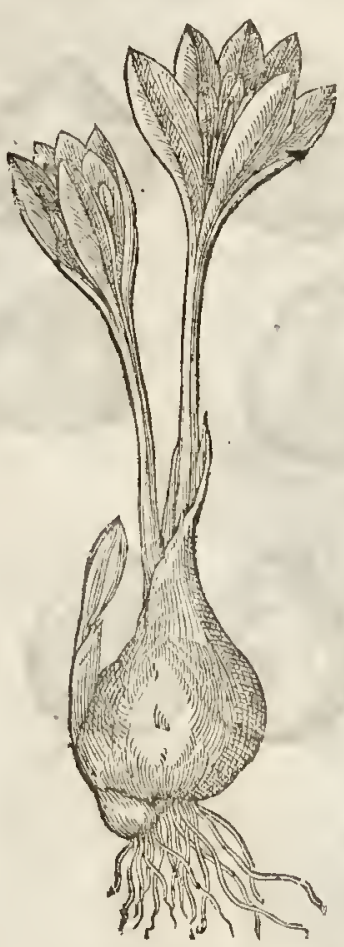

14 Colchicum varieg stum Chicne.

Checquered Metle Saffron of Chio.

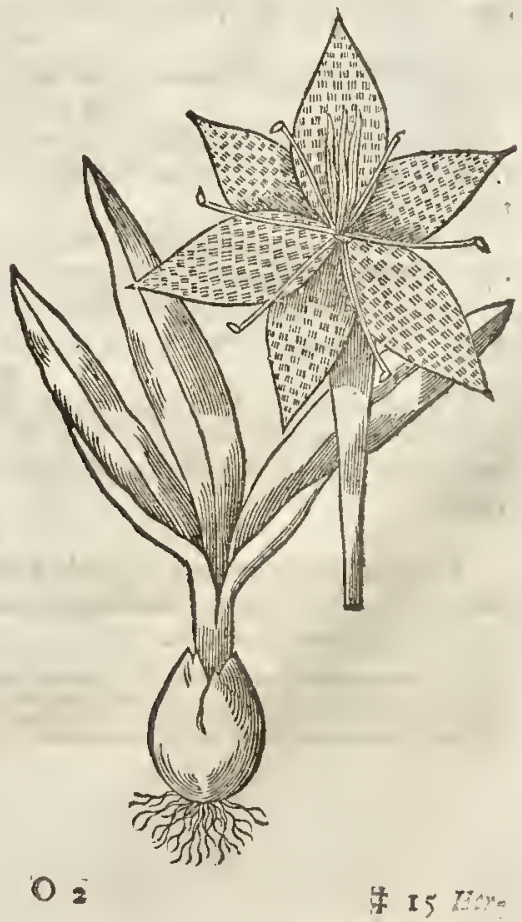


† 5 Hermodictyli officinarum.

The true Hermodactyls of the thops.
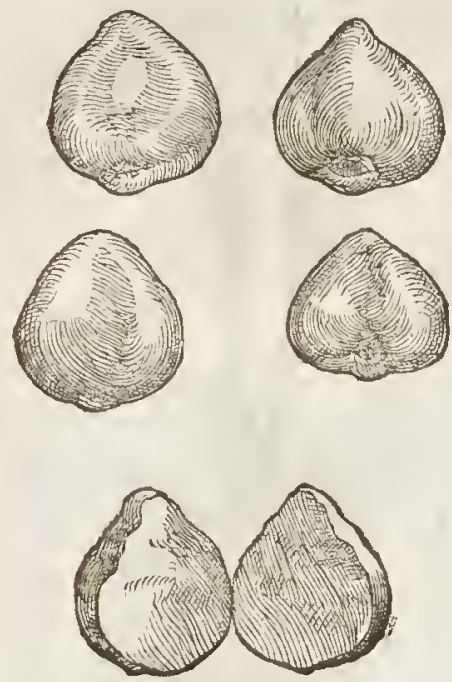

inceafers of fperme. The which the Authors of the Aidus and Actuarius, which were cordial, and bum or rubrum of the Arabians. And to thefe vnknowne ones are the vertues fet downe by our Author in the third place vnder $\mathrm{C}$, ro be referred. $\neq$

- The Temperature.

Medow Saffron is hot and dry in the fecond degree.

$$
\text { T) The Vertices of Hermodictyls. }
$$

A . $t$ The roots of Hermodactyls are of force to purge, and are properly ginen (faith Paulus) to thofe that hatie rhe Gout, euen then when the humors are in flowing. And they are alfo hurtful to the ftomackse.

B The fame ftamped, and mixed with the whites of egges, barley meale, and crums of bread, and applied plaifterwife, eafe the paine of the Gout, fwellings and aches about rhe ioynts.

C The fame frengrhnetl, nourifheth, and makerli good iuyce, encreafeth fperme or naturall feed, and is allo good toclcanfe vlecrs or rotten fores.

\section{Tl "The correction.}

The pouder of Ginger, long Pepper, Annife feed or Cumine feed, and a little Mafticke, correcteth the churlifh working of that Hermodactyll which is vfed in Shops. But thofe which have eaten of the common medow Saffron mutt drinke the milke of a cow, or elfe death prefently enfucth.

$$
\text { T T he Danger. }
$$

The roots of all the forts of Mede Saffrons are very hurt full to the ftomacke, and being eaten they kill by choaking, as Murhromes do,according vnto Diofcorides; whereupon fome haule called it Colchicum ftrangulatorium.

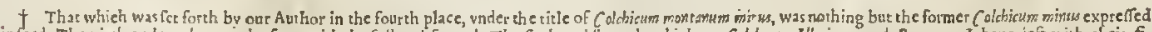

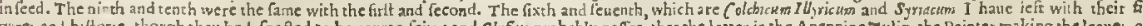
the 


\section{Cнар. 92. Of Starre.of Betblem.}

\section{Tा The Kindes.}

$T$ Here be fundry forts of wilde field Onions called Starres of Bethlehem, differing in ftature, tafte, and fmell, as thall be declared.

I Ornithogalum.

Star of Bethlehem.

Oanithogalum umbellatum

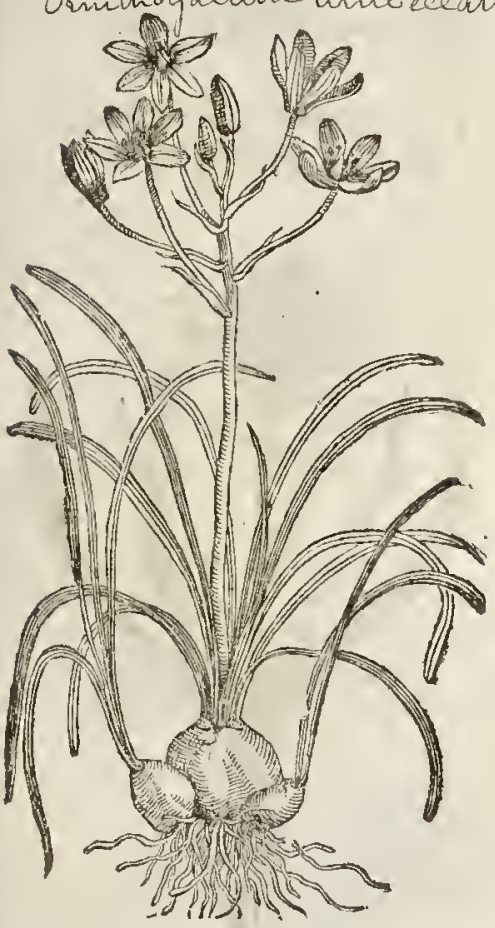

2 Ornithogalsm lutesm, fure Cepa agraria. Yellow, or wilde Star of Bethlehem, Arnithogahum enteum

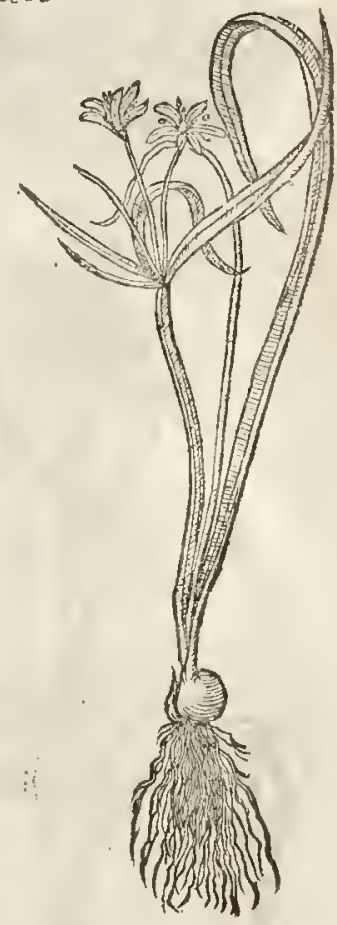

T) The Defcription.

C Vr common Starre of Bethlehem liath many narrow leaues, thicke, fat, full of iuyce, and of a very greene colour, with a white ftreake downe the middle of each leafe: among the which rife up fmall naked falkes, at the top whereof grow floures compact of fix little leaues, Atripped on the backefide with lines of greene, the infide being milkewhite. Thefe floures open themfelues at the rifing of the Suntse, and fhut againe at the Sun fetring; whereupon this Plant hath beene called by fome, Bubus Solfequius. The floures being paft, the feed doth follow inclofed in three cornered.husks. The root is bulbous, white both with in and withour,

$\dagger_{2}$ The fecond fort hath two or three graffy leaues ptoceeding from a clouren bulbous root. The ftalke rifeth vp in the miditeft naked, but toward the top there doe thrutt forth more leaues like vnto the other, but fmaller and inorter; among which leaues do ftep forth very fmall, weake, and tender foot-ftalkes. The floures of this are on the backefide of a pale yellow ftripped witl greene, on the infide of a bright thining yellow colour, with Saffron co'oured threds in their middles. The fecd is contained in triangular veffels.

$t 3$ This Star of Hungarie, contrarie to the cufome of other plants of this kinde, fenderh forth before Winter fiue or ix leaves fread vpon the ground, narrow, and of fome fingers length, foncwhat whitith greene, and mueh refe mbling the leates of Gillofoures, but fomewhat ronghin. In Aprill the leaues beginning to d cay, among th them rifes vp a fallke beatring at the top a 
fpokc of flourcs, which confifting of fix lcaues apiece fhew themfelues open in May; they in colour are like the firft deferibed, as alfo in the greene ftreake on the lower fide of cach lcafc. The feed is blacke, round, and contained in triangular beads. The root is bulbous, long, and whitc. $¥ 4$ This fouth, which is the ornithogalum Hifpanicum minus of Clufrus, bath a little wlite root which fends forth leates like the common one, but narrowcr, and deftitute of the whitc line wherwith the other are marked. The ftalkc is fome two handfulls high,bcaring at the top thereof fomc feten or eight floures growing cach aboue other, yet fo, as that they fccme to makc an vmbell: cach of thefe floures hath fix leaues of a whitin blow colour, w ith fo many white chines or threds, and" a littlc blewin vmbone in the mide. This flourcs in Aprill.

5 This fifth firt fends vp onc onely leafe two or three inches long, narrow, and of a whitifh colour, and of an acide tafte: nigh whereto rifeth v a finall ftalke fome inch or two high, hauing onc or two leaues thercon, bctwcene which come forth fmall ftar-floures, ycliow within, and of a greenifh purple without. The fecd, which is reddifn and fmall, is contained in trangular heads. 7 he rot is white, round, and conered with an Arh-coloured filme.

3 Ornithogalum Pannonicum. Star of Hungary.

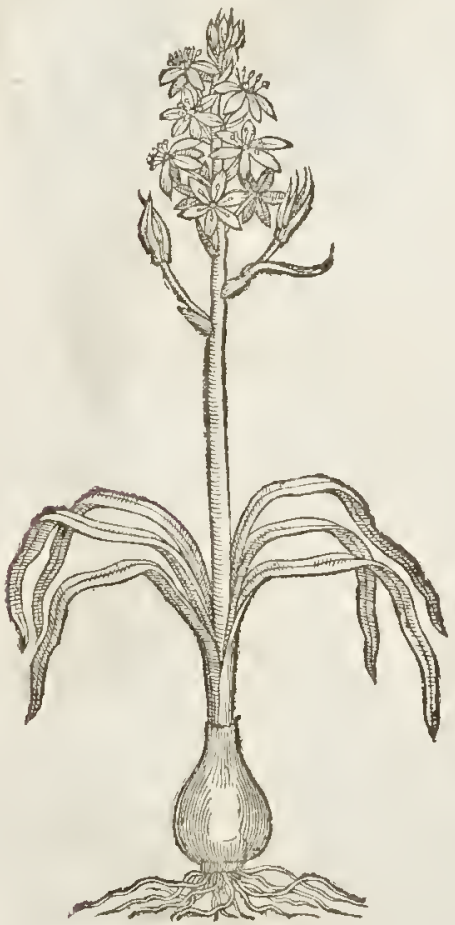

¥4 Ornithogalum Hifparicumminus. The lefler Spauin Star-floure.

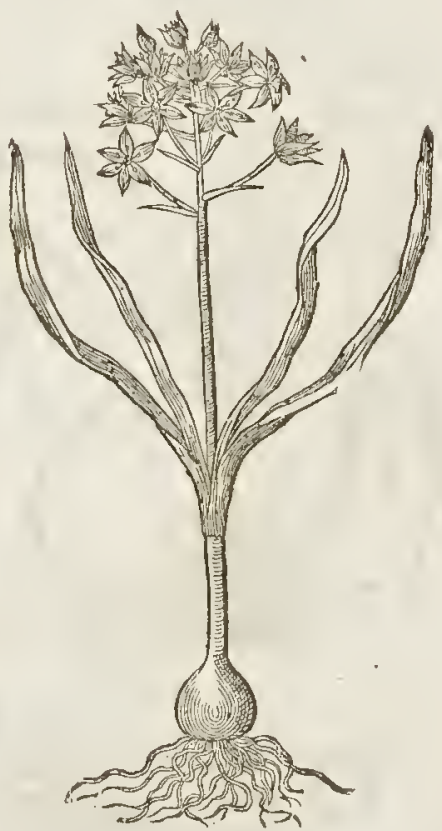

6. I thinke it notamiffe, hereto to adde another fmall bulbous plant, which Clufius calls Bulbus moriqumos, The onc leaued Bulbe. This from a fmall root fends forth one rufh-leafc of fome foot in lcngth, which about two inches abouc the carth, being fomewhat broader than in the other places, and guttcred. fends forth a littlc falke fome three inclues long, whofe top is fer with three little floures, each ftanding aboue orher, about the bigneffe here prefented vnto your view in the figurc: cach of thof confifteth of fix very whitc leaucs, and arc not much vnlike the flourcs of the grafle of Parnaffus, but yet without Icaues to fuftaine the flourc, as it hath : fix white threds tipt witl yellow, and a threc fouare head with a white pointall poffefic the middeft of the floure; the fmell thereof is fomewhat like that of the floures of the Haw-thorne. It floures in the midft of Iune.

7 Hauing donew ith thefe two fmall plants, I muft acquaint you with threc or foure larger, beionging alfo to this Clafis. The firft of thefe is that which Dodoneus calls ornithogalum maju, and Cinfius, orai bogalum Arabicum: 'This by Lobeland fome others is called Lilium Alexandrinum, 
* 5 Ornithogalum luteum parvum. Dwarfe yellow Star of Bethlehem.

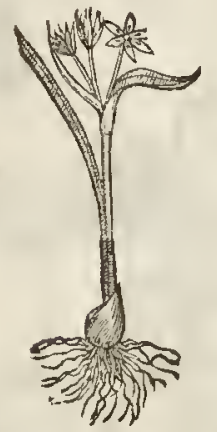

* 7 Ornithogalum majus Arabicum. The great Arabicke Star-floure?

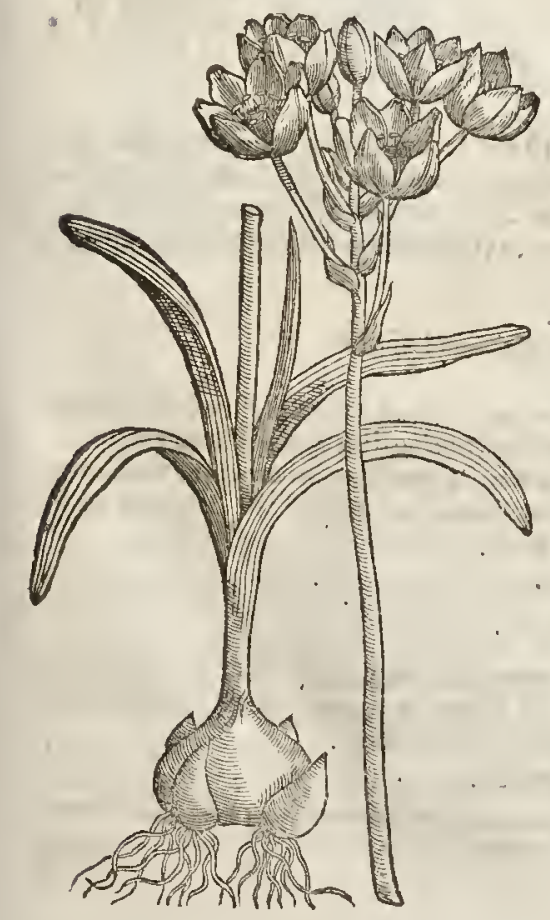

$\ddagger 6$ Bullous urifolius.

The one leaued Bulbe,

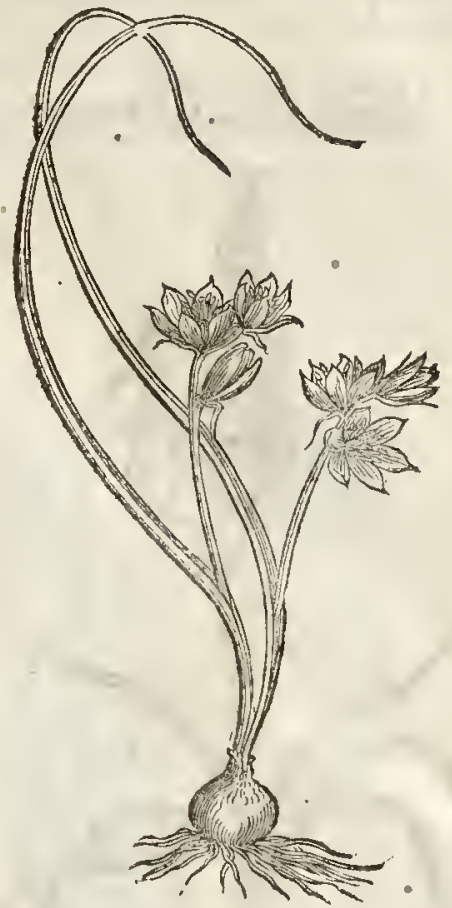

or the Lilly of Alexandria, as our Author calls it in the ehapter of Cotton-graffe. This faire, but render plant, hath broad greene leaues comming from a large white flat bottomed root; among it which rifeth vpa ftalke fome cubit high, whofe top is garnifhed with fundry pretty large floures made of fixe very white leaues, with a thining blackifh head, ingirt with fix white threds tipt with yellow. This Houres in May.

8 This, which is commonly called oratho. galum fpicatum, hath large leates and roots, and the flalke growes fome eubit or more high, wheron grow many ftarre-floures in thape and colour like thofe of the ordinarie, but latger, and they begin to floure below, and floure vpwards to the top. There is a larger fort of this Spicatum, whofe floures are not Atreaked with greene on their backes. There is alfo a leffer, differing from the firft of thefe onely in bigneffe.

9 This Neapolitan hath three or foure long leaues not mueh vnlike thofe of the Hyaeinths, but narrower, the ftalke is pretty thicke, fome foot high, and hath vfually growing theron fome fue or fix floures hanging one way, though their ftalkes grow alternately nut of each fide of the maine ftemme. Thefe floures are eompored of fix leates, being about an ineh long, and fome guarter of an inch broad, white within, and of an Ath-eoloured greene without, with whire edges; 


\section{8}

Of the Hiftorie of Plants.

L 1 B. I.

the middle of the floure is poffeffed by another little floure, confifting alfo of fix little leaties, hauing in them fix threads headed with yellow, and a white pointall. A blacke wrinkled feed is contained in three eomered heads, whieh by reafon of their bigneffe weigh downe the ftalke. This floures in Aprill. $\ddagger$

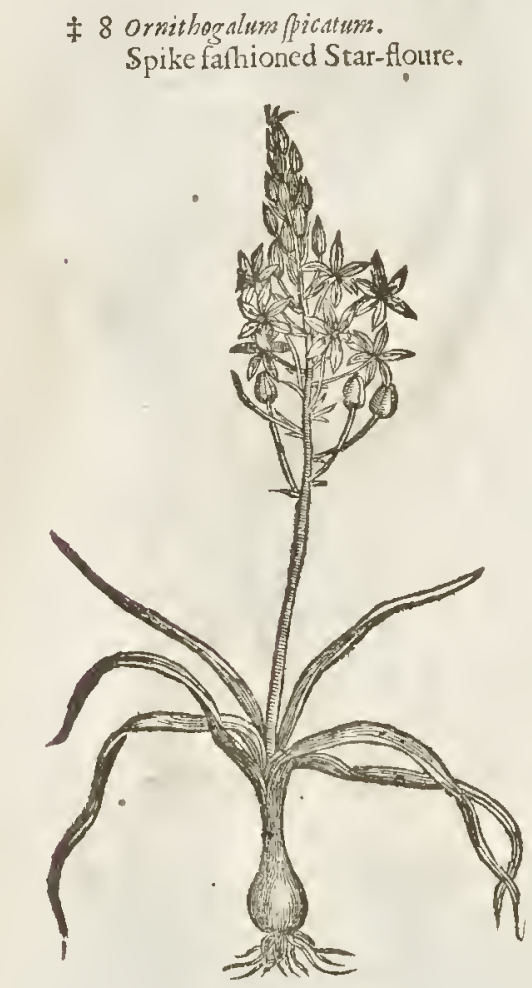

¥ 9 Ornithog alum Neapolitanum. The Neapolitan Star-floure.

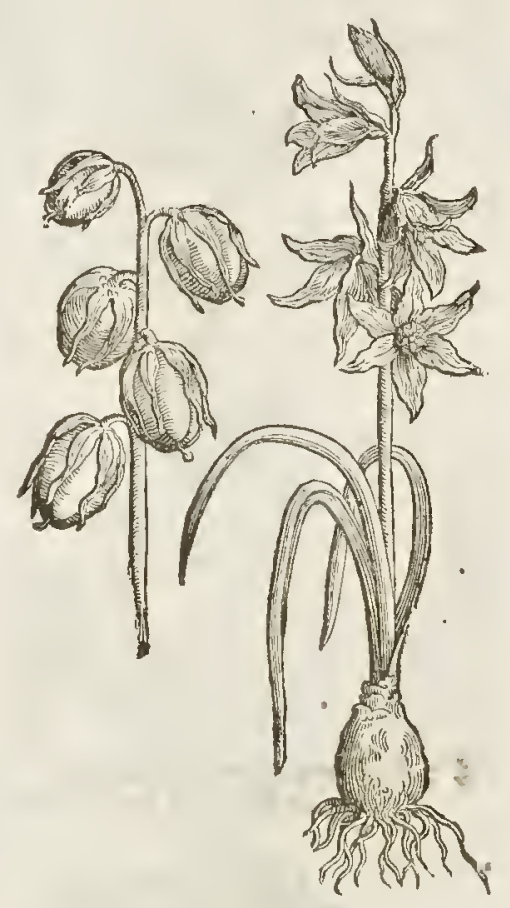

T The Place.

Stars of Bethlehem, or Stur-floures, efpecially the firft and fecond, grow in fundry places that lie open to the aire, not onely in Germany and the Low-eountries, but alfo in England, and in our gardens very common. The yellorv kinde Lobell found in Somerfet-fhire in the corne fields. The reft are ftrangers in England; yet we haue moft of them, as the third,fourth, eighth, and ninth, in fome of our ehoice gardens.

$$
\text { T) The Time. }
$$

Thefe kindes of bulbed plants do floure from Aprill to the end of May.

$$
\text { 4) The Names. }
$$

'Touching the names, Diofcorides calls it 'ommoranor : Pliny, ornithogale : in high Duteh it is called Feld

\pm The reft are named in their titles and hiftory ; but Clufius queftions whether the Bulbus wnifolins be not Bulbine of Theophraftus, 7. hift. I3. Bashisas feemes to affirme the Spicatum to be Moly of Drofcorides and $T$ heophraftus, and Epimedium of pliny.

Thefe are temperate in heare and drineffe.

$$
\text { I The Nature. }
$$

$$
\text { q The tertues. }
$$

A The vertues of moft of them are vinknowne; yet Hieronymus Tragus writeth, That the roor of the Star of Bethlebem rofted in hot embers, and applied with honey in manner of a Cataplafme or pulteffe, healeth old eating vleers, and roftens and difeuffes hard tumors.

The roots, faith Diofcorides, are eaten both raw and boyled.

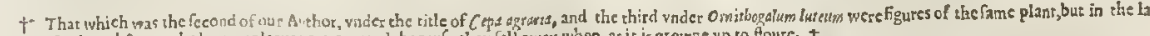

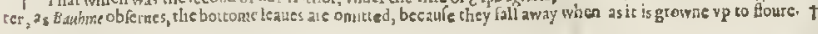

Chap. 


\section{Cнар.93. OfOnions. \\ T) The Kindes.}

$T$ Here be, fait! 1 heophraftus, diuers forts of Onions, which haue their fyr-names of the places 1 where they grow : fome alfoleffer, others greater; fome be round, and diuers others long;
but none wilde,as Pliny writeth.

I Cepa alba. White Onions.

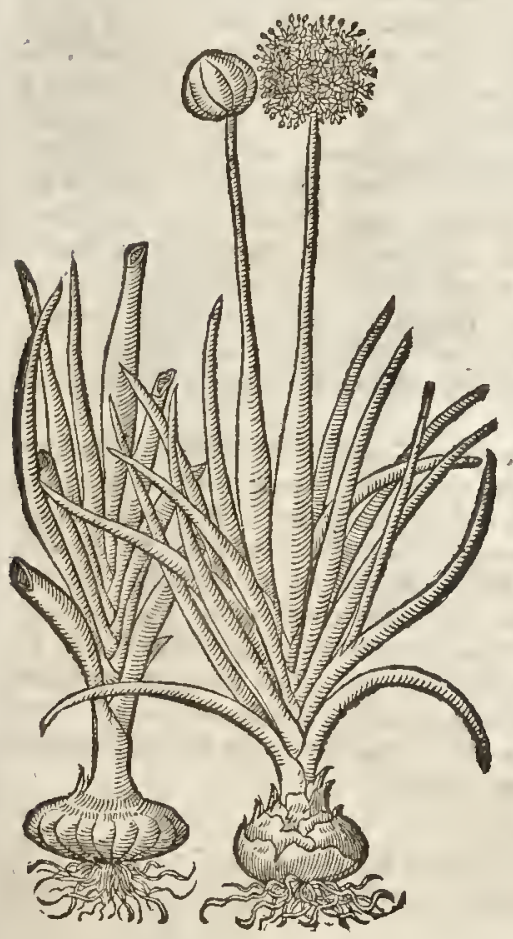

\$ Cepa Hipanica oblonga. Longinh Spanith Onions.

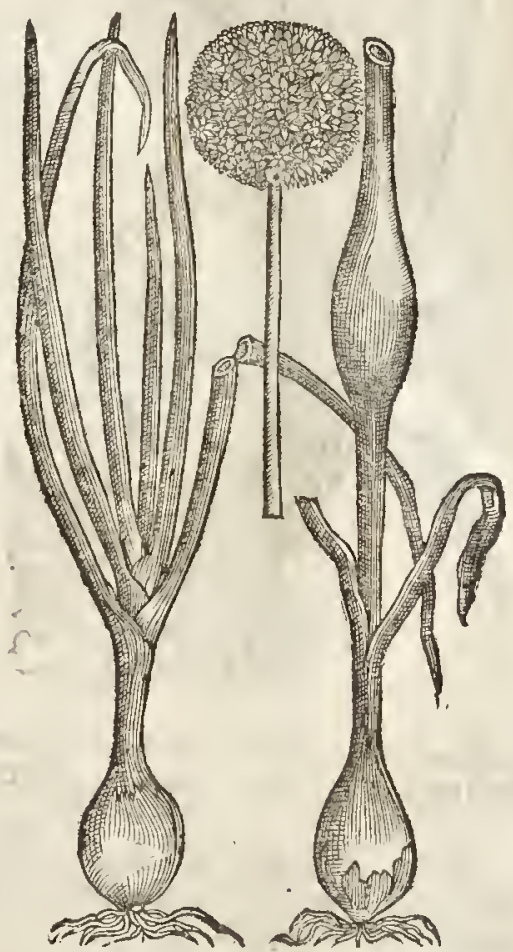

Th The Defription.

I Te Onion hath narrow leaues, and hollow within; the ftalke is fingle, round, biggeft in the middle, on the top whereof groweth a round head eouered with a thinne skin or filme, which being broken, thereappeare little white floures made vp in forme of a ball, and afterward blaeke feed three eornered, wrapped in thinne white skinnes. In fead of the root there is a bulbe or round head compact of many eoats, which oftentimes becommeth great in manner of a Turnep, many times long like an egge. To be briefe, it is coucred with very fine skinnes for the moft part of a whitih colour.

2 Thered Onion differeth not from the former but in tharpneffe and redneffe of the roots, in other refpects there is no differenee at all.

$¥ 3$ There is alfo a Spanith kinde, whofe root is longer than the other, but in other refpects very little different.

¥ 4 There is alfo annther finall kinde of Onion, called by Lobel, Afcalonit is Lntiquorum,or Seallions, this hath but fmall roots, growing many together : the leaues ate like to Onions, but leffe. It feldome beares either ftalke, floure, or feed. Ir is vfed to be eaten in fallads of 


\section{ब The Place.}

The Onion requireth a fat ground well digged and dunged, as Palladius faith. It is eherifhed euerywhere in kitchen gardens : it is now and then in beds fowne alone, and many rimes mixed with other herbes, as with Lettuee, Parfeneps, and Carrets. Palladus likethwell that it fhould be fownewith Saucry, becaufe, faith Pliny, it profpereth the better, and is morewhole fone.

\$ 4 Afcalonitidcs.
Scallions.

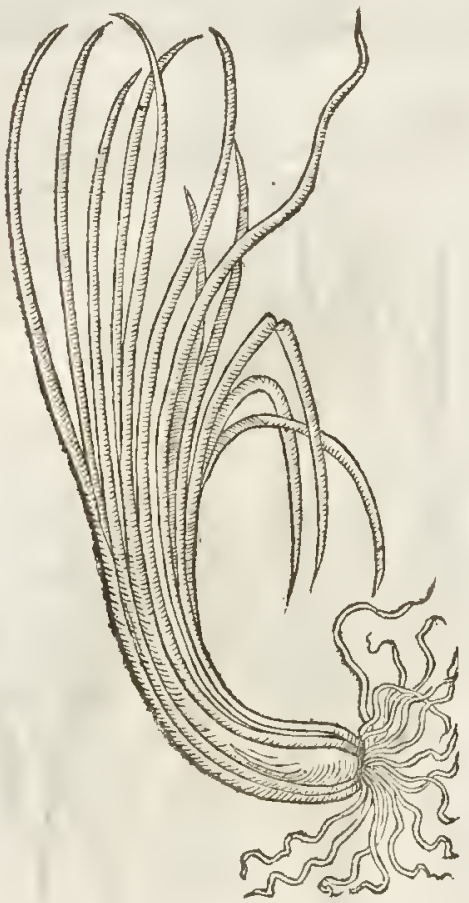

बा The Time.

It is fowne in Marchor Aprill, and fomtimes in September.

\section{T The Names.}

The Onion is called in Grecke, keirpus : in I atine, Cepa, and many times Cepe in the neuter gender:the thops kecpe that name. The old Writers haue giuen vnto this many fyr-names of the places where they grow, for fome are named Cipric, Sardix, Cretice, Sumothracie, Afcalonia, of a towne in Iudea, otherwife called Pompeiana : in Englifh, Onions. Moreouer, there is one named Grarfea, which the Countrey-men call $V$ rio, faith columella; and thereupon it commeth that the Freneh men call it orgnon, as Ruelluws thinketh : and peraduenture the LowDurch men name it alusuim, of the French word eorrupted : they are called Setanie which are very little and fweet; and thefe are thought tobetiofewhich Palladius nameth cepulle, as though hecalled them parve Cepe, or little Onions.

There is an Onionwhich is without an head orbulbe, and hath as it were a long necle, and fpends it felfe wholly in the leaues, and it is often eropped or cut for the pot like the Leekes. This Theophraftus names rnava: of this Pliny alfo writeth, in his nineteenth booke, and fixt chapter. Tlere is with vs two prineipall forts of $\mathrm{O}$ nions, the one feruing for a fauce, or to feafon meate with, which fome eall Gethyon, and others Pallacan : and the other is the headed or common Onion, which the Germanes call Duion $z$ wí $=$ bel : the Italians, Cipolta : the Spaniards, Cebolla, Ceba, and Ccbola.

The Temperalure.

All Onions are fharpe, and mone teares by the fincll. They be hot and dry, as Galen faith, in the fourth degree, but not fo extreme hot as Garlick. The iuyce is of a thin waterie and airy fubitance: the reft is of thicke parts.

II The Vertues.

The Onions do bite, atrenuate, or make thinne, and caufe drineffe : being boyled they doe lofe their tharpeneffe, efpecially if the water be twice or thriee ehanged, and yet for all that they doe not lofe their attenuating qualitie.

B they alfo breake winde, provoke vrine, and be more foluble boyled than raw; and raw they nourifh not at all, and but a litrle though they be boyled.

C They be naught for thofe that are cholericke, but good for fich as are replete wfer by reafon they open the paffages that are ftopped.

D

Galen writeth, That they prouoke the Hemorrhoides to bleed if they be laid vnto them, cither by thenfelues, or ftamped with vineger.

E The iuyce of Onions fniffed vp into the nofe, purgeth the head, and draweth forth raw flegmaticke humors. Dog.

G Rofted in the embers, and applied, they ripen and breake cold Apoftumes, Biles, and fuch like.

Tie 
The inyce of Onions mixed witl the decoction of Penniriall, and annointed vpor the goutie $H$ member with a feather, or a cloath wet therein, and a pplied, eafeth the fame very much. dily.

The iuice annointed vpon a pild or bald head in the funne, bringing agane the haire very fpee- I

The inyce taketh away the heate of falding with water or oyle, as alfo burning wirh fire and $K$ gun-pouder,as is fet forth by a very skilfull Chirurgion named Mafter wrilliam Clowes, one of the Queens Chirurgions; and before him by $\wedge$ mbrofe Parey, in his Treatife of wounds made by gun fhot.

Onions niced, and dipped in the iuyce of Sorrell, and giuen vnto the ficke of a tertian Ague, to eate, take away the fit in once or twice fo taking them.

$$
\text { बा The Hurts. }
$$

The Onion being eaten, yea though it be boyled, caufeth head-ache, hurteth the cyes, and maketh a mandimme fighted, dulleth the fences, ingendreth windineffe, and prouketh ouermuch flecpe, efpecially being eaten raw.

\section{....... CH A. 94. Of Squils, or Sea-Onions.}

I scilla Hijpanica vulgaris. The common Spanim Squill,
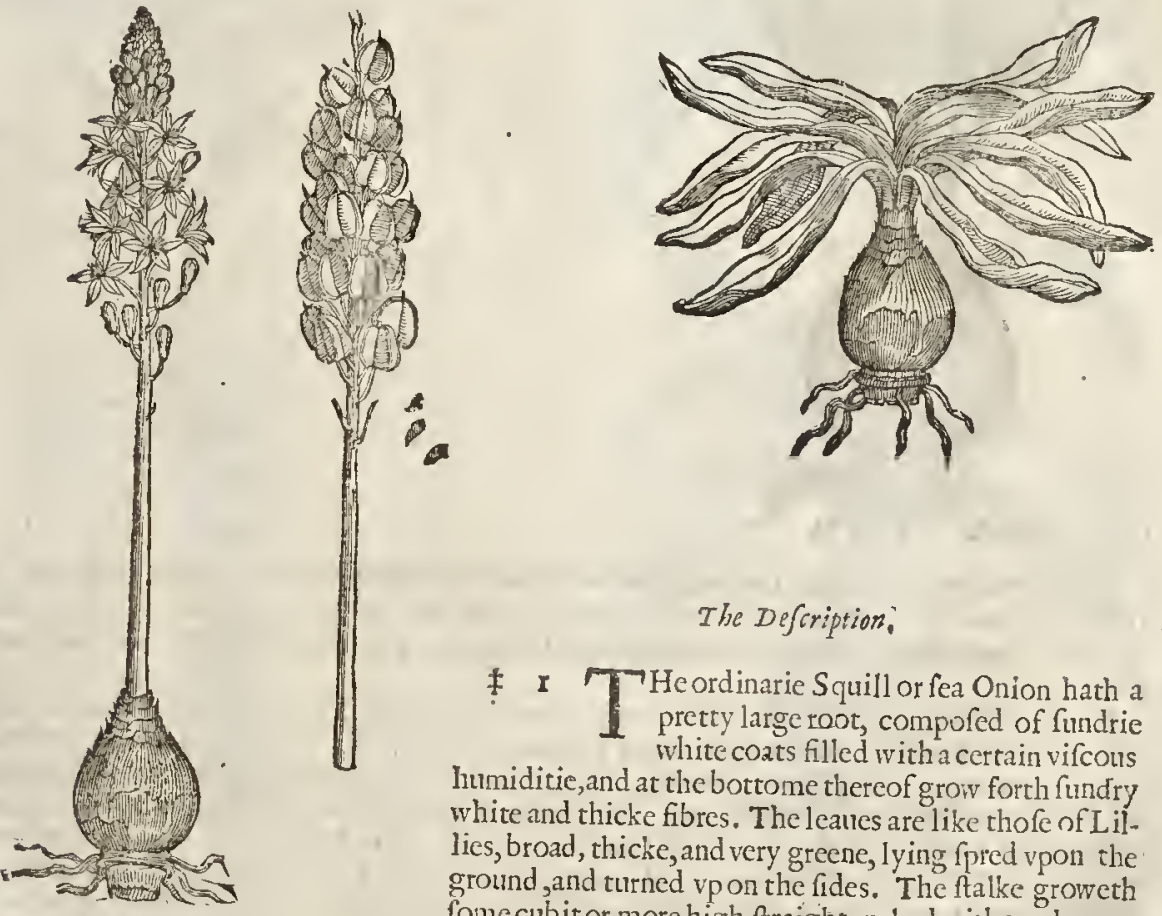

\section{L}

The Defcription?

I $\neg$ He ordinarie Squill or fea Onion hath a pretty large root, compofed of fundrie white coats filled with a certain vifcous humiditie, and at the bottome thereof grow forth fundry white and thicke fibres. The leaues are like thofe of $L$ illies, broad, thicke, and very greene, lying fpred vpon the ground, and turned vp on the fides. The ftalke groweth fome cubit or more high, ftraight, naked without leaues,
beautified at the top with many ftarre-fathioned floures, very like thofe of the bigger ornithogalum. The feed is contained in chaffie three cornered feed-veffels, being it felfe alfo black, fmoot ${ }_{2}$ and chaffie. It floures in Augut and September, and rhe feed is ripe in Oocober. The leaties
fpring vp in Noumber and December, afrer that the feed is ripe,and ftalke decayed. $\neq$

2 The great Sea Onion, which Clufures hath fet forth in his Spaniff hiforie, hath very great and broad leaues, as Diofcorides faith, longer than thofe of the Lilly, but narrower. The bulbe or headed root is very great, confifting of nany coats or fealy filmes of a reddifh colour. The floure is fometimes yellow, fometimes purple, and fometimes of a light blew. $\neq$ Clufgrs faith it is like that of the former, I thinke he meanes both in fhape and culour. $\ddagger$

3 The fea-Onion of Valentia, or rather the fea Daffodilt, hath many long and fat leates, and narrow like thole of Narciffus, but fmoother and weaker, lying vpon the ground; among which rifeth wp a talke a foot high, bare and naked, bearing at the top a tuft of white floures, in thape lite 
vnto our common yellow Daffodil. The feed is inelofed in thieke knobby huskes, blaeke, flat, and thieke,very foft, in thape like vnto the feeds of Ariftolochialonga, or long Birth-iwort. The roor is great, white, long, and bulbous .

4 Red floured Sea Daffodill, or fea Onion, hath a great bulbe or root like to the preeedent; the leaues long, fat, and Tharpe pointed, the ftalke bare and naked,bearing at the top fundry faire red floures in Thape like to the laft defcribed.

2 Pancratium Clufij.

Great Squill, or Sea Onion.

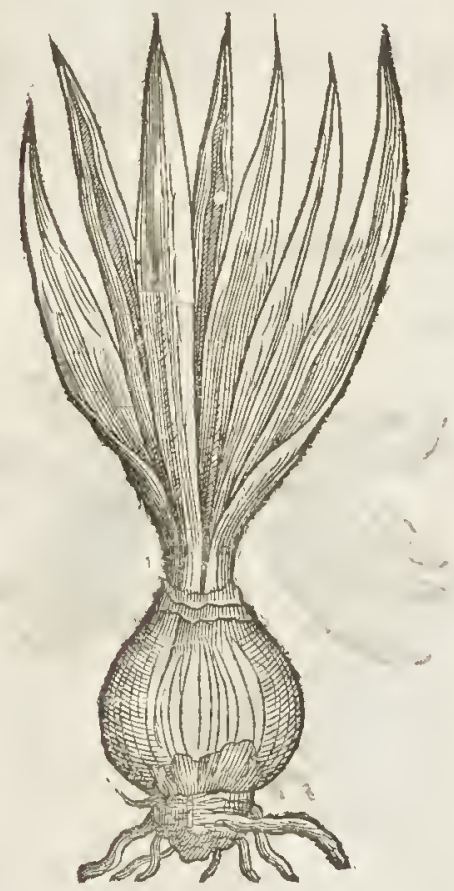

3 Paucratium Marinum. Sea Onon of Valentia." Ganceratium marit

5 The yellow flomed fea Daffindill, or fea Onion, lath many thieke fat leaues like vnto the common Squill or fea Onion, among which rifeth vp a tender ftraight ftalke full of iuyee, bearing ar the top many floures like the eommon yellow Daffodill. The feed and root is like the precedent.

$¥ 6$ To thefe may fitly be added that elegant plant which is knowne by the name of 2 arciffustertius of Matthiolus, and may beealled White Sea Daffodill. This plant hath large roots, as bigge fometimes as the ordinarie Squill; the leates ate like thofe of other Daffodils, but broa. der, rounder pointed, and not very long. The falke is pretty thieke, being fometimes round, otherwhiles eornered, at the top whereof grow many large white foures : each floure is thus eompofed; it hath fix long white leaues, in the midft growes forth a white pointall which is ineompaffed by a welt or eap dituded into fix parts, which fix are againe by threes ditided into eighreen iagges ordinifions, a white thred tipt with greene, of an ineh long, eomming forth of the middle of each diuifion. This floureth in the end of May. It is faid togrow naturally about the fea coaft of Illyria. $\ddagger$

$$
\text { T The Place. }
$$

The firt is found in Spaine and Italy, not far from the fea fide.

The fecond alfo neere vnto the fea, in Italy, Spaine, and Valentia. I haue had plants of them brought me from fundry parts of the Medirerranean fea fide, as alfo from Conftantinople, where it is numbred among the kindes of Nareiffus.

The third groweth in the fands of the fea, in moft places of the coaft of Narbone, and about Montpellier.

The fourth groweth plentifully about the eoafts of Tripolis and Aleppo, neere to the fea, and alfo in the falt marfhes that are fandie and lie open to the aire. 
They floure from May to the end of Iuly, and their feed is ripe in the end of Augurt.

$$
\text { aा } 7 \text { be Names. }
$$

The firf is ealled of the Grecinns, oxiar : and of the Latines alfo Scilla : the Apothecaries name

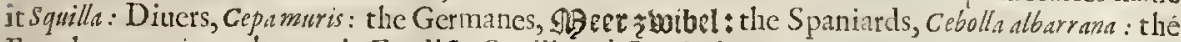
French-men, Oignon de mer : in Englifh, Squill, and Ser Onion.

\# The fecond is called ramparmor, and Scilla rubramajor.

$3,4,5$. Thefe are all figures of the fame plant, but the leatt (which is the wort) is the figure of the Adwerfaria, where it is called Pancratim murinum: Dodoneus calls it Narciffus marimus: and Cluffus, Hemerocallis Valenitina; and it is iudged to be the Huevgrats of Theophraftas, Lib. 6. Haft. cap. I. The Spaniards call this Amores mios : the Turkes, Con $\approx$ ambach : the Italians, Grglio marino. Thefe three (as I faid) differ no otherwife than in the colour of their floures.

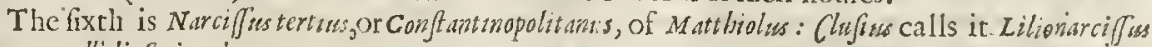
Hemerocallidis fasie. $\neq$

\section{Pancrativm foribus rubris.} Red floured fea Daffodill.

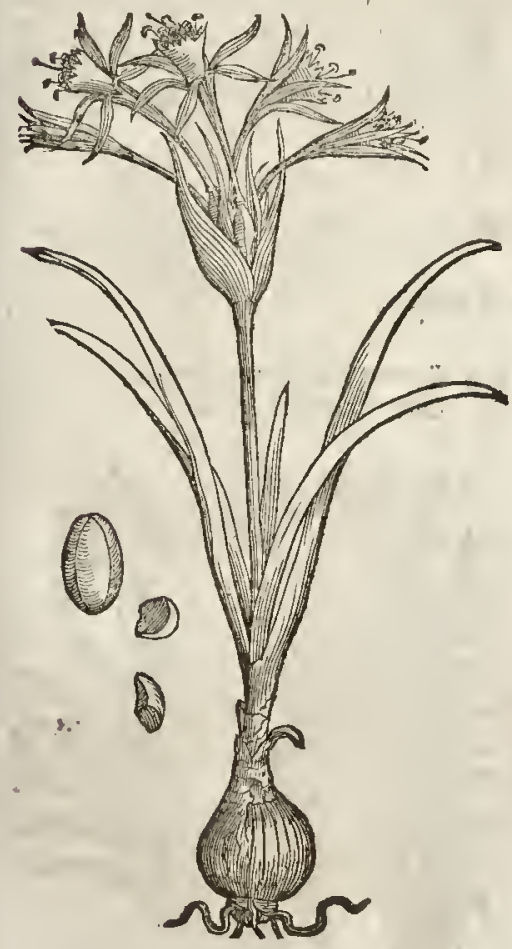

\$ Narciffustertius Matthioli.

The white fea Daffodill.

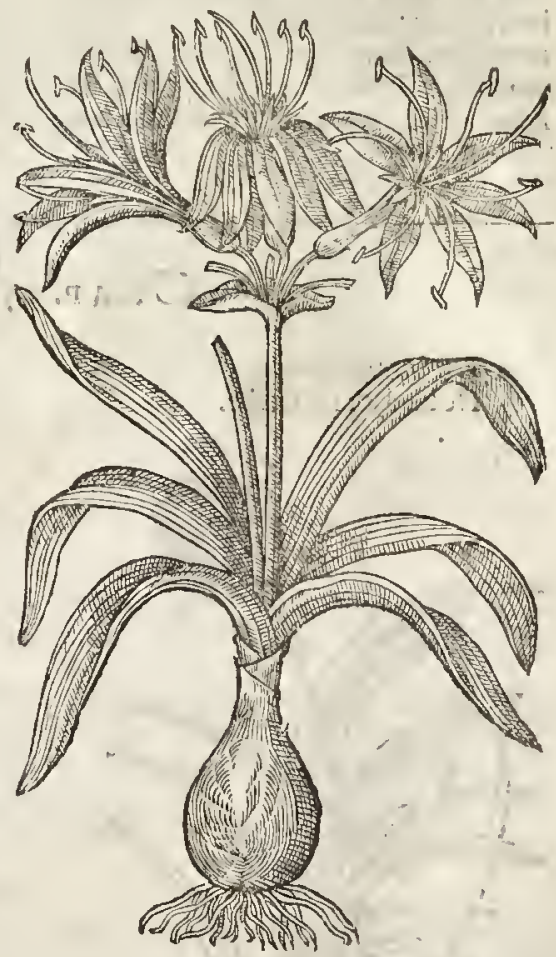

T The Temperature.

The fea Onion is hot in the feeond degree, and eutteth very nutueh, as Galen faith. It is beft when it is taken baked or rofted, for fo the vehemencic of it is taken away.

The root is to be conered whe Vertues of Squills.

The root is to be conered with palte or clay, (as $D$ :ofcorides teacherli) and theil put into an ouren baked or rofted it is very hurfull to the inner partse as it be thronghly rofted : for not being to It is likewife bal very hurfull to the inner parts.

efpecially which is in the midtthen pot clofe couered and fet in an oten. That is to be takken be efialiy which is in the midt, which being cut in pieces mut beboyled, but thewater is ftill to be changed, rill fuch time as it is neither bitter nor fharpe: then mute the pieces be hanged on a thread,and dried in the thato w, fo thar no one piece touch another. $¥$ Thus vfed it fofeth moft of the ftrength; therefore it is better to vfe it lightly dried, without any other preparatina. $\$$ 


\section{4}

Of the Hiftorie of Plan ts.

L I B. I.

C Thefe flices of the Squill are vfed to make oyle, wine, or vineger of Squill. Of this vineger of Squill is made an Oxymel. The afewhereof is tocut thicke, totghynd clammy humors, as alfo to be ved in vomits.

D This Onion rofted or baked is mixed with potions and other medicines which pronoke vtine, and open the ftoppings of the liuer and fpleene, and is alfo put into treacles. It is giuen to thole that hate the Dropre, the yellow Iaundife, and to fuch as are tormented with the gripings of the belly, and is veed in a licking medicine againft an old rotten cough, and for thortneffe of bteath.

E Onepatt of this Onion being mixed with eight parts of falt, and taken in the morning falting to the quantitic of a fpoonefull or two, loofeth the belly.

F The inner part of Scuilla boyled with oyle and turpentine, is with great profit applied to the chaps ot chil-blanes of the feet or heeles.

G. It driueth fotth long and tound wormes if it be giuen with honey and oyle.

¥ The Pancratium marinum, or Hemerocallis V'alentina (faith Clufius) when as Iliued with Ronde. letius, at Montpellier, was called Scilla; and the Apothecaries theteof made the trochifees for the compofition of Treacle : afterwards it began to be called Pancratim flore Lily. Rondeletius alfowas wont to tell this following ftory concetning the poy fonous and maligne qualitic thereof. There were two Fithermen, whereof the one lent vnto the other (whom he hated) his knife, poyfoned with the iuyce of this Hemerocallis, for to cut his meate withall; he fufpecting no tteachery cut his victuals thetew ith, and foeat them, the other abfaining therefrom, and faying that he had no ftomacke. Some few dayes after; lie that dil cate the vistuals died; which thewed the ftrong and deadly qualitien this plant: which therefore (as Clufius faith) cannot be the Scilla Epimenidia of Pliny, which was eatable, and without malignitic $\ddagger$

\section{Cна. 95. Of Leekes.}

I Dorrum capitatum:

Headed, or fet Leeke.

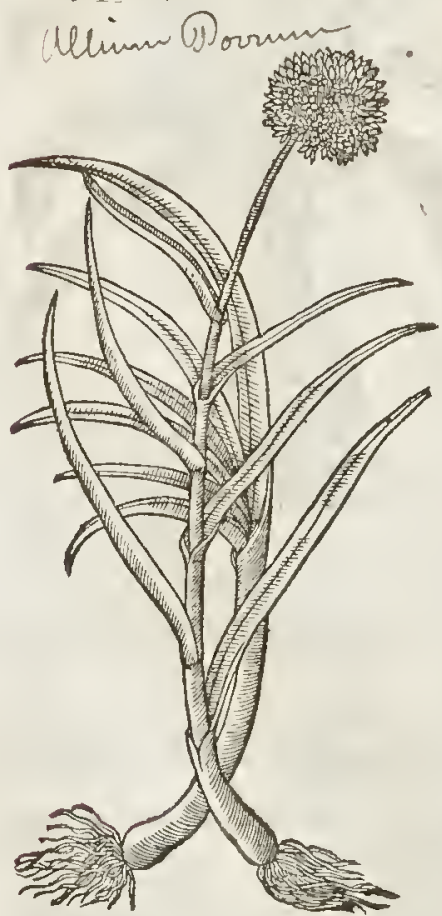

\#2. Porrum fectivum aut tonfile. Cut, or vnfet Lecke.

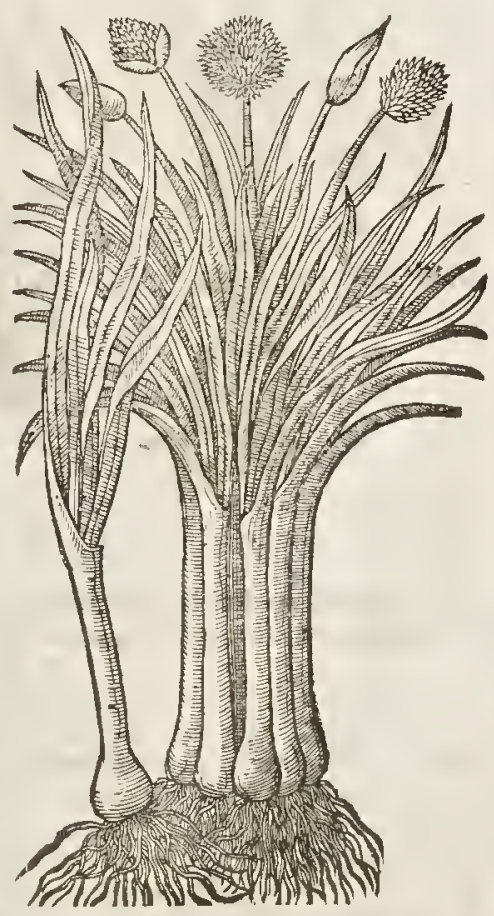


th The Defription.

I THe leauesor the blades of the Leeke belong, fomewhat broad, and very many, hauing a keele or creft in the backfide, in fmell and tafte like to the Onion. The fails, if the blades be nor often cut, do in the fccond or third yeare gtow vp round, bring ing forth on the top floures made vp in an round head or ball as doth the Onion. The fects are like. The bulbe or root is long and flender, efpeciully of the vnfet Leeke. That of the other Lecke is thicker and greater.

₹ 2 "Moft Writers diftinguilh thc common Leeke into Porrum capitatum do fictivum; and Lobal giues thefe two figures wherew ith we here prefent you. Now both thefe grow of the fame fced, and they dittur onely in culture; for thatwhich is often cut for the vio of the kitchen is called Sectivum : the other, which is headed, is not cut, but pared, and remoued in Atrimne. $\neq$

$$
\text { C) The Place. }
$$

It requireth at meane earth, fat, well dunged and digged. It is very common cuery where in othet countries, as well as in England.

$$
\text { It may be forne in The Time. }
$$

It may be fowne in March or April!, and it to be remoued in September or Ostober.

$$
\text { Ti The Names. }
$$

The Grecians call it weaw: the Lat ines, Porrtm. The Emperour 2 ero had great pleafue in this root, and therefore he was called in fcoine, Porrophigus. But Palladias in the mafculine gender cal-

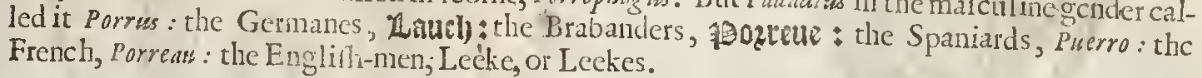

The Leeke is hot and dry, and doth attenuate or make thinne as doth the Onion.

$$
\text { बा The Verties. }
$$

Being boyled it is leffe hurt full, by reafon that it lofeth a great part of his tharpencffe: and yet being fo vfed it yeeldeth no good iuyce. But being takcnwith cold hetbes his tooliot quality is
tempered.

Being boyled and caten with Ptifana or barley creame, it concosteth and bringeth, vp raw humors that lie in the cheft. Some affirme it to be good in a loch or liching nedicine, to clenfe the
pipes of the lungs.

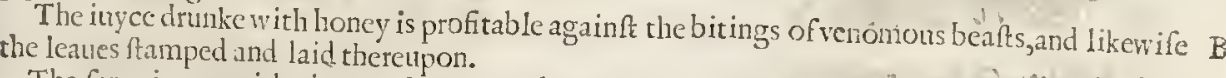
The fanc iuyce, with vineger, frankincenfe, and milkc, or oyle of tofes, dtopped intorhe eares, $\mathrm{C}$
mitiguteth their paine, and is good for the noyfe in them.

Two drams of the feed, with the like weight of nyrtill berries drunk, rtop the foitting of bloud which hath continued a long time. The fame ingredients put into Wine keepe it from fouring, and being alreadie foure, amend the fame, as diucrs write. It cutteth and attenuatcth groffe and
rough humors.

$\ddagger$ Lobel commends the following Loch as very effectuall againf phlegnatick Squinances, and othercold catarmes which are like to caufe fuffocation. This is the defcription thereof; Take blanched almonds three ounces, foure figges, foft $\Delta$ dellitsm halfe an ounce, iuyce of Liquorice, two ounces, of fugar candy diffolued in a fufficient quantitie of iuyccofl.cekes, and boyled in Balrse to the height of a Syrup,as much as thall be requifit to make the refe into the formc of an $E_{C}$ -
legma. $\neq$

T) The Hurts.

It heatcth the body, ingendreth naughty bloud, caufeth troublefone and terrible dreames, offendeth the cyes, dulleth the fight, hurteth thofe that are by nature hot and cloleticke, anci is
noyfome to the ftomacke, and brecdeth windinefle.

\section{Cha p. 96. \\ Of Ciues or Cbiues, and wilde Leekes. \\ 9I The Kindes.}

Here bediners kindes of Leekes, fomewilde, and fome of the garden, as thall be declared. Thofe called Ciues hamebeene taken of fome for a kinde of wilde Onion : Dut all the thi thors that I hate beene acquainted with, doaccord that there is not any wild Onion. 


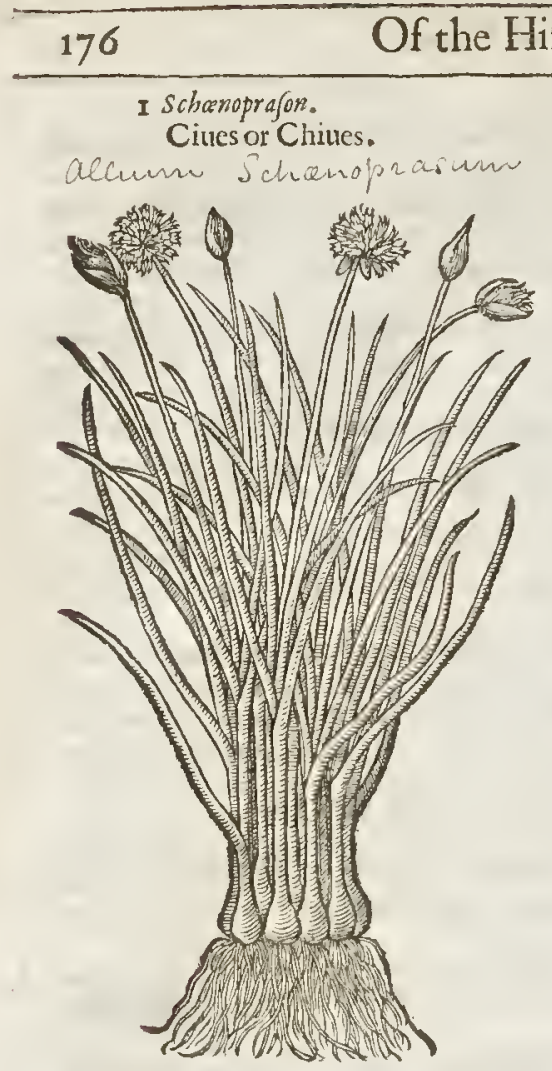

3 Ampeloprafon fine porrum filueftre. Wilde Leeke.

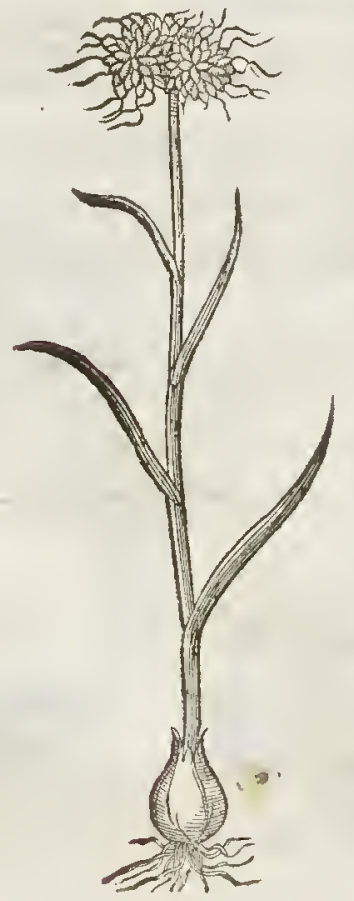

II The Defcription.

I Iues bring forth many leaues about a hand-full high, long, flender, round, like tolittle ruthes; among $f$ which grow ip fmall and tender italkes, fending forth, certaine knops with floures like thofe of the Onion, but much leffer. They haue many little bulbes or headed roots faitned together: out of which grow downe into the earth a great number of little ftrings, and it hath both the fmell and tafte of the Onion and Leeke, as it were participating of both.

2 The Vine Lecke or French Leeke groweth vp with blades like thofe of Leekes : the ftalke is a cubit high, on the top whereof ftandeth a round head or button, conered at the firft with a thinne skinne, which being broken, the floures and feeds come for th like thofe of the Onion. The bulbe or headed root is round, hard, and found, which is quickly mul tiplied by fending forrh many bulbes.

* 3 The wilde Leeke hath leaucs much like vnto thofe of Crow-garlicke,but larger, and more acride. The flonres and feeds alfo refemble thofe of the Crow-garlicke, the feeds being about the bigneffe of cornes of wheat,with fmal things comming forth at their ends. $\neq$ 


\section{T The Time and Place.}

I Ciues are fet in gardcns, they flourifh long, and continue many yeares, they fuffer the cold of Winter. They are cut and polled ofren, as is the vafet Leekc.

2 The Vine-lecke groweth of it fclfe in Vineyards, and neere vnto Vines in hor regions, wherof it both tooke the namc Vine-Leckc, and French Leeke. It beareth his greene leates in Winter, and withereth away in the Sommer. It groweth in moft gardens of England.

¥ Thus farte our Author defcribes and intimatcs to you a gardcn Leeke, much like the ordinarie in all refpe uts, but fomew hat larger. But thc following names belong to the wilde-Lecke, which herc we give you in the third place. $\neq$

The Names.

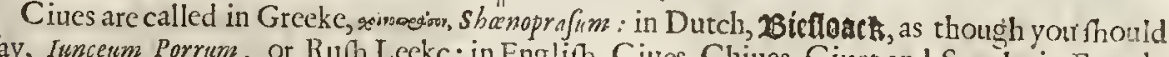
fay, Inncewm Porrm, or Rufh Leekc: in Englih, Ciues, Chiues, Ciutet and Sweth: in French,
Brelles.

$t_{2}$ TheVine-lecke, or rather wild Leekc, is called in Greeke, 'sumisacsor, of the place where it naturally groweth : it may be called in Latine, Porrum Vitum, or Vitigineum Porrum: in Englifh, after the Greeke and Latine, Vine Lceke, or French Leckc.

\section{बा The Temperature.}

Ciues are like in facultie vnto the Lcekc, hot and dry. The Vine leeke heateth more than doth the other Leeke.

\section{बi TheVertuss.}

Ciues attenuate or make thinne, open, prouoke vrinc, ingender hot and gtoffe vapours, and are A hurtfull to the eyes and braine. They caufe troublefomedreames, and worke all the efficets that
the Leeke doth.

The Vinc-leekc, or Ampeloprafon, prouoketh vrine mightily, and bringeth downe the floures. B It cureth the bitings of venomous beafts, as Diofcorides writerh.

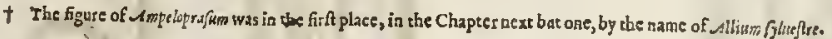

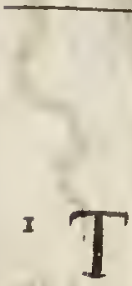

\section{C нар. 97. Of Garlicke.}

\section{The Defcription.}

$T$ He bulbe or head of Garlickc is conered with mont thinne skinnes or filmes of a vary light white purple colour, confifting of many cloues feuered one from another, vnder which in the ground below growcth a taffell of threddy fibres : it hath long greene leaues like thofe of the Lecke, among which rifeth vp a ftalke at the end of the fecond or third yeare, whe reupon doth grow a tuft of floures coured with a white skinne, in which,bcing broken
when it is ripc,appeareth round blacke feeds.

$\ddagger 2$ There is alfo another Garlicke which growes wilde in fome places of Germanie and France, which in thape much refembles the ordinarie, but the cloues of the roots are fmaller and redder. The foure is alfo of a more duskic and darke colour than the ordinarie. $\neq$

\section{Tा The Place and Times.} A

cember, and fome fownc of feed, but planted in gardens of the fmall cloues in Nouember and December, and fometimes in Februarie and March.

$$
\text { It is called in } \text { It The Names. }
$$

It is called in Latine, Alliwm : in Greeke, oxesen: The Apothecaries keepe the Latine name: the Germanes call it thoblauch: the Low Dutch, Look : the Spaniards, Aios, Albo : the Iralimans Treacle.

\section{Garlicke is very Themperature.}

skinnc by raiing blifters.

Being eaten, it it The Vertues.

humors; cutterh fuch as are tough cxtremely, attenuaterh and makcth thinne thicke and groffe ftrutions, is an enemic to all cold and clammy, digetterh and confumeth them; alfo openeth obGalcn nameth it Theriac Ruf

It yeeldcth to the body no nourifhment at all, it ingendreth naughty and fharpe bloud. There- 
fore fuch as are of a hot eomplexion muftefpecially ab taine from it. But if it be boyled in water vintill fueh time as it hath loft his tharpeneffe, it is the lefte forcible, and retaineth no longer his cuill inyee, as Galen faith.

C It taketh away the roughneffe of the throat, it helpeth an old eough, it prouoketh vrine, it breaketh and confumeth winde, and is alfo a remedie for the Dropfie which proceeedeth of a cold eaule.

D It killeth wormes in the belly, and driueth them forth. The milkealfo whetein it hath beene fodden is giuen to yong ehildren with good fueceffe againft the wotmes.

I Allium. Garlicke.

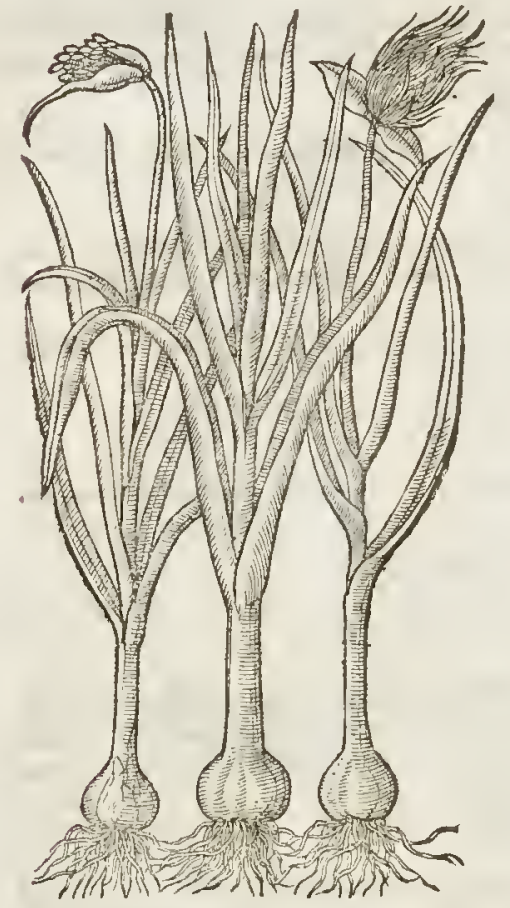

$\ddagger 2$ Allium fylueftre rubentibus nucleis. Wilde Garlieke with red cloues.

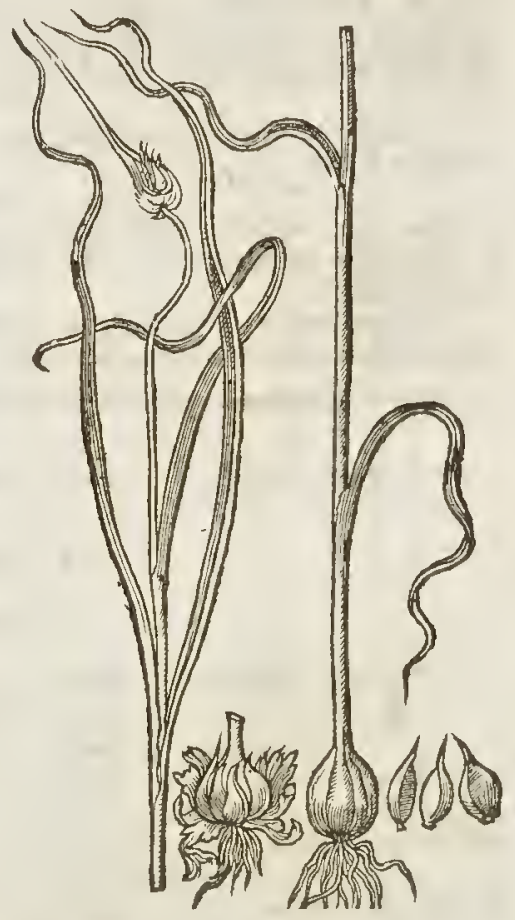

E It helpeth a vety cold ftomacke, and is a pteferuatiue againt the contagious and peftilent aire.

F The decoction of Garliek vfed for a bath to fit ouer, bringeth downe the floures and fecondines or after-burthen, as Diofcorides faith.

G It taketh away the morphew, tetters, or ring-wormes, feabbed heads in ehildren, dandraffe and feurfe, tempered with honey, and the parts anointed therewith.

H With Fig leates and Cumin it is laid on againft the bitings of the Moufe called in Greeke, maza $a$ : in Englinh, a Shrew. 


\section{С н в. 98. Of Crow-Garlicke and Ramfons. if The Defription.}

r T Hewilde Garlicke or Crow-garlickehath fmall tough Ieaues like vnto rumes, fmooth and hollow within; among which groweth vp a naked ftalke, round, flipperie, hard and found: on the top whereof, after the Houres be gone, grow little feeds made vp in a round clufter like fmall kernels, haung the fmell and tafte of Garlick. In ftead of a root there is a bulbc or round head without any cloues at all.

2 Ramfons do fend forth two or three broad longih lcaues fharpe pointed, fimooth, and of a light greene colour. The ftalke is a fpan high, fmooth and flender, bearing at the top a clufter of white ftar-farhioned floures. In ftead of a root it hath a long flender bulbe, whieh fendeth downe a multitude of frings, and is coucred with skinnes or thicke coats.

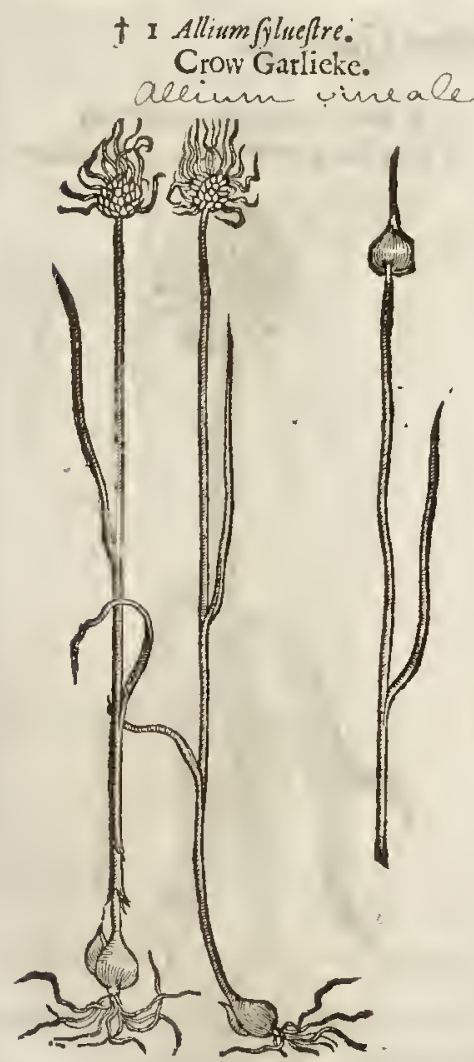

2 Allium vrfinum. Ranufons.

aleium uroinum.

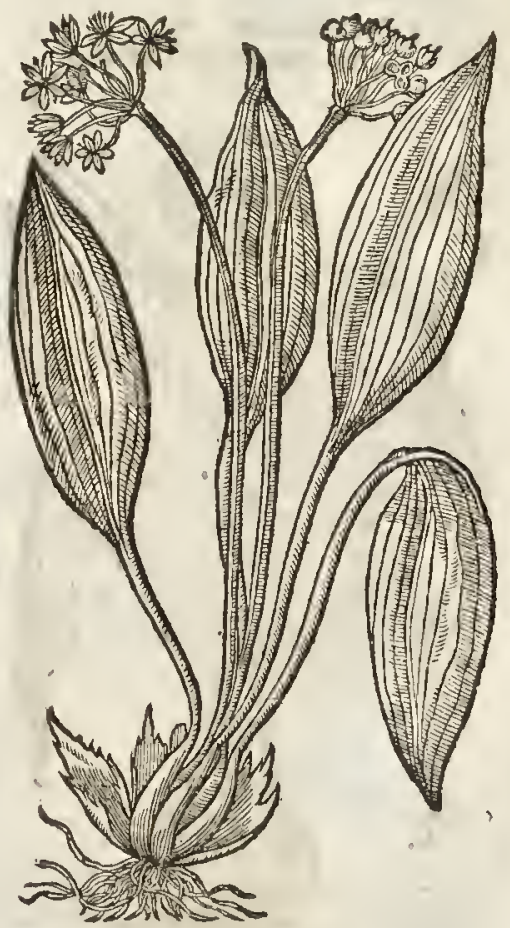

They fpring vp in Aprill and May. Their feed is ripe in Auguft.

\section{T The Place.}

The Crow Garlicke groweth in fertile paftures in all parts of England. I found it in great plentie in the fields ealled the Mantels; on the back fide of Intington by London.

Ramfons grow in the Woods and borders of fields vnder hedges, among the buthes. I found it in the next field vnto Boobies barne, vnder that hedge that bordereth vpon the lane; and alfo vpon the left hand, vnder an hedge adioyning to a lane that leadetl to Hampited, both places neere London. 


\section{The Names.}

Both of them be wilde Garlicke, and may be ealled in Latine, Alliwa fyluefria: in Greekes

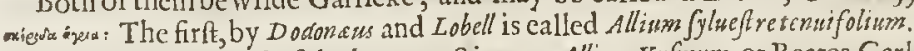

Ramfons are named of the later practioners, Allium Vrfinum, or Beares Garlicke: Allium latifolism, and croly Hippocraticum : in Englifh, Ramfons, Ram fies, and Buckrams.

I The Nature.

The temperatures of thefewilde Garliekes are referred vnto thofe of the gardens. The Vertues.

A Wilde Garlieke, or Crow-Garlieke, as Galen faith, is ftronger and of more force than the garden Garlicke.

B The leaues of Ramfons be famped and eaten of diuers in the Low-countries, with fifh for a fauce, enen as we do eate greenc-fauce madewith forrell.

C The fame leaues may very well be eaten in April and May w ith butter, of fuch as are of a ftrong conftitution, and labouring men.

\section{$\mathrm{D}$}

The diftilled water drunke breaketh the ftone, and driucth it forth, and prouoketh vrine.

\section{С н в. 99. Of OMountaine Garlicks:}

\section{Scorodoprafum.}

Great mountaine Garlicke.

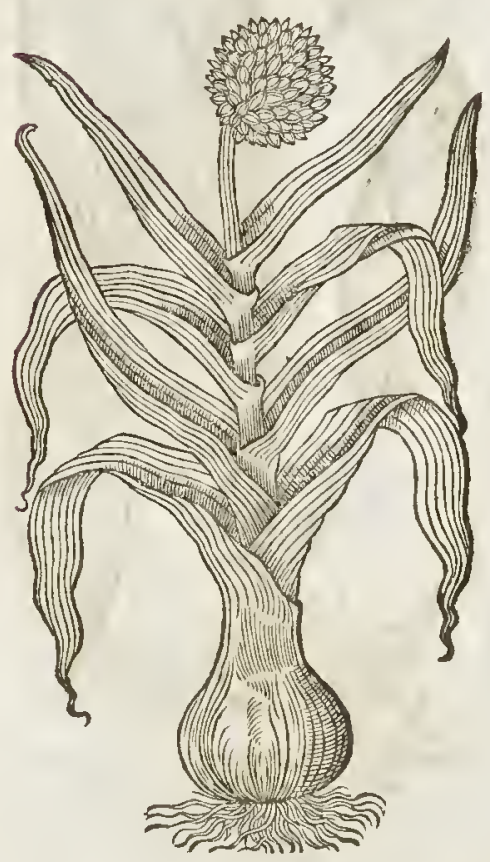

$¥ 2$ Scorodoprafum primum Clufij. clufiss his great mountaine Garlicke.

$$
\text { aceium Anbeloprasmum }
$$

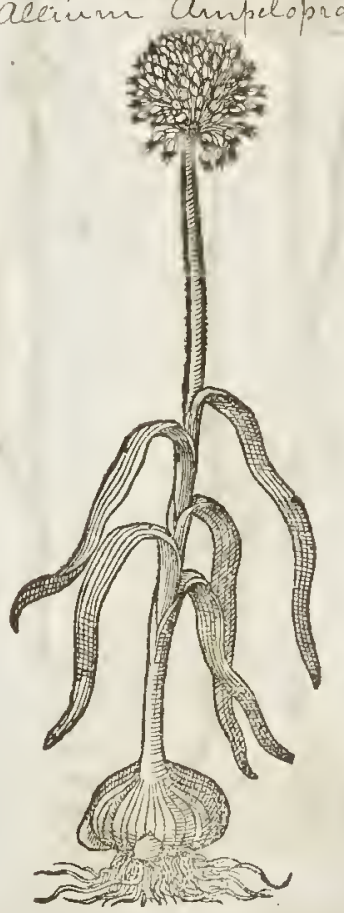

Tf The Defcription.

1 = $T$ He great Mountaine Garlicke hath long and broad leaues like thofe of Leekes,

1 but much greater and longer, embracing or clafping about a great thicke ftalke, foft and full of juyce, bigger than a mans finger, and bare toward the top; vpon which is fet a great head bigger than a tennife ball, eouered with a skinne after the manner of an Onion. The skinne when it eommeth to perfection breaketh, and difeouereth a great multitude of whitifh floures; which being paft, blacke feeds follow, inelofed in a three cornered huske. The root is bulbous, of the bigneffe of a great Onion. The whole plant finelleth very ftrong like vnto 
Garlieke, and is in thew a Leeke, whereupon it was ealled Scorodoprafum, as if we thou!d fir, Garlicke Lecke; participating of the Leeke and Garlieke, or rather a degenerate Gar'icke yrome monftrous.

₹ I eannot eertainely determine what differenee there may be betweene the plants exprefred by the firt figure, which is our Authors, and the fecond figure which is taken out of clufius. Now the hiftorie which Clufus giues vs to the fecond, the fame is (out of him) giuen by our Author to the firft: fo that by this reafon they are of one and the fame plant. To the which opinion I rather ineline, than affirme the contrariewith Babine, who diftinguilhing them, puts the firft among t the Leekes, vnder the name of Porrum folio latißimo: following T abernamontanus, who firf gaue this figure, vnder the name of Porrum Syriacrm.

3 This plant is leffer in all the parts than the former; the root is fet about with longer and flenderer bulbeswrapped in brownilh skinnes; the floures and leaues are like, yet fmaller than Garlicke.

¥ 3 Scorodoprafum minus.

The leffer lecke-leaned Garlicke.

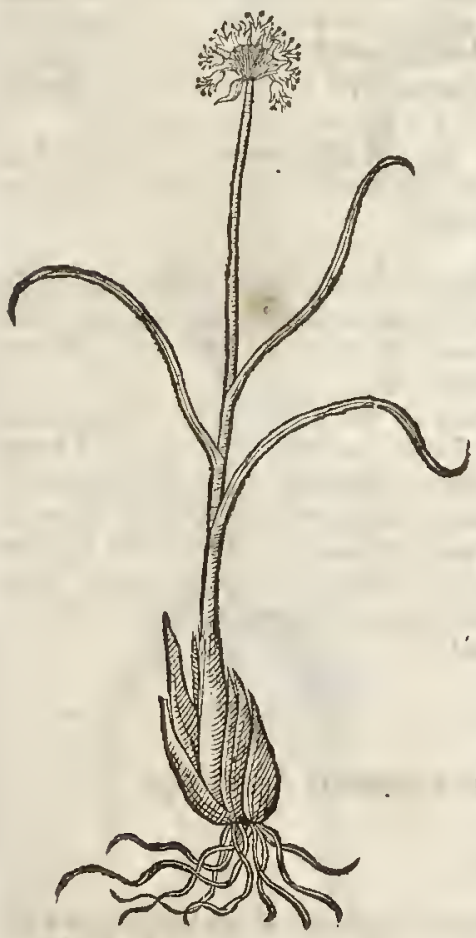

4 opbiofcoridon. Vipers Garlike.

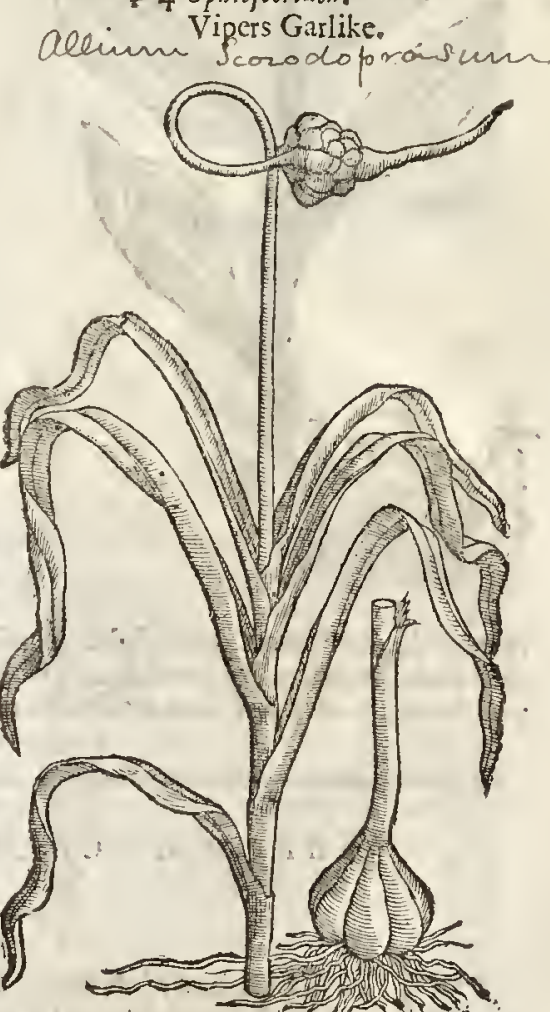

4. The third, which clufus makes his fecond scorodeprafum, hath ftalkes fome two eubits high, hauing many leates like thofe of Leckes from the bottonie of the falke to the middle thereof; their fimell is betweene that of Leckes and Garlieke; the reft of the ftalke is naked, green,finooth, fuftaining at the rop a head eompofed of many bulbes, eouered with awhitifh skinne ending in a long greene point; which skinne by the growth of the bulbes being broken, they fhew themfelues, being firt of a purplin, and afterwatds of a whitith eolour, amongt whieh are fome fioures. The top of the ftalke at firft twines it felfe, fo that it in fome fort reprefents a ferpent ; then by little it vntwines againe, and beares the head ftraight vp. The root eonfifts of many eloues much like
that of Garlieke. $\neq$

5 The broad leated Mountaine Garlicke, or rather the Mountaine Ramfons, ifeth vp with a ftalke a eubit high, a finger thicke, yet very weake, full of a fpongenus fubfanee, neere ro the bottome of a purplin eolour, and greene aboue, bearing at the top a multitude of fmali whitith floures, fomewhat gaping, ftar-fanhion. The leaues are three or foure, broud ribbed lite the leatres of great Gentian, refembling thofe of Ramfons, but greater. The root is great and long, comered with many fealy eoats and hairy itrings: 
5 Allim Alpinum latifolium, feu Victorinlis.

Broad leaucd Mountaine Garlieke.

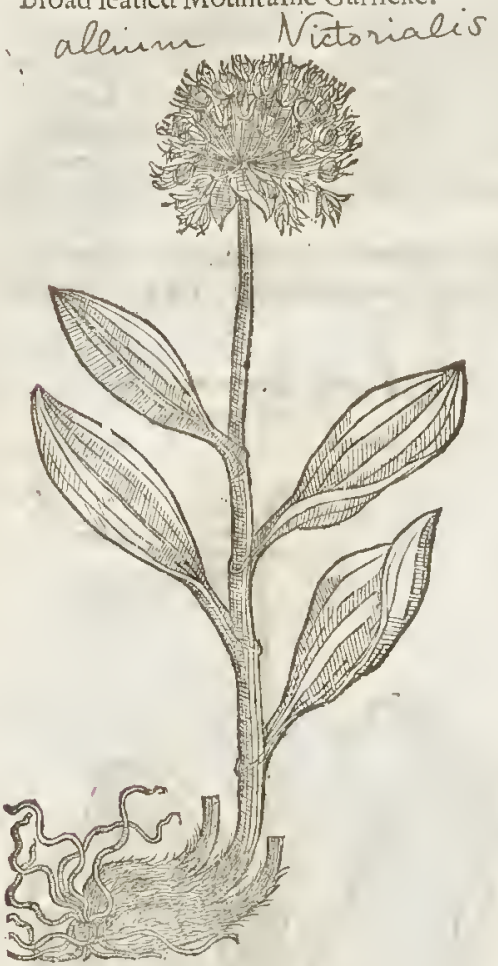

बा The Place.

The great mountaine Garlicke growes about Conftancinople, as fuith chafus. Ireceined a plant of it from M. Thomats Edwurd: Apothecary of Excefter, whe found it growing in the Weft parts of England.

Viclorials groweth in the mountaines of Germany, as faich Carolus Clufius, and is yet a franger in England for any thing that I do know.

$$
\ddagger \text { T The Time. }
$$

$\ddagger$ Moft of thefe plants foure in the months of Inne and Inly,

$$
\text { of The Names. }
$$

Of the firft and fecond I hame fpolen already. The third is Scorodngrafjum minus of Lobell. The fourth is Allium fativum fecundum of Dodoneus, and Scurodoprafum ficundum of Clufius. The fifth is Allinm angrinum of Matholus; Ophiofcoridon of Lohall, and victornalis of Chufies and others, as alif Allimm Alpinum. The Germanes call it soigs wutts

$$
\text { T. The Temper. }
$$

They are of a niddle tenuper between Leckes and Garlicke.

$$
\text { or Their Vertucs. }
$$

scorodoprafum, as it partakes of the temper, fo alfo of the rertues of Leekes and Garlicke; that is, it attenuates grofle and tough matter, helpes expestoration, \&.c.

Victorals is like Garliclse in the operation thereof. Some (as Comberarius writeth) hang the root thereof about the necks of their cattell being falne blinde, by what occalion focter it happen, and perfuade thenfelves that by this meanes they will reconer their figlt. Thofe thatworke in the mines in Germany affirme, That they find this root very powerfull in defending them from the affults of impure fpirits or dituels, which often in fucli places are troublefome vinto them. Corf. 立

\section{C н а т.100. Of M Noly, or the Sorcerers Garlicke.}

$$
\text { 9) The Defoription. }
$$

$x$ He firf kinde of Moly hath for his root a little whition bulbe fonewhat long, not inlike to the root of the vnfet Leeke, which fendeth forth leames like the blades of corne or graffe : among which doth rife vp a flender weake fallie, fat and full of iuyce, at the top whereof eommeth forth of a skinny filme a bund le of milke-white floures, not vnlike to thofe of Ramfons. The whole plant hath the fmell and tafte of Garlicke, whereof no doubt it is a kinde.

2 Scrpents Moly hath likew ife a fimall bulbous root with fome fibres faftned to the botton, from which rife vp wcake graffie leaues of a thining greene colour, crookedly winding and turning themfelues toward the point like the taile of a Serpent, wherc of it tooke his name: the ftalke is tough, thickc, and full of iuyce, at the top whereof ftandeth a clufter of fmall red bulbes, litie into the fmalleft cloue of Garlicke, before they be pilled from their skinne. And among thofe buibes there do thruft forth finall and weake foot-ftalkes, euery one bearing at the end one fimall white floure tending to a purple colour : whieh being paft, the bulbes do fall downe vpon the ground, where they without helpe do take hold and root, and thereby greatly encreafe, as alfo by the infinitc bulbes that the root doth caft off : all the whole plant doth fmell and tafte of Garlick, whereof it is alfo a linde.

3 Homers Moly hathicry thicke leates, broad toward the bottome, marpe at the noint, ant 


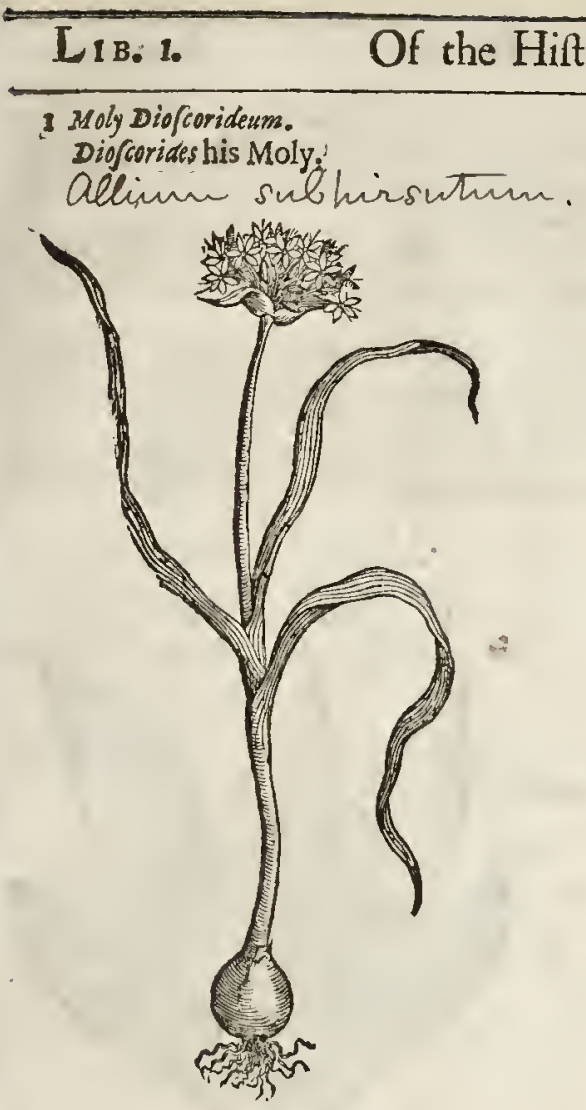

\section{Moly Homericum. Homers Moly.}
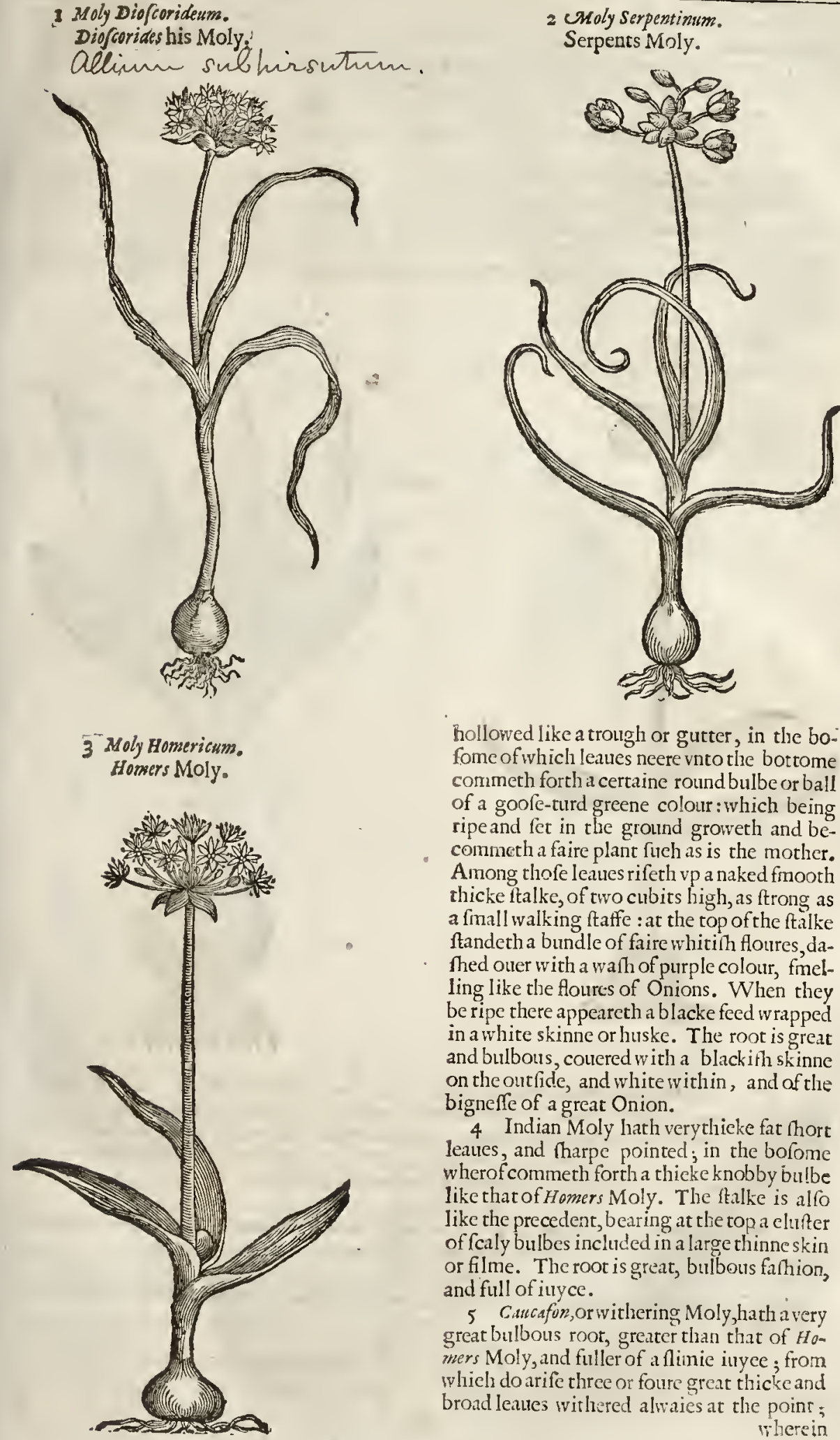

hollowed like a trough or gutter, in the bofome of which leaues neere vnto the bottome commeth forth a certaine round bulbe or ball of a goofe-turd greene colour : which being ripe and fet in the ground groweth and becommeth a faire plant fitch as is the mother. Among thofe leaues rifeth vp a naked fmooth thicke ftalke, of two cubits high, as ftrong as a fmall walking ftaffe : at the top of the ftalke ftanderh a bundle of faire whition floures, dathed oner with a wath of purple colour, fme!ling like the floures of Onions. When they be ripe there appeareth a blacke feed w rapped in a white skinne or huske. The root is great and bulbous, coured with a blackifh skinne on the outfide, and white within, and of the bigneffe of a great Onion.

4 Indian Moly hath verychicke fat thort leaues, and tharpe pointed; in the bofome wherof commeth forth a thicke knobby bu!be like that of Homers Moly. The ftalke is alfo like the precedent, bearing at the top a clufter of faly bulbes included in a large thinne skin or filme. The root is grear, bulbous fachion, and full of iuyce.

5 Callofor, or withering Moly, hath a very great bulbous root, greater than that of $\mathrm{HO}_{\mathrm{O}}$ mers Moly, and fuller of a flimie iuyee; from which do arife three or foure great thicke and broad leates withered alwaies at the point; wherein 


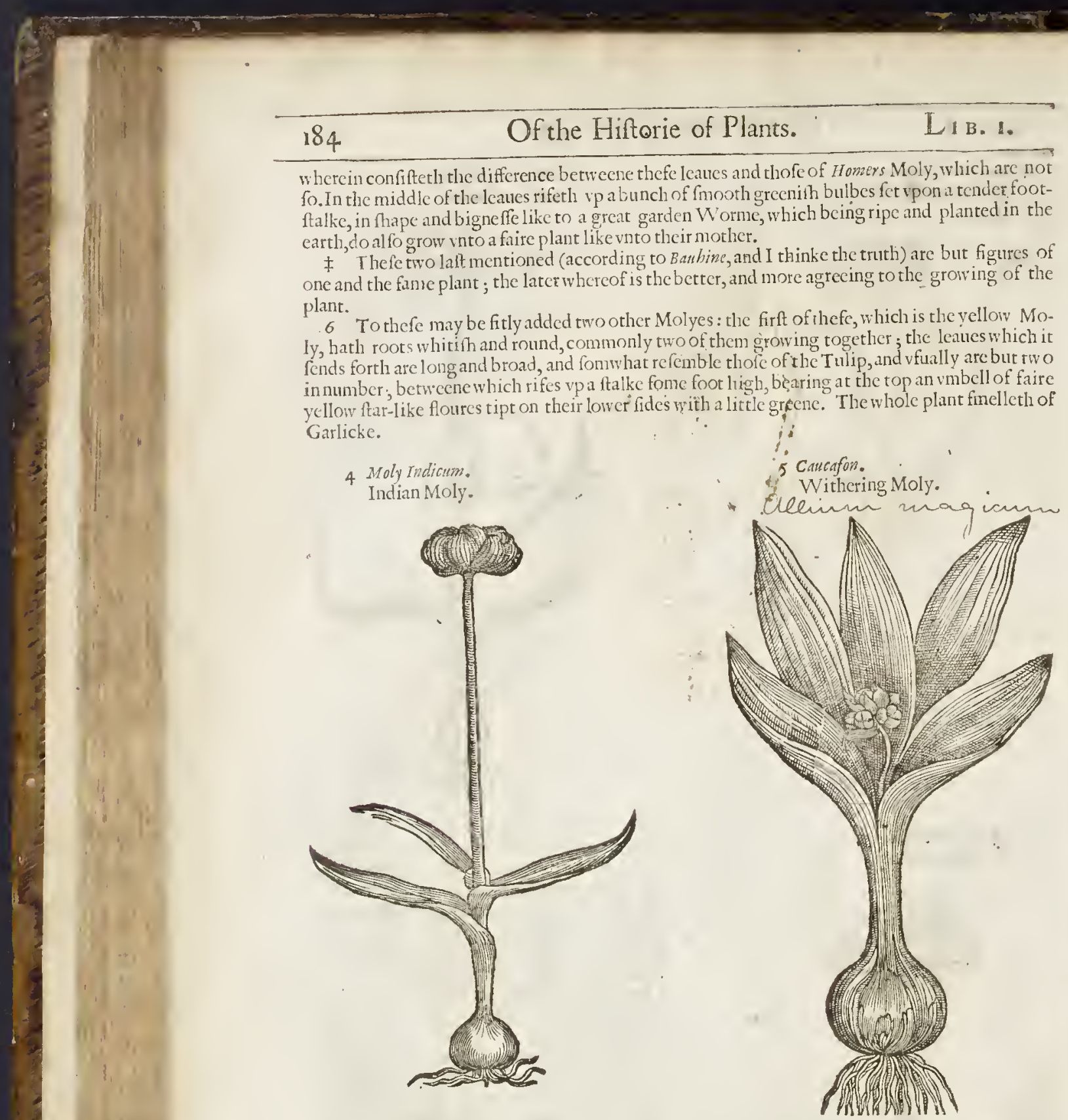

7 This little Moly hath a root about the bignefle of an Hafell nut, white, with fome fibres hanging thereat ; the ftalke is of an bandfull or little more in height, the top thereof is adorned with an vmbel of ten or twelue white floures, each of which confifts of fix leaues, not tharpe pointed, but turned round, and pretty large, confidering the bignefte of the plant. This plant liatli alfo vully but two leaues, and thof like thofe of Lcekes, but far lefle. $¥$

$$
\text { - The Place. }
$$

+ Thefe plants grow in the garden of M. Iohn Parkinfon Apothecaric, and with M.Iolm Irade ront and fome others, ftudious in the know ledge of plants.

$$
\text { The Time. }
$$

They foring forth of the ground in Februaric, and bring forth their floures, fruit, and focd in the end of Auguft.

The Names.

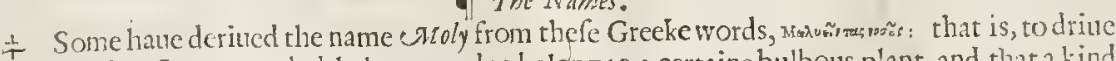
away difeafes. It may probably be argued robelong to a certaine bulbous plant, and that a kind 
of Garlicke, by the words $x$ winzas, and wixus. The former, Galen in his Lexicon of fome of the dificul-

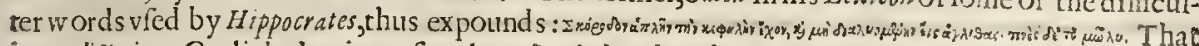
is, Moli $z$ is a Garlickehauing a fimplcor fingle head, and not to be parted or diftinguifhed into cloutes: fome terme it Moly. Erotianus in his Lexicon cxpotinds the later thus : Mraus (faith hee)

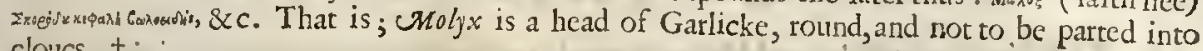
cloucs. $\ddagger^{*}$

The Names in particular.

₹ I This is called Moly by Watthiolus; Moly Anguftifoliurn by Dodoneus; Moly Diofcorideum by Lobel and Clufius.

2 This, Moly Serpentinum vocatum, by Lobel and the Author of the Hift. Lugd.

3 This fame is thought to be the Moly of $T$ heophraftus and Pliny, by Dodoneus, Clus $6 u s$, \& c. and fome alfo would hate it to be that of Homer, mentioned in his twenticth 0 dyff. Lobel calleth it Moly Liliflorum.

45 The fourthand fif th bcing one, are called caucafon, and Moly Indicum by Lobel, clufus, and orhers. par, 2.

6 This is Moly Montanum latifolinm flawo flore of Clufus, and Moly luterm of Lobel, Aduerfar.

7 This fane is Moly minus of Clufuss. $\neq$

* 6 Moly lairfolium fore fasso.

Broad leaucd Moly with the yellow floure.

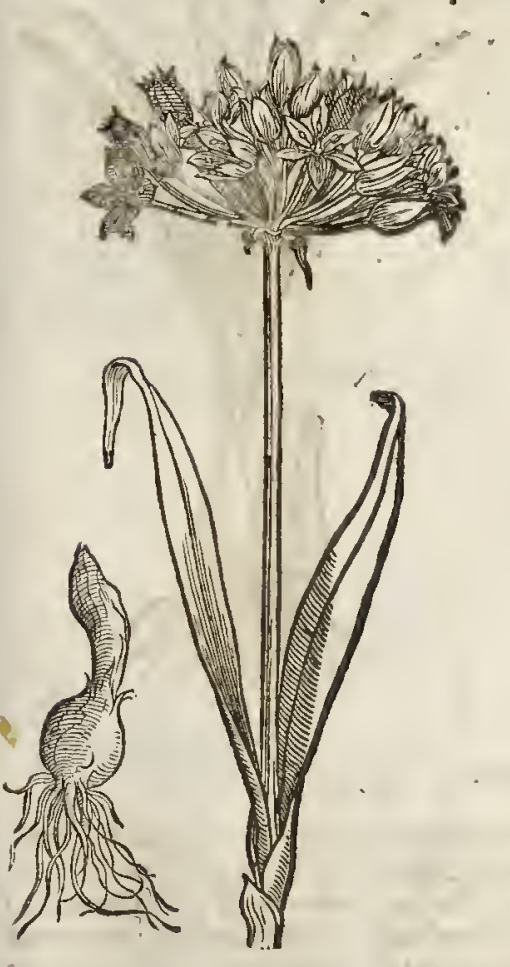

$\$ 7$ Moly minus fiore albo. Dwarfe whitc floticd Moly. allimm Censianium

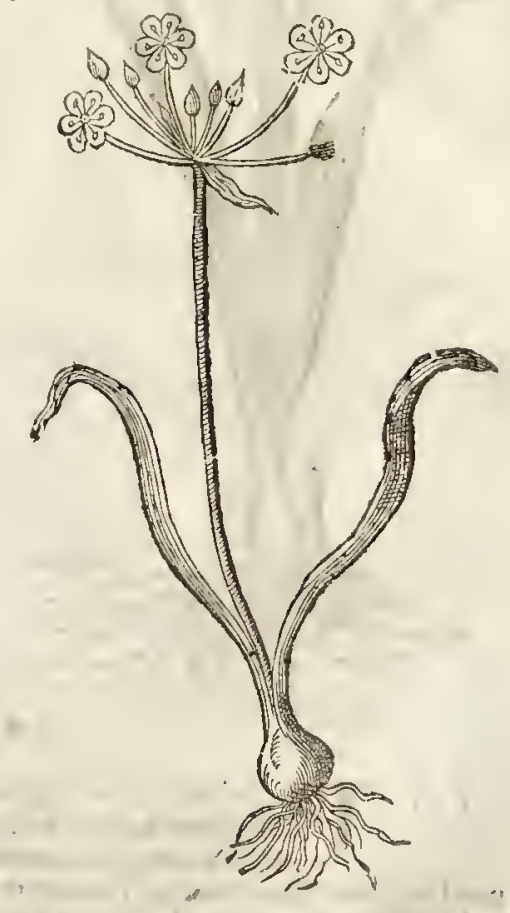

T) The Temperature and Vertues.

Thefe Molyes are very hot, approching to the naturc of Garlicke, and I doubt not but in time fome ex cellent man or other will find out as many good vertues of them,as their fately and conely proportion thould feeme to be poffefled wath. But for my part, I haue neither proued, nor heard of others, nor found in the writings of the Antients, any thing touching their faculties. Only $D i$ of corides reporterh, That they are of maruellous efficacic to bring downe the termes, if one of them be ftamped with oylc of Floure de-lucc according to art, and vfed in manner of a peffaric or mo
ther fuppofitorie.

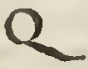

ChaP: 


\section{\# С н Р. 1010 of dimersotber Molyes.} ate more than comeniently could be added to the former chaptets, (which are fufficiently large) I thought it not amiffe to allot them a place by themfeluest

¥ Moly Narcifinis folijs primum.

The firft Natciffe-leaned Moly.

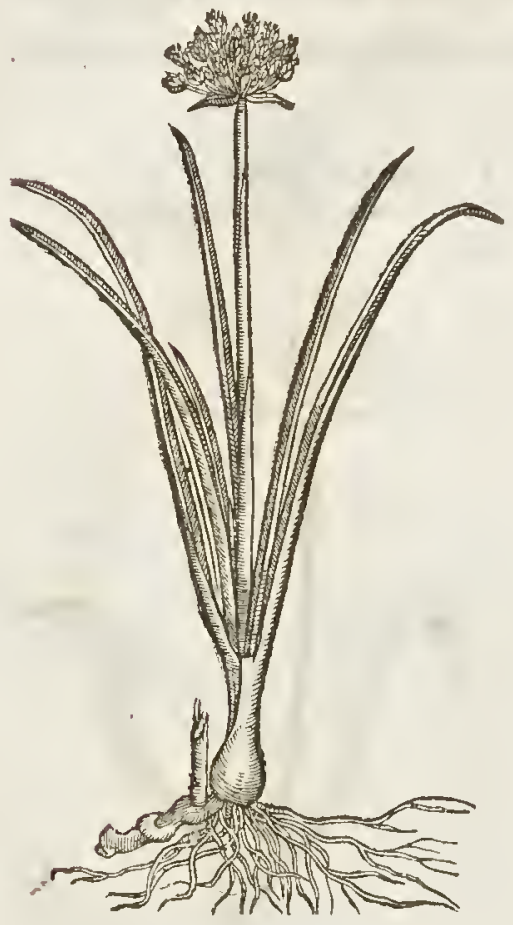

$\ddagger 2$ Moly Narcifinisfolys fecundum. The fecond Narciffe-leaued Moly:

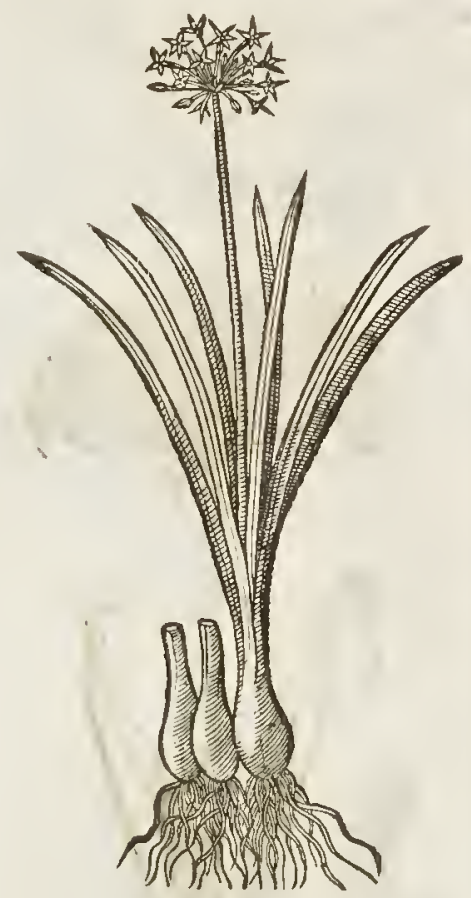

T The Defcription:

\# I THis, which in face nigheft reprefents the Molyes deferibed in the laft Chapter, hath a root made of many fcales, like as an Onion in the vpper part, but the lower part is knotty, and runnes in the ground like as solomons Seale; the Onion-like part harh many fibres hanging thereat; the leaues are like thofe of the white Narciffe, very greene and hining, amongft which rifeth vp a ftalke of a cubit high, naked, firme, greene, and crefted; at the top come forth many floures confifting of fix purplinh leaues, with as many chittes on their infides : after which follow three fquare heads, opening when they ate ripe, and containing a tound blacke feed.

2 This other being of the fame kinde, and but a varietie of the former, hath fofter and mote An-coloured lcaucs, with the floures of a lighter colour. Both thefe floure at the end of Itne, or in Iuly.

3 This hath fiue or fix leaues equally as btoad as thofe of the laft defcribed, but not fo long, being fomcwhat twined, greene, and fhining. The ftalke is fomc foot in length, fmaller than that of the formet, but not lefe ftiffe, crefted, and bearing in a round head many floures, in manner of growing and hape like thofe of the formet, but of a more clegant pur ple colout. In feed and root 


LI B. I. Of the Hiftory of Plants. 187

\# 3 CMoly Narcißinis folys tertium. The third Narciffe-leated Moly.

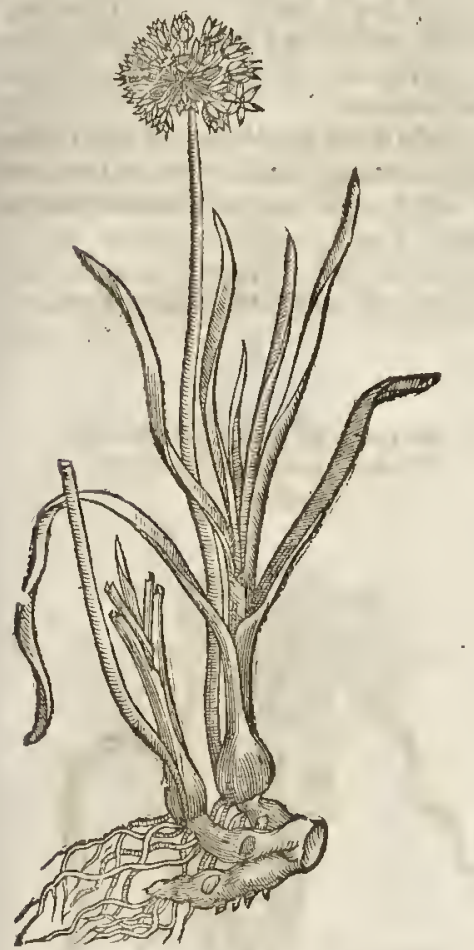

\$5 Moly mort anum fecurdum Clufije? The fecond mountaine Moly.

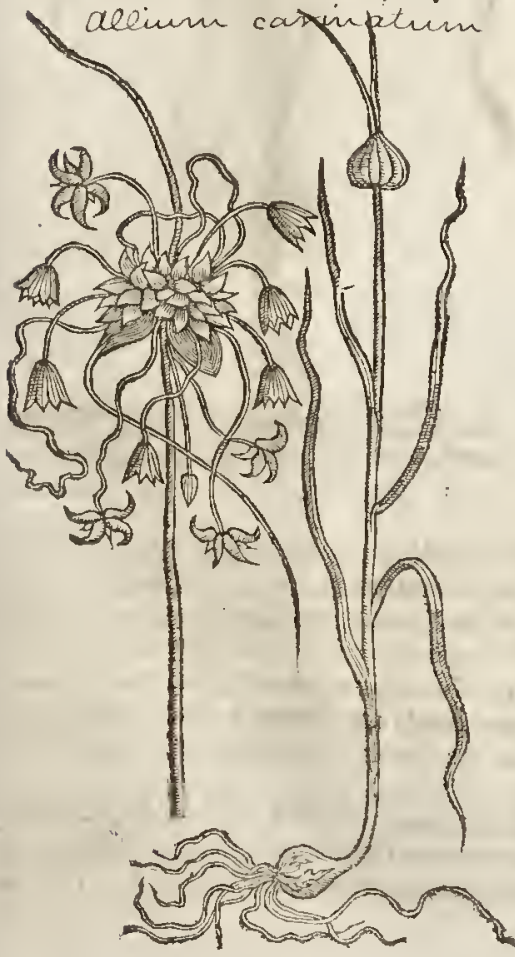

¥ Moly montanam latifolinm t.Clufij.

The firtt broad leaued mountaine Moly.

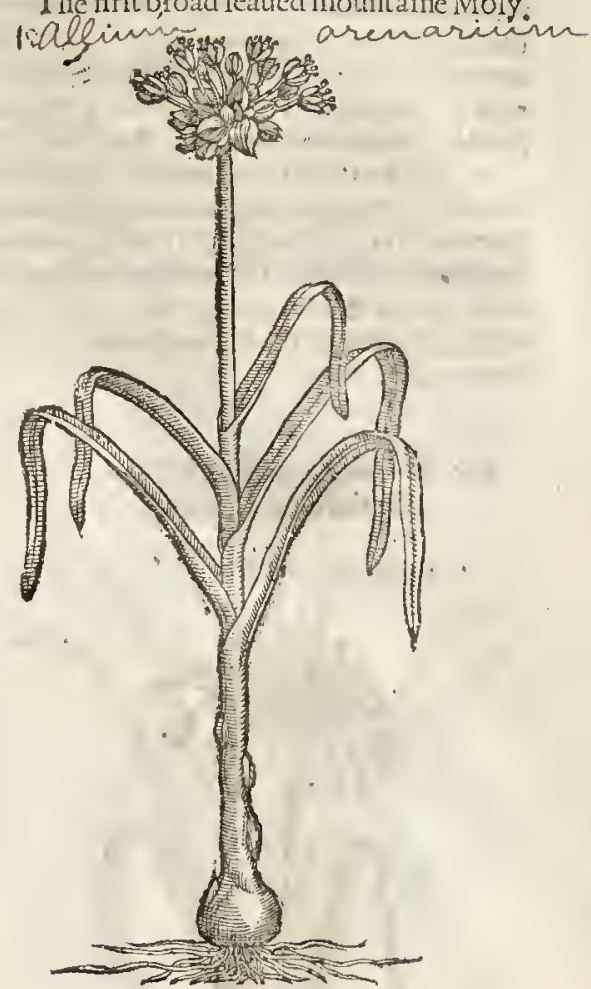

it refembles the precedent. There is alfo a varictic of this kinde, with leates longer and narrower, neither fo much twined, the ftalks weaker, and floures mueh lighter coloured.

This floures later than the former, to wit, in Iuly and Auguft.

All thefe plants grow narurally in Teitenberg and other hills neere to Vienna in Autria,where they were firft found and obfented by $C_{\text {arolus }}$ Clinguss.

4 This hath a ftalke fome tivo eubits high, whieh enen to the niiddle is ineompaffed with leaues mueh longer and broader thin thofe of Garlieke, and very like thofe of the Leeke: on the top of the fmoorh and rufl-like ftalke groweth a tuft confinting of many darke purpleeo'o:red bulbs growing elofe together, from among ff which eome forth pretty long falkes bearing light purple ftarre-farhioned ficures, whieli are fueceeded by three eornered fied-veffels. The root is bulbous, large, eonfinting of many cloues, and hauing many white fibres growing forth thereof. Moreoner, there grow out eertain round bulbes about the root, almort like thofe whicin grow in the head, and being planted apart, they produce plants of the fame kinde. This is Altim, fiuc Molymontanum latifolius I. Clufij.

5 Thishath a frooth round grecre falke fome eubit high, wheren doestry moft con-

$$
\text { Q } 2
$$

monily 
monly three leanes narrower than thofe of the former, and as itwere graffy. The top of the ftalke fuftaines a head wrapped in two lax filmes, each of them running out with a tharpe point like rwo hornes, which opening themfelues, there appeare many fmall bulbes heaped together, among ft which are floures compofed of fix purplifh little leaues, and faftned to long falkes. The root is round and white, with many long white fibres hanging thereat. Clufiss calls this, Allium, fiue Moly mont anum (ecurdurs. And this is Lobels Ampeloprafon proliferum.

6 Like to the laft deferibed is this in height and fhape of the ftalke and leaues, as alfo in the forked or horned slinne inuoluing the head, which confinterh of many fmall bulbes of a reddin greene colour, and ending in a long greene point; among ft which, vpon long and flender ftalkes hang downe floutes like in forme and magnitude to the former, but of a whitifh colour, with a darke purple ftreake along the middle, and vpon the edges of each leafe. The root is round and white, like that of the laft defcribed. This Clufius gimes snder the title of Allium fiuc Moly montanumtertium.

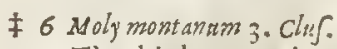

The third mountaine Moly".

$$
\text { aleiman oleraceum }
$$

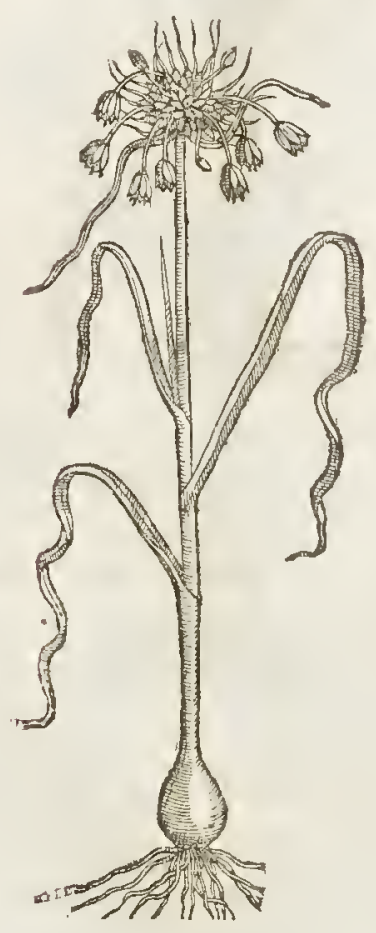

$\ddagger 7$ Molymontani quartijpec. I. Cluf. The fourth mountaine Moly; the firft fort thereof.

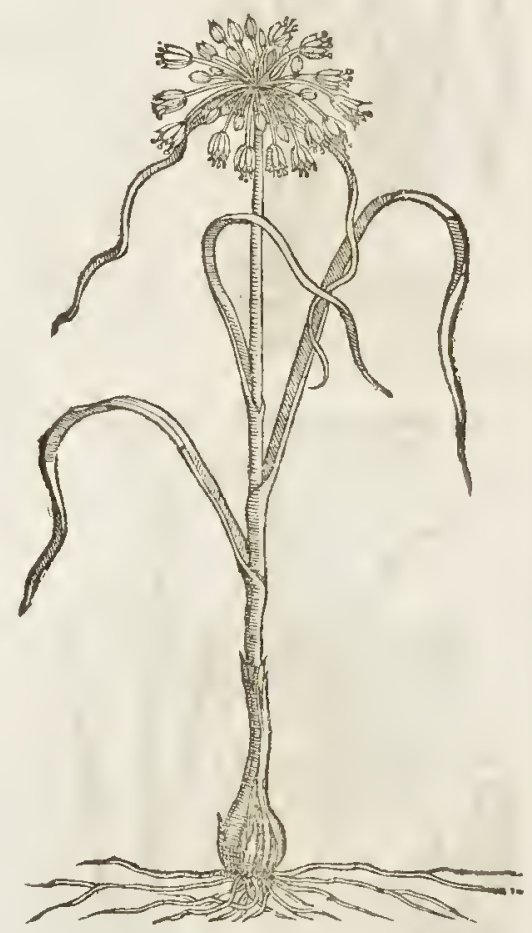

7 This alfo hath three rufhy leaues, with a round ftalke of fome cub it higl, whofe top is likewife adorned with a forked membrane,containing many pale coloured floures hanging vpon long: ftalkes, each foure confifting of fix little leaues, with the like number of chiues,and a peftil in the midf. This tuft of floures eut off with the top of the italke, and carried into a chamber, wil yeeld a pleafant fmell (like that whieh is found in the floures in the earlier Cyclamen) but it will quiekly decay. After thefe foures ara paff fuceed three cornered beads containing a blacke fmall feed, not much valike Gillofloure feed. The root is round like the former, fometimes yeelding off-fets. This is Alÿmontani 4 . pecies $\mathrm{x}$. of Clufius.

8 There is another kinde of this laft deferibed, which growes to almoft the fame heigtat, and hath like leaues, and the head ingirt with the like skinny long pointed huskes; but the floures of this are $w$ a very darke colour. The roots are like the former, with off-fets by their fide. This is
clicfsus 
Clufus his Moly montani quarti ßpecies fecunda. The roots of the three lait defcribed fmell of garlick, but the leaues haue rather an hearby or graffe-like frnell.

The fifth and fixth of thefe grow naturally in the Styrian and Auftrian Alpes. The feuenth growes about Presburg in Hungarie, about Niclafpurg in Morauia, but moft aboundantly about the Baths in Baden.

\section{\$ Moly montani quarti pecies secunda Clarij.}

The fecond kinde of the fourth mountaine Moly.

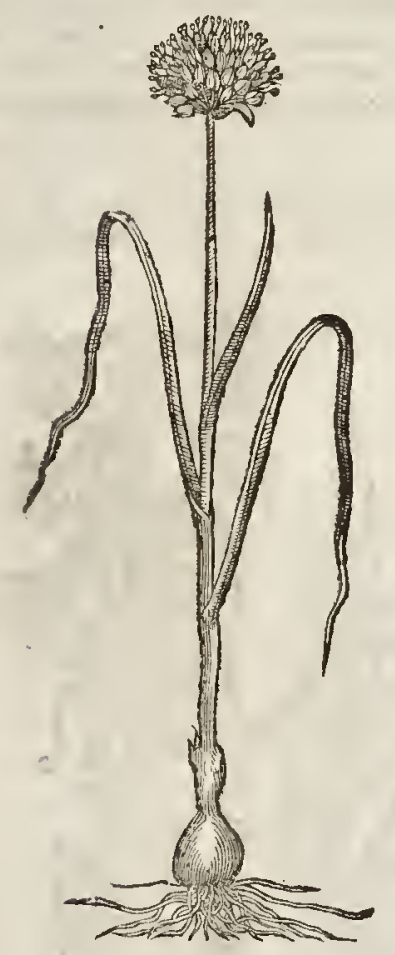

\$ Moly nontanum quintum Clufij。 The fifth mountaine Moly aleimon rotundium

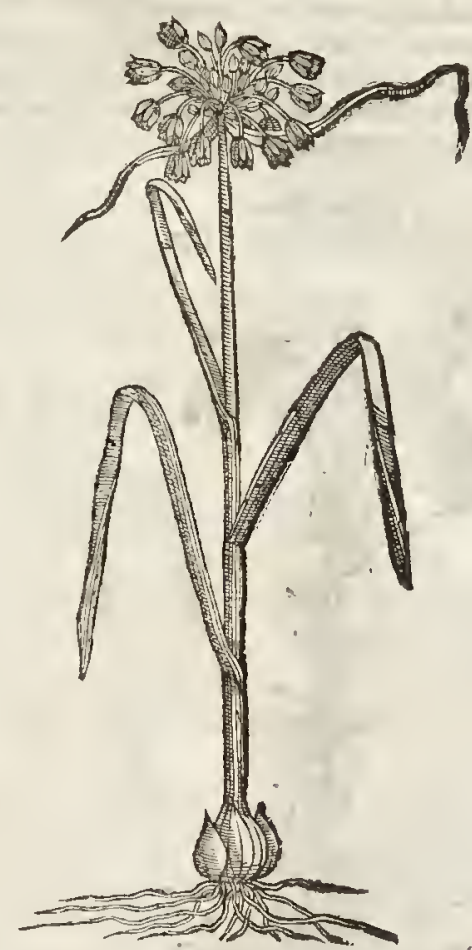

9 This growes to the like height as the former, with a greene falke, hauing few leaves thereupon,and naked at the top, where it carieth a round head confifting of many ftar-like fmall floures, of a faire purple colour, faftned to Thort ftalkes, each floure being compofed of fixe little leaues, with as many chiues, and a peftill in the middle. The root is bulbous and white, hauing foritimes his off-rets by his fides. The fmell of it is like Garlicke. This groweth alfo about Presburgh in Hungarie, and was there obferued by Clufus to beare his floure in May and Iune. He calleth this Allium, feu Moly moxtanum qquintum. ‡

\section{Cна р. 102. Of White Lillies. \\ II The Kindes.}

THerebe fundry forts of Lillies, whereof fome be wilde, or of the field ; others tame, or of the garden; fome white, others red; fome of our owne countries growing, others from beyond the feas : and becaufe of the variable forts we will diuide them into chaptets, beginning with tlke two white Lillies, which differ little but in the natiue place of growing. 

grow faire white like leaues, but growing fmallerand fmaller toward the top; and vpon them doe grow, wide or open in the month like a bell. pointals tipped with a duft y yellow eolour, ribbed or chamfered on the backe ide, confifing fix fmall leaues thicke and fat. The root is a bulbe made of fealy cloues, full of tough and clam mic iuyce, wherewith the whole plant doth greatly abound.

2 The white Lilly of Conftantinople hath very large and fat leaues like the former, but narrower and leffer. The ltalke rifeth ip ro the height of three cubits, fet and garnifhed with leaues alfo like the precedent, but much leffe. Which ftalke ofrent imes doth alter and degencrate from his naturall roundneffe to a flat forme, as ir were a lath of wood furrowed or chanelled alongit the fame, as it were ribs or welts. The floures grow at the top like the former, fauing that the leaucs do turne themfelues more backward like the Turkes cap, and beareth many more foures than our Englifh white Lilly doth.

I Lilium album. The white Lilly:

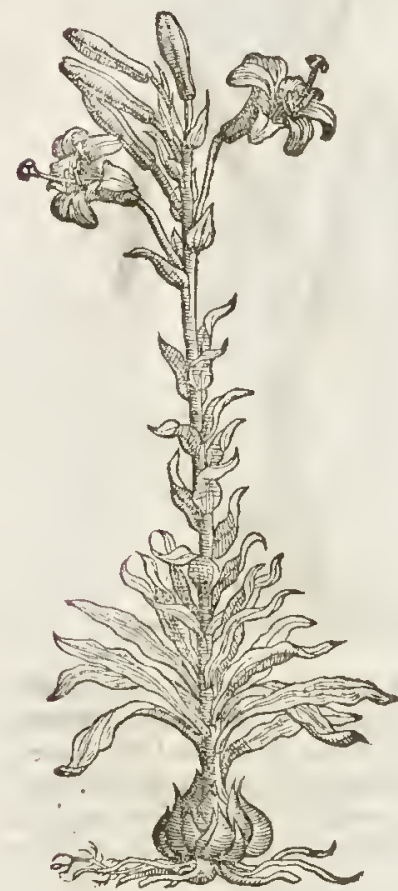

2 Lilium album Bizantinum.

The white Lilly of Conftantinoplc.

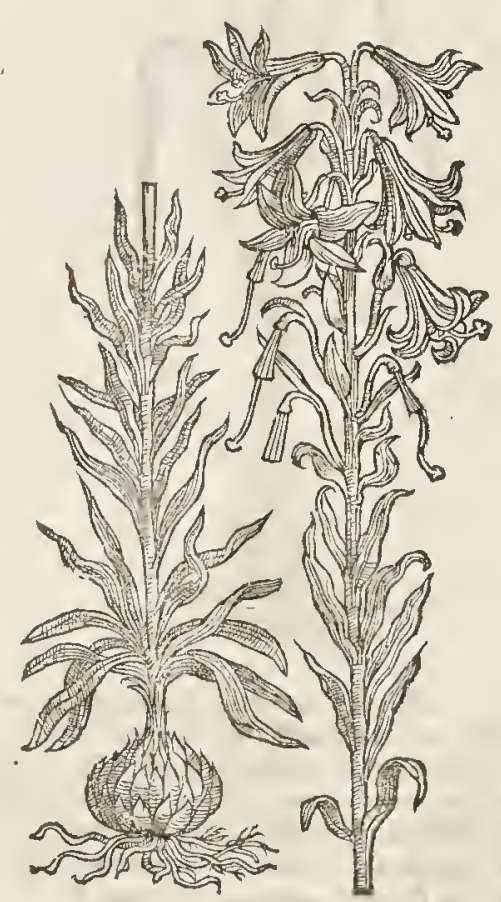

Tा The Place.

Our Englith white Lilly groweth in moft gardens of England. The other groweth naturally in Conftantinople and the parts adiaeent, from whence wee had plants for our Englinh gardens, where they flourith as in their owne countrey.

$$
\text { T The Time. }
$$

The Lillies floure from May to the end of Iune.

\section{The Names.}

The Lillic is called in Greeke whon: in Latine, Lilium, and alfo Rofa Iunosis, or Iuno's Rofe, becaufe as it is reported it came vp of her milke that fell vpon the ground. For the Pocts feigne, That Hercules, who Iupiter had by Alcumena, was put to Iuno's breafts whileft thee was afleepe, and after the fuck ing there fell atvay aboundanee of milke, and that onc part was fpilt in the heaucns, and the other on the earth; and that of this fprang the Lilly, and of the other the eire e in the ha. arens 
called Latzus Circalus, or the milky way, or otherwife in Englinh Watling fteet. Saint Bafill in the explieation of the 44. Pfalme faith, That no floure fo lituely fets forth the frailty of mans life

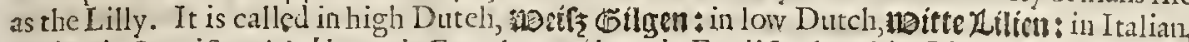
Giglio : in Spanifh, Lirio blanco : in French, Lys blanc: in Englifh, the white Lilly.

The other is called Liliwm album Bizantinum, and alfo Murtagan album Bizantinum : in Englion, the white Lilly of Conftant inople : of the Turkes themfelues, sultan Zambach, with this addition, (that they might be the better knownewhich kinde of Lilly they meant when they fent roots of them into thefe countrics) Fa foragrandi Bianchi, fo that Suldan Zambach fa for a grandi Bianchi, is as much to fay as, Sultans great Lilly with white foures.

$$
\text { T The Nature. }
$$

The white lilly is hot, and partly of a fubrill fubfance. But if you regard the root, it is dry in the firft degree, and hot in the feeond.

$$
\text { T) The Vertucs, }
$$

The root of the garden Lilly fta mped with honey gleweth together finewes that be cut un fin- A der. It confumeth or fcoureth away the vlcers of the head called Achores, and likewife all fcuruineffe of the beard and face.

The Root ftamped with Vineger, the leates of Henbane, or the meale of Barley, curcth the tumours and apoftumes of the priuy members. It bringeth the haire againe vpon places which haue beene burnel or fcalded, if it be mingled with oyle or greafe, and the place anointed therewith.

The fame root rofted in the embers,and ftamped with fome leauen of Rie bread and Hogges $\mathrm{C}$ greafe, breaketh peftilentiall botches. It ripeneth A poitumes in the flankes, comming of venery and fuch like.

The floures fteeped in Oyle Oliue, and fhifred two or three rimes during Sommer, and fet in the Sunne in a ftrong glaffe, is good to foften the hardneffe of finewes, and the hardneffe of the matrix.

Florentinus a writer of husbandry faith, That if the roorbe curioufly opened, and therein be put E fome red,blew, or yellow colour that hath no caufticke or burning qualitie, it will caufe the floure tobe of the fame colour.

Iulits Alexandrinus the Emperors Phyfitian faith, That thewater thercof diftilled and drunke caufeth eafie and fpeedy deliuerance, and expelleth the fecond ne or after-burthen in moft fpeedy manner.

He alfo faith, the leates boyled in red Wine, and applied to old wounds or vicers, doe mich good, and forward the cure, according to the doetrine of Galen in his fetienth booke de fimpl. med. facultat.

The root of a white Lilly ftamped and ftrained with wine, and ginen to drinke for two or three dayes together, expelleth the poyfon of the peftilence, and cauferh it to breake forth in blifers in the outward part of the skinne,aecording to the experience of a learned Gentlenran M.William Godorus, Sergeant Surgeon to the Qneenes Maieftie: who alfo hath eured many of the Dropfey with the inyce thereof, tempered with Barley meale, and baked in calses, and fo eaten ordinarily forfome moneth or fix weekes together with meate, but no other bread during that time.

\section{С н}

The Kindes.

7 Here be likewife fundry forts of Lillies, which we do comprehend vnder one generall name 1 in Englith, Red Lillies, whereof fome are of our owne countries growing, and others of beyond the feas, the which thall be diftinguifhed fenerally in this chapter that followeth.

$$
\text { T) The Defription. }
$$

I 7 He gold-red Lilly gtoweth to the height of two, and fometimes thee ctbits, and often higher than thofe of the common white Liily. 'The leaues be blacker and narrower, fet very thicke about the ftalke. The floures in the top be many, from ten to thirty floures, according to the age of the plant,and fertilitie of the foile, like in forme and greatneffe to thofe of the white Lilly, but of a red colcur tending to a Saffron, fprinkled or poudred with many little blacke fpecks, like to rude vnperfeet dranghts of cer taine letters. The roots be great bulbes, confiring of many clotes, as thofe of the white Lilly.

\section{D}

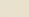


$\ddagger 2$ In Itead of the Plantaine leated red Lilly, defcribed and figured in this fecond place by ourt Author out of $T$ abernamont anus, for that I iudge both the figure and defcription counterfeit, I haue omitted rhem, and here giue you the many-floured red Lilly in his ftead. This hath a root like that of the laft defcribed, as alfo leaues and italkes; the floure alfo in thape is like that of the former, but of a more light red colour, and in number of floures it exceedeth the precedent, for fometimes it beares fix ty floures vpon one ftalke. $\neq$

$\dagger 3$ This red Lilly is like vnto the former, but not fo tall; the leaues be fewer in number; broader, and downy towards the top of rhe ftalke, where it beares fome bulbes. The floures in thape be like the former, faung that the colour hereof is more red,and thicke dafht with blacke fpecks. The root is fealy like the former.

4 There is another red Lilly which liath many leaues fomewhat ribbed, broader than the laft mentioned, but thorter, and not fo many in number. 'The ftalke groweth to the height of two cubits, and fometimes higher, whereupon do grow Houres like the former : among the foot-ftalks of which floures come forth certaine bulbes or cloued roots, browne of colour, tending vnto redneffe; which do fall in the end of Auguft vpon the ground, taking root and growing in the fame place, whereby it greatly encreafeth, for feldome or neuer it bringeth forth feed for his propagation.

I Lilium aureum.

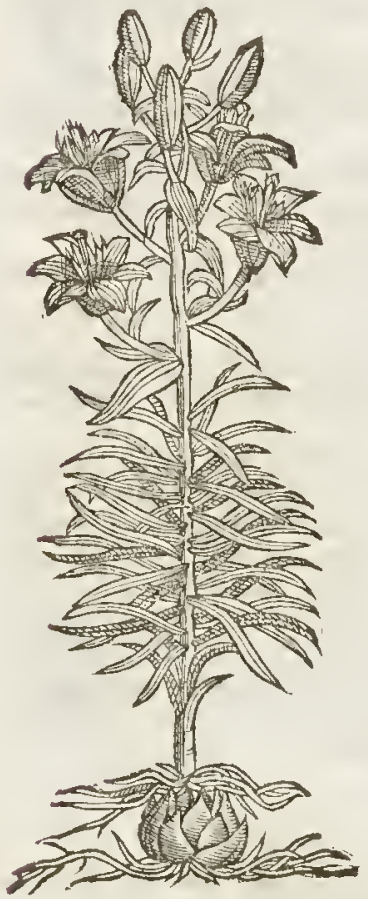

+2 Lilium rubrum. The red Lilly.

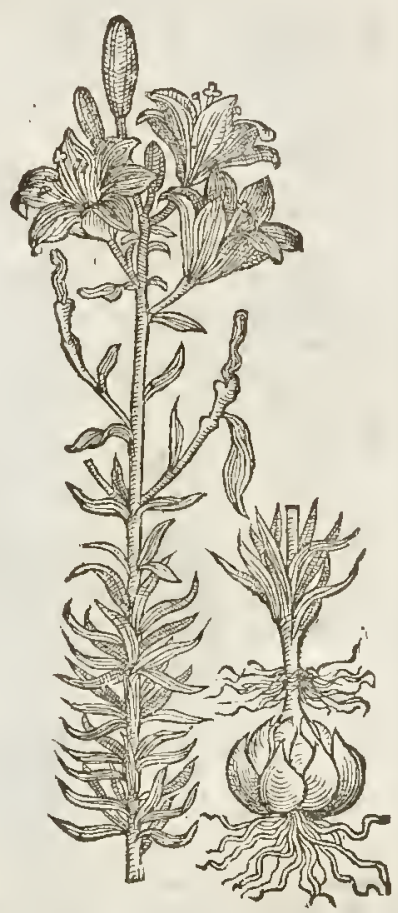

5 There is another fort of red Lillie hauing a faire fcaly or cloued root, yellow aboue, and browne toward the bottome; from which rifeth vp a faire ftiffe ftalke crefted or furrowed, of an ourer-worne browne colour, fet from the lower part to the branches, whereon the floures doe grow with many leaties, confufedly placed without order. Among the branches clofe by the ftem grow forth certaine clones or roots of a reddifh colour, like vnto the clones of Garlicke before they are pilled : which being fallen vpon rhe ground at their time of ripeneffe, do thoot forth certaine tender frings or roots that do take hold of the ground, whereby it greatly encreafeth. The floures are in thape like the other red Lillies, but of a darke Orange colour, refembling a flame of fire fpotred with blacke fyots.

$\ddagger 6$ This liath a much fhorter ftalke, being but a cubit or leffe in height, with leaues blac- 
kifh, and narrower than thofe a fore going. The fourcs, as in the reft, grow out of the tor of the falke, and are of a purplifh Saffron eolour, with fome blackinh fpors. The root in thape is like the precedent. $\ddagger$

$$
\text { II The Plite. }
$$

Thefe Lillies do grow wilde in the plowed fields of Italy and Languedoekc, in the monatrines and vallies of Hetruria and thofe places adiacent. They are conmon in our Englith gardens, as alfo in Germany.

Thefe red Lillies do floure commonly a little before the white Lillies, and fomctimes togecherwith then.

3 Lilium cruentum latifolium. The fieric red Lilly.

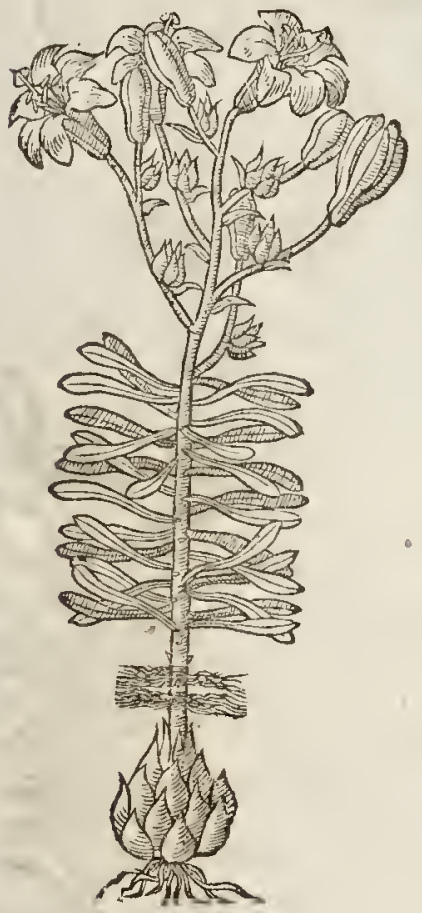

\pm 4 Lilins cruentumbulbiferum. Red bulbe-bearing Lilly.

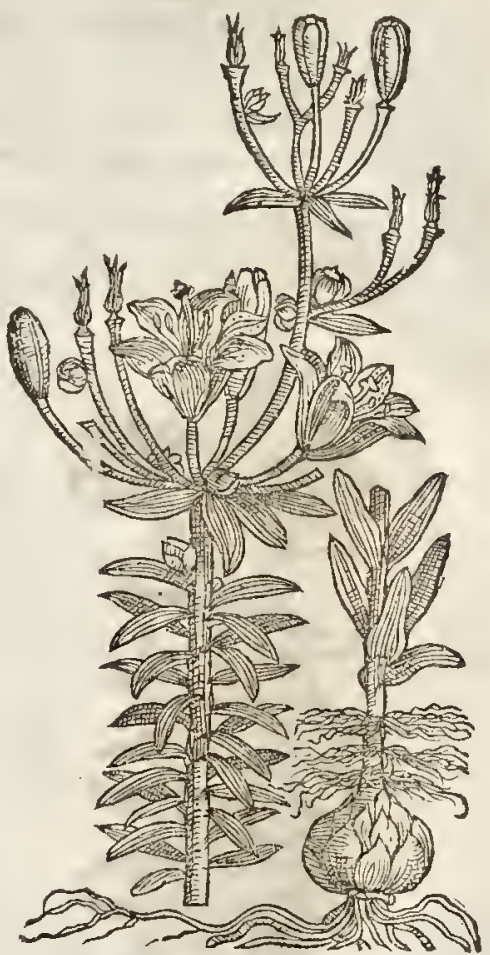

The Names.

* I The firft of thefe is thought by fome to be the Buthus cruentus of Hiprocrates; as alfo the Lilium purpuresm of Diofcordes: Yet Matthiolus and fone others would haue it his Hezzerocallis. Dodoneus and Bapt. Porta thinke it the Hyacintbus and ofmofindulos of the Poets, of which you fhall finde more hereafter. It is the Martagon Chymiftarum of Lobell, and the Lilium anveummajus of Ta-
bernamgntanus.

2 This is Martggon Chymiftarum alterum of Lobell. 3 This is Clufurs his Martag onbulbiferum

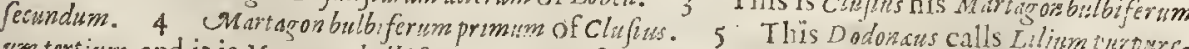

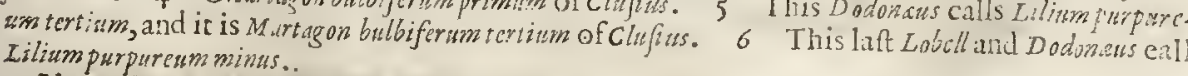

- I haue thought good here alfo to gite you that difcourfe touching the Pocts Hyacmth, which being trantlated out of Dodonews, was formerly vnfitly put into the chapter of Hyacinths; which pempt.2.lib. there onitted, and haue here reflored to his duc place, as you may feeby Dociouserts,

There is a Lilly which ond, Metamuph.lib. ro.calls Byacinthus, of the boy Frvacizathess, of whofebloud he feignath that this foure forng, whon he perithed as hewas phiyine wirh a poll, 
for whofe fake, he faith, that Apollo did print certaine letters and notes of his mourning. Thefe are hiswords:

\author{
Eccecruor, quifufus humo fignuucrat herbas, \\ Dc finit effecruor, Tyriogue nitentior of tro \\ Flos oritur, formamine capit guam Lilu, finon \\ Purpuress color his argenteus cffet inillis. \\ Non atis hoc Phebo eft, (us enim fuit anctor bonoris) \\ Ip fe fuos gemit us folijs infcribit, ó ai ai, \\ Flos habet inscriptum, funeftaque litera dhetta eft.
}

Which lately were elegantly thus rendred in Englifh by M. Sands :

Bchold ? the bloud which late the graffe had dy'de

Was now nobloud: from thence a fioure full blowne,

Fur brigliter than the Tyrian fearlet flione:

Whicl feem'd the fame, or did refemble right

A Lilly, changing but the red to white.

Nor fucontented, (for the Youth receiu'd

That grace from $P$ hrabus ) in the leates he weat'd

The fad inpreffion of his fighs, $\mathrm{Ai}, \mathrm{Ai}$,

They now in funerall characters difplay, \&c.

* 5 Liliurs cruentum fecundum caulem bulbulis donatum.

Red Lilly with bulbes growing along t the ftalke.

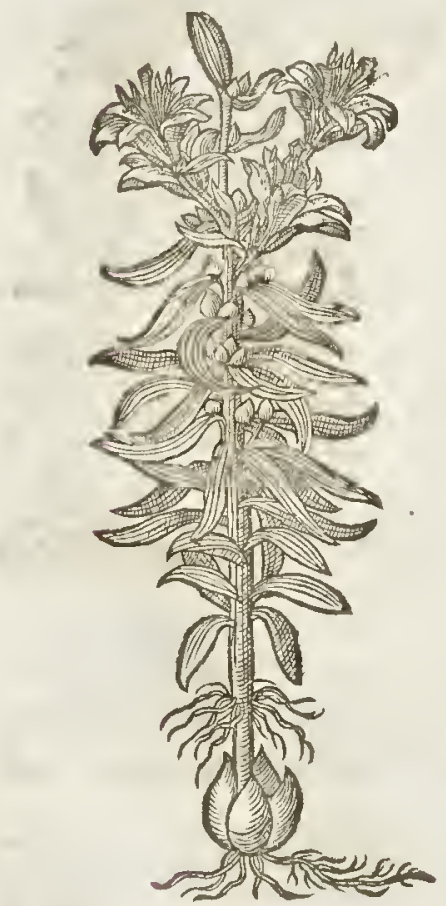

‡ Liliumpurpureum minus. The fmall red Lilly.

Theocritus alfo hath made mention of this Hyacinth, in Bions Epitaph, in the Ig, Eidyl. which Fidy/by fome is attributed to Mofchus, and made his third. The words are thefe:

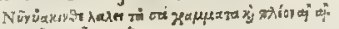

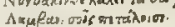

In Englion thus :

Now Iacinth fpcake thy letters, and once more

Imprint thy leaues with $\mathrm{Ai}, \hat{\mathrm{h}} \mathbf{i}$, as before.

Likewife 
Likewife virgill hath written hereof in the third Eclog of his Bucolicks.

Et me Phabus amat, Phabo fua femper apud me

Monerafunt, lowri of fune rubens Hyacinthas.

Phoebus loues me, his gifts I alwayes haue,

The e're greene Laurel, and the lacinth braue.

In likc manner alfo Nemefunus in his fecond Eclog of his Bucolicks:

Ie fine me, mifero mibi Lilia nigra videntur,

Pallentef gue Role, nec dulce rubens Hyacinthus:

At $s$ in venias, oc candida Lilia fient

Purpureaque Rofs, of dulce rubens Hyacint bus.

Withour tiee, Loue, the Lillies blacke do feeme;

The Rofes palc, and Hyacinths I deemc

Not louely red. But if thou com'ft to nie,

Lillies are white, rcd Rofe and Iacinths be.

The Hyacinths are faid tobe red which ouid calleth purple; for the red colour is fomtimes termed purple. Now it is thought this Hyacinthus is called Ferrugineus, for that it is red of a rufty iron colour : for as the putrifaction of braffe is named etirugo; fo the corruption of iron is called Ferrugo, which from the reddifh colour is ftilcd alfo Rubigo. And certainly they are not a few that would haue Color ferrugine us to be fo called from the ruft which they thinke Ferrugo. Yct this opinion is not allowed or by all men; for fome iudge, that Color ferrugineus is inclining to a blew, for that when the beft iron is heated and wrought, $w$ hen as it is cold againe it is of a colour neere vnto blew, which from Ferram (or iron) is called Ferrugineus. Thefe latter ground themfelues vpon $V i r g i l s$
and prefently calleth the fame blew. His words are thefe:

Ipferat em conto fabig it velifgue miniftrat,

Et fer ruginea frobue et at cor pora Cymba,

He thrufting with a pole, and fetting failes at large,

Bódies tranfports in
And then a little after he addes ;

Bódies tranfports in ferrugineous barge.

Carulcam aduertit puppim, ripeque propinguat.

He then turnes in his blew Barge, and the fhore

Approches nigh to.

And Claudius alfo, in his fecond booke of the carrying away of Proferpina, doth not a little con: firme their opinions ; whowriteth, That the Violets are painted, ferragine dulci, with a fweet iron
colour.;

Sanguineo plendore rofas, vaccineanigro

Induit, of anlciviolas ferrngine pingit.

He trimmes the Rofewith bloudy bright,

And Prime-tree berries blacke he makcs,

And decks the Violet with a rweet

Darke iron colour which it takes.

But let vs returne to the proper names from which we hatic digreffed. Moft of the larcr Herbar rifts do call this Plant Hyacinthus Poeticus, or the Poets Hyacinth. Paufanias in his fccond bookc of his Corinthiackes hath made mention of Hyacintbus called of the Hermonians, Comof andalos, fet. ting downe the ceremonies done by them on their feftiuall dayes, in lonour of the goddeffe chthonia. The Priefts (fauth lic) and the Magifrates for that yearebeing, doe leade the troupe of the pompe; the women and men follow after; the boyes folemnly leade fortb the goddeffewith a ftately thew : thcy go in white veltures, with garlands on their heads made of a floure which the Inhabitants call comofandalos, which is the blew or sky-coloured Hyacinth, hating the marks and letters of mourning as aforcfaid.

The foure of the red Lilly (as fod The Rature. of anearthly cffence. confumc away.

T. The Vertues.

The leaues of the herbe appliec are good againt the ttinging of Serpents. The fame boiled and tempered with vineger are good againt burnings, and healc green wounds $A$
and Vlcers. The root rofted in the embers, and pounded with oyle of Rofes cureth burnings, and foftneth $C$
hardncfee of the matrix. 
D The fame ftamped wth honcy cureth the wounded frnewes and members out of ioynt. It takes away the morphew, wrinkles, and deformitic of the face.

E Stamped with Vincger, the leaues of Henbane, and wheat mealc, it remoueth hot fincllings of the ftones, the yard, and matrix.

F The roots boyled in Wine (faith pliny) caufetly the comes of the fect to fall away within fer dayes, with remouing the medicine vntill it haue wrokght his effect.

G Being drunke in honied water, they driuc out by fiege vnprofitable bloud.

\section{Cu s. 104: Of Momataine Lillies: \\ T The Defcription.}

i THe great mountaine Lilly hath a cloued bulbe or faly root like to thofe of the fied Lilly, ycllow of colour, icry fmall in refpca of the greatnefle of the plant : From the which rifeth vp a ftalke, fometimes two or three, according to the age of the plant where of the middle ftalke commonly turneth from his roundneffe into a flat forme, as thofe of the white Lilly of Conftantinople. Vpon thefe ftalkes do grow faire leates of a blackin greene colour, in roundles and fpaces as the leates of Woodroofe, not vnlike to the leaues of white Lillie, but fmaller at the top of the ftalkes. The floures be in number infinite, or at the leaft hard to be counted, very thicke fet or thruft together, of an oucrworne purple, fpotted on the infide with many fmall fpecks of the colour of ruity iron. The whole floure doth turne it felfe backew ard at fuch time as the Sunne hath caft his beames vpon it, like vnto the Tulipa or Turkes Cap, as the Lilly or Martagon of Conftantinople doth; from the middle whereof doe come forth tender pointalls with fmall dangling pendants hanging thereat, of the colour the floure is fpotted with.

1 Lilium montanum majus.

The great mountaine Lilly:

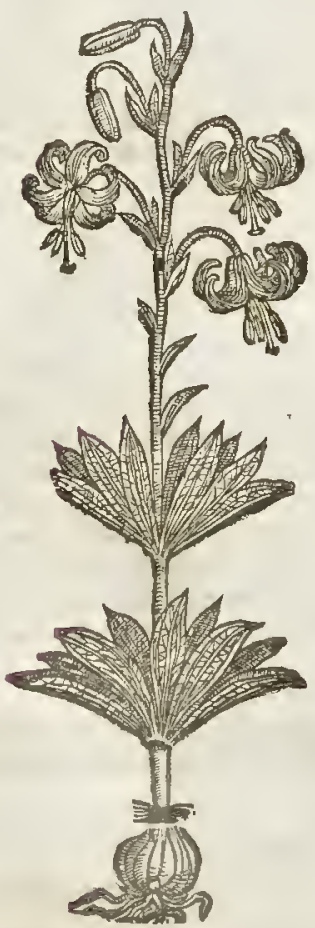

- Liliam montanum minus? Small Mountaine Lilly: Silium Nhartagon

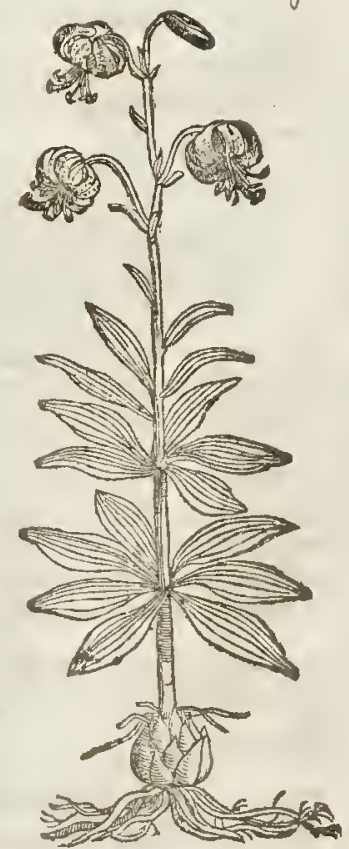


2 The fimall mountaine Lilly is very like vnto the former in reot, leafe, falke, and floures :differing in thefe points; The whole plant is ffer, the falke neuer leaucth his round forme, and beareth fewer floures.

\# There are two or three more varicries of thefe plants mentioned by clicfus; the one of this lefferkinde, with floures on the outfide of a flefh colour, and on the infide white, with b'achish fpots; as alfo another wholly whitewithout fpots. The third varietie is like the firf, but difiers in that the foures blow later, and mell fweet.

Thefe plants grow in the woody mountaines of Styria and Hungarie, and alfo in fuch like places on the North of Francfort, vpon the ivoenc. $\ddagger$

The fmall fort I haue had many yeares growing in my garden : but the greater I haue not had till of late, giten me by my louing friend M. Iames Garet Apothecarie of London.

$$
\text { 91 The Time. }
$$

Thefe Lillics of the mountaine foure at fuch time as the common white Lilly doth,and fometimes fooner.

$$
\text { The Names: }
$$

The great mountaine Lilly is called of Tabernamontanus, Liliwm Saracenicum, receiued by Mafter Garret aforefaid from Linc in Flanders, by the name of Xurtigon Impcriale : of fome, Lilium Sardcenicum mas: It is Hemerocallis flore rubello, of Lobcl.

The finall mountaine I.illy is called in I atine; Litium mont anum, and Litium fyluefrè : of Dodonens, Hemerocallis : of others, Martazon : but neither truly; for that there is of either, other Plants properly ealled by the fame names. In high Dutch it is called Goldwute, from the yellownefie of the roots : in low Dutch, Lilikeng van caluarien: in Spanifh, Lirio Amarillo : in French, Lys Sawvage : in Englifh, Mountane Lilly.

T. The Nature and Vertues.

There hath not beenc any thing left in writing cither of the nature or vertues of thefe plants: notwithftanding we may deeme, that God which gaue them fuch feemely and beautifull fhape, hath not left them without their peculiar vertues; the finding out whereof weleaue to the learned and iridultrious Searcher of Nature.

\section{Cн а р. 105. Of the Red Lillie of Conftantinople.}

I Lilium Bizantinum.

The red Lilly of Conftantinople.

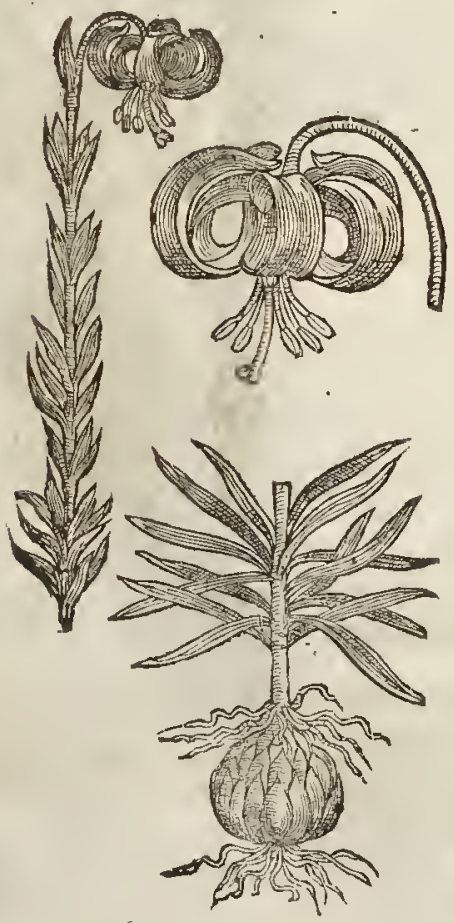

\$ 2 Lilium Byzantinum flo. purpuro anguineo. The Byzantine purplifh fanguine-coloured Lilly.

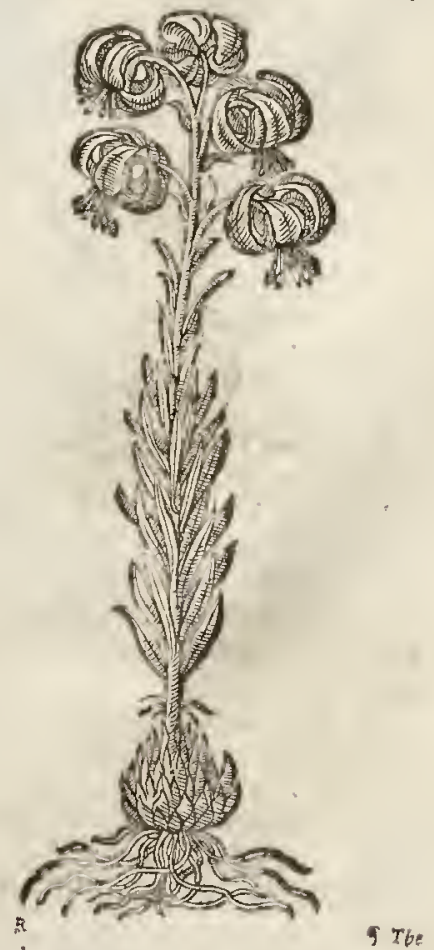



his naturall roundneffe into a flat forme, like as doth the great mountaine Lilly : vpon which ftalk grow fundry faire and moft beautifull floures, in thape iike thofe of the mountaine Lilly, but of greater beauty, feeming as it were framed of red wax, tending to a red leade colour. From the middle of the floure commeth forth a tender pointall or peftell, and likewife many finall chines tipped with loofe pendants. The floure is of a reafonable pleafant fauour. The leaues ate confufedly fet about the ftalke like thofe of the white Lilly,but broader and thorter.

$\ddagger 2$ This hath a large Lilly-like root, from which arifeth a ftalke fome cubic or more in height, fet eonfufedly with leaules like the preecdent. The floures alfo refermble thofe of the laft deferibed, bur vfually are more in number, and they are of a purplinh fanguine colour.

\section{$\ddagger 3$ Lalium By Zantinum flo.dilutern- bente.}

The light red Byzantine Lilly.

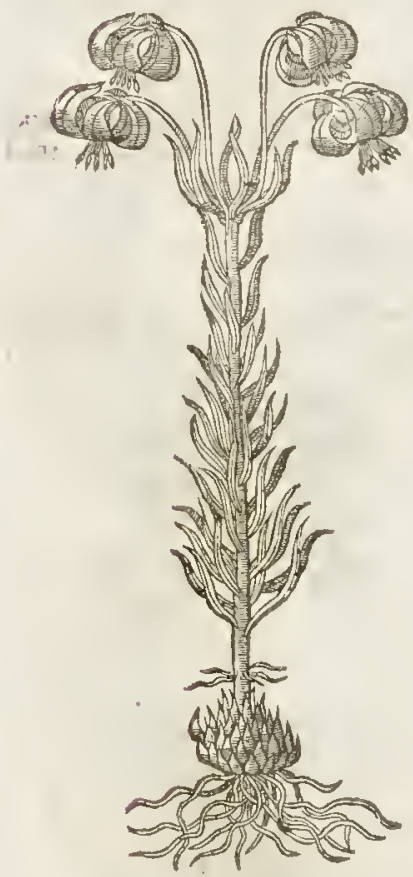

$\ddagger 4$ Liliwm Byzantisum miniatum polyanthos.

The Vermilion Byzantine manyfloured Lilly.

$$
\text { Silium chalcedon ic }
$$

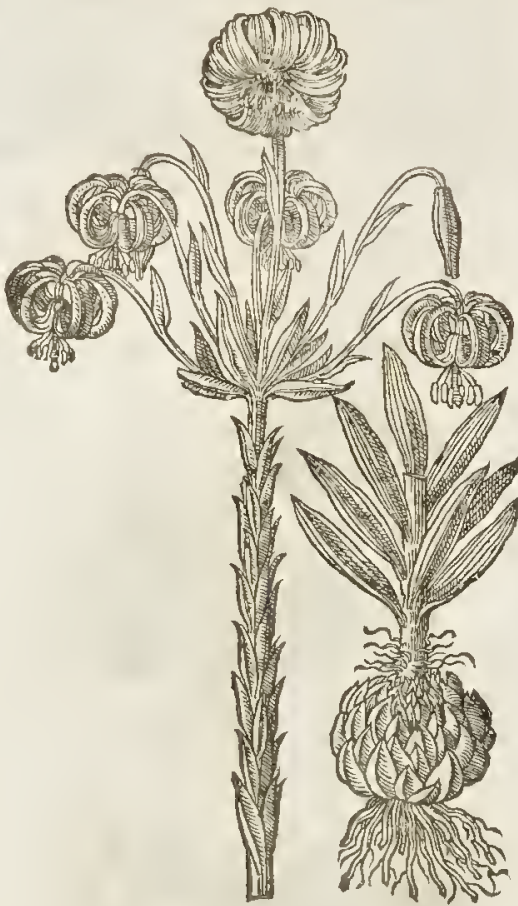

3 This differs little from the laft, but in the colour of the floures, which ate of a lighter red eolour than thofe of the firft deferibed. The leaues and ftalkes alfo, as Cluguns obferuetl, are of a lighter zreene.

4 This may alfo more fitly be termed a varietie from the former, than otherwifu : for aceording to Chr fus, the difference is onely in this, that the floures grow equally from the top of the falke, and the middle flourerifes higher than any of the reft, and fomet imes confifts of twelue leaules as it were a twinne, as you may perceine by the figure.

$$
\text { बा The Time. }
$$

They floure and flourith with the other Lillies. 


\section{I B. I. Of the Hiftory of Plants.}

T. The Names.

The Lilly of Conftantinople is called likewife in England, Martagon of Conftantinople : of Lobel, Hemerocallis Chalcedonica, and likewife Lilium Bizantinum: of the Turks it is called Zufiniare: of the Venetians, Marocali.

\section{- The Nature and Vertues.}

Of the nature or vertues there is not any thing as yet fet down,but it is efteemed efpecially for the beautic and rareneffe of the floure; referring what may be gathered hereof to a further confideration.

\section{₹ C н а р. гоб. \\ Of the narrow leaued reflex Lillies. \\ T The Defcription.}

\# $\mathrm{T}$ He root of this is not much vnlike that of other Lillics, the ftalke is fome cubir high, or better; the leaues are many and narrow, and of a darker green than thofe of the ordinarie Lilly; the floures are refex, like thofe treated of in the laft chap. of a red or Vermilion colour. This thoures in the end of May : wherefore Chufues calls it Lilinm ru brum pracox, The early red Lilly.

I Liliwm rubrum angufifolium.

The red narrow leaued Lilly, Lilium Oomponime

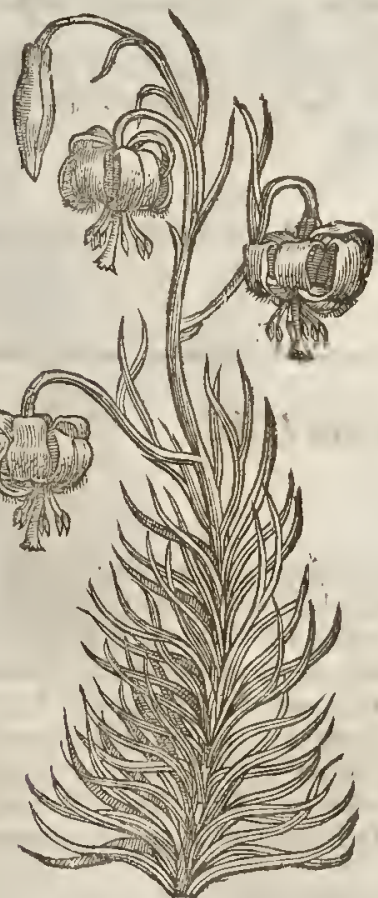

*3 Lilium mont. flore flatro purnctato. The yellow mountaine Lilly with the fpotred floute.

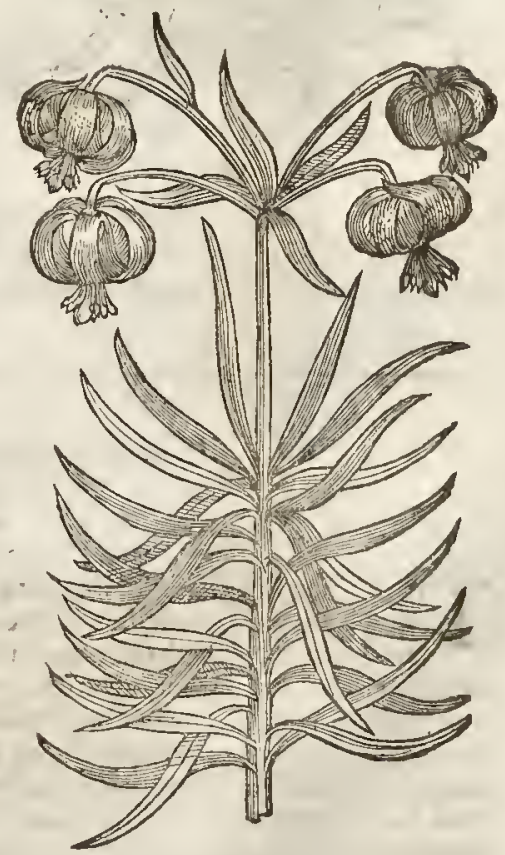

2 This Plant is much more beautifull than the latt de feribed; the roots are like thofe of LiIlies, the falke fome cubit and an halfe in height, being thicke fet with finall grafie leatues. The floures grow out one aboue another, in thape and colowr like thofe of the laft defcribed, but oft- 
times are more in number, fo that fome one ftalke hath borne fome $t^{8}$ foures. The root is much like the former.

\$ Lilium mont. fore faruonon punctato. The yellow Mountaine Lilly with the vifpotted floute.

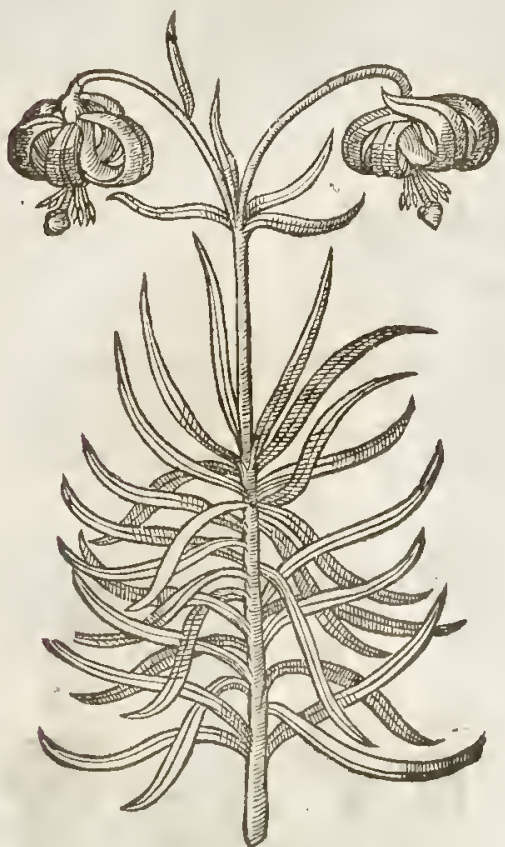

This in roots is like thofe afore defcribed, the ftalke is fome zeubits high, fet eonfuredly with long narrow leaues, with three confpienuns nerues running alongft them. The floures are at firtt pale eoloured, afterwards yellow, eonfifting of fix leaues bended baeke to their ftalkes, \& marked with blackifh purple fpots.

4 There is alfo another differing from the laft deferibed onely in that the foure is not fpotted, as that of the former.

$$
\text { q The Place. }
$$

Thefe I.illies are thought Natiues of the Pyrenean mountaines, abd of late yeares are become Denizons in fome or our Englinh gardens.

$$
\text { If The Time. }
$$

The firf (as I hauc faid) floures in the end of May : the reft in Itune.

$$
\text { T The Names. }
$$

I This is ealled by Clufurs, Liliunn rubrumprocos.

2 Clufurs names thịs, Lilitum rubrumprecox 3. angufifolium. Lobel files it, Hemeron. callis Macedonica, and Martagon Pomponcum.

3 This is Lilium flau fore maculis diftin. ctum of Clufins, and Lilium mont anum flatio flo. of Lobel.

4 This being a varietie of the laft, is called by Clufus, Lithum flau fore macul is nom diftinttum.

T The Temper axd Vcrtucs.

Thefe in all likelihood earnot much differ from the temper and vertues of other Lillies, which in all their parts they fo muel refemble. $¥$

\section{С н а . 107. Of the Perran Lilly. \\ IT The Defription.}

$\mathrm{T}$ He Perfian Lilly hath for his root a great $w$ hite bulbe,differing in thape from the other Lil lies, hating one great bulbe firme or folid, full of juyee, which eommonly each yeare fetteth off or enereafeth one otherbulbe, and fometimes more, which the next veare after is taken from the mother root, and fo bringeth forth fueh foures as the old plant did. From this root rifeth vp a fat thieke and ftraight itemme of two eubits high, whereupon is placed long narrow leaues of a grecne colour, deelining to blewnes as doth thofe of the woade. The floures grow along th the naked part of the ftalke like little bels, of an ouer-worne purple eolour, hanging down their heads, ctery one hauing his owne foot-ftalke of two inehes long, as alfo his peftell or elapper from the middle part of the flonre; whieh being patt and withered, there is not found any feed at all, as in other plants, but is inereafed onely in his root.

$$
\text { of The Place. }
$$

This Perfian Lilly groweth naturally in Perfia and thofe plaees adiaeent, whereof it tooke his -name, and is now (by the indufrie of Trauellets into thofe countries, loners of Plants) made a Wraizen in fome fcw of our London gardens. 
Th is plant floureth from the beginning of May, to the end of Iune:

This Perfan Lilly is calledin The Names.

This Perfian Lilly is called in Latine, Lilium Perficum, Lilium Sufarmim, Penmacio Perfiano, and England; but which of both is vncertaine when as he fent the figure of this Plant vnto Alphonfus Pancius, Phyfition to the Duke of Ferrara,

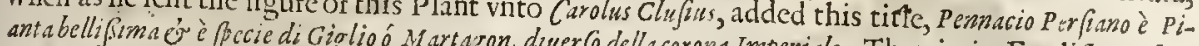
moft elegant plant Pennacio led the Crowne Imperiall.

Lilivem Perfisum.

The Perfan Lilly.
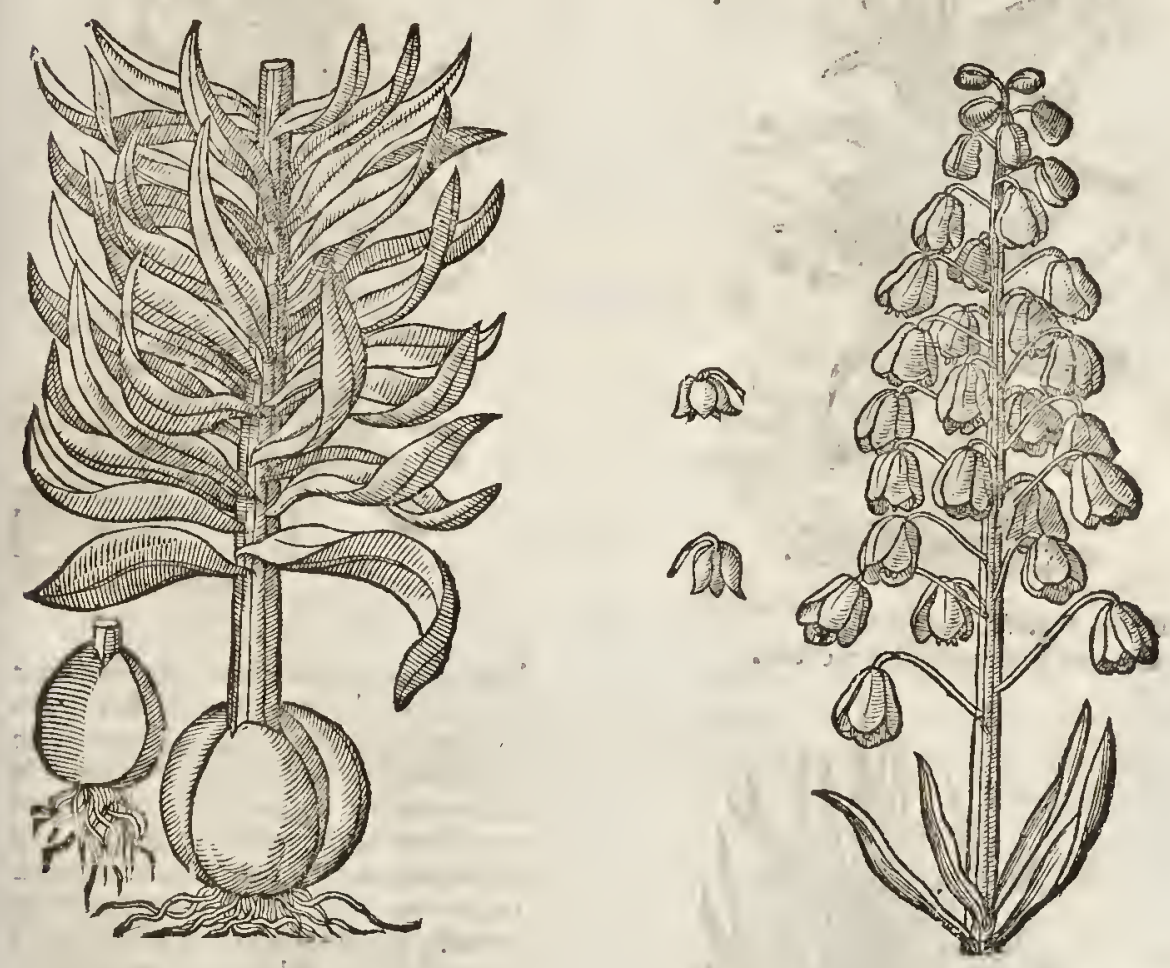

Ti The Nature and Vertives?

There is not any thing knowne of the nature or vertues of this Perfian Lilly, efteemed as yet for his rarcneffe and comely proportion; although (if I might be fo bold with a ftranger that hath vouchfafed to trauell fo many hundreds of finiles for our acquaintance) we haue in our Engtifh fields many fcores of floures in beauty far excelling it.

\section{С.на Р. 108. Of the Cromne fmperiall. \\ 9T The Descripsion.}

Te Crowne Imperial hath for his root a thicke firme and folid bulbe, conered with a yellow: 1 ifh filme or skinne, from the which rifeth vp a great thicke fat ftalke twn cubits high, in the
bare and mked part of a darke ouew one dusky purple colour. The leaues grow the ftalke like thofe of the white Lilly, but narrower : che four. The leatues grow confufedly about compafing it round in forme of an Imperiall crowne

$$
\text { Ii }_{3} \text { (whereof it tooke his name) hangitg their }
$$


Corons Inperialis. The Crowne Imperiall.

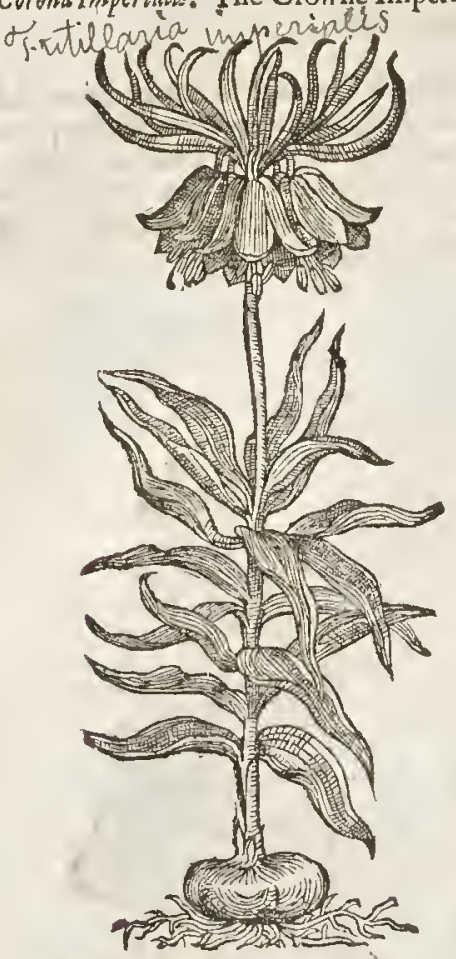

Corona Imperialis cum femine?

Crowne Imperiall with the feed:

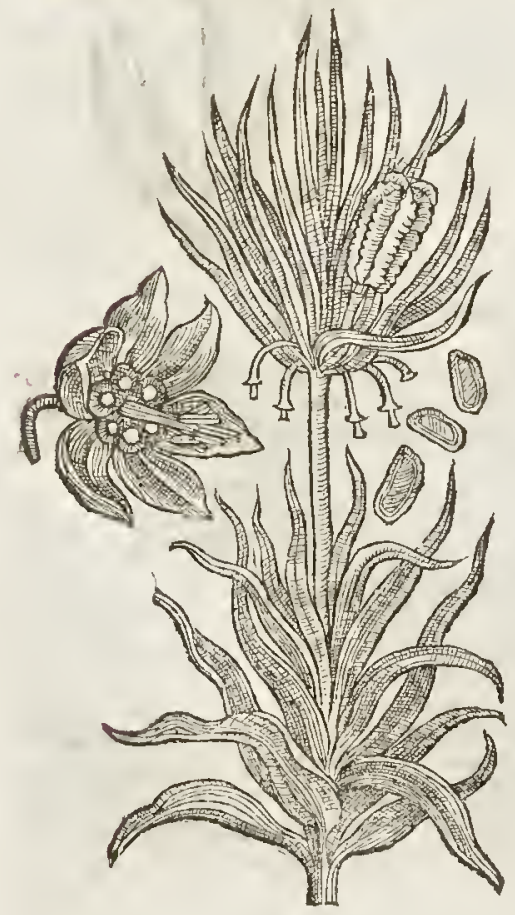

Corona Imperialis duplici corona.

The double Crowne Imperiall.

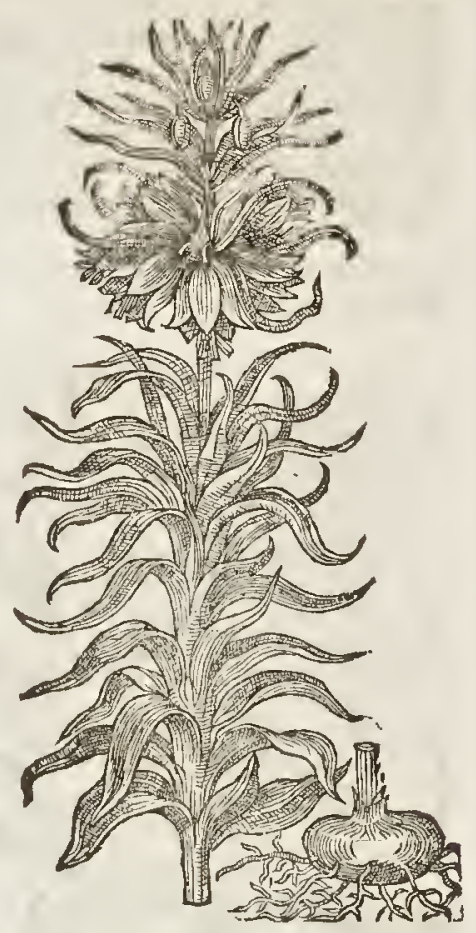

heads downward as it were bels : in colour it is yellowith; or to giue you the true colour, which by words otherwife cannot be expreffed, if you lay fap berries in fteepe in faire water for the fpace of two houres, and mix a little Saffron with that infurion, and lay it von paper, it theweth the perfect colour to limne or illumine the foure withall. The backfide of the faid floure is ftreaked with purplifh lines, which doth greatly fot forth the beauty rhereof. In the bottome of each of thefe bells there is placed fix drops of moft cleere thining. fweet water, in taft like fugar, refembling in thew faire Orient pearles; the which drops if you take away, there do immediately appeare the like: notwithftanding if they may be fuffered to ftand fill in the floure according to his ow ne nature, they wil neuer fall away, no not if you ftrike the plant vntill it be broken. A mongtt thefe drops there ftandeth out a certaine peitell, as alfo fundry fmal ehiues tipped with fmall pendants like thofe of the Lilly : abone the whole floures there growes a tuft of green leaues like thofe vpon the ftalke, but fmaller. After the floures be faded, there fo!low couls or feed-veffels fix fquare, wherein 
is contained flat feeds, tough and limmer, of the colour of Mace. The whole plant, as well roots as floures, do fauour or fmell very like a Fox. As the plant groweth old, fo doth it wax rich, bringing forth a Crowne of floures anongft the vppermolt greeneleatics, which fome make a fecond kinde, although in truth they arebut one and the felfe fame, which in time is thought to grow to a triple crowne, which hapneth by the age of the root, and fertilitie of the foile; whofe figure or tipe I hate thought good to adioyne with that picture alfo which in the time of his infancic it had.

$$
\text { If The Place. }
$$

This plant likewife hath been brought from Conftantinople among ft other bulbous roots, and made Denizons in our London gardens, whereof I haue great plenty.

$$
\text { वा The Time. }
$$

Ir floureth in Aptill, and fometimes in March, when as the weather is warme and pleafant. The feed is ripe in Iune.

\section{This rate $\&$ ftrate IT The Names.} doe call it Causle Lle, and Tufi dne call it Cauale lale, and $T u f a t$. And as diucrs haue fent into thefe parts of thefe roots at fundry times, fo hauc they likewife fent them by fundry names; fome by the name Tufai; others, Toufait, and $T$ iyfchinchi, and likewife $T$ urfani and Turfanda. $\neq$ Clufius, and that not without good reafon, iudgeth this tobe the Hemerocallis of Diof corides, mentioned lib.3. cap. 20 . $f$

$$
\text { II The Nature andV crtues. }
$$

The vertue of this admirable plant is not yet knowne, wither his faculties or temperature in working.

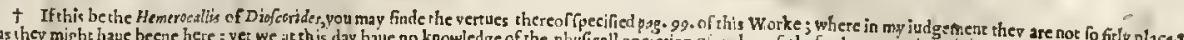

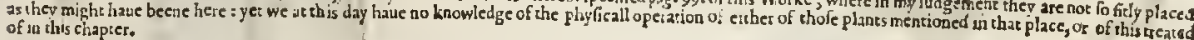

\section{H A P. 109. Of Dogs Tootb:}

\section{IT The Defcription.}

I Tere hath not long fince beene found out a goodly bulbous roored plant, and termed Satyrion, which was fuppofed to be the true Satyrion of $D$ iof corides, after that it was cherined, and the vertues thereof found out by the fudious fearchers of nature. Little difference hath bin found betwixt that plant of Diofcorides and this Dens caninus, except in the colour, which (as you knowv) doth commonly vary according to the diuterfitic of places where they grow, as it falleth out in Squilla, Onions, and the other kindes of bulbous plants. It hath moft commonly two leaues, very feldome three; which leafe in thape is very like to w Alium Vrfinum, or Ramfons, though farre leffe. The leaues turne downe to the groundward; the falke is tender and fiexible like to Cyclamen, or Sow-bread, about an handfull high, bare and without leaues to the roor. The proportion of the fourc is like that of Saffron or the Lilly Houre, full of ftreames of a purplifh white colour. The root is bigge, and like vnto a date, with fome fibres growing from it : vnto the faid root is a finall flat halfe round bulbe adioyning, like vnto Gladiolus, or Corn-flag.

2 The fecond kinde is farre greater and larger than the firf, in bulbc, italke, leaues, foure, and cod. It yeeldeth two lcaues for the mont part, which do clofe one within anorher, and at the firft they doe hide the floure (for fo long as it brings not out his foure) it feemes to lauc but one leafe like the Tulipa's, and like the Lillies, though fhorter, and for the molt part broader; wherefore I haue placed it and his kindes next vnto the Lillies, before the kinds of 0 rchis or ftones. The leaues which it beareth arc fpotted with many great fpots of a darke purple colour, and narrow below, but by little and little toward the top wax broad, and after that grow to be fharpe pointed, in form fomervhat necre Ramfons, but thicker and more olcous. When the leaues be wide opened the floure theweth it felfe rpon his long weake naked falke, bowing toward the earth-ward, which floure confitteth of fix very long leaucs of a fine delayed purple colour, which with the hear of the Sunne openeth it felfe, and bendeth his leates backe againe after the manner of the Cyclamen floure, within which there are fix purple chitues, and a white three forked ftile or peftell. This flourc is of no plcafant fmell, but commendable for the beauty: when the foure is faded, there fucceedcth a three fquare huske or head, wherein are the feeds, which are very like them of Leucnium butbofurs preco.x; but longer, flenderer, and of a yellow colour. The root is long, thicker below than aboue, fetwith many white fibres, waxing very tender in the vpper part, liauing one or more off-fets, or young thoots, from which the ftalke arifeth out of the ground (as hath been faid)britging forth two leaues, and not three, or oncly one, fate when it will not foure. 
3 The third kinde is in all things like the former, faue in the lcaues, which are narrower,arid in the eolour of the floure, which is altogether white, or confiting of a colour mixt of purple and white. Wherefore fith there is no other differenee, it thall fuffiee to hate faid thus mueh for the deleription.

The Place.

Thefe three plants grow plentifully at the foot of certain hills in the greene and moift grounds of Germanie and Italy, in Styria not far from Gratz, as alo in Modena and Bononia in Italy, and likewife in fome of the choiee gardens of this countrey.

$$
\text { I The Time. }
$$

They floure in Aprill, and Cometimes fooner,as in the middle of March.

I Dens caninus.

Dogs tooth.

Enthrominem 6 tens-camis.

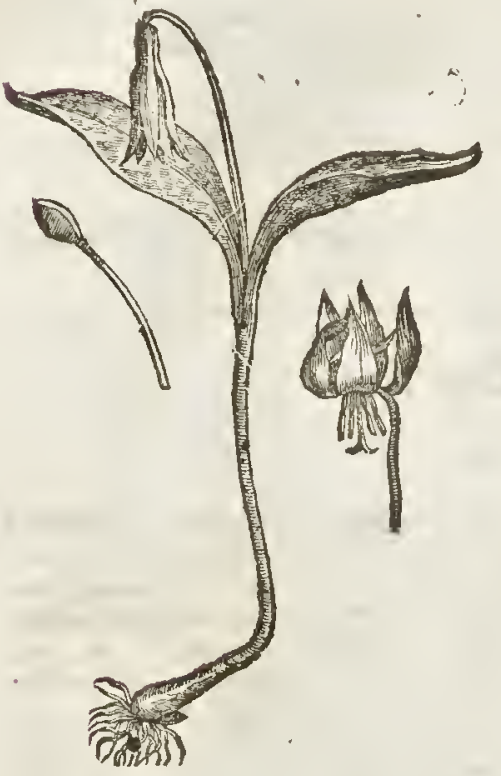

2 Dcns caninus flore albo anguftioribus folys. White Dogs tooth.

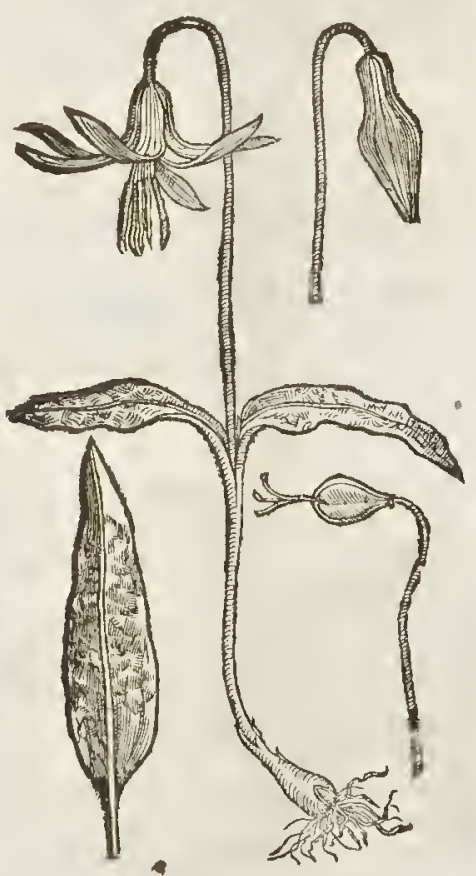

ขा The Names.

This plant is called in Latine; Dens caninus ; and fome haue iudged it Satyrium Erythronitm. Matthiolus ealls it Pfertobermodactylus. The men of the eountrey where it groweth eall it $S_{\text {cholt }}$ wurts: and the Phyfitians about Styria eall it Dentali. The fecoud may for diftinations fake be termed Dens caninus fore albo, anguftioribus foliys; that is, Dogs tooth with the white floure and nar: row leaties.

\section{If The Nature.}

Thefe are of a very hot temperament, windic, and of an exerementitious nature, as may appeare by the vertues.

A The Women that dwell about the plaee where thefe grew, and do grow, haue with great profit put the dried meale or pouder of it in their ehildrens pottage, againft the wormes of the belly.

3. Being drunke with Wine it hath been proued maruelloufly to affwage the Collieke paffion.

It ftrengthneth and nourifheth thebody in great meafure, and being drunke with water it eureth eliildren of the falling fiekneffe. 


\section{Chа в. 110. Of Dogsfones. \\ I The Kindes.}

Tones or Tefticles, as Diofcorides faith, are of two fores, one named cynoforchis, or Dogs ftones, the other Orchis Serapias, or Serapias his ftones. Butbecaufe there be many and findry orher forts differing one from another, I fee not how they may be contained vnder thefe two kinds onely : therefore I haue thought good to diuide them as followeth. The firft kind we haue named. Cynoforchis, or Dogs ftones : the feeond, Tefticulus exorionis, or Fooles ftones : the third, Tragorchis, or Goats ftones : the fourth, orchis Serapias, or Serapia's ftones: the fiftl, Tefticulus odoratus, or fweet fmelling ftones, or after Cordus, Tefficul lus Pumilio, or Dwarfe ftones.
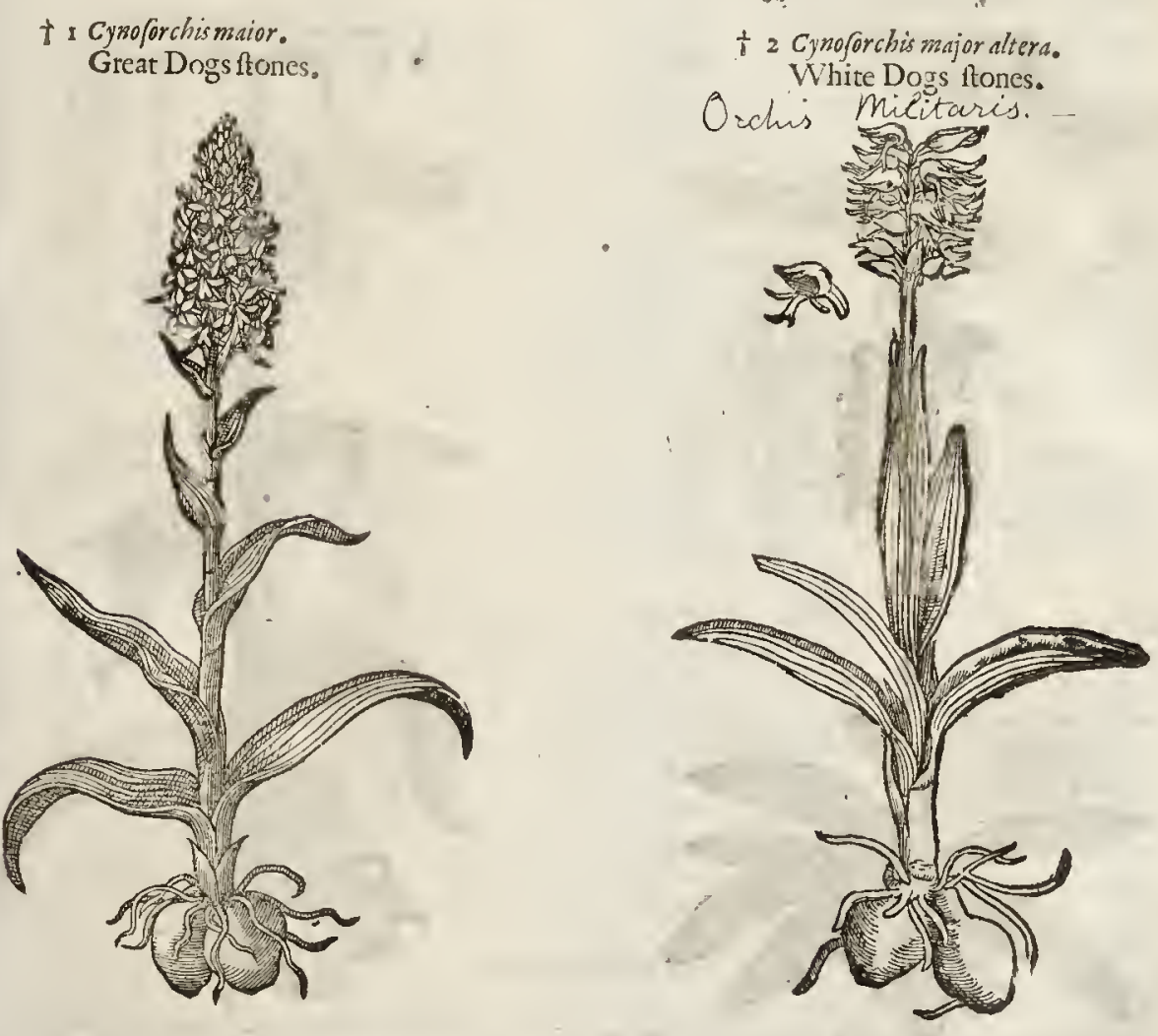

TT The Deription.

Reat Dogs ftones hath foure, and fometimes fiuc, great broad thicke leanes, fomwhat like thofe of the garden Lilly, but fmaller. The italke rifetl vp a foot or more in red floures thickht; at the top whereof doth grow a thicke tuft of carnation or horfe-flefh colouin fhape like to an open hood or helmet. And from the hollow place there liangeth purple fpots, ragged chive or taffell, in or helmet. And from the hollow place there liangeth forth a certain The roots be round like vnto the ftone the skinne of a Dog, or fome fuch other foure footed beaft. than the other, whereof the higheft or vppermo th is the fnaller, but finging fomewhat thorter moft is the greaft lige highelt or vppermoft is the fmaller, but fuller and harder. The lower2 Whitifh Dogs ftones and molt wrinkled or thriueled, not gond for any thing.

${ }^{2}$ thofe of the firf kinde. The ftalke is a fnan mooth, long broad lcanes, bur leffer and narrower than the fame round about. His f ikic four f pan long, fet with fue or fix leaues clafping or embracing 
purple coloured floures, fported on the infide with many fnall purple fpots and little lines or ftreakes. The fmall fioures are like an open hood or helmet, hauing hanging out of euery one as it were the body of a little man without a head, with armes ftretched out, and thighes ftradling abrond, after the fame manner almoft that the little boyes are wont to be pictured hanging out of saturnes mouth. The roots be like the former.

3 Spotted Dogs ftones bring fortl narrow leaues, ribbed in fome fort like vnto the leaues of narrow Plaintaine or R ib-wort, dant with many blacke ftreakes and fpots. The ftalke is a cubit and more high : at the top whereof doth grow a tuft or eare of violet-coloured floures, mixed with a darke purple, but in the hollownelfe thercof whitin, not of the fame forme or fhape that the others are of, but leffer, and as it were refembling fomewhat the floures of Larkes-fpur. The roots belike the former.

4 Marilh Dogs ftones liaue many thicke blunt leaues next the root, thick ftreaked with lines or nerues like thofe of Plantaine. The floure is of a whitifn red ot carnation : the falk and roots be like the former.

† 3 Cynoforchis maculata. Spotted Dogs ftones.

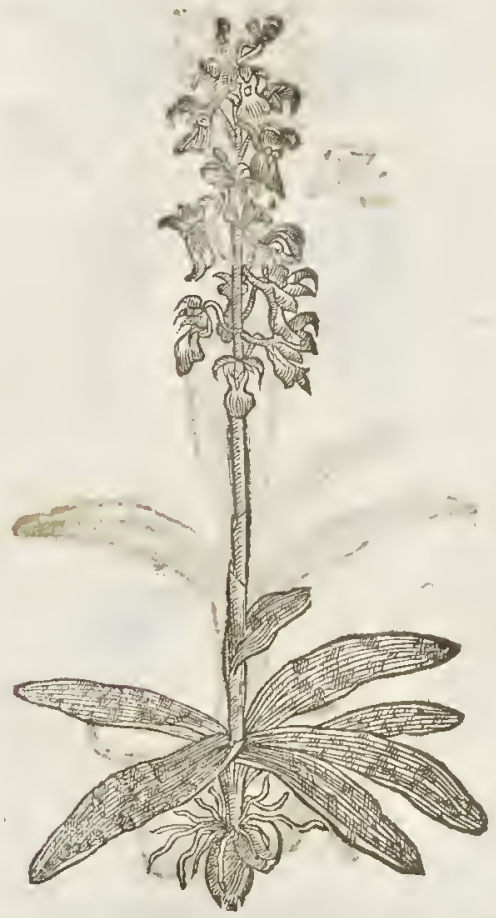

‡ 5 This hath fite or fix little leaues; the ftalke is fome handfull or better in height, fet about with fonew hat leffe leaues : the tuft of floures at the top of the ftalke are of a purple colour, finall, with a white lip diuided into foure partitions hanging downe, which alfo is lightly fpotted with purple; it hath a little fpurre hanging downe on the hinder part of each floure. The feed is finall, and contained in fuch twined heads as in other plants of this kinde. The roots are like the former, but much leffe. $\ddagger$

\section{T The Place.}

There kindes of Dogs ftones dogrow in moift and fertile medowes. The marith Dogs ftones grow for the moft part in moift and waterifh woods, and alfo in marifh gtounds. $¥$ The 5 gtowes in many hilly places of Auftria and Germanic. ま

9 The Time.

They floure from the beginning of May to the midft of Auguf:

4 Cynoforchis paluftr is.

Marifh Dogs ftones.

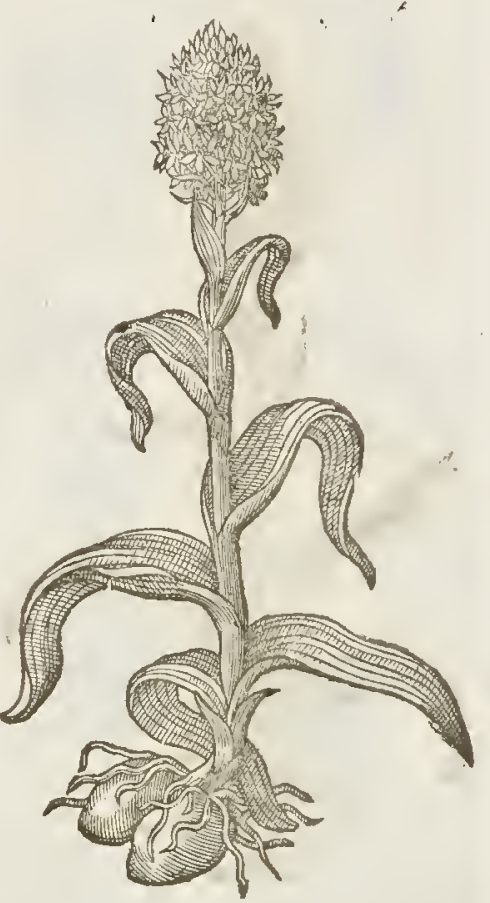




\section{The Names.}

The firft and fecond are of that kindewhich Diofcorides calleth Cynoforchos; that is. in Englin,

Dogs ftones, after the common ot vulgar fpeceh; the one the greater, the other the leffer.

$¥ I$ This is Cynoforchis prior of Dodoncues; Cynoforchis noftra major of Lobei.

2 Dodonaus names this Cynoforchis altera. Lobel, Cynoforchis majoris fecunda jpecics.

3 This LoSel calls Cynoforchis Delpbinia, Ec. Tabern. Cynoforchis masulata.

4 Dodonaus ealls this, Cynoforchis tertia: Lobel, Cyroforchis major altera nofleas: Tabermama. Cynoforchis major quarta.

5 This is Chuffus his Orchis $P$ annonica quarta.

T The Temperature.

Thefe kindes of Dogs ftones be of temperatute hot and moift; but the greater or fuller ftone feemeth to have mueh fuperfuous windineffe, and therefore being deunke it firreth vp fienhly lunt.

\$5 Cynoforchis minor Pannnonica. The leffet Auftrian Dogs ftones. Orchis nsturlata

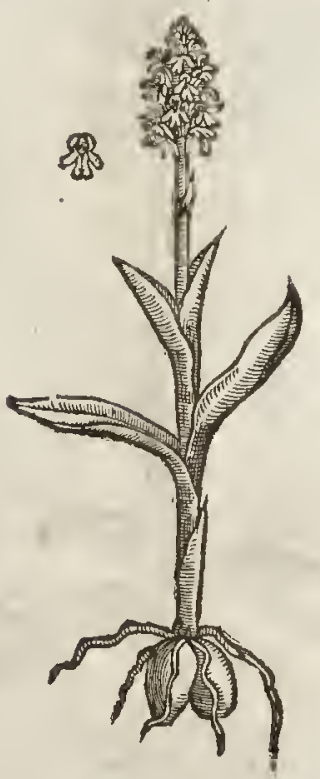

The fecond, whieh is leffer, is quite eontrario in nature, rending to a lot and dry temperature; therefore his toot is fo far from moning venerie, that contrarivife it ftaicth and keepeth it backe, as $G$ allen teacheth.

He alfo affirmeth, that Serapia's ftones are of a more dry facultic, and doe not fo much preuaile to ftirse vp the luit of the fleth.

\section{Tf The Vertues.}

Diofcorides writeth that it is reported, That if men doe eate of the great full or fat roots of there kindes of Dogs Rones, they caufe them to beget male ehildren; and if women eate of the leffer dry or barren root which is withered or thriueled, they fhall bring forth females. Thefe are fome Doctors opinions onely.

It is further reported, That in Theffalia the women giue the tender full toot to be drunke in Goats milke, to moue bodily luit, and the dry to reftaine the fame.

$$
\text { It The Choice. }
$$

Ourage vfeth all the kindes of ftones to ftire vp venery, and the Apothecaries mix any of them ind ifferently with compofitions ferming for that purpore. But the beft and mot effectuall are thefe Dogs ftones, as moft haue deemed:yet both the bulbes or ftones are not to be taken indifferently, but the harder and fuller, and that which containes moit quanticy of iuyee, for that which is wrinkled is leffe profitable, or not fitat all to be vfed in medicine. And the fuller root is not alwaics the greater, but often the leffer, efpecially if the roots be gathered before the plant hath thed his floure, or when the ftalke firft commeth greateft before the feed be perfectly tipe. Fot feeing that eutery other yeare by courfe one ftone or bulbewaxeth full, the orhetempty and perifheth, it cannot be that the harder and fullet of iuyce fhould be alwaies the greater; for at fuch time as the leaues come forth, the fuller then beginins to encreafe, and whilit the fame by little \& little encreafeth, the other doth deereafe and wither till the feed be ripe : then the whole plant, togethet with the leaucs and ftalkes doth forthwith fall away and perifh, and that whieh in the meane time encreafed, remainetli ftill frefh and full vato the next yeate.

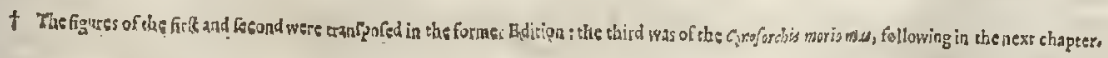




\section{C н A P. 11 I. Of Fooles Stones.}

T) The Defiption.

1 He male Foole ftones hath fiue, fometimes fix long broad and fmooth leaties, not vr1 like to thofe of the Lilly, fauing that they ate dafht and fpotted in fundty places with blacke fpots and freakes. The floutes grow at the top, tuft or fpike fahion, fomewhat like the fotmet, but thruft more thicke together, in thape like to a fooles hood, or cocks combe,wide open, or gaping before, and as it were crefted aboue, with cettaine eares ftanding vp by encry fide, and a fmall taile or fput hanging downe, the backefide declining to a violet colour, of a pleafant fautur ot fmell.

t I Cynoforchis Morio mas.

The male Foole ftones.

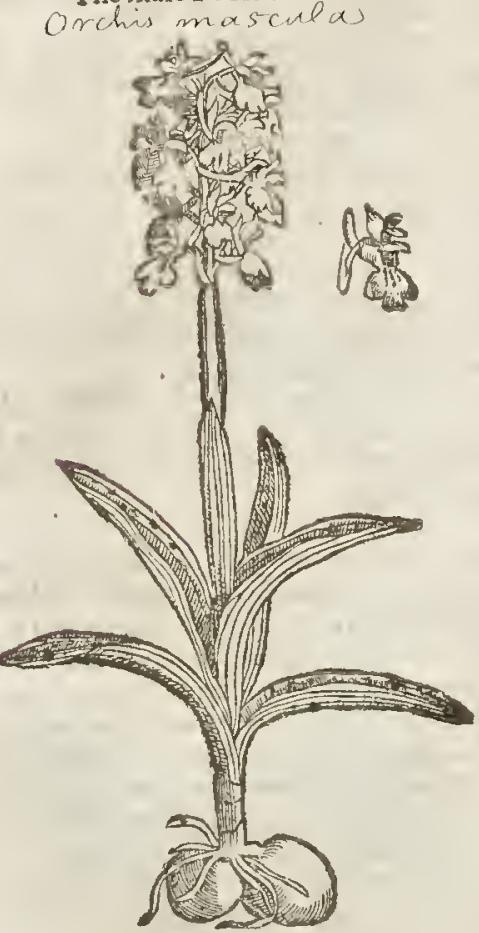

2 Cynoforchis Morio femina. The female Foole ftones.

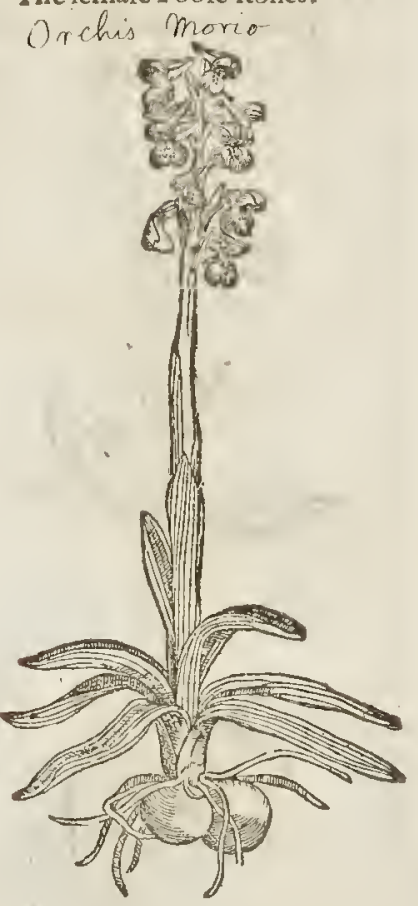

2 The Femalc Fooles ftones haue alfo fmooth natrow leaues, ribbed with netues like thofe of Plantaine. The floures be likewife gaping, and like the formet, as it were open hoods, with a lirtle horne or heele hanging behinde cueric one of them, and fmall greene leaues forted or mixed among them, refembling cockes combes, with little eares, not ftanding ft taight vp, but lying flat spon the hooded fioure, in fuch fott, that they cannot at the fudden view be petceiued. The toots are a paire of fmall ftones like the formet. The flotires of this fort doe varie infinitely in colour, according to the foile or countrey where they do grow : fome bring forth their floures of a deepe violet colour, fone as wilite as fnow; fome of a flefh colout, and fome garnithed with fpots of diuers colours, which are not poffible to be diftinguifhed.

$\neq 3$ This liarh narrow fpotted leaues, with a ftalke fome foot ot more high, at the top wherof groweth a tuft of purole toures in thape much like thofe of the laft defctibed, each floure confifting of a little hood, two fuall wings or fide leaues, and a btoad lippe ot leafe hanging doivne. + i. 
LI B. I.

Of the Hiftory of Plants.

209

\$ 3 Cynoforchis Morio minor.

The leffer fpotted Fooles ftones:

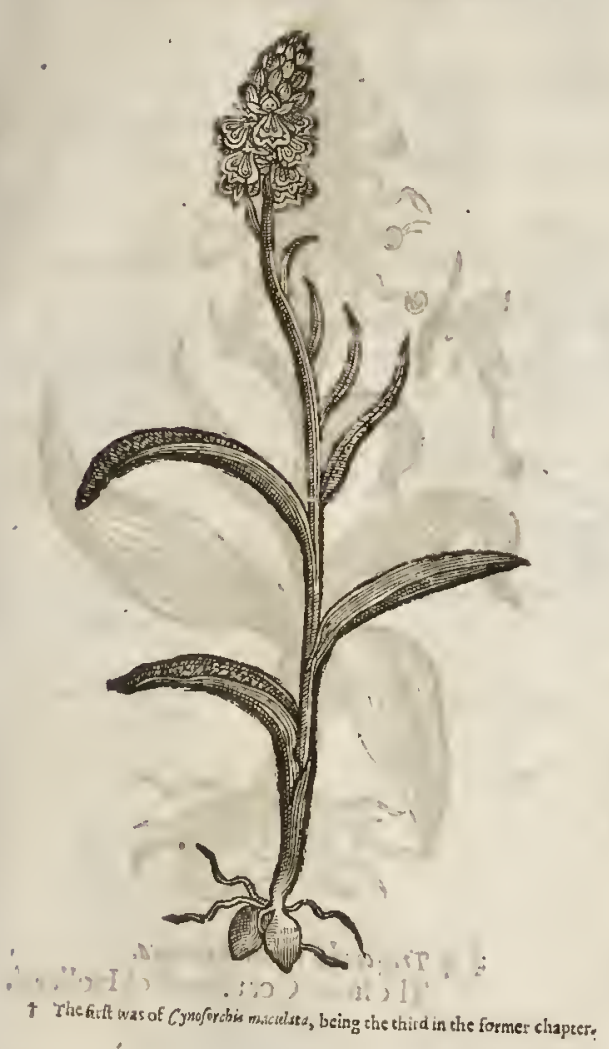

It The Place,

Thefekindes of Fooles ftones do grow naturally to their beft liking in paftures and fields that feldome or neuer are dunged or manured.

Tा The Timi.

They floure in May and Iune. Their fones are to be gathered for medicine in Septenber, as are thore of the Dogstones.

II The Names.

The firft is called cynoforchis Morio : of Fuch. fius, orchis mas anguftifolia : of Aprelcins, satyrion: and alfo it is the orchis Delphinia of Corneliss Gemma.

\# The fecond is cynoforchis morio fermina of Lobel: Orchis anguftifolin farmin. of $F_{u c h}$ fures: T en ficulus Morionis formina of $D$ odonaus.

3 This is Cynofor chis minims is fecundum carblent, oc. matculafis foliys, of Lobel. +

9) The Tompcrature.

Fooles ftones both male and female are hof and moift of nature.

IT The Vertues.

Thefe Fooles ftones are thought to haue the vertues of Dogs ftones, whereunto they are ret ferred.

CHAP. 112. Of Goats Stones.

I) The Defiription.

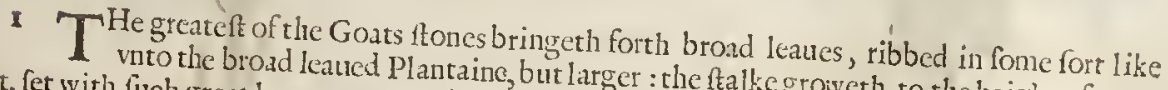
bit, fet with fuch brozd leatied Plantaine, but larger : rhe ftalke groweth to the height of a cuof floures is fmall of thofe fmall floures, fat open,with many tender ltrings or laces comming from the middle part Vine, or ratherthe la, crookedly tangling one with another, like to the fmall tendrels of the of 2 purple colour. The ror frings that grow vpon the herbe Saurie. The whole floure confintert 2 The male Goats routs are like the reft of the Orchides, but greater. long, wrapped about stones haue leaues like to thofe of the garden Lilly, with a falke a foot in this burh or tuft be rery the tuft of the floure with thofe his leates. The floures which grow tailes, and fpotted heads. Eull, in forme like vits a Lizard, beciufe of the twifted or writhen bigneffe of a peafe, which when of thefe fnall floures is at the firft like a round clofe huske, of the or taile, white toward the fettin it openeth there commeth out of it a little long and tender fpurre each fide a fmall thing adioy ing of it to the foure; the reft fported with red daffes, hatring vpon twifted crookedly about, and bng vnto it, lkke to a little leg or foot; the reft of the faid taile is or fatour like the fmell of a $G$ ongeth downward. The whole plant hath a ranke or ftinking finel 2 The female Goats ftont, whereof it rooke his name.

ler, hauing many foures on haue leates like the male kinde, fauring that they be much fmalfones or roots, as alfo the finell are like the former.

$$
+ \text { t Tilis, }
$$


I Tragorchis maximus.

Sathribegreateft Goat ftones-

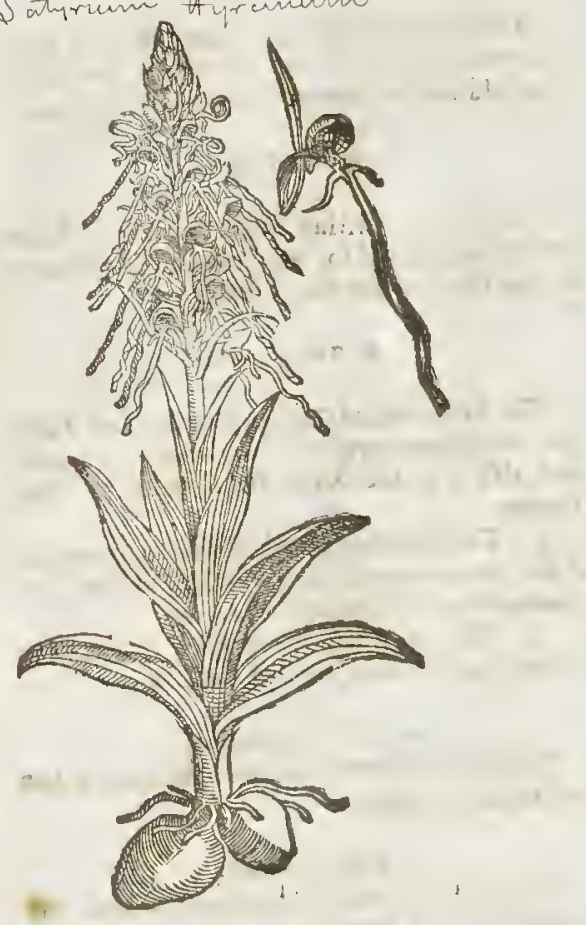

3 Tragorchis femina.

The female Goars fones?

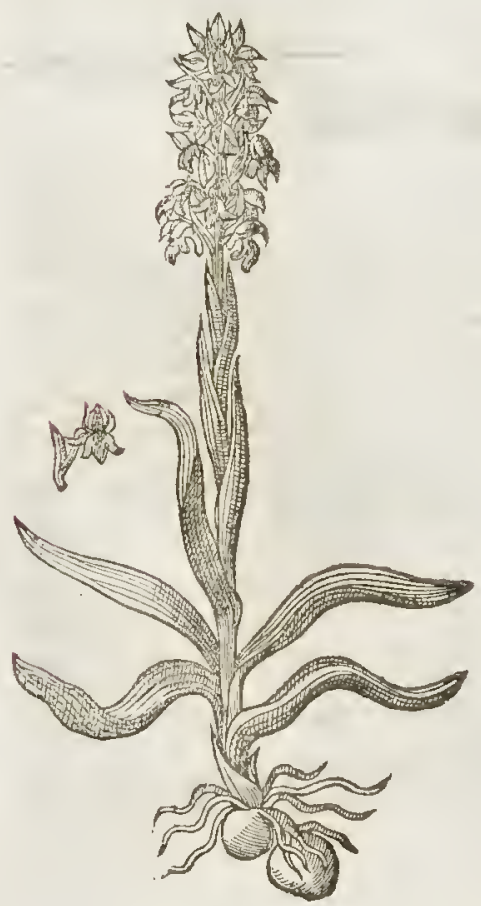

2 Tragorchismas.

The male Goat ftones.

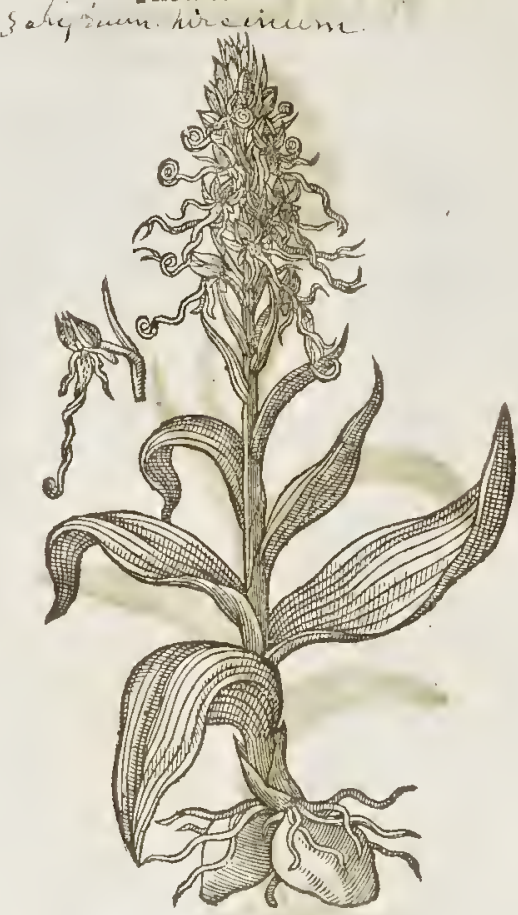

+ 4 Tragorchis minor Batauisa. The fmall Goat fones of Holland. Orcilis Pramidali, 
$\mp 4$ This alfo becaufe of the vnpleafant fmell may fitly bereferred to this Claffis. The roots hereof are finall, and from them arife a ttalke fome halfe a foot high, befet with three or foure narrow leaues: the tuft of floures whieh groweth on the top of this ftalke is fmall, and the eolour of them is ted without, but fomewhat paler within ; each floure langing downe alippeparted in three. $\neq$

$$
\text { T The Place. }
$$

1. 2. 3. Thefe kindes of Goats ftones.delight to grow in fat elay grounds, and feldome in any other foile to be found.

$\neq 4$ This growes vpon the fea bankes in Holland, and alfo in fome places neere vnto the Hage. $¥$

They floure in May and Iune with the other kindes of Orehis.

$$
\text { T The Names. }
$$

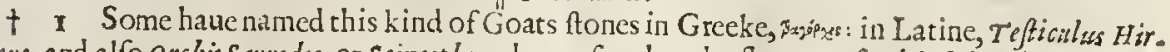
cinus, and alfo orchis Saurodes, or Scincophora, by reafon that the floures refemble Lizards. The fecond may be ealled Tragorchis mas, male Goats ftones; and orchiv Saurodes, or Scincopho.
rz, as well as the former.

The third, Tragorchis femina, as alfo Coriofmitcs, and Coriophora, for that the floures in thape and their vngratefull fmell refemble Tieks, ealled in Greeke xipurs: $t$.

$$
\text { Tा The Nature and Vertucs. }
$$

The temperature and vertues of thefe are referred to the Fooles ftones, notwithiftanding they are feldomeor nemer vfed in phy fiek, in regard of the ftinking and loath fome fmell and fauor they
are poffeffed with.

\section{$\mathrm{C}_{\text {HAP.11ziz }}$ Of Fox Stones:}

Is Orchis Hermaptiroditica. Butter-fly Satyrion.

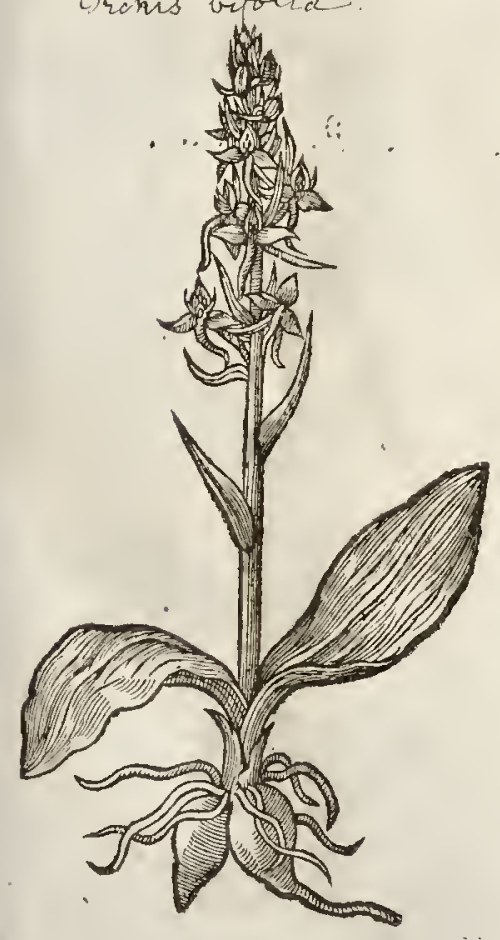

\author{
+2 Tefticulus pfycodes? \\ Gnat Satyrion.
} Orinis Bipolia

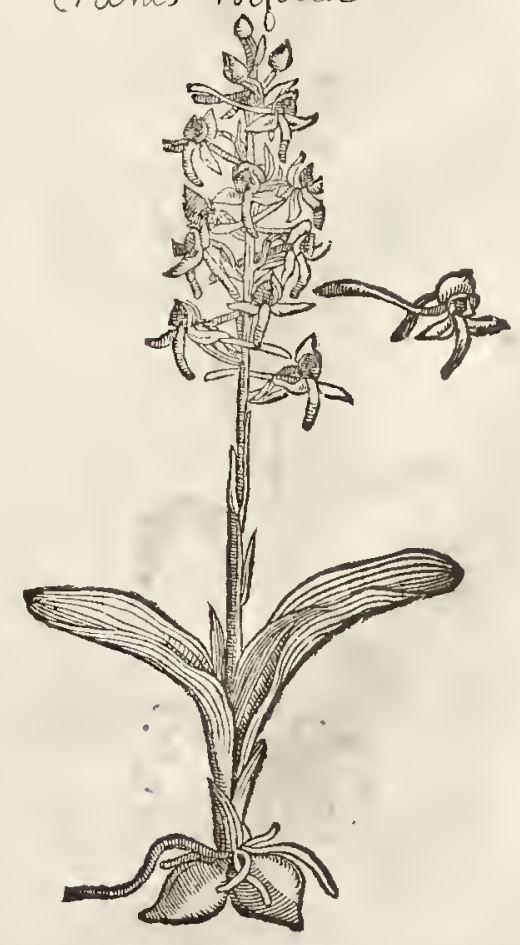

$S:$ 


\section{बा The Kindes.}

THere be diuers kindes of Fox-ftones, differing very much in thape of their Jeaues, as alfo in

floures : fome haue Aloures wherein is to be feene the thape of fundry forts of liuing ereatures fome the fhape and proportion offlics, in other gnats, fome humble bees, others like vnto honey Bees; foine like Butter-Alies, and others like Wifpes that be dead; fome yellow of colour,others white; fone purple mixed with red, others of a browne ouer-worne colour : the which feucraliy to diftunguifir, as well thofe here fet downe, as alfo thofe that offer them felues dayly to our view and confideration, would require a partieular volume; for there is not any plant whieh doth offer fueh varietie vnto vs as thefe kindes of Stones, exeept the Tulipa's, whieh go beyond all aceount : for that the moft ingular Simplet that ener was in thefe later ages, Carolus clufins (who for his fingular induftrie and knowledge heren is worthy triple honour) hath fpent at the leaft fiue and thirty yeares, fowing the feeds of Tulipa's from yeare to yeare, and to this day he could neuter attane to the end or certaintie of their feverall kindes of eolours. The greateft $r$ a fon whereof that I can yeeld is this; that if you take the feeds of a Tulipa that barewhite floures, and fow them in fome pan or tub with earth, you fhall receiue from that feed plants of infinite colours : contrariwife, if you fow the feeds of a plant that beareth fioures of variable eolours, the mott of thofe plants wll be nothing like the plant from whence the feed was taken. It thall be fuffieiene therefore to fet downe moft of the varieties, and comprehend them in this chapter.

$$
\text { Tf The Defcription. }
$$

I Veter-fly Orehis, or Satyrion, beareth next the root two very broad leatres like thore of 3 the Lilly, feldome three : the floures be white of colour, refembling the thape of a Butter-fly: the ftalke is a foot high; the root is two ftones like the other kindes of fones or Cullions, but fomewhat tharper pointed.

† 3 Tefriculus Vulpinus z. Pphegodes. Humble Bee Orehis.

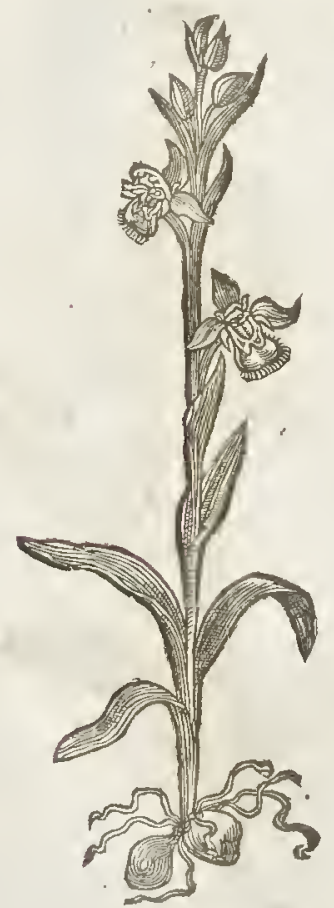

4 Teficulus Vulpinus nzajor ßphegodes. Wafpe Orchis.

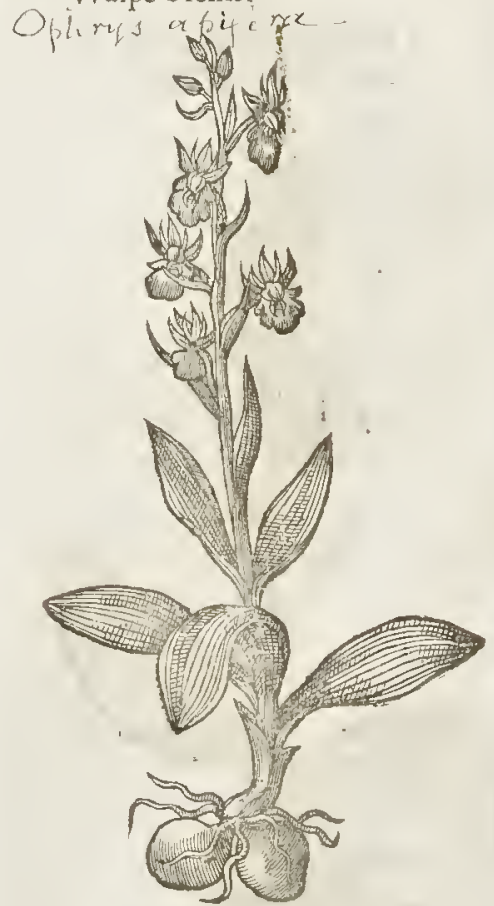

2 Wafpe Satyrion commeth forth of the ground, bearing two, fomtimes three leaues like the former, hut much finaller. The ftalke groweth to the height of an hand, whereon are plaeed very orderly fuall foures like in thape to Gnats, and of the fame colour. The root is like the former: 
3 The Humble Bee Orchis hath a few fmall weake and Thort leaues, which grow fcatteringly about the ftalke : the floures grow at the top among the fmall leates, refembling in thape the humble Bee. The root confitterh of two ftones or bulbes, with fome few threds annexed thereunto.

4. The Wafpe Satyrion groweth out of the ground, hauing ftalkes fmall and tender. The leaues are like the former, but fomewhat grearer, declining to a browne or darke colour. The floures be fmall, of the colour of a dry Oken leafe, in thape refembling the great Bee, called in Englim an Hornet or drone Bee. The root is like the other.

5 The leaues of Bee Satyrion are longer than the laft before mentioned, narrower, turning themfelues againft the Sun as it were round. The ftalke is round, tender, and very fragile. At the top grow the floures, refembling, the Thape of the dead carkafle of a Bee. The ftones or bulbes of the roots be fmaller and rounder than the lait deferibed.

6 The Fly Satyrion is in his leaues like the other, fauing that they be not of fo dark a colour: the floures be fmaller and more plentifully growing about the ftalke, in thape like vuto flies, of a greenith colour.

t 5 Orchis cxelittizs.

Bee Orchis.

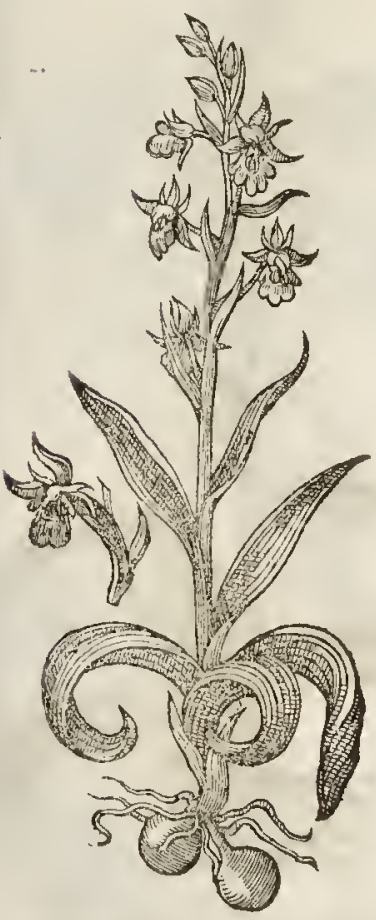

+ 6 orchis Myodes.

(o) ply Satyrion.

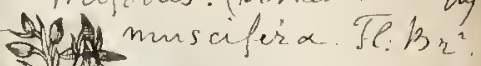
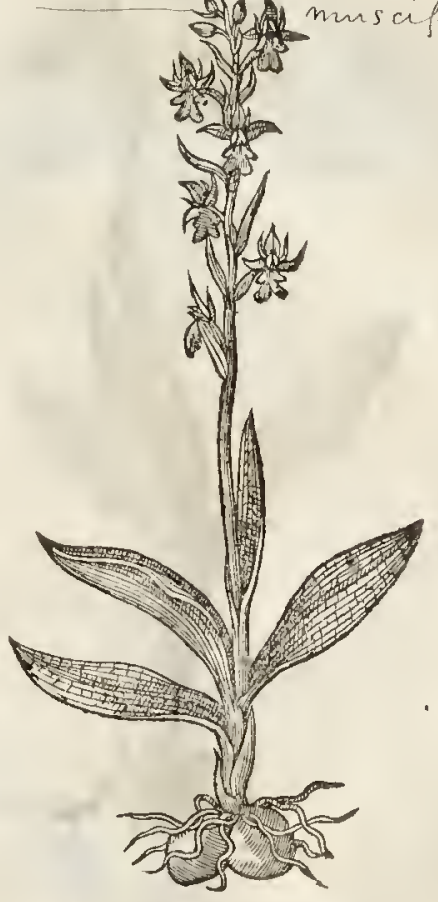

7 Yellow Orchis rifeth out of the ground with browne leaues, finaller than the laft before mentioned : the ftalk is tender and crooked. The floures grow at the top yellow of colour, in fhape refembling the yellow flies bred in the dung of Kine after raine.

8 The fmall yellow Satyrion hath leaties fpread vpon the ground, at the firft comming vp; the flender ftalkerifeth $v$ in the midnt, of halfe a hand high. The Aloures grow featteringly toward the top, refembling the fies laft before mentioned, darke or rufty of colour. The ftones or bulbes are very round.

9 Birds Orchis hath many large ribbed leaues, fpread vpon the ground like vnto thofe of Plantaine; among the whicl rife vp tender ftalkes conered euen to the tuft of the floures with the like leaues, but leffer, in fuch fort that the ftalkes cannot be feene for the leaues. The floures grow at the rop, not fo thicke fer or thruft together as the others, purple of colour, like in thape vinto little Birds, with their wings fpread abroud ready to Ay. The ronts be like the former.

Io Sporte. Birds Satyrion harh leames like ints the former, fruing that they be dalled or

$$
S_{3}
$$


fpotted here and there with darke fpots or ftreakes, hauing a falke conered with the like leaues, fo that the plants differ not in any point, except the blacke fpors which this kinde is datht with.

II White Birds:Satyrion hath leates rifing immediately forth of the ground like vnto thcblades or leaues of Leckes, but fhorter; among the which rifeth vp a flender naked ftalke two hand fills high; on'the top where of be white floures refembling the thape or forme of a fmall bird ready to fly, or a white Butter-fly with herwings fpread abroad. The roots are round, and fmaller than any of the former.

I2 Souldiers Satyrion bringeth forth many broad large and ribbed leanes, fpred vpon the ground like vnto thofe of the great plantaine : among the which rifeth vp a fat ftalke full of fap or iuyce, cloathed or wrapped in the like leates euen to the tuft of floures, whereupon do grow little foures refembling a little man hauing a helmet vpon his liead, his hands and legges cut off, white vpon the infide, fpotted with many purple fpots, and the backe part of the floure of a deeper colour teriding to redneffe. The roots be greater than any of the other kindes of Satyrions.

t 7 orchis Myodes Lutea. Yellow Satyrion.

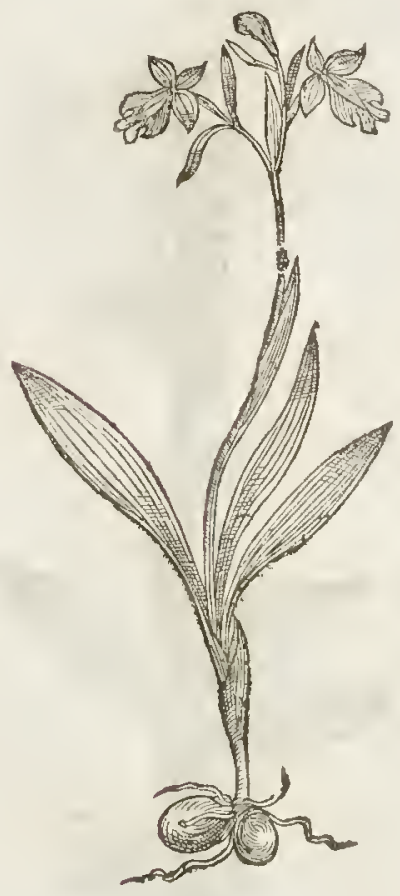

† Orchis Myodes minor. Small yellow Satyrion.

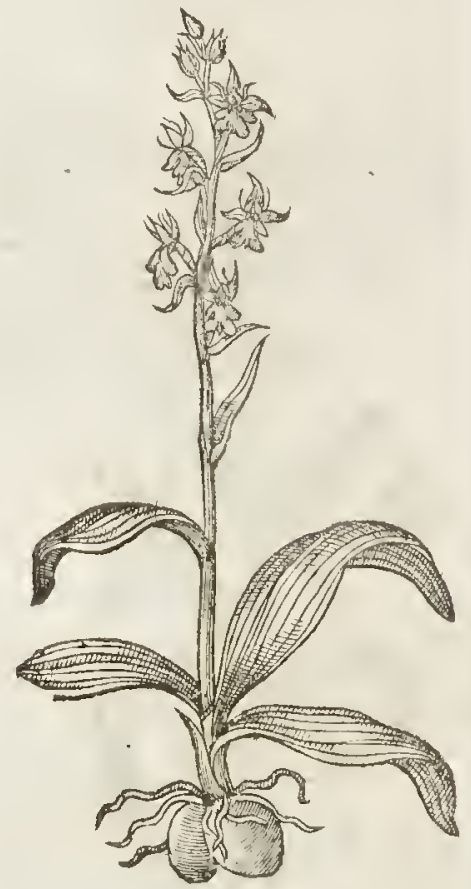

If Souldiers Cullions hath many leaues fpread vpon the ground, but leffer than the foldiers Satyrion, as is the whole plant. The back fide of the floures are fomwhat mixed with whiteneffe, and fometimes are an coloured : the infide of the floure is fpotted with white likewife.

14 Spider Satyrion hath many thinne leates like vnto thofe of the Lilly, fatteringly fet vpon a weake and feeble ftalk; whereupon doth grow fmall foures, refembling as well in thape as colour the body of a dead humble Bee, $\neq$ or rather of a Spider; and therefore I thinke Lobel, who was the Author of this name, would haue faid Arachnitis, of Asexixs, a Spider. ‡

$\neq 15$ Tluis by right fhould hatue beene put next the Guat Satyrion, defcribed in the fecond place. It hath thort, yet pretty broad leates, and thofe commonly three in number, befides thofe imall ones fet vpon the ftemne. The floures are fmall, and much like thofe of the fecond formerly defcribed.

I6 Our Authorgate you this figure in the fourteentl place, vnder the title of orchis Andrachnitis . but it is of the Orchis I 6. minor of Tabernam. Or Orchis Anguftifolia of Baubinus. This Orchis is of the kinden the Modes, or Fly Satyrions, but bis leaues are farre longer and narrower 


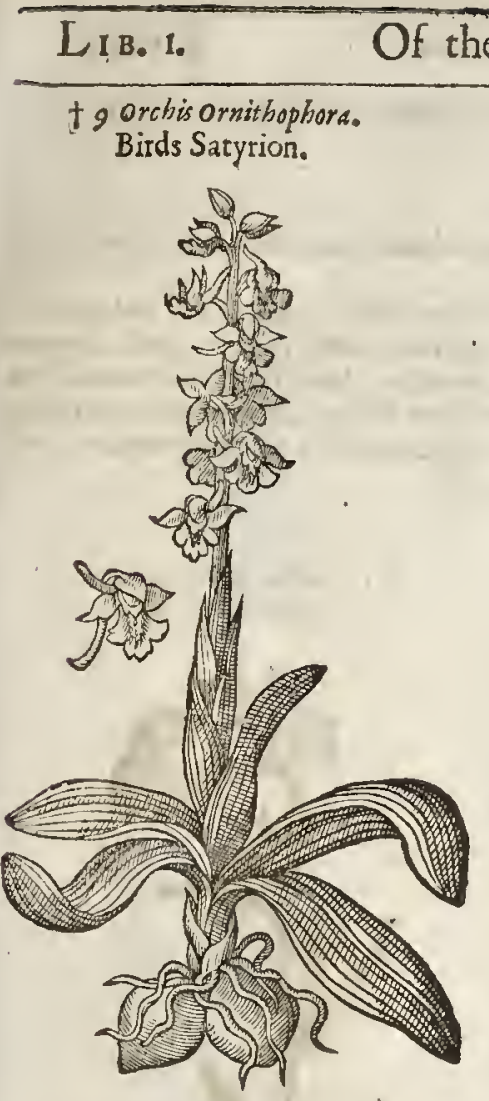

f 1 orchis ornithophor a catedida. White Birds Orchis.

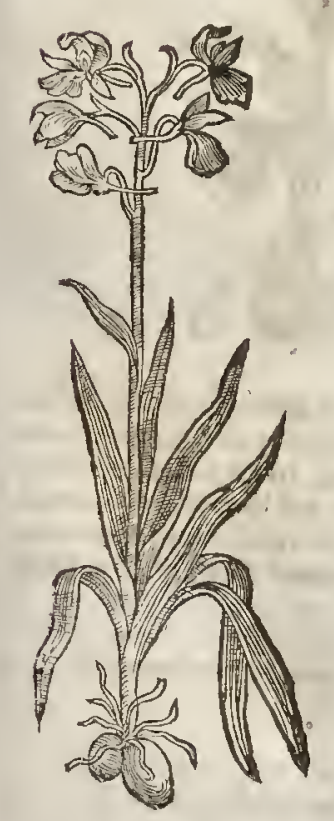

t ro orchis Ornithophora folio maculoso.
Spotted Birds Orchis.

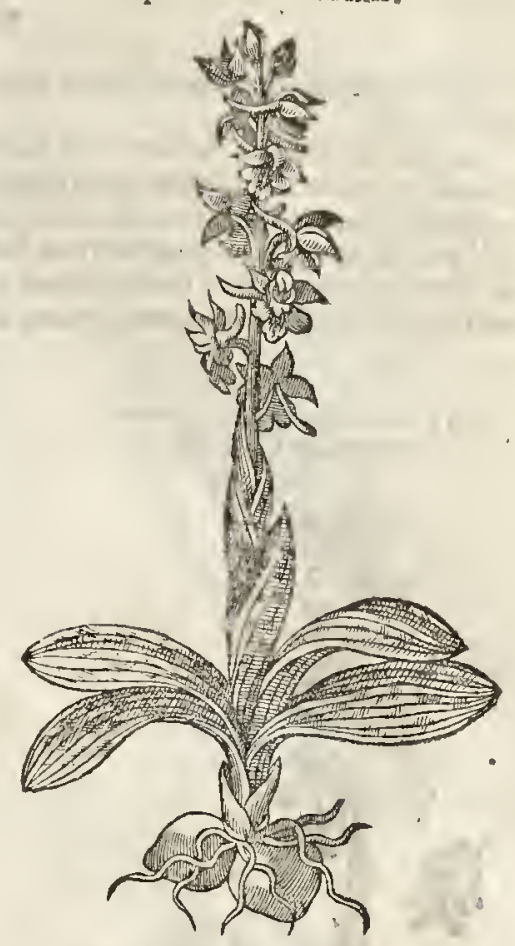

I1 12 Orchis Stratermatica. Souldiers Satyrion.

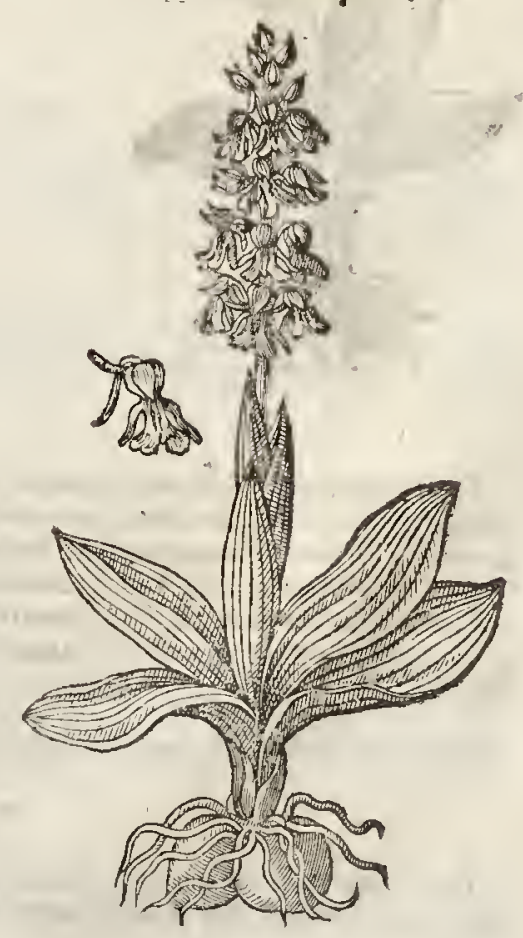


than any of the reft of that kinde, and therein confifts the onely and chiefeft difference. $\ddagger$

$$
\text { T. The place. }
$$

Thefe kindes or Oreh is grow for the moft part in moift medowes and fertile paftures, as alfo in moift woods.

The Bee, the Fly, and the Butter-fly Satyrions dogrow vpon barren chalkie hills and heathie grounds, vpon the hils adioyning to a village in Kent named Green-hithe, vpon long ficld downes by South-fleet, two miles from the fame place, and in many other places of Kent : likewife in a field adioyning to a fmall grone of trees, halfe a mile from Saint Albons, at the South cnd thereof. They grow likewife at Hatfield neere S. Albons, by the relation of a learned Preacher there dwelling, M. Robert Abot, an excellent and diligent Herbarift.

t 13 Orchis Strateumatica minor. Souldiers Cullions.

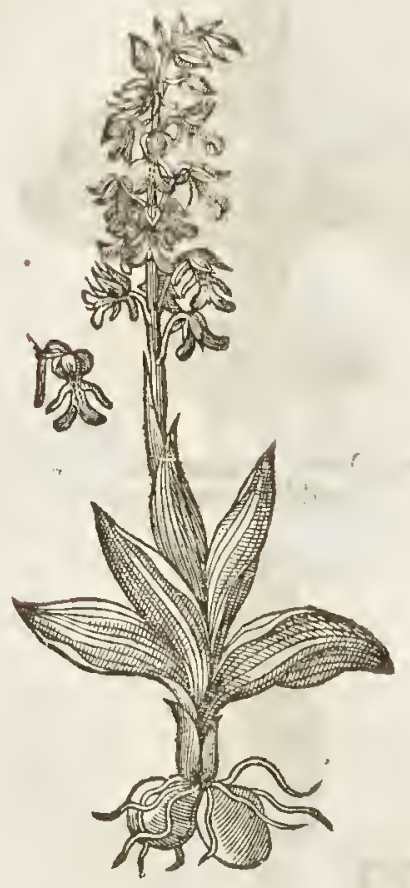

I 14 orchis Andrachritis. Spider Satyrion.

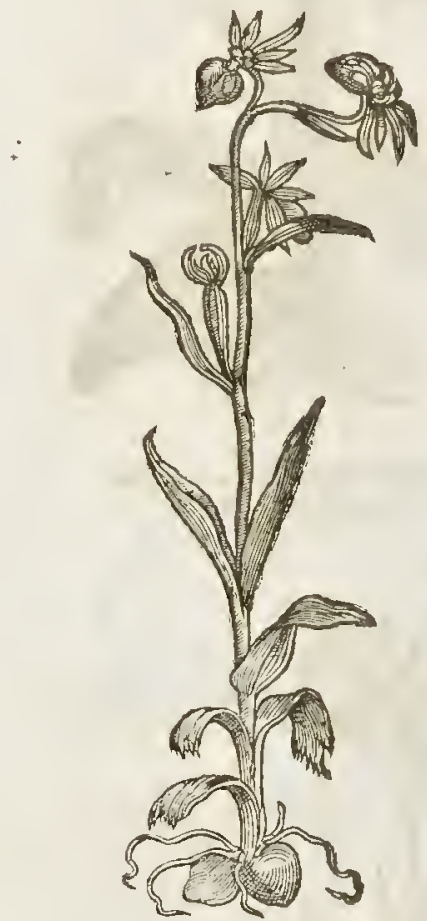

That kinde whichrefembleth thewhitc Butter-fly groweth vpon the declining of the hill at the North cnd of Hamplted heath, neere vnto a fmall cottage there in the way fide, as yee go from London to Henden a village thereby. It groweth in efic fields adioyning to the pound or pinnefold without the gate, at the Village called High-gate, neere London : and likewife in the wood belonging to a Worhipfull Gentleman of Kent named Mafter Sidley, of South-fleet; where doe grow likewife many other rare and daintie Simples, that are not to be found elfew here in a great circtit.

\section{The Time.}

They foure for the moft part from May to the end of Auguft, and fome of them fooner.

$$
\text { T The Names. }
$$

Tlefe kindes of Orchis hauc not bin much written of by the Antients, ne ither by the late writers to any purpofe, fo that it may content you for this time to receiuc the names fet dow $n$ in their 

feuerall titles, referuing what el fe might be faid as touehing the Greeke, Freneh, or Duteh names,
or any generall definition vntill a further confideration.

\section{\# 15 Orchis trifolia minor. \\ Small Gnat Satyrion.}

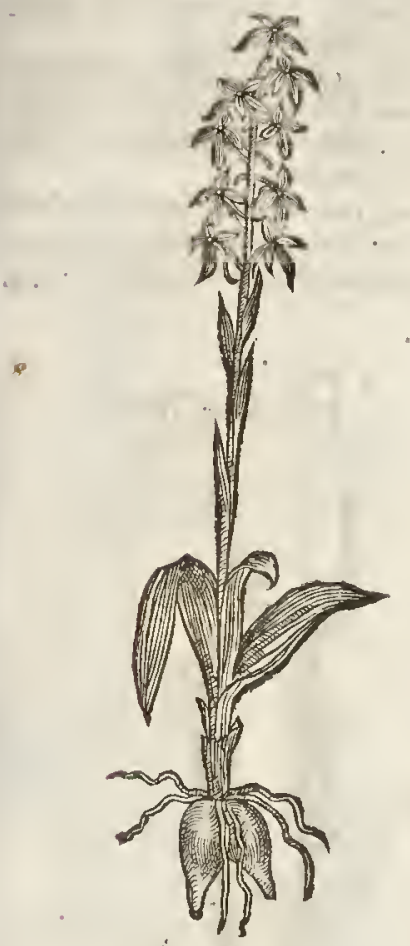

* 16 orchis angufifolia.

Narrow leaued Satyrion.

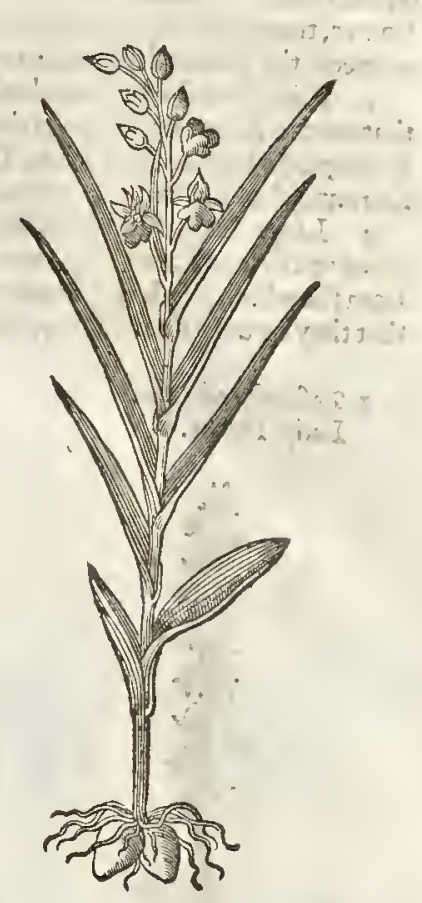

If The Nature and vertues.

The nature and vertucs of thefe kindes of Orehis are referred vnto the others, namely to thofe of the Fox ftones; notwithftanding there is nogreat vfe of thefe in phyficke, but they are chicfly regarded for the pleafant and beautifull floures, wherewith Nature hath feemed to play and di-
port her felfe.

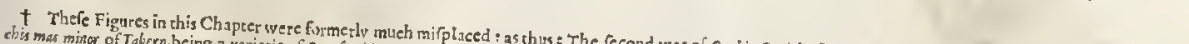

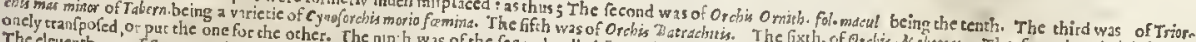

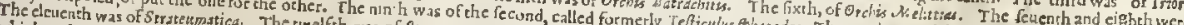
which we heregiue you in the fixcenth place."

\section{Char.14. Of Sweet Cullions.}

$\mathrm{T}$

Here be fundry forts of fweet fmelling Thindes.

pleafant in fmell, the others ofleff Teftieles or Stones, whereof the firf is moft fweet and white floures, others yellow, fome fefle fmell or fautour, differing in floure and roots. Some haue wafh : fome haue two ftones, others three and fourd, fomedafhe von white with a little reddifh

I Thefirt kinde of Sweet Defription.

$\mathrm{T}$

The leaues be fmill naros is a mall bafe and low plant in refpeet of all the ref: which rifeth vp a finall wew, and thort, growing flat vpon the ground; amongft the render ftalke of a finger long, whereupon doe gro:v 


\section{$218 \quad$ Of the Hiftorie of Plants.}

fmall white floures fpike farhion, of a pleafant fweet fmcl. The roots are two fnall ftones in thape like the other.

2 Triple Orchis hath commonly thrce, yet fomctimcs foure bulbcs or tubcrous roots, fomewhat long, fet with many fmall fibres or thort threads; from the which roots rife immediately many flat and plainc leaucs, ribbed with ncrues aiongft them like thofe of Plantaine : among the which come forth nakcd ftalkes, fmall and tender, whereupon arc placcd certainc fmall white floures, trace fantion, not fo fiveet as the formcr in fmell and fauour. $¥$ The top of the falke whereon the floures do grow, is commonly as if it wcre tw ifted or writhcn about, $\ddagger$

3 Friefeland Lady traccs hath two fmall round fones or bulbes, of thc bigneffe of thc peafe that we call Rouncifalls; from the which rife vp a few hairy lcaues, leffer than thofc of the triple ftones, ribbed as the fmall leafed Plantainc : anong the which commeth forth a fmall naked falk, fet round about with little ycllow floures, not tracc fafhion as the former.

4 Liege Lady traces hath for his roots two greater ftones, and two fmaller; from the which come vp two and fometimes more leaues, furrowed or madc hollow in the midit likc to a trough, from the which rifett vp a flender nakcd ltalke, fet with fuch floures as the laft defcribed, fauing that they bc of an onerworne yellow colour.
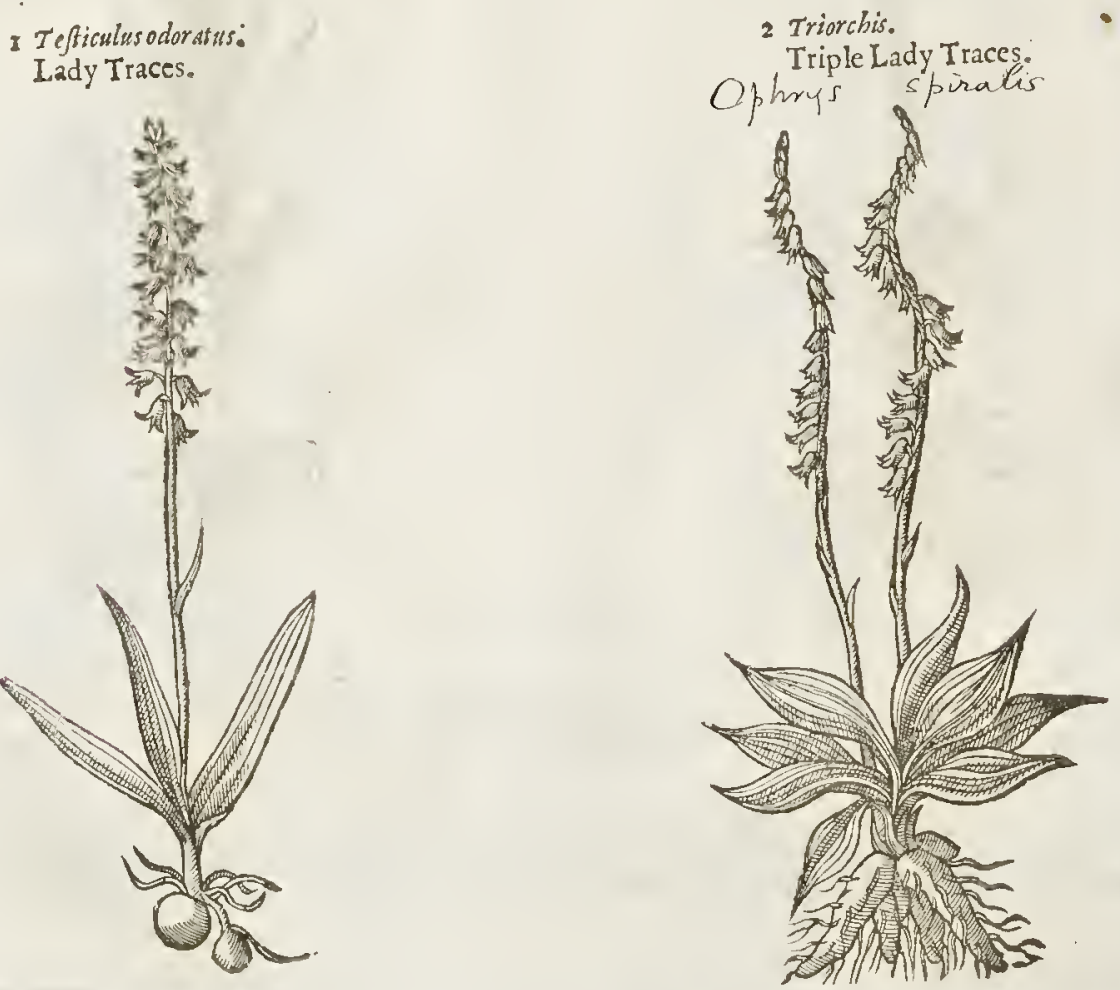

- The Place.

Thefc kindes of Stones or Cullions do grow in dry paftures and heaths, and likewifc vpon chalkie hills, the which thate found growing plentifully in fundry places, as in the field by Inlington, neerc London, wherc therc is a bowling place vnder a few old fhrubby Okes. They grow likew ife vpon the heath at Barne-elmcs, neerc vnto the head of a conduit that fondeth water to the houfe belonging to the latc Sir Francis Walfing ham. They grow in the field next vnto a Villagc called Thiftcworth as you go from Branford to her Maicfties houfe at Richmond; alfo vpon a common Heath by a Village neerc London called Stepney, by the relation of a learned merchant of London, named M. Imes Cole cxceedingly well expcrienced in the knowledgc of Simplcs.

The yellow kindes grow in barren paftures and borders of fields about Ouenden and Clarc in 
Effex. Likewife neere wnto Muche Dunnow in Effex, where they were thewed me by a learned Gentleman Mafter Iames Twaights, excellently well feene in the knowledge of plants.

¥ I receiued fome roots of the fecond from my kinde friend M. Thomas WVallis of WertminAter, the which he gathered at Dartford in Kent, vpon a piece of ground commonly called the Brimth : but I could not long get them to grow in a garden, neither do any of the other Satyrions loue to be pent $v$ in fuch ftraight bounds. $\neq$

3 Orchis Frifialutea.

Friefeland Lady-traces.

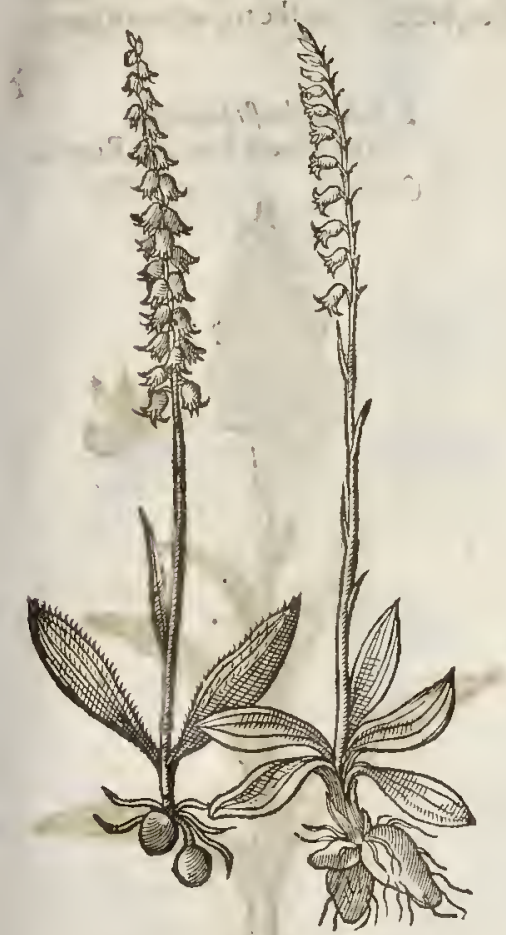

4 Orchis Leodienfis. Liege Lady-traces。

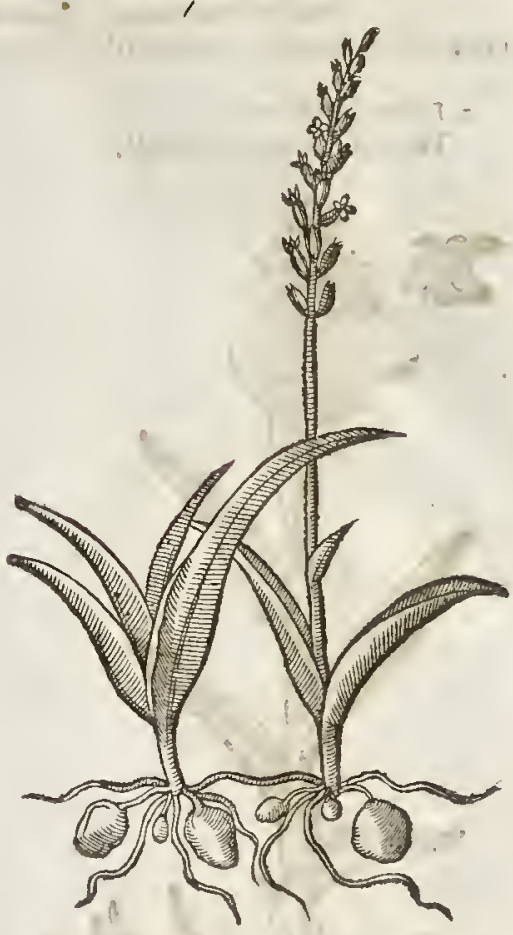

The Time.

Thefe kindes of ftones do floure from Auguft to the end of September .

Q1 The Names.

The firft is called in Latine Tefticulus o dor atus : in Englifi, Sweet fmelling Tefticles or ftones, not of the fweetneffe of the roots, but of the floures. It is called alfo orchis fpiralis, or Autumanalis, for that this (as alfo that which is fer forth in the next place) hath the top of the ftalke as it were twifted or twined fpire farhion, and for that it commeth to flouring in Autumne: of our Englifh women they be called Lady-traces; but euery countrey hath a feuerall name; for fome call them Sweet Ballocks, fweet Cods, fweer Cullions, and Stander-graffe. In Dutch, kntabentitaut, and Stondelctaut: In French, Satyrion.

The fecond fort is called Triorchis, and alfo Tetrorchis : in Englith, Triple Lady-traces, or white Orchis.

The third is called orchis Frifia: in Englifh Friefeland Orchis.

The laft of thefekindes of Tefticles or Stones is called of fome in Latine, Orchis Leodienfis, and orchis Lstea as alfo Baflica minor Serapias, and Triorchis efg inete: In Englinh; Yellow Lady-traces.

$$
\text { q The Temperaure. }
$$

Thefe kindes of fweet Cullions are of nature and temperature like the Dogs itones, although notvfed in Phyficke in times paft; notwithttanding later Writers hate attributed fome vertues vnto them as followeth.

$$
\text { I The Vertues. . }
$$

The full and fappy roots of Lady-traces eaten or boyled in milke, and drunke ${ }_{j}$ prouoke venery, A nourith and ftrengthen the body, and be good for fuch as be fallen into a Confumption or Fener Hedique. 


\section{A A P. 115. Of Satyrion Royall. \\ Tf The Defcription.}

I THe male Satyripn toyal hath large roots, knobbed, not bulbed as the others, but bran? ehed or cut into fundry fections like an hand, from the which comevp thick and fat ftalkes fet with large léaues like thofe of Lillies, but leffe; at the top whereof groweth a tuft of floures, fpotted with a deepe purple colour:
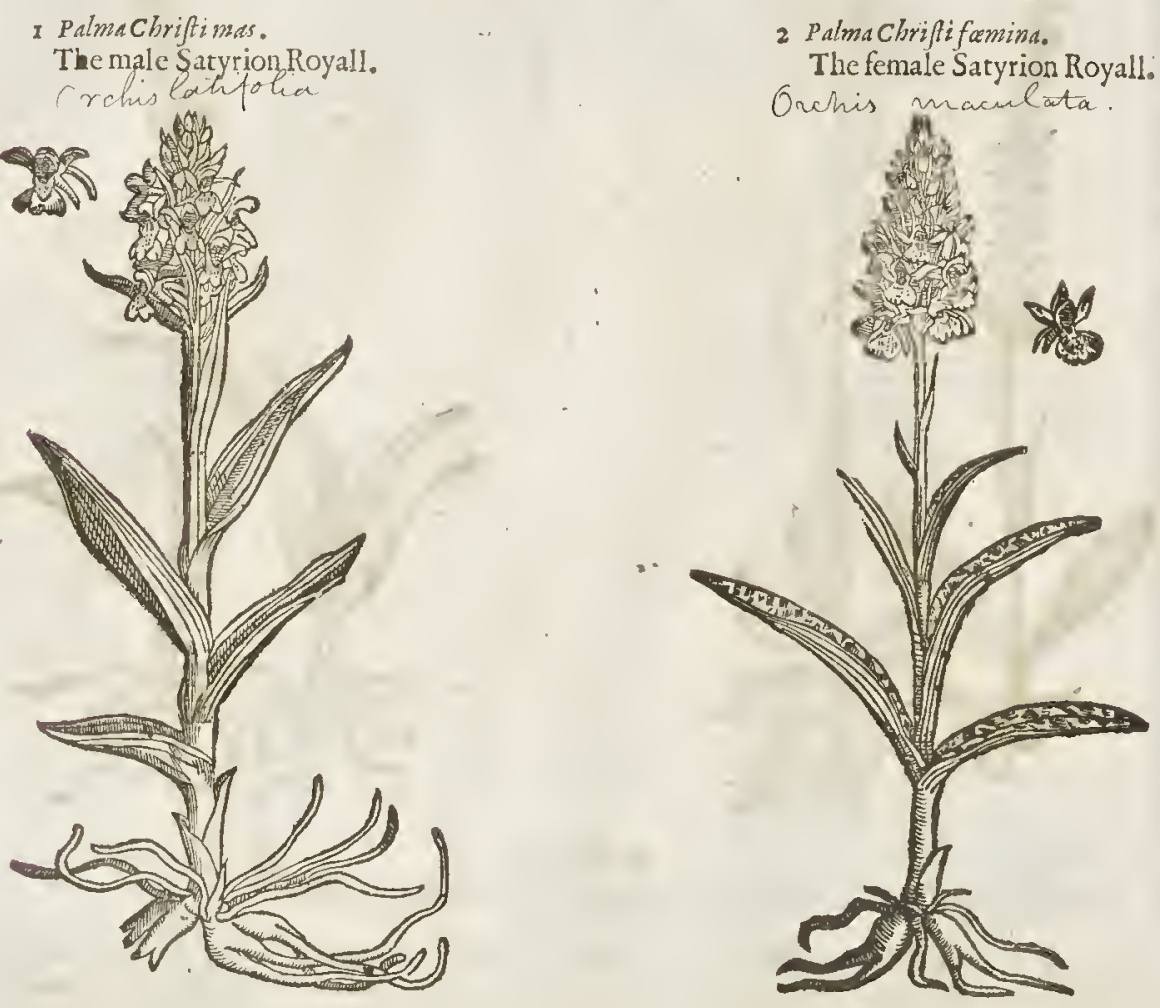

2 The female Satyrion hath elouen or forked roots, with fome fibres ioyned thereto. The leaues be like the former, but fmaller and narrower, and eonfufedly dafhed or fported with black fpors : from the which fpringeth up a tender ftalke, at the top whereof doth grow a tuft of purple floures, in farhion like vnto a Friers hood, changing or varying aeeording to the foile and clymar, fometimes red, fometimes white, and fometimes light earnation or flerh colour.

$\neq 3$ This in roots and leaues is like the former, but that the leaues want the blaek fpots, the ftalke is but low, and the top thereof hath floures of a whitin colour, nor fpotted : they on the forefide refemble gaping hoods; with eares on each fide, and a broad lip hanging down; the backe part ends in a broad obtufe fpur. Thefe foures fmell like Eldet blofomes. $\neq$

$$
\text { If The Place. }
$$

The royall Satyrions grow for the moft parr in moift and fenny grounds, medowes, and Woods that ir: cery moiftand thadowie. I haue found them in many places, efpecially in the midft of $a$ "wond in Kent called Swainefcombe wood neere to Gratefend, by the village Swainefcombe, and
likewife in Hanopfed wood foure miles from London.

They loure in May and Iune, but feldome later. 
$\$ 3$ orchis Palmata Pannonica 8. Cluf. The Auftrian handed Satyrion.

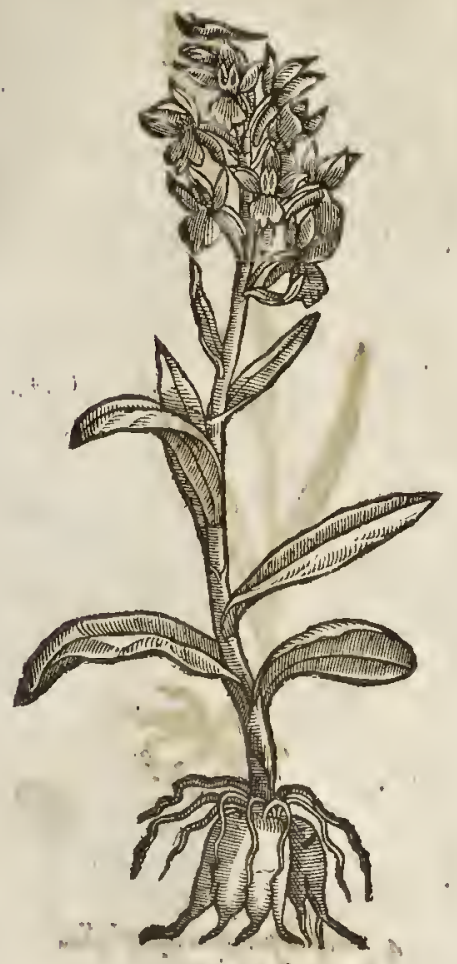

$$
\text { ब. The Names. }
$$

+ Royal Satyrion,or finger Otchis is called in Larine, Palma chrifti; notwithftanding there is another herbe or plant called by the fame name, wh ich otherwife is called Ricinus. This plant is called likewife of fome, Satyrism Baflicum, or Salyrium regium. Some would hauc it to be Buzeiden, or BuZidan Arabum, but Auicen faith Buzeiden is a woody Indian medicine : and serapio faith, Buzeiden be hard white roots like thofe of Beben album, and that it is an Indian drug:but contrariwife the roots of $P$ alma Chrifti are nothing leffe than woody, fo that it cannot be the fame. Cxatthiolus would hauc Satyrion royall to be the Digiti Citrini of U A uicen, finding fault with the Monkesw hich fet forth Commentaries vpon Mefues Compofitions, for doubting and lcauing it to the indgement of the difereet Reader. Yet do we better allow of the Monkes doubt, than of Matt biolus his affertion. For Auicens words be there, What is a faliafafruts or Digiti Citrini? and anfwering the doubt himfelfe, he faith, It is in figure or thape like the palme of a mans hand, of a mixt colour betweene yellow and white, and it is hard, in which there is a little fweetneffc; and there is a Citrine fort dufty and ivithout fwectneffe. $R$ Rafis alfo in the latt booke of his Continent calls thefe, Digni Crocet, or Saffron fingers; and he faith it is a gumme or veine for Dyars.

Now thefe roots are nothing leffe than of a Saftron colour, and wholly vnfit for Dying. Wherefore without doubt thefe words of Autcen and $R h$ afs, in the cares of men of iudgment do confrme, That Satyrion.Royall, or Palma ( hrifti, are not thofe Digiti Citrini. The Germans call it Cteutf blum: the low Dutcl, 戡andeteng ceupt: the French, Satyrion royal.

$$
\text { oT } T \text { be Tempera'ure and rertues. }
$$

The Roots of Satyrion royall are like to Cynoferchis or Dogs ftones, both in fatiour and tafte, and therefore are thought by funte to be of like facultics. Yet Nicolaus Nicolus, in the chapter of the cure of a $Q$ uartaine Ague, faith, That the roots of Palma Chriliz are of force to purge vpward and downward; and that a piece of the root as long as ones thumbe ftamped and gituen with wine before the fit commeth, is a good remedic againft old Quartaines after purgation: and reportetl,
That one Baliolus, after he had endured 44 fits, was cured therewith.

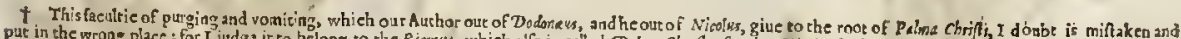

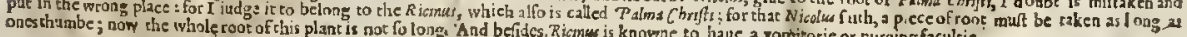

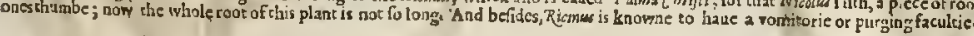

\section{C н в. 116. Of Serapiais Stunes.}

c) The Kindes.

$T^{4}$ Here be fundry forts of Serapias ftones, whereof fome be male, others fermale; fome great, 1 and forne of a fmaller kinde; varying likewife in colour of the floures, whereof fome be white, others purple; altering according to the foileor elymate, as the grcateft part of builbous. roots do. Moreoner, fone grow in marhie and fenny grounds, and forne in fertilc paftures, lying onen to the Sun, varying likew ife in the fhape of their floures; retaining the forme of flics, But-
rer-flies,and Gnats, like thofe of the Fox ftones.

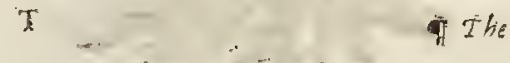


I Serapias Candido forc.
White handed Orchis?

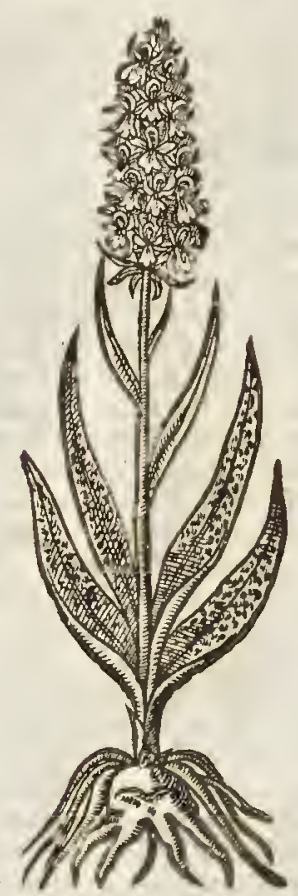

3 Serapias paluftris latifolia. Marifh Satyrion, -

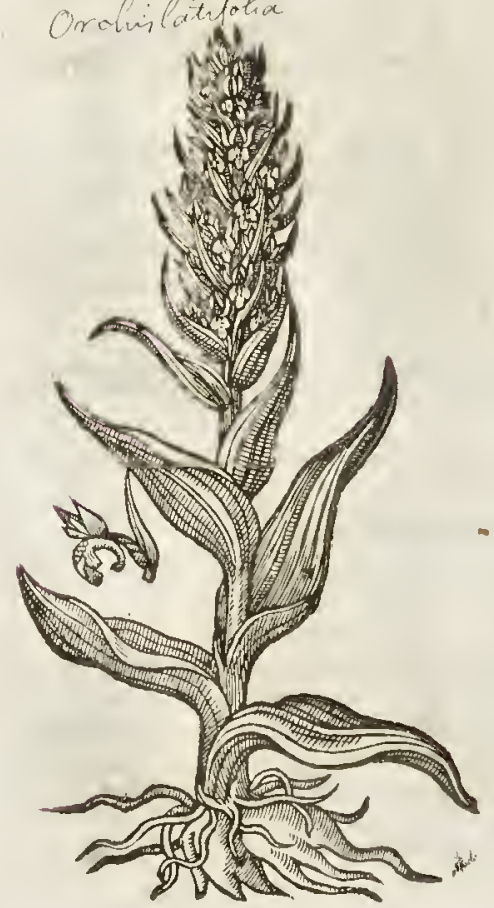

$L_{1 B:}$.

z Serapias mimr, mitente flore. Red handed Orchis. Orchis conofied.

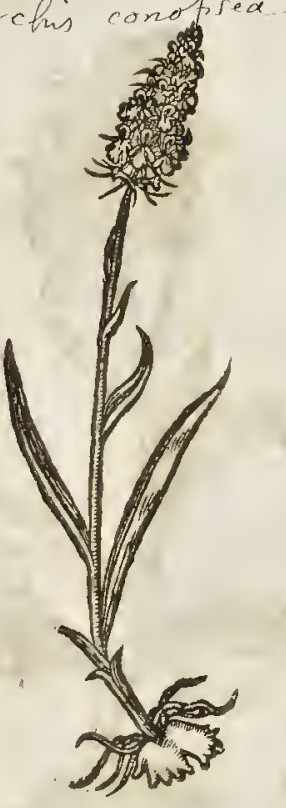

is Serapie palufiris leptophy laty Fenny Satyrion.

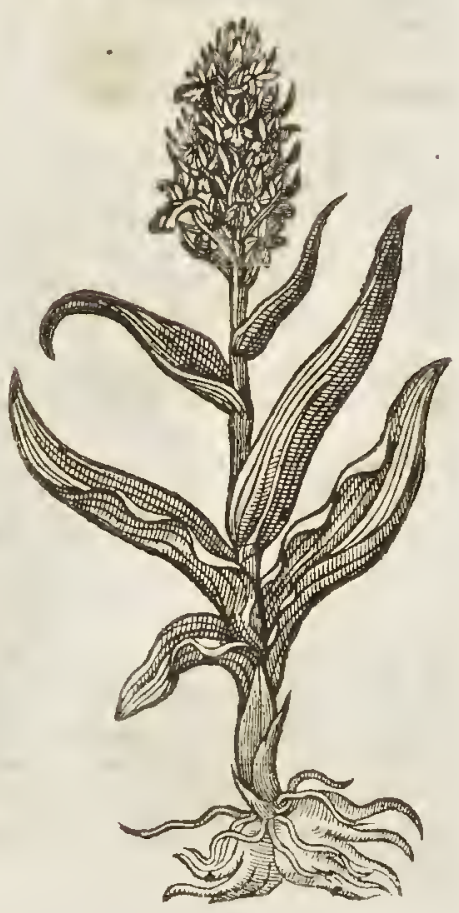




\begin{tabular}{|c|c|c|}
\hline LI в. I. & Of the Hiftory of Plants. & 223 \\
\hline $\begin{array}{l}\text { \5 Serapias Montana. } \\
\text { Mountaine Satyrion? }\end{array}$ & $\begin{array}{l}6 \text { Serapias Gariophy } \\
\text { Sweet-fmelling } \\
\text { feed expreft at }\end{array}$ & root and \\
\hline
\end{tabular}
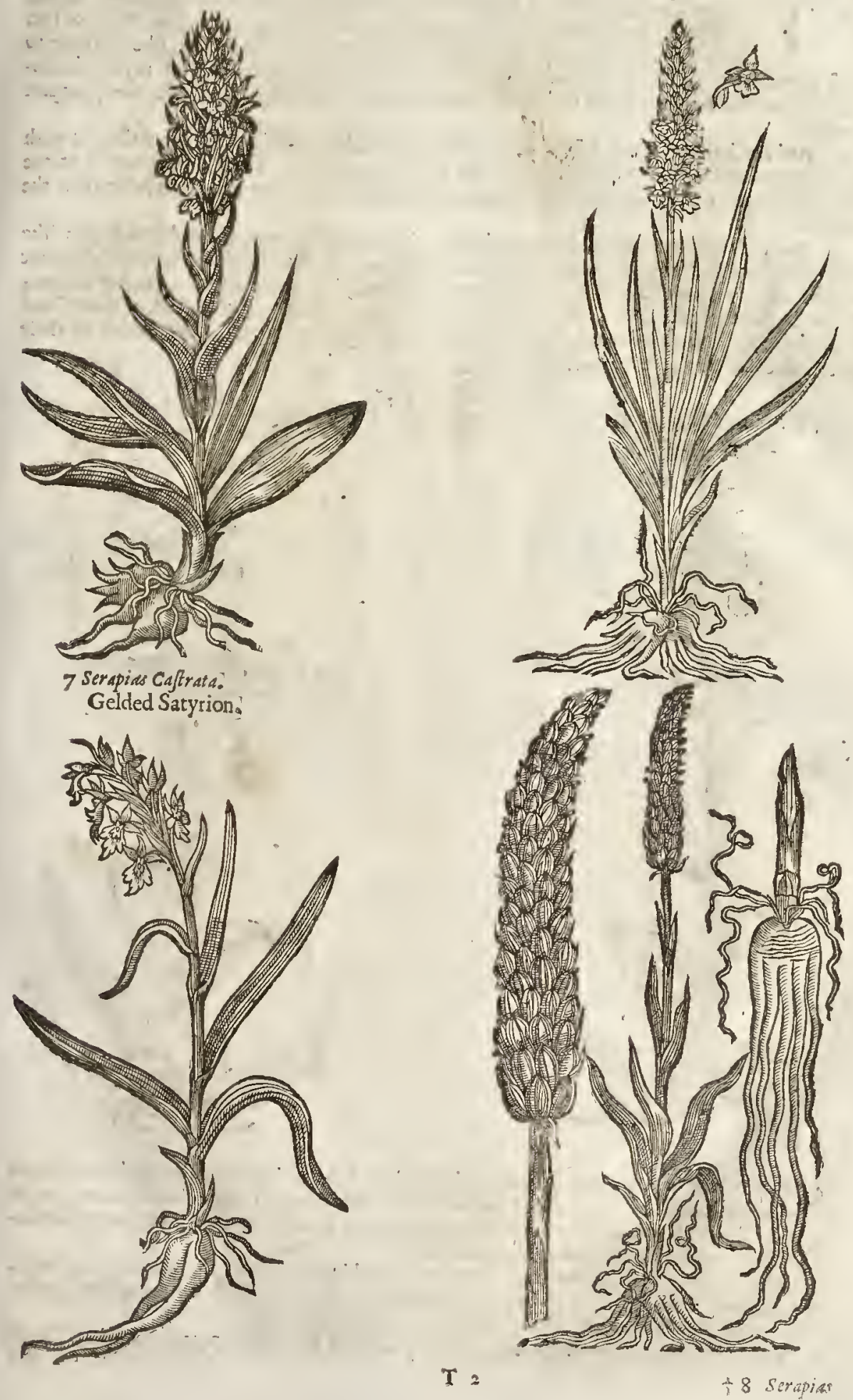


\section{T) The Defription.}

I

T. He white handed Orehis or Satyrion hath long and large leaues, fported and dathed with blacke fpors, from the which doth rife vp a fmall fragile or brittle ftalke of two hands high, hauing at the top a bufh or fpoky tuft of white flomres, like in thape to thofe of $p_{\text {alma }}$ Chrift , whereof this is a kinde. The root is thicke, fat, and full of iuyee, farhioned like the hand and fingers of a man, with fome tough and fat ftrings faltned to the vpper part thereof.

2 Red handed Satyrion is a fmall low and bafe herbe, hauing a fmall tender, Italke fet with two or three finall leaues, like vnto thofe of the Lecke, but fhorter. The floure groweth at the top tuft fafhion, of a gliftering red eolour, with a root fafhioned like an hand, but leffer than the former.

3 Serapia's Itones, or marifh Satyrion hath a thicke knobby root, diuided into fingers like thofe of $P$ alma $C h r i f t$, whe reof it is a kinde : from which rife thicke fat and fpongeous ftalkes, fer with broad leaues like thofe of Plantaine, but much longer, enen to the top of the tuft of floures but the higher they rife toward the top the fmaller they are. The floure confitteth of many fmall hooded floures fomewhat whitifh, fpotted within with decpepurple fpots; the backfide of thefe little floures are Violet mixed with purple.

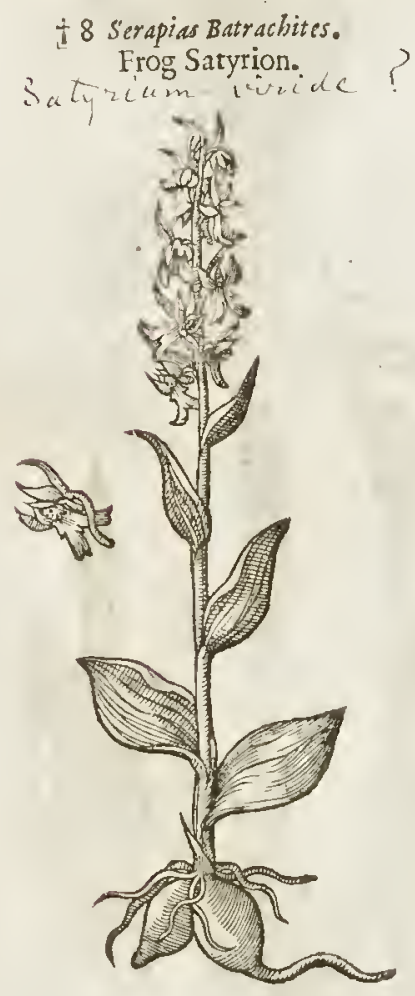

\section{\# Serapias Batrachites altera. The other Frog Satyrion. Satyriom ruide?}

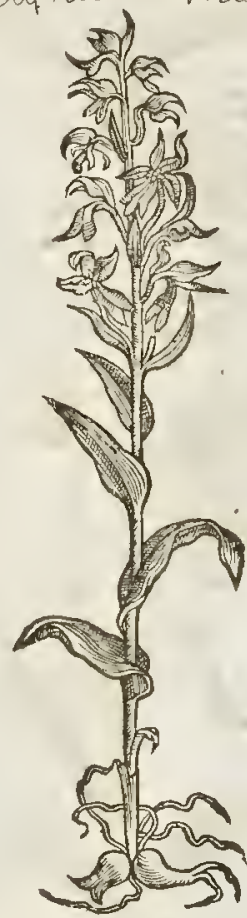

4 Fenny Satyrion (or Serapia's ftones) differeth little from the former, fauing that the leaues are finaller, and fomewlat fpotted, and the tuft of houres hath not fo many greene leaues, nor fo long, mixed w ith the floures, neither are they al together of fo darke orpurplinh a colour as the former. The roots are like thofe of the laft defcribed.

5 Mountaine Orehis or Satyrion hath thicke fat and knobby roots, the one of them for the moft part being handed, and the other long. It growes like the former in ftalkes, leaues,and floures, but is fomcw hat bigger, with the leanes fmoother, and more thining.

6 Cloue Satyrion, or fiveet fmelling Orchis, hath flat and thicke roots diuided into fingers 
like thofe of Palma Chrifti, faning that the fingers are longer, frialler, and niore in number ; fron the which rife vp long and narrow leaues like thofe of Nareifus or, and nore in number ; fron meth forth a finall tender ftalke, ar the top whereof Nareifus or Daffodill : anong which eomfloures refembling Flies, but in fauour and fmell like the Cloue, tuft compact of many fmall farre fweeter and pleafanter, as ny felfe with many others canwithefor Clour Gillo-floure; but feene and finelt them in my garden. F After the fors can withefle now liuing, that hatie both with a fmall feed, and growing after the manneras you fee is paft, come many feed veffels filled together with the root alfo fet forth at full. $\neq$. you fee them here at large expreffed in a figure,

7 Gelded Satyrion hath leanes with nerues and finewes like ro thofe of Daffodill, fet upon a

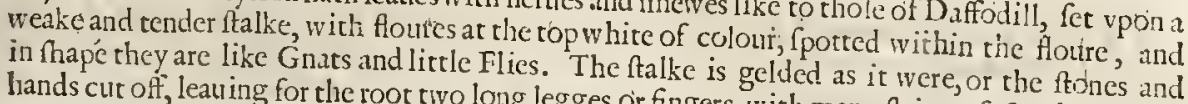
top.

8 Frog Satyrion hath fmall Hat leaues fet vpon a flender weake ften; at the top wherof growes a tuft of Houres compact of fundry fmall floures, which in thape do refemble litrle frogges, whereof it tooke his name. The root is likevife geIded, onely referued two fmall mifhapen lumps with
certaine fibres annexed thereto.

¥ 9 This alfo may fitly be added to the laft defcribed, the root thewing it to be of a kinde betweene the Serapia's and Orchis. It groweth to the height of the former, with thort leaues engirting the falke at their fetring on. The floures on the top refemble a Frogge, with their long leaues; and if you looke vpon then in another pofture, they will fomewhat refemble little Flies: calls it as well Moides, as Bar rachites. $\neq$

\section{Tा The Time.}

There Plants flourith in the monerh of May and Iune, but feldome after; except fome degeneratekinde, or that it hath had fome impediment in the time when it fhould haue floured,as of-
ten hapneth.

$$
\text { 7) The Names. }
$$

We haise called thefe kindes, Serapia's ftones, or Serapiades, efpecially for that fundry of them dobring forth floures refenbling Flies and fuch like fruitfull and lafciuious infects, as taking their name from Serapias the god of the citifens of Alexandria in Ægypt, who had a mort famous Temple at Canopus, where he was worfhipped with all kinde of lafcinious wantonneffe, famous dances, as we may reade in Strabo, in his feulentecnth Booke. Apuleius confountonneffe, fongs, and Serapiades, vnder the name of both the Satyrions. and withall faith confounds the Orchides and and of the Latines, Tefticulus Leporinus. In Englion withall faith it is called Entaticos, Panion, chis, and Hares ftones.

\section{If The Nature and $Y$ ertues.}

Serapia's ftones are thought to be in nature, temperature, and Vertues, like vnto the Saryrion Royall ; and although not fo much vfed in phyficke, yet doubtleffe they worke the effect of the
other Stones.

\section{CHAP. I17. \\ Of Fenny Stones.} His hath cleft or dinided roots like fingers, much like vnto the Roots of other
Palma Chrift's; whereof this is a kinde: from the which rifeth vp a talke of a
foothigh, fet here and there with wer: frire which do clip or eot high, fet here and there with very faire Lilly-like leawes, of colour red, the 
top of the italke groweth a faire buth of very red floures, among the which floures do grow many fnill tharpe pointed leaues. The feed I could neter obferue, being a thing like dutt that flicth in the winde.

2 The other Marilh handed Satyrion differeth little from the preeedent, bur in the leaues and floures, for that the leaues are fmaller and narrower, and the floures are faire white, gaping wide open; in the hollowneffe whereof appeare eertaine things obfeurcly hidden, refembling little helmets, which fetreth forth the difference.

I I Serapias Dracontias paluftris. Marifh Dragon Satyrion.

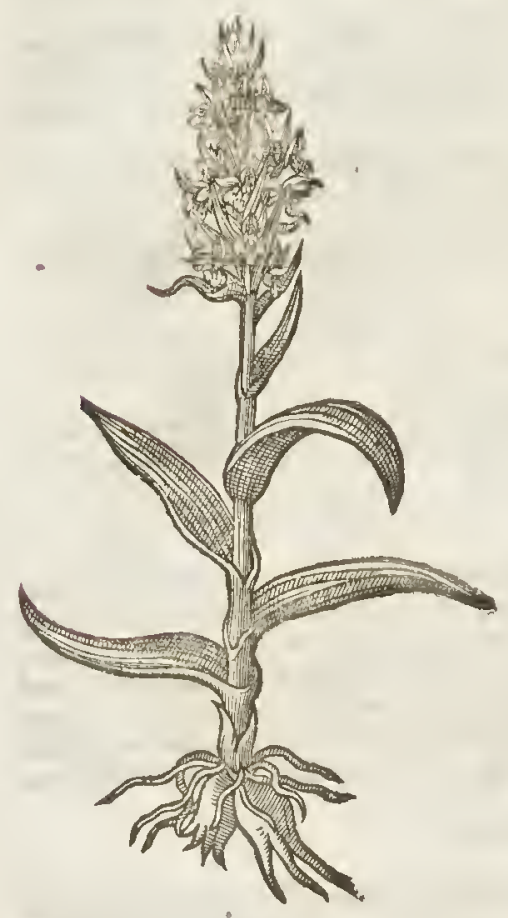

t 2 Serapias paluftris leptophylla altera. The other Marin handed Satyrion.

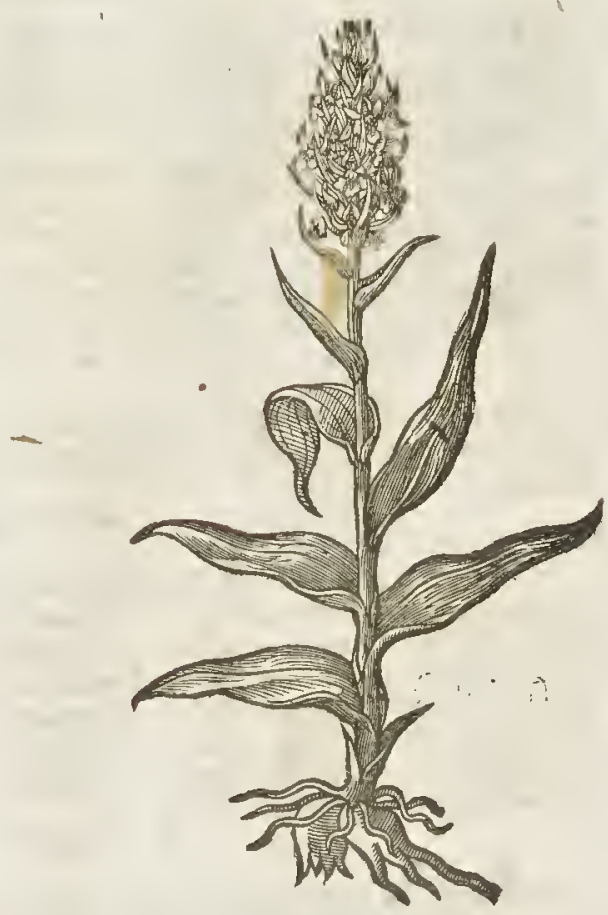

3 This third handed Satyrion hath roots famioned like an hand, with fome ftrings faftned to the vper part of them; from which riferh vp a faire ftiffe ftalke armed witl large leaues, very no. tably dafht with blackith fpots, elipping or embraeing the ftalke round about :at the top of the ftalke ftandeth a faire rufr of purple foures, wirh many greene leaues mingled among ft the fame, which maketh the bufh or tuft much greater. The feed is nothing elfe but as itwere duft like the - other of hiskinde : $\ddagger$ and it is contained in fueh twined veffels as you fecexpreft apart by the fide of the figure; which veffels are not peeuliar to this, but eommon to moft part of the other Satyrions. $\ddagger$

4 Thecreeping rooted Orehis or Satyrion without reftieles, harl many long roots difperfing themfelues, or ereeping far abroad in the ground, contrarie to all the reft of the Orehides: which Roots are of the bigneffe of Atrawes, in fubstance like rhofe of Sopesort ; from the which immediately doch rife foure or fiue broad fmooth leaues like vnco the fmall Plantaine, from the whieh fhootcth vpa fmall and tender ftalke, at the top whereof groweth a pleafant fpikic eare of a whitith colour, fpotted on the infide with little fpeckes of a bloudic colour. The feed alfo is iery fmall.

* 5 This from handed roots like others of this kinde fends vp a large ftalke, fomerimes attuining to the height of tro eubits; the leanes are much like to thofe of the marifh Satyrions; the floures are of an elegant purple, with little hoods like the top of an helmet (whence Gemma 
3 Palma Chriffipaluffris.

The third handed mariph Satyrion.

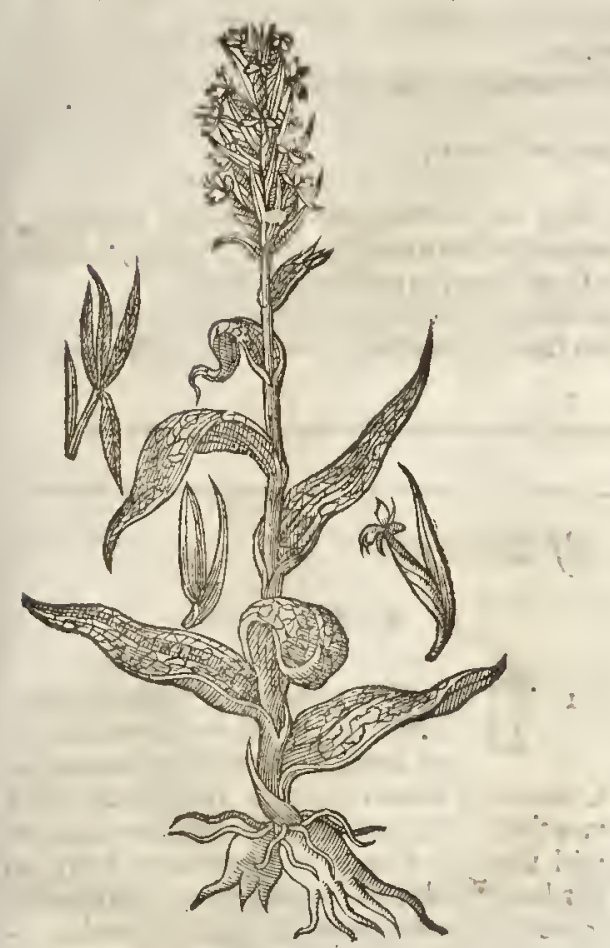

4 Palima Chrifti, radice repente.

Creeping Satyrion.

Saty rimmi repiens.

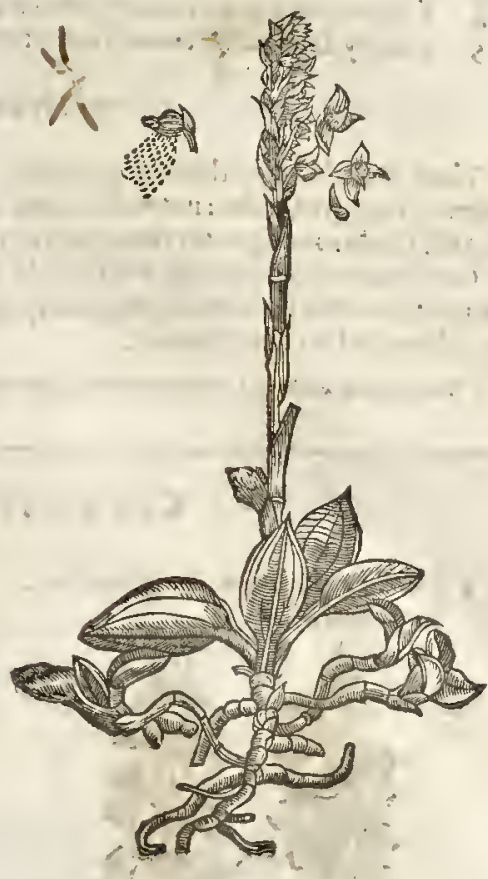

\$ Palma Chriftimaxima.

The greateft handed Satyrion: Orchis Comoperat

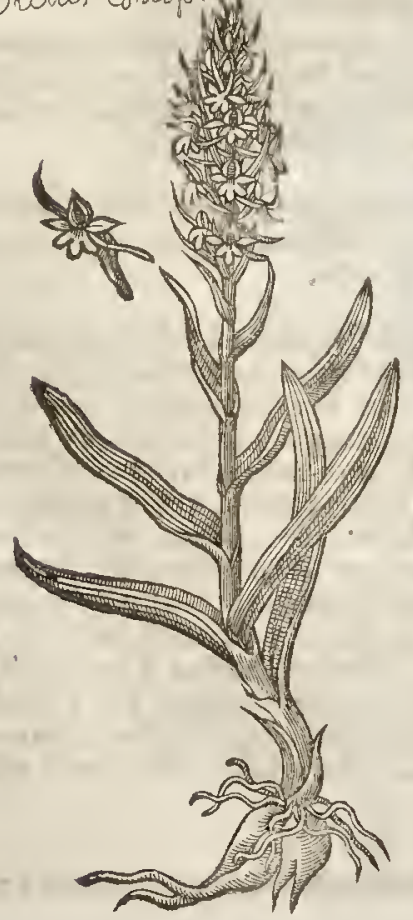

termed the plant, Cynoforch. conop reat and from the height he called it Macrocazlos.) Thefe floures fmel fweet, and are fucceded by feeds like thofe of the reft of this kindred.

It delights to grow in grounds of an indifferent temper, not too moift nor too dry. It floures from mid-May to mid-Iune. $\ddagger$

\section{The Place.}

They grow in marith and fenny grounds, and in thadowiewoods that are very moift.

The fourth was found by a learried Preacher called Mafter Rabert Abbot, of Bifhops Hatfield, in a boggy groue where a Conduit head doth ftand, that fendeth water to the Queenes houfe in the fame towne.

¥ It growes alfo plentifully in Hamphire, within a mile of a market Towne called-Perersfield, in a moift medow named Wood-mead, neere the path leading from Peters-field, towards Bery. ton. $\ddagger$

$$
\text { 9f The Time. }
$$

They floure and flourin about May and Iune.

$$
\text { \$ बा The Namcs. }
$$

¥ I This is Cynoforclais Dracurtias of Lobell and Gemma

2 This 
2 This is Cynoforchis painftris altera Leptapbylla, of Lobell; Tefliculus Galericulatus, of Tabernamon. tames.

3 Lobell and Gemma terme this, Cynoforchis paluftris altera Lophodes, vel nep helodes.

4 This is Orchis minor radice reperte, of Camerarius.

5 This by Lobell and Gemma is called cynoforchis macrocaulos, fiue conopfea.

\section{The Temperature and Vertues.}

There is little ve of thefe in phyficke; onely they are referred vnto the handed Saryrions, whereof they are kindes: norwitftanding Dalefcampius hath writren in his great Volume, that the Marifh Orchis is of greater force than any of the Dogs ftones in procuring of luft.

Camerurius of Noremberg, who was the firtt that defcribed this kinde of creeping Orchis, hath fet it forth $w$ ith a bare defcription onely; and I am likewife conftrained to do the like, becaufc as yet I haue had notriall thereof.

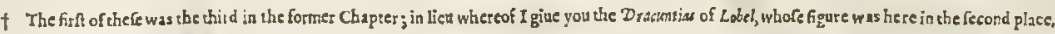

\section{C н a r.i18. Of Birdsneft.}

I Satyrium abortizum, fine 2idus aris.

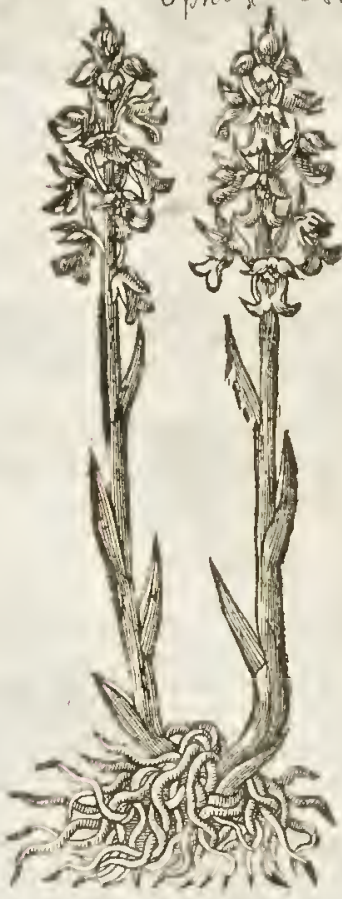
Birds neft. Ophrus uridus-aris

T) The Defription.

D Irds Neft hath many tangling roots platted or crofied one ouer another very intricately, which refembleth a Crowes neft made of ftickes f from which rifeth vp a thicke foft grofle ftalk of a browne colour,fet with fmall thort leaues of the colour of a dry $\mathrm{O}$ ked leafe that hath lien vnder the tree all the winter long. On the rop of the ftalke groweth a fpikie eare or tuft of floures, in thape like vnto Maimed Satyrion, whercof doubtlefe it is a kinde. The whole plant, as well fticks, leatres, and floures, are of a parched browne colour.

‡ I receiued out of Hampthire from my often remembred friend Mafter Goodyor this following defcription of a Nidus axis found by him the twenty ninth of Iune, $162 \mathrm{r}$.

II Nidus avis flore of caule violaces purpureo colore; an Pfeudoleimodoron Cluf. Hift. Rar. plant.

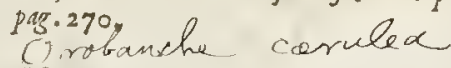

This rifeth vp with a falke about nine inches ligh, with a few fmal narrow tharpe pointed fhort skinny leates, fet without order, very little or nothing at all wrapping or inclofing the ftalke; hauing a fpike of floures like thoie of orobanche, without tailes or leaues growing amongft them: which fallen; there fucceed fmall feed-veffels. The lower part of the ftalke within the ground is not round like orobanche, but flender or long, and of a yellowith white colour, with many finall brittle roots grow ing vnderneath confufedly, wrapt or folded together like thofe of the common Nidus asis. 'The whole plant as it appeareth aboue ground, both ftalkes, leaues, and floures, is of a violet ordeepe purple colour. This I found wilde in the border of a field called Marborne, neere Habridge in Haliborne, a mile from a townecalled Alton in Hampihire, being the land of one William Balden. In this place alfo groweth wilde the thiltle called Corona fratrum. Ioh. Goodyer.

T The Place.

This baftard or vnkindely Satyrion is very feldome feene in thefe Southerly parts of England. 


\section{1 в. 1. Of the Hiftoric of Plants.}

It is reported, That it groweth in the North parts of England, neere vnto a village ealled Knaefborough. I found it growing in the middle of a Wood in Kent two miles from Grauefend, necre vnto a worhipfull Gentlemans houfe ealled Mafter William Swan, of Howeke Greene. The wood belongeth to one Mafter Iobn Sidley : whieh plant I did neuer fee elfewhere; and beeaufe it is very rare, I am the more willing to giue you all the markes in the wood for the better finding it, be= caufe it doth grow but in one pieee of the Wood : that is to fay, The ground is conered all ouer in the fame plaee neere about it with the herbe Sanycle, and alfo with the kinde of Orchis called Hermaphroditica, or Butter-fly Satyrion.

\section{If the Time.}

It floureth and flouritheth in Iune and Auguft. The dufty or mealy feed (if it may be called feed) falleth in the end of Augurt ; but in my iudgement it is an vnprofitable or barren dult, and not any feed at all.

\section{If The Names.}

Ir is called Satyrium abortitum : of fome, Nidus auis : in French Nid d' oifeau : in Englinh $h_{j}$ Birds

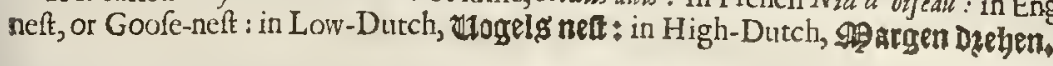

$$
\text { T) The Temperature and Vertues. }
$$

It is not vfed in Phyficke that I can finde in any anthoritic either of the antient or later Writers, but is efteemed as a degenerate kinde of Orchis, and therefore not vfed.

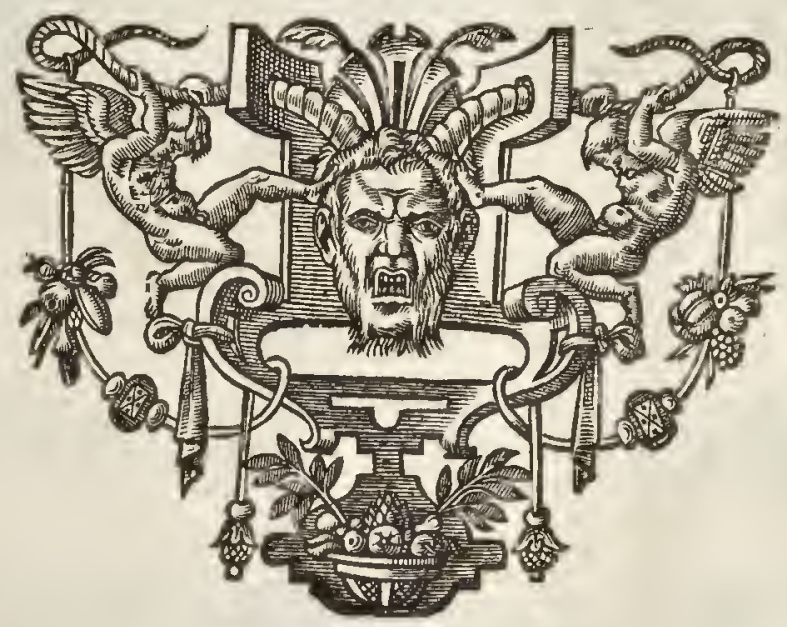




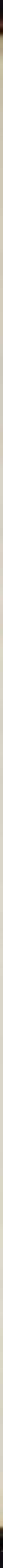




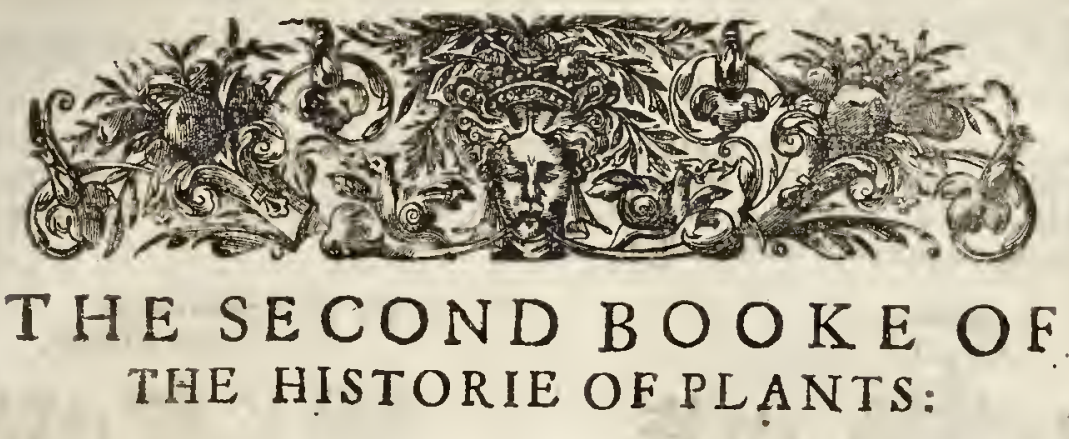
Containing the defription, place, time, nawses, natkre, and vertues of all forts of Herbes for meate, medicine, or fweet fmelling $v / e$, drc.

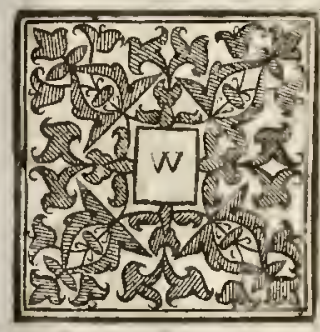

E hate in our firft booke fufficiently defcribed the Graffes, Rufhes, Flags, Corne, and bulbous rooted Plants, which fot the moft part are fuch as with theirbraue and gallant floures decke and beautifie Gardens, and feed rather the eyes than the belly. Now there remaine cer. taine other bulbes, whereof the moft (though not all) ferue for food: of which we will alfo difcourfe in the firft place in this booke, diuiding them in fuch fort, that thofe of one kinde fhall be fepatated from another. ¥ In handling thefe and fuch as next fucceed them, we fhall treat of diuers, yea the moft part of thofe Herbes that the Greekss call by $a$ generall name sexou : and the Latines, olera $:$ and we in Englin, Salletherbes. When we haue paff ourer thefe, we fhall fpeake of other plants, as they thall haue reforn? blance each to other in their extemall forme. $\ddagger$

\section{Cнат.1. Of Turneps. \\ Tा The Kindes.}

THere be fundry forts of Turneps; fome wilde; fome of the garden; fome with round roots globe fahion; other ouall or peare farhion, and another fort longith or fomwhat like a Radifh : and of all thefe there are fundry varieties, forne being great, and fome of a fmallor fort.

\section{TI Te Defoription,}

7 He Tumep hath long rough and greene leaues, cut or fnipt about the edges with 29 reepegahes. The ftalke diuideth it felfe into fundry branches or armes, bearing

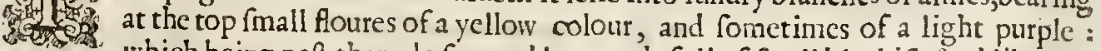
which being paft, there do fuceed long cods full of fmall blackith feed like rape reed. The root is round like a bow le, and fometimes a litele ftretehed out in length, growing very Shallow in the ground, and often thewing it felfe aboue the faee of the earth.

$\ddagger 2$ This is like the preeedent in each refpeet, but that the root is not made fo globous or bowle-fafhioned as the former, but flenderer, and numeh longer, as your may perceive by the figure wee here give you. $\ddagger$

3 The fmall Turnep is like vnto the firf deferibed, fauing that it is lefter. The root is much fiveeter in tafte, as my felfe hath often proted.

4 There is another fort of fmall Turnep faid to haue red roots; $\neq$ and there are other-fome whene rnots are yellow both within and withont; fome alfo are greene on the outfide, and orherfonc blackih. $\ddagger$

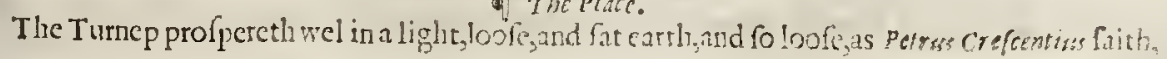


that it may be turned almof into duft. It growcth in fields and diners vineyards or Hop gardens in moft places of England.

The fmall Turnep groweth by Haekncy, in a fandy ground; and thofe that are brought to Clieape-fide market from that Village are the beft that eurer I tafted.

\section{- The Time.}

Turneps are fowne in the fpring, as alfo in the end of Augut. They floure and feed the fecond yeare after they are fowen : for thofe which floure the fame yeare that they are fowen are a dcgenerate kinde, called in Chefhire about the Namptwitch, Madueeps, of their euill cutalitie in caufing frenfie and giddineffe of the braine for a feafon.

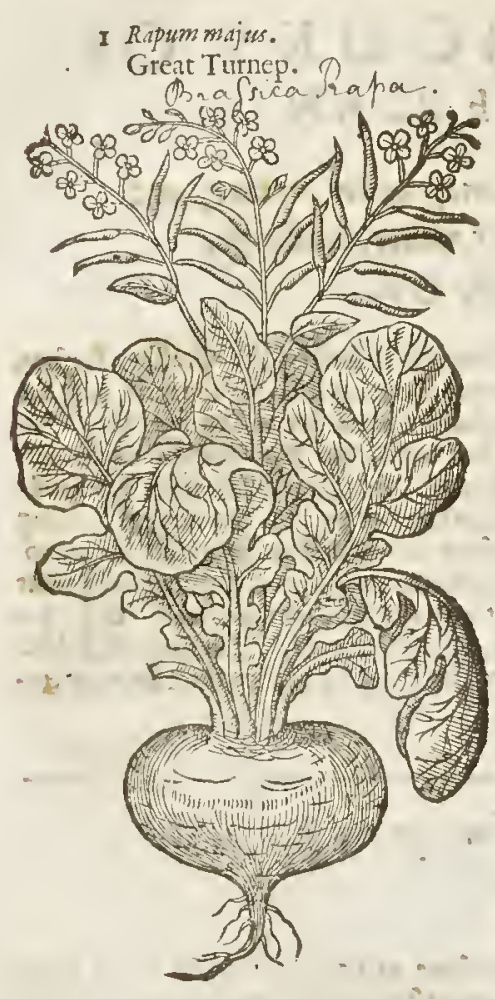

\section{$\ddagger 2$ Rapunz radice oblonga. Longifh rooted Turnep.}

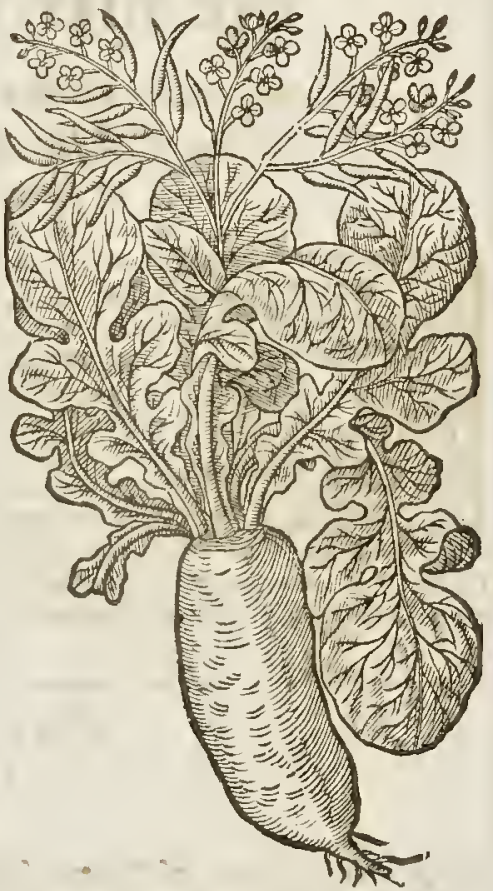

T The Names.

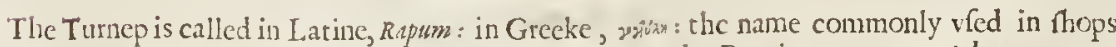

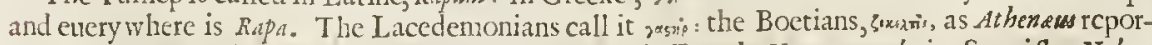
terh: in high Dutch, 1huben: in Iow Dutch, toapen: in French, Naweau rond: in Spanifh, Nabo: in Englifh, Turnep, and llape.

\section{-1 The Tempcrature and Vertues.}

A The bulbous or knobbed root, which is properly called $R_{a p u m}$ or Turnep, ind hath giuen the name to the plant, is many times catcn raw, efpccially of the poore people in Wales, but moft common!y boiled. The raw root is windy, and engendreth groffe and cold bloud; the boyled doth coole leffe, and fo little, that it cannot be perceived to coole at all, yet it is moift and windy.

$B$ It aunileth not a little afrer what manner it is prepared, for being boyled in water, or in a ccrtaine broth, ir is more moift, and fooner defcendeth, and makcth the body more foluble; bur being rofted or baked it drieth, and ingendreth leffe winde, and yet it is not altogether without winde. But how foetuer they bedreffed, they yee Id more plenty of nourifhment than thofe that are caten raw : they do increafe milke in womens brefts, and naturall feed, and pronoke vrine.

C The decoction of Turneps is good ngainft the cough and hoarfenefle of the voice, being drunke in the enening with a little fugar, or a quantitic of clarified honey.

D Dioforidiswriteth, That the Turnep it felfe being ftamped, is with good fucceffe applied wpon mouldie 
mouldie or kibed heeles, and that alfo oile of rofes boiled in a hollow turnep vader the hot embers doth eure the fame.

The young and tender thoores or fprings of Turneps at their firt comming forth of the $E$ ground, boiled and caten as a fallade, prouoke vrine.

The feed is mixed with counterpoifons and treacles : and being drunke it is a remedic againf $F$ poifons.

They of the lowe countries doe gine the oile which is preffed out of the feed,againft the after $G$ throwes of women newly broúght to bed, and alfo minifter it to young children againt the wormes, which it both killeth and driueth forth.

The oile warhed with water doth allaie the feruent heat and ruggedneffe of the skin.

\section{$\mathrm{C}_{\mathrm{HA}} \mathbf{2}$.2. Of wille Turneps.}

$$
\text { Tा The Kindes. }
$$

T Here be three forts of wilde Turneps; one our common Rape which beareth the feed whereof is made rape oile, and feedeth finging birds the other the common enemy to conne, which call Charlock, whereof there be two kindes, one with a yellow, or cls purple floure, the other with a white floure: there is alfo another of the water and marinh grounds.

I Kapum fylueftre. Wilde Turneps:

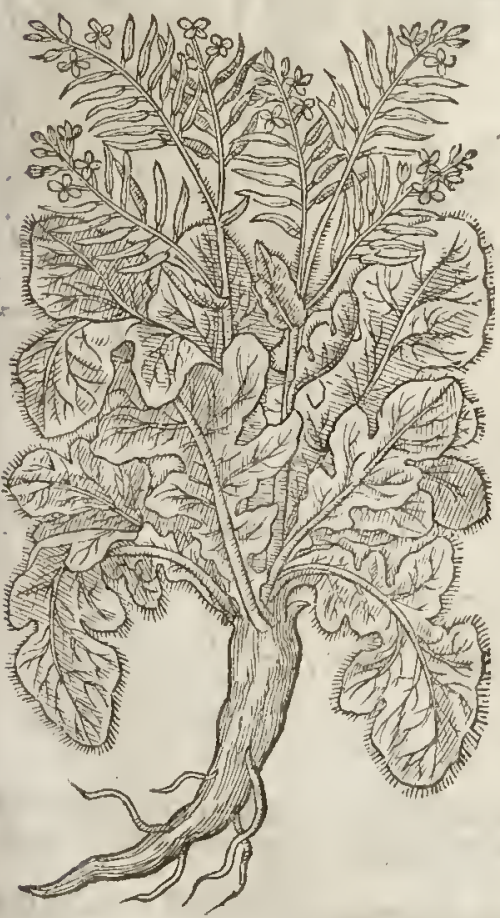

2 Rapiftrum aruorum: Charlockeor Chadlocke: Suiapis arveiasis

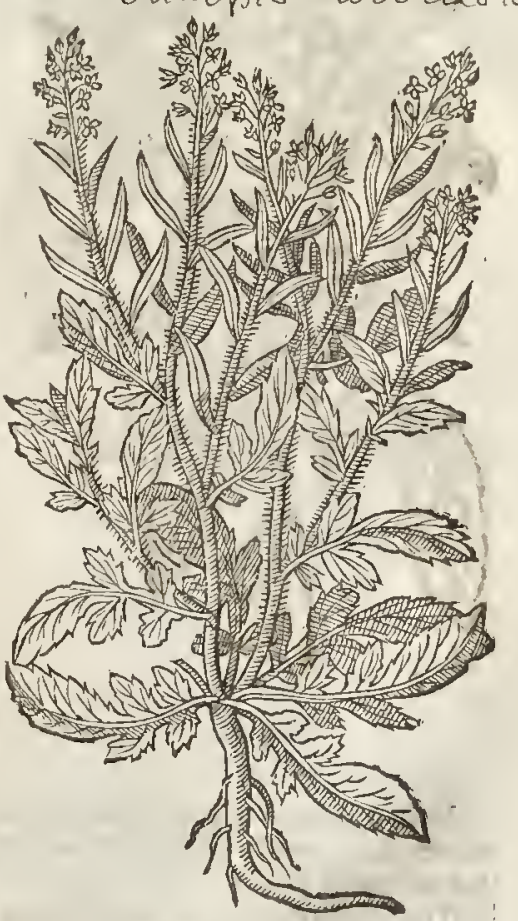

T) The Defcription?

i $\sqrt{ }$ not fodecply or Rapes, haute long, broad, and rough leaues like thofe of Turneps, bue not fodeeply gafhed in the edges. The ftalkes are flender and brittle, fomewhat haiwhereon doe grow little yellowi hh, diuiding themfelues at the top into many armes or branehes, whieh containe the feed yitow flowers : which being paft, there doe fueeced fmall long cods wheli containe the feed like that of the Turnep, but fmaller, fomewhat reddifh,and of a firie hot 
234

Of the Hiftory of Plants.

L 1 B. 2.

and biting tafte as is the muftard, but bitterer. The root is fmall, and perifheth when the feed is ripe.

2 Charlocke, or the wilde rape, bath leanes Iike vinto the former,but leffer, the ftalke and leaues being alforough. The ftalkes bee of a eubitehigh, flender, and branched; the floures are fometimes purplifh, but more often yellow. The rootes are flender, with certaine threds or ftrings hanging on rlien.

₹ There is alfo another varietic hercof with the leaues leffe diuided, and mueh fmoother than the rwo laft deferibed, haung yellow Houres and eods not fo deeply joynted as the laft defcribed: this is that,which is fet forth by Matthiolus vnder the name of Lampfana.

3 Water Chadloek groweth vp to the height of three foot or fomewhat more, with branches flender and fmooth in refpect of any of the reft of his kinde, fet with rough ribbed leatucs, deeply indented about the lower part of the leafe. The floures grow at the top of the branehes, vmble or tuft fathion, fometimes of one eolour, and fometimes of another. ₹ The root is long, tough, and full of ftrings, creeping and putring forth many ftalkes: the feed veffells are thort and fmall. Baubine hath this vnder the title of Raphonus aquaticus alter. $\ddagger$

2- Rapistrum aruenfe alterwm. Another wilde Charlocke.

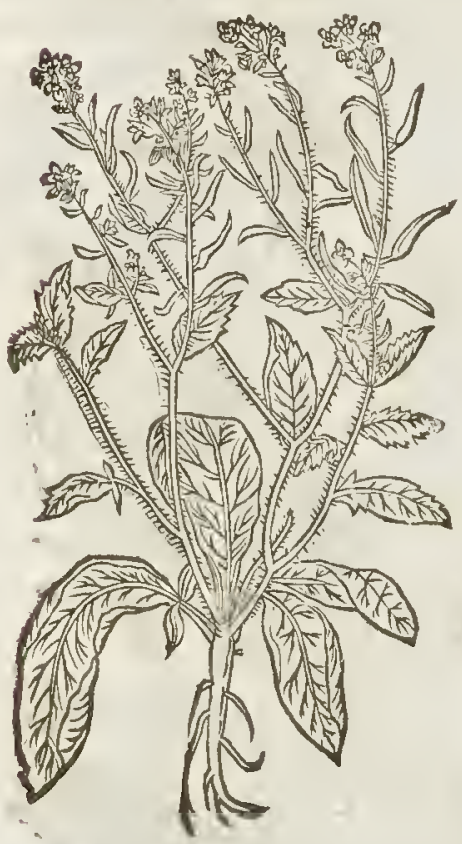

3 Rapiftrum aquaticam. Water Chadlocke.

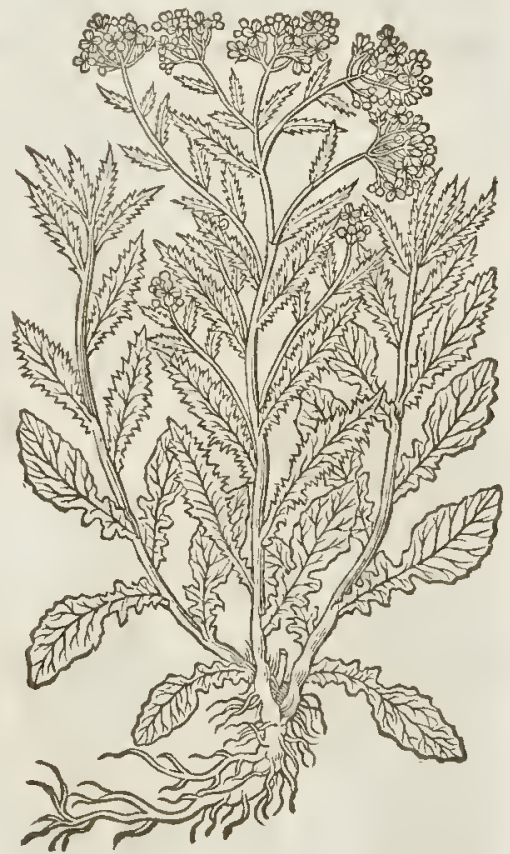

T The Place?

Wilde Turneps or Rapes, doe grow of themfelues in fallow fields, and likewife by high wayes neere vnto old walls, vpon diteh-bankes, and neere vnto townes and villages, and in orher vntoiled and rough places.

The Chadloeke groweth for the moft partamong corne in barraine grounds, and often by the borders of fields and fuch like places.

Water Chadloeke groweth in moift medowes and marifh grounds, as alfo in water ditches, and fuch like places.

T) The Time:

Thefe doe floure from March,till Summer be farre fpent, and in the meane feafon the feed is ripe. 


\section{Liв.2. Of the Hiftory of Plants.}

Wilde Turnep is ealled in Latine Rapiftrum, Rapums fylucfre, and of fone, sinapifyluffre, or wild mutard : in high Dutch, foderteh: in low Dutch, Rape, andRape feed. Rapiftrum aruorum is ealled Charloek, and Carloek.

\section{T) The Temperature.}

The feed of thefe wild kindes of Turneps as alfo the water Chadlock, are hot and drie as muftard feed is. Some haue thought that Carloek hath a drying and elenling qua'itie, and fomewhat digefting.

$$
\text { IT The Vertues. }
$$

Diters vfe the feed of Rape in feed of muftard feed, who either make liereof a fauee bearing $A$ the name of muftard, or elfe mixe it with muftard feed: but this kinde of fauce is not fo pleafant
to the tafte,becaufe it is bitter.

Galen writerh that thefe being eaten engender euill blond : yet Dioflorides faitl, they warme the B ftomacke and nourifh fomewhat.

\section{CHA r.3. Of $\mathcal{X}$ (anewes. \\ The Kindes.}

There be fundric kindes of Nape or Nauewes degenerating from the kindes of Tumep: of which fome are of the garden; and other wilde, or of the field.

N Auew gentle is like vnto Tumeps in ftalkes, floures, and feed, as alfo in the fhape of the leaues, but thofe of the vauew are mueh fmoother; it alfo differeth in the root:the Turnęp is round like a globe, the Nauew root is fomewhat ftretehed forth in length.

I I Bunias. Nauew Gentle.

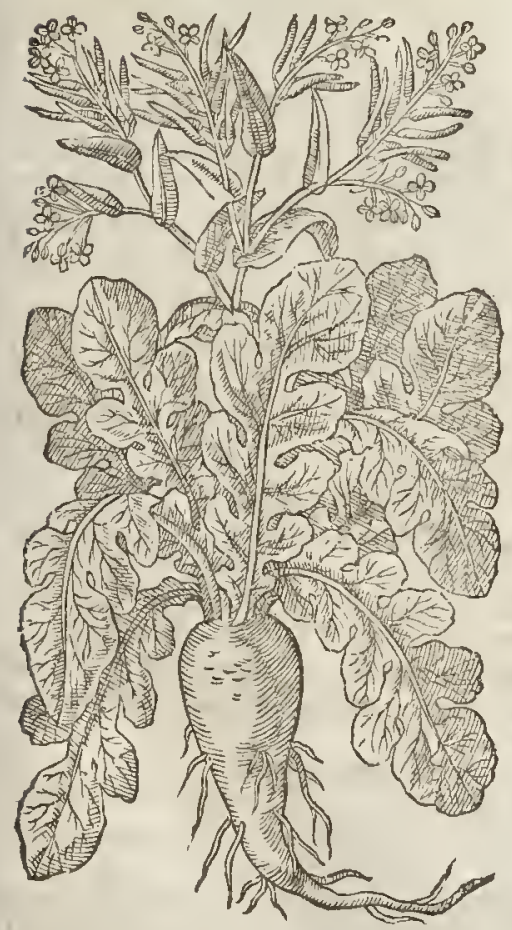

+2 Bunias fylueftres L'Obely. Wilde Namer. Brafsica Mapors.

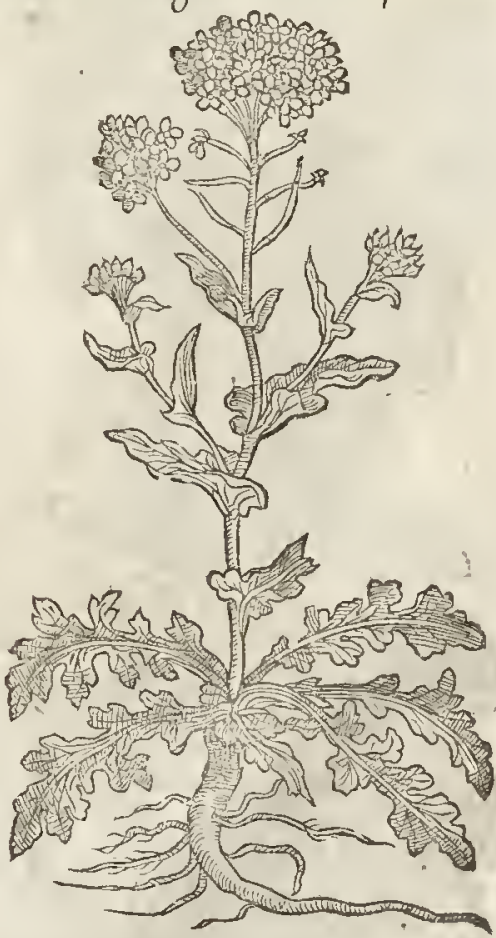

2 The fmall or wilde Nanew is like vnto the former, fauing that it is altogether leffer; The root is fmall, lomewhat long, with threads long and tough at the end thereof. 


\section{6 \\ Of the Hiftory of Plants. \\ $L_{1 B .2 .}$}

\section{- The Place.}

Nauew-gentlc requireth a loofe and ycllow mould cuen as doth the Turncp, and profpereth in a fruitfull foilc : he is fowen in France, Batraria, and other places in the ficlds for the feeds fake, as is likcwife that wild Colewort called of the old writers Crambe : for the plentifull increafe of the feeds bringetl no fmall gaine to the husbandmen of that countrey, becaufe that being preffed they yeeld an oile which is ved not onely in lampes, but alfo in the making of fope; for of this oilcand a lie made of certaine athes, is boilcd a fope which is vfod in the Lowe-countries cuery where to fcourc and wath linnen clothes. I have heard it reported that it is at this day fowcn in England for the fame perporc.

The wildc Naucw groweth vpon ditch bankes ncere vnto villages and good townes, as alfovpon frefh marhic bankes in moft places.

$$
\text { T. The Time. }
$$

The Naurew is fowen, floureth and fcedcth at the fame timcthat the Turnep doth.

$$
\text { q1 The Names. }
$$

The Nautew is called in Latine Napus, and alfo Bunias : in Greeke Brwis: the Germaincs call it Stectruben: the Brabanders, Stectropen: in Spanifh, $N_{a p s}:$ in Italian, Namo: the Frenchmen, 2 nuenu: in Englifh, Nauew-gentle, or Frcnch Naueau. The other is called Napus fylucftru, or wild Naucw.

\section{The Temperature and Vertues.}

The Nauew and the Turnep are all one in temperature and vertues, yer fome fuppofe that the Nauew is a little dricr, and not fo foonc concosted, nor pafteth downe fo eafily, and doth withall ingender leffe winde. In the reft it is anfwerable to the Turnep.

A $\mp$ The feeds of thefe taken in drinke or broth are good againft poyfon,and arc vfually put into Antidotes for the fame purporc. $\neq$.

The figure that was in the firf place is a kinde of the long Turnep delcribed by me in the lecond place of the firit chapter of this fecond book s. And shat in the fecond place was a leffe kande of the Iame.

Turnep, or Lyons leafe.

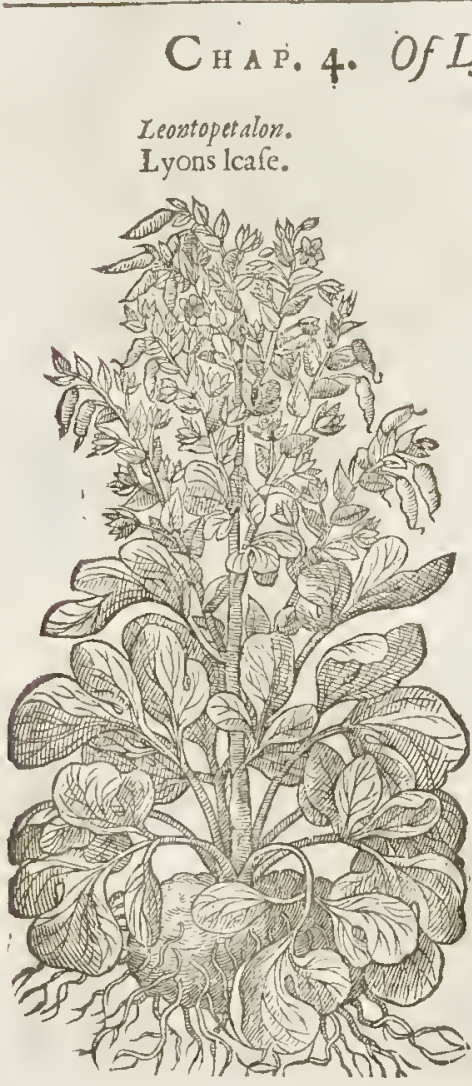

Leontopetalon.

Lyons lcare.

\section{T) The Defcription:}

T Yons Turnep or Lyons leafe, hath broad leaues likc unto Colcworts, or rather like the pionyes cut and diuided into fundry great gafhcs: the ftalke is two foot long, thicke, and full of iuycc, diuiding it felfe into diuers branches or wings; in the tops whereof itand red floures : afterward there appcareth long cods in which lie the foeds like nnto tares, or wilde chichs. The root is great, bumped liken Turnep, and blackewithout.

\section{T) The Place.}

It groweth among conc in diucrs places of Italy, in Candiealfo, and in other Prouinces towards the South and Eaft. The right homorable Lord Zouch brought a plant hereof from Italy at his returnc into England, the which was plantcd in his garden. But as farre as I doe know, it perifhed.

$$
\text { T) The Time. }
$$

It floureth in winter, as witneffeth Petrus Bel. lonizs.

$$
9 \text { The } 2 \text { ames. }
$$

The Grccians call it Ammerresh, that is, Leonis folium, or Lyons leafc: Plinie doth call it alfo Leontopetalon: Apuleisu, Leontopodion : yet there is another plant called by the fame namc. There bce many baftard Names giucn vnto it, as 


\begin{tabular}{ll}
\hline L I B. 2. & Of the Hiftory of Plants. \\
\hline Rapcium, Papauerculum, Semen Leoninum, Pes Leopinus, and Brumari
\end{tabular}

Lyons Iurnep.

Iyons Turnep is of force to digen The Temperature.

is of force to digent; it is hot and dric in the third degree, as Galen teacheth.

I The Vertues.

The root (faith Diofsorides) taken in wine doth helpe them that are bitten of Serpents, and it A doth moft peedily alay the paine. It is put into glifters which are made for them that bee tormented with the Sciatica.

\section{HA. 5: Of Radijh.}

T The Kindes.

7 Here be fundrie forts of Radih, whereof fome be long and white; others long and blacke; fome round and white; others round, or of the forme of a peare, and blacke of colour ; fome wilde, or of the fieid; and fome tame, or of the garden, whereof we will intreat in this prerent chapter.

\section{I Raphanas fativus?} Garden Radifh.

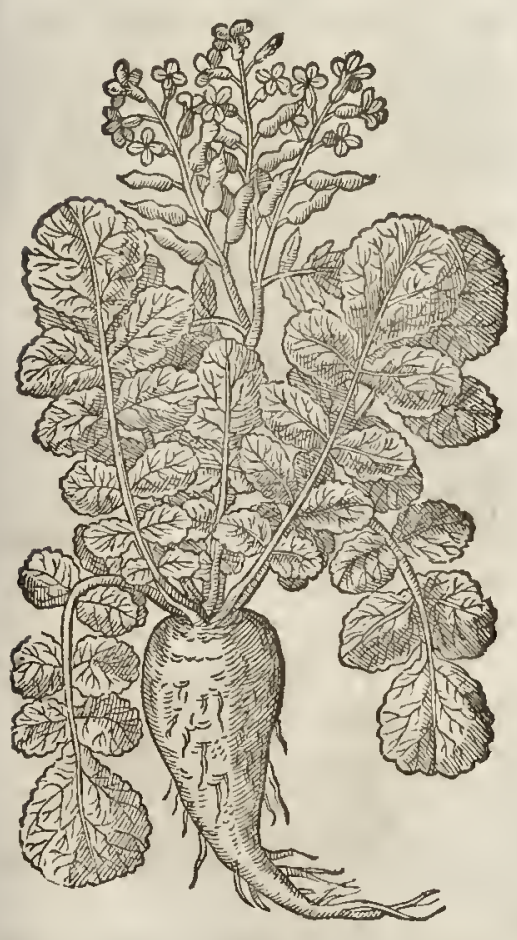

$\$ 2$ Radicula fatiraminor. Small garden Radifh.

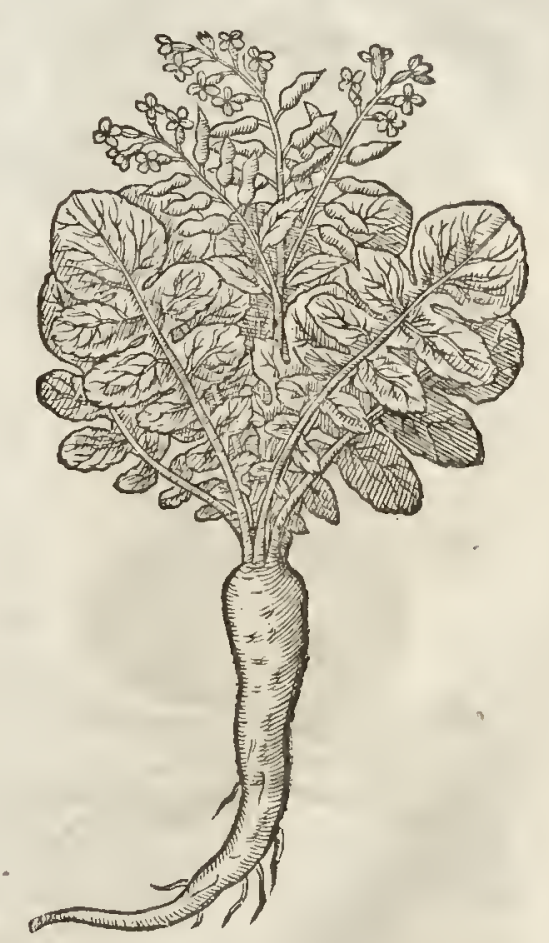

T The Defcription.

THe garden Radiph fendeth forth great and large leaues, greenc, rough, cut on both round and parted into meen ganthes nolike to the garden Turnep, but greater. The ftalkes bee made of foure little leaues : and when huft or blowne vp toward the when they be aat, there doe come in place tharpe pointed cods of a light browne colour, fomewhe, full of fpungious fubftanee, wherein is contained the feed, is groffe, long, and white both hat greater than the feeds of Turneps or Coleworts. The roor 
2 The fmall garden Radioh hath leaues like the formct, but fmaller,and nore britte in landling. The ftalke of two cubits high, wherconbe the flomes like the former. The fced is fmaller, and not fo tharpe in tafte. The root is fmall, long, white both withinasd witlont, execpt a little that theweth it felfe aboue the ground of a reddith eolour.

3 Radifh with a round ront hath leaues like the garden Tumep : among which leaves fpringeth vp a round and fmooth talke, dividing it felfe toward the top into two or thrce brarehes, whereondoe grow fmall purplifh Houres made of foure leaucs apece : which being pant, there doecome in plize fmall long cods puft vo or bunehed in two, and fometimes thrce places, full of pith as the common Radith ; wherein is eontained the feed, fomcwhat fmaller than the Colewort feed, but of a hotter tafte. The root is round and firme, rothing watcrifh like tlie common Radifh, more pleafant in tafte, whol fomer, nor caufing fuch finking belehings as the garden Radin doth.

4. The Radih with a root fanhioned like a peare, groweth to the height of three or fourecubits, of a brightreddith colour. The leaues aredeeply cut or joged like thofe of the Tumep,

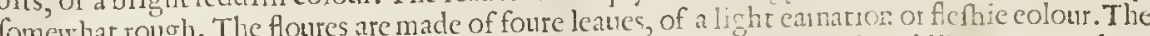
feed is eontained in fmall bunched eods like the former. The root is fafhioned like a peare or long Turnep, blackew ithout and white with in, of a firme and folide fubtance. The tafte is quicke and harpe, biting the tongue as the other kindes of Radin, but more ftrongly.

3 Rhiphanus orbiculatin. Round Radith.

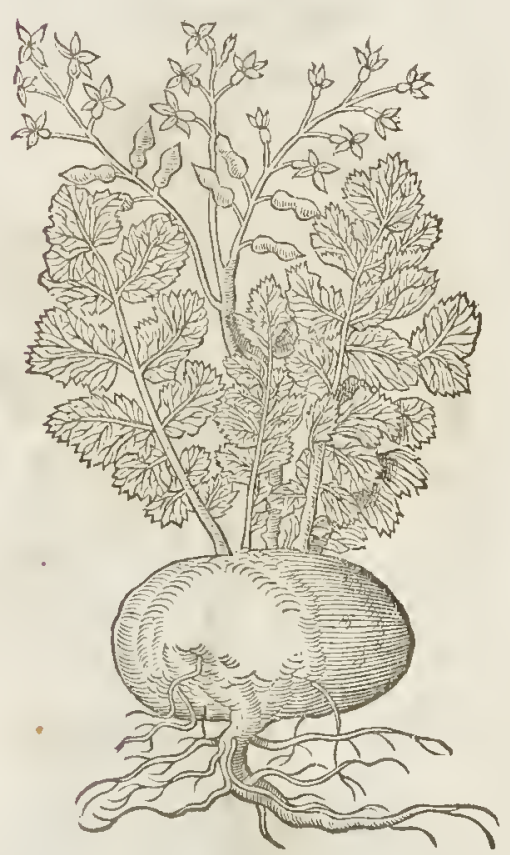

4 Ropharas pyriform, fuse radice nigra. The blacke, or Peare-fathion Radifh.

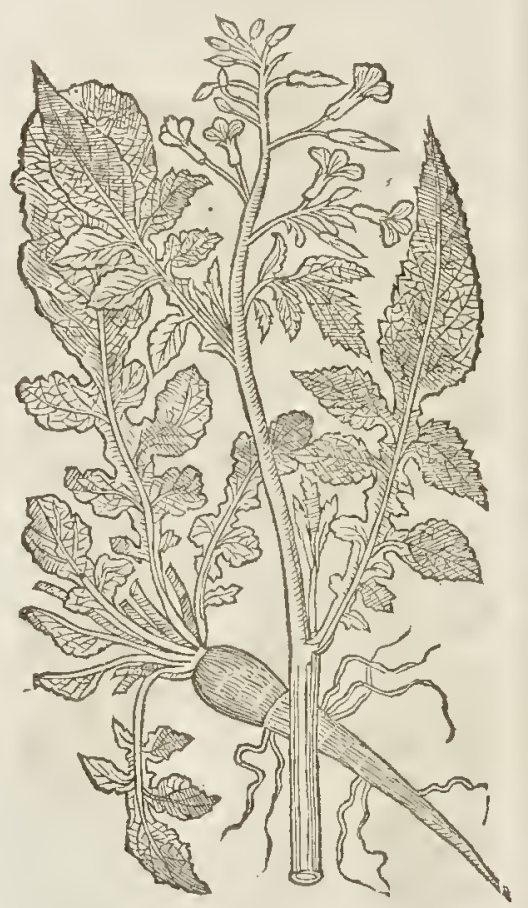

The Place.

All the kindes of Radifly require a loofe ground which hath beene long manured and is fomewhat fat. They profperwell in fandie ground, where they are not fo fubiect tow ormes,as in other grounds.

T The Time.

Thefe kindes of Radith are noft fitly fowen a fter the Summer Solftice in Iune or Iulie: for be ing foret betimes in the fpring they yeeld not their roots fokindly nor profitably, for thes they doe for the moit part quiekly run vp ro ftalkeand feed, where otherwife they doe not floure and feed till the next fpring following. They may be fowen ten moncths in the yeere, but as I faid bciore, the beft time is in Iune and Iulie. 
Ti The Nanzes.

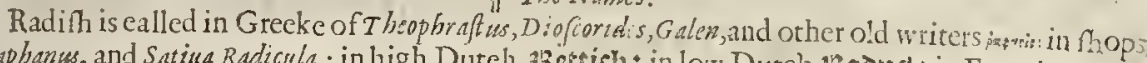
Raphanu, and Satiua Radicula : in high Duteh, isettich: in low Dutch, 1Radus : in French, Rafuri: in Italian, Raphano: in Spanih, Rawano : in Englifh, Radifh, and Rabone: in the Bohemian tongre

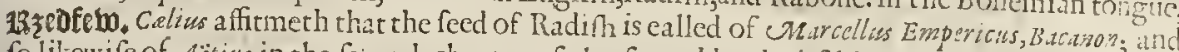
folikewife of Aëtius in the fecond chapter of the fecond booke of his Tetrabible : vet Cornarives doth not reate Bacanon, but Cacmon: The name of Bactmom is alfo found in N. Myrefses, in the 255. Compofition of his firit booke.

ๆ The Temperature.

Radith doth manifelty heat and dric, open and make thin by reafon of the biting quality that rulerl in it. Galen maketh then hot in the third degree, and drie in the fecond,and therreti that it is tather a fuee than a noutiliment.

9) The Vicrtues.

Radih areeaten taw with bread in Atead of other food; but being eaten after that manner, they A yeeld very little nourifhment, and that faulric and ill. But for the molt part, they are vfed as fauce Wrethe falty, than eaten alone ot with bread onely: but feeing they be of a harder digeftion than meares, they are alfo many times troublefome to the ftomacke; neuertheleffe, they ferue to diftribute and difperfe the no: rifhment, efpecially being takenafter meat; and taken before meat, they eaufe beiehings, and
ouerthrow the fomacke.

Before meate they eaufe vomiting, and efpeeially the rinde:the which as it is more biting than $B$ the inner fubtance, fo doth it with more force eaufe that effect if it be giuen with Oximel, whieh
is a fyrupe made with vineger and hony.

Moreouer, Radifh prousketh vrine, and diffolueth clutteted fand, and driueth it forth, if a good C draught of the decoction thereof be drunke in the morning. Pliny writeth, and Diofcorides likwife, that it is grod againft an old eutgh; and to make thin, thicke and groffe flegme which ftieketh
in the ehert.

In fead hereof the Phifitions of our age doe vfe water dittilled thereof: which likewife pro- D cuteth vrine mighrily, and driueth forth !ftones in the kidnies.

The root flieed and laid ouet night in white ot Rhenim wine, and drunke in the morning dri ueth out vrine and grauell mightily, but in tafte and fmell it is very lothfome. The toot ftamped with hony and the powder of a theepes heart dried, eauleth haire to grow in $\mathrm{F}$
nhort fpace.

The feed caufeth vomite, ptouoketh vrine: and being drunke with honied vineger, it killeth and $\mathrm{G}$
iueth forth wormes.

The root ftamped with the meale of Darnell and a little white wine vineget, taketh away all $H$ blew and blacke fpots, and brufed blemithes of the face. The root boiled in broth, and the decotion drunke, is good againft an old cough : it moueth I
womens fiekneffe, and eaufeth much milke.

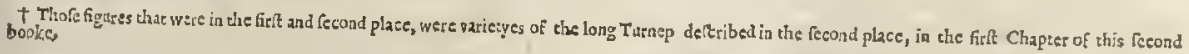

\section{С нар: 6: Of wilde $\mathbb{R}_{\text {dijf }}$ :}

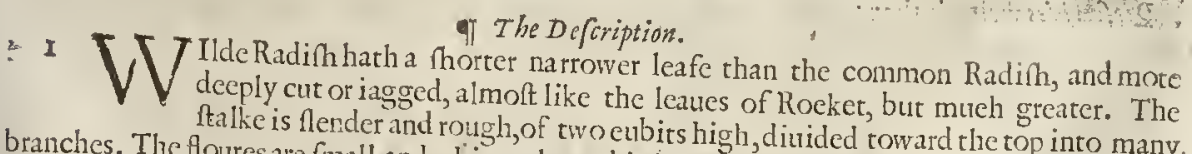
branches. The floures are fmall and white: the cot is long, flender, aud ioynted, wherein is the feed. The root is of the bigneffe of the finger, white within and without, of a fharpe and biting
tafte.

2 The water Radifh hath long and broad leaues, deeply indented or eut euen to the middle rib. The ftalke is long, weake, and leaneth this way and that way, being not able to fand vpright withvon the mudior mire where it thall neuer find it, no not when it is very young, but leaning down leaues. The root is long, fet in froweth. The floures grow at the top made of foure fmall yellow hot and burning in tafte more fundrie fpaces with finall fibres or threds like the rowell of a fpur, The firft growes vpon the borders of 9 The Place.

The ir grow es vpon the borders of bankes and ditches caft vp, and in the botders of fields. 


\section{0

The feeond growes in ditehes, ftanding waters, and riuers; as on the ftone wall that bordeteth vpon the ritet Thames by the Sauoy in London.

1 Raphamus fylueftris.

Raphamas Raphanistrum

Raphamas Raphamistrum

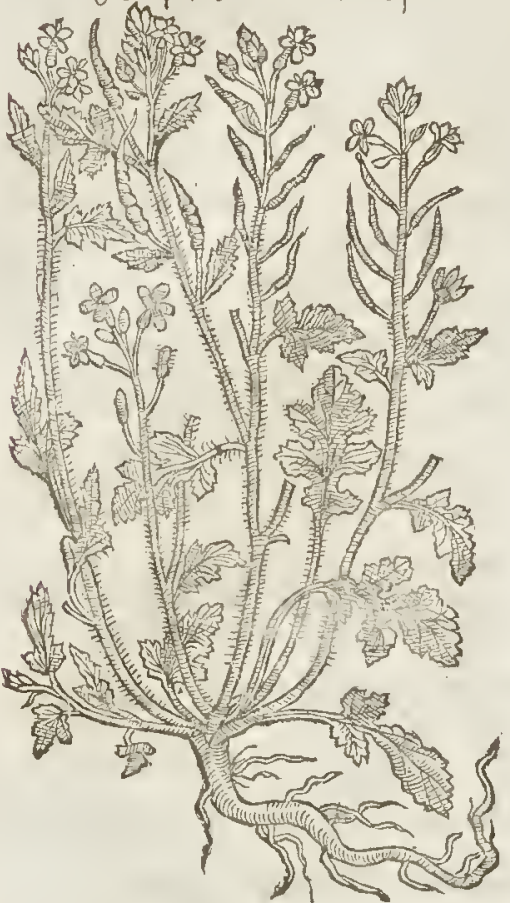

2 Raphanus aquaticus. Sis Water Radifh.

phibi in

\section{Ti The Time.}

They floure in Iune, and the feed is ripe in Augut.

$$
\text { If The Naimes. }
$$

t The firft of thefe is Rapiftrum fore albs Eruce folys, of Lobell : Armoratia, or Rapiftrums album of Tabirnamontanus : and Raphitnus fylveftris, of our Author : in Englinh, wilde Radifh.

The fecond is Radicula fytueftris of Dodoneus:and Rhaphanus aquaticus, or paluftris of others: in Englifh, water Ravifh.

\section{T) The Temperature.}

The wilde Radithes are of like temperature with the garden Radin, but hotter and drier. If The vertues.

A Dioforides writeth, that the leaucs are receiued among the por herbes, and likewife the boiled root, whieh as he laith, doth heate, and prouoke vrine.

\section{Cin a . 7. Of Horje Radifh.}

of The Defcription.

I T Orfe Radifh bringeth forth great leatres, long, broad, tharpe pointed and fnipped a. - 1 bout the edges, of a deepe greene eolour like tho ${ }^{2}$ of the great garden Docke, called, of fome Monkes Rubarbe, of others Patienee, but longer and rougher. 'The ftalke is flender and brittle, bearing at the top fmall white floures: which being paft, there follow fmall cods, wherein is the feed. The root is long and thieke, white of colour, in tarte fharpe, and very much biting the tongue like muftard.

2 Ditrander or pepperwort, hath broad leaues, long, and fharpe pointed, of a blewifh greene colour like woad, fomewhar fnipt or cut about the edges like a fawe. The ftalke is round and 


\section{I B. 2: Of the Hiftory of Plants:}

tough: vpon the branches whereof grow little white flourcs. The root is long and hatd, creeping farre abroad in the ground, in fuch fort that when it is once taken in a ground, it is not poffible to root irout, for it will vnder the ground creepe and thoot vp and bud forth in many places farre abroad. The root alfo is fharp and biteth the tongte like pepper, whereof it tooke the name pepperwort.

$\neq 3$ This which we gite you in the third place hath a fmall fibrous root, the ftalke growes vp to the height of two cubits, and it is diuided inro many branches furnifhed with white Houres, after which follow feeds like in thapeand tafte to Thlafpi, or Treacle muftard. The leaues are fomewhat like thofe of Woad. This is nourifhed in fome Gardens of the Low Countryes, and Lobcll was the firfthat gaue the figure hercof, and that vnder the fame title as wee here giue you it. $¥$.

I Raphanus rufticanus. Horfe Radifh.

Cochlearia Armoracia 2)

35 , (1) encis at 8 . Fin $=1.120$ A 3 .

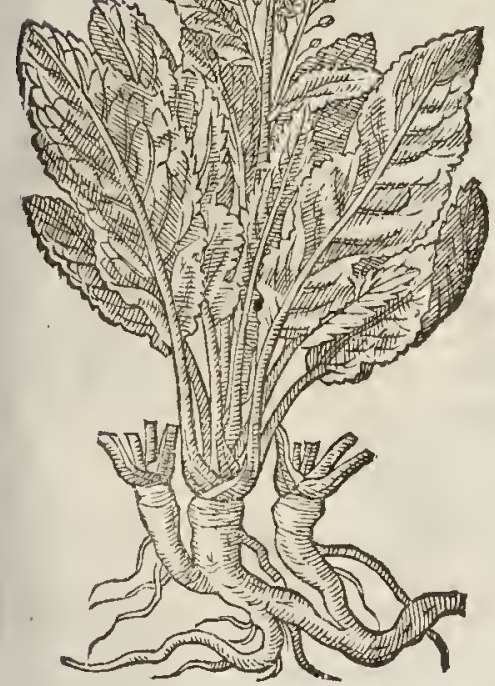

2 Raphanus fyluefris offic. Lepidium Winete Lob: Dittander, and Pepperwort.

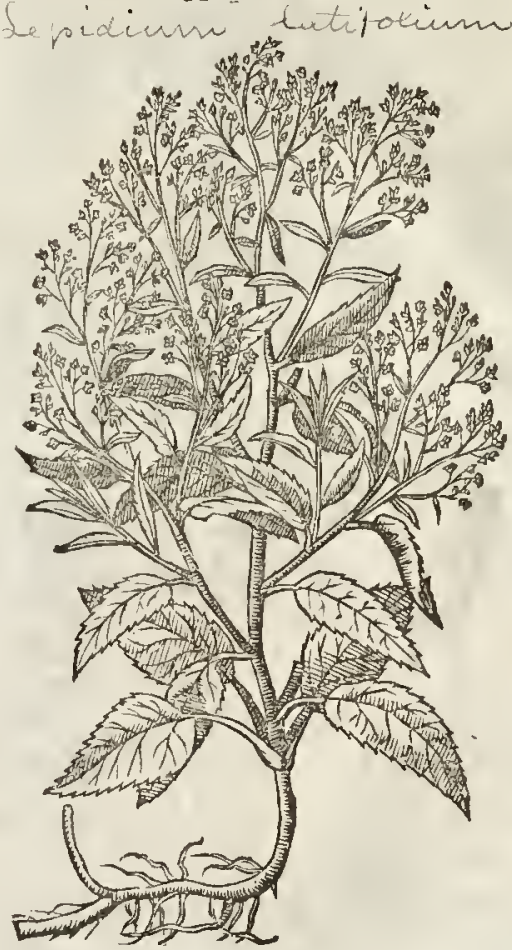

The Place.

Horfe Radifh for the moft part groweth and is planted in gardens, yet have I found it wilde in fundrie places, as at Namptwich in Cherhire, in a place called the Milne eye, and alfo ar a fmall village neere London called Hogfdon, in the ficld next unto a farme houfe leading to Kings-land, where my very good friend mafter Bredwoll practitioner in Phifick, a learned and diligent fearcher of Simples, and mafter William Martin one of the fellow fhip of Barbers and Chirurgians, my deere aud louing friend, in company with him found it,aid gaue me knowledge of the place, where it flourifheth to this day.

Dittander is planted in gardens, and is to be found wild alfo in England in fundry places, as at Clare by Ouenden in Effex, at rhe Hall of Brinne in Lancarhire, and neere vnto Excefter in the Weft parts of England. It delighteth to grow in fandie and fhadowie places formew hat moift,

Torfe Radim for the moft part floureth in A prill or May, and the feed is ripe in Auguft, and
Hot that fo rare or feldome feene, as that Petrus Placentiws hath written, that it bringeth forth no feed at all. Dittander floures in Iune and Iuly.

Horfe Radifh is commonly called Raphapus rufficarus, or Nagnus, and of diusers fimply Raphanus 


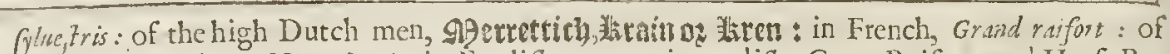
the low Germaines, Agrtradus: in Englinh, mountaine radirh, Great Raifort, and Horfe Radith. It is called in the North part of England, Redcole.

Diters thinke that this Horfe Radith is an enemy to Vines, and that the latred betweene them is fo great, that if the roots hereof be planted necie to the Vine it bendeth backward from it, as not willing to haue fellow fhip with it.

It is alforeported that the root hercof ftrmped, and caft into good and pleafant wine, doth forthwith turne it intovineger: but the old writers doe afcribe this cnnity to the vine and Braffica, our coleworts, which the moit ancients liatie named pararyes:

Dittander is defcribed of Plimy by the name of Lepidium in his 19 .booke, 9. Chapter: 1ikewife Egineta maketl mention of this plant, by the name Lepidium: in fhops, Raphanms fyluef ris, and Piperitis : the" Germans call it, 1 gerffetheant : the lowe Dutch men,19epper crupt : the Englin men,Dittander,Dittany, and Pepperwort.

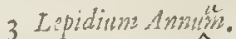
Annuall Ditander.

A

B

C

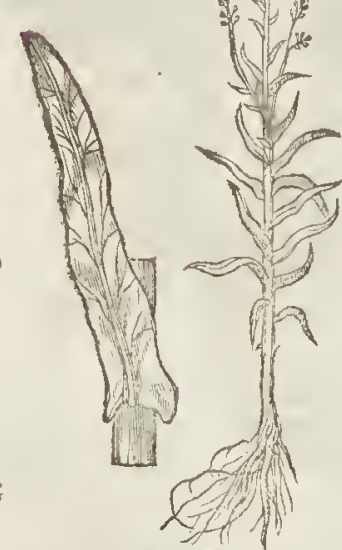

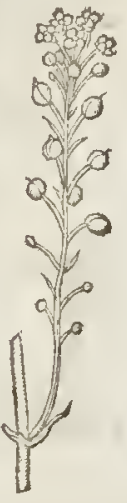

T) The Temperature.

Thefe kindes of wilde Radifhes, are hot and drie in the third degree : they hatue a urying and clenfing quality, and fomerviat digefting.

$$
\text { पा The fertses. }
$$

Horfe Radih ftamped with a little vineger put th:creto, is co.unonly ved among the Germanes for fauce to eate fith with, and fuch like meates, as we doe muftard; but this kinde of fauce doth heate the itomacke better, and caufeth better digeition rhan multard.

Oxi nel or fyrupe made with vineger and honie, in which the rindes of Horfe radifh haue beene infufed three dayes, caufeth vomit, and is commended againft the quartaine ague.

The leates boiled in wine, and a little oile oliue added thereto and laid vpon the griened parts in manner of a Pultis, doe mollifie and take away the hard fwellings of the liuer and milte and being applied to the bottome of the belly is a remedic for the ftranguric.

Ir profiteth much in the expulfion of the fecondine or after-birth.

It mittigateth and affivageth the paine of the hip or haunch, commonly called Sciatica.

It profiteth much againft the collicke, ftrangutie, and difficultic of making water, vfed in itead of muftardas aforefaid.

The root ftamped and giten to drinke, killeth the wormes in children : the ityce giuen doth the fame : an ointment made thereof, doth the like, being annointed upon the belly of the child.

H The leates of Pepperwort but efpecially the rootes, be extreame hot, for they haue a burning and bitter tafte. It is of the number of fcorching and bliftring fimples, faich Pliny in his 20.booke, the 17. chap. and therefore by his hot qualitie, it mendeth the skin in the face, and takcth away fcabs, fcarres, and nuang ineffe, if any thing remaine after the healing of vlcers and fuch like.

\section{С нар: 8. Of Winter Creffes.}

\section{1) The Defcription.}

7 He Winter Creffes hath many grecne, broad, fnoothe and flat leates like vnto the com: 1 mon tumeps, whofe falkes beround, and full of branches, bringing forth at the top fmall yellow floures:after them doe follow frall cods, whercin is conteined fmall reddilh feed. 
I Barbarea.

Evijsinum Crefles,

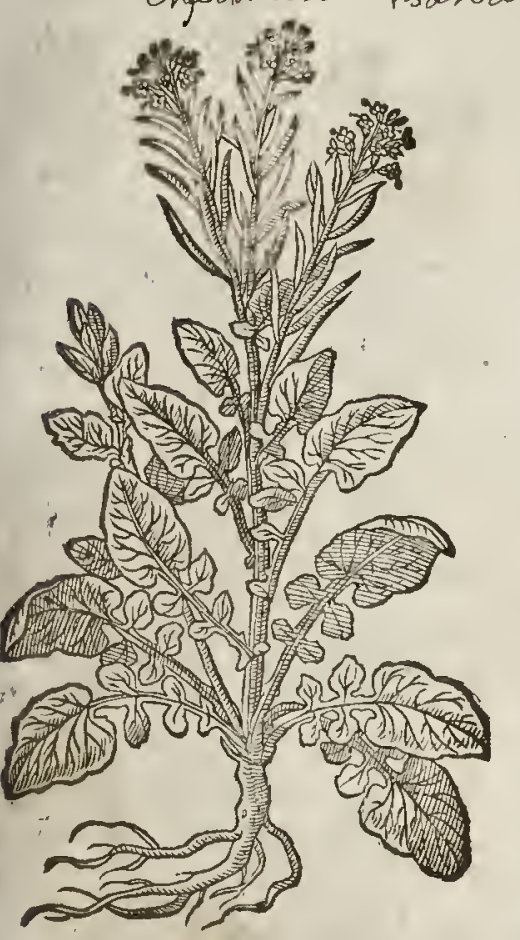

बा The Place.

It groweth in gardens among pot herbes, and very common in the fields, neere to pathes and high waycs, al moft euery where.

IT The Time.

This herbe is green all winter long, it floureth in May, and feedeth in Iune.

$$
\text { T The Nimes. }
$$

Winter Creffe is called of the Latines, Car. damum, or Nafturtium Hibernum, of fone, Barbarea, and Pfcrudobunium: the Germanes call it

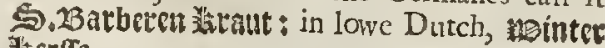
崔ertie.

It feemeth to be Diofcorides his wivisivino, that is to fay, falfe or bafard Bunium : in Englifh, winter Creffes, or herbe Saint Barbara.

$$
\text { Tा The Nature. }
$$
gree.

This herbe is hot and drie in the fecond de-

\section{Tा The Vertues.}

The feed of winter Creffc caufeth one to A makewater, and driuerh forth graull, and hel. peth the franguric.

The iuyce thereof mundifieth corrapt and fil- $B$ thy vlcers, being made in forme of an vnguent with waxe, oyle, and turpentine.

Inwinterwlien falad herbes bee farce, this $\mathrm{C}$ hetbe is thought to be equall with Creffes of the garden,or Rocket:

This herbehelpeth the fcuruie, being boiled among fcuruie graffe, called in Latine Cochlearia, caufing it to worke the more effectually.

\section{C на г.9. Of Muftard.}

\section{IT The.Defcription:}

I He tame or garden Muftard, bath grear rough .leates like to thofe of the Turnep, but rougher and leffer. 'The ftalke is round, rough, and hairie, of three cubits high, ditided into many branches; whercon doe grow fmall yellow foures, and after them long cods, flender and rough, wherein is contained round feed bigger then Rape feed, of crlour yellow, of tafte
fharpe, and biting the tongue as doth ourcommon ficld muftard.

$\ddagger 2$ Ourordinary Muftard hatl leaues like Turneps, but not fo rough, the ftalkes are fmooth, and grow fometimes to three, foure, or fue cubits high, they haue many branches, and the leaues rpon thefebranches, ef pecially the vppermort,are long and narrow, and hang downeward on fmall falkes, the cods are fhort, and lie flat and clofe to the branches, and are fome-
what fquare; the feed is reddinh or yellow. $\neq$

3 The other tame Muftard is like to the former in leaues, and branched ftalkes, but leffer, and they are morewhirith and rough. The floures are likewife yellow, and the feed browne like the Rape feed, which is alfo not a little tharpe or byting.

$\neq 4$ This which I gine you bere being the Sirnapi fativum alterum, of Lobel; and the Sinapi album of the thops, growes but low, and it hath rougli crooked cods, and whitifh feeds; the fralks;
floures, and leaures, are mueh like the firfteferibed. $\neq$.

5 The wilde Murfard hath lcaues like thofe of thepheards purfe, but larger, and more deeply made of fourc leates: the cods be the height of two foot, bearing at the top fmall yellow floures fmaller than any of the others, but not fo fharpeorbinerein is contained reddin feed, much fne thers, but not fo tharpe or biting. 
$\mathrm{L}_{1 \mathrm{~B} .2 .}$

† I Sinapi faivum. Garden Muftard.

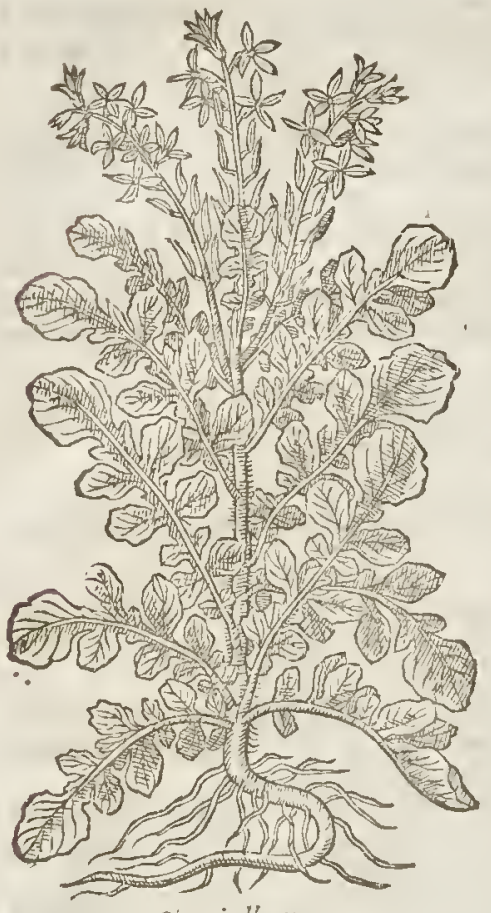

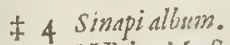
White Muftard.

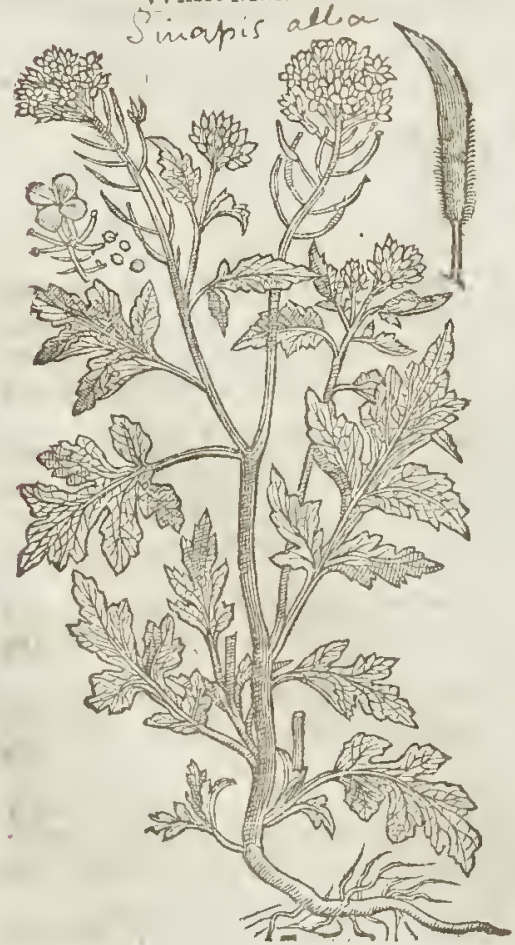

+3 Sinapifativn altcrum, Dod. Field Mufard.

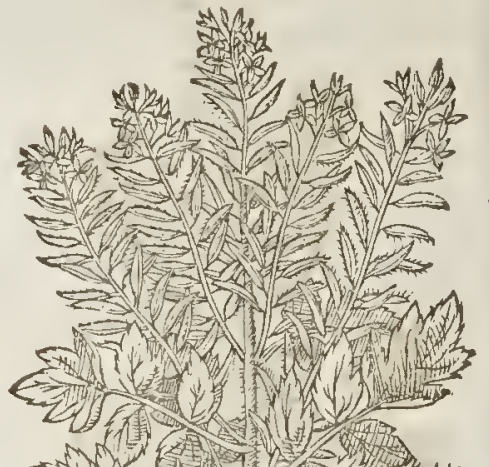

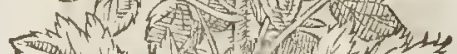

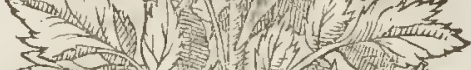

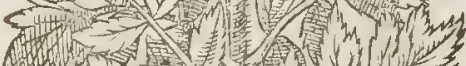
An

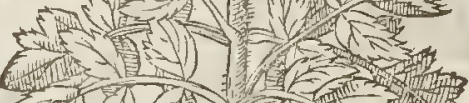

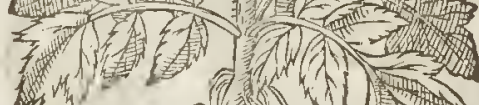
$\Rightarrow 3=-3$

t 5 Simapifyluefire minus. Snallwilde Muftard:

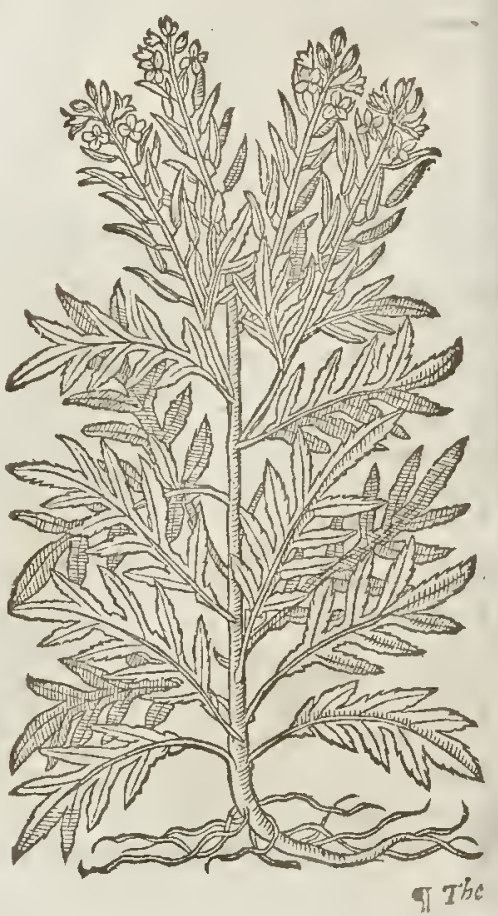




\title{
If The Place.
}

¥ Our ordinarie Muftard (whofe defcription I hauteadded) as alfo the wite and fmall groiv wilde in many places of this kingdume, and may all three be found on the bankes about the sack
of Old-ftreet, and in the way to Illington. $\ddagger$

$$
\text { ब1 The time. }
$$

Mutard my be fowen in the beginning of the Spring : the feed is ripe in Iuly or Auguft : It commeth to perfection the fame yeare that it is fowen.

$$
\text { T The Names. }
$$

The Greekes call Muttatd, aim : the Athenians called it vim : the Latines, Sinapi: the rude and barbarous, sinapium: the Germanes, Sanff: the French, seneme and Mouftarde : the low- Datchmen, 990 oftacet late : the Spuniards, Moftaza, and CMoftalla : the Bohemians, Horcice : Pliny calls it $T$ hla $p$, whereofdoubtlefle it is a kinde : and fo ne hate called it $S$ surion.

$\neq$.Thefe kndes of Muttard hane beene fo briefely treated of by all Writers, that it is hard to giuc the right diftinctions of them, and a matter of more difficultie than is expected in a thing fo vulgarly knowne and vfed: I will therefore endeauour in a few words to diftiuguifh thofe kindes of muftard which are vulgarly written of.

I The firft is Sinatpiprimum of cilatthiolus and Dodonaws; and Sinapi fativem Eruca aut Rapifolio
of Lobcl.

2 The fecond I cannot iuftly referre to any of thofe which are written of by Authours; for it hath not a cod like Rape, as Pena and Lobel defcribe it; nor a feed bigger than it, as Dodonacus a fir $r$ meth; yet I fufpect, and almoft dare affirme that it is the fame with the former mentioned by
them, though numuch differing from their figures and defeription.

3 The third (which alfo I fufped is the fame with the fourth) is sinapi alterum of crattbiolus, and Sinapiagrefte Apy, aut potius Laweris folio, of Lobel: and sinapi fativum alterum of Dodonaus.

4 The fourth is by Lobel called Sinapialtcrum fativum; and this is Sinapi aloum officinarum, as pena and Lobel affirme, Aduer.pag.68.

5 The fifth is Sinapifylueftre of Dodoneus : and sinapi fylucf re minus Burfepaffor is folio, of Lobel. It is much like Rocket, and therefore Baubine fitly calls ir Sinapi Erucc folio : in Englifhit may be
called Small wilde Muttard. \$

$$
\text { T The Temperature. }
$$

The feed of Murtard, efpecially that which we chiefely vfe, doth heat and make thinne, and alfo draweth forth. It is hot and dry in the fourth degree, according to Galen.

\section{It The vertues.}

The feed of Muftard pound with vineger, is an excellent fauce, good to be eaten with any groffe meates either fith or flelh, beculie it doth helpe digeftion, warmeth the ftomacke, and prouoketh
appetite.

It is ginen with good fucceffe in like manner to fuch as be fhort winded, and are ftopped in the $B$
reaft with tough flegme from the head and braine.

It appeafech the tooth-ache being clewed in the mouth.

They vfe to make a gargarifme with honey, vineger, and fwellings of the Vunland the almonds abour

Muttard drunke with water and honey proulethroat and root of the tongue.

The feed of muth tris water and honey prouoketh the termes and vrine. of the mother out of their fits.
It .

It is good againft the falling fickeneffe, and fuch as have the Lithargie, if it be laid plaifter- $G$ wife vpon the hear (after fhaning) being rempered with figs.

It helpetls the Sciatica, or ache in the hipor huckle bonc: it alfo cureth all manner of paines $H$ proceeding of a cold caule.

It is mixed with good fucceffe with drawing plaifters, and with fuch as wafte and confume I
odes and hard fwelings.

It helpeth thofe that bine

come of brui fings.

\# The feed of the white Muftard is vfed in fome An̂tidotes, as Electuarium dcouto, $80 c$.

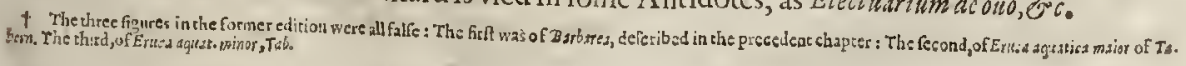
.

.




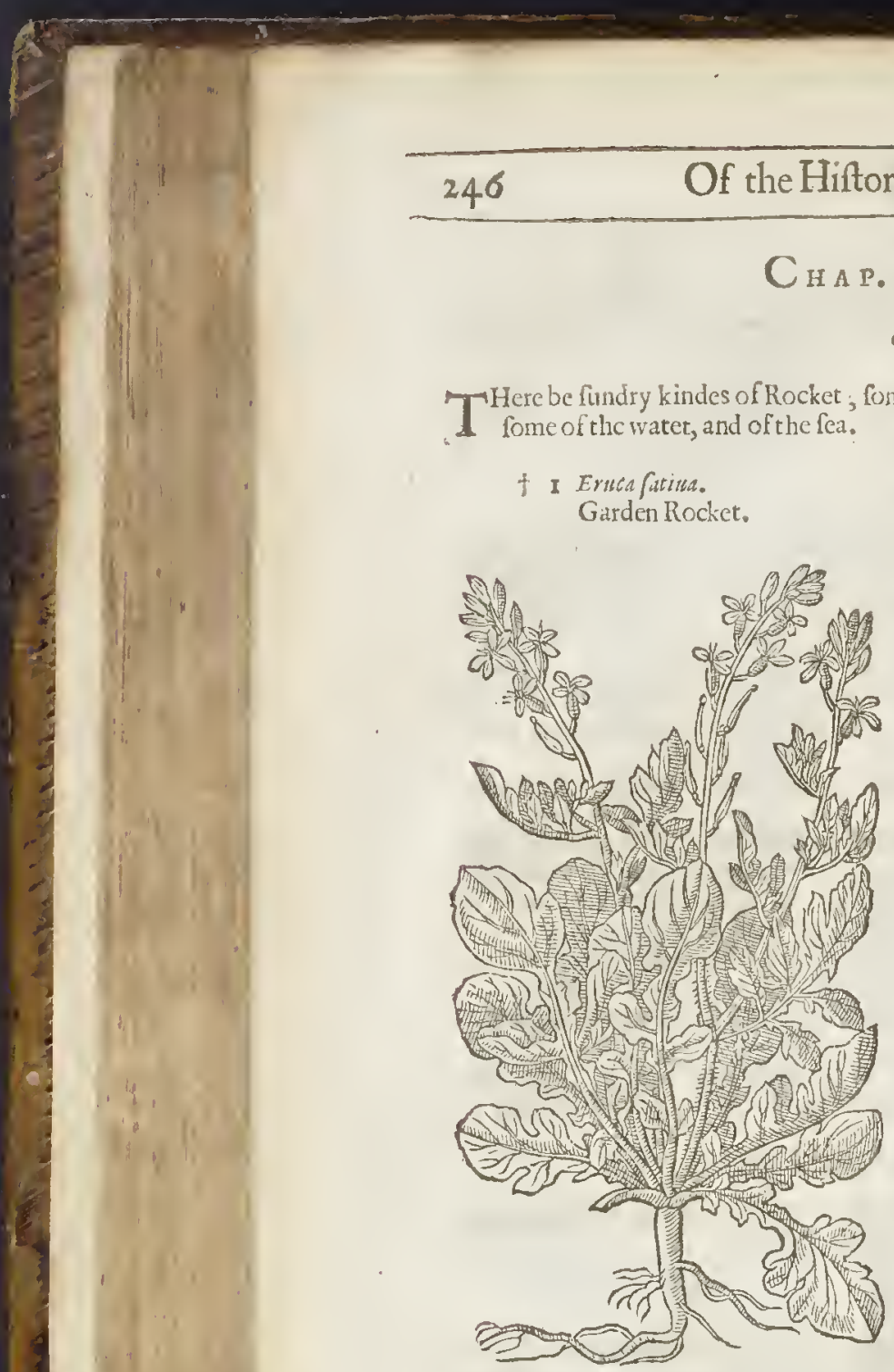

The Kindes.

$\rightarrow$ Here be fundry kindes of Rocket; fome tame, or of the garden; fome wilde, ot of the field ;

$f$ I Eruea fatius.

Garden Rocket.
2 Erucafylueftris.:

Wilde Rocket.

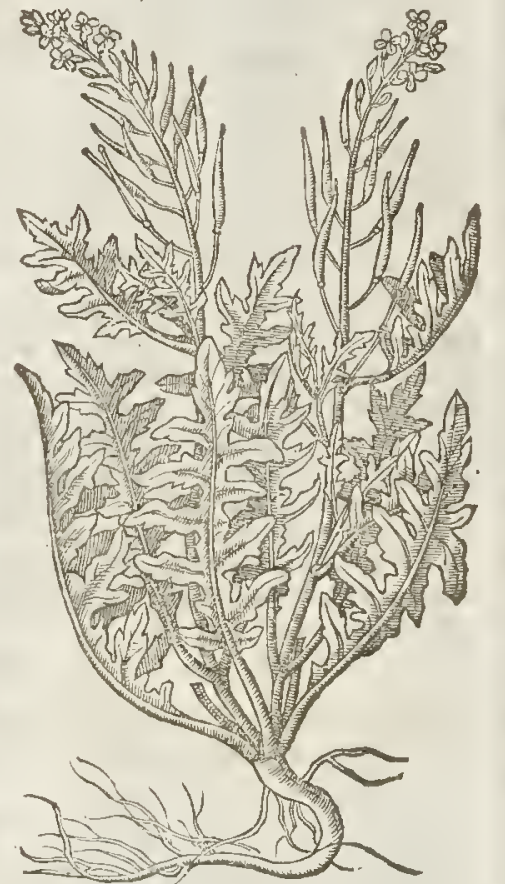

T The Defeription.

1 Atden Rocket, or Rocket gentle, hath leaues like thofe of Turneps, but not neere fo Treat nor rough. The falks rife vp of a cubit, \& fomtimes two cubits high, weak and brittle; at the top whereof grow the floures of a whitilh colour, and fonetimes yellow ifh; whieh being part, there do fucceed long cods, which containe the feed, not vnlike to rape feed, but fmaller.

2 The common Rocket, which fome keepe in Gardens, and which is vfually called the wilde Rocket, is leffer than the Romane Kioeket, or Roeket-gentle, the leatues and falkes narrower, and more iagged. The fioures be yellow, the cods alfo flenderer, the feed thercof is reddinh, and biteth the tongue.

3 This kinde of Rocket hath long narrow leaues almoft fuelu as thofe of Tarragon, but thicker and fatter, refembling rather the leaues of Myagrum, al together vnlike any of the reft of the Rockers, fauing that the braneh, Houre, and feed are like the garden Rocket.

4 There is another kinde of Roeket, thought by that reuerend and exeellent Herbarift Carolus Chifus to beat kinde of Creffes; if not Creffes it felfe, yet eoufine germane at the leaft. Vnto whofe cenfure zoblizs is indifferent, whether to eall it Rocket with thinne and natrow leates, or to eall it Coutre to the kindss of Crefles, hauing the tafte of the one, and the thape of the other. The leaucs are mueh diuided, and the floures yellow.

5 There is is a wild hind of Seathocket which hath long weake and tender branches trailing 
vpon the ground, with long leatks like vnto eommon Rocket, or sather Groundfwell, hauing fmall and whitih blew floures; in whofe place commeth fmall cods, wherein is conrained feed like that of Barley.

$\$ 6$ Befides the fe there is another plant, whofe figure which here I gine was by our Autio: formerly fet forth in the preectent ehapter, ,nder the title of Sinapifylueftre; together wirh a large kinde thereof, vnder the name of sisapi fatioum alterum. Now I will onely deferibe the larer, which I haue fometimes found in wet plaees: The root is woódy : the ftalke fome frot long, erefted, and hauing many branches, lying on the ground : the leafe is mueh diuided, and that after the manner of the wilde Rocket : the floures are of a bright yellow, and are fueceeded by ftor: crooked cods, wherein is contained a yellowith feed. $\ddagger$

t 3 Erucalglueftris angufifolia. Narrow leaned wilde Roeket.

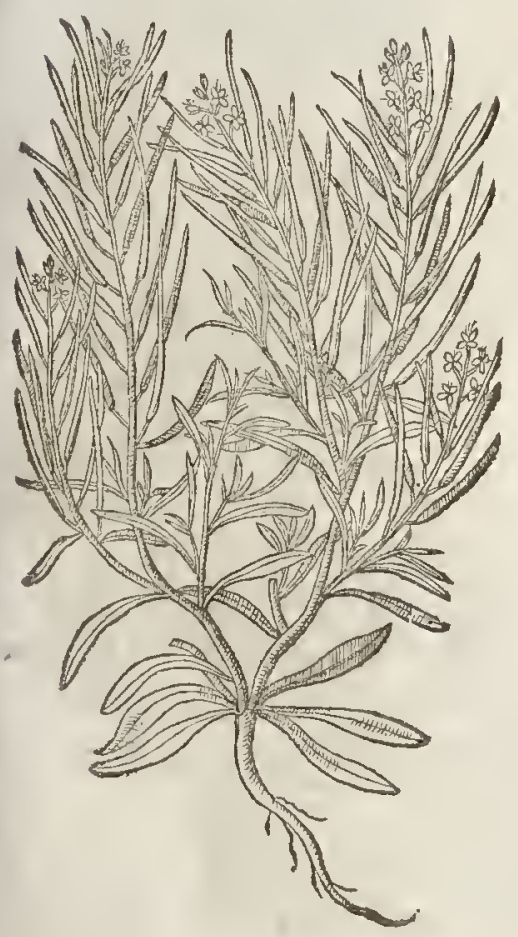

\$ 4. Erucanaftíntiocognatatenuifolis:" Creffy-Rocket.

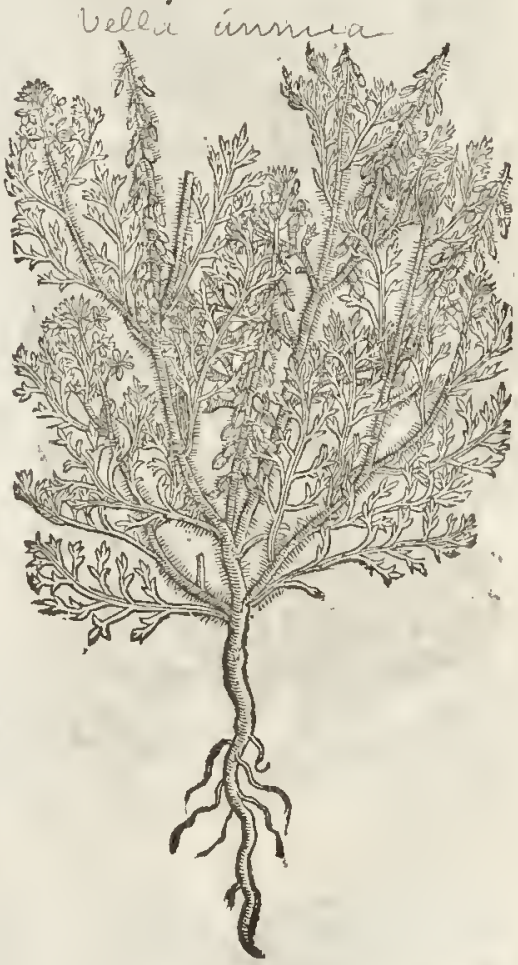

ก The Place.

Romane Rocket is eherifhed in Gardens,

Common orwilde Rocket groweth in moft gardens of it felfe : you may lee moft bricke and ftone walls about London and elfewhere couered with it.

The narrow leatied Roeket groweth neere vnto water fides, in the ehinkes and creuifes of ftone walls among the morter. I found it as ye go from Lambeth bridge to the village of I.ambeth, vn:
der a fmall bridge that.you muift paffe ouer hard by the Thames fide.

I found Sea Rocket growing vpon the fands neere vnto the fea in the Ifle of Thanet, hard by houfe wherein Sir Heary Cripe did fometimes dwell, ealled Queakes houfe.

\section{T The Time.}

Thefe Kindes of Roeket floure in the moneths of Iune and Iuly, and the feed is ripe in Sep-

The Romane Rocket dieth ettery yeare, and recoureth it felfe againe by the falling of his
wne feed. 


\section{or The Names.}

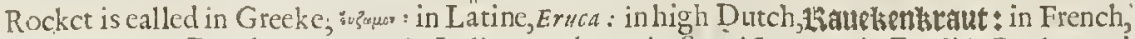

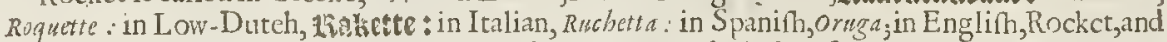
Racket. The Poets do oft times name it Herbafalax : Eraca doth fignific likewife a certainc cankcr worme, which is an enemie to pot-herbes, but efpeeially to Coleworts.

‡ The firft is called Eruca fatiua, or Hortenfis major: Grcat Garden Rockct.

2 The fecond, Eruca fylucfris: Wilde Roelet.

3 This third is by Lobel called Eruca fy lueftris anguft folia : Narrow lcaued wilde Rockct.

4 Clufus fitly calls this, Nafturtium fylueftre : and he reprehendeth Lobel for altering the name into Eruca Nafurio cognatatennifolia: Creffy-Rocket.

5 The fifth is Erucamarina, (thought by Lobel and others to be Cakile Serapionis,) Sca Rocket,

6 Eruca aquatica: Water Rockct.

$\ddagger 5$ Erucanurina. Sea Rockct.

Bunias Cakile

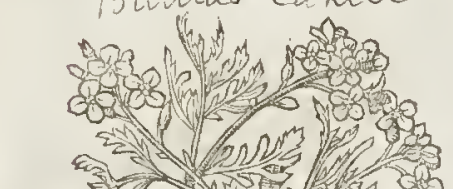

हो mus

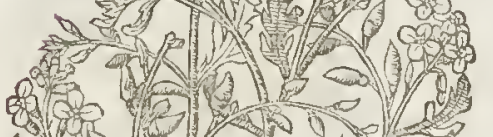

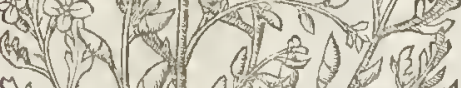
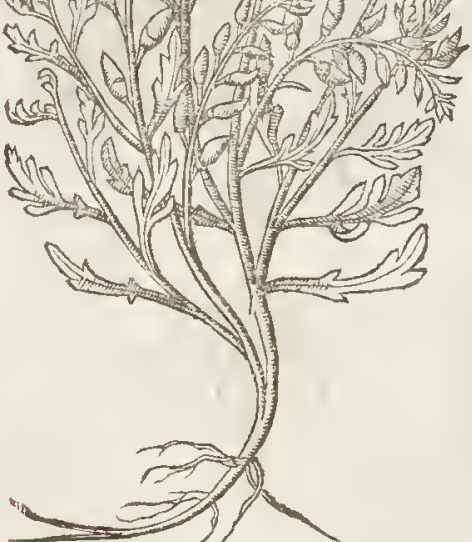

† 6 Eruca muatica. Sisymabiume Syluestre

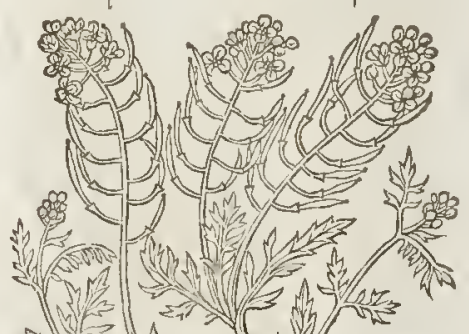

सI

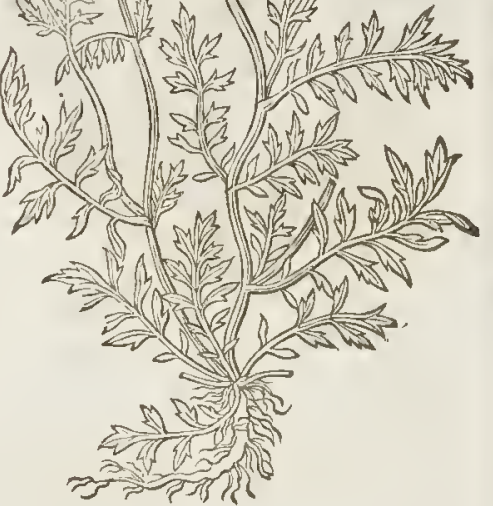

I The Temperature.

Rocket is hot and dry in the third degree,thercforc faith Galen it is not fit nor accuftomed to be eatcn alone.

$$
\text { ब The Vertues. }
$$

A Rocket is a good fallct hcrbc, if it bc carcn with Lettucc, Purflane, and fuch cold herbes; for be? ing fo eaten it is good and wholefome for the ftomacke, and caufcth that fueh eold herbes do not otrer-coolc the famc : othervife, to be catcn alonc, it caufeth head-achc, and hearcth too much.

B The ve of Rocket ftirreth vp bodily luf, efp:cially the fecd.

C It prouoketh vrine, and caufcth good digeftion.

D Plinv reporteth, That whofocucr taketh the fced of Rocket bcforc he be whipt, thall bc fo hardened, that he fhall eafily endure the paines.

E The root and feed ftamped, and mixed with Vineger and the gall of an Oxe, takcth away freckles, lentiles, blacke and blew fpots, and all fueh dcformities of the face.

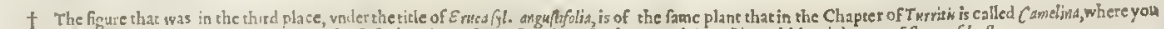

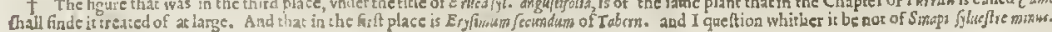




\section{Ch A.11. Of Tarragon.}

Dracoherba.

Tarragon.

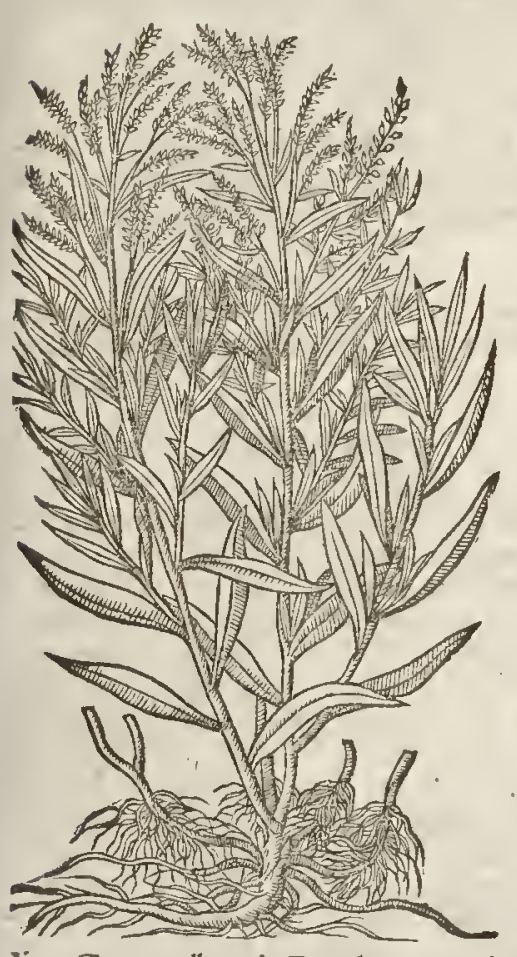

T) The defcription.

TArragon the fallade herbe hath long and narrow leaues of a deepe greene colour. greater and longer than thofe of eommon $\mathrm{Hy} \mathrm{I}^{-}$ lope, with flender brittle round ftalkes two cubites high: about the branehes whereof hang little round flowers, neuer perfcetly opened, of a yellow colour mixed with blaeke, like thofe of common VVormerrood. The root is long and fibrous, creeping farre abroad uncter the eart l, as doe the rootes of Couch-grafie, by which fprouting forth it increafeth, yeelding no feede at all, but as it were a eertaine chaffie or dnftic matter that flieth aw ay with the winde.

$$
9 \text { The place. }
$$

Tamagon is cherithed in gardens, and is encreafed by the young thootes: Rucllius and fieh others haue reported many ftrange tales hereof fcarfe worth the noting, faying, that the feed of flaxe put into a radifh roote nr fea Onion, and fo fer, doth bring forth this herbe Tarragon.

$$
\text { 9) The time. }
$$

It is greene ail Summer long, and a great part of Autumne,and floureth in Iuly.

$$
\text { Thenames. }
$$

It is called in Latine, Draco, Dracunculus hor-

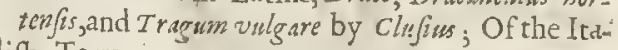
lians, Dragoncellum; in French, Dragon, in Englifh, Tarragon.

It is thought to be that Tarchors which Aincer mentioneth in his 686 . chapter:but he writed fo little thereof, as that nothing can certainly be affirmed of it. Simeon Seibi the Greeke allo maketh mention of $T$ archon.

\section{T. Thetemperature and vertues.}

Tarrigon is hot and drie in the third degree, and not to be eaten alone in fallades, but ioyned with other herbes, as Lettuce, Purflain, and fuch like, that it may alfo tempe: the coldnes of them, like as Rocket doth,neither doe we know what other vfe this lierbe hath.

\section{Cin A P.12: Ofgarden Crefses. \\ T) The defcription.}

I Arden Creffes or Towne Crefles hath fmall narrow iagged leanes, tharpe and burning in tafte. The ftalks be round, a cubite high,which bring forth many fmall whice flowers, andafter little flat huskes or feede veffels, like to thofe of the pheards purfe, wherein are contained feeds of a browne reddifh colour: The roote dieth when the feede is ripe.

2 There is anodher kinde in talte like the former, but in leanes farre different, which I reco: uered of fcedes, fent me from Robinus dwelling in Paris. The ftalkes rife vp to the height of a foor, garnifhed with miny broad leanes deepely cut or indented about the edges : the middle of the leafe is deckt and garnifhed with many little fmall leaues or rather fhreds of leaues, which make the fame like a curlde fanne of feathers. The feede is like the former in fhape.

3 Spanifh Creffes rifeth forth of the ground like vnto Bafill, aftervards the leaues grow larger and broader, like thofe of Marigolds; among the which riferh vp a crooked lymmer ftalke, 
whereupon do grow fnall tufts or fpokie rundles of white flowers. The feede followetl, bronne of colour, and bitter in tafte. The whole plant is of a loathfome fmell and fautour.

4 Stone-Creffe groweth flat vpon the ground, with leaues iagged and cut abo:1t the ed ges like the oake leafe, refembling well the leaues of thepheardes purfe. I hawe not feene the flow ers, and thercfore they be not expreft in the figute; norwithftanding it is reported vnto me, that they bee fmall and white of eolour,as are thofe of the garden Crefles. The feed is contained in fnall pouches or feede veffels, like thofe of Freaele muftard or Thlafpi.

$$
\text { Tf The Place. }
$$

Creffes are fowneingardens, it skils not what foile it be ; for that they like any ground,efpecially if it bewell watered. $\neq$ M. Bowles found the fourth growing in Shropfhire in the fields aoout Birel in the parifh of Elefmere, in the grounds belonging to M. Richard Herbert, and that in great plenty. ‡

$$
\text { If The Time: }
$$

It maybe forvne at any time of the yeere,vnleffe it be in Winter; it groweth vp quickly, and bringeth forth betmes both falke and feede: it diethenery yeere, and reeouereth it felfe of the fallen or thaken feed.

1 Nafturtiunz bortenfe. Garden Creffes.

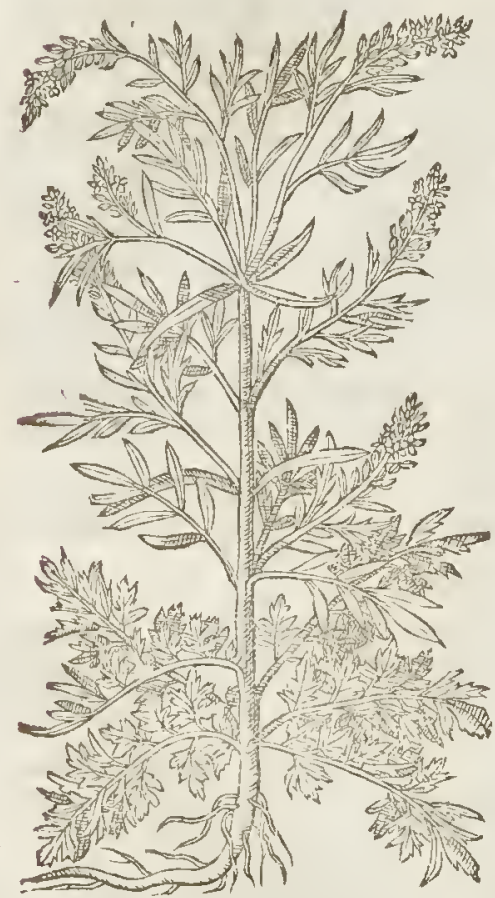

The Names.

Creffes is called in Greeke wastum: in Latine $N$ aftursum; in Englith Creffes:tle Germaines call

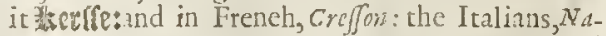
furtio, and Agretto: of fome, towne Creffes, and garden Karffe. It is ealled Noffurtim, as Virro and plinte thinke in narribus torquendis, that is io fay, of writhing the Lofhrils, which alfo by the loathfome fmell and tharpnefie of the feededoth eaufe fileefing. $\neq$ The firft is called Niffurtium bortense, Garden Crefles, 2 Lafurtium borterife cripum, Garden Creffes with erifpe, or eurled le.ues. 3 Nafurtium Hipsazicum, or Latifolum; Spanifh Crefles, or Broad-leaued Creffes, 4 This is Nafurtium petream of Tolernamontanus (and not of Lobell, as our Author termid it.) Stone Creffes.

\section{T The Temperature.}

The herbe of garden Creffes is tharpe and biting the tongue; and therefore it is very liot and drie, but lefie hot 'whileft it is yong and tender,by rea fon of the waterie moifture mixed therewith,by whieh the tharpeneffe is fomewhat allaied.

The feede is mucl more biting then the herbe, and is hot and dric almoft in the fourth degree.

\section{of The lertues.}

Gilen faith that the Crefles may be eaten with breal $r$ chtiobfonimm, and fo the Antient Spartanes vfually did; and the low-Countrie men many times doe, who commonly ve to feed of Creffes with bread and butter. It is caten with orher fallade hearbes, as Taragon and Roeket: and for this caufe it is elicfely fowen.

It is good againt the difeafewhieh the Germaines eall Scopbuch and Scotbupe: in Latine,

B Scorbutus : which we in England call the Seuruic,and Seurby, and vpon the feas the Skyrby: it is as good and as effectuall as the Scuruie graffe, or water Cieffes.

C Diofiorides faith, if the feed be ftamped and mixed with lony, it cureth the lardneffe of the milt: w itl Vineger and Barley meale parcled it is a remedic againft the Seiatica,and taketh away hard fwellings and inflammations. It feourethaway tetters, mixed with brine : it ripeneth felons, called in Greeke, som : it foreibly cutteth and raifeth vp thieke and tough humors of the eheft, if it be mixed with things proper againft the fuffing of the lungs.

Diofiorides faith it is hurfull to the ftomacke, and roublech the belly. 
32 ajurtium Hipanicum. Spaninh Creffes.

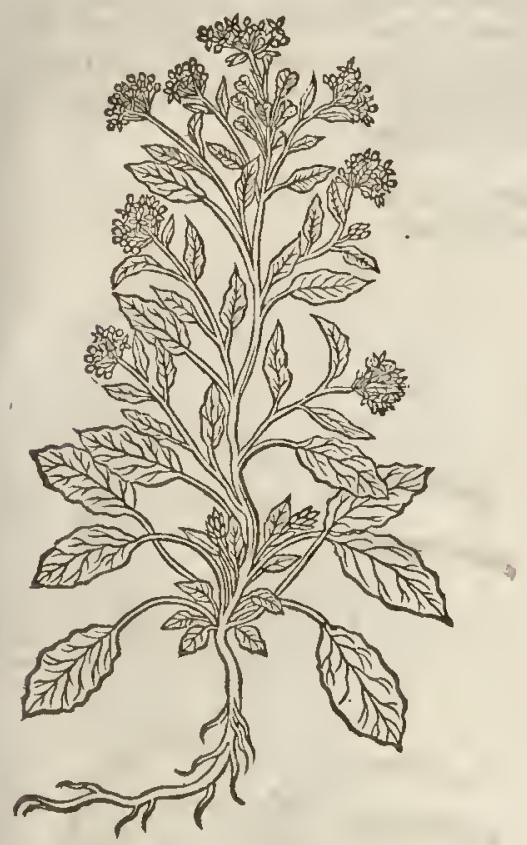

4 Nafluritism Petreum.

Stone Crefles.

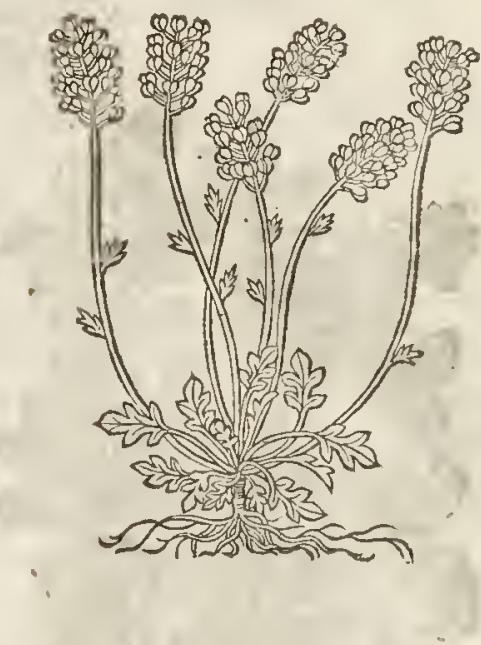

It drineth forth wornies, bringeth downe the foures, killeth the child in the mothers womb, D and prouoketh bodily lutt.

Being inwardly taken, it is good for fuch as haue fallen from high places : it diffolucth clitte- E red bloud, and preuenterh the fame that it do not congeale and thicken in any part of the body: it procureth fweat, as the later Phyfitions late found and tried by experience.

\section{Cна Р. 13. Of Fndian Creßes.}

\section{If The Defcription.}

C Reffes of India haue many weake and feeble branches, rifing inmediately from the ground, difperfing themfelues far abroade ; by meanes whereof one plant doth occupie a great circuit of ground, as doth the great Bindcweede. The tender ftalkes.diuide themfelues into fundry branches, trailing likewie vpon the ground, fonewhat bunched or fivollen vp at cuery ioint or knce, which are incolour of a light red, but the fpaces betweene the ioints are greene. The leaues are round like wall peniwort, called Cotyledon, the footeitalke of the leafe conmeth forth on the backefide alnolt in the middef of the leafe, as thofe of Frogbit, in tafte and fmell like the garden Creffes. The flowers are difperfed throughout the whole plant, of colour yellow, with a croffed ftarre onerthwart the infide, of a deepe orange colour; vnto the backe part of the fame doth hang a taile or fpurre, fuch as lath the Larkes heele, called in Latine Confolida Regalis, but greater, and the fpurre or leele longer; which being patt there fucceed bunched and knobbed cols or feede icffels, wherein is contained the feede, rough, browne of colour, and like vnto the
fectes of the beete, but fmaller.

The feedes of this rate and fait T be Place.

France and Flanders, from whare plant came firt from the Indies into Spaine, and thence into ef pecially thofe I receiued from my louing friend Iom Robin of Paris.

The feedes mit be foun in The Time.

The feedes muft be fowen in the besinning of Aprill, vpon a bed of hot horfe dung, and fomie 
fine fifted eartis caft thereon of an handfull thicke. The bed muft be couered in fundry places witl hoopes or poles, to fuftaine the rizat or fuch like thing rhat it muft be couered with in the night, and layd open ro the Sunne in the day time. The which being fprung vp, and lawing gotten three leaites, you muft replanr rhem abroad in the hotteft place of the garden, and moit fine and fertile mold. Thus may you do with Muske-Melons, Cueumbers, and all coid fruits that requirc hafte, for that otherwife the frof will ouertake them before they cone ro fruit-bearing.

$\neq$ They may alfo be fowen in good mold like as other feeds, and vfually are. $\ddagger$

Nafturtium Indicum cum flore er femine.

Indian Creffes with flomre and feed.
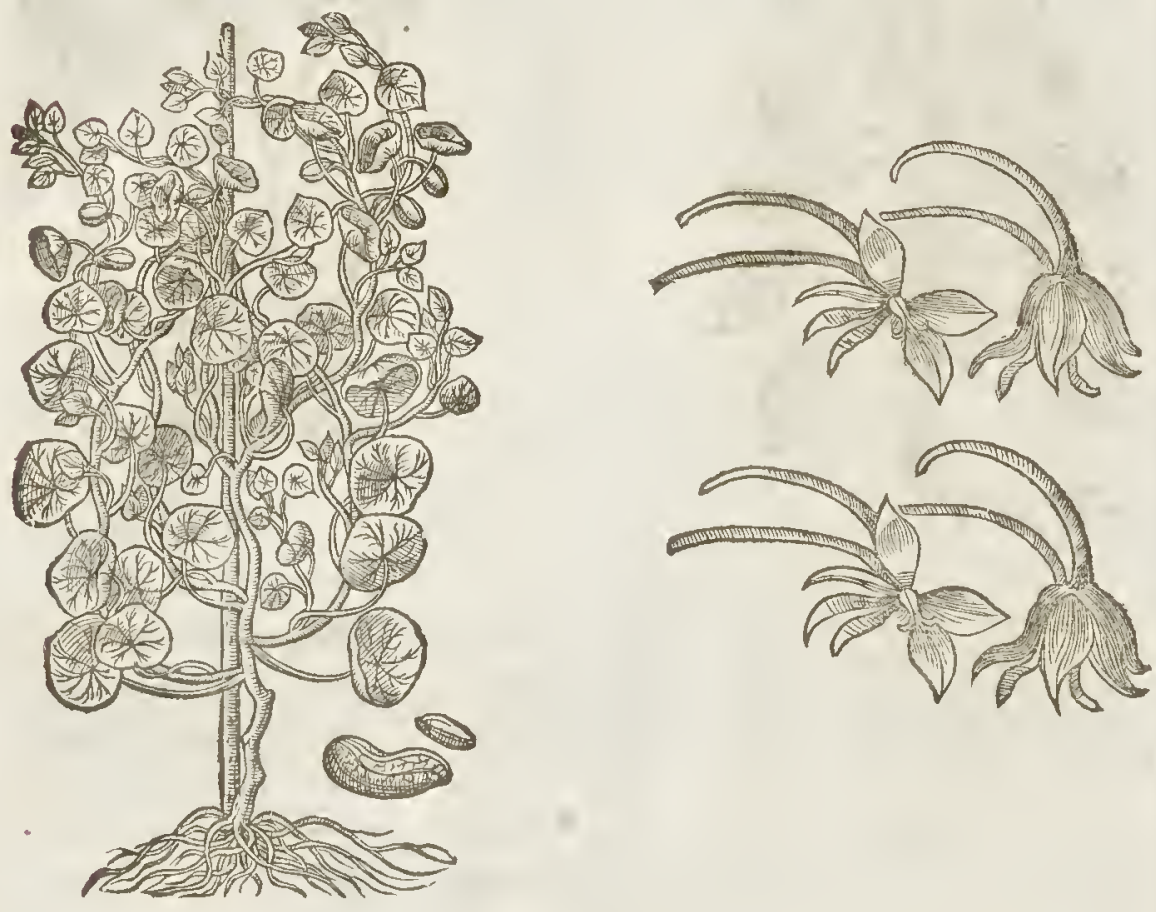

The Names.

This beautifull plant is called in Latine, Nafurtium Indicum ; in Englifh, Indian Crefles. Alchough fome hame decmed is a kinde of Cortolvwlus, or Binde-weed; yet I am well contented chat, it retaine the former name, for thar the fnell and rafte fhew it to bea kinde of Creffes. of 'I be Niture and Vertues.

We hate nocertain knowledge of his nature or vertues, but are content to refer it to the kindes of Creffes, or to a further confideration.

\section{Cна р.14. Of Sciatica Creßes. \\ If The Defcription.}

1 C Ciarica Creffes hath many flender branches growing from a ftalke of a cubit ligh, with $\checkmark$ fmall long and narrow leaues like thofe of Garden Creffes. The floures be very fmall, and ycllow of colour, the feed-veffels be little flat chaffic huskes, wherein is the feed of a reddith gold colour, fluarpe and very bitrer in tafte. The root is mall, tough, white within and without, and of a biting tafte.

¥ The plant whofe figure I here giue you in ftead of that with the narrower leaues of our Author hath lawes fomewhat like Rocket, tut not fodeepe cut in, being only fnipt about the edges: 
the vppet lcaues arc not fnipt, not diuided at all, and arc narrower. The floures deeking the tops of the branehes are fmall and white, the feed veffels are Icffe then thofe of Creffes, and the feed it felfe exeeeding fmall, and of a blackifh eolour; the toot is woody, fometimes fingle, otherwhiles diuided into two btanehes. $\neq$

If The place.

It groweth vpon old wals and rough places by highwaics fides, and fich likc: I haue found it in. corne fields about Southfleete neete to Gtauciend in Kent.

Iberis Cardamantica.

Seiatica Creffes.

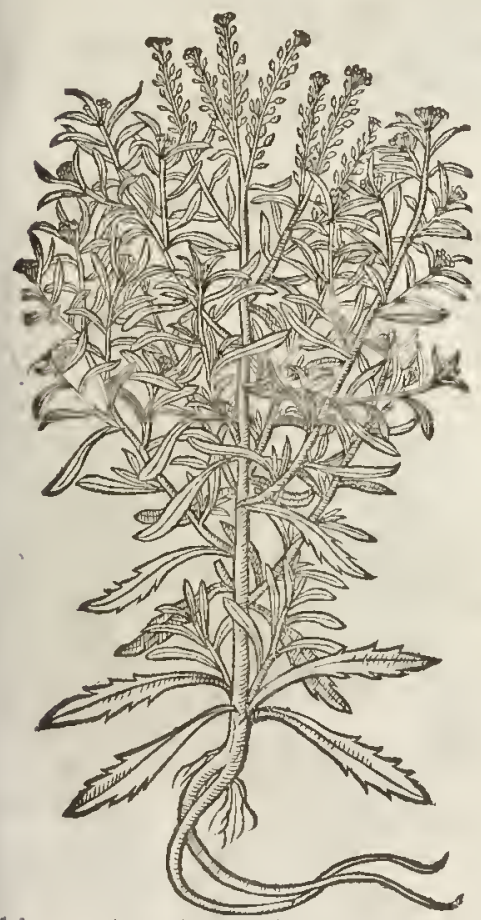

Tा The Time.

It floureth aceording to the late or earely fowing of it in the fields, in Iune and Iuly,

$$
\text { The Names. }
$$

Seiatica Creffes is called in Greckciecess,and

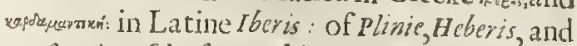
Naffurtium fylueftro, and in like manner alfo $L e$. pidium. There is another Lepidium of Plinie : in Englifh, Seiatica Creffe. $¥$ The firft deferibed may be ealled Leris Cardamantica temsifolia, Small leaued Sciatica Creffes. The fecond, Iberis latiorc folio, broad leaned Seiatica Crcl. fes. ‡

$$
\text { The Nature. }
$$

Sciatica Creffe is hot in the fourth degree, and like to garden Cteffes both in fmell and in talte.

$$
\text { T The Fortues. }
$$

The rootes gathered in Autumne, faith $D$ :ofcorides, doe heate and burne, and arc with good fuceeffe with fwines greafe made vp in manner of a plaifter, and pur vpon fuch as are tormented with the Seiariea: it is tolie on the grieucd place but foure houts at the moft and then taken away, and the patient bathed with warme water, and the place afterwards anointed with oile, and wooll haid on it; which things $G$ alen in his ninth booke of medicines, according to the place grecued, eiteth out of $D$ emocrates, in eertaine vetfes tending to that effeet. Anke Creffes hath long leaties, decpely cut ot jagged vpon both fides, not vnlike to thofe of Rocket, or wilde muftard. The ftalkes be fmal, limber or pliant, yet very tongh and wil twift and writhe as doth the Oziet or watet willow, wherupon do grow fmall yellow flowers, which being paft there do fueceed little flender cods, full of finall feedes, in tafte tharpe and biting the tongue as thofe of Ctcffes.

2 The feeond kinde of banke Creffes hath leaties like vnto thofe of Dandelion, fomewhat refembling Spinach. The branehes be long, tough, and pliant like the other. The flowers be yellowith, which are fucceeded by fuallong eods, hauing leatres growing amongft them : in thefe cods is containcd fmall biting feed like the othet of this kinde. The fmell of this plant is very
vngratefull.
Banke Cretles is found in The Place. walls, and in other vntoilcd places. placcs among rubbifh, by path waies, vpon carth ot mudde 
The fecond kinde of banke Creffes groweth in fuch places as the former doth: I found it groiving at a place by Chelmes forde in Effexcalled little Baddoive, and in fundrie other places.

† If our Author meant this which I haue defcribed and giuen you the figure of, (as it is probable he did) I doubt he fcurce found it wilde : I haue feene it in the garden of Mafter Parkinfon, and it groweth wilde in many places of Italy. $\neq$

$$
\text { (1) The Time. }
$$

They flower in Iune and Iuly, and the feed is ripe in Augutt and September.

\section{The Names.}

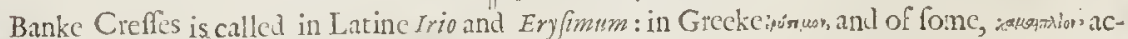
cording to Diofiorides: T heoplurafus liath an orher Ery/2mum. + The firft is called irio, or Eryfomum by cratthiolus Dodoneu, and others. Tismer, Fuchfius and Tragus call itVerbena fomina, or recta. The fecond is Irio alter of MLattbiolws, and Saxifraga Rornanorm, Lugd. It may be called I talian Banke Crefled: or Roman Saxifrage. $\neq$
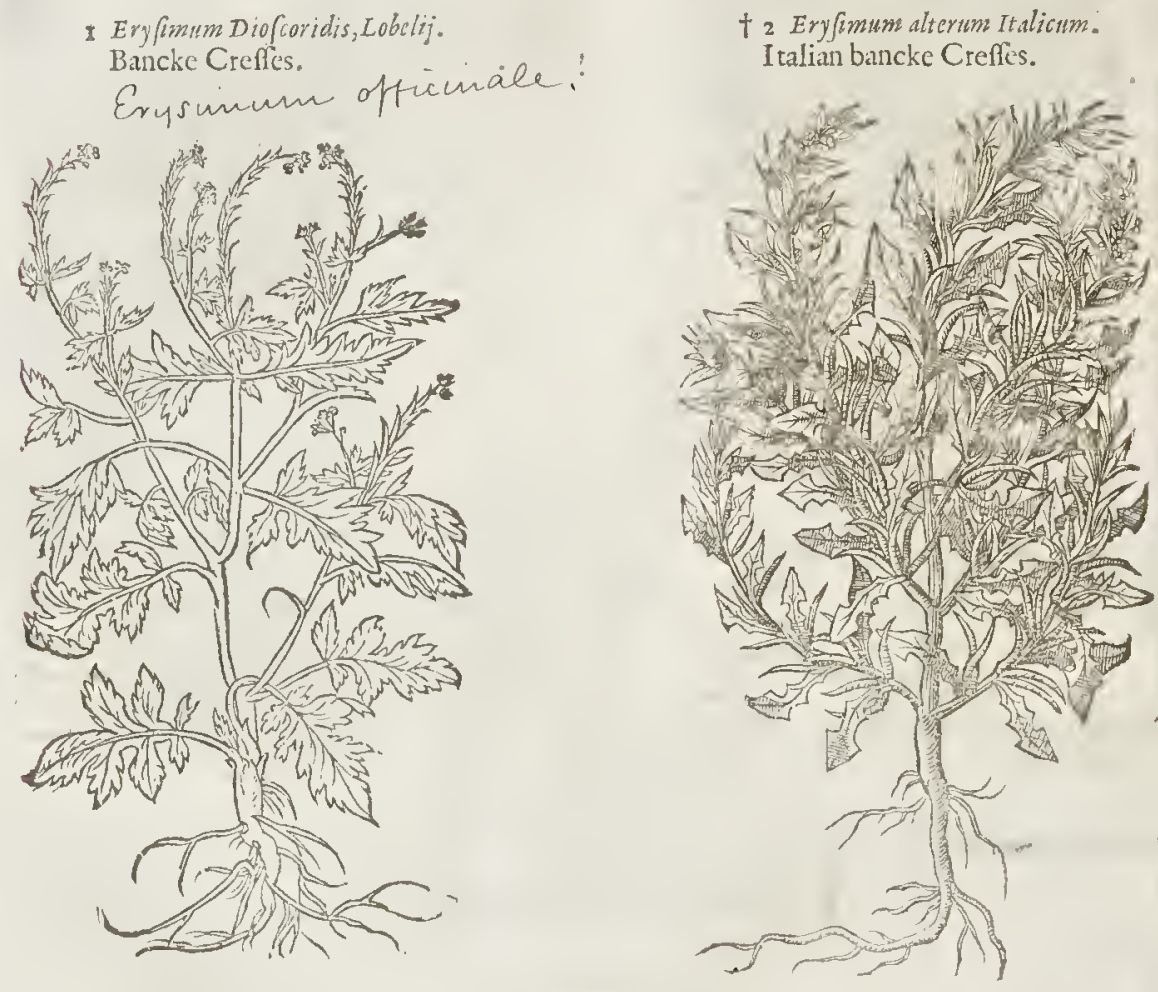

T) The Notture.

The feed of bancke Creffes is like in tafte to garden Creffes, and is as Galen faith of a fierie temperature,and doth extreamely attenuate or make thinne.

\section{T The ricrtues.}

A The feed of bancke Creffes is good againft the rheume that fulle th in to the cheft, by rotting the fame.

B It remedieth the cough, the yellow jandife, and the Sciatie ar ache of the hucklebones, if it be taken with hony in minner of a lohoc and often licked.

C It is alfodrunke againfteadly poifons, as Diofcorides addeth : and being made vp in a plaifter with water and hony and applied, it is a remedie againft hidden eankrous apoftumes behind the eares, hard fwellings and inflammations of the pappes and ftones.

D $\neq$ The feeds of tice Italian Banke Crefies, or Roman Saxifrage taken in the weightof a dram; 
in a decoction of Graffe toots, effectually eleanfe the teines, and expell the ftone, as the Authour of the hiff. Lugd.affitmes. $\ddagger$

\section{С на P. 16. Of Docke Creffes.}

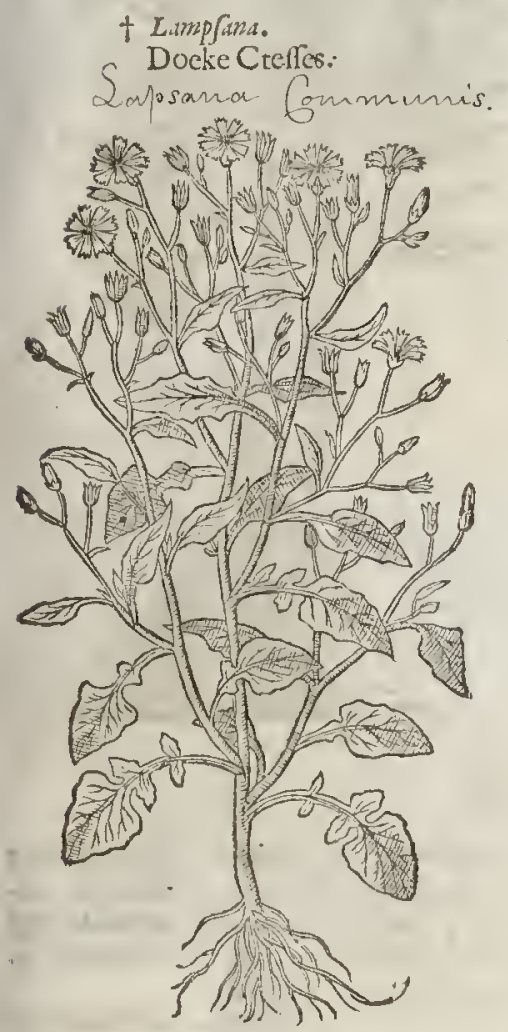

-1 The Defcription.

+ Oeke-Creffes is a wilde Wort or 1 pothethe hauing roughioh hairy leaues of an onerworne greene co: lour, deepely eut or indented, vpon both fides like the leaves of fimall Turneps. The ftalkes grow to the height of two or three eubits, and fometimes highet, diuiding themfelues toward the top into findry little branehes, whereon do grow nany fmall yellow floures like thofe of Hicracium, or Hawke-weed; which decaying, ate fucceeded by little erefted heads eontaining a longifh fmall feed fomewhat like Letrice feed, but of a yellowith eolour : the plant is alfo nilkie, the ftalke woody, and the root fmall, fibrous, and white.

\section{The Place.}

Doek-Creffes grow encry where by Highwaies, vpon walls made of mud or earth, and in ftony places.

$$
\text { T) The Time. }
$$

It flourcth from May to the end of Augut: the feed is tipe in September.

$$
\text { T) The Names. }
$$

Docke-Creffes are called in Greeke, Aautám: in Latine, Lamplana, and Y.apium, by Dodoners : Tabernamont anus calleth this, Sonchus fyluaticus : Camerarius affirmes, That in Puffia they eall it Papillaris.

\section{T The Nature.}

Docke-Creffes are of nature hot, and fomewhat abfterfue ot eleanfing. 9] Thevertues.

Taken in meate, as Galen and Diofcorides affirme, it ingendreth euill iuyce and naughtie nots- A: rifliment.

$\mp$ Camerarius affirmetl, That it is vfed with good fueceffe in Ptufia 'againft vleetated or fote $B$ breafts. $\ddagger$

\section{C'HA . 17. Of Water-Parfenep, and Watcr-Creffes.}

I CReat Water-Parfenep groweth vpright, aud is deferibed to haue leates of a pleafane

I fanour, fat and full of iuyee as thofe of Alexanders, but fonewhat leffer, refembling the Garden Parfenep: the ftalke is round; fmooth, and hollow, like to Kexe or Cafhes : the tont eonfifteth of many fmall ftrings ot threds faftned vnto the ftalke within the water 


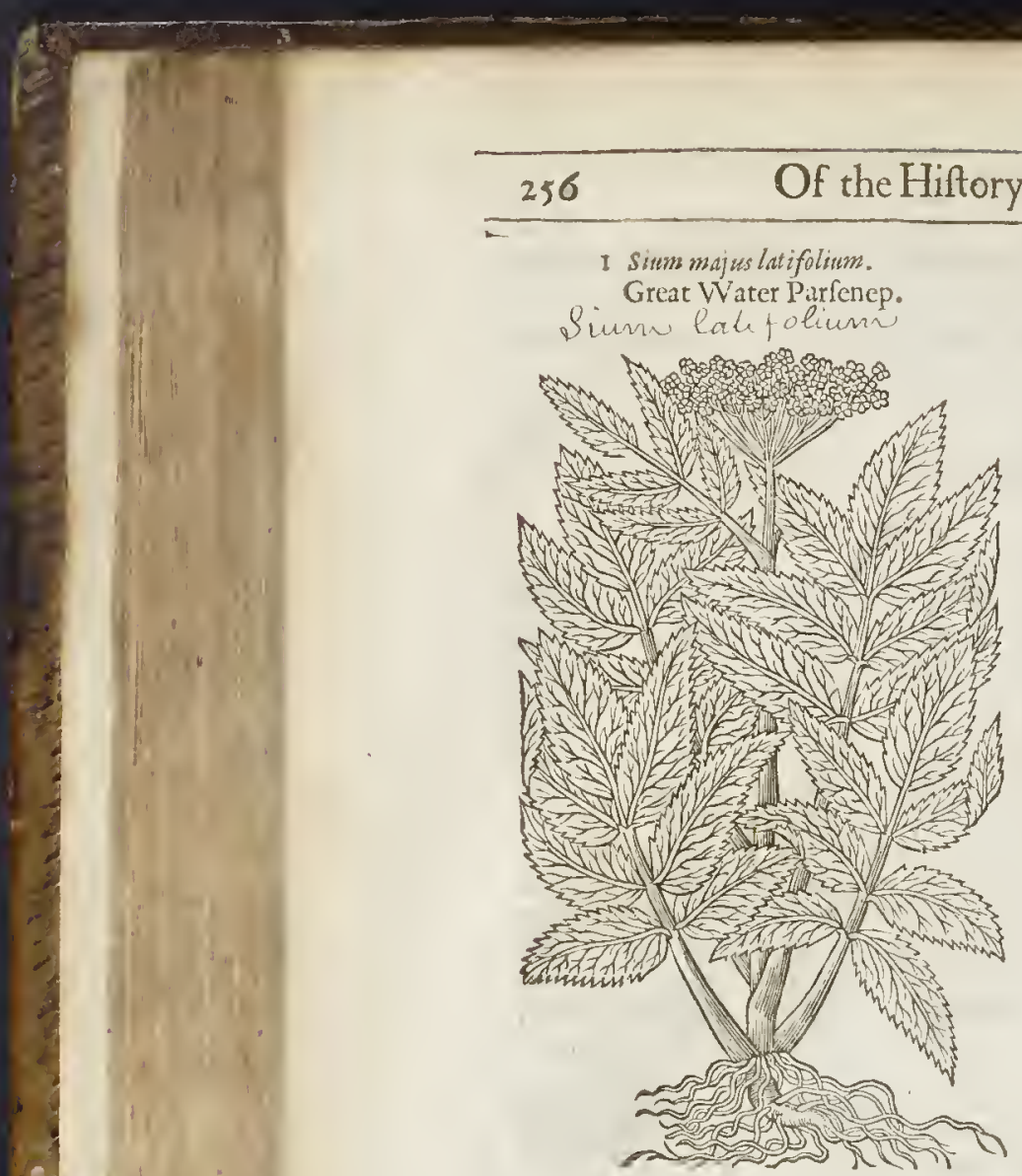

LI в. 2.

+ 4 Sium alterum olufatri facie.

Long leaued water-Creffes. cicuta virosa

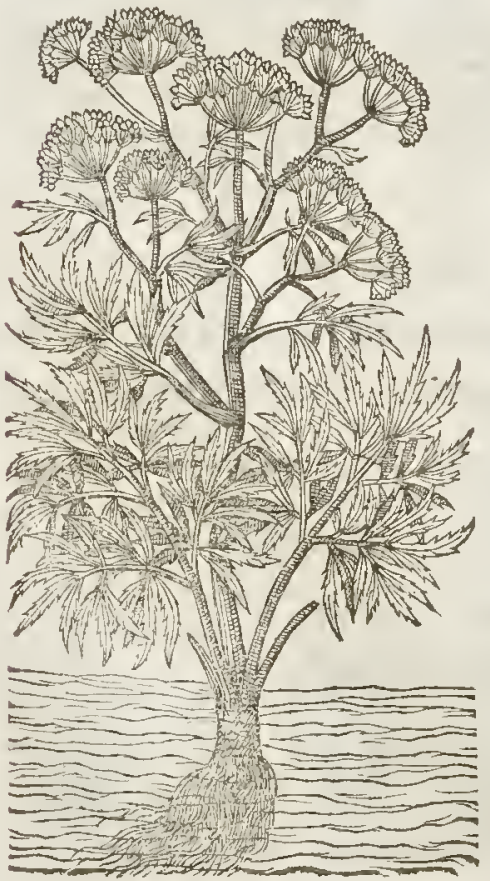

or miry ground: at the top go grow many white Houres, in fpoky roundles like fennell; which being bruifed do yeeld a very ftrong fautour, fmelling like Petroleum, as doth the reft of the plant.

$\ddagger 2$ This plant mueh refembles the laft deferibed, and growes vp fome cubit and a halfe high, with many leates finely fniptabout the edges, growing vpon one rib, and commonly they ftand bolt vpright. The vmbell confints of little white floures : the root is fmal, and confifteth of many ftrings.

$\ddagger 3$ There is another very like this, but they thus differ:the ftalkes and leaues of this later are leffe than thofe of the precedent,and not fo many vpon one rib; the other growes vpright, to fome yard or more high: this neuer growes vp, but alwaies ereepes, and almoit at eueric ioynt puts forth an vmbel of floures.

4. To thefe may be added another, whofe root confifts of aboundance of writhen and finall blacke fibres; the ftalkes are like Hemlock, fome three eubits high, the leaues are lono, narrow, and fnipped about 
about the edges, growing commonly two or three toget her: the vmbel of foures is commonly of a yellowith greene : the feed is like parltey feed, but in tafte fomewhat refembles Cumine, D artus Creticus; and the rinde of a Citron, yet feemes fomew hat hotrer. $¥$

5 Water-Creffeharh many fat and weake hollow branches trailing vpon the grauell and earth where it groweth, taking hold in fundry places as it creepcth ; by meanes whereof the plant preadeth ouer a great compaffe of ground. The leaues are likewife compact and winged with many fmall leaues fer vpon a middle rib one againtt another, except the point leafe, which fands by it felfe, as doth that of the afh, if it grow in his naturallplace, which is in a gratelly fpring. The vpper face of the whie plent is of a browne colour, and greene vnder the leates, which is a perfect marke to know the phy ficill kinde from the others. The white floures grow along th the ftalkes, and are fucceded by cods wherein the feed is contained. The root is nothing elfe but as it were
a thrumme or bundle of threds.

5 Nafturtiwm aquaticiom, fiue Craters Sirm.

Common Wäter-Creffes. Lysian Sis ymbrium

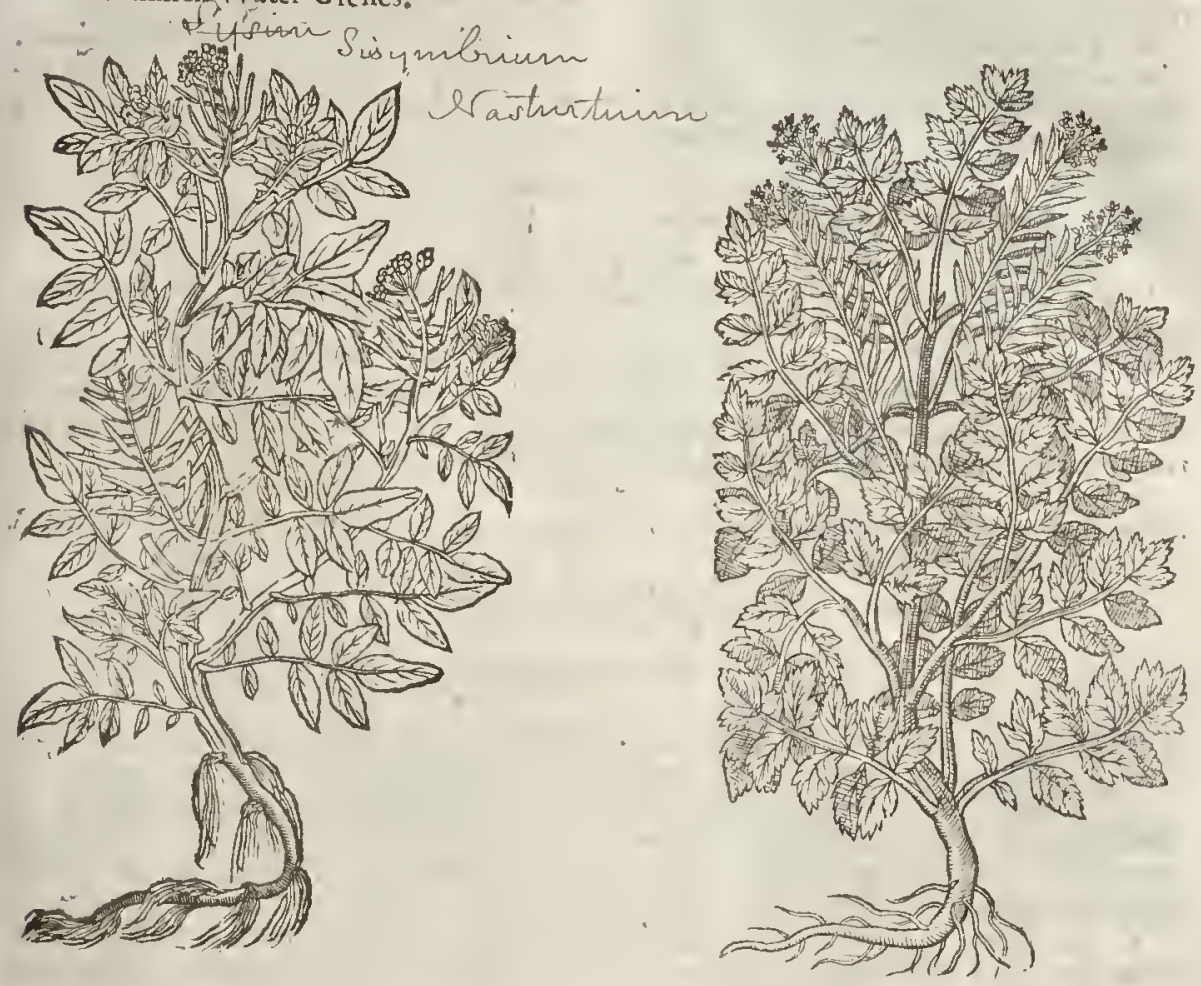

I 6 There is alfo another kinde hereof, hauing leaues growing many on one ftalke, fnipt about the edges, being in thape betweene the garden Creffes and Cuckow-floures : the ftalke is crefted, and diuided in to many branches, the floures white, and are fucceeded by cods like thofe of our
ordinarie Warer-Creffe lust defcribed.

$$
\text { F } 9 \text { The Place. }
$$

¥ I The firft of thele I tawe not found growing, nor as yet heard of within this kingdome.

2 The fecond I firt found in the company of M. Robert Larkin, going betweene Redriffe and Deptford, in a rotten boggy p!ace on the right hand of the way.

3 The third growes alinolt in cuery watery place about London.

4 This is more rare, and was found by $\mathrm{M}^{5}$. Goodyer in the ponds about Moore Parke; and by M. Georze Bonles in the ditches about Ellefmere, and in diuers ponds in Flint-fhire.

5 The fifth is as frequent as the third, and commonly they grow necre together. 6 This Lobel fuith be found in Piemont, in riuelets among fit the hills: I haue not yet heard
thar it growes with vs. $\ddagger$ 
T) The Time.

They fpring and wax greene in Aprill, and floure in Iuly.

The water Creffe to be eaten in fallads theweth it felfe in March, when it is beft, and floureth in Summer with the reft.

$$
\text { T The Names. }
$$

7. I The firft of thefe is Sium maius latifolium of Tabernamontanus.

- This is Sioiz odoratum Tray $i$ : Stum, of Matrholus, Dodonaus, and others : it is taken to be Sium, or Lauer, of Diofcorides. Lobel ealls it al fo Paftinaca aquatica, or water Parfencp.

3 This may be callal sium vmbellatum repens, Creeping water Parfenep. Of this there is a reafonable good figure in the Hiftoris Lugdunenfis,p.g. $\log _{2}$. vnder the title of Sium vermm Matuhioli; but the defeription is of that we here gine you in the fixth plaee.

4. This is Sinn alserum of Dodoncus: and Simm alterum ulufatrifacic of Lobel.

5 Many iudge this to be the Sifymbrium alterum, or Cardamine of Dioforides: as alfo the Sion of Cratenas : and therefore Lobel termes it Sion Cratence eruce folium. It is called by Dodoneus, and vulgatly in thops know ne by the name of Nafturtium aquaticum, or water Crefies.

6 This is called Sium vinlgare by Mathiolus: Lobel alfo termes it Sism Mathioli of Italorum: 'This was thouglit by nur Countrey-man Doctor Turner to be no other than the fecond here deferibed : of which opinion I muft confeffe I al fo was; but vpon better confideration of that which Lobel and Bauline haue written, I haue ehanged my minde. $¥$

Water-Crefle is euidently hot and dry.

$$
\text { The Temperature. }
$$

$$
\text { The Tertues. }
$$

A Water-Creffe being boyled in Wine or Milke, and drunke for certaine dayes together, is very good againft the Seuruy or Seorbute.

B Being ehopped or boyled in the broth of fert, and earen for thirty dayes together, at morning, noone, and night, it prouoketh vrine, wafts the ftone, and driucth it forth. Taken in the fame maner, it dorh cure yong maidens of the green fickneffe, bringeth downe the termes, and fendeth inta the faee their accuftomed liuely colour, loft by the ftopping of their Menftrus.

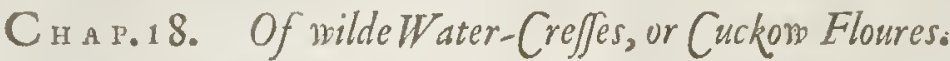 ब The Defcription.}

27 He firfe of the Cuckow floures hath lcaucs at his fpring ing vp fomwhat round, and thofe that fpring aftervard grow iagged like the leaues of Greeke Valetian: among whieh rifeth vp a ftalke a foot long, fet with the like leaues, but fmaller, and more iagged, re-

fembling thofe of Rocket. The floures grow at the top in fmall bundles, white of colour, hollow in the middle, refembling the white fweet-lohn : after which do come fmall chaffie husks or feed veffels, wherein the feed iscontivined. The root is fmall and threddy.

2 The fecond fort of Cuekow floures hath fmall iagged leaues like thofe of fmall watcr Valerian, agreeing with the former in falkes and roots : the floures be white, ouerdatht or declining toward a light carnation.

$\neq 3$ The leaues and ftalks of this are like thofe of the laft defcribed; neither are the floures which firft thew themfelues mueh vnlike them; but when as they begin to faile, in their middle rife vp heads of pretty double floures made of many leaues, like in colour to thefe of the fingle. $\ddagger$

4 The fourth fort of Cuckow Floures groweth erecping vpon the ground, with fmall threddy ftalkes, whereon do grow lcaues like thofe of the ficld Clatier, or three leaued Graffe: amongft which do eome vp fmall and tender ftalkes two hand fulls high, hauing foures at the top in greater quantitic than any of thereft, of eolour white; and after them follow cods containing a fmall feed. The root is nothing elfe but as it were a bundle of thrums or threds.

5 Milkewhitc Lady-fmoeke hath ftalkes rifing immediately from the root, diuiding themfelues into fundry fmall twiggy and hard branehes, fet with leaues like thofe of Serpillum. The floures grow at the top, made of foure leaues of a ycllowith eolour : the root is tough and woody, with fome fibres annexed thereto. $\neq$ This is no other than the firft deferibed, differing onely thetefrom in that the houres are milke white, as our Author truly in the ticle of lis figure made them ; yet forgetting himfelfe in his defcription, he makes them yellowilh, contrarie to himfelfe and the truth.

6 Mountaine 
I Cardanine. Cuckow floures. Cardamime proatemses

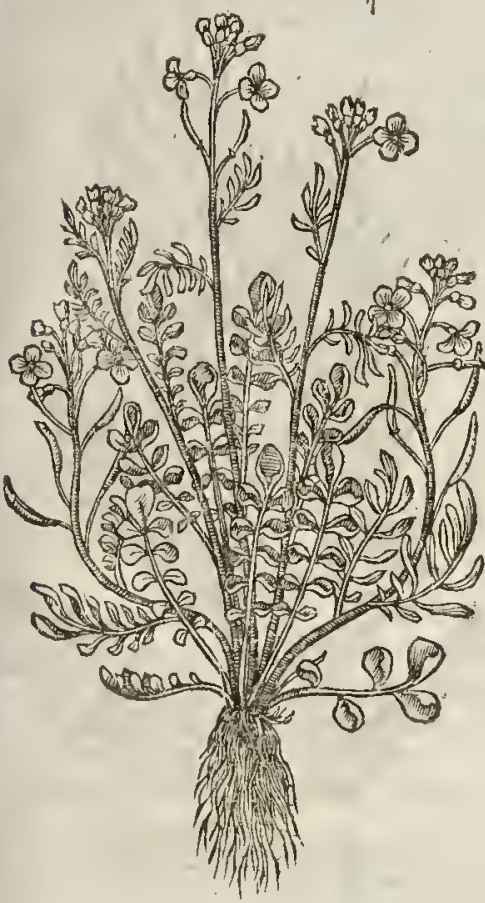

\# Cardanine altera floreplesso. Double floured Lady-fmocke?

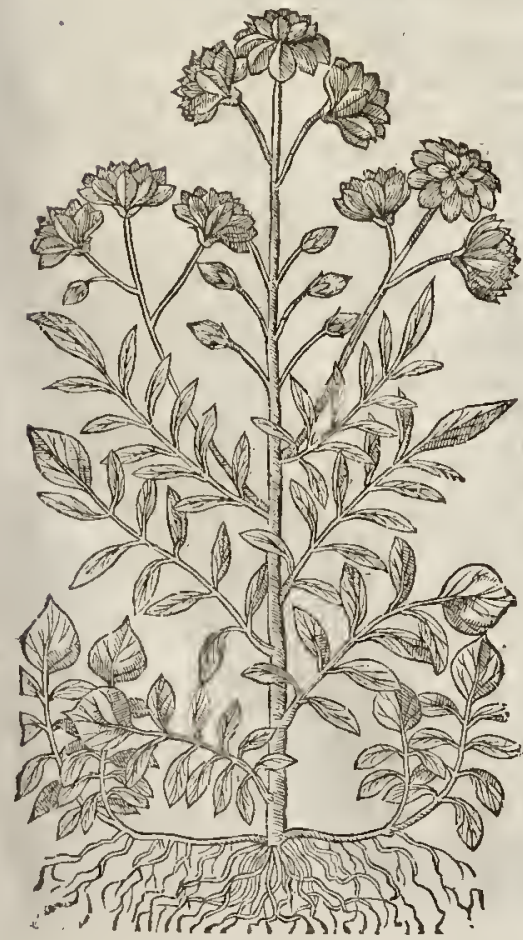

2 Cardamine alicra. Ladies-fmocks.

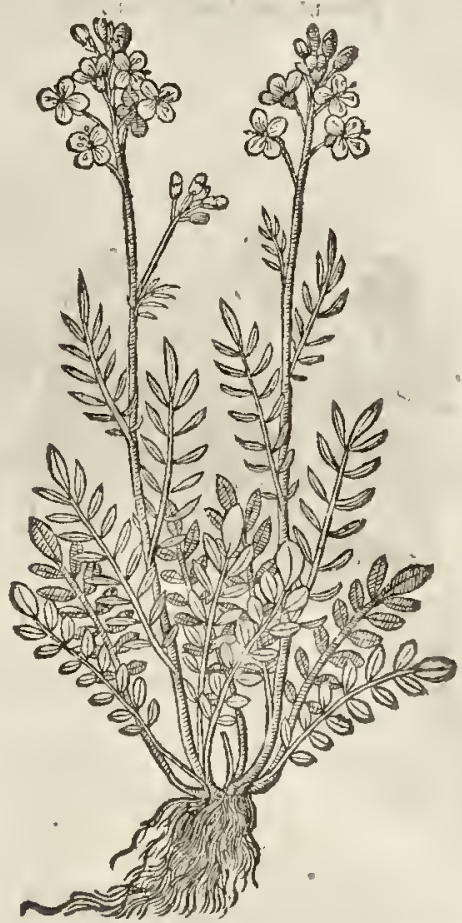

4. Cardamine Trifolia:

Three leaued Lady-fonocke.

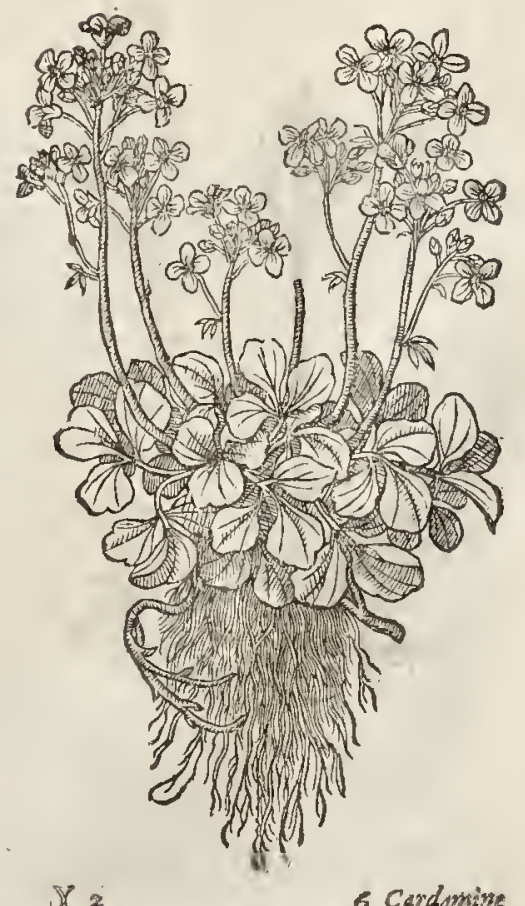


6 Cardamine Alpina.

Mountaine Lady-Smocke.

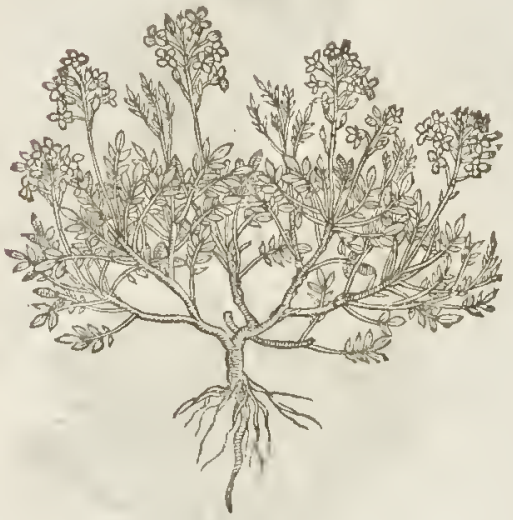

8 Cardamine puntila Bellidis folio alpina. The Dwarfe Dafie-leaued Ladyfrocke of the Alpes.

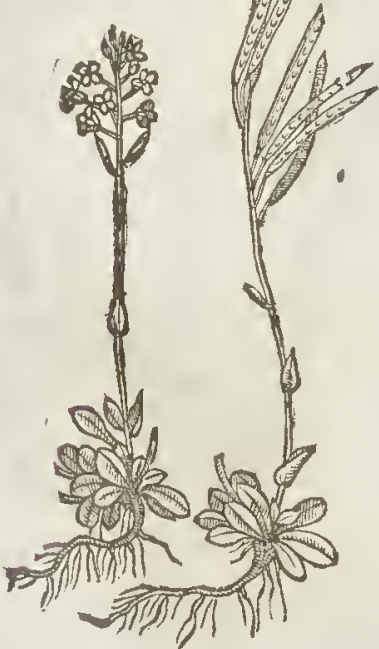

$\ddagger 7$ Sium minus impatiens. . .

The imparieht Lady-fnocke.

Cardamping impa

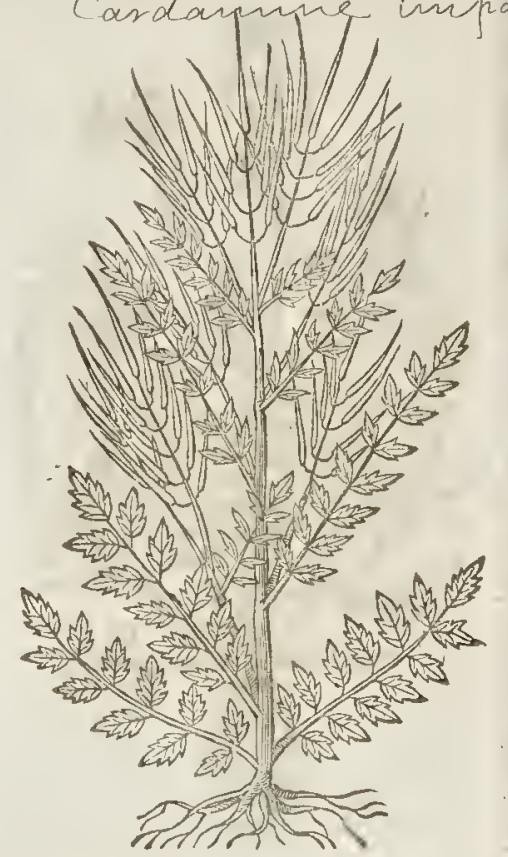

6 Mountaine Lady-finocke hath many roots, nothing elfe but as it were a bundle of threddy frings, from the which do come forth three or foure fmall weak or tender leaues made of fundry fmall leaues, in thew like to thofe of fmall water Valerian. The ftalkes be fmall and brittle, whereupon doe grow fmall floures like the firit kinde.

$\ddagger 7$ I hould beblame worthy if in this place I omitted that pretry conditioned Sium which is kepr in diuets of our londongardens, and was firft brought hicher by that great Treafurer of Natures rarieries, M. Iobn I rodectunt. This plint hath leaues fet many vpon a rib, like as the other Sium defcribed in the fecond place hath; but rhey are cut in wirl two or three prety deep gathes: the ftalk is fome cubit high, \& ditided into many branches, which haue many finall white floures growing vpon them : after thefe floures are paif there follow finall long cods containing a fmall white feed. Now the nature of this plant is fuch, that if you touch but the cods when as the feed is ripe, though you do it neuer fo gently, yet will the feed fly all abroad with violence, as difdaining to be touched: whencethey vfually call it Nolime tarzere; as they for the like qualitic name the Perficaria filiquofa. The nature of this plant is fomew hat admirable, for if the feeds (as I faid) be fully ripe, 
ripe, though you put but your hand neere them, as profering to touch them, tho ugh yoil doe it not, yet will they fly our vpon you, and if you expect no fuch thing, perhaps make you aftraid by reafon of the-fuddenneffe thereof. This herbe is written of onely by proplper Alpinis, vnder the title of Sum Minimum : and it may be called in Englinh, Imparient Lady-fmocke, or Cuckow floure. It is an annuall, and yecrely fowes it felfe by the falling feeds . $\neq$

$\neq 8$ The leaues of this fomewhat refemble thofe of Dafyes, but leffe, and lic fpread vpon the ground, among ft which rifes vp a weake and flender ftalke fet with 3 or 4 leaues at certaine diftances, it being fome handful high, the top is adorned with fmal white floures confifting of foure Jeaues apecec, after which follow large and long cods, confidering the fmallnes of the plant; within the fe in a double order is conteined a fmall reddinh feed, of fomewhat a biting tafte. The root creepes vpon the top of the ground, putting vp new buds in diuers places. Clufius found this growing vpon the rockes on the Etfcherian mountaine in Auftria, and hath giuen vs the hiftory and figure thercof winder the nance of Plantula Cardamines emula, and sinapi pumulum Alpinum.

T. The Time and Place.

That of the Alpifh mountaines is a ftranger in thefe cold Countries : the reft are to be found cuery where, as aforefaid, efpecially in the caftle ditcl at Clare in Effex. ¥ The fenenth growes naturally in fome places of Italy. $t$

Thefe fower for the moft part in Aprill and May, when the Cuckowe doth begin to fing her pleafant notes with out ftammering.

They are commonly called in Latine, Flos Cuculi, by Brunfelfus and Dodonats, for the reafon aforefaid; and alfo fome call them Nafturtium aquat icum minus, or leffer water Creffe: of fome, Car. damine, and Sifymbrium alterum of Dioforides : it is called in the Germane tongue, veiloercter: in French,Paferage fatuage : in Englifh, Cuckowe flowers : in Northfolke, Canterbury bells : at the Namptwich in Chefhire, where I had my beginning, Ladic fmockes, which hath giuen me caufe to Chriften it after my Country fanhion.

T) The Nature and Fertues.

Thefe herbes be hot and drie. in the fecond degree: we haue no certaine proofe or auth ority of their vertues, but furely from the kindes of water Crefe they cannot much differ, and therefore to them they may be referred in their vertues.

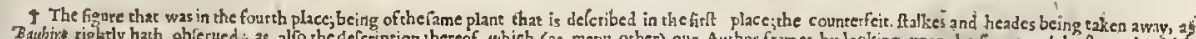

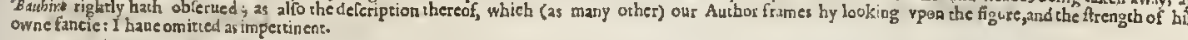

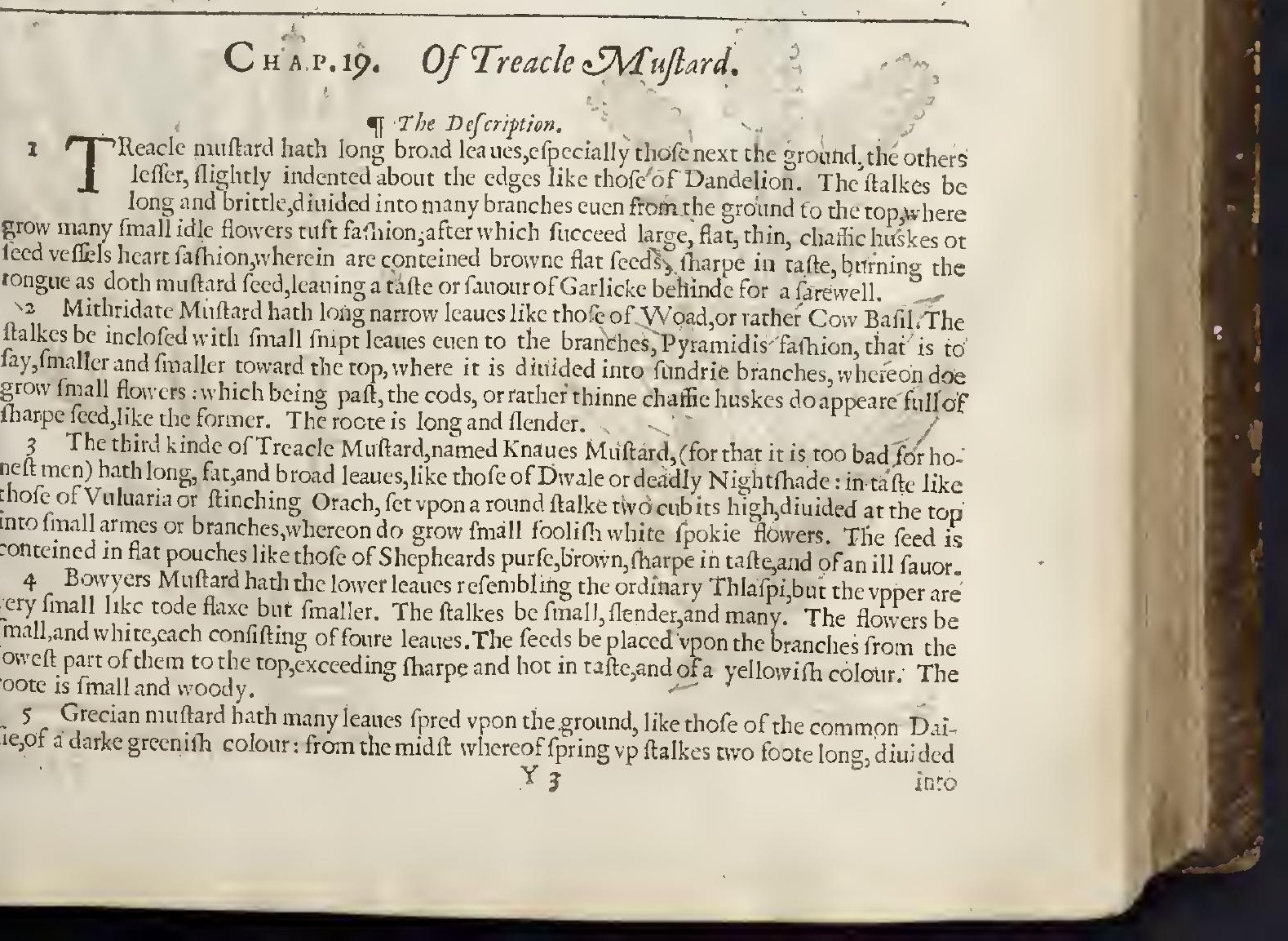


$\perp_{1 \mathrm{~B}, 2}$.

I Thlajpi Diof cor dis. Treacie Muftatd.

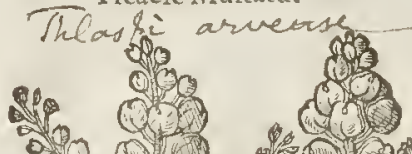

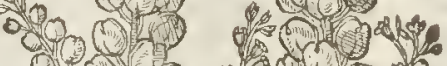
Qu

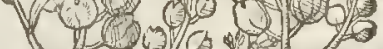
M I I कै a
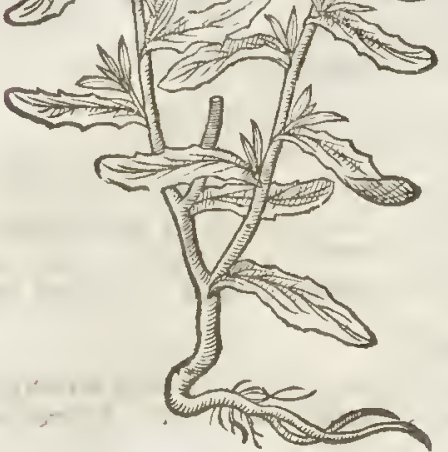

3 Thlapimaiws.

Knaues Multard, D

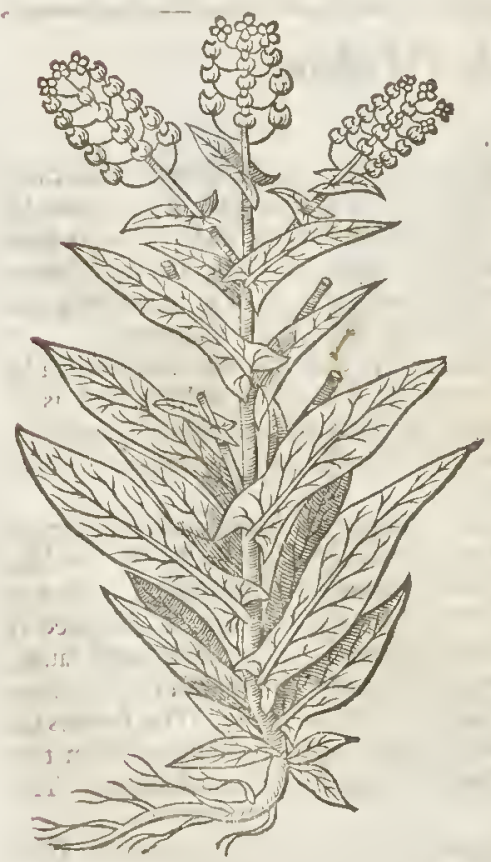

2 Thinjpi Vulgat.j.mum.

of Mithidate Muftard.

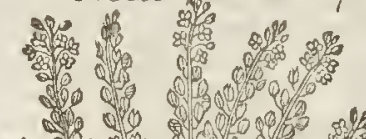

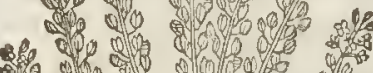

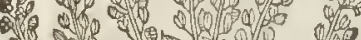
a $01,1,0$ arou

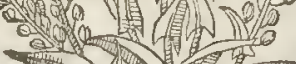

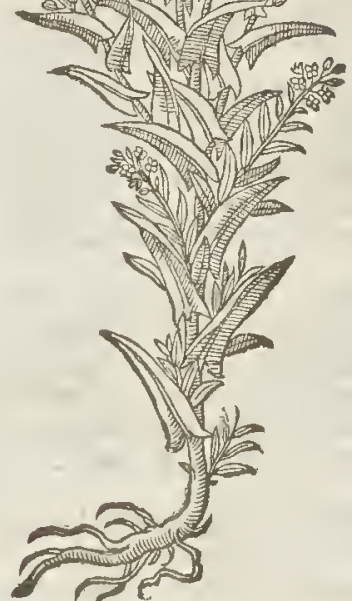

4 Thlapininus. Bowyers Muftard.

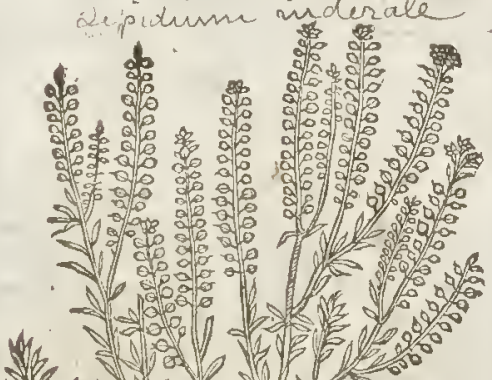

$N$

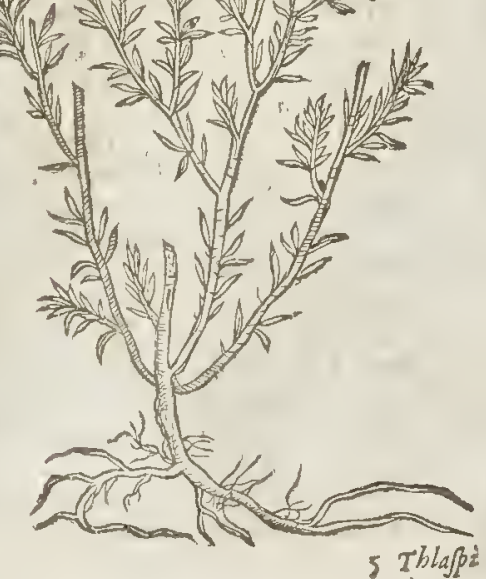


5 Thlappi Grecum.

Grecian Muftard.

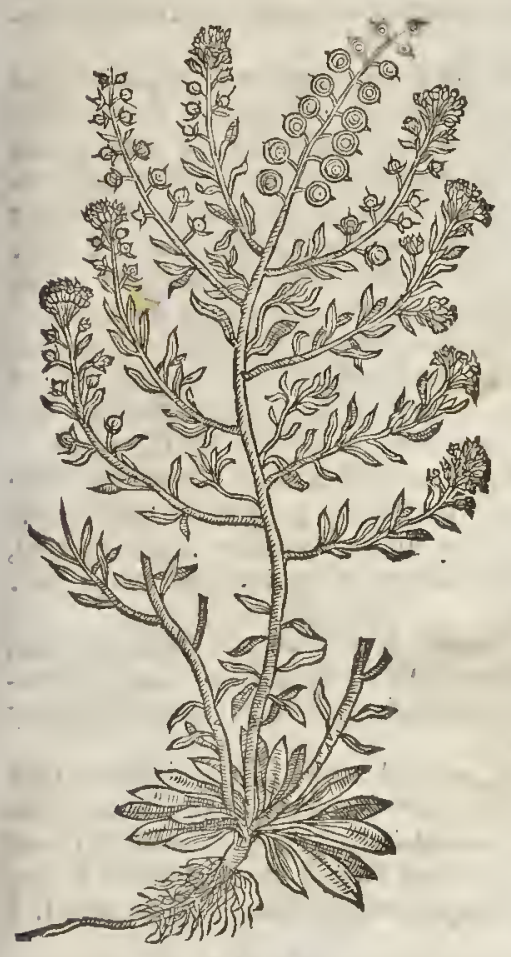

7 Thlapiclypeatum Lobely.

Buckler Muftard.

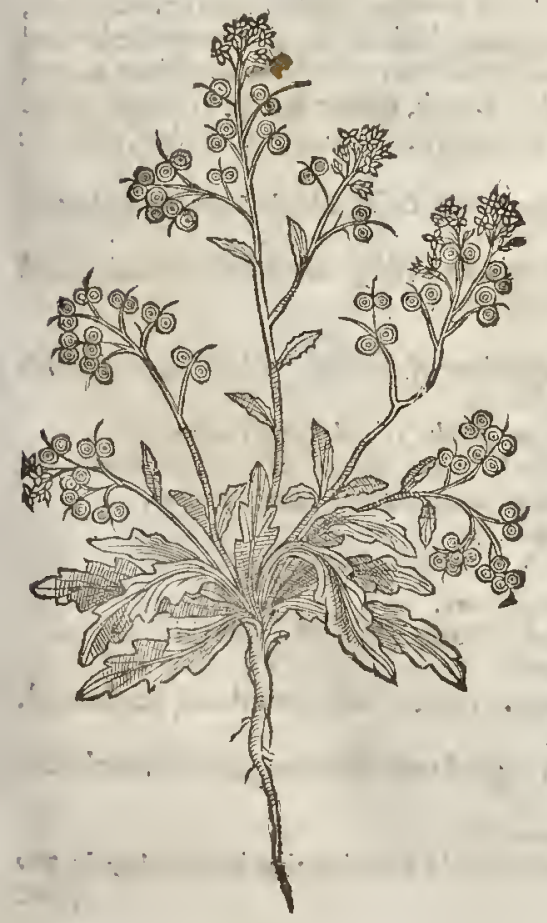

6 Thlapi amarrm.

Clownes Muftard.

S.benis am ara

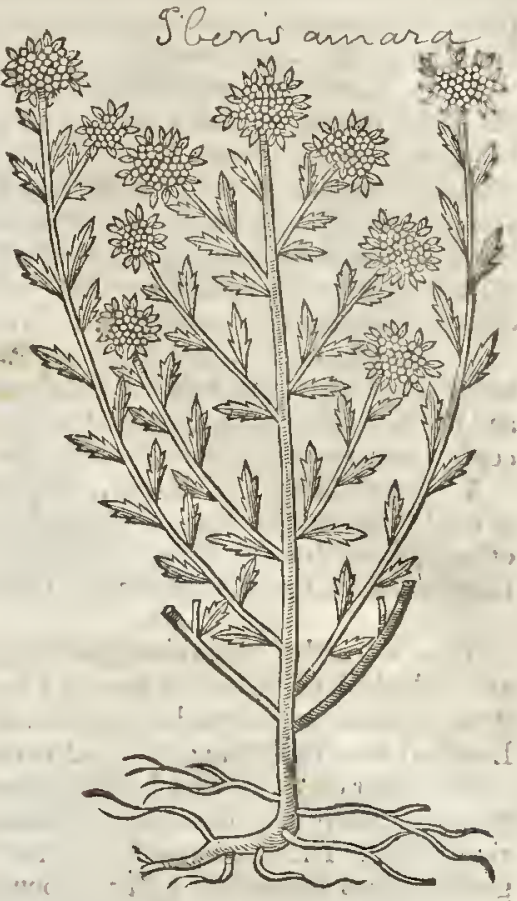

\& Thlapi minuselpecitum.

Small Buckler Muftard.

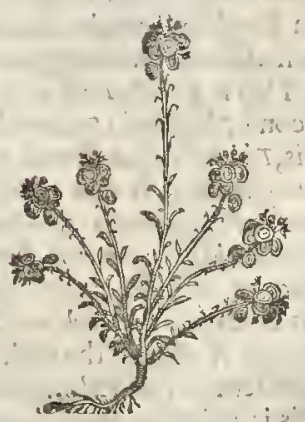


into many fmall btanches, whereupon grow fmall white flowers compofed of foure leaues, a fter which fucceed round that huskes or leed veffels, fet vpon the ftalke by couples, as it were fundry paires of fpectaeles, wherein the feed is eontained, tharpe and biting as the other. This is fometimes feen with yellow flowers.

$\ddagger 6$ Clownes muftard hath a thort white fibrous root, from whence arifeth vp a ftalke of the height of a foot, which a little aboute the root diuides it felfe into fome foure or fiue branches, and thefe againe are fubdiuided into other, fmaller fo that it refembles a little fhrub: longifh nartorv leaues notehed after the manee of Seiatiea Creffes by turees garnifh thefe branches, and thefe leaues are as bitter as the fmaller Centaury. The fowers ftand thieke together at the tops of thefe branehes in manner of little vmbels, and are eommonly of a light blew and white mixed together (being feldome onely white, or yellow.) After the flowers fueceed feed veffels aftet the manner of the other plants of this kinde, and in them is conteined a fmall hot feed $\ddagger$

7 Buekler muftard hath many large leaues, fpread vpon the ground like Hie racium or Hawke weede, fomewhat more toothed or fnipt about the edges: among whieh eomes ip ttalkes fmall and brittle, a eubit high, garnifhed with many fmall pale yellowith flowers: in whofe place fuc. ceed many round flat cods or pouches, buckier fafhion, eonteining a feed like vnto the orhers.

8 Small Buckler Muftard, is a very fimall, bafe, or low plant, hauing whitifh leaues like thofe of wild Time, fet vpon fmall, weake and tender branches. The flowers grow at the top like the other buckler Muftard. The feed veffels are like, but not fo round, fomewhat tharpe pointed, tharp in tafte, \& burning the tongue. The whole plant lieth flat vpon the gtound, like wild Tyme.

If The Place.

Treacle or rather Mithridate Muftard growes wild in fundry places in corn fields, ditch banks, and in fandy, drie, and barren ground. I haue found it in corne fields betweene Croydon \& Godsftone in Surrey,at South-fleete in Kent,by the path that leadeth from Harnfey a fmall villageby London) vnto Waltham croffe, and in many other places.

The other do grow vnder hedges, oftentimes in fields and in ftonie and vntoiled places; they grow plentifully in Bohemia and Germany : they are,feene likewife on the ftonie bankes of the riuer Rhene. They are likew ife to be found in England in fundtie places wilde, the which I haue gatheted into my garden. $¥$ I haue found none but the firft and fecond growing wilde in any patt of England as yet; but I deny not, but that fome of the other may be found, though not all. T T The Time.

Thefe treacle Muftards are found with their flowets from May to Luly, and the feed is ripe in the end of Auguit.

The Thames.

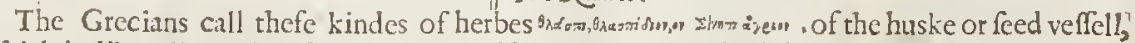
which is like a little fhield. They haue alfo other names which be found among the baftard words: as Scandulaceum, Cutpella, Pes gallinaceus. Neither be the later writers without their names,

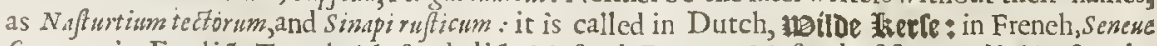
fruugge: in Englinh, Treacle Muftard, dirh Muftard, Bowyers Muftard:of fome, Thlaffi, after the Grecke name, Chutrles muftard, and wilde Creffes.

\#. I This is Thla and the fecond Thlapiof cratthiolus.

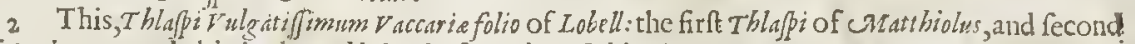
of Dodoncus; and this is that Thlapiwhofe feed is vfed in thops.

3 This is Thlafpi majus of $T$ abernamontanus.

4 This is Thlapi minus of Dodoneus: T blaffi:anguffifolium of Fubbfus: Thlapiminus hortenfe ofyridis folio, $2 \mathrm{c}$. of Lubell: and Nafturt isim fylveftre of Thalius.

5 This is Alyffon of Matt hiolus : T hlappt Grecum Polygonati folio, of Lobell and Tabern.

6 This the Author of the Hift. Lug. Calls Nafturtium fylveftre; Tabern. calls it Thlafpi amarum?

7 Lobell termes this Thlapi parvum Hieracifolium, and Lunaria Lutea Monfpelicnfum.

8 This is Thlapi minus clypeat wm Serpillifolio of Lobell. $\neq$

t The figures of thefe tivolatt mentioned vere trantpofed in the former Edition.

T The Temperature.

The feed of thefe kindes of Treacle Murtards be hot and drie in'the end of the third deg tee. T) The Vertues.

The feed of Thlafpi or treaele Muftard eaten, purgeth colour both vpward and downewatd ptouoketh flowers, and breaketh inward apofthumes:

The fame vfed in clyfters, helpeth the fciatica, and is good vnto thofe purpofes for which Mu: ftard feed ferueth.

The Danger.

The feed of thcfe herbes be fo extreame lot and vehement in working, that being taken in too 
great a quantitie, purgeth and fcoureth euen vnto bloud, and is hurtfull to women with child, and therefore great care is to be had in gituing them inwardly in any great quantitie:

\section{Сна р. 20. Of Candie cMufard. \\ IT The Defcription.}

Andic muftard excelleth all the reft, as well for the comely floures that it bringeth forth for the decking vp of gardens and houfes, as alfo for that it goetl beyond the reft in his phy fl. call vertues. It tifeth vp with a very brittle ftalke of a cubit high, which diuideth it felfe into fundry bowes or branches, ferwith leatues like thofe of ftocke gillifloures, of a gray or onerworne grene colour. The floures grow at the top of thes ftalke roundt, hicke clutering together, like thofe of Scabious or diuels bit, fometimes blew, often purple, carnation or horfe flen, but feldome white for any thing that I haue feen; varying according to the foile or Clymate. The feed is reddith, tharpe,and biting the tongue, wrapped in little huskes farhioned like an heart. $¥$ There is a leffer variety of this with white well fmelling flowers, in other refpects little differing from the ordinary. $\ddagger$

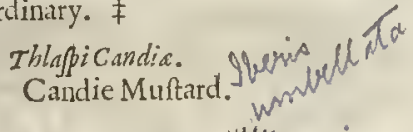

$¥$ Thlapic cardia parsum flo albo.

Small Candy muftard with a white floure.
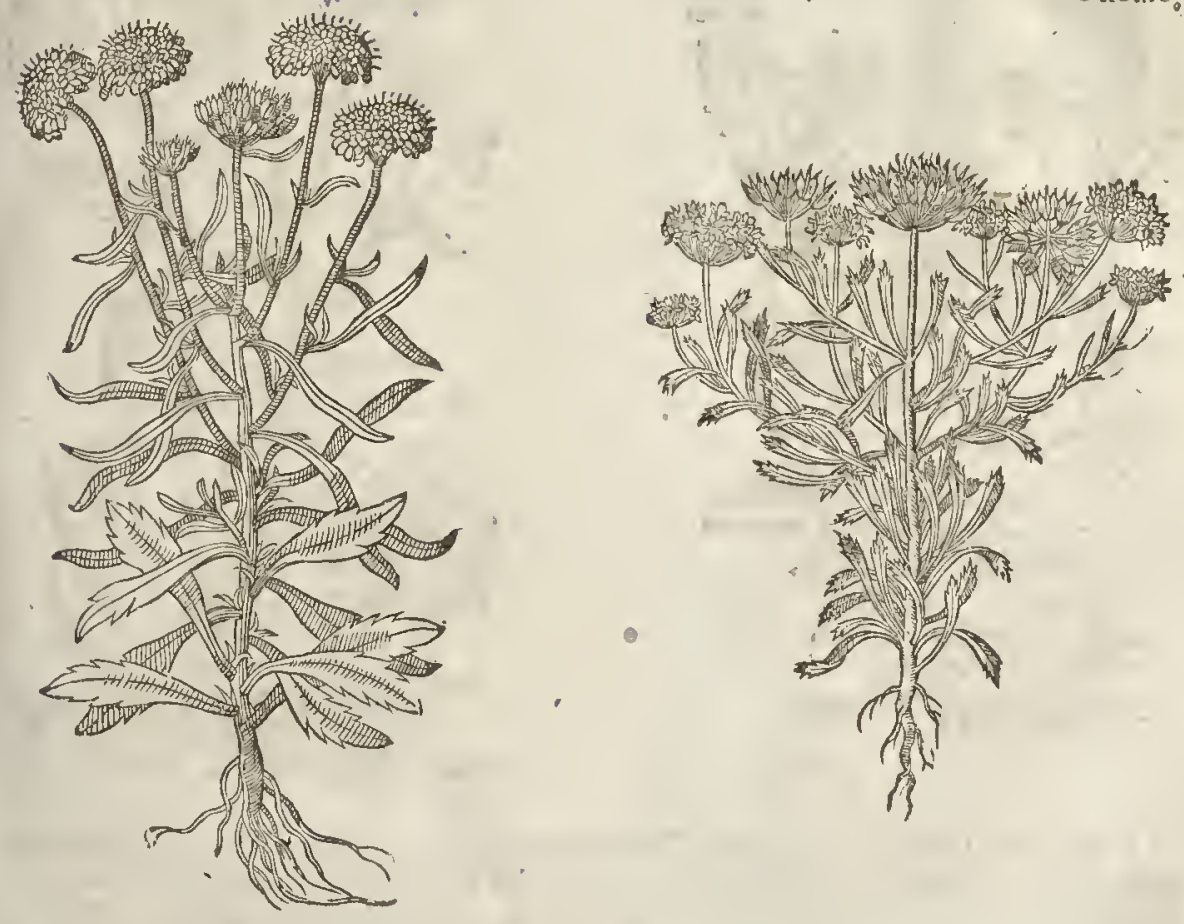

T) The place.

This growes naturally in fome places of Auttria,as alfo in Candy, Spaine, \& Italy, fion whence I receiued feeds by the liberality of the right Honorable the Lord Edward Zouch, at his returne into England from thofe parts. $\neq$ Chufus found the later as he trauelled through Sivitzerland into Germany. $\neq$ ' T The Time.

It foureth from the beginning of May vnto the end of September, at which time you thall hate floures and feeds vpon one branch, lome ripe, ond fome that will not ripen at all.

$$
\text { Iा The Name. }
$$

$t$ This plant is called by Dodoneus (but not rightly) $\Delta r a b i$ and $D$ raba: as alfo $T$ hlajpi Candid: whicls laft name is reteined by moft writers : in Englifh, Candy Thlafpi,or Candy Muftard. $t$

TI The Temperature.

The feed of Candic. Muftard is hot and drie at the end of the third degree,as is that called Sco. rodothlapi, or treacle muftard. 


\section{С ніг. 21. Of Treacle Muftard.}

\section{If The Dercription.}

I Ound leaued Muifard hath many large leaues laid flat wpon the ground like the leaues of the wilde Cabbage, and of the fame eolour; among which rife vp many tlender ftalkes of fome two handfills high or thereabouts, whieh are fet with leaues far vnlike to thofe next the ground, enielofing or embraeing the ftalkes as do the leaues of Perfoliatum, or Thorow-wax. The floures grow at the top of the branehes, white of colour; which being paft, there do fuceed flat huskes or pouches like vnto thofe of Shepheards purfe, with hot feed biting the tongue.

I Thlapi rotundifolium.

Round leaued Muturard.

Wheas pis perfolintim

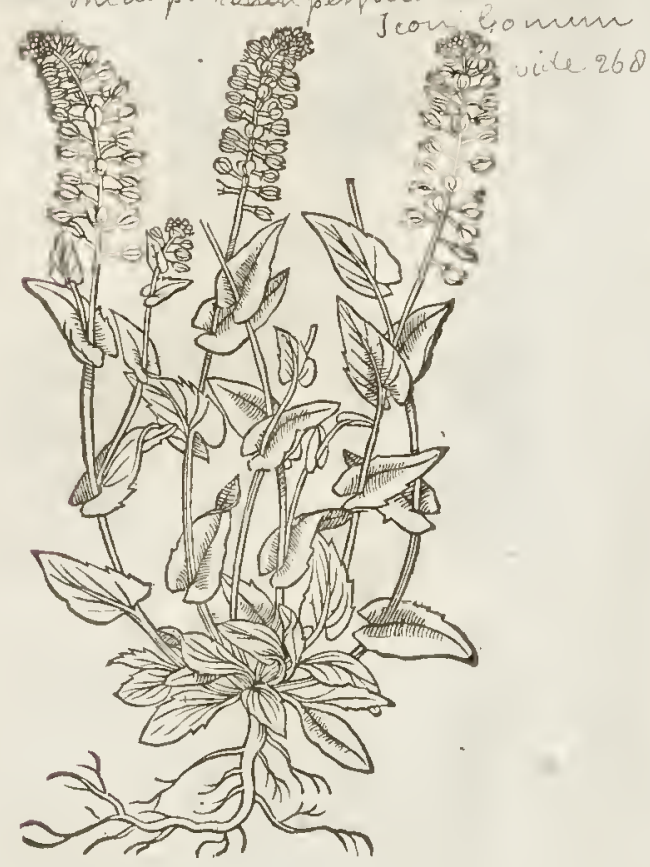

2 Thlapi i annonicum Clusij. Hungary Muitard.

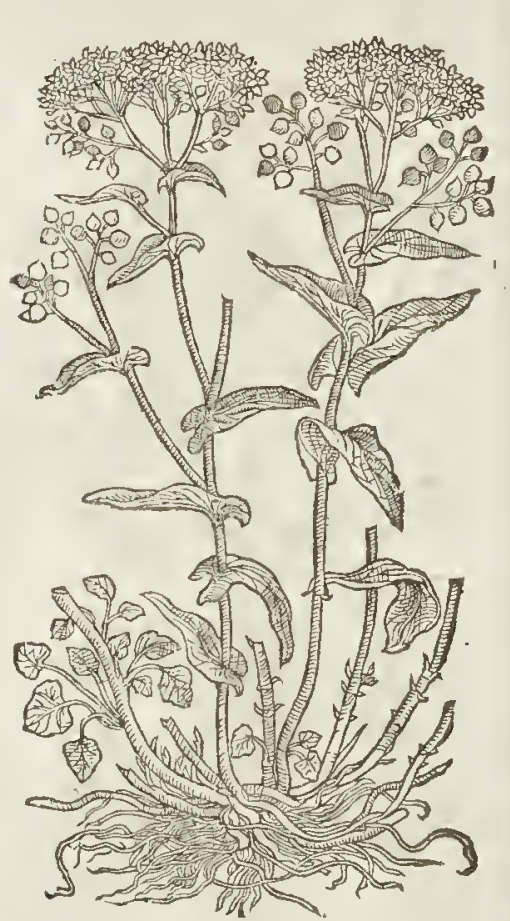

2 Hungary Muftardbringeth forth lender ftalkes of one cubit high: the leames which firt appeare are flat, fomew hat round like rhofe of the wilde Beet; but thofe leates whieh after doe garnifh the ftalkes are long and broad like thofe of the garden Colewort, but leffer and fofter, greene on the vpper fide, and vnder deelining to whireneffe, fmelling like Garlieke. The floures be fmall and whire, eonfifting of foure fmall leaues, which in a great tuft or vmbel do grow thick thruft together: which being palt, there followeth in enery fmall huske one duskifh feed and no more, bitter and tharpe in tafte. The root is white and fmall,creeping vnder the ground far abroad' like the roots of Couch-graffe; preparing new fhoots and branches for the yeare following, contrarie to all the reft of his kinde, whieh are enereafed by feed, and not otherwife.

3 Churles Muftard hath many fmall twiggy ftalkes, flender, tough, and pliant, fet with fmall leanes like rhofe of Cudweed, or Lanander, wirh fmall white flours: the huskes and feeds are fmall, few, harpe, bitter, and vnfauorie : the whole plant is of a whitifh colour.

4 Peafants Muftard harh many pretty large branches, with thin and iagged leaues like thore of Creffes, but fmaller, in fauror and tafte like to the ordinarie $\tau$ hlafi $i$ : rhe floures be whition, and grow in a finall fpoky tufr. The feed in tafte and fauor is equall with the other of his kinde and eountrey, or rather exceeds then in Chatpneffe. 


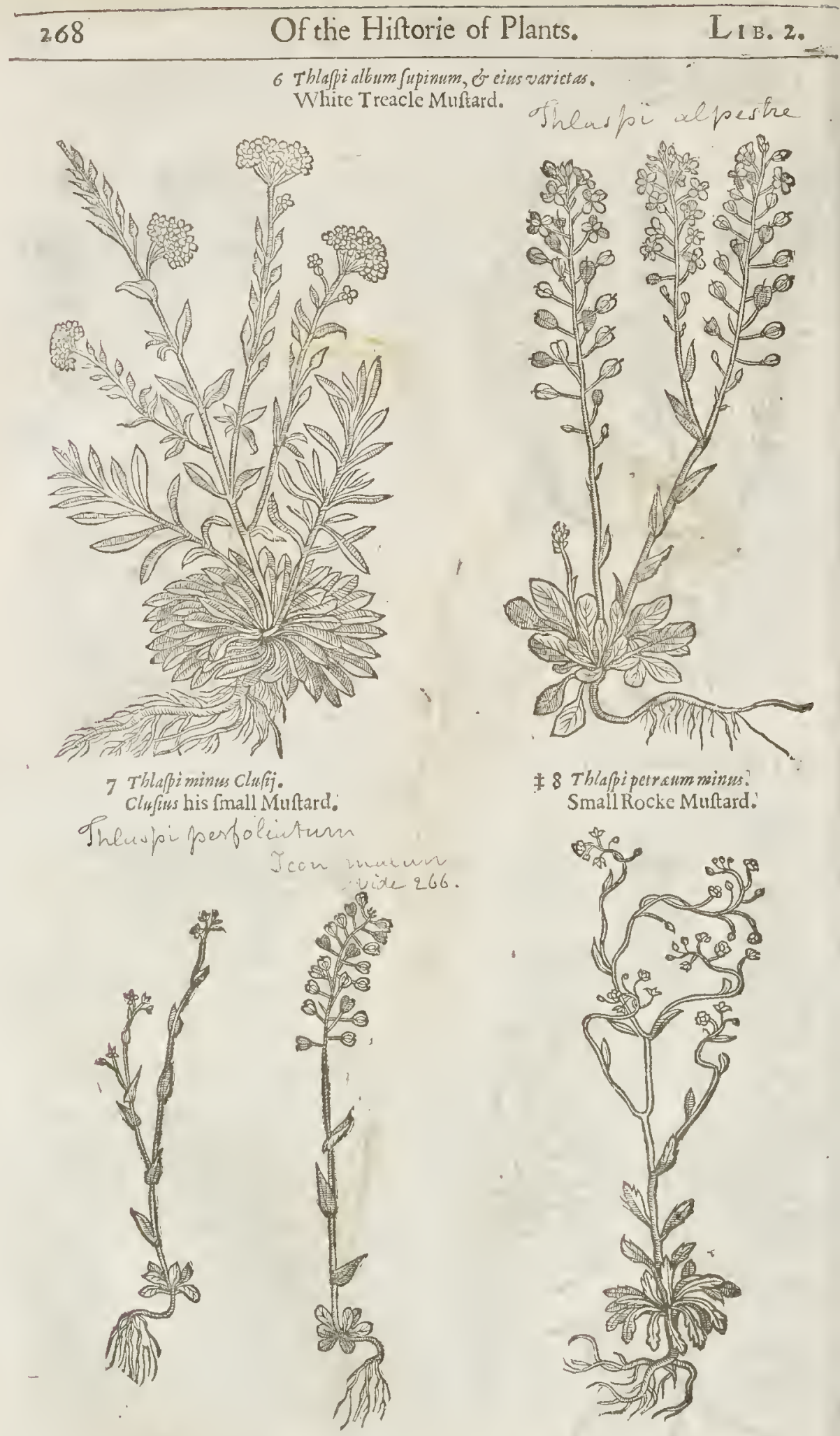


7 This fmall kinde of Muftard hath a few fmall leaues fpread vpon the ground like rhofe of the leffer Dafie, but of a blewifher greene colour; from which rife vp fmall tender ftalks fer with three, and fomerimes foure fmall tharpe pointed leaues : the floures grow at the top, fmall and white; the cods are flat; poueh-fafhion, like thofe of Shepheards purfe,and in each of them there
is contained two or three yellowin feeds.

$\neq 8$ To the fe we may fitly adde another friall mountaine Thlafpi, firft deferibed by that diligent and learned A potheearie Iobn Pona of Verona, in his defcription of Mount Baldus. This from a threddy root brings forth many.fmall whitifh leaucs lying fpred vpon the ground,and a little nicked about their ed ges : among thefe rifeth vp a falke fome two or three handfulls high, dtuaricated toward the top into diuers fmall branches, vpon whieh grow white little floures confifting of foure leaues apiece : which fading, there follow round feed-veffels, like to thofe of $x \mathrm{xya}_{\text {. }}$ grum : whenee Pona, the firft deferiber thereof, calls it $T$ blapi petraum myagrodes. The feed is as thar: - and biting as any of the other Thlarpies. This growes naturally in the chinkes of the rocks; in that part of Baldus that is termed $V$ allis frigida; or, The cold Valley.

$$
\text { Tt The place. }
$$
Thefe kindes of Treaele Muftard grow vpon hills and mountaines in eorne fields, in ftony bar.
ren and grauelly grounds.

If The Time.

There foure in May, Iune, and Iuly : the feed is ripe in September,

I The Names.

mitius rotundifolium of Columna. Our Author contanus: Thlappi primum, of Dalegchampius : Thlapi the enfuing Chapter, and called it Thlapi confounded it with that whofe figure is the firft in

2 ' Thlapi mont anum peltatum of Clufurs : and Thlapi Pannonicum of Lobel and $T_{\text {aber. }}$.

3 Thlapi Narbonerfe centunculi anguftifolio, of Lobel: and T blappi maritimum of Dalefchampiass.

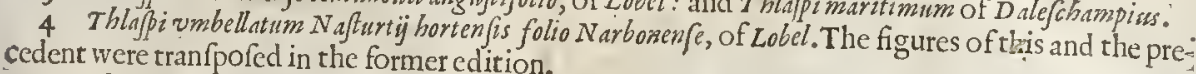

5 Thla pi i upinum luteum of Lobel. Our Authors figurewas a varictie of the next following.

6 Thlapi album frpinum of Lobel: T blapi montanum fecundum of (lis fus.

7 Thlapipumilum of Clufus : Thlapininimum of Tabernamont anus. thiolus. $\ddagger$

$$
\text { If The Temperature and vertues. }
$$

The feeds of thefe churlinh kindes of Tteaele Muftard hane a tharpe or biting qualitic, breake inward apoftumes, bring downe the floures, kill the birtl, and helperh the Sciarica or pain in the
hip. They purge cholervpward and downeward, if you take two ounces and a halfe of them, as $D$ i-
ofcorides writeth. They ar ofcorides writeth. They are mixed in counterpoyfons, as Treacle, Mythridate, and fuch like Com.
pofitions.

\section{A}


Thlapifraticofum incanum.

Hoary wooddy Muftard.

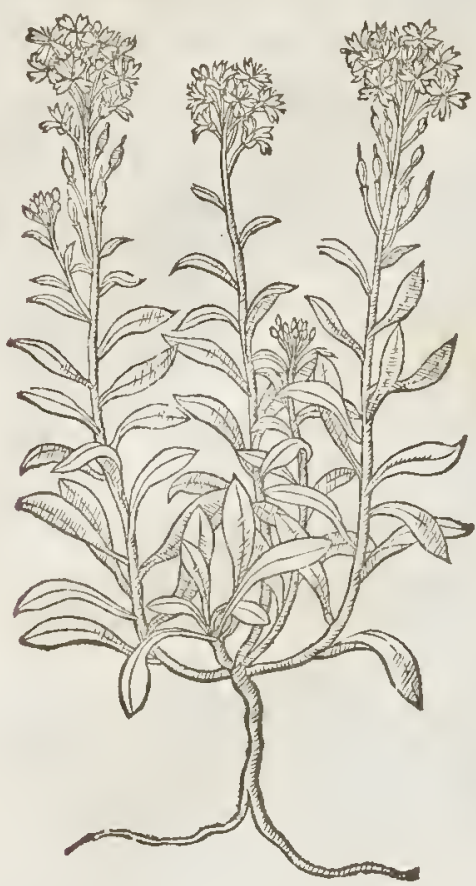

3 Thlapipinofum.

Thorny Muftard.

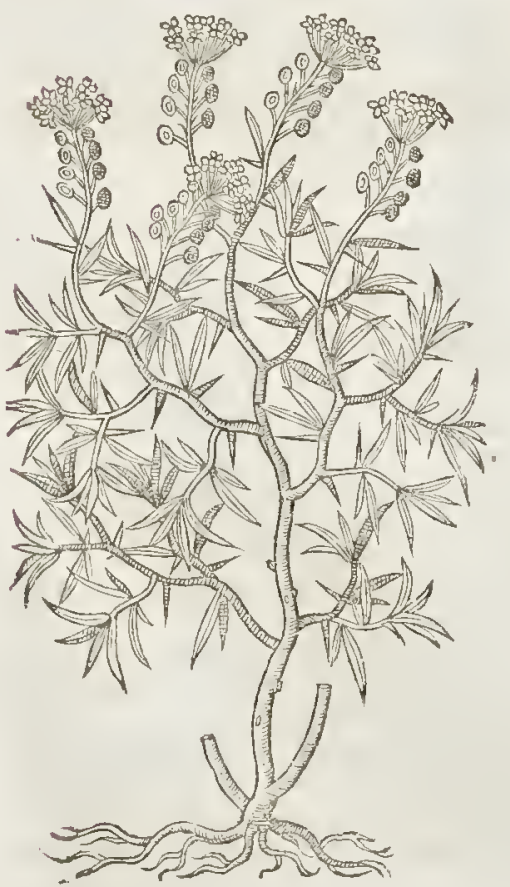

2 Tblapifruticofum minus. Small wooddy Mutard.

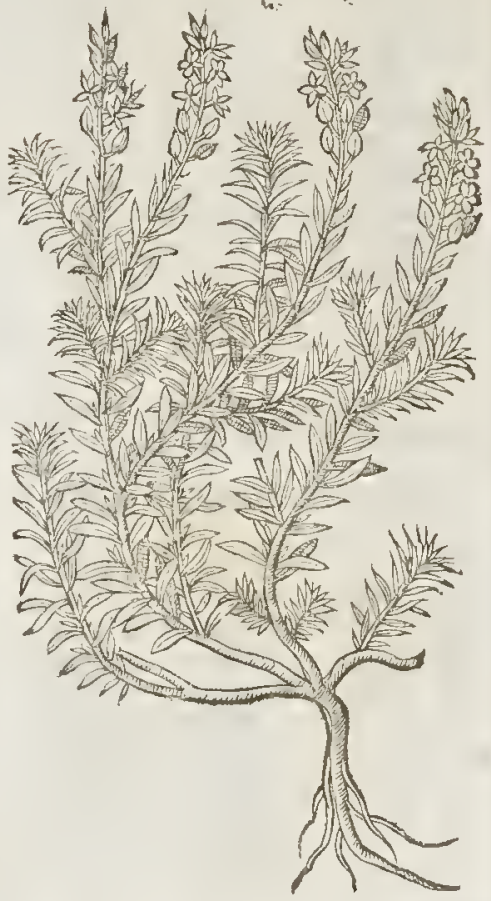

+ 4 Thlapifruticofum folio Leucoï marini? Buthy Muftard.

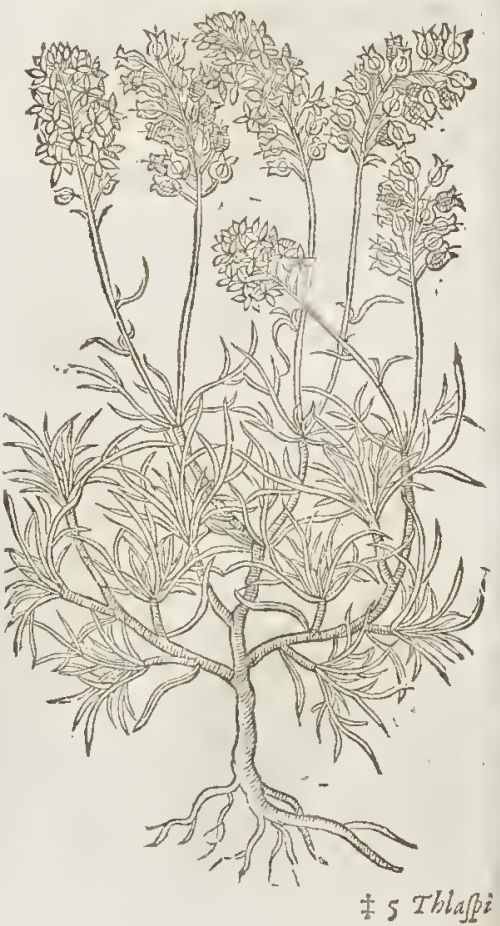


¥ 5 Thlappibederacism. Iuy Muftard. Cochlearia 6 anica

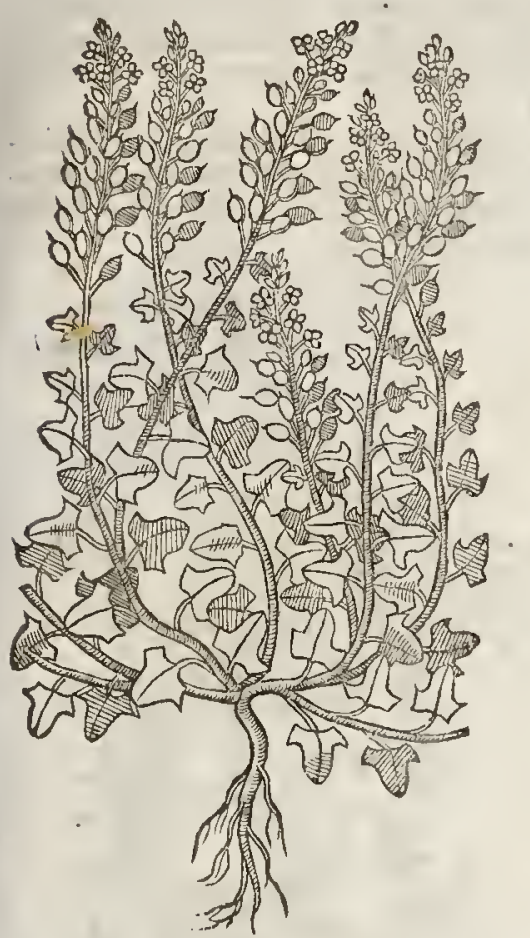

4 There is another fort of wooddy Muiftard growing in thaduwie and obfcure mountaines, and roing ftony places refembling the latt defcribed; fauing that this plant hath no pricks at all, but many fmall branches fet thick with leaues, refembling thofe of the leffer fea Leucoion : the floures are many and white; the feed like the other Thlarpies : the root is wooddy and fibrous.

$\mp 5$ There is (faith $L_{0 b}$ el) in Portland and about Plimouth, and vpon other rockes on the fea coaft of England, a creeping little herbe hauing fmall red crefted ftalkes about a fpanne high : the leaues are thicke and farhioned like Iuy; the white floures and fmali feeds do in tafte and hape refem. ble the Thlafpies. $\neq$

$$
\text { 91 The Place. }
$$

I The firf of thefe groweth about Mechline.

2. 3. 4. Thefe plants grow vpon the Alpin and Pyrenemountaines:in Piemont and in Italy, in ftony and rockie grounds.

\section{The Time.}

They floure when the other kindes sf Thlafpies 'do; that is, from May to the end of Augurt.

$$
\text { T) The Names: }
$$

I This Clugeus and Lobel call Thlapi incanum Adecblinienfe : Baubinc thinks it to be the Iberisprima of $T$ abernamontanws, whofe figure retained this
place in the former edition.

2 This is Thlapifruttcofum alterum of Lobel: Thlapi s. Hiparicum of Clufius.

3 Lobel calls this, Thlaspi fruticofum jpinofum.

4. Camerarius calls this, Thlapi fempervirens biflorum folio Leucoü, erc. Lobel, Thlajpi fruticofum folio Leucoü foc.

5 This Lobel calls $T$ blapi bederaceum;

\section{T) The Nature andVertues.}

I finde nothing extant of their nature or vertues, but they may be referred to the kinds of Thlafpies, whereof no doubt they are of kindred and affinitie, as well in facultie as forme.

\section{CHA P. 23. Of Toxers SMufard.}

The Defcription.

I 7 Owers Mufard hath beene taken of fome for a kinde of $C$ reffes, and referred by them to it : of fome, for one of the Muftards, and fo placed among the Thlafpies as a kinde thereof; and therefore my felfe muft needs beftow it fomewhere with others. Therefore thauewith Clufius and Lobel placed it among the Thlarpies, as a kinde thereof. It commeth out of the ground with many long and large rough leates, like thofe of Hounds-tongue, efpecially thofe next the ground : among?t which rifeth vp a long ftalke of a cubit or more high, fet abont with harpe pointed leaues like thofe of Woad. The floures grow at the top, if I may terme them floures, but they are as it were a little dufty chaffe driuen vpon the leaues and branches with the winde : after which come very fmall cods, wherein is fmall reddin feed like that of Cameline or Englifh Worm-feed, with a root mare of a tuft full of innumerable threds or ftrings .

$$
\mathrm{Z} 2
$$


$\ddagger 2$ This feeond kinde hath a thieker and harder root than the preeedent, hauing alfo fewer fibers; the leaues are bigger than thofe of the laft deferibed, fomewhat eurled or finuated,yet leffe, rough,and of a lighter greene; in the middeft of thefe there rife vp one or two ftalkes or more, vfually fome two eubits high, diuided into fome branches, which are adomed with leaues almoft ingirting them round at there fetring on. The floures are like thofe of the former, but fomewhat larger,and the colour is cither white, of a pale yellow : after thefe fueeed many long cods filled with a feed fomewhat larger than the laft deferibed. $\ddagger$

3 Gold of pleafure is an herbewith many branehes fet vpon a ftraight ftalke, round, and diuided into fundry wings, in height two enbits. The leaues be long, broad, and tharpe pointed, fomewhat fnipt or indented about the edges like thofe of Sow-thiftles. The flowers along the ftalkes arewhite; the feed eontained in round little vefiels is fat and oily.
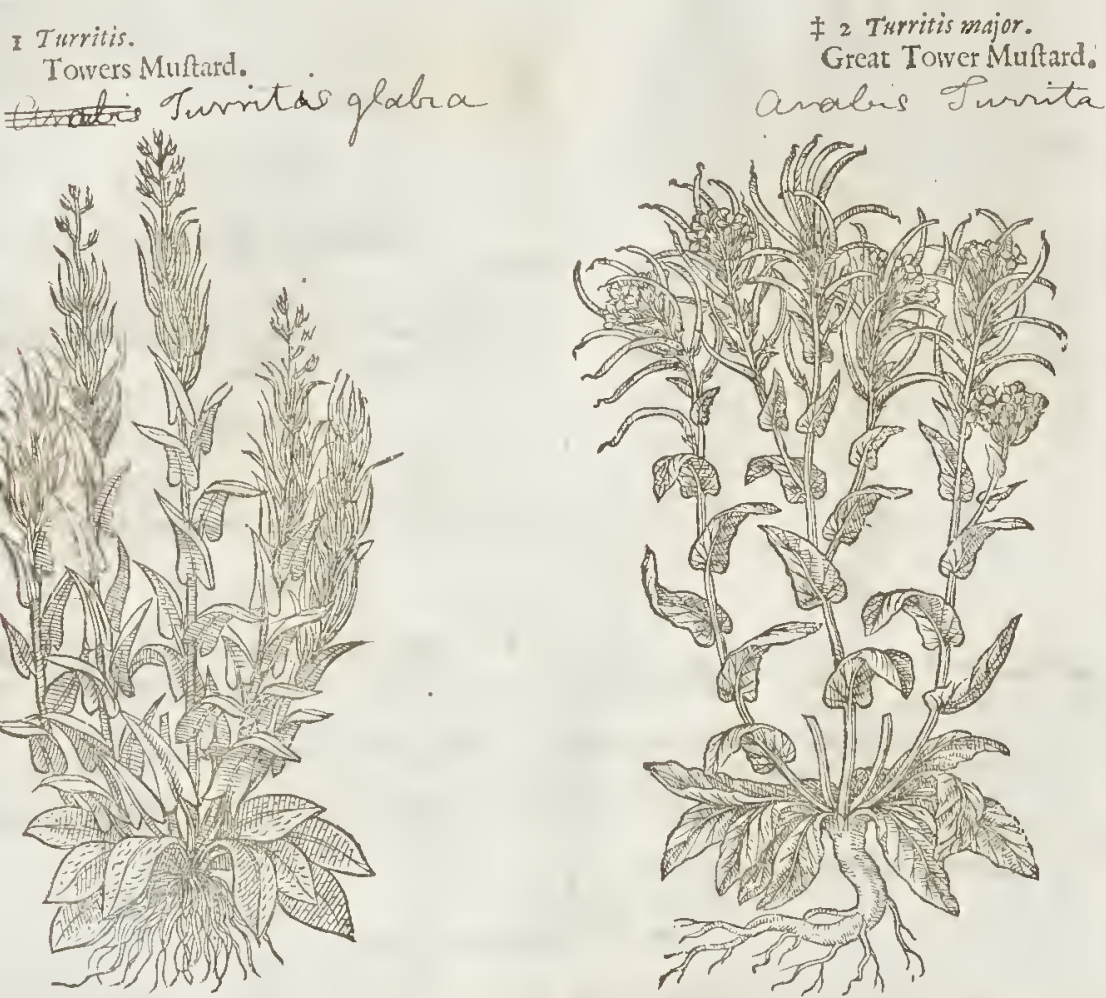

4 Treacle Wormefced rifeth vp with tough and pliant branehes, whereupou do grow many fmall yellow flowers; after which eome long flender cods like Flixe-weed, or Sophia, wherein is conteined fmall yellowith feed, bitter as Wormefeed or Coliquintida. The leates are fmall and darke of eolour, in thape like thofe of thew ilde ftocke Gillofloures, but not fo thieke, nor fat. The root is finall and fingle.

T The Place.

Towers Treale groweth in the Weft part of England, vpon dunghils and fueh like places. I haue likewife feen it in fundrie other plaees, as at Pyms by a village ealled Edmonton neere London,by the Citie wals of Weft-chefter in eorne fields, and where flaxe did grow about Cambrilge. ₹ The feeond is a franger with vs; yet I am deceiued if I hame not feene it growing in M.Parkinfons garden. ‡

The other grow in the territorie of Leiden in Zeeland, and many places of the Low-countries? and likewife wilde in fundrie places of England.

T) The Time.

Thefe herbes doe floure in May and Iune,and their feed is ripe in September.

T The Names.

$\ddagger$ I This is Turritis of Lobell: Turrita Vulgation of Clufus.

2 This is Iurrita maior of Clufins, who thinkes it to be Braffica Virgata of Cordus. 
3 Matthiolss calls this, Pfeudomydgrum: Tragus calls it, Sefanmm : Dodoneus, Lobel, and others call it Myagrum.

4. This Lobel calls Myagrum thlapi effigie. I abcramontanis hath it twice; firft vnder the nanie of Eryfomum tertium : fecondly, of $M$ yagrum fecundum. And fo alfo our Authour (as I formerly noted) had it beforevnder the name of Eruca Jjlueflris anguftifolis; and here vnder the name of camelins. $\neq$

3 Magrum.

Gold of pleafire. of 8 thigum Sationm din:

4 Camelina.

Treacle Worm-feed.

Erysimum

cheiranthoides
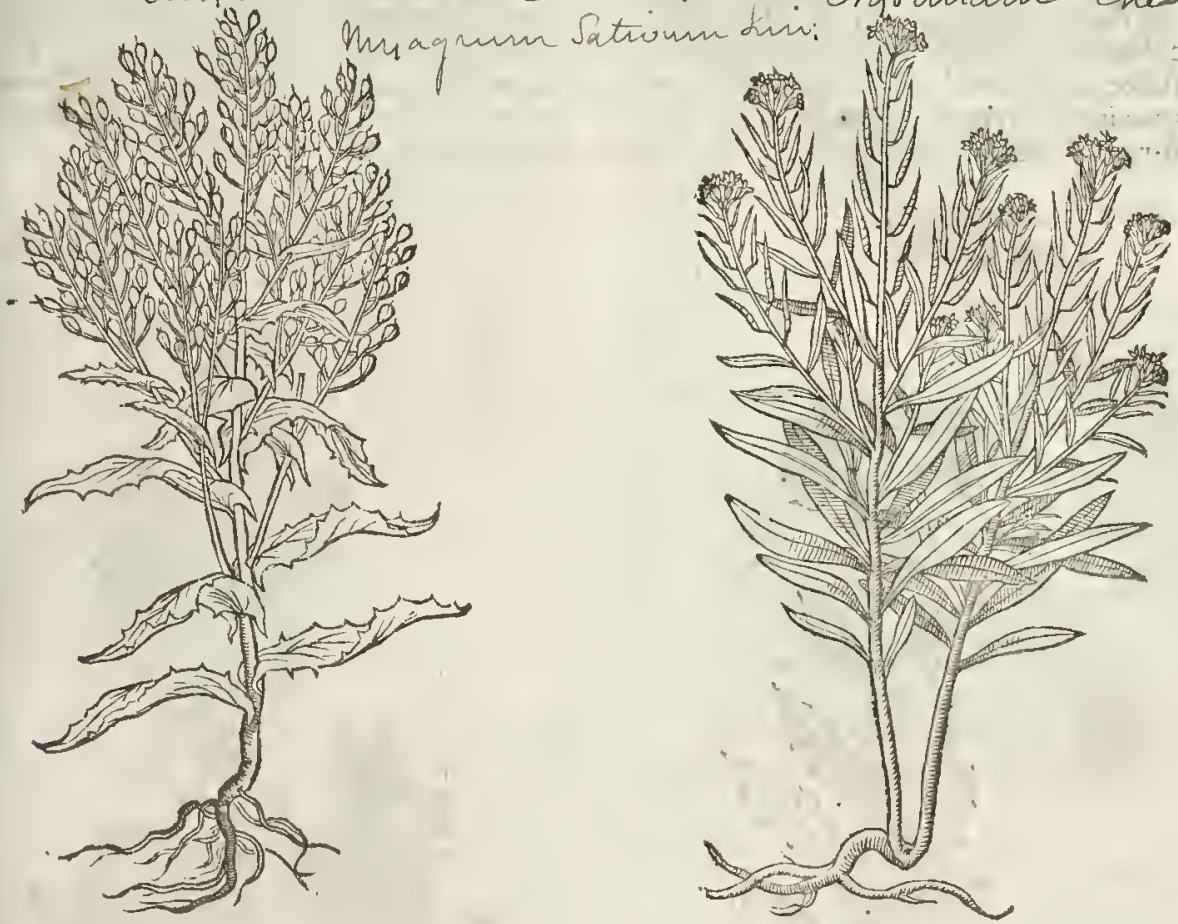

T The Temperature.

Thefe Plants be hot and dry in the third degree. T TheVertues.

It is thought, faith Diofcorides, That the roughneffe of the skinne is polifhed and made fmooth $A$ with the oylie fatneffe of the feed of Myagram.

Ruellius teaeheth, That the iuyce of the herbe healeth vlcers of the mouth; and that the poore $B$ peafant doth vfe the oile in banquets, and the riel in their lampes.

The feed of Crmelina ftamped, and gitien children to drinke, killeth the wormes, and driueth C. them forth both by liege and vomit.

† Thetwo Drabaes here omisted are treated of at large in the following Chapter.

\section{\# C нар.24. Of Turky Creffes.}

¥

6 Vr Author did briefely in the precedent Chapter make mention of the two plants wee firft mention in this Chapter; but that fobriefely, that I thought it eonuenient to difeourfe more largely of them, as alfo to adde to them other two, being by moft Writers adiudged to be of the fame Tribe orkindred. The vertues of the firft were by our Author out of Dodoneus formerly put to the $T$ blaßi Candie, Chapter 20 . from whence I hatie brought them to their proper place, in the end of this prefent Chapter. 


\section{T The Defcription.}

t I The firt hath crefted flender,yet firme ftalkes of fome foot long,which are fet with leaues of fome ineh in leng th, broad at the fetting on, finuated about the edges, and tharpe pointed; their eslour is a whiting greene, and tafte aeride; the lcsaues that are at the bottome of the ftalke are many, and larger. The tops of the ftalkes arediuided into many branehes of an vnequall length, and fuftain many floures; eaeh whereof eonfints of foure litle white leaues, fo that together they much refemble the vmbell of the EIder when it is in floure. Little fwolne feed veffels diuided into tw o eells follow the fading floures : the feed is whitih, about the bigneffe of millet; the root alfo is white, flender and ereeping.

$t^{2}$ This hath ereeping roots, from whieh arife many branehes lying vpon the ground here and there, taking root alfo; the leates, which vpon the lower branehes are many, are in forme and colour mueh like thofe of the laft deferibed, but lefe, and fomewhat fuipt about the edges. The ftalkes are about a handfull high, or fomewhat more, round, greene, and hairy, hauing fome leaues growing vpon them. The floures grow fpoke fathion at the top of the ftalkes, white, and confifting of foure leaues; whieh fallen, there follow cods conteining a fmall red feed.

\section{- I Draba Diofcoridis. \\ Turkic Creffes.}

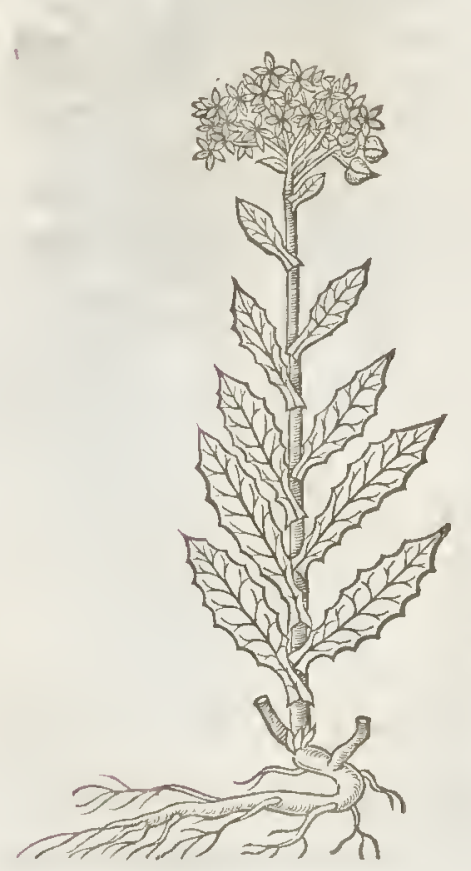

$\neq 2$ Drabatprimarepens. 'The firtt ereeping Creffe:

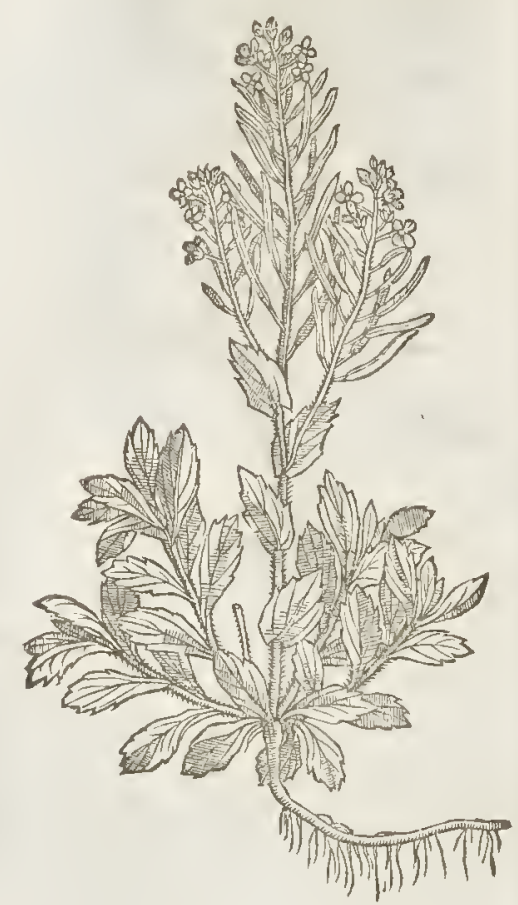

3 From a fmall and creping root rife vp many fhootes, which while they are young haue many thicke juicy and darke greene leaues rofe fathion adorning their tops, out of the middeft of which fpring out many flender ftalkes of fome foor high, which at certain fpaces are eneompaffed (as it were)with leaues fomewhat leffer then the former, yet broader at the bottome: the floures, cods, and feed are like the laft mentioned.

4 There is a plant alfo by fome refer'd to this Claffis; and I for fome reafons thinkegood to make mention thereof in this place. It hath a ftrong and very long root of colour whitioh, and of as tharpe a tafte as Creffes; the ftalkes are many, and oft times exceed the height of a man, yet flender, and towards their tops diuided into fome branches, which make no vmbell, but eanry their floures difperfed; which confint of foure fmall yellow leates: after the floure is paft there follow long flender cods eonteining a fmall,yellowifh, acride feed. The leaues which adone this plant are long, tharpe pointed, and fnipt about the edges, fomew liat like thofe of Saracens Confound, but that thefe towards the top are inore vnequally cut in. 
Draba altera repens.

- Dthe orher creeping Creffe.'

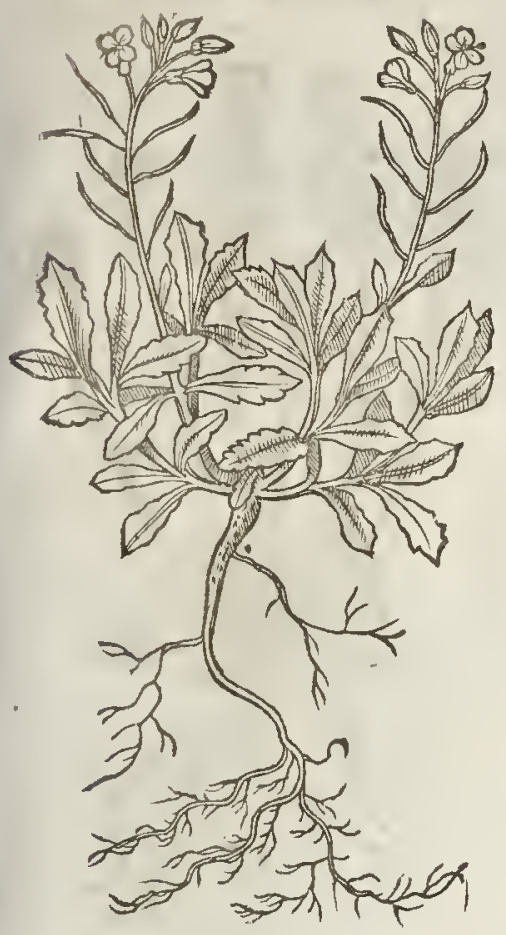

91 The Time.

The firft of thefe foures in May and the beginning of Iune. The 2 and 3 in Aprill. The fourth in Iune and Iuly.

\section{T The place.}

None of thefe(that I know of) are found naturally growing in this kingdome; the laft excepted, which I thinke may be found in fome plaees.

$$
\text { T) The Names. }
$$

I This by a generall confent of Mathio. lus, Anguillar a, Lobell, doc is iudged to be the Arabis, or Draba of the Ancients.

2 Draba alteri of Clufiss.

3 Draba tertia fucculento folio, of Clufies: Eruca ciuralis of Dalefchampius.

4 This by camcrarius is fet forth vndet the name of Arabis quorundam, and he affirmes in his Hor. Med.that he had it outof England vnder the name of Solidago; The which is very likely, for without doubt this is the very plant that our Author miltoolse for Solidago Sarracenica, for he berraies himfelfe in the Chap. ter of Epimedium, whereas he faith it hath cods like Sarraccens Confound; when as both he and all other giue no cods at all to Sarracens Confound. My very good friend $\mathrm{M}^{\mathrm{r}}$. $10 \mathrm{hn}$ Gosdyer was the firft, I thinke, that obferued this miftake in our Author; forwhich his obferuation,together with fome others formerly and hereafter to be remembred, I aeknow ledge ny felfe beholden to him.

The Vertues, attributed to the firf.

I Diofcorides faith, that they vfe to eate the dryed feed of this herbe with neate, as we do pepper efpecially in Cappadocia.

They vfe likewife to boyle the herbe with the decoction of barly, called Ptifana ; wich being fo boiled, eoneosteth and bringeth forth of the eheft tough and raw flegme which ficketh thercin.

The reft are hot,and come necre to the vertues of the preedent. $\ddagger$

\section{C н н Р.25. Of Shepheards-purfe.}

IT The Defription.

I He leaties of Shepleards purfe grow vp at the firft long, gathed in the edges like thofe of Rocket, fpred vpon the ground : from thefe fpring vp very many little weake falks diuided into fundry branches, with like leaues growing on them, but lefier; at the rop whereof are orderly placed fmall white floures : after thefe come vp little feed veffels, flat, and cornerel, narrow at the ftem like to a certaine little pouch or purfe, in which lieth the feed. The rout is white not without ftrings. $¥$ There in a nother of this kinde with leaues not finuated, or cut in. $\neq$

2. The fmall Shepheards purfe commeth forth of the ground like the Cuckow floure, which I haue Englinhed Ladie-Imockes, hauing fmall leaues deepely indented about the edges; among which rife vp many frall tender ftalkes with floures at the top, as it were chaffe. The luuskes and feed is like the other before mentioned.

Thefe herbes do grow of The Place. Thele herbes do grow of themfelues for the mot part,neere eommon high waies, in defert and
vntilled plaees, among rubbith and old walls. 


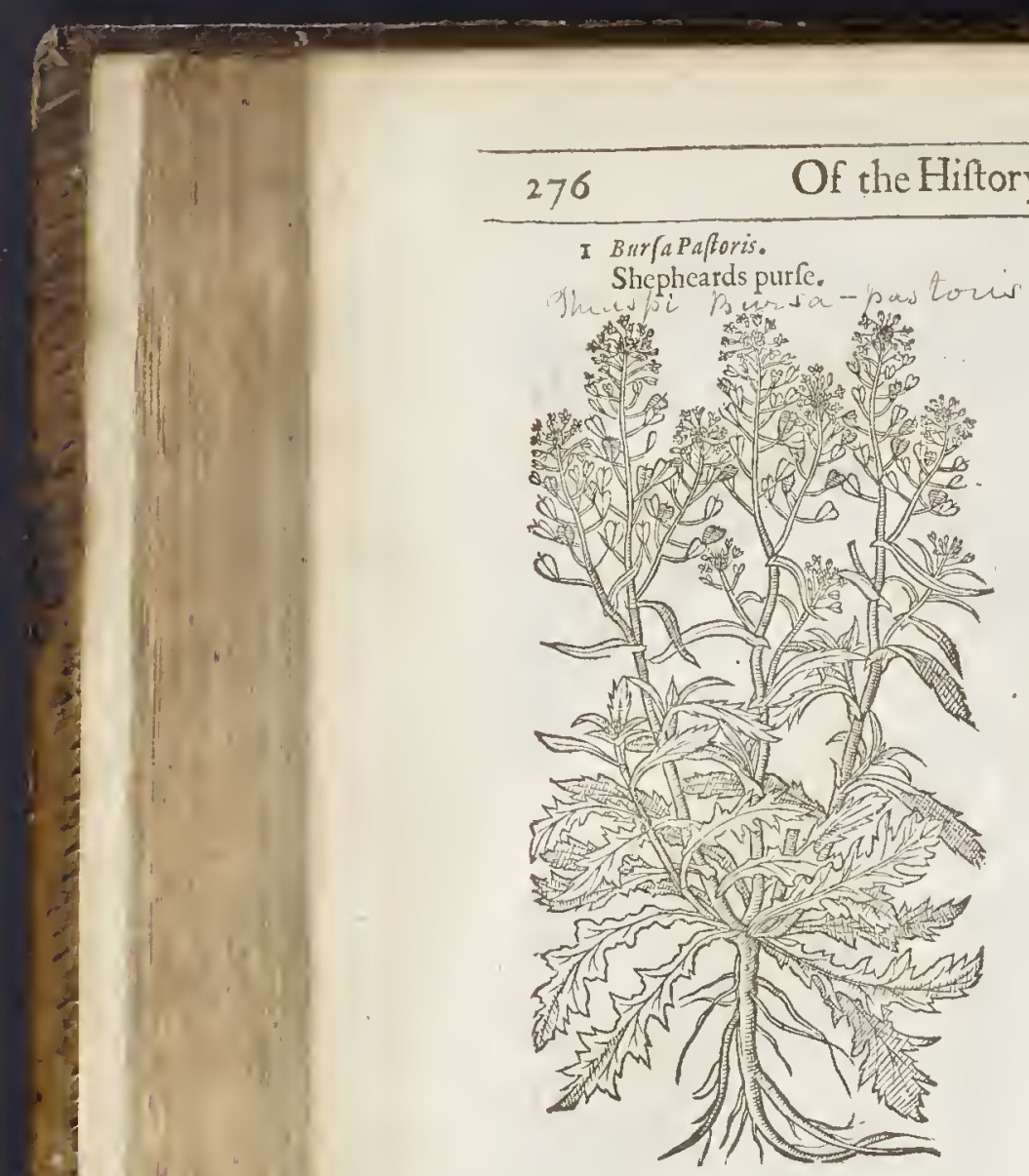

$L_{1}$ B. 2:

y of Plants.

2 Burfa Paftoria minima.

Small Shepheards purfe?

Jeeris madianatio

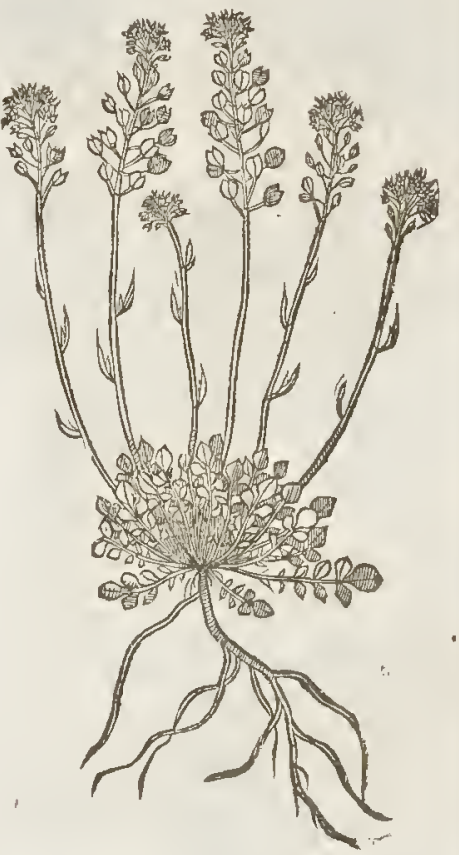

T The Time.

They floure, flourifh, and feed all the Sommer long.

T. The Names.

Shepheards purfe is called in Latine, Paftoris burfa, or Perapaftoris: in high Dutch, Sectel: in low-Dutch, Boafekens erupt : in French, Bourfe de pafteur ou Curé : in Englifh, Shepheards purfe or fcrip : of fome, Shepheards pouch,and poore mans Parmacetic : and in the North part of England, Toy-wort, Pick-purfe, and Cafe-weed.

9 The Temperature.

They are of temperature eold and dry, and very much binding, after the opinion of Ruellius, Mat thiolus, and Dodoneus ; but Lobel and Perit hold them to be hot and dry, iudgaing the fame by their tharpe tafte: which hath caufed me to infert them here among the kindes of Thlafpi, eonfidering the farhion of the leaucs, cods, fced, and tafte thercof: which do fo wel agree together, that I mighe very well haue plaeed them as kindes thereof. But rather willing to content others that hate written before, than to pleafe my felfe, I hatre followed their order in marfhalling them in this place, where they may ftand for coufine germanes.

9) The Vertues.

A Shepheards purfe ftayeth bleeding in any part of the body, whether the inyce or the decoction thereof be drunke, or whether it be vfed pulteffe-wife, or in bath, or any other way elfe.

B In a Clyfter it eureth the bloudy flix: it healeth greene and bleeding wounds : it is maruellous good for in fammations new begun, and for all difeafes which mult be checked backe and cooled.

C The decolion doth flop the laske, the fpitting and piffing of bloud, and all other fluxes of bloud.

CHAP. 


\begin{tabular}{ll}
\hline$L_{1}$ B: 20 & Of the Hiftorie of Plants. \\
\hline
\end{tabular}

\section{C н а р. 26. Of Italian Rocket。}

\section{TI The Defcription.}

I Talian Rocket hath long leaucs cut into many parts or dittifions like thofe of the $\dot{A}$ in. tree, refembling Ruellius his Bucks-horne : among which rife vp ftalks weake and tender, but thicke and groffe, two foothigh, garnithed with many fnall yellowith foures like 2. the middle part of Tanfie floures, of a naughty fauor or fmell. The feed is fmall like fand or dut, in tafte like Rocket feed, whereof in truth wee fufpeet it to be a kinde. The root is long and wooddy.

I Rhefida Plinï.

Italian Focket.

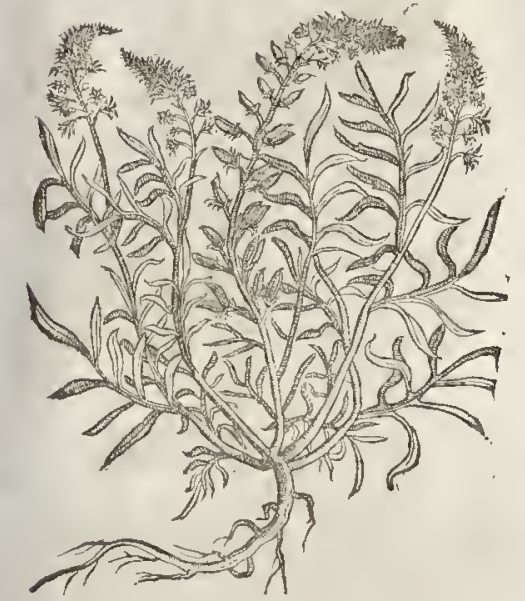

2 Rhefedamaxima. Crambling Roeket.

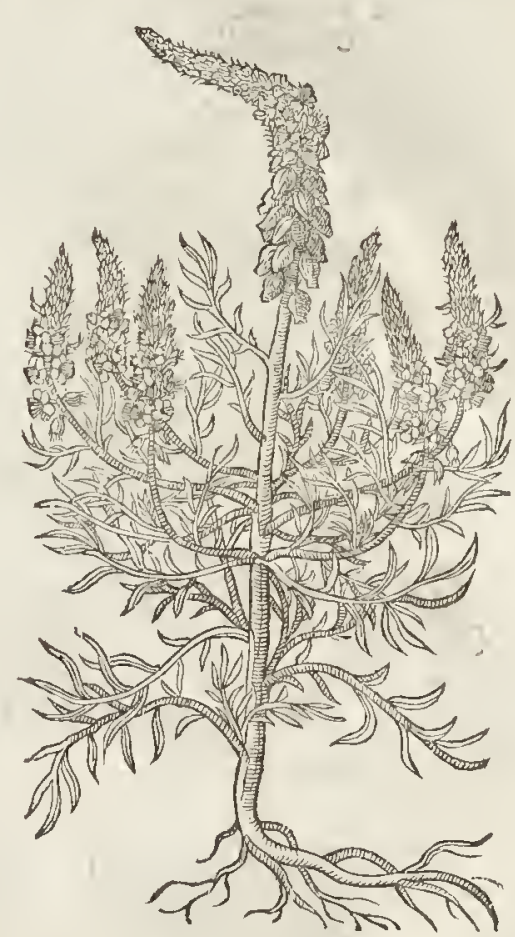

2 Crambling Rocket hath many large leaties cut into fundry fections, deeply diuided to the middle rib, branched like the homes of a ftag or hart : among which there do rife vp long fat and Herhy ftalkes two cubits high, lying flat vpon the ground by reafon of his weake and feeble branches. The floures grow at the top, cluftering thicke together, white of colour, with brownith threds in them. The feed is like the former. $\neq$ Lobel affirmes ir growes in the Low-country gardens with writhen falkes, fometimes ten or twelue cubits high, with leaues much diuided. $\ddagger$

\section{IT The Place.}

Thefe Plants grow in fandy, ftony, grauelly, and chalky barren grounds. I haue found them in fundry places of Kent, as at South-fleet, vpon Long-field downes, which is a chalkic and hilly ground very barren. They grow at Greenhithe vpon the hills, and in other places of Kent. ‡ The firft growes alfo vpon the Wolds in Yorke-fhire. The fecond I haue not feene growing except int gardens, and much doubt whether it grow wilde with ws or no. ‡

Thefe Plants do flourip in Iune, Iuly, ot 7 he Time 


\section{The Names.}

The firft is called of Pliny, Refeda, Erucaperegrina, \& Eruca Cantabrica:in Englifh, Italian Rocket.

The fecond is called Refeda maxima : of Anguillara, Pignocomon, whercof I finde notling cxtant Forthy the memorie, either of temperature or vertues.

\section{C н А. 27. Of Groundfell. \\ TI The Defription.}

17 He falke of Groundfell is round, chamfered and diuided into many branches : the leaues be greene, long, and cut in the edges almoft like thofe of Succorie, but lefrer like in a manner to the leaues of Rocket. The floures be yellow, and turne to downe, that is carried away with the winde. The root is full of Atrings and threds.

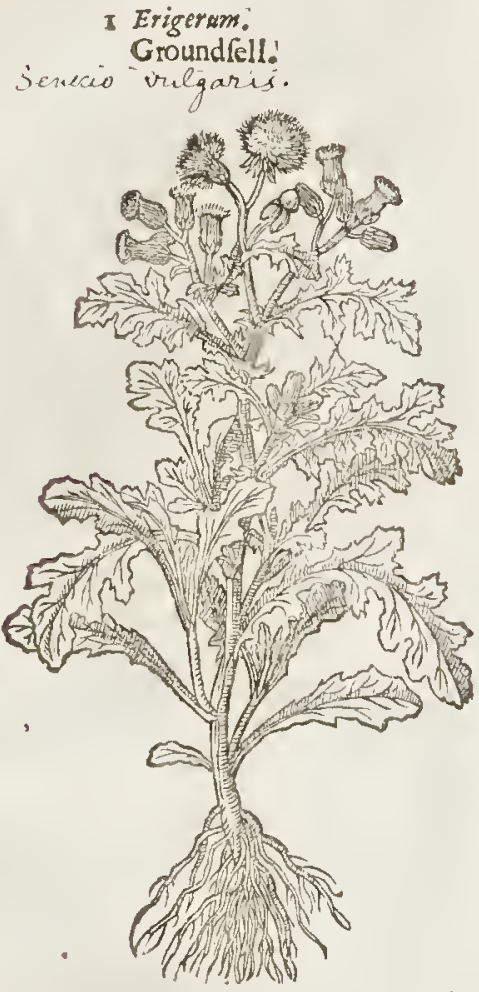

\section{- Erigerum Tomentofum. Cotton Groundfell.}

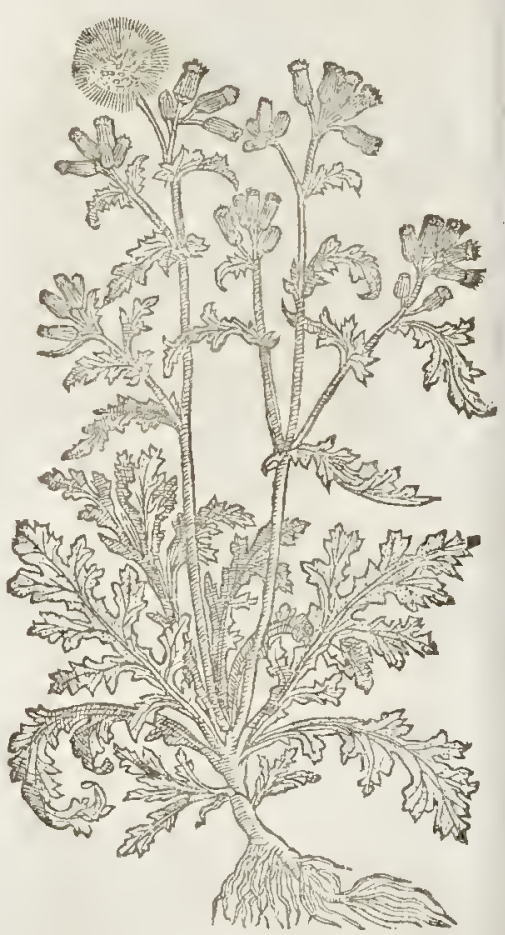

$\overrightarrow{3}$ Cotton Groundfel hath a fraight ftalke of a browne purple colour, couted with a fine cotton or downy haire, of the height of two cubits. The leaues are like thofe of S. Iames Wort, or Rag-wort; and at the top of the ftalke grow fmall knops, from which come floures of a pale yellow colour; which are no fooner opened and fpred abroad, but they change into downe like that of the Thiftle, euen the fame houre of his flouring, and is carried away with the winde : the root is fmall and tender.

$¥ 3$ There is another with leaues more iagged,and finelier cut than the laft mentioned, foft alfo and downie : the floures are fewer, leffe and paler than in the ordinarie, but turne fpeedily into downe like as the former. $\ddagger$

T) The Place.

Thefe herbes are very common throughout England, and do grow almof euery where? T) The Time.

They flourith aimoft euery moneth of the yeare. 


\section{$\$ 3$ Erigerontomentofium alterum.}

The othet Cotton Gtoundfell.

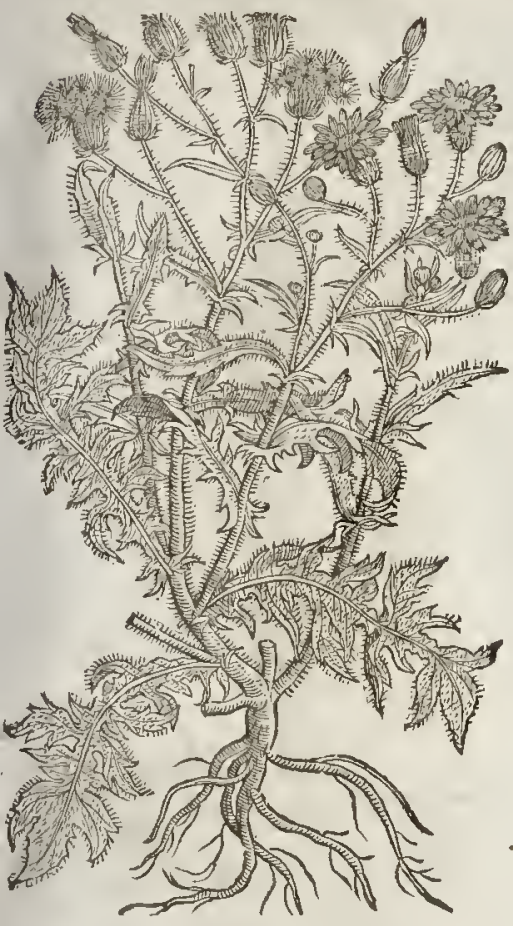

Tा The Names.

Groundfel is ealled in Greek ievipur? in Latine, senecio, beeaufe it waxeth old quickely : by a baftard name Herbutum : in Germany, orturs: wurt: : in low-Duteh, $\mathbb{C r u p s}$ ctupt, and $\mathbb{C r u p E}$ ten crupt : in Spanifh, Yerwa cana : in Italian, Cardoncetto, Speliciofa : in Englih, Groundfel.

Cotton Groundfell feemeth to be all one with Theophraftus his Aphace; hee maketh mention of Aphace in his feutenth booke, which is nor onely a kinde of pulfe, but an herbe alfo, vnto which this kinde of Groundfell is very like. For as Theophra. ftus faith, The herbe Aphace is one of the pot-herbs and kindes of Suceorie: adding further, That it floureth in hafte, but yet foone is old, and turneth into down; and fixeh a one is this kind of Groundfell. But Theophraftus faith further, That is floureth all the winter long, and fo long as the Spring lafterh, as my felfe have often feene this Groundfell do.

$$
\text { 11 The Temperature. }
$$

Groundfell hath mixt faeulties; it cooleth, and withall digefteth, as $P$ aulus Agincta writeth.

\section{T The Fertues.}

The leaues of Ground fell boyled in wine or wa: ter, and drunke, healeth the paine and aehe of the ftomaeke that proeeedeth of eholer.

The leaues and floures ftamped with a little $B$ Hogs greafe ecafeth the burning heat of the ftones and fundament. By adding to a little faffron ot falt it helpeth the Struma or Kings Euill.

The leautes ftamped and ftrained into milke and dtunke, helpeth the red gummes and frets in children.

Diofcorides faith, That with the fine pouder of Frankinfenee it healeth wounds in the finewes, The like opetation hath the downe of the floures mixed with vineger.

Boyled in Ale with a little honey and vineger, it prounketh vomit, efpeeially if you adde thereto a few roots of $1 \iint a$ a abacca.

\section{C н а Р. 28. Of Saint fames bis Wort.}

\section{II $T$ he Kindes.}

7 He herbe ealled Saint Iames his wort is not without caufe thought to be a kinde of Ground1 fel: of which there be fundry forts, fome of the pafture, and one of the fea ; fome fweet-fmelling; and fome of a loathfome fauror. All whieh kindes I will fer downe.

\section{If The Defcription.}

I Aint Iames his wort or Rag-wort is very well knowne enery where, and bringeth forth at the firft broad leaues, gafhed round about like to the leaues of eommon Wormewood, but broader, thieker, not whitifh or foft, of a deepe greene eolour, with a ftalke which rifeth v aboue a cubit high, ehamfered, blaekifh, and fomewhat red withall. The armes or wings are fet with leffer leaues like thofe of Groundfell or of wilde Roeket. The floures at the top be of a yellow eolour like Marigolds, as well the middle button as the fmall foures that ftand in a pale round about, whieh turne into downe as doth Groundfell. The root is threddy.

$\ddagger 2$ This hath ftalkes fome eubit high, erefted, and fet with long whitinh leaues , the lower leaues are the thorter; but the vpper leates the longer, yer the narrower: at the top of the ftalke grow fome foure or fiue floures as in an vmbell, which are of a darke red colour before they open themfelues, 


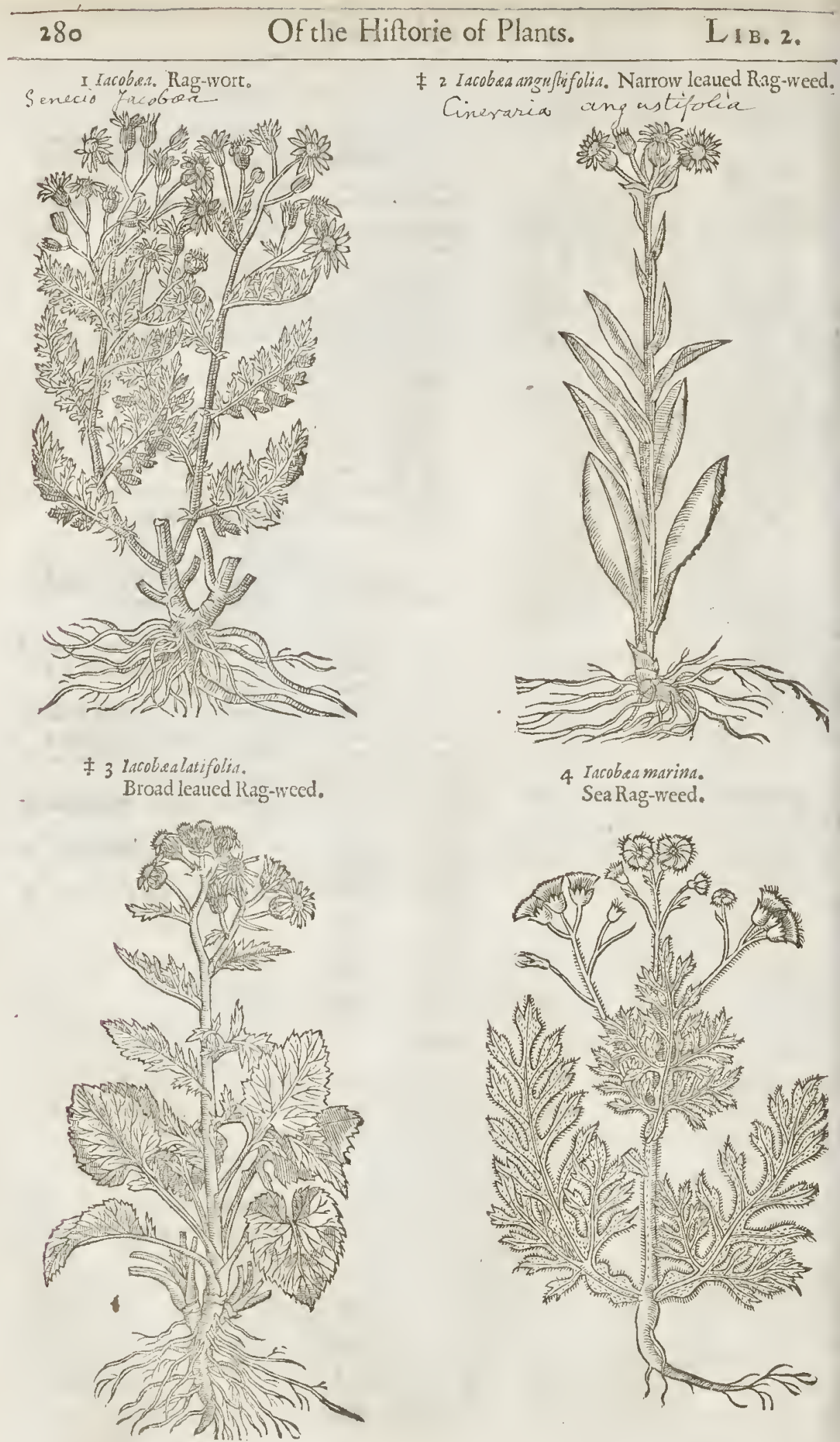


themfelues; but opened, of a bright golden colour, and thofe are ingirt by fifteeneor more little leaues, which are of a Hame colour aboue, and red vnderneath. The Houres fly avay in domne, and. the fect is blackith, and like that of the former. The roots are made of many frings like thore of the precedent.

3 I lis broad leaned Rag-weed hath ftiffe crefted falkes, which are fetwith broad wrinckled tharpe fointed leaues, of a greene coiour: the bottome leautes are the larger and rounder, the rop lcaues the lefte, and more diuided. The foures grow at the top of the ftalkes, in thave and colour like thofe of the common Rag-weed, but much bigger : They alfo turne into Downe as the fotmier. $\ddagger$

4 Sea Rag-w ort groweth to the height of two cub its : the ftalkes be not reddifn as the other, but contrariwile A hh-coloured, gray and hoary: the leaues be greater and broader than the other: the floures grow at the top, of a pale yellow colour, conered on the cup or huske of the floure, as alfo the leaues, with a certaine lof white Downe or freefe: the floures vanifn into Downe, and fly away with the winde.

Ti The rlace.

Land Rag-wort growethenery where in vintlled paftures and ficlds, which are fomeivatmoif efpecially, and necre vnto the borders of fields.

$\ddagger^{2} 3$ Thefe grow vpon the Auftrian and Heluetian Alpes. $\ddagger$

The fourth kinde of Rag-w ort groweth neere the fea fidc in fundry places : I haue feene it in the field by Margate, by Queakes houre, and by Byrcheriton in the Ifle of Tenet: likewife it groweth neere the Kings ferry in the Ille of Shepey, in the way leading to Sherland houfe, where $S^{r}$. Edward Hobby dwelletli: and likewife at $Q$ reenbornugh caltle in the fame Inc; and in other places. $\neq$ I hate been at the former and later of thefe p'aces to fincie out plants, yet conld I not fee this plant. It growes in the garden of $\mathrm{M}^{\mathrm{r}}$. Ralph T $\mathrm{uggy}^{\prime}$; but I teare hardly wilde in this kingdome. $\ddagger$ Qf The Time.

They foure in Iuly and Augutt, at which time they are carried away with the Downe. \&ा The Names.

The firt is called in Latine, Herba S. Iacobi, or $S$. lacobi flos, and Iacobsa: in high-Dutch, Gatie 7acobs bloumen: in low. Dutch, Sant Jacobs ceupt: in French, Flucr de S. Lacques : in Englith, $S$. Iames his $\mathrm{W}$ ort : the countrey people do call it Stagger-wort,and Staner-wort, and alfo Rag-wort, $\neq$ and Rag-weed. In Holderneffe in Yorke-rhire they call it Segorum.

The fecond is Incobar Pamonica 3. of Claysus.

The third is his Iacoticalatifolia. Gefner calls it Conina montana. ‡

The fourth is nansed Cincraria, or A h-coloured S. lankes Wort : fome cell it Erigeron marinsm; or Sea Groundfell : of fome, Artumifta marina. F And by Proper Alpizus, Artemifisalba. $\neq$

\section{T) The Temperasture.}

$S$. Tames wort is lot and dry in the fecond degree, and al fo cleanfing, by reafon of the bitterneffe which it hatl.

It is commended by the tater 7 the Vertucs. which are not fenred, thundified ly fitions to be good for greene wounds, and old filthy Vlcers of temperedwith hourey mundifed, and made cleane, it alfo healeth them, wrth the iuyce heretalue.

It is much commended, and not without caufe, to helpe old aches and pains in the armes, hips, and legs, boyled in logs grease to the forme of an ointment.

Moreouc, the decoition herenf gargarifed is much fet by as a remedie againft fivellings and impoftumations of the throat, which it wafterh away and throughly healeth.

The leanes famped very fimall;and boyled ivith fome hogs greafe vnto the confumption of the ityce, adding thereto in the end of the boyling a little Mafticke and Olibanum, and then ftrained, taketh away the o!d ache in the huckle-bones called Sciatica.

\# The Egyptians (faicl P.opper Alpints) vfe the Sea Rag-ivort, for many things : for they commend the decocion made with the leaues thereofagaint the ftone in the kidnies and bladder, as alfo to lielpe theold obftructions of the inward parts, but principally thofe of the wonbe; as alfo the coldneffe, ftrangulation,barrenneffe, inflation therenf, and it alfo brings downe the intercepted courfes: therefore women troubled with the mother are mucl eafed by baths made of the leates and fionres hereof. $\neq$ 


\section{Сйі г29. Of Garden Succorie.}

T. The Kindes.

There be fundry forts of plants eomprehended vnder the title of Cicheracea, that is to fay, $\mathrm{Ci}$ 1 chorie, Endiue, Dandelion, \&ce.differing not fo mueh in operation and working,as in thape and forme, which hath eaufed many to deeme them diuers, who haue diftinguifhed them vnder the ritles aforefaid:of euery whieh kinde there be diuers forts, the whieh thall be diuided in their fenerall chapters, whercin the differenees thall be expreft.

$$
\text { T The Defcription. }
$$

1

Y Arden Suecory is of two forts, one with broadileanes, and the other with narrow, drep-

T ly eut and gafhed on both fides. The firt hath broad lcaus fomewhat hairie, not mueh vnlike to Endiue, but narrower; among ft whieh doc rife vp ftalkes, whereon are placed the like leaues, but fmaller. The ftalke diuideth it felfe toward the top into many branehes, whereon doe grow little blew floures confifting of many fmall leanes, afterwhich followeth white feed. The root is tough, long, and white of colour, continuing many yeeres; from the which as from euery part of the plant doth iffae forth bitter and milkie juice. The whole plant is of a bitter taftelikewife.

2 Cichorium futivum. Garden Suecorie.

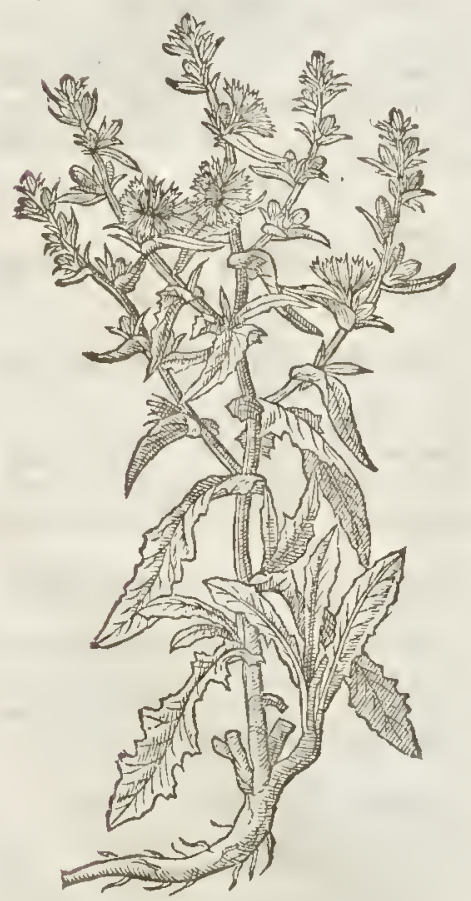

3 Itrbus fatiud. Garden Endiue.

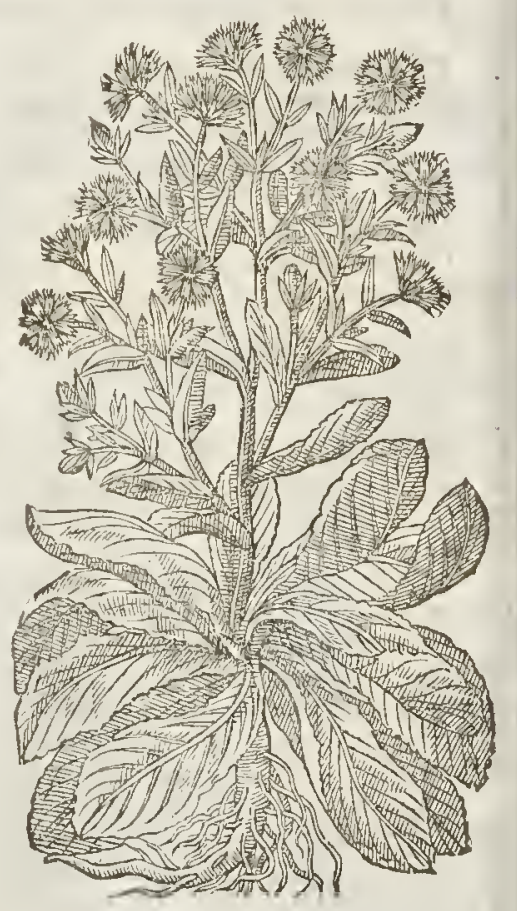

2 The fecond kinde of Succorie is like rnto the former, but greater in euery point. That which eaufeth the differenee is, that this beareth floures white of eolour tending to blewneffe; the others blew, as I hate faid.

3 Garden Endiue bringeth forth long leaues, broad, fmooth, more greene than white, like a Imoft to thofe of lettuee, fomething niekcd in the edges. The ftalke groweth vp among the leaues, being round and hollow, diuided into branehes; our of whieh being broken or eut there iffueth $a$ juice like milke, fomewhat bitter : the floures vpon the branches confift of many leaues, in colour 
₹ 5 Cichorium pinefum. Thornic Succory.

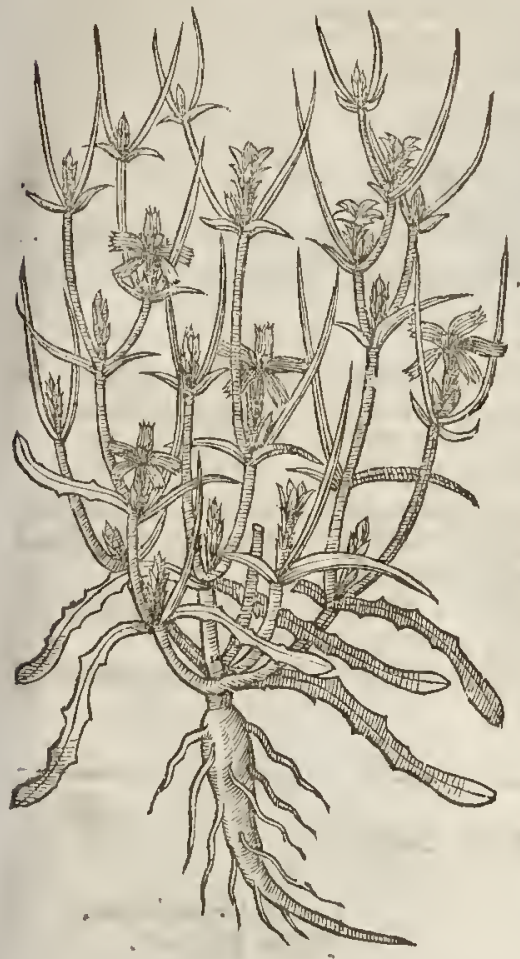

commonly blew, feldome white. The root is long, white; with ftrings growing thereat, which withereth after the feed is ripe.

4 Curled Endiue hath leaues not vnlike to thofe of the curled or Cabbage lettuce, but much greater; among which rife vp frong and thicke ftalkes, fet with the like leaues, but leffer, and not fonotably curled or crifped. The Pours grow at the top, blew of colour. The root peri1hech,as doth the whole plant, when it hath brought forth his ripe feed.

\# 5 To thefe may fitly be added the thorny or prickly Succory of Candy, being of this kindred, and there vfed in defect of the true Succorie, in ftead thereof. The root is pretty long, white, with few fibers hanging thereat; the ftalke is hard, wooddy, and diuaricated into many branches, which commonly end in two or threc prickes like hornes: The leaucs are bitter, long, narrow, and tharpe pointed, and lie fpread vpon the ground, and arc a little finuated, or cut about the edges: The flours, which vivally grow vpon little footfallies at the diufions of the branches, arc much like thofe of the ordinary Succory, yet much leffe, confiring of fiue blew leanes, with yellow chiues in the middle. The feed is like thofe of the common Succory. It fipures in Inly and Augurt. $\neq$

$$
\text { TI The place and Time. }
$$

This Succory, and thefe Endiues are only fownc in gardens.

Endiue being forven in the fpring quickly commeth vp to floute, which feedeth in harueft, and afterward dieth: But being fowen in Iuly it remaineth till wintet, at which time it is taken vp by the roots,and laid in the funne or aire for the fpace of two hourcs; then will the leaues be tough, and eafily endure to be wrapped vpon an heape, and buried in the earth with the roots vpward, where no earth can get within it (which if it did, would caufe rottenneffe) the which fo coucred may be taken yp at times conuenient, and ved in fallades all the winter,as in London and other places is to be feen; and then it is called white Endiue, whereof $P$ liny feemeth not to be ignorant, fpeaking to the fame purpore in his 20 .booke and 8 . cliaptet.

$$
\text { 91 The Rames. }
$$

Thefe hetbes be called by one name in Greek Ispost notwithtanding for diftinctions fake they

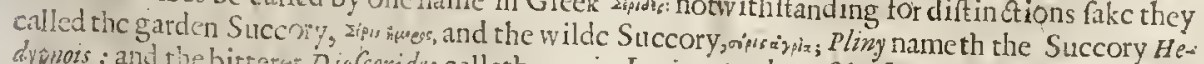

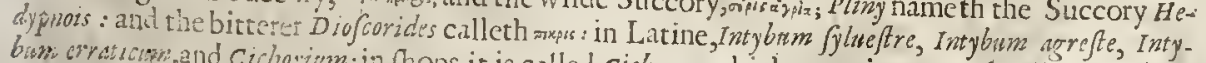
bum cryachand and Cichorizn: in thops it is called cichorea, which name is not onely allowed of the late Phyitions, butalio of the Poet Horace in the 31 . Ode of his fith booke,

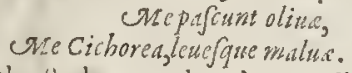

With vs, faith ptiny in his 20. booke, s.chapter, they haue called Intybum crraticum, or wilde Endiue, SArbugia (others reade Ambrbeia:) and fome there be that name it Rofrum fortirum: and Dthers, as Guiliclimus Placentinus, and Petrus Crefcentus, terme it Sponfa folus; the Germanies call it nogwaten, which is as much to fay, as the keeper of the waies : the Italians, Cichorea : the Spaniards, Almeromes : the Englinh-men, Cicorie and Succory : the Bohemians, Cakinka.

Endiue is named in Greeke sfishues: in Latine, Intybum fativurn: of fome, Endiuid : and Serepio, Tarawacon : of the Italians, Scariola, which name remaineth in molt thops; alfo Serioin as though they fhould fitly call it seris, but not fo well serriola, with a double $r$ : for Serriola is

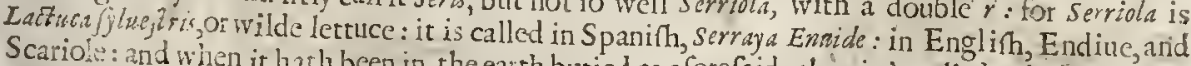
Scario's: and when it hat been in the eath buticu as aforefaid, then it is called white Enditie.

A a 2

+5 This 
¥ 5 This was firft fet forth by Clufus vnder this name, chondrilla genus elegans cantleo fare: finee, by Pona and Baubre, by the title we giue you, to wit, Cachorium ffinofum Hororius Bellus writes that in Candy where as it naturally growes, they vulgarly terme it sawasm, that is, Hydrie Bua, the Pitcher Thorne, beeaufe the pcople fetch all their water in ftone pots or Pitchers, which rhey fop with this plant, to keepe mice and other fuch things from crecping into them : and it growes fo round, that it feems by nature to be prouided for that purpole. $¥$

$$
\text { q) The Nature. }
$$

Endiue and Suecorie are cold and drie iw the fecond degree, and withall fomewhat binding: and becat fe they be fomething bitter, they doe alfo clenfe and open.

Garden Endiue is co'der,and not fo tric or clenfing, and by reafon of thefe qualities they are thought to be exeellent medicines for a hot liuer, as Galcn hathwritten in his $\delta$.book of the eompofitions of medieines according to the places affected.

$$
\text { The Vertues. }
$$

A Thefe herbs when they be greene haue vertue to eoole the hot burning of the liuer, to helpe the ftopping of the gall, yellow jaundice, laeke of 1 eepe, ftopping of vrine, and hot burning feauers.

B A fyrup made thereof and fugar is very good for the difeafes a forefaid.

C The diltilled water is good in potions, cooling and purging drinkes.

C The diftilled water of Endiue, Plantaine, and rofes, profiteth againft exeoriations in the conduit of the yard to be iniented with a fyringe, whether the hurt came by vncleaneneffe or by fmall ftones and grauell iffuing forth with the vrine; as often hath been feene.

Thefe-herbes eaten in fallades or otherwife, efpecially the white Endiue, doth comfort the

E weake and feeble ftomaeke, and coo'eth and refrefheth the ftomacke ourermuch heated.

F The leates of Suceorie brufed are good againf inflammation of the eyes, being outwardly applicd to the grieued place.

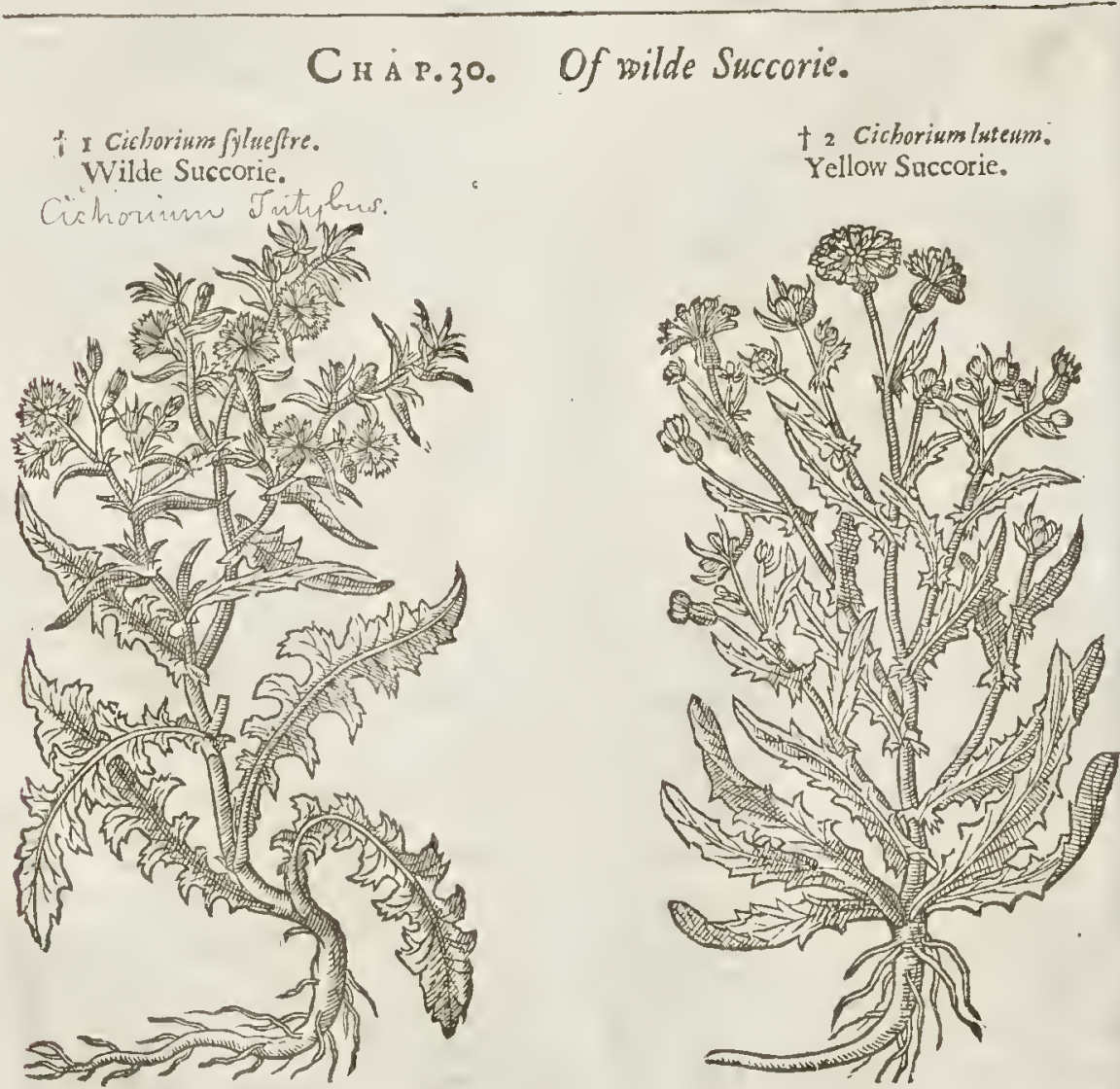



N like manner as there be fundtic fotts of Succories and Endiues, fo is there wilde kindes of
either of them.

\section{The Defoription.}

I TVIIlde Succorie hath long leaues, fomewhat fnipt about the edges like the leaues of Sow-thifle, with'a ftalke growing to the height of two eubits, which is diuided towards the top into many branches. The floures grow at the top blew of colour : the root is tough, and wooddie, with many ftrings faftred thereto.

2 Yellow Suecorie hath long'and large leaues, deepely cut about the edges like thofe of the Hawkeweed. The ftalke is branehed into fundry arms, wheron do grow yellow flours very double, refembling the floures of Dandelion, or Piffe-abed; the which being withered, it flieth away in
downe with euery blaft of winde.

3 Intybum flueftre.

Wilde Endiue.

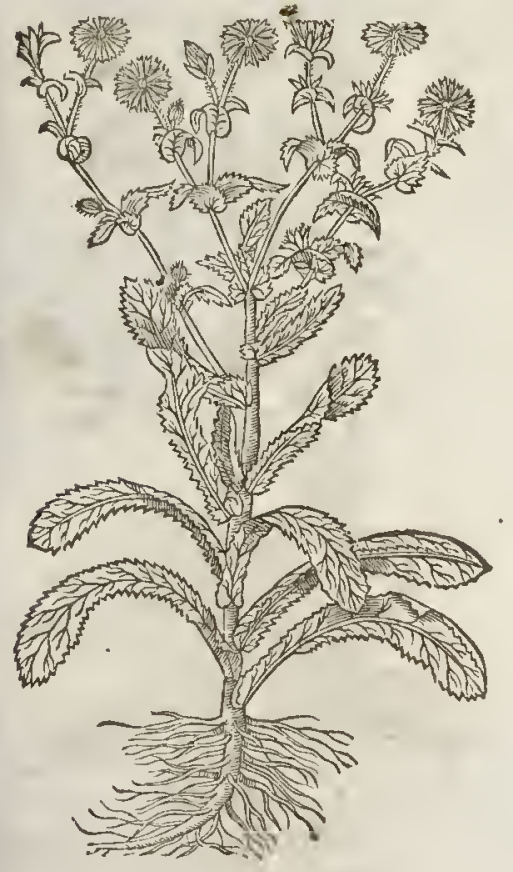

3 Wilde Endiue hath long frnooth leaues flightly finipt about the edges. The ftalke is brittle andfull of milkic juiee, as is all the reft of the plant: the floures grow at the top, of a blew or skie colour : the root is tough and threddie.

4 Medow Endiue, or Endiue with broad leaues, hath a thieke, tough, and wooddie root with many ftrings faftened thereto, from whieh rife vp many broad leaues fpread vpon the ground like thofe of garden Endiue, but leffer, and fomewhar rougher, among which rife vp many ftalkes immediately from the root; euery of them are deuided into fundrie bran. ehes, whereupon doe grow many foures like thofe of the former, but fimaller.

$$
\text { T The Place. }
$$

Thefe plants doe grow wilde in fundrie places in England, vpon wilde and vntilled barren grounds, efpecially in chalkie and ftonie plaees.

\section{T The Time.}

They floure from the middert to the end of Auguft.

If The Names.

$\ddagger$ The frift of thefe is Scris Picris of Lobell, or Cichoritum fylueftre: or Intybus erratica of $T$ aber: somontanus. ‡

Yellow Suceorie is not without caufe thought to be Hyofiris, or (as fome copies haue it) Hyofoiris, of which Pliny in his 20. booke and 8.chapter writeth; Byofiris (faith he) is like to Endiue, but leffer and rougher:it is ealled of Lobelins, Hedypnois : the reft of the names fet forth in their feueall tit les thal Ibe fusfieient for this time.

They agree in temperature witls the garden Succorie, ot

\section{T The Vertses.}

The leatles of thefe wilde herbes are boiled in pottage or btothes, for ficke, and feeble perfons that haue hot,weake, and feeble ftomaekes, to ftrengthen the fame. king.

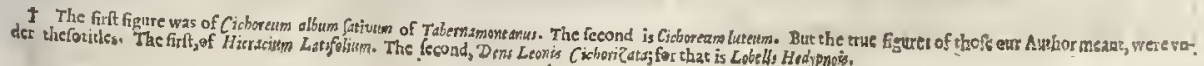
$\mathrm{A}_{2} 3$

Chapi 


\section{C н а . 31. Of Gumme Succorie.}

T The Defcription:

I

OVmme Succorie with blew floures hath a thicke and tough root, with fome ftrings

T annexed thereto, full of a milkic iuyce, as is all the reft of the plant, the floures excepted. The leaues are great and long, in thape like to thofe of garden Succoric, but deeplier eut or iagged, fomewhat after the manner of wilde" Roeket: among whicli rife tender ftalkes vcry eafie to be broken, branched toward the top in two or fometimes three branches, bcaring very pleafant floures of an azure colour or decpe blew; which being paft, the fced flieth away in downe with the winde.

I Chondrilla carmlea. Blew Gum Succorie.

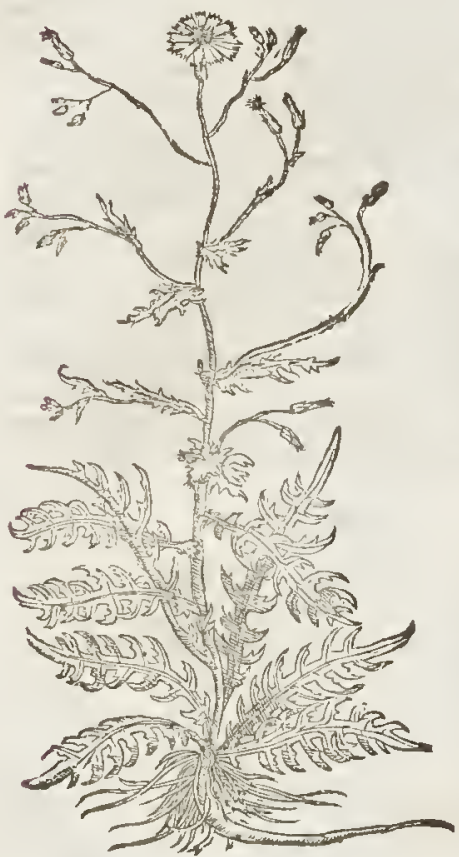

3 Chondrilla carulea latifolia. Robinus Gum Sụceory.

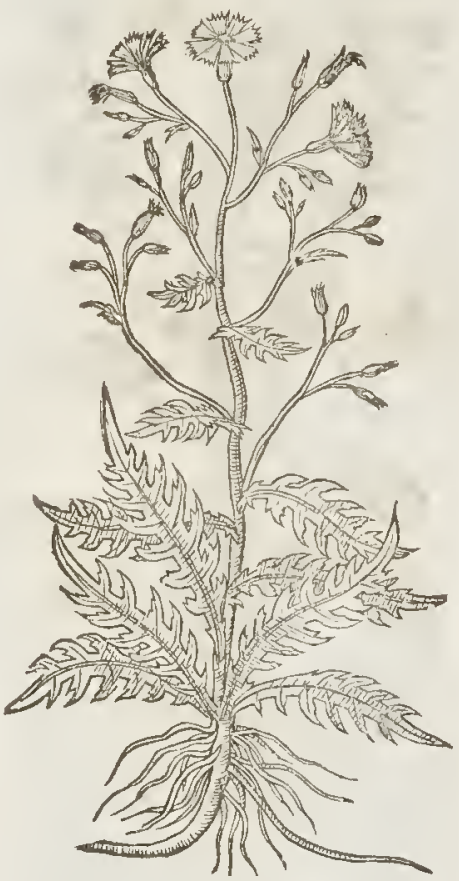

2 Gum Succorie with broad leaues, which I haue named Robinus Gum Succorie (for that he was the firft that made any mention of a fecond kind, whieh he fent me as a great dainty, as indeed I confeffe it) in roots is like the former: the leaues begreater, not vnlike to thofe of Endiue, bue cut more deeply enten to the middle rib : the ftalkes grow to the height of two foot : the floures likewife are of an azure colour, but fprinckled oner as it were with filuer fand; whicls addeth vnto the floure great graee and beauty.

3 Yellow gum Suceoric hath long leates like in forme and diuifion of the cut leaues to thofe of wild Succorie, but leffer,eonered all ouer with a hoarie down. The ftalke is two foot high,white and downie alfo, diuided into fundry branches, whereupon doe grow torne floures like thofe- of Succoric, but in eolour yellow, whieh are turned into downe that is caried away with the winde: The root is long, and of a meane thickneffe, from which, as from all the reft of the plant, doth if fue forth a milky iuvee, whieh being dried is of a yellowifh red, tharp,or biting the tongue. There is found vpon the branches hercof a gum, as Dioforides faith, which is ved at this day in phy ficke in the Ifle Lemnos, as Bellowius witneffeth. 
4 Spanifh Gum Succoric hath many leanes fpred vpon the ground, in finape tike thofe. of . Groundrell, but mueh more diuided, and not fo thicke nor fat : among ft whiel rife vp branehed ftalkes fet with leaues like thofe of Stabe falamantica minor, or Siluer-iveed, whereof this is a kinde. The floures grow at the top, of an onerworne purple colour, which feldome theiv thenfelnes abroad blowne: $\neq$ The feed is like that of Carthatus in thape, but blaeke and thining. $\neq$

$\neq 3$ Chondrilla lutea.

Yellow Gum Succorie.

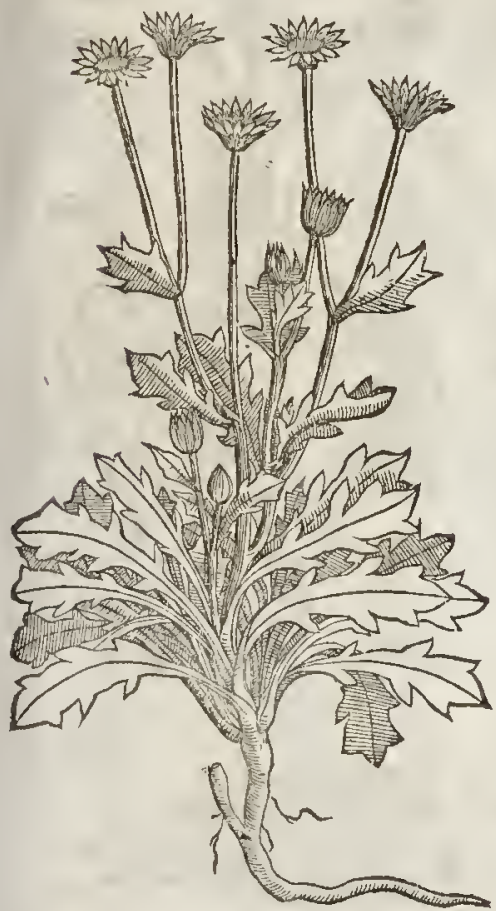

$\$ 4$ Chondrilla Hifpunica.

Spanith Gum Sueeorie.

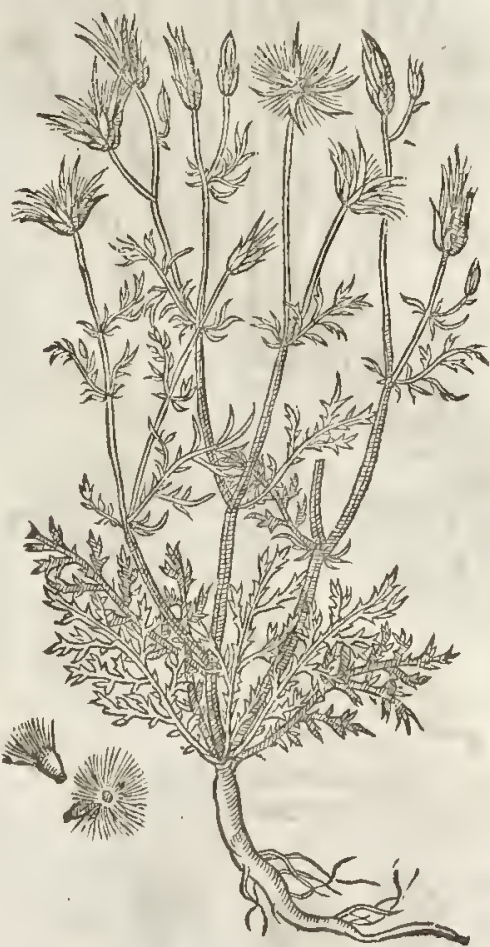

5 Ruihy Gum Succorie hath a tough and hard root, with a few flort threds faftned thereto; from the whieh rife vp a few iagged leaues like thofe of Suceoric, but mueh more diuided: The ftalke groweth vp to the height of two foot, tough and limmer like vnto rufhes, whereon are fet many narrow leaues. The Houres be yellow, fingle, and fmall; which being faded doe tly away with the winde : the whole plant hauing milky iuyce like vnto the other of his kinde.

\# There is another fort of this plant to be found in fome plaees of this kingdome, and it is mentioned by Baubinus vnder the name of chondrilla vifcofa bumilis.

† 6 Sea Gum Suceorie hath many knobby or tuberous routs full of iuyee, of a whitihn purple colour, with long ftrings faftned to then, from whieh immediately rife vo a few fmall thinne leaues farhioned like thofe of Suecory, narroiver below, and fomewhar larger towards their ends; among which fpring vp fmall tender ftalkes, naked, fmooth, hollow, round, of fome foot high, or thereabout : eaeb of thefe ftalkes hate one floure, in fhape like that of the Dandelion, but leffer, The whole plant is whitith or loary, as are many of the fea plants. †

7 Swines Suceorie hath white fmall and tender roots, from the which rife many indented leates like thofe of Dandelion, but mueh leffe, fpred or laid flat vpon the ground; from the midft whereof rife vp fmall foft and tender ftalkes, bearing at tlie top double ycllow floures like thofe of Dandelion or Piffe-abed, but fmaller : the feed with the doivny tuft flieth away rvith the wind. 8 The male Swines Suceorie hath a long and nender root, with fome few threds or ftrings faftned thereto; from which fpring vp fmall tender leaues abour the bigneffe of thofe of Dafies, fpred vpon the ground, eut or fnipt about the edges confufedly, of an onterworne colour, full of a milky iuyce: anong which rife up diucrs fimall tender nuked ftalkes, bearing at the top of etery ftalke one floure and no more, of a faine yellow colour, and fomething double: whieh being ripe, 


Of the Hiftorie of Plants. $\quad$ L $_{1 \text { B. 2. }}$

5 Chondilla juncea.

Ruhy Gum Succoric.

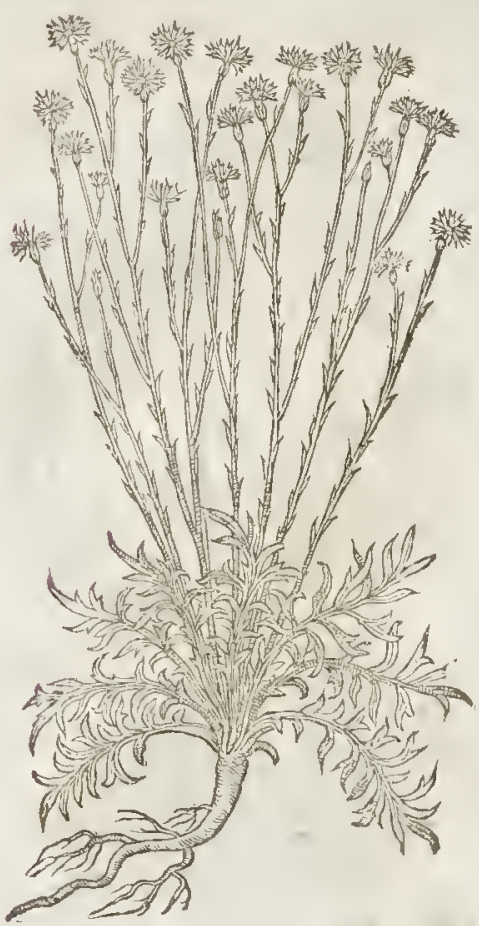

7 Hypoch.eris, Porcellia.
Swines Succoric.

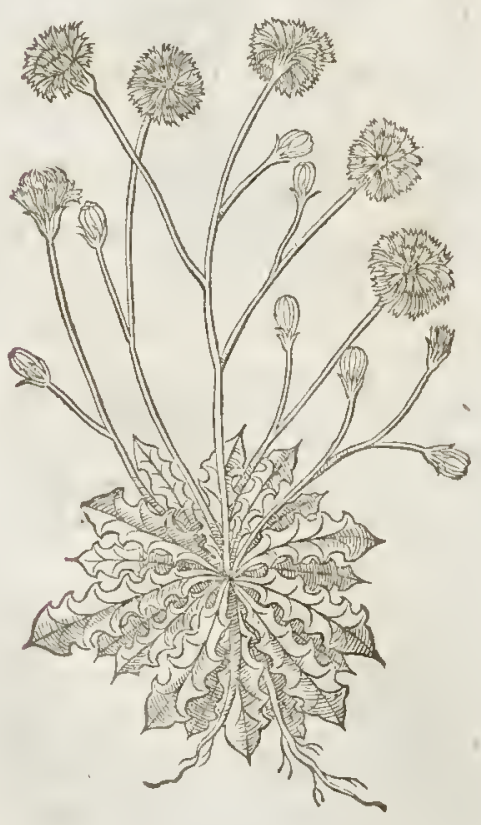

6 Chondrilla marina Lobely. Sea Gum Succoric.

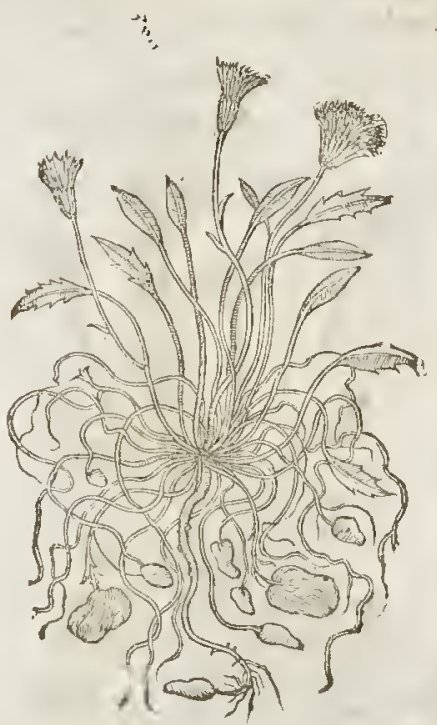

8 Byoferis mafoula.

Malc Swines Succorie.

Ayoseris minima

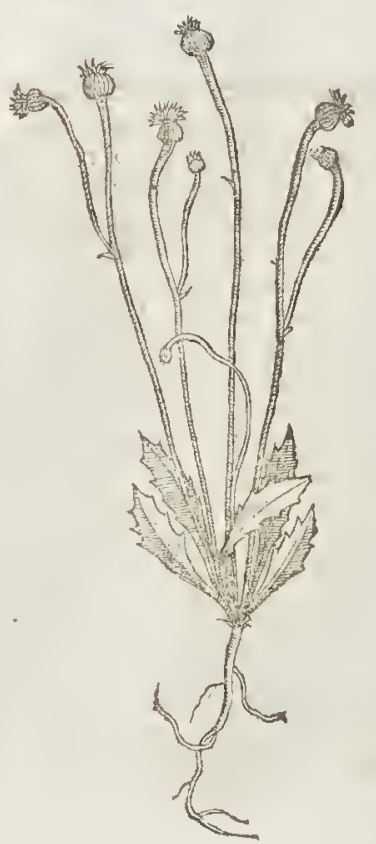


doe turne into downe that is carried away with the winde : the feed likcwife cleaue th vnro the faid downe, and is alfo carried away with the winde. The whole plant petinherh when it hath perfected his feed, and recoucreth it felfe againe by the falling thereof.

$\neq 9$ Cichorium verricarium.

Wart-Succorie.

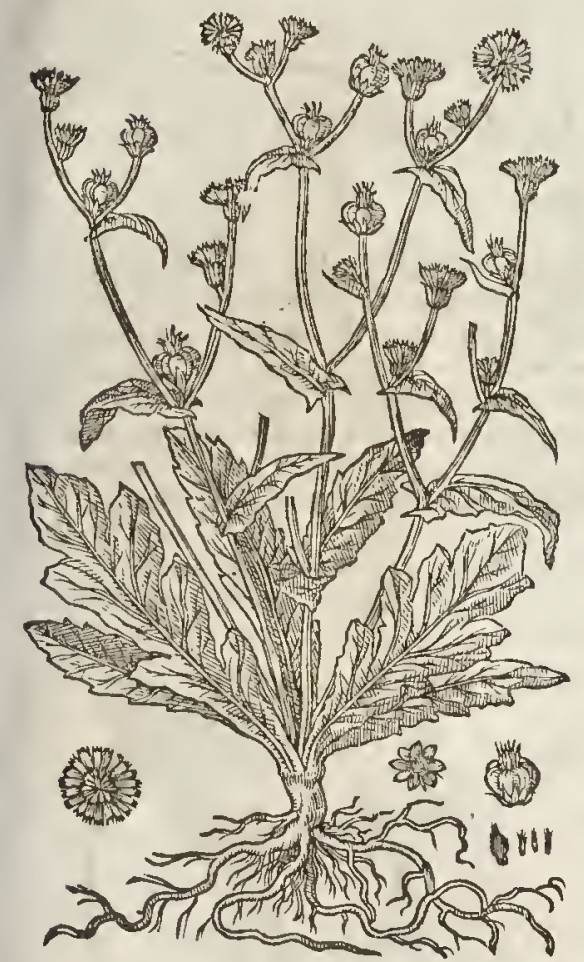

‡ , I thinke it expedienr in this place to deliner vnro you the hiftorie of the Cichorium verrucariun, or $Z_{\text {acintha }}$ of Matthiolss; of which our A withor makerh mention in his Names and Verrues, although he neither gaue figure, nor the leaft defcription thereot. This Wart-Succory (for fo I will call it) hath leaues almoft like Endite, greene, with pretry deepe gathes on their fides; the ftalkes are much crefted, and at the rop diuided into many branches; betweenewhich, and at rheir fides grow many thort italkes with yellow floures like thofe of Succorie, but that thefe turne nor into Downe, but into cornered and hard heads, moft commonly diuided into eighr cels or parts, wherein the feed is contained. ¥

$$
\text { I The Place. }
$$

$\dagger$. Thefe plants are found only in gardens in this country; the feuenth \& cighth excepted, which peraduenture may be found to grow in vntilled places, vpon dit: ches bankes and the borders of fields, or the like.

$$
\text { T The Time. }
$$

They do floure from May to the end of Augurt.

$$
\text { T The Tlames. }
$$

Gum Succorie hath beene called of the Grecians, yereim : of the Latines, Condralla, and Chondritla : Diofcorsdes and Pliny call ic Cichorion, and Seric, by reafon of fome likeneffe they hanewirh Succorie, efpecially the two firft, which hate blew floures as thofe of the Succories. Lobelius maketh Cichorea verrucat via to be Zacintha of Matthiolus.

‡ I This iscalled Chondrill $¥$ T Names in particalar.

I This is called Chondrills carralea Belgarum, of Lobel: Apate, of Daleschampius.

2 Condrilla 2. of Mattbiolus: Chondrilla latifolia carulea, of $T_{a}$ bernamontansis.

3 Chondrilla prior Diofcoridis, of Clufius and Lobel.

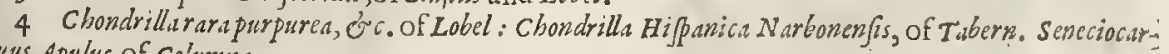
duus Apulus, of Columina.

5 Chondrillaprima Diogcoridis, of Columia and Bashinus : Viminea, vif cooft, of Lobel and Clas cus.

6 Chondrilla altera Diofioridis, of Columnat fomethinke it to be aposizar of Theophraftus ; Lobels calls it, choodrilla pufilla marna lutea bulbofa.

7 Hypocheris, porcellia, of $T_{\text {a }}$ ernomont arus.

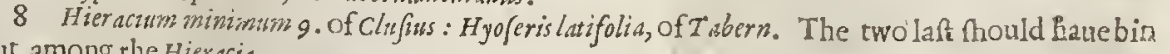
put among rhe Hieracia.

9 Cichorium ver rusarium, and Zacinthus of Matthiolus and Clufuss. $\ddagger$

\section{T I be Nature and Vertues.}

Thefe kinds of gum Succoric are like in temperature to the common Succory, but drier.

The root and leaues tempered with hony, and made into Trochiskes, or lit:le flat cakes, with ni- A ter or falt-peter added to them, cleanfe away the morphew, fun-burnings, and all fpots of the face.

The gum which is gathered from the branches, whereof it tooke lus name, layeth downe the $B$ ftairing haires of rhe cye-browes and fuch like places : and in fome places it is vfed for Maftick,as Bellonius obferues.

The gum poudcred with myrrh, and put into a linnen cloath, and a peffarie made thereof like a $c$ finger, and put vp, bringethidowne the termes in yong Wenches and fuch like. 


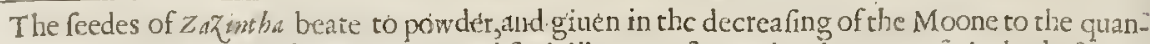
ritic of a fpoonefull, taketh away warts, and fuch like excrefcence, in what part of the body foeuer they be; the which medicine a certaine Chirurgion of Padua did much vfe, whereby he gained great fums of mony, as reporteth that ancient Phyfition Ioachimus Cnmerarus of Noremberg a famous citic in Germanic. And Matthiolus affirmes that he hath knowne fome helped of warts, by once cating the leates hereof in a Sallade.

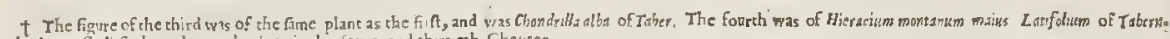
which you intili finde in the tenth piace in the foure and thircieth Chaprer.

$$
\begin{gathered}
\text { CHAP: } 32 . \quad \text { Of Dandelion: } \\
\text { it z be Defription. }
\end{gathered}
$$

i The herbe which is commonly called Dandelion doth fend forth from the root long 1 leaues deepely cut and gathed in the edges like thofe of wilde Succorie, but fmoother: vpon euery ftalke itandeth a floure greater than that of Succorie,butdouble, and thicke fer together, of colour yellow, and fweet in fmell, which is tumed into a round downie blowball, that is carried away with the winde. The roor is long, flender, and full of milkie juice when any part of it is broken, as is the Endiue or Succoric, but bitterer in tafte than Succorie.

‡ There are diuers varieties of this plant, confifting in the largeneffe, fmallifeffe, deeceneffe, or thallowneffe of the diuifions of the leafe, as alfo in the fmoothneffe and roughneffe thereof.

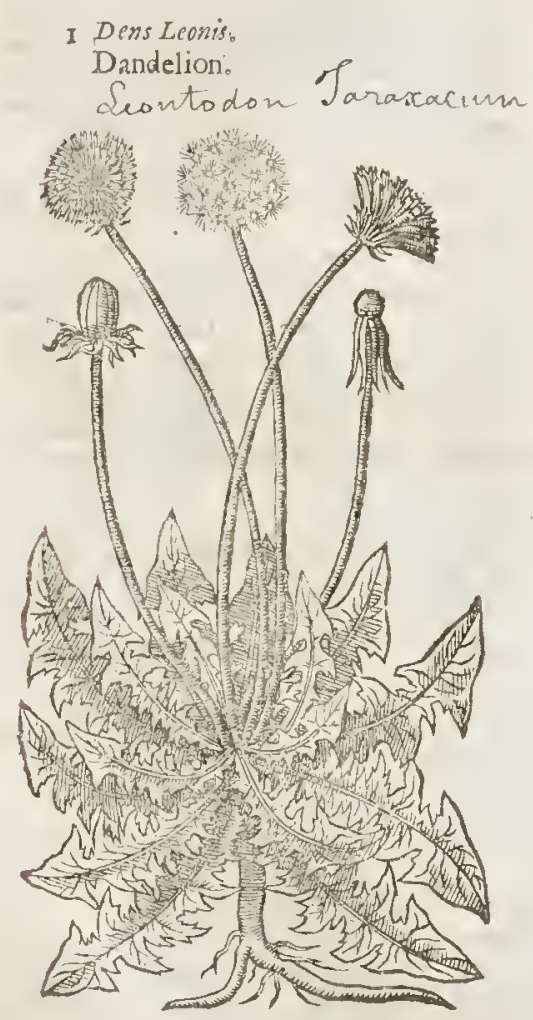

$\$ 3$ Dens Leonis bullofus.

Knottie rooted Dandelion.

2 There is aifo another kinde of Succorie which may be referred hecreunto, whofe leaues are Iong, cut likc thofe of broad leafed Succoric : the ftalkes are not vnlike, being diuided into branches as thofe of Dandelion, but leffer, which alfo vanifheth into downe when the feed is ripe, hauing a long and white root.

\$ 3. Tlere is another Dens Lconis, or Dandelion,which hatl many knorty, and tuberous roots 
like thofe of the Afphodil; the leanes are not fo deeply cut in as thofe of the common Dandelion, but larger, and fonewhat, more hairy : the floures are alfo larger, and of a paler yellow, which flie away in fuch downe as the ordinary: $\neq$

If The place.

They are found often in medowes necre vnto water ditches, as alfo in gardens and high waies nuch troden.

The Time.

They floure moft times in the yeere, efpecially if the winter be not extreame cold. Ti The Names.

Thefe plants belong to the Succory which T beopliraftus, \& Pling call Aphaca, or Aphace Leonardus: Fuclufus thinketh that Dandelion is Hedypnois Plinij, of which he writeth in his 20 . booke, and eighth chapter,affirming it to beawilde kinde of broad leafed Succorie, and that Dandelion is Taraxacon : but Taraxacon, as Atucen teächeth in his 692 . chapter, is garden Endiue, as Serapio mentioncth in his 143 .chapter; who citing Patilus for a w itneffe concerning the faculties, fetteth down thefe words which $p_{\text {unlus writeth of Eridiue and Succoric. Diners of the later Phy fit ions do alfo }}$ call it Dcrs Leonis, or Dandelion:it is called in high Dutch, 3hollitaut:in low-Dutch, 13 apenecuit: in French, piffenlut on couronne de preftre, or Dent de lyon: in Englifh, Dandelion: and of diuers, Piffeabed. The firlt is alfo called of fome, and in thops T araxacon, Caput monachi, Rof rum porcititm, and Irinarra. The other is, Dens Leonis Monjpelienfurin of Lobell, and Cichoreum Conftantinopolitanum,
of Matibiolus.
Ti The Temperatureand Vertues.

Dandelion is likc in temperature to Succorie, that is to fav, towilde Endiue. It is cold, but it drieth more, and doth withall clenfe, and open by reafon of the bitterneffe which it hath ioyned with it : and therefore it is good for thofe things for which Succory is. $¥$ Boiled, it ftrengthens the weake ftomacke, and eaten raw it fops the bellie, and helpes the Dyfentery, efpecially being boy!cd witl Lentiles; The juice drunke is good againt the vnuoluntary effufion of feed; boyled in vineger, it is good againft the paine that troubles fome in making of water; A dccoction made of the whole plant helpes the ycllow jaundice. $\ddagger$

t The fogure which was in the a place was of the (ich. Luteum, where you may find ir, but to what planthe defcription may be referred I cannor yee determine:

\section{С н Р. 20. Of Sow-tbiftle.}

t I Senchus asper. Prickly Sow-thiftle.

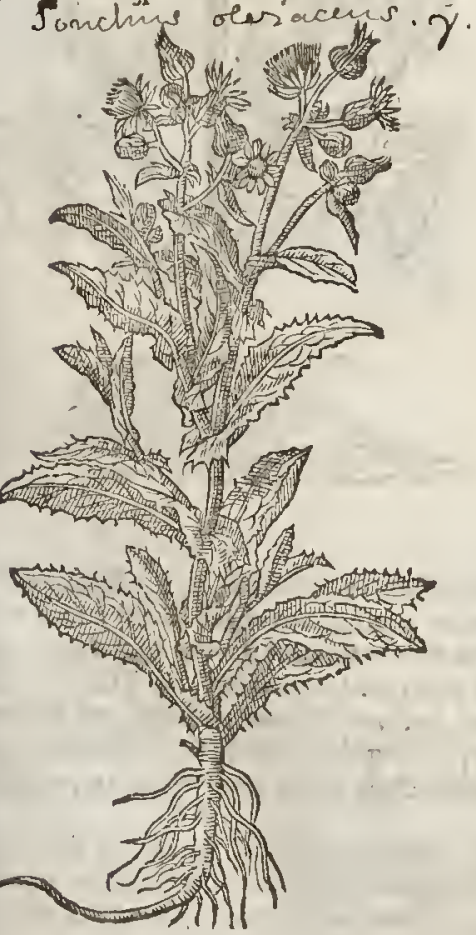

¥2. Sonchus aperior. The more prickly Sow-thifte:

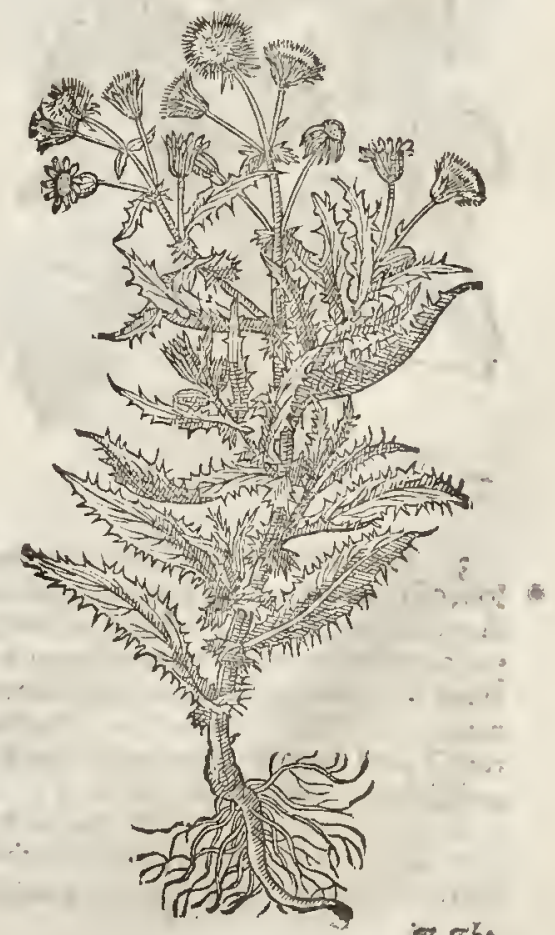


\% The Kindes.

There be two chiefe kindes of Sow-thiftles; one tenderer and fofter; the other more prieking 1 and wilder : but of thefe there be fundry forts more found by the diligence of the later Writers ; all whieh thall be comprehended in this chapter, and cuery one be diffingtifhed with a feuerail defcription.

\section{Tा The Defoription.}

I

7 He prickly Sow-thifte luath long broad leaues cut very little in, but fullof fmal pric: kles round about the edges fomething hard and tharpe, with a rough and hollow It alke: the floures ftand on the tops of the branehes, confifting of many fmall leaues, fingle, and yellow of eolour; and when the feed is ripe it turneth into downe, and is carried away. with the winde. The whole plant is full of a white milky iuyee.

$\ddagger$ I There is another kinde of this, whofe leatres are fometimes pretrily decpe cut in like as tholc of the ordinaric Sow-thiftle; but the ftalkes are eommonly bigher than thofe of the laft defcribed, and the leaues more rough and prickly; but in other refpects nor differing from the reft of this kinde. It is alfo fometimes to be found with the leaucs leffe durided. $\ddagger$

+3 Sonchus Leuis. Hares Lettuce.

Sonchurs Geracens. a

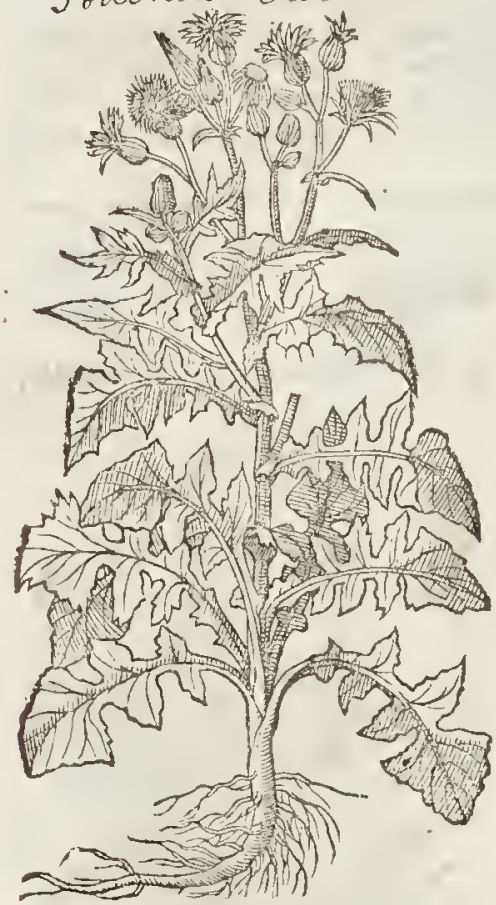

4 Sonchus latis latifolius. Broad leaued Sow-thifte.

Soncturns oleracens. B.
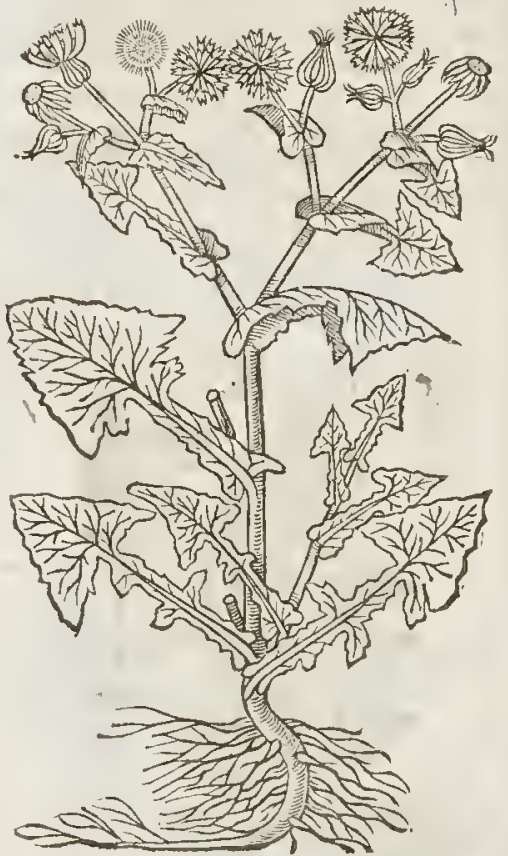

3 The falke of Hares Letuce, or fmooth-Thiftle is oftentimes a cubit high, edged and hol: - Jow, of a pale colour, and fometmes reddish : the leaues be greene, broad, fet round about witl dcepe cuts or gathes, f nooth, and without prickles. The floures ftand at the top of the branches, yellow of eolour, which are caried away with the winde when the feed is ripe. $¥$ This is fomerimes found wirh whitifh, and with fnow-white floures, but yet feldome: whence our Authour made two kindes more, which were the fourth and fifth; calling the one, The white floured Sowthiftle; and theother, The fnow-white Sow-thifle. Both thefe I have omitted as impertinent, and gine you others in their ftead. $\neq$

4 Broad leatred Sow-thiftle harh a long thicke and milky root, as is all the reft of the Plant, with manv ftrings or fibres; from the which comneth forth a hollow flalke branched or diuided into fundry fections. The leates be great, fmooth, tharpe pointed,and greene of colour : the floures 

be white, in thape like the former. $\neq$ The floures of this are for the moft part yellow like as the
former. $\neq$

. 5 Wall Sow-thiftle hath a fibrous wooddy root, from which rifes vp a round falke not crefted : the lcaucs are much like to thofe of the other Sow-thiftes, broad at the fetung on, then narrower, and after much broader, and tharpe pointed, fo that the end of the leafe much refembles the flape of an iuy leafe; thefe leaues are very tender, and of fomewhat a whitifh colour on the vnder fide : the top of the ftalke is diuided into many fmall branches, which beare little yellow
foures that fly away in downe.

6 This hath longin narrow leaues foft and whitinh, vnequally diuided about the edges. The falkcs grow fome foot high, hauing few branches, and thofe fetwith few leaues, broad at their fetting on, and ending in a fharpe point : the floures are pretty large like to the great Hawk-weed, and fly away in downe : the root is long, white, and lafting. It floures molt part of Summer; and in Tufcany, where it plentifully growes, it is much eaten in fallets, with oile and vineger, it ha-
uing a fweetion and fomewhat aftringent tafte. $\neq$.

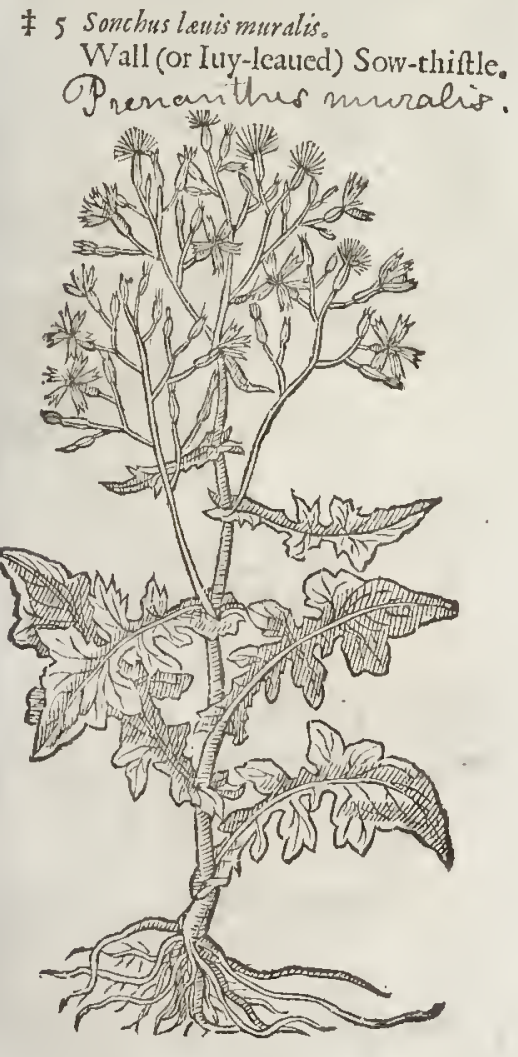

\$6 Sonchus lanis anguffifolius.
Narrow leaned Sow-thiftle.

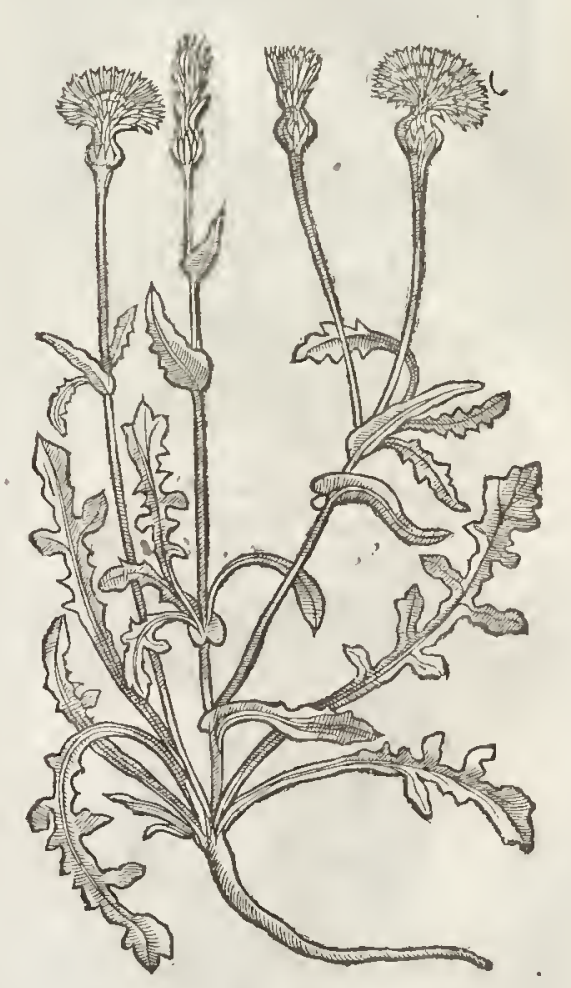

$\dagger 7$ This blew floured Sow-thiftle is the grcateft of all the reft of the kindes, fomew hat refembling the laft defcribed in leates; but thofe of this are fomewbat rough or hairy on the vnde fide: the floures are in thape like thofe of the ordinarie Sow-thiftle, but of a faire blew colour; which fading, flie away in Downe that carries with it a fmall afh-coloured feed. The whole plant
yeeldetlmmilke as all the reft do. $t$

8 Tree Sow-thiftle hath a very great thickeand hard root fet with a fow hairy threds; from Languedebeefe, but inor great ftalke of a wooddy fub ftance, fet with long leaues not vnlike to faire double yellow flore deepely cut in about the edges, and not fo rough : vpon which do grow whole plant is poffeft with which turne into Downe, and are caried away with the winde. The certainly theweth it to be fuch a milky iuyce as are the tender and hearby Sow-thiftes; which whereunto in face arid fhew it is like. ftalkes are very rough and hairy. F * This hath a running root, and the heads and tops of the 
7 Sonchus flore cerulco.

Blew-Houred Sow-thiltle.

Sonchus Sondens Sans. Iing

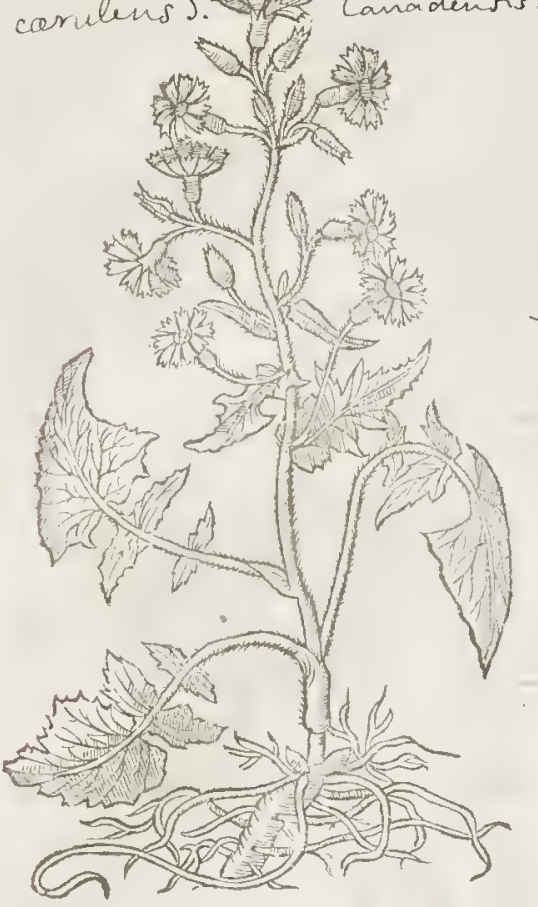

¥ Sonchus arborefcens alter. .

The other Tree Sow-thiftle.

whe Sonch palu tris
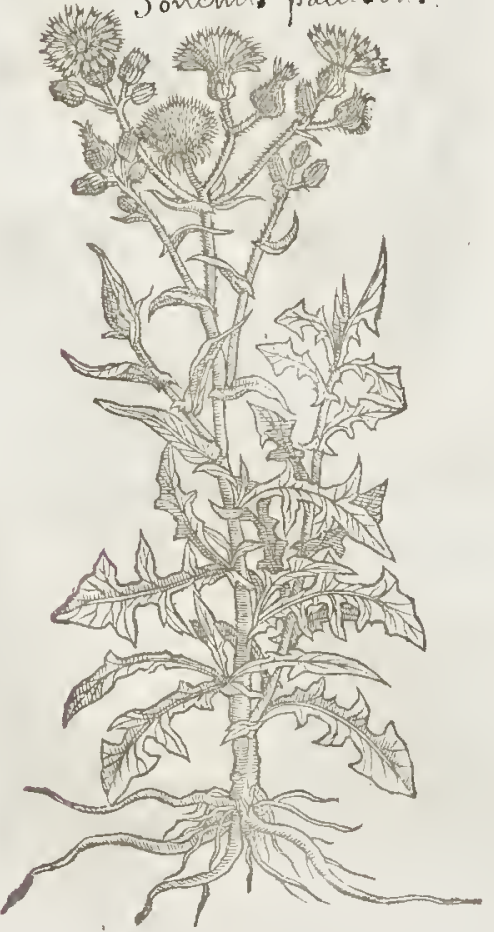

8 Sonchus Arborefcens.

Tree Sow-thiftle.

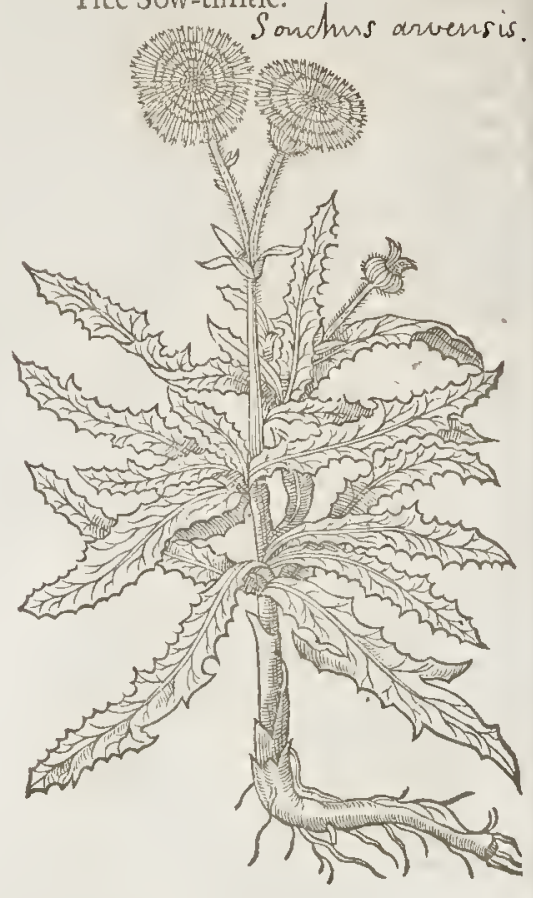

Io Sonchus fyluaticus:

Wood Sow-thiftle:

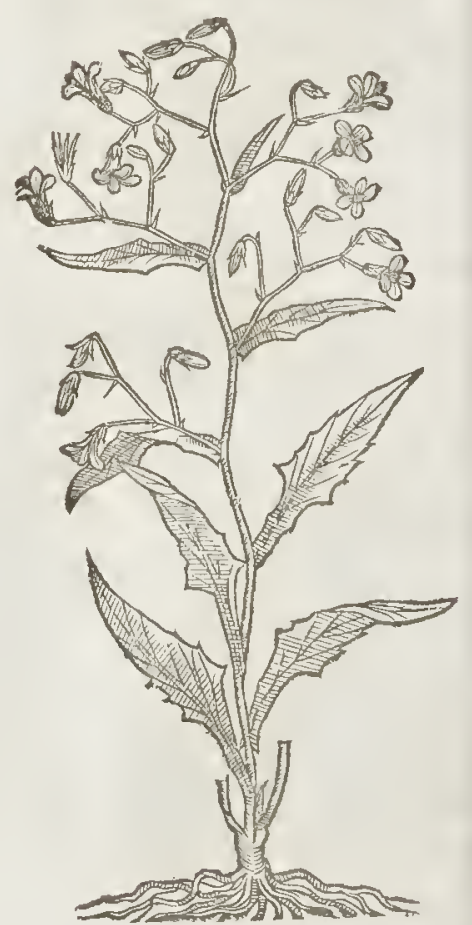


$\mp 9$ This other Tree Sow-thitle growes to a mans height or more, hauing a firme cre?ed ftalke, fmooth, without any prickles, and fet with many leaues inconpafing rlie fallse at ti:cir

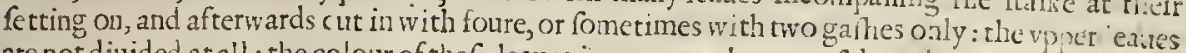
ate not diuided at all : the colour of thef leaues is green on tle vpper fide, anc grayth underneatl: the top of the ftalke is hairy, and diuided into many branches, wlich beare the toures in are height, as it were in an vmoell : the foures are not great, confidering the largeneffe of the plant, burvfually as bigas thofe of the common Sow-thitle, and yellow, hauing a hairy head o: cap: the feed is crefted, longih, and alh-coloured, and flics aw ay with the dovine : the ront is thicke, whitih, hauing many fibres, puttingout new thouts, and fpieading euery yeare. Bablin? mat kcth this all one with the other, according to Clufus lus defcription: but in my opinion there is fome difference betweene them, which chiefely confifts, in that the formet hath larger and fewer foures; the plant alfo not growing to fo great a height. $\neq$

$\neq$ ro 'This plant (whofe figure our Author formetly gatre, pag. r 4 8. vnder the title of Ery/6mum fylueftre) hath long knotry creeping roots, from whence arifeth a round llender ftalke fome two foot high, fet at firtt with litt! e leaues, which grow bigger and bigger as they come neerer the middle of the ftalke, being pretty broad at their fetting on, then fomewhat narrower, and fo broader againe, and fharpe pointed,being of the colour of the Wall (or Iuy-leaued) Sow-Thifte. The top is dinided into many fmall branches, which cnd in fmall fcaly heads like thofe of the wilde tettuce, containing floures confifting of foute blewih purple leaues, turned backe and fnipped at their ends; there are al fo fome threds in the midle of the foure, which turning into Do,vne,carry away with them the feed, which is fmall, and of an Af-colour. Banhine makes a bigger and a lef fer of thefe, diftinguithing betweene that of Clufus (whofe figure I here give you) and that of $\mathrm{Co}_{-}$ lumna; yet Fabus columna himfelfe could finde no difference, but that clufius his plant bad fiue leaues in the floure, and his but foure : which indeed clufus in his defcription affirmes; yet his figure (as you mav fec) (xprettes but foure : adding, That the root is notwell expreffed; which notwithitanding Clufrus deforibes according to Columnis expreffion. $\ddagger$

\section{- The Place.}

The firft foure grow wilce in pafures, medowes, woods, and marimes neere the fea, and among pot-herbes.

The fifth growes vpon wa!ls, and in wnotdy mouptainous places.

The Tree Sow-tlift'e groves amongft corne in waterie places.

The fixth, feuenth and teith are ftrangers in England.

They floute in Iune, Iuly,

or The Time.

Tा The Names. * * a

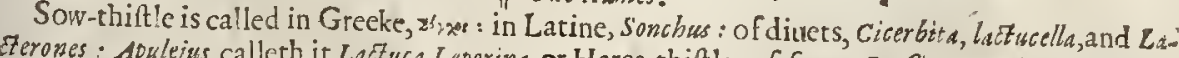
cterones: Apuleins calleth it LaEfuca Leporina, or Hares-thiftle: of fome, Braßica Leporina, or Hares Colewort. The Engliph names are fuficiently rouched in theit feutrall titles : In Durch it is called baten $\mathrm{Lat}$ aube: the French, Palays de lieure.

\section{‡ Tा Names in particular.}

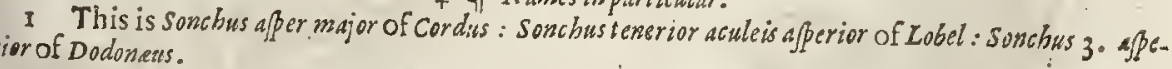

2 This is Sonchus atmer, of : Mathiolus, Fuchfius, and others.

3 This, Mathiolus, Dodoneus, Lobel, and others call Sonchus leuis : Tragus calls it Intybuserratica

4 This Tabernamontanus onely giues, vnder the title as you haue it here.

5 Mattbiolus tiles this, Sonchus lesus al er : Cefalpinus calls it Laduca nurorum : and $T$ abern. Son. chus fylnaticus quartus: Lobel, sonchus alter folio finuato bederacco

6 Lobel calls this, Sonchus leuis Mattholi: it is Terracrepulus of Cafalpinus : and Crepis of Dale.

7 Clufus and Camer arius giue vs this vnder the title of Sonchus corulens. 8 Onely $T$ abern. hath this figure, vnder the title our Author giues it: $B$.ubine puts it amonglt
the Hicracia, cal'ing it Hieracium arbore cens paluftre.

9 This Buhine alfo makes an Hieracism, and would perfuade vs that clu fus his defcription belongs to the laft mentioned, and the figure to this : to which opinion I canno: confent. Ciufus gi-
ueth it vnder the name of smohus 3 leurs alt S mms. ro This Clufus giues vnder the name of soms.

Libanotis Theophrafti feril is: Colum the name of Sonchus lavior Pannonicus 4. fiorepurp. Tabern. calls it

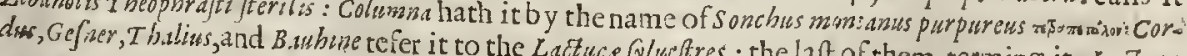
montanapurpuro-carulea. \# 


\section{The Temperature.}

The Sow-thiftles, as Galen writeth, are of a mixt temperature; for they confift of a watery and catthy fubftance, cold, and likewife binding.

\section{e The Vertues.}

A Whileft they are yet yong and tender they are eaten as other pot-herbes are; but whether they be eaten,or outwardly applied in manner of a pulteffe, they do cuidently eoole: therefore they be good for all inflammations or hot fwellings, if they be laid thereon.

B Sorv-thifte giuen in broth taketh away the gnawings of the fomacke proceeding of an hor caufe; and inereafe milke in the breafts of Nurfes, caufing the children whom they nurfe to haue a good eolour: and of the fame vertue is the broth if it be drunken.

C The iuyee of thefe herbes doth eoole and temper the heate of the fundament and prity parts.

$$
\begin{gathered}
\text { Ch A P.34. Of Hawke-weed. } \\
\text { T The Kindes. }
\end{gathered}
$$

T. Awke-weed is alfo a kinde of Suecoric ; of which Diofcorides maketh two fotts, and the later Writets more : the which thall te defcribed in this ehapter following, where they thall be diftinguithed as well with feuerall titles as fundry defetiptions.

I H Hieracium majus Diof coridis. Great Hawke-weed.

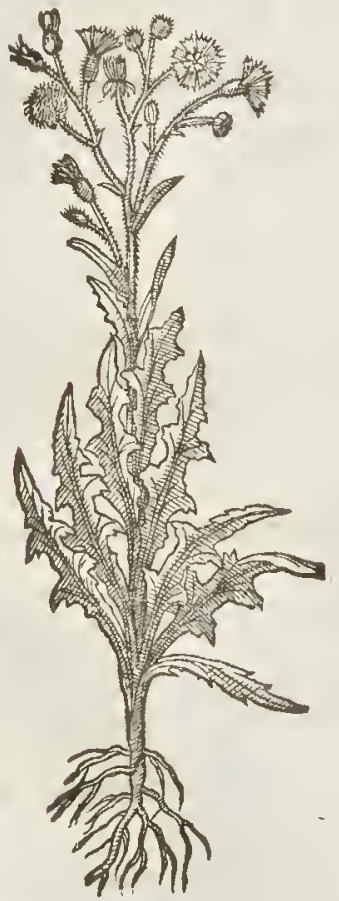

2 Hieracium minus, fue Leporinum.

Small Hares Hawk-weed,ot Yellow Diuels-bic: Leoutodon Hedypusis

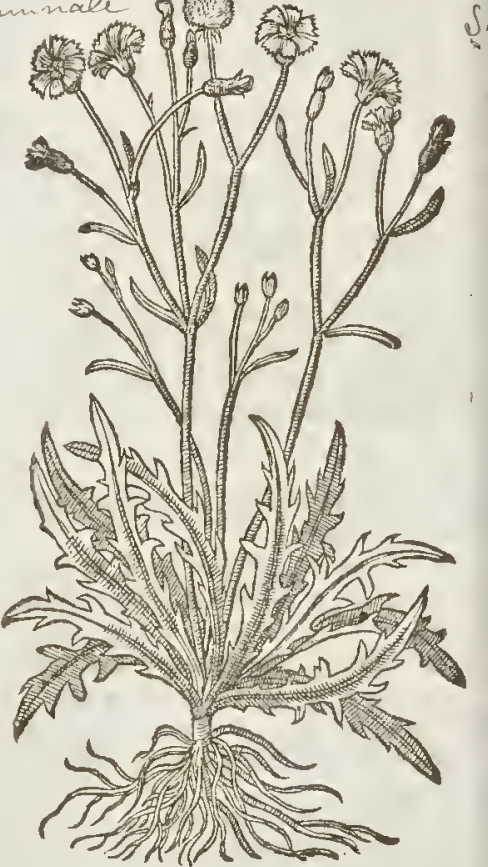

TI The Defeription:

- The great Hawke-weed hath large and long leates fpred vpon the ground, in thape like 1 thofe of the Sow-thiftle: the ftalk groweth to the height of two eubits, branehed into
fundry armes or diuifions, hollow within as the yong Kexe, reddifh of colour; whereupon do grow yellow floures thieke and double, which turne into Downe that flieth aw ay with the winde when the feed is ripe. The root is thicke, tough and threddy. 
2 The fmall Hawke-weed, which of moft writers hath been taken for yellow Divels-bit, hath long leaues decpely cut about the edges, with fome tharpe roughneffe thereon like vnto Sow-thiItle. The ftalkes and floures are like the former : the root is compact of many fmall ftrings, with a fmall knob, or as it were the ftumpe of an old root in the middle of thofe frings, cut or bitten off; whereupon ir tooke his name Diuels bit.

3 Blacke Aawke-weed hath very many long iagged leaues, not much vnlike to thofe of Bucks horne, fpred flat and farre abroad vpon the ground, which the pieture cannot expreffe as is requifite, in fo little roome: among which rife vp many ftalkes Aender and weake, the floures growing at the top yellow and very double : it hath alfo a threddy root.

$\ddagger$ Our Author formerly gaue three figures,and fo many defcriptions of this fmall Hicracitum, which I haue contra eted into two; for the onelydifference that I can finde is, that the one hath the root as it were bitten off, with the leaues leffe cut in; the other hath a root fomewhat longer, and fibrous as the former; the leaues alfo in this are much more finely and deepe cut in: in other re. fpects there is no difference. $\neq$

3 Hieracium nigrum.

Blacke Hawke-weed.

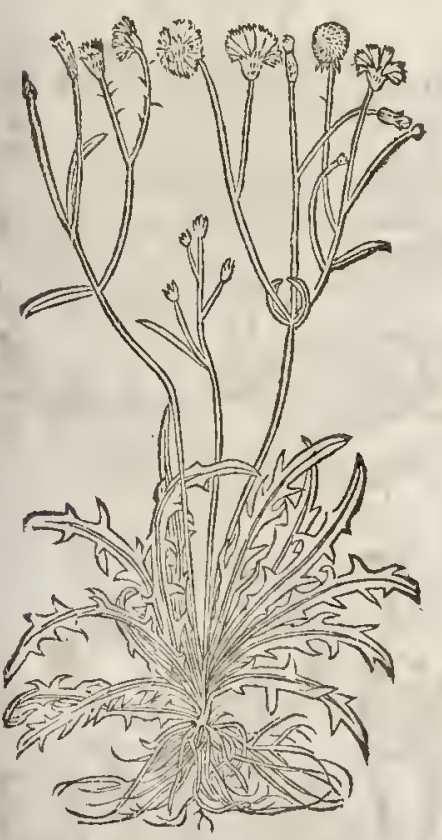

4 Hieracium Aphacoides.

Succory Hawke-weed.
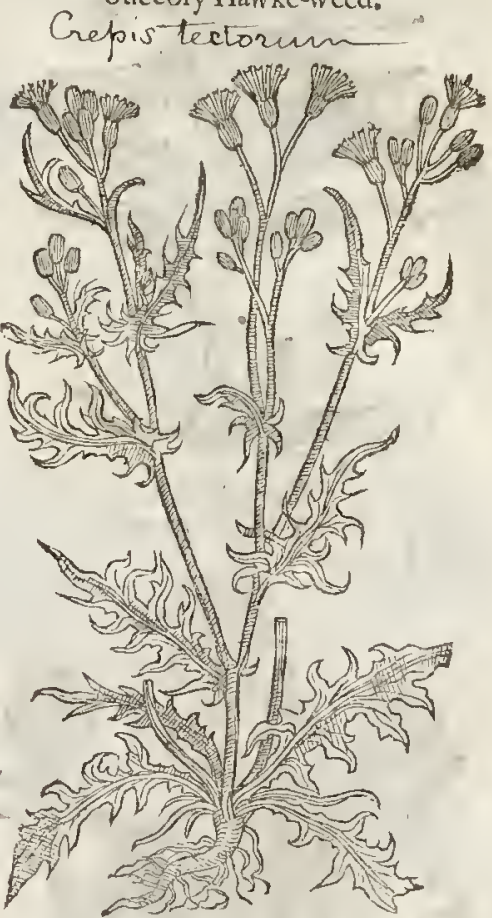

4 Succory Hawke-weed hath many long and large leaues fpred vpon the ground, deepely cut on both fides almoft to the middle rib ; from which rife vp fmall ftalkes and foures like thofe of the leffe Dandelion, but leffer. The root confifteth of many fmall threddy ftrings.

5 Endiue Hawke-weed hath many broad leaues, indented about the edges very like vnto Garden Endiue, but narrower; among which rife vp ftalkes a foot or more high, ,lender, hairy, and britve : the floures are yellow, and grow at the top double, and thick fet in a fealy huske like the Knapweed or Iacea, hauing great thicke and threddy roots. ‡ This hath a falke fometimes more,and otherw hiles leffe rough, with the leaues fomtimes more cut in, more long and narrow, and againe otherwhiles more thort and broad. $\neq$

6 Long rooted Hawk-weed hath many broad leates fpread vpon the ground, fleightly \& confufedly indented about the edges, with fomewhat a bluntifh point ; among which leaues fpring vp ftrong and tough ftalks a foot and halfe high, fer on the top with faire double yellow floures much likevnto a Piffe-abed. The root is very long,white and tough.

7 Sharpe Hawk-weed hath leaues like thofe of Languebeefe or Ox-tongue, but much narrower; tharpe about the edges,and rough in the middle: the ftalks be long and lender, fet with the Iike leaues, butleffer : the floures grow at the top, doubleand yellow:the root is tough \& threddy. 
L $_{1 \text { в. } 2 .}$

6 Hicracium loagins radicatum.

Long rooted Hawke-weed.
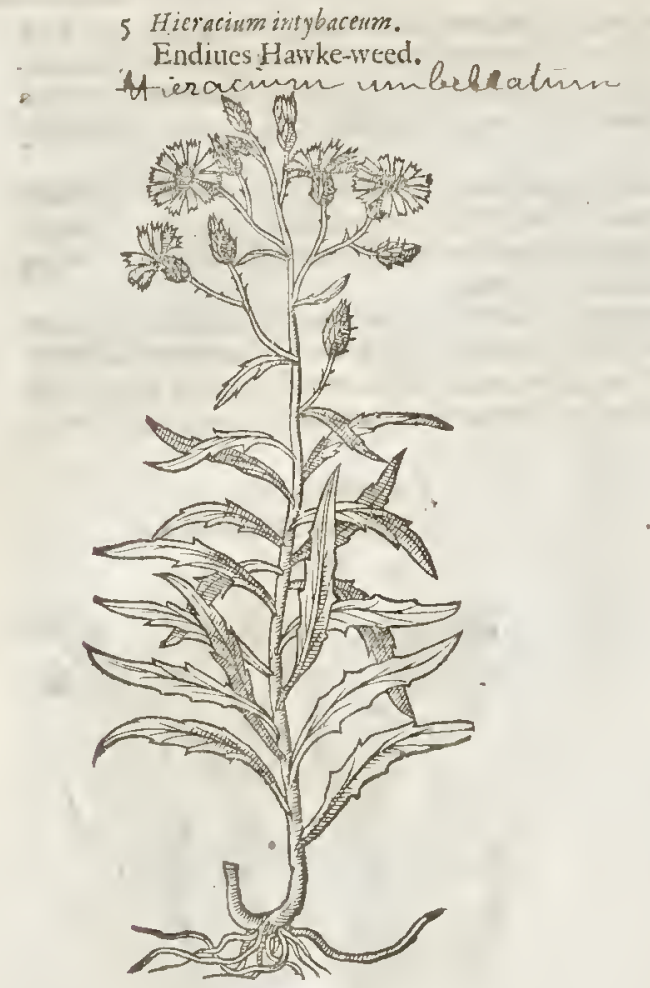

\section{Hicracism aperum.}

Sharpe Hawle-weed.

Oicris hieracioixes.

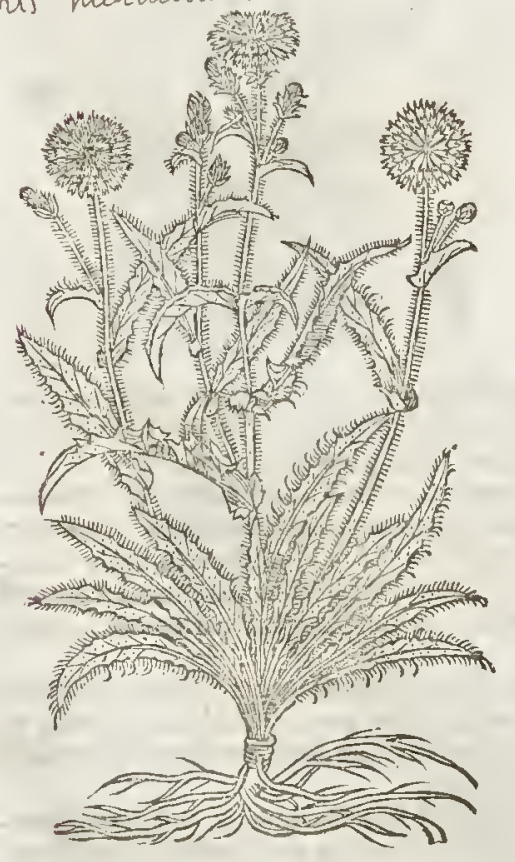

Hypocharis zadicata.
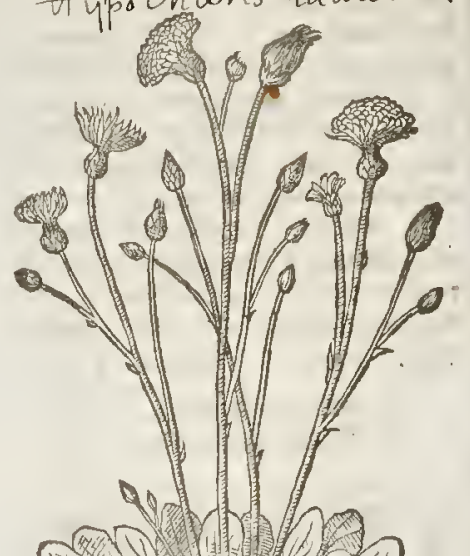

N
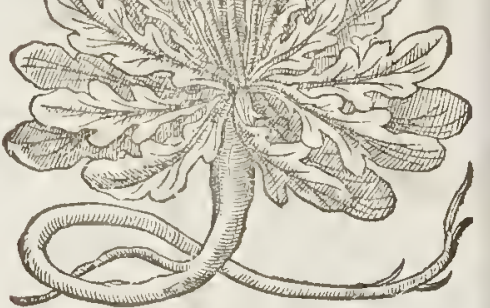

8 Hieracium falcatum Lobclig.

Crooked Hawhe-weed.

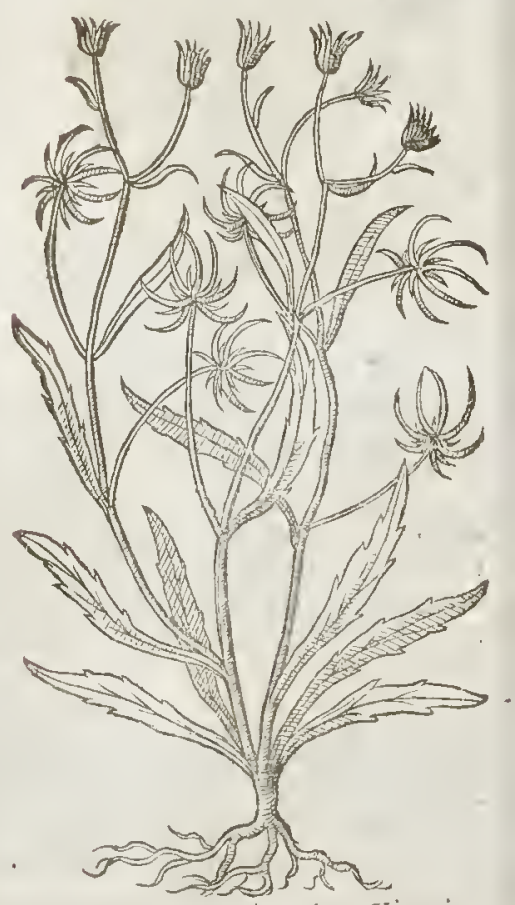

\pm o Hicracium. 
t 8 Crooked or falked Hawkerveed hath leates like vnco the garden Succory, yet nuteh fmaller,and lefe diuided, flighty indented on both fides, with tender, weake, and cronked falkes, wherempon doe grow floures like thofe of Lamp $a$ ma, of a blacke, or pale yellow co'our, and the roote fruall and threddy. The feedes are long, and falcated, or crooked, fo that they fometwat refemble the foot or clawes of a bird, and from thefe feeds the plant hath this Epithite, Falcatm, nrerooked in maner of a Siele or Sithe.

* This in leates is not mueh wnlike the laft deferibed, hut that they are fonewhat broader, and leffe eut in, hauing litele or nobitternefle nor milkineffe, the ftalkes are fome foot high commonly bending, or falling vpon the gromn; the floures are finall and yellow, and feéme in grow out of the middeft of the feed, whenas indeed they grow at the top of them, the reft being but an empty buske which is falcated like that of the laft defcribed. This figure ne gine you was taken before the floures were blowne, fo that by that meanes the faleated or erooked feed veffels are not expreft in this, but you may fee there manner of growing by the former. $\neq$

¥ Hicracium falcatum alierum.

The other crooked" Hawkeweed.

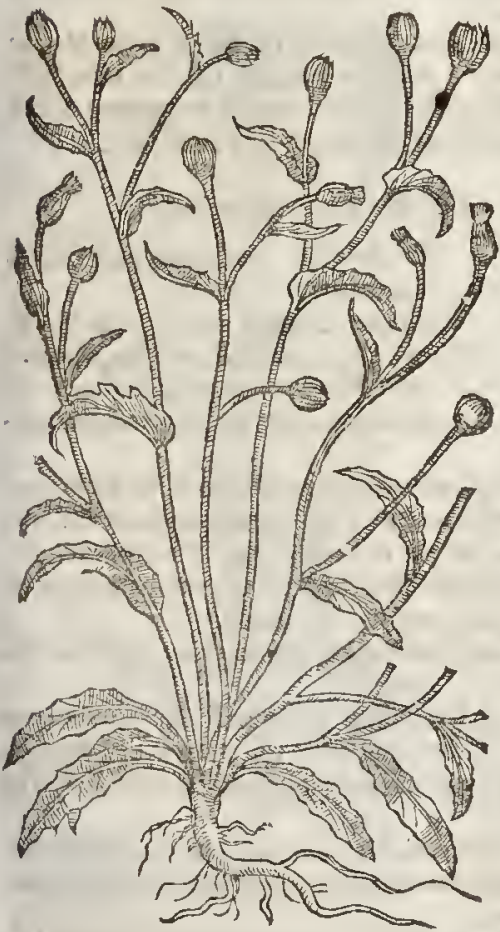

† ro Hieracium Latifolium montanum. Broad leaued mountainc Hawkeweed.

Io The broud leaucd mount ane Hawkeweed hath broad, Iong, finooth leates, deepely indented toward the ftalke, refembling the leates of the greateft Sow thitle. The falke is hollow, and fpungious, full of a milkie iuce, as is the reft of the plant, as alfo all the other of his kinde: the foures grow at the top of the ftalkes, double and yellow.

I T The natrow leaned mountaine Hawkeweed hat leaues likethofe of the lafteferibed, but narrower. The ttalkes be fat, hollow and full of milke : the flotres grow ar che top double, and yellow of eolour. The root is fmall and threddy.

There is a finall mountaine Hawkeweed haung leaues like vnto the former, but more deepely cut about the edges, and fharper pointed, the falkes are tender and weake; the foures be double and yellow like thofe of Pilofella, or great Moufe-eare; the roor is fmall and threddy.

$$
\text { 9 T he Place. }
$$

Thefe kindes of hetbes doe grow in vatoiled places neere vnto the borders of come fields, in medowes, high-waics, woode, mountaines, and hillie places, and neete to the brinks of dirches. F The two falcated Hawkerveeds grow oncly in fone ferv gardens, $\neq$ 
II Hieracium montanum Latifolium minus. The lefier broad leaued mountaine Hieracium paludosinn

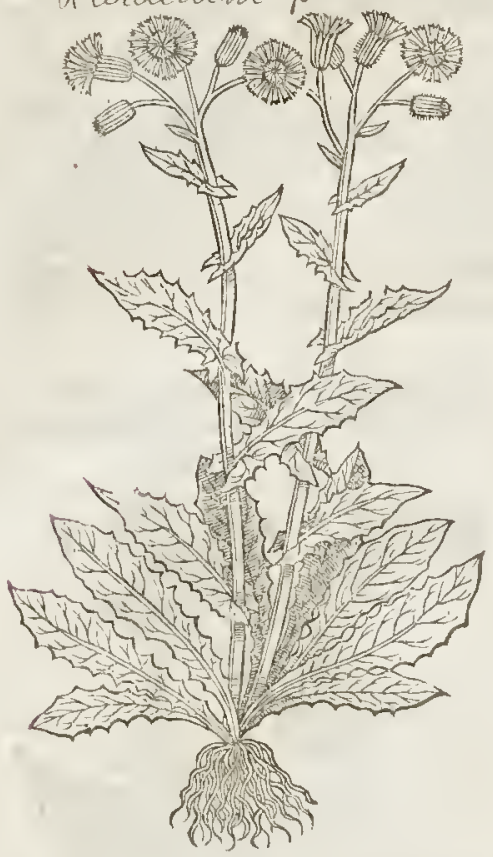

\section{TI The Time.}

They floute for the mon part all the fummes long, fome fooner, and others later.

Tा The Lames ingenerall.

Thefe plants are all eonteined vnder the name of Hieracum : which is ealled in Greeke alfo inpozen diuers name it in Latine, Acciputrina, whieh is termed in French, Cichoree iaulne: in Englion, Hawkeweed. Thefe herbes tooke there name from a Hawke, which is ealled in Latine Accipiter, and in Greeke, itexž , for they are reported to elecre their fight by conueying the juice heereof into their eyes. Gaza ealleth it porcellia for it isnumbred among the Sueeories, they ate ealled alfo Lampuca.

Yellow Hawkeweed is ealled of fome Mor fus diaboli, or yellow Dituels bit, for that the root doth very well refemble the bitten or eropt root of the common Diuels bit, being like Seabious.

\section{$\ddagger$ The Names in particular.}

I Mattholuf, Fuchfiws, Dodonaus, and others call this Hzeracium maius.

23 "Thefe are varieties of the fame plant, the firft of them being ealled by Fuch fins, Dodone. "us, and Giattbiolus, Hieracium minus, Lobell ealls it, Hicracium minus premorfardice. That fott of this with more eut leaues is by $T$ abernamontanus called, Hieracium nigrum.

4 Lobell ealls this Hicracium folÿs of facie Chondrille; Bauhinus makes this to differ from that which our Author gaue in this 4 . plaee out of $T$ abern. for he termes this Hicracium Chondrille folto fir futum, and the other, Hicracium Chondrills folio Glabrum; the one fmooth leaued, the other rougls; yet that which growes frequently with vs, and is very well reprefented by this figure, hath fmooth leates, as he alfo obferued it to haue in Italy and about Mountpelier in Franee.

5 This is Hieracium altcrum grandius, and Hieracium munt anum angufifolium primum of $T$ abernamontants.

6 Lobell ealls this from the length of the root (though fometimes it be not fo long) Hieracium Longius radicatum; as alfo $T$ aber. Hieracium macrorhizon, it is thought to be the Apargia of Theophraftus, by Daleforampius in the Hift. Lugd.pag. 562 . but the figure there that beares the title is of Hie. racium minus.

7. Tabcrnamontanus firt gaue this vnder the name of Hieracium intybacum aperum:Bauhine refers it to the wilde yellow Succorics, and ealls it Cichoreum mont anum anguftifolium bir futie apperum.

8 This Lobell calls Hieracium Narbonen fe falcata fliqua.

9 He ealls this Hicracium facie Hedyprois: and Cefalpinus termes this Khagadiolus; and the laft mentioned, Rhagadiolus alter.

ro This by 7 abernumontanus is ealled Hicracium montanum majus Latifolinn. The figure of this was giuen by our Author, chap.30.vnder the title of Chondrilla Hipanica.

II Tabernamontanus alfo ftiles this Hieracium montanum Latifolium minus. $\ddagger$

I The Niture.

The kindes of Hawkeweed are cold and $\mathrm{dr}$ ic, and fomewhat binding.

II The Vertues.

A They are in vertuc and operation like to Sonchus or Sowthifte, and being vfed after the fame manner, be as gond to all purpofes that it doth ferue vnto.

They be good for the eie-fight, if the juice of them be dropped into the eyes, efpeeially that whieh is called Diuls bit, whieh is thought to be the beft, and of greatef force.

Therefore 
white woollineffe or hairinefle, bittet in tafte, of an inche broad. The falke is a fnot hich,at the top wherenf doth grow one yellow floure like that of the gteat Hawkeweed, whicl is caried away with the winde when the feed is ripe. The root is blache and full of milkie juice, and hath cer caine white ftrings annexed thereto.

3 Thiskinde of Hawkeweed hath blacke roots a finger thicke, full of milkie juice, decpely thruft into the gtound, with fome fmall fibers belonging there to from which come vp many long leaues halfe an inch or more broad, coucred with a foft downe or hairineffe, of an oucrworne ruf. fet colour : and amongt the leaues come vp naked and hard ftalkes, whereupon coe grow yellow foures fet in a woollie cup ot chalice, which is turned into downe, and caried away with his feed by the winde.

4 The fourth Hawkeweed hath a thicke root aboue a finger long,blackifh, creeping vpon the top of the ground, and putting out fome fibres, and it is diuided into fome heads, each whereof at the top of the carth putteth out fome fix or feuen longifh leaues fome halfe an inche broad, and fomewhat hoarie, hairie, and foft as are the others precedent, and thefe leaues are fnipt about the edges, thut the deepeft garhes are neereft the flalkes, where they are cut in euen to the middle rib, which is ftrong and large. The ftalke is fmooth, nakcd, and fomewhat high : the foures be yellow and double as the other.

3 Hieracium 6.Clufij.

clufus his 6.Hawkeweed.

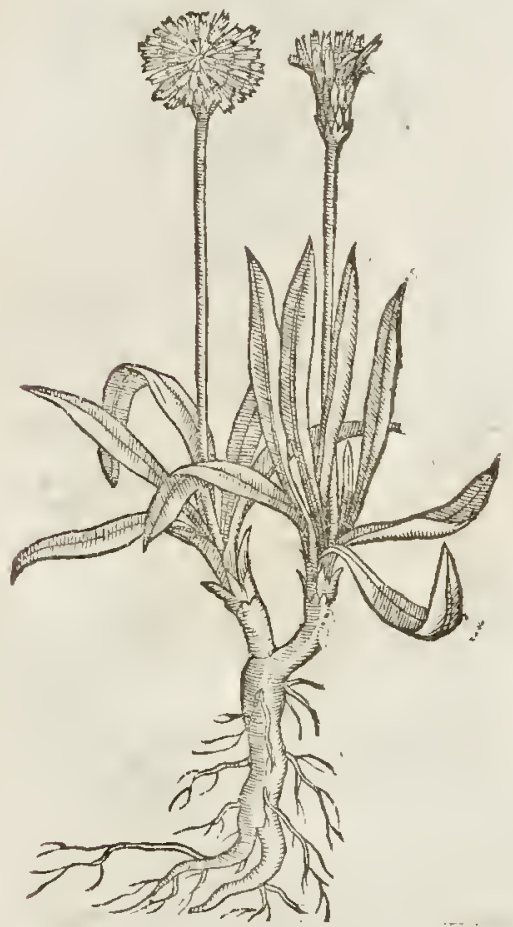

4. Hieracium 7.Clwfij. clufus his 7 . Hawkeweed.

¥5. The fame Author hath alfo fet forth another Hieracium, vnder the name of Hieracium par: vum Crticim, which he thus defcribes; this is an elegant little plant fpreading fome fix, or more leates vpon the top of the ground, being narrower at that part whereas they adhere to the toot, and broader at the other end, and cut about the edges, hauing the middle rib of a purple co.our; amongft thefe nfe vp two or three little ftalkes about a foor high, withour hrot vntill you come almoft to the ion, whereas they are diuided into two little branches, at whicl: place growes forth leaues much diuided; the floures grow at the top of a fufficient bigneffe, confidering tlic magni. tude of the plant, and they confift of many little leates lying one vpon another,on the vpper fide wholly white, and on the vider fide of a fleh colout. The root is fingle, longih, growing fmall 


\section{1 B. 2. Of the Hiftory of Plants.}

towards the end, and putting forth ftringy fibres on the fides. Thus much clufus, who receiued th is figure and defcription from his friend Iaques Platen of Tournay. I coniecture this to be the fame plant that Batbine hath fomewhat more accurately figured and defcribed in his Prod. p.ig.68. ruder the title of Chondrilla pur para forns fotida: which plant being an annuall, I haue feen growing fome yeares fince with $\mathrm{M}^{r}$. Tuggy at $\mathrm{W}$ eftminfter; and the laft Summer with an honet and skilfill A porhecarie one $\mathrm{M}^{\mathrm{r}}$. Nicholas Swayton of Feuerfham in Kent: but I muft confeffe I did not compare itwith Clufus; yet now I am of opinion, that both thefe figures and defcriptions are of one and the fame plant. "It floures in Iuly and Auguft, at the later end of which moneth the feeds alfo come to ripeneffe.

" 6 This other(not defcribed by clivfrus, but by Lobel) hath long rough leaues cut in and toothed like to Dandelion, with naked hairy ftalkes, bearing at their tops faire large and very double yellow floures, which fading fly aw ay in downe. It growes in fome medowes. -

\$ $\$$ Hieracium parvum Creticum. Small Candy Hawk-weed.

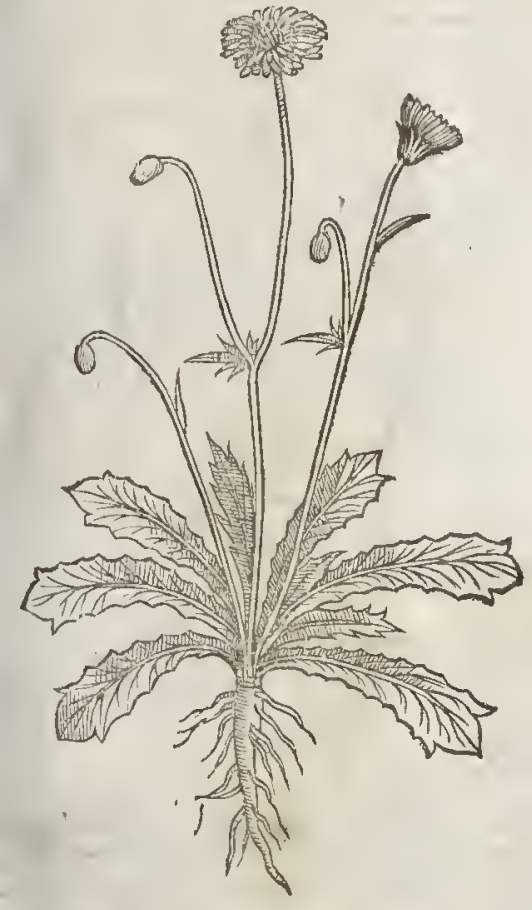

\$ Hieracium Dentis leonis folio hirfutum. Dandelion Hawk-weed.

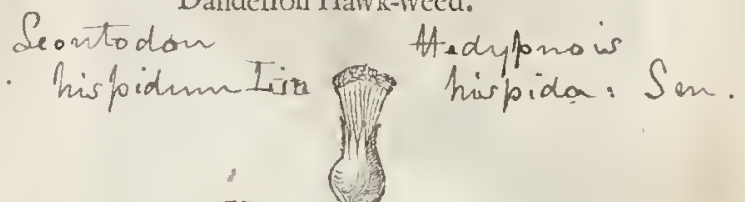

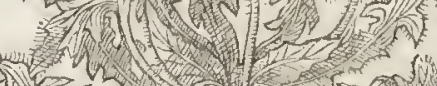

9i The Place.

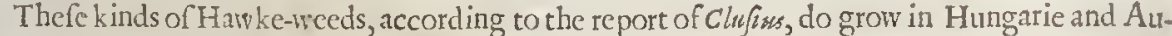
ftria, and in the graffy dry hills, and herby and barren Alpifh mountaines, and fuch like places: notwith tanding if my menorie faile me not $\mathrm{I}$ haue feene them growing in fundry places in England; which I meane, God willing, better to obferuc hereafter, as opportunitic fhall ferue me.

$$
\text { Tा The Time. }
$$

He faith they floure from May to Auguft, at what time the feed is ripe.

$$
\text { IT The Names. }
$$

The Author himfelfe hath not faid more than here is fet downe as touching the names, fo that it fhall fuffice what hath now been faid, teferring the handling thereof to a further confideration.

$$
\text { T) The Nature and Vertues. }
$$

I finde not any thing at all fet downe either of their nature or vertues, and therefore I forbeare to fay any thing elfe of them, as a thing not neceffarie to write of their faculties vpon my owne conceit and imagination. 


\section{C н А Р. 36: \\ * Of Frenchor Golden Lung-swort.}

\$ I Pulmonaria Gallica fue curea latifolia. Broad-leaued French or golden

Lung-wort.

Af iraciium murorum

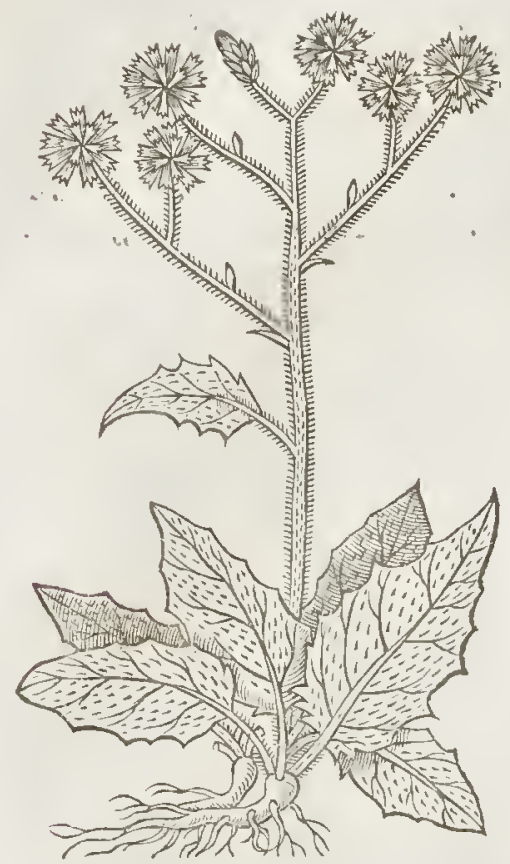

\$2 Pulmonarin Gallica fiue aurea anguftifolia? Narrow leaued French or golden Lung-wort.

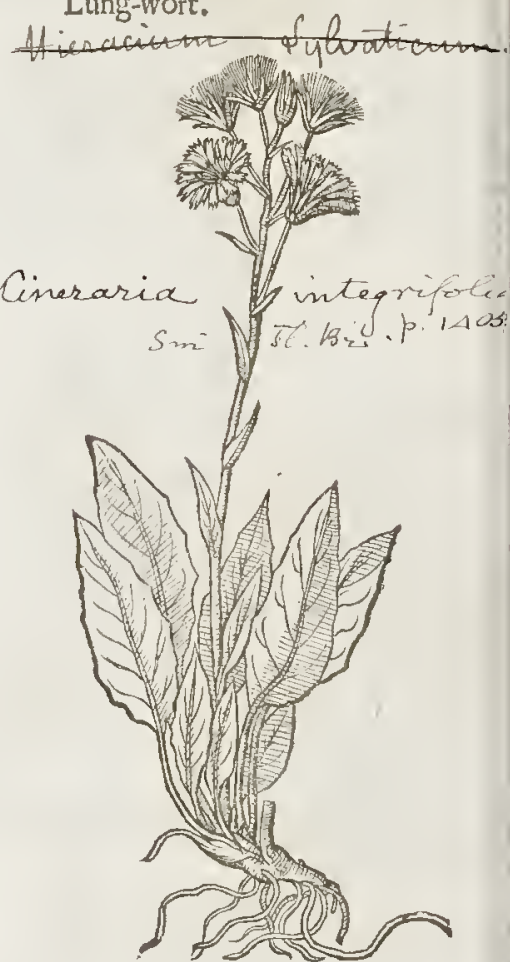

TI The Defcription.

* I THis which I here gitue you in the firft place, as alfo the other two, are of the kinds of Hawke-weed, or Hieracium; wherefore I thought it moft fit to treat of them in this place, and not to handle them with the Pulmonaria maculofa, or Sage of Ierufalem: whercas our Author gaue the name Prlmonaria Gallorum, and pointed at the defeription. but his figure being falfe, and the defeription imperfect, I iudged it the beft to handle it here next to thofe plants which both in fhape and qualitics it mucl tefembles. This firft hath a pretty large yet fibrous and ftringy root ; from the which arife many longith leanes, hairy, foft, and vnequally driided, and eommonly eut in the deepeft neereft the ftalke; they are of a darke green colour, and they are fometimes broader and thorter, and otherwhiles narrower and longer (whence Tabernamont anus makes three forts of this, yet are they nothing but varicties of this fame plant.) A mongft thefe leates grow vp one or two naked ftalks, commonly hauing no more than one leafe a piece, and that about the middle of the ftalke; thefe ftalks are alfo hairy, and about a eubit high, diuided at their tops into fundry branches, which beare double yellow floures of an indifferent bignefle, which fading and turning into downe, are together with the feed earried away with the winde. This whole plant is milky like as the other Hawk-weeds.

2 This Plant (though confounded by fome with the former) is much different from the laft defcribed; for the ront is fnall and fibrous; the leaues alfo are fmall, of the bigneffe, and fomewhut of the fhape (though otherwife indented) of Dafic leaucs, whitifh and hoarie; the fta!ke is not abouc an handfull high, crefted, hoary, and fer with many longifh narrow leaues, and at the top on fhort foot-ftalkes it beares foure or fiuc floures of a bright yellow colour, and pretty large, confidering 


\section{\$ 3 Hieracium hortenfe latifolium, fue} Pilofella major.

Golden Moufe-eare, or Gtimme the Colliat.

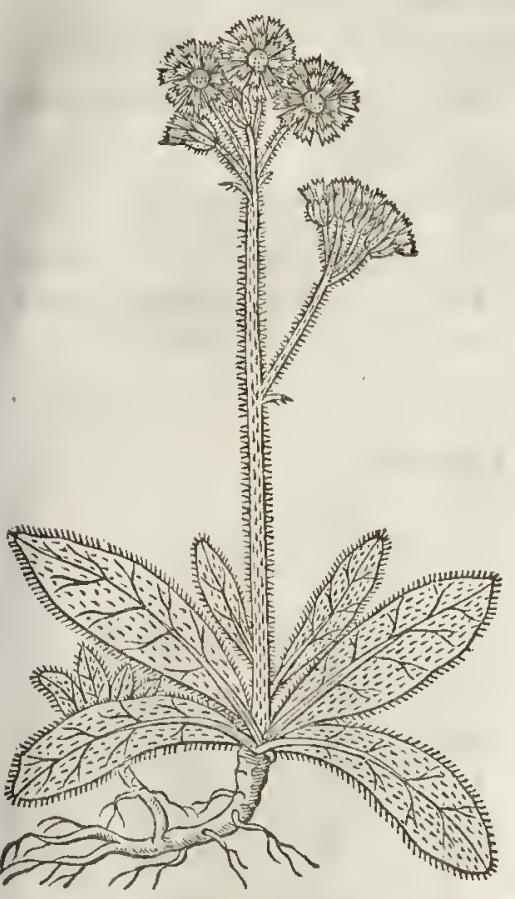

confidering the fmallneffe of the plant. The floures, like as others of this kinde, fly away in downe, and carry the feeds with them.

3 This plant (which fome alfo haue confounded with the firft defcribed) hath a root at the top, of a teddith or brownith colour, but whitish within the earth, \& on the lowet fide fending forth whitim fibtes : it bringeth forth in good and fruitfull grounds leaures about a foot long, and two or three inches broad, of a darke greene colour, and hairy, little ot nothing at all cut in about the edges; amongtt thefe leates rifeth vpa ttalke fome cubit high, round, hollow, and naked, but that it fometimes hath a leafe or two toward the bottome, and towards the top it puts forth a branch or two. The floures grow at the top as it were in an vmbell, and are of the bignes of the ordinarie Moufe-eare, and of an orange colour. The feeds are round, \& blackih, and ate caried away with the downe by the wind. The Italkes and cups of the floures are all fet thicke with a blackinh downe or hairineffe as it were the duft of coles, whence the women, who keep in it gardens for noueltie fake, haue named it Gtim the Colliar.

$$
\text { I) } T \text { be Time. }
$$

All thefe floure in Iune, Iuly, and Auguf; about the later patt of which moneth they tipen their feed.

\section{ब The Place.}

I I receitued fome plants of this from

M. Yohn Goodyer, who firft found it May 27, 163r. in floure; and the 3 of the following May, not yet flouting, in a copfe in Godlemen in Surtey, adioyning to the orchatd of the Inne whofe figne
is the Antilope.

2 This I had from my kinde ftiend $M$. William $\dot{C}$ oote, whowrot to mee, That he found them gtowing on a hill in the Lady Bridget King fmills ground, in an old Romane campe, clofe by the Decumane port, on the quarter that regards the Weft-South-Welt, vpon the skirts of the hill.

3 This is a ftranger, and onely to be found in fome few gardens.

$$
\text { It The Names. }
$$

I This was firt fet forth by Trazus, vnder the name of Auriculd muris major: and by $T_{a b}$ ern. (who gate three figures expreffing the feuerall varieties theteof) by the name of Pulmonaria Gallin. cafiue aurea: Dalechampins hath it voder the name of Corchorus.

2 This was by Lobel (who firf fet it forth) confounded with the former, as you may fee by the ritle ouerthe figute in his Obferuations, $p_{t} t g .3 \mathrm{I} 7$. yet his figure doth much differ ftom that of T'ragus, who neither in his figure nor defcription allowes fo mich as one leafe vpon the italke; and Tabernamont thus allowes but one, which it feldome wants. Now this by Lobels figure hath many narrow leates; and by the Defcription, Adure.p.p. 253 . it is no morethan an handfull, or handfull and halfe high : whicli very well agrees with the plant wee heete giue you, and by no meanes with the former, whofe naked ltalkes are at leaft a cubit high. So it is manifeft that this plant I haue defcribed is different from the formet, and is that which $P$ ena and $L$ tobel gaute vs vnder the tite of Pulmonaria Gallorum flore Hicracij. Baubine al fo confounds this with the former. 3 Bafi $l_{B}$ eflcr in his Hortus Eyftettenfis hathwell expreft this plant vnder the title of Hier acium atifolium peregrinum Phlomoides. Baubinus calls it Hieracium hortenfe floribus atropurpurafcentibus and faith that fome call it Pilofella major : and I iudge it to be the Hieracium Germanicum of Fabius columna. This alfo feemes rather to be the herbe Cofta of Camerarius, than the firft defcribed; and dare almoft be bold to affirme it the fame: for he faith that it harh fat leaues lying flat vpon the round,and as much as he could difcerne by the figure, agreed with the Hieracium latifolium of cluins : towhich indeed in the leaues it is very like, as you may fee by the figure which is in the firft lace in the foregoing chapter, which vety well tefembles this plant, if it had mote and fmaller
loures. 


\section{Tा The Temper and $v^{2}$ erturs.}

I indge thefe to be temperate in qualitie, and endued with a light aftriction.

A I The decoction or the diftilled water of this herbe taken inwardly, or outwardly applied, conduce much to the mundifying and healing of greene wounds; for fume boyle the herb in wine, and fo gine it to the wounded Paticnt and alfo apply it outwardly.

B It alfo is good againft the intermall inflammations and hot diftempers of the heart, Ptomacke, and limer.

C The iuyce of this herbe is with good fucceffe dropped into the eares when they are troubled with any pricking or fhooting puine or noy fe.

D Laftly, The water hath the fame qualitic as that of Succoric. Tragus.

E 2 Pena and Lobelaffirme this to be commended againft whitlowes, and in the difeafes of the lungs.

F 3 This (if it be the Cofta of Camcrarius) is of fingular vfe in the Pthifis, that is, the vlceration or confumption of the lungs : whereupon in Mifnia they giue the conferue, fyrrup, and pouder thereof for the fame purpofe: and they alfo vfe it in broths and otherwife, Cam. $\neq$

\section{C н А . 37. Of Lettuce.}

1 Lactuca fatiua. Garden Lettuce.

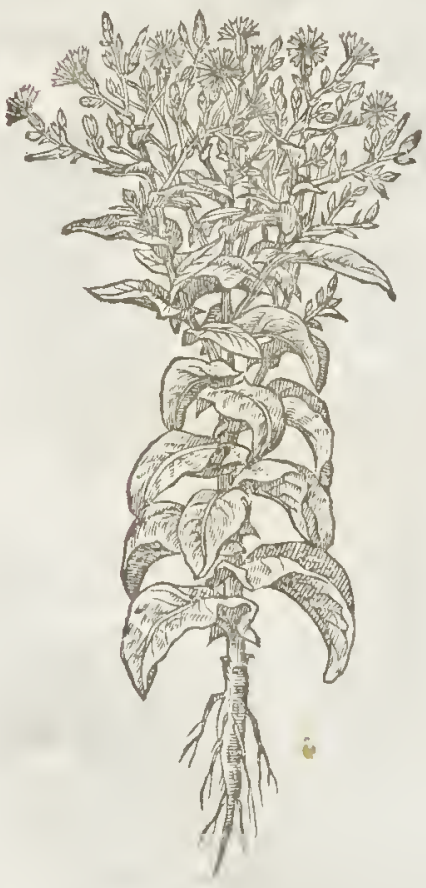

2 Lactucacriffa.

Curled Lettuce.

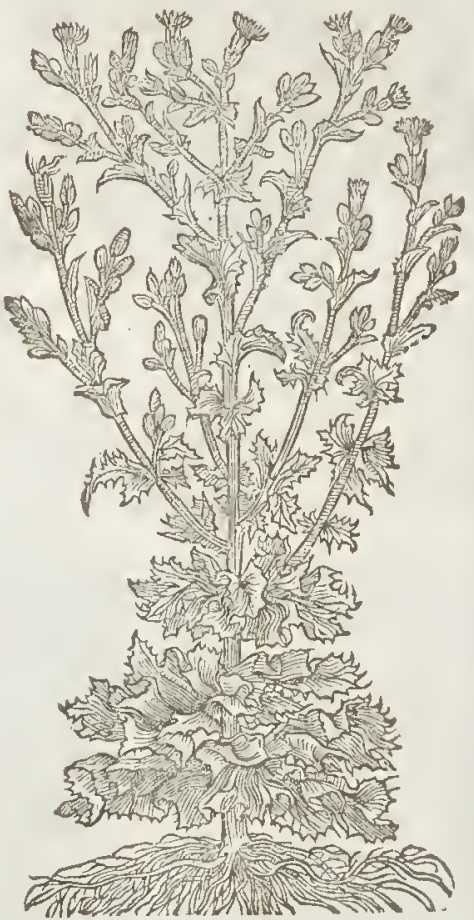

TI The Kindes.

Here be according to the opinion of the Antients, of Lettuce two forts ; the one wilde, or of the field ; the other tame, or of the Garden : but time, with the induftric of later Writers hare found out others both wilde and tame, as alfo artificiall, which I purpofe to lay downe. 
Arden Lettuce hath a long broad leafe,fmooth, and ofa light green eolour : the falke is round, thicke fet with leaues full of milky iuyee, buthed or branched at the top: whereupon do grow yellowith floures, whieh turne into downe that is catried arvay with the winde. The feed fticketh faft vnto the cottony downe, and flieth away likewife, wlyite of colour, and fomewhat long: the root hath hanging on it many long tough ftrings;wbich being etut or broken, do yeeld forth in like manner as doth the ftalke and leatles, a iuyee like to milke. And this is the true defeription of the naturall Lettuce, and not of the artifieiall ; for by manuring; tranfplanting, and hauing a regard to the Moone and other eireumptances, the leates of the arrifi: eiall Lettuee are oftentimes transformed into another thape : for either they are curled, or elfe fo drawne together,as they feeme to be like a Cabbage or headed Colewort, and the leaues whieh be within and in the middeft are fomething white, tending to a very light yellow.

5 Lactuca capitata. Cabbage Lettuee.

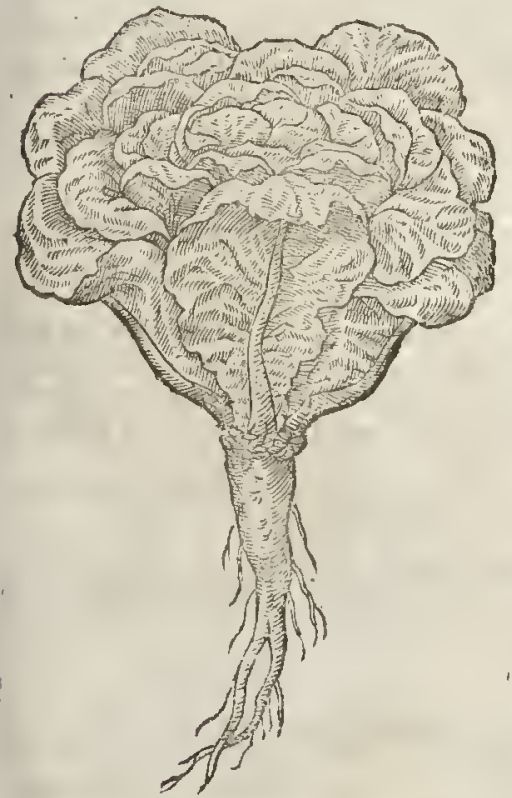

\section{Lactuca intybacea.} Lumbard Lettuce.

2. The curled Lettiree hath great and large leates deeply cut or gafhed on both the fides, not plaine or finooth as the former, but intricately eurled and eut into many fections. The floures are fmall, of a bleake eolour, the which do turne into downe, and is earried away with the winde. The feed is like the former, faling that it ehangeth fometime into blackneffe, with a root like vnto the
former.

3 This fmall fort of curled Lettuce hath many leaues hackt and torne in pieces very confit:fedly, and withall curled in fuch an admirable fort, that euery great leafe feemeth to be made of many fmall leaues fet vpon one middle rib, refembling a fan of curled feathers vfed among Gen: tlewomen : the floures, roors, and feeds agree with the former.

broad, eut or gartht attuee hath very large leaues fpred vpon the ground, at the firt comming vp

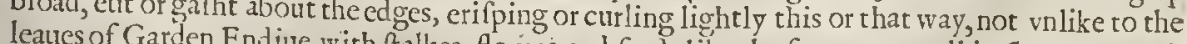
leaues of Garden Endiue, with talkes, floures, and feeds like the former; as well in thape, as yeclding that milky inyee wherewith they do all abound.

5 Cabbage Letruce hath many plaineand fmooth leanes at his firft growing vp, which for the moft part lie flat ftill vpon the ground : the next that do appeare are thofe leates in the midit, which turn themfelues together,embraeing each other fo clofely, that it is formed into that globe 
in wholegarden I faw it growing fome two yeares agoe. The other grow plentifully be twecn Lonuton and Pancridge Church, about the ditches ard higliway file. The Trme.

They comevp in the Spring,and fometimes fooner, and ripen their fecd in Iuly and Augut.

IT The Names.

I Iake the firft of tliefe to be the Laduca Sylief.ri. of Dicfunces ard the Arcicnts, ard that

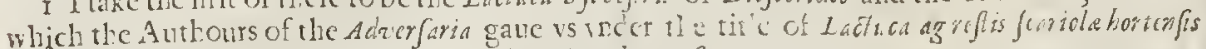

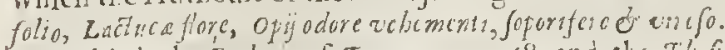

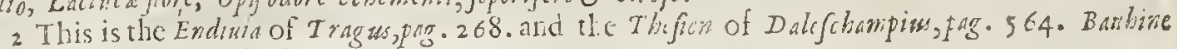
confounds this witli the former.

3 This is the Lactuca Sylveftris prior, of Trarus: the Lactuca Sylvefris of Mathiolus, Fuchfius, Dodoneus, and others: it is the Seris Domeftica of Lobill.

This Timper.

Thefecertainly, efpecially the two firf, accold, and that in the later end of the thind or be. ginning of the fourth degree (if opium be cold in tLe fourth.)

The Vertus.

A Some (faith Diefcorides) mix the milkic iuice lercof withojium; (for his Meconium is ouz opium.) in the malsing thereof.

B He alio laith, that the iuice he reof drunke in Crycrate in the quantity of abuli, (which make fome one fcruple ) purgeth watrifh lumors by foole; it alfo clcnfeth the little viccr in the eye colled Argimion in Greeke, as al fo the myftines or darheneffe of fight.

C Alfobeaten and applied with womans milke it is cod againf burses and fcaldes,

D Lafly, it procures fieepe, affwages paire, moues the courfes in women, and is drunkeagainft the ftingings of fcorpions, and bitings of tpiders.

E The feed taken indrinke, like as the Garden Lettuce, hindreth generation of feed and venereous imaginations. $\neq$

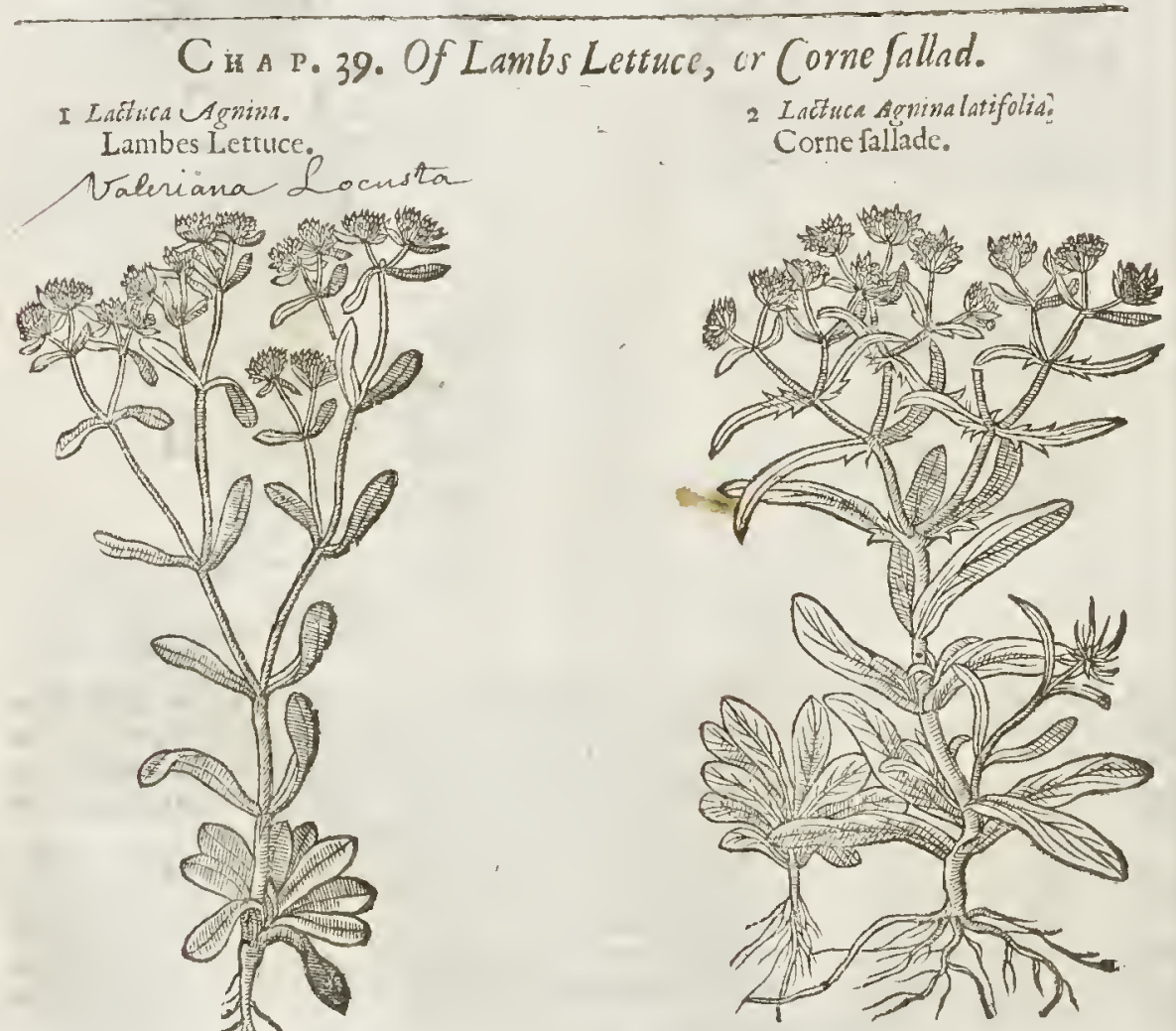




\section{T The Defcription.}

I The plant whieh is commonly ealled olus album, ar the white pot-herbe(which of fome hath been fet out for a kinde of Valerian, butwproperly, for that it dotls very nota. bly refemble the Letruce, as well in forme, as in meate to be eaten; which popertie is not to be found in Valerian, and therefore by reafon and atthoritie I place it as a kinde of Let tuce) hath many flender weake ftalkes trailing vpon the ground, with certaine edges a foor hiv when it growes in moft fertile ground; orherwife a hand or two high, ivith fundry ioynts or knees: out of cuery one whereof grow a couple of leaues narrow and long, not vnlike to Lettuce at the firt comming vp,as well in tendernefle as tafte in eating; and on the top of the ftalkes ftand vpon a broad tuft as it were eertaine white floures that be maruellous little, which can fcarfely be 'sionn to be floures, fauing that they grow many together like a tuft or wmbel: it hath in fead of roots a few flender threads like vnto haires.

. 2 The other kind of Lettuee, which Dodonases in his laftcdition fetteth for th vnder the name of Album olus : the Low-eountrey men call it neitmoes, and vfe it for their meate called Wermofe; with vs, Loblollie. This plant hath fmall long leates a finger broad, of a pale green colotir; among which fhooteth vp a fmall eornered and flender ftem lalfe a foor high, ioynted with two or three ioynts or knces, out of which proeeed two leaues longer than the firft, bearing at the top of the branches tufts of very f mal white floures clofely eompact together, with a root like the former.

$\neq$ Both thefe are ofone plant, differing in the bigneffe and broadneffe of the leafe and the whole plant befides. $\ddagger$

$$
\text { T) The Place. }
$$

Thefe herbes grow wilde in the eorne fields; and fince it hath growne in ve among the French and Duteh ftrangers in England, it hath beene fowen in gardens as a fallad herbe.

$$
\text { of The Time. }
$$

They are found greene almort all Winter and Sommer.

The Dutch-men do call it noyturoes; that is to fay, Album olus: of fome it is called vielterop:

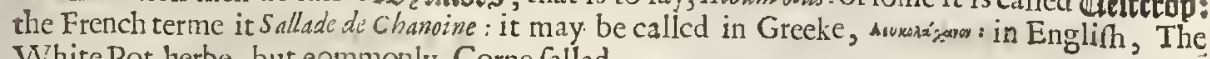
White Pot-herbe; but eommonly, Come fallad.

\section{IT The Temperature and Vertues.}

This herbe is cold and fomerhing moift, and not vnlike in faeultie and temperature to the garden Lettuce; in ftead whereof, in Winter and in the firft moneths of the $S$ pring it forues for a fallad herbe, and is with pleafure eaten with vineger, falt and oile, as other fallads be;among which it is none of the wort.

\section{Cha r. 40. Of Coleworts。}

II The Kindes.

D rofcorides maketh rwo kindes of Coleworts; the tame and the wilde : but $T$ heoploraftus makes morekindes hereof; the ruffed or curled Cole, the fmoorh Cole, and the wilde Colc. Cato imitating Theoghraftzus, fetteth downe alfo three Coleworts : the firf hee deferiberh to be
fmooth, great, broad leated, with a big ftalke; the fecond ruffed; the third with little ftalks, tender, and very much biting. The fame diftinetion alfo Pliny maketh, in his twentieth booke, and ninth clapter; where he fitith, That the moft ancient Romanes haue dituicled it intothree kindes,

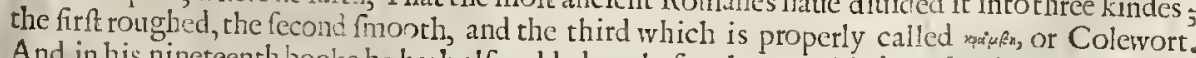
And in his ninetecnth booke he hath alfo added to thefe, other moe kindes; that is to fay, Tritia-
rum, Cumanum, Pompeisnum, Brutianm, Sabellium, and Lacuturriwm.

The Herbarifts of our time haue likewife obferued many forts, differing either in colour or elfe in forme; other headed with the leates drawne together; molt of them white, fome of a deepe greene, fone fmooth leaued, and others curled or ruffed ; differing likew ife in their ftalkes, as fhall
beexpreffed in their feueralldeferiptions. 
$\mathrm{L}_{1 \text { B. } 2 .}$

I Braßsucaulgar is fatiun. Garden Colcwort.

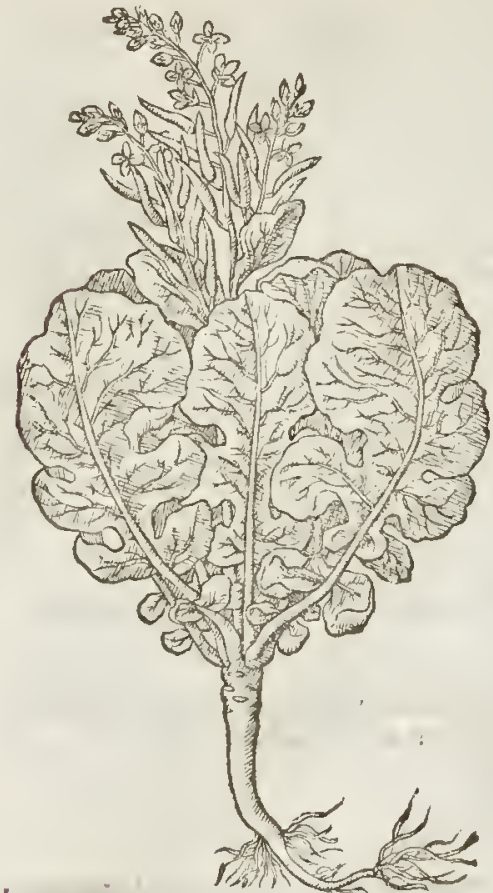

: 3 Breficarula. Red Colewort.

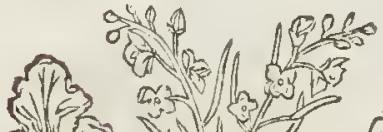
(w)

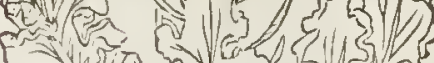

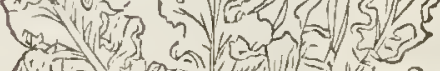
\&in 1 -

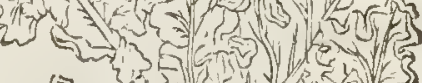
हnow (1) $\Rightarrow$
2 Brafica fatiua cripa. Curled Garden Cole. है ron $N$ (4) an 113

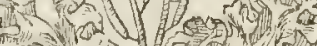

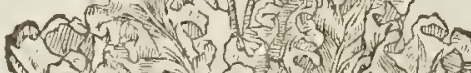

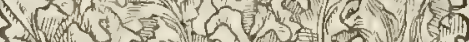

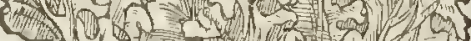

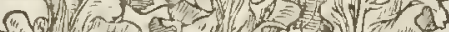

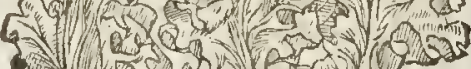

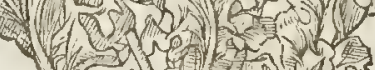

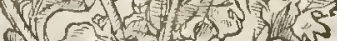
aton

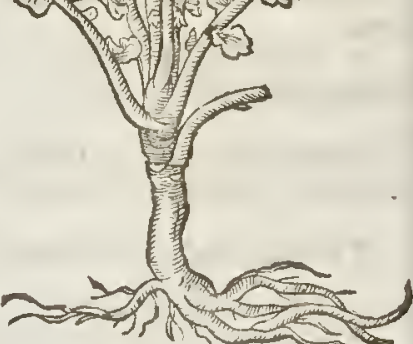

4 Brafica capitata allia.

Whice Cabbage Cole.

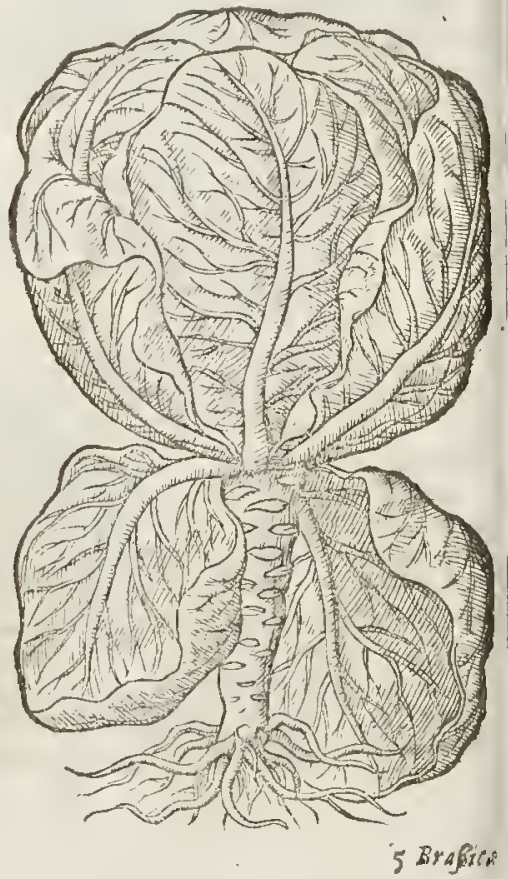




\section{Tा The Defription.}

I $\neg$ He Garden Colewort hath many great broad leaues of a deepe blacke greene colour, mixed with ribs and lines of reddirh and white eolours : the ftalke groweth out of the middeft from among the leaues, branched with fundry armes bearing at the top little yellow floures : and after they be paft, there do ficceed long eods full of round feed like thofe of the Turnep, but finaller, with a wooddy root hauing many ftrings or threds faftned thereto.

2 There is another leffer fort than the former,with many deepe cuts on botl fides euen to the middett of the rib, and very mueh eurled and roughed in the edges; in ocher things it differeth not.

3 The red kinde of Colewort is likewife a Colewort of the garden, and differeth from the common in the colour of his leaues, which tend vnto redneffe; otherwife very like.

4 There is alfo found a certaine kinde hereof w ith the leaues wrapped together into a round head or globe, whofe head is white of colour, efpecially toward Winter when it is ripe. The roo: is lard, and the ftalkes of a wooddy fubrtance. $¥$ This is the great ordinarie Cabbage knowne cuery where, and as eommonly eaten all ouer this kingdome. $\neq$

5 Braficacapitata rubra. Red Cabbage Cole.

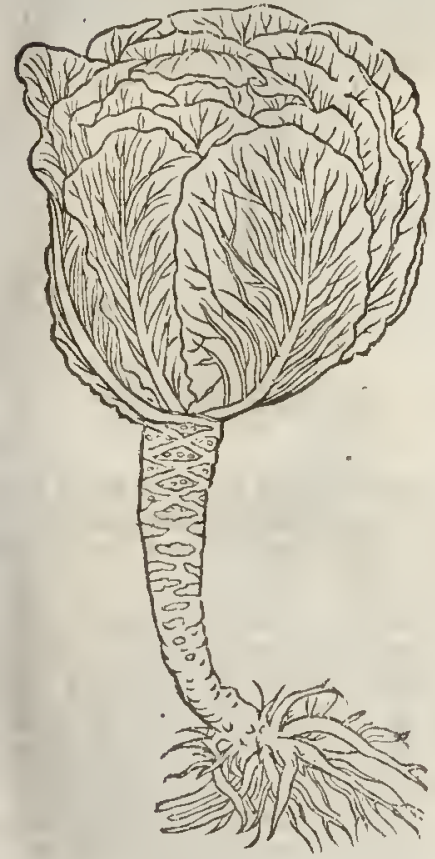

6 Braficapatula

Open Cabbage Cole.

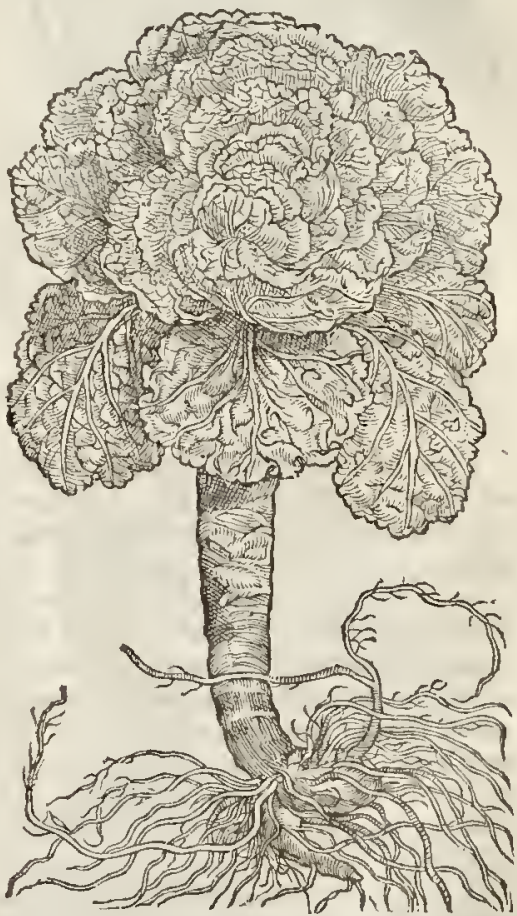

5 There is another fort of Cabbage or loued Colew ort which hath his leaures wrapped toge:ther into a round head or globe, yet leffer than that of the white Cabbage, and the colour of the leaucs of a lighter red than thofe of the former.

6 The open loued Colewort hath a very great hard or wooddy ftalke, whereupon do grow very large leanes of a white greene colour, and fet with thickewhite ribs, and gathereth the reft of the leaues clofely together, which be leffer than thofe next the ground; yet when it commeth to the fhutting vp or clofing together, it rather dilateth it felfe abroad, than clofeth all together.

7 Double Colewort hath many great and large leaues, whereupondoe grow here and there other fmall iagged leaues, as it were made of ragged threds and iagges fet vpon the fmooth leafe, which yiueth thew of a plume or fan of feathers. In ftalke, root, and euery other part befides it doth agree with the Garden Colewort. 
8 The double crifpeor curled Colewoott agreeth with the laft before defcribed in etrery re: fpect, onely it differcth in the leaues, which are fo intricately eurled, and fo thick fet ouer with other fmall cut leaues, that it is hard to fee any part of the leafe it felfe, except ye take and put afide fome of thofe iagges and ragged lcates with yout hand.

9 Brasicaflorida. Cole-Florie.

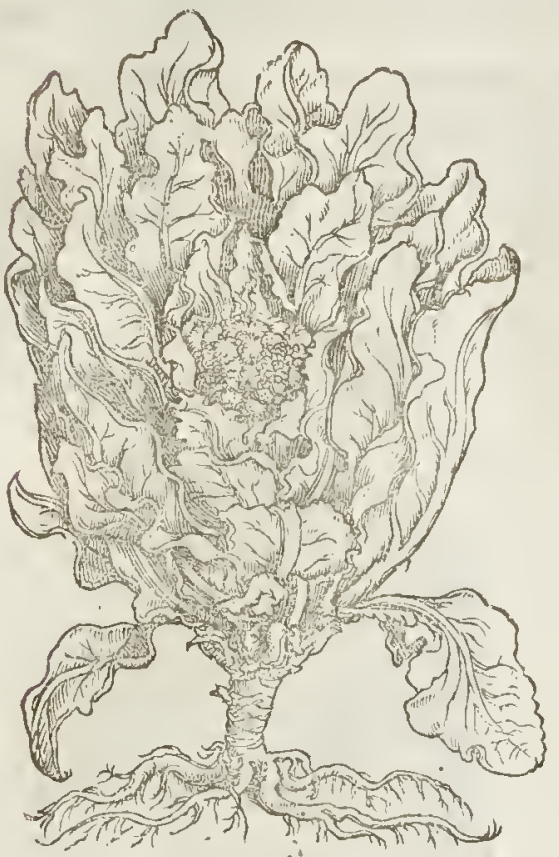

Io Braßica Tophofa. Swollen Colcwoort:

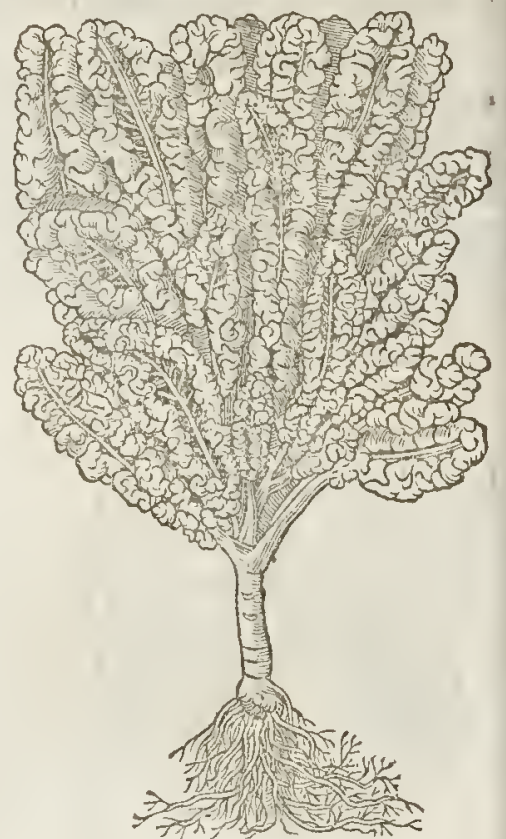

9 Cole flore, or after fome Coliefote, hath many large lcaues fleightly indented about the edges, of a whitith greene colout, narrower and tharper pointed than Cabbage : in the middeft of which leaues rifeth vp a great white head of hard floures elofely thruft togethet, with a root full of trings, in other parts like vnzo the Coleworts.

10 The fwollen Colewort of all other is the ftrangeft, which I receiued from a worfhipfull merehant of London mafter Nicholss Lete, who brought the feed thereof out of France; who is greatly in loue with rare and faire floures \& plants, for which he doth earefully fend into Syria, hauing a feruant there at Aleppo, and in many other eountries, for the which my felfe and likewife the whole land are much bound vnto him. This goodly Colew ort hath many leaues of a blewith green, or of the colour of Woade, bunched or fivollen vpabout the edges as it were a peece of leather wet and broiled on a gridiron, in fuch ftrange fort that I cannot with words defcribe it to the full. The floures grow at the top of the ftalkes, ofa bleake yellow colour. The root is thiche and ftrong like to the other kindes of Colewrorts.

I Sauoy Colc is alfo numbred among the headed Colewoorts or Cabbages. The leaues are great and large very like to thofe of the great Cabbage, which turne themfelues vptvards as though they would embrace one another to make a loued Cabbage, but when they come to the Shutting vp they ftand at a ftay, and rather fhew themfelies wider open, than thut any neeter together ; in other refpeets it is like vnto the Cabbage.

I 2 The curled Sauoy Cole in enery refpeet is like the precedent, fauing that the leaues hereof doe fornew hat curle or crifpe about the midle of the plant : which plant if it be opened in the fpring time, as fometimes it is, it fendeth forth branched ftalks, with many fmall white floures at the top, which being paft their follow long eods and feeds like the common or firftinde dereribed.

I 3 This kinde of Colewoor hath very large leates deepely iagged cuen to the middle rib, in face refemblinggreat and ranke parfley. It hath great and thieke talke of threc cubis high, whcreupon doe grow floures, cods, and feed like the other Colewoots. 


$\mathrm{L}_{1 \mathrm{~B}, 2 .}$ Of the Hiftorie of Plants.

I I Braßica Sabauda.

Sauøy Cole.

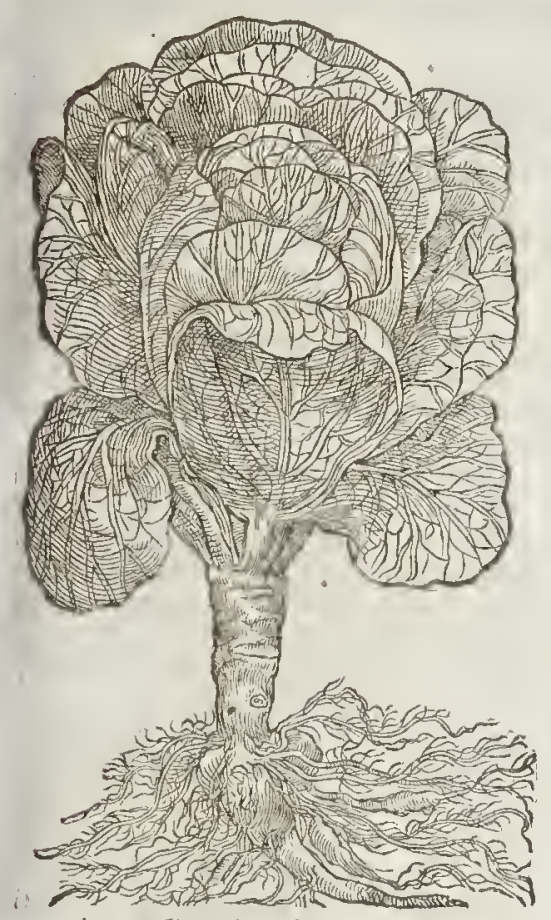

is Braßica Selinoides.

Parfeley Colewoort.

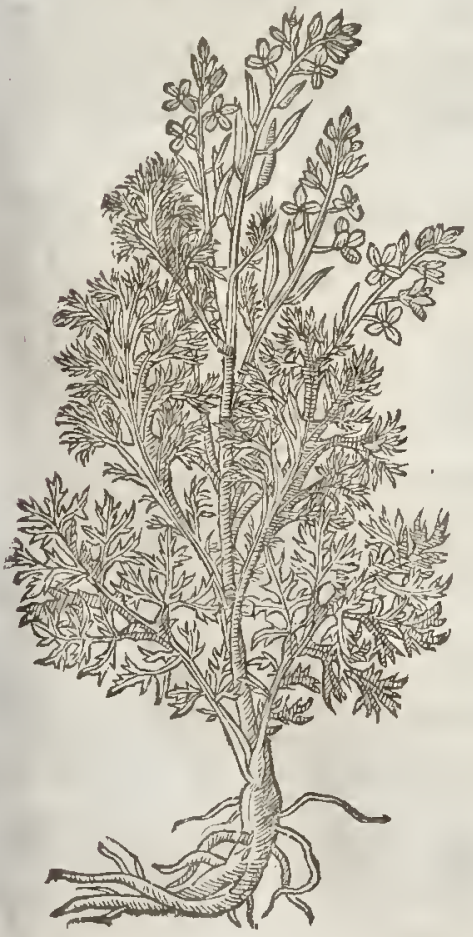

I 2 Braßica Sabauda cripa.

Curked Sauoy Cole.

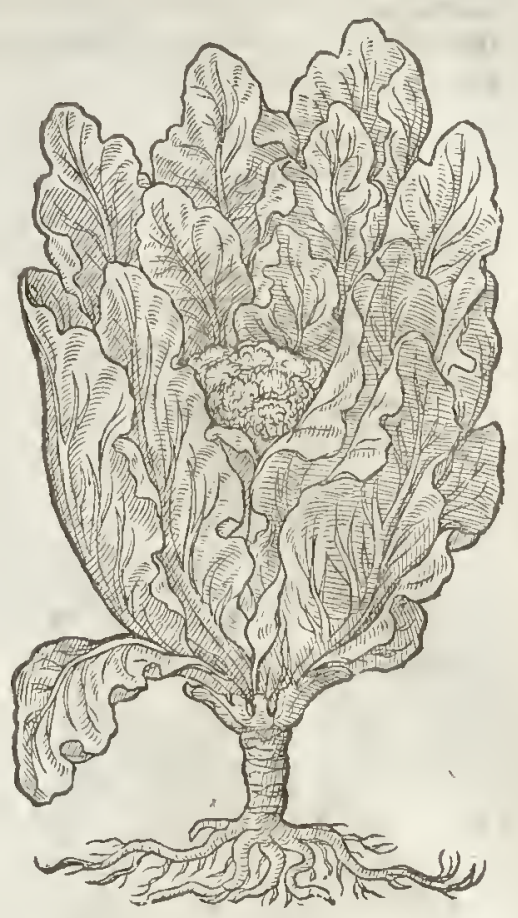

t I 5 Braßicamarina Anrlica. Englin fea Colewoorts.

Crambesion aretivisa बifo

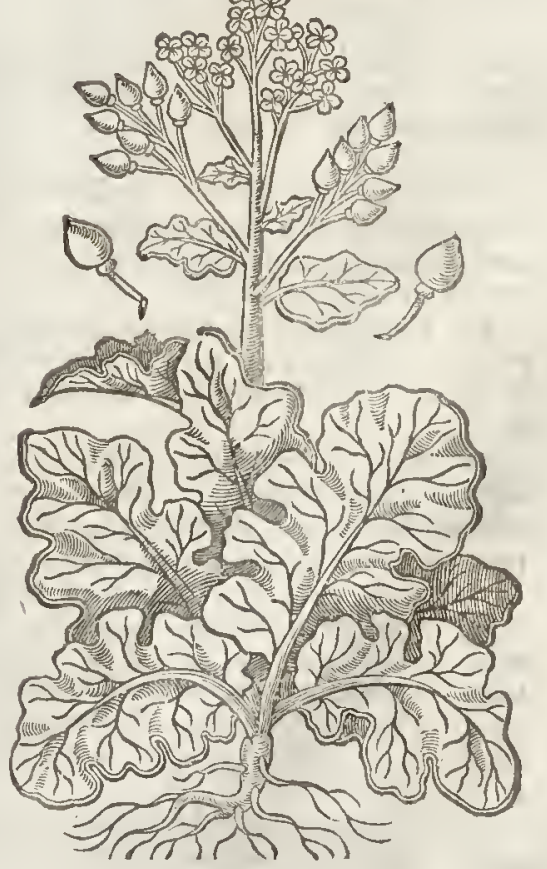

14. The 
I4 The fmall cut Colewoort hath very large leaues, wonderfully cut, hackt and hewen euen to the middle rib, refembling a kinde of curled parfley, that thall be defcribed in his place, (which is not common nor hat hot beene knowne nor defcribed vntill rhis time) very well agreeing with the lant before mentioned, but differeth in the curious cutting and iagging of the leaues: in ftalke toures and feed not vnlike.

t I6 Brafica fyluefris. Wilde Colewoorts.

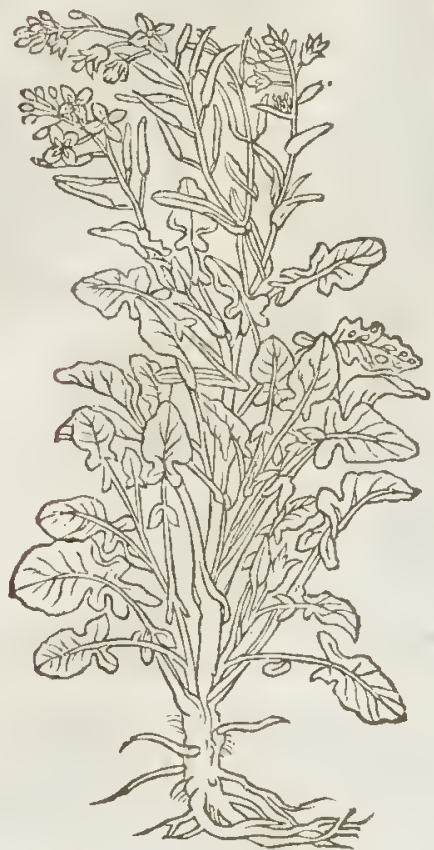

I5 Sea Colewnort hath large and broad leaues very rhicke and curled, and fo brittle rhat they cannot be handled withoutbreaking, of an ouerworne greene colour, tending ro grayneffe: among which rife vp falkes two cubits high, bearing fmall pale floures at the top; which being paft their follow round knobs wherein is contained one round feed and no more, blacke of $\mathrm{co}$ lour, of the bigneffe of a tare and a fetch : $\ddagger$ And therefore Pen and Lobell called it Brafica marina monojpermos. $\ddagger$

I 6 The wilde Colewoort hath long broad leates not vnlike to the tame Colcwoort, but leffer, as is all the reft of the plant, and is of his owne nature wilde, and therefore not fought after as a meate, but is fowen and husbanded up on ditch bankes and fuch like places for the feeds fake, by which ofrentimes great gaine is gotten.

$$
\text { T) The Place. }
$$

The greateft fort of Colewoorts dne grow in gardens, and doe loue a foile which is fat and throughly dunged and well manured : they doe beft profper when they be remooued, and every of them grow in our Englifh gardens, except the wilde, which groweth in fields and new digged ditch banks .

The fea Colewoort groweth naturally vpon the bayche and brims of the fea,where there is no earrh to bee feene, but fand and rowling pibble ftones, which thofe that dwell neere the fea doe call Bayche: I found it growing betweene Whytftable and the lle of Thanet neere the brinke of the fea, and in many places neere to Colchefter and elfewhere by the fea fide.

$$
\text { T The Time. }
$$

Petrus Crefentius faith that the Colewoort maybe fowen and remootied at any time of the yeere; whofe opinion I altogether miflike. It is fowen in rhe fpring, as March, Aprill, and oftentimes in May, and fometimes in Auguft, but the fpeciall rime is about rhe beginning of September.

The Colewoot, fairh Coltmell, muft be remoued when it attaineth to fix leates, after it is come vp from feed; the which muft be done, in Aprill or May, efpecially thole that were fowne in Autumne; which afterwards flourifh in the winter moneths, at what time, they are fitteft for meate.

But the Sauoy-Cole, and the Cole florey, nutt be fowne in Aprill, in a bed of hot horfedung, and covered with ftraw or fuch like, ro kecpe it from rhe cold, and frofty mornings; and when it hath gotten fix leaues after this fort, then thall you remouc him as aforefaid,orhervife if you tar. ry for temperate weather before you fow, the ycare will be fpent, before it come to ripenefle.

\section{The Names.}

Euery of the Colewoorts, is called in Greeke by Diofcorides and Galen mpinkm : it is alfo called

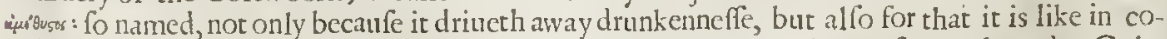
lour to the precious ftone called the Amethyft : which is meant by the firft and garden Colewoort. The Apothecaries and the common Herbarifts doe call it Caulis, of the goodreffe of the falke : in rhe Germane tongue it is called lkoole braut: in Freneh, des Chour : in Englifh, Colcwoorts.

Cole-florcy is called in Latine Braßica Cypria, and Canliflora : in Italian, Canlifore : it feemeth to agree with Brafica pompeiana of Pliny, whereofhewriteth in his 19 . booke, and 8 . chapter. af $T$ be 


\section{Lı в. 2. Of the Hittory of Plants:}

(1) The Temperature.

All the Colewoorts haue a drying and binding facultie, with a certaine nitrous or falt quality, whereby they mightily cleanfe, either in the illice, or in the broth. The whole fubftance or body of the Colcw oort is of a binding and drying faculty, becaufe it leaucth in the decoction this falt quality; which licth in the iuyce and watry part thercof:the water wherein it is firft boyled, drawerh to it felfe all the quality; for which caufe the decoetion thercof loofeth the belly, as doth alfo the iuyce of it, if it be drunke : but if the fire broth in which it was boyled be cait away, then doth the Colewoort dry and binde the belly. But it yeeldeth to the body fmall noutifhment, and doth not ingender good, hut a groffe and Melancholicke bloud. The white Cabbage is beft next vnto the Cole-florey; yet Cato doth chicfy commend the ruffet Cole: but he knew ucither the white ones, nor the Cole-florey; for ifhe had, his cenfure had beene otherwife.

$$
\text { of The vertues. }
$$

Diofcorides teacheth, that the Colewoort being caten is good for them that haue dim eyes, A and that are troubled with the thaking palfie. The fame author affirmeth, that if it be boiled and eaten with vineger, it is a remedie for thofe $B$
that be troubled with the fpleene.

It is reported, that the raw Colewoort being eaten before meate, dorh preferue a man from $\mathrm{C}$ drunkenneffe: the reafon is yeelded, for that there is a naturall enmity betweene it and the vine, which is fuch, as if it grow neere vnto it, forthwith the vine perifheth and withereth away : yea, if wine be poured vnto it while it is in boyling, it will not be any more boiled, and the colour thercof quite altered, as Caßsius and Diony fius Vticenfis doe write in their bookes of tillage : yet doth not At heness afcribe that vertue of driuing away drunkenneffe to the leaues, but to the feeds of Colewoort.

Morenuer, the leaucs of Colewoorts aregood againf all inflammations, and hot fivellings; D being ftamped with barley and meale, and laid vpon them with falt:and alfo to breake carbuncles.

The iuyce of Colcw oorts, as Diofcorides writeth, being taken with flourc-deluce and niter, doth $E$ make the belly foluble : aud being drunke with wine, it is a remedie againft the bitings of veno-
mous bearts.

The fame being applyed with the powder of Fennugreeke, taketh away the paine of the gout, F and alfo cureth old and foulc vlcers.

Being conueied into the nofthrils, it purgeth the head: being put $v$ p with barley meale it brin- $G$ geth downe the floures. Pliny writeth, that the iuyce mixed with wine, and dropped into the eares, is a remedie againft $H$
deafeneffe.

The feed, as Galen faith, driucth forth wormes, taketh away freckles of the face, fun-burning, I and what thing focuer that need to be gently fcoured or clenfed away.

They fay that the broth wherein the herbe hath beene fodden is maruellous good for the fi- $\mathbb{I}$ newes and ioynts, and likewife for Cankers in the eies, claled in Greeke Carcinomata, whieh cannot be healed by any other meanes, if they be warhed therewith.

$t$ The fifteenth and fixecench figures ware fornte ly nanfgoited.

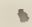

$$
\text { Cнар: 41. Of Rape-Cole. }
$$

- The Defription.

1 Te firt kinde of Rape Cole hath one fingie long root, garnithed with many threddy 1 ftrings : from which rifeth vp a great thicke falke, bigger than a great Cicumber or great 'Turnep: at the top whercof thooterl forth great broad leanes, like vnto thofe of Cabbage Cole. The floures grow at the top on flender ftalkes, compa et of foure fmall yellow floures:which being paft the feed followeth inclofed in litle long cods, like the feed of Muftard.

2 The fecond lath a long fibrous roor like vnto the precedent; the tuberous ftalke is very great and long, thrufting forth in fome fer places here and there, fmall footitalkes; whercupon doe grow fmooth leaues, fleightly indented about the edges:on the top of the long Turnep falke grow leane ftalkes and floures like the former. \# This fecond differs from the former onely in the length of the frolne ftalke, whence they call it Caulorapum longum, or Long Rape Colc. $\neq$

They grow in Italy, Spaine, 9 The Place.

They grow in Italy, Spaine, and fome places of Germanic, from whence I hatue receitied feedes Minories neere London. 
I Cuulorapum rotundum. Round rape Cole.

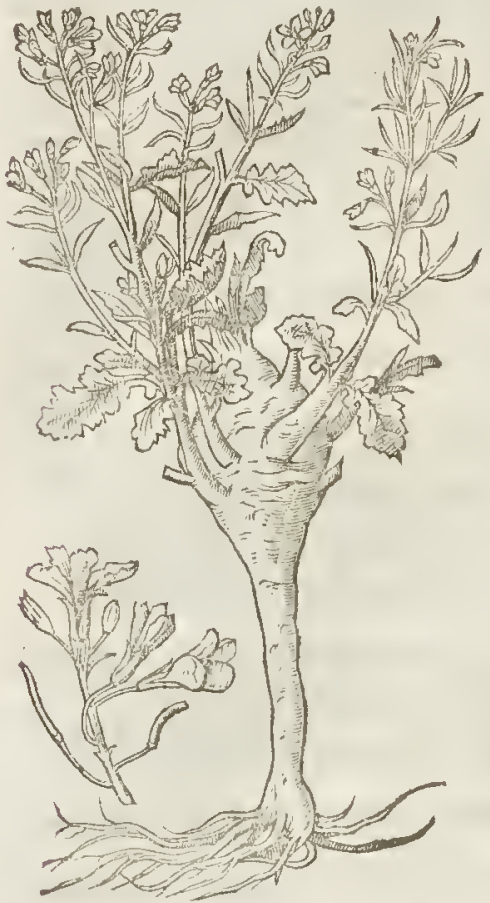

I Betaalba, White Beets.

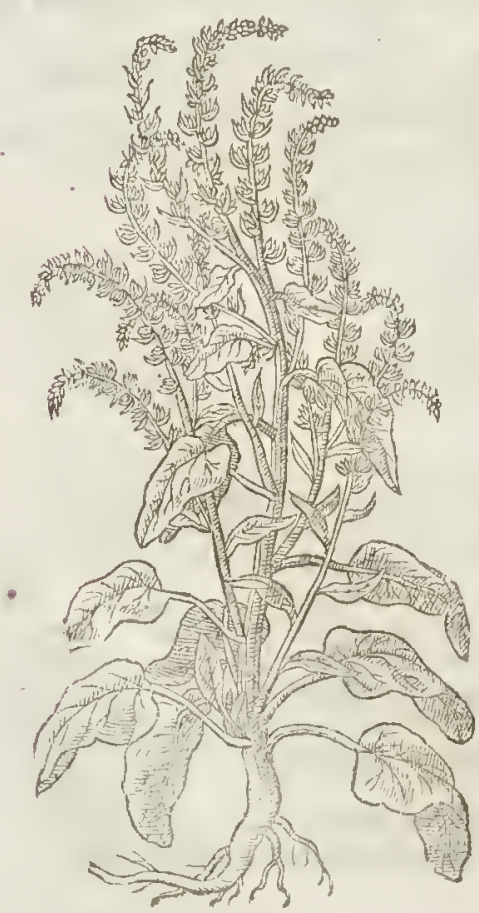

- The Time.

They flomre and flourifh when the other Colewoorts doe, whereof no doubt they are kinds, and mult be earefully fet and fowne, as muske Melons and Cueumbers are.

\section{T. The Names.}

They are ealled in Latine, Caulorapum, and Rapocanls, bearing for their ftalkes, as it were Rapes and Turneps, partieipating of two plants, the Colewort and Turnep; whereof they tooke their names.

T The Temperature and Vertues.

There is nothing fet downe of the faeulties of thefe plants, but are aceounted for daintic meate, eontending with the Cabbage Cole in goodneffe and pleafant tafte.

\section{Cha P. 42. Of Beets. The Defription.}

I $I$ He common white Beet hath great which rife thicke erefted or ehamfered Atalks: the floures grow along the ftalks eluftering to. gether, in thape like litrle ftarres; which being paft, there futeceed round and vneuen prikly feed. The root is thieke, hard, and great.

2 Beta rubra, Red Beets.

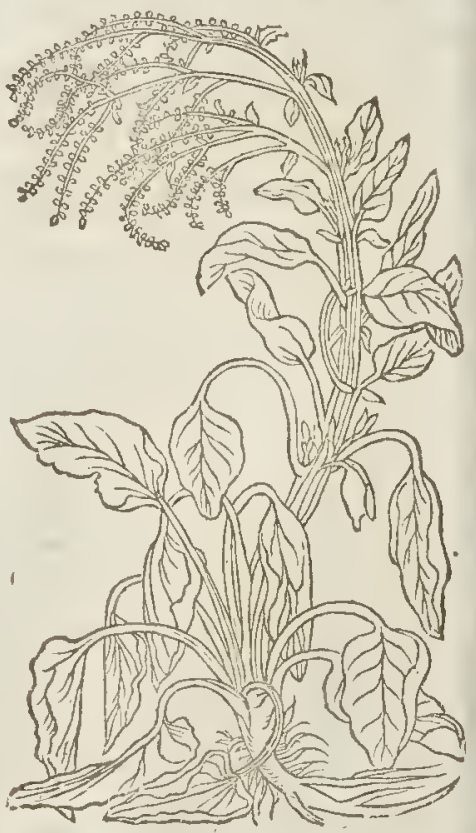




\section{¥ 3 Betarubra Romana.} Red Roman Beet.

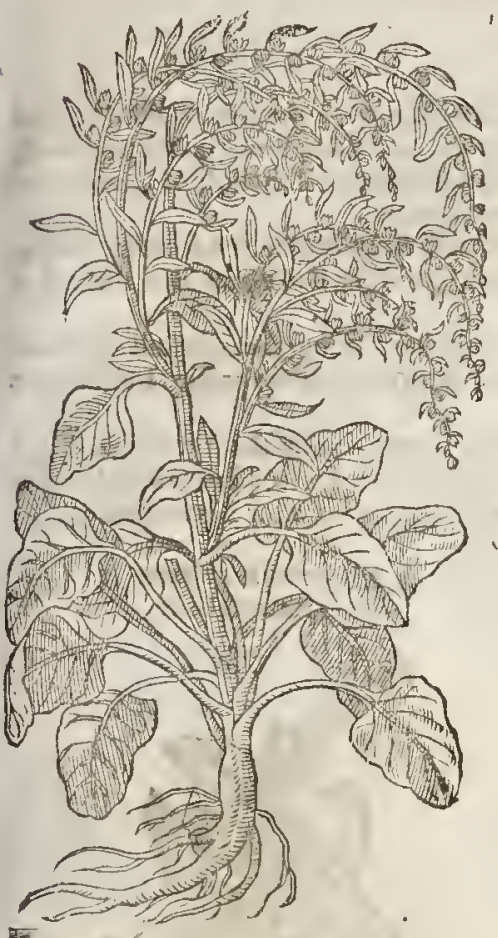

2 There is mother fort like in thape and proportion to the former, faung that the leaves of this be ftreaked with red liere and there confufedly, which ferterls forth the diffetence.

3 Thete is likew ife another fort hereof, that was brought vinto me from beyond the feas, by that coutteous metcliant mafter Lete, before remembred, the which hath leaues very gtear, and ted of colour, as is all the reft of the plant, as well root, as ftalke, and floutes, full of a petfect purple iuyce tending to redneffe: the middle tib of which leaues are for the moft. patt vety broad and thicke, like the middle part of the Cabbage lea fe, which is equall in goodnefle with the leaues of Cabbage being boyled. It grew with me 1596. to the height of viij. cubits.and did bring forth his rough and vaeuen feed very plentifully: with which plant natute doth feeme to play and fpott herfelfe : for the feeds taken from that plant, which was altogether of one colour and fowen, dorh bring forth plants of many and variable colours, as the worthipfull gentleman mafter Yohn Norden canvery well teftifie, vnto whom I gaue fone of the feeds aforefaid, which in his garden bruoght forth many.othet of beautifull colouts.

\section{The Place.}

The Beete is fowen in gatdens: it loucth to grow in a moift and fettile ground. ₹ The otdinary white Beet growes wilde vpon the fea-coaft of Tenet and diuers other places by the Sea, for this is not a different kind as fome would haue it. $\ddagger$

\section{The Time.}

The fittelt time to fow it is in the fpring : it floutimeth and is greene all fornmer long, and likewife in winter, and bringerl forth his feed the next yeare following.

\section{The 2ames.}

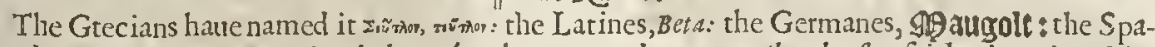
niards, Afelgas : the French, de la Porser, des Iotes, and Bects : Theophraftus faith, that the white Becte is furnamed $\pi \times x+x x^{n}$, that is to fay, sicula, ot of Sicilia : heteof commeth the name Sicla, by which the Barbarians, and fome A pothecaties did call the Beet; the which wotd we in England doevfe, taken for the fame.

$$
\text { 9) The Nature. }
$$

The white Beets ate in moiftute and heate ternperate, but the othet kinds are drie, and all of them abfterfite: fo that the white Beete is a cold and moift pot-herbe,which hath ioyned wirh it a certaine falt and nitrous quality, by teafon wheteof it clenfeth and dtaweth flegme out of the nofthrils.

$$
\text { The Vertues. }
$$

Being eaten when it is boyled, it quickly defcendeth, looferh the belly, and prouoketh to the A ftoole, efpeeially being taken with the broth wherein it is fodden : it nourifheth little or nothing, and is not fowhole? ome as Letruee.

The inyce eonteied vp into the nofthrils doth gently draw fotth flegme, and purgeth the head. $B$

The great and beautifull Beet laft deferibed may be vfed in winter for a fallad hetbe, with $\mathrm{C}$ vineger, oyle, and falt, and is not onely pleafant to the tafte, but alfo delight full tu the eye.

The greater red Beet or Roman Beet,boyled and eaten with oyle,vineger and pepper, is a moft D excellent and delicate fallad: but what mighe be nuade of the red and beautifull root (which is to be preferred before the leaues, as well in beaury as in goodnefie ) I refer vnts the curious and cunning cooke, who no doubt when he hath had the view thereof, and is affured that it is both good and wholefome, will make thereof many and ditets difhes, both faite and good. 


\section{С на . 43. Of Blites.}

$r^{\circ}$... T The Defription.

1 Te great white B lite groweth three or foure foot high, with grayifh or white round ftalkes : the leaures are plaine and fmooth, almoft like to thofe of the white Orach, but not fo foft nor mealy : the floures grow thruft together like thofe of Orach:after that commeth the feed inclofed in little round flat husky skinnes.

2 There is likewife another fort of Blites very fmooth and flexible like the former, fauing that the leaues are reddinh, mixed with a darke greene colour, as is the ftalke and alfo the reft of the plant.

3 There is likewife found a third fort very like vnto the other, fauing that tle falkes, branches, leaues, and the plant is altogether of a greene colour. But this growes vpright, and creepes not at all.

4 There is likew ife another in our gardens very like the former, fauing that the whole Plant trailet hupon the ground : the ftalks,branches, and leanes are reddi $\mathrm{h}$ : the feed is fmall,and clufteting together, greene of colour, and like vnto thofe of Ruellius his Coronopus, or Bucks-hotne,

I Blitum majus album.

The great white Blite.

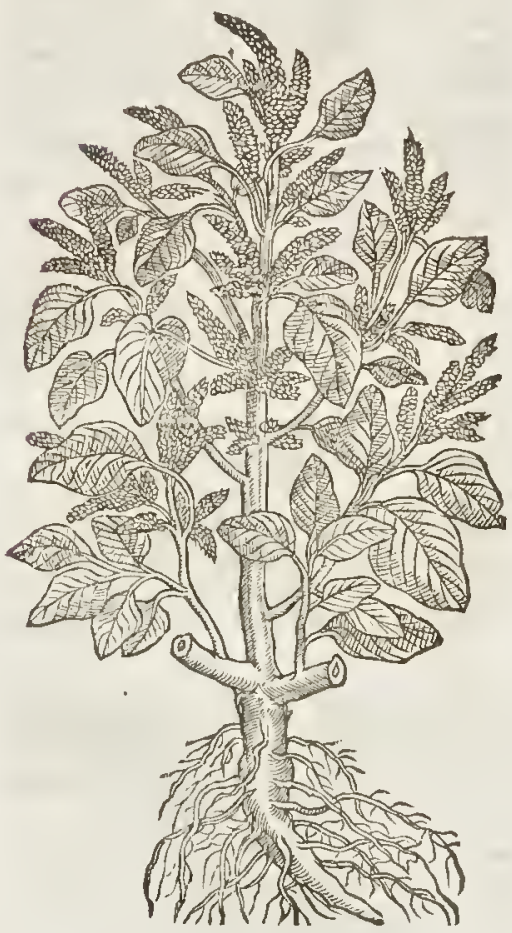

2 Blitum majus rubrsm.

The great ted Blite.

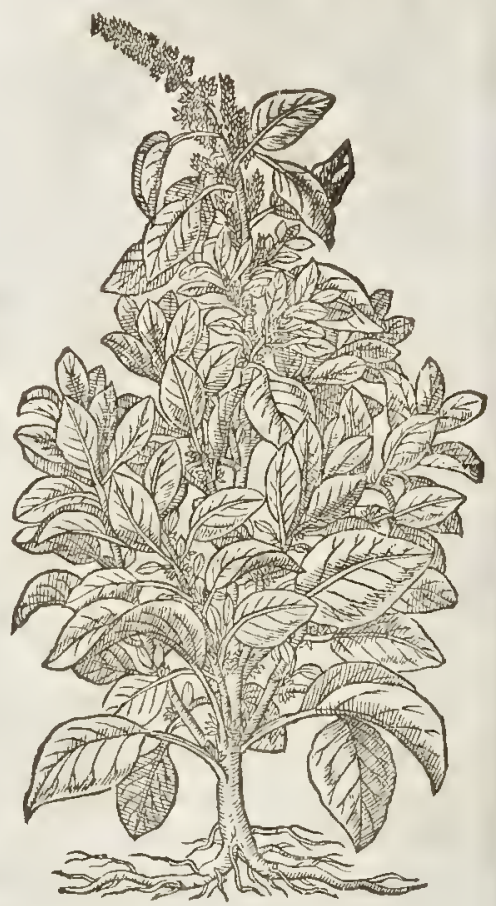

T The Place.

The Blites grow in Gatdens fot the molt patt, although thete be found of them wilde many times.

They flourifh all the Summet long, and grow very gteene in Winter likewife?

$$
\text { T) The Time. }
$$

If The Names.

It is called in Gteeke, Bhraw : in Latine, Blitmm : in Englioh, Blite, and Blites : in French, Blites, or Blitres. 


L1 B. 2. Ot the Hiftoric of Plants. 321

$\$ 3$ Blitum minus album. The fmall white Blite:

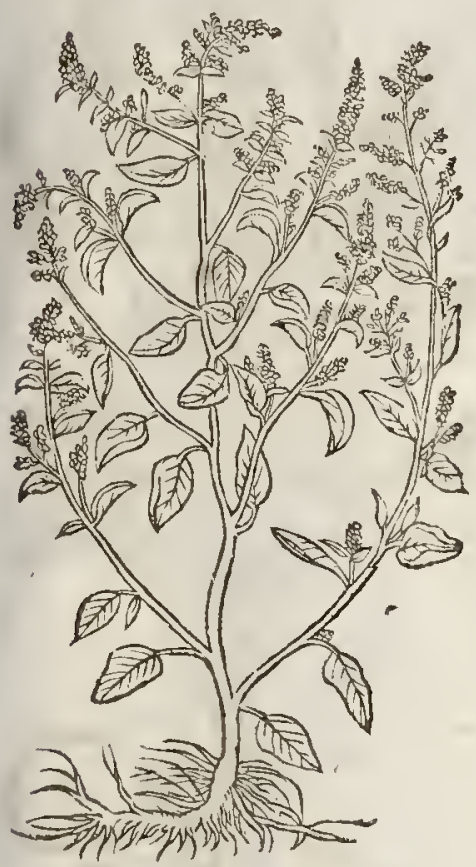

I 4 Bitum miruorubrum.

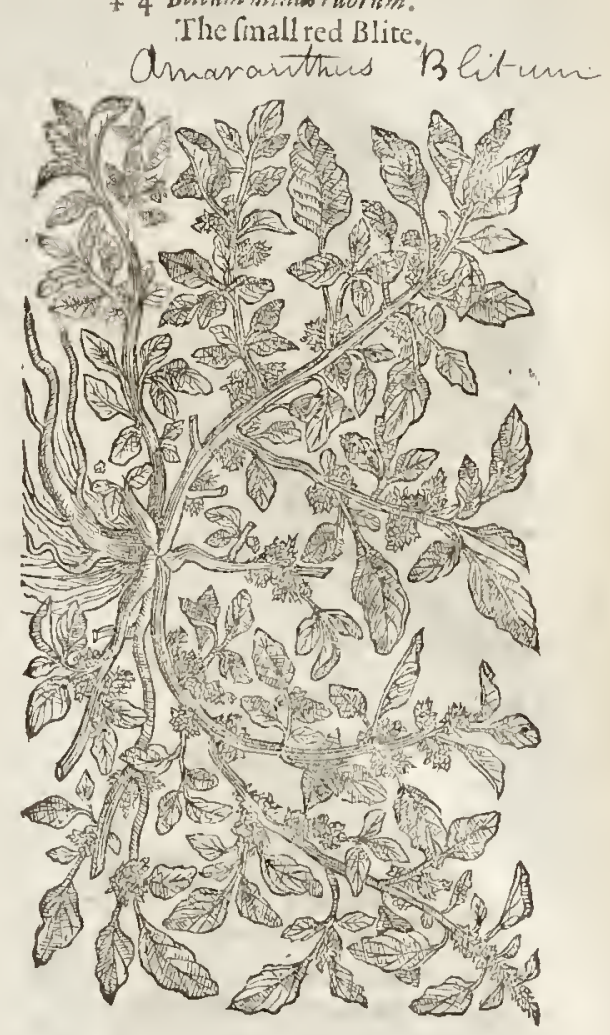
Amaranthis Blitum

The Nature.

The Blite (faith Galen in his fixth booke of the faculties of fimple medicines) is a pot-hearbe which fertueth for meate, being of a cold moift temperature, and that chiefely in the fecond degree. It yeeldeth to the body fmall nourithment, as in his fecond booke of the faculties of nourithments he plainly fhewes; for it is one of the pot-herbes that be vnfauoury orwithout tafte, whole fubftance is waterin.

\section{The Vertues.}

The Blite doth nourish little, and yet is fit to make the belly foluble, though not vehemently; A feeing it hath no nitro:ss or tharpe qualitie whereby the belly fhould be prouoked. I haue heard many old wiues fay to their feruants, Gather no Blites to pat into my pottage, for they are not gond for the eye-fight: whence they had thofe words I know not, it may be of fo ne Do tor that netrer went to fchoole, for that I can finde no fuch thing vpon record, either a mong the old or later Writers.

\section{Си а . 44. Of Floure-Gentle. \\ 9T The Kindes.}

$T$ Here be diuers forts of floure-Gentle, differing in muny points very notably; as in greatnefte and finallneffe; fo ne purple, and others ofa skarlet co our; and one a ove the reft whertwitly Nature hath feemed to delight her felfe, efpecially in the leules, which in variable colours do ftritue witl the Parats feathers for beautic.
$\mathrm{Dd}_{3}$
1 Amutututhes 
I Antranhus purpureus. Purple Floure-Gentle.

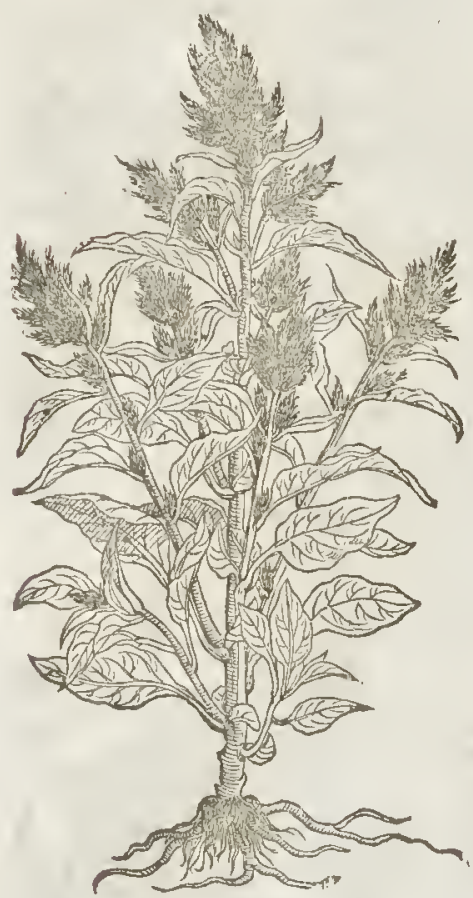

3 Amarambus tricolor. Floramor and Paffeuelours.

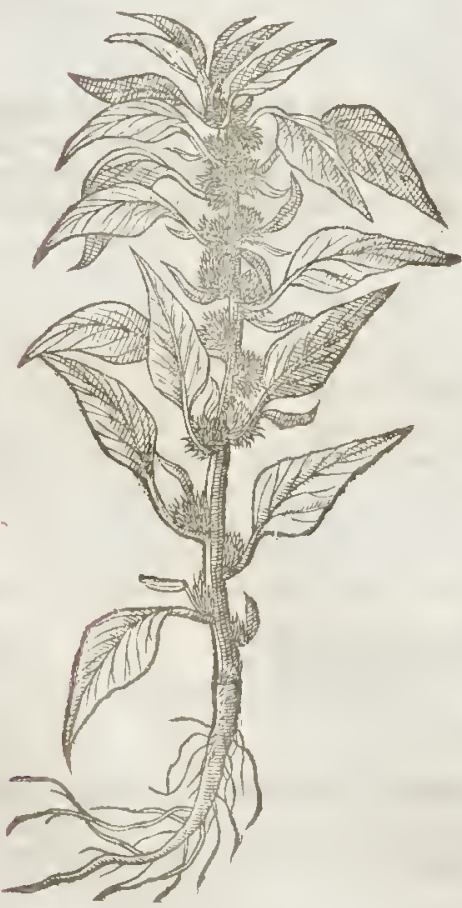

2 Amaranthus coccinens.

Scarlet Flourc-Gentle.

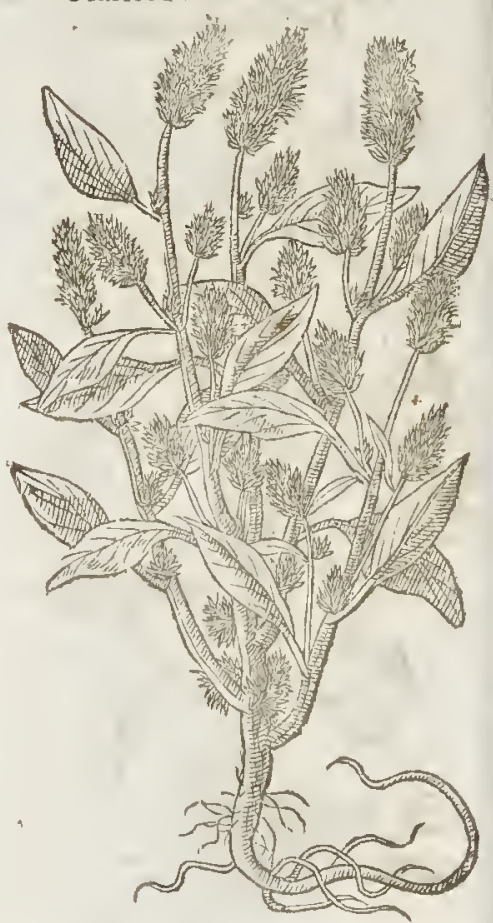

4. Amaranthus Pannicula jparfa。 Branched Floure-Gentle.

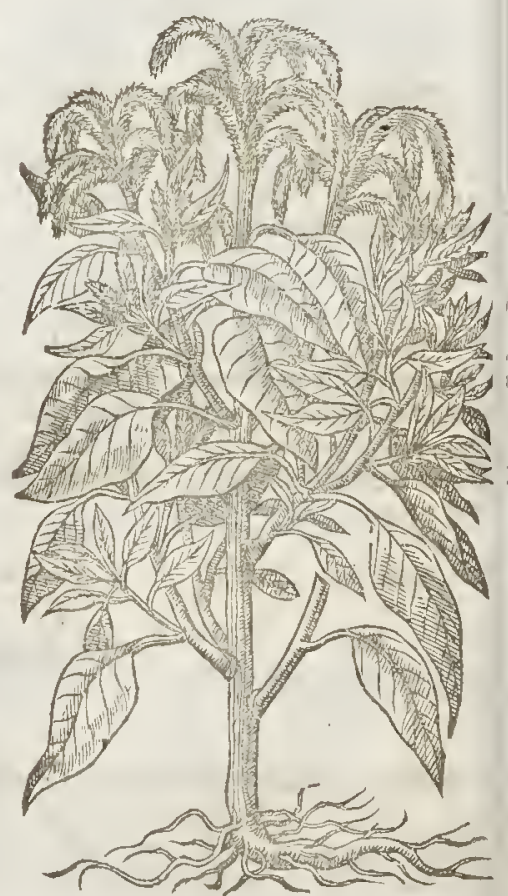

5 Amarasthits 

1 Vtple flottre Gentle tifeth vp with a ftalke a cubit high, and fomet ime ligher, treaked
or chamfered along th the fame, often reddith toward the root, and very fmooth:which ditideth it felfe toward the top into fmall btanches, about which ftand long leaues, btoad, tharpe pointed, foft, lippery, of a greene colour, and fometimes tending to a reddith : in ftead of Houres, come vp eares or frokie tufts, very braue to looke vpon, but without fmell; of a fhining light purple, with a gloffe like veluet, but far paffing it : which when they are bruifed, doe yeeld a iuyce almoft of the fame colour, and being gathered, doe keepe their beauty a long time after; infomuch that being fet in water, it will reuiue againe as at the time of his gatlocring, and it remaineth fo, many yeares, whcreupon likewife it hath taken its name. The feed ftandeth in the ripe eares, of colour blacke, and much glittering : the toot is thort, and full of trings.

\$ Amarantbus pannicula incurua halojerica.

Veluet Floures Gentle.

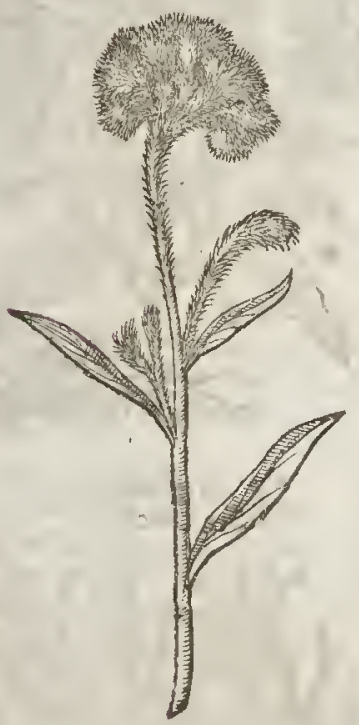

tawnie colour the feed it were little chaffie husks of an ouerworne tuus variegated as leed is blacke, and thining like burnithed horne. $¥$ I haue not feene this part, or that next middle yellow, 4 This plane hatrome greenc. $\neq$

4 This plant hath a great many of threds and Atrings, of which his roots doe confit. From which doe rife vp very thicke fat ftalkes, crefted and ftreaked, exceeding fmooth; and of a thining red colour, which begin at the ground to diuide themfelues into branches; whereupon doe grow many great and large leaues of a darke greene colour tending to tedneffe, in thew like thofe of the red Beet, ftreaked and dalht here and thete with red, mixed with greene. The floures grow number of chafies, from the middeft thereof euen to the top, in thape like $P$ nnicum, that is, a great the thape thereo confuled eares thruft hard together, of a deepe purple colour. I can compare as is the for the veluet head of a Stag,compact of fuch foft matter $\ddagger 5$ This in ftalkes and leaned, in colour white, lound, and bored through the middle. bended round, and laced leates is much like the purple floure Gentle, but the heads are larger, Crimfon with anothet looking very beautifully like tr? dens of veluet:this is feldome to be found with vs; but for the beauties fake is kept in the Gardens of Italy, whereas the women efteemed it not only for the comelineffe and beautious a fpect, 
Of the Hiftorie of Plants.

L I E.2.

I Atriplex fatina alba.

White Orach.

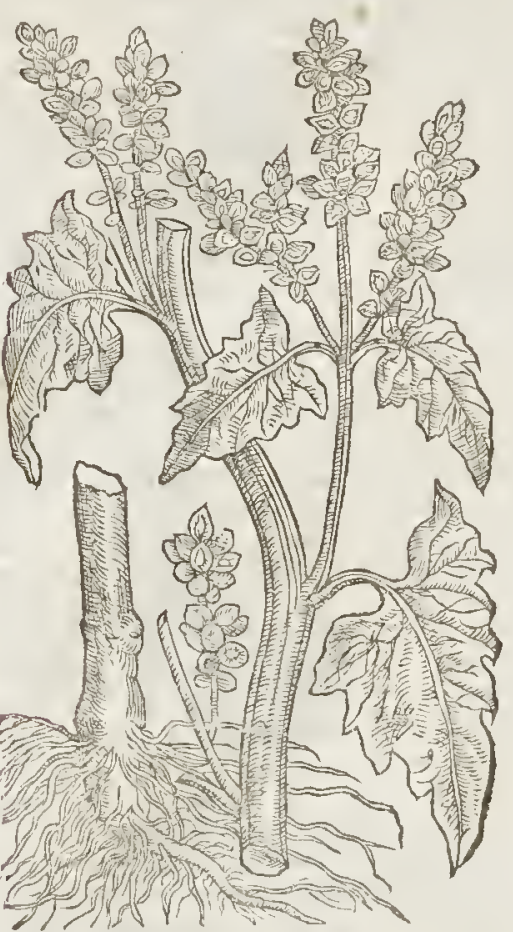

3 Atriplex fyluefrix, fine Polyspermon: Chenopodium Wilde Orach, or All-fecd.

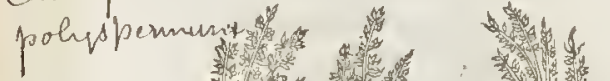

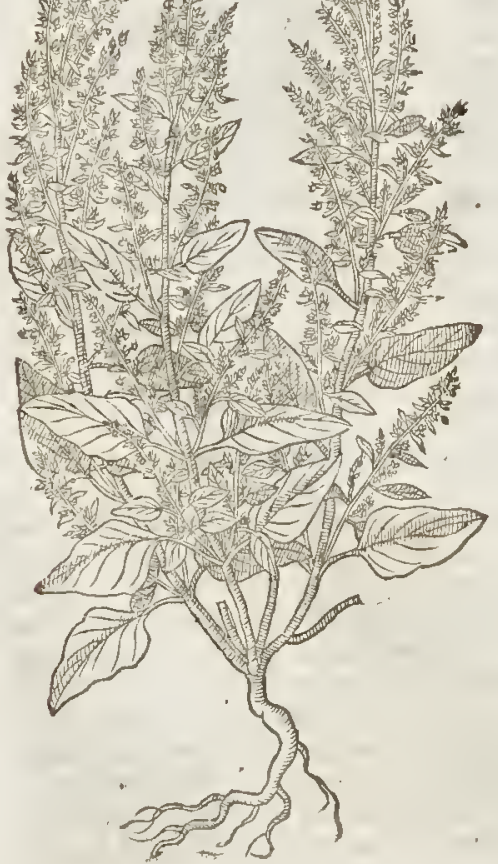

I 2 Atriplex fatiuaporpurea. Purple Orach.

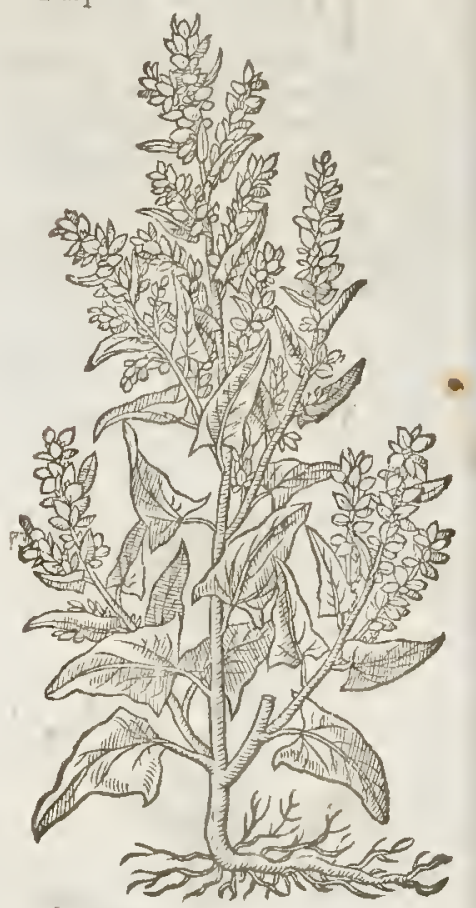

If 4 Ariplexmarina.

Sea Orach.

Uiripex 2acinixta $\rho^{\circ}$

然 1) 5 8 (2) 8 (1) of 4 3.

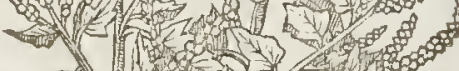

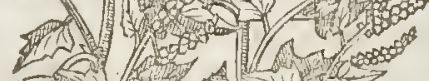

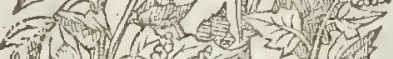
Q.

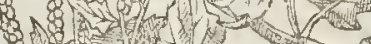

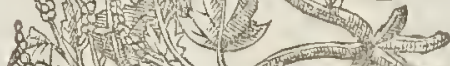

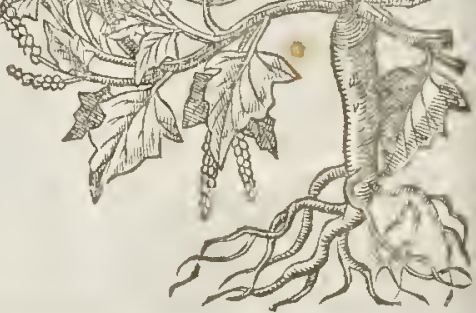


bur alfo for the efficacy thereof againfte bloudy iffues, and finious vlcers of the wonive and kidneyes, as the Authors of the Aduerfaria affirme. $t$

$$
\text { Tा The Place and Time. }
$$

Thefe pleafant floures are fowen in gardens, efpecially for their great beauty. They floure in Augurt, and continue flourinhing rill rhe froft ouertake rhem, at what rime rhey
perifh. But the Floramor would be fowne in a bed of hor horfe-dung, with fome carth ftrewed
thereon in the end of March, and ordered as we doe muske Melons, and the lite thereon in the end of March, and ordered as we doe muske Melons, and the like.

This plant is called in Greeke Augenore, becau

$$
\text { Tा The Names. }
$$
ranthes purpureus : in Duch, Samatbluomen: in Italian, wither and wax old : in Larin, Ampin Englin, floure Gentie, purple Veluet floure, Floramor; and of fome floure Velure, Pafe velours r

$$
\begin{aligned}
& \text { II The Temperature, and Vertucs. } \\
& \text { The floure Velure. }
\end{aligned}
$$

Moft attribute to floure Gentle a bindingfaculty, with a cold and dry remperature.

It is reported they ftop all kinds of bleeding; which is not manifent by any apparantquality in them, except peraduenture by the colouronly that the red eares hate: For fome are of opinion, fanguis Draconis, terra Sigillata, and fuch like of thed colour doecufe fone things, as Bole armoniacke, de fimp. facult. plainly theweth, that rhere can of red colour doe fop blond: But Galen, lib. 2. \& 4 . the vertues of fimple and compound medicines: wherefore they are from the colours, touching floure Gentle to ftanch bleeding, to ttop the laske : werefore they are ill perfuaded, that thinke the they' bad no other reafon to induce them thereto.

\section{A}


\$ 5 Atriplex fylueftris vulgaris. Commonwilde Orach.

ctribex bajuca

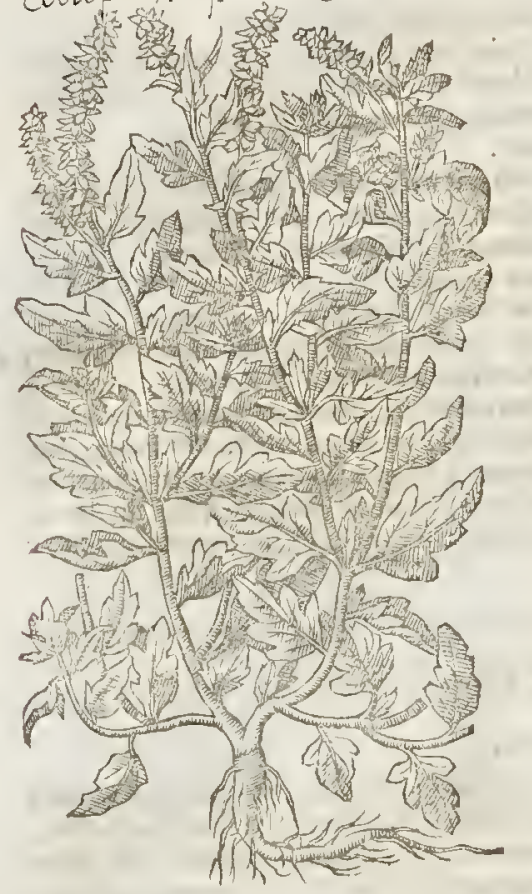

7 Atriplex fylueftris anguftifolia: Narrow leaued wilde Orach. Cltivex angustivax

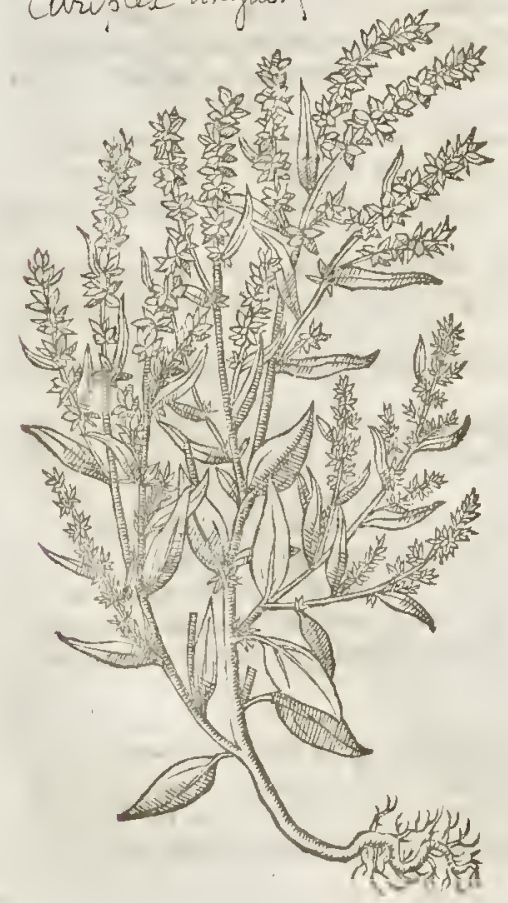

\$ 6 Ariplexfylueftris altera.

Theotherwilde Orach.
Chenopodiuntu, aleum. Nar.

$$
\text { (1) }
$$

\# 8 Atriplex baccifera.

Berry-bearing Orach;

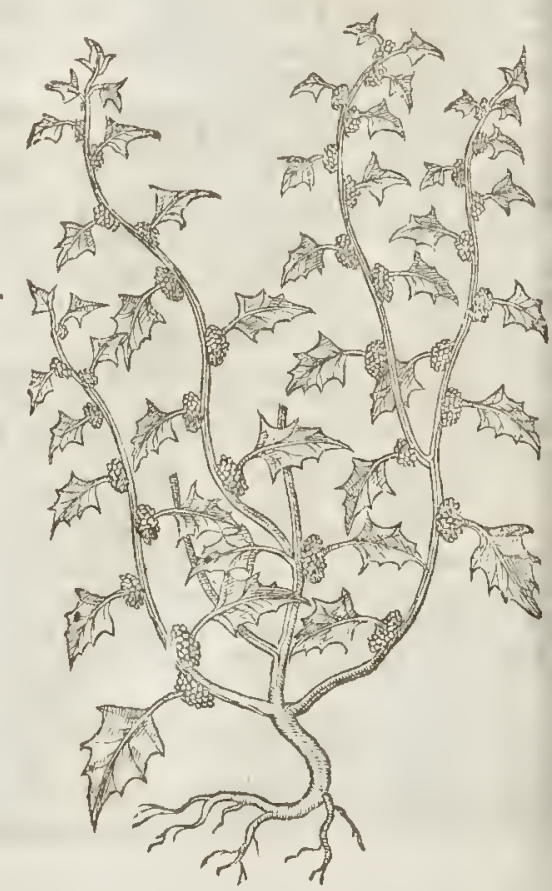


They flotre and feed from Iune to the end of Augurt.

Garden Orach is called in Greeke, It The Narnes.

Hold : in French, Arrouches ou bonnes dames: in Englin, Atriplex, and Aurcum Olus: in Dutch, Iith, Orach, and Orage : in the Bohemian they differed one from anorher; for of Atriplex berwsene Atriplex and chryfolachisum, as though achanum in his twenty eighth booke, and eigh he writeth in his twentieth booke; and of Chryjo.

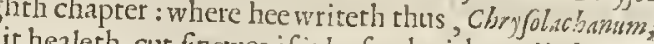

.

3 This wilde Orach hath beene called of Lobel, Poly/permon Caffani Bafsi, or All feed.

If The Temperatrre.

TI The Vertues.

Diofcorides writeth, That the garden Orach is borh moift and cold, and that it is eaten boyled A as other fallad herbes are, and that it foftnerh and looferh the belly.

It confumeth away the fwellings of the throat, whether it be laid on raw or fodden.

The feed being drunke with meade or honied, water, is a remedid an raw or fodden. liver.

Gelen thinkerh, that for thatcaufe itharh a conf

\section{C н н. 46. Of Stinking Orach.}

Atriplex olida.

Stinking Orach.

Chenopodicem olidum

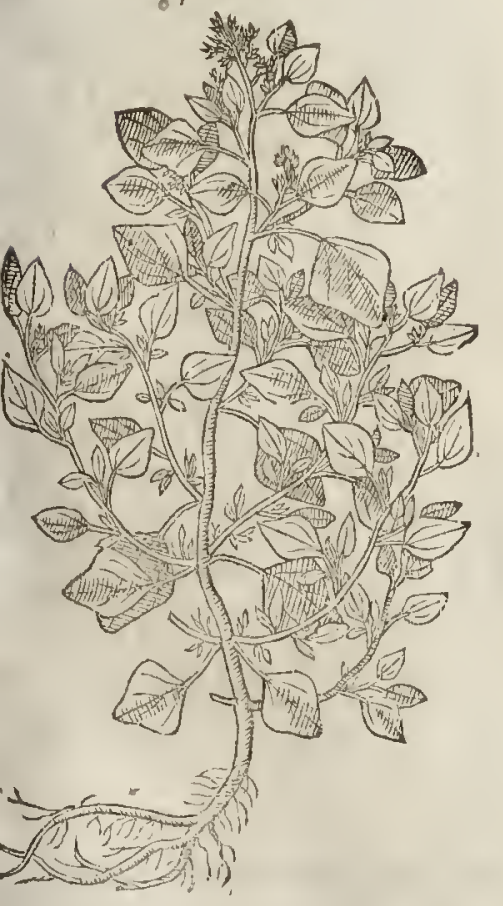

\section{The Defcription.}

Tinking Orach growes flat wpon the ground and is a bafe and low plant with niany weak and feeble branches, whereupon doe grow fmall leaues of a grayinh colour, fprinkled ouer with a certaine kinde of dufty mealineffe, in Thape like the leaues of Bafill: amongft which lealles here and there confufedly be the feeds difperfed, as it werc nothing but duft or afhes. The whole plant is of a moit loarhfome fautour or fmel; vpon which plant if any fhonld chance to reft and fleepe, he might very well report to his friends, that he had repored him felfe among the chiefe of Scoggins heires.

$$
\text { If The Place. }
$$

It groweth vpon dunghills, and in the moft filthy placcs that may be found, as alfo about the common piffing places of great princes and Noblemens houfes. Sometime it is found in places neere bricke-kilns and old walls, which dorh fomewhat alter his fmel!, which is like tofed cleefe: but that which groweth in his naturall place fmells like ftink ing falt-fifh, whereof it tooke his name Garofrnus.

$$
\text { T The Time. }
$$

It is an herbe for a yeare, which fpringeth vp, and when the feed is ripe it perifheth, and recouereth it felfe againe of his owne feed; fo that if it be gotten into a ground, it caunot be deftroyed.

Stinking Orach is called of Cordus, Garofmus, $N_{\text {ames }}$. called 


\section{Of the Hiftory of Plants.}

called Tragium Germanicum, and Atriplex fortidazarum olens, by $P_{c n a}$ and Lobel: for it fmellech more ftinking than the rammith male Goat : whercupon fome by a figure haue called it Vulvaria : and it may be called in Englith, ftinking Mother-wort.

The Nature and rertues.

A There hath been little or nothing fet down by the Antients, either of his nature or vertues, notwithtanding it hath beene thought profitable, by reafon of his ftinking fmell, for fuch as are troubled with the mother: for as Hyppocrates faith, when the mother doth fifle or ftrangle, fuch things are to be applied vnto the nofe as haue ranke and ftinking fmell.

\section{С на 4 47. Of Goofe-foot. \\ Tा The Defcription.}

I: Cole-foot is a common herbe, and thought to be a kinde of Orach : it rifeth vp with I a ftalke a cubit high or higher, fomewhat chamfered and branched : the leaues be broad, fmooth, fharpe pointed, fhining, hauing certaine decpe cuts about the edges; and fefembling the foot of a goofe: the floures be fmall,fomething red : the feed fandeth in clufters vpon the top of the branches, being very like the feed of wilde Orach, and the root is diuided into fundry ftrings.

$\mp 2$ This differs from the laft defcribed, in that the leaues are fharper cut, and more diuided, the feed fomewhat fmaller, and the colour of the whole plant is a deeper or darker greene.

I Atriplex fylueftris latifolia, fuec Pes Anforinus. Goofe-foot.

Chersopodium rubum

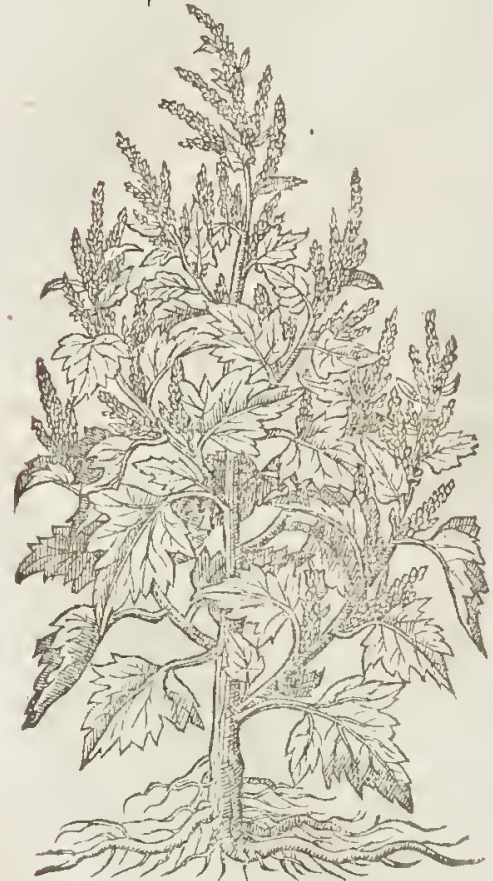

$\neq 2$ Arriplex fyluefris latifolia altirs. The other Goofe-foot.

Chenopodium inurale

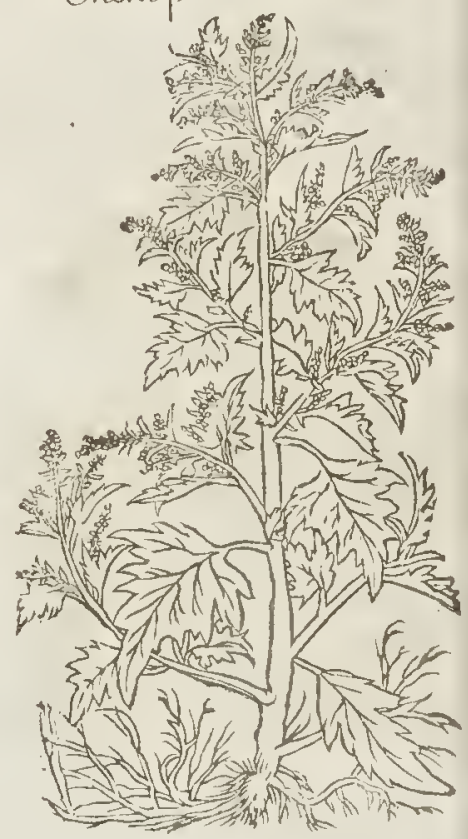

\$ The Place.

It growes plentifully in obfcure places neere old walls and high-waies, and in defart places, qT The Time.

It flourisheth when the Orach doth, whereof this is a wilde kinde.

The Names.

The later Herbarifs hate called it Pes anferinus, and Chesopodium, of the likenefie the leares hate with the foot of a Goofe: in Englin, Goofe-foot,and wilde Orach. 


\section{Tा The Temperature.}

This hetbe is cold and moift,and, that no leffer than Orach, but as it appeareth more cold.

$$
\text { Tा The Vertues. }
$$
It is teported that it killeth fwine if they do eate thereof : it is not vfed in Phyficke : and much
leffe as a fallade hetbe.

\section{С на р.48. Of Englifh Mercurie.}

Bonus Henricus.

-Englih Mercuric ot good Hentie.

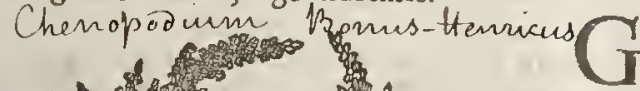

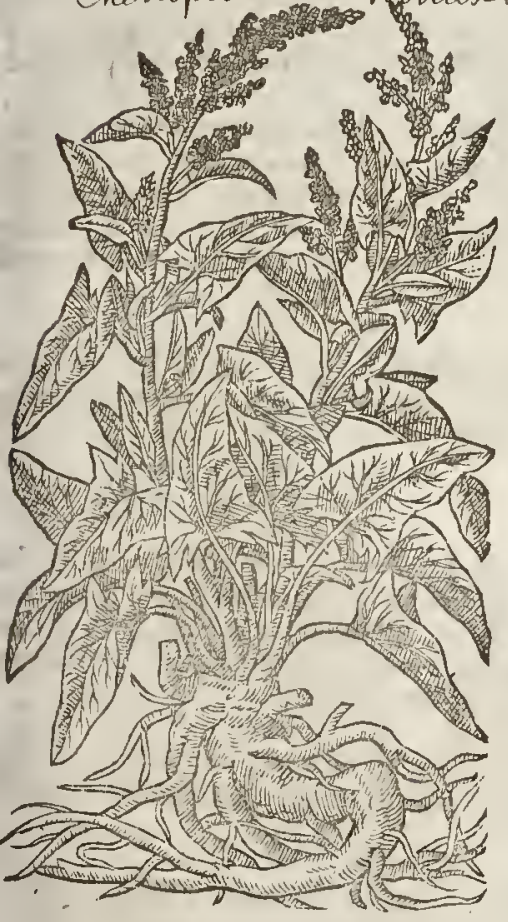

Tा The Defcription:'

Yood Henrie called Totabona, fo named

of the later Herbarifts, is accounted of them to be one of the Dockes, but not ptoperly. This bringeth forrh very many thicke ftalkes, fet wirh leates two foot high. on the branches wherof towards the top ftand greene floures in clufters, thicke thruft together. The feed is flat like rhat of the Orach, whereof this is a kinde. The leaues be faftenod rolong foote-ftalkes, broad behinde, and fharpe pointed, farhioned like the leaues of Aron, or Wake-robin, white, or grayin of colour, and as it were coucred onerwith a fine meale: in handling it is fat and olious, with a very thicke root, and parted into many diuifions, of a yellow colour within, like the Tharpe pointed Docke.

$$
\text { The Place, ' . ' }
$$

It is commonly found in vntilled places, and among rubbith neere common waies, old walls, and by hedges in fields.

$$
\text { T) The Time. }
$$

It floureth in Itine and Inly efpecially:

$$
\text { Tा The Names. }
$$

It is called of fome Pes $A n$ ferinus, and $T$ ota the Germanes in Englih,All-Good, and Good Hentie : in Cambridg thire it is called Goodking Harry: certaine pernicious buter heimritt, of a certaine good qualitie it hath, as they alfo name a but vnproperly, for that it hath no participation or Henry. It is taken for a kinde of Mercurie, yee will call euery herbe Mercurrie participation with Mercuric, either in forme or quality, except (the belly.

\section{T The Temperature.}

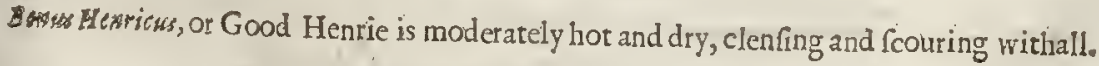

$$
\text { TI The Vertues. }
$$

The leaues boiled with other pot-herbes and eaten, maketh the body foluble.
The famebrufed and laid vpon greene wounds, or foule and old vlcers, doth fcoure, mundific nd heale them. 


\section{C н. Р. 49. Of Spinach.}

spinacia.

Spinach.

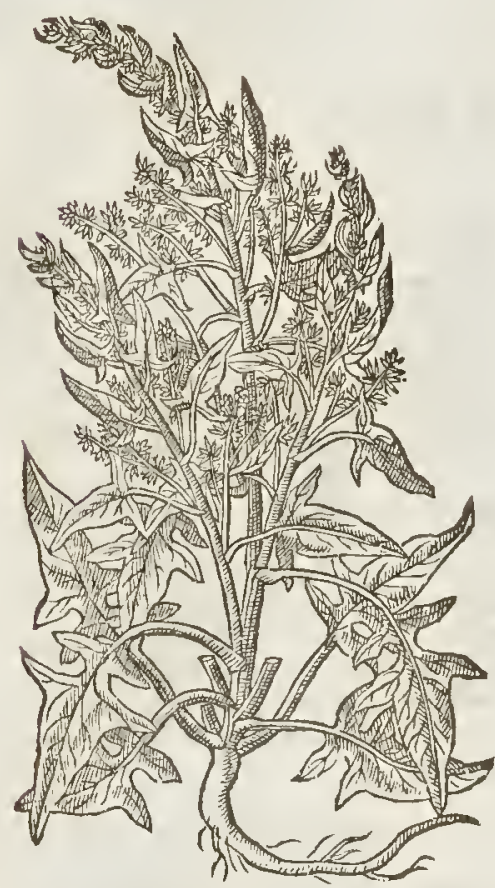

\section{The nefcription.}

1 Cinach is a kinde of Blite, after fome; $\checkmark$ notw ithftanding I rather take it for a kinde of Oraeh. It btingeth forth foft and tender leaues of a darke greene colour, full of juice, tharpe pointed, and in the largent part or nearber end fquare; parted oftertimes with a dcepegath oneither fide next to the ftemme or foot-ftalke: the ftalke is round, a foot high, lollow within: on the tops of the branches ftand litt) Houres in elufters, in whofe places doth grow a prickly feed. The root confifteth of many fmall threds.

2 There is another fort found in our gardens like vnto the former in goodneffe, as alfo in thape, fauing that the leates are not fo great, nor fo deepely gafht or indented : and the feed hath no prickles at all, for which caufe it is called round Spinach.

$$
\text { _. The Place. }
$$

It is fowne in gardens without any gteat labor or industrie, and forfaketh not any ground being but indifferent fertill.

\section{The Time.}

It may be fowne almoft at ary time of the ycere, but being fowne in the fpring it quickly groweth vp, and commeth to perfection within two moneths : but that which is fowne in the fall of the leafe groweth not fo foone to perfection, yet continueth all the win terand feedeth prefently vpon the firft fpring.

Tा The Names.

It is ealled in thefe daics Spinachia: of fome, Spinacheum olus : of others, Hipanitum olus : Fuchfius nameth it zmroxia: the Arabians and Serapio call it Hifpane : the Germanes, Spinct: in Ergilith, Spinage and Spinach: in Freneh, Epinus.

The Nature.

Spinal is enidently eold and moift almoft in the fecond degree, but rather moift. It is one of the pot-herbes whofe fubftance is wateric, and almoft without tafte, and therefore quickly defeendeth and loofetl the bellie.

$$
\text { The Veriwes. }
$$

It is catentoiled, but it yecldeth little or no nourifhment at all : it is fomething windie, and eafily eaufeth a defire to romit : it is ved in fallades when it is young and tender.

This herbe of all other yot-herbes and fallade herbes maketh the greatef diuctitie of meates and fallades.

\section{C на Р.50. - Of Pellitorie of the rasll.

$$
\text { If The Defcription. }
$$

DEllitorie of the wall hath round tender ftalkes fomcwhat brow re or reddifh of colour ane 1. tomer hat thining : rhe leaues be rough like to the leates of Mereurie, nothing fnipt about the edges. The foures be fmall, growing elofe to the ftemmes:the feed is blacke and ver fmall, coucred wirh a rough tuske which hangeth faft rfon garments: the rot is fomewha reddifh. 


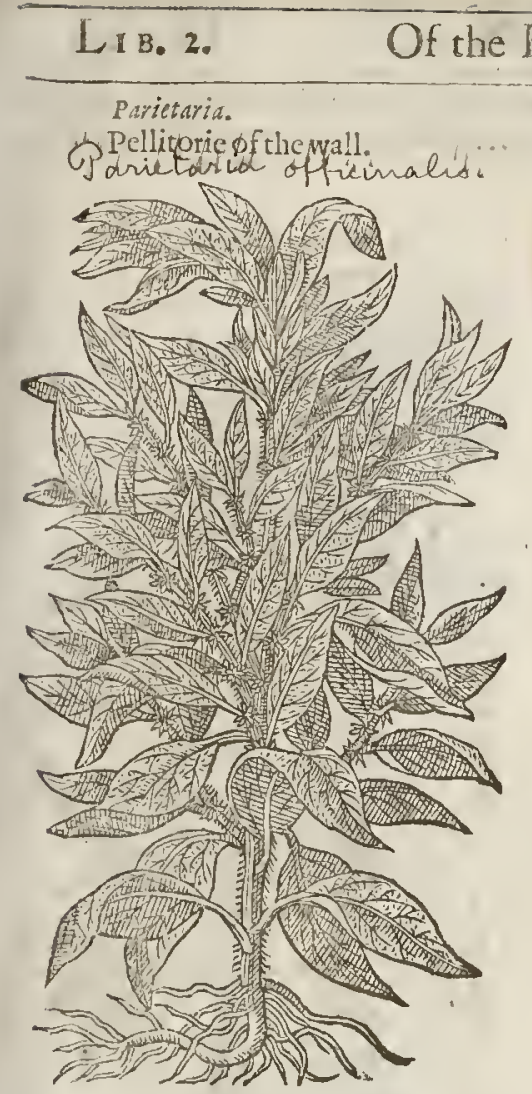

Tit The place.

It groweth neere to old walls in the moift corners of Churches and ftone buildings, among rubbith and fuch like places.

$$
\text { פा Tlue Time. }
$$

It commeth vp in May : it feedeth in Iuly and Augut : the root onely continucel and is to be found in Winter.

\section{बा The Names.}

It is commonly called Parictaria, or by a corrupt word Partaria, becaufe it groweth neere to wa'ls: and for the fame caufe it is named of diuers $M$ utu Lis: alfo cMuralium of pliny and Celfus: of the Gre-

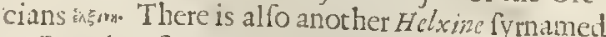
Ciffumpelos : fome call it Perdicium, of Partridges which fomtimes feed hereon: fome, Vrceolsyis, and Fitraria, becaufe it ferueth to fcoure ylaffes, pipkins, and fuch like: it is called in high-Dutcb, Tag von nacht: in Spanioh, Yera del muro: in Englith, Pellitoric of the wall: in French, Parietaire.

\section{The Temperature.}

Pellitorie of the wall (as Galen faith) hath force ro fcoure, and is fomething cold and moift.

$$
\text { Iा The Fertues. }
$$

Pellitory of the wall boyled, and the decostion of it drunken, helpeth fuch as are vexed with an old cough, the grauell and fone, and is good againft the difficultic of making water, and ftopping of the fame, not onely invardly, but alfo outwardly applied vpon the region of the bladder, in manner of a fomentation or warme bathing, with fpunges or double clouts, or fuch like.

Diofcorides faith, That the iuyce tempered with Cetufe or white leade maketh a good ointment againtt Saint Anthonies fire and the Shingles : and mixed with the Cerot of Alcanna,or with the male Goats tallow, it helpeth the gout in the feet: which Pliny alfo affirmeth, Iib.2 2.cap.I 7 . It is applied (faith he) to paines of thefeet wirh Goats fuet and wax of Cyprus; where in ftead
of wax of Cyprus there mutt be put the Cerot of Alcanna.

Diofcorides addeth, That the inyce hereof is a remedy for old coughs, and taketh away hot fwellings of the almonds in the throat, if it be ved in a gargarifine, or othervife applied: it mitigateth alfo the paines of the eares, being poured in with oile of Rofes mixed therewith.

It is affirmed, That if three-ounces of the iuyce be drunke it prouoketh vrine out of hand.

The leaues tempered with oyle of fweet almonds in manner of a pulteffe, and laid to the pained parts, is a remedic for them that be troubled with the ftone, and that can hardly make watcr.

\section{Cir A P. 51. Of French OMercurie.}

$$
\text { I The Kindes. }
$$

Here be two lindes of Mercury reckoned for gond, and yet both fomtimes wilde; befides two wilde neuer found in gardens, vnleffe they be brought thither.

\section{The Defcription.} I THe male garden Mercuric hath tender ftalks full of ioints and branches, whereupon do which come forth two hairy bullets round, and ioyned together like thofe of Goofegrafe or Cleuers, each containing in it felfe one fmall round feed : the root is tender, and full of White hairy ftrings.

2 The female is like vnto the former in leanes, ftalks, and manner of growing differing bir in 
the floures and feed : for this kinde hath a greater quantitie of floures and feed growing together like little clufters of grapes, of a yellowin colour. The feed for the moft part is loft before it can be gathered.

I Mercurialis mas.

Male Mercurie.

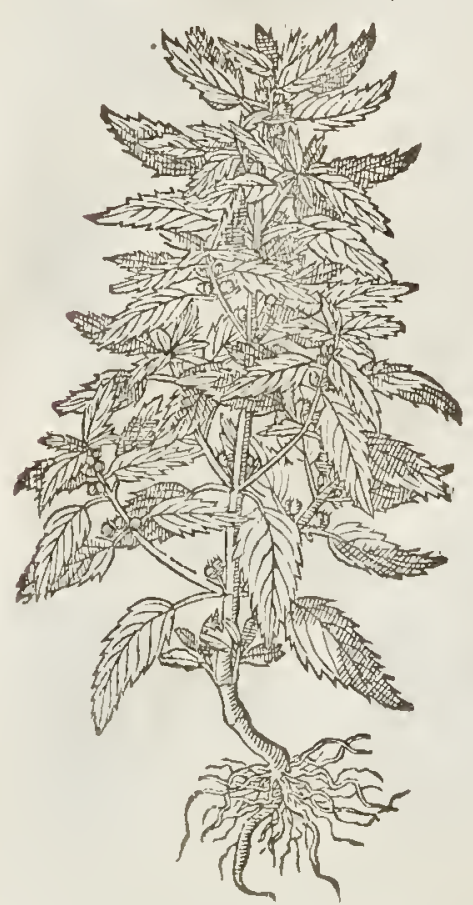

Mercurialis fawina. Female Mercurie.
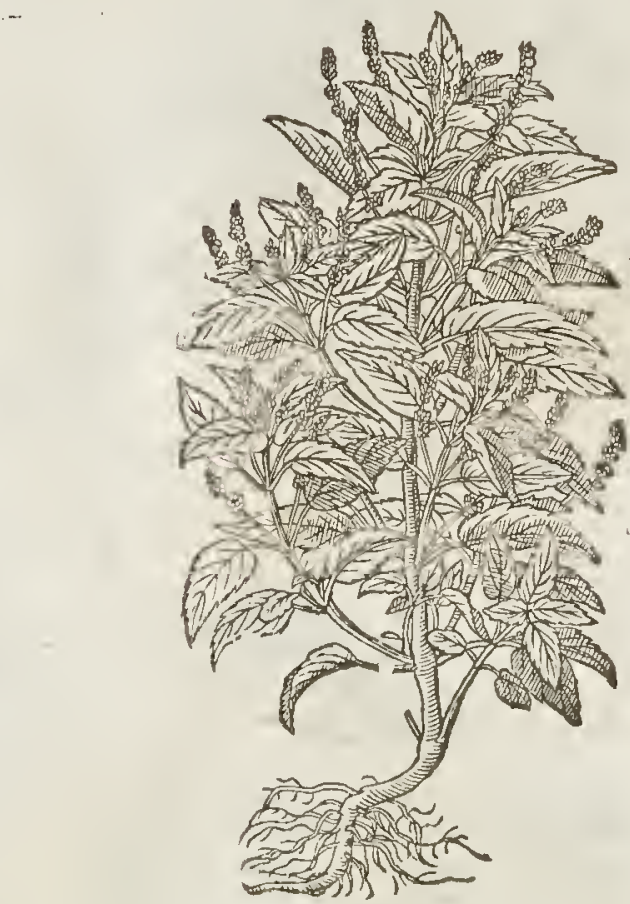

T The Plase.

French Mercurie is fowen in Kitchen gardens among por-herbes; in Vineyards, and in moift Shadow ie places: I found it vnder the dropping of the Bifhops houfe at Rochefter; from whence I brouglut a plant or two into my garden, fince which time I cannot rid my garden from it.

They floure and flourin all the Sommer long.

$$
\text { ब The Time. }
$$

\section{The Names.}

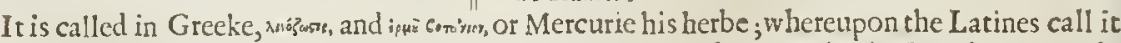
Mercurialis : it is called in Italian, Mercorella : in Englih, French Mercuric : in French, Mercurale, vigrable, and Foirelle, quin Flundim laxamue alvum reddit, Gallobelga enim foize ef foizeus, ventr is Fluorem vocant.

\section{-1 The Temperature.}

Mercury is hot and dry, yet not aboue the fecond degree: it hath a cleanfing facultie, and (as Galen writerh) a digefting qualitie alfo.

\section{The Vertues.}

A It is vfed in our age in clifters, and thought very good to clenfe and fcoure away the excrements and other filth contained in the guts.It ferueth to purge the belly, being eaten or otherwife taken, voiding out of the belly not only the excrements, but alfo phlegme and choler. Diofcorides reporteth, that the decoetion hereof purgeth waterifh humors.

B The leanes ftamped with butter, and applied to the fundament, prouoketh to the ftoole; and the herbe bruifed and made vp in manner of a peffary, cleanfeth the mother, and helpetls conception.

C. Coffeus in his booke of the nature of plants faith, that the inyce of Mercurie, Hollihocks, \& purflane mixed together, and the liands bathed therein,defendeth them from burning, if they be thruft inco boyling leade. 


\section{LI в: 2. Of the Hiftory of Plants:}

\section{Cha P. 52. Of Wilde Mercurie.}

* I Cynocrambe.

Dogs Mercury:

Mencariales perennis.

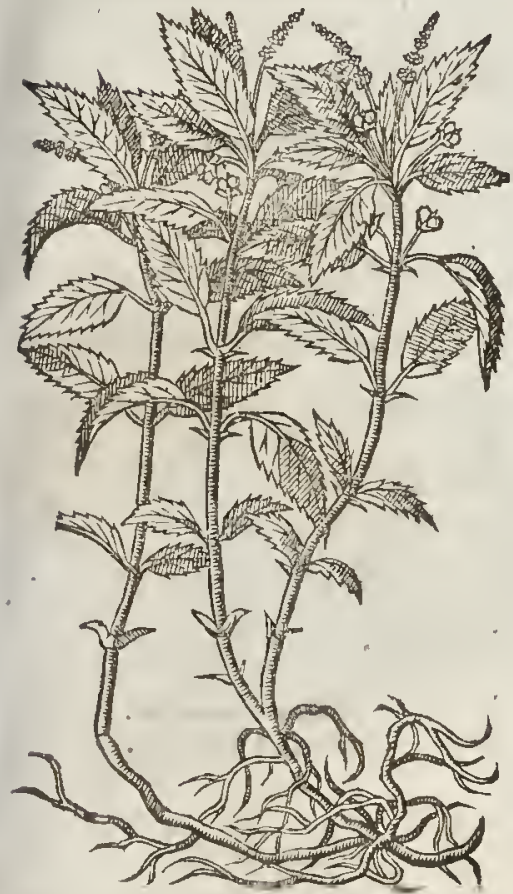

3 Phyllon Thelygonon, fine Farminificum.

- Childrens Mercurie, the female.

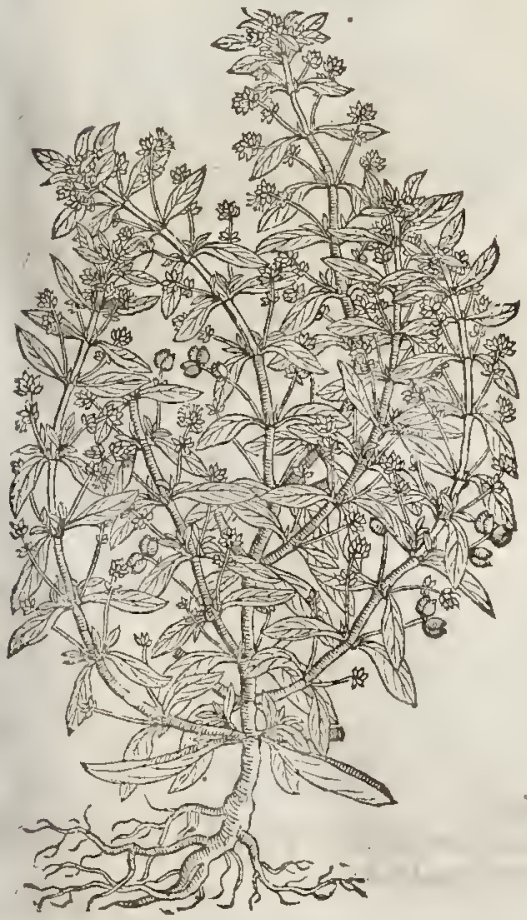

I 2 Phyllon arrhenogonon, fise marifickm, Male childrens Mercury.

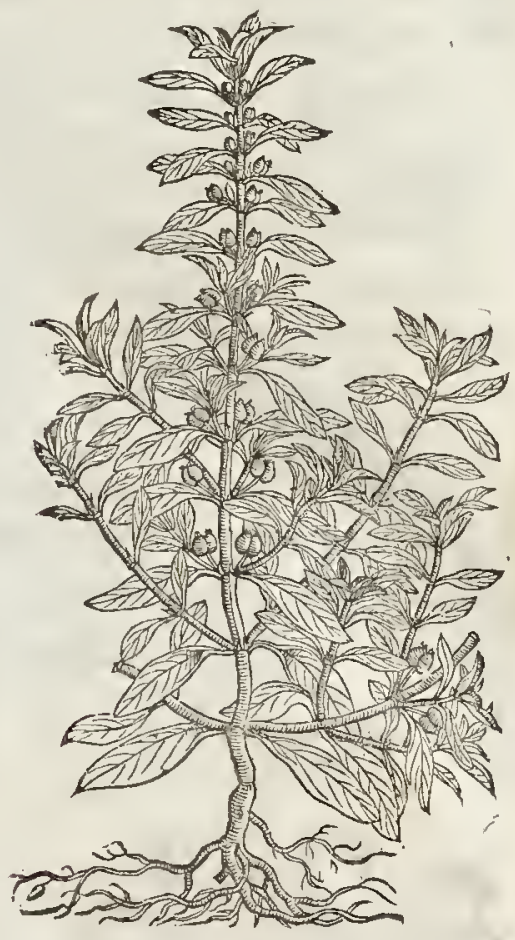

T) The Defription:

1 Ogs Mercurie is fomewhat like vnto the garden Mercury, fauing the leaues hereof are greater, and the fralke not fo tender, and yet very brittle; growing to the height of a cubit, without any branches at all, with fmal yellow floures. The feed is like the female Mercurie. $\neq I t$ is alfo found like the male Mercurie, as you fee them both expreft in the figure, and fo there is both male 8 r female of this Mercury alfo $\neq$

2 Male childrens Mercury hath three or foure ftalkes, or moe : the leaues be fomwhat long, not much vnlike the leaues of the olitue tree, conered onser w ith a foft downe or wooll gray of colour; and the feed alfo like thofe of Spurge, growing two toget her, being firf of an an-colour,butäfter turne to a blew.

$\neq 3$ This is much in thape like to the laft defcribed, but the ftalkes are weaker; and haue more leaues vpon them; the foures alfo are fmall and moffy, and they grow vpon long ftalks, whereas the feeds of the other are faftned to very thortones : the feed is contained in round little heads, benig fometimes two, otherwhiles three or more in a cluffer, $\neq-$ 
The defcription.

I 7 He great Tornefole hath great ftraight ftalks coured with a white hairy cotton, efpecially about the top; the leaues are foft and hairy in handling, in thape like the leaules of Bafill : the floures grow at the top of the branches, in colour white, thicke together in rowes vpon one fide of the ftalke, which ftalke doth bend or turne backward like the taile of a fcorpion: the root is fmall and hard.

2 The fmall Tornefole hath many little and weake branches trailing vpon the ground, whereupon doe grow fmall leaues, like thofe of the leffer Bafill. The floures doe grow without any certaine order, among ft the leaues and tender branches, gray of colour, with a little fpot of yellow in the middent, the which turne into crooked tailes like thofe of the precedent, but not altogether fo much.

\section{† 3 Heliotropium fupinsm Cluf ÿ fo L'obelij. Hairie Tornefole.}

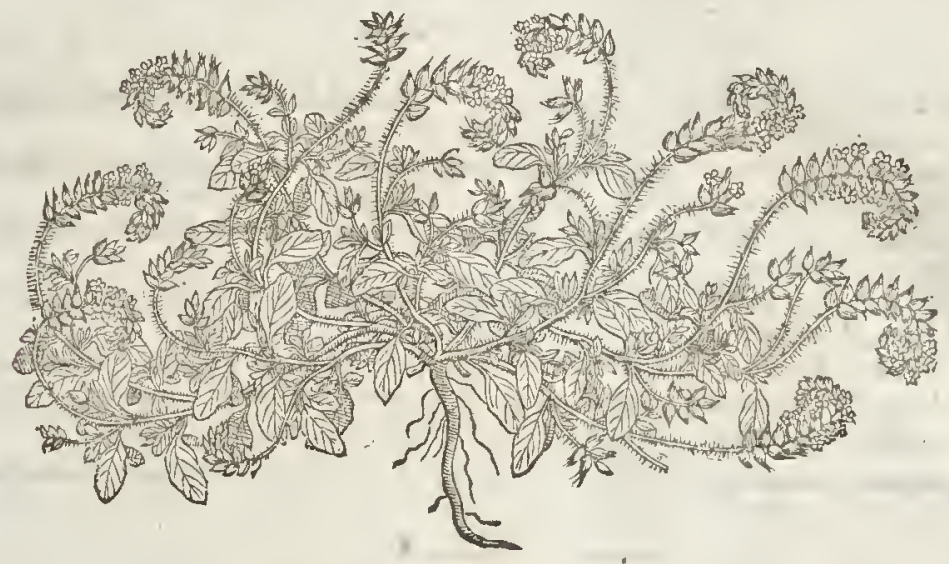

\section{Heliotropiun Tricoccum?}

Widowvaile Tornfole。

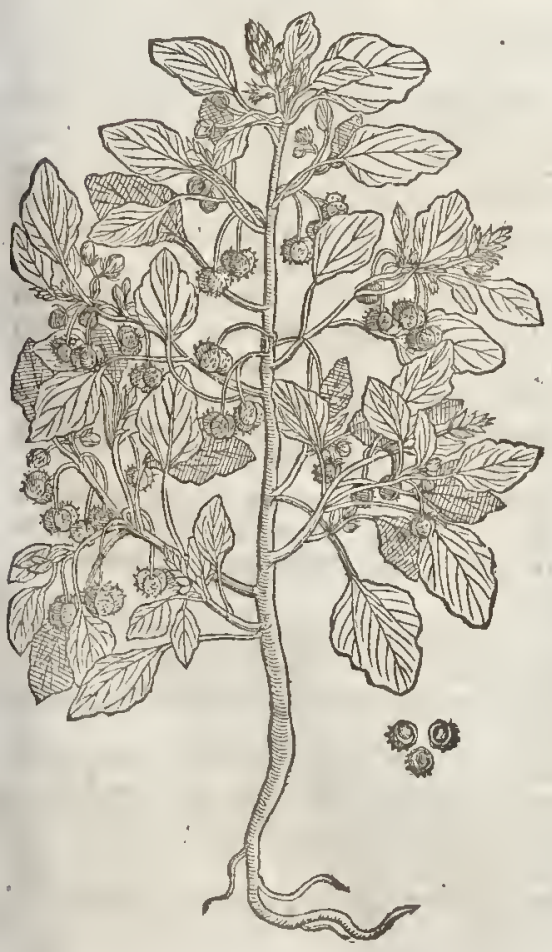

3 Hairy Tornefole hath many fecble and weake branches trailing vpon the ground, fet with fmall leaues, leffer than the great Tornfole; of which it is a kinde, hauing the feed in fmall chaffie husks, which do turne back like the taile of a fcorpion, iuft after the manner of the firtt defcribed.

4 This kinde of Tornefole harle leaues very like to thiofe of the great Tornfole, but of a blacker greene colour:the foures be yellow, and vnprofitable; for they are not fucceeded by the fruit, but after them commeth out the fruit lianging vpon finall foot-ftalks three fquare, and in enery comer there is a fmall feed like to thore of the Ty thimales; the root is fmall and threddy.

$$
\text { Tt The Place. }
$$

Tornfole, as Diofcorides faith, doth grow in fennie grounds and neere vnto pooles and lakes. They are ftrangers in England as yet: It doth grow abour Montpelier in Languedock, where it is had in great vfe to ftaine and die clonts withall, wherewith through Europe meat is co. loured.

$$
\text { T The Time. }
$$

They flourithefpecially in the Sommer folftice, or about the time when the fun entreth into Cancer.

$$
\text { - The Names. }
$$

The Grecians call it Aeliotropium : the Latines keepe thefe names, Heliotropium magnum, 


\section{6}

Of the Hiftory of Plants.

L 1 в. 2.

and Scorpiurum : of Rucllius, Herba Cancri : it is named Heliotropium, not becaufe is is turned about at the daily motion of the fun, but by reafon it flowreth in the fommer folftice, at which time the fun being fartheft gone from the Equinoftiall circle, returneth to the fame:and Scorpiurum of the twiggie tops, that bow backeward like a feorpions taile : of the Italians, Tornefole bobo; in French, Iournfol: fome thinke it to be Herba Clytic;into which the Poets feigne Clytia to be met amorphofed; whence one hath thefeverfes:

$$
\begin{gathered}
\text { Herbavelut Clytice femper petit obuia folem, } \\
\text { Sicpiamens Chriftum, quo prece fpectet, habet. } \\
\text { TI The Nature. }
\end{gathered}
$$

Tonfole, as Panlas a E gineta writeth, is hot and dry, and of a binding faculty.

\section{If The Vertues.}

A A good landfull of great Tornfole boyled in wine, and drunke, doth gently purge the body of hot cholericke humours and tough clammie or flimie flegme.

B The fame boyled in wine and drunke is good againft the ftingings of Seorpions, or other venomous bealts, and is very good to be applyed outwardly vpon the griefe or wound.

C The feed ftamped and layd vpon warts and fuch like excrefcences, or fuperfluous ont-grow ings, caufeth then to fall away.

D The fmall Tornefole and his feed boyled with Hyfope, Crefles, and falt-peter and drunke, driueth forth flat and round wormes.

E With the fmall Tornfole they in France doe die linnen rags and clouts into a perfect purple colour, wherewith cuokes and confectioners doe colour iellies, wines, meates, and fundry confectures : which clouts in thops be called Tornfole, after the name of the herbe.

t The fecond and third foures were furmerly uragho fed : the forreh was the figure of the bairy, Scorpion-grafte defcribed in the fourth place, in the fol glowing Chaprer.

\section{H A P. 54. Of Scorpion Grafe.}

\section{9) The Defcription.}

I Coïpion graffe hath many fmooth, plaine, cuen leaues, of a darke greene colour ; ftalks $\checkmark$ frall, feeble and weake, trailing vpon the ground, and occupying a great circuit in refpect of the plant. The floures grow vpon long and flender foot-ftalks, of colour yellow, in thape like to the floures of broome; after which fuceeed long, crooked, rough cods, in thape and colour like vnto a Caterpiller; wherein is contained yellowifh feed like vnto a kidney in forme. The roote is fmall and tender the whole plant perimeth when the feed is ripe.

2 There is another Scorpion graffe, found among(or rather refembling ) peafe and tares, and thereupon called Scorpioides Legumiszof $a_{3}$, which hath fmall and tender ropts like fmall threds : branches many, weake and tender, trailing vpon the ground, if there be nothing to take hold vp. on with his clafping and crooked feed veffels; othervife it rampeth vpon what foener is neere vnto it. The leaues be fewe and fmall : the floures very litele and yellow of colourthe feed followeth, little and blackinh, conteined in little cods, like vnto the taile of a Seorpion.

3 There is another fort alınoft in cuery thallow grauelly running ftreame, hauing leaues like so Becabung a or'Brooklime. The floures grow at the top of tender fat greene ftalkes, blew of co. lour, and fometimes with a fpot of ycllow among the blew; the whole branch of floures doe turne thenfelues likewife round like the fcorpions taile.

There is alfo another growing in watric places, with leaues like innto 4 nagallis aquatica; orwater Chickweed, hauing like flender ftalkes and branches as the former, and the floures not vnlike, fauing that the floures of this are of a light blew or watched colour, fomewhat bigger, and layd more open, whereby the yellow fpot is better feene.

4 There is likewife another fort growing vpon moft dry gramelly and barren ditch bankes, with Tyyosotis leaues like thofe of or Moure-eare:this is called Myofot is forpioides, it hatl rough and hairy leaues, Scoupisides of anouerwonne ruffet colour : the floures doe grow vpon weake, feeble, and rough branches, as is all the reft of the plant. They liker ife grow for the moftpart vpon one fide of the ftalke, blew of colour, with a like little for of yellow as the others, turning them felues backe againe like the taile of a Scorpion. 


\section{1 в. 2. Of he Hiftory of Plants:}

Therc is another of the land called CMyofot is scorpioides repens, like the former: but the floures Myyos ot s arc thicker thruft together; and doe nor grow all vpon one fide ast he other ${ }_{2}$ and part of the floures arc blew, and part purple, confufedly mixt together.

TT The Place.

$x, 2$ Thefe Scorpion graffes grow not wilde in England, notwithnanding I haue receincd feed of the firft from beyond the feas, and have difperfed them through England, which are eftemed of gentlewomen for the bcauty and ftrangeneffe of the crooked cods refembling Catcrpillers.

The others doe grow in watets and ftreames, as alfo on drie and barren bankes,

$$
\text { T) The Time. }
$$
The firft floureth from May to the end of Augurt:the orhcrs I have found all the fommer long.

I Fabius Columnaludges this to be the Clymenor of Diofcorides : others call it Scorpioides, and Scorpiondes buplearifolio.

2 This is the Scurpioides of exattbiolus, Dod. Lobell, and others; and I iudge it was this plant our Author in this place intended, and not the Scorpivides Leguminofa of the Aduerfaria, for that hath not a fewleaules, but many vpon onc rib; and befides, Dodone us, whom in defcriptions \& hifory our Author chiefcly followes, deferibes this immediatly after the other: Guillaidinas; Cafaloznus, and Baubine iudge it to be the Telephium of Diofcorides.

3 This and the next want no nimes, for almoift euery writer hath giuen them feuetall oncs: Brunfelfsus called it Cyroglopia minor: Tragus, Tabernamontanus, and our Author (page 537. of the formcr cdition) hate it vnder the name of Euphraja Carulea: Dodoneus cals it Scorpioides fremina: Lonicerus, Leontopodium; Cafalpinus, Heliotropium minus in paluftribus : Cordus and Thalits, Echium paluftre.

4 This is Auricula muris minor tertia, Euphrafia quarta, and pilofella fylveftris of Tragus : Scorpioides mas of Dodoneus; Alfme CMy fot is: and Myofot is hirfuta repens of Lobell; Heliotropium minus alterum of Cafalpinus, Echium minimum of Coliumna; and Echium paluftre alterum of $T$ halius :Our Authour had it thrifc: fitf in the precedent chapter, by the name of Heliotropizm rectum, with a figure : fecondly in this prefent chapter; without a figuic : and thirdly pag. 514 . alfo with a figure
vnder the name of $P$ ilofella fore caruleo. $\neq$

It The Niture and Verruts.

There is not any thing remembred of the temperature: yet Diofcorides faith; that the lacues of Scorpion graffc applyed to the place, is a prefent remedy againft the ftinging of Scorpions s and likewifc boyled in wine and drunkc, preuaileth againft the faid bitings, as alfo of adders, fnakes, and fuch venomous beafts : being made in an vnguicnt with oile, wax, and a little gum Elemm, is profitable againft fuch hurts as requirc a hcaling modicine.

\section{Cнат: 55: Of $\mathcal{X}$ ight/hade.}

The kindes.

THere bediuers Night thades, whcreof fome are of the garden; and fome that loue the fields, and yet eucry of them found wilde; whereof fome caufc flecpincfe eucn vnto dicath : others caufe flcepineffe, and yet Phyficall : and others very profitable vnto the health of man, as thall be
declared in their fewerall vertues.

Tt The Defeription.

I Arden Night thade hath round talkes a foot high, and full of branches, whercon are I fet leaues of a blackin colour, foft and full of iuice, in fhape like to leaues of Baffll. but much greater : among which doe in the middle; which being : among which doe grow fmall whitc foures with yellow pointals they be ripe, like thofe of I fat, there fucceed round berries, greene at the firf, and blacke when $\neq 2$ The root of this is long, pretty thicke, and full of hairy ftrings.

his root grow vp many fmal falks of the he and hard, being coucred with a brownin sk in ; fromi leaues that grow alongft the ftalke are like thofe a cubit and better, fomewhat thick withall:the nye. The floures grow about the fralke at the fcring colour,diuided into fourc parts, which are fucceeded on of the leafe, fomewhat long and of a pale acles: which when they come to ripeneffe are red, or of reds contained in hairy or woolly recepThis The Place.

This Nighthade commethyp in mary places, and not only in gardens, of which not withitan- 
I Scorpioides Bupleari folio, Pena of L’obely. Scorpion grafle, or Caterpillers.

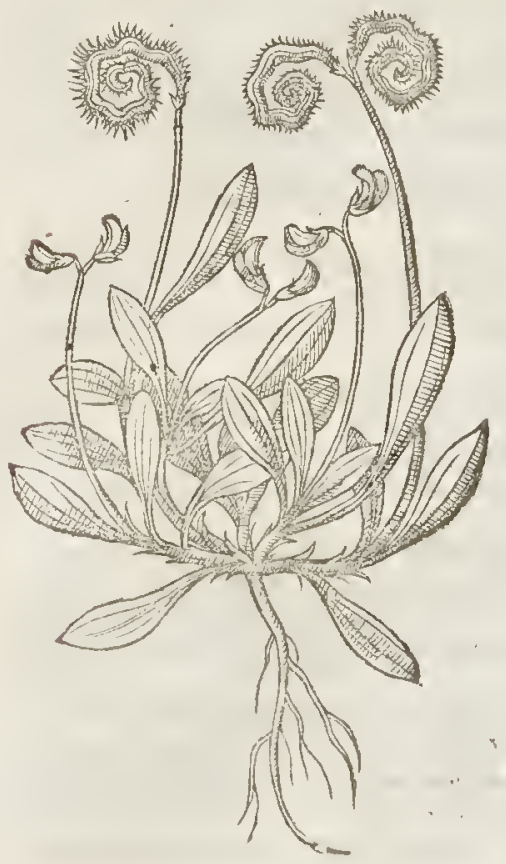

\$ Myofotis foorpioides paluf tris? Water Scorpion graffe. myosotis siorpioides. 8. palustris 24

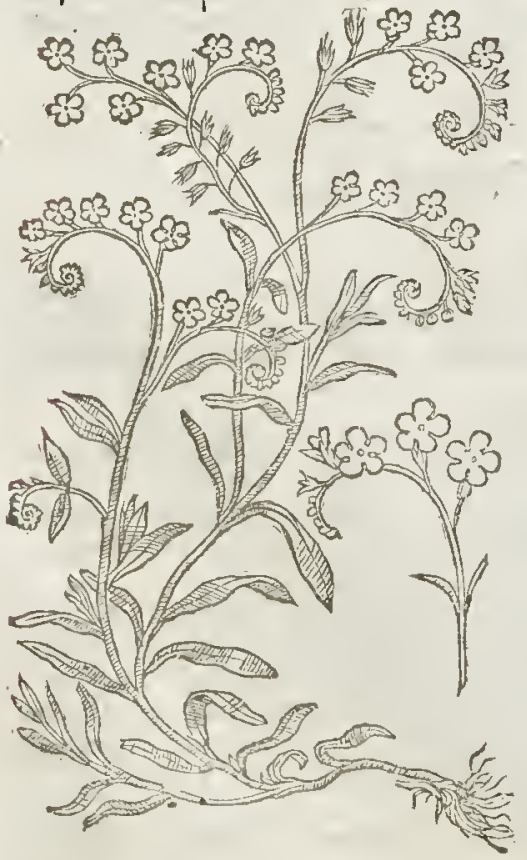

‡2 Scorpioides Mathioli. Matthiolus his Scorpion graffe.

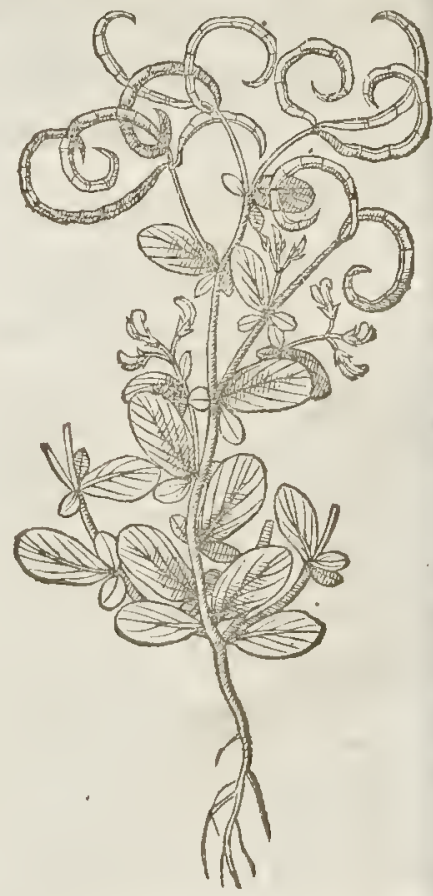

I + Migofot is foopioides aruerafis hirfutd. Moufe-eare Scorpion graffe. Muosotis Scorpioides 0

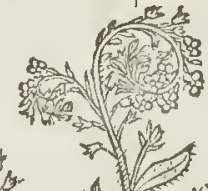
c. \&ु, os

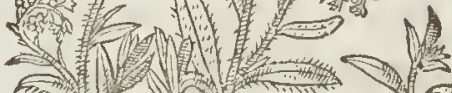
等,

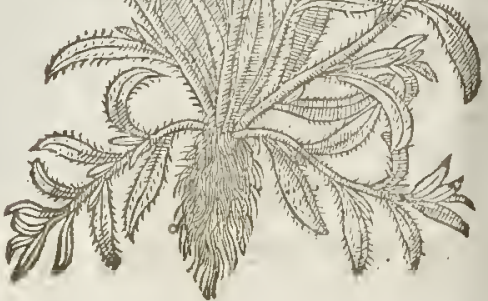


ding it hath taken his furname, and in which it is often found growing with other lectbes, but al fo neere common high waies, the borders of fields, by old walls and ruinous places.

$¥ 2$ This growes not with vs, but in hotter Countries Cluf fus found it growing among rubbifh ar Malago in Spaine. $\neq$

I Solanum Hortenfe.

Garden Nightíhade:

Solanum nigrim

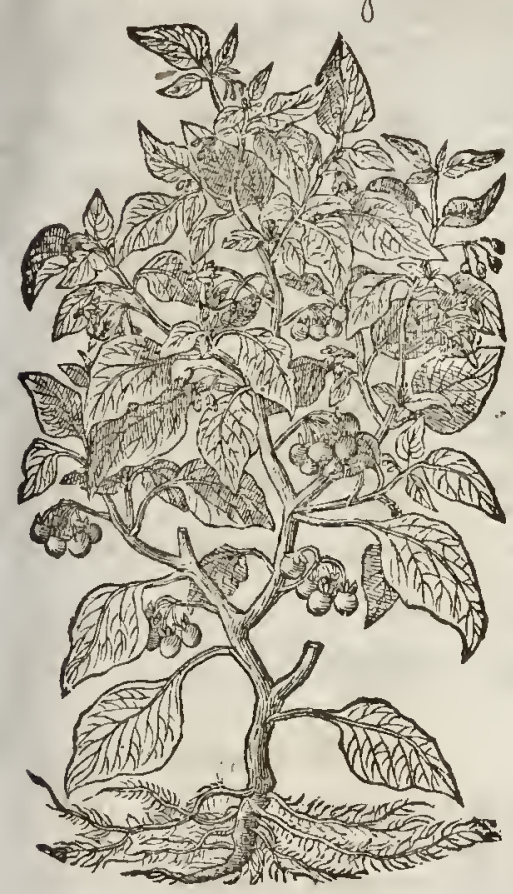

$\mp 2$ Solunum Somniferum.

Phys alis sommitera Nighthade.

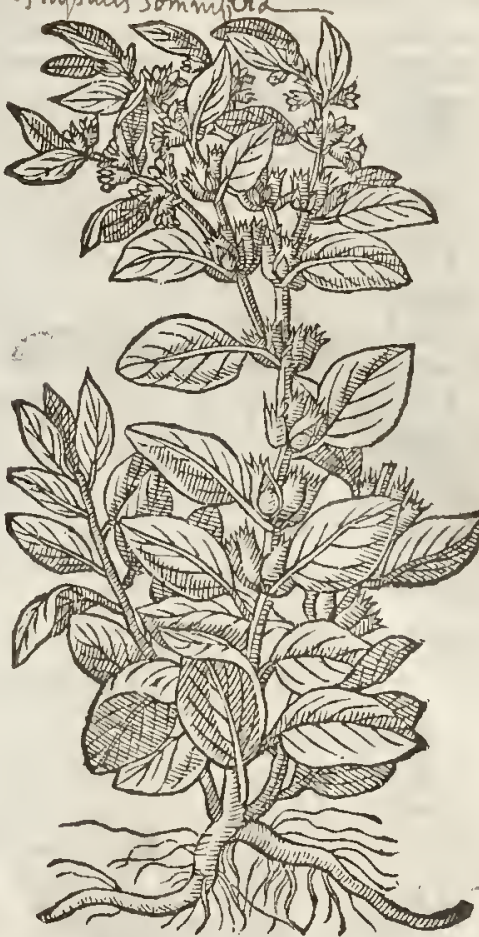

The Time?

It flowreth in Sommer, and oftentimes till Autumne be well fpent; and then the fruit commeth to ripeneffe.

$\neq 2$ This Clusfus found in flower and with the fecderipe in Februarie; for it liueth many yeares in hot Countties, but in cold it is but an annuall. $\neq$

$$
\text { T The Names. }
$$

It is called of the Græcians Iruveos: of the Latines, Selanum, and Solanum Hortenfe: in fhops, Sola. trum : of fome, Morella, Marcellus an old Phificke writer, and diuers others of his time called it Strumum : plinie in his 27.booke chap. 8. Theweth that it is called Cucubalus : both thefe words are likewife extant in $\mathrm{A}_{\text {s }}$ proteius among the ennfured names of Nighthade; who comprehending all the kindes of Nightthade together in one chaptet; being fo many, hath ftrangely \& abfurdly confounded their names, In Englith it is called Garden Night hade, Morel, and Petie Morcllin French, Morelle, Gallobelgis:
few ardent : quia medetur igni facro.

T The Temperature.

infirmities that haten faitl in his booke of the factilties of fimple medicines) is vfed for thofe deoree which boling and binding; for thefe two qualities it hath in the fecond degree : which thing alio hee affirmeth in his booke of the faculties of nourithments, where hee Nighthate thath is pot-herbe which wee vfe to eat that hath fo great aftriction orbinding as but alwaies as a medicine.

of Diofcorides writeth, that Night thade is good againft $S$. Anthonies fire, the thingles, paine $A$ and biting humours. Notwith thandino the ftomacke, and other like accidents proceediug of tharp hond be applied vato tain honld be applied vato tho e infituitie;, for that muny times there hapneth nore dangers by ap. 
plying of thefe remedies, than of the difeafe it felf c:tor as Hipfocrates writeth in the 6.6cok of his A phorifmes, the 25.partienlar, that it is not good, that $S$. Ant onies fre th ould bedricn from the outward parts to the inward. And likewife in his Proc rofticks he faith, that it is neeeffary that S.Anthonies fire thould breake forth, and that it is deatly to haue it driten in; whieh is to be vnderftood not onely of S. Anthonies fire, but alfe of other like burfings out procured by rature. Forby vfing of the fe kindes of cooling and repelling medieines, thebad, corrupt,and harpe humors are driuen backe inwardly to the ehiefe and princi pall parts, whieh cannot be done withont great danger and hazard of life. And therefore we muft not inaduifedly, lightly, or rahhly miniter fuch kinde of medieines vpon the eomming out of Saint Anthonies fire, the fhingles, or fuch hot pimples and blemithes of the skinne.

B The inice of the greene leaues of Garden Nightthade mixed with Barley mcale, is very profitably applied vnto Saint Anthonies fire, and to all hot inflammations.

C The iuice mixed with cile of Rofes, Cerufe, and Littarge of gold, and applied, is more proper and effe tuall to the purpofes before fet dorne.

D. + Neither the iuice hecreof, nor any other part is vfually ginen inwardly, yet it may without any danger.

E The leaues ftamped are profitably put into the ointment of Popler buds, called $v$ nguentum yopuleon, and it is good in all other ointments made for the fame purpofe.

IF $\neq 2$ The barke of the root of Slecpie Night fhade, taken in the weight of $\bar{z}$ I. hath a fomniferous qualitic: yet is it milder then opirm, and the fruit thereof vehemently proudes vrine. But (as Pliny faith) the remedies hereof are nor of fuch efteeme that we fhould long infift von them, efpecially feeing wee are furnifhed with fuch ftore of medicines leffe harmefull, yet feruing for the fame purpofe. $\neq$

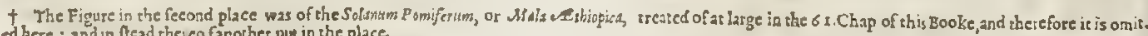
ed bere : asd in flead thes co fanothes pur in the place.

С на в. 56. Of Reepy $\mathcal{X}$ (ight) bade.

Solamm Labiale.

Dwale,or deadly Nightfhade.

utroba Belladouna.

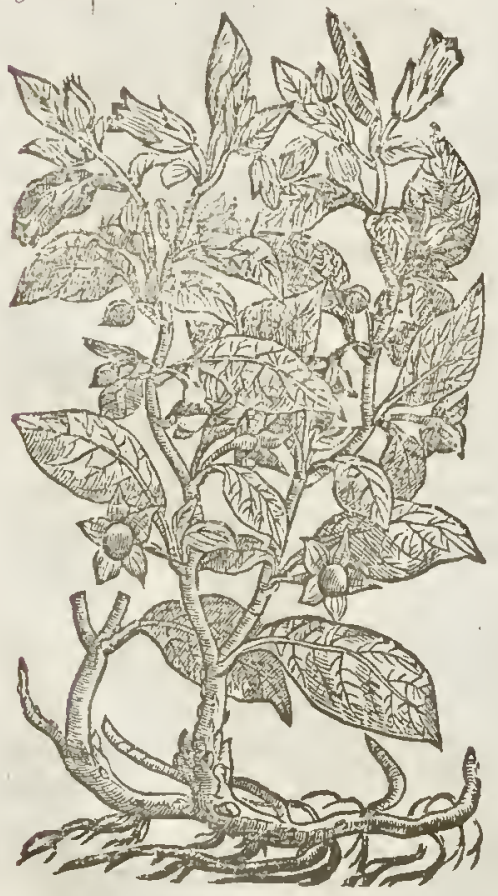

$$
\text { IT The Defcripion. }
$$

Wale or fleeping Nighthade bath round blackith ftalkes fix foot high, wherupon do grow grcat broad leaues of a darke greene colour; among which doe grow fmall hollow flowers bel fafhion, of an ouerworne purple colour; in the plaeewherof come forthgreat round berries of the bigneffe of the blacke eherry, greene at the firft, but when they be ripe of the color of black iette or burnithed horne, foft and full of pur ple iuice: among which inice lic the feeds like the berries of Iuy:the root is very great, thicke, and long lafting. The plate.

It groweth in vntoiled places neere vnto high waies and the fea marthes, and fuch like places.

It groweth very plentifully in Holland in Lineolnfhire, and in the Ile of Ely at a place called Walfoken,neere vnto Wisbitch

I found it growing without the gate of Highgate neere vnto a pound or pinfold on the left hand.

\section{The Time.}

This flouritheth all the Somner and Spring, beareth his feed and forver in Iuly and Augue.

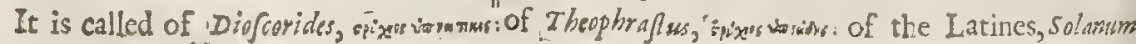
forraferwm, 
forniferum, or fleeping Night thade; and Solanum letbale, or deadly Nighthade; and Solamumanicum, raging Nighthade: of fome, Apollinaris minor vlticana, and Herba Oplago: in Englifh, Dwale, or fleeping Nighthade : the Venetians and Italians call it Bella dona : the Getmanes, 100 ollwuttz: the low Dutch, Doulle befiet : in French, Morelle mortelle : it commeth vety neere vnto Thaphra. ftus his Mandragoras, (which diffeteth ftom Diofcorides his Mandragoras.)

It is cold euen in the fourth degree. I The Nature.

\section{The Veriues.}

This kinde of Night thade caufeth fleep, troubleth the minde, bringeth madnefle if a few of the berries be inwardly taken, but if moe be giuen they alfokill and bting prefent death. Theophraft us in his 6. booke doth likewife write of Mandrake in this manner; Mandrake caufeth fleepe, and if alfo much of it be taken it bringeth death.

The greene lenues of deadly Nighthade may with great aduice be vfed in fuch cafes at Petti- $B$ mortell : but if you will follow my counfell, deale not with the fame in any cafe, and banifh it from your gardens and the $v$ fe of it alfo,being a plant fo furious and deadly : for it bringeth fich as haue eaten thereof into a dead fleepe wherein many hauc died, as hath been often feen and prouued by experience both in England and clfe where. But togiue you an example heeréof it fhall not be amife : It came to paffe that three boyes of Wisbich in the Ile of Ely did eate of the plea fant \& bcautifull fruite hereof, two whereof died in leffe than cight houres after that they had eaten of them. The third child had a quantitie of hony and water mixed together giuen him to drinke, caufing him to vomit often : Godbleffed this meanes and the child recouered. Banith therefore thefe pernicious plants out of your gatdens, and all places neete to your houfes, where children or women with child do refort, which do oftentimes long and hit after things moft vile and filthie; and much more after a berry of a bright fhining blacke colour, and of fuch gteat beautie, as it were able ro allure any fuch to eate thereof.

The leawes heereof laid vn to the temples caufe llcepe, efpecially if they be imbibed ot moirened in wine vineger. It eafeth the intollerable paines of the head-ache proceeding of heate in furious agues, caufing reft being applied as aforefaid.

\section{С н P.57. Of winter Chëries.}

\section{If The Defoription.}

I Hered winter Chertic bringeth forth falkes a cubit long, round, flender, fmooth, and 1 fomewhat reddith, rceling this way and that way by reafon of his weakenerfe, not able to ftand vprightwithour a fuppotter : whereupon do grow leaues nor vnlike to thofe of common Night fhade, but greater; among which leates come forth white floures, confifting of fue fmall leames : in the middle of which leaucs fandeth out a berry, greene at the firf, and red when it is ripe, in eolour of our common Cherry and of the fame bigneffe, inclofed in a thinne huske or little bladder, it is of a palc reddish colour, in which berric is conteined many fmall flat feeds of a pale colour. The rootes be long, not vnlike to the rootes of Couch-graffe, ramping and creeping twithin the pper eruft of the carth farre abroad, whereby it encreafeth grearly.

2 The blackewinter Cherric hath weake and Ilender ftalkes fomewhat crefted, and like vnto the tendrels of the vine, cafting it felfe all about, and taketh hold of fuch things as are next vnto it : whereupon ate fet jagged leatres deepely indented or cut about the edges almof to the middle ribbe. The floures bevery finall and white ftanding vpon long foote-ftalkes or femmes. The skinnie bladders fueceed the floures, parted into three fells or chambets, euery of the which conteineth one feed and no more, of the bigneffe of a fmall peafe, and blacke of colour, haand threddie.

The red winter Cherrie 9 The Place.

moift thadowic places, and growethvpon old broken walls, about the borders of fieldes, and in and others for the great and worthy vertues there fome cherifh it for the beautie of the betries, 2 The blacke winter Cherrie is broughter

whenee I have had of thofe blacke feeds andhaueplanted them in my garden marked with the fhape of a mans hart, white, as afore faid: fruit could grow to matutitie garden where they haue borne floures, but haue perifhed before the to matutitic, by reafon of thofe vnfeafonable yeetes, I594.95. 96. 


\section{- The Time.}

The red winter Cherrie beareth his Houres and fruite in Auguft.

The blacke bearetl them at the fame time, where it doth waturally grow.

- The Names.

The red winter Cherric is called in Grecke, zrewe : in Latine, reficaria, and Solanum I"eficarium: in thops, Alkekengi: Plimic in his 21 . booke nameth it Halicacabus, and Veficaria, of the littlebladders: or as the fame Author writeth, becaufe it is good for the biadder and the ftone: it is called in Spanith, Vexiga de porro : in French, Alqueruenges, Bagenauldes, and Cerifes d'ortre mer: in Englin, red Nighthade, Winter Cherries, and Alkakengic.

I Solanum Halicacabum.

Red winter Cherries.

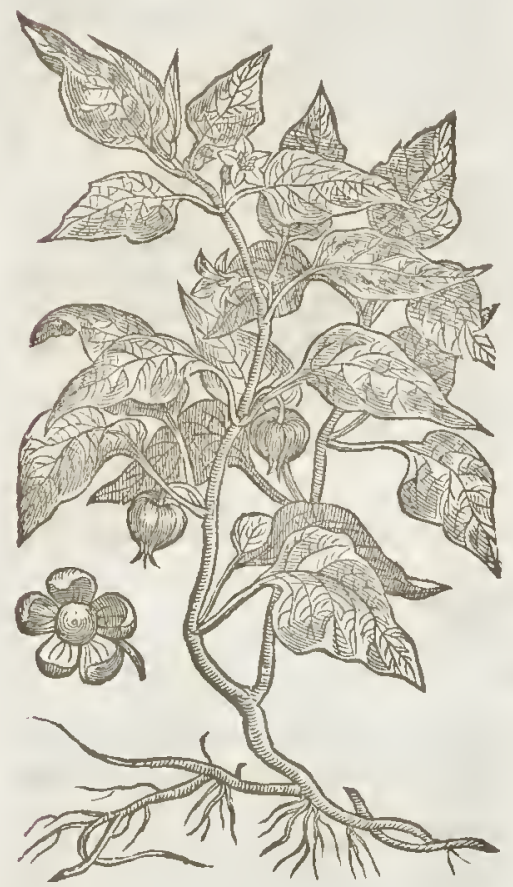

2 Halicacabum Peregrinum.

Cardis Blactiewinter Cherries.

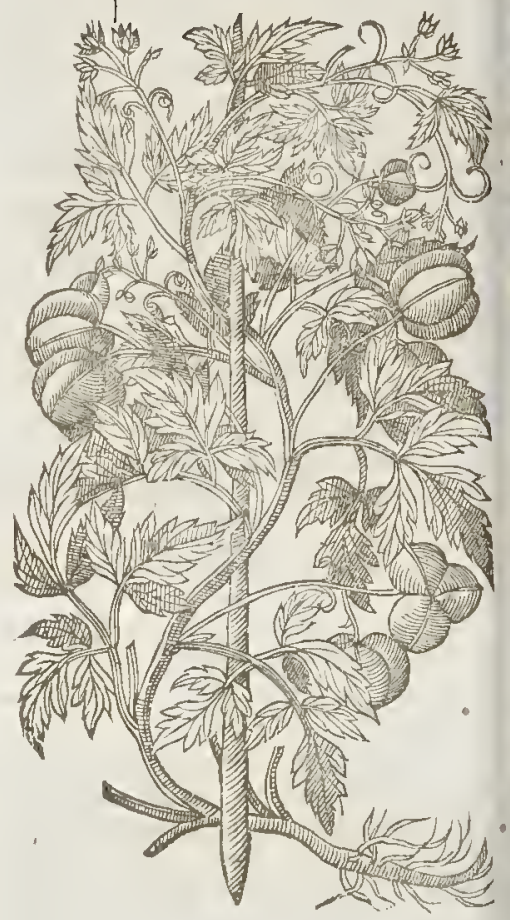

The blackewinter Cherric is called Hulacacubum Peregrimum, Veficaria Peregrina, or ftrange winter Cherrie: of Pena and Lobel it is called, Cor Indum, Cor Indicum : of others, Pifam Cordum : in Englith, the Indian heart, or heart peafe:fome hate taken it to be Dorycnion, but they are greatly deceiued, being in truth not any of the Night fhades; it rather feemeth to agree with the graine named of serapio, Abrong, or Abrugi, of which he writeth in his 153 . chapter in thefe words : It is a litrle graine fpotted with blacke and white, round, and like the graine Maiz, w ith which notes this dotl agree.

$$
\text { II The Temperature. }
$$

The red winter Clerric is thought to be cold and drie, and of fubtile parts.

The leaues differ not from the temperature of the garden Nightihade, as Galen faith.

$$
\text { T) } T \text { be Vertucs. }
$$

A The fruite brufed and put to infufe or fteepe in whitew ine two or three houres, and after boiled two or three bublings, ftraining it,and putting to the decodtion a little fugar and cinnamon, and drunke, pretraileth very mightily againft the ftopping of vrine, the ftone and grauell, the diffcultic and tharpenes of making water, and fuch like difeafes : if the griefe be old, the greater quantity nuft be talien; if new and not great, the lefle: it fcoureth away the yellow jaundife alfo,as fonewrite.

Chap- 


\section{18. 2. Of he Hiftory of Plants.}

\section{C на P.58. Of the cMaruell of the World.}

Mirabilia Pcruriana flore luteo.

The maruell of Peru with yellowifh floures.

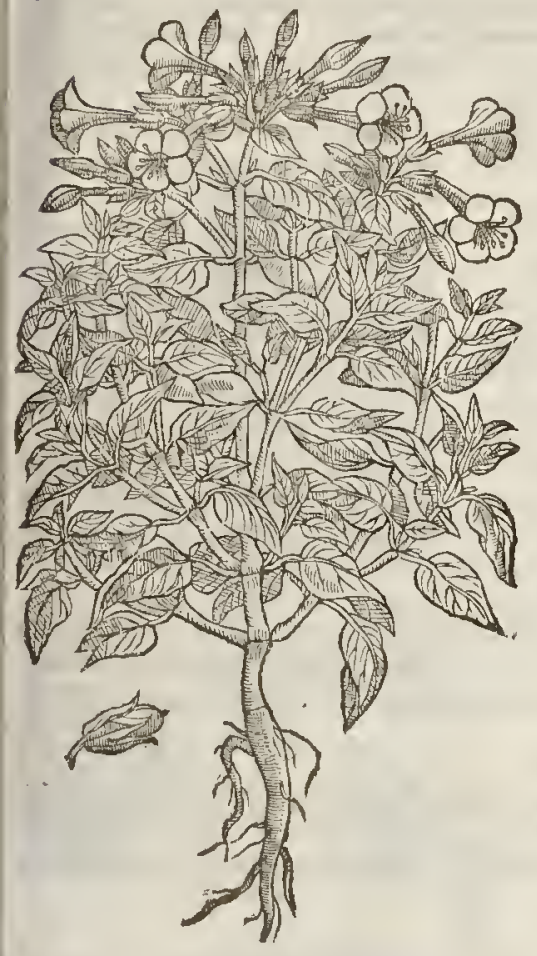

₹ Mirabilia Perumiana flore albo. The maruell of Peru with white floures?

The defcription.

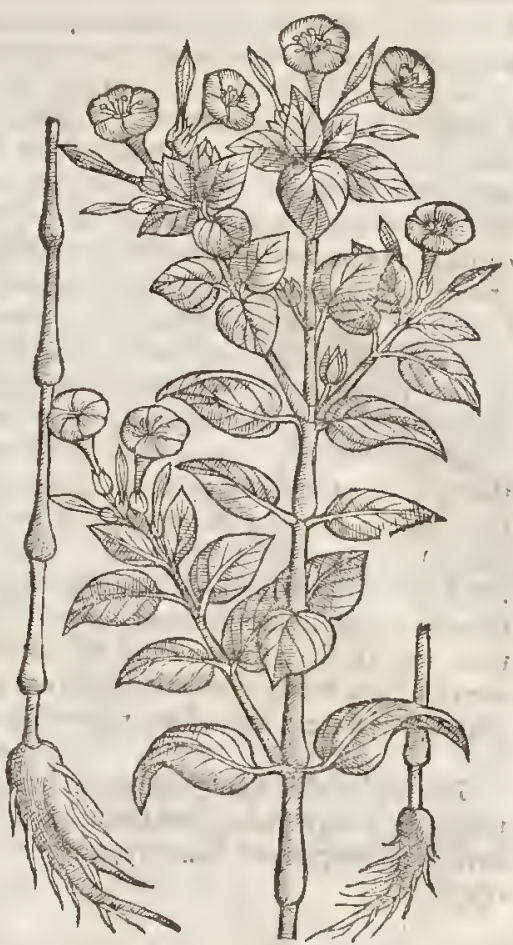

His admirable plant called the maruell of Pcru, or rhe maruell of the World, fpringeth forth of the ground like vnto Bafill in leaues; amongf which it fendeth out a talke two cubits and a halfe high, of the thickeneffe of a finger; full of iuice, very firme, and of a yellowifh grcene colour, knotted or knced with ioints fomew hat bunehing forth, of purplinh color, as in the female Balfamina : which ftalke diuideth it felfe into fundric branches or boughes, and thofe alfo knotrie like the falke. His branches are decked with leaues growing by couples at the ioints like the leates of wilde Pcafeods, greene; fiefhic, and full of inints; which beeing rubbed doe yeeld the like vnpleafant fmell as wilde Peafcods doc, and are in rafte alfo verie vnfauorie, yet in the latrer end they leawe a tafte and tharpe fmacke of Tabaco. The ftalkes tow ards rhe top are garnifhed ing fully blowne foe refemble the fled, as it were, into fiue parts before they be opened; but beg the forvers of Tabae, not ending into tharpe corners, but blunt and round as the flowers of Bindeweede, and larger than the flowers of Tabaco, glittering oftenfimes witli a fine purple or Crimfon colour; many times of an horfe-fleth; fometime yellow fometime pale, and fonctime refembling anold red or yellow colour; fometime whitifh, and noft eommonly two colours occupying halfe the flower, or intercour fing the whole flower with treakes and orcerly ftreames, now yellow,now purple, diuided through the whole; hauing fome-ime great, fonctime little fpots of a purple colour, fprinkled and fcattered in a moft variable orter, and braue mixture. The ground or field of the whole flower is either pale, red, yellow, or whire, Ontaining in the middlc of the bollownefle a prieke or pointell fet round about with fixe fmall Daffodill, and are very fudden are verie fweet and pleafant, refembling the Narciffe or white ntill cight of the elncke the next moning for at night they are flowred wide open, and fo cont inte he manner of the Bindeweede) (n) erate they remaine Ff 2 
fting but onely one day, like the true Ephemerum or Hemerocallis. This maruellous varietie doth notwithout caufe bring admiration to all that obferue it. For if the flowers be gathered and referued in fetterall papers, and compared with thofe flowers that will fpring and flourifh the next day, you thall entily perceiue that one is not like another in colour, though you thould compare one hundruth which Hower one day, and another hundred which you gathered the next day; and fo from day to day during the time of their flowring. 'The cups and huskes which containe and embrace the flowers are diuided into fiue poirted fections, which are greene, and, as it were, confifting of skinnes, wherein is contained one feede and no more, coucred wirl a blackifh skinne, hauing a blunt point whereon the flower groweth; but on the end next the cup or huske it is adornid with a little frue cornered crowne. The feed is as bigge as a pelper corne, which of it feife fadeth with any light motion. Within this feede is contaned a white kernell,wlich being bruifed, refolueth into a very white pulpe like ftarch. The root is thicke and like vnto a great radifh, outwardly blacke, and within white, tharpe in tafte, wherew ith is mingled a fuperficiall fweetnes. It bringcth new floures from Iuly vnto Oetober in infinite number, yea euen vntill the trofts doe caufe the whole plant to perith : notwith ftanding it may be referued in pots, and fet in chambers and cellars that are warme, and fo defended from the iniurie of our coldclimate; prouided alwaies that there be not any water caft vpon the pot, or fet forth to take any moifture in the aire vntill March following; atwhich time it mutt bee tatien forth of the pot and replanted in the garden. By this meanes I haue prcferued many (though to fmall purpofe) becaufe I haue fowne feeds that haue borne foures in as ample manner and in as good time as thofe referued plants.

of this wonderfull herbe there be other forts, but not foamiable or fo full of varictic, and for the moft part their floures are all of one color. But I laume fince by practife found out another way to keepe the roots for the yeare following with very little diffeultie, which neuct faileth. At the fire froft I dig vp the tootes and put vp o: rather hide the roots in a butter ferkin,or fuch like veffell, filled with the fand of a riuer, the which I fuffer ftill to ftand in fome corner of a houfe wherc it neter receitueth moifture vntill Aprill or the midft of $\mathrm{March}$, if the weather bewarme; at which time I take it from the fand and plant it in the garden, where it doth flourifh exceeding well and increafeth by roots; which that doth not which was either fowne of feed the fame ycarc,nor thofe plants that werc preferued after the other mamner.

$$
\text { The Place. }
$$

The feed of this trange plant was brought firt into Spaine, from Peru, whereof it tooke his name Mirabilia Peruan, or Permutana: and fince difperfed into all the parts of Europe : the which my felfe haue planted many yeares, and hauc in fome temperate yeares receiucd both floures and ripe feed.

$$
\text { The Time. }
$$

It is forv ne in the midit of A prill,and bringeth forth his variable floures in September,and pe rinhe th with the firft frolt, except it be kcpt as aforefaid.

$$
\text { 9. The Names. }
$$

It is callod in Peru of thofe Indians thcre, Hachal. Of others after their name Hachal Indi : of the high and Jow Dutch, Solanum Odorifurum: of fome, Iafminum mexicanum : and of Carolus Clufus, Admirabilia Peruniana : in Englih rather the Marucll of the World, than of Perualone.

$$
9 \text { The Nature and Vertses. }
$$

We haue not as yet any inftrufions from the people of India concerning the nature or vertues of this plant: the which is efteemed as yct rather for his rareneffc, beautie, and fweetneffe of his floures, than for any vertues knowne; but it is a pleafant plant to decke the gardens of the curious. Howbcit Iacobus Antonius Cortufus of Padua hath by experience found out, that two drams of the root thereof taken inwatly doth very notably purge waterifh humours.

\section{Сна г.59: Of Madde Apples.}

9) The Defription.

$\mathrm{R}$

A ging Apples hath a round Italke of two foot high, diuided into fundry branches, fet with brodu leaues somewhat indented about the edges, not vnlike the leaues of white Henbane, of a darke browne greene colour, fomewhat rough. Among the which come the floures 
vpon fhort ftems or foot ftalks, cluftering together in bunches : which being fallen, there do eome in place faire and goodly apples, ehamfered, vneten, and bunched out in many places; of a bright thining red colour, and the bigneffe of a goofe egge or a large pippin. The pulpe or meat is verie full of moifture, foft, reddirh, and of the fub ranee of a weat plumme. The feed is fmall, Hat and rough : the root finall and threddie : the whole Plant is of a ranke and ftinking fauour.

There hath happened vnto my hands another fort, agreeing very notably with the former,as well in leaues and Ptalkes as a!fo in floures and roots, onely the fruic hercof was yellow of eolour, where in confifted the difference.

Poma Amoris.

Apples of Loue.

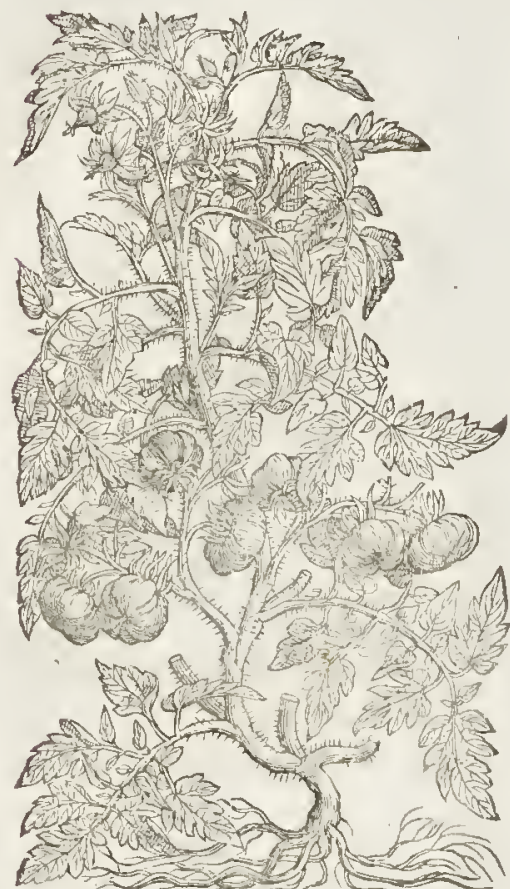

T The Place.

Apples of Ioue grow in Spaine, Iralie, and fuel hot Countrics, from whenee my felfe haue receitued feeds for my garden, wherc they do increafe and profper.

\section{T The Time.}

It is fowne in the beginning of Aprill in a bed of hot horfe dung,after the maner of musk Melons and fueh like cold fruits.

$$
\text { II The } 1 \text { ames. }
$$

'The Apple of Loue is called in Latine $P_{0}$ mum Aureum, Poma Amoris, and Lycoperficum: of fome, Glaucium: in Englith, Apples of Loue, and Golden Apples: in Freneh, Pommes d'amours. Howbeit there be ot her golden Apples whereof the Poets doe fable, growing in the Gardens of the daughters of Heperus, which a Dragon was appointed to keepe, who, as they fable, was killed by Hercules.

\section{T The Temperature.}

The Golden Apple, with the whole herbe it felfe is cold, yet not fully fo cold as Mandrake, after the opinion of Dodonass. Bur in my iudgement it is very cold, yea perhaps in the highe? degree of coldneffe:my reafon is, becaufe I haue in the hotteft time of Sommer cut aw ay the fuperfluous branches from the mother root, and caft them away carelefly in the allies of my garden, the which (notwith fanding the extreme heat of the Sun, the hardneffe of the trodden allies, and at that time when no raine at all did fall) haue growne as frefh where I eaft them, as before I did cut them off; which argucth the great coldneffe eontained thercin. True it is, that it doth argue alfo a great moifure wherewith the plant is poffefled, but as I hate faid, not without great cold, which I leauc to euery mans cenfure.

\section{- The rertues.}

In Spaine and thofe hot Regions they rfe to eat the Apples prepared and boiled with pepper,

A falt,and oile: but they yeeld very littic nourifhment to the bodic, and the fame nought and corrupt.

Likewife they doe eat the Apples with oile, vineger and pepper mixed together for fauce to theirmeat, encn as we in thefe cold Countries doe Muftard.

\section{C нг ар: 61. Of the Ethiopian Apple.}

9) The Defcription.

THe Apple of Ethiopia hath large leaues of a whitifh greene colour, decpely indented about the edges, almoft ro the middle rib; the which middle rib is armed with a few tharpe prickles, The Houres be white, confifing of fix fmal leaues, with a certain yellow pointel in the midft. 


\section{Of the Fiftory of Plants.}

$\mathrm{L}_{1 \mathrm{~B}, 2 .}$

about the edges, with many vneuen fharpe eorners : among thefe leaues come white round floutes made of the great Binde-iveed, whereunto it is very like, of a fweet fmell, but fo ftrong, that it offends the fences. The fruit followeth round, fomet imes of the farhion of anegge, fet about on euerie part with moft marpe prickles; whercin is contained very mueh feed of the bigneffc of tares, and of the fame farhion. The root is thicke, madc of great and fmall ftrings : the whole plant is fowen, bearcth his fruit, and perifhcth the fame yeare. $\ddagger$ There are are fome varieties of this plant, in the culour and doubleneffe of the floures. $\ddagger$

I Stramonium Peregrinum.

The Apple of Peru.

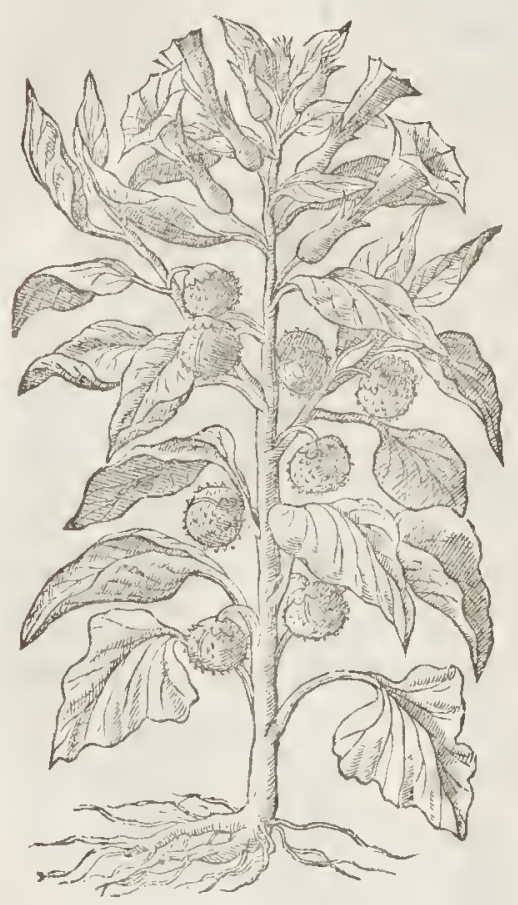

2 Stramonitum pinofim.

Thorny Apples of Peru.

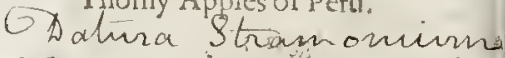

Datina Strownowim

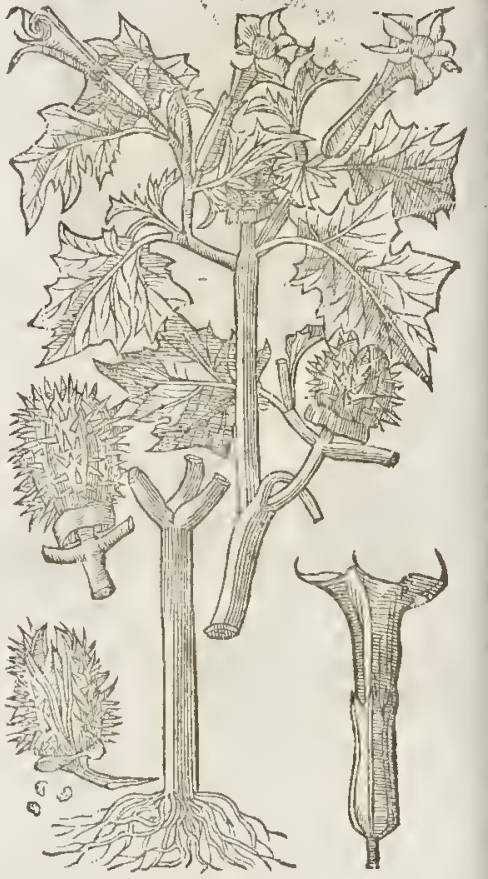

बा The Place.

I This plant is rare and ftrange as yet in England: I reeeiued feeds thereof from Iolun Robin of paris, an exeellent Herbarift; which did grow and bate floures, but perifhed bcfore the fruit came to ripenefle.

2 The Thorne-apple was brought in feed from Conftantinople by the right honoutable the Lord Edward Zouch, and giuen vnto me, and beareth fruit and ripe feed.

$$
\text { q The Time. }
$$

The firft is to be forven in a bed of horfe-dung, as we do eueu mbers and ivuske-melons.

The other may be fowen in March or Aprill, as other feeds are.

$$
\text { ๆ } T \text { be Names. }
$$

The firft of thefe Thorne-apples may be ealled in Latine, Stramonia, and Pomim, or Malum pinofum : of fome, Corona regia, and Melopinum: The Grecians of our time name it resuninxxp, or rat liet

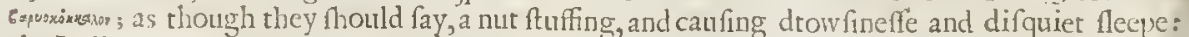
the Italians, Paracoculi : it feemeth to Valerius Cordus tobe Hyof cyamus Peruvianus, or Henbanc, of Peru: Cardinus doubteth whether it thould be inferted among the Night-thades as a kinde there-

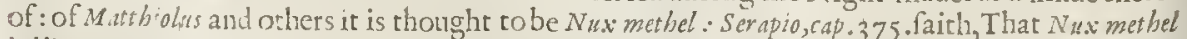
is like vnto Nutvomica; the feed whereof is like that of Mandrake : the buske is rough or full of prickles; the tafte pleafing and ftrong: the qualitie thereof is eold in the fourth dcgree. Which defcription agrecth herewith, except in the forme or fhape it fhould haue with Not vomica: Anguilhura fufpecteth it to be Hippomanes which Theocritus mentioneth, wherewith in his fecond Ecloy 
he theweth that horfes are made mad : for Cratewas, whom Theocritus his Scholialt doch cite, writeth, That the plant of Hippomants hath a fruit full of pricklcs, as hath the fruit of wilde Cueurabers. In Englith it may be called Thorne-apple, or the Apple of Peru.

\$ The words of Theocritus; Eidyll..2. are thefe:

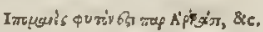

Which is thus in Englifh:

\section{Hippomanes'mong st the Arcadians ßprings, by which enea all The Colts and agile CMares in mountaines mad do fall.}

Now in the Greeke Scholizamongft the Expofitions there is this : xpanuaspum, \&e. That is ; Crateuas faith, That the plant hath a fruit like the wilde Cucumber, but blacker; the leatues are like a pop. pie, but thorny or prickly. Thus I expound thefe words of the Greeke Scholiant,being pas.5 I. of the edition fet forth by Dan. Heinfurs, Ann. Dom. 1603. Iulius Scaliger blames"Theocritus, becaufc he calls Hippomanes surio, a Plant : but Hcinfrus, as you may fee in his notes vpon Theocritus, p.g .120 , probably iudges, that ovio in this place fignifies nothing but wñm, a Thing [growing.] Such as are curious may haue recourfe to the places quoted, where they may finde it more largely handled than is fit for me in this place to infift vpon. There is no plant at this day knowne, in mine opinion, whereto Craterus his defcription may be more fitly referred; than to the Paparer Jpinofium, or ficus infermals, which we thall hereafter deferibe. $\neq$

\section{T The Nature.}

The whole plant is cold in the fourth degree, and of a drowfie and numming qualitie, not inferior to Mandrake.

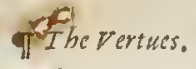

The iuyce of Thorne-apples boiled with hogs greafe to the forme of an vnguent or falue,cureth all inflammations whatfocuer, all manner of burnings or fcaldings, as well of fire, water, bnyling leade, gun-pouder, as that which comes by lightning, and that in vêry flhort time, as my felf haue found by my dayly practife, to my great credit and profit. The firft experience came from $\mathrm{Col}-$ chefter, where Miftreffe Lobel a Merchants wife there being molt grieuouly burned with lightning, and not finding eafe or cure in any other thing, by this found helpewhen all hope was paft, by the report of $\mathrm{M}$. William Ramme, publique Notarie of the faid towne, was perfectly cured.

The leaues ftamped fmall, and boiled witli oyle Oliue vntill the herbes be as it were burnt, then $B$ frained and fet to the fire againe with fome wax, rofin, and a little Turpentine, and made into a falue, doth moft fpeedily cure old vlcers, new and frefh wounds, vleers vpon the glandulous part of the yard, and other fores of hard curation.

\section{Ch A .63. \\ OfBitter-fweet, or Wooddy Night/hade. \\ iा The Defription.}

B

Itter-fweet bringeth forth wooddy ftalkes as dorh the.Vine,parted into many fender creeping branches, by which it climeth and taketh hold of hedges and fhrubs next vnto it. The barke of the oldeft ftalkes are rough and whitith, of the colour of anhes, with the outward rinde of a bright greene colour, but the yonger brinches are greene as are the leaues : the wood brittle, haung in it a fpongie pith; it is clad with long leaues, fmooth, tharpe pointed, leffer than thofe of the Binde-weed. At the lower part of the fame leaues doth grow on either fide one fmall or leffer leafe like vnto two eares. The finures be mall, and fomew hat eluftered together, confitting of fue little leatrcs apiece, of a perfect blew colour, with a certaine pricke or yellow pointall in the middie : which being paft, there do eome in place faire berries, more long than round, at the firft green, but very red when they be ripe; of a fweet tafteat the firt, but after very vnplea fant, of a ftrong $\mathrm{fa}$ uour, growing together in clufters like burnifhed coral. The roor is of a meane bigneff $c_{c}$, and full of ftrings.

I have found another fort which bringeth forth mof pleafant white floures with yellow pointals in the middle, in other refpects agreeing with the former.

$$
\text { Qा The Place. }
$$

Bitter-fweet doth grow in moilt places about ditehes, risers, and hedges, almont eury where. 


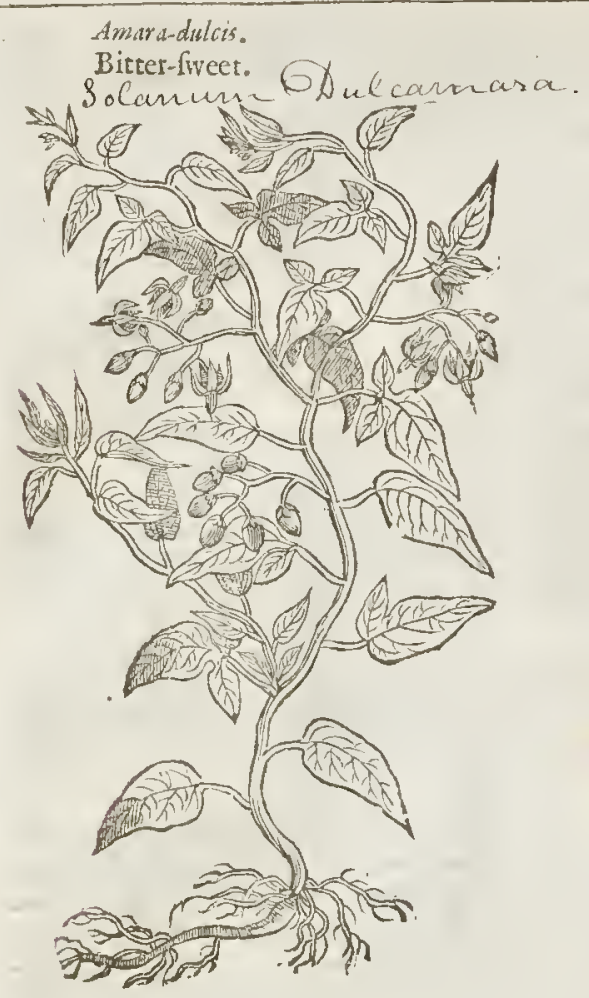

The other fort with the white floures I found in a ditch fide againft the right honorable the Earle of Suffex his garden wall at his houfe in Bermonfey ftreet by London, as you go from the court which is full of trees, vnto a farme houfe neere thereunto.

$$
\text { बा The Time. }
$$

The leaues come forth in the Spring, the floures in Iuly, the berries are ripe in Auguft.

$$
\text { of The Names. }
$$

The later Herbarifts haue named this plane Dulcanzara, Imarodulcis, and Amaradulcis; that is in Greeke, 2rou :mzeror : they call it alfo Solanum lignofum, and Siliquaftrum : Pliny callech it Melortum: Theophraftus, Vit is fylueftris: in Englion we call it Bitter-fweet, and Wooddy NightThade. But enery Author muft for his credit fay fomthing, alrhough to fmall purpofe; for Vitis fylueftris is rhat which we call our Ladies Seale, which is no kinde of Nighthade : for Tamus and Vitu fylucfre is areboth one; as likewife Solanum lignofum or Fruticofum; and alfo rad anum rubrum: whereas indeed it is no fuch plant, nor any of the Nighthades, although I hate followed others in placing it here. Therfore tho e that vfe to mixe the berries thereof in compofitions of diters cooling ointments, in ftead of the berries of Nighthade haue committed the greater errour; for the fruit of this is not cold at all, but hot, as forthwith Thall be thewed. Diofcorides faith it is Cycla mimus alters; defcribing it by the defcription of thofe with white floures aforefaid, whereunto it doth very well agree. $\neq$ Diofcorides defcribeth his $M u$ ufofo flore with a moffy floure, that is, fuch an one as confifts of finall chiues or threds, which can by no meanes be agreeable to the floure of this plant. $\neq$

$$
\text { Tा The Temperature. }
$$

The leaues and fruit of Bitter-fweet are in temperature hot and dry, clenfing and wafting away.

$$
\text { a) The Vertues. }
$$

A Thedecoction of the leaues is reported to remoue the ftoppings of the liuer and gall ; and to be drunke with good fucceffe againtt the yellow jaundice.

B The inycc is good for thofe that haue fallen from high places, and haue beene thereby bruifed, or dry beaten : for it is thought to diffolue bloud congealed or cluttered any where in the intrals, and to heale the hurt places.

C. Hieronymus Tragus teacheth to make a decostion of Wine with rhe wood finely fliced and cuc int o fmall pieces; which he reporterh to purge gently both by vrine and fiege thofe that haue the dropfic or jaundice.

D Diofcorides doth afcribe vnro Cyclaminus altcra, or Bitter-fweet with white floures as I conceiue it, the like faculries.

E The fruit (faith he) being drunke in the weight of one dram, with three ounces of white wine, for forty dayes together helpeth the fpleene.

F It is drunke againt difficultie of breathing : it throughly cleanfech women that are newly brought a bed.

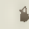

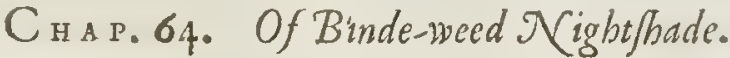

T) The Defription.

Nchanters Night-fhade hath leates like to Peti-morel, tharpe at the point likevnto Spinage: the ftalke is ftraight and vpright, very brittle, two foot high: the foures are white tending to carnation, with certaine fmall browne chites in the midft: the feed is contained in fmall round 
gre at root, euren as Nature lift to beftow vpon it, as to other plants. But the idledrones that haue litt le or nothing to do but eate and drinke, haue beftowed fome of their time in earuing the roots of B rionse, forming them to the thape of men \& women : which falfifying practife hath eonfirmed the errour amongft the fimple and vnlearned people, whohate taken them vpon their report to be the true Mandrakes.

- The female Mandrake is like vnto the male, fauing that the leaues hereof be of a more fwart or darke greene colour; and the fruit is long like a peare, and the other is round like an apple.

Mandragoras mas of formina.

The male and female Mandrake.

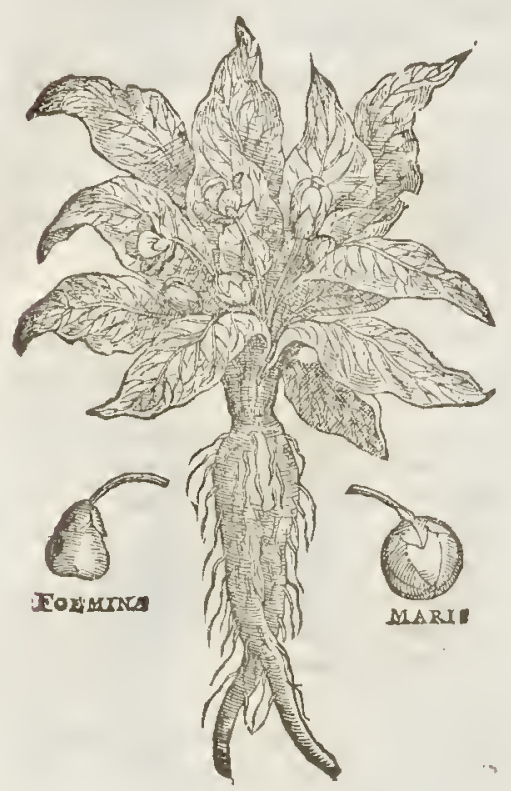

T The Place.

Mandrake groweth in hot Regions, in woods and mountaines, as in mount Garganus in Apulia, and fueh like places;we haue them onely planted in gardens, and are not elfewhere to be found in England. of The Time.

They fpring vp with their leanes in March, and floure in the end of A prill : the fruit is ripe in Auguit.

$$
\text { 9ा The Nomes. }
$$

Mandrake is called of the Grecians Mardearaps: of diuers, kupre, and Circiea, of Curce the witch, who by art eonld procure lone: for it hath beene thought that the Root hereof feructh cowin loue: of fome, aimimine Anthropomorphos, and Morion: fome of the Latines haue called it Terre malnm, and $T \mathrm{cr}$ reftremalum, and Caninamalus: Sloops, and alfo other Nations doe reeeitue the Greeke name. Digfcorides faith, That the male is called of diuers Morion and deferibeth alfo another Mandrake by the name of Morion, which, as muel as can be gathered by the defcription, is like the male, but leffe in all parts : in Englifh we eal it Mandrake, Mandrage, and Mandragon.

\section{T The Temperature.}

Mandrake hath a predominate cold faeultie, as Galen faith, that is tor fay cold in the third de: grce : but the root is eold in the fourth degree.

$$
\text { II The Vertues. }
$$

A viofcoridis dath particularly fet downe many faculties hereof; of which notwichftanding there be none ptoper vnto it, fauing thofe that depend vpon the drow fie and fleeping power thereof: whieh qualitie confifteth more in the root than in any other part.

B The Applesare milder, and are reported that they nay be eaten,being boyled with pepper and other hot fpiees.

C Galen faith that the Apples are fomething eold and moift, and that the barke of the root is of greateft ftrength, and doth not oncly eoole, but alfo dry.

D The iuyee of the leaucs is very profitably put into the ointment called populeon, and all eooling ointments.

E The iuyee drawne forth of the roots dried, and taken in fmall quantitie, purgeth the belly exceedingly from flegme and melaneholike humors.

F It is good to be put into medieines and colliries that do mitigate the paine of the eyes; and put vnder a peffarie it draweth forth the dead ehilde and fecondine.

G . The greene leaues ftamped with barrowes grcafe and barley meale, eoole all hot fwellings and inflammations; and they hate vertue to eonfune apoftumes and hot vleers, being bruifed and applied thereon.

H A fuppofitorie made with the fame iuyee, and put into the fundament eaufeth fleepe.

I The wine wherein the roor hath becneboyled or infufed proucketh fleepe and affwageth paine.

K The imell of the Apples moucth to fleepelikewife; but the iuyce workcth more effectually if you take it in fmall quantitie. 
Great and ftrange effects are fuppofed to be in the Mandrakes, to caufe women to befruitfull I and beare children, if they fhall but carry the fame neere vnto their bodies. Somedoe fron hence gtound it, for that Rabcl defired to hate her filters Mandrakes (as the text is trantlated) but it we looke well into the circumltances which there we thall finde, we may rather deeme orhenrife. Young Rubenbrought home amiable and fiv cet finelling floures ( for fo fignifieily the Hebrew word, which is vfed Cantic. 7. I3. in che fame fenfe :) and the lad brought them home, racher for rheir beatry and fmell, than for theirvertue. Now in the floures of Mandrake there is no fich delectable or amiable fincll as was in thefe amiable floures which Ruben brought ho'ne: Befides, wee read not that Rabel conceited heretipon, for Leah Iacobs wife had foure children before God granted that blefing of fruitfulnefe vnto Rabel. And lat of all (which is my chiefert reafon ) racob was angty with kabel when fhe faid, Giue me children elfe I die : and demanded of her, whether he were in the ftead of God orno, who had withheld from her the fruit of her body. And we know that the Prophet Dasid faitl, Children and the fruit of the wombe are the inheritanee, that commeth from the Lord, $P$ falm. I 27.

Serapio, Anicen, and Panlus Egzneta doewrite, that the feed and fruit of Mandragoras taken $M$ in drinke, doe clenfe the matrix or mother, and Diofcorides wrote the fame long before them.

He that would know more hereof, may reade that chapter of do tor $T$ urner his booke, coneerning this matter, where he hath written largely and learnedly of this Simple.

\section{С а г. 66. Of Henbine.}

I Hyofoyamus 2iger.

Blaeke Henbane.

Hyoscyanus niger

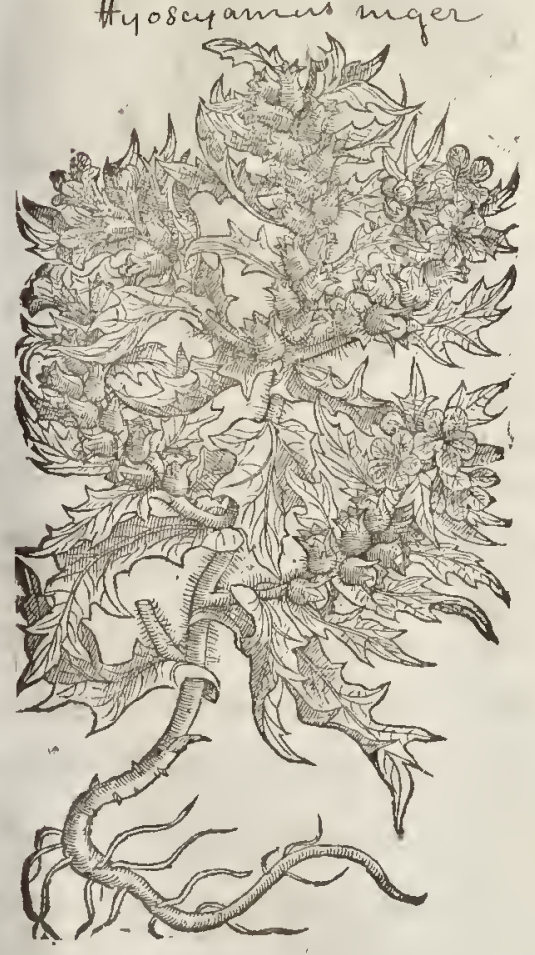

2 Hyofcyamus Albus. Whire hlenbane.

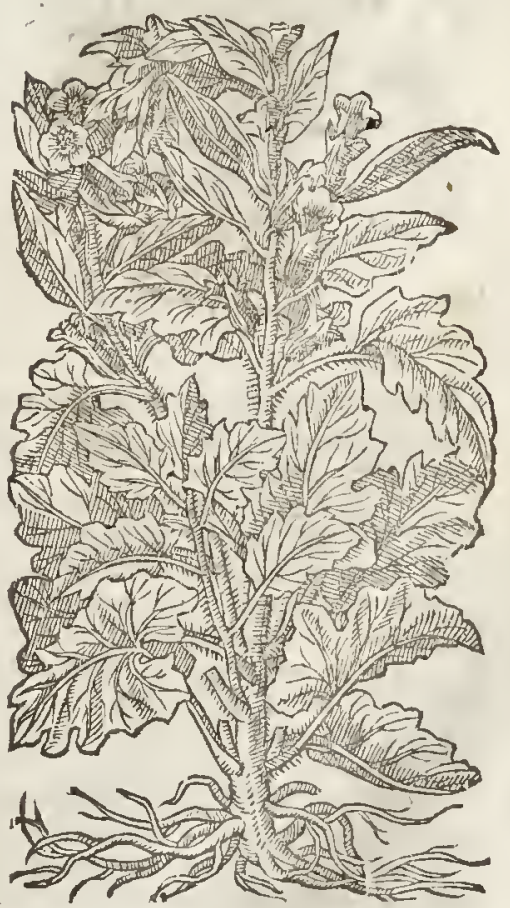

I) The Defcription.

17 He common blacke Henbane hath great and foft ftalkes : leaues very broad, foft, and woolly, fomewhat iagged,efpecially thofe that gro v neere vuto the ground, and thofe that grow vpon the ftalke, narrower, fmaller, and tharper. The floures are bel fathion,
of a faint yellowin white, and browne within to.vards the botroms; when the floures are 
gone, there eommeth hard knobby huskes, like fmall eups or boxes, wherein are fmall browne feeds.

2 The White Henbane is not mueh vnlike to the blacke, faung that his leaues are fmaller, whiter and more voolly, and the floures alfo whiter. The eods are like the other, but withour pricks; it dieth in winter, and mult likew ife be fowne againe the next yeere.

‡ 3 Hyofyamus albus minor.

The leffer Whire Henbane.

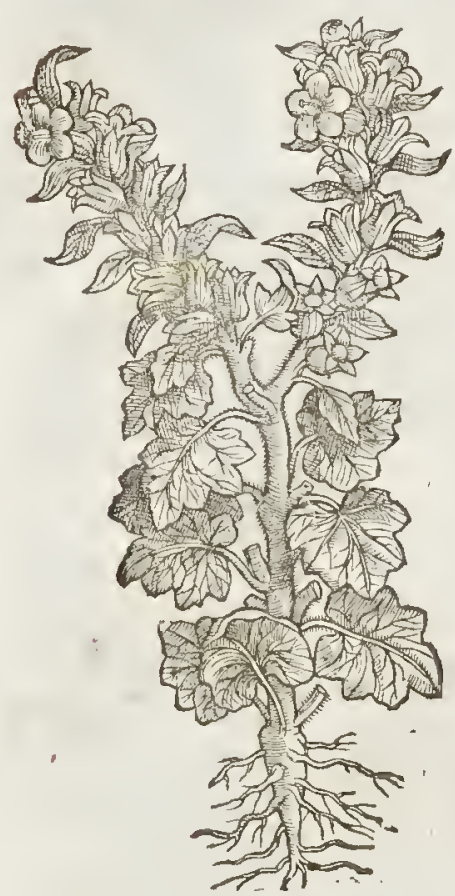

† Hyofcyamus albus Creticus: White Henbane of Candy.

¥ 3 This other white Henbane is mueh like the latt deferibed, bur that it is leffer: the leaules fmaller and rounder, hanging vpon pretty long ftalkes, the floures and feed veflels are like thofe of the laft mentioned.

4 This is fofter and tenderer than the lant deferibed, the leaues alfo hang vpon long footftalkes, and are couered oner with a foft downines:and they are fomew hat broader, yet thinner and more finuated than thofe of the white, and fomewhat refemble the forme of a vine leafe, being fnipt about the edges; the flalkes are alfo coucred with a white downe. The floures are of a gold yellow, with a veluet eoloured eirele in their middles:the root is fuffieiently thieke and large:Clut fius had the figure and defeription of this from his friend Iaques Platenu, who had the plant growing of feed reecined from Candy.

5 The ftalke of this growes fome eubit high, being pretty ftiffe, about the thiekeneffe of ones little finger, and couered ouer with a foft and white downe:the leaues grow difperfed vpon the ftalk, nor much vnlike thofe of the common kinde, but leffer and more divided, and white (while they are young ) eoucred with a flender and long downineffe : the top of the ftalke is dituded into eertaine branehes that bend or hang downe their heads, which alternately amongft narrower, Teffer andvndiuided leaues earry eups like as the eommon one,ending in fue pretty ftiffe points, in which are contained floures at firt fomew hat like the eommon kinde, but afterwards, as they grow bigger, they change into an elegant red purplinh colour,with deepe coloured veines:neither is the ring or middle part purple as in the eommon kinde, but whitim, hauing a purplifh pointall, and fiue threds in the middle : the feeds and feed veffels are like thofe of the common kind. Clusurs receiued the feed herenf from Paludanus returning from his trauailes into Syria and Egypt, wherefore he ealls it Hyofcyamus eEgyptius, Egyptian Henbane. ‡ 


\section{¥ Hyofcyanus fore rubello.}

Henbane with a reddish floure.

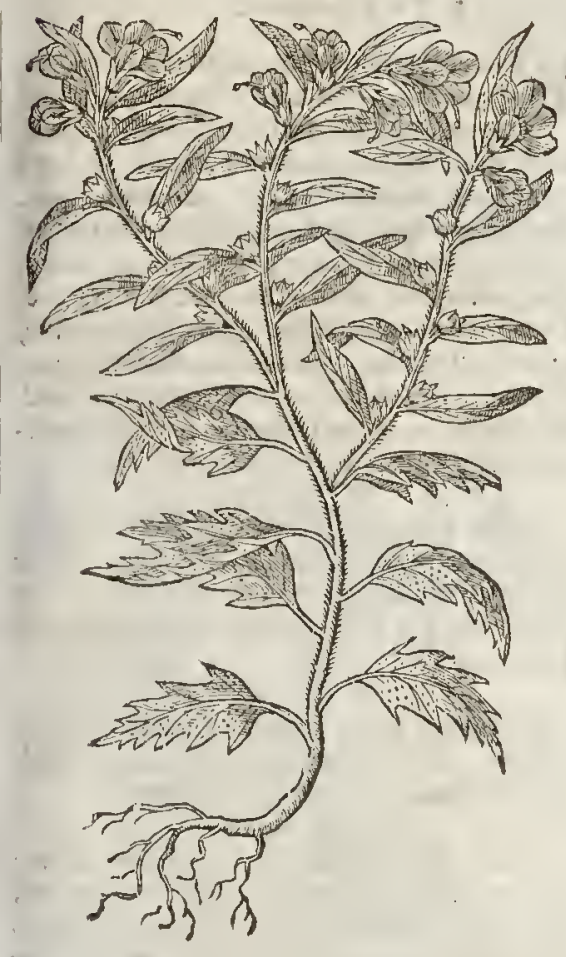

If The Place.

Blacke Henbane grows almoft enerie where by high-wayes, in the borders of fields, about dung-hills and vntoiled places; the white Henbane is nor found but in the gardens of thofe that loue phyficall plants : the which groweth in my garden, and doth fow it felfe from yeare to yeare.

$$
\text { If The Time }
$$

They fpring out of the ground in May, bring forth their floures in Augurt, and the feed is ripe in Ostober.

$$
\text { T The Names. }
$$

Henbane is called of the Grecians, ionkix soos of the Latines, Apollinaris, and Faba fuilla: of the Arabians, as Pliny faith, Altercum : of fome, Faba Iouis, or lupiters beame: of Pythagoras, $Z Z_{0}$. roaftes, and Apuleius Infana, Alterculum, Sympho. niaca, and calicularis : of the Tufcanes, Fabulonia, and Faba lupina: of crattheus fyluaticus, Dens Caballinus, cMilimandrum, Caßilago : of Iacobus à Manlys, Herbapinmula : in Mhops it is cal. led Infquiamus, and Hyofcyamus : in Englih, Henbane in Italian, Hyugguiamo : in Spanifh, Velenno: in high Dutch, 23ilten kraut: in French, Hanmebane, Endormie : the other is called Hyof. cyamts albus, orwhite Henbane.

I The Temperature.

Thefe kindes of Henbane are cold in the fourth degree.

If The Vertues.

Henbane caufeth drowfineffe, and mitigateth all kinde of paine : it is good againft hot and marpe diftillarions of the cyes and other parts : it fayeth bleeding and the difeafe in women : it is applied to inflammations of the ftones and other fecret parts.

The leates ftampad with the oint ment Popteon, made of poplar buds, affwageth the paine of the $B$ gout, and the fivellings of the ftones, aud the tumors of womens brefts; and are good to be put
into the fame oinment, but in fmall quantitie Towath the feet in the dccootion of Henbane.caufeth fleepe; or giuen in a clifter it doth the $\mathrm{C}$
fame; and alfo the often finelling to the floutes.

The leates, feed, and iuyce taken inwardly caufeth an vnquier fleepe like vnto the fleep of drunlienneffe, which continucth long, and is deadly to the party.

The feed of whire Henbanc is good againft the congh, the falling of waterie humours into the cyes or breft; againft the inordinate flux of womens iffues, and all orher iffies of blour, taken in the weight of ten graines, with water wherein honey hath beene fodden.

The ront boyled with vineger, and the fame holden hot in the mouth, eafeth the paine of the rceth. The feed is ved by Mountibanke Tooth-drawers which runne about the countrie, for to
caufe wormes come fortl of caufe wormes come forth of mens teeth, by burning it in a chafing-difh with coles, the party holding his mouth ouer the fume thereof: but fome crafty companions to gaine mony conuey fmall mouth or other parts which he intended to eatient that thofe fmall creeping beafts came out of his

\section{B} 等。 


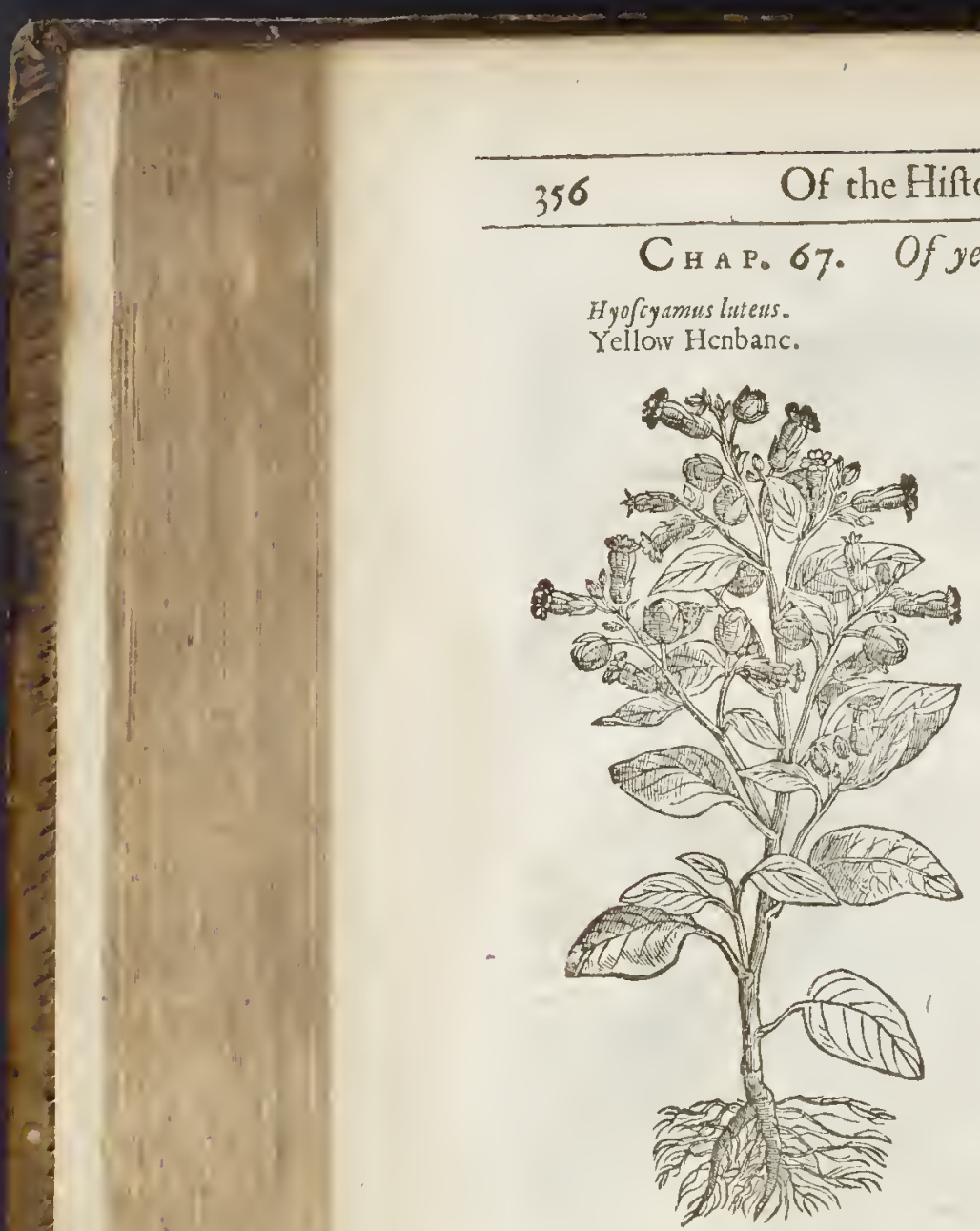

L. 1 B. 2.

y of Plants.

Englifh Tabaco.

Hyolcyamus luteus.

Yellow Hcnbanc.

The Defcription.

TEllow Henbane groweth to the height of two cubits : the italkc is thicke, far, and greene of colour, full of a fpongcous pith, and is diuided into fundry branches fet with fmooth and cuen leaucs, thick, and ful of juice. The floures grow at the tops of the branches, orderly placed, of a pale ycllow colour, fomething leffer than thofe of the blacke Henbane. The cups wherein the floures do ttand are like, but leffer, tenderer, and without tharpe points, wherein is fet the husk or cod fomwhat round, full of very fmall feed like the fced of Marjerome. The root is fnall and threddy. er The Place.

Ycllow Henbane is fowen in gardens, wherc it doth profper exceedingly, infomuch that it cannot bc deftroycd where ic hath once fowen it felfe, and it is difperfed into the molt parts of England.

$$
\text { of } T \text { be Time. }
$$

It floureth in the Sommer moneths, and oftentimes till Autumne be farre foent, in which time the feed commeth to perfection.

$$
\text { 9T The Names. }
$$

Yellow Henbane is called Hyofyamus luteus: of fome, Petum, and Petun : of others, Nicofiana, of Nicot a Frenchman that brought the feeds from the Indies, as alfo the fecds of the true Tabaco, whereof this hath beene taken for a linde ; infomuch that Lobel hath called it $D$ ubius $H y$ of cyamus, or doubtfull Henbane, as a plant participating of Henbane and Tabaco: and it is ved of diuers in ftead of $\mathrm{Tabaco}$, and called by the fame name, for that it hath bccne brought from Trinidada, a place focalled in the Indies, as alfo from Virginia and Norcmbega, for Tabaco; whicls doubtleffe taken in fmoke worketh the fame kinde of drunkenneffe that the right Tabaco doth. \$ Somevre to call this Nicotian, in Englih, being a name taken from the Latine. \$

$$
\text { बT The Nature. }
$$

This kinde of Henbane is thought of fome to be cold and moift; but after Lobel it rather heateth than coolcs at all, becaufc of the biting tafte, as alfo that rofennine ffe or gummincs it is poffeffed of which is euidently pcrceiucd both in handling and chewing it in the mouth.

\section{The fertues.}

A This herbe auaileth againft all apoftumes, tumors, inneteratc vicers, botclics, and fuch like, being made into an vngucnt or falue as followetl : Take of the grcene leaues thrce pounds and an halfe, ftampe them very fmall in a ftone morter : of Oyle Olite one quart; fet them to boyle in a braffe pan or fuch like, vpon a gentle fire, continually ftirring it vntill the herbes feem blackc, and will not boyle or bubblcany more : then fhall you hate an excellent greene oylc; which being ftraincd from the feces or drofle, put thc clcare and ftrained oyle to the fire againe; adding thereto of wax halfe a pound, of rofen foure ounces, and of good Turpentine tro ounces : melt them all together, and kcepe it in pots for your vfe, to cure inueterate vlcers, apoftumes, burnings, greenc wounds, and all cuts and hurts in the head; whercwith I hauc gotten botls crownes and credir.

B It is vfcd of fome in ftead of Tabaco, but to fmall purpofc or profit, although it doftupific and dull the fences, and caufe that kindc of giddineffc that Tabaco doth, and likewife foitting; which any other herbc of hot tcmperature will do,as Roíemary, Tine, winter Sauorie, fweet Marjerome, and fuch like: any of the which I like betrer to be taken in fmokc than this kindc of doubtfull benbane. 


\section{C на Р. 68: \\ Of Tabaco, or Henbane of Teru. \\ T $T$ be Kindes.}

7 Herebe two forts or kindes of $T$ abaco; one greater, the other leffer : the greaterwas brought into Europe out of the prouinces of America, which wc call the Weft Indies; the other from Trinidada, an Inland neere vnto the continent of the fame Indies. Some haue added a third fort: and others make the yellow Henbane a kinde thereof,

t I Hyocyamus Peruriasus:

Tabaco or Henbane of Pera:

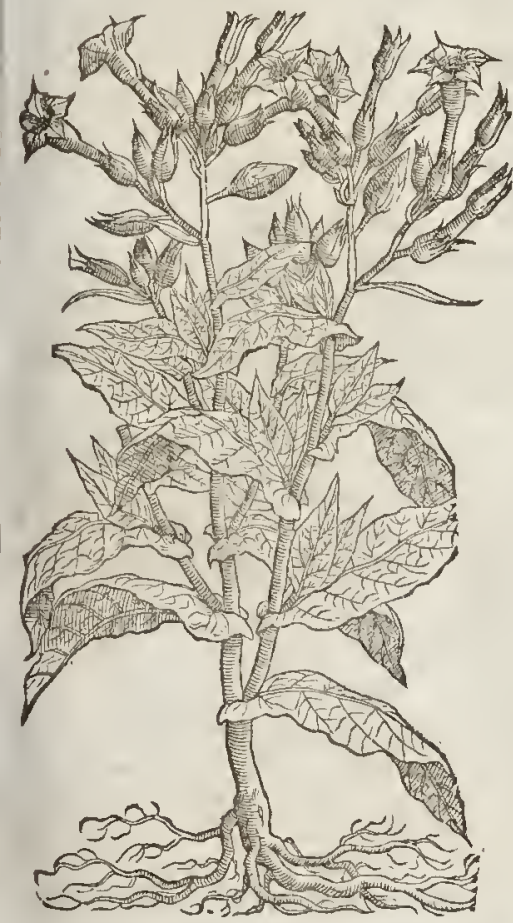

I 2 Sana Santia Indoruan: Tabaco of Trinidada:

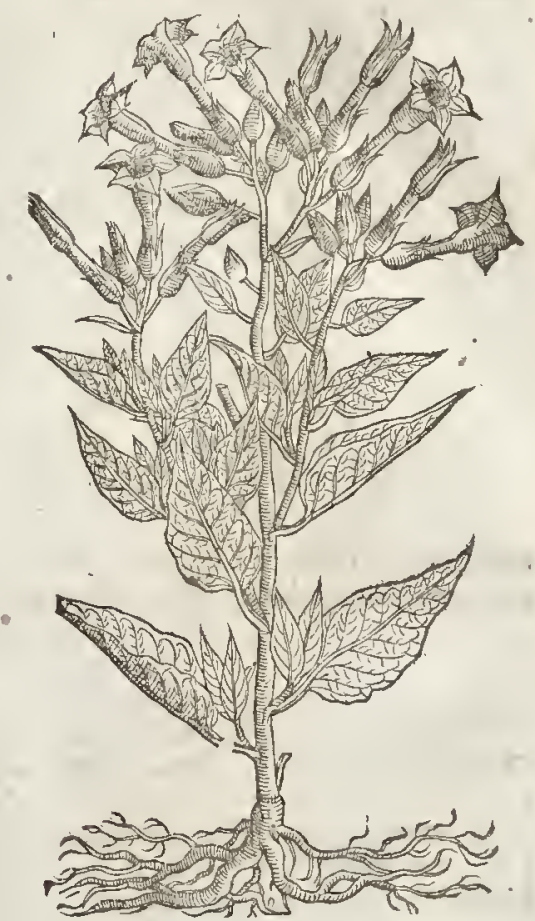

T) The Defoription: I Abaco, or Henbane of Peru hath very great ftalkes of the bigneffe of a childes arme,
growing in fertile and well dunged ground of feuren or eight foot high, diuiding it felfe into fundry branches of great length ; whereon are placed in moft comely order very faire long leautes, broad, fmooth, and tharpe pointed, fint, and of a light grecne culour, fo fantned about the ftalke, that they fecme to embrace and compaffe it about. The floures grow at the top of the ftalkes, in thape like a bell-floure, fomewhat long and cornercd, hollow within, of a light carnation colour, tending to whiteneffe toward the brimmes. The feed is contained in long tharpe pointed cods or feed-veffels like vnto the feed of yellow Herbane, but fomewhat fmaller and browncr of colour. The root is great, thicke, and of a wooddy fubftance, with fomc thrcddie ftrings anexed thereunto.

2 Trinidada Tabaco hath a thicke tough and fibrots root, from which immediatcly rife vp long broad lcaues and fmooth, of a grecnith colour, lefer than thofe of Peru : among which rifeth vp a ftalke diutiding it felfe at the ground into diuers branches, whereon are fet confufedly the like leates, but leffer : at the top of the ftalks itand vp long necked hollow foures of a palc purple ten-ding to a blufh colour: after which fucceet the cods or feed-veffels, incliding many finall feeds like vnto the feed of Marjerome. The whole plant perifheth at the firt approch of Winter.

Gg 3

$\frac{ \pm}{3}$ This 
¥ 3 Tabacum minimum. Dwarfe Tabaco.

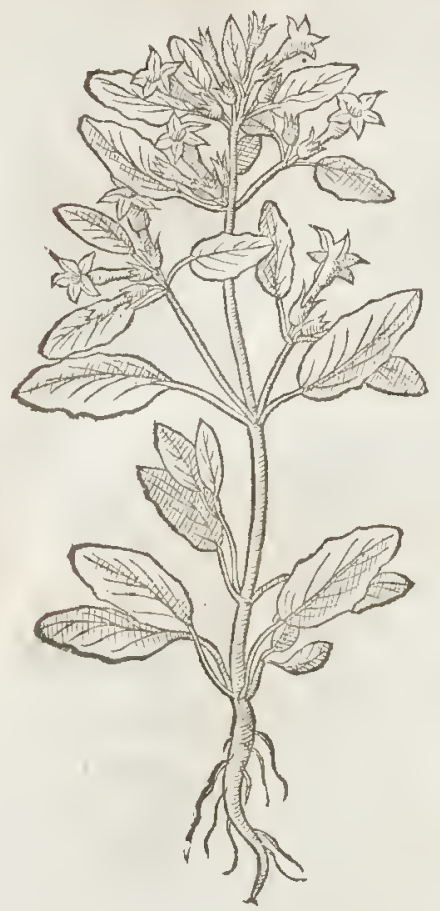

₹ 3 This thitd is an herbe fome fpanne or better long,not in face vnlike the preedent, neither defectiue in the hot and burning tafte. The flotres are much leffe than thofe of the yellow Henbane, \& of a greenirh yellow. The leaues are frall, and narrower thofe of Sage of Ierufalem. The root is fmall and fibrous. $\ddagger$

$$
\text { The Place. }
$$

Thefewere firft brought into Europe out of America, which is called the Weft Indies, in which is the prouinee orcountrey of Peru : but being now planted in the gardens of Etrope it profpereth very well, and commeth from feed in one yeare to beare botll floures and feed. The which I take to be better for the conftitution of our bodies than that which is brought from India; and that growing in the Indies better for the people of the fame Countrey: notwithitanding it is not fothought,nor receitued of our $T a$. baconifts; for according to the Englifh Prouerbe, Far fetcht and deare bought is beft for Ladies.

$$
\text { - The Tisne. }
$$

Tabaeomult be fowen in the moft fruitfull sround that may be found, carlefly caft abroad in the fowing, without raking it into the ground or any fuch paine or induftrie taken as is requifite in the fowing of other feeds, as my felf haue found by proofe, who haue experimented cuery way to eaufe it quickly to grow: for I haue committed fome to the earth in the end of March, fome in Aprill, and fome in the beginning of May, becaule I durft not hafard all my feed arone time, left fome vikindely blaft thould happen after the fowing, which might be a great enemic thereunto.

$$
\text { T The Names. }
$$

'T'he people of America call it Petun: Some, as Lobel and Pena, haue giuen it thefe Latine names, Sacra ber ba, Sancta berba, and Sana fancta Indormm : and orher, as Dodoneru, eall it Hyof cyamus Pcruvianns, or Henbane of Peru: Nicolaus Monardus names it Tabarum. That it is Hyoformi Becies, or a kind of Henbane, not onely the forme being like to yellow Henbane, but the qualitic alfo doth declare; for it bringeth drow funeffe, troubleth the fenees, and maketh a man as it were drunkeby taking of the fume onely; as Andrem Theuet teftificth, (and common experienee fherveth:) of fome it is called Nicosiana: the which I :efer to the yellow Henbane, for diftinctions false.

$$
\text { I The Temporature. }
$$

It is hot and dry, and that in the feecnd derree, as monardis thinketh, and is withall of power to difcuffe or refolue, and to cleanfe away filthy lumors, hauing alfo a fmall altriction, and a fupifying or benumming qualitic, and it purgeth by theftoole : and Monurdiswriteth that it hath a certaine power to refift poyfon. And to proue it to be of an hot temperatute, the biting qualitie of the leaues doth fhew, which is eafily perceiued by tafte : alfo the greene leatues laid vponvlcers in finewse parts may ferue for a proofe of heate in this plant; beculfethey do draw out filth and corrupted matter, which a eold Simplewould neuer do. The leates likewife being eherved draw forth flegme and water, as doth alfo the fume taken when the leates are dried :which things declate that this is not a little hot ; forwhat things foeuer, that being ehewed or held in the nouth bring forth flegme and water, the fame beall aecounted hot $;$ as the root of Pellitorie of Spaine, of Saxifrage, and other things of like power. Moreoter, the bentmming qualitie hereof is not hard to be pereciued, for voon the taking of the fume at the mouth there followeth an infirmitie like vato drunkennefie, and many times lleepe; as after the taking of opium: which alfo fheweth in the taftea biting qualitie, and therefore is not without heate; which when it is chewed 
and inwardly taken, it doth forthwith thew, caufing a cettaine heat in the cheff, and yet withall troubling the wits, as Petrus Bellonius in his thitd Booke of Singularities dothdeclare; where alfo hee theweth, that the Tutkes oftentimes doe ve opium, and take one dramme and a halfe thereof at one time; without any other hut following, fauing that they are the reupon (as it were) caken with a certaine light drunkenneffe. So alfo this Tabaco being in tafte biting, and in temperature lhot, harh notwithftanding a benumming qualitie. Hereupon it feemcth ro follow, that not onely this Henbane of Peru, but alfo the iuice of poppie otherwife called opium, confiftet of diuers parts; fome biting and hot, and others extreme cold, that is to fay, ftupifying or bemumming: if fo bee that this benumming qualitic proceed of extreme cold (as $G$ alen and all the old Phytitions doe hold opinion) Then fhould this bee cold ; but if the benumming facultie doth not depend of an extreme cold qualitie, but proceedeth of the effence of the fubstance; then Tabaco is not cold and bentmming; but hot and benumming, and the latter not fo much by reafon of his temperature, as through the propertie of his fubitance; no otherwife than a purging medicine; which hath his force not from the temperature, but ftom the efience of the wlole fubltance.

$$
\text { ขा The vertus: }
$$

Nicolums Monardis faith, that the leaues hereof are atemedy for the paine in the head called the A Megram or Migraime that hath beene of long contintance : and alfo for a cold ftomacke; efpecially in children; and that it is good againft rhe paines in the kidncies.

It is a prefent remedie fot the fits of the Mother : it mitigateth the paine of the gout if it bee $r$ ofted in hot embers and applied to the grieued part.

It is likew ife a remedie for the tooth-ache, if the tecth and gums be rubbed with a linnen cloth $\mathrm{C}$ dippesd in the iuice; and afterward a round ball of the leaues laid vnto the place.

The inice boiled with Sugar in forme of a firrup and invardly taken, driucth forth wotmes of is the bellie; if withall a leafe be laid to the Nauell.

The fame doth likewife fcoure and clenfeold and totten vlcers, and bringeth them to petfeat $E$ digeft ion as the fame Authot affirmeth.

In the Low Countreyes it is vfed againft fcabbes and filthineffe of the skinne,and for the cure $\mathrm{E}$ of wounds : but fome hold opinion that it is to bee vfed butoncly to hotand itrong bodies: for they fay that the vfe is not fafe inweake and old folkes : and for this caufe, as it feemeth, the women in America (as Theut fayth) abftayne from the hearbe Petun or Tabaco, and doe in no wife vfe it.

The weight of foure ounces of the inice heeteot dtunke putgeth both vpwards and downe- $\mathrm{G}$ vatds, and procuretl after, a long and found fleepe, as wee haue learned of a friend by obferuation, affirming that a ftrong Comntreyman of a middle age, hauing a dropfic, tooke of it,and beng wakened out of his fleepe, called for meat and dtinke, and after that became perfectly whole.

Moreouer the fame man reported, that lic had eured many countriemeri of agues with the di- $\mathrm{H}$ filled water of the leaues drunke a little while before the fit.

Likewife thete is an oile to be taken out of the leaves that healeth merry-gals, kibed heels and I Cuch like.

It is good againft poifon, and taketh away the malignitie thereof, ifthe inice be giuen to dtink $K$ or the wounds made by venemous beafts be wathed therewith.

The drie leaucs are vfed to be taken in a pipe fet on fire and fuckt into the ftomacke, and theuf L forth againe at the nofturils againt the pains of the head, rheumes, aches in any part of the body whereof foener the originall proceed, whether from France, Italy, Spaine, Indies, or from our familiar and beft knowne difeafes: thofe leates doe palliate or eafe for a time, but neuer performe uny cure abfolutely : for although they emptic the body of humours, yet the caufe of the griefe ionot be fotaken away. But fome liaue learned this ptinciple, that repletion requirch cuacuaion; that is, fulnefe cratueth emptinefle, and by cuacuation afure themfelues of health: $B$ ur his dotl not take away fo much with it this day, but the next bringeth with it more: $A$ s for exmple, a Well doth neuer yeeld fuch ftore of water as when it is moft drawne and emptied. My ilfe fpeake by proofe, who haue cured of that infectious difeafe a great many; dituers of which ad coucted or kept vnder the fickeneffe by the helpe of Tabaco as they thought, yet in the end aute beene conftrained to haue vnto fuch an hard knot, a ctabbed wedge, or elfe had viterly pe-
ithed. ithed.

Some yfe to drinke it (as it is tearmed) for wantonneffe or rather cuftome, and cannot fotbeare , no not in the midat of their dinner, which kind of taking is vnwholefome and very dangerous:al hough to take it feldome and that Phyfically is to be tolerated and my do fome good : but I M ommend the fyrrup aboue this fume or mokie nuedicine, 
N It is taken of fome phyfically in a pipe for that purpofc once in a day at the mot, and that in the morning fafting againft paines in the head, ftonacke, and griefe in the breft and lungs:againf catarrhes and theumes, and fuch as liaue gotten cold and hoarfeneffe.

o Some hauc reportcd that it littic preuaileth agannt an bot difeafe, and that it profiteth an hot complexion nothing at all : but cxperiencchath not thewed it to bee iniurious vnto either.

P They that haue feene the proofe hereof haue credibly reported, that when the Moores and Indians hauc fainted either for want of food or reft, this hath beenca prefent remedievnto them to fupplie the one, and to helpe them to the other.

Q The pricfts and Inchanters of the hot countrics do take the fumc thercor vntill they be drunke, that after they haue lien for dead threc or foure houres, they may tell the people what wonders, vifions, or illufions they hauc fcene, and fo giue them a propheticall direction or foretelling(if we may truft the Diuell) of the fucceffe of their bufineffe.

$\mathrm{R}$ The iuice or difilled water of the firt kind is very good againft catarrhes, the dizzinc fe of the head, and rheumes that fall downe the cies, againt rhe paine called the Megram, if either you applic it vnto the temples, or take one or two greenc leaues, or a dry leafe moiftued in wine, and dried cunningly vnon the embers and laid thereto.

$S$ It clecrcth the fight and taketh away the webs and fpotsthereof, being annointed with the iuice bloud warmc.

T The oilc or itri cedropped into the eares is good againft deafeneffe; a cloth dipped in the fame and laid vpon the facc, taketh away the lentils, redncfie, and fpots thereor.

$V$ Many notable medicines are made hercof aga in ft the old and inuetcrate cough,againft afthmaticall or pcetorall griefes, which if I thould fet downe at large, would require a peculiar Vo. lumc.

X It is alfo giucn to fuch as are accultomed to fwounc, and are troubled with the Collicke and windinefic, againft the Dropfie, the Wormes in cliildren, the Pilcs and the Sciatica.

Y It is vfed in outward medicincs cither the herbe boiled with oile, waxc, rofin and turpentine, as beforc is fet downe in yellow Henbanc, or the extraction thereof with falt, oile, balfame, the diftilled watcr and fuch like, againft tumours, apoftumes, old vlccrs, of hard curation, botches, fcabbcs, finging with netties, carbuncles, poifoncd arrowes, and wounds made with gunnes or any other wcapon.

2 It is excellent good in burnings and fcaldings with fire, water, oile, lightning, or fuch like, boiled with Hogges greace in formc of an Ointmenr, which I haue often prooued, and found moft truc, adding a little of the iuicc of thornc apple leaues, fprcading it vpon a cloth and fo applying it.

A I doe makc hereof anexcellcnt balfame to cure decpewounds and punctures, made by fome narrow fharpe pointed wcapon. Which balfame doth bring vp the fich from the bottome verie fpecdily, and alfo heale fimple cuts in the flefh aceording to the firfe intention, that is, 10 glew or foder the lips of the wound together, not procuring matter or corruption wnto it as is commonly feene in the healing of wounds. The receit is this: Takc oilc of rofes, oile of S. Iohnswort, of either one pinte, the leaues of $\mathrm{T}$ abaco ftamped fmall in a fone morter two pounds, boile them together to the confumption of the iuicc, ftraine it and put it to the fire againe, adding thercto of Venice Turpentine two ounces, of Olibanum and maftickc of either halfe an ounce, in moft fine and fubtill pouder, the which you may at all times makcan vnguent or falue by putting thereto wax and roin to gitic unto it a fiffe body, which worketl exceeding well in maligne and virulent vlcers, as in wounds and punctures. I fend this icwell vnto you women of all forts, efnecially to fuch as curc and helpe the poore and impotent of your Countrey without reward. But vnto the beggerly rabble of witches, charmers, and fuch like coufeners, that regard more to get money, than to helpc for charitic, I wifh thefe few medicines far from thcir underftanding, and from thofedecciuers whom I wifh to be ignorant herein. But courteous gentlewomen, I may not for the malice that I doe bearcvnto fuch, hide any thing from you of fuch importance : and therefore take one more that followeth, wherew ith I hate done very many and good cures, although of fmall cont, but

B regard it not the lefle for that caufe. Take the leaues of Tabaco rwo pound, hogges greafe one pound, ftampe the herbe fmall in a fone mortcr, putting thereto a fmall cup full of red or claret wine, ftis them well together, coner the morter from filth and fo let it reft vntill morning; then put it to the fire and let it boilc gently, continually ftirring it vntill the confumption of the wine; ftraincit, and fet it to the fire againe, putting thereto the iuice of the herbe onc pound, of Venice turpentine foure onnces; boilc them togcthet to the confumption of the iuice, then adde therto of 


\section{C на р.70. Of Balme Apple, or eApple of Hierufalem.}

I Balfarnina mas.

The male Balfam Apple.

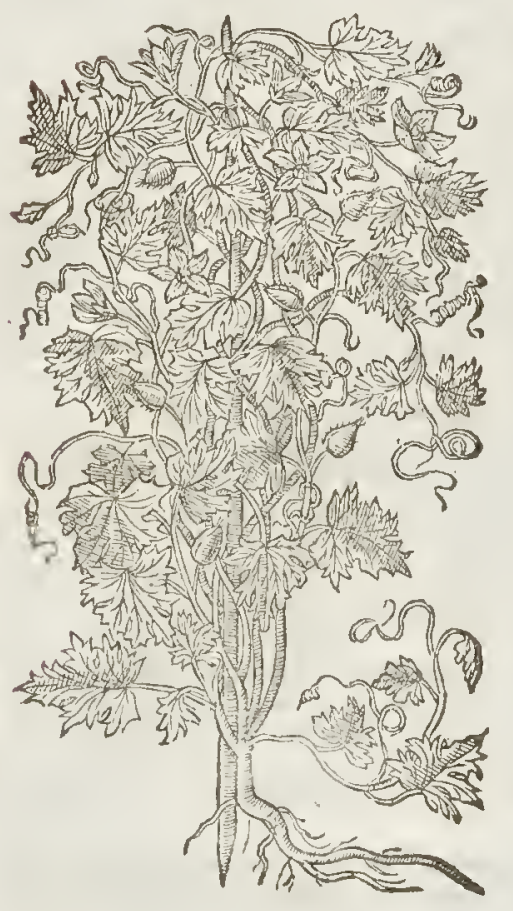

2 Balsamina farmina. The female Balfam Apple.

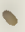

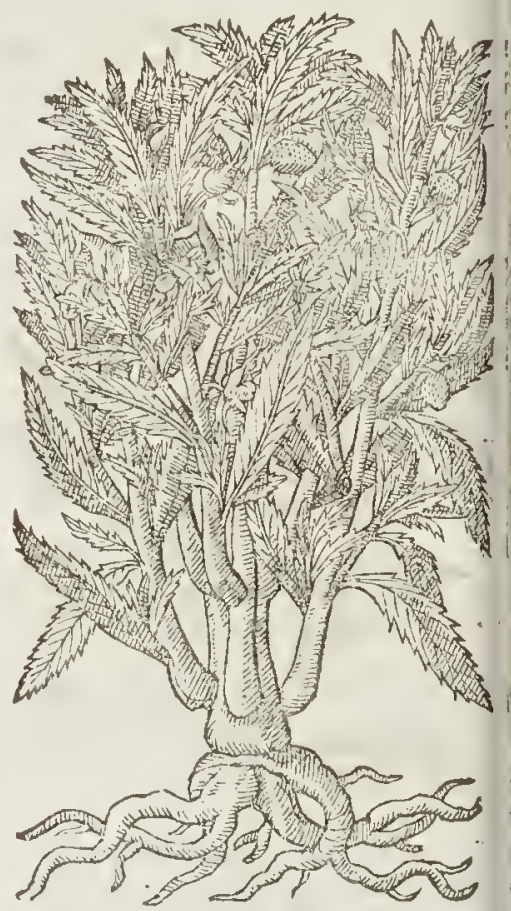

The Defription.

I Te male Balme Apple hath long, fmall,and tender branches, fet with leates like thofe of the vine; and the like Imall clafping tendrels wherewith it eateheth hold of fuch things as do grow neere unto it, not able by reafon of his weakenefle to ftand ypright without fome pole or other thing to fupport it. The floures confift of fue fmall leaues of a meane bigneffe, and are of a faint yellow colour : wh heh being palt, there doe come in place long Apples, fomething fharpe toward the point almoft like an egge, rough all ouer as it were w ith fmall harmelefle priekles, red both within and without when they be ripe, and cleate in funder of themfelues : in the Apple lieth great broad flat feeds, like thofe of Pompion or Citrull, but fomething blacke when they be withered. The root is threddic, and difperfet h it felfe far abroad in the ground.

2 The female Balm Apple dotl not a little differ from the former : it bringeth forth ftalks not running or climing like the orher, but a moft thieke and fat truncke or toeke full of iuice, in fubfanee like the ftalks of Purflane, of a reddith color and fomewhat thining. The leaues be long and narrow, in thape like thofe of Willow or the Peaeh tree, fomewhat toothed or notched about the edges : among which grow the floures of an inearnate colour tending ro blewneffe, hauing a fmall . fpur or taile annexed thereto as hath the Larks heele, of a faire light crimfon colour : in their places come vp the fruit or Apples rough and hairy, but leffer than thofe of the former, yellow when they be ripe, which likew ife eleaue a funder of themfelues and eaft abroad their feedes much like vnto Lentils, faith mine Author. But thofe which I haue from yeate to yeare in my Garden bring forth feed like the Cole-Porey or Muftard feed; whether they be of two kindes, or the climate doe alter the thape, it refteth difputable. 
IT The Place. Thefe plants do profperbeft in hot Regions : they are ftrangers in England,and dos witl great
abour and induftrie grow in thefe cold Countries.

T The Time.

They muft be fowne in the beginning of A prill in a bed of hot horfe dung, euen as MuskeVelons, Cucumbers, and fuch like cold fruits are; and replanted abroad from the faid bed into he mof hot and fertile place of the Garden at fuch time as they hauegotten three leaues a seee,

Diuerly the Names.

ne as it feemed good to his faneie. Baptiffa Sardus ealleth one name, and fome by another,euery ill ella, and Charantin,as alfo Ponum Hierofolynatanum, or Apples of Hierufalem: in Englifh, Balme Apple:in Italian, $C_{a} r a n Z a:$ in the Germane tongue, 2Balfam opffel : in French, Merueille: fome of he Latines hatre ealled it Pomum mirabile, or maruellous Apples. It is thought to benamed $B$ al $F a_{n}$ nima, beeaufe the oile wherein the ripe Apples be fteeped or infufed, is taken to bee profitable for nany things, as is opobalfamum, or the liquour of the plant Balfamum.

The female Balfam Apple is likewife called Balfamina, and oftentimes in the Neuter Gender Balfaminum : Gefner choofeth rather to name it Balfamina amygdaloides: Valerius Cordus, Balfamella: others, Ball, tminat fomina : in Englinh, the Fernale Balme Apples.

\section{T The Iature.}

The fruit or apples hereof, as al fo the leaules, doe notably drie, hauning withall a certaine mode: :ate coldneffe very neere to a meane temperature, that is after forne hot, in the firft, and drie in the Feond degree.

The leatues are reported to of The Vertuls.

The leaues are reported to heale greene wounds if they be bruifed and laid thereon; and taken $A$.
with wine they are faid to be a remedie for the collicke. and a effeet with wine they are faid to be a remedie for the collicke; and an effectuall medieine for burftings
and convulfions or erampes.

The leaues of the male Bal famina dried in the fhadow, and beaten into pouder and gituen in IB wine vnto thofe that are mortally wounded in the body, doth cure them inwardly, and helpeth alfo
the Collieke.

The oile which is drawne forth of the fruit doth cure all greene and freft wounds as the true aturall Balfam : it helpeth the crampes and convulfons, and the fhrinking of finewes, being an-
hointed therewith.

It profiteth women that are in great extremitie of childe-birth in taking away the paine of the natrix, caufing eafie deliuerance beeing applied to the place, and annointed vpon their bellies, or It eureth the Hemorrhoides, and eafeth the dolour of the inward parts.

lint of old elouts.

The leaues drunken in wine, heale ruptures:

I finde little or norhing written of the property or vertues of the female kinde, but that it is $F$ hought to draw neere vnto the firft in temperament and vertue.

Oile oliue in whieh the fruit (the feede taken forth) is either fet in the Sun, as we do when wee $\mathrm{H}$
nake oile of rofes, or boiled in a double nake oile of rofes, or boiled in a double glaffe fet in hot water, or elfe buried in hot horfe dung,taseth away inflammations that are in wounds. It doth alfo eafily and in fhort time con folidate or slew them together,and perfectly eure them.

hereof being inie ted or eonueied into the head of the yard or matrix,as alfo the inflammation $t$ hereof being inie.ted or eonueied into the place with a fyringe or mother peffarie.

This apple is with good fuceeffe applied vnto wounds, prickes and hurts of the finewes. It hath $\mathrm{K}$ ime the pouder of the leaves be taken for certaine daies together.
It is reported that fuehes bestif in the meane

It is reported that fuch as be barren are made fruitfull herewith, if the woman firf be bathed in $L$ fithand the woman prefently purpore, \& the parts about the thare and matrix annointed here. fith, and the woman prefently haue the company of her husband.

\section{D} 西 .

\section{,}




\section{С на р.71. Of Ginnie or Indian Pepper.}

I Capficum longioribus filiquis.

Long cotded Ginnie Pepper.
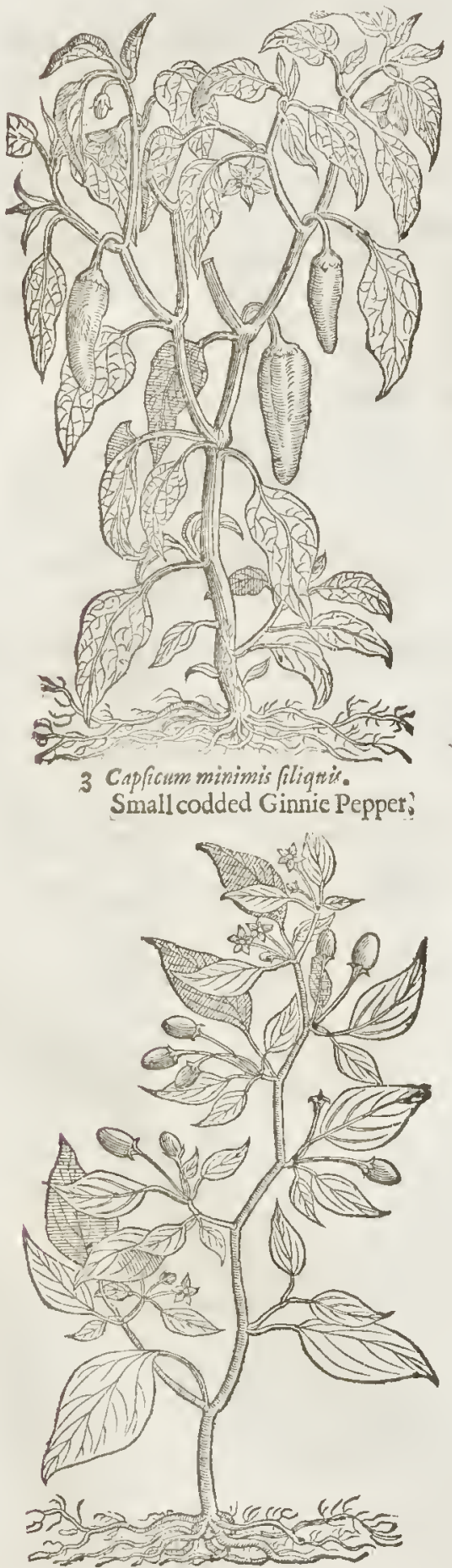

$\neq 2$ capfaim rotundioribus filiguis. Round codded Ginnic Pepper.

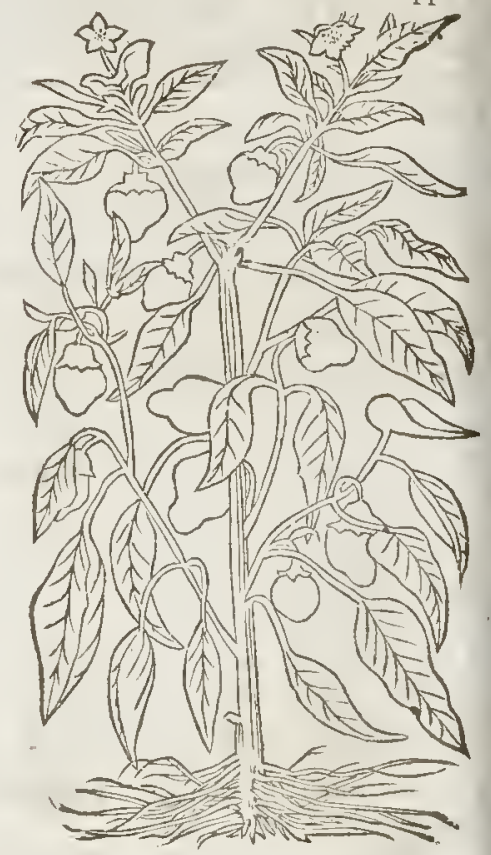

\# Capficiflique varia. Varicties of the cods of Ginnie Pepper:
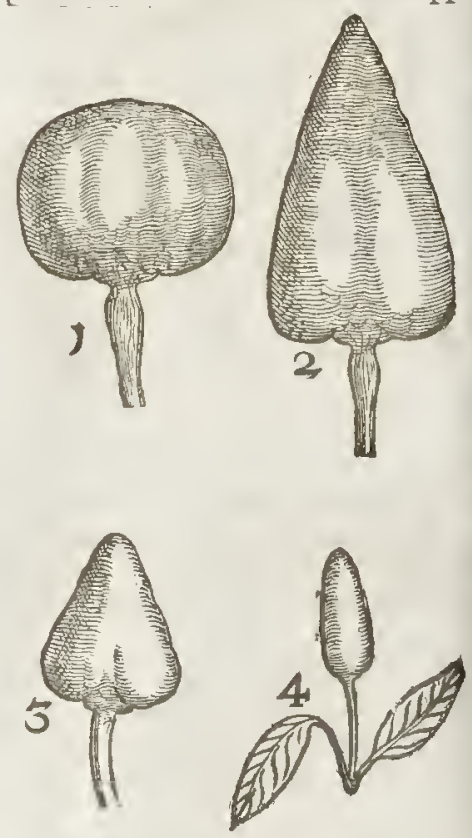

The! 


\section{$\mathrm{L}_{\mathbf{1} \text { B. 2. }}$ Of the Hiftorie of Plants.}

\section{The Defription.}

I 7 He firft of thefe plants hath fquare ftalkes a foot higli or fonewhat more fit withinany thicke and fat leaues, not vnlike to thofe of garden Night thade, bur harrowerand. harper pointed, of a darke greene colour. The floures grow alongt the falkes, out of the wings of the leaues, of a white colour, hauing for the moft part fue fmall leaues bla fing out like a far, with a greene button in the middle. After them grow the cods, greene at the firft, and when they be ripe of a braue colour glittering like red corall, in which is contained little flat feeds, of a light yellow colour, of a hot biting tatte like common pepper, as is alfo the cod it felfc : which is long, and as big as a finger, and tharpe pointed.

$\ddagger 2$ Thedifference that is betweene this and the laft defcribed is fmall, for it confifts in nothing but that the cods are pretty large and round, after the fafmion of cherries, and not fo long as thofe of the former. $\ddagger$

3 The third kinde of Ginnie pepper is like vnto the precedent in leaues, floures, and Atalkes. The cods hereof are fmall, round, and red, very like to the berries of $D$ ulcumara or wooddy Night. thade, both in bigneffe, colour, and fubftance, wherein confifteth the difference : notwithitanding the feed and cods are very tharpe and biting, as thofe of the firft kinde.

¥ Capficifiliquevarie.

Varieties of the cods of Ginnie pepper.
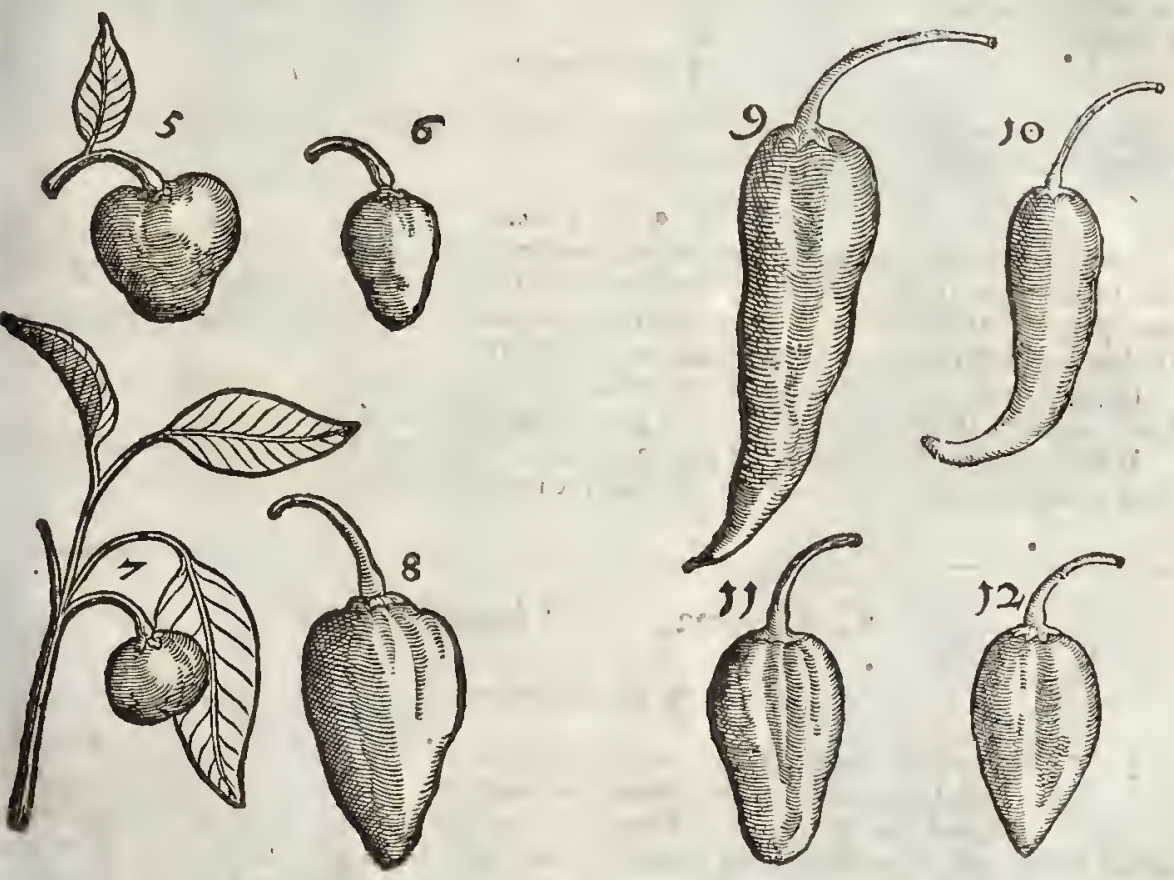

* There are many other varieties of Ginnie pepper, which chiefly confint in the fhape and colour of the cods : wherefore I thought good ( and that chiefely becaufe it is a plant that will hardly brooke our climate) only to prefent you with the figures of their fenerall hhapes, whereof the cods of fome ftand or grow vpright, and other fome hang downe : fuch as defire fuither information of this plant, may be aboundantly fatisfied in Clufuses his Curepofter. from pag. 95 . to pag. I 08. where they thall finde thefe treated of at large in a treatife written in Italian by Gregory de Regio, a Capuchine Fryer,and fent to Clufus, who trandating it into Latine, left it to be fet forth with other his obferuations, whith was performed 2. yeares after his death, to wit Anno Domini 1611 . The figures we here giuc arc the fame $w$ hich are in that tratate. $\neq$

T The Place.
Thefe plants are brought from forrein countries, as Ginnic, India, and thofe parts, into Spaine
$\mathrm{H} \mathrm{hl}$ 
and Italy : from whence we haue receiued feed for our Englith gatdens, where they come to ftuitbearing: but the cod doth not come to that bright ted colour which naturally it is poffeffed with, which hath hapened by reafon of thefe vnkindly yeeres that are paft : but we exped betier when God thall fend vs a hot and temperate yeere.

$$
\text { aा The Time. }
$$

The feeds liereof mut be fowen in a bed of hot horfe-cung, as muske-Melons ate, and remonued into a pot when they haue gotten three or foure leaues, that it may the more conueniently be catied from place to place to receite the heate of the funne and are towar: A tutumne to be caried into fome houfe, to atroide the iniuric of the cold nights of that time of the yecte, whern it is to beate his fruitc.

$$
\text { बI The Names. }
$$

Acturius calleth it in Gtecke katus: in Latine, Capfacum: and it is thoughe to be that which Auicen namcth zinifiber caninm, or dogs Ginger: and pliny, Siliguaftrum, which is more like in rafte to pepper thin is $P$ m $m$, and it is therefore called Piperitis, as he hath wtitten in his $I g$. booke, 12. chap.Panax (fith he) luth the talt of pepper and Siliguaftrum, for which caufe it is called pipiritss. The later Hetbarifts do of tentimes cal! it Piper Indianum, or Indicum, fometimes Pzper Calicuthium,or Piper Hipanicnm: in Englih it is called Ginnie pepper,and Indian peppet: in the Ger-

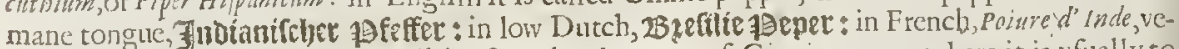
rie well knowne in the thops at Billingfgate by thename of Ginnie pepper, where it is vfually to bebought.

$$
\text { T) The Temperature. }
$$

Ginnie pepper is extreame lot and trie euen in the fourthogegrec : that is to fay, far hotterand drier then 1 witu thaveth dogs ginget to be.

\section{- Tlic Vertues.}

A. Ginnic pepper hath the tafte of pepper, but not the power or vertue, notwithitanding in Spaine and fundrie parts of the Indies they do vfe to dreffe their meate therertith, as we doe with Calecute pepper : but (faith my Authout) it hath in tt a malicious qualitie, whereby it is an enemy to the liuer and other of the entrails. Aucen writeth that it killeth dogs.

B

It is faid to dic or colour like Saffron; and being receiued in fuch fort as Saffron is vfually taken, it warmeth the ftomacke, and helpeth grearly the digeftion of meates.

C It diffoluech the fwellings about the thtoat called the Kings Euill, as ketncls and cold fwellings; and taketh away fpots and lentiles from the face, being applied thereto with honie.

\section{Cн A P.72. OfbornedPuppie.

$$
\text { Tा The Defeription. }
$$

I He yellow homed Poppic hath whitifh leates vety much cut ot jagged, fomewhat
like the lemes of gatden Poppic, but roughet and more hairic. The ftalks be long, round, and brittle. The Aloures be latge and yellow, confifting of foure leaues; which being paft, there come long huskes ot cods, crooked like an lorne or cornet, whetein is conteined fimall blacke feete. The roote is great, thicke, fcalie, and rough, continuing long.

2 The ficond kinde of horned Poppic is much flendercr and leffer than the precedent, and Thath lcaues ivith like decpe cuts ss Rocket hath, and fomcthing haitie. The ftalks bevery flender, brittle, and branched into diuets armes ot wings, the floutes fmall, made of foure little leaucs, of a red colour, iv ith a fmall ftake of blacke toward the bottome; after which commeth the fecd, inclofed in ! lendcr, long, crookcd cods full of blackifh fecd. The toot is fmall and fungle, and dicth eucry ycere.

$\mp$.3 This is much like the laft deferibed, and according ro Clufizes, tather a variety than difference. It is diftinguiblyed from the laft mentioned by the fmoothnes of the leatses, and the colour of the floures, which ate of a pale yellowinh red, both which accidents Chuflse affirnes happen to the fotmer, towards the later end of fommer. $\neq$

4 There is another fort of homed Poppie altogether leffer than the laft deferibed, hating tendeter leaues, cut into fine little parcels : the floure is likewife leffer, of a bletv purple colour like the double Violets 


\section{Li в. 2. Of the Hiftory of Plants:}

367

I Papaucr cornutum flore lutco. Yellow horned Poppic.

Glansium Revima smitio

$\frac{1}{2}$

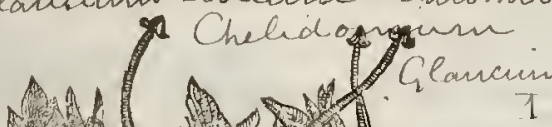

2. Papauericornutum fore rubro. Geancium Ropgie.

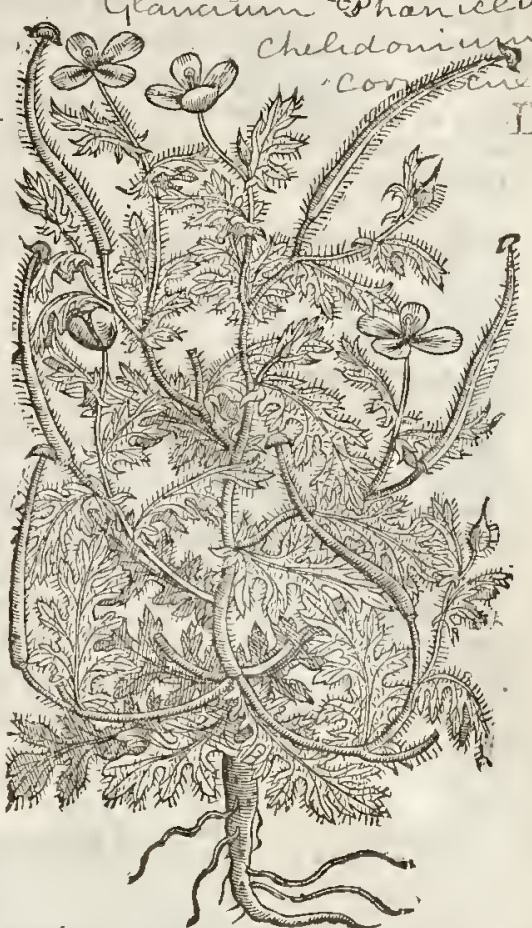

4 Papauer cornutum flore violaceo?

Glancinmiolet coloured horned Popgice?

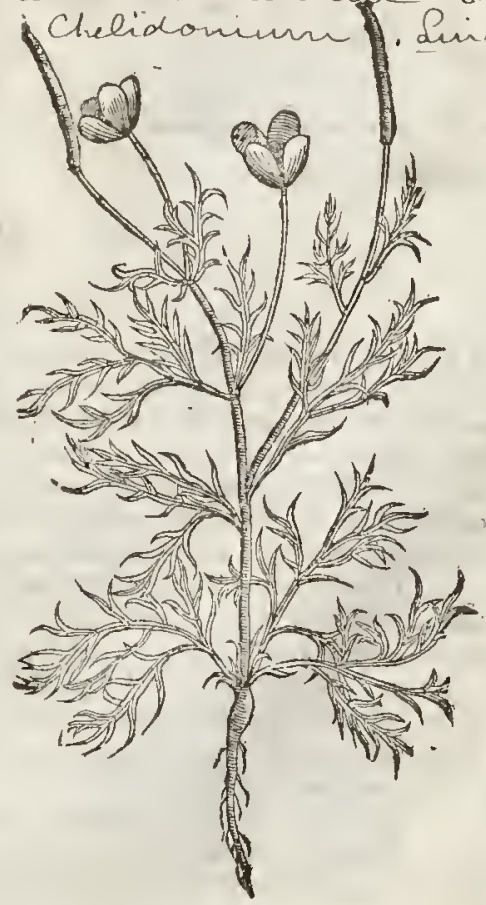

the 


\section{T) The Place.}

The yellow horned Poppic groweth vpon the fands and banks of the fea : I have found it growing neere vnto Rie in Kent, in the Iles of Shejey and Thanet, at Lee in Effex, at Harwich, at Whitentable, and many other plaees alongft the Englifh coaft.

The fecond groweth not wilde in England. Angelas Palca, and Bartholomatus ab vrbe-veterum, who hane co mmented vpon Mefue, write that they found this red horned Poppie in the kingdomes of Arragon and Caftile in Spaine,and the fields neere vnto common paths. They doe grow in my. Garden very plentifully.

They floure from May to the end of Auguft. T $T$ be Time.

बI The Names.

Moft Writers haue taken horned Poppic, efpecially that with red floures to be Glaucium : neither is this their opinion altogether nprobable; for as Diofiorides faith, Glaucium hath leaues like

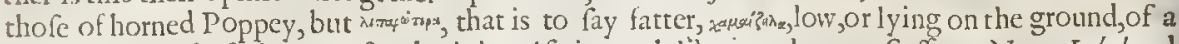
ftrong fmell and of a bitter tafte, the iuiee alfo is mueh like in colour to Saffron. Now Lobel and Pena witneffe, that this homed Poppie hath the fame kinde of ituice;as my felfe likewife ean teftifie. Diofcorides faith that Glaucium groweth about Hierapolis, a citic in Syria; but what hindereth that it fhould not bee found alfo fomewhere elfe? 'Thefe things thew it hath a great affinity with Glascium, if it be not the true and legitimate Glaucium of Diofcorides. Howbeit the firft is the Mecon Ceratites, or Papancr cor niculatum of the Antients, by the common confent of all late Writers : in English, Sea Poppie' and Horned Poppie : in Dutch, Geelbeul and

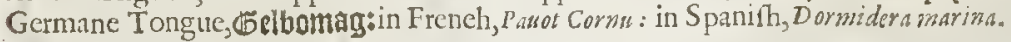

$$
\text { II The Nature. }
$$

Horned Poppies are hot and drie in the third degree.

$$
\text { If The Vertues. }
$$

A The root of horned Poppie boiled in water vnto the confumption of the one halfe, and drunke, prouk eth vrine, and openeth the ftopping of the liuer.

B The feed taken in the quantutic of a fpoonefull loofeth the belly gently.

C The iuice mixed with meale and honie, mundificth old rorten and filt hie vleers.

D The leaues and floures put into vnguents or falues appropriate for greene wounds, digeft them that is, bring them to white matter, sw ith perfect quatture or fanies.

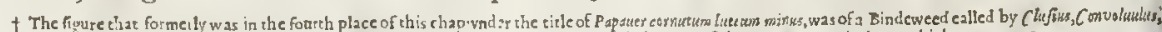

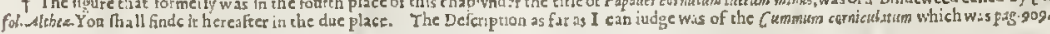

\section{С н г. 73. Of Garden Poppies. \\ T. The Defcription.}

I THe leaues of white Poppie are long, broad, fmooth, longer than the leates of Lettuce, whiter,and eut in the edges : the ftem or ftalke is ftraight and brittle, oftentimes a yard. and a halfe high: on the top whereof grow white floures, in which at the very beginning appeareth a finall head, aceompanied with a number of threds or ehiues, which being full growne is round, and yet fomething long withall, and hath a eouer or erownet vpon the top; it is with many filmes or thin skins diuided into eoffers or feuerall partitions, in which is contained ab undanee of fmall round and whitifh feed. The root groweth deepe, and is of no eft imation nor eontinuance.

2 Like vnto this is the blacke garden Poppie, fauing that the floures are not fo white and fhining, but vfually red, or at leaft fpotted or ftraked with fome lines of purple. The leaues are greater, more iagged, and tharper pointed. The feed is likewife blaeker, which maketh the differenee.

\$ There is alfo another garden Poppie whofe leaucs are muel more finuted, or erefted, and the floure alfo is all iagged or finely eutaboutthe edges, and of this fort there is alfo botle blacke and white. The floures of the blacke are red,and the feed blacke; and the other hath both the floures and feed white.

4 There are diners varieries of double Poppies of both thefe kindes, and their colours are commonly either white, red, darke purple, fearlet, or mixt of fome of thefe. They differ from the former onely in the doubleneffe of their Houres. 


\section{Li в: 2. Of the Hittorie of Plants.}

I Papauer fativum album. White garden Poppic.

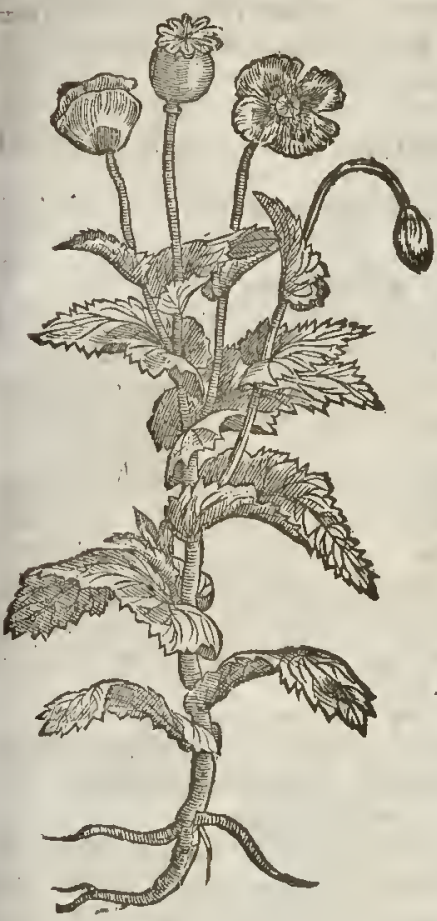

\# Papauer fimbriatum albumi: White iagged Poppie.
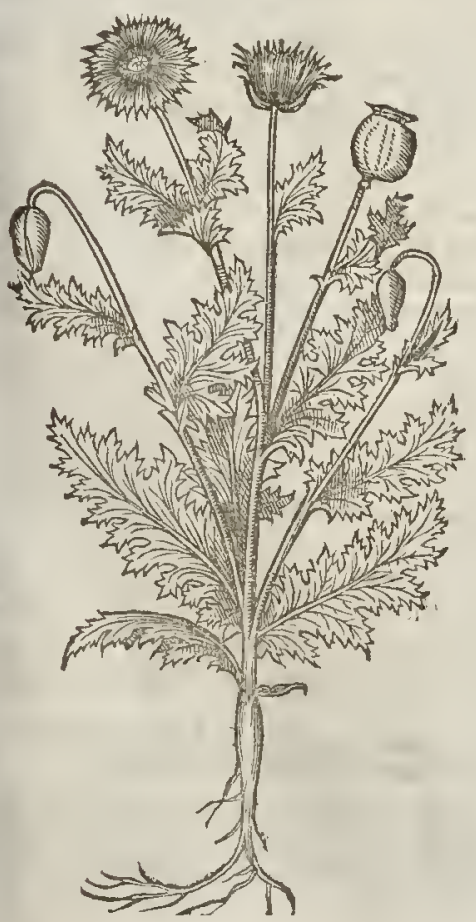

2 Papaier fatioum nigrim. Blacke Garden Póppie.

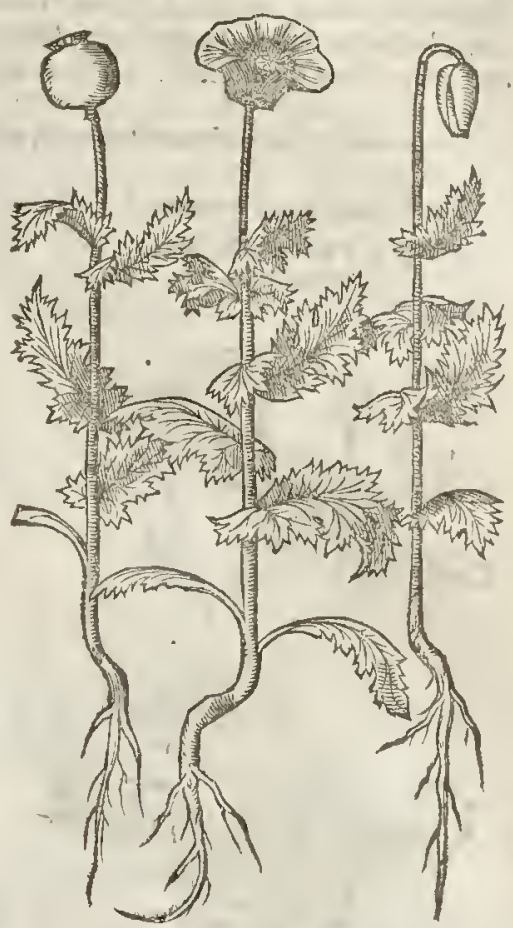

4 Papaner flo multipl.albo of nizro. The double trhite and blacke Poppic.

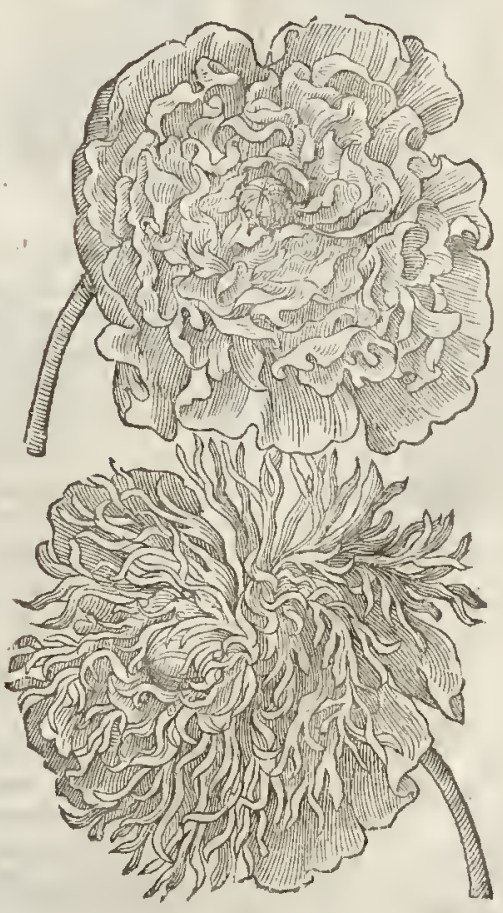

5 There 
5 There is alfo another kinde of Poppie which oft times is found wilde; the ftaltes, Icancs floures, and heads are like, but lefie thanthofe of the precedent:the floures are of an cucsw orn blcw in purple color; after which follow heads flort and round, which vnder their coucr or crcwecthate little boles by which the feed may fall out; contrarie to the heads of the former, which are clofe and open not of themfelues. There is alfo a double one of this kirde. $\neq$

T The Place.

Thefekinde of Poppies are fowne in garden's $8 x$ do afterward come of the fallings of their feed . T T be Time.

They floure moft commonly in Iune. The feed is perfeetcd in Iuly and Augutt.

$\neq 5$ Papauer fyluefle.

$\checkmark$ Wupower sommifenm
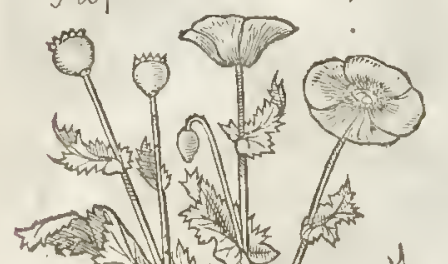

A

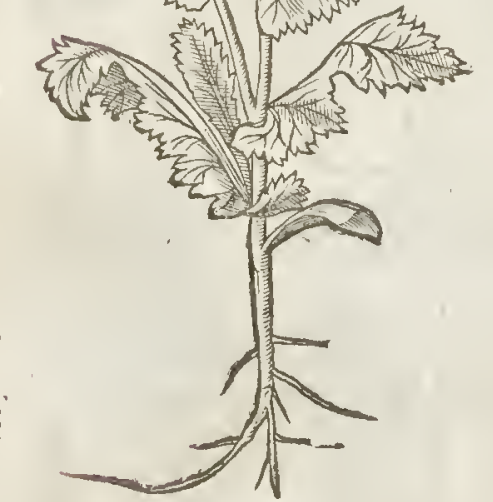

$$
\text { 91 The Names. }
$$

Poppic is called of the Gracians $\mu$ ixw: of the Latines, $P$ apaner : the thops keepe the Latice name $;$ it is

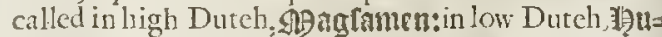
el and 99 ancop:in Englith, Poppie \& Cheefebowls: in French, Pat ot, and olictie, by the.Wallons.

The garden Poppic which hat b blache feeds, is furnamed of Diofcorides aporo, orwilde, and is as hee faitl called iores, beeaufe opiwm fowes from it : of Pliny and of the Latines, Papaucr nigrum. whereof there be many variable colours, and of great beautic, although of euill fmell, whereúpon our gentlewomen doecall it Ione Siluer pin.

\section{The Tompcrature.}

All the Poppies are eold, as Galen teftifieth in his booke of the Faculties of fimple medicines.

$$
\text { Tा The Vertues. }
$$

This feed, as Galcn faith in his booke of the Faculcies of nourifhments, is good to feafon bread with; but the white is better than the black. Healfo addeth, that the fame is cold and caufeth fleepe, and yeeldeth no commendable nourithment to the body; it is often vfed in comfits, ferued at the table with other iunketting dinhes.

The oile which is preffed out of it is pleafant and delightfull to be eaten, and is taken with bread or any other waies in meat, without any fence of cooling.

A greater foree is in the knobs or heads, which doe fpecialiy preuaile to mooue fleepe, and to fay and repreffe diftillations or rheums, and come neere in force to opium, buit more gentle.opium, or the condenfed itviee of Poppie heads is ferongeft of all: $M_{e}$. cown (which is the iuice of the heads and leaues) is weaker. Both of them any wies ratien either inwardly, or outwardly applicd to the head, prouoke flepe. o pum fomewhat too plentifully taken doth alfo bring death, as Plinie truely writeth.

D It mitigateth all kinde of paines : but it leauch behinde it oftentimes a mifeliefe worfe than the difeafe it felfe,and that hatd to be cured, as a dead palfie and fueh like.

E The vie of it, as Galen in his I I booke of medicines aceording to the places affected, faith, is fo offenfue to the firme and folide parts of the body, as that they bad need afrerwards to be reftored.

F So alfo colliries or cie medicines madewith opium haue beene hurtfull to many; infomueh that they haue weakned the cies and dulled the fight of thofe that hame ved it:what foeuer is compounded of opium to mittigate the extreeme paines of the eares bringeth. hardneffe of hearing. Wherefore all thofe medicmes and compounds are to bee thunned that are to be made of opium, and are not to be vfed but in extreme neeeffitic; and that it is, when no other mitigater or aflwager of paine doth any thing preuaile,as Galen in his third booke of Medicines,according to the places affected, doth euidently deelare.

G. The leaues of poppic boiled in water with a little fugar and drunke,caufeth fleep:or if it be boiled without fugar, and the head, fect, and temples bathed therewith, it doth effect the fame.

H The heads of Poppic boiled in water witl fugar to a firmp eauferh flecpe, and is good againft rheumes and eatarrhes that diftill \& fal downe from the brain into the lungs, \& eafeth the cough.

I The rrecne knops of Poppic famped with barley neale, and a little barrorres greafe, helpeth $S$. Anthonies fire, called Ignisfucer. 


\section{B. 2. Of the Hiftory of Plants.}

The leaues, knops and feed ftamped with vineger, womans milke, and fuffron, cureth an Erylipe- $k$ las, (anorher kinde of $S$. Anthonies fire, and eafeth the gout mightily, and put in the fundament as a elifter eauferh flecpe.

The feed of black Poppy drunke in wine ftoppeth the fix of the belly, and the ouernuclu flow - I. ing of womens ficknefie. Alepe.

A Caudle made of the feeds of white poppy, or made into Almond milk, and fo giuen eaufeth $M$

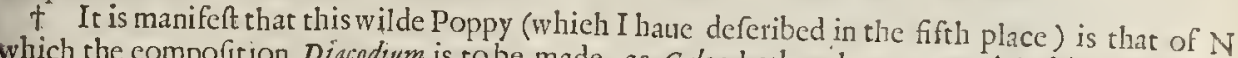
which the eompoittion Diacodum is to be made; as Galen hath at large treated in his feucnth mocrates do appoint acom, or the wilde Poppy, affected. Crito alfo, and after him Themifon and $D e$ lde Poppy, tobe in the fame eompofition; and euen that fame Democritus addeth,that it thould be that which is not fowen : and fuch an one is this, whieh grow-
eth without fowing. Dod.

\section{С на в. 74: Of Corne-Ro, e, or wilde Poppy.}

I Paparer Rhoens.

Red Poppy, or Corne-rore.

Papaver Ghaas:

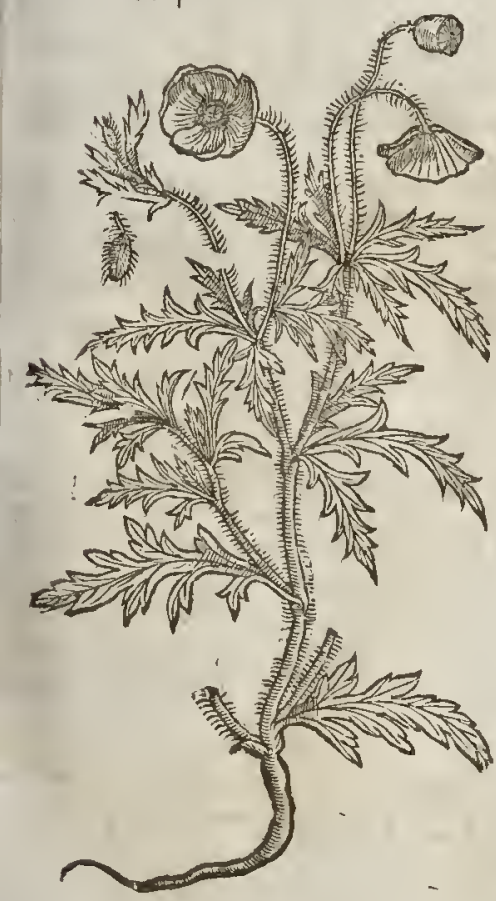

$\$ 4$ Papauer pinofum. Prickly Poppy.

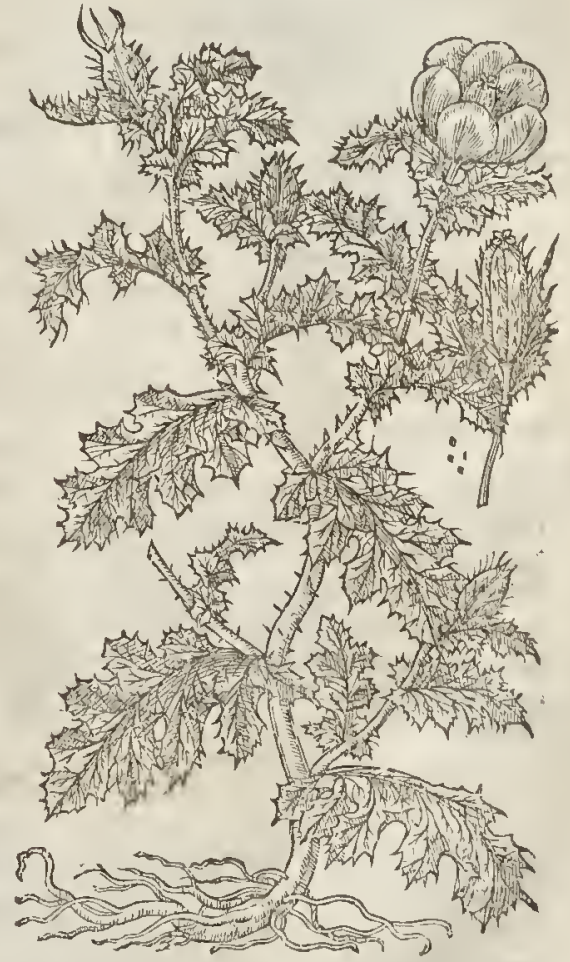

T) The Defcription. .

He ftakkes of red Poppy be blacke, tender, and brittle, fomewhat hairy : the leaves arc cut round about with deepe ga hes like thofe of Suecory or wilde Roeket:the floures grow forth at the tops of the ftalks, being of a beautifull and gallant red eolour,with blackith threds compafing about the middle part of the head: which being fully growne, is lefier than that of the garden Poppy: the feed is fmall and blacke.

$t \quad 2$ There is alfo a kinde hereof in all poins agreeing with the former, fruing that the toures of this are very double and beatutifull, and therein only conlifts the differenee. 
$\neq 3$ Thete is a fmall kinde of ted Poppy growing commonly wilde together with the firf defcribed, which is lefer in all parts, and the thoures ate of a faintet or ouerworne red, inclining fomenhat toorange.

+ 4 Beficles the fe there is another rare plant, which all men, and that very fitly, hate referred to the kindes of Poppy. This hath a dlender long and fibrous root, from which arifes a falle fome cubithigh, diuided into fundry branches, round, crefted, ptickly, and full of a white pith. The leaues itre diuided after the maner of homed poppy, fmoorh, with white veins \& prickly edges : the floute is yellow, and confifts of foure or fue leanes; afterwhich fucceds a longifh head, being cither foure, fue, or fix corneted, huving many yellow threds incompaffing it : the head whileft it is tender is reddith at the top, but being ripe it is blacke, and it is ferwith many and ftiffe pricks. The feed is round, blacke, and pointed, being fix times as big as that of the ordinaty Poppy. $\neq$.

$$
\text { बा The Plact. }
$$

They grow in curable grounds, among wheat, fpelt, ric, barley, otes, and other graine, and in the borders of fields. \$ The double red, and prickly Poppy ate not to be found in this kingdome, vnleffe in the gardens of fone prime lierbarifs. $\neq$

$$
\text { (I) The Time. }
$$

The fields aregarninied and oucrfpted with thefe wilde poppies in Iune and Auguft.

$$
\text { 6. The Names. }
$$

+ Widde Poppy is called in Greeke of Diofcardes, puxwowis : in Latine, Papaner erraticum: Gasa

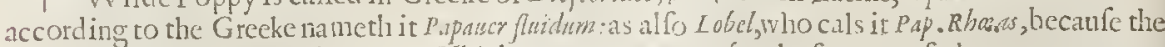
Houre thercof foone falleth away. Which name Rowas nay for the fame caufe be common; not onely to thefe, butalio to the others, if it be focalled of the fpeedy falding of the floures : but if it be fymaned kbeas of the falling away of the feed (as it appeareth) then fhall it be propet to that which is defcribed in the fifth place in the foregoing chapter, out of whofe heads the feed eafily and quickly falls; as it dothalfo out of this, yot leffemanifeftly. 'They name it in French cocque-

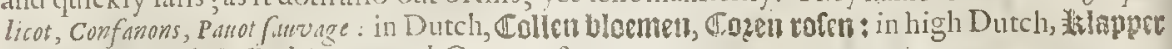
Lioltar: in Englin, Red Poppy, and Come-rofe.

$\$ 4$ Some hauc called this Ficus infernalis, fron the Italian name Figodelinferno. But Clas: fus and Baubine laume tetmed it Papaner ft inofurm : and the later of them would hate it (and that not without good rea fon) to be Glancium of Diofcorides, hl. 3. .ap. I00. And I alfo probably coniceture it to bethe Hipromanes of Crateras, mentioned by the Gteeke Scholiaft of I hcocritus, as I haule formerly briefely declared Ch.tp.62. $\neq$

$$
\text { The Nature. }
$$

The facultie of the wilde poppies is like to that of the other poppies; that is to fay cold, and caufing fleepe.

$\Lambda$

Moft men being led rather by falfe experiments than teafon, commend the floures againt the Pleurifie, gitung to drinke as foone as the paine commeth, either the diftilled water, or fyrup made by often infuring the leaues. And yet many times it happencth that the paine ceafeth by that meanes, thougl liardly fometimes, by reafon that the fpittle commeth vp hardly, and with more difficultie, efpecially in thofe that are veake, and hauc not a itrong conftitution of body. Baptifta $S$ urdus might be counted the Author of this etror; who hath written, That moft men haue giwen the floures of this poppy againft the paine of the fides, and that it is good againft the fpitting ofbloud.

\section{Cil a P. 75. Of Baftard wilde Poppy.}

$$
\text { 9. The Defiription. }
$$

$\mathrm{T}$ He firt of the fe baltard wilde Poppies hath flender weake ftemmes a foot high, rough and hairy, fet with leates not vnlike to thofe of Rocket, made of many finall leaues deeply cut or iagged about the eiges. The fioures grow at the top of the ftalkes, of a ted colour, with fome fmall blackneffe toward the bottome. The feed is fonall, contained in little round knobs. The feed is fmall and threddy.

2 The fecond is like the firft, funing that the cods hereof be long, and the other more round, wherein the difference doth confift.

$$
\text { T) The Place. }
$$

Thefe plants do grow in the come fields in Somerfethire, and by the hedges and highawayes, as ye traucll from London to Bathe. Lobel found it growing in the next field wnto a village in Kent called 


\section{LiB: 2. Of the Hiftory of Plants:}

called Southflect, my fclfe being in his company, of purpofe to difcouer fome ftrange plants not hitherto written of.

$\neq M^{\prime \prime}$. Robert Lorkin and I found botll thefe growing in Chelfey fields, as alfo in thofe bclonging to Hamer fmith : but the thorter headed one is a floure of a more elcgant colour, and not fo plentifull as theother. $\neq$

I Argemone capitulotorulo. Baftard wilde Poppy.

Papaner hylindum

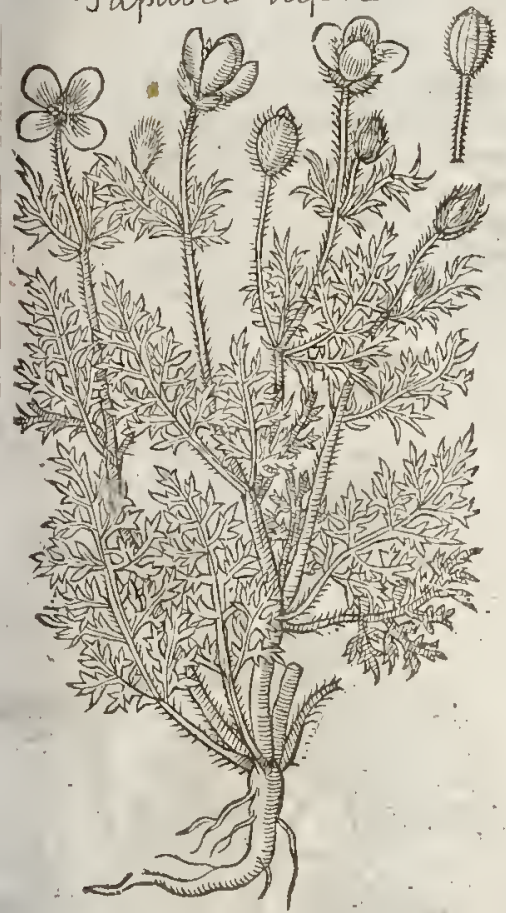

$\overrightarrow{2}$ Argemonecapitulolongiore: Long codded wilde Poppy? T) apaver Asgenuine

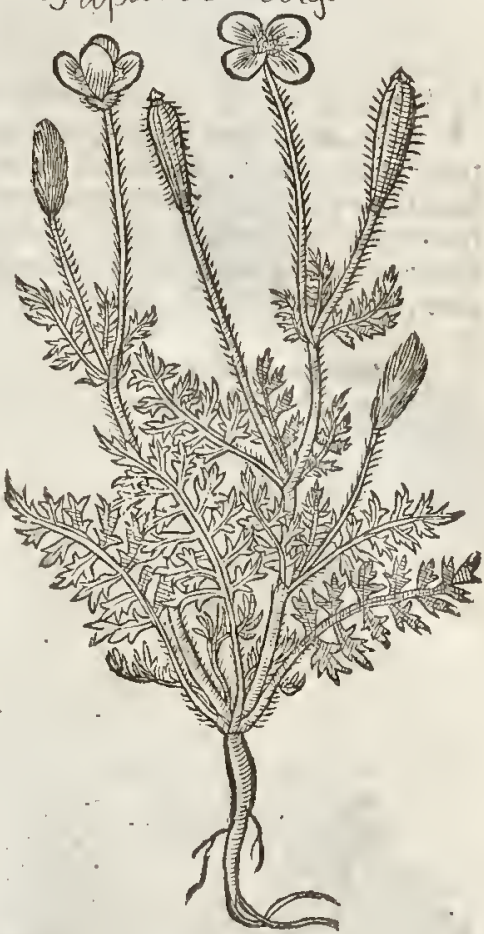

if The Time.

Thcy floure in the beginning of Auguft, and their feed is ripe at the end thereof.

it The Names.

The baftard wilde Poppy is called in Grecke Aspupin: in Latine, Argemone, Argemonia, Concordia, Concordalis, and Herba liburnica : of fome, Pergalium, Arfela, and Sacrecolla Herba : in Englin, Windrofe, and battard wildc poppy.

They arc hot and dry in the third degree.

$$
\text { बा The Temperature. }
$$

\section{T The Vcrtues.}

The leaues ftamped, and the iuyee dropped into the eyes eafeth the inflammation theręof, and cureth the difeafe of the eye ealled Argems, whereof it tookc his name : whieh difeafe when it hapneth on the blacke of the eye it appcares white; and contrariwife when it is in the white then it aps peareth blacke of eolour.

The leatres ftamped and bound vnto the eyes or face that are blacke or blew by meanes of fome blow or ftripe, doth perfectly takcit away. The dry herbc ftecped in warme water worketh the like effect.

The lcaues and roots ftamped, and the iuycc gituen in drinke,helpeth the wringings or gripings $\mathbf{C}$ of the belly. Thedry herbe infufed in warme water doth the famceffectually.

The herbe ftamped, eureth any wound, vlcer, canker, or fiftula, being made vp into an vnguent $D$ or falue, with oile, wax, and a little turpentinc.

The inyce taken in the weight of two drammes, with wine, mightily expelleth poyfon or venome. 
F The iuyce taketh away warts if they be rubbed therewith; and being taken in meate it helpes the milt or f pleene if it be wafted.

\section{Cна в. 76: \\ Of Winde-floures. \\ If The Kindes.}

T

He floche or kindred of the Amemones or Winde-floures, efpecially in their variet of co-

lours, are without number, or at the leaft not fufficiently knowne vinto any one that hathwritcen of plants. For Dodonaus hath fet forth fiue forts; Lobel eight; Tabernamontanus ten : My felfe haue in my garden twelue different forts : and yet I do heare of divers more differing very notably from any of thefe, which I haue bricfely touched, though not figured, enery new yeare bringing with it new and ftrange kindes; and cuery countrey his peculiar plants of this fort, which are fent vato vs from far countries, in hope to receiuc from vs fuch as our countrey yceldeth.

I Anemonetuberoja radice.

Purple Winde-floure.

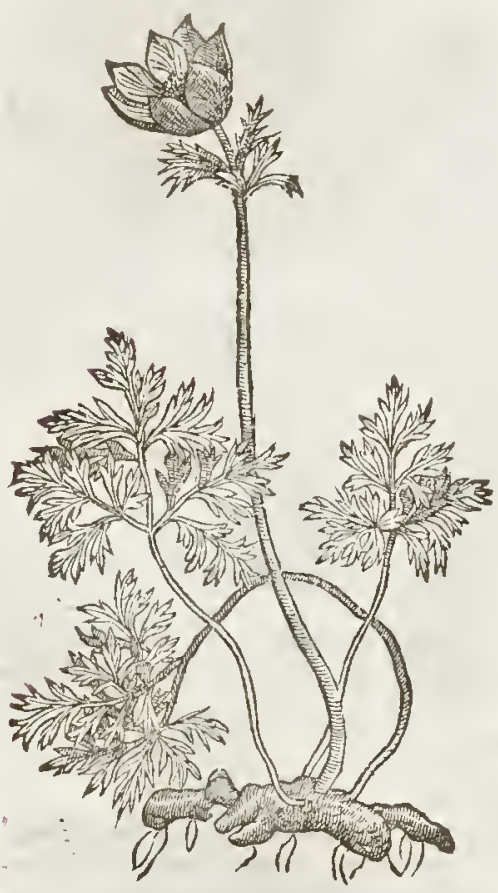

2 Anemone coccinea multiplex."Double Skarlet Winde-floure.

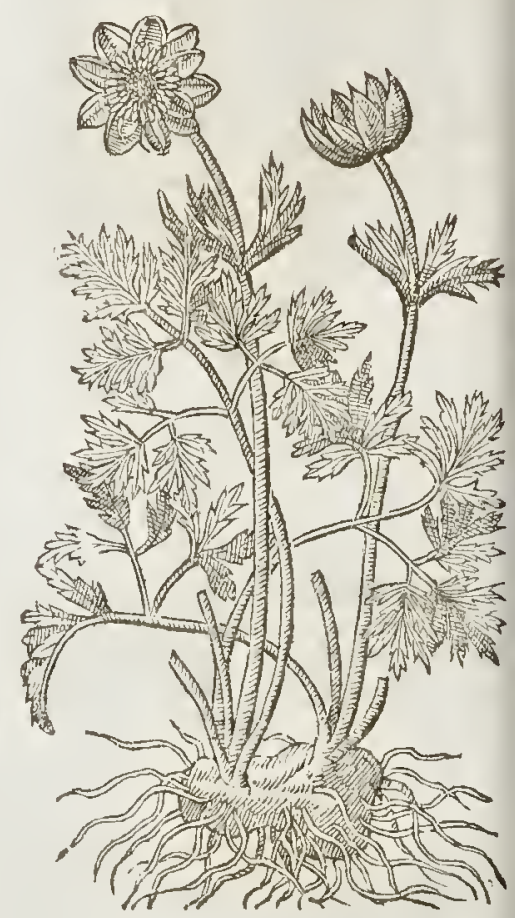

Th The Defription.

5 THe firl kinde of Anemane or Winde-floure hath fmall leaues very much fnipt or iagged almoft like vnto Camomilc, or Adonis floure: among which rifeth vp a ftalke bare or naked almoft vnto the top; at which place is fet two or three leaues like the other : and at the top of the ftalke commerh forth a faire and beautifull floure compact of feuen leaues, and fometimes eight, of a violet colour tending to purple. It is impoffible to defcribe the colour in his full perfection, confidering the variable mixtures. The root is tuberous or knobby, and very brittle. 
fome foot high, the top whereof is adorned with a foure confifting of two ranks of leaucs, whercof thofe on the outfide are larger, rounder pointed, and fometimes fript in a lirtle; the reft arc natrower and tharper pointed: the colour of thefe lcaues is yellow, dceper on the infide, and on the outfide there arc fone fmall purple veines running alongtt thefe leaues of the foure. The root is fome two inclics long, the thickcneffe of ones little finger, with fome tuberous knobs hanging thereat $\ddagger$

8 The eighth hath many large lcaues decply cut or iagged, in Thape like thofe of the Storks bil or Pinkc-needle; among which rifeth vp a naked italke, fet about toward the top wirl the like Icaucs, but fmaller and more finely cut, bearing at the top of the ftalke a fingle foure eonlifting of many fmall blew leaues, which do change fomctimes into purple, and oftentimes into white, fet about a black ifh pointall, with fome fmall threds like vnto a pale ur boider. The root is thick and knobby.

9 The ninth fort of Anemonc hath leaues like vnto the garden Crow-foot : the ftalke rifeth vp from amongt the leaues, of a foot high, bearing at the top fairc white floures made of fiue imall leaues; in the middle whercof are many little y cllow ehites or threds. The root is made of inany ficnder threds or ftrings, eontraric to all the reft of the W indc-foures.

1o The tenth fort of Anemone hath many leaues like vnto the common medow Trefoile, neightly fnipt about the edges like a faw : on the top of the flender ftalkes ftandeth a fingle white foure rend ing to purple, eonfifting of eight fmall leaues, refembling in fha pe the flourcs of common field Crow-foot. The root is knobby, with certainc ftrings faftned thereto.

I t The elcuenth kinde of Ancmone hath many iagged leates cut enen to the middle rib, refembling the leates of Geranum columbumm, or 1 ) oues foot. The leanes that do cmbrace thetender weake ftalkes are flat and fleighty eut : the floures grow at the top of the ftalkes, of a bright thining purple colour, fet about a blackin pointall, with fmall thrums or ehines like a pale. The foot is knobby, thicke, and very brittle, as are moft of thofe of the Anemones.

II The Placc.

All the forts of Anemones are ftrangers, and not found growing wildc in England; notwithftanding all and cucry fort of them do grow in my garden very plentifully.

$$
\text { The Time. }
$$

They do floure from the beginning of Ianuarie to the end of A prill, at what time the flonres do fade, and the feed flieth aw ay with the winde, if thete be any feed at all; the which $l$ could teter as yet obferuc.

$$
\text { Qf The Names. }
$$

Anemone, or Winde foure is fo called, drin re eitpu; that is to fay, of the winde; for the flourc doth nener open it felfe but when the winde doth blow, as Pling writeth : whereupon alfo it is named of diuers Herba venti : in Englim, Winde-floure.

Thofe with double flourcs are called in the Turky tonguc Giul, and Gul Catamer: and thofewith fntall iagged leaucs and double flourcs are called Lalébenzede, and Galipoli laté. They do call thofe with fmall iagged lcaues and finglc flourcs Binizatc \& binizade, and Binizunte.

$$
\text { T) The Temperature. }
$$

All the kindes of A nemones are fharpe, biting the tongure; and of a binding qualitie.

$$
\text { of The vertues. }
$$

A The lcancs ftamped, and the iuyce fniffed vp into the nofe purgeth the head mightily.

B The root champid or chewed procureth fpitting, and caufeth water and ficgme to run forth out of the mouth, as Pellitorie of Spaine doth.

C It profitcth in collyries for the eyes, to ceafe the inflammation thereof.

D The iuyce mundifieth and elenferh maligne, virulent, and corrofue vlcers.

E The lcaucs and ftalkes boyled and eatcr of Nurfes eaufe them to haue much milke : it prouoketh the termes, and eafcth the leprofic, being bathed therewith.

\section{¥ С н а . 77. Of diuers otber Anemones, or $W$ inde-fioures.}

\section{If The Kindes.}

\# Tefe foures which are in fuch efteeme for their beauty may well be diuided into two forts, that is, the Latifolna, or broad leamed, and the Temanfolra, or narrow leaued : now of cach of thefe forts there are infinite varieties, which confift in the fingleneffic and doubleneffe of the floures, and in rheir ditierfitie of eolours; which would aske a large difeourfe to handic exantly. Whercfore I onely intend (befides thore fet downe by our Authour) to give you the 


\section{$\mathrm{L}_{1 \mathrm{~B} .2 .}$ Of the Hiftory of Plants.}

figures of fome few others, with their defeription, briefly taken out of the Workcs of the learned and diligent Herbarift Carolus clufius; where fuch as defire further difcourfe vpon this fubien may be aboundantly fatisfied : and fueh as do not vnderfand Latine may finde as large fatisfaction in the late Worke of $\mathrm{M}^{\mathrm{r}}$. John Parkinfon; whereas they fhall not onely haue their hiftorie at large, but alfo learne the way to raifc them of feed, which hath been a thing not long knowne (exeept to fome few ; ) and thenee hath rifen this great varietie of thefe floures, wherewith fome gardens fo muteh abound.

\section{T) The Defcription.}

1 He root of this is like to that of the great double red Anemone defcribed in the third loured. The ftalkc growes fome foor leaues alfo are like, but leffer and deeper eogroweth a fingle floure, confifting of eight lcaucs of with a paler coloured ring incompaffing a hairy hcad fet about with purplet eolour on the infide, be floure is hairy or downie. This is Anem. latifol. fmpl. flo. I 6 . of purple thrums : the out fide of

\# I Anemone latifolia fore coccineo.

The broad leamed skarlet Anemone.

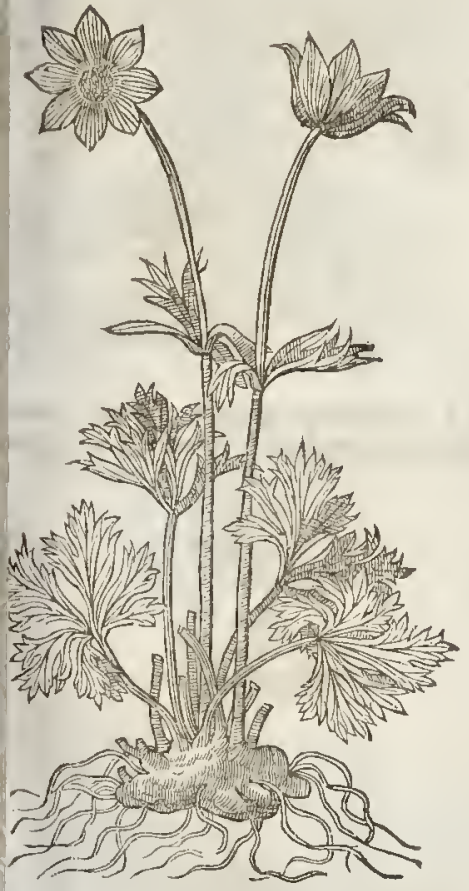

¥ 2 Anemone latifolia flore migno coccineo. The skarlet Anemone with the large floure.

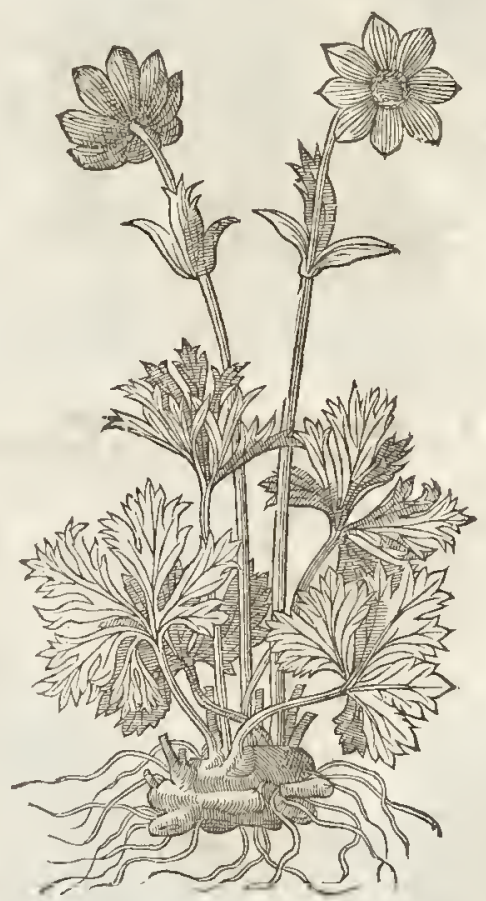

- This in fhape of roots \& leates is like the former, but the leaties are blaeker,and more fhining ithcir vper fides : the ftalke alfo is like to others of this kindc, and at the top carrieth a large oure confifting of cight broad leaues, being on the infide of a bright skarlet eolour, without any rcle; and the thrums that ingirt the hairy head are of a fangume eolour. This head (as in others this kindred) growes larger after the falling of the floure, and at length turnes into a downie oftanee, whercin a fmooth blaeke fecd is inelofed like as in other Anemones; which fowen as Jnc as it is ripe vfually comes vp beforc winter. This is Anem. Latifol. fimpl. fore 17 . of Clu firs. at of Codifers not from the former but in floures, which are of an orange-tawny colour, like Ir, which make ar red Poppy ; and the bottomes of the leaucs of the floures are of a paler eo. Befides thefc varict of eircle about the hairy head. This is the eighteenth of clufsus. the floure, or the miles which ow let vs eome to the narrow lankc a circle at the bottome thcrcof, doe differ eaeh from other. WW let vs eome to the narrow leaued ones, whieh alfo differ little but in colour of their floures. 
¥ Anemone latifolia ByZantina.

The broad leaued Anemone of Conftantinople.

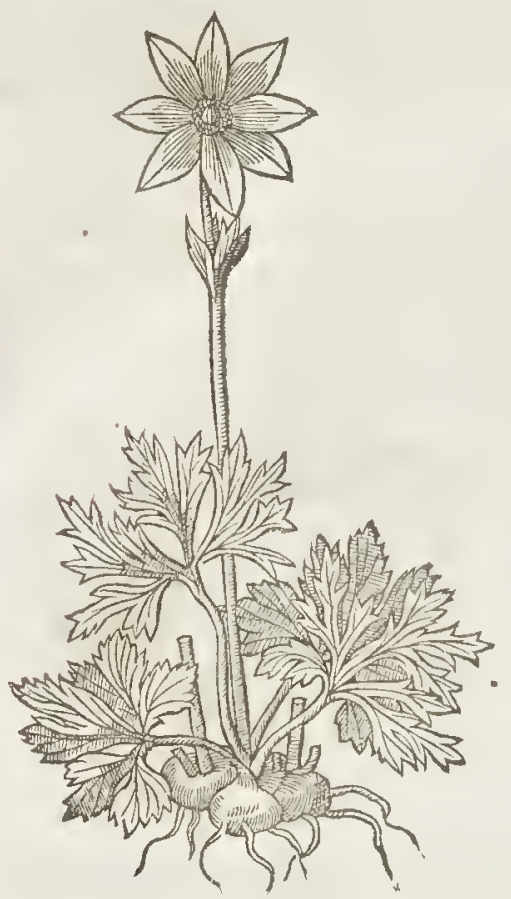

\# s Anemone tenuifolia flore coccineo. The fmall leaued skarlet Anemone.

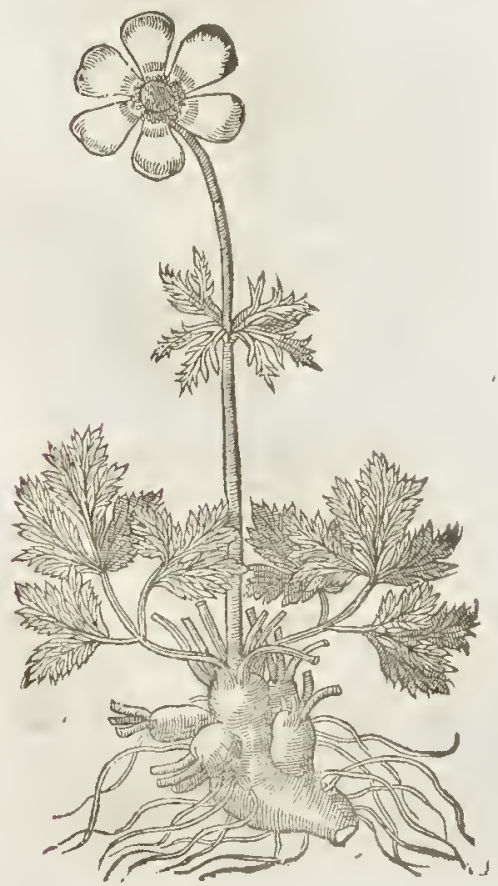

¥ Anemone tenuifolia flore amplo fanguineo. Small leaued Anemone with the fanguine floure.

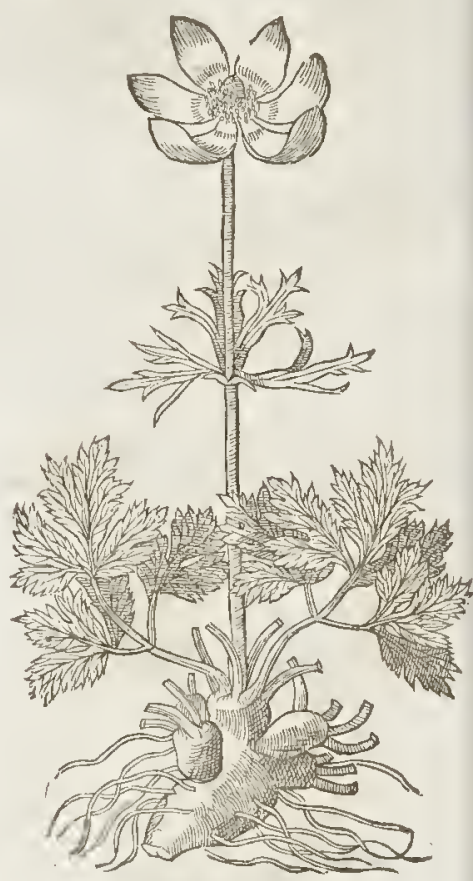

* 6 Anemonetenuifol, flo. dilute purpurco. The light purple fmall leaued Anemone,

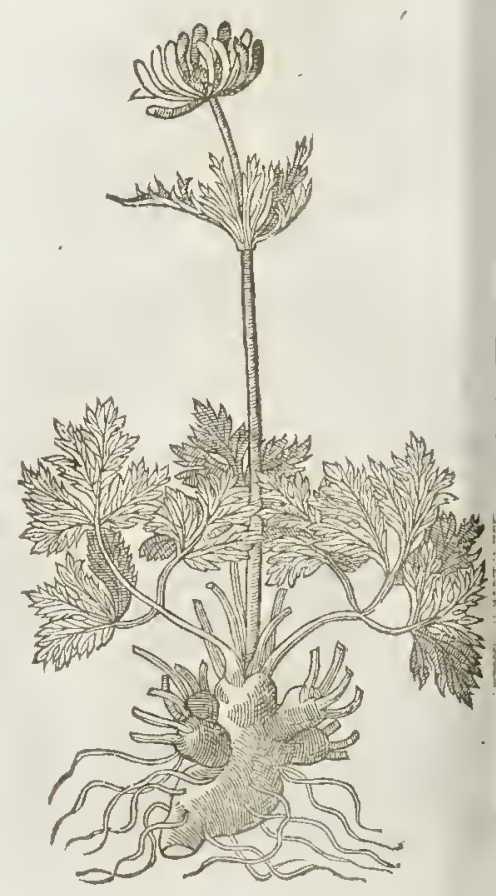


\$ Anemone tenuifol. flo. exalbido. The whition fmall leaued Anemone.

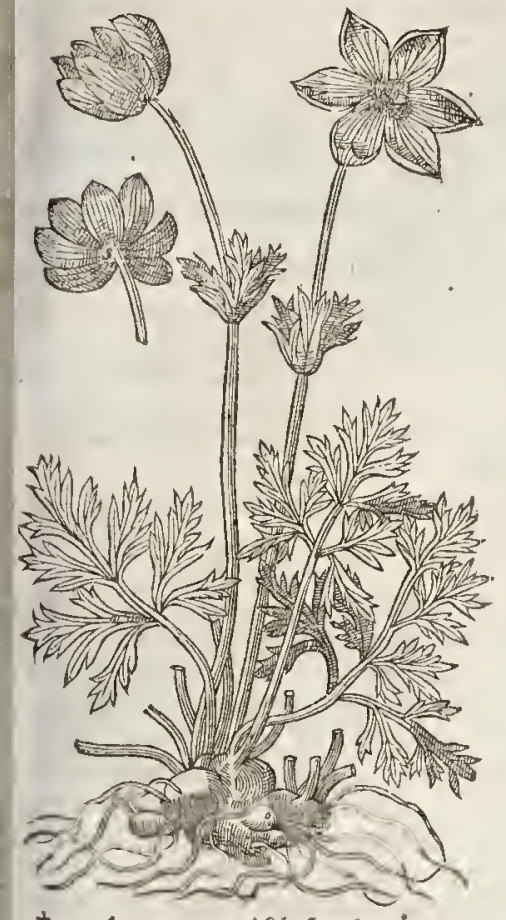

¥ 9 Anemone tenuifol. flo pleno coccin.

The fmall leaued double crimfon Anemone.

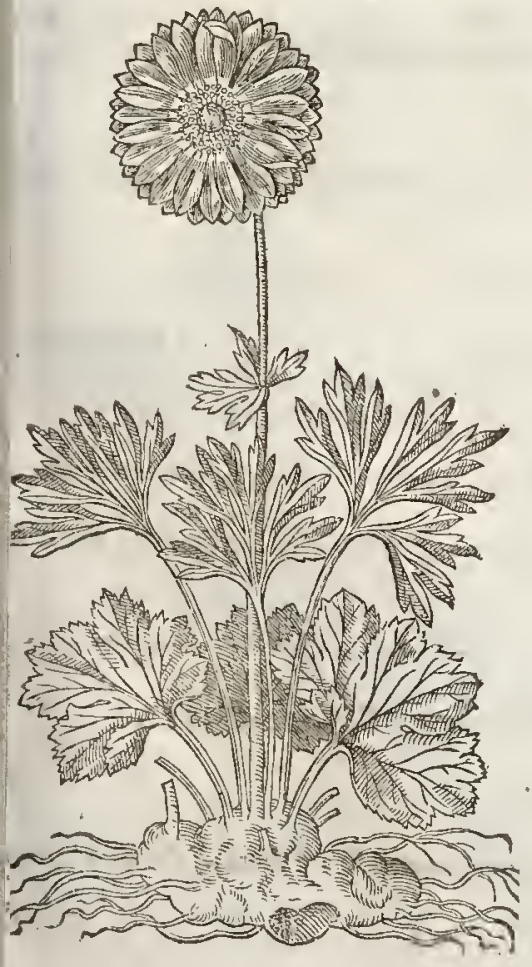

t 8 Anemone ternifolia fio. carneo friato. The ftriped flen-coloured Anemone.

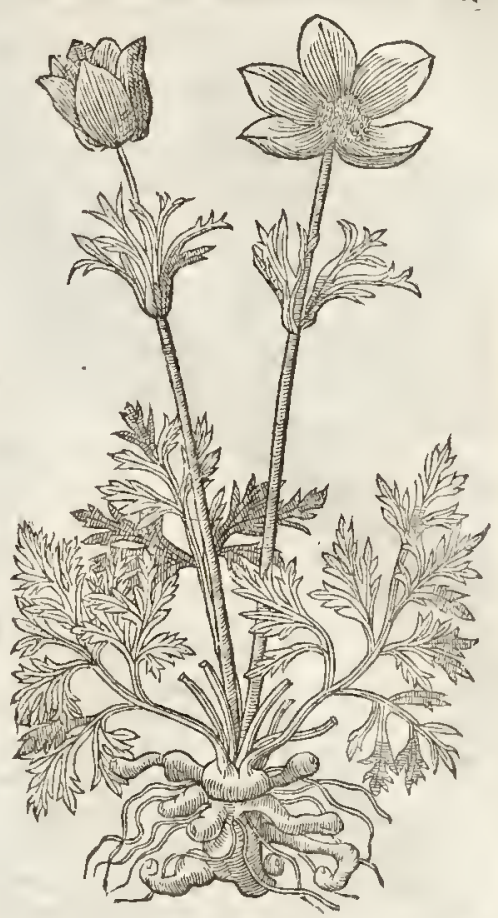

¥ 10 Anemone tenuifol. flo. pleno at ropurpurafcente? The double darke purple Anemone.

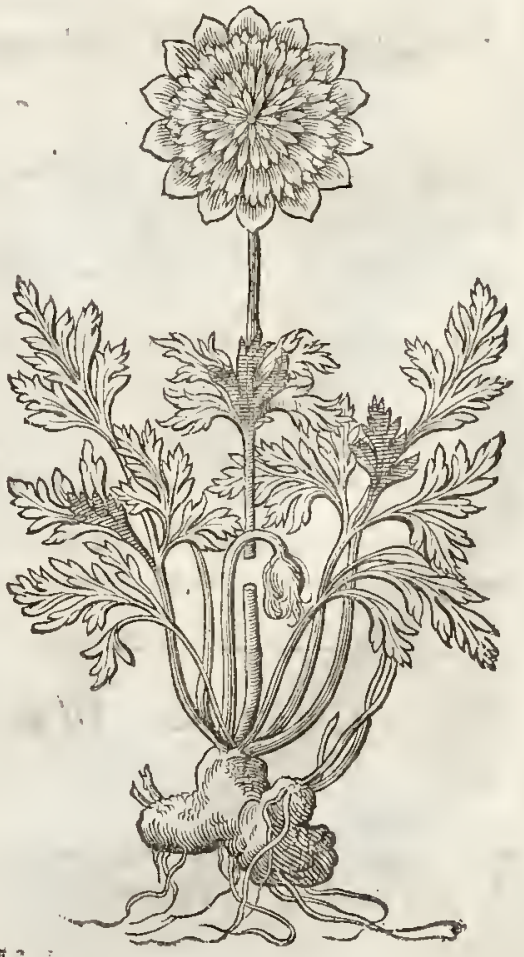


4. The roor of this is knotty and tuberous like thofe of other $A$ nemones, and the leaues are much diuidectand cur in like to thofe of the firft deferibed in the former Chapter: the italke (which hath three or foure lcaues ingir ting it, as in all other Anemones) at the top futtainerh a faire fungune floure confifting of fix large leaueswith great white nailes. Th feeds are contained in downie heads like as thofe of the tormer. This is Ancm tenufol. fmpl.fto 6. of cur ius.

5 This differs from the former in the foure, which confifts of fix leaues made fo nwhat rounder than thofe of the precedent : their colour is betweene a skarlet and fangume. And rhere is a varietie hereof alfo of a bricke colour. This is the eighth of clufius.

6 This differs from the reft, in that the floure is compofed of fome fourteene or more leaues, and thefe of a light purple, or fleth-colour. This is the ninth of Clufius.

7 The floure of this is large, confifting of fix leatues, being at the firft of a whitith greene, and then tending to a Alefh coluur, with their nailes greene on the outfide; and white within, and the threds in the middle of a flen colour. There is a leffer of this kinde, with the floure of a fleth colour, and white on the outfide, and wholly white within, with the nailes greenifh. Thefe are the tenth and cleuenth of clufius.

8 This Antrealfo confifts of fix leaues of a flefh colour, with whitifh edges on the out fide; the infide is whitifh, with fleth coloured veines running to the middet thereof.

Befides thefe fingle kindes there are diuers double both of the broad and narrow leaued Ane. mones, where of I will only defcribe and figure two, and refer you to the forementioned Authors for the reit, which differ from thefe onely in colour.

9 This broad leaued double Anemonie bath roots, ftalkes, and leaues like thofe of the fingle ones of this kinde, and at the top of the ftalke therc ltands a faire large floure compofod of two or three rankes of leaues, fmall and long, being of a kinde of skarlet or orange-tawny colour ; the to:tomes of thefe leaues make a whitifh circle, which giues a great beauty to the foure, and the downie head is ingirt with fanguine threds tipr wirlu blew. This is the Pano major 1 . of clufus.

10 This in thape of roots, leaues, and ftalkes refembles the formerly defcribed narrow leaned Anemones, but the floure is much different from them; for it confifts firft of diuers broad lcaucs, which incompaffe areat number of fmaller narrow leaues, which togerher make a rery faire and beautifull floure: the outer leatres hereof are red, and the inner leaues of a purple Veluer co'our.

Of this kinde there are diuers varieties, as the double white,crimfon, bluth, purple, blew, carriation, rofe-coloured, \&c.

Tा The Place and Time.

Thefe are onely to be found in gardens, and bring forth their floures in the Spring.

Tा Their Names.

I iudge it no waies pertinent to fet downe more of the names than is already deliuered in their feuerall titles and defcriptions.

\section{T Their Temper andVertues.}

A Thefe are of a hot and biting facultic, and not (that $I \mathrm{knOw}$ of) at this day vfed in medicines, vnleffe in fome one or two ointments : yet they were of more vfe among it the Greeke Phyfitions, who much commend the iuyce of them for taking away the fcares and faleswhich grow on the eyes; and by them are called : ixu, and surwirata.

B Irallinms alfo faith, That the floures beaten in oyle, and fo anointed, caufe haire to grow where it is deficient.

The vertues fet downe in the former Chapter do alfo belong to thefe here treated of, as thefe here deliuered are alfo proper to them. ‡

\section{С н а т. 78. Of milde eAnemones, or Winde-floures.}

I The Kindes. L Ike as there be many and diuers forts of the gardan Anemones, fo are there of the wild kindes
alfo, which do vary efpecially in their floures. 


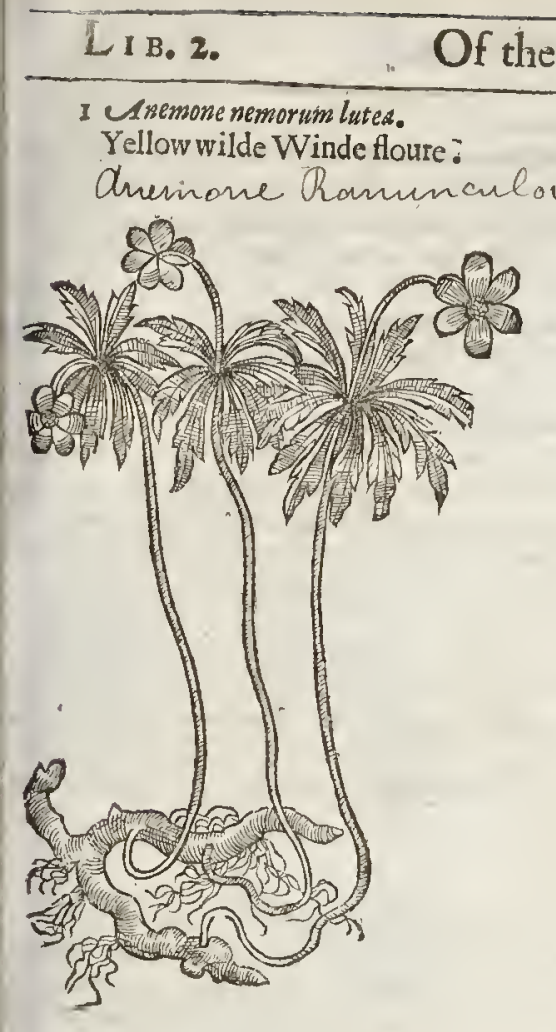

\$ Anemone remorum flo. pleno albo: The double white wood Anemone.

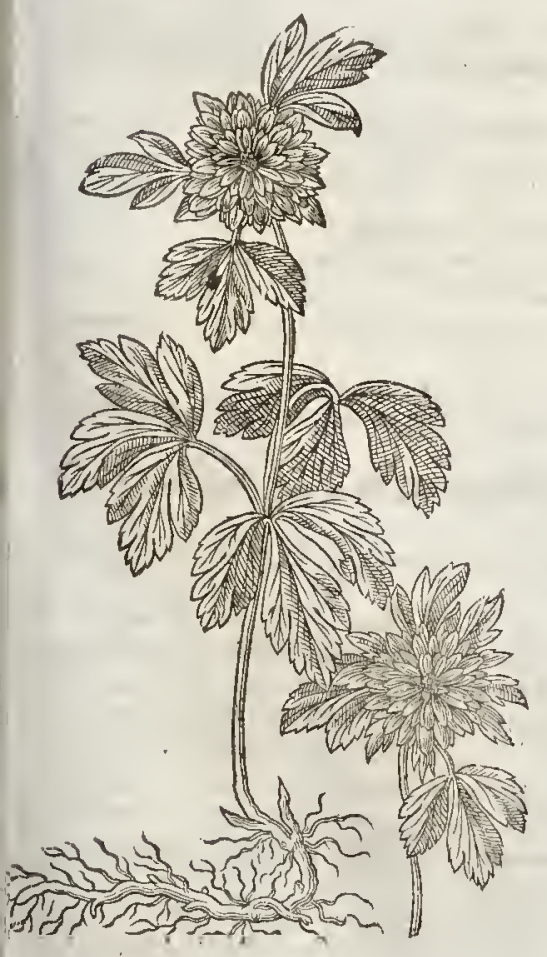

2 Anemone nemorumalba. Whitewinde floure.

$3^{8} 3$

Anemone memorosa.

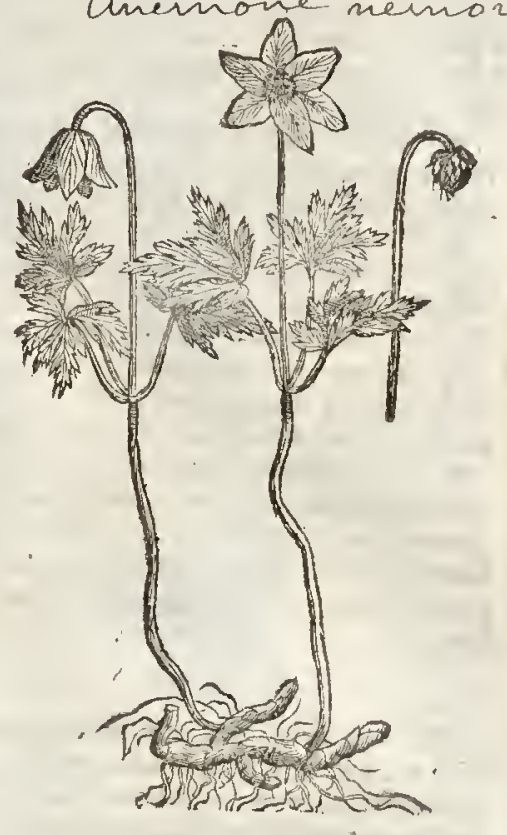

\$ Anemone nemorum flo.pleno purpurafcente? The double purplin wood Ancmone.

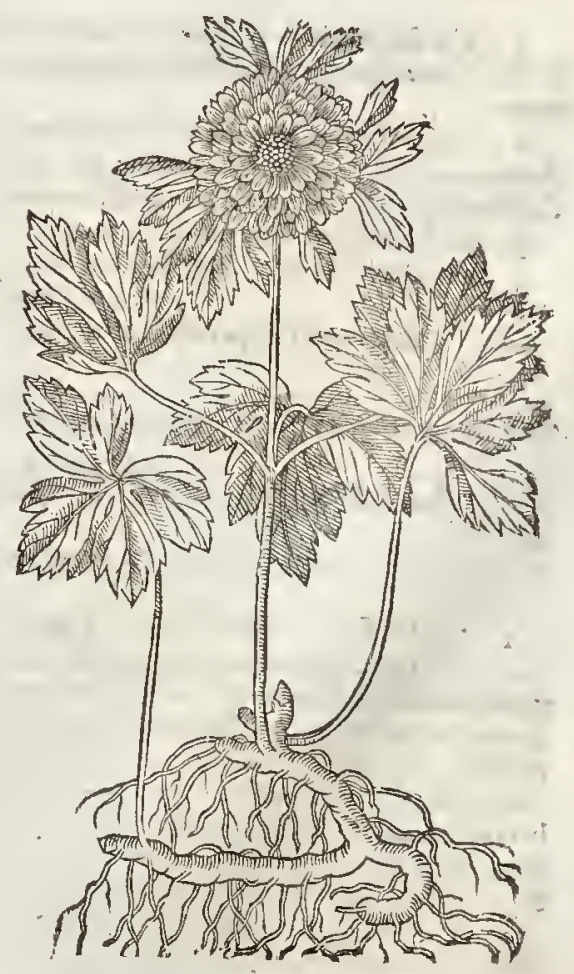


I THe firt of thefewilde Anemones hath iagged leaues deepely eut or indented, which do grow vpon the middle part of a weakeand tender ftalke: at the top whereof doth ftand pretrie yellow floure made of fix fmall leaues, and in the middlc of the floure there is a little black in pointell, and certaine thender eliwes or threds. The root is finall, fom ewhat knotrie and very brittle.

2 The fecond hath iagged leames, not vnlike to water Crowfoot or mountaine Crow foot. The fower groweth at the top of the ftalke not vnlike to the preedent in mape, lauing that this is of a milke white colour, the root is like the other.

‡ There is alfo of this fingle kinde two other varieties, the one with a purple floure, which wee may therefore eall Ancmone nemorum purpurea, the wilde purple Winde-floure. And the other with a Scarlet (or rather a Bluth) eoloured floure, which we may terme Anemone nemorum corcinia, The wilde Scarlet wind flotre. Thefe wo differ not in other refpeets from the white wind floure. $\neq$

2. There is in fome choice gardens one of this kinde w ith white Houres very double, as is that of the Searlet Ancmone, and I had one of them giuen mee by a wor/hipfull Merchant of London, called $\mathrm{M}^{\mathrm{r}}$.tohn Franquewille, my very good friend.

+4 This in roots and ftalkes is like the laft deferibed wood Anemones, or winde floures. But this and the laft mentioned double one haue lcaues on two places of their ftalks, whereas the fingle ones haue them but in one, and that is about the middle of the ftalkes. The floure of this double one confifts of fome fortie or more little leaues, whereof the outermoft are the biggelt; the bot tomes or nailes of thefe leaues are of a deepe purple, but the other parts of a lighter blufh eolour.

$$
\text { Ti The Place. }
$$

All thefe wilde fingle Anemones grow in molt woods and eopfes through England, exeept that with the ycllow Houre, which as yer I luaue not feene: notwithftanding I haue one of the greater kindes which beareth yellow floures, whofe figure is nor expreffed nor yer defcribed, for that it dothvery notably refemble thofe with fingle floures, but is of fmall moment ${ }_{3}$ either in beautie of the floure, or otherwife. ‡ The double ones grow onely in fome few gardens. $\ddagger$

$$
\text { The Time. }
$$

They floure from the middeft of Februarie vnto the end of Aprill, or the midft of May.

$$
\text { - The Names. }
$$

\# The firft of thefe by moft Writers is referred to the Ranunculi, or Crow feet; and Lobel cals it fitly Ramunculus nemorofus luteus: Only Dodoneus, Cafalpinus, and our Authour have made it an $\mathcal{A}$ nemone.

2 Thiswith the varieties al fo, by Tragus, Fuchfrus, Cordus, Gefner, Lobell, and others, is made a ranunculus: yet Dodonens, Cefalpinus, and our Authour haue referred it to the Anemones. Clufsus thinkes this to be Anemone, Aemwi:iz of Theophraftus.

3 Cluftus calls this i nemone Limonia, or Ranunculus fy luarum flo.pleno albo.

And he ftiles this Anem. Limonia, or Ranunc. glffore pleno purpurafcente.

T The Temperature and Vertues.

The faeulties and temperature of thefe plants are referred to the garden forts of Anemones.

\section{C н а . 79. Of Baftard efnemones, or Pafquefloures.}

\section{T The Defcription.}

1 THe firft of thefe Pafque floures hath many fmall leaues finely eut or iagged, like thofe of Carrots: among which rife vp naked ftalkes, rough and hairie; whereupon doe grow beaurifull Houres bell farhion, of a bright delaied purple colour : in the bot tome whereof groweth a tuft of yellow thrums, and in the middle of the thrums it thrufteth forth a fmall purple pointell : when the whole floure is paft there fuecedeth an head or knop eompaet of many gray hairy lockes, and in the folide parts of the knops lieth the feed flat and hoarie, euery feed hauing his owne fmall haire langing at it. The root is thicke and knobby, of a finger long, running right downe, and there fore not like vnto tho fe of the Anemone, which it doth in all other parts very notably refemble, and whereof no doubt this is a kinde.

There is no difference at all in the leaues, roots, or feedes, betweene this red Pafque floure and the precedent, nor in any arher point, but in the colour of the floures : for whereas the other 
are of a purple colour, thefe are of abright red, which fetteth forth the diffcrence.

3 The white Paffe floures hath many fine iagged leaues, clofely couched or thruft together, which refemble an Holi-water fprinckle, agreeing with the others in rootes, feedes, and thape of floures, faung that the fe are of a whitc colour, wherein chiefely confifterh the difference.

$\ddagger 4$ This alfo in thape of røots and leates little differs from the precedent, but the fourcs are leffer, of a darker purple culour, and feldome open or thew themfelues fo much abroad as the other of the firft defcribed, to which in all other refpects it is very like.

5 There is alfo another kinde with leaues leffe diuided, but in other parts like thofe already defcribed, fauing that the floure is of a yellow colour fomething inclining to a red. $\neq$

I Pulfatilla vulgaris. Purple Paffe floure. Anemone upul saticea

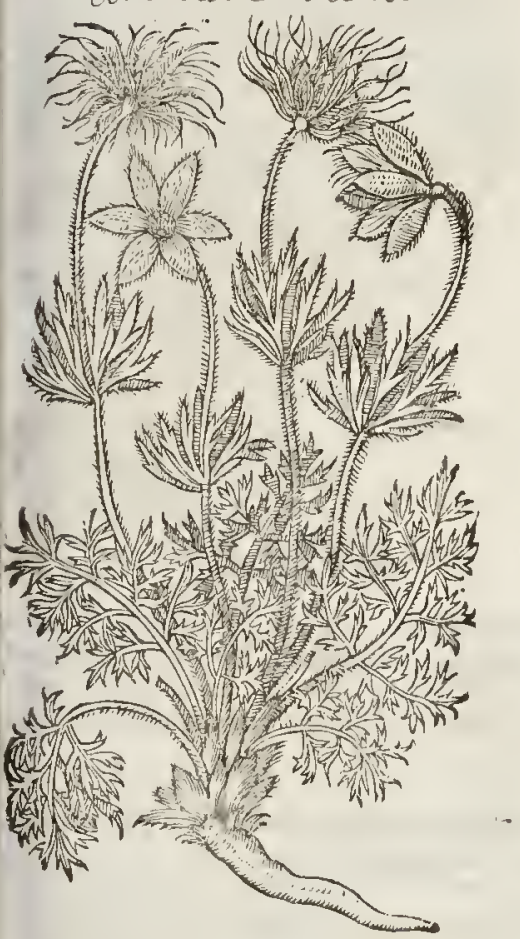

2 Pulfatilla rubra.

Red Paffe floure,

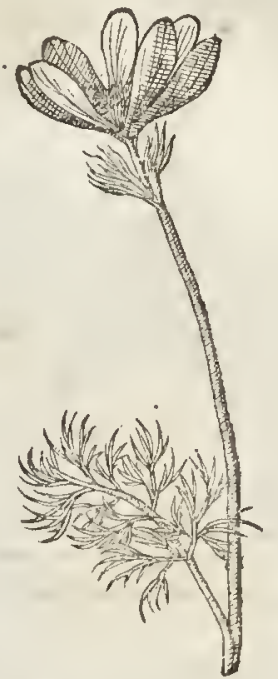

9 The Place. grow in rough afld ftonie places, fnd freweth in France in vntoiled places: in Germanic they wockes.

Thofe with purple foures doe grow verie plentifully in the pafture or clofe belonging to the parfonage houre of a fmall village fix miles from Cambridge, called Hilderfham : the Parfons name rhat lined at the impreffion hcreof was $\mathrm{M}^{\mathrm{r}}$. Fuller, a very kind and louing man, and willing to fhew vato any man the faid clofe, who defired the fame.

They flourefor the molt part about En Tा The Time.

Eafter Hourc : and ofren they about Eafter, which hath mooued mee to name it Pafque Floure,

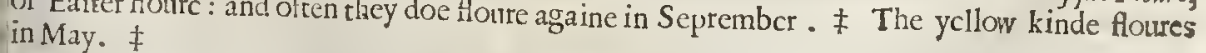

+ Paffe flonrc is called The Names.

ti. Dalefchampirs would late it to be Ancmone Lime Pulfatilla: and of fome, Apium rifus, ,o herbavena in Durch,

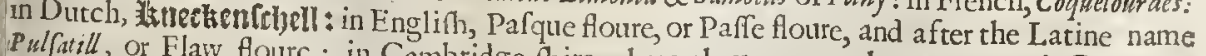
bels.
bulfath, or Flaw flourc: in Cambridge-fhire where they grow, they are named Coutentrie 


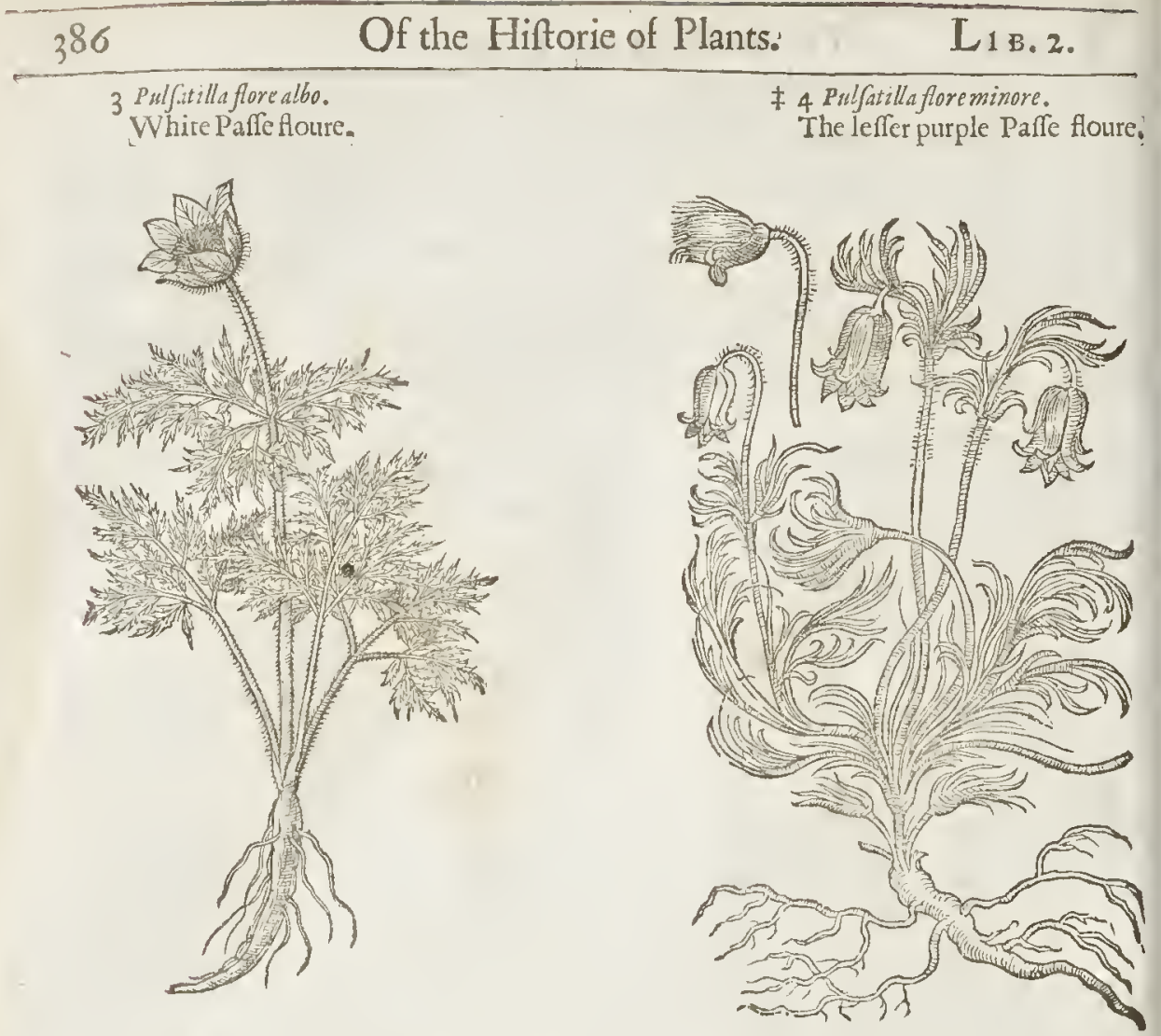

The Temperature.

Paffe floure doth extremely bite, and exuleerateth and eateth into the skinne if it befamped and applied to any part of the body; whereupon it hath been taken of fome to bea kinde of Crowfoot, and not without reafon, for that it is not inferiour to the Crow foots : and therefore it is hor and drie.

T) The V'ertues.

There is nothing extant in writing anong Authours of any peeuliar vertue, but they ferue onely for the adorning of gardens and garlands, being loures of great beautic.

$$
\begin{gathered}
\text { Ch a P. 8o. Of eAdonis floure. } \\
\text { T The Defcription. }
\end{gathered}
$$

I THe firft hath very many flenderweake ftalkes, trailing or-leaning to the ground, fet on enerie part with fine iagged leaues very decpely cut like thofe of Camomill,or rather thofe of May-weed : vpon which ftalkes do grow fmall red floures, in fhape like the field Crowfoot, with a blackifh greene pointell in the middle, which being growne to maturitie turneth into a fmall greenith bunch of feeds, in thape like a little buneh of grapes. The root is fmall and threddic.

2 The fecond differethnot from the preeedent in any one point, but in the colour of the floures, which are of a perfeet yellow colour, wherein confifterh thic differenee.

$$
\text { - The Place. }
$$

The red floure of $\Lambda$ donis groweth wilde in the Weft parts of England among their corne, euen as May-weed doth in other parts, and is likewifean enemic tocorne as May-weed is : from thence I brought the feed, and haue fowne it in my garden for the beautic of the floures fake. That with the yellow Aloure is a tranger in England. 


\section{I в: 2. Of the Hiftory of Plants:}

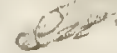

I Flos Ldonis fore rubro. Adonis,with sed floures. Adomis ant tromancili.

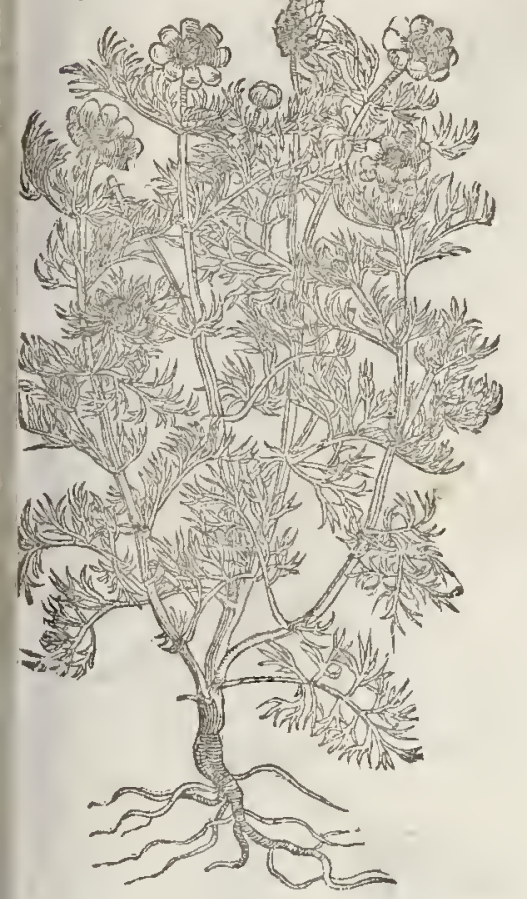

9 The Time.

They foure in the Sommer moneths, May, Iine,a nd Iuly, and fometimes later.

$$
\text { of } 7 \text { 'be } N \text { anzes. }
$$

Adonis foure is called in Latine Flos. A. domis, and Adonidis : of the Dutchmen, fro Dtofilin: in Englion wee may call it Red Maythes, by which name it is called of them that dwell where it groweth naturally, and generally Red Camomill : in Greeke, ìdás;ruor, \& Eranthemum: our Londonwomen doe call it Rofe-a-rubie.

Tा The Temperature.

There hath not beene any that hath written of the Temperature hereof; notwithtanding, fo farry as the rafte thereof theweth, it is fomething lot,but not much.

$$
\text { S... githe Versues. }
$$

The feed of Adonis flower is thought to $\mathrm{A}$ bee gond againft the frone: a mongft rhe Ancients it was not knowne to haue any other facultie : albeit experience hath of late taught vs, that the feed ftamped, and the pouder giuen in wine, ale, or beere to drinke, doth wondetfully and with great effect helpe the collicke.

\section{Char: 81. Of Dockes.}

T) The Kindes.

D

Iolcorides ferteth fotth foure kindes of Dockes; wilde or Tharpe pointed Docke; Garden Docke ; round leafed Docke; and the Soute Doeke called Sorrell :befides thefe the later Herbarifts haue added certaine other Dockes alfo, which I purpofe to make mention of.

$$
\text { 9) The Defcription. }
$$

I Tatwhich among the Latines fignificth to foften, eafe, or purge the bellie, the fame

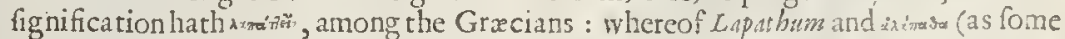
do reade) tooke their names for lrerbes which are vfed in pottageand medicine, very well knowne to hate the power of cleanfing : of thefe there be many kindes and differences, great ftore entery where growing, among whom is that which is now called tharpe pointed Docke, or tharpe leafed Docke. It groweth in mof medowes and by rumning ltreames, hauing Iong narrow leates tharpe and hard pointed: among the which commeth w round hollow ftalks 0 f a browne eolour, hauing ioynts like knees, garnifhed with fuch like leates, but imaller : at the end whereof grow rnany Houres of a pale colour, one aboue another; and after them commeth a brownith three fquare feede, lapped in browne charlie huskes like Patience. The roote is great, long, and yellowe within.

\# There is a varietic of this with crifped or curled leanes whofe figurewas by our Authout gimen in the fecond place in the following chapter, vnder the Title of Hydiolapatbum minus. $¥$

2 The fecond kind of tharpe pointed Docke is like the fiut, bur mueh finaller, and duth beare his feed in rundles about his branehes in charine huskes, like Sorrell, not fo nuch in vfeas the former,called al fo tharpe puinted Docke.

\# 3 This in roots, talkes, and feeds is like to the prececient; but the leates are thorter, and founder than thofe of the firft defcribcd, $\&$ therin confifts the chicfe difference betwixt this $\&$ it. F दा The Plate.

Thefe hindes of Docks do grow, ns is before fid, in nedowes an iby riners fides, 


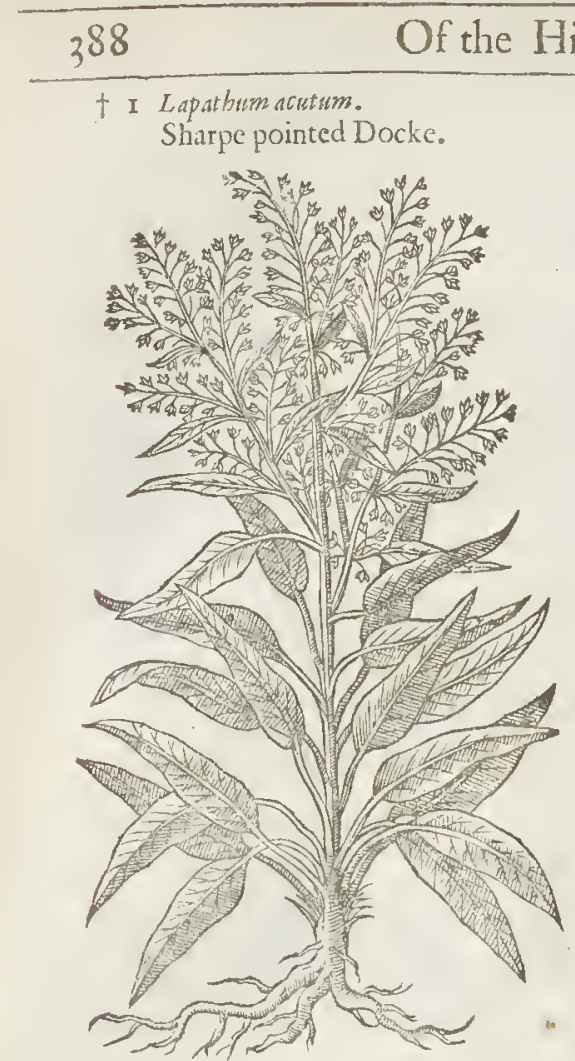

\$ Lapatbum fyluefre fol.minus acuto.

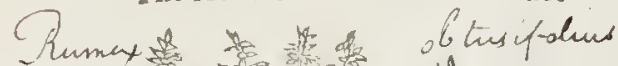
新 재

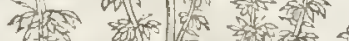

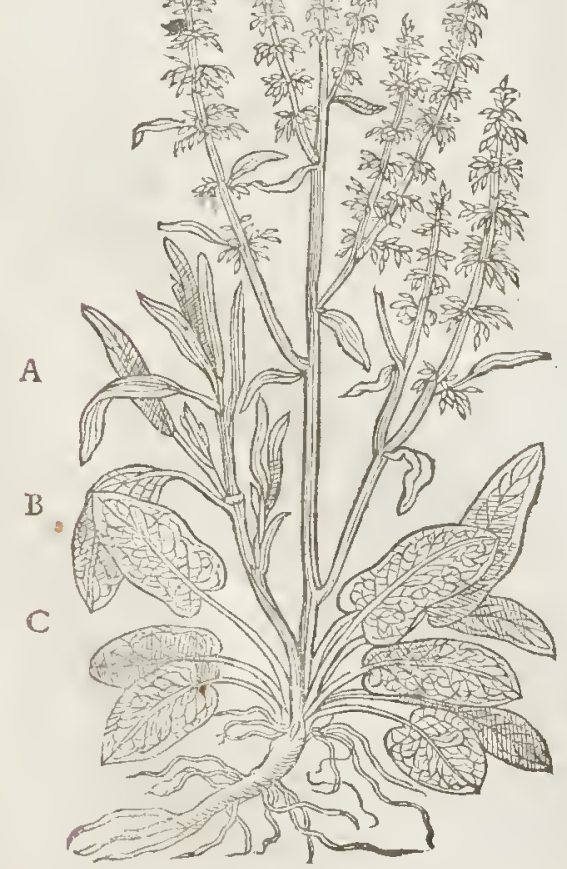

$L_{13} 2$.

2 Latpatbum asutum minzmum. Small tharpe Docke.

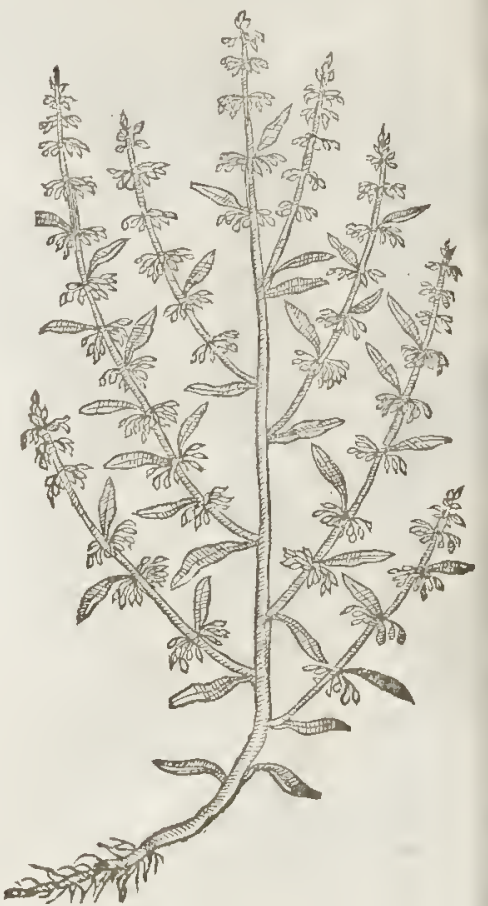

- The Time.

They floure in Iune and Inly.

$$
\text { e The Names. }
$$

They are called in Latine Lap at burs acutum, Rut mex, Lapatium, \& Lapathium: of fome, Oxylapat brm: in Englifh, Docke, and marpe pointed Docke, the

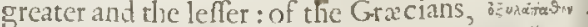
in high Duteh, mengelwumts, Streijfitwietz: in Italian, Rombice : in Spaninh, Romazh, paradilla, in Low Duteh, 19atich (which word is deriued of Lapathum) and alfo 19 eecoicts: in French, Parcille.

\# The third is Lapathum folio retilfo, or minuse acuto of Lobell; and Hippolapat lum fylucft. Of Tabern. - The Nature and rertucs.

Thefe herbes are of a mixture betweene enld and hear,and almoft drie in the third degree,efpeeially the feed which is very aftringent.

The pouder of any of the kinds of Docks drunk in wine, ftoppeth the laske and bloudie fluxe, and. eafeth the pains of the fomacke.

The roots boiled til they bevery foft, and ftamyed with barrowes greafe, and made into an ointment helpeth the iteh and all fouruie feabs and mangines. And for the fame purpofe it thall bee neceffiric ro boile them in water,as aforefaid, and the partie to be bathed and rubbed therewith.

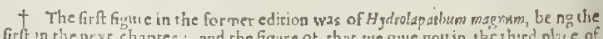

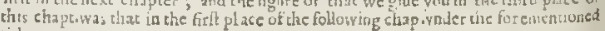
title. 


\section{LIв. 2. Of the Hitorie of Plants.}

389

$\mathrm{C}_{\text {HA P. 82. Of Water Dockes. }}$

I I Hydrolap.atbum magnum. Great Water Docke.

Rumex som aquaticus -
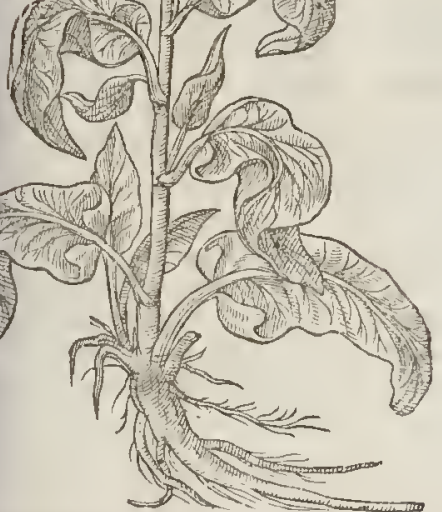

+ 3 Hippolapathum fatrowm

Patience, or Munkes Rubarb.

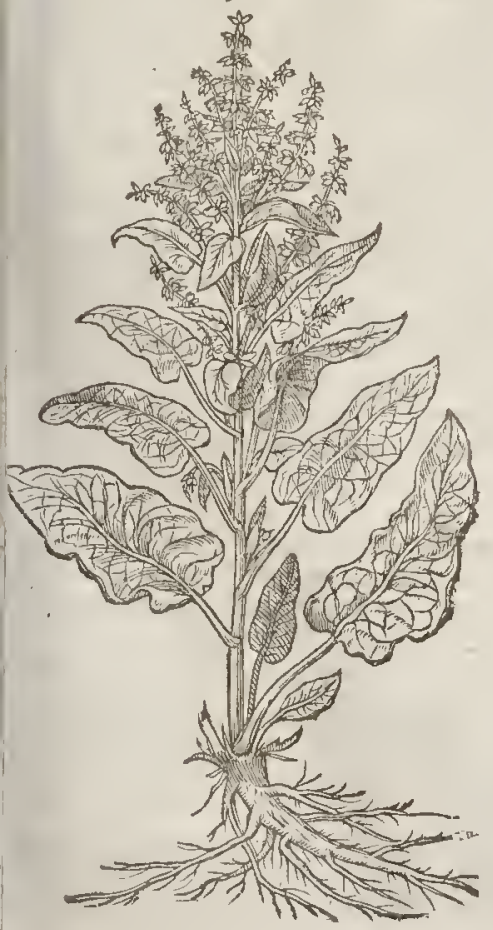

$\dagger \cdot 2$ Hydrolapathum minus.

Small Water Docke.

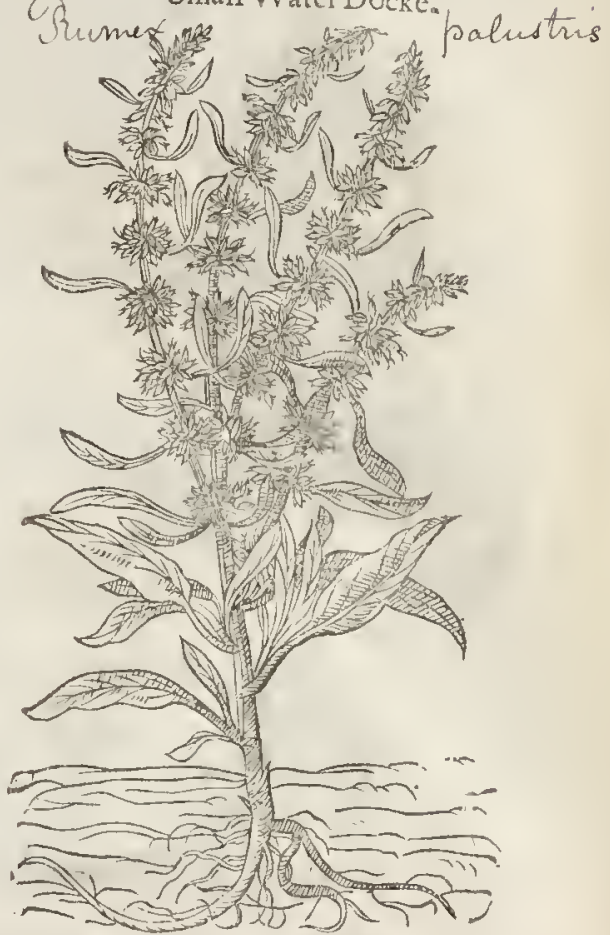

4 Hippolapathum rotundifolium. Baftard Rubarb.

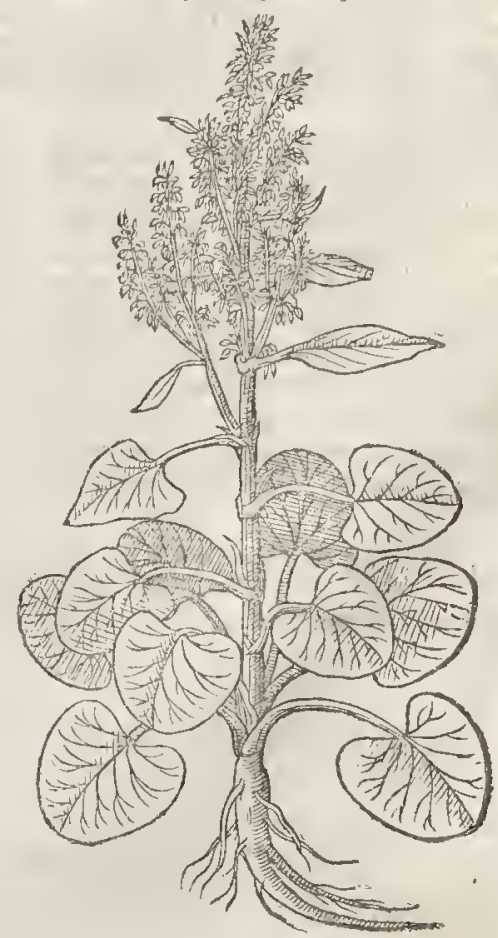


‡ Lapathum fativum fanzuincum. Bloudwoort. $6)$

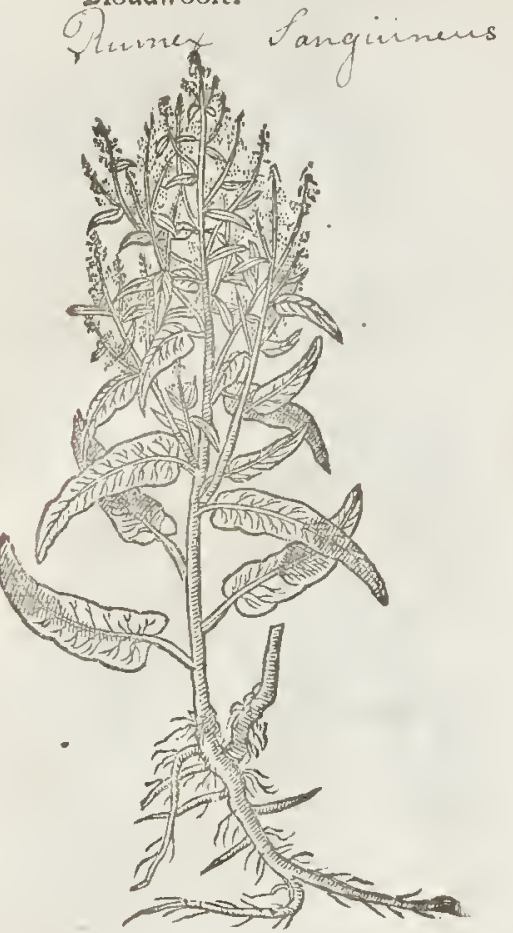

The Deforipion.

I THe Greatwatcr Docḱc hath very long and great leaves, fitte, and hard, not valike to the Gardon Patienee, but much longer. The flatke rifeth ip to a great heighr,ofentimes to the lecigle of fiue foot or more. The foulc groweth at the top of the ftalke in fyolic thifts, brewn of colour. The feed is contaircd in cliaffic huskes, three fquare, of a misirg falc colour. The root is very grear, thiche, ticnte. without, and ycllowim wirlin.

2 The fmall water Docke hath hort narrow leaues, fet vron a ftiffe ftalke. Tle floures grow fromtle middle of the fia $k \mathrm{k}$ vpward in fpokie rundles, fict in fprecs by certaine diftances tourd at cut it e ftallic, as are the floures of Horct onnd : Which Docke is of all the kirces nolt conmon and of leffe vfe, and taheth roplcafure or delight in any one foile or civellir gplace, but is found almont every where, as well vpon the land as in wateric places, but ef peeially in gardens among good and lolefome pot-herbes, being there betterkrown than welcome or defired: wherefore I intend not to fpend futther time about his deícription.

3 'The Garden Patience hath very ftrong ftalks, furrowed or chamfered, of eiglts or nine foot high when it groweth in fertile ground, fet about with great large leaues like to thofe of the water Docke, hauing alongt rhe Aaikes toward the top floures of a light purple colour declining to btowneneffe. The feed is three fquare, eontained in thun chafie huskes, like thole of the common Docke. The root is veric great, brownewithout, and yellow within, in colour and tafte like the true Rubatb.

4 Baftard Rubarb hath great broad round leaues, in Thape like thofe of the great Bur-docke. The ftalke and feeds are fo likic vnto the preedent, that rhe onc cannot be knowne from the other, fauing that the feeds of this arc fomewhar leffer. The root is exceeding great and thicke, very like vnto the Rha of Barbaric, as well in proportion as in colour and tafte, and purgeth after the fame manner, but muff be taken in greater quantitie, as witncffeth that famous learned Phyfition now liuing, $M^{r}$. Doctor Brizht, and others, who have experimented clic fame.

5 This fifth kinde of Doeke is bet knowne vnto all, of the ftocke or kindred of Doekcs; it hath long thin leaues, fometimes red in cuery part thercof,and often ftripped lere and there with lines and htrakes of a darke ted colour ; among which rife vp ftiffe britrlc flalkes of the fame co: lour : on the top whereof come forth fueh flourcs and feed as the common wilde docke hath. The root is likewife red, or of a bloudie colour.

\section{बा The Place.}

They do grow for the moft part in ditehes and water-coufles, very common througl, Eing land. The two laft fauc one do grow in gardens; $m y$ felfe and others in London and elfrhere hatue them growing for our vfe in Phyfreke and chirurgerie. The laft is fowne for a pot-herbe in moft gardens.

$$
\text { 9 The rime. }
$$

Moft of the dockes do rife vp in the Spring of the yeare, and their feed is tipe in Iune and Augुutt.

$$
\text { T The Names. }
$$

The doeke is called in Greeke $x_{i_{m a n}}$ : in Latine, Rumex, and Laputhum, yet Pliny in his 19 Booke, Chapter feemeth to attribute the name of Ramex onely to the garden docke. 
The Monkes Rubarbe is called in Latine Rumex fativus, and Patientia, or Patience, which word, is borrowed of the French, who call this herbe Patience : afterwhom the Dutch men name this pot herbe alfo 3 atientic: of fome, Rhabarbarum Monachorum, or. Monkes Rubarbe : becaufe as it hould feeme fome Monke or other haue v fed the root hercof in ftead of Rubarbe.

Bloudwoort, or bloudy Patience, is called in Latine Lapathum fanguineum : of fome, Sanguis Dracons, of the bloudie colour wherewith the whole plant is poffeft, and is of pot-herbes the chiefe or principall, hauing the propertic of the baftard Rubarbe; but of leffe force in his purging quality.

$$
\text { T The Temperature. }
$$

Generally all the Dockes are cold, fome little and moderately, and fome more : they doe all of them dric, but not all after one manner : notwith ftanding fome are of opinion that they aredry alnoft in the third degree.

$$
\text { I The Vertues. }
$$

The leaues of the Garden Docke or Patience may be eaten, and are fomewhat colde, but more $\mathrm{A}$ moift,and have withall a certaine elammineffe; by reafon whereof they eafily and quickely paffe through the belly when they be eaten : and Diofcorides writeth, that all the Dockes beeing boiled doe mollifie the bellie:which thing al fo Horace hath noted in his fecond booke of Sermons, the ourth Satyre,writing thus,

$$
\begin{aligned}
& \text { Mugilus, is vilespellent obfantia conche, } \\
& \text { El lapat bi brewisherba. }
\end{aligned}
$$

He calleth it a thort herbe, being gathered before the ftalke be growne vp; at which time it is fit- $\mathrm{B}$ eft to becaten.

And being fodden, it is not fo pleafant to bec eaten as either Bectes or Spinage : it ingendreth $C$ noift bloud of meane thicknefle, and which nouritheth little.

The leaues of the Tharpe pointed Dockes are cold and dric : but the feed of Patience, and the vater Docke doe coole, with a certaine thinneffe of fủ tance.

The decosion of the roots of Monkes Rubarbe is drunke againt the bloudy flix, the laske, the $\mathrm{E}$ vambling of the ftomacke which commeth of choler : and alfo againft the finging of ferpents,
s D of corides writeth. It is alfo good againft the fpitting ofbloud, being taken with Acacia(or his fuccedanemm, the
Iried iuice of floes) as Plinie writeth.

Monkes Rubarb or Parience is an excellent wholefome pot-herbe ; for being put into the pot- $G$ age in fome reafonable yuantitie, it doth loofen the belly; helpeth the iaunders; the timpany and uch like difeaf's, proceeding of cold caufes.

If you take the roots of Monkes Rubarb, and red Madder, of each halfe a pound; Sena foure $H$ unces, annife feed and licorice, of each two ounces; Scabioufe and Agrimonie, of each one handull; flice the roots of the Rubarb, bruife the annife feed and licorice, breake the herbes with your ands, and put them into a ftone pot ealled a fteane, with foure gallons of itrong ale to itcepe or nfufe the fpace of three daies; and then drinke this liquour as your ordinarie drinke for three reckes together at the leaft, though the longer you take it, fo much the better; protiding in a realineffe another fteanc io prepared that you may haue one vnder another, being alwaies carefull to eepe a good dict : it eure th the dropfre, the yellow iaunders, all manner of itch, feabbes, breaking ut, and mangineffe of the whole body : it purifietl the bloud from all corruprion; preualethagainft the greene fiekneffe very grearly, and all oppilations or ftoppings : maketh young wenches o looke faire and eherrie like, and bringeth downe their tearmes, the ftopping whereof hatl caulThe rame.

The feed of baftard Rubarb is of a manife ft aftringent nature, infomuch that it cureth the blou$y$ flix, mixed with the feed of Sorrell, and giuen to drinke in red wine.

There haue not beene any other faculties attributed to this planteicher of theantient or later riters, but generally of all it hath beene referred to the orher Docks or Monks Rubarb; of which umber I afture my felfe this is the beft, and dotl approch neereft vneo the true Rubarb. Manie afons induce me fo to thiuke and fay, firt this hath the thape and proportion of Rubarbe, the ime colour, both with in and without, without any difterence. They agree as ivell in tate as fmell: coloureth the fpittle of a yellorv eolour when it is chewed, as Rubarb doth; and lafty it purgeth le belly after the fame gentle manner that the right Rubarb doth, onely herein it differeth, that ith muft be given in three cimes the guantitie of the other. Other diftinkions and differences, lith the temperature and eucry other eiremmitance, I leaue to the learned Phyfitions of our I.onon colledge (who are very well able to fearch chis matter) as a thing farre aboue my reach, being

$$
\mathrm{K} K \mathbf{2}
$$


no graduate, but a Countey Scholler, as the whole ftaming of this Hiftorie doth wcll deelare:but I hope my good meaning will be well taken, confidering I doe my beft; not doubting but fome of gteater learning will petfect that which I hauc beg!nn according to my fnall skill, elpeeially the ice being broken unto hin, and the wood rongh hewed to his hands. Notwith ftanding I thinke it good to fay thus much mote in mine owne defence, that althougl therc bec many wants and defects in me, that were requifite to performe fuch a worke; yet may niy iong experience by eliance happen vpon fome one thing or other that may do the learned good : confidering what a notable experiment Ilearned of one Iohn Bennet a Clirurgion of Madftone in Kent, a man as flendetly learned as my felfe, whicli he ptantifed rpon a Butchers boy of the fame towne, as himfelfe reported vnto me; his practife was this:Being defired to eure the forefaid liad of an aguc, whieh did grieuoufly vex him, he promifed him a medicine, \& fot want of one for the prefent (for thift as himfelfe confeffed vnto me) he tookeout of his garden three or fourc leaucs of this plant of Rubarb, which my felfe bad among other fimples giuen him, which he ftamped \& ftrained with a dtaught of ale,and gaue it the lad in the morning to drinke: it w rouglit extrencly downeward and vpward within onc houre after, and neuer ceafed vntill night. In the end the ftength of the boy ouercame the foree of the Phyficke, it gauc oner working, and tl:e lad loft his anue; fince which time(as hec faith) he harli cured with the fame medieine many of the like maladie, hauing euer great regard vnto the quantitic, whieh was the eaufe of the violent working in the firft curc. By reafon of whieh aeeident, that thing hath been reuealed vnto pofteritic, which hetetofore wis not fo mueh as dreamed of. Whofe blunt attenupt nay fet an edge vpon fome fliarpet wit, and greater itdgement in the faculties of plants, to feehe farther into their nature than any of the Antients haue done: and none fitter than the learned Phy ficions of tic Colledge of London; whete are many fingularly wel leatned and cxperienced in natutall things.

I. The roots flieed and boild in the water of Cardus Bencdictus to the confumption of the thitd part,adding thereto a little honie, of the which decoftion eight or ten fpoonfuls drunke before the fit, cureth the ague in two or three times fo taking it at the moft: vnto tobuftous or ftrong bodies twelue fpoonfuls may be giuen. This cxperimentwas praftifed by a worhipfull Gentlewoman mifteffe Anme Wylbrabam, vpon diucts of het poore Neighbours with good fucceffe.

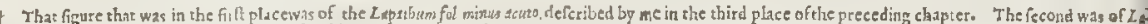

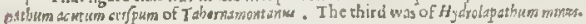

\section{С на . 83. Of Rubdrb.}

‡ $\mathrm{T}$ hath happened in this as in many other forreine medieines ot fimples, which though they be of gièat and frequent vfe, as Hetmodactyls, Muskc, Turbeth, Scc. yet haue we nocertaine knowledge of the very plaee which produces them, nor of their cxact manner of grow ing, whieh hath giuen occafron to diuers to thinke diuerfly, and fome haute been fo bold as to counterfeit figures out of their owne faneies, as catathiolus: fo that this fuying of Pliny is found to bevery teue, Nullamedicine pars magu incertis quam qua als alio quam nostro orbe petitur. But wewill endeanour to fhew you more cettaintic of this here treated of than was knowne vntill of very late yeres.

\section{- I'be Defcription.}

I THiskinde of Rubarb latl very great leaues, fomewhat fnipr or indented about the ed. ges like the teetl of a Saw, not vnlike the leaues of Enula campana, callcd by the vulgar fort Elecampane, but greater : amony which rifeth vp a ftraight ftalke of two eubits high, bearing at the top a falie head like thofe of Knuppe-weed, or Iacea mator : in the middle of which knap or head thrufteth forth a faire floure contilking of many purple threds like thofe of the Articlioke; which being pat, there followeth a great quantitic of downe, wherein is wrapncd long feede like vnto the grear Centoric, which the whole plant dorh very well refemble. The toot is long and thicke, blackifn without, and of a pale colour within: whieh being chewed maketh the fpittle very ycllow, as doth the Rubarb of Burbaric.

$\mp 2$ This orher baltatd Rha, whieh is alfo of Lobels defeription, hatl a root like that of the laft aicfcribed : but the leaues atc natrowet almoft like thofe of the eommon Docke, but hoarie on the other fide : the falkegtowes vp fraight, and beateth fueh heads and floures as the precedent.

$¥ 3$ I haue thonght good here somit the counterfeir figure of Matthiolus, giuen vs in this place by our Authour; as alfo the Hiftoric, which was not much pettinent, and in lieu of them to prefent you with a petfeet figure and defetiption of the true $k h a$ Pontizum of the Anticuts, whieh 
was firf of late difcomered by the leaned Proper Alpinus, who writ a peculiar traet thereof, and it is alfo againe figured and deforibed in his worke de Platus exoticts. Our Countryman $\mathrm{M}^{r}$ Iobn $\boldsymbol{P}$ ar. kin ow hath alio tet forth very well both the figure and defeription hereof, in his Paradifus terreftras. This plant huth many large roots diues lly fpreading in the ground, of a yellow colour, from which grow vp many very great leaues like thofe of the Butter-burre, but of a fren greenc colour, with great and manifef veines difperfed cuer then. The ftillie alfo is large and crefted, fending forth fundry branches bearing nany fmall white floures, which are fucceded by feeds three fquare and brownifh, like as thofe of uther Docks. Dr. Lifter one of his Maieflies Phyfitions was the firft that enricht this kinglome with this elcgant and vfefull plant, by fending the feedes thereof to $\mathrm{M}^{\mathrm{r}}$. Parkinfon. Profper Alpinus proues this to be the true Rhu of the Antients, defcribed by Dioferides, tib. 3.cap. z.yet neither he nor any other (that I know of) haue obferwed a fault, which I more than probably fufped tobec in the text of viofcorides in that place, which is in the word $\mu$ ine wh which I iudge thould be $\mu$ mirry that is,yellow, and not blacke, as Ruelliws and others baue tranflated it : now wrave is a word frequent ly $v$ fed by Diofcorides, as may appeare by the Chapters of Hicracium matgmm Lumum,Conyra, Peuceduntm, Ranuricnlus, and diuersothers, and I fufpect the like fault may bee found in fome orber plices of the fame Authour. But I will no further infift vpon this, feeing the thing it felfe in all other refpeets, as allo in yellowneffe thewes it felfe to be that deferibed by $D i$ ofcridis, and that ny conic Sture mut therefore be true. And befides, the root wherto he compares it is wipules, that is Rubcfecns, or rather ex faun rubefeens, as any verfed in reading Dioforides may eafily gather by diuers places in him. Now I here omit hiswords, becaufe they are in the next defcription alledged by our A uthour, as alfo the defcription of our ordinarily vfed Rubarb, for that it is fufficiently deferibed vinder the following title of the choife thereof. $\mathrm{M}^{\mathrm{r}}$. Parkm on is of opinion that this is the truc Rubarbe vfu in frops, onely lefe heauy, bitter, and ftrong in working, by reafon of the diuer fity of our climat from that whereas the driced Rubarb brought vs viully grows. This his opinion is ver y probable, and if you compare the roots together, you nay cafily bee induced to be of the fame belecfe. $\ddagger$

t 4 The Pontiche Rubarbe is leffer and flenderer than that of B arbarie. Tonching Pontick Rubarbe Dioforides writeth thus : Rha that diuers call Rheon, which groweth in thofe places that are beyond Bofphorus, from whence it is brought, hath yellow roots like to the great Centorie, but

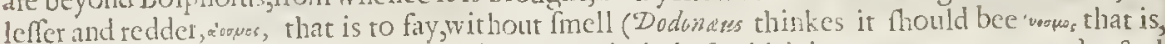
well fmelling) fpongie, and fomething light. That is the beft which is nor worme-eaten, and tafted is Comewhat vifeide with a light aftriction, and chewed becomes of a yellow or Saffron colour.

- The place

It is brought out of the Countrey of Sina (commonly called China) wlich is roward the Eaft in the vper part of India, and that India which is without the riuer Ganges: and not at all $E x$ Sccnitarum pronincia (as many do vnaduifedly thinke) which is in Arabia the Happic,and far from China:it groweth on the fides of the riuerRha now called Voiga, as Amanus Marcellus faith, which river foringeth out of the Hyperborean mountaines, and running through Mufcouia, falleth into the Cifpian or Hircan faa.

+ The Rha of the Antients growes naturally, as Alpinus faith, won the hill Rhodope in Thrace, now called Romania. It growes alfo as I hatie been informed vpon fome mountaines in Hunga. ric. It is alfo to be found growing in fome of our choice gardens. $\neq$

$$
\text { The choice of Rub,rbe. }
$$

The beft Rubarbe is that which is brouglit from China freth and new, of a light purplin red, with certaine veines and branches, of an incertaine varietic of colour, commonly whitith : but when it is old the colour becomneth ill fauored by turning ycllowifh or pale, but more, if it bee worme eaten : being chewed in the nouth it is fomewhat gluic and clammic,and of a fatfron colour, which being rubbed vpon pa per or fome white thing theweth the colour more plainely: the fubfance thereof is neither hart or clofely compacted, nor yet heauy; but fomething light, and as it were in a middle betweene hard and loofe anu fomething fpungic: it hath alfo a pleafing fumell. "The fecond in goodneffe is that which commeth from Barbarie. The laft and worf from Bofphorus and Pontus.

$$
\text { I) The Names. }
$$

It is commonly callet in Latine $R h$ h Barbarum, or $R$ ha Barbaricum of diuers, $R$ licu Barbarum : the Moores and Arabians doe more truely name it Raned Sent, a Sinenfit pronincia; from whence it is brought into Perfia and Arabia, and afterwards into Europe: and likew ife from Tanguth, through the land of Cataia into the land of the Perfians, whereof the Sophie is the ruler, and from thence into Egypt,and a ftcrwards into Europe. It is called of the Arabians and the people of China,and

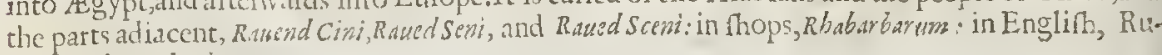
barb.and kewbarbe. 
4 Rha Ponticum Siccutum. Rubarb of Pontus dried.

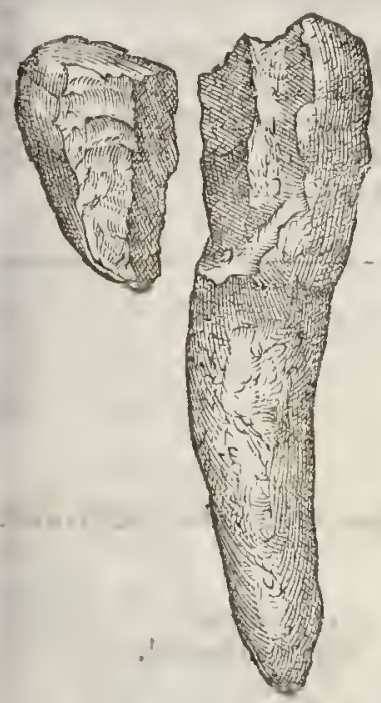

of The Tompcriture.

Rubarb is of a mixt fubftance, temperat ture and faculties : fome of the parts thereof arc earthy; binding and drying : others thit, airious, hot,and purging.

$$
\text { T } T \text { be vertucs. }
$$

Rubarb is commended by Diofiarides a. gainft windineffe, weakneffe of the ftomack, and all griefes thereof, convulfions, difeafes of the fplecne, liuer, and kidinies, gripings and inward gnawings of the guts, infirmities of the bladder and chent, fivelling about thë heart, difeafes of the matrix, paine in the hucklé bones, fpitting of bloud, fhortneffe of breath, yexing, or the hicket, the blondie flix, the laske proceeding of raw humors, fits in Agues, and againft the bitings of venomous beafts.

Morcouter he faith, that it taketh away blackeand blew fpots, and tetters or Ringwormes, if it be mixed with vineger, and rhe place anointed therewith.

Galcn affirmes it to be good for burfeings, cramps, and convulfions, and for tho fe that are fhorr winded, and that fpit bioud.

But totiching the purging facultie nei- D ther Diofcorides nor Galen hath written any thing, becaure it was not vfed in thofe daies to purge with. Galen held opinion, that the hinne airious parss doe make the binding qualitie of more force; not becaufe it dorth refitt the old and earthy fubftance, but by reafon that it carrieth the fame, and maketh it dceply to pierce, nd thereby to worke the greater effect; the dry and thinne effence containing in it felfe a puroing orce and qualitie to open obftructions, but helped and made more facile by rhe fubtil and air ous arts. Paulus Eg ineta feemeth to be the firft that made triall of the purging faculre of Rutharb ; or in his firft booke, Chap.43. he maketh mention thereof, where he reckoneth vp Turnentine arong thofe medicines which make the bodies of fuch as are in health foluble: But when we nurofe, faith he, to make the turpentine more ftrong, weadde vnto it a little Rubarb. The Arabians hat followed him brought it to a further vfe in phyficke, as chicfely purging downward choler, nd oftentimes flegme.

The purgation which is made with Rubarb is profitable and fit for all fucl as be roubled witli holer, and for thofe that are ficke of tharpe and tertian feuers, or haue the yellow jaund ice, or bad iners.

It is a good medicine againft the pleurifie, inflammation of the lungs, the fquinancie or Squin- $F$ ie, madneffe, frenfe, infammation of the kidnies, bladder, and all the inward parts, and efpeciallagainft S. Anthonies fire, as well outwardly as inwardly taken.

Rubarb is vndoubredly an efpeciall good medicine for the liuer and infirmities of the ga!l ; for G efides that it purgeth forth cholericke and naughty humors, it remouth ftoppings out of the
onduits.

It alfo mightily ftrengthneth the intrals themfelues : infomuch as Rubarb is iuftly termed of If iters the life of the liuer, for Galen in his eleuenth booke of the method or manner of curing, afimeth that fucli kinde of medicines are moft fit and profitab le for the liter, as haue ioyned iv ith purging and opening qualitic an aftringent or binding power. The quantitie that is to be gitien from one dran to two; and the infufion from one and a halfe to three.

It is given or fteeped, and that in hot difeafes, with the infufion or diftilled water of Succory, I ndiue, or fome other of the like nature; and likewife in Whay ; and if there be no heate it may giten in Wine. 
$\mathrm{K}$ It is alfo oftentimes giuen being dried at the fire, but fo, that the leaft or no part thereof at all be burned; and being fo ved it is a remedie for the blondy flix, and for all kindes of liskes : for it both purgeth away naughty and cormpt humors, and likewife w ithall ftoppeth the belly.

L The fame being dried after the fame manner dothalfo ftay the ouermuch flowing of the monethly fickneflc, and ftoppeth bloud in any part of the body, efpecially that which commeth thorow the bladder; but it thould be giuen in a little quantitic, and mixed with fome other binding thing.

M Mefues faith, That Rubarb is an harmelefte medicine, and good at all times, and for all ages, and likewife for children and women with childe.

\pm My friend $M^{x}$. Samp fon Tobnfon Fellow of $\mu a g d a l e n$ Colledge in Oxford afiures me, That the Phyfrtions of Vienna in Auftria vfe fcarce any orher at this day than the Rubarb of the Antients, which grows in Hungary not far from thence : and rhey prefer it before the dried Rubarb broughe out of Perfia and the Eaft Indies, becaufe it hath not fo ftrong a binding facultie as it, neither doth it heate fo much; oncly it muft be ved in fomewhat a larger quantitie. $\ddagger$

\section{C н а . 84: Of Sorrell. \\ The Kindes.}

There be diuers kindes of Sorrell, differing in many points, fome of the garden, others wilde; fonc great, and fome leffer.

I oxalis, fiue Acetofa. Sorrell.

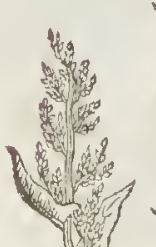

tiv

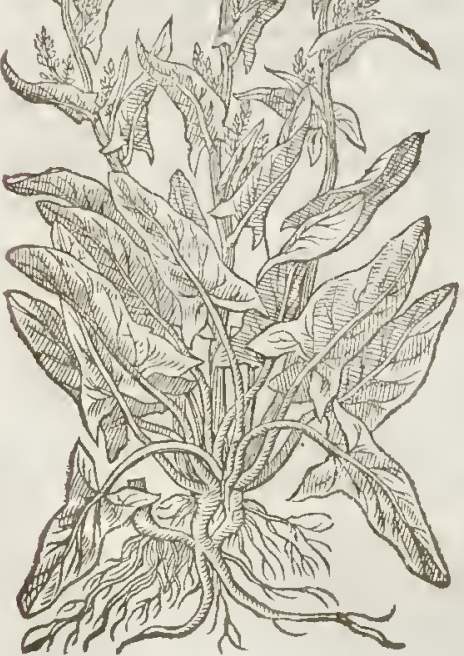

2 oxalis tuberofa. Knobbed Sorrell.

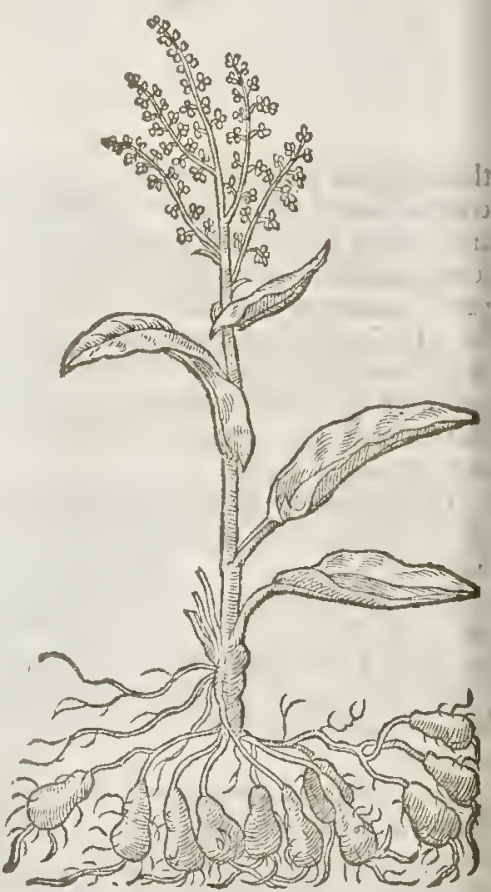

II The Defcription.

Hough Diof corides hath not expreffed the oxalides by that name, yet noneought to doubt but that they were taken and accounted as the fourth kinde of Lapashsm. For though fome 
2 The fmall Biftort growech in great aboundance in Weftmerland, at Crosby, Rauenfwaith, at the head of a Parke belonging to one $\mathrm{M}^{\mathrm{r}}$. Pickering : from whence $1 \mathrm{t}$ hath beene difperfed into many gardens; as alfo fent vinco me from thence formy garden.

They Hourc in May, and the feed is ripe in Iline.

$$
\text { ot The Time. }
$$

Biftorta is called in Englifh Snake-weed: in fome places, Oifterloit : in Chefhire, Paffions, and Snake-weed, and therevfed for an excellent Pot-herbe. It is called Bifforta of his wrythed roors, and alfo Colubrini, Serfentaria, Brittanica; Dracontion, Pleny; Dracunculus, Dodonai; and Limorisum Gefneri.

Biftort doth coole and dry in the third degree.

$$
\text { ๆ) The Nature. }
$$

Tlise Veriues.

A.

The iuyce of Biftort put into the nofe preuaileth much againtt the Difcafe called Polypus, and the biting of Serpents or any venomous beaft, being drunke in Wine or the water of Angelica.

B

The roor bovled in wineand drunke. Atopperh the laske and bloudy fix; it ftayethalfo the ouermuch flowing of womens monethly ficknefles.

C The root taken as aforefaid ftayeth vomiting, and healeth the inflammation and foreneffe of the mouth and throat : it likewife faftneth loofe teeth, being holden in the mouth for a certaine jpace, and at fundry times.

$$
\begin{gathered}
\text { C H A. 86. Of Scuruy-Graffe, or Spoon-mort. } \\
\text { I The Defoription. }
\end{gathered}
$$

D

Ound leaucd Scuruy. Graffe is a low or bafe herbe: it bringeth fortl leaues vpon fmal ftems or foot-ftalks of a meanc length, comming immediately from the root, very many in number, of a thining greene colour, fomewhat broad, thicke, hollow like a ! little fpoone, but of no great depth, vnetren, or comered about the edges: annong which leates fpring vp fmall ftalkes of a fpanne high, whereon doe grow many litclewhite foures: after which commerh the feed, fmall and reldith, contained in little round pouches or feed-velfels : the routs be fmall, white, and threddy. The whole plant is of a hot and fpicie tafte.

The common Scuruy-graffe or S poone-wort hath leaues tomewhat like a fpoone, hollow in the middle, but al together vnlike the former : the leaues hereof are blunty toothed about the ed. ges, tharpe pointed, and fomewhat long : the falkes rife vp among the leatus, of the length of halfe foot, whereon do grow white floures with fome yellowneffe in the middle: which being palt, there fucced fnall feed-veffels like vito a pouch, not vnlike to thofe of Shepheards purfe, greene at the firt, next yellow inh, and laftly when they be ripe, of a browne colour,or like a filberd nut. The root is fmall and tender, compact of a number of threddy ftrings very thicke thruft together in manner of a little turfe.

$$
\text { T) The place. }
$$

The firf groweth by the fea fide at Hull, at Bofton, and Lynne, and 1 is many otier places of Lincolnthire neere vnto the fea, as in Whaploade and Holbecke Marthes in Hoilland in the fame Counry. It hath beene found oflate growing many miles from the fea fide, wpon a great hill in I ancaithire called Ingleborough hill; which may feeme ferange snto thofe that do not know that ir will be content with any forle, place, or clyne whatfocuer: for proofe whereof, my felfe haue fowen thefeeds of it in my garden, and giten them vnto others, with whom they floure, flourifh, and bring forth their feed, as naturally as by the fea fide; and likewife retaine the famelot fuicio tafte: which proueth that they refufe noculture, contrary to many other fea-plants.

The fecond, which is our common fcuruie graffe, groweth in diuers places vpon the brimmes of the famous riter 'Thanres, as at Woolwich, Erith, Greenhithe, Grauefend, as well on the Effex thore as the Kenting; at Portfmouth, Briftow, and many other places along ft the Weftern coaft but toward the North I hawe not heard that any of this kinde hath growne. 


\section{LIB: 2. Of the Hiftory of Plants:}

The Time

It floureth and flourifheth in May. The fecd is ripe in Inne.

2 Cochlearia rotundifolia.

Round leafed Scuruie graffe

Cochlewria officinalis

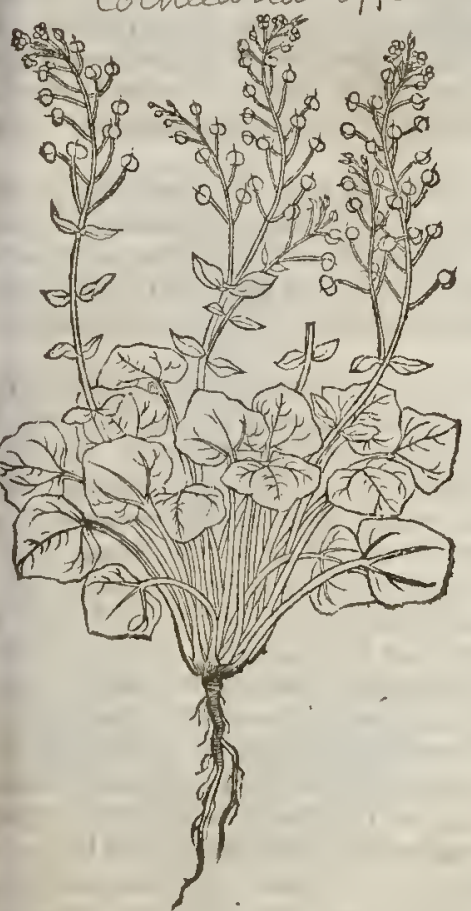

2 Cochlearia Eritamica.

Common Englinh Scuruie grafte.

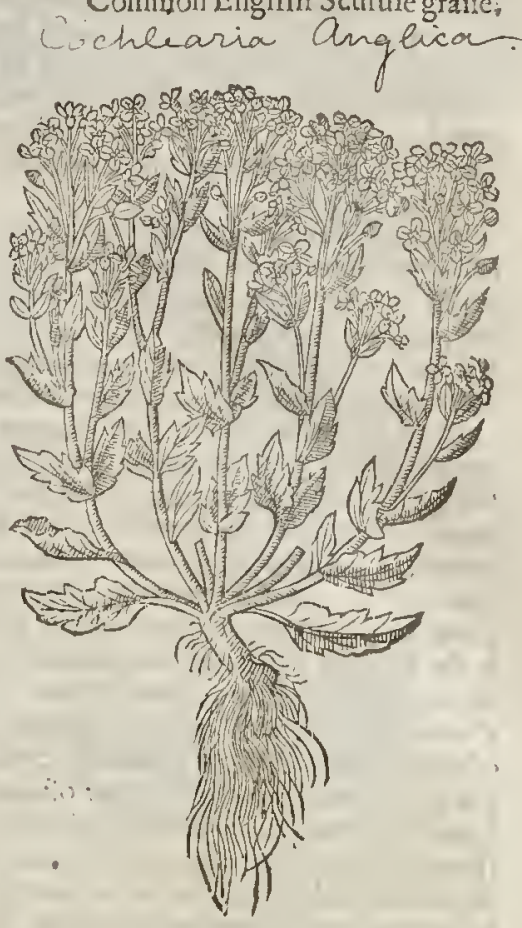

17 The Naries.

$t$ We are not ignorant that in low Germany, this hath feemed to fome of the beft learned to be the true Brit annicat, and namely to thofe next the Ocean in Friefland and Holland. The Gernanes call it Leffelktaut: that is, Cocblearia or Spoonwort, by reafon of the compafied roundnes ind hollownes of the leaues, like a fpoone; and haue thought it to be Plinie's Britamica, becaufe hey finde it in the fame place growing, and endued with the fame qualities. Which excellent lant $C$ afars foldiers (when they remooued their camps beyond the Rhene) found to preunile (as he Frifians had taught it them) againft that plague and hurtfull difeafe of the teetl, guns, and inewes, called the Scuruie, being a depriuation of all good bloud and moifture, in the whole bolie, called Scorbutum; in Englin, the Scurtuic, and Skyrby, a difeafe happening at the fea among ifhermen, and frefh-water fouldiers, and fuch as delight to fit ftill without labour and exercife if their bodies; and efpecially aboue the reft of the caufes, when they make noc cleane their bif et breal from the floure or mealines that is vpon the fame, which doth fpoile many. Bur frr thi

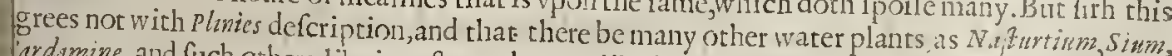
iardamine, and fuch others, like in tafte, and not vnlike in proportion and vertues, which are remeies againft the difeates aiorefaid, there can be no certaine argument drawne therefrom to rooue it to be Britannica. For the leaues at their firft comming forth are fomewhat long like Pyrola r Adders tongue, foone after fomewhat thicker, and hollow like a natell, after the manner of un-dew, but in greatneffe like Soldarella, in the compaffe fomewhar cornered, in farthion fornehat like a fpoone: the floures white, and in thape like the Cuckow floures : the feed reddifh ke the feed of $T$ hinfpi, which is not to be feen in Britansica, which is racher holden to be Biftort garden Patience, than Scuruie grafe. In Englifh it is called Spoonewort, Scruby graffe, and
curuie grafie.

Thic Temperature. 1 aromaticke or fpicie tafte. 


\section{The Vertues.}

A The juice of Spoonewoort gituen to drinke in Ale or Beere, is a fingular medicine againft the corrupt and rotten vicers, and ftench of the mouth : it perfectly curetla the difeafe called of Hippo. crates, foluulus Hematites : of Pliny, Stomacace: of Marcellus, ofcedo: and of rhe larer writers, Scorbu. twm : of rhe Hollanders and Frifians, Scuerbilyck : in Englifh, the Scuruie : either giuing rhe juice in drinke as aforefaid, or putting fix great handfuls to fteepe, with long pepper, graines, an. nife-feede, and liquorice, of each one ounce, the fpices being braied, and the herbes brufed with your hands, and fo put into a pot, fuch as is before mentioned in the chapter of baftard Rubarbe, and vfed in like maner; or boiled in milke or wine and drunke for certaine daies toger her it worketh the like effect.

B The juice drunke once in a day falting in any liquor, ale, beere, or wine, doth caufe the forefaid medicine more fpeedily to worke his effect in curing rhis filthy, lothfome, leauy, and dull difeafe, which is very troublefome, and of long conti nuance. The gums are loofed, fivolne, and exulcerate; the mouth greeuoufly ftinking; the thighes and legs are withall very often full of blew fpots, not much inlike thof that come ofbrufes: the face and the relt of the body is oftentimes of a pale colour : and the feet are firolne, as in a dropfie.

C There is a difeafe (faith oraus magnus in his hiftorie of the Northerne regions) haunting the campes, which vexe them that are befieged and pinned vp: and ir feemeth to comeby eating of falt meates, which is increaled and cherished wirh the cold vapors of the ftonewalls. The Germanes call this difeafe(as we hauc faid) Scorbuck; the fymptome or paffion which hapneth to the moutly, is called of Pliny soparaxi: Stmmarace and rhat which belongeth to the thighes munomipa : Marcellus an old writer nameth the infirmities of the mouth ofcedo: which difeafe commeth of a groffe cold and tough bloud, fuch as malancholy juice is, not by adultion, but of fuch a bloud as is the feculent or droffie part thercof: which is gathered in the body by ill diet, flothfulneffe ro vorke laifineffe (as we terme it) much fleepe and reft on fhip-boord, and not looking to make cleane the bifquet from the mealinefle, and uncleane keeping their bodies, which are the caufes of this difeafe called the fcuruie or fcyrby; $;$ hich difeafe doth not onely touch the outward parts, fut the invard alfo: for the liuer oftentimes, but moft conmonly the foleene, is filled with this kinde of thicke, cold and tough juice, and is fwolne by reafon that the fubitance thereof is flacke, fpungie and porous, very apt ro receiue fuch kinde of thick and cold humors. Which thing alfo Hippocrates hath written of in the fecond booke of his Prorshet ikes : their gums (faith he) are infected, and their mouthes ftinke thar haue great fpleenes or milts : and whofoetrer haue great milts and vfe not tobleed, can hard ly be cured of this malladic, efpecially of the vlcers in the legs, a blacke fpots. The fame is affirmed by Paulus Agineta in his rhird booke, 49 . chapter, where you may eafily fee the difference between this difeafe and the black jaunders; which many times are fo confounded tooether, that the diftinction or difference is hard to be known, but by the expert chiruroion:who oftentimes feruing in the fhips, as wel her Maiefties as merchants, are greatly peftered with the curing therc of : it thall be requifite tocarric with them the herbe dried : the water ciftilled, and rhe juice put into abottlewith a narrow mouth, full almoft to the necke, and the reft filled $v$ w with oile oliue, to keep it from putrifaction. the which preparations difereetly vfed, will ftand them in great fead for the difeafe aforefaid.

The herbe ftamped and laid voon fpots and blemithes of the face, will take them away within fix houres, but the place mut be walhed after with water wherein bran hath been fodden.

\section{С н г. 87. Of Twayblade, or berbe Bifoile.}

\section{- The Defcription.}

I

T Erbe Byfoile hath many fmall fibres or tlureddy ftrings, faftened vnto a fmall knot of root, from which rifeth vp a flender ftem or ftalke, tender, fat, and full of juice; in the middle whereof are placed in comely order two broad leaues, ribbed and chamfered, in thape like the leaties of Plantaine: vpon the top of the ftalke groweth a flender greenifh Spike made of many fmall Houres, each litt le floure relembling a gnat, or little golling newly hatched. very like thofe of the rhird fort of Serapias ftones.

2 opluris Trifolia, or Trefoile Twaiblade, hath roots, tender ftalkes, and a bufh of flours like the precedent; but differeth in that, that this plant hath three leaues which do clip or embrace the 


\section{1 в. 2. Of the Hiftory of Plants.}

ftalke about ; and the other hath but two, and neuer more, wherein efpecially confifteth the difference : although in truth I thinke it a degenerate kinde, and hath gotten a third leafe fer accidins, as doth fometimes chance vnto the Adders Tongue, as thall be deelared in the Clapter that followeth.

$\neq 3$ This kind of Twaiblade, firft defcribed in the laft edition of Dodonems, hath leates, floures, and ftalkes like to the ordinarie, but at the bottome of the ftalke aboue the fib:ous roots it hath a bulbe greenifh within, and couered with two or three skins : it growes in moift and wet low plaees of Holland.
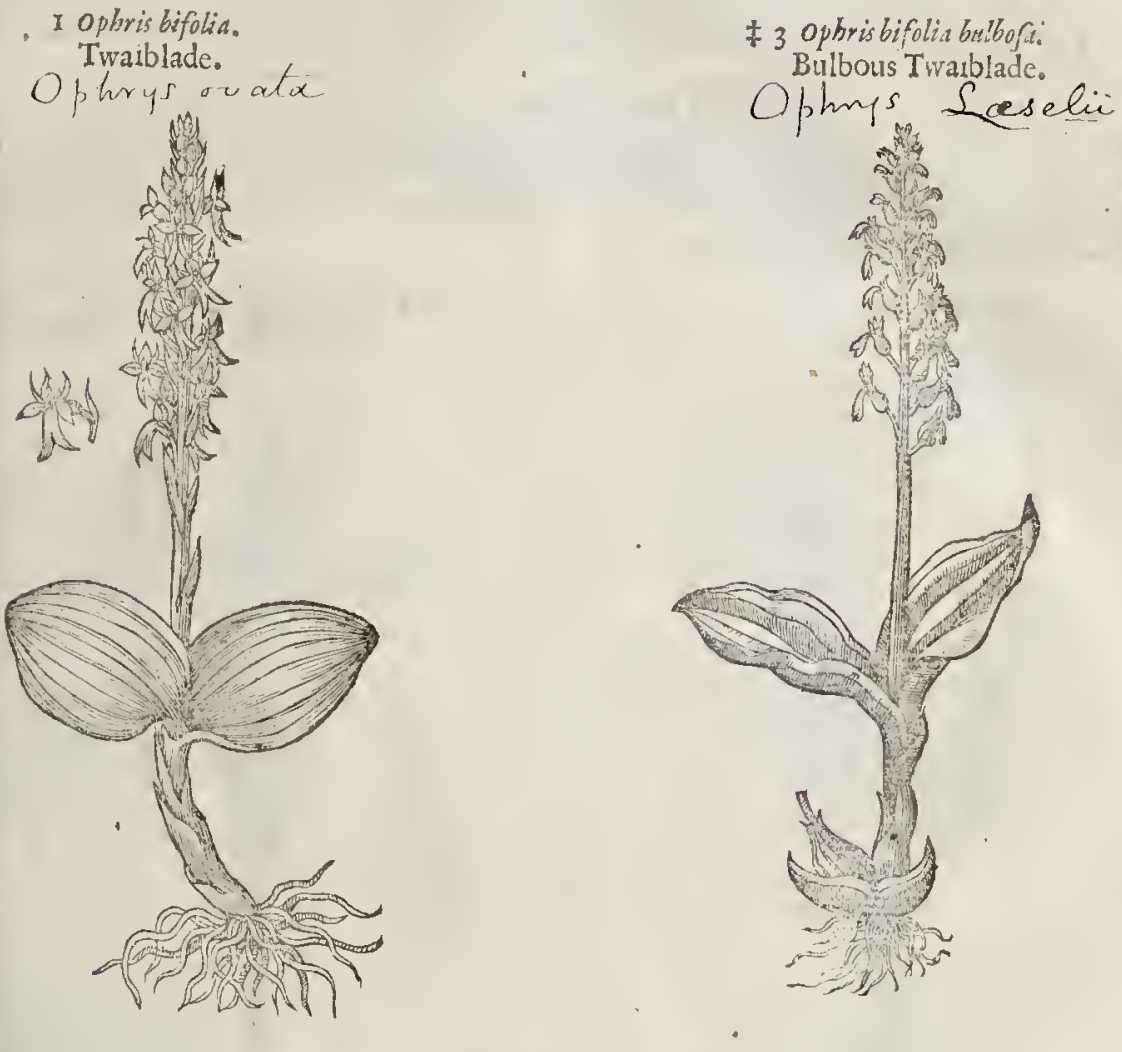

if The Place.

The firft groweth in moift medowes, fenny grounds, and thadowie places. I lune fonnd it in many places, as at Southfleet in Kent, in a Wood of Mafter Sidleys by Long. fiel.t D jwnes, in a Woodby London ealled Hamptead Wood, in the fields by High-gate, in the Wonds bv Onenden necre to Clare in Effex, and in the Woods by Dunmow in Eflex. The fecond fort is feldome
feene.

They foure in May and Iune.

$$
\text { T. The Time. }
$$

Tा The Names.

It is called of the later Herbarifts, Bifolium, and ophris.

\section{of The Nature ard Vertues.}

Thefe are reported of the Herbarits of our time to be good for greene wounds, burftings, and A uptures, whereof I have in my vnguents and Balfams for greene wounds had great experierce,
and good fuceeffe.
$\mathrm{L}_{2}$
CHAT. 


\section{Cн н. 88. Of eAdders-Tongue. \\ T) The Defcription.}

( phioglo/fon, or Lingu Serpentis (called in Englith Adders tongue; of fome, Adders Graffe, though vnproperly) rifcth forth of the ground, hauing one leafe and no more, fat or olcous in fubitance, of a finger long, and very like the yong and tender leaues of Marigolds : from the botrome of which leafe fpringeth out a fmall and tender ftalke one finger and a halfe long, on the end whereof doth grow a long fmall tongue not vnlike the tongus of a ferpent, where of it tooke the name.

2 I haue feene anorher like the former in root, Italke, and leafe; and differeth, in that this plant hath two, and fometimes more crooked tongues, yet of the fame fathion, which if my iudgment faile not chanceth per accidens, enen as we fee children borne with two thumbes vpon one hand: which moucth me fo to thinke, for that in gathering twenty buthels of the leaues a man thall hardly finde one of this fathion.
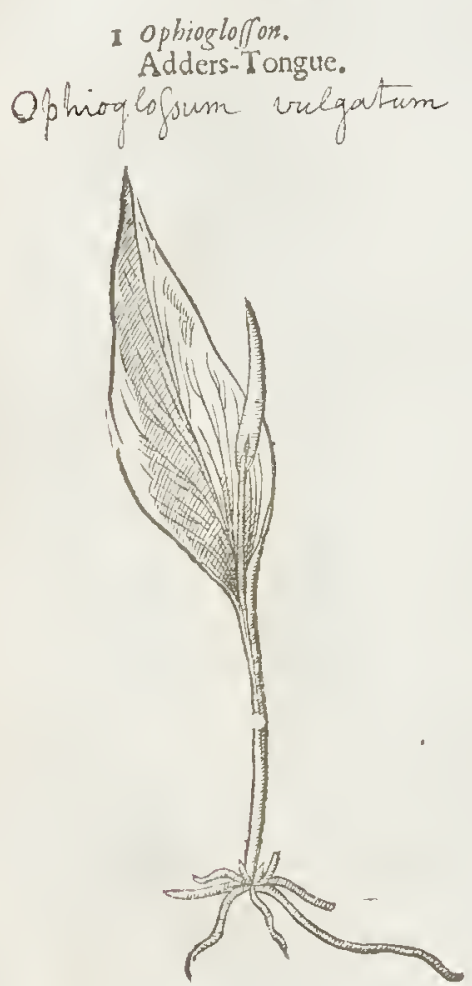

\section{+ 2 ophiogloffor abortivum. Mil-thapen Adders-Tongue.}

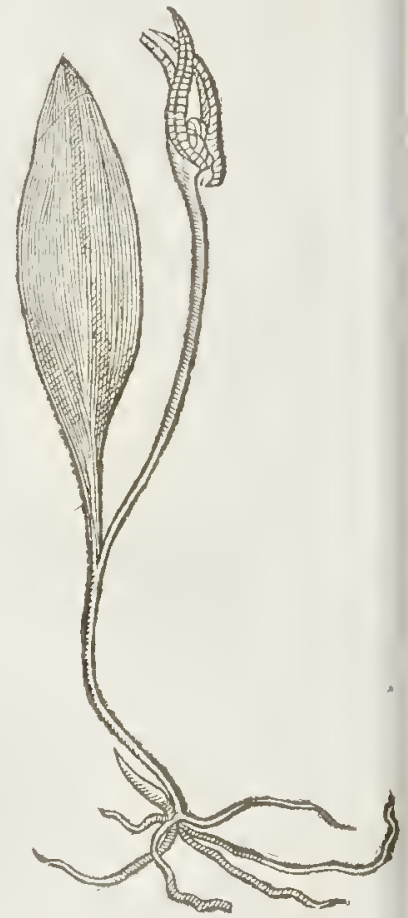

q The place.

Adders-Tongue groweth in moift medowes throughout moft parts of England; as in a Mea: downeere the preaching Spitt'e adioy-ing to London; in the Manrels by London, in the medowes by Cole-brooke, in the fields in Wa'tham Forreft, and many other places.

They are to be found in A prill and Mav; but in Iune they are quite vanifhed and gone.

4) The Names.

ophiogloffum is called in thops Lingua ferpent is, Linguace, and Lingualace $:$ it is alfo called Lancea Chrifti, Enephyllon, and Lingun vilnerarin. in Englith, Addets tongue, or Setpents tongue; in Dutch, fatertonguct : of the Germanes, Pater zungelitr. 
F In England (fath Cumerarius) there growes a certaine kinde of Lunaria, which hath many leaues, and fometimes alfo fundry branches; which therefore I haue caufed to be delineated, that other Herbarifts might alfotake notice hereof. Thus much Camerarius, Epit. Mat.p.644.where he giues an elegant figure of a varietic hating more leaues and branches than the ordinary, otherwife not differing from it.

3 Befides this varietie there is another kinde fet forth by Clufius; whofe figure and defcription I thinke good here to fet downe. This hath a root confifing of many fibres fomer hat thicker than thofe of the common kinde: fron which arife one or two winged leates, that is, many leaues fet to one Atalke; and thefe are like the leaues of the other Lunaria, but that they are longer, thic$\mathrm{ker}$, and more diuided, and of a yellowilh greene colour. Amongft thefe leaues there comes vp a ftalke fat and juycie, bearing a greater tuft of flowes or feeds (for I know not whether to cal them) than the ordinaric, but otherwife very like thereto. It groweth in the mountaines of Silefia, and in fome places of Auftria. $\ddagger$

\section{\$ Luniritiminor ramofa.}

Small branched Moon-wort.

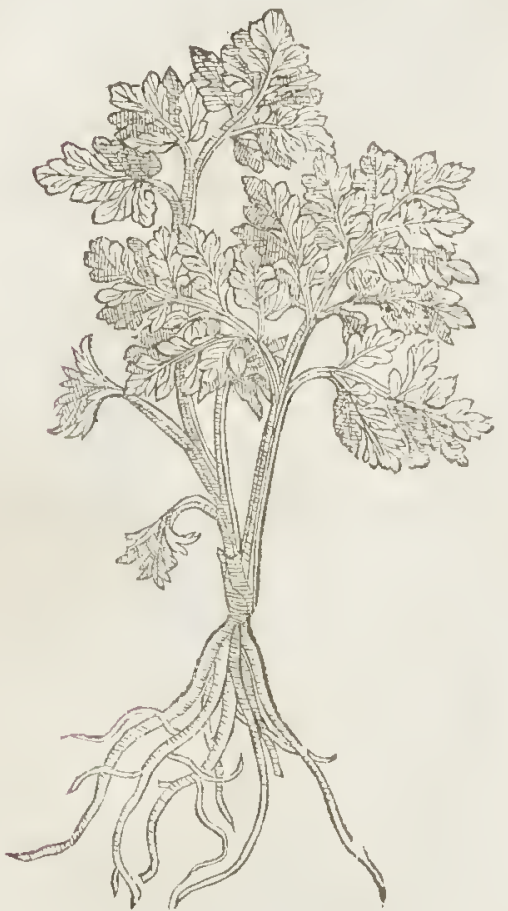

T. The Place.

Hcrba Paris groweth pientifully in all thele places following; that is to fay, in Chalkney wood neere towakes Coulne, fenen miles from Colchefter in Effex, and in the wood by Robinhoods well, neere to Notringham; in the parfonage orchard at Radwinter in ERex, neere to Saffron Walden; in Blachburne at a place called Merton in Lancalhire; in the Moore by Canturbury called the Clapper; in Dingley wood, fix miles from Prefton in Aundernefle; in Bócking parke by Braintree in Effex; at Heffet in Lancalhire, and in Cotting wood in the North of England; as that excellent painefull and diligent Phyfition $\mathrm{M}^{ }$. Doctor Turner of late memorie doth record in his Herbal.

Lutnitia or fmall Moone-wort groweth vpon dry and barren mountaines and heaths. I haue found it growing in thefe places following; that is to fay, about Bathe in Somerfethire in many places, cfpecially at a place called Carey, two miles from Bruton, in the next Clofe vnta the Church-yard; on Cockes Heath betweene Lowfe and Linton, three miles from Maidftone in Kent : it groweth alfo in the ruines of an old bricke-kilne by Colchefter, in the ground of $\mathrm{M}^{x}$. George Sayer, called Milesend: it groweth likewife vpon the fide of Blacke-heath, necre vnto the ftile that leadeth vnto Eltham houfe, about an hundred paces from the ftile : alfo in Lancafhire neere vntoa Wood called Faireft, by Latham: moreouer, in Nottingham hire by the Weftwood at Gringley, and at Wefton in the Ley field by the Weft fide of the towne; and in the Bifhops field at Yorke, neere vnto Wakefield, in the Clofe where Sir George Sawill his houfe ftandeth, called the Heath Hall, by the relation of a learned Doetor in Phy ficke called M'. Iohn cier fhe of Cambridge, and many orher places.

$$
\text { ब Tlse Time. }
$$

$H$ crba $F$ aris flouret in Aprill, and the berry is ripe in the end of May.

Lunaria or fmall Moone-wort is to be feene in the moneth of May.

$$
\text { T) The Names. }
$$

One-berry is alfo called Herbe True-loue, and Herbe Paris : in Latine, Herba Paris, and Solumm tetraphyllum by Gefizer and Lobel.

Lmaria minor is called in Englifh Small Lunaric,and Moon-wort.

$$
\text { T The Nature. }
$$

Herbe Paris is exceeding cold; whereby it reprefles the rage and force of poifon. Lumaria minor is cold and dry of temperature. 
बा The Vertus.

The berries of Herbe Paris giten by the fpace of twentie daies; are excellent gool againt A poifon, or the pouder of the herbe drunke in like nanner halfe a fpoonfull at a time in the moming fafting.

The fime is minifted with great fueceffe vnto fuch as are become peenith, or without vnder- $B$ ftanding, being miniftred as is aforefaid, etrery morning by the fpace of twentic daies, as Buptafta Surdus, and Matthiolus hauc recorded. Since iwhel time there hath been further experience made thereof againt poifon, and put in practicc in the eitic of Paris, in Louaine,and at the baths in $\mathrm{Hel}-$ uetia, by the right excellent Herbarifts Matthess the L'obel, and Petrus $P$ ena, who hauling ofen read, that it was one of the Aconites, called Pardaluanches, and fo by eonfequenec of it poifoning quality, they gaue it vnto dogs and lambes, who receiued no hurt by the fime : wherefore they further profecuted the experience thereof,and gauevnto two dogs fat bound or coupled together, a dram of Arfenicke, and one dram of Mercuric fublimate mixed wirh fleth (t in the Lednerfuris it is but of each halfe a dram, and there pag. Ios. you may finde this Hittrite more largely fer downe. ‡) which the dogs would not willingly cat, and therefore they lad it erammed downe their throats : wnto one of thefe dogs they gaue this Antidote following in a little ted wine, whercby he reeouered his former health againe within a few houres: but the other dog whieh had none of the medicine, died incontinently.

This is the receit.

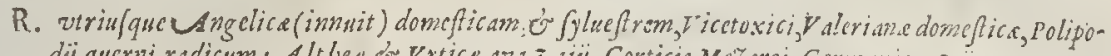

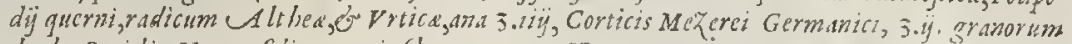
berbie Paridis, $N .24$. foliorum einfdem cumtoto, $N u m$. 6 . Ex mutceratis in accio radicibus, of ficcater fit omnium pulits.

The people in Germany dovfe the leaues of Herbe Paris in greene wounds, for the which it is $\mathrm{C}$ very good, as Toachimus Camerarizs teporteth; who likewife faith, that the pouder of the roo:s giuen ro drink doth fpeedily ceafe the gripings and paine of the Colliekc.

Small Moonewoort is fingular to licale greene and frefh wounds:it fareth the bloudy fix. It $D$ hath beenevfed a mong the Alchymiftes and witches to doc wonders withall, who fay, that it wifl loofc lockes, and make them to fail from the fect of horfes that grafe where it doth grow, and hatl beene called of them Marfagon, whereas in truth they are all but drow fie drcames and illufions; $b_{\text {but }}$
je is fingular for wounds as aforefaid.

\section{Снар.9о. Of Winter-Greene.}

of The Defoription.

I Drola hath many tender and verie greene leaucs, almoft like the leates of Beete, but tather in my opinion like to the leates of a Peare-tree, whereof it tooke his name Pyrola, for that it is Pyrfformis. Among theie leaues commeth vp aftalke garnithed with prettie white foures, of a verie pleafant fweet fmell, like Lilliwm Conualium, or the Lillie of the Valley. The tont is funall and threddie, creeping farre abroad vnder the ground.

$\mp 2$ This differs from the late deferibed in the flenderneffe of the ftalkes, and fmalnefie of the leates and floures: for the leates of this are not fo thieke and fubrantiall, but very thinne, Tharpe pointed, and very finely finipt about the edges, blacker, and refembling a Peare-trecleafe. The flnures are like thefe of the former, yer fmaller and more in number: to which fueceed fue eornered feed veffels with a long pointell as in the precedent : the root alfo ereepes no leffe than that of the former, and here and rhere puts vp new ftalkes rnder the noffe. It growes ipon the Auftrian and Styrim Alpes, and floures in Iune and Itily.

3 This is an elegant plant, and fometimes becomes fhrubbic, for the ner and fhort branches growing vp cach yeare, dor remaine firmeand greene for fome yeares, and grow ftraight vp, incill ar length borne downe by their ownewcight they fall downe and hide themfelues in the mofte. It harl enmmonly at each place where new branehes growe forth, two, three, or foure thickeveric greene and thining leates, almot in formeand magnitude like to the leates of Laureolus, yer fnipt about the edges, of a very drying tafte, and then bitterinh. From among thefe leatues at the $S$ pring of the yeare new branches fioor ve, hauing fmall leanes like feailes ypon them, and at their toppes 


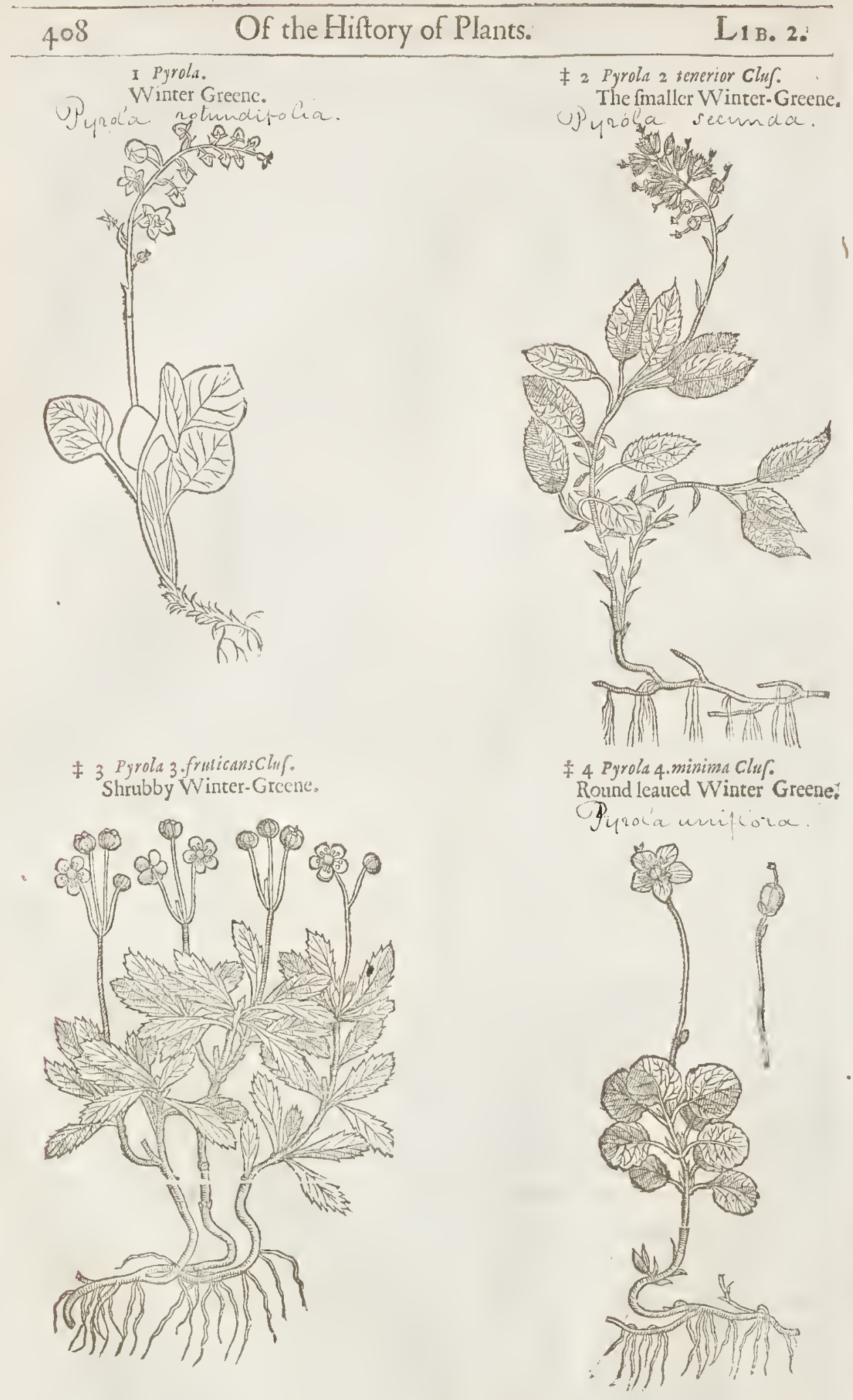


5 Monophyllon.

One Blade.

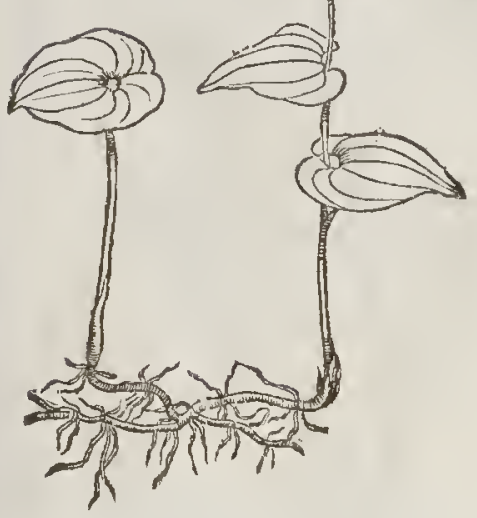

grow thoures like to thore of the firft defcribed, yet fomewhat larger, of a whitih purple colour; which fading, are fuceceded by fuc cornered feed veffels containing a very fmall feed; the roots are long \& erceping. It growes a little from Vienna in Aultria in the woods of Entzeftorf, and in diuers places of Bohemia and Siletic.

4 This from creeping roots fends vp Thort ftalkes, fet at certaine fpaces with fmall, round, and thin leaues, alfo fnipt about the edges,amongft which vpon a naked ftem growes a Houre of a pretty big. nes, confifting of fue white frarpith pointed leaues with ten threds, and a long pointell in the midf. The feed is contained in fuch heads as the former, and it is very fmall. This growes in the thadow ic places of the Alpes of Sneberge, Hochbergerin, Durrentaine, towards the roots of thefe great mountaines. Clur. $\neq$

5 Monophyllon, or Vnifolium, hath a lea fe not much vnlike the greateft leafe of Luie, with many ribs or Yinewes like the Plantaine leafe; which fingle leafe doth alwaies fpring forth of the earth alone, but when the ftalke rifeth vp, it bringeth vpon his fides two leaues, in fanhion like the former; at the top of which flender ftalke come forth fine fnall floures like Pyrola; which being vaded, there furceed fnall red berries. The roote is fmall, tender, and creeping farre abroad vnder the vpper face of the earth.

$$
\text { q) The Place. }
$$

I Pyrola growteth in Lanfdale, and Crawen, in the Nortli part of England, efpecially in a clofe called Crag-clofe.

2 Monophyllon groweth in Lancafhire in Dingley wood, fix miles from Prefton in Aunder. neffe; and in Harwood, neere to B lackburne likewife.

\section{T The Time.}

I Pyrola floureth in Iune and Iuly, and groweth winter and fommer.

2 Moropbyllon floureth in May, and the fruit is ripe in September.

$$
\text { TT The Names. }
$$

I Pyrola is called in Englifh Winter-greene: it hath beenecalled Limonium of divers, but vntruly,

2 Monophyllon, according to the etymologic of the wor, is called in Latine Vmifolim : in Englith, One-blade, or One-leate.

-T The Nature:

I Pyrola is cold in the fecond degree, and drie in the third.

2 Morophyllon is hot and dry of complexioni.

T The vertues.

Pyrola is a moft fingular wound hentbe, either giuen inwardly, or applied outwardly : the leatues A whcreof ftamped and frained, and the itrice made into an vinguent, or healing falue, with waxe, oile, and turpentine, doth cure wounds, vleers, and fiftulaes, that are mundified from the callous \& tough matter, which keepeth the fame from healing.

The decoetion hereof made with wine, is commended to clofe vp and heale wounds of the en- $B$ trailes, and inward parts: it is alfo good for vlcers of the kidneies, efpeeially made with water, and the roots of Comfrey added thereto.

The leaues of Monophyllon, or Vrifolium, are of the fame force in wounds with Pyrold, efpecially C in wounds among the nerues and finewes. Moreoner, it is efteemed of fome late writers a molt perfeit medicine againt the peftilence, and all poifons, if a dram of the root be ginen in vineger mixed with wine or water, and the ficke go to bed and fweat vpon it. 


\section{С н а P. 21. Of Lilly in the valley, or May Lilly.}

I Litium conuallium:

Conuall Lillies.

Comallaria thaialis.

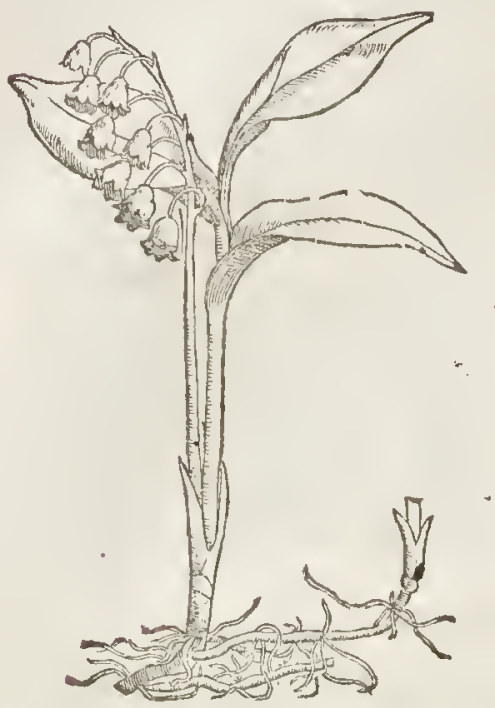

2 Lilium conuallium foribus func. rubentibus. Red Conuali Lillies.

Comalcaria thaiabis. Var.

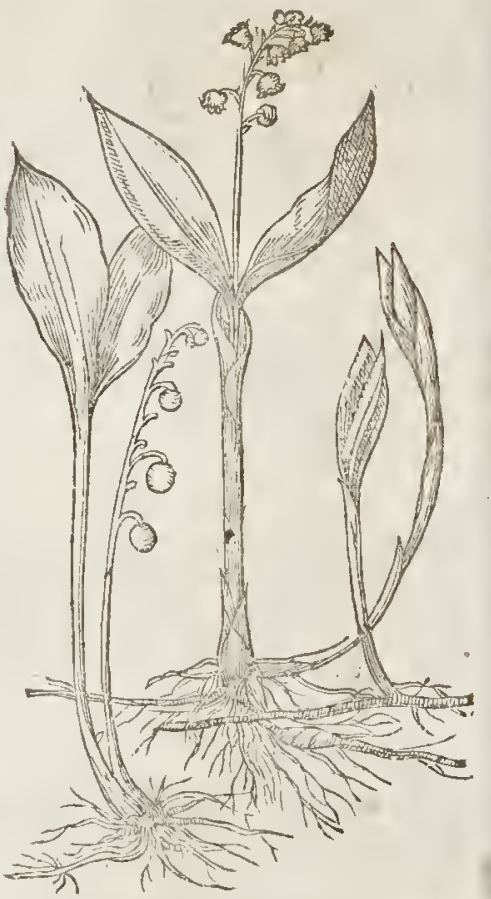

9) The Defription.

I THe Conuall Lillie, or Lilly of the Vally, hath many leares like the fmallet leanes of Water Plantaine, among which rifcth vp a nakcd fathe haife a foot tiogh, garnifhed with many white floures like little bels, with blunt and turned el ges, of a ftrong fauour, yet pleafant enougb; which being paft, there eome fmall red berries, much like the berries of Afparag ats, wherein the feed is contained. The ront is imall and fercer, erce pirc fir abroad tin the ground.

2 The fecond kinde of May Lillies, is like the formcr in cuery refpeet; and herein variech or differeth, in that this kinde harh reddin foures,and is thought to have the fwecter fmell.

$$
\text { of The Place. }
$$

I The firft groweth on Hampted heath, foure miles from London, in great abundanee: neere to Lee in Effex,and vpon Buhic heath, thirtecne miles from Loncion, and many otler places.

2 That other kind with the red floure is a ftranger in England:how bcit Ihatre the fame growing in my garden.

$$
\text { T The Time. }
$$

They floure in May,and their fruit is ripe in September.

$$
\text { T The Nasnes. }
$$

'The Larines hane named it Lilium Conualliwm: Gefner doth thinke it to be Calliongmum : in the

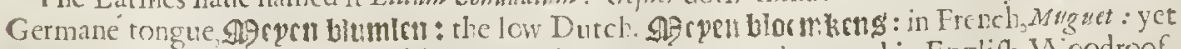
there is likewife ato the herbe which they eall Murut, common'y named in Englifh, Woodroof. It is called in Englifh Lillie of the Valley, or the Comull Lillie, and May Lillies, and in fome places Liriconfancie.

$$
\text { If The Nature. }
$$

They are lot and drie of complexion. 


\section{IT The vertues.}

The floures of the Valley Lillie diftilled w ith wine, and drunke the quantitie of a fponfull, reftoreth fpeech vnto thofe that haue the dum palfie and that are falne into the Apoplexie, and is good againft the gout, and comforteth the heart.

The water aforefaid doth ftrengthen the memoric that is weakened and diminifhed; it helpeth $B$ alfo the inflammation of the eies, being dropped thereinto.

The floures of May Lillies put into a glaffe, and fet in a hill of antes elofe ftopped for the fpace C of a moneth and then taken out, therein you fhall find a liquour, that appeafeth the paite $8 x$ griefe of the gout, being outwardly applied, which is commended to be moft exeellent.

\section{Cи а P. 92. Of Sea Lauander.}

I Limonium.

Sea Lauander.

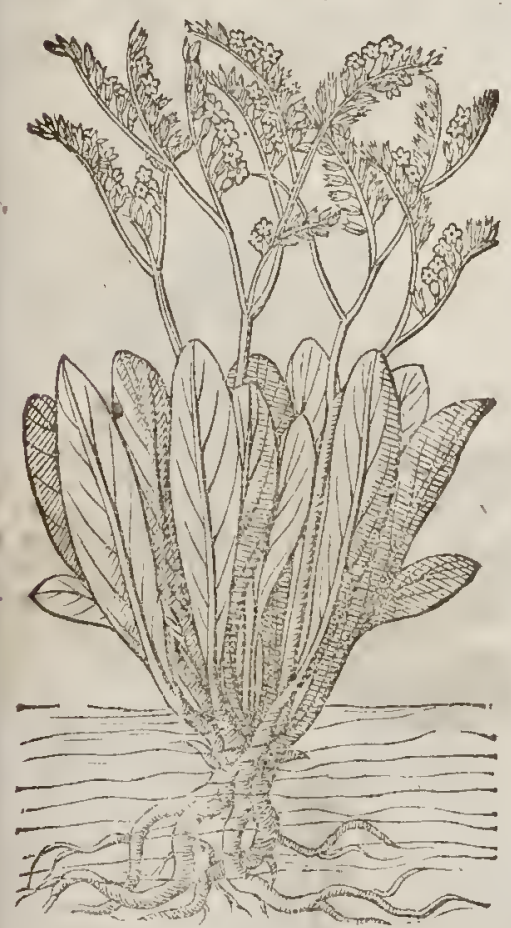

Stalice Simonimm.

2 Limoniumparvum. Rocke Lauander.

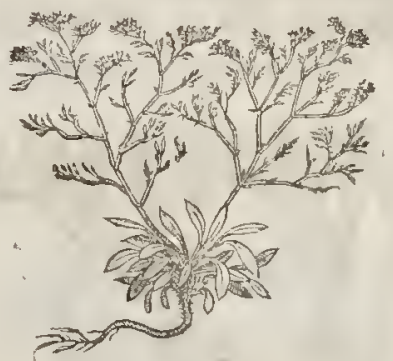

Tा The Defcription.

1 Here hath beene among writers from time to time, great contention about this plant Limonium, no onc authour agreeing with another: for fome haue called this herbe $\mathrm{Li}_{\mathrm{i}}$ monium; fome another herb by this name; \& fome in remouing the roek, haue mired themfelues in the mud, as Matthiolus, who defcribed two kindes, but made no diftinction of them, nor yet expreffed which was the true Limonium; but as a man hecrein ignorant, hee fpeakes not a word of them. Now then to leaue controucrfies and cauilling, the true Limonium is that which hath faire leaucs, like the Limon or Orenge tree, but of a darke greene colour, fonewhat fatter, and a little crumpled : among ft which leaues rifeth vp an hard and brittlc naked ftalke of a foothigh, diuided at the top into fundry other fmall branehes, which grow for the moft part vpon the one fide, full of little blewith floures, in thew like Lauander, with long red feed, and a thicke roor like vnto the finall Docke.

2 There is a kinde of Limonium like the firft in each refpect, but leffer, which groweth vpon rockes and chalkie cliffes.

\# 3 Befides thefe two here defcribed, there is another elegant Plant by clufus and others referred to this kindred: the defcription thereof is thus, from a long flender root eonse forth long: greene leaues lying fpred vpon the ground, being alfo deepely finuated on both fides, and fomewhat roughin. Amongt thefe leaues grow vp the ftalkes welted with flender indented skinnes, and towards their tops they are diuided into fundry branches after the manner of the ordinarie one; but thefe branches are alfowinged,and at their tops they carry floures fome foure or fue 
cluftering together, confitting of one thin erifpe or erumpled leafe of a light blew eolour (which continues long, if you gather them in their perfe et vigour, and fo drie them) and in the middeft of this blew cones vp litrle white foures, eonfiting of fuc litrle round leaues with fone white threds in their middles. This plant was firt obferued by Rawwolfus at Ioppa in Syria : but it groves alfo vpon the eoafts of Barbaric, and at Malacea and Cadiz in Spane: I haue feene it growing with many other rare plants, in the Gardenof my kinde friend $\mathrm{M}^{\mathrm{r}}$. Iohn Tradercant at, South Lambeth.

4 Clufius in the end of his fourth Booke Itistorix Plamtarum, fers forth this, and faith, hee reeciued this figure with one dryed leafe of the plant fent him from Paris from clawde Gowier an A potheearie of that eitic, who receiued it (as you fee it here expreft) from Lisbone. Now Clufius deferibes the leafe that it was hatd, and as if it had been a piece ofleather, open on the vpper fide, and diftinguifhed with many large purple veines on the infide, \&xe. for the reft of his defeription was onely taken from the figure (as he himfelfe faith) which I hold impertinent to fet downe, feeing I heere giue you the fame figure, which by no meanes I could omit, for the ftrangeneffe thereof, bur hope that fome or other that trauell into forraine parts may finde this elegant plant, and know it by this fmall expreffion, and bring it home with then, that fo we may come to a perfecter knowledge thereof. $\ddagger$

\pm 3 Limonism folio finuaro.

Sca-Lauander with the indented leafe.
$\$ 4$ Limonio congener, Clus. Hollow leaued Sea-Lauander:
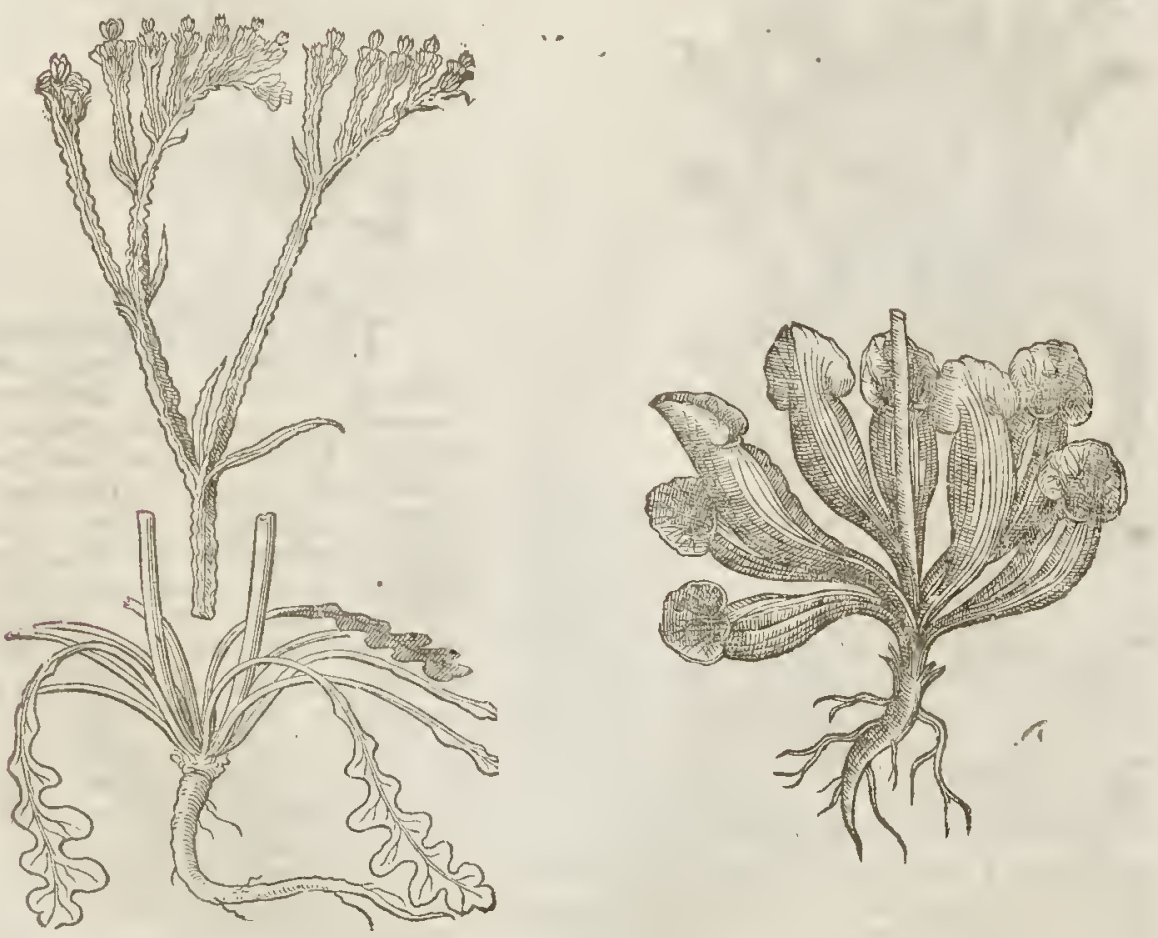

e: The Place.

I The firf groweth in great plentic vpon the walls of the fort againft Grauefend: but abundantly on the bankes of the Riuer below the fame towne, as alfo below the Kings Store-houfe at Chattam: and faft by the Kings Ferrey going into the Ifle of Shepey: in the falt marlhes by Lee in Effex: in the Marfh by Harwieh,and nany other places. 
The fmall kinde I could netrer finde in any other place but vpon the chalky cliffe going from the towne of Margate downe to the fea fide, vpon the left hand."

They floure in Iune and Iuly. of The Time.

The Names.

It thall be needleffe to trouble you with any other Latine name than is expreft in their titles: the people neere the fea fide where it groweth do call it Marh Lauander, and fea Launder.

† This cannot be the Limonitum of Diofcorides, for the leates are not longer than a Beet, nor the ftalke fo tall as that of a Lillie, but you thall finde more hereafter concerning this in the Chapter of water Plantaine. I cannot better refer this to any plant deferibed by the Antients than to Britannica defcribed by Diojcorides, lib. 4.cap. 2. ¥

The feed of Limonium is very aftringent or binding.

$$
\text { Tा The Nature. }
$$

The feed beater into pouder, and drunke in wine, helpeth the collieke, ftrangurie, and Dyfen- $A$ ceria. feed raken as a forefaid, ftaieth the ouermuch fowing of womens termes, and all other $B$ fuxes of bloud.

\section{Cн а Р. 93. Of Serapiar Turbith, or Sea Siarwort.}

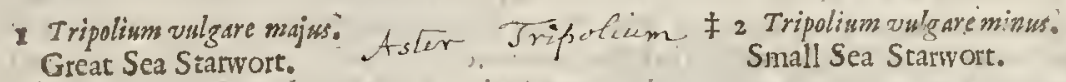
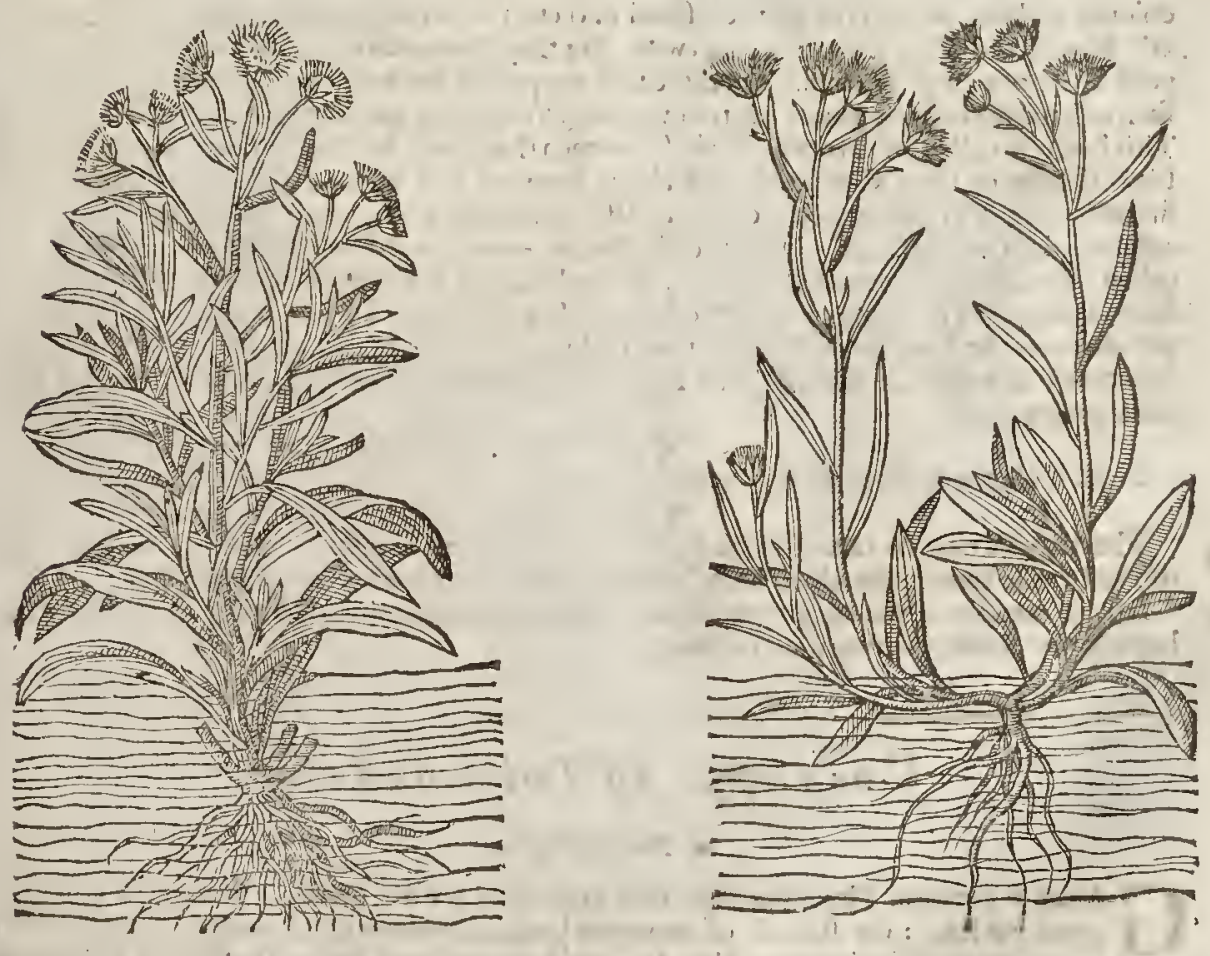

I The Defcription.

I THe firf kinde of Tripolium hath long and large leatues tomewhat hollow or furrowed, of a thining greene colour declining tn blewneffe, like the leaues of Woade : among which rifeth vp a ftalke of two cubits high, and more, which toward the top is diuided iuto many fmall branches garnilhed with many floures like Canomill, yellow in the middle, fer about 
ot bordercd with fmall blcwish leaues, like a pale, as in the foures of Canomill, which grow into a whith rough downe, that fieth away with the winde. The root is long and threddy.

2 There is another kinde of I ropolzm like the firft, but mueh fmaller, whercin confifterh the difference.

$$
\text { TT The Place. }
$$

Thefe herbs grow plentifully alongft the Englitheoafs in many places,as by the fort agairnt Grauefend, in the lle of Shepey in fundry places, in a marfh which is snder the rowne nal!s of Harwich, in the marfh by :Lee in Effs $x$, in a marth which is betwcen the Ile of Shepey and Sirciwich, efpecially where it ebbeth and foweth : being brouglit into gardens, it fourifheth a lone rime, but there it waxeth huge,great, and ranke; and ehangeth the great roots into ftrings.

Thefe herbs do floure in May and Iune.

$$
\text { T The Time. }
$$

The Nomit's.

It is reported by men of great fame and learning, that this plantwas called Tripolium, becaufe it doth change the colour of his floures thriec in a day. This rumour we may beleeve, and it nay be true, for that we fee and pereeine things of as great and greaterwonder to proceed out of the earth. This herbe I planted in my garden, whither (in his teafon) I did repaire to finde out the truth hereof, but I could not $e$ pie any fuch variableneffelerein ; jet thus mueh I may fay, that as the heate of the funne doth ehange the eolour of diuers foures, fo it fell out with this, wheh in'the morning was very taire, but afteward of a pale or wan colour. W'hich prooueth that to be but a fable which Diofrorides faith is reported by fone, that in one day it changeth the colour of his floures thriee: that is to fay, in the morning it is white, at noone purple, and in the cuening aunz: or erimfon. But it is not vntrue, that there may be found three colours of the foures in one day, by reafon that the fioures are not all perfeeted together(as before I partly touched) but one after anothet by little and little. And there may eafily be obferued tirce colours in them, which is to be vnderftood of then that are beginning to floure, that are perfectly floured, and thofe that are falling aw ay. For they that are blowing and be not wide open and perfeet, are of a furplish eolour, and thofe that are perfeet and wide open, of a whitish blew; and fuch as haue fallen away haue a hitc down: which changirg hapreth into fundry other plants. This herbe is called of Serapio, Turbth: women that crell by the fca fide, call it in Englifh, blew Daifies, or blcw Camomill, and about Hawich it. is called Hogs beares, for that the fwine do greatly defire to ferd $1 \mathrm{l}$ cscon : as alfo for that the knobs about the rnotsdoe fomewhat

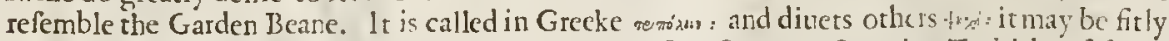
called After Marinus, or Amelize Marives: in Englin, Sea Stawort, Serapio's Turbith: of fome, Blew Daifies. "The Arabian Surafio, doth call Sea Stanort, Turbith, and after him, duicen: yet AItuariws the Gteeian doth thirle that 'Tubith is the root of Alypum: Mcfucs iudect it tobe the root of an herbe like fennell. The Hiftoric of 'Turbith of the thops niall bedifcourfel ipon in his propet place.

\section{Tripolium is hot in the third degree, as Galcn faith.

$$
\text { q The fertues. }
$$

The root of Tripolium taken in wine by the quantitie of two drams, driueth fortl by fiege waterith and groffe humots, for which eaufe it is often giten to them that hate the dropfie.

It is an excellent herbe againf poifon, and eomparable with Pyrola, if not of greater efficacy in healing of wounds either outward or inward.

\section{С на т. 94. Of Turbitb of Antioch. बा The Defcription.}

Orcias a Portugal Phyfition faith that Turbith is a plant hauing a rootwhich is neither T great nor long: the falke is of two fpans long, fometimes much longer, a finger thicke, which ereepeth in the ground like Iuie, and bringeth forth leaues like thofe of the marifh Mallow. The floures be alfo like thofe of the Mallow, of a reddith white eolour : the lower part of the ftalke only, which is next to the root and gummic, is that which is profitable in medicine, and is the fame that is vfed in thops: they chufe that for the beft which is hollow, and round like a reed, brittle, and with a fmooth barke, as alfo that whereunto doth cleauc a congealed gum, which is faid to be grmmeofum, or gummy, and fomewhat white. But, as Garcies faith, it is not alwaies 
gummie of his owne nature, but the Indians becaufe they fee that our merchants note the bef Turbirh by the gummineffe; are wont before they gather the fame, either to writhe or elfe lightly to brufe them, that the fap or liquor may iffue out; which root being once hardned, they picke out from the reft to fell at a greater price. It is likewife made white, as the faid Author theweth, being dried in the funne: for if it bedried in the thadow it waxeth blacke, which notwith ftanding may be as good as the white which is dried in the Sunne.

Turbith Alexandrinum officinarum. Torpetum, or Turbith of the fhops.

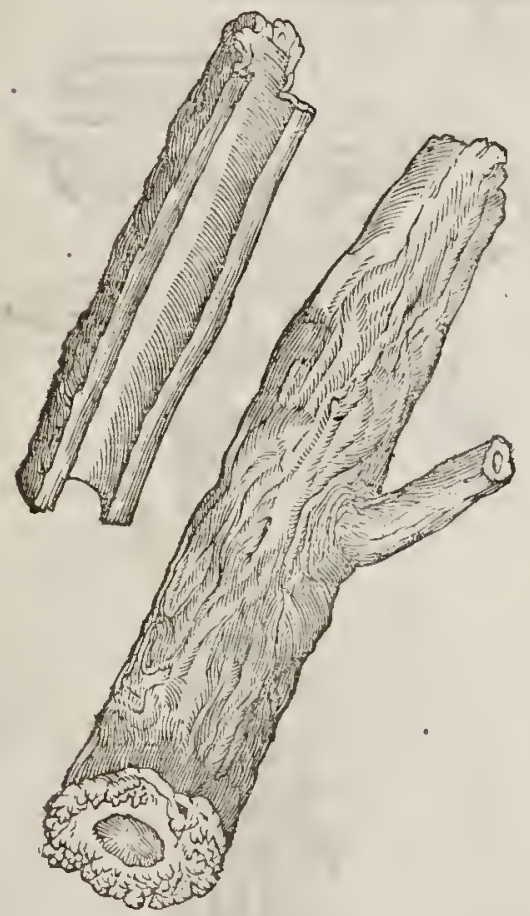

$$
\text { 91 The Place. }
$$

It groweth by the fea fide, but yet not fo neere that the wah or water of the fea may come to it, but neere about, and that for two or three miles in vntilled grounds, rather moift than drie. It is found in Cambaya, Surrate, in the Ile Dion, Bazaim, and in pla. ces hard adioining; alfo in Guzarate,wliere it groweth p'entifully, from whence great abundancace it is brought into Perfa, Arabia, Afra the lefle, and alfo into Portingale and other parts of Europe : but that is preferred which growerh in Cambaya.

$$
\text { 9 The 2lames: }
$$

It is called of the Arabians, Perfians, and Turkes Turbith : and in Guzarata Barcaman: in the protinee Canara, in which is the city Goa, Tiguar : likewife in Europe the learned call it diterfly, according to their feucrall fancies, which hath bred findry controuerfies, as it hath fallen out afwell in HermodaEyls, as in Turbith; the vfe and poffeffion of which we cannot feeme to want : but which plant is the true Turbith, we haue great caufe to doubt; Some hate thought out $T$ ripolinm mavinum, defcribed in the former chapter, to be Turbith: others hate fuppofed it to be one of the Tithymales, but which kinde they know not: Guillandinus faith, that the root of Tithymalus myrgenit is is the true Turbirh; which caufed Lobeluus and Pena to plucke vp by the roots all the kindes of $T$ it thymales, and drie them very curiounty; which when they had beheld, and throughly tricd, they found it nothing fo. The Arabians and halfe Moores that dwell in the Eaft parts haue giuen diuers names vnto this plant : and as their words are dimers, fo baue they diuers fignificatious; but this name Turbith they feeme to interpret to be any milky root which doth ftrongly purge flegme, as this plant doth. So that as men haute thought good, plea fing themfeltes, thcy hate made many and diters conftucions which haue troubled many excellent learned men to know what root is the true Turbirh. Burbriefly to fet downe my opinion, not varying from the ittgment of men which are of great experienee; I thinke affuredly that the roor of Scanmony of Antioch is the true and vindoubted Turbith, one reafon efpecially that mouth me fo to thinke is, for that I laaue taken vp the soots of Scammony which grew in nuy garden, and eompared them with the rosts of Turbith,between which I found little ot no difference at all

\# Through all Spain(as Cluffus in his notes vpon Garcias teftifies) they vfe the roots of $T$ hap. fa for Turbith which alfo haue been broughr hither,and I keepe fome of them by me, but they purge little or nothing at all being drie, though it may be the green root or juice may laate fome purging faculty. $¥$ of The Temperature and Vertues.

The Indian phyfitions vfe it to purge flegme, to which if there be no feuer they adde ginger,otherwife rhey gituc ir withour in the broth of a chicken, and fometimes in faire water.

Mcfues writerh, that Turbitl is hor in the third degree, and that it voideth thicke rough fiegme out of the ftomacke, cheit, finewes, and out of the furthermoft parts of the body : but (as he faith) it is flow in working, and troubleth and ouerturneth the ftomacke : and therefore ginger, matticke, and other fpices are to be mixed wirh ir ; alfo oile of fweet almondes, or almondes themfeltes, or fugar, leat the body with the ve herof thould pine and fall away. Others tem- 


\section{C н а . 95. Of Arrow-bead, or Water-arcber.}

I Sagittaria maior.

Great Arrow-head.

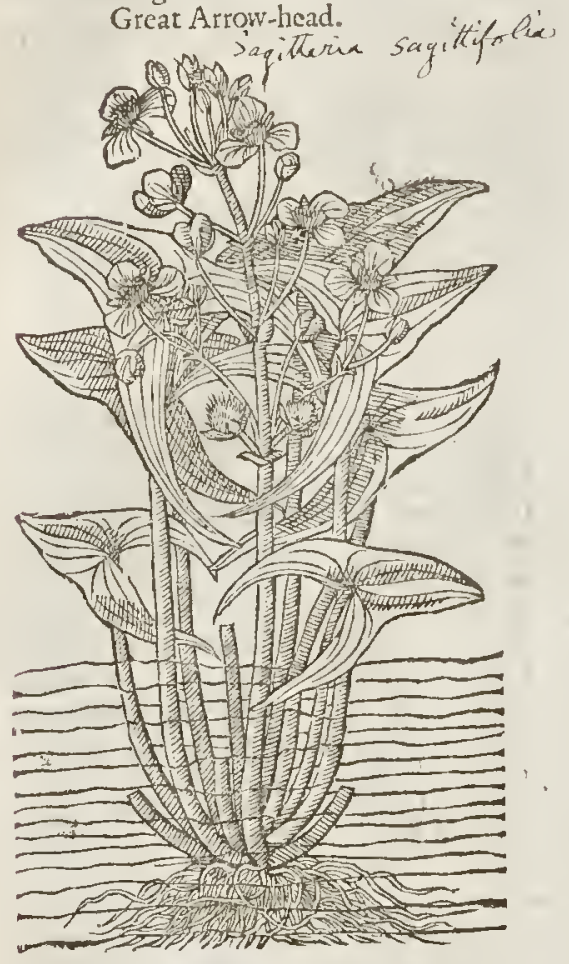

2 Sazittariaminor. Small Arrow-head.

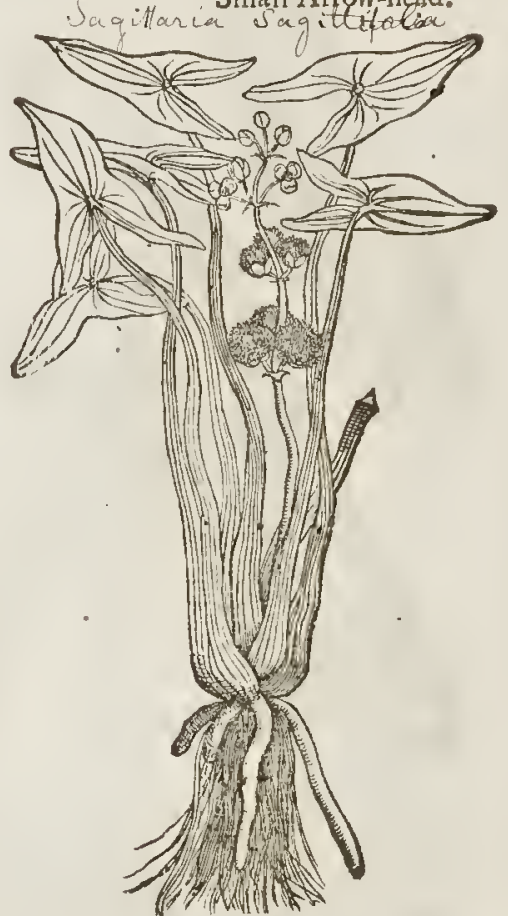

- The Defcription.

I He firft kinde of Water-archer or Arrow-head, hath large and long leaues, in thape like the figne Sagitturius, or rather like a bearded broad Arrow head. Among which rifeth vp a fat and thicke ftalke, two or three foot long, hatring at the top many prettie white floures, de. clining to a light earnation, compact of three fmall leaues: which being pat, there come after great rough knops or burres wherein is the feed. The root confifteth of many ftrings.

The feeond is like the firft, and differeth in that this kinde bath fmaller leaues and fioures, and greater burres and roots.

3 The third kinde of Arrow -head harh leaues in thape like the broad Arrow-head, ftanding vpon the ends of tender foot ftalkes a cubit long: among which rife vp long naked fmooth ftalks of a greenith colour, from the middle whereof to the top doe grow floures like to the piecedent. The root is fmall and threddie.

\section{The Place.}

Thefe herbes doe grow in the watrie ditehes by Saint George his field neere vnto London ; in the Tower ditch at Londen; in the ditehes neere the wals of Oxford; by Chelmesford in Effex, and many other places, as namely in the diteh necre the place of exeeution, ealled Saint Thomas Watcrings not far from London.

They foure in May and Iune. T The Time. 
Li в. 2. Of the Hiftory of Plants:

Tा The Names.

Sagittaria, may be called in Englifh the Warer-archer, or Arrow-hedd. F Sonc would hate it

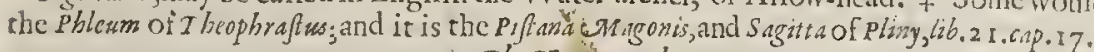

I The a stitive and vertues.

I finde not any thing extant in whiting either concerning their vertucs or tempcrament, but doubtleffe they are cold and drie in qualitic,and are like Plantaine in facultie and remperament.

\section{$\mathrm{C}_{\text {H A P. 96. Of Water Plantaine. }}$}

I. Plantago aquatica maior.

Great Water Plaritainc.

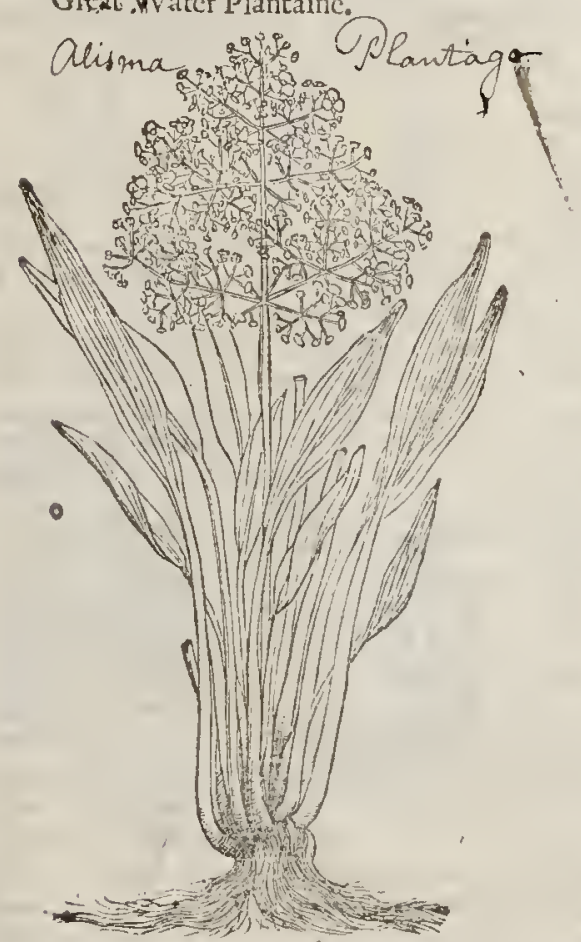

a Plantago dquatica minor fellata.

Setrry headed frmall Water Plantaine.

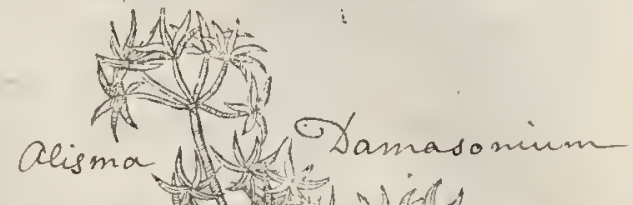

3 Plartago aquatica humilis. Dwarfe water Plantaine,

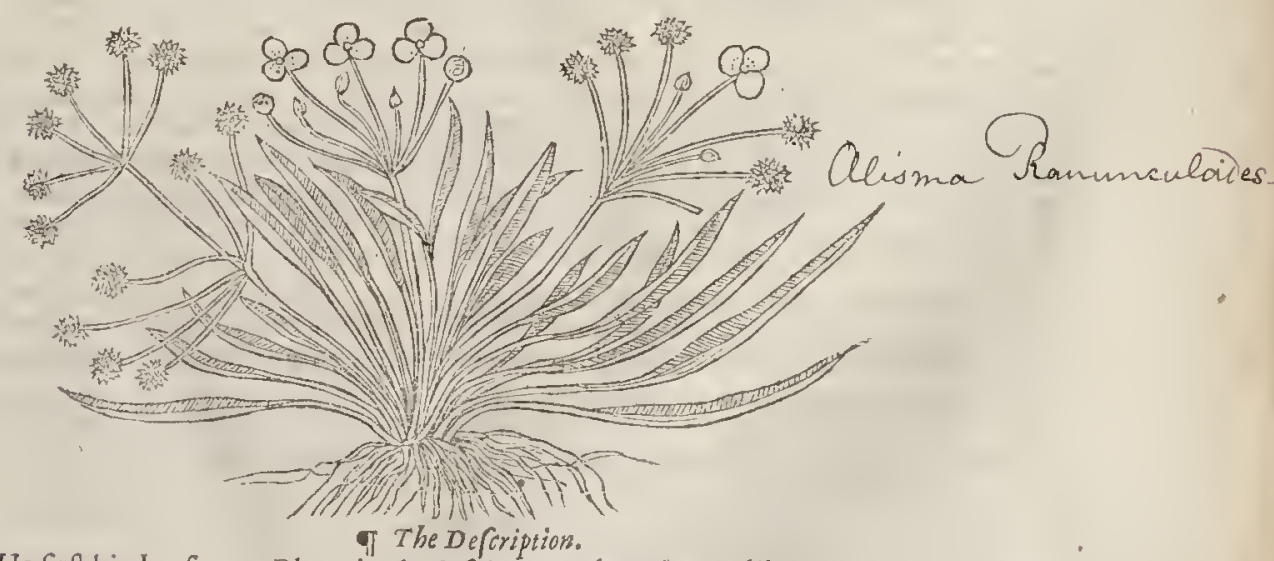

I $T^{\text {He firft kinde of water Plantaine hath faire great large leates like the land Plaintaine, }}$ but fmoother, and full of ribs or finewes : among which riferh vp a tall ftemme fourc foot high, diuiding it felfe into many flender branches, garnifhed with in finit frmall white flourcs, $\mathrm{Mm}$

which 
which being pafthere appeare triangle luskes or buttons wherein is the feed. The root is as it were a gteat tuft of threds or thtums.

+2 This plant in his toots and leaues is like the lait defcribed, as alfo in the ftalke, but much leffe in each of them, the ftalke being about fone foot high; at the top whereof ftand many ptetty ftatre-like skinny feed-veffels, containing a yellowith feed $\ddagger$

3 The feeond kinde hath long, little, and narror leaues, much like the Plantaine called Ribwoort : among which rife vp fmall and feeble ftalks branched at the top, whereon are placed white floures, confifting of three llender leaues; which being fallen; there come to your view round knobs, or rough burs : the root is threddy.

\section{बा The Place.}

I This herbe growes about the brinkes of riuers, ponds and ditehes almoft euery where.

\$ 3 Thefe aremote rare. I found the fecond a little beyond Ilford, in the way to Rumford, and Mr. Goodyer found it alfo growing vpon Hounflow heath. I found the third in the Company of $\mathrm{M}^{\mathrm{r}}$. Willian Brond, and $\mathrm{M}^{\mathrm{r}}$. Leonard Buckner, in a ditch on this fide Matgate in the Ifle of Tenet.

They floure from Iune till Auguft.

$$
\text { 9] The Time. }
$$

$$
\text { 9. The Names. }
$$

The firft kinde is called Plamtago aguatien, that is, water Plantaine. $¥$ The fecond Lobell calls

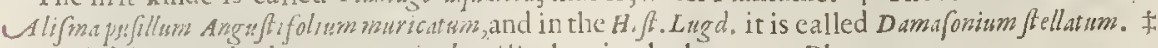
The thitd is named Plantugo ayratical bmilis, that is, the low water Plantane.

$\mp$ I tlunke it fit hete to reftore this plant to his antient dignitie, that is, his names and titles wherewith hewas anciently ditnified by Diojcorides and Pliny. The former whereof ealls it by

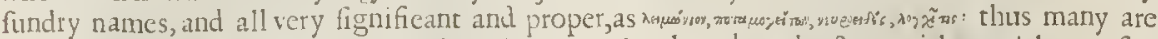
Greek, and therefore ought not to be reiceted, asthey haue been by fome without either reafon or authoritic. For the barbarous names we ean fay nothing; now it is faid to be ealled Limonism,

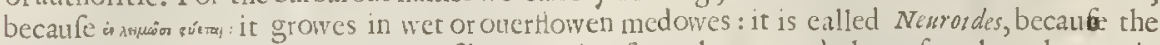
leafe is compofed of diuers ftrings or fibres running from the one ent thereof to the other, as in Plantain, which ther fore by Diofcorides is termed by the fame reacon zovirues: Alfo it may beas fitly termed Lonchutis for the fimilitude which the leafe hath to the top or head of a lanee which sizx properly fignifies, as that other plant defetibed by Diof.li6.3.cap. 16 I. for that the feed (a lefte eminent part) refembles the fame thing. And for potamogeiton which fignifies a neighbour tothe Riner ot water, I thinke it loues thewater afwell, and is as neere a neighbour to it as that which takes it's name from thenee, and is defcribed by Diofcorides, 26.4 . cap. 101 . Now to come to Pliny, lib. 20.cap. 8. he calls it, Beta fircftrix, Limonion, and Newrotes: the two later namesare out of Diofcorides, and I thall thety you wherealfo you thall finde the former in him. Thus much I thinke might ferue for the vindieation of my affertion, for I dare boldly atfrme that no late writer can fitall thefe names to any other plant, and that makes me more to wonder that all our late Herbarifts as Matibiolus, Dodoneus, Fishfus, Cefalpinus, Dialefchampius, but aboue all Pena and Lobell, who wduerf.pag. I 26. call it to queftion, nould not allow this plant to be Limonium, efpecially feing that Angmillara had before or in thcir time afferted it fo tobe; but whether he gaue any teafons or no for his afertion, I eannor tell, beeafe I could neuer by any meanes ger his Opinions, but only finde by Bubine his Priat that fuel was his opinion hereof. But to returne from whenee I digreft, I will giue you Diofcorides his defcription, and a briefe explanation thereof, and fodefift; it is thus: It hath lenues like a Beer, $r l$ inner and larger, 10. or more; a ftalke flender, Atraightand as tall. as that of a Lilly, and full of teats of an aftringent tafte. The leates of this

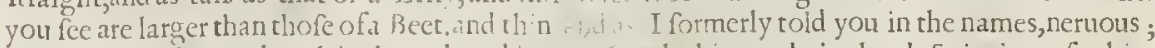
which to be foma be plainely gatherced by n.fe. 's hiswords in the defeription of white

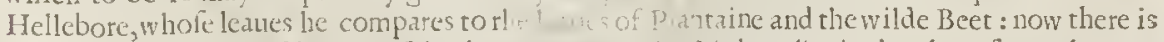
no wild Beet mentioned by any of the Ant $\cdots, 1 t$ on! y this bv Pliny in the place formerly quoted, nor no leafe note fit to compare tliofe of t te Hellctore to, than thofe of water Plantaine, efpecially for the nerues and fibres that rum . ${ }^{\prime} \mathrm{O}$, the leaues, the falke alfo of this is but flender confidering the height, and it growes ftrigh t,and as high as that of a Lilly, with the top plentiriftlly ftored with altringent feed; fo that no one note is wanting in this, nor feate any to be found in the other plants that many hate of late fet forth for Limonium. $\ddagger$

$$
9 \text { The Nature. }
$$

Water Plantaine is cold anul dry of temperatute. 
9ा The Vertues.

The leates of warer Plantaine,as fome Authors report, are good to be laid vpon the legs of fuch A as are troubled $w$ ith the Dropfie, and hath the fame propertie that the land Plantaine hath.

$\ddagger$ Diofcorides and Galen commend the feed hereofgiuen in Wine,againft Fluxes, Dyfenteries, $B$ the fpitting of bloud, and ouermuch flowing of wonens termes.

Pliny laith, the leaues are good againft burnes. $\neq$

\section{C н A P.97: Of Land Plantaine.}

I Plaintigo latifolia.

Broad leatied Plantaine.
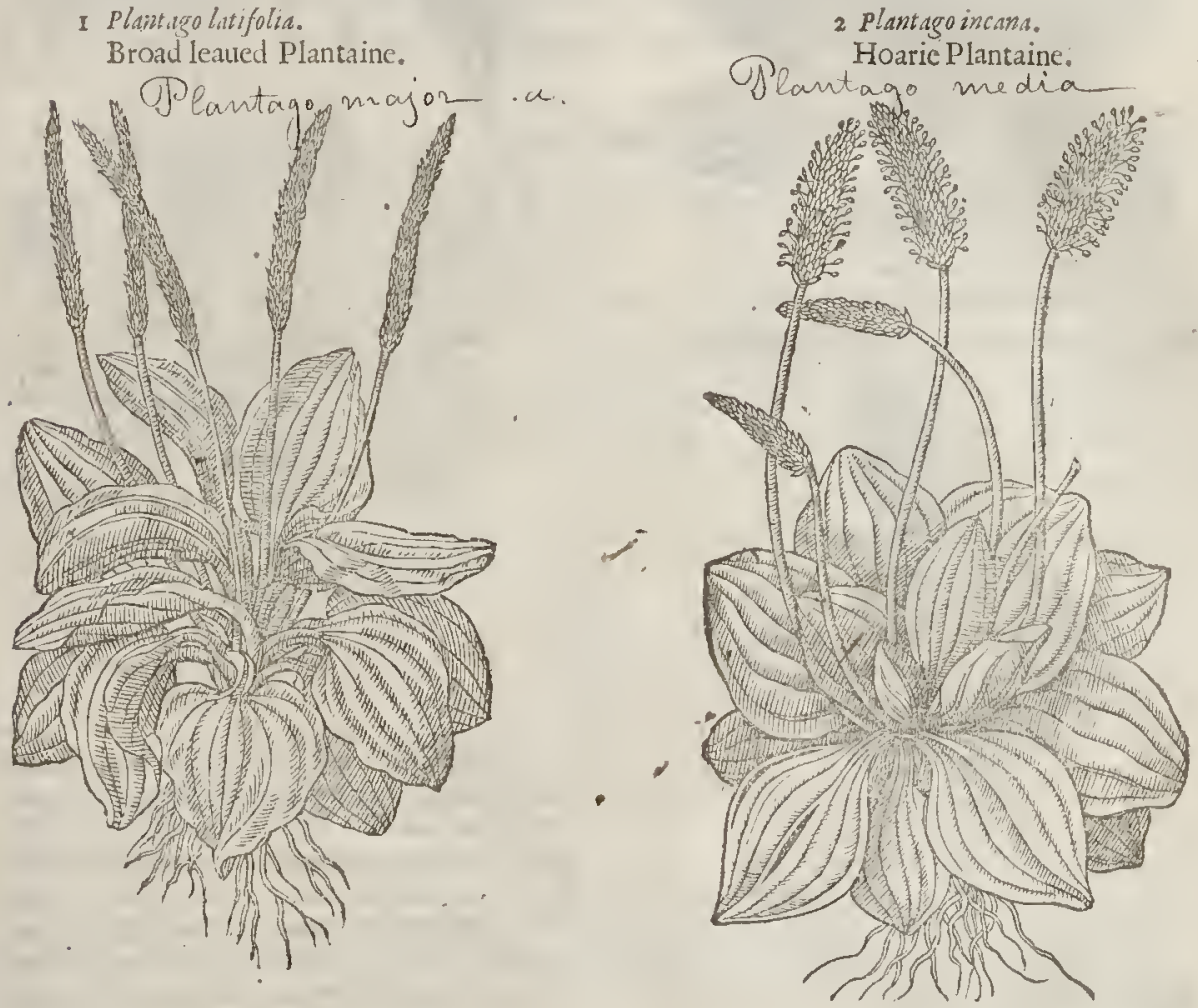

ब The Defeription.

I S the Greakes Lauecalled fome kindes of Herbes Serpents tongue, Dogs tongue,and A Oxe tongue; fo haue they termed a kind of Plantaine Arnoglogjon, which is as if you fhould fay Lambes tongue, very well knowne vnto all, by rea fon of the great commoditie and pienty thereof growing euery whete; and therefore it is needleffe to fpend time about them. The greatnelle and fafhion of the leaues hath been the caufe of the varieties and diuerfities of their names

2 The fecond is like the firft kinde, and differeth in that, that this kinde of Plantaine hath greater, but fhorter fpikes or knaps : and the leaues are of an hoarie or ouerworne greene colour : the falkes are likewife hoary and hairy.

3 The fmall Plantaine hath many tender leaves ribbed like vnto the great Plantaine, and is very like in each refoef vnro it, fauing that it is al together leffer.

4 The fpiked Rofe Plantaine hath very few leaues, narrower than the leaues of the fecond kinde of Plantaine, fharper at the ends, and further growing one from another. It beareth a very double floure vpon a thort ftem like a role, of a greenith colour tending to yellowneffe. The feed groweth vpon a fpikie tuft aboue the higheft part of the plant; notwithitanding it is but very loiv in refpect of the other Plantaines aboue mentioned. 


\section{Plantago Rofea picata.}

Spiked Rofe Plantaine.

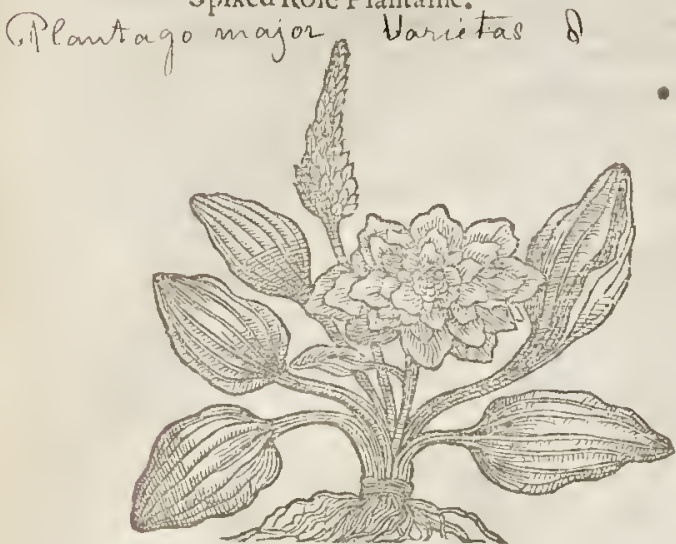

Plantaine with fpoky tufts;

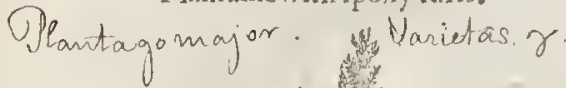

¥ 6 Plantago parriculis pirfis.

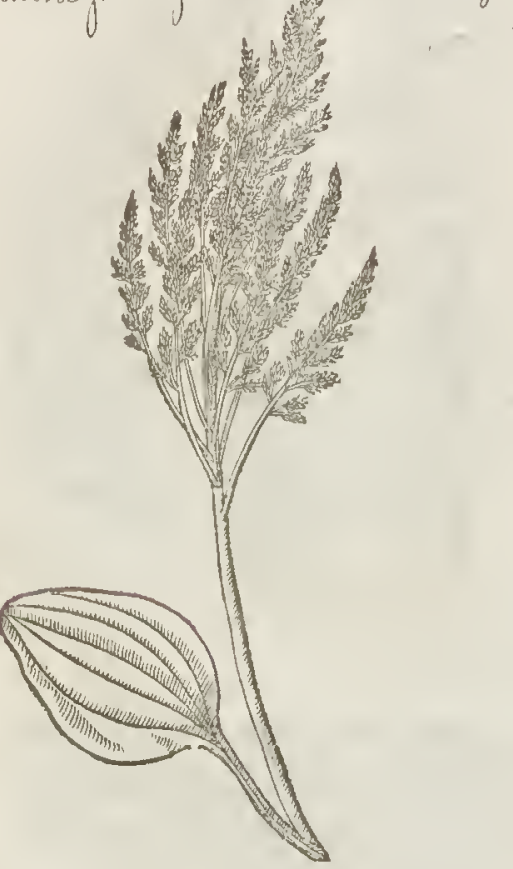

5 Plantago Rofea exotica. Strange Rofe Plantaine.

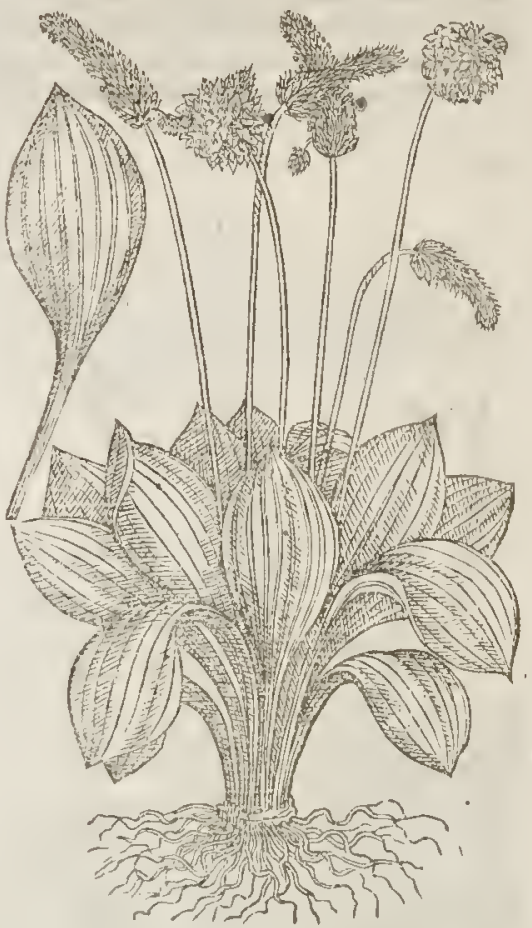

5 The fifth kinde of Plantaine hath beene a ftranger in England and elfewhere, vntill the imprefition hereof. The caufewhy I fay fo is, the want of confideration of the beauty which is in this plant, where in it excelleth all the other. Moreoner, becaufe that it hath not bin ivritten of or recorded before this prefent time, though plants of leffer moment haue beane very curiouly fet forth. This plant hath leutes like vnto them of the former, and more orderly fpred vpon the ground like a Rofe : among which rife vp many fmall flatks like the otlier plantaines, hauing at the top of eucry one a fine double Rofe altogether vnlike the former, of an hoary or ruifty greene colour.

‡ I take this fet forth by our Author to be the fame with that which Clsfus receited from rames Garret the yonger, from London; and therefore I gine yout the figure thereof in this place, together witl this addition to the hiftorie out of Clufias: That fone of the heads are likc thofe of the former Rofe Plantaine; other fome are fpike farthion, and fome haue a fpike growing as it were out of the midtt of the Role, and fome heads are otherwife thaped : alfo the whole plant is more hoary than the common Rofe Plantaine.

6 This plantain muft not here be forgot, though it be fomwhat hard to be found : his leaues, roots, and ftalkes are like thofe of the ordinarie, but in ftead of a conpaet foike it hath one much diuided after the maner as you fee it here expreffed in the figure, and the colour thereof is greeniih. $\neq$ 
9ा The Place.

The greater Plantaines do grow almoft ettery where.

The leffer Plantaine is found on the fea coafts and bankes of great riners, which are fometimes walhed with brackifh water.

\# The Rofe Plantaines grow with vs in gardens; and the fixth with fpokie tufts groweth in fome places in the Ifle of Tenet, where I firt found it, being in company with $\mathrm{M}^{*}$. Thonzas Hickes, M. I conard Bucknex, and other London A pothecaries, Amo 1632 . $\neq$

The Time.

They are to be feene from A prill vnto September.

TT The Names.

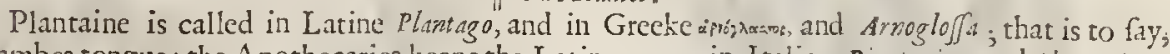
Lambes tongue: the A pothecaries keepe the Latine name: in I talian, Piantagine, and Plantagine : in Spanih, Lhantem: the Germanes, 9 Aegrich: in Low-Lutch, neechbe: in Engliph, Plantain, and Weybred: in French, Plantaira.

\section{- The Tempcrature.}

Plantaine (as Galen faith) is of a mixt temperature; for it hath in it a certaine wateric coldneffe, with a little harthneffe, earthy, dry, and cold : therefore they are cold and dry in the fecond degree. To be bricfe, they are dry withour biting, and cold without benumming. The root is of like temperature, but drier, and not fo cold. The feed is of fubtill parts, and of temperature leffe cold.

9) The Virtues.

Plantaine is good for vlcers that are of hard curation, for fluxes, iffues, rheumes, and rottenneffe, A and for the bloudy fix : it ftayeth bleeding, it heaies vp hollow fores and vlcers, as well old as new. Of all the Plantaines the greateft is the beft, and excelleth the reft in facultie and vertue.

The iuyce or decontion of Plantaine drunken ftoppeth the bloudy fix and all other fluxes of $B$ the belly, ftoppeth the piffing of bloud, fpitting of bloud, and all other iffues of bloud in man or woman, and the defire to vomit.

Plantaine leates ftamped and made into a Tanfie, with the yelkes of egges, ftayeth the inordi- C nate flux of the termes, although it haue continued many yeares.

The root of Plantaine with the feed boyled in white Wine and drunke, openeth the conduits or paffages of the liter and kidnies, cures the jaundice, and vicerations of the kidnics and bladder.

The juyce dropped in the cyes doth coole the heat and inflammation thereof. I finde in anci- E ent Writers many good-morrowes, which I thinke not meet to bring into your memorie againe as that three roots ivill cure one griefe, foure another difeafe, fix hanged about the necke are good for another maladie, \& c a all which are but ridiculous toyes.

The leaues are fingular good to make a water to wafh a fore throat or mouth,or the priuy parts of a man or woman.

The Feaues of Plantaine ftamped and put into Oyle Olite, and fet in the hot Sun for a moneth together, and after boyled in a kettle of feething water (which we doe call Balneum Grarice) and then ft riuned, prenaleth againft the paines in the eares, the yard, or matrix, (being dropped into the eares, or caft with a fyringe into the other parts before rehearfed) or the paines of the fundament, proued by a learned Gentleman Mr. Willian Godowrus Sergeant Surgeon to the Queenes Maieftie.

\section{CHA r. 98. Of Rib-mort.}

If The Defoription.

I D Ib-woit or fmall Plantaine hath many leates flat fpred vpon the ground, narrow, fharp 1 pointed, and ribbed for the moft part with fiue nerties or finewes, and therefore it was called Quinque-neruia ; in the middle of which leaues rifeth vp a crefted or ribbed ftalke, bearing ar the top a darke or dusky knap, fet with a few fuch white floures as are the floures of wheat. The root and other parts are like the other Plantaines.

* There is another leffe hinde of this Rib-wort, which differs not from the laft mentioned in any thing but the fimallneffe thereor. $\neq$

2 Rofe Rib-wort hatli many broad and long leaues of a darke greene colour, tharpe pointed, and ribbed witl fitue nerves or finewes like the common Rib-wort; amonglt which rife vp naked Italkes furrowed, chamfered, or crefted with certaine tharpe edges: at the top whercof groweth a great and large tuft of fuch leaues as thofe are that grow next the ground, making one entise tuft 
or vmbel, in thape refembling the rofe (wherof I thought good to giue it his fyrname Rofe) which is from his floure.

† This alfo I think differs not from that of Clufius; wherefore I giue his figure in the place of that fet forth by our Author. $\neq$

I Plantago quingueseruia. Ribwort Plantaine.

OPlaritayo Cance olata

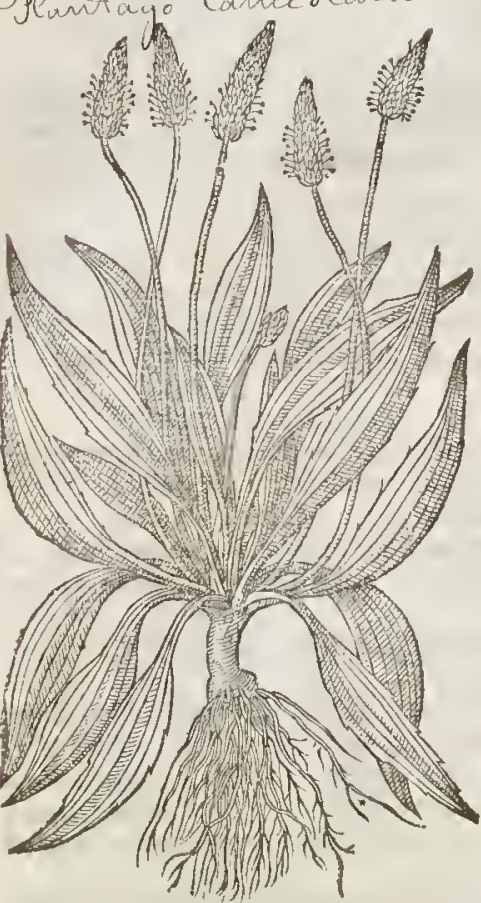

2 Plantago quinqueneruiarofea. Role Ribwort. 


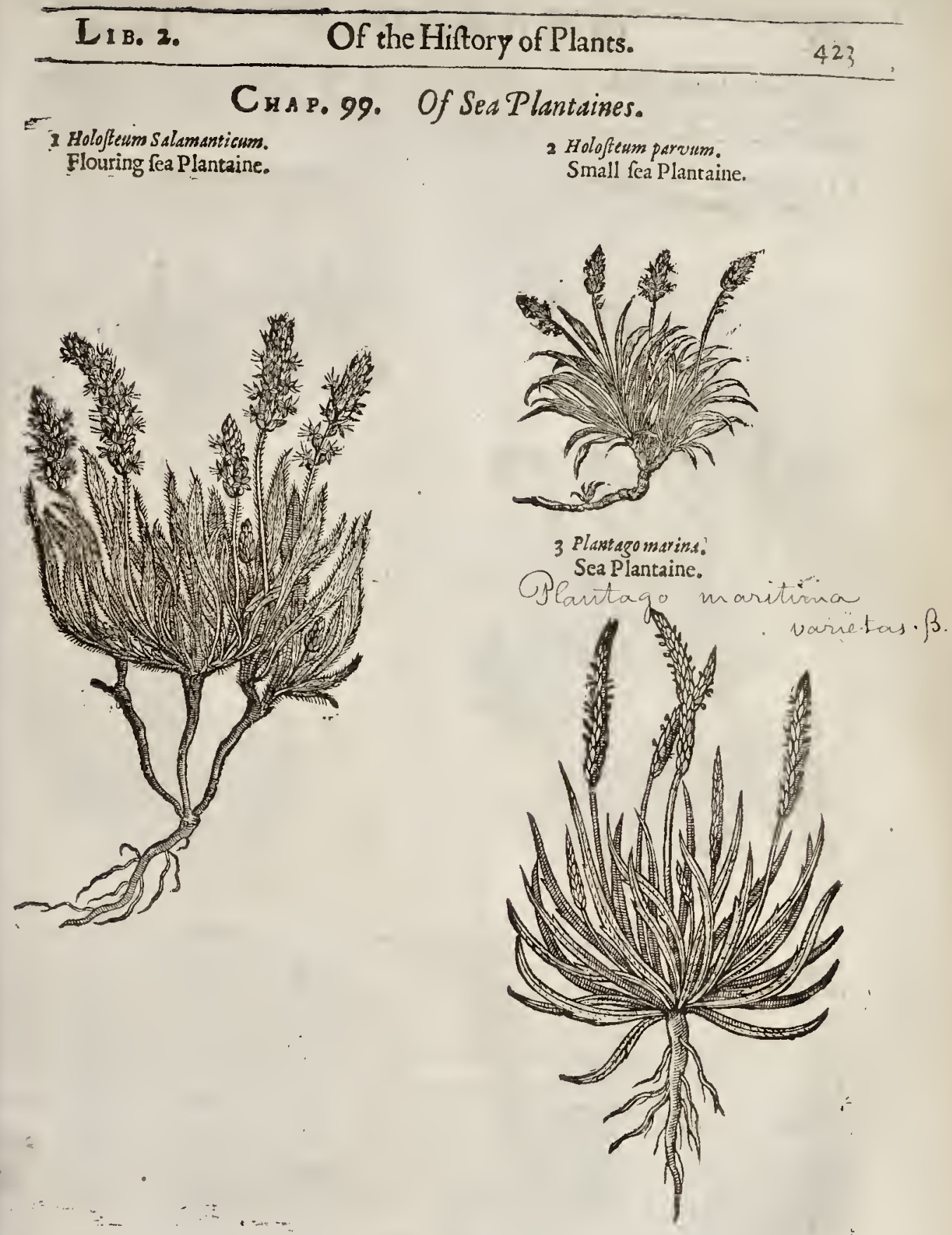

IT The Defcription.

1 Arolus Clufsus that excellent Herbarif hath referred thefe two forts of Holofteurs vnto the kindes of Sea Plantaine. The firt hath longleaues like the common Rib-wort, but narrower, couered with fome hairineffe or wollineffe : among which there rifeth vp a ftalke, bearing at the top a fpike like thekindes of Plantaine, befer with many friall floures of an herby colour, declining to whiteneffe. The feed is like that of the Plantaine : the root is long and wooddy. This floures in Aprillor May.

2 The fecond is like the former, but fmaller, and not fo gray or hoary: the floures are like to Coro. mopus, or the leffer Ribwort. This floures at the fame time as the former. 
3 The third kinde, which is the fea Plantaine, hath fmall and narrow leaucs like Bucks-ho:n, but without any manifcft incifurc, cuttings or notches vpon the one fide: among which rifeth vp a fpikie ftalkc, like the common kinde, but fmaller.

\section{¥ Holofeum, fuc Leontopodium Creticum. Candy Lyons foot.}

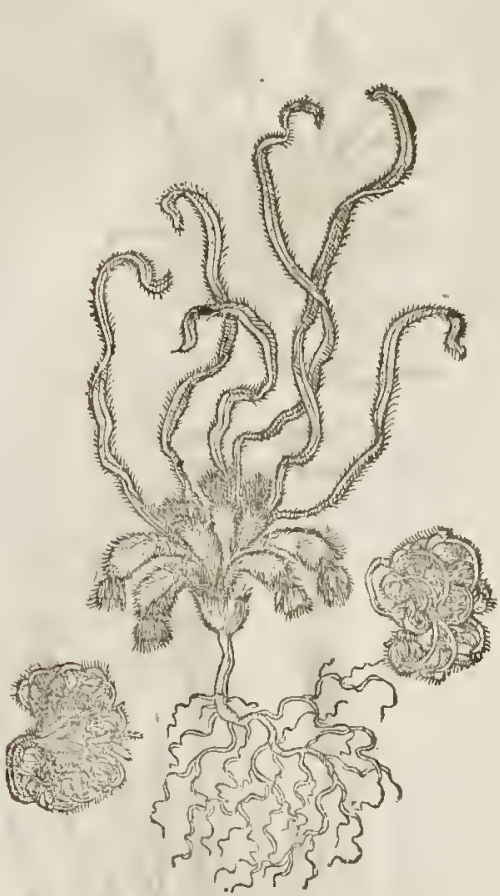

+ 5 Holofteum; fue Leontopod. Cret alterum. The other Candy Lyons foot.
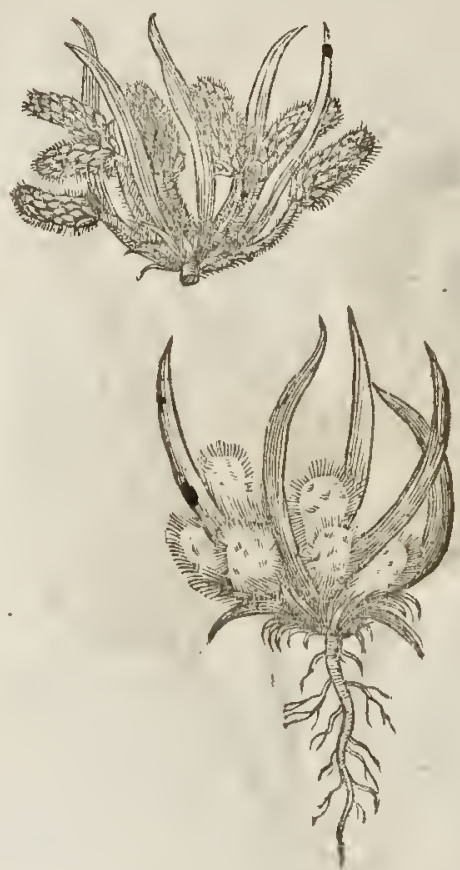

₹ 4 Thefe two following Plants are by clufus and 8 aubine referzed to this Tribe: wherefore I thinke it fitting to place them here. The former of them from a reddifh, and as it were fcaly root growing leffe by little and little, and diuided into fibres, fends forth many lcaues, narrow, hoary, an band full long, and hauing three ncrues or ribbes ur nirg a'orgft cach of them : among ft thefe come forth diters foot-ftalkes, conered with a foft reddifh downc, and being fome two or three inclies long, hauing heads fomew hat thickeand reddith : the floures arc whitifh, with a blackifh middle, whicl makes it feeme as if it were per? orated or lo?ed. Now when the plant growes old, and withers, the ftalkes becomm ing more thicke ard ftiffe, bund downc their lcads towards the root, fothat in fome fort they refemb!e the foot of a L y on.

5 This Plant which is figured in the rpper place (for I takc the lower to be an cxacter figure of the laft defcribed) hath leaues like to tle fmall fea Plantainc, but tonderer, and ftanding r pright; and among ft thefe on little foot-ftalkes grow heads like thole of $P \int y$ llium, but prettier, and of a whition red colour. $\neq$

$$
\text { The Place. }
$$

The two firft grow in moft of the kingdomes of Spaine. Carolss clufius writeth, that lace neter faw greater or whiter than ncere to Valentia a city of Spaine, by the high-waics. Since, thcy baue beene fne rd at Baftable in the ifle of Wight, and in the illes of Gernfcy and Iarfey.

The third doth grow neere rnto the fea in all the places about England where I baue trauelled, efrecially by $t$ e forts on both the fides of the water at Grauefend; at Erith neere London; at Lee in Effex; at P in Kent; at Weft-Chefter, and at Briftow.

$\ddagger$ The fourth and fifth grow in Candy, from whence they haue been fent to Padua and diuers otler places. F 
L 1 8. 2.

Of the Hiftory of Plants.

425

T The Names.

Holofteum is also called by Dodona us, Plantago anzufifolia albida, or Plantago Hijpanienfis : in Englint, Spanish hairy foal Plantains, or flouring fe Plantain.

$\ddagger$ The fourth is called by Clufius, Leontopodium Cretzcum : by forme it hath beerie thought to be Cat rance of Diofcorids : the which Honorius Bells will not allow of: Bashing calls it Holofterm, fur Leontopodium Creticum.

The fifth is Leontopodium Creticum alterum of Clufius; the Habbures of Camerarizs; and the Hold. Ileum Creticum alterum of Baubine. $\ddagger$

The Temperature and Virtues,

$\dot{G}$ ale faith, That Holofeum is of a binding and drying facultie.

Galen, Diofcorides, and $P$ liny have proved it to be foch an excellent wound herbs, that it prefent- $A$ by clofeth or thutteth vp wound, though it be very great and large :and by the fame authority I fpeake it, that if it be put into a pot where many pieces of the th are boyling, it will fader them to. gether.

Thee herbs have the fame faculties and vertus that the other Plantains haue,and are thought to be the belt or all the kinds.

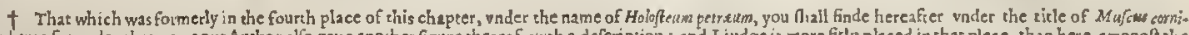

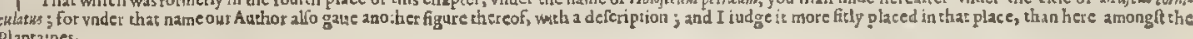
planxasnes.

Cha p. 100. Of SeaBuck-borne Plantains.

I Coronopus.

Sea Buck-horne.

Plantago maritime . a.

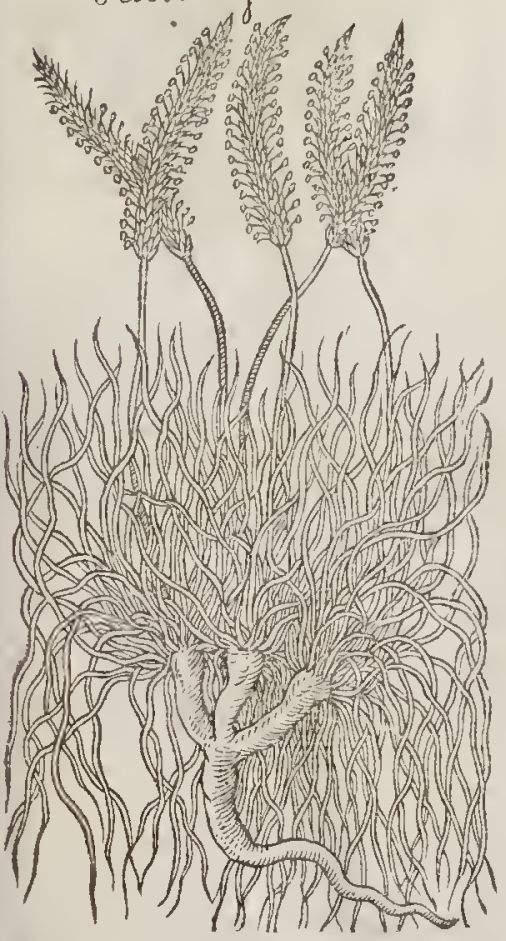

2 Coronopus, fie Serpent ina minor? Small Sea Buck-horne.

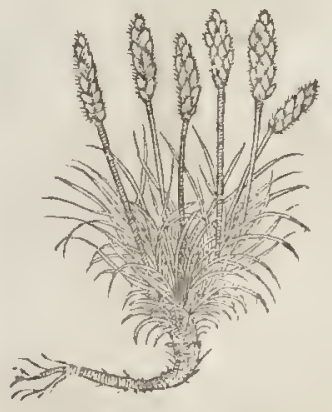

Sf The Deferiplion.

* THe new Writers following as ic were by tradition tho fe that have written long agone, hate beene content to hare themfelues fpeake and fer down certainties by vncertaine fpeeches; which hath wrought fuck confufion and corruption of writings, that fo many Writers, fo many feuerall opinions; as may molt evidentty appear in the fe plants and in others : And. my felfe am content rather to fifer this fear to paffe, than by correcting the error, to renew the old wound. But for mine own opinion thus $I$ think, the plant which is reckoned for a kind of Corontpus is doubrleffe a kind of Holofteum : my reafon is, becaufe it hath griffe leaves, or rather leaves like Veronica Jylaefris or wilde Pinks, a root like thole of Garyophyllata or Avens, and the fp ikif care of Holofterm or Sea Plantain: which are certain arguments that the fe writers hate never feene the Plant, but only the picture thereof, and fo have fer dow ne their opinions by heare-fay.

in

This 
This plant likewife hath beene altogether vnknowne vnto the old Writers. It groweth moft plentifully vpon the cliffes and rocks and the tops of the barren mountains of Auergne in France, and in many places of Italy.

2 The fecond fort of wilde fea Plantaine or Serpentina differeth not from the former but onely in quantitie and flenderneffe of his ftalkes, and the fmallneffe of his léaues, which exceed not the height of two inches. It groweth on the hills and rockes necre the wafhings of the fea at Mafilia in great plenty almoft eutery where among the Tragacant bum, hauing a moft thicke and fpreading clufter of leaucs after the manner of Sedum minimum faxeum montanum, fomew hat like Pinafer, or the wilde Pine, as well in manner of growing, as fiffeneffe, and grcat increafe of his flender branches. It hath the fmall feed of Plantaine, or Serpentina vwlgaris, contained within his fpiky cares. Theroot is fomewhat long, wooddy, and thicke, in taftc fomewhat hot and aromaticall.

3 Coronopus fue Serperstina minima. Small Buck-hornc Plantainc.

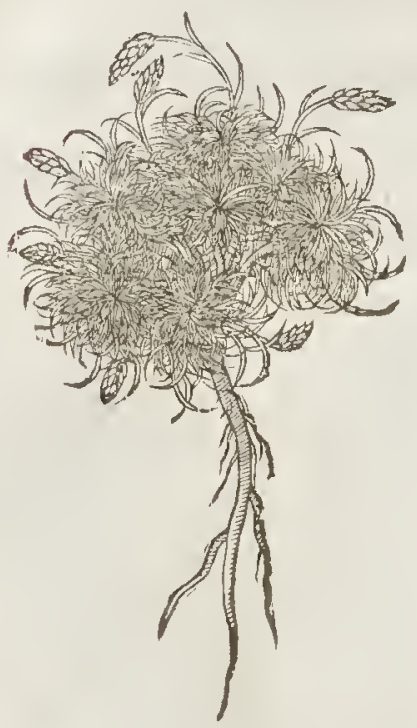

4 Canda Muris. Moufe-tailc.

Myosurus minimus.

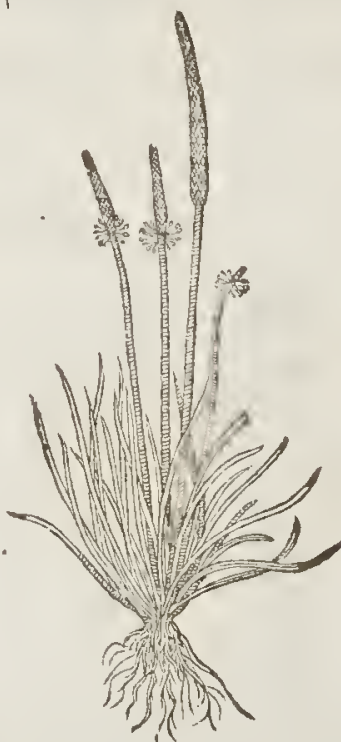

3 This fmall fea plant is likewife one of the kindes of fca Plantaine, participating as well of Buek-horne as of Holoftium, being as itwere a degenerate kinde of fea Plantaine. It hath many graffie leaucs very like vnto the herbe Thrift, but much fmaller; among which eome forth little tough and threddy.

4 Moufe-taileor Couda mur is refembleth

fmall fpik ie knops, leaues, and is refembleth the laft kindeof wilde Coronopus or fea Plantaine, in well place this fmail herbe among the that I know no reafon to the contrarie, but that I may as placed kindes of Holofikm in the fame foet of Coronopes or Bucks horne, as other Writers haue be tolerated in me, confidering that without and if that be pardonable in them, I truft this may Holofium, hauing many fmall more : among which do rife fmall tender leatues fped on the ground, an inch long or fomew hat te blackifh torch or fpikieknop in thape like thalkes of rwo inches long, bearing at the top a littaile of a Moufe, whereofit took hise like that of the Plantaines, refembling very notably the

The firf and fecond ot thefe plants are

$$
\text { T The Place. }
$$

that they grow vnon the rocks in Silley, Garnfey in England; notw ithftanding I hatre heard fay Moufe raile groweth vpon a barren ditch ban, and the Ithe of man.

riglit land of the way, as ye go from ditch barke neere vnto a gate leading into a pafture ou the from Edmonton a village go from London to a village called Hamptead; in a field as you goe Fides; in Voodiond linw in Waltham Foref a houfe thereby called Pims, by the foot-paths pore in Efex, ard in otler places. 
Liв.2. Of the Hiftorie of Plants.

They floure and flourinh in May and Iune.

$$
\text { ข) The Time. }
$$

बा The Names.

Matthiolus writeth, That the people of Goritia do comnonly call thefe wo former plants $S \mathrm{Cr}$ pentaria and Serpentina; but vuproperly, for that there be other plants which nay better be called Serpentina than thefe two: we may cal them in Englifh wild fea Plantaine, whercof doubtleffe tley arekindes.

Moufe-taile is called in Latine Canda muris, and Catuda murinat: in Greeke, wuassere, or wuisivex. Iryofuros is called of the Frencli-men 2ucue de four is : in Englih, Bloud-ftrange, and Moufe-taile.

$$
\text { If The Temperature. }
$$

Coronopus is cold and dry much like vnto the Plantaine. Moufe-taile is coid and fomthing drying, witl a kinde of aftriction or binding qutlitic.

$$
\text { Tit The Vertues. }
$$

'Their faculties in working are referred vnto the Plantaines and Harts-horne.

\section{Cin A P. 101:}

\section{Of Bucke-borne Plantaines, or Harts-borne.}
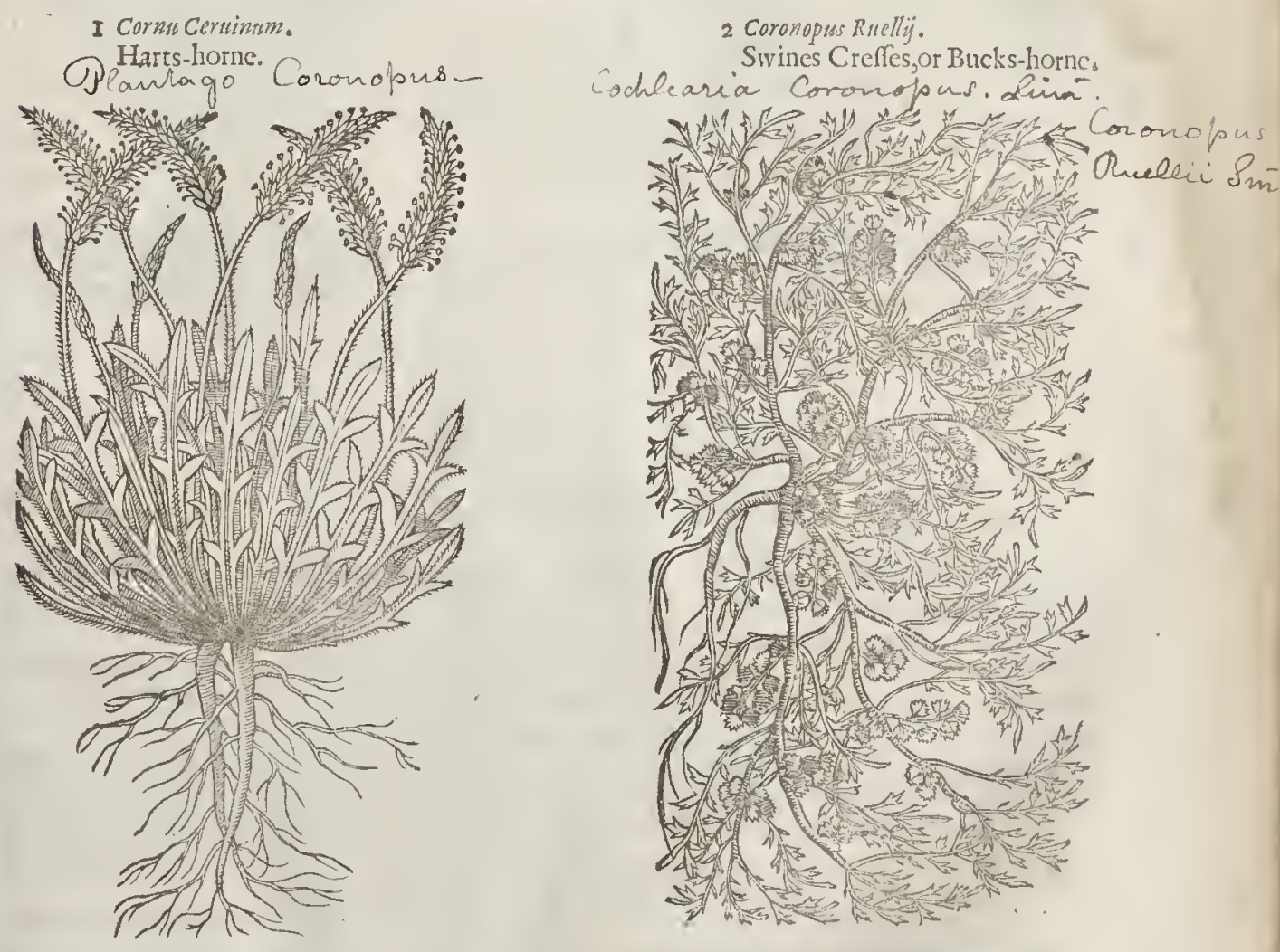

IT The Defription.

I R Vcks-horne or Harts-horne hath long narrow hoary leates, cut on both the fides witix

B three or foure fhort ftarts or knags, refembling the branches of a harts home, fpreading it felfe on the ground like a far: fron the middle whereof fpring vp fmall round nated hairy ftalks : at the top whereof do grow little knops or fpikic torches like thofe of the fnul Plantaines. Theroos is flender and threddy. 
2 Rucllus Bucks-horne or Sirines Crefles hath many final and weake ftragling branclies, trailing here and there vpon the ground, fetwith muny fmall cut or iagged lemes, fomewhat like the former, but fnaller, and nothing at all hairy as is the other. The floures grow among the leaues, in fuall rough elufters, of un herby greenith colour : which being paft, there come in place little flat pouehes broad and rough, in which the feed is contained. The root is white, threddy, and in taftelike the garden Crelles.

\section{- The Place.}

They grow in barren plaines, and wntilled places, and fordy grounds; as in Touthill field neere vnto Weftminfter, at Waltham twelue miles from London, and vpon Blacke-heath alfo necre London.

$$
\text { T) The Time. }
$$

They floure and flourith when the Plantaines doe, whereof thefe laaue beene taken to be kindes.

$$
\text { - The Nitmes. }
$$

Bucks-horne is called in I atine Cormu Ceruinum, or Harts-horne : diuers name it II crba flella; or Sicliaria, although there be another herbe focalled: in low-Duteh, thettshoozen: in Spanifh, Guiabellat: in Irench, Corne de Cerf: It is thought to Diofcorides his xeparasous, whieh doth fignifie ciornicis pedem, a Crowes foot. It is ealled alfo by certaine baftard names, as Harenarea, Sanguinaria. and of many, Herbe Ity, or luerbe Euc.

\section{बा The Temperature.}

Bucks-horne is like in temperature to the common Plantaine, in that it bindeth, cooleth, and dricth.

$$
\text { 9I The Vertucs. }
$$

A The Leaucs of Buckes-lorme boyled in drinke, and giuen morning and euening for certaine dayes together, helpetl molt wonderfully thofe that haue fore eyes, wateric or blafted, and - moft of the griefes that happen vnto the eyes; experimented by a learned Phyfition of Coleheftercalled Mafter Duke; and the like by an excellent Apotheearic of the fame Towne ealled $\mathrm{M}^{\mathrm{r}}$. Buckfone.

B The leaues and toots ftamped with Bay lalt, and tied to the wrefts of the armes, take away fits of the A gue : and it is reported to worke the like efiect being hanged about the neeke of the patient in a certaine number; as vuto men ninc plants, roots and all; and vnto women and children feucu.

$$
\begin{gathered}
\text { - Cir a I. I02. Of Saracens Confound. } \\
\text { If the Defoription. }
\end{gathered}
$$

I Araecns Confound hath many long narrow leaues.eut or flcightly fnipt about the edges : among which rife vp faire browne lollow falkes of the height of foure eubits; along which euen from the bottome to the top it is fetwith long and prety large leaues like them of the Peach tree : at the top of the ftalkes grow faire ftarre-like yellow floures, whicl turne into downe, and ate eatried away with tine winde. The root is very fibrous or threddy.

$$
\text { a 'The place. }
$$

Saracens Confound groweth by a wood as ye ride from great Dummow in Effex, vnto a place called Clare in the fid contiey; from whence I brought fome plants into my garden.

₹ I formerly in the twenty fouth Clapter of this fecond bookc told you what plant our Author tooke for Suracens Confound, and (as I hauc becn credibly informed) kept in his garden for it. Now the true Soldago here deferibed and figured was found Amo I632, by my kinde Friends $\mathrm{M}^{\mathrm{i}}$. Georre Bowles and $\mathrm{M}^{\mathrm{r}}$. Willim Coot, in Shrophire in Wales, in a hedge in the way as one goeth from Dudfon in the parith of Cherbery to Guarthlow.

It fourcth in Inly, and the feed is ripe in Auguft.

$$
\begin{aligned}
& \text { 97 The Time. } \\
& \text { in Auguf. } \\
& \text { बा The Names. }
\end{aligned}
$$

Saracens Confound is called in Latine Solidago Saracenica, or Saracens Comfrey, and Confolida

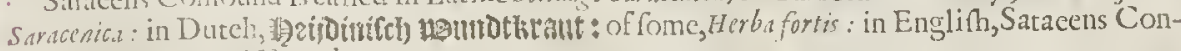
found, or Saraecns Wound-wort. 


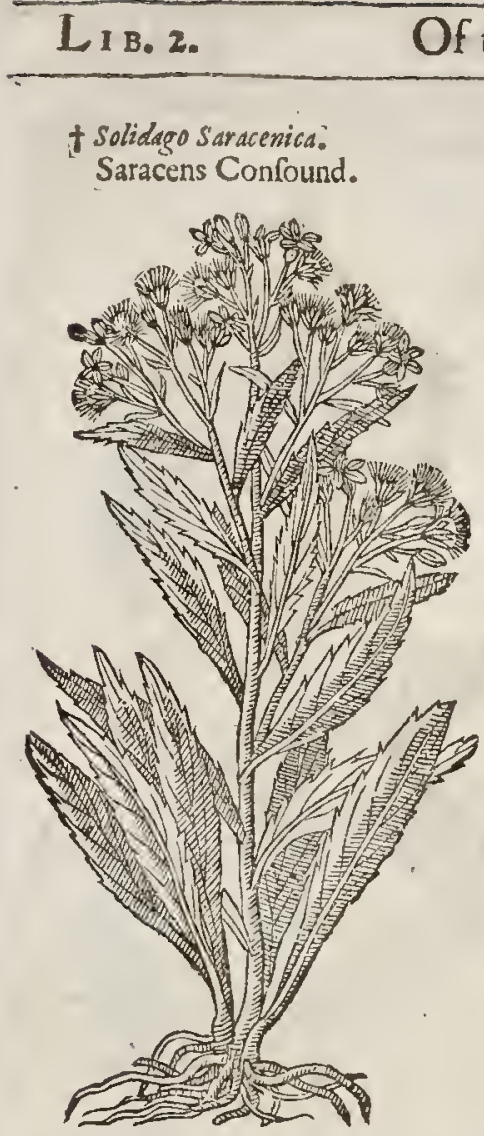

+ Solidago Saracenica. Saracens Confound.
The Tature.

Saracens Confound is dry in the third degree, with fome manifeft heate.

$$
\text { II The Vertucs. }
$$

Saracens Confound is not inferiour to $A$ any of the wound-herbes whatfoeter, being inwardly miniftred, or outwardly applied in ointments or oyles. With it I cured Mafter Curtwright a Gentleman of Grayes Inne, who was grieuouly wounded into the lungs, and that by Gods permiffion in thore fpace.

The leaues boyled in water and drunke, B dotlreflraine and ftay the wafting of the liuer, taketh away the oppilation and flopping of the fame, and profiteth againft the Jaundice and Feuers of long continuance.

The decoction of the leatues made in $\mathrm{C}$ water is excellent againft the foreneffe of the throat, if it be therewith gargarifed : it increafeth alfo the vertue and force of lotion or wafhing waters, appropriate for priuy maimes, fore montlies, and fuch like, if it be mixed therewith.

t The figure that was formerly in this place was of Confolida paluffit enerate

\section{C н а Р. 103. Of Golden Rod.}

IT The Defcription.

I

Olden Rod hath long broad leates fomwhat hoary and tharpe pointed;among which

I rife vp browne ftalkes two foot high, diuiding thenfelues toward the top into fundry branches, charged or loden with fmall yellow floures; which when they be ripe turne into downe which is carried away with the winde. The root is threddy and browne of colour. $¥$ Lobel makes this with vnfnipt leaues to be that of Arnoldus de vills noura. F

2 The fecond fort of Golden Rod hath fmall thin leautes broader than thofe of the firft deferibed, fmooth, with fome few cuts or nickes about the edges, and harpe pointed, of a hot and har h tafte in the throat being chewed; which leaues are fet vpon a faire reddifh ftalke. It tooke his name from the floures which grow at the top of a gold yellow colour : which floures turne into Downe, which is carried away with the winde, as is the former. The ront is fmall, compact of many fttings or threds.

\section{IT The Place.}

Theybotl grow plentifully in Hampitead Wood, neere vnto the gate that leadeth out of the wood vnto a Village called Kentifh torne, not far from London; in awood by Ravleigh in Eflex, hard by a Gentlemans houfe called $M^{\mathrm{x}}$. Leonard, dwelling vpon Dawes heath; in South fleet and ink Swainefcombe wood alfo, neere vnto Grauefend.

They floure and flourin in the end of Auguft.

$$
\text { T The Time. }
$$

It is called in Englith Golden Rod : in Latine, Virga aurea, becaufe the branches are like a golden rod: in Dutch, Eulden toede: in French, Verged" or.

$$
\mathrm{Nn}_{3}
$$


I Virga aurea.

Golden Rod.

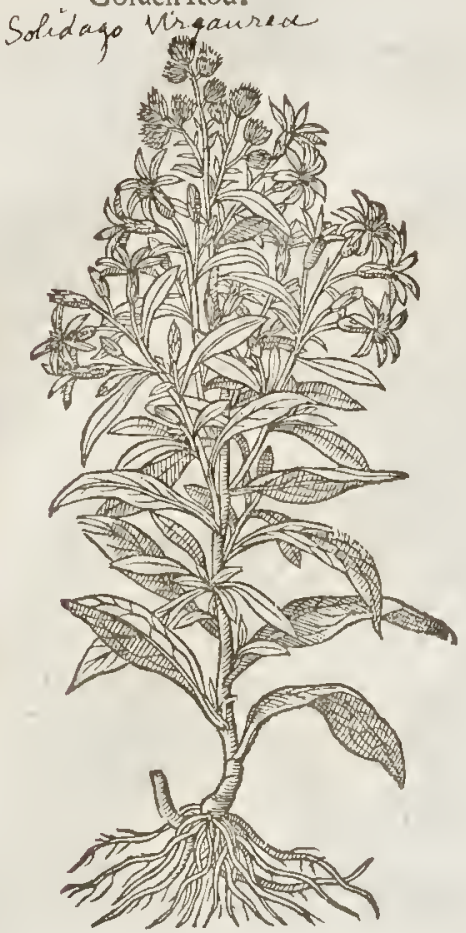

2 Virga aurea Arnolde Villanonani. Arnold of the new tow ne his Golden rod.'

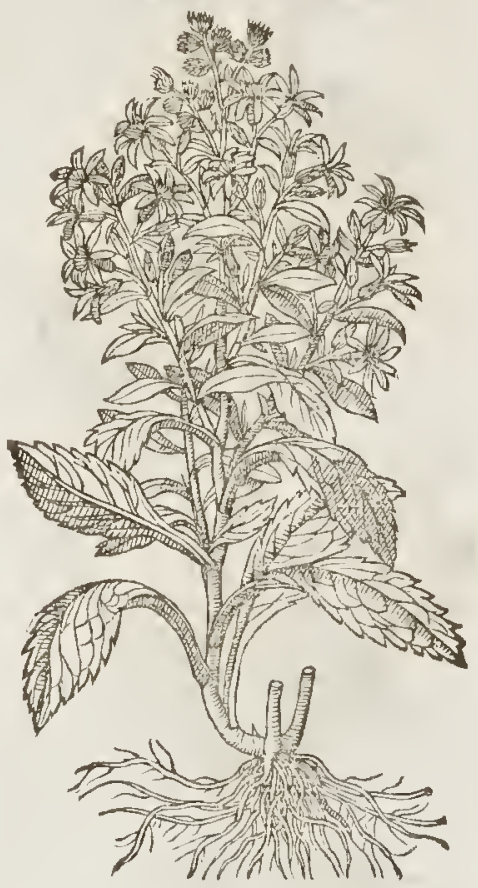

The Temperature.

Golden Rod is hot and dry in the fecond degree : it clenfeth, with a certaine aftriction or binding qualitie.

Golden Rod pronoketh vrine, wafteth away the ftones in the kidnies, and expelleth them, and

A withall bringeth downe tough and raw flegmatick humors ftieking in the vrine veffels, which now and then do hinder the comming away of the ftones, and eaufeth the grauell or fand whieh is brittle to be gathered together into one ftone. And therefore ArnoldusYillznounus by good reafon hath eommended it againt the ftone and paine of the kidnies.

B It is of the number of thofe plants thar ferue for wound-drinks, and is reported that it ean fully performeall thofe things that Saracens Confound ean; and in my practife thall be placed in the formoft ranke.

Arnoldus writeth, That the diftilled water drunke with wine for fome few dayes together, wor : keth the fame effect, that is, for the ftone and grauell in the kidnies.

D

It is extolled aboute all other herbes for the ftopping of bloud in fanguinolent slcers and bleeding wounds; and hath in times paft beene had in greater eftimation and regard rhan in thefe dayes : for in my remembrance I haue knowne the dry herbe which eame from beyond the fea fold in Backlers Bury in London for halfe 2 crowne an ounce. But fince it was found in Hamplead wood, euen as it were at our townes end, no man will gitue halfe a crowne for an hundred weight of it : which plainly fetteth forth our ineonttancie and fudden mutabilitie, efteeming no longer of any thing, how pretious foeuer it be, thanwhilet it is ftrange and rare. This verificth our Englih prouerbe, Far fetcht and deare bought is beft for Ladies. Yet it may be more truely faid of phantaftieall Phyfitions, whowhen they baue found an approued medicine and perfeot remedie neere home againft any difeafe; yet not content therew ith, they wil feeke for a new farther off,and by that meanes many times hurt more than they helpe. Thus much I baue fpoken to bring thefe new fangled fellowes backe againe to efteeme better of this admirable plant than they haue done, which no doubt hath the fame vertue now that then it had, although it growes fo neere our owne homes in netrer fo great quantitic. 


\section{C r a r. 103. Of Captaine Andreas Dorias bis Wound-biort.}

t Herba Doria L'obely. Dorias Woundwoort.

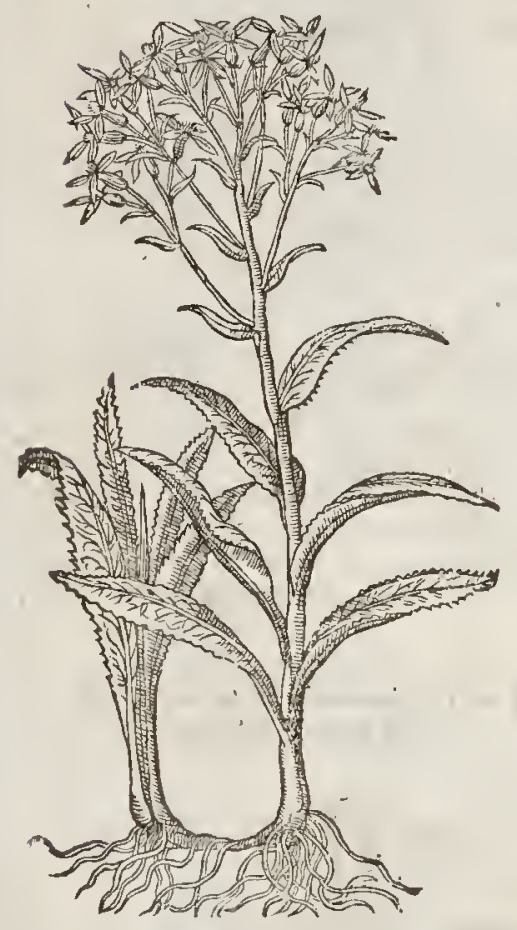

T The Defcription. hands hath a prettie fpicie fnell. A. mong thefe leaues rifeth vp a ftalk of the height of a tal man,diuided at the top into many other branches, wheteupon grow fmall yellowifh iloures, which turneth into downe that flieth away with the wind. The root is thick almont like Helleboras albus.

of which kinde there is another like the former,but that the leases are rougher, fomewhat bluntly indented at the edges, and not fo fat and groffe.

\section{\# Berba Doris altera.}

This herbe growes vp with a green round britrle ftalke, very much champhered, linewed, or firrowed, abour foure or fine foot high, full of white pith like thar of Elder, and fendeth forth fmall branches : the leates grow on the ftalk out of order, \& arc fmooth, Tharpe pointed, in liape like thofe of Herba Doria, but much fhorter \& narrower, the broadeft and Iongeft feldome being aboue ten or eleuen inches long, and fcarce two inches broad, and are more finely and fmally nickt or indented about the edges; their fmell being nothing pleafant, butrather when to. gether with the falke they are broken and rubbed yeeld forth a fmell hauing a fmall touch of the fmell of Hemlocke. Out of the bofomes of thefe leaues fpring other fmaller leaues or branches. The floures are many, and grow on fmall branches at the tops of the falkes like thofe of Herba Doria, but more like thofe of Incobea, of a yellow colour, as well the middle button, as the fmall leaues that ftand round about, cuery floure haung commonly eight of thofe fmall Ieaues. W/hich beeing paft the button turneth into downe and containeth very fmall long feedes which flie away with the winde. The root is nothing elfe but an infinite of fmall ftrings which moft hurtful1y fpread in the ground, and by their infinite increafing deftroyeth and ftarueth orher herbes that grow neere it. Its naturall place of growing I know not; for I had it from $M$ : Iobin Coys, and yet keep it growing in my garden. Iobn Goodyer. $\ddagger$

$$
\text { - The Place. }
$$

Thefe plants grow natirally about the borders or brinkes of riuers neere to Narbone th France, from whence they were brotight into England, and are contented to be made denizons in my garden, where they flourith to the height afotefaid.

$$
\text { बा The Time. }
$$

Theyflotred in my garden about the twelfth of Iune.

$$
\text { of The Nature. }
$$

The roots are fweet in fmell, and hot in the thisd degree.

$$
\text { IT The vertucs. }
$$

Twodrams of the roots of Herba Doria boiled in wine and given to drinke, draweth downe wa. A - terifh humors, and prouoketh vrine.

The fame iswith good fucceffe ved in medicines that expell poifon, 
+ All thefe Plants mentioned in the three laft Chapters, to wit, Solidago, $V$ irga aurea and this $H e r-$ Dore $a$, are by Bambine fitly comprehended vnder the title of Virga aurea; becaufe they are much alike in thape, and for that they are all of the fame facultic in medicire. $\neq$

$t$ The Ggure thas was here war of Solideso Suracemica.

\section{CHA P.105. Of Felwoort, or Baldmoney. \\ II The Kindes.}

hollow ftalke as thicke as a mans thumbe, full of ioints or iknees, with two leaues at each of them, and towards the top euery ioint or knot is fet round about with finall yellow ftarre-like floures, like a coronet or garland: at the bottome of the plant next the ground the leaues do fpread themfelues abroad, embracing or clipping the ftalke in that place round about, fet together by coutples one oppofite againft another. The feede is fmall, browne, flat, and fmooth like the feeds of the Stocke Gillo-floure. The roote is a finger thicke. The whole Plant is of a bitter tafte.

1 Gentidna maior.

Great Felwoort:

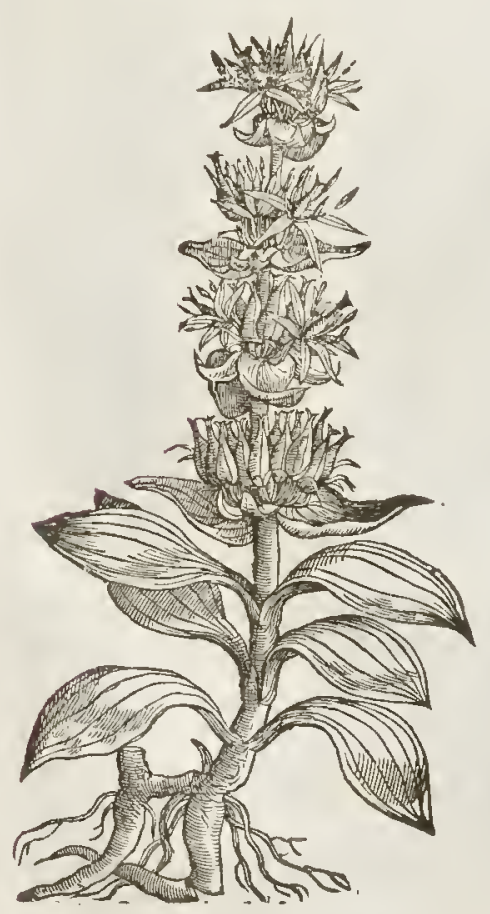

$\$ 2$ Gentiana maior purpuren, I.Clafij. Great Purple Felwoort.

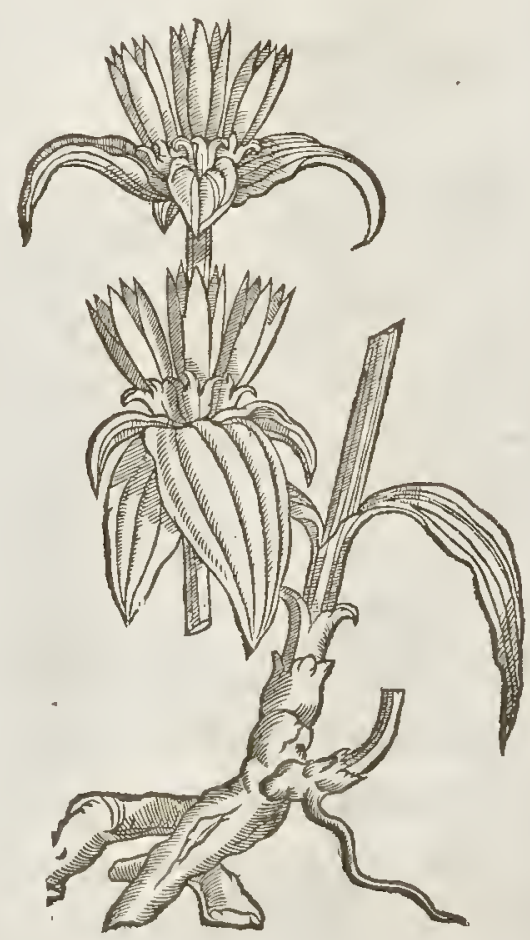




\section{L і в. 2. Of the Hiftory of Plants.}

Gentiana maior $\ddot{j}$.caruleo flore Clufij. Blew floured Felwootr.

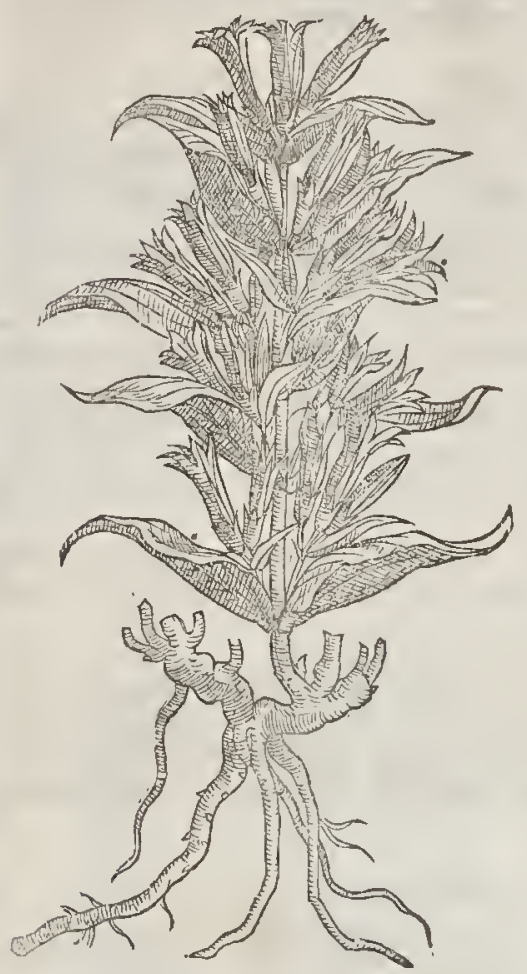

5 Gentiana Pennei minor.

Spotted Gentian of $D^{*}$. Pennie.

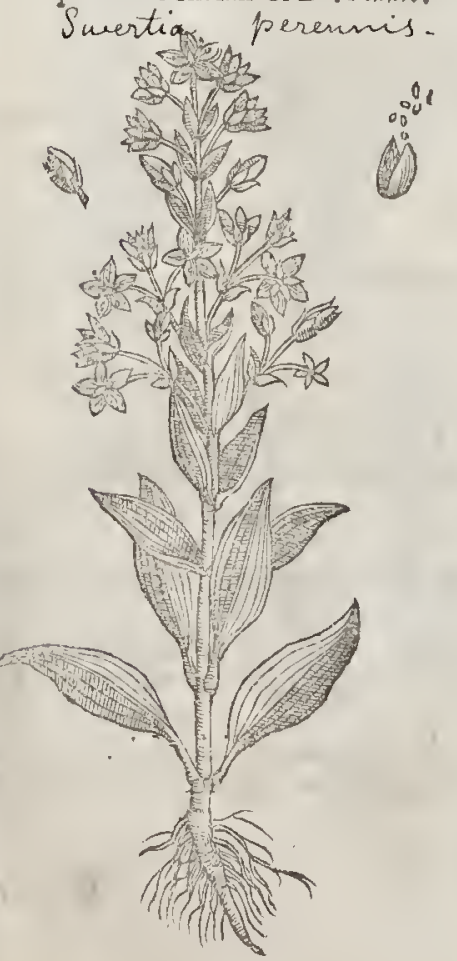

4 Gentianaminor Cruciata.

Ctoffewoott Gentian.

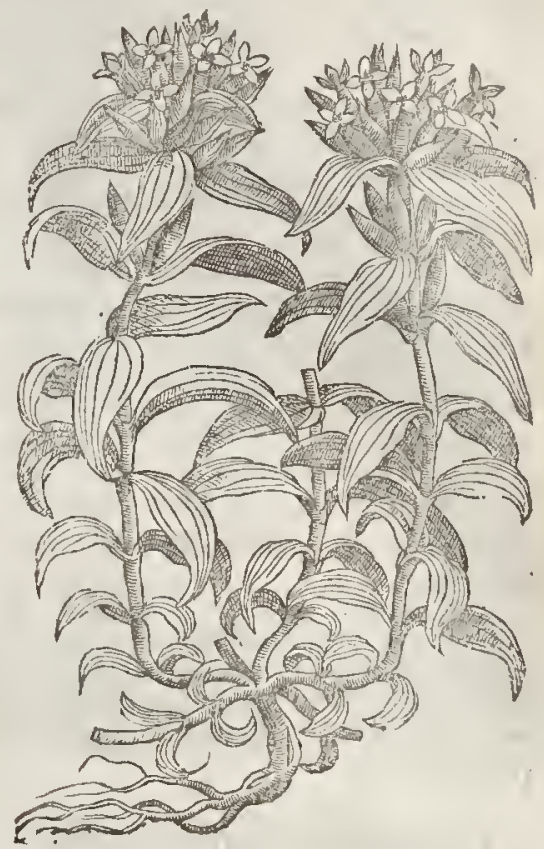

* 2 This deferibed by clufus, harh leates and ftalkes like the precedent; thefe ftalkes are fome eubite and halfe or two cubits high, and towards the toppes they are ingirt with two or three coronets of faire purple floures, which are not ftarfalhioned, like thofe of the former, but long and hollow, diuided as it were into fome fiucor fix parts or leau es, which towards the bottome on the infide are fpotted with deepe purple fpots : thefe floures are without fmell, \& haue fo many chitues as they hauc iagges, and the fe chities compaffe the head, which is parted into two cells, and containes ftore of a fmooth, chaffic, reddin feed. The roor is large,yellow on the outfide, and whitewithin, very bitter, \& it fends fortl euery yere new fhoots. It growes in diuers places of the Alps; it floures in Augut, and the feeds are ripe in September. $\ddagger$

3 Carolus Clufius alfo fettcth forth another fort of a great Gentian, rifing forth of the ground with a ftiffe, frme or folide ftalke, fet with leaues like vnto A fclepiss, by couples one oppofiteagainft another, eticn from the bottome to the top in certaine difances : from the bofome of the 
leaues there fhoot forth fet vpon flencier foot-falkes certiline long hollow fioures lihe bels, tlie mouth whercof enderh in fue thatpe concrs. The rithe finure changeth many times his colour aceording to the foile and climate; now and then purple or blcw; fomerimes whitifh, and of ten of an athe colour. The root and feed is like the precedent.

4 Crofe-woort Gentian hath many ribbed leaues fpred tpon the ground, like into the leates of Sopewoort, but of a blacker greene colour: among, which rite rpweake iointed ftalkes trailing or leaning toward the ground. The floures grew at the top in birclles tliche tlituft togetlice, like thofe of fiveet Williams, of a light blew colour . The root is thicke, and creepeth in the ground far abroad,whercby it greatly increafeth.

5 Eavolus Cly furs hath fet forth in his Panonicke hiföric a kinde of Gentian which he receiucd from M . Thomas Pennic of London, Dr. in Ṕhificke, of famous memoric, and a fecond Diofcori. des for his fingular knowledge in Planrs : which 7 'abrmamontan us hath fer forth in his Dutch tooke for the feucntls of clufurs, wherein, he greatly deceined himfelfe, and hath wirh a falfe defeription wronged others.

This twelfth fort or kinde of Gentian after Clufrus, hath a rourd ftiffe ftalke, firme ard folide, fomewhat reddith at the bottome, iointed or kneed like unto Croffwoor Gerrian. The lantes are broad, fmooth, full of ribbes or fiucues, fet about the ftalkes by couples, cric opforfte againt another. The foures grow tpon fimall tender ftalkes, compa ef of fue fiender blewifh leaucs, fpotted very euriounly with many blacke frots and little lines; liaurig in the middle fiue yellow chimes. The feed is fmall like fand : the root is litrle,gar nifhed with a few frings of a yellowifh colour.

$$
\text { 9ा The Place. }
$$

Gentian groweth in fhadowic woods, and the mountains of Italic, Sclatonix, Germany, France, and Burgundic; from whence Mr. If furc de Lame a learsed Phifition fent me plants for, the increafe of my garden. Croffewoort Gentian groweth in a pafture at the Weftend oflitrle Rayne in Effex on the North fide of the way leading from Braintrec to Much-Dunmow; and in the horfe way by the fame clofe.

They floure and flourith in Auguft, and the feed is ripe in September.

$$
9 T \text { The Nomes. }
$$

Gentius King of Illyriawas the firft finder of this herbe, and the firft that ved it in medicine, for which caulec it was called Gentian after his ownename: in Greeke smati: which name alfo the A pothecaries retaine vito this day, and call it Gentiana: it is named in Englifh Felwoort Gentian. Bittcrwoort; Baldmoyne, and Baldmoney.

I This by mont Writers is called Gentiana, and Gentiana maior Lutea.

2 Gefaer calleth this Gentiana prnicea; Clufier, Gentzwna mator flore purpureo.

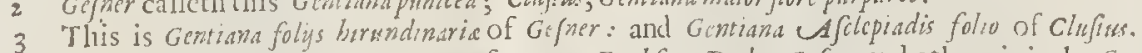

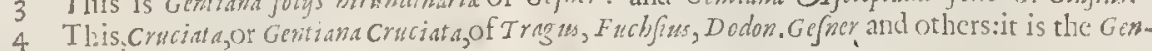
tianaminor of Matthiolus.

5 Chufus calls this Gentiana maior pallidapunct is diffincta.

ब The Temporature.

The root of Felwoort is ho:, as Diofrorides faith, elenfing or fcouring: diucrs copies liaue, that it is likewife binding, and of a bitter tafte.

\section{T The Vermes.}

A It is excellent good, as Galen faith, rw hen there is need of attenuating, purging, clenfing, and remouing of obftructions, which qualitic it taketh of his extreme bitterneffe.

$\mathrm{B}$ It is reported to be good for thofe that are troubled with crampes and convulfions; for fuch as are burft, or hate falne from fome high place: for fuch as haue cuill liucrs and bad ftomacks. It is put into Counterproifons, as into the compofition named $T$ heriaca diateffaron: which Aetires calleth Myferimm, anyfteric or lid fecret.

C This is of fuch force and vertuc, faith Pliny, that it helpeth cattell which are not onely troubled with the cough, but are alfo broken winded.

D The roor of Gentiangiten in pouder the quantitic of a dramme, with a little pepper and herbe Grace mixed therewith, is profitable for them that are bitten or fung with any manner of venomons beaft or mad dog: or for any that hath taken poifon.

The decoctiondrunke is good againft the ftoppings of the liter, and cruditie of the ftomacke, helpeth digeftion, diffoltucth and feattereth congealed bloud,and is good again lt all cold difeafes of the inw ard parts. 


\section{CHA Р. 106. Of Englif/ Felwoort:}

$$
\text { TT The Defoription. }
$$

$\mathrm{H}$ Ollow leafed Fclwoort or Englith Gentian hath many long tough roots, difperfed hither and thither within the vpper crutt of the earth; from which immediarly riferb a fat thicke ftalke,iointed or knced by certaine diftances, fet at euery knot with one leafe, and fometimes moe,keeping no certaine number: which leaues dec at the firt inclofe the ftalkes round about, being one whole and entirc leafe without any incifure at all,as it were a hollow trunke; which after it is growne to his fulneffe, breaketh in one fide or othcr,and becommeth a that ribbed leafc, like vnto the great Gentian or Plantaine. The floures come forth of the bofomc of the vpper leates, fet vpon tender foot ftalkes, in thape like thofe of the fmall Bindweed, or rather the flowres of $S$ opewoort, of a whitifh colour,watht about the brims with a littlc light carnation. Then followctl the feed, which as yet I hame not obferned.

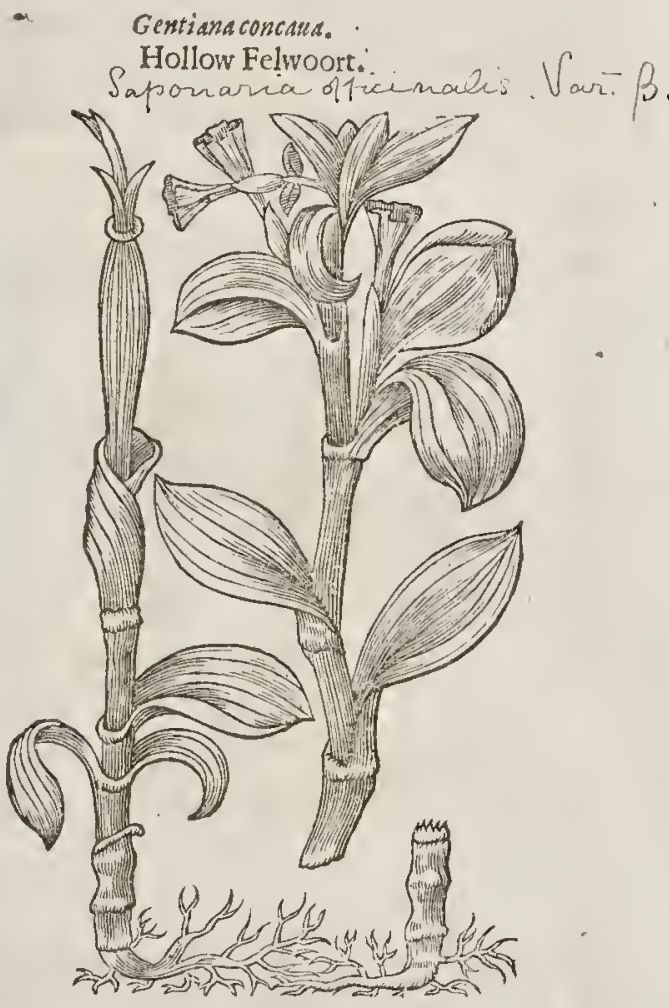

TI The Place.

$I$ found this ftrange kind of Gentian in a fmall groue of a wood called the Spinie, nectc vnto a fmall village in Northamp. con thire callad Lichbarrow : clfewhere I hauc not heard of it.

\section{T The Time.}

It fpringeth fortl of the ground in $A$. prill, and bringerh forth his floures and feed in the cnd of Augurf.

$$
\text { T The Names. }
$$

I hauc thought good to gite vnto this plant, in Englifh, the name Gentian, being doubtleffe a kinde therof. The which hath not been fet forth, nor remembred by any that hauc written of plants vntil this time: In Latine we may call it Gontiana concaut, of the hollow leaues. It may be called alfo hollow leaucd Felwoort.

T The Temperature and Vertues.

Of the facultics of this plant as yer I can fay norhing,rcferring it vnto the other Gentians, vntill time fhall difclofe that which yet is fecret and vnknowne.

$¥$ Baubine reccitued this plantwith the figure thereof from Dodtor Lifter one of his Maiefties Phyfitions, and he referres it vnto Saponaria; calling it Saponaria cencaua Anglica; and (as farre as I can conicéture) hath a good defcription thereof in his Prodrom.pag.103. Now borlh by our Authour and Bauhines Defcription, I gather, that the roote in this Figure is not rightly expreffed, for that it thould bee long, thicke, and creeping, with few fibers adhering thereunto; when as this figure expreffeth an annuall wooddy root. But not hauing as yet fcene the plaut, I can affrme nothing of certaintie. $\neq$ 


\section{‡ С н г. 107. Of Baftard Felwoort.}

\section{The Defcription.}

‡

Or Authour in this Chapter fo confounded all, that I knew not well how, handfomely to fet all right, for his defcriptions they were fo barrcn, that little might be gathered by them, and the figures agreed with their titles, but the place contradiets all; for the firit figured is found in England; and the fecond is not that euer I could learne: alfothe fecond foures in the fpring,according to Clufus and all others that haue written thereof, and alfo by our Authours owne title, trucly put ouer the figure:yct he faid they both floure and flourith from Augutt to the end of Septcmber. Thefe things confidercd, I thonght it fitter both for the Readers benefit, and my owne credit to giuc you this chapter wholly new with additions, rather than mangled and confufed, as otherwife of neceffitie it muft haue beene. $\neq$

¥ I This clegant Gentianella hath a fmall yellowish creeping root, from which arife many greene fmooth thicke hard and tharpe pointed leaues like thofe of the broad leaued Myrtle, yet larger, and hauing the veines running a longtt the leaues as in Plantaine. Amongft the leaucs come vp thort ftalkcs, bearing very large floures one vpon a ftalke; and thefe floures are hollow like a Bel-floure,and end in fiuc fharpe points with two little cares betwecne each diuifion, and their colour is an exquifite blew. After the floure is paft there followes a fharpe pointed longifh veffell, which opening it felfe into two equall parts, fhewes a fmall crefted darke coloured feede.

‡ I Gentianella verna maior.

Spring large floured Gentian.

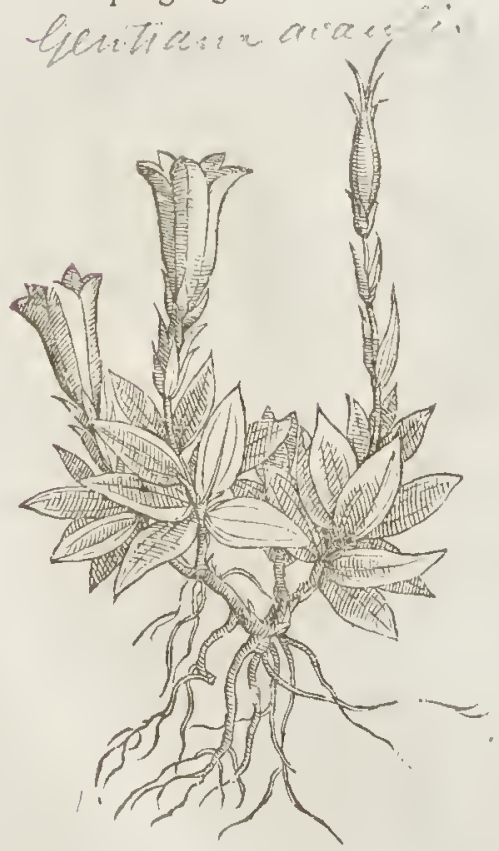

2 Gentianella Alpina verna.

Alpes Felw oort of the fpring time, Gentiana verna.

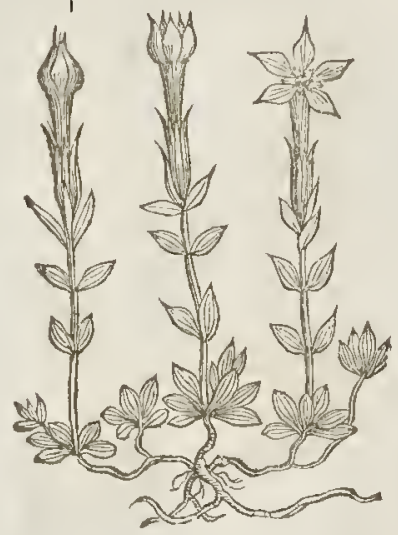

2 This fccond rifes up with a fingle flender and purplifh ftalkc, fet at certaine fpaces with fix or cight litrle ribbed leaues, ftanding by couples one again t another. At the top ftands a cup, out where of comes one long floure without imell, and as it werc divided at the top into fue parts ; and it is of fo elegant a $\mathrm{co}-$ lour, that it feemes to cxceed blewneffe it felfe; each of the foldes or littlc leaues of the flourc hath a whitifh line at the fide, and other five as it were pointed leaues or appendices fet betweene them : and in the middeft of the floure are certaine pale colourcd chines : a longith fharpe pointed veffell fucceeds the floure which contains a fmall hard round fced. The root is fmall,ycllowifh and creeping, putting vp here and therc ftalkes bearing floures, and in other places onely leaues lying orderly fprcd vpon the ground. 
3 Gentianclla fugax minor. Baftard or Dwarfe Felwoort . Gentiana mivalis.

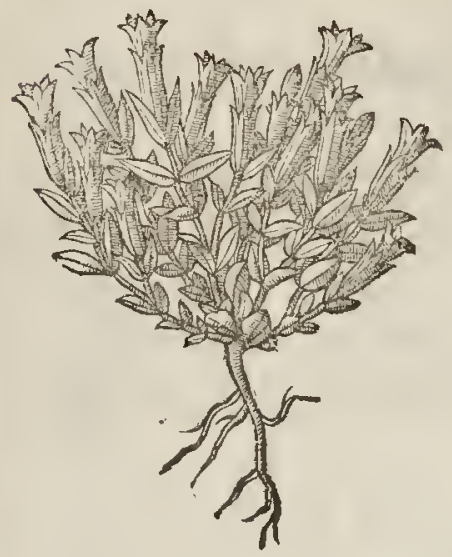

3 Befides thefe two whofe roots lait long and increafe cuery yeare, there are dituers other Divarfe or Baftard Genti. ans which are annuall, and wholly perim euery yeare affoone as they haue perfested their feed; and therefore by Clufsas they are fitly called Gentians fugnces. Of theie I hatre onely obferued two kindes (or rather varieties) in this Kingdome, which I wil here deferibe nto you. The firft of the fe, which is the lcifer, $\&$ whofe figure we here give you, is a proper plant fome two or three inches high, ditided immediatly from the root into three or foure or more branches, fet at certaine fpaces with little longith leates, being broadeft at the fetting on, and fo growing narrower or fharper pointed. The rops of thefe ftalkes are beautified with long, hollow, and pretty large floures, confidering the magnitude of the plant, and thefe fioures are of a darke purplifh colour, and at their tops dituided into fiue parts. The root is yellowith, fmall, and wooddy. The feedewhich is fmall and round is contained in longith veffels. The ftalkes and leaues are commonly of a darke green, or elfe of a brownifh colour:

4 This from a root like,yet a little larger than the former, fends vp a pretty ftiffe round ftalke of fome fpan high ; which at certaine fpaces is fer with fuch leaues as the laft defcribed, but larger : and out of the bofomes of thefe leaues from the bottome to the top of the ftalke come forth little foot ftalkes, which vfually carry three floures a piece ; two fet one againft another, and the third vpon a falke fomew hat higher; and fometimes there comes forth a fingle floure at the root of thefe foot ftalkes. The floures in their thape, magnitude and colour,are like thofe of the laft mentioned, and alfo the feed and feed veffels. The manner of growing of this is very well prefen. ted by the figure of the third Gentian, formerly defcribed in the Chapter laft faue one aforegoing.

$$
\text { If The Place. }
$$

I 2 Thefe grow not wilde in England that I know of,but the former is to bee found in mont of our choice Gardens. As with $\mathrm{M}^{5}$. Parkinfon, Mafter Tradefcant, and Mafter Tugs)e, \&c.

34 Thefe are found in diuets places, as in the Chalke-dale at Dartford in Kent, and according to our Autho.r (for I know he meant the fe) in Waterdowne Foreft in $S_{u f f e x}$, in the way that leadeth from Charlwoods lodge, vnto the houfe of the Lord of Abergauenie, called Erilge houfe by a brooke fide there, efpecially vpon a Heath by Coibrooke neere London : on the Plain of Salisburie, hard by the turning from the fiid Pluise, vnto the right Honourable the Lord of Pembrooks houfe at Wilton, and vpon a Chalkie banke in the high way betweene Saint Albons and Goramberric.

$$
\text { (of Tho Time. }
$$

I 2 Thefe rwo floure in Aprill and May. The other from Augut vnto the end of October.

$$
\text { T) The resmes. }
$$

I This is the Gentiana 4.of Trazus. The Gentianella Alpina of Gefiner. Gentianella campanai. flore and Heluetica of Lobel; the Gentians 5 . or Gensianella maior verna of Chafus.

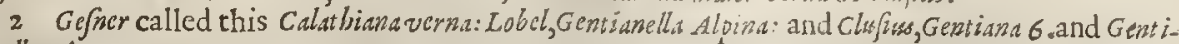
anella minorverna.

3 This is the Calatbiama veri of Dalefchampizs : and the Gentidad fugax 5. or Gentiand I 5 .minima of Clugus.

4 I take this to bee Cluftus his Gestiana fugat 4. Or Gentiana ro. We may call this in Englih, Small Autumne Gentian. 
9) Their Temperature and Vcrtues.

Thefe by their tafte and forme thould be muchlike to the greater Gentians in their operation and working,yet not altogether fo effectuall. ¥

\title{
C і A P. 106. Of CalatbianViolet,or eAutumne Bel-floure.
}

\author{
T The Defeription.
}

A Mong the number of the hafe Gentians there is a fmal plant,which is late before it eommeth vp, hauing ftalk $s$ a fpan high, and fometimes higher, narrow leaues like vnto Time, fet by couples about the ftalkes by certaine diftanees: long hollow floures growing at the top of the ftalks, like a eup ealled a Beaker, wide at the top, and narrower toward the bottome, of a deepe blew eolour tend ing to purple,w ith eertain white threds or chiues in the bottome: the foure at the mouth or brim is fiue cornered before it be opened, but when it is opened it appeareth with fiue elifts or pleats. The whole plant is of a bitter tafte, which plainly fheweth it to be a kinde of wilde Gentian. The root is fnall, and perineth when it hath perfegted his feed, and reeouercth it felfe by falling of the fame.

Pneumonanthe?

Calathian Violer.

Gentiana. Preumonar the

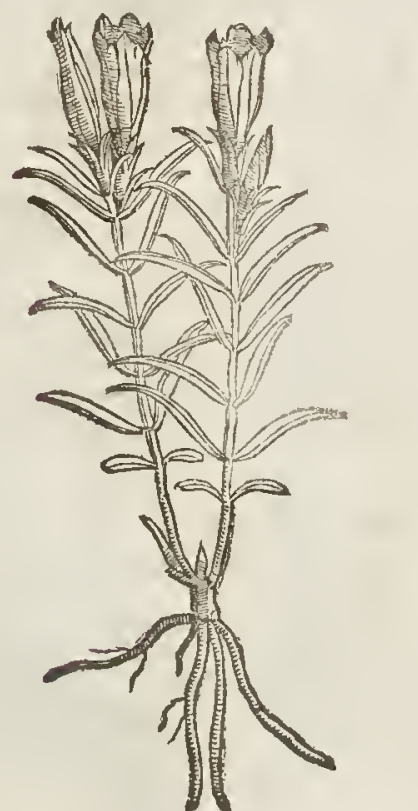

T The Place.

It is found fometimes in Meadowes, oftentimes in vntilled places. It groweth vpon Long-field downes in Kent, neere vito a village ealled Longfield by Grauerend,vpon the chalkie eliffes necre Greene-Hythe and Cobham in Kent, and many other places. It likewife groweth as you ride from Sugar-loafe hill vnto Bathe, in the Weft eountrey.

₹ This plant I neuer found but once, and that was on a wet Moorifh ground in Lincolnthire, 2 .or 3.miles on this fide Cafter, and as I remember, the place is called NerletonMoore. Now I fufpeit that our Authour knew it nor; firf, becaufe he deferibes it with leaues like vinto 'Tine, when as this hath long narrow leaties more like to Hyftop or Rofemary. Secondly, for that he faith the root is fnall \& perinheth when as it hath perfected the feed:whereas this hath a liuing, ftringie and ereeping ront. Befides, this feldome or neucr growes on chaikie cliffes, but on wet Moorith grounds and Heaths:where. fore I fufpect our Authour tooke the Imall Autumne Gentian (defcribed by me in the fourth place of the laft Chapter) for this here treated of. $\neq$

$$
\text { The Time. }
$$

The gallant floures hercof be in their brauerie about the end of Auguft, and in September.

$$
\text { T) The Names. }
$$

‡ This is thought to be Viola Calathiana of Rullius, yet not that of Pliny; and thofe that defire to know more of this may hate recourfe to the twelf th chapter of the firft booke of the 2.Pempt. of Dodon. his Latine Herball, whence our Authour tooke thofe words that were formerly in this place, though he did not well rnderftand nor expreffe them $\neq$. It is called Viola Autumnalis, or Autumne Violet, and feemeth to bee the fame that $V$ alerims Cordus doth call $P$ neumonanthe, which he faith is named in the Germane tongue Zungen blua men, or Lung-floure : in Englinh,Autumne Bel-floures, Calathian Violets, and of fome, Harueftbels.

$$
\text { Tा The Temperature. }
$$

This wilde Felwoort or Violet is in Temperature hot, fomewhat like in facultie to Gentian, whereof it is a kinde, but farwealer in operation.

$$
\text { T) The Vertues. }
$$

A The latter Phyfitions hold it to be effectuall againft peftilent difeafes, and the bitings \& ftingings of venomous benfts. 
Lrв. 2. Of the Hiftory of Plants:

\section{C н A P.109. Of Venus Looking-glaj]e. \\ T The Defcription.}

I Efides the former Bel-floures, there is likewife a certaine other, which is low and little;

B the ftalkes whereof are tender, two fpans long, diuided into many branches moft commonly lying vpon the ground. The leaues about the falks are little, ileightly nicked in the edges. The floures are fmall, of a bright purple colour tending to blewnes, very beautifull, w ith wide mouths like broad bels, haung a white chitue or thred in the middle. The Houres in the day timeare wide open, and about the fetring of the Sun are fhut vp and clofed fatt together, in fiue comers, as they are before their firt opening, and as the other Bel-floures are. The roots be verie flender, and perifh when they haue perfected their feed.

$\ddagger 2$ There is another which from a fnall and wooddy roor fendeth vp a ftraight ftalk, fometimes but two or threc inehes, yet otherwhiles a foot high, when as it lights into grod ground. This ftalke is crefted and hollow, hauing little longith leates crumpled or finuated about the edges fet thereon: and out of the bofomes of thofe leaues towards the top of the ltalke and fonetimes lower, cone little branches bearing littlewinged ends, at the tops of which in the middeft of fue little greene leaues ftand fmall purple floures, of little or no beauty; which being patt the eods become much larger, and eontainc in them a fmallyellowifh feed, and they ftill retaine at their tops the fute longih greene leaues that incompaffed the floure. This plant is an annuall like as the former. $\neq$

I Speculum Veneris.

Venus Looking-glafe.

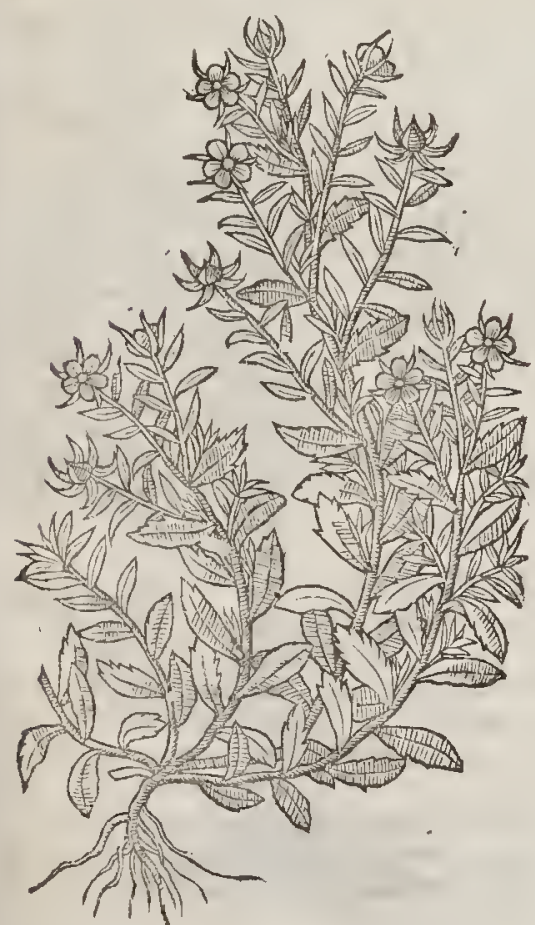

¥ 2 speculum Veneris minis. Codded eorne violet. Campanila hyGica

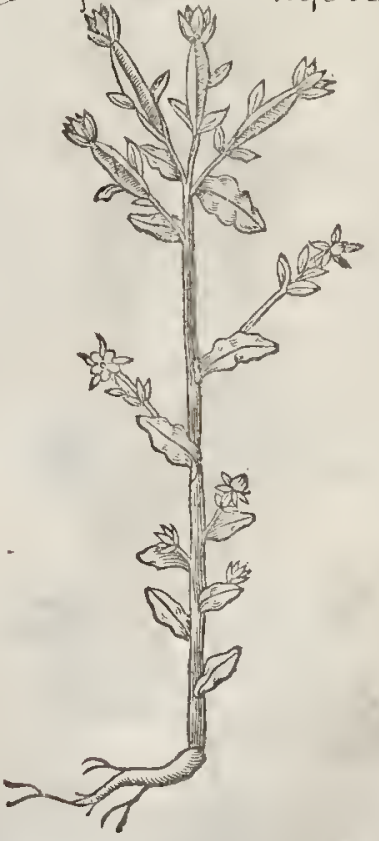

4 The Place.

It groveth in ploughed fields among the eorne, in a plentifull and fruitfull foile.I found it in a field anong the corne by Greene-hithe, as I went from thenee toward Dartford in Kent, and in many other places thereabout, but not elfwhere: from whenee I brought of the feeds for my Garden, where they come vp of themfelues from yeare to yeare by falling of the feed.

† That which is here figured and deferibed in the firt place I neuer found growing in Eng: 
land, I haue feene only fome branehes of it brought from Leiden by my friend $\mathrm{M}^{\mathrm{r}}$. William Parker. The other of my defcription I hauc clisers rimes found grow ing among the eorn in Chelfey field, and alfo haue had it brought me from other places by $\mathrm{M}^{\mathrm{I}}$. George Bonls, \& $\mathrm{M}^{\mathrm{r}}$. Lconard Buckner. बi The Time.

It floureth in Iune and luly, and the feed is ripe in the end of Augunt.

9] The Nimes.

It is called Campana Aruenfes, and of fone onobrychis, but vnproperly, ofother Cariophyllus fegewmm, or cone Gillofloure, or Corne pinke, and speculwm Veweris, or Ladies glaffe The Brabanders in their tongue call it trotwit Spiezel,

† Tabernamont amms hath two figures there of, the one vnder the name of Violnarwangs, and the other by the title of Viola Pentagonia, becaufe the floure hatl fiuc folds or corners. 2 This of my defcription is not mentioned by any Authour; wherefore I am content to follow that mamewhich is giuen to the former, and terme it in Latine Speculum Vereris minus : and from the colour of the foure and codded feed veffell, to call it in Englifh, Codded Corne Violet.

बा The Temperature and Veriues.

We haue not found any thing written either of his vertue or temperature, of the antient or late Writers.

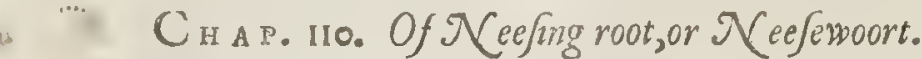

Helleborus albis.

White Hellebor.

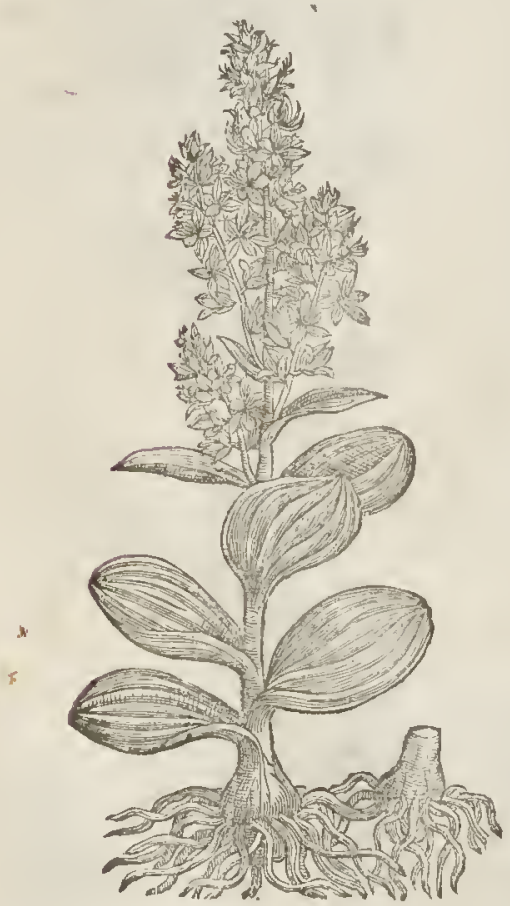

2 Helleborus albus pracox. Timely white Hellebor.

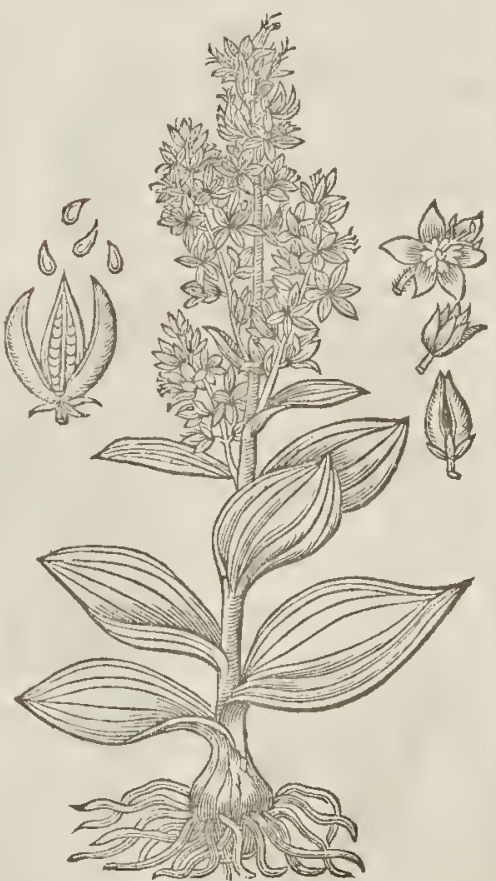

II The Defcription.

1. He firft kinde of white Hellebor hath:leaues like vnto great Gentian, but much broader, and not vnlike the leaues of the great Plantaine, folded into pleats like a garment pleated to bee laied vp in a cheft; amongft thefe leaues rifeth vp a falke a cubite long, fet 
towards the top full of little ftarte-like floutes, of an herbiegreen eolour tending to whiteneffe, which being paft there come fmall huskes eontaining the feed. The root is great and thicke,witl] many fmall threds hanging thereat.

2 The feeond kinde is very like the firf, and differeth in that, that th is hath blacke teddin floures, and eommeth to flouting before the othet kinde, and feldome in my garden eommeth to feeding.

$$
\text { T) The Plate. }
$$

The wbite Hellebor groweth on the Alps, and fuch like mountains where Gentian doth grow. It was reported vnto me by the bihhop of Norwich, that white Hellebor groweth in a wood of his owne neere to his houfe at Norwieh. Some fay likewife that it doth grow vpon the Mountaines of Wales. I fpeake tbis vpon report, yet I thinke not, but that it may be true. Howbeit I dare affute you, that they grow in my garden at London,whete the firft kinde foureth and feedeth very well.

The fitt floureth in Iune, and the feeond in May.

$$
\text { बा The Tinte. }
$$

$$
\text { Tा The Names. }
$$

Neefewoort is ealled in Greeke imigopos aroxiss: in Latine, Veratrum Album, Helleborus albus, ahd Sam. guis Herculeus. The Germans eall it meifł niefwurt: the Dutchmen, fitefmotel: the Italians, Elleboro bianco: The Spaniards, Verde gambre blanco : the French, Ellebore blanche: and we of England eall it white Hellebor, Niefwoort, Lingwoort, and the root Neefing pouder.

\section{बा The T emperature.}

The root of white Hellebor, is hot and dtie in the thitd degtee.

\section{The Vertuss.}

The root of white Hellebor proeureth vomite mightily, wherein confifteth his chiefe vertue, $A$ and by that means voideth all fuperfitous flime and naughtie humors. It is gond againft the falling fiekneffe, phrenfies, fcia tica, dropfies, poifon,and againft all eold difeafes that bee of hard cti: ration, and will not yeeld to any gentle medieine.

This ftrong medicine made of white Hellebor, ought not to be gitten inwardly vinto delicate B bodies without great eorredion,but it may more fafely be gitten vnto Country people which feed groffely, and haue hard, rough, and ftrong bodies.

The root of Hellebor cut in fmall piees, ftreh as may aptly and eonuen iently be eonueied into $\mathbf{C}$ the Fiftulaes doth mundifie then, and taketh away the callous matter which hindereth curation, and afrerward they may te healed vpwith fome inearnatite vnguent, fit for the purpofe. $¥$ This facultic by Diofcorides is attributed to the blacke Hellebor, and not to this. $\ddagger$

The pouder drawne vp into the nofe catfeth fneefing, and purgeth the braine from groffe and $D$ flimie humours.

The root ginen to drinke in the weight of two penee, tak eth away the fits of agues, killeth Mice E and rats being made vp with honie and floute of wheat : Pliny addeth that it is a medieine againf the Loufie enill.

\section{Cha p.11. Of Wilderobite Hellebor.}

$$
\text { The Dcfipion. }
$$

I $T$ Elleborine is like vnto white Hellebor, and for that eaufe we haue gituen it the name of Helleborine. It hath a ftraight ftalke of a foot high, fet from the bottome to the tuft of floures, with faire leaues, ribbed and eh amfered like thofe of white Hellebor, but no thing neere fo large, of a darke greene colour. The floures bee orderly plaeed from the middle to the top of the ftalke, hollow within, and white of colour, ttra ked here and there with a dafh of purple, in thape like the floures of Satytion. The feed is fmall like duft ot motes in the Sun. The roor is fmall, full of iuice, and bitter in tafte.

2 The feend is like vnto the firf, but al together greater, and the floures white, without any mixtere at a!l,wherein eonfifteth the difierenee.

3 The thitd kind of Helleborime, being the 6 . after clusfus aecount, hath leaues like the firft deferi003 


\section{$44^{2}$ \\ Of the Hiftorie of Plants. \\ LI B. 2 .}

bed, but fmaller and narrower. The ftalke rifeth vp to the height of two fpans; at the top whereof grow faire thining purple coloured floures, eonfiftug of fix little leaues, within or among which lieth hid things like fmall helmets. The plant in proportion is like the othet of this kinde. The The root is fmall, and creepeth in the grond.

I Helleborine.

Wilde white Hellebote:

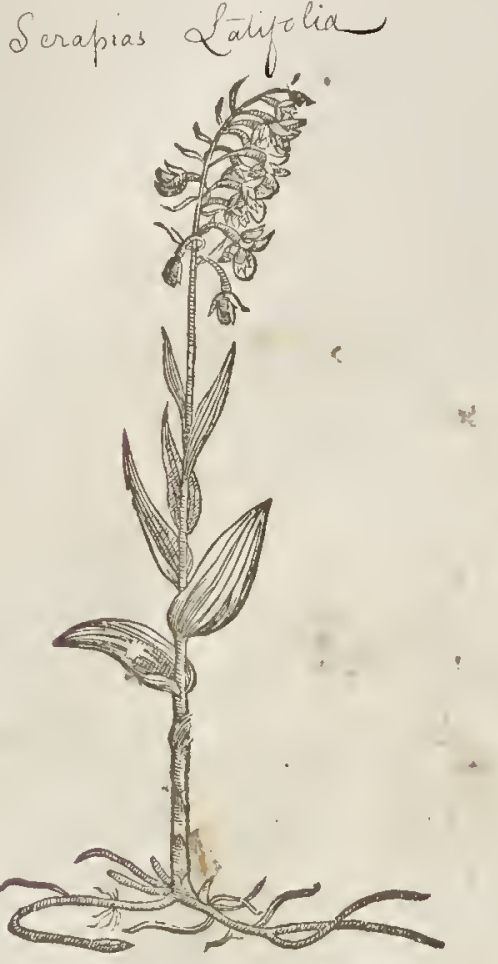

3 Helleborine anguffifolia 6. Clufij. Narrow leafed wilde Neefewoort. Serapias Songitolia $\underbrace{}_{\text {iruora }}$

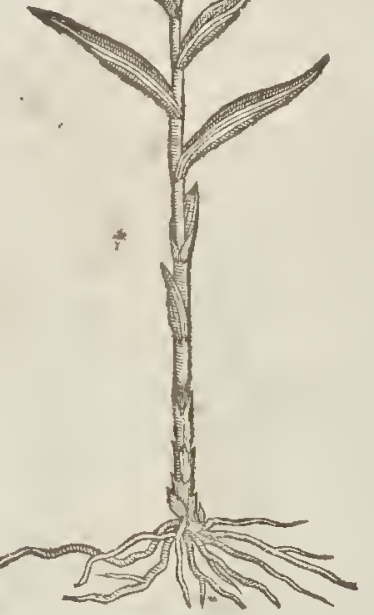

The Thlace.

They bee found in dankith and thadowie places; the firft was found growing in the woods by Digges well paftures, halfe a mile ftom Welwen in Hartfordhire:it groweth in a wood fiue miles from London, neere vnto a bridge called Loekbridge: by Nortingham neere Robinhoods well, where my friend :Mr. Stenen lirctwell a learned Phyfition found the fame: in the woods by Dunmowe in Eftex : by Southtleet in Kent; in a littlegroue of Itniper, and in a wood by Clare in Effex.

$$
\text { T The Time. }
$$

They floure in May and Iune, and perfect their feed in Augutt.

$$
\text { T) The Names. }
$$

The likeneffe that it hath wish white Hellebor, doth thew it may not vnproperly bee named

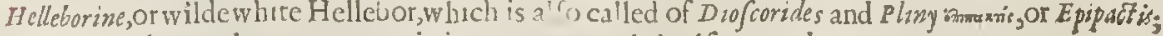
But from whenee that name came it is not aly, . crtit is alfo named anis.

They are thought to be hot and drie of nat

$$
\text { बा The Tinpsare. }
$$$$
\text { Gi } 7 \text { : } V_{\text {e }} \text { ints. }
$$

A arekindes.

The faeulties of thefe wilde Hellebors are referred unto the white Neefewoort, whereof they It is reported that the decostion of wilde Hellebor drunken,openeth the ftoppings of the Li$B$ wer, and helpeth any impetiections of the fame. 


\section{C н а . 112. Of our Ladies Slipper.}

\section{If The Defcription.}

10 Vr Ladies Shoo or Slipper hath athicke knobbed root, with certaine marks or notes vpon the fame, fuch as the roots of Solomons Seale haue, but much leffer, creeping within the vpper cruft of the earch : from which rifeth vp a fiffe and hairy ftalke a foot high, fet by cerraine fpaces with faire broad leaues, ribbed with the like finewes or nerues as thofe of the Plantaine. At the top of the ftalke groweth one fingle foure, feldo ne two, fartioned on the one fide like an egge; on the other fide it is open, cmpty, and hollow, and of the forme of a fhoo or flipper, whereof it tooke his name; of a yellow colour on the outfide, and of a thining deepe yellow on the infide. The middle part is compaffed about with foure leaues of a br: ght purple colour, often of a light red or obfcure crim fon, and fometimes yellow as in the middle part,
which in thape is like an egge, as aforefaid.

$\neq 2$ This other differs not from the former, vnleffe in the colour of the floure; which in this hath the foure long leaues white, and the hollow leafe or Ilipper of a purple colour. $\ddagger$

I Calceolus charic. Cuinis our Ladies Slipper.
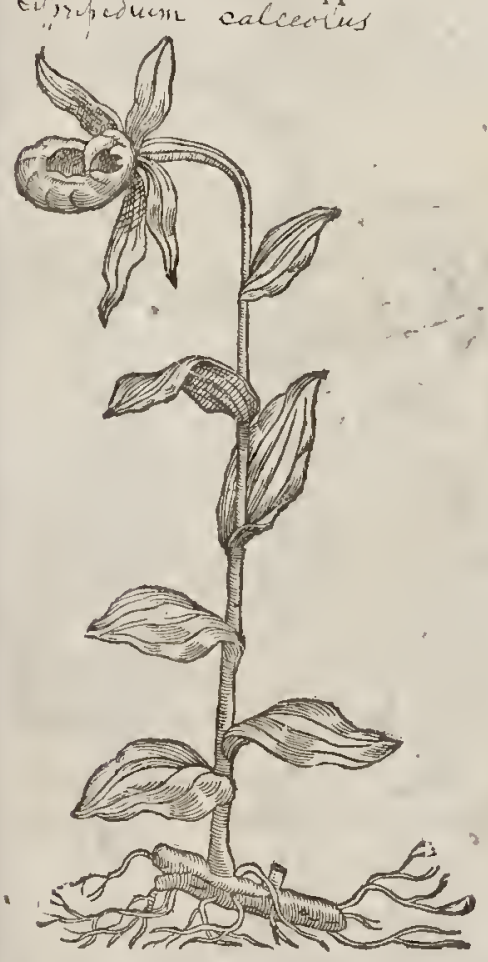

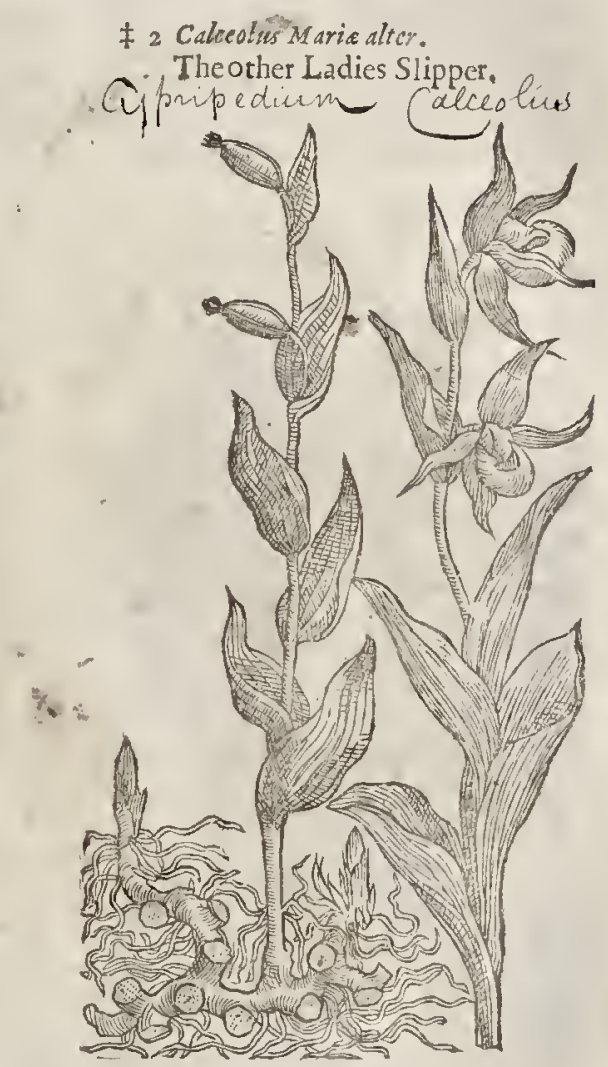

$\$ 2$ Calceotus Maric alter.

The other Ladies Slipper,

T The Place.

Ladies Slipper groweth vpon the mountains of Germany, Hungary, and Poland.I haue a plant thereof in my garden, which I receiued from $\mathrm{M}^{\mathrm{r}}$, Garret Apothecary, my very gond friend.

$\neq$ It is alfo reported to grow in the North parts of this kingdome; and I faw it in floure with Mi.Tradef cant the lait Sommer. $\ddagger$

It floureth abour the midft of Iune.

$$
\text { II The Time. }
$$

$$
\text { T The Names. }
$$

It is commonly called Calceolus D. CMaria, and Marianus: of fome, Calceolus Sacerdotis:of fome, Alifma, but vnproperly: in Englifh, Our Ladies tho; or flipper : in the Germane tongue, 13 fafter

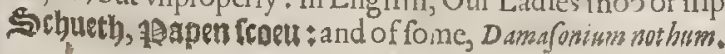




\section{If The Temperature and Vertues.}

Touching the faculties of out Ladies Shoo we haue nothing towtite, it being not fufficiently knowne to the old Writers, no nor to the new.

\section{Cha P.113. Of Sope-wort. \\ T) The Defeription.}

$\mathrm{T}^{\mathrm{H}}$ He falkes of Sope-wott ate flippet ie, flender, round, ioynted, a cubit high or higher : the leates are broad, fet with veincs vety like broad leaued Plantaine, but yet lefler, ftanding out of euery ioynt by couples for the mott part, and efpecially thofe that are the neereft the roots bowing backwards. The floures in the top of the ftalkes and about the vppernoft ioynts are many, well finclling, fometimes of a beautifull red colour like a Rofe; orher-while of a lighr purple or white, which grow out of long cups confilting of fune leaucs, in the middle of which are certaine little threds. The roots are thicke, long, creeping aflope, hauing certaine 1trings langing out of them like to the roots of blacke Hellebor: and if they hatue once taken good and fur $=100$ ting in any ground it is impoffible to deftroy them.

$\neq$ There is kept in fome of our gardens a varietie of this, which differs from it in that the floures are double and fomewhat larger : in other refpects it is altogether like the precedent. $\neq$.

I Saposaria. Sope-wott, or Brufe-wott.

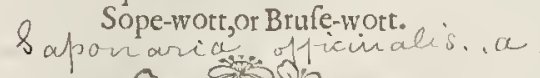

A

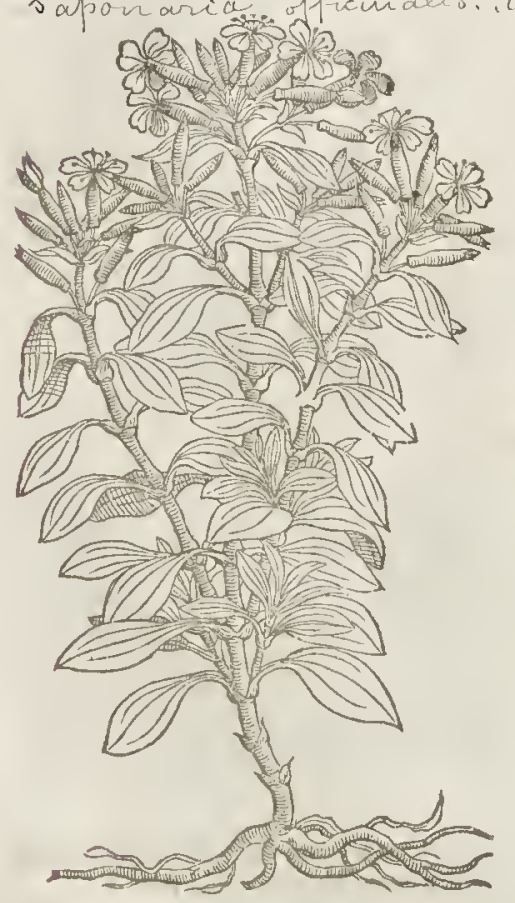

of The Place.

It is planted in gardens for the floures fake, to the decking vp of houres, for the which purpofe it chiefely ferueth. It groweth wild of it felfe neere to riners and running brookes in funny places.

$$
\text { बा The Time. }
$$

It floureth in Iune and Iuly.

$$
\text { If The Names. }
$$

It is commonly called Saponaria, of the gteat fcouring qualitie that the leates hate: for they yeeld out of themfelues a certaine inyce when they are bruifed, which fcoureth almo? as well as Sope: although Ruelliws defcribe a certaine other Sopew ort. Of fome it is called Alifm, or Damafonium: or others, Saponaria Gentiana,whereof doubtleffe it is a kinde : in Englifh it is called Sopewort, and of fome Bruilewort.

T The Temperature and Verutes.

It is hot and dry, and not a little fcouring withall, hauing novfe in phyficke fet dorvi.e by any Author of credit.

‡ Although our Authour and fuch as before him hate written of Plants were ignorant of the facultie of this herbe, yet hath the induftrie of fome later men found out the vettue thercof:and Septalius reports that it was one Zapatd a Spanifh Empericke. Since whofe time it hath beenewritten of by Rudrus, lib. 5 . de morbis occult. \& venenat. cap. 18. And by Cafar Clasidinus, de ingreffu ad infirmos, pag. $41 \mathrm{1}$. o pag. 417. But principally by Ludouicus Septalius, Animaduerf. med. lib. 7. mum. 2 14. where treating of decoetions in vfe araint the French Poxes, he mentions the fingular effect of this herb againft that filthy difeafe. His words ate thefe: I muft not in this place omit the vfe of another A lexipharmicall decoction, being very effectuall and vfefull for the poorer fort; namely that which is made of Sore-wort, an herbe common and knowne to all. Moreoucr, I have fomctimes ved it with happy fuccerfe in the moft contumacious difeafe : but it is of fomerv hat an vingratefull tafte, 
and therefore it muft be refetued for the poorer fort. The decotion is thus made : R. Snwanaric an

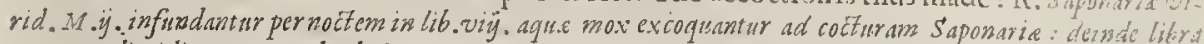
wha crsm dimidia aque cum berba inm coct a cxcoletur cume expreßione, gue refeructur pro potione matt utina ad fudores proliciendos fumendo $\overline{3}$ wij. ant viï, quod vero fupereft dulcorctur cum paffulis aut faccaro pro porse cum cibus : aftate \& biliagis naturis addi poterit aut Sonchi, aut Cymbalaria M.j. Valet or pro mulicribus ad

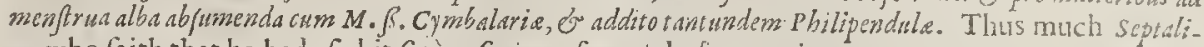
us, who faith that he had ved it fepè ac fepius, often and often againe.

Some haue eommended it to be very good to be applied to greenewounds, to hinder inflamma- $B$ tion, and fpeedily to heale them. $\neq$

\section{Ch A.114. Of Arfmart or Water-Pepper. \\ - The Defription.}

I Rfmatt bringeth forth falkes a eubit high, round, fmooth,ioynted or kneed, dividing themfelues into fundry branehes; whereon grow leaues like thofe of the Peach or of the Sallow tree. The floures grow in elufters vpon long ftems, ont of the bofome of the branehes and leaues, and likewife vpon the falkes themfelues, of a white colour tending to a bright purple : after which eommeth forth little feeds fomewhat broad, of a reddifh yellow, aud fornetimes blackinh, of an hot and biting tafte, as is all the reft of the Plant, and like vnto pepper, whereof it tooke his name; yet hath it no fmell at all.

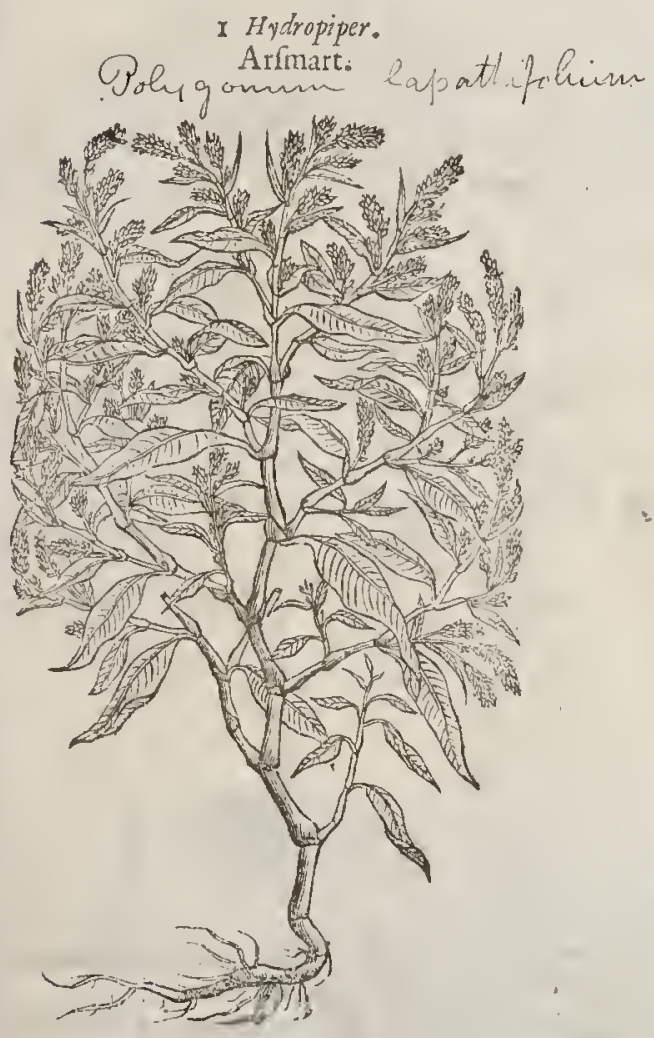

2 Perficarionaculora.

Dead or fpotted Arfmart.

Poligo oumm Cjersicarea

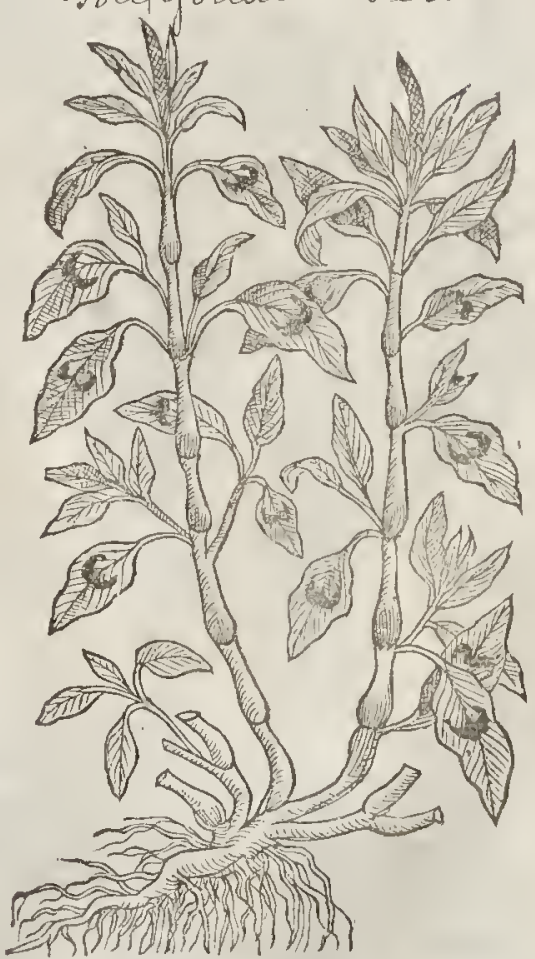

2 Dead Arfmart is like vnto the precedent in ftalkes, cluftering floutes, roots and feed, and differeth in that, that this plant hath certaine fpots or marlss vpon the leaues, in farhion of a halfe moone, of a darke blackith eolour. The whole plant hath no fharpe or biting tafte, as the other hath, but as it were a little foure fmackevpon the tongue. The root is likewife full of atrings or threds, creeping vp and downe in the ground. 


\section{Of the Hiftory of Plants.}

L 1 B. 2.

$\ddagger 3$ This in roots, leaues, and manner of growing is very like the fitf defcribed, but leffer by much in all thefe parts : the ficures alfo are of awhition, and fometimes of a purplinh colour: it growes inbarren grauelly and wet places.

4 I hate thought good to omit the impertinent defctiption of our Author fitted to this plant, and to gitue one fomewhat more to the putpofe : the ftalkes of this are fome two foot high, rendet, greene, and fometimes purplith, lollow, imooth,fucculent and tran furent, with large and eminent ioynts, from whence proceed leatres like thofe of French Mercurie, a little bigger, and broader toward their ftalkes, and thereabout alfo cut in with deeper notches: ftom the bofomes of each of thefe leaues come forth long ftalkes hanging downewatds, and ditided into thtee ot foure branches, ypon wh ich hang foures yel! ow, and much gaping, with crooked fputs or heeles, and fpotted alfowith red or fanguine fpors : after thefe are paft fucceed the cods, which containe the feed, and they are commonly two inches long, flender, knotted, and of a whitith greene co'our, crefted with greenith lines; and as foone as the feed begins to be ripe, they are fo mpatient that they will by no meanes be touched, but refently the feed will fly out of them into your face. And this is the caufe that Lohel and others late called this Plant Noli me tangere. As for tl:e like teafon fo ne of late haue impole.i the fame name vpon the Sium minimum of Alpinus, formerly defcribed by me in the feuenth place of the eighteenth chapter of this booke, pag.260. $\neq$

\$ Perficariapufilla repens. Small creeping A rfmart.

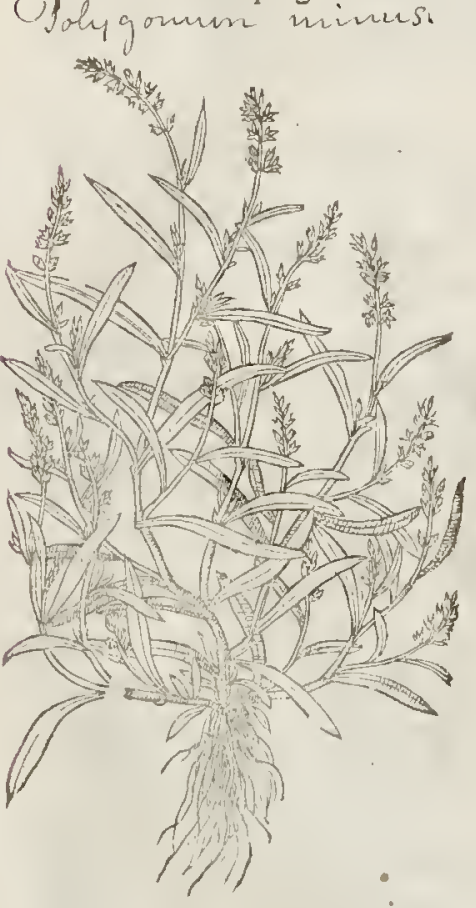

4 Perficariafiliguola.

Codded Arfmart.

Jmpatiens Moli-me-Langere

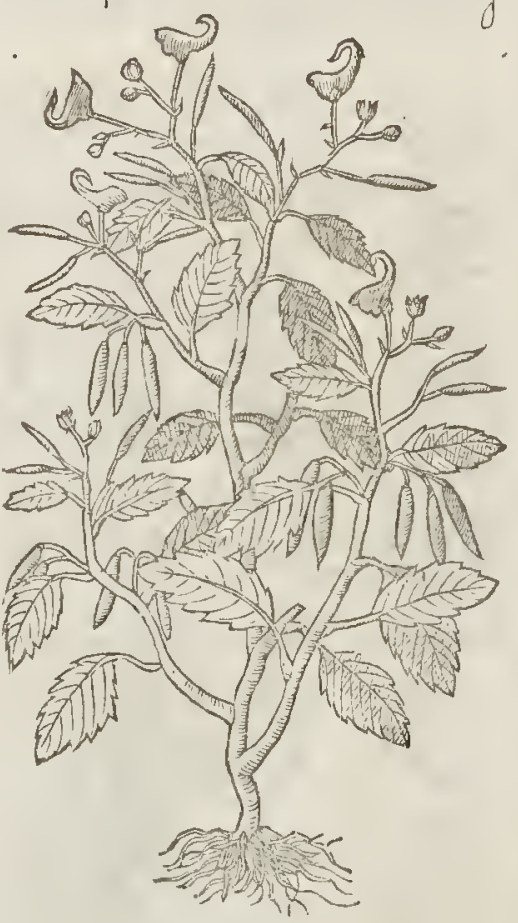

T) The Place and Time.

They grow very commonalmof euery where in moift and waterith plathes, and necte vnto the brims of rimers, ditches, and running brookes. They floure from Iune to Auguit.

₹ The codded or impatient Arfmart was freft found to grow in this kingdome by the induftrie of my good friend $M^{5}$. George Bomles, who found it at thefe places : firft in Shropfhire, on the bankes of the rituer Kemlet at Marington in the parifh of Cherberry, under a Gentlemans houre called Mr. LLoyd; but efpecially at Guerndee in the patith of Cherfocke, halfe amile from the forefaid Riuer, among ft great Alder ttees in the highway. $\neq$

$$
\text { of The Names. }
$$

$\mathrm{r}$ - Arfmart is called in Grecke serniaes: of the Larines, Hydropiper, or Piper aquaticum,or Aqua-

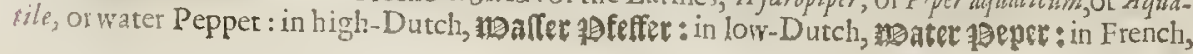


Curage, or Culrage : in Spanith, Pimenta aquatica: in Englin, V'ater-Pepper, Culrage, and Arífmart, according to the operation and effe $f$ when it is vfed in the abfterfion of that part.

2 Dead Arfmart is called Perficaria, or Peach-wort, of the likeneffe rhat the leaues hatewieh thofe of the Peach tree. It hath beene called Plumbaro of the leaden co!oured markes whicl are feene vpon it : but Pliny would hate Plsmbago not to be focalled of the colour, but rather of the effect, by reafon that it helpeth the infirmitic of the eyes called Plumbum. Yet there is another $P$ lum. bago which is rather thought to be that of Plinies defcription, as thal be fhered in his proper place. In Englifh we may call it Peach-wort, and dead Arfmart,becaufe it dorh nor bite thofe places as the otherdoth.

$¥ 3$ This is by Lobel fet forth, and called Perficaria pufilla repens : of Tabernamontanus, Pcrficaria pumila.

4 No plant I thinke hath found more varietie of names than this: for T ragus calls it Mercuria-

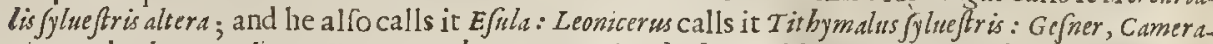
rius, and others, Nolime tangere: Dodonaus, Impatiens berba: Cafalpinus, Catanance altera: in the Hift. Lugd. (where it is fome three times ouer) it is called befides the names gituen it by others, Cliry $\int_{k a:}$ Lobel, Thatius, and others call it Perficaria fliquofa! yet none of the fe well pleafing Columna, he liath accurately defcribed and figured it by the name of Balfamita altera : and fince him Bawbine hath named it Balfamina lutea : yet both the fe and moft of the other keepe the title of Noli me tangere. $\neq$

\section{The Temperature.}

Arfmart is hot and dry, yet not fo hot as Pepper, according to Galen.

Dead Arfmart is of temperature cold, and fomething dry.

\section{T The Vertues.}

'The leaues and feed of Arfmart dowafte and confumeall cold fwellings, diniolue and fcatter A congealed bloud that commeth of bruifings or ftripes.

The fame bruifed and bound vpon an impoltume in the ioynts of the fingers (called among the $B$ vulgar forta fellon or vncome) for the fpace of an houre, taketh away the paine : but (faith the Author) it mult be firft buried vnder a ftone before it be applied; which dorh fomewhat difcredit the medicine.

The leates rubbed vpon a tyred jades backe, and a good handfull or two laid vnder the faddle, $\mathrm{C}$. and the fame fet on againe, wonderfully refrefheth the wearied horfe, and caufeth him to traucll much the better.

It is reported that Dead Arfmart is good againf inflammations and hot fwellings, being ap- D plied in the beginning: and for greene wounds, if it be ftamped and boyled with oyle Oliue,waxc, and Turpentine.

\# The faculties of the fourth are not yet knowne. Lobel faith ithath a venenate qualitie : and $\dot{\mathrm{E}}$ Tragus faith a vomitorie : yet neither of them feemes to affirme any thing of certaintie, but rather by heare-โay. $\ddagger$

\section{C н з. 115. Of Bell-Flowres.}

\section{IT The Defcription.}

$\mathbf{I}$ $\longrightarrow 0$ Ouentry-Bells haue broad leaues rough and hairy, not vnlike to thofe of the Garden Bugloffe, of a fwart greene colour : among which do rife vp ltiffe hairie ftalks the fecond yeare after the fowing of the feed : which ftalkes diuide themfelues into fundry branches, whercupon grow many faire and pleafant bell-floures, long, liollow, and cut on the brim with fue fleight gafhes, ending in fuc comers toward night, when the floure thuttech it felfe vp, as do moft of the Bell-floures :in the middle of the floures be three or foure whitith chitues, as alfo much downy haire, fuch as is in the eares of a Dog or fuch like beat. The whole floure is of a blew purple colour : which being paft, there fucceed great fquare or cornered feed-veffels, diuided on the infide into diuers cels or chambers, wherein doe lie fcatteringly many fmall browne flat feeds. The root is long and great like a Parfenep, garnifhed with many threddy ftrings, which perifheth when it hath perfected his fecd, which is in the fecond yeare after his fowing, and recouereth it felfe againe by the falling of the feed.

2 The fecond agreeth with the firft in each refpect, as well in leaues, ftalkes,or roots, and differeth in that, that this plant bringeth forth milke-white floures, and the other not fo. 
Viola Mariana. Blew Conentry-Bells.

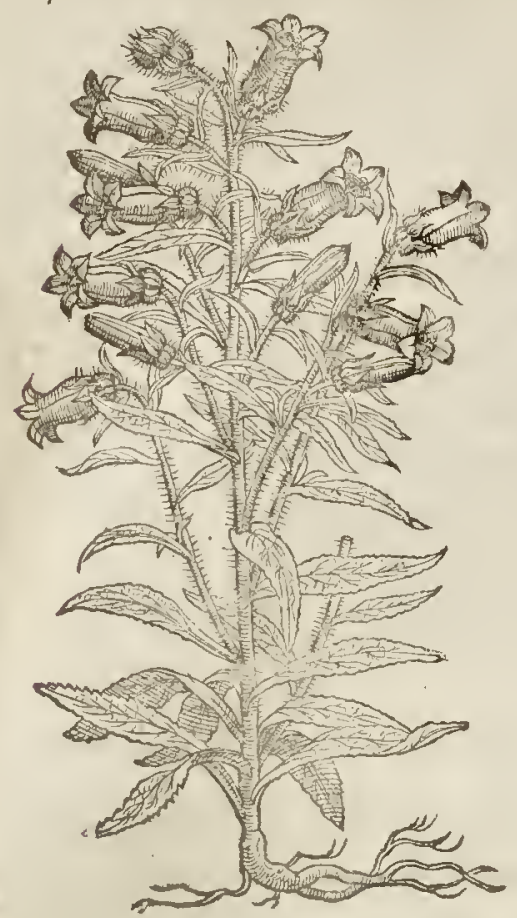

I The Phace and I ime.

They grow in woods, monntaines, and batke vallies, \& vnder hedges among the buhlece, efpecially about Conentry, whote they grow tery plentifully abroad in the ficlds, \& are there called Couentry-bcls ; and of fome abour London Canturbury-bels, but inproperly, or that there is another kindc of Eell-toure growing in Ke1t about Canturbury, which manom fitly be called Canturbury-bells, becaure they stow there more plentifully than iu any other Country. Thefe pleafint Bel-foures we hate in our London gardens efpecially for the beauty of their floure, although they be kinds of Ranjpions, and the roots eaten as Rampions are.

They floure in Iune, Inly, and A uguft; the feed waxeth ripe in the meanc tine; for thefe plants bring not forth their floures all at once; but when one floureth another feederh.

$$
\text { If The Nomes. }
$$

Courentry bels are called in Iatine Viola Mariana : in Englifh, Mercuries viole ts, or Couentry Rapes; and of fome, Mariets. It hath bin taken tobe Medium,but rnfitly : of fome it is cal-

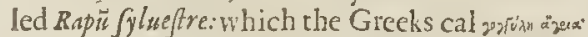
T The Temperature and leriues.

The root is cold and fomewhat binding, and notvfed in phyficke, but only for a fallet root boyled and eaten with oyle, vineger, and pepper.

CHAP.116. Of Tbroat-wort, or Canturbury-Bells.

Trachelium majus.

Blew Canturbury-Bels?

Campanmea Srachelium

3 Tyachel majus Delg. frue Gigantcum.

Gyant Throatwort.
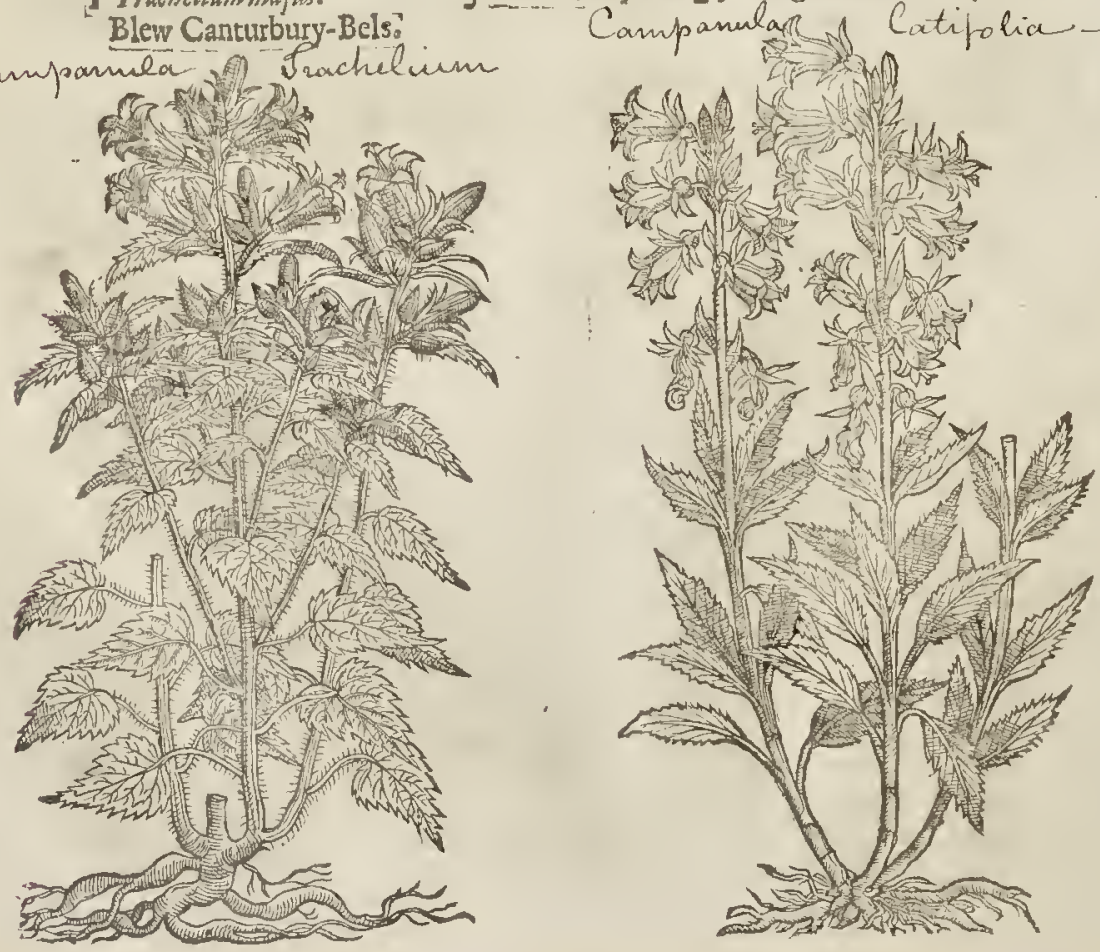


\section{T. The Defription.}

17 certaine fquareneffe, diryiding hath rough and hairy birtle ftalkes, erefted into a very rough tharpe pointed leanes, cut about the diuers branches, whereupoin dogrow folike the leaues of nettles, that it is hard to bnow about the edges like the teetlo of a fawe; and The floures are hollow, hairy within, and of a perfe bne from the other, but by touching then. Conentry bells. The root is white, thicke, and kept a variety hereof hauing double foures.

2 The white Canterbury bells are fo like 7

them, but by the colour of the foures. which precedent, that it is not pofible to diftinguinh other a blew, which fetteth forth the differenee.

\section{Tracbelium minus.}

Small Canterbury bells: Campanmea glo nuerata.

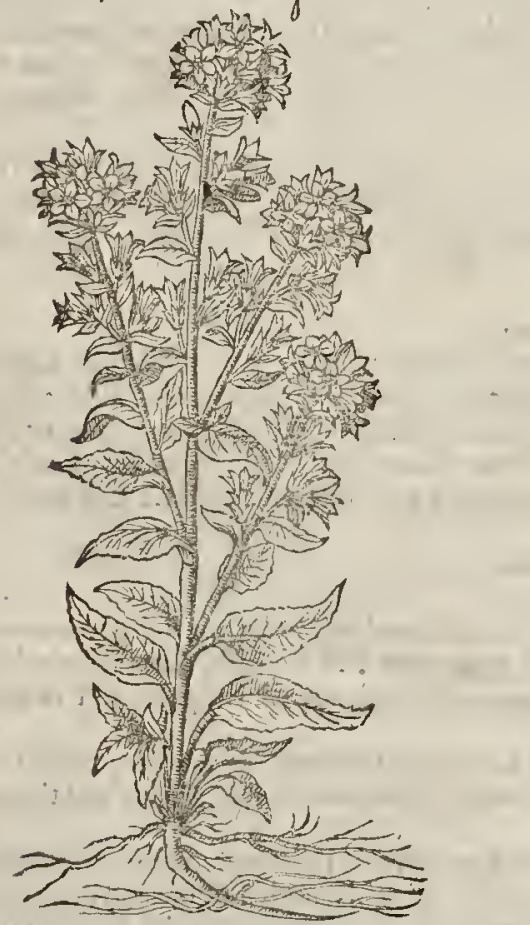

\section{₹ Trachelism majus petreum. Great Stone Throtewort.}

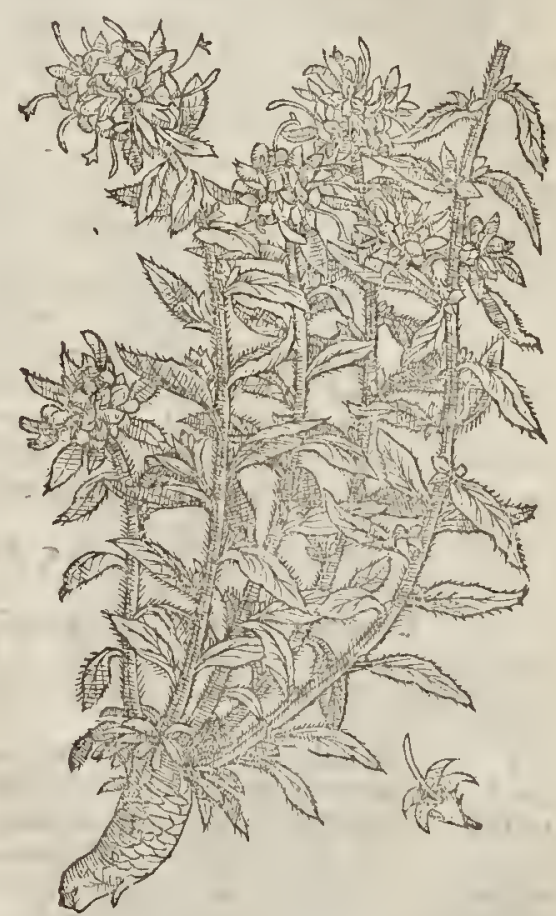

Out Author much miftaking in this place (as in many other) did againe figure and de

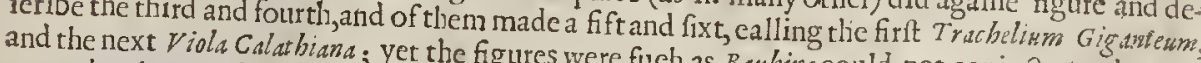
meant by them and the Gerardum, quid? but the deferiptions we faith, Trachelium Giganterm, of Viola Calathana apral tion and here giuen you the later. $t$ were better, wherefore I liaue omitted the former deferip-

3 Giants Throteroit ba

the middle like the Mort hath very large leaues of an onerworne greene co'ourr, hollowed in ftalke is two eubirs holconites fpoone, and very rough, lightly indented about the edges. The fomenfeach leafe com whereon thofe leanes are fet from the bottome to the top; from the bo. floure farhioned like a bell, of foure turne themfelues of a whitith eolour tending to purple. The pointed comers of each meth forth a fharpe ftile orelike a ferole, or the Dalmatian cap; in the middle whereof contannexed thereto.

4 The fmaller kinde of Throtewort hath falkes and leaues very likevnto the grene Then+e- 
woort, but altogether leffer, and not fo hairy: from the bofome of which leanes thoot forth very beatifull floures bell futhion, of a bright purple colour, with a fmall peftle or clapper in the middic, and in other refpects is like the precedent.

5 This from a wooddy and wrinkled root of a pale purple colour fends forth many rough crefted itallses of fome cubit high, which are vnorderly fet with leaues, long, rough, and fnipt lightly about their edgee, being of a clarke colour on the vpper fide, and of a whitin on their vnder part At the rops of the ftalkes grow the fioures, being many, and thicke thruft together, white of co'our, and diuided into fure or feuen parts,each floure hauing yellowith threds, and a pointall in their middles. It floures in Auguft, and was firt fet forth and deferibed by pona in his defeription of Mount Baldus. $\neq$

$$
\text { If The Place. }
$$

The firt deferibed and fometimes the fecond growes very plentifully in the low woods and hedgc-rowes of Kent, about Canterbury, Sittingborne, Gratefend, Southfleet, and Greenchyth, efpeeially vnder Cobham Parke-pule in the way leading from Southfeet to Roehefter, at Eltham about the parke there not furre from Greenwich; in mon of the paftures about Watford and Buthey, fiftecne miles from London.

$\neq 3$ The third was kept by our Author in his Garden, as it is alfo at this day preferued in the garden of $M^{*}$. Parkinfon: yet in the yeere i 626 I found it in great plenty growing wilde vpon the bankes of the Riser Oufe in YorkThire, as I went from Yorke to vifite Selby the place whereas I was borne, being ten miles from thence. $\ddagger$

The fourth groweth in the medow next vnto Ditton ferrie as you goe to Windfore, vpon the chalky hills about Greenehithe in Kent; and in a field by the high way as you go from thenee to Dartford, in Henningham parke in Effex, and in Sion medow neere to Brandford, eight miles from London.

The fifth growes on Mount Baldus in Italy.

$$
\text { If The Time. }
$$

All the kindes of bell floures do flonre and flourith from May vntill the beginning of Auguft, except the laft, which is the plant that hath been taken generally for the Calathian violet, whieh floureth in the later end of September; notwithtanding the Calathian violet or Autumne violet is of a moft bright and pleafant blew or azure colour, as thofe are of this kinde, although this plant fometimes changeth his colour from blew to whiteneffe by fome one accident or other.

$$
\text { I The Names. }
$$

I 2 Throtewoort is called in Latine Cersicaria, and Ceruicaria major : in Greeke, ruxinw : of moft, Imularia : of Fuchfou, Camparmla : in Duteh, Haskewoorte, Throtewoort, or $V$ smla woort, of the vertue it hath againft the paine and fwelling thereof.

$\neq 3$ This is the Trachelism majses Belgarum of Lobell, and the fame (as I before noted) that our Author formerly fet forth by the name of Trachelinm Giganteum, fo that I haue put them, as you may fee,together in the ritle of the plant.

4 This is the Trachelum maiss of Dodonews, Lobell, and others: the Ceraicaria minor of Taberna-

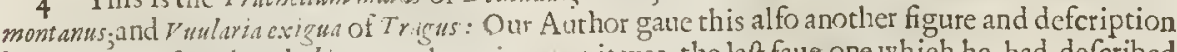
by the name of Vioia Calat hiana, noi knowing th it was the laft fate one whieh he had defcribed by the name of Trachelium minus. $\neq$

$$
\text { 7. Th. smperature. }
$$

Thefe plants are eold and dry, as are mo. Rell foures.

A The Anrients for any thing that we knis ? wentioned, and therefore not fet downe any thing concerning the vertues of thele Beit...... withttating we haue found in the laterwriters, as alfo of our owne experience, that $t: v$ a e excellent good againft the inflammation of the throte and trull or almonds, and all manner $c^{\prime \prime}$. nkers and vlcerations in the mouth, if the mouth and throte be gargarized and wafhed with the dn oction of them:and they are of all orhet herbes the chiefe and principall to be put into lotions, of wathing waters, to iniea into the priuy. parts of man or woman being boiled with hony and Allom in water, with fome white wine. 


\title{
C н А P.117. Of Peach-bells and Steeple-bells.
}

\author{
I The Defcription.
}

I THe Peach-leaued Bell-flourc hath a great number of fmall and long leaues, tifing in a great buth out of the ground, like the leaues of the Peach tree: among which rifath vp a ftalke two cubits high : alongft the ftalke grow many floures like bells, fontrime white, and for the moft part of a faire blew colour; but the bells are nothing fo deepe as they of the other kindes; and thefe alfo are more dilated or fpred abroad than any of the reft. The leed is fmall like Rampions, and the root a tuft of laces or fmall ftrings.

2 The fecond kinde of Bell-floure hath a great number of faire blewifh or Watchet floures, like the other laft before mentioned, growing vpon goodly tall ftems two cubits and a halfe high, - which are garniohed from the top of the plant vntos the ground with leates like Beets, diforderly placed. This whole plant is exceeding full of nilke, infomuch as if you do but breake one leafe of the plant, many drops of a milky iuyce will fall vpoil the ground. The root is very great, and full of milk alfo: likewife the knops wherein the feed fhould be are empty and void of feed, fo that the whole plant is al together barren, and muft be increafed with flipping of his root.

I Campanula perficifolia.

Peach-leaued Bell-floure.

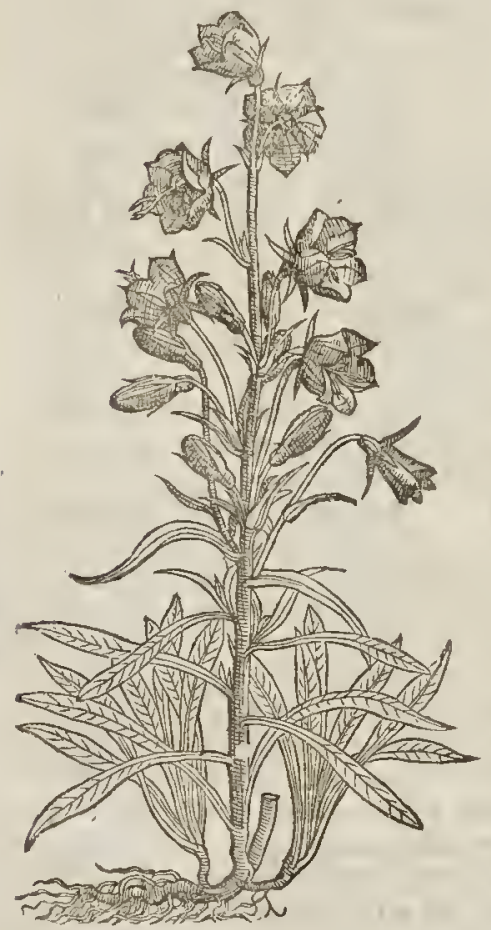

2 Camparasla lactefcens pyromidalis. Stecple milky Bell-floure.

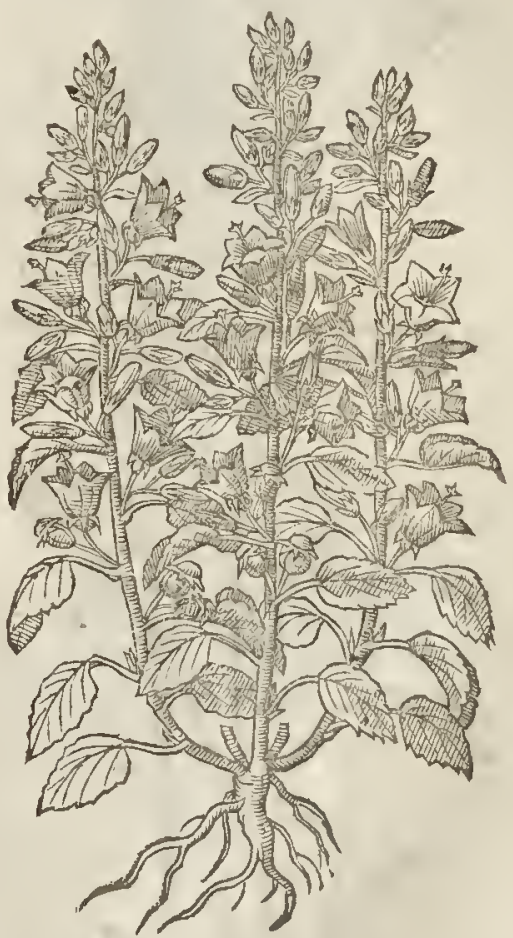

3. The finall Bell-floure hath many round leaues very like tho? $\mathrm{e}$ of the common ficld Violet, fpred vpon the ground; among which rife vp fmall flender ftems, diforderly fet with many grafie narrow leates like thofe of flax. The frnall fem is diuided at the top into fundry little branches, whereon do grow pretty blew floures bell-farhion. The root is fnall and threddy.

4 The yellow Bell-floure is a very beautifull plant of an handfull high, bearing at the top of his weake and tender ftalkes moft pleafant floures bel-fafhion,of a faire and bright yellow colour. The leaues and roots are like the preeedent, fauing that the leaues that grow next to the ground of this plant are not fo round as the former. $\neq$ Certainly our Author in this place meant to fet forth

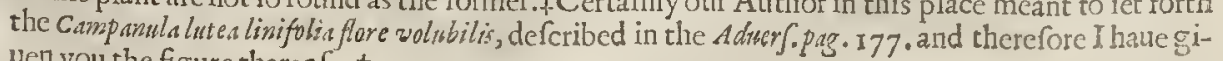
uen you the figure thereof. $\neq$ 
3 Campanularotundifolia. Round leaucd Bell-floure.

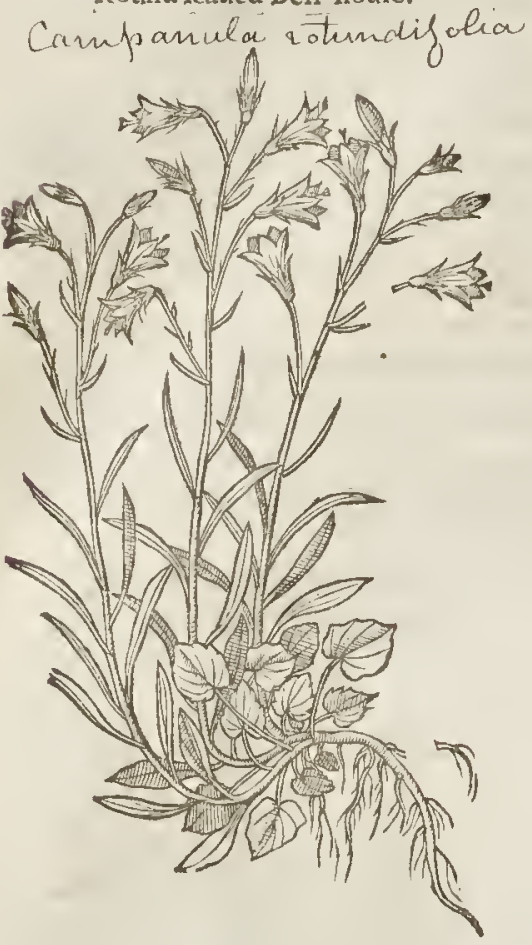

5 Campanuld minor alba, fiuepurpured. Little white or purple Bel-floure. Lampanuke patrila? -

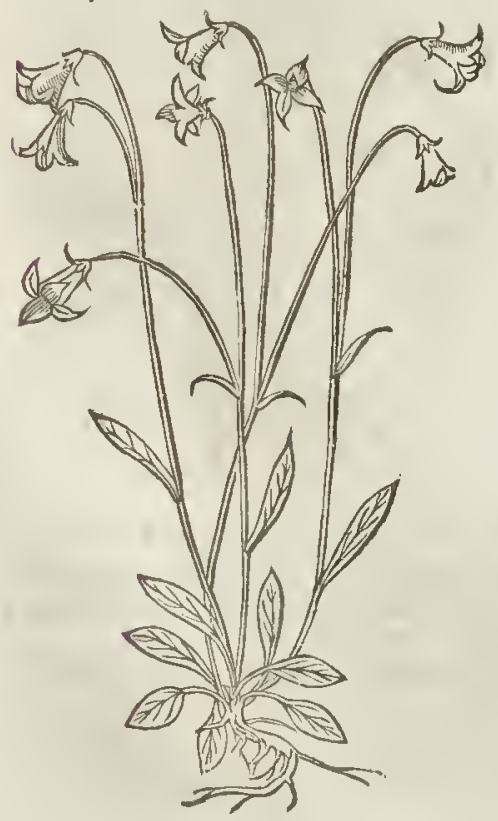

I 4 Campanula lutea linifolia. Yellow Bell-floure.

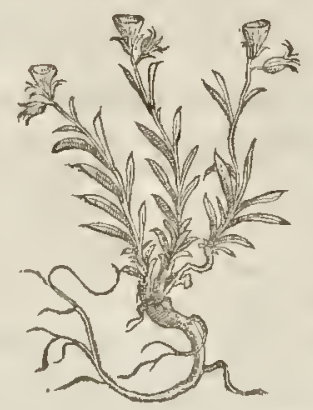

5 The little white Bell-floure is a kinde of wilde Rampions, as is that which followeth, and alfo the laft faue one beforedefcribed. This fmall plant hath a flender root of the bigneffe of a fmall ftraw, with fome few ftrings anexed thereto The leaues are fomwhat long, fmooth, and of a perfect greene colour, lying flat vpon the ground: from thence rife vp fmall tender ftalkes, fet heere and there with a few leaues. The floures grow at the top, of a nilke white colour.

6 The other fmall Bell-floure or

- wilde Rampion differeth not from the precedent but onely in colour of the floures; for as the others are white, thefe are of a bright purple colour, which fets forth the difference.

¥ 7 Befides thefe here defcribed, there is another very frmall and rare Bellfoure, which hath nor beene fer forth by any but onely by Baubine, in his Prodrom? $\mathrm{Can}$ vnder the title of Campanula Cymbalariafo- heder $i$ ijs, and that fitly, for it hath thinne and finall cornered leaues much after the maner of Cymbalaria, and thefe are fet without order on very fmall weake and tender ftalkes fome handfull long; and at the tops of the branches grow little fmall and tender Bell-Houres of a blew colour. The root, like as the whole plant, is very fmall and threddy. This pretty plant was firft difcouered to grow in England by Mafter George Bowles, Unno 1632. who found - it in Montgonerie Thire, on the dry bankes in the high-way as one rideth from Dolgeogg a Worfhipfull Gentlemans houfe called $\mathrm{M}^{\mathrm{*}}$. Francis Herbert, vnto a narket towne called Mahuntlech, and in all the way from thence to the fea fide. It may be called in Englifh, The tender Bellfloure.

9. The 
T Thi Place.

The two firft grow in our London gardens, and not wilde in England.

The reft, except that mall one with yellow floures, do grow wilde in moft places of England, efpecially vpon barren fandy heaths and fuch like grounds.

Thefe Bell-floures do floutifh from May vnco Auguft.

T The Names.

Their feuerall titles fet forth their names in Englifh and Latine, which is as much as hath been faid of them.

of The Temperature and Vertues.

Thefe Bell-floures, efpecially the foure laft mentioned, are cold and dry, and of the nature of Rampions, whereof they be kindes.

1. The figure inche fourth place ws of Rapinculus nemorofus $3^{\text {tof }}$ of $T$ bern. whereof you fhall finde mention in the following chapter-

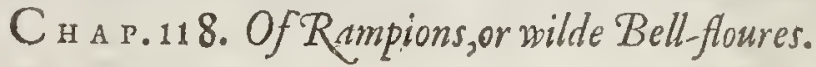

I Rapurtium majus.

Great Rampion:

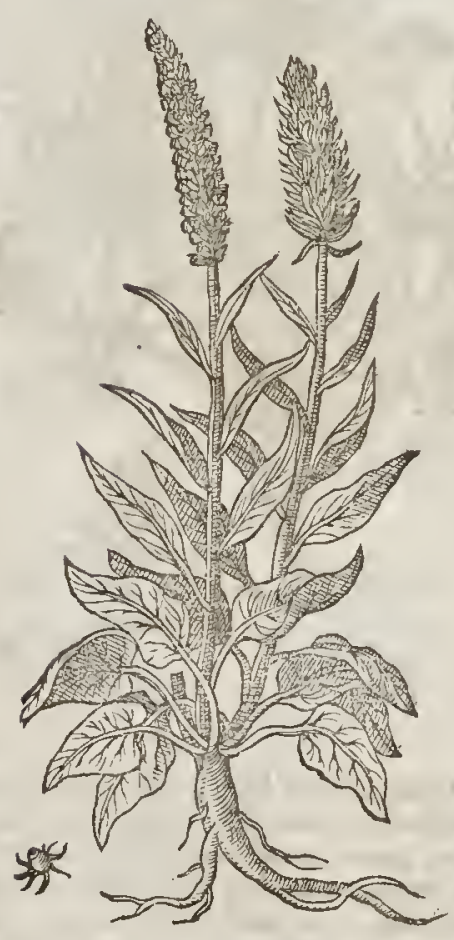

2 Rapuntium parvism. Small Rampion.

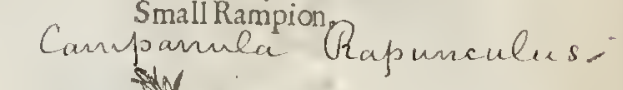

T) The Defcription.

I Hegreat Rampion being one of the Bell-floures, hath leaues which appeare or come forth at the beginning fomew hat la:ge and broad, fmooth and plaine, not vnlikexo the leatues of the fmalleft Beer. Among which rife vp ftemmes one cubit high, fer with fuch like leaties as thofe ate of the firlt fpringing vp, but fmaller, bearing at the top of the ftalke a great ticke buthy eare full of little long floures clofely chruft rogether like a Fox-taile: which fmall floures before their opening are like litrle crooked hornes, and being wide opened they are fmall blew-bells, fonerimes white, or fometimes purple. The root is white, and as thicke as a mans thumbe.

$$
\text { PP } 32 \text { The }
$$


2 The fecond kind being likew ife one of the bel-floures, and yet a wild kind of Rampion, hath leaues at his firft comming vp like vnto the garden Bell-floure. The leaues which fpring vp after. ward for the decking vp of the ftalke are fomewhat longer and narrower. The floures grow at the top of tender and britrle ftalkes like vnto little bells, of a bright blew colour, fometimes white of purple. The toot is fmall, long, and fomewhat thicke.

3 This is awilde Rampion that growes in woods: it hath fmall leaues fpred vpon the ground, blunty indented about the edges : among which rifeth vp a fraight ftem of the height of a cubit, fer from the bottome to the top with longer and narrower leaues than thofe next the ground : at the top of the Italkes grow fmall Bell-floures of a watchet blewifh colout. The root is thicke and rough, with fome few ltrings anexed thereto.

$\neq$ Thete is another varietie of this, whofe figure was formerly by our Author fet fortl in the fourth place of the laft chapter : it differs from this laft onely in that the floutes and other parts of the plant are lefler a little than thofe of the lant defer ibed. $\neq$

3 Rapunculus nemorofus.

Wood Rampions.

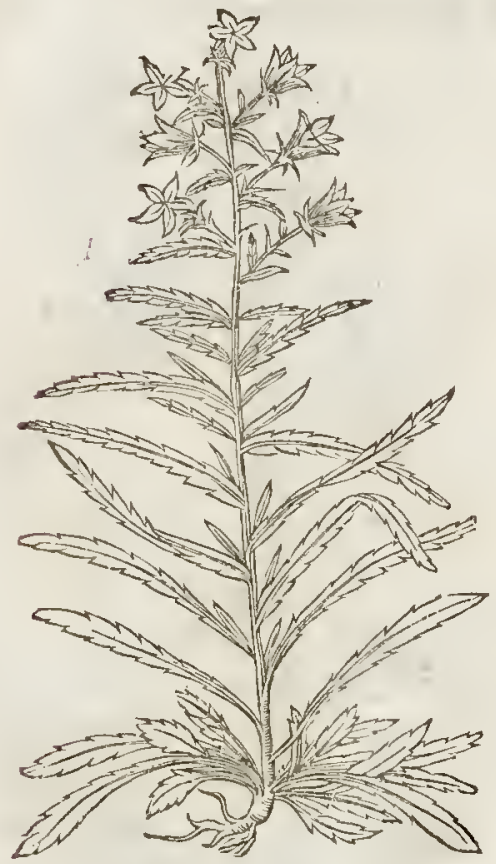

\$ 4 Rapunculus Alpinus Corniculatus. Horned hampions of the Alpes.

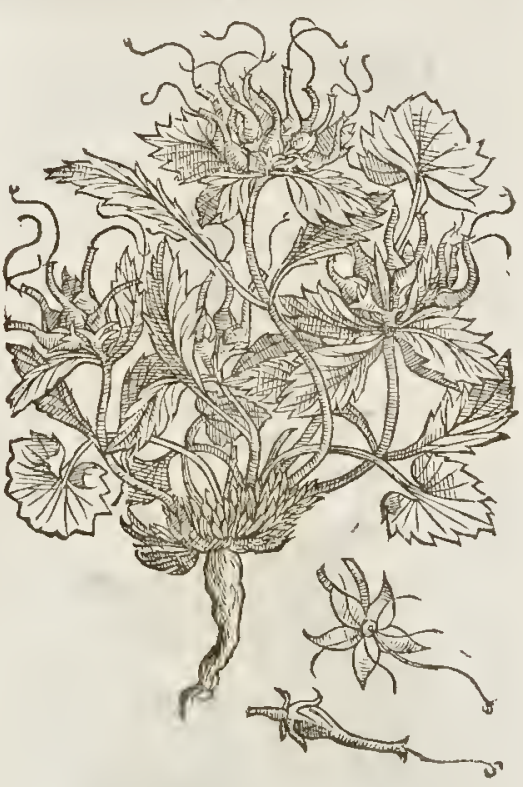

* 4 This which growes amongt the rockes in the higheft Alpes hath a wooddy and verie wrinckled root an handfull and halfe long, from which arife many leatles fet on pretty long ftalks, fomewhat round, and diuided with reafonable deepe garhes, hauing many veines, and being of a darke greene colour : among ft thefe grow vp little ftalkes, hauing one leafe about their middles, and three or foure fet about the floure, being narrower and longer than the bottome leaues. 'The flotres grow as in an vmbell, and are fhaped like that Chymicall veffell we vfually call a Retort, being big at their bottomes, and fo becomming fmaller towards their tops, and liauing many threds in them, whereof one is longer than the reft, and comes forth in the middie of the floure: it floures in Auguft. Ponawas the firft that defcribed this, vnder the name of Trachelium petrasm minus.

s The roots of this otherkinde of horned Rampion grow after an vnufuall manner; for firft or lowermolt is a root like to that of a Rampion, but flenderer, and from the top of that commeth forth as it were another root or two, being fmalleft about that place whereas they are faftned to the vnder root, and all thefe baue fmall fibres comming from them. The leawes which firnt grow v) are fmooth, and almoft like thofe of a Rampion, yet rounder,and made fomw hat after the maner of a violet leafe, but nothing fo big : at the botrome of the ftalk come forth 7 or eight long nartow 
Jeaues fnipt about the edges, and fharpc pointed,and vpon the reft of the ftalke grow alfo three or foure narrow tharp pointed lcaties. The floures which are of a purple colour at firt refe nble thofe of the laft de fcribed ; but aftcrwards parte themfclues into fue flender Atrings with rheds in the middles; which dccaying, they are fucceded by little cups ending in fue little pointels, and concaining a fnall yellow feed. This is defcribed by Fabius Columa, vinder the name of $k$ prentiven Corniculatum montanum: And I receited fecds and roots bereof fron $\mathrm{M}^{\mathrm{x}}$. Goodyer, who found it growing plentifully wilde in the inclofed chalkie hilly grounds by Maple-Durham neere Peterffield in Hamp?hire.

6 This which is defcribed in Clufus his Curapofter. by the name of Pyramidalis, and was firft found and fent to him by Gregory de Reggio a Capuchine Frier, is alfo of this kindred; wherefore I will giue you a briefe defcription thereof. The root is white, and long lafting; from which come diucrs round hairie and writhen ftalkes, about a fpan long more or leffe. At the top of thefe ttalks and all amongft the leares, grow many clcgant blew floures, which arc fucceeded by feed veffels like thofe of the leffer Trasheliwem, being full of a finall feed. The whole plant yeclds milke like as the reft of this kinde, and the leaues as well in thape as hoarineffe on their vnder fides, well refenzble thofe of the fecond French or Golden Lungwoort of my defcription. It was firf found growing in the chinkes of hard rockes about the mouthes of Caues, in the mountaines of Brefcia in Italy by the forefaid Ftier. $¥$

*5 Rapunculas Corniculatus mont dxus. Mountaine horned Rampions. Phytenma os irvalare.

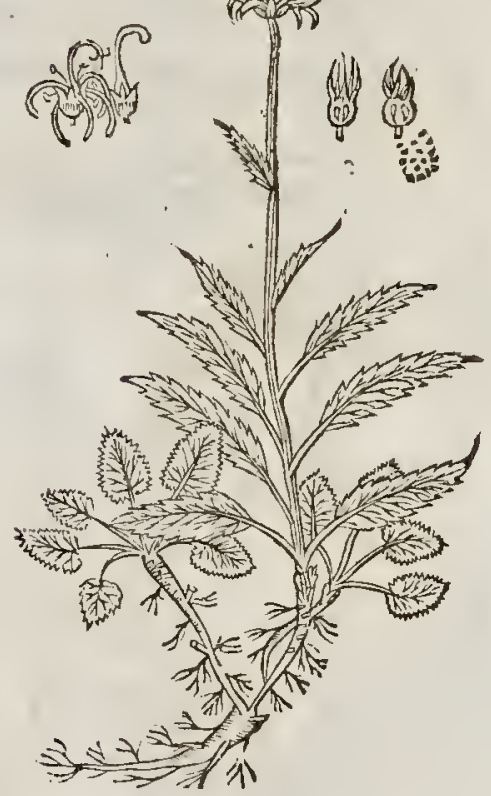

\$ 6 Raprneulus.fixatilis, fove Pyramidulis alter. Rocke Rampion.

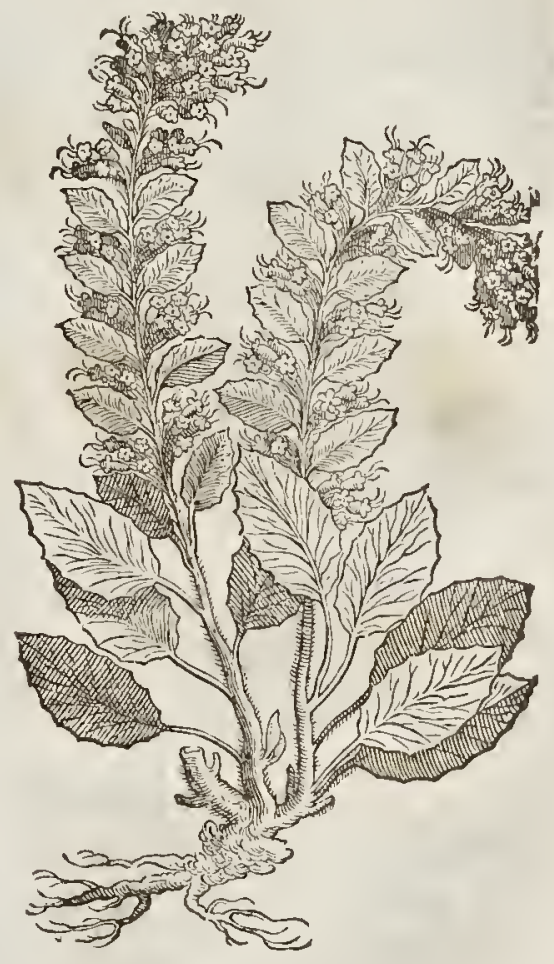

9f The Place.

The firf is fowne and fet in Gardens, efpecially becaufe the roores are eaten in Sallads. The fecond groweth in woods and thadow ie places, in fat and clayic foiles.

They floure in May, Iune, and Iuly.

$$
\text { I The Time. }
$$

Rampions by a generall name are called Rapuntium and Rapuraculus; and the firft by reafon of the long fpokie tufte of floures is called Rapuntium maiss Nlopecuri comofo flore by Lobell and Pena: Rapunculum fyluegtre, and Rapunculus fyluestris fpicatus by othets. The fecond, which 
is the ordinaty Rampion is called Rapunculus, and Rapuntium minus; Lobell thinkes it the Pes Locufte of Auicen; and Columma iudges it to be Erinss of Nicander and Difforides. The third is the Rapunculus nemor ofus fcundus of Tabernanont annes; \& the varictic of it is Rapunc.nemor tertus. Tlie names of the reft are fhewen in their deforiptions. $\ddagger$

$$
\text { का The Temperature. }
$$

The roots of thefe are of a cold temperature, and fomething binding.

$$
\text { of } T \text { he vertues. }
$$

A The ronts are efpecially vfed in fallads, being boiled and eaten with oile, vineger, and pepper. B Some affirme, that the decoction of the roots are gool for all inflammations of the mouth, and Almonds of the throte, and other difeafes luappening in the mouth and throte, as the other Throtewoorts.

\section{C n a P.nig. Of Wall-floures, or yellow Stocke-Gillo-floures: \\ बा The Kindes.}

* THefe plants which wee terme commonly in Englith, Wal-floures and Stocke Gillo-

- foures are comprchended under one generall name of Lescoion, (i) Viola alba, White Violet, גuris fignifying white, and iw a Violet; which as fome would haue it is not from the whiteneffe of the floure, for that the moft and moft vfuall of them are of other colours, but from the whitenes or hourineffe of the leaues, which is proper rather to the Stocke Gillourers than to the wal-floures, I therefore thinke it fit to diftinguith them into Lencoia folys viridibrs, that is VVal-Houres; and Leucoi. folis incanu; S tocke Gilloners. Now thefe againe are diftinguifhed into fenerall fuecies,as you nay finde by the following Chapters. Morconer you nuft remember there is anotherViola alba or Leucoion (which is thought to be that of $T$ heophraftus and where of we haue treated in the firft boọe) which is far different from this, and for diftinction fake called Lencoium bulbofum. $\neq$

I Viola Lutes. VVal-floure:

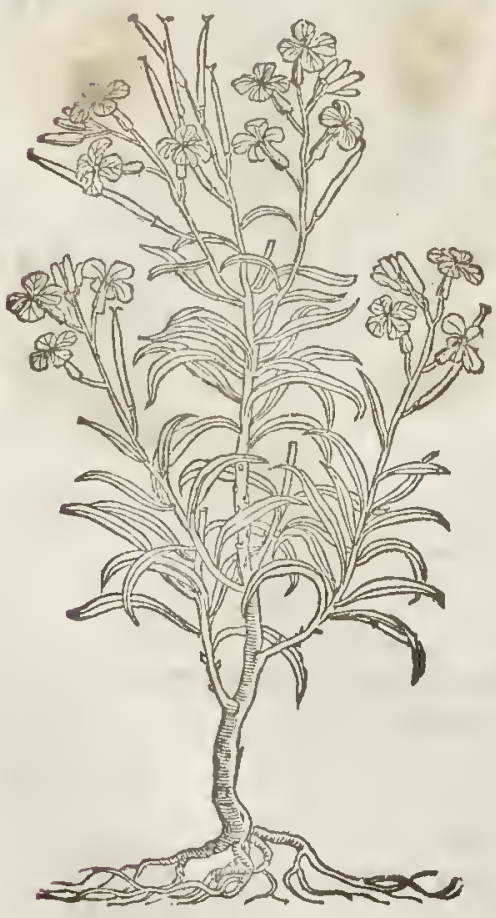

2 Violnlutea multiplex. Double VVal-foure:

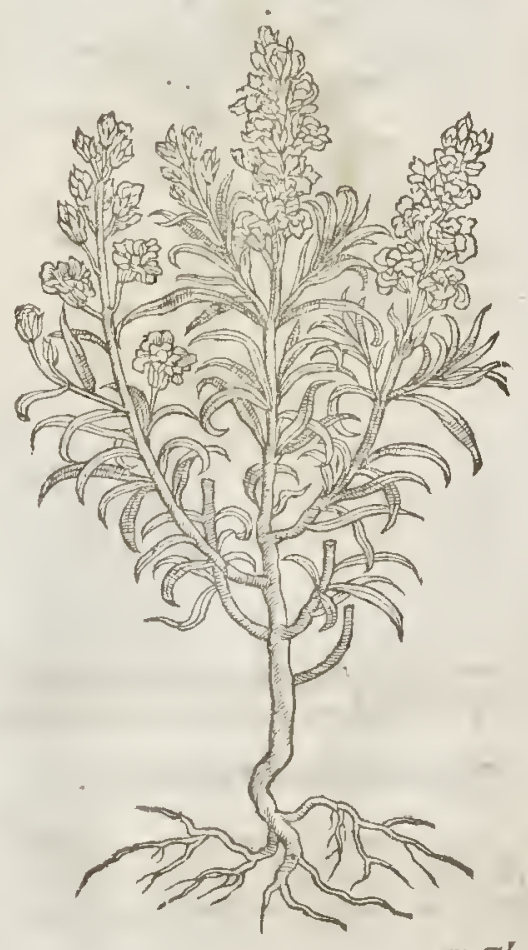


t 4 Leucoium fylueftre.

Wilde wall floute.

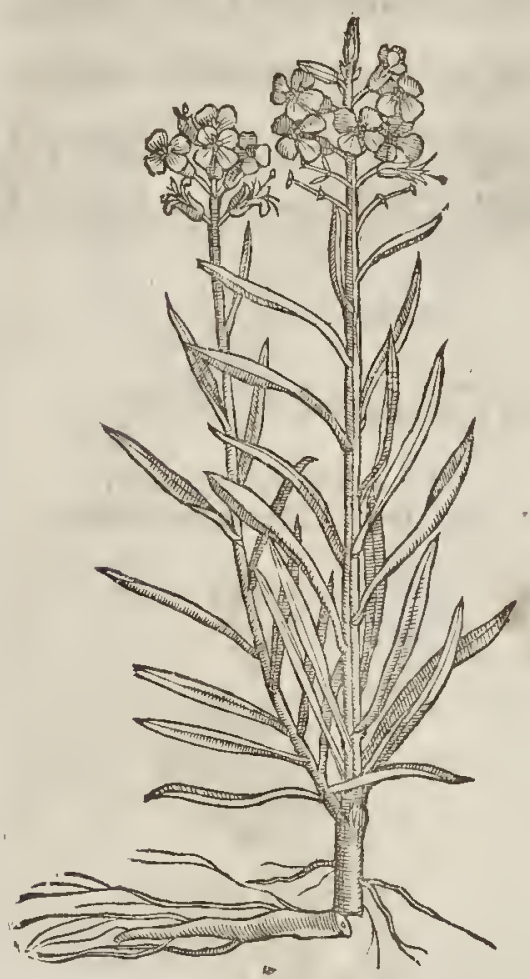

4 The Defcription.

I The ftalks of the Wall Houre ate full of greene branehes, the leaues are long, narrow, fmooth, flippery, of a blackinh greene colour, and leffer than the leanes of ftocke Gillofloures. The floures are fimall,yellow, very fwecte of fmell, and made of foure little leaues; which being pait, there fuceed long flender cods, in which is contaned Hat reddirh feed. The whole plant is fhrubby, of a wooddic fubftance, and can eafily endure the colde of winter.

2 The double Wall foure hath long leaucs greene aud fmooth, fet vpon tiffe branehes, of a wooddie fubftance: whereupon do grow molt pleafint fweet yellow flours very double; which plant is fo well knowne to all, that it thall be needleffe to fpend much time about the defeription.

3 Of this double kinde we haue another fort that bringerh his foures open all at onee, whereas the other doil floure by degrees, by meanes whereof it is Jong in Pouring.

\$. This plant which was fomerly fea ted in the fourth place of the following clapter, I haue brought to enjoy the fame place in this, for that by reafon of the greeneffe of his leates and other things he comes neareft to thefe here defcribed, alfo I wil defcribe it anew, becaufe the former was almolt wholly falfe: Ir hath many greene leaues at the top of the root like to thefe of the wall floure, but narrower, and bitter of tafte, among whieh rife vp one ot more ftalks of a foot or more in height, crefted and fet with carinated leaues. The floures grow at the tops of the ftalkes many together, confifting of foure yellow leaues a piece, leffer than thofe of the ordinary wall floures; there foures are fuceeeded by long ends containing a flat feed. The root is long and whitin, with many fibres.

5 Befides thefe, there is in fome gardens kept anotherwall-floure differing from the firtin the bigneffe of the whole plant, but efpecially of the floure, which is yellow and fingle, yet very large and beautifull.

6 Alfo there is another with very greene leaues, and pure white and well fmelling floures. $\neq$ - The Place.

The firft groweth vpon bricke and ftone walls, in the corners of churches encry where, as alfo among rubbirh and fuch orher ftony places.

The double Wall-floure groweth in moft gardens of England.

$$
\text { T The Time. }
$$

They foure for the moft part all the yeere long, but efpecially in winter, whereupon the people in Cheihire do call them Winter-Gilloflonres.

$$
\text { ब The Names. }
$$

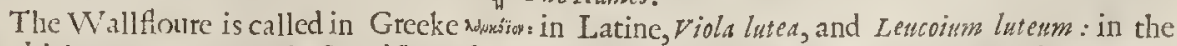
A rabicke tongue, $K$ cyri: in Spanifh, Fiolettas Amarillas: in Dutch, triolíeten: in French, Girofflees iarlizes,yiolieres des mur ailles : in Englifh, Wall-Gillofloure, Wall-floure, yellow ftocke Gillofoure, and Winter-Gillotoure.

$$
\text { Gi The Temperature. }
$$

All the whole fhrub of Wall-Gillofloures as Galen faith, is of a clenfing faculty, and of thinne parts.

\section{The Vertues.}

Diofcorides writeth that the yellow Wall-floure is moft vfed in phy ficke, and more than the reft $A$ of fracke-Gillofloures, whereof this is holden to be a kinde: which hath mooued mie to preferre it vnto the firft place. He faith, that the juice mixed with fome vnctious or oilie thing, and boiled to the forme of a lyniment, helpeth the chops or rifts of the fundament. 
B The herbe boiled with white wine, honie, and a little allom, doth cure hot vicers, and cankers of the nouth.

C The leaues ftamped with a little bay falt, and bound about the wrifts of the hands, taketh away the thaking fits of the Aguc.

$D \neq$ A decoftion of the foures together with the leates, is vfed with good fucecfe to mollifie Schirrous tumors.

E The oile alfo madewith thefe is good to be vfed to anoint a Paralyticke, as alfo a goutie part to mitigate paine.

F Alfo a frong decotion of the flotres drunke, mouth the Courfes, and expelleth the dead childe. $\neq$

CHA P:120. Of Stocke Gillofioures.

I Leucoimm alium, fine purpurenm, fune violaceim.

White,purple, or Violet eoloured Stoeke Gillofloure.
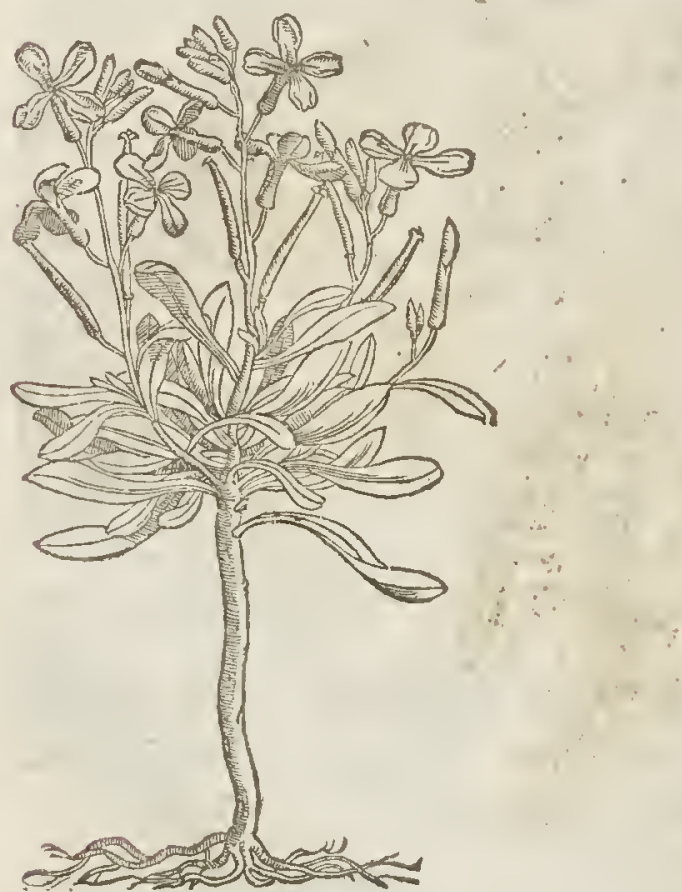

\$2 Lencoinm flore multiplici. Double Stocke Gillofloure,

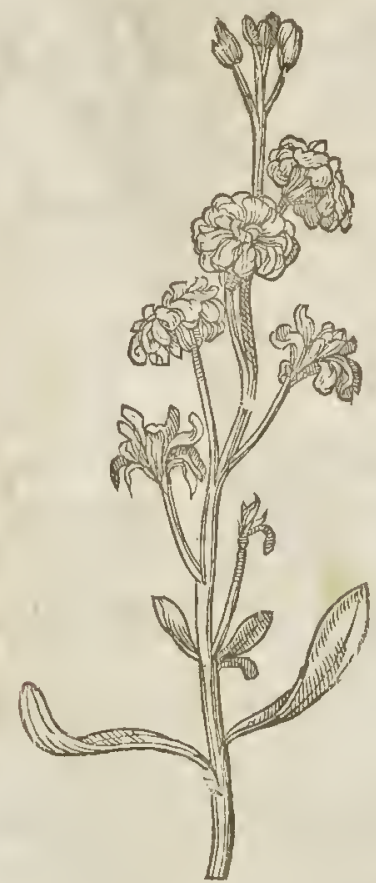

Ti The Dcfoription.

I THe ftalke of the great ftocke Gillofloure is two foot high or higher, round, and parted 1 into diuers branehes. The leates are long, white, foft, and hauing vpon them as it were
a downe like vnto the leaues of willowe, but fofter : the floures confif of foure little leatses grow ing all along the vpper part of thebranches, of a white colour,exeeding fweet of imell : in their places come vp long and narrow cods, in whieh is contained broad,flat, and round fecd. The root is of a wooddy fublanec, as is the ftalke alfo.

The purple ftocke Gillothoure is like the preedent in each refpect, fauing that the floures of this plant are of a pleafant purple colour, and the others white, which fetteth forth the differenee: of which kinde we hauc fome that beare double flotres, which are of diuers colours, greatly eftee med for the beautie of their floures, and pleafant fiveet fmell. 
3 Lewcoium pinofum Creticum. Thornie Sincke Gillouets.

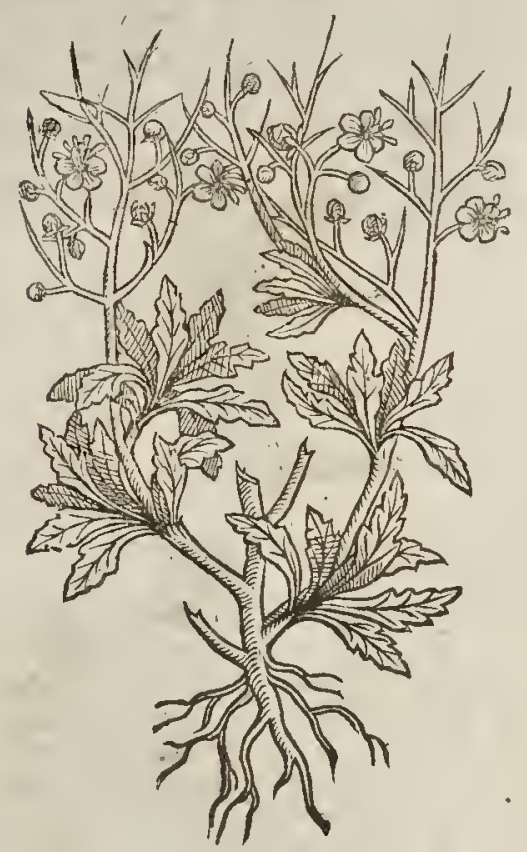

This kinde of stocke Gillo itoure that beareth floures of the colour of a Violet, that is to fay of a blew tending to a purple colour, which ferteth forth the difference betwixt this plant E the other ftocke Gillohoures, in cuery other refpent is like the precedent.

2 \& There were formerly ; figures of the fingle Stocks, which differ in nothing but the co:our of their floures; wherefore we haue made them content witl one, \& haue given (which was formerly wanting) a figure of the double Stock, of which there ate many and prettie varieties lept in the garden of my kirde friend $\mathrm{M}^{\mathrm{x}}$,Ralph $\mathrm{T}^{\text {thy }}$ gye at VVeftminfter, and fet forth in the bookes of fuch as purpofely treat of floures and their varictics. $\ddagger$

$\neq 3$ To thefe I thinke it nor amiffe to adde that plant which Clufers hath fet forth vnder the name of $L$ cucoium (pinofum Creticrim. It growes fome foot or more high, bringing forth many talkes which are of a grayith colour,and armed at the top with many and ftrong thorny prickles: the leaues which adorne thefe. ftalkes are like thofe of the focke Gillouer, yet lefie and fomewhat hoary; the floures are like thofe of Mulleine, of a whirifh yellow colour, with fome purple threds in their middles; the cods which fucceede the floures are fmall and raund, containing a little feed in them. They $v$ fe, faith Honorius Bellus, to bear ovens therewith in Candy, where it plentifully growes; and by reafon of the fim ilitude which the prickles hereof haue with siabe and the white colour, they cal it Gala Stivida, or Galaftivida, and not becaufe it yeelds milke, which Gala fignifies.

$$
\text { Tf The Place. }
$$

1. 2. Thefekindes of Stocke Gillofioures do grow in moft Gardens throughout England:

$$
\text { - The Time. }
$$

They floure in the beginning of the Spring, and continue flouring all the Sommer long.

"I The Nanes.

The Stocke Gillofiouze is called in Greeke acurcioy: in Latine, Viola alba : in Italian, Viola bianca: in Spanifh, Violettas blangurar : in Englim, Stocke Gillofloure, Garnfey Violet, and Caftle Gillofloure.

The Temperature and Vertues.

They are referred vnto the VVal-floure, al though in vertue much inferiour; yetare they not vfed $A$ in Phy ficke, except among ft certaine Empericks and Quackfaluers,about loue and luft matters, which for modeftie I omit.

Ioachimus Camierariws reporteth, that a conferue made of the floures of Stocke Gillofaure,and B often giuan with the difilled water thercof, preferueth from the Apoplexy, and helpeth the palfie.

\section{y A 12r. Of Sea Stocke Gillofloures.}

The Kindes.

F Stocke Gillofloures that grow necre vnto the Sea there bee diuers and fundrie forts differing as well in leaues as floures; which thall bee comprehended in this Chapternext following. 
I Lencoium marinum flore candido $L^{\prime}$ obely. White Sea Stocke Gillofloutes.

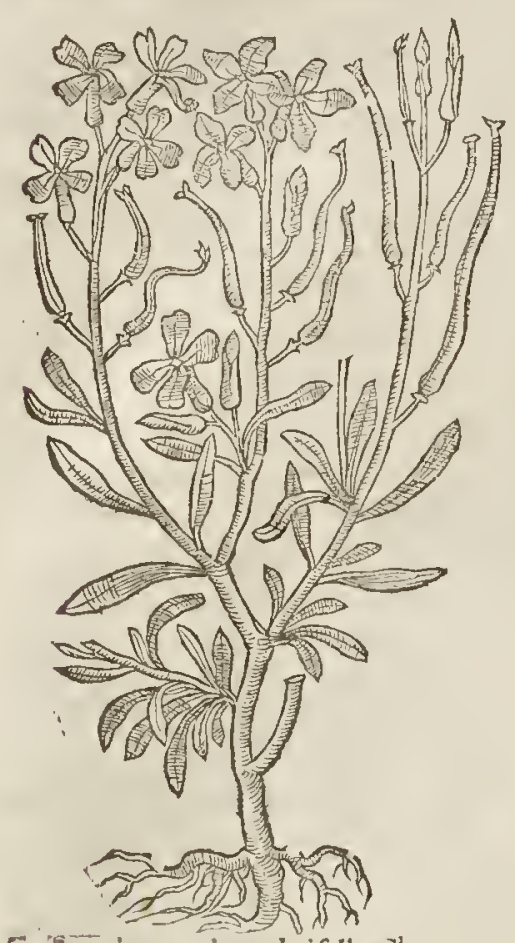

5 'encoium marinam latifolium?' Broad leafed fea focke Gillofloure.

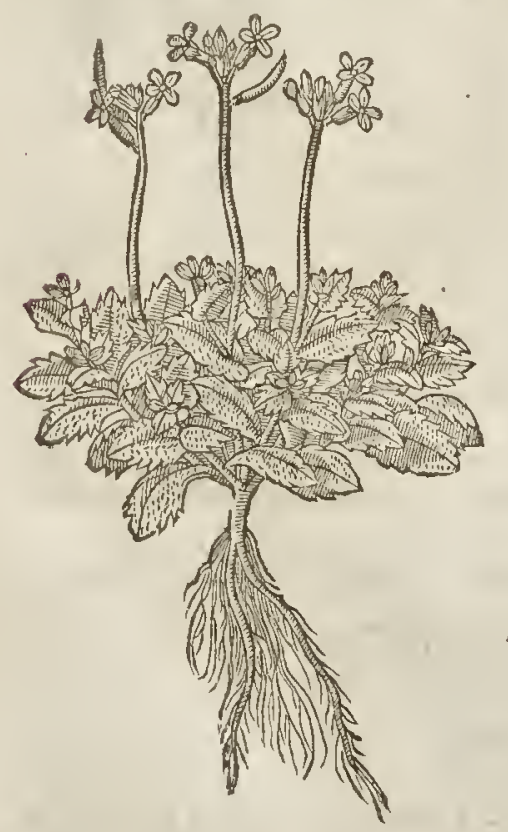

2 Lencoium marinum puipureum Liobelig. Purple fea Stoche Gillofloures.

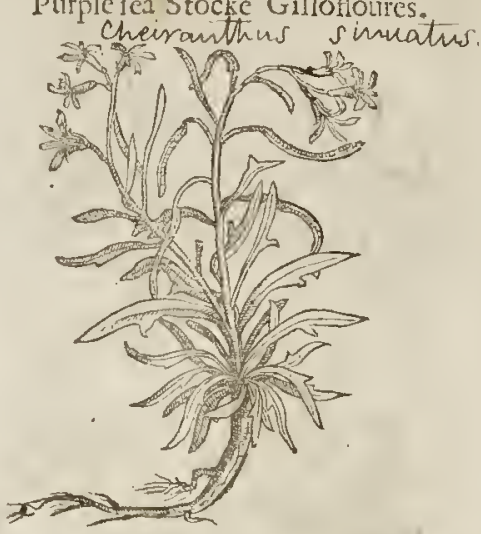

9ा Tlie Defcriftion.

I $T^{\mathrm{H} e}$ Sea foeke Gillofoure 1 hath a fnall wooddy root very threddic; from which tifeth vp an hoarie white falke of two foot high, diuided in to ditiers. fmall branches, whercon are placed confufedly many narrow leaues of a foft hoatic fubftance. The foures grow at the top of the branehes, of a whitin colour, made of foure little leaues; which being pait, there follow long coddes and feed, like vnto t? garden focke GilloPoure.

$\ddagger 2$ The purple ftockc Gillofloure hath a very long tough root, thrufting it felfe dccpe into the ground, from which riferp thicke, fat, foft, and loaric falkes. The leaues come forth of the falkes next the ground, long, foft, thicke, full of iuice, couered oner with a eertaine downic hoarineffe, and finuated fomcwhat deefcon borh fides, after the manner you may fee expreft in the figure of the fourth defcribed in this Cipter. The falle is $\mathrm{fet}$ here and there with the likeletues, but leffer. The foures grow at the top of the ftalkes, compact of foure fmall leaues, of a light purple colour. The fiede is contained in long crooked cods like the garden ftocke Gilloflofte.

$\neq$ The figure of Lobels which herewerive you was taken of a dried plant, and therefore theleauesare not exprett fo firuate as they fhould be. $\ddagger$

3 This fea ftock Gillc foure hath many broad leaues fpred vpon the ground, fomwhat fnipe or cut on the edges; amongef which rife v fmall naked tlalkes, bearing at the top many little fioures of a blcw colout tending to a purple. The feede is in long cods like the others of liskinde. 4 T'l: 
4 The great Sea ftock Gillofloure hath many broad leaues, growing in a great tuft, fleightly indented about the edges. The floures grow at the top of the falkes, of a gold yellow coicur. The root is fmall and fingle.

5 The fmall ycllow Sea ftocke Gillofloure hath many fmooth, hoary, and foft leaues, fet vpon a branched ftalke:on the top whereof grow pretty fweet fmelling yellow floures, bringing his feed in little long cods. The root is fmall and threddy. $\neq$ The Floures of this are fometimes of a red, cr purplich colour. :

4 Lencoium marinem luterm maius Clufij ơ L'obelÿ.

The yellow Sen ftocke Gillofloure.

5 Leucoism marinum minus L'obely \& Clufo

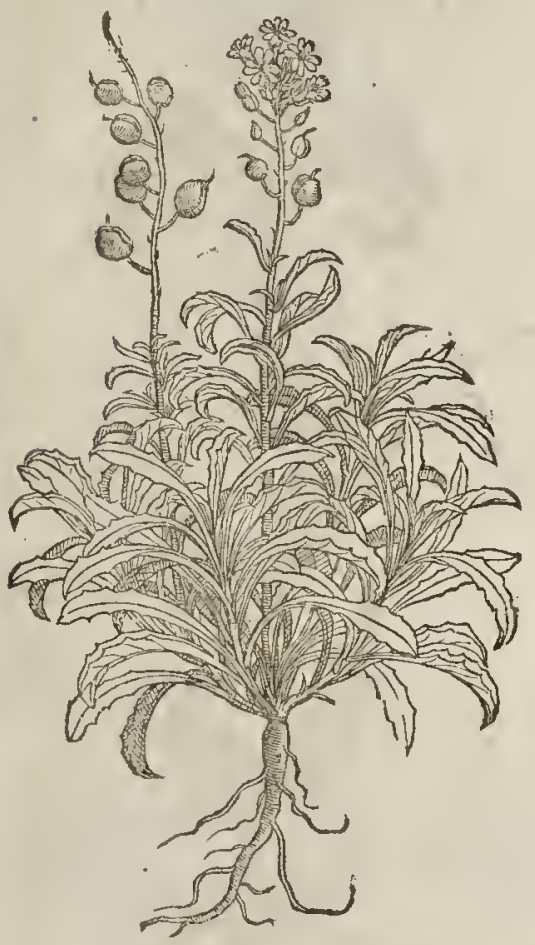
Small yellow Sea ftocke Gillotioure.

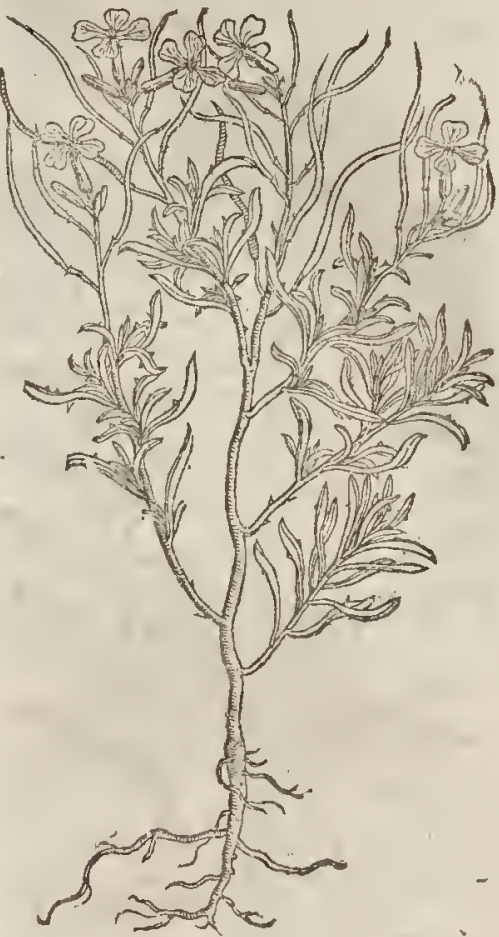

T The Place.

Thefe plants do grow neere vnto the fea fide,about Colchefter, in the Inle of Man, neere Prefton in Aunderneffe, and about Weftehefter.

\# I haue not hard of any of thefe wilde on our coafts but onely the fecond, which it may bee growes in thefe places here fet downe; for it was gathered by $\mathrm{M}^{\mathrm{r}}$. George Bowles vpon the Rocks af Aberdovye in Merioneth fhire. $\neq$

They flourin from A prill to the end of Augun.

$$
\text { 91 The Time: }
$$

$$
\text { T. The Names. }
$$

There is little to bee faid as touching the names, more than hath been touched in their feuerall titles.

$$
\text { T The Temperatureand vertues. }
$$

There is novfe of thefe in Phyficke,but they are efteemed for the beauty of their floures.

\section{Cir as.122. Of Dames Violets, or Queenes Gillofioures.}

\section{T) The Defcriptions.}

DAmes Violets or Queenes Gillofloures, haue great large leaues of a darke greenc co lour, fomewhat fnipt about the edges : among which fpring yp falkes of the height of 
two cubits, fet with fitclike leates : the floures come forth at the rops of the branches, of a fire purple colour, veric like thofe of the ftocke Gillofloures, of a very fweet fmell, after whicl come vp long cods, wherc in is contained lmall long blackifh feed. The root is llender and threddie.

The Quecnes white Gillofloures are like the laft before remembred, fauing that this piant bringeth forth fare white floures, and the other purple.

+ 2 By the induftric of fome of our Florifts, within this two or three yeares lath beene brought to our knowledge a sery beat ifull kinde of thefe Dame Violets, hauing very faire double white floures, the leaues, ftalks and roots, are like to the orher plants before defcribed.

I Viola Matronatis flore purpureo, fine albo.

Purple, or white Dames Violets.

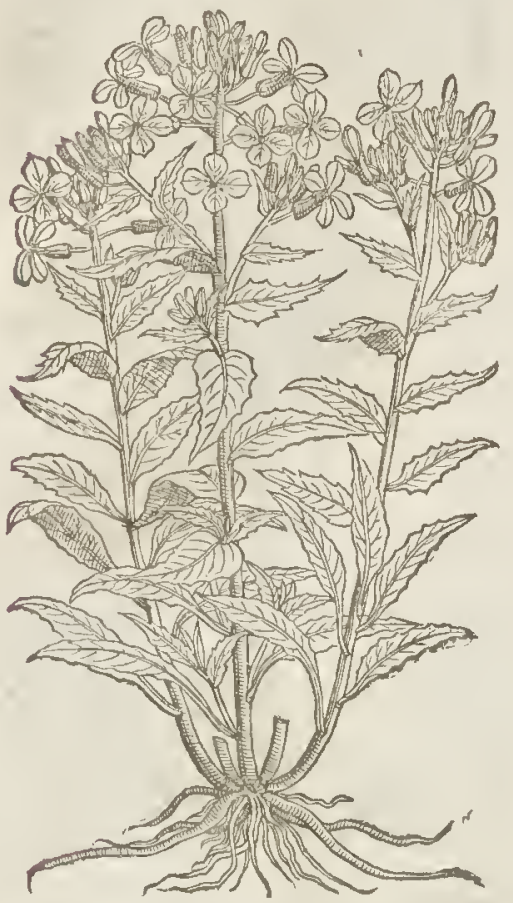

\$ Viola matronalisfore obfoleto. Ruffet Dames Violets.

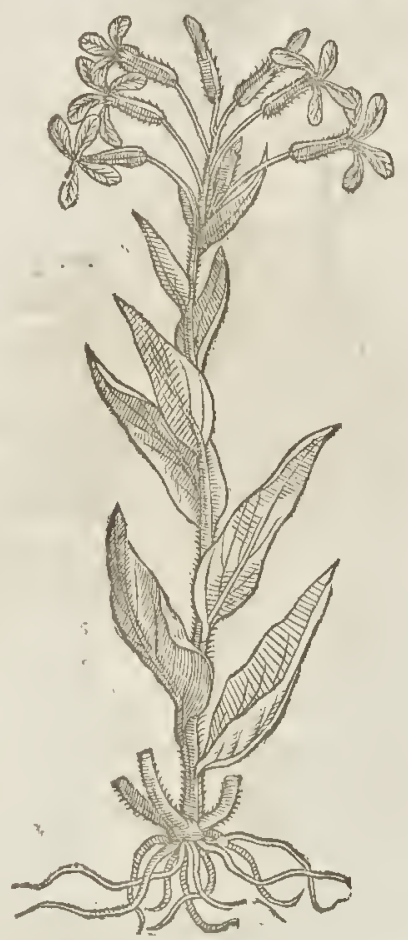

f. 3 This plant hath a fallie a cubit high, and is diuided into many branches, vpon which in a confufed order grow leaues like thofe of the Dame Violet, yet a little broader and thicker, being firf of fomewhat an acide, and afrerwards of an acride tafte; at the tops of the branches in long cups grow Houres like thofe of the Dames violet, confifting of foure leatues, which ftand not faire open, but are twined afide, and are of a ouerworn rufiet colour, compofed as it were of a yellow and browne with a number of blacke purple veines diuaricated ouer them. Their fmetl on the day sime is little or none, but in the euening very pleafing and fiveet. The Houres are fucceeded by long, and here and there firolne cods, which are almoit quadrangular and containe a teddifh feed. like that of the commion kinde. The root is fibrous, and vfually liues not aboue two yeares, for after it hath borne feed it dies; yet if you cut it dow ne and keepe it from feeding, it fometimes puts forth fhouts whereby it may bee increafed. 'I very much fufpeet that this figure and defcription which I lere giue you tiken sut of Clufius, is no other plant than that which is kept in fome of our gardens, and fet foorth in the Hortus Eyfettenfis by the name of Leucoium cMelancholicum : now I iudge the occafion of this crror to haue come from the figure of $C$ luf fus whicin we here prefent you with, for it is in many particulars different from the defeription: firt in that it expreffes notmany branches. fecondly, in that the leaues are not fnipt \& diuided:thirdly, in that the Floures are not expreft wrefted or twined:fourthly, the veins are not rightly expreft in the foure; \& laftly, the cods are omitted. Now the Iencoinm molancbolicum hath a hairy ftalke diuided into fundry branches of the height formerly mentioned, and the leaucs about the middle of the ftalke are fonewhat finuared or deepely or vnequally cut in; the thape and colour of the floure is the famewith that now 


\title{
Li B. 2. Of the Hiftory of Plants.
}

\pm 4 Lincoinm melancholicum.

The Melancholly foure.

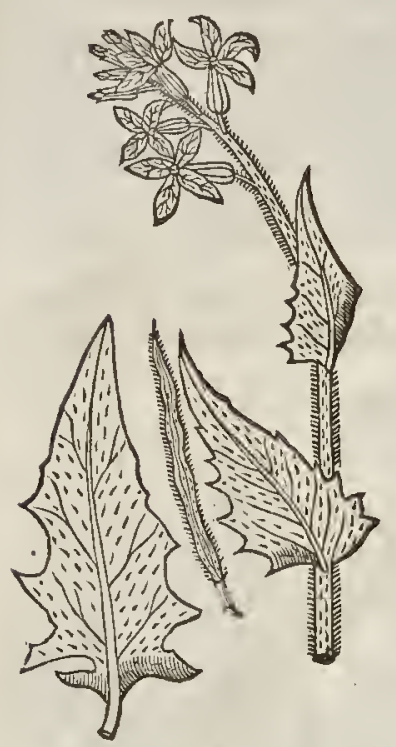

defcribed, and the feed veffels the fame, as far as I remember : for I munt conferfe, I did not in writing take any particular note of them though I hatle ditiers times feene them, neither did I ener compare them with this defcription of Clufius; oncly I tooke fome yeares agone an exact figure of a branch with the vpper leanes and flotres, whereof one is expreft as thicy vfually grow twining backe, and the reft faire open, the better to fet fotth the veines that are fprat ouer it. There are al fo cxpreft a cod or feede veffell, and one of the leaues that grow about the middle of the ftalke ; all which are agreeable to Clwfins defcription in mine opinion; wherefore I oncly gitue you the figure that I then drew, with he ti te that I had it by. $\neq$

$$
\text { ๆ The Place. }
$$

They are fown in gardens for the bcauiy of their floures.

$$
\text { 91 The Time. }
$$

They efuecially foure in Maie and Iune, the fecond yeare after they are fowne.

$$
\text { . IT The Nimes. }
$$

Dames Violet is called in Latine Viola matronalis, and Violn Hyemalis, or Winter Violets, and Viola Damajcena : It is thought to be the Heperis of Pliny, lib. 2 r. cap. 7 . fo called, for that it frnels more, \& more pleafantly in the euening or night, than at any other time. They are called in French Violettes des $D$ ames, ơ de domas, and Girofflees des dames, or Matrones Viocettes: in Englifh, Damaske ¿Violets,winter Gillofloures, Rogues Gillofloures, and clofe Sciences.

\section{वा The Temperature.}

The leaues of Dames Violets are in tafte tharpeand hot,very like in tafte and facultic to Eruca or Rocket, and feemeth to be a kinde thereof.

9 The Vertues:

The diftilled water of the foures hereof is counted to be a moft effectuall thing to proctire fweat.

\section{C н а р. 123. Of White Sattin floure.}

\author{
It The Defoription.
}

3 Rolbonac or the Sattin floure hath hard and round ftalkes, diuiding themfelties into miniy Oother fmall branches, befet with leates like Dames Violets, or Queenes Gilloflunres, fomewhat broad, and fnipt about the edg es, and in fafhion almoft like Saucealone, or lacke by the hedge, but that they are longer and marper pointed. The ftalkes are charged or loden with many foures like the common ftorke Gillo foure, of a purple colour, which being falne, the

$$
\text { Q? } 2
$$


feed commeth forth contained in a flat thin cod, with a fharp point or prick at oneend, in fafhion of the Moone, and fomew hatblackith. This cod is compofed of thee filmes or skins, whereof the two outmoft are of an ouerworne afh colour, and the innermoft, or that in the middle, whereon the feed doth hang or cleaue, is thin and cleere fhining like a thred of white Satrin newly cut from the peece. The whole plant dieth the fame yeare that it hath borne feed, \& muft be fowne yearely. The root is compact of many tuberous parts like key clogs, or like the great Afphodill.

2 The fecond kind of Bolbonac or white Sattin hath many great and broad leates, almoft like thofe of the great burre Docke:among which rifeth vp a very tall ftem of the height of foure cubits, fitfe, and of awhitith greene colour, fet with the like leaues, but fmaller. The Houres grow vpon the nender branches, of a purple colour, compact of foure fmall leaues like thofe of the ftocke Gillofloure; after which cone thin long cods of the fame fubftance and colour of the former. The root is thicke, whereunto are faftened an infinite number of long threddie frings: which roote dieth not enery yeare as the other doth, but multiplicth it felfeaswell by falling of the feede, as by new thoots of the root.

I Viola Lunaru five Bolbonat. White Sattin.

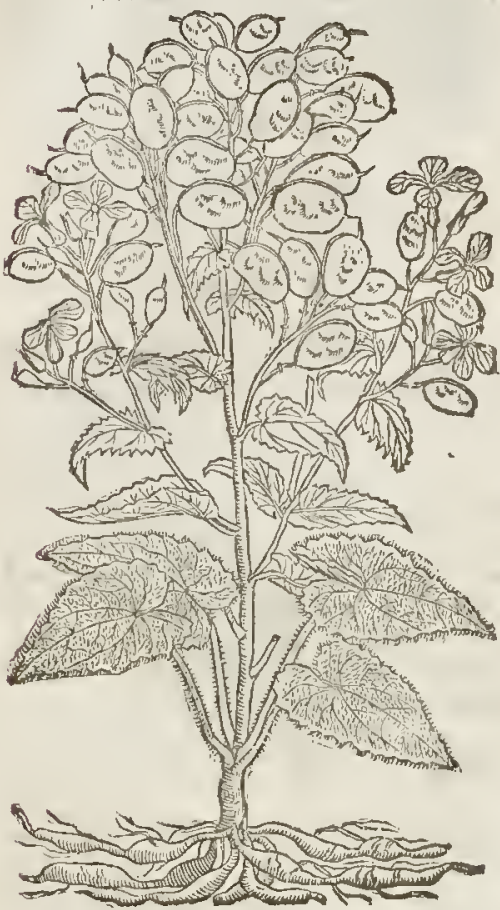

2 Viola Lunaris longionibus filiquis. Long codded white Sattin.

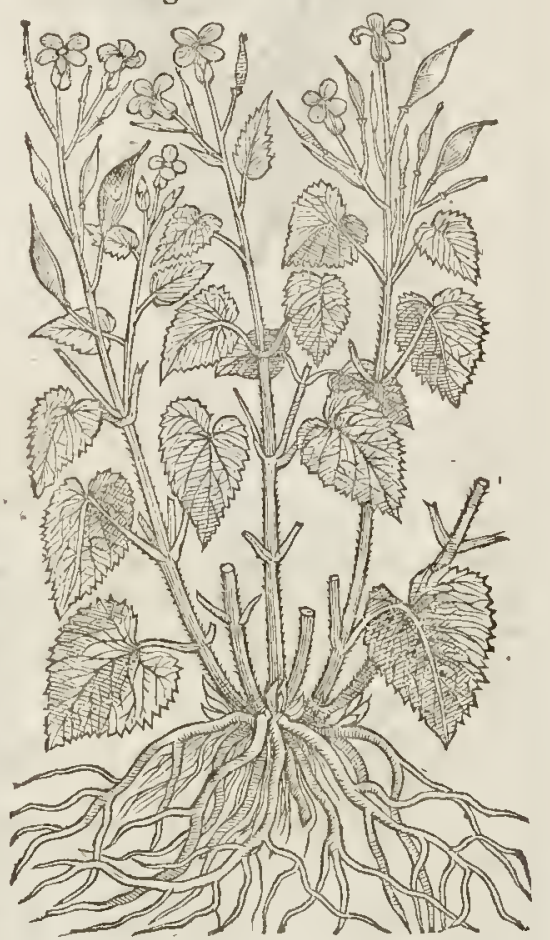

बा The Place.

Thefe plants are fet and fowne in gardens; notwithetanding the fitfthatiben found wilde in the woods about Pinner, and Harrow on the hill, twelue miles from London; and in Effex likewife about Horn-churcli.

The fecond groweth about Watford,fifteene miles from London. बा The Time.

They floure in Aprill the next yeate after they be forne. बI The Names.

They are commonly called Bolbonac by a barbarous nameswe had rather call it with Dodoncus \& clat fus, Violalatifolia,and Viola lunaris, or as it pleafeth mof Herbarifts, Viola peregrina: the Brabanders name it 1 genmints blomen, of the farhion of the coddes, like after a fort to a groat or refterne,and 39 acch blocmen, becaufe it alwaies floureth neere about the Feaft of Eafter : molt of the later Herbarifs doecall it Lunaria : Orhers, Lunaria Greia, either of the farthion of the fecd, or of the filuer brightneffe that it hath, or of the middle skinne of the cods, when the two outtermoft skinnes or luskes and feedes likewife are falne away. We call this herbe in Englifh Penny Noure, or Money foure, Siluer Plate, Pricke-fongwoort, in Norfolke, Sattin, and White 


\section{Liв. 2. Of the Hiftory of Plants:}

Sattin,and among our women it is called Honeftic: it feemeth to be the old Herbarifts $T$ blappi alterum, or fecond Treacle muftard, and that which Cratenar defcribeth, called of diucrs Sinapi Perficum; for as Diofcorides faith, Crat esas maketh mention of a certaine Thlafpi or Treacle Muthard, with broad leaues and bigge roots,and fuch this Violet hath, which we furname Latifolia or broad leafed: generally taken of all to be the great Lunaria, or Moonwoort.

\section{9f Their Temperature and Vertues.}

The feed of Bolbonac is of Temperature hot and drie, and tharpe of tafte, and is like in tafte and A force to the feed of Treacle Muftard; the roots likewife are fomewhat of a biting qualitie, butnot much : they are eaten with fallads as certaine other roots are.

A certaine Chirurgian of the Heluetians compofed amoft fingular vnguent for wounds of the $B$ leaues of Bolbonac and Sanicle ftamped together,adding thereto oile and wax. The feed is grearly commended againft the falling fickneffe.

\section{C н а 12 4. Of Galen and Diofcorides Moonwoorts or Madwoorts.}

I Alypum Galeni.

Galens Madwoort.

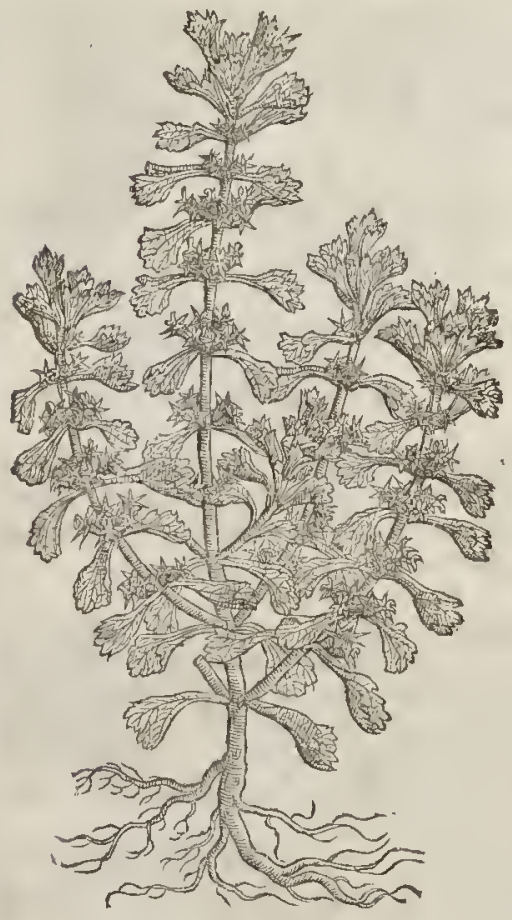

$\dagger 2$ Alyfum Diofioridis. Diofcorides Moonwoort or Madwoort.

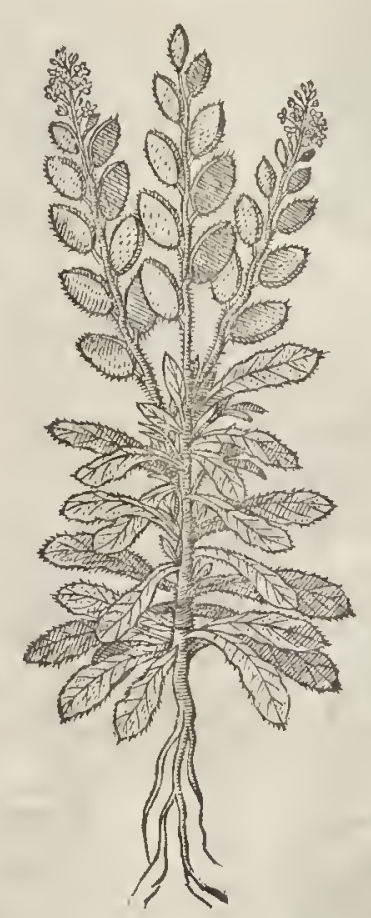

of The Defoription:

I This might be one of the number of the Horehounds, but that $G$ alen vfed it not for a kind 1 thereof,but for $A l y$ fon, or Madwoort : it is like in forme and thew vnto Horehound, and alfo in the number of the ftalks, but the leaues thereof are leffer, more curled, more hoary, \& whiter without any manifeft fmell at all. The little coronets or fpokie whurles that compaffe the ftalkes round about are full of tharpe prickles : out of which grow floures of a blewifh purple colour like to thofe of Horchound. The root is hard,wondy, and diuerfly parted.

2 I haue one growing in my garden, which is thought to be the true \& right Lunary or Moonwoort of Diofcorides defcription, hauing his firft leaues fomew hat round, and afterward more long, whitinh, and rough, or fomewhat woolly in handling : among which rife vp rough brittle ftalkes, fome cubite high, ditided into many branches, whereupon doe growe many little yellow 
Houres; the which bcing paf, there follow flat and rough huskes, of a whitifh colour, in fhape like little targers or bucklers, where in is contained flat feed, like to the feeds of ftoek Gillofloures, but bigger. The whole huske is of the fame fublanee, fafhion, and colour that thofe are of the white Satrin.

$$
\text { T. The Flate. }
$$

Thefe Plants are fowne now and then in Gurdens, efpceially for the rarenefe of the $\mathrm{m}$; the feede beeing broughr out of Spainc and Italy, from whenee I rcceiued fome for my Garden. बा The Time.

They foure and flourith in May ; the feede is ripe in Augut, the feeond ycare after theit fowing.

$$
\text { If The Names. }
$$

Madwoort, or Moonwoort is ealled of the Grixeians à vare or axuary : of the Latines $A$ ly/fum : in Englifh, Galens Madwoort of fome, Heale-dog: and it hat the name thercof,becaufe it is a prefent remedy for them that are bitten ofa mad dogge, as Galen writeth; who in his fecond booke $D$. Antidotis, in Antoninus Cous his compofition defcribcth it in thefe words: Madwoort is an herbe very like to Horehound, but rougher, and nore full of prick les about the floures: it beareth a floure tending to blew.

$\ddagger 2$ The feeond by Dodonie zs, Lobell, Cumerarius and others, is reputed to bee the Alyfjon of

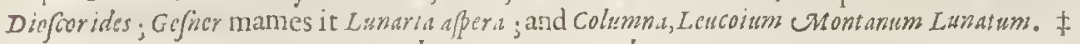

The Temperature and Vertues.

Galen faith it is gituen vnto fuels as are inraged by the biting of a mad dogge, whieh thereby are A perfcitly cuted, as is knowne by experience, without any artificiall applicarion or method at all. The which experiment if any thall proue, he thall finde in the working thereof. It is of temperaturc meanly dric, digefteth and fomething lcourcth withall:for this eanfe it takech away the morphew and Sun-burning, as the fame Authour aftirmeth.

$\dagger$ That which was formerly deferibed in the fecond place, being a kinde of Sideritr, I haue here onited, that I may giue you it more fitly amongt the reft: of that nameanilkindred hereatice.

\section{Chap.125. Of Rofe Campion.}

Lychnis Chalcedonica.

Floure or Conftantinople.

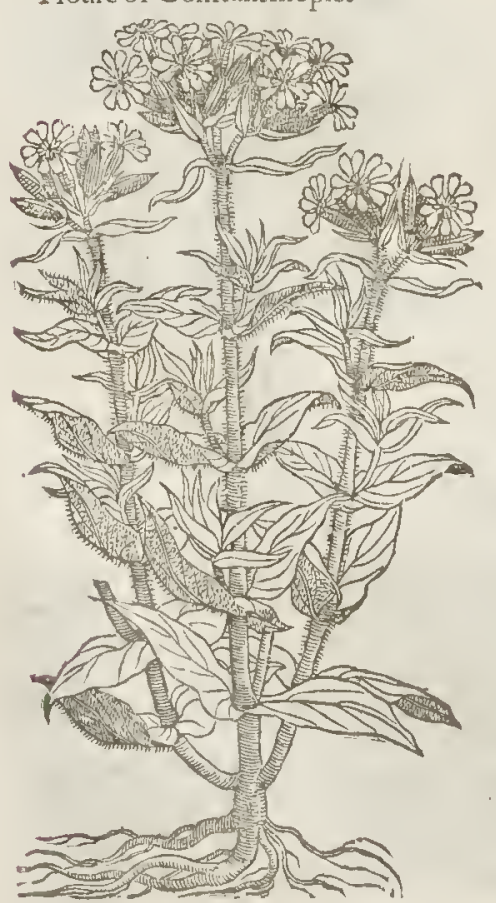

\section{TT The Rindes.}

THercbc diuers forts of Rofe Campions; fome of the Garden, and others of the Field : the which fhal be diuided into feucrall chaptersiand firft of the Campion of Conftantinoplc.

$$
\text { T) The Defription. }
$$

7 He Campion of Confanrinople hath fundry vp: right ftalks, two cubits high and ful of ioynts, with a ccrtaine roughneffe; and at euery ioynt two large leaues, of a browne grecne colour. The floures grow at the top likc Sweet-Williams,or rather like Dames vi. olets, of rhe colour of red lead, or Orenge tawny. The ront is fonewhat tharpe in tafte.

\# There are diuers varieties of this, as with white and bluih coloured foures, as alfo a double kinde with very large, double and bcautiful floures of a Vcrmelion colour like as the fingle one here defcribed. $\neq$

$$
\text { The Place. }
$$

The floure of Confantinople is planted in Gar. dens, and is very common almoft eueriewhere.

¥ The white and bluth fingle, and the double one are more rarc, and not to be found but in the Gardens of our prime Florifts. $\neq$

\section{\% The Time.}

It floureth in Iunc and Iuly, the fecond ycare after it is planted, and many yeares after; for it confifteth 
Li B. 2. Of the Hiftory of Plants.

confifteth of a root full of life; and endureth long, and can away w ith the cold of our clymate.

II The Rames.

It is called Conftantinopolitanusfos, and Lychnis Chalcedonica : of Aldrousandus, Flos Creticus; of Floure of Candy : of the Germans, flos Hierofolymitanus, or Floure of Ierufalem : in Eng Iin, Floure of Conftantinople; of fome, Floure of Briftow, or None-fuch.

TI $T$ be Temperature and Vertues.

Floure of Conftantinople, befides that grace and beauty which it hath in gardens and garlands, is, for ought we know, of no ve, the vertues thereorbeing not as yet found out.

\section{Char.126. Of Roje-Campion.}

I Lychnis Coronaria rubra.

Red Rofe Campion.

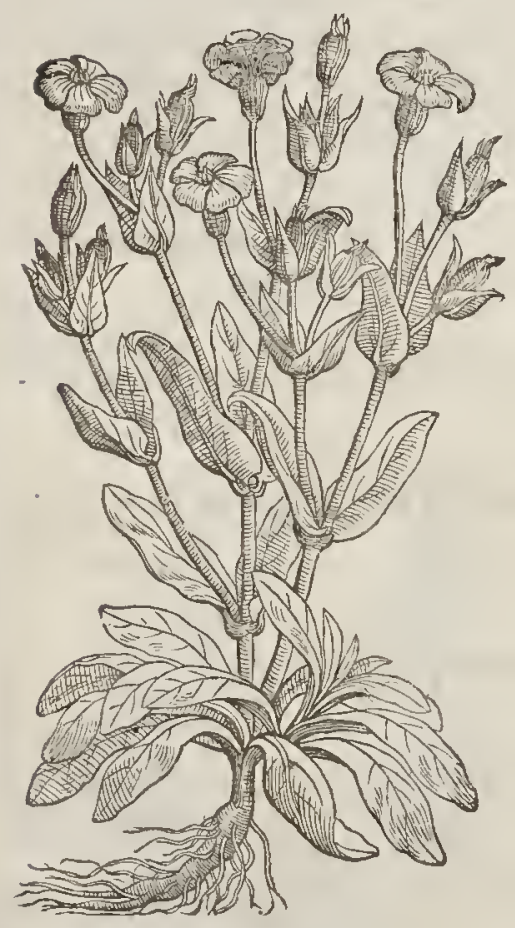

2 Lychnis Coronariaalbs. White Role Campion.

$$
\text { Ti The Difcription. }
$$

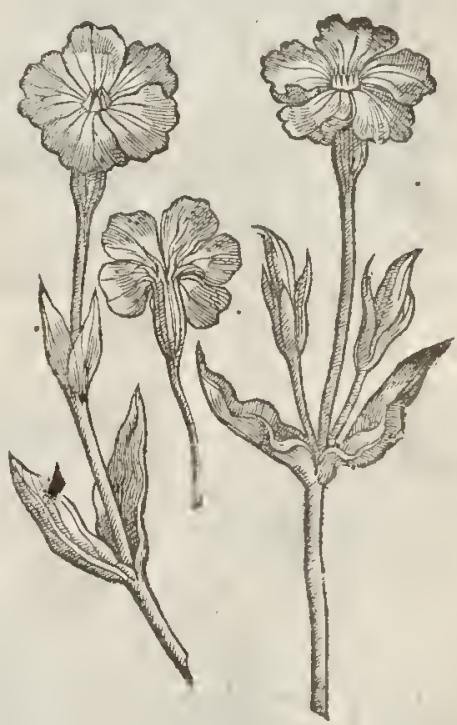

\pm He firf kinde of Rore-Campion hath round falks very knotty and woolly, and at cue. rie knot or ioynt there do ftand two woolly foft leaues like Mulleine, but leffer, and much narrower. The floures grow at the top of the ftalke, of a perfect red colour
2 The fecond, there follow round cods full of blackifh feed. The root is long and threddy.

2 The fecond Rofe Campion differs not from the precedent in ftalkes, leanes, or fathion of the foures : the onely difference confitteth in the colour; for the floures of this plant are of a milke
white colour, and the orher red.

$\ddagger 3$ This alfo in ftalks, roots, leates, and manner of growing differs not from the former; but the floures are much more beautifull, being compofed of fome three or foure rankes or orders of
leaues lying each aboue other. $\neq$ 
\$ Lychnis coronaria mult iplex. Double Rofe Campion.

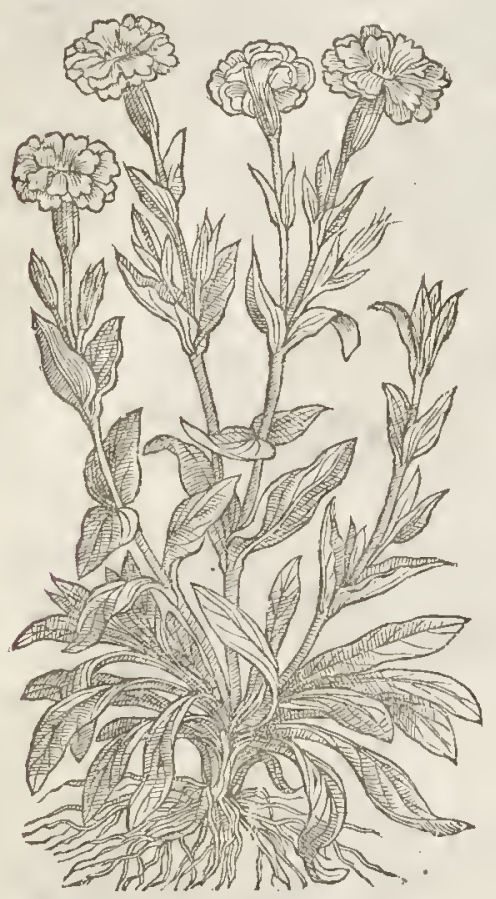

T The Place.

The Rofe Campion growes plentifully in molt gatdens.

$$
\text { 9 The Time. }
$$

They floure from Iune to the end of Augut.

$$
\text { The Names. }
$$

The Rofe Campion is called in Latine Dominarum Rofa, Mariana Rofa, Calt Rofa,

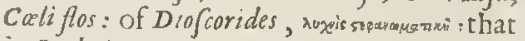
is, Lychnis Coronaria, or Satiua: Gaza tranfla. teth numise, Lucernula, becaufe the leaues thereof be foft, and fit to make weekes for candles, aceeording to the teftimonie of Diofcorides : it was called Lychnis, or Lychnides, that is, a torch, or fuch like light , aecording to the fignifieation of the word, clecre, bright, and light-giting floures: and therefore they were ealled the Gardners Delight, or the Gardeners Eye: in Duteh, Cutites eie: in Freneh, oetllets, \& oeiles Dien : in high-Dutch, פ⿴囗十 atien cors zlín, and

$$
\text { T The Temperature. }
$$

The feed of Rofe-Campion, faith Gales, is hot and dry after a fort in the fecond degree.

9) The Vertues.

A The feed drunken in wine is a remedie for them that are ftung with a Scorpion, as Diofcorides teftifieth.

\section{C н а. 127. Of wilde Role-Campions.}

ब The Defcription.

I THe wilde Rofe-Campion hath many rongh broad leates fomewhat hoary and woolly: among which rifevp long foft and hairy ftalkes branched into many armes, fer with the like leaues, but leffer. The floures grow at the top of the falkes, compact of fue leaues of a reddilh eolour : the root is thicke and large, with fome threds anexed thereto.

‡ There alfogrowes commonly wilde with vs another of this kinde, w ith white floures, as alfo anotier that hath then of a light blufh colour. $\neq$

2 The fea Rofe Campion is a fmall herbe, fet about with many greene leaues from the lower part vpward; which leaues are thicke, fomewhat leffer and narrower than the leaues of fea Purflane. It hath many erooked ftalkes fpred vpon the ground, a foor long; in the vpper part whereof there is a fmall white fioure, in fathion and fhape like little cup or box, after the likeneffe of Bchen album, or Spatling Poppy, hauing within the faid floure little threds of a blacke colour, in tafte fait, yet not vnpleafant.

It is reported vnto me by a Gentleman one $\mathrm{M}^{\mathrm{r}}$. Tho. Hesket, that by the fea fide in Lancafhire, from whence this plant came, there is another fort hereof with red floures.

$\neq .3$ This brings many falkes from one root, round, long, and weaker than thofe of the firft deferibed, lying vfually vpon the ground: the leaues grow by couples at each ioynt, long, foft, and hairy; amongit which alternately grow the floures, about the bigneffe of thofe of the firft deferibed, and of a bluth eotour ; and they are alfo fucceeded by fuch feed-reffels, containing a reddith feed. The root is thicke and fibrous, yet commonly out lites not the fecond yeare. 


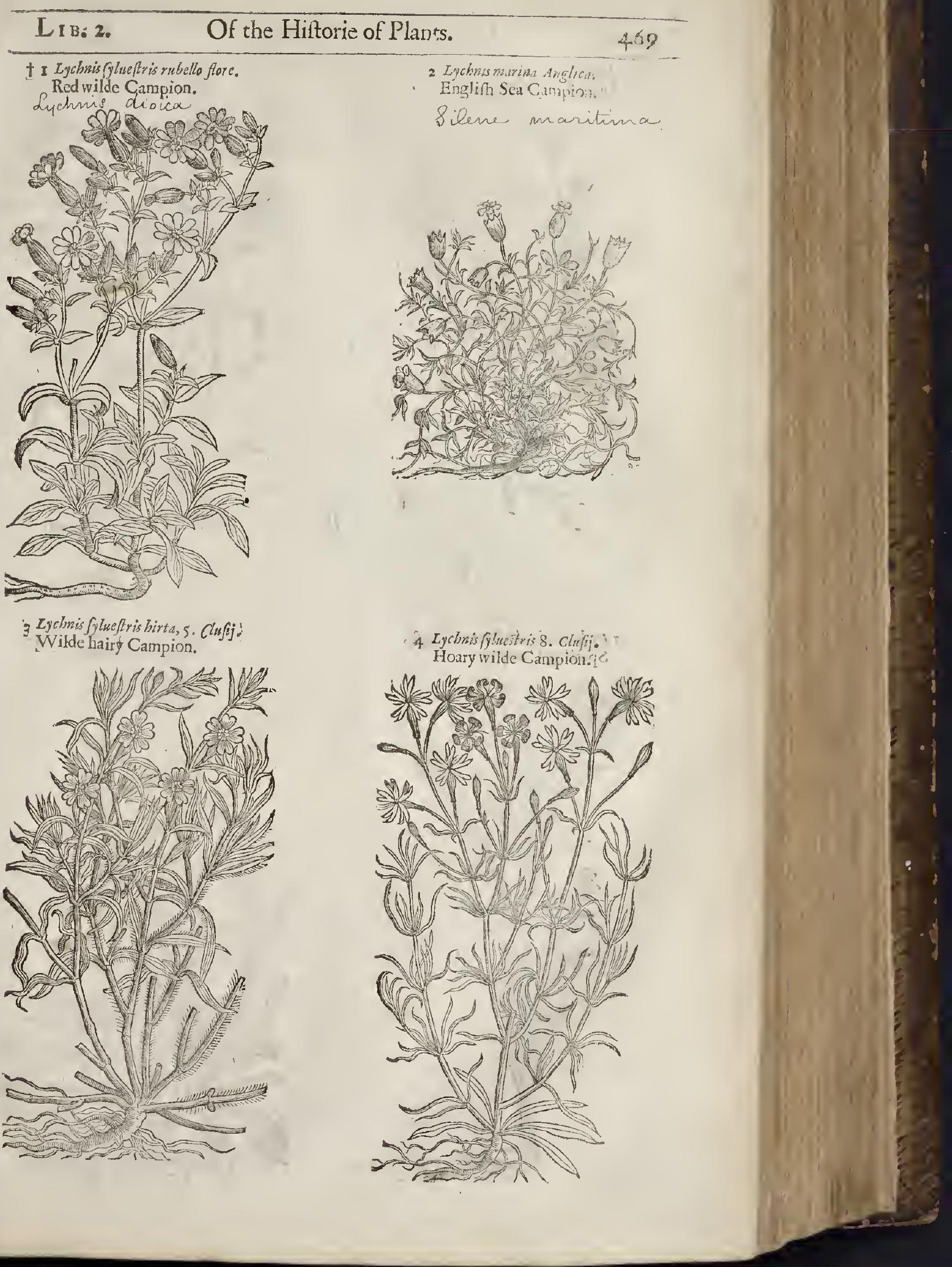




470 Of the Hiftory of Plants.

5 Lychnis hirta mirima, 6. Clus. Small Hairy Campion.

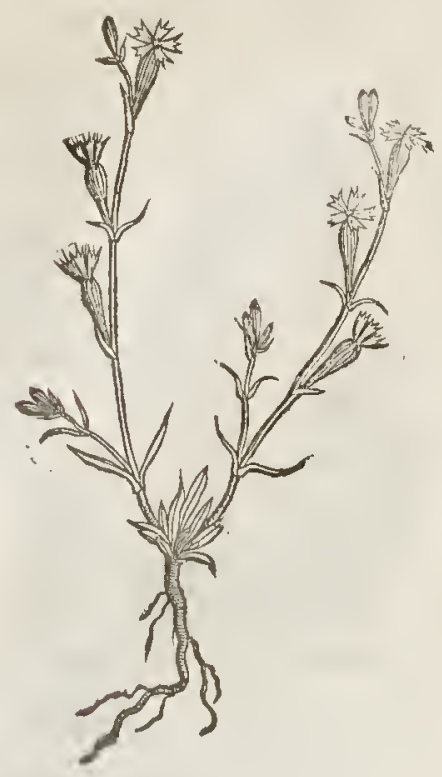

7 Lychnis caliculis friatis 2. Clufij: Spatling Campion,

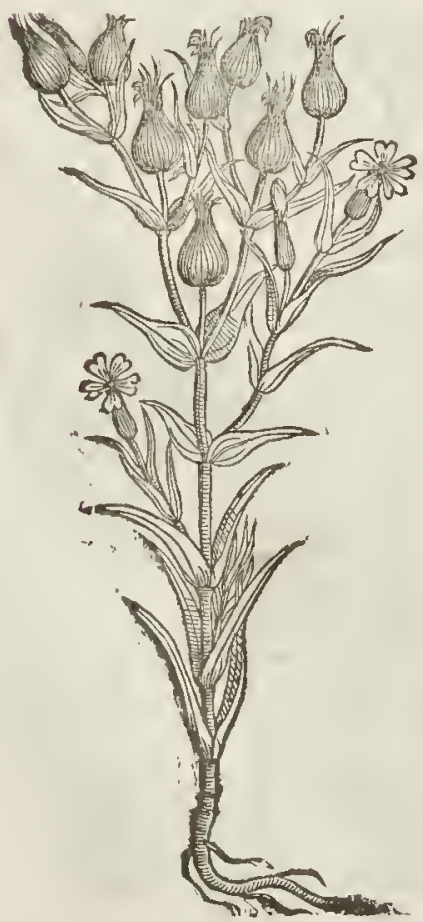

L в. 2.

† 6 Lychnisfyluefr is incana, Lob. ' Ouerworne Campion.

Silene conica.

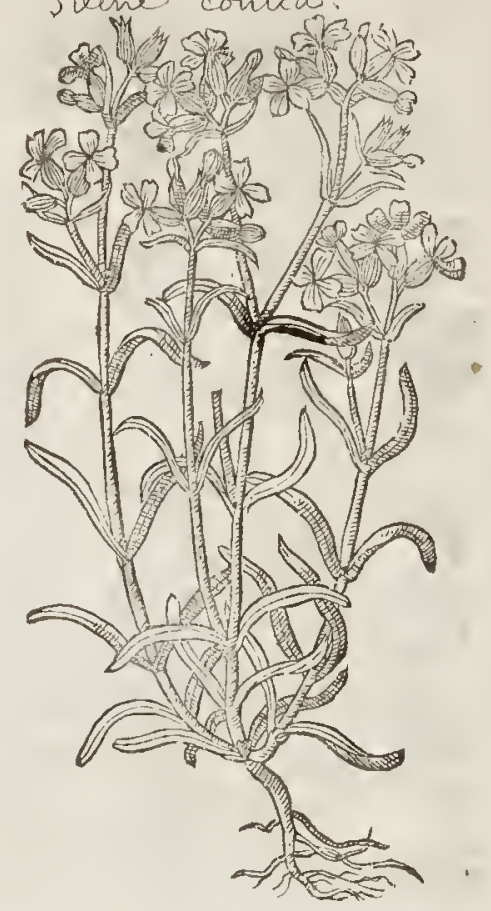

t8 Lychnis fylueftris alba 9. Cluf. Whitewilde Campion. Silene nutans.

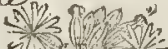

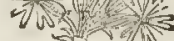
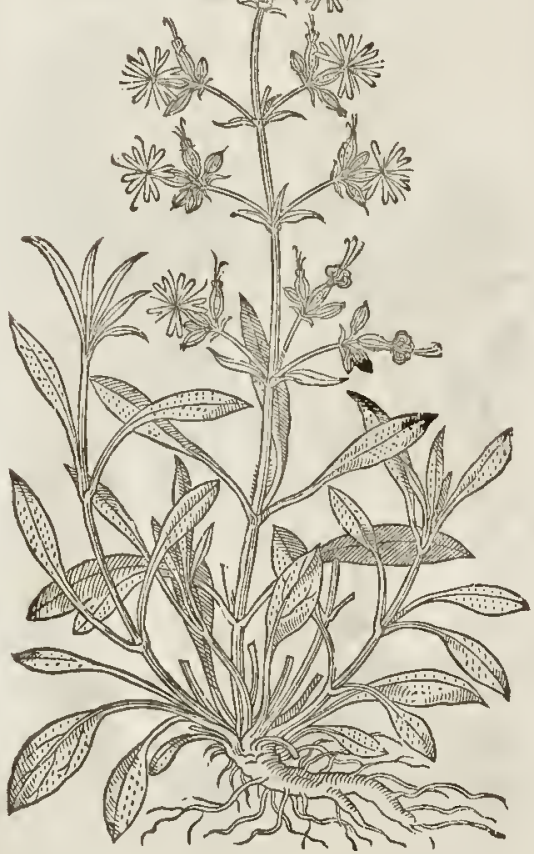
4 The fourth kinde of wilde Campions hath long and flender ftems, dividing themfelues into fundry other brancles, which are full of ioynts, hauing many fmall and narrow leaues procecding from the faid ioynts, and thofe of a whitifh greene colour. The floures dog grow at the top of the ftalke, of a whitim colour on the inner fide, and purplifh on the outer fide, confinting of fiue fnull lewes, cirery leafe hauing a cut in the end, which maketh it of the rhape of a forke : the feed is like the wilde Poppy; the root fomewhat groffe and thicke, which alfo perifheth the fecond yeare.

5 The fifth kinde of wilde. Campion hath three or foure foft leates fomew hat downy, lying flat vpon the ground; among which rifeth vpan hairy afh-coloured ftalke, diuided into diuers branches; wherecipon do grow at certaine fpaces; euen in the fetting together of the ftalke and branches, fmall and grafe-like leaues, hairy, and of an oucrivorne dusky colour, as is all the reft of the Plant. The floures grow at the top of the branches, compofed of fiue fimall forked leates of a bright thining red colour. The root is fmall, and of a wooddy fubftance.

6 The fixth kinde of wilde Campion hath many long thicke fat and hoary leaues fpred vpori the ground, in thape and fubfance like thofe of the gatden Campion; but of a very dufty ouerworne colout : among which rife vp finall and tender ftalkes fet at certaine diftances by couples; with fuch like leaues as the other; but finaller. The floures do grow at the top of the falks in little tufts like thofe of fweet Williams, of a red colour. The root is fmall, with many threddy
ftrings faftned to it.

$¥ 7$ This growes fome cubit high, with ftalkes diftinguifhed with fundry joynts, at each whereof are fet two leaucs, greene, fharpe pointed, and fomewhat ftiffe : the foures grow at the tops of the branches, like to thofe of Mufcipula or Catch-Aly, yet fomew hat bigger, and of a darke red: which paft, the feed (which is anh-coloured, and fomerwhat large) is contained in great cups or veffels coucred with a hard and very much crefted skin or filme; whence it is called $L y c b$ is $C_{a-}$

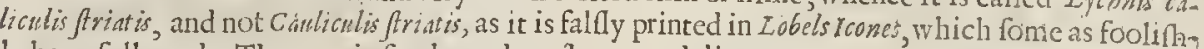
ly haue followed. The root is fingle, and not large, and dies euery yeare.'

8 That which our Author figured in this place had greene leaues and red floures, whicly no way forted with his defcription : wherefore I hate in lieu thereof gituen you one out of Cluf ins, which may fitly carry the title. This at the top of the large fibrous and liuing root fendeth forth many leaues fomewhat greene, and of fome fingers length, growing broader by degreeś, and at laft ending againe in a fharpe point. The ftalkes are fome cubit high, fet at each ioynt with two leaues as ir were embracing it with their foot-ftalkes; which leaues are leffe and leffe as they are higher vp, and more fharpe pointed. At the tops of the branches grow the floures, confitting of fite white leaues deepely cut in almoft to the middle of the floure, and haue two fharpe pointed appendices at the bottome of each of them, and fiue chiues or threds come forth of their middles: thefewhen they fade contract and twine themfelues vp, and are fucceeded by thicke and fharpe pointed feed-veffels, containing a finall round Afh-coloured feed. I coniestre that the figure of the Lychnis plumaria, which was formerly here in the ninth place out of 7 abern. might be of this plant, as well as of that which Barbine refers it to, and which you thall finde mentioned in the end of the chapter. $\ddagger$

$$
\text { IT The place. }
$$

They grow of themfelues neere to the borders of plowed fields, medowes, and ditch banks, com? mon in many places. $\ddagger$ I haue obferued none of thefe, the firft and fecond excepted, growing
wilde with vs. $\ddagger$

The fea Campion groweth by the fea fide in Lancafhire, at a place called Lytham, fue miles from Wygan, from whence I had feeds fent me by M'. Thomas Hesketh; who hath heard it repor. ted, that in the fame place doth grow of the fame kinde fome with red floures, which are very rare tobe feene. \# This plant (in my laft Kentinh Simpling voyage, $16_{32}$, with $\mathrm{M}^{*}$. Thomas Hickes; $\mathrm{Mr}$. Broad, \&c.) I found growing in great plenty in the low marinh ground in Tenet that lieth directly oppofite to the towne of Sandwich. $\neq$

$$
\text { of The Time. }
$$

They floule and flouitith moft partof the Sommer euen vnto Autumne:

T) The Names.

The wilde Campion is called in Greeke Avees aseu $:$ in Latine, Lychris fylueftris : in Englifh,wild: Rofe Campion.

Tt The Timperature.

The temperature of thefe rvilde Campions are referred vato thofe of the garden.

$$
\text { q) The Vertues. }
$$

Theweight of two drammes of the feed of Wilde Campion beaten to poudet and drunke, fa doth 
doth purge choler by the ftoole, and it is good for rhem that are ftung or bitten of any venomous beaft.

\begin{abstract}
t The figute that was in the firtt place, and was intended for our ordinary prilde Campion, is thas whieh you fee here in the eighth flace; and thofe that were in the fixch and eighth places ynu fha.! hereatier fiude with $M u^{\prime}$ (I)

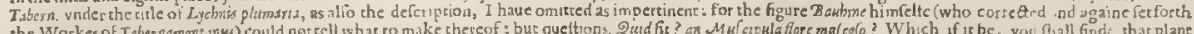

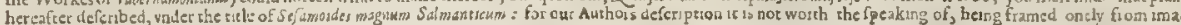
gination.
\end{abstract}

\title{
${ }_{+}$С н а Р. 128. Of diwers other wilde Campions. If The Defription.
}

\pm I He firft of thefe which we here giue you is like in leaues, ftalkes, roots, and manner 1 of growing vnro the ordinarie wilde Campion defcribed in the firft place of the precedent Chaprer; but the floures are very double, compofed of a great many red leaues thicke packr rogether, and they are commonly fer in a thorr and broken huske or cod. Now the fimilirude that thefe floures haue to the iagged cloath burrons anciently worne in this kingdome gaue occafion to our Gentlewomen and other louers of floures in thofe rimes to call them Bachelours Buttons.

2 This differs not in thape from the laft $\mathrm{dcfcribcd}$, but only in the colour of the flourcs, which in this plant are whire.

$\mp$ I Lychis fyl.multiplexpurpurea, Red Bachelors Butrons.

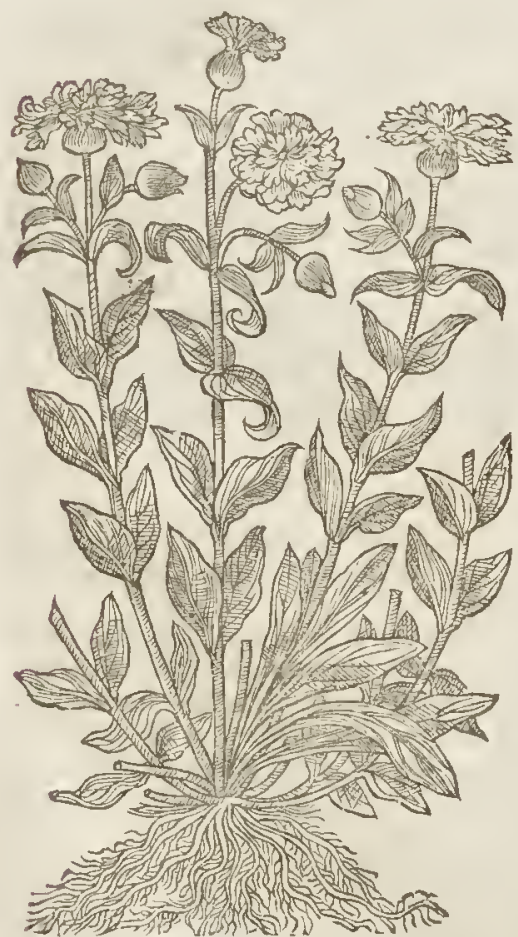

$¥ 2$ Lychnis $\int y l$. alba multiplex. White Bachelors Buttons.

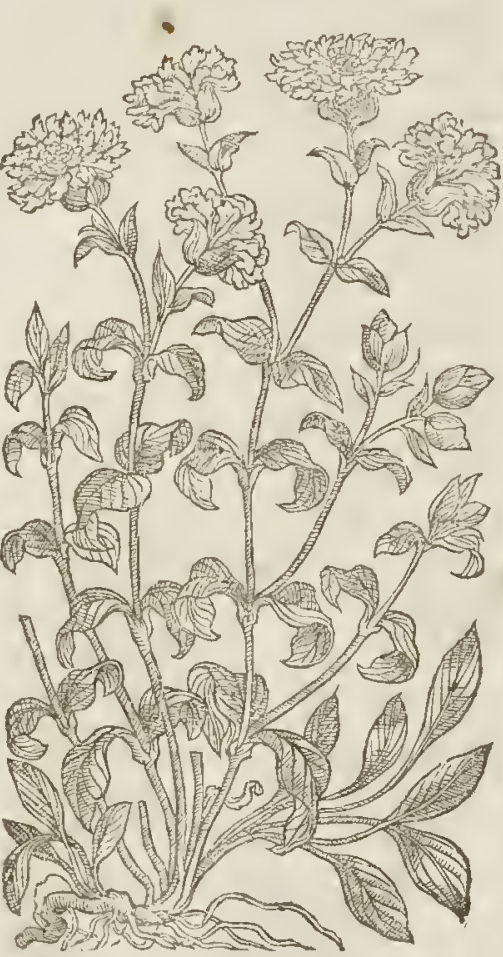

3 Neither in roots, leaues, or ftalkes is there any difference betweene this either degcnerate or accidentall varierie of Bachelors buttons, from rhe two laft mentioned; onely the floures hereof are of a greenith colour, and fomerimes through the middeft of them they fend vp italkes, bearing alforutts of the likc double floures.

4 This (faith clufus) harh fibtous roots like to thofe of Primroles; out of which co me leaues 
\$. Lychnis abortina fore rat liplici viridi.

1) egenerate Bachelors Buttons with greene flcures.
+5 Lychnisfyl.tatifolin Clur. Broad leated wilde Campion.

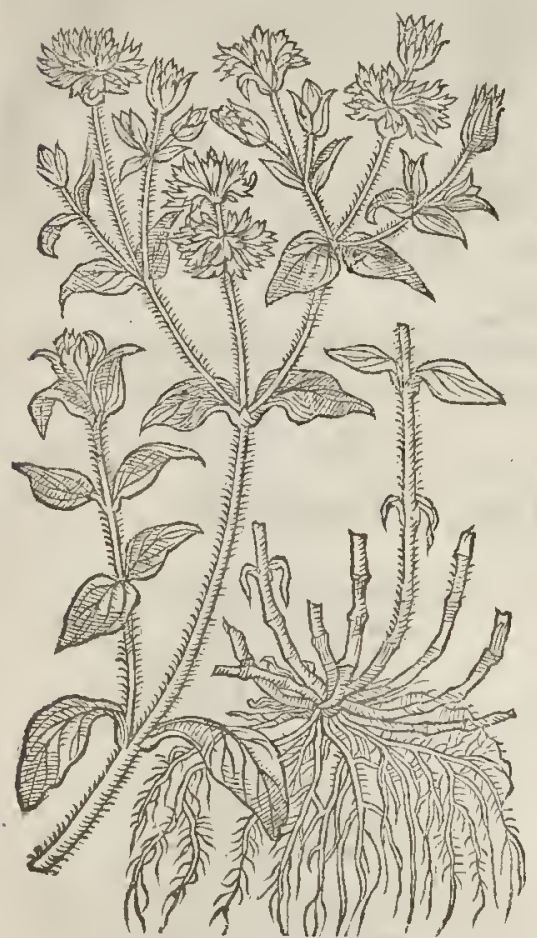

\$ Luchnis montana repens.

Creeping mountaine Campion.

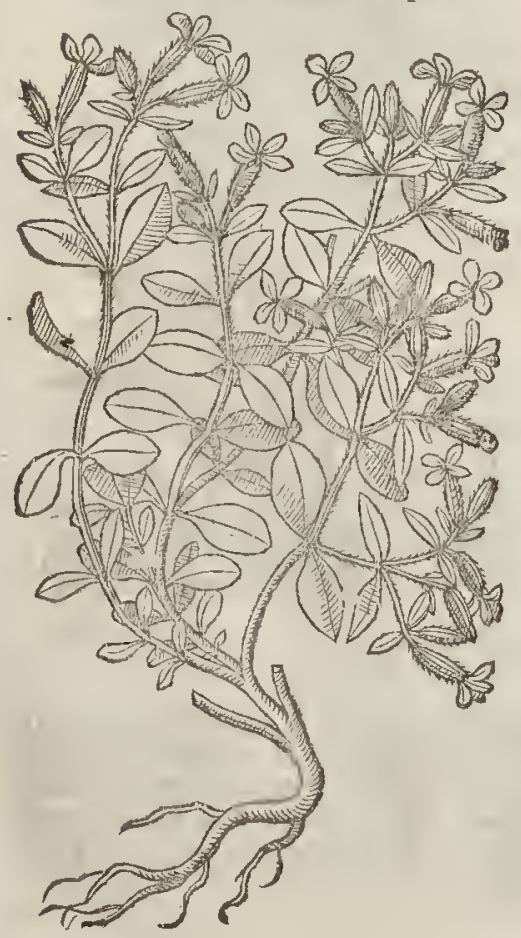

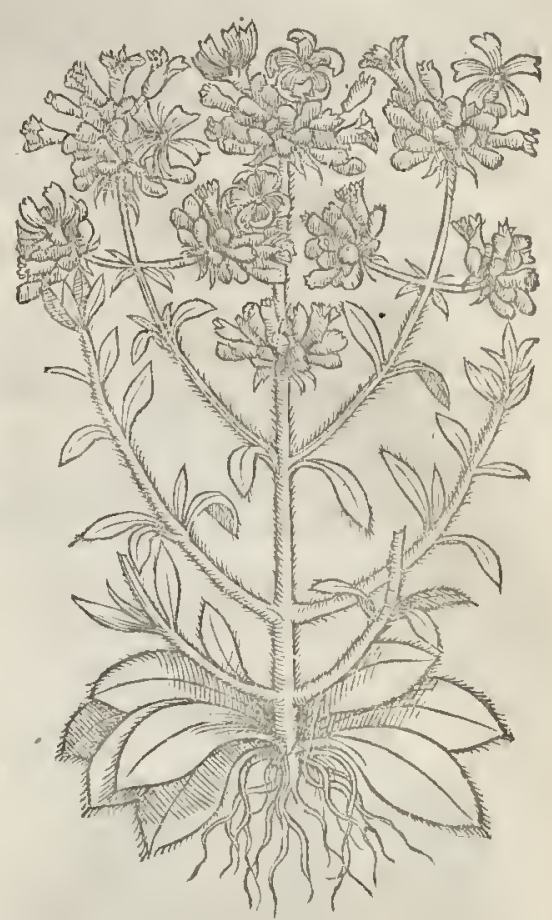

of a fufficient magnitude, not much valike thore of the great yellow Beares-eare, yet white, nore downy, thiche, and iuycie. The next yeare aft-r the fowing thereof it lends vpa fa ke bs two or three cubits high, here and tlere fending forth a vifcous and glutinous iuyce, which detaines and holds faft fies and fuch initicts as do chunce to light theteon. At the top of the branches it yeeldeth many foures fet as it were in an vmbel, euen fometimes an hundred; ret fufficiently fmall,confidering the magnitude of the plant; and each of thefe confints of fiue little yellowith greene forked leaues.

5 The Ralkes of this are Ilender, ioynted, and creeping like to thofe of the greater Chickweed, and at eacl ioynt grow two leates like thofe of the myrt le, or of Knot-grafe yet fomewhat broader. The floures grow in fuch long cups like as thole of Saponaria, and are much lefle, yet of the fame colour. The root is fmall.

$$
\text { If The Place. }
$$

r. 2. Thefe are kept in many Gardens of this kingdome for their beauty, efpecially the firf, wh hich is the more conmon.

The fourth growes naturally in Candy; and the fifth by riuelets in the mountainous places of Sauoy.

$$
\text { aा The Time. }
$$

Thefe floure in Iune and Iuly with the other wild Campions.

$\mathrm{R}$ :

ब) $T$ b 


\section{- Tlic Names.}

I The firft of thefe is Lychnis agreft is multiflore of Lobel; and ocymoides flore plero of Camerarius.

2 The fecond is by Pena and Lobelalfocalled Lychnis fylueftris multiflora: it is the ocymafium multiflorum of Tabernamontanus; by which title our Aurhor alfo had it in the former edition, $p .551$.

3 Lobel hath this by the name of Lychnis agreft is abortiua multiplici viride flore.

4 Clufues calls this Lychnis fylucfris latifolia; and he faith he had the feed from lofeph de Cafa Bona, by the name of Mufcipula auricule orfs facie: Baubine hath it by the name of Lychnis auricule vorfificie.

5 'This (according to Balbine) was fet forth by Matthislus, by the name of cneoron alud' 'Theo. phrafi $:$ it is the ocimoides repens polygonifolia fore saponaria, in the Adner faria: and Saponaria miror Dalefchampiy, in the Hift. Lugd. It is alfo ocimoides Alpinum, of Gefner; and ocymondes repens, of Camerarius.

\section{The Nature and Vertues.}

The natures and vertues of thefe, as of many others, lie hid as yet, and fo may continue, if chance, or a more curious generation than yet is in being do not finde them out.

\section{C на в. 129. Of Willow-berbe, or Loofe-frife.}

I Ly franchis lutea.

Yellow Willow-herbe.

Lysimachia vulgaris

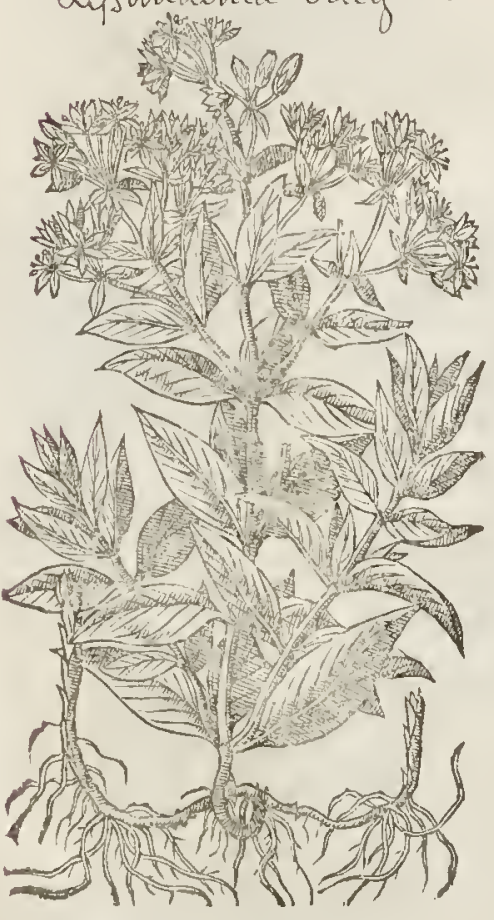

\$ Lyfmachia luteaminor. Small yellow Willow-herbe:

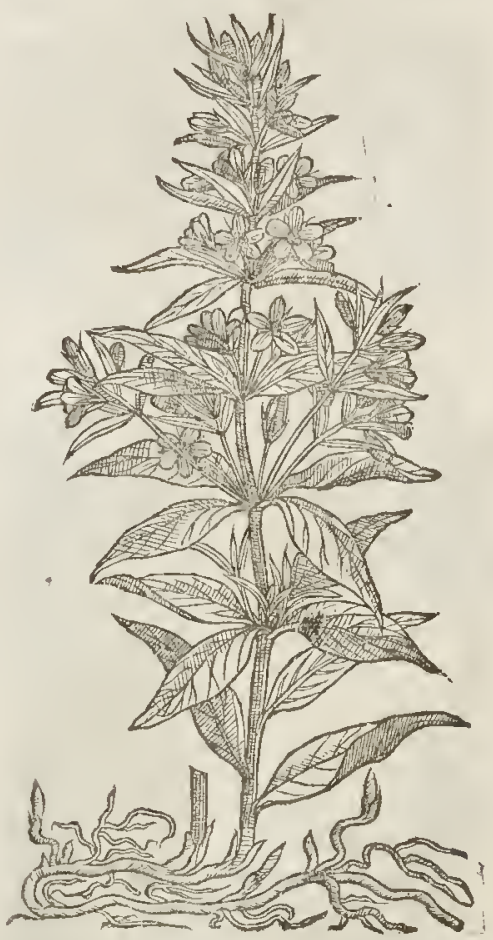

T) The Defription.

I Me firf kinde of Willow-herbe hath long and narrow leaues of a grayion greene colour, in thape like the Willow or Sallow leaues, ftanding three or foure one againft it felfe into many other branches, on the tops whereof grow tufts of faire yellow floures, confifting of fiue leaues a piece, wirhour finell : which being paft, there commeth forth feed like Coriander. The root is long and llender. 
$\Varangle \quad 2$ This leffer of $C \ln f$ izus his defeription hath a ftalke a cubit high, and fomerimes ligher firme, hatd, and downy; about which at certaine diftances grow commonly foure leaues together, yer fomerimes but three, and they are foft and fontewhat downy, leffer than thofe of the former, being firt of an acide tatte, ind then of an acride; and they are vifully marked on their lower fides with blacke fpots. Abour the top of the ftalke, out of the bofomes ot each leafe come forth lirtle branehes bearing fome few floures, or elfe foot-ftalkes carrying fing le floures, which is more vfuall torvards the top of the ftalke. The floures are yellow, wirh fomewhat a frong finell, coufinting of fue tharpe pointed yellow leaues, with fo many yellow threds in their middle. The root is ioynted, or creeping here and there, putting vp new fhouts.

¥ 3 Lyfimachial lutea flore globofo.

Yellow Willow-herbe with bunehed floutes.

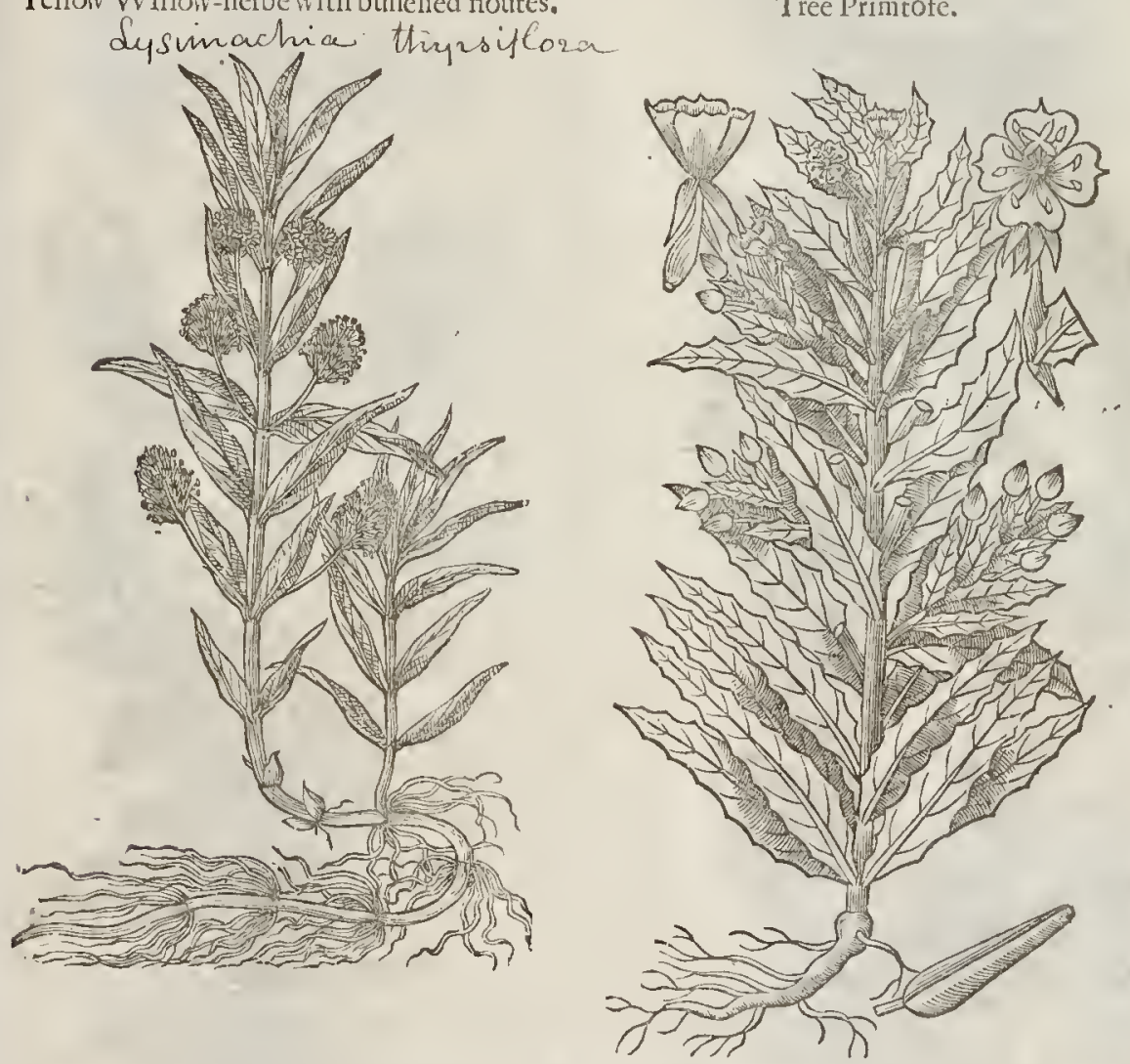

$$
\text { . }
$$

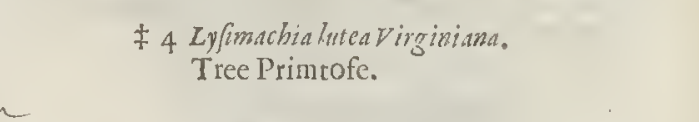

¥4. Lyfmachialuteavirgiviana. Tree Primtofe.

3 This alfo may fitly be teferred to the former. The ftalke is a cubit high, ftraight, and as it were ioynted, naked oft times below by the falling away of the leaues ; but from the middle to the top fet with two leaues at a ioynt, like thofe of the former; and out of their bofoms on thort ftalks grow round tufts of fmall yellow Houres as in bunehes : the root which cteepes fends forth many fmall fibres at eaeh ioynt. This was fet forth by Lobelvider the ritle of $L y$ fimachialuter altera, ot

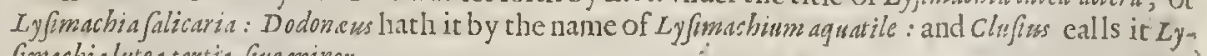
fimachialuteatertin, ine minor.

4 This Virginian hath beene defcribed and figured onely by Proper Alpinus, vnder the tit le of Hyoccyamus Virginianus: and by $\mathrm{M}^{3}$. Parkinfon, by the name of $L$ y frmachia lutea fliquofa Virginiand: Alfo Bawbine in the Append ix of his Pinat hath a large defeription thereof, by the name of $L$ yfrma chia lutea corniculata. The root hereof is longith, white, about the thichneffe of ones thumbe, from whence growes v a tall ftalke diuided inro many btanches of an ouerworne colour, and a little hairie: the leates are like thofe of the former, but fomewhat fiutuated along it their edges, and hauing their middle veine of a whitifh colour : tow ard the tops of the branehes among th the leaues come ip pretry thieke cods, which growing fmaller on their tops fuftaine pretty large yellow floures confifting of foute leaues, with a peftill in the middle vpon which ftand foute yellowith thrums 


\section{Of the Hiftory of Plants.}

L1 в. 2:

in farhion of a croffe; and therc are alfo eight threds with their pointals in the middles of them. Thefe foures haue fomewhat the fmell of a Primrofe (whenee $\mathrm{M}^{\mathrm{r}}$. Parkisfon gaue it the Englifh name, which I haue alfo here ginen you: ) after the floures are fallen, the eods grow to be fome two inehes long, being thicker below, and fharper at the top, and fomwhat twined, which in fine open themfelues into foure parts to fhatter their feed, which is blacke and fmall ; and fowne, it growes not the firf yeare into a ftalke, but fends vp many largc leautes lying hand fomely one vpon another Rofe-fafhion. It flourcs in Iune, and ripens the feed in Auguft. $¥$

5 The fecond kindc of Willow-herbe in ftalks and leaues is like the firft, but that the leaues are longer, narrower, and greener. The floures grow along the ftalke toward the top, fpike-farhion, of a faire purple colour : which being witheted turne into downe, whieh is carried away with the winde.
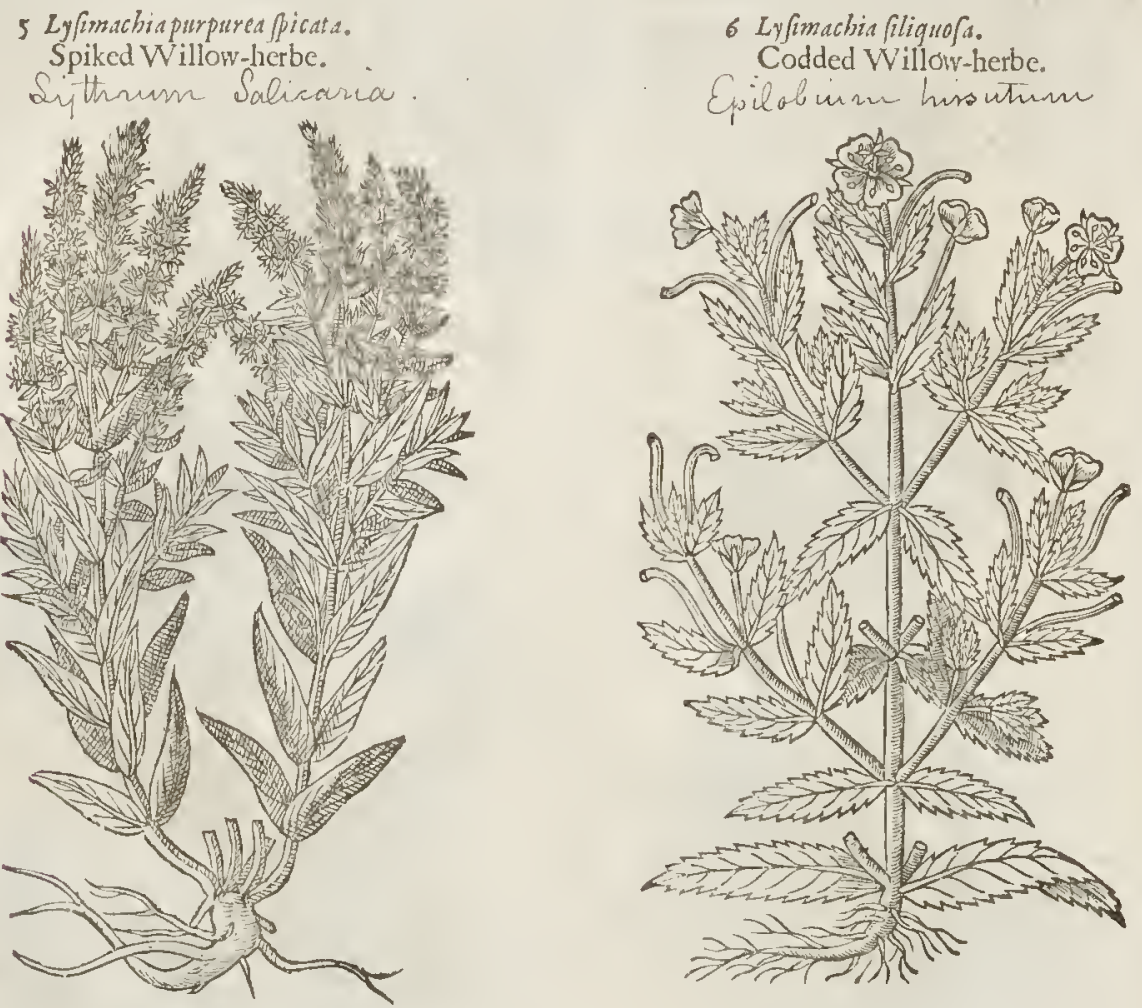

6 This Lyfmacbia hath leaues and ftalkes like vnto the formet. The flouregroweth at the top of the ftalke, comming out of the end of a fmall long eod, of a purple colour, in thape like a frocke Gillofloure, and is ealled of many Filius ante Patrem (that is, The Sonne before the Father) becaufe that the cod eommeth forth firft; hauing feeds therein, before the floure doth thew it felfe abroad. F The leanes of this are nore foft, large, and hairy than any of the former : they are alfo fnipt about the edges, and the floure is large, wherein it differs from the twelfth, hereafter deferibed, and from the cleuenth in the hairinefle of the leaues, and largeneffe of the flourcs alfo, as you thall finde hereafter. $t$

7 This being thought by fome to be a batard kinde, is (as I do efteeme it) of all the reft the moft goodly and ftately plant, hauing leates like the greateft Willow or Ozier. The btanehes come out of the ground in great numbers, growing to the height of fix foot, garnifhed with braue floures of great beauty, eonfifting of foure leanes a picce, of a n orient purple colour, hauing fome threds in the middle of a yellow eolour. The cod is long like the laft fpoken of, and full of downy matter, which flicth away with the winde when the cod is opened.

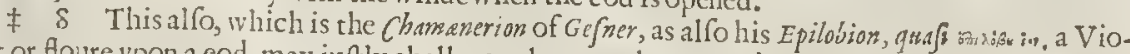
let or Aloure vpon a cod, may iufly challenge the next place. Dodoneur calls it Pfeudoly fimachium 


\section{$\mathrm{L}_{18.2 .}$}

Of the Hiftory of Plants.

† 7 Chamanerion.

Rore bay Willow-herbe,

Epilobium o angustipolimm

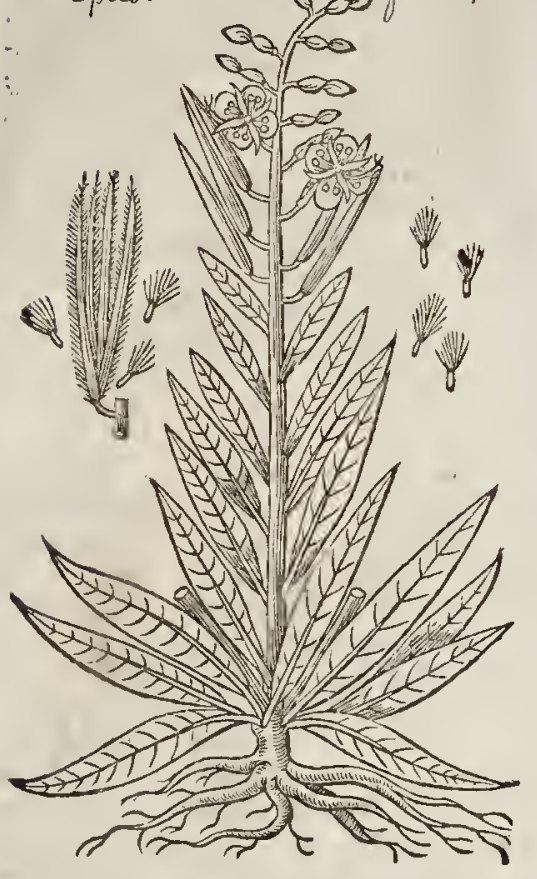

\$ Lyfimachia carulen. Blew Loofe-ftrife.

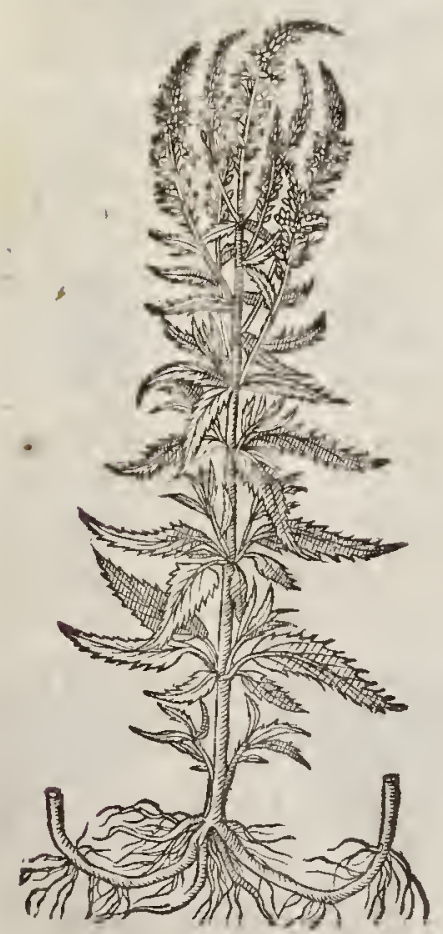

\$ Chamenerion alterumangaffifoliwm.

477

Narrow leaued Willow-Houre.

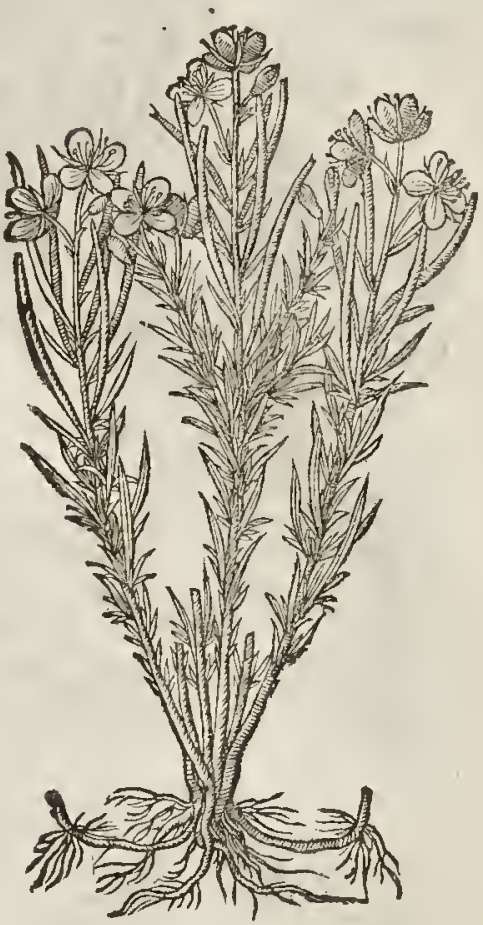

\$ 10 Lyfimachiagalericulats. Hooded Loofe-frife.

Scutellaria galesiculata

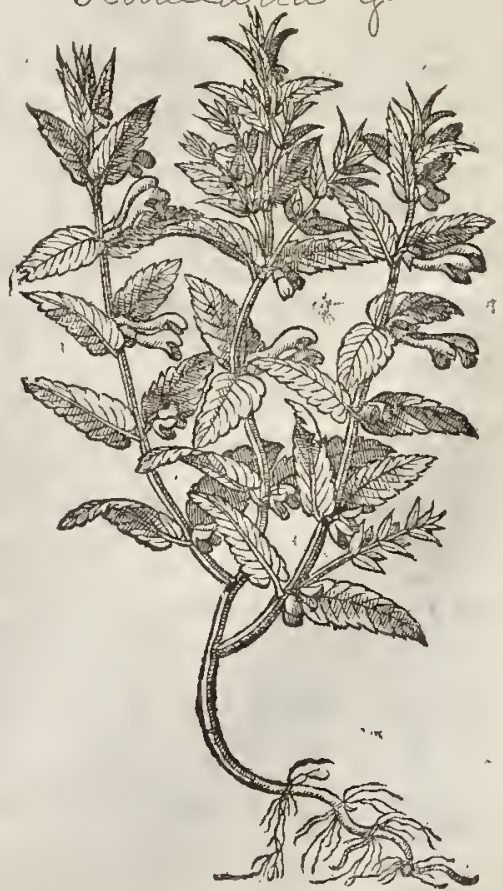

$R+3$ 
II Lyfimachiacampeftris. Wilde $\mathrm{T}^{\mathrm{T}}$ illow-hetbe. Epilobium montamme

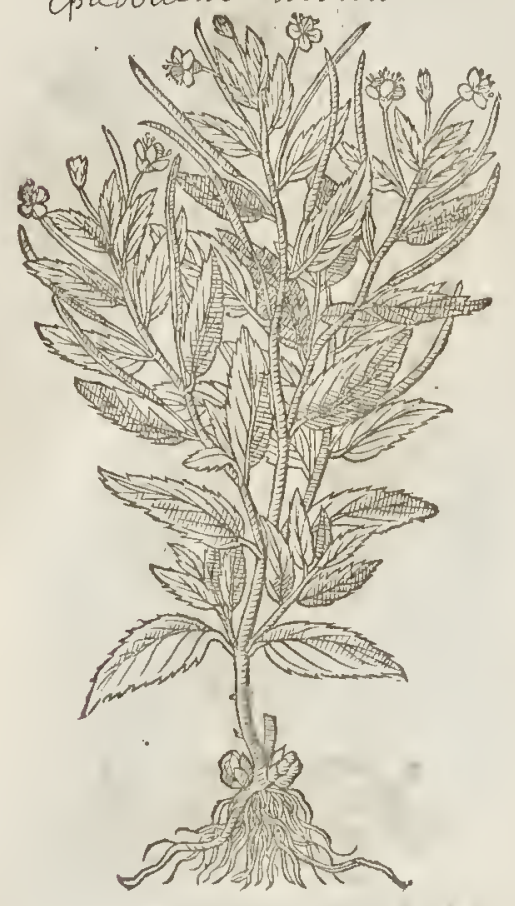

purpuresm minus : and it is in the Hillor.Lurdun. inder the name of Linaria rubra. It groweth vp with falkes fome foot high, fet with nany narrow leaues like thofe of Toad-fax, of a grayith colous,and the ftalke is parted into diuc rs branches, which at their tops tpon long eods earric purple floures confifting of loure leutes apicee. "The root is long, yellowith, and wooddy.

9 There is another baftard Loofe-ftrife or Willow-herbe hauing ftalkes like the other of his kinde. whereon are placed long leaues inipt about the edges, in thape like the great $V$ cronica orherbe Fluellen. The floutes grow along the ftalkes, fpike-farhion, of a blew eolour ; after which freeced finall eods or pouches. The root is fmall and fibrous : it may be ealled $L y / i m a$. chia carulea, orblew KVillow-herbe.

Io We hate likewife anothet Willow: hetbe that groweth neete vnto the bankes of riuers and water-eourfes. This I found in a wateric lane leading from the Lord Treafurer his houfe ealled Theobalds, into the backefide of his flatgghter-houfe, and in other plaees,as fhall be declared hereaftet. Which Lobel hath ealled Ly fimaclial galcriculata, or hooded VVillowherbe. It hath many fmill tender falkes trailing vpon the grouled, befet with diuers leanes fomwhat fnipt about the edges, of a deep green colour, like to the leaues of Scordinm or watet Germander: among which ate plaeed fundric fmall blew floures fathioned like a little hood; in thape refembling thofe of Ale-hoofe. The root is fmall and fibrous, difperfing it felfe indet the earth farre abroad, whereby it greatiy

II Thewilde Willow-Herbe hath fraile and very brittle ftalkes, flender, eommonly about the height of a eubit, and fomerimes higher; whereupon doe grow fharpe pointed lcates fomewhat fnipt about the edges, and fet together by conples. There come fotth at the firft long flendet eoddes, whetein is contained fmall feed, wrapped in a eottony or downy wooli, which is earried away with the winde when the feed is ripe: at the end of whieh eommeth forth a fmall floute of a purplifh colour; whereupon it was ealled Filius ante Patrem, beedufe the floure doth not appeare vntill the eod be filled with his feed. But there is another Sonne before the Father, as hath beene declared in the Chapter of Medow-Saffron. The root is fmall and thred. die. \# This differeth from the fixtl onely in that the leates are lefle, and leffe hairy, and the
floure is fmaller. $\$$

I 2 . The Wool VVillow-hearbe hath a flender ftalke diuided into other fmaller branches, wheteon are fet long leaues rough and tharpe pointed, of an oucrworne greene eolour. The floures grow at the tops of the branehes, confiting of foure or fiue fmall leaues, of a pale putplifh eolour tending to whitenefe : afterwhieh eome long cods, wheteinare little feeds wrapped in a eertaine white Downe that is catried away with thewinde. The root is threddie. $¥$ This differs from the fixth in that it hath leffer floures. There is alfo a leffet fort of this haitio Ly fimachia with fmall floures.

There are two mote varieties of thefe eolded Willow-herbes; the one of which is of a middle growth, fomewhat like to thatwhich is deferibed in the eleuenth plaee, but leffe, with the leaties alfo fnipped about the edges, fmoorh, and not hairie:and it may fitly be ealled $L$ v/ma chia filiquof glabramedia, or minor, The leftet fmootl-leaued Willow-herbe. The other is alfo finooth leaued, but they are leffer and narrower: wherefore it may in Latine be termed, Lyfimacha filigrofa glabra minor anguftifnlia : in Englifh, The leffer fmooth and narrow leaued Willow-herbe.

* 13 This lefer purple Loofe-frife of clufus, hath ftalkes feldome execeding the height of a cubit, they arealfo flender, weake and quadrangular, cowatds the top, diuided iato branehes 
LIE.2。

growing one againft another, the leaves arc leffe and narrower than the common puple kinde, and growing by couples, vnleffe at the top of the ftalkes and branches, whereas they kecpe no certaine order; and among ft thefe come here and there connered cups containing floures compofed of fix little red leanes with threds in their middles. The root is hard, woody, and not creeping, as in others of this kinde, yet it endures all the yeere, and fends forth new fhoots. It foures in lune and Iuly, and was found by Chisfius in diucrs wet medowes in Autria.

$$
\text { का The rlace. }
$$

The firlt yellow Ly/imachingroweth plentifully in moift medewos, cfpecially alcng the mo dowes as you go from Lambeth to Batterfy neerc London, and in many other places throughour England.

\# 3 Lyfimacbia purpureaninor Clufs. Small purple Willow herbe.

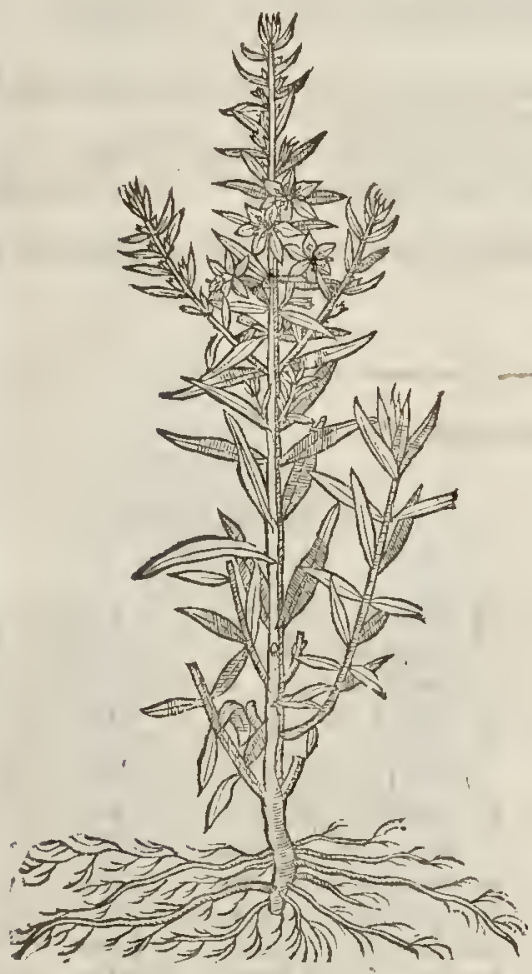

$\ddagger$ The fecond and third I hauc not yet fecne.

The fourth groweth in many gardens. \pm

The fift groweth in places of greater moifture, yea almoft in the running ftreames and ftanding waters, or hard by them. It growcth vnder the Binops houfewail at Lambeth, neere the water of Thames, and in moift ditches in moft places of England.

The fixth groweth necre the waters (and in the waters) in all places for the moft part.

The feuenth groweth in Yorkfhirc in a place called the Hooke, ncer vinto a clofe called a Cow pafture, from whence I had thefe plants, which doc groiv in my garden very goodly to bchold, for the decking vp of houfes and gardens.

\# The eighth I hauc not yet found growing.

The ninth growes wild in fomc places of this kingdome, but I hate feene it only in Gardens.

The tenth growes by the ponds and waters fidcs in Saint Iames his Parke,in Tuthill fields and many other places. $\neq$

The elcuenth groweth hard by the Thames, as you goe from a placc called the Dincls $\mathrm{Nec}$ kerchicfe to Redreffe,neere vnto a ftilc that itandeth in your way vpon the Thames banke, among the plankes that doe hold vp the famc banke. It growcth alfo in a ditch fide not farre from the placc of execution, called Saint Tho. mas Waterings.

$¥$ The other varieties of this grow in wet places, about ditches, and in woods and finch like moift grounds.

\section{- The Time.:}

Thefe herbcs floure in Iune and Iuly, and oftentimes vntill Augurt?

$$
\text { of The Names: }
$$

Lyfimachin, as Diofcorides and $P$ liny writc tonke his namc of a fpeciall vertue that it hath in appeafing the ftrife and vnrulineffe which falleth out among oxen at the plough, if it bee put about their yokes : but it rather retaineth and kcepeth the name Ly fimacbia, of King $L y$ fimachus the fonnc of $A$ gathocles, the firlt finder out of the nature and vertues of this herb, as $P$ ling faith in his 25 .book chap. 7. Which retaineth the name of him vnto this day, and was made famous by Erafferatus. $k$ s.

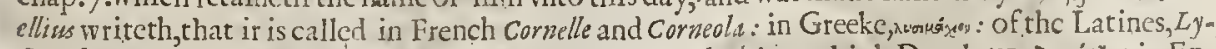
fimachium : of Pliny, Ly fim atbia: of the later Writers, salicaria: in high Dutch, ueederick: in En. glifh, Willow herbe, or herbe Willow, and Loofe ftrife.

chumenerium is called of Gefner, Epilobion : in Englifh, Bay Willow, or bay yellow herbe. 
‡ The names of fueh as I haue added hane been fuffieiently fet forth in their titles and $\mathrm{Hi}$ ftories. $\neq$

$$
T \text { he Nature. }
$$

The yellow Lyfimachia, which is the chicfeand beft for Phyfieke vfes, is eold and dric, and very aftringent.

The Vertues.

A The iniec, aceording to Diofcorides, is good againt the bloudy fix, being taken cither by potion or Clifter.

B It is exeellent good for greenewounds, and ftaneheth the bloud : being alfo put into the noAthrils, it fopueth the bleeding at the nofe.

C The fmoke of the burned lerbe driteth away ferpents, and killeth flies and gnats in a houfe, whieh Pliny fpeaketh of in his 25 .book, chap. 8. Snakes, faith he, craull away at the finell of Loof ftrife. The fame Authour affirmeth in his 26 booke, laft ehap.that it diech haire yellow, whieh is notvery wnlike to be done by reafon the floures are yellow.

D The others haue not been ex perimented, wherefore vatill fome matter worthy the roting doth offer it felfe vnto our confideration, I will omit further to difeour fe her cof.

E The iniee of yellow Lyfimachia taken inwardly, ftoppeth all fluxe of bloud, ard the Dyfenteria or bloudy fix.

F The itice put into the nofe, ftoppeththe blecding of the fame, and the bleeding of wounds, and mightily elofeth and healeth them, being made into an vnguent or falue.

G The fame taken ina mother fuppofitorie of wooll or cotton, bound vp with rhreds (as the manner thereof is, well knowne to women) ftaicth the inordinate flux or onernuel flow ing of womens termes.

H. It is reported, that the fume or fmoke of the herbe burned, doth dritue away flies and gnats, and all manner of venomous beafts.

\section{Снар.130. Of Barren-soort.}

Epimedium.

Barren Woort: Epinediem alpinum

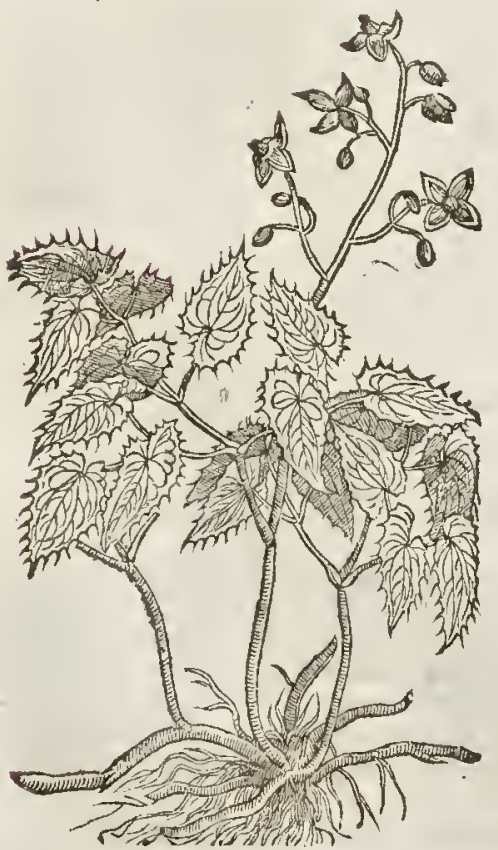

TI The Defcription.

$T$ His rare and f range plant was fent to me from the Frenel Kings Herbarift Robinus, dwelling in Paris at the figne of theblacke head, in the ftreet ealled $D$ w bout dr alonde, in Englifh, The end of the world. T his herbe I planted in my garden, $\& x$ in the beginning of May it eame forth of the ground, with fmall, hard \& woodie crooked ftalks: whereupon grow rough \& tharpe pointed leates, almott like Alliaris, that is to fay, Sauce alone, or laeke by the hedge.Lobel and Dod.fay, that the leaues are fomew hat like luie; but in my iudgement they are rather like Alliarin, fomwhat fnipt abour the edges, and turning them. felues flat vpright, as a manturneth his hand vpwards when hee receineth money. Vpon the fame ftalkes eome forth fmall floures, ennlifting of foure leaues, whofe out fides are purple, the edges on the inner fide red, the bottomeyellow, $\&$ the middle part of a bright red eolour, and the whole floure fomewhat lollow. Theroot is fnal, and ereepeth almolt vpon the vppermoft face of the earth. It bcaretb his feed in wery fmall cods like Saraeens Confound, ( $\ddagger$ to wit that of our Authour formerly 
merly defcribed, pag. 274. ) but thoiter : which came not to ripeneffe in my garden, by reafon that it was dried away with the extreme and vnaccuftomed heat of the Sun, which happened in the yeare 2590 . fince which time from yeare to yeare it bringeth feed to perfection. Further, $D$ io fori des and Pliny do report, that it is without floure or feed.

$$
\text { T The Place. }
$$

+ It groweth in the moift medowes of Italie about Bononia and Vincentia:it groweth in the garden of my friend $\mathrm{M}^{\mathrm{r}}$. Lohm Milion in Old-ftreet, and fome other gardens about towne.

$$
\text { TT The Time. }
$$
before.

It floureth in Aprill and Mayswhen it hat taken faft hold and fetled it felfe in the earth a yeare

T The 2 dames.

It is called Epimedium : I haue thought good to call it Barreh woort in Englifh ; not becaufe that $\mathrm{niof}$ corides faith it is barren both of floures and feeds, but becaufe(as fome authors affirme) being drunke it is an enemie to conception.

TT The Temperature and Vertues.

Gales affirmeth that it is moderately cold, with a wateric moifure : we haue as yet no ve hereof in Phyficke.

\section{¥ С на во 131. Of Fleabane.}

* I Conyza maior.

Great Fleawoort.

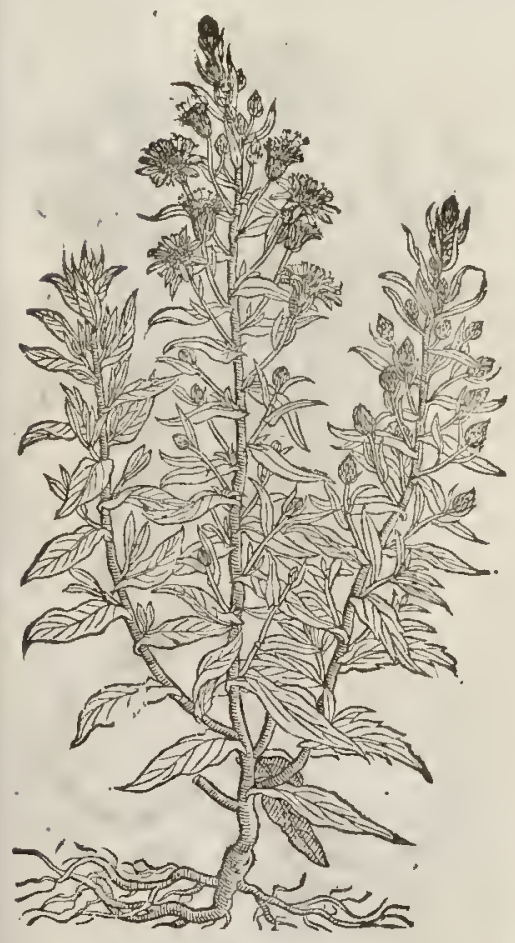

\#2 Conyua minorvera. Small Fleabane.

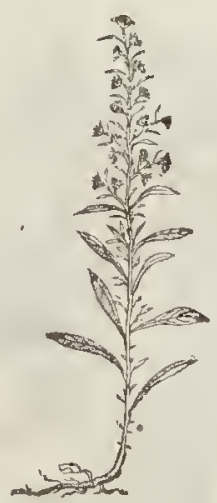

¥ THe fmalnefre of the number of thefe plants here formerly mentioned, the confufion notwith. ftanding in the figures, their nominations \& hiftoric,not oneagreeing with another, hath eaufed me wholly toomit the defcriptions of our Authour, and togiue you new, agreeable to the figures; together with an addition of diuers other plants belonging to this kindred. Befides there is one thing I mutt aduertife

firf place defcribed the Baccharis Monpelienferm of Lobel, or Conyzamaiorof Mattholus, \& it is that which grows in Kent and Effex on chalkie hils; yet he gaue no figure of it, butas it were forgetting what he had don,allotted it a particular chap.afterwards, where alfo another figure was put for it: but there you thall now finde it, though I muft corfeffe that this is as fit or a fitter place for it; but I will follow the courfe of my Authour, whofe matter, not method I indeauour to amend. 
9ा The Defcription.

lour : the leatalkes of fome yard high or more; hard, wooddy, rough, fat, and of an ou crworne co. of the Olitue tree, rough and fat, being as it were befmeared with a gummineffe or fattineffe, and of a yellowith greene colour : the floures grow after a fort fpoke fathion, ftanding at the ends of footitalkes conming out of the bofomes of the leates, and they are yellow and round almoft like to Ground fwell, and flie away in downe like as they doe; the feed is fmall and afh eoloured. The whole plant is fattic and glutinous, with a ftrong,yet not altogether vnpleafant fmell. This growes not that I know of in thefe cold Comntries, vnlefe forv ne in gardens. Clufius found it by Lisbone, and in diuers places of Spaine. Hc,as alfo Dodomerus, Lobel, and others, call this Conyza maior, and it is thought to be the Conyza mas of Theophraftus, and Conyza maior of Diofcoridos.

2 The leffer feldome fends vp more than one ftalke, and that of a eubit high, yet vfually not fo much :it is diuided into little branches, and alfo rough and glutinous as the precedent, but more greene. The leaues are thrce times leffe than thofe of the former, fomewhat maped like thofe of Toad-flax, yet hairy and vetious; the tops of the branches as in the bigger, carrie leffe, and leffe thining and fightly floures, vanithing in like fort into downe. The root is fingle and annuall, and the whole plant more fmelling than the former. This is iudged the conyza famima of $T$ heophraftus: and Con. minor of Diofcorides; it is the Con minor of Gefner, Lobel, Clufius and others. It growes in diuersparts of Spaine and Prounee in France, but not hese,vnlefle in Gardens.
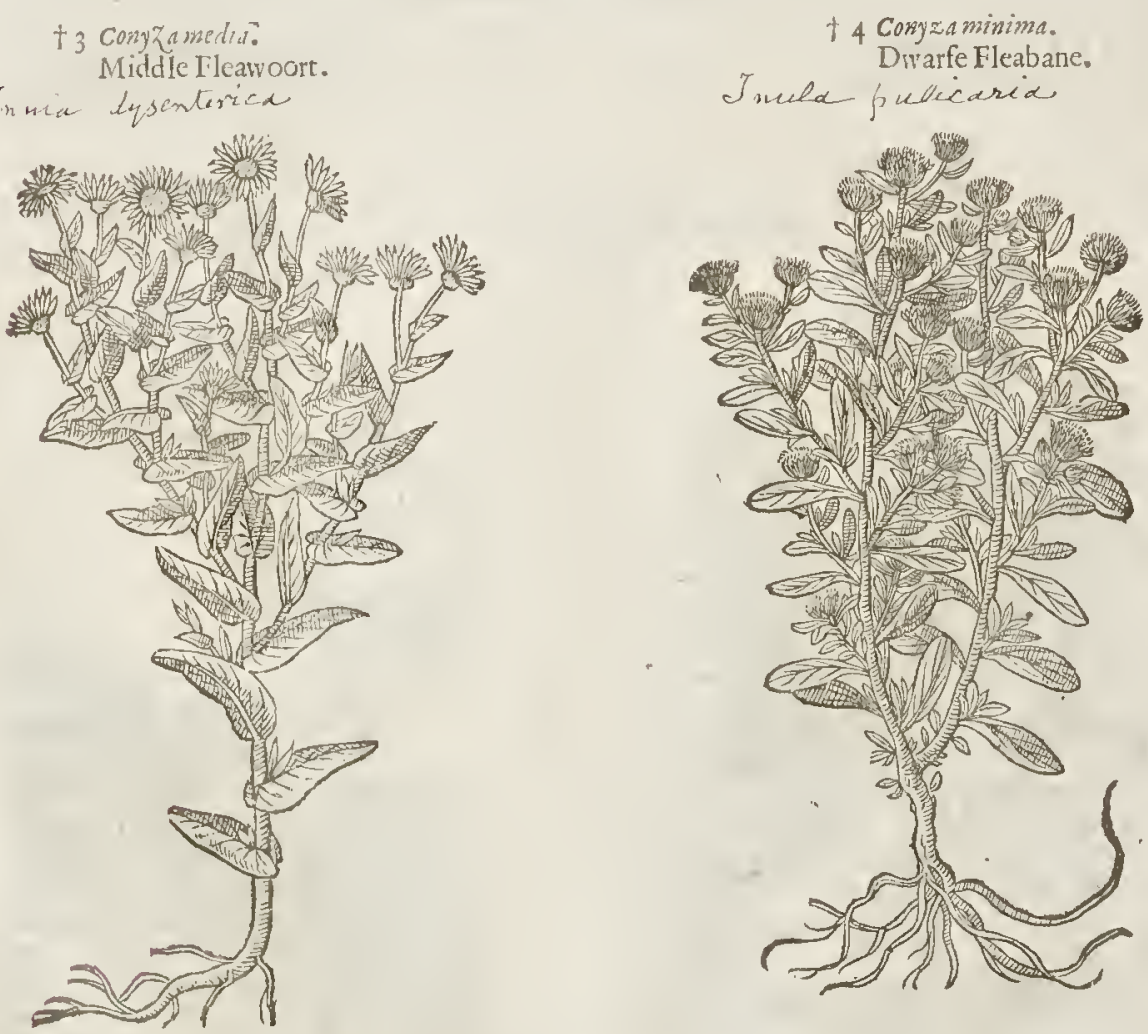

3 The root of this middle kinde is prettie large and fibrous, from whence arifeth a branched falke of fone cubite high, engirt at eertaine fpaces with thieke, rough, grayifh greene leaues :at the tops of the branches grow pretty faire yellow floures of the bignes of a little Marigold; which fading turne to downe, and are carried away with the winde. This floures in Iuly and Auguft, and may be found growing in moft plaees about riuers and pond fides, as in S.Iames his Parke, Turhill fields, \&c. This is Cony $\{$ media of Mathiolus, Dodonsus, and others. Some haue referred it vnto the 
L 1 в. 2. Of the Hittory of Plants.

Mints, as Fuchfus, whomakcs it Calcmintbe $3 . \mathrm{genus}$; and Lonjerws, whocalls it Mentha Luter. In Cheape-fide the berbe-women eall it Herbe Chrifopher, and fell it to Empericks, who with it (as they fay) make Medicines for the eyes, but againft what affect of them, or with what fueeefe I know not.

4 In like places, or rather fueh as are plathy in winter this may be plentifully found growing. The ruots are fmall and fibrous; from whenee arifeth a branched ftallse fome foot high, fer with fmall longith leates fomewhat roundiln pointed, foft alfo and woolly, with a fmell not altogether vnpleafant, like as the lat deferibed : the floures are eompofed of many yellowith threds like to the middle part of Camomill floures, or thofe of lanfey : and as the former, rurne into downe, and are carried away with the winde; it floures in Iuly and Augutt. This is the Conrzaminor of $T$ ragu, Clatholves, and others : Lobcl and Dodon. call it Cony a minima.

5 This eut leaued Fleabane hath fmall fibrous roots, from which arife thicke, erefted, \& hollow ftalks, diuided towards the tops into fundry branches the leates that ineompafte the ftaike are gamed, or elfe onely fintated on the edges: the floures are ftar fanhion and yellow, and alfo lie away in do:vne; the whole plant is eoucred ouer with a foft and tender downe,and hath fomcwhat the imell of Honic. This is a varictie of the third,and is ealled by Dodon. Conyzemedis $\beta$ ecics alker. Lobcl names it Conyza helenit is folys laciniatis.

6 The figurewhieh you hame in thus fixth place was formerly vifitly giuen by our Authour for Solzdago Suracenica; it hath a large root whiel fends foorth many fibres, and a erefted hollow ftalke fome two eubites or more high, which is vnorderly fet, with long, yet narrow fript leaues fomewhat hairic and Marpe pointed : the toppe is diuided incobranehes, which beate prettie large yellow floures, made after the manner of thofe of Ragwort, and like as they, are alfo carricd away with the winde. This $T$ halius cals Cony Zn maxima ferratifolia. It is the Lingua maior of Dalefchampius, and the Confolida paluftris of Tabernamontanus. It groweth neere water fides, and floures towads the latter end of Sommer: I haue not yet heard that it doth growwilde a. mongft vs.

* 5 Conyza folys latiniatis.

Great iagged leaued Fleabane. Cineratic fralestris

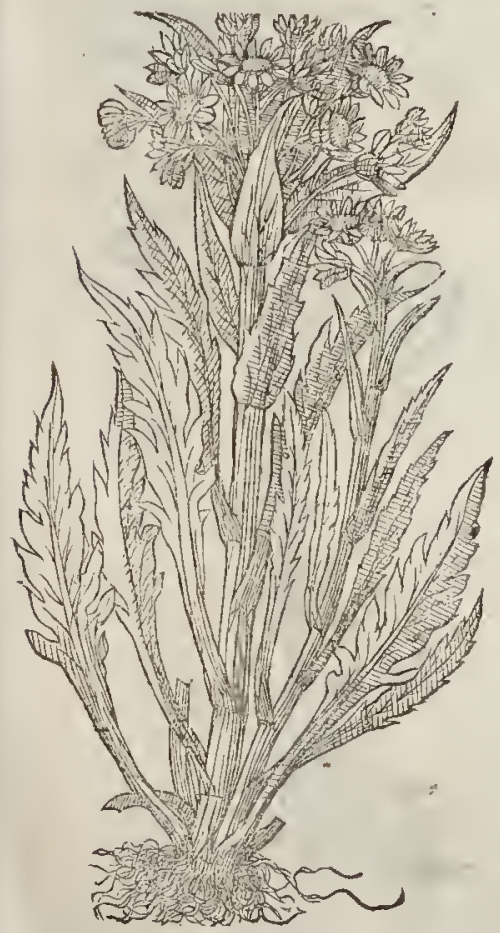

\$ Cony $\approx$ a paluftris ferratifolia. Water fript Flcabane.

Sinceio paludosus

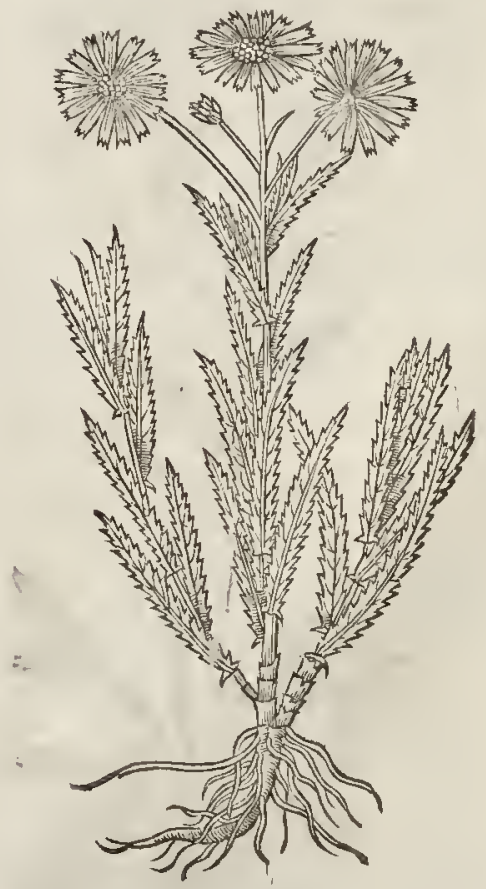




$$
\begin{aligned}
& \frac{484}{\neq 7 \text { Coryzacusiniaca Clafij. }} \\
& \text { Aufrian Fleabane: }
\end{aligned}
$$
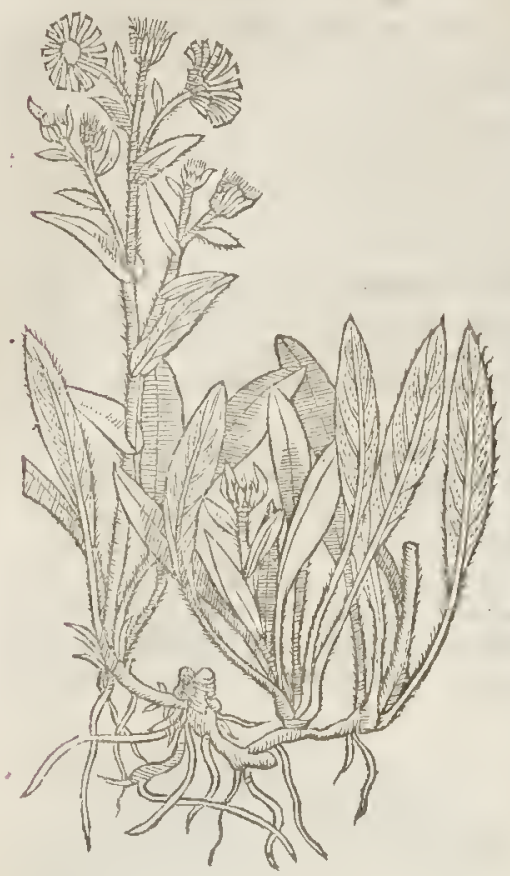

9 Conyza Alpinapiloffsima.

Hairie Fleabane of the Alpes:

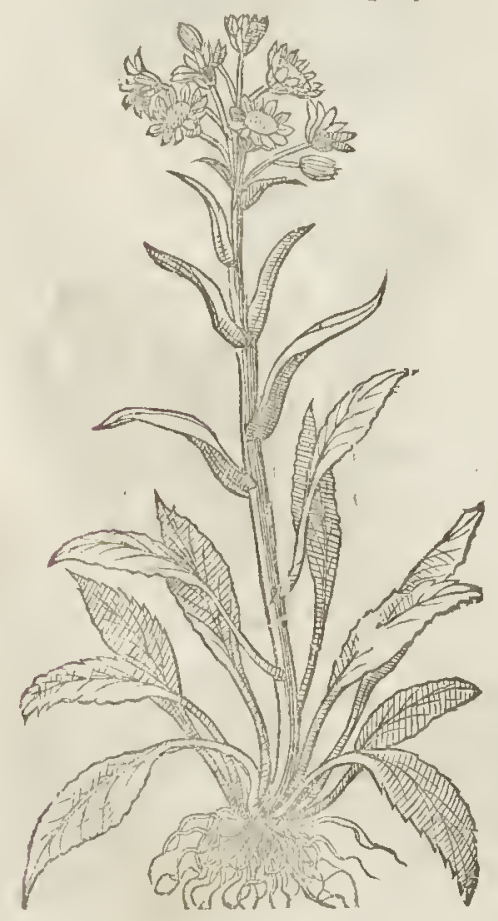

LIв. 2.

$\ddagger 8$ Conyza incana. Hoary Fleabane:

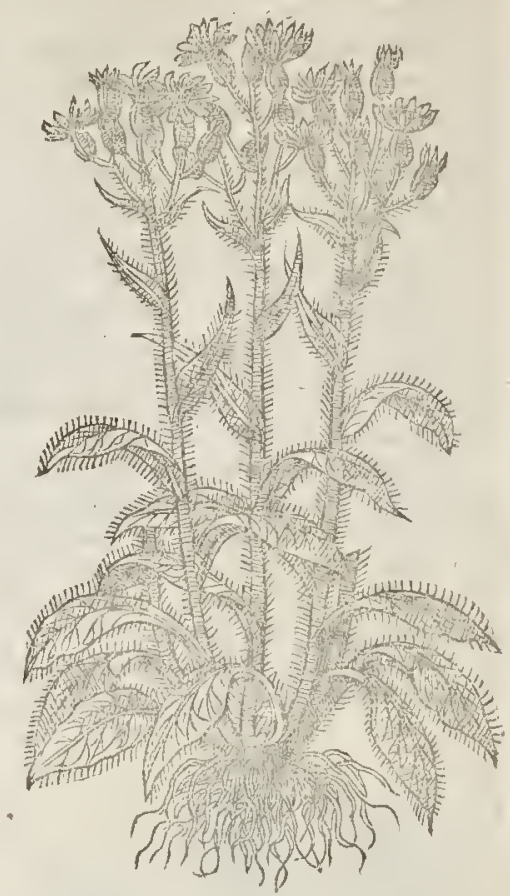

t 10 Conyza Caruleat acris. Blew floured Fleabane. ivioprose acse

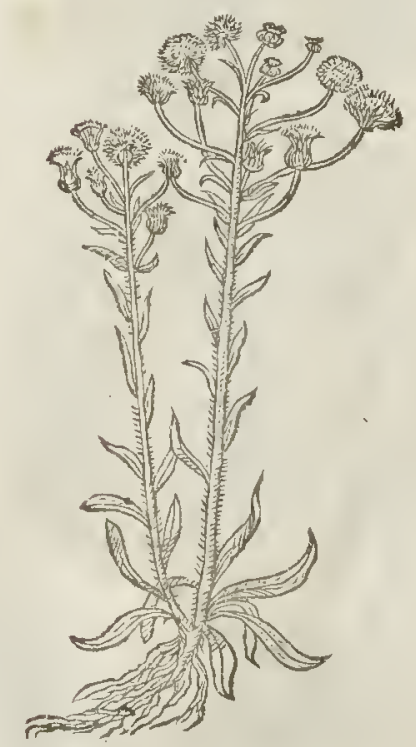


7 The ftalkes of this are about a foot high, ftraight, thiffe, hard, and conered with awhirifh downe: the leates at the root grow vpon long ftalkes, and are foft and hairie; but thof which are higher vp, hauc a thort, or elfe no ftalke at all, and rubbed, they yeeld no vnpleafant fimell, and tafted, they are fomwhat bitter and acride. The floures that grow vpon the tops of the branches are large, and farhioned like thofe of Elecampane, and are of the fame yellow color. The roor is long, flender and blackifh,creeping and putting wp new ftalkes; it hath many whire fibres and a tefinous fmell. Clufius found it growing on dry hilly places in Aufria, and calls it Coxyza 3. Lw.
friaca.

8 This which Lobel fets forth vnder the title of Coryza belentis mellitrincand, I tate to be the

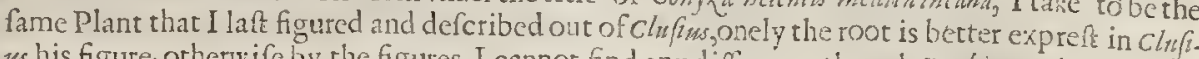
us his figure; otherwife by the figures I cannot find any difference, thoigh baubine reckon it vp in
his Pina. as differing therefrom.

9. This alfo feenes not much to differ from the lat mentioned, but onely in the hairineffe of the leaues and ftalkes, and that the floutes are fmaller. This Lobel cals Conyza Helenitis mellit in incan.r: Helenit is, becaufe the floures and leates haue fome femblance of Elecampane; and Exell ta, for that they fmell fomewhat like Honic. Thefe latt grow wpon mountaines, but none of them with is in England that I can yet heare of.

so This hath a fmall fibrous and yellowint root, of a very hot and biting tafte, which fends vp diters longifn leates about the head thereof; the ftalke is fome foot and halfe high,and fet alternately with twined, longifh, narrow and fomcwhat rough leaucs of an onerworne greene colour; the top of the ftalke and branches are adorned with floures fet in longifh fcaly heads like thofe of $H z$ ie raium: the outer little leaues are of a faint blew colour,and the inner threds are yallow. It Houres in Auguft, and the floures quick ly turne into downe, and are cartied aw ay with the wind. It grows

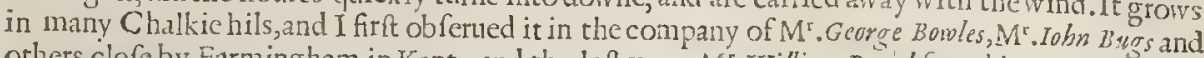
others, clofe by Farming ham in Kent ; and the laft yeare $\mathrm{M}^{\mathrm{r}}$. William Broud found it growing at the Bluckeh oufe at Grauefend. Tragus calls it Tinctorius flos alter: Dodoneus becaufe the floure yu ickly turns to doirne makes it Eriger on quartums and Gefner for that the root is hot, and drawes rlicing like as Pellitorie of Spaine, which therefore is vfed againft the Tooth-ache, names it Dentclaria: le alfocals it Conyza muralis, and coryzoides Carulea: Tabernamontanus alfo calls it conyza carnilea and laft ly, Fabius Columna hath it by the name of Amellus Montanus, ro which kinde it may in mineopinion be as fitly referred, as to thefe Conyza's. Our Authour had the figure lrereof in the third place in this Chapter.

$$
\text { T) The Place, Time, and Names. }
$$

All thefe haue beene fufficiently thewne in their particular Titles and Defcriptions. $\neq$

$$
\text { Cony } \approx a \text { is hot and dric in the third degree." The } \mathcal{N} \text { ature. }
$$

If The Vertues.

The leates and foures be good againft the ftrangurie, the iaundife, and the gnawing or griping $A$ of the bellie.

The fame taken with Vineger, helpeth the Epilepfie or falling fickneffe. ther.

If Women doe fit oner the decoution thereof, it greatly eafeth their paines of the Mo- $C$ The away.

The Herbe burned, where flies, Gmis, fleas, or any vanemous things are, doth driue them $D$

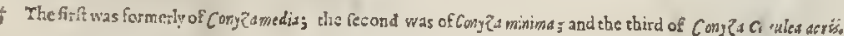

\section{CHA P.132. Of Starre-2000 :}

IT The Defoription.

I T He firt kinde of $A$ fer or Inguinalis, hath large broad leaues like $v$ erbaf cum Salvifolitum or the great Cony $\approx a$ - among which rifetls vp a ftalke foure or fiue handfuls high, hard, rough and hairic, befer w ith leaues like Rofe Campions, of a darke greene colour. Ac the top of the faid ftalkes cone forth floures, of a fhining and gliftering golden colour ; and vaderneath about thefe flotres grow fue or fix long leates, fharpe pointed and rongh, not much in

$$
\text { S\& thape }
$$


fhape vilike the fin called stellit marina. The floures turne into downe, and are earried away with the winde. The root is fibrous, of a binding and inarpe tafte.

* 2 The feeond ealled Italian Starrwwoort hath leaues not much vnlike Marigolds, but of a darke greene colour, and rough, and they are fomewhat round at the vpper end : the ftalkes are nany, and grow fome eubite high; and ar their tops are diuided into fundry branches, $w$ hich bcare faire blew ith purple foures, ycllow in their middles, and thaped like Marigolds, and almoft of the fame bigneffe, whenee fome hate called them blew Marigolds. $\ddagger$

2 The third kinde harh lcaues fo like Italian Starvort, that a man can fcarcely at the fudden diftinguih the one from the other. The fingle ftalke is a cubit long,vpright and flender; on the top whereof grow faire yellow foures, like thofe of Enula Compint, and they fiy away in downe: the root is fmall and threddie.

4 The fouth kinde in talnefie and floure is not mueh vnlike that laft before fpecified, but in ftallse and leaues more hairie, and longer, fomewhat like our fmall Houndf-tongue; and the rootes are lefte fibrous or threddie thun the former.

5 Tluce is another fort what luath a browne ftalke, with leates like the fmall coniza. The floures are of a darke yullow, wh ich tume into downe that fieth away with the wind like Conyza. The root is full of threds or ftrings.

6 There is alfo another that hath leates like the great Campion, fomewhat hairie; among ft which come vperoked erambling ttalkes, lcaning lamely many waies. Whereupondoe growe faire yellow Poures, Starc-fithion; which patt, the cups become fo hard, that rhey will fcarcely be broken withones nailes to take forth rhe feed. The toot is long and fraight as a finger, with fome few ftrings annexect vnto the vppermolt patt thereof. It gtoweth wilde in fone parts of Sp.ine.

I Uffer Atticus.

Starrewsort. $\ddagger 2 \cup A f$ ir It dorum.

Italian Starrewoort.
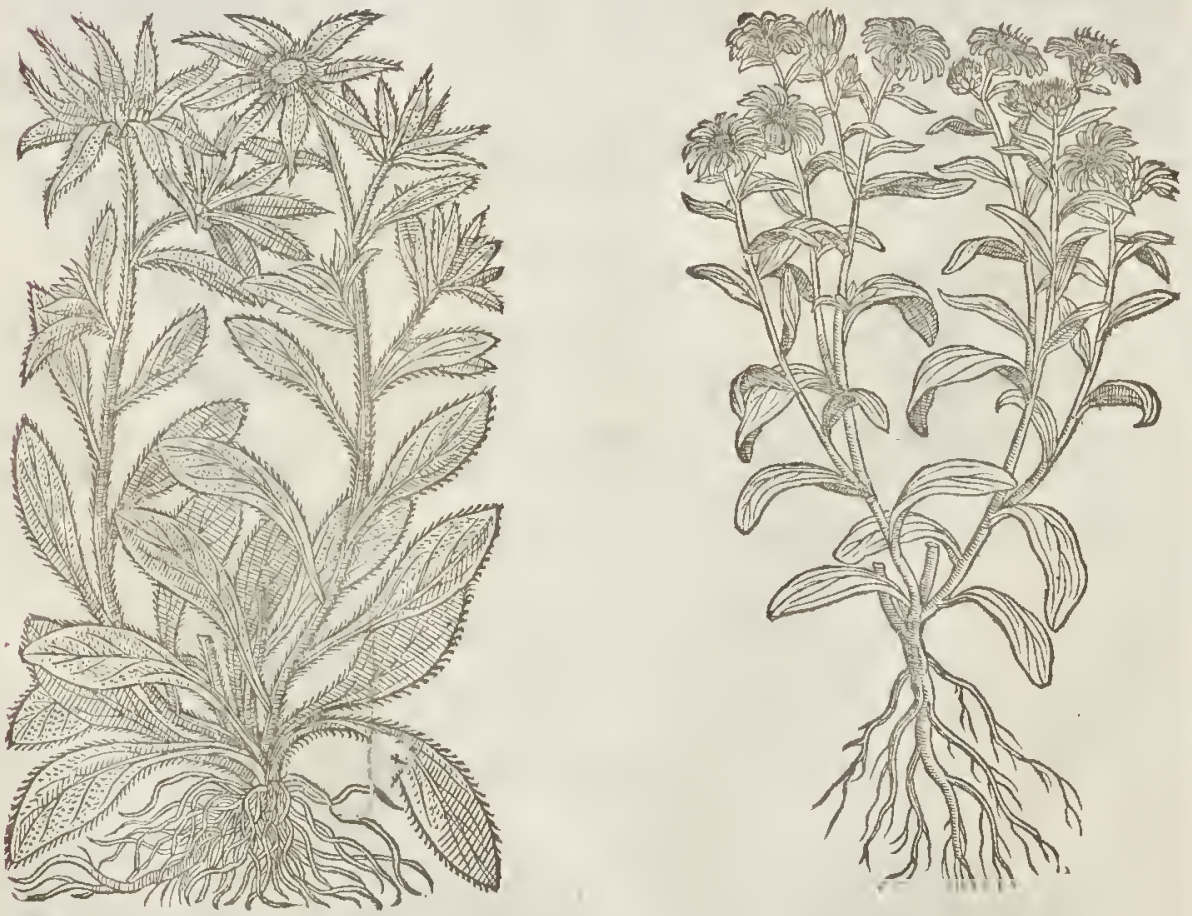

7 There groweth another kinde of Starretwoot, which bath many leaues like Scabious, but thinner, and of a more greene eolour, coucred with a woollie hairineffe, frarpe and bitter in tafte; a mongft which pringethvy a round taike more than a cubite high; often growing vnto a red- 
dith colour ; fet with the like leaues, but fmaller and fharper pointed, diuiding it felfe towatd the top into fome few branehes; whereon doe grow large yellow floures like Doronicum or Sonchas. The root is thicke and erooked. I This is After Pannonicus mator, five tertius of Cluf. and his Aus.
friacus primus.

8 Wee haue feene growing vpon wilde Mountaines another fort, which hath leaues much leffer than the former, fomewhat like to the leates of Willow, of a faire grcene colour, which doe adorne and dceke vp the ftalke euen to the top; whereupon doe grow yellow floures ftarre faflion, ereaferh. $\neq$ This is the root is fnall and tender,ereeping farre abroad, whereby it nightrily inBubonium lutem of Tabern. And our Authour : five After 4. Liuftriacus 2. Of Clufies. It is rum. ‡ 9 Clufus hath fet forth a kinde that hath an vpright ftalke, fomewhat hairy, two cubits high, faire yellow foures like Enuld Coollie like to thore of the Sallow, hauing at the top of the ftalke the root is thicke, with fome campana, which turne into down that is earried away with the wind. 5. of Clufius. Our Authour gaue the figus fatened thereto. \# This is Afterlamuginofo folio, five Luteo of Tabcr.

Io Hee hath likewife deferibed another fort, that hath leaues, ftalks, floures, and roots like the ninth, but neuer groweth to the height of one cubite. + It bringeth forth many ftalkes, and the leates that grow diforderly vpon them are narrower,blaeker, harder and tharper pointed than the former, not vnlike thore of the common $F$ tarmica, yet not finipt about the edges: the floures are yelClufius. $\neq$ II There is likewife fet forth in his Pannonicke obferuation, a kind of After that hath many
fmall hairie leaues like the common great Daifie: among which rifeth vp an hary falke of a high, hauing at the top faire blew floures inclining to among which rifeth wp an hairy ftalke of a foot (in the time of feeding) into a woollie downe, that flieth away wheir middle yellow, which turn hath a drying, binding, and bitter tafte. The roor is threddie lite the the winde. The whole plant Scabious. $\neq$ This is Afper Alpinus carteo flore, fue 7 . of Clufurs.

3 After montamus flore amplo. 4 After birfutus. Mountaine Starwoort." Hairie Srarwoort.

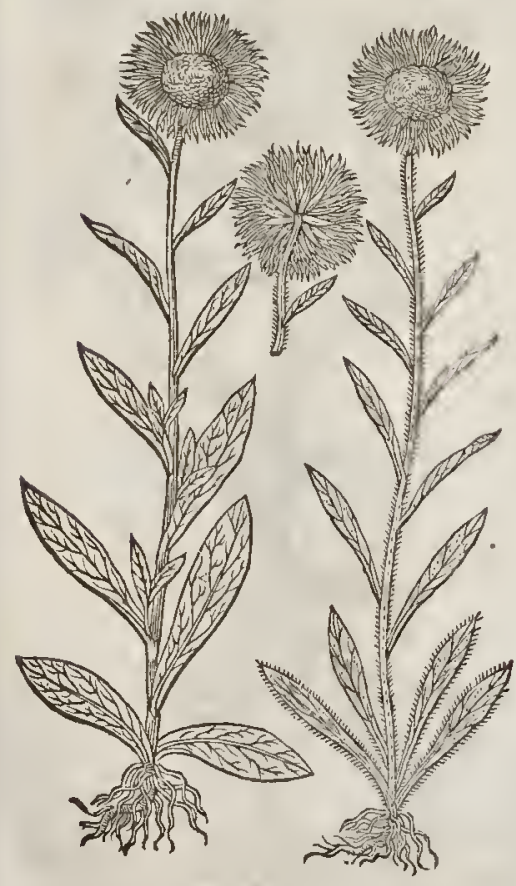

₹ After Conyzoides Ge fneri. Fleabane Starrewoort. 
‡ After Lutreus fapinus Clufit. Creeping Starwoort.

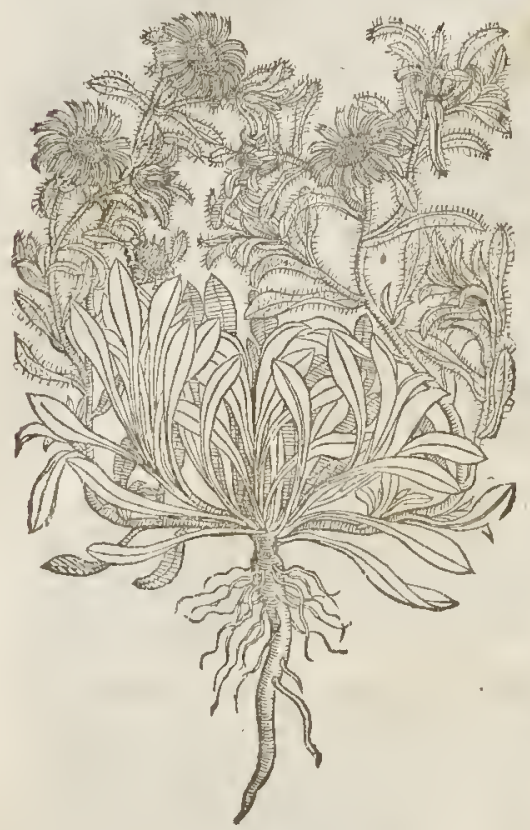

$¥ 8$ After Salicis folio.

Willow leaued Starwoort.

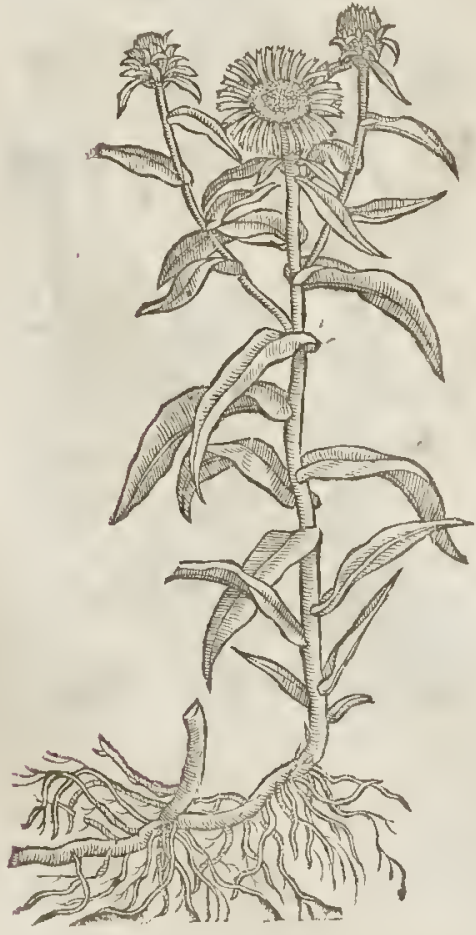

$\neq 7$ After luteus folits succife. Scabious leaued Starwoort.

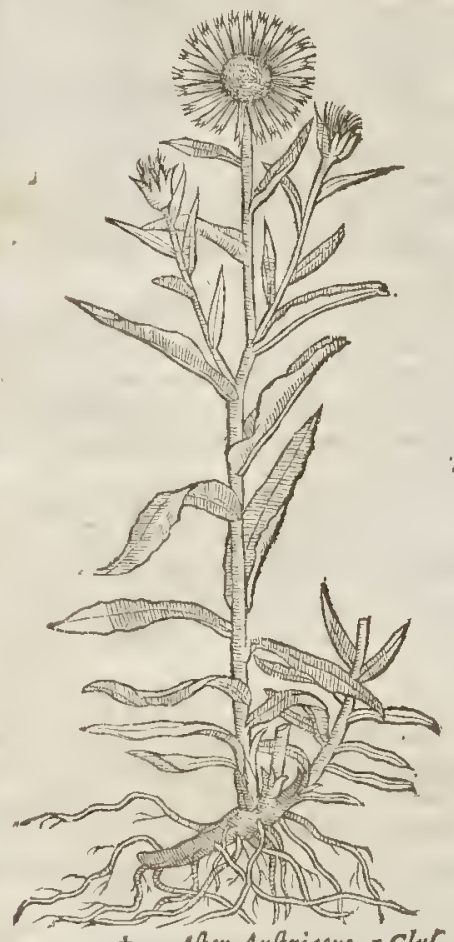

$\ddagger 9$ Afer Auftriacus, s clus. Sallow leaued Starwoore?

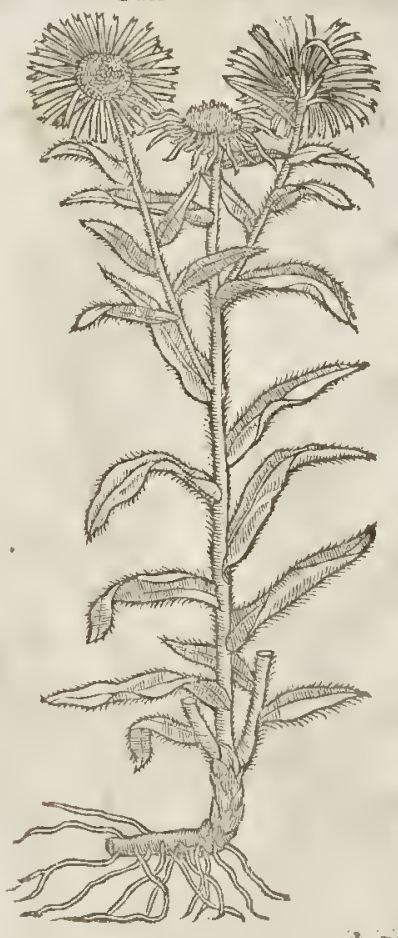

12 There 
LI B. 2.

Of the Hiftoric of Plants.

\# 12 There are kept in the Gardens of $\mathrm{M}^{\mathrm{r}}$. Trad fant, Mr. Tagryc, and others, tiwo Starre woorts different mueh from all thefe formerly mentioned : the firfof them is ro bee efteemed, for that it foures in October and Nouemberwhen as ferv other foures are to be found: the root is large and liuing, which fends vp many fmall ftalks fome two cubits high, wooddy, ilender, and not hollow, and towards the top they are diuided into aboundance of fmall twiggic branches : the leaues that grow alternately vpon the ftalkes, are $J$ ong, narrow, and harpe pointed, haung foure or fixe fcarce difcernable nicks on their edges : the foures which plentifully grow on finall branches much after the maner of thof of $v$ irga durea, confof of twelue white leaues fet in a ring, with many threds in their middles; which being young are yellow, but becomming elder and larger they are of a reddith colour, and at length turne into downe. I haue thought fit to eall this plant, not yet defcribed by any that I know of,being reported to be a Virginian, by the namc of Afrer Vigini-
anus frutico fus, Shrubbie Stanoort.

- I3 This which in gardens floures fome moneth before the former,growes not fo high, neither are the ftalkes fo itraight, but often crooked,yet are they dinided into many branehes which beare fnall blew ih floures like thofe of the former : the leaues are longith and narrow. This alfo is faid to hate come from Canada or Virginia; and it may be ealled Afer fiuticofus minor, Small mrubby Starwoort. $\ddagger$

\$ 10 Afer 6. Clufij.

Narrow leaued Starwoort.

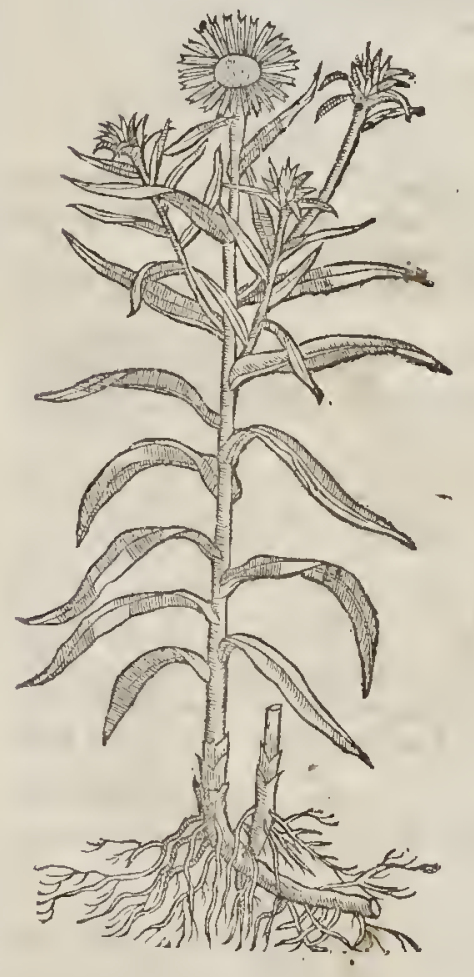

$\neq$ II After 7.Clafi.

Divarfe Dafieleaued Starwoort:

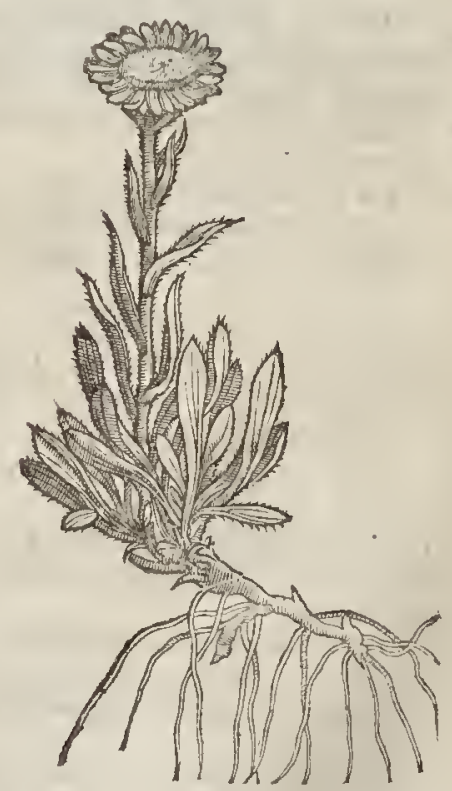

of The Place.

The kindes of Starwoort gro: vpon mountaines and hillie places, and fometimes in woods and medorves lying by riuers fides.

The two firft kindes doa grow vpon Hampitead heath foure miles from London, in Kant vpon Southfleet Dovnes, and in many other fueh downie places. \# I could neuer yet finde nor heare of any of thefe Startloures to grov wilde in this kingdo ne, but hate ofren feene the Italian Starwort growing in gardens. Thefe two kindes that our Authour mantions to grow on Hampltead heath and in Kent, are no other than two Hieracia, or Hutke-weedes, whieh aie much difizing from
thefe. $\neq$

They floure from Iuly to the end of Augut.

9. The Time. 


\section{$T$ The Names.}

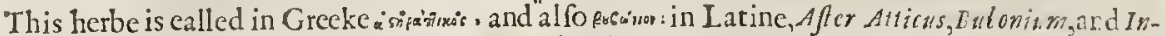
guinalis : of fome, Asterion, Aftersfcon, and Hyophtbalmon : in hioh Dutch, gBenctlitaut: in Spa-

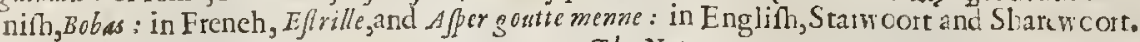

- The Nature.

It is of a meane temperature in eooling and drying. Gaten faith it doth moderarely wafte and confume, efpeeially while it is yet foft and new gathered.

That with the blew floure or purple, is thought to be that, which is of I'irgilealled flos Amellss : of which he maketh mention in the fourth booke of his Georgickes.

$$
\begin{aligned}
& \text { Eft etiam flos in pratis, cui nomen Amello } \\
& \text { Fecere agricole : facilis quarentibus berba ; } \\
& \text { Namque vno ingentem tollt de ce pite fylvam : } \\
& \text { Aureus ip fe, jed in folys, qua plurima circum } \\
& \text { Fundunur, viole fublucet purpura nigre. }
\end{aligned}
$$

\section{In Englifh thus.}

In Meades there is a floure Amello nam'd, By him that feekes it eafie to be found,

For that it feemes by many branehes fram'd Into a little W'ood: like gold the ground

Thereof appeares, but leaues that it befet Sline in the eolour of the Violet.

\section{Tा The Vertuts.}

A The leaues of After or Inguinclis ftamped, and applied vnto botches, importhumes, and venereous bubones (which for the moft part happen in Inguine, that is, the flanke or thare) doth mightily maturateand fuppurate them, where of this herbe Afer tooke the name Ingursal is.

B It helpetl and preuaileth againt the inflammation of the fundament, and the falling forth of the gut called Saccus ventris.

C The floures are good to be giuen vnto children againft the Squinaneie, and the falling ficknes.

that fioure which formerly was in the fecond place vnder the title of $A$ fer Articus, was of the eighth here deferibed;alfo in the hird place formerly

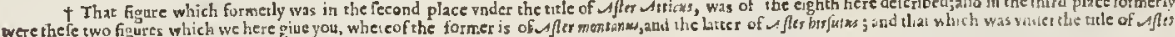

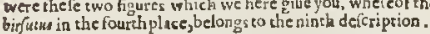

\section{C н A P. 133: Of Woade.}

\section{T The Defription.}

I Caftum or Garden Woad hatl long leaues of a blewirh greene colour. The falk growetli two cubits high, fet about with a great number of fueh leaues as come vp firf, but fmaller, branching it felfe at the top into many little twigs, wheretipon do grow many fmall yellow floures: which being paft, the feed commeth forth likelittle blackin tongues : the toot is white and fingle.

2 There is a wilde kinde of VVoad very like vnto the former in ftalks, leaues, and fafhion, ${ }_{2}$ uing that the ftalke is tenderer, fmaller, and browner, and the leaues and litt le tongues narrower; otherw ife there is no difference betwixt them.

$$
\text { T The Place. }
$$

The tame or garden VVoad groweth in ferrile fields, where it is fowne : the wilde kind growes where the tame kinde hath been fowne.

They floure from Iune to September.

$$
\text { I The Time. }
$$

9T The Names.

VVoad is called in Grecke ians: in Latine, Ifatis, and Glaftam : Cafar in his fifth booke of the French wars fairh, that all the Brittons do eolour them felues wirh VVoad, which gitueth a blew onlour : the which thing alfo Pliny in his 22, booke, chap. $\mathbf{r}$. doth teftifie : in Franee they call it Glafumwhich is like vnto Plantaine, wherewith the Brittin wiues and their daughters are coloured all ouer, and go naked in fome kinde of facrifiees. Ir is likewife ealled of diucrs Cnadum:of the Italians, Guads; a word as it feemeth, wrung out of the word Glastum. in Spanifh and French, paftcl: in Duteh, nert: in Englioh, VVoad, and VVade. 


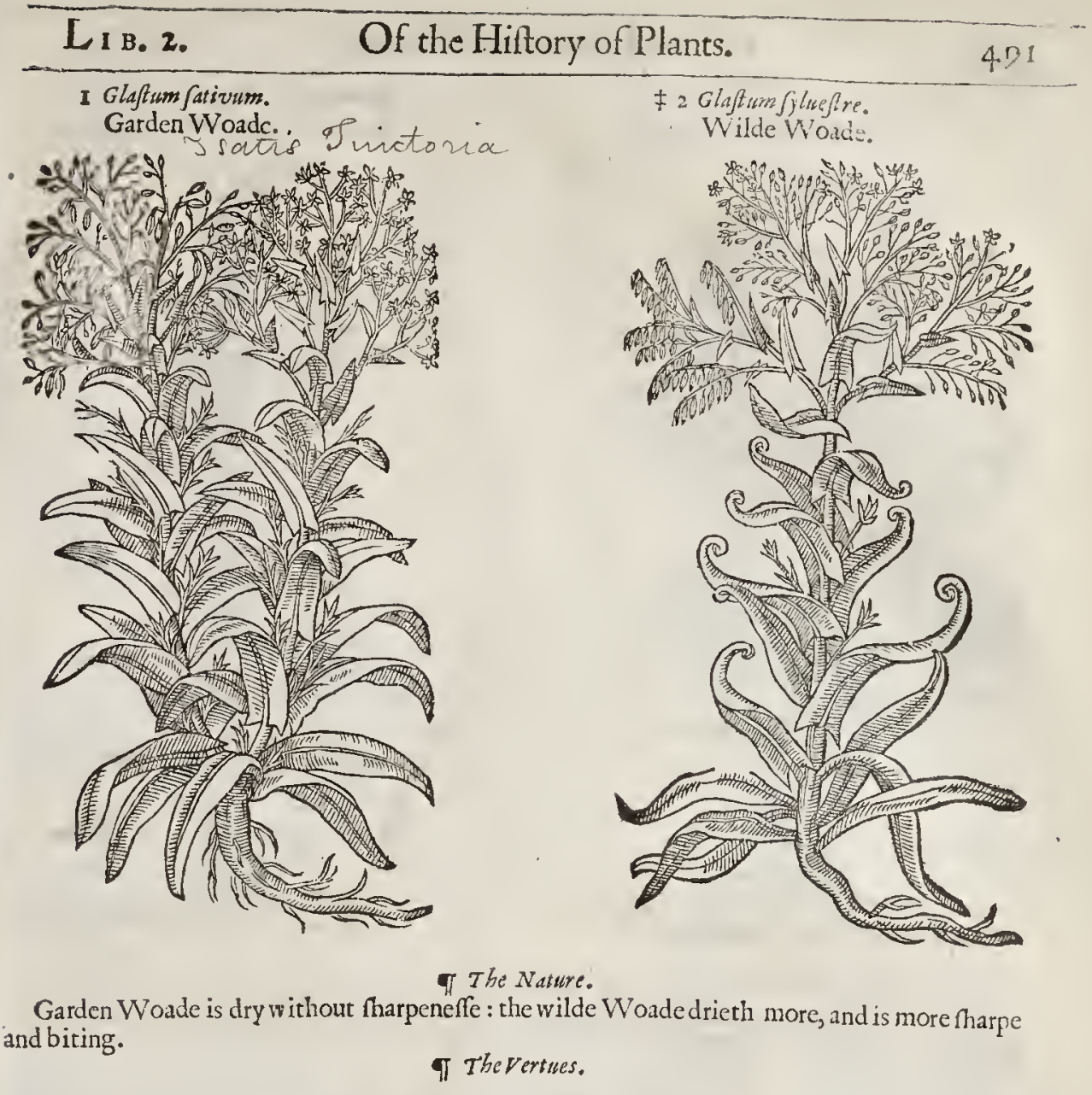

The decoction of Woade drunken is gond for fuch as haue any ftopping or hardneffe in the milt or fpleene, and is alfo good for wounds or vleers in bodies of a ftrong conftitution, as of eourtrey people, and fueh as are accuftomed to great labour and hard courfe fare.

It ferteth well to dye and eolour eloath, profitable to fome few; and hurrfull to many.

\section{A}

\section{CH A P. 134: Of Cow-Bafill. \\ I The Defoription.}

I 7 His kinde of wilde Woade hath fat long leaues like $V$ alcriana rulur $D 0$ loce; , or Bebes: rubrum: the ftalke is fmall and tender, hauing thereupon little purple fourcs eonfifting of foure leaues; which being patt, there eome fquare comered huskes full of round blacke feed like Coleworts. The whole plant is eoured ouerwith a clammy fubtance like Bird-lime, fo that in hot weather the leaues thereof will take flies by thewings (as M:if cipala doth) in fuch manner tilat they cannot efcapc away.

2 Ephemerum Matthioli hath long fat and large leaues like vnto Woad, but much leffe anong whieh rifeth vp a round falke a eubit high, diuiding it felfe into many branches at the top, the whieh are fet with many fmall white foures confifting of fure leaues; which being paft, there fo' low little round bullets containing the feed. The root is fuall and full of fibres.

$$
\text { बा The Place. }
$$

Cow-Bafill groweth in my garden : but Ephemerwm is a ftranger as yet in England.

They floure in May and Inte.

$$
\text { If The Time. }
$$




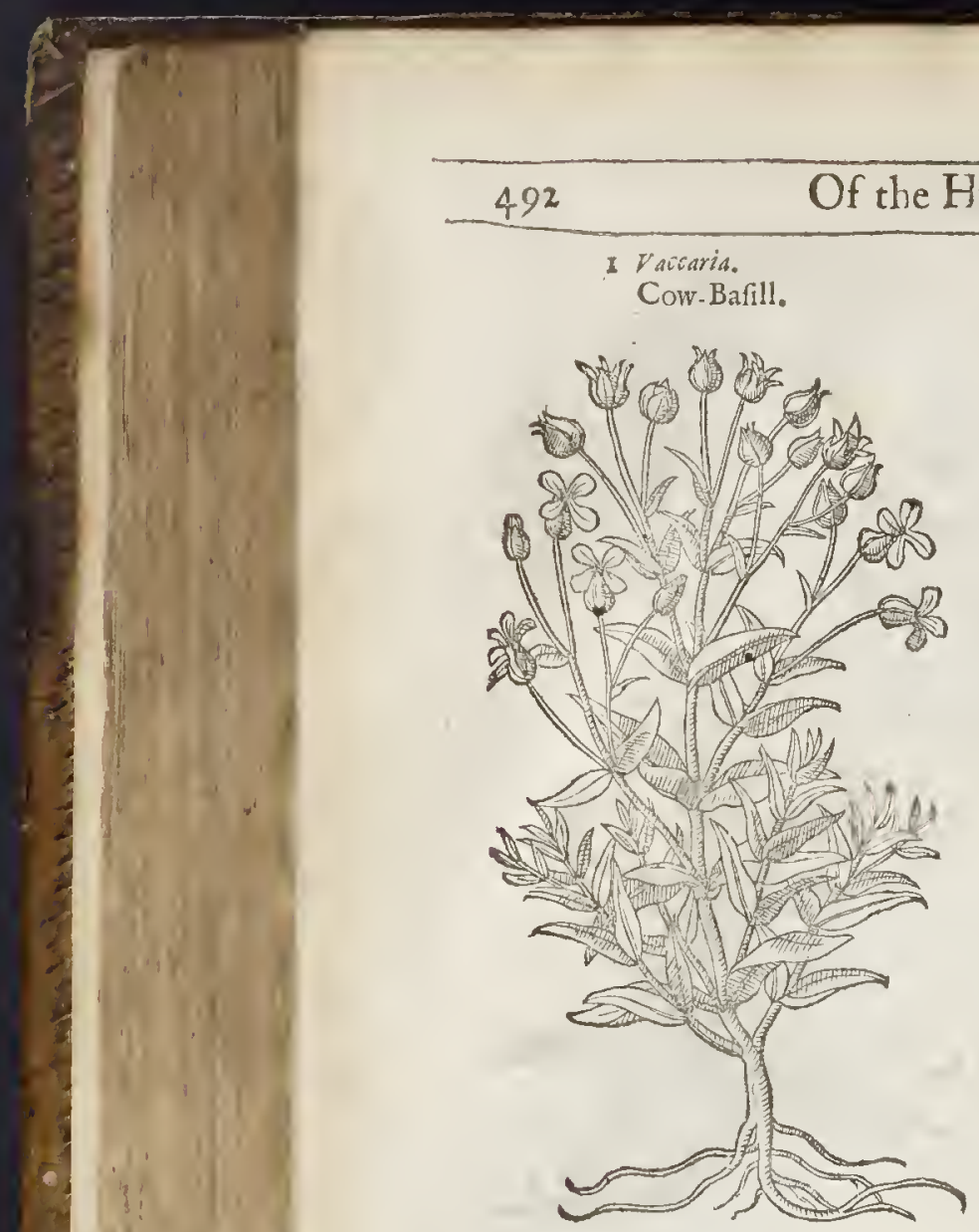

LI в. 2.

2 Ephemcrum Mathioli.

Quicke-fading floure.

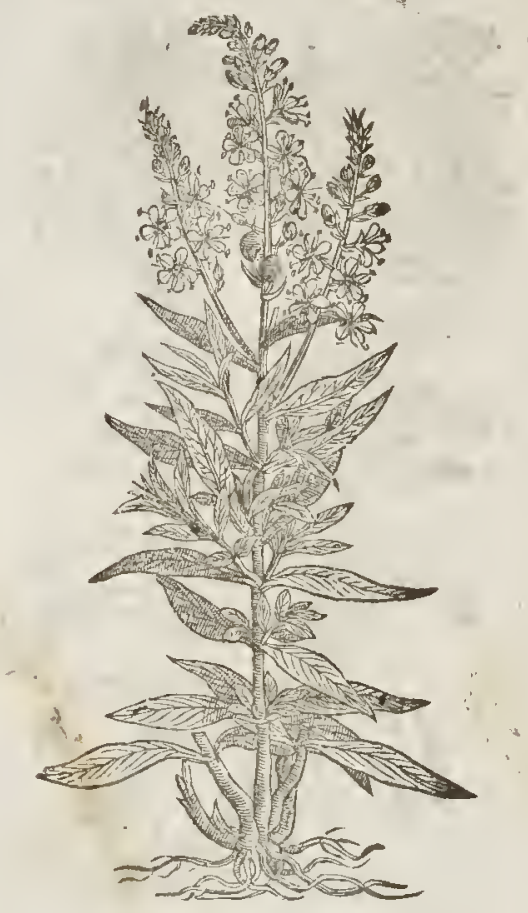

$\mp$ of The Names.

I Corv-Bafill is by Cordus called Thamecnemon: by fome, according to Gefner, Lychnis or Perfoliata rubra: Lobel termes it ifat is fylueftris, and raccaria : the laft of which names is retained by moft late Writers.

2 This by Lobel is faid to be Ephamerum of Mattbiolss; yet I rhinke Matholus his figure, (which was in this place formerly) was but a counterfeit, and fo alfo doe Columnand Bartinus iudge of it ; and Baibine thinkes this of Lobel to be fome kinde of $L y$ fomachia. $\neq$

\section{The Nature and Veriues.}

I finde not any thing extant concerning the Nature and Vertues of Vaccaria or Cow-Bafill.

A Ephemesum (as Diofcorideswriteth) boyled in wine, and the mouth walhed with the decoction thereof, taketl away the tooth-ache.

\section{Ch а Р. 135 . Of Sefamoides, or Baftard Weld or Woade. \\ 9) The Defcription.}

I. THe great Se amoides hath very long leaues and many, flender toward the ftalk,and broader by degrees toward the end, placed confufedly vpon a thicke fiffe ftalke: on the top whereof grow little foolim or idle white floures: which being paft, there fo low finall feeds like rnto Canarie feed that birds are fed withall. The root is thicke, and of a woodsy fubrance.

$\ddagger 2$ This lefter Sefamoides of Salamanca, from a long liuing, whe, hard, and pretrie thicke root fends vp many litrle ftalks fet thicke with fmall leaues like thofe of Line; and from the middie to the top of the ftalke grow many floures, at firft of a gecenith purple, and then purting forth yellowifh threds; out of the midft of which appeare as it were foure greene graines, which when the foure is fallen grow into little cods full of a fmall blackifh feed. Ir growes in a fiony foilespon the hills neere Salamanca, where it Houres in May, and thortly after perfeets his feed. + 
$\mathrm{L}_{\mathrm{I} \text { в: }}$ 2. Of the Hiftory of Plants:

1 Sefamoides Salamanticum magnum. Great baftard Woade.

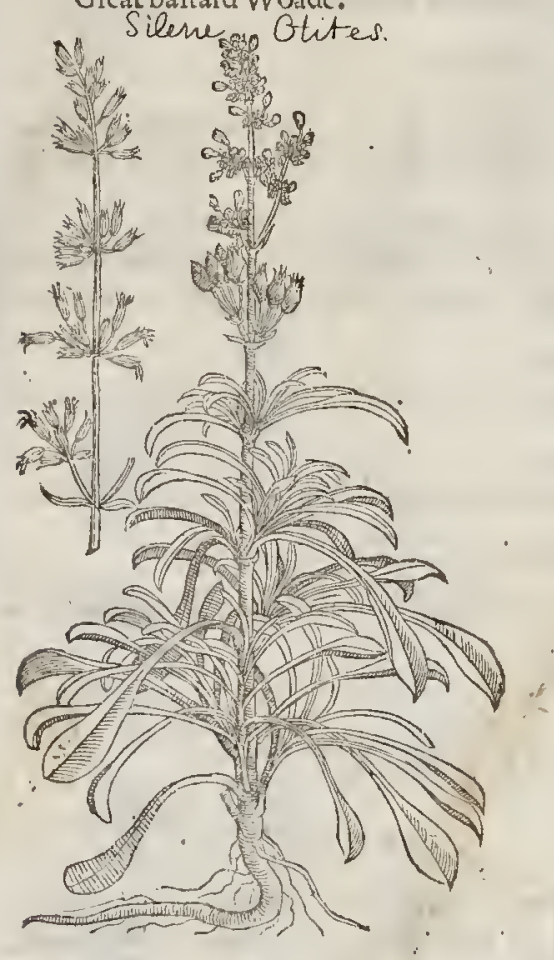

3 Sefamoides parvum Mathioli.

Bucks-horne Gum-Succoric

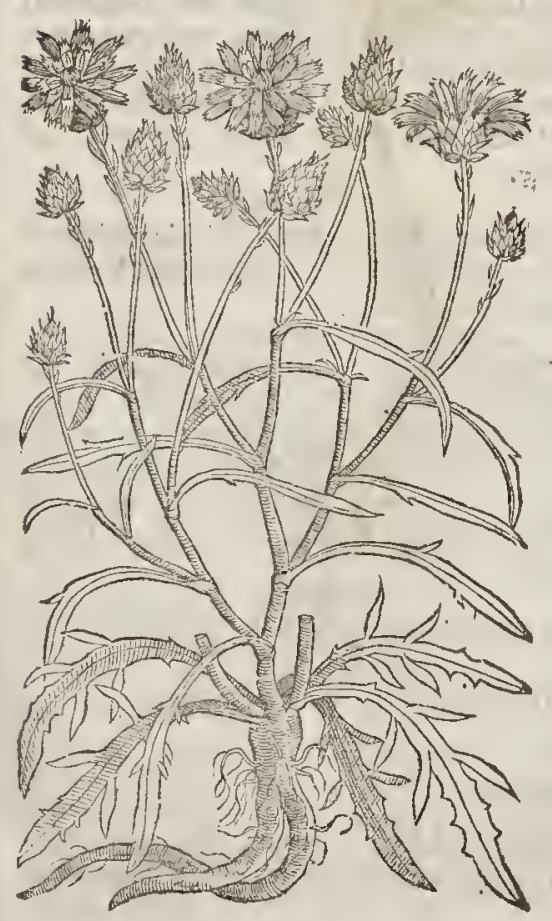

2. Sefamoides Salamaraticum parvam. Small Baftard Woade.

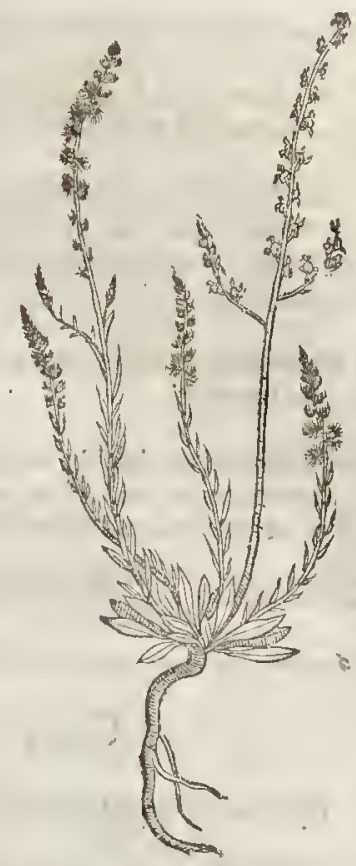

0

$\mp 3$ Our Author formerly in the Chapter of Chondrilla fpoke (in Dodonews his words) againft the making of this plant a Sefamoides; for of this plant were the words of Dodoneus; which are thefe: Diuers (faith he) haue taken the plant with blew floures to be Sefamvides parvum, but without any teafon; for that sefamoides hath borrowed his name from the likenefle it hath with Scfarn:m : but this herbe is not like to Sefamm in any one point, and therefore I thinke it better referred vnto the Gum Succories for the floures hame the form and colour of Gum Succory, and it yeeldeth the like milky juyce. Our Authour it feemes was cither forgetfull or ignorant of what he had faid; for herehee made it one, and defcribed it meerly by the figure and his fancie. Now I following his tras, hauc (thoughvnfity) put it bere, becaufe there was nohiftorie nor figure of it formerly there, but both here, though falfe and vaperfect. This plant hath a root fonewhat like that of Goatf-beard ; from which arife leaues roughand hairy, diuided or cut in on both fides after the manner of Bucks-horne, and larger than they. The ftalke is fome foot high, diuided into branches, which on their tops carry floures of a faireblew colour like thofe of Succoric, which fand in rough fcaly heads like thole of Knapwoed, $\neq$ 


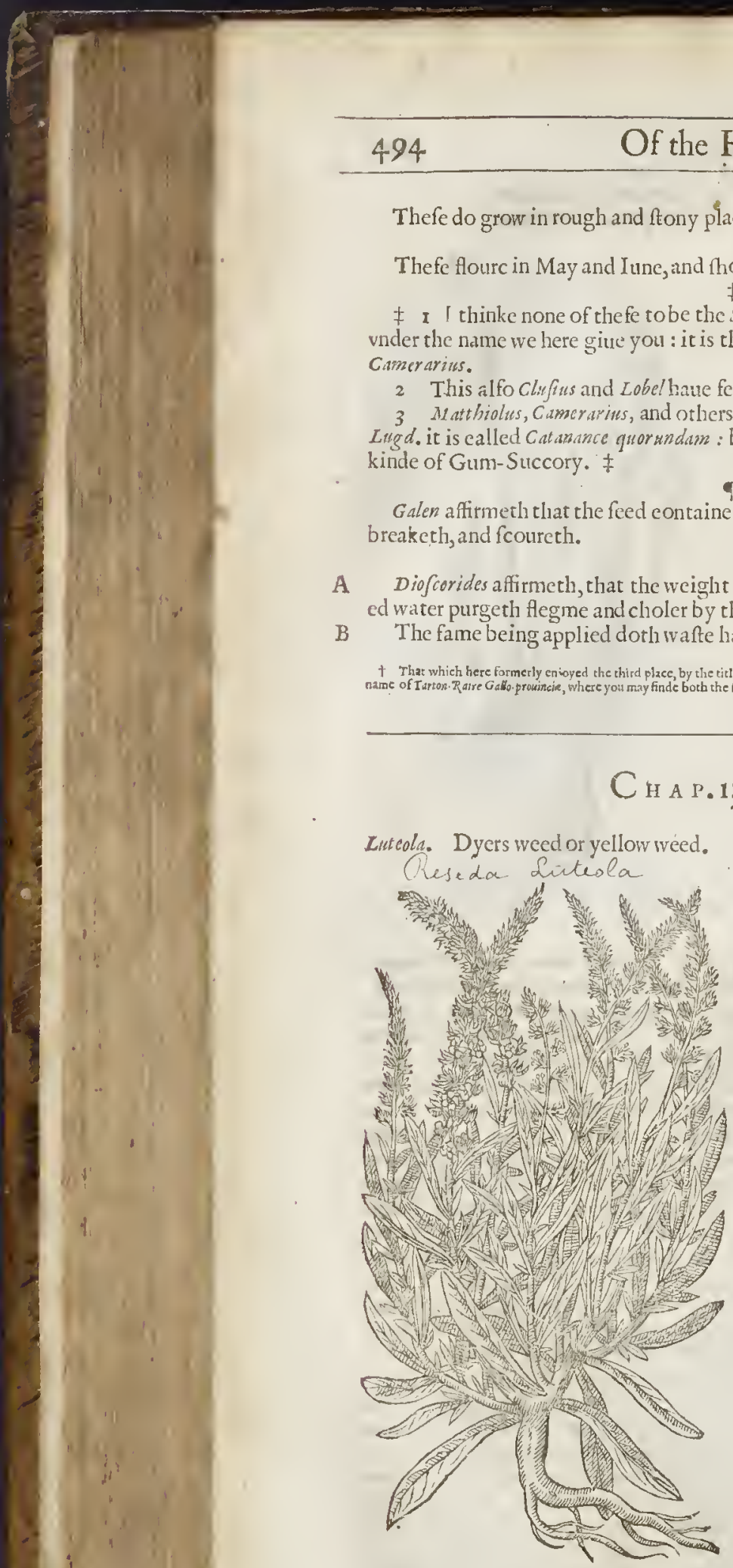

L 1 B. 2.

\section{The Place.}

es, but arc all frangers in England.

बा The Time.

Thefe flourc in May and Iune, and thortly after ripen their feed.

‡ I The Names.

the Sefamoides of the Antients : The firft is fet forth by clufius Cumerarius.

2 This alfo clinfus and Lobel baue fer forth by the fame name as we giue you them.

3 Matthiolus, Camerarins, and others haue fet this forth for Sefamoides parum : in the Biforia ungd. it is called Catanance quorandam : but mof fitly by Dodon.Chondrille pecicstertia, The third of Gum-Sticcory.

$$
\text { I The Temperature. }
$$

Galen affirmeth that the feed eontaineth in it felfe a bitter qualitie, and faith that it heateth, T The Vertucs.

Diofcorides affirmeth, that the weight of an halfe-penny of the feed drunke with Meade or honied water purgeth flegme and choler by the ftoole.

7 That which here formerly crinyed the third place by the title of $S$ esmoides masiu Sctlisers, was wo other than the plant that is hereafier defcribed by the The forte and dercription.

1 The Defription.

$\mathrm{D}$ Yers wced hath long narrow and greenifh yellow leaues, not much vnlike to woad, but a great deale frnaller and narrower. from among which commeth vp a falke two cubits high, befet with littlc narrow leaues : cuen to the top of the ftalke come forth fmall pale yellow floures, clofely cluftering together one aboue another, which doe turne into fmall buttons, cut as it were croffe-wife, wherein the feed is contained. The root is very long and fingle.

\section{T The Place.}

Dyersweed groweth of it felfe in moift, barren, and vntilled places, in and about Villages almoft eucry where.

$$
\text { T The Names. }
$$

Pliny, lib.33. cap.5. maketh mention by the way of this herbe, and calleth it Lutea: Vitruvius in his feuenth booke, Lutum : it is the Anfwith ticarhinum of Tragus: \& Pfeudofruthium of $M a-$ thiolus : Virgill, in his Bucolickes, Eglog 4.cals it alfo Lutum : in Englifh, Welde, or Dyers weed.

$$
\text { The Time. }
$$

This herbe flourifheth in Iune and Iuly. बI The Nature.

It is hot and dry of temperature.

\$ The Fertucs.

A The root as al fo the whole herbc heates and dries in the third degree : it cuts, attenuates, refolueth, opens, digefts. Some alfo commend it againft the punctures and bites of venomous crea- 
L. I. 2

tures, not onely outwardly applied to the wound, but alfo taken inwardly in drinke.

Alfo ir is commended againft the infection of the Plague: fome for thefe reafons terme it $T$ he.

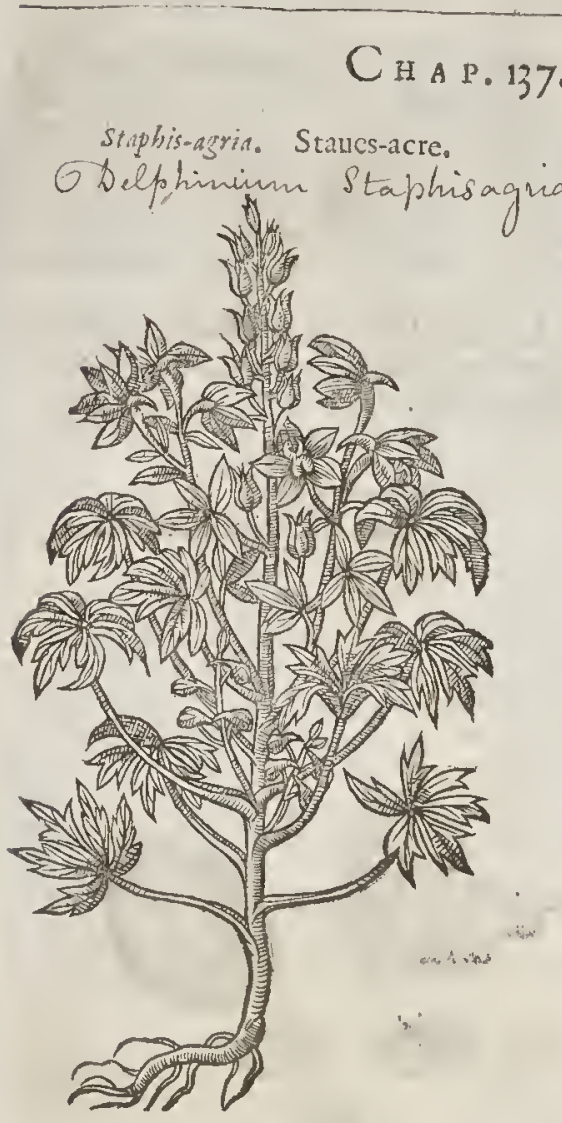

Of Stanes-acre:

9) The Defcription.

Taues-acre hath ftraight ftallses of a browne $\checkmark$ colour, with teaues clouen or cur into fundry fections, almoft like the leaues of the wilde Vine. The floures dogrów vpon thort ftems, fathioned fomewhat like vnto our common Monks hood, of a perfect blew colour ; which being paft; there fucceed welted huskes like thofe of Wolfsbane, wherein is contained triangular brownif rough feed. The root is of a wooddy fubftance, and perifherh when it hath perfected his feed.

of The Place.

It is with great difficultic preferued in our cold countries, albeit in fome milde VVinters I haue kept it conered oner wirls a little Ferne, to defend it from the iniury of the March winde, which doth more harme vnto plants that come forth of hot Countries, than doth the greaten frofts.

$$
\text { बif The Time. }
$$

It floureth in Inne, and the feed is ripe the recond yeare of his fowing.

$$
\text { Tा The Names. }
$$

It is called in Greeke suais azue : in Latine,Herba Pedicularis, and Peduncularia, as Marcellus reporteth. Pliny in his 26 Booke, chap. 1 3. feemeth to name it Vur Taminia : of fome, Pituitaria, and Paffula mointara: in fhops, Staphifarria: in Spanifh, Yeruapidente: in French, Herbe aux poul $x$ : in high-Dutch, Leng keaut : in low-Dutcl, Zuvfcuit: in Englifh, Staues-acre, Loufe-wort, and Loufe-pouder.

- The Temperature.

The feeds of Stalles-acre are extreanc hot, almoft in the fourth degree, of a biting and burning qualitic

The Vertues.

Fiftcene feeds of Staucs-acre taken with honied water, will caufe one to wonit groffe flegme A and flimie matrer, but with great violence, and therefore thofe that haue taken them ought to walke without taying, and to drinke honied water, becaufe it bringeth danger of cboling and burning the throat, as 1 iofcorides noteth. And for this caufe they are reiected, and not vfed of the phyfitions, either in prouoking vomit, or elfe in mixing them with other inward medicincs.

The feed mingled with oyle or greafe, driueth away lice from the head, beard, and all other parts $B$ of the body, and curcth all feuruy itch and mangineffe.

The fame boyled in Vineger, and holden in the moutl,affivageth the tooth-ache,

The fame chewed in the mouth drawetl fortl much gafte braine, efpecially if litrle of the roor of Pellito meinte from

The fame tempered with vineger is good aivay Lice.

The feeds hereofare perillous to be taken inwardly withour good aduice, and correction of the $F$ fame : and therefore I aduife the ignorant not to be ouer-bold to meddle with it, fith it is fo dangerous that many times death enfueth vpon the taking. of it. 


\section{Cна а. 138. Of Palma Chrifti.}

बI The Defcription.

I D linus, PalmaChrifti, or $K i k$ hath a great round hollow ftalke fue cubits high, of a 1 browne colour, dicd with a blewilh purplevpon greene. The leaues are great and large, parted into fundry feations or diuifions, fafhioned like the leaues of a fig-tree, bur greater, fpred orwide open like the hand of a man; and hath toward the top a bunch of floures cluftering togetiner like a bunch of grapes, whercof the loweft are of a pale yellow colon, and withcr asvay without bcaring any fruir; and the vppermoft are reddith, bringing forth three comered huskes which cointaine feed as big as a kidney beane, of the colour and fhape of a certaine vermine which haunteth cattell, called a Tik.

2 This Palma Chmfti of Amcrica growes vp to the height and bigneffe of a fmall tree or hedge thrub, of a wooddy fubftance, whofe fruit is exprefied by the figure, being of the bignes of a great beane, fonewhat long, and of a blackifh colour, rough and faly.

I Ricinus.

Palma Chrifi.

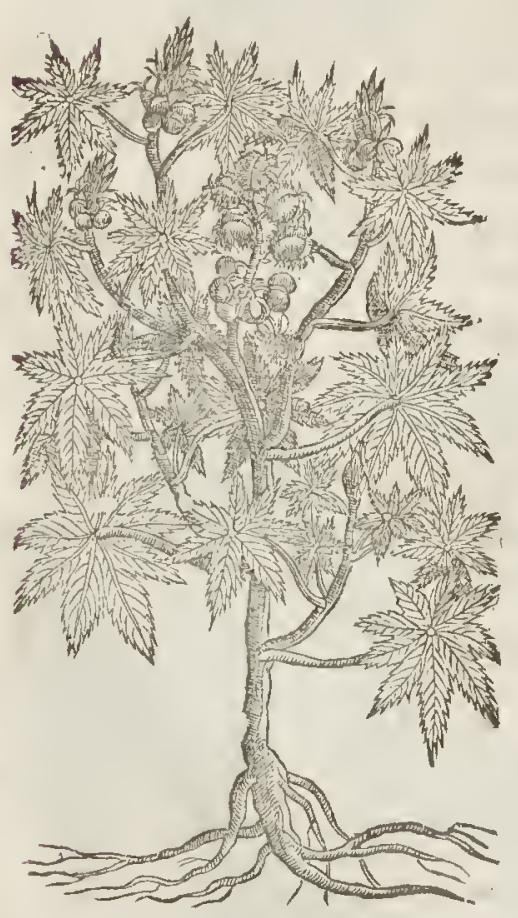

2 Ricinus Americanus.

Palma Chrifti of America?

\section{9ा The Place.}

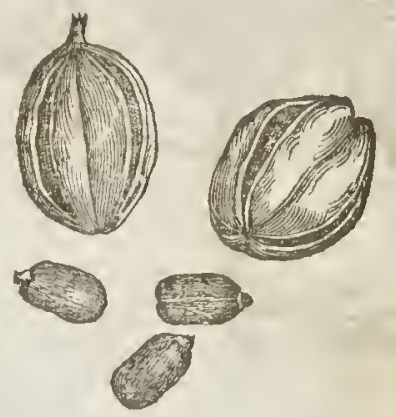

The firft kinde of Ricinus or Palme Chrifigroweth in my garden, and in many other gardens ikewife.

$$
\text { of The Iime. }
$$

Ricinus or hik is forne in Aprill, and the feed is ripe in the end of Auguft?

$$
\text { If The Name, and carrethereof. }
$$

Richum (whereof mention is made in the fourth chapter and fixt verfe of the prophecic of Ionus) 
L, I B. 2.

Of the Hiftory of Plants.

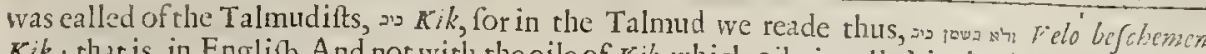
$K i k$ : that is, in Englifh, And not with the oile of $K i k$ : which oile is called in the Arabian tongue, Alkerua, as Rabbi Samul the fonne of Hophri teftifieth. Moreouer, a cerraine Rab bine monerh queftion, faying, what is Kik? Hereunto $R i f h$ Lach $f b$ maketh anfwer in Ghemara, faying, Kik is nothing elfe but Ionas his Kikaijon. And that this is true, it appeareth by rhat name Kin: which the aneient Greele Phyfitions, and the Egiptians vfed; which Grecke word commeth of the Hebrew word $K z$. Hereby it appeareth, that the old writers long agoe ealled this plant by the true and proper name. But the old Latine wrirers knew it by the name Cucurbita, which cuidently is manifefed by an hiftory which Saint Anguftine recorderh in his Epiftle to Saint Ierome, where in effect he writeth thus; That name $\boldsymbol{K}$ ikajon is of fmall moment, yet fo fmall a matrer catred a great tumult in Africa. For on a time a certaine Bithop liauing an oceafron to intreat of this which is mentioned in the fourth chapter of Ionas his prophecie (in a collation or fernot, which he made in his eathedrall chureh or place of aftembly) faid, that this plant was called cucubito, a Gourde, beeaufe it enereafed vnto fo great a quantitie, in fo thort a fpace, or elfe (faith he) it is ealled Hedera. Vpon the nouelry and vntruth of this his doetrine, the peoplevere grearly offended, and thereof fuddenly arofe a tumult and hurly burly; fo that the Binop was intorced to goe to the Iewes, to aske their iudgment as touching the name of this plant. Arid when he had receiued of them the true name, which was $K_{i}$ ika error, \& was iufty aceufed for a falfifier of the holy ferinture. \pm The Greeks ealled this plantalfo мgтау $: i$. Ricinus, by reafon of the fimilitude that the feed hath with that infect, to wit, a Tik. $\neq$ बा The Nature.

The feed of Palma Chrifti,or rather $K i k$, is hot and dry in the third degree.

T) The Vertues.

Ricimus his feed taken inwardly, openeth the belly, and caufeth vomit, drawing flimy flezme and eloler from the places poffeffed therewith.

The broth of the meare fupped vp, wherin the feed harh been fodden, is good for the collieke and the gout, and againft the paine in the hips called sciatica : it preuaileth alfo againft the jaundife and dropfie.

The oile that is madeordrawne from the feed is called oleum Cicinum : in thons it is called oleum de Cherua : it heaterh and drieth, as was faid before, and is good to anoint and rub all roigh hardnefle and feuruineffe gotten by itch.

This oile, as Rabbi David Chinchi writeth, is good againft extreme coldneffe of the body.

\section{С а в. 139. Of Spurge.}

I The Defeription:

I He firft kinde of Sea Spurge rifeth forth of the fands, or baich of the fea, with fundry reddith ftems or ftalkes growing vpon one fingle roore, of a wooddy fubitance: and the falkes are befet with fmall, fat, and narrow leaues like vnto the leaues of Flaxe. 'The floures are yellowifh, and grow out of little dithes or faucers like the common kinde of Spurge. After the floures eome triangle feeds, as in the other Tithymales.

2 The fecond kinde(called Heligfopius, or Solifequius: and in Englion, aceording to h is Greek name, Sunne Spurge, or time Tithymale, of turning or keeping time with the funne) hath fundry reddith ftalkes of a foot high : the leaues are like vnto Purflane, not fo great nor thicke, but fnipr about the edges : the floures are yellowith, and growing in little platrers.

3 The third kinde hath thicke,fat, and flender branches trailing vpon the ground, befet with leaues like Knee-holme, or the great Myrte tree. The feed and floures are like vnto the other of
his kinde.

4 The fourth is like the laft before mentioned, but it is altogether leffer, and the leaues are narrower, it groweth more vpright, otherwife alike.

5 Cypres Tithymale hatl round reddith ftalkes a foot high, long and narrow like thofe of Flaxe, and growing buthie, thicke rogether like as thofe of the Cypres tree. The floures, feed, and root, are like the former, fomerimes yellow, of tentimes red.

6 The fixt is like the former, in floures, falkes, rootes, and f'eedes, and differeth in thar, this kinde hath leaues narrower, and much fmaller, growing after the farhion of thofe of the Pine
tree, othervife it is like.

7 There is another kinde that groweth to the height of a man; the fa!ke is like the lut 


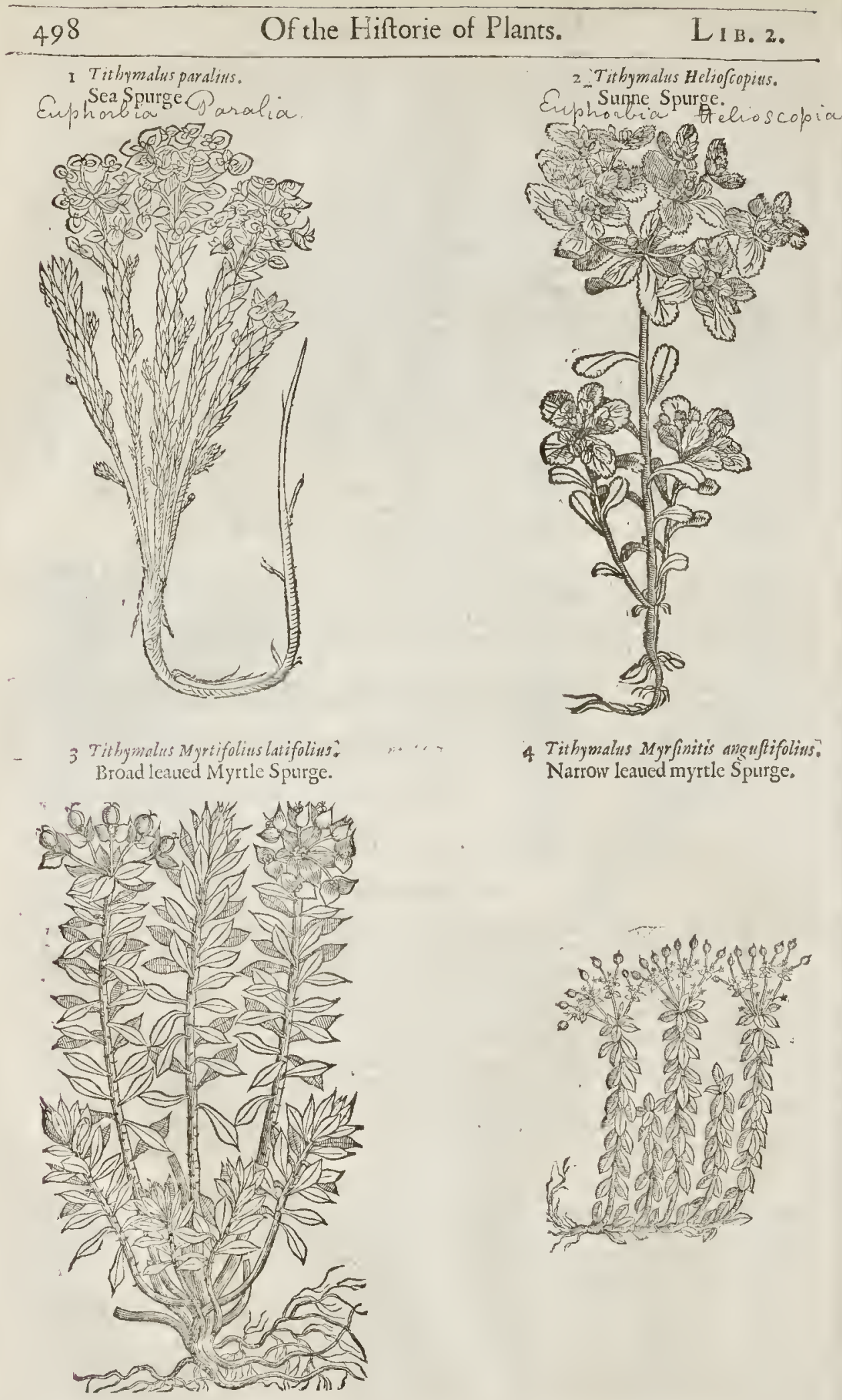




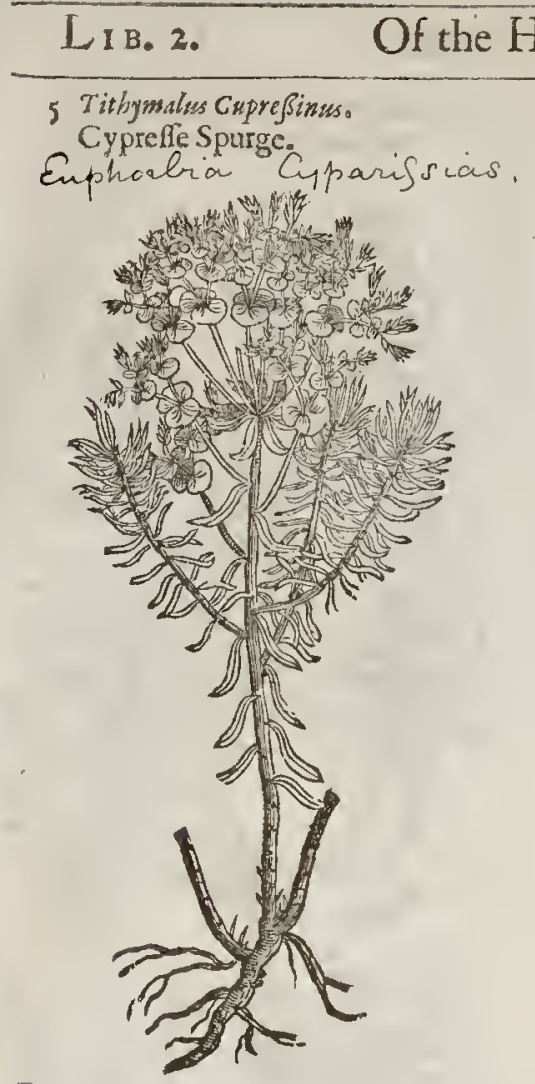

t 7 Titbymalus Myrfinitis arborefcens: Tree Myrtle Spurge.
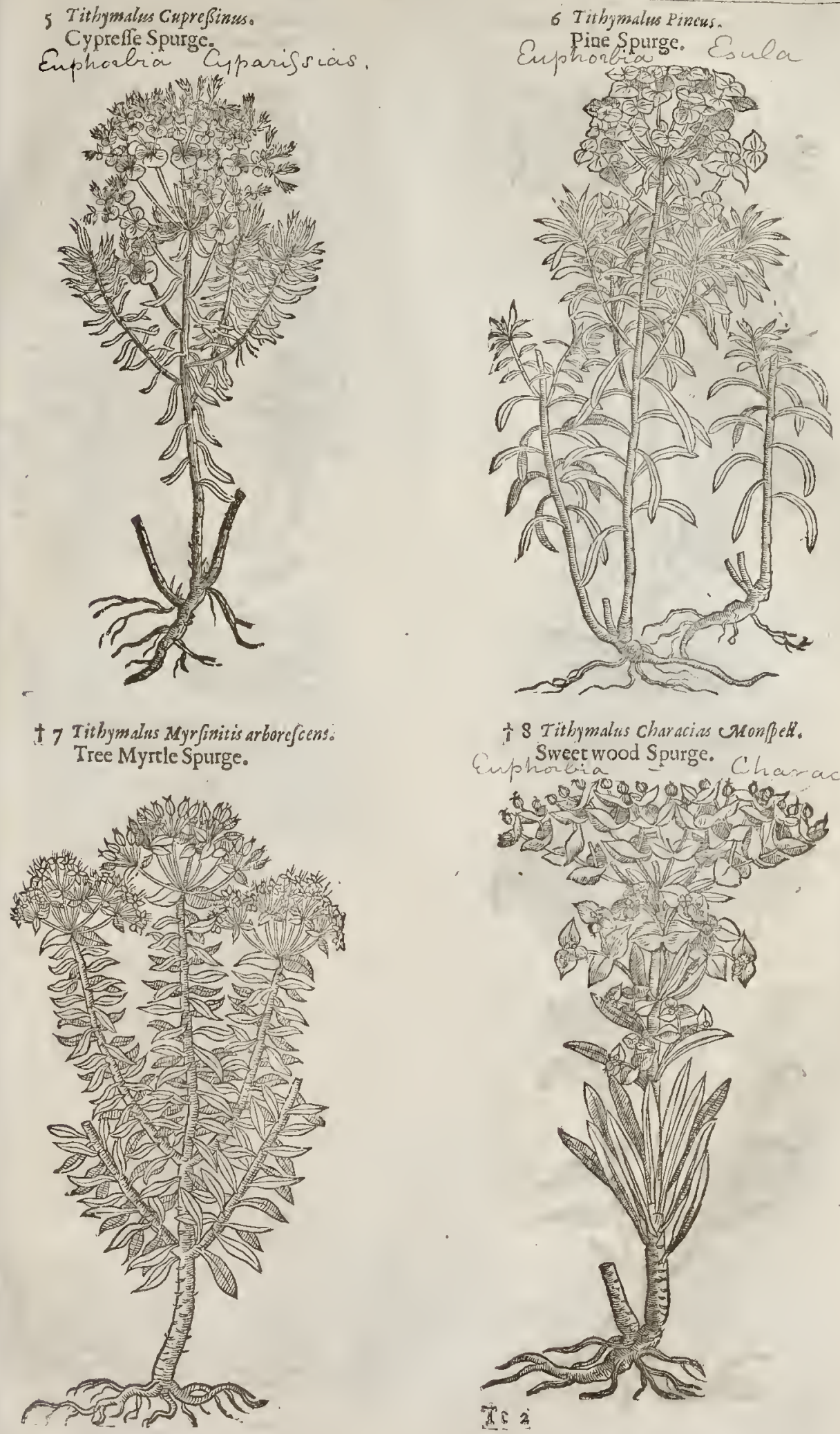

I 8 Tithymalus characies crompel, Euphoretwood Spurge. Characias

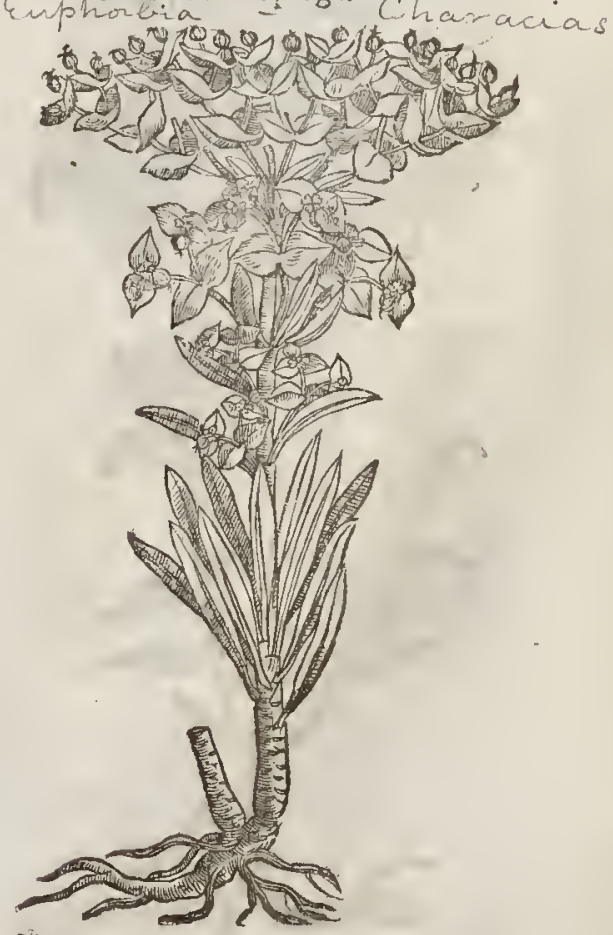

TE 2 
t 9 Tithymalus Characias Amygdiloides. Vnamoric Wood-fpurge.

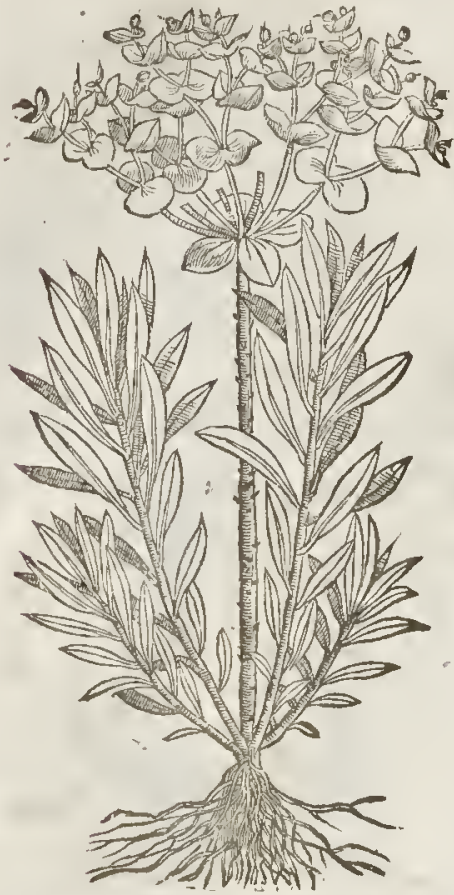

\$ xI Tithymalus Characies ferratifolius. Cut leaued Wood-fpurge.

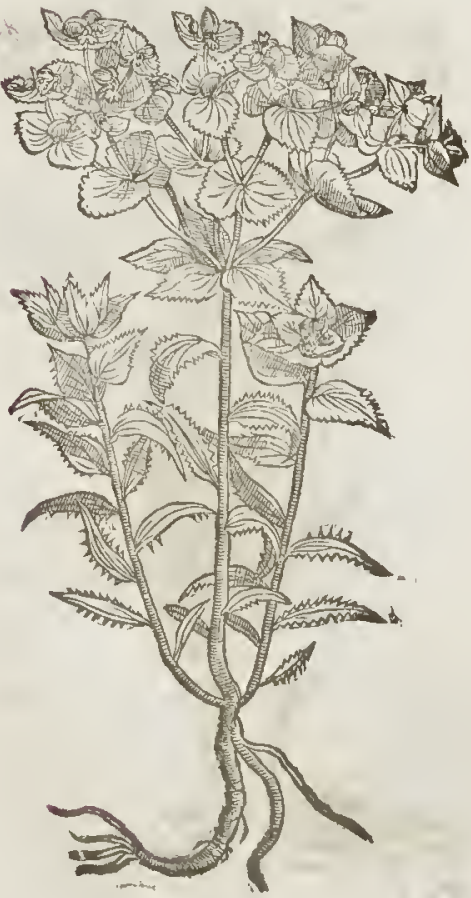

\# Io Tithymalas Characias anguftifolus. Narrow leaued Wood-fpurge.

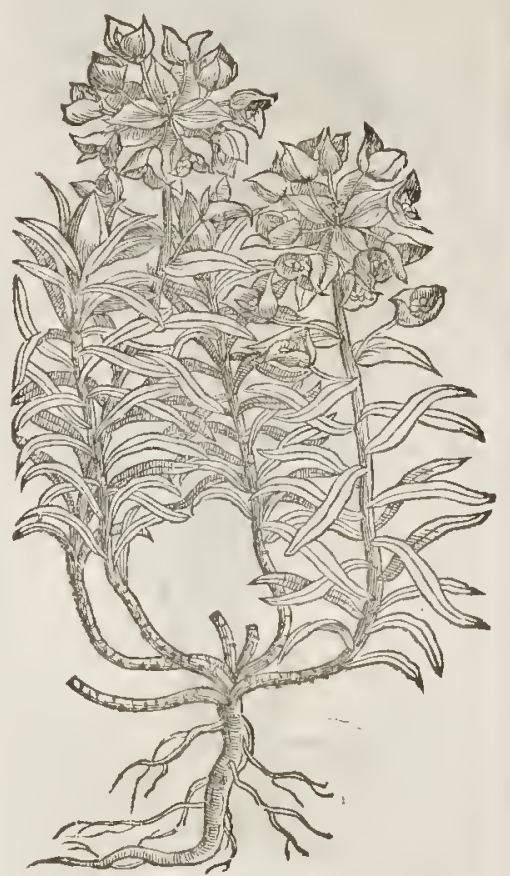

I2 Titbymalus platyphyllos.

Broad leaued Spurge Enphonbra miterma

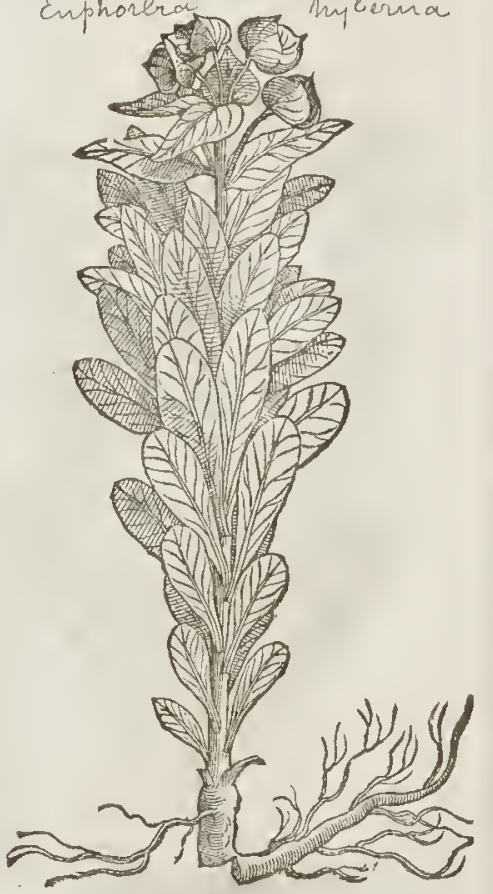


mentioned, but diuided into fundry btanehes a finger thieke, and fomewhat hairy, not red as the others, but white: the leaues be long and narrow, whitifh, and a little downy: the floures are yel. low, but in other points like to the reft of this kinde.

8 The eighth kinde rifeth wp with one round reddifh ftalke two cubits high, fet about with long thin and broad leaues like the leaues of the A lmond tree : the floures come forth at the top like the others, and of a yellow eolour. The feed and root refemble the other of his $k$ inde.

9 The ninth (which is the common kinde groving in mont woods) is like the former, but his leates be thorter and leffe, yer like to the leaues of an Almond tree : the floures are alfo yellow;
and the feed contained in three eornered feed-veffels.

Io This fourth knde of Tithymalus Characias, or Valley Tithymale (for fo the name imports) hath long, yet fomew hat narrower leates than the former, whitith alfo, yet not hoary, the vmbels or tufts of floures are of a greenith yellow, which before they beopened do reprefent the fhape of a longifh fruit, as an Almond, yet in colour it is like the reft of the leates : the floures and feeds are like thofe of the former, and the root defeends deef - into the ground.

Ir The fifth characias hath alfo long leates harpe psinted, and broadet at their fetting on, and of a light greene colour, and fnipt or eut about the edges like the teeth of a faw. The vmbels are fmaller, yet carry fueh foures and feeds as the former. $\neq$

12 This kinde hath great broad leaues like the yong leaues of Woad, fet round about a ftalk of a foot high, in good order : on the top whereof grow the floures in fmall platters like the common kinde, of a yellow colour declining to purple. Thewhole plant is full of milke, as are all the reft before fpecified.

\# $\mathrm{I}_{3}$ Tithymalus Dendroides ex Cod.Cre.treo. Great Tree Tithymal.

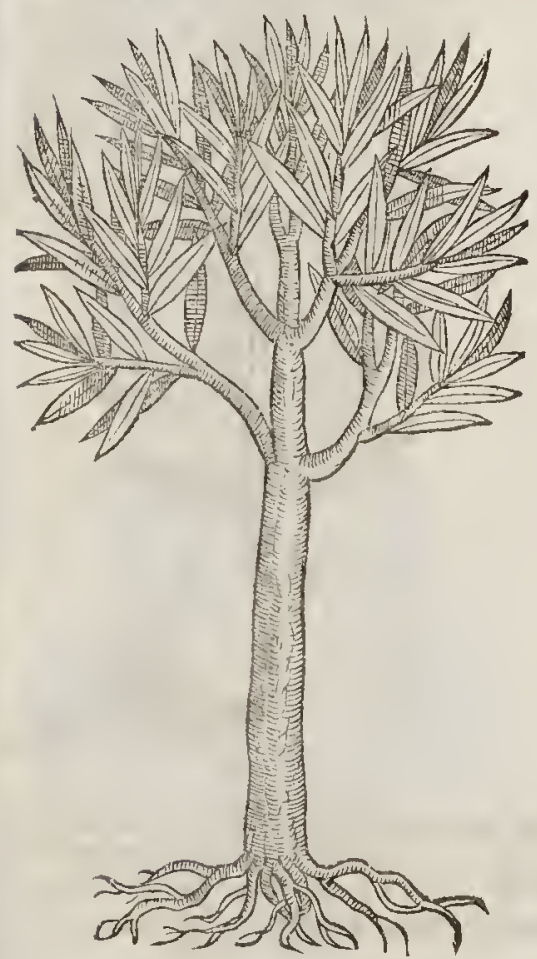

14 Efulamior Germanica. Quaekfaltuers Turbith.

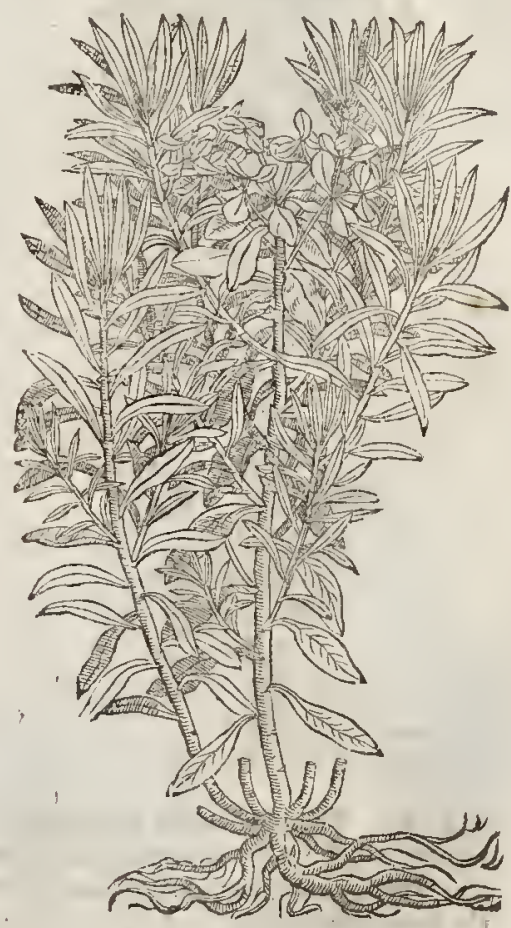

I3 There is another kinde of Tithymale, whofe figurewas taken forth of a Manufeript of the Emperors by Dodonets, that hath a ftalke of the bigneffe of a mans thigh, growing like a tree vnto the height of two tall men, dittiding it felfe into fundry armes or branches toward the top, of a red colour. The leaues are fmall and tender, mueh like vnto the leaues of Myrtus : the feed is like vnto that of wood Tithymale, or Characias, aecording to the authority of Peter Bellowe.

I 4 There is a linde of Tithymale called Efula maior, which carartinus Rulandiss had in great 
reneration,zs by his extra otior which levfed for many infimities may and doth appeareat large, in his bookes entituled Cen'sy a curionsm Empincarm, dedicated vnto the duke of Bauria. This

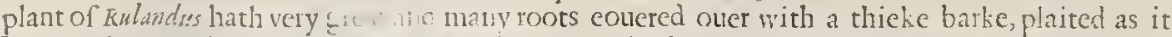
were with many furcuious ! pr. , in $n$ w hich arife fundry ftrong and large ftemmes of a fingers thickneffe, in height twn eut ts, betew with many pretty large and long leaues like Lathyris, but that they are nor fo thicke th feed and floure are not vnlike the other Tithymales.

Is This is liketic fith aue that it hath fmalter and more fecblebranehes; and the whoie plant is altogether icfle sowng but fome fpan or foot high; and the foures are of a red or elfe a greene eolour.

I6 There is another rare atd ftrange hinde of $E f_{u l}$, in alliance and likeneffe necre vnto $E f_{y} l_{a}$ minor, that is the fmall Ifuh or Piryu a vfct among the Phyfitions and Apotbeearies of Veniee as a kind of E fula, in the Confeetion of rheir Bencdidt and Cathartieke pills, in ftead of the true E/s$l_{a}$ : It yeeldeth a fungous, rough, and browne ftalke two cubits high, diuiding it felfe into fundry branches, furnifhed with ftiffeand tat leaues like Licorice, growing together by couples. The floures are pendulous, hanging downe their heads like fmall bells, of a purple colour, and withiu they are of a darke colour like Ariflolochia roturda.

t 15 Efula minar, fou Pityurfa. Small Efula.

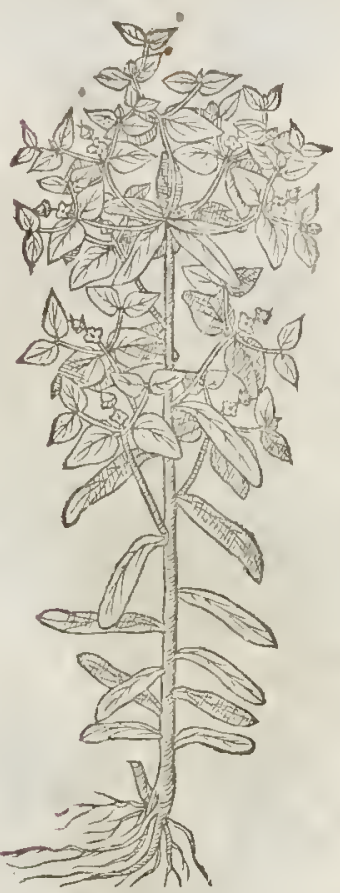

¥ 6 Efuld Veneta maritiona. Venetian Sea-Spurge.

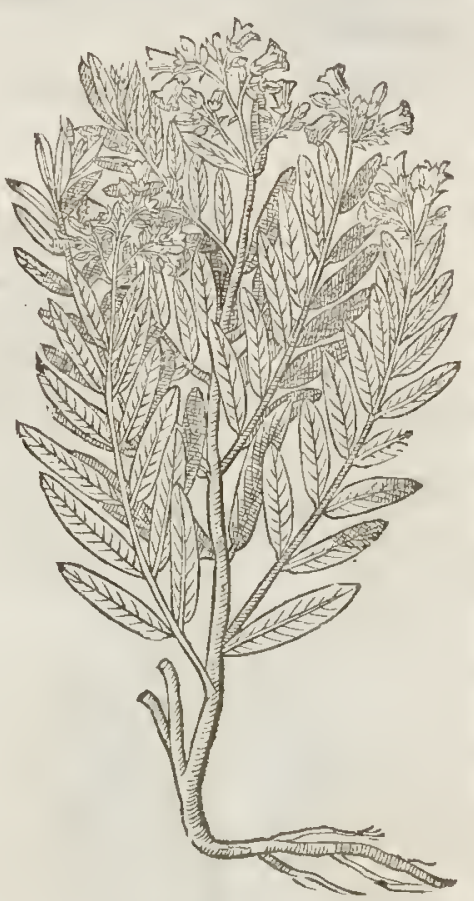

¥ 7 There growes in many chalkic grounds and fuch dry hilly places,among corne,a fmall Spurge which feldome growes to two handfuls high; the root is finall, and fuch alfo are the falks and leaues, which grow pretty thicke thereon; which oft times are not tharpe, but flat pointed: the feed-veffels and floures are very fmall, yet fathioned like thofe of the other Tithymales. It is to be found in eorne fields in Iuly and Auguf. $\ddagger$

I 8 The bigger Cataputia or the common garden Spurge is beft knowne of all the reft, and moft ved; wherefore I will not fpend time about his defeription.

The fmall kinde of Cataputia is like vn to the former, but leffer, whereby it may eafily be diftinguifhed; being likewife fo well knownevnto all, that I thall not need to deferibe it.

¥ Thefe two (I meane the bigger and leffer Cat aputia of our Author) differ not but by reafon of their age, and the fertileneffe and barrenneffe of the foile, whence the leates are fomtime broader, and otherwhiles narrower. 
¥ 7 Efula exigur Tragi.

Dwarfe Efula.

Enphobia exigua
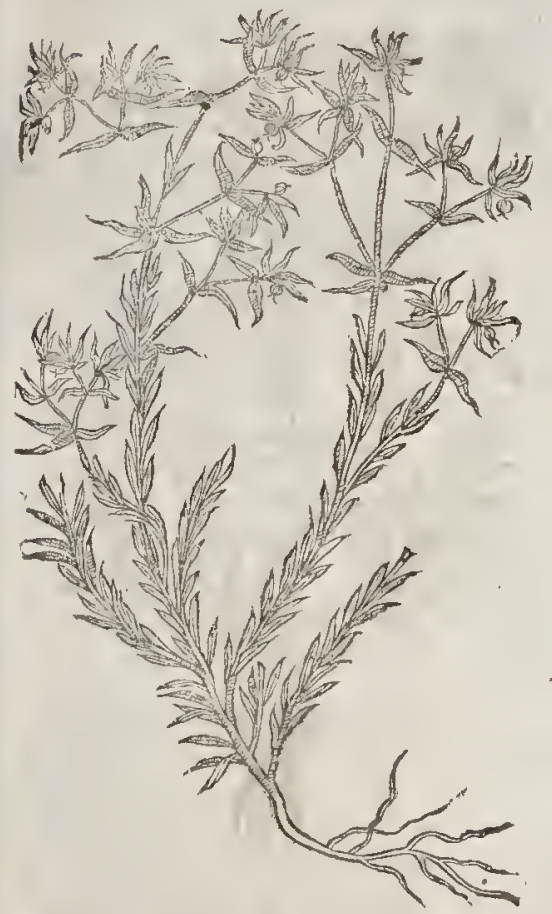

19 Pepluse, five Efula rotundd: Euphorbia Ppplus. Emportions

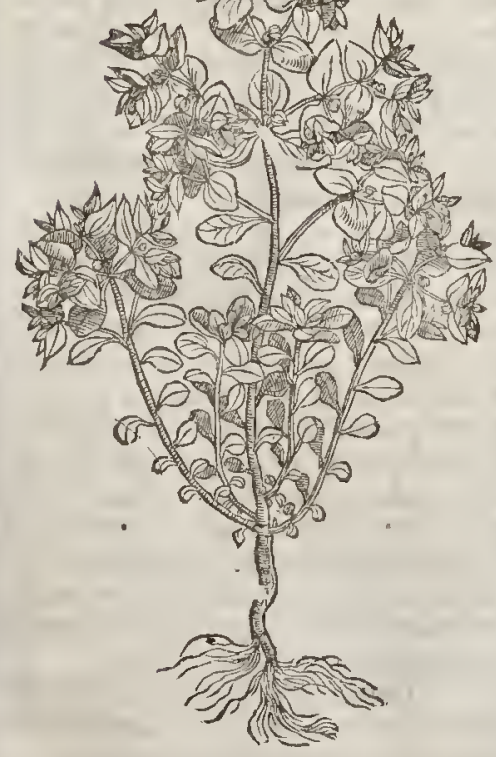

IStathyrs (cu Cataputia minor. Garden Spurge.

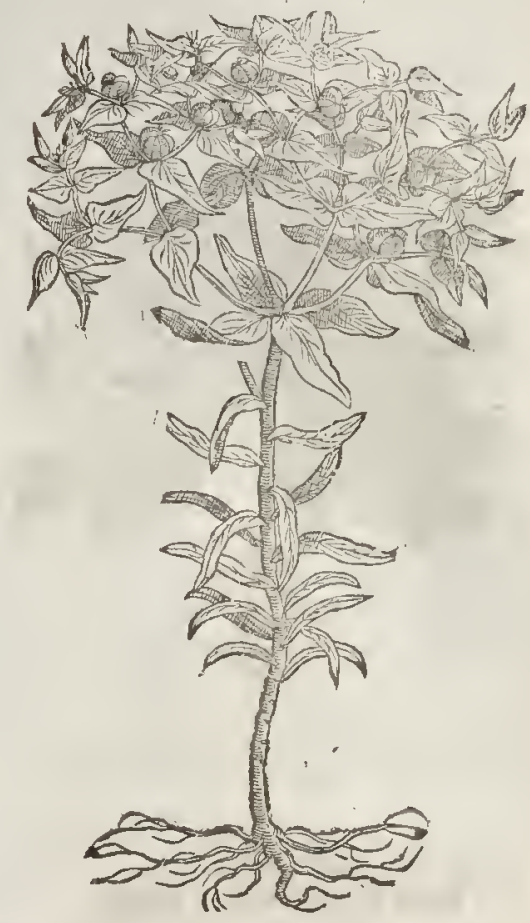

20 Peplis.

Euphortia Spurge'

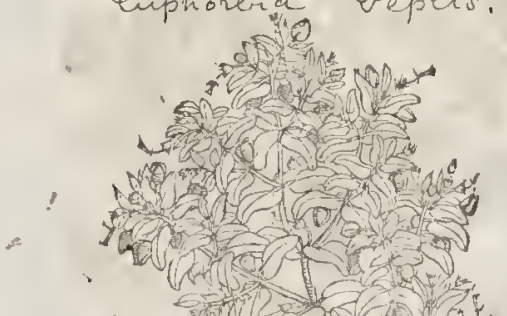

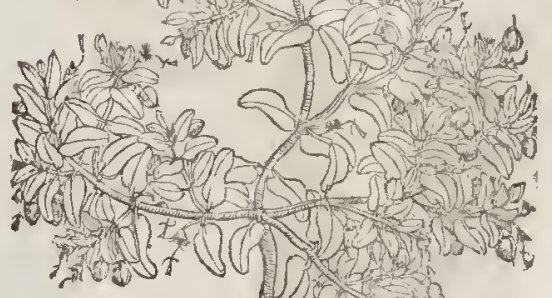

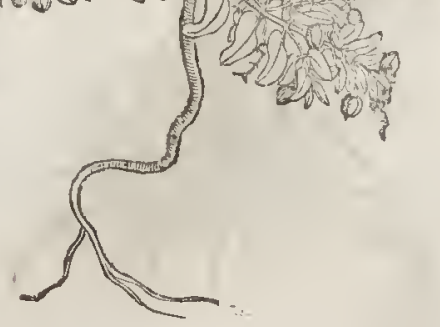


504 Of the Hiftory of Plants.

2 I Chamafyce.

Spurge Tinie.
22 Apios vera.

Knobbed Spurge.

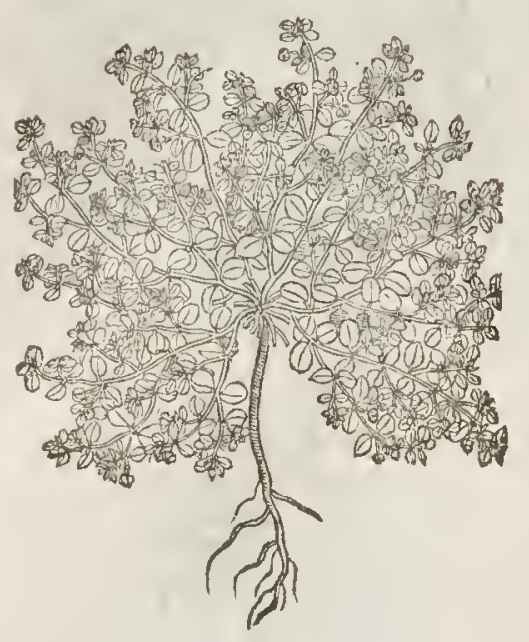

* 3 Apios radice oblonga.

Long knottic rocted Spurge.
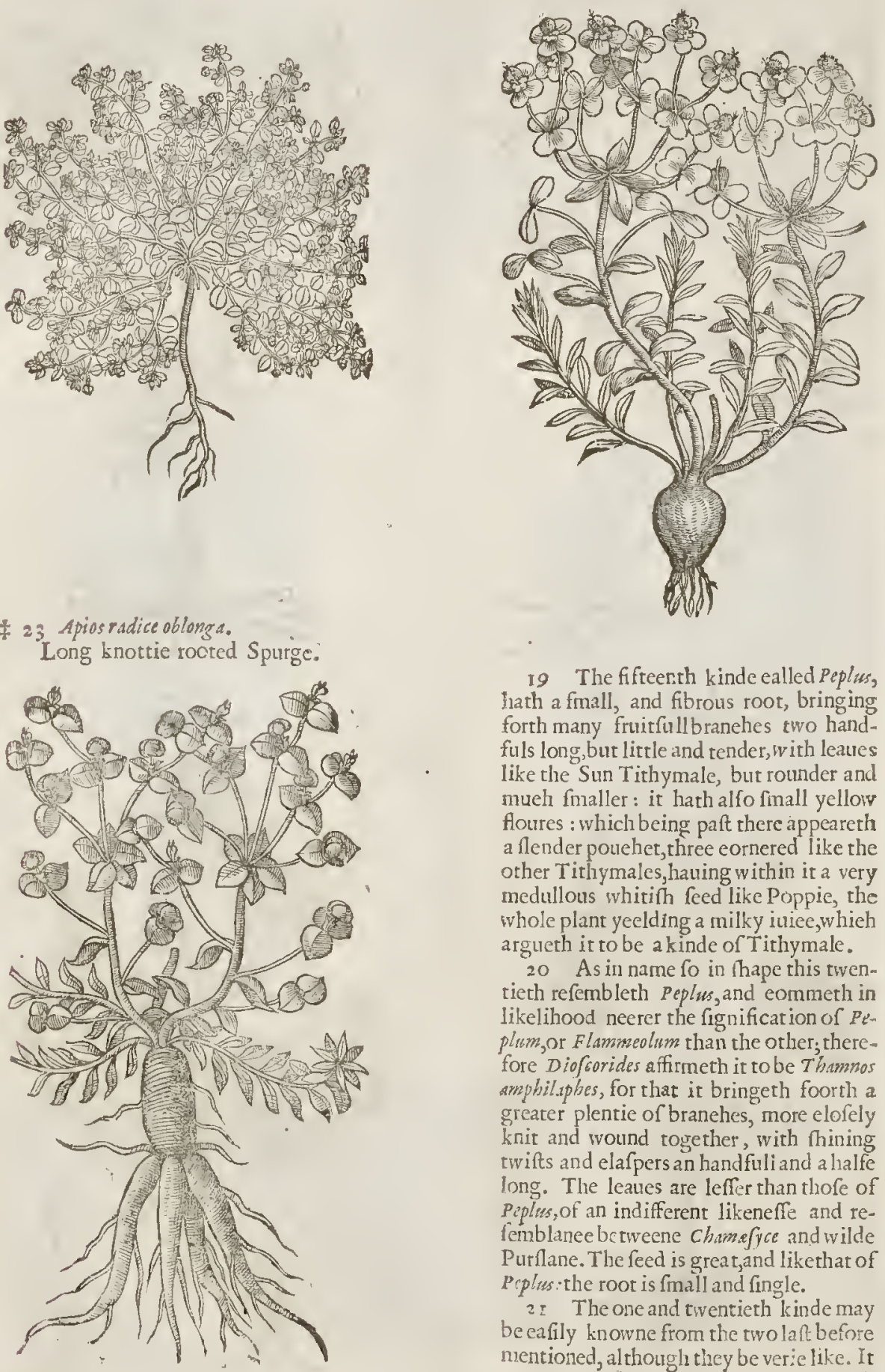

19 The fifteenth kinde ealled Peplus, lath a fmall, and fibrous root, bringing forth many fruitfullbranehes two handfuls long, but litrle and tender, with leates like the Sun Tithymale, but rounder and mueh fnaller: it hath alfo finall yellow floures : which being paft there appeareth a flender pouchet, three eornered like the other Tirhymales, hauing within it a very medullous whirith feed like Poppie, the whole plant yeelding a milky iuiee, whieh argueth it to be a kinde of Tithymale.

20 As in name fo in thape this twentieth refermbleth Peplu, and eornmeth in likelihood neerer the fignification of $P t^{2}$ plum,or Flammeolum than the other; therefore $D$ iofcorides affirmeth it to be $T$ hamnos amphilaphes, for that it bringeth foorth a greater plentic of branehes, more elofely knit and wound together, with thining twifts and elafpers an handfuli and a halfe long. The leaues are leffer than thofe of $P$ cplus, of an indifferent likeneffe and refenblaneebctweene Cham fyce and wilde Purflane. The feed is grear,and likethat of $\boldsymbol{P}$ cplus: the root is fmall and fingle.

2 I The one and twentieth kinde may be eafily knowne from the two lan before mentioned, al though they be verie like. It liath 
hatlı many branches and leaucs creeping on the ground of a pale greene colour, not vnlike to frem mara, but giting milke as all the other Tithymales doe, bearing the like feed, pcuch, and floures,
but fmaller in each refpeat.

22 The two and twentieth kinde of Tithymale hatl a round root like a fmall Turnep, as enery Authour doth report:yet my felfe hate the fame plant in my garden which doth greatly inereafe, of which hate given diters rnto my friends, whereby I haue often viewed the roots, which do ap. des, pena, and others haue exprefed and fet foin nothing anfwering the deferiptions which Dio/cori deferibed the fame by expreficd and fet forth. This argueth, that either they were deceived, and foile.The leaucs are fet a reddith vnderneath. The feed growerh among the Fraxinella, fomew hat round, greene aboute, and full of milke like the other Tithymales. ich rewes that hecirher never reades other Writers of plants, \& niofcorides \& Penaby name, (nor any bother that I know of) refeniles the roof of Diofor rhis to a Turnep, out fay it hath a tuberous

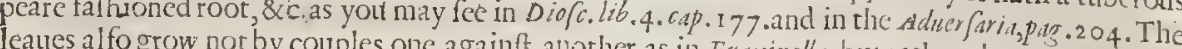
without any certaine order, as in other Tint another, as in Fraxinella, but rather alcrinately, or elfe

but almoft etrery where of ans, hath alfo a tubcrous root, but not peare falhioned like as the former long, and thelower part thereof is diuided into foing about an inch and fonctimes two inches ler by little and litte and fending forthed into foure other roots, or thicke fibers, growing tmaller by little and little, and fending fortly fone ferv fibers : it is blacke without, and white within, 8 full of a milkie inice: the ftalkes are fhort and weake, fet wirh little leaues like thofe of the former : rhe floures arc of a yellowith red coloni, and the feede is contained in fuch veffels as the other 'Tithymales. This is Tithymalus triberofus, or I/chas altera of Clufius. $\neq$

ot The Place.

The furt kiride of Spurge groweth by the Sea fide vpon the rowling Sand and Bajeh, as at Lee in Effex, at Lang-tree point right againft Harwieh, at Whitfable in Kent, and in many other
places.

The feeond growerh in grounds that liewafte, and in barren earable foile, almoft every where. The third and fourth, as alfo the foureteenth and eighteentl,grow in gardens, but notwilde in
England.

The ninth Spurge called Characias groweth in moft VVoods of England that are drie and warne. The eighteenth and nineteentligrow in falt marfhes neere the fea, as in the inle of Thanet by the
fea fide, betw ixt Reculvers and. Margate in great plentic.

Thefe plants floure from Th the Time:

Thefe plants floure from Iune to the end of Iuly.

Sea Spurge is called in Larine Tithom The Names.

wolfer milch, that is to fay Lupinum las alus paralius : in Spanifh, Lesho trefua: in high Dutel, characias. The firt is eallat Lapmunlac, or Wolfes milke. Wood Splirge is called Tithymalus the third and fourt Mirtle Spurge : Sea Spurge, or Sea VVartwoort. The lecond, Sun Spurge; our houf our houfe; the fixth Pine Spurge; the feucnth fhrub Spurge, and tree Mirtle Sourge; the eighth and ninth VVoot Spurge; the twelfth Broad leafed Spurge: the rhirteenth Great Tree Spurce: the foureteenth and fifteenth Q arekfaluers Spurge; the fixteenth Venice Spurge, the feuenteenth Divarfe Spurge; the eighteenth common Spurge; the rineteenth and twentieth Petie Spurge; theone and twentieth Spurge Time: The two and twentieth, True Apios or the knobbed
Spuge.

All the kinds of Tirlyymates or Spe Therature.

and biting qualitie, fretting or confuming. Firft the milke almot in the fourth degree, of a fharp A and leaues, but rlie root is of leaft ftrength. Firft the milke and fap is in fpeciall vfe, then the fruit is that of the fea.

Some write by report of others, that it infl ameth exceedingly, but my felfe fpeak by expericnce; $B$ for walking along the fea conft at Lee in Effex, with a Gentleman ealled Mr. Rich, dwelling in the firell in my throte that I one drop of it into my mourh; which netrertheleffe did fo inttame and caufed vs to take our horfes, and pofte for ourliues vn. And in like cafe was the gentleman, which to quench the extremitic of our heate, which then ceafed 


\section{- Ihe Vertues.}

A The iuiec of Tithymale,, do not meane fea Tithymale, is a ftrong medicine to open the belle, and caufing vomite, bringeth vp tough flegme and eholerieke humours. Likevertue is in the feed and root, which is good for fuch as fall into the dropfie, being minifred with diferecion and good aduice of fomeexecllent Phyfition,and prepared with his Correctories by fome honett Apothe. carie.

B The inice mixed with honie, catifeth haire to fall from that place which is anointed therewith, if it be done in the Sun.

C The iuice or milke is good to ftop hollow tecth, being put into them warily, fo that you toueh neither the gums,nor any of the other teeth in the mouth with the faid medicine.

D The fame enreth all roughnefle of the skin, manginclfe, leprie, fetirfe, and running fcabs, and the white fcurfe of the licad. It taketl away all manner of warts, knobs, and the hard ealloufneffe of $\vec{F}$ ftulaes, liot fwellings and Carbuneles.

E It killeth fith, being mixed with any thing that they will eat.

F Thefe herbes by mine aduife would not be recciued into the bodie, confidering that there be fo many other good and wholecome potions to be madewith other herbes, that may bee taken without perill.

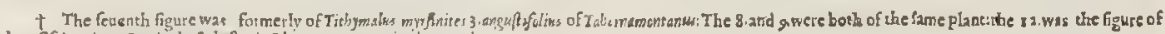
the Efula erigutatragi, whole binorie I hauegiuen you in che i7 place-

\section{С н р. 140. Of Herbe Terrible.}

I Alypsm mont is Ceti. Herbe Terrible.

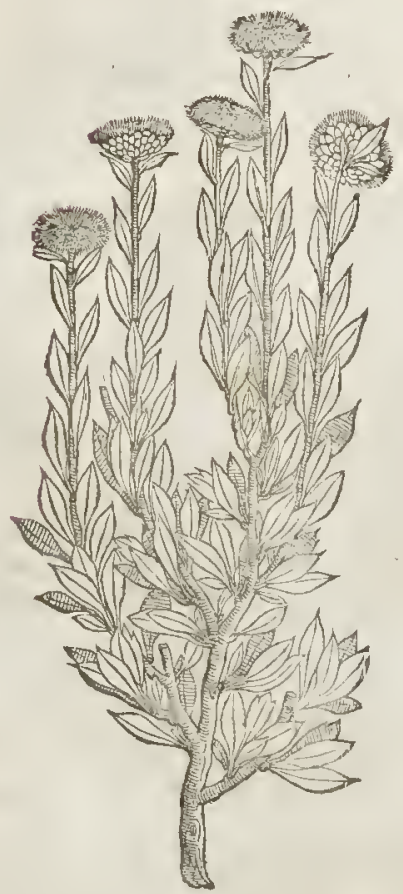

2 Tirton-R aire Gallo-Prouincia: Gutwoort.

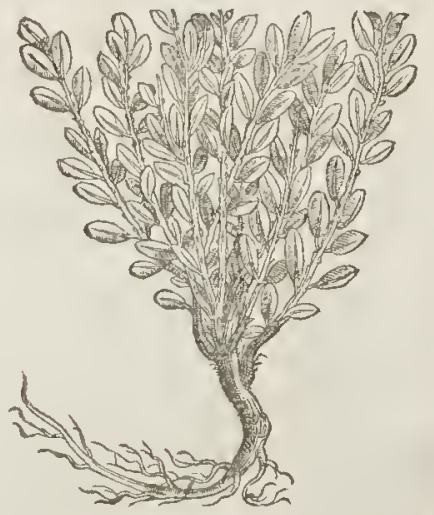

If The Defcription.

1

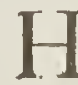

Erbe Terrible is a fnall fhrub two or three cubits high, branched with many frall twigges, hauing a thin rinde firft browne, then purple, with many little and thinne leanes like Myrtle. The floures are rough like the middle of Scabious floures, of a blew purple colour. The root is two fingers thicke, browne of colour, and of a wooddie fubstance : the whole plant very bitter, and of an vnpleafant tafte like Chamelea,yea fomewhat ftronger.

2 Tartonrairc, called in Englifh Gutwoort, groweth by the fea, and is Cathatticall, and a ftrangerwith vs. In the mother tongue of the Maffilians, it is called Tartonraire, of that abundant 
LI B. 2.

Of the Hiltory of Plants.

and vabridled facultic of purging, which many times doth eaufe Dyfouterie, and fuch like imm . derate fiures, efpecially when one not skilfull in the we thereof thall adininifter the pouder of the

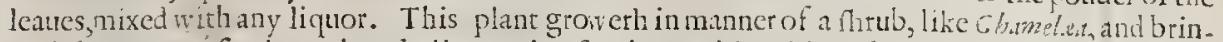
geth forth many fmal, tough, and pliant twigs, fet aboutwith a thin and cotony hairinef:, $3 x$ hat it many leaues of a gliftering filuer colour, growing from the loweft purt euen to the top, alcogether like Alypun before mentioned:and vpon thefe rough and thick branches (if my memory faile not) do grow finall foures, firft white, afterward of a pale yellow:the feed is of a rufet co'our: theront hatd and wooddy, not very hot in the mouth, leaning vpon the tongue fo ne of his inbred heat and tifte, fomewhat refembling eommon Turbith,and altogether wirhour milke.

$$
\text { If The Place. }
$$

Thefe plants do grow vpon the mountains in France,and other places in the grauclly ground's, and are as yet $\mathrm{n}$ tangers in England.

$$
\text { बा The Time. }
$$

They flourin in Auguft and September. $\neq$ The firft Clufiess found flouring in diuers parts of Spaine, in Februrie and Mareh; and I coniecture the other floures about the fame time, yet I can finde nothing faid thereof in fuch as haue deliuered the hiftorie of it. $\neq$

$$
\text { of The rames. }
$$

There are not any other names appropr iate to thefe plants more than are fet forth in the titles.

¥ The firft of thefe is the Alypum mont is Ceti, Se Herbaterribilis of Lobel; Cluf.ealls it Hippoglo/fum Valentinum, Sz in Hift. Lugd. it is named Alypum Pcne, \& Empetrum Phacoides. The fecond is the Tartonraire Galloprowincie Mafjilienfum, in the Adnerfaria; Sefamoides mains multorum of Dalefc. \& the Sefamoides mains Scalegeri of Tabern.by which title out Author alfo gaue his figute, in the 397. pag. of the former Edition. $\neq$

$$
\text { If The Temperature and Vertues. }
$$

There is nothing either of their nature or vertues, more than is fet forth in the Deferiptions.

\# Both thefe plants hauc a ftrong purging faetilty like as the Tithymales; but the latter is far more powerfull, and comes reere to the qualitie of cMezercon; wherefore the vfe of it is dangerous, by rea on of the violence and great heat thereof. $\ddagger$

\section{C н а р. 11.1. Of Herbe Aloe, or Sea Houfleeke.}

I dioc vulgaris, five sempervinam marinum.

Common Aloe, or Sea-Houllecke.

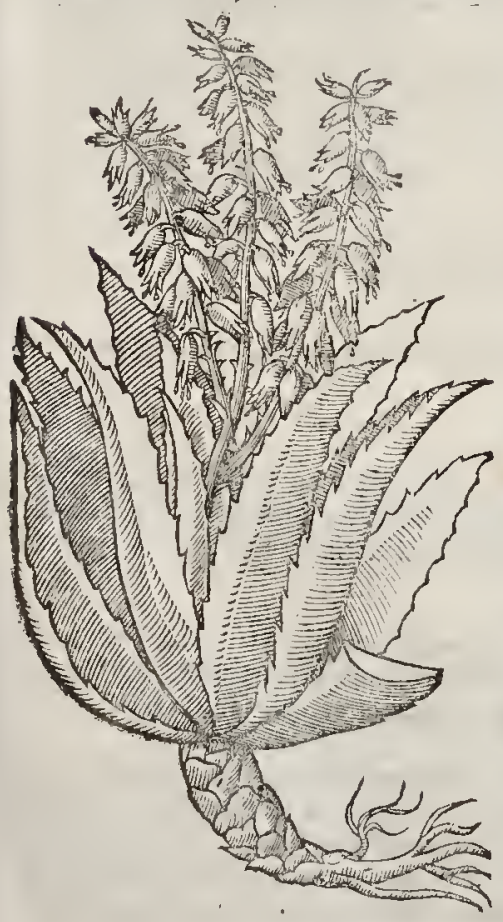

\section{Aloe folio mucronato.}

Prickly herbe Aloc, or Sea Houlleeke;

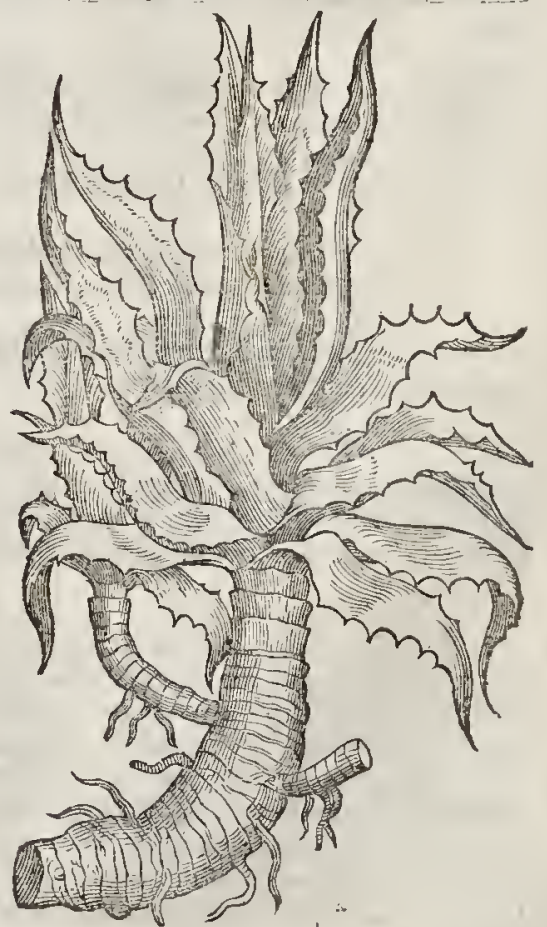




\section{था The Defcription.}

I T Earbe Alloehath leaues like thofe of fea Onion, very long, broad, fmooth, thick, bending backewards, norehed in the edges, fet with eertaine little blunt prickles, full of tough and elammie iuice like the leates of Houflecke. The ftalke, as D w fortes faith, is like to the Atalke of A ffodill : the floure is whituh; the feed like that of Affodill; the roor is fing $\mathrm{e}$, of the fafhion of a thieke pile thruft into the ground. The whole herbe is extrene bitter, fo is the iuice alfo that is garhered thereof.

+2 There is another herbe A loe that groweth likew ife in diuers protinees of America; the leaues are two cubits long, alfo thieker, broader,yreater, and tharper pointed than the former, and it hath on the edges far hardor prickles. The falke is three eubits high, and a finger thicke, the which in long eups beares violet coloured foures. $t$

$$
\text { 1) The Plice. }
$$

This plant groweth very plentifully in India, and in Arabia, Colofyria, \& Egypt, from whenee the iuice put into skins is brought into Europe. It groweth alfo, as Diofiorıdes writeth, In A fra, on the fea coafts, and in Andros, but not verie fit for iuiee to be drawne out. It is likewife found in Apulia, and in diuers places of Gtanadoand Andalufia, in Spaine, but not far from the fea : the iuiee of this is alfo vnprofitable.

$$
\text { 9ा The Time. }
$$

The herbe is alwaies greene, and likew ife fendeth forth branehes, though it remaine out of the earth, efpee ially if the root be couered with lome, and now and then watered: for fo teing hanged on the feelings and vpper pofts of dining romes, it doth not onely continue a long time grcene, but it alfo groweth and bringeth forth new leaues : for it muft haue a warme place in winter time, by teafon it pineth away if it be frozen.

\section{The Names.}

The herbe is called in Grecke exн: in Latine, and in fhops alfo, Aloe : and fo is likewife the iuice.

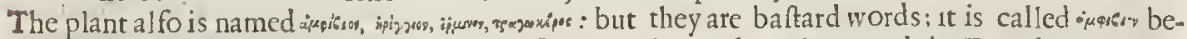
caufe it liueth not onely in the earth, but alfo out of the earth. It is ramed in French, Porogut : in Spanifh, Azewar, and Yeruabanofa: in Englin, Aloes; herbe Aloes, Sea Houfelecke, Sea Aigrene.

The hearbe is ealled of the latter Herbarifts oftentimes Semperviuum, and Sempervisum Mari. mum, becaufe it lafteth long after the manner of Houfe-lecke. It feemeth alfo that Columella in his tenth booke nameth it Sedum, where he fetteth downe remedies againft the canlset-wormes in trees.

$$
\begin{aligned}
& \text { Profuit ó plant is latices infundere amáros } \\
& \text { Marrubij, multogue sedi cont } n \text { gere fucco. }
\end{aligned}
$$

In Englinh thus :

Liquours of Horehound ptofit much b'ing pour'd on ttees:

The fame effect Sea Houfletke works as well as thefe.

For lie reeiteth the iuice of Sedum ot Houfeleeke among the bitter iuices, and thete is none of the Houfleckes bitter but this.

\section{The Temperature}

Alö̈, that is to fay, the iuice which is vfed in Phyficke, is good for many things. It is hot, and that in the firft or feeond degree, but dric in the third, extreme bitter, yet without biting. It is alfo of an emplaifticke ot clammie qualitie, and fomething binding,externally applied.

$$
\text { बT The Vertues. }
$$

A It purgeth the belly, and is withall a wholefome and eonuenient medieine for the ftomacke, if any at all bee wholefome. For as Pulus Aeginet a writeth, when all purging medieines are hurtfill to the ftomacke, Aloës onely is comfortable. And it purgeth more effectually if it be not washed: and if it be, it then ftrengtheneth the ftomacke the more.

It bringeth forth eholer, but efpecially it purgeth fuchexerements as be in the fomacke, the

$B$ firf veines, and in the neereft paflages. For it is of the number of thofe nediejnes, whieh the Grem ejans call inximemong, of the roiding away of the Ordure; and of fueh whofe purging force paffeth not farbeyond the ftomacke. Furthermore Alös is a nenemie to all kindes of putrefacions; and defendeth the boly from all manner of corruption. It alfo preferueth dead cavkafes from putrifying; 
it killeth and purgeth away all manner of wormes of the belly. It is good againft a finking breath proeeding from the imperfection of the ftomacke: it openeth the piles or hemorthoides of the findament; and being taken in a fmall quantity, it bringeth down the monthly coutfe:it is thought: to be good and profitable againft obftructions and ftoppings in the reft of the intrals. Yet fome there be who thinke, that it is not conuenient for the liuer.

One dramme thereof giten, is fitficient to purge. Now and then hal fe a dranme or little more 6 is enough.

It healeth vp greene wounds and deepe fores, clenfeth vlcers, and cureth fireh fores as are hard- D ly to bee helped, efpecially in the fundament and fecret parts. It is, with good fueceffe mixed with imines, or med icines which ftanch bleeding, and with plaifters that be applied to bloudy wounds; for it helpeth them by reafon of his emplaift icke qualitic and fubftance; It is profitubly put into medi cines for the eies, forafmuch as it clenfeth and drieth withour biting.

Diofcorides faith, that it muft be torrified or parehed at the fire, in a cleane and red hot veffell, $\mathbf{E}$ and continually ftirred with a Spatula, or Iron Ladle, till it bee torrified in all the parts alike : and that it muft alfo bee wafhed, to the end that the vnprofitable and fandie droffe nay finke downe vnto the bottome, and that which is fmooth and mont perfect beetakenand refertied.

The lame Authour alfo teacheth, that mixed with honie it taketh away blacke and blew fpots, $;$. which come of ftripes: that it helpeth the inward ruggedneffe of the eye-lids, and itching in the corners of the eies: it remedieth the head-ache, if the temples and forehead bee annointed therewith, being ntixed with vineger and oile of Rofes : being tempered with wine, it ftaicth the falling off of the haire, if the head be wafhed therewith: and mixed with wine and honie, it is a remedie for the fivelling of the Vuula, and fivelling of the Almonds of the throte, for the gums \& all vlcers of the mouth.

The iuice of this hetbe Aloc : (whereof is made that excellent and moft familiar purger, ealled G Aloe Succotrina; the beft is that which is cleere and thining, of a browne yellowith eolour) it openeth the bellic, purging cold, flegmaticke, and cholericke humours, efpeeially in thofe bodies that are furcharged with furfecting, either of meat or drinke, and whofe bodies are fully repleat with bumours, fairing daintily, and wanting exercife. This wloes I fay, taken in a fmall quantitic after fupper (or rather before) in a ftewed prune, or in water the culantitie of twodrammes in the morning, is a moft foueraigne medicine to comfort the ftomaeke, and to clenfe and driue foortla all fupetfutous humours. Some vfe to mixe the fame with Cinnamon, Ginger, and Mace, for the purpofe abouie faid; and for the laundies, fpitting of bloud, and all extraordinarie iffues of bloud.

The fame vfed in vicers, efpecially thofeof the fecret parts or fundament, or made into pouder, $H$ and frawed on freth wounds, ftaieth the bloud, and healeth the fame, as thofe vlcers before fpoken of.

The fame taken inwardly canfeth the Hemornhoids to bleed, and being liaid thereon ir caufeth I them to ceale bleeding.

\section{CHA P. 142: Of Houfleeke or Sengreene.}

$$
\text { If The Kindes. }
$$

SEngreene,as Divfcorides writeth, is of three forts, the one is great, the orher fmall, and the third is that which is called $I$ llecebra, biting Stone-crop, or VVall pepper.

\section{Tt The Defcription.}

I Te great Sengreene, which in Latine is commonly called Iovis Barba, lupitcis beard; bringeth forth leaues hard a dioyning to the ground and root, thicke, fat, full of tough iuice, thar pe pointed, growing clofe and luard together, fet in a circle in fafhion of an eye, and bringing forth very many fuch circles, fpreading it felfe out all abroad: it oftentimes alfo fendeth forth fmall ftrings, by which it fpreadeth farther, and maketh new circles; there rifeth vp oftentimes in the middle of thefe an vpright ftalke about a foot high, coucred with leaues grow ing leffe and le fee toward the points, parted at the top into certaine wings or branches, about which are floures orderly placed, of a darke purplifh colour : the roor is all of frings. 
2 There is alfo another great Houfleck or Sengreen (fyrnamed tree Houflecke) that bringeth forth a ftalke a cubit high, fometimes higher, and often two; which is thicke, hard, woody, tougl, and that can hardly be broken, parted into diuers branehes, and eouered with a thicke groffe barke, which in the lower part refertieth eertaine prints or impreffed markes of the leaues that are fallen away. The leaues are fat, well bodied, full of juice, an ineh long and fomewhat more, like little tongues, very curioufly minced in the edges, ftanding vpon the tops of the branehes, hauing in them the thape of an eye. The floures grow out of the branehes, whieh are diuided into many fprings ; which floures are flender, yellow, and fpred like a ftar; in their plaees eommeth vp very fine leed, the fprings withering away : the root is parted into many off-fprings. This plant is alwaies greene, neither is it hurt by the cold in winter, growing in his natiue foile; whereupon

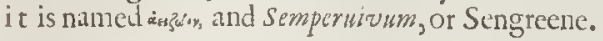

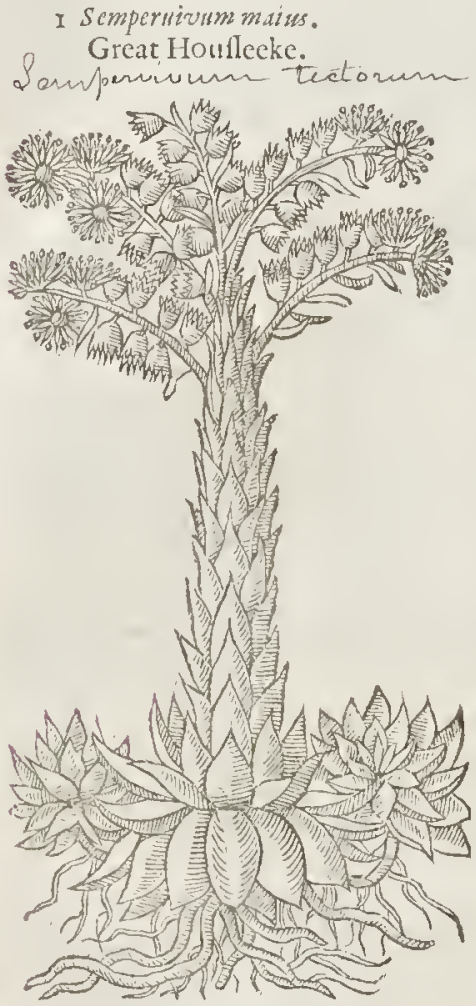

$\ddagger 2$ Sedum matius arborefcens. Tree Houllecke.

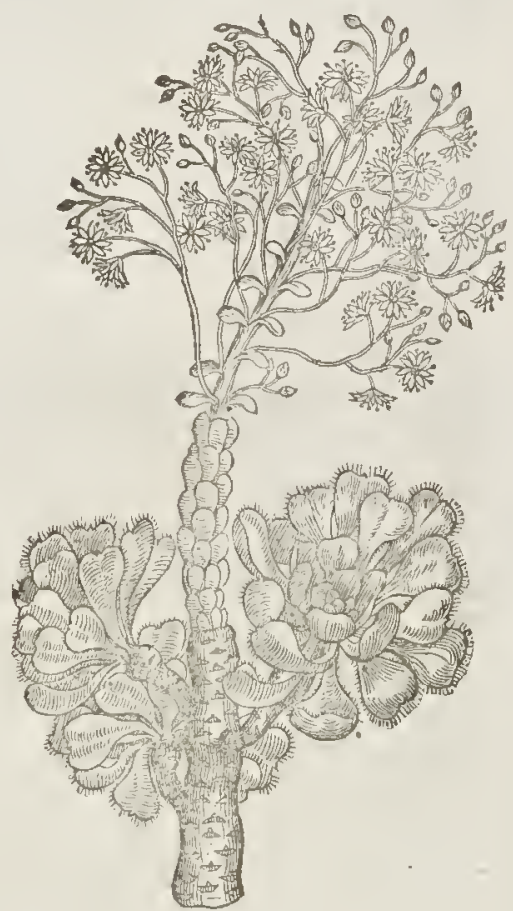

3 There is alfo another of this kinde, the circles whereof are anfwerable in bigneffe to thore of the former, but with leffer leates, moe in number, and elofefly fet, hatung ltanding on the edges very fine haires as it were like foft priekles. This is fomewhat of a deeper greene:the italke is thorter, and the floures are of a pale yellow. $\neq$ This is the third of Dodonates defcription, Pemptad.I. li6. 5. cap. 8. +

4 There is likewife a third to be referred hereunto : the leaues hereof be of a whitith greene, and are very curiounly nicked round about. ‡ The floure is great, eonfifting of fix white leaues; This is that deferibed by Dodoneus in the 4 . place : and it is the Cotyledon alter a fecunda of Clufius. +

5 There is alfo a fourth, the circles whereof are leffer, the leaues tharpe pointed, very clofely fer, of a darke red eolour on the top, and hairy in the edges: the floures on the fprigs are of a gallant purple colour. $¥$ This is the fift of Dodoners; and the Cotyledon alteratertia of Clufius. $\ddagger$

\section{- The Place.}

I The great Sengreen is well knowne not onely in Italy, but alfo in France, Germany, Bohemia, and the Lowe-Countries. It groweth on ftones in mountaines, vpon old walls, and ancient buildings, efpecially vpon the tops of houfes. The forme bereof doth differ aecording to the nature of the foile; for in fome places the leaues are narrower and lefier,but mo in number, and haue one onely circle; in fome they are fewer, thicker, and broader: they are greene, and of a deeper 
greene in fome places; and in others of a lighter greene: for thofe which we laue defcribed grow not in one place, but in diuers and fundry.

$\ddagger 5$ Sedum maius angufifolium. Great narrow leatied Houllcke.

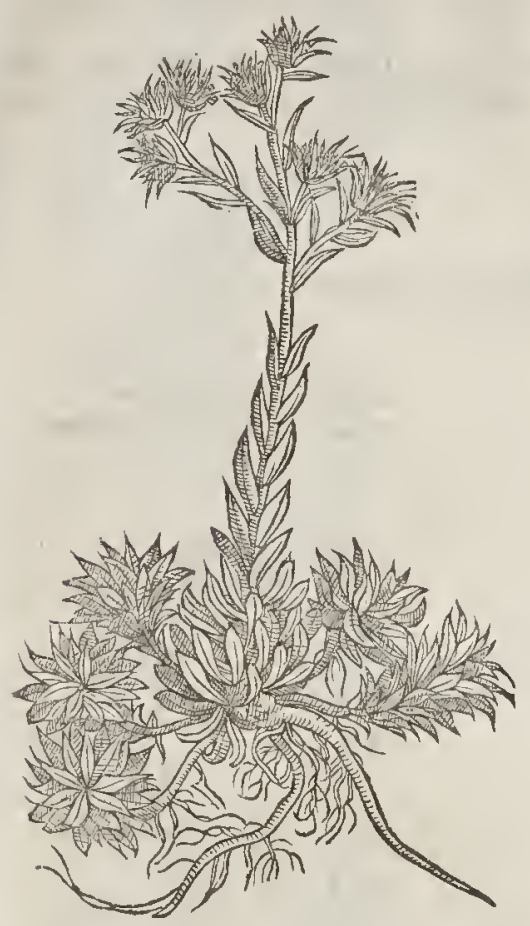

2 Great Sengreene is found growing of it felfe on the tops of houres, uld walls, and fuch like places in very many prouinces of the Eaft,and of Grecce:and alfo in the Illands of the Mediterranian fea ; as in Crete, which now is calicd Candy, Rhodes, Zant, \& others; neither is Spaine without it: for (as Conolus Cluf fus witneffeth) it groweth in many places of Portingale; orlerwife it is cherihed in earthen pots. In cold countries, and fuch as lie Northrard, as in both the Germanies, it neither growetl of it felfe, nor yet lafteth long, though it be carefully planted, and diligently Ionied varo, but through the extremitic of the wearher, and the ouermuch cold of winter it perimeth.

$$
\text { I The Time. }
$$

The ftalke of the firft doth ar length fioure after the Summer Solfice, which is in Iune about Saint Barnabies day, and now and than in the nmoneth of Augun:; but in Aprill, thate is to fay, after the xquinoctiall in the fpring, which is about a moneth after the fpring is begun, there grow out of this among the leates fmall ftrings, which are the groundwork of the circles, by which being at length full growne, it fpreadeth ir felfe into very many circlcs.

2 Houlleeke that growerh like a tree, doth flourc in Porringale at the beginning of the yeere prefently after the winter Solftice, which is December,about \$. Lucies day.

of The Names.

The firft is commonly called toris barba, or Iupitcrs beard, and alfo Scdum mains vulare : the Germanes call it Derbaet : the Hollinders, Hunfloock : the French-men, Toubarbe : the Italians, Scmpresivo ma zgiore: the Spaniards, Siempremint,yersia penter, the Englith-men, Houflecke, and Sengreene, and Aygreene:of fome, Iupiters cie, Bullocks cie, and Inpiters beard:of the Bohemians, Netresk. Many take it ro be Cotyledon aller. Difocoridss; but we had rather laate it one of the Sengreenes: for it is continually greene, and alrwies fouriheth, and is hardly hurt by the extremity of winter.

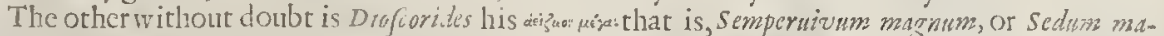
jus, great Houfleck, or Sengreen : Apulcius calleth it Vitalis, and Semperforiurs: it is alfo named

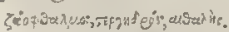
E The Tomperature.

The great Houfleeks are cold in the third degree : they are alfo dry, but not much, by reafon of the watery efience that is in them.

\section{of The terises.}

They are goxd againn Saine Anthonies fire, the fhingles, and orlier creepingvlcers and inflammations, as Gialin faith, that proceed of rheumes and fuxes : and as Diofcorides teacheth, againft the inflammations or fiery lieare in the eyes:the leaues, faith $P$ liny, being applied, or the juice lard on, are a remed for rheumatike and watering eies.

They take away the fire in burnings and fcaldings; and being applied with Barly meale dried, do take away the paine of the gout.

Diofcorides teacheth, that they are ginen to them that are tronbled with a hot laske : that they likewife driue forth wormes of the belly if they be drunke with wine.

The juice put vp in a peffiry do fay the fulxes in women,proceeding of a hot caufe : the leates held in the nouth do guencly thirf in lot burning feauers.

The juice mixed with Barly mcalc and vineger prenaileth againf $S$. Anthonies fire, all hot burning and fretring vecrs, and againf fcaldings, burnings, and all in fammations, and alfo the gont $E$ comming of an liot caufe.

$\mathrm{Vu} 2$ 
A The iniee of Honfleeke, Garden Night thade, and the buds of Poplar boiled in CAxungiaporci, or hogs greafe, maketh the moft fingular Populeon that euer was vfed in Chirurgeric.

B The iuiee hereof taketh away eornes from the toes and feet, if they be wafhed and bathed therwith,and euery day and night as it were implaiftered with the skin of the fame Houfleeke, whieh certainly taketh them aw ay without ineifion or fueh like, as hath beene experimented by my very good friend $\mathrm{M}^{\mathrm{r}}$. Nicholas Belfon, a man painefull and eurious in fearehing forth the feerets of $\mathrm{Na}$ ture.

C The deeo aion of Houfleeke, or the iuiee thereof drunke, is good againt the bloudie flixe, and cooleth the inflammation of the eics being dropped thereinto, and the bruifed hearbe layed upon them.

\section{C н а . 143. Of the Leffer Houfleekes or Prickmadams.}

I Sedum minus batmatoides.

Prieke-madame.

Sedum rellexum 3

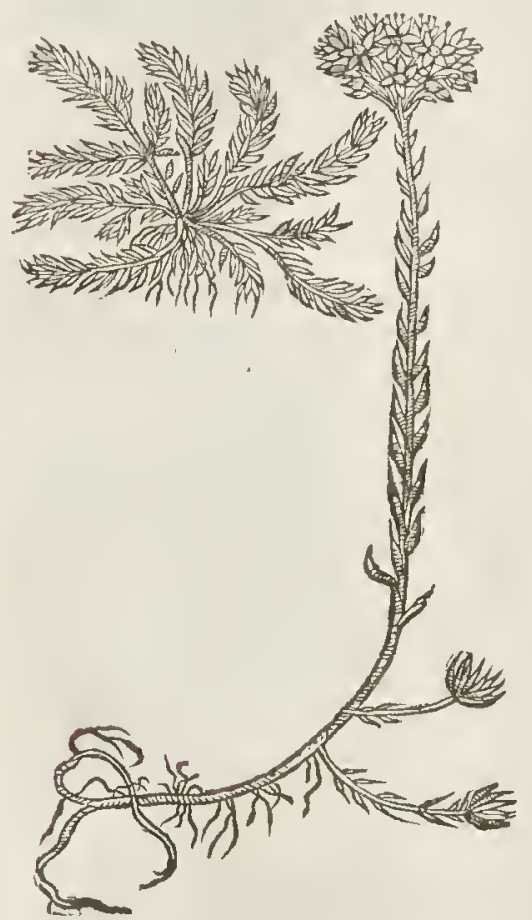

2 Sedum minus officinarum. White floured Prickmadme,

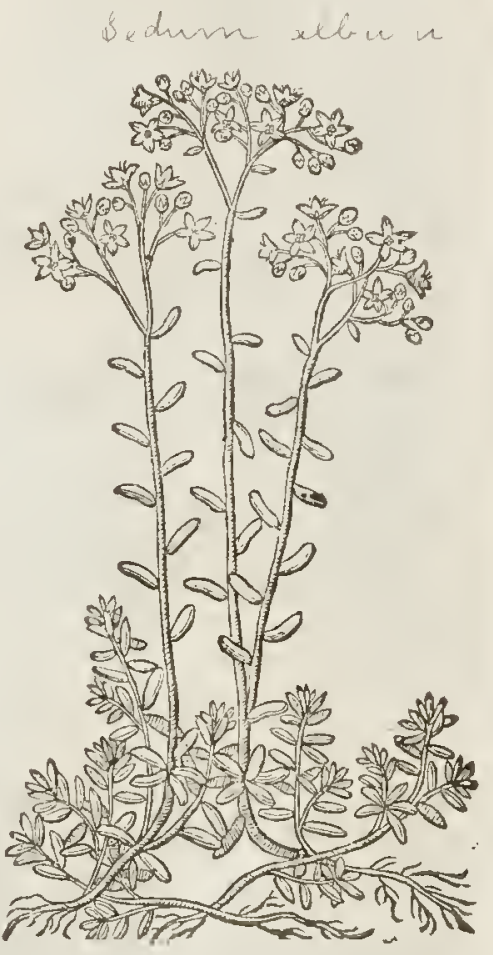

Tा The Defoription.

1

THe firft of thefe is a very little herb,ereeping vpon the ground with many fender Italks? whieh are eompaffed about with a great number of leaues, that are thieke, ful of ioints, little, long, fharpe pointed, inelining to a greene blew. There rifevp among the fe, little ftalkes, a handful high, bringing forth at the top, as it were a fhadowie tuft; and in thefe fine yellow floures: the root is full of ftrings.

i: 2 The other little Sengreenc is alfo a mall berbe, bringing forth many flender falkes, feldome aboue a farn high; on the tops whereof ftand little floures like thofe of the other, in fmall 


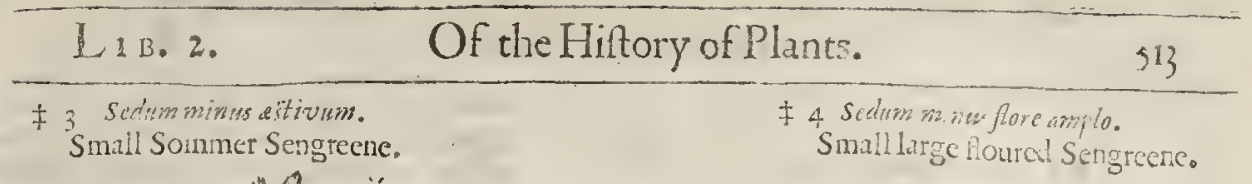
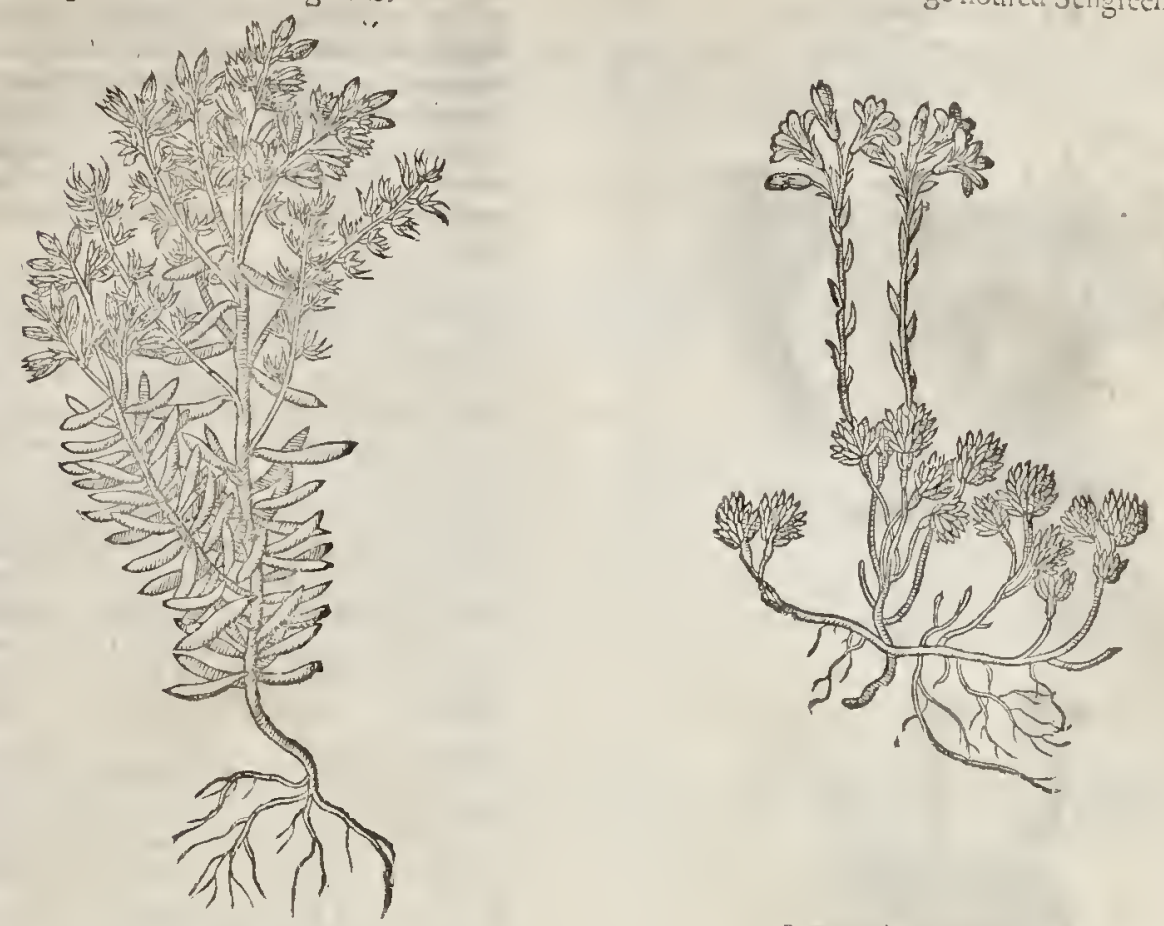

¥5 Sedsme med' um terctifol uns!

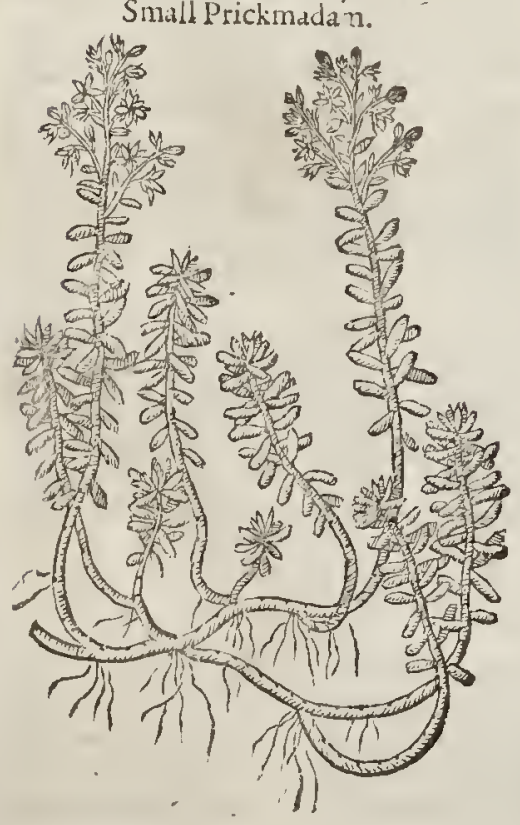

+6 Aizoon Scorpioides: Scorpion Sengreene:

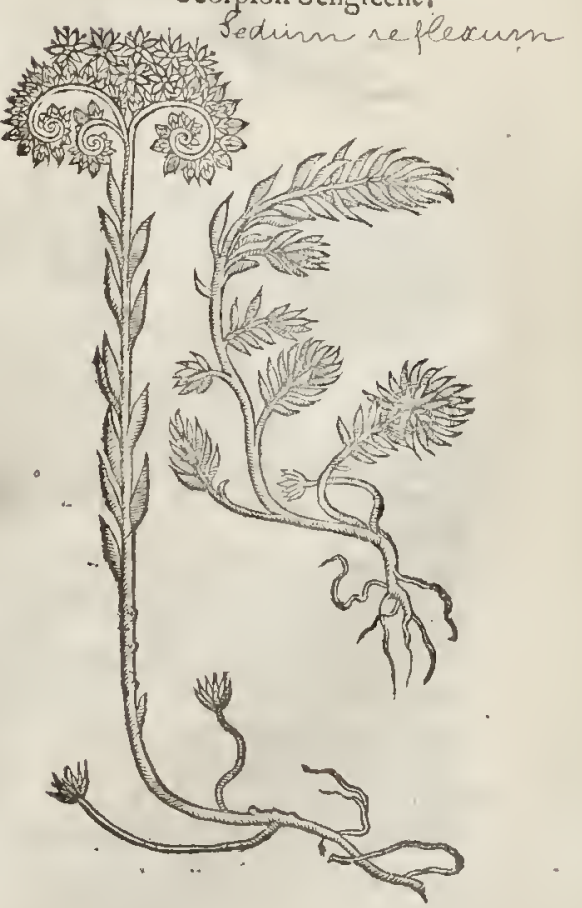

$\mathrm{Nu}_{3}$ 
† Sedum Portlandicum. Portland Sengteene.

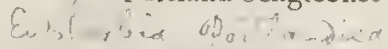

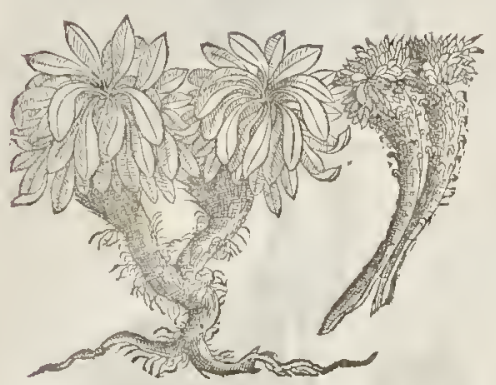

¥8 Sedum petreum.

Small rockc Sengreene.

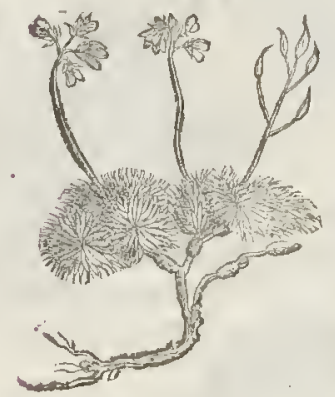

loof tufts; but tey are white and fomething leffer: the leaues about the ftalkes are few and little, but long, blunt, and round, bigger than wheaten cornes, fomething leffer than the kernels of the Pine Apples, O. therwife not vnlike; which of tentimes are fomething red, falkes and all : the roote creepeth rpon the fuperficiall or vppermiof. part of the earth, fending downe lkender threds.

3 There is a fmallkinde of Stonecrop, which hath little narrow leaues, thicke, Tharpe pointed, and tender ftalkes, full of fattic iuice; on the top wherenf doe grow fmall yellowe floures, Stare fathion. The roote is fmall, and runung by the ground.

4 There is likewife another Stonecrop called Frog Stonccrop, which lath little tufts of leaues rifing from fmall and and threddic rootes, creeping vpon the ground like vnto Kalior Erog-graffe; from the which tufts of leaues rifeth a flender italke, fet with a few fuch like leaues, hauing at the top prettic large yellow floures, the imalneffe of the plant beeing confide. red.

\# 5 This is like that which is deferibed in the fecond place; but that the ftalks are leffer, and not fo tall, and the floures of this are ftar farhioned, and of a golden yellow colour. $\neq$

6 There is another Stonecrop, or Prickmadam called Aizoon Scorpioides, which is altogether like the great kindc of Stonecrop, and differeth in that, that this kinde of Stonecrop or Pricknadam hath his tuft of yellow floures turning again,not much vnlike the taile of a Scorpion,refem-

bling Myofet is Scorpioides, and the leaues fomewhat thicker, and cloler thruft together. The root is fnall and tender.

7 There is a plant called Sedum Portlandichu, or Portland Stonecrop, of the Englifh Ifland called Portland, lying in the South coatt, which hath goodly branches and a rough rinde. The leaues imitate Laureola, growing among the Tithymales, but thicker, , horter, more fat and tender. The ftalke is of a wooddy fubitance like Laurcola, participating of the kindes of Craffula, sempervinum, and the Tithymales, whercof wee thinke it to bee a kinde; yet not daring to deliuer any vncertaine fentence, it thall be leffe preiudiciall to the truth, to account it as a fhrubbe, degenerating from bothkindes.

‡ Pena and Lobel, who firft fet this foorth knewe, not veriewell what they thould fay thercof ; nor any fince them: wherefore I haue onely giuen you their figure put to our Authours defeription. $\neq$

8 There is a plant which hath receined his name Sedum Petram, becaufe it doth for the mo? part grow vpon the rocks, mountains, \& fuch like ftonic places, hauing very fmal leaues, comming. forth of the ground in tufts like $P$ feudo- Moly; that is, our common herbe called Thrift: among the leaues come forth flender ftalkes an hand full high, loden with fmall yellow floures like vnto the common Prick-Madam : afrcr which come litrle thicke tharpe pointed cods, which containe the feed, which is fmall, fat, and yellowih. 


\section{T. The Place.}

The former of thefe groweth in gardens in the Low-counerics : in other places vpon ftone wals and tops of houfes in England almoft cuery where.

The other groweth about rnbbith in the borders of fields, and in other places that lye open to the Sunne.

They floure in the Sommer moneths.

$$
\text { T) The Time. }
$$

of The Names.

The leffer kinde is called in Grecke arsen muar : in Latine, Sedum, and Semperuivmm minus : of the

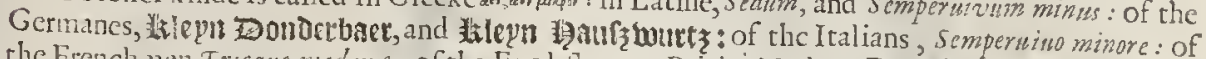
the Frenchimen, Tricque-madaic : of the Englih men, Pricke-Mudam, Dwarfe Houfe-lecke, and fimall Sengreene.

The fecond kinde is named in thops Craffulaminor; and they fyrname it minor, for difference betweene it and the other Craffula, which is a kinde of Orpin: it is alfo called Vermicular is : in Italian, Pignola, Granellof $a$, and Grafella: in low-Dutch, Blaber loofett: in Englith, Wilde PrickeMadam, Grent Stonc-crop, or Worme-grafe. \& That which is vulgarly knowne and called by the name of Stone-crop is the Illecebra defcribed in the following chapter, and fuch as grow commonly with vs of thefe finall Houfeleekes mentioned in this chapter are generally named PrickeMadames : but our Author hath confounded them in this and the next chapter; which I would not alter, thinking it fufficient to giue you norice thereof. $\neq$

$$
\text { IT The Temperature and Vertues. }
$$

All thefe fma!l Sengreens are of a cooling nature like vnto the great ones, and are good for thofe things that the others be. The former of thefe is vfed in many places in fallads, in which it hath a fine relifh, and a pleafant tafte it is good for the heart-burne.

\section{‡ CHA P. 144. Of diuers other Jmall Sengreenes. \\ T) The Defcription.}

* I He falke of this fmali water Sengreene is fome fpanne long, reddifh, fitceulent, and wpon the rops of ceeded by as ceeded by as many little cods containing a finall feed : the root is fmall and threddy, and the whole plant hath an infiprde or waterith tafte. This was found by clufus in fome watcrie places of Germany about the end of Iune; and hecalls it Sedum minus 3 fue paluftre.

2 This fecond fro:n fmall fibrous and creeping roots fends vp fundry little falkes fet with leaues like thofe of the ordinary Pricke-Madam, yet lefle, thicke, and flatter, and of a more aftringent tafte : the floures, which are pretty large, grow at the tops of the branches, and confift of fiue pale yellowith liaues. It growes in diucts places of the Alps, and floures about the end of luly, and in Augute. This is the Sedum winns 6. or Alpinum 1 , of Clufus.

$3 T$ his harb fimall lictie and thicke leaues, lying bedded, or compact clofe together, and are of an Afh co? our inclining to blew : the ftalkes are fone two inches long, fender, and almoft naked; vpon which grow commonly fome three floures confifting of fue whire leaues apiece, with fome yellow theds in the middle. This mightily encreafes, and will mat and couer the ground for a gond lpace together. It Houres in Auguit, and growes vpon the craggy places of the Alpes: Cinfius calls it Scdrm minus nonum, fuuc Alpinim 3 .

4 The leates of this ate fomewhat larger and longer, yer thicke, and fomewhat hairy about their edges; at firft alfo of an acide tafte, but afterwards bitterifh and hot: it alfo fendeth forth fhoors, and in the middeft of the lcaucs it puts forth ftalkes fome two inches high, which at the top as in au vmbel carry fome fix little foures confiting of fue leaues apicce, hauing their botcomes of a yellow ih colour. It is found in the like places, and Houres at the fame time as the for mer. Clufins makes it his Scdum minus 10 . Alpinum 4 . and in the Hist. Lngd. It is called Infme mon
tana. 


\section{6 \\ Of the Hiftorie of Plents. \\ $\mathrm{L}_{1 \text { в. } 2 .}$}

\$ Sedum minus paluflre.

Small water Sengreene.

Sedwem whlosum
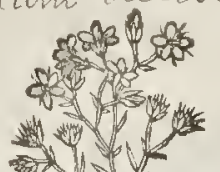

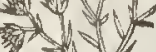

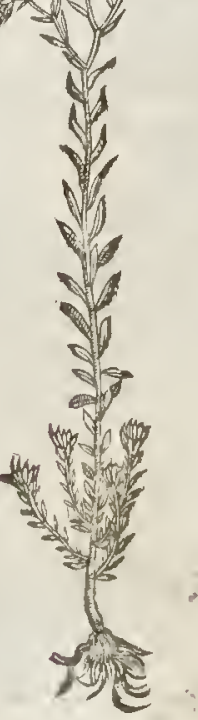

₹ Sedum Alpintm I. Clufij.

Small Sengreene of the Alps.

Saxifinóga Cliz, ides

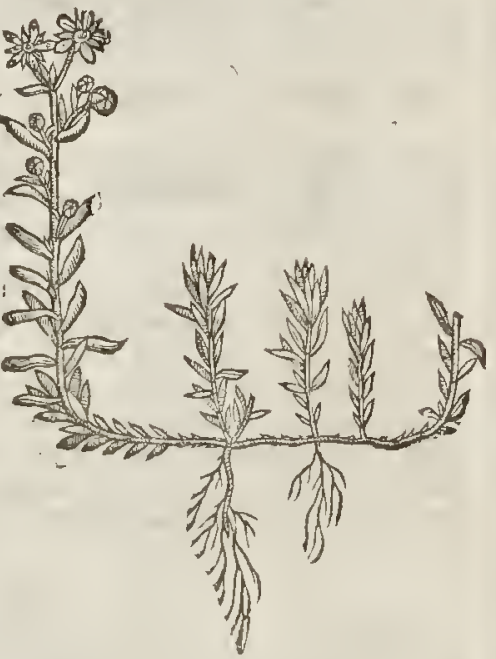

* Sedum Alpinums? clufï.

White Sengreence of the Alpes:

4 Sedam slpinum 4. Clufij.

Hairy Sengreene of the Alpes.
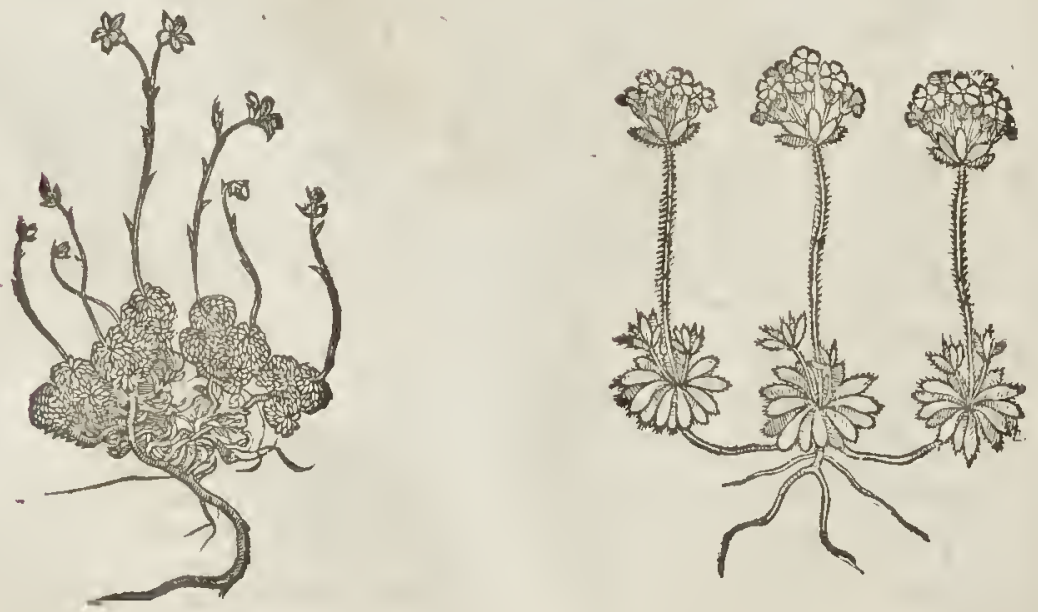


\section{$\mathrm{L}_{1 \mathrm{~B}, 2 .} \quad$ Of the Hiftorie of Plants.}

‡ Sedum petrenm Bupleurifolio. Bublunrum graminifoliim. (Vahl)

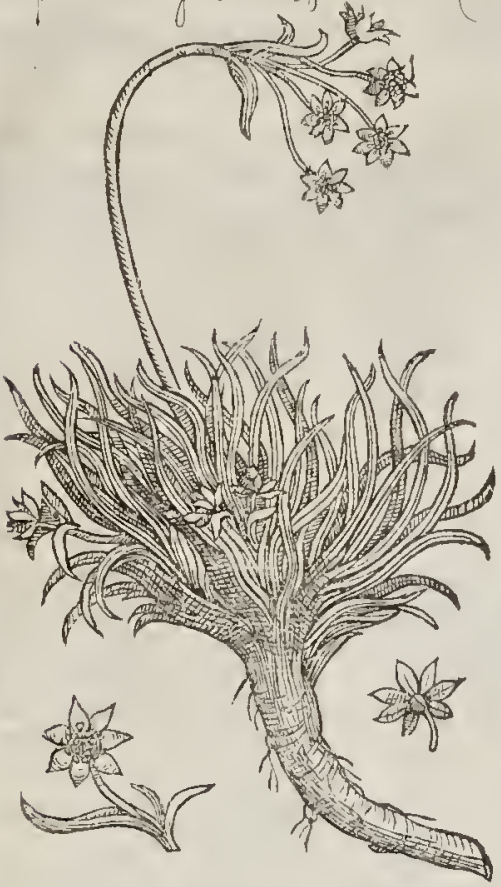

5 For thefe foure laft defcribed we are beholden toclufurs; and for this fifth to Pona, who thus defcribes it : It hath one thicke and large root with few or no fibres, but fon knots bunching out here and there: it is courered with a thicke barke, and is of a blackin red colour on the outfide: the leaties are many, long and narrow, lying fpred vpon the grouid, the ftalke grows fome foot high, and is rom and naked, and at the top carries floures confi. Ating of 7 tharpe pointed pale yellow leatues; which are fucceeded by feeds like thole of $B u$; pleurum, and of a frong fmell. It floures about the middle of Inly, and the feed is ripe about the middle of Auguet. Ponat, who firt obferued this growing vpon Mount Baldus in Ita$1 y$, fets it forth by the name of Sedum petroum Baplearifolio. Bauhine hath it by the name of Perfoliata Alpina Graminco folio, and Buplewron nnguffifolium Alpisum.

\section{9f The Temper and $V$ ertues.}

The three firf defcribed without doubt $A$ are cold, and partake in vertues with the other frall Sengreenes; but the two laft are rather of an hot and attenuating facultic. None of them are commonly knowne or vfed in Phy ficke. $\neq$ :
Vermicularis fue Illecebra minor acris.

Wall-Pepper,or Stone-crop. Sedum acre

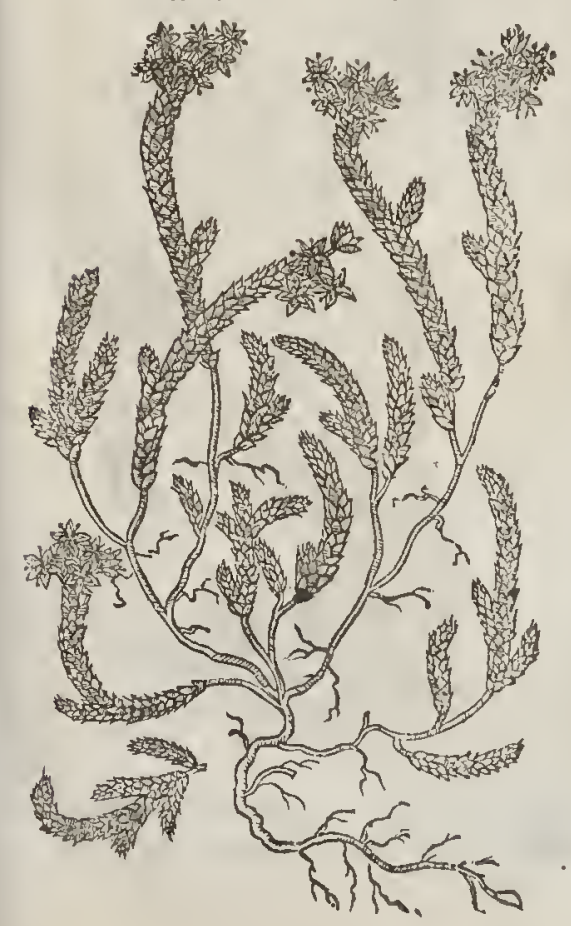

\section{Ch A P: 145.}

Of Stone-crop, called Wall-pepper.

$$
\text { If The Defription. }
$$

THis is a low and littleherbe: the ftalks 1 be flender and fhort: the leaues about thefe ftand very thicke, and fmall in growth, full'bodied, tharpe pointed, and full of iuyce: the floures ftand on the top, and are maruellous little, of colour yellow, and of a tharp biting tafte : the toot is nothing but ftrings.

$$
\text { it The Place. }
$$

It groweth euery where in ftony and dry places, and in chinks and crannies of old wals, and on the tops of houfes : it is alwaies green, and therefore it is very fitly placed among the Sengreenes.

It floureth in the Sommer moneths.

$$
\text { IT The Names. }
$$

This is Tertiom fempervivum Diofcoridis, of Diofcorides his third Sengreene, which he faith

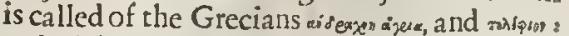
and of the Romanes, Illecebra. Pliny alfo wit. neffeth, that the Latines name it Illecebra. Yet

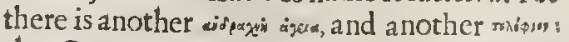
the Germanes call this herbe 9 gaurpfeffer,

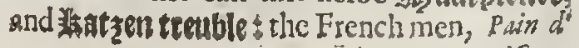
vifisas: 


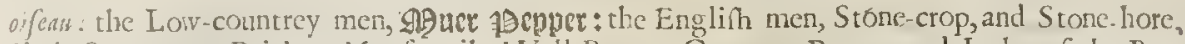
little Stone-crop, Pricket, Moufe-taile, Wall-Pepper, Eountrey Pepper, and Iacke of the Butteric.

$$
\text { of The Temperature. }
$$

This little herbe is tharpe and biting, and very hot. Being outwardly applied it raifeth blifters, and at length exulcerateth.

$$
\text { 4) The Vertues. }
$$

A It wanteth away hard kernels, and the Kings Euill, if it be layd vnto them, as Diofcorides writes.

$B$ The inyechereof extrased ordrawne forth, and taken with vineger or other liquor, procureth romit, and bringeth vp groffe and fegmaticke humors, and alfo cholericke; and doth thereby oftentimes cure the Quartan Ague and other Agues of long continuance : and ginen in this manner it is a remedy againit poyfons inw ardly taken.

\section{Cin a p. 146. Of Orpyne. \\ T) The Defcription.}

I THc Spanilh Orpyne fendeth forth round ftalkes, thicke, flipperie, haming as it were - little ioynts, fomew hat red now and then about the root : the leates in like manner be thicke, fmooth, groffe, full of tough iuyce, fometimes fleightly nicked in the edges, broader leafed, and greater than thofe of Purlane; otherwife not much vnlike; which by couples are fet oppofit one againft another vpon euery joint, coucring the ftalke in order by two and two:the floures in the round tufts are of a pale yellow : the root groweth full of bumpes like vnto long kernels, waxing tharpe toward the point : thefe ketnels bewhite, and liate ftrings growing forth of them.

\section{Craftula major Hifpanica.}

Spanith Orpyne.

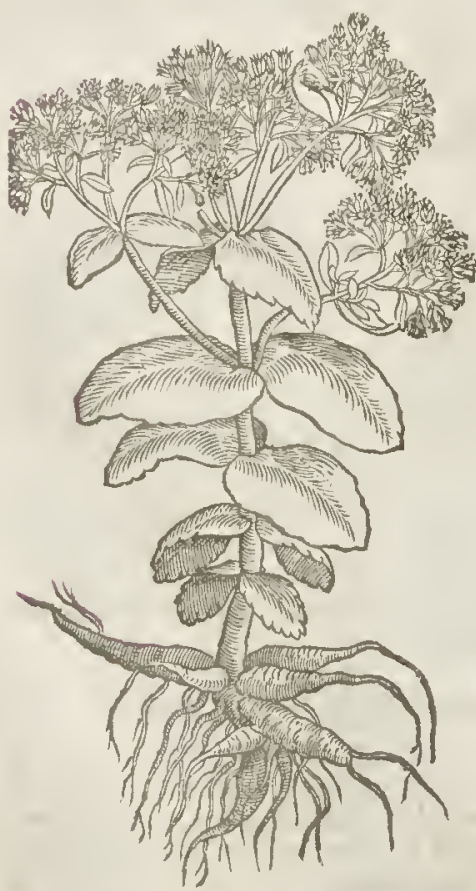

2 Crafjula fane faba inucr.ja. Common Orpyne.

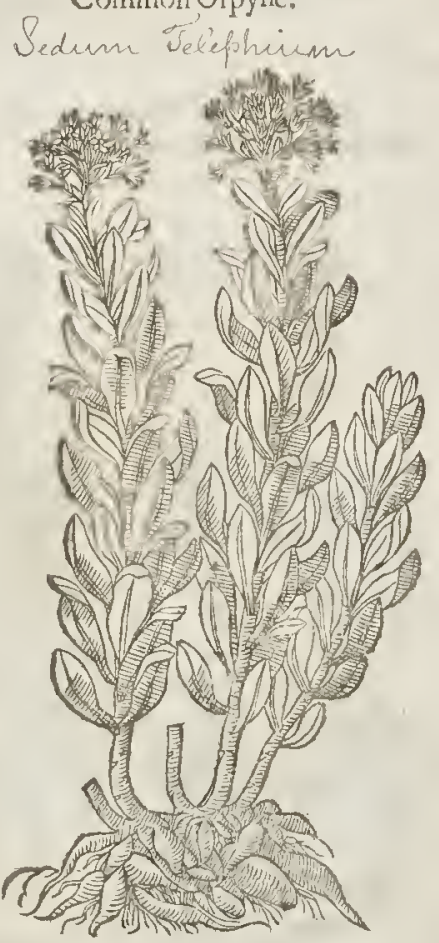

2 The fecond, which is our common Orpyne, doth likewife rife vp with very many round ftalkes thatare fmonth, but not ioynted at all : the leaues ase groffe or corpulent, thicke, broad, 
and oftentimes fomewhat nicked in the edges, leffer than thofe of the former, placed out of order. The floures be cither red or yellow, or elfe whitith : the roor is white, well bodied, and full of kernels. This plant is very full of life: the ftalkes fet onely in clay continue greene a long time; and if they be now and then watered they alfo grow. We hane a wilde kinde of Orpyne growing in corne ficlds and thadowy woods in moft places of England, in each refpect like that of the garden, fatuing that it is altogether leffer.

\section{The Place.}

They profper beft in thadowie and ftony places, in old walls made of lome or ftone. Oribafius faith, That they grow in Vineyards and tilled places. The firt groweth in gardens; the other eueriewhere: the firft is much found in Spaine and Hungarie, neither is Germanie without it ; for it groweth vpon the bankes of the rimer of Rhene neere the Vineyards, in rough and ftony places, nothing at all differing from that which is found in Spaine.

The fecond groweth plentifully both in Germany, France, Bohemia, England, and in orher countries among vines, in old lomic daubed and ftony walls.

The Orpynes floureabout Auguft or before.

$$
\text { T The Time. }
$$

I The Names.

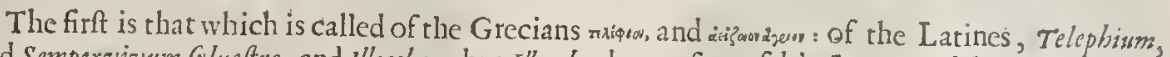
and Scmpervivum fylueftre, and Illecebra : but Illecebraby reafon of his tharpe and biting qualitie doth much differ from it, as we haue declared in the former Chapter. Some there be that name it eispex, or Portulaca fylueftris : yet there is another Portulaca fylucftris, or wilde Purflane, like to that which groweth in gardens, but leffer: we may call this in Englifh, Spanifh Orpyne, Orpyne of
Hungarie, or ioynted Orpyne.

The fecond kinde of Orpyne is called in hops Crafula, and Craffula Fabaria, and Craftula maior, that it may differ from that which is defcribed in the chapter of little Houflecke: it is named alfo

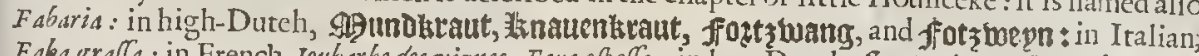

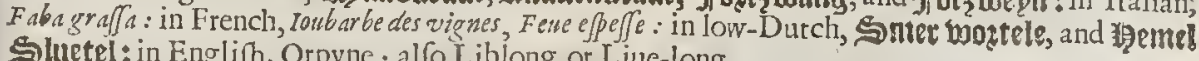
Sluetel: in Englíh, Orpyne; alfo Liblong, or Liue-long.

The Orpyns be cold and dry, and of thin or fubrill parts.

\section{The Vertues.}

Diofcordes faith, That being laid on with Vineger it taketh away the white morphew: Galeis faith the blacke alfo; which thing it doth by reafon of the fcouring or cleanfing qualitie that it lath. Whereupon Galcnattributeth vnto it an hor facultic, though the tafte fherveth the eontrarie: which aforefaid fcouring facultie declarcth, That the other two alfo be likewife cold. But cold things may as well cleanfe, if drineffe of temperature and thinneffe of efienee be ioyned to gether in then.

\section{Cнар. 147. Of the fmaller Orpyns.}

9. The Defcription.

I THe Orpyn with purple floures is lower and leffer than the common Orpyn : the ftalkes be flcnderer, and for the moft part lic along vpon the ground. The leaules are alfo thinner and longer, and of a more blew greene, yet well bodied, ftanding thicker below than aboue, confufedly fet together without order: the floures in the rufrs at the tops of the ftalks be of a pale blew tending to purple. The roors be not fet with lumpes or knobbed kernels, but with a multitude of hairy ftrings.

2 This feend Orpyn, as it is knowne to few, fo harh it found no name, but that fome Herbarifts do call it Telephium fempervivinm or virens : for the ftalkes of the orher do wither in winter, the root remaineth greene; but the ftalkes and leaues of this endure alfo the fharpeneffe of Winter; and therefore we may eall it in Englifh, Orpyn euerlafting, or Nener-dying Orpyn. This hatl leffer and rounder leaues than any of the former : the floures are red, and the root fibrous.

$\ddagger 3$ Clufrus receined the feeds of this from Ferranto Imperato of Naples, vnder the name of 
I Telephum floribus purpureis. Purple Orpyn.

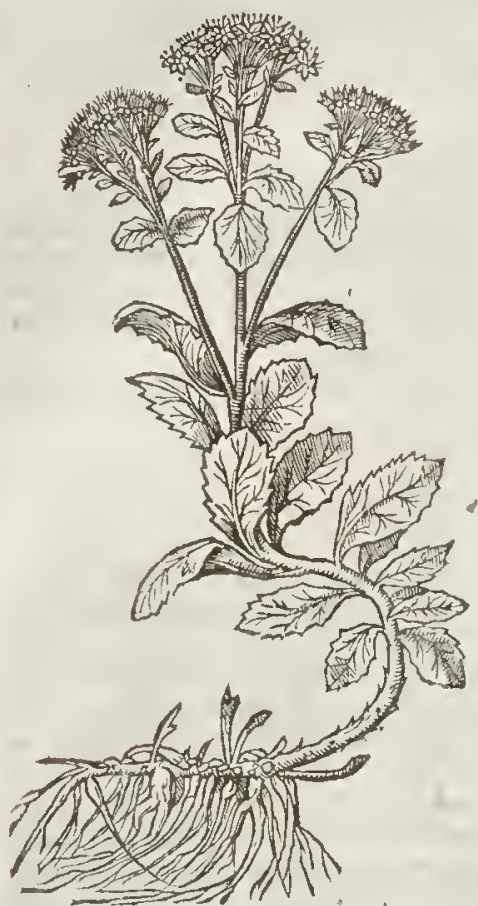

2 Telephism femper-vircns. Neuer-dying Orpyn.

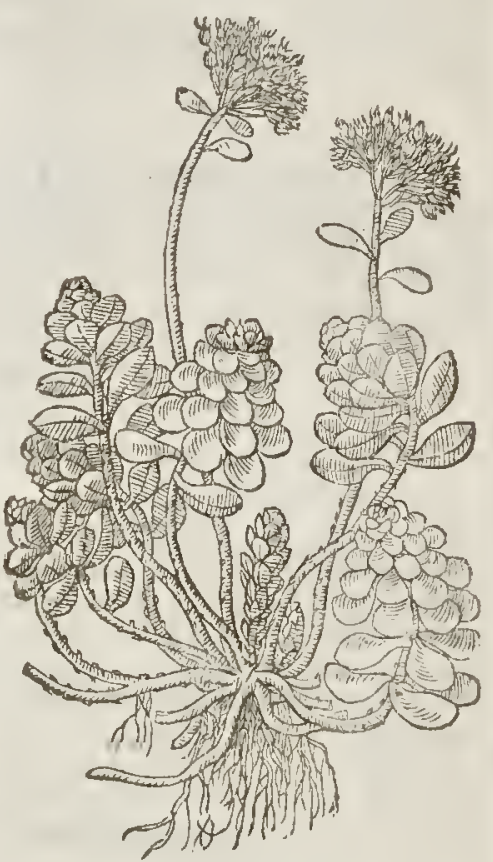

Creeping Orpyn.

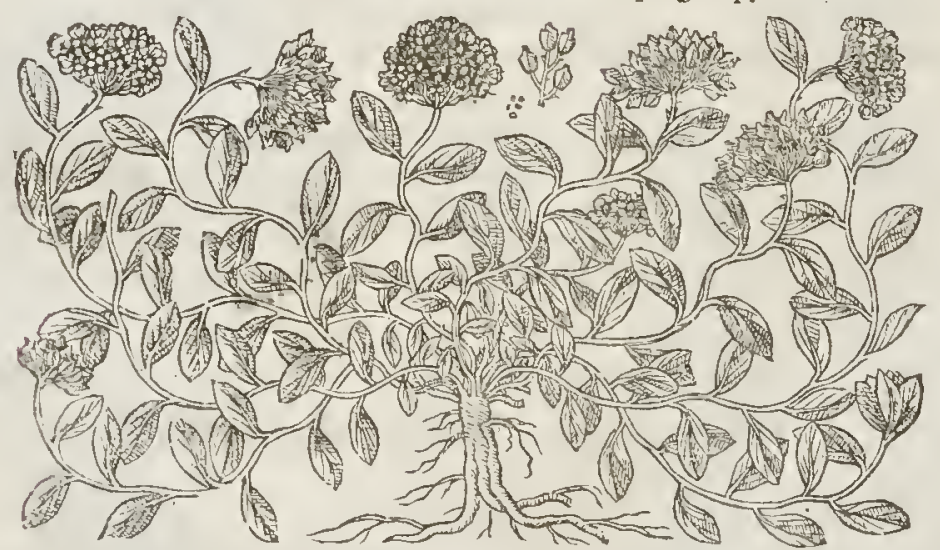

Telephium legitimum; and he lath thus giuen vs the hiftory thereof: It produces from the top of the root many branches fpted vpon the ground, which are about a foot long, fet with many leaues, efpecially fuch as are not come to flotre; for the other haue fewer : thefe leaues ate fmaller, Iefle thicke alfo and fucculent thau thofe of the former kindes, neither are they fo brittle: their colour is gtcen, inclining a little to blew:the tops of the branclses atc plentifully ftored with little floutes growing thicke together, and compofed of fue little white leaues apiece : which fading, there fucceed cometed feed-veffels full of abrownith feed. The root is fometimes as thicke as ones little finger, tough, white, diuded into fome branches, and liuing many yeares. $\ddagger$ q] The Place, Time, Names, Temperature, and Vertues.

The firtt growesnot in England. The fecond flourfhes in my garden. $\neq$ The third is a tranger with ws defcriptions and their temperature and faculties in working ate referred to the common Orpyn. 
CH A. $148 . \quad$ Of Purflane.

ब The Defoription.

I He ftalkes of the great Purflane be round, thicke, fomewhat red, full of juice, fmooth, glittering, and parted into certaine branches ttailing vpon the ground : the leaues be an inch long, fomething broad, thicke, fat, glib, fomewhat greene, whiter on the neither fide : the floures are little, of a fuint yellow, and grow out at the bottome of the leanes. After them fpringeth vp a little huske of a greene colour, of the bigneffe almolt of halfe a barly corne, in which is fmall blacke feed : the root hath many ftrings.

I Portulacidomeitict.

Garden Purtlane.

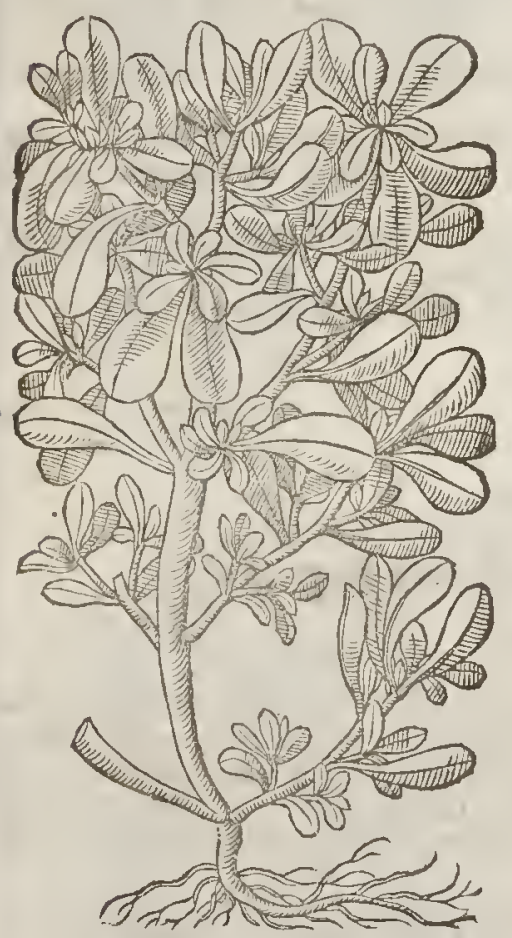

2. Portrlacafilveftris. Wilde Purflane.

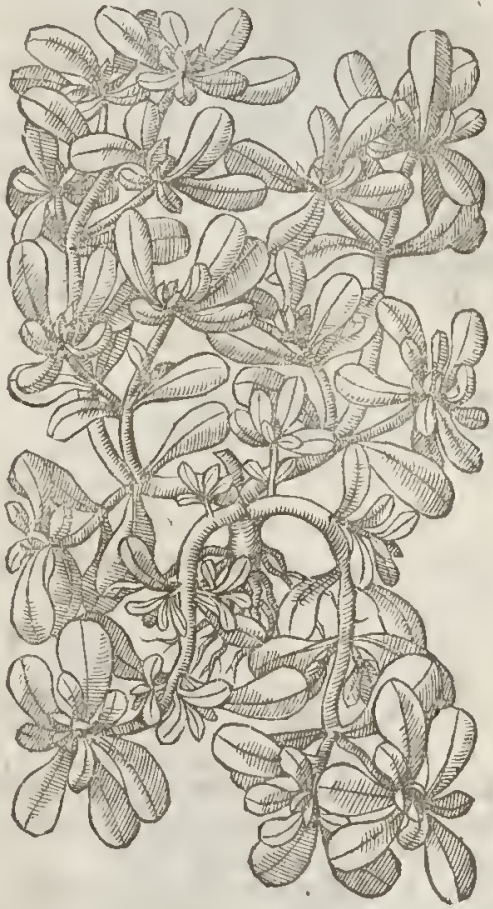

2 The other is leffer and hatl like ttalkes, but fmaller, and it fpreadeth on the ground: the lcaues be like the fornuer in fanion, f woothnefe, and thickneffe, but farre leffer.

\section{- The Place.}

The former is fitly fowne in gardens, and in the waies and allies thereof being digged and dunged, it delighteth to grow in a fruitfull and fat foile not dry.

The other conmeth vp of his owne accord in allies of gardens and vineyardes, and oftentimes von rocks : this alfo is delighted with watery places being once fowne, if it be let alone till the feed be ripe it doth eafily fpring vp afrech for certaine yeeres after.

$$
\text { q The Time. }
$$

It may be fowne in March or Aprill; it flourimeth and is greene in Iune, and afterwards euen vntillwinter.

$$
\text { 9. The Names. }
$$

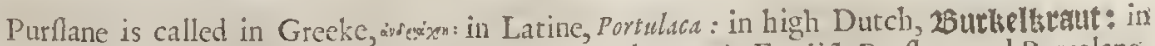
French, Poupier: in Italian, Prochicci, : in Spanifh, Terdolagas : in Englifh, Purllane, and Porcelane.
$\mathrm{XX}$ 
Tा The Temperature.

Purflane is cold, and that in the third degree, and moift in the fecond : but wilde Purflane is not fo moift.

$$
\text { बा The rertues. }
$$

A Rawe Purflane is much vfed in fallades, with oilc, falt, and vineger : it cooleth an hot ftomacke, and prouoketh appetite; but the nourithment whieh commeth thercof is little, bad, eold, groffe, and inoift : being clrewed it is good for teeth that are fet on edge or aftonied; the juice doth the fame being held in the mouth,and alfo the diftilled water.

B Purflane is likewife eommended againf wormes in young children, and is fingular good,efpecially if they be feucrifh withall, for it, both allaies the oucrnueh heate, and killeth the wormes : which thing is done through the faltnes mixed therewith, whieh is not only an enemy towormes, but alfo to putrifaction.

C The leatues of Purflane either rawe, or boiled, and eaten as fallades, are good for thofe that haue great heate in their ftomackes and inward parts, and doe coole and temper the inflamed bloud.

D The fume taken in like manner is good for the bladder and kidnies, and allaieth the outragious luft of the body : the juice alfo hath the fame vertuc.

E The juiec of Purflane ftoppeth the bloudy fuxe, the fluxe of the hemortoides, monthly termes; fpitting of bloud, and all other fluxes what foener.

F The fame thrown vp with a mother fyringe, eureth the inflammations, frettings, and vlcerations of the matrix; and put into the futument with a elifter pipe,helpeth the vlcerations and fluxe of the guts.

G The leaues eaten rawe, take away the paine of the teeth, and fafteneth them; and are good for teeth that are fet on edge with eating of Tharpe or foure things.

H The feed being taken, killeth and driueth forth wormes, and foppeth the laske.

\section{Ch А. 149. \\ Of fea Purflane, and of the /brubby Sengreens. \\ I The Defcripsion.}

I Ea Purflane is not a hetbe as garden Putflane, but a little fhrub : the ftalkes whereof be

$\checkmark$ hard and wooddy : the leaues fat, full of fub tance, like in forme to common Purlane, but much whiter and harder : the moffie purple floures fand round about the vpper parts of the ftalkes, as do almoft thofe of Blyte, or of Orach : neither is the feed vnlike, being broad and lat: the root is wooddy, long lafting, as is alfo the plant, which bearech out the winter with the loffe of a ferv leaucs.

+2 There is another fea Purflane or Halimus, or aftet Dodos ass, Portulaca marina, which hath leaues like the former, but not altogether fo white, yet are they fomewhat longer and narrower, not mueli vnlike the leatres of the Oliue tree. The flender branehes are not abouc a eubit or cubit and halfe long, and eommonly lie fpred vpon the ground, and the floures are of a decpe onerworne herby colour, and after them follow feedes like thofe of the former, but fmaller.

3 Our ordinary Halimus or fea Purfanc hath fmall branches fome foot or better long, lying eommonly fpred vpon the ground, of an ouerworne grayifh eolour, and fometimes purple; the leaues are like thofe of the laft mentioned, but mote fat and thicke, yet leffe hoary. The floures grow on the tops of the branclies, of an herby putple colour, whieh is fucceded by finall feeds like to that of the fecond kinde. $\ddagger$

4 There is found another wilde fea Purflane,w hereof I baue thought good to make mention; whieh dnth refemble the kindes of Aizoons. The firft kinde growetl vpright, with a trunke like a finall trec or hrub, huuing many vpright wooddy branches, of an athe colour, with many thicke, darke, greene leaues like the fmall Stone crop, ealled Vermicularis: the floures are of an herby ycllowith grecne eolour : the root is very hard and fibrous : the whole plant is of a falt tang tafte, and the juiec like that of Kaly.

5 There is another kinde like the former,and difiereth in that, this ftrange plant is greater, the leanes more fharpe and narrower, and the whole plant more wooddy, and commcth neere to the forme of a tree. The floures are of a greenith colour. 


\section{1 в. 2.}

Of the Hiftory of Plants.

$\$ 1$ Halimus latifolins.

Tree Sea Purlane.

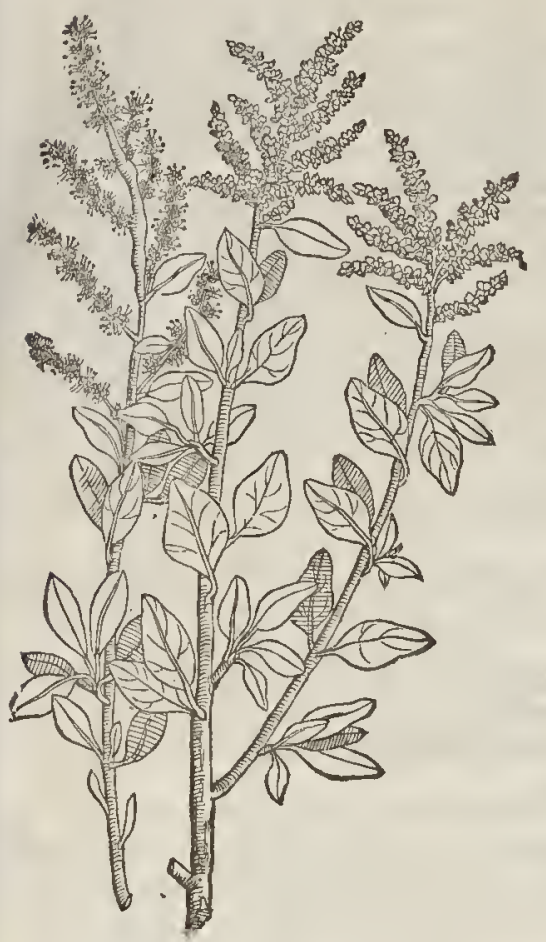

† 3 Halimus vulgaris, fine Portulacamarina Common Sea Purflane.

otripex protulacoídes

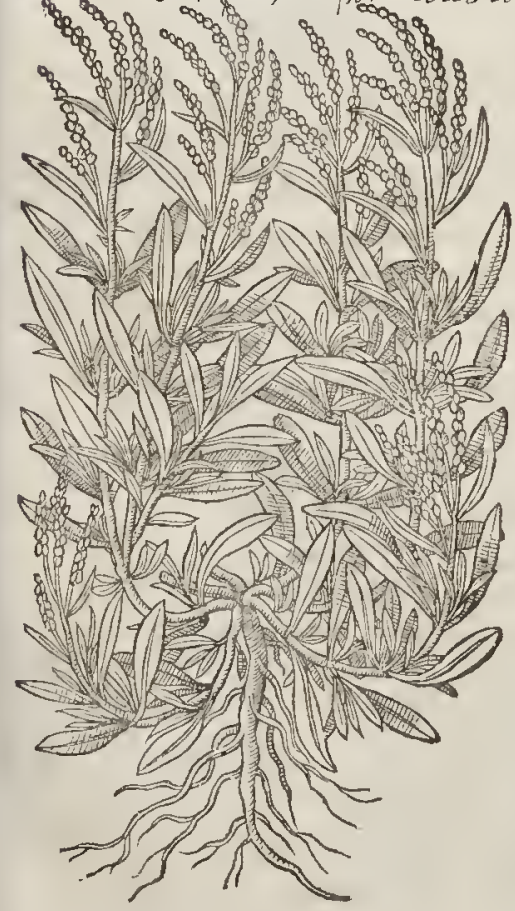

+ 2 Halimus anguf tifolius procambers. Creeping Sea Purdane.

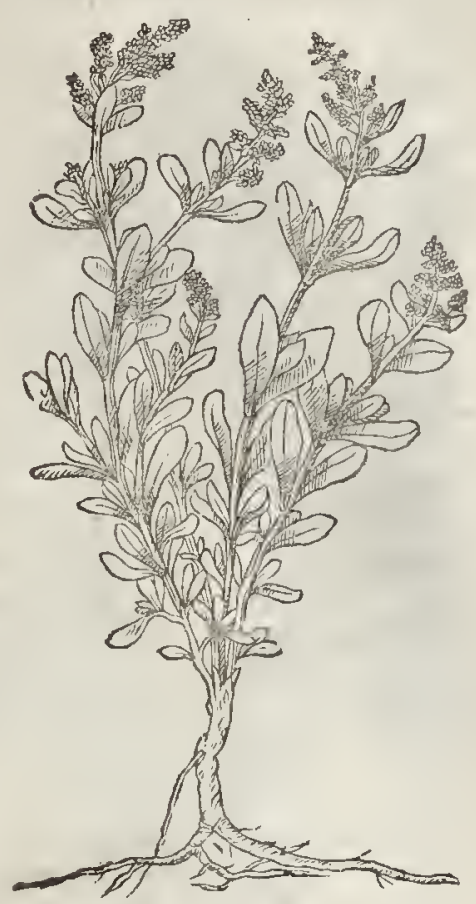

† Vermicular is frutex minor:

The leffer Ihrubby Sengreen.

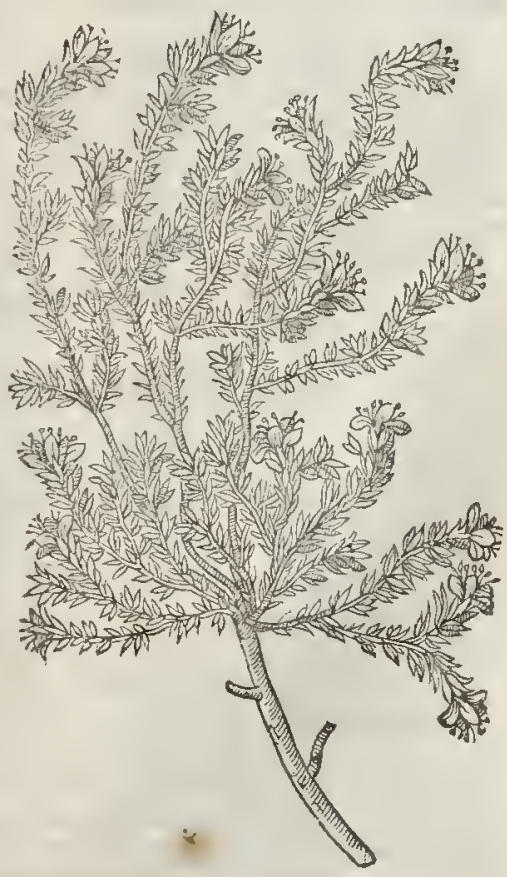

$X \times 2$ 
¥ 5 Vermicularis frutex major. The grater Tree Stone-crop.

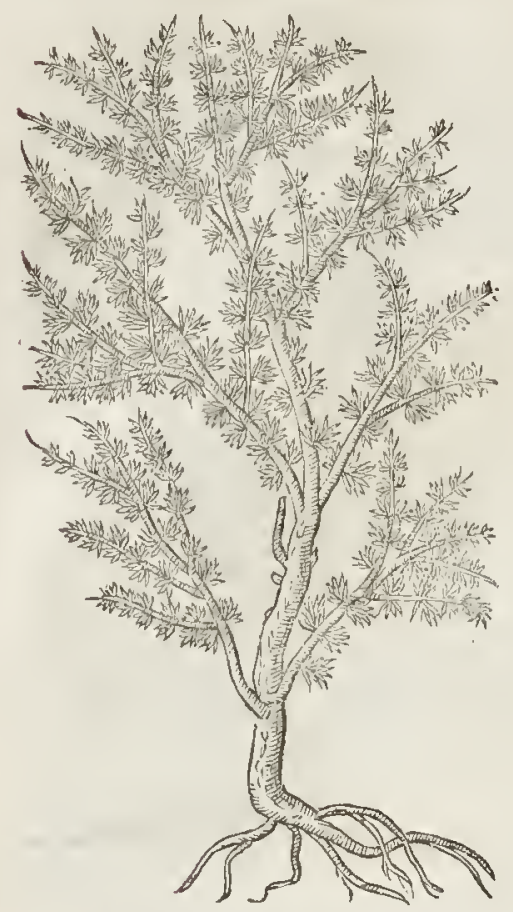

If The Place.

$\ddagger$ The firft and fecond grow vpon thic $\mathrm{Sca}_{\mathrm{ca}}$ coatts of Spaine and other hor countrics $\ddagger$ : and the third groweth in the falt marifhes neere the fca fide, as you paffe ouer the Kings ferrcy into the ine of Shepey, going to Sherland houfe $(b c-$ longing fometime vnto the Lord chciny, and in the yeare 1590 , vnto the Wornhipfull S". Edward Hobby) fate by the ditehes fides of the fame marifh: it groweth plentifully in the ifle of Thanet as you go from Margate to Sandwiel, and in many other places along the eoaft. The other forts grow vpon bankes and heapes of fand on the Sca coults of Zceland, Flanders, Holland, and in like places in other countries, as befides the Iffe of Purbecke in England; and on Rutuen-fpurne in Holderncffe, as I my felfe hate fene.

$$
\text { बा The Time. }
$$

Thefe flourion and floure efpecially in Iuly and $\Lambda$ uguift.

$$
\text { The Names. }
$$

Sea Purflane is called Portulaca Grarina: In Greekc, axums : it is alfo called in Latine Halimus: in Dutch, Zee glopecleijue : in Englifh, Sea Purflanc.

The baftard ground Pines arc ealled of fome, Chamepitys virmicerlata : in Englifh, Sea ground Pine : $\ddagger$ or more fitly, Tree Ston-crop, or Pricket, or Shrubby Sengreene. †

\section{- The Temperature.}

Sea Purflane is (as Galen faith) of vnlike parts, but the greater part thercof is lot in a meane, with a moifturc vnconcocted, and fomewhat windic.

\section{of The rertues.}

A The leaues (faith Diofcorides) are boyled to be eaten : a dram weight of the root being drunke with meade or honied water, is good againft erampes and draw ings awric of finewes, burftings, and gnawings of the belly : it alfo eaufeth Nurfes to haue ftore of milkc. The leaues be in the Lowcountries prefermed in falt or piekle as capcrs are, and be ferued and eaten at mens tables in ftead of them, and that without any miflike of tafte, to which it is plcafant. Galen doth alfo report, that the yong and tender buds arciwont in Cilicia to be eaten, and alfo laid vp in ftore for wfe.

B † Cluf isus faith, That the learned Portigal Knight Damianus a Goes aftured him, That the leates of the firft deferibed boyled with bran, and fo applied, mitigate the paines of the Gout procecding of an hor eaure. $\neq$

T The figtie that was formerly giuen by nut Author by the title of Portulaca marina, and is Eet forth by Taberm. vider the fame name, is either of none of theie plants, oi dis ar is vipcrf

\section{C на р.150. Of Herbe-Iuy, or Ground-Pine. \\ बा The Defcription.}

I THe common kindc of Chamepitys or Ground-Pine is a fmall herbe and very tender,crecping vpon the ground, hauing fmall and erooked branebes trailing about. The leatures be fmall, narrow and hairy, in fauour like the Firre or Pine trec; but if my fenee of fmelling be perfect, me thinkes it is rather like unto the fmcll of hempe. The floures be little, of a pale ycllow colour, and fomtimesw hite: the root is firall and fingle, and of a wooddy fubftance.

$t_{2}$ The feeond hath pretty ftrong foure fquare ioynted falkes, browne and hairy; from which grow pretry large bairy leaues mueh elonen or cut : the floures are of a purple colour, an:t grow about the ftalks in, roundles like the dcad Nettlc : the feed is blaek and round, and the wholc

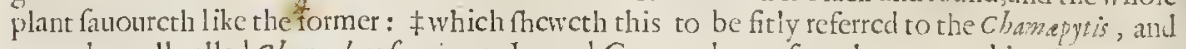
not tobc wcll called Chamadrys famina, or lagged Germander, as fome haue named it. $\neq$ 
LIB. 2.

I Chamepitys mas.

The male ground Pine.

ajinga hromce pitts. Ange. $y=\sqrt{3}$

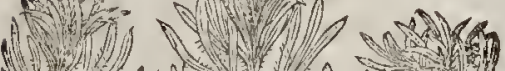
W. 4 年 a.te (I) N A2

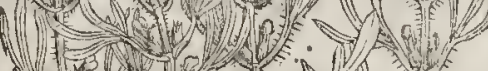

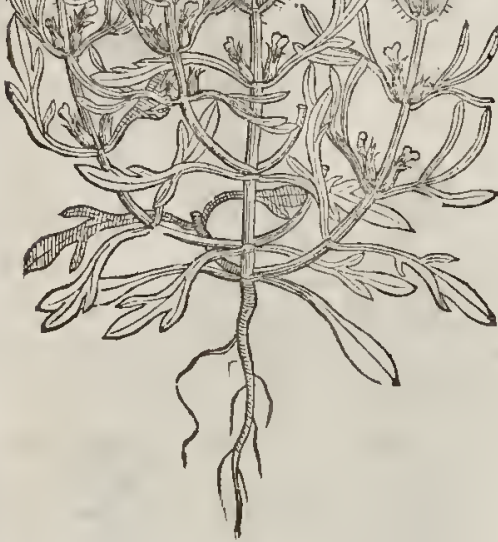

\section{Chamapitys 3.Doden:}

Small Ground-Pine.

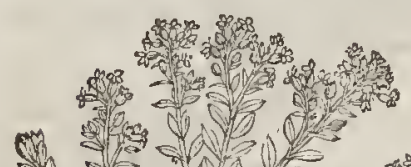

a $(s)+1$

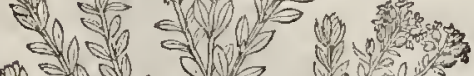
W $=$ we Noven. W * *ै *ै

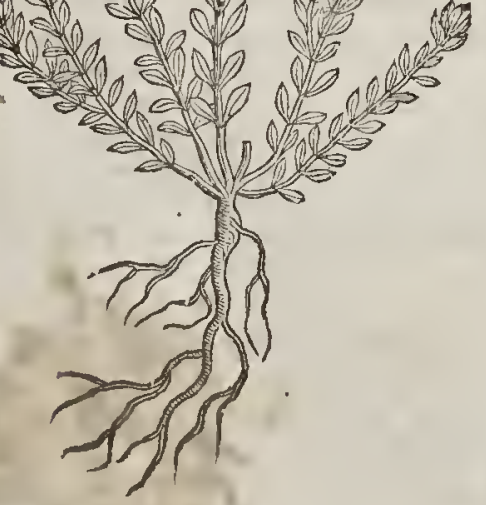

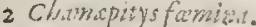

The female ground-2 jne.

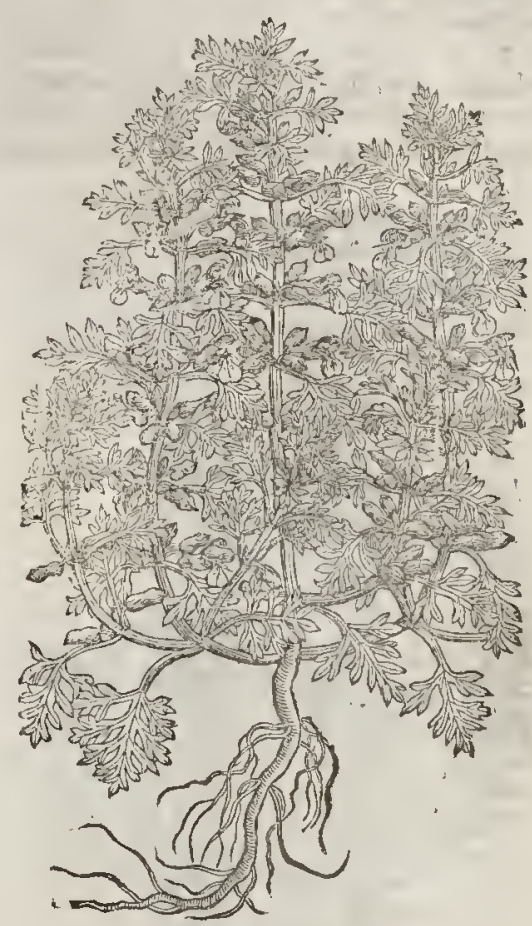

4 Ina murata Ronpeliaca.

French Herbe-Iuy or Ground-Pines

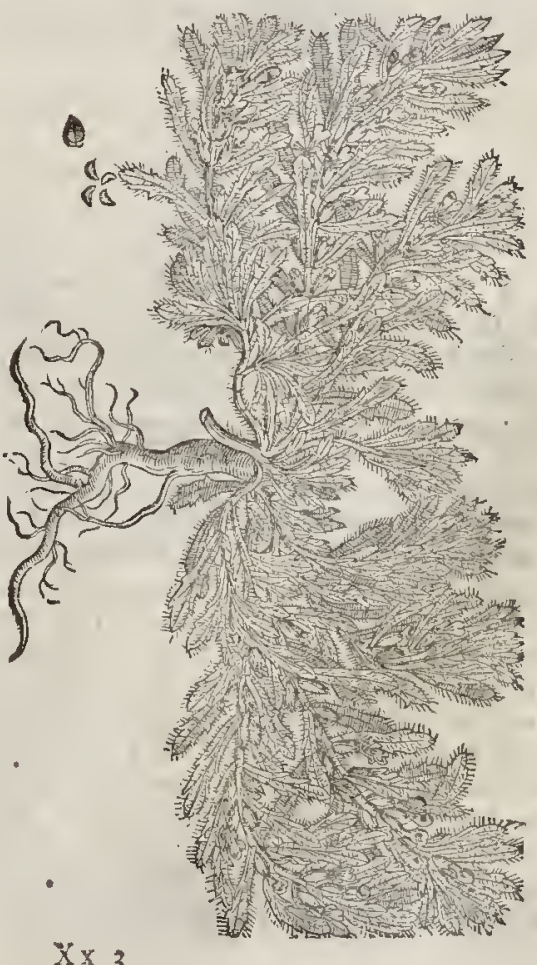


3 This kinde of Herb-Iuy, growing for the moft part about Montpelier in Franee, is theleaft of all his kind, hauing fmal white and yellow floures, in fmell and proportion like vnto the others,
but much fmaller.

$\dagger 4$ There is awilde or baftard kinde of chamxpitys, or ground-Pine, that hath leaues fomewhat like vnto the feeond kinde, bntnot iagged in that manner, but oncly fnipt about the edges. The roor is fomewhat bigger, wooddy, whitifh, and bitter, and like vnto the root of Succorie. All this herbe is very rough, and hath a ftrong vnpleafant fmell, not like that of the ground-Pines:

\$ Chamapitys puria altera Dodon. Baftard Ground-Pine.

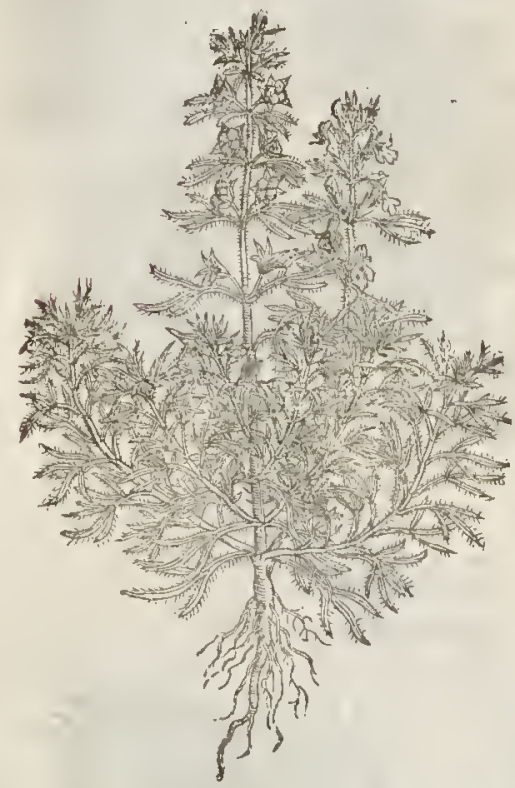

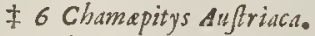
Auftrian Ground-Pine. 


\section{-1 The Place.}

Thefe kindes of Chamapitys (exeept the two laft) grow very plentifully in Kent, efpeeially about Grauefend, Cobham, Southfleet, Horton, Dattford, and Sutton, and not in any other thire in England that euer I could finde.

$\mp$ None of thefe, exeept the firf, for any thing I know, or ean learne,grow wilde in England, the fecond I have often feene in Gardens. $\neq$

They floure in Iune, and often in Auguft.

$$
\text { था The Time. }
$$

बा $T$ lhe $N$ ames.

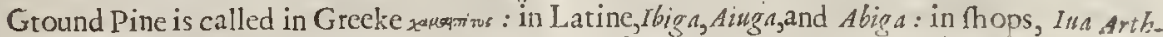

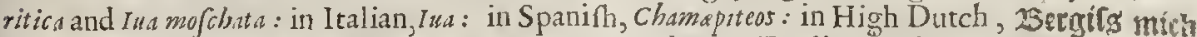

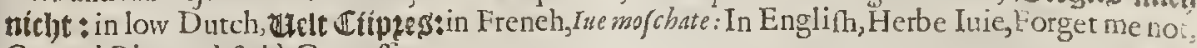
Ground Pine, and field Cyprefle.

$\ddagger$ I The firft of thefe is the Chamepitys prima, of ckat biolus, Dodoneus and others, and i, , which is eommonly ved in thops and in Phylieke.

2 This Mathiolus cals Chamedrys altera : Lobel, Chamedrys Laciniatis foliys : Lonicerus, 7 ; : vera; Tabernamontanus, Iva mofinata; and Dodon. (whom in this Chaptet we chiefely (ollow) Ch: mepitys altera.

3 Thirdly, this is the Chamapitys r of Fuch fus and others; the Chamapitys s. Diofcoridisodo alor of Lobel; and the Chamepitys 3 . of CMattbiolus and Dodon.

4 Gefner cals this Chanapitys Jpecies Monjpelly: Clufius, Dodon. Anthyllis altera; and Lobel, An. thyllis Chamepityides minor; and T abern. Iua Mofchat a Monpelienfum.

5 This is Chasepitys adulterina of Lobel: P fendochamepitys and Aingandulterina of Clufius : and Chamapitys puria altera of Dodon.

6 This is Chamepitys Auftriaca of Clufius; and Chamapitys cerulea of Camerarius. T The 2 arure.

Thefe herbes are hot in the fecond degree, and dric in the third.

बा The Vertues.

The leaues of Chamepyt is tunned vp in Ale, or infufed inwine, or fodden with hony, and drunke A by the fpace of eight or ten daies, eureth the iaundies, the Seiatiea, the ftoppings of the liuer, the difficultie of making water, the ftoppings of the fpleene, and eaufeth women to haue their natural lickneffe.

Chamebyt is ftamped greene with honie eureth wounds, malignant and rebellious vleers, and dif- B folueth the hardneffe of womens btefts or paps, and profitably helpetl againit poifon, or biting of any venomous beaft.

The deco tion drunke, diffolueth congealed bloud, and drunke with vineget, driueth forth the $\mathbf{C}$ dead ehilde.

It elenfeth the intrals : it helpeth the infirmities of the liuer and kidneies; it cureth-the yellow D iaundies being drunke in wine : it bringeth downe the defred fickneffe, and prouoketh vrine:being boiled in Mead or honied water and drunke, it helpeth the Sciatica in fortic daies. The people of Heraclea in Pontus dovfe it againft Wolfes bane in ftead of a counterpoifon.

The pouder heteof taken in pils with a fig, mollifieth the bellie :it wafteth away the hardneffe $\mathrm{E}$ of the paps:it healeth wounds, it cureth putrified vleers being applied w ith hony:and thefe things the firf ground Pine doth performe, fo doth the other two: but not fo effectually, as witneffeth Diofcorides.

Clufus of whom mention was made, hath not faid any thing of the Vertues of Chamapytis CAu. F friaca: tut verily I thinke it better by many degrees for the purpofes aforefaid : my eoniecture I take from the tafte, fmell, and comely proportion of this Hearbe, which is more pleafing and familiar vnto the nature ofmap, than thofe whieh wee haue plentifully in our owne Counttey growing.

\section{Cis A . 152. Of Xaulwoort, or Penniwoort of the Wall.}

$$
\text { T) The Defription. }
$$

1 He g: at Nauelwoort hath round and thieke leaues, fomewhat blunty indented about I the edges, and fomew hat hollow in the midft on the vpper patt, hauing a hort tender 
ftemme faftened to the middeft of the leafe, on the lewer fide wrderneath the falke, whercon the foutes doe grow, is frmall and hollow, an handinll high and more, befetwith many fnall foctrs of an oucrworne incarnate colour. The root is round like an oliue, of a white colour.

\# The root is not well expreft in the figure, for it fhould baue becn more vnequall or tuberous, with the fibers not at the bottome but top thereof. $\neq$

2 The fecond kinde of Wall Penniw oort or Nanclwoort hath broad thicke leaues fomewhat deepely indented about the edges : and are not fo round as the leates of the former, but fomewhat long towards the fetting on, fpred vpon the ground in manner of a tuft, fet about the tender ftalke, like to Sengreene or Houflceke; among which rifeth vp a tender falke whereon do grow th e like leaucs. The floures fand on the top confifting of fiue fmall leaues of a white colour, with red fpots in them. The root is fmall and threddic. ₹ This by fome is called Sedum Serratum. $\neq$

$\neq 3$. This third kinde hath long thicke narrow leanes, very finely fnipt or nick on the edges, which lie fpred very orderly vpon the ground; and in the midft of them rifes vp a ftalke fome toot high, whieb beares at the top thereof vpon three or foure little branches, diucrs white floures confifting of fucleaues apicec.

4 The leaues of this are long and thieke, yet not fo fincly fnipt about the edges, nor fo narrow as thofe of the former: the falke is a foot high, fet here and there with fomewhat fhorter and rounder leaues than thofe below; and towards the top thercof, out of the bofiomes of thefe leaues come fundry little foot-ftalkes, bearing on their tops pretty large foures of eolnur white, and fpotted with red fpots. The rootes are fmall, and here and there put vp new tufts of leaues, like as the common Horflceke. $¥$

5 There is a kinde of Nauelwoort that groweth in waterie places, which is ealled of the hufbandmen Sheeps banc,becaufe it killcth fheepe that do eat thereof $;$ it is not much vinlike the precedent, but the round edges of theleaues are not fo cuen as the other; and this creepeth vpon the ground, and the orher vpon the ftone walls.

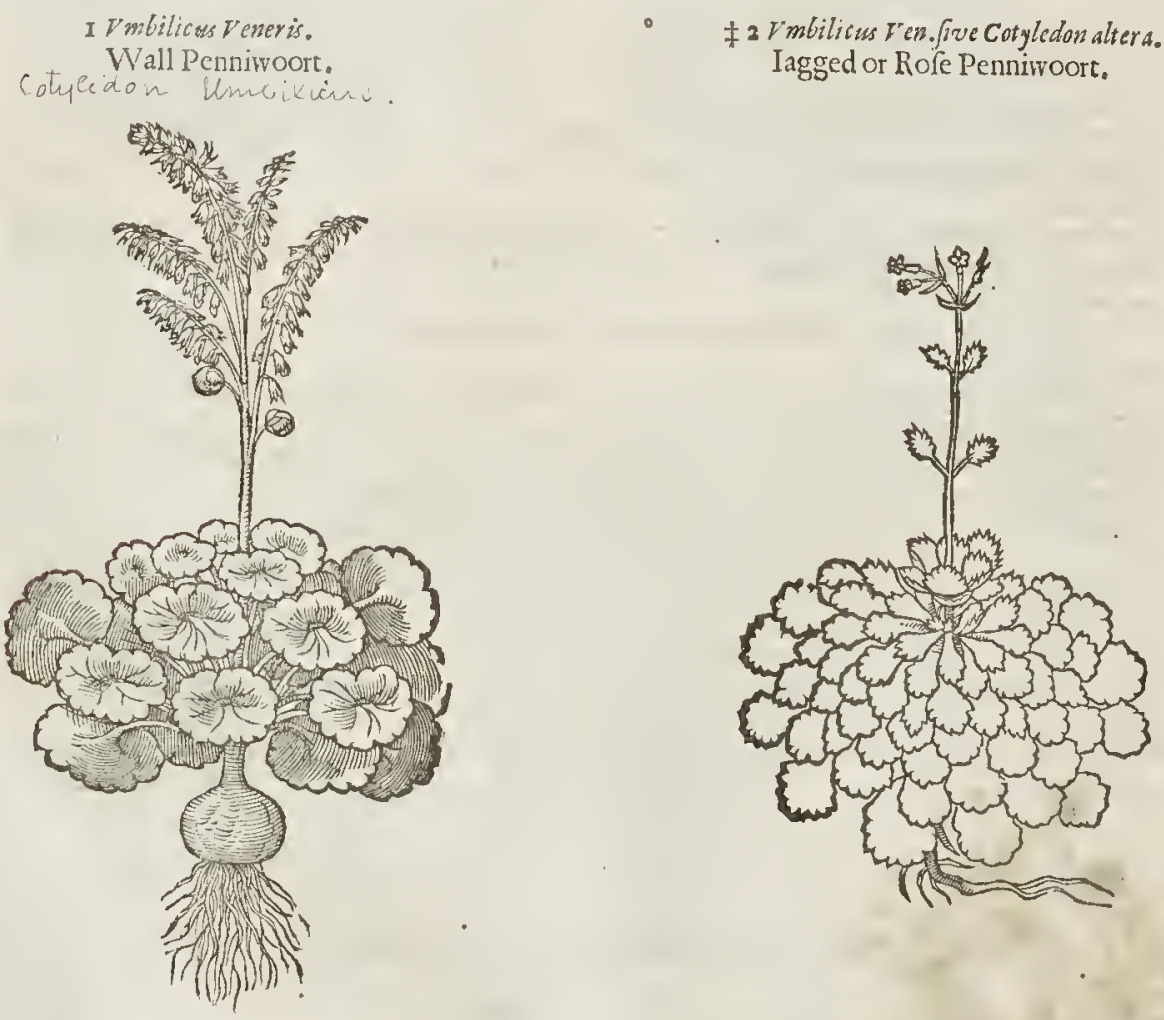

\# 6 Becaufe fome in Italy haue vied this for $\boldsymbol{V}$ mbilicus $V$ eneris, and otherfome hate fo called it, I thought it not amiffe to follow $M$ at thiolus, and gine you the hiftory thereof in this place, rather than to omit it, or giue it in another which may be perhaps, as vnfit, for indeed I cannot fitly ranke 
it with any other plant. Bawhine fets it betweene Hedera Terre/lris, and Naftutiwn Indumz : ind Colmmn refers it to the Linaria's, but I muft confeffe I cannot referre it to any; wherefore I thinke it as prop: to giue it here as in any other place. The branches of this are many, Iong, flender, and creeping, vpon which grow wirhout any certaine order many little fmooth thicke leates fahioned like thofe of Ivic, and faftened to ftalkes of fome inchlong: and together with thefe ftalkes come forth others of the fame length, that carry fpur-fathioned Houres, of the thape and bioneffe of thofe of the female Fluellen : their outfide is purple, their infideblew, with a forof yellow in the opening. The roor is fmall, creeping, and threddie. It flotres toward the end of Sonmer, and growes wilde vpon walls in Italic, but in gardens wirls vs. Mattholus calls ir Cymbaluriz (to whicli Lobel addes) It alica Hederaceo folio: Lonicerus termes it Vmbilicus Veneris officinzrumz: and laltly Co. limna cals it Limoria hederafolio. $\ddagger$

$$
\text { T The place. }
$$

The firft kind of Penniwoott groweth plentifully in Northampton vpon enesy ftone wall about the rowne, at Briftow, Bathe, Wells, and moft places of the Weft Countrie vpon ftone walls. It groweth vpon Weftminfer Abbey, ouer the doore that leadeth from chaucers tombe to the old palace. $\neq$ In this laft place it is not now to be found. $\neq$

The fecond, third, and fourth grow vpon the Alpes necre Piedmont, and Bauicrand vponthe mountaines of Germanic: I found the third growing vpon Biefton Cafte in Chenhire.

-- $\neq$ The fiftl growes vpon the Bogges vpon Hampltead Hearh,and many fuch rotten grounds in other places. $\mp$

They are greene and floutifh efpecially in VVinter : They flourealfo in the beginning of Sommer.

q T he Names.

1 Nauelwoort is called in Grecke xorixnows : in Latine, $V m b i l i c u s ~ V e n e r i s, a n d ~ A c e t a b u l u m$ : ofdiuets; Herba Coxendicum : Iacobus Manliss nameth it Scatum Cali, and Scarellum: in Dutch, 看aucletupt: in Italian, Cupertoiule: in Ftench, E/cuelles: in Spanifh, Capudella: of fome, Hortus Veneris, or Venus garden, and Icrre vmbilicus, or the Nauel of the carth : in Englih, Penniwoort, Wall-penniwoort, Ladies namell, Hipwoort and Kidney-woort.

VVater Penniwoort is called in Latine Cotyledon palustr is: in Englifh, Sheepe-killing Penni- Hydrocotyle gtaffe, Penny-tot, and in the North Countrey VVhite-tot: for there is alfo Red-rot, which is $R \circ f_{a}$ folis : in Northfolke it is called Flowkwoort. ¥Columna and Bawhine fitly tefer this to the Ranumculi, or Crowfeet; for it hath no affinitie at allwith the Cotyledons (but onely in the roundneffe of the leafe) the former of them cals it Ranunculus aquaticus vmbilicatofolio, and the later, Ranunculus aquat. Cotyledonis folio.

\section{T) The Temperature.}

Nauelwoort is of a moif fibitance and fomew hat cold, and of certaine obfcure binding qualitie : it cooleth, repelleth, or driueth backe, fcoureth, and confumeth, or wafteth away, as Galen teitifieth.

₹ The VVarer Pennywoort is of an hot and vlcerating qualitie, like to the Crow feet, whereof it is a kinde. The baftard Italian Natelwort feemes to partake with the true in cold and moiftute. $\ddagger$

\section{q The Vertues.}

The iuice of VVall Pennywoort is a fingular remedie againft all inflammarions and hot tumors, $\mathbf{A}$ as Eryfipelas, Saint Anthonies fire, and fuch like : and is good forkibed heeles, being bathed tluerwith, and one or more of the leanes laid vpon the heele.

The leaues and rootes eaten doe breake the ftone, prouoke vrine, and preuaile much againfthe $B$ dropfie.

The ignotant Apothecaries doe vfe the VVarer Pennywoort in ftead of this of the wall,which $\mathrm{C}$ they cannot doe wirhout grear error, and much danget to the patient : for husbandmen know well, that it is noifome vnto Sheepe, and other cattell that feed thereon, and for the moft part bringeth death vnto them, much mote to men by a fronger teafon. 
3 Vmbilicus Veneris minor. Small Nauelwoort.

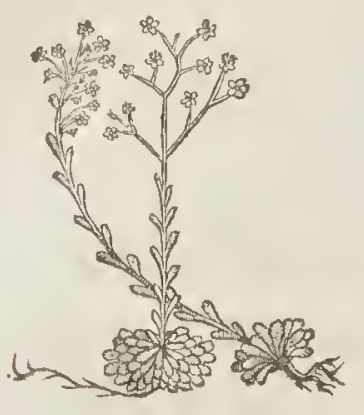

5 Cotyledon paluftris. Water Pcrniwoorr?

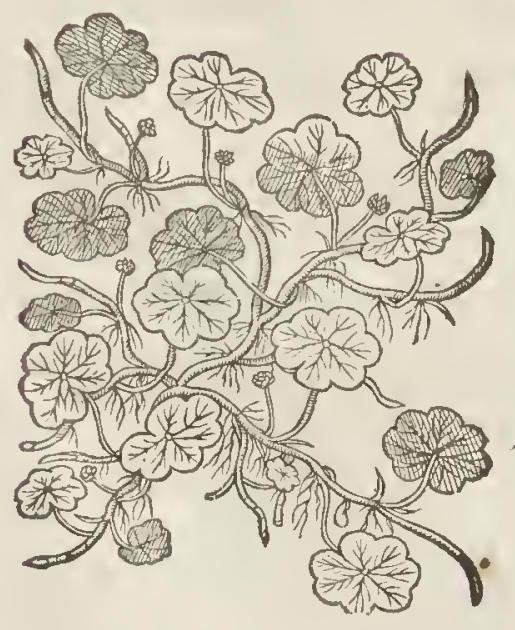

+4 Cotyledon minor montana altera. The other fmall mountaine Nauelwoort.

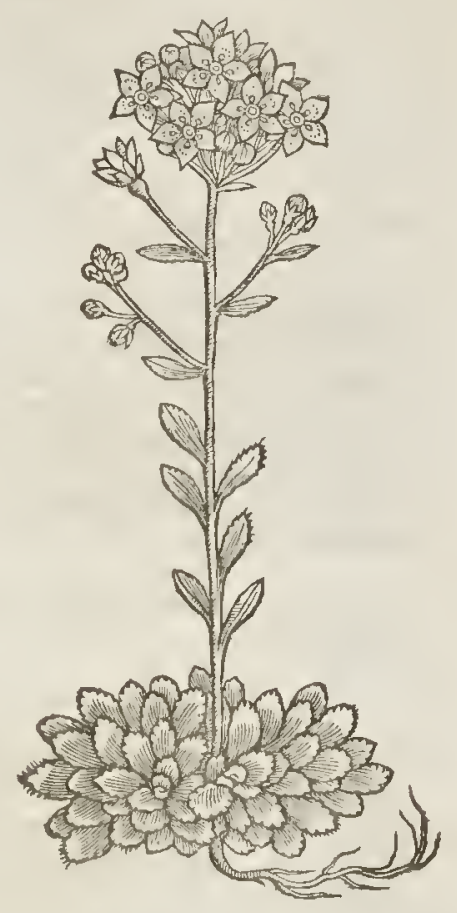

6 Cymbalariattalica.

Italian Baftard Nauclwoort.

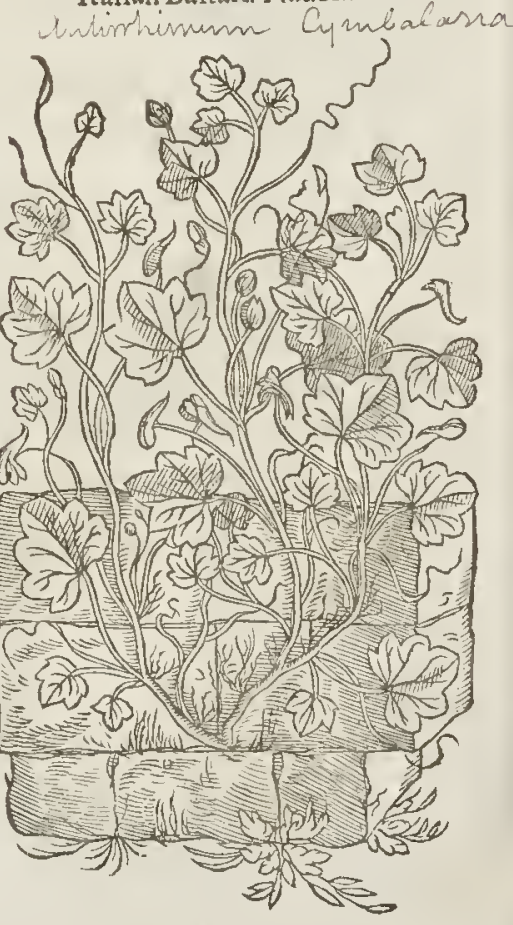




\section{1 B. 2. Of the Hiftory of Plants.}

\section{Chap. 152. Of Sea Pennywoort.}

I Androface Mattbioli.

Sea Naucl-woort.

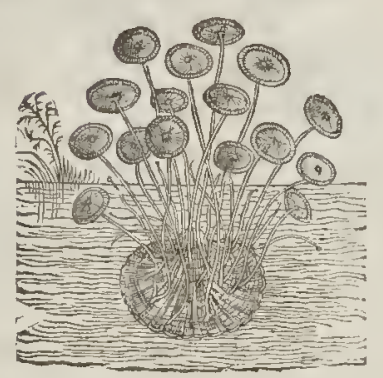

2 Androface annua puris.

One Sommers Nauell-woort.

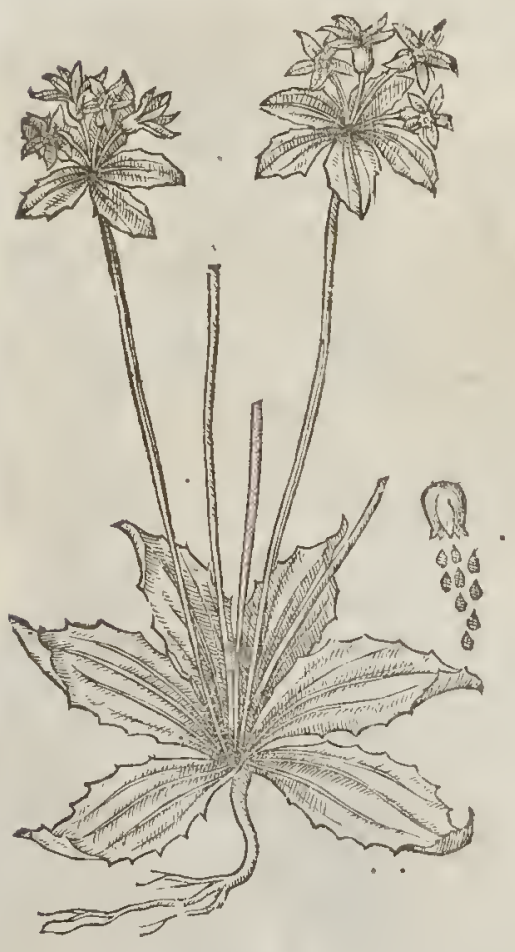

$$
\text { if The Defription. }
$$

I $T$ He Sea Nauel-woort hath many round thicke leaues like vnto littlc fauccrs, fet vpon fmall \&o tender ftalks, bright, ihining, and f mooth, of two inches long, for the moft part growing vpon the furrowed thels of eockles or the like, euery fmall ftem bearing vpon the end or point, one little buckler and no more, refembling a nauell ; the ftalke and leafe fet togerher in the mid. dle of the fame. Whereupon the Herbarifts of Montpelier have called it $\mathrm{Vm}$ bilicus Marinus, or fea Nauel. The lcaues and ftalkes of this plant,whileft they are yet in the water,are of a pale arh colnur, but being taken fortl, they prefently waxe white, as Sea Moffe, called Corallina,or the fhel of a Cockle. It is thought to be barren of feed, and is in taftefaltifh.

2 The fecond Androface hath little fmooth leaues, fpred vpon the ground like vito the leanes of finall Chiekriveed or Henbit,whereof doubtles it is a kind: mong which rifeth vp a flender ftem, hauing at the top certaine little chatfie flourcs of a purplifh colour. The fecd is contained in fmall fcaly husks, of a reddifh eolour, \&z a bitter tafte. The whole plant perifheth when it hath perfeeted his feede, and muft be fowne againe the next yeare:which plant was giuen to $M_{a-}$ thiolus by Cortufus, who(as he affirmeth) receitied it from Syria; but I thinke hee faid fo to make Mat hiolus more ioyfull: but furely I furmife he picked it out of one old wal or other, where it doth grow euen as the fmall Clickweed,or Nailewoort of the wall do.

₹ The figure that was here was that vnperfeet one of Matthiolus ; and the dereription of our Authour was framed by it,vnleffe the latt part theror, which was taken out of the Aduerjaria pag. I 66.to amend both thefe, we here prefent you with the true figure and defeription, taken out of the workes of the indieious

hath(faith he) meny leaues lying flat wpon the ground, like to thofe of Plantaine, but leffer and of a pale greene colour, and toothed about the cdges, foft alfo and itiicie, and of fomewhat a biting tafte. Amongft thefe leaues rife vp fue or fix ftalkes of an handfull high, conmonly of a green, yer fometimes of a purple colour, naked and fomewhat hairy, which at their tops earry in a cirele fite roundifh leates alfo a little toothed and hairy; from the midft of which arife fite or more foot- ftalks,each bearing a greenifh rough or hairic, cup \& parted alfo in to fiuc little leautes or ings, in the 
midft of which ftands a little white foure parted alfo into fiue; after wheh fueceed pretry large feed veffils iv hich containe an vinequall red feed like that of Primofes, but bigger $:$ the root is fingle and flender, and dies as foon as the feed is perferted. It growes naturally in dituers places of Aultria, and amongft the cone about the Bathes of Baden, whereas it floures in Aprill, and ripens the feed in May and Iunc. $\ddagger$

$$
\text { II The Place. }
$$

Androfice will not grow any where but in water: great ftore of it is about Frontignan by Montpellier 10 Languedoc,where cuery filher-man doth know it.

The fecond groweth vpon old ftóne and mud walls : notwithftanding I hauc(the more to grace Mathisolms great icwell) planted it in my garden.

$$
\text { T) Tise Time. }
$$

The baftard Androf tee floureth in Iuly, and the feed is ripe in Augunt.

$$
\text { T. The } 2 \text { esmes. }
$$

Ardrofuce is of fone called 'T'mbilicus marinus, or fea Nauell.

\# The fecond is knowne and called by the name of Androface altera Mattholi. $\neq$

$$
\text { of The Temperaiure. }
$$

The fea Naucll is of a diureticke qualitie, and more drie than Galen thought it to be, and leffe hot than othe rs haue deemed it : there ean no moifture be found in it.

$$
\text { I The vertues. }
$$

A Sea Nauclwoort proukcth trine, and digefteth the filthineffe and fliminefle guthered in the ioints.

B Two drams of it, as Diof condes faith, drunke in wine, bringerh downe great ftore of vrine nut of their bodies that haute the dronfie, and maketh a good plaifter to ceafe the paune of the gout.

Rofe-woort, or Rofercot.

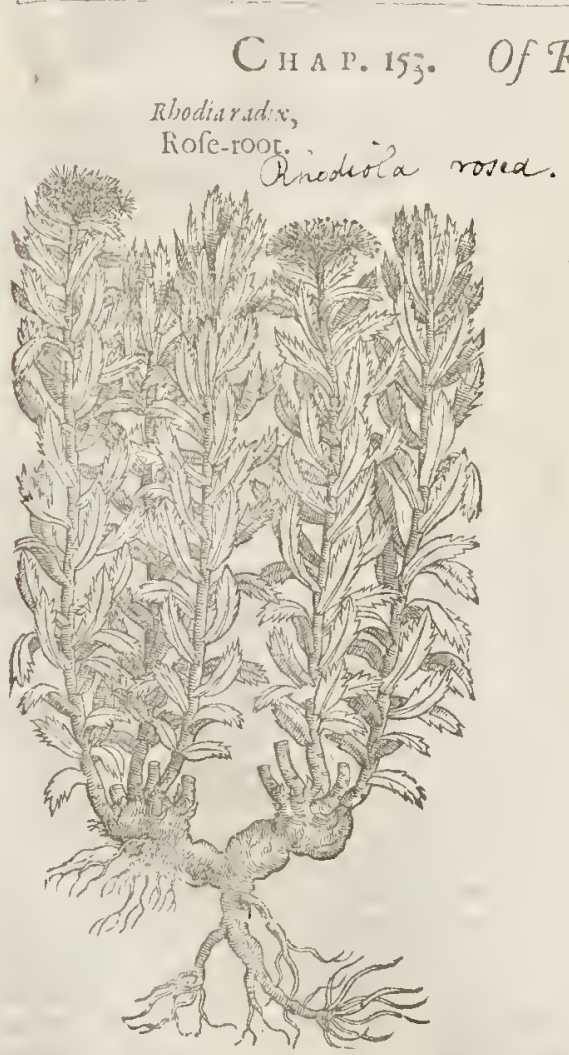

T The Defoription.

D Ofewoot hath many fmall, thieke, and fat 1 ftems, growing from a thicke and knobby root: the vpper end of it for the moft part fandeth out of the ground, and is the re of a purplifh colour, bunched \& knobbed like the root of Orpin,tvith many lairy ftrings hanging therat, of a pleafant fmell when it is broken, like the damaskerofe, whereof it tooke his name. The leaues are fet round about the ftalks, euen from the botrome to the top, like thofe of the field Orpin, but narrower, and more finiprabout the edges. The floures grow at the top of a faint ycllow colour.

$$
\text { T) The Place. }
$$

It groweth very plentifully in the North part of England, e fpeciaily in a place ealled Ingleboroigh Fels, necre vnto the brookes fides, and not elfewhere that I can as yet finde out, from whence I haue had plants for my garden.

$$
\text { Ti The Time. }
$$

It floureth and fouritheth in Iuly, and the feed is ripe in Auguft.

$$
\text { I The Numes. }
$$

Some halue thought it hath taken the name Rhodia of the Inland in the Meditcranean fea, called Rholes: but doubrleffe it took his name Rhodia radix, of the ront which fmelleth like a rofe:in Englih, Rofe-root, and Rofe-woort.

- The tertues.

There is little extant inw riting of the fleultes of Rofewont : bur this I have found, that if the rootbe ftamped with oile oi Rofes and laid to the temples of the head, it : afeth the paire of the

CHAP. 
1 Crithmum marinum. RockeSampier.

Citthmusomaritiman

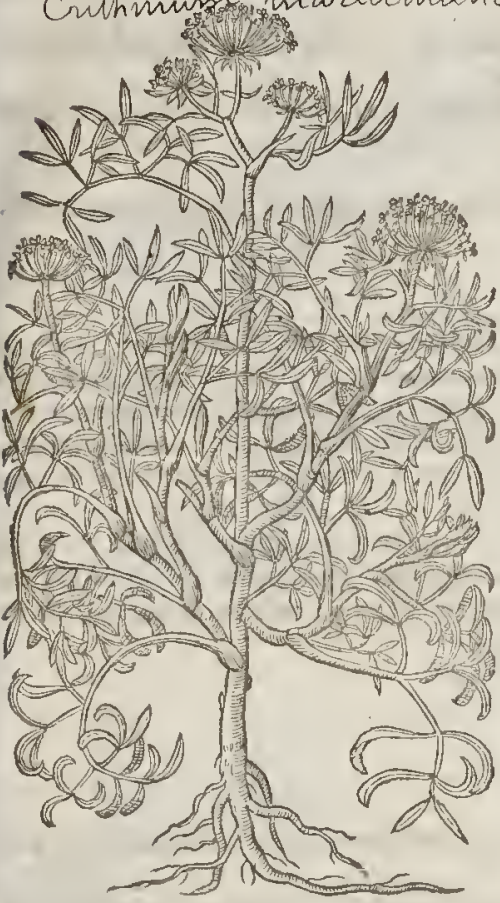

3 Crithmum chryfanthemum. Inula crolden Sampici. id as

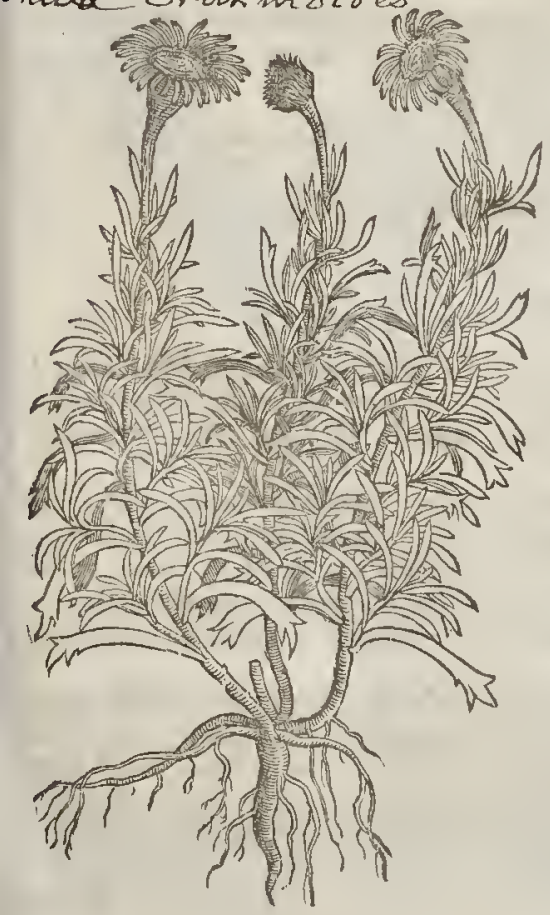

2 Crithmum Spinofim.

Chimobhoza Thornie Sampier. spen osa.

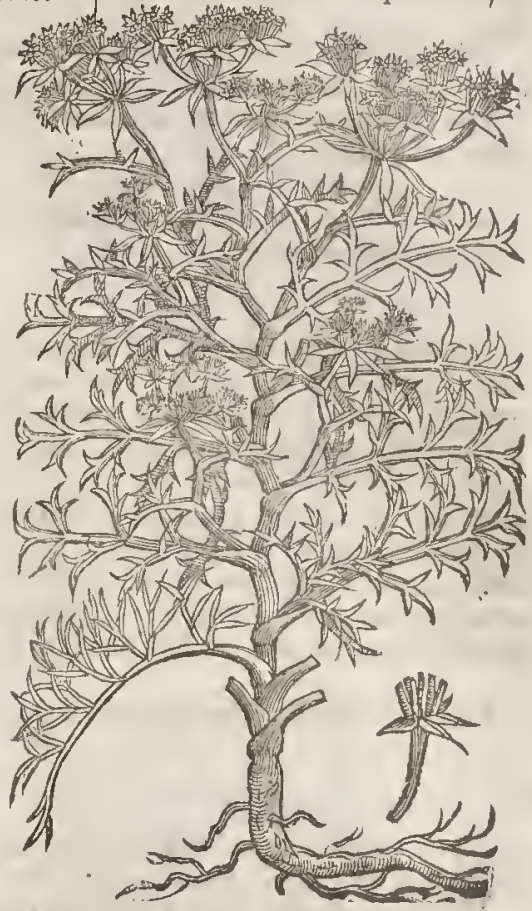

The Defription.

I $\mathrm{R}$ Ocke Sampicr hath many fat and thicke leaues, fomewhat like thofe of the leffer Purflane, of a fpicy tafte with a certaine faltnefle; amongit which rifeth vp a ftalke, diuided into many fmal fpraies or fprigs; on the top wherof doe grow fpokie rufts of whitefloures, like the tufts of Fenell or Dill, after that commeth the feed like the feed of Fenell, but greater. The root is thicke and knobbie,being of fmell delightfull \& pleafant

2 The fecond Sampier called $P$ aftinaca marina, or Sea Parfnep, hath long fat leaucs, very much iagged or cut eten to the middle rib, tharpe or prickley poinred, which are fervpon large fat iointed ftalks; on the rop whercof do grow tuftes of whitifh, or els reddith floures. The feed is wrapped in thornie huskes. The root is thick and long, not vnlike to the Parfnep, vcry good and wholefome to be eatcn.

3 Golden Sampier bringeth forth many italks from one root, compaffed about with a multitude of long fat leaues, fet together by equall difances; at the top whereof come yellow floures. The feed is like thofe of the Rocke Sampier. Y y 


\section{The Place.}

Rocke Sampier groweth on the rockic eliffes at Douer, VVinehclfey, by Rie, about South. hampton, the Ifle of VVight, and mott rockes about the Wcft and North-wct parts about Eng-
land.

The fecond groweth neere the Sea vpon the fands, and Bayche bctrecn Whitfable and the Iflc of Thanct, by Sandwich, and by the fea necre Wefthefter.

The third groweth in the myric marh in the Iflc of Shepcy, as you go from the Kings Ferrie, to Shcrland houfe.

$$
\text { ๆT The Time. }
$$

Rocke Sampiet flourifheth in May and Iune, and mut bc gathered to be kept in pickle in the beginning of Auguft.

Rocke Sampier is ealled in Greekexibur : in Latine, Crithmum : and of diuers, Bati : in fome Thops, Cretamirina: of Pctrus Crefcewtius, Cretamum, and Rincum marinum: in high Dutch, $910 \mathrm{ex}$ fencbel: which is in Latine, Faniculum marirum, or Sea Fenell : in Italian, Fenocchio marino, Hefba di San Pietro; and hereupon diuers name it Sampetra : in Spanilh, Perexil de la mer, Hinoio marno, F enolmarm: in English, Sampier, and Rockc Sampict, and of fome, Creftnarinc; and thefe bee the names of the Sampic: gcrerally catcn in fallads.

The other two be alfo crithma or Sampiers, but moft of the later writers would draw them to fome other plant : for one ealleth the fecond Paftinaca marina, or fea Parfnep, and the third $A$ fter atticus marinus; and Lobclnames it Chryfanthcmum Littorcum: but we had rather entettaine them as Mat hiolus doth, among the kindes of Crithrnum, or Sampicr.

Sampier doth dric, warme,and feoure, as Galen faith.

$$
\text { T The Temperature. }
$$

\section{The Vertues.}

A The lcaules, feeds, and roots, as $D$ iof corides faith, boilcd in wine and drunke,prouoke vrine, and womens fiekneflc, and premaile againft thc iaundies.

B The leaucs kept in pieklc, and eatcn in fallads with oile and vincger, is a pleafant fauce for meat? wholefomc for the ftoppings of the liner, milt, kidneies and bladider : it prouoketh vrine gently; it openeth the ftoppings of thc intrals, and ftirretl vp an appetitc to meat.

C It is the plcafanteft fauce, moft familiar, and beft agreeing with mans body, both for diget:... of meats, breaking of the ftone, and voiding of grauell in the reines and bladder.

\section{C н а P. 155. OfGlajfe Saltwoort.}

\section{Tf The Defcription.} Laffewoort hath many groffe, thickc and round falkcs a foot high, full of fat and J thieke fprigges, fet with many knots or ioints, without any lcaucs at all,of a reddifh greene colour. The whole Plant refemblctha btaneh of Corall. The root is very fmall and fingle.

2 There is anorher kindc of Saltwoort, which hath been taken among the antient Hcrbarifts for a kinde of Sampier. It hath a little tender ftalke a cubitc high, diuided into many fmall branches, fet full of little thicke leaucs very narrow, fomcwhat long and tharpe pointed, yet not prick: ing; among it which commeth forth fmall feed, wrapped in a crooked huske, turned round likca crooked perwinkle. The ftalkes areof a reddifh colour. The whole plant is of a falt and biting raftc. The root is fmall and threddic.

+3 There is likewife another kinde of $K$ ali, whereof Lobel maketh mention vnder the name of $K$ ali minus, which is like to the laft bcfore rcmembred,but altogether leffer, $\ddagger$ hauing many flender weake branches lying commonly fpred vpon the ground, and fet with many, fmall round long fharpe pointed leaues, of a whitith green colour:the feed is fmall and fhining, not much rnlike that of Sorrell : the root is flender with many fibcrs; the whole plant hath a faltinh tafte like as the former.Dodow. cals this Kali albm $\frac{ \pm}{4}$ 


\section{1 B. 2. Of the Hiftorie of Plants.}

I Salicornia, five Kaligeniculatum.

Glaffewoort, Saltwoort, or Sea-grape. Saliconia herbarea

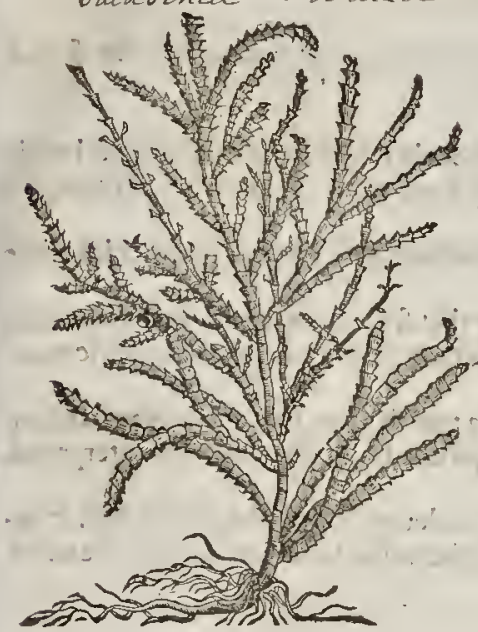

$\ddagger 2$ Kalimaius emine cocbleaio. Snaile Glaflewoort.

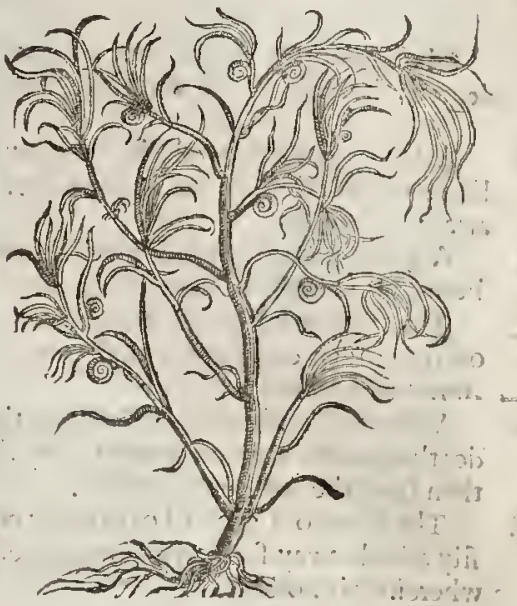

it The Place?

Thefe plants are to be found in falc marhes almólt euery where.

* The fecond excepted, which growes nothere, but vpon the coafts of the Mediterranean fea. $\neq$

$$
\text { q The Time. }
$$

They floure and flourith in the Som: mermoneths.

$$
\text { Tा The Names. }
$$

Saltwoort is called of the Arabians $K a l i$,and Llkali. Uateen, chap. 724 . defcribeth them vnder the name of $V \int$ nen, which differeth from $V$ fnee: for $V \int n e e$ is that which the Grxcians call Bpior: and the Latines, $\mathrm{CM}$ f Cus, or Moffe of fome, as Baptifta Montanus; it hath bin iudged to be Enspetron.

The axen orathes hereof arc named of Mattheus Siluatious, Soda: of moft, $S a l$ Slkali: diners call it Alumen catinum. Others make this kind of difference betweene SalKali, and Alumen catinum, that Alumen catinum is the arhes it felf and that the falt that is made of the aThes is Sal Alkali.

Stones are beaten to pouder, \& mixed with athes, which beeing melted together become the matter wherof glaffes are made. VVhich while it is made red hot in the furnace, and is melred, becomming liquide and fit to work vp-

on,doth yeeld as itwere a fat floting aloft; which, when it is cold, waxeth as hard as a ftone, yer it is brittle, and quickely broken. This is commonly called Axunziavitri. In Englifh, Sandener: in French, Suin de Voirre: in Italian, Fior decriftalo,(i)Floare of Chrifall. The Herbe is alfo called 


\section{Of the Hitorie of Plants.}

L 1 B. 2.

of diners $K$ ali articulatum, or iointed Glaffe-wo ort and in Englifh, Crabbegraffe, and Froggegrafie.

of The Temperature.

Glaffe-woort is hot and drie : the athes are both drier and lotter, and that euen to the fourth degree : the anhes hauea cauticke or burning qualitie.

- The Vertues.

A A little quantitie of the herbe taken inwardly, doth not onely mightily prouoke vrine, but in like fort cafteth forth the dead childe. It draweth forth by fiege waterin humours, and purgeth away the dropfie.

B A great quantitic taken is mifchicuous and deadly. The fmell and fmoke alfo of this hearbe being burnt doth dritue away ferpents.

C The afhes are likewife tempered with thofe medicines that ferte to take away fcabs and filth off the skin: it eafily confumeth proud and fuper fuous Herh that growerh in poifonfome vlcers, as Auicen and Sexapio report.

D Wee read in the copies of Serapio, that Glaffe-woort is a tree fo great, that a man may ftand $v$ n. der the thadow thereof: but it is very like, that this errour proceedeth rather from the interpreter, than from the Authour limfelfe.

E The floure of Chriftall, or (as they commonly terme it, Sandeuer)doth wonder fully drie. It eafily taketh away fcabbes and mangineffe, if the foule parts bewafhed and bathed with the water wherein it is boiled.

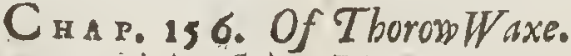
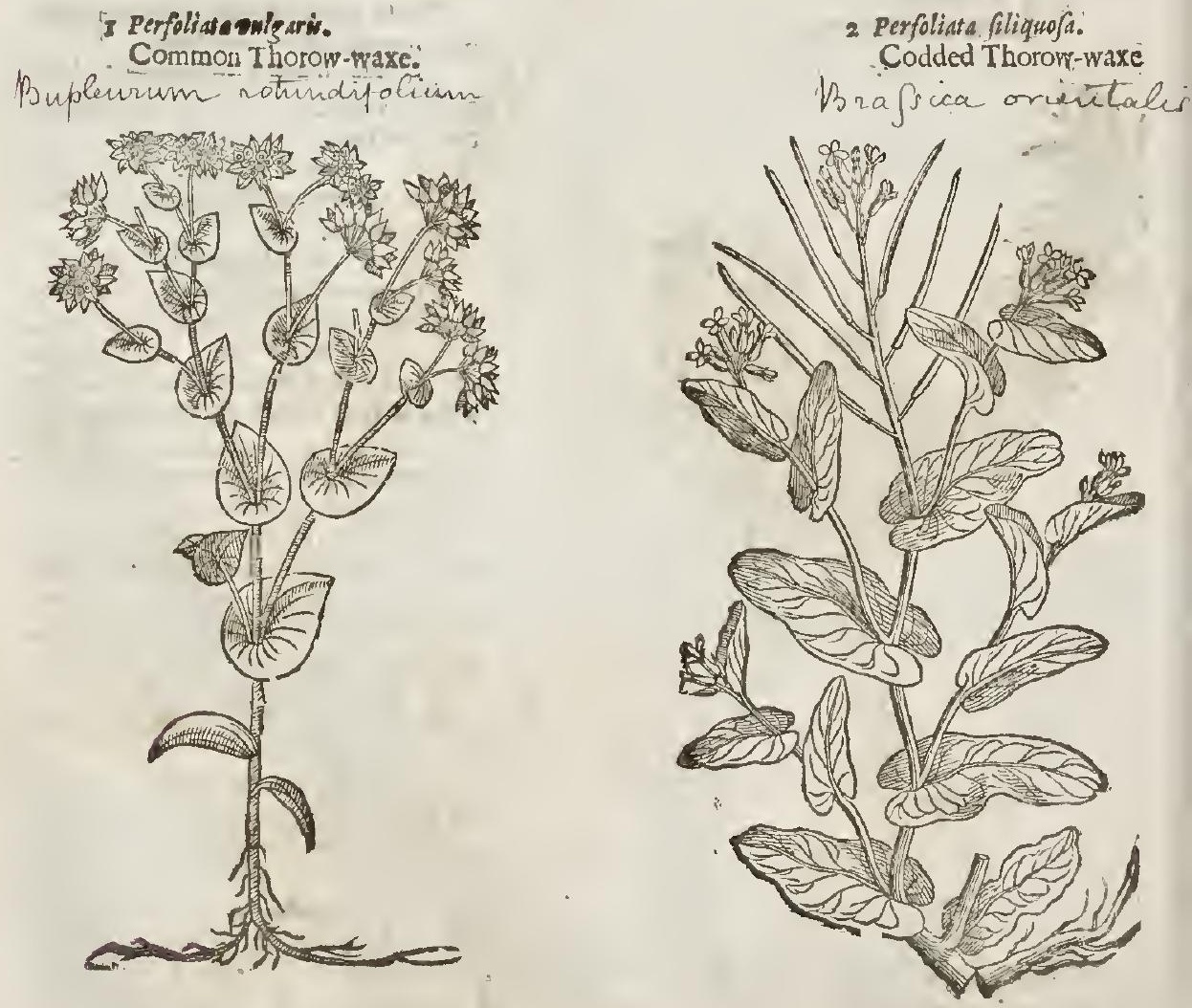
9T The Defeription.

I Horow-wax or Thorow-leafe, harl a round, flender, and britrle falk, diuided into many fmall branches, which paffe or goe thorow rhe leaues, as rhough they in d beene drawne or thruft rhorow, and to make it more plaine, euery branch doth grom t' nrow enery leafe, making them like hollow cups or fatcers. The feed groweth in fpokie citcs or rundles like Dill, long and blackifh. The floures are of a faint yellow colour. The root is ingle, white
and threddie.

2 Codded Thorow-wax reckoned by Dodonews among the Brafickes or Colewoorts, and ma. king it a kinde thereof, and calling it braßsica flucfris perfulat : though in mine opinion without realon, fith ir hath neirher fhape, afinirie, nor likcneffe wirh any of the Colewoorts, bur altogether moft vnlike, refembling very well the common Thorow -wax; whereunro I rather refer ir. It harh fmall, terider, and brirrle ftalkes two foor high, bearing leaues, which wrap and inclofe rhem fulues round abour, although bey do not run rhorow as the other do, yer they grow in fuclimaner, that von the fudden view thereof, they feeme ro paffe thorow as the other:vpon rhe fuall brânches do grow lirrle white floures : which being paft, there fucced Alender and long cods like thofe of Tur. neps or Naucwes, whofe leates and cods do fomewliar refemble the fame, from whence ir harh the name $N$ apifolin, that is, Thorow-wax wirh leaues like vnto the Nauev. The root is long and fingle,
and dierh when is harh brought forth his feed.

There is a wilde kinde hereof growing in Kenr, in many places anong rbe corne, like to the for mer in each refped, but alrogether leffer:rhe which no doubt brought into the garden would proue
the very fame.
$\neq$ The firftefcribed growes plentifully in Place.

han and Ainsford it orowes in fuch cuantirie in many places about Kent, and betweene Farningfields on the tops of the hils, thar it quy

The later growes not wilde with vs well be termed rhe infirmirie of them.

contrary. $\neq$ i

They grow in the gardens of Herbarift, and in my garden likewife.

T The Time.

They floure in May and Iune, and their feed is ripe in Auguft.

Tt The Nines.

I It harh beene called from the beginning Perfoliata, becaufe the ftalke doth paffe thorotw the leafe, following the fignification of the fame: wee call it in Englifh, Thorow-waxe, or Thorow-
leafe.

* 2 This by the molt and beft part of VVritcrs (rhough our Authour be of another opinion) is very fityreferred to tha wilde Cole-woorts, and called Brafficn campeftris by Clufius and by Camerarim; Brafica agreftis by Tr.gus: yet Lobcl callethit Perfolinta Napifolia Anglorum filiquof. t

Thorow-waxe is of a dry complexion. The Tempcrature.

The decosion of Thorowertues.

for wounds nade either into an oile or vnguent.

The greene leaues ftamed boile or viguent. guent or faltue roincarnate, or bring vp flen in deepe wounds.

\section{C \\ T) The Defcription.}

Civio Erintbe or Honie-woort riferh forrh of the ground after the fowing of his feed, with fat, fmooth, render, anofe of Bafil; betweene the which leaues commeth forth a rhick branches; whichooth, render, and brittle ftalk full of iuice, rhat diuideth it felfe into many other toward the ground, being not a in fundry other armes or branches likewife,crambling or leaning Y Y 3 of 
I Cerintbe maior. Gteat Honic-woott.

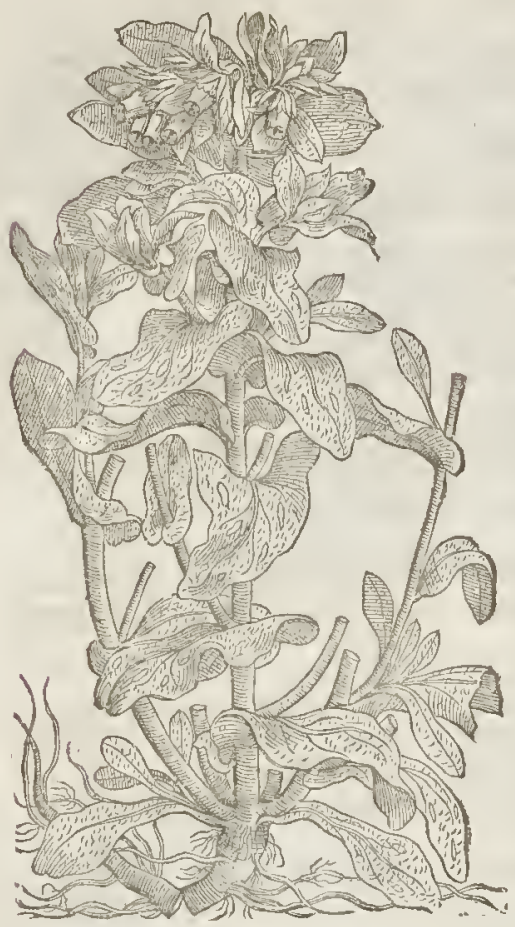

3 Cerinthe minor.

Small Honic-woort.
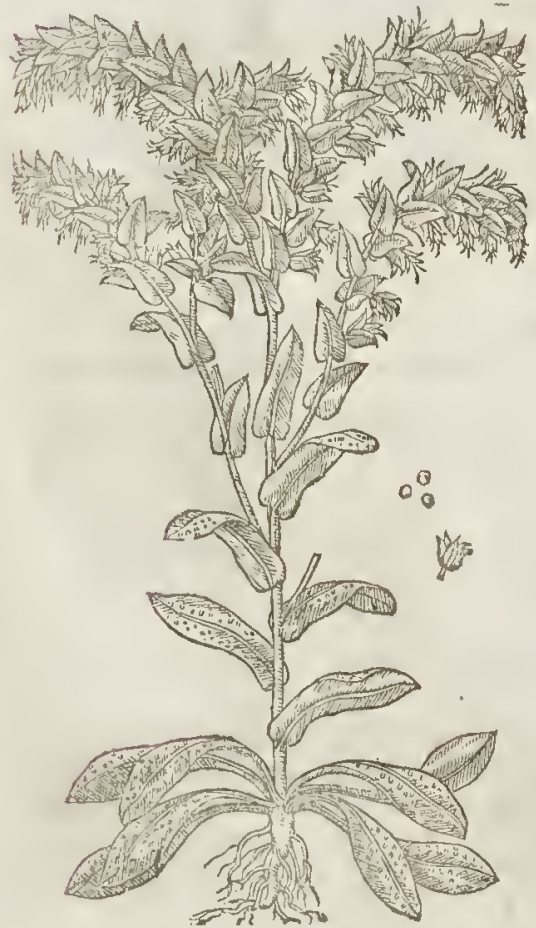

\$2 Cerinthe aperior fiore favo. Rough Honie-woott.

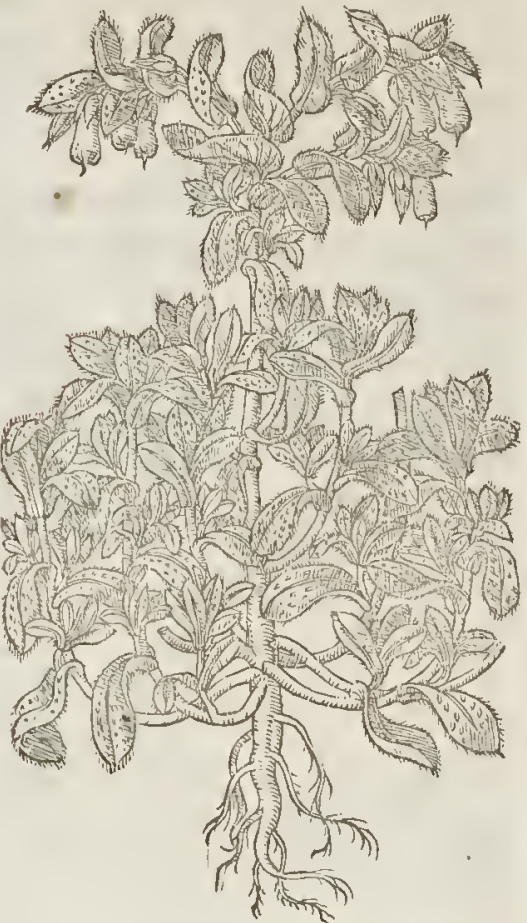

of leaues, branches, \& much iuice, the whole plant is furcharged with ; vpon which branches ate placed many thicle rough leaues, fet $w$ ith very tharpe prickles like the rough skinne of a Thomebackc, of a blewith green colour, fpotted very notably with white ftrakes and fpots, like thofe leates of the truc Pulmonaria or Cowflips of Icrufalem, and in thape like thofe of the codded Thorow-waxc, which lcaues do clip or embrace the ftalkes round about: from the bofome whercof come forth finall cluters of yellow Aloures, with a hoopc or band of bright purpic round about the middle of the ycilow floure. The foure is hollow, farhioned like a littlc boxe, of the tafte of honic when it is fucked, in the hollow nefle whercof are many fmal chitucs or threds; which being palt, ther fucceed roulad blacke feed, contained in foft skinnic husks. The root perifhetliat the firft approch of Winter. $\neq$ This varies in the colour of the fioures, which are yellow, or purple, and fometimes of both commixt. $\ddagger$

$\ddagger 2$ The leaues of rhis other great Honicwort (of $C$ luf. defcriprion) are thaped like thofe lait deferibed, but that they are narrower at their fetting on, and rougher; the floures are alfo ycliow of color, bur in thape \& magnitude like the former,as it is allo in the feeds, \& all the other parts thereof.

3 This 
LI B. 2. Of the Hiftory of Plants.

3 This other Cerinth or Honyw ort hath fmall long and Iender branches, reeling this way and that way, as not able to fuftaine it felfe, very brittle, befet with leaues not much vnlike the precedent, but leffer, neither fo rough nor fpotted, of a blewing greene colour. The floures be fimall, hol

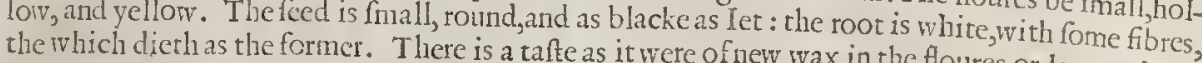
ed, as the name doth feeme to import. T. The Place.

Thefe plants do not grow wilde in England, yet I hate them in my garden; the feeds wherof I receiued from the right honorable the Lord zouch, my honorable good friend.

$$
\text { ब) The Time. }
$$

They foure from May to Auguft, and perifh at the firft approch of Winter, and mut be foweri againe the next Spring.

$$
\text { \% The Names. }
$$

¥ I The firft of thefe by Gefner is called Cynoglojfa montand and Cerintse : Dodonaws calleth it charm herba: and Lobel and orhers, Cerint he major.

2 The fecond is Cerint he quorindam major flaso flore of Clufius. 3 The third by Dodoneus is called Maru berba minor: and by Clufus, Cerinthe quorundam minor
fano fore: Lobel alfo calls it Cerinibe minor. $\ddagger$

$$
\text { T) The Temperature and Vertues. }
$$
Pliny and Awicen feeme to agree, that thefe herbes are of a cold complexion; notwithfanding
there is not any experiment of their vertues worth the writing.

\section{Ha P. 158. Of S. Iobns wort.}

I Hypericum.

S. Iohns wort.

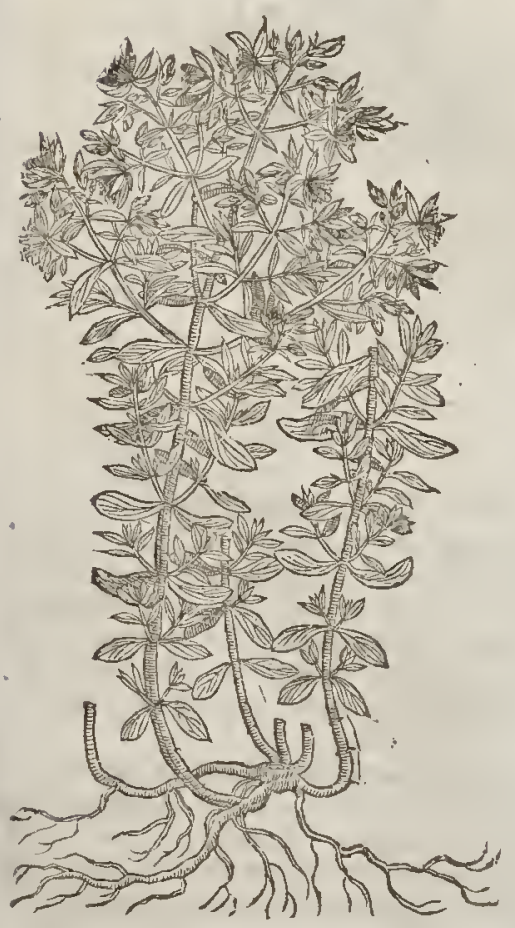

2 IHypcricum Syridswm: Rew S. Iohns wort,

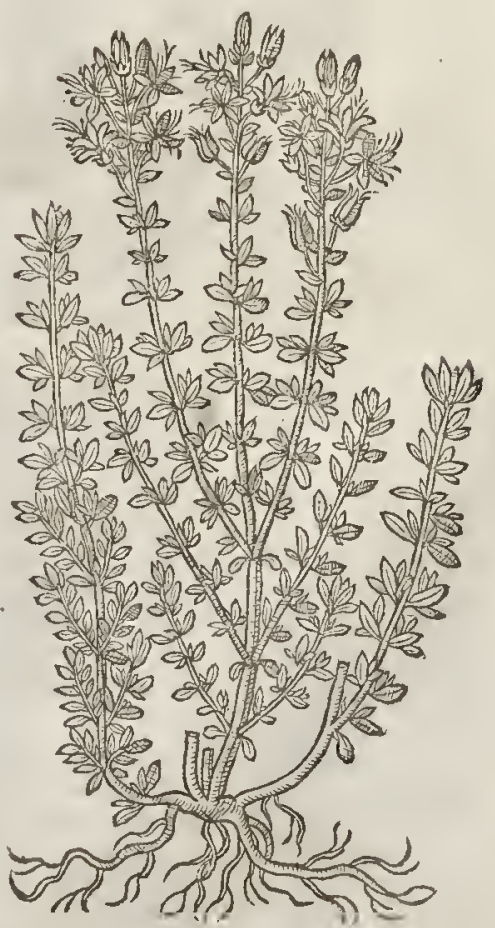




\section{था The Defription.}

I Aint lohns wort hath brownifh ftalkes befet with many fmall and narrow leaues, which if you behold betwixt your eyes and the light do appeare as it were bored or thruft tho. row in an infinite number of plaees with pinnes points. The branehes diuide themfelues into fundry fmall twigs, at the top whereof doe grow many yellow foures, which with the leaues bruifed do yeeld a reddith iuyee of the eolour of bloud. The feed is eontained in little fharpe pointed huskes, blacke of colour, and fmelling like Rofin. The root is long, yellow, and of awooddy fub tanee.

2 The feeond kinde of S. Ioluns wort named syrincum, of thofe that haue not feene the fruitfull and plentifull fields of England, wherein it groweth aboundantly, hauing fmall leaues almoft like to Rew or Herbe-Graee : wherein Dodon ess hath falled,entituling the true Androfemum by the namic of Ru:a yluefris; whereas indeed it is no more like Rew than an Apple to an Oifter. This plant is altogecher like the preeedent, but fmaller, wherein eonfifteth the differenee. ‡ It had beene fitter for our Author to haue giuenvs a better and perfecter defeription of this plant(wliels as he faitl growes fo aboundantly with vs) than foabfurdly to cauill with Dodonens, for calling, as he faith, the true Andro (emwan, Ruta fylmeftr is : for if that be the true Androfernum which Dodoneus nade mention of by the forefaid name, why did not our A uthor figure and defcribe it in thenext chapter fauc one, for Androfamum, but followed Dodoness in figuring and defcribing Tut fan for it? See more hereof in the chapter of $T u ! f n$. I cannor fay 1 haue feene this plant ; but Lobel the Author and fetter fortl there of thus bricfely deferibes it : the leaucs are foure times leffer than thofe of ours, which grow thicke together as in rundles vpon ftalkes, being a cubit higl. The floures are yellow, and like thofe of our common kinde. $\neq$

3 Woolly S. Iolns worthath wany fmall weake branches trailing vpon the ground, befet witl many little leaues, eoucred oucr with a certaine foft kinde of downineffe : among whicli commeth forth weake and tender branehes charged with fmall pale yellow floures. The feeds and roots are like vnto the true S. Iohnswort.

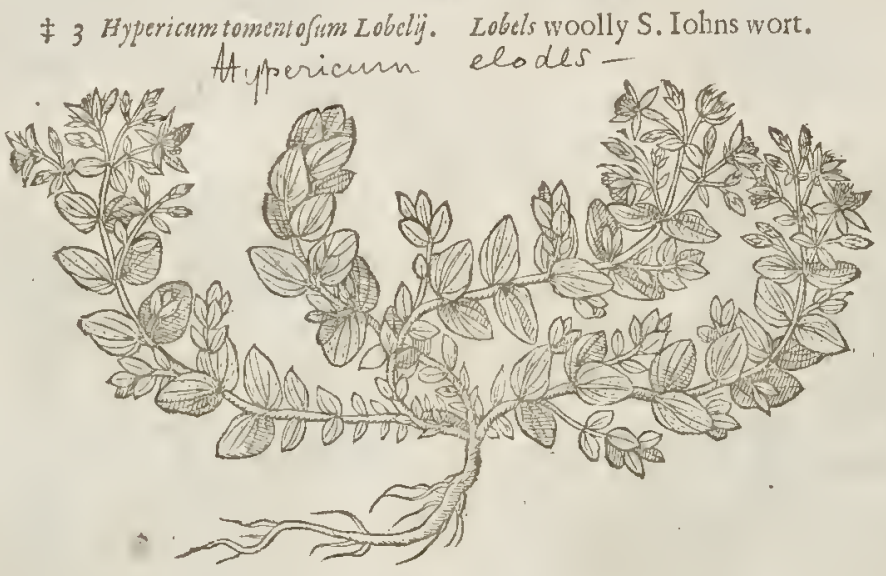

\# The figure that our Author gaue was of that which I hete gite you fecond in the third place, vinder the title of Hyper. oment. Clufij; for Cluf fus faith it was his, and blames Lobel for making it all one with that he found about Montpelier; whofe figure alfo I giue you firft in the third place, that you may feewliat difference you can obferue by them : for Clufius faith Lobels is but an handfull higin; yet tells he not vs how high his growes, neither infances how they differ, neither can I gather it by Lobels defeription : but I coniceture it is thus; That of Clufius his defeription is taller, more white and hairy, and hath the floures grow ing along little foot-ftalks, and not in manner of an vmbel, as in the other.

+4 Befides thefe two creeping hoary S. Ioluns worts here deferibed, there is another fmall kinde which is ealled by Dodoneus, Hypericum minus; and by Lobel, Hypericum minimum fupinum Sep. tentrionalc. It growes fome handfull or more high, with weake and flender branches fet with leaues like thofe of the ordinarie kinde, but leffe: the floures are alfo like thofe of the firft deferibed, but fewer in mumber, and leffe. It is to be found in dry and barren grounds, and floures at the fame time as the the fo:mer.

5- I hame obferued growing in S. Iohns wood and other places, that kinde of S. Iohn Wort which 
which by Tragus is ealled Hypericum pulchrum; and both by him and Lonicerus is thought to be Diofcorides his Androfamum; the which we in Englih may for diftintions fake eall Vpright Saint Iohns wort.It hath roots like thole of the ordinarie kinde; from which arife ftraight flender ftalks fome eubit high, fet at equall fpaces with pretty fmooth lcaues, broad, and almoft ineompafing the ftalke at their ferting on, and bcing fo netımes of a green, and otherwhiles of a reddifh eolour: towards the rop they are parted inco fome few branches, which beare fueh yellow floures as the common kinde, but fomewhat fmaller. It floures about the fame time as the former, or a little after. $\neq$

\section{Hypericum tomextofum Clufij.}

Woolly S. Iohns wort of Clufius:

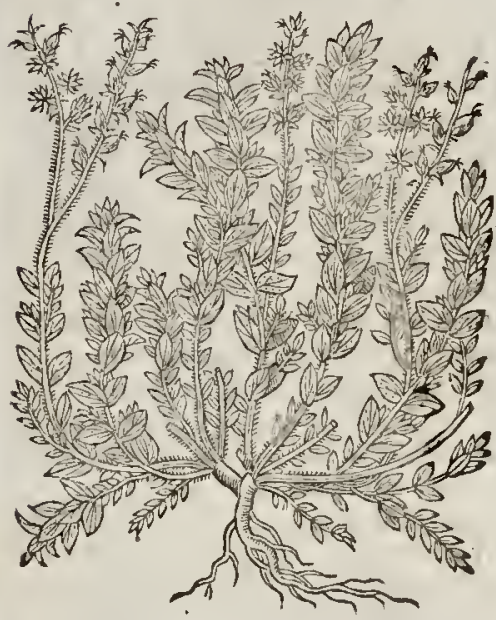

\$4 Hypericum fupinum glabrum: Small creeping $S$. Iohns wort.

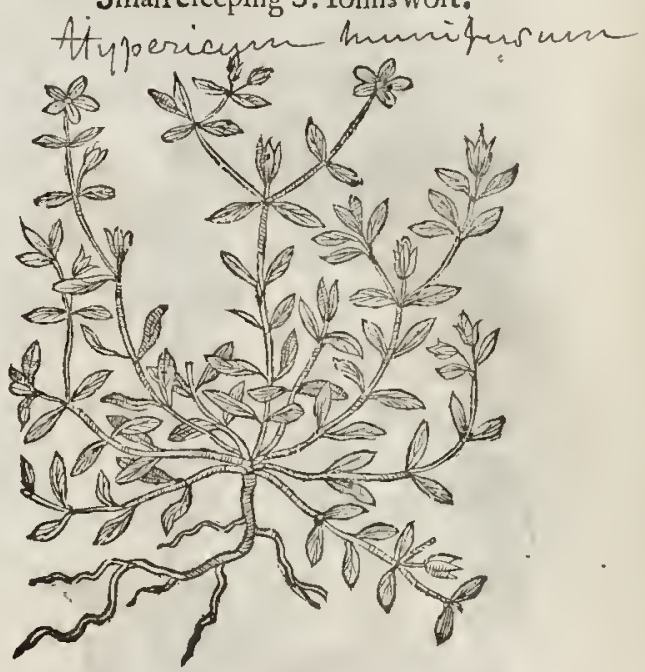

They grow very plentifully in the paftures in enery countrey? Tा TheTime.

They floure and fourith for the molt part in Iuly and Auguf:

$$
\text { T) The Names. }
$$

S. Iohns wort is ealled in Greeke iafues : in Latine, Hypericum : in thops, Perforata : of diuers, Fugademonum : in Duteh, San 3 lohang heaut: in Italian, Hyperico: in Spanifh, Caraconzillo : in French, Mille Pertugs : in Englirh, S. Iolns wort, or S. Iohns grafe.

\section{of The Temperature.}

S.Iohns wort (as Galen teacheth) is hot and dry, being of fubftance thinne. T The Vertues.

S. Iohns wort with his floures and feed boyled and drunken, prouoketh vrine, and is right good againft the fone in the bladdcr, and ftoppeth the laske. The lcaues ftamped arc good to be layd vpon burnings, fcaldings, and all wounds; and alfo for rotten and filthy vicers.

The leaues, floures, and feeds ftamped, and put into a glaffe with oyle Oliue, and fet in the hot B Sunne for certaine weekes together, and then ftrained from thofe herbes, and the like quanticie of new put in, and funned in like manner, doth make an oyle of the eolour of bloud, whieh is a moft precious remedy for deepe wounds, and thofe that are thorow the body, for finewes that arc prickt, or any wound made with a venomed weapon. I am accuftomed to make a compoind oyle hereof; the making of which ye fhall receiue at my hands, becaufe that I know in the world there is not a better, no not naturall balfam it felfe; for I dare vndertake to cure any fueh wound as abfolutely in eaeh refpeet, if not fooner and better, as any man what fneuer fhall or may with naturall ballam.

Take white wine two pintes, oyle oliue foure pounds, oile of Turpentine two pounds, the leatres, C floures, and feeds of S. Iohns wort, of each two great handfiulls gently bruifed; put them all together intn a grear double glaffe, and fer it in the Sunnceight or ten dayes; then boyle them in the fame glafie per balneum $M$ arie, that is, in a kcttle of watcr with fome ftraw in the bottome, wherein the glaffe muft fland to boyle : whieh done, ftraine the liquor from the herbes, and do as you did before, putring in the like quantitic of herbes, floures, and fecds, but not any more wirse. And in haue you a great fecret for the purpoles aforefaid. 
E Diofcorides faith, That the feed drunke for the fpace of fourty dayes together, cureth the Scisti$\tau a$, and all aehes that happen in the hips.

F The fame Author faith, That being taken with Wine it taketh away Tertian and Quartane Agues.

\section{C н А P. 159. Of Saint Peters wort, or qquare S. Fohns Graffe.}

I Afyron. H ypericumor.

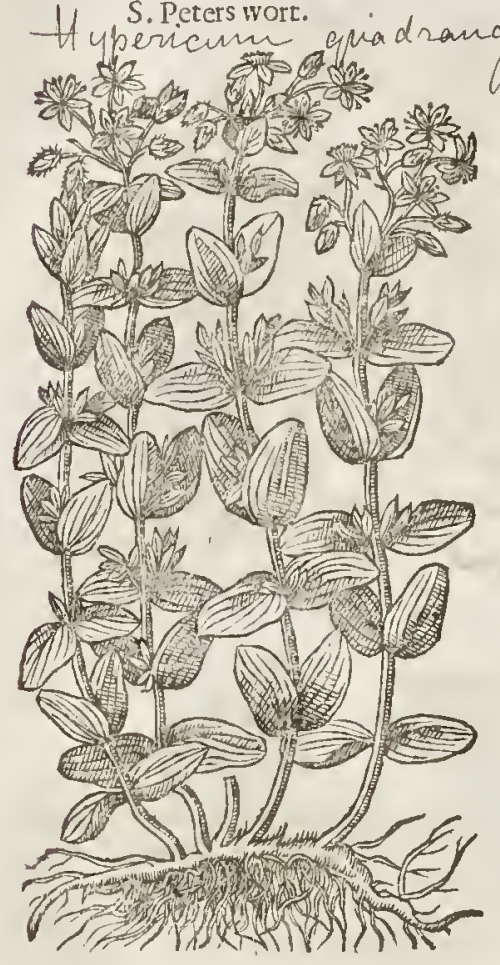

T The Defoription.

I

Aint Peters wort groweth to the height of a enbit and a balfe, hauing a fraight vpright ftalke fomewhat browne, fetby couples at certaine diftanees, w ith leaues much like thofe of S. Iohns wort, but greater, rougher, and rounder pointed : from the borome of which leaucs come forth many fmaller leaues, the which are not bored through, as thofe of S. Iolins wort are; yet fometime there be fome few fo bored through. The floures grow at the top of the branches of a yellow colour : theleaues and foures when they are bruifed do yeeld forth a bloudy iuyce as doth S. Iohns wort, whereof this is a kinde. The roor is tough, and of a wooddy fubftanee.

$¥ 2$ Vpon diuers boggy grounds of this kingdome is to be found growing that 5 . Peters Wort which Clufius defcribes in his Auctarium, by the name of $A$ cyrum fupinuminoss. This fends forth diuers round hairy creeping ftalkes, which heere and there put out new fibres or roots; and thefe are fet at eertaine fpaces with very round and hairie leaues of a whitith colour, two at a ioynt, and on the tops of thefe ftalkes grow a few fmall yeliow floures whieh confift of fiue leaues a piece; thefe falks feldome fend forth branehes, vnleffe it be one or two at the tops. It may well be called in Englifh, Round leaued S.Peters wort. $\ddagger$

\section{S. Peterswort or S. Iohns Grafe o The Place.}

ly in ly in Landfdale and Craucn : I haue found it in many places of Kent, efpecially in a copfe by Mafter sidleys houfe neere Southileet.

The Time.

$$
\text { The Time. }
$$

T The Names.

It is called in Greeke sonuev : the Latines haue no other name but this Greeke name $A$ fyron. It is called of fome Androfemum : Galen maketh it both a kinde of Tutfan, and S. Iohns Wort : and faith it is named Afyron, and Afcyroides: in Englifh,S.Peters wort, S quare or great S. Iohns graffe: and of fome, Hardhay. Few know it from S.Iohnswort.

This herbe is of temperature hot and dry.

$$
\text { T) The Temperature. }
$$

$$
\text { Therertues. }
$$

A. Ir is endued with the fame vertues that S. Iohns wort is endued withall. The feed, faith Diofco rides, being drunke in foure ounces and a halfe of Meade, doth plentifully purge by fiege cholerieke excrements. Galen doth likewife affirme the fame. 
C HA. 160. Of Tutfan or Parke-leaues:

$$
\text { II The Defoription. }
$$

I 7 He ftalkes of Tut fan be fraight, round, chamfered or crefted, hard and wooddy, being for the molt part two foot high. The leaues are three or foure times bigger than thofe of S. Iolnns wort, which be at the firft greene; aftervards, and in the end of Sommer of a dark red colour: out of which is preffed a iuyce not like blacke bioud, but Clatet or Gafcoigne wine. The floures are yellow, and greater than thofe of S. Peters wort, a fter which rifeth vp a little round head or berry, firft greene, atterwards red, laft of all blacke, wherein is contained yellowith red feed. The root is hard, wooddy, and of long continuance.

$\Varangle \quad$ This (which Dodoneres did not vnfitly call Ruta Jylueftris Hypericoides, and which othets haue fet forth for Androfemmm, and our Author the laft chapter fauc one affitmed to be the true $s n$ drofemum, tliough liere it feemes he had cither altered his ninde, ot forgot what he formerlywrot) may fitly ftand in competition with the laft defcribed, which may paife in the firft place for the Androfemam of the Antients; for adbuc fub judice lis eft. I will not here infift vpon the point of con-
trouerie, but giue you a defcription of the plant, which is this : It fends vp round flender reddifh ftalkes fome two cubits high, fetwith fewer yet bigger leaues tlian the otdinarie S. Iohns Wort, and thefe alfo more hairy : the floures and feeds are like thofe of the common S. Iohns wort, but fomewhat larger. It growes in fome mountininous and wooddy placcs; and in the Aduerfaria it is callcd Androfanum excellentins, fers magnum: and by Dodonerts (as we but now noted) Ruta fylueftris Hypericoides, thinking it to be the Ruta fyluef ris which is defcribed by Diofcorides, lib. 3. cap. 48 . in

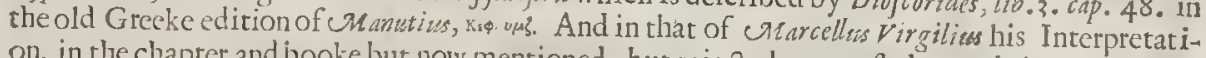
on, in the chapter and booke but now mentioned; but reiected among th the Notha in the Paris Edition Anno $\mathrm{r}$ 49. You may finde the defcription alfo in Dodoness, Pcmpt. prime, li6.3.cap. 25. whither I refer the curious, being loath here to infint further vpon it. $\neq$

I Clymenon Italorum.

Atupericum ark androsommm

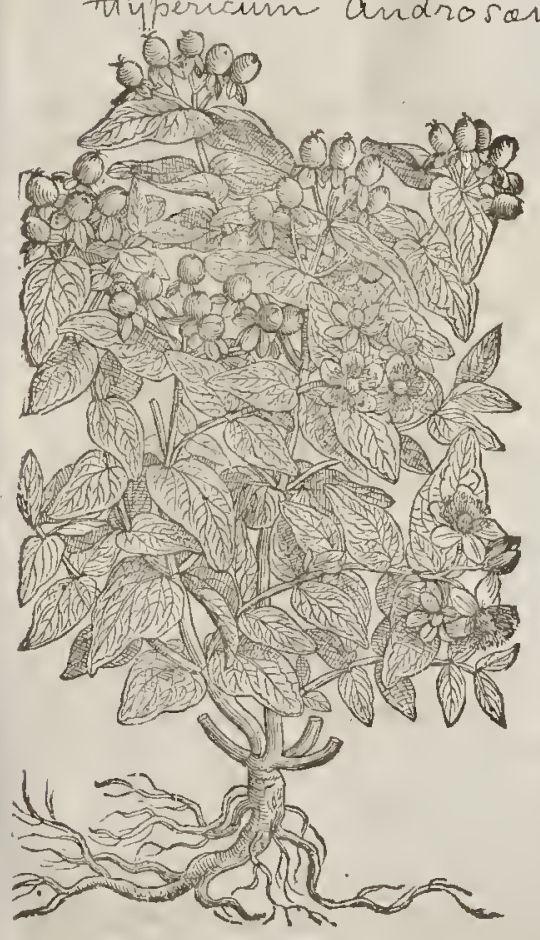

\section{¥ 2 Androfemusn Hypericoides.}

Tutfan S. Iohns wort.

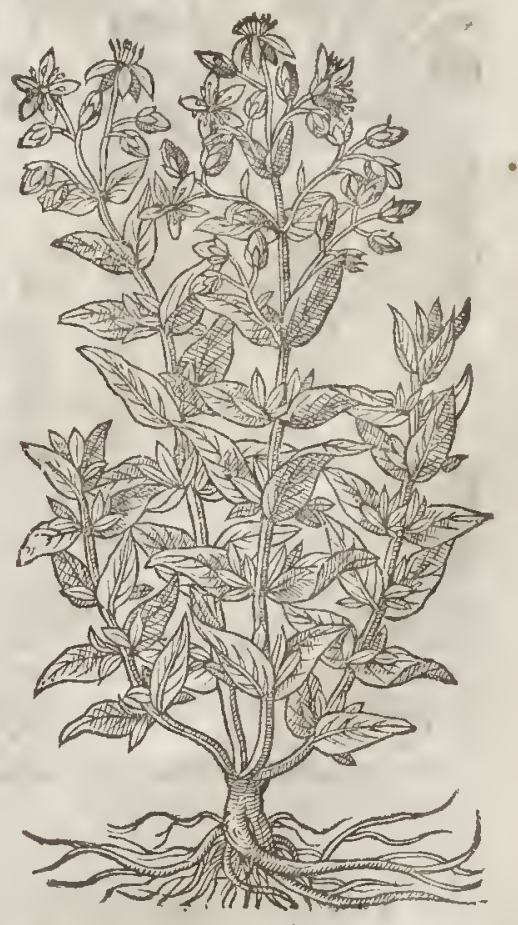

T The 
e) The Place.

Tutfan groweth in woods and by hedges, efpecially in Hampited wood, where the Golden rod doth grow; in a wood by Railie in Effex, and many orher places.

$$
\text { of The Time. }
$$

It foureth in Iuly and Auguft : the feed in the meane timewaxethripe. The leaues becomered in Autumne; at that tine is very cafily prefied forth his winie iuyce.

$$
\text { बा } T \text { be Names. }
$$

It is called in Grecke aiserajesy : and the Latines alfo Androfamon : it is likewifccalled Diony fias, as Galen witneffeth. They are farre fron the truth that take it to be Clymenum, and it is needlefie to finde fault with their error. It is alfo called Siciliana, and Herba Siciliana : in Englim, Tutfan, and Parkc-lcaucs.

$$
\text { बा The Tcmperature }
$$

The facultics are fuch as S. Peters wort, which doth fufficiently declare it to be hot and dry. oT TheVertues.

A The feed hereof beaten to pouder, and drunke to the weight of two drams, doth purge cholericke excrements, as Diofcorides writeth; and is a fingular remedie for the Sciarica, prouided that the Pacient do drinke water for a day or two after purging.

B The herbecureth burnings, and applied vpon new wounds it ftancheth the bloud, and healech then.

C The leaues laid vpon broken fhins and feabbed legs healeth them, and many other hurts and griefes, whereof it tookc his name Tout-faine, or Tutfane, of healing all things.

\section{* С н A 161. Of Baftard S. Fobnswort.}

I Coris Matthioli.

Matthiolus his baftard S. Iohns wort.

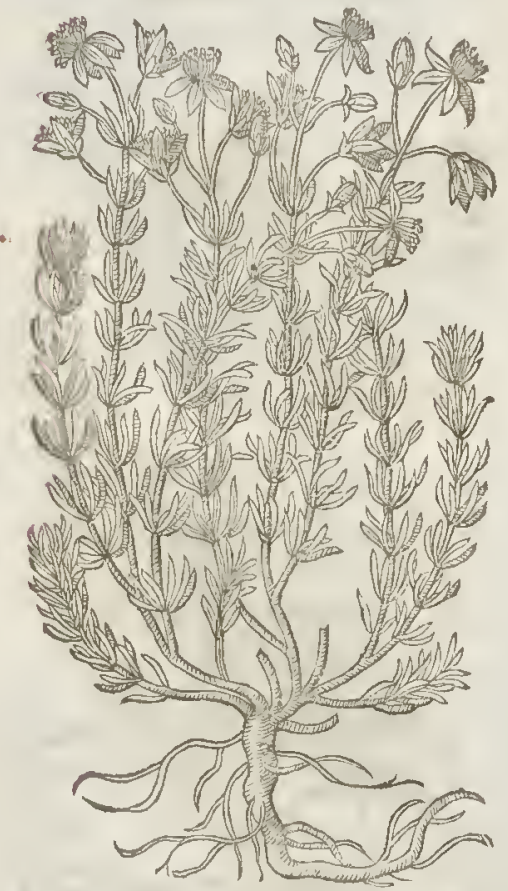

$\$ 2$ Cor is carulea Monpeliaca.'

French baftard S.Iohnswort。

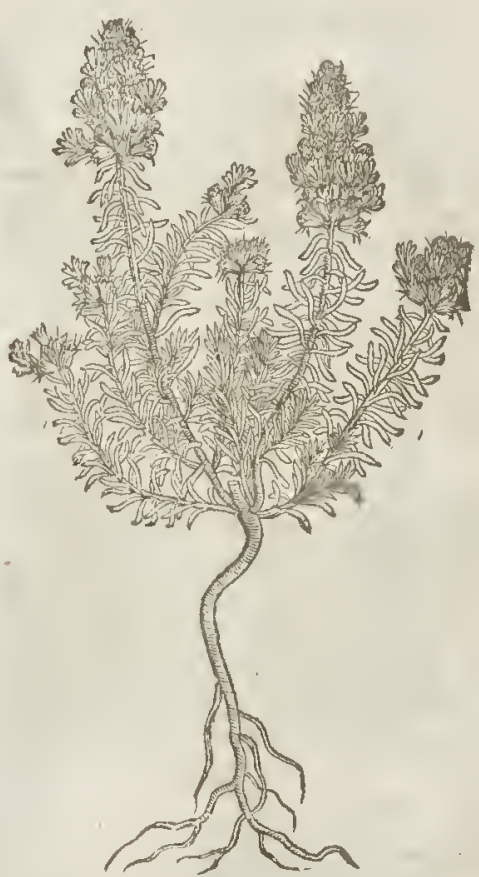

₹ Thediligence of thefe later times hath beene fitch to finde out the Materia medica of the 1 Antients, that there is fcarfe any plant defcribed by them, but by fome or orher of late there laue been two or more fenerall plants referred thereco : and thus it hath happened vito that 
which Diofcorides lib. 3. cap. 174. hath fet forth by the name of Coris; and ptefently defcribes after

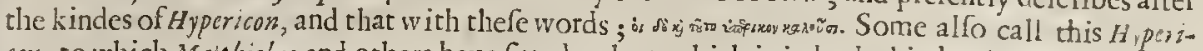
con; to which Matbiolus and others haue fitted a plant, which is indeed a kinde of Hypericon, as you may perceiuc by the figure and defcription which I giue you in the firft place. Some (as Hefyclizus) referre it to Chamepytio, (and indeed by $D$ iof corides it is placed betweene Androfimos and Cliamspytis) and to this that which is defcribed by Pent and Lobel in the Aduerf. and by Clufus in his Hiitorie, may fitly bc referred: this I giue you in the fecond place.

$$
\text { TI The Defoription. }
$$

I $\mathrm{Hc}$ firtt hath a wooddy thicke and long lafting root, which fendeth vp many branches fome foot or more high, and it is fet at certaine fpaces with round leaues like thofe of the fmall Glafle-wort or Sea-Spurry, but thorter: the tops of the ftalkes are diuided into fun trie branches, which carry floures like thofe of S. Iolns worr, of a whition rcd colvur, with threds in their middles hauing little yellow pendants. It growes in Italy and other hot countries, in places not far from the fea fide. This is thought to be the true Coris, by Mattbrolus, Gifner, Lonicerus, La-
cuma, Bellns, Pona, and othets.

2 This from a thicke root red on the outfide fendeth vp fundry ftalkes, fome but an handfull; other fomea foot or more long, ftiff, round, purplith, fet thicke with leaues like thofe of Hcath, but thicker, more fucculent and bitter, which fo nctimes grow orderly, and othcrwhles out of order. The fpikes or heads grow on the tops of the branches, confiftug of a number of little cups, diuided into fiue tharpe points, and marked with a blacke fpot in each diuifion : out of thefe cups comes a floure of a blew purplc colour, of a moft elegant and not fading colour ; and it is compo. fed of foure little bifide lcaues, whereof the two vpermoft are the larger : the feet, which is round and blackin, is contained in fecd-vcflels hauing points fomewhat fharpe or prickly. It floures in Aprill and May, and is to bc found growing in many places of Spane, as alfoabout Mompelicr in France; whence Pena and iobel called it coris cMonpelaaca; and Clufius, Corus guormindam Gallorum do Hipanorum.

$$
\text { a) The Tesperature. }
$$

Thefe Plants feeme to bc hot in the fecond or third degree.

\section{The Vertues.}

Diofcorides faith, That the feed of Coris drunke moue the courfes and vrine, are good againft the biting of the Spider Phalungium, the Sciatica; and drunke in Wine, againft thatkinde of Convulfion which the Greekes call opifthotonos, (which is when the body is drawne backwards) as alfo againt the cold fits in Agues. It is alfo good anointed with oyle, againft the aforefaid Convulfion. ‡

\section{Cна в. 16z. Of the great Centorie.}

$$
\text { Thi Defcription. }
$$

I The great Ccntory bringeth forth round fmooth falkes three cubits high: the leaues are long, diuided as it were into many parcels like to thofe of the Walnut trec, and of an onerworne grayin colour, fomewhat fnipt about the edges like the teeth of a faw. The floures grow at the top of the ftalks in fcaly knaps like the great Knapweed, the middle thrums whereof are of a light blew or sky colour: when the fced is ripe the wholc knap or head turneth into a downy fubftance like the head of an Artichoke, wherein is found a long fmooth feed, bearded at one end like thofe of Baftard Saffron, called Cartamus, or the feed of Cardas Bent. dizzus. The root is great, long, blackc on the out fide, and of a fangurine colour on the infide, fome: what fweet in tafte, and biting the tongue.

2. There is likewifc another fort, hauing great and large leaues like thofe of the water Docke, fomewhat fnipt or toothed about the edges. The ftalke is horter than the other, but the root is more oleous or fuller of iuyce, orherwife like. The floure is of a pale yellow purplinh colour, and the feed like that of the former. 
I Centaurium magnum. Great Centoric.

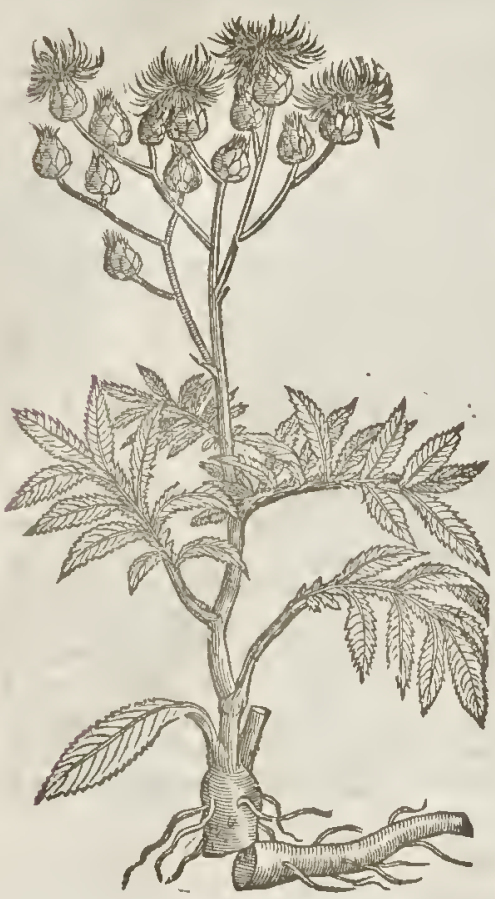

¥ 2 Centaurism mains altcrum. Whole leaued great Centorie.

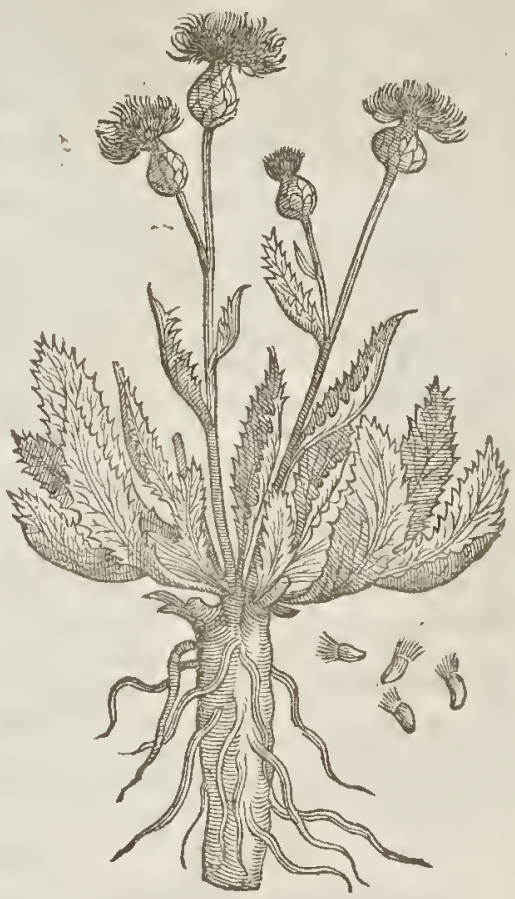

T The place.

The great Centorie ioycth in a fat and fruitfull foile, and in Sunny bankes full of Graffe and herbes. It groweth very plentifully, faith Diofcorides, in Lycia, Peloponnefus, Arcadia, and Mo rea : and it is alfo to be found vpon Baldus a mountaine in the territories of Verona, and likewife in mygarden.

$$
\begin{aligned}
& \text { It floureth in Sommer, and the roots may be gathered in Autumne. } \\
& \text { Tा The Names. }
\end{aligned}
$$

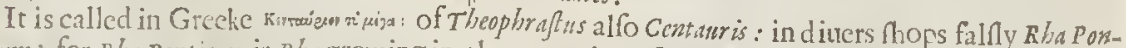
ticum: for Rha Ponticrm is Rha growing in the countries of Pontus; a plant differing from great Centoric. Theopliraftus and $P$ liny fet downe among the kindes of Panaces or All. heales, this great Centorie, and al o the leffer, whereof we will write in the next chapter following. Pliny reciting the words of $T$ theophraftus, doth in his twenty fifth booke and fourth chapter write, that they were found outby churan the Centiare, and fyrnamed Centauria. Alfoaffirming the fame thing in his fixth ehapter (where he mote largely expoundeth both the Centauries) hee repeateth them to be found out by chiron : and thereupon he addeth, that both of them are named Chironia. Of fome it is reported, That the faid chiron was eured therew ith of a wound in his frot, that was made with an arrow that fell vpon it when he was entertaining Hercules into his houfe; whereupon it was called Chironium : or of the curing of the wounds of his fouldiers, for the wh ich purpofe it is moft ex-
cellent.

$$
\text { प The Temperature. }
$$

It is hot and dry in the third degree. Galen faith, by the tafte of the root it fhereth contraric qualities, fo in the vfe it performcth contrarie effects.

$$
\text { 9T The Vertues. }
$$

A The root taken in the quantitic of two drans is good for them that be burfen, or fpit bloud. againft the crampe and thrinking of finewes, the thortneffe of wind or difficultie of breathing, the congh and gripings of the belly.

B There is not any patt of the herbe but it ratherworketh miracles than ordinariecures in greene wounds; for it ioyneth together the lips of frmple wounds in the flerh, aceording to the firft intentention, that is, glewing the lips together, not draving to the place any matter at all. 
L 1 в. 2. Of the Hiltory of Plants.

The root of this Plant (faith Diofcorides) is a remedie for ruptures, crizulfozs, and cramps, ta- A ken in the weight oftwo drams, to be giuen with wine to thofe that are without a feut, and vinto thofe chat haue, with water.

Galen faith, that the inyce of the leaues thereof performeth thofe things that che root doth ; B which is alfo vfed in ftead of Lycium, a kinde of hard iuyee of a fharpe tafte.

\section{Chap. 163: Of Small Centorie. \\ Tा The Defcription.}

I $T$ He leffer Centorie is a little herbe : it groweth vp with a cornered falke halfe a foot high, with leatus in forme and bigneffe of S. Iohns wort : the floures grow at the top in a fpoky buh or rundle, of a red colour tending to purple; which in the day time and after the Sun is vp do open themfelues, but towatds euening hut vp againe: afrer them come forth fmall feed-veffels, of the thape of wheat cornes, in which are contained very little feeds. The root is flender, hard, and foone fading.

2 The yellow Centorie hath Jeaucs, ftalkes, and feed like the orher, and is incach refper alike, fauing that the floures hereof are of a perfect yellow colour, which ferteth forth the difference.

\# This is of two forts; the one with broad leaues through which the falkes paffe; and the other hath narrow leaues like thofe of the common Centoric. $\neq$

I Centauritum parvum.

Small Céntorie.

Chiroma Centaurixan:

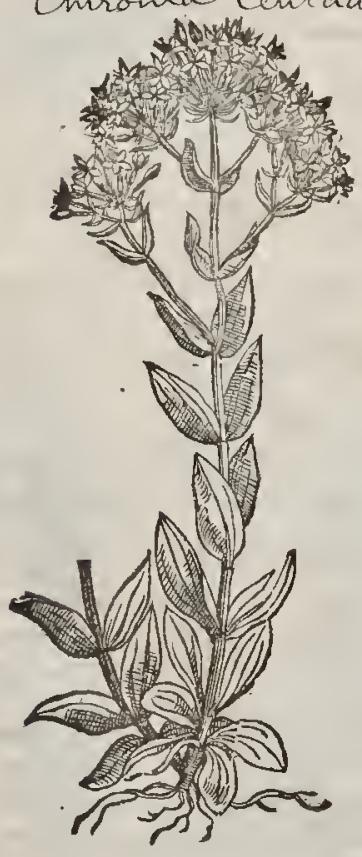

2 Contatrium parvum lutesm Lobelï. Yellow Centoric.

Chlora peryotrata.

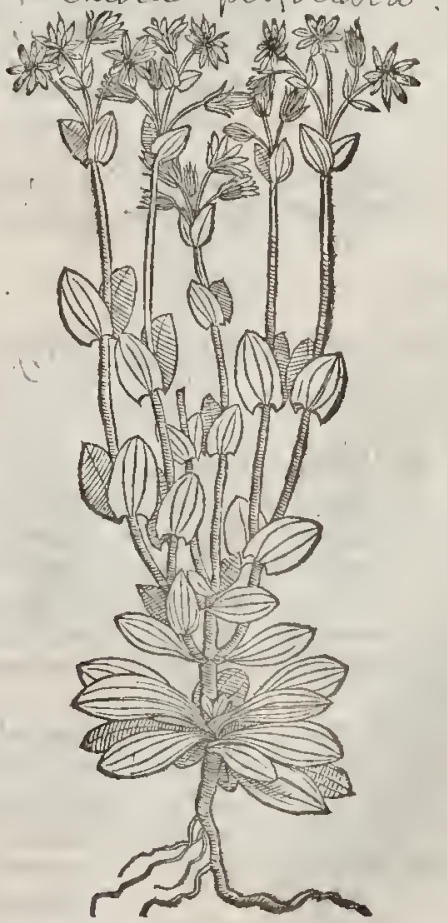


- The Time.

They are to be gathered in their flouring time, that is in Iuly and Auguf : of fome that gather them fuperfitioufly they are garhcred betweene the two Lady dayes.

of The Names.

The Greekes call this Kurweur purat : in Latine it is called Contantium minus; yet Pliny nameth it Libadion, and by reafon of his great birterneffe, Fel terra. The Italians in Herruria call it Biondcl. $\checkmark a$ : in Spanifh, Certoria: in low-Dutch, Centozye: in Englifh, Small, lirtle, or common Centorie : in French, Centoire.

9T The Temperature.

The fmall Centorie is of a bitter qualitie, and of temperature hot and dry in the fecond degree; and the yellow Centorie is hot and ciry in the third degree.

\section{The Vertues.}

A Being boyled in water and drunke it openeth the ftoppings of the liuer, gall, and fpleene, it helpeth the yellow jaundice, and likewife long and lingering agues : it killeth the wormes in the bellie; tobebriefe, it cleanferh, fcourerh, and makerli thinne humors that are thicke, and doth cffeEtually performe whatfoeuer birter things can.

B Diofcorides, and Galen after him report, that the decofion draweth downe by fiege choler and thiche humors, and helpeth the Sciatica; but though wee haue vicd this often and luckily, yet could we not perceite euidently thar it purges by the ftooleany thing at all,and yet it hath performed the effects a forefaid.

C This Centoricbeing ftamped and laid on whilet it is freth and greenc, doth healc and clofe vp greene wounds, cleanfeth old vlcers, and perfeetly cureth them.

D The ityce is good in medicines for the eyes; mixed with honey it cleanfeth away fuch things as hinder the fight; and being drunke it hath a peculiar vertue againft the infirmities of the finues, as Diofcorides reacheth.

E The Italian Phy fitions do gitue the pouder of the leaues of yellow Centorie oncc in three daies in the quantiric of a dram, with annife or caraway feeds, in winc or other liquor, which preuailerh againft the dropfie and greene fickneffe. Of the red foured, loanes Poftius hath thus written : :

Flos milbi fuatue rubet, fed ineft quoque fuccus amarus, Quijuzat objeffum bile, aperifque jecur.

My floure is fwcet in fmell, bitter my iuyce in tafte,

Which purge clioler, and helps liuer, thatelfe would wafte:

\section{H P. 164. Of Calues frout, or Snapdragon. \\ T) The Deforiprion.}

I The purple Snapdragon hath great and brittle falks, which diuidcth it felfe into many fragile branches, whereupon dogrow Iong leaues tharpe pointcd, very greene, like viro thofe of wilde Hax, but nuch greater, fet by couples one oppofite againft another. The fioures grow at the top of the ftalkes, of a purple colour, fathioned likea frogs moutl, or rather a dragons mouth, from whence the wonen haue taken the name Snapdragon. The feed is blacke, contained in round huskes fathioned like a calues fnout, (whereupon fome haue called it Calues finout) or in mincopinion it is more like vnto the bones of a theeps head that hath beere long in the water, the fleth confumed cleane away.

2 The fecond agreeth with the precedent in euery part, except in the colour of the fioures, for this planr bringeth forth whire foures, and the other purple, wherein confifts the difference.

3 The yellow Snapdrazon harh a long thicke wooddy root, with certain frings fafted thereto; from which rifeth vp a brittle falke of tivo cubits and a halfe high, diuided from the bottome to the top into diuers branches, whereupon doe grow long greene leaues like thofe of the former, burgrearer and longer. The floures grow at the top of the maine branches, of a pleafant yellow colour, in thape like vntorhe precedent.

4 The finall orwilde Snapdragon differeth not from the others but in fature: the leaues are leffer and narrower : the floures purple, but altogether fmaller : the heads or feed-vefels are alfo like thofe of the former.

₹ 5 There is another kinde hereof which hath many flender branches Iying of times vpon the ground: the leaues are much fimaller than thefe of the laft defcribed : the foures and fed-verfels are allo like, but inuch leffer,and herein confifts the onely difference. + 
LIB. 2.

Of the Hiftory of Plants.

549

1.2. Antirrhinum purpurenm fiue album. Purple or white floured Snapdragon.

Anturhion majus.

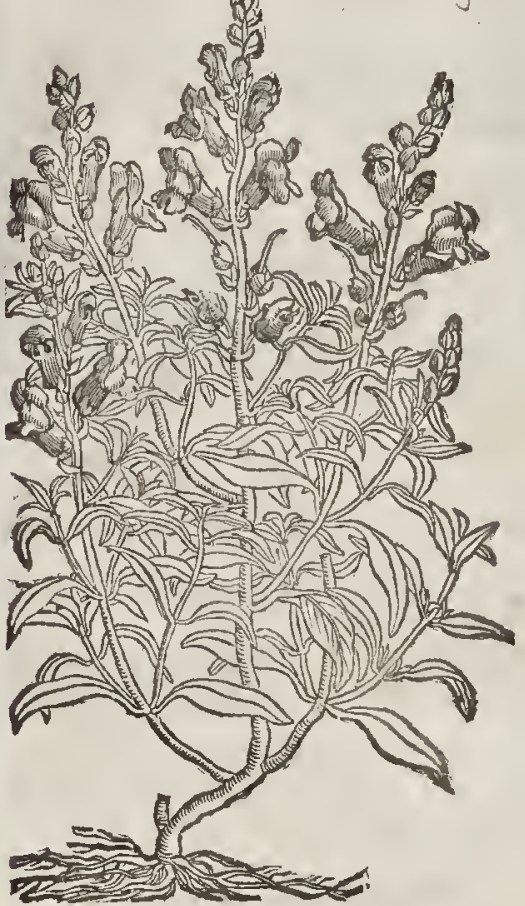

4 Antirrbisum minus.

Sinall Snapdragon.

entirnhinume Orostiem

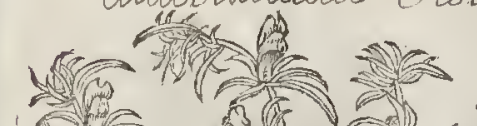

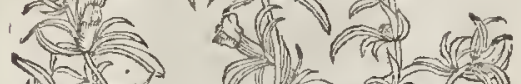

mula hen

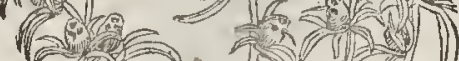

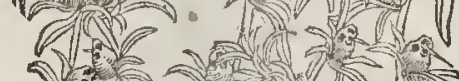
(1) Non $\checkmark$ ancon a.

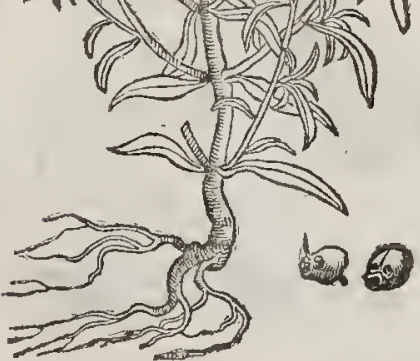

3 Antirrhinum luterm.
Yellow Snapdragon.

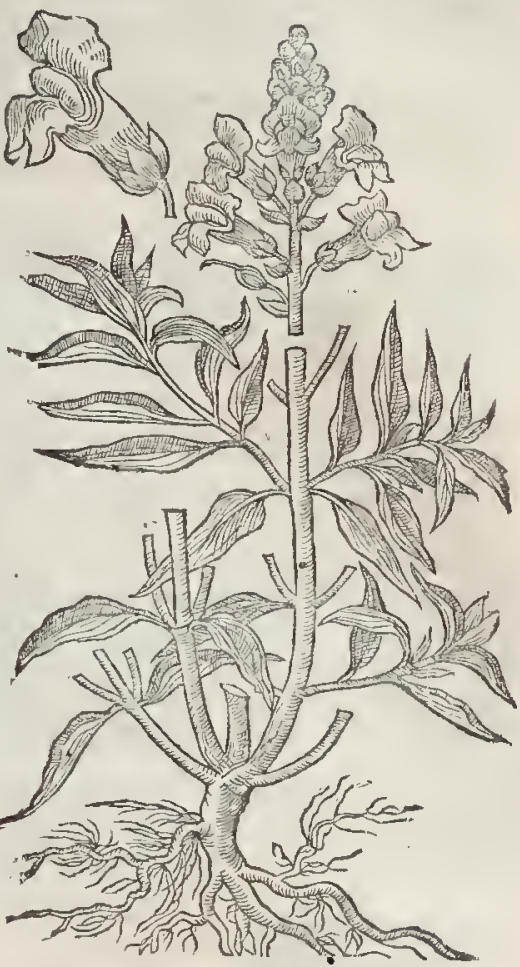

\# 5 Antirbinum miximum repens. Small creeping Snapdragon.

omirorivum inires

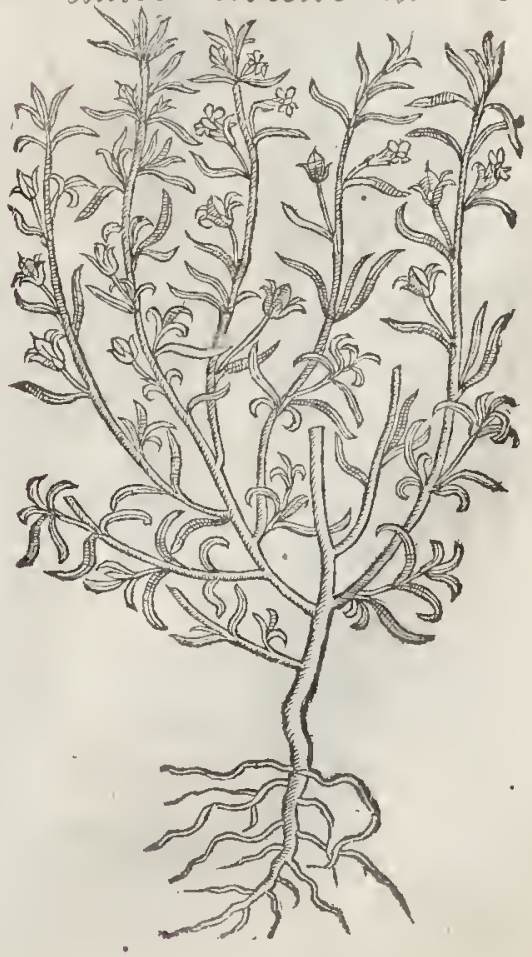


If The Place.

"The three firf grow in moft gardens; but the yellow kinde groweth not colnmon, except in the gardens of curious: Herbarifts,

$\ddagger$ The fourth and fifth grow wilde amongft corne in diuers places. $\ddagger$

9ा The Time.

That which hatly continued the whole Winter doth foure in May, and the reft of Sommer afterwards; and that whieh is planted later, and in the end of Sommer, floureth in the fpring of the
following yeare : they do hardly cndure the iniurie of our cold Winter.

Snapdragon is ealled in Greetc witho : in Latine alfo Antirybinum: of Apuleius, canis cerebrum, Herb. Simiana, Veinf a minor, opalis grata, and orontium : it is thought to be Lco berba, whieh Coln. mella, $h 6.10$. reckons among the floures: yet Gefner hath thought that this Leo is Colsmbine, which for the fame eaufe he hath ealled Lcontostomium : but this name feemeth to vs to agree better with Calues fnout than with Colimbine; for the gaping foure of Calues fnout is more like to Lyons fnap than the floure of Columbine: it is called in Dutch Dzant: in Spanifh, Cabeza de termera: in Englin, Calues fnour, Snapdragon, and Lyons fnap : in French, Tefte de chien, and Tefte de Vcan.

They are hot and dry, and of fubrill parts,

$$
\text { Ti The Tempcralure. }
$$

$$
\text { Qt The Vertues. }
$$

A The feed of Snapdragon(as Galen faitly) is good for nothing in the vfe of phy ficke; and the lierb it felfe is of like facultie with Bubonimm or Star-wort, but not foeffectuall.

B They report (faith Diofiorides) that the herbe being hanged about one preferuetha man from C being bew itehed, and that it maketh a man graeious in the fight of people.

C Apuleius writeth, that the diftilled water, or the decoetion of the herbe and root made in water, is a fpeedy remedy for the watering of eyes proceeding of a lot eaufe, if they be bathed therewith.

CHAP.165. Of Tode-Flax.

I Linariavulgaris luta.

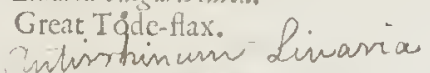

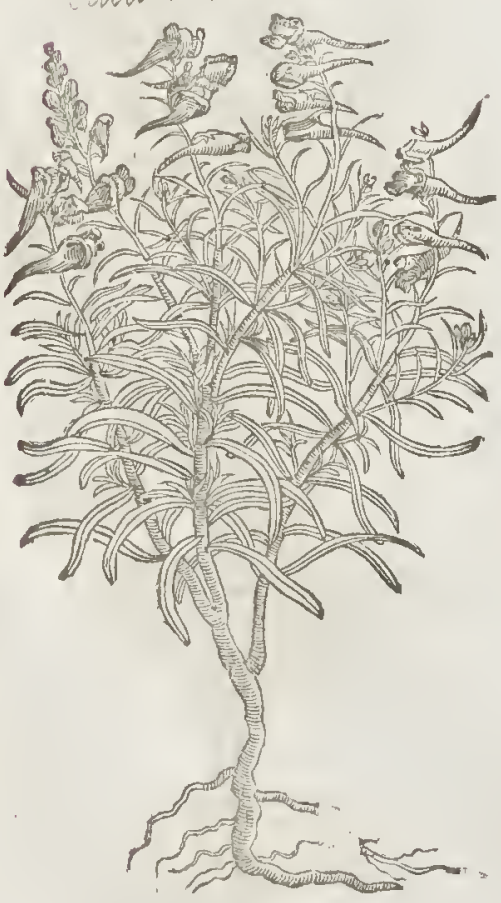

2 Linaria purpurea odorata. Swect purple Tode-flax.

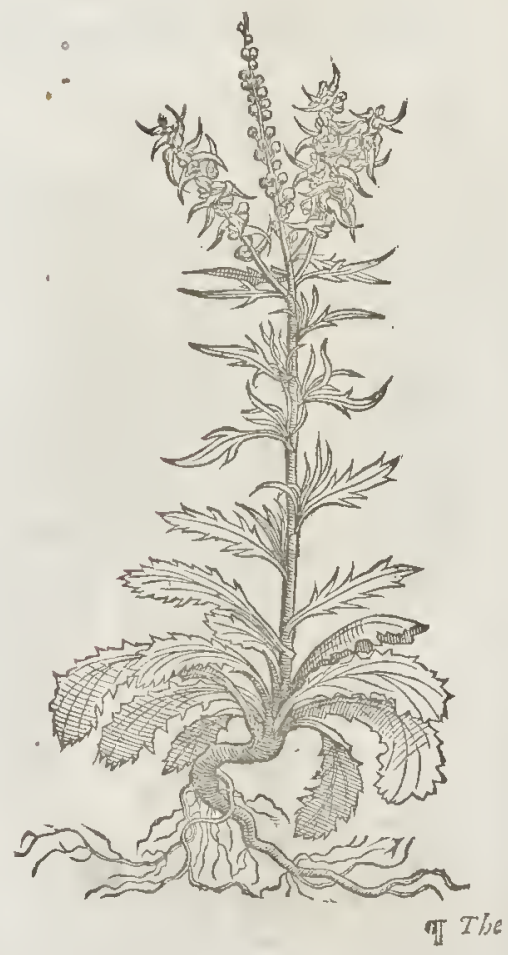




\section{If The Defcripion.}

I Inaria being a kinde of Antyrrhinum, hath frmall, nender, Elackifh ftalkes; from whieh do Grow many long narrow leaties like flax. The foures be yellow, with a fpur hanging at the fame like vnto a Larkes Ppur, hauing a mouth like vnto a frogs mouth, euen fuch as is to bee feene in the eommon Snapdragon; the whole plant before it eome to foure fo mueh re. fembleth Efula minor, that the one is hardly knowne from the other,but by this old verfe:

\section{Efula lactefirt, fine lacte Linaria crefoit: \\ $¥$ Efalawith milke doth flow, \\ Toad-flaxwirhout milke doth grow. $\neq$}

2 The feeond kinde of Tode-flax hath leates like varo Bellis maior, or the great Dafie, but not febroad, and fomewhat ingged about the edges. The ftalke is fmall and tender, of a cubit hight, befet with many purple floures like vnto the former in fhape. The root is long, with many threds langing thercat, the floures are of a reafonable fweet fatour.

3 The rhird, being likewife a kinde of Tode-flax, hath fmall and narrow leanes like vnro the firfthinde of Linuria : the ftalke is a eubit high, befet with floures of a purple colour, in fathion like Linaria, but that it wanteth the taile or fpure at the end of the flourewhieh the other hath. The root is fnall and threddic.

+4 Linaria falcutinath hath Jeates like the lefier Centorye, growing at the bottome of the ftalke by three and three, but higher vp torvards the top, without any ecrtaine order: the falkes are of a foot high, and it is ealled by Cluf ous, Valentina, for that it was found by himfelfe in Agro Valentino, about Valentia in Spaine, where it beareth yellow floures about the top of the stalke like common Linaria, but the mouth of the floure is downie, or mofrie, and the taile of a purple eolour. It Hourcth at Valentia in March, and goweth in the medowes there, and hath not as yet been feene in thefe Northesne parts.

5 ofyris alba hath great, thiek, and long roots,with fome threds or ftrings hang ing at the fame; from which rifevp many branehes very tough and pliant, befer towards the top with floures not m tel vilike the eommon Toad-fiaxe, but of a pale whitinh eolour,and the inner part of the mouth fo mewhat more wide and open, and the leaties like the common Tode-flax.
† 3 Linaria purpurca altcra.
+ 4 Linaria Valentia Cluf:
Variable Tode-flax. Tode-flax of Valentia,
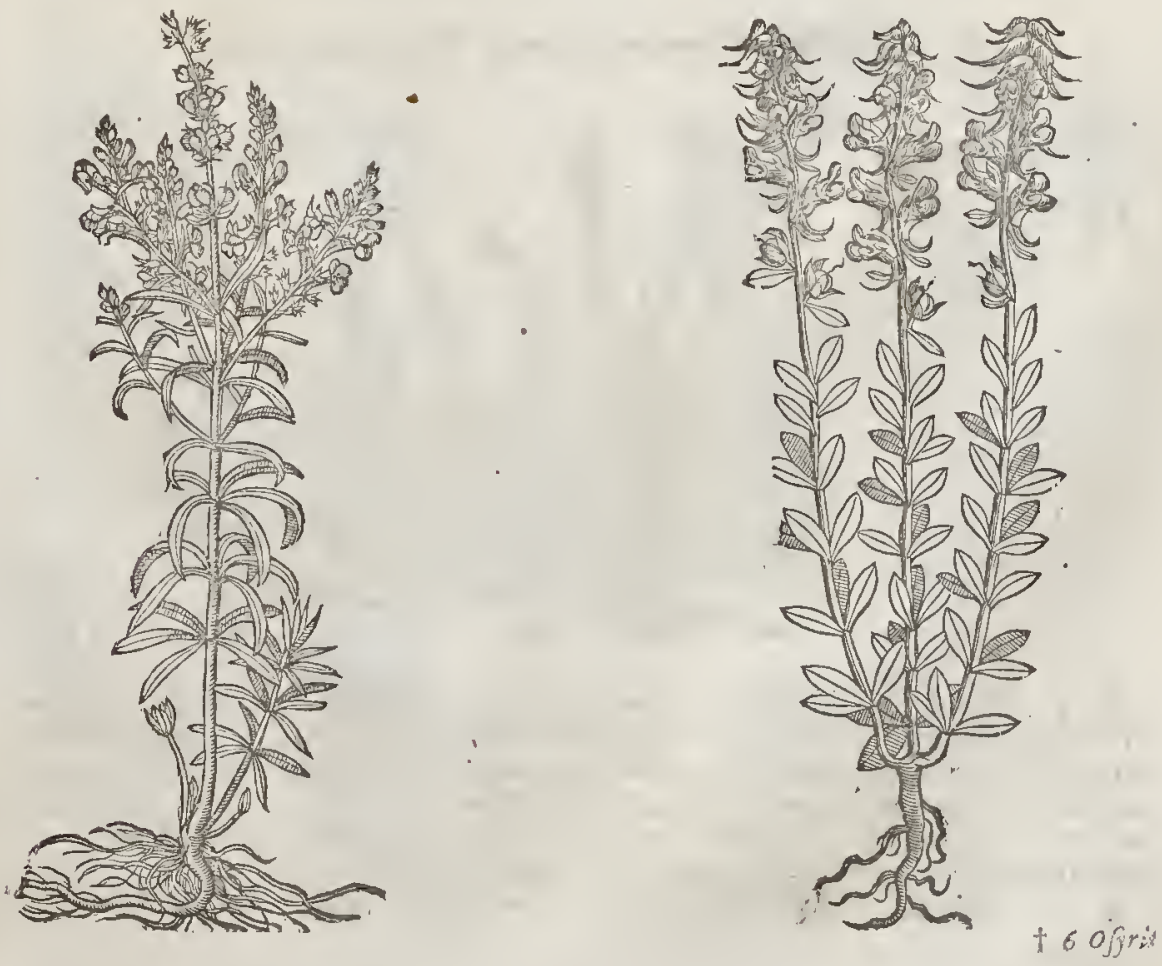
I 5 ofyris alba, Lob. White Tode-flax.

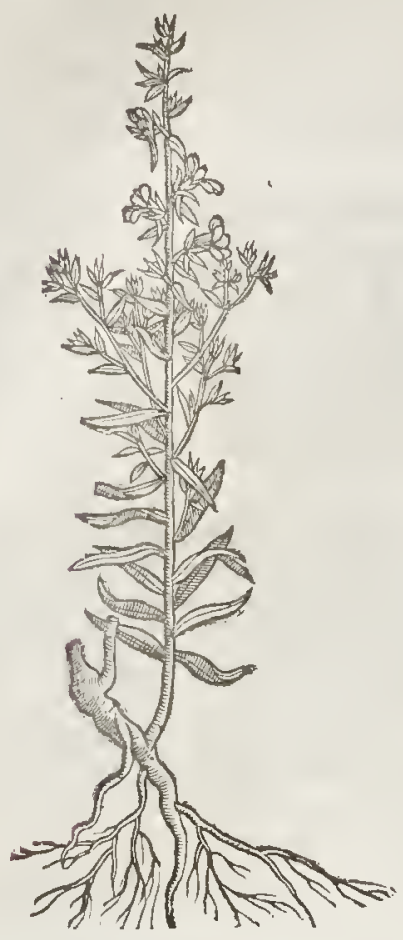

6 ofyris parpurucarulea is a kinde of Todefax that hath many fmall and weake branches, trailing vpon the ground, befer with many Jirte leaues like flaxe. The foures grow at the top of the ftalke like vnto the common kinde, but of a purple colour declining toblewneffe. The root is fmall and threddie.

\# This hath many mall creeping branches fome handfull or better high,and hath fuch leaues, floures, and feed, as the common kinde, but all of them much leffe, and therein confifteth the difference. It growes naturally in the dry fields about Salamanca in Spaicue, and foures all Sommer long. Lobel calls it ofyris flova fylucftris; and Ciufus, Linaria Hifpanica.

8 The branches of this eight kind are fpred vpon the ground, and of the length of thore of the laft defcribed : the leaues are leffer than thofe of the common Tode-flax, thicke, iticic, and of a whitith greenecolour, and they grow not difor derly vpon the falks, but at certaine fpaces fome. times three, but moft vfually foure together: the floures in thape are like thofe of the ordinarie kinde,but of a mont perfest Violet colour, and the lower lip where it gapes of a golden yellow, the tafte is bitter. After the floures are paft come veffels round \& thick, which contain a Hat black feed in two partitions or cells: the root is flender, white, and long lafting, and it floures vnto the end of Autumne. It grows naturally vpon the highed Alps. Gefner cals it Linaria Alpira: and Clufins, Limariatertia Styriaca. $\neq$

t 6 ofyris Purpurocarulearepens. Purple Tode-Alaxe.

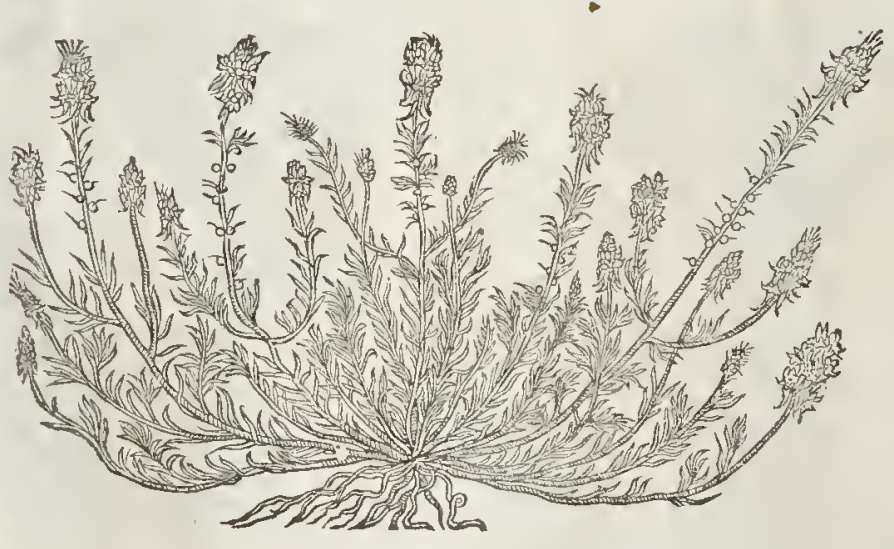

† Forafmuch as this plant is ftalked and leafed like common Flaxe, and thought by fome to be Ofyris; the new writers haue called it Linofyris: it hath ftalkes very ftiffe and wonddie, befet with leates like the common $L$ inarid, with foures at the top of the ftalkes of a faint Thining yellow colour, in forme and fhape fomewhat like unto Cony a mitior. The whole plant groweth to the height of two cubits, and is in tafte fharpe and clammie, or glutinous, and fomewhat bitter. The root is compact of many ftrings, intangled onewithin another.

† 10 Gsillandinus calletly this plant Hyfopus ambellifer Dioforidis, that is, Diofcorides his $\mathrm{Hy}$. 
fope, which beareth a tuft in all points like Linofyris, whereofit is a kinde, not differing from it in Thew $\&$ leaues. The ftalks are a cubit high, diuided aboue into many fmall branehes, the tops wherof are garnithed with tufts of fmall floures, each little floure being parted into fiuc parts with a lit tle thred or peftell in the middle, fo that it feemes full of many golden haires or thrums. The feed is long and blackifh, and is carr ied away with the winde. $\neq$ Bashine in his $P$ inax makes this all one with the former, but vnfitly, efpecially if you marke the defcriptions of their floures which are far vnlike. F abius Columan hath proued this to be the Chryfocome deferibed by $D i$ ofs.lib.4.6ap.55.

\section{\# Ofyrisfluafyluestris. Creeping yellow Tode-flax.}

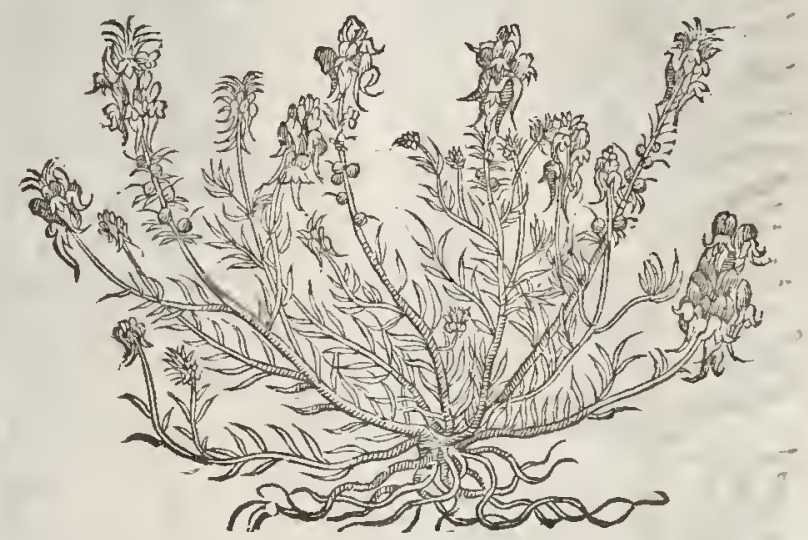

* 8 Linaria quadrifoliafupina.

Foure leaued creeping Tode-Hlax: to Linofyris Nuperorim, Lob: Golden Star-floured Tode-flax:
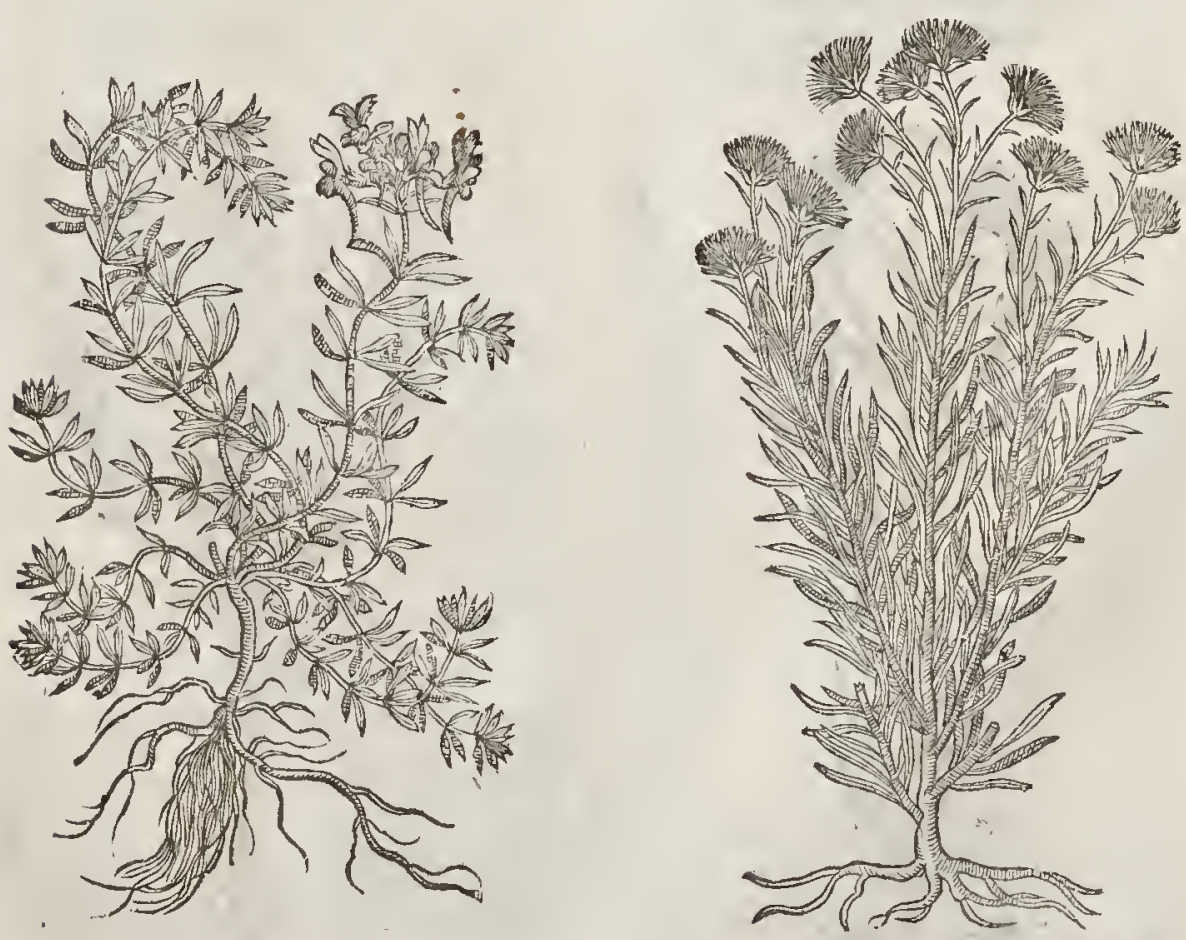
10 Linaria aurca Tragi. Golden Tode-flax.

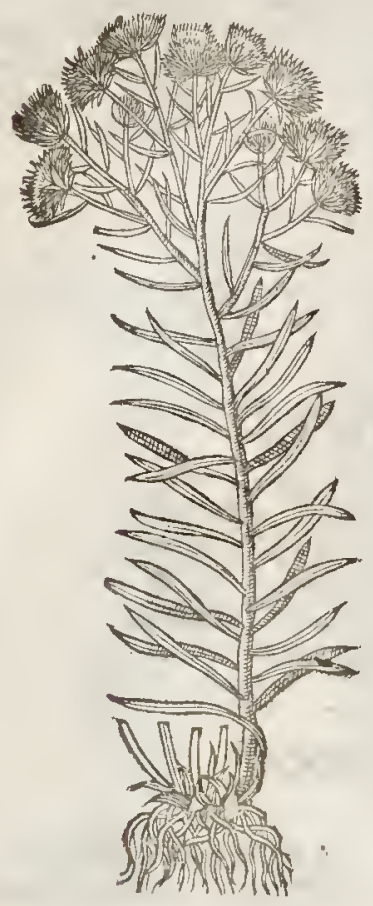

+ 7.2 Paferinalinaria folio, Lob. Sparrowes Tode-Hax.

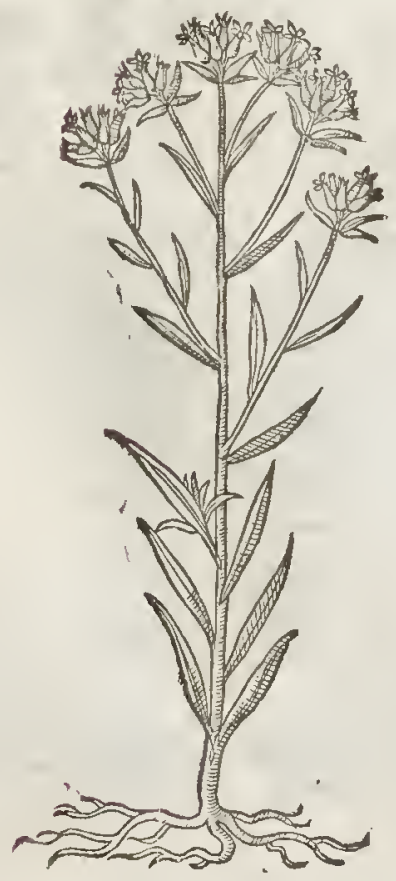

II Scopariafive ofyris Grecorwm. Buhicor Befome Tode-fax.

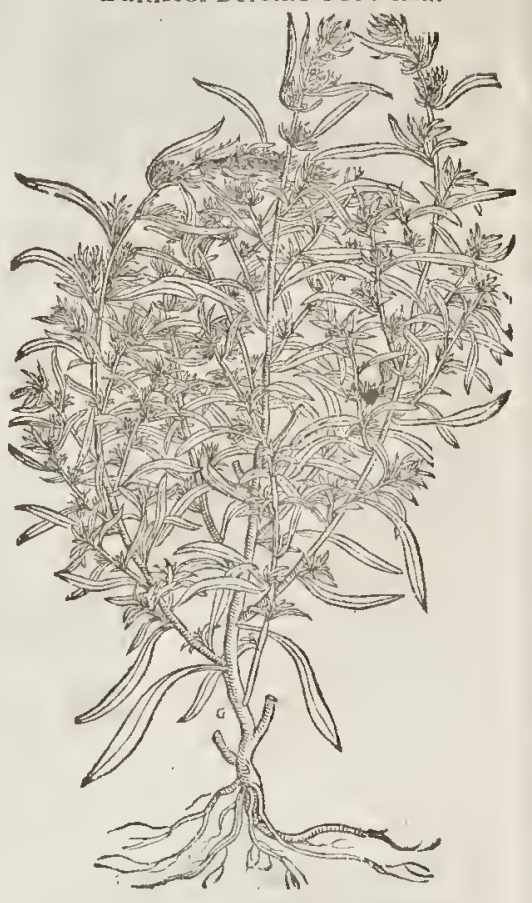

+ 13 Pafjerina altera. Sparrow-tongue.

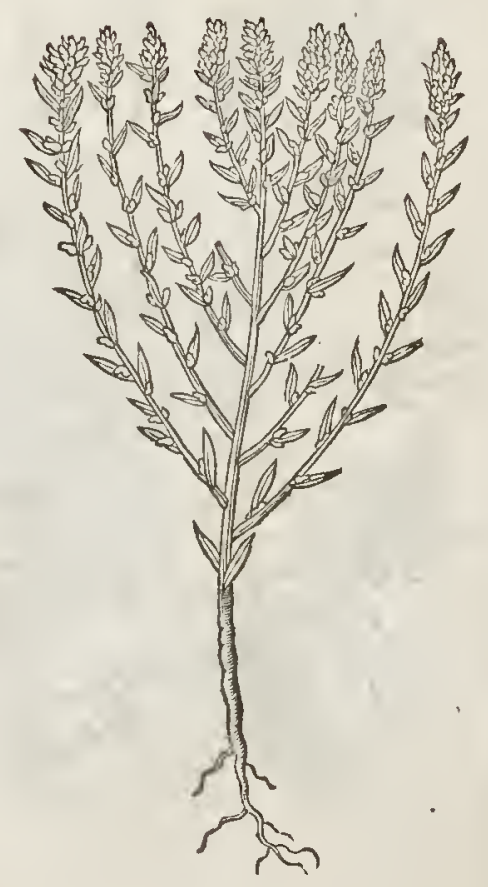


I 4 Limaria adulterinid.

OS Baftard Todg-flax. *ilf 2021

(1).

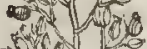

$\Rightarrow$

S. 0.4 .

$\rightarrow 10$

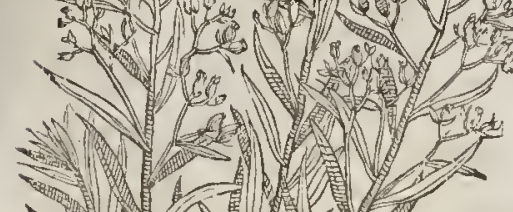

( in
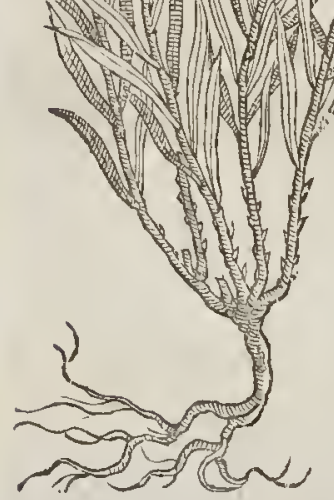

$\dagger$ II Scopsrig, or after Dodomates, ofyris, which the Italians cal Belvidere, Inath very ma. ny thoots or fprigs rifing from one fmal ftalk, making the whole plant to refemble a Cypres tree, the branches grow fo landfomely ! now it growes fome three foot hight,and very thick and burhie, fothat in fome places where it naturally groweth they make befones of it, whereof it tooke the name Scoparia. The leates be fmall and narrow, almoft like to the leates of flax. The floures be fintall, and of an hearbie colour,growing among the leaues, whicli keep greene all the Winter. $\neq$ I neuer knew it here to ripen the feed, nor to ont-liue the firft froft, $\neq$

I2 This plant alfo for refemblance fake is referred to the Linaries, becaufe his leautes be iike Linaria. At the top of the finall branched Atalks do grow litrleyellowinh floures, pale of colour, fomew hat like the tops of $C /$ / ryfocome. Iohn errouton of Turnay taketh it to be Chryfocome altera. And becaufe there hath bin no concordance among Writers, it's fufficient to fet forth his defcription with his name $P$ affferina. $\neq$ Batbine refers it to the Gromills, and calls it Lithopermum Linarief folio Monpeliactins.

¥ 3 This which $T$ ubem. calls Lingun Paferima, and whofe figure was giten by our Authour for the former, hath a finall fingle whitifh roor, from which it feisds vp a flender ftalke fome cubit and halfe ligh, naked on the lower part,but diuided into litrlebranches on the vpper, which branches are fet thicke with little narrow leaues like thofe of Winter Sauoric or Tyme: amongft which grow many little longith feeds of the bigneffe and tafte of Millet, but fomewhat hotter and bitterer. The floures confift of foure fmall yellow leates. Tragus calls th is Paferina; Dodonaus makes it Lithopermum minus: and Columna hath fet it forth by the name of Linaria altera botryodes montma. $\neq$

\# I4 This which Cluf Ims, hath fet forth by the name of Anomymos, or Nameleffe, iscalled in the Hist.Lugd.pag. I I50. Anthyllis montana; and by Taborn.Linariadulterina. It hath many hard pale greene branches of fome foot high; and vpon the fe without any order grow many hard narrow long leaues like thofe of flaxe, at firft of a very tart, and afterwards of a bitterifh tafte: the tops of the ftalkes are branched into fundry foor-ftalkes, which carry little white floures confinting of fure fnall leaues lying ftarre-fathion, with fome threds in their middles : afterwhich at length come fingle feeds fiue cornered, containing a white pith in a hard filme or skin. The root is white, diuided into fundry branches, and lines long,etery yeare fending vp many ftalkes, and fontetimes cree. ping like that of Tode-flax. It flotres in May, and grows vpon mountainous places of Germany. $M^{*}$.Goodyer found it growing wilde on the fide of a chalkie hill in an inclofure on the right hand of the way, as you goe from Droxford to Poppie hill in Hampthire. $\dot{f}$

\section{T) The Place.}

The kindes of Tode-flax grow wilde in many places, as vpon ftone walls, grauelly grounds, barren medowes, and along by hedges.

\# I do not temember that I hate feene any of thefegrowing wildewith vs, vnleffe the firft ors dinary kinde, which is enery where common. $\ddagger$

They floure from Iune to the end of Auguft.

$$
\text { 9 The Time. }
$$

$$
\text { T T The Names. }
$$

t Tode-flax is called of the Herbarits of our time, Linaria; or Flax-weed,and Vrinalis: of fome,

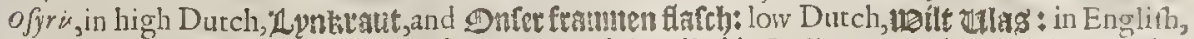
Wild-flax, Tode-flax, and Flax-rveed: the cleuenth is called in Italian, Bel-videre, or Faire in fight. The fame plant is alfo called scopariag, and Herba ftudioformm, becaufe it is a fit thing to make brooms 
of,wherewith fehollers and ftudents may fwcepe their owne ftudies and clofets. The particular names are expreffed both in Latine and Englin in their feuetall titles, whereby they may be difunguirhed. $\neq$ It is thought by moft that this Belvudere, or Scoparia is the 0 fy ris deferibed by $D$ iofico. rides lib.4.cap. I 4 ? For befides the notes, it hath agreeing with the defeription:it is at this day by

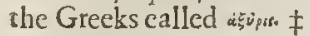

\section{T The Temperature.}

The kindes of Tode-flax are of the fame tempcrature with wilde Snap-dragons, whereof they are kindes.

$$
\text { The Vertues. }
$$

A The decoction of Tode-flax taketh away the yellowneffe and deformitic of the skinne, beeing wathed and bathed therewith.

B The fame drunken, openerh the ftoppings of the Liucr and fpleene, and is fingular good againft the iaundife which is of long continuance.

C The fame decodtion doth al fo prouoke vrine, in thofe that piffe drop after drop, vnftoppeth the kidneics and bladder.

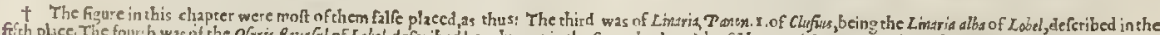
friber by me was if the Lineria

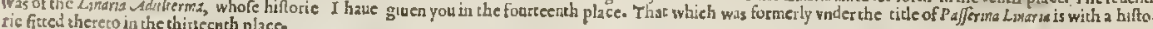

\section{C н а .166. Of Gardenflaxe.।}

+ I Linsws fativum.

Garden flax.

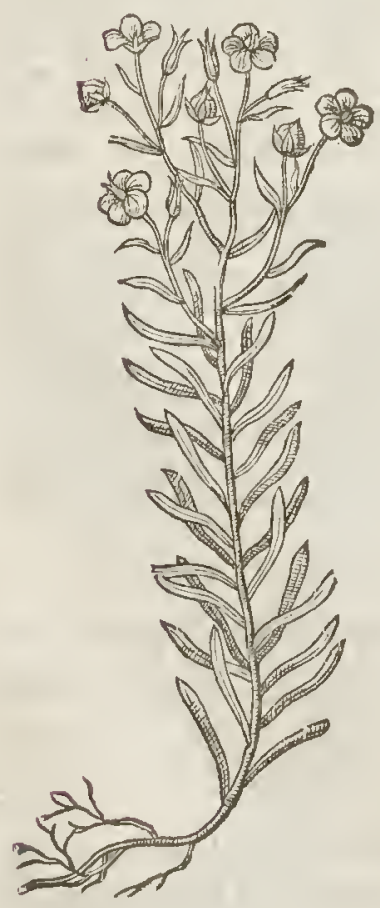

The Defription.

FLaxe rifeth vp with flender and round ftalks The lcaucs thereof bec long, narrow, and fharpc pointed : On the tops of the lprigs are faire blew flourcs, after which fpring vp little round knops or buttons, in which is contained the feed, in forme fomewhat long, fmooth, glib or flipperie, of a dark colour. The toots be fmal and threddie.

\section{Tा The Place.}

It profpereth beft in a fat and fruitfull foile; in moift and not dric places; for it requireth as Columella faith a very fat ground, and fomewhat moift. Some, faith Palladtus, do fow it thicke in a lcane ground, \& by that means the flax groweth fine. Pliny faith that it is to be fowne in grauelly places, efpecially in furrowes: Nec magis feftinare alind: and that it burneth the ground, and maketh it worfer:which thing alfo Virgil teftificth in his Georgickes.

Vrit lini campum feges, arit Luena. Frunt letheo perfusapapausera fommo.

In Englin thus:

Flaxe and Otes fowne confume The moifture of a ferrile ficld: The fame worketh Poppie, whofe Iuice a deadly fleepe doth yeeld. 


\section{The Time.}

Flaxe is fowne in the fpring, it floureth in Iune and Iuly. After it is cut downe (as Pling in his 19.booke, firft chapter faith) the ftalkes are put into the water fubject ro the heate of tbe funne, and fome weight laid on them to be fteeped therein; the loofenes of the rinde is a figne when it is well fteeped : then is it taken vp and dried in the funne, and after vfed as moft hulviues can tell better than my felfe.

It is called both in Greeke and Laine hior: Linum : in high Dutch, flachiz: in Italian and Spatnith, Lino: in Ftench, Dulin: in low Dutch, oulas: in Englih, Flaxe, and Lyne.

$$
\text { of The Tcmperature and Vertuss. }
$$

Galer in lis firt booke of the faeulties of notrinments faith, that diuets vfe the feed hereof $A$ parehẹ as a fuftenacne with Garum, no orherwife than made falt.

They alfovfe it mixed with hony, fome likewife put it nmong bread; but it is hurtull to the $B$ ftomacke, and hard of digeftion, and yeeldeth to the body but lirrle nourihment : but touching the quality whieh maketh the belly foluble, neitler will I praife or difpraife it ; yet that it hath fome foree to prouloke rrine, is mote apparant when it is patehed:but then it alfo ftayeth the belly more.

The fame author in his bookes of faeulties of fimplemedieines faitly,that Linefeed beitigea- C ten is windy although it be patched, fo full is it of fuperfluous moifture: and it is alfoafter a fort hot in the firf degree, and in a meane betweene moift and dry. But how windy the feed is, and how full of fuperfuous moifture it is in euery part, might very well haue been pereciued a ferw yeetes finee as at Middleborough in Zeland, where for want of graine and other corne, moft of the Citizens were faine to eate bread and cakes made hereof with hony and oile, whowere in thort time after fwolne in the belly below the fhort ribs, faces, \& other parts of their bodies in fucl fort, that a great number were brought to their graues thereby: for thefe fymptomes or aceidents eame no otherwife than by the fuperfluous moiture of the feed, which cauferh windineffe.

Lincfeed as Diofcorides hath written, bath the fame ptoperties that Fenugreeke hath : it waiteth away and mollifieth all inflammations or hot fwellings, as well inward as outward, if it be boiled with hony, oile, and a little faire water, and made vp with elarified hony; it taketh away b lemithes of the face, and the funne burning, being raw and vnboiled; and alfo foule fpots, if it be mixed with falt-petet and figs : it caufeth tugged and ill fauouted nailes to fall off, mixed with hony and water Crefles.

It draweth forth of the cheft corrupted flegmeand other filthy humors, if a compofition with E hony be made thereof to lieke on, and eafeth the cough.

Being taken largely wirh pepper and hony made into a eake, it ftirteth vpluit. F

The oile which is preffed out of the feed, is profitable for many purpofes in phyficteand furge- $G$ ry; and is vfed of painters, picture makers, and other artificers.

Ir fofteneth all hard fwellings; it ftreteheth forth the finewes that are fhrunke and drawne to- $H$ getler,mitigateth paine, being applied in maner of an ointment.

Some alfo giue it to drinke to fuch as are troubled with paine in the fide and enllicke; but it I muit be frefh and newly drawne:for if it be old and ranke, it eaufeth aptneffe to vomit, and wirball it ouermuch heateth.

Linefeed boiled in water with a little oile, and a quantity of Annife-feed impoudered and im- $\mathrm{K}$ plaiftered vpon an angina, or any fwelling in the thtoat, helpeth the fame.

It is with good fuceeffe ved plainterwife, boiled invineger, vpon the difeafes called coliaca and I. Dyfenteria, which are bloudy fluxes and paines of the belly.

The feeds Aanped with the roots of wilde Cueumbers, draweth forth fplinters, thornes, btoken $M$ bones, or any orher thing fixed in any part of the body.

The decotion is an exeellent bath for women to fit oner fot the inflammation of the fecret $\mathrm{N}$ patts, becaufe it fofteneth the hardneffe thereof,and eafeth paine and aking.

The feed of Line and Fentgreek made into powder,boiled with Mallowes, violet leanes, Smal- $O$ lage, and Chickweed, vntill the herbs be foft ; then ftamped in a ftone morter with a little hogs greafe to the forme of a cataplafme or pulteffe, a ppeafeth all maner of paine, foftneth all cold tumors or fwellings, mollifieth and bringeth to fuppuration all apofumes; defendeth wounded members from frellings and rankling, and when they be already rankled, it taketh the fame aw ay being applied very warme euening and morning.

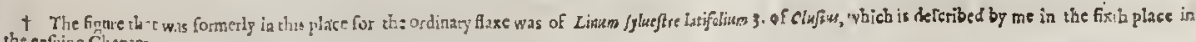
the enfising Clapier.

A a a

CHAT. 
Chas. 167.

\section{Of Wilde Flaxe.}

बा The Defcription.

17

His Wilde kinde of Line or Flaxe hath leaues like thofe of garden Flaxe, but narrower, growing vpon round bright and thining fprigs, a foot long, and floures like the manured flaxe, but of a white colour.The root is tough and fmall, with fome fibres annexed thereto. $\neq$ This is fometimes found with deep blew floures, with violet colouted floures, and fometimes with white, ftreaked with purple lines, $\ddagger$

I Linum Syluejtre floribus albis.

Wilde white flaxe.

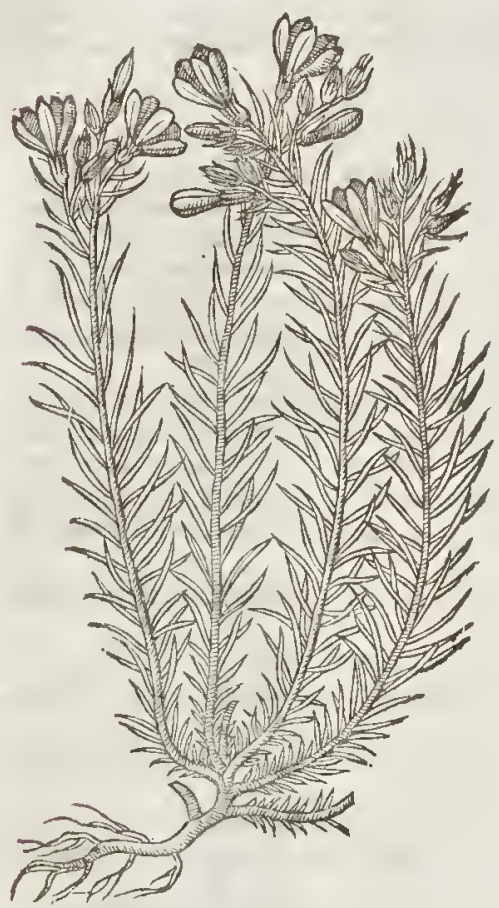

2 Linum flvefretenuifolium. Thin leaued wilde flaxe.

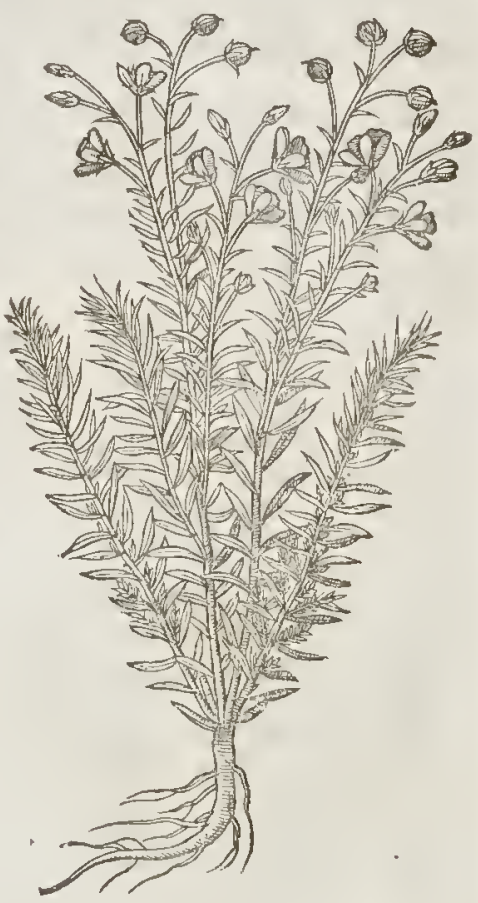

2 The narrow and thinne leafed kinde of Line is rery like to the common flaxe, but in all points leffer. The floures confift of flue leaues, which do foone fade and fall away, hauing many ftalkes proceeding from one root, of a cubit high, befet with fmall leaues, yea letfer than thofe of Linaria purpurca.

¥ Our Author in the former edition gane two figures vnder this one titlc of $L$ inum fylveftre tenuifolium, making them the fecond and rhird; but the defcription of the third was of the Rough broad leaued wilde flaxe, whofe figure therefore we haue put in that place. Now the two whofe figures were formerly here are but varieties of one fpecies, and differ thus; the former of them (whofe figure we haue omitted as impertinent) hath fewer leaues, which therefore ftand thinner vpon the ftalke, and the floures are eirher blew or elfe white. The later, whofe figure you may finde here fet forth, hath more leaues, and thefe growing thicker together: the foure is of a light purple or flefh colour. $\neq$

3 There is a kinde of wilde flaxe which hath many hairy branehes, rifing vp from a very fmall root, which doth eontinue many yeeres without fowing, inereafing by roors into many orher plants, with falles amounting to the height of one cubite, befer with many rongh and hairy broad leaues : at the top of the ftalkes do grow many blew floures, compair of fiue leaues, much greater and fairer than eonmon Line or flaxe; which being patt, there fucceed fmall tharpe pointed heads full offeeds, like I. inefeed, but of a blackifh thining colour. 


\section{Li в. 2. Of the Hiftory of Plants.}

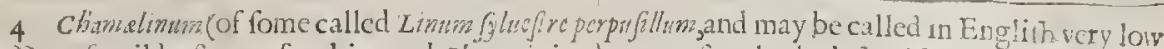
or Dwarfewilde flaxe; for this word chame ioned toany fimple, ctoth fignifie, thar it is a low or dwarfe kinde clereof) becing fcarce an handfull high, hatl pale ycllow floures : bue as it is inall things like vnto flaxe, fo the floures, leaues, and falkes, and all other parts thereof, are foure times lefer than Lintm.

₹ 5 There is alfo growing wide in this king dome a fnall kinde of wilde Aaxemhich I take to be the Limucarpos defcribed by $T$ kaliws, and nentioned by Camurarizs, by the name of Linum cylueftrepuffllum candicantibus figribus. Anno 1629 , when as I firf found it, in a Iournall (written of fuch plants as we gathered) I fot downe this by the name of Limerm (yluef re pufllim candides floribus, which my friend Mr.Iobr Goodyer lecing, he told me he had long knowne the plant,and refer'd it to Lines. but there verefome which calicd it in Englih, Mil-mountaine, and ved it ropurge, and of late he hath fent me this hiforic of it, which you thall laue as I receited it from hius.

$$
\text { Linum fylueftrecatburticmm. Mil-mountaine. }
$$

It rifetl vp from a fmall white threddy crooked root, fometinc with one, but moft commonly with fiuc or fix or more round ftalks, about a foot or nine inches high, of a brow ne or reddifh color, euery ftalk diuiding it felfe neere the top, or from the middle vpward into many pas:s or branches of a greener colour than the lower part of the falke : the lcaucs are fmall, fmootl, of colour green, of the bignes of Lentill leates, and hate in the middle nne rib or finew, and no more that mabee perceitued, 2 grow along th the ftalke in very good order by couples, one oppofite againft the other: at the tops of the fmall branclies grow the floures, of a white colour, confiting of fiue fmall leatues apiece, the nailes whercof are yellow : in the infide are placed fmall thort clivies alfo of a yellow colour, after which come ip little knobs or butenns, the top whereuf when the feede is ripe diuidetl it felfe into fute parts; wherein is contained fmal!, fmooth, Hat, lippery, yellow feed:when the feed is ripe the herbe perithet : the whole herbe is of a bitter tafte, and herby fmell. It groweth plentifully in the vnmanured inclofures of Hamphire, on chalkic downs, \&z on Purfleet hils in Effex, and in many other places. It rifeth forth of the ground at the beginning of the Spring,and floureth all the Sommer.

\# Limum fluefrelatifolium. Broad leaucd Wilde flax.

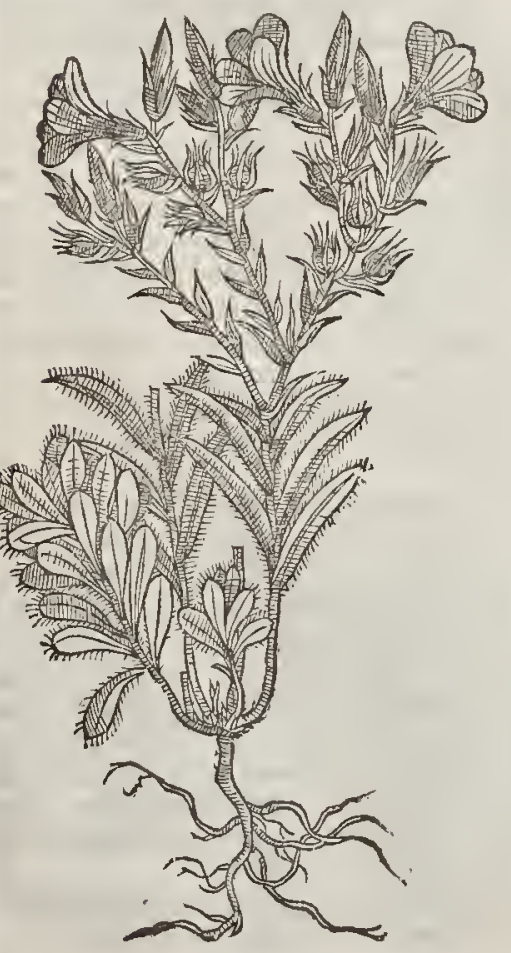

4 Clamelinum perpufiulum.

Dwarfe Wilde flax."

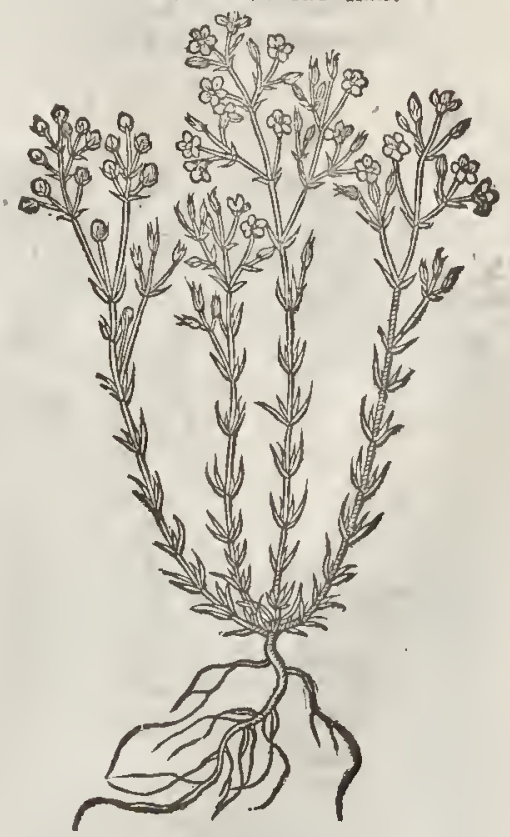




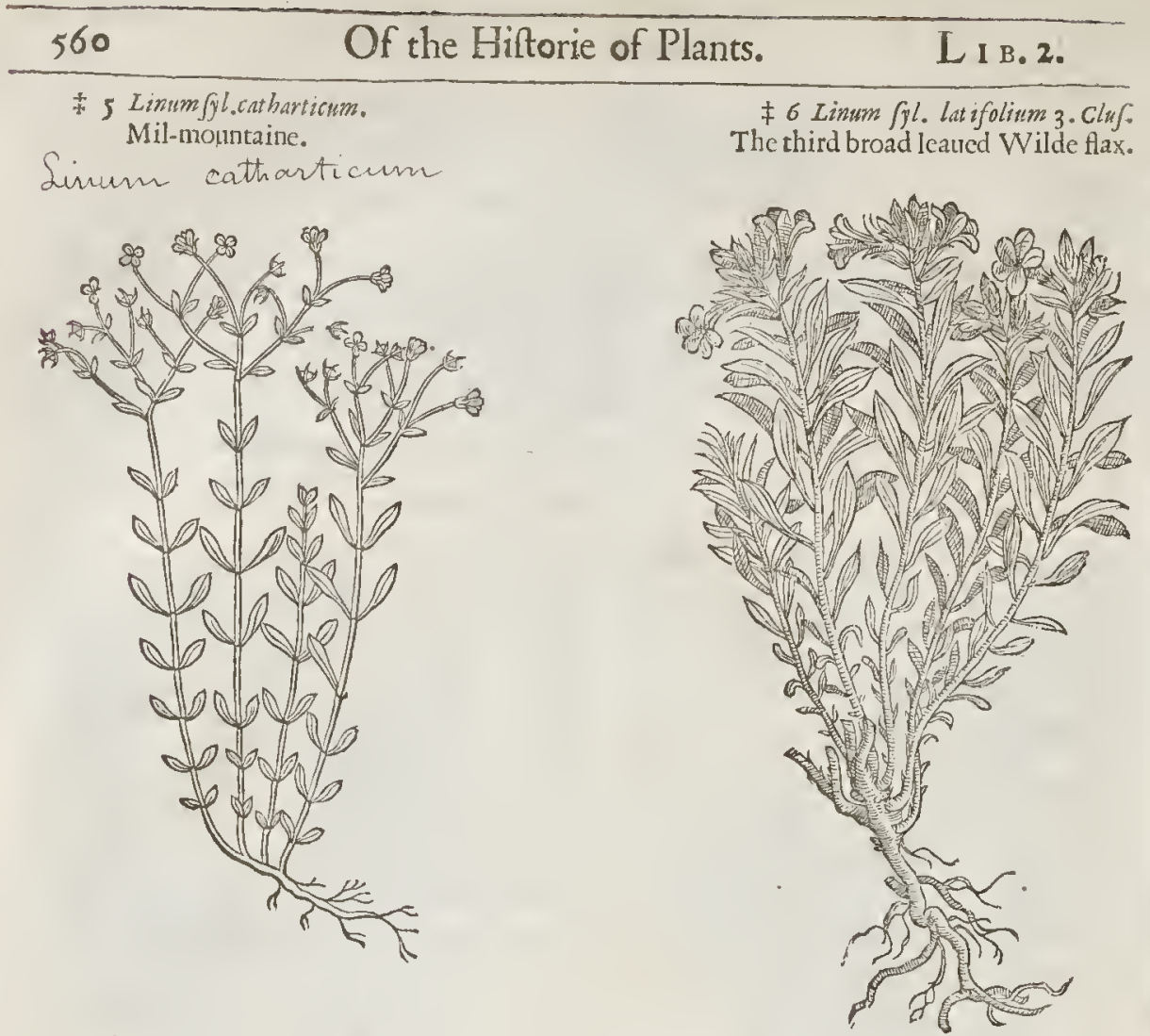

\$ Linum marinum Lutcum. Yellow floured Wilde flax.

A

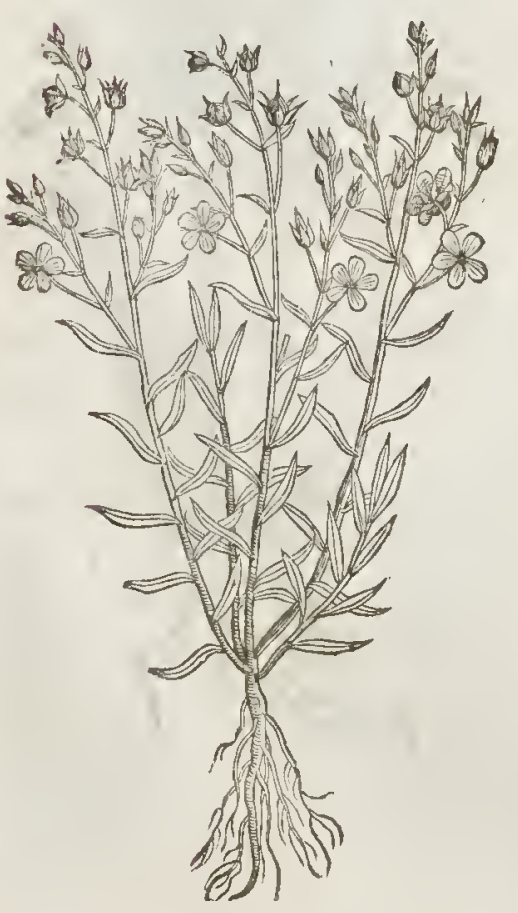

I came to know this herbe by the name of Mil-mountaine, and his vertue by this meanes. On the fecond of Oetober 1617. going by $\mathrm{M}^{\mathrm{r}}$. Colfons thop an Apothecary of VVinchefter in Hampinire, I faw this herbe lying on his ftall, which I had feene growing long before : I defired of him to know the name of it, he told me that it was called Mill-mountain, and he alfo told me that beeing at Doctour Lake his houfe at Saint Croffe a mile from VVinchefter, fce. ing a man of his haue this hearbe in his hand, he defired the name; hee toldhimas before, and alfo the vfe of it, which is this.

Take a handfull of Mill mountaine, the whole plant, leaucs, feedes, floures and all, bruife it and put it in a fmall tunneor pipkin of a pinte filled with white VVine, and fet in on the enbers to infufe all night, and drinke that wine in the norning fafting, and hee faid it would giue eight or tenne ftooles. This Dostour Lake was afterward made Bithop of Bath and VVells, who alwaics vfed this hearbe for his purge, after the faid manner, as his man affirmed, Iuly 20. 16 I9.Iohn Goodyer.

I haue not as yet made tryall hereof, but finec in $G e f n$. de Lurarijs $p \cdot g$. 34 . Ihaue found 
I laue found the like or a more purging facultic attributed to this herbe,as I thinke'for I cannot referre it toany other) where hee would hate it to be Ilelleborine of the Antients : I thinke it not amifle here to fet downe his words, becaufe the booke is not commonly to be had, being fet forth Anno 1555 . Lnte annos 15 . Ant circiter cum Anglus quidam, cx Itala rediens, me falutarer (Tumerus is fuerit, vir cxcellent is tum in re medica tum alÿs plevifque difciplinis doctrina, aut alins guip an wix at is memivi ) iner alias ruriorum ffirpiusn icones quas depingendas commodabat, Elleborinem quoquc of endebat

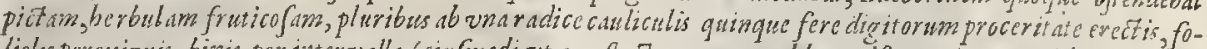
liols porexiguis, binis per intervalla (cinfmodi vt ex afpectu genus quoddans Alfine exiguun videretur) vafculis in fummo c.xiguis, rotundis tanquam lini. Hanc ajebat crefcere in prails ficcis, vel clivis Montiums; inutiliradice, Jubamara, purgare viringue of in Anglia vulgovjurpariarufticis. Thus much for Gerner.

6 Clufius amongit other wilde Lines or Flaxes hath fet forth this, which from a liuing, thicke, writhen root, fenderh vp many falkes almoft a cubite high, fomewhat red and ftiffe, fet with prettie large and thicke leates not rough and hairie, but fmooth and hard the floures grow plentifully on the tops of the ftalkes, being large, and compofed of fuie leaues of a faire yellory colour, with fiue threds comming forth of their middles, wirh as many fmaller and thorter haires. The feed is contained in flatter heads tlin thofe of the firftefcribed, containing a blacke, but not fhining feed. It floures in Itune and Iuly, and ripens the feed in Augurt. It growes naturally vpon diuers hils in Germany.

7 Mattbiolus and Dodonetus hate vnder the name of Linum fylueftre; and Lobelby the name of Lixum marinum luteum Narbonenfe, fet forth another yellow floured wilde flaxe. This growes with flender ftalkes fome cubite high, fer with leaues like th ofe of flaxe, but fomewhat leffer, and fewer in number : at the tops of the italkes grow floures fmaller than thofe of the common Line, and yellow of colour. It growes naturally vpon the coafts of Ftance that lie towards the Meditetrancan fea,but not in England that I haue heard of: $\neq$

बा The Place.

They gtow generally in grauelly grounds. The firft groweth in well mannured places, as in gardens and fuch like foiles. The fecond groweth by the fea fide. The third and fourth grow vpon rockes and cliffes neere to the fea fide. I haue feene them grow vpon the fea bankes by Lee in Ef: fex,and in many places of the Ifleor Shepey. They grow alfo betweene Quinborow and Shetland houfe.

$\ddagger$ I haue not feene any of thefe growing wilde, but onely the fifth of my defctiption.

They floure from May to the middeft of Auguif.

$$
\begin{aligned}
& \text { The Tine. } \\
& \text { Auguit. }
\end{aligned}
$$

$$
\text { T) The Names. }
$$

'Their names are fufficiently expreft in their feucrall titles.

$$
\text { बा TheNature and Vertucs. }
$$

The faculties of the fe kindes of Wilde-flax are teferred vnto the manuted flax,but they are feldome vfed either in Phyficke ot chirurgerie.

\section{С н н. 168. Of Blacke Saltwoort.}

\section{IT The Defiption.}

1 Nold time, fay the Authours of the Aduerfaria, this plant was ved for meat, and received a-

Imong the Legsmina. It was called Glaux; by reafon of the colour of the leates, which ate of a blewith gray colour, called in Latine, Glaucus color, fuch as is in the Sallow leafe: of othets it is called Galax or Glax : and Eugalazton, quafilatea or latifica, becaufe it is good to increa fe milke in the breits of women, if it be much vied. Rucllius and others haue fet downe Galeza, Securidic Polygala, $_{3}$ and many other plants for the true Glau, $x$, which hath bred a confufion. The true Glawx of $D$ iofcorides hath many fmall branches, fome cteeping on the ground, and fome ftanding vpright, tender, and fmall,befer with many little fat leaues like Tribulus terreftris, or Herniaria, growing along the ftalks by couples; betwecne whom grow fmall purple floures; which being paft, there fucceed certaine litrle bullets or feed veffels. The ront is vety fmall and threddy, and taking hold of the vppet face of the earth,as it doth run abroad, by which meanes it doth mightily increafe. 
L1 в.2.

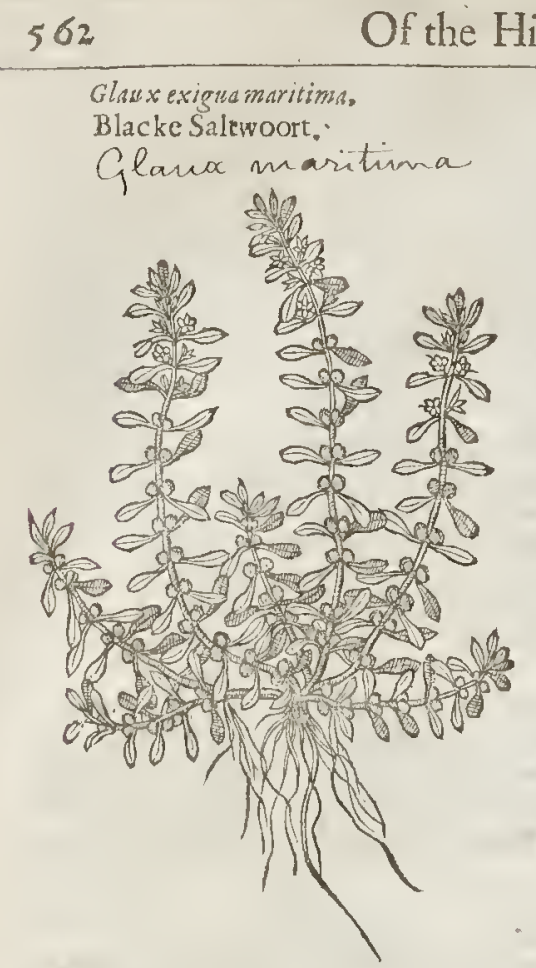

Glas x exigudmaritim

Blacke Saltwoort.
T) The Place.

The true Glaux or Milkwoortgroweth very plentifully in falt plaees \& marthes neere the fea, from whence I haue brought it into mygarden, where it profpereth as well as in his natiue foile. I found it efpeeially betweene Whitftable and the Inle of Thanet in Kent, and by Grauefend in the fame countie,by Tilbery Bloek-houfe in Effex, and in the inle of Shepey, going from Kings ferry to Sherland houfe.

$$
\text { T The Time. }
$$
Ieine.

It floureth in May, and the feed is ripe in

$$
\text { oा } T \text { he Numes. }
$$

The names hauc beene fufficiently fpoken of in the defeription. It thall fuffice to call it in Englifh, Sea Milkwoort.

$$
\text { If The Nature. }
$$

Pulus Acginets faith,it is hot and moif of temperature.

$$
\text { 91 The Vertues. }
$$

This Milkwoort taken with milke, drinke, or pottage, ingendereth ftore of milke, and therefore it is good to be vfed by nurfes that want the fame.

\section{Char. 169. Of Q Yilke-2roort. \\ 9. The Defiription.}

I There haue beenc many plants neerely refembling Polygala, and yet not the fame indced, Which doth verifie the Latine faying, Nullum fimile cft idem. This neere refemblance doth rather hinder thoie that haue fpent much time in the knowledge of fimples, than inereafe their knowledge. And this alfo hath been an oeeafion that many haue inagined a fundry Palygala vnto themfelues, and fo of other plants. Ofwhich number, this (whereofl fipcake) is onc, obtaining this name of the beft writers and herbarifts of our time, de feribing it thus. It hath many thick fpreading branehes, ereeping on the ground bearing leaues like them of Fermaria, ftanding in rowes like the Sca Milkwoort; among which do grow fmall whorles, or erownets of white floures, the root being exeeding fmali and threddie.

2 The fecond kinde of polygala is a finall herbewith pliant flender ftems, of a wooddie fistftanee, tin handfull long, erecping by the ground, the lcaucs be fmall \& narrow like to Lintels, or little Hy frope. The floures grow at the rop, of a blew color, fafhioned like a little bird, witl wings, taile, and bodie, eafie to be difeerned by them that doe obferue the fame : which being pait, there fuceed fmall poutes, like thofe of Burfapaftoris, but leffer. The root is fmall and wooddie

3 Thisthird kinde of polygala or Milkewoort, hath leanes and ftalkes like the la ft before mentioned,and differetl from it herein, that this kinde hath fmaller branehes, and the leates are not fo thiekethruft together, and the foures are like the other, but that they bee of a red or purplecolour.

4 The fourth kinde is like the laft fpolen of in euery refpect, but that it hath white floures; otherwife it is very like.

5 Purple Milliewoort differeth from the others in the colour of the floures; it bringeth foorth moe branehes than the preecent, and the floures are of a purplc colour; whercin efpecially eonfi-
fteth the difference. 
L 1 в. 2.

Of the Hiftory of Plants.

I Polygalarpens.

Sllecelum

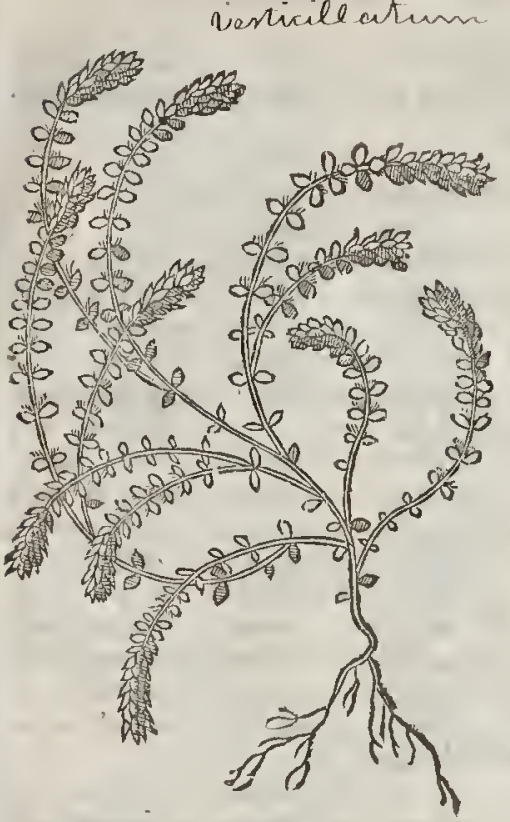

3 Polygaldrubris foribus:

- Red Milkcworr.

Tolygala vulgans $36 \Delta$.

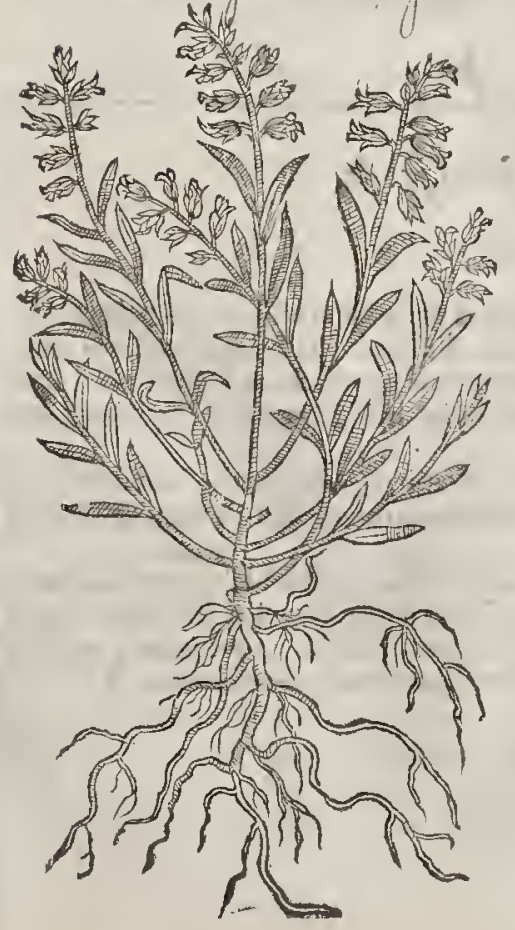

2 Polygala flore caruloo.

Blew Milke-wort.

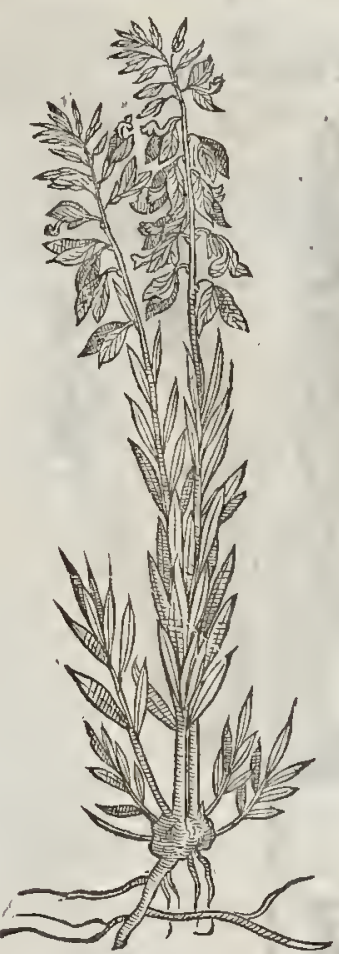

${ }_{4}$ Polygals albis floribus:

White Milkewort,

Polygala wielgarns. $56 \mathrm{~A}$

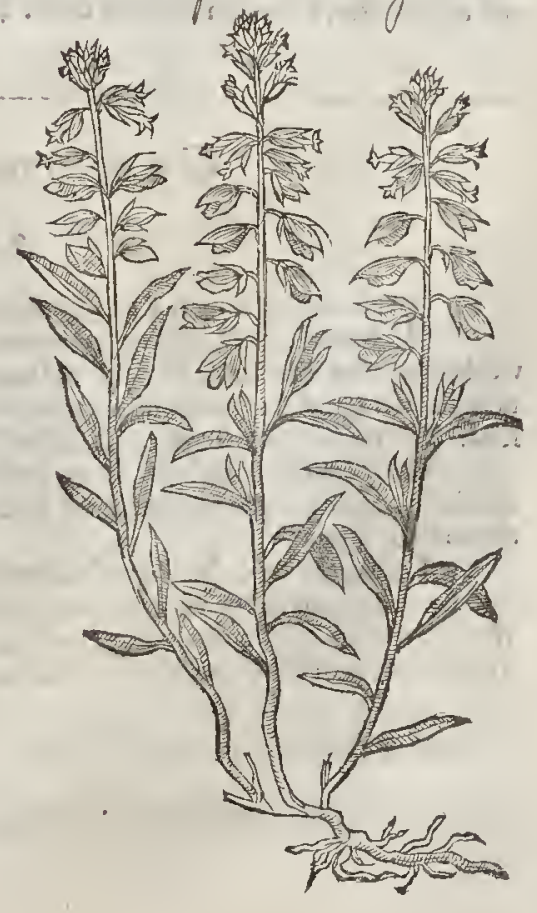


6 The fixth Milke-wort is like vnto the reft in eaeh refpect, fauing that the floures are of an onerworne ill fauoured colour, which maketh it to differ from all the other of his kinde.

5 Polygala purpurea.

Purple Milke-wott.

A

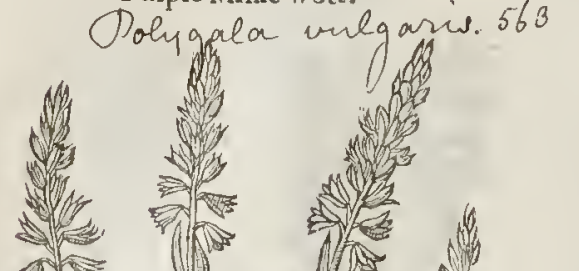

B

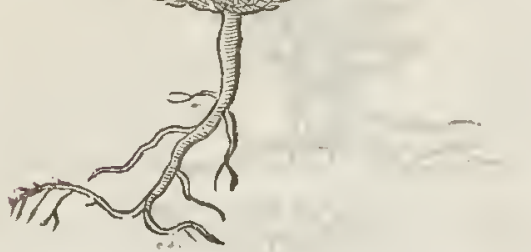

I The Place.

Thefe plants or Milke-worts grow commonly in euery wood or fertil pafture whetefoeuer I hate tranelled.

$$
\text { ff The Time. }
$$

They floure from May to Augurt.

T) The Names.

Milke-wort is called by Dodonaus, Flos Ambarualis; fo ealled beeaufe it dorl efpecially flourih in the Croffe or Gang weeke, or Rogation weeke. of which floures the maidens which vfe in the eountries to walke the Proceffion doe make themfelues garlands and nofegaies : in Englifh we may eall it Croffe-Houre, Proeeffion-floure, Gangfloure, Rojation-floure, and Milkewort, of theit vertues in proeuring milke in the brefts of nurfes. Hieronymus Tragus, as alfo $D$ iof corides calleth it $P_{0-}$ lygalon. $\neq$ ciefreer ealls this Crucis fos; and in his Epiftles he nameth it Amarell $n$ : it is vulgarly knowne in Cheapfide to the herbe-women by the name of Hedge-Hyffop; for they take it for Gratiols, or Hedge-Hyflop, and fell it to fueh as are ignorant for the fame. $\ddagger$

$$
\text { of The Vertucs. }
$$

Galen, Diofcorides, and Theophraftus doe account thefe for Milkew orts, and that they may without error be vfed for thofe purpofes whereunto Glanx. ferueth.

$¥$ I doubt that this is not the Polygalon of $D$ io. fcorides; for Gefner affirmes that an handful hercof fteeped all night in wine, and drunke in the motning, will putge cholet effectually by ftoole without any danger, as he himfelfe had tried. ¥

$$
\text { С А Р. 170. Of Knot-Grafje. }
$$

I THe common male Knot-graffe ereepes along vpon the ground, with long flendet weake weake branches, like thofe of fmall $S$. weake branches, like thofe of fmall S. Iohns wort, but longer and narrower. The floures are maruellous little, and grow out of the knots, of an herby colour; in their places come vp triangular
feed. The root is long,flender,and full of ftrings.

2 The feeond differeth not from the former, but onely that it is altogether leffer, whetein efpecially eonfifteth the difference. $¥$ Beeaufe the difference is no otherw ife, I hane thought good
to omit the figure.

3 The Authors of the Aduerfariamention anothet larger Knot-grafe which growes in diuers places of the eoaft of the Mediterrancan fea, hauing longer and larget branehes and leaues, and thofe of a white fhining colour. The feeds grow at the ioynts in ehaffic white huskes, and the whole plant is of a falt and aftringent tafte. They call it Polgonum marinm maxirwum.

Thefe Knot-graffes do grow in The Place.

They arein floure and feed all the Sommer long. 
I Polygonummas villgare. Common Knot-grafle.

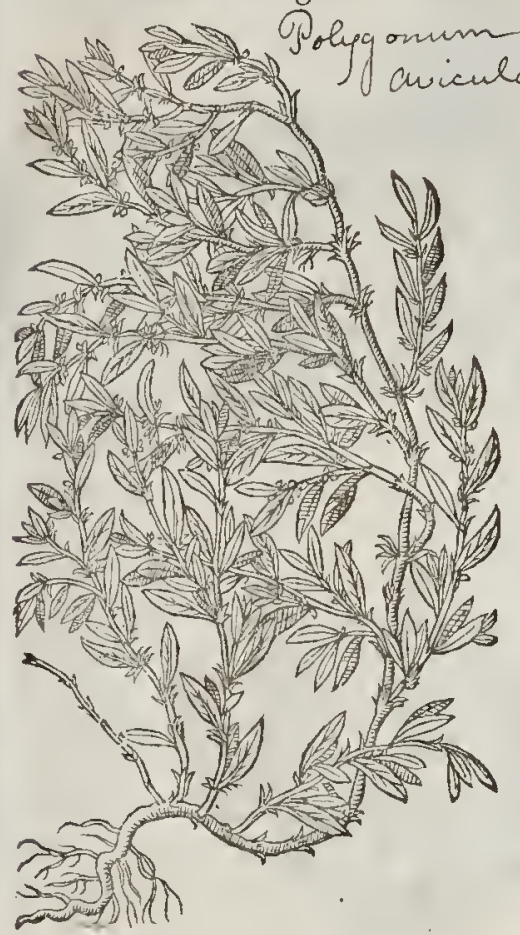

9) The Names.

Knot-graffc is called of the Grecians,

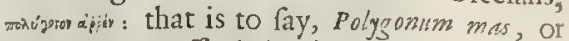
Male Knot-graffc : in Latinc, Seminalis, Saxgui naria: of Columella, Sanguiralis : in thops, Cen. tumriodia, and Corrigiola: of Apule ws, Pro erpin ca: in high-Dutch, 990 g,gozvt : in low-Dutch, aterkeng grats, and 0 uifent knop: in Italian, Polygono: in Spanifh, corrold: in French, Renouce : in Wallon, Mariolaine de Cure : in Englifh, Knot-grafe, and Swines graffe: In the North, Birds tongue.

$$
\text { of The Temperature. }
$$

Knot-grafe (as Galen tcacheth) is of a bin. ding qualizie, yet is it cold in the fecond, if not in the beginning of the third dcgrce.

$$
\text { at The Vertues. }
$$

The iuyee of Knot-graffe is good againt the fpitting of blond, the piffing ofbloud, and all other iffucs or fluxes of bloud, as Brafanolses reportetl : and camerarius faith he hath cured many with the inyce thereof, that hane vomited bloud, giuen in a little ftipticke Wine. It greatly pretraileth againft the Gonorrhat, that is, the running of the reines, and the weak neffe of the backe comming by meanes thereof, bcing fhred and made in tanfe with egges and eaten.

The decostion of it cures the difafc afore- B faid in as ample manner as the iuyce: or gituen? in pouder in a reare egge it helpeth the backe vety much.

The herbe boyled in wine and hony cureth the vlcers and inflammations of the feeret parts of $\mathrm{C}$ man otwoman, adding thereto a little allom, and the parts wafhed therewith.

Diofcordes faith that it prouoketh vrine, and helpeth fuch as do piffe dtopafter drop, when the D vrine is hot and tharpe.

It is giucn vnto Swine with good fucceffe, when they are ficke and will not eate theit meate ; E whereupon the eomtrey peopledo call it Swincs grafie and $S$ wines skir.

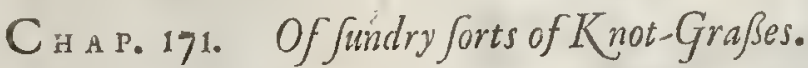

\section{If The Defcription.}

I The fnowic whiteand leaft kinde of Polygonum or Knot-graffe, ealled of Clufius, Puromychiat Hipanica, is a ftrangc and worthy plant to behold, handle, and confider, although it be but frmall. It is feldome aboue a foot long, hauing finall branches, thiekc, tough, laard, and full of ioynts; Out of which the leanes come forth like fmall tceth, leffer than the lcaues of Herniaria, or Thymum termifolium. At the top of the ftalkes ftand moft delicatc floures framed by nature as it were, with fine parchment leaues about them, fanding in their fingulat whiteneffe and fnowie colour, rfembling the perfeat white filkc, fo many in number at the top, and fo thickc, that they ouerfinadow the reft of the plant beneath. The root is flender, and of a wooddy fubftanee. The focd is courered as it wete with chaffe, as it wete with chaffe, and is as fmall as duft,or the motes in the Sunne.

2 Antbyllis of Valentia, being likcwife a kindc of Knot-graffe, hath fmall lcanes like Glaux exigua, or rather likc chame fyce, fer orderly by couples at the ioynts : among which come floures confifting of foure little whitifh purplc leaues, and other fmall leaues like the firft but altogether leffer. The root is fmall, blacke, and long, and of a wooddy fubftance.

$\neq$ Our Author, though he meant to haue gituen vs the figure of Knavell in the third plaee, as may be perceined by the title, yet he deferibed it in the fourth, and in the third place went abont 
I Polyganum montanum. Mountaine Knot-graffe.

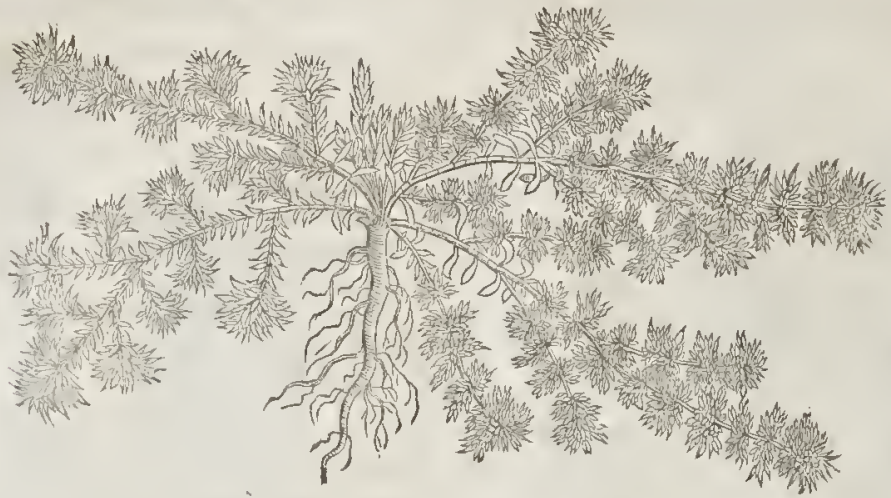

¥ 2 Anbyllis FalontinaClufij. Valentia Knot graffe.

- Trankeria pulverucenta.

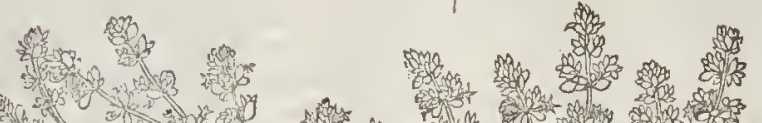

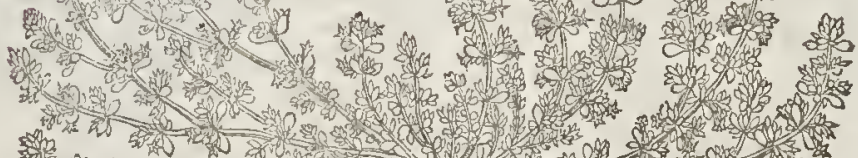
in s.

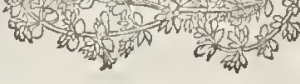

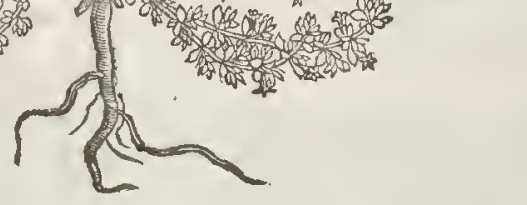

+ 3 Polygunum fervillt folium. Small round leaued Knot-grafle. Franklemia lavis.

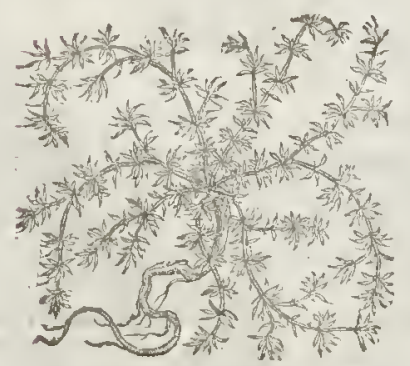

I 4 Polygonum Sclinoides, fure Knanel. Parlley Piert.

Scier-arthus ammens.

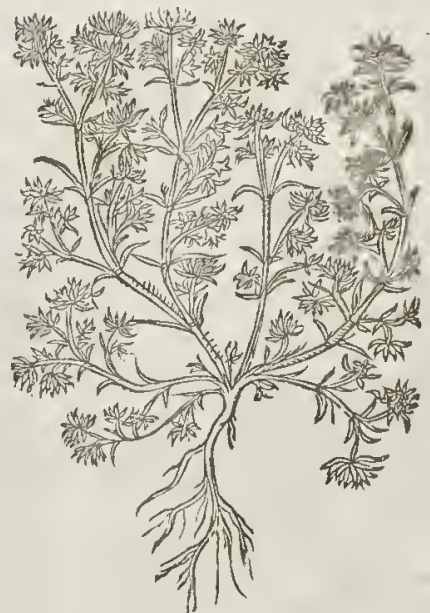


to defcribe Polygonum Serpillifolio of Pena; as may be gathered by the defcription whic in fhould haue ftood; but that I opportunely receiued a better from my oft mentioned friend $\mathrm{M}$ ". Goodyer, which therefore I thought good to impart vnto yout.

\section{Polygonum alierum pufillo vermiculato Serpilli foliolo Pene.}

This hath many fnall iound fmooth wooddy branches, fomewhat reddifh, trailing vpon the ground, nine inches or a foot long; whereon by fmall diftances on thort ioynts grow tufts of very finall thort blurit topped fmooth greene leates, in a maner round, like thofe of the fnalleft Time, but nuch fmaller, and without fmell, diuiding themfelties at the bofomes of thofe leaues into fmall branches; at the tops of which branches grow fmall floures, one floure on a branch, and no mori, confifting of foure little round topped teaues apiece of a faint or pale purplifh colour: I obferted no feed. The root is wooddy, blackith withont, very bitter, with fome tafte of heate, and groweth decpe into the ground. The leaues are nothing fo full of iuyce as Aizoon.I found it flouring rhe third day of Seprember, I 621 , on the ditch bankes at Burleldon ferrey by the fea fide in Himpthire. 10. Gudyer. $\ddagger$

4 Among the Knot-grafies may ivell be futed this finall plant, bit lately written of, and not fo commonly knowne as growing in England, being about an handfull high, and putting out from a fibrous root fundry flender ftalkes full of little branches and ioynts : about which grow confufedly many narrow leaues, for the moft part of an vnequall quantitie, yet here and there two longer than the rent, and much alike in 'greatneffe : at the outmoft parts of the bràches and ftalks (where it hath thickeft tufts) appeare out of the middeft of the leaues litcle floures of an herby colour, which are fucceeded by feed-veffels ending in fue tharpe points: the whole plant is of a whitifh colour. If my memorie faile me not, Pena means this herbe where lie fpeaketh of Saxifr. Angl, in lis Aducr.p. I03." and alfo reporteth that he found this plant by theway fide as he rode from London to Briftow, on a little lill not far from Chipnam : his piecure doth very well refemble the

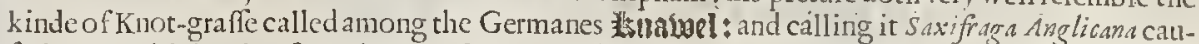
feth me to thinke, that fome in the Weft parts where he found it do call it Saxifrage, as we do call fundry other herbes, efpecially if they ferue for the ftone. My friend $\mathrm{M}^{\mathrm{T}}$. Stephen Bredwel, Practitioner of phyficke in thofe parts, heard of a fimple man who did much good with a medicine that he made with Parflcy Piert againft the ftone, which he minifted vnto all forts of people. This myt friend requefted the poore man to thew him the herbe called Parfley Piert ; who frankly promifed it him, and the next morning brought him an handfull of the herbe, and told him the compofiti. on of his medicine withall, which you thall finde fet downe in the vertues, and proucd by fundry of good account to be a fingular remedic for the fame.

t 5 Saxifraga Anglicana alfinefolia.

Chick-wced Breake-ftone.

Scleranthos. Peremmis.

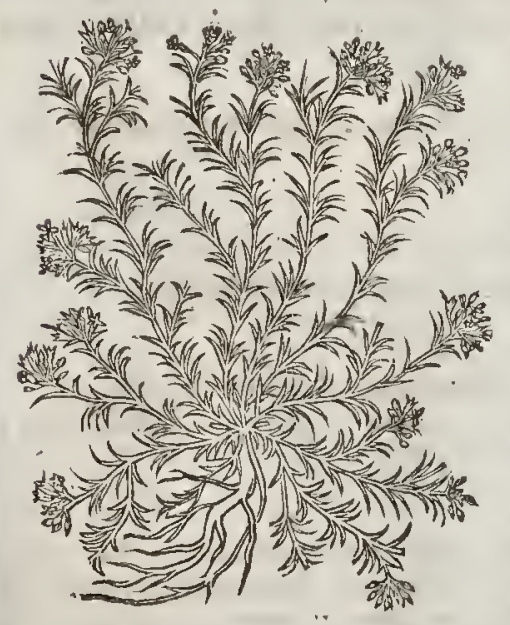

¥6 Saxifraga paluftris alfinefolia. Small water Saxifrage.

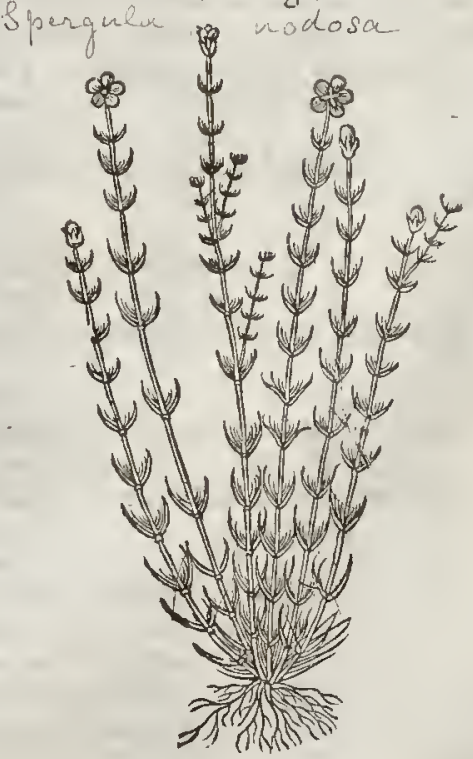


₹ 4 Our Aurhorhere in the fourtl place dcferibed the Knawel, and he figured it in the fecond place, vnder the tirle of Anthyllis Valentina Clufij : for the figure which was in the third place we here give you in the fifrh; and I coniesture it is not of Knawel, but of Savifrega Anglicana of rhe Adserf. So that our Authors words are true, if he meant of the picture which he fet forth by rhe name of Polygonura filynoides fuie $\mathrm{K}$ nowel; burfalfe if of rhe plant which he defcribed. But if the conie eture of Pena and Lobeibe true, who iudge their Saxifraga Anrlicana to be Symanchice Dale chan$P i_{2}$, then it is neither of $\mathrm{K}$ mmel, as our Authorwould hate it, nor of this which I here gitic, but of a fmall plant which you thall finde amongft the Rubin's. Now this plant that I take ro be the Saxifraga Anglican of Pena and Lobel, is a fmall little herbe growing thicke, with very many branches fome twoor three inches high, with fome falkes ftand ing vpright, and other fome creeping : at each ioynr grow two hort narrow tharpe pointed greene leaues, out of whofe bofomes come diuers Ieffer lcaues : at the tops of the branches vpon pretty long ftalkes grow vpon each ftalkc one round whirith fealy head, confinting commonly of foure vnder greenifh leates which make the cup, and foure grayion or whitilh leaues which are rhe foure. Now after thefe come to fome maturitie they appeare all of a whitim colour, and through the thinne filmes of the e heads appeares the feed, which at the firft view feems to be pretry large and blacke; for it lies all cluftering together; but if you rub it out you thall finde it as fmall as fand, and of a darke reddith colour. The tafte of this plant is very hor and piercing, like that of Golden rod or our common Saxifrage,and without doubr it is more effestuall to mouevrine than the former Knawel. I hate found it growing in many places abour bricke and ftone walls, and vpon chalky barren grounds. I called this in my Iournall Anno i6;2. Suxifray minor alsera fof cal lis albis femine nigro: and queftioned whether it were not Alfine Safifraga anguftifolia minima montana of Colama. But now I rhinke it rather (if the number of leaues in the floure did not difagree) the other which is defcribed in the next place, of which I fince that time haue receiued both the figure and defcription;as alfo a dry plant from $\mathrm{M}^{\text {. }}$. Goodyer. He conic sturcs it may be this plant which I haue here defcribed, that is fet forth in the Hiftoria Lngd.pag. I 235 . by the name of Alfine mufcofa.

$$
\text { Alfine paluftris folijs tenuißsmis : fiue Saxifraga paluftris alfinefolia. }
$$

6 This hath a great number of very fmall graffe-like leaues, growing from the root, about an inch long, a great deale fmaller and tlenderer than fmall pinnes; amonget which fpring vp many fmall tlender round fmooth firme branches fome hand full or handfull and halfe high, from which fomerimes grow a few other fualler branches, whereon at certaine ioynts grow leaues like the former, and rhore fet by couples with other thorter comming forth of their bofomes; and fo by degrees they become thorter and thorter towards the top, fo that toward the top this plant fomwhat refembleth $\tau$ bymum durius. The floures are great for the flenderneffe of the plant, growing at the tops of the branches, each floure confinting of fure fmal blunt round in topped white floures, with whitechities in the middeft. The feed I obferued not. The root is fmall, growing in the myre wirh a few ftrings. This groweth plentifully on the boggy ground below the red Well of Wellingborough in Northampton hire. This hath not becne deferibed that I finde. I obferued it at the place aforefaid, Auguft 12.1626. Tohn Goodyer. \#

\section{बr The Place.}

$t$ The firft and fecond are ftrangers in England : rhe reft grow in places mentioned in their defcriptions.

Thefe floure for the moft part from

$$
\text { of The Time. }
$$

9 $T$ he Names.

That which hath beene faid of their names in their feuerall defcriptions thall fuffice.

T) The Nature.

They are cold in the fecond degree, and dry in the third, aftringent and making thicke.

\# Thefe, efpecially the three laft, are hot in the fecond or third degree, and of fubtill parts; but the Parley Piert feemes not to be fo hot as the other two. $\neq$

\section{T The Tertues.}

Here according to my promife I hame thought good to infert this medicin madewith Knawel A which herbe is called (as I faid before) Parfley Piert, but if I might withoutoffence it fhould be called Petrapungens : for that barbarous word Parfley Piert was giuen by fome fimple man ( $\neq$ as alfo the orher, that faurs of as much fimplicitie $\neq$ ) who had not wellearned the true terme. The compofition which followeth muft be giuen in warme white wine, halfe a dram, tro fcruples, or
more, according to the conftitucion of the body which is to receive it. 
The leanes of Parney Piet,, Mouf-eare, of each one ounce when the berbes be dried, bay berryes, $E$ Turmericke, Cloues, the feeds of the great Burre, the feeds in the berryes of Hippes, or Briertree, Fentgreeke, of each one ounce, the ftone in the oxe gall, the weight of 24 . Barley cornes, or halfe a dram, made togerher into a moft fine and fubtill pouder, taken and drunke in maner aforefaid hath been proued moft fingular for the difeafe aforefaid.

\# The fifrli and fixth are of the fame faculty, and may be vfed in the like cafes. $\neq$

$f$ The figne that formerly was in the fecond place was of Knawell, and that in the chird place of polygonum monm polyearpor of Tabern.

\section{C на P. 172. Of Rupture woort.}

\section{Herniaria. Rupture woort.}

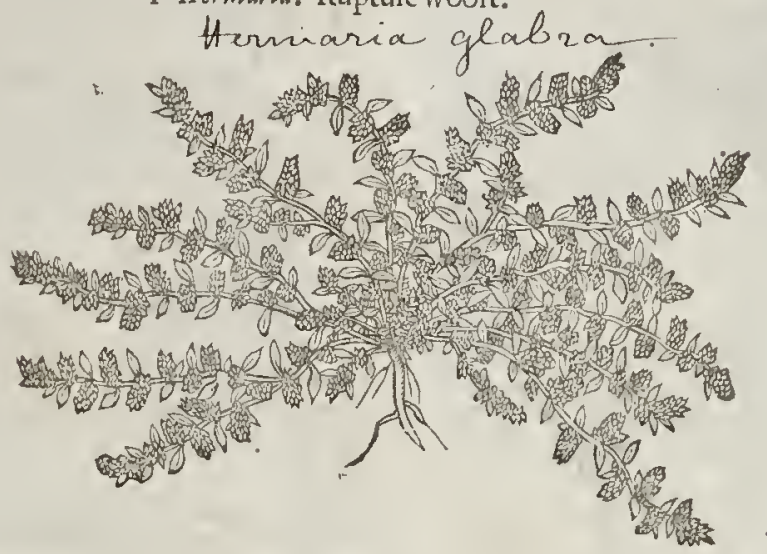

¥ 2 Millegranaminima. QR Dwarfe Allfeed.

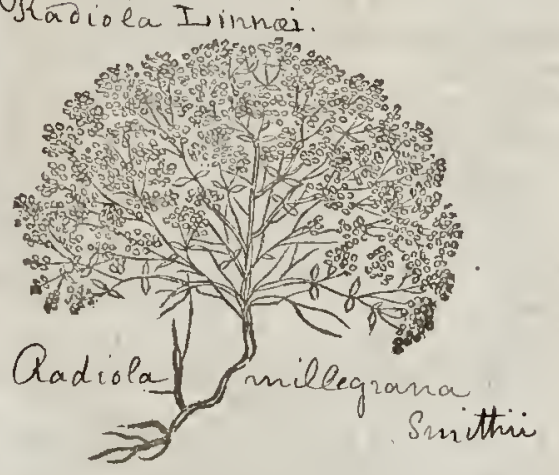

शा The Defcription.

1 Here is alfo a kinde of Knot graffe commonly called in Latine Herniaria: in Englim, Rupture woort, or Rupture graffe. It is a bafe and low creeping herbe, hauing many fma ll flender branches rrailing vpon the ground,yet very tough, and full of lirrle knots fomewhat reddifh, whereupon do grow very many finall leaues like thole of Tine; among which come forrb litrle yellowith floures which turne into very fmall feed, and great quantity thereof, confidering the fnallneffe of rhe planr, growing thickecluftering together by cerraine fpaces. The whole plant is of a yellowifh greene colour. The root is very flender and fingle.

2 There is anorber kinde of Herniaria, called Mille grana or All-feed, rhat groweth vprighta landfull high, with many fmall and tender branches, fer with leaues like rhe former, but few in number, lauing as ir were rwo fmal leaues $\&$ no more. The whole planr feemerb as it were couered oner wirh feeds or graines, like rhe feed of Panicke,bur much leffer. $\ddagger$ I haue not feen many plants of this, but all thar eucr I yer faw neuer artained to the heighr of rwo inches. $\neq$

$$
\text { वा The Place. }
$$

I Ir ioyerh in barren and fandy grounds, and is likewife found in dankifh places rhat lie wide open ro rhe funne:ir dorh grow and profper in my garden exceedingly. $\neq 2$ I found this in Kent on a Hearla not farre from Chifte-hurft, being in eompany with $\mathrm{M}^{\mathrm{r}}$. Bowles and dituers others, in Iuly, 1630. 9T The Time.

It floureth and fourithen in May, Iune, Iuly, and Auguft.

$$
\text { वा The Names. }
$$

It is called of the later Herbarifts Herniaria and Herniola; raken from the effect in curing the difeafe Hernia: of diuers, Herba Turca, and Empetroiz; in French, Boutonot : in Englinh, Rupture woorr, and Burftwoort. 


\section{of The Temperature and Vertme.}

A Rupture woort doth notably dric, and throughly elofeth vp together and faftenetl]. It is reported rhat being drunke it is fingular good for Ruptures, and that very many that haue been burften, were reftored to health by the vfe of rhis herbe;alfo the pouder hereof taken with wine, doth make a man to piffe that hath his water ftopt; it alfowalteth away the fones in the kidnies, and expe!leth them.

\section{C н а р.173. Of wilde Time.}

I Serpillum vulgre. Wilde Time.

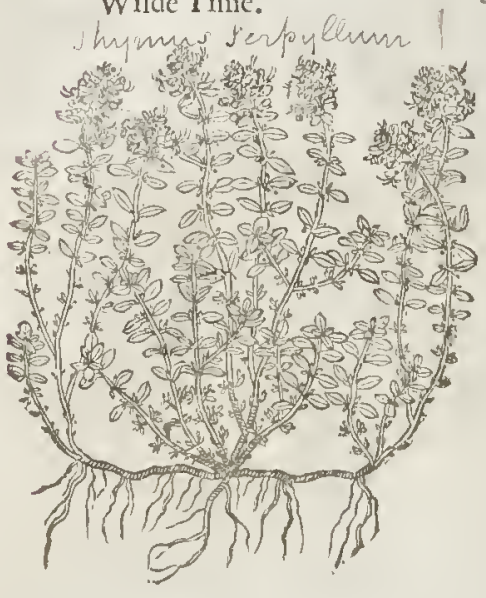

3 Scrpillum majus flore purpurco. Great purple wilke Time.

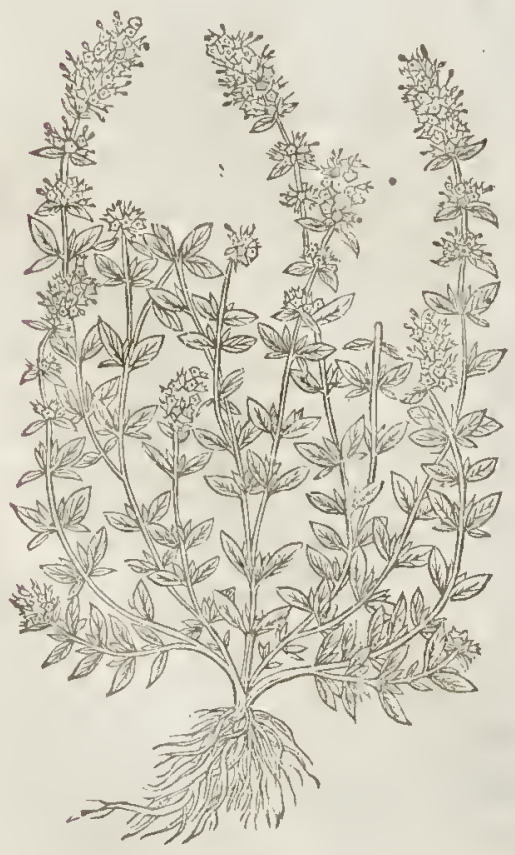

The Defription.

I ROth Diofiontdes and Pliny mahe two kindes of serpillum, that is, of ereeping or wilde Time; where of the firlt is our common ereeping Time, which is fowell knowne, that it neederh no defeription; yet this ye thall voderftand, that it bearcth floures of a purple colour, as euery body knoweth. Of which kinde I found another fort, with floures as white as fnow, and haue planted it in my garden, where it becommeth an herbe of great beauty:

2 This ivilde Time that bringeth forth white floures differeth not from the other, but only in the eolour of the floures, whenee it may be ealled serpullum vulgare fore albo. White floured Wilde Time.

There is another kinde of serpillum, which groweth in gardens, in fmell and fauour refembling Marjerome. It hath leaues like Organy, or wilde Marjerome, but fomewhat whiter, putting forth many fmall ltalkes, fet full of leaues like Ruc, but longer, narrower, and harder. The foures are of a biting talte, and pleafant fmell. The whole plant groweth vpright, whereas the other ereepeth along ypon the earth, eatehing hold where it growes, \& fpreading it felfe farabroad.

3 This great wilde Time ereepeth not as the others doe, but fandeth vpright, and bringeth forth little flender branches full of leaues like thofe of Rue; yet narrower, longer, and harder. The flours be of a purple colour ${ }_{3}$ and of a twingging biting tafte : it growetly vpon roeks, and is hotter than any of the others.

4 This other great one with white floures differeth not from the preecdenr, hauing many knaps or heads, of a milke white eolour, which fetteth forth rhe differenec; and it may be ealled serpillum, maius flore allo. Great white floured wilde Time.

5 Thiswilde Time ereepeth vpon the ground, fet wirl many leaties by eouples like thofe of Marjerom,but leffer, of the fame fmel:the flours are of a reddifh color. The root is very threddy.

6 Wilde Time of Candy is like vnto the other wild Times, fauing rhar his leaues ate narrower and longer and more in number at each joint.'The fmell is more aromaticall than any of the others, wherein is the differenee.

7 There is a kinde of wilde Time growing tpon the mountaines of Italy, ealled Serpillum

Citratum, 
L I B. 2.

Of the Hittory of Plants.

5 Serpillum folys amaraci. Marjerome Time,

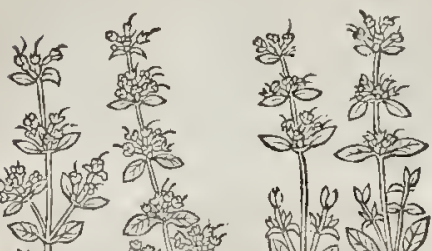

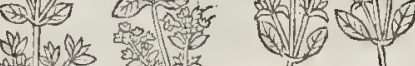
(n)

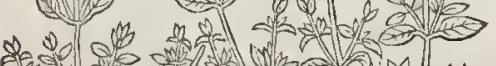
ona in Q

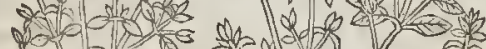
H. 601050

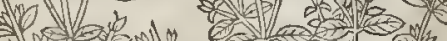

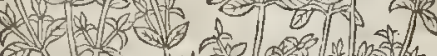
178 b 10 . an aren 0 (2) 2021

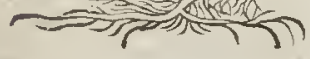

\# 7 Serpillum citratum.

Limon Time.

Shymus Serpyllum. $\beta$

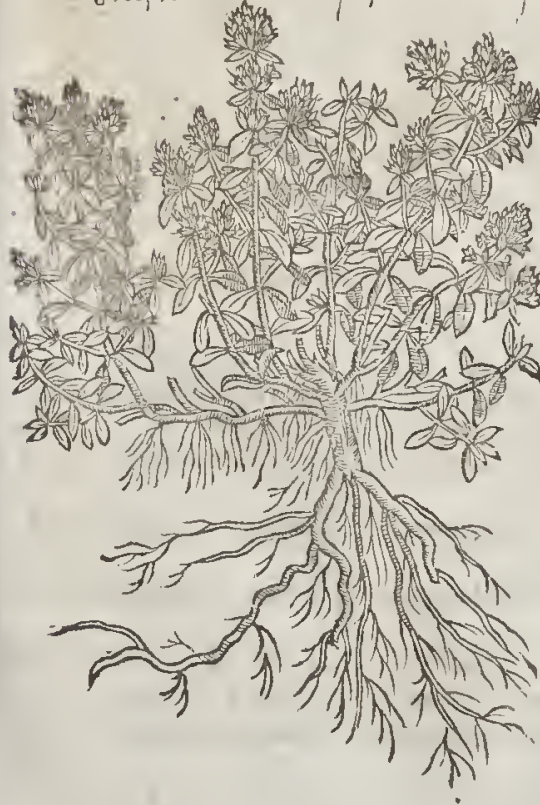

6 Serpillum Cretrcissz Wilde Time of Candy.

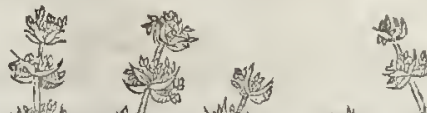
10 11 1. If 20 (3) W.M.10 a N14.

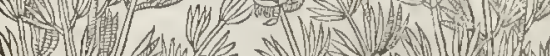

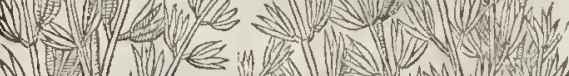
Ny-1,

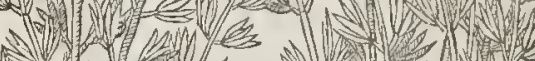
U.v.

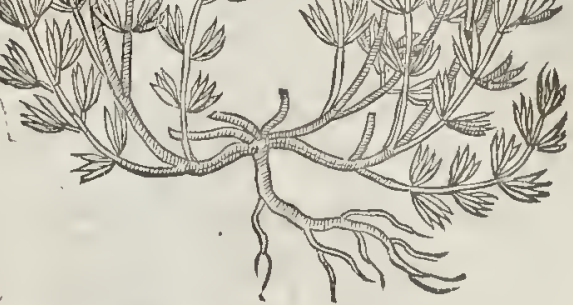

¥8 Serpillumbirfution. Hoary wilde Time.

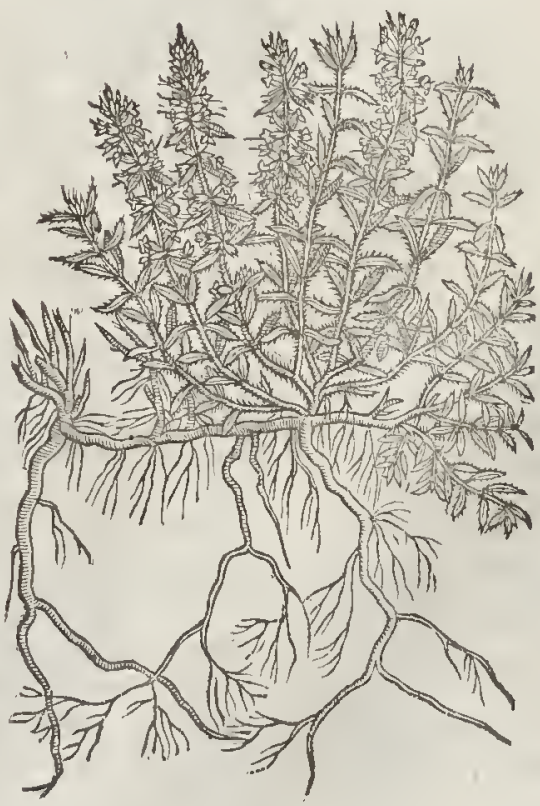


Citratum, that is, hauing the finel of a Pome Citron, or a limon, which giueth it the difference from the other wilde times. $\neq$ It growes in many gardens alfo, and (as I haue been told)wildein diuers places of Wales.

8 This (which is the Scrpillum Pamonicum 3. of Clufus) runnes or fpreds it felfe far vpon the groumd. For though ir haue a hard and wooddy root like as the former kindes, yet the branches which lie fured round about here and there take root, which in time become as hard and wooddy as the former. The leaues and ftalkes are like thole of the laft defcribed, but rough and hoaric: the floures al fo are not vnlike thofe of the common kind. The whole plant harh a kinde of refinous fmel1. It floures in Ine with the reft, and growes vpon the like nountainous places; but whether with vs in England or no I cannot yet affirme any thing of ccrtaintie. $\ddagger$

\section{The Place.}

The firft groweth vpon barren hills and vntoiled places: the fecond groweth in gardens. The fw hite kinde I found at Southfleet in Kent, in a barten field belonging to one $\mathrm{M}^{\mathrm{r}}$. William Swan.

$$
\text { T The Time. }
$$

They floure from May to the end of Sommer.

$$
\text { T) The Names. }
$$

Wild Time is called in Latine Serpillum, is erpendo, of crecping: in high and low-Dutch, $\mathbb{Q}$ uen $=$ Del, and wilorn Chpmms, and alin Dnfer Ytouben beoftroo: in Spanifh, Serpoll : in Italian, Serpillo: in French, Ptlolit: in Englih, Wilde Time, Puliall Mountaine, Pella mountaine, running Tine, crecping Time, Mother of Time : in Thops it is called Serpyllum; yet fonc call it $P u-$ legium mont anum : and it is euery where (faith Dodoncus) thought to be the Serpyllum of the Antients. Notwith tanding it anfwereth not fowel to the wilde Times as to Diofcorides his Savifranga; for if it be diligently comparcd with the defcription of both the Sexpilla and the Saxifranga, it fhal be found to be litcle like the wilde Times, but very much like the Saxifranga : for (faith Diofcorides) Saxifranga is an herbe like Time, growing on rockes, where our common wilde Timc is oftentimes found.

Elianus in his ninth booke of his fundry Hiltories feemeth to number wilde Time among the floures. Dionyfius lunior (faith he) comming into the city Locris in Italy, poffeffed moft of the houfes of the city, and did frew them with rofes, wild Time, and other fuch kindes of floures. Yet Virgil in the fecond Eclog of his Bucolicks doth moft manifeftly teftifie that wilde Time is an herbe, in thefe words:

\section{Theftylis or rapido foßis mefforibus aftu Allia, ferpillumque, herbas contundit olentes.}

Theftilis for mowers tyr'd with parching heatc,

Garlicke, wilde Time, frong fmelling herbes doth beate.

Out of which place it may be gathered, that common wilde time is the truc and right Serpillum,or wilde Time, which the Grecians call iprusor. CMarcellus an old antient Author among the Frenchmen faith it is called Gilarum; as Plinius Valerianus faith it is called of the fame, Laurio.

\section{T The Temperature.}

Wilde Time is of temperature hot and dry in the third degree : it is of thin and fubtill parts, catting and much biting.

$$
\text { 9i The vertues. }
$$

A It bringeth downe the defired fickneffe, prouoketh vrine, applied in bathes and fomentations it procureth fiveat : being boyled in wine, it helpeth the ague, it eafeth the ftranguric, it ftaycth the hicket, it breaketh the ftones in the bladder, it helpeth the Lethargie, frenfie, and madneffe, and fayeth the vomiting of bloud.

3) Wilde Time boyled in wine and drunkc, is good againt the wambling and gripings of the bellie, ruptures, convulfions, and inflammations of the liuer.

C It helpeth againft the bitings of any venomous beaft, either taken in drinke, or outwardly applicd.

1) Aetius writcth, That Serpillum infufed well in Vineger, and then fodden and mingled with rofe watcr, is a right fingular remedie to cure them that haue had a long phrenfie or lethargie.

E Galen prefcribeth one dram of the iuyce to be giuen in vineger againit the vomiting of bloud, and helpeth fuch as are gricued with the fpleene. 
LIE. 2. Of the Hiftoric of Plants.

\section{C н A 174: Of Gorden Time.}

\section{The Defcription.}

I $7 \mathrm{He}$ fref kinde of Time is fo well knowne that it needech no defcription; becaufe there is not any which are ignorant what $T$ hymum durius is, I meane our common garden Time.

2 The fecond kinde of Time with broad leaues hath many wooddy branches rifing from a threddy root, befet with leaues like Myrtus. The floures are fet in rundles about the falke like Horehound. The whole plant is like the common Time in tafte and fimell.

I Thymum duritus. Hard Time.

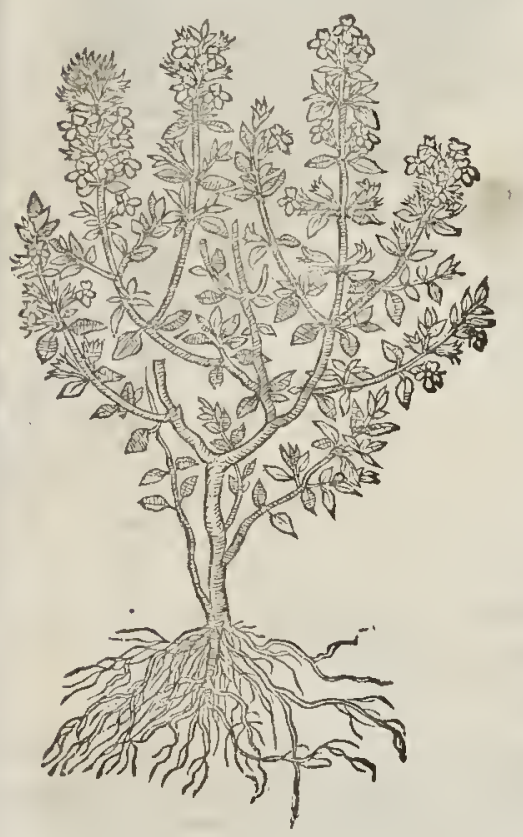

t 2 Thymum latifoliwn.

Great or broad leated Time.

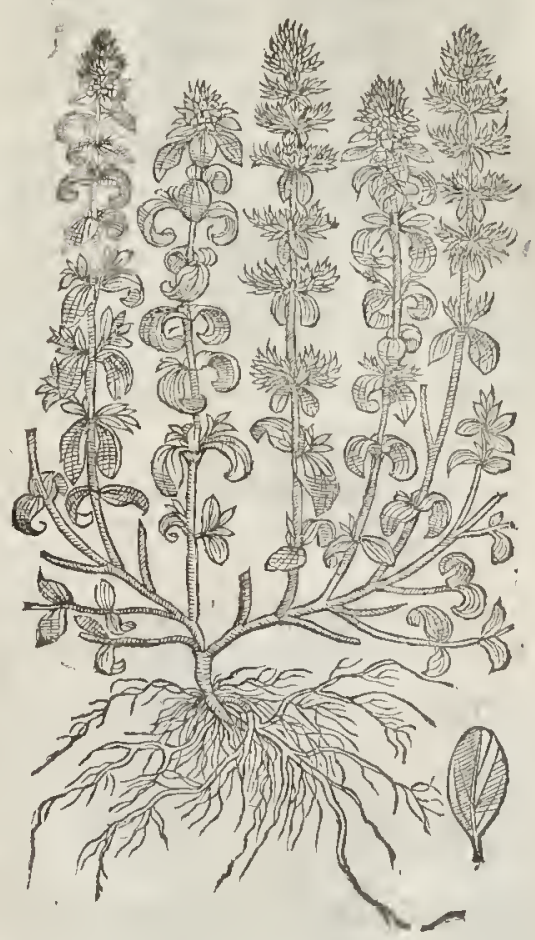

3 Time of Candy is in all refpeets like vnto common Time, but differeth in that, that this kinde hath certaine knoppy tufts not mucli vnlike the fpikes or knots of Stecados, but much leffer, befet w ith flender foures of a purple colour. The whole plant is of a more gracious finell than any of the other Times, and of another kinde of tafte, as it were fauouring like fpice. The root is brittle, and of a wooddy fubitance.

4. Doubtleffe that kinde of Time whereon Epithymum doth grow, and is called for that caufe Epithymum, and vfed in hlops, is nothing elfe than Dodder that growes vpon 'Time; and is all one with ours, though Matthiolus makes a contronerfie and difierence thereof: for $P$ enat traulling oner the hills in Narbone neere the fea, hath fecne not onely the garden Time, but the wilde Time al fo loden and garnithed with this Epithymtm. So that by his fight and nine owne knowledge I am affured, that it is not another kinde of Time thatbeareth Epithymum, but is common Tine : for I haue often found the fame in England, not onely vpon our Time, but vpon Saurorie, and other herbes alfo: notwithiftanding thus much I may coniecture, that the clymate of thofe Countries doth yeeld the fame forth ingreater aboundance than ours, by reafon of the intemperance of cold, wheremnto our countrey is fubiect. 


\section{$574 \quad$ Of the Hiftory of Plants.}

\section{L1 8. 2.}

t 3 Thymum Creticum. Time of Candy.

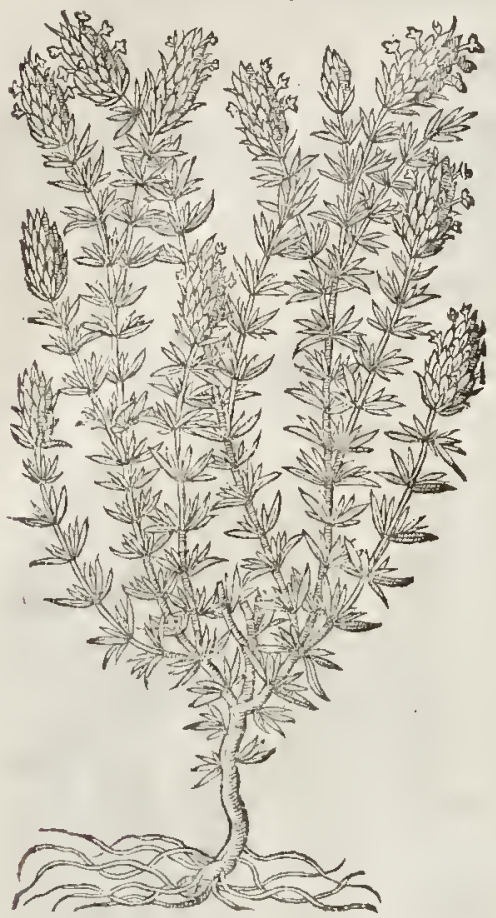

4 Epitbynum Grerorum, Laced Time.

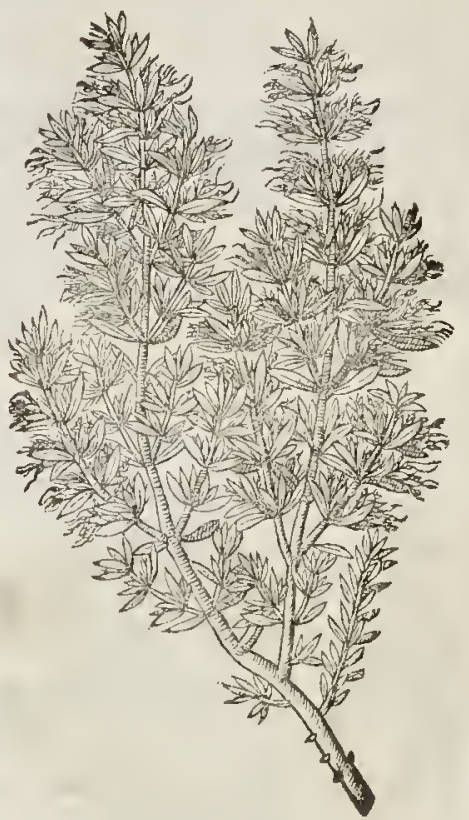

If The Place.

Thefe kindes of Time grow plentifully in England in moft gardens cuery where, except that with broad leaues, and Time of Candy, which I haue in my garden.

They fourifh from May vnto September. I The Time.

The firf may be called hard The Nims. the third, Time of Candy der Time.

Thefe kindes of Time are hot and dry in the third degree.

\section{The Vertues.}

A Time boyled in water and hony drunken, is good againft the cough and thortnes of the breath; it prouoketh vrine, expellerh the feeond ne or after-birth, and the dead childe, and diffolues clotted or congealed bloud in the body.

B The fame drunke wirh vineger and falt purgeth flegne : and boyled in Mede or Methegline, it cleanfeth the breaft, lungs, reines, and matrix, and killeth wormes.

C Made into pouder, and taken in the weight of three drams with Mede or honied vineger, called Oxymel, and a little falt, purgeth by ftoole tough and elammie fiegme, tharpe and cholericke humors, and all corruption of blond.

b The fame taken inlike fort, is good againt rhe Seiatica, the paine in the fide and breft, againft the winde in the fide and belly, and is profitablealfo for fuch as are fearefull, melancholike, and
troubied in minde.

E It is good to be given unto thofe that hane the falling fiekneffe to fmell vnto.

F. Etwtymum, after Galen, is of more effeitualloperation in phy ficke than Time, being hot and dry in the third degree, more mightily cleanfing, heating, drying, and opening than Cufcuta, haning right gond effea ro craclicat melaneholy, or any other humor in the fplcen, or other difeafe, fprung
by occafion of the fpleene. 
L, I . 2.

Of the Hiltory of Plants.

It helpeth the long eontinued paines of the head, and befides his fingular ffeots about folene- $G$ ticall matters, it leclpeth the lepry,or any difeafe of melanclioly; all quart aine agues, and fuel like griefes proceeding from the fpleene. cholv.

Diofcorides faith, Epithymum drunke with honied water, expelleth by fiege, Hegme, and melan. H

Of his natine propertic it relieneth them whieh be melancholieke, fwolne in the faee and other parts, if yo:1 pound Epithym: and take the fine pouder thereof in the quantity of foure feruples in the liquour which the A potheearies call Pafum, or with Oxymell and falt, which taketh away
all flatuous humours and ventofities.

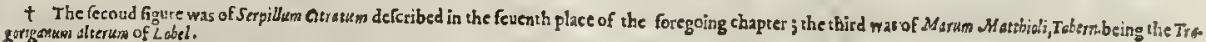

\section{Снат. 175. Of Samorie.}

\section{The Kindes.}

$\mathrm{T}$

Here be two kindes of Saurie, the one that indureth VVinter, and is of long continuanee: the other an annuall or yearely plant, that perifheth at the time when it hath perfected his feed, and mutt be fowne againe the next yeare; which we call Sommer Sauorie, or Sauoric of

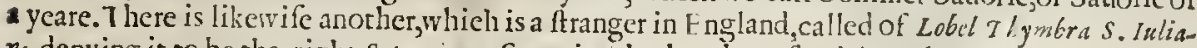
$m_{i}$, denying it to be the right Satweia, or Sauorie:whether that of Lobel, or that we haue in our Englith gardens be the true winter Sauoric, is yet difpttable; for we thinke that of $S$. Iulians roeke to be rather a wilde kinde than otherwife. $¥$ Pena and Lobel do not denie, but affirme it in thefe words, Null es son fatetur $S_{\text {atureiam veram }}$ that is, which none can denic to be the true Saturcia or Satorie. Yid.Adaerfar.pag. $182 . \neq$

I Satureia bortenfos.

VVinter Sauoric.

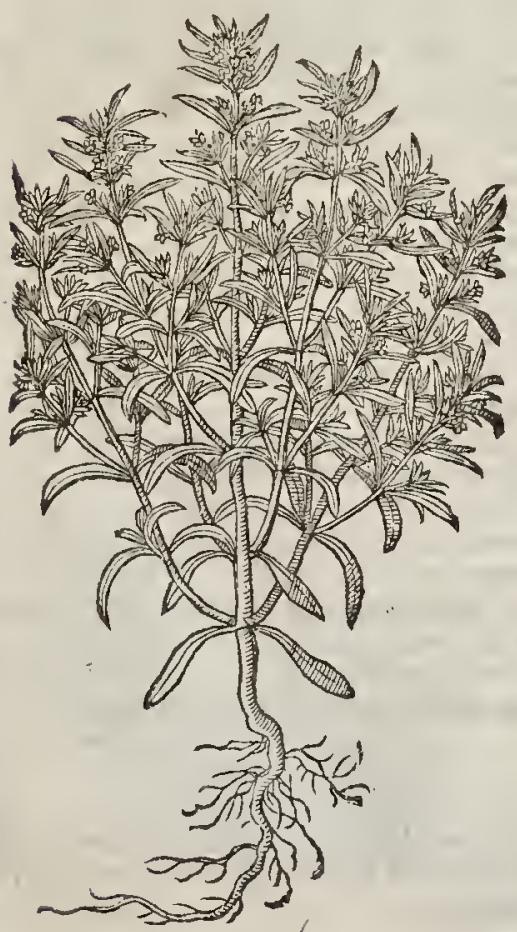

2 Satureia hortenfos \&fiva: Sommer Sallorie.

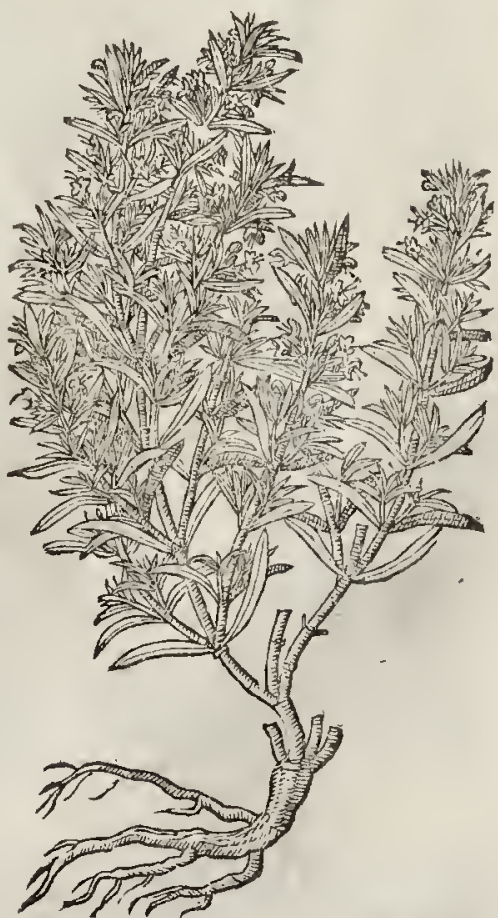




\section{TI The Defoription.}

I T Inter Saurie is a plant refembling Hyffope, but lower, more terder anibrittle: it bringeth forth very many branches, compaffed on euery fidew irh narrow and tharpe pointed leaues, longer than thofe of Time; among which grow the foures from the bottome to the top, out of fmall husks, of colour white, tending to al lighit purple. The root is hard and wooddic, as is the reft of the plant.

2 Sommer Saurie groweth vp with a flender brittle ftalke of a foot high, diuided into littic branches : the leanes are narrow, leffer than thofe of Hyfope, like the leaues of winter Sauorie, but thinner fet vpon the branches. The floures ftand hard to the branches, of a light purple tending to whiteneffe. The root is fmall, full of ftrings, and perifheth when it bath perfected his feed.

3 S.unreia Sanctiluliani. Rocke Saurorie.

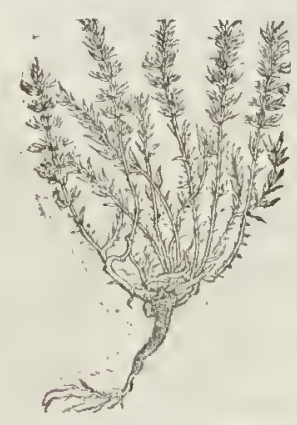

₹ 4 Satureia Cretica. Candie Sauorie.

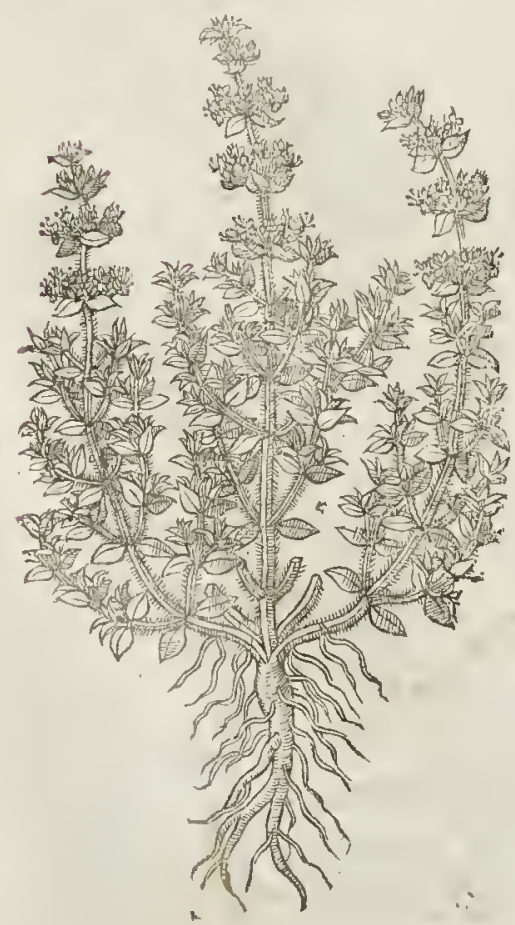

3 This fmall kinde of Sauorit, which Lobel hath fet forth vader the title of $T$ hym bra S. Iuliami, becaufe it groweth plentifully vpon the rough cliffes of the Tyrrhenian fer in Italie, called Saint Iuliars socke, bath tender twiggie branches an handfull hight; of a wooddie fub ftance, fet ful of leaues fron the bottome to the top, very thicke thruft together like vnto thofe of Time, faung that rliey be fnialler \& narrower, bringing forth at the top of the fprigs a round fuikie tuft of fmall purplifh foures. Thewhole plant is whitifh, tending to a bleake colour, and of a verie lot and tharpe tafte, and alfo well fmelling.

$\neq 4$ This in the opinion of Honorizs Bellus, Clufius, and Pona, is thoughe, and not without good reafon, to be the true Thymbra, or Satureia of Diofcorides and the Anticnts, for (befides that it agrees with their defeription, it is to this day called in Candie super and spues, ) Clufium defcribes it thus: It fends forth many branches immediately from the roote like as Tyme,and thofe quadrangular, rough, and of a purplifh colour : vpon thefe growe alternately little roughifh leaues much like thofe of the true Tyme; and out of their bofomes come little branches fetwith the like, but leffer leaues. The toppes of the branches are compaffed with a rundle made of manie little leaues, whereout come foures of a fine purple colour, and like the floures of Tyme, becing diuided into foure parts, whereor the lower is the broader, and hangs downe: The vpper is alfo broad but fhorter, and tlic other two leffe. Out of the middle of the foure come fiue whitifh threds, pointed with browne, and a forked ftile. The feed is fmall and blacke like that of Tyme. The root hard and wooddic. It floured with clufus (w ho receitud the feedes out of Candic fron Hon-rius Bellsus) in Oetober and Noucmber. $¥$

$$
\text { T) The Place. }
$$

They are fowne in Gardens, and bring foorth their floures the firft yeare of tlicir
fowing. 


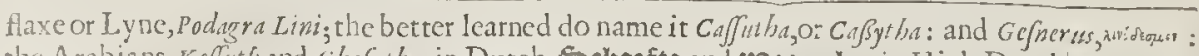
the Arabians, Kefuth and Chajuth: in Duteh, Schorffe, and noqanghe: in High Dutch, filktaut: in French, Goule d'Lin, and Tinne de Lin: in English, Dodder.

The leffer and flender $r$ which wrappeth it felfe vpon 'T" ime and Sauotic, is called of Diofcorides

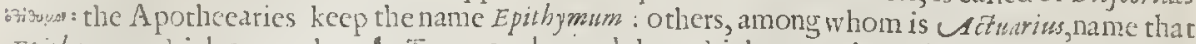
Epribyrum which groweth vpon Tyme oncly, and that whieh groweth on Sauric Epthymbrum, and that alfo which hangerh vpon Stabe, they terme Epiftebe, yiuing a peculiar name toenery kind. 4) The Nature.

The nature of this herb ehangethand altereth, aceording to the nature and qualitie of the herbs whereupon it groweth: fo that by fearehing of the nature of the plant you may eafily finde out the temperanent of the laces growing vpon the fame. But morepartieulariy: it is of temperature fomerhat more dric than hor, and that in the fecond degree: it alfo elenfeth with a certaine aftrictiue or binding qualitic, and efpecially that which is found growing voon the bramble : for it alfo receituth a certaine nature from his parents on whieh it groweth; for when it groweth vpon the lotter herbes, as Tyme and Sauory, it becommeth hotter and drier,and of thinner parts:that which eommeth of Broome prousketh vine more foreibly, and maketh the belly more foluble : and that is moifter whieh groweth vpon flaxe: that which is found vpon the bramble hath ioined with it as wee hate faid a tinding qualitie, which by reafon of this facultie ioyned with it is good to cure the infirmities of the Liucr and Milt: for feeing that it hath both a purging and binding facultie vnited to it, it is moft fingular good for the entrals : for Galen in his thirtecnth Bookc of the Methode of euring, doch at large dcclare that fuch Medicunes are fitteft of all for the Liuer and Milt.

A Dodder remooneth the ftoppings of the liuer and of the milt or fpleene, it disburdeneth the veines of flegmaticke, cholericke, corrupt and fuperfluous humours : prouoketh vrine gently, and in a meane openeth the kidacics, cureth the yellow iaundife which are ioyned with the ftopping of the liter and gall : it is a remedie againft lingring agues, bantard and long tertians, quartains alfo, and properly agues in infants and young elildren, as Mefues faith in Scrapio; whoalfo teacheth, that the nature of Dodder is to purge choler by the ftoole, and that more effectually if it haue Wormeryood ioined with it ; but too much ving of it is hurtfull to the ftomacke: yet Auicen writeth that it doth not hurt it, but itrengtheneth a weake or feebleftomacke; which opinion al fo we dobetter allow of.

3) Eproymun, or the Dodderwhich groweth vpon Tyme, is hotter and drier than the Doddet that groweth wpon flax, that is to fay euen in the third degree, as Galen faith. It helpeth all the infirmirjes of the milt : it is a remedy againft obftructions and hard fwellings. It taketh away old headacbes, the falling lickneffe, madneffe that commeth of Melancholy, and efpecially that which proecedeth from the fplecne and parts thercabout : it is good for thofe that haue the French difeafe, and fuch as be troubled with eontagious vleers, the leprofie, and the fcabbic euill.

It purgetli downewards blacke and Melaneholicke humours, as Actius, Adzarius, and Mefue write, and alfo Hegme, as Diofcorides noteth : that likewife purgeth by ftoole which gtoweth vpon Saurie and Scabious, but more weakly, as Adtuarius faith.

D Cufcuta, or Dodder that groweth vpon Hax, boiled in water or wine and drunke, openeth the ftoppings of the liuer, the bladder, the gall, the milt, the kidneies and veines, and purgeth both by frege and vrine eholericke humours.

E It is good againft the ague which hath continued a long time, and againt the iaundife, I meane that Dodder efpecially that groweth vpon brambles.

F Epiurtica or Dodder growing vpon nettles, is a moft fingular and effectuall medicine to ptouoke vrine, and to loofe the obftuctions of the body, and is proued oftentimes in the Weft patts with good fuceefle againft many maladies.

\section{Cнар. 177. Of Ofyjope.}

Ti The Defription.

I Iofcorides that gaue fo many tules fot the knowledge of fimples, hath lefr Hyffope altogether without defeription, as beeing a plant fo well knowne that it needed none: whofe example I follow not onely in this plant, but in many othets which bee com. mon, to atoid tedioufneffe to the Reader. 
\$ Hyfopus parva angufti folijs. Dwarfe narrow leaued Hyffope.

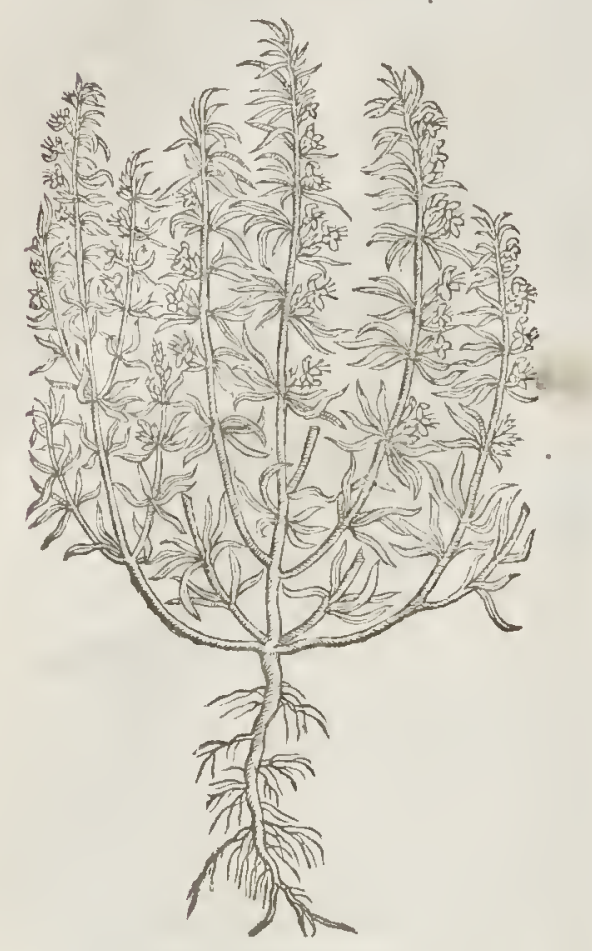

2 The feeond kind of Hy ffope is like the former, which is our eommon Hyffope, and differeth in that, that this Hyffope hath his fmall and flender branches decked with faire red floures.

3 The third kinde of Hyffop hath leaues ftalkes, branehes, feed, and roor, likc the eommon Hy ffope, and differeth in the floures on$\mathrm{ly}_{2}$,which are as white as fnow.

4 This kinde of Hyffope ofall the reft is of the grcateft beauty; it hath a woodd ie root tough, and full of ftrings; from which rife vp fmall, tough, and flender flexible ftalkes, wherupon do grow infinite numbers of frnall Fennel-like leaues, much refembling thofe of the fmalleft graffe; of a pleafant fiveet fmel, \&aro. matiek tafte, like vnto the reft of the Hyffops but much fweeter; at the top of the ftalks do grow amongft the leaucs fmal hollow floures, of a blewirh eolour tending to purplc. The feeds as yet I could neucr obferue.

$\neq 5$ This differs from the firft defcribed, in that the ftalkes are weaker and fhorter, the leaues alfo narrower, and of a darker colour : the floures grow after the fame manner, $\&$ are of the fame colour as thofe of the common kinde. $\ddagger$

We hate in England in our gardens anotherkinde, whofe pisture it thall be needleffe to expreffe, confidering that in few words it may be deliuered. It is like vnto the former, but the leaues arc fome of them white, fome greene, as the other; and fome green and white mixed and fpotted, very goodly to behold.

Of which kinde we haue in our gardens moreouer another fort, whofe leaues are wonderfilly "curled, rough, and hairie, growing thicke thruft together, making as it were a tuft of leaues;in tafte and fmell, and in all other things like vnto the common Hyffope.

I haue likewife in my garden another fort of Hyffope, growing to the forme of a mall wooddic fhrub, hauing very faire broad leates like vnto thofc of Numularia, or Monywoort, but thicker, fuller of iuice, and of a darker greene enlour; in tafte and fmcll like the common Hyffope. T The Place.

All thefe kindes of $\mathrm{Hy}$ ffope do grow in my garden, and in fome others alfo.

They floure from Itune to the cnd of Auguft.

$$
\text { Tा The Time. }
$$

of $T$ he Rames.

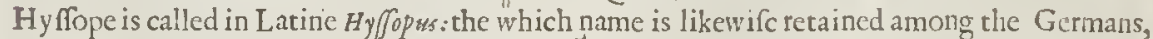
Brabanders, French-men, Italians, and Spaniards. Therefore that fhall fuffice whieh hath been fet downe in their feuerall titles.

¥ This is by moft Writers iudged to be Hyffope vfed by the Arabian Phyfitions, but not that of the Greekes, which is neerer to origanum and Maricrome, as this is to Saturein or Sanorie. ¥ T The Temperature and Vertues.

A A decoetion of Hyffope made with figs, and gargled in the mouth and throte, ripeneth \& breaketh the tumors and importhumes of the mouth and throte, and eafeth the difficultie of fwallowing,comming by cold rheumes.

B The fame made with figges, water, honie, and rue, and drunken, helpeth the inflammation of the lungs, the old congh, and thortneffe of brcath, and the obftruetions or ftoppings of the breaft.

C The firrup or iuice of Hy ffope taken with the firrup of vineger, purgeth by ftoole tough and clammic flegme, and driuctl forth wormes if it be eaten with figges. D The difilled watcr drunke, is good for thofe difeafes before named, but not with that fpeed and
force. 


\section{С на г.178. Of Hedge Hyffope:}

\section{If The Defription.}

1 Edge Hyffope is a low plant or herbe about a fpan long, very like vnto the commoxi

1 Hyflope, with many fquare italkes or flender branches, beferwith leaues fomewhat larger than Hyffope, but very like. The floures grow betw ixt the leanes vpon fhort ftems, of a white colour declining to blewneffe. All the herbe is of a moft bitter tafte, like the fmall Centory. The root is little and threddy, dilating it felfe farre abroad ; by which meanes is multiplieth greatly, and occupieth much ground where it groweth.

I Gratiola.

Hedge Hyffope.

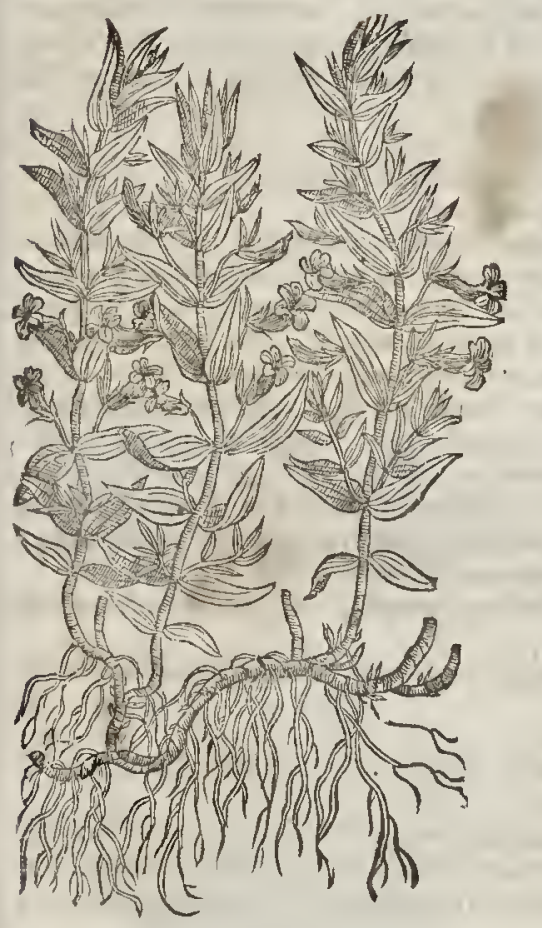

* 2 Gratiola angufifolia. 3 Gratiolalatifolia.

Graflè Poley. Broad leaued Hedge Hyffope: Sythrum Scitelearia minor

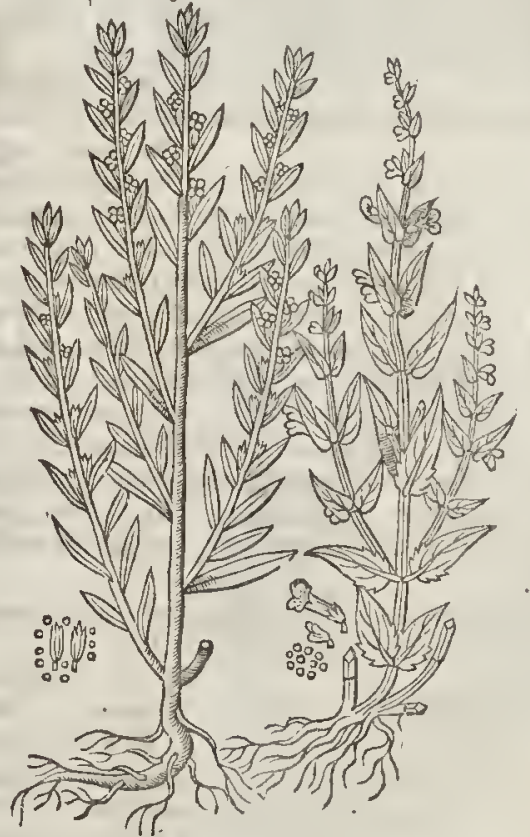

$\not 2$ Narrow leaued Hedge Hyfope from a fnall fibrous white root fends vp a reddifh round crefted ftalke diuided into fundry branches, which are fet with leates like thofe of knot grafie of a pale greene colour, and without any ftalkes : out of the bofomerof thefe come floures let in long cups compofed of foure leaues of a pleafing blew colour, which are fucceded by longith feed-veffills conteyning a fmall dusky feed. The whole plant is without fimell, neither hath it any bittemeffe or other manifeft tafte. It varies in leates, fonetimes broader, and otherwhiles narrower, the plant growing fometimes but an handfull, and orherwhiles a foot high. Gefrer called this Gratiolaminor:and Camerarius, Hy/Jupoides: and Baubine onely hath figured it, and that by the name of Hyfopifolia fue Gratiola minor. Cordus firf mentioned it, and that by the Dutch name of Graffe Poley, which namewe may alfovery firly retaine in Englih. $\neq$

3 Broad leaued hedge Hy fope hath many fmall and tender branches, foure fourare, and fomewhat hollow or furrowed, befet with leaucs by couples one oppofite againf another, like vnto the former, but fomewhat fhorter, and rmuch bioader: among which grow the foines of a purple $\mathrm{Ccc}$ colour 
colour, fpotted on the infide w ith white, and of a brighter purple than the reft of the floure, fafhioned like the fmalleft Antirrhimum, or leat Snapdragon; which being paft, there fucced lit le feed veffels, farhioned like the nut of a croffebow, which containe fmall yellowifh feed, extreame bitter of tafte. The whole plant is likewife bitter, as the common or well knowne Gratiola. The roor is compact of a great number of whitifh ftrings, entangled one within another, which mightily encreafeth and fpreadeth abroad.

$¥$ This plant is onely a leffer kinde of the Ly/machia galericulat of Lobell, which fome haue called Gratiola latifolia: our Authors figure was very ill, wherefore I haue endeauoured by the helpe of fome dricd planes and my memory to prefent you with a better exprefion thereof. $\neq$

$$
\text { The Place. }
$$

The firft groweth in low and moift places naturally, which I haue planted in my Garden. \# The fecond was found growing by my oft mentioned friend $\mathrm{M} r$. Buwles at Dorcheiter in Oxfordthire, at the backe fide of the enclofed grounds on the left hand of the rowne, if you would ride from thence to Oxford in the graffe places of the Champion corne fields. $¥$ The third groweth likewife in moift places. I found it growing vpon the bog or marrifh ground at the further end of Hampltead heath, and vpon the fame heath towards London, necre vnto the head of the fpi ings that were digged for water to be conueied to London, 1590 . attempted by that carefull citizen Iobr Hart Knight, Lord Major of the City of London : at which time my felfewas in his Lordihips company, and viewing for my pleafure the fame goodly fprings, I found the faid plant, not heretofore remembred.

$$
\begin{aligned}
& \text { The Girft flonreth in May:the fecond in Iune and Iuly:the third in Auguft. } \\
& \text { 9ा The Nomes in generall. }
\end{aligned}
$$

Hedge Hyfiope is called in Latine Gratiola, and Gratia Dei, or the Grace of God, notwithfanding there is a kind of Geranium, or Storkes bill,called by the later name. Of Cordus, Limnefium, and Centauroudes: of Anguillaria it is thought to be Diofcorides his Papauer fpumeum,or Spatling Poppy : but fome think Papauer fpumum to be that which we call Behen album: in Dutch it is called 1 odtg gratie : in Italian, stanca can illo, becaufe that horfes when they haue eaten thereof dowax leane, and languilh thereupon : and in Englifh, Gratia Dei, and Hedge Hyllope. The feed hereof is called Gelbencth, which name the Arabians retaine vnto this day.

$$
\ddagger \text { qा } N \text { ames in particular. }
$$

\# I Matibioius, Dodoneus and others haue called tl is Gratiola; Anguillara,Gratia Dei; Cordus; Limnefium, Centauroides, he alfo thought it but vnfitly to be the Eupatoreum of Mefue: Gefner thinks it may be Polemonium paluftre amarum of Hippocrates, that write of the difeafes of cattell. $\neq$

2 Cordus ealled this Graffe Poley; Gefner, Gratiola minor: Camerarius, Hy/fopoides:and Bubhime, Hyjopifolia.

3 This is not fet forth by any but our Author, and it may fitly be named Lyfimachia gálericulataminor, as I latie formerly noted. $\neq$

$$
\text { of The Temperature. }
$$

Hedge Hyflope is hot and dry of temperature. And the firft is onely vfed in medicine. . "

$$
\text { gा The Pertues. }
$$

A Who fo taketh but one fcruple of Gratiola brufed, (hall perceiue enidently his effectuall operarion and vertue, in purging mightely, and that in great abundance, waterifh, groffe, and flimy humors. Conradus Gefnerus experimented this, and found it to becrue, and fo have Imy felfe, and many others.

B Gratiolaboiled, and the decoction drunke or eaten with any kinde of meate, in manner of a fallade, openeth the belly, and caufeth notable loofenes, and to fcoure freely, and by that meanes pur. geth groffe flegme and cholericke lummors.

$G$ atiola or Hedge Hyfope boiled in wine and giuen to drinke, helpeth feuers of what fort fo-
cuer, and is moft excellent in dropfres, and fueh like difeafes proeeding of cold and watery
caufes. caufes.

D The extraction giuen with the powder of cinamon and a little of the juice of Calamint,preuaileth againft tertian and quotidian feters, fet downe for moft certaine by the learned leachimus Ca:
me rarius. 
Li s. 2. Of the Hiftory of Plants:

\section{С на Р. 179. Of Lamander Spike.}

\section{T The Defription.}

I Auander Spike hath many ftiffe branches of a wooddie fubfance, growing vp in the manner of a fhrubbe, fet with many long hoarie leaues, by couples for the moft part. of a ftrong fmell, and yet pleakant cnough to fuch as doe loueftrong fatours. The floures grow at the rop of the branches fpike farhion, of a blew colour. The roote is hard and wooddie.

2 The fecond differeth not from the precedent, but in the colour of the fioures: For this Plant bringeth milke white foures; and the other blow, wherein efpecially confifteth the difference.

3 Wee haue in our Englin gardens a fmall kinde of Lauander, which is altogether lefer than the other, $\neq$ and the floures are of a more purple colour and grow in much leffernd thorter heads; yet hate they a farre more gratefull fmell: the leaues arealfo leffe and whiter than thofe of the ordinarie fort. This did, and I thinke yet doth grow in great plentie, in his Maiefties priuate Garden at White hall. And this is called Spike, without addition, and fomet imes Lauander Spike: and of this by diftillation is made that vulgarly known and ved oile which is termed olewn $\beta_{i c a}$ or oile of Spike. $\$$

I Livandula fiore iaruleo. Conmon Lauander.
2 Lavandula fiore albo. VVhite foured Lauander.
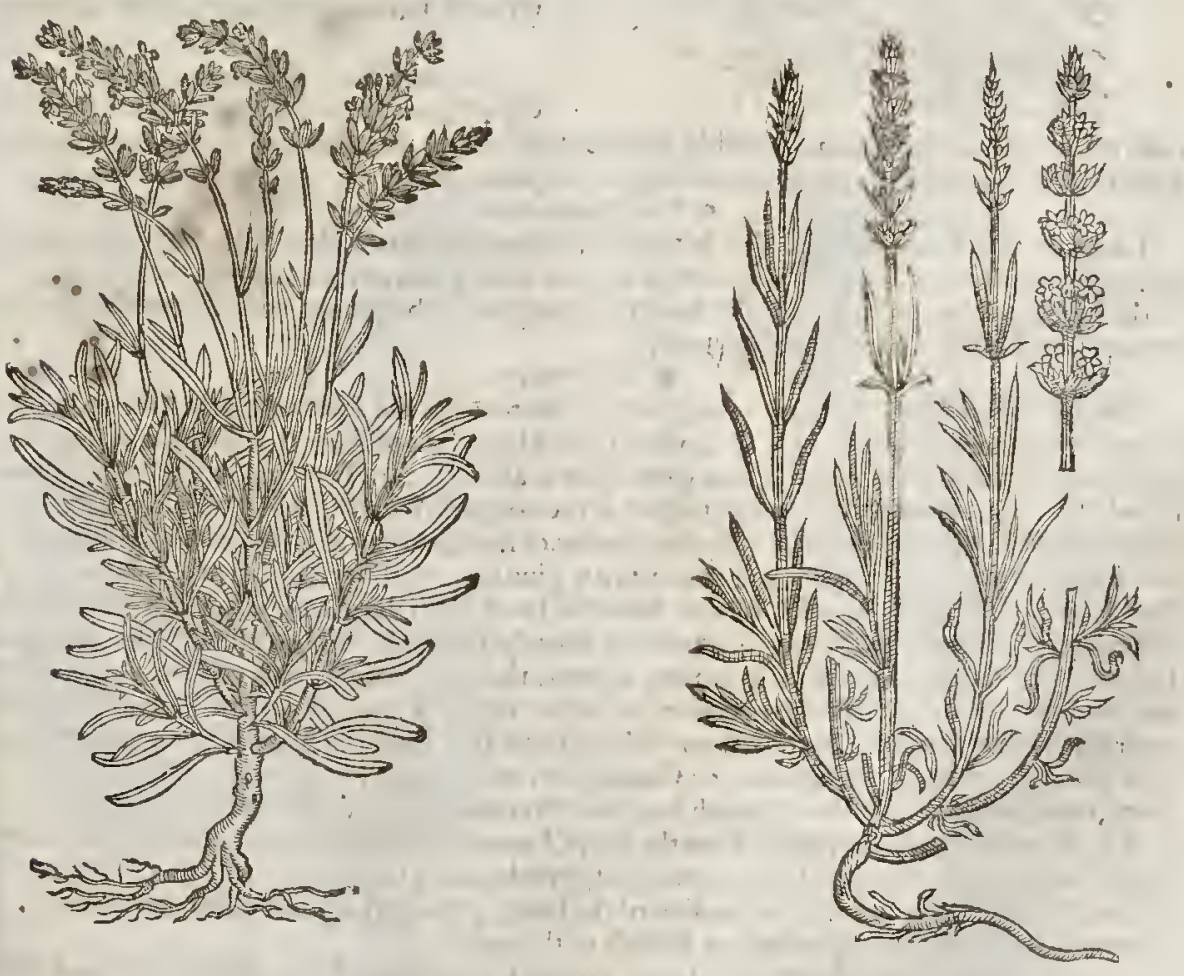

वा Th be Place.

In Spaine and Languedocke in France, moft of the mountaines and defert fields, are as it were 
3 Lavcndula minor, fve Spica. Lauander Sjike.

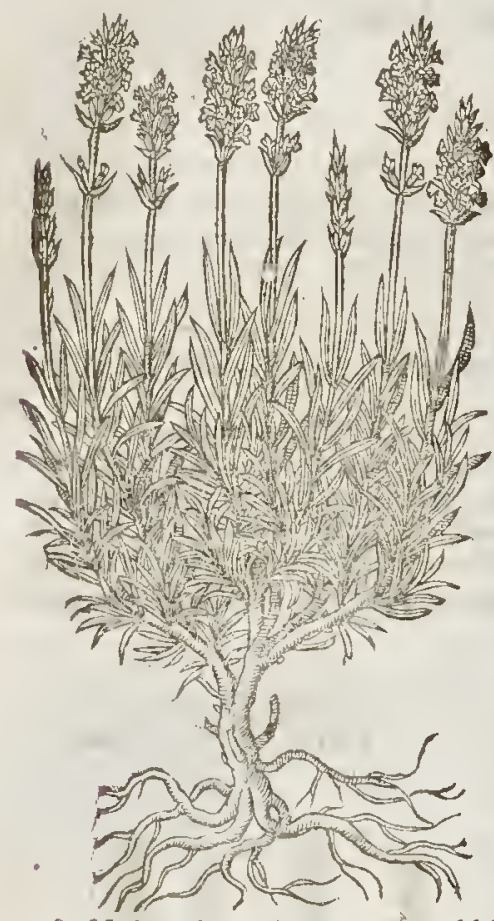

coured cuer with Lauancer: In tlefecoid count ries they are plarked in gardons. बा The.Time.

They floure and flourifh in Iune and Iuly. ब TheNames.

Lauander Spike is called in Lattire Larnendula, and Spica: in Spanih, spicio, and Larguda. The firft is the malc, and the fecond the fe. male. It is thought of fonc to be that fivcet herbe $C a f i n$, wher ef $V$ irgil makcth mention in the fecond Eclog of his Bucolicks: .

Tum Cafra atque alys intexens fuavibus bo bus, Mollia lutcolapingit vacixia Caltha.

(infold)

And then thee'l Spike and fuch fwect herbs And paint the Iacinth with the Marygold.

And likewife in the fourth of his Georgicks, where hee intreatcth of choofing of feats and places for Bees, and for the ordering thereof, lie faith thus :

\section{Hec circum Cafra virides, \& olcntin late scrpilla, or graniter fpirant is copin $T$ bymbre Floreat;orc.}

About them let frefh Lauander and ftore Of wild Timewith ftrong Samoric to floure?

Yct there is another cafor called in thops Cafor Lignea, as alfo Cafiamigra, which is named Cafia fiftula; and another a fnallinrubbie plant extant among the thrubs or hedge bufhes, wich fome thinke to be the Cafia Poetica, mentioned in the prccedent verfes.

(i) $T$ he $T$ comperature.

Lauander is hot and drie, and that in the third degrce, and is of a thin fubftance, confifting of many airic and fpiritu.ll parts. Therefore it is good to be gituen any way againfthe cold difeafes of the head, and cfpecially thofe which hane their originall or beginning not of abundance of hu. mours, bur chiefely of a cold quality onely.

$$
\text { T The Vertucs. }
$$

A The difilied water of Lauander fmelt vnto, or the remples and forehead bathed therewish, is refrefhing to them that hate the Catalepfre a light Migram, \& to them that haue the falling fick: neffe, and that vfe to firoune much. But when there is abundance of humours, efpecially mixt with blond, it is not then to be vfed fafely, neither is the compofition to be taken which is made of diftilled wine : in which fuch $\mathrm{k}$ inde of herbes, floures, or feeds, and ccrtaine fpices are infufcd or ftee ped, thongh mon men do rafhly and at aduenture giue them wirhout making any difference at all For by ring fuch bot things that fill and fuffe the head, both the difeafe is made greater, and the ficke man alfobrotigh inin danger, efpecially when letting of bloud, or purging haue sor gone before. Thus much bvway of admonition, becaufe that euery where fomc vnlearned Phy fitions and diuers rafh and nuerbold A pothecaries, and other foolin women, do by and by gitue fuch compofitions, and othets of the lite kinde, not only to thofe that haue the A poplexy; but alfo to thofe that are taken, or laue the Catuche or Catalepfis with a Fcuer; to whom they can giue nothing worfe, feeing thof things dovery much hurt, and oftentimes bring death it felfe.

B The foures o! Latunder picked from the knaps, I meane the blew part and not the huske, inixcal with Cinamon, Nutmecs, and Cloues, made into pouder, and ginen todrinke in the diftilled water thercof,doth helpe the panting; and paffion of the heart, preuailcthagainft giddinefic, turning, or frimming of the brane, and members fubiect to the palfie.

C Conferte madc of the Boures with fugar, profiterh much againf the difeafes aforefaid, if the quantiticof a leane be taken thercof in the morning fafting.

D. Ir profitch them much that hauc the palfie, if they bee wathed with the difeilled water of the finures 
L 1 . 2.

floures, or annointed with the oile made of the floures, and oile oliue, in fuch manner as oile of rofes is, which thall be exprefed in the treatife of Rofes.

\section{HA P. 180. Of French Lawander, or Stickeadoue.}

\section{The Defcription.}

I FRench Lauander hath a bodie like Lauander, fhort, and of a wooddic fubftance, but flenderer,be fet with long narrow leaues, of a whitilh colour, leffer than thofe of Lauander:it hath in the top bufhy or fpikic heads, well compa a or thruft together; out of the which grow forth fmall purple Houres, of a pleafant fmell. The feede is fmall and blackith : the roote is hard and wooddie.

2 This iagged Sticadoue hath many fmall ftifte falks of a wooddy fubstance; whereupon do grow ingged leaues in thape like vnto the leaues of Dill, but of an hoaric colour: on the top of the italkes dogrow fpike floures of a blew in colour; and like vnto the common Lauander Spike-the root is likewife wooddie. $\neq$ This by Clufins who firte defcribed it, as alfo by Loól, is called $L$ a vendulamultifido folio, or Lauander with the diuided leafe; the plant more refembling Lauander than Sticadouc ₹

3 'There is alfo a certaine kind chereof, differing in fmalnefle of the leaues oncly, which are round about the edges nicked or coothed like a faw, refembling thofe of Lauander cotton. The root is likewife wooddic.

¥ 4 There is alfo another kinde of stachas which differs from the firft or ordinaric kind, in that the tops of the falkes are not fet with leaues almoft clofe to the head as in the common kinde, but are naked and wholly without leaues: alfo at the tops of the fpike or floures (as it were to recompence their defect below) there growe larger and fairer leates than in the other forts. The other parts of the plant differ not from the common Stechas. $\ddagger$

\section{Stechas five pica bortulana. Sticadoue and Sticados.}

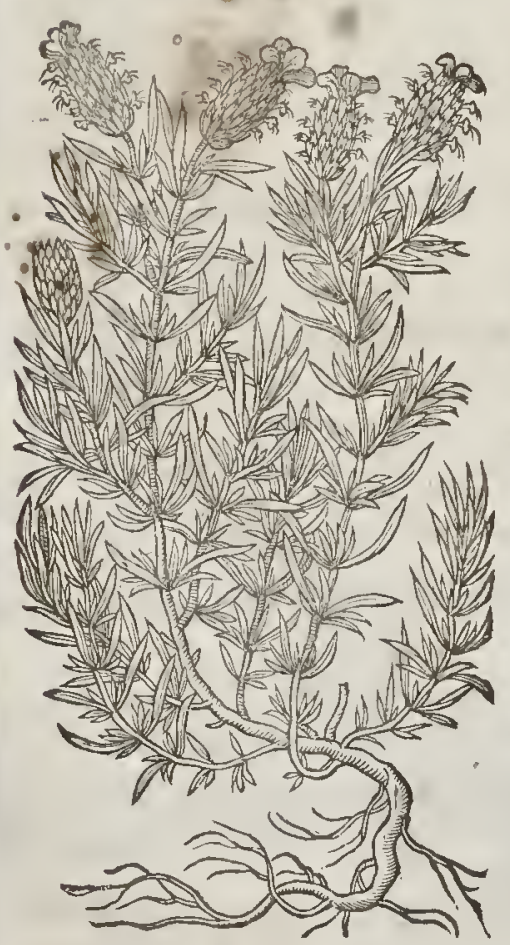

2 Stochas multifida. Iagged Sticados。

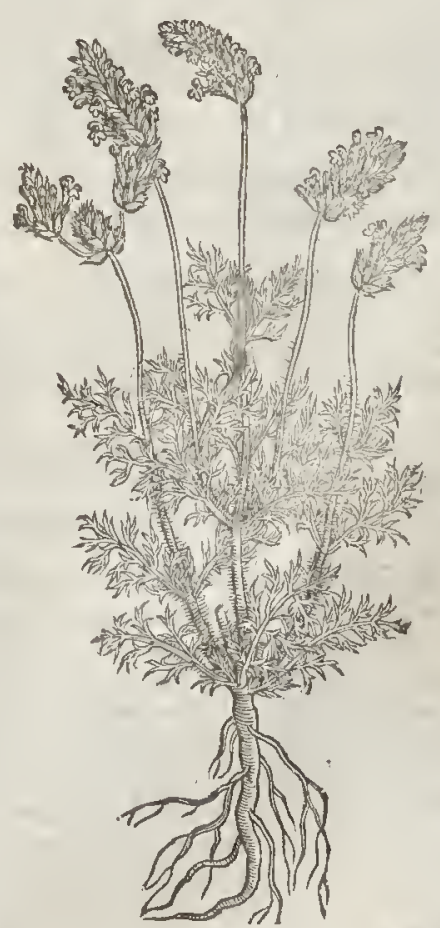

बा Ths 
3 Strechas folio ferrato.

Toothed Sticadoue.

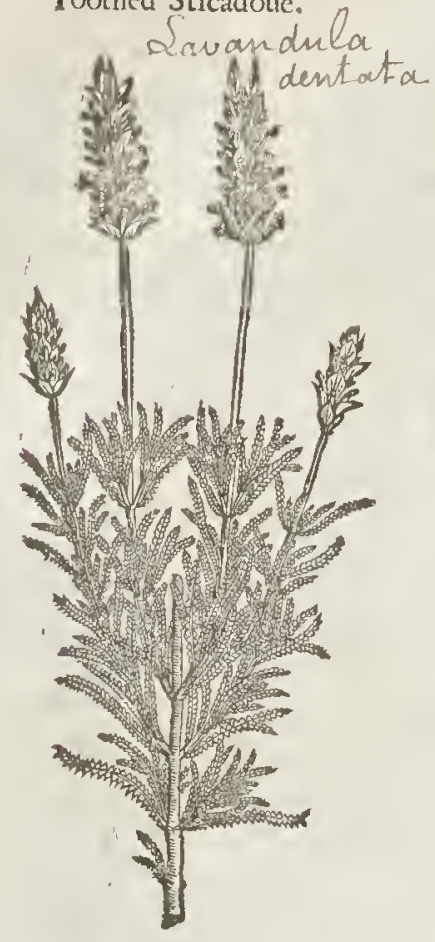

$\ddagger 4$ Stachos fummis sauliculis nudis. Naked Sticadoure.

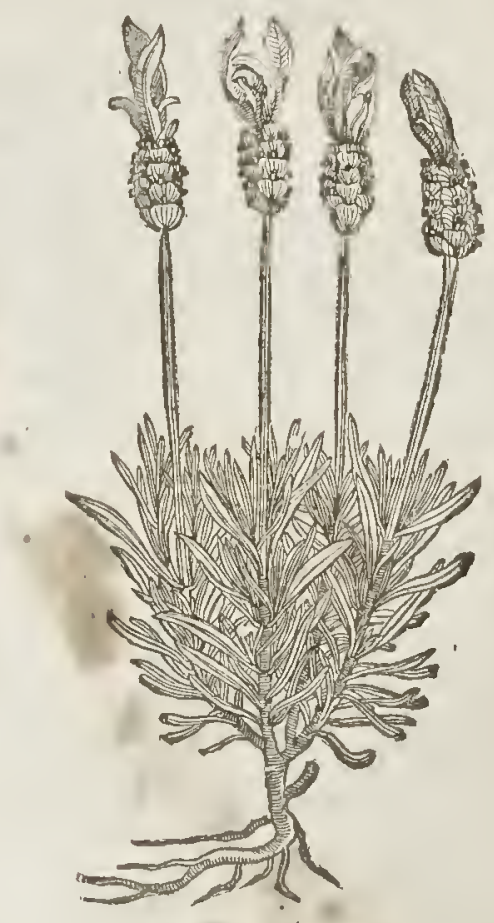

Thefe herbes do The Place.

chades ourer againft Maffilia: in Spaine, in Languedocke in France, and the Inlands called Stoe. from the initrie of our cold clymate.

They are fowne offeed in the The Time. in pots or tubs with carth, and carried into houfes.

The Apothecaries call the foure Stocatos The Names. the firt fyllable : in Larine foure Stecados: Diofcorides, sixas: Galen, suxas, by the distonng in Cantuefo: in Englinh, Frencl Lauander Srect Dutch, Stichas kraut: in Spanith, T homani, and imitaring the fance name do call it Cafteckado, Stickadouc, Caffidonic, and fome fimple people

$$
\text { French Iaduander faith Galen is of } 1 \text { The Temperature. }
$$

French Laduander faith Galen is of temperature compounded of a little cold earthic fubftance, to fcoure and clenfe, and th: it is of force to take away obftuctions, to exrenuate or make thinne, fcotre and clenfe, and to ftrengthen not onely all the entrails, but the whole bodie alfo.

Diofcorides teacherh The Vertues.

A good fucceffe mixed with counterpoifons. The later Phyfirions affire

B gainft paines of the head, and all difer Stachas, and efpecially the foures of it, are moft effe etuall amixed in all compofitions almoft which therenf proceeding of cold caufes, and therefore they be poplexie, the falling fick neffe, and fuch like diferfes. The deco falng fick neffe, and fuch like difeafes.

C milr, hecoction of the husk sand floures drunke, openeth the ftoppings of the lituer, the lungs, the cuilland corrupthumours, and procuring vrine. 


\section{CHA в. I 1. Of Flea-wort.}

\section{It The Defcription.} - I Syllium, or the common Flea-wort hath many round and tender branches, fer full of ?ung round chaffie knops, befer with fmall yellow foures: which being ripe containe mar y little fhining feeds, in proportion, colour, and bignefie like vinto fleas.

2 The fecond kinde of $P$ fyllum or Flea-wort hath long and tough branches, of a wooddy fubftance like the precedent, but longer and harder, with leates refembling the former, but much longer and narrower. The chaffie tuft which containeth the feed is like the other, but more like the eare of Phalaris, which is the eare of Alpiffi, the Canarie feed which is meate for birds that come from the Iflands of Canarie. The root hereof laftech all the Winter, and likewifekepeth his greene leaues, whereof it rooke this addition of semper virens.

I Pfyllium fuepalicaris berba. Flea-wort.

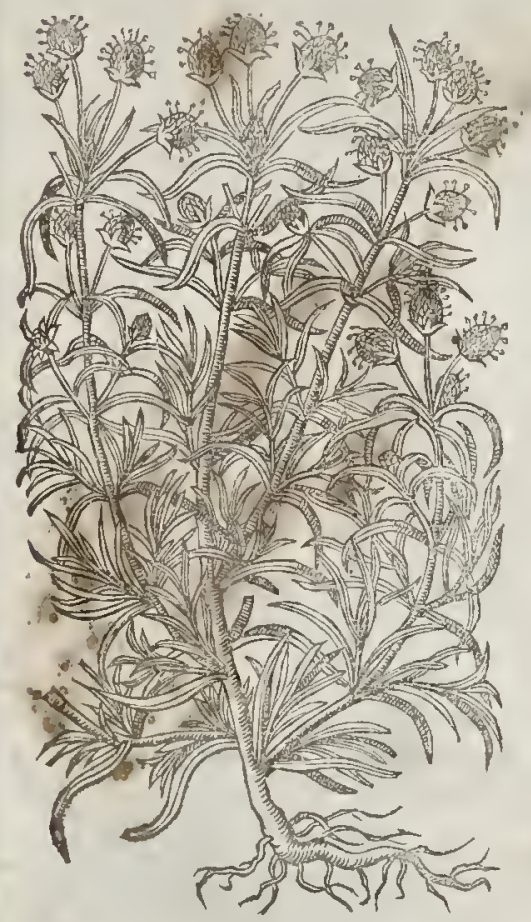

2 Pfylliwm fempervirens Lobelï. Neucr dying flea-wort.

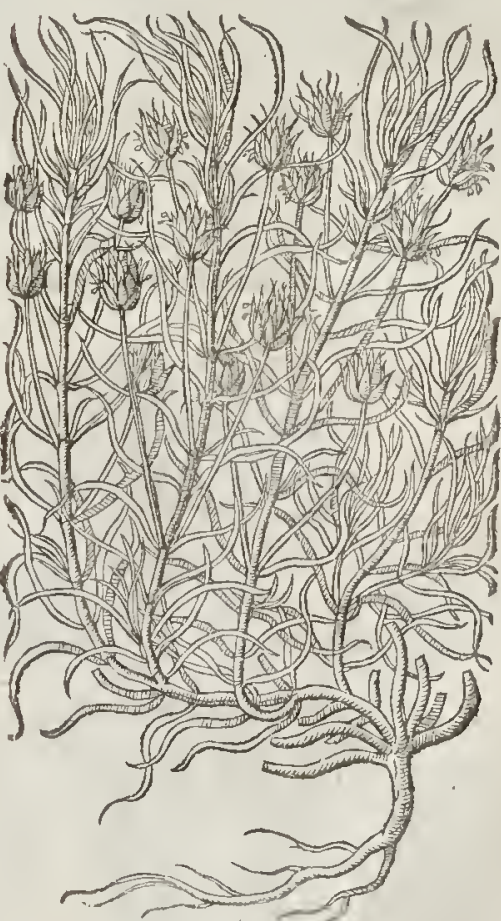

Ti The Place.

5 Thefe plants are not growing in our fields of England, as they doc in France and $S$ plaine, yet hate them growing in my garden.

They floure in Iune and Iuly.

a) The Time.

The Names.

Flea-wort is called in Greeke wiasor : in Latine, Pulicaria, and Herbut Pulicar is : in fhops, pyylititis in Englifh, Flea-wort; nor becaufe it killeth feas, but becaufe the feeds are like fleas: of fonte, Flea-bane, but vnproperly : in Spanin, Zargatona: in French, L'berbé aus pulces : in Dutch, slope-ecupt.

Galen and serapio record, that the feed of $P$ fyllium (which is chiefely ved in melic tha) is co'd in the fecond degree, and temperate in moifture and drineffe. 
A The feed of Flea-wort boyled in water or infufed, and the deco 9 ion or infufion drunke,purgeth downewaids aduft and cholericke humors, coolech the leate of the inward parts, hot feauers, burning agues, and fueh like difeafes proeed ing of heate, and quencheth drouglut and thirf.

$B$ The feed 1tamper, and boyled in water to the forne of a plaiter, and applied, taketh aw ay all fwellings of the ioynts, efpceially if you boyk the fume with vineger and oyle of Rofes, and apply it as aforcfaid.

C. The fame applied in manner aforefaid vnto any burning heate, cailed S. Anthonics firc, or any hot and riolent impotume, affivageth the fane, aid bringeth it ro ripeneffe.

D) Some hold that the herbe ftrowed in the chamber where many fleas be, will driuc them away; for wheh eaufe it tooke the name Flea-wort: but I thinke it is rather beculfe the feed dorh refomble a flea fo much, that it is hard to difeerne the nic from the other.

$$
\text { of The Dinger. }
$$

Ton much Flea-wort feed taken inwardly is wery hurt fu? to maus nature : fo that I with you not to follow the minde of Galen and Dioforide in this point, being a medieine tather bringing a maladie, than akking away the griefe : remembring the old prouerbe, A man ma buy gold tco deare; and the hony is too deare that is lickt from thornes.

$\ddagger$ Diofcorides nor Galen mention no $v$ fe of this inwardly; but on the contrarie, Diofcorides in lis fixth booke, which treats wholly of the curing and preuenting of poyfons, mentions this in the tenth ehapter for a poyfon, and there fets downe the fymptomes which it caufes, and refers you to the foregoing chapter for the remedies. $\neq$

\section{Cна в. 185. Of Glonie Gilloflowres.}

I Caryophyllus maximus multiplex. The great double Carnation.

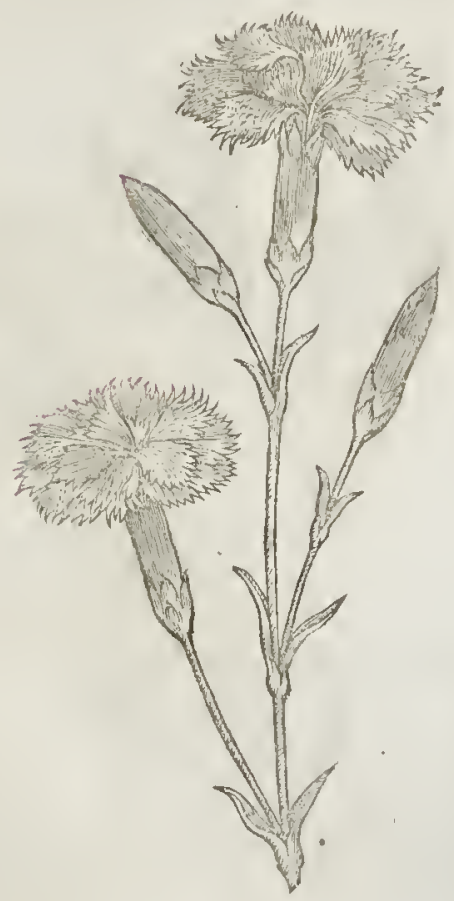

2 Caryophyllas multiplex.

The double Cloure Gilloflourc.

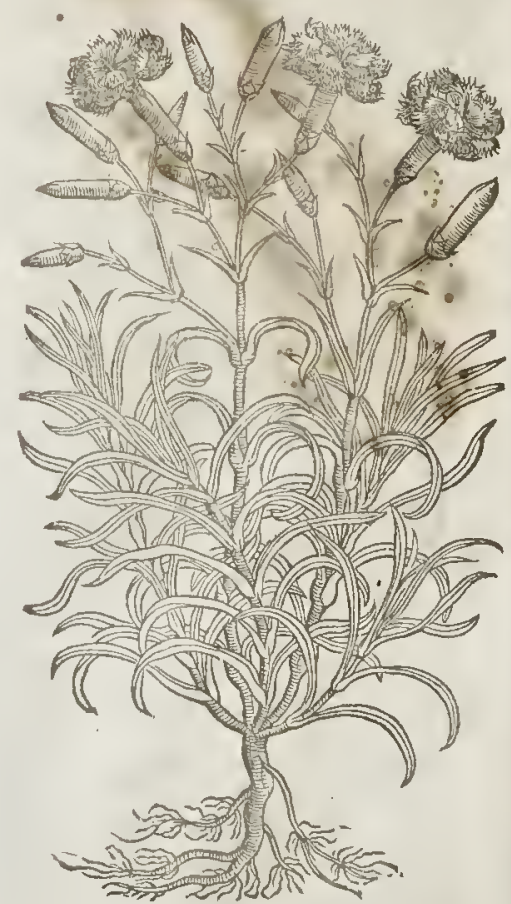

T The rindes.

micre are at this day voder the name of Caryophyllus comprehended diuers and fundry forts of 1. ints, of fuch various colours, and dlfo feurall mapes, that a great and large volume would. 
not fuffice to write of euery one at large in particular; confidering how in finite they are, wnil how euery yeare eucry clymate and countrey bringeth forth new forts, fuch as hane not herecoforebin written of; fome whereof are called Camations, others Cloue Gillofoures, fone Sops in wine, fome Pagiants, or Pagion colour, Horfe-Aefh, blunket, purple, white, double and fingle Gillofloures, as alfo a GilloHoure with yellow floures : the which a worhipfull Merchant of London $\mathrm{M}^{\prime}$. Nicolas Lete procured from Poland,and gaue me the reof for my garden, svlich before that time was nemer feene nor heard of in thefe countries. Likewife there be fundry forts of Pinkes com. prehended vnder the fame title, which thall be defcribed in a feuerall chapter. There be wnder the name of Gillofloures alfo thofe floures which wee call Sweet-Iohns and Sweet-Williams. And firt of thegreat Carnation and Cloue Gilletloure.

$\neq$ There are very many kindes both of Gillofloures, Pinkes, and the like, which differ very little in their roots, leaues, feeds, or manner of growing, though nutch in the colour, thape, and magnitude of their floures; wherof fome are of one colour, other fome of more; and of them fone are ftriped, others fpotted, \&c. Now I (holding it a thing not fo fit for me to infift vpon thefe accidentall differences of plants, hauing (pecifique differences enough to trcat of) refer fuch as are addicted to thefe commendable and harmetefle delights to furuey the late and oft mentioned Worke of my friend $\mathrm{M}$. Iohn Parkinfon, who hath accurately and plentifully trcated of thefe varieties; and if they require further fatisfaction, lct them at the time of the yeare repaire to the garden of Miftreffe $T_{u z g y}$ (the wife of my late deceafed fricnd $\mathrm{M}^{\mathrm{r}}$. Ralph $T_{u g g y}$ ) in Weftminfter, which in the excellencie and varietie of thefe delights exceederh all that I haue feene : as alfo hee himfelfe whileft he lined exceeded moft, if not all of his time, in his care, induftry, and skill in rai. fing, encreafing, and:preferuing of thefe plants and fome others; whofeloffe therefore is the more to be lamented by all thofe that are louers of plants. I will onely gine you the figures of fone three or foure more, whereof one is of the fingle one, which therefore fome terme a Pinke, though in mine opinion vnfitly, for that it is produced by the feed of moft of the doubleones, and is of different colour and thape as they are, varying from them onely in the fingleneffe of the floures. $\ddagger$

* Caryophyllas maior or minor, rubro on albo variegati. The white Carnation, and Pageant.

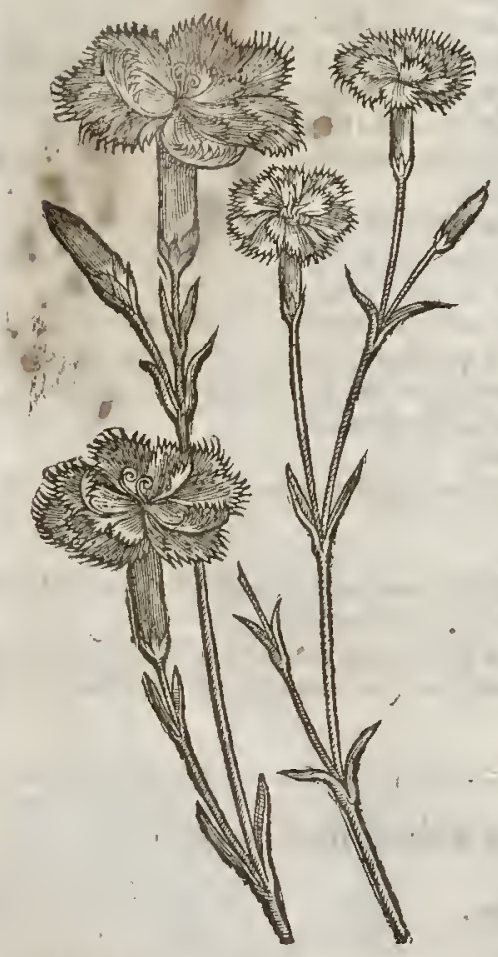

¥ Caryophyllus purpurcus profunde lacinialus. The blew, or deep purple Gillogloure.

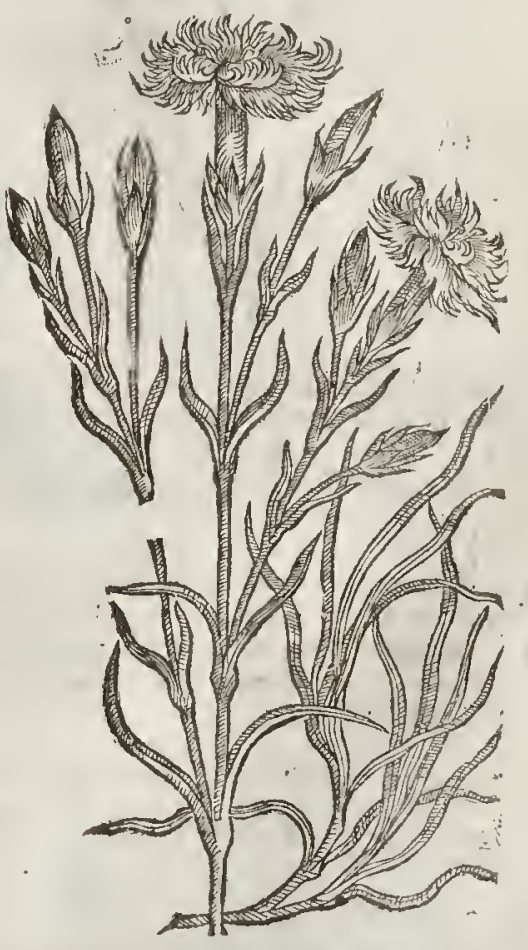




\section{If The Defcription.}

I The great Carnation Gillow-floure hath a thicke round wooddy root, from which rifech vp many ftrong ioynted ftalkes fetwith long greene leates by couples: on the top of the ftalkes dogrow very faire floures of an excellent fweet fnell, and pleafant Carnation colour, whercof it rooke his name.

3 The Cloue Gillofloure differeth not from the Carnation but in greatnefreas well of the floures as leaues. The floure is exceeding well knowne, as alfo the Pinks and orher Gillofloures, wherefore I will not ftand long vpon the defeription.

$¥$ Caryophyllus fimplex maior. The fingle Gillofloure or Pinke.

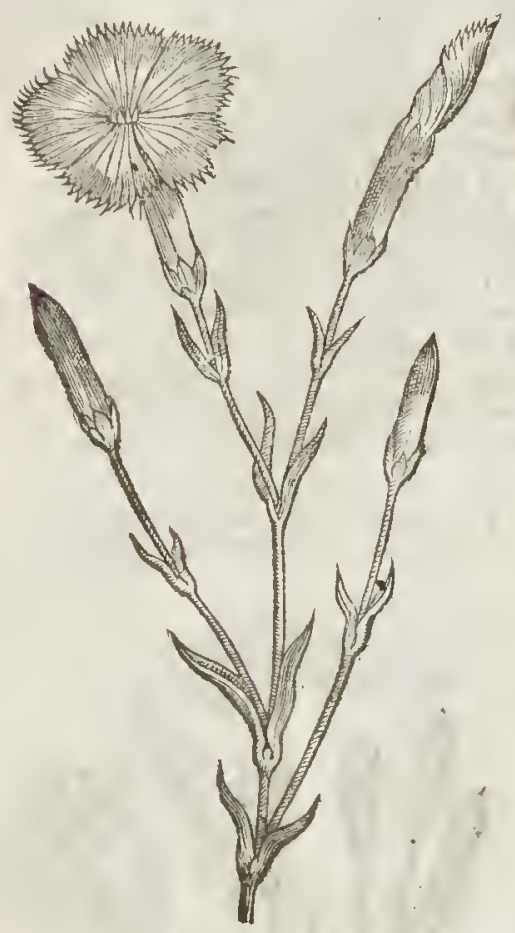

The Place.

Thefe Gillofloures, efpecially the Carnations, are kept in pots from the extremity of our cold Winters. 'The Cloue Gillofoure endureth better the cold, and therefore is planted in gardens.

\section{The Time.}

They flourith and floure mot part of the Sommer.

The Cloue Gillofloure is called of the later Herbarifts Caryophyllous flos, of the finell of cloues wherewith it is poffeffed: in Italian, $G$ arofoli: in Spanith, Claucl: in French, ocillets : in low-Dutch, Bbuoffelbloenucn : in Latine of molt, Ocellus D amafcemus, Ocellus Barbaricus, and Barbarica : in Englifh, Camations, and Cloue Gillohoures. Of fome it is ealled Vetonica, and Herba Tunica. The, whicl Berwitus Gordonizs hath fet downe for Diofcorides his Polemoniwm.

That worthy Herbarift and learned Plyyfition of late memoric $\mathrm{M}^{\mathrm{r}}$. Doctor Turner maketh Caryophyllus to be Cantabrica; which Pliny, lib. 23. cap. 8. writeth to haue beene found out in Spaine about Auguftus time, and that by thofe of Bifcay.

Iohames Ruellius faith, That the Gillofloure was vnknowne to the old writers : whofe iudgment is very good, efpecially becaure this herbe is not like to that of Vetonica or Camiabry. $c a$. It is maruell, faith he, rhat fuch a famous floure, fo pleafant and fweet, fhould lic hid, and not be made knowne by the old Writers : which may be thought not inferiour to the rofe in beaty, fmell, and varietic.

$$
\text { 9 The Temperature. }
$$

The Gillofloure with the leaues and roots for the molt part are temperate in heate and drineffe.

$$
\text { The Vertues. }
$$

A. The conferue made of the floures of the Cloue Gillofloure and fugar, is exceeding cordial,and wonderfully aboue meafure doth comfort the heart, being eaten now and then.

B It preuaileth againft lot peitilentiall feuers, expelleth the poy fon and furic of the difeafe, and greatly comforteth the ficke, as hath of late beene found out by a learned Gentleman of Lee in Effex, called $\mathrm{M}^{5}$. Rich.

$$
\begin{gathered}
\text { CH A P. 18;. Of Pinks, or milde Gillofloures. } \\
\text { I The Defcription. }
\end{gathered}
$$

1. He double purple Pinke hath many graffie leaues fervpon fmall ioynted falkes by cuuples, one oppofite againft another, whereupon doe grow pleafant double purple floures, 
- I Caryopbyllus fyluestris fimplex. Single purple Pinks.

W cain thing Caryophylens.

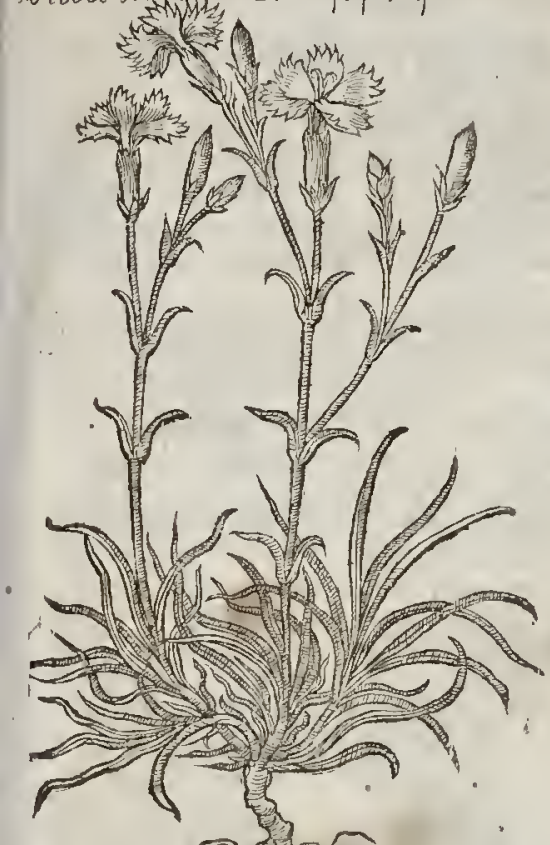

क्रुराण

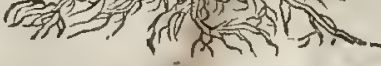

3 Caryophyllus plumarius albus. White jagged Pinks.
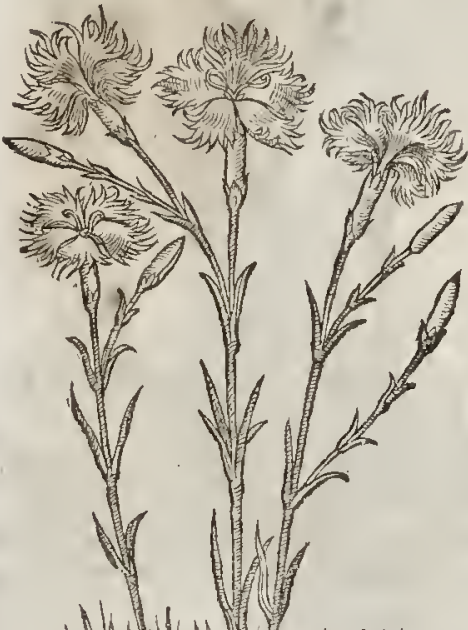

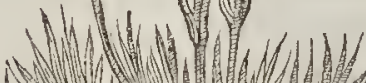
A wow HW D

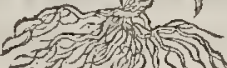

2 Caryophyllas fylueftris fimplex, fuaue rubcas. Single red Pinks.

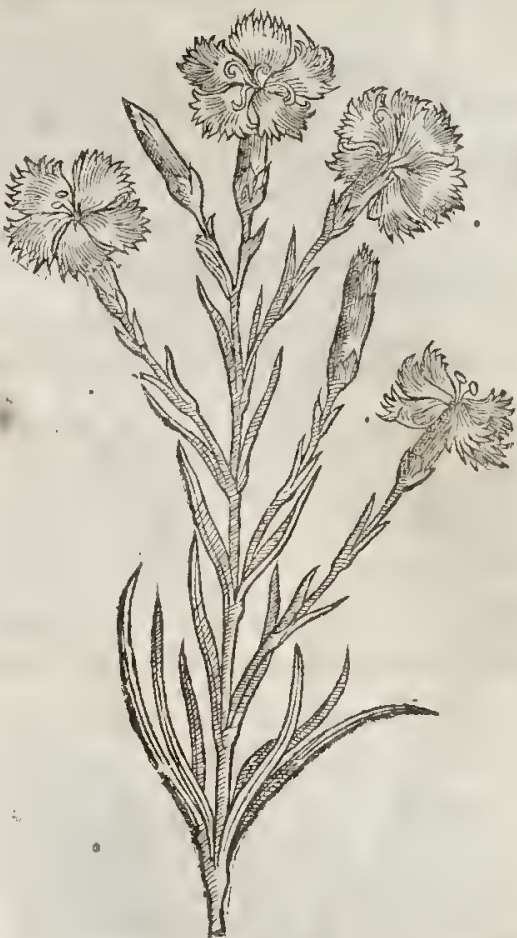

¥ Caryopbyllus plumarius albus odoratior. Largewhite jagged Pinks.

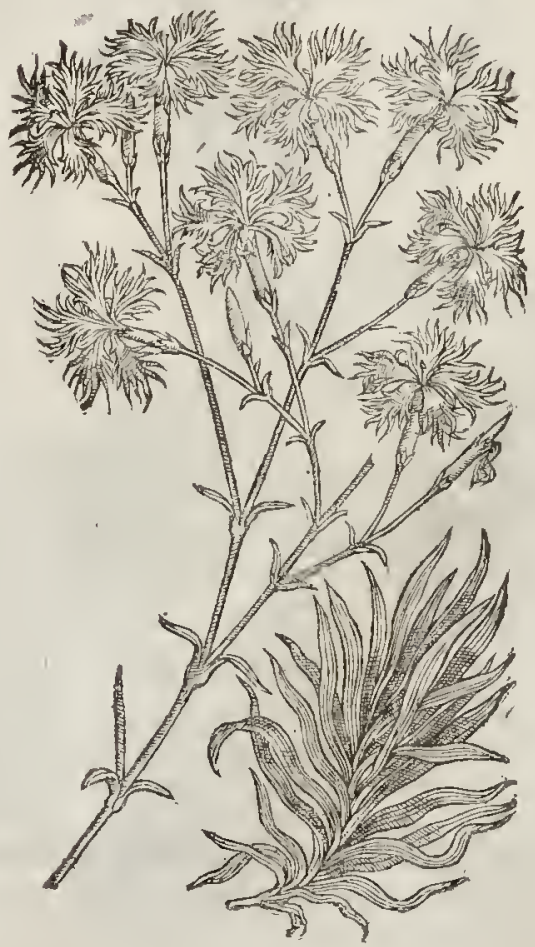


floures of a moft fragrant fmell, not inferiour to the Clone Gillofioure. The root is fmall and wooddy.

$\neq$ There is alfo a fingle one of this kinde, whofe figure I here giue you in ftead of the double onc ofour Authot. $\ddagger$

2 The fingle red Pinke hath likewife many fmall graffe leates leffer than the former : The floures grow at the top of the fmall talkes fingle, and of a fiveet bright red colour.

3 The white iagged Pinke hath a tough wonddy root : from which rife in:mediately many graffe leaues, fet vpon a fmall tealke full of ioynts or knees, at euery ioynt two one againfte another euen to the top; whereupon do grow faire double purple floures of a fweet and fpicie fmell, confiting of fuc leates, fometimes more, cut or decpely iagged on theedges, refembling a feather : whereupon I gaue it the name Plumarius, or feathered Punke. The feed is foft, blackinh, and like vnto Onion feed.

$¥$ There is another varietie of this, with the leaues fomewhat larger and greener than the laft mentioned : the floures alfo are fomew hat bigger, more cut in or diuided, and of a much fweeter fmell. $\ddagger$

4 This purple coloured Pinke is very like the precedent in ftalkes, roots, and leaues. The floures grow at the top of the brancbes leffer than the laft defcribed, and not fo deepely iagged; of a purple colour tending to blewneffe, wherein confifteth the difference.

There be diuers forts of Pinks more, whereof to write particularly were to fmall purpofe, confidering they are all well knowne to the moft, if not toall. Therefore thefe few fhall ferue at this time for thofe that we do keepe in our gardens : notwithftanding I thinke it conuenient to place thefe wilder forts in this fame chapter, confidering their nature and vertues doe agree, and few or none of them be vfed in phy ficke, befides their neereneffe in kindred and neighbourhood.

4 Caryophyllus plumarius purpureus.

Purple jagged Pinkes.

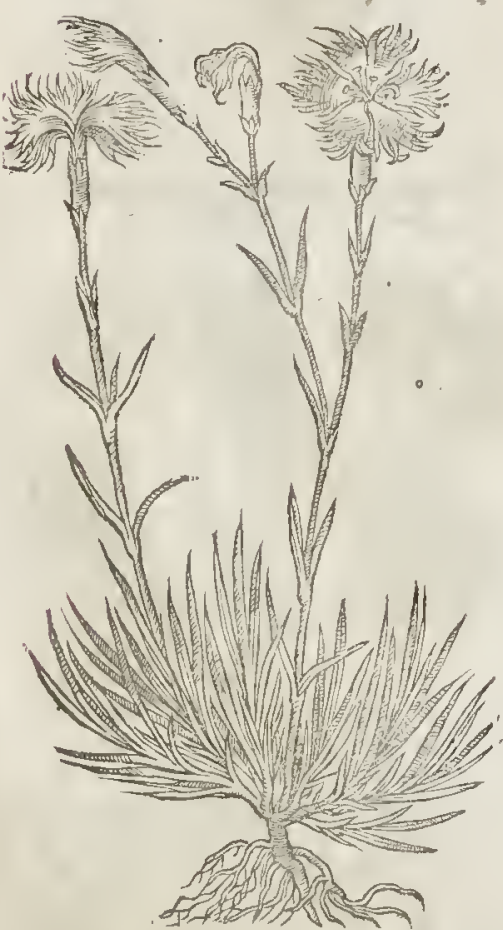

5 Cariopbyllus plumarius fylueflis albus. White wilde jagged Pinkes.

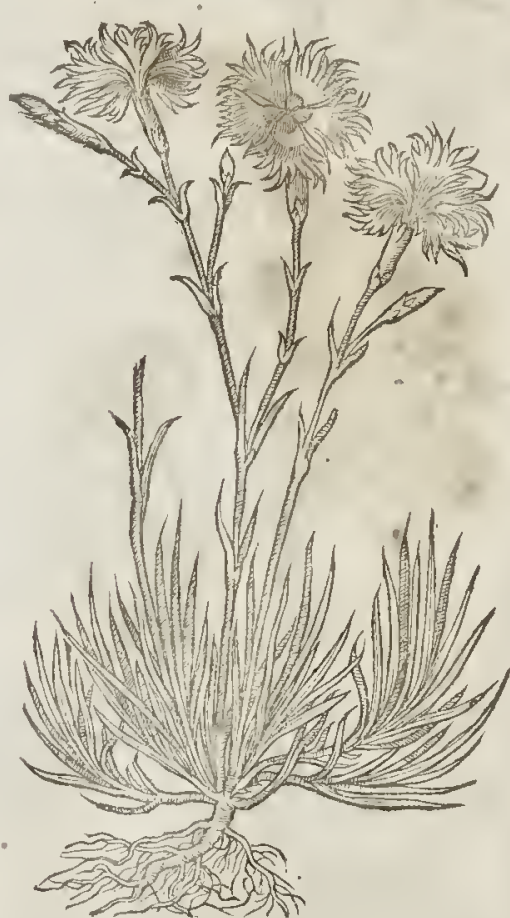

5 This wilde iagged Pinke hath leaues, ftalkes, and floures like vnto the white iagged Pinke of the garden, but altogether lefler, wherein they efpecially differ.

6 The purple mountaine or wilde Pinke hath many fmall graffe leaues : among which rife vp Alender ftalks fet with the like leanes, but leffer ; on the top whereof do grow fmall purple floures, fpotted finely with white or elfe yellowinh fpors, and much leffer than any of the others before de-
fcribed. 
6 Caryophyllus montanus purpureus. Wilde Purple iagged Pinke.

ODianttims deltoides -

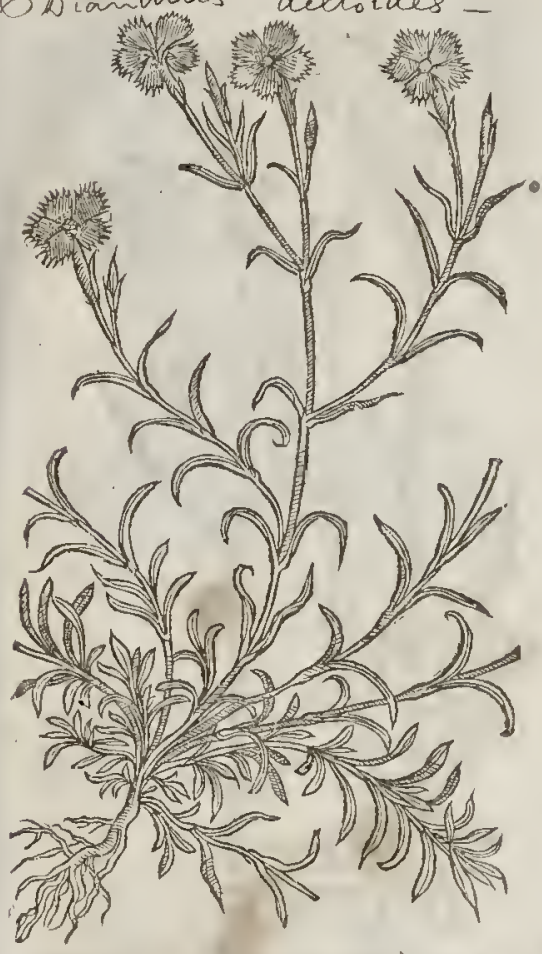

9 Caryophyllus caruleus fue Aphyllamibos. Leafeles Pinke, or rufhy Pinke.

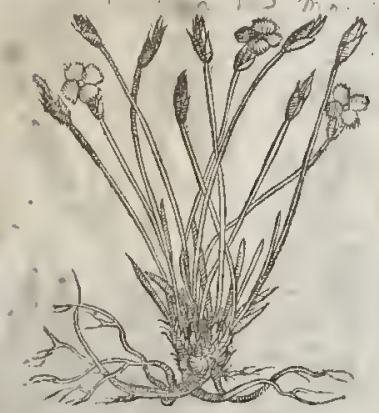

7 Caryophyllus monianus Clufij. Clufius mountaine Pinke.

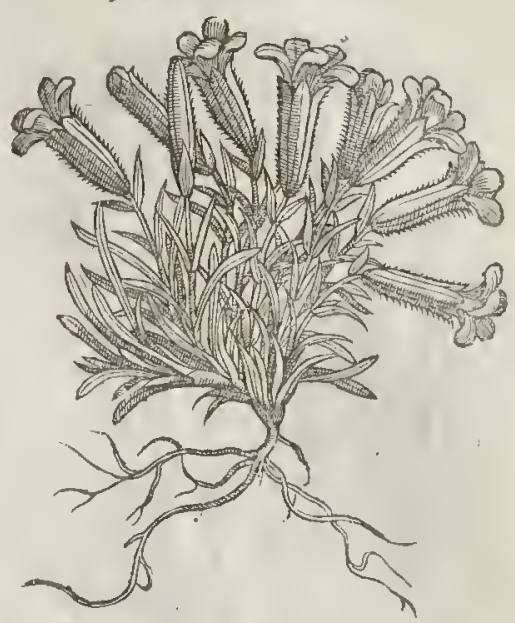

$\$ 8$ Caryophylluspumilio Alpinus. Dwarfe Mountaine Pinke.
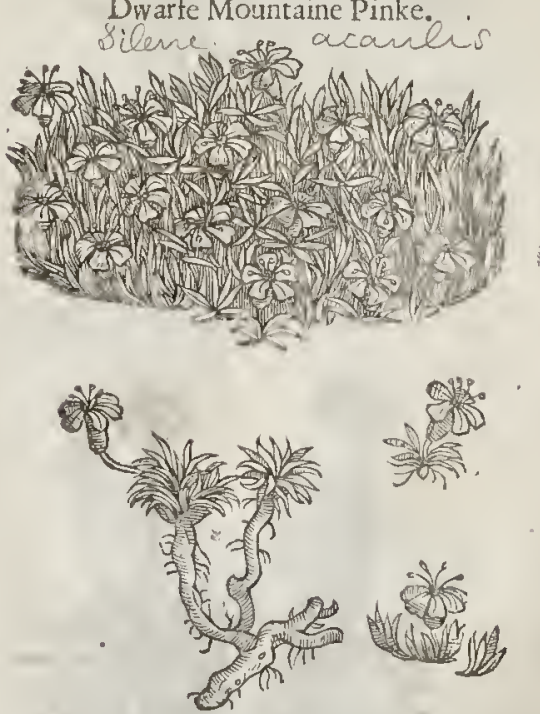

7 The mountaine Pinke of clufurs his defcription hath many leaues growing into a tuft like vnto thofe of Thrift, and of a bitter tafte : among ft which rife vp fmall Alender foot-ltalkes, rather than ftalkes or ftems themfelues, of the height of two inehes; whereupon do grow fuch leaues as thofe that were next the ground, but leffer, fet by couples one oppolite to another: at the top of eaeh fmall foot-ftalke doth ftand one red floure without fmell,confifting of fue little leaues fet in a rough hairy huske or hofe fue cornered, of a greenifh colour tending to purple. The root is tough and thicke, cafting abroad many thoots, whereby it greatly encreaferl.

₹ 8 This for his ftature may iuftly take the next place; for the talke is fome ineh high, fet with little fharpe pointed greene graffie leaues : the floures which grow vpon thefe ftalks are compofed of fiue little flefh-eoloured leaues a little diuided in their vpper parts : the feed is contained in blacke thining heads, and it is fmall and reddinh, and thaped fomwhat like the farhion of a kidney, whereby it comes neerer to the Lychrides, than to the Caryopbylli or Pinkes. The root is long, blacke, and much fpreading, whereby this little plant couers the ground a good fpace together like as a morfe, and makes a curious fhew when the floures are blowne, whieh is commonly in lune. It 
Io Caryophyllus montanus albus. White mountaitıe Pinke.

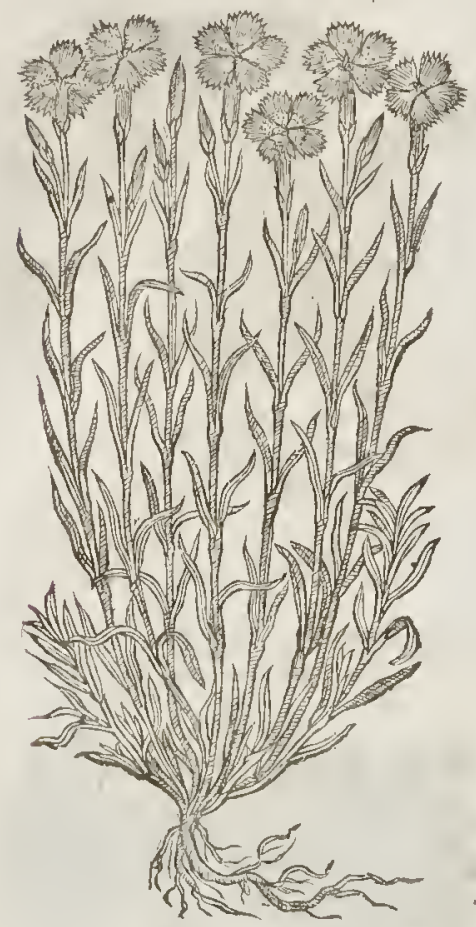

12 Caryoplsyllus Virgincus. Maidenly Pinkes.

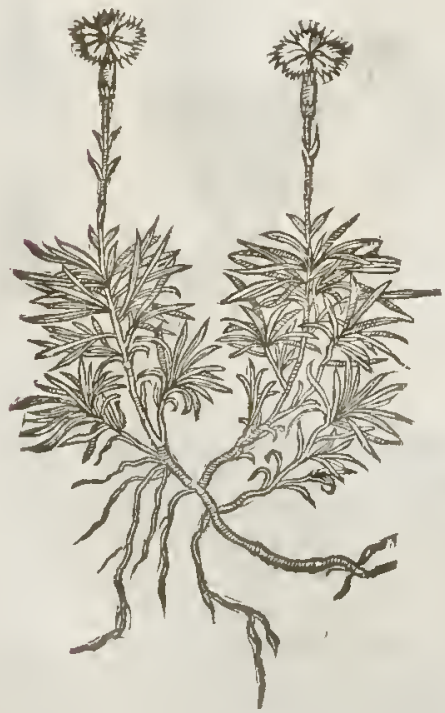

† I I Caryophyllus pratenges. $6 x$. Deptford Pinke.

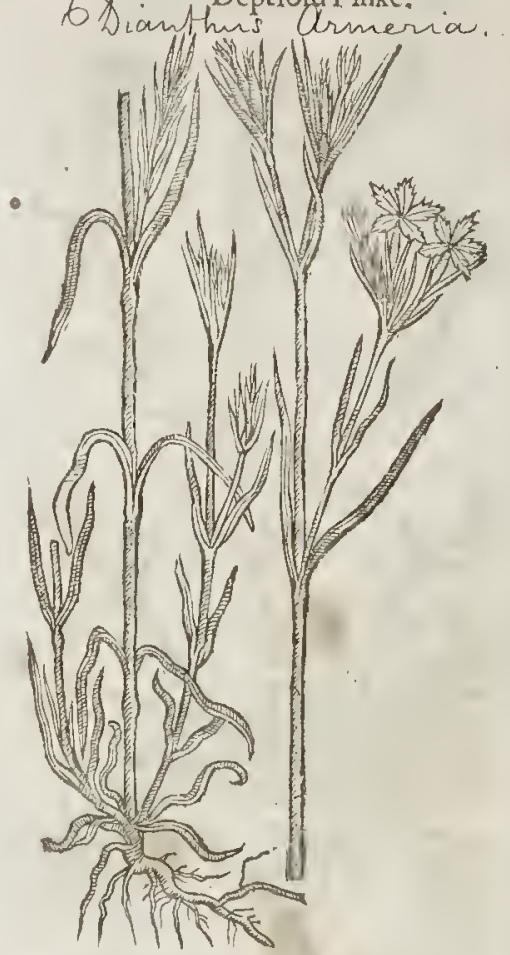

¥ 13 Caryophyllus montarus humilis latifolius? Small mountaine broad leaued Pink.

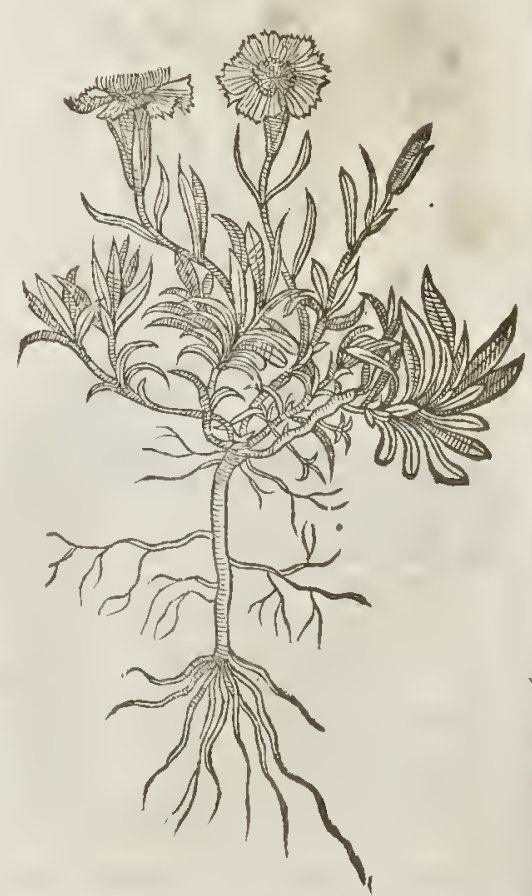


L. 1 B. 2.

Of the Hiltory of Plants.

†े I Caryophyllus montanus albus. White mountaine Pinke.

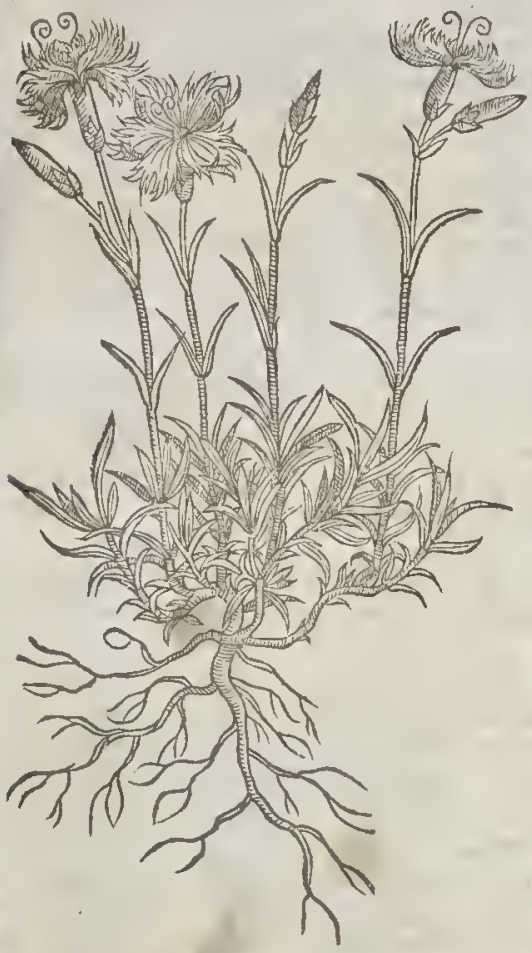

I 6 Carvophylus Ho'nfius aruen is.

Broud leafal wilde pinke.

Holosterm umbellatum

of

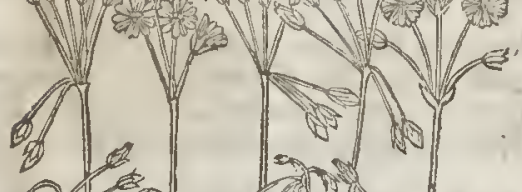
(1) a) 1 (2)

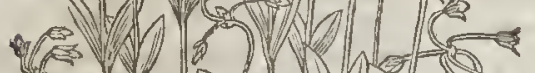
(5) W W 12
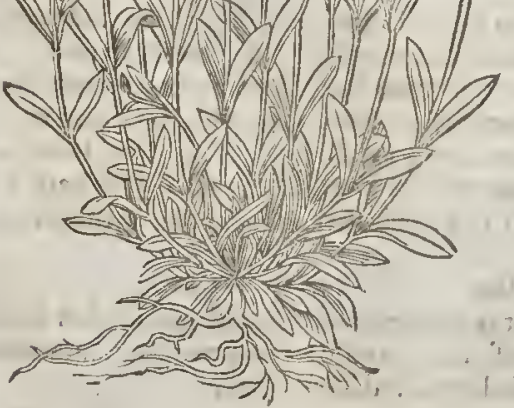

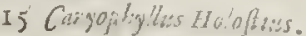

Wilde Sea Pinke.

Cerastium arvense.

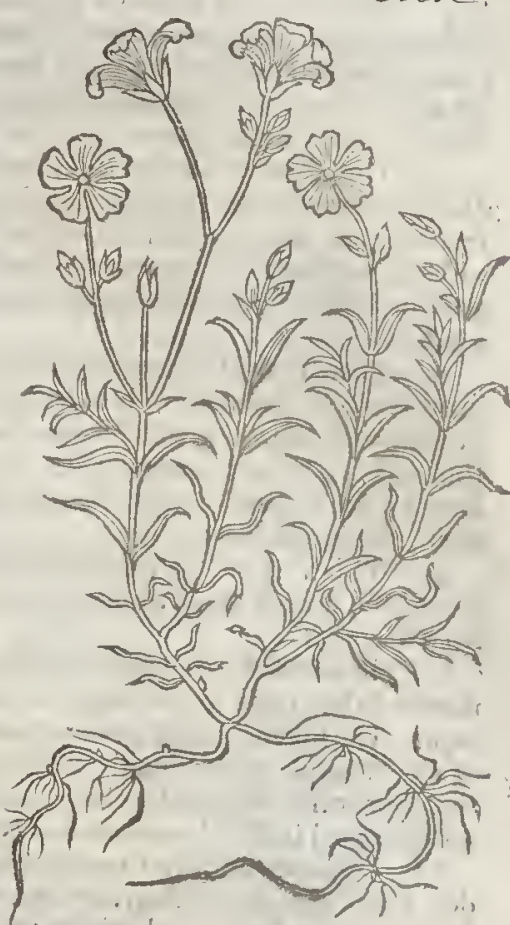

‡ 7 Caroplyyl. bumilis flor .cand.amseno. White Campion Pinke.

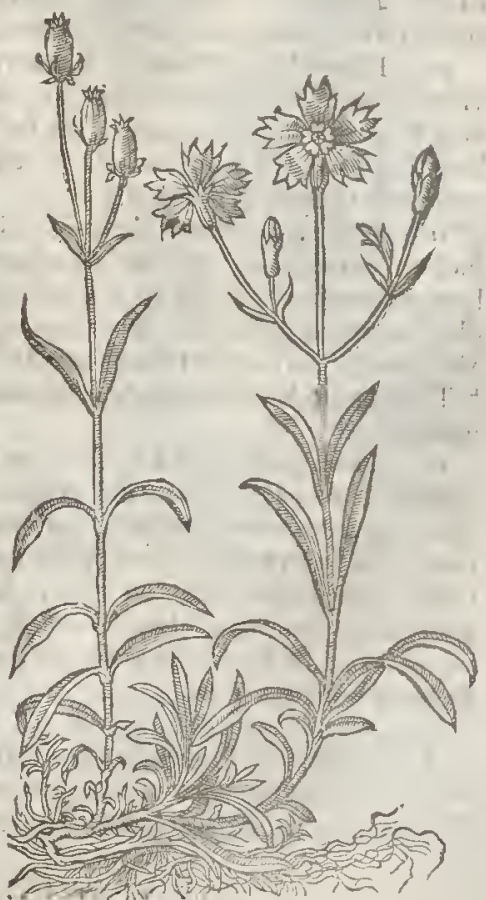

D dd 2 
It growes naturally on diters places of the Alpes. Gefner called it canfeus floridus: Pona, oci. moides Mufcofus: and Clufus, Coryophyllus fumblio Alpinus 9. †

9 This leafe-leffe Pinke (as the Grecke word doth feeme to import) hath many fmall rurhy or benty leaues rifing immediatcly from a tough ruthy root : among which rife tp falkes like wito ruthes, of a fpan high, without any ioynt at all, but fmooth and plaine; on the top w liercof growcth a fmall Houre of a blewinh or sky colour, confifting of foure litrle leanes fomewht iagged in theedges, not wnlike thofe of wilde flax. The whole plant is very biter, and of a hor tafte.

10 The white mountaine Pinke hath a great thicke and wooddy ront, from the which immediately rife vp very many fmall and narrow leaues, finer and leffer than grafle, not vnlike to the fmalleft rufh : among which rife vp little tendet ftalkes, ioynted or kneed by certaine diftances, fet with the like leaues euen to the top by couples, one oppofite againft another : at the top whereof grow ptetty fwect fmelling floures compofed of fiue litele white leaues. The feed is imall and blazckifh.

I I There is a wilde creeping Pinke which growerh in our paftures neere about London, and in orher places, but efpecially in the great field next to Detford, by the path fide as you goe from Redriffe to Greenwich; which hath many fmall tender leaues thorter than any of the other wilde Pinkes, fet von little tender ftalkes whieh lie flat vpon the ground, talking loold of the fame in fundry places, whereby it greatly encreafeth; whercupon grow litt: reddifh foures. The root is fmall, tough, and long lafting.

I2 This Virgin-like Pinke is like vnto the reft of the garden Pinkes in fullkes, leaues, and roots. The floures are of a bluth colour, whereof it tooke his name, which inc weth the difference from the other.

‡ Thiswhofe figute I giue you for that fmall leaued one that was formerly in this place, harh nender ftalkes fome fpanne high, ferwith two long narrow hard harpe pointed leates at each ioynt. The floutes (which grow commonly but one on a falke) confitt of fuc little fnipt leaucs of a light purple colour, rough, and deeper coloured about their middles, with two litrle crooked threds or hornes: the feed is chaffic and blacke : the root long, and creeping : it floures in Aprill and May, and is the Flos caryophyllews fyluefris i. of Clufius.

I 3 Clufius mentions alfo another whore ftalkes are fome thee inches high : the leaues broader, fofter, and greener than the former : the floures alfo that grow vpon the top of the ftalkes are larget than the former, and alfo confift of fue leaues of a decper purple than the former, with longer haires finely intermixt with purple and white.

₹ 4 This from a liard wooddy root fends vp fuch ftalks as the former, which are fet at the ioynts with thort narrower and darker greene leaues: the floures are white, fweet-fmelling, confifting of fute much diuided leaues, hauing two threds or hotnes in their middle. It Houres in May, and it is the Caryophyllus fyluefris quintus of clufus. +

15 This wilde fea pinke hath diuers fmall tender weake branches trailing vpon the ground, whereupon aré fet leaues like thofe of our fmalleft garden Pinke, but of an old hoary colour tending towhiteneffe,as are moft of the fea Plants. The floures grow at the top of the ftalks in thape like thofe of Stitch-wort, and of a whitifh colour. Neither the feeds nor feed-ieffels luate I as yet obrerued : the root is rough and fingle.

I6 There is another of thefe wilde Pinkes which is found growing in ploughed fields, yet in fuch as are necie vnto the fea : it hath very many leaues fpred vpon the ground of a frefh green co. lour ; amongft which rife vp tender ftalkes of the height of a foot, fet with the like icaucs by couples at certaine diftances. The floures grow at the top many together, in manner of the SweetWilliam, of a white, or fometimes a light red colour. The root is fmall, tough, and long lafting.

\# This is a kinde of Gramen Leucanthemum, or Holofesm Ruellÿ, defcribed in the 38 . Chapter of the firftbookc.

I Clufus makes this a Lychnis : and Lobel(whom I here follow) a Pinke, calling it Caryophyllus mingmus humilis alter exoticus flore candido mano. This from creeping roots fondeth vp euery yeare many branches fome handfull and better high, fet with two long narrow greene leaues at each iuyn : the floures which grow on the tops of the branches are of a pleafing white colour, compofed of fuc iagged leaucswithout fmell. After the floures are gone there fueced round blunt pointed vefels, containing a fmall blackin flat feed like to that of the orber Pinks. This harh a vifcous or clammy iuyce like as that of the Mufcipula's or Catch-fies. Clufus malies this his Lych. 23is fy!neftris decim.t.

\section{If The Place.}

Thefe kindes of Pinkes do grow for the moft part in gardens, and likewife many other forts, the which were ouer long to write of particularly. Thofe that be wilde doe grow vpon mountaines, ftony rockes, and defart places. The teftarefpecified in their deferiptions. 


\section{1 в. 2. Of the Hiftory of Plants.}

\section{T The Time.}

They floure with the Cloue Gillofloure, and often after.

T The Names.

The Pinke is called of Pliny and Turner, Cantalbrica and Stattice : of Fuchfous and Dodonaus, $V_{\text {cto- }}$ nicaaliera, and Vetomicaltulis: of Lobclins and Fuchfius, Supcrba: in French, Gyrofflees, oeilletz, and Violettes herbues : in Italian, Gurofoli, and Garoni : in Spanin, clawis : in Englinh, Pinkes, and Small Honefties.

$$
\text { TT The Tempcrature. }
$$

The temperature of the Pinkes is referred vnto the Cloue Gillofloures.

$$
\text { I The Vertues. }
$$

Thefe are not vfed in Phyficke, but efteemed for their vfe in Garlands and Nofegaies. They are good to be put into Vineger, to giue it a pleafant tafte and gallant colour, as Ruellius writeth. Fuch furs fathl, that the roots are commended againt the infection of the plague; and that the iuice thereof is profitable to wafte away the ftone, and to dritue it forth: and likewife to cure them that haue the fulling fickneffe.

\section{C н A P. 184. Of Swect Saint fohns and Sweet Williams.}

I Armirianlba.

White Ioluns.

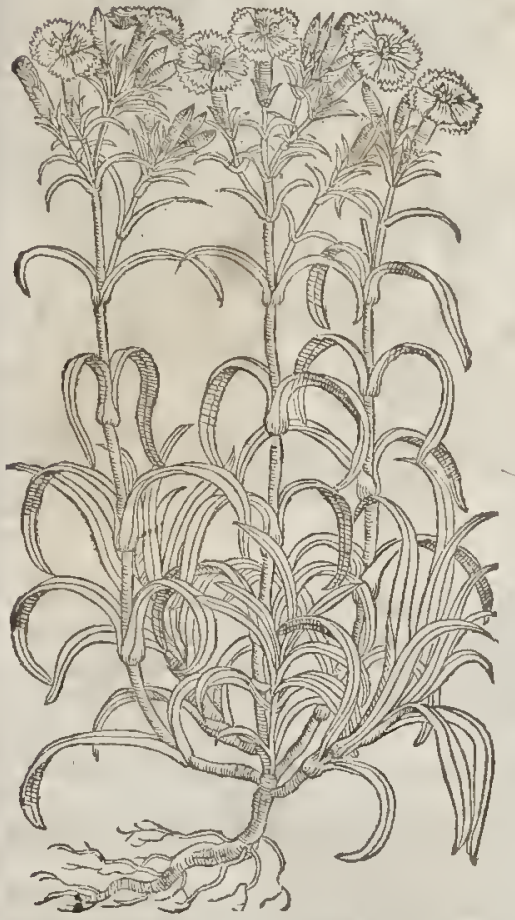

2 Armerialba do rubramuliplex. Double white and red Iohns.

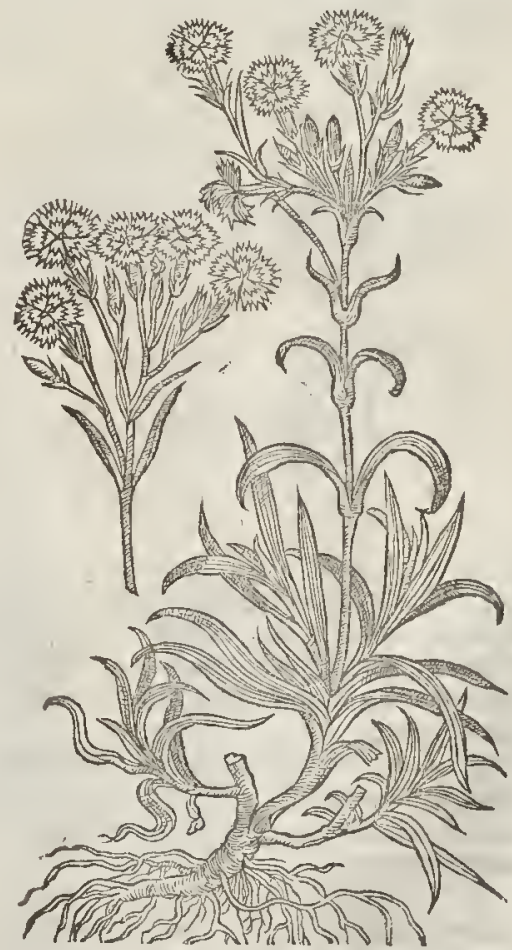

I'The Defoription.

I Weet Iohns have round ftalkes as haue the Gillofloures, (whereof they are a kinde) a cubir higin, whereupon do grow long leaues broader than thofe of the Gillofloure, of a greene graffie colour : the Houres grow at the top of the ftalkes, very like vnto Pinks, of a perfect white colour.

2 The fecond differeth not from the other but in that, that this plant harh red floures, and the otherwhite. 
We hate in our London gardens a kinde hereof bearing moft fine and pleafant white floures, fpotted very confufedly with reddin fpots, which fetteth forth the beauty thereof; and hath bin taken of fome (but not rightly) to be the plant ealled of the later Writers Superba Aufriac, or the Pride of Auftria, ‡ It is now eommonly in moft plaees ealled London-Pride. ‡

$\dagger$ Wee haue likewife of the fame kinde bringing forth moft double floures, and thefe cither very white, or elfe of a deepe purple colour.

3 Armeria rubral latifolit.

Broad leaued Sivect-Williams.

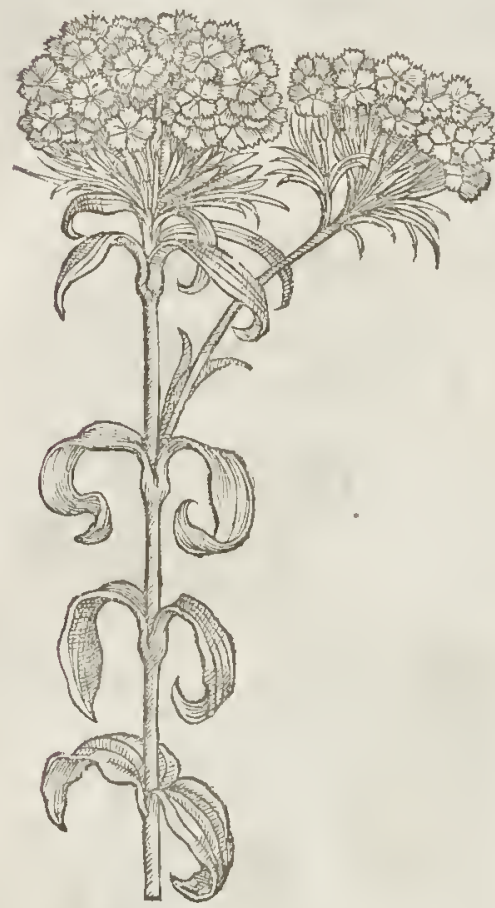

4. Armeriafuaue rubens.

Narrow leaued Sweet-Williams.

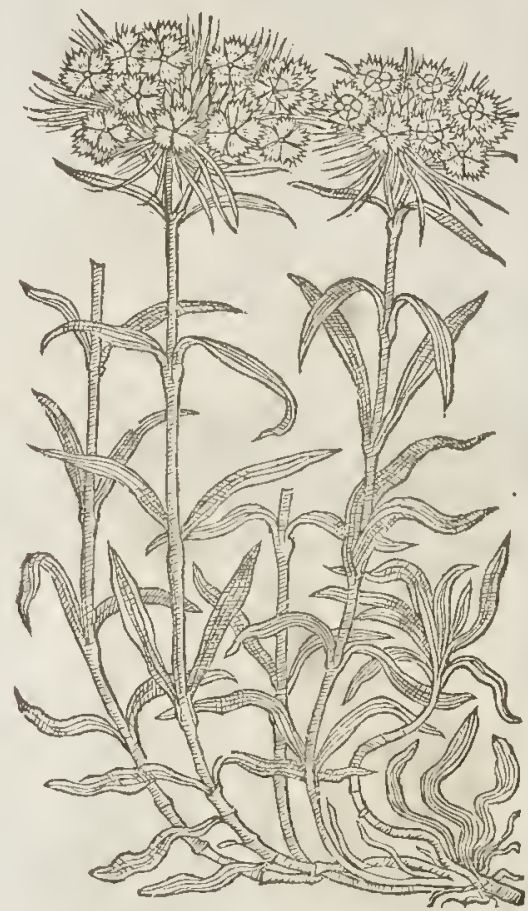

3 The great Sweet-William hath round ioynted falkes thicke and far, fomewhat reddifh about the lower ioynts, a eubit high, with long broad and ribbed leaues like as thofe of the Plantaine, of a greene grafic colour. The floures at the top of the ftalkes are very like to the fmall Pinkes, many ioyned together in one tuft or fpoky vmbel, of a deepe red eolour : the root is thiek and wooddy.

4 The narrow leated Swect-William groweth vp to the height of two eub its, very wel refembling the former, but leffer, and the leaues narrower : the floures are of a bright red colour, with many fmall tharpe pointed graffie leaues ftanding vp amongft them, wherein efpecially eonfifteth the difference.

$¥ 5$ This little fruitfull Pinke (whofe figure our Author formerly gane in the firft place of the next chapter faue one) hath a fmall whition wooddy root, which fends forth little ftalks fome hand full and better high, and thefe at each ioynt are fet with two thinne narrow little leaues : at the top of each of thefe ftalkes growes a fingle skinny fmooth fhining huske, out of which (as in other Pinkes) growes not one oncly floure, but many, one ftill comming out as another withers; fo that of times out of one head eome feuen, eight, or nine floures one after another, which as they fade leaue behinde then a littic pod containing finall blacke Hattifh feed. The floure is of a light red, and very foull, ftanding with the head foncwhat far out of the hofe or huske. $\neq$

$$
\text { ब1 The Place. }
$$

Thefe plants are kept and maintained in gardens more for to pleafe the eye, than cither the nofe or belly. 


\section{I в. 2. Of the Hiftory of Plants:}

\section{\& 5 Cimeriaprolifera, Lob. Childing fitcet Willians.}

6 biantivis probifer.

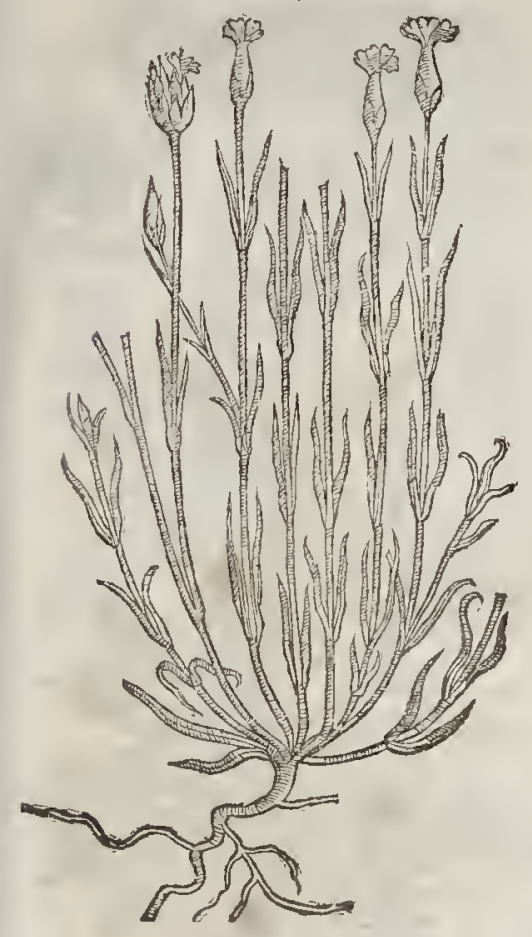

T The Time:

They flourifh and bring forth their foures in April and May, fomewhat before the Gillofoures, and after beare their floures the whole Sommer.

$$
\text { - The Names. }
$$

The fweet Ioln, and alfothe fweet William are both eompreliended vnder one title, that is to fay, Armeria: of fone, supcrba, and Caryophyllus fylueftris : of fome Herbarifts, $V e$ tonica agreftis, or Sylucftris : of fome, Herbatumi$c a$ : but it doth no more agree here with than the Clone Gillofloure doth with Fetomen aliera, or Polemonium . in Freneh, Armoires: hereupon Ruellius nameth them Armory Flo-

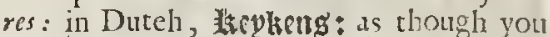
hould fay, a bundell or elufter, for in their vulgar tongue bund les of floures or noregaies they eall fiktkeng: doubtlefle they are wild kindes of Gillofloures: In Englin the firft two are called Sweet Iohns; and the two lat, Sweet Willians, Tolmeiners, and London Tufts.

\section{T The Temperature and Fertues.}

Thefe plants are not vfed either in mear or medieine, but efteemed for their beauty to deeke vp gardens, the bofomes of the beauti. full,garlands and erownes for pleafure.

\section{С н а Р.185. Of Crom floures, or Wilde Williams.}

$$
\text { If The Defription. }
$$

I Eifides there kindes of Pinkes before deferibed, there is a eertaine orher kinde, either of B the Gillofloures or elfe of the Sweete Williams, altogether and etrery where wilde, which of fome hath beene inferted amongft the wilde Campions; of orhers taken to be the true Flos Cucul. Notw ithftanding I am not of any of their mindes, but doe hold it for nei= ther : but rather a degenerate kinde of wilde Gillofoure. The Cuekow fioure I haue eomprehended vnder the title of Sifmbrimm: Englithed, Ladies fmoeks; whieh plant hath been generally taken for Flos Cuculi. It hath falks of a fpan or a foot high, wherupon the leates do ftand by eouples out of euery ioint; they are fmall and bluntly pointed,very rough and hairy. The floures are placed on the tops of the falkes, many in one tuft, finely and eurioufly fnipt in the edges, leffer than thofe of Gillofloures, very well refembling the Sweet VVilliam (whereof no doubt it is a kinde) of a light red or Searlet eolour.

2 This female Crow-floure differeth not from the male, faung that this plant is leffer, and the floures more finely iagged like the feathered Pinke, whereof it is a kinde.

3 Of thefe Crow-houres we hate in our gardens one that doth not differ from the former of the field, furing that the plant of the garden hath many faire reddouble Houres,and thofeof the fieid fingle.

\section{- The Place.}

Thefe grow allabout in Medowes and paftures, and dankifh places. 


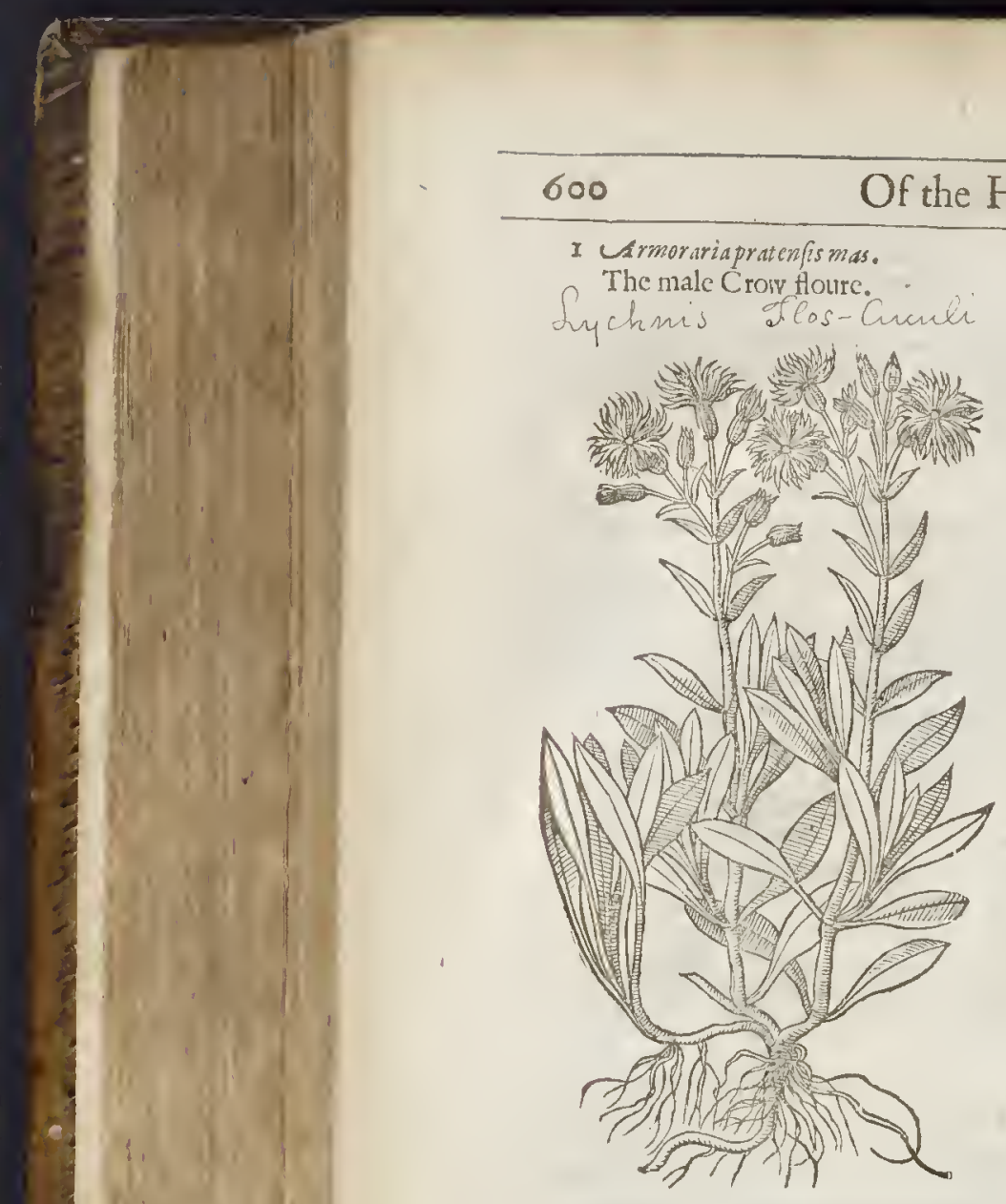

$\mathrm{L}_{1 \text { в. } 2 .}$

I. Lamorariapratenfismas.

The male Crow Houre. rychms a cos-curcula
\$3 Armoraria pratenfis fiore pleno. The double Crow-floure.

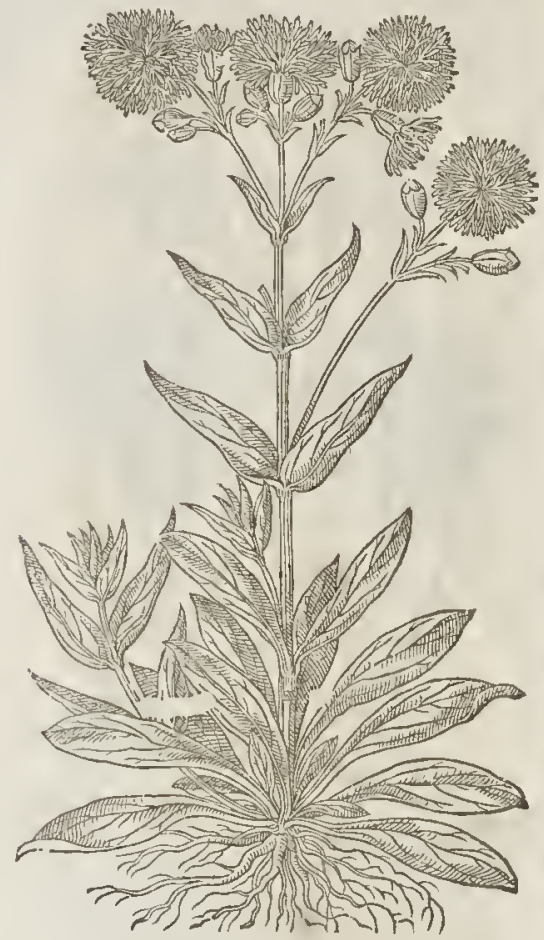

They begin to floure in May, and end in Iune.

9) The Time.

9 The Names.

The Crow floure is called in Lat ine Armorariafyluefris, and Armoracia: of fome, Flos Cucult, but not properly, it is alfo called Tunix : of fome, Armeric, $A$ rmerius Pos primus of Dodon. and likewife Caryophillus minor fylueftris folys latioribus: in Duteh, Ccaepnbloemikeng : rhat is co fay, Cornicis fores: in Freneh, Cuydrelles. In Englifh, Crow floures, wilde Williams, marfh Gillofloures, and Cockow GilloHoures.

The Temperatures and Vertues.

Thefe are not $v$ fed either in medieine or in nourithment : but they ferue for garlands \& crowns, and to decke vp gardens.

\section{Снар. 186. Of Catcb-Flie, or Limemoort.}

Ti The Defcription.

I Tis plant, called $F$ ifearia, or Lymewoore, is likewife of the ftoeke and kindred of the wilde Gillofloures : notwithftanding Clufius hath ioined it with the wilde Campions, making it a kinde thereof, but not properly. Lobel among the Sweet Williams, wherof doubtlefe it is a kinde. It hath many leaues riting immediately from the root like thofe of the Crow flourc, or wikic fweet V Villiam : among which rife vp many reddifh ftalkes iointed or kneed at eertaine fpaces, fet with leaues by couples one againft another; at the top whereof eome foorth pretric ted foures which being patt there commeth in place fmall blackifh feed. The root is large with many fibres. The whole plant, as well leates and ftalkes, as alfo the floures,ase here and there - couered ouer with a moft rhick and elammic matter like snto Bird-lime, which if you take in your hands, 
t'i Vifcaria, frue Mufcipuls. Limewoort.

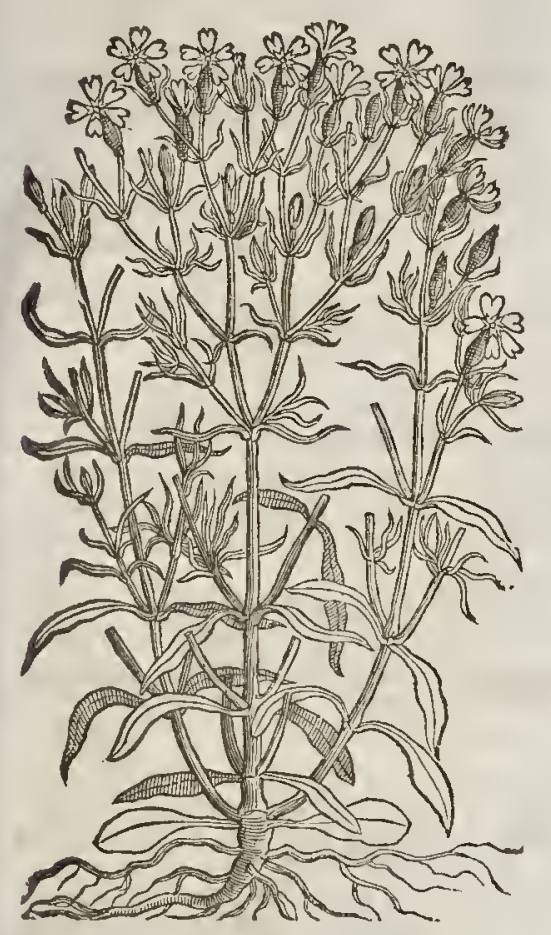

¥ 3 Mufcipula angufifolia.

Narrow leaued Catch-flic.

Sychmis oforos viscouria

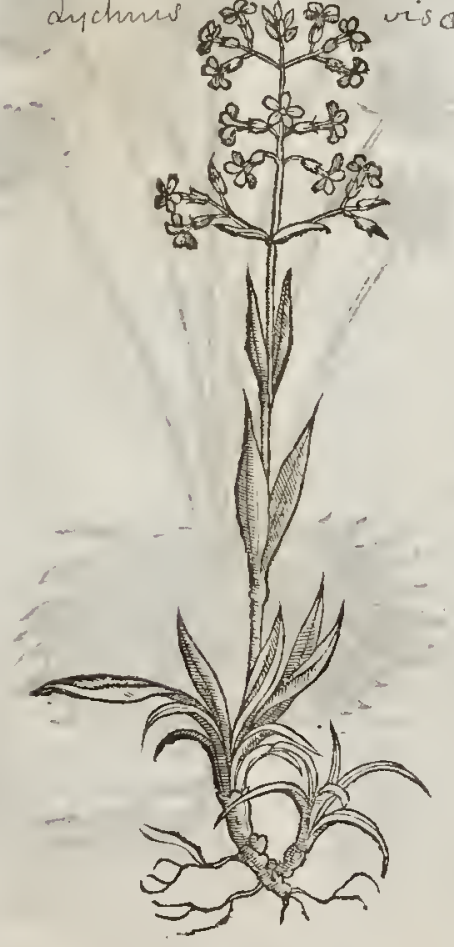

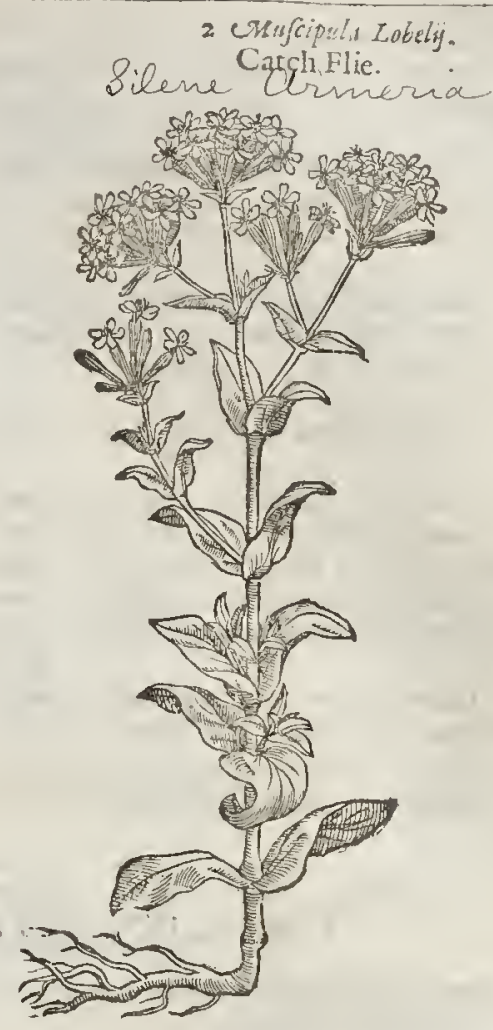

hands, the fliminefie is fuch, that your fingers w ill it ick and cleate together, as if your hand touched Bird-lime : and furthermore, if flies do light vpon the fame, they will be fo intan. gled with the limineffe, that they cannot the away; infonuch that in fome hot day or othe r you hal fee many flies caught by that means. VVhereupon I hauccalled it Catch Elie, or Limewoort. $¥$ This is Lychnisfyl. z. of Clufius; Pifcago of Camerarius, and Mufcipula fue $V i f c a-$ ria of Lobel.t

2 This plant hath many broad leaues like the great fiveet VVilliam, but thorter(where. of it is likewife a kinde) fet vpon a ftiffe and brittle falk; fro n the bofon of which leates, fpring forth fnaller branches, clothed wirh the like leaues, but much leffer. The floures grow at the top of the ftrlkes many rogether tuft falhion, of a bright red colour. Thewliole plant is alfo polfeffed with the like liminefle as the other is, but leffe in quantitie. + This is Lychnis fyl. 1. of Clufius; and Mufcipula fove Ar. moraria altern of Lobel: Dodoneus calls it Armerius flos 3 . in his firft Edition: but makes it his fourth in the laft Edition in Folio.

$¥ 3$ There is alfo belonging vnto this kindred another plant which clufus mukes his Lychnis/yl.4. "It cones vp conimonly wirlt one falke a foot or more high, of a green pur- 
plith colour, with two long tharpe pointed thicke greene leaucs, fer at each ioint : from the mid dle to the rop of the ftalke grow little branches, which ypon pretty long ftalkes carry floures confifting of fue little round leaues, yet diuided at the tops: they are of a faire incarnate colour, with a deepe purple ring in their middles, without fmell : after the floures are paft fuccede skinny and hardheads, fmaller rowards the ftalkes, and thickcr aboue; and in thefe arc contained rerie fmall darke red feeds. The root is thicke and blacke, with many fibers, putting vp new hootes and ftalks after the firft yeare, and not dying euery yeare like as the rwo lafteferibed.

\section{If The place.}

Thefe plants do grow wilde in the fields in the VVeft parts of England, a mong the corne: wee hate them in our London gardens rather for toyes of pleafure, than any vertues they are poffefied with, that hath as yet been knowne.

T The Time.

$$
\begin{aligned}
& \text { T The Time. } \\
& \text { Sommer. }
\end{aligned}
$$

I The Names.

Catch Elies hath beene taken for Behen, commonly fo called, for the likeneffo har it liath with

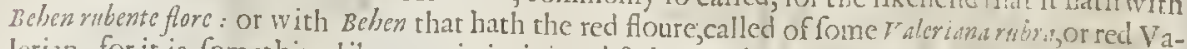
lerian; for it is fomcthing like vnto it in iointed ftalkes and leaues, but more like in colour : of Lobel, Mufcipula and Vifaria : of Dodon. Armerus flos tertius : of Clufim, Lychyis/yluefris, silene Theoplorafti, and Beben rubran Salamanticum: in Englifh, Catch Flie, and Limewoort.

\section{The 2 ature and Vertucs.} floures.

The nature and vertues of thefewilde VVilliams are referred to the Wilde Pinkes and Gillo-

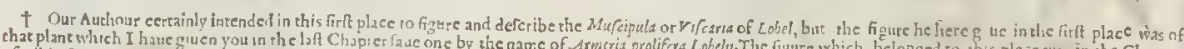

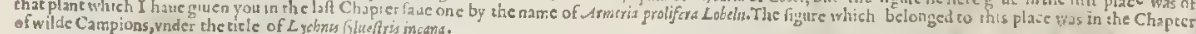

\section{H A P. 187. Of Tbrift,orour Ladies Cuftion.}

I Cayophyllas marinus minimus Lobelï.

Thrift or Sea Gillolloure.

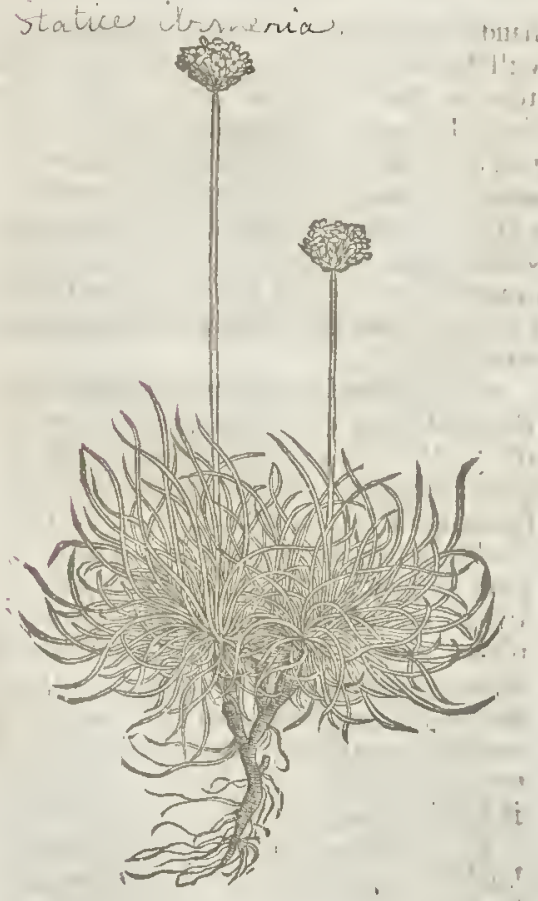

2 Caryophyllus Meditirrancus. Leuant Thrift, or Sea Gillohoure

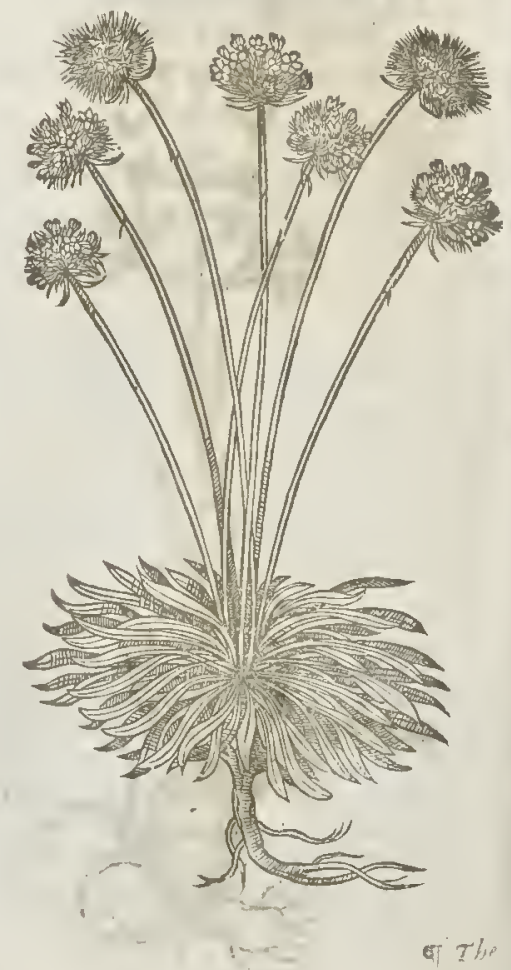


T The Defoription.

I Hrift is alfo a kind of Giliofloure, by Dodonats reekoned among graffes, which brings forth leaues in great tufts, thick thruft together, fmaller, flenderer, \& fhorter than graffe: among which rife vp fmall tender ftalkes of a fpanne high,naked and wirhout leaues; on the tops wherupon ftand little floures in a fpokic tuft, of a white eolour tending to purple. The root is long and threddic.

The other kinde of Thrift, found vpon the mountaines neere vnto the Leuant or Med iterran tan fea,differeth not from theprecedent in leaues, ttalkes, or floures, but yet is altogether greater, and the leaues are broader.

$$
\text { TI Ihe Place. }
$$

2 The firt is found in the moft falt marthes in England, as alfo in Gardens, for the bordering vp of beds and bankes, for thawhich it ferueth very fitly. The other is a ftranger in thefe Northerne Regions.

They floure from May, till Sommerbe far fpent.

$$
\text { i) The Time. }
$$

$$
\text { If The Names: }
$$

Thrift is called in Latine Gramen Polyanthemum, of the multitude of thefloures: of fome, Gramen marinum: of Lobel, Caryophyllus Marinus: In Englifh, Thrift, Sea-graffe,and our Ladies Cufhion.

$$
\text { T) The Temperature and Vertues. }
$$

Their vfe in Phy ficke as yet is not knowne, neither doth any feeke into the Nature thereof, but eftecme them onely for their beaurie and pleafure.

\section{H A P. 188: Of the Saxifrage of the Antients, and of that graat one of Mattbiolus, with that of Pena and Lobel.}

\# His name Saxifraga or Saxifrage, hath of late been impofed vpon fundry plants farre different in their thapes, places of growing, \& temperature, but all agreeing in this one facultie of expelling or drituing the ftone out of the Kidneies, though nor all by one meane or manner of operation. But becaufe almolt all of them are defcribed in their fit places by our Authour, I will not inffit vpon them : yet I thinke it not amiffe a little to enquire, wherher any Saxifraga were knowne to the Antients, and if knowne, to twhat $k$ inde it may probably be referred. Of the Antients, Diofcorides, Parslus exgineta, and Apuleius, feeme to mention one Saxifraga, but Pli$n y$, lib.22. cap.21. by the way, thewes that foine called Aduntbum by the name of Saxifragum: but this is nothing to the former; wherefore I will not infift vpon it, but returne to examine that the other three haue written thereof. Diofc.lib. 4 . betweene the Chapters of Tribulus and Limonium, to wit, in the feuenteenth place hath dclitiered the Hiftorie of this plant, both in the Grecke Edition of Aldus Manutuzs, as alfo in that of Marcellus Virgiluzs, yet the whole Chapter in the Paris $\mathrm{E}$ dition, 1549 , is reiected and put amongt the Notha. The beginning thereof (againftwhich they

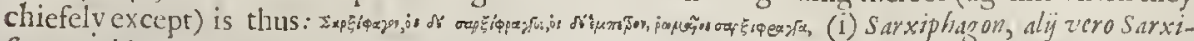

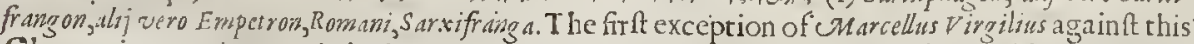
Chapter is Peregrina Grecis of aliena rox Saxifraga eft, doc. The fecond is, 2 Irod mulio fill ciorcs in componendis ad certionem rer alicuius fignificatronem vocibus Graci, auam Latini, or C. The third is, solam in toto boc opere priman, of a principio propofitam andiri Romanam vocem, tamique inopes in appellanda hac berba fuife Grecos, vt nifi Romana voce cam indicagfent, nulla fibi futuratßet. Thefe are the arguments which he ves againft this Chapter; yet reicets it not, but by this means hath occalioned others without fhewing any reafon, to doe it : Now I will fet downe what my opinion is concening this matter, and foleaue it to the iudgement of the Learned. I grant Marcellus, that Saxifrag $a$ is a ftrange and no Grekeword; but the name in the title, and firt in the Chapter both in his ow ne Edition and

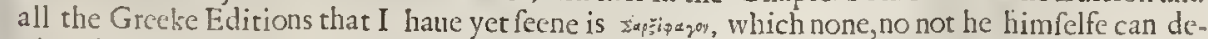

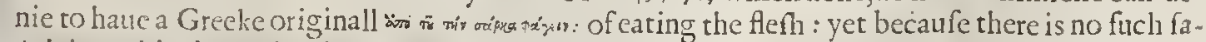
culticas this denomination impores attribured thereto by the Authour, therefore hee will nor allow it to be fo. But you muft note tlyat many names are impofed by the vulgar,and the reafon of the name not alwais explained by thofe that hate written of them, as in this fame Author may be 


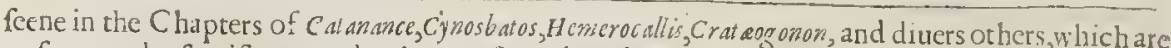
or feeme to be fignificant, and to import fonctling by their name: yet he faitl notling thereof. It mabe that which they would exprefe by the name, was, that the hearbe had fo piereing a facultie that it would eat into thevery flefh. The feeond and third Argument both are anfwered, if this firft word be Greeke, as I hauc aireadie fhewcd it to be, and there ate not many words in Greeke that more frequently enter into fuch compofition than qus : as Pamph.agos, Polyphagos, op fiphagos, and many other may thew. Moreouer, it hath beene dbfurd frefor Dioficorides, or any elfeliow fimple fo. eucr they were, if they had knowne the firft word to haue beene Latine and Saxifraza, to fay avaine

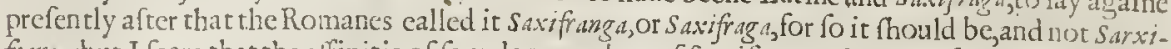
frang a:but I feare that the atfinitic of founds more than of fignification hath caufed this confufion, efpecially in the middle times betweene vs and Digforides, when lcarning was at a very low ebbe. The chicfercalons that induce mee to thinke this Chapterwarthie to kcepe his former place in Dioficrides, are thefe: Firft, the generall confent of all both Grecke and Latine copies (as $M$ arceliss faith) how antient foeuer they be. Secondly, the mention of this betbe for the fame effeat in fome Grecke Authours of a reafonable good antiquitic, for Paulus Eginetateftifieth that

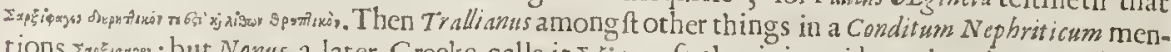

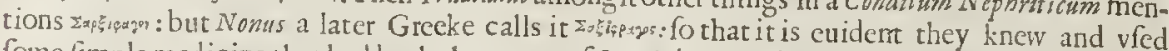
fome fimple medicine that had both the names of Sarxiphagon and Saxiphragos, which is the Latine Saxifraga. Now fecing they had, and knew fuch a fimple medicine, it remaines we enquire after the thape and figure thereof. Diofiorides defcribes it to be a thrubby plant, gtowing vpon rockes and craggie places, like vnto Epih hymum: boiled in wine and drunke, it hath the faculty to helpe the Strangurie and Hicket; it alfo breakes the ftone in the bladder and prouokes vrine. This woid Epithymm is not found in moft copies, but a fpace left for fomeword or wotds that were wanting : But Marcellus faith, he found it expreft in a booke which was Omnium vetufiffmus of probatißmm : and Hermolaus Earbarus faith, I'eterem in Diofcoride pictur am buius herba vidi, non plus folys quam cirris minut is per ramos ex intervallo conditis, nec frequentibus, in cacumine furculorum foccifeu arentes potius quam flofouli, fubrubida radice non fine fibris. A figute reafonable well agrecing with thisdefcription of Hermolaus, I lately receiued from my friend $\mathrm{M}^{\mathrm{r}}$. Goodyer, who writ to me that he had fought to know what Saxifraga (towit, of the Antients) Phould be; and finding no antient Authour that had defcribed it to any purpofe, he fought Apueius; which word Apuleius (faith lie) is the printed title: my Manufcript acknowledgeth no Authour but Apolicnfis plato; there is no defeription neither, but the Manufeript hath a figure which I haue drawne and fent you, and all that verbatim that hee hath written of $i t$, I hould be glad to haue this figure cut and added to your wotke, together with his words, becaufe there hath beene fo little written thereof by the Antients. This his requeft I thought fit to perfotme, and haue (for the better fatisfaction of the Reader) as you fee made a further enquirie thereof : wherefore I will onely adde this, that the plants here defcribed, and the $A:$ fine Savifraga of Colwm.togetherwith the two Chickweed Saxifrages formerly defcribed Chap. I 7 . come neereft of any that I know to the figureand deliniation of this of the Antients.

2 Tomen iftius herba, Saxifrigat.

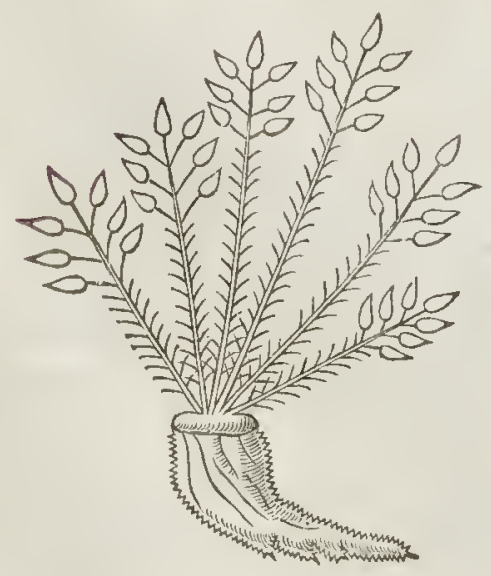

Icon \& defcriptio ex Manufcripto vetutiffimo.

Quidam dicunt eam Scolopendriam, alij Scoliomos, aly Vtis canum, quidam vero Brucos. Itali Saxifrag.rm. Egyptÿ Peperem, alij Lamprocam eam nominant. Nafcitur enimin Montibus of locis faxofis.

Vnacura ipfus adcalculos expellendos. Herban istam Saxifragam contufam calculoso potum dabis in vino. Ip fe vero fo febricitatuerit cum aqua calida, tam pre ens effcctum ab expertis traditum, vt eodem die perfectus eiectifque calculis ad foritutern vjgue produ. cit.

I This firft little herb, faith camera. rius, hath been called Saxifraga magna, not from the greatneffe of his growth, but of his faculties: The ftalke iswooddic, writhen 
writhen, and below fometimes as thicke as ones little finger,from which grow many fmall $\&$ hard branches, and thofe flender ones; the leaues are little, long and tharpe pointed : the floures are white and fnall, and grow in cups, which are finely fnipt at the top in manner of a coronet, wherein is contained a fmall red feed she rootes grow fo faft impact in the Rockes, that it cannor by any meanes be got out. It grows vpon diuers rocks in Italy and Germany; and it is the Saxifragn mag. na of Matthiolus, and the Italians.

+ I Saxifraga magra CMatthioli. Matthiolus his great Saxifrage.

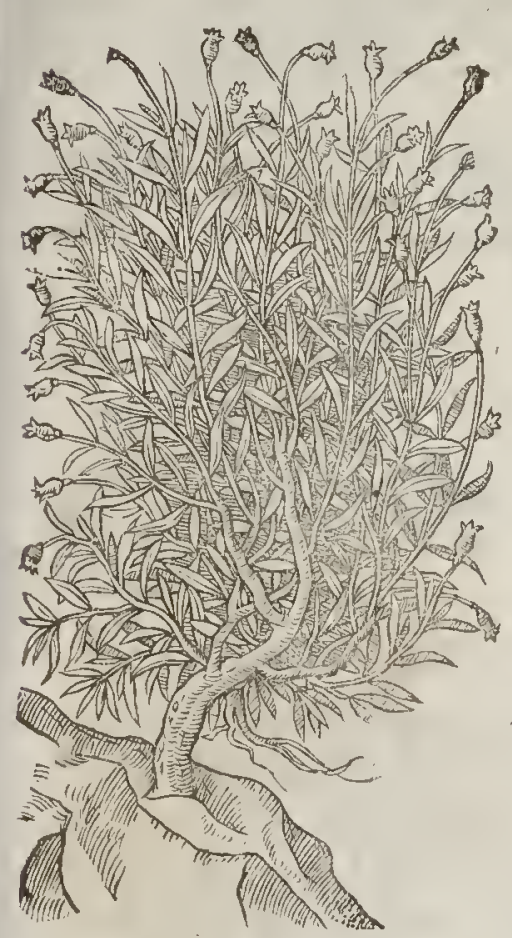

\# 2 Saxifraga Antiquorum, Lob. Saxifrage of the Antients, according to Lob.

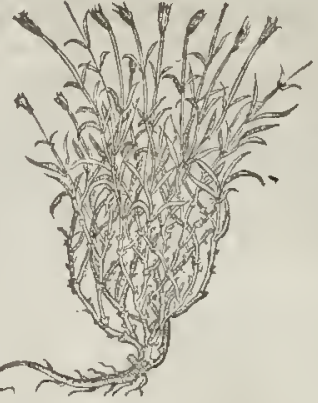

2 Pesa and Lobel fay, this growes in great plenty in Iralie, in Dolphonie in France, and England, hauing many fmall tlender branclies a foor high, in. tricately wrapped within one another, where they are fet with many graftic ioynts : the roote is fmall and white with fome few fibers : the leaules ftand by couples at the ioynts, becing long and narrow; of the bigneffe and fimilitude of thofe of the wilde Pinks, or Rocke Salloric: vpon each wooddie, fmall, capillarie, ftraight, and creeping little branch, growes one little flotre fomewhat like a Pinke, beeing finely fnipt about the edges: and in the head is containct a cound fmall roddith feed. The forefaid Authours call this $S_{a x i f r a g r a, \sqrt{2}-}$ ve Saxifraga Antiguorum.

$$
\text { The Vertucs. }
$$

I Mattbiolus faith, that Calceolarius of Verona mightily commended this plant to him, for the A fingular qualitic it had rocxpell or drite forth the ftone of the Kidneies, and that I might in verie deed bcleene it, he fent me abundance of ftones, whereof diuers exceeded the bigneffe of a beane, which were voided by drinking of this plant by one onely citizen of Verom, called Hieronymo de Tort is; but this made me moft ro wonder, for that there were fome ftones amongft them, that fee. med rather to come out of the Bladder, than forth of the Kidneies.

2 This(fay the Authours of the $A$ ducr.) as it is the lateft receiued in vfe and name for Saxi- B frage, fo is it the better \& truer, efpecially fo thought by the Italians, botl for the highly commended facultic, as alfo for the neere affinitie which it feemes to haue with Epithymum, \&c. $\neq$ 


\section{CH A P. 189. Of Snee ferwourt. \\ I The Defcription.}

I THe frnall Sneefe-woort hath many round and brittle branehes, befet with longand 1 narrow leaues, hackt about the edges like a faw; at the tops of the falks do grow fmall
fingle flotres like the wilde field Daife. The in the earth, and in thort time oceupic. The root is tender and full of ftrings, creeping far abroad o tongue and mouth like Pellitorie of The full of his plant proeure The fmell of this plant procureth fneeing, whereof it tooke the name Stermutamentoria, that is the herbe which doth procure fneefing, or Neefewoort.

2 Double floured Sneefewoort, or Ptarmica, is like vnto the former in leates, ftalks, and roots, fo that vnleffe you behold the floure, you cannot difeerne the one from the other, and it is exeeeding white, and double like vnto double Fetherfew. This plant is of great beautie,and if it be cut downe in the time of his flouring, there will come within a month after a fupplie or crop of floures
fairer than the reft.
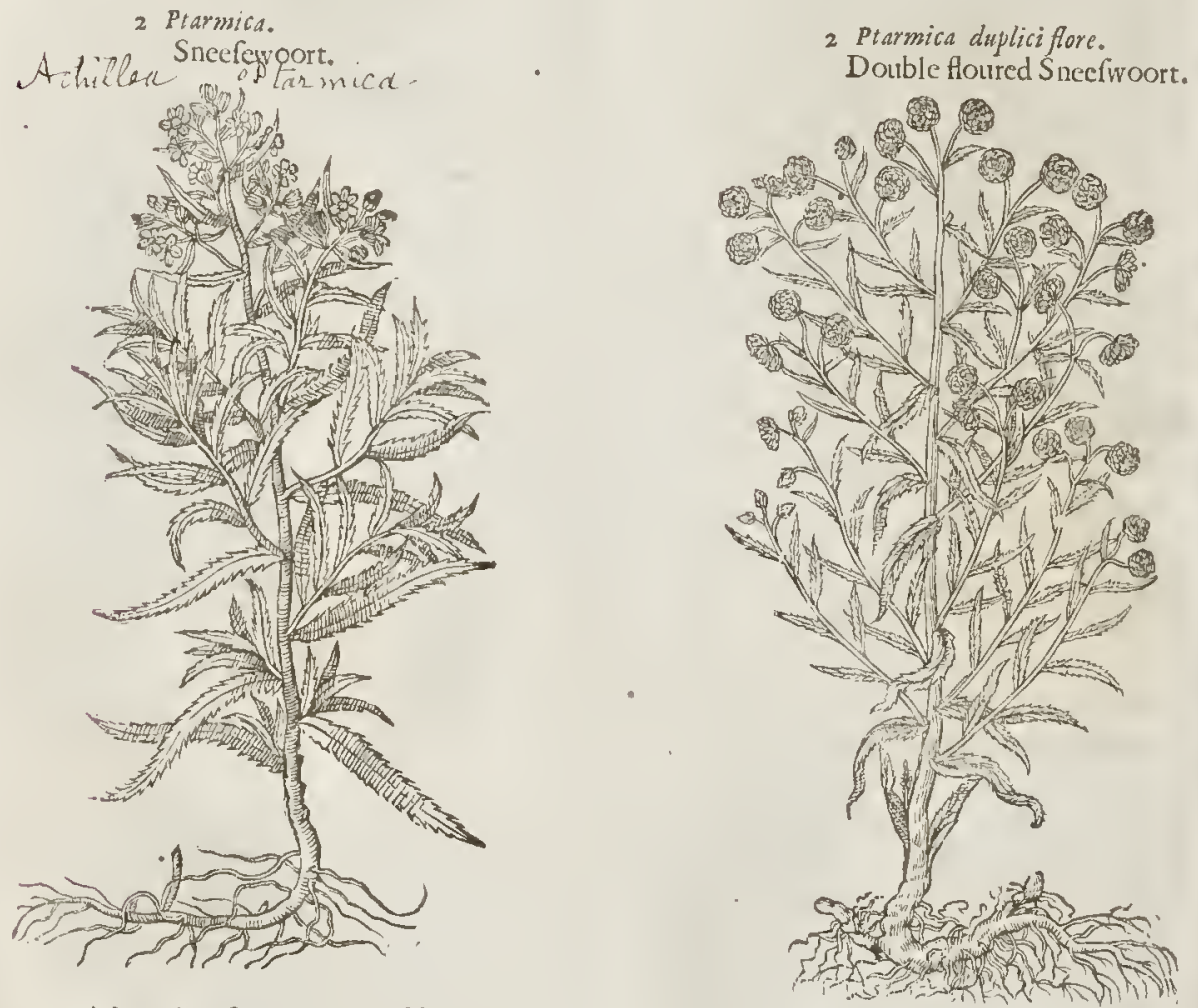

3 There is alfo another kind hereof, of exceeding great beauty, hauing long leaues fomewhat narrow like thofe of Oline tree: the ftalks are of a eubit high, on the top whereof doe growe verie beautifull floures of the bignes of a fmall fingle Marygold, confifting of fifteene or fixteene large leaues, of a bright thining red eolour tending to purple; fet about a ball of thrummie fub tance, fueh as is in the middle of the Daifie, in manner of a pale; which floures fand in fcalie knops like thofe of Knapweed, or Matfellon. The root is ftraight,and thrufteth deepe into the ground.

$$
\text { \# Ptarmica Imperati; an Ptarmice Auftriace pecies Cluf.Cur.poft.p. } 32 \text {. }
$$

4 This rifeth vp with a fmall hard tough cornered whitin woolly falke, diuided into many branches, 


\section{$\mathrm{L}_{1 \mathrm{~B}}$ 2. Of the Hiftory of Plants.}

3 Ptarmica Aufriaca.

Sneefewoort of Auftrich.

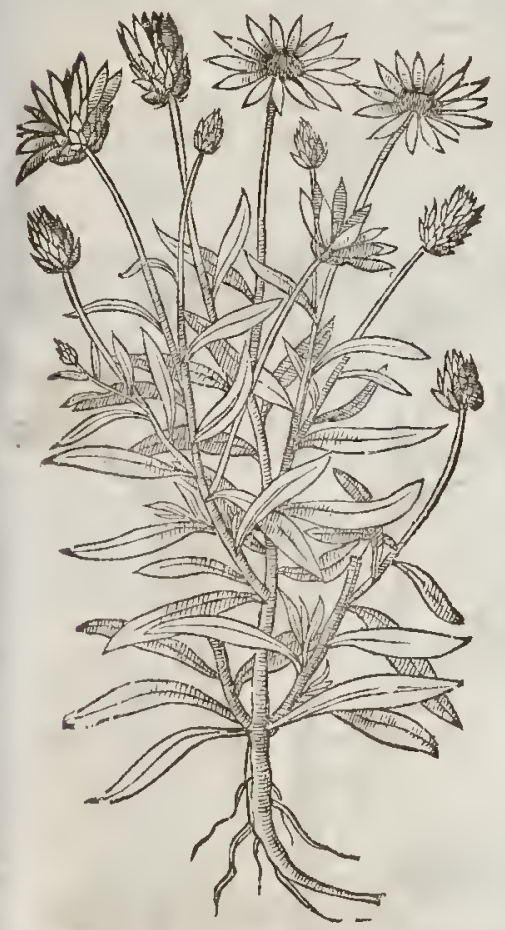

branches, and thofe againe diuided into other branches like thofe of Cyarus about two foot high, wherein grow long narrow whitinh Cottonic leaues out of order, of a bitter talte, whiter below than abone, of thecolour of the leaues of Wormwood, hauing but one rib or finew \& that in the middle of the leafe, and conmoniy turne downewards : on the top of each flender branch groweth one fmall fcalie head or knap, like that of Cyanus, which bringeth forth a pale purple floure without fmell, containing fixe, feuen, eight, or more, fnal hard drie tharp poirted leaues: in the middle whereof grow eth many fiffe chiues, their tops being of the colour of the floures : thefe floures fall not away till the whole hearbe peritheth, but change into a ruftic colour : among ft thole chiues grow long flat black ifh feed, with a little beard at the top. The root is fmall, whitish, hard and threddie, and perifheth when the feed is ripe, and foone fpringeth vp by the fall of the feede, and remaineth greene all the Winter, and at the Spring fendeth foorth a ftalke as aforefaid. The herbe touched or rubbed fendeth forth a pleafant aromaticall fmell. Iuly $26.1620 .50 h s$ Goodyer.‡

$$
\text { T The Place. }
$$

The firt kinde of Sneefewoort grows wilde in drie and barren paftures in many places, and in the three great fieldes next adioyning to $a$ Village neere London ealled Kentifh towne, and in fundry fields in Kent about SouthHeet.

$t$ The reft grow onely in gardens.

They floure from May to the end of September.

$$
\text { T) The Time. }
$$

TT The Names.

Sneefewoort is called of fome Ptarmica, and Pyrethrum fjineftre, and alfo Draco fylueftris, or $T$ arion fgliseffris: of noof, Stcrnut amentoria, taken from his effect, becaufe it procureth fneefing: of $T$ ragus \&e Tabern.Tanacetum acutum album : in Englinh, wilde Pellitorie, taking that name from his fharp and biting tafte; but it is altogether vnlike in proportion to the true Pellitorie of Spaine.

They are hot and dric in the third degree.

$$
\text { Ti The Nature. }
$$

II The Vertues.

The iuice mixed with Vineger and holden in the mouth eafeth mueh the paine of the Tooth- A

The herbe chewed and holden in the moutb, bringeth mightily from the braine flimie flegme, $B$ like Pellitorie of Spaine, and therefore from time to time it hath beene taken for a wilde kinde thereof.

\section{С на Р. 190. Of Hares Eares.}

\section{The Defcription.}

I T Arrow leafed Hares Eares is called in Greeke Bantatuen, and is reptted of the larewriters to be Bupleurmm Plinij, from which the name or figure difagreeth not: it hath the long narrow and graflic leaues of LachrymaIob, or Gladiolus, ftreaked or balked as it were with fundry ftiffe ftreakes or ribbes running along cuery leafe, as Plinie fpeaketh of 
his Heptapleurm. The ftalkes are a cubite and a lialfe long, full of knots or knees, very rough or Aiffe, fpreading themfelues into many branelies : at the tops whereof grow yellow floures in round tufts or heads like Dill. The root is as big as a finger, and blacke like Peucedanum, whereunto it is like in rafte, fmell, and refemblance of feede, which dorh the more perfuade me that it is the true Bupleurum, whercof I now fpeake, and by the authoritic of Nicander and Pliny confirmed.

I Bupleurnm angufifolium Monpelienge.

Narrow leafed Hares Eare.

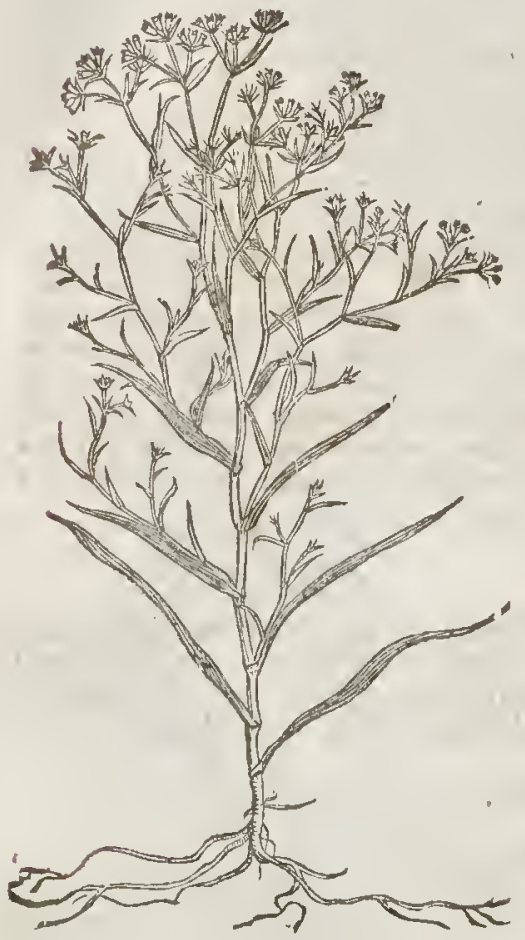

2 Bupleurum latifolium Monfpeliense. Broad leafed Hares Eare.

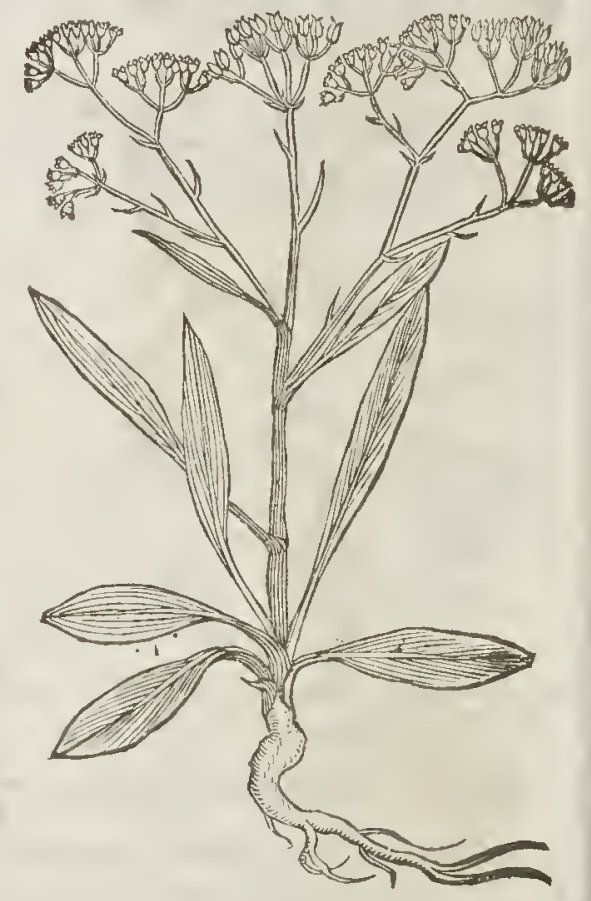

2 The fecond kinde called broal leafed Haies Eares, in figure, tuftes, and floures, is the very famewith the former kinde, fauc that the leates are broader and ftiffer, and more hollow in the midf:which hath caufed me to eall it Hares Eares, hauing in the middle of the leafe fome hollowneffe refembling the fante. The root is greater and of a wooddie fibtanee.

The Place.

They grow among Oken wonds in ftony and hard grounds in Narbon. I haue found them grow ing naturally among the buthes vpon Bieton eaftle in Cherhire.

The Timic.

They foure and bring forth their feed in Iuly and Auguft.

बा The Names.

Hares Eare is ealled in Latine Bupleurum: in Greeke, Euratuger:the A pothecaries of Montpelier in Franced neall it Auricula leporis, and therefore I terme it in Englifh Hares-Eare: Valerius Cordes nameth it yophyllon, but whence he had that name, it is not knowne.

They are tenuperate in heat and drineffe.

$$
\text { ๆ } T \text { he Tempcrature. }
$$

$$
\text { 9) The Tertues. }
$$

Hippocrates hath commended it in meats: for fallads and Pot-learbs: but by the authoritic of

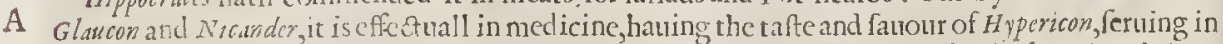
the place there of for wounds, and is taken by Trazus for Panas Chironium, who doth reckon it inter Herbes vulnerarias. 


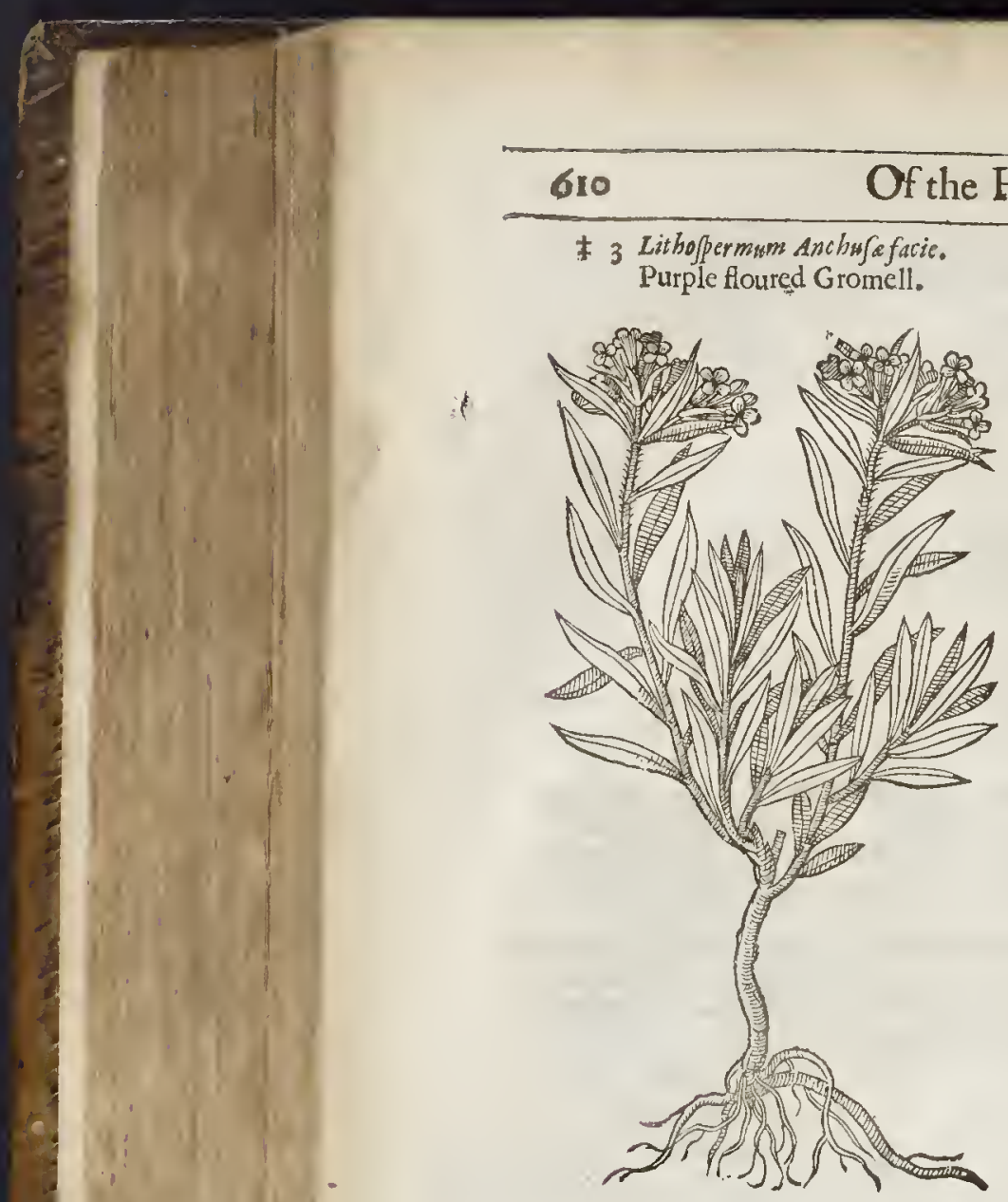

L 1 в. 2.

* 3 Lithojpermum Anchus facie. Purple floured Gromell.

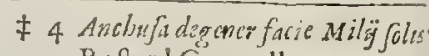
Baftard Gromell.

Sithospermum arwense

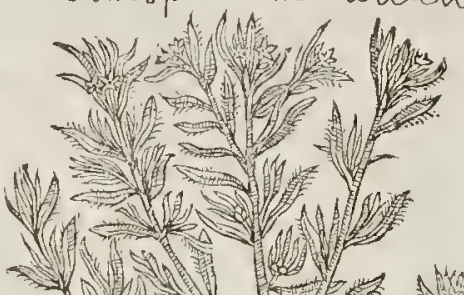

त्र

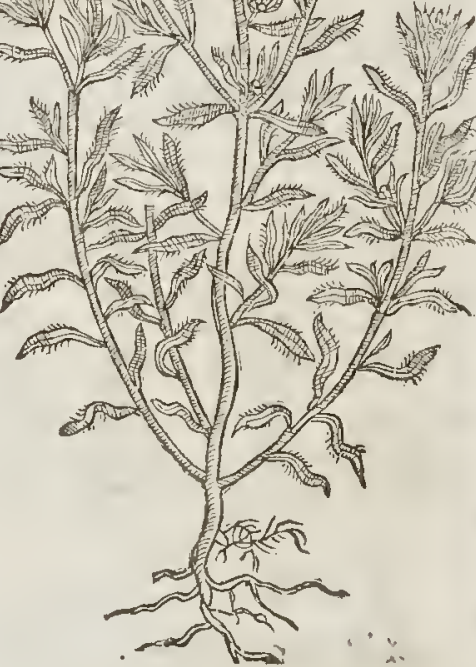

The two firt kindes do grow in vntoiled places, as by the high waies fides, and barren places, in
e ftreet at Southfleet in Kent, as yougoe from the the ftreet at Southfleet in Kent, as you goe from the church vntoan houfe belonging to gentleman of worfhip, called $M^{r}$. William Swan, and in fundry other places.

The two laft kindes grow vpon the fands and Bach of the Sea,in the ifle of Thanet neere Recul. vers, among the kindes of wilde Bugloffe there growing.

They floure from The Time.

and in the meane feafon the feed is ripe.

$$
\text { Gromell is called in Gre Names. }
$$

Gromell is called in Greeke a,ranpus, of the hardneffe of the feed:of diuers, Gorgonium: of others, ans, Milium foler : in Gremill, and Herbe auxperles : in Englig Italians, Milium folis : in Spanifh,Mÿodilfol: in French, wale.

The feed of Gromell is hot and T T he Temperature.

A The feed of Gromell pound, and drunke in White wine, breaketh, diffolueth,and driueth forth
the ftone, and pronoketh vrine,and efpecially breakech the ftone in the bladdcr. the fecond degree.

\section{Chap.192 Of Cbickeneed.}

i 7 He great Chickeweede rifeth vp with ftalkes a cubit high, and fometime higher, great

\section{\$T The Defcription.}

many. from one roote, long and round, tender, full of ioints, with a couple of leaves 
growing out of euery knot or ioynt aboue an inch broad, and longer than the leaues of pellicorie of the wall, whereunto they are very like in thape, but fmooth without hires o: downc, and of a light greene colour : the ftalkes are fomthing cleere, and as itwere tranfparent or thorow-fhining, and abour the ioynts they be oftent imes of a very light red eolour, as be thofe of Pellitorie of the wall : the floures be whitifh on the top of the branches, like the floures of Stitelivort, but vet leffer: in wliofe places fuceed long knops, but not great, wherein the feed is contained. The root confinteth of fine little ftrings like haires.

2 The fecond Chickweed for the moft part lyeth vpon the ground : the ftalkes are fuall, fiender, long, and round, and al fo ioynted : from which flender branches do fpring leaues refembling the precedent, but much Icffer, as is likewife the whole herbe, which in no refpect atraineth to the greatnes of the fame: the floures are in like fort little and whitc: thcknops or feed-lieads are like the former : the root is alfo full oflictle frings.

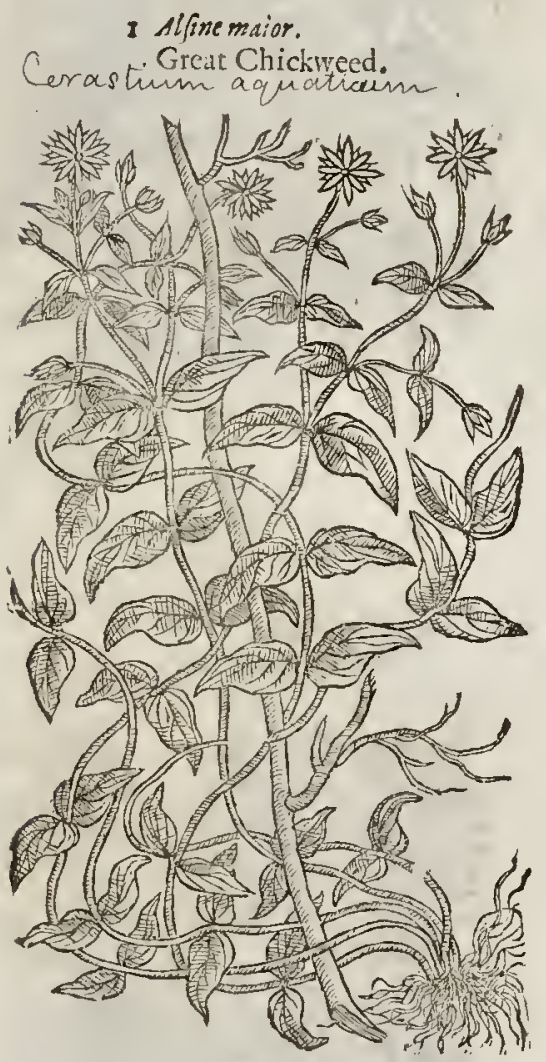

$$
\begin{aligned}
& 2 \text { Alfine minor, fue media. } \\
& \text { Middle or fmall Chichweed. } \\
& \text { llome media. }
\end{aligned}
$$

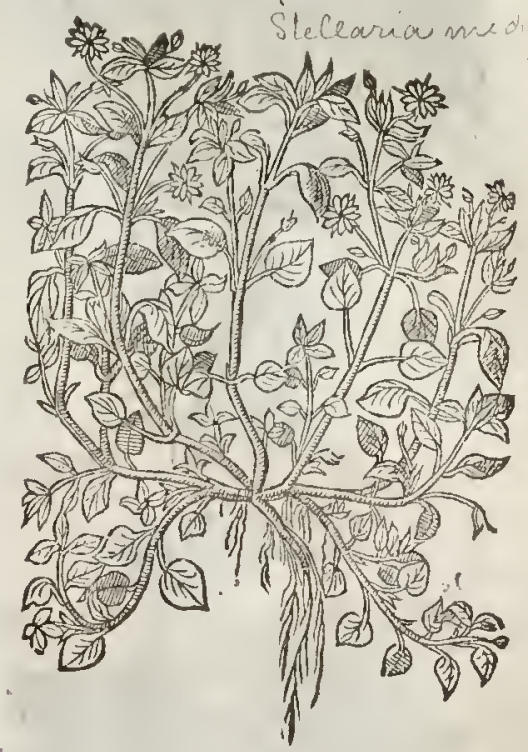

Smitivi

3 The third is like the fecond, but farre lefter : the ftalkes be moft tender and fine : the leaues are very fmall, the floures very little, the ront maruellous flender.

4 Alfo there is a fourth kinde which groweth by the fea : this is like to the fecond, but the ftemmes are thicker, thorter, and fuller of ioynts : the leaues in like fort be thicker: the knops or feed-heads be not lung and round, but fomew hat broad, in which are three or foure feeds contained.

5 The vpright Chickweed hath a very fmall fingle threddy root, from which rifeth vp a flender ftemme, diuiding it felfe into diuers branches euen from the bottome to the top; whereon do grow fmall leaues, thicke and fat in refpeet of the others, in fhape like thofe of Rue or HerbeGrace. The floures grow at the top of the branches, confifing of foure fmall leaties of a blev colour.

6 The ftone Chickweed is one of the common Chickweeds, hauing very threddy branehes conering the ground farre abroad where it groweth : the leanes be fer together by couples : the floures be imall and very white : the root is tough and very lender. 
3 Alfinc minima.

Fine Chickweed.

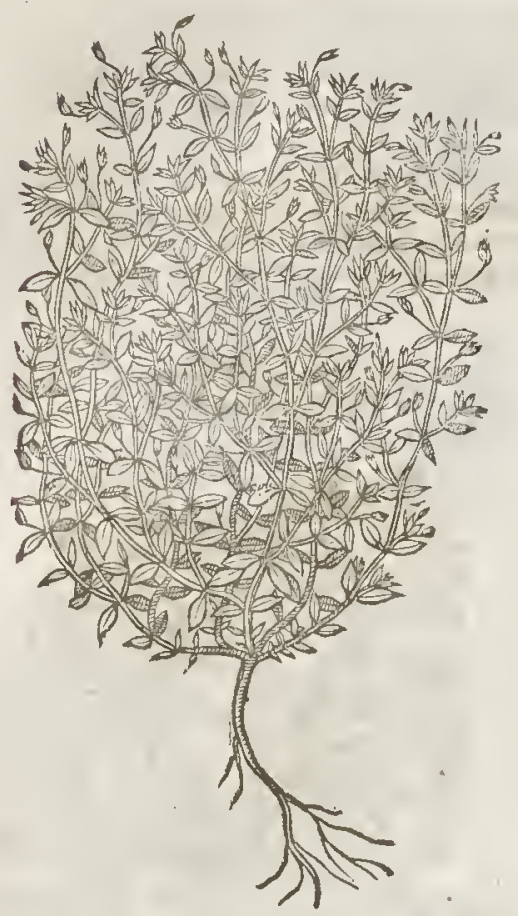

5 Alfine recta.

Denomica Right Chickweed: entis

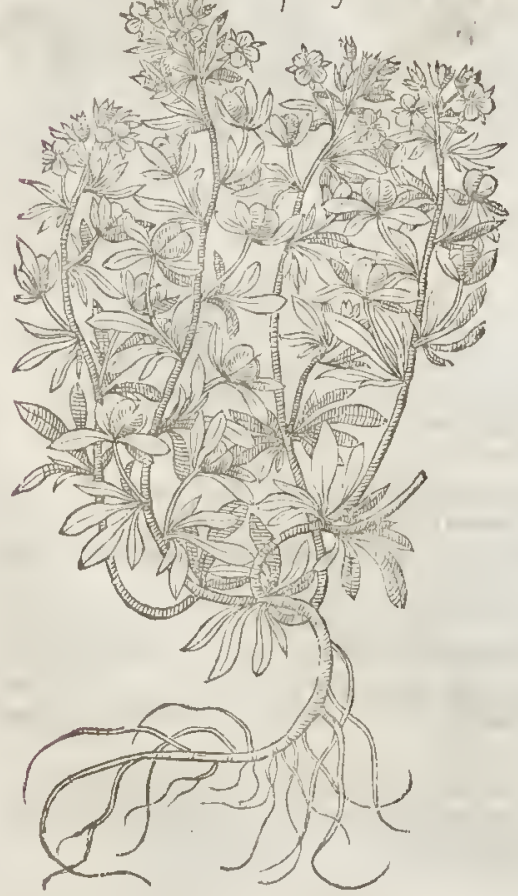

4 A! finc marina.

Sea Chickweed.

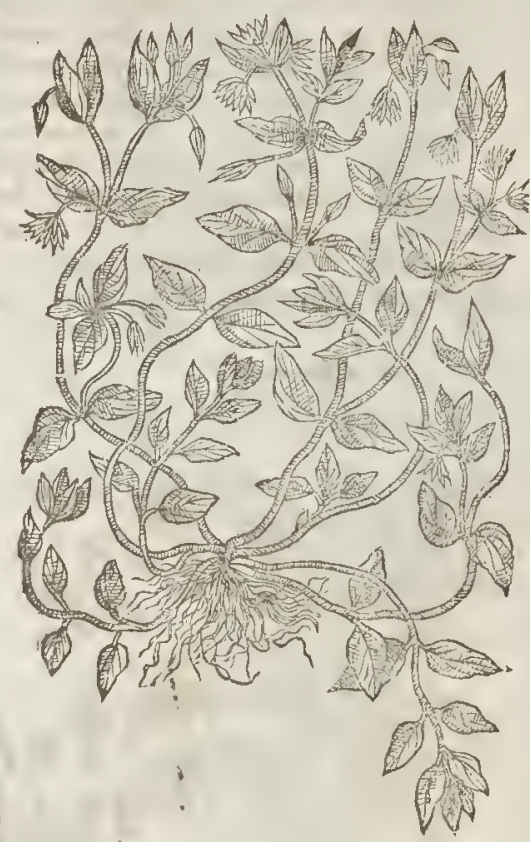

6 Alfine Petrea:

Stone Chickweed.

Stellaria seppopleifoli

然

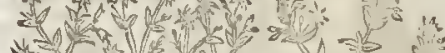
* -1.0 -

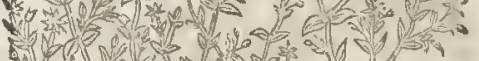

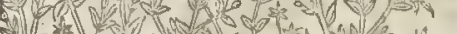
C

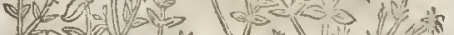

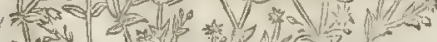

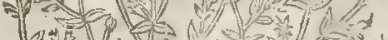

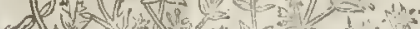
x. $v$ en H. \& an 2 (2)

$$
\Rightarrow
$$


7 Alfine folys t'eronice.

- Speed-rwet1 Chickweed.

Veromica anvensio

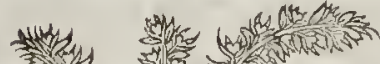

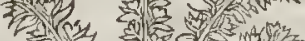

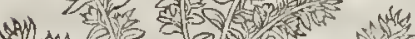
Hy यin

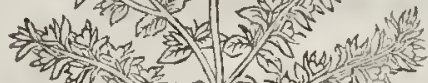

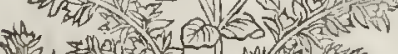
H प.

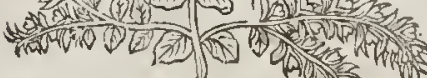

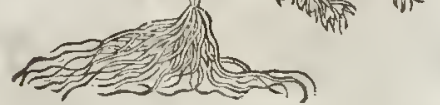

9 Alfne furvintilis.

Riwer Clickweed.

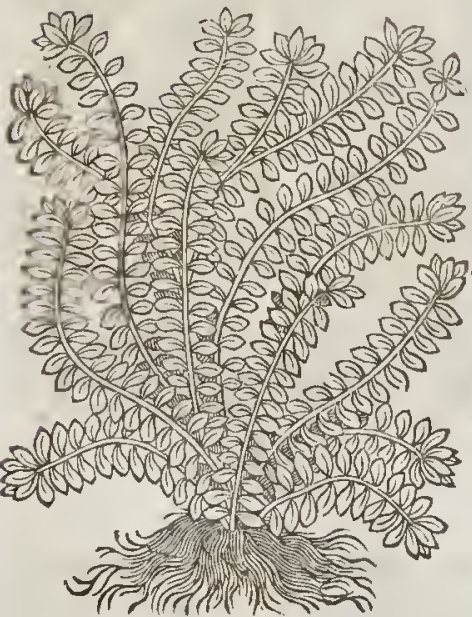

8 Alfne fon:ana.

Fountaine Clickwed.

Stellaria uliqunosa

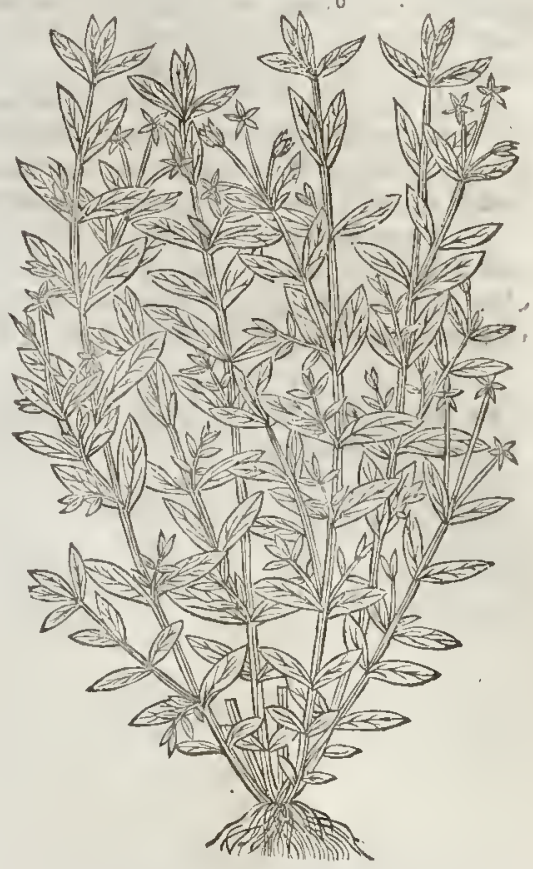

Io Alfune palnftris.

Marin Chichweed.

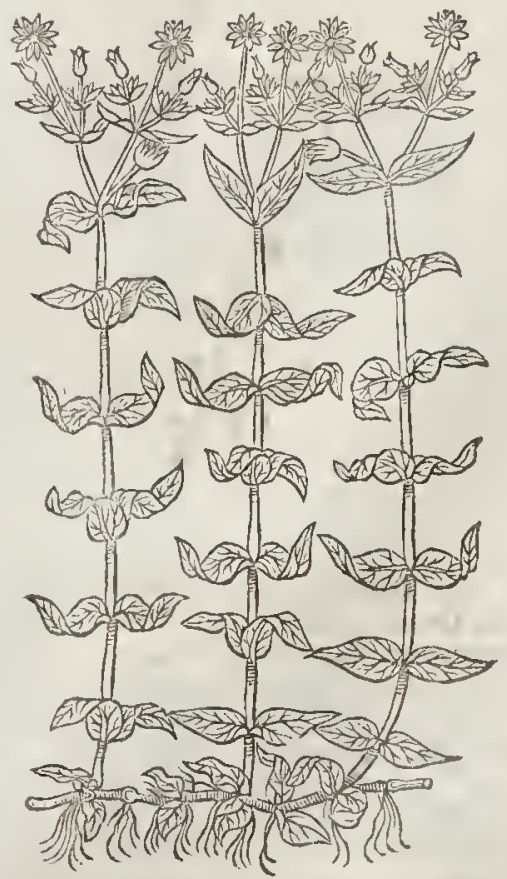


7 Speedwel Chickweed hath a Iittle tender ftalk, from which comediuers fmall armes or branches as it werewings, fet together by couples; whereon do grow leaues fet likervife by couples, like thofe of Veronica, or herbe Fluellen, whereof it tooke his name. The floures grow a long the branches of a blew colour; after which come little pouches wherein is the feed : the root is fmall, and likewirethreddy. This in the Hif. Lugd. is called Elatine polyfardes : and Fabus Columna iudgeth it to be the Alyffor of $D$ iofcoredes. $\neq$

8 There is a kind of Chickweed growing in the brinks and borders of Wels, Fountains, \& 8 thallow Springs, hauing many threddy roots from which rife vp diuers tender ftalks, whereupon doe grow long narrow leaues; from the bofomes of which come forth diuers frmaller leaues of a brighr grcene colour. The floures grow at the top of the ftalkes, fmall, and white of colour.

9 There is likewife another water Chickweed fmaller than the laft deferibed, hauing for his root a thicke haflocke or tuft of threddy ftrings : from whuch rife vp very many tender ftems, ftretching or trailing along the ftreame; whereondo grow long leaues fet vpon a middle rib, like thofe of Lentils or wilde Fetch : the floures and feeds are like the precedent, but much fmaller.

\# I Alfine rotundifolia, fine Portulaca aguatica. Water Purflane.

$$
\text { OPeplis sootuia }
$$

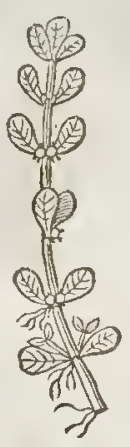

\$2 Alfine palustris ferpillifolia. Creeping water Chickweed. Callitriche aquatica
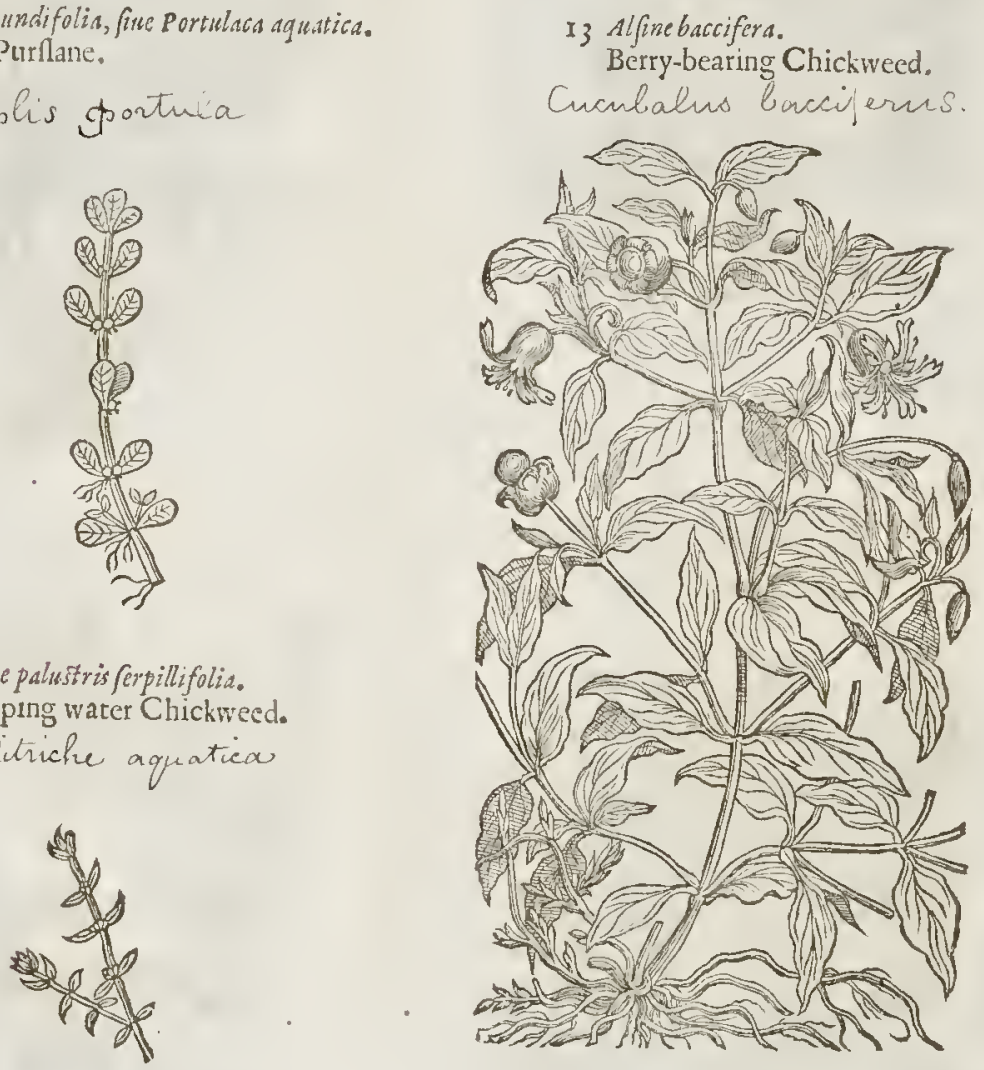

Io There growes in the nurith or waterith grounds another fort of Chickweed, not much vnlike the reft of the ftocke or kindred of Chickweeds. It hath a long root of the bigneffe of a whear ftraw, with diuers ftrings hanging thereat, very like the root of Couch-grafe : from the which rifeth vp diuers vprighteflender ftalkes, fet with pretty large fharpe pointed leaues ftanding by coulples at certaine diftanecs : on the top of the falkes grow. fmall whute floures like thofe of Stitehwort, but leffer, and of a white colour.

‡ II To thefe water Chickweeds may fitly be added thofe two which I mentioned and figured in my laft iournall : the former of which, that I haue there called alfine aquation foligs rotumdhoribus, fure Portuica agratica, (that is) Round leaned Chickweed, or water Purflane, hatl! a fmalt ftringy root which fends forth dirers creeping fquare branches, which here and there at the ioynts 

put out fmall fibres, and take ront againe: the leaues grow at the ioynts by couples, fomwhat lon-
gith, and round at the points, refembling thore of Purllane, but much finaller, and of a yellowifn greene colour : at the bofomes of the leaues come forth little Houres, which are fueceded by little round feed-veffels containing a fmall round feed. Barhwne hath fet his forth by the name of Alfine paluftris minor folys oblongzs.

I2 Theorherwater Chickweed, which lolon Baubina hatl mentioned by the name of Serpilli. folia ; and Cafper $B$ arline by the title of Alfine paluftris minor Serpilly folm, hath alfo weake and tender creeping branches lying fpred vpon the ground; fet wirh two narrow hiarp pointed leaues at each ioynt, greene aboue, and of a whitith colour below : at the fetting on of thefe leaues grow fmall reflels parted as it were into two, with a little creft on each fide, and in thefe is contained a verie fmall feed. Both thefe may be found in waterie places in Iuly and Augut, as betweene Clapham heath and Touting, and betweene Kentifh towne and Hampitead.

I3. This Plant that Cliffus and others haue called Alfine repens major, and fome haue thought the Ciclaninus alter, of Diofrorides; and Cucubalus of Pliny, may firly be put in this ranke; for it fendetl vp many long weake branehes like the great Chickweed, fet with two leaues at a ioynt, bigger than thofe of rhe greatef Chickweed, yet like them in hape and colour : at the tops of the branches, out of pretty large eups come whitifh grcene floures, which are fucceded by berries as big as thofe of Iuniper, ar firtt greene, but afterwards blaeke: the feed is finall and fmooth: the root white, very fibrous, long and wooddy, and it endures for many ycares. It floures inof part of Sommer, and growes wilde in fundry plaees of Spaineand Germany, as alfo in Flanders and England, aecorting to Pena and Lobel: yet I hate not feene it growing but in the garden of my friend $\mathrm{M}^{\mathrm{r}}$. Pemble at Marribone. The Authors laft mentioned affirme the berries hercof to haue a poyfonous facultie like as thofe of Dwale or deadly Nightrhade. $\ddagger$

$$
\text { TI The Place. }
$$

Chickweeds, fome grow among bufhes and briers, old walls, gutters of houfes, and thadowie places. The places where the reft grow are fet forth in their feuerall deferiptions.

$$
\text { Tा The Time. }
$$

The Chickweeds are greene in Winter, they floure and feed in the Spring.

$$
\text { a The Names. }
$$

Chickweed or Chickenweed is ealled in Greeke sxm: : in Latine it retaineth the fame name Al fine: of fome of the Antients it is ealled Hippia. The reft of the plants are diftinguthed in their feuterall fitles, with proper names which likewife fetteth forth the place of their growings.

Chickweed is cold and moit, and of a waterilh fubitance; and thereforc it eooleth without a. itriation or binding, as Galen faith.

T) TheVertues.

The leates of Chickweed boyled in water very fofr, adding thereto fome hogs greafe, the pou- $A$ der of Fenugreeke and Linefeed, and a few roots of marfh Mallowes, and Atamped to the forme of cataplafme or pulteffe, taketh away the fwellings of the legsior any other part ; bringeth to fuppuration or matter hot apoftumes; diffolueth fwellings that wil notwillingly yeeld to fuppuration; eafeth members that are fhrunke vp; comforteth wounds in finewie parts; defendeth foule maligne and virulent vlcers from inflammation during the cure $:$ in a word, it comforteth, digefteth, defendeth, and fuppurateth very notably.

The leames boyled in Vineger and falt ate good againf mangines of the hands and legs, if they $B$ be bathed therewith.

Littlebirds in cadges (efpecially Linnets) are refrefhed with the leffer Chiekweed when they loath their meat ; whereupon it was called of fome Pajerina.

\section{С н А. 193. Of the baftard Clickpeeds.}

\section{T The Defcription.}

I Ermander Chickweed hath fmall tender branehes trailing vpon the ground, befet with leates like vnto thofe of Scordium, or VVater Germander. Among which come forth littlc blew Houres : which being faded, there appeare fmall flat husks or pouches, wherein lieth the feed. The root is fmall and threddy; whicls being once gotten into a garden ground is hard to be deftroyed, but naturally commeth vp fron yeare to yeare as a noifome
weed. 
I Afine foliystrifioinis. Germander Chickweed. Neronica Agrestion

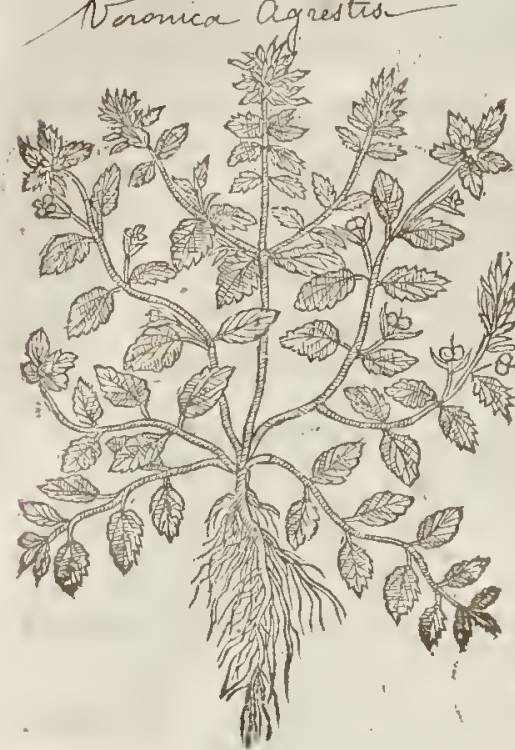

3 Alfine Hederaced.

Ity Chickweed. Neromia hederifohi.
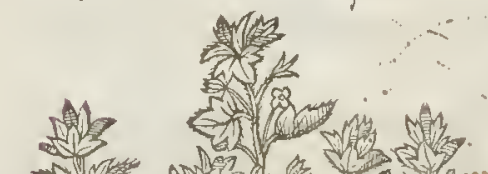

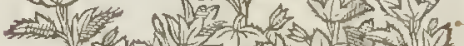

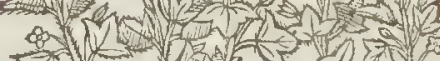
1. I 1,120

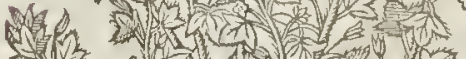

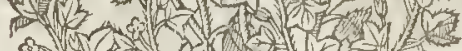
aves
2 Algine corniculata Clufij. Horned Chickweed.

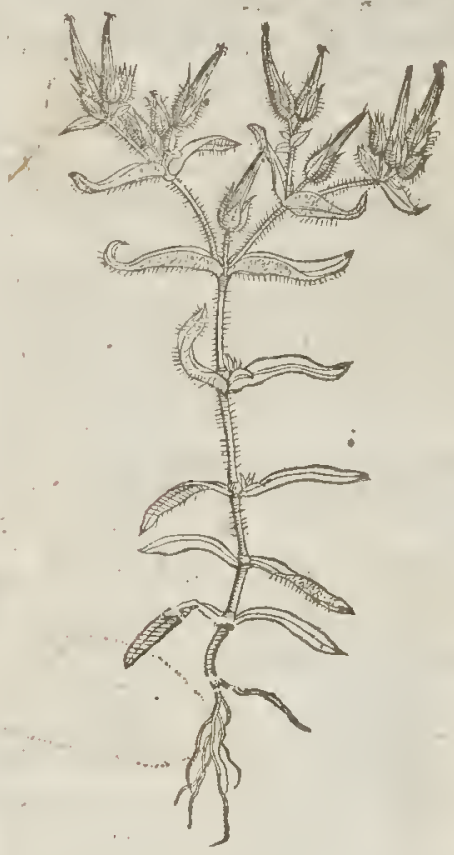

+ Aline Hederuld aliera.

Great Henne-bit.

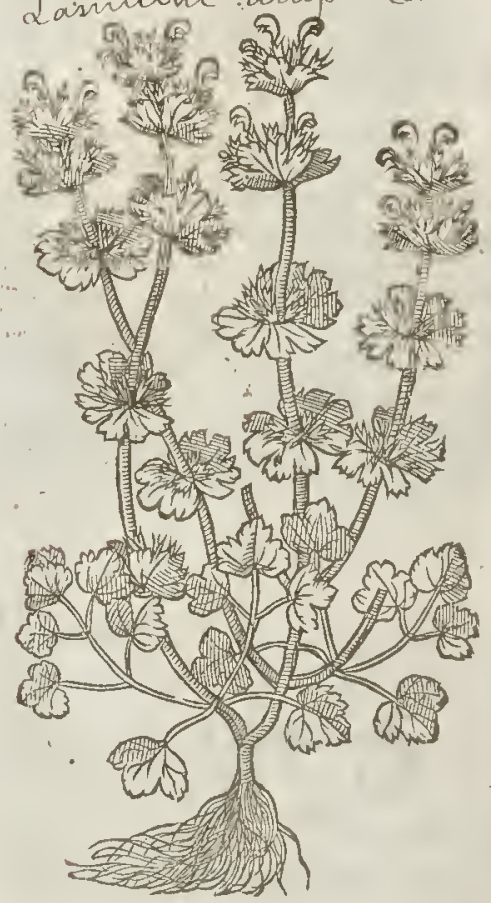




\section{If The Defipion.}

I Impernell is like vnto Chickeweed; the falkes are foure fquare, trailing here and there

1 vpon the ground, whereupon do grow broad leaues, and harpe pointed, fer together by couples:from the bofome whereof come forth flender tendrells, whereupon doe grow fmall purple foures tending to redneffe: which being paft there fuceed fine round bullets, like vito the feed of Corianders, wherein is conteined fmall duftie feed. The root confifteth of flender ftrings.

2 The female Pimpernell differeth not from the male in any one point, bur in the colour of the floures; for like as the former hath reddith floures, this plant bringeth forth floures of a molt perfect blew colour, wherein is the difference.

$\$ 3$ Of this there is another variety fet forth by Clufus by the name of Anagallistenuifolia $\because 0$. nelli, becaufe he receined the figure and Hiftory thereof from $10 \mathrm{bn}$ Monell of Tournay in France it differs thus from the laft mentioned, the leaues are longer and narrower, fomewhat like thofe () Gratiola, and they now and then grow three at a joint, and out of the bofomes of the leanes eome commonly as many little footftalkes as there are leates, which carry Houres of a blew colour with the midd le purplifh, and thefe are fomewhat larger than them of the formet, othew ife like.

\$ Anagallis tenuifolia. Narrow leaned Pimpernell.

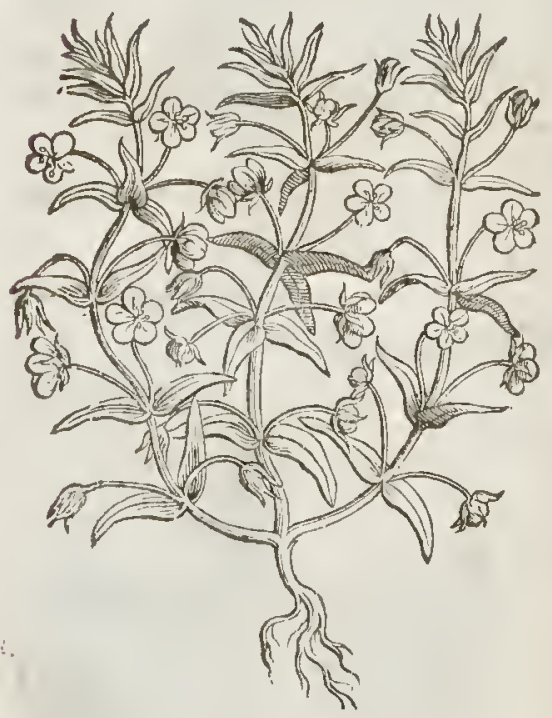

4. Anagallis luten. Yellow Pinpcrnell. Lysinachia nemorum

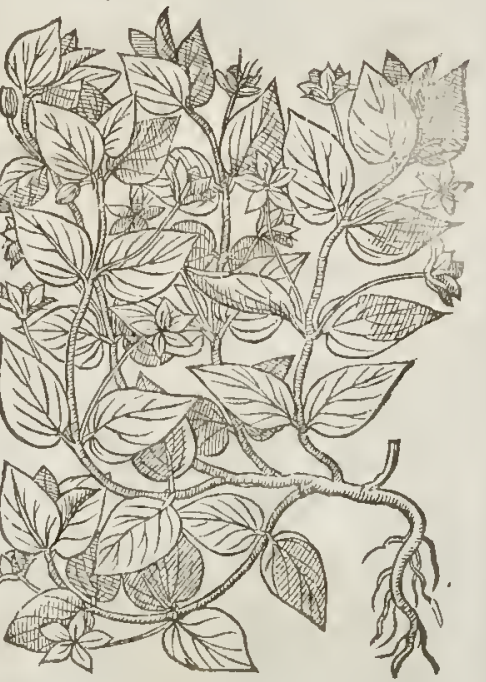

4 The yellow Pimpernell hath many weake and fecble branehes trailing vipon the ground, befet with leates one againft another like the great Chickweed, not vnlike to $N$ ummularia, or Money woort; betweene which and the ftalke's, come forth two fingle and finall tender footestalkes, each bearing at their top one yellow floure and no more. The roor is fmall and threddy. T The Place.

They grow in plowed fields neere path waies, in gardens and vineyardes, almolt euery where: I found the fenale with blew floures in a ehalkie eorne field in the way from $M$ : William Swaines houfe of Southfleet to Long field downs, but neuer any where elfo. $\$ 1$ alfo being in Encx in the company of my kind friend $\mathrm{M}^{\mathrm{r}}$. Nathaniel Wright found this among the corne at Wrightsbridge,

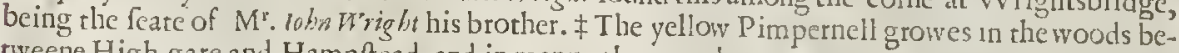
tweene High-gare and Hampltead, and in many other woods.

$$
\text { q The Time. }
$$

They Aoure in Summer, and efpecially in the monerly of Augut, at what time the husbandmen hauing oceafion ro go vnto their harueft worke, will firt behold the flotires of Pimpernell, whereby they know the weather that fhall follow the next day after as forexample, if the floures be flut clofe vp, ir betokeneth raine and foule weather; contrariwife, if they be fpread abroad, faire
wearher. 


\section{If The Nomes.}

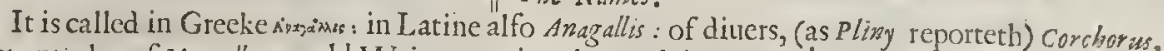
but untruly : of Marcellus an old Writer, Macia; theword is extant in Diofcorides among rlic baftard names. That with the crimfon flourc, being the male, is named threxicion, and corallion : of this is made the compolition or receit called Diacorallson, that is vfed againgt the gout; which compofition Paulus Es hath becne called Aetrits, efgitis, and Sauritis: in Englin, Red Pimpernell, and blew Pimpernel.

$$
\text { T The Temperature. }
$$

Both the forts of Pimpernell are of a drying factiltiew ithout biting, and fomewhat hot, with a certaine draving quality, infomuch that it doth draw forth fplintets and things fixed in the fleth, as Galen writeth.

$$
\text { T The Vertues. }
$$

Diofcorides writes, That they are of power to mitigate paine, to cure inflammations or lot fwel- A lings, to dtaw out of the body and flent thornes, fplinters, or hiuers of wood, and ro helpe the
Kings Euill.

The iuyce purgeth the head by gargarifing or wathing the throat therevith ; it cures the tooth- B ache being fnift vp into the nofethrils, efpecially into the contrary nofethrill.

It helpeth thofe that be dim fighted : the iuyce mixed with honey cleanfes the vlcers of the cye $C$ called in Latine Argcma. beafts.

Moreouet he affirmeth, That it is good againf the finging of Vipers, and other venomous D

It preuaileth againf the infirmities of the liuer and kidneyes, if the iuyce be drunk witl? wine. E He addeth further, how it is reported, That Pimpernel with the blew floure helpeth vp the funda. ment that is fallen downe, and that red Pimpernell applied, contratiwife bringeth it downe.

\section{C н A. 195. Of Brooke-lime, ormater Pimpernell.}

TI The Defeription.

I Rooke-lime or Brooklem hath fat thicke ftalkes, round, and parted into ditiers branches: the leaues be thickc, fmooth, broad, and of a dcepe greene colour. The floures grow vpon fmall tender foot-italkes, which thruft forth of the bofome of the leaues, of a perfect blew colour, not rnlike to the foures of land Pimpenell : the root is white, low creeping; with fine ftrings faltned thereto: out of the toot fpring many other falkes, whercby it greatly encreaferh:

\# There is a Icfer varietic of this, which our Author fet forth in the fourth place, differing not from this butonely in that it is leffe in all the parts thereof; $w$ herefore I hateomitted the hiftorie and figure, to make roome for more confpienous differenees. $\neq$

3he great water Pimpernell is like vnto the precedent, fauing that this plant hath harper pointed or larger leaues, and the floures are of a more whition or a paler blew colour, wherein confifteth the difference.

* There is alfo a leffervarietic of this, whofe figure and defcription our Authour gaue in the next place; but becaufe the difference is in nothing but the magnitude I haue madebold to omit it alfo.

3. Now that I haue briefely giuen you the hiftory of the foure formerly deferibed by our Author, I will acquaint you with two or three more plants which may fitly be here inferted: The firft of thefe Lobel calls Anagallis aquaticatertia; and therefore I haue thought fit to giue you it in the fame place here. It hurh awhite and fibrous root; from which arifeth a round fmooth falke a foot and more ligh, (yet I la ure fometimes found it not aboue three or foure inches high :) vpoin the ftalkes grow leaues round, greene, and fhining, ftanding not by couples, but one aboue another on all fides of the ftalkes. The leaues that lie on the ground are longer than the ref, and are in hape fonewhat like thofe of the common Daifie, but that they are not fnipped about the edges : the floures arc white, confifting of one leafe diuided into fiue parts; and they grow at the firft as it were in an vmbel, but afterwards more fpike fafhioned. It floures in Iune and Iuly, and grow-* eth in many waterie places, as in the marithes of Dartford in Kenr, alfo betweene Sandwich and Sindowne eaftle, and in the ditches on this fide Sandwieh. Barbine faith, That Guillandinus called it fometimes Alifma, and otherwhiles Cochlearia : and others would haue it to be Samolum of $P$ liny, lib.25.Cap. I I. Bawhine himfelfe fitly calls it Anazalls aquatica folio rot undo non crenato. 


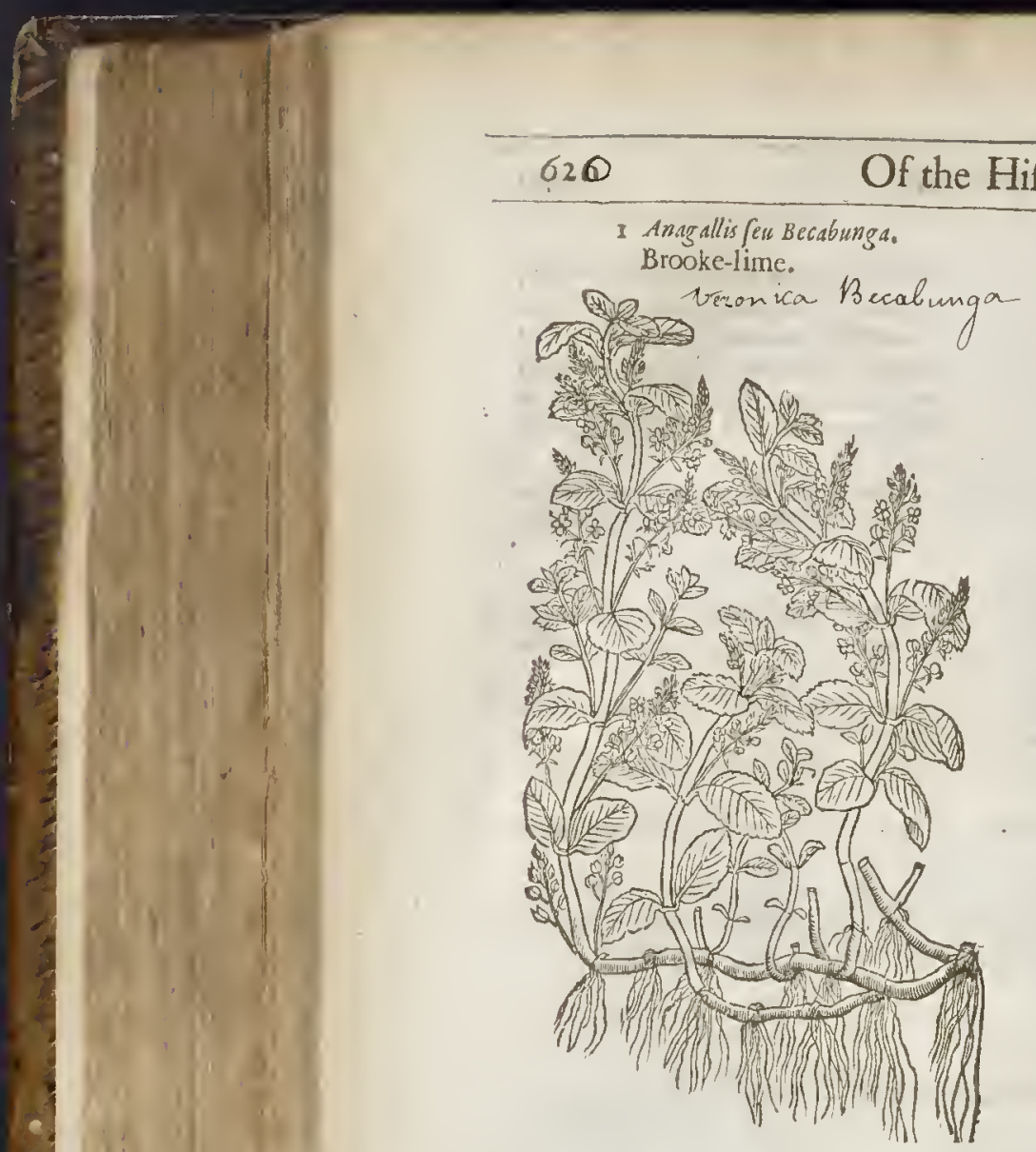

$\mathrm{L}_{1 \text { в. } 2 .}$

+3 Anagallis aguatica rotundifolia.

Round leaued watcr Pimpernel.

Samoles Valerandi.
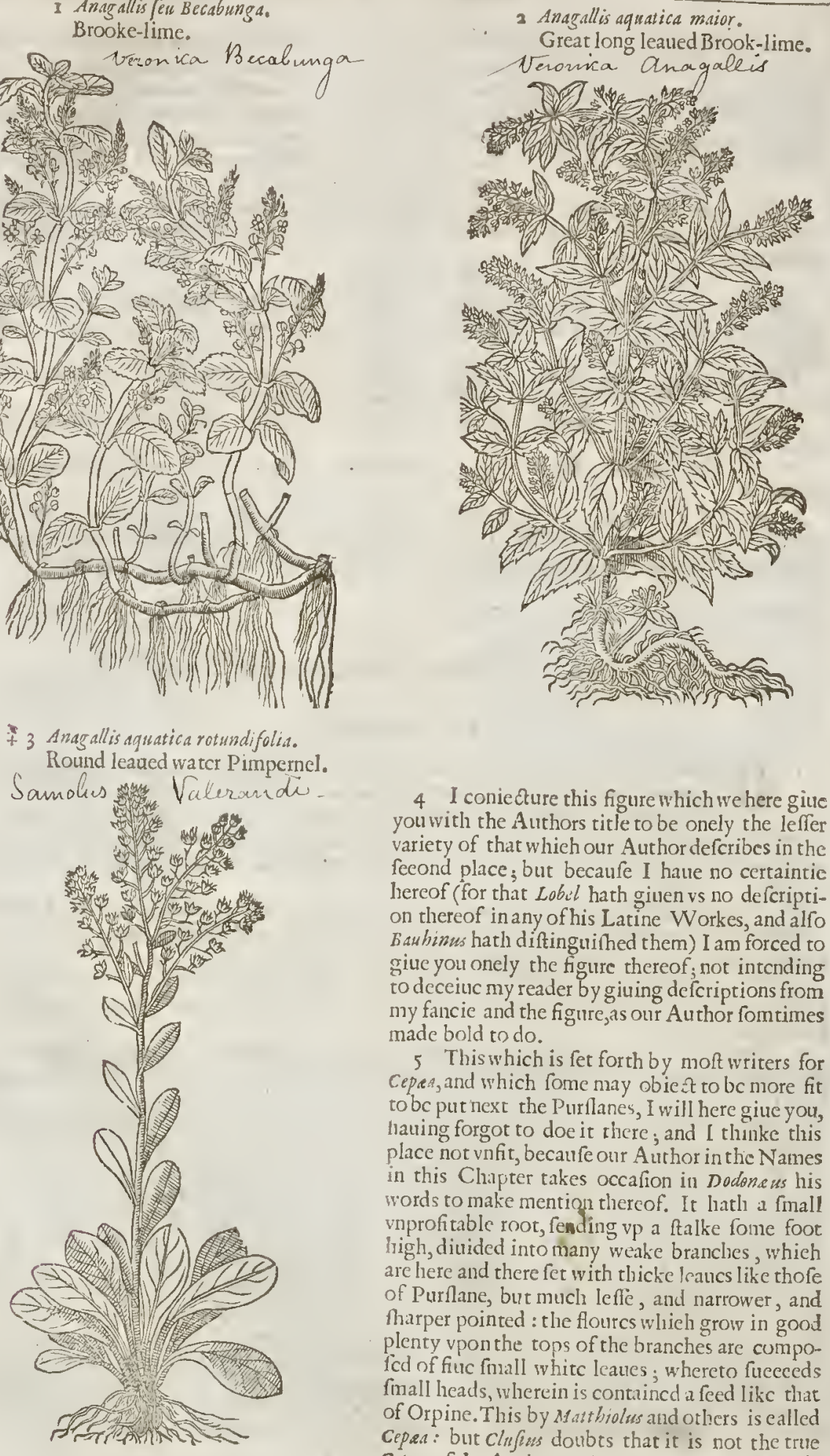

4 I coniecture this figure which we here gitic youwith the Authors title to be onely the leffer variety of that which our Author deferibes in the feeond place; but becaufe I haue no certaintic hereof (for that Lobil hath giuen vs no defeription thereof in any of his Latine Workes, and alfo Bashimus hath diftinguifhed them) I am forced to giue you onely the figure thereof ; not intending to deceiuc my reader by giuing defcriptions from my fancie and the figure, as our Author fomtimes made bold to do.

5 This which is fet forth by moft writers for cepas, and which fome may obic at to be more fit tobc put next the Purflanes, I will here giue you, hauing forgot to doe it there; and I thunke this place not vnfit, becaufe our Author in the Names in this Chipter takes occafion in Dodoneus his words to make mention thereof. It hath a fmall vnprofitable root, fending vp a ftalke fome foot ligh, diuided into many weake branches, whieh are here and there fet with thicke leaucs like thofe of Purflane, but much leffe, and narrower, and Aharper pointed : the flourcs which grow in good plenty vpon the tops of the branches are cumpoficd of fuic fmall whitc leaues; whereto fuceceds forall heads, wherein is contained a feed like that of Orpine. This by Mathiolus and others is ealled Cepea: but clufius doubts that it is not the true Cepsa of the Antients. + of The 
- Lobels fourth water Pimpernel.

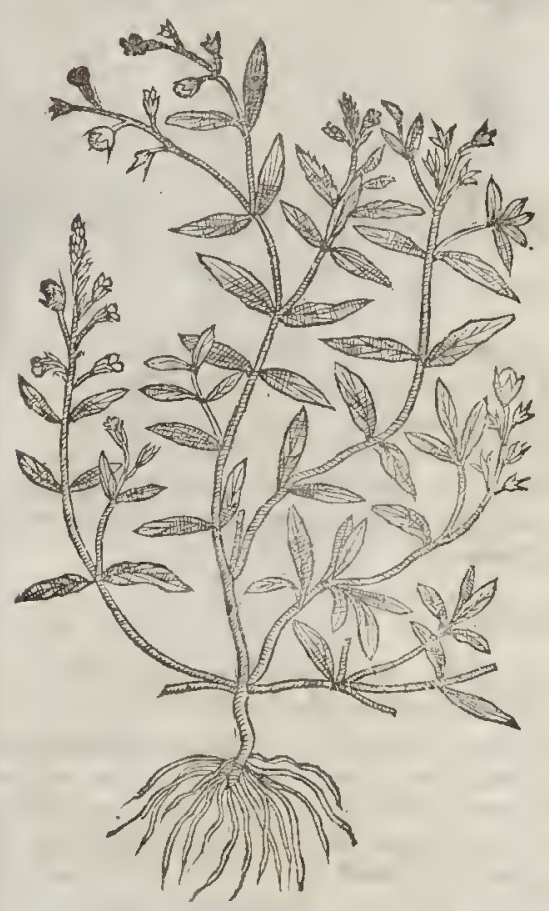

\$ Anagallis aguatica quart $n$, Lob.

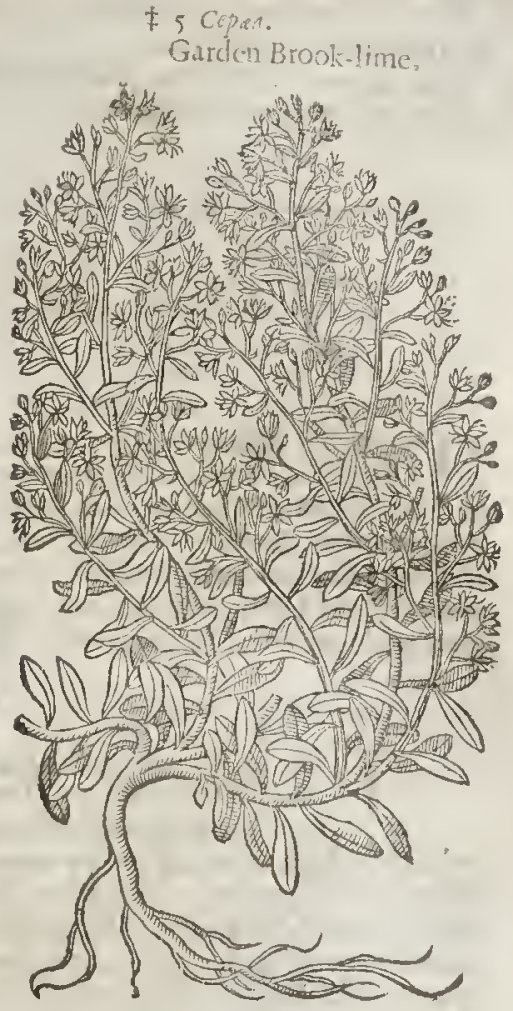

\# 5 Cepien.

The Place.

They grow by riuers fides, fmall running brookes, and waterie ditches. The yellow Pimpernell I found growing in Hamplted woot neere London, and in many otherwoods and copfes.

$$
\text { ब1 The Time. }
$$

They bring forth their floures and feed in Iune, Ituly, and Augult.

$$
\text { If The Names. }
$$

Water Pimpernel is called Anagallis aquatica: of mof, Bcobunga, which is borrowed of rlic Germane word $23 a c h$ punghen: in low-Durch, Beckpumghen: in French, Berle; whereupon fome do call it Berula : norwithfanding Marcellus teporteth, That Berula is that which the Greci. ans call rapsamin, or rather Creffes : it is thought to be Cepea; that is ro fay, of the garden; which $D i$ ofcorides writeth to be like vnto Purflane, whereunto this Brook-limedoch very well agree. But if it be therefore faid to be киту becaufe ir groweth eirher onely or for the not part in gardens, this pimpenel or Brook-lime fiall not be like vnto it, which groweth no where leffe than in gardens, being altogether of his owne nature wilde, defiring to grow in waterie places, and fich as be conсіныalfonerfowne : in Englith the firt is called Brooklime, and the reft by nopartienlar names: butwe nray call them water Pimpernels, or Brook-limes.

\section{- The Temperature.}

Brogk-lime is of remperature hot and dry likewater Cieffes, yet not fo much.

\section{बा The Vertues.}

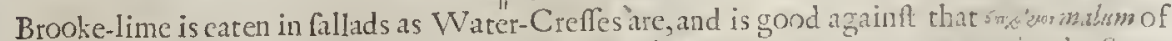
fuch as dwell neere the Germane feas, which they call Siruetbupexe: Or is we terme ir, the Scurwie, or Skirby, being ved after the fame manner that Wirer Crefles and Seuruy grafe is vied, yet is it not of fo great operation and vertue.

The herbe boyled maketh a good fomentation for fwollen legs and the droplie.

The leaues boyled, frained, and famped in a ftone morter with the pouder of Fentrgreek, Linefeeds, the roots of marith Millowes, and fome hogs greafe, vato the forma of a eataphine or pul. C reffe, taketh aw ay any fivelling in leg or arme; wounds alfo that are ready to fall into apoltunition it minlutily defendeth, that no humor or accident thell hippen therento'.

$$
\text { Fif } 3
$$


D The leaues of Brooke-lime ftamped, frained, and giuen to drinke in wine, helpeth the ftrangu rie, and griefes of the bladder.

E The leaues of Brook-lime, and the tendrels of Afparagus, eaten with oyle, vineger, and Pepper, helpeth the frangurie and ftone.

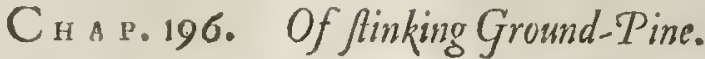

\author{
IT The Kindes.
}

¥ Dofcorides hath antiently mentioned two forts of Anthyllis: one with leaues like to the Len. till, \& the other like to $C$ ham spitys. To the firtt, fome late writers haue referred diuers plants, as the two fir ft defcribed in this Chapter; The Antby/lus Leguminof B Belp arum hereafter to be defcribed; the Antbyllis Valentina Clufiy formerly fet forth Chap. $17 \mathrm{l}$. To the fecond are refer ed the Ina M.of chat a Monpeliaca, defcribed in the fourth plaee of the I 50. Cliap.of th is booke;tre Linariandulserina defcribed formerly ehap. 165. in the 14 . place, and that which is here deferibed in the third place of this elapter, by the name of Anthyllis altera Italorum. +

\section{T The Defcription.}

I 7 Here hath beene much adoe among Writers about the ecrtaine knowledge of the true Anthyllis of Dioforides: I will therefore fet downe that plant whicl of all others is found mott agreeab le thereunto. It hath many fmall branches full ioynts, not aboue an handfull high, creeping fundry wayes, befetwith fmall thicke leates of a pale colour, refembling Lenicula, or rather alfme minor, the leffer Chickwced. The floures grow at the top of the ftalke, ftarre-fafhion, of an herby colour like boxe, or Sedmm muns : it fofteretl his fmall feeds in a three eornered huske. The root is fomewhat long, flender, ioynred, and deepely thruft into the ground like Soldawella: all the whole plant is faltifh, bitter in tafte, and fomcthat heating.

I Antbythis lentifolia, fue Alfine cruciata maris.a.

Sea Pimpernell.

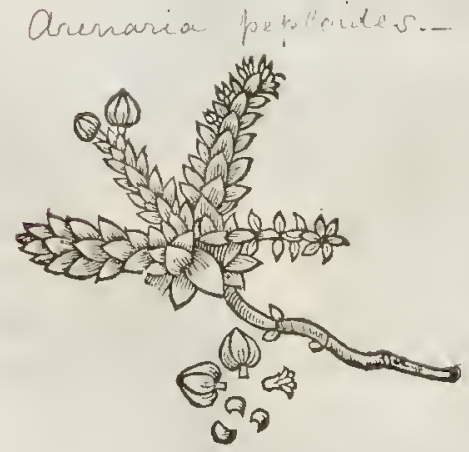

\$2 Anthyllis catrina incana Alfinefolia.

Mnny Houred Ground-Pine.

Pohicarpon Setrapityllum

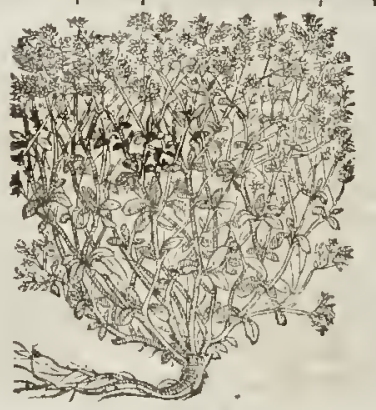

¥ This defeription was taken out of the Aduer faria, pag. 195. Where it is ealled Anthylis prior lentifolia Peplios effigie maritima : alfo Clufius liath defcribed it by the name of Alfines ginuspelnoicum: I haue ealled it in my laft iournall by the name of Alfine cruciata marina, becaufe the leaues which grow thicke together by eouples croffe each other, as it happens in moft plants whieh haue fquare ftalkes with two leaues at cach ioynt. I haue Englifhed it Sea Pimfernell, becaufe the leaues in thape are as like thofe of Pimpernel as of any other Plant; and alfo for that our Author hath ealled another plant by the name of Sea Chickcweed. The figure of the Aducr ariawas not good, and Clif tw hath none; wh ich bath eatfed fome to reeh on tlis snthylis of Lobiland Alfine of Clufius for two feucrall plants, whieh indeed are not fo. I have given you a figure hercof whirh T rookefrom the growing plant, and whichwell exprefferl the growing therenf. $\neq$ 


\section{Antbyllis altcra It alorum. Stinking ground Pine.}

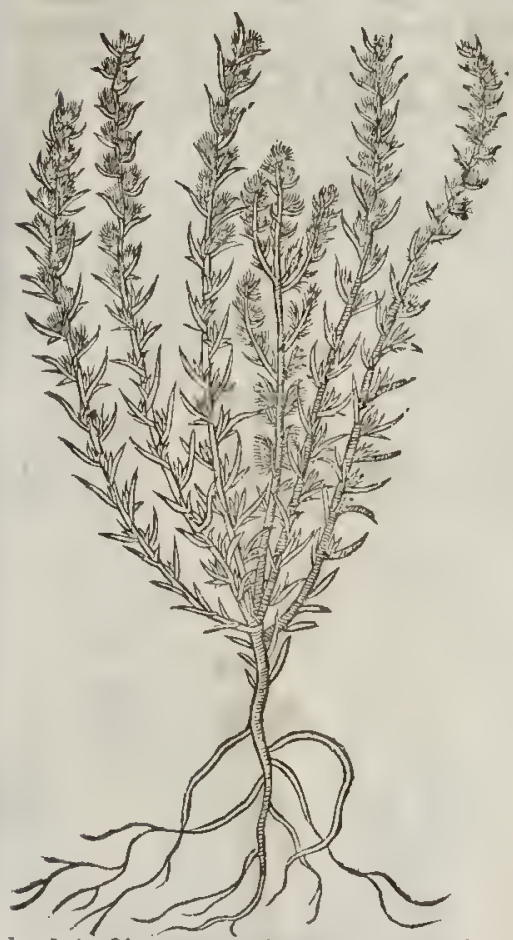

2 There is likewife another fort of $A n$ thyllis or Sea Ground Pine, but in rruth no. thing els than a kinde of Sea Chickeweed, hauing fmall branches trailing vpon the ground of two hunds high, wheremuon do grow little leatres like thofe of Chickweed, not unlike thofe of Lenticulamirina, or $S$ a Lentils : on the top of the ftalks itand in. ny fmall moffe foures of a white colour. The wholc plant is of a bitter and faltion talte. F This is the Marina incana Antbyllis Alfine folin Narbonenfirm of Lobel: it is the $P$ aronychia alters of Matthiolus. $\ddagger$

$\neq 3$ To this figure (which formerly was gituen for the firft of there by our A A thour) I will now giue you abriefedefcription. Th is in the branches, leaties, and whole face thereof is very like the Freneh HcrbeItice, or Ground Pine, but that it is much leffe in all the parts thereof, but chicfely in the lcaues which alfo atc not fuipt like thofe of the French Ground Pine, but Tharp pointed : the tops of the branches are dow nie orwoolly, and fet wirh little pale yellow foures. $\ddagger$

$$
\text { The Place. }
$$

Thefe do grow in the Sourh Ifles belonging to England, efpecially in Portland in the grauclly and fandy foords, which lie low and againt the fea ; and likewife in the inte of Shepey neere the water fidc. \& I hatue oncly found the firt deferibed, and that

both in Sliepey, as alfo in Weft-gate bay by Margate in the Ine of Thanet.

They floure and four ith in Iune and Inly.

$$
\text { T) The Time. }
$$

T TheNancs.

Their titles and deferiptions fufficiently fet forth thcir feuerall names.

I The Temperature.

Thefe fea herbes are of a temperate facultie betweene hot and eold. The Veriwes.

Halfe an ounce of the dried leaues drunkc, pretailet greatly ag aint the hot piffe, the ftrangu- A rie,or difficultie of making water, and purgcth the reines.

The fame taken with Oxymell or honied water is good for the falling fieknefie, gitien firtat B morning,and laft at night.

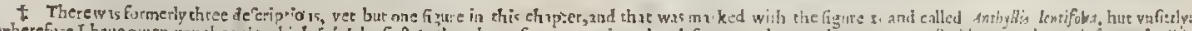

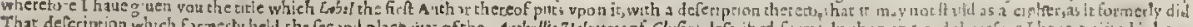

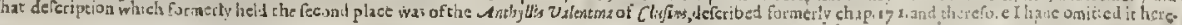

\section{С н м.197. OfWbiteblow, оr Wbitelow Graffe.}

\section{T'he Kindes.}

I Te firft is a very flender plant haing a ferve fmall leates like the leaft Chickcivecde, growing in little tufs, trom the midft whereofrifeth vp a fmallifalke, thres or foure inehes long; on whofe top do grow very litrle white floures; which being paft, there enme in place fmall flat pouches compofed of three filmes; which being ripe, the two out fides fall away, Icaming; the middle pare ftanding long time afterwhich is like white Sattin,as is that of Bolbonat, which our women call white Satrin, bur mueh fuller : the tafte is fomewhat fharpe.

2 This sinde of $P_{a}$ ronychia, hath fmall thicke and fat leates, cue into three or more diuifions, much refuiding the lentes of Rue, but a great deale fnaller. The ftalks are like the former, \&u the 
leatres alfo; but the cafes wherein the feede is contained, are like vnto tle ficedruffls of Myofit is Scorpioides,or Mouleare Scorpion grafe. Tle floures are fmall and wbite.

There is another fort of Whitlow graffe or Nailew oort, that is likewife a low orbafe herbe, hauing a fmall tough roote, with fome threddic ftrings annexcd thereto: from which rife vpdiuers Ilender tough ftalkes, fet with little narrow leanes confufedly like thofe of the fnalleft Chickweed whercof doubricffe thefe be kindes along ft the falks do grow very little white floures, after which come the feeds in mall buttons, of the bigneffe of a pins head. $\neq$ Our Author fecmes here to defcribe the P.ronychia 2.ofTabern. $\neq$

I Paronychia vulgaris.

Common Whitlow graffe.
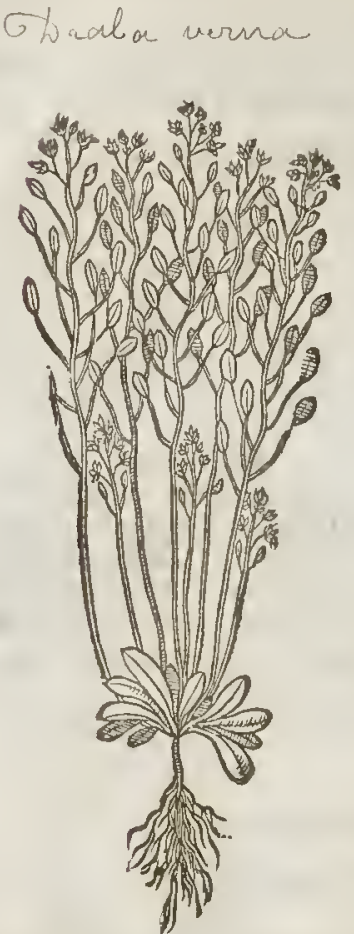

2 Paronychia Rusacio folio.

Rew leafed or ingged Whitlow grafe.

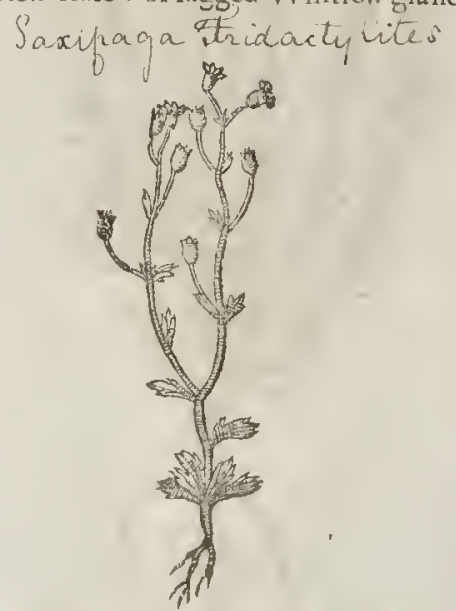

I The Flace.

Thefe fmall, bafe and low herbs grow vpon bricke and ftone wals, vpon olut tiled houfes, which are growne to hane much moffe vpon them, and vpon fome thadowie, and dry muddy wals. It groweth plentifully vpon the bricke wall in Chancerie Lane, belonging to the Earle of Southampton, in the Suburbs of London, and findry other places.

$$
\text { Tा The rime. }
$$

Thefe floure many times in Ianuary and February, and when hot weather approcheth, they are no more to be feen all the yeare after.

The Grocian hatecallet Thes,

The Grecians hate called thefe plants mporvia: which Cicero calleth Redurin: There be many kindes of plants, called by the faid name of Paronychis, which hath caufed many writers to doubt of the true kinde : but you may very boldly take thefe plants for the lame, vntill time hath reuealed or raifed vp fome new plant, approching necrer vnto the truth: which I thinke will neuer be, fo that we may call them in Engliih, Naile-woort, and Whitelow graffe.

Ti The T'mperatures and Vertues.

A As touching the qualitie hereof, wc hate nothing to fer downe: onely it hath beene taken to heale the difeafe of the nailes called a Whit low, whereof it took his name:

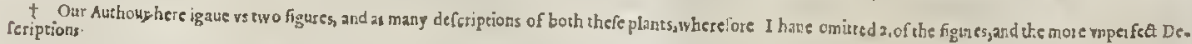




\title{
C н А P. 198. Of the fermale Fluellen, or Speedwell.
}

\author{
If The Defcription:
}

$1 \mathrm{TH}$ fitf kinde of Elatine, beeing of Fuchfus and Mattbiolus,called veronica famina, or the female Fluellen, hooteth from a fmall and fibrous root many flexible and tender branches, difper fed flat vpon the ground, ramping \& ereeping with leaues like $N_{w m}$ mularia, but that the leaues of Elatine are of an hoarie, hairie, and ouerworne greene colour ; among whieh eome forth many fmall floures, of a yellow colour mixed with a little purple, like vnto the fmall Snapdragon, haung a certaine taile or $S$ pur faftened vnto euery fueh foure, like the herbe called Larkes fpurre. The lower iaw or ehap of the floure is of a purple colour,and the vpper iawe of a faire yellowe; which beeing paft, there fucecedes a fmall blacke feede contained in round husks.

2 The fecond kinde of Elatine harh ftalkes, branches,floures, and roots, like the firf : but the leaues are farhioned like the fornter, but that they haue two little ears at the lower end, fomew liat refembling an arrow head, broad at the ferting on: but the fpur or taile of the floure is longer,and more purple mixed with the yellow in the floure.

I Veronica famina Fuch $\ddot{y}$, five Elatise.

The Fenale Fluellen.

untishivion sporium

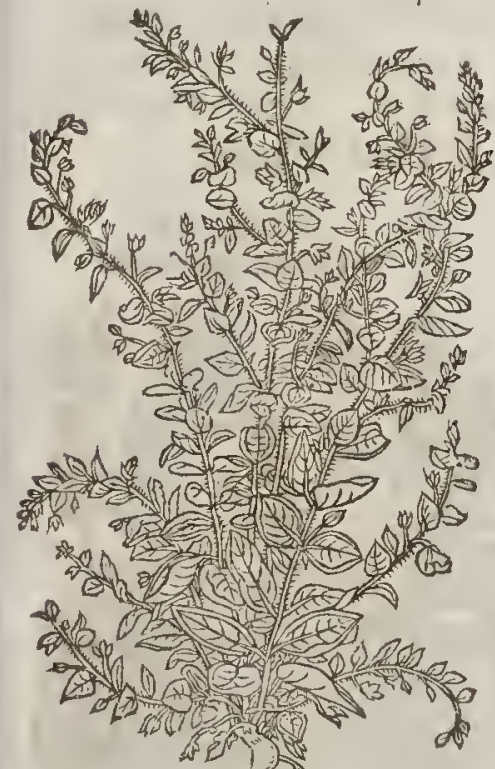

3⿻

\section{Elatine altera.}

Sharpe pointed Fluellen.

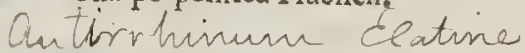

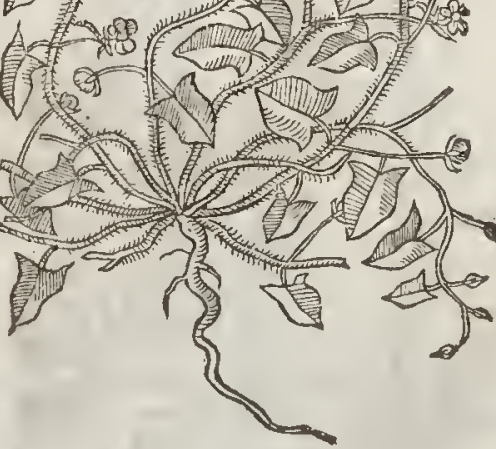

The Place.

Both thefe plants I hate found in fundry places where corne hatli growne,efpecially barley, as in the fields about Southfeet in Kent, where within fix miles compaffe there is not a field wherein it doth not grow.

Alfo it groweth in a field next vnto the houfe fometime belonging to that honourable gentleman Sir Frances Walfing ham,at Barn-elmes, and in fundry places of Effex; and in the next field vnto the Churchyard at Chifwicke neere London, towards the midft of the field.

They foure in Augut and September:, 


\title{
T) The 2 ames.
}

Their feuerall titles fet forth their names as well in Latine as Englifh.

\author{
T) The 2 ature and 0 crtues.
}

A Thefe plantsarenot onely of a fingular aftringent facultie, and thereby helpe them that bee grieuted with the Dy fenterie and hot fwelling; but of fuch fingular efficacy to heale fpreading and eating cankers, and corofute vlcers, that their vertue in a manner paffeth all credit in thefe fretting fores, von fure proofedone vnto fundry perfons, and efpecially vpon a man whom $P$ cna reporteth ro hauc his nofe caten moft grieuoufly with a canker or eating fore, who fent for the Phy fitions \& Chirurgions that were famoufly knotvne to be the beft, and they with one confent concluded to clic the faid nofe off, to preferue the reft of his face: among thefe Surgeons and Phyfitions came a poore forie Barbar, who had no more skill than he had learned by tradition, and yet vndertooke to curc the patient. This forefaid Barbar ftanding in the companie and hearing their determinarion, defired that he might make triall of an herbe which he had feene his mafter vfe for the fame purpofe, which herbe Elatine, though he were ignorant of the name whereby it was called, yet hee knew where to ferch it. To be fhort, this herbe he ftamped, and gaue the iuice of it unto the patient todrinke, and ourwardly applied the fame plaifterwife, and in very fhort fpaee perfectly cured the man, and ftaied the refe of his body from further corruption, which was ready to fall into a leprofie,
Aducr ar.pag.197.

B Elatine helpeth the inflammation of the eies, and defendeth humours fioving vnto them, beeing boiled, and as a pultus applied thereto.

C The leates fodden in the broth of a hen,or Veale, ftaieth the dyfenterie.

D "he new writers affirme, that the female Fluellen openeth the obftrutions or ftoppings of the liver and fpleen, prouketh vrine,dritieth forth ftones, and clenfeth the kidneies and bladder, according to Paulus.

E The weight of a dram or of a French crome, of the pouder of the herbe, with the like waight of rreacle, is commended againlt peftilent Feuers.

\section{С н Р. 192. Of Fluellen the male, or Paul's Betonie.}

I Feronica vera \& maior.

Fluellen, or Speedivell.

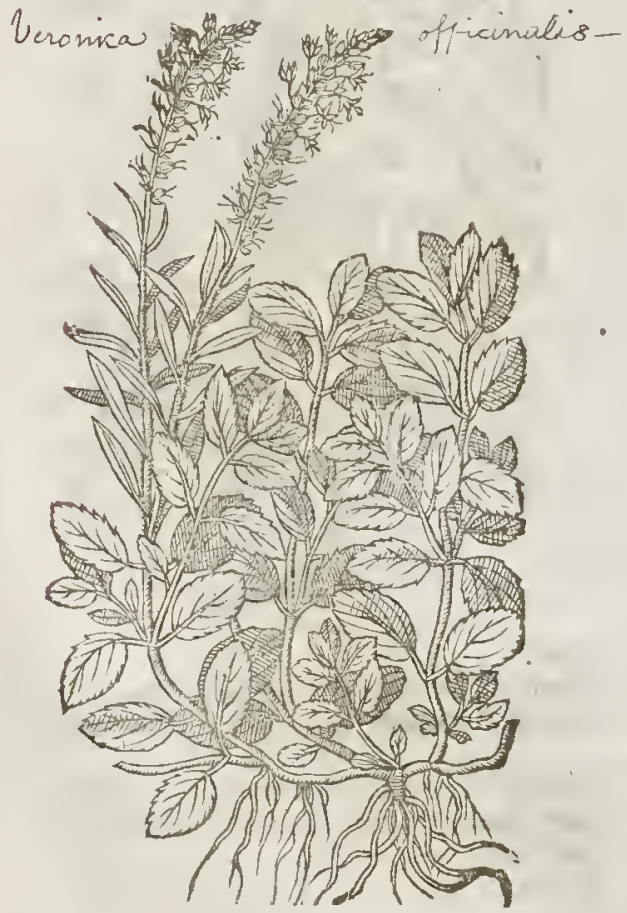

t 2 Veronica recta mas. The male Speedwell.

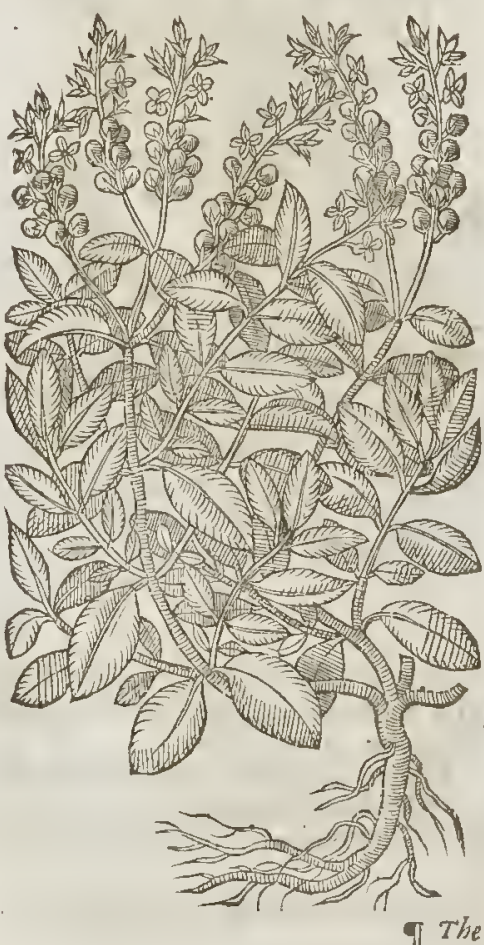




\section{T) The Defcription.}

I THe firft kinde of veronica is a fmall herbe, and creepeth by the ground, with litcle reddifn and hairy branches. The leafe is fomething round and hairy, indented or fnipped round about the edges. The foures are of a light blew colour,declining to purple : the feed is contained in lictle flat pouches : the roor is fibrous and hairy.

$t \quad 2$ The fecond doth alfo crecpe vpon the ground, hatiing long flender ftemmes, fome foor high, and fomewhat large leaucs a little hairy, and pleafantly fort. The floures be blew like as thofe of the former, but fomewhat bigger, and of a brighter colour; and they are al fo fucceeded by round
feed veffels.

3 The third kinde of $V$ cronica creepeth with branches and leaues like vnto Serpillum, for which caule it hath beene ealled $V$ eronica Serpillifolia. The floures grow along the finall and tender branches, of a whitim colour declining to blewneffe. The root is truall and threddie, taking hrold vpon the vpper face of the earth, where it fpreadeth. The feed is contained in fmall pouehes like the for-
mer.

4 The fourtl hath a root fomewhat wooddie, from the which rife vp lealies like vnto the former. The finall vpright italke is befet with the like leaues, but leffer; at the rop whereof coumeth forth a flender fpikc clofely thruft together,and full of blew ith floures, which are fuceeded by many horned feed veffels.

¥5. This hath many wonddie round fmooth branches, forme handfuil and halfehigh or better : the leaues are like thofe of wilde Tyme, but longer, and of a blacker colour, fometimes lightly fnipt: at the tops of the branches grnw floures of a whitifh blew colour, confifting of foure, fuc, or elfe fix e little leaues a piece; which falling, there follow round feede veffels, containing a round fmall and blacke feed. It floures in Auguft, and growes vpon cold and high mountaines, as the Alpes. Pona calls this Veronica Alpina minima Serpilifolio : and Cliffues hath it by the name of Veronica 3 . fruticans. $\neq$

\section{Veronicaminor.}

Little Flucllen,

$$
\text { Teronica serpyllifolias }
$$

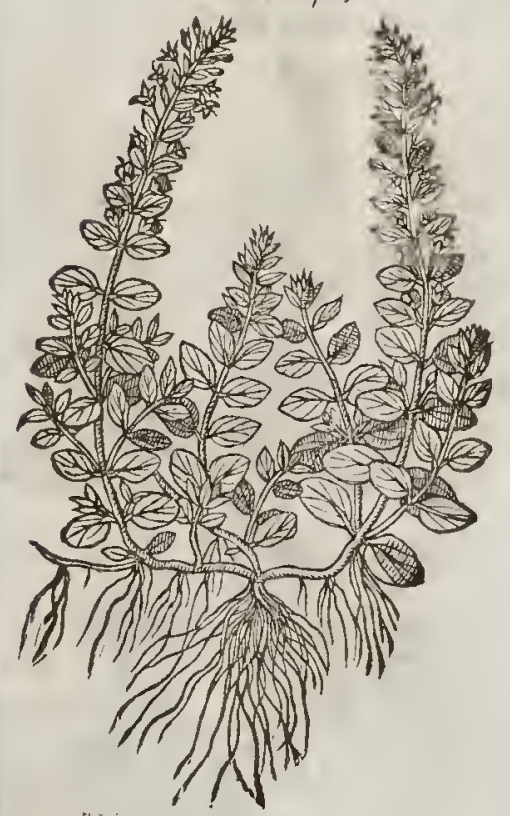

4 Veronica redt minima.

The fmalleft Fluellen. Verunice oficata-

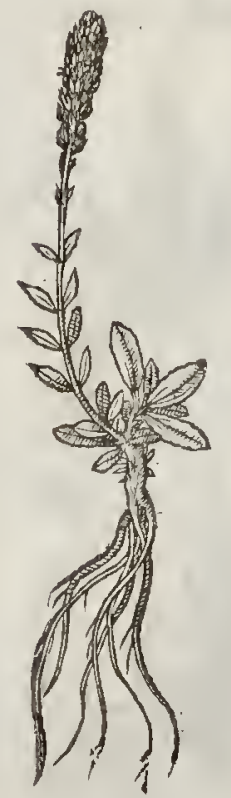




\section{8 \\ Of the Hiftorie of Plants.}

L 1 в. 2.

\$ 5 Veronica fruticans Serpillifolia.

Shrubbie Fluellen.

Veronica saxatilis

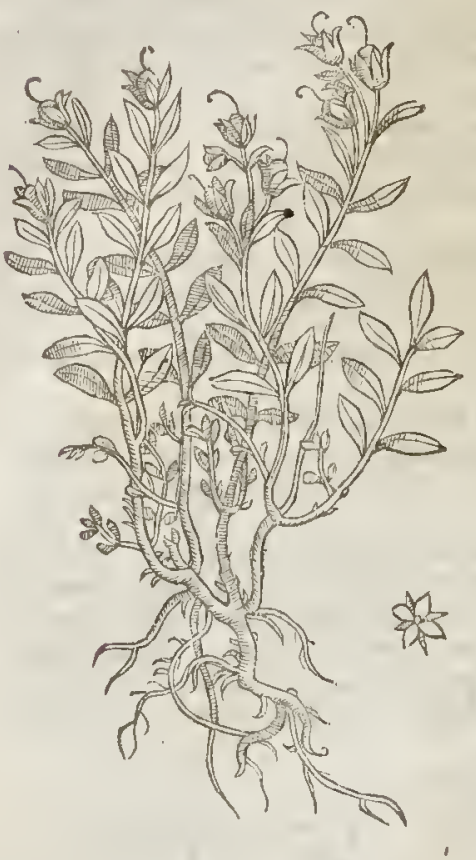

7 Veromea picata Latifolia.

Vpright Fluellen.

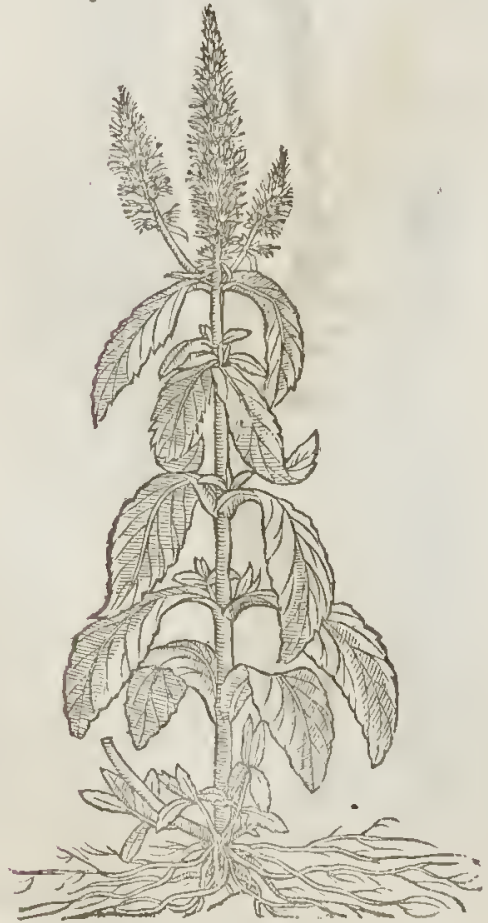

6 Veronica afjurgens, fire Spicata. Iree Fluellen.

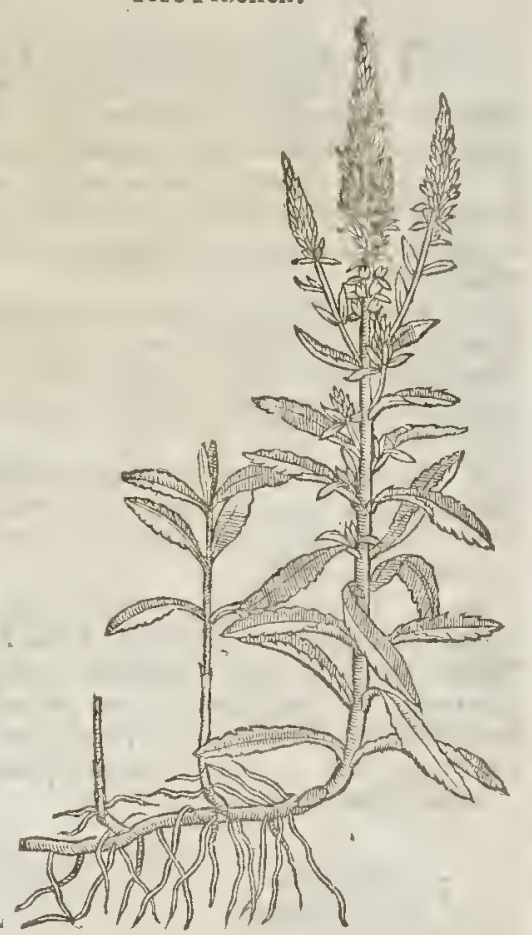

$\ddagger 8$ Veronica fupina.

Lcaning Fluellen.

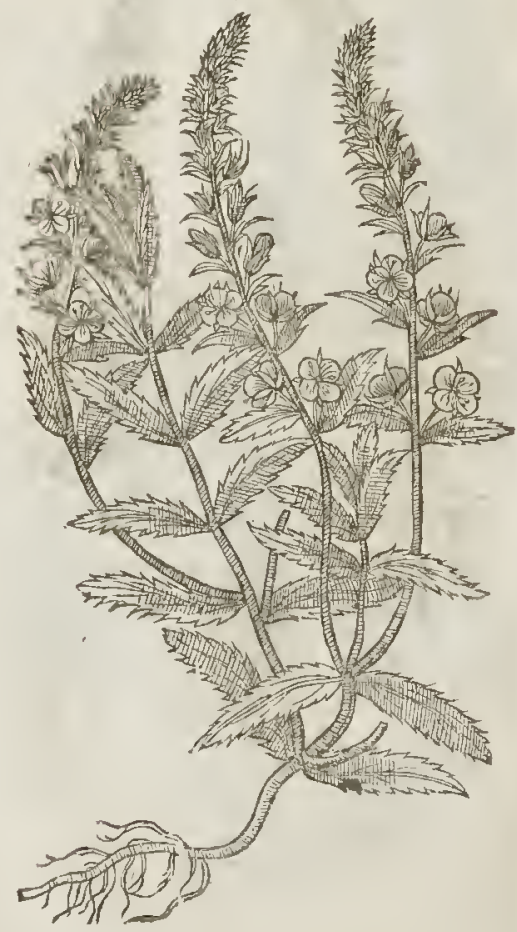


6 The fixt kinde of Verowica hath many vpright branches a foote high and fometimes more, diuiding themfelues into fundry other fmall twigs; at the top whereof do grow faire fpric tufs, like a faw : the root is compact of nany threds, or ftrings.

$\neq 7$ This hath falkes fomecubit high and fometimes ches, yet hauing diuers joints, at each whereof do grow forth long, and one broad, and thefe leaues are alfo thicke frow forth two leates, two or three inches the elges, and of a very afringen and ftalkes grow fuokic tufts or blew floures like tlofe of laft fomewliat biting. At the top of the ter colour, and they begin firt to foure or hew which is finall and blacke, is conteyned in flat feed veffels : below, and fo go vpwards; the feed, euery yeere thrufting vp new fhoots. There is a varicty of this roote is thicke with many fibres, Thining, but hatuing unore branches. and an a varicty of this with the leaues not fo blacke and clufues calls this Veronica erectior latifolia. $\ddagger$

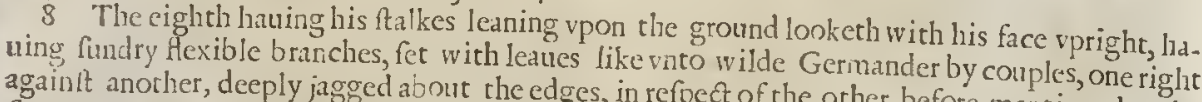
againt another, deeply jagged about the edges, in refpect of the other before mentioned. The
foures are of a blew colour : the root is long, with fome threds appendant thereto.

$$
\text { T. The Place. }
$$

I' erowica groweth vpon bankes, borders of fields, and grafsie mole-hils, in fandy grounds, and in woods, almoft euery where.

The fourth kinde, try good friend $\mathrm{M}^{\mathrm{r}}$. Stephen Bredwell,practitioner in phyricke found and thewed it me in the clofe next adjoining to the houfe of $\mathrm{Mr}^{\mathrm{r}}$. Bele, chiefe of the clerkes of her Maicities Counfell, dwelling at Barnes neere London. The fixth is a franger in England, but I haue ic
growing in my garden.

\section{Thefe floure from May to September. \\ T The Names.}

$t$ Thefe plants are comprehended vnder this generall name $V$ cronica; and Dodoneus would haue the firt of them to be the Betonica of Paulus ineta; and Turner and Gefner the third: we do call people do atrith, Pauls Betony, or Speedwell : in Welch it is called Fluellen, and the Welch eu paíg, that is to fay, Honor and praife.

\section{of The Nature.}

Thefe are of a meane temperature, betweene heate and drineffe.

$$
\text { (T) The Virtucs. }
$$

The decoction of Veronica drunke, fodereth and healeth all freth and old wounds, clenfeth the blott from all corruption, and is good to bedrunke for the kidnies, and againft fcuruineffe and foule fpredding terters, and confuming and fretting fores, the fmall pox and meafels.

The water of Veronica diftilled with wine, and re-diftulled fo often vntill the liquor wax of a red. dith colour, preuaileth againft the old cough, the drineffe of the lungs, and all vlcers and inflam.

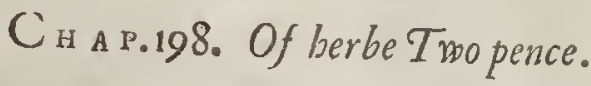

$\mathrm{H}$ T The Defription.

vpon the ground; from which rife vp many litrle, tender, flexible ftalkes trailing vpon the ground, fet by couples at certaine fpaces, with fmooth greene leaues fomewhat round, whereof it tooke his name : from the bofome of which leates thoote forth fmall tender foot-ftalkes, whereon do grow little yellow floures, like thofe of Cinkefoile or Tormentill:

2 There is a kinde of Money woort or herbe Two pence, like the other of his kinde in each re-

+ , is altogether leffer, wherein they differ.

$\ddagger 3$ There is another kinde of Money-woort which hath many very flender creeping bran-
ches which here and there pur forth fintes, ftanding by couples one again arth fibres, and take root againe : the leaues ate fmall and round, 


\section{0 \\ Of the Hiftorie of Plants. \\ L 1 B. 2.}

bearing prety litrlewhitin purple floures confinting of fic little leaues ftanding together in manner.of a little bell-foure, and feldome orhcrvife : the feed is fmall, and conteined in round heads. This growes in many wet rotten grounds and vpon bogges: I firf fornd it Anno I 62 6, in the Bifhopricke of Durham, and in two or three places of Yorkthire, and not thinking any had taken notice

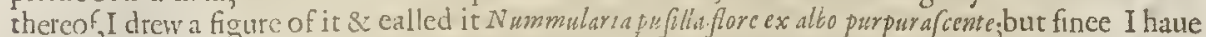
found that Baubine had formerly fet it forth in his Prodromus by the name of 2 ummularia fore perpurafcerte. It growes alfo on the bogges vpon the heath, neare Burnt wood in Effex:it doures inIuly and Augult. $\ddagger$

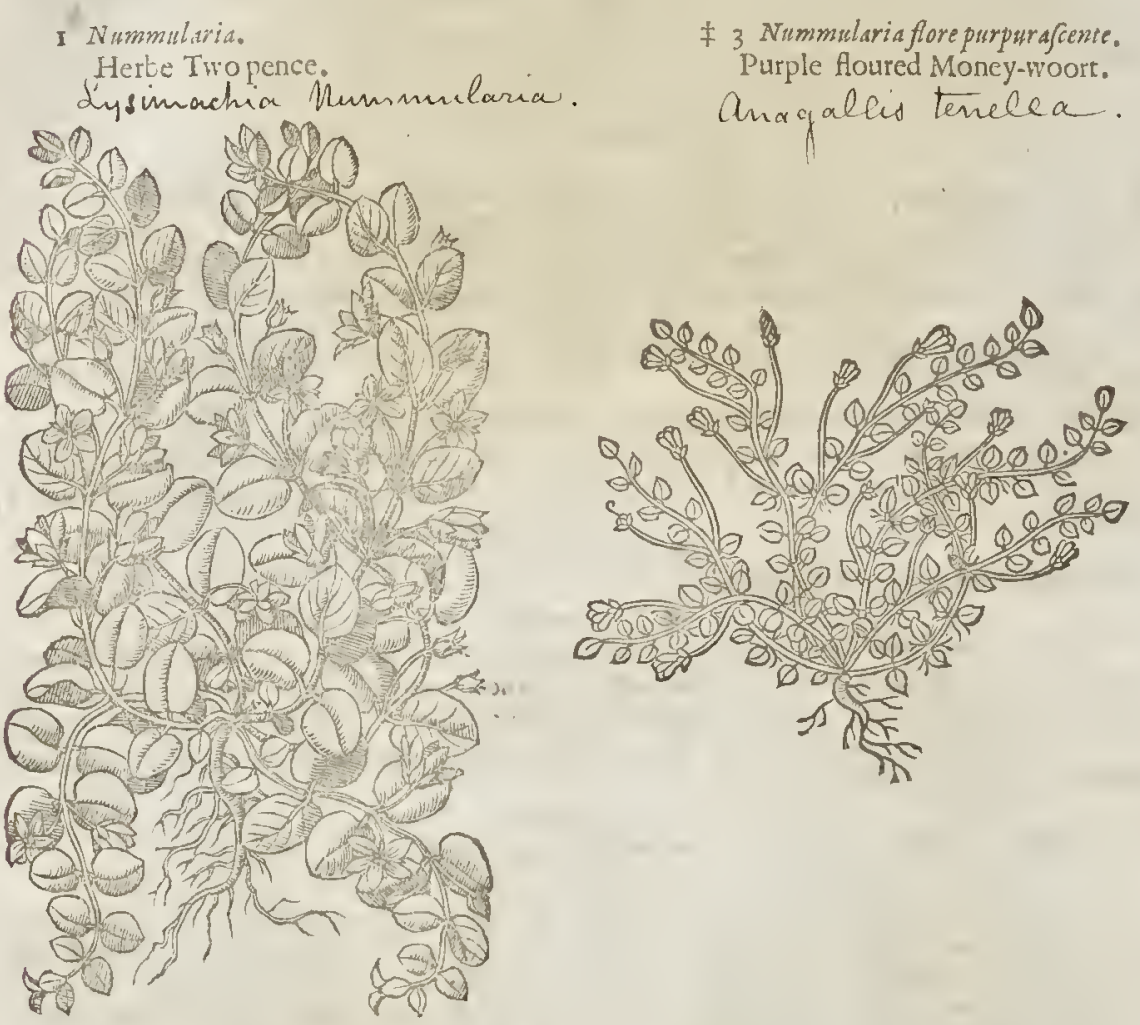

The Place.

It groweth neere vnto ditehes and ftreames, and other watery places, and is fometimes found in moitt wonds : I found it vpon the banke of the riuer of Thames, right againft the Queenes pal. lace of White hall; and almolt in euery countrey where I haue trauelled.

It floureth from May till Summer be well fpent.

4T The rime.

T) The $N$ ames.

Herbe Two penee is ealled in Latine Nummularia, and Centummorbia : and of diuers Scrpentaria. It is reported that if ferpents behurt or wounded, they do heale themfelues with this herbe, where- unn came the name Serpentarta: it is thonght to be ealled Centummorbia, of the wonderfull effect which it hath in curing difeafes; and it is ealled Nummularis of the forme of money, whereunto the leates are like: in Duteh, 10 cnnincketurt : in Englifh, Money woort, Herbe Two pence, and Two penny graffe.

$$
\text { -The Temperalure. }
$$

That this herbe is dry, the binding taite thereof doth thew : it is alfo moderate colde.

$$
\text { a The Vertues. }
$$

A The flotres and leaues ftamped and laid vpon wounds and vleers doth eure them : but it wor: keth moft effeetully being ttamped and boiled in oile oliue, with fome rofen,wax, and turpentine atded thereto. 
The iuce drunke in wine, is god for the bloudie flix, and all orher iffues in blond of man on in woman; the weakenefle and loofeneffe of the belly and laske; it helpeth thofe that vomite blotui, and the Whites in fuch ashaue them.

Boiled with wine and honie it cureth the wounds of the inward parts, and vlcers of the lungs, \&: C in a word, there is not a better wound herbe, no nor Tabaco it felfe, nor any other what foetuer.

The herbe boiled in wine with a little honie, or meade, prenaileth much againft the cough in $D$ children, called the Chine cough.

\section{Cir a P. 200. Of Bugleor cMiddle Comfrey.}

\section{T The Defcription.}

I Dguls fpreadeth and creepeth a longtt the ground like Monie woort; the leaues be lorg, D at, \& neous, and of a brown calour for the moft part. The Houres yrow about the ftalks in rundles, compaffing the ftalke, leauing betweene euery rundle bare or naked fpaces; and are of a faire blew coloutr, and often white. I found many plants of it in a moift ground vpon $B$ lacke Heath neere London, faft by a villagecalled Charleton, but the leaues were green, and nor browne at all like the other.

I Bugula.

Middle Confound.

divigareptams

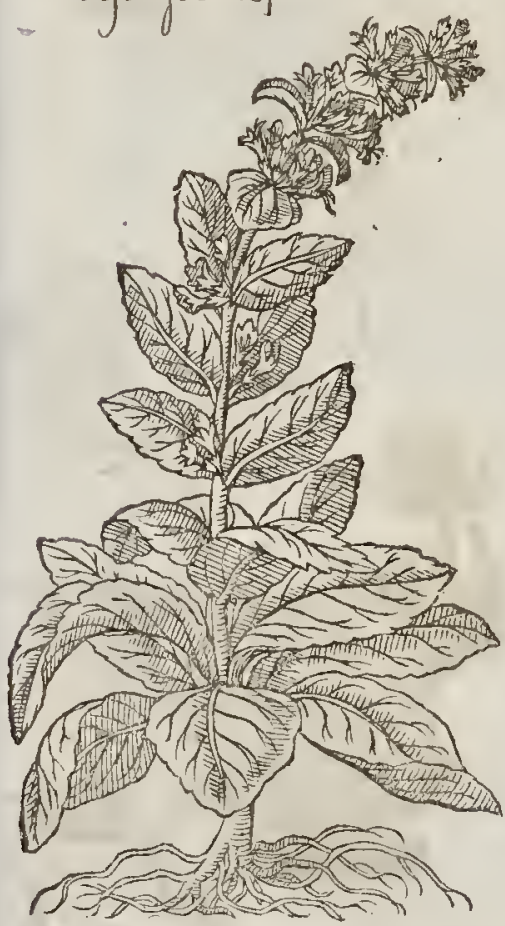

2 Bagula forealbo, fire carneo.

White or catpation toured Bugle.

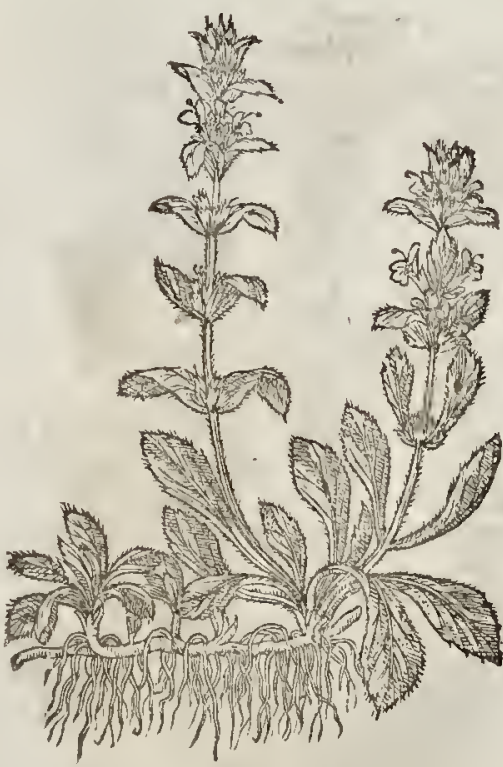

2 Bugle with the white foure differeth not from the ptece dent, in roots, leaues, and ftalks the onely difference is, that this plant bringeth forth fuire mitk white fon res, and the ocher thofe that are blew. $¥$ It is alfo found with a feth coloured Houre, and the lea tes are lefe fnipt than thore of the formcr. Baubine makes mention of one m:tch tefe than tho'e, with ro.nd fin pe leaues and a yellow floure, which he faith he had out of Engldid, but I hau no: as y'et feene it, nor found any other mention thereof. $\neq$

$$
\text { बा The place. }
$$

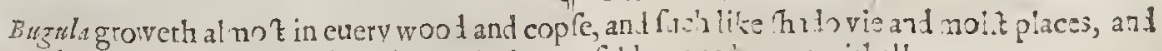
is much planted in gardens: the other varieties a e feldone to je mas withall.

$$
\mathrm{Gg} 2
$$


Bugula floureth in Aprill and May.

बा The Time.

$$
\text { 9. The Names. }
$$

Bugle is reckoned among the Confounds or wound lerbes : and it is called of fonc confolide

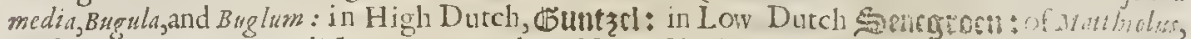
Herlua Laurewtina : in Engtih, Browne Eugle : of fome, Sicklewourt, and licrbe Carjenter, but not truly.

$$
\begin{aligned}
& \text { Bugle is of a meane temperature, betweene heat and drineffe. } \\
& \text { If The Vertucs. }
\end{aligned}
$$

A It is commended againft inward burftings, and members torne, rent, and bruifed : and thercfore it is put into potions that ferue for nodes, in which it is of fuch icrtue, that it can diffolue \& wafte away congealed and elotted bloud. Ruellizu writeth that they commonly fay in France, bow he needeth neicher Phy fition nor Surgeon that hath Bugle and Sanickle, for it dorly not only cure rotten wounds being inwardly taken,but alfo applied to them outwardly; it is good for the infirmitics of the Liuer, it taketh away the obftructions, and ftrengthneth it.

B The decoation of Bugle drunken, diffolueth clotted or congealed bloud withn the bodic, healeth and maketh found all wounds of the bodie, borh inward and ontward.

C The tame openeth the ftoppings of the Liuer and gall, and is good againft the iaundife and feuers of long continuance.

D The fame decoetion cureth the rotren vicers and fores of the mouth and gums.

E Bugula is excellent in curing wounds and feratehes, and the iuice cureth the wounds, vleers and fores of the fecret parts, or the herbe bruifed and laid thereon.

.

\section{Chas. 201 Of Selfe-beale.}

I Prunella.

Selfe-heale.

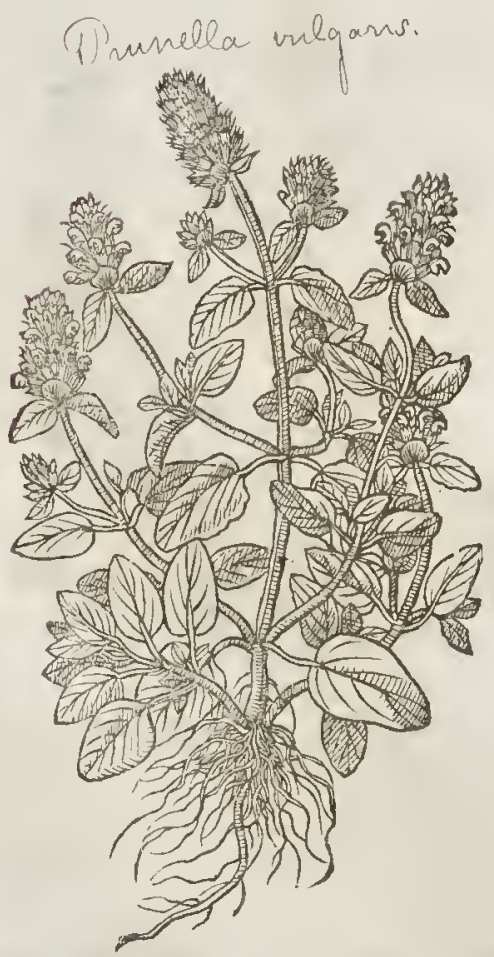

2 Prunella Lobelig.

The fecond Selfe-heale.

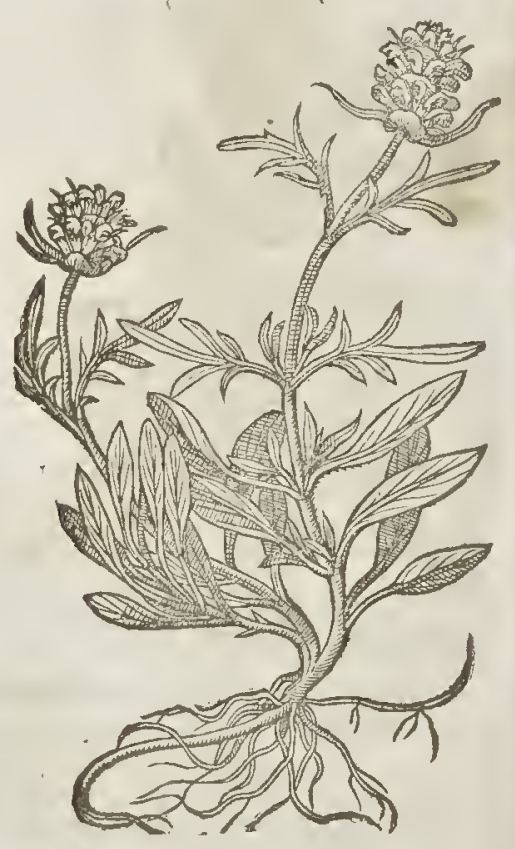




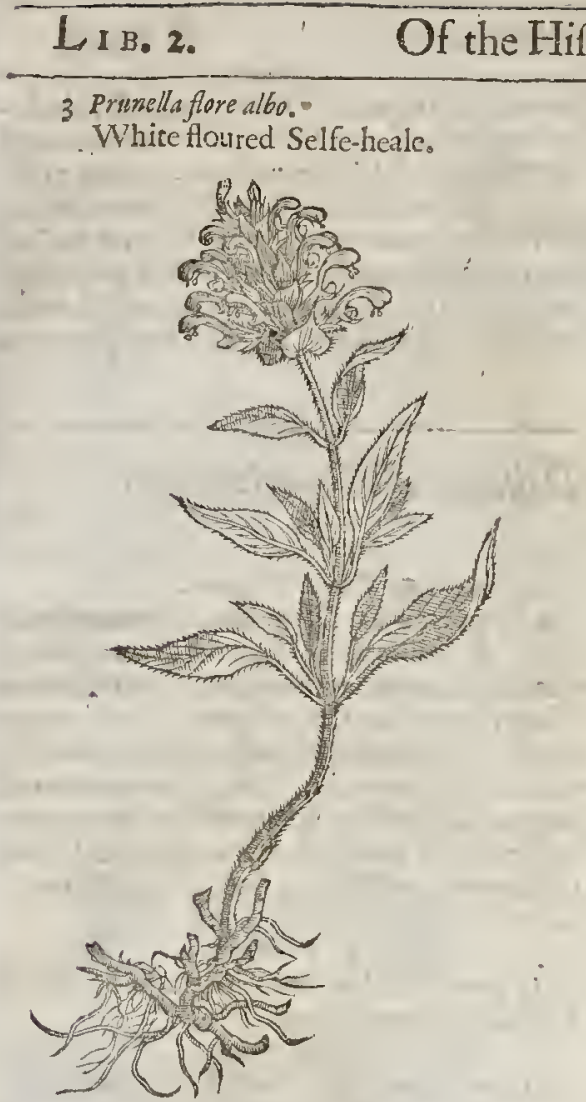

Prunella flore albo.

White floured Selfe-heale.
TI The Defeription.

1 Dinell or firunel hath fuuare hai-

1 ry ftalks of a foor high, belcrwith long, hairy and tharpe pointed leaues, s at the top of the falks grow fourcs thicke fet together, like an eare or fpiky knap, of a browne colour mixed with blew Hotires, and fometimes white, of which kinde I found fome plants in Effex necre Henning harn caftle. The root is mall and very threddie.

it 2 Pranclla altera, or after Lobcl and Pena, symphytum pitrasm, hath leaties like the lat deferibed, but fontewhat narrower, and the leames that grow commonly towarls the tops of the ftalks, are deeply ditided or crit il, after the manner of the leaues of the fmall Valerian, and fometimes the lower leaues are alfo diuided, but that is nore feldom, the lie ads and fioures are like thofe of the former,and the colour of the floures is commonly pirple yet fomtimes it is found with Acth coloured, and otherwhiles with white or afhe coloured floures.

3 The third fort of Selfe-heale is like vnto the laft defctibed in root, ftalke, \& leaues, $\&$ in euery other point, fauing that the floures hereof are of a perfect white colour, and the others not fo, which maketh the difference.

\# The figure which our Authour gaue in Tabern. which I indge to be all one with the Prencliat $\mathbf{I}$. mon vutzaris of Clufius and that becaufe the floures in that of Tobernamontanus are expreffed $V$ cntre laxiore, whicl $\mathrm{Clus}$ fus complaines his drawt er did not obferue; the other parts alfo agree : now this of Clufur hath mueh larger foures than the ordinary, and thofe commonly of a deeper purple colour, yet they are fometimes whitinh, and otherwhiles of an afhe colour : the lea ues alfo are ionewhat more hairie, long and fharpe pointed, than the ordinary, and herein confists the greateft difference. $\neq$

The Place.

$$
\text { it The Place. }
$$

England.

The fecond Brunel or Symphytum petroum groweth naturally vpon rocks, ftorie mountaines, and grauelly grounds.

$\neq$ The third for any thing that I know is a ftranger with vs:but the fort common kinde I hate foun $d$ with white floures. $\neq$

$$
\text { The Time. }
$$

Thefe plants floure for the mot part all Sommer long.

Brunel is called in Bnglufh Prunell, Carpenters Therbe and Solidiso and Solidigominor, but faith Ruelliw, the Daifie is the right Confolidaminor, and alfo'the Solida. gominor.

The Thature.

Thefe herbes are of the temperature of $B$ mgula, that is to fay, moderately hot and drie, and fomething binding.

The deeosionof Princiticrues.

found all wounds both inell made with wine orwater, doch ioine together and make whole and $A$

found all wounds, both inward and outward, cuen as Bugledoth.

Pruncll brtifed with oile of Rofes and Vineger, and laied to the forepart of the head, fwageth $B$ and helpeth the paine and aking there of.

To bee ihort, it ferueth for the fame that Bugle doth, and in the world there are no: two better $\mathrm{C}$ wound herbs, as hath been often proued.

$$
\operatorname{Ggg} 3
$$


C на P. 202. Of the great Daifie, or Maudelen woort.

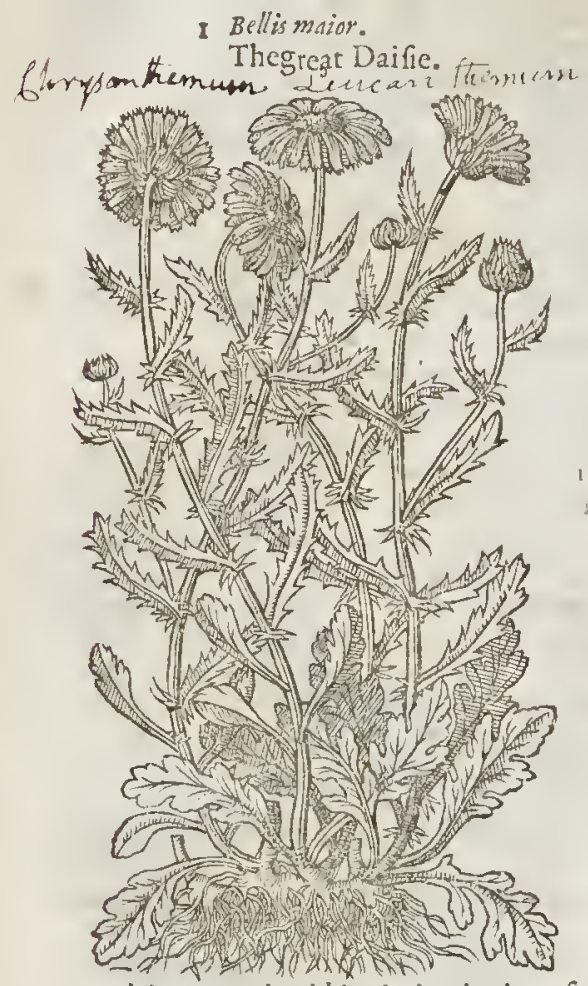

cond degree, and cold in the beginning of the fame.

$$
\text { बा The vertues. }
$$

A The leates of the great Mandleine woort are good againf all burning vicers and apoftemes,againt the inflammation and running of the eics, being applied theroto.

B The fame madevp in an vnguenc or falue with wax, oile, and turpentine, is moftexcellent for wounds, efpecially thofe wherein is any inflammation, and will not come to digeftion or maturation, as are thnie weeping wounds made in the knees, elbowes, and other ioints.

C The iuice, decoction, ordifilled water, is drunk to very good purpofe againft the rupture or any inward burftings.

D The herbe is goot to be put into Vulnerarie drinks or potions, as one fimple belonging there to mott neceflarie, to the which effect, the bent practifed dovfe it, as a fimple in fuch cafes of great effect.

E It likewifcaffrageth the cruell roments of the gout, vfed with a few Mallows and butter boiled and made to the forme of a pultis.

F The fame receipt a forefaid vfed in Clyfters, profiteth much againft the vehement lieat in agues, and ceaferh the torments or wringing of the guts or bowels. 


\section{LiB: 2. Of the Hiftory of Plants:}

\section{C на т. 203. Of little Daifres。}

\section{If The Defcription.}

1 THe Daifie bringeth forth many leaues from a threddy roor, fmooth, fat, long, and fonwhat round withall, very fleightly indented about the edges, for the moft part lying vpon the ground : among which rife vp the floures, euery one with his owne flender ftem, almoft like thofe of Camomill, but leffer, of a perfect white colour, and very double.

${ }_{2}$ The double red Daific is like vnto the precedent in eurery refpect, fauing in the colour of the floures : for this plart bringeth forth floures of a red colour, and the other white as a forefaid.

$\neq$ Thefe double Daifies are of two forts, that is either fnaller or larger; and thefe againe cither white or red, or of both nixed together: wherefore I hate giuen you in the firft place the figure of the fmall, and in the fecond that of the Iarger.

3 Furthermore, there is another pretty double daifie which differs from the firft defriber ontly in the floure, which at the fides thereof puts forth many foot-ftalkes earying alfo litrle double Houres, being commonly of a red colour ; fo that each ftalke carries as it were an old one and the brood thereof: whence they haue fitly termed it the childing Daifie. $\neq$

I Bell is minor multiplex flore albo vel rubro.

The leffer double red or white Dairie.

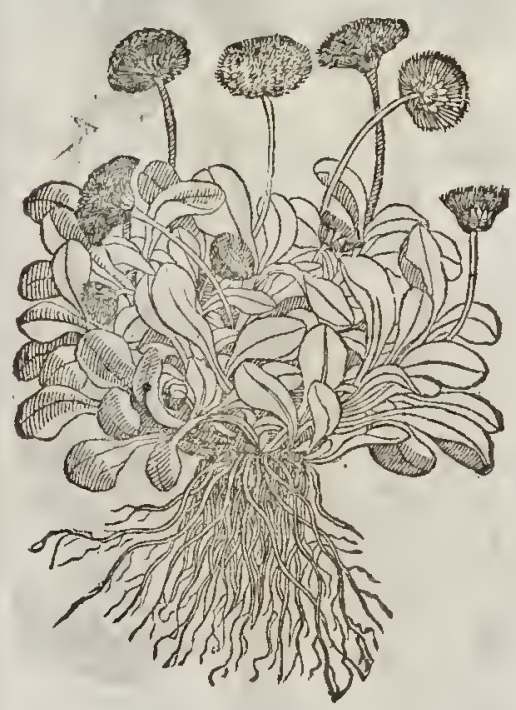

2 Bellis medianulisiplex flore alto vel ribro.

The larger double white or red Daife.

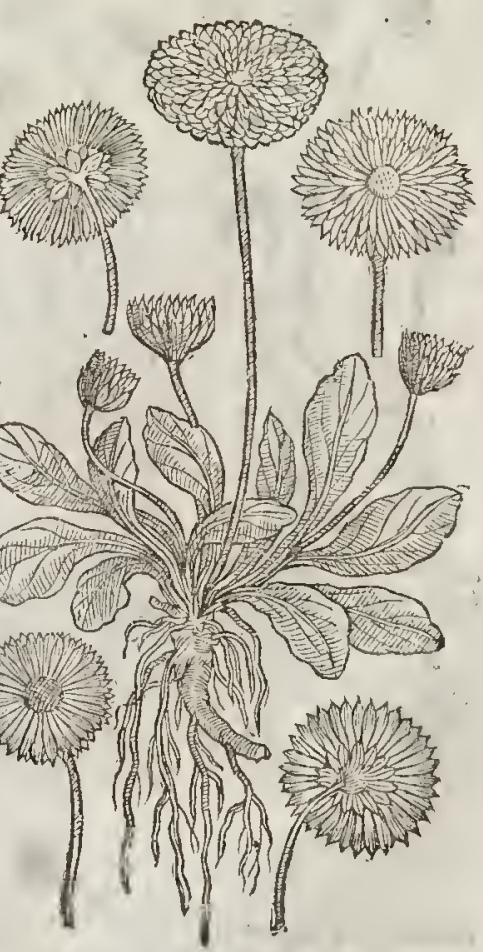

4 The wilde field Daifie hath many leaues fpred vpon the ground like thofe of the garden Daifre: among which rife ip flender ftens; on the top whereof do grow fmall fingle floures like thofe of Camomill, fet about a bunch of yellow thrums, ivith a pale of white leates, fomerimes white, now and then red, and often of both mixed together. The root is threddy.

5. There doth likewife grow in the fie!ds another for of wilde Daife, agreeing with the former in eaeh refpect, fauing that it is fomewhat greater than the other, and the lenves are fomwhat more eur in the edges, and larger.

6 The blew Italian Daifie harh many fmall threddy roots, from the which rife wp leaues like 


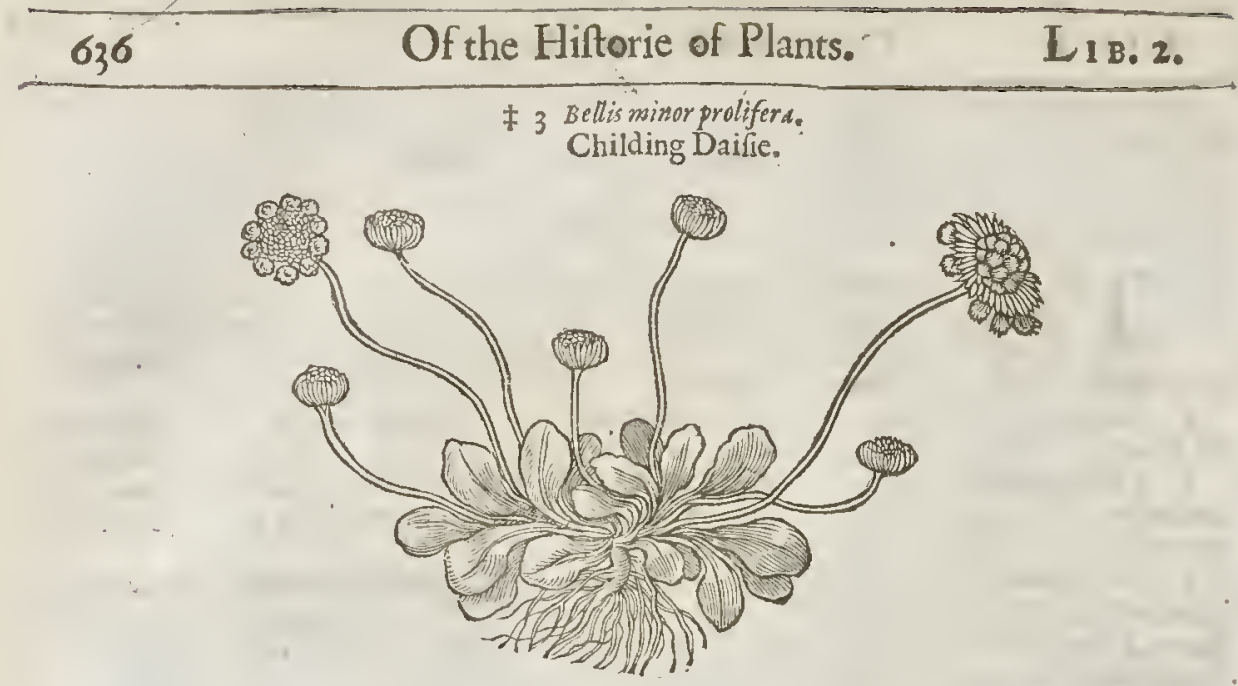

4. Bellis minor fyluefris. The frall wilde Daifie. 6 Bellit perennis

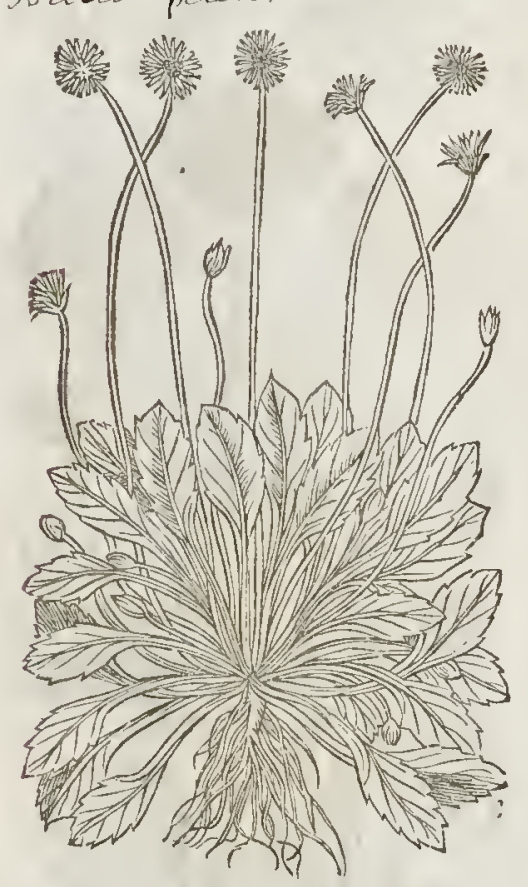

5 Bellis media fylueftris.

The middle wilde Dalfe: 
The blew Daifies are ftrangers in England; their naturall place of abode is fet forth in their fewerall titles.

6 Belliscerulea fune Glabularia Apila. The blew Italian Daifie.

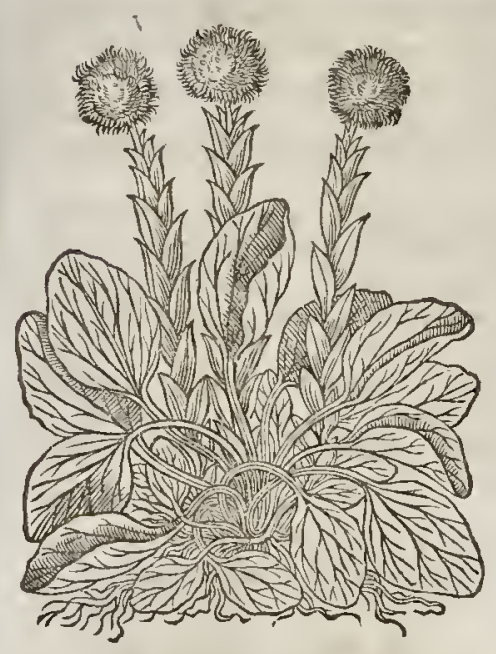

7 Bellis carulea Monpeliaca. $B$ lew French Daifies.

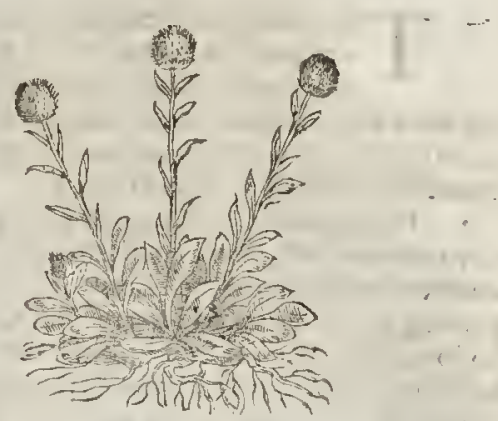

-T The Time.

The Daifies do floure moft part of the Sommer.

Tt The Names.

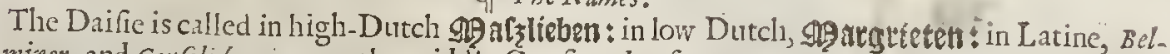
lis minor, and Confolidaminor, or the middle Confound of Truysu, Primulaveris; but that name is more proper vnto Primrofe: of fome, Herba Margarita, or Margarites herbe: in French, Marguerites, and Caffactes : in Italian, Fioridiprima veri gentili. In Englith, Daifies, and Bruifewort.

The blew Daifie is called Bellis cartlea : of fome, Globularia, of the round forme of the floure: it is alfo culled Aphyllint hes, and Frondisfora: in Italian, Botanaria: in Englinh, blew Daifies, and
Globe Daifie.

\section{The Temperature.}

The leffer Daifies are cold and moift, being noift in the end of the fecond degree, and cold in the beginning of the fame.

of TheVertues.

ding from an hot and dry hute all kinde of paines, but efpecially of the ioynts, and gout proceeding from an hot and dry humor, if they be ftamped with new but ter vnfalted, and applied vpon the pained place, but they worke more effectually if Mallowes be added thereto.

The leaues of Daifies vfed among ft other Pot-herbes doe make the belly foluble; and they B arealfo put into Clyfters with good fucceffe, in hot burning feuers, and againft inflammations of the intertines. The ityce of the leaues and roots fnift vp into the nofthrils, purgeth the head mightily of foule $\mathrm{C}$
and filthy flumic humors, and helpeth the megrim.

The fame giuen to little dogs with milke keepeth them from growing great.

The leaues ftamped taketh away bruifes and fivellings proceeding of fome ftroke, if they be $D$ ftamped and laid thereon; wheretipon it was called in old time Bruifewort.

The iuyce put into the eyes cleareth them, and taketh away the watering.

The dccoet ion of the field Daifie (which is the beft for plyyfichs vfe) made in water and drunke, F is good againft agues, in fammation of the liver, and all orher the inward parts. 


\section{C на.?. 204. Of Mousereare. \\ T) The $D e f c r i p t i o n$.} and full of orings the fourescome forth it Dandelion, of a bright yellow colour.

2 The fecond kinde of $P$ y'ofella is that which we ca'l Auricula wu'ic, or Moufe-eare, being a very common lucrb, but few more worthy of confideration becaufs of his good effeet, and yet clcin vnrementbred of the old Writers. It is called Pylofella of the rough hairy ar.d whitin fubftance groving on the leaues, which are fomewhat Inng likethe little Daife, but that they haue a fmall hollowneffe in them refembling the eare of a Moufe : vpon the which confideration fome haue cailed it : Mvoforss; wherein they were greatly deceived, for it is rothing like vuro the Myefotes of Dioforides : his fmall ftalkes are likewife hairy, flender, and creeping vpon the ground; his floures are douole, and of a pale yellow colour, much like unto Soncbus, or áticracium, or Hawkeweed.

I Pvior!"amior.

Great Moufe-eare.

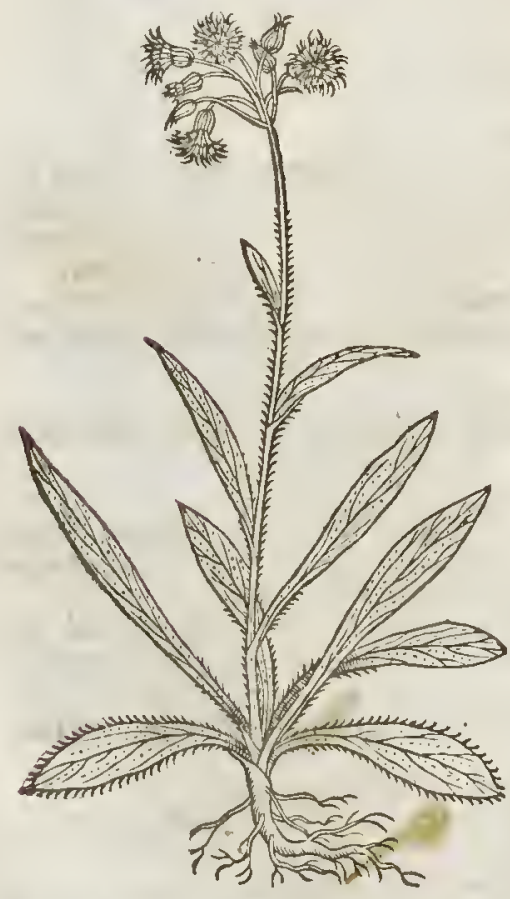

2 Plofella repens.

Creeping Moufe-eare.

Hieraciam Bilosellai.
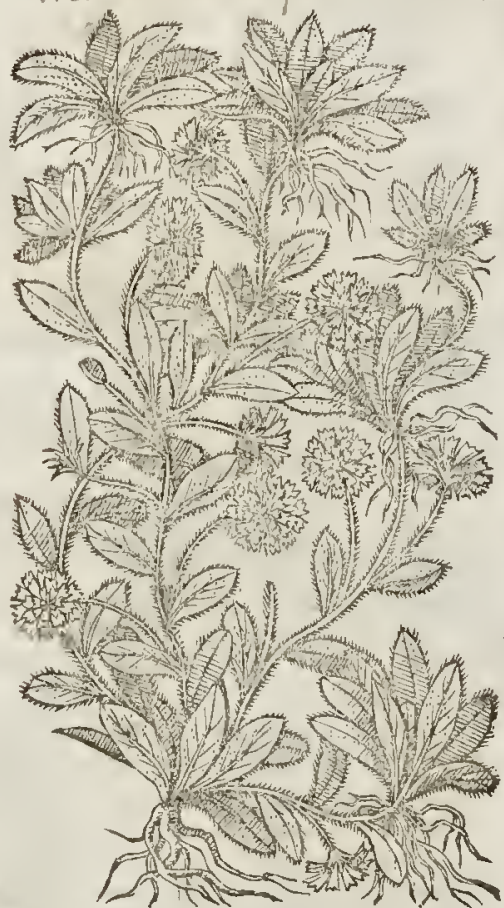

3 The fmall Moufe eare with broad leaues hath a fmall tough root, from which rife vp many hairy and horrie broad leaues fpred vpon the ground, among which growes vp a fiender ftem, at the top wherenftand two or thice finall yellow floures, whieh being ripe turne vnto downe that is caried aw ay with the winde.

$$
\text { Qf The place. }
$$

Thefe plants do grow vpon fandy bankes and vntoiled places that lie open to the aire.

They floure in May ard Iune.

$$
\text { If The Time. }
$$




\section{Sithe Names.}

Great Moufe-eare is called of the later herbarifts Pylofella: the fmaller likewire pylofdla, and

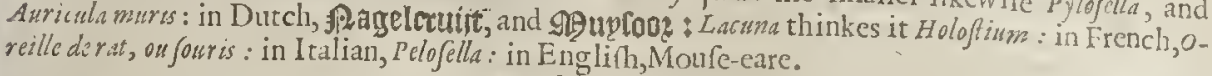

They ate $T$ he Tempcrature. nuitic admixed.

The decoction of pylofel d T the vertues.

cutcth hernies, ruptures, or burftings.

The leaues dried and made in to pouder, do profit much in healing of wounds, being ftrewed $R$ thereupon.

The deeotion of the iuyce is of fuch excellencie, that if ftecle-edged tooles red hot be drenched and eooled therein oftentimes, it maketh them fo hard, that they will cut foneor iron, be they neuer fohart, without turning the edge or waxing dull.

This herbe being vfed in gargarifmes cureth the loofeneffe of the Vuula.

Being taken in drinke it healeth the fuxes of the wombe, as alfo thedifealescalled $D$ yenteria and Enteroccle : it glueth and confoundeth wounds, fayeth the fwelling of the fpleene, and the bloudy exerements procured rheriby. The Apothecaries of the Low-countries make a fyrup of the iuyce of this herb, which they ve F:
fot the cough, confumption, and otificke.

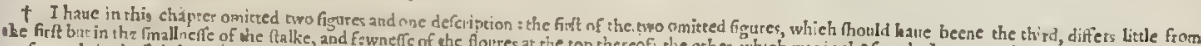

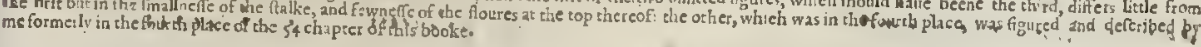

\section{С н т. 205. Of Cotton-2need or Cud-need.}

I Graphalium Anglicum. Graphaliesm recturin

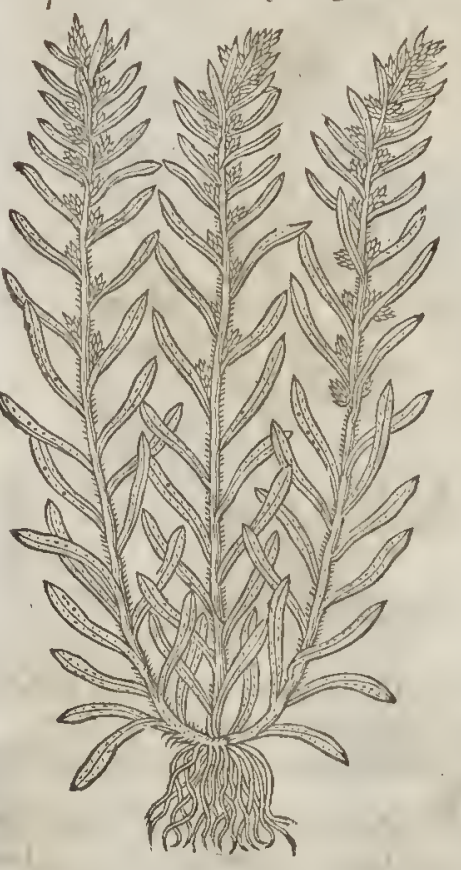

2 Graphalium vulgare.'

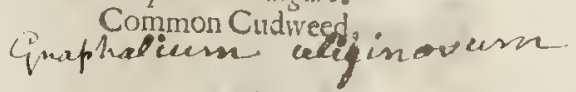

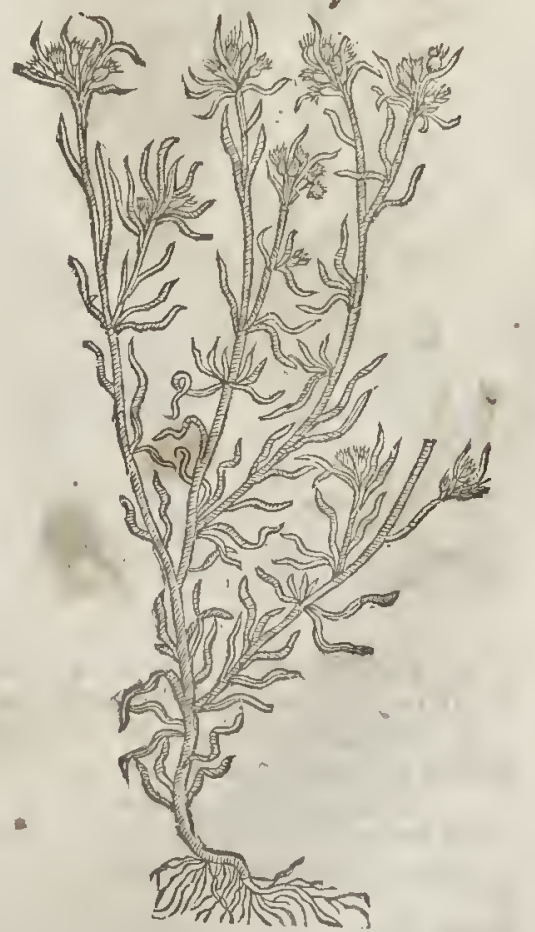


If The Defoription.

I Tglifh Cudweed hath fundry flender and vpright ftalkes diuided into many bran-

1 ches, and groweth as high as common Wormwood, whofe colour and thape it doth much refemble. The leaues thoot from the bottome of the turfe ful of haires, in thape fomewhat like a Willow leafe below, but aboue they be narrower, and like the leaues of $P$ fyllium or Flea-wort: anong which do grow fmall pale coloured floures like thofe of the fmall comiza or Flea-bane. The whole plant is of a bitrer tafte.

2 The fecond being our common Gnaphabium or Cudweed is a bafe or low herbe, nine or ten inches long, hating many fmall ftalks or tender branches, and little leatres, couered all ouer with a certain white cotton or fine wooll, and very thick : the floures be yellow, and grow like buttons at the top of the ftalkes.

3 The third kinde of Curdweed or Cotton-weed, being of the fea, is like vnto the other Cudweed laft defcribed, but is altogether fmaller and lover, feldome growing much aboue a handfull high : the leaues grow thicke vpon the falkes, and are fhort, flat, and very white, foft and woolly. The floures grow at the top of the ftalkes in fmall round buttons, of colour and farhion like the other Cudweed.

4 The fourth being the Cotton-weed of the hills and ftony mountains, is fo exceeding white and hoary, that one would thinke it to be a plant made of wooll, which may very eafily be known by his picture, without other defcription.

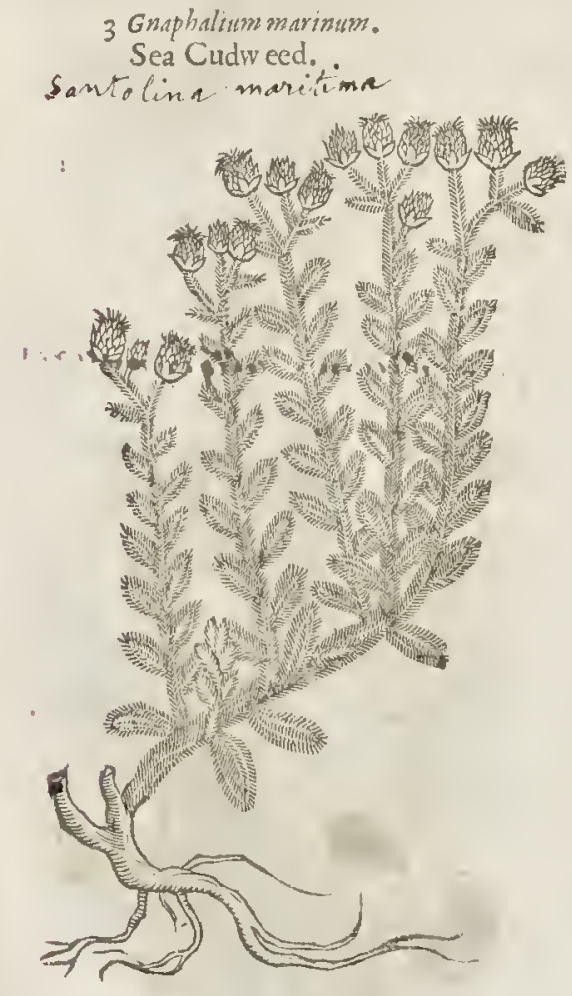

4. 5. Gnaphalium montansm purpureum bo album. White and purple mountaine Cotton-weed Santoline marition Graphalium disicum

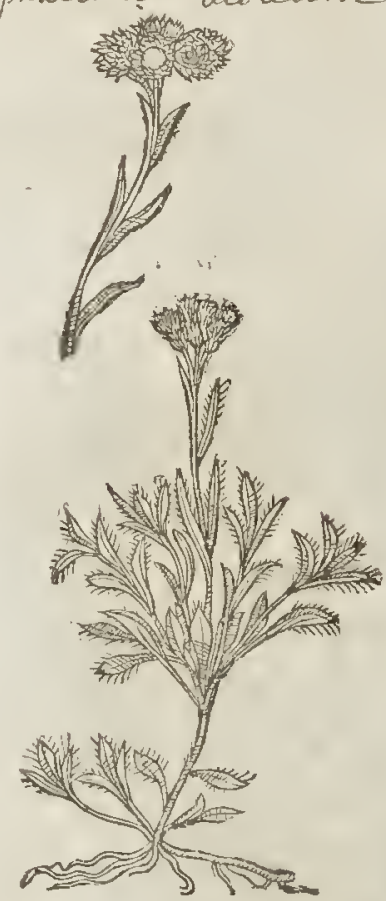

5 The fiftl kinde of Cotton-weed hath leaues and falkes like the other of his kinde, and differeth in that, that this plant beareth a burn or tuft of purple foures, otherwife it is very like.

6 The fixth is like vnto the laft recited, but greater : the floures are of an exceeding bright red colour, and of an aromaticall fweet fmell.

7 The feuenth kinde of Graphalium or $€$ otton-weed of Clufus his defcription, growes nine or ten inches high, hauing little long letues like the fmall Mouf-eare,woolly within, and of a hoare colour on the outfide : the ftalkes in like manner are very woolly, at the top whereof commeth forth a faire Houre and a frange, hauing fuch woolly leaues bordering the floure about, that a man would thinke it to be nothing elfe but wooll it felfe : and in the middeft of the floure come forth 


\section{1 в. 2. Of the Hiftorie of Plants.}

641

6 Gnaphalium montanum fuanc rubens. Bright red mountaine Cotton-weed.

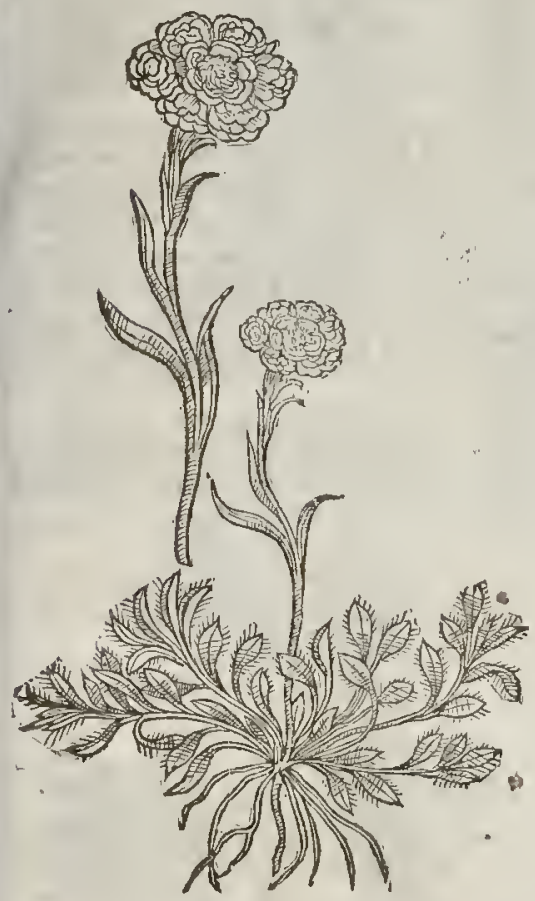

\$ Gnaphalium Americanwm.

Liue for cuer.

aphalium marqaritaccum

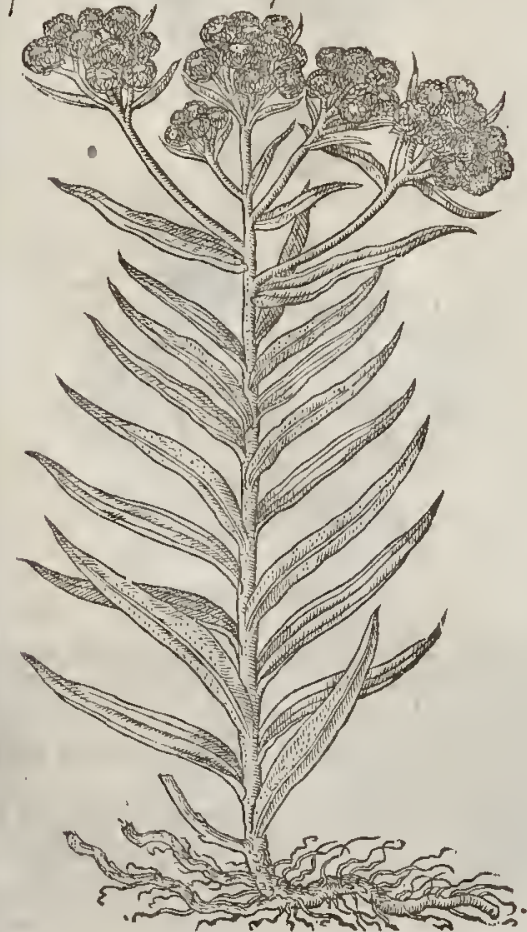

† Graphalium Llpinan. Rocke Cotton-weed.

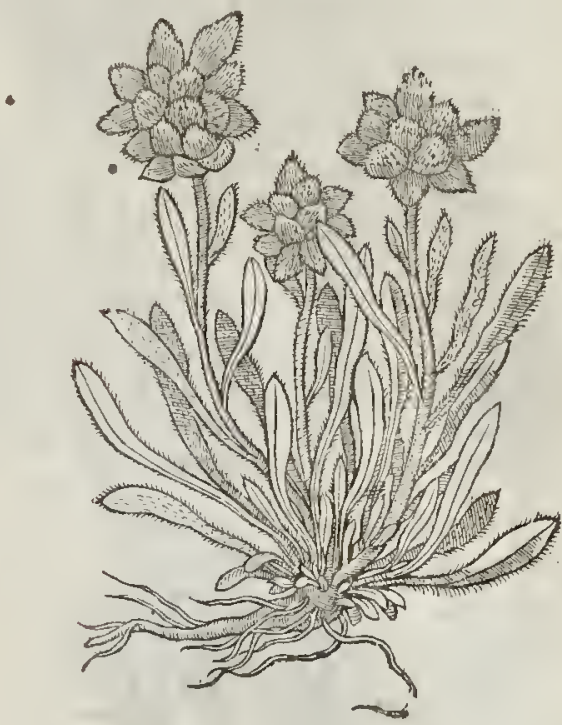

9 Filagominor.

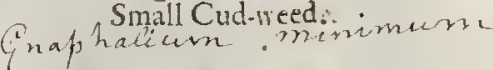

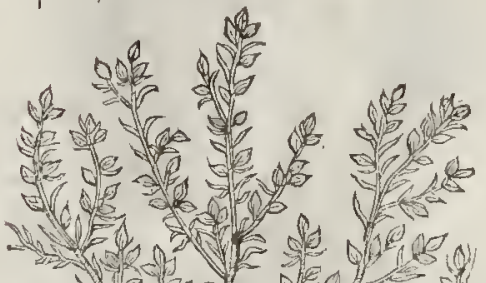

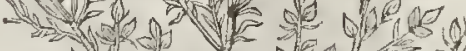

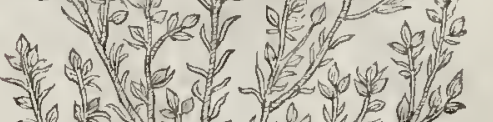

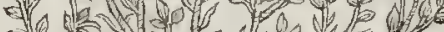

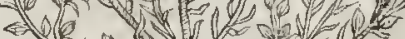

$\Rightarrow$ is 1 .

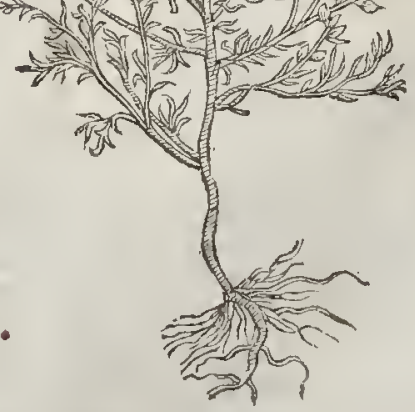

$\mathrm{Hhh}$. 
fundry fmall heads of a pale yellow colour, like vnto the othet of this kinde. The toot is blacke and fomerhat fibrous.

8 There is a kinde of Cotion-weed, being of greater beauty than the reft, that hath ftrait and vpright ftalks 3 foothigh or more, conered with a molt foft and finewooll, and in fuch plentifull manner, that a man may w ith his hands take it from the falke in great quantitie: which falke is befet with many fmall long and narrow leaues, greene vpon the inner fide, and hoary on the othet fide, fathioned fonewhat like the leaues of Rofemary, but greater. The floures do grow at the top of the ftalkes in bundles or tufts, confifting of many fuall Houtes of a white colour, and very dou ble, compant, or as it were confifting of little filuer feales thruft clofe together, which doe make the fame vety double. When the fioure hath long fourifhed, and is waxenold, then comes therc in the niddef of the floure a certaine browne yellow thrum me, fuch as is in the midf of the Daifie : which floure being gatheted when it is young, may be kept in fuch manner as it was gatheted (I meane in fuch frefhneffe and well li ing) by the fpace of a whole yeare after, in your cheft or elfewhere: wherefore our Englifh women have caldedit Liue-long, or Liue for cuet, which name doth aptly anfwet his effests. $\neq$ clufius receiued this plant out of England, and firft fet it forth by the name of Gmaphalium Americunum, or Argyrocume on

9 This plant hat three or foure finall gtayith cotony or woolly ftalkes, growing ftrait from the roor, and commonly diuided into many little branches : the leaues be long, narrow, whition, foft, and woolly, like the other of his kinde: the floures be round like buttons, growing very many togethet at the top of the ftalkes, but nothing fo yellow as Moufe-eare, which turne into downe, and are caried away with the winde.

Io Filggo, fine Herba impra.

Herbe impious, or wicked Cudweed".

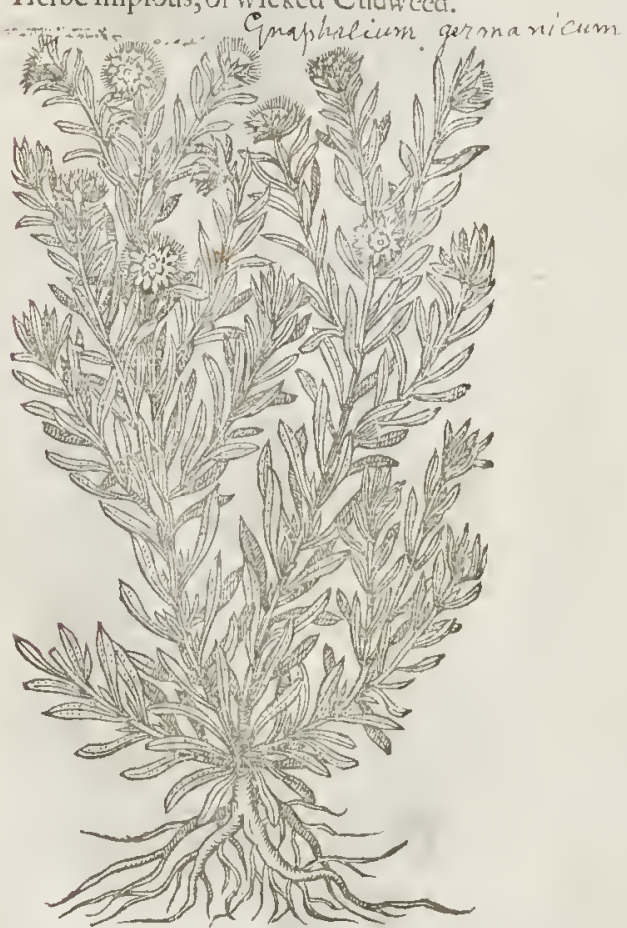

I I Leontopodium, finc Pes Leoninus. Lions Cudweed.

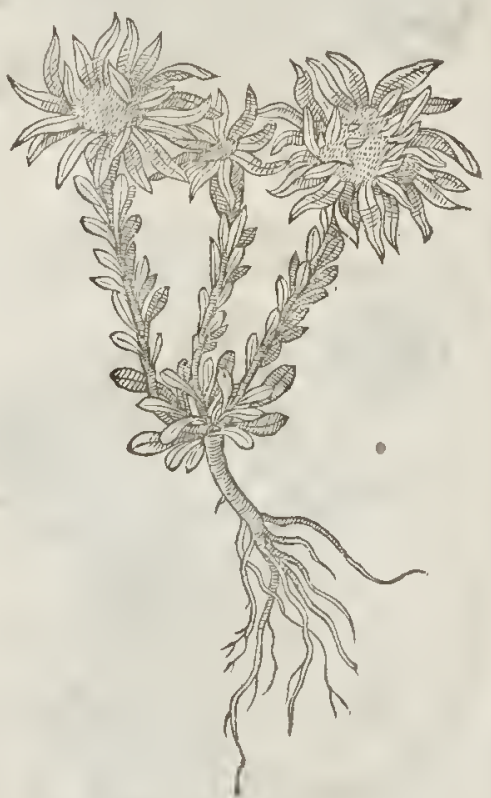

Io The tenth is like vnto the lattbefore mentioned, in ftalkes, leaues, and floures, but much larger, and for the moft part thofe floures which appeate firf are the loweft and bafeft, and they are ouertopt by other floures which come on younger branches, and grow highet, as children feeking to oucrgtow or oucrtop their parents, (as many wicked children do) for which caufe it hath beene called Herbaimpia, that is, the wicked Herbe, ot Herbe Impious.

I r The eicuenth plant comprehended vnder the title of Gnaphalitum, (being without doubt a kinde thereof, as may appeare by the thape of his floures and falks, coucred duer with a foft wool like vnto the other kindes of Cotton-weed) is an handfull high or thereabouts, beferwith leaues 


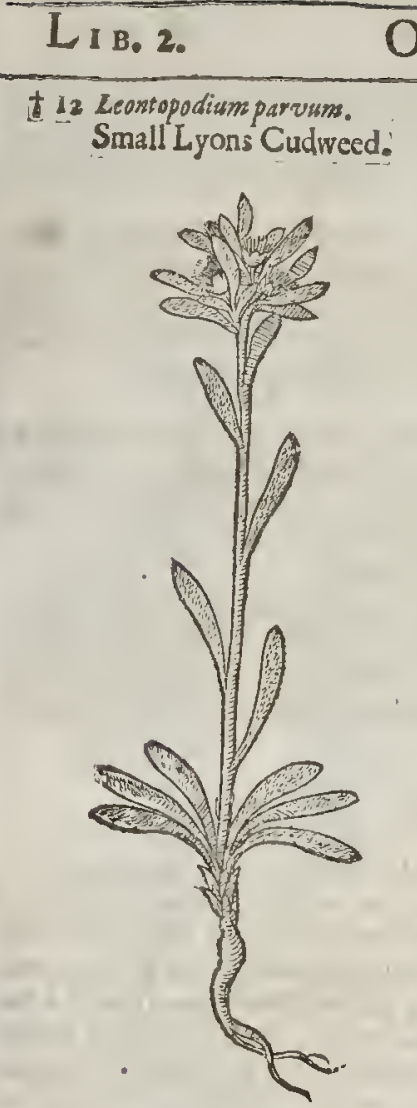

\section{* I4 Gnaphalium minus latione folio. Small broad leaued Cudweed.}
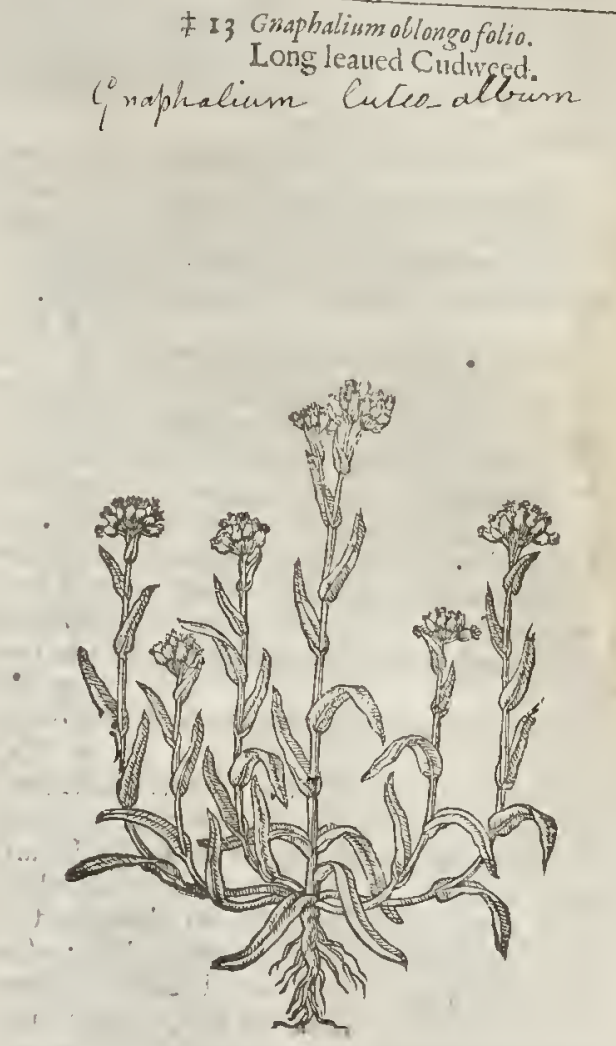

like Graphalium Anglicum, but fonewhat broader. At the top of the ftalke groweth a floure of a blackith brown violet eolour, befct about with rough and woolly hairie leatues, which make the whole floure to refemble the rough halred foot of a Lyon, of a Hare, or a Beare, or rather in mine opinionof a rough footed Doue. The heads of thefe floures when they are fpred abroad carry a greater circumference than is required in fo fmall a plant; and when the floure is faded, the feed is svrapped in fueh a deale of wooll that it is fcarfely to be found out.

I2 This fnall kinde of Leontopodsm being likewife a kind of Corton-wsed, neither by Diofcorides or any other antient writer once remembred, harly one fingle ftalke nine inehes in beight, and the leaues of Gmphalium montanm; whiels leanes and ftalkes are white, wits a thicke hory wor lineffe, bearing at the to pale yelloy floures like Gnaphalium montanum : the root is flender and wooddy.

$¥$ I3 This, whieh Clafins catls Gritphalium Platea' 2. lath finell ftalkes fo ne handfull high o: fonewhat more, of which fone 
fome ftand vptight, others lic along vpon the ground, being round, hairy, and worderly fet with foft hoary leates ingitting their falkes at their fetting on, and tharpe pointed at their vpper ends. The tops of the falkes carry many whitith heads full of a yellowifn downe : the root is thieke and blackifh, with fome fibres.

I4 This fends vp one falke parted into feuerall branches fet hereand there with broad foft and hoarie leaties, and at rhe diuifion of the branehes and amongft the leaues grow feven or cight little heads thicke thruft rogether, being of a grayifh yellow colour, and full of mueh downe : the toot is vinprofitable, and perishes as foone as it hath perfected his feed. Clufius calls this Gnaphalium Platean 3 . he hawing as it feemes teceiued them both from his friend Iagues Plateau. $¥$

\section{The Place.}

The firf groweth in the darkewoods of Hampled, and in the woods neere vnto Deptford by London. The feeond groweth vpon dry fandy bankes. The third growerh at a place called wherezey, fix miles from Colchelter, neere vito the fea fide. ‡ I alfo had ir fent me from my worthipfull friend $\mathrm{M}^{\mathrm{r}}$. Thom as Glynn, who gathered it vpon the fea coaft of Wales. $\$$

The reft grow vpon mountaines, hilly grounds, and barren paftures.

The kinde of Gnaphalium newly fet forth (sowit Americanum) groweth naturally neere vnto the Mediterranean fea, from whenee is hath beene brought and planted in our Englingardens. $¥$ If this be true whieh our Aurhor here affrmes, it might haue haue had a fitter (at leaft a neerer) de. nomination than from Ameriea : yet Bahbine affirınes that it growes frequently in Brafill,and it is not improbable that both their affertions betrue. $\ddagger$

$$
\text { 9) The Time. }
$$

They floute for the molt part from Iune to the end of Augurt.

$$
\text { -T The Names. }
$$

Cotton-weed is called in Greeke Graphalion; and it is called Gnaphalion, beeaufe men vfe the tender leanes of it in ftead of bombafte or Cotton, as Paulss efininetawriteth. Pliny faith it is ealled Cham.xylon, as though he thould fay Dwarfe Cotton; for it hath a foft and white cotton like vnto bombafte: whereupon alfo it was called of diners Tomentitin, and Coronarin: of others, Centun. culus, Centuncularis, and Albinum; which word is found among the baftard names : but the later word, by rea fon of the white colour, doth teafonably well agree with it. It is alfocalled Bombax, Humilis filaso, and Herba Impia, beeaufe the yonger, ot thofe floures that fpring vp later, are higher, and ouerton thofe that eome firf, as many wicked ehildren do vnto their parents, as before touched in the defcription : in Englim, Cotton-weed, Cud-weed, Chaffe-weed, and petry Corton.

$$
\text { बा The Nature. }
$$

Thefe herbes be of an aftringent orbinding and drying qualitic.

\section{The Vertues.}

A Gnopalimm boyled in ftrong lee cleanfeth the haire from nits and liee : alfo the herbe being laid in ward-robes and preffes keepeth apparell from moths.

B The fame boyled in wine and drunken, killeth wormes and btingeth them fortl, and pteuaileth againft the bitings and ftingings of venomous beafts.

C The fume or fmoke of the herbe dried, and raken with a funnell, being burned rherein, and receined in fueh manner as wevfe to take the fume of Tabaco, that is, w ith a crooked pipe made for the fame purpole by the Potter, preuaileth againft the cough of the lungs, the great aehe or paine of the head, and elenfeth the breft and inward parts.

f The figute that was formerly in the feuenth phee fhould haue beene in the eleuench ; aud that in the eleuenth ia the feucarh.

\section{Cн а Р. 206. \\ Of Golden Noth-wort, or Cudweed. \\ T The Defcription.}

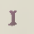

Olden Moth-wort bringeth forth flender ftalkes fomewhat hard and wooddy, diulded

Intodiuers finall branches; whereupon do grow leaues fomewhat rough, and of a white colour, very mueh iagged like Southernwood. The floures ftand on the tops of the ftalkes, ioyned together in tufts, of a yellow eolour glittering like gold, in forme refembling the fcaly floures of Tanfic, or the middle button of the floutes of Camomil, which being gathred before they be ripe or withered, remaine beautifull long time after, as my felfe did fee in the hands of $\mathrm{M}^{\mathrm{r}}$. Wadc, one of the Clerks of her Maiefties Counfell, which were fent him anong other things 


\section{B. 2. Of the Hiftoric of Plants.}

from Padua in Italy. For which caufe of long lafting, the images and carued gods were wont to weare garlands thereof: whereupon fome haue called it Gods floure. For which purpofe Ptolowy King of Egypt did moft diligently obferue them, as Pliny writeth.

I Elyochryfon, fine Coma aurea. Golden Moth-wort.

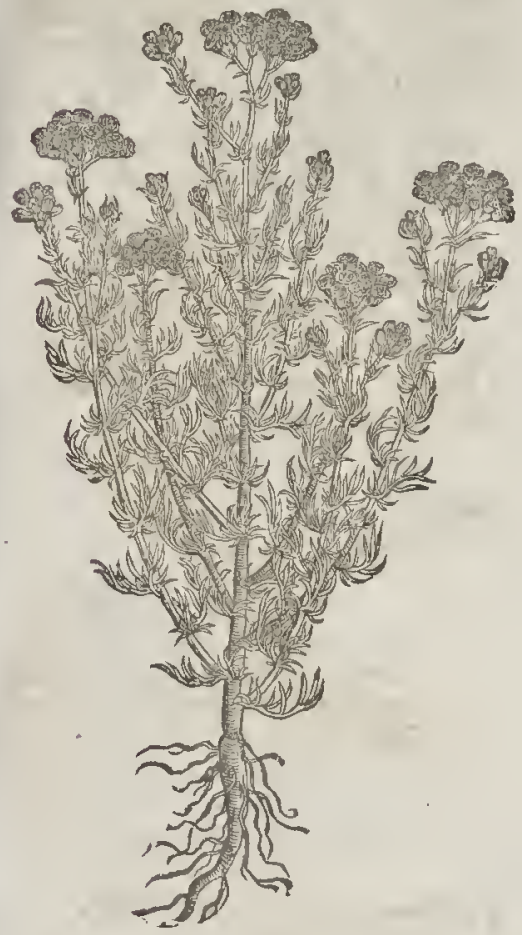

The Thiace.

It growes in molt untilled places of Italy and $S$ paine, in medowes where the foile is barren, and about the banks of riuers ; it is a flranger in England.

\section{The Time.}

It floures in Auguet and September: notwithetanding $T$ hcophraftus and pliny reckon it among the floures of the Spring.

$$
7 \text { The Nancs. }
$$

Golden Moth-wort is called of Diofrorides Elecbryfon: Pliny and Thcophraftes call it Hcli. chryfon: Gaza tranflates it Aurth : in Englifh, Gold-florre, Golden Morh-wort.

$$
\text { बा The 'Temprrature. }
$$

It is (faith Galen) of power to cut and make thinne.

$$
\text { qा The vertues. }
$$

Diofcorides teacheth, that the tops thereof drunke in wine are good for them that can hardly make water; againft fingings of Serpents, paines of the huckle bones : and taken in fireer wine it diffoluetl congealed bloud.

The branches and leaues laid among ${ }^{\prime} B$ cloathes keepeth them from moths, whereupon it hath beene called of fome Moth-weed, or Mothwort.

† Here formerly were two figures and defcriptions of the fame Plant.

\section{Cin в.207. Of. Golden Fluure-Gentle.}

T Tlie Defcription.

I This yellow Euerlatting or Fioure-Gentle, called of the later Herbarifts Yellow Stiecas, is a plant that hath ftalkes of a fpan long, and flender,whereupon do grow narrow leaues white and downie, as are alfo the ftalks. The floures ftand on the tops of the ftalks, confifting of a fcatrered or difordered fcaly tuft, of a reafonable good fmell,of a bright yellow colour; which being gathered before they be ripe, do keep their colour and beatry a long time without withering, as do moft of the Cottonweeds or Cudweeds, whercof this is a kinde. The root is blacke and flender. F There is fome varietie in the heads of this plant, for they are fometimes very large and longih, as Camerarius notes in his Epitome of Matthiolus; otherwhiles they are very compat and round, and of the bigneffe of the ordinarie.

2 This growes to fome foot or more high, and hath rough downie leaues like the former, but broader : the thoures are longer, but of the fame yelluw colour and long continuance as thofe of the laft defcribed. This var1es fomthing in the bredth and length of the leaues, whence Tabernimontanus gane three figures thereof, and therein was followed by our Author, as you mall finde more particularly fpecified at the end of the chapter. $\ddagger$

3 About Nemautium and Montpelier there growes another kinde of Chy yfocome, or as Lobel termes it, Stachas Citvinalterd, but that as this plant is in all points like, io in all points it is leffer and flenderer, blacker, and not of fuch beaury as the former, growing more neere vnto an aith colour, confitting of many fmall twigs a foot long. The root is leffer, and hath fewer ftrings annexed thereto ; and it is feldome found but in the cliffes and crags, among rubbirh, and on walls of cities. This plant is browne, without fent or fator like the other : euery branch hath his own bunch of floures comming forth of a faly or round head, but not a number heaped together, as in the firft kinde. It profpereth weli in our London Gardens. 


\section{Of the Hiftorie of Plants.}

L 1 в. 2.

† I Stechas Citrina, fure Amaranthus luteus. Golden Stœclias, or Goldilockes.

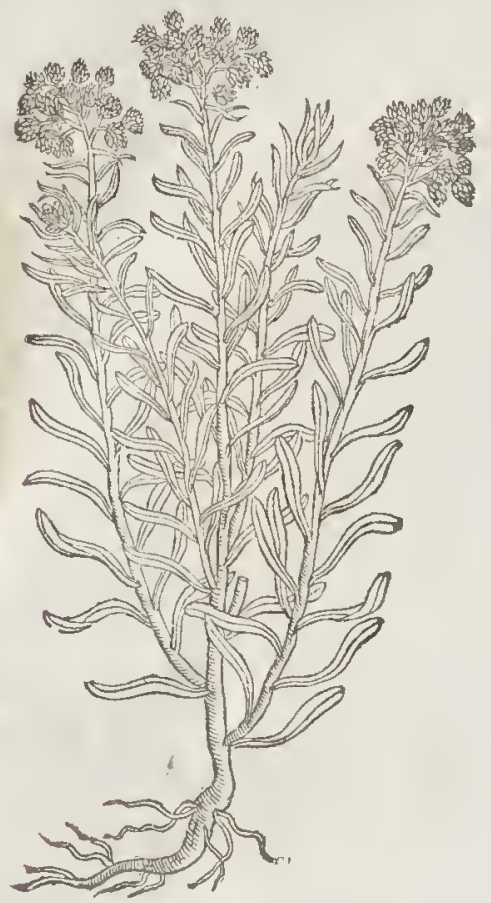

t 3 Chry focome capitulis conglobatis: Round headed Goldilockes.

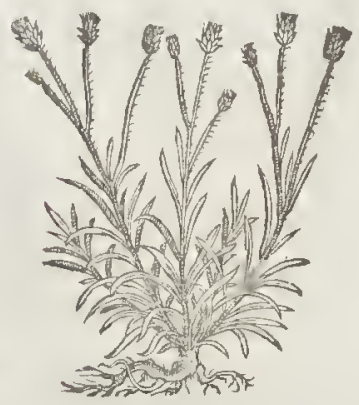

t 2 Amarapthus luteus latifoliws. Broad leaued Goldilockes.

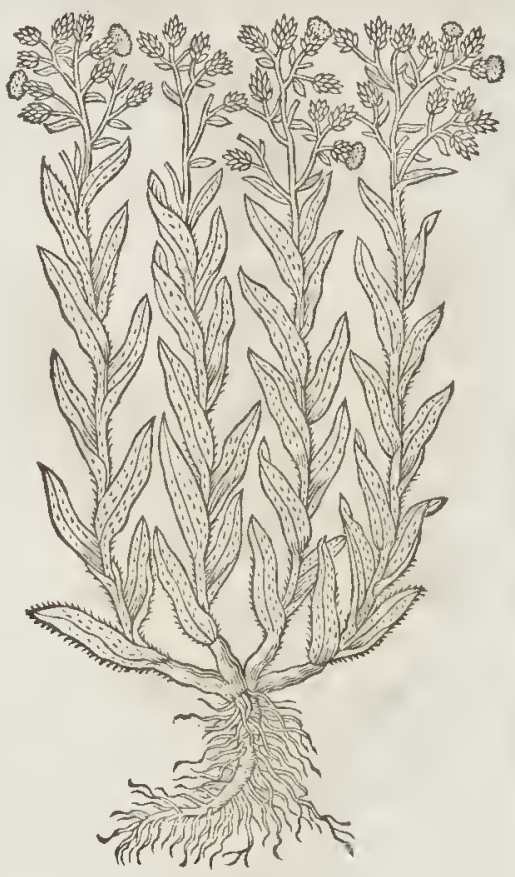

I 4 Anar ant bus lutess fore oblongo. Golden Cudweed.

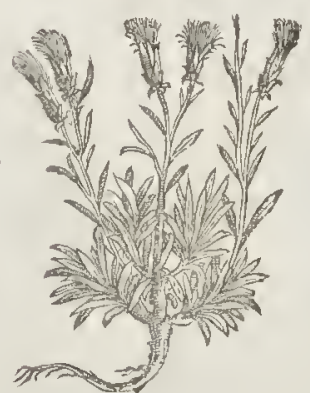

4 There is a kinde hereof beeing a very rare plant, and as rare to be found where ir naturally groweth, which is in the woods among the Scarlet-Okes betweene Sommieres and Mountpellier. It is a fine and beautifull plant, in hew paffing the laft defcribed Stoechas Citrina alter $a$ : but the leaues of this kinde are broad, and fomewhat hoarie, as is all the reft of the whole plant; the falke a foot long, and beareth the very floures of Strechas Citrina altera, but bigger and longer, and fomewhat like the floures of Lat Iuca agreft is:the root is like the former, without any manifelt fmel, little knowne, hard to finde, whofe faculties be yet vnknowne. 
† 5 Heliochryfos fyluestris. Wilde Goldyloekes.

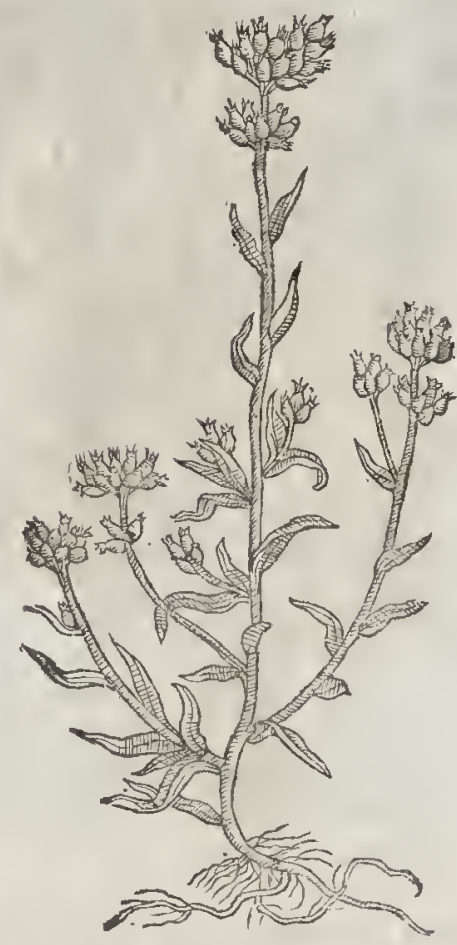

+5 This is a wilde linde (which Lobel fetterh forth) that here may be inferted, called Eliochry fos fyl feftris. The woolly or floekey leafe of chis plane refembleth Graphalium vulgare, bue that it is fomewhat broader in the middle: the foures grow clulteringु together vpon the tops of the branches, of a yellow colour, and almoft like thofe of Matrdine: the roots are blacke and wooddie.

$$
\text { Tt The Place. }
$$

The firf mentioned growes in Italy, and other hot countries: and the fecond growes in rough and granelly places a!twoft euery where neere vnto the Rhene, efpecially between Spires and Wormes.

$$
\text { If The Time. }
$$

They floure in Iune and Iuly.

$$
\text { ot The Rames. }
$$

Golden foure is called in Latine co ma aurea of his golden loeks or beautifu! buth,and alfo Tineraria : in thops, stacibas citrina, Amaranthus lutcus, Fubl fy, \& T ragi: of fome, Linaria aurea, but not truely: in Greeke, chryfocome : in Dutch, 1heyublo= emen, and Spotten ctupt: in Italian, $A$. marantho Giallo: in Englih, Gold-floure, Gods floure, Goldilockes, and Golden Stcechas.

The Temperature and Vertues. The floures of Golden Stoechados A boiled in wine and drunke, expell worms out of the bellie; and being boiled in Lee made of ftrong anhes doth kill lice and nits, if they bee bathed therewith. The other faeulties are refered to the former plants mentioned in the lat chap-

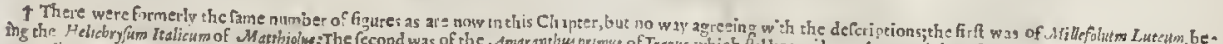

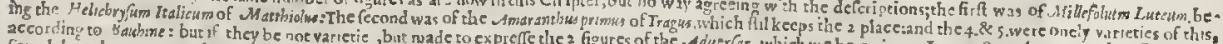
fourth have beene put in the third place, and the fift in the fourth \&

\section{C н а т. 208. Of Coftmarie and Maudelein.}

\section{TT The Defription.}

I Onmary groweth vp with round hard italkes two foot high, bearing long broad leaues finely nicked in the edges, of an ouerworn whitith green colour. The cuff or bundle is of a golden colour, eonfifing of many little floures like clufters, ioyned together in a rundle after the manner of golden Stœchados. The root is of a wooddy fubitance, by nature verie durable, not w ithout a multitude of little ftrings hanging thereat. The whole plant is of a pleafant fmell, fauour, or tafte.

2 Maudleine is fornewhat like to Cofnuary (whereofit is a kinde) in colour, fmell,tafte, and in the golden floures, fet von the tops of the falks in round clufters. Ir bringeth forth a number of $\mathrm{ftalkes}$, lender, and round. The leaues are narrow, long, indented, and deepely cut about the edges. The clufter of floures is leffer than tbat of Coftmarie, but of a better fmell, and yellower colour. The roots are long lafting and many.

$\$ 3$ There is another kinde of Balfomian minor, or L geratum, which hath leates leffer and narrower than the former, and thofe not fnipt about the edges : the vmbel or tufe of Houres is 


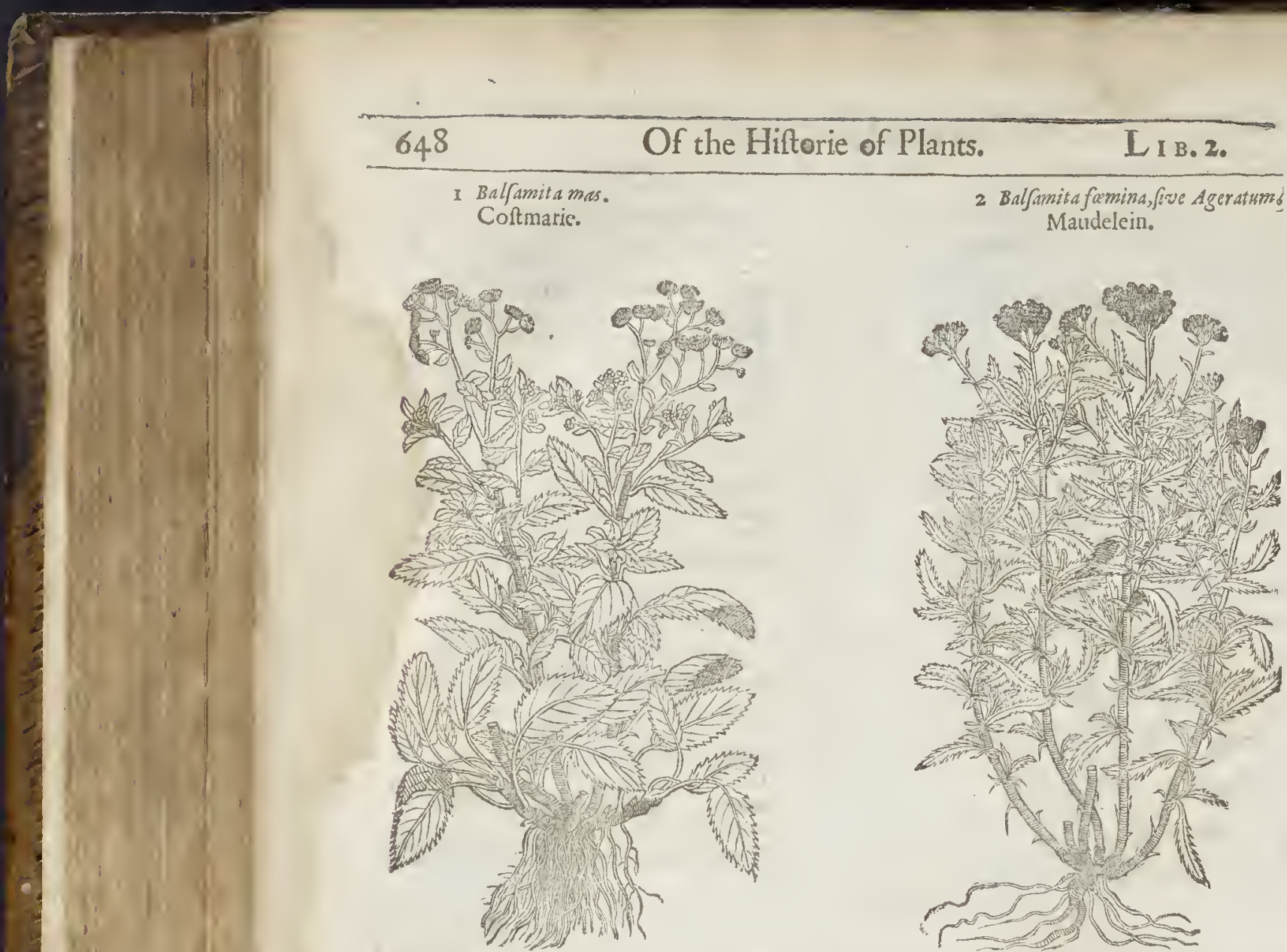

* 3 Ageratum folys non ferratis. 4 Ageratum floribus albis. yellow likeas the former, and you may Maudelein with vncut lcaues. White floured Maudlein, call each of thefe laft defcribed at your

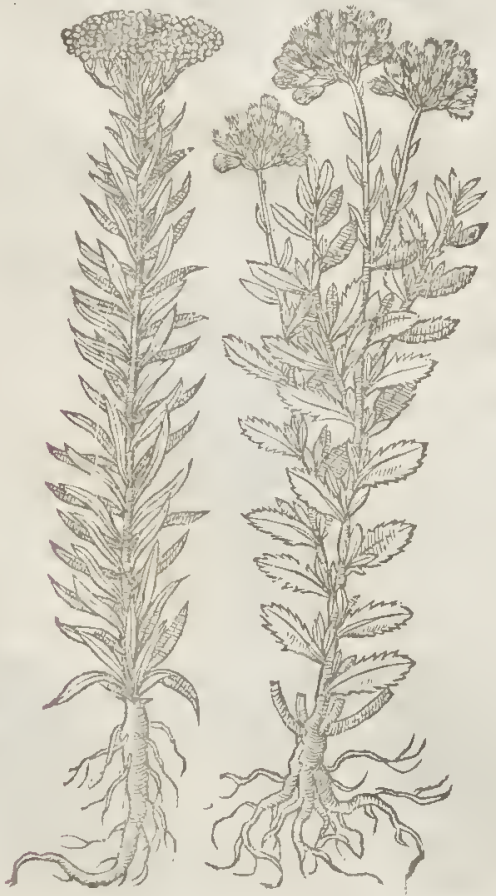
pleafure, either Ageratum, or Balfarnita: the Gracians call it Ayparvory which is in Latine Ageratum, vel non fenejcens, called in thops (though vntruly) Eupatoriwm Mefve. The floures are of a beautifull and feemely fhew, which will not lofe their excellencie of grace in growing, vntill they be very old, and therefore called Ageratum, or Non fencleens, as before; and are like in tuft to Eliochryson, but of a white colour ; and this is thought to be the true and right 1 geratum of Diofcorides, although therehath been great, controuerfie which thould be the true plant.

¥ This differeth not from the common Maudelein, but in the colour of the floures, which are white, when as thore of the ordinarie fort are yellow.

9. The Place.

They grow euery where in gardens,and are cherithed for their fweet floures and leaues.

T The Time.

They bring forth their tufts of yellow Doures in the Sommer moneths.

ब The 
Coftmarie is called in Latine Balfamita maior or mas: of fone, Coftsu hortorum: it is alfo called Mentha Greca : and Saracenica officinarum : of Tragus, Alifma: of Matthiolus, $H_{1}$ rba Grëca: of others, Salusia Romang, and Herbalaffulat a: of fome,Herba D.Maria : in Englifh, Coftnarie, and A le-coalt : in

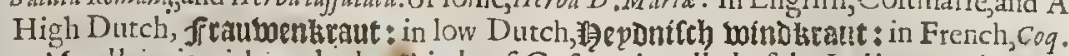

Maudlein is without doubt a kinde of Coftmarie, called of the Italians Herba Giulia:; of valeriws Cordue, Mentha Corymbifera minor:and Eupatoriam Mefue: It is iudged to be Diofcorides his Agrra tum, and it is the Coftus munor bortenfis of Gefner:we call it in Englinh Maudlein.

They are hot and drie in the fecond degree?

$$
\text { \$I he Nature. }
$$

\section{T) The Vertues.}

Thefe plants are very effectuall, efpecially Maudlein, taken either inwardly or elfe ontward- A ly to prouloke vrine; and the fume thereof doth the fame, and mollifieth the hardneffe of the Matrix.

Coftmarie is put into Ale to fteepe, as alfo into the barrels and Stands amongft thofe herbes $B$ wherewith they.doe make Sage Ale; which drinke is very profitable for the difeafes before fpo-
ken of.

The leaues of Maudleine and Adders tongue ftamped and boiled in Oile Oliue, adding thereto $\mathrm{C}$ a little wax, rofin, and a little turpentine, maketh an excellent healing vnguenr, or incarnatiue falue to raife or bring vp flefh from a deepe and hollow wound or vlcer, whereof I haue had long experience.

The Conferue made with the leaues of Coftmarie and Sugar, doth warme and drie the braine, D and openeth the ftoppings of the fame: ftoppeth all Catarrhes, rheumes and diftillations, taken in the quantitic of a beane.

The leaues of Coftmarie boiled in wine and drunken, cureth the griping paine of the bellie, the $\mathbf{E}$ guts and bowels, and cureth the bloudie flix.

It. It is good for them that have the greene fickneffe, or the dropfre, efpecially in the beginning; and F it helpeth all that have $a$ weake and cold liuer.

The feed expel leth all manner of wormes out of the belly, as wormfeed doth.

\section{C н а р. 209. Of Tanfie.}

$$
\text { T The Defeription. }
$$

I TAnfie groweth $v$ with many falkes, bearing on the tops of them certaine cluftered tufts, with floures like the round buttons of yellow Romane Cammomill, or Feuerfew (without any leaues paled about them) as yellow as gold. The leaues be long made as it were of a great niany fet together vpon one ftalke, like thofe of Agrimony, or rather wild Tanfie, very like to the female Ferne, but fofter and leffer, and euery one of them lalhed in the edges as are the leaues of Ferne. The root is tough and of a wooddie fub tance. The whole plant is bitter in tafte, and of a frong fmell, but yet pleafant.

2 The double Englifh Tanfie hath leaues infinirly iagged and nicked; and curled withall, like vnto a plume of feathers : it is altogether like vnto the other, both in fmell and tafte, as alfo in floures, but more pleafantly fmelling by many degrees, wherein efpecially confifteth the difference.

3 The third kinde of Tanfie hath leaues, roots, ftalkes, and branches like the other, and diffeteth from them, in that this hath no fmell or fawour atall, and the floures are like the common fingle Fetherfew.

\# 4 Clufius hath defcribed another bigger kind of vnfautorie Tanfie, whofe figure here we gine you, it grows fome cubit and halfe ligh,w irh crefted ftalks, hauing leaues fet vpon fomw hat longer ftalks than thofe of the laft defcribed, otherwife much like them : the foures are much larger, being of the bigneffe of the great Daifie,and of the fame colour : the feede is long and blacke: The root is of the thieknes of ones finger, running vpon the furface of the ground, $8 x$ putting forth fome fibres, and it lafts diuers yeares, fo that the plant may be encreafed thereby. This foures in May and Iune,and grows wilde vpon diuers hills in Hungary and Auftria. $\neq$ 
1 Tanacetum.

Tanfie.

Janacetum velgare

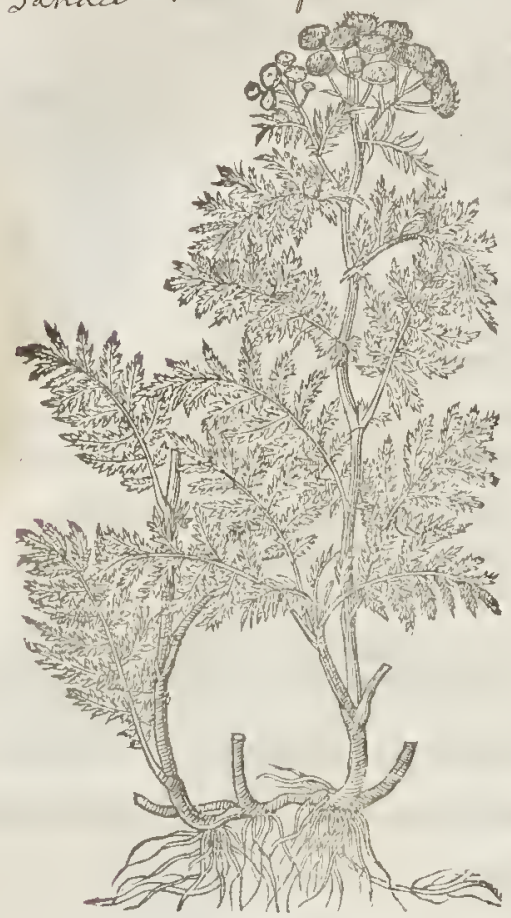

3 Tanzctum non odorum.

Vnfauoric Tanfic.

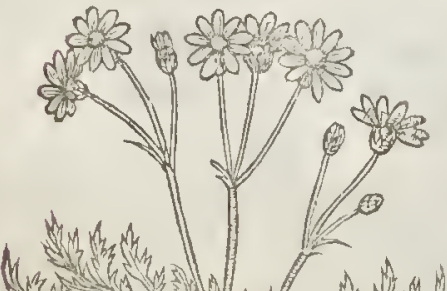

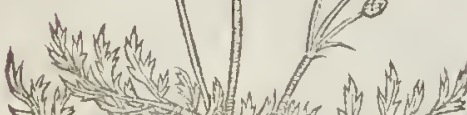

H(3

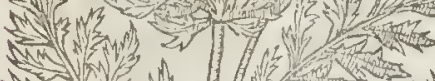

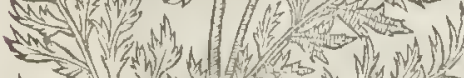

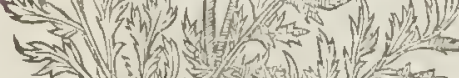

thi

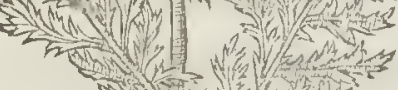

Ning

(1) in

1.
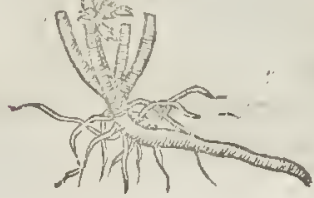

Domble Englin Fanfic.

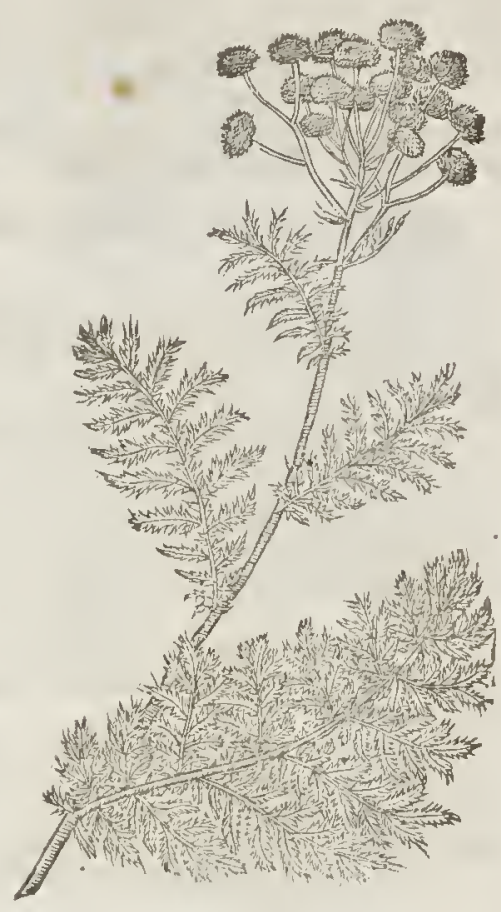

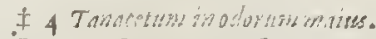
Great wnfamoic Tasfie.

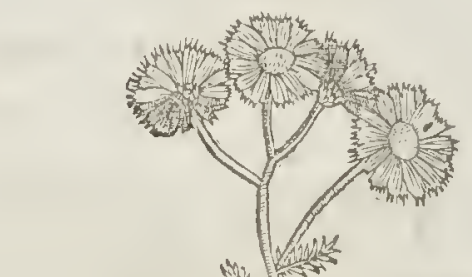

(vi) low

+ 4 (4)

tha $\mathrm{N}^{\mathrm{N}}$

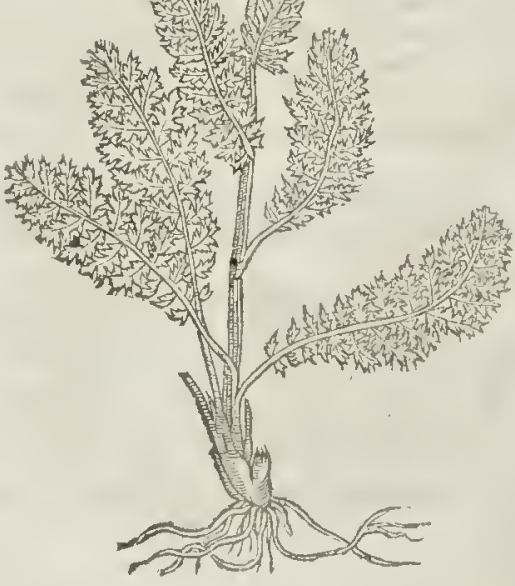


† Tanacetum minus album. Small white Tanfe.

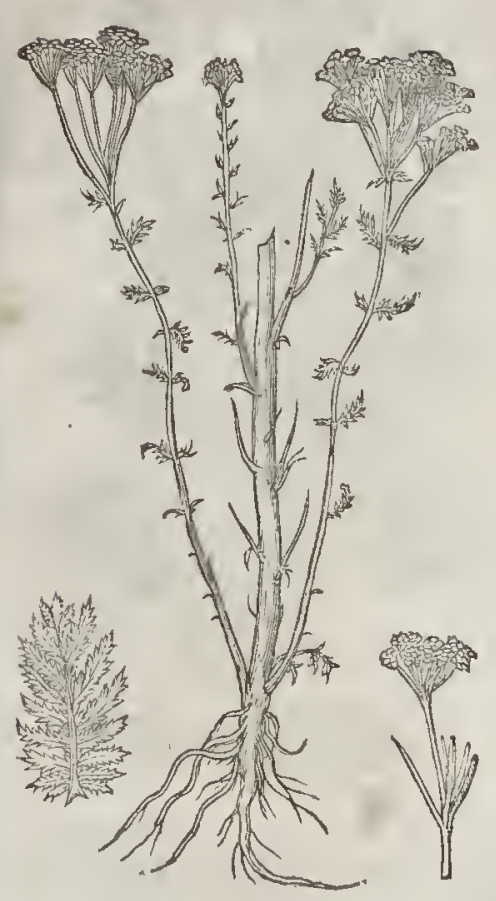

fonable quantitie thercof be caten fa fing.
5 The fift kinde of Tanfie hath broad leaucs,much iagged and wel ent, like rhe leaues of Fetherfew, but fmaller,and more deeply cut. The ftalke is fmall, a foot long, whereupon doe grow little tufts of little whire flotres, like rhe tuft of Milfoile or Yarrow. The lerbe is in fneil and fauour like the common Tanfie, but not altogether fo ftrong.

$$
\text { a) Thic plice. }
$$

The firt grometh wilde in ficlds as well as in gardens : the ochers grow in uny garden.

$$
\text { बा The Time. }
$$

They floure in Iuly and Auguft.

$$
\text { of The Names. }
$$

The firt is called Tanfie ; the feeond double 'Tanfie, the rhird vnfatory Tanfe, the laft white Tanfer in Latine, Twactum and Uthanafia, as though it were immortall : beciufe the foures do not fpeedily wither : of fome, Artemifa, but rntruly.

$$
\text { - बा The Nature. }
$$

The Tanfies whieh fmel fweet are lot in the fecond degree, and dry in the third. That without fmell is hot and drie, and of a meane temperature.

$$
\text { 9) The Vicrues. }
$$

In the Spring time are madewith the leaues $\mathrm{A}$ hereof newly fprung vp, and with egs, eakes or tanfies, which be pleafant in tafte, and good for the ftom :cke. For if any bad humours eleaue thereunto, it doth perfectly coneoct them, and feowre them downewards. The root preferued with hony or fugar, is an efpeeial thing againif the gout, if cuery day for a certaine f pace, a rea. euer it be taken, it killeth and driteth them forth. finewes.

The fame pound, and mixed wirh oile Oliue, is very good againt the paine and thrinking of the $\mathrm{C}$

Alfo being drunke with wine, it is good againtt the paine of the bladder, and when a man can- $D$ not pife but by drops.

\section{CHA. 210. Of Fetberfew.}

IT The Defriplion.

I FEurtew bringeth forth many littic round ftalkes, diuided into certaine branehes. The thermoft leates of Coriander, but greane and iagged, and niekt on the edges like the firt and nefmall pale of white leaues, fet round abouter. "The Houres ftand on rhe rops of rhe branehes, with a rot is hard and tough: the whole plant is of a ligh ball or button, like the wilde ficld Daifie. The bittertafte

2 The fecond kinde of Feuerfew, Matricaria, or Parthenium, differeth from the former, in that uerfew.

3 There is a third fort called Mountaine Feuerfew, of Carolus Clufus his defeription, that hath 


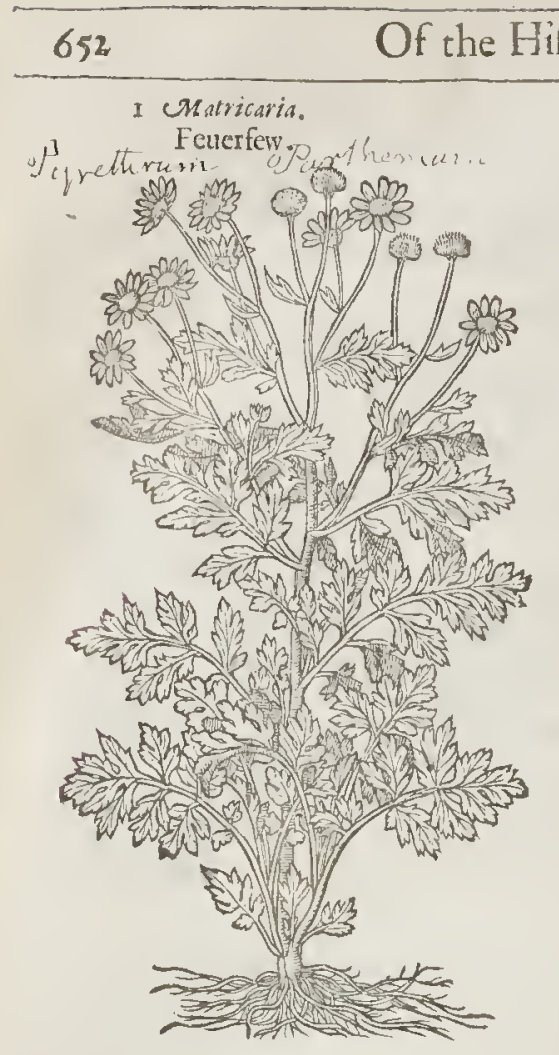

₹ Matricaria Alpina Clusy.

Mountaine Fcuerfew.

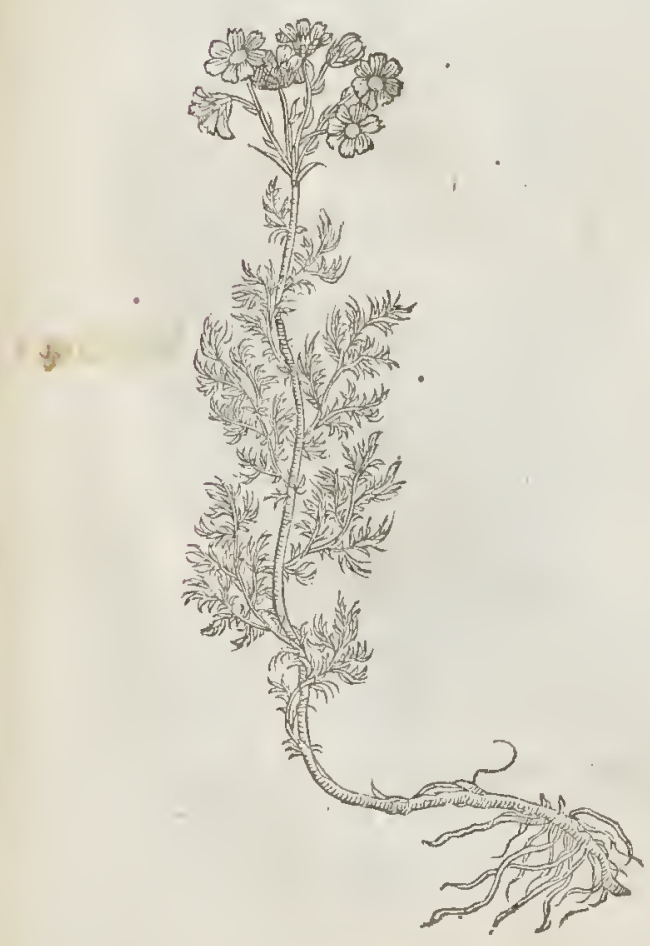

2 Matricaria duplicifore.

Double Feuerfiw.

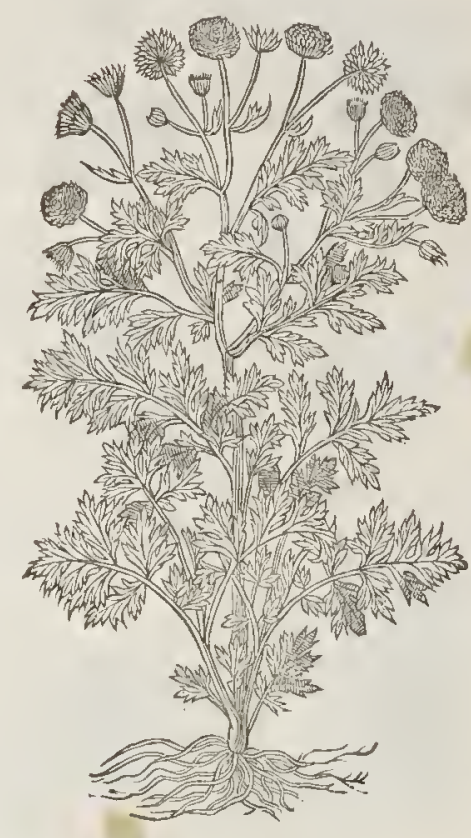

finall and fibrous roots; from which proceed flender wooddic ftalks, a foot high and fomewhat more, befet or garnifhed about with leaues like Camomill,decpely iagged or cut, of the fauour or fmell of Feterfew, but not fo ftrong; in tafte hot, but not vnpleafant. At the rop of the ftalks there come forth Imal white floures not like vnto the firft, but rather like vnto Abfynthium album, or White Wormewood.

4 I haue growing in my Garden another fort, like vnto the firft kinde, but of a molt pleafant freet fauour, in refpect of any of the reft. $\neq$ This feemes to be the Matricaria altera ex Ilua,mentioned by Camerarius in his Hortus medicus. $\ddagger$

$$
\text { T The place. }
$$

The common fingle Feuerfew groweth in hedges,gardens, and about old wals, it ioyeth to grow among rubbirh. There is oftentimes found when it is digged vp a little cole vnder the frings of the root, and neuer without it, whereof Cardane in his booke of Subtilties fetteth down diters vaine and trifling things. aा The Time.

They floure for the moft part all the Sommer long.

$$
\text { T The Names. }
$$

Fenerfew is called in Greeke of Diofcorides mappinut: of Galen, and Paulus one of his fect, Apsipus in Latine, Partbenium, Matricaria, and Febrifu- 
Febrifuga, of Fuchfus, Artersifia Tenuifolia: in Italian, Amarella: in Dutch, SDoedrecrumt: in French, Efpargonte' : in Englilh, Fedderfew and Feuerfew, taken from his foree of drining away Agues.

\section{ef Thi Temperature.}

Fenerfew dotl manifefty hent, it is hot in the third degree, and drie in the fecond, it clenfeth, purgeth, or fcoureth, openeth and fully perforneth all that biter things can do.

It is a great remedic againft the difeafes of the matrix; it proeureth womens fichnes iv ith fipeed; $A$ it bringeth forth theafter birth and the dead childe, whether it bee drunke in a decoctinn, or boi. led in a bath and the wonan fit ouer it; or the herbes fodden and applicd to the pricuic part, in manner of a cataplafine or pulris.

Diofiorides alfo teacheth, that it is profitably applied to Saint Anthonies fire, to all hot inflammarions, and hot frellings, if it be laid vnto, borh leaues and foures.

The fame Author athmeth, that the pouder of Feucrew drunkew ith Oxymell, or fyrup if Vineger, orwine for wanr of the others, drawerh away flegme and melancholy, and is gond for them that are purfic, and haue their lungs ftuffed with flegme; and is profitable likewife ro be druked gainf the ftone, as the fanc Aurhor faith.

Feucrficw dred and made into pouder, and two drams of it taken with lionie nr fivectwine, pur- D geth by fiege melaneloly and Alegme; wherefore it is very good forthem that are giddie in rlie head, or which baice the turning called vertigo, that is a fiviming and tuming in the heid. Alio it is good for fuch as be melancliolike, fad, penfue, and w ithout fpeeel.

The herbe is gnod againft the fuffocation of the mocher, that is, the hardneffe and ftopping of $\mathrm{E}$ the fane, being boilcd in wine, and applicd to the place.

"The deceftion of the fame is good for women to fit ouer, for the purpofes aforefaid.

It is ved both in drinks,and bound ro the werts with bay falt, and the pouder of glafic itamped together, as a moft fingular experiment againft the ague.

\section{$\mathrm{C}_{\text {н }}$ А P. 211. Of Poley, or Pellamountaine.}

I Polium montmum album.

White Poley mountaine.
2 Poliummontinum Lutum. Yellow Poley mountaine.
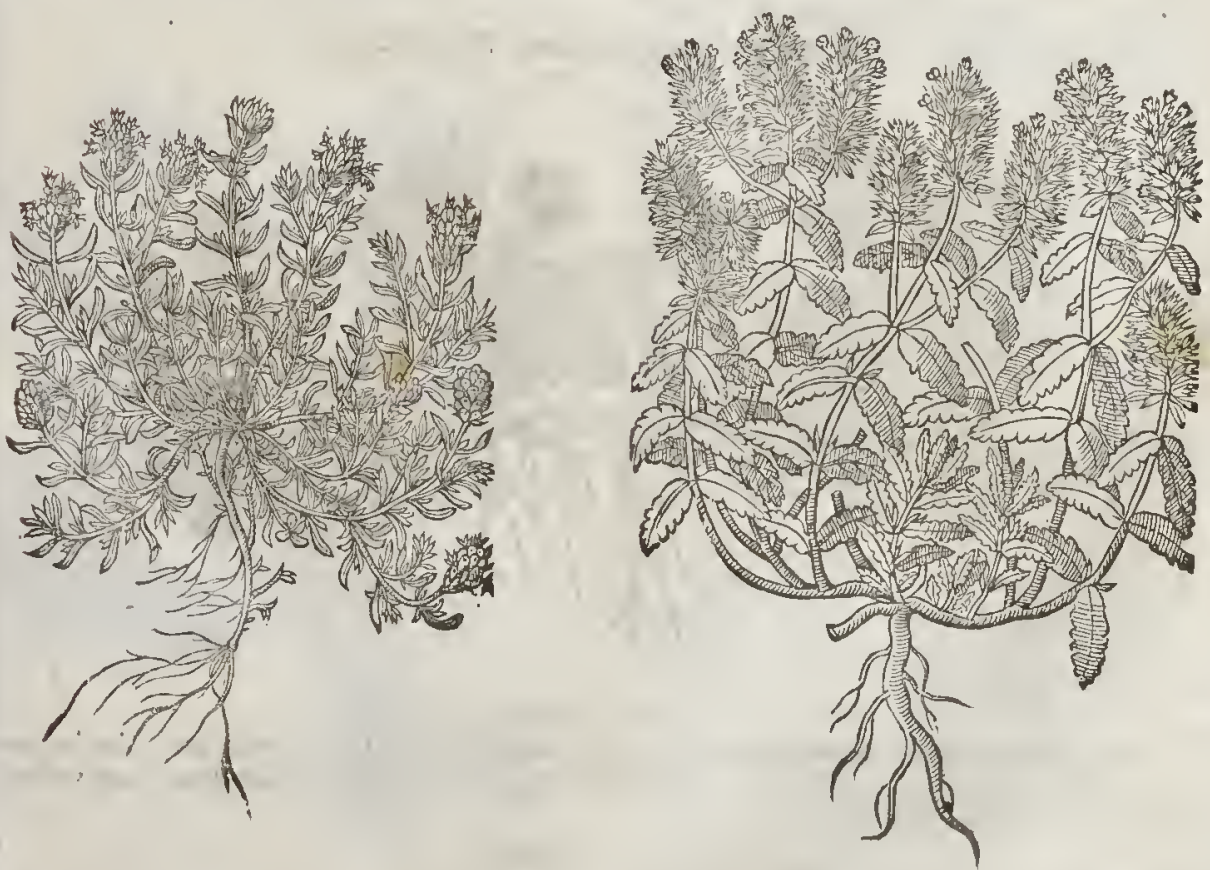


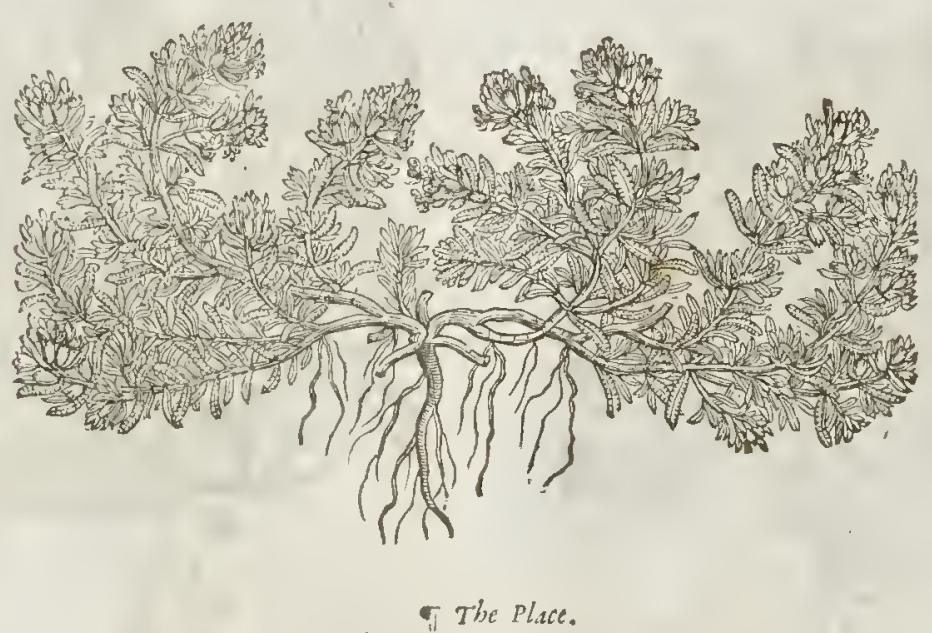

Thefe planrs do grow naturally ipon thie mountaines of France, Italie, Spaine, and other hot regions. They are ftrangers in Englankl, nowithftanding I haue plants of that Poley with yellow floures byt he gift of Lobel.

They floure from the end of May, to the beginning of Augut. 


\begin{tabular}{ll}
\hline $\mathrm{L}_{1 \text { в. 2. }}$ & Of the Hiftory of Plants. \\
\hline
\end{tabular}

4 Polium mont anum minimum. Creeping Poley.

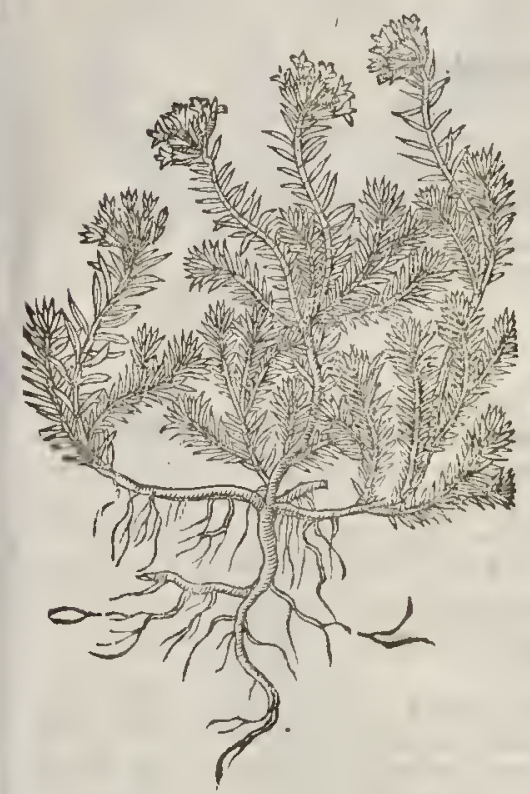

Another figure of the Lauander leaued Polcy.

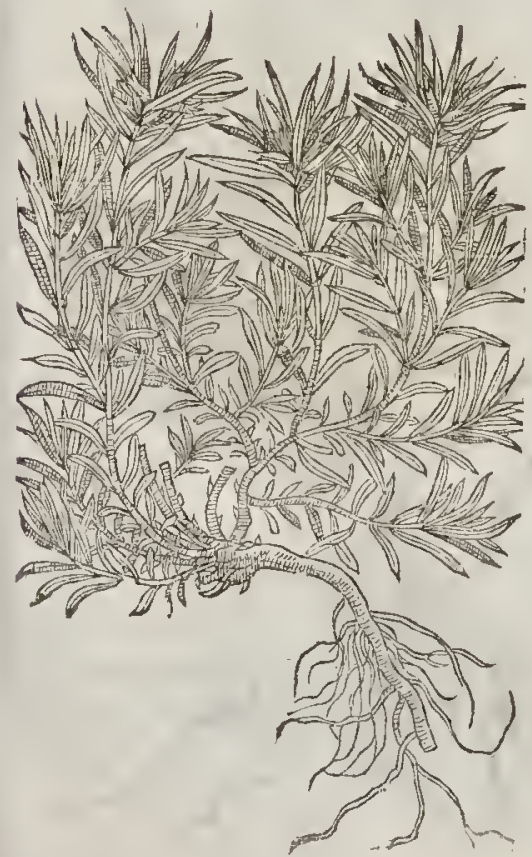

I 5 Polium Lavandulafoiro, fore alion?. . Lavander leaued Poley.

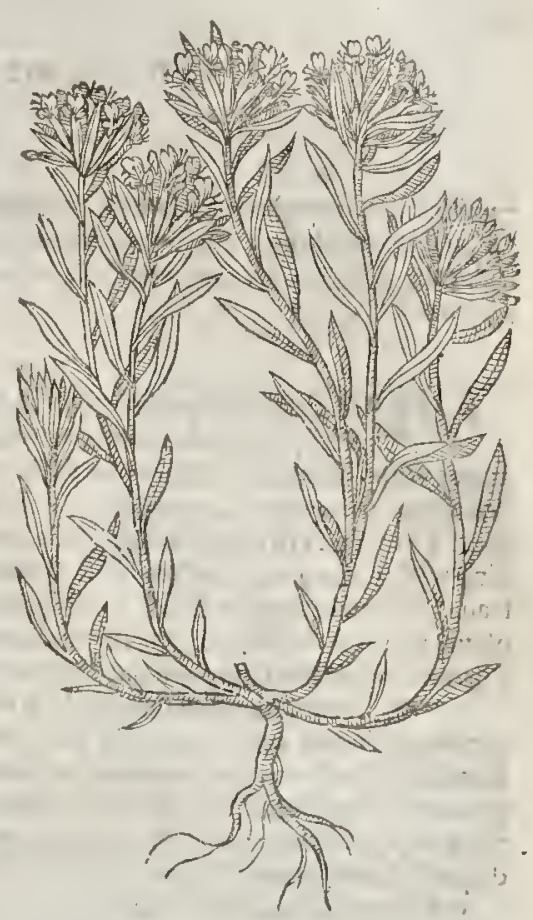

4) The Rames.

Poley mountaine is ealled in Greeke" " "rokn, of his hoarinefle, and in Latineallo Poliwa. Diuers fufpect that Polium is Leucas, and that Diofcorides hiath twife intreated of that herbe, vnder diuers names; the kindes, the secalion of the name, and likewife the faeulties do agrec. There bee two of the Leucades, one ipenm: that is of the mountainc:the other, rimes, which is that with the broader leafe: it is ealled Lencos of the whitith eolour, and Polion of the hourinefic, becaufe it feemech like to a mans hourie head; for whatfoeuer waxeth hoarie, is faid to bewhite.

T) $T$ he Tcmperalure.

Poley is of temperature drie in the third degree, and hor in the end of the fecond.

का The Vertues.

Diofcorides faith, it is a remedie for them that A haue the dropfie, the yellow iaundice, and that are troubled with the foleene.

It prouoketh vrine, \& is pur into Mithridate, B treacle, and eounterpoifons.

It profiteth much againf the bitings of ve- $C$ nomous beafts, and driteth away all venomous beats from the place where it is ftrewed or burnt. Iiiz

The famedrunke with vineger, is gord for $D$ tle 
the difeafes of the milt and fuleene, it troubleth the ftomacke, and afficteth the head, and prouoketh the loofeneffe of the bellie.

\section{Ch а P. 212. Of Germander. \\ qT The Kindes.}

7 He old writers haue fet downe no certaine kinds of Germander, yet we haue thought it good, 1 and not without caufe, to intreat of mo forts than have been obferued of all, ditiding thote under the title of Teucrium from Chamadryes : although they are both of one kind, but yet differing very notably.

aा The Defcription.

3 He firft Germander groweth lowe, with very many branches lying vpon the ground, tough, hard, and wooddie, fpreading it felfe here and there : whereupon are placed fmall leaues fnipt about the edges like the teeth of a faw, refembling the fhape of an oken leafe. The floures are of a purple colour, very finall, ftanding clore to the leates torvard the top of the branches. The feed is little and blacke. The root flender and full of ftrings, creeping, and alwaics fpreading within the ground, whereby it greatly increafeth. \# This is fometimes found with bigger leaues, orherwhiles with leffe; alfo the floure is fometimes white, and otherwhiles red in the fame plant, whence Tabernam. gaue two figures, and our Authour two figures and deferiptions, whereof I haure omitted the later, and put the two titles into one. $\neq$

2 The fccond Germander rifuth vp with a little ftraight ftalk a fpan long,and fometimes Ionger,wooddie and hard like varo a little fhrub : it is afterwards diuided into very many little fmall branches. The leaues are indented and nicked about the edges, leffer than the leaues of the former, great creeping Germander : the floures likewife ftand neere to the leaues, and on the vpper parts of the fprigs, of colour foinetimes purple,and oftentimes tending to blewneffe: the roote is diuerfly difperfed with many ftrings.

I Clsamadrys maior latifolia.

Great broud lcaued Germander.

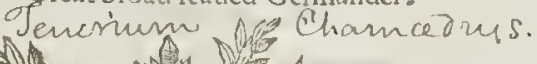

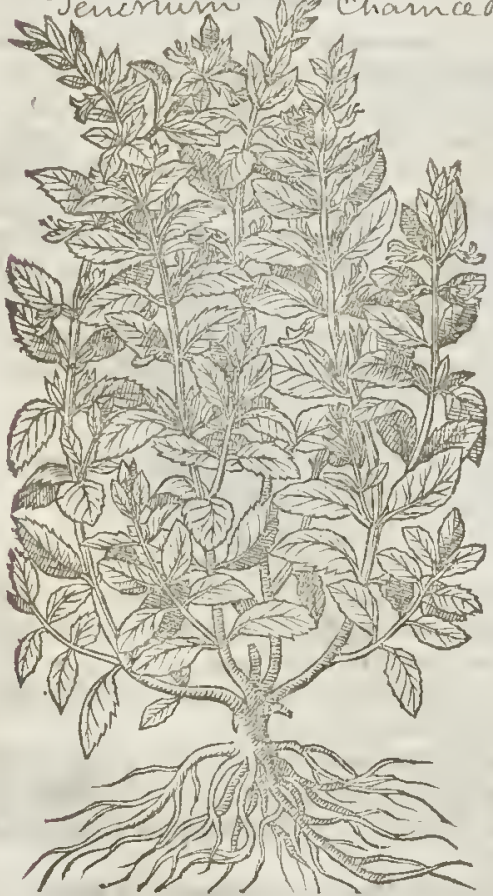

2 Chamedrys minor. Small Germander.

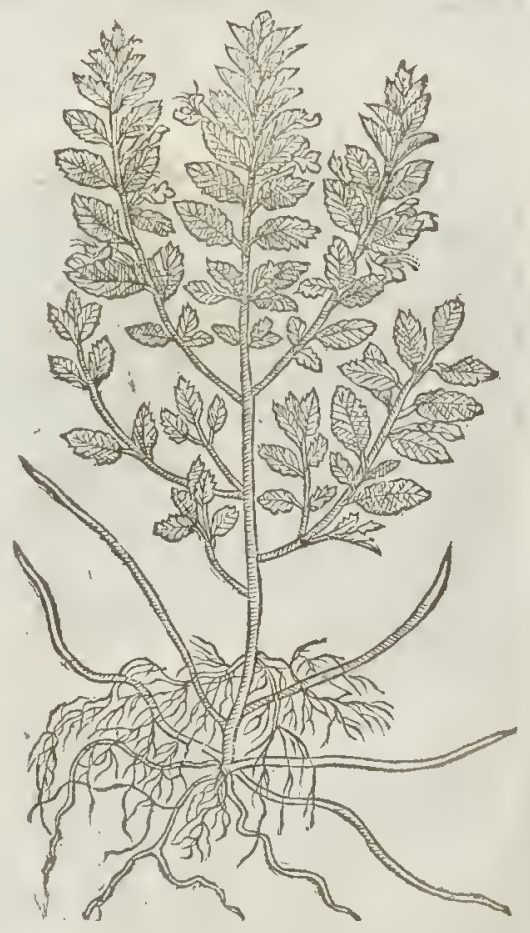

; Will: 
3 Chamadrys fyluestris. Wilde Germander. Neranica Chamadups -

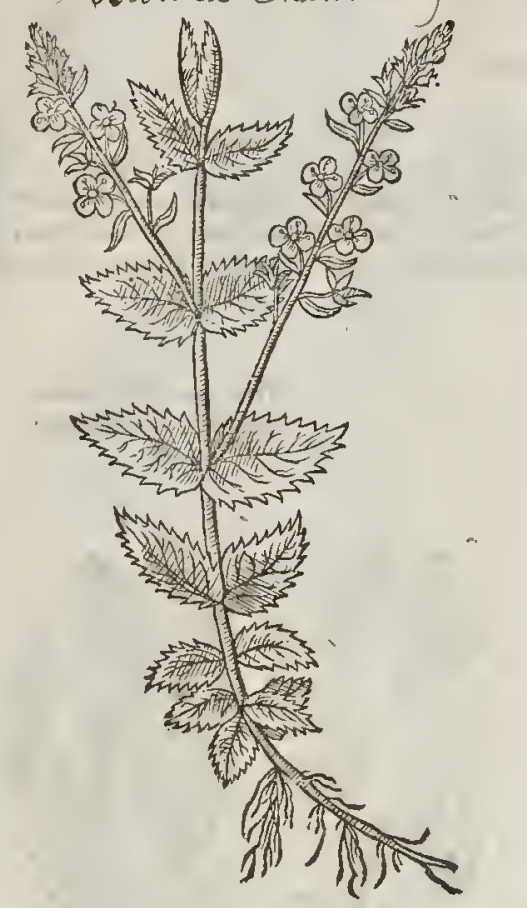

3 Wilde Germander hath little \&alkes, weake and feeble, edged or connered, fomewhat hairie, and fet as it were with ioines ; a but the which by certaine diftances theré come forth at each ioint two leaues fomething broad, nicked in the cdges, and fomething greater than the leates of crecpines Germander, and fofter. The foures be of a gallant blew colour, made of foure fmall leaues a peece, ftanding ordcriy on the tops of the tender Spriggie fpraies; after which come in place litrle hu ckes or feede veffeis. The root is fmall and threddie.

$$
\text { 91 The Place. }
$$

Thefe plants do grow in rocky and rough grounds, and in gardens they do calily prorper.

The wilde Germander groweth in manie places about London in Medowes and ferril fields and in enery place wherefocuer I haue trauciled in England.

$$
\text { II The Time. }
$$

They floure and fourith fron the end of May, to the later end of Augurt.

$$
\text { q The Namzes. }
$$

Garden Germander is called in Greeke,

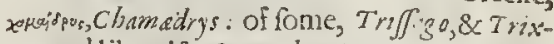
ngo,and likew ife 2uercula minor; notwithftanding moft of thefe names do more properly belong to Scordum, or water Germander : in Italian, 2uerciwla : in Englith, Germander, or Englith Treacle: in trench, Germadre. Before creeping Germander was knowne, this wilde kinde bare the name of Germander amongft: the Apothecaries, and was vfed for the right Germander in the compofitions of Medicines : buc atrer the former were brought to Iight, this began to be named sylueftris, and spuria Chamedrys : that is wilde and baftard Germander : of fome, Teucrium pratenfe, and without errour; becaufe all the forss of plants comprehended vinder the tit le of $T$ cucrum, are doubtleffe kindes of Germander.

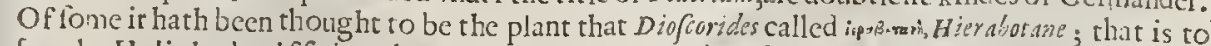
fav, the Holic herbe, iffo bee that the Holicherbe, and Verberac $n_{3}$ or Veruaine, which is called in Grecke werspitur, be fundrie herbes. Diofcorates maketh them fundrie herbes, defcribing them apart, the one afrer the other: but other Authors, as Paulus, Actius, and oribafizes, make no mention of $H$ er b: S.tra, the Holic herbe, but onely of Periffereor : and this fame is found to be likeryife called Hierabotanc, or the Holie Herb, and therefore it is euident that it is one and the felfe fame planr.called by diuers names : the which things confidered, if they fay fo, and fay truely, this wilde Germander cannot be Hicrabotane at all, as diuers hate written and faid it ro be.

$$
\text { 9 The Temperature. }
$$

Garden Germander is of thin parts, and hath a cutting facultie, it is hot and drie almoft in the rhird degree, enen as Galea doth wrire of Teurrium, or wilde Germandet.

The wilde Germander is.likew ife hot and dric, and is not altogerher without force or poiver to open and clenfe : it may be counted among the number of them that do open the litier and fpleen:

$$
\text { T) The vertues. }
$$

Germander boiled in water and drunk, delituereth the bodie from all obftuctions or ftoppings, $A$ diuideth and cutteth tough and clammie humors: being receiued as aforefaid, it is good for them that hate the cough, and fhortnefic of breath, the ftrangurie or ftopping of vrine, and hel peth thofe which are entring into a dropfie.

The leaues ftamped with hunic and ftrained, and a drop at fundrie rimes put into the eie's, takes B away the web and have in the fame, or any dimneffe of fight.

It protroketh mightily the termes, being boiled in wine, and the decoetion drunk; with a fomen- $C$ ation or batl made alfo thereof, and the fecret parts bathed cherewish.

$$
\mathrm{Ii} \mathrm{i}_{3} \text {. }
$$




\section{Cin P. 213: OfTree Germander.}

\section{9ा $T$ be $D$ efcription.}

I He firf kinde of Tree Germander rifeth wp with a little ftraight ftalke a cubite high,
wooddic and hard like vnto a fmall wooddie Thrubbe. The ftalke diuideth it felfe from the bottome vnto the toppe into diuers branches, whereon are fet indented leaues nicked about the edges, in thape not much vnlike the leafe of the common Germander. The floures grow among the leaues of a purple colour. The root is wooddie, as is all the reft of the plant.

I Terium latifolium.

Tree Germander with broad leaues.
2 Teucrium Pannonicum. Hungarie Germander.
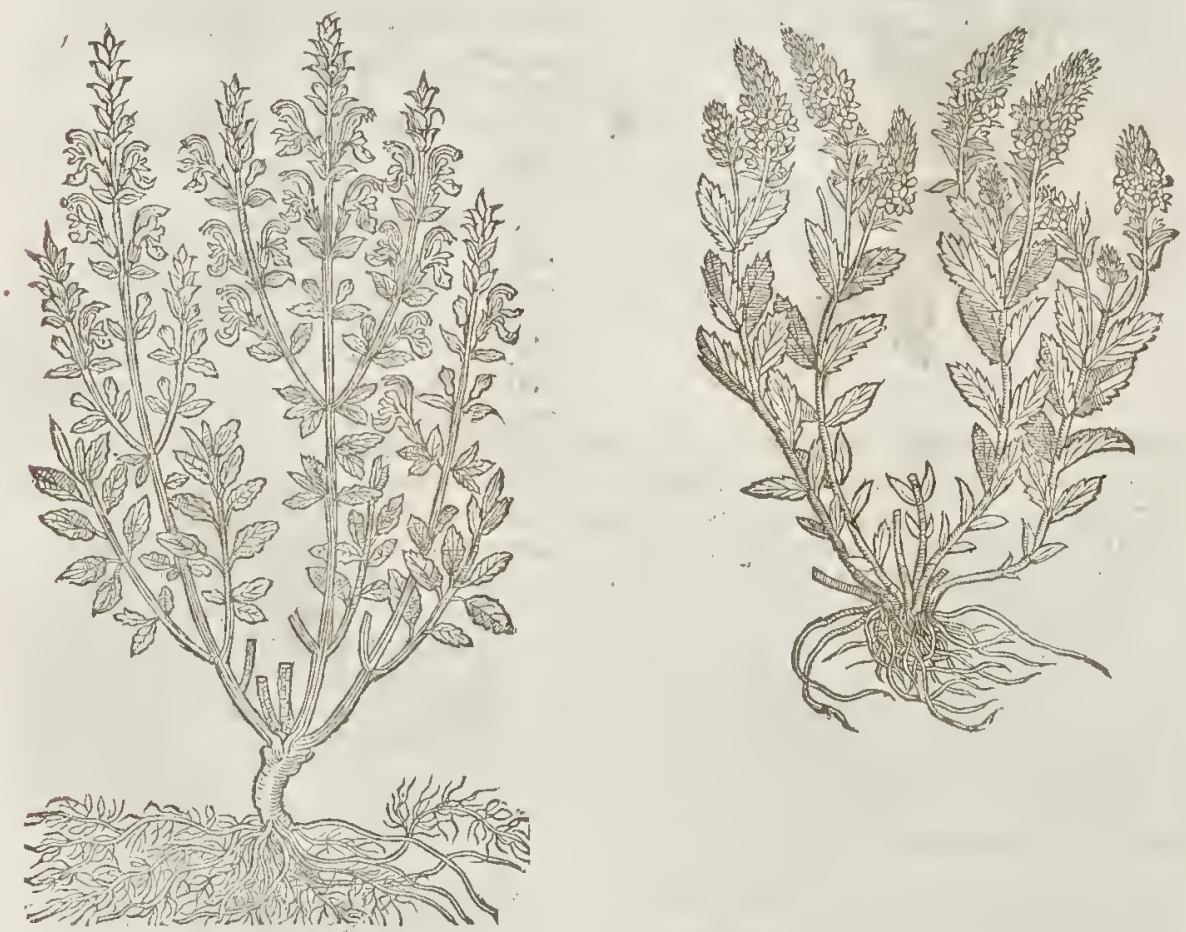

2 The Tree Germander of Hungaric hatl many tough threddie roors, from which rife vp diuers weake and feeble ftalks, reeling this way and that way; whercupon are fet together by couples, long leaues iagged in the edges, not vnlike thofe of the vpright Fluellen : on the tops of the ftalks fand the floures Spike fafhion, thicke thrult together, of a purple colour tending towards blewneffe.

$\neq 3$ This (which is the fourth of Clu(uns defcription) hath diuers falkes fome cubite high, foure fquare, rough, and fet at certaine fpaces with leaues growing by couples like thofe of the wilde Germander : the tops of the ftalkes are diuided into fundry branches, carrying long fpokes ofblew foures, confitting of foure leaues, wherenf the vppermolt leafe is the largeft, and diftinguifhed with veines: after the foures are paft follow fuch flat feed veffels as in Fluellen : the root is fibrous and lites long, fending forth enery yeare new branches. f 
† 3 Tcucrinm musus Panonicum. Great Auftrian Germander.

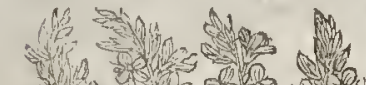

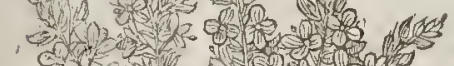
yns

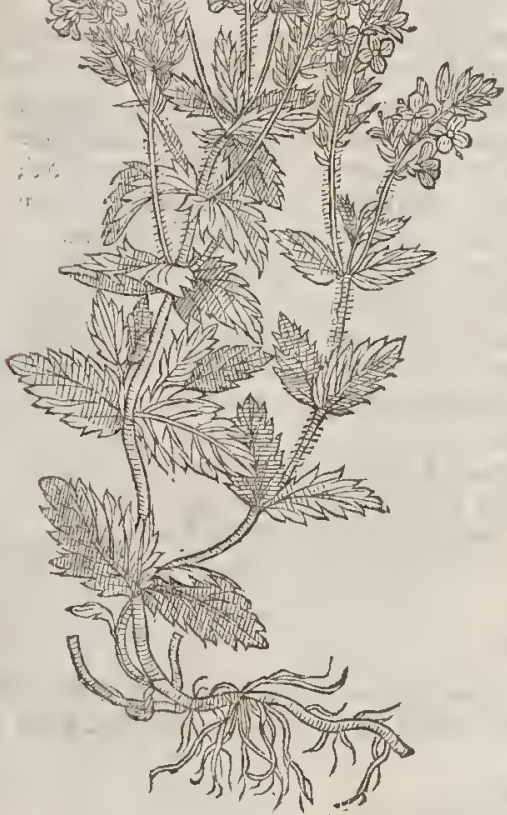

5 Teucrim Beticum.

Spanifh Tree Germander.

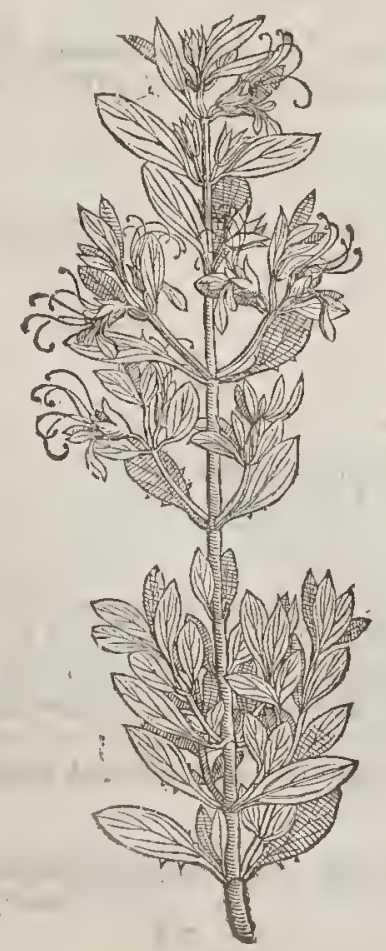

+ 4 Tcucrinir petrerm prenilum. Dwarfe Rocke Germander.

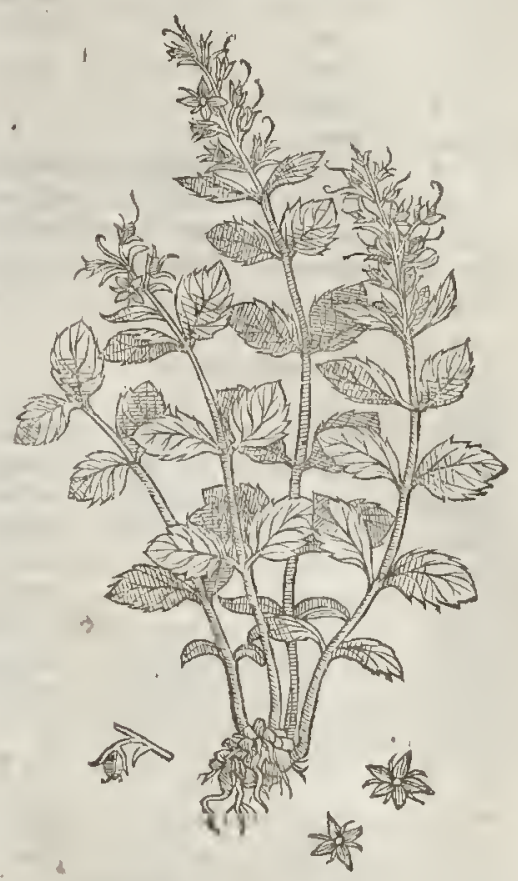

6 Tiürium Alpinum Ciffiflore.

Rough headed Tree Germander. ODmas octopetala

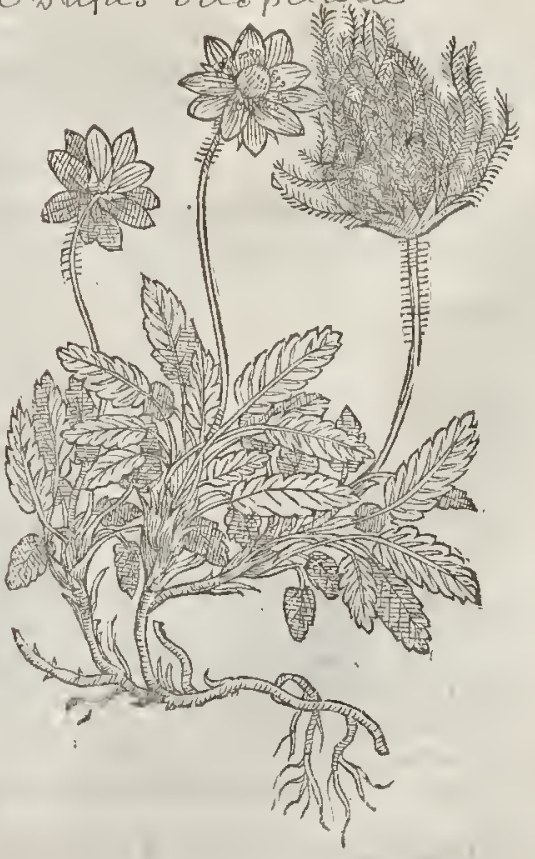


4 This Dwarfe Germander fends vp ftalkes fome handfull high, round, not branched : the leanes grow vpon thefeftalkes by couples, thicke, thining, a little hairy and greene on their vpper fides, and whitilh below : the tops of the ftalkes carry fpoky tufts of floures, confifting of foure or fuc blewith leaues; which falling, there followes a feed-veffell, as in the Vtronica's. The root is knotty and fibrous, and growes fo faft among ft the rockes tliat it cannot cafily be got out. It f.o.rreth in luly. Cunfus defcribes this by the name of Teucrium 6. Pumilum: and Pona fets it forth by the name of $V$ crowica petresfimpir virens. $f$

5 This Spanin Gernander riferh vp oft times to the height of a man, in manner of a hedge buth, with one ftiffe ftalke of the bigneffe of a mans little finger,conered oner with a whitin barit, dinded fomerimes into other branches, which are alwayes placed by couples one right againft a norher, of an onerworne hoarie colour; and vpon them are placed leaues not much vnlike the connmon Germander, the vpper parts whereof are of a gray ith hoarie colour, and the lower of a deepe greene; of a bitter tafte, and fomewhat crooked, turning and winding themfelues after the manner of a w elt. The foures come forth from the bofome of the leaues, ftanding vpon fmall tender footftalkes of a white colour, without any helmet or hood on their tops, hauing in the middle many threddy ftrings. The whole plant keepeth greene all the Winter long.

6 A mong the reft of the Tree Germanders this is not of leaft beauty and account, hauing many wcake and feeble branches trailing v pon the ground, of a darke reddith colour, hard and wooddie ; at the bottome of which nalks come forth many long broad iagged leaues not vnlike the precedent, hoary vnderneath, and greene aboue, of a binding and dryingtafte. The floutes grotv at the top of the ftalkes, not vnlike to thore of Ciftus famina, or Sage-rofe, and are white of colour, confifting of eight or nine leaues, in the middle whereof do grow many threddy chiues without fmell or fauour : which being paft, there fucceedeth a tuft of rough threddy or flocky matter, not vnlike to thofe of the great Auns or Pulfatilla: the root is wooddy, and fet with fome few hairie Atrings fattned to the fame.

$$
\text { I The Place. }
$$

Thefe plants do ioy in ftony and rough mountaines and dry places, and fuch as lie open to the Sunne and aire, and profperwell in gardens : and of the fecond fort I haue receiued one plant for my garden of $\mathrm{M}^{\mathrm{r}}$. Garret Aporhecarie.

$$
\text { T) The Time. }
$$

They floure, flourin, and feed when the other Germanders do.

$$
\text { I The Names. }
$$

Tree Germander is called in Greeke xaysidpus, retaining the rame of the former Chamedrys, and riverest according to the authoritic of Diofcorides and Pling: in Latine Teurrium: in Englifh, Great Germander, vpright Germander, and Tree Germander.

$$
\text { IT The Temperatsre and Vertues. }
$$

Their temperature and faculties are referred vnto the garden Germander, but they are not of fuch force and working, wherefore they be not nuch vfed in phyficke.

$$
\begin{gathered}
\text { С а Р. } 214 . \\
\text { Of Water Germander, or Garlicke Germander. } \\
\text { I The Defription. }
\end{gathered}
$$

I Corditm or water Germander hath fquare hairie falkes creeping by the ground, befec

s with foft whitith crumpled leaues, nickt and fnipt round about the edges like a Saw : among which grow fmall purple floures like the floures of dead Nettle. The root is fmall and threddy, creeping in the ground very deepely. The whole plant being bruifed fnelleth like Garlicke, whereof it tooke that name Scordium. $\neq$ This by reafon of goodneffe of foile varieth in the largeneffe thereof; whence $T$ abernamontanus and our Author made a bigger and a leffer thereof, but I huse onitted the later as fuperftuous.

$$
\text { ot The Place. }
$$

Water Germander groweth neere to Oxenford, by Ruley, on both fides of the water, and in a medow 


\section{I B. 2. Of the Hiftorie of Plants. .}

medow by Abington called Nietfotd, by the relation of a learned Gentleman of S. Tohis in the faid towne of Oxenford, a diligent siaborubs, my very good friend, called M*. Richurd slater. Alfo it groweth in gteat plenty in the Ifle of Elic, and in a medow by Harwood in Lancanire, and diuers other places.

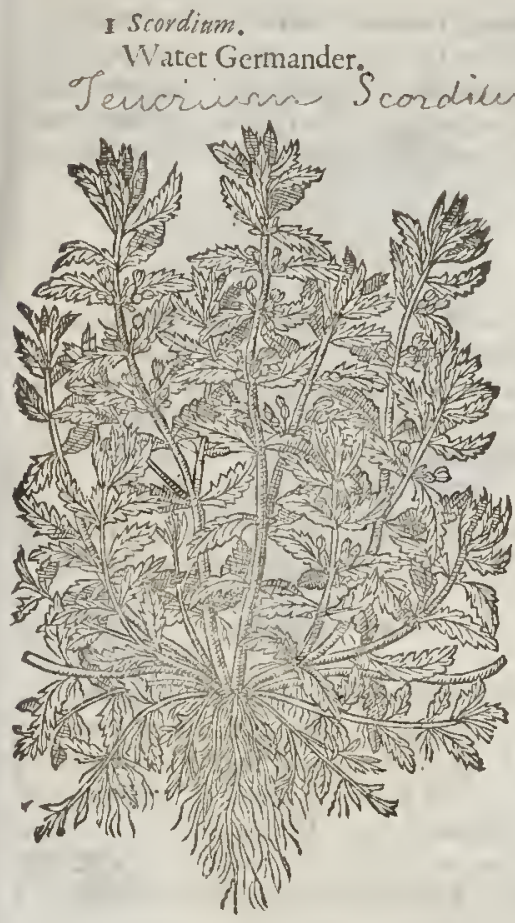

T) The Time.

The floures appeare in Itune and Iuly : it is beit to garlher the herbe in Auguft: it perifheth not in Wintet, but onely lofeth the ftalkes,which come vp againe in Sommet : the root remaineth freth all the yeare.

$$
\text { II The Names. }
$$

The Grecians call it zxipdo : the Latines do keepe that name Scardium : the A pothecaries haue no other name: It is called of fome Trixago Paluffris, 2uercula, and alfo cMithridatium, of crithridstes the finder of it out. It tooke the name Scordium from the fincl of Garlicke, which the Grecians call oxiesoy, and Nirope, of thie ranckneffe of the finell : in high-Dutch, ferer battentus : in French, scordron: in Italian, Chalamandrina paluftre: : in Englin, Seordium, Water Getmander, and Garlicke Germander.

$$
\text { The Temperature. }
$$

Water Germander is hot and dry : it hath a certaine bittet tafte, harih and hatpe, as Galen witneffeth.

$$
1 \text { T The Vertues. }
$$

Water Germander cleanfeth the intrals, and likewife old vlcers, being mixed with honey according to art : it prouoketh vrine, and bringetl downe the monethly fickenefie : it draweth out of the cheft thicke flegme and rotten matter: it is gool for anold cough, paine in the fides which commeth of ftopping and cold, and for burftings and inward ruptures.

Thedecoction made in wine and drunke, is good againft the bitings of Serpents, and deadly poyfons; and is vfed in antidotes or counterpoyfons with good fucceffe.

and water. Some affirme, that raw fleth being laid among the leaues of Scordium, may be preferued a long
ine from corruption.

Being dtunke with wine it openeth the ftoppings of the liter, the milt, kidnies, bladder, and matrix, prouroketh vrine, helpetl the ftrangurie, that is, when a man cannor piffe but by drops,and is a molt fingular cordiall to comfort and make merry the heart.

The pouder of $S$ cordion taken in the quantitic of two drams in meade or honied water, cureth and ftoppeth the bloudy flix, and comforteth the ftomacke. Of this Scordium is made a moft fin- $\mathrm{F}$ gular medicine called D infordinm, which ferueth very notably for all the purpofes aforefaid.

The fame medicine made with Scordium is giuen with very good fucceffe vnto children and aged people, that haue the fmall pockes, meafles, or the Purples, or any other peftilent fickneffe whatfoewer, euen the plague it felfe, ginen befote the ficknes haue vnituerfally poffeffed the whole body 


\section{С н н. 215. Of Wood Sage, or Garlicke Sige. \\ G. The Defription.}

7 Hatwhich is called Wilde Sage hath ftalkes foure fquare, fomewhat hairie, about whichare 1 leaucs like thofe of Sage, but thorter, broader, and fofter : the floures grow vp all vpon one fide of the ftrlke; open and forked as thof of dead Nettle, but leffer, of a pale white colour : then grow the fecds foure together in one huske: the root is full of ftrings. It is a plant that liueth but a yeare : it fmelleth of garlicke when it is bruifed, being a kinde of Garlicke Germander, as appeareth by the fmell of garlicke wherewith it is poffened.

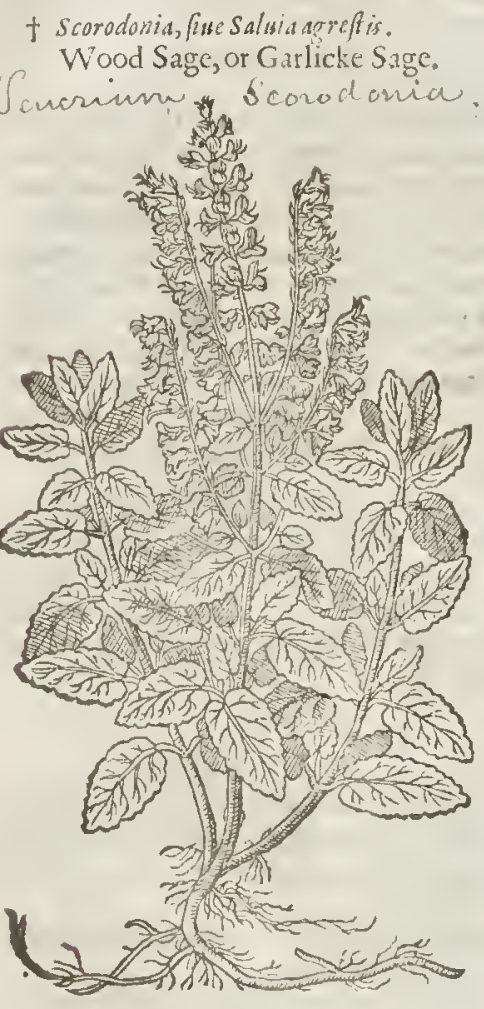

di The plase.

It groweth vpon heaths and barren places : it is alfo found in Woods, and neere vnto hedgerowes, and about the borders of fields : it fonewhat delighteth in a leane foile, and yet nut a? together barren and dry.

\section{The Time.}

It floureth and feedeth in Iune, Iuly, and $f$ at guft, and it is then to be gathered and laid vp.

$$
\text { T The Names. }
$$

It is called of the later Herbarifts Saluia agreA is : of diuers alfo Ambrofun; but true Ambrofa, which is Oke of Cappadocia, differs from this. $V$ alcrius Cordus names it Scordonia, or Scorodonia, and Scordium altcrum. Ruellizus faith it is called Bofcifalwia, or Saluia Bofci.in high Dutch, WaIDt falbey: in Englith, wilde Sage, wood Sage,and Garlicke Sage.

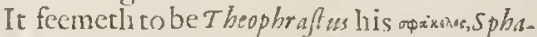
celus, which is alfo taken for the fm.ll Sage, but not rightly.

$$
\text { 9. The Temperature. }
$$

Wilde Sage is of temperature hot and drie, yet leffe than common Saye; therefore it is hot and dry in the fecond degree.

97 The Vertues.

A It is commended againft burftings, dry beatings, and againft wounds : the decoetion thereof is ginen to them that fall, and are inwardly bruifed : it alfo pronoketh vrine.

B Some likewife siue the decoction hereof to drinke, with good fucceffe, to them that are infected with the French Pox; for it ciuferls fiveat, drieth vp vlcers, digefteth humors, wafteth away and confumeth firellings, if it be taken thirtic or forty dayes together, or put into the decostion of Guiacum, in fecad of Epithymsm and orber adiutories belonging to the faid decoction.

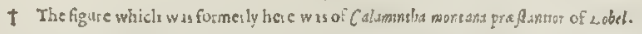

$$
\begin{gathered}
\text { Cна Р. 216. Of Eye-bright. } \\
\text { The Defription. }
\end{gathered}
$$

Erphroffur or Eye-bright is a mall low herbe not aboue two liand fuls high, full of branches, coE uered, with little black ifh leatues dented or fnipt about the edges like a faw : the floures are 
fmall and white, fprinkled and poudered on the innet fide, with yellow and purple fpecks mixed thetewith. The root is fmall and hairie.

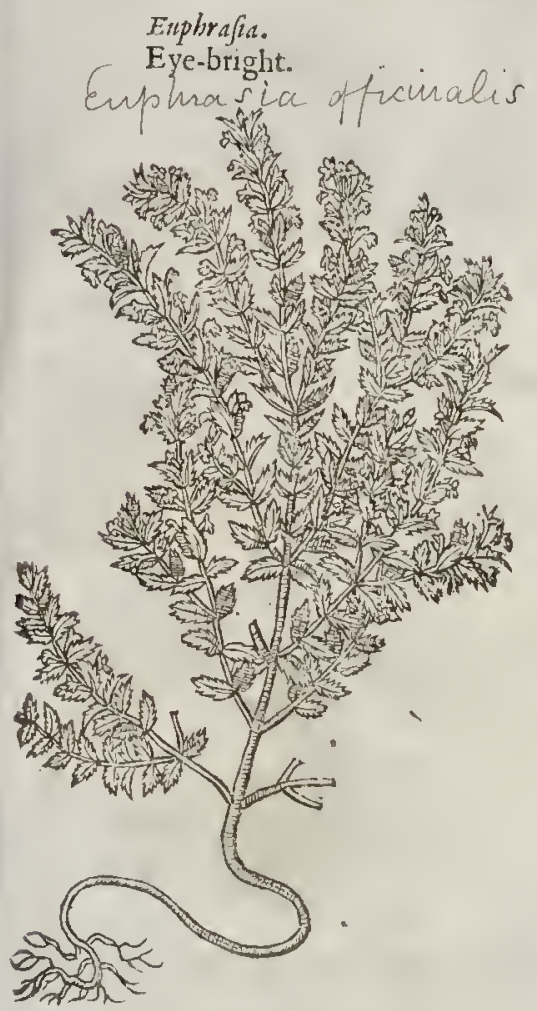

ขा The Place.

This plant growes in diy medows, in green and graffic wayes and paftures ftanding a gainft the Sunne.

T) The Time.

Eyc-bright beginneth to foure in Auguft and continue th vito Seprember, and mutt be gathered while it foureth for phyfichs vfe. gi The Nomes.

It is conumonly called Euphrafia, as alfo Euphrofyne; now ithitanding there is another Euphrofyne, vin. Bugloffe $:$ it is ealled of fome Octularts, S. Ophethalmica of the effect : in highDutch, alugen tront: in low -Dutch, (1) oghets ttooft: in Italian, Spanifh, and French, Eufrafia, afrer the Latine name: in Englin, Eyebrights.

T The Nature.

This herbe is hot and dry, but yet more hot than dry.

\section{TheVertues.}

It is very much commended for the eyes. A - Being taken it felfealone, orany way elfe, it prefertues the fight, and being fecble and loft it teftores the fame : ir is giuen molt fitly being beaten into pouder; oftentimes a like quantitie of Fennel feed is added thereto, and a little mace, to the whieh is put fo much fugar as the weight of them all commeth to.

Eyc-bright ftamped and layd vpon the eyes, or the inyce thereof mixed with white Wine, and $\vec{E}$ dropped into the eyes, or the diftilled water, taketh away the darknefie and dimieffe of the eyes, and cleareth the fight.

Three pirts of the ponder of Eye-bright, and one part of maces mixed rherewith, taketh away all hurts from the eyes, comforterl the memoric, and cleareth the fight, ifhalfe a fpoonfull be taken euery morning fafting with a cup of white wine.

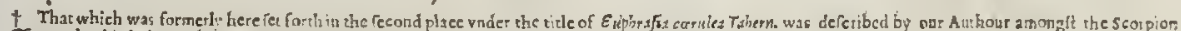

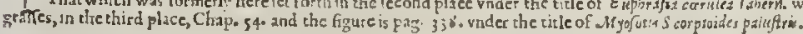

\section{C н А. 217. Of Marierome.}

\section{9) The Deficiption.} Weet Marjerome is a low and fluruby plant, of a whitith colour and marucllous fivect fmell, a foot or fomewhar morehigh. The ftalkes are nender, and parted into diters branches; about whiel grow forth little leates foft and hoaric: the floures grow at the top in fcaly or ehaffie fpiked eares, of a white colour like vnto thofe of Candy Organy. The root is compact of many fmall threds. The whole plant and cuerie part thereof is of a molt pleafant tafte, and aromaticall fmell, and perisheth at the firft approch of Winter.

sort $z$ Pot Marie ronce or Winter Maierome hath many threddy tough roots, from which rife immediately diuers finall branehes, whereon are placed fuch leaues as the preeedent, but not fo hoarie, nor yet fo fireet of fnell, bearing at the rop of the branehes tufts of white floures tending to purple. The whole plant is of long continuanee, and keepeth greene all the Winter; whercupon our Englifh women haue called it, and that very properly, Winter Marierone.

3 Marierome Gentle hath many branches rifing from a threddy root, whereupon do grow fo fo and fweet fmelling leates of an oucrwone ruffet eolour. The floures ftand at the top of the ft. $1 \mathrm{ks}$, 


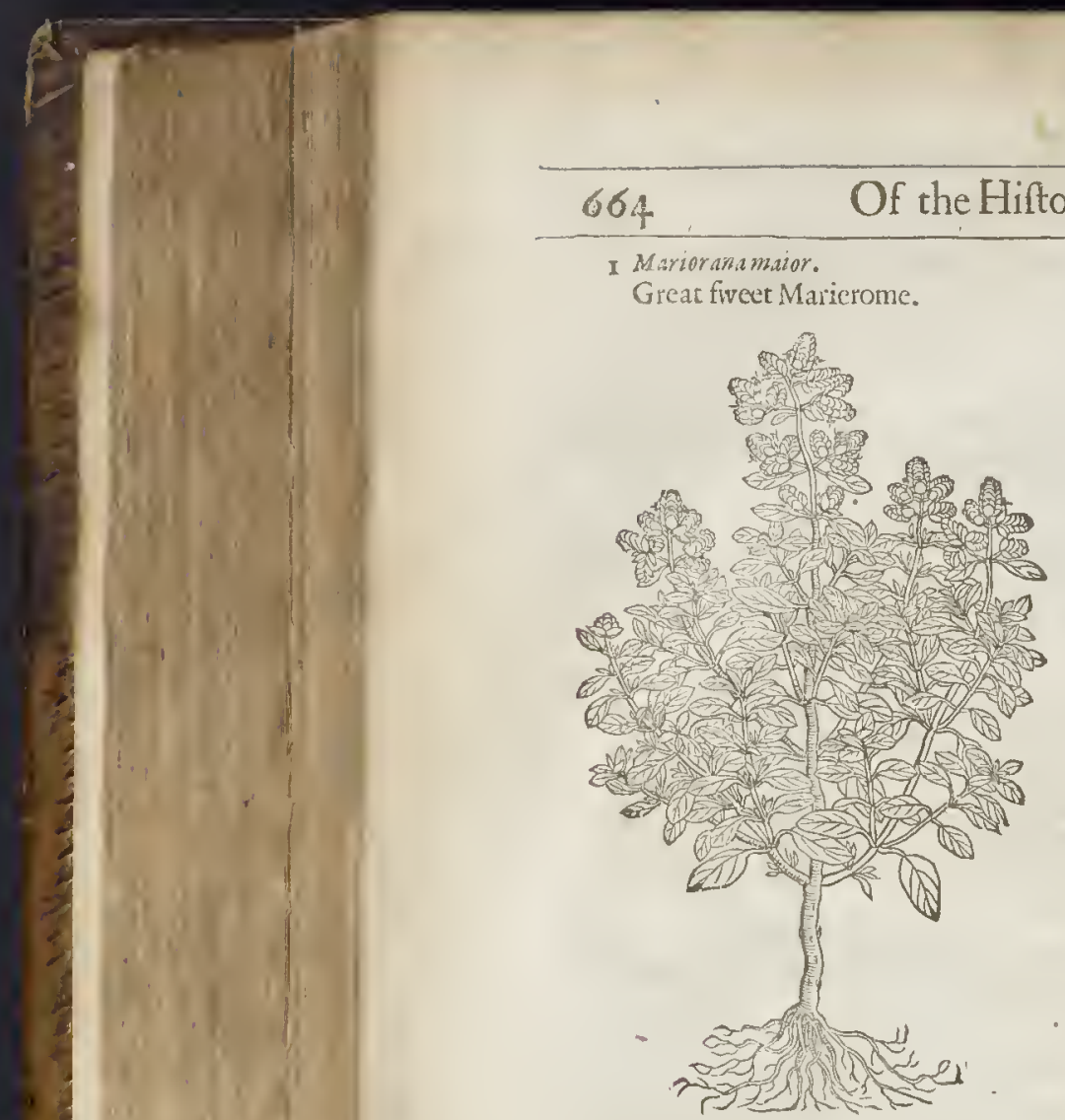

3 Miriorinatenifolta. Maricrome gentle.

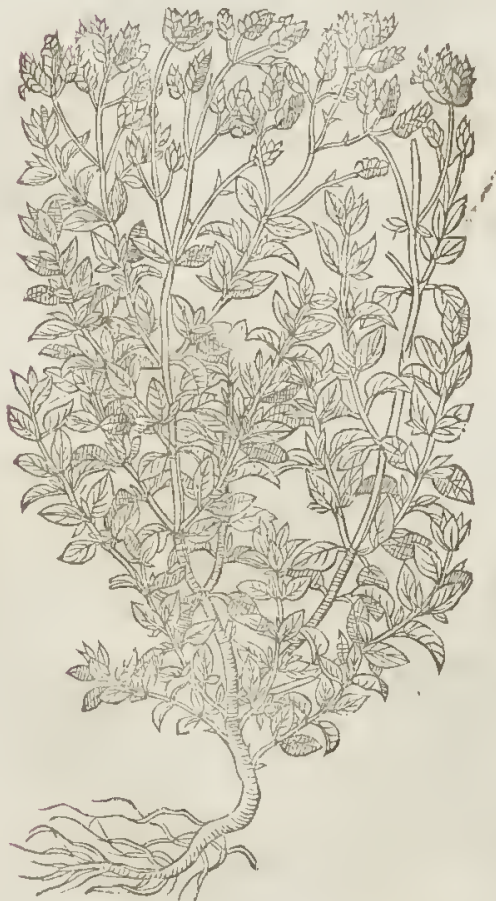

2 Marioranamior Anglica. Pot Marierome.

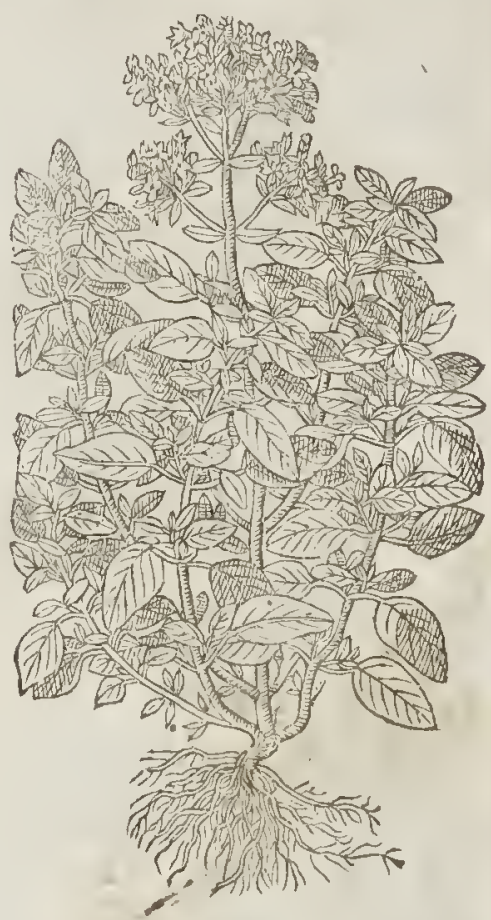

compact of diuers finall chaffic fcales, of a white colour tending to ablurh. Tlue whole plant is altogether like the great fwcet Maricrome, faung that it is altogether leffer, and far fwceter, wherein efpecially confifteth the difference.

4 Epimaiorana is likewife a kind of Marierome, differing uot from the laft deferibed, fauing in that, that this plant hath in his naturall country of Can$d y$, and not elfewhere, fome laces or threds faftned vnto his branches, fuch, and atter the fame manner as thofe are that doe grow vpon Sauorie, wherein is the difference.

$$
\text { T) The place. }
$$

Thefe plants do grow in Spaine, Italy, Candy, and other Iflands thereabout, wilde, and inthe fields; from whence wee haue the feeds for the gardens of our cold countries.

$$
\text { The Time. }
$$

They are fowne in May, and bring forth their fealy or chaffie huskes or eares in Augutt. They are to be watcred in the middle of the day, when the Sunne fhineth botteft, eucn as Bafill thould be, and wor in the cuening nor morning, as moft Plants are.

$$
\text { - The Names. }
$$

Maricrome is called Mariorana, and Amaracus, and alfo Marum and Sumpfychum of others : in highDutch, 9Papo:ant: in Spanith, exayorana, Moradux, and Almoradex: in French, Mariolaine : in Englilin, Sweet Maricronc, Fine Maricrome, and Marie- 
rome gentle; of the beft fort Marjerane. The pot Marjerome is alfoealled Winter Marjerome: Some haue rnade a doubt whetber Mutorana and Sampfychum be all one; which doubr, as I take it, is becaufe that $G$ alen maketh a differenee betweene them, intreating of then apart, and attributeth to either of them their operations. But Umaracus Galeni is Parthenium, or Feuerfer. Dioforides likewife witneffeth, that fome docall LAmaracts, Parthenium; and $G$ alen in his booke of the fa. eulties of fimple medieines, doth in no plaee make mention of Partherisum, but by the name of Amaracus. Pliny in his 2 I booke, ehap.2. witneffetb, that Diocles the phyfition, and they of Sicily did eall that Amarateu, which the Egyptians and the Syrians did call Sampfichum.

Virgill in the firtt booke of his Eneidos thewetb, that Amaracus is a fhrub bearing foures, writing thus :

$$
\begin{aligned}
& \text { Vhi mollis Amaracus illum } \\
& \text { Floribus, \& dulci afpirans complectitur unbra. }
\end{aligned}
$$

Likewife Cutrillus in his Epithalamium, or mariage fong of Lulia and Mallius faith;

$$
\begin{aligned}
& \text { cinge tempora floribus } \\
& \text { Srezue olcntss A maraci. }
\end{aligned}
$$

Compafle the temples of the head with floures.

or Amarac affording fwecte fauours.

Notwithitanding it may not feeme ftrange, that Majorane is vfed in ftead of Samp $\int y c h u m$, fecing that in Galens tine alfo Marum was in the mixture of the ointment called Amaracinum vrgucntum, in the place of $S a m p$ fychum, as he himfelfe witneffeth in his firft booke of counterpoifous.

They are hot and dry in the fecond II The Temperature.

They are hot and dry in the fecond degree; after fome eopies, hor and dry in the third.

Sweete Marjerome is a remędy againft cold difeafes of the braine and head, being taken any $A$ way to your beft liking; put vp into the nofthrils it prouoketh fneefing, and draweth forth much baggage flegme : it eafeth the tooth-ache being ehewed in the mouth, being drunke it prouoketh vrine, and draweth away waterifh humors, and is vfed in medicines againft poifon.

The leaues boiled in water,and the decoction drunke, belpeth them that are entering into the B dropfic:it eafetli them that are trotbled with diffieultic of making water, and fuch as are gituen to ouermueh fighing, and carech the paines of the belly.

The leaues dried and mingled with hony, and giten, diffolueth eongealed or eloted blood, and C putteth away blacke and blew markes after ftripes ąnd brufes, being applied thereto.

The leatues are exeel lent good to be put into all odoriferous ointments, waters, pouders, brotbs, D
Deates.

The dried leaues poudered, and finely fearehed, are good to be put into Cerotes, or Cere-eloths E and ointments, profirable againtt colde fwellings, and members out of joint.

There is an exeellent oile to be drawne forth of thefe herbes, good againt the fhrinking of $F$ finewes, crampes, convulifions, and all aches proceeding of a colde eaufe.

\section{С н а r.218. Of milde Marjerome.}

T) The Defeription. 1 Aftard Marjeromegtoweth fraightyp witb little round ftalkes of a reddifh colour, full round, of a whiting greene colour on the top of the branches ftand long fpikie fealed eares, out of which thoot forth little white floures like the flouring of wheate. The whole plant
is of a fwcete fmell, and tharpe bitung tafte.

2 The white Organy, or baftard Marjerome with white foure's, differing hittle from the prewhercin eonfifteth the differure. This plant lath whiter and broader leates, and al fo mueh higher,

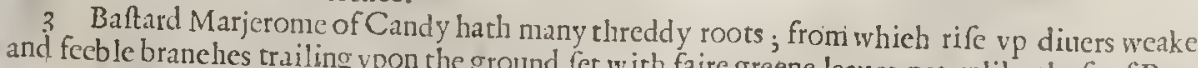
iny Royall, but broader and horter : at the top of thofe brane greene leaues, not vnlike thofe of Penpurple colour. The whole plant is : at the top of thofe branches ftand fealic or elaffie eares of a $\mathrm{Kkk}$ 
$x$ origanum Heraileoticum.

Baitard Marjerome.

-

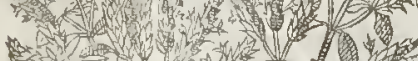

(4) U

7 1. ON

m(4)

- 5 -

4xing

in

है

ODN

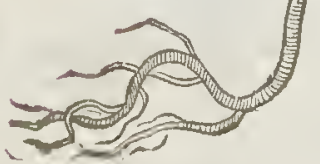

+3 origanum Crcticum.

Wilde Marjerome of Candy.

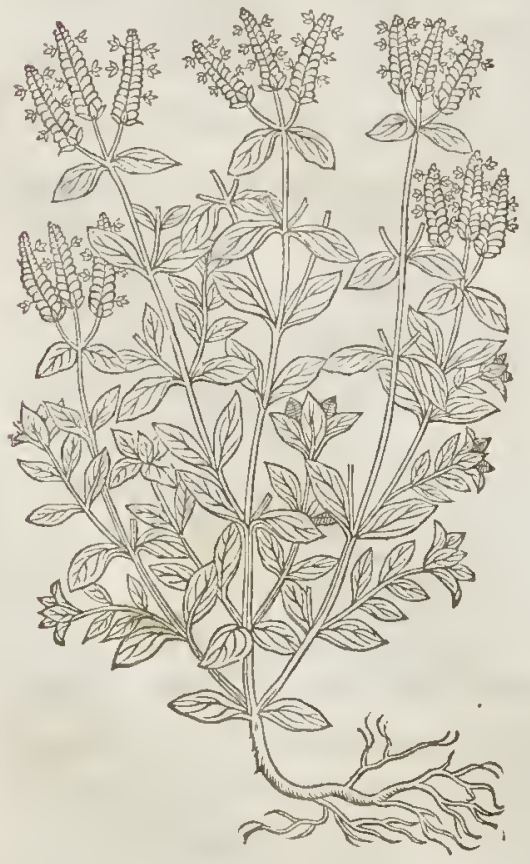

t 2 orignnum album, Tabcrn.

White baftard Marjerome.

40 ons 10. (vi) (s)
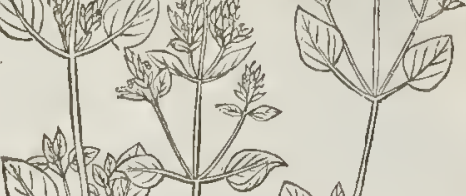

(1ivitis $\Leftrightarrow$

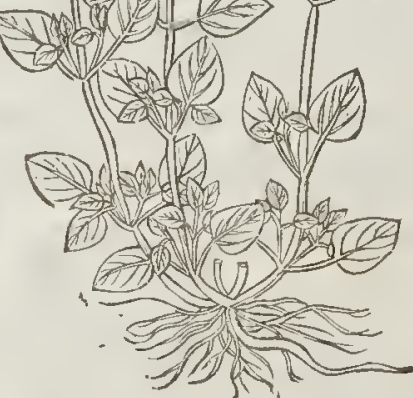

4 Origanum Anglicun.

Englin wilde Marjerome.

Giganuma irulgare

当 -1) $z^{2} 3^{2}$

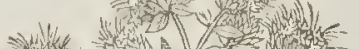

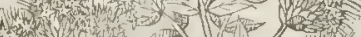

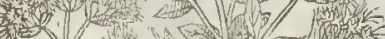

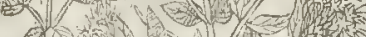
an $\rightarrow 21$ a * 4 - 11 . 7 . fun 612)

al 91 in

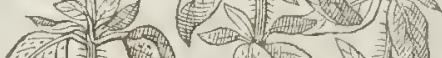

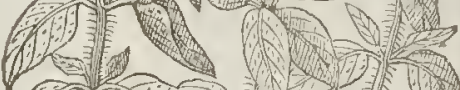
G.

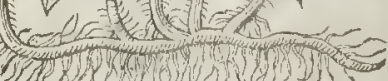


and the leaues alfo greene all this winter long, 1597 alt hough it hath been faid that it doth perith at the firft frof, as fivecte Marjerome doth.

4 Englin wilde Marjerome is exeedingly well knowne to all, to haue long, ftiffe, and hard ftalkes of two eubits high, fet with leanes like thofe of fweet Marjerome, but broader and greater, of a ruffet greene eolour, on the top of the branehes ftand tufts of purple floures, compofed of many fmall ones fet together very elofely vmbell fanhion. The root creepeth in the ground,and is long lafting.

\section{T The Place.}

Thefe plants do grow wilde in the kingdome of Spaine, Italy, and other of thofe hot regions. The laft of the foure dorh grow wilde in the borders of fields, and low eopfes, in moft places of England.

前 The Time.

They floure and flourith in the Sommer moneths, afterward the feed is perfected. T) The Names.

Baftard Marjerome is ealled in Greeke, jes;rivos;and that which is furnamed Heraclcoticum, act;anos spaxx+ankn: of diuers it is ealled Cunila: in thops, origanum Huppanicum, Spanifh Organy : our Euglifh wilde Marjerome is ealled in Grecke of Diofiorides, Galcn, and Plizy, Onitis, of fome, Agriorigamum, or Sylecftre orig awn : in Italian, origano: in Spanifh oregano: in French, cMariolaine baftarde: in Englifh, Organe, baftard Marjerome: and that of ours, wilde Marjerome, and groue Marjerome.

$$
\text { I The Temperature. }
$$

All the Organies do eut, attenuate, or make thin, dry, and heate, and that in the third degree; and Galca teacheth that wilde Marjerome is more foreeable and of greater ftrength; notwithitanding Organy of Candy which is brought dry out of Spaine (where of I haue a plant in my garden) is more biting than any of the reft, and of greateft heate.

$$
\text { IT The Vertues. }
$$

Organy gituen in wine is a remedy againft the bitings, and ftingings of venomous beafts, and eu- $A$ reth them that haue drunke opitum, or the juice of blacke poppy, or hemloekes, efpecially if it be gituen with wine and raifons of the func.

The decoction of Organy prouoketh vrine, bringeth downe the monethly enurfe, and is giuen $\mathrm{B}$ with good fueeeffe to thofe that haue the dropfic.

It is profitably vfed in a looeh, or a medieine to be lieked, againft an old eough and the fuffing $C$ of the lungs.

It healeth feabs, itehes, and feuruinefe, being vfed in bathes, and it taketh away the bad colour which commeth of the yellow jaundiec.

Theweight of a dram taken with meade or Lonicd water, drawerh forth by itoole blacke and $E$ filtry humors, as Diofcorides and Pliny write.

The juiee mixed with a little milke, being poured into the eares, mitigateth the paines $F$ thereof.

The fame mixed with the oile of Ireos, or the rootes of the white Florentine floure de luee, and drawne vp into the nofthrils, draweth downe water and flegme:the herbe ftrowed vpon the ground driucth away ferpents.

The decoction loofeth the belly, and voideth eholer; and drunke with vineger helpeth the infir- $H$ mities of the fpleene, and drunke in wine helpeth againft all mortall polfons, and for that eaufe it is put into mithridate and treacles prepared for that purpofe.

Thefe plants are eafie to be taken in potions, and therefore to good purpofe they may bevfed and miniftred vnto fueh as eannot brooke their meate $e_{2}$ and to fuch as haue a fowre and fqamifh and watery ftomacke, as al fo againft the fwouning of the heart.

$t$ The fecond and third figures were formerly tranfpoled.

\section{Cнаг. 219. Of Goates Marjerome, or Organy: \\ 9) The Defcription.}

I THe ftalkes of Goates Organy are flender, hard and wooddy, of a blackifh colour; whereon are fer long leaues, greater than thofe of the wilde Time, fweete of fmell, rough, and fomewhat hairy. The floures be fmall, and grow out of little erownes or wharles round about the top of the ftalkes, tending to a purple enlour. The root is finall and threddy. 
f I Tragoriganum Dod.

Coats Mariciome.

† Tragoriganum Lob.

*y

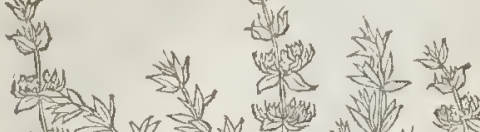

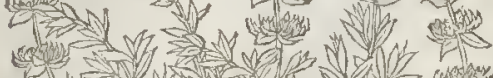

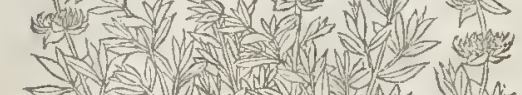
敞

D.

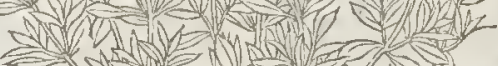

I

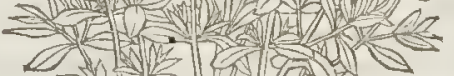

aym as an

-1ments

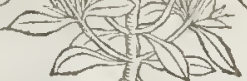

3)

i 2 Tragoriganum Clufit.

Clufguts his Gonts Marierome.

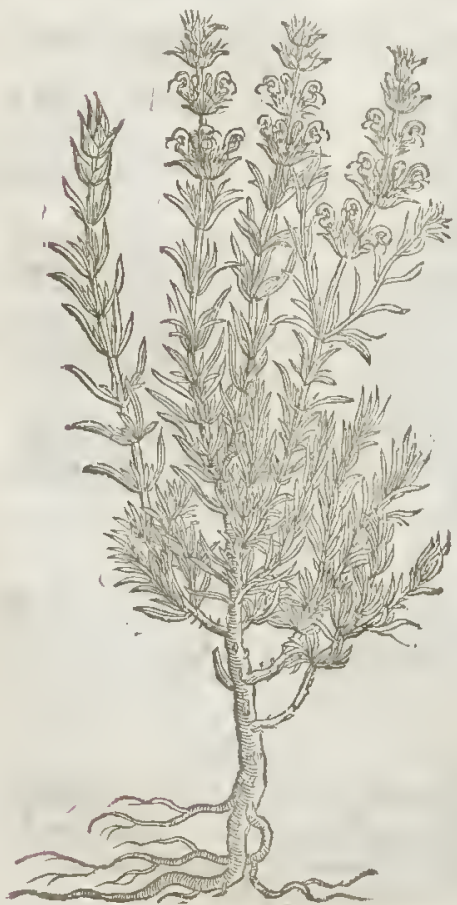

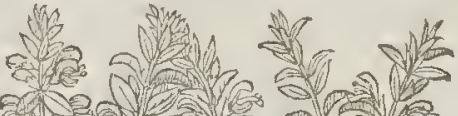
6. (12)

(1)

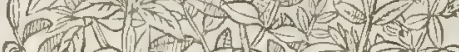

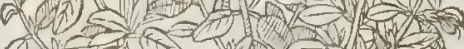
(1) N W N DENAñ tol जीए MW

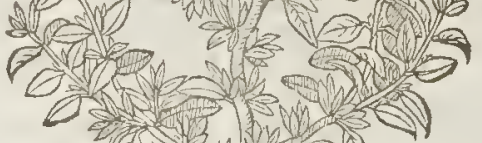
$4=12(3)$ a

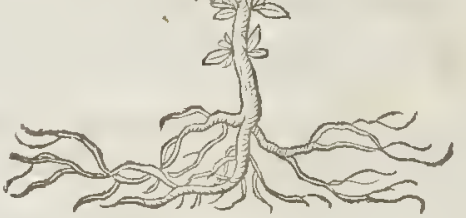

\# Trugoriganum croine.

Candy Goars Marierome.

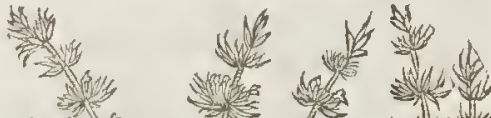
is

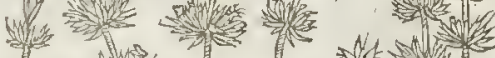

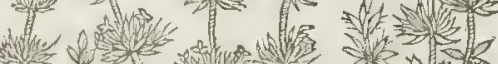
- y $=4$ thy

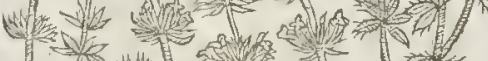

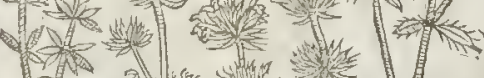
190 aly why 11.

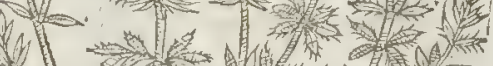
4 a t 1. 1 (1) 10 - 19

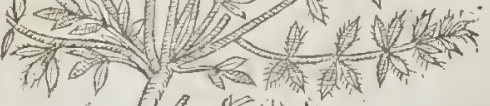
$\rightarrow$ v ग) 3) न) 
2 Carolus Clufius hath fet forth in his Spanith Obferuations another fort of Goats Mariaroize growing vp like a fmall thrub : the leaues are longer and more hourie thasivilde Marierone, and alfo narrower, of a hot biting tafte, but of a fweet fmell, though noc very plau fant. The floures do ftand at the top of the falkes in fpokie rundles, of a white colour. Thernot is thicke and wood: $\mathrm{v}$.

$\ddagger 3$ This differs little in forme and magnitude from the laft deferibed, but the brunclus are of a blacker colout, with rougher and darket coloured leaues : the floures allo are leffer, and of a purple colour. Both this and the laft defcribed continue alwaies greene, but this luft is of a mucl more fragrant fmell. This floures in March, and was found growing wilde by clufus in the fields of Valentia : hecalls it Tragoriganum Hipanicum tertium. Pena and Loúl call it Tragoriganum Cretenfe apsdrenetas; that is, the Candy Goats Marierome of the Venetians.

$$
\text { The Place. }
$$

Thefe plants grow wilde in Spaine, Italy, and other hot eountries. The firft of thefe I found growing in diuers barren and chalky fields and high-wayes neere vnto Sittingburne and Rocheftet in Kent, and alfo neere vnto Cobham houfe and Southfleet in the fame county.

$\ddagger$ Idoubt our Authorwas miftahen, for I haue not heard of this growing wildewith vs. $\ddagger$ था The Time.

They floure in the moneth of Auguft. I remember (Faith Dodoneus) that I hate feene Tragoriganum in the Low-countries, in the gardens of thofe that apply their whole ftudy to the knowledge of plants; or as we may fay, in the gardens of cumning Herbarifts.

$$
\text { वा The Nanzes. }
$$

Goats Otganic is called in Greeke reverairos: in Latine likewife Ty agdriganum: in Englifh, goats Organie, and Goats Marierome.

$$
\text { था } T \text { be } T \text { emperature. }
$$
litie.

Goats Organies are hot and dity in the thitd degree: They ate (faith Galen) of a binding qua-

$$
\text { 9T TheVertues. }
$$

Tragoriganum or Goats Matietome is very good againft the wamblings of the ftomacke,and the $A$ foure belching s of the fane, and ftayeth the defire to vomit, efpecially at fea.

Thefe baftatd kindes of Organic or wilde Marieromes haue the fame foree and faculties that $\mathrm{B}$ the other Organies haue for the difeafes mentioned in the fame chapter.

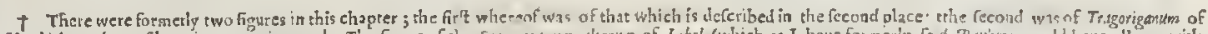

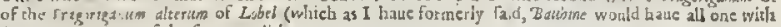

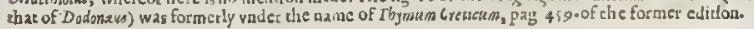

\section{С н г. 220. Of Herbe Mafticke.}

\section{The Defcription.}

17 He Englion and French herharifts at this day do in their vulgar tongues call this herb Mafticke or Mattich, taking this ne ne Mrum of Maro King of Thrace; though fome rather fuppofe the name corputiv ro bederiued from this word w Amacus, the one plant being fo like the other, that many leaned haue taken them cobe one aut the felfe fame plant : others haue taken Marum for S amplusbus, wi icli doubtleffe is a kinde of Marierome. Some (as Dodonaus) haue called rhis our Maram ive the nume of clinopodum; which name rather belongs to another plant than to Malticic. $\$$ i his fr.m. fonc foot high, with little longilh leaues fet by eouples: at the tops of the falkes amoliz, wh. te downie heads come little white floures: the whole plant is of a very fweet and pleatng fmill. $\neq$

2 If any be defrous to fearch for the true Marum, let them be affured that the plant laft mentioned is the fame : but if any do doubt thereof, for nouelties fake here is prefented rnto your view a plant of the fame kinde (which cannot be reiested) for a fpeciall kind thereof, which hath a moft pleafant fent or fmell, and in fherv refembleth Marierome ard origanum, confifting of fmal twigs a foot and more long; the heads tufted like the common Marierome; but the leaues ate lefle, and like Myrtus : the root is of a wooddy fubftance, with many frings hanging thereat.

3 There is another kinde hereof fet forth by Lobel, which I haue not as yet feen, nor himfelfe hath well defcribed, whieh I leaue to a better confiderution. \# Though our Authour':new not how to deferibe this creeping Marum of Lobel, yet no queftion, if he had knowne fo much, he would hate giuen vs the figure thereof as wel in this place, as in the third place of the next chapter $\mathrm{Kkk} 3$ 


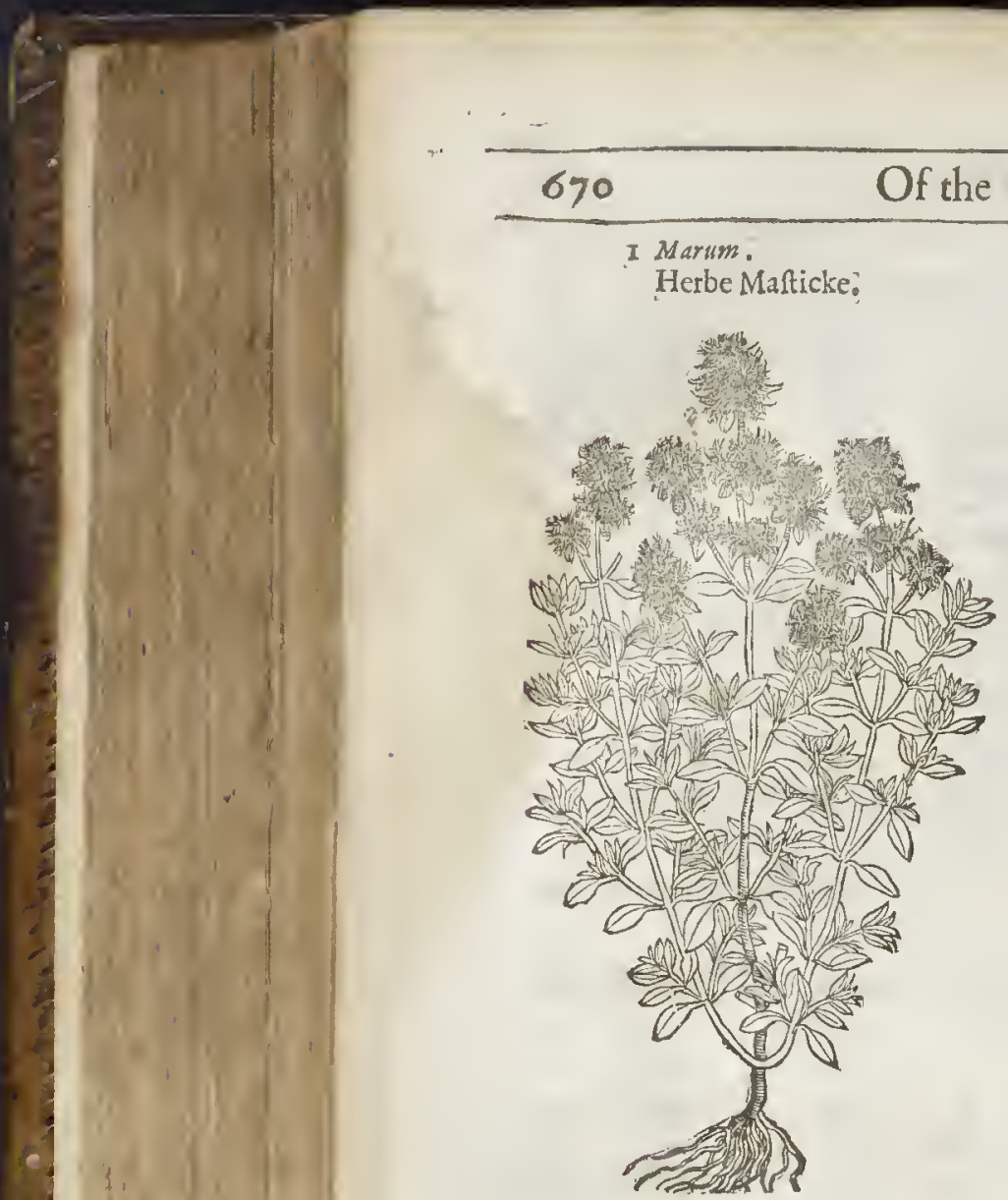

$L_{18.2 .}$

2 Marum Syracum.
Affrian Mafticke.

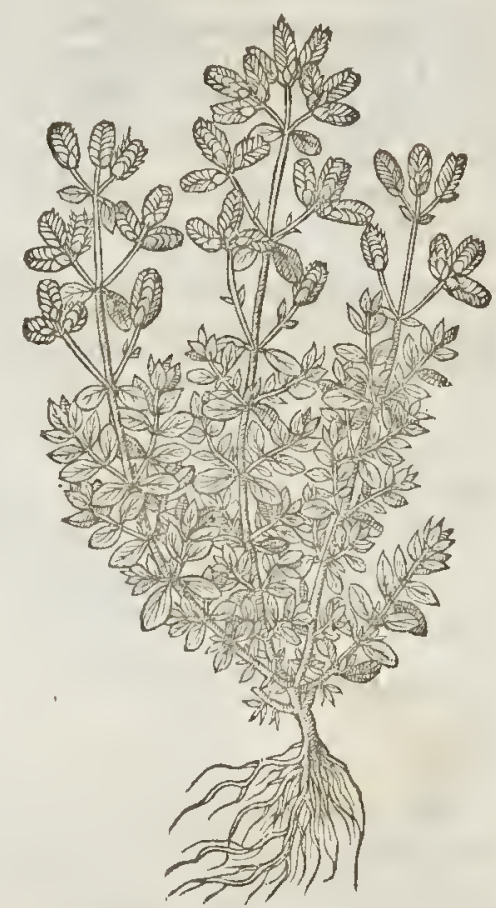

† 3 Marum Jupinum Lobelÿ. Creeping Malticke.

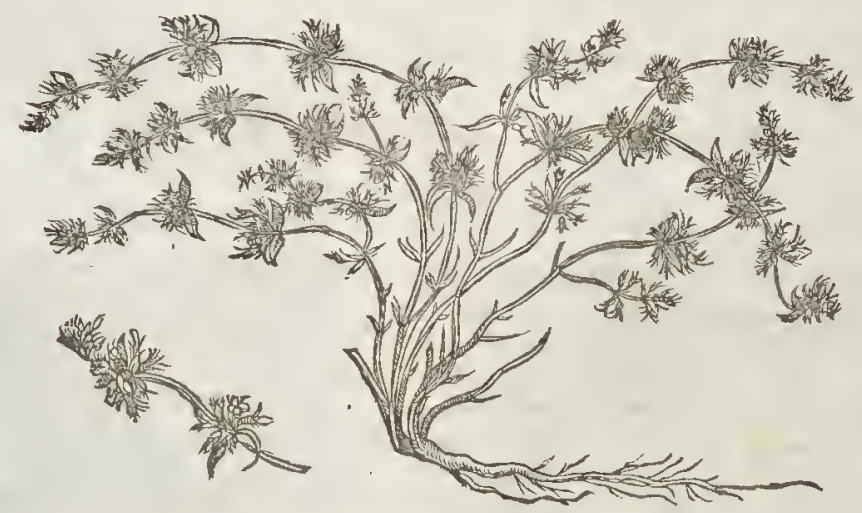

for a Penny-Royall, and might as well here as there, and mueh more fitly hane ventured at a defeription. But that whieh is defectiue in him and Lobel, I will endeauour to fupply out of Cafalpinus. This plant hath many creeping branches like to thofe of wilde Time, but fetwsth whiter and fhorter leaues like to thofe of the fmaller Marjerome, but fomewhat narrower: the floutes grow in rundles among ft the leaues, as in Calamint, and are of a purple colour : the whole plant is of a ftrong and fweet fmell, and of an hot and bitter tafte. Cefalpinus thinkes this to be the $S$ ampfucbum of Drofcorides : and fo alfo do the Authors of the $\mathcal{L}$ duerfaria. Tabernamontenus calls it Marum repens. $\ddagger$

$$
\text { 4. The Place. }
$$

Thefe plants are fet and fowne in the gardens of England, and there maintained with great care and diligenee from the iniuric of our eold elymate. 
L 1 в. 2. Of the Hiftory of Plants.

9. The Time.

They floure about Augut, and fomewhat lacer in cold Sommers.

9ा The Names.

\# Marticke is called of the new writers Marum: and fome,as Lobeland Anguillarathinke it the Helentum odorum of Theophrafus. Dodoneus iudges it to be the Clinopodsum of Dioficorides. Clafius makes it lis Trageriganm I. and faith he receiued the feeds thereof by the name of Ambradul. cis. $\neq$

Thefe plants are hot and dric in the third degree.

9 The Nature.

9ा The Vertues.

Diofcorides writeth, that the herbe is drunke, and likewife the decoction thereof, againft the bitings of venomous beafts, crampes and convulfions, burftings and the ftrangurie.

The decotion boiled in wine till the third part beconfumed, and drunke,ftoppeth the laske in $\mathrm{B}$ them that haue an ague, and into orhers in water.

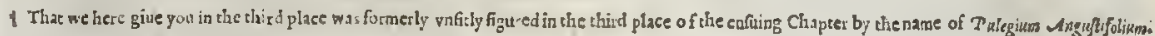

\section{С н Р. 221. Of Temie Royall, or pudding grafje.}

t I Pulcgium rcgium. Pennic Royal!

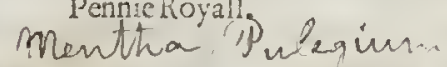
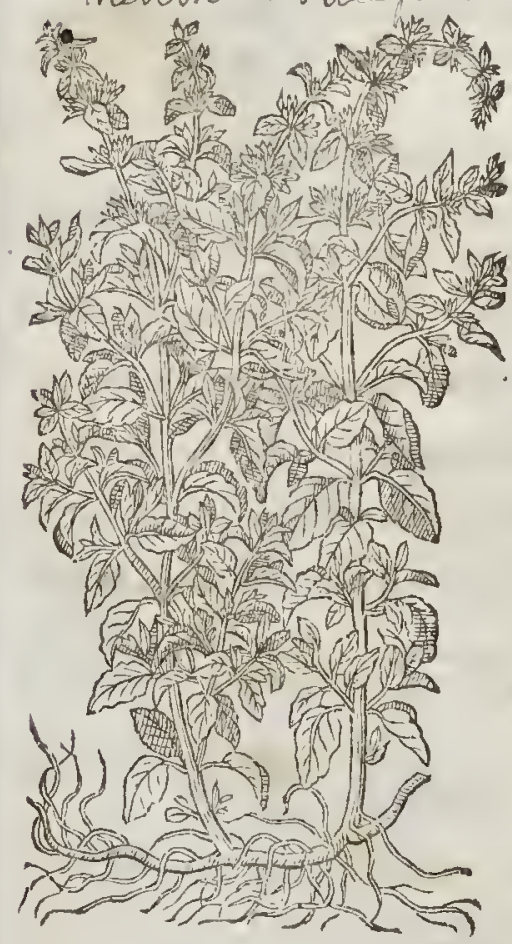

t2 Pulegisus mas.

Vpright Pennie Royall.

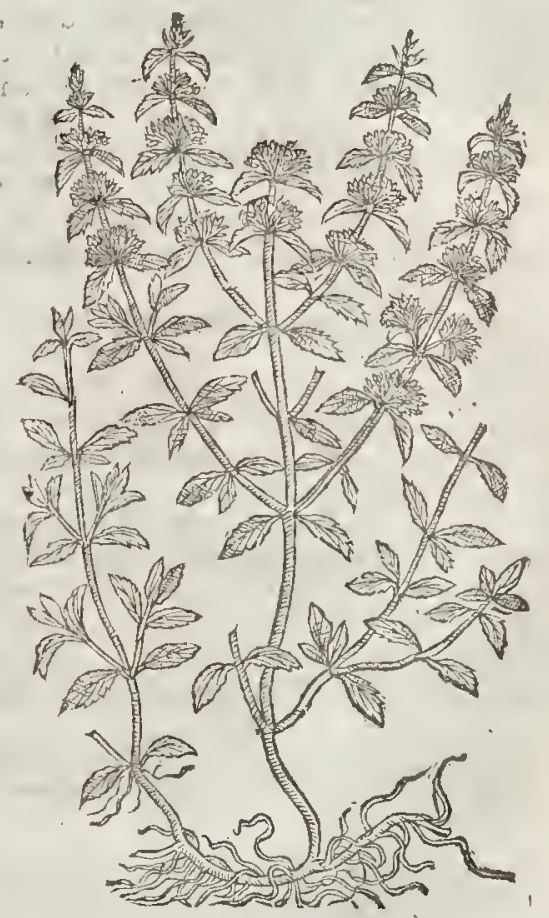

\section{Tा The Defeription.}

Drleginm regium valgatum is fo cxceedingly well knowne to all out Englith Nation, that 1 ic needeth no deferiprion, being our common Pennie Royall.

2. The feeond being the male Pennie Royall is like vnto the former, in feanes, flonres and finell, and differeth in that this male kinde groweth vpright of himfelfe withour creepings
muely like in thew vnto wilde Marierome. 
$t_{3}$ Pulegium angufifolium. Narrow leated Pennie Royall.

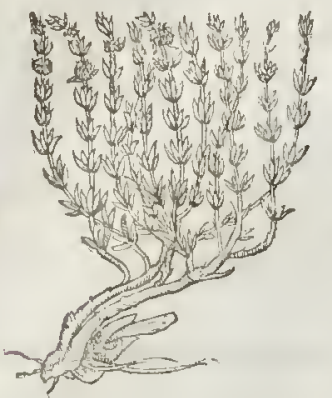

3 The third kinde of Pennie Troyall growes like vnto Tyme, and is of a wooddie fubrtance, fomewhat like vnto the thinne leafed Hyfope, of the fauour of common Pennie Royall, $¥$ but much ftronger and more pleafant: the longih natrow leates ftand vpon the ftalkes by couples, with litrle leates comming forth of theirbofomes : and towards the tops of the kranehes grow rundles of fnall puryle foures. This grows plentifully about Montpellier,and by the $\mathrm{Au}$. thors of the Aducrfaria, who firft fet it forth, it is ftiled Puleginm, anguffifol. fove cruinum Monfpelicnfium. Tf The Place.

The firt and eommon Pennic Royall groweth naturally wilde in moift and ouerflown places, as in the Common neere London called Miles end, about the holes \& ponds thereof in fundry places, from whence poore women bring plentie to fell in London markets ; and it groweth in fundrie other Commons necte London likewife.

The fecond groweth in my garden: the third I haue not as yer feenc.

$$
\text { बा The Time. }
$$

They floure from the beginning of Iune to the end of Auguft.

$$
\text { IT The Names. }
$$

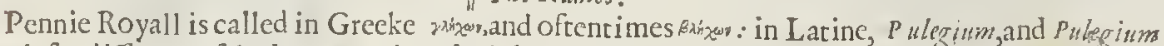
regalc, for differenee fake betweene it and wilde Tyme, which of fome is called Pulerium mont tarum: in Italian, Pule gio : in Spanih, Poleo: in Dutch, Pooley: in French, Pouliot : in Englith, Pennie Royall,Pudding graffe, Puliall Royall,and of fome Organic.

$$
\text { 9ा The 2Nature. }
$$

Pennie Royall is hot and drie in the third degree,and of fubtill parts, as Galer faith.

$$
\text { If The Vertues. }
$$

A Pennic Royall boiled in wine and drunken, pronoketh the monthly termes, bringeth forth the fecondine, the dead childe and vnnaturall birth : it pronoketh vrine, and breaketh tle ftone, efpecially of the kidneics.

B Pennie Royall taken with honie clenfeth the lungs, and clecreth the breaft from all grofle and rhicke humours.

C The fame taken witli honie and Aloes, purgeth by ftoole melancholie humours ; helpeth the crampe and drawing together of finewes.

D Tlie fame taken with water and Vineger affwageth the inordinate defire to romite, \& the pains of the fomacke.

E If you haue when you are at the fea Pennic Royal in great quantitie drie,and eaft it into comupt water, it helpeth it much, neither will it hurt them that drinke thereof.

F A Garland of Pennic royall made and worne about the head is of great foree againft the fwimming in the head, the paines and giddinefle thereof.

$G$ The decoetion of Pennie Royall is very good againt ventofitie, windineffe, or fuch like, and againft the hardnes \& ftopping of the morher being ved in a bath or ftew for the ry man to lit oucr.

I It is apparant by the eitles and defcriptions that our Anthour in this eha pt followed $L_{0}$ bel but the figures were not agreeabie to the hiftorie, for the two fir ft Ficures werc of the Pulegium Angufuf olum deferibed in the third places and the third fignte was of the Markm fupmum deferibed in the latt place of che foregoing
Chapeer.

\section{Cнар. 222. OfBaflll.}

\section{T) The Defcription.}

I Arden Bafill is of two forts, differing one from another in bigneffe. The firft lath J broat, thicke, and fat leaues, of a picafant fiveet fmell, and of which fonie one here and there are of a black reddifh colour, fomewhat fnipped about the edges, nor unlike the leaues of French Mcrcurie. The ftalke groweth to the he ight of halfe a cubite, diuiding it felf into diuers branches, whereupon doe ftand fmall and bafe floures fomerimes whitifh, and often tending to a darke purple. The root is threddie, and diecl at the approch of Winter. 
LI B. 2.

Of the Hiftory of Plants.

673

1 ucimmanminum.

Great Barill.

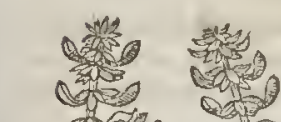

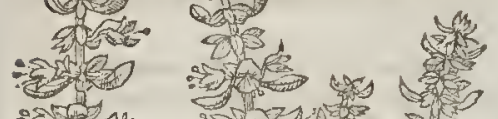
- है। a. I I 201 , n

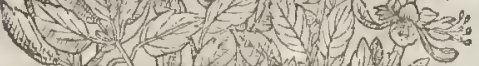

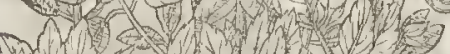

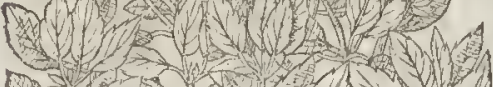
na $-2,1$ -

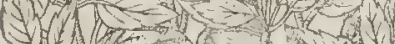

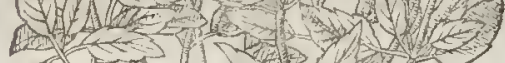
1. 12 - $2 x$

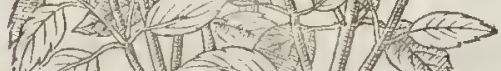

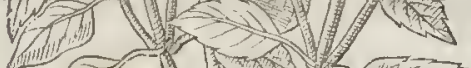

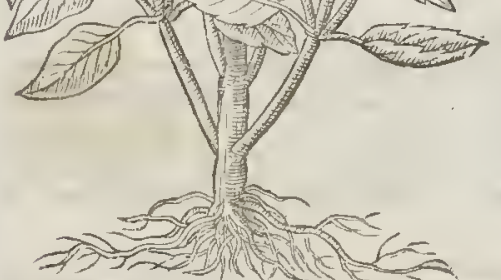

3 Ocimsum minus Gariophy lldum, Buh Bafill.

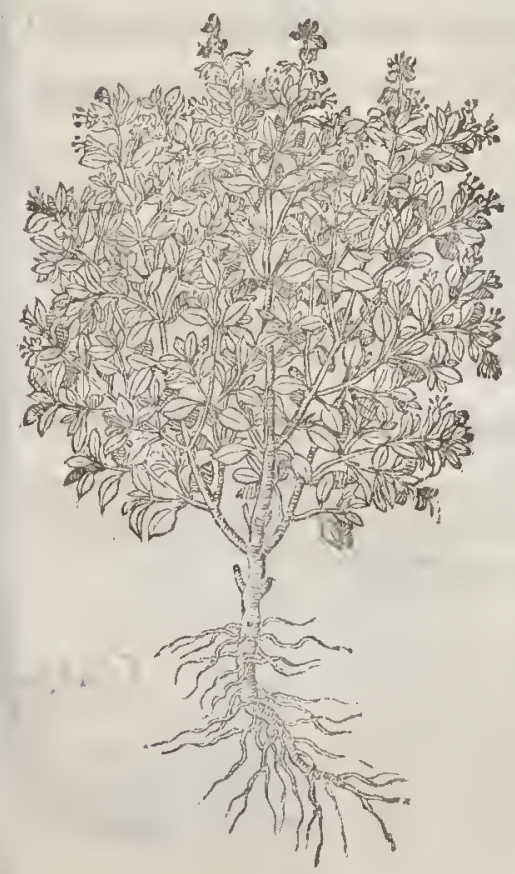

2 Ocinum medium citratam.
Citron $B$ alll.

$+$

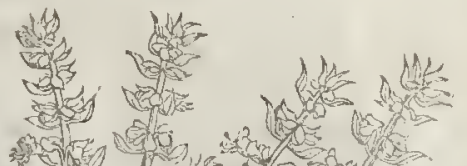

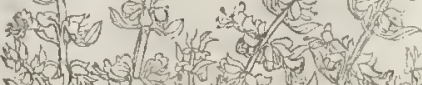

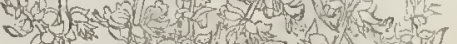

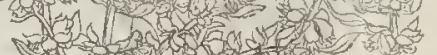

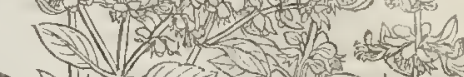
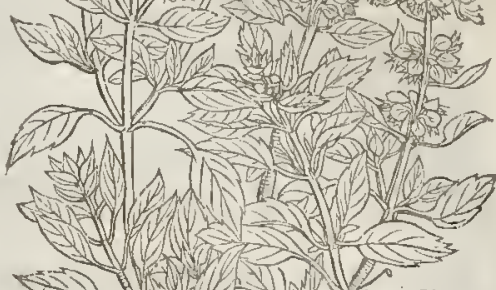

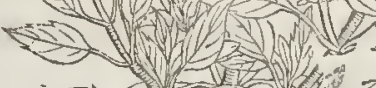
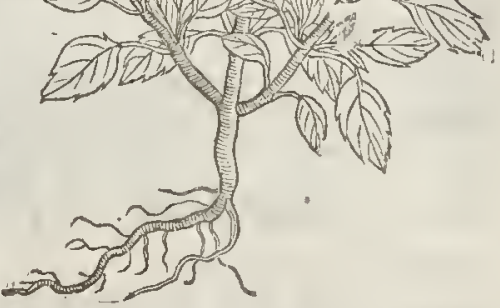

+ 4 ocimun Tidicum Indian Bafill.

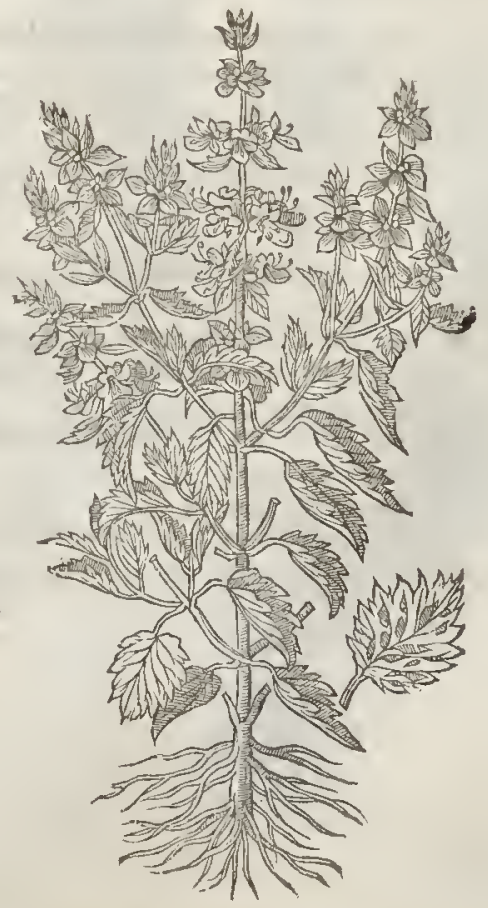


2 The middle Bafill is very like vnto the former, but it is altogether leffer. The whole plant is of a moft odoriferous fmell, not vnlike the finell of a Limon, or Citron, whereof it tooke his furrame.

3 Bufh Bafill, or fine Bafill, is a low and barfe plant, hauing a threddie root, frosh which rife vp many fmall and tender ftalks, branehed into diuers armes or boughes; whereupon are plaeed many little leates, lefter than thofe of Pennic Royall. The whole plant is of a moft pleafing fwecte fnell.

\$ 4 This whieh fome call ocimm Indicum, or tarher(as Camernius faith) Hifpanicum, fends spa ttalk a foot or more high, foure fquare, and of a purple colour, fet at eaeh ioint with two leates, and out of their bofomes come little branches: the largeft leaues are fome two inehes broad,and fome three long;growing vpon long ftalks, and deepely eut in about their edges, being alfo thieke, fat and inieie, and either of a darke purple colour, or elfe fpotted with more or lefle fueh eoloured fpots. The tops of the branehes end in fpokie tufts of white floures with ptirple veines running alongft them. The feede is contained in fuch feed veffels as that of the other Bafils, and is round, blacke and large. The plant perihes cuery yeare as foone as it hath perfected the feed.Clufius ealls this orimum Indicum, $\neq$

$$
\text { T) The Place. }
$$

Baftl is forne in gardens, and in earthen pots. It commeth vp quiekly, and loueth little moifture exeept in the middle of the day; otherwe if it be fowne in rainie weather, the feed will putrifie, and grow into a icllie or flime, and eome to nothing.

$$
\text { T The Time. }
$$

Bafill foureth in Iuneand Iuly, and that by little and little, whereby it is long a flouring, be: ginning firtt at tle top.

$$
\text { ๑1 The Nizmes. }
$$

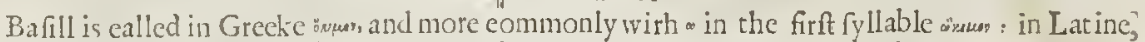
ocimmm. It differcth from ócymum whieh fome haue ealled cercale as we (faith Dodonerus) haue thewed in the Hiftorie of Graine. The later Graeians haue ealled it $\beta \times \pi \lambda_{i} * *:$ in thops likewife $B_{A-}$ flicum, and Regimm : in Spanihh, Albahacis: in Freneh, Baflic: in Englith, Bafill, garden Bafill, the grenter Bafill Royall, the leffer Bafill gentle,and buh Bafill : of fome, Baflicum Gariophyllatum, or Clone Bafill.

$$
\text { -1 Tlac Terinperature. }
$$

Bafill, as Galen teaeheth, is hot in the fecond degree, but it hath adioined with it a fuperflous moifture, by reafonwhereof he doth not like that it hould be taken inwardly; but being applied. outwardly, it is good to digeft or diftribute, and to eoneoct.

T T be Vertues.

A Diofcorides fairh that if Bafil be mueh eaten, it dulleth the fight, it mollifieth the belly, breedeth winde, prouketh vrine, driethvp milke, and is of a hard digettion.

$B$ The itriee mixed with fine meale of parehed Barly, oile of rofes and Vineger, is good againft in: f.ammations, and the ftinging of venomous bealts.

C The iuice drunke in wine of Clios or frong Saeke, is good againft head ache.

D The iuiee elenfeth away the dimmeneffe of the eyes, and drieth vp the humour that falleth into them.

E The feededrunke is a remedie for melancholicke people; for thofe that are fhort winded, and them that can hardly make water.

F If rhe fame be fnift vp in the nofe, it eaufeth often neefing : alfo the herbe it felfe doth rhe fame.

$G$ There be that fhunne Bafill and will not eat thereof, beeaufe that if it be ehewed and laid in the Sin, it ingendreth wormes.

$H$ 'They of A frieke doalfo affitme, that they who are ftung of the Seorpion and haute eaten of it; thall fecle no paine at all.

I The Later writers, among whom Simeon Zethy is one, doe teach, that the fmell of Bafill is good for the heart and for the head. That the feede eureth the infirmities of the heart; taketh away forrowfulneffew hiels comneth of melaneholy, and maketh a man merry and glad. 


\section{Cиат. 223. Of wilde Bafill. \\ 9) The Defoription.}

I THewilde Bafil or Acynos, called of Pina, Clinopodium vulg,ars, bath fquare hairie ftems, be: 1 fet with little leaues like vnto the fmall Bafil, but much fmaller, and more hairie, harp pointed, and a litcle fnipt towards the end of the leafe, with fmall foures of a purple colour, faihi oned like vinto the garden Bafill. The roor is full of hairie threds, and creepeth along the ground, and fpringerh pp yearely anew of it felfe withour fowing. $\neq$ This is the Clinopodiwn alterwm of Matthiolis. ‡

2 This kinde of wilde Bafill called amongt the Gracians axws,which by interpretation is Sine femine, or sterilis, hath caufed fundry opinions and great doubts concerning the words of plinie and Theophrastus, affirming that this herbe hath no foures nor feeds; which opinions I am fure of mine owne knowledge to be witlout reafon : but to omit controuerfies, this plant beareth purple floures, wharled about fquare ftalkes, rough leautes and hairie, verie like in mape vnto Bafil : $¥$ The ftalkes are fome cubite and more high, parted into few branehes, and fer at certaine fpaces with leaues growing by couples. This is rhe Clinopodium vuilgarc of cruatthiolus, and that of Cordus, Gefner, and others; it is the Acinos of Lobel. $\neq$

3 Serapio and orhers haue fer forth another wilde Bafill vnder the tirle of Molochis ; and Lobel after the minde of Iohn Brancion, calleth it Corcoros, which we have Englifhed, Eifh Bafill, the feeds whereof the faid Brancion receined from Spaine, faying that Corcoros Plinij hath the leaues of Ba fil: the ftalkes are two handfuls high, the floures yellow, growing clofe to the falkes, bearing his feed in fmal long cods. The root is eompact and made of an innumerable companie of ftrings, creeping far abroad like running Time. $¥$ This figure of Lobels which here we gite you is (as Camberarius hath obferued) vnperfeet, for it expreffes not the long cods wherein the feed is contained, neirher the two little frings or beards that come forth at the fetting on of each leafe to the falke. $\neq$

I Ocymum fylueftre. Wilde Bafill.

Thymers acinos.

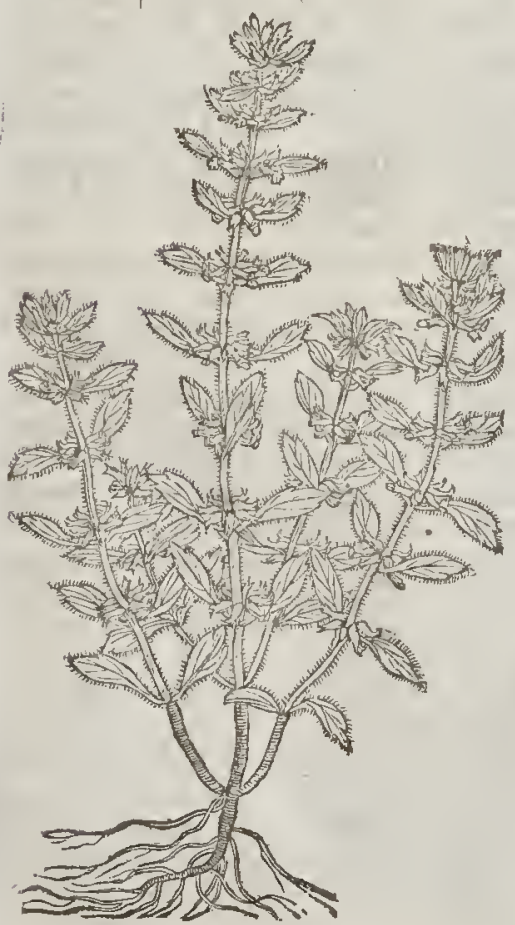

2 Acynos.

Stone Bafill.

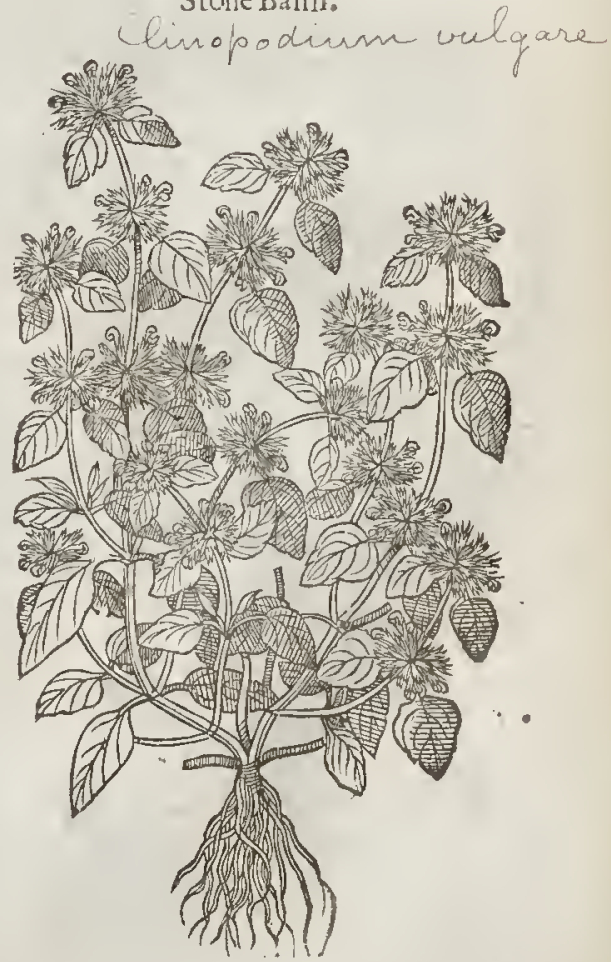

$4 \mathrm{Iz}$ 


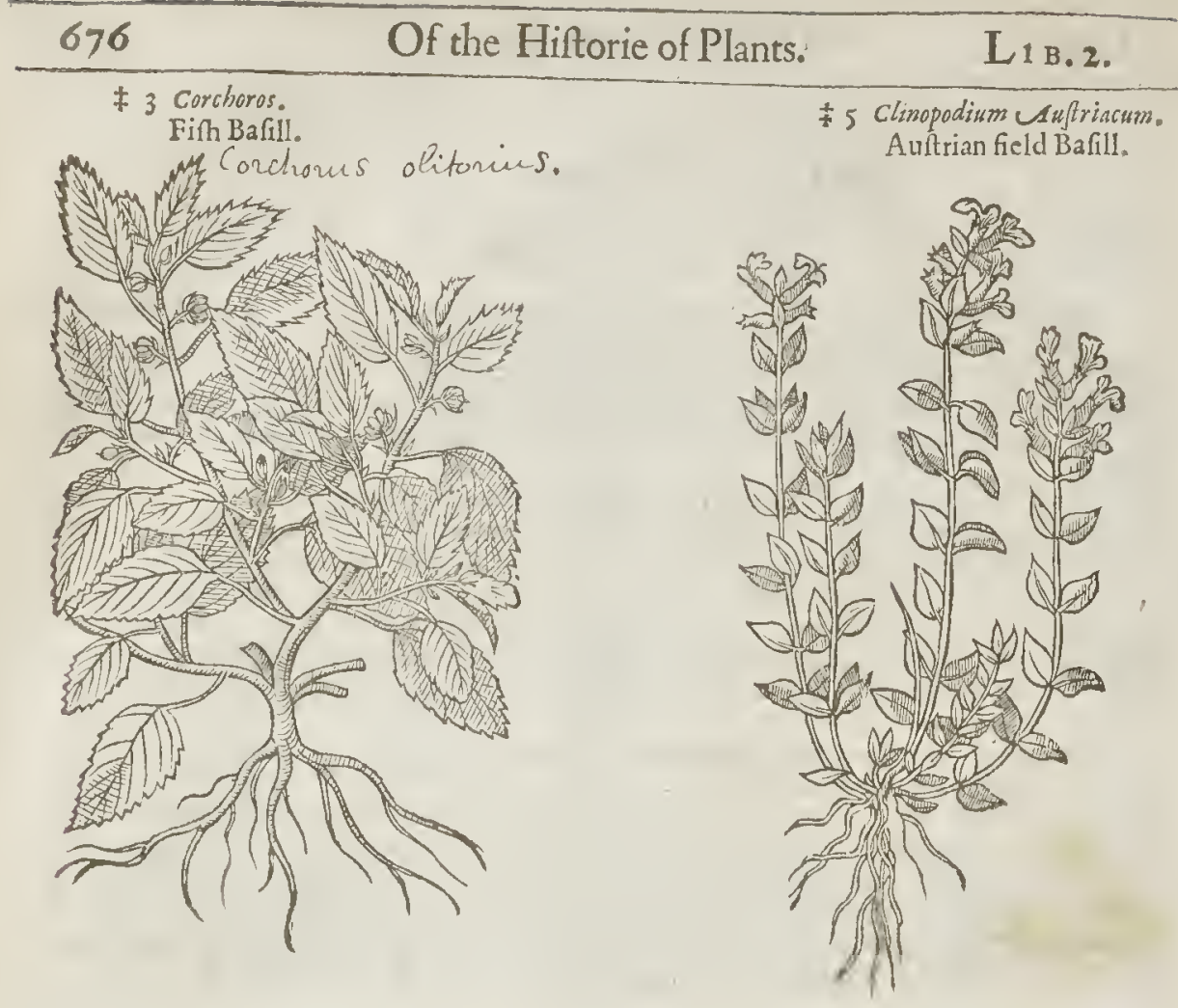

\$ 6 clinopodium Llpinsm. Wilde Bafill of the Alpes. Bastia alisin

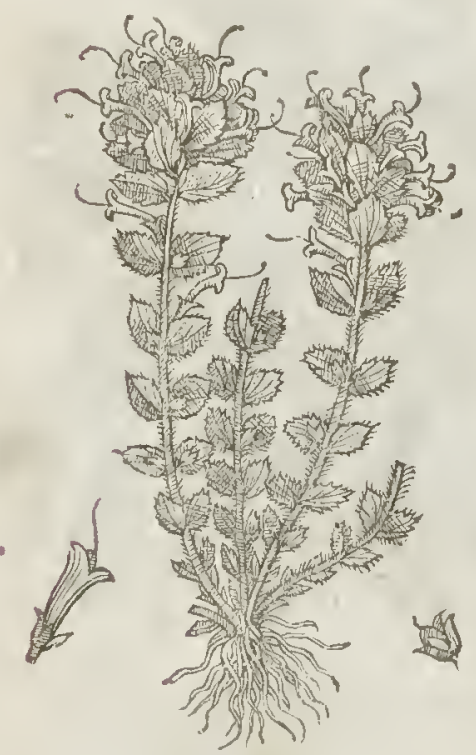

\# 4 It may be our Authour would haue deforibed this in the firft place, as I coniecture by thofe words which he vfed in mentioning the plaee of their growing; and [Clinopodium vulgare groweth in great plentie vpon Longfield downs in Kent; ] but to this neither figure nor deferip. tion did agree, wherefore I will giue you the $\mathrm{Hi}$ ftorie therof.It fends vp many little fquare ftalks fome handful and an halfe high,feldome diuided into branches: at each ioint ftand two fmal greenifh leaues, little hairy, and not diuided or fnipt about the edges, and mueh like thofe of the next deferibed, as you fee them expreft in the figure: the little hollow and fomewhat booded foures grow in roundles towards the tops of the ftalkes, as in the firtt deferıbed, and they are of a blewinh violet eolour. The feeds I haue not yet obferued: the root is fibrous and wooddie, and lafts for many yeares. The wholeplant hath a pretty pleafing but weake fmell. It foures in Iuly and Augurt. I firft obferued it Amo 1626 , a little on this fide Pomfret in Yorkthire, and fince by Datford in Kent,and in the Ile of Tenet. I haue fometimes feene it brought to Cheaplide market, where the herbe women called it Poley mountaine, fome it may bee that have taken it for Polium montanum milinforming them ; Cluf fus firft tooke notice of this plant, and called it Acinos Anglicum, finding it growing in Kent, Anno, 158 r.and he thinkes it to 
be the Acinos of $D$ iof cordes: now the verties attributed by Diof corids to his Acinos are fer downe at the end of the chaprer vnder the letter $B$.

5. This whieh clufus hath alfo fet forth by the ane efclinupga. muely differ from the laft defcribed, for it hath tender fquarc hard ftalkes like thofe of the laft deferibed, fet alfo with tivo leaues at each joint, heere and rbere a little fript (which is omitred in the figure) the floures grow onely at the tops of the lalkes, anc thefe pretiy large, ard of a violet eoloir (yet they are fometimes found white:) they hang eonimonly forvard, and at is were with there vpper parts turned downe. The feed vefiels are like rhofe of the firit deferibed, and containe each of them foure little blicke feeds: This foures in May, and the feed is ripe in Iune: It growes about the bathes of Badon aud in diuers places of Auftria.

6 Pena alfo hath giuen vs knowledge of another, that from a fibrous root fends vp many quadrangular rough branehes, of the height of the two former, fet alfo with two leates at each joint, and thefe rough and lightly fnipt about the edges; the foures grow thicke together at the tops of the falkes of a darke red eolour, and in thape like thofe of the mountaine Calaminte. It floures in the beginning of Iuly, and growes vpon mount Baldus in Italy; Pona fets it forth by the
name of Clinopodium Aipinum.

7 To thefe I thinke fit to adde another, whofe defcription was fent me by $\mathbf{M}^{\mathrm{r}}$. Goodyer, and I queftion wherher it may not be the plant which Falius Columna Phytobafani, pag: 2 ?. Fets fotth by the name of Acinos Diofcoridis; for he makes his to be enclued olore fragramisimo:but to the purpofe.

\section{Acinos odoratißimum.}

This herbe hath foure, fiue, or more, foure fquare hard wooddy talkes growing from one root, diuided into many branches, couered with a fof twhite hairinefle, two or three foor long or longer, not growing vpriglt, but trailing vpon the ground; the leates grow on littlethort foor ftalkes by couples of a light greene colour, fomewhat like the leaues of Bafill, very like the leaues of $\mathrm{Aci}$. nos Lobcly, but fmaller, about three quarters of a ineli broad, and not fully an incli long, fomewhat tharpe pointed, lightly notehed about the edges, alfo couered with a light foft hoary hairineffe, of a very fweete fmell, little inferiour to Garden Marjerome, of a hot biting tafte : out of their bofomes grow other fmaller leaues, or elfe branches; the floures alfo grow forth of rhe bofomes of the leaues toward the tops of the ftalkes and branches, not in whorles like the faid Acinos, but hauing one little fhort foot talke growing forth of the bofome of each leafe, on which is pla ced three, foure, or more fmall foures, gaping open, and diuided into foure vnequall parts at the top, like the foures of Bafill, and very neare of the likeneffe and bigneffe of the Houres of Garden Marjerome, but of a pale blewith colour tending towards a purple. The feed I neucr obferued by reafon it floured late. This plant I firft found growing in the Garden of Mr. William $\Upsilon_{\text {alden }}$ in Sheete neere Peterffield in Hampthire, Anno 1620 . among f fiveete Marjerome, and which by chanee they bought with the feedes thereof. It is tobe confidered whether the feedes of fiveete Marjerome degenerate and fend forth this herbe or not. I1. Oetsber, I 62 I. Iobn Goodyer. 1

\section{T) The Place.}

The wilde kindes doe grow vpon grauelly grounds by water fides, and ef́peeially I found rle three laft in the barren plaine by an houfe in Kent two miles from Dartford, ealled Saint Ioncs, in a village called Sutton; and Clinopodium vulgare groweth in great plontic vpon Long fielu downes in Kent. $¥$ One of the three laft of our Authors defeription is onitted, as you mav finde noted at the end of the chapter : yet I cannot be perfuaded that euer he found any of the foure he deferibed ener wilde in this kingdone, vnleffe the feco.sd, which growes plentifully in Autumne almoft by cuery hedge : alfo the fourth being of my defeription growes neere Durtford and in ma. ny fueh dry barren places in fundry parts of the kingdome. $\neq$

Thefe herbes foure in Iune and ItIly.

$$
\text { of The Time. }
$$

Vnprofitable Bafil, or wilde Bafill is ealled by fone Clinopodium.

बा The Nature.

The feed of the fe lierbes are of eomplexion liot and dry.

$$
\text { of The Vertues. }
$$

Wilde Bafll pound with wine appeafetl the paine of the eyes, and the juice doth mundifie the A fume, and putteth away all obfeurity and dimneffe, all catarrhes and flowing humors that fall into
the eies, being often dropped into the fame. 


\section{8 \\ Of the Hiftory of Plants.}

L 1 B. 2.

B plied it helper hot Tumors and inflammarions.

$\ddagger$ Thefe plants are good for all fueh effects as require moderate heateand aftriction. ‡

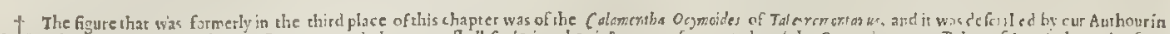

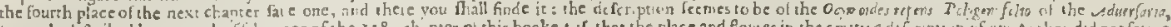

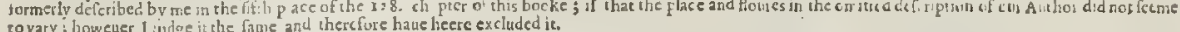

\section{С н в. 224. Of Bafill Vallerian.}

T The Defoription.

I

THe firft kinde of ocymaft rum, ealled of Dodonews, Folcrimarulra, bringeth forth long and brittle ftalkes two eubits higl, full of knots or joints, in whicl place is joined long leatues mueh like vinto great Bafill, but greater, broader, and larger, or rather like the leaues of Woade. At the top of the falkes do grow very pleafant and long red foures, of the fafhion of the Goures of Valcrian, which hath eaufed Docivaus to eall this plant red Valerian; which being yaft, the feedes are earied away with tle winde being, few in number, ard litte in quantity, fo that without great diligenee the feed is not to be gatherco or preferued : for my felfe liane often inderoured to fee it, and yet haue lof my labour. The roote is wry thiek, and of an excellent fwecte fanour.

I Valcriana vubra Dodonsi. Red Valerian. laleriana rulia

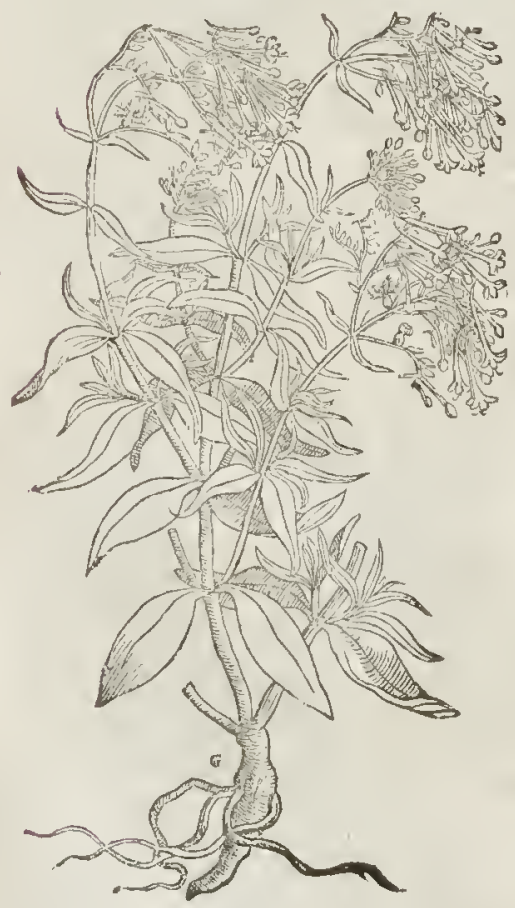

2 Behen album.

Spatling poppy.

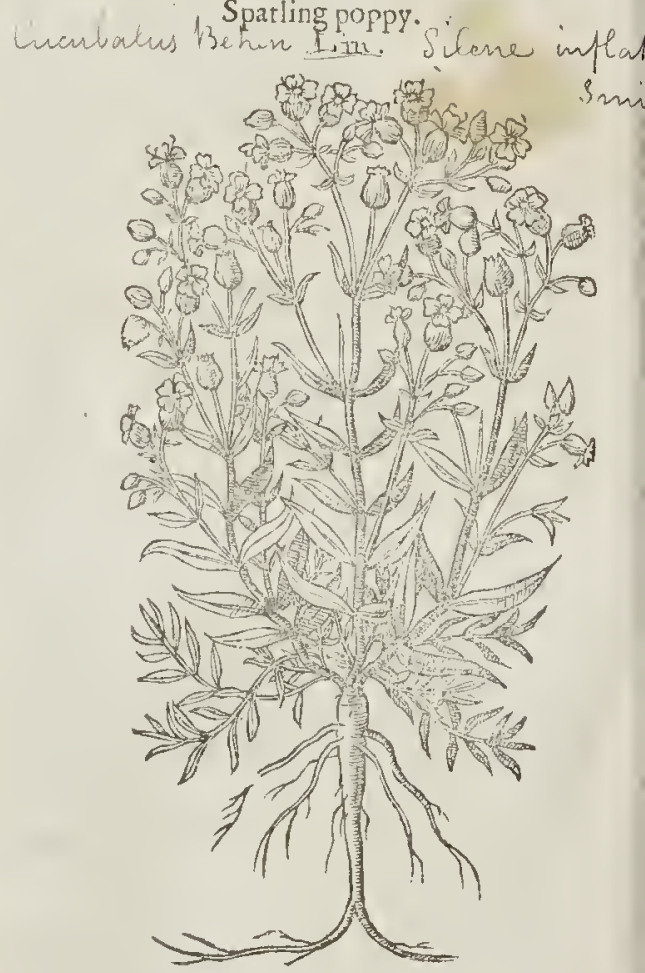

2 The fecond is taken for Spumeumpapaser, in refpeet of that kinde of frothy fpartle, or fpume, which we eall Cuekow fpittle, that more aboundeth in the bofomes of the leaues of thefe plants, than in any other plant that is hnowne: for which eaufe Pena ealleth it Papaver foumerm, that is, frotlyy, or fpatling Poppy $:$ his floure doth rery little refemble any kinde of Pofpy, but onely the feede and eod, or bowle wherein the feede is contained, otherwife it is like the orher 0 cymn- 
frum : the floures grow at the top of the ftalkes hanging downewards, of a white colour and it is taken generally for Behen album : the roote is white, plaine, and long, and very tough and hard to
breake.

$$
\text { The Place. }
$$

The firft groweth plentifully in my garden, being a great ornament to the fame, and not com. mon in England.

The fecond groweth almoft in euery palture.

$$
\text { बा } T \text { be Time. }
$$

Thefe plants do floure from May to the end of Auguit.

$$
\text { T) The Names. }
$$

Red Valerian hath beene fo called of the likeneffe of the floures and fpoked rundles witl Valerian; by which name we had rather haue it called, than rafly to lay vpon itan vnproper name. There are fome alfo who would haue it to be a kinde of Beben of the later Herbarifts, naming the fame

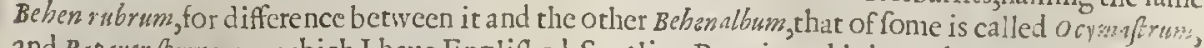
and $P$ apauer purnew $:$ which I haue Englifhed, Spatling Poppie; and is in truth another plant,much differing from Bchen of the Arabians: it is alfo called Valerianthon, Saponaria alter a, Struthium Aldroandi, and Condurdum : in Englifh,red Valerian,and red Cow Bafill.

Spat ling Poppie is called Behen album, ocymaftrum alterum; of fome, Polemonium, and Papauer ßumeum : in Englih, Spatling Poppic, frothic Poppic, and white Ben.

Thefe plants are drie in the fecond degree.

$$
\text { T The Nature. }
$$

9. The Veriues.

The root of Beben Album drunke in wine, is good againft the bloudic fluxe : and beeing pound leates and floures, and laid to, cureth the ftingings of Scorpions and fuch like venomous beafts; infomuch that who fo doth hold the fame in his hand, can receiue no damage or hurt by any veno. mous beaft.

The decotion of the root made in water and drunke, pronoketh vrine, it helpeth the ftrangutie, $B$ and paines about the backe and Huckle bone.

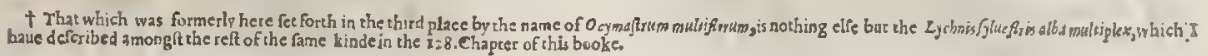

\section{Cha. 225: Of vints.}

बा The Kindes. Here be diuers forts of Mints; fome of the garden; other wilde, or of the field; and alfo fome
of the water.

$$
\text { IT The Difeription. }
$$

I The firft tame or garden Mint commeth vp with ftalkes foure fquare, of an obfeure red colour fomew hat hairie, which are coured with round leatres nicked in the edges like a. faw, of a deepe greene colour : the floures are little and red,and grow about the ftalkes circle-wife, as thofe of Pennie Royall : the roote creepeth aflope in the ground, hauing fome frings on it, and now and then in fundry places it buddethout afref : thewhole herbe is of a pleafant fmell,and it rather lieth downe than itandetl vp.

2 The fecond is like to the firft in hairic ftalkes fomething round; in blackifh leaues, in creeping roots, and alfo in fmell, but the floures do not at all conpaffe the ftalkeabout, but ftand vp in the tops of the branches being orderly placed in little eares, or rather catkines or aglets.

3 The leaues of Speare-Mint are long like thofe of the Willow tree, butwhiter, fofter, and more bairic:the floures are orderly placed in the tops of the ftalks, and in ears like tho fe of the fecond. The root hereofdotl alfo creepeno otherwife than doth that of the firft, wnto which it is like.

4. There is another fort of Mint which hath long leaues like to the third in ftalks,yet in leaues and in roots leffer; but the floures hereof ftand not in the rops of the branches, but compaffe the ftalks about circle-wife as do thofe of the firft, which be of a light purple colour.

$¥ 5$ This hath round leaues broader than the common Mint, rounder alfo, and as crifp or curled as thofe defcribed in the fecond place (of which it feemes but a larger varietie;) the ftalkes are

$$
\text { L } 112
$$


$\mathrm{L}_{1 \text { B. } 2}$.

+ I Mentbafativarubra. Red Garden Mints. Manthe ubia.

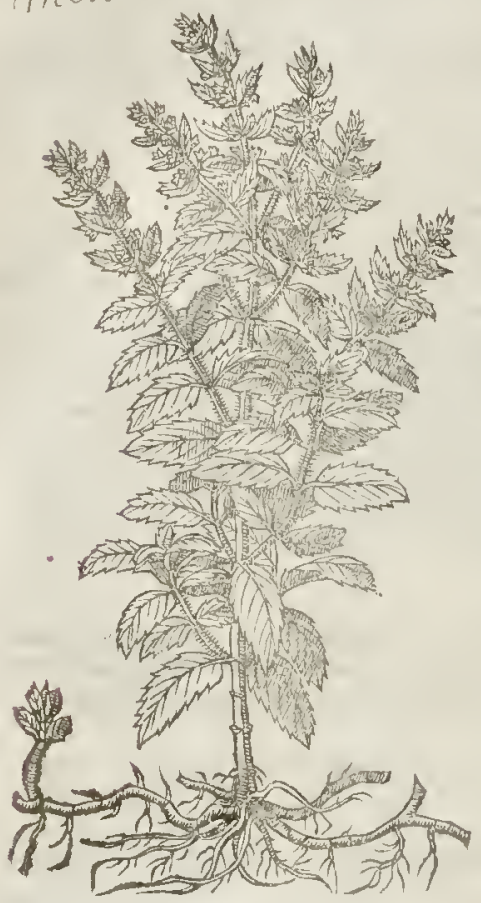

+ 3 Mentha Romana. Whentha Speare Mint.

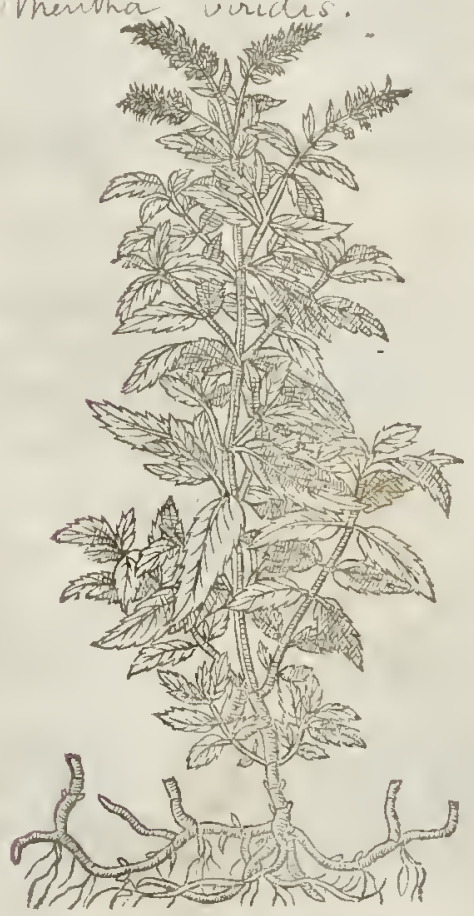

† 2 Mentha cruciata, foccripa. Croffc Mint, or curled Mint:

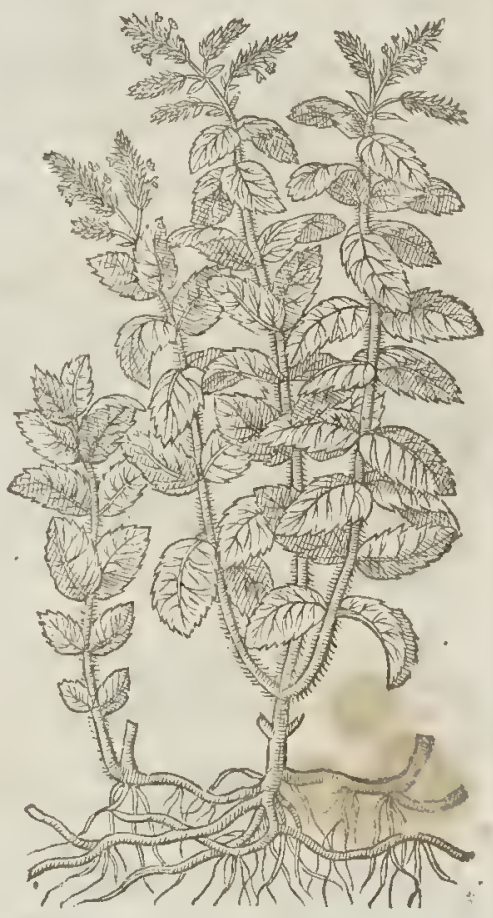

\$ Mentha Cardinca.

Ni: tha grarielis. Var. $\gamma$.

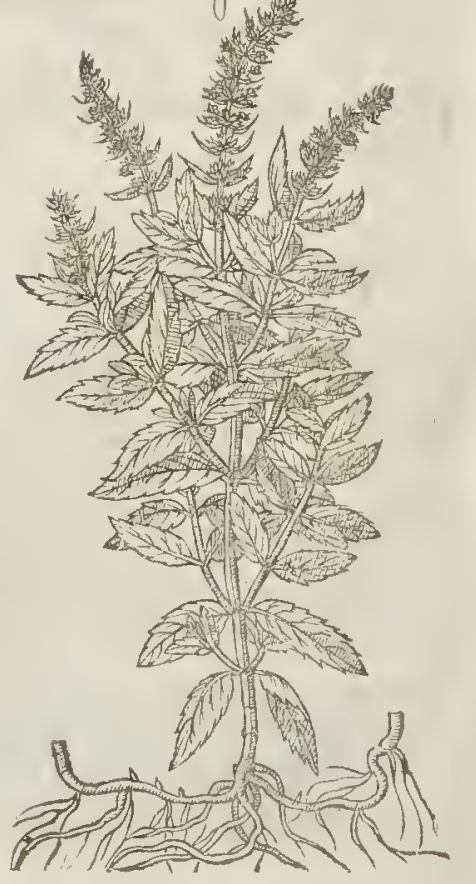




\section{‡ Mentbapicats allera. Balfam Mint.}

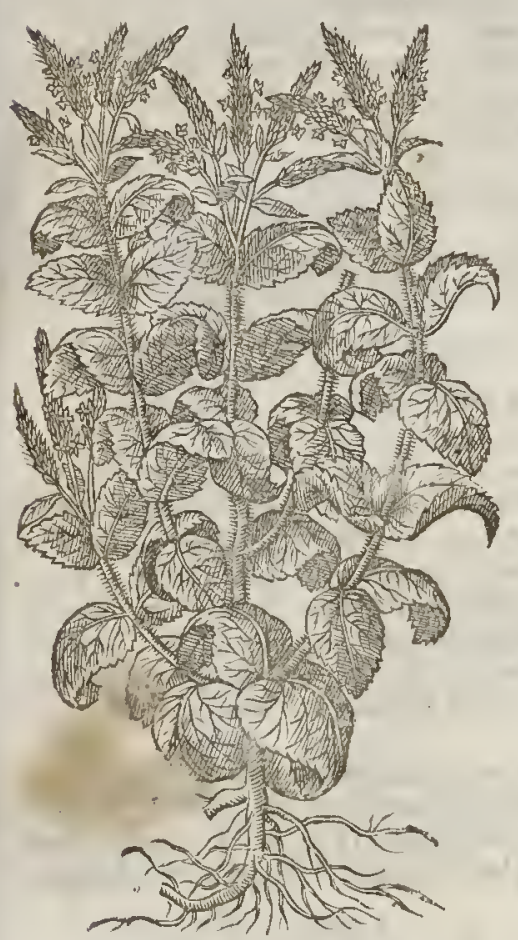

fou re fquare, and the floures grow in eares or fpokie tufts, like thofe of the fecond: $\neq$ of The Place.

Moft vfe to fet Mints in Gardens almoft euery where.

$$
\text { 9) The Time. }
$$

Mints do floure and flourifh in Sommer, in Winter the roots onely remaine : being once fet they continue long, and remaine fure and faft in the ground.

$$
\text { 9ा The Names. }
$$

Mint is called in Greekcisiogus and $\mu$ urvi: the fircet fmell faith Pliny in his 19 .booke cap.8. hath changed the name among the Grxcians when as otherwife it fhould be called Mintba, from whence our old writers hauc deriued the name: for wos fignifieth fweet, and i $\tau_{\mu u s}$ fmel: The Apotheearies, Italians, and French men, do keepe the Latine name Merstbs: the Spaniards do call it Ycrua buen, and ortelana: in

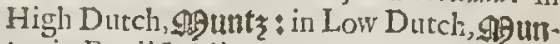
te: in Englifh, Mint.

The firt Mint is called in High Dutch, Doiement : in Low Duteh, 2Btupn herliobe? he that would tranflate it into Latn,muft call it Sacra nigricans, or the holy blackifh mint: in Englifh, browne Mint; or red Mint.

The fecond is alfo called in High Dutch

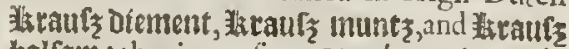
balfam: that is to fay, crenthacruciala: in French, Beaume crefpr : in Englifh, CroffeMint, or curled Mint.

The third is called of diners Menthas Sarracenica, Mentha Romana: it is called in High Dutch 23alfam munt, DD tha anguffifolia : that is to fay, Mint with the natrow leate: and in Englinh, Speare Mint, common garden Mint, our Ladies Mint, browne Mint, and Maerell Mint.

The fourth is called in High Duteh Yetrtzktaut, as though itwere to bee named Cardiaca, or Cardeaca Mentha : in Englith, Hart-woort, or Heart-mint $\ddagger$ This is the Sifymbrium fativum of $M$ atthiolus, and Mentha bortenfis alter of Gefrer. the Italians call it Sijembrio domeffico, and Balformita; the Germanes, wataenbaltam, $\ddagger$

\section{Tा The Temperature.}

Mint is hot and drie in the third degree. It is faith Galen, fomer hat bitter and harh, and it is inferiour to Calamint. The fmell of Mint, faith Pliny doth fir vp the minde, and the tafte to a greedy defire to meat.

$$
\text { 9 The Iertues. }
$$

Mint is maruellous wholefome for the ftomacke, it faieth the Hickets parbraking, vomiting \& 'A fcowring in the Cholerike paffion, if it be taken with the itiec of a foure pomegranate.

It ftoppeth the eafting vp of bloud, being giuen with water and vineger, as Galen teaeheth. B

And in broth faith Pliny, it ftaierh the foures, and is fingular good againft the whites, that is to $\mathbf{C}$ fay, that Mint which is defcribed in the freft place. For it is found by experience, that many haue had this kinde of flux faied by the continuall vfe of this oncly Mint: the fame being applied to the forchead, or to the temples, as Pliny teacheth, doth take away the headactic.

It isgood againft watcring cies, and all manner of breakings out in the head, and againft the in- D firmities of the fundament, it is a fure remedic for childrens fore heads.

It is poured into the eares with honie water. It is taken inwardly againft Scolopenders, Beare- E wormes, Sea-feorpions and ferpents.

It is applied with falt to the bitings of mad dogs. It will not fuffer nilke to cruddle in the fto- F macke (Pliny adderh to wax foure.) therefore it is put in Milke that is drunke for feare that thofe who haue drunke the tof fhould be ftrangled.

It is thought, that by the fame vertuc it is an enemy to generation, by ourthick ing the feed.

$$
1.115 \text { Difforides } \mathrm{G}
$$



H Dioforides teacheth, that being applied to the fecret part of a woman before the act, it hindreth
conception.

I Garclen Mint taken in meat or drinke warmeth and ftrengtheneth the ftomacke,and drieth vp all fuperfinous humours gathered in the fame, and cauferh good digeftion.

i Mints mingled with the leaues of parched Barly,confumeth tumors and hard fwellings.

L The water of Mints is of like operation in diuers medicines, it cureth the trenching and griping paines of the belly and bowels, it appea feth leadach, ftaieth yexing and vomiting.

$M$ It is fingular againft the grauell and ftone in the kidncies, and againft the ftrangurie, being boi-

N They lay it to the ftinging of wafpes and bees with good fucceffe.

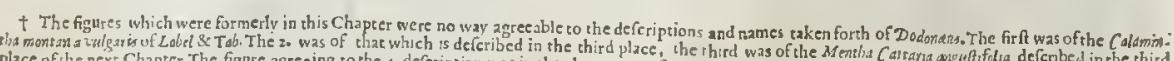

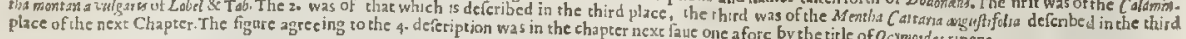
place of the next Chapter. The figure agreeing to the 4- defeription was in the chapter nexs faue one a forc by the ticle of o cymordes rupens.

\section{Сия г.226. Of Xep,or Cat oxint.}

I At Mint or Nep groweth high; it bringeth forth ftalks abouc a cubit long, cornered,

The Defcription. chamfered, and full of branches; the lea ues are broad, nicked in the edges like thofe of compaffe about the ppermoft fprigs, and partly grow on the very of whitin colour, they partly an care or carkin. herbe together with the leaues and parted, and ful of ftrings, and endureth a long time. The whole Horfe-mint; it is of a tharpe fmel, and pearceth into conered with a white downe, but leffer than tr neffe:

2 Our Authour figured this and defcribed the next inthe fecond place of this Chapter. This hath pretty large fquare ftalks, fet at each ioint with two leaues like thofe of Cofmary, but of a gray or outerworn colour: the floures grow at the tops of the ftalks in long fpokie tufts like thofe of the laft defcribed, and of a whitilh colour, the fmel is pleafanter than that of the laft defcribed.

Sepeta

$x$ Mentha Felimis fou Cattari.t. Nep; or Cat-mint.

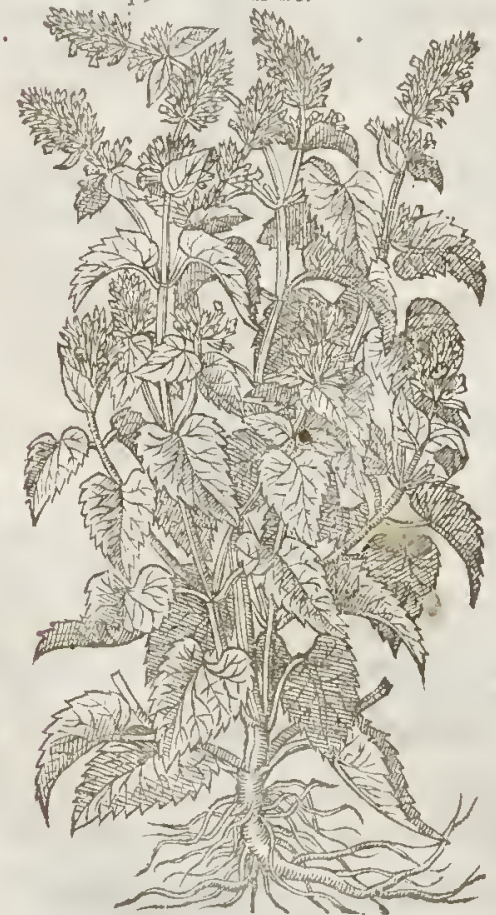

2 Mentha Cattarialtera. Great Cat-mint.

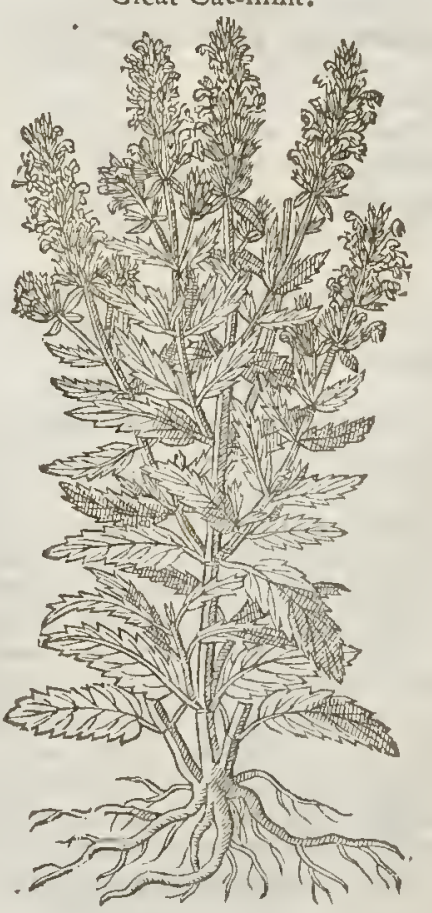


3 Thete is alfo another kind heteof that hath a longet and narrower leafe, and not of fo white a colour : the ftalkes hereof are foutc fquare : the floures be more plentifull, of a red lig ht pi:ple colour inclining to blew, fptinkled with little fine purple fpecks : the fmell hereof is ftronger, but the tafte is more biting. ₹ The figutc of this was formetly in the third place of the laft chapter. $\neq$

† 3 Merstha Cattaria anguftifolia. Small Cat-Mint.

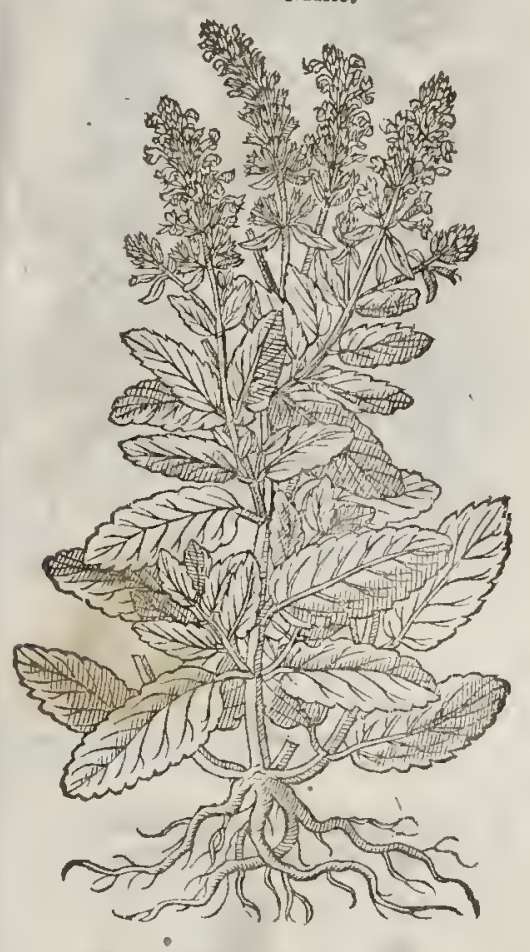

II The Place.

The firft growes about the botders of gardens and fields, neere to rough bankes, ditches, and common wayes : it is delighted with moift and waterie places: it is brought into gardens.

\# The othet too commonly grow in gardens with vs. $\ddagger$

$$
\text { T The Time. }
$$

The Cat-Mints flourion by and by afrer the Spring: they floure in Iuly and Auguft.

$$
\text { T) The Numes. }
$$

The later Herbarifts do cal it Herba Cattaria, and Herba Catti, becaufe the Cats are very much delighted herewith; for the fmel of it is fo pleafant to them, that they rub themfelues vpon it, and wallow or tumble in it, arid alfo feed on the branches and leaues very greedily. It is named of the A pothecaries Nepcta : but Nepeta is pto. perly called (as we hate faid) wilde Penny-roy-

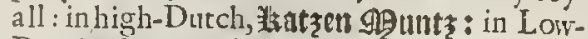
Dutch, Catte cruijit : in Italian, Gattaric, or herba Gatta: in Spanifh, Terwa Gatera : in Englifh; Cat Mint and Nep. $\neq$ The true Nepeta is Calds. mintha Pulegü odore. $\neq$

$$
\text { T The Temperature. }
$$

Nep is of temperature lot and dry, and hath the faculties of the Calamints.

\section{The vertues.}

It is commended againft cold paines of the $A$ head, ftomacke, and matrix, and thofe difeafes that grow of flegme and raw humots, and of winde. It is a prefent helpe for them that be burfen invardly by meanes of fome fall receitued from an high place, and that are very much bruifed, if the iuyce be giuen with wine or mede.

It is ved in baths and decoctions for women to fit outer, to bring dow ne their fickneffe, and to $B$ make them fruitfull.

\# It is alfo good againft thole difeafes for which the ordinarie Mints do ferue and are vfed. $\neq \mathbf{C}$

\section{С н Р. 227. Of Horje-Mintor Water - M Mint. \\ Ti The Defription.}

x T Ater Mint is a kinde ofwilde Mint, it is like to the firft GardenM int, the leaues thereof arc round, the ftalkes cornered, both the leatres and ftalkes are of a darke ted colour : the roots creepe far abroad, but enery part is greater, and the herbe it felfe is of a ftronget fmell : the floutcs in the tops of the branches are gathered together into a round eare, of a purple colour.

t 2 The fecond kinde of watcr Mint in each refpect is like the others, fauing that the fame hath a more odoriferous fauot being lightly touched with the hand : otherwife being hardly touched, the fauour is ouer hot to fmell vnto : it beareth his floures in fundry tufts or toundles ingirting the ftalkes in many places; and they are of a light purple colout : the leaines are alfo leffe than thofe of the former,and of an hoary gray colour.

\# 3 This common Hotfe-Mint hath creeping roots like as the other Mints, from which proceed italkes partly leaning, and partly growing vpright : the leaues are pretty large, thicke, wrinkled, 


\section{Of the Hiftorie of Plants: L $_{1 \text { в. } 2 .}$}

+ I Mentha aquatica, fue Sifymbrium. Water Mint.

Mentiu action..a.

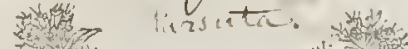
Tif 11, $\Rightarrow$ int $=0$

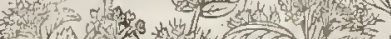

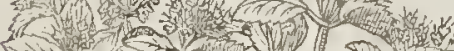

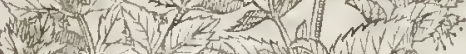

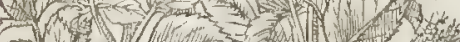

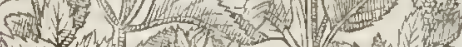

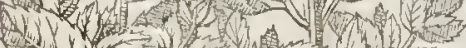

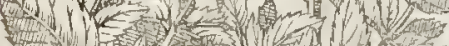

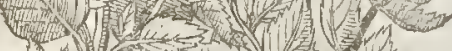

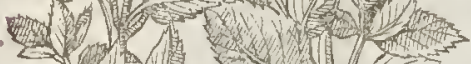
10. $\rightarrow-1 n$ (L) ID

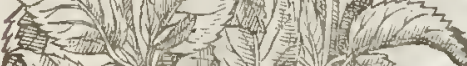

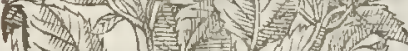

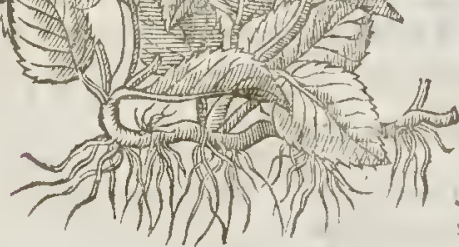

¥ cxentifirum. Horfe-Mint

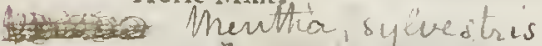

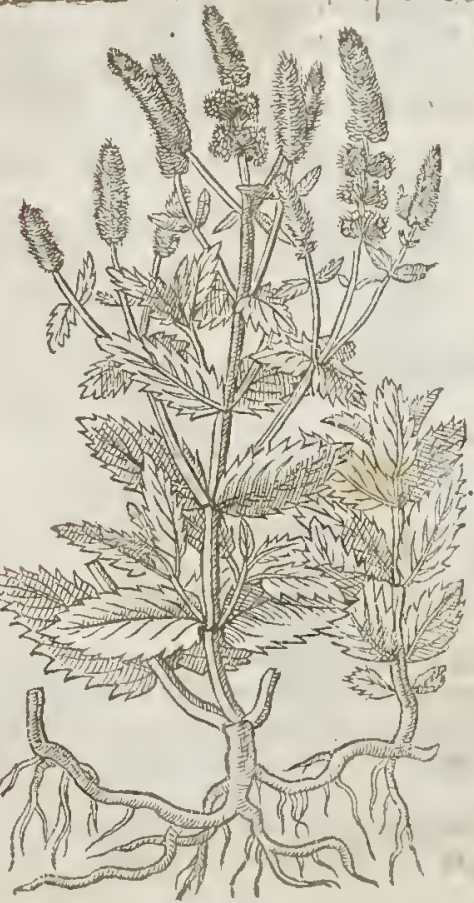

† 2 Calaminiha aquatica. Vater Calamint.

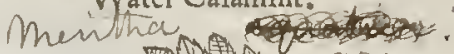

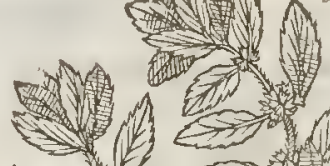
(1)

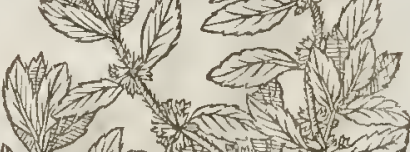

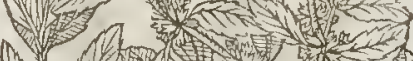
(1) in a D. N

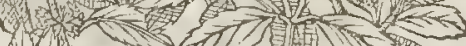

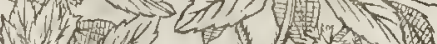
viver 51

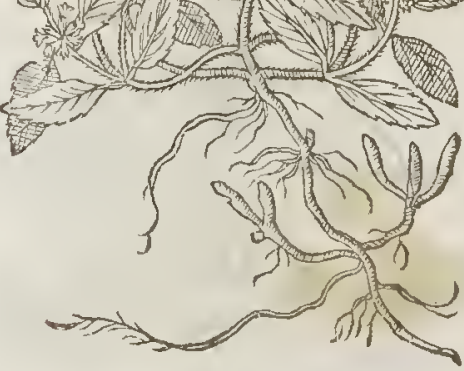

‡ Mentafrum niucum Anglicums.

Party coloured Horfe-Mint.

Muntha rotmoritolia. m.

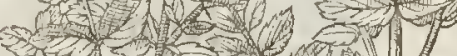

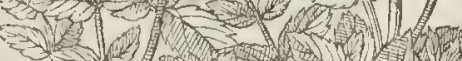

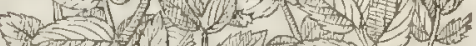

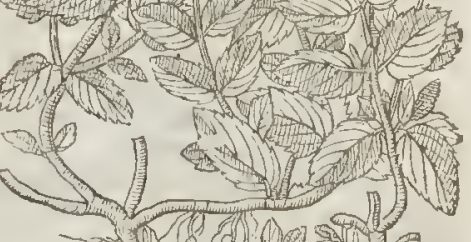
(2)

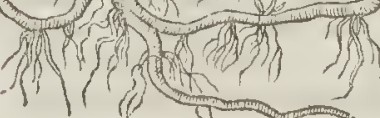


L 1 в. 2. Of the Hiftory of Plants.

685

\$5 Mentafrum minus.

Mnentwa Smorfe-Mint a)

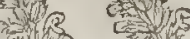
and a nith ofing var ant wo nen hing$$
\text { ant }
$$

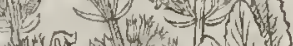
and

Aivio
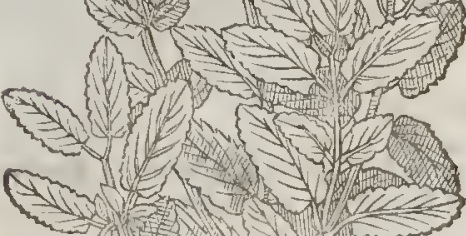

Niv

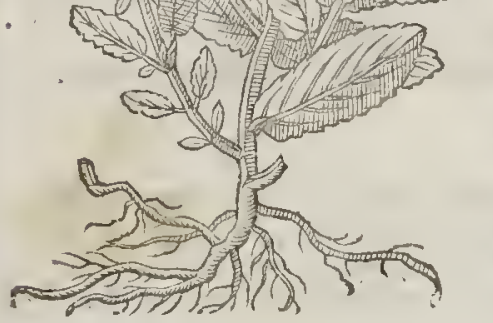

\$ 7 Mentaffrum tuberofaradice Clutip.

Turnep-rooted Horfe-Mint.

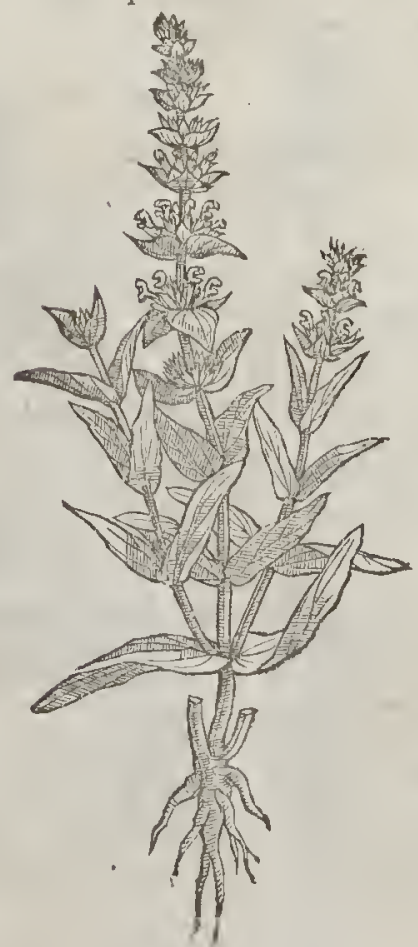

$\$ 6$ cMentuffrum montarium $\mathrm{r}$. Chufij. Mountainc Horfe-Mint.

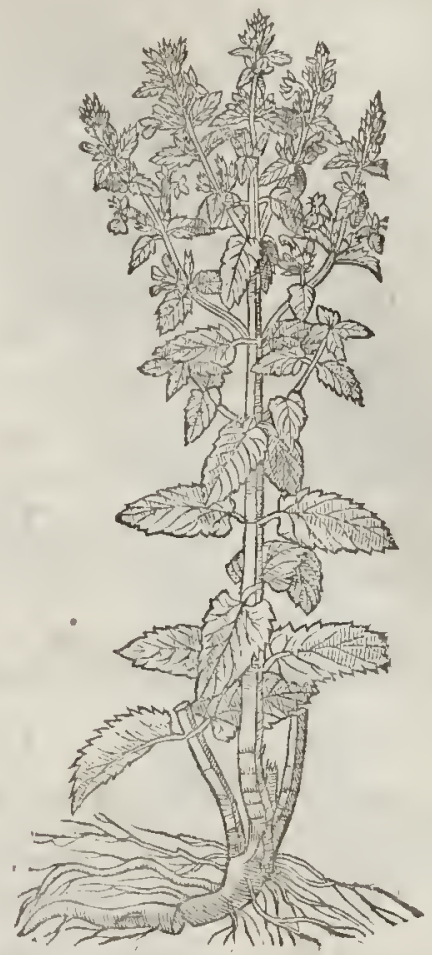

wrinkled, hoary and rough both aboue and be low, and lightly fnipped about the edges; the floures grow in thicke compact eares at the tops of the ftalks, and are like thofe of eommon Mint. The whole plant is of a more vnpleafant fent than any of the other Mints. It growes in ditiers wet and moift grounds, and floures in Iune and Inly. This by molt writers is called only Mentaftrum, without any other attribute.

4 In fome of our Englifh gardens (as Pena and Lobeb obferued) groives another Horfe-mint, much leffe, and better fmelling than the laft mentioned, hauing the leaues partly greene, and partly nilke white; yet fometimes the leaues are fome of them wholly whire, but more, and more eommonly all greene : the ftalkes, floures, and other parts are like thore of the former, bue leffe. This is the Mentaftrum niucum Anglicim, of Lobel; and Mentastrums alterum of Dodonases.

5 This growes inwaterie places, hauing a falke of a eubit or eubit and halfe high, fet with longith hoary leates likethofe of Horfe-mint: the Houres grow in fpokie tufts at the tops of the ftalkes, of a duskic purple colour, and in thape like thofe of the common Mint : the fmell of this eomes neere to that of the water Mint. This is the Mentaf rifolin aquatica birfuta, fune Calamintha 3. Diofcoridis, of Lobel: : in the biff. Lulug d. it is called Mentaforum minus picatum. 
6. The ftalke of this is fome cubit and halfe high, fquare, and full of pith : the leaucs are like in thape to thofe of Cat-Mint, but not hoarie, but rather greene: the tops of the branches ate fet with roundles of fuch white floures as thofe of the Cats-mint : the fmcll of this plant is like to that of the Horfe-Mint; whence Clufurs calls it Mentuftrum montanum primum. It floures in Auguft, and growes in the mountainous plaecs of Auptria.

7 The fame Author bath alfo fet forth another by the name of Mentaftrum tuberofa radice. It hath roughin falkes like the former, and longih crumpled leaucs fomewhat fnipt about the edges like thofe of the laft defcribed : the floutes grow in roundles alangft the tops of rhe branches, and are white of colour, and like thofe of $\mathrm{Cat}-\mathrm{Mint}$. The root of this (whieh,as alfo the leaues, is not well expreft in the figure) is like a Radith, and blackin on the out fide, fending forth many fuceours litie to little Turneps, and alfo diuers fibres : thefe fuccours taken from the maine roor will alfo take root and grow. It floures in Inne. Clufus receitued the feed of it from Spaine. $\neq$

$$
\text { g) The place. }
$$

They grow in moift and waterie places, as in medowes necre vnto ditches that hawe water in them, and by riuers.

T The Time.

They floure when the other Mints do, and retiue in the Spring.

The Names.

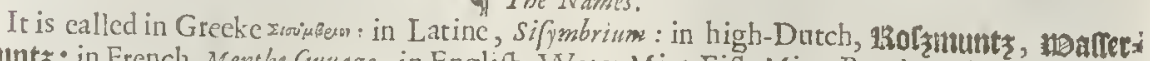
muntz: in French, Menthe fanduge: in Englifh, Water Mint, Finh-Mint, Brooke-Mint,and Horfe-
mint.

Water Mint is hot and dry as is the Garden Mint,and is

9 TheVertues.

A It is commended to haue the like vertues that the garden Mint hath; and alfo to be gooda: gainf the ftinging of Becs and Wafpes, if the place be rubbed therewith.

$B$ The fauour or fmell of the Water-Mint reioyceth the heart of man; for which caufe they vfe to ftrew it in clambers and places of recreation, pleafure, and repofe, and where feafts and banquets
are madc. C There is novfe hereof in pliyficke whileft we haue the garden Mint, which is fweeter, and more
agreeing to the nature of man.

$f$ The figure that wis in the firlt plice was of the Horfe-Mint, and that in the fecond place fhould have beene in the firft, as now it is.

\section{C н а P. 228. Of CMountaine Mint or Calamint. \\ IT The Defription.}

I Ountaine Calamint is a low herbe, feldome aboue a foot high, parted into many branches : the ftalkes are foure fquare, and haue ioynts as it were, out of etrery one whereof grow forth leaues fomething round, lefier than thofe of Bafill,couered with a very thinne hairy downe, as are alfo the ftalkes, fomwhat whitifh, and of a fweet fmell: the tops of the branches are gallantly deckt with floures, fomewliat of a purple eolour; then groweth the fecd which is blacke : the roots are full of ftrings, and continue.

2 This moft excellent kunde of Calamint hath vpright ftalkes a cubit high, concred oner with a woolly moffineffe, befetwith rough leaues like a Nettle, fomewhat notched about the edges among the leaues come forth blewilh or sky-coloured floures: the root is wooddy, and the whole
plant is of a very good fnell.

3 There is another kinde of Calamint which hath hard fquare ftalks, couered in like manner as the other with a eertaine houryor fine cotton. The leaues be in thape like Bafill, but that they are rough; and the floures grow in roundles toward the tops of the branches, fometimes three or foure vpon a ftemme, of a purplifh colour. The root is threddy, and long lafting.

t 4 There is a kinde of frong fmelling Calamint that hath alfo fquare falks coucred with foft cotton, and almoft creping by the ground, hauing enermore two leaues ftanding one againft and whiter: the fourcs the root is fmall and threldy : addition of Pulegï odore. 
T, в. 2. Of the Hiftory of Plants:

687

1 Colatsw. ntin montara vulgaris.

Calamint, or Mouncaine Mint.

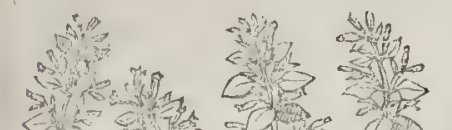

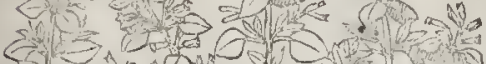

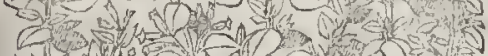

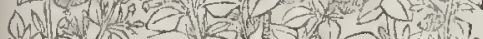

Sif a n

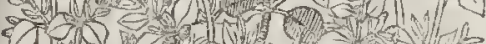

Den

Q 1 -

of f

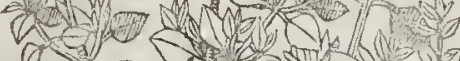

$0-3$ - 12 an

010 and

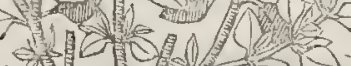

Ning

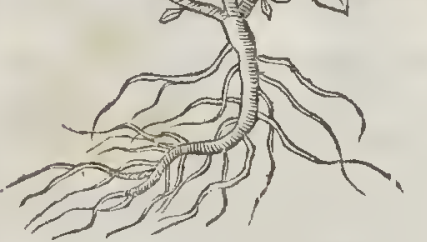

$+{ }_{3}$ Calamintba vul rar is officinarmo

Common Calamint.

thelifsa Calarmutha sen

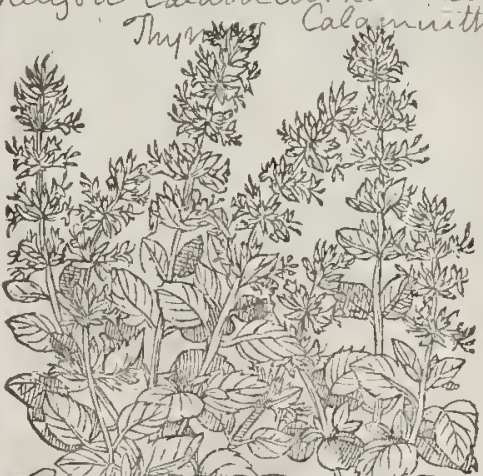

कीज

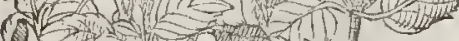

(2)

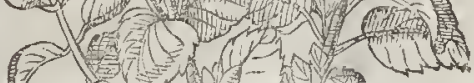

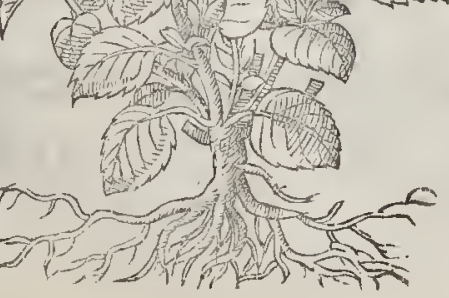

t 2 Calamintbamontanaprefantior. The more excellent Calamint.

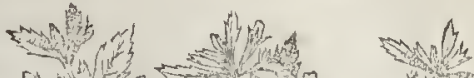

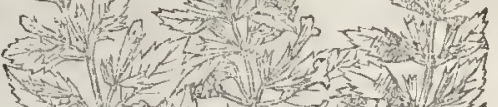

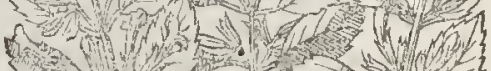

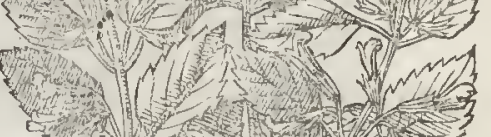

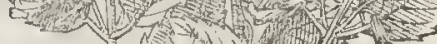

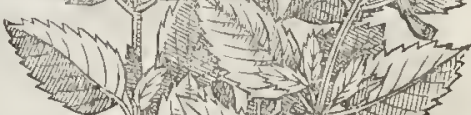

$\sum_{\rightarrow \rightarrow \infty}(1)+1$

-

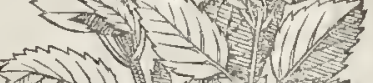

स्थातो)

z

(19)

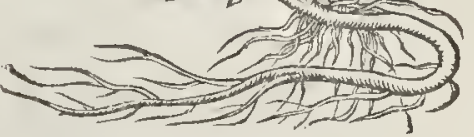

† 3 Calamixtha odore Pulgg̈̈.

Field Calamint.

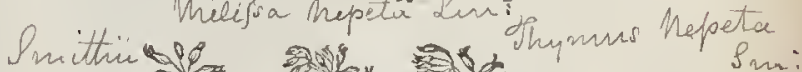

2.10\% w

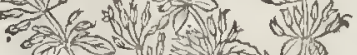

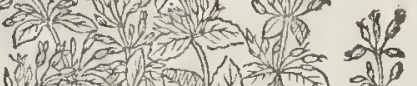
1. Uis Iivin

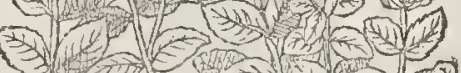

(1) $\rightarrow+2$ -

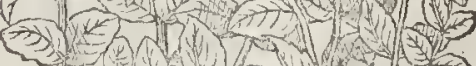
[0.

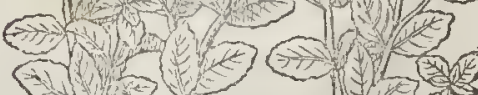

$\rightarrow 1,0$ का

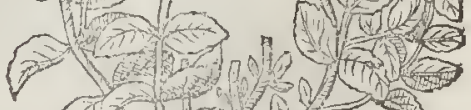

(2) (aij)

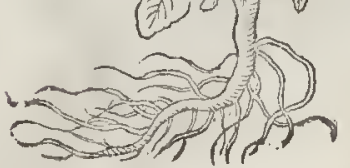


I The Place.

It delightetl to grow in mountaines, and in the hadowy and grauclly fides thereof : it is found in many places of Italy and Franec, and in other countries: it is brought into gardens, where it profpereth martiellous well, and very eafily foweth it felfe. I hauc found thefe plants growing vpon the clualkic grounds and highwayes leading from Graucfend vnto Canturbury, in moft places, or almoft euery where. $¥$ I hitue onely obferted the third and fourth to grow wilde wirh vs in England. $\ddagger$

$$
\text { q) The Time. }
$$

It flourifheth in Sommer, and almont all the yeare thorow : it bringeth forth floures and feed from Iune to Autumne.

$$
\text { ब The Names. }
$$

It is called in Greeke Kaxamirn, as though you thould fay, Elegans nut wtilis catemtha, a gallant or profitable Mint : the Latines keepe the name Calamintha : Apuleins alfo nameth it amiffe, cMentafrum, and confoundeth the names one with another : the A pothecaries call it CMontana Calamin. tha, Calamentum, and fometime Calamentum montanum : in French, Calment : in Englih, Mountain Calamint. $\neq$ The fourth is certainly the fecond Calamint of Drofrorides, and the true Nepeta of the Antients. †

$$
\text { T) The'Tempcratare. }
$$

This Calamint which groweth in mountaines is of a feruent tafte, and bicing, hot and of a thin fubstance, and dry after a lort in the third degree, as Galen faith : it digefteth or wafteth away thin humors, it cutteth, and make th thicke humors thin.

\section{The Verties.}

A Therefore being inwardly taken by it felfe, and alfo with meade, or honied water, it doth manifeftly heate, prouokech fweat, and confumeth fupertluous humors of the body; it taketh away the fhiuerings of Agues that come by fits.

B The fame alfo is performed by the fallet oyle in which it is boyled, if the body be anointed and well rubbed and chafed therewith.

C The decoction thereof drunke prouoheth vrine, bringeth downe the monethly ficlineffe, and expelleth the childe, which alfo it doth being but oneiy applied.

D It helpeth thofe that are bruifed, fuch as are troubled with crampes and convulfons, and that cannot breathe vnleffe they hold their neeks vpright (that haue the wheefing of the lungs, faitl $G a-$ $l(n)$ and it is a remedie faith Diofcoridss for a cholericke paffion, otherwife called the Felony.

E It is good for them that haue the yellow jaundice, for that it remoueth the ftoppings of the liuer and gall, and withall elenfeth : being taken aforc-hand in Wine, it keepeth a man from being poyfoned : being inwardly taken,or outwardly applied it cureth them that are bitten of Serpents: being burned or ftrewed it dritues ferpents away : it takes away black and blew fpors that come by blowes or dry beatings, making, the skin fare and white; but for fuch things (faith Galen) it is better to be laid to greene thandry.

F It killethall manner ofwormes of the belly, if it be drunk with falt and honey : the iuyce dropped into the eares doth in like manner kill the wormes thereof.

$G$ Pliny faith, that if the iuyce beconucyed vp into the nofthrils it fancheth the bleeding at the nofe; and the root (which Diofcorides writeth to be good for nothing) helpeth the Squincie, if it he gargarifed, or the throat wafhed therewith, being ved in Cute,and Myrte feed withill.

It is applied to thore that haue the Sciatica or ache in the huckle bone, for it drawes the humor from the very bottome, and bringeth a comfortable heat to the whole ioynt: $P$ aulus esigineta faith, that for the paine of the haunches or hucklebones it is to be vfed in Clyfters.

Being much eaten it is good for them that haue the leprofie, fo that the patient drinke whay after it, as Diofcorides witneffeth.

II Apuleius affrmeth, that if the leates be often eaten, they are a fure and certaine remedy againft the lenrofie.

L There is made of this an Antidote or compofition, which Galen in his fourth booke of the Gouernment of health deferibes by the name of Diacalamint bos, that doth not onely notably digeft or wafte aw ay crudities, but alfo is maruellous good for young maidens that want their courfes, if their botics be firft well purged; for in continuanc: of time it bringeth them downe very gently without force.

t The figure which formerly was in fise fecond place belonged to the fourth deferintion; and the figute thar belonged thereto was before falfy pat for the

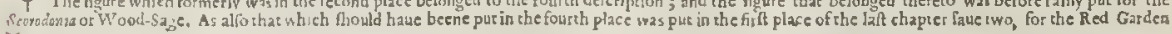
Mist. 


\section{Ch а р. 229. Of Banme.}

\section{The Defcription.}

I. Piaftrum, or Mrliffa, is our conmon beft knowne Balme or Bawme, hauing many fquare f alkes and blackifh leaues like to Ballote, or blacke Hore-hound, but larger, of a - pleafant fmell, drawing neere in fmell and fauour vnto a Citron : the floures are of a Carnation colour; the root of a wonddy fubftance.

2 The fecond kinde of Bawme was brought into my garden and others, by his feed from the parts of Turky, wherefore we lraue called it Turky Balme : it excelleth the reft of the kinds, if you refpect the fweet fauour and goodly beauty thereof, and deferueth a more liuely defcription than my rude pen can delituer. This rare plant hath fundry fmall weake and brittle futare talkes and branches, mounting to the height of a cubit and fomewhat more, befet with leaues like to Germander or Scordinm, indented or toothed very bluntly about the edges, but fomewhat tharpe poinred at the top. The floures grow in fmall coronets, of a purplith blew colour : the root is fmall and threddy, and dieth at the firft approch of Winter, and mut be fownc anew in the beginning of May, in good and fertill ground.

I Meliffa.

Bawme.

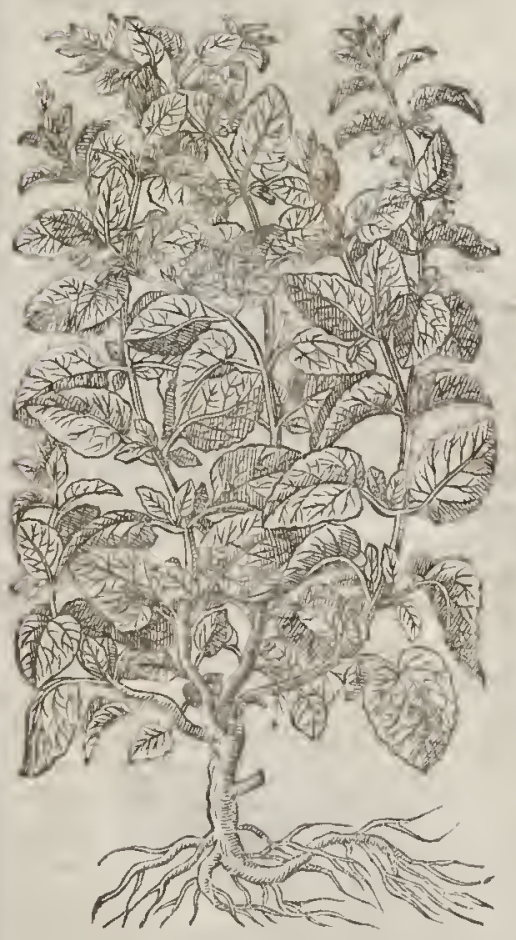

2 Melifa Turcica. Turky Bawmc.

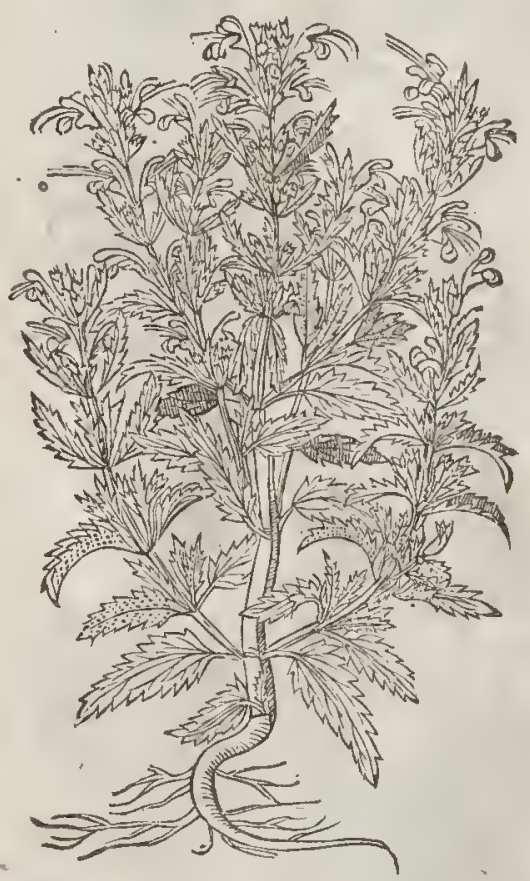

3 Fuchfius fetteth forth a kinde of Barme hauing a fquare falke, with leaues like vnto common Bawme, but larger and blacker, and of an cuill fauour; the floures white, and much grcater than thofe of the common Bawme; the root hard, and of a wooddy fub ftance. $\neq$ This varies with the leatres fomet imes broader and otherwhiles narrower: alfo the floures are commonly purple, yet fometimes white, and otherwhiles of diuers colours : the leaues are alfo fometines broader, otherwhiles narrower: wherefore I haue gitien you one of the figures of Cluf furs, and that of tobel, that you may fee the fetrerall expreffions of this plant. Clufurus, and afrer him Bauhine, referre it to the Lamium, or Arch-angell : and the former calls it Lamium Pasnonicum : and the later, Laminn montanum Melijfrefolio. $\neq$

4 There is a kinde of Bawme called Herba Iudaica, which Lobcl calles Tetrabit, that hatb many. $\mathrm{Mm} \mathrm{m}$ treake 


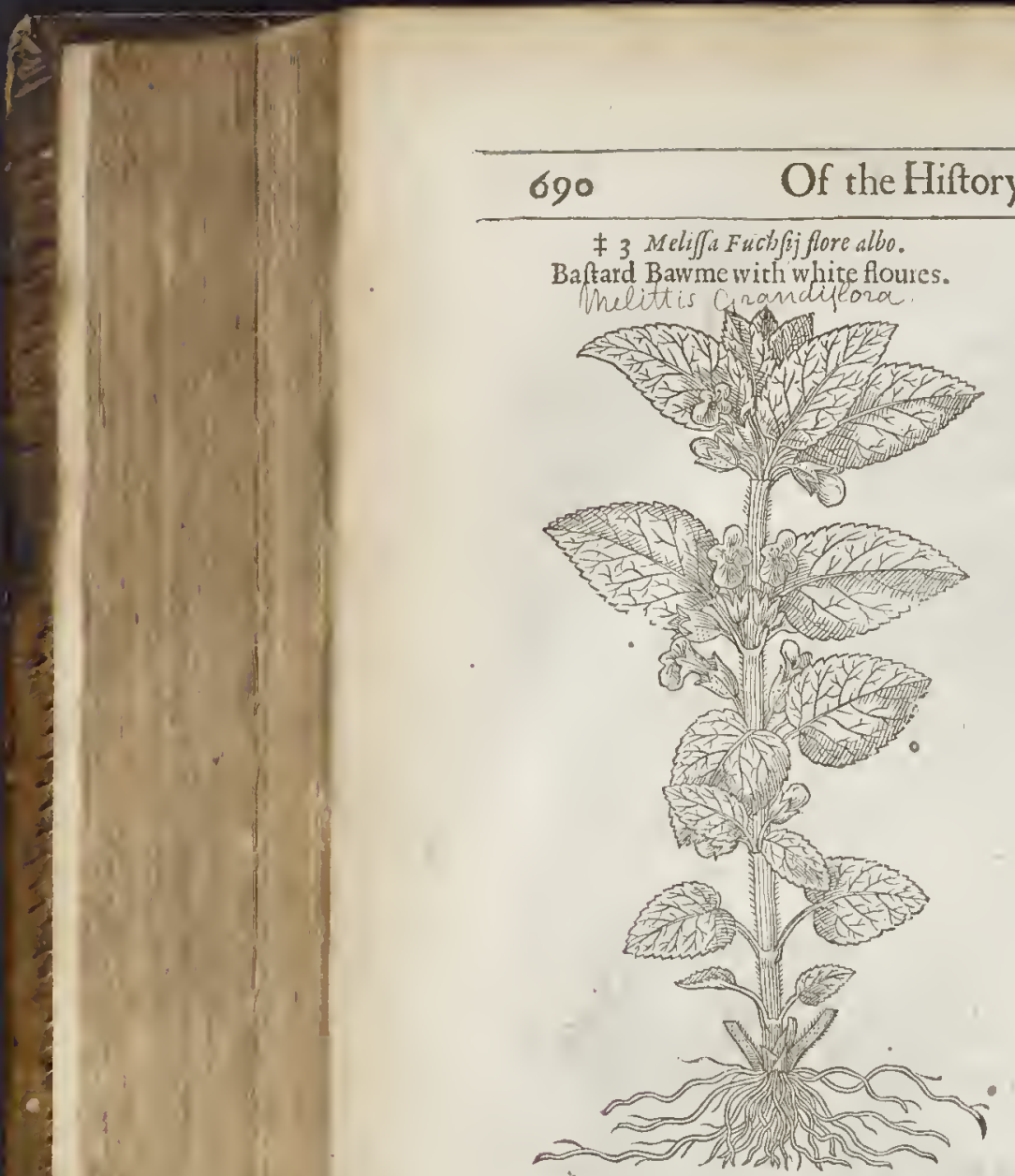

L 1 , 2.

$\neq 3$ Melifa Fuchy ij flore albo.

Baltard Bawme with white floures.

¥ 4 Herba Treduica Lobeliy.

Smiths Bawme, or Iewes All-heale.

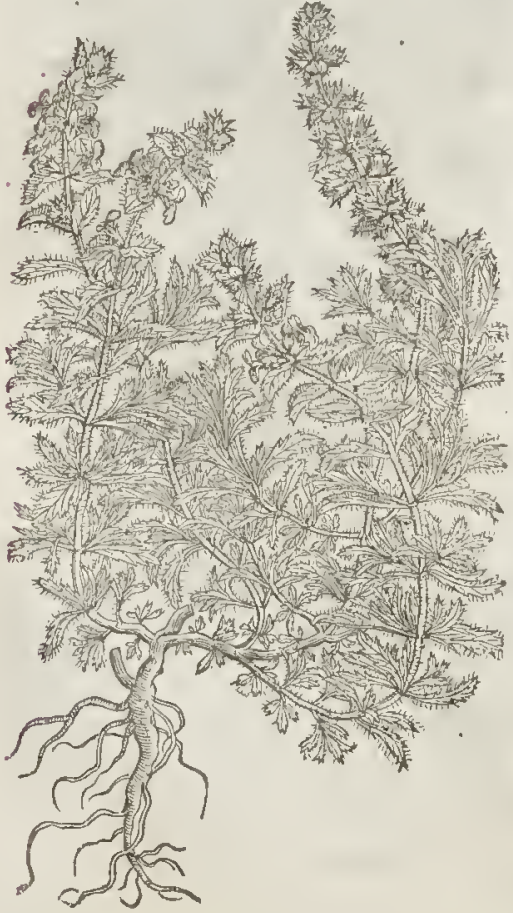

¥ 3 Melifja Fuchoj flore purpureo. Baftard Bawmewith purple floures.

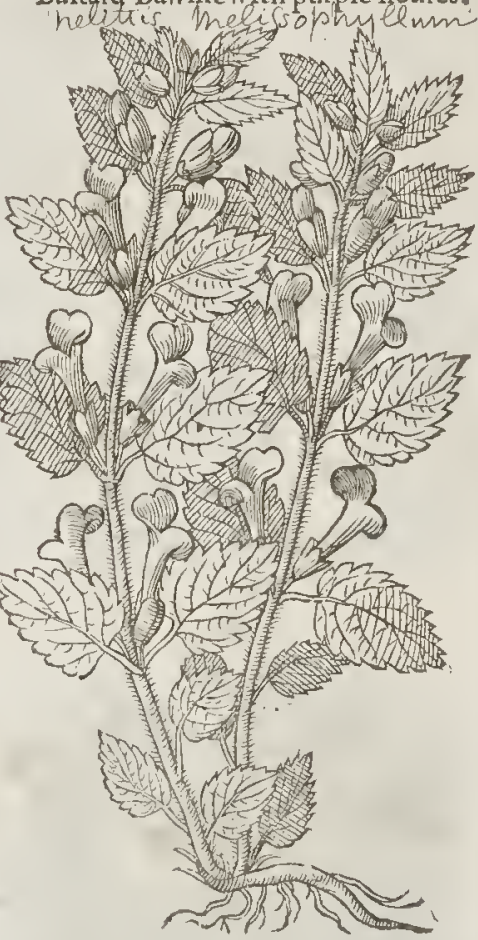

wcake and tender fquare hairie branches fome leaning backward, and others turning inward, diuiding themfelues into fundry other fmall armes or twigs, which are befet with long rough leates dented about, and finaller than the leaues of Sage. And growing in another foile or clymat, you thal fee the leates like the oken leaf; in other places like Marrubium Cretucum, very hoary, which caufed Diofcorides to defcribe it with fo many thapes, and alfo the floures, which are fometimes blew and purple, and oftentimes white: the ront is fmall and crooked, with fome hairic ftrings faftned thereto. All the whole plant draweth to the fauour of Balme, called Melif $a$. $\ddagger$. This might much more fitly hauc beene put to the reft of the Siderites, but that our Authour had thruft it as by force into this Chapter. $¥$

5 There bealfo two other plants comprehended vnder the kindes of Balme, the one very like vnto the other, although not knowne to many Herbarifs, and haue been of fome called by the title of Cardiacn : the firftkinde Pena ealleth Cardiac Melica, or Moluccal Syriaca, fo called for that it was firft brought out of Syria : it groweth three cubits 
rabitshigh, and yeeldeth many fhoors from a wooddy root, full of many whitifn ftrings; the ftalkes be round, fonewhat thickc, and of a reddifh colour, which are hollow within, with certaia a) fcure prints or fmall furrowes along the falkes, with equall fpaces halfe kneed or knotred, and at euery fuch knee or ioynt ftand two leaues one againft anorher, tufted like Melz $f_{n}$, but more rough and deeply indented, yet not fodeepely as our common cardincal, called Mother-is ort, nor fo fharpe pointed : about the knees there come forth frall little prickles, with fir or eight imall open wide bells, hauing many corners thinne like parchment, and of the fame colour, fomewlat ftiffe and long; and at the top of the edge of the bell it is cornered and pointed with fharpe prickles; and our of the middle of this prickly bell rifeth a foure fonewhat purple tending to whiteneffe, not vnlike our Lamium or Cardiaca, which bringerh forth a cornered feed, the bottone flat, and fmaller toward the top like a ftceplc: the faurour of the plant draweth toivard the fent of $L a$ miturn.

6 The orher kinde of Mcúca, otherwife called Molucan aperior (ivhereof pena writeth) differeth from the laft before mentioned, in that the cups or bells wherein rhe floures grow are more prickly than the firt, and much tharper, longer, and more in number: the falke of this is foure fquare, lightly lrollowed or furrowed; the feed three connered, tharpe vpward like a twedge; the tunnels of the floures browning, and not fo white as the firft.

5 Meliffamolurcaleuts.

Smooth Molucca Bawme,

Milaccila i lavis

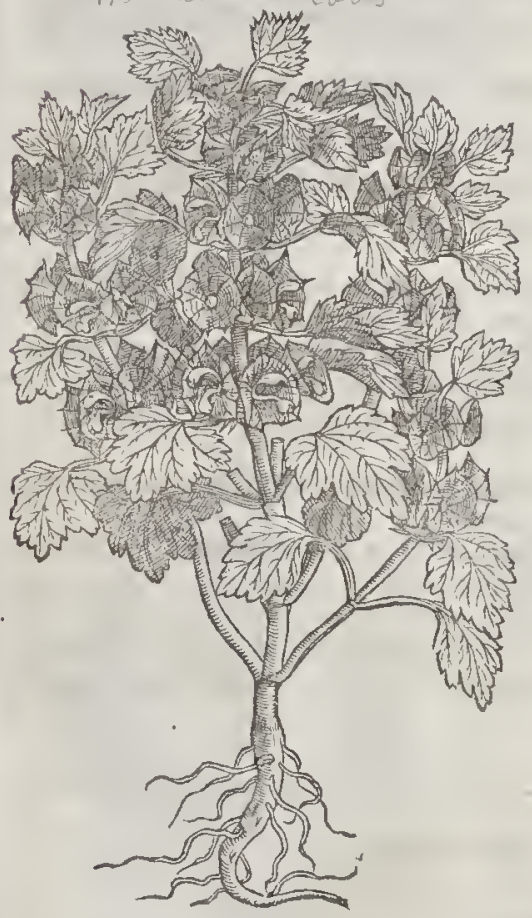

6 Molucrapinora.

Thorny Molucca Bawme. tis 1 ,

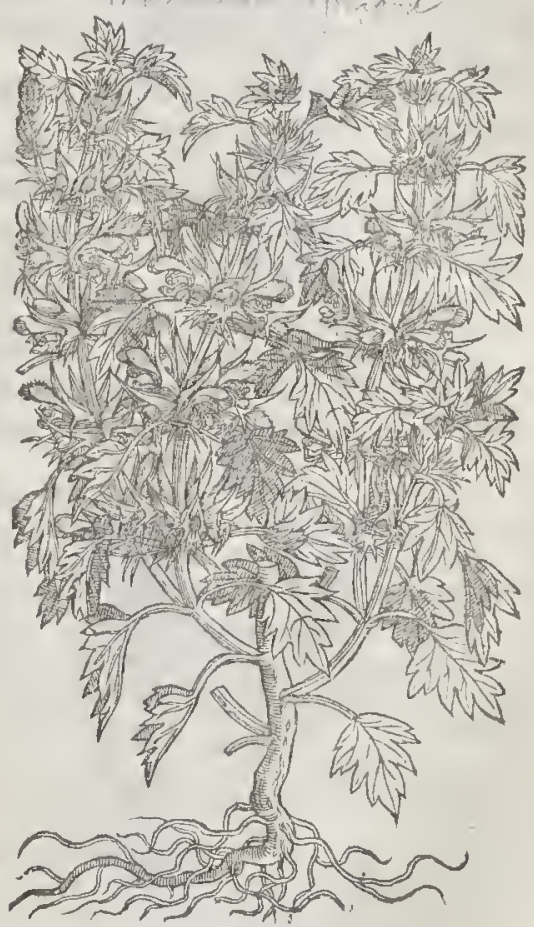

iा The Place.

Bawme is much fowen and fet ingardens, and oftentimes it groweth of it felfe in Woods and mountaines, and other wilde places : it is profitably planted in gardens, as Pliny writeth, lib. $2 x$. sip. 1 2.about places where Bees are kept, becau fe they are delighted w wh this herbe aboue orhers; whereupon it hath beene called Apiaftrum: for, faith he, when they are ftrayed away, they do finde their way home againe by it, as virgilwriteth in his Georgicks:

\section{ituctu inffos afperge liquores,}

Trita Melipbylla, \& Cerintbe nobile gramen.

Vfe here fuch helpc as husbandry doth vfually prefcribe

Bawme bruifed in a mortar, and bafe Hony-wort befide.

All thefé I haue in my garden from yeare to yeare. 


\section{T The Time.}

Baw me flouteth in Iune, Iuly, and Auguit: it withereth in the Winter; but the toot remaineth, which in the beginning of the Spring bringeth forth frefh leaues and ftalkes.

The otler forts do likewife flourith in Iune, Iuly, and Auguf; but theyedoe perifh when they haue perfected their feed.

Bawme is oalled in Greete The Names.

Baw trago: of fome, Mcliffophyllor, and creliphyllon: in Dutch, Conftlle De grepu: in Freneh, Poucyrade, ow Meliffe: in Italian, Cedronella, and LArantiata: in Spanith, Torongal: in Englifh, Balme, or Bawme.

$$
\text { q. The Temperature. }
$$

Baw me is of temperature hot and dry in the fecond degree, as Awicen faith: Galer faith it is like Horehound in faculric.

A Bawme drunke in wine is good againft the bitings of venomous bearts, comforts the heart, and driueth away all melaneholy and fadneffe.

B Common Bawme is good fot women which have the ftrangling of the mother, eithet being ea. ten or fmelled vnto.

C. The iuyee thereof glueth together greene wounds, being put into oyle, vnguent, or Balme, for that purpore, and maketh it of greater efficacic.

D The herbe ftamped, and infufed in Aqun vita, may be ved vnto the purpores aforefaid(I meane the liquour and not the herbe) and is a moft eordiall liquour againft all the difeafes before fpoken of.

E The hiues of Bees being rubbed w ith the leaues of Bawme, eaufeth the Bees tokeep together, and eaufeth others to eome vnto them.

F The later age,together with the Arabians and Mauritanians,affirme Balme to be fingular good for the heart, and to be a remedie againt the infirmities thereof; for Aucen in his booke written of the infirmitics of the heart, teacheth that Bawme makes the heart merry and ioy full,and ftrengtheneth the vitall fpirits.

G Seraproaffirmeth it to be comfortable for a moift and eold ftomacke, to ftir vp coneostion, to open the ftopping of the braine, and to driue aw ay forrow and care of the minde.

H Diofcorides writcth, That the leaues drunke with wine, or applied outwardly, are good againf the ftingings of venomous beats, and the bitings of mad dogs: alfo it helpeth the tooth-ache,the mouth being wafhed with the decostion, and is likew ife good for thofe that canot takebteath vnlefle they hold their neeks vpright.

I The leates being mixed with falt (faith the fame Author) helpeth the Kings Eutil,or any other hard fivellings and kernels, and mitigateth the paine of the Gout.

K. Smiths Bawme or Carpenters Bawme is moft fingular to heale vp greene wounds that are cut with iron; it eureth the rupture in thorttime; it ftayeth the whites. Diofrorides and Pliny haule attributed like vertues vnto this kinde of Bawme, which they eall Iron-wort. The leautes (fay. they) being applied, elofe vo wounds without any perill of in flammation. Pliny faith that it is of to great vertue, that though it be but tied to his fword that hath giuen the wound, it fancheth the bloud.

\section{C н а Р. 230. Of Horebound.}

$$
\text { The } D \text { cfoription. }
$$

I T Tite Horchound bringeth forth very many ftalkes foure fquare, a eubit high, eouered oucr w ith a thin whition downinefle: whereupon are placed by couples at eertaine diftances, thieke whitifh-leaues fomewhat round, wrinkled and nieked on the edges, and coneted oner with the like downineffe; from the bofomes of which leaues come forth fnall floures of a feint purplifh colour, fet round about the ftalke in round wharles, which turne into harpe orickly husks after the floures be paft. The whole plant is of a ftrong fauror, but not inpleafant : the root is threddy.

2 The feeond kinde of Horehound hat 1 fundry erooked flender ftalkes, diuided into many finall branehes eouered ouer with a white hnarineffe or eottony downe. The lcaues are likew ife hourie and eotrony, longer and narrower than tle preedent, lightly indented about the edges, and fharply pointed like the Turky Bawme, and of the fame bigneffe, hauing fmall wharles of white floures, 
1. 1 B. 2.

Of the Hittory of Plants.

693

1 Marrubiumalbum.

Wv hite Horchound.

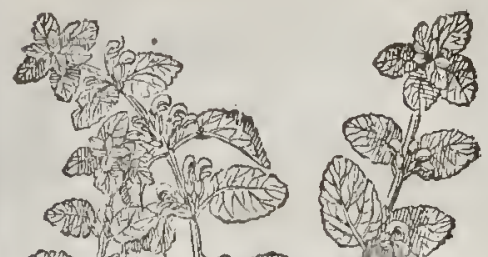

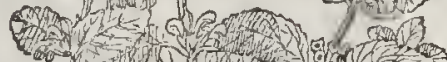

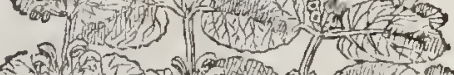

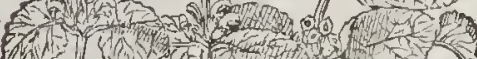

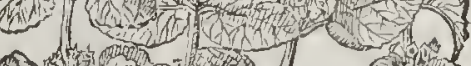

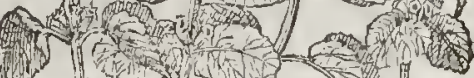

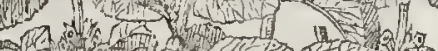

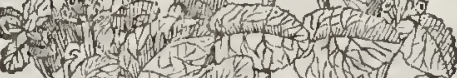

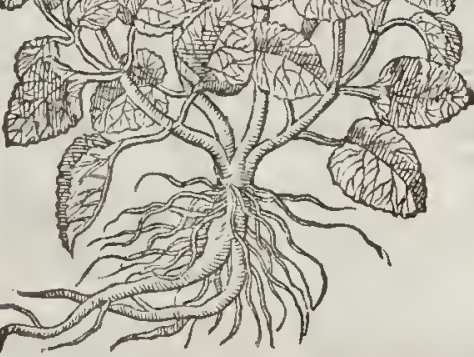

3 Marrubium Hipanicum. Spanifh Horehound.

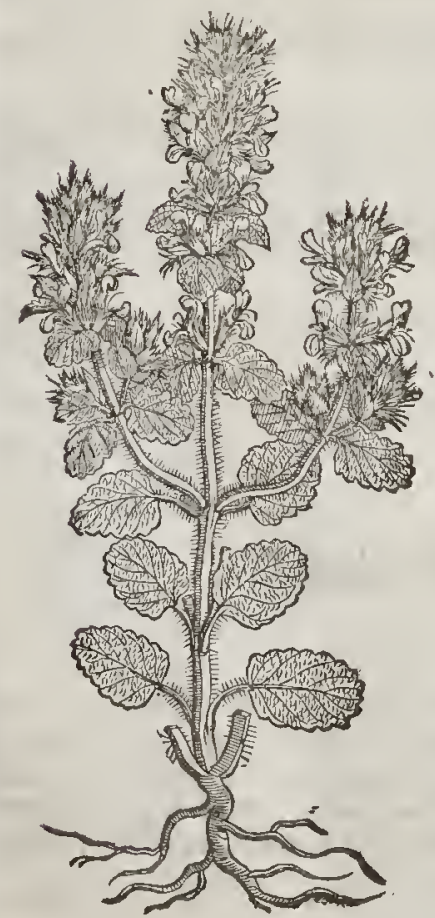

2 Marrubitum candidum.

Stiow white Horchound.

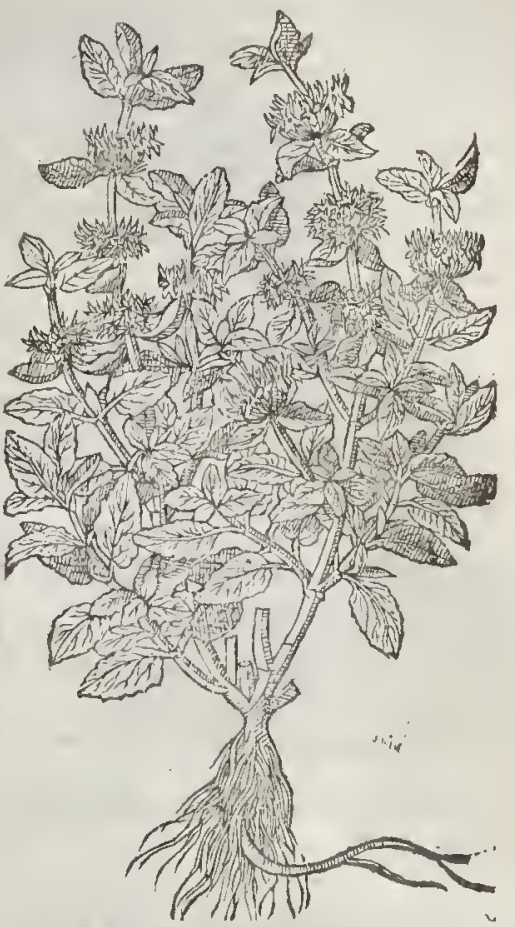

4 Marrubium Creticum.

Candy Horehound.

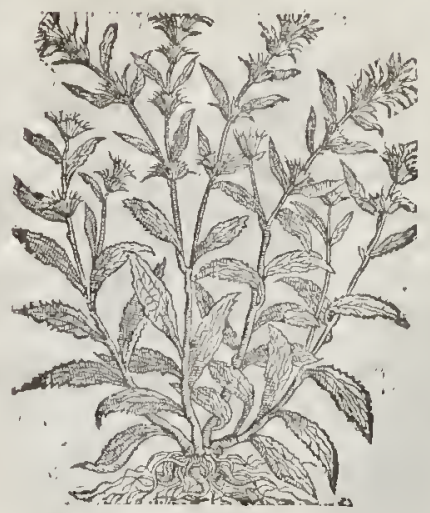

Mm的 


\section{4}

Of the Hiftorie of Plants.

LI B. 2 .

floures, and prickly rundles or feed-vefiels fet about the ftalks by certaine diftances. The roor is likewife threddy.

3 Spanifh Horchound hath a fiffe hoaric and lairy ftalke, diuiding it felfe at the bortome into two wings or more armes, and likew ife toward the top into two others; whereupen are placed by couples at certaine fpaces faire broad leaues, more round than any of the ref, and likervife more woolly and hairy. The floures grow at rhe top of the ftalkes, fpike farnion, compofed of fmall gaping floures of a purple colour. The whole plant hath rhe fauor of Sicechados.

4 Candy Horehound hath a thicke and hard root, with many hairy rhreds faftned thereunto; from which rife rp immediately rough fquare ftalkes, fet confufedly with long leaues of a hoarie colour, of a moft pleafant ftrong finell. The floures grow roward the top of the ftalkes in cbaffie rundles, of a whirinh colour.

9) The Place.

The firf of thefe Horehounds, being the common kinde, growerh plentifully in all places of England, neere vnto old walls, highwayes, and beaten paths, in vntilled places. It growerh in all orlier countries likew ife, where it altereth according to the fcituation and nature of the countries; for commonly thar which growes in Candy and in Hungary is mucl whiter, and of a fiveeter fmel, and rhe leates oftentimes narrower and leffer than that which groweth in England and thefe Northerne Regions.

$$
\text { ब The Time. }
$$

They floure in Iuly and Augut, and that in the fecond yeare afrer the fowing of them.

$$
\text { T The Names. }
$$

Horehound is called in Greeke wesiso : in Larine, Marrubium : in Thops, Praßum, and alfo Marrubium. There be certaine baftard names found in Apuleius, as Melittena, Labeonia, and I'lceraria: in Iralian, Marrubio : in Spanifh, Marrusio : in Dutch, 98 altoue: in French, Marubin: in Englifh, Horehound. $\neq$ clufus calls the rhird ocimaftrum Valentinum. $\neq$

qT The Temperature. talte.

Horehound (as Galen teacheth) is hot in the fecond degree, and dry in the third,and of a bitter

$$
\text { T The Vertues. }
$$

Common Horehound boyled in water and drunke, openeth the litier and fpleene, cleanfeth the

A breft and lungs, and pretrales grearly againf an old cough, the paine of the fide, fpitting of bloud, the ptyficke, and vlcerations of the lungs.

B The fame boyled in wine and drunke, bringeth downe the rermes, expellet the fecondine,afrer birth, or dead childe, and alfo cafeth rhofe that haue fore and hard labour in cliilde-bearing.

C syrrup made of the greene frefh leaues and fugar, is a moft fingular remedie againft rhe cough andwheefing of rhe lungs.

The fame fyrrup doth wonderfully and aboue credit eafe fuch as haue lien long ficke of any

D confumption of the lungs, as hath beene often proued by the learned Phyfitions of our London Coliedge.

E It is likewife good for then that haue drunke poyfon, or that haue beene bitten of Serpents. The leaues are applied with honey to cleanfe foulc and filthy vlcers. It ftayeth and keepeth back rhe pearle or wob in rhe eyes.

F The iuyce preffed forth of thcleates, and hardned in the Sun, is very good for the fame things, efpecially if it be mixed with a little wine and honey; and dropped into the eycs, it helps them, and clecreth the fight.

$G$. Being drawne vp into the nof hrils it cleanfeth the yellowneffe of the eyes, and ftayeth the running and watering of them.

\section{C н Р. 23r. Of wilde Horebound. \\ It The Dcfeription.}

1 Ilu Horchound is alfo like to common Horehound : there rifeth from the root hereof a reat number of ftalkes high and ioynted, and out of eucry ioynt a couple of lextes onpofite, or fer one againft another, fomewhat hard, a little longer than thofe of common Horehound, and whiter, as alfo rhe ftalkes are fet with fort haires, and of a fweet fmell : the floures do compaffe the falke about as thofe doe of common Horehound, but they dre yellow, and the iv lariles be narrower : the root is wooddy and durable. 
1. 1 ‥ 2. Of the Hillory of Plants. 695

I Siachys.

Wilde Hore-lound.

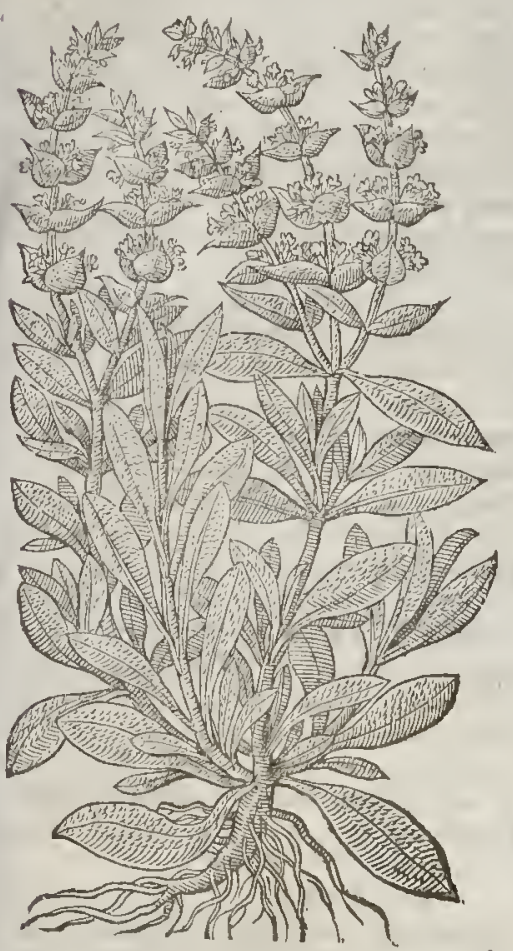

* 3 Stachys finofa Cretica, Tlionny Horehound.

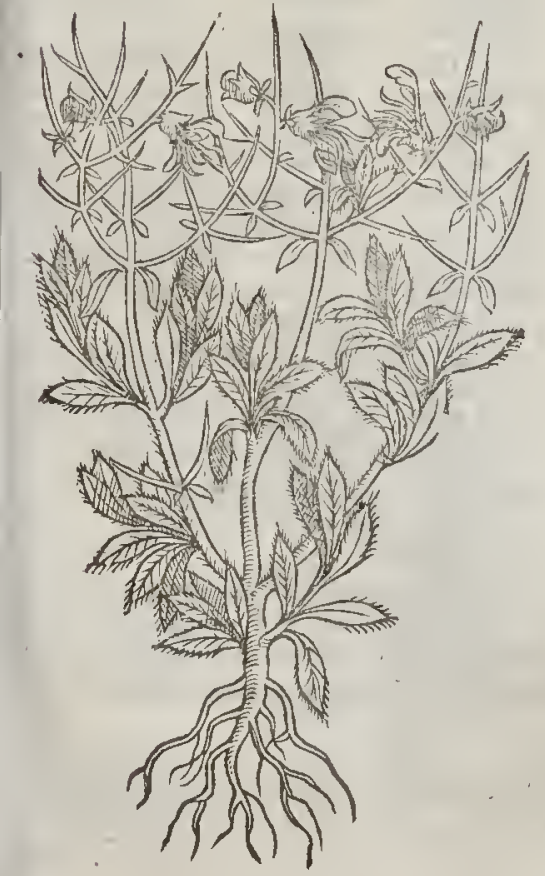

2. Stachys Fuch?y.

Wilde firking Horchound.

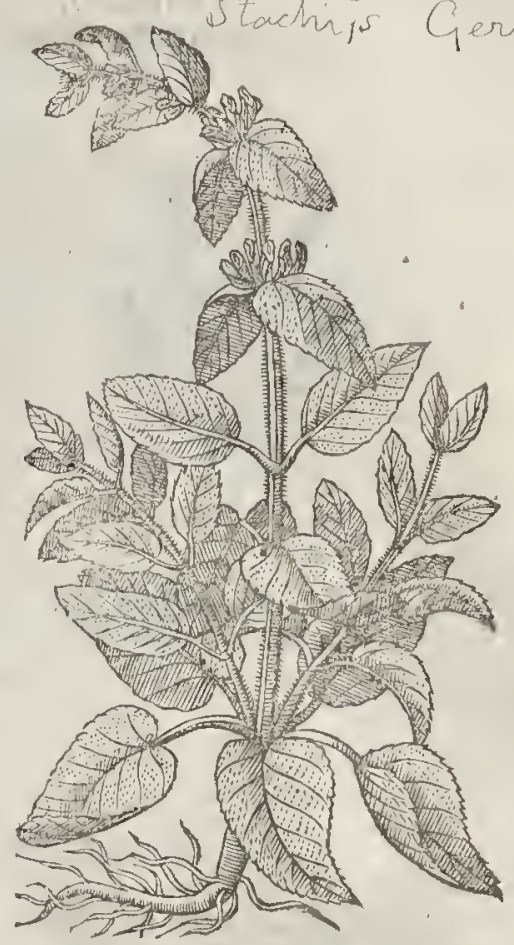

\$ Stachys Lufitanica.

Portugall Wilde Horehound:

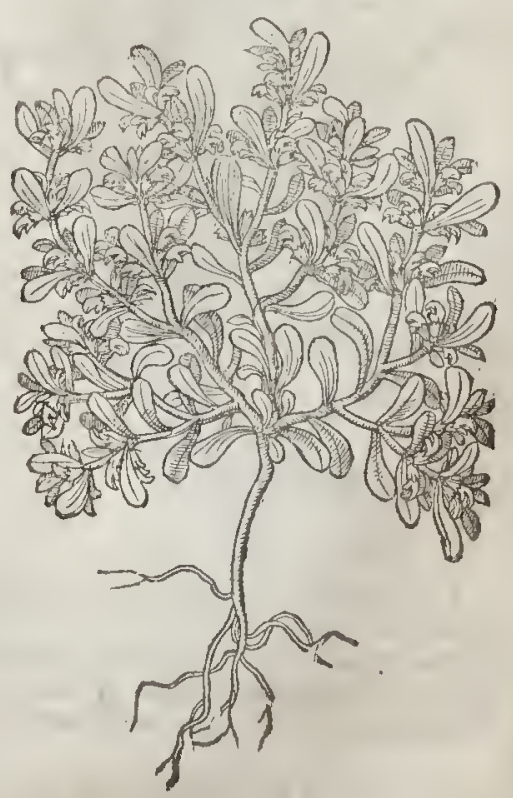




\section{\# siderit is Scordioides.}

Germander Ironwoort.

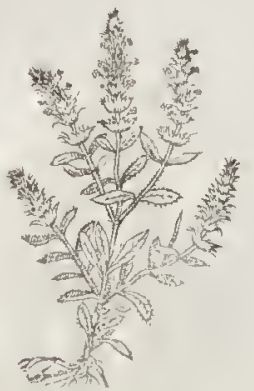

* 6 Sideritir Alpina HyJopifolia. Hy fiop-leaned lron-wort.

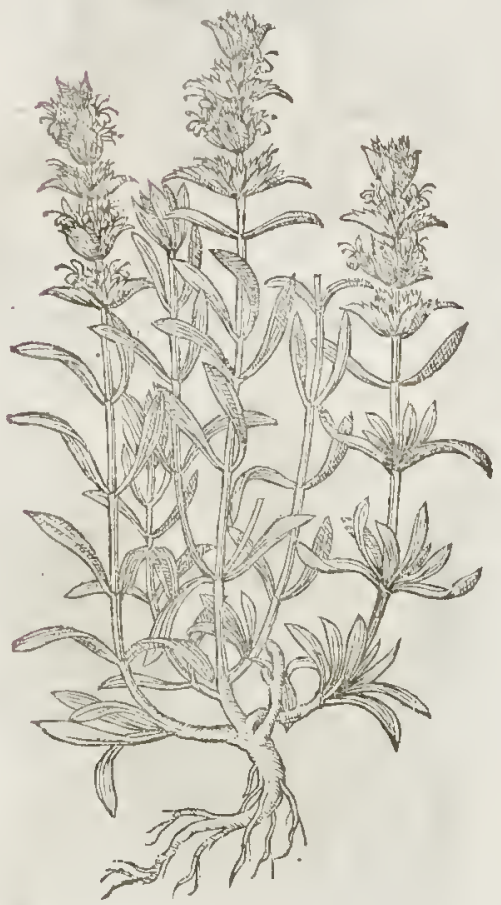

2 Befides this there is al fo another deferibed by Fucthises: the falkes hereot are thicke, foure fquare, now and then two or three foot long: the lesues be broad, long, hoarie, nicked in the cdges, hairie as are al. fo the ftalks, and much broader than thotc of the common Horchound: the foutes in the whorles which compafic the ftalke abour, are of a purple colour; the feedc is round and blaekill : the root hard \& fomthing yellow.

$\neq 3$ 'This thorny stachys lath leaucs before it eomes to fend forth the ftilk, like thofe of the leffer Sage, but morewhite \& hairie, thofe that grow vpon the ftalkes are much narrover : the flalks are fyuare fone foot high: and at the parting of thems into branches grow alwaics two leaues onc op?pofit againft another: the tops of ilic branches cnd in long marpe thomieprickles: the floures grow about the toppes of the branehes like thofe of $S$ agc, but of fomewhat a lighter colour. This grows ratural ly in Candy, about a Tow ne called Larda, where Honorius Bellusfirft ob ferued it there it is called Guidarotbymo, or Afres Tume, though it agreewith Iyme in nothin but the place of growth. Clufus fets it forth by the name of Stachys jpinofa.

4 Lobel hatli giuen vs the figurc and firf defeript ion of this by the name of $s t i t-$ chys Lufitamica. It hatle creeping and downie falkes fome hand full and halfeligh, fer with little leaucs : anong of which in rund les grow fual foures like thofe of the otherwilde Horclourds, the wholc plant is of fornew hat a gratefull finell. $\neq$

5 There is anotherwilde Horchound or Mountpclier, ealled Sideritis Moinpelliaca Scordivides, fine Scordiy folio: being that kind of Sideritis or wilde Horelound which is like vnto scordium, or water Germander, which growetb to the height of a handfull and a halfe, with many finall brinches rifing vpright, of a wooddie fub tance, ha uing the tops and fpokie coronets of Hyffop; but the leaues do refemble $D$ : f forides his Scordium, fauc that they be fonewhat leffer, ftiffer,morc wrinckled or eurled and hairie, than Tetrabit, or the Iudaicall herb: the floures do re femble thofe of the com mon Saurie, in tafte bitter, and of an aromaticall fmell.

6 Mountaine sideritis beeing alfo of the kindes of Horchound, was firf found by Valerandus Donraz, in the mountains of Sauoy, refembling very wel the laft dcferibed, but the lcautes are much narrower, and like thofe of Hyflope: the floures grow in fmall rough rundlets or tufts, pale of $\mathrm{co}$. lour like Marrubium or Tetrahit; the root long and bending, of a wooddie fub fanee, and purple $\mathrm{CO}$ lour, bitter in tafte, but not vnpleafant,whofevertuc is yet vnknowne.

If The place.

The fe herbes are formencrs, they grow in rough and barren places, notwith farnding I hauc then growing in my garden. $\neq$ My kinde friend $\mathrm{M}^{\mathrm{r}}$. Bucker an Apotheeary of London the laft yeare, 


\section{Li B. 2. Of the Hiftory of Plants:}

being $16 ; 2$, found the fecond of thefe growing wilde in Oxfordhire in the field ioyning to VVitnay Parke a mile from the Towne.

$$
\text { It The Timic. }
$$

They floure in the Sommer moneths, and w ither tow ards winter:the root remaineth alive a cer taine time.

9. The Names.

The former is taken for the right Stachys, which is called in Greeke seo's: it is knowne in thoppes and euery where : we name it in Englifh yellow Horehound, and wilde Horehoond. $\neq$ Lobel calls ic Stachys Lychnites purria Flandrorum.

The other wilde Horehound, feeing it hath no name, is to be called Stachys puria : for it is not the right,neither is it Sphacelus (as moft haue fufpedted) of which $T$ heophraft us hath made mention * it is called in Englifh purple Horehound,baftard wild Horehound, \& F F uhfrus his wild Horehound. ¥ Fabius Columana prones the fecond to be the Sideritis Heracha of Diofcorides and the Antients. $\neq$ IT The Temperative.

Thefe herbes are of a biting and bitter tafte, and are hot in the third degree according to Galcm.

* The Stachys Fischjy and sideritides feem to be hot and drie in the firft degree. $\neq$ TT The vertues:

The decortion of the leatues drunk doth draw downe the menfes and the fecondine; as Diofcori des teacheth.

$¥ 2$ This is of fingular vfe (as moft of the herbes of this kindeare) takeep wounds from inPamnuation, and fpeedily to heale them vp, as alfo to ftay all fluxes and defluctions, hauing a dry- B ing and moderate aftrictiue facultic.

Aetius and Egrineta commend the vfe of it in medicines vfed in the cure of the biting of a mad C Dog. $\neq$

\section{${ }_{\text {}}$ C на P. 232. Of the fromwoorts or albeales.}

\# $\mathbf{r}$ Sideritis vulears.

Ironwoort, or A lheale.

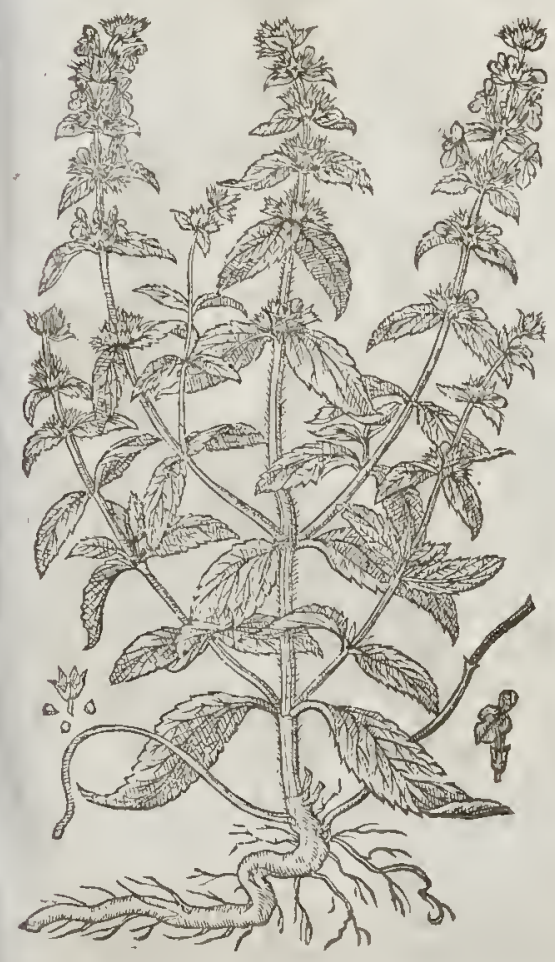

\$ 2 Sideritis Anguftifolia: Narrow leaued Alheale.

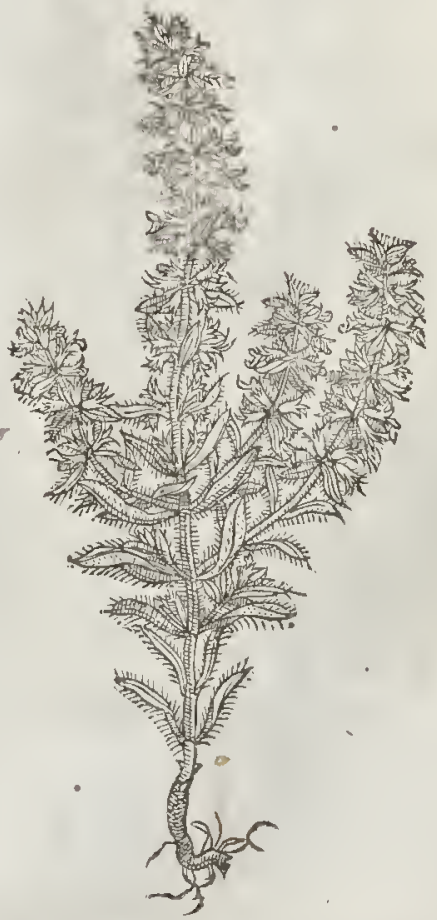

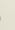




\section{The Kindes.}

* THerc are many plants rhat belong to thiskindred of the sideritides, or Ironwnorcs, and

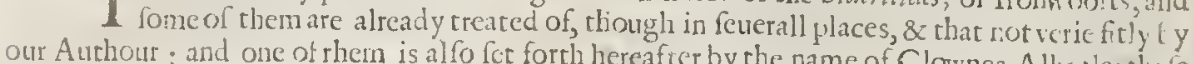
our Atriour; and one of then is allo ict forth hereafter by the name of Clownes Allicale: tlice that are formerly handled, and properly belong to this Chapter, are firt the Herba Iudaica Lobe $\ddot{y}$, being in the foutrly place of the 229. Chapter. Secondly, the Stachys Fuchly (being tlie firft sidivitis of Diofcorides) defcribed in rhe fccond place of the laft chapter. Thirdly, the siderits Scordioides fet forth in the fift place, and fourchly rhe Siderit is Alpina Hyffopifolia fet forth in rlue fixe place of tue latt chapter. Now befides all the fe, I will in rhis Chapter gitue you the Defcriptions offome others like to them in face and Vertues, and all of them may be referred to the firt Sidertis of $D z$. of corides lis dufcription.

$$
\text { The Defription }
$$

17 His hath fyuare ftalkes fome cubite high, rongh,and iointed with two leaues at each toint which arcivrinkled and, hairie, of an indifferent bignieffe, fnipt about the edges, of a frong fmell, and of a bitterifh and fomew lat hortifh tafte : almoft forth of euerv ioint grow brancles, ferwith leficr leaues: the floures which in roundles incompaffe the tops of the ftalks end in a fpike, being fomewhar hooder, whitith, well fnelling, and marked on the infide witl fangtine fpots. The feed is rough and blackc, being contained in fute cornered feed ieflels. The root is liard and wooddic, fending forth many falkes. This is the Sideritis primo of Fuchfius, Cordus, Clufbus, and others; it hath a very great affinitic with rhe Panax Cotoni,or Clownes Al-heale of our Authour, and the difference betweene them certainly is very fmall.

* 3 Sidertis procumbens ramofit.

Creping branched Ironwoort.
¥ 3 Sideritis procumbens non ramefa. Not branched Crecping Ironwoort.
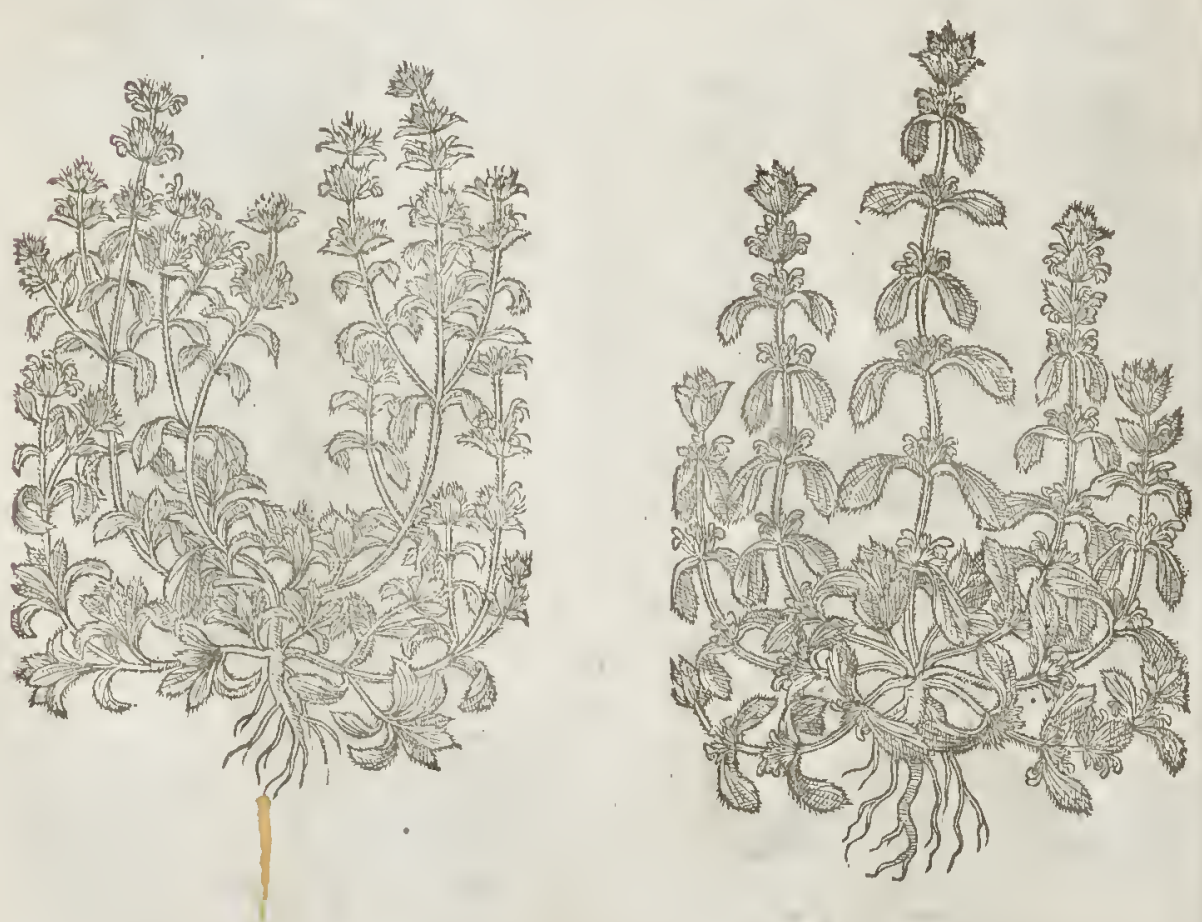

2 The fourc fume falke of thus plant is not aboue a foor high,and ir is prefently from the toor diuided into diucrs branches; rhe lemes are long and narrow w ith fome nerues or veincs run- 
+6 Sideritis latifolin glabra. Smooth broad leaued Alheale.

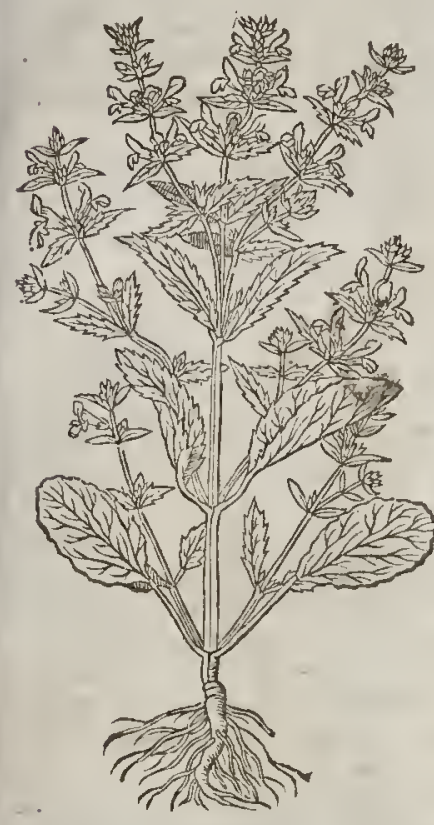

ning along ft them, being alfo very haitie, but not fnipt about the edges : the foures 0 : alongft the branches, and vpon the ma in $f$ talk in round les like thofe of the firf mentioned, but leffer, and of a darke colour,with a yellow ith fpot on their infides : the feed is alfo contained in fite cornered veffels like as the former. It floures in Iune and Iuly, and growes a. mongft the corne in Hungarie and Auftria. This is onely fet forth by Clufius, and that vinder the name of Sideritis 6.Panonica.

3 This hath fome branclies lying alono vpon the ground, llender, quadranguiar \& hai. rie, which at certain fuaces are fet with leaues grow ing by couples, almoft like thofe of the firt, but much lefie, and fnipt onely from the * middle to the end : the floures grow after the manner of the former, and (as Clufius thinkes) are like them, as is alfo the feed. Clufius hath this by the name of Sideritis 4 .

4 The fame Authout hath alfo giuen vs another, which from the rop of the roor fends foorth many branches, partly lying fpred on the ground, and partly fanding vpright, being hairy, iointed, and fquare like thofe of the former, and fuch alfo are the leaues, but that they are leffe fnipt about the edges:and in theirbofomes from the bottome of the falkes to the top grow roundles of whitifh floures thaped like others of this kinde. Clufsus calls this $\mathrm{Si}$ diritis 5. Hehad oncly the figures of thefe elegantly drawne by the hand of Iagues Plateau,

5 This from a fmall wooddie root fends forth a fquare hairie ftalke fome halfe foot high, and fome times higher, and this ftalke moft commonly fends forth fome foure branehes, whicli fubdiuide them felues into fmaller ones, all of them fometimes lying von the ground, and the ftalke ftanding vpright; the leaues grow by couples at each ioint, from a broader botrome, ending in an obtufe point, the lower leaues being fome inch long, and not much leffe is breadth : the floures are whition, or light purple, fmall and hooded, engirting the ftalkes in roundles, which falling, foure longifh blacke feeds are contained in fuc cornered veffels. I firft found it Auguit 1626 in floure and leed a mongt the corne in a field ioining to a wood fide wor far from Grene-hiue in Kent,and I at that time, not finding it to be written of by any, called it Sideritis hum lis lato obtiro folio, but fince I finde that $B$ awhinc hath fet it forth in his Prodromus by the name of Sideritis Alfine Trifjagi-
$n$ us folio.

6 This (which Tabernamontanus calls Alyfum Germanicum, and whofe figure was formerly given with the fametitle by our Authour in the I 8 Chapter of the former Edition, with a Defeription nowaies agreeing therewith) grows vp with fquare ftalkes fome cubite high, fet with pretry large and greene fmooth leaues fniptabout the edges : the floures grow in roundles at the tops of the branches, being hooded, and of a pale yellow colour. This grows in the Corne fields in fome pla ces of Germany and Italy : and it is the Suderitis 2. of Mattliolus in Bawhizes opinion, who cals it $S$ i. derit is aruenfis latifolia glabra.

7 There is another plant that growes frequently in the Corne ficlds of Kent, and by Purfleet in Effex which maly fitly be ioined to thefe, for Camerarius calls it siderit is arvenfis flore rubro, and in the Hiftoria Lugd. it is named Tetrabit anguftifolium, and thonght to be Ladanum feretum of Pliny, mentioned $l i 6.29 . c a p .8$. and $l i 6.26$. cap. I I. It liath a ftalke fone foot or better high, fet with fharp pointed longifh leaties, hauing two or thice nickes on their fides, and growing by couples, at the top of the brunches, and alfo the maine it alke it felfe, ftand in one or two roundles faire red hooked floures: the rout is fmall and fibrous, dying euery yeare when it hath perfected the feed. It floures in luly and Auguft. This is alfo fomerines found with a white floure.

All thefeare fufficiently deliuered in the deferiptions. 
TT The Temperatures and Vertues.

A Thefe plants are drie with little or no lieat, and are endued with an africtiue faeulty. They conduee much to the healing of greene wounds being beaten and applied, or put in inguents or plaifters made for that purporfe.

B They arealfo good for thofe things that are mentioned in the haft chapter, in B, and C.

C Clufins faith, the firlt and fecond are vfed in Stiria in fomentations, to bathe the head againt the paines or aches thereof, as alfo againft the ftiffenefle and wearineffe of the limbs or ioints.

D. And the fane Author affirmes that he hath knowne the decostion ved with very good fueceffe in euring the inflammations and vleerations of the legs. $\ddagger$

\section{H P. 233. OfWater Horebound.}

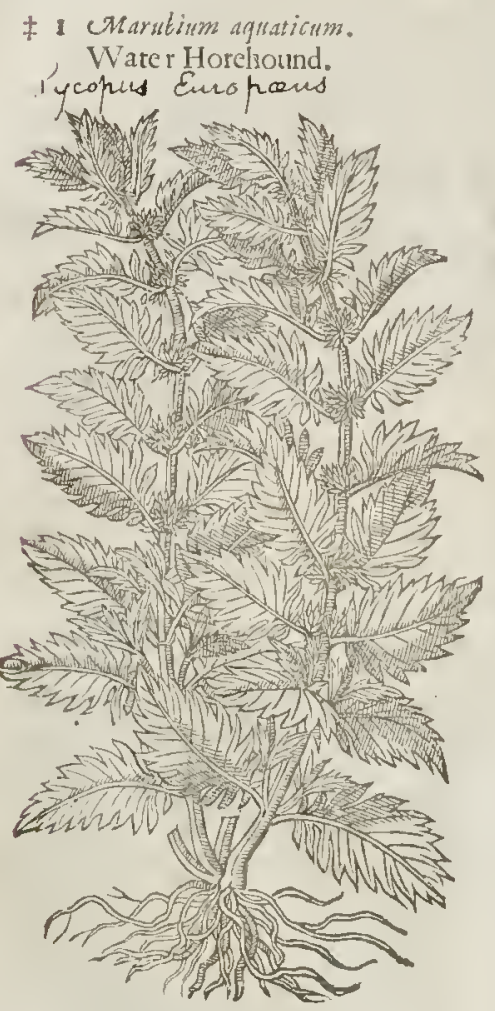

\section{The Defcription.}

I T 7 Ater Horehound is very like to blacke and ftinking Hore. hound in ftalke and floured cups, which are rough, pricking, \& compaffing the flalks round about like garlands: the leaues there of be alfo blacke, but longer, harder, more deeply gafhed in the edges than thofe of $\mathrm{ft}$ inking Horchound,yet not hairie at all, but wrinkled: the foures be fnall and whitifh:the root is faftened with many blacke ftrings.

$$
\text { T The Place. }
$$

It growes in Brooks on the brinks of water ditelies and neere vnto motes, for it requireth ftore of water, and groweth not in drie places.

$$
\text { I) The Time. }
$$

It flourinhes and floures in the Sommer moneths, in Iuly and Auguft.

$$
\text { T The Names. }
$$

It is called Aquatile, and Paluftrc Marubium: In Englilh,water Horehound. Matthiolus ta. keth it to be Species prima Sideritidis; or a kind of Ironwoort, which Diofcorides hath deferibed in the firft place; butwith this doth better agree that which is called Herba Indaica, or Glid woo:t; it mueh lefle agrecth with siderit is fecanda, or the fecond Ironwoort, which opinion alfo hath his faumrers, for it is like in leafe to none of the Fernes. Some alfo thinke good to cal it Herba eEgytia, beeaufe they that feine themfelues Egyptians (fuel as many times wander like vagabond's from eitie to citic in Germanie and other places) do vfe with this herbe to giue theinfelues a fwart colour, fuch as the Egyptians and thę people of A fricke are of; for the iuice of this herbe doth die cuery thing with this kinde of colour, which alfo holdeth fo faft, as that it cannot be wiped or wathed aw ay: infonuch as linnen cloth being died herewith, doth alwaies keepe
that colour.

$$
\begin{aligned}
& \text { It feemeth to be cold, and withall very aftringent or binding. } \\
& \text { T }
\end{aligned}
$$$$
\text { There is little ve of the water Horehound in Plyfieke. }
$$

t The figure thax heretofine was in the firft piace was of the Miarybium rigrim deferibed in the nexr chapper;and the figure and defcipeion thar were in the

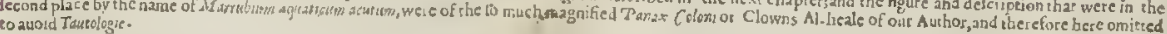




\section{Сна Р. 234. Of blacke or finling Horebound.}

9. The Defeription.

I Racke Horehound is fomewhat like vnto the white kinde. The ftalkes bealfo fquare and hairic. The leaues fomewhat larger, of a darke fwart or blackith colour, fomewhat like the leaues of Nettles, fnipt about the edges, of an vnpleafant and itinking fausur. The floures grow about the ftalks in certain fpaces, of a purple colour, in thape like thoie of Arclangell or dead Nettle. The roote is fmall and threddic. $\ddagger$ I hate found this alfo with whice Houres.

$\ddagger 2$ To this may fitly be referted that plant which fome haue called Parietaria, Sideritis, and

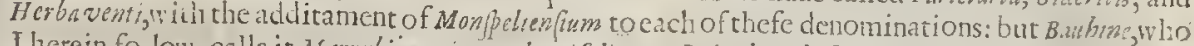
I here in fo. low, calls it Marrubium nigzum longifoliun. It is thus deferibed : the root is thicke and very fibrous, fending wp many fquare rough falkes fome cubite high, fet at certaine fpaces with leates longer and broader than Sage,rough alfo and fnipt about the edges : and out of their bofomes come foures, hooded, and purple of colourengirting the falkes as in other plants of this kinde. Some hame rhought this to be othoma of rhe Anticuts, becaufe the leaues plants of this Winter,are either eaten by the Wormes, or wafted by the iniurie of the weather to the very nerues or veines that runne ouer them; fo that by this meanes they are all perforated, and eafily blowne thorow by each blaft of winde: which caufed fome to giue it alfo the name of Horba venti. It grows in the corne fields about Montpelier.t

† I cMurrubiurs nigrum.

Stinking Horehound.
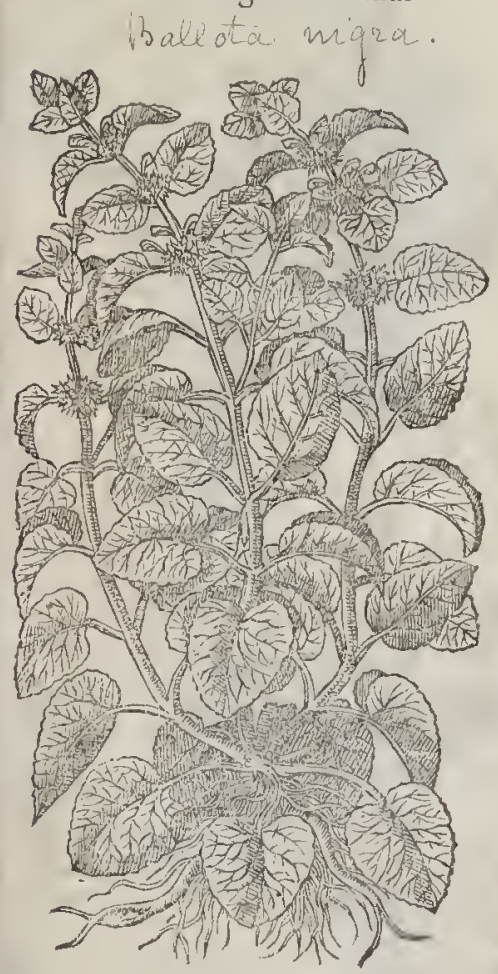

† Marrubium nigmum Longifótum. Long leatred Horehound.

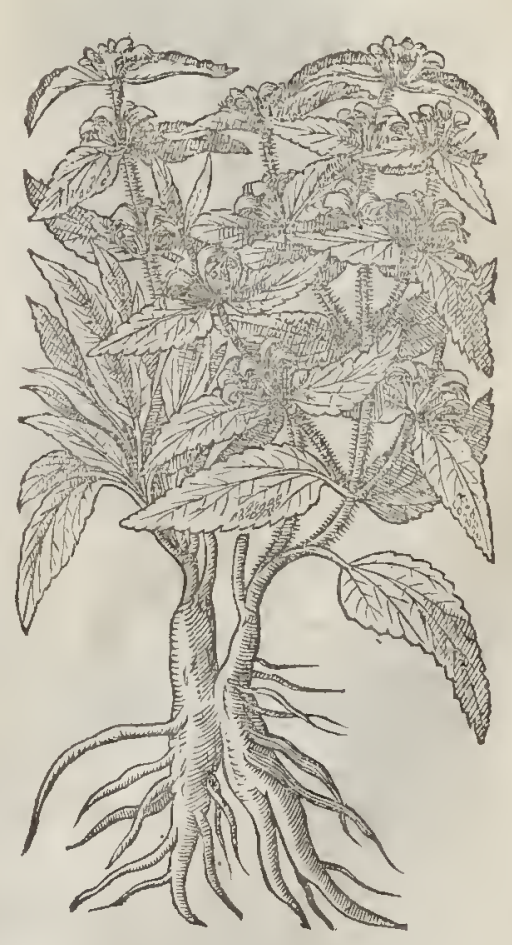

4 The Place.

It is found in gardens anongll pot herbes, and oftentimes amougft fones and rubbiln in drie 
It foureth and flourifheth when the others do.

\section{T The Time.}

\section{G. The Names.}

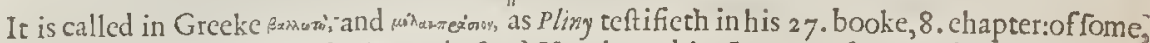
Marrubiaftrum, or Marrubium fpurium, or baftard Horchound:in Shops, Prafum fatidum, and Ballote: in Italian, Marrubiaforo : in Spanifh, Marrakio negro : in French, Marubin noir \& putant : in Englifh ftinking Horchound.

Stinking Horehound is hot and dry, and as Patulus Agineta tcacheth, of a fharpe and clenfing faculty.

A Being ftamped with falt and applicd, it cureth the biting of a mad dogge, againftwhich it is of $B$ great fficacy, as Diofcorideswriteth.

- The leaues rofted in hor embers dowafte and confume away hard lumpes or knots in or about the fundament. It alfo clenfeth foule and filthy vleers, as the fame Author teacheth.

† The figure was of Limium dibum, or Archangell with the white flute ; and the figare that thould hauebeene here was in the former Chapter.

\section{II P. 235. Of Archangell,or dead $\mathcal{N}$ (ettle.}

$\dagger$ I Lanium album.

White Archangell

Lamium alburit

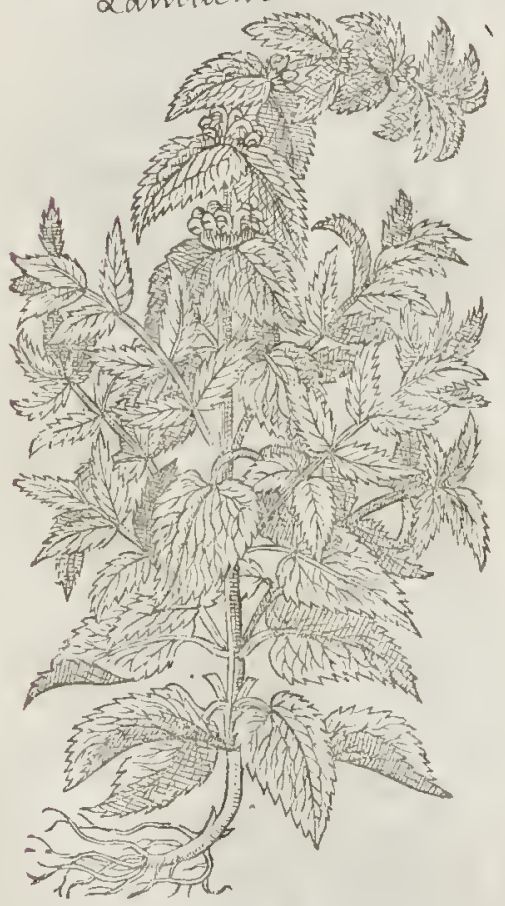

2 Lamium luteum. Yellow Archangell. alrobdolon hiterum

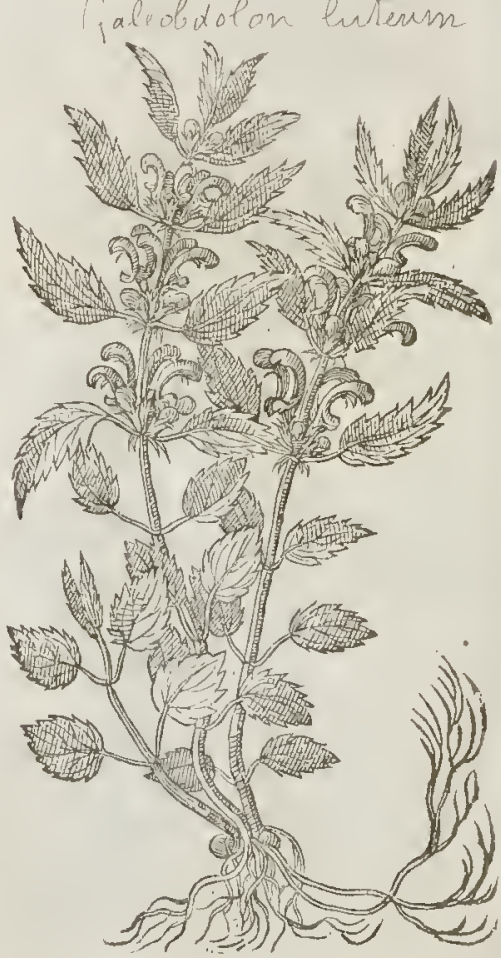

Tf The Defcription.

I T T Hite Areliangell hath foure fquare ftalkes, a cubit high, leaning this way and that way, by reafon of the great weight of his ponderous leaues, which are in thape like thofe of Nettles, nicked round about the edges, yet not flinging at all, 
but foft, and as it were downy. The floures compaffe the ftatkes, round about at ecruine diftanees, euen as thofe of Horehound doe, whereofdoubteffe this is a kinde, and not of Nertes, ar hath been generally holden: whieh floures are white of eolour, faftrioned like to little gaping lioods or

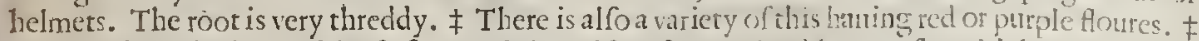

2 Yellow Archangell hath fquare ftalkes rifing from a thectely roor, fet with leaues by eniples, very mneh cut or haekt about the edges, and tharpe pointed. The vppermof whereof are oftentimes of a faire purple colour. The Houres grow among the fane leatues, of a gold yellow colour, farhioned like thofe of the white Arehangell, but greater, and more witer gaping open.

3 Red Archangell being ealled Vrtica non mordax, or dead Nettle, hath many leaucs fpred vpon the ground; among which rife vp ftalkes hollow, and fqure, whercupon do grow rongh leaucs of an outer worne colour, among which come forth purple floures, fet abour in round wharles, or rundles. The root is mall, and peritheth at the firft approzeh of winter.

† 3 Lamikm rubrum. Red Archangell. Laniuna welnem

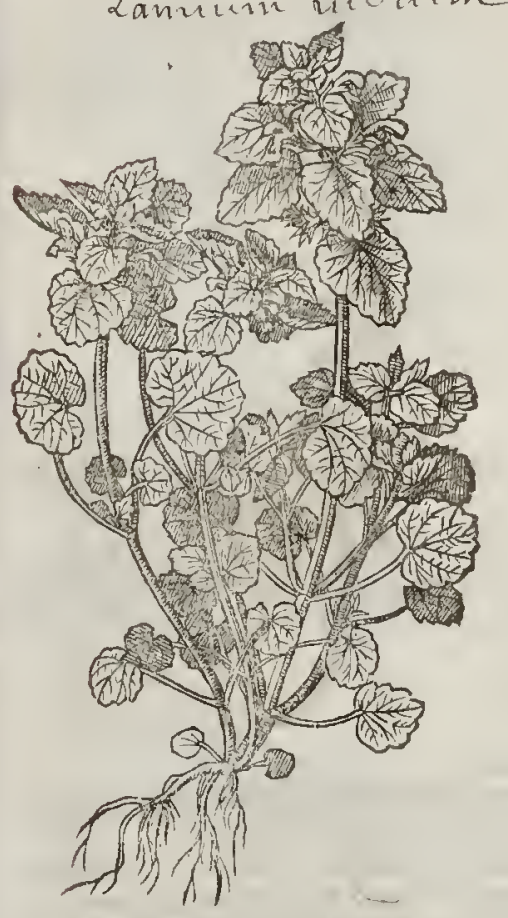

† Lanium Pannonicum, fiue Galcopfis. Hungary dead Nettle.

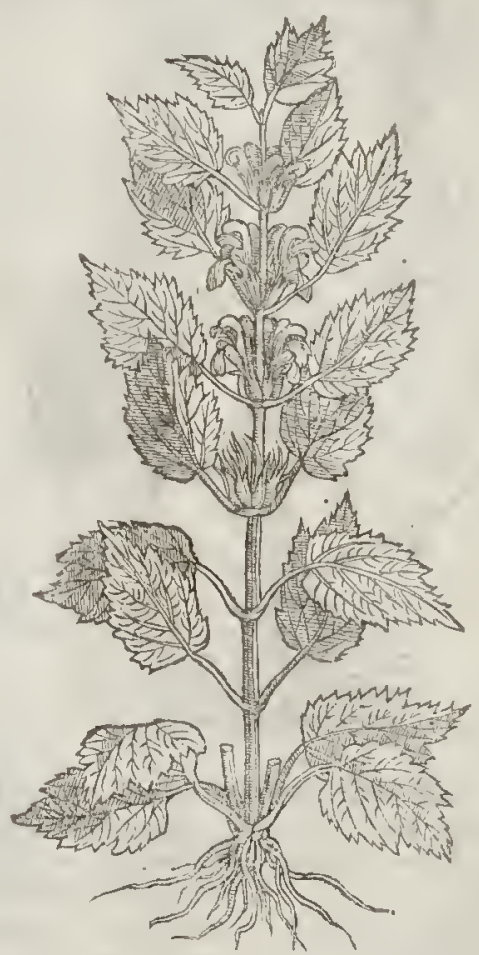

4 Dead Nettle of Hungary hath many large rough leaues very much curled or erumpled like thofe of the ftinging nettle, of a darke greene colnur, fnint about the edges like the teeth of a fawe, fet vpon a foure fquare ftalke by couples; from the bofome of which leaues come forth the thoures clofe to the ftalkes, of a perfeet purple colour, in thape like thofe of the white Archangell, gaping like a dragons mouth, the lower chap whereof is of a bright purple fpotted wirh white, which being paft, there dorh follow feed inclofed in roush hushes, with fine tharpe points ficking out. The root is thicke, tough, confinting of many thrcds and long ftrings.

$¥ 5$ To this of $c$ luf fus, we may fitly refer 2 other plants; the firft of whieh Tragis and others call Vrtica Heraclen, or Herculea, and Clufius indges it to be the trus Gateopfis of Divforides, as Tragus alfo thought before hini. The root hereof is fibrous and erceping, fending forth many foure fquare ftalkes, vpon which at each joint grow two leaues vpon Iong ftalkes very like thofe of Nettles, but more foft and hairy, not ftinging: the tops of the branehes and as it were in a five made of feuerall roundles of flotres like thofe of A rehangell but lefle and of a purple enlour for ted with white on their infdes; the feedes are conteined foure in veffell, and are blacke when they cone to be ripe; It growes about hedges in very many places, and foures in Iune and Iuly.

$$
\mathrm{N} n n_{2}
$$




\section{Of the Hiftory of Plants.}

L13.2.

¥ This hath roots like thofe of the lift deferibed, fending vp al fo fquare ftalkes a foor high, fet at each ioint with lcaues growing vpon long ftalkes like thofe of the fmall dead Nettle, or ra. ther like thofe of A lehoole: ont of the bofoms of thofe come three or foure ftalks carrying floures like tliofe of Alchoof,gaping, but w ithout a bood, but with a lip turned vp, which is variegated with blew, white, and purple. This biftorie $C$ lufwes (who did not fee the plant, but an exaet figure thereof in colours) giues $v$, and he names it as you finde expreft in the tirle. $\neq$

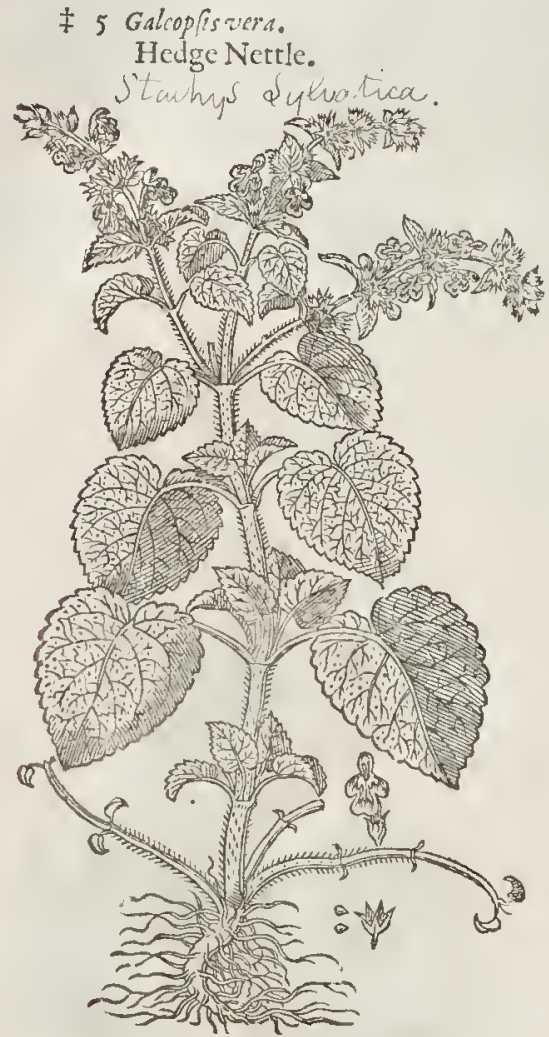

6 Lamium Pannonicun 3. Clufij. Hungary Nettle with the variegated floure.

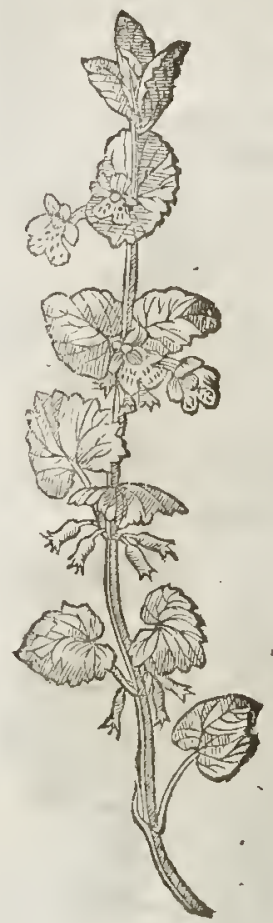

The Place.

Thefe plants are found vnder hedges, old wals, common waies, among tubbin, in the borders of fieldes, and in earable grounds, oftentimes in gardens ill husbanded.

That with the yellow floure groweth not fo common as the orhers. I haue found it vinder the hedge on the left hand as you go from the village of Hamplted neere London to the Church, and in the wood thereby, as alfo in many other copfes about Lee in Effex, neere Watford and Buthic in Middlefex, and in the woods belonging to the Lord Cobham in Kent.

\section{- The Time.}

They floure for the moft part all Sommer long,but cliefely in the beginning of May.

9ा The Namzes.

A rchangell is called of fome Vrtica iners, and Mortsa: of fome, Lamsium : in Englifh, Archangell, blinde Nercle,and dead Nettle.

A

$$
\text { 91 The Temperature. }
$$

$$
\text { I The Verues. }
$$

takehange] [or rather the hedge Nettle] Atamped with vineger, and applied in manner of a pultis taketh away Wens and lard lwellings, the Kings enill, infammation of the kernels vnder the eares and lawes, and allo hot fierie inflammations of the kernels of the neeke, arme-holes and flanks.

C It is good to bathe thofe parts with the decostion of $1 \tau$, as Diofcorides and Pliny fay.

the Tater Phyfitions thinke that the white floures of Archangell doe faie the whites, and for they appoint to be taken for certaine daies rogether. 
The floures are baked with fugar as rofes are, which is called fugar Rofet: as alfo the dinilled D water of them, which is yfed to make the beart merry; to make a good colour in the face; and to nake the vitall fpirits more frefh and liticly.

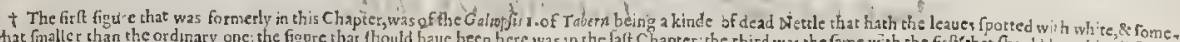

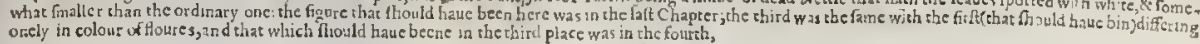

\section{Of Motberwoort.}

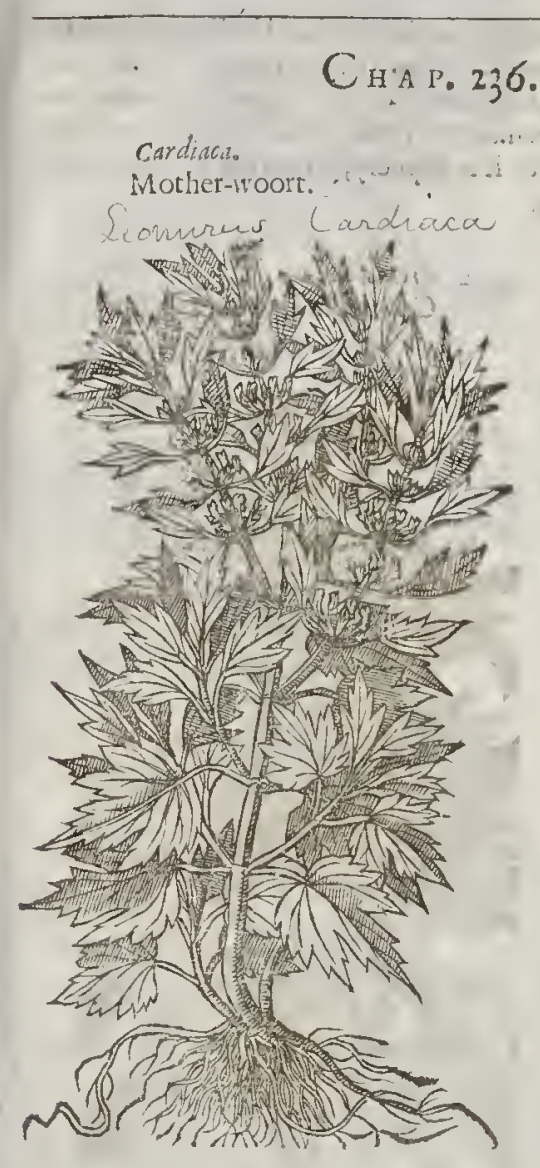

Cardincis.

Mother-woort.

comras Lardiaca

$$
\text { I The Defeription. }
$$

T Other woortbringeth forth falks foure fquare, thick, hard, two cubites high, of an obfcure or oucrw orn red colour: the leaues are fomewhat black, like thofe of Nettles, but greatcr and broader than the leaues of Horehound, deeply indonred or cut on the edges. The husks arc hard \& pricking, which do compafte the falks abotit like wharles, or little crownets, out of which do growpurpling floures, not vnlike to thofe of dcad Nettle, but leffer: The roote is compact of many fmall frings, the whole plant is of a very rankc fmel and bitter talte.

$$
\text { If The place. }
$$

It ioieth among rubbirh, in ftony and other barren and rough places, efpecially about $\mathrm{Ox}$ ford; it profitcth well in gardens.

$$
\text { 91 The Time. }
$$

It flouritheth, floureti, and feedeth from Iune to September: the leaues and ftalks petirh in winter, but the roor indureth.

$$
\text { q) The Names. }
$$

It is called in our age Cardiaca $:$ in High Dutch, gefpan: in French, 1 gripaulme : in Englifh, Motherwoort. Somethere be that make it a kinde of Bawme, it feenies that it may bealforeferred to Sideritis Herculima, or Hetcules Irontwoort.

T) The Temperiture.

Motherwoort is lor and dry in the fecond degree, by reafon of the clenfing aud binding quality that it hath.

$$
\text { of The terincis. }
$$

Diuers commend it againft the infirmities of the heart : it is iudged to be fo forceable, that it $A$ is thought it tookc his name cardiaca of the effect.

It is alfo reported to cure convulfions and cramps, and likewife the palfie : to open the obftu- $B$ fions or foppings of the intrails: to kill all kindes of Wormes of the bellie.

The pouder of the herbe giuen in wine, pronoketh not onely vrinc, or the monthly courfe, but $\mathbf{C}^{\circ}$ alfo is good for them that are in hard trauell with childe.

Moreoner, the fame is commended for greenewounds: it is alfo a remcdie againf certain difea- D fes in cattellas the cough and murcine, and for that caufe diuers husbandmen of tentimes much defire it. 


\section{С н А. 237. Offtinging $\mathcal{X}$ (ettle. \\ T) The Defcription.}

r THe ftalkes of the firt be now and then halfe a yard bigh, round, and hollow wirhin: the

leaues are broad, tharp pointed, cut round about like a faw, they be rough on both fides, and couered with a ftinging downe, which with a light touch onely caufeth a great burning, and raifeth hard knots in the skin like blifters, and fometimes makcth it red. The feed eommeth from the roots of the leaues in round pellets bigger than Pcafe; it is Rippery, glittering like Line-feed, but yet leffer and roundet. The roote is fet with ftrings.

I Vrtica Romana. Romane Nettle.

- Uirica piliciera

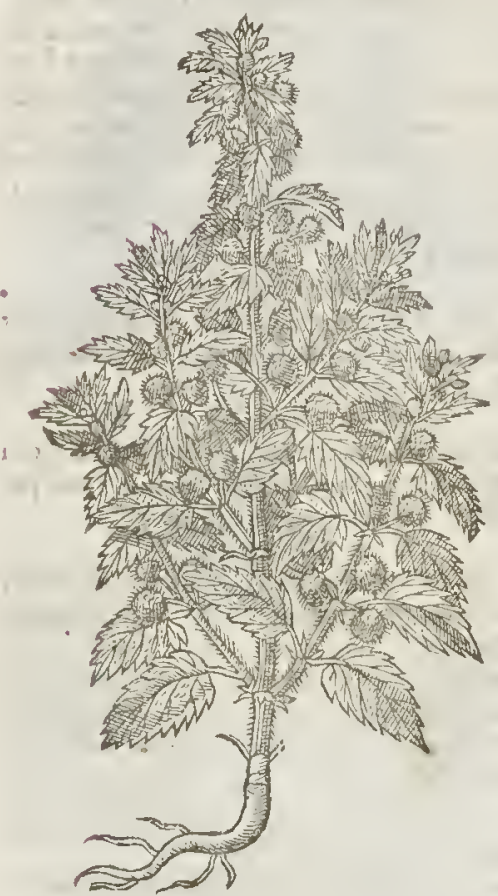

2 Vrtica urens.

Common ftinging Nettle.

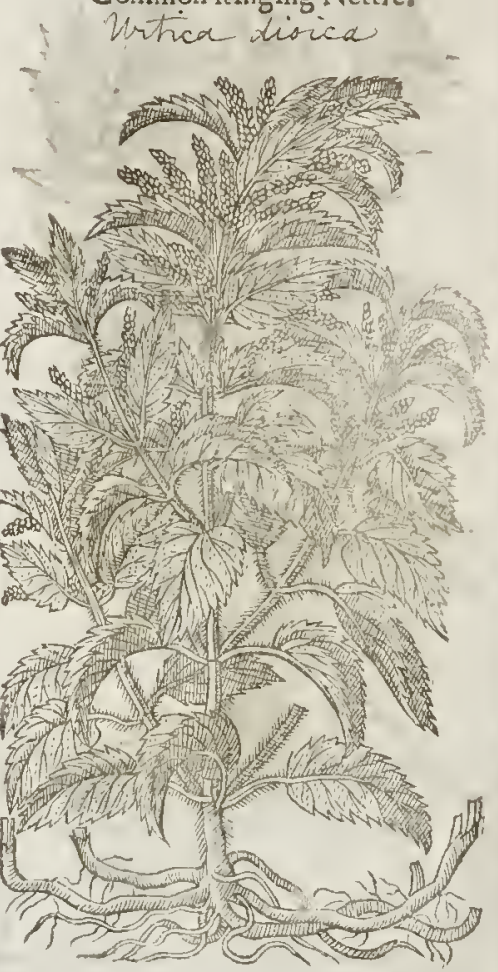

2 The fecond Nettle beeing our common Nettle is like to the former in leaucs and ftalkes, but yet now and then higher and more full of branches: it is alfo couered with a downe that ftingeth and burneth as well as the other : the feed herenf is fmall, and groweth not in round bullets, but on long flendet ftrings, as it were in elufters, as thofe of the fema le Mereury, whieh grow along the ftalkes and branches aboue the leates, very many. The ront is full of ftrings; of colour fomething yellow, and crecpeth all about. $¥$ This hath the ftalkes and sootes fometimes a little reddifh, whenee Taberzamontans and our Authour gate another figure thereof by the name of $\boldsymbol{V}$ rtica rubra, Red Nettle. $\ddagger$

3 The third is like to the feeond in ftalkes, lcaues and feed, that groweth by clufters, but leffer, and commonly more full of branches of a light grcene, more burning and fting ing; the root is finall and not without itriggs. 


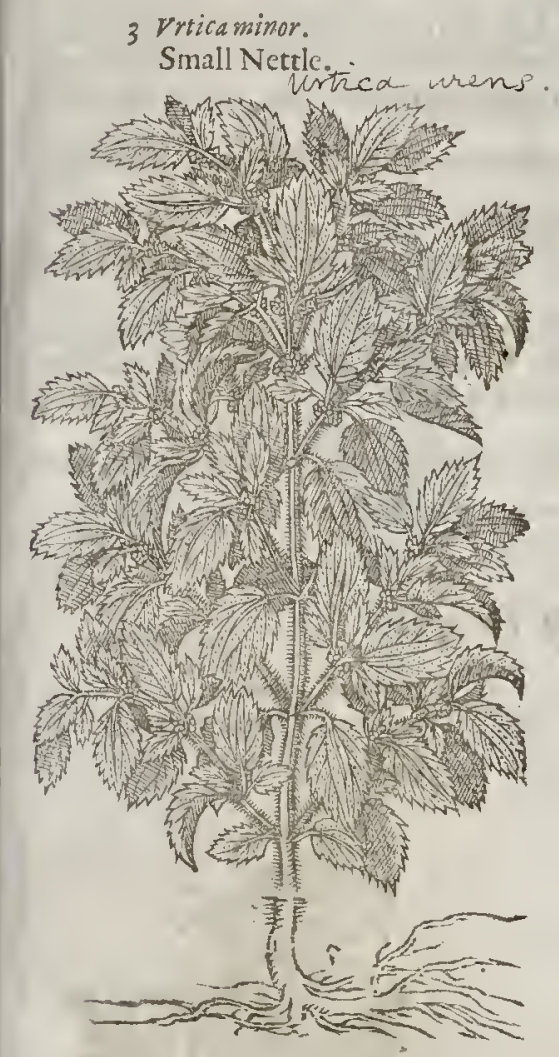

II The Elace.

Nettles grow in vatilled places, and the firt in thickewoods, and is a ftranger in England, notwithiftanding it groweth in my garden.

The fecond is more eommon, and groweth of it felfe neere vnto hedges, buhnes, brambles, and old walls, almoft encry where.

The third alfo eommeth vp in the fame plaecs, whieh notwithetanding groweth $x$ gardens and moift carable grounds.

$$
\text { The Time. }
$$

- They all fiourig in Sommer : the fceond furfeteth the winters cold: the feed is ripe, and may be gathered in Iuly and Auguft.

$$
\text { G The Natmes. }
$$

It is ealled in Grecke Agrasis : in Latine, Fritica, ab vycndlo, of his burning and ftinging qualitie: whereupon Marer faith,

$$
\text { - nec immerito nomen fump fiff widet ur, }
$$

Neither without defert his nane lee feemes to git,

As that which quickly burnes the fingers touching it.

And of diuers alfo wish, beeaufe it ftingeth with hurtfull downe: in high-Duteh, Rerfis : in Italian, Ortuea: in Spanifh, Hortuga in French, ortie : in Englith, Nettle The firt is ealled in

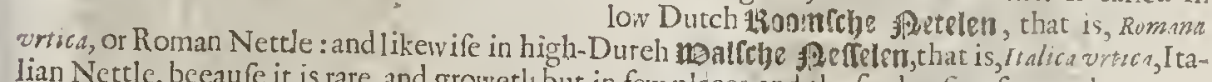
lian Nettle, beeaufe it is rare, and groweth but in few plaees, and the feed is fent from other countries, and fowne in gardens for his vertues : it is alfoealled of ditiers $\mathrm{Drt} \cdot \mathrm{camas}$ : and of Diofiortdes, Vrtica fylueftris, or wilde Nettle, whieh he faith is more rougl, with broader and longer leaucs, and with the feed of Flax, but leffer. Pliny maketh the wilde Nettle the maic, and in his $2 \mathrm{r}$ book, chap. 5 . Faith that it is milder and gentler: it is ealled in English Romane, Nett!e, Grecke Nettle, Male Nettle. The fecond is called Vrisafemina, and oftentircs Vruca maror that it mayd 1 ffer from the third Nettle: in Englim, Female Nettle, Great Nettle, or enm non Nettle. The

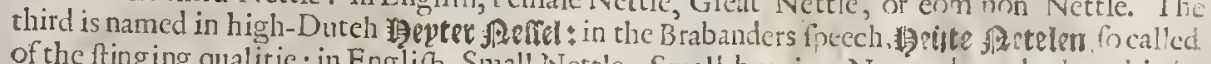
of the finging qualitie : in Englinh, Snall Nettle, Small butning Nett e:butwhether this be that or no whieh Pliny ealleth Cania, or rather the firft, let the Students confider. There is in the wilde Nettle a more finging qualitic, whieh, faith he, is ealled $C$ anza, with a ftalke more ftinging;
hauing nieked leaues.

Nettle is of temperature dry a The Temperature. for it doth not therefore burne and fting by, ferrfe in the firft degree: it is of thin and fuhtil parts, torfe ftiffe and hard, piereing like fine little prickles or Atngs, and entring inro the skin: for if ir be withered or boyled it ftingeth not at all, by reafon that the ftiffeneffe of the downe is fallen away.

\section{T $T$ he Verwues.}

Being eaten, as Diofcorides faith, boyled with Perywinkles, it maketh the bodv foluble, doing it by a kinde of eleaning qualitie : it alfo prouoketh vrine, and expelleth ftones nut of the kidneves: being boyled with bariey ereame ir bringeth vp tough humours that fieke in the eheft, as it is thought.

Being ftamped, and the iuyce put vp into the northrils, it ftoppeth the blecding of the nofe:the $B$ inyee is good againft the inflammation of the Vuula.

The feed of Nettle ftirreth wp luft, efpecially drunke with Cute : for (as Gulen faith) it hath in it C accrtaine windineffe, 
D It concocteth and draweth out of the clief raw humors.

E It is good for then that cannor bieathe vnicffe they hold their necks vpright, and for thofe that haue the pleurifie, and for fuch as be fiek of the inflammation of the lungs, if it be taken in a looeh or licking medicinc, and al fo againft the troublefome cough that children hatuc, called the Chineough.

F Nicander affimeth that it is a temedic againft the venomous qualitie of Hemlocke, Muthtoms, and Quick-filucr.

$\mathrm{H}$ And Apollodoris faith that it is a counterpoyfon for Henbane, Serpents, and Scorpions.

$H$ As Pliny witncffeth, the fame Authot writch, that the oyle of it takes away the finging whic the Nettle it felfe naketh.

I The lame groffely pomned, and drunke in white wine, is a mott fingulat medicine againft the ftone either in the bladder or in the rcines, as hath beene often proued, to the great eafe and com$K$ fort of thole that hate been gricuounly tormented with that maladic.

It expelleth gratell, and caufeth to makewate?

I. The lcames of any kinde of Nettlc, or the feeds, do worke the likeeffect, but not with that good fpeed and fo affuredly as the Romane Nettle

\section{Chap. 238. Of Hempe.}

I Camabi mas. Male or Stecle Hempe.

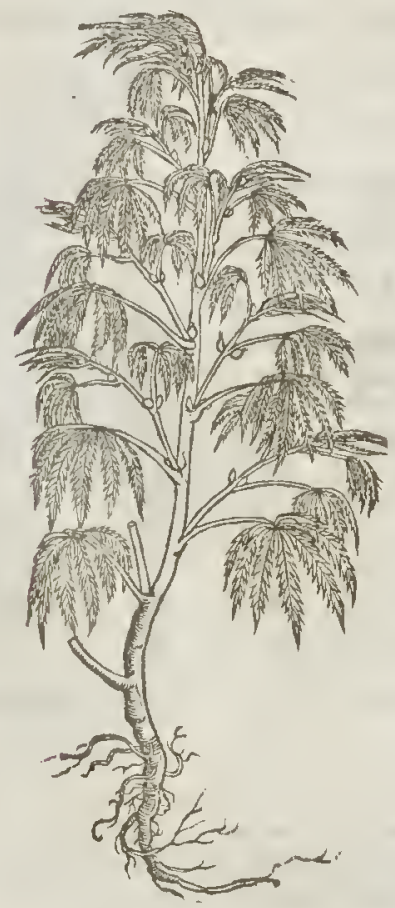

\$ Cansabis formina.

Femeline, or Female Hempe.

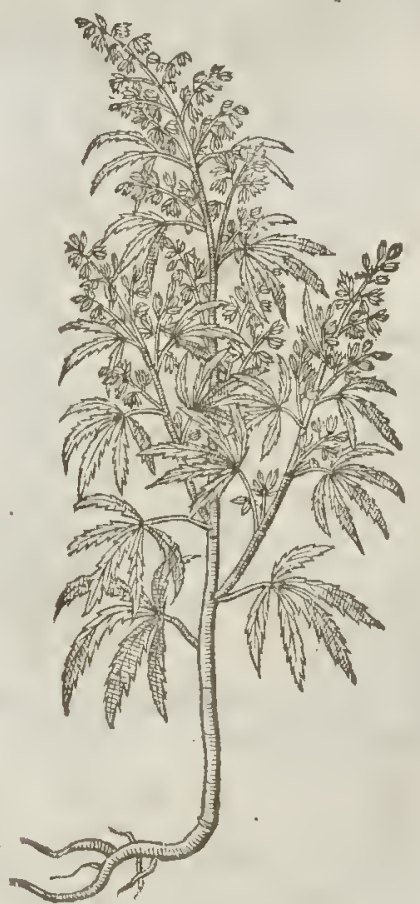

The $\dot{D}_{c}$ feription.

1 T Empe bringeth forth round ftalkes, ftraight, hollow, fute or fix foot high, full of bran1 ches when it growcth wildc of it felfe; but when it is fowne in fields it hath very few or nobranches atall. The lentes thereof be hard, toughi, fomcwliat blacke, and if they bebruifed they be of a ranke fnell, made vp of diuers little leaucs ioyned together,euery particular leafe whereof is na,row, long, tharpe pointed, and nicked in the edges : the feeds come forth from the bottomes of ithewings and leates, being round, fomewhat hard, full of white fubstance. The roots haue many ftrings.

2 There is an $x$ lice, being the femalc Hempe,yct barren and without feed, contrarie vnto the 
nature of that fex; which is very like to the otlier being the male, and one nuft be gathered befort the other be ripe, elfe it will wither away, and come to no good purpofe.

$$
\text { If The Place. }
$$

Hempe, as Columella writeth, delightecth to grow in a fat dunged and waterie foile, or plaine and moin, and deepely digged.

Hempe is fowne in Marchand Aprill; the freft is ripe in the end of Augut, the other in Iuly.

This is named of the Grecians romsen, alfo of the Latines Cannab is : the A pothecaries keep that name :in high-Dutch, Zzimer bauf $\$$ of the Italians Canipe : of the Spaniards, Canmo : in French,

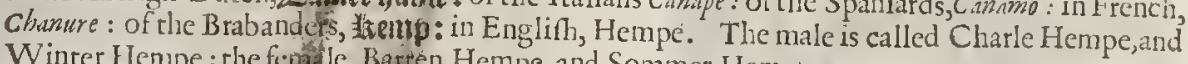
Winter IIenpe : the fenoule, Barten Hempe, and Sommer Hempe.

The feed of Hempe, a G ala witeth in his bookes of the faculties of fimple medicines, is hard of digeftion, hurtull to the fomacke and head, and containeth in it an ill inyee : notwithftanding fome do vfe to eate the fame parched, cum alys tragemat is, with other jtinkets. * Ir confumeth winde, as the faid Author faith in his booke of the faculties of medicines, and is

Diofcorides faith, That the inyce of the herbe dropped into the eares affwageth the paine there- $\mathrm{C}$ of proceeding (as I take it) of obftuction or ftopping, as $G$ r'en addeth.

The inner fub tance or pulpe of the feed preffed out in fome kinde of liquor, is ginen to thofe that haue the yellow jaundice, when the difeafe firtt appeares, and ofientimes with good fuccefe, if the difeafe come of obftruction without an agie ; for it openetin the patrage of the gall, and difperfeth and concoeteth the choler through the whole body.

Matthivlus faith, that the feed giuen to hens caufeth them to lay egges more plentifully.

1. Casnabis spuria.

Wilde Hempe. ialcopsis tetralial

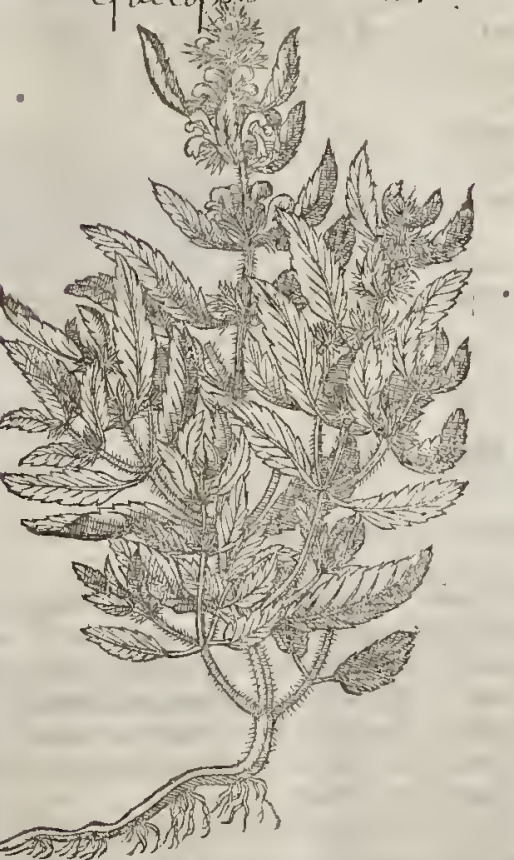

\section{Cha p. 239. Of wilde Hempe.}

\#2 Camnabis Spurianalecrs. Baitard Hempe.

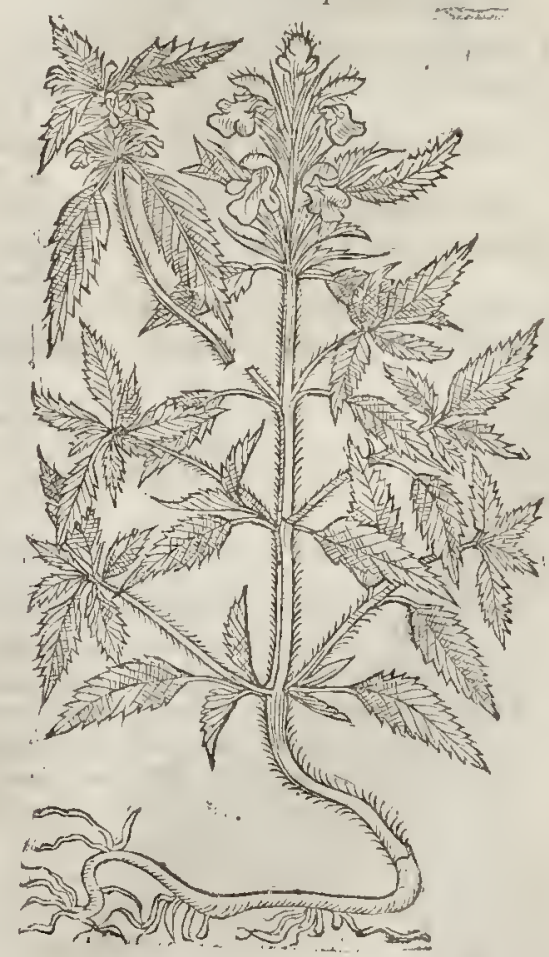


¥ Canmabis Spuriatertit.

Small Baftard Hempe.

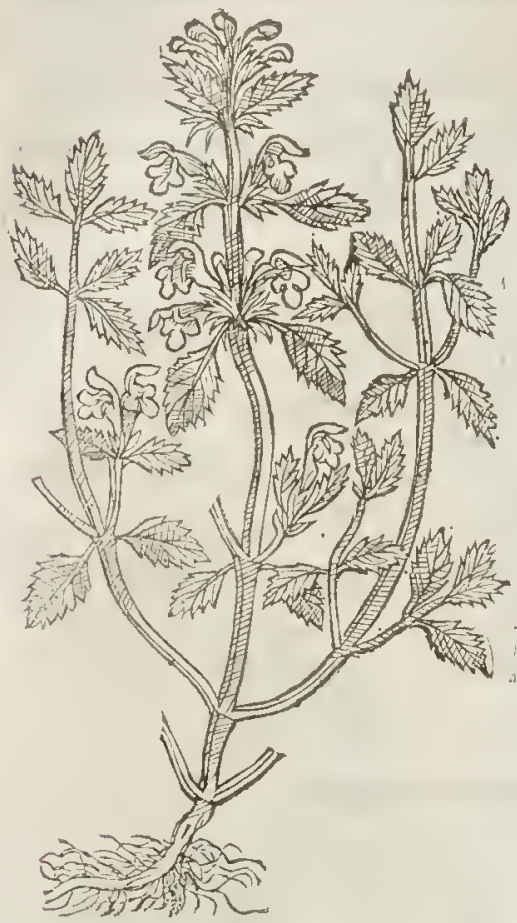

If $I$ he Deferiplion.

I THis wilife Hempe, called Canna1 bis Spurt., or Battard Hempe, hath fmal flenter hoary and hairic ftalkes a foot high, befet at cuery ioynt with two leanes, fmally indented about the edges fomewhat like a Nertle. The Houres grow in rundlcs about the ftalkes, of a purple colour, and fometimes alfo white: the root is little and threddy.

2 There is likewife another kind of wild Hempe which hath hairie ftalkes and leates like the former, but the floures are greater, gaping wide open like the foures of Lamiros, or dead Nettle, wherc of this lath becin taken for a kinde : but hee that knoweth any thing may cafily difcerne the fauor of hempe from the foncll of dead Nettle. The floures are of a cleare and light carnation colour, declining topurple.

3 There is alfo another kinde of wilde Hempe like unto the lut before mentioned, fauing that it is fmaller in each refpeit, and not fo hairy. The leafe is foncw liat iounder: the root fmall and threddy : the floute is larger, being purple or white, with a yellow fpot in the infide.

$$
\text { 9f The Place. }
$$

Thefe kinds of wild or baftard Hempe do grow upon hills and mountaines, and barren hilly grounds, efpecially in earable land, as I Thame often feene in the corne fields of Kent, as abour Gramefend, Southfleet, and in all the tract from thence to Canturbury, and in niany places about London.

$$
\text { T) The Time. }
$$

Thefe herbes do floure from Inly to the end of Augutt.

$$
\text { T The Names. }
$$

It thall fuffice what luth been fet downe in the titles for the Latine names: in Englin, Wilde Hempe, Nertle Hempe, and Baftard Hempe.

T The T cmperature and Vertues. The temperature and faculties are referred to the manured Hempe, now ithetanding they are
not vfed in plyficke where the other may be had.

$$
\begin{gathered}
\text { Cн а P. 240. OfWater-Hempe. } \\
\text { T The Defcription. }
\end{gathered}
$$

I VV Ater-Hempe or Water-Agrimony is feldome found in hot regions, for which caufe Northerne countries in moitt places, and in the fomidna Septentrionalum, and groweth in the cold The rumet contimuetl long, having many long and flender onds, flow running riucrs, and ditclies. the ftalkes grow a cubit an a h o diftares one fromanorler. The leanes af a darke purple colour, with many branches ftanding by flowes grow at the top, of a browne yellow colour, ported with be hairy than the malekind : the whicin confifteth of fuch a funtere is is in thour, potred with blacke pots like affer atticus; about with fmall and fharpe leancs, as is in the midit of the Daifie, or the Tanfic floure, and is fet refemble a ftar, and it fauoreth like gum Elemni, nu fine Rofe, which caufeth the whole floure to is long like Pyethrum, clofely the gur Elmmi, Ralme, or Cedar wond when it is burned. The feed toucinet? 
toucheth by reafon of his roughneffe. $¥$, This is found with the leaues whole, and alfo with them parted into three parts : the firft varietie was expreft by our Authors figure; and the feeond is axpreft by this we gitte you in the place thereof. $\neq$

2 . There is another wilde Hempe groving in the water, whereof there be two forts more, delighting to grow in the like gtound, in thew differing very little. This fprings vp with long round ftalkes, and fomewhat reddirh, about two eubits high, or fomething higher: they are befet with long greene leates indented about the edges, whereof you thal fee eommonly fuc or feuen of thofe leaues hanging vpon one ftem like the leaucs of Hempe, but yet fofter. The floures are little, of a pale reddin colour, confifting of foft round tufts, and ftand perting vpon the top of the fprigges, which at length vanifh away into downe : the toot vinderneath is full of threddy ftrings of a mean bigneffe.

I Eupatorism Cannabinum fomina.

Water Hempe, or Water Agrimony. Bidens tripartita

(n)

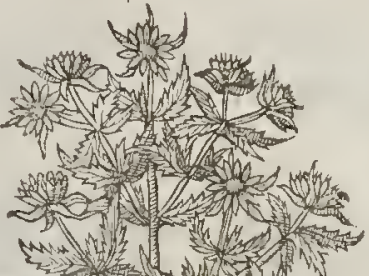

st
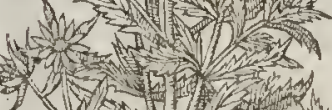

sim $\rightarrow$

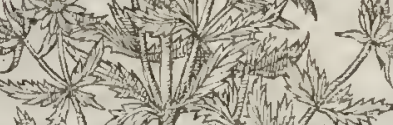

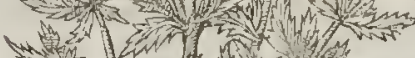

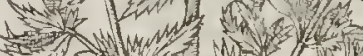

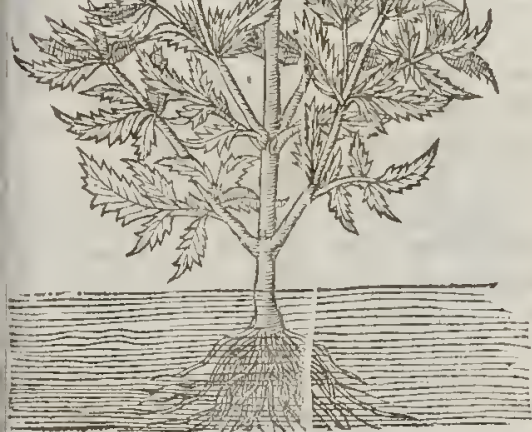

$\ddagger 2$ Euprorium Cannatinum mas.

Common Duteh Agrimonie.

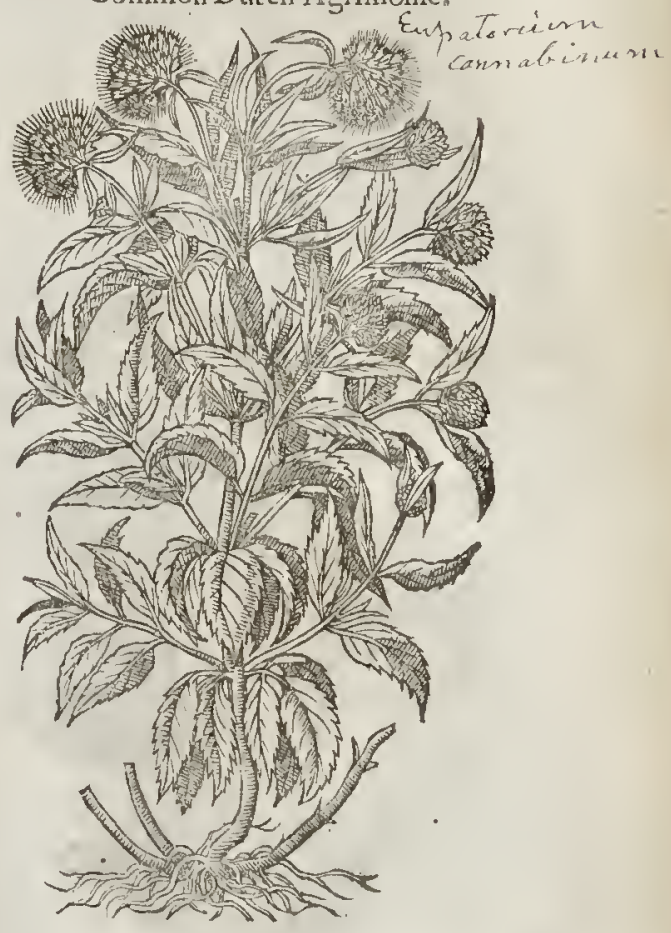

Qf The Place.

'They grow about the brinks of ditehes, runuing waters, and ftanding pooles, and in watety places almoit eutery where.

They foure and flourith in Iuly and Auguft : the root continues, but the falkes and leaties wither avvay in Winter.

TI The Nomes.

The baftard or wilde Hempes, efpeeially thofe of the warer, are eommonly called Hepatorium Fannabinum: of diuers alfo Eupatorium, Leonhar. Fuchlous nameth it Eupatorium 1 Adulterinum : of

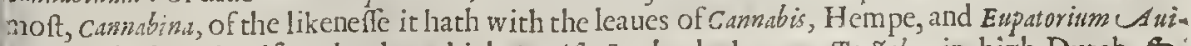

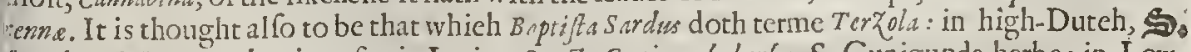
Utunigumb litaut ; that is to fay in Latine, sancta Cunigunde herba, S. Cunigunds herbe: in LowDuteh, 2Boellsetsy ktuit : in Englifh, Water Hempe, Baftard and water Agrimonie. It is called Itepatorium, of the facultie, being good for Hepar, the lituer. $\neq$ I haue nanted the feeond Common Duteh Agrimonie, becaufe it is eommonly ved for Agrimonic in the thops of that countrey. T The Tesinperature.

The leaues and roots of thefe herbes are bitter,aifo hot and dry in the fecond degree they hate vertue to feoure and open, to attenuate or make thinne thieke and groffe humours, and to expell or drite them forth by vrine: they clenfe and purifie the bloud. 


\section{T) The Vertues, which chiefcly beions to the laft deforibed.}

A Thedecoction hercof is profitably giuen to thofe that be feabbed and hauc filthy skinnes; and likewife to fuch as hauc their fpleen and liuer fopped or fwolne : for it taketh away the floppings of both thofe intrals, and alfo of the gall : whereforc it is good for them that haue the jaundice, efpecially fomewhat after the beginning.

B The lserbe boyled in wine or water is fingular good againft tertiah Feuers.

C The decoction drunke, and the leaues outwardly applied, do heale all wounds both inward and outward.

D $\doteqdot$ Fachfous faith that the fccond is very effectuall aga inf poyfon. And Gefner in his Epiftles affirmet $h$, that he boyled about a pugil of the fibres of the root of this plant in wine, and drunkc it, which an houre after gaue him one ftoole, and a fterw ards tweluc vomits, whereby he caf vp mueh flegme : fo that it workes (waith he) like whitc Hellcbor, but much more eafily and fafely, and it did me very much good. $\ddagger$

\section{Cнар. zq⿻: Of Egrimonie.}

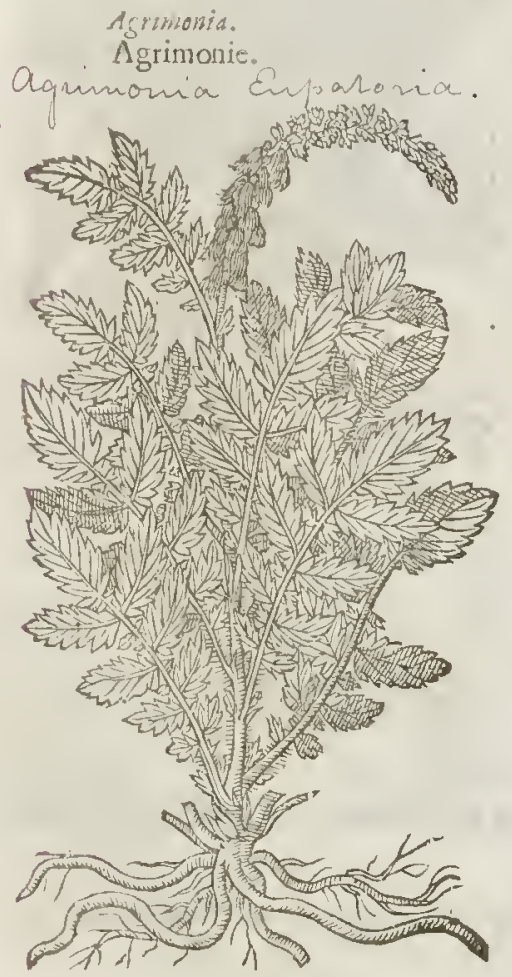

T) The Defription.

Tic leaues of Agrimonic arc long \& hai rie, greenc aboute, and fomewhat grayith vnderneath, parted into diucrs other fmall leaues fnipt sound about the edges, almolt like the leaues of hempe: the ttalke is two foot and a halfe long, rough $\&$ hairy, whercupon grow many fulall yellow floures one aboue another vpivards toward thc top : after the floures come the feeds fomewhat long and rough, like to fmall burs hanging downwards; which when they be ripe doe catch hold vpon peoples garments that paftc by it. The root is grcat, long, and blacke.

$$
\text { T The Place. }
$$

It growes in barren places by highwayes? inelofures of medowes, and of corne fields, and oftentimes in woods and copfes, and al. moft euery wherc.

$$
\text { I The Time. }
$$

It floureth in Iunc and fomwhar larer, and feedeth 2 ftcr that a great part of Sommer.

$$
\text { The Names. }
$$

The Grecians eall it ivtrawen : and the Latines alfo Eupatorium: Pliny, Euputoria: yet there is another Eupatorium in Apuleiss, and that is Warmbium, Horehound. In like numer the Apothecaries of Germany hauc another Hepatorim that is there commonly ved, bcing deferibed in the latt ehapter, and may be named Hepatorium adulterinum. Agrimonic is named Lappa inuerfa : and it is fo called, becaufe the fecds which are rough like burres do hang dow nwards: of fome, Philanthropos, of the cleauing qualicie of the fecds banging to mens garments : the Itnlians and Spaniards call it Agramonia: in higls

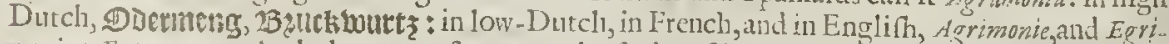
monic : Euputoriwn taketh the name of Eupator, the finder of it out : and (faith Pling) it hath a roy: all and princely atthoritie.

$$
\text { The Temperature. }
$$

It is hot,and dotin moderately binde, and is of a temperate drineffe. Galen fizith that Agrimonie is of fine and fubtill parts, that it eurteth and foureth , thereforc, faith he, it remoucs obftriftions or ftoppings out of the liuer, and doth likewife ftrengthen it by reafon of the binding quality that
is in it. 
Tा The Vertues.

The decotion of the leaues of Egrimony is good for them that haue natughty liuers, and for A fuch as piffe bloud vpon the difeafes of thckidnics.

The feed being drunke in wine (as pliny affirmeth) doth helpe the bloudy fixe.

$D$ iofcorides addeth, that it is a remedy for them that haue bad liuers, and for fuch as are bitten $B$ with ferpents.

The leaues being famped with old fwines greafe, and applied, elofeth vp vicers that be hardly $D$ healed, as $D$ iof corides faith.

¥ Agrimony boiled in wine and drunke, helpes inucterate hepaticke fluxes in old people. $\neq$ E

\section{Снав: 242. Of Samewoort.}

x. 2. Serratulapurpurea, fue alba.

Saw-woort with purple, or white floures。 Sernatula finctoria.

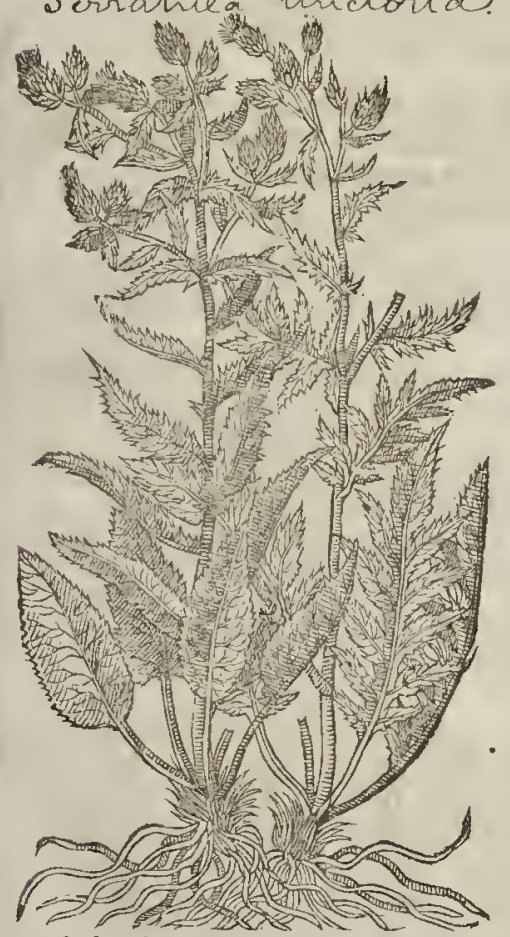

7) The Defeription:

i He plant which the new writers haue called Serratula differeth from Betonica, although the Antients haute fo called Betony; It hath large leates fomewhat fuipt about the edges like a faw (whereof it tooke lis name) rifing immediately from the root: $a-$ mong which eome vp ftalkes of a cubite hict, befer with leaues very deepely eur or jageed euen to the middle of the rib, not much vuilite the male Scabious. The ftalkes towards the top dituide themfelues into other fmall branches, at the top whereof thcy beare floures fomewhat fcaly, like the Kinapweed, but not fo great nor hard:ar the top of the knap commeth forth a buhie or thrummy floure, of a purple colour. The root is threddy, and thereby increafeth and becommech of a great quantity.

2 Sawewoort with white houres differeth nor from the precedent, but in the colnur of the floures : for as the other bringeth forth a buth of purple floures; in a mun or this plant bringeth forth foures of the fame falhion, but of a fnow white eolour, whercin confiftetl the differenee.

$\$$ Our Authour our of Tabernamontanus gaute 'three figures, with as many defcriptions of this plant, yet made it onely to vary in the colour of the foures, being either purple, white, or red; but he did not touch the difference which Tabernamontanus by his figures expreft, which was, the firt had all the leanes whole, being only fnipt about the edges; the lower leates of the fecond were moft of them whole, and thofe vpon the ftalkes deepely eut in, or dituided, and the third had the leates both below and aboue all cur in or deepely dinided. The figure which we here give you expreffes the firft and third varieties, and if you pleale, the one may be with whice, and the other with red or purple floures. $\ddagger$

$$
\text { T) The Place. }
$$

Sawe-woort groweth in woods and thadowie places, and fometimes in medowes. They grow in Hampfted wood: likew ife I haue feene it growing in great abundance in rhe wood adjoinng to Iflington, within halfe a mile from the further end of the towne, and in fundry places of Eflex and Suffolke.

If The Iime.

They floure in Iuly and Auguit.

000 


\section{4) The Names.}

The later age doe call them Serratula, and Serratula tinctoria, it differeth as we have faid from Betony, which is alfo called serratuld. Other names if it haue any we know not: it is called in Englifh Sawewoort. $\ddagger C$ c falp.nus calls it Cerretta and Serretta, and Thalius, Ccntauroides, or Centaurium maius fylveftre Germancum . †

भ. The Temperature andVertues.

A Serratula is wonderfully commended to be moft fingular for wounds, ruptures, burftings, and fuch like : ard is referred vnto the temperature of Sanicle.

\section{Cнар. 243. Of Betony: \\ I) The Dcfeription.}

$x$

B Etony groweth up with long leates and broad, of a darke greene colour, lightly in dented about the edges like a faw. The ftalke is flender, foure fqutre, fomw har rough, a foote high more or leffe. It beareth eared floures, of a purplith colour, and fomc. times reddith; after the foures, commeth in place long cornered feed. The root confiftetl of many ftrings.

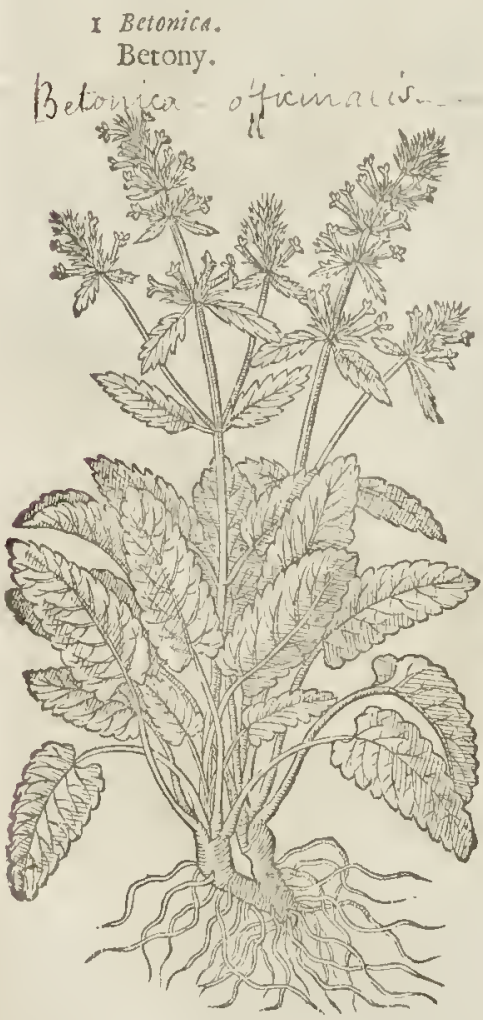

2 Betony with white floures is like the precedent in each refpeot, fauing that the Hours of this plant are white, and of greater beautie, and the others purple or red,as a torefaid.

\section{q) The Place.}

Betony lones Thadowic wo ids, hed ge-rowes, and copfes, the boivers of paftures, and fuch like places.

Betony with white floures is feldome feene. I found it in a wood by a village called Hampfead, ncere vnen a worhipfull Gentlemans houfe, one of the Clerkes of the Queenes counfell called Mr. Wade, from whence I brought plants formy garden, where they flourith as in their naturall place of growing.

$$
\text { 9. The nime. }
$$

They floure and flourith for the moft part in Iune and Iuly.

$$
\text { Tा The Names. }
$$

Betony is called in Greeke reses: in Latine, Betonica: of diuers Fetosica : but vnproperly. There is likewife another Betonica, which Paulus Asineta defcribed; and Galen in his furt booke of the goucrument of health theweth that it is called wiser, that is to fay, Bctonica, Betonic, and alfo Sarxiphazon: Diofcorides notwithltanding doth defcribe another Surxiphogen.

$$
\text { Tा The Temperiture. }
$$

Betony is hot and dry in the fecond degres: if hath force to cut, as Galen faitl.

The Fertues.

A

Betony is good for then that be fubject to the falling fickeneffe, and for thofe alforhat luate ill heads vpon a cold caufe.

B It clenfeth the lings and cheft, it takel away obftructions or ftoppings of the liuer, milt, and gall : it is good againft the ycllow jaundife.

Itmaketh a man to hauca good ftomack and appetite to his meate:it pretuileth againff fower belclings : 
belchings : it maketh a man to piffewell : it mitigateth painein the kidnies and bladder : it breaketh ftones in the kidnies, and driueth them foth.

It is alfo good for ruptures, ctamps, and convulfions : it is a tcmedie againft the bitings of mad dogs and venomous ferpents, being drunke, and alfo applied to the hurts, and is mof fingulat a-
gainft poy fou.

It is commended againft the paine of the Sciatica, or ache of the huckle bone.

There is a Conferue made of the floures and fitgar good for many things, and efpecially for the $E$ hcad-ache. A dram weight of the root of Betonic dried, and taken with meade or honied water, procureth vomit, and bringeth forth grofle and tough humors, as diuers of out age do report.

The pouder of the dried leaues drunke in wine is good for them that fpit or piffe bloud, and cureth all inward wounds, efpecially the greeneleaues boyled in wine and guen.

The pouder taken with meate loofeth the belly vety gently, and helpeth them that haue the fal- $\mathrm{H}$ ling fickneffe with madneffe and head-ache.

It is fingular againftall paines of the head : it killeth wormes in the belly; helpeth the Agut: it cleanfeth the mothet, and hath great vertue to heale the body, being hurt within by bruifing or fuch like.

$$
\begin{gathered}
\text { CHAp.244. Of Water-Betony. } \\
\text { T The Defription. }
\end{gathered}
$$

VV Ater Betony hath great fquare hollow and brown falks, wheteon are fetverybroad leaties notched about the edges like vnto thofe of Nettles, of a fwart greene colour, growing for the moft part by two and two as it were from one ioynt, oppofite, or ftanding one right againit an other. The foures grow at the top of the branches, of a darke purple colour, in thape like to little helmets. The feed is mall, contained in tound bullets or buttons. The root is compact of many and infinite ftings.

Betorica aquatica.

Vater Betony.

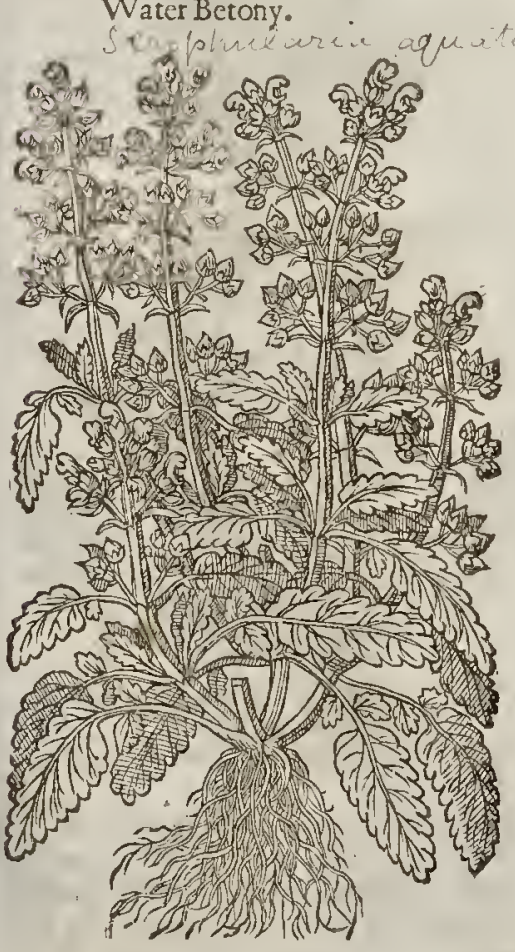

If The Place.

Ir groweth by brookes and running watcts, by ditch fides, and by the brinks of riuets, and is feldome found in dry places. 9ा The Trme.

It floureth in Iuly and Auguft, and from that time the feed waxeth ripe.

$$
\text { 9) The Nomes. }
$$

Water Betonic is called in Latine Betonica aignatica: fome haue thought it Diofcorides his Clymenum : orhers, his Giteop is : is is sirophulavialtera of Dodonaus : of Turner, Clymenon: of fome, Sefamoides minus, but not properly: of others, Serpentaria : in Dutch, 5 , alntonies ctupd in Englifh, Water Betonic : and by fome, Browne-wott : in Yorke-Thire; Bithops leaues:

$$
\begin{gathered}
\text { The Temperature. } \\
\text { Water Betony is hot and dry. } \\
\text { of The Vertues. }
\end{gathered}
$$

The leaues of Water Betony are of a fcou- A ring ot cleanfing qualitic, and is very good to mundifie foule and feinking vlcets, efpecially the inyce boyled with honcy.

It is reported, if the face be warhed with $B$ the iuyce thereof, it taketh away the tedneffe and deformitic of it.
$\mathrm{OOO}_{2}$
CHA P. 


\section{II A P. 245. \\ Of Great Figge-wort, or Brownewort. \\ Tा The Defription.}

I THe great Fig-wort fpringeth vp with ftalkes foure fquare, two cubits high, of a darke purple colour, and hollow within : the leaues grow alwayes by eouples, as it were from one ioynt, oppofite, or Atanding one right againft another,broad, tharpe pointed, fnipped round about the edges like the leanes of the greater Nettle, but bigger, blacker, and nothing at all ftinging when they be touched : the floures in the tops of the branehes are of a darke purple colour, very like in forme to little helmets : then eommeth vp little fmal feed in pretry round buttons, but fharpe at the end : the root is whitifh, befet with little knobs and bunches as it were knots and kernels.

2 There is another Figge-wort ealled Scropbularia Indica, that hath many and great branches trailing here and there vpon the ground, full of leaues, in fathion like the wilde or common Thiftle, bur altogether without prickes : among the leatues appeare the floures in fathion like a hood, on the out fide of a feint eolour, and within intermixt with purple; which being fallen and wi. thered, there eome in place fmall knops very hard to breake, and tharpeat the point as a bodkin: which containeth a fmall feed like vnto Time. The whole plant perifheth at the firit approdh of Winter, and muft be fowen againe in Aprill, in good and fertile ground. \# This is the Scrophuldriacretica 5 . of Clafins. $f$
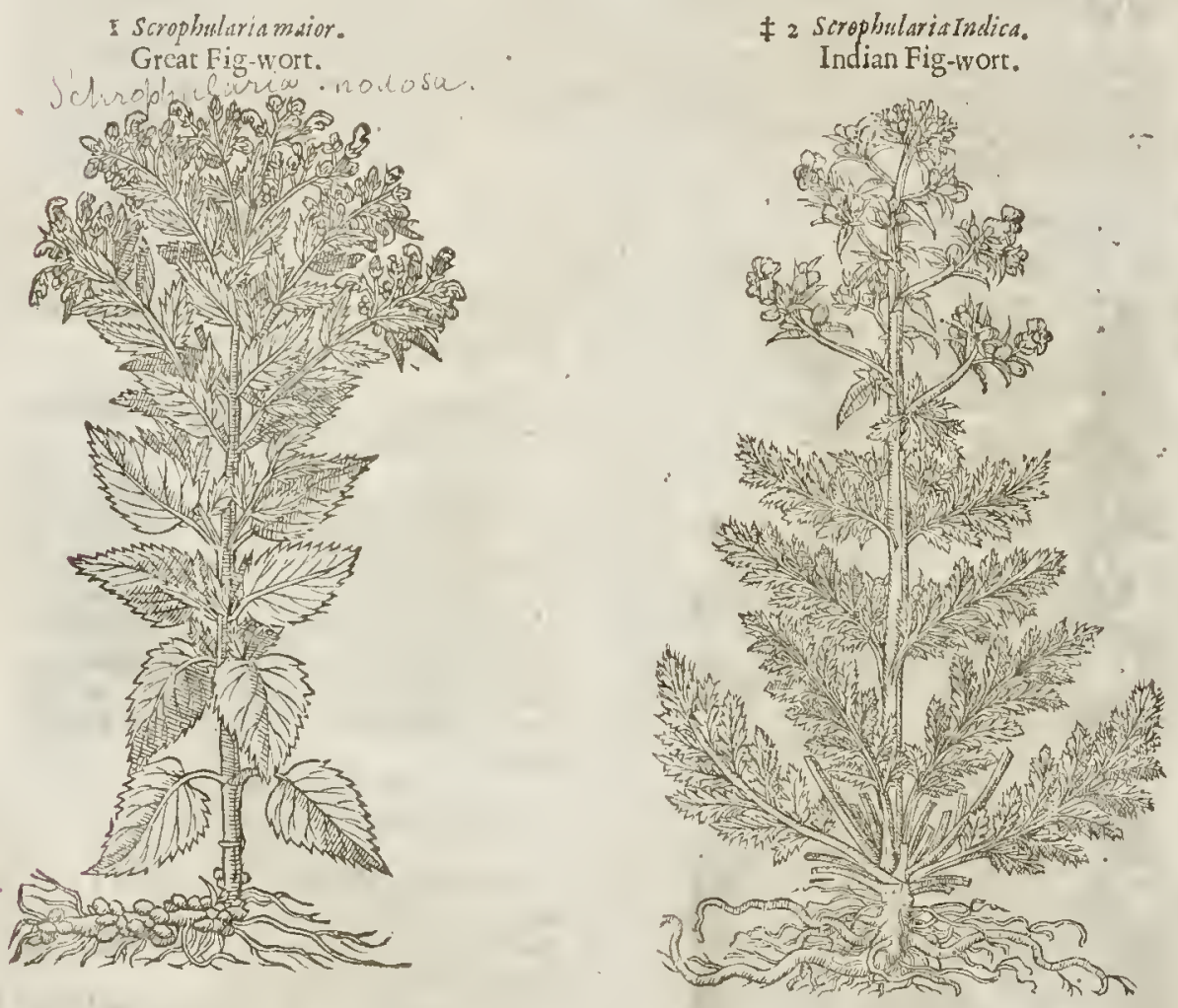

\#3. The ftalke of this is alfo fquare, and fome yard high, fet with leaues like thofe of the hedge Nettle, but fomewhat larger and thicker, and a little deeper cut in : out of the bofomes" of thefe leatres eome little rough foot-ftalkes fome ineh or two long,earrying fome foure or fue hollow round foures of a greenifh yellow colour, with fome threds in them, being open at the top, and eut in with fiue litrle garhes: the feeds are blacke, and contained in veffels like thofe of the 
firf deferibed : the root is like that of the Nettle, and liues many yeares : it floures in May, and the feeds are ripe in Iune. I haue not found nor heard of this wilde with vs, but feen it flourining in the garden of my kinde friend M: lohn Parkinfon. Clufius ealls it Lamizm 2. Pannonicum exotzcum : and Baubine hathfet it forth by the name of Scrophulariaflore luteo: whom in this I follow. $f$

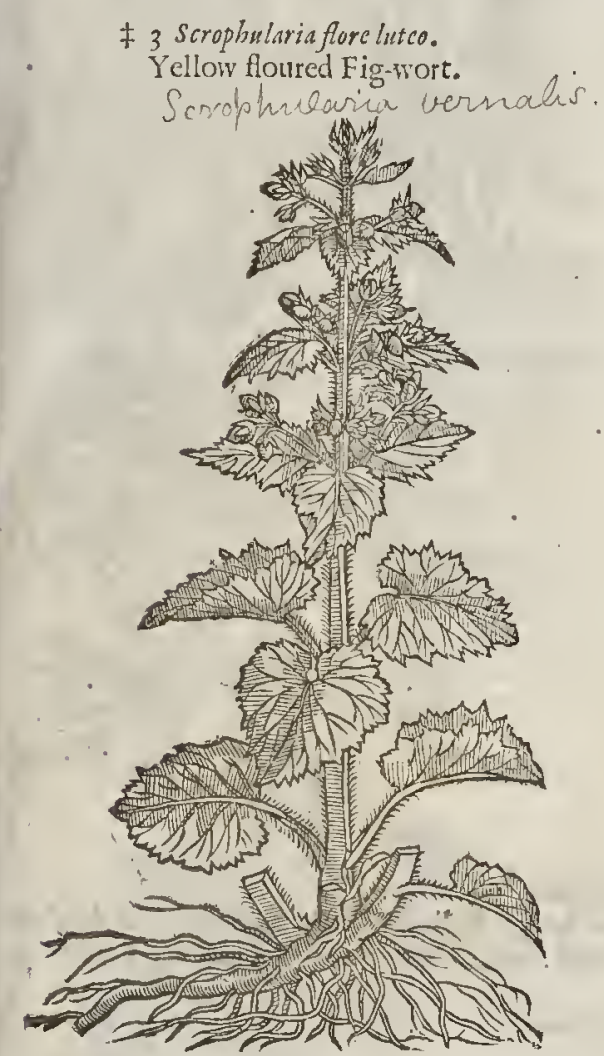

3 Scrophulariaflore lutco.

Yellow floured Fig-trot.

Scrophmaria vernalis.

Tf The Place.

The great Scrophularia groweth plentifilly in Thadowie Woods, and fometimes in moif medowes, efpecially in greateft aboundanee in a wood as you go from London to Harnefey, and alfo in Stow wood and Shototier neere Oxford.

The ftrange Indian figure was fent me from

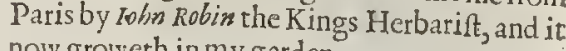
now groweth in my garden.

$$
\text { The Tinac. }
$$

They floure in Iune and Iuly.

$$
\text { Tा The Names. }
$$

Fig-wort or Kernel-wort is called in Latine Scrophularia sinaior, that it might differ from the leffer Celandinc, whieh is likerr ife ealled scrophalaria, with this addition minor, the lefler : it is called of fome Millemorbia, and caftrangrila: in Englifh, great Fig-wort, or Kernel-wort, but moft vfually Brown-wort.

$$
\text { of } T \text { the Vertues. }
$$

Fig-wort is good againft the hard kernells $A$ whieh the Grecians eall ximest : the Latines, Strumas, and commonly Scrophulas, that is, the Kings Euill : and it is reported to bea remedy againt thofe difeafes whereof it tooke bis name, as alfo the painefull pilés and frvelling of the hæmorrhoides.

Diters do rafhly teach, that if it be lianged $B$ about the necke, or elfe carried about one, it keepeth a man in health.

Some do fampe the root with butter, and fet it in a moift thadow ie piace fifteene dayes toge- $\mathbf{C}$ ther: then they do boyle it, fraine it,and keepe it,wherewith they anoinethe hard kernels, and the hamorrhoide veines, or the piles which are in the fundament, and that with good fueeeffe.

\section{C.HA Р. 246. Of Veruaine.}

\section{9t The Defcription.}

I I ftalke of vpright Veruaine rifeth from the root fingle, eornered, a foot high',
feldome abouc a eubite, and afterwards diuided into many branches. The leaues reldome aboue a eubite, and afterwards diuided into many branehes. The leaues
are long, greater than thofe of the Oke, but with bigger cuts and deeper : the foures along the fprigs are little, blew, or white, orderly plaeed : the root is long, with ftrings growing on it.

2 Creeping Veruaine fendeth forth ftalkes like vnto the former, now and then a eubit long, cornered, more flender, for the moft part lying vpon the ground. The leaues are like the former, but witlideeper cuts, and more in number. The floures at the tops of the fprigs are blew, and purplewithall, very fmall as thofe of the laft deferibed, and plaeed after the fame manner and order. The root groweth fraight downe, being flender and long, as is alfo the root of the
former. 
1 Vexpena communis.

Common Veruaine.

Verliency officimalis.

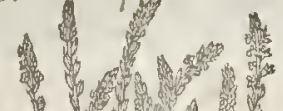

in
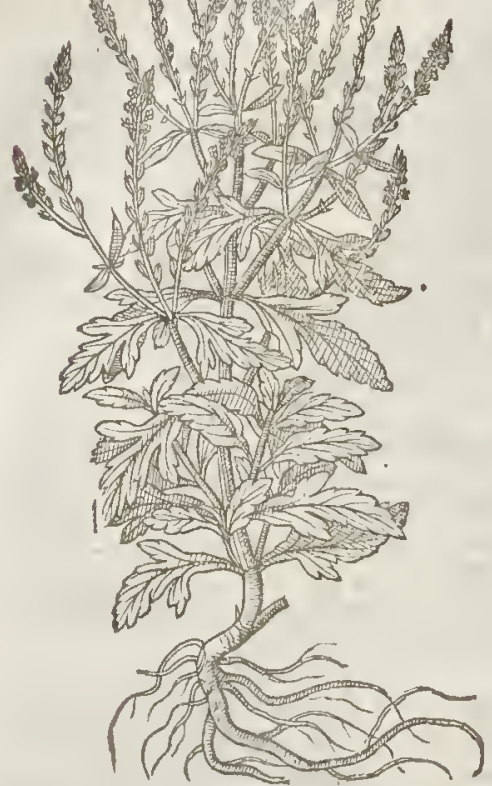

2 Terbena facra.

Common Veruaine.

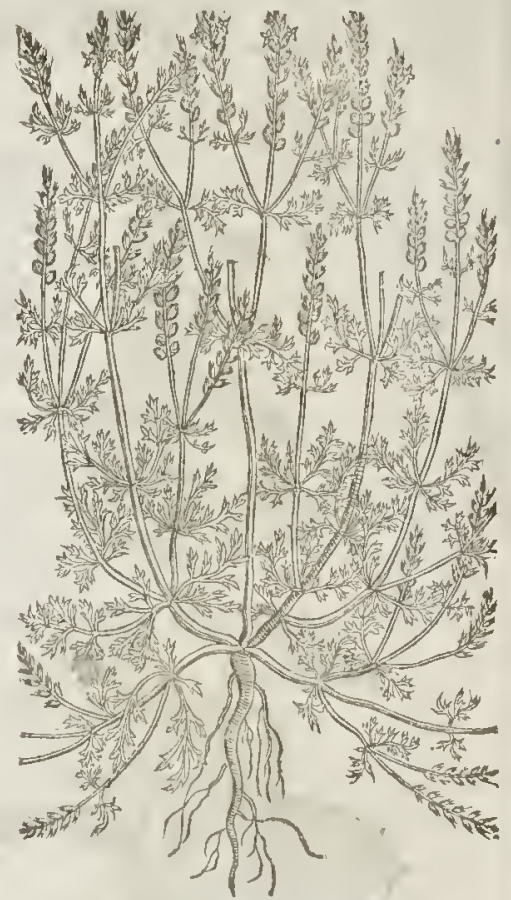

- The Place.

Both of them grow in vntilled plaees neere vnto hedges, high-wayes, and eommonly by ditches almolt everywhere. \$ I haue not feene the fecond, and doubt it is not to be found wilde in England. $\ddagger$

The Veruxines foure in July and Augutt.

$$
\text { Ti The Time. }
$$

a The N.tmes.

Veruaine is ealled in Greeke areust:m : in Latine, Verbena, and Verbenaca, Herculania, Ferraria, and Exapera : of fome, Marricalts, and Hicra botane: of orbers, Veruesa, and Sacra berba: Verbene are herbes that were taken from the Altar ${ }_{3}$ or from fome holy plaee, whiel becaufe the Confull or Pretor did eut vp, they were likewife ealled Sagmin.t, whieh oftentiures are mentioned in Limy to be graffic herbes euc vp in the Capitoll. Pliny alfo in his two and twentieth booke, and eleuenth Chapter witneffeth, That Verbine and Sigmma beall one : and this is manifeft by that whieh wee reade in Andwa in Terence: Exa averbenss bunc fume; Take herbes liere from the Altar : in which. plaee T crence did nor meane Vertaine to betaken from the Altar, but fome eertaine herbes : for in Menunder, out of whom this Comedie svas tranflated, is read usprim, or Myrtle, as Donatus faith. In Spanifh it is ealled Vroeban: in Italian, Verminasula: in Duteh, 3 fer eruit : in French, Veruaive : in Englith, Imo's teares. Mircuries moilt bloud, Holy-herbe ; and of fome, Pigeons graffe, or Columbine, becaufe Pigeor is delighted to be amongft it, as alfo to eat thereot, as Apuleiws writeth.

$$
\text { The Temporature. }
$$

Both the Vertaines are of temperature very dry, and do meanly binde and coole.

$$
\text { जा The Vertues. }
$$

A The leates of Vermaine pownd with oile of Rofes or hogs greafe, doth mitigate and appeafe the paines of the morher, being applied thereto.

B The leatus of Veruane and Rofes famped with a little new hogs greafe, and emplaiftered a frer the manner of a pultelfe, doth ceafe the inflammation and grieuous paines of wounds, and fuffereth tlien not to come to eorruption: and the greene leates ftamped with hogs greafe takes away the fwelling and paine of hot impotunes and tumors, and eleanfeth eormpt and rocten vleers.

C It is reported to be of fingular foree againft the Tertian and Quartane Feuers: but you muft obferue 
obferue mother Bombies rules, to take iuft fo many knots or fprigs, and no more, lef it fall out fo that it do you no good, if you eareh no harm by it. Many odde old wines fables are wricten of Veruaine tending to witeheraft and forcerie, whieh you nuay read el fewhere, for l am not willing to trouble your eares wirh reporting fueh trifles, as honeft eares abhorre to heare.

Archigenes maketh a garland of Veruaine for the head-aehe, when the caufe of the infirmitie D proceedeth of hear.

The herbe ftamped with oile of rofes and Vineger, or the decotion of it made in oile of rofes, $E$ keepeth the haires from falling, being bathed or annointed therewith.

It is a remedie againft putrified vlcers, it healeth vp wounds, and perfectly cureth Fiftulaes, it F wafteth away old fwellings, and taketh away the heat of inflammations.

The decoction of the roots and leaues fwageth the toorh-ache, and fatteneth thetn, and healeth $G$ the vleers of the mouth.

They report faith Pliny, that if the dining roome be fprinekled with water in whieh the herbe $H$ hath beene fteeped, the gue tts will be the merrier, which al fo Diofcorides mentioneth.

Moit of the latter Phy litions do gine the iuice or deeoction hercof to them that hath the plague I but thefe men ate deeeiued, not only in that they looke for fome truth from the father of falihood and leafings, but alfo beeaufe in ftead of a good and fure remedie they minifter no remedy at all for it is reprated, rhat the Ditull did reteale it as a feeret and diuine medieine.

\section{C н}

I I Scabiofamaior vulgaris.

Common Seabious.

Seabio sa arvensis.

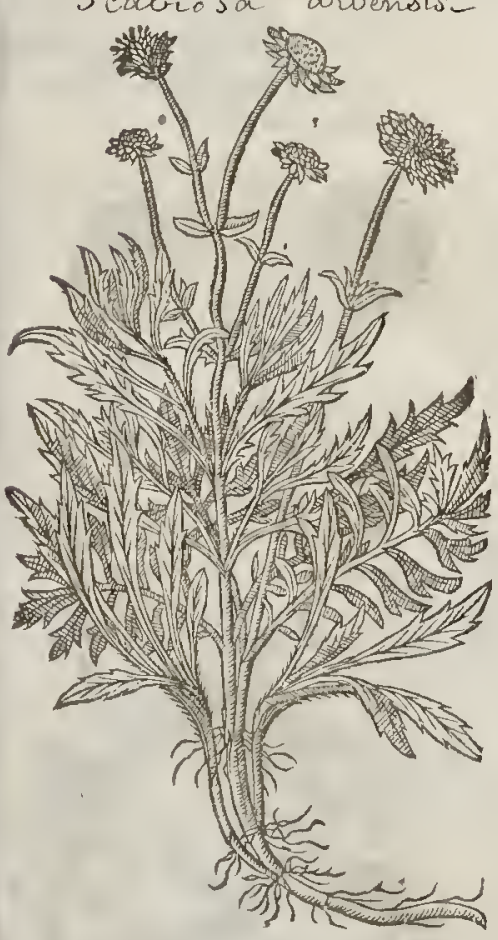

$\dagger 2$ Scabiefansinor, fure Columbaria. The fmill comion Seabious, Scaliosa Columbaria

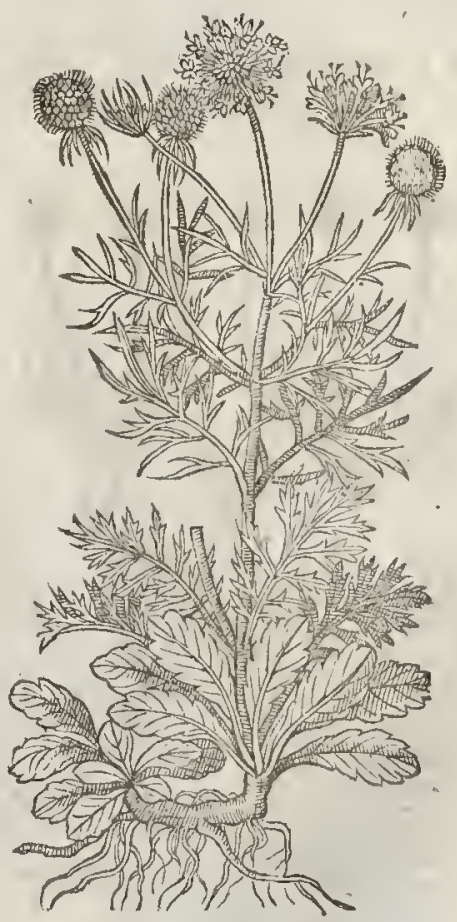

T The Defcription.

i THe firft kinde of Seabious being the moft eommonand beft known, hath leaues long and broad, of a grayinh, hoary, and hairy eolour, fpred abroad vpon the ground, among which rife vp round and rough ftems, befet with hairy iagged leates, in fafhion like 
great Valcrian, which we eall Setwall. At the top of the ftalks grow blew floures in thicke tufts orbuttons. The root is white and fingle.

2 The feeond is like vnto the former, fauing that his Leaucs are mucl cuc or iagged, and the whole plant is altogether leffer, feareely growing to the height of a foot.

3 The third kinde of Seabious is in all things like vnto the fceond, fauing thar the knap or head doth not dilate it felfe fo abroad, and is not fo thicke or elofely thruft together, and the low. eft leates are not fo deepely eut or iagged, but the vpperare mueh fmaller,and alfo the more di. uided.

† 4 The fourth groweth with large ftalkes, hauing two leaues one fet right againf another, very much iagged, almoft like vnto common Ferne, or rather $A f_{1}$ : and at the top of the falks rhere grow larger foures, like vnto rhe firft, but greater, and the roote is alfo like it, and it differs nowaie from the firf deferibed, but onely by reafon of the foile.

5 Purple flotred Seabious hath a rough hairie ftalke, whereon doe grow broad leates deepely cut in rhe edges, in forme like thofe of Sow thifte, rough likewife and hairic; the floures grow at the top of the ftalks, compoled of an innumerable fort of purple thrums : after which come fealy knaps like thole of Iacea, or Knapweed, where in is the feed. The root is fmall and threddic.

$\mp 6$. The fixth fort of Seabious hath falks fome cubite high, round, and fet with leaues not cut and iagged almoft to the middle rib, as in the former, yet fomewhat rough and hairie, fnipt about che edges, and of a light greene colour;among it which rife vp rough falkes, on the top iv hereof do grow faire red floures confinting of a bundle of thrummes. The root is long, tongh, and fibrous. $\ddagger$

7 The feuenth kinde of Seabious hath fundrie great, rough and round femmes, as high as a tall man, befetwith leaues like the firft Seabious, but far greater. The floures grow ar the rop of the ftalkes like unto the others, but of a faint yellow enlour,which fall as forne as ir is touched with the hand, whereby it mightily inereafeth, now ith ftanding the roote cndureth for many yeares, and groweth to be wonderfull great:and in my garden it did grow to the bignefle of a mans body.

t 3 scabiofamedia. Middle Scabious.

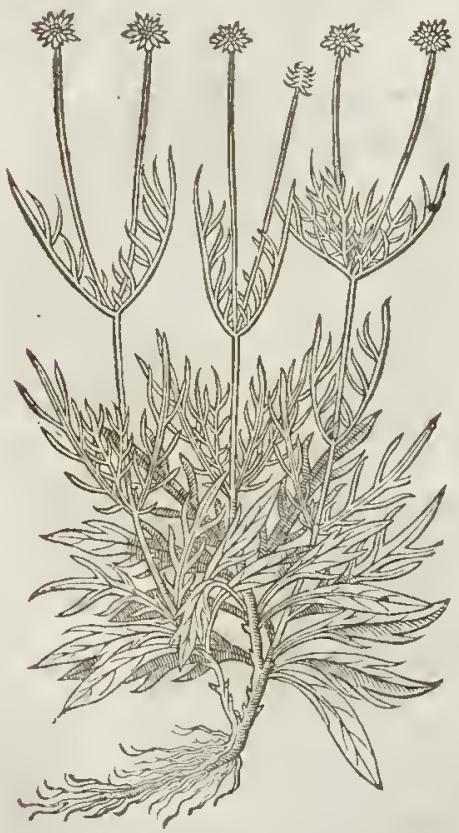

4 Scabiofa compefris, fue caretum. Corne Seabious.

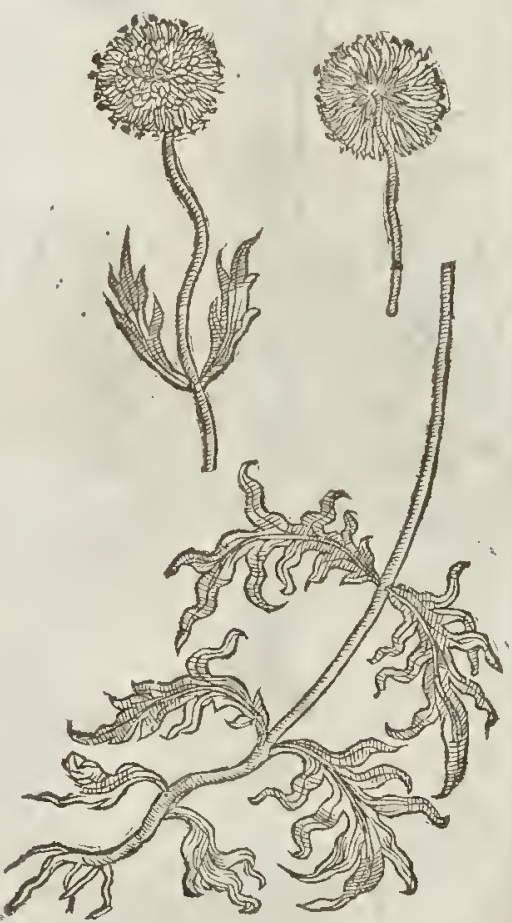

+8 The 
5 Scabiof a flore purpurco. Purple floured Scabious.

int $-y_{1}$

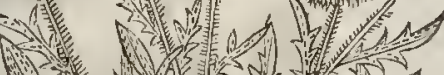

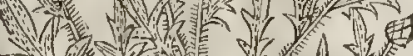

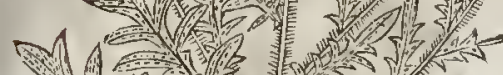
4. snd En

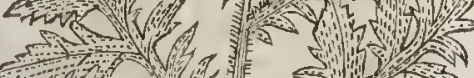

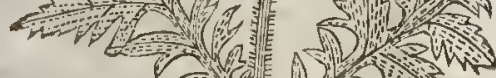
ond<smiles>[As]=[W]</smiles>

sic

(iv)

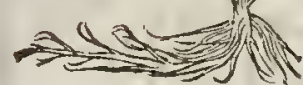

t 7 Scabiofa montana maxima. Mountaine Scabiotts.

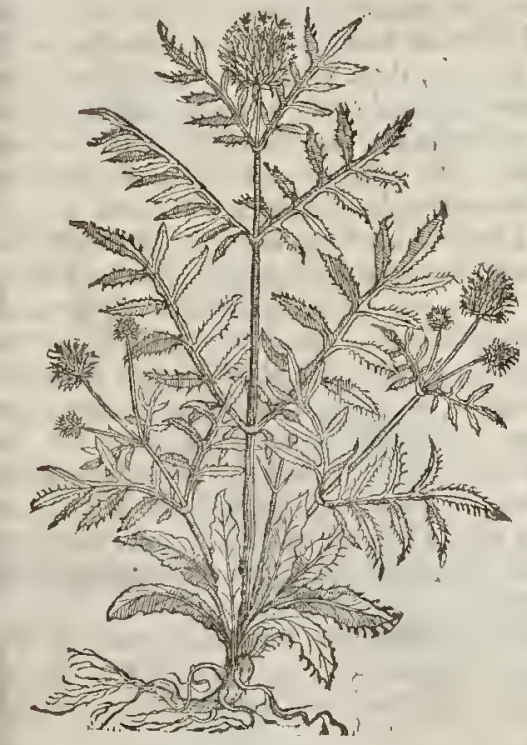

t 6 Scabiefa rshra Aufriaca. Red Scabious of Auftrich.

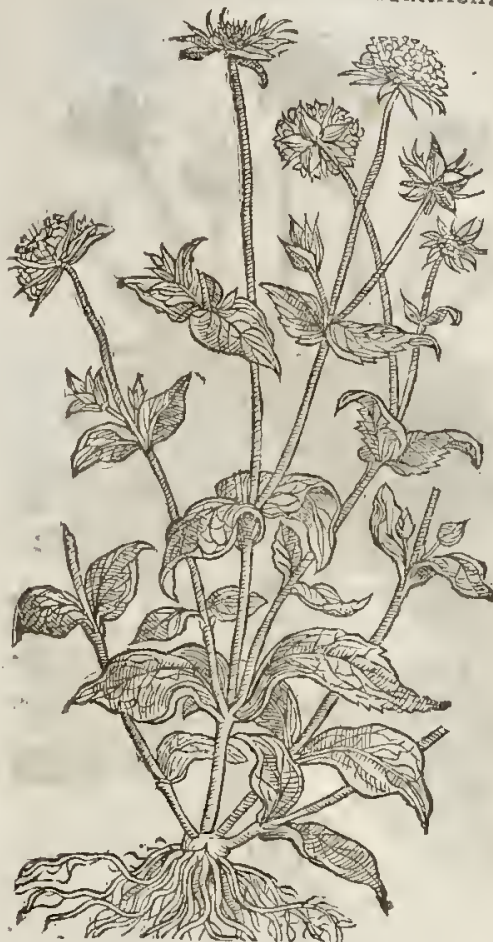

‡8. Scabiofa montanaalba. White mountaine Scabious?

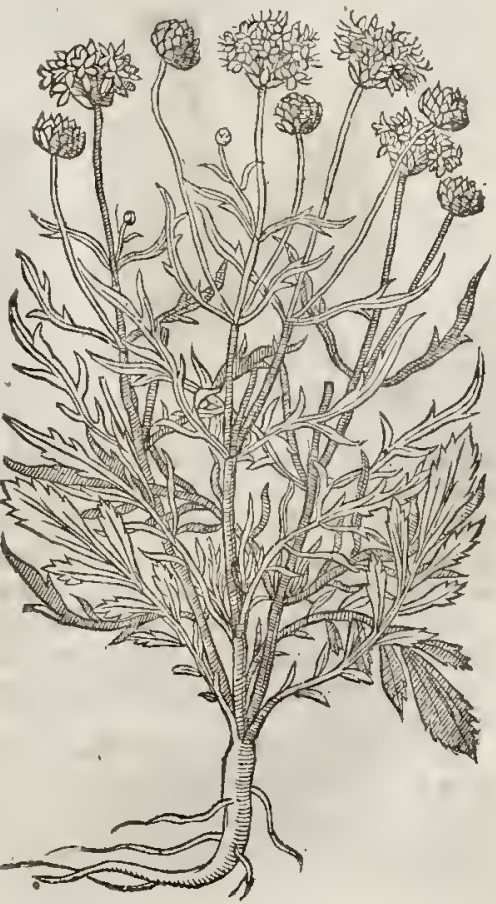


to Scabioja peregrima. Strange Scabious.
6 Scabiofamaior Hifpanica. Spanifh Scabious.

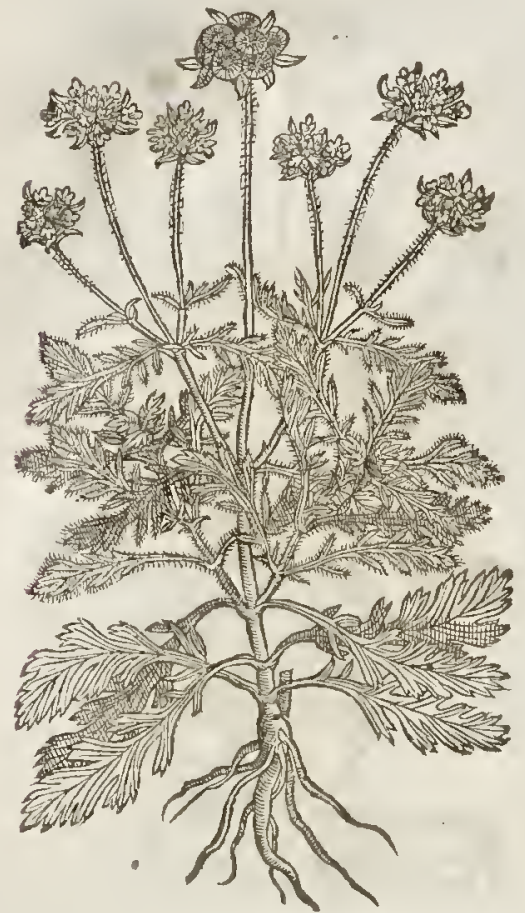

I. I Scabiofa amnium minima. Sheepes Scabious.

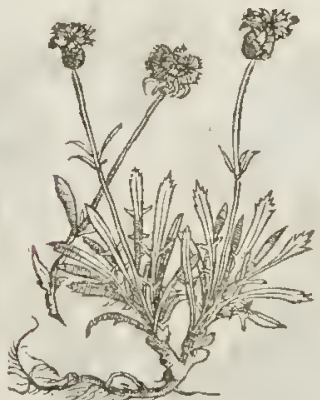

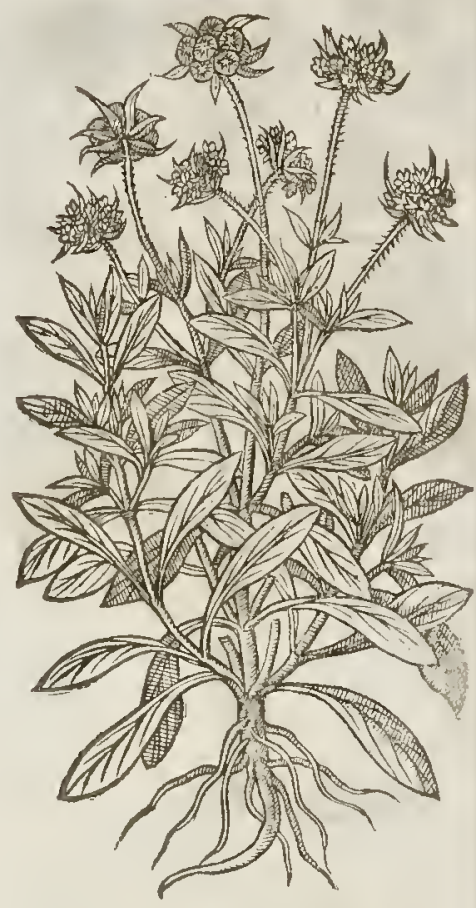

¥8 The white mountaine Scabious hath broad leaues fpred vpon the ground, like thofe of the field Primrofe, but greater. Amongft which rifeth vp a gteat Piffe falke fmooth and plain,garnimed with leaus not like thofe next the ground, but leffer, much more diuided, and of a greener colour \& har der. The floures are like thofe of the common Scabious, but white of colour: the root of this perifhes enery yeare after the perfecting of the feed. $\neq$

9 The ninth tinde of Scabious is like vnto the mountaine Scabious, but lower and fmaller, hauino fundry large and broad leaties next the ground Inipt confufedly and out of order at the edges like the Oken leafe, among which rifeth vp a ftem two cubites high, ditiding it felfe ints fundry other ked ftalkes, of a whitith colour; which being pranches. The feed appearcth like a tuft of fopall bucklers, round, and fomewhat hollow within, and made as it were of parchment, very ftrange to behold: and within the bucklers there are fundry fmall croffes of blacke fattened to the bottome, as it were the needle in a diall, running vpon the point of a ncedle. The plant dieth at the beginning of wirter, and muft be fow ne in Aprill in good and fertile ground.

Io The tenth is like vrito the laft before mentioned, in ftalkes, root, and floures, and differeth that this plant lath leaues altogether without any cuts or iagges about the edges, but is fmooth and plaine like the leaues of Marigolds, or Diucls bit, and the floures are like vnto thofe of the laft defcribed.

II Sheeps Scabious hath fmall and tender branches trailing vpon the ground, whereupon do grow fmall leates very finely iagged or minced etien almoft to the muddle ribbe, of an oucrworne colour. The floures grow at the top of a blew ifh colour, confifting of much thrummie matter, hard thruft together like abutton: the root is fmall, and creepeth in thetound. 
₹ I2 $_{2}$ The other Sheeps Scabious of our Author (according to the figure) is grearer than tie laft defcribed, growing fome foot or better high, with flender rougli branches fer with leaues not fo much diuided, but orely nieked about the edges: the floures are in colour and frape like thufe of the laft defcribed, or of the blew daife; the root is fingle, and like that of a Rampion, whence ff: bius Colmma (the feed and milkie juice inducing him) hath refer'd this to the Rampions, ealling it Rapuatium montanum captatum leptophyllow. Lobell calls it Scabiofamedia: and Dodonatus, Scabiog

13 To thefe litt! e plants we may fitly adde another fmall one refer'd by Cirfius to this Cliffis,

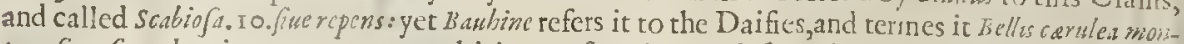
tana frutefens; but it matters not to which we referre it : the defcription is thus; The root is hard, blacke, and ereeping, fo that it fpreds much vpon the furface of the ground, fending forth many thicke, fmooth, greene leaues, like thofe of the blew Daife, not fhatpe pointed, but ending as we vulgarly figure an heart, hauing a certaine grafsie but not vnpleafant fmell, and fomewhat a bitter and hot tafte:out of the middeft ot thefe leaues grow flendernaked ftalks fome hand high, hauing round floures on their tops, like the fe of Diuclis bit, and of the fame colour, yet fometimes of $a$ lighter blew. It growes in the mountaines of Hungary and Auftia. It floures in Anrill and May, and ripens the feed in Iuly and Auguft.

\section{¥ I6 Scabiofarubra Indica. Red Indian Seabious.}

$¥ 17$ Scabiofa eftivalis clufij. Sommer Scabious.
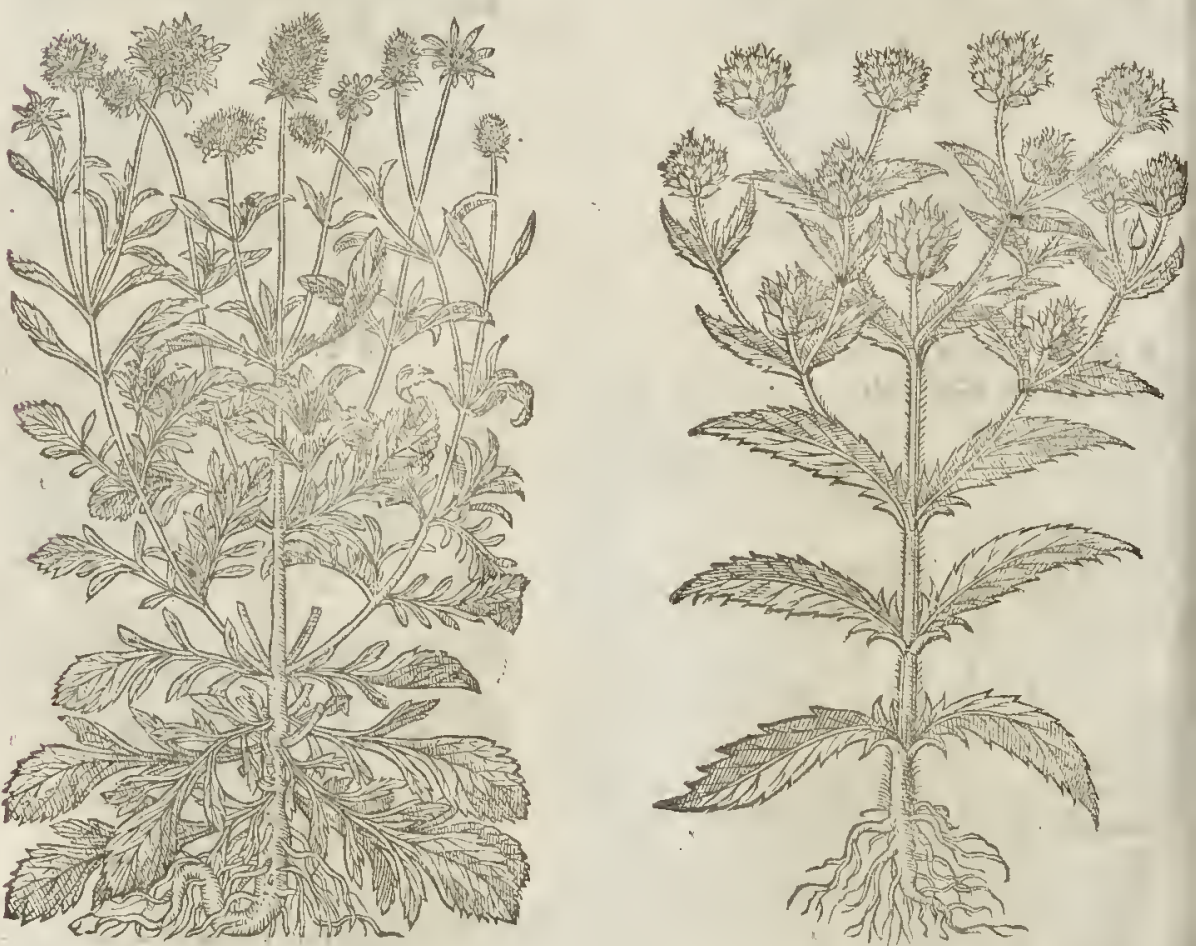

14 This (which is the feuenth Scabious of Clufins, and which he termes sixersuris, of the whitifh yellow colour of the floure)hath round, flender, ftiffe, and greene ftalkes fet at caely joint with two large and much diuided leanes of a whitifh greene colour : thofe leates that eone from the root before the ftalke grow vp are broader, and leffe diuided; vpon the tops of the branehes and ftalkes grow floures like thofe of the common Scabious, being white or rather (before they be throughly onen) of a whitin yellow colour; which fading,there follow feedos like as in the ordinary kinde. This floures in Iune and Iuly, and growes very plentifully in all the hilly grounds and dry Meades of Auftria and Morauia.

15 There is alfo a kinde of Scabious hauing the leaues much cut and diuided, and the Atalkes and floures like to the common fort, of a blewifh purple colour, but differing in this, that at 
the fides of the floure it puts forth little falkes, bearing fmaller floures, as is feene in fome other plants, as in Dailies and Mari colds, which therefore are fitly terned in Latine Prolf ford or Chil-
uri.g. This growes oncly in Gardens, and floures at the fame time with the former.

16 The italkes of the red Scabious grow fomecubit or more in height, and are diuided into nany very flender branches, which at the tops carry floures compofed after the manner of the other forts of Scabious, that is, of many little floures diuded into fue parts at the top, and thefe are of a pcrfeet red colour, and hawe fmall threds with pendants at them comming forth of the midle of each of thefe little floures, which are of a whitini colour, and make a pretty lhow. The leates are greene, and very much dinided or cut in. The farry feeds gron in long round hairy heads handfomely fet together. This is an annuall, and perines as foone as ir hath perfected the feed. Clufius makes it his fixt Scabious, and calls it Scabiofi Indica. It floures in Iuly, and growes.
in the Gardens of our prime Herbarifts.

17. The fame Auphour hathalfo gincnus the figure and defcription of another Scabious, which fend's va falke fome three cubits or more high, fet at certaine faces with leanes linge, and finipt about their edges, and a little cut in neere their ttalkes. The ftalkes arc diuided into others, which at there tops carty blewith floures in long fealy heads, which are fitcceded by long whitith feed. The roote is whition and fibrous, and dyes chery yeare. This is the Scaliofa g, fiue
aftivalis of chofus. $\ddagger$

$$
\text { T The Place. }
$$

Thefe kindes of Scabious dogrow in paftures, medowes, cornc fields, and barren fandy grounds almoft enery where.

The ftrange forts do grow in my garden, yet are they frangers in England.

They floure and fourith in the Somner moneths.

$$
\begin{aligned}
& \text { of The Time. } \\
& \text { T moneths. } \\
& \text { The Names. }
\end{aligned}
$$

Scabious is commonly callcd scabiofat diuers thinke it is named wiew, which fignifieth a fcabbe, and a cerraine herbe focalled by Aztius : I do not know, faith Hermoluus Bubbrus, whether it be Sicabious which Aerius doth call Pfora, the fmoake of which being burnt doth kill cankers or little wormes. The Author of the Pandeas doth interpret Scabiofa to be Diofcorides lis itabe - Diofco rides defcribeth Strebe by no markes at all, being commonly knowne in histime; and Galer in his firft booke of Antidotes faith thus: There is found amongft vs a certaine nrubby herbe, lot, rery fharpe and biting, hating a little kind of aromaticall or fpicy fmell,which the inhabitants do call Colymbade, and stabe fingulat good to kecpe and preferue wine:but it feemeth that this stcebe doth differ from that of which he hath made mention in his booke of the faculties of medicines, which agreeth with that of Drofcorides: for he writeth that this is of a binding quality wirlout biting; fo that it cannot be very Tharpe.

T) The Temperature.

Scabious is hot atd dry in the later end of the fecond degrce, or neere hand in the third, and of thin and fubrile parts : it cutteth, attciuteth, or maketh thin, and throughly concoeteth tough
and gtoffe humours.

of The Vertues. Scabious fcourcth the cheft and lungs; it is good againt an old cough, thortneffe of brcath, A
paine in the fides, and fuch like infitmities of the cheft.

The fame prouoketh vrine, and purgeth now and then rotren matter by the bladder, which hap- B peneth when an importume hath fomewhere lien within the body. It is reported that it cureth feabs, if the decoetion there of be drunke certain daies, and the juice $\mathrm{C}$
fed in ointments.

The later Herbarifts doealfo affirme that it is a remedy againt the bitings of Serpents and $D$ tingings of venomous beafts, being outwardly applied or invardly taken.

The juice being drunke procurcth fweat, efpecially with Treacle; and ir fpeedily confunieth $\mathrm{E}$ lague fores, if it be gitucn in time, and forthwith at the beginning : but it muft be vfed often. F It is thought to be forceable, and that againft all peftilent fevers.

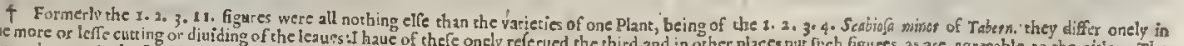

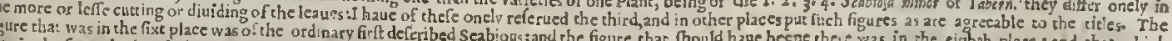

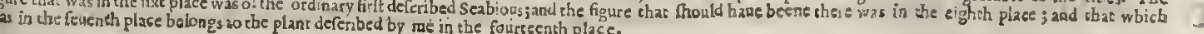

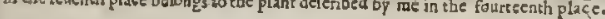




\section{C'н а Р. 248. OfDinels bit.}

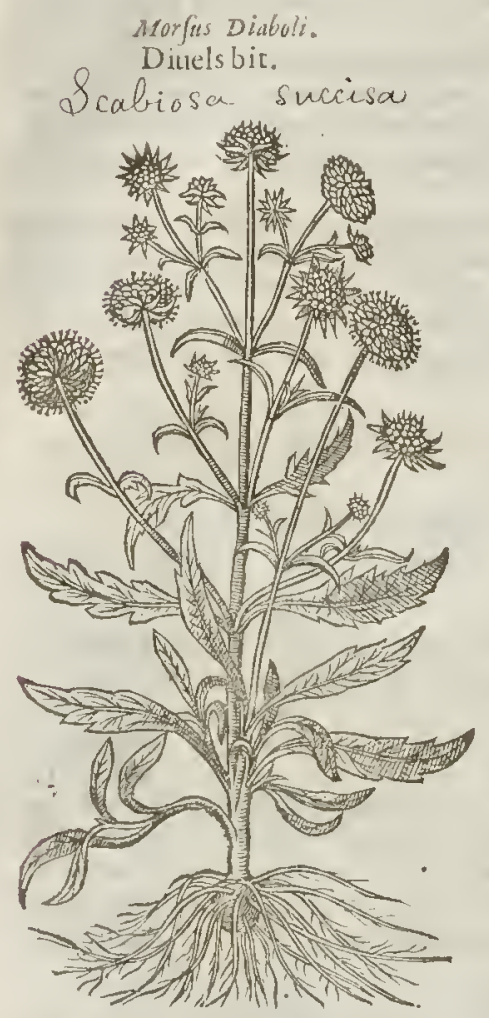

Itucls bit hath fmall spright round Aalks of a cubitc high, befetwit! long leaucs fomewhat broad, very litcleor nothing finipt about the edges, fomewhat hairic and eticn. The flourcs alfo arc of a darkc purple colour, faihioned like the floures of Scabious, which being ripcarc carricd away with the winde. The root is blacke, thicke, hard and hort, with many thicddie ftrings faftened thereto. The grcat part of the root fcometh to be bitten away: old fantafticke charmers repost, that the ditiell did bite it for enuic, bccaufc it is an herbe that hath fo many gond vertues, and is fo bencficiall to mankinde.

Diticls bit groweth in drie medows and woods, and about waies fides. I haue found great ftore of it growing in Hampits ad wond neerc London, at Lec in Effex, and at Raleigh in Efex, in a wood called Hammcicll, and fundrie other pla-
ces.

\section{The Time.}

It Houreth in Auguft, and is hard to beknowne from Scabious, fauing when it flourech.

\section{- The Names,}

It is commonly called Mor (us Diaboli, or Dituels bit of the root (as it fecmeth) that is bitten off:for the fuperftirious people hold opinion, that the diuell for entric that he beareth to mankinde bit it off,bccaufe it would be otherwife good for many vfcs:it is called of Fushfores, succifa: in High Dutch Geuffels abbifz: in Low Dutch, Toupuelles beet in French Mors du Diable in Englih, Diucls bit, the Pycnocomon of Diofcorides, lefcribed by him $l, b$. Forebit. $\neq$ Fabius Columa iudgeth it to bee Ditucls bit is fomething bitter, The Temperature.

Diucls bit is fomething bitter, and of a hot and drietemperature, and that in the later end of
the fecond degrec.

A There is nobctter thing a

A There is nobetter thing againft old fivellings of the Almonds, and vpper parts of the throat that
behardly ripencd.

B. It clenfcth away flimic fegmc that ficketh in the iaves, it digefth and confumeth it : and it quickcly taketh away the fwcllings in thofe parts, if the dccoction thcreof beoften held in the mouth and gargarized, efpccially if a litcle quanticie of Mel Rofarm, or honic of Rofes be put in-
to it.

C It is reportcd to be good for the infirmities that Scabious feruech for, and to be of no lefie force againft the flingings of venomous bcafts, poifons, and peftilent difeafes, and to confume and wafte
away pla gue forcs, bcing framped and laid vpon them.

A Andalfo to mitigatc the paines of the matrix or mother, and to driue fortb winde, if the deco-
ction thereof be drunke. 


\title{
C н в. 24.9. Of Matfellon or Knapmeed.
}

\author{
I The Defcription.
}

I T Atfellon orblacke Knapweed is doubtleffe a kinde of Scabious, as all the others are, intituled with the name of Itcea; yet for diftinction I hauc thought good to fet them downe in a fenerall Chapter, beginning with that kinde which is called in Englinh Knapw eed and Matfellon, or Materfilom. It hath long and narrow leaues, of a blackifh grcen colour, in thape like Diuels bit, but longer, fet vpon ftalks two cubits high, fonew hat bluntly cut ur fnipe - about the edges : the floures do grow at the top of the ltalks, being firft fmall fealy knops, like to the knops of Corne floure, orblew bottles, but grcater;our of the midit thereof growerh a purple thrumm ie or threddie floure. The root is thicke and fhort.

2 The great Knapweed is very like vito the former, but that the whole plant is much greater, the leates bigger, and more deeply eut, euen to the middle rib : the floures come forth of fuch like fcaly heads, of an excellent faire purp'e colour, and much greater.

3 The third kinde of Matfellon, or Knapweed is s cry like vnto the former great Knapweed laft before mentioned, fauing that the floures of this plant are of an excellent faire yellow eolour,proceeding forth of a fcaly lead or knop, befet with moft fharppricks, not to be touebed without lutrr: the floure is of a pleafing fnel, and very fwect ${ }_{3}$ the root is long and lafting,and creepeth far abroad, by means whereof it greatly increafcth.

\section{Tacensigra.}

Blacke Matfellon, ? Centaurea niqra...?

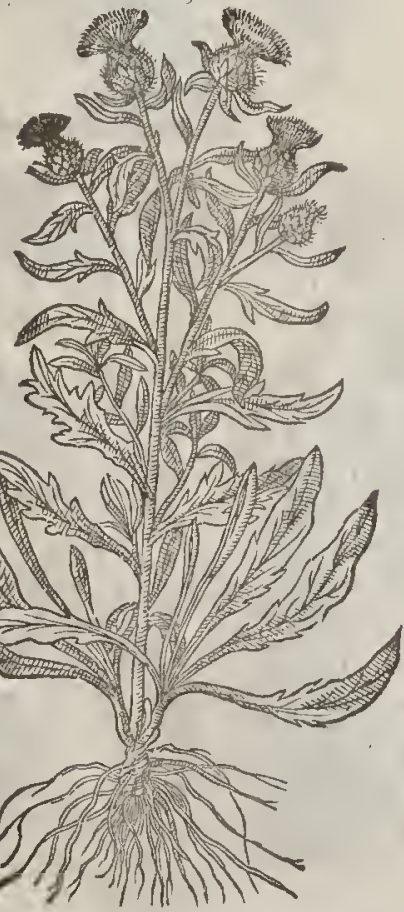

t 2 Iacea maior. Grear Matfellon.

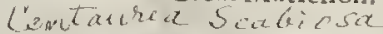

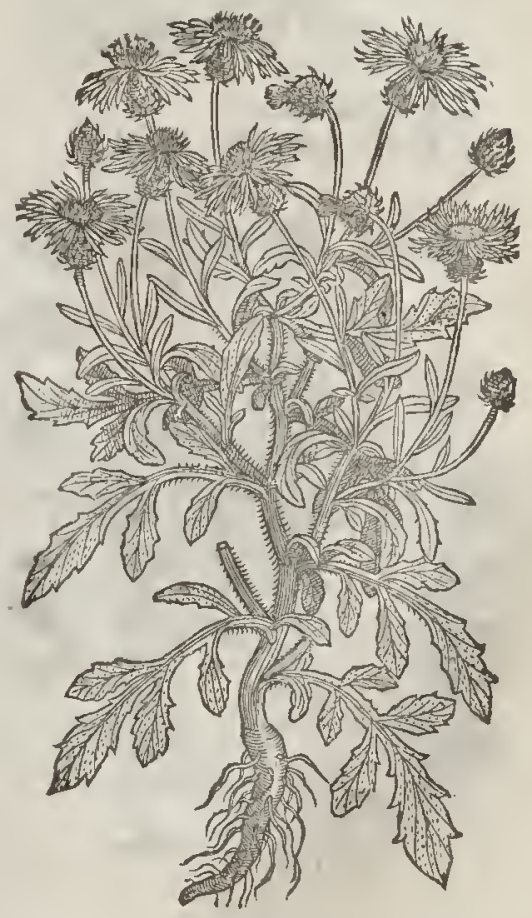

4. The mountaine Knnapiveede of Narhone in France, hath a ftrong ften of tw: 0 citirs high; and is very plentifull about Coueritric among the hedges and buhes: the leaues are very micli iagged, in forme of Lonchirs, or Spleencwoort; the floures are like the reft of the Kinapreeds, of a purple colour. 
3 Iacea maior lutea.

Yellow Knapweed.

wishtsh

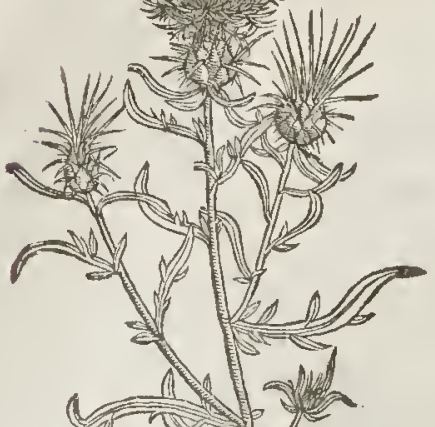

N

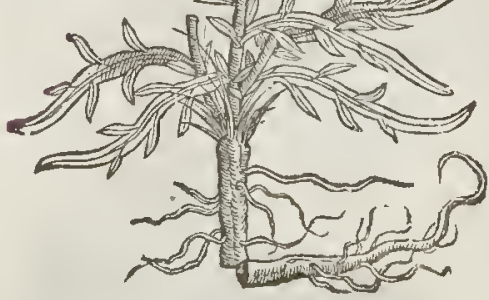

5 Iacea flore albo.

White floured Knapweed.

(4)

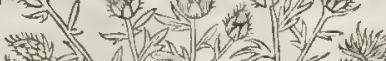
w4 w w H,

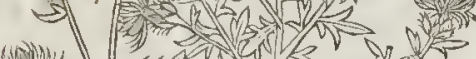

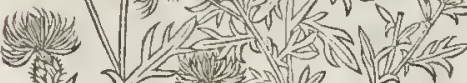

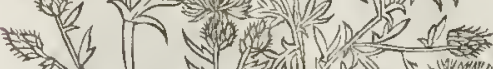
37.

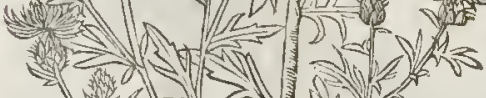
the
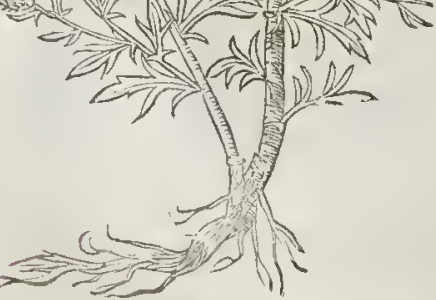

4 Iaceamontana

Mountaine Knapweed.

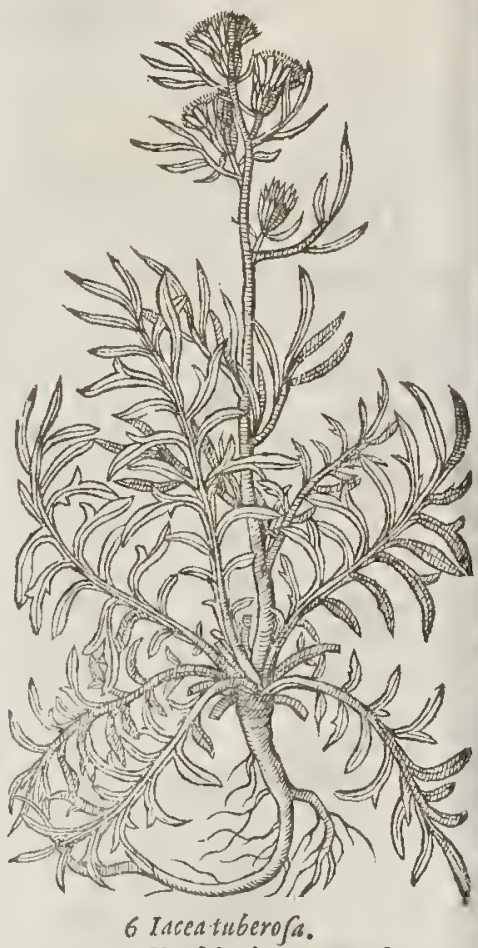

Knobbed Knapweed.

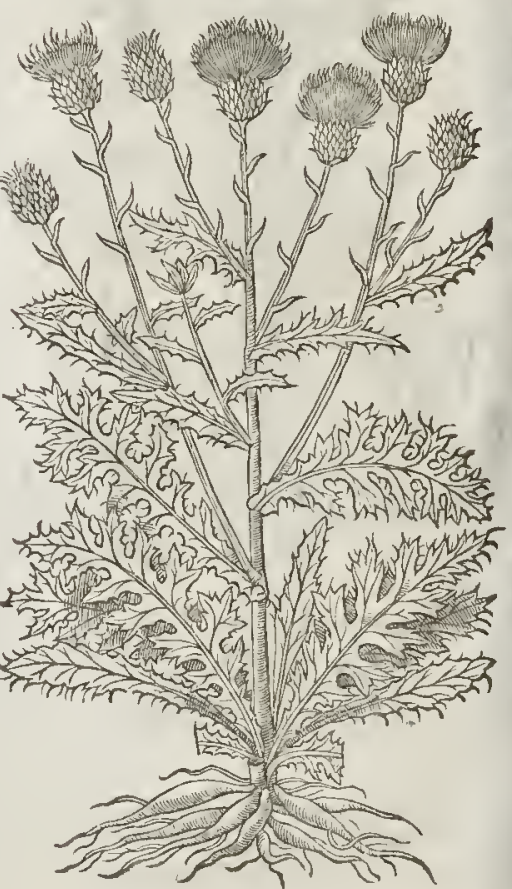


$\$ 7$ Incea Auftriaca villora.

Rough headed Knaptreed.

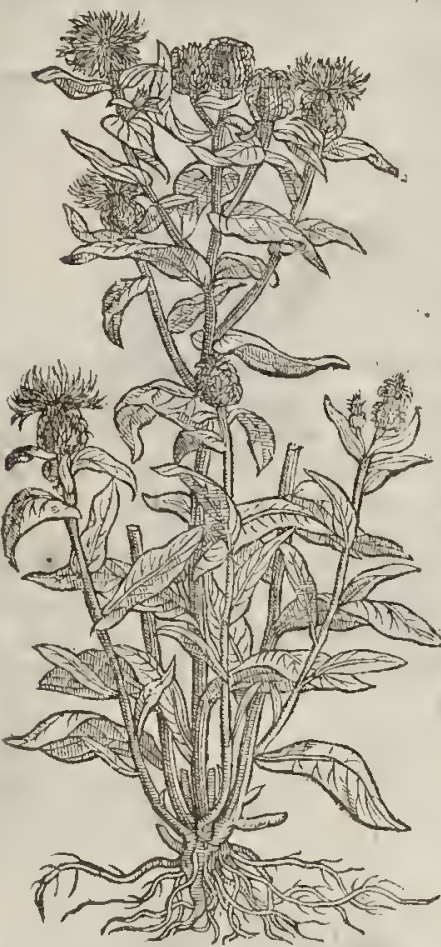

$\ddagger$,5 The white floured Knapweed hath creeping roots; which fend vp pretty large whitifh greene leatres;much diuided or cut in almoit to the middle rib; from the midit of which rifes up a ftalke fone two foot high, fet alfo with the like diuided leaues, but leffer : the floures are like thofe of rhe common fort, but of a pleafing white eolour. I firft found this growing wilde in a field nigh Martine Abbey in Surrey, and fince in the Ifle Tenet. $\neq$

6 The tibet,ous or knobbie Knapweed being fet forth by $T$ abernam, whieh and is a ftranger in thefe parts, hath many leaues fpred vpon the ground, rough, deeply gatht or hack about the edges, like thofe of Sowthiftle : among which rifeth vp a ftraight ftalke, diuiding it felfe in tn other branclies; whercon do grow the like leanes, but fmaller: the knappic floures ftand on the top of the branches, of a bright red colour, in thape like the orher Knapweeds. 'The root is great, thieke and ruberous, confifting of many cloggie parcels, like thore of the Af. phodill.

$\ddagger 7$ This (faith Clufius) is a comely plant, lauing broad and long leanes white, foft, and lightly fnipt about the edges: the tafte is gummy, 8c not a little bitter: it icnds vp many crefted italks from one roor, fome cubit high or more: at the toppes of them grow the heads fome two or three to. gether, confifting of many fcales, whore ends are hairy, and they are fet fo orderly, that by this meanes the heads feeme as they were inclo fed in litele nets : the floures are purple,and like thofe of the firtt defcribed; the feede is fmall and long,and of an afh colour. This clufius calls Iacen 4 . Auftriaca villofo capite *

\section{Iacea cipitulis birfut is Boely.}

8 This hath many fmall cornered fraked liairic trailing branches grow ing from the rnot,and thofe aga in diuided into many other branches, trailing or fpreading vpon the ground three or foure foot long, imploying or couring a good plot of ground, whereon grow hairy lentes diuided or iagged into many parts, like the leaues of Iacea maior, or Rocket, of a very bitter tafte: at the top of each branch groweth one fcaly head, each fcale ending with fiuc, fix, nt feuen little weake prickles growing orderly like halfe the rowell of a fpurre, but farre leffer : the floures grow forth of the heads of a light purple colour, confifting of many fmal floures, like thofe of the common Itcea, the bordering floures, being bigger and larger than thofe of the middle of the floure, each fmall floure being divided into fiue fmall parts or leaues, nor much vnlike thofe of Cyumus:the feed is fmall, and inclofed in downe. The root perinheth when the feed is ripe.

This plant hath not been hitherto written of that I can find. Seeds of it I receiued from Mr. WWilliam Coys, with whom alfo I obferued the plant, O tober 10 . I 62 r. he receitued it from Boclins a Low countrey man. Iohrs Goodyer. $\ddagger$

T) The Place.

The two firft grow commonly in euery fertile pafture:the reft grow in my garden.

They floure in Imne and Iuly. ๆ The Time.

\section{T) The Names.}

The later age doth call it Iacea nigra, putting nigra for a difference betweene it and the Heartseafe or Pancie,which is likewife called Iacea : it is called alfo Materfillon, and cratrefillen: in Englinh,Marfellon, Bulweed,and Knapweed.

$$
\text { PPP } 3 \text { की the }
$$


The Temperature and Vertues.

A Thefe plants are of the nature of Seabious, whereof they be kindes, therefore the ir faeulties are like, al though not fo proper to Phy fickes vfe.

B They be eommended againft the fwellings of the Vuula, as is Diuels bit,but of leffe force and vertue.

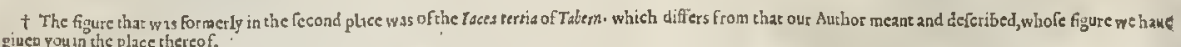
giver gou th the place thereof.

\section{Cha p. 250. Of Siluer Knapmeed.}

\section{T) The Defcription.}

I THe great Siluer Knapweed hath at his firft comming vp diuers leaues fpred vpon the ground,of a deepe greenc eolour,cut and iagged as are the other Knapweeds, ftraked here and there with fome filuer lines downe the fame, whereof it tooke his furname, Argenter: among which leaues rifeth vp ftraight ftalke, of the height of two or threc eubits, fomwhat rougl and brittle, diuiding it felfe toward the top into other twiggie branehes: on the tops whereof do grow floures fet in fealy heads or knaps like the other Matfellons, of a gallant purple eolour, conlifting of a number of threds or thrums thicke thruft together : after which the feedes appeare, flipperic, fmooth at one end, and bear ded with tlacke haires at the other end, whieh maketh it to leap and skip away when a man doth but lightly touch it. The root is fmall,fingle, and peritheth when the feed is ripe. $¥$ This is not ftreakedwith any lines, as our Author imagined,nor called Argenteaby any but himfelfe, and that very vnfitly. $\neq$

t I Stecbe argentea mainr.

Great Siluer Knapweed.

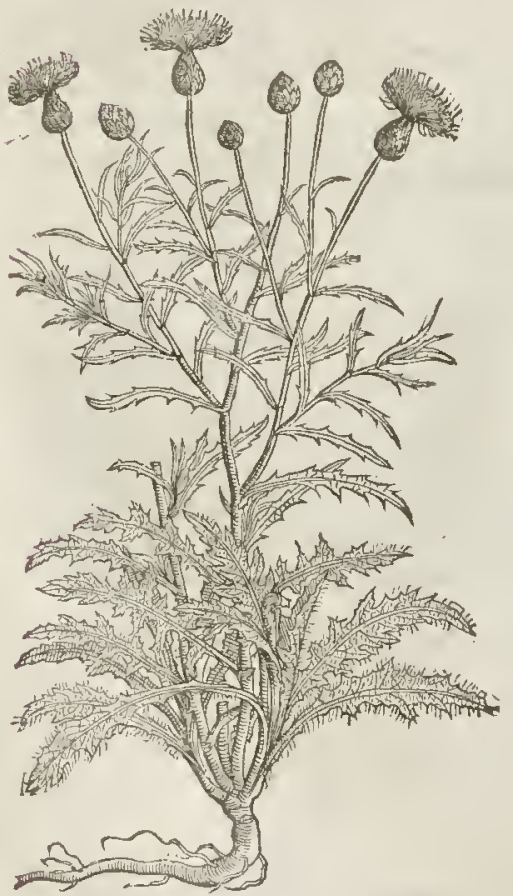

$\dagger 2$ Stabe argenteaminor. Little filuer Knapweed.

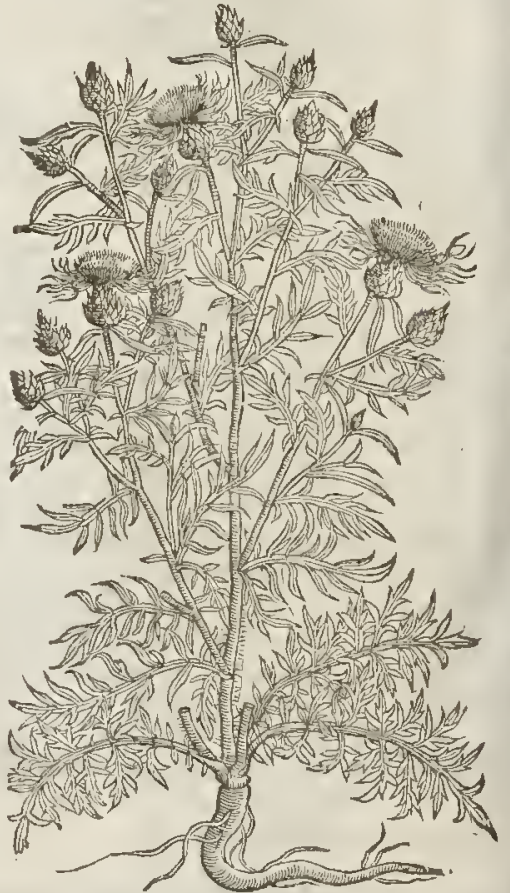

2 The fecond agrecth with the firft incach refpen, fauing that the leaues hereofare more iagged, and the fituer lines or ftrakes are greater, and more in number, wherein eonfifteth the diffe- 
$\ddagger 4$ Steebe Rogmarinifolio.

Narrow leafed Knapweed.

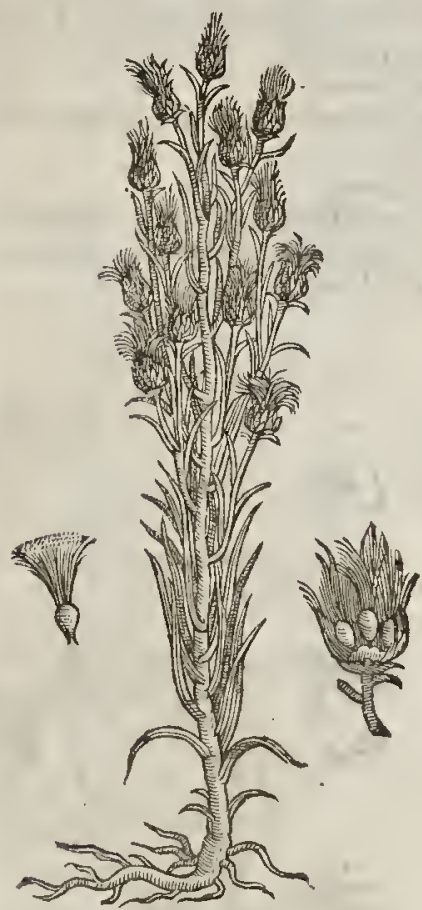

¥ Stabe ex Codice Cefareo; Thornie Knapweed.

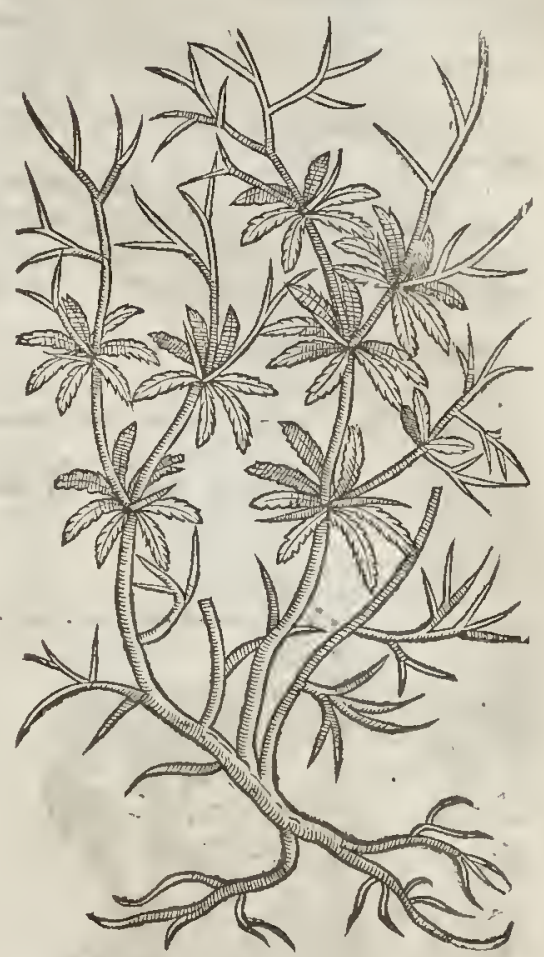

rence. $¥$ The leaues of this are very much diuided and hoarie, the ftalkes fome two cubites high, fet alfowith much diuided leaues, that end in foft harmleffe prickles : at the tops of the branches ftand the heads compofed as it were of filuer fcalẹs (whence $L o b \varepsilon l$ and others haue called th is plant Stcebe argentea) and out of thefe filuer heads come floures like thole of the blew bottles, but of a light purple colour, the feed is fmall,blackirh,and hairy at the tops. $\ddagger$

$\$ 3$ There is another like this in each refpect, but that the heads haue not fo white a fhining filuer colour:and this I haue alfo feene growing with Mafter Jobn Tradefcant at South Lambeth.t

$\mp 4$. To thefe may be added that plant which Pona luath fet forth by the name of Stabe capitata Rofmarini folio. It hath a whitifh wooddy root, from whence arife diucrs branches fet with long narrow leates fomew hat like thofe of Rofemary, but liker thofe of the Pine, of a greenifh colour aboue, and whition below : at the tops of the branches grow fuch heads as in the firf defcribed St cabe, with floures of fomewhat a deeper purple colour : the feed is like that of Carthamus, but blackifh. The root is not annuall, but laits many yeares. $\ddagger$

$¥ 5$ Though thefe plants haue of late been vulgarly fet forth by the name of stabe's,yet are they not iudged to bee the true Stabe of Diofcorides and the Antients, but rather another, whore figure which ive here giue was by Dodon eus taken forth of a manufcript in the Emperours Library, and he faith; Paludanus brought home fome of the fame out of Cyprus and Morea, as he returned from his journey out of Syria : the bottome leaues are faid to be much diuided; thofe on the falkes long; and onely fnipt about the edges, and white: the floures white, and contaned in fcaly heads like the Blew-bottles, and the tops of the branches end in harpe prickles. $¥$

T) The Place.

The fe doe grow of them felues in fields neere common highwaies, and in vntilled plaees, but they are ftrangers in England, neuertheleffe I have them in my garden. 


\section{The Time.}

They furing vp in April, they floure in Auguft, and the feed is ripe in September.

9 The Names.

Siluer Knapweed is called of Label, Stabe Salamantica : of Dodonaus, Aphyllanthes, that is, withoue leaues, for the floures confift onely of a number of threds without any leaues at all: in Englifh, Siluer Knapweed,or Siluer Scabious, whereof doubtleffe they be kindes.

$$
\text { T The Temperature andVcrtues. }
$$

The faculties of thefe Matfellons are not as yet found out,ncither are they vfed for meat or medicine.

† The faculties of Stabe out of Diofcorides.

A The feed and leanes are aftringent, wherefore the decoction of them is caft vp in Dyfenteries, and into purulent eares, and the leaules applied in manner of a pultis are good to hinder the blackneffe of the eies occafioned by a blow, and ftop the flow ing of bloud. $\neq$

\section{Cha I. 251. OfBlew Bottle, or Corne Floure.}

I Cyanusmaior.

Great blew Bottle.

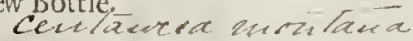

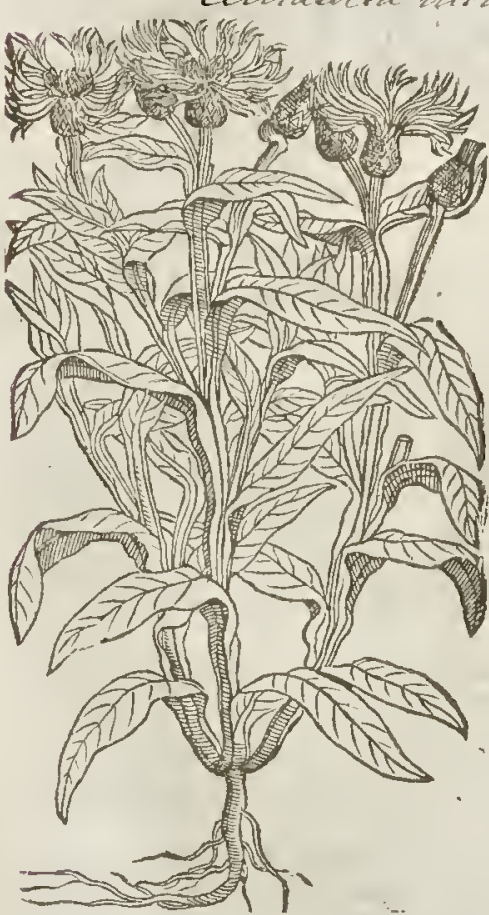

2 Cyanus vulgaris. Comnonblew Bottle. centared cyanis

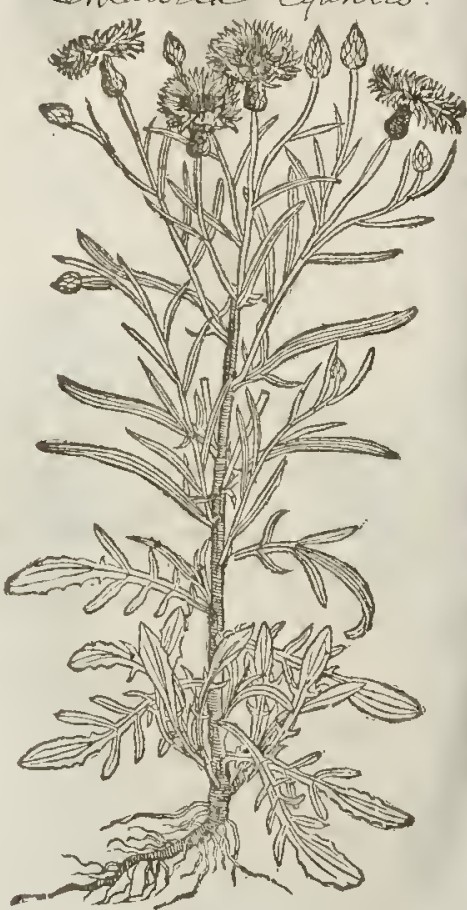

The Defcription.

I He great blew Bottle hath long leaues, fmooth, fo ft, downie, and hrarpe pointed:among the leaues rife vp crooked, and prettie thicke branches, chamfered, furrowed, and garniThed with fuch leaues as are next the ground : on the toppes whereof ftand faire blew floures tending to purple,confifting of diuers little floures, fet in a fealy huske or knap like thofe of the Knapweeds : the feed is rough or bearded at one cnd, fmooth at the other,and fhining. The root is tough, and long lafting (contrary to the ret of the Corne floures) and groweth yearely into new thoots and fprings, whereby itgrearly increafeth. 


\section{B. 2. Of the Hiftory of Plants.}

7 Cyanus corvileus multiflorus. Double Blew-Bottles.

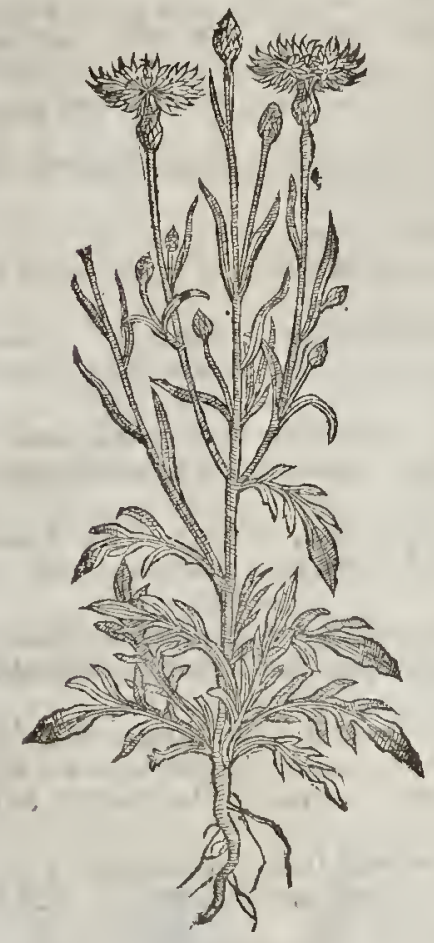

$¥$ 9 Cyarus repens latifolius.

Broad leafed creeping Blew-Bottle.

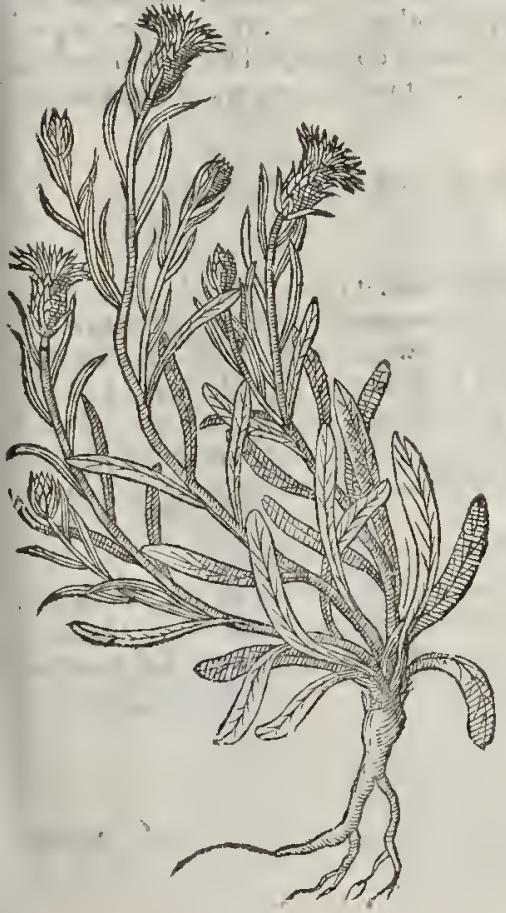

8 Cyanus purpurcts moltiforus. Double Purple-Bottles.

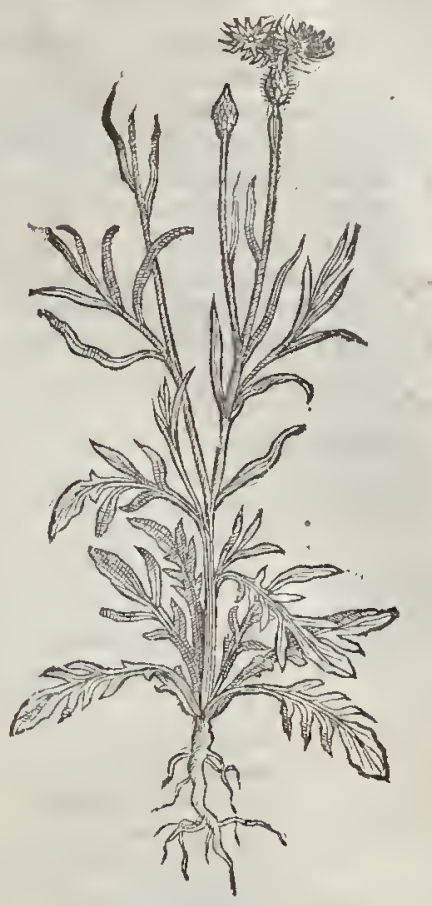

* 10 Cyanus repens angufifolius.

Small creeping Blew-Bottle.

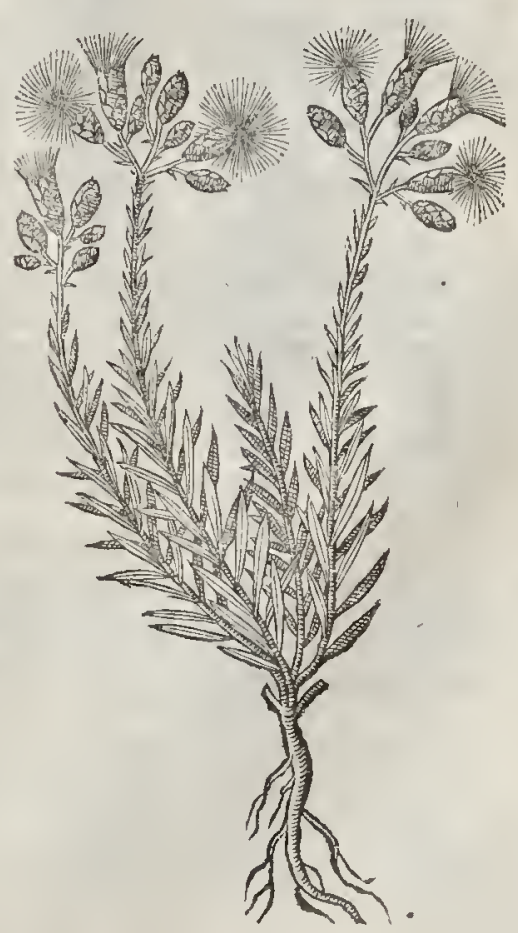


2 The common Corne-floure hatli leaues fpred vpon the ground, of a whitifh greene colour, fomewhar hack or cut in the edges like thofe of Corne Scabious : among which rifeth vp a falke diuided into diuers fmall branches, whereon dogrow long leaues of an oucrworne greene colour. with few cutsor none at all. The floures grow at the top of the falkes, of a blew colour, confifting of many fmall floures fet in a fcaly or chaffe head like thofe of the Knapweeds:the feed is finnoth, bright thining, and wrapped in awoolly or flocky matter. The root is fmall and fingle, and perifherh when it hath perfected his feed.

3 This Bottle is like the laft deferibed in each refpeet, fauing in the colour of rhe floures; which are purple, wherein confifteth the difference.

4 The fourth Bottle is alfo like the precedent, not differing in any point but in the floures for as the laft before mentioned are of a purple colour, contrariwife thefe are of a milke white colour, which fetteth forth the difference.

5 The Violet coloured Bottle or Corue-floure is like the preeedent, in ftalkes, leaues, feeds, and roors : the onely difference is, that this bringeth floures of a violet colour, and the ouhers not fo.

6 Variable Corne-floure is fo like the others in falks, leaues, and proportion, that it cannot be diftunguifhed with words ; onely the floures herenf are of two colours mixed together, that is, purpleand white, wherein it differeth from the reft.

7 There is no difference to be found in the leaues, ftalkes, feed, or rootes of this Cornefoure from the other, but onely that the floures hereof are of a faire blew colour, and very
double.

8 The eighth Corne-floure is like vnto the precedent, without any difference at all, fauing in the colour of the floures, the which are of a bright purple colour, that fetteth forth the difference.

$\mp 9$ This from a fmall root fends vp diuers creeping branches fome foot long, fet with long hoary narrow lcaues : at the tops of the talkes fand the floures in fcaly heads, like as the other Blew-Botrles, but of a darke purple colour. The whole plant is very bitter and vngratefull to the tafte. Lobel calls this Cyamis repens.

10 This is like the laft defcribed, but that the leaues are much fmaller or narrower, alfo the fcaly heads of this are of a finer white filuer colour : and this plant is not poffeffed with fuch bit-, ternetfe as the former. Lobel calls this Cyanus minimus repens. $\ddagger$

\section{T) The place.}

The firft groweth in my garden, and in the gardens of Herbarifts, but not wilde that I know of. The others grow in cornc fields among wheat, Ric, Barley, and other graine : it is fowne in gardens, which by cunning to looking doth oft times become of other colours, and fome alfo double, which hath beene touched in their feucrall defcriptions. $\neq$ The two laft grow wilde about Mont-
pellier in France. $\neq$

They bring The Time.

They bring forth their floures from the beginning of May vnto the end of tharuet.

T) The Names.

The old Herbarifts called it Cy.mus flos, of the blew colour which it naturally hath: molt of the later fort following the common Germane name, call it Flos frumentorum; for the Germans name it Coen blumen : in low-Duich, Cozn bloenten : in French, Bbaueole, and Bluet : in Italian, Fior cam. peje, and Bladiferis, i. Seris blad, and Eattifecula, or Baptifecula, as though it fhould becalled Blapti. fecula, becatife it hindereth and annoyeth the Reapers, by dulling and turning the edges of their fickles in reaping of corne: in Englith it is called Blew-Bottle, Blew-Blow, Corne-floure, \& hurtSickle. $¥$ Fabius Column a would haue it to be rhe Papuner pumesm, or Haracleum of the Antients. $\neq$

T) The Temperaturead Vertues.

A The faculties of thefe fioures are not yet fufficiently knowne. Sith there is no vfe of them in phyficke, we will leate the reft that might be faid to a further confideration : notwithitanding
fome haue thought the common J3 lew-Bottle to be of good againft the inflammation of the eyes, as fome thinke. 


\section{C н а . 252. Of Goats Beard, or Go tobed at nome.}

$$
\text { If The Defcription. }
$$

Y Oats-beard, or Go to bed at noone hoth hollow ftalks, fmooth, and of a whitith green

T eolour, whereupon do grow long leaues crefted downe the midcile with a fivelling rib, tharpe pointed, yeelding a milky inyeewhen it is broken, in thape like thofe of Garlick; from the bofome of which leates thtuft forth fmall tender ftalks fet with the like leaues but leffer : the floures grow at the top of the ftalkes, eonfinting of a number of purple leates, dafht oucr as it were with a hitele yellow dult, fet about with nine or ten tharpe pointed greene leaties: the whole floure refembles a itarre when it is fpted abroad; for it fhutteth it felfe ar twelue of the clocke, and theweth not his face open vntill the next dayes Sun doth make it floureanew, whereupon it was ealled Go to bed at noon : when the fe floures be come to their full maturitie and ripeneffe, they grow into a downy Blow-ball like thofe of Dandelion, whieh is carried away with the winde. The feed is long, hating at the end one pieee of that dorvnic matter hanging at it. The root is long and fingle, with fome few threds therero anexed, which perifherh when it hath perfeated his feed, yeelding mueh quantitic of a milky iuyce when it is eut or broken, as doth all the reft of the plant.

2 The yellow Gouts beard hath the like leaues, ftalkes, root, feed, and downic blow - bails that the other hath, and alfo yecldeth the like quantitie of milke, infomuch that if the pilling while it is greene be pulled from the ftalkes, the milky inyee followeth : but when it hath there remained a little while it waxeth yellow. The floures hereor are of a gold yellow eolour, and haue not fuch long greene leaues to garnin it withall, wherein eonfifteth the difference.
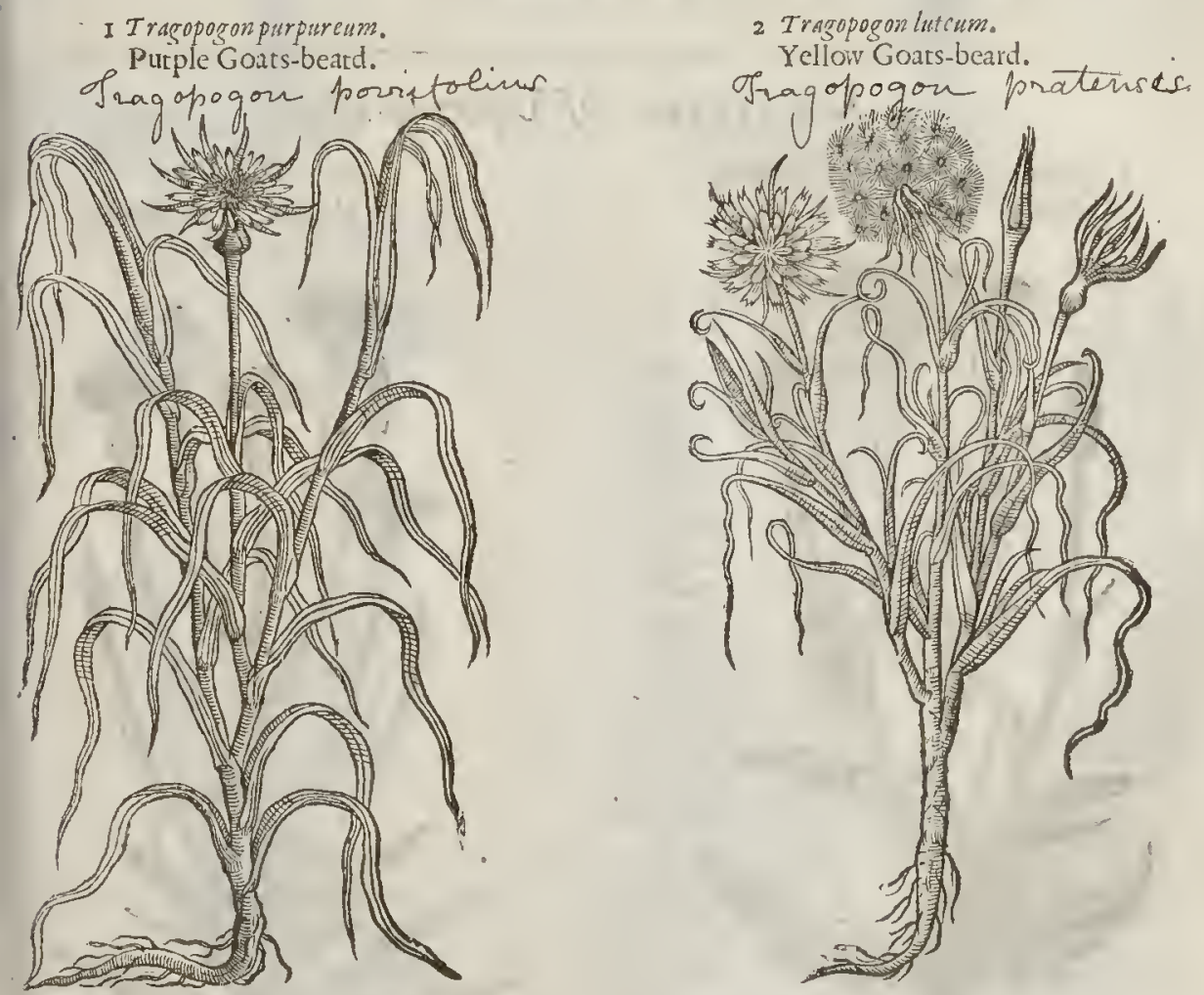

3 There is another fmall fort of Goats-beard or Go tobed at noone, which barls a thicke root full of a milky fap, from which rife v many leaues fpred vpon the ground, very long, narrow, thin, and like vnto thofe of graffe, but thieker and groffer : among which rife vp tender falkes, on the tops whereof do ftand faire doubleyellow floures like the precedent, but leffer. The whole plant 
yeeldeth a milkic fap or inyce as the others do : it perifheth like as the other when it hath perfeoted his feed. This may be called·Trayopogon minus anguflifoliwm, Luttle narrow lẹaued Goatsbeard.

\section{- The Place.}

The firlt growos not wild in England that I could cuer fee or heare of, except in Lancathire vpon the banks of the riuer Chalder, neere to nuy Lady Heskiths houfe, two miles from Whawley : it is fowen in gardens for the beauty of the Houres al linoft enery where. The others grow in medows and fertil paftures in moft places of Eng land.It growes plentifully in moft of the fields about London, as at.Ifling ton, in the medowes by Redrife, Detford, and Putncy, and in diuers other places. of The Time.

They floure and flourith from the beginning of Iune to the end of Augut.

$$
\text { बा The Names. }
$$

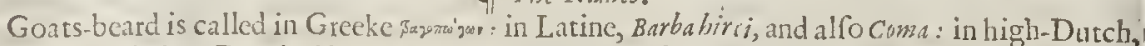

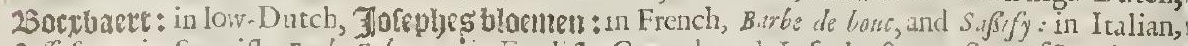

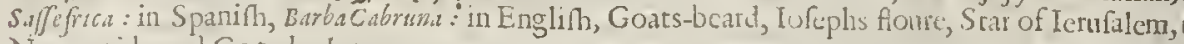
Noone-tide, and Go to bed at noone.

Thefe herbes are temperatebetweene heate and moifture.

$$
\text { If The Tertues. }
$$

A The roots of Goats beard boylcd in wine and drunke, affwageth the paine and pricking ftitches of the fides.

B The fame boyled in water vntill they be tender,and butcred as parfeneps and carrots, are a moft pleafant and wholfome meate, in delicate tafte farse furpafing either Parfenep or Carrot: which meate procures appetite, warmeth the tomacke, preuaileth greatly in confumptions, and ftrengthnet th thofe tluat haue been ficke of a long lingring difeafe.

\section{C й а т. 253. Of Vipers-Gra/fe.}

I Viperaria, fune Scorzonera Hifpanica. Common Vipers Grafle.

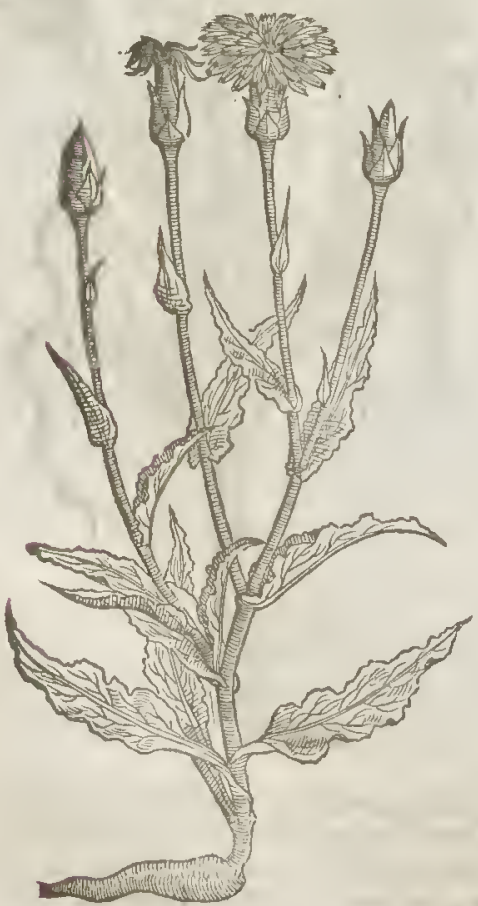

2 I'iperaria humilis. Divarfe Vipers Graffe.

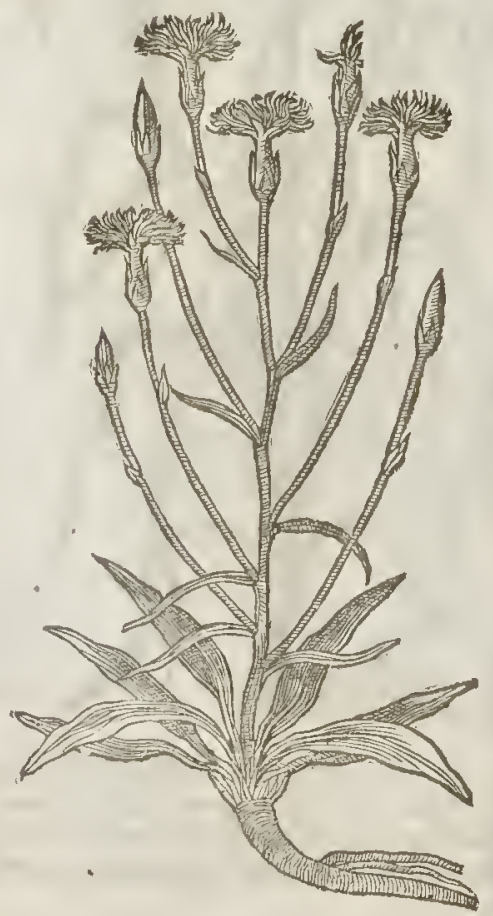


t 3 Viperaria Parnonica. Auftrian Vipers graffe.

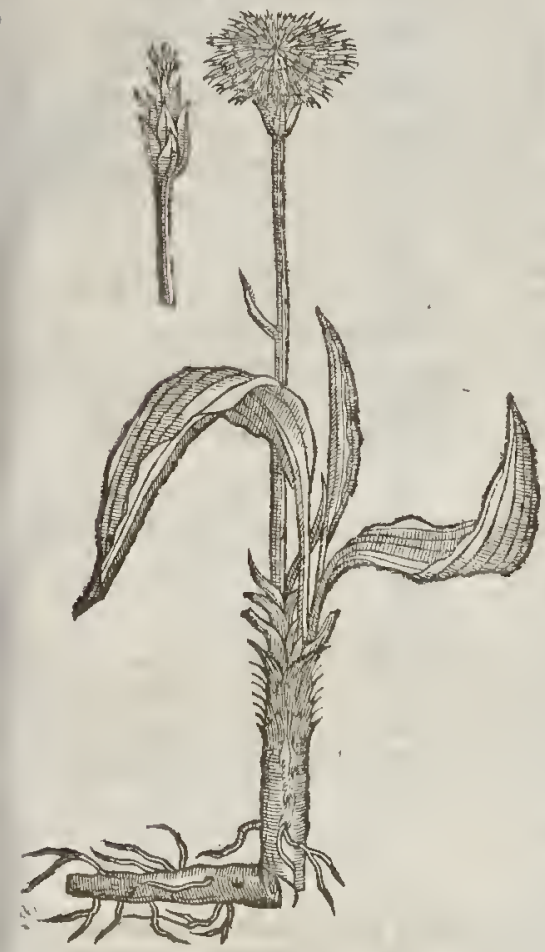

5 r"iperaria Parnonica anguftifolid. Narrow leafed Vipers graffe.

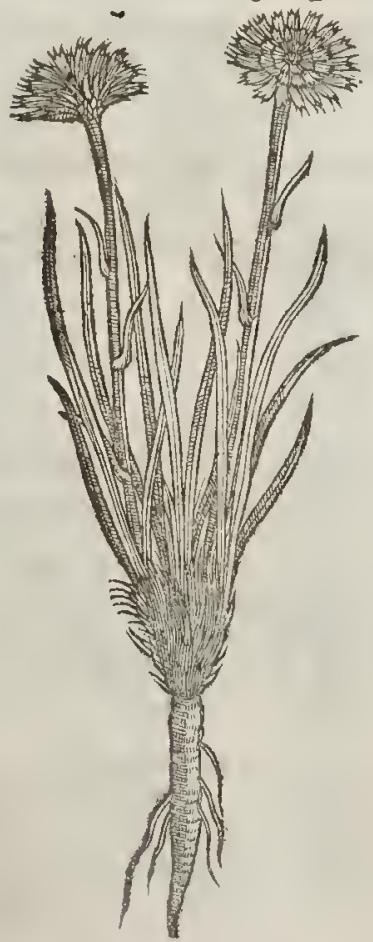

¥4 Viperaria anguftifolia clatior: Hungary Vipers grafe.

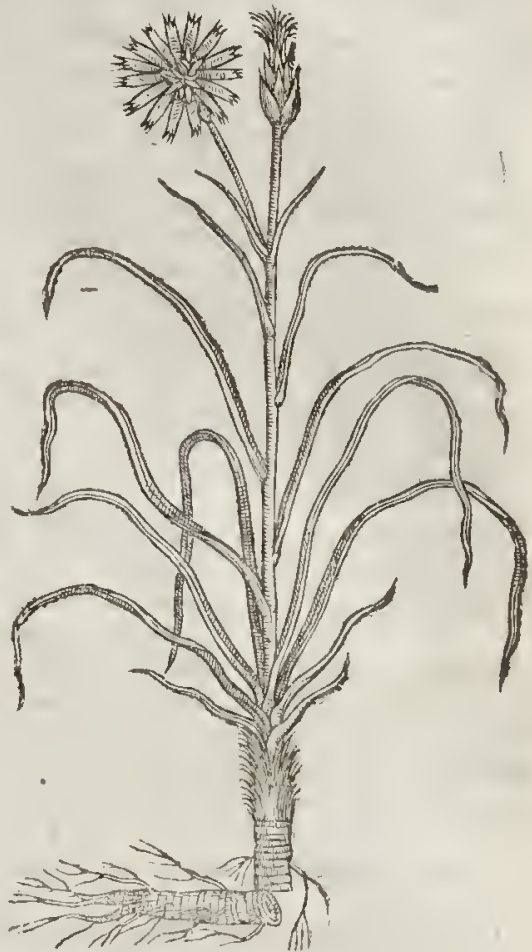

T The Defcription.

I Te firft of the Viper graffes hath long broad leaues, far, or full bodicd, vneuen about the edges, tharpe pointed, wirh a higli fwolne ribbe downe the middle, and of an onerworne eolour, tending to the eolour of $\mathrm{V}^{\prime}$ oxde: amons which rifeth vp a fiffe ftalie, fmooth and plaine, of two cubits high, whereon do grow fuch leaues as thofe next the ground. The flours ftand on the top of the ftalkes, confriting of many friall yellow leates thieke thruft togcther, very double, as are thofe of Goares beard, whereof it is a kinde, as are all the reft that doe follow in this prefent ehapter : the root is long, thicke, very brittle, eontinuing many yeeres, yeelding great inereafe of roots, blacke without, white within, and yeelding a milkic juice, as doe the leaues alfo, like vnto the Goates beard.

2 The dwarfe Vipers grafle differeth not from the precedent, fauing that it is altogether leffer, wherein efpeeially confifteth the difference.

+3 The broad leafed Auttian Vipers-grafle hath broad leaues tharpe pointed, vneuen ahout the edges, of a blewifh greene eolout : the ftalke rifeth vp to the height of a foot or better; on the rop whereof do ftand faire yellow floures, very double, greater and broader than any of the reft. Qq9 
of a refonable good fmell. The feed followeth, long and harpe, like vnto thore of Goates-beard. The root is thicke,long, and full of a milkie juice, as are the leaues alfo.

4 The narrow leaued Hungary Vipers-graffe hath long leaues like to thofe of Goates-beatd, but longer and narrower, among which rifeth vp a flender hollow italke, ftiffe and fmooth, on the top where of do ftand faire double floures of a faire blew colour tending to purple, in Thape like the other of his kinde, of a pleafant fweer fmell, like the fmell of fweet balls made of Bcnzoin. The feed is conteined in fimall cups like thofe of Goates beard, wrapped in a downie matter, that is caried away with thew inde. The root is not fo thicke nor long as rhe others, very fingle, bearded at the top,with certain hairy thrums yeelding a milkie juice of a refinous tafte, and fomewhat fharpe withall. It endureth the winter euen as the others do.

$\neq 5$ This (whofe figure was by our Authour put to the laft defcription) hath leaues like thofe of Goates-beard, but ftiffer and fhorter,amongft which there growes vp a fhort hollow ftalke fome hand full high, fer with a few fhort leates, bearing a yellow foure at the top, almoft like that of the laft faue one, bur leffe, the feed is conteined in fuch cups as the common Vipers-graffe, and being ripe is caried away wirh the leaft winde. The root is blacke, with a wrinkled barke, and full of milke, hauing the head luairy, as alfo the laft defcribed hath. This by $C$ lufsus is called $S c o r f o-$ nera humilis anguftifolia Pannonica. $\neq$

I The Place and Time.

Moft of thefe are ftrangers in England. The two firft defcribed dog tow in my garden, The teft are touched in their feticrall titles.

They floure and flourith from May to the end of Iuly.

$$
\text { 9] The Names. }
$$

Vipers-graffe is called of the Spaniards Scorzonera, which foundeth in Latine Viperaria, or Viperina, or Serpentar $i t$, fo called becaufe it is accounted to be of force and efficacy againt the poifons of Vipers and ferpents, for Vipera or a viper is called in Spanifh Scurzo: it hath no name either in the high or low Dutch, nor in any other, more than hath been faid, that I can reade: in Engltifh we may call it Scorzonet,after the Spanifh name, or Vipers-graffe.

They are hot and moift as,are the Goates-beards.

$$
\text { 9) The Temperature. }
$$

\section{T TheVertues.}

A It is reported by thofe of great iudgement, that Vipers-graffe is moft excellent againft the infections of the plague, and all poifons of venomous beafts, and ef pecially to cure the bitings of vipers, (of which there be very many in Spaine and other hot countries, yet hate I heard that they haue been feen in England) if the juice or lierbe be drunke.

B It helperh the infirmities of rhe heart, and fuch as vfe ro fwoune much:it cuteth alfo them that haue the falling fickenefle, and fuch as are troubled wirh giddinefle in the head.

C The rootbeing eaten, cither rofted in embers, fodden,or raw, doth make a man merry, and temoucth all forrow.

D The root condited with fugar, as are the toots of Eringos and fuch like, worke the like effects: but more familiarly, being thus dreffed.

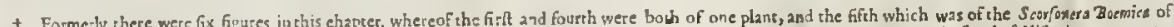

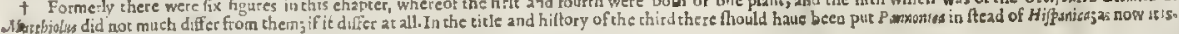

\section{C н Р. 254. Of Marigolds.}

9) The Defcription.

I THe greateft double Marigo!d hath many large, fat, broad leaues, fpringing immediately

1 from a fibrous or rhreddy root; the upper tides of rhe leaues are of a deepegreene, and the lower ide of a more light and thining greene. among which rife vp ftalkes fomewhat hairie, and alfo fomewhat jointed, and full of a fung rours pith. The floures in the top are beautifull, round, very large and double, fomething fweet, w w il is ctaine ftrong fmell, of a light faffron colour, or like pure gold:from the which foliow a number flong crooked feeds, efpecially rhe outmoft, or thofe that ftand about the edges of the foure; whiclibeing fowne commonly bting forth fingle floures, whereas contrarivife thofe feeds in the middle are le ffer, and for the moft part bring forth fuch floures as that was from whence it was taken

2 The common double Marigold hath manv far, tr:cke, cru upled leaues fet vpona groffe and fpungious ftalke:whereupon do grow faire double yellow floures, hauing for the moft part in the middle a bunch of threddes thicke thut together: which being paft there fucceed fuch crooked feeds as the firt defcribed. The root is thickeand hard, with fome threds annexed thereto. 
LI B. 2. Of the Hitory of Plants.

1. 2. Calcndula maior polyantbos.

The greater double Marigoid.

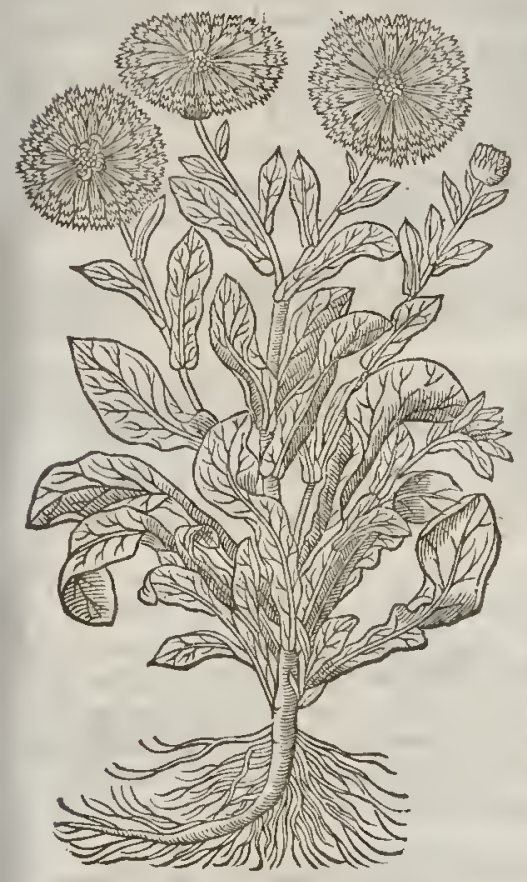

\section{Calendula fimplici flore.}

Single Marigold.
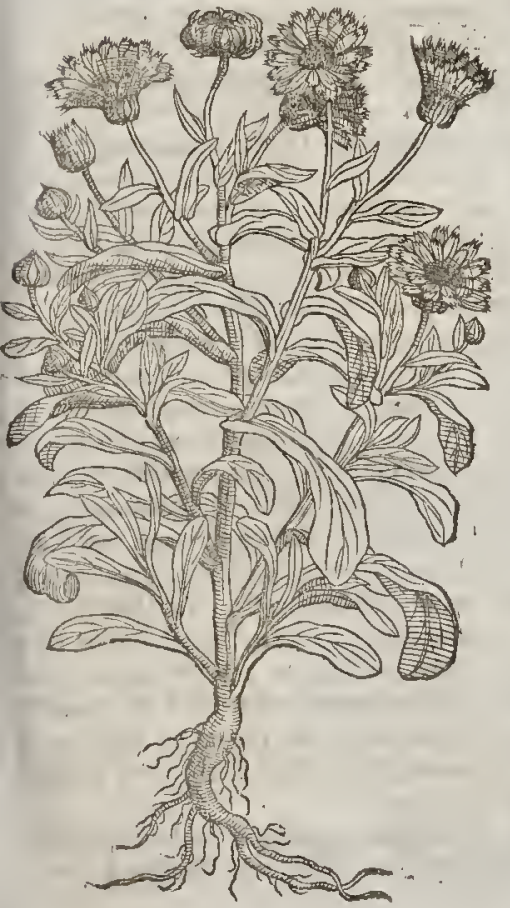

Q99
4 Calendula multiflora orbiculata. Double globe Marigold.

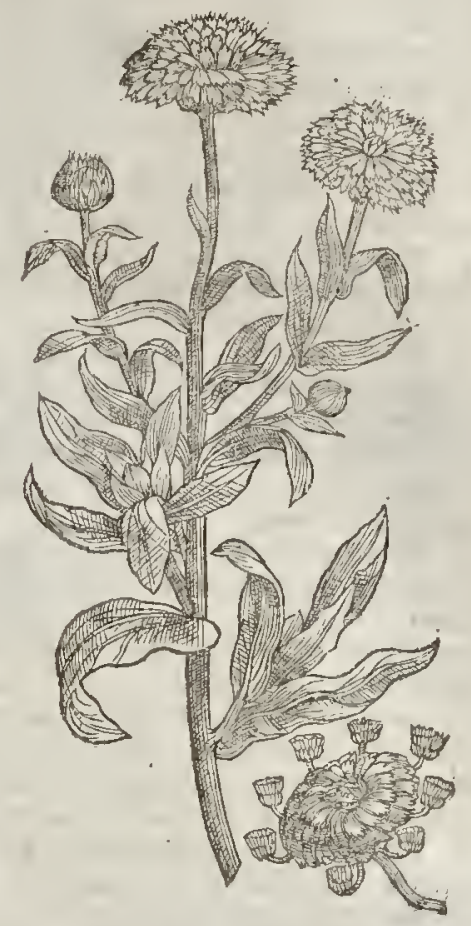

7 Calendulaprolifera.

Fruitfull Marigold.

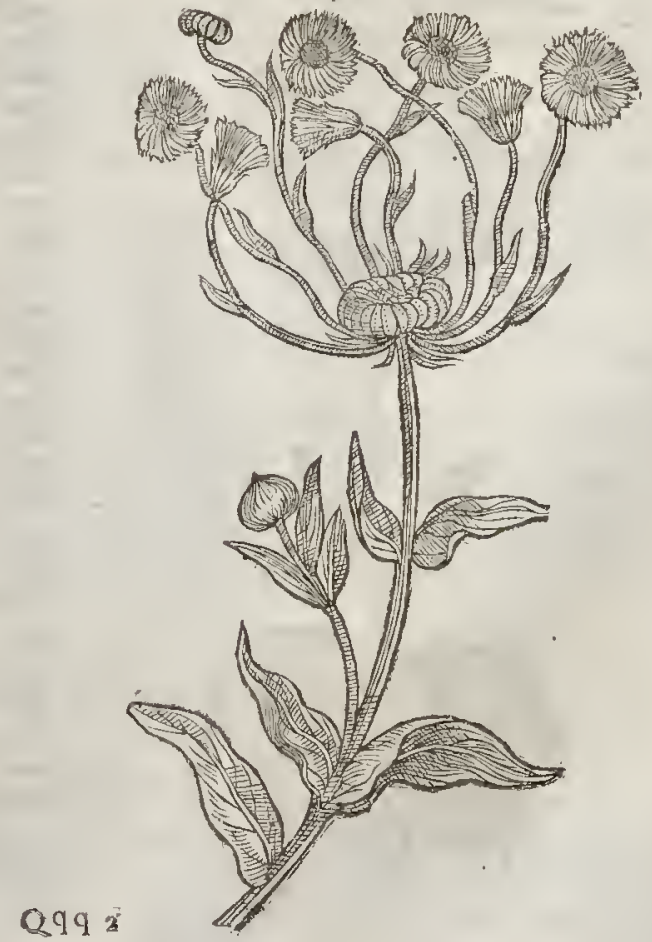


3. The fmaller or finer leafed double Marigold groweth vpright, lauing for the moit part one ftem or fat fpongeous ftalke, garnithed with fmooth and fat leaues confufedly. The fioures gro: at the rop of the fnull branches, very double, but lefler than the otlicr, confitinj of more finc iaggedneffe, and of a fare yellow gold colour. The root is like the precedent.

4 The Globc-flouring Marigold hath many largebroad leaues rifing immediateiy forth of the ground, a mong which rifeth vp a falke of the height of a cubit, diuiding it felfe toward the top into other fmaller branches, fet orgarnifhed with the like leaues, but confufedly, or without otder. Ile floures grow at the top of the ftalkes, very double; the fmall leaves whercof are fet in comely order by ccrtainc rankes or rowes, as fundry lines are in a Globe, trauerfing the wholc con1paffe of the fame, whereupon it tooke the name orbiculata.

5 The fifth fort of double Marigold differeth not from the laft defcribed, furing in the co our of the floures, for this plant bringeth forth floures of a ttraw or light yeilow colour,and the orhers not fo, wherein confifteth the difference.

¥ All thefe fiue here deferibed, and which formerly bad fo many figures, differ nothing but in the bigneffe and littlencfic of the plants and floures, and in the intenfeneffe and remifnefic of their colour, which is cither otange, yellow, or of a ftraw colour. $\ddagger$

6 The Marignld with fingle Houres differeth not from thofew itl double floures, but in that it confifteth of fewer leaues, wh hich we therefore terme Simgle, in comparifoul of the reft, and that maketh the difference.

7 This furicull or much bearing Marigold is likewife called of the vulgar fort of women, Iacke-an-apes on horfcbacke : it hath leaues, ftalkes, and roots like the common fort of Marigold, differing in the thape of his floures, fot this plant doth bring forth at the top of the ftalke one fourc like the other Marigolds; from the which ftart forth fundry other fmal flourcs, yellow like. wife, and of the fame fafhion as the firft, which if I be not deceiued commetlito paffe per accidens, or by chance, as Nature of tentimes liketh to play with other floures, or as children are borne with two thumbes on onc hand, and fuch like, which liuing to be men, do get children like vnto otliers; euen fo is the feed of this Marigold, which if it be fowen, it brings forth not one flourc in a thoufand likc the plant from whence it was taken.

8 The other fruitfull Marigoid is doubteffe a degeneratekind, comming by chance from the fecd of the double Marigold, whereas for the moit part the other commeth of the feed of the fingIe floures, wherein confifteth the difference. $¥$ The floure of this (whercin the onely difference confifts) you thall finde expreft at the bottome of the fourth figute. $\ddagger$

9 Calendula Alpina. Mountaine Marigold.

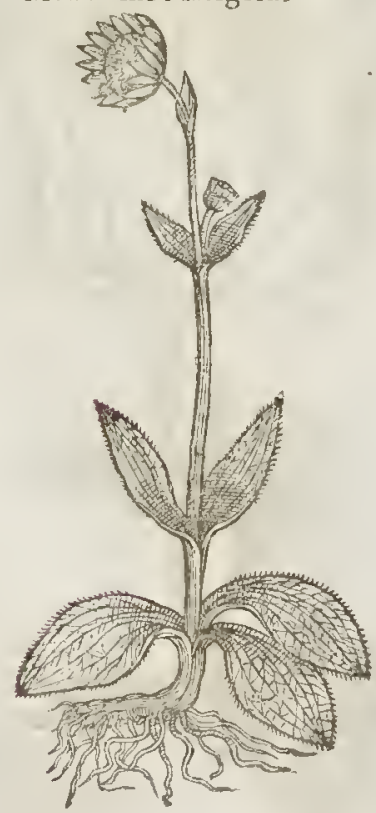

9 The Alpilh or mountainc Marigold, which Labelizes fetteth downe for Nardus Celtica, or Planiago Alpina, is called by Tabcrisamontanus, Caltha, or Calendula Alpina : and becaufe I fee it rather refembles a Marigold, than any other plant, I hatic not thought it amiffe to infert it in this place, leauing the confideration thereof vnto the friendly Reader, or to a futther confideration, becaufe it is a plant that I anm not well acquainted withall; yet I doe reade that it hath a thickc root, growing aflope under the vpper cruft of the earth, of an atomaticall or fpicic tafte, and fomewhat biting, with many theeddy ftrings annexed thereto: from which rife ip broad thicke and rough leaues of an oucrw orn green colour, not vnlike to thofe of plantaine : among which therc rifeth rp a rough and tender ftalke fet with the like leaues; on the top wherof commeth forth a fingle yellow floure, paled about the edges with fmall leaucs of a light yellow, rending to a ftraw colour the miiddle of the floure is compofed of a bundle of thrcds, thicke thruft together, fuch as is in the middle of the field Daifie, of a deepe yellow colour.

‡ This Plant is all one with the two defcribed in the next Chapter: they vary oncly 


\section{Li в. 2. Of the Hiftory of Plants.}

thus; the ftalkes and leaues are fometimes hairy, otherwhiles fmootly; the floure is yellow, or elfe blew. I hauing three figures ready cut, thinke it nor amife to gine you one to expreffe each varictic. $\neq$

-10 The wilde Marigold is like vnto the fingle garden Marigold, but altogether leffer, and the whole plant peritheth at the firft approch of Winter, and recouereth it felfe againe by falling of the feed.

Ti The Place.

There Marigolds, with double floures efpecially, are fet and fowen in gardens: the reft, their titles do fet forth their naturall being.

$$
\text { T The Time. }
$$

The Marigold floureth from Aprill or May enen vntill Winter, and in Winter alfo, if it be warme.

$$
\text { ขा } T \text { he Names. }
$$

The Marigold is called Calenduls: it is to be feene in floure in the Calends almoft of eurie moneth: it is alfo called Chryfanthemum, of his golden colour: of fome, Caltba, and Caltba Poetsrum: whercof Columells and Virgil doewrite, faying, That Caltha is a floure of a yellow colour: whereof $V$ irgil in his Bucolickes, the fecond Ecloge, writeth thus;

$$
\begin{aligned}
& \text { Tum Cafia atque alys intexens fuaribus berbis } \\
& \text { Mollia Lateola pingit vaccina Caltha. }
\end{aligned}
$$

And then fhee'l Spike and fuch fweet herbes infold, And paint the Iacinth with the Marigoid.

Columella alfo in his tenth booke of Gardens hath thefewords; .

$$
\text { Candida Leucoia of flauentia Lumina Calthe: }
$$

Stoek-Gillofoures exceeding white, And Marigolds moft yellow bright.

It is thought to be Gromphena Plinï: in low-Dutch it is called Æoud bloenten : in high-Dutch,

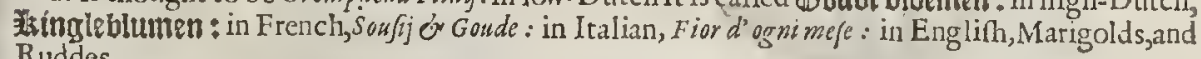
Ruddes.

T The Temperature andVertues.

The floure of the Marigold is of temperature hor, almolt in the fecond degree, efpecially when it is dry : it is thought to ftrengthen and comfort the heart very much, and alfo to withltand poyfon, as alfo to be good againf peftilent Agues, being taken any way. Fuchfows hath written, That being drunke with wine it bringeth downe the termes, and that the fume thereof expelleth the fecondine or after-birtl

But the leaues of the herbe are hotter; for there is in them a certainbiting, but by reafon of the $B$ moifture ioyned with it, it doth not by and by nhew it felfe; by meanes of which moifture they mollifie the belly, and procure folubienefie if it be ved as a pot-herbe.

Fuchfius writeth, That if the month be wafhed with the iuyce it helpeth the tooth-ache.

The floures and leaues of Marigolds being diftilled, and thewater dropped into red and watery cyes, ceafeth the inflammation, and taketh away the paine.

Conferte made of the floures and fugar taken in the morning fafting, curcth the trembling of $\mathrm{E}$ the heatt, and is alfo giuen in time of plague or peftilence, or corruption of the aire.

The yellow leaues of the foures are dried and kept throughout Dutchland againf Wiriter, to put intobroths, in phyficall potions, and for diuers other purpofes, in fuch quantity, that in fome Grocers or Spice-fellers houfes are to be found barrels filled with them, and retailed by the penny more or leffe, infomuch that no broths are well made without dried Marigolds.

\section{Cна т. 255. Of Germane Marigolds.}

\section{I) The Defcription.}

Ylden Marigold with the broad leafe doth forthwith bring from the root long leaues

f pred vpon the ground, broad, greene, fomething rough in the vpper part,vnderneatlz fmooth, and of a light greene colour : among which fpring vp flender ftalks a cubit 
high, fomethng hoarie, hauing three or foure ioynts, out of euery one whereof grow two leatues, fet one right againft another, and oftentimes little flender ftems; on the rops whereof fland broad round foures like thofe of Ox-eye, or the corne Marigold, liauing a round ball in the middle(fich as is in the middle of thofe of Camomil) bordered about with a pale of bright yellow leaues. The whole floure turneth into downe that is carried away with the winde; among which down is found long blackifh feed. The root confifteth of threddy ftrings.

$t 2$ The leffer fort hath foure or fune leaues fpred vpon the ground like vnto thofe of the laft defcribed, but altogether leffer and fhorter : among which rifeth vp a flender ftalke two hands ligh; on the top whercoffand fuch foures as the precedent, but not fo large, and of a blew colonr.

₹ Thefe two here defcribed, and that defcribed in the ninth place of the foregoing Chapter, are all but the varieties of one and the fame plant, differing as I haue thewed in the foregoing Chapter. $\ddagger$

\section{Chryfunthemum latifolium:}

Golden Marigold with the broad leafe.

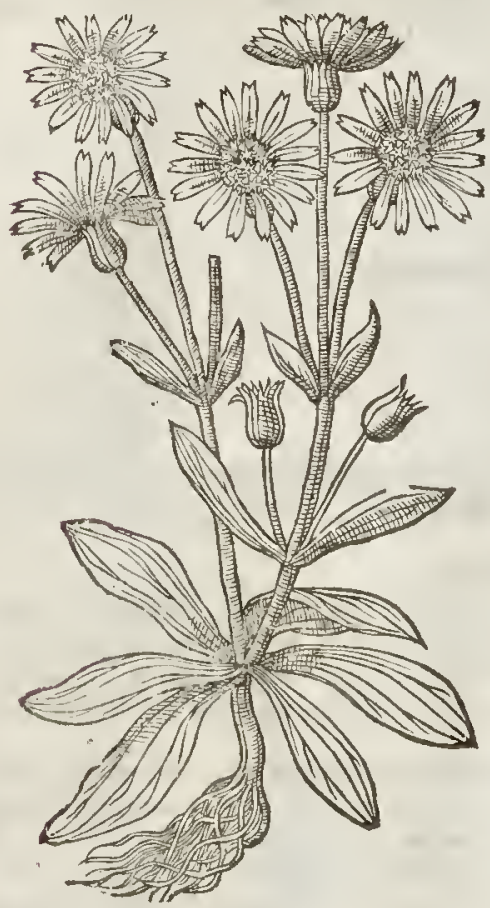

2 Chryfantbemum latifolium minus. The leffer Dutch Marigold.

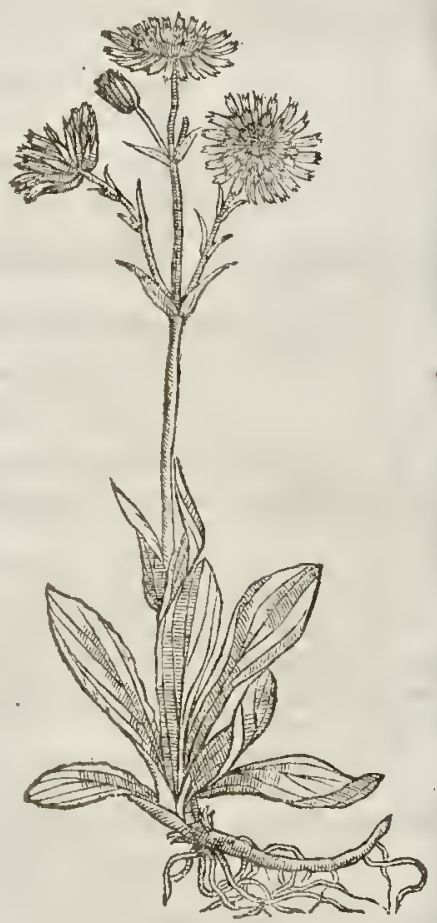

9. The Place.

They be found emery where in vatilled places of Germanie, and in woods, but are ftrangers in England.

\section{T The Time.}

They are to be feene with their floures in Iune, in the gardens of the Low-countries.

$$
\text { T. The Names. }
$$

Golden Marigold is called in high-Dutch noaloiblume, There are that would have it to be $A$ lifma Diofcorides, which is alfo called Damafonium, but vnproperly; there fore we muft rather call it Chry fonthenumlatifolium, than rafhly attribute vnto it the name of slifma. $\ddagger$ This plant indeed is a Doronicuza, and the figure in the precedent chapter by Clufius is fet forth by the name of Doronucum 6. Panmonicum: Mathiolus calls this plant Alifma: Gefner, Caltha Alpina: Dodoneus, Chryfanthemum latifolium: Pena and Lobel, Nardus Celtica alters. Now in the Hiftoria Lugd. it is fet forth in in foure fencrall places by three of the former names; and pag. I 169 . by the name of prarmicamontana Dalefchampï.

It is hot and dry in the fecond degree being greene, but in the third being dry. 
i B. 2.

Of the Hifory of Plants:

$-7+3$

T The Vertues.

The women that liue about the A lps wonderfully commend the root of this plant againft the fuffocation of the mother, the floppings of the courfes, and the green fickneffe and fuch like affects in raids. Bifror, Lugd. $\neq$

C н а р. 256. Of Corne-c Marigold.

of The Defoription.

- Orne Marigoldor golden Corne floure hath a foft ftalke, hollow, and of a greene colour,wherupon do grow great leaues, micl luackt and cut into diuers feitions, and placed confufedly or out of order:vpon the top of the branches ftand faire farlike floures, yellow in the middle, and fuch likewife is the pale orborder ofleates that compaffeth the foft bal in the ruiddle, like that in the middle of Camomill floures, of a reafonatble plea fant frnel. The roots are full of ftrings.

$$
\text { † I chryfonthemum regetum. }
$$

Come Marigold. segation
Chysanthesmoz.

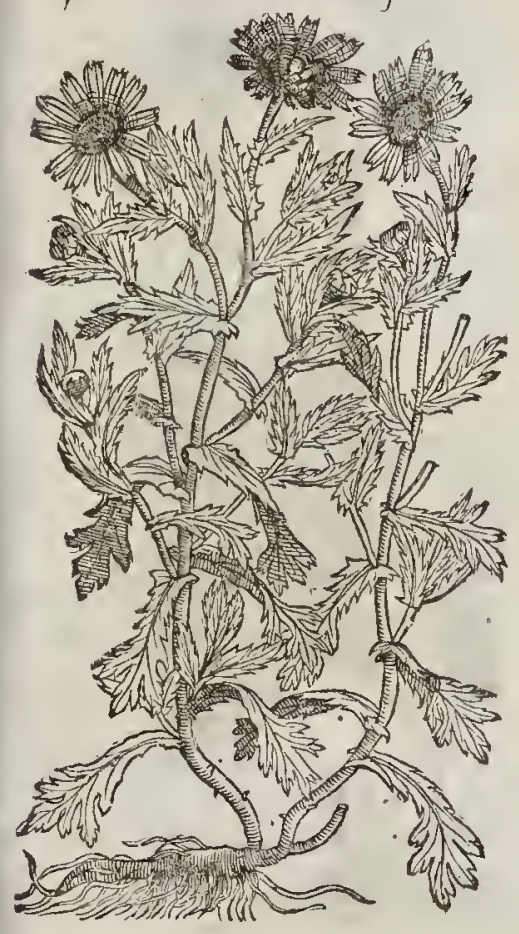

2 Cloryanthemum Valentinum: Corne Marigold of Valentia.

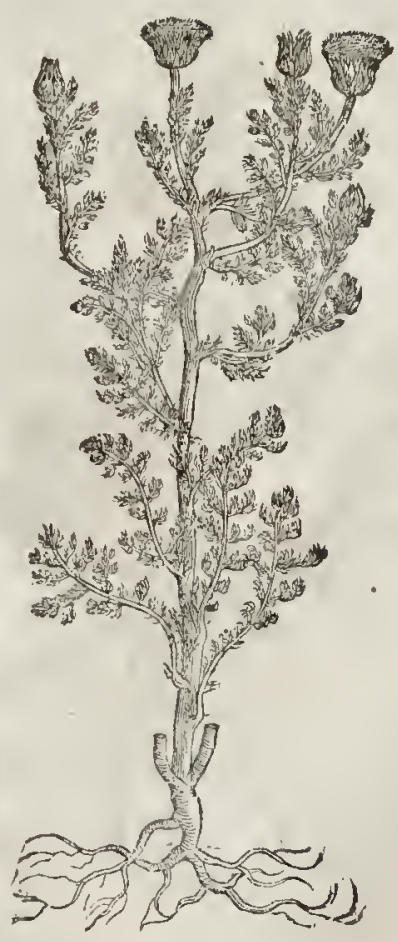

2 The go'den foute of Valentia hath a thicke fat Aalk, rotgh, vnevien, and fomewhat crooked, whereupon do grow long leanes, confiting of a long middle rib, with ditiers lirtle fetherlike leaues fet therenin w ithout order. The Aoures grow at the top of the Atalks, compofed of a yellow thrummie matter,fich as in the middle of the Camomill Houres, and is altogether like the Corne Marygold laft de feribed, fauing it doth want that border or pale of liftele leaues that do compaffe the ball or head:the root is thicke, tough, and difperfeth it felfe far abroad.

¥ 3 To thefe may be added dituers other, as the Chryfant heris Alpina, of Clufius, \&zluis Chryfarthemum Creticum, \& others. The firft of thete fmal mountain Marigolds of cliffus his defeription hath leaues like thofe of white Wotmewoot, but greener and thicker the ftalks grow fu ne handfull high, fet with few and inucli ditided 'eaues; and ar the tops, as in an vinbell, they carry fome do-

zen 
zen foures more or leffe, not much vnlike in thape, eolour, and fmell, to thofe of the comn:on Iacebea,or Ragwoort. The root is foncwhat thicke, and puts forth many long white fibres. It Aloures in Iuly and Auguft,and growes vpon the Alpes of Stiria. Clufus ealls it Chryfanthemum ulpinum. $\mathrm{I}$.

4 The fecond of his defcription hath many leaues at the root, like the leaues of the male Suthernwood, but of a lighter and brighter greene, and of no vnpleafant fmell, though the tafte be bitterish and vngratefull : in the middeft of the leaues grow vp falkes fone foot high, diuided at their tops into fundry branches, which carry each of then two or three foures bigger than,yet like thofe of the common Cammomill, but without fmel, and wholly ycllow : the root is fibrous, blaekifh, and much fpreading. It floutes in Auguf, and growes in the like places as the former. Bumbine iudges rhis to be the Achilldamontan Artemifra tenuifolia facic of the Aduer fand the Ageratum fermlaceum in the Hift.Lugd.But I cannot be of thatopinion; yet I iudge the Achilles montana, and Ageratum ferulacerem to be but of the fame plant. But different from this, \& that chiefely in that it hath many more, and thofe much leffe floures than thofe of the plant here figured and deferibed.

5. Now thould I haue giuen you the biftorie of the 6 bry ant hemus Creticum of the fame Authour, but that my friend $\mathrm{M}^{\mathrm{r}}$. Goodyer hath faued me the labour; by fending an exact defcription thereof, together with one or two others of this kinde, which I thinke fit here to gitue you.

¥ 3 Chryfanthenum Alpinum x.clur. Small mountaine Marigold.

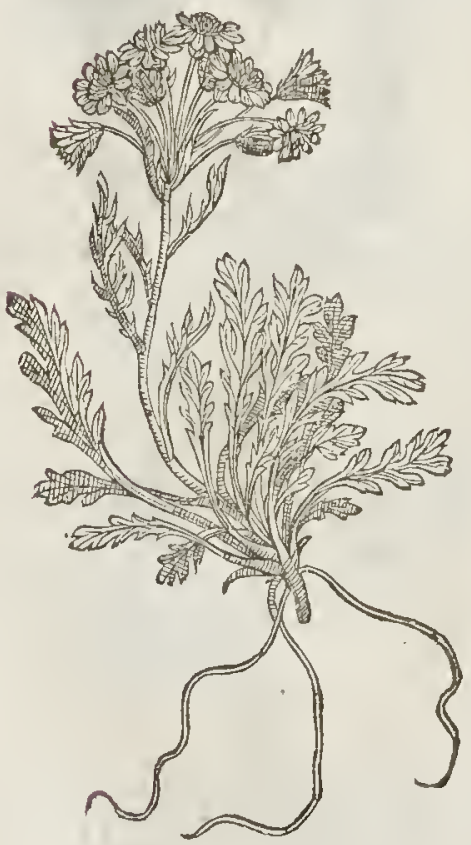

\$ Chryfinthemum Alpimum 2.Cluf. The other Alpine Marigold.

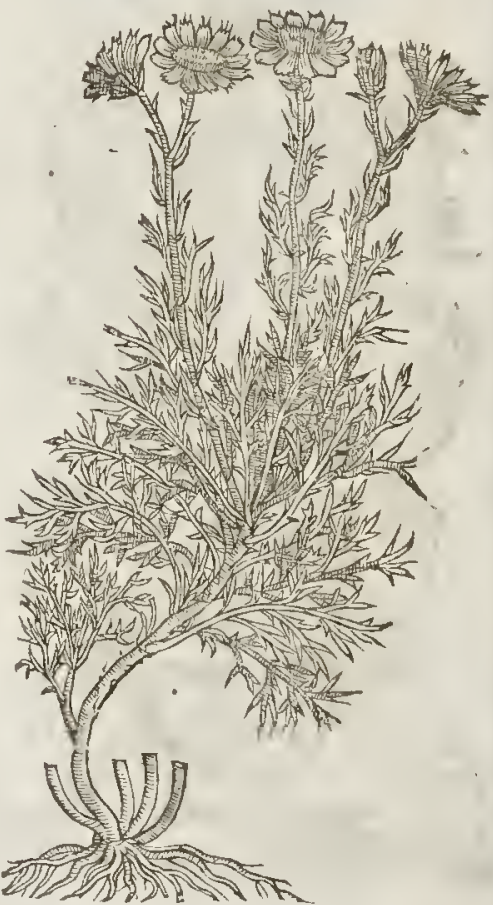

Chryfanthemum Creticum primum Clugy,pag. 334 .

The ftalkes are round, ftraked, branched, hard, of a whit ifh greene, with a very little pirh within; neere tlire font high : the leaues grow out of order, diuided into many parts, and thofe again fnipt or diuided, of the enlour of the ftalkes : at the tops of the ftalkes and branehes grow great flourcs, bigger than any of the reft of the Corne-ifoures, forth of fcaly heads, confifting of twelue or more broad leaues apece, notehed at the top, of a thining golden eolour at the firf, which after turne to a pale, whitifh,or very light yellow, and grow round about a large yellow ball, of fmell fomewhat fwect. The foures paft, there eommeth abundanee of feed clofely compact or thruft together, and it is thort, blunt at both ends, ftraked, of a falue colour, fomwhat flat, \& of a reafonable bignes. The 
5 Cloyfantbemum Creticum: Candy Corne Marigold. is

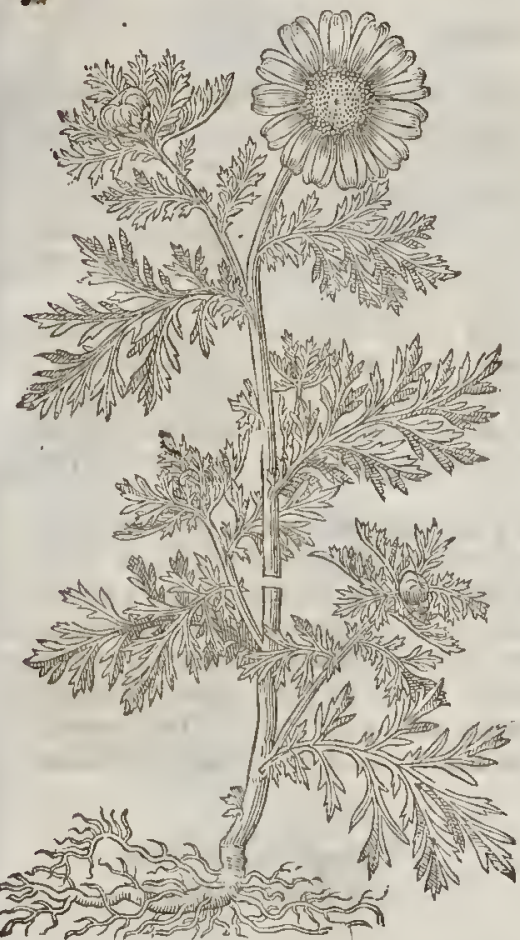

toot is whitith, neere a fingers bigneff, thort, with many threds hang ins thereat and perilhethwhen the feede is ripe; and at rhe Spring groweth vpagaine by the falling of the feed.

\section{Chryfantbemum Bat icum Bo:lig, inf criptum?}

The ftalks are round, fraked, reddin brotvn, tiuided into branehes, entaining a forngious white pith within, a cubite high: the leanes grow out of order, without footitulkes, about three inehes long, and an inch broad, notched about the edges, not at all diuided, of a darke greene eolour : the floures grow at the tops of the ftalkes and branches, forch of great faly heads, eontaining twentic leaues a piece or more, notched at the top, of a thining vellow co'our, growing about a round yellow ball, of a reafonable good funell, very like thofe of the eonmon Chryluntbemum figetum : the feede groweth like the other, and is vety fmall, long, round, erooked and whitith : the rotot is fmall, whitin, threddie,and perioneth aliowlien the feed is ripe.

\section{Chryfanthemum tenuifolium Bsticum Bocly.}

The ftalks are round, finall,ftraked, reddith, fomewhat hairie, branched, a cubit high,or higher:the leanes are tinall, mueh diuided, iagged, and vety like the leaues of Cotula fetida : the floures are yellow, thining like gold,eompofed of thirteene or fourteene leaues a pieee,

notehed at the top, fet about a yellow ball,alfo like the common Chryfint hemum ferctum : the feed groweth among ft white flattifh fcales, which are elofely eompa cted in a round head together; and are fmall, flat, grayifh, and broad at the top : the root is fmall, whitifh, with a few tlireds, and dyeth when the feed is ripe. Iuly 28.162 I.Iobn Goodyer. $\neq$

$$
\text { T The Place. }
$$

The firft groweth among corne, and where come lath been growing : it is found in fome plaees with leaues more iagged, and in others leffe.

The fecond is a ftranger in England.

They floure in Iuly and Augut.

$$
\begin{aligned}
& \text { II The Time. } \\
& \text { व The Names. }
\end{aligned}
$$

Thefe plants are ealled by one name in Greeke, of the goldeng littering colour, zisansur. in High Duteh, Sant Johans bltim: in Low Duteh, doblat: in Englith, Corne Marigold, yellow Corne floure, and golden Corne floure.

There be divers o her Houres ealled Chryfans hemum alfo, as Eatrachion, a kinde of yellow Crowfoot, Heliochry fon, but thefe golden floures difier from them.

$$
9 \text { The Temperature. }
$$

They are thought to be of a meane temperature betweene heat and moifture.

$$
\text { of The Vertues. }
$$

The ftalks and leaues of Corne Marigold, as Diofcoridis faith,are eaten as otler pot-herbes are.

The flotres mixed with wax,oile, rofine, and frankinfenee, and made vp into a feare-cloth, wa. feth away eold and hard fwellings.

The herbe it felfedrunke, after the comming forth of the bath, of them that haute theyellow $\mathrm{C}$ imulife, doth in thorr time make them well colouted. 


$$
\begin{gathered}
\mathrm{C} \text { HA } 0.257 . \text { OfOxe-Eis. } \\
\text { II The Defription. }
\end{gathered}
$$

I THe plant whichwee haue called Buphtbalmum, or Oxe-eie, hath flender falks growing

fronr the roots, three, foure, or more, a foot high, or higher, about which be green lcaues finely iagged like to the leaues of Fenell, but much lefter: the thoures in the tops of the ftalks are great, much like to Marigolds, of a light yellow colour, with yellow threds in the iniddle, after whiels eommeth vp a litrle head or knap like to that of red Mathes before deferibed, called $\boldsymbol{A}$ donis, confiting of many feed's fet together. The roots are flender, and nothing but ftrings, like to the roots of blacke Ellebor, whereof it hath beene taken to be a kinde.

2 The Oxe-eie which is generally holden to be the true Bupht halmum hath many lcaues fpredvpon the ground, of a light greene colour, laied far abroad likewings, confifting of very many fine iags, iet vpon a tender middle rib : among which fpring vp diuers ftalks, ftiffe and brittle, vpon the top whereof do grow faire yellow leaues, fet about a hedd or ball of thrummie matter, fuch as in the middle of Cammomill,like a border or pale. The root is tough and thicke, with certaine ftrings fattred thereto.

3 The white Oxe-cie hath fmall vpright ftalks of a foot high,wheteon do grow long leaues, compored of diuers final leanes,and thofe fnipt about the edges like the teeth of a faw. The floures grow on the tops of the ftalks, in thape like thofe of the other Oxc-cie; the middle part whereof is likewif made of a yellow fubftanee, but the pale or border of little leaues, are exceeding white, like thofe of great Dafic, called Confolidamedia vulnerariorum. The root is long,creeping alongft vnder the vpper cruft of the earth, whereby it greatly increafech. $\neq$ This by the common confent of all writers that haue delinered the hiftorie thereof, hath not the pale or out leaues of the floure white, as our Author affirmes, but of a bright and perfect yellow colour. And this is the Buphthalmum, of Tragus, Matthiolies, Lobel, Cluffurs and oihers. ‡

I Buphthalmum five Helleborus niger ferilaceus. Oxe-cic.

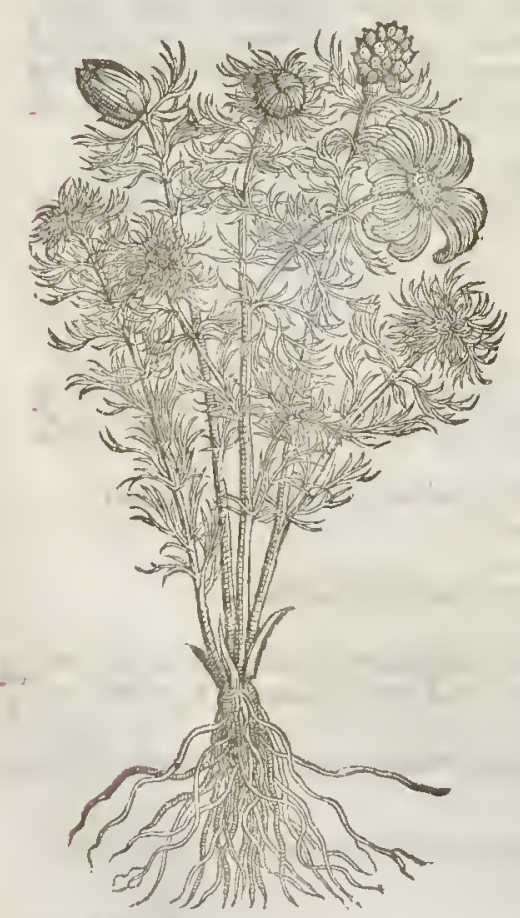

2 Buphthalmum verum: The right Oxe-eie. 
3 Buphthalmum vulgare. White Oxe-cie. - Anthemis tinctoria

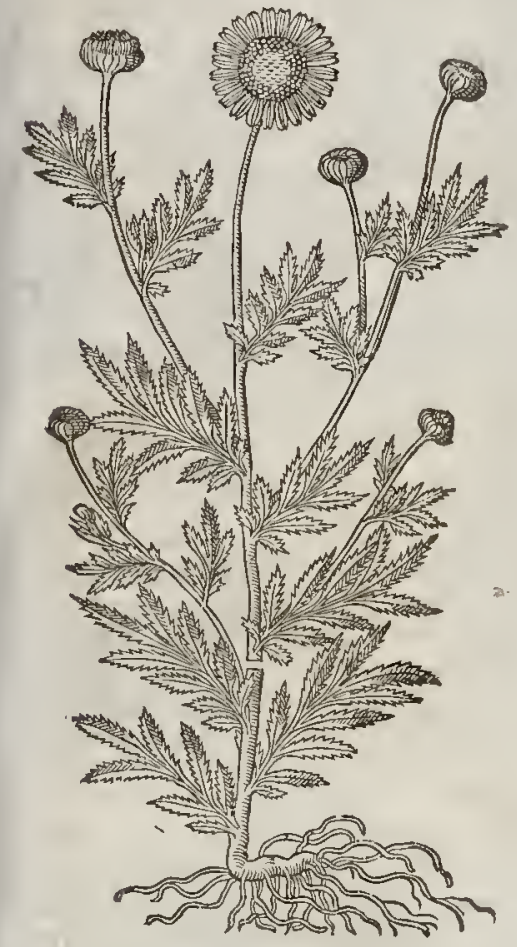

T) The Place.

0

The two firt growe of themfelues in Germany, Bohemia,and in the Gardens of the Low-countries; of the firft I haue a plant in my garden. The laft groweth in barren paftures and fields almoft cuery where.

\# The laft is alfo a ftranger with vs, for any thing that I know or can learne, neither can I coniecture what our Authour meant here : firtt in that he faid the floures of this were white, and fecondly in that ic grew in barren paftures and fieids almoft eucry where. $\neq$

$$
\text { I The Time. }
$$

They floute in May and Iune. The laft in Augurt.

$$
\text { T) The } 2 \text { ames. }
$$

Touching the naming of the firft of thofe plants the late writers are of ditiers opinions: fornewould hate it to be a kind of Veratrsm nigrum, blacke Hellebor:other fonte Confiligo, or Bearefoot and againe, uthers, Sefamoides; and fome, Elleboraftrum : But there be found twokindes of blacke Ellebor among the old writers, one with a leafe like vnto Laurel, with the fruit of $\mathrm{Se}$ famum:the other with a leafe like that of the Planc tree, with the feed of Carthimus or Baftard Saffron. But it is moft etrident, that this buphthalmom, in Englifh, Oxe-eie, which in this Chapter we in the firft place haue defcribed, doth agree with neither of thefe: what form Confiligo is of, we finde not among the old writers.Pliny 26 . cap.7. Faith, That in his time it was found aniong ft the $M$ ar $f$, and was a prefent remedy for the infirmitie of the lungs of fivine, and of all kinde of eattell, though it were but drawne thorow the eare. Colvernella in his 6 . booke, Claap. 5 . doth alfo fay, that in the mountaines called Marfi there is very great ftore thereof, and that it is very helpfull to all $\mathrm{k}$ ind of eattel, and he tellech how and in what manner it mut be put into the eare; the roots alfo of our Oxe-cie are faid to eure certain infirmities of cartel, if they be pur into the flit or bored eare: but it followeth not that for the fame reafon it fhould be Confligo; and it is an or dinary thing to find out plants that are of a like foree and qualitie: for Pliny doth teftifie in his 25 booke, 5 chapter, That the roots alfo of blacke Ellebor can do the fame: it cureth(faitl lie) the cough in cattel, if it be drawn thorow the eare, and taken out again the next day at the fame houre : which is liketvife molt eertaine by experiments of the countrcy men of our age; who do cure the difeafes of their cattell with the roots of common biack Ellebor. The roots of white Ellebor alfo do the like, as $A b / y r t u s$, and after him Hierocles doth write : who notwirhitanding do not thruft the roots of white Ellebor into the eare, but vnder the skin of the breft called the dew lap : after which manner alfo $V^{\prime}$ egctius Renatus doth vfe Confligo, in his firt tooke of the curing of catrell, chapter I 2 . intituled, Of the cure of the in firmities vnder the skin : although in his 3. booke, 2 . Chapter, de Malleo, he writeth, that they alfo murt be faftned thorow the eare:which things do fufficiently deelare, chat fundry plants haue oftentimes like faculties:and that it doth not at all follow bv the fämerea fon, that our Oxe eic is Confiligo, becaufe it doth cure difeafes in Cattel as wel as Confiligo doih But if we nuft coniceture by the faeultiès, Confilizo then fhould bee White E!lebor : for Veyctius veth Confligo in the very fame maner that $A b$ fyrtus and Hievocles do vfe white Ellebror. This fufpicion is made the greater,becaufe it is thought that Vegetios hath taken this manner of curing trom the Grecians; for which eaufe alfo moft doe take Conflizo to be nothing elfe but white Ellebor : the whieh if it be fo, then thall this prefent Oxe-eie much differ from Corfitigo; for it is nothing at all like towhite Ellebor.

And that the fame is not Sefamoides, either the firft or the fecond, it is better knowne, than needfull to be confured. 
This fame alfo is vnproperly called Hellcboraftum; for that may aptlybeecalled Hclleborastrum which hath the forme and likeneffe of Hellebor: and this Oxe eic is nothing at all like to Ellebore. For all whicly caufes it feemeth that none of thefe names agree with this plant, but only the name Buphbalmum, with whofe defcription which is extant in Diofcorides this plart doth moit aptly igree. We take it to be the right Oxe eie; for Oxe eie bringeth forth Ilender fof ftalks, and hath leatues of the likeneffe or fimilitude of Fennell leaues : the floure is yellow, bigger than that of Cammomill, cuen fuch an one is this prefent plant, which doth fo exquifity expreffe that form or likeneffe of Fennell leates, both ir flenderneffe and manifold iaggedneffe of the leaues, as no otherlittle leafed herb can do better; fo that withour all doube this plant feemeth to be the true and right Oxe eic. Oxe eie is called Cachla, or racher Calshaj but Calba is Calendala, or Marigold, which we faid that on Oxe cie in floure did neereft reprefent. There are fome that would haue Buphthatmum or Uxe eie to be Chy farbemum, yellow Cammomil, \& fay that Dioforides hath in fundry places, and by diners names intreated of this herbe; but if thofe men lad fomewhat more diligently weighed Diof corides his words, they would haue bin of another minde : for although deferiptions of either of them do in many things agree, yet there is no property wanting that may thew the plants todiffer. The leaues of Chry/inthernm are faid to be diuided and cut into many fine iags : and the leaues of $B$ uphthalmum to be like the leaues of Fennell: for all things that be finely iagged and cut into many parts haue not the likeneffe of the leaues of Fennell. Moreouer, Diofcorides faith, that Chry fum hesm doth bring forth a foure much glitt ring, but f e telleth not that the floure of suph- $_{\text {- }}$ thatmum, or Oxecie is much glittering, neither doth the foure of that which we liaue fet downe glitter,fo that it can or ought not to be faid to glitter much. Do not thefe things declare a manifeft difference betwe- ne Buphthalmm and $C h r y$ fum hemum, and confirme that which we have fet down to be the truc and right Oxecie? We are of that minde, let others thinke as they will : and they that would haue Chryfonthemum to be Buphthulmum, let them feeke out another, if they denie this to bee Oxe cic: for that which we and others hatic defcribed for Chryfant bemum cannot be the true buphthalmum or Oxe eie; for the leaues of it are not like Fennell, fuch as thofe of the true Buphthamum
ought to be.

\section{The Temperature.}

But concerning the faculties Mathiolus faith, that all the Phy fitions and Apothecaries in Bohemia, vfe the roots of this Oxe eie in ftead of thofe of blacke Ellebor, namely for difeafes in cattel: but he doth not affirme that the roots hereof in medicines are fubititutes, or quidpro quo ; for, faith he. I do temember that I once faw the roots hereof in a fufficient big quantitie put by certain Phyfitions into decoctions which were made to purge by fiege, but they purged no more than if they liad not been put in at all: which thing maketh it moft plaine, that it cannot be any of the Ellebors, although it hath been vfed to be faftned through the cares of cattell for certaine difeafes, and doth cure them as Ellebor doth. The roots of Gentian do mightily open the orifices of Fiftuldes, which be coo natrow, fo do the roots of A riftolochia, ot Birthwoort, or Brionie, or pieces of $\int$ punges, which notwithetanding do much differ one trom another in other operations: wherefore though the roots of Oxe eie can do fomething like mro blacke Ellebor,yet for al that they cannot perform all thofe things that the fame can. We know that thomes, ftings, f plinters of wood, and fuch like, bring pain, caufe inflammations, draw vnto them bumors from the parts neere adioining, if they be faftned in any part of the bodic;no part of the bodic is hurtwithout pain; the which is increafed if any thing be thtuft through, or put inco the wound : peraduenture alfo if any other thing befide be put into the flit or bored eare, the fame effect would follow which hapned by the toot of this plant thruft in; notw ithftanding we here aftirme nothing, we onely make way for curious men to make more diligent fearch touching the operations hereof. $\neq$ Chufus affirmes that when heecame to Vienna in Aufria, this was uulgarly bought, fold, and vfed for the ttue blacke Ellebor, the ignotance of the Phyfitions and Aporhecarius in the knowledge of fimples was fuch to make vfe of this fo far diffe rent plant, when as they had the true blacke Hellebor growing plentifully wilde within feuen miles of the citie, the which afterward vpon his admonition, they made vfe of. $\neq$

GT The Vertues.

Dioforides faith, that the floures or Oxe eie made vp in a feare-cloth doe affwage and wafte a-
thay coldhard fwellings; and it is teported that if they be drunk by and by after bathing, they make
them in thott timewell colouted that baue been tho them in thott time well colouted that haue been troubled with the yellow iaundice. 


\section{С н г. 258. Of French Marigold, or African $M$ Marigold.}

$$
\text { GI The Defcription. }
$$

- THe great double Afriean Marigoid hath a great long browne reddifh ftalke, erefted, furrowedand fomewhat knobby, diuiding it felfe toward the top into other branehes; swlieseupon do grow leates compofed of many fmall leaues fet vpon a middle rib by eouples, mueh like vnto the leaues of wilde Valerian, bearing at the top very faire and beatififll double yellow floures, greater and more double than the greateft Damaske Rofe, of a frong fmell, but not vnpleafant. The floures being paft, there fucceedeth long blacke fat feed : the whole plant peritheth at the firft approach of winter.

2 There is little differenee betweene this and the preeedent, or laft deferibed, fauing that this plant is much leffer, and bringeth forth more ftore of foures, whieh maketh the difference. $\neq$ And we may therefore call it Flos Aphricanus minor multiflorm, The finall double Africane Marigold. :

I. Flosuphricanus maior Polyantlios.

The great African double Marigold.

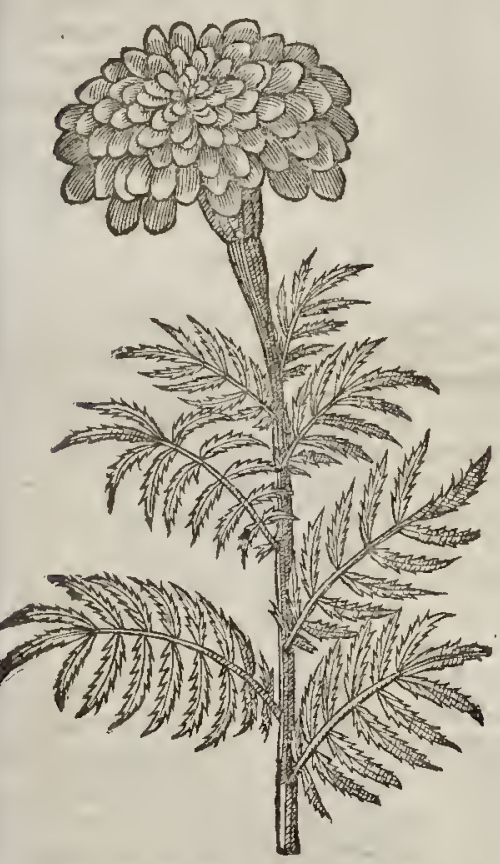

3 Flos uploricanus maior (implici flare. The great fingle French Marigold;

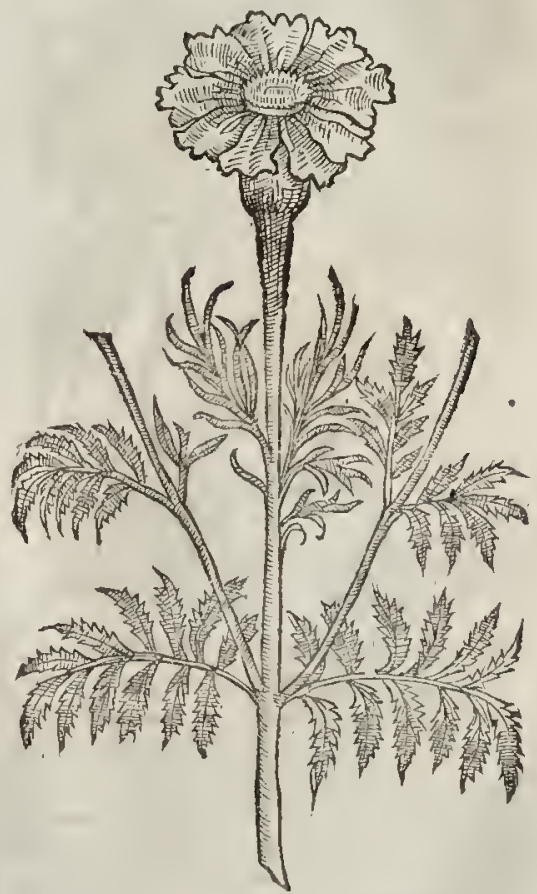

3 The fingle great Afrieane Marigold bath a thicke ront, with fome fibres annexed thereto: from which rifeth vp a thieke ftalke eliamfered and furrowed, of che heighrof two cubits, diuided intoother fmall branehes; whereupon are fet long leaucs, co mpad or eonpofed of many litrle Jeaues like thofe or the Ath trec, of a ferong fmell, yet not very vnpleafant : on the top of the bran. ches do grnw vellow fingle fhrmes, compofed in the nuiddle of a bundle of yellow thrummes hara thruft together, paled abo: the edges with a border of yellnw leaves; afer which eommeti long blacke feed. Thewhole plant perifhech with the firt froft, and muft be forwne yeercly as the other forts muít be.

4 The common A frieane or as they vulgarly terme it Freneh Marigold hath fmall weate and tender branehes trailing vpon the ground, reeling and leaning this way and that wav, befet wirl leaues confitting of muny particular lexues, indented about the edges, which being held vpagaint the fune, or to rhe light, ars feene to be full of holes lik za fieue, euen as thof of Saint Iohns 
woort: The foures ftand at the top of the fpringie branches forth of long cups or huskes, confifting of eight or ten fmall leaues, yellow vnderneath, on the vpper fide of a deeper yellow tending to the colour of a darkecrimfon veluet, as alfo foft in handling: but to defcribe the colour in words, it is not poffible, but this way; lay vpon paper with a penfill a yellow colour called Mafticot, forth most liuely the colour. "The whole plant is faffron fteeped in witer or wine, which fetteth ritheth at the firft frof.

4. Flos Aphricanus minor fimplici fore. The finall French Matigold.

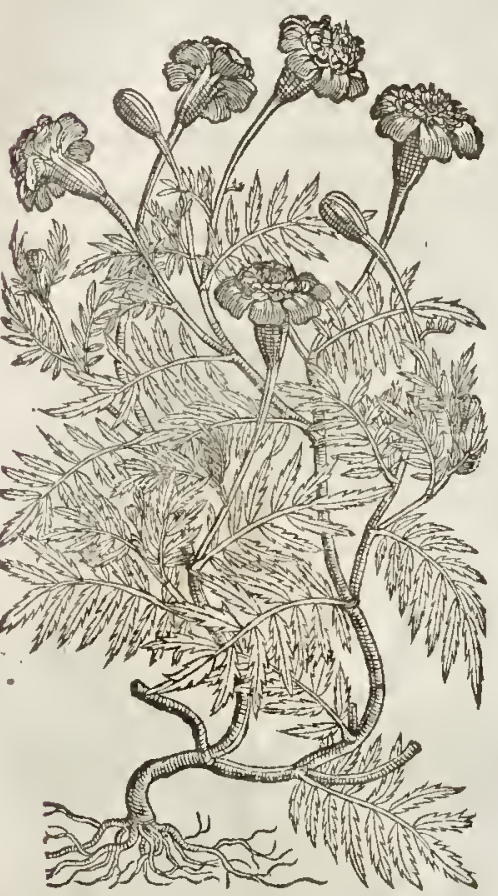

They are cherinhed and fowne in gardens euery yeere: they grow euery where almolt in Africke of themfelues, from whence we firft had them, and that was when Charles the fifth Emperour of Rome made a famous conquef of Tunis; whereupon it was called Flos Aphri-
canus, or Flos Tunctanus.

\section{- T The Time.}

They are to be fowne in the beginning of Aprill, if the feafon fall out to be warme, other. wife they munt be fowne in a bed of dung, as fhall be thewed in the chapter of Cucumbers. They bring fortl tleir pleafant foures very late, and therefore there is the moredilicence to be vfed to fow them very carely, becaufe they fhall not be ouertaken with the frof before their feed be ripe.

$$
\text { T The Names. }
$$

The Africane or French Marigold is called in Dutch, dunis bloetnen : in high Dutch, 3) noianifch ncgelin, that is, the floure or Gillotoure of India: in Latine, Griophillus Indicus ; whereupon the French mencall it ocillet $\approx$ d'Inde. Cordus calleth it Tanacctum Peruviaritum, of the likeneffe the leates haue with Tanfie, and of Peru a Prouince of America, from whence hee thought, it may be, it was firt brought inro Europe. Gefner calleth it Caltha Aplricam, and faith that it is called in the Carthagenian congue, $P e d w a$ : fonewould haue it to be Petilius flos Pliniy, but not properly : for Petilius flos is an Autumne floure growing among briets and brambles. Andreas I acuna calleth it otbonnt, which is a certaine lerbe of the Troglodytes, growing in that part of Arabiawhich lieth toward Egypt, hating leatcs full of holes as though they were eaten with mothes. Galen in his firf booke of the faculties of Simple medicines, maketh mention of an herbe called I ycoperfurm, the juice wherenf a certain Centurion did cary our of Baras tafe of $1 t$, but conjestured it to be deadly fo lothfome, as Galen himfelfe durft not fo much paines of the joints, and it feemeth to the patients themfelues, but doubtleffe of a poifonfome quality, very neere to that of hemlockes.

\section{iT The Temperature and Fertues.}

A The unpleafunt fmeil, efpeciall that common fort with fingle floures (that fuffeth the head like to that of Hemlocke, Iuch as the juice of Lycoperfium had) doth thew that is of a poifonfome and cooling qua! itie; and alfo the fame is manifefted by diuets experiments: for I remember, faith frellexiremely as it hathoften hapened moutl when he began to chew the floures did of Hemlockes, do hold them a while between their lipwes a playing or piping with quils or kexes floures with their cups, tempered with freth clocir lippes: likewife he faith,we gatre to a cat the while after died: alfo, things do declare that this herbe is of a venome feed thereof have been found dead. All which 
L. I E. 2.

not to be hearkned vnto, that fuppole this berbe to bean harmles plant:fo to conclude, thefe plants are moft venomons and full of poifon, and therefore not to be touched or fmelled vnto, nuch leffe vfed in mear or medicine.

\section{C н А Р. 259. Of the floure of the Sun, or the Marigold of Peru.}

$$
\text { 9i The Defcription. }
$$

I THe Indian Sun or the golden floure of Peru is a plant of fuch ftatureand talneffe that in one Sommer being towne of a feede in Aprill, it hath rifen vp to the height of fourteene foot in my garden, where one floure was in weight thrce pound and two ounces, and croffe ouerhwart the floure by meafure fixteene inches broad. The ftalkes are vpright and ftraiglit, of the bigneffe of a ftrong mans arme, befet with large leaues euten to the top, like vn to the great Cloc Bur: at the top of the ftalke commeth forth tor the moft parr one floure, yet many times there fpring out fucking buds, which come to no perfection:this great floure is in mape like to the Cammomil foure, befet round about with a pale or border of gondlyyellow leaues, in thape like the leaucs of the floures of white Lillies: the middle part whereof is made as it were of vnfhorn veluet, or fome curious cloth wrought with the needle, which braue worke; if you do thorowIy view and marke well, ir feemeth to be an innumerable fort of fmall floures, refembling the nofe or nozell of a candlefticke, broken from the foot thereof: from which fmall nozell fweateth forth excellent fine and cleere Turpentine, in fight,fubftance,fauour and tafte. The whole plant in like manner being broken, fmelleth of Turpentine : when the plant groweth to maturitie, the floures fal away, in place whereof appeareth the feed, blacke, and large, much like the feed of Gou:ds, fet as though a cunning workeman had of purpofe placed them in very good order, much like the honiccombes of Bees : the root is white, compact of many ftrings, which perifh at the firft approch of winter, and muft be fet in moft perfeet dunged ground: the manner how , thall be fhewed when vp: on the like occafion I thall fpeake of Cucumbers and Melons.

I Flos Solismaior.

The greater Sun floure.

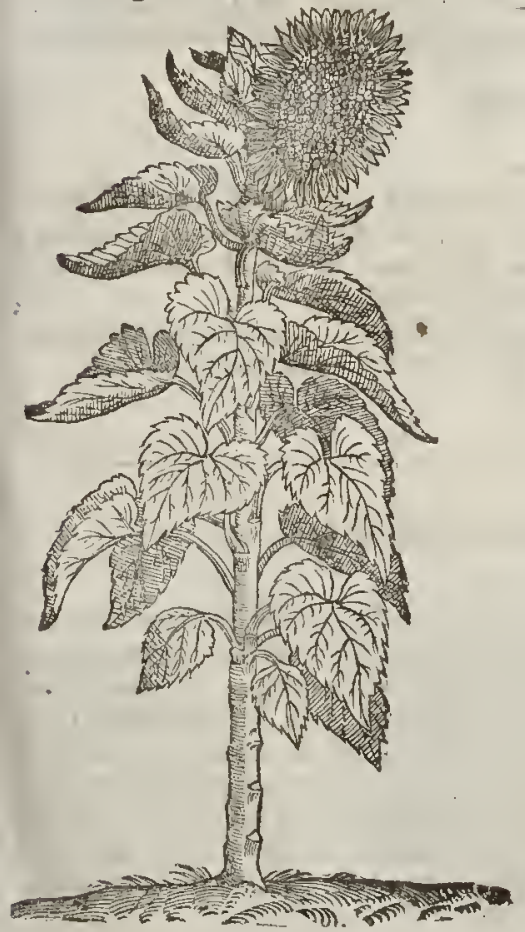

2 Flos Solis minor.

The leffer Sunne floure:

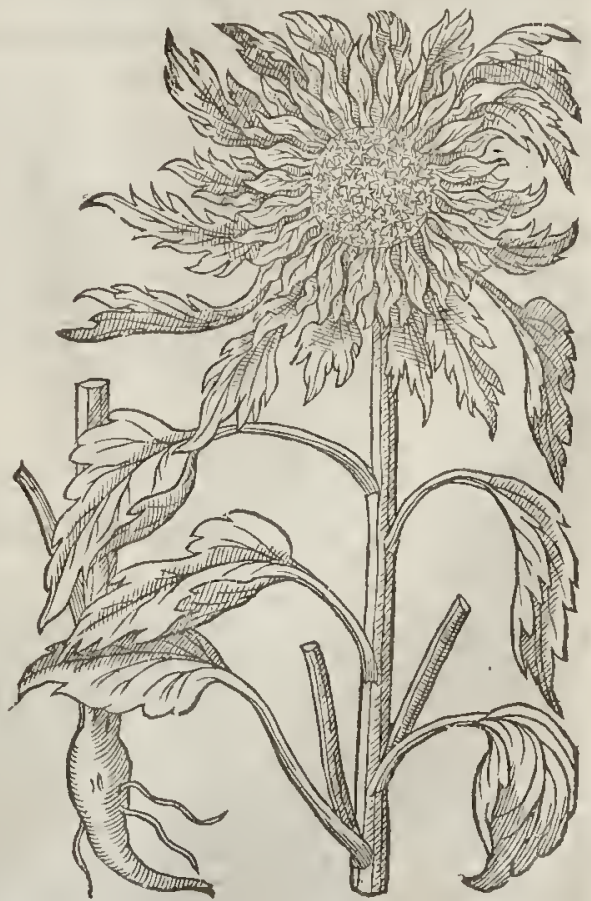


2 The other golden floure of Peru is like the former, fauing that it is altogether lower, and the leates more iagged, and very few in number.

3 The male floure of the Sun of the fmaller fott hath a thicke root, hard, and of a wooddy fubftane, with many threddic trings annexed thereto, from which riferh vp a gray or ruffet it alle, to the height of fiue or fix cubirs, of the bignefe of ones arme, whereupon are let great broud leaues with long foot-falkes, very fragill or cafie to breake, of an ouerw orne greene colout, fharp pointed, and fomew hat eut or hackt about the edges like a faw : the Aoure groweth at the top of tle falks, bordered about witl a pale of ycllow leaucs:the thrummed middle part is blacker than that of the laft deferibed. The wole floure is compaffed about likewife with diuers fuch ruffer leaties as thofe are rhat do grow lower vpon the ftalks, but leffer and narrower. The plant and euery part therof doth fmell of Turpentine, and the Aoure yeeldeth forth mot eleere Turpentine, as my felfe hauc: roted diuers yeares. The feed is alfo long and blacke, with certaine lines or trakes of white running alongtt the fame. The roote and eucry part thereof peritheth when it hath perfected his feed.

4 The femalc or Marigold Sun foure hath a thickeand wooddie root, from which rifeth vp a ftraiglt ftem, diuiding it felfe into one or mote branches, fet with fmooth leaues tharpe pointed, fleightly indented about the edges. The floures grow at the top of the branehes, of a faint yellow colour , the middle part is of a decper yellow tending to blackneffe, of the forme and thape of a fingle Marigold, whereupon I haue named it the Sunne Marigold. Tlief feed as yet I haue not obferued.

$$
\text { T) The Place. }
$$

Thefe plants do grow of themfelues without fetting or fowing, in Peru,and in dituers othet prouinces of Ameriea, ftom whenee the feeds haue beene brought into thefe parts of Europe. There hath been feen in Spaine and other hot tegions a plant fowne and nourihed vp from feed, to attain to the height of 24 . foot in one yeare.

$$
\text { T The Time. }
$$

The feed mutt be fer or fow ne in the beginning of Aprill if the weather be temperate, in the moft fertile ground that may be, and where the Sun hath moft power the whole day.

\section{T The Names.}

The floure of the Sun is ealled in Latine Flos Sols, taking that name from thofe that haue reported it to turne with the Sun, the which I could neuer obferue, although I haue endeutoted to findeout the truth of it; but I rather thinke it was foealled beeaufe it doth refemble the radiant beames of the Sun, whereupon fome hate ealled it Corons Solis, and Sol Indianus, the Indian Sunne Roure : others haue ealled it Chryfanthemum Permuanum, or the golden floure of Petu: in Engliph, the floute of the Sun, or the Sun floute.

They are thought to be hot and dry of complexion.

$$
\text { Ti The Temperature. }
$$

Ti The Vertues.

A There hath not any thing been fet downe either of the antient or later writers concerning the vertues of thefe plants, notwithftanding we haue found by triall, that the buds befote they be floured,boiled and eaten with butter, vineger, and pepper, after the mannér of Artichokes, are exceeding pleafant mear, furpaffing the Artichoke far in proeuring bodily luht.

B The fame buds with the ftalks neete vnto the top (the hairincte being taken away) broiled vpon a glidiron, and afterward eaten with oile, vineger, and pepper, haue the lite propetty.

\section{C н а 1. 260. Of Fermalem Articboke.}

O Ne may wel by the Englith name of this plant pereeiue that thofe that vulgarly impofe names vpon plants haue little either iudgement or knowledge of them. For this plant hath no fimilitude in leafe, ftalke, root ot manner of growing with an Artichoke, but onely a little fumilitude of tafte in the dreffed root; neither came it from Ierufalem or out of A fia, but out of America, whenee Fabius Colvmnat one of the firft fettets of it forth fitly uames it After permismus tuberofus, and Flos folis Farmefianus, becaufe ir to much refembles the Flos folis, and for that he firt obferued it gtowing in the garden of Catdinall $F$ arnefus, who had proeured roots thereof from the Weft Indies. Pelliterius ealls this Feliotropium Indicum tubcrofum; and Bubinus in his Prodromus fets this forth by the nume of Chryfanthekum latifolium Brafilianum, but in his Pinax he hath it by the name 
of Helianthemum Indirum tuberofum. Alfo our Countreyman $\mathrm{M}^{\mathrm{r}}$. Parkinfon hath exactly de'iuered the hittory of this by the name of Batiatas de Canda, Englining it. Potatoes of Canada : rov all thefe that haue written and mentioned it, bring it from Ameriea, but from far different p!aces, as from Peru, Brafil,and Canada:but this is not mueh material, fecing it nowgrows fowel \& plentifully in fo many places of England. I will now deliuer you the Hiftorie, as I haue reeciued it from my oft mentioned friend $\mathrm{M}^{\mathrm{r}}$. Goodyer, who, as you may fee by the date, took it prefentiy von the firt ar-
riuall into England.

TT The Defoription.

†. Flos Solis Pyranzidalis. Ierufalem Artichoke.

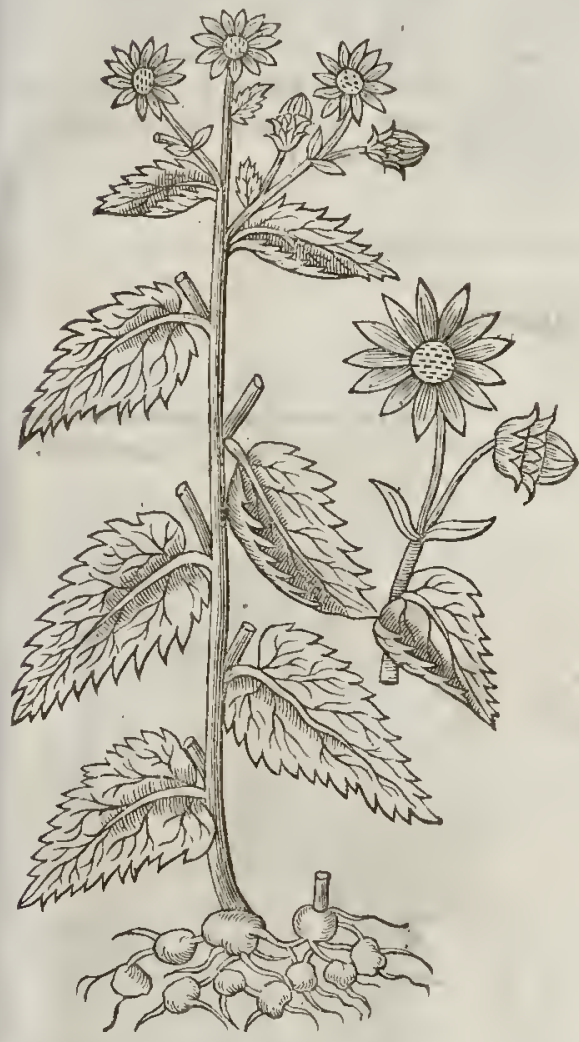

Elos folis Pyramidalis parvo fore, taberofa radice. Heliowopium Indicum quorundam.

x Hiswonderfull increaling plant hatl growing vp from oic roor, one, fometimcs two, three or more round green rough hairy ftraked ftalks, eommolsIy about twelue foot ligh, fometimes ilxteene foot high or higher, as big as a eliilds arme, full of white fpungious pith within. The leaues grotw all along th the falkes out of order, of a light green color, tough, tharp pointed,abont eight inches broad, and ten oreleuen inehes long, deeply notclued or indented about the edges, very like the leaues of the common fos folis Pcruarus, but nothing erompled, and not fo broad. The falkes ditide themfelues into mary long branehes euen from the roots to their very tops, bearing leaues fmaller and finaller toward the tops; making the herbe appeare like a litrle tree, narrotyer and flenderer toward the top, in farhion of a fteeple or Pyramide. The floures with vs grow oncly at the toppes of the ftalkes and branches, like thofe of the faid flos folis, but no bigger than our eommon firgle Marigold, eonfitting of twelve or thirteene ftraked harpe pointed bright yellow bordering leaues, growing fonrth of a fealy fmall hairic bead, with a fmall yellow thrummie matter within. 'Thefe floures by reafon of their late fouring, which is commonly two or thice weeks after Miehaelmas,neuer bring rheir feed to perfextion, \& it makerh thew of abundance of fmall heads neere the tops of the ftalkes and branches forth of the bofomes of the leaues, whish neuer spen and foure with vs, by reafon they are deftroyed with the frofts, which otherwife it feemes would be a goodly fpectacks. The ftalke fendes foorth many fmallereeping roots, whereby it is fed or nourithed, full of hairie threddes euen from the vpper part of the earth, preading farte abroad: amongft which from the maine root grow forth nany tuberous ronts,clufering zogether, fometimes faftened to the great root it felfe, fomctimes growing on long ftrings a footor more from the root, raifing or heauing vp the earth aboue them, and fometimes appearing aboue the earth, producing from the inereafe of one ront, thirty, forty, of fifry in number, or more, making in all wually abouc a peeke, many times steere halfe a buthell, if the foile be good. Thefe tuberous roots are of a redd If colour wirhour, of a foft white fubftancew ithin, bunehed or bumped out many waies, fometimes as big as a mans fift, or.not fo big, with white nofes or peaks where rhey will fprout or grow the next yeare. The falkes bowed downe, and fome pate of them conered ouer with earth, fend forth fmal ereeping threddie roots, and alfo tuberous roots like the former, which I hate found by experiense. Thefe tuberous roots will abide aliue in the earth allwinter, 
though the ftalkes and rootes by the which they were nourifhed vtterly rot and perifhaway, andwill beginne to fpring vp againe at the beginning of May, feldome fooner.

$$
\text { T) The Plice. }
$$

Where this plant groweth naturally I know not, in Anno I 6 I 7 I receiued two fmall roots thereof from Mafter Franquenill of Lendon, no bigger than hens egges: the one I planted, and the other I gaue to a friend, mine btought mee a pecke of roots, wherewith I ftored HampThire.

\section{Gi The Vertues.}

A Thefe rootes are dreffed diuers waies; fome boile them in water, and after ftew them with facke and butter,adding a little Ginger : others bake them in pies, put ting Marrow, Dates, Ginger, Raifons of the Sun, Sacke, \&cc. Others fome otherway, as they are led by their skill in Cookerie. But in my iudgement, which way foeuer they bedreft and eaten they ftirre and caufe a filthieloathfone ftinking winde within the bodic, thereby caufing the belly to bee pained and tormented, and are a meat more fit for fy ine, than men : yet fome fay they haue viually eaten them, and haue found 110 fuch windie qualitie in them. 17. Octob. 621 . Jobn Goodyer. $\ddagger$

\section{C н А . 26i. Of Cammomill.}

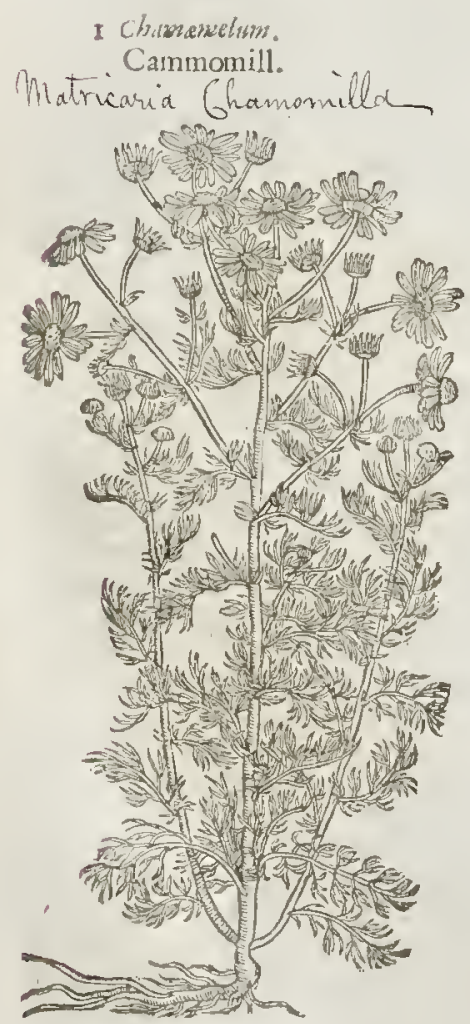

a Chamamelum mudurs odoratum. Sweet naked Cammomill.

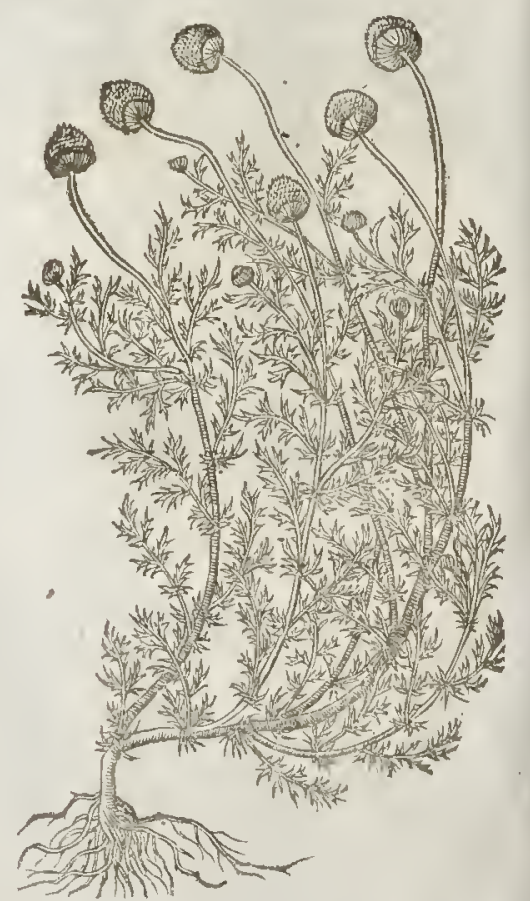


If The Defeription.

1 T diftinguith the kindes of Cammomils with fundry defcriptions wonld be t. ut to enlarge the volume, and fmall profitwould thereby redound to the Reader, conticiering they ate fo well knowne to all : notwithltanding it fhall not be amiffe to fay fomething of them, to keepe the order and methot of the bouke, hirberto obferued. The coin-mon Cammonill hath muny weake and feeble branches trailing ypon the ground, tai ing hold vpen the top of the earth, as it runnerh, whereby ir greatly encreateth. The leates ate very fine, and much iagged or deepely cut, of a ftrong fweet fmell : a mong which come forth the Houres like vnto the field Daifie,bordered about the edge with a pale of white leaues : the middle part is ycllow, compofed of fuch thrums clofe thruft togerher, as is that of the Daifie. The toot is very friall and threddy.

2 The fecond kinde of Cainmomill hath leaues, roots, ftalks, and creeping branches like the precedent : the floures grow ar the tops of fmall render ftems, which are nothing elfe but fuch yellow thremmie nutrer as is in the midft of the reft of the Cammomils, wirhout any pale or horiler of whire floures, as the others haue: the whole plant is of a pleafing fweet fmell; whereupon fome haue giuen it this addition, o doratum.

3 This third Canmomil differeth not from the former, fauing that the leawes betcof are very much doubled with white lenues, infomuch that the yellow thrum in the middle is but littc feen, and the othet very fingle, wherein confinteth the difference.

3 Chamamelurn Anglicum flore multiplici.

Double floured Cammomill.

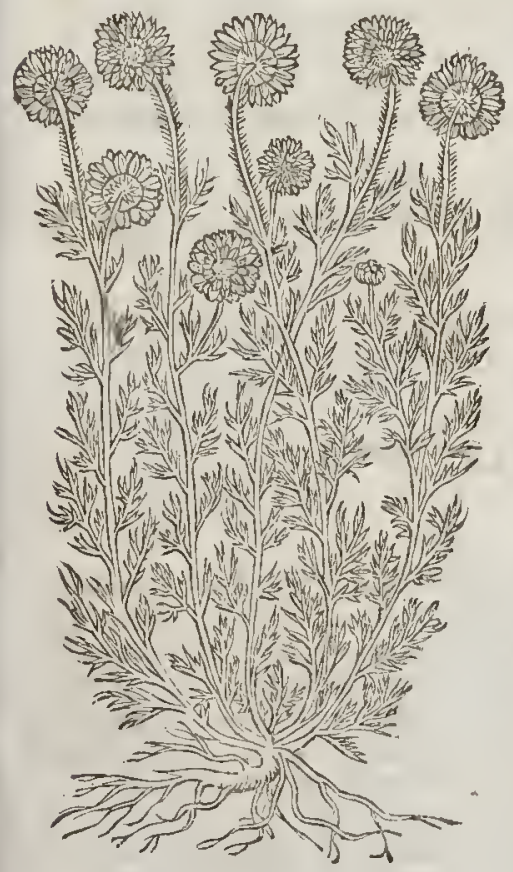

4. Chameme'un Rominum.

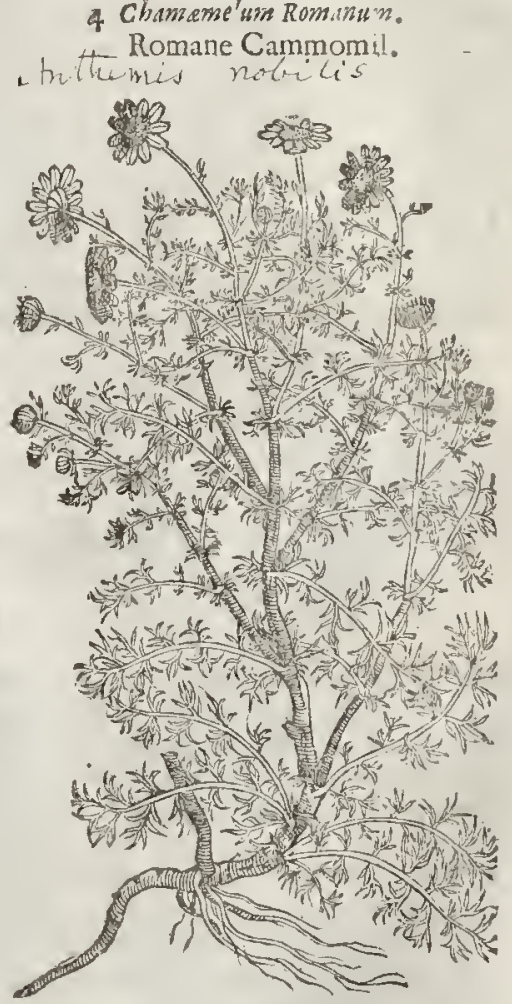

4 Romane Cammomill hath many flender ftalkes, yet ftiffer and ftronger than arty of the orthers, by reafon whereof it ftandeth more vpright, and dorh nor creepe vpon the earth as the others doe. The leaues are of a more whirith colour, tending to the colour of the leaues of -Woad. The floures be likewife ycllow in the middle, and paled about with abotder of fmall white floures.

\section{The Place.}

Thefe plants atc fet in gardens both for pleafure and alfo profic:

They floure molt part of all the Sommer.

$$
\text { q The Time. }
$$




\section{ब1 The Nomes.}

Cammomill is called chamamelum : of fomc, Antbernis, and Leucanthemis, and alfo Leucunthemon, efpeeially that double floured Cammomill : which Greeke name is taken from the whitenes of his thoure: in Englirh, Cammomill : it is ealled Cammomil, beeaufe the floures haue the fmel of $\mu$ mor, anapple, whieh is plainly perceited in eommon Cammomill.

\section{IT The Temperature.}

Cammonill, faith Galen, is hot and dry in the firt degree, and is of thinne parts : it is of foree to digeft, flaeken, and rarifie; alfo it is thought to be like the Rofe in thinneffe of parts, eomming to the operation of oyle in heate, which are to man familiar and temperate: wherefore ir is a fpeeiall helpe againft wearifomeneffe; it eafeth and mitigateth paine, it mollifieth and fuppleth, and all thefe opera tions are in ourvulgar Cammomill, as common experienee teacheth, for it beam, teth moderately, and drieth little.

\section{बा The Vertues.}

A Cammomill is good againt the collieke and ftone; it prouketh vrine, and is mont fingular in Clyfters which are made againft the forefaid difeafes.

B Oilc of Cammomill is execeding good againft all manner of ache and paine, bruifings, thrinking of finewes, hardnefle, and eold fwellings.

C The decostion of Cammomill made in wine and drunke, is good againt coldneffe in the ftomacke, foure belehings, voideth winde, and mightily bringeth downe the monethly courfes.

D The Egyptians haue vfed it for a remedie againft all eold agues; and they did thereiore confeerate it (as Galen faitl) to their Deities.

E The deeotion made in white wine and drunk, expelleth the dead child,and fecondine or afterbirth, fpeedily, and elenfeth thofe parts.

F The herbe boyled in poffet Ale, and giuen to drinke, eafeth the paine of the chct comming of winde, and expelleth tough and elammy flegme, and helpeth ehildren of the A gue.

$G$ The herbe $v$ fed in baths prouoketh fweat, rarifieth the skinne, and openetl the pores : briefely, it mitigateth gripings and gnawings of the belly; it alayeth the paines of the fides, mollifies hard fwellings, and wafteth arvay raw and vndigefted humors.

I]

The oyle eompounded of the floures performeth the fame, and is a remedie againf all wearifomeneffe, and is with good fueceffe mixed with all thofe things that are applied to mitigate
paine.

\section{Ch A 262. \\ of May-weed, or wilde Cammomill. \\ The Kindes.}

$\mathrm{T}^{\prime}$ Here be tlire kindes of wilde Cammomill, whieb are generally called in Latine Cotula ; one ftinking, and two other not feinking : the one bath his floure all white throughout the eompalle, and alfo in the middle; and the other yellow. Befides thefe there is another with veric faire double floures voyd of fmell, whieh a Kentifh Gentleman ealled $\mathrm{M}^{\mathrm{s}}$. Bartholmew Lane found grow ing wilde in a field in the Ifle of Thanet, neere vnto a houfe ealled Queakes, fometime the boure of Sir itenry Crifpe. Likewife $\mathrm{M}^{*}$. Hesketh, before remembred, found it in the garden of his Inne at Barnet, if my memorie faile me not, at the figne of the red Lyon, or neere vnto it, and
in a poore womans garden as he was riding into Laneafhire.

$\neq$ The double floured May-weed, the laft yeare, being $1632 . I$ (being in eompany with $\mathrm{M}^{\mathrm{r}}$. Willtam Broad, $\mathrm{M}^{5}$. I ames Clarke, and fome other London A pothecaries in the Ifle of $T$ hanet) found it growing wild vpon the eliffe fide, clofe by the towne of Margate, and in fome other places of the
Inland. $\neq$

$$
\text { T The Deferiptict. }
$$

I T Ay-weed bringeth forth round ftalkes, greene, brittle, and full of iuyce, parted into IV many branehes thiekcr and higher than thofe of Carmmomil , the leaues in like manerare broader, and of a blaeking greenc eolour. The floures are like in forme and colour, yet eommonly larger,and of a ranke and naughty fmell : the root is wooddy, and perifheth when the feed is ripe. The whole plant ftinketh, and giveth a ranke fmell. 
$\neq$ This herbe varies, in that it is found fomet imes with narrower, and ot herwhiles with broader leaues; as alfo with a ftrong vnpleafant fmell, or without any fimell at all : the floures allo are fingle, or elfe (which is feldome found) very double. $\ddagger$

2 The yellow May.weed hath a fmall and tender roor, from which rifeth vp a feeble ftalke diuiding it felfe into many other branehes, whereupon do grow leaues not vnlike to Camnomill, but thinner, and fewer in number.' The floures grow at the top of the ftalkes, of a gold yellow eolour, $¥$ This I take to be no other than the Buphthalmum verum of our Author, formerly deferibed in the fecond plaee of the 257 . chapter.

3 This mountaine Cammomill hath leaues fomewhat deepely cut in almoft to the middle rib, thicke alfo and inyeic, of a bittcrìth tafte, and of no pleafant fmell : the ftalkes are weake, and fome foot high, carrying at their tops fingle floures, bigger, yet like thofe of Cammomill, yel'orr in the middle, with a border of twenty or more long white leates, encompaffing it. It inereafth much, as Cammomill doth, and hath creeping roots. It is found vpon the Stirian Alpes, and Houmreth in Iuly and Augute. clufius hath fet this for th by the nane of Lewcunthemum Alpinum. ‡

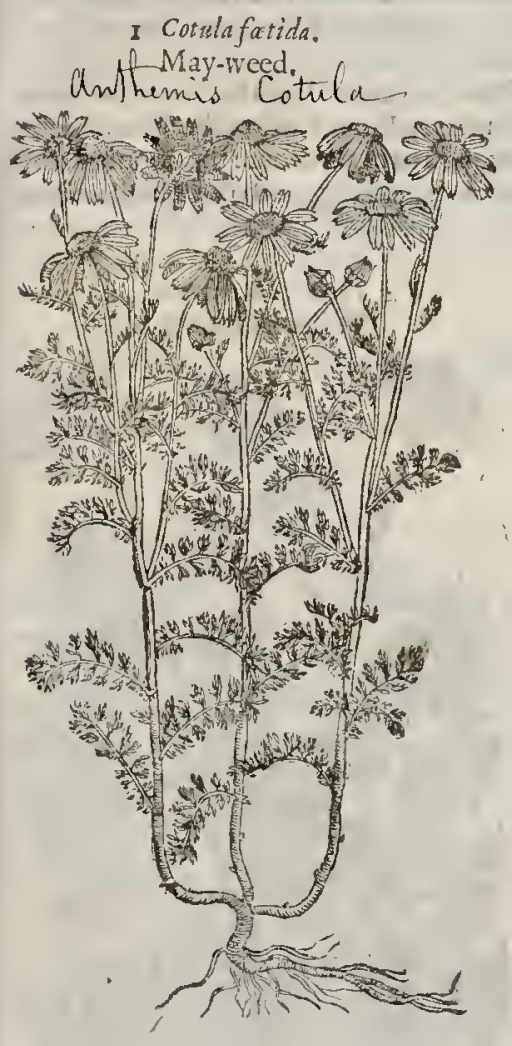

\section{\pm 3 Leucart hemum Alpinum Clufij. Wilde Mountaine Cammomill.}

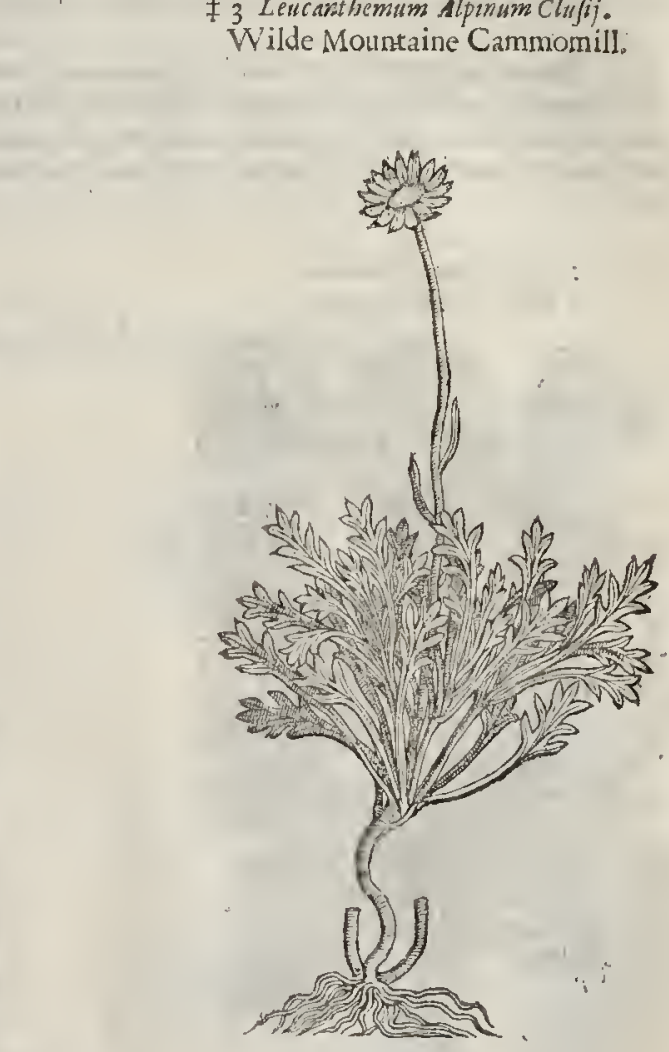

iा The Place.

They grow in Corne fields neere vnto path wayes, and in the borders of fields.

Thee floure in Iuly and Augunt.

T The Time.

बा The Names.

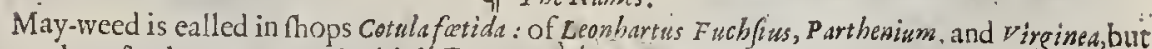

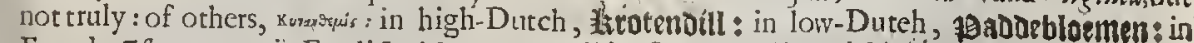
French, Espargoutte : in Englioh, May-weed, wilde Cammomill, and finking Mathes.

of The Temperature and Vertues.

May-weed is not $v$ fed for meate nor medicine, and therefore the faculties are vnknowne; yet all A of them are thought to be hot and dry, and like after a fort in operation to Cammomill, but nom thing at all agreeing with mans nature ; norwithftanding it is commended againt the infirmities

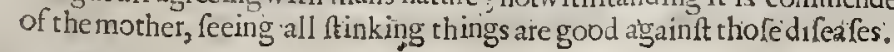


It is anvnprofitable weed among corne, and raifetli blifters vpon the hands of the weeders and reapers.

\section{С на . 263. Of Pellitorie of Spaine. \\ T) The Defcription.}

-I Drethrism, in Englinh, Pellitorie of Spaine (by the name whereof fome doe vnproperly call another plant, which is indeed the true Imperatorin, or Mafter-wort, and not Pellitorie) hath great and fat leates like vato Fennell, trailing vpon the ground : among it which, immediately from the root rifeth vp a fat great ftem, bearing at the top a goodly floure, farhioned like the great fingle white Daifie, whofe bunch or knob in the midft is yellow like that of the Daiffe, and bordered about with a pale of fmall leaues, exceeding white on the vpper fide, and under of a faire purple colour : the roor is long, of the bigneffe of a finger, very hot, and of a burning tafte.

2 The wilde Pellitorie groweth wp like vnto wilde Cheruile, refembling the leaues of Caucalis, of a quicke and nipping tafte, like the leaues of Dittander, or Pepper-wort : the floures grow at the top of flender ftalkes, in fmall tufts or fpoky vmbels, of a white colour : the root is tough, and of the bigne fe of a little finger, with fome threds thereto belonging, and of a quicke biting tafte.

I. Pyrethrem officinarim. Pellitoric of Spaine.

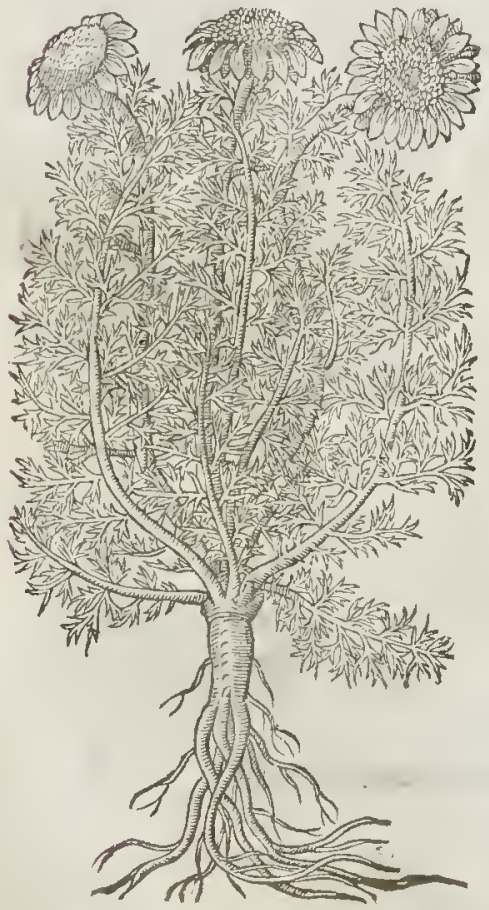

2. Pyrethrum fylueftre. Wilde Pelliturie.

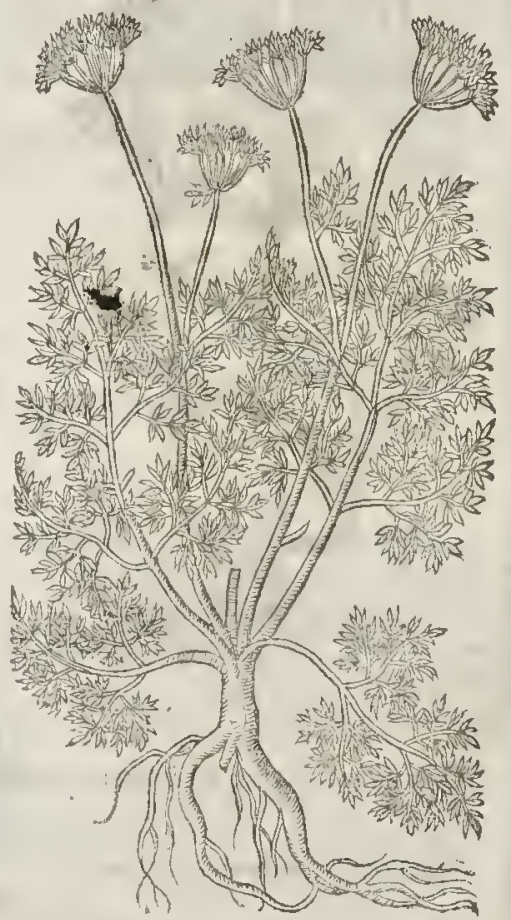

It groweth in myzarden very plentifully.

T) The place.

It flourcth and feedeth. in Iuly and Augurt.

$$
\text { The Time. }
$$

of The Names.

Pellitoric of Spaine is called in Greeke miptrow, by reafon of his hot and fierie tafte: in thops alfo Pyrethrom : in Latine, Salinutris in Italian, Pyrethro: in Spanifh, Pelitre: in French, Pred do 
Alexandre, that is to fay, Pes Alexandrinus, or Alexanders foot: in high and Iow Dutch, 25 crerain: in Englifh, Pellitorie of Spaine; and of fome, Bertrum, after the Dutch name: and this is the right Pyrethrum, or Pellitorie of Spane; for that whicl diters here in England take to be the right, is not fo, as I laue before noted.

I The Tcmperature and $y$ crtues.

The rooc of Pellitoric of Spaine is very hot and burning, by rea fon whereof it taketh away the A cold thitering of Agues, that haue been oflong continuance, and is good for thofe that are taken with a dead palfie, as Diofcorides writeth.

The fame is with good fucceffe mixed with Antidotes or countcrpoy fons which ferue againft $B$ the megrim or continuall paine of the head, the dizzineffe called $V$ ertigo, the apoplexie, the falling ficknefle, the trembling of the finewes, and palfies, for it is a fingular good and effectuall remeciy for all cold and continuall infirmiries of the head and finewes.

Pyrethrum taken with honey is good againft all cold difeafes of the braine.

The root chewed in the mouth draweth forth great ftore of rhettme, flime, and filchy waterifh humors, and eafeth the paine of the teeth, efpecially if it be ftamped with a little Stauef-acre, and tied in a fmall bag, and put into the mouth, and there fuffered to remaine a certaine fpace.

If it be bovled in Vineger, and kept warme in the mouth it hath the fame effect.
The oyle wherein Pellitorie hath been boyled is good to anoint the body to procure fweating, and is excellent good to anoint any part that is bruifed and blacke, although the memberbe declining to mortification: it is good alfo for fuch as are frricken with the palfie.

It is moft fingular for the Surgeons of the Hofpitals to put into their vnetions contra Neapolitamum morbum, and fuch othet difeafes that be coufin germanes theretinto.

\section{Cна в. 264. Of Leopards bane.}

I Doronicum minus officinarum. Small Leopards bane.

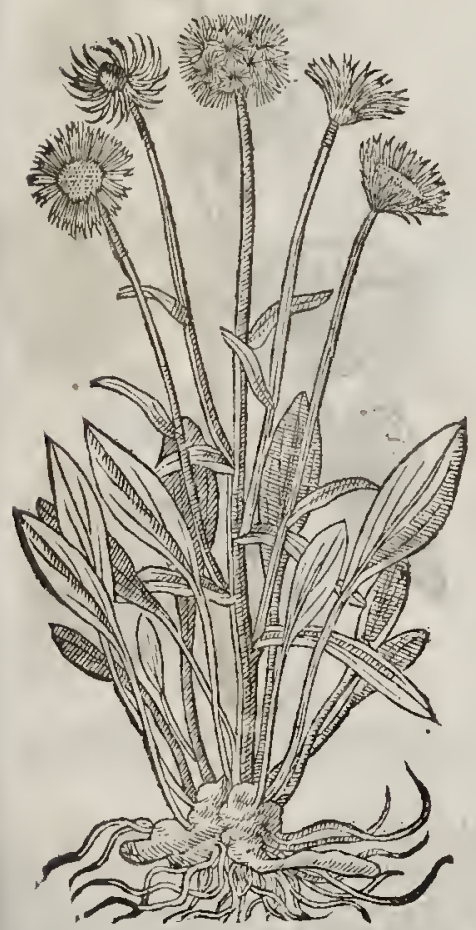

† 2 Doronicum maius officinarum. Creat Leopards bane.$$
\text { crotice in }
$$

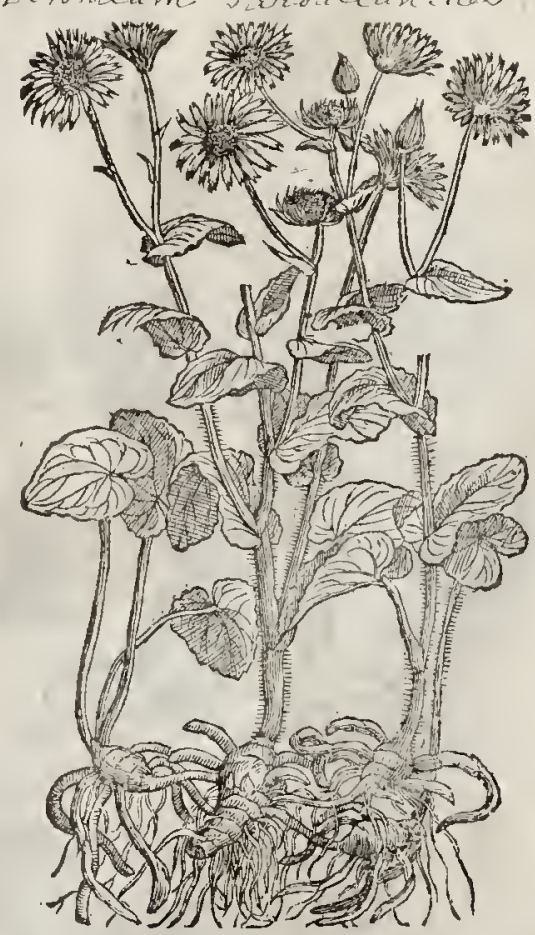

TI The Defription: 
negligenee of $D$ iofcorides and $T$ bcophraft ws, who in defcribing Dor onicum, hatuc not niely onifres the floures thereof, but haue committet thar negligenee in many and diuers other platis, icaung out in many plants which they haue deferibed, tibe fpccial aceidents; wiel hath nor a little trotbled the ftudy and determination of the beftherbarifts of are yeares, rot lisowing certaincly what to determine and fet downe in fo ambiguous a matter, fome raking it one way, and fome another, and fome efteming it to be Aconitum. But for the beter vndertanding hereof, know that this word Aconitum, as it is a name attributed to diuers plants, fo it is to be confidered, rluat dl plants called by this name are malignant and venomous, as with the iuyee and roorwhereof fuch as hunted after wilde and noyfome beafis were wont to embrue and dip their arowes, the fooner and more furely to difpateh and flay the beaft in chafe. But for the proofe of the goodneffe of this $D$ oronicum and the reft of his kind, know alfo, That Lobelwriteth of oneealled lohn de Iroede, who ate very many of the roots at fundry times, and found them very pleafant in taft, and very eomfortable. But to leatie controuerfies, circumftances, and obiections which here might be brought in and alledged, affure your felues that this plant Doronicum minus offinamm (whofe roots Pen reporteth to have found plentifully growing vpon the Pede-mountaine hills and ecrtaine high places in France) hath many leaues fpred vpon the ground, fomewhat like Plantaine : among wieh rife vp many tender hairy falks fome handfull and an halfe high, bearing at the ropcertain fingle yellow floures, which when they fade change into downe, and are caried awny with the winde. The ronts arc thicke and many, very crookedly croffing and tangling one within another, refembling a Scorpion, and in fome yeares do grow in our Englim gardens into infinitenumbers.

3 Doronicum radice repente. Cray-fith Wolfes bane.

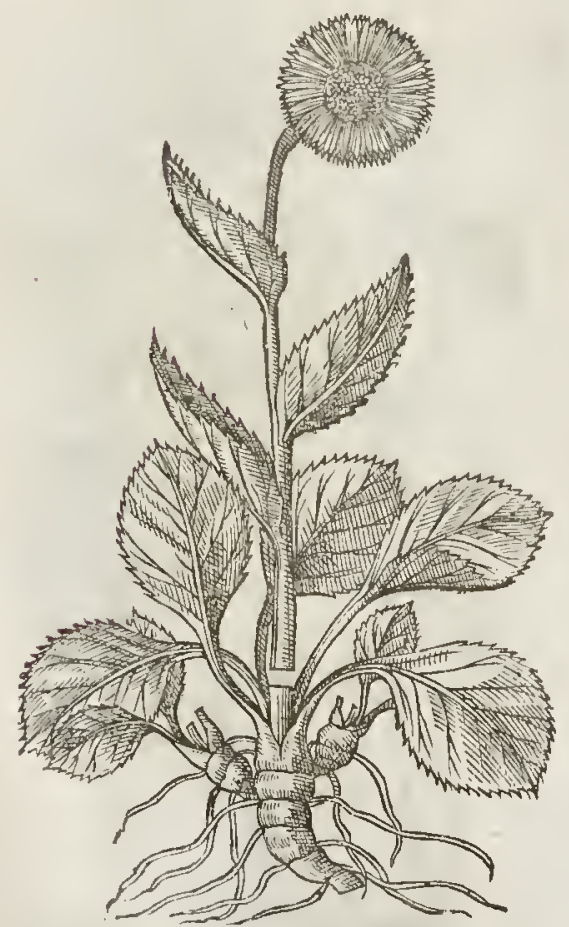

4 Dorinicum branbiataradice. Winged Wolfes baue.

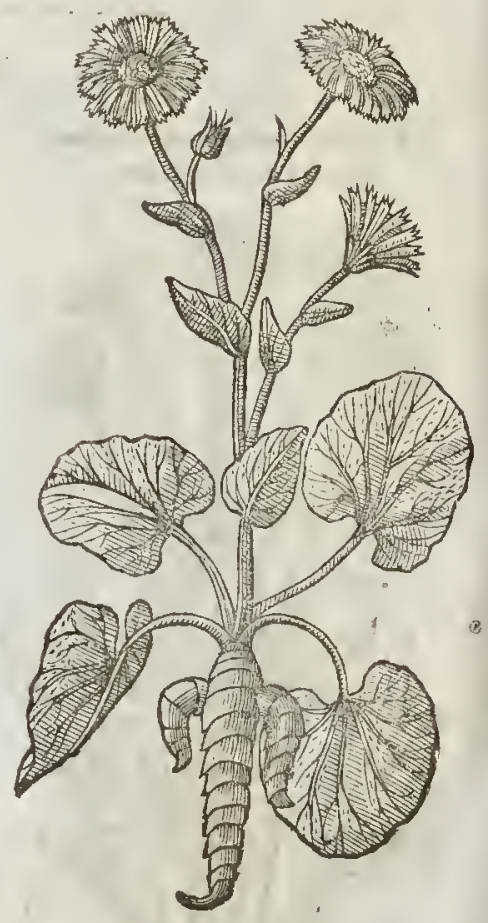

2 The fecond kinde of Dorouictm liath larger leaues than the former, but round, and broader, almoft like the fmall leates of the Clot or Burre; among which rifeth vp a falke fearfe atcubit high : the fioures are like the former : the root is longer and bigger than the former, barred ourer
with many fcaly barks, in eolour white, and with many icaly barks, in eolour white, and thining like white marble, having on each fide one arme or finne, not unlike to the fea Shrimpe called squilla marina, or rather like the ribbes or fcales
of a Scorpions body, and is fweet in tafte.

3 The third kinde of Doronicum, growing naturally in great aboundance in the motntaines 
of Franee, is alfo brought into and aequainted wirh out Engling grounds, bearing very large leaues of a light yellowin gicene, and hairy like Pilofella, or Cucim is agreft is. The ftalkes are a cubit high, hauing at the top yellow floures like Euphthalmum, or Con follda media vulnerarioram : all the root is barred and welted ouer with feales like the taile of a Scorpion, whitc of colour, and in tafte fweet, with fome bitternefle, yeelding forth much clammine lfe, which is very aftringent.

4 The fourcli kinde hereof is tound in the wooddy mountaines about Turin and Saioy, very like vnto the former, fauing that the leaues are fomw hat rougher, the floures greater, and the ftalks higher. But to be fhort, each of thefe kindes are fo like one another, that in therv, tafte, fmell, and manner of growing they feeme to be as it were all one : therefore it were fuperfluous to ftand $\mathrm{v}$ non their varietic of names, Pardalianches, CMyoctonum, Thelyphosium, Camorum, and fuch like, of Theophraftus, Diefcorides, Pliny, or any of the new Writers, which names they haue giuen vnto Doronicum; for by the opinion of the mo t skilfull in plants, they are but Synoninies of one kinde of plant. And though thefe old writers fpeake of the hurtfull qualities of thefe plants; yer experience teacheth vs that they haue writen what they haue heard and read, and not what they hate knowne and proued; for it is apparant, that Doronicum (by the eonfent of the old and new writers) is vfed as an antidote or eertaine treac'e, as well in the confections de Gemmis Mefud, as in Eleciusyio Aromatum. And though Matthrolus difclaimeth againft the vfe thereof,and calleth it Pardalianches, that is, Wolfes bane; yet let the Learned know, that quantitas, non qualitas, nocet : for though Saffron be eomfortable to the heart, yet if you giue thereof,or of muske, or any fuch cordial thing, toogreat a quantitic, it killeth the party which receitueth it.

\# Doronicum angufifolium Aufriacum. Nartow leaued Wolfes bane.

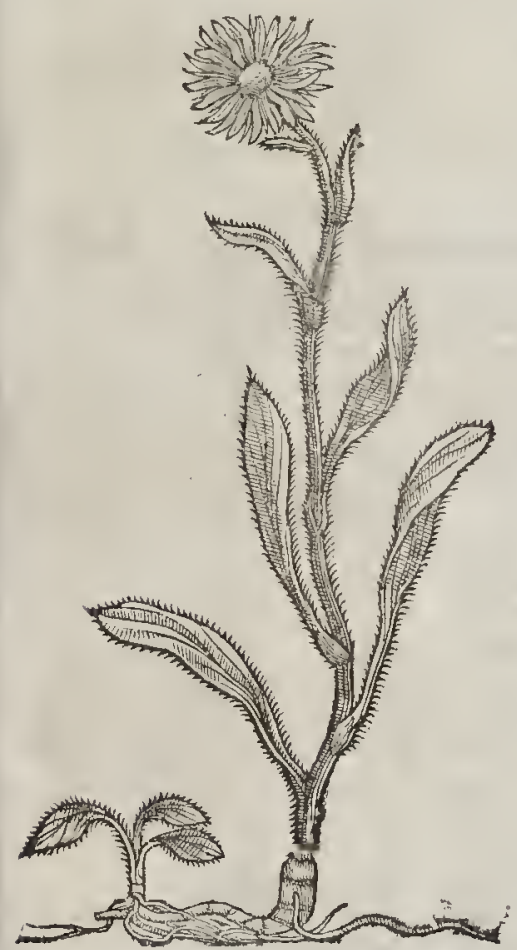

I 6 Doronicum Stiriacum flore amplo. Large floured Wolfes bane.

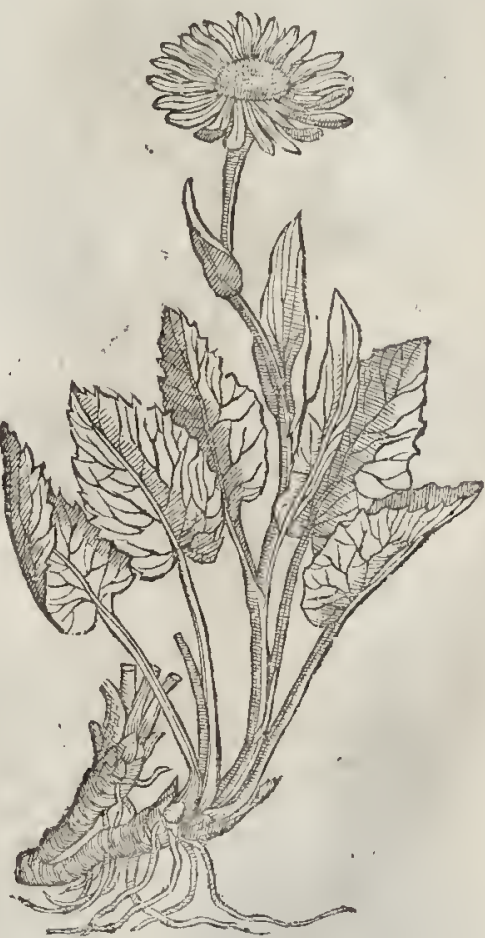

* 5 To the fe foure formetly intended by our Author, may we fitly adde fome others ont of cluffus. The firft of thefe hath a ftalke fome foot high, foft,roug h, and erefted: the leaucs are few, thicke, narrow, long, very greene and fhining, yet hairy on their vpper fides, but fmooth on the lower fides, and of a lighter greene; yet thofe that adorne the ftalke are narrower : there groweth commonly at the top of the ftalke one fingle floure of the thape and bigneffe of the conmon $D_{0}$ ronicum defcribed in the fecond place, but of a brighter yellow : the feed is littleand blackith, and is carried away with the winde : the root is fmall, blackith, and ioynted, hauing formew har thieke 
white fibres, and an aromaticke tafte. This foures in Iuly and Augut, and growes in rockic piaces vpon the highent Alpes. Clufius (the firft and onely deferiber thereof) calls it Doronicmin 2. fue unsiriachios.

6 This growes fomew hat higher than the laft deferibed, and lath much broader and rounder leates, and thofe full of veines, and fnipt about the edges. The knots and off-fets of the roots defcend not down, but run on the furface of the ground, and fo fend forth fibres on each fide; to faften them and attract nourithment. The floure is like that of the former, bur much larger This growcrl in the bigh mountainous placcs of Stiria, and floures at the fame time as the former. Chufus calls this Doronicess 4 . Striacum.

7 This is the largeft of all the reft, and hath a falke two cubits or more higli, of the thickneffe of ones little finger, crefted, rough, and towards the top diuided into fucdry bianches. The leates next to the root are lound, wrinkled, hairy, and faftned to a long ftalke: thofe towards the ron of the ftalke are longer and narrower, and ingirt the ftalke at their fetting on. The fnures ate large and yellow, like to the other plants of this kinde : the feed alfo is carried away with the winde, ard is longint, and of a greenith colour: the root is knotty or ioynted like to a little Shrimpe, and of a whitifh greene colour. This foures in Iunc or Iuly, and growes vpon the like places as the former. Clufurs calls this Dorowicum 7. Anfrianm 3. ‡

₹ Doroxicummaximum. The greateft Wolfe-bane.

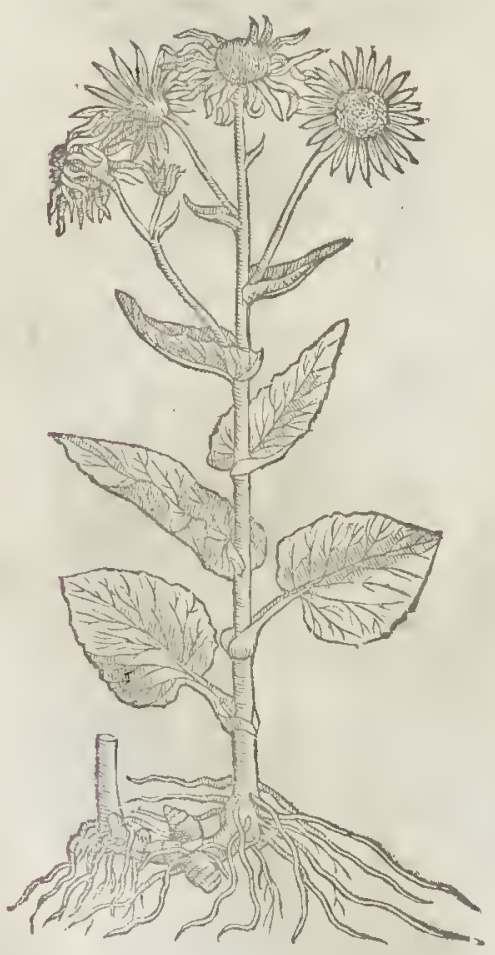

T The Plice.

The place is fufficiently fet forth in the de. fcription; yet you thall vinderfand, that I hatic the two firt in my giddo; the fecond hath beene found and gathered in the cold mountaines of Northumberiand, by Dr. Penny lately of London deceafed, a man of much ceperience and knowledse in Simples, whofe death my felfe and many othets do greatly bewaile.

बा The Time.

They foure in the montlss of Iune and Itily. का The Names.

Concerning their names I hase already spoken; yet fith I would be glad thar our Englinh women may know how tocall it, they may terme Dorosicum by $\mathrm{r}$ l, is name, Cray-filh Piffe-a-bed, becaufe the Houre is like Dandelion, which is cal ed pifle a-bed.

\# Our Author certanly at the beginning of this chapter did not well inderfand what he faid, when he afirmes, Thas the realon of the not wel knowing the Doronicum of the Antientswas, [through the neyligence of $D: 0 / 60$ rides and $T$ beophrings, whoin defcribing $D$ orenictm, \&c.] Now it is manifent, that neither of thefe Authors, nor any of the antient Greekes euer fo much as named Doronicunt : but that which he thould haue faid, was, That the want of exact deferibing the conitum thelyphonon in Theophraftus, and Aconitum Pardalianibes in D:of corides, (which are iudged tobe the fame plant and all one with our Doronicum) isath beene the caufe, that the controucrfiewhich Mathiolus and others haue of late raifed cannot bc fully determined; which is, Whether that the vulgar Doronicum, ved in thops, and defcribed in this chapter, be the Aconitum Pardalianches? Mattholus affrmes it is, and much and vehemently cxclaimes againt the ve thereof in cordiall Electuaries, as that which is of a mot pernitious and deadly qualitie, becaufe that (as he affirmes) it will kill dogs : now Dodoncms alfo feems to incline to his opinion: but others (and not without good reafon) deny it; as Gefner in his Epiftles, who made often triall of it vpon himfelfe : part of his words are fet downe hereafter by our Aurhor (being tranflated out of 1 odonsess) and fome part alfo you thall finde added in the end of the vertues: anct thefe are other fome; Plure alia nurc omitto, quibus oftendere liquido poffem, nec Doronicums nofrum, :3es 
Aconitury vilo modo effe venenatum bomini. Canibus autem letiferum effe fcio, non folwm fi draclmatrum 4 . fed ctiam fi unzos pondere fumant. And before he faid, qisafi non alia multa canibus fint venena, qus bomirifalubria /unt; vt de afp.rrag ofertser. Of the fame opinion with Gefiner is Pena and Lobel, who, Aduerf.p.290, \& 29 t. do largely handle this matter, \& exeeedingly deride and feoffe at Matshiolus, for his vehement declaiming againte thevfe thereof. Now bricfely my opinion is this, That rhe Do. ronicum here mentioned is not that mentioned and written of by Serupio and the A rabians; neither is it the Aconitum Pardalianches of Diofcorides, nor of fo malignant a qualitic as Matthiolus would hatue it; for I my felfe alfo haue often eaten of it, and that in a pretty quantitie, without the leat offenee. $\neq$

\section{9f The Natureand Vertucs.}

I haue fufficiently fpoken of that for which I haue warrant to write, both touching their natures $A$ and vertues ; for the matter hath continued fo anbiguous and fo doubrfull, yea, and fo ful of eontrouerfies, that I dare not commit that to the world which 1 hane read : thefe few lines therefore fhall fuffiee for this prefent; the reft which might be faid I referre to the great and learned Dostors, and to your owne confideration.

Thefe herbes are mixed with eompound medicines that mitigate the paine of the eyes, and by $B$ reafon of his cold qualitic, being freth and greene, it helpcth the inflammation or fierie heate of the eyes.

It is reported and affirmed, that it killeth Panthers, Swine, Wolues, and allkindes of wilde C beafts, being giuen them witli fleth. Theophraftus faith, That it killeth Cattell, Sheepe, Oxen, and all foure-foored beafts, within the compaffe of one day, not by taking it inwardly onely, but if the herbe or root be tied vnto their priuy parts. Yet he writeth further, That the root being drunke is a remedie againft the ftinging of Seorpions; which theweth, that this herbe or the root thereof is not deadly to man, but to diuers beafts onely : which thing alfo is found out by trial and manifent experienee; for Conrade Gefner (a man in our time fingularly learned, and a moft diligent feareher of many things) in a certaine Epiflewritten to .4dolphos Occo, theweth, That he himfelfe hath oftentimes inwardly taken the root hereof greene, dry, whole, preferued with honey, and alfo beaten to pouder; and that euen the very fame day in whieh hee wrote thefe things, hee had drunke with warmewater two drams of the roots made into fine pouder, neither felt he any hurt thereby: and that he oftentimes alfo had giten the fame to his fieke Patients, both by it felfe, and alfo mixed with orher things, and that very luckily. Moreouer, the A potheearies in fead of Doronicum doe vfe (though amiffe) the roots thereof without any manifelt danger.

That th is Aconite killeth dogs, it is very ecrtainc, and found out by triall : which thing Mathio- D lus could hardly beleete, but that at length he found it out to be true by a manifeft example, as he confeffeth in his Commentaries.

$¥$ I hauc (faith $G(f n e r)$ oft with very good fuceeffe preferibed it to my Patients, both alone,as $E$ alfo mixed with other medicines, efpecially in the $V$ critigo and falling fiekneffe : fomtimes alio I mix therewith Gentian, the pouder of Mifle-toc, and Afrantia : thus it workes admirable effects in the Epilepfic, if the vfe thereof be continued for fome time. $\ddagger$

+ Formerly the figure that was in the find glace thould hute beenein thefecond, and che fint and ficond were confounded in the defeription.

\section{C н а т. 265. Of Sage.}

91 The Defoription.

I $\neg$ He grcat Sage is very full of falkes, foure fquare, of a wooddy fubfanee, parted into branches, about the which grow broad leaues, long, wrinckled, rough, whitih, verie like to the leaues of wilde Mullein, but rougher, and not fowhite, like in roughneffe cowollen eloath thread-bare : the floures fand forked in the tops of the branches like thofe of dead Netrle, or of Claric, of a purple blew colour; in the place of which doth grow little blackinh feeds, in fmall huskes. The roor is hard and wooddy, fending forth a number of little ftrings.

2 The leffer Sage is alfo a Thrubby plant, fpred into branehes like tothe former, but :effer: the falkes hereof are tenderer : the leaues be long, leffer, narrower, but not lefie rough; to which there do grow in the plaee wherein they atc fixed to the ftalke, two little leaues ftanding on either fideone right againtt another, fomewhat after the manner of finnes or litele eares: the floures are $S \int f_{2}$. cared 
cared blew like thofe of the former : the root alfo is wooddy : both of them areof a certaine ftrong fmell, but nothing at all oftenfue; and that which is the leffer is the better.

3 . This Indian Sage hath diuers branches of a wooddy fubfance, whereon doe grow fimall leates, long, rough, and narrow, of anouerworne colour, and of a noft fweet and fragrant fmell. The floures grow along ft the rop of the branches, of a white colour, in forme like the precedent. The toot is tough and wooddy.

$$
\begin{aligned}
& \text { I Saltis maior. } \\
& \text { Great Sage. }
\end{aligned}
$$

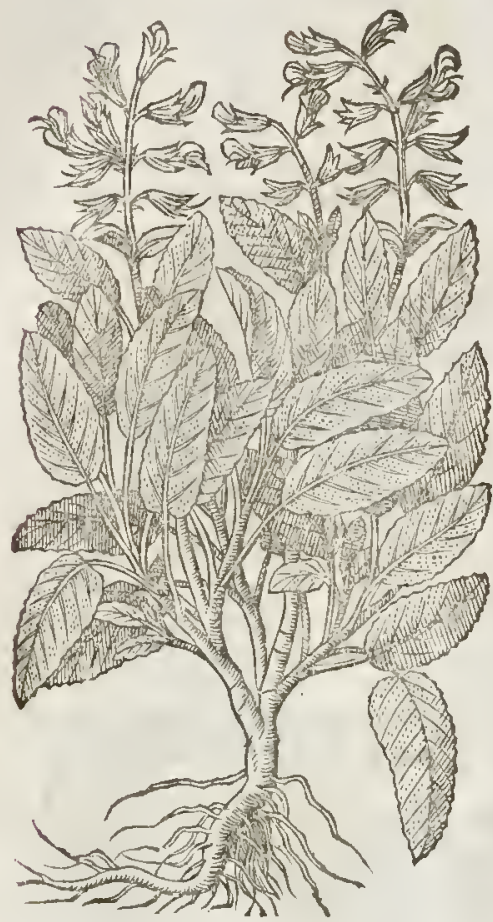

2 Salwiaminor. Smalt Sage.

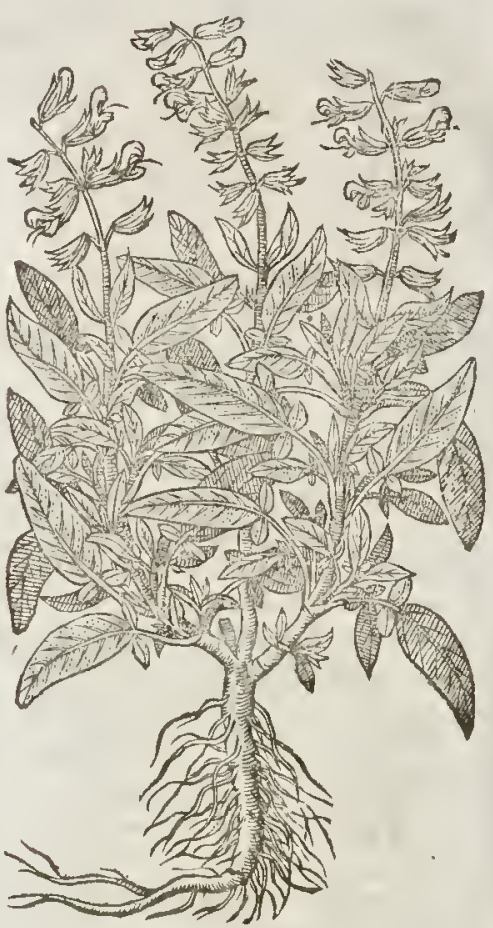

4 The Mountaine Sage hath an vpright ftalke fmooth and plaine, whereupon do grow broad rotghand rugged leates, flcighty nicked, and vnetrenly indented about the edges, of an hoarie colour, fharpe pointed, and of i ranke fmell : the foures grow alongft the top of the ftalke, in thape like thofe of lof maric, of a whith ted colour. The root is likewife wooddy.

5 Wehate in our gardens a linde of Save, the leates wherenf are reddith, purt of thofe red leatesate friped with white, orhers mixed with white, greene, and red, euen as Nature lift to play with fuch plants. This is an elegant varictie, and iscalled Salmia variegata elegans, Variegated or painted Sage.

6 We hame alfo another, the leates whereof are for the mof part white, fomew hat mixed with greene, often one leafe white, and another greene, euen as Nature lit, as we hate faid. This is not fo rare as the former, nor neere fo beautifull, wherefore it may be termed Salnat curiegata vilgarzs, Common painted Sage.

₹ 7 Thure is kept in fome of our chiefe gardens a fine Sage, which in fhape and manner of growing refembles the fmaller Sage, but in fmell and tafte harb fome affinity with Wormwood: whence it may be termed Salwia Abfm bites, or Wornew ond Sage. Barbine onely hath mentioned

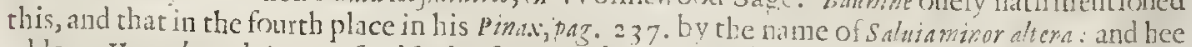
addes, Hac odore of fapore eft Abfinthï, forcque rubente: That is, This hat h the fmell and talte of Wormewood, and a red floure : but ours (if my memorie faile me uot) bath a whith t?oure: $1 t$ is a tender plant, and mut he carefully preferued from the extremitie of Winter. I furt faw this Sagewith Mr. ramon, and by hin it was communicatcd to fome otlic rs. 


\section{B. 2. Of the Hiftory of Plants.}

3 Saluia lindica.

Indian Sage.

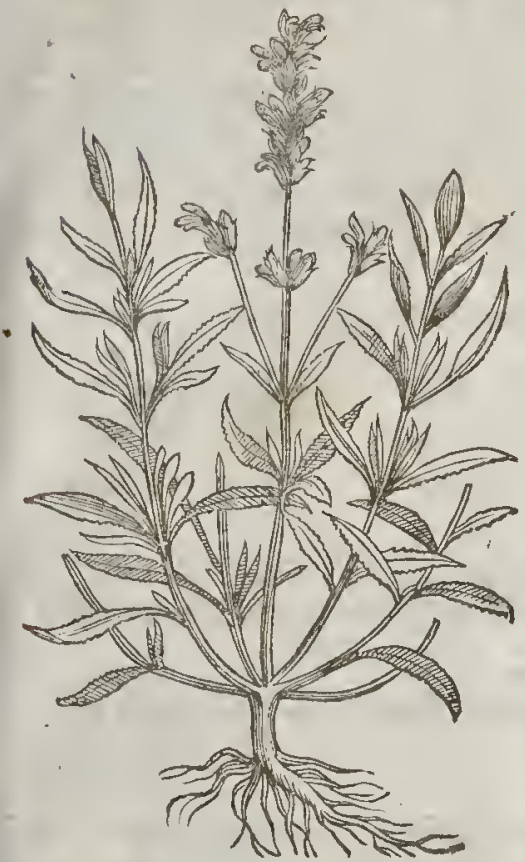

$\$$ Salsia Cretica pomifera.

Apple-bearing Sage of Candy.

and

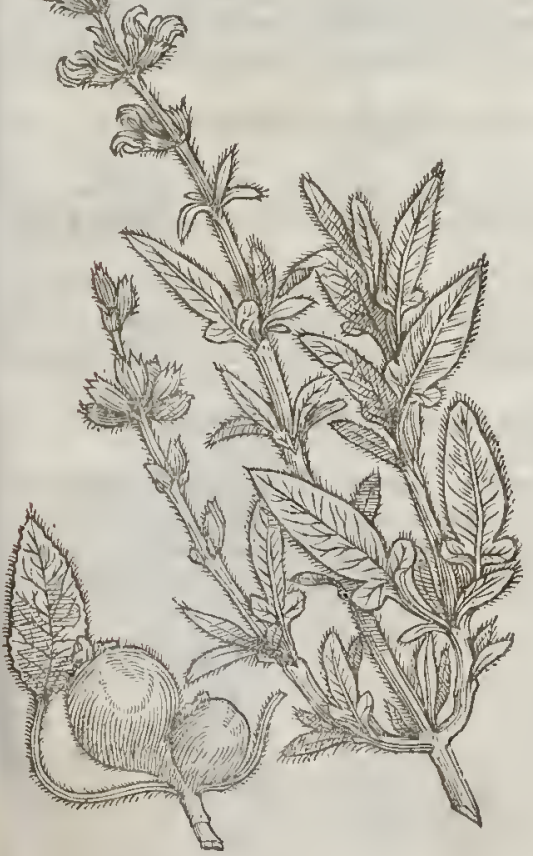

4 Saluia Alpina.

Mountaine Sage.

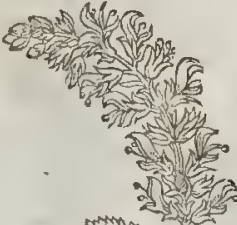

FIn

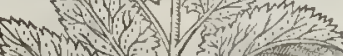

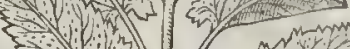

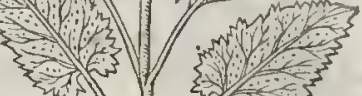

(1)
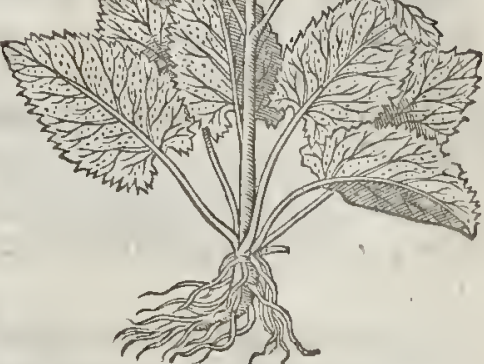

¥ S Siluia Cretica non pomifora: Candy Sagewithout Apples.

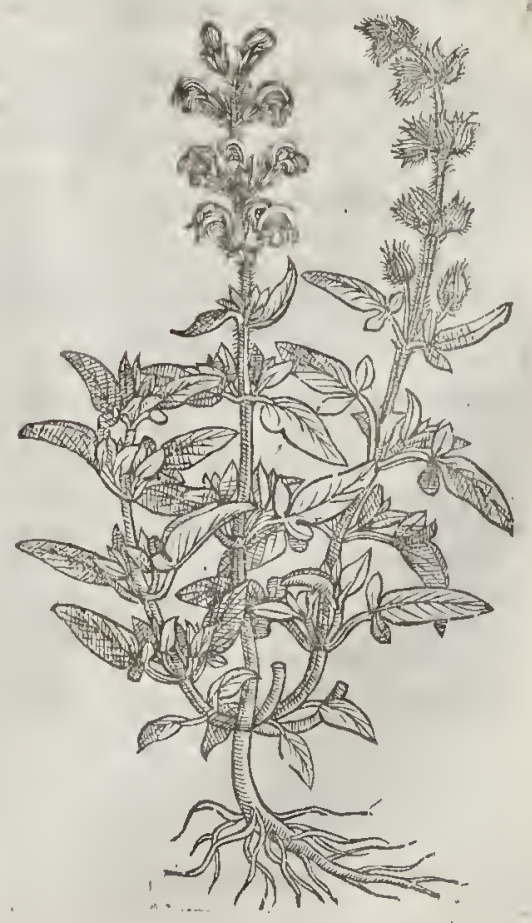


8 This which wehcre giue you hach pretry large leaues, and thofe alfo very hairy on the vnder fide, but rough on the vper lide like as the ordinaric Sage. The ftalkesare rough and hairie, foure fquare below, and round at their tops. The Aloures in their growing and hape are like thofe of the ordinarie, but of a whitith purple colour ; and fading, thcy are each of them fucceeded by threc or foure feeds, which are larger than in other Sages, and fo fill theit feed-reffels, that they new like berrics. The fmell of the whole plant is fomew hat more vehement than that of the ordinaric : the leaucs alfo haue fomet imes littlc cares or appendices, as in the fmaller or Pig. Sagc: and in Candy (the naturall place of the grow th) it beares excrefcences, or Apples (if we may in terme them) of the bigneffcoflarge Gails, or Oke-Apples: whence Clufius harh giuen you wo figures by the fame titles as I here prefent the fame to your view. Martholzes, Dodons ys, and others alfo haue made mention hereof.

$$
\text { oा The Place. }
$$
Thefe kindes of Sage grow not wilde in England: I haue them all in my garden : moft of them
are very common. $\ddagger$ The fine or elegant painted Sagewas fitt found in a countrey garden, by $\mathrm{M}^{\mathrm{r}}$. Lohn Tradef-
cont, and by him imparted to other louers of plants. $\neq$

$$
\text { 9ा The Time. }
$$

Thefe Sages floure in Iune and Iuly, or later : thcy are fit ly remoucd and planted in March.

9 The Names.

Sage is called in Greeke insioqaxis: the A pothecaries, the Italians, and the Spaniards keepe the Latine name Salma : in high-Dutch, Baben: in French, Sange : in low-Dutch, 5 auie: in Eng-
lifh, Sage.

Sage is manifefty hot and dry in the beginning of the third degree, or in the later end of the fecond; it hath adioyned no little aftriction or binding.

T The Vertues.

A. Agrippa and likewife Astius haue called it the Holy-herbe, bccanfe women with childe if they belike to come before their time, and are troubled with aborments, do eate thereof to thcir great good; for it clofeth the matrix, and maketh them fruitfull, it retaineth the birth, and giuerh it life, and if the woman about the fourth day of her going abroad a ftet her childing, thal drink nine o unces of the iuyce of Sage wirl a little falt, and then ve the companie of her husband, the thall without doubt conceime and bring forth ftore of children, which are the blefling of God. Thus far Agrippa.

B

Sage is fingular good for the head and braine; it quickneth the fences and memory, ftrengthneth the finewes, reftorct h health to thofe that haue the palfie vpon a moift caufe, takes away flaking or trembling of the members; and being put vp into the nofthrils, it draweth thin flegme out
of the head.

C It is likewife.commended againt the fpit ting of bloud, the cough, and paines of the fides, and bitings of Scroents.

D The iuyce of Sage drunke with honey is good for thofe that fpit and vomit bloud, and ftoppeth the flux thereof incontinently, cxpelleth winde, drieth the dtopfie, helpeth the palfie, frengthneth the finewes, and cleanferh the bloud.

E The leares fodden in water, with Wood-bindeleaues, Plantaine, Rofemary, Honey, Allome, and fomewhitew ine, makean excellentwater to wath the fecret parts of man or woman, and for cankers or or her foreneffe in the mouth, efpecially if you boyle in the fame a faire bright thining Sea-cole, which maketh it of greater efficacie.

F No man needs to doubt of tle who ciomneffe of Sage Alc, being brewed as it thould be, with Sage, Scabious, Betony, Spikenard, Squinanth, and Fcnnell feeds.

- G The leaues of red Sage put into awooddendith, whercin is put very quicke coles, with fome athes in the botrome of the dith to keepe the fame from burning, and a lirtle vineger fprinkled vpon the leaues lying vpon the coles, and fowrapped in a linnen cloath, and holden very hot vnto the fide of thofe that aretroubled with a grieuous Aitch, takcth away the paine prefently: The fame helpeth greatly the extremitie of the pleurifie. 

(to whom we arebeholden for this figure and defeription) calls this, phlomos Lyshnitcs altcra sy.
ritca. $\neq$

$$
\text { T The Place. }
$$

Thefewilde Mulleins do grow wilde in diuers Prouinees of Spaine, and alfo in L anguedne, vpon drie bankes, and ftony places: I haue them both in my garden, and many others likewife.

They floure in Iune and Iuly. If The Time.

$$
\text { T The Names. }
$$

They are ealled of the learned men of our time, $v$ erbafca sylueftria : the firft is called of the Gre-

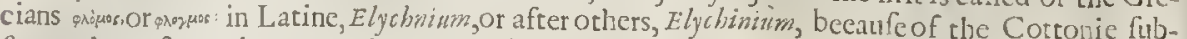

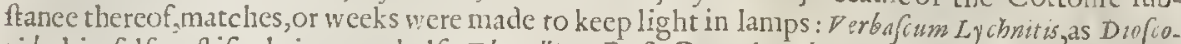
rides himfelfeteftificth, is named alfo Thryallis or Rofe Campion; but the foure of $T$ bry.llis is red of colour as Nicinder in his Counterpoifons doth thew, but rhe foures of rlefe are ycllow : therefore they are neither Thryallis nor Lychnitis, but Sylueftre Verbafcum, or wilde Mullein, as we hane already taught in the Chapter of Rofe Campion, rlat Thryallis is Lychnitis fatiua, or Rofe Campion. There is nothing to the eonrrary, but that there may be many planrs with foft downic leaues fit to make Candle weeke of : in Englith it is generally ealled French Sage:wee may call it Sage Mulleine.

\section{The Temperature.}

As thefe be like in vertues to the others going before, fo they te likewife dric in temperature.

A Diofcorides faith, that the leaues are ftamped and laied in manner of a pultis vpon burnings and fcaldings.

$$
\text { T The Vertues. }
$$

$$
\text { CHA P. 267. Of Clarie. }
$$

I Galluticum, fue Horminum. Common Clarie.

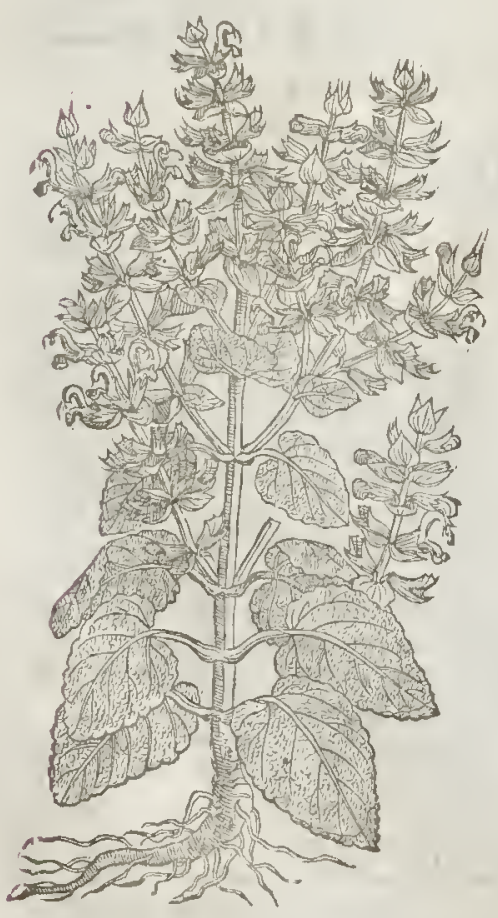

2 Gallitricum alterum. Sinall Clarie.

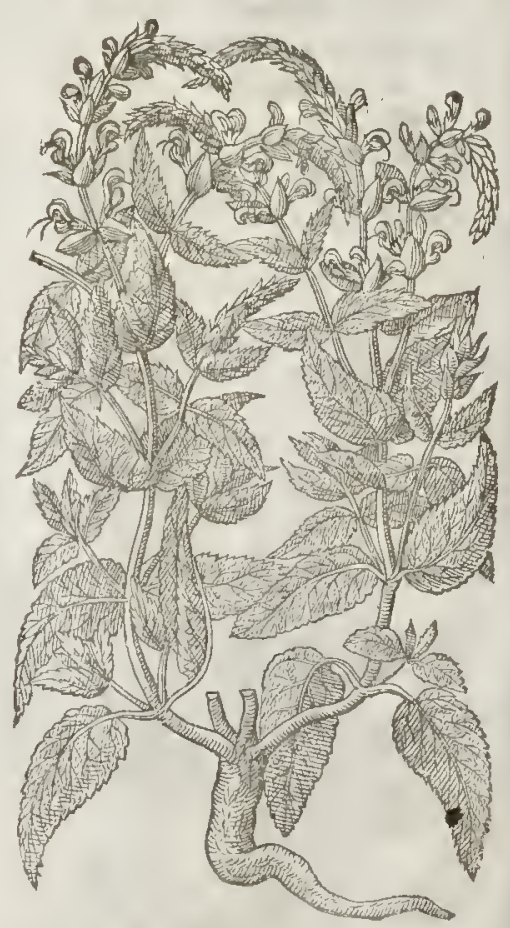

का $T$ is 
the righr Clarie: the husks or cods when they are ripe bend downwards : the feed is blackifh; the roots in like manner are blacke and full of ftrings.

4 The fouth hind of Hormmum, called Iovis Colus, reprefenteth in the higheft top of the ftalke a diftaffe, wrapped about with yellow flax, whereof it tooke his name, hauing knobbic roots, with forth fundry foure fired rhcreto like Galeoplis, or like vnto the roots of Clarie, which doe yeeld ine Nettle, rough, harpe pointed, and of an ouerw orne greene colour : the floures do grow along ft rhe top of the ftalks, by certaine fpaces, fet round about in fma I coronets, or wharles, like thofe of Sage
in forme, but of a yellow colour.

\title{
T The Place.
}

Thefe doe grow wilde in fome places, notwithtanding they are manured and planted in Gardens,almoft euery where, except Iupiters diftaffe, beeing a kinde thereof, which I hatic in my
Garden.

They floure in Iune, Iuly, and Auguf.

$$
\text { Tf The Time. }
$$

T The 2 ames.

Clarie is called of the Apothecaries Gallitricum; it is likewife named oruala: of fome, Tota Gona. but not properly: of others, Scariea, Sclarea, Centrum Galli, and CMatrifaluia. in Italian, Scirra: in French, or rale : in High Dutch, Schatlach: in Low Dutch, Schatlepe: in Englifh, Clarie, or Cleere eie.

Iupiter s diftaffe is called Colus Iovis : of fome, Guleop(is lutea, but not properly : of diuters, Hormi. num luzeum, or yellow Clarie, and Horminum 7 ridentinum, or Claric of Trent.

Clarie is hot and drie in the third degree. T The Temperature.

$$
\text { G. The Vertues. }
$$

A The feed of Clarie poudered, fincly fearced and mixed with hony, raketh away the dimneffe of the eies, and clecreth the fight.

B The fame famped,infufed, or laied to fecpe in warme water, the mufilag or flimie fubftance taken and applied plaifterwife,draweth forth fplinters of wood, thornes, or any other thing fixed in the bodie : it alfo fcattereth and diffolueth all kindes of fwellings, efpecially in the ioints.

C The feed poudered and drunkewith wine, ftirreth vp bodily luft.

D The leaucs of Clarie taken any manner of way, helpeth the weakneffe of the baeke proceeding of the ouermuch flowing of the whites, but moft effectually if they be fried with egges in manner of a Tanfic,either the leaues whole or ftamped.

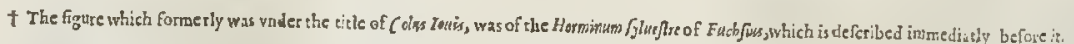

\section{C на p. 268: Of wilde Clarie, or Oculus Chrifti.}

\author{
Tf The Defoription.
}

I

Q Culus Chrifti is alfo a kinde of Glarie, but leffer: the ftalkes are many, a cubite high, fquared, and fomewhat hairic: the leaues be broad, rough, and of a blackifh green colour. The floures grow alongt the falkes, of a blewifh colour. The feed is round and blackifh, the root is thicke and tough, with fome threds annexed thereto. $\ddagger$ Tlis is Hormint fyluestris 4 . quintapecies of Clufurs. $\neq$

2 The purple Clarie hath leaues fomewhat round, layd ouer with a hoaric cottony fubftance, not much vnlike Horchound: anong which rife vp fmall hairie fquare ftalks, fet torvard the top with little leaues of a purple colour, which appeare at the firft view to be Houres, and yet are nothing elfe but leaucs, turned into an exeellent purple eolour: and among thefe beautifull leaues come forth fmall floures of a blewith or watchet eolour, in farhion like vnto the floures of Rofemarie; whieh bcing withered, the husks wherein they did grow containe certaine blacke feed, that falleth forth vpon the ground very quickely, becaufe that euery fuch hushe doth turne and hang downe his liead toward the ground. The root dieth at the firft a pproch of $W$ inter.

‡ 3 Broad leaued Clarie hath a fquare ftalke fome cubite high, hairy, firme, and iointed; the leaues are large, rough, and tharpe pointed, fnipt about the ed ges, wrinekled, and fand ing by eouples at each ioint : vpon the branehes in roundles grow purple foures, leffe than thofe of Clarie, and fcarce any bigger than thofe of Lauander : the feed is fmal and blacke: the root is large, hard, 


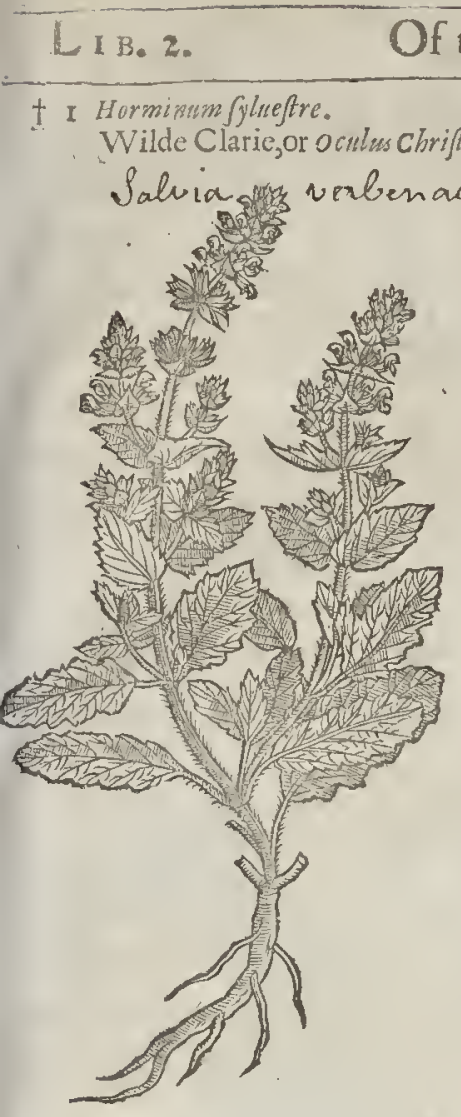
* 3 Horminum fyluefre latifoliums.
Broad leaued wilde Clarie.
2 Horminum fylueftre folyis purpurcis: Claric with purple leaues.

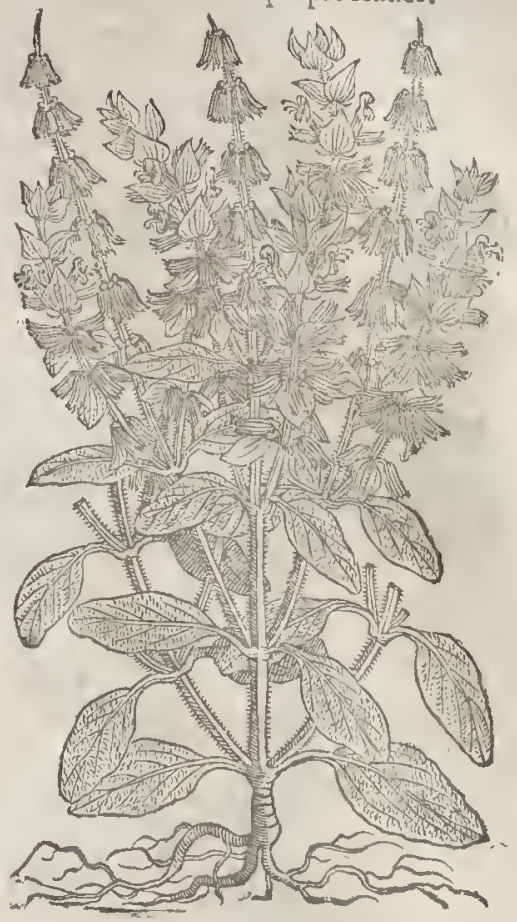

₹ Horminum fyimeftre fore albo.
Whice foured wilde Clarie:

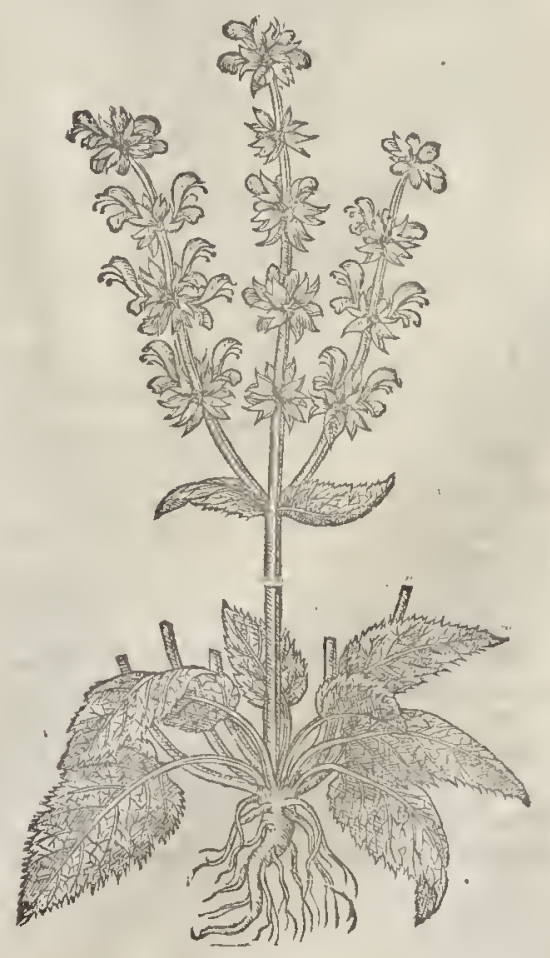


$\$ 5$ Horminum flueftre fore rubro. Red hourcd wilde C!arie.

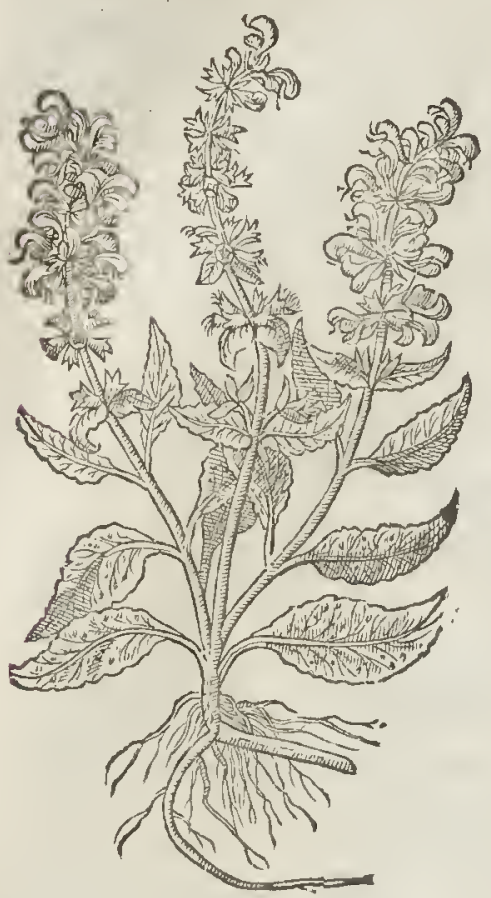

blacke, and lines many yeares. It foures in lune and Iuly, and growes wilde in many monntaicous places of Germany. Clufins calls it Horminum fyl
ueftre tertnum.

4 This hath long leaues next vnto the ground, growing vpon prettie long nalkes, broad at their fetting on, and fo ending by little and little in tharpe points, they are not decply eut in, but onely lightly fnipt about the edges: they atealfo wrinekled on the vpper fide, and whitin but hairie on the vnder fide. The fouare falkcs are fome eubite high, iointed, and fowith two leaues at each ioint. The floures grow along ft the tops of the branehes, and are of a fnow white colour. There is a varietie of this w ith the leanes greener, and the floures of an elegant deepe purple colour. This is the Hor mnum fyluefris quarti pecies proma of Clufins, and the varietie with the white floures is his Horman fyluefris quartifpecies prima; and the figure that our Authour gaue in the firft plaee was of thefe.

5 There is another variety of the laft deferibed,whieh alfo hath fquare ftelks fet with rough fnipt leates, which cnd in fharp roints, but are narrower at the lower end than tlie former, and they are grecne of colour : ipon the tops of the falkes grow red hooded foures, and thofe not very large: the feed is fnill and blacke, and the root liues many yeares. Tlit is foures in luly. Clisfou makes this his Hormini fylueftris guartipecies
quarta. $\neq$

T The Place.

The firft growcth wilde in diucrs barren plaees, almoft in cuery Country, efpecially in the fields of Holborne neere rnto Grayes lnne, in the high way by the end of abrieke wall: at the end of Chelfey next to London, In the high way as you go from the Queenes pallaee of Richmond to the
waters fide,and in diuers other places.

The ot her is a ftranger in England:it groweth in my garden.

They floure and fourin from The Time.

They floure and fourinh from Iune to the end of Augutt.

Wilde Clarie is called after the The Names.

of the eies:in Greeke apmon and likewife in Larine, oculus Chrifti, of his effect in helping the difeafes Clarie, and oculus Chrifti.

The feeond is thought of fome to be the right Claric, and they hauc called it Horminum verum, butwith greater errour: it may be called in Latine Horminum fylueftre folys of formibus purpureu,

¥ Our Authour fhould haue fhewn his rea fons why this is not the Horminum verum, to hate eonuincted the crrour of Angwillara, Matthiolus, Gefner, Dodonass, Lobel and others, who haue aecounted eannot be done, $\neq$,

$$
\text { I The Tempcrature andVcrtucs. }
$$

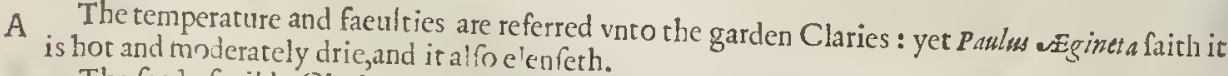

B fethe feed of,wilde Clarie,as Diof corides writeth, being drunke with wine, ftirreth vp luff, it elenfeth the cies from filmes and or her imperfections, being mixed with honie.

C mours, redneffe, inflammation the eies, e'enfech and purgeth them exeeedingly from waterin hisaway the paine and fmarting thereof,erseciallyaladies, or all that happen vnto the eies, and takes away the paine and fmarting thereof,efpecially being put into the eies one feed at one time, and 
no more, which is a generall medicine in Cherhire and other Countries thereabout, knoivne of all, and vied with good fuece ffe.

The leaues are good to be put into pottage or brothes among other potherbes; for they fcartet $D$ congealed bloud, warme the ftomacke, and helpe the dimneffe of the eies.

\section{Снат. 269. Of Trullein.}

\section{It The Defcription.}

I Te male Mullein or Higtaper hath broad leaues, very foft, whirith and downie; in the a hoarie downe, and couered wirh a Italke, ftraight, fingle, and the fame alfo whition all ouer, with tapenvife are fet a multitude of ycllow floures, confifting of fue leaues apeec:among which whereof come vp litrle round ger thicke,blackewithout, and full of trings.

I Tapfus Bribatus. Mullein or Higtaper.

- Com Vorlascum
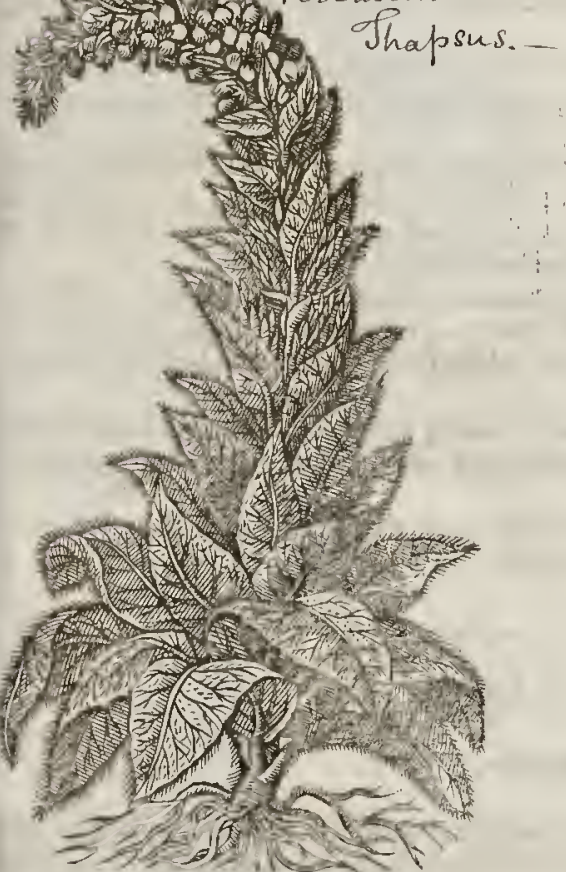

2 The female Mullein hath likewife many white woolley leaues, fet vpon an hoariecottonie vpright ftalke, of the height of foure or fue cubits : the top of the falks refembleth a torch decked with infinite white flotres, which is the fpeciall marke to know it from the male kinde, being like
in etrery other refpeit.

Thefe plants dogrow of themfelues The Place.

and drie fandie ditcl banks, and in lyme kill vpon the end of necre vnto Dartford in Kent. in Heath next to London,as alfo about the Queens houfe at Eltham rries of England that are of a fandic foile. 


\section{T The Time.}

They are found with their floure from Iuly to September, and bring forth their feed the fecond yeare after the feed is fowne.

$$
\text { If The Names. }
$$

Mullein is called in Greeke 4 ripas in thops, Tap was Barbatus: of diuers, Candela Regin, Candeleria, and Lanarin: Diofcorides, $P_{l i n y}$, and Galen, do eall it Verbafcum : in Italian,Verbatco, and Taffo Barbaffo : in Spanifh,Gordolobo : in High Dutch, noullktat: in French, Bouillon : in Englih, Mullein, or rather Woollen,Higtaper, 1 orches,Long-woort, and Btillockes Long-woort; and of fome Haresbeard.

$$
\text { Ti The Temperature. }
$$

Mullein is of temperature drie : the leaues haue alfo a digefting and clenfing qualitic, as Galen affirmeth.

$$
\text { The Vertues. }
$$

A The leaues of Mullein being boiled in water, and laid vpon hard fwellings and in lammations of the eies,cureth and ceafeth the paine.

3 The root boiled in red wine and drunke, foppeth the laske and bloudy fix:

C The fane boiled in water and drunke, is good for them that are broken and hurt inwardly, and preuaileth much againft the old cough.

D A little fine treacle fpred vpon a lea fe of Mullein, and laied to the piles or Hemorhoides, cureth the fame : an ointment alfo made with the leaues thereof and old logs greafe worketh the fame effect.

E The leaues worne vnder the feet day and night, in manner of a thooe fole or fock, bringeth down in yong maidens their defired fickneffe, being kept vnder their feet with fome focks or other thing for falling away.

F The Countrey people, efpecially the husbandmen in Kent, doe giue their cattell the leaues to drinke againft the cough of the lungs, being an excellent approued medicine for the fame, whereupon thcy doe eall it Bullocks Lung-woort.

G Frankenfenee and Maftieke burned in a cluafing dith of coles,and ferw ithin a clofe ftoole; and the fume thereof taken vnderneath, doth perfectly eure the piles, hemorrhoids, and all difeares Jappening in thofe lower parts, if al fo there be at euery fuch fuming (which mulk bee tw iee euerie day) a leafe of the herbe bound to the plaee, and there kept vitill the next dreffing.

H There be fome who thinke that this herbebeing but carried about one, doth helpe the falling fickneffe, efpeeially the leaues of that plant whieh liath not as yet borne floures, and that is gathered when the Sun is in Virgo, and the Moone in Aries; which thing notw ithftanding is vaine and fuperftitious.

I The later Phyfitions commend the yellow floures, beeing fteeped in Oile and fet in warme doung vntill they bee wafted into the Oile and confuned away, to bee a remediangainft the piles.

$\mathrm{K}$ The report goeth, faith Pliny, that figges do not putriffe at all that are wrapped in the leaues of Mullein: which thing Diofcorides alfo maketh mention of.

\section{C н а P. 270. Of bafe Mullein. \\ II The Defription.}

r THebafe white Mullein hath a thieke wooddie loot, from which rifeth vpa fiffe and hairie Italke, of the height of foure eubites, garnifhed with faire grayith leaues like thofe of Elecampane, but leffer:the Roures grow round about the ftalks taper or torch fath ion, of a white eolour, with certaine golden thrums in the middle:the feed followeth, fmal, and of the eolour of duit.

2 Blacke Mullein hath long leaues, not downic at all, large and tharp pointed, of an ouerworne blackifh green colour, fomewhat rough, and ftrongly fmelling : the floures grow at the top of the ftalks, of a golden yellow colour, with eertaine threds in the middle thereof. The root differeth not from the precedent.

3 Candle weeke Mullein hath large, broad,and woollie leaues, like vnto thofe of the comnon Mullein : among which rifeth vpa falke couered with the like leaues, cuen to the branches wheron the floures do grow, but leffer and lefier by degrees. The ftalke diuideth it felfe tow ard the top into diuerfebranehes, whereon is fet round about many yellow floures, which oftentimes doe change intowhite, varying according vnto the foile and clymate. The root is thick and wooddy. 
L IB: 2.

I Verbafcum album.

Bafe white Mullein.

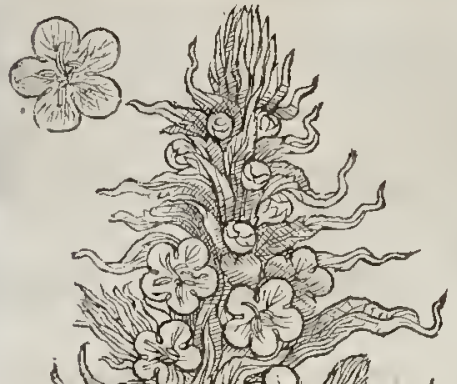

(1) - vil)

(c.s)
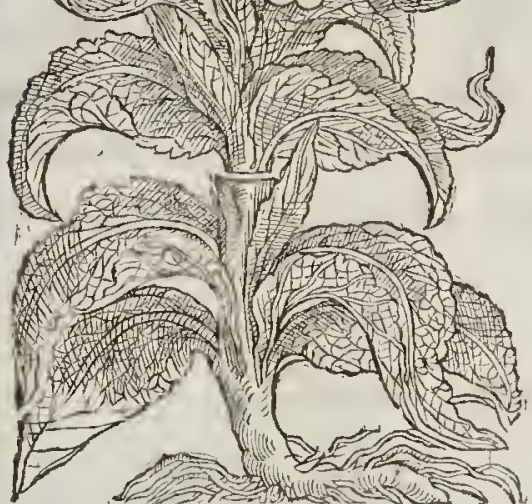

3 Verbafoum Lychnite Mathioli:

Candle-weeke Mullein.

\section{Verbascumn}

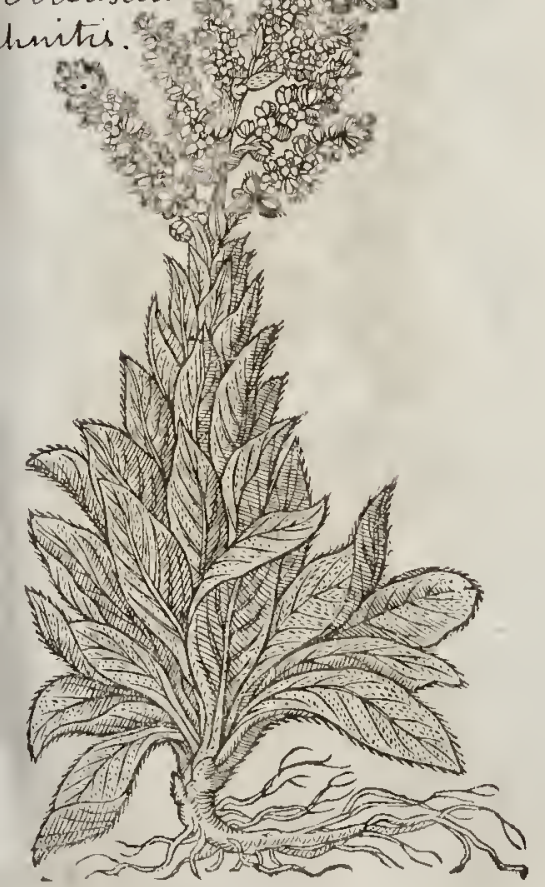

Tt?
2. Verbafam nigrum.

Bafe blacke Mullein.

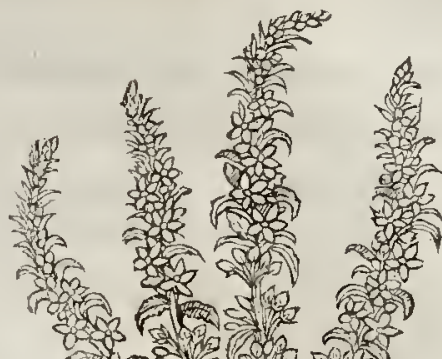

at al 003

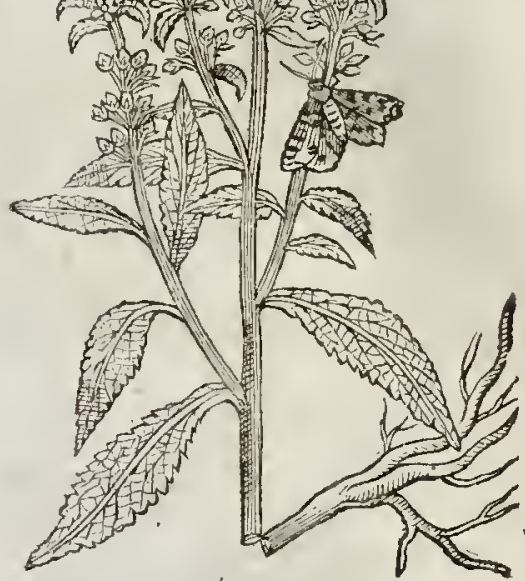

4 Terb.tcum Lychnite winus.

Small Candle-weeke Mullein.

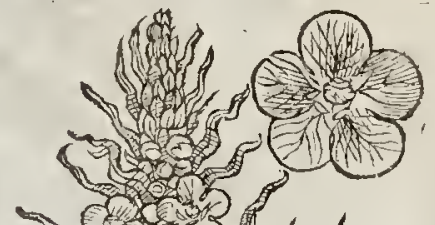

$\rightarrow$ e

$1+x-2015$

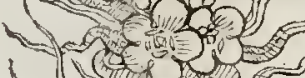

(. (1)

1.

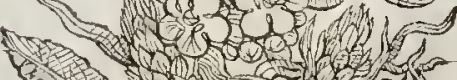

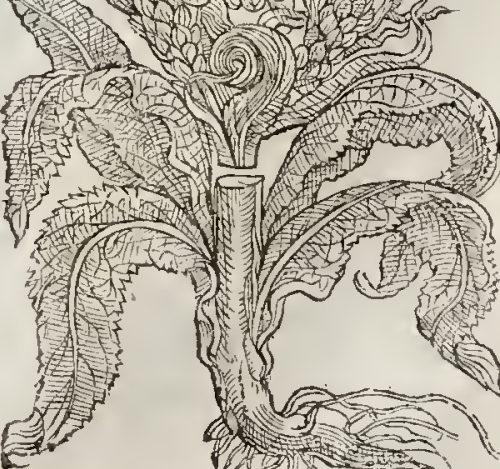




\section{Of the Hiftorie of Plants.}

L. 1 в.2.

4 The fmall Candle-weeke Mullein differeth little from the laft rehearfed, fauing that the whole plant of this is of a better fauour, whercin efpecially confifeth the difference. $\$$ The floure alfo is muel larger, and of a ftriw, or pale yellow colour. $¥$

$$
\text { If The Place. }
$$

Thefe plants do grow where the other Mulleins do, and in the like foile.

$$
\text { वा The lime. }
$$

The time likew ife anfwereth their flouring and feeding.

$$
\text { - The Names. }
$$

Their capitall names expreffed in the titles fhal ferue for thefe bafe Mulleins, confidering they are all and enery of them kindes of Mulleins.

$$
\text { of The Tempcrature. }
$$

Thefe Mulleins are drie without any manifeft heat, yet doubtlefe hotter and dricr than the common Mullein or Hyg taper.

$$
\text { 9T The Vertues. }
$$

A The blacke Muliein, with his pleafauc yellow floures, boiled in water or wine and drunken, is good againtt the difeales of the breft and lungs, and againf all fpitting of corrupt rotten matter.

B The leaues boiled in water, ftamped and applicd pult is wife vpon cold fwellings (called oedemati) and alfo vpon the vicers and inflammations of the eies, cureth the fame.

C The floures of blacke Mullein are put into lic, which caufeth the haire of the head to wax yellow, if it be wathed and combed therewith:

D The leaucs are put into cold ointments with good fucceffe, againft fealdings and burnings with fire or water.

E Apulcius reporteth a tale of $V$ lyffs, Mercurie, and the inchantreffe Circe,and theirvfe of thefe herbes in their in cantations and witchorafts.

\section{C н в. 27і. Of Motb Mullein.}

I Blattariaplinij. plivics Moth Mullein. Nerbasemin Blattaria

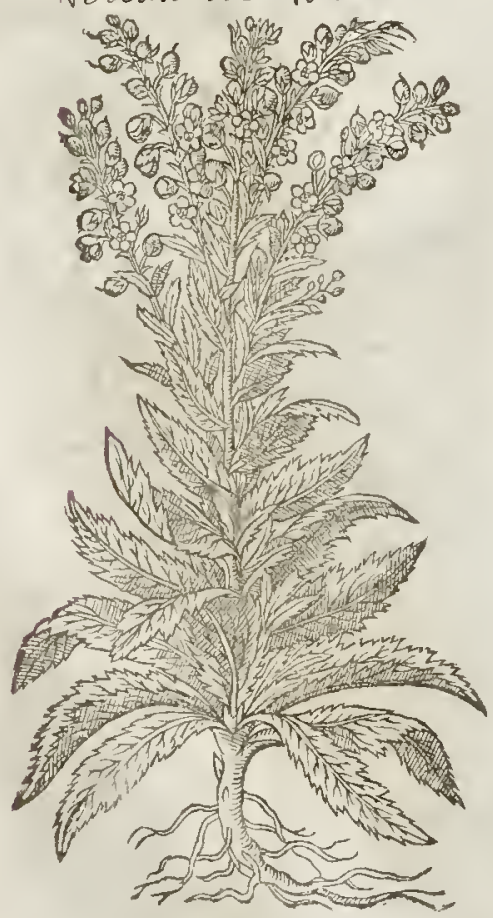

2 Blattariaflere purpureo. Purple Moth Mullein.

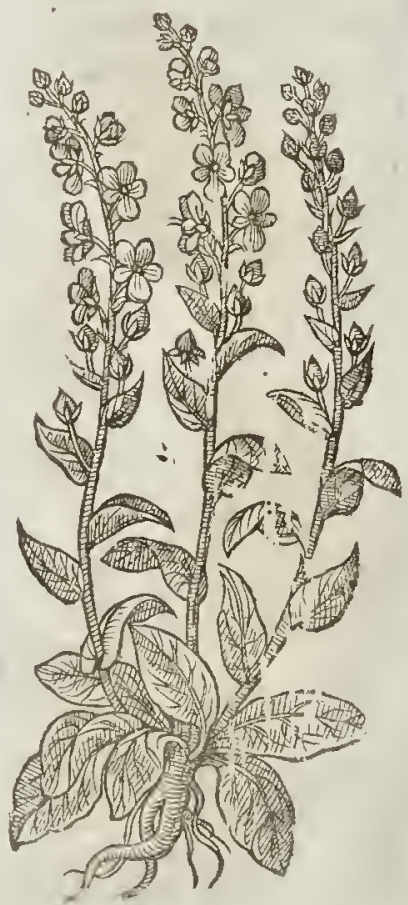




\section{The Defcription.}

1 Dinie hath fet forth a kindc of Blattaria, which hath long and fmooth leaues, fomewhat iagged or fnipt about the edges : the ftalke rifeth vp tothe height of three cubits, diuiding it felfe toward the top into fundry armes or branches, befet with yellow floures like vntoblacke Mullein.

2 Blat taria with purple floures hath broad blacke leaues, without any manifeft fnips or totches by the fides, growing flatvpon the ground: among which rifeth vp a ftalke two cubits high, garnithed with floures like vnto the common Blattaria, but that they are of a purple colour, and thofe few threds or chines in the middle of a golden colour : the root is as thick as a mans thumb, with fome threds hanging thereat,and it indureth from yeare to yeare.

3 There is another kinde like vnto the blacke Mullein, in ftalks, roots, and leaues, and other refpects, fauing that his frall floures are of a greene colour.

4 There is another like vnto the laft before written, fauing that his leaues are not fodeepely cut about the edges, and that the fmall floures haue fome purple colour mixed with the greenseffe.

* 3 Blattaria flore viridi. Greene Moth Mullein.
$¥ 4$ Blattaria fiore ex viridi purpurafcente? Moth Mullein with the greenifh purple coloured floure.
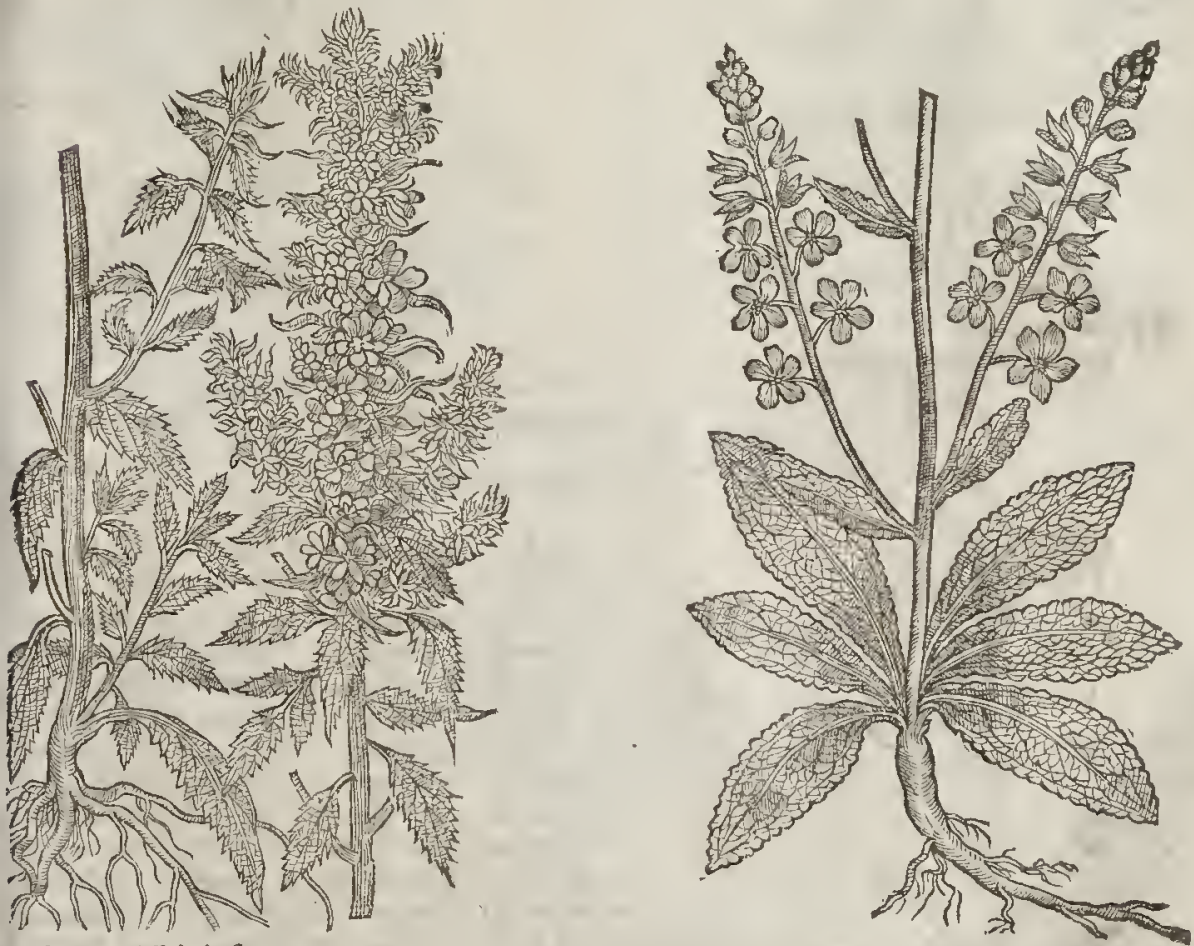

¥ 5 This is fomewhat like the firfteferibed in leasues and ftalks, buit much leffe, thefloures alfo are of a whitish or grayifh colour, and therein confifts the chiefeft difference.

6 There is alfo another varietic of this kinde, which hath very faire and large floures, and there either of a brighr yellow, or elfe of a purple colour.

7 This hath long narrow leaues like thofe of the fecond, fnipt about the edges, and of a darke greene colour : the ftaikes grow fome two cubits high, and feldome fend forth any branches; the floures are large and yel low, with rough threddes in their middles tiptwith red, and thefe grow in fuch an order that they fomewhat refemble a"flie : the feed is fmall, and contained in round buttons. This is an annua!I, and perifheth when the feed is ripe. 
¥ 5 Blatbaria flore albo.

White floured Moth Mullein.

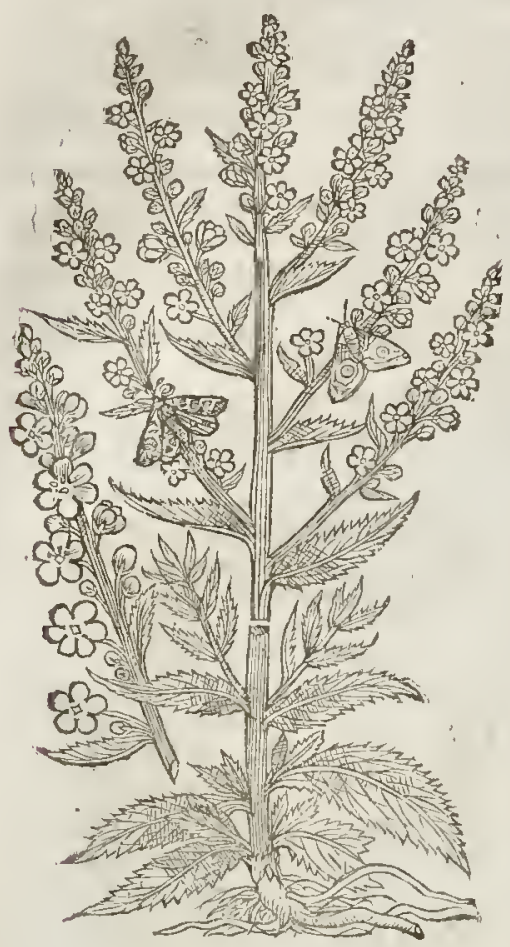

7 Blattaria flore Lutco.

Yellow Moth Mullein.

A

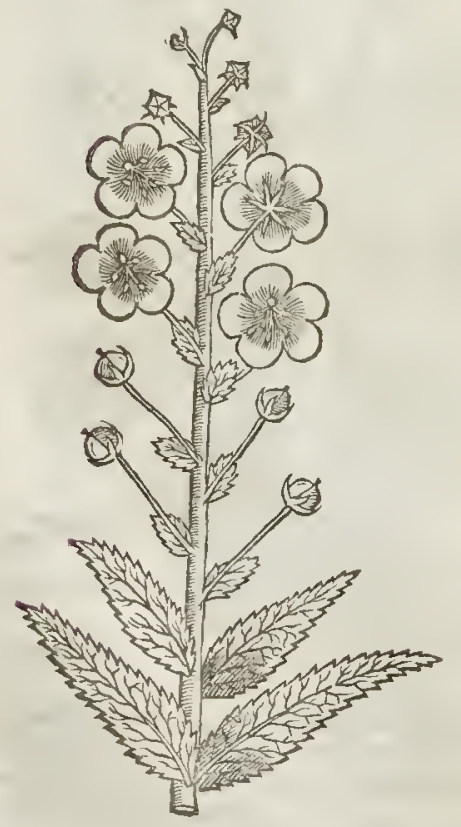

¥6 Blattaria fiore amplo.

Moth Mullein with the great foure:

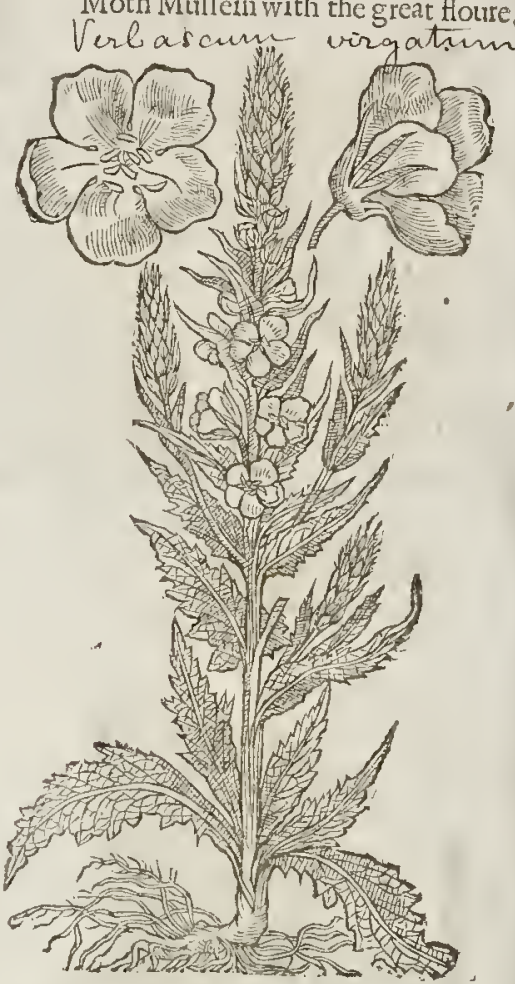

T) The Place.

$t$ The fir t and fift of thefe grow wilde in fundrie places,and the reft onely in gardens with vs. बा The Time.

They floure in Iuly and Auguft.

$$
\text { TI The Names. }
$$

The later Herbarilts call Moth Mullein by the name of Blattaria, and doe truly take it to bee that which Plinie defcribeth in his 22. bookc,cap.9. in thefe words. [ There is an herbe like Mullein, or Verbafcum nigrum, which oftentimes deceiueth, being taken for the fame, with leaues not fo white, moe falks, and with yellow floures (as weehaue written) which do agree with blacke Mullein, but we haue not as yet learned by obferuation that they do gather mothes and flies vnto them, as wee haue faid. ] Valevius Cordus names it Verbafoum Lcptophyllon, or narrow leafed Muilein:their feueral ritles fufficiently fet forth their Englifh names. 91 The Nature and Vertues.

Concerning the plants comprelended under the titles of Blattaria, or MothMulleins, I find nothing written of them, fauing that moths, butterflies, and all manner of fmall fies and bats do refort to the place where thefe herbs are laied or frewed. ¥The decoetio of the foures or leaues of the firft defcribed opcns thc obftuctions of the bowels,as alfo of the Meferaickc veins, as Camerar . affirmes. f 


\section{0}

Of the Hiftorie of Plants:

$\mathrm{L}_{1 \text { в. } 2 .}$

faue that the foures are not fo thieke thrult together as the former, and they are fairer, and fewer in number, and do not fmell fo pleafantly as the other: of whieh kinde wee haue one lately eome into our gardens, whofe foures are curled and wrinkled after a moft ftrange manner, which our wo. men haue named Iaek-an-apes on lorfebacke.

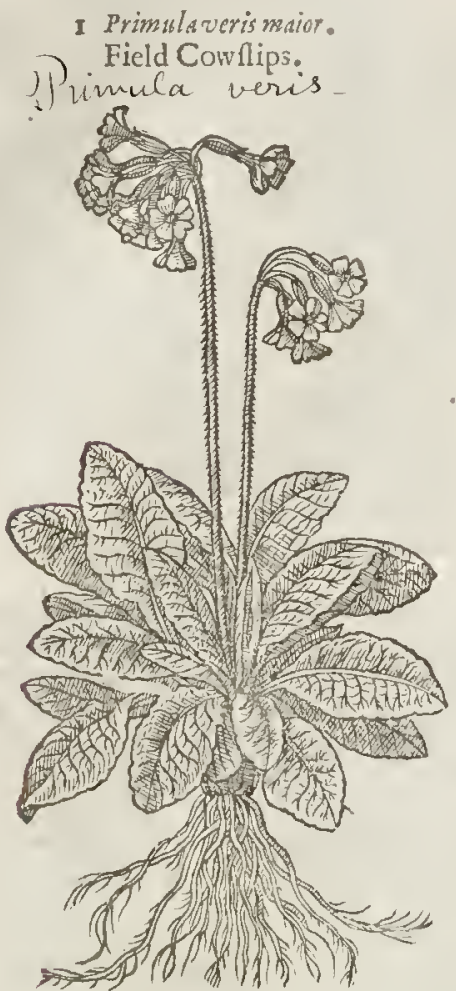

2 Primula pratenfis inodoraluten. Ficld Oxlips.

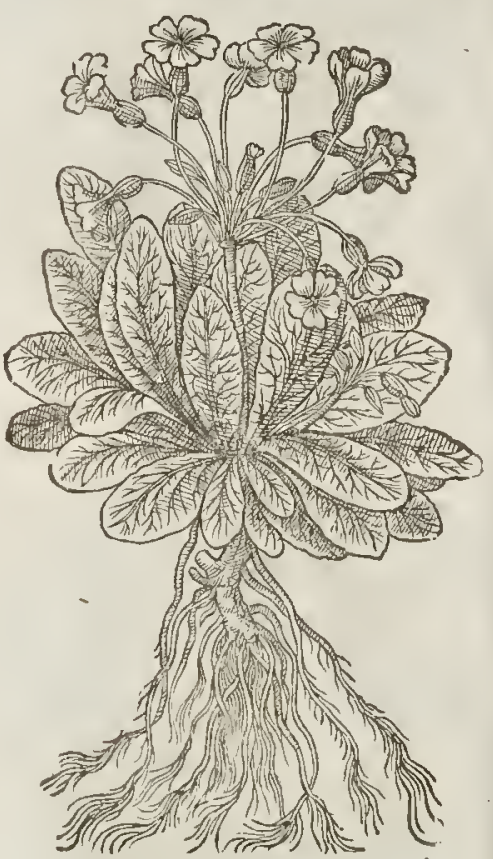

3 Double Paigle, called of Pena, Primula bortenfis Anglica omnium maxima, \& ferotinafloribus plents; that is, The greateft Englifh garden Cowflip with double yellow floures, is fo eommonly know ne that it needeth no defeription.

4 The fourth is likewife known by the name of double Cownips, hauing but one floure within another, whiel maketh the fame onee double, where the other is many times double, ealled by Pena, Geminata, for the likenefle of the floures, which are brought forth as things againft nature,or twinnes.

5 The fifth being the eommon white field Primrofe, needeth no defcription.

6 The fixth, whieh is our garden double Primrofe, of all the reft is of greateft beauty, the defeription whereof I refer vnto your owne confideration.

7 The feuenth kinde is alfo very well knowne, being a Primrofe with greenifh foures fomewhat welted about the edges: for whieh eaufe $P$ ena hath ealled it Siluarm primula, floribus obfoure virentibus fimbriatis.

8 There is a Arange Primrofe found in a wood in Yorkfhire growing wilde, by the trauell and induttric of a learned gentleman of Lancathire called $\mathrm{M}^{\mathrm{r}}$. Thomas Hesketh, a diligent feareher of Simples, who hath not onely brought to light this amiable and pleafant kinde of Primrofe, but many others likewife, neuer before his time remembred or found out. This kinde of Primrofe hath leaues and roots like the wilde field Primrofe in each refpect : it bringeth forth among the leaues a naked ftalke of a grayin or ouerworne greenifh eolour : at the top whereof doth grow in the Winter time one foure and no more, like vnto that fingle one of the field : but in the Sommer time it bringeth forth a fof ruflet huske or hofe, wherein are eontained many fmall floures, fometimes foure or fiue, and oftentimes more, very thieke thruft together, whieh maketh one.entire Houre, feening to be one of the common double Primrofes, whereas indecd it is one double floure made of a nunber of fmall fing le floures, neter ecafing to beare foures Winter nor Sommer, as before is fpecified. 


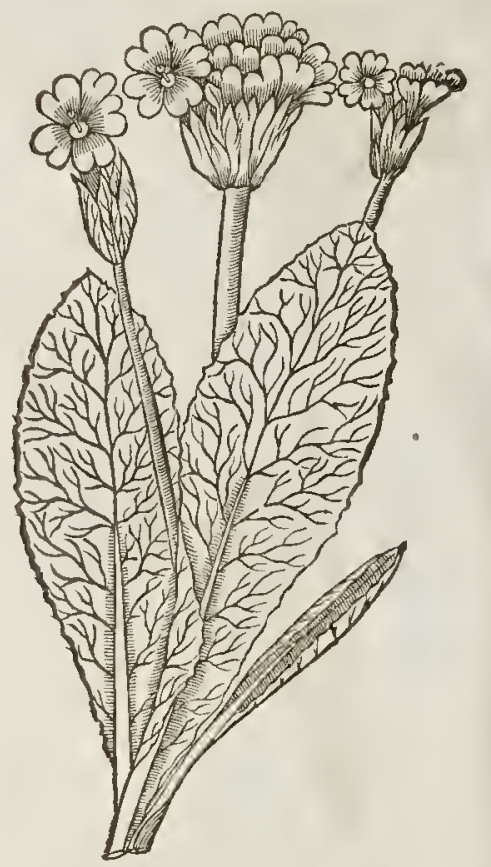

T) The place.

Cowlips and Primrofes ioy in moift and dankifh places, but not altogether conered with wa= ter; they are found in woods and the borders of fields : the Primrofe found by $M:$. Hesket $h$ growes in a wood called Clap-dale, three miles from a towno in Yorkefhire called Settle.

4. The Time.

They flourifh from Aprill to the end of May, and fome one or other of them do floure all the, Winterlong.

\section{The Names.}

They are commonly ealled Primula veris, beeaufe they are the firft among thofe plants that doe floure in the Spring, or becaufe they do floure with the firf. They are alfo named Arthritice, and Herbs paraly fis, for they are thought to be good againft the paines of the ioynts and finewes. They are called in Italian, Brache cucreli : in Englifh, Petty Mulleins, or Palfie-worts : of moft, CowIips.

The greater fort, called for the moft part Oxlips or Paigles, are named of diters Herba S.Petri. In Englifh, Oxlip, and Paigle.

The common Primiofe is vfually ealled Primula veris: moft Herbarifts do refer the Primrofes ro the qaopisu, called in Latine Verbafcola, or Petty Mulleins ; but fecing the leaues bencither woollie nor round, they are hardly drawn wnto them : for $P$ hlomides are deferibed by leaues, as $P$ liny hath interpreted it, Hirfutis e Rotundis, Hairy and round; which Pliny, lib.25. cap. 1o. tranflateth thus: Sunt of Pblomides dux Hirfute, rotundis folys, humiles: which is as much to fay in Englifh as, There be alfotwo pretty Mulleins, hairy, round leafed, low, or thort. $¥ F$ abius Columa tefers thefe to the Alifma of Diofcor,and calls the Cownlip Alifmapratorum: and the Primrole, Alifma fyluarum, $\ddagger$ IT The Temperature.

The Cownips and Primrofes are in temperature dry, and a little hot.

A The Cow lips are commended againft the paine of the ioynts called the Gout, and laekeneffe of the finewes, which is the palfie. The deeoction of the roots is thought to be profitably giuen againt the ftone in the kidneyes and bladder; and the iuyce of the leaues for members that are loofe and out of ioynt, or inward parts that are hurt, rent, or broken.

B A dramme and a halfe of the pouder of the dried roots of field Primrofe gathered in Aurumne, 
giuen to drinke in Ale or Wine purgeth by vomit very foreibly (but fafely) waterifh humours, choler, and flegme, in fuch manner as Azarum doth, experimented by a learned and skiffull Apothecaric of Colehefter $\mathrm{M}^{\mathrm{t}}$. Thomas Buck fone, a man fingular in the knowledge of Simples.

A conferue madewith the floures of Cowflips and fugar preuaileth wonderfully againft the $C$ palfie, convulfions, cramas, and all the difeafes of the finewes.

Cow lips or Paigles do greatly reftraine or ftop the belly in the time of a great laske or bloudy flix, if the decostion thereof be drunke warme.

A practitioner in London, who was fanous for curing the frenfie, after that hee had performed E his cure by the due obferuation of plyyfieke, accuftomed euery yeare in the moneth of May to diet his patients after this manner: Take the leaues and floures of Primrofe, boyle them a little in fountaine water, and in fome Rofe and Betony waters, adding thereto fugar, pepper, falt, and butter, which being ftrained, he gate them to drinke thercor firft and laft.

The roots of Primrofe ftamped and ftrained, and the inyce fniffed into the nofe with a quill or $\mathrm{F}$ fuch like, purgerh the braine, and qualificth the paine of the megrin.

An vinguent made with the iuyce of Cowflips and oyle of Linfeed cureth all fealdings or bur- $G$ nings with fire, water, or otherwife.

The floures of Primrofes fodden in vineger and applied, do heale the Kings Euill, as alfo the $\mathrm{H}$ almonds of the throat and uvula, if you gargarife the part with the decostion thereof.

The leaucs and floures of Primrofes boyled in wine and drunke, is good againt all difeafes of I the breft and lungs, and draweth forth of the flerh any thorne or fplinter, or bone fixed therein.

\section{С н в. 274. Of Birds-eine.}

1 Primulaveris fore rubro. Gied Bird-eyne.

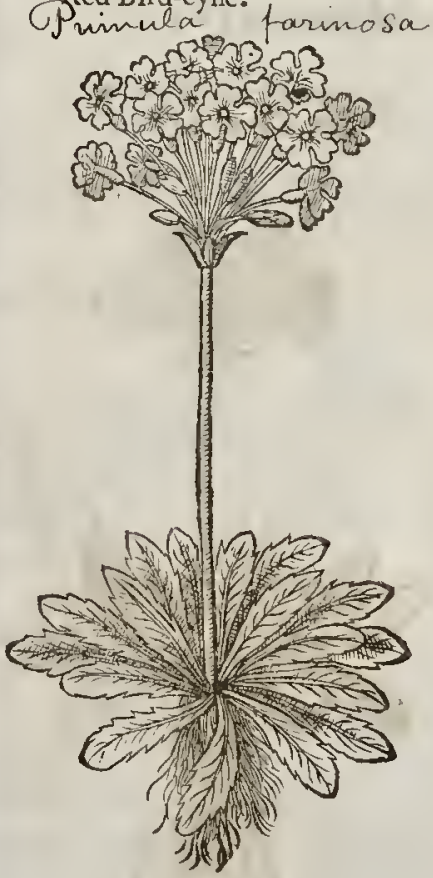

2 Primula veris flore albo. White Bird-eyne.

I Ome Herbarifts call this plant by the name of Sanienla anguftifolia, making thereof two

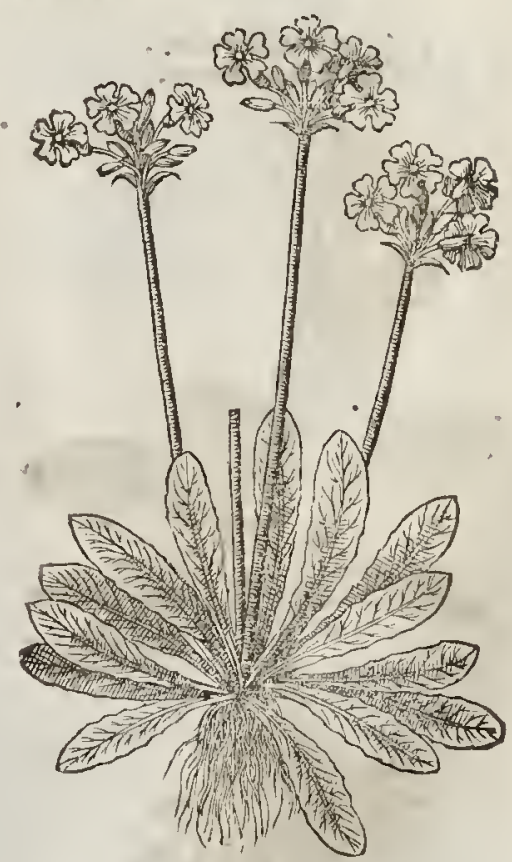

kinds, and diftinguirhing them by thefe termes, maior of minor, fute media : others cal them Paralytica alpina, which without controuerfie are kindes of Cowflips, agreeing with them as well in Ihape, as in their nature and vertues, hauing leautes much likevnto Cowflips, but fmaller, 
growing flat vpon the ground, of a faint greenith colour on the vpper fide \& vnderneath of a white or mealy colour : among which rife vp imall and tender falkes of a foot high, hauing at the top of eucry ftalke a buth of fmall floures in thape like the common Oxlip, faung that they are of a faire ftarmell colour tending to purple : in the middle of cucry fmall floureappeareth a little yellow fpor, refembling the eye of a bird; which hath moned the people of the North parts (where it aboundeth) tocall it Bircs eyne. The feed is fmall like duit, and the root white and threddy.

2 The fecond is like the firft, faung that the whole plant is greater in each refpect, and that. the floures are of a whitifh colour.

$$
\text { TiT the Place. }
$$

Thefe plants grow very plentifully in moift and fqually gronnds in the North parts of England, as in Harwood neere to Blackburne in Laneafhire,and ten miles from Prefton in Aunderneffe; alfo at Crosby, Ratenfwaith, and $\mathrm{C}_{\mathrm{rag}}$-Clofe in Weftmerland.

They likcwife grow in the medowes belonging to a village in Lancafhire neere Maudncy, called Harwood, and at Hesketh not far from thenee, and in many other places of Lancafhire, butnot on this fide Trent, that I could euer haue any certaine know ledge of. Lobel seporteth, That dodor Penny (a famous Phy fition of our London Colledge) did finde them in thefe Southerne parts.

$$
\text { IT The Timme. }
$$

They foure and flourifh from A prill to the end of May.

$$
\text { II } T \text { he Names. }
$$

The firft is called Primrofe with the red floure: the fecond, Primrofe with the white floure, and Birds cyne. aboue naned.

$$
\text { T) The Nature and Vertues. }
$$

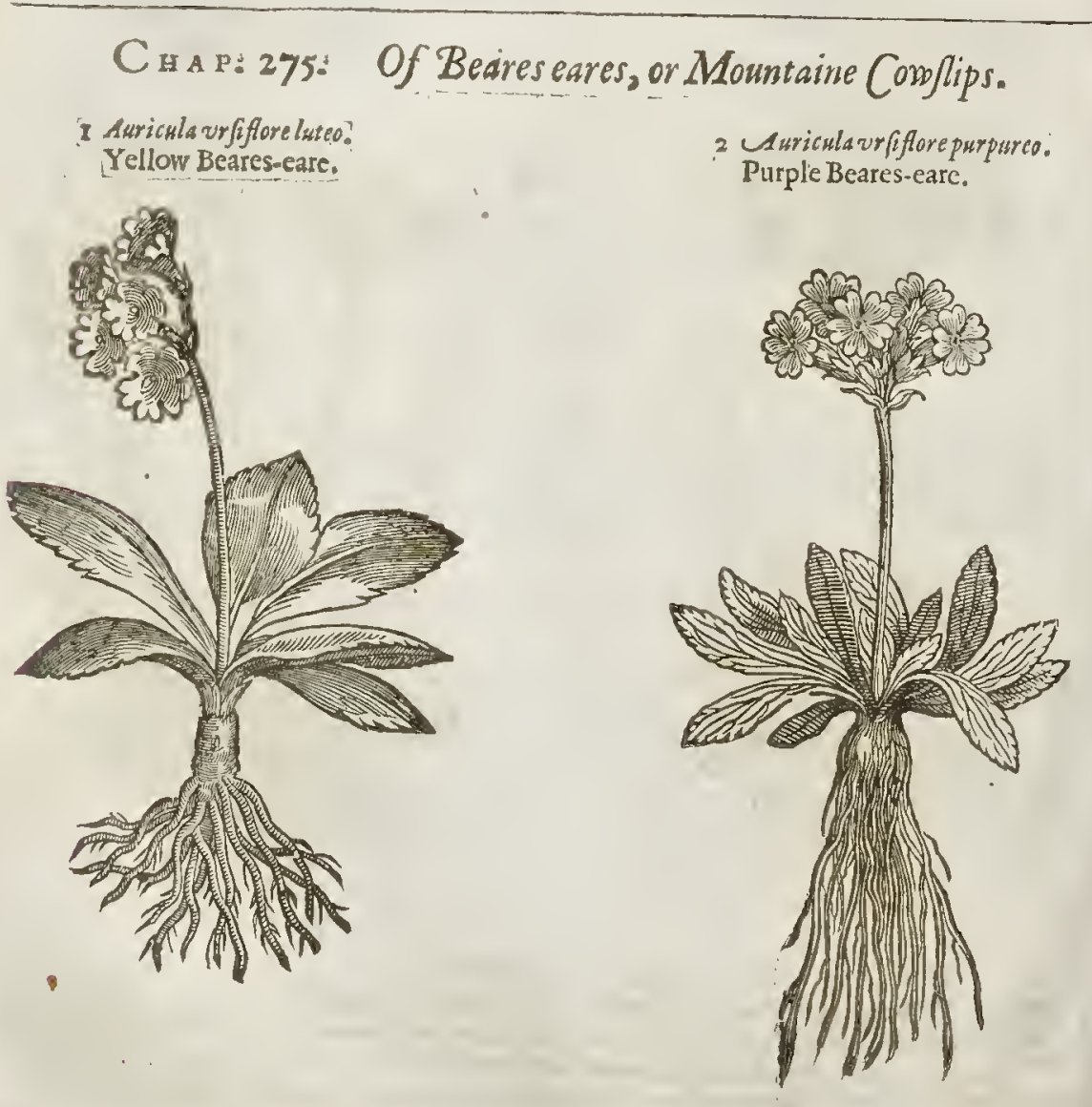


I The Kindes.

Here be diuers forts of Mountaine Corvlips, or Beares-eares, differing efpecially in the co. lour of their floures, as thall be declared, notwithftanding it may appeare to the curious, that there is great difference in the roots alfo, confidering fome of them haue knobby roots, and others threddy : notwith itanding there is no differenee in the roots at all.

$\neq$ There are diuers varieties of thefe floures, and the ehiefe differences arife, either from the leaues or floures; from their leaues, which are either fmooth and greene, or elfe gray and hoary, againe they are fmooth about the edges, or fnipt more or leffe; The floures fome are fairer then otherfome, and their colours ate fo various, that it is hard to finde words to expreffe them, but they may be refcr'd towhites, reds, yellowes, and purples; for of all the varieties and mixtures of the fe they chiefely confift. The gardens of $\mathrm{M}^{\mathrm{r}}$. Tradefcant and $\mathrm{M}^{\mathrm{r}}$. Trtygie are at this prefent furniThed with very great varicties of thefe floures. $¥$

3 Auricula Prfi $\ddot{y}$. Clarifj. Red Beares eare.

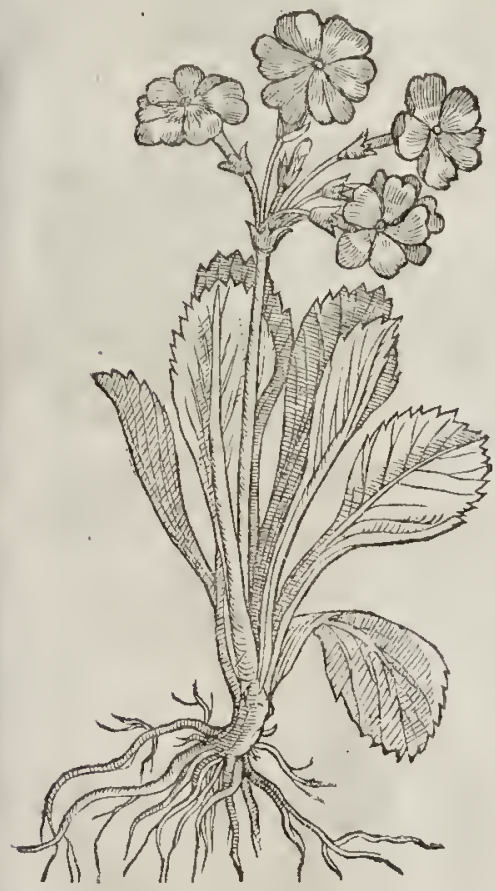

4. LariculaVriaiï. Clufy. Searlet Beares eare,

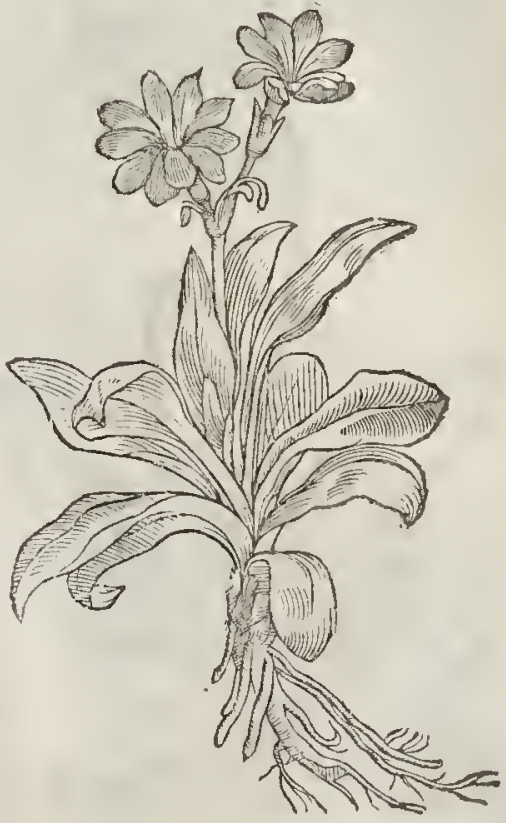

If The Defcription.

A Vricula Vrfa was ealled of Matthiolus, pena, and other Herbarifts, Sunicula Alpina, by reafon of his fingular faeultic inlrealing of wounds, both inward and outward. They do all call it $\boldsymbol{P}$ aralityca, becaufe ofhis vertues in curing the palfies, cramps, and convulfions, and is numbred among the kindes of Cowllips, whereof no doubt they are kinds, as others are which do hereafter follow vnder the fame title, although there be forie differenee in the co. lour of the floures. This beautifull and braue plant hath thicke, greene, and fat leaues, fomewhat fincly fnipt about the edges, not altogether vnlike thofe of Cowlips, but finoother, greener, and nothing rough or crumpled : anong which rifeth vp a flender round ftem a handfull high, bearing a tuft of floures at the top, of a faire yellow eolour, not murch vnlike to the floures of Oxe-lips, but more open and confifting of one only leafe like Cotiledon : the root is very threddy, and like vnto the Oxe-lip.

2 The leaues of this kinde which beareth the purple floures are not fo mueh fnipt about the edges : thefe faid purple floures haue alfo fome yellowneffe in the middle, but the floures are not fo mueh laid open as the formier, otherw ife in all refpects they are like. 
3 Carolus Clufins fetteth forth in the bookc of his Pannoniche trauels two kindes more, which he hath found in his traull oner the Alpes and other mountaines of Germanie and Heluetia, being the third in number, according to my computation : it hath leaues like the former, but longer, fmaller, and narrower toward the bottome, greene aboue, and of a pale colour vnderneath. The Houres are in fafhion like to the former, but of a noft mining red colour within, and on the out fide of the colour of a mulberry : the middle or eye of the foure is of a whitin palc colour : the root is like the former.

4 The fourth is a maller plant than any of the forefaid, whofe leaues are thicke and fat, nothing at all fnipt about the edges, greene aboue, and grayin vnderneath. The foures are like the former, hining about the edges, of an ouerw orne colour toward the middle, and in the middle commeth a forke coucred with an haitineffe : the root is blacke and threddy.

5 Awricula Vrficrubefoens.

Blum colouted Beatcs eare.

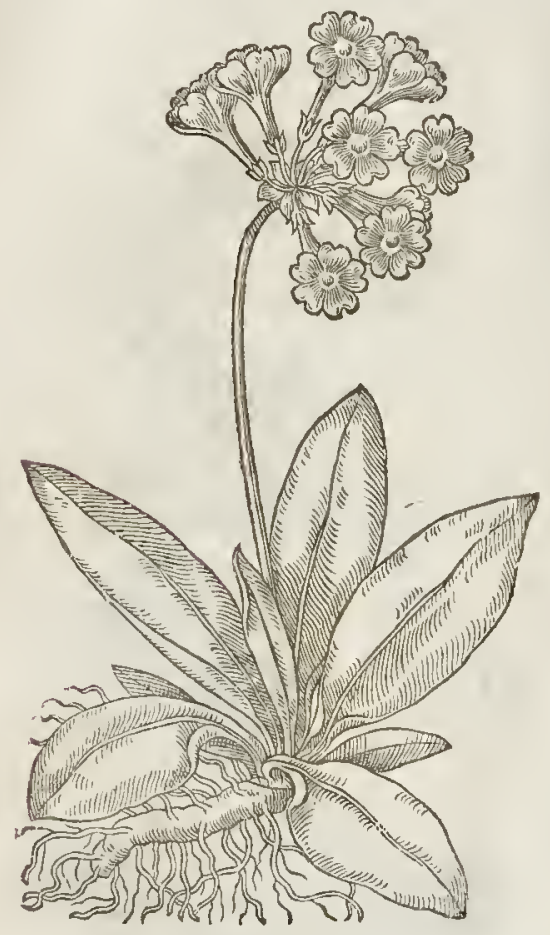

6 Auricula vyfifuane rubens. Bright red Beares eare.

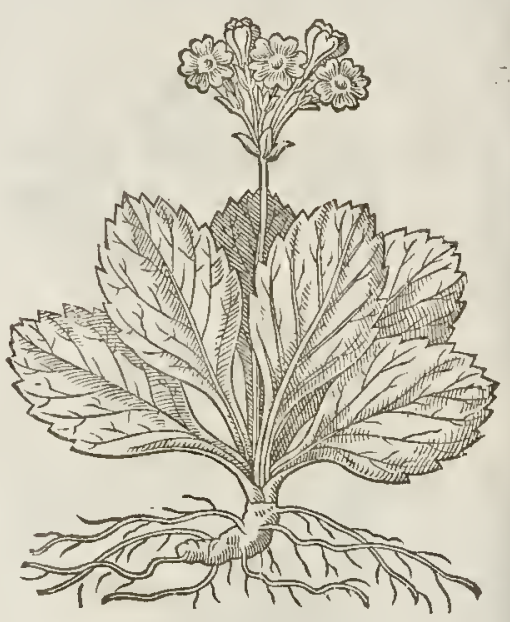

7 AuriculaVrfaminima. Stamell Beares eare.

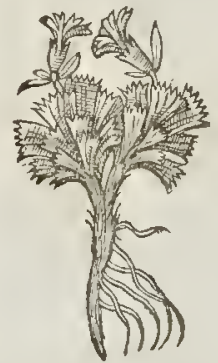

5 Thebluth-coloured Beares eare hath diutets thicke fat leaues fpred vpon the ground, of a whikifh grcen colour, fleightly or not at all indented in thc edges : among whichriferhvp a naked ftalke likewife hairy or whition, on the top whercof ftand very fairc floures, in thape like thofe of the common Cownip, but of a whitifh colour tending to purple, which wee terme bluh-colou. The root is tough and threddy, as are all the reft.

6 The bright thining red Beares cate of $M$ att hiolus defeription feemes to late Hcrbarifts to be tather a figure made by conceit or imagination, than by the fight of the plant it felf; for doubtlcfewe are perfuaded that there is no fuch plant, but oncly a figure foifted for oftentations fake, the defcription ivhereof we leaue to a furthet confideration, becaufe we have not feenc any fuch plant, neither do we beleeue there is any fuch. ₹ Our Author is hercwithout caufc iniurious to Matthiolus: for he figures and defcribes onely the common firft dcfcribed yellow Beares eare : yet if he had faid the floures wcre of a light fhining red, bc had not erred; for I haue fcen thefe floures of all the reds both bright and darke that one may imagine: $\neq$ 
7 Pena fetreth forrh a kinde of Beares eare vnder the name of Sunitula Ay ina, hauing his i ppermoft lcaues an inchlong, fomew hat iagged and hem'd ar the ends, and broad before like a thouel the lower lcaues next rhe ground are fomew hat thorrer, bur of rhe fame forme; among which rifert a fmall flender foot-ftalke of an inch long, whercon dorh ftand a fmall fourc, confifting of fiue little leaucs of a bright red or ftammell colour.

w. 8 The fnow white Beares care differcth not from the latt defcribed but in the colour of the floure, for as rhe others arc red, contrarie rhefe arc very white, and the whole planr is leffer, wherein confinteth the difference. The roor is long, tough, with fome fibres rhereto belong ing. Neither of thefe two laft deferibed will be content to grow in gardens.

$$
\text { Tf The Place. }
$$

They grow naturally vpon rhe Alpith and Heluetian mountaines : moft of them do grow in our London gardens.

Thefe herbes do floure in Aprill and May.

$$
\text { 4T The Time. }
$$

$$
\text { T The Ninmes. }
$$

Either the antienr writers knew not thefe plants, or elfe rhe names of them were not by rhem or their fucceflors diligenrly commirted vnro pofteritie. Gatthiolus and other larer writers faue giuen names according ro the fimilitude, or of rhe thape rhat they bcare vnro other plants, according to rhc likeneffe of the qualiries and operations: you may call it in Englih, Beares eare : they that

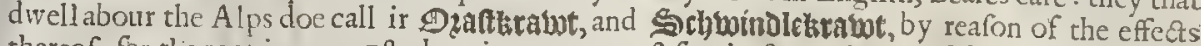
thereof; for the root is amongft them in grcat requeft for rhe ftrengthning of the head, rhat when they are on the tops of places that are high, giddineffe and the fwimming of the braine may not afflict rhem : ir is there called the Rocke-rofe, for that it groweth wpon the rockes, and refembleth the brame colour of rhe Rofe. $\neq F$ abium Colums proues this to be the Alifm or $D$ amafomm of $D i$ oforides and rhe Antients.

Thefe herbes are dry and very aitring The Thature.

\section{TheVertues.}

It healerh all outward and inward wound of the breft, and the enterocele alfo, if for fome realo- A nable fpace of time ir be put in drinkes, or boyled by itfelfe.

Thefe planrs are of the nature and temperature of Primula ver is, and are reckoned amongtt the $B$ Sanicles by rafon of rheir vertue.

Thofe thar hunt in rhe Alps and high mountaines after Goats and Bucks, do as highly cfteeme hereof as of Doronicsm, by rea fon of the fingular effects that it hath, but (as I faid before) one efpecially, cuen in that it preuenterh rhe loffe of their beft ioynts (I meane their neckes) if they take the roots hercof before rhey afcend the rocks or other high places:

* The root of Damafonimm (according ro Diofcorides) taken in rhe weight of one or two drams, D helpeth fuch as haue deuoured the Lepus marizus or fea Hare, or haue been bitten by a Toad, or taken too great a quantitic of opium.

It is alfo profitably drunke, cither by it felfe, or with the like quantitie of $D_{\text {auc }}$ feeds, againft $\mathbf{E}$ gripings in the belly, and the bloudy flux.

Alfo ir is good againft convul fions and the affects of the wombe.

The herbe ftayes rhe fluxes of rhe belly, moves the courfes, and appled in forne of $\mathrm{F}$ Thageth oedematous tumors. $\neq$

\section{CHA . 276. Of MTountaine Sanisle.}

\section{g) The Kindes.}

THere be fundry forts of herbes contained vnder the name of Sanicle, and yet not one of them agreeing wirh utr common Sanicle, called Diapenfun, in any one refpect, except in the vertues, whereof no doubt they rooke that name; which number doth dayly increafe, by reafon that the later writers hate put downe more new plants, not written of before by the Antients, which fuall be diftinguifhed in this chapterby feuerall titles.

$$
\text { TI The Deforiptions. }
$$

I Potted Sanicle of the mountaine hath frnall fatis round leares, bluntly indenred abour the edges, and farhioned like vnto the leaues of Suxifr.sgia duret; or rather Cydlaimen folio

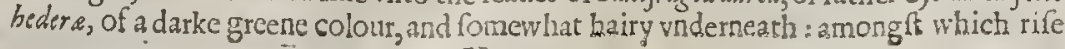

Vuu? 


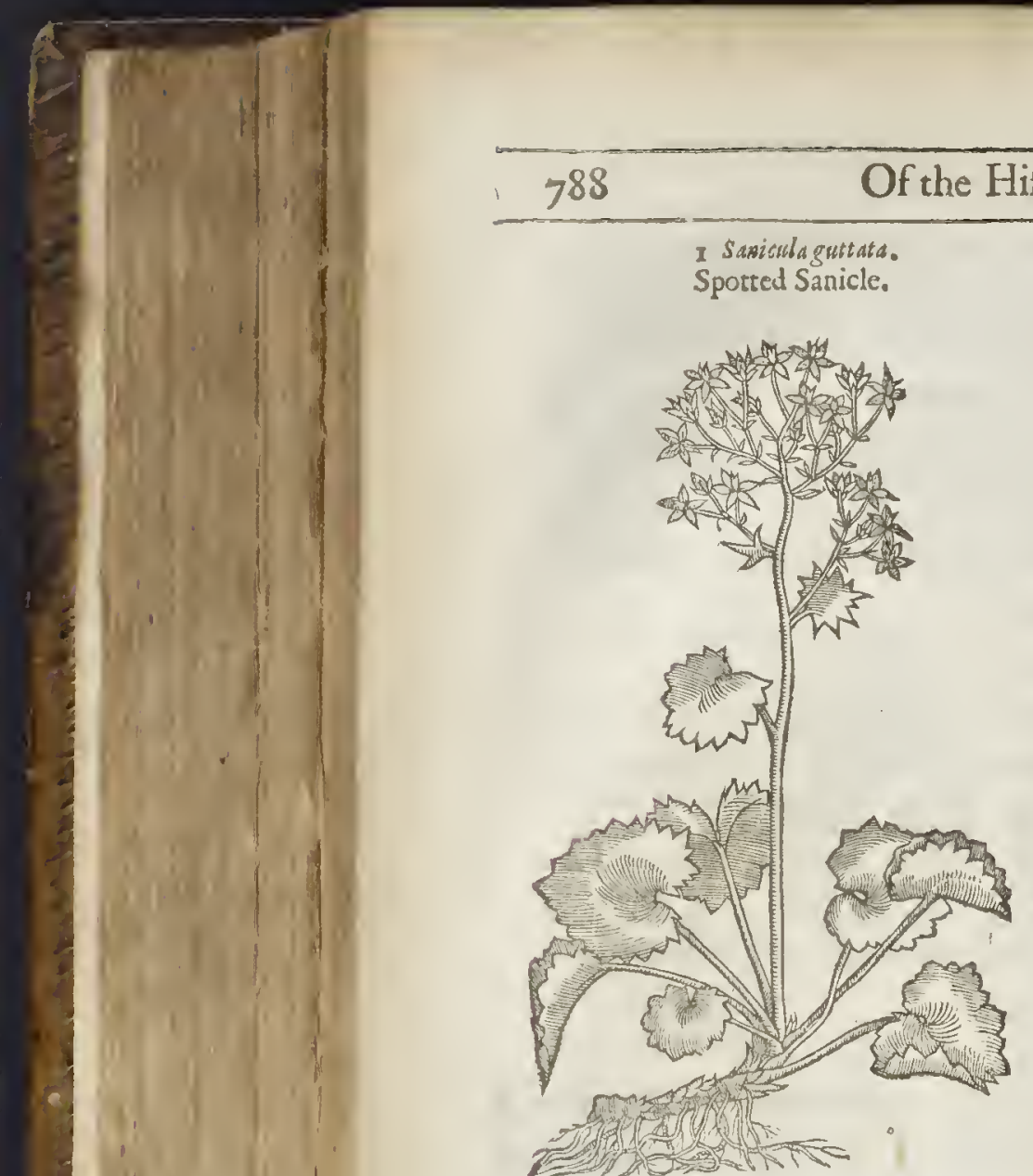

$L_{1}$ B. 2.

I Saxisuld guttata.

Spotted Sanicle.

3 Saricula Alpira Clufij, fue Cortufa Matthioli: Beares eare Sanicle.

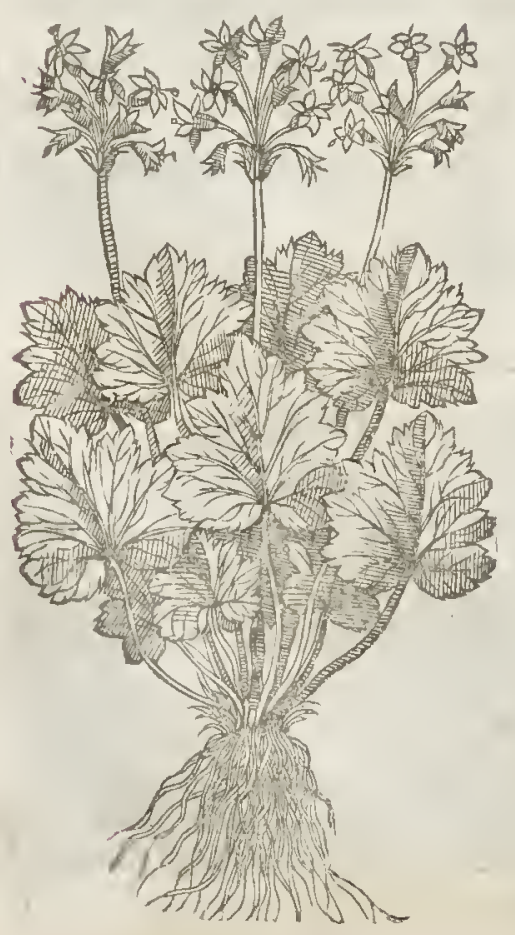

2 Pingwicula fime Samicula Eboracenfis. Burterwort, or Yorkthire Sanicle. Pingricula irelgaris-

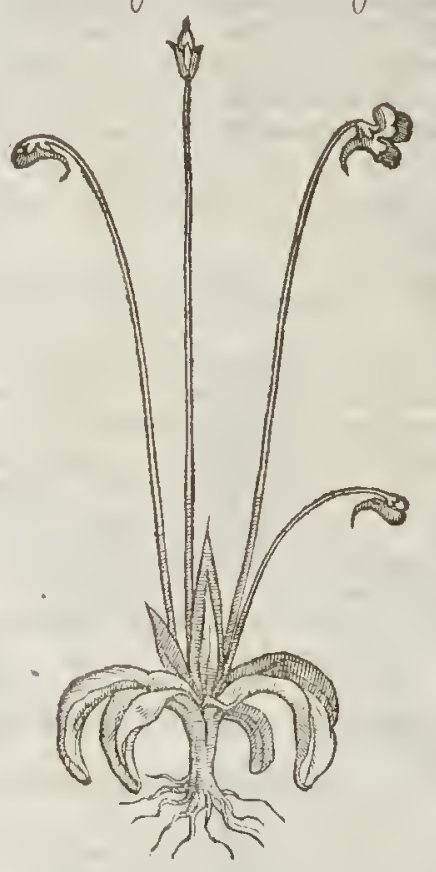

up fundry ftalkes, befer with like leaues, buic fmaller, and of a cubit high, diuiding themfelues inro many fmall armes or branches, bearing diuers litrle white floures, fpotted mof curioufly with blondy fpecks or prickes, infomuch that if you marke the admirable workemanthip of the fame wrought in fuch glorious manner, it muft needs put euery creature in minde of his Creator : the floures are in fmell like the May floures or Hawthorne: the feed is fmall and blacke, conrained in frall poinrals like vnto white Saxifrage:the root is fcaly and full of frings.

2 The fecond kind of Sanicle, which clsfins calleth Pinguicula, not before his rime remembred, hath fmall thicke leaues, fat and ful of iuyce, being broad towards the root, and Tharpe towards the point, of a faint greene colour, and bitter in tafte: our of the middeft wherof fprouteth or fhooteth vp a naked flender ftalke, nine inches long, ewery ftalke bearing one floure and no more, fomerimes whtte, and commonly of a blew ih purple colour, fafhioned like vnto the common Confalida regalis, hauling the like fpur or Larks lieele anexed the"cto.

3 The third kinde of mounraine Sanicle fome 
fome Herbarifts haue called sanicula alpina flore rubro: the leaues fhoot forth in the beginning of the Spring, very thicke and fat, and are like a purfe or round lumpe at their firft comming out of cleground; and when it is fpred abroad, the vpper part thereof is full of veines or finewes, and houenyp or curled like Raruxculus Luffanucus, or like the crumpling of a cabbage leafe; and are nor onely indented about the edges, but each leafe is diuided into fix or more iagges or cuts, deepely hacked, greenifh abone, and of an oucworne greene colour vndurne a h, hor in tate, fron che middle whereof thooteth forth a bar ur maked ftalke, fix inches long, fomewhat purple in crifour, bearing $2 t$ the top a tuff of fmall hollow floures, looking or hanging downicw arcis like little bells, not vnlike in forme to the common Cowllips, but of a fine deepe red colour tending to purple, haung in the middle a certaine ring or circle of white, and alfo certaine pointals or ftrings, which turne into an head wherein is contained feed. The whole plant is conered as it werewith a rough wool. lineffe : the root is fibrous and threddy.

\section{T The Place.}

Thefe plants are ftrangets in England; their naturall countrey is the Alpifh mountains of Heluetia: they grow in my garden, where they fourith excedingly, except Butterw ort, which groweth in our Englifh fqually wet gtounds, and will not yeeld to any culturing or tranfplanting : ic groweth efpecially in a field called Crag-Clofe, and at Crosby, Ratenfwaith, in Weftmerland, vpon Ingleborow fels twelne miles from Lancafter, and in Harwood in the fanie countie neere to Blackbume, ten miles from Prellon in Aunderneffe vpon the bogs and marifh grounds, and in the boggie medowes about Bifhops Hatfield, and alfo in the fens in the way to Wittles meare from London, in Hiuntingatonihire. $\ddagger$ It groweth alfo in Hamprhire,and aboundantly in many places
of Wales. $\neq$

They floureand fout ith from May to the end of Itrly.

$$
\text { II The Names. }
$$

The firft is called Saniculn guttata, taken from the fpots wherewith the floures ate marked : of $L d$ bel,Geitm Alpinzm, making it a kind of Auens : in Englifh, fpotted Sanicle: of our London dames, Pratling Parnell.

The fecond is called Pingwisulu, of the fatneffe or fulneffe of the leafe, or of fatning: in Yorkethire, where it doth efpecially grow; and in greateft aboundance, it is called Butterworts, Butterroot, and white toot; but the laft namebelongeth more ptoperly to Solomons Seale.

They ate hot and dry in the third degree.

$$
\text { 1T The Temperatureand Vertues: }
$$

The husbandmens iviues of Yorkfhire dovfe to anoint the dugs of their kine witl the fat and A oilous iuyce of the hetbe Butterw ort, when they are bitten with any venomous worme, or clapped, rifted, and hurt by any other meanes.

They fay it rots their theepe, when for want of otlier food they eat thereof.

\section{Сн м. 277. Of Fox-Gloues.}

The Defcription.

I Fox-gloue witl the purple foute is moft common ; the leanes whereof are long, nicked in

$F$ the edges, of a light greene, in manner like thofe of Mullein, but leffer, and nor fodownie: the ftalke is ftraight, from the middle whereof to the top ftand the foures, fet in a courfe one by another vpon one fide of the ftalke, hanging downwards with the bottome vpivard, in forme long, like almoft to finger ftalks, whereof it tooke his name Digitalis, of a red purple colour, with certaine white fpots datht within the floure; after which come vp round heads, in which lics the feed, fomew hat browne, and as fmall as that of Time. The roots are many flender ftrings.

2 The Fox-gloue with white floures differs not from the precedent but in the colour of the floures; for as the others were purple, the fe contrarivife are of a millse-w hite colour.

3 We haue in our gardens another fort hereof, which bringeth forth moft pleafant yellow foures, and fomewhat lefe than the common kinde, whercin they differ. $\ddagger$ This alfo differs from the commonk ind in that the leates are much fmoother, natrower, and greener, hauing the nerues or vrines running alongft it, neither are the nerites fnipt, nor linuated on their edges. $¥$

4 We haue alfo another fort, which we call Digitalis ferrug inea, whofe foures are of : lour of rufty iron; whereofit tooke his name, and likewife maketh the difference. Of this fort there is a bigger and a leffer; the bigger hath the lower leates fome foor long, of a darke green colour, with veines running along them; the ftalks are fome yard and halfe high: the flowes lorge- 
I Digitalis purpurea.

oy Purple Fox-gloues. Oyu laki

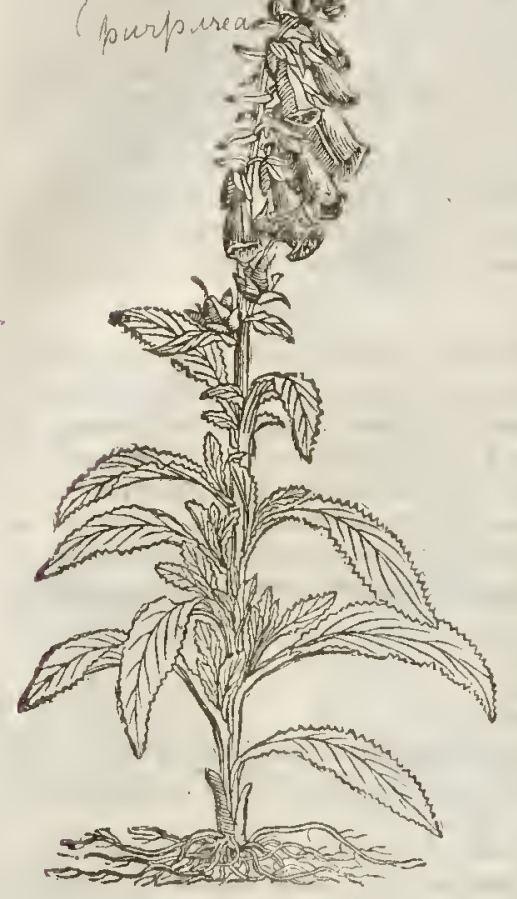

¥ Digitalislutea: Yellow Fox-gloues. Igitalis graudiffora

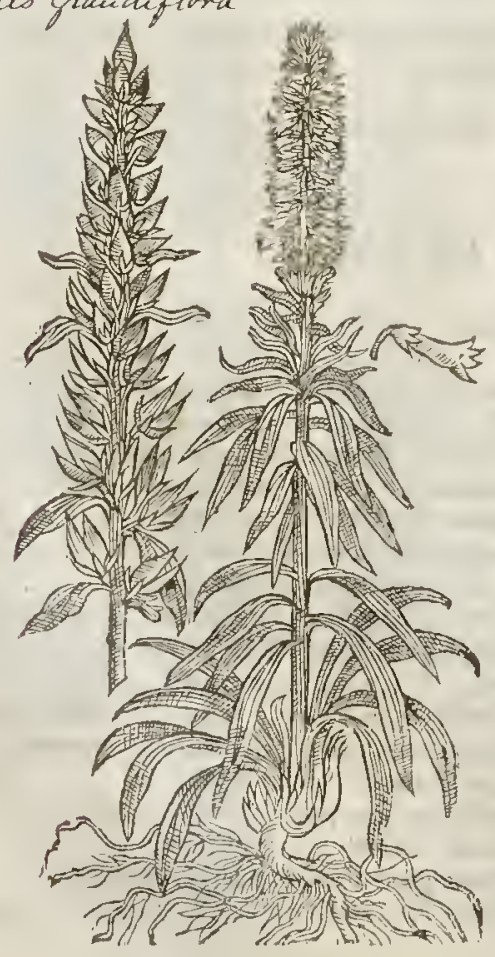

2 Digitalis alba. White Fox-gloues.

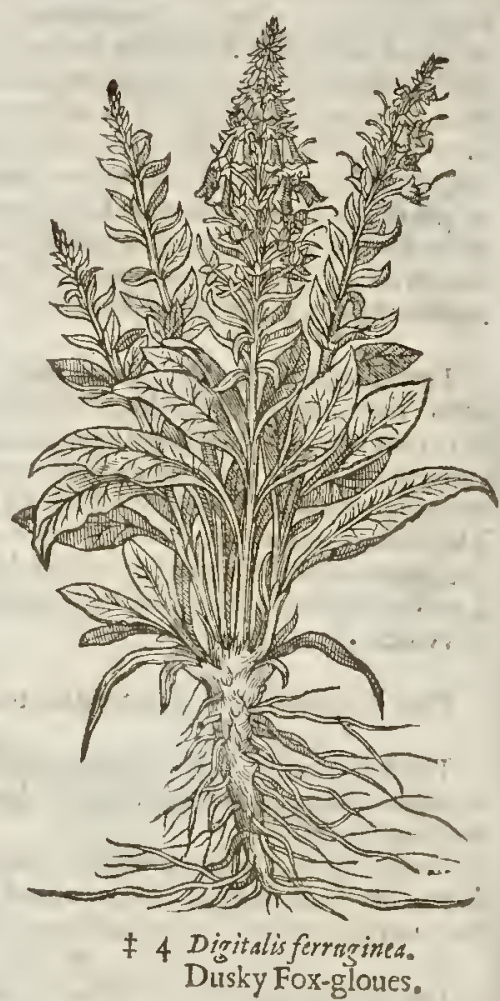

15

100

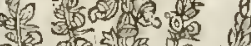

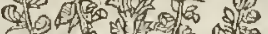

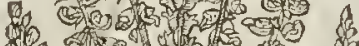
4 dis Y s. VIN क्ष

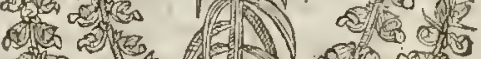

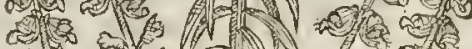

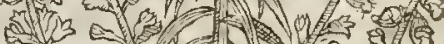

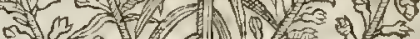

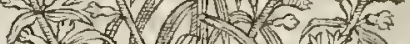

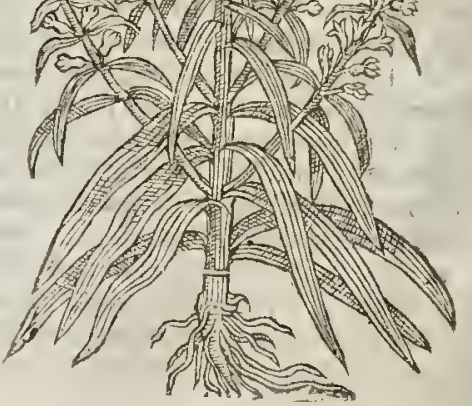



and ending in a fharpe turncd vpend as you fee in the figure, and they are of a ruftie colour, mixed
of a yellow and red.

5 The le fer duskie Fox-gloue hath much Icffe leaues and thofe narrow, fmoorh, and exceeding greene: among f whicli comes vp a ftalke fome foot high, hauing fmall floures of the colou of the laft deferibed. This I obferued the Ia f yeare 1632 , in floure with $\mathrm{M}^{5}$. Iobn I radefcant in the middle of Iuly. It may fitly becalled Digitalis ferruginea minor, Sinall duskie Fox-gloues. बा The Place.

Fox-ǵlone groweth in barren fandie grounds, and wnder hedges almoft cucry where.

Thofe with white foures do grow naturally in Landefdale, and Crauen, in a field called Cragge clofe, in the North of England: likewife by. Colchefter in Effex; necre Exeeftcr in the Weft parrs, and in fome few other places. Thc other two are ftrangers in England, neurtheleffe they do gtow with rhe others inny garden.

They floure and flourith in Iune and Inly. The Time.

$$
\text { It The Names. }
$$

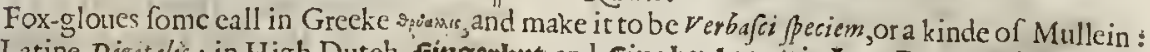
in Latine, Digitalis : in High Duteh, fritgerbut, and fingher ktaut: in Low Dutch, ttinger boct: in French, G smes noftre dame $:$ in Englin, Fox-gloues. $¥$ Fabius Columnathinks it to be that Ephemacrum of Diofcorides defcribed in his fourth booke, and cap.75.

\title{
If The Temperature.
}

The Fox-gloues in that they ar e bittcr,are hot and drie,with a certaine kinde of clcnfing qualitie ioined therewith;yet are they of no vf, neither haue they any place amongft medicines, aceording to the Antients.

\section{I he Vertues.}

Fox-gloue boiled in water or winc, and drunken, dotl cut and confume the thicke toughneffe of $A$ groffe and flimie flegme and naughtic humours; it openeth alfo the ftopping of the liuer, fpleene,
and nilt, and of other inward parts.

The fame taken in like manner, or boiled with honied watcr or fugat, doth feoure and clenfe the $B$ breft, ripeneth and bringech forth tough and clammie flegmé. They ferue for the fame purpofes whereunto Gentian doth tend, and harh beene vfed in ftead $C$
thereof,as $G$ alen faith.

$\neq$ Where or by what name Galen cither mentions, or affirmes this which our Authour cites $D$ him for, I mult confeffe I am ignorant. But I probably conie Aure that our Authour would haue faid Fuchfirs: for I onely finde him to hauc thefe words fet downe by our Authour, in the end of his Chapter of Digitalis. $\neq$

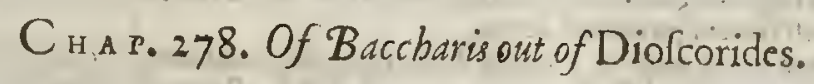

\author{
I The Defoription.
} Bout this plant Baccharis thcre hath becne great contention amongft the old apd new
writers; CMatthiolus and Dodon eus haue miftaken this plant, for Coniza maior, or Coni-

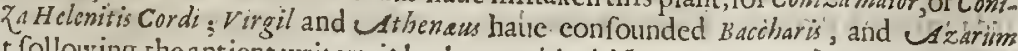
together : but following the antient writcrs, it ha th many black ifh roughl leaues, fomewhat bigger than the leates of Primrofe: among ft which rifeth vp a falke two eub its high, bearing at the top little chaffic or $f(a)$ ic floures in mall bunches, of a darke yellowinh or purple colour, which turne into downe, and are carried aw ay with the winde, like vnto the kindes of thiftles : the root is thiek, groffe, and fat, fpreading about in the earth, full of ftrings: the fragrant fmell that the root of this plant yeeldeth, may wcll be compared vnto the fauour of Cinnamon, Helenium, or Emila Campana becing a plant knowne vnto rery many or moft forts of people, I meane in moft parts of Eng.
land.

$$
\text { I The Place. }
$$

Bacbharis delighteth to grow in rough and craggy places, and in a leane foile where no moiture 


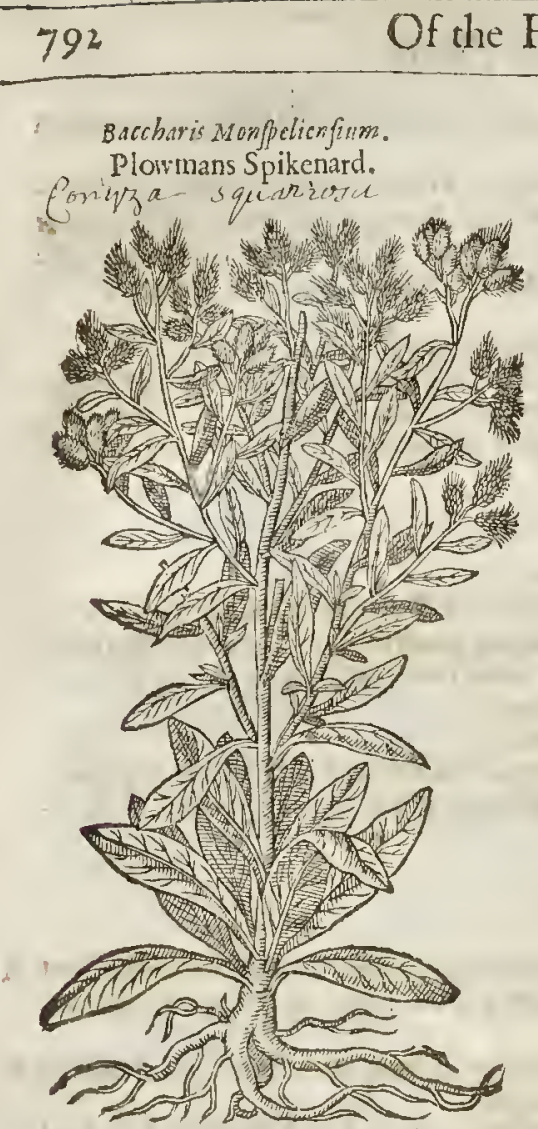

$L_{1 \text { B. } 2 .}$

is : it groweth very plentifully about Montpellier in France, and diucrs places in the Weft parts of England.

$$
\text { I The Time. }
$$

It fpringeth vp in April,it foureth in Iune, and perfecteth his reed in Auguit.

$$
\text { it The Names. }
$$

The learned Herbarifts of Montpellier have called this plant Baccharis : the Greci-

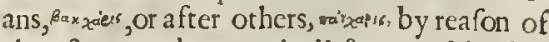
that fiveet and aromaticall fauour which his root containeth and yceldeth : in Englin it may be called the Cinamom root, or Plowmans Spiknard: Virgill in his fo uenth Eeloge of his Bucolicks maketh mention of Bacchares,and doth not onely fhew that it is a Garland plant, but alfo fuch a one as pretiaileth againft inchantments; faying,

Cingite, ne vatu noceat malal lingua futuro.

With Plowmans Nard my forchead girt, Left euill rongue thy Pret lure.

Baccharis is likewife an ointment in Athemeus, in his 15 booke, which may take his name of the fivect lierbe Buccharis: for as Pliny writeth, Arislophanes of old,being anantient comical Poet witneffeth, that ointments were wont to bee made of the root thercof: to bee briefe, Cratcras his Afartm is the fame that Diofcorides his Baccharis is. $\neq$ This plant here defcribed is the Coniza mutior of Matthioluts, Tragus, and others. $\neq$

$$
\text { TI The Temperature. }
$$

Bacchar is cr Plowmans Spiknard is of temperature very aftringent or binding.

$$
\text { Ti The Vertues. }
$$

A Baccharis, or the decnction of the root, as Paulus a Eineta briefely fetteth downe, doth open the pipes and paffages that are ftopped, prouoketh vrine, and bringeth downe the defired fieknefic: the leates thercot for that they are aftringent or binding, ftop the eonrfe of fluxes and rheumcs.

B Baccharis is a fingular remedic to heale inflammations and Saint Anthonics fire, called Igaris $\int a-$ $\mathrm{eer}$; and the fmell thereof prouoketh fleepe.

C The decoction of the roots of Bacchar is helpeth ruptures and convulfions, thofe alfo that have falne from an high place, and thofe that are troubled with the thortneffe of brcath.

D It helpeth alfo the old cough, and difficultie to make water.

E When it is bod in wine it is gituenwirh grcat profit againft the bitings of Scorpions, or any venomous beat, being implaiftered and applied thereto.

F A bath made thereof and put into a clofe ftoole, and receined hor, mightily voideth the birth, and furthereth thofe that hane extre ame labour in their childing, cauring them to have eafie deliuerance.

\section{Char. 279: Of Elecampane.}

\section{T) The? Defoription.}

TLecampane bringeth forth prefently from the root great white leates, fharpe pointed, almolt Elike thofe of great Comfrey; but fort, and coured with a hairie downe, of a whiting grecne eo- 


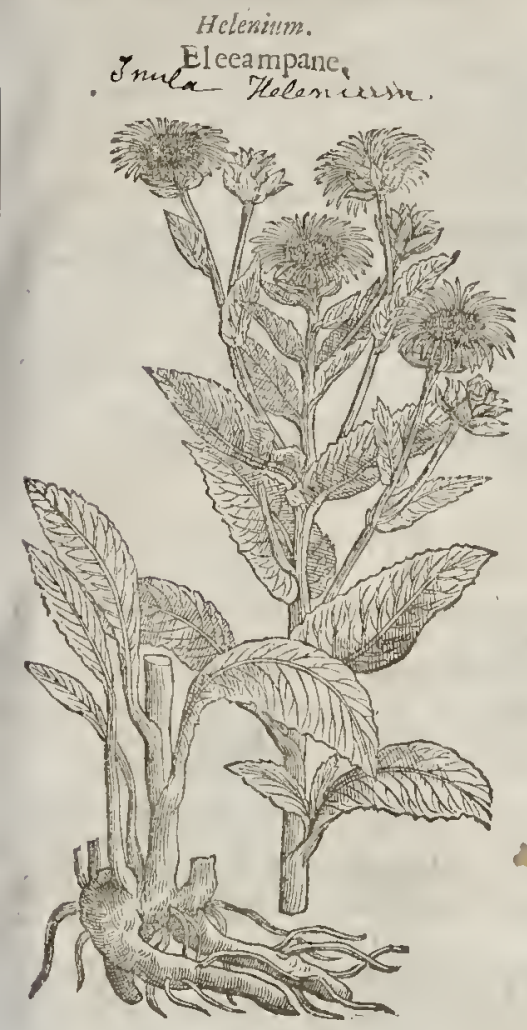

lour, and are morcwhite indernearh, flejghily nicked in rhe edges : the ftalke is a yardand a . halfe long, about a finger thieke, not without downe, diulded at the top into diuers-branehes, vpon rhe top of euery fprig ftand great floures broad and round, of which not only the long fima ] leaues that compaffe round about ate yellow, but alfo the middle ball or circle, which is filled vp with an infinit number of threds, and at length is curned into fine downe; under which is nender and long feed : the toot is vneuen, thicke, and as much as a man may gripe, not long, of rentimes blackith without, white within, and full of fubAtance, fiveet of finell, and birter of rafte.

$$
\text { T) The Place. }
$$

Ir groweth in medowes that are fat and fruitfull: it is alfo oftentimes found vpon mountains, Thadowie places, that be not altogerher dric : it groweth plenrifully in the fields on the lefr hand as you go from Dunftable ro Puddle hill: alfo in an orcharí as you go from Colbrook to Ditton ferry, which is the way to Wind for, and in fundry other plaees, as at Lidde,and Folkeftone, necre to Douer by the fea fide.

$$
\text { I) TheTime. }
$$

The floures are in their braterie in Iune \& I I . ly: the roors be gathered in Autumne, and ofren. times in Aprill and May.

$$
\text { T The Names. }
$$

That whiel the Grecians name inis the La. tines call Inula and Enula : in Thops Enula campana : in high Dutch, all antwouttr:in low Dutch, allandt wottele : in Italian, Enoa, and Enola :irespanith, Ratz del alla : in French, Erula Campane : in Englith, Elecampane, and Scab-woort, and Horfe-heale: fome report that this plant tooke the name Helenium of Helena wife to Menelaus, who had her hands full of it when $P$ wis is fole her away
into Phrygia.

\section{9f The Temperature.}

The root of this Elceampane, is maruellous good for many things, being of naturc hot and drie in the third degree, efpecially when it is drie: for beeing greenc and as yet full of iuice, it is full of fuper fuous moifture, which fomewhat abateth the hot and drie qualitie thereof.

$$
\text { of The Viertues. }
$$

It is good for thormeffe of breath, and an old cough, and for fuch as canrot breathe vnleffc they A
old their necks vpright. hold their necks vpright.

It is of great vertue both giuen in a looeh, which is a medicine to be licked on, and likewife pre- B ferted, as alfo otherwife gituen to purge and void out thicke, tough,and clammichumours, which fticke in thecheft and lungs.

The root preferued is good and wholefome for the ftom tek :being taken after fupper it doth not $\mathrm{C}$ onely helpe digeftion, but al fo keepeth the belly foluble.

The inice of the fame boiled, driteth forth all kinde of wormes of the belly, as Pliny teacheth: who alfo writeth in his twentic booke, and fift chapter, the fame being chewed fafting, doth faiten
the teeth.

The root of Elecampane is with good fuceefe mixed with counterpoifons: it is a remedie a- D gainlt the bitings of ferpenrs, it refifteth poifon : it is good for them that are burftenand troubled
with cramps and convulfions.

Somealfo affirme, that rhe decoltion thereof,and likewife the fame beaten into powder and E mixed with honie in manner of an ointment, dorh clenfe and heale vp old vicers.

Galen faith, that herew irh the parts are ro bemade red, whieh be vexcd with long \& cold griefs: F as are diuers paffons of the huckle bones, called the Seiatica, and little and continual bunnies and loofeneffe ofcertaine ioints, by reafon ofouermuch moifure. 
I The decoction of Enuladrunken, prouoketh vrine, and is good for them hat ate yrieured with in ward burftings, nr haue any member out of ioint .

I The root taken with honic or fugar, made in an electuarie, clenfeth the breft, ripeneth tough flegme, and maketh it eafie to be fpet forth, and preuaileth might ily againft the cough and nefle of breath, comforteth the ftomacke alfo, and lielpeth digeftion.

$\pi$ The toots condited after the manner of Eringos feruet hor the purpofes aforefaid.

I. The root of Enwla boiled very foft, and mixed in morter with frefh butter and the pouder of Ginger,maketh an excellent ointment againt the itch, fcabs, mangineffe, and fuch like.

$M \quad T h e$ roots are to be gathered in the end of September, and kept for fundrie ves, but it is efpecially prefertued by thofe that make Succade and fuch like.

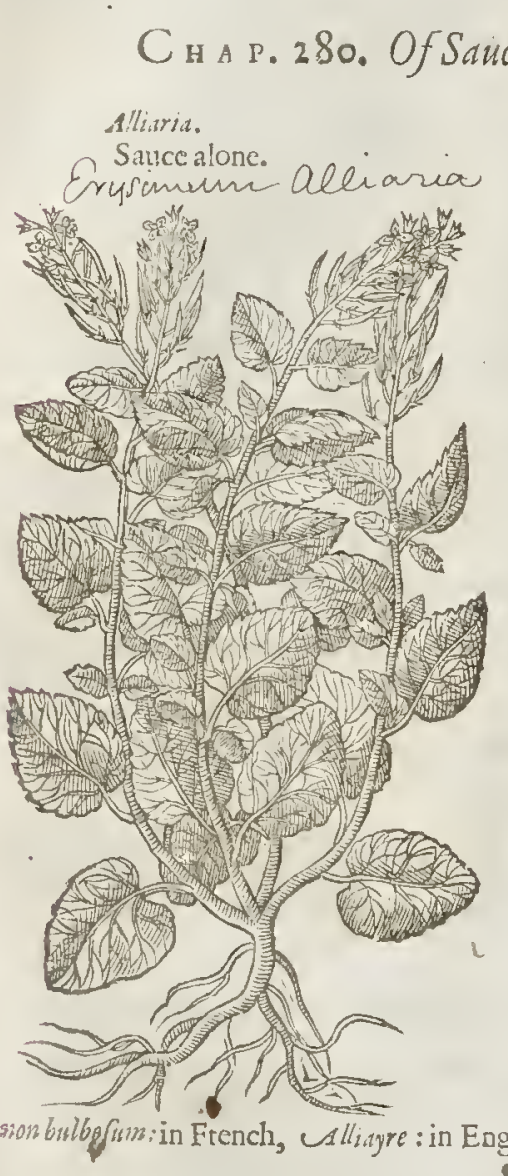

alone, or facke by the bedge.

TI The Defcription.

The Temperature.

Auce alone hath affinitie with Gatlicke in S name, not becaufe it is like it in forme, but in fmell : for if it be bruifed or ftamped it fmelleth altogether like Gat licke: the leaues hereof are broad, of a light green colour, nicked round about, and fharpe pointed: the ftalke is dendet, about a cubit high, about the btanches whereof grow little white floures; after which come vp flender fmal and long cods, 8 in the fe black feed: the root is long, flender, and fomething hard.

\section{The place.}

It groweth of it felfe by garden hedges, by old wals, by highwaies fides, or oftentimes in the borders of fields.

$$
\text { I The Time. }
$$

It foureth chiefely in Iune and Iuly, the feed waxeth ripe in the meane feafon. The leaues are $v-$ fed fot a fauce in March or Aprill.

$$
\text { Tा } T \text { be Names. }
$$

The later writers call it Alliaria, and Alliaris: of fome, Rima Maria ; it is not Scordium, or watet Germander, which the apothecaries in'times paft miftooke for this herbe : neither is it Scordiy pecirs,or a kinde of water Germander, whereor wee haue written : it is named of fome, $P$ es Afrninus: it is called in High Dutch, lanoblauch traut 2leut

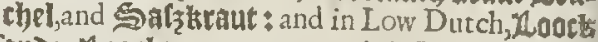
Conder Loock: you may name it in Latine; Alliven Iacke of the hedge is hot and drie, but much
fecorsd degtec, or in the beginning of the third.

$$
\text { ot } T \text { be vertues. }
$$

1. Wc know not what vfe it hath in medicine : diuets eat the ftamped leaues hereof with Salt-fifh?

B Somealfo boile the leaues in cliftets which are vfed againft the paine of the collicke and ftone; in which not only winde is notably watted, but the pain alfo of the ftone mitigated and very much
eared. 


\section{C на Р. 28r. Of Dittiny.}

If The Defcription.

I Ittanie of Crete now called Candie (as Diofcorides faith) is a hot and tharpe hearbe; much like vnto Penni-roiall, fauing that his leates be greater and fomewhat hoary conered oner with a foft downeor white woollie cotton: at the top of the branches grow fmall fptkie eares or fcaly aglets, hanging by little fmall ftemmes, refembling the fpiky tufts of Marierome, of a white colour: amongft which fcales there doe come forth fmall floures iike the flouring of wheat, of a red purple colour; which being palt, the knop is found full of fmall feed, contrarie to the faying of $D$ iefcorides, who faith, it neither beareth floure nor feed, but my felfe haue feene it beare both in iny Garden : the whole plant perifhed in the next VVinter fol. lowing.

\section{Dictannum Creticum. \\ Dittanie of Candie.}

2 Pfoudodictannum. Baftard Dittanic.
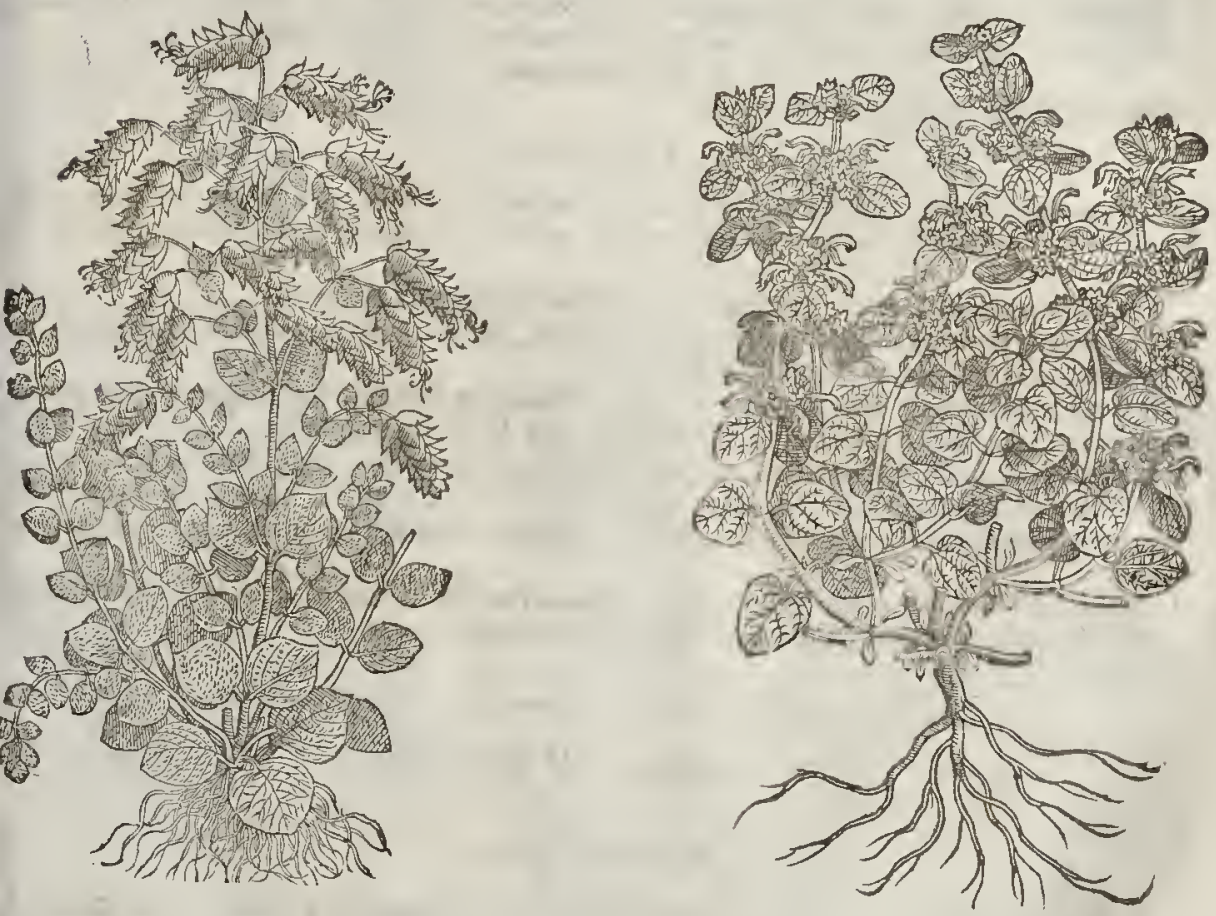

2 The fecond kind called Pfendodictamarm, that is, Baftard Dittanie, is much like vnto the firts fauing that it is not fweet of fmell, neither doth it bite the tongue, hauing round foft woolly ftalks with knots and ioints, and at etrery knot two leanes fomewhat round, foft, woolly, and fomewhat bitter: the floures be of a light purple color, compafing the ftalks by certain fpaces like garlands or wharles, and like the floures of Peni-roiall. The root is of a wooddie fubitance : the whole plan groweth to the height of a cubite and an halfe, and lafteth long.

It The Place.

rally : I have fowne ir in my of the iniuric of at ourtratdinatie cold winter that then happened : neuertheleffe Diofcorides wri- 
writeth againft all truth, that it neither beareth floures nor feed : after Theophraftus, Virgil witnef feth that it doth beare floures in the twelfth of his Eneidos.

Dict ammum genitrix Creten carpit ab Ida,
Fuberibus coulem folys, o flore cowantem
Purpurco.

In Englith thus :

His mother from the Cretaan Ida crops

Dictumnus hauing foft and tender leaues,

And purple floures vpon the bending tops, \&ec.

\section{Tा The Time.}

They floure and flourith in the Sommet moneths, their feed is ripe in September.

$$
\text { TI The Names. }
$$

It is called in Grecke s'xum : in Latine, Dictamnus and DiCtamnum : of fome, Pulegium fylueftre, or wilde Pennic-roiall : the Apothecaries of Germanic for Diclammum with c, in the firft fyllable,doe read Diptamnum with $p$ : but (faith Dodoneus) this errour might hate beene of fmall importance, if in ftead of the leaues of Dittanic, they did not vfe the rootes of Fraxinella for Dittany, which they falfely call Dict ammum : in Englifh, Dittanic, and Dittanic of Candie.

The other is called P fendodict amnum,or baftard Dittanie, of the likeneffe it hath with Dittanie; it skilleth not, though the hoppes know it not : the reafon why let the Reader gueffe.

Thefe plants are hot and dric of natute.

$$
\text { T The Temperature. }
$$

$$
\text { The Vertues. }
$$

'A Dittanic beeing taken in drinke, or putvp in a peffarie, ot vfed in a fume, bringeth away deadchildren : it procureth the moncthly termes, and driucth foorth the fecondine or the after: birth.

B The itice taken with wine is a remedic ag ainft the ftinging of ferpents.

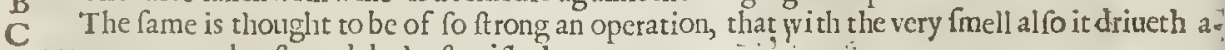
way venomous beafts, and doth aftonith them.

D It is reported likewife that the wilde Goats and Deere in Candiewhen they bewonnded with arrowes, do fhake them out by eating of this plant, and heale their wounds.

E It pretaileth much againft all wounds, and efpecially thofe made with invenomed weapons, arrowes thot out of guns, or fuch like, and is very profitable for Chirurgians that vfe the fea and land wars, to carry with them and hate in readineffe : it draweth forth alfo fplinters of wood, bones, or fueb like.

F Thebaftard Dittanie, or Pfeudodicammum, is fomewliat like in vertues to the firft, but not of fo great force, yet it ferueth excecding well for the purpofes aforefaid.

\section{C н А P. 282; Of Borage.$$
\text { Tा The Defcription. }
$$

I Orage hath broad leates, rough, lying flat vpon the ground, of a blacke or fwart green co. Blour : among which rifeth vpa ftalke two cubits high, diuided into diuers branches, whereupon do grow gallant blew floures, compofed of fiuc leaues apiece; out of the middle of which grow forth blacke threds ioined in the top, and pointed like a broch or pyramide:the root is threddic, and cannot away with the cold of winter.

2 Borage with white floures is like vnto the precedent, but differeth in the floures, for thole of this plant are whice, and the others of a perfect blew colour, wherein is the difference.

† 3 Neuer dying Boragehath manie verie broad leates, rough and hairie, of a blacke darke greene colour : among which rife vp ftiffe hairie ftalkes, whereupon doe grow faire blew floures, fomewhat rounder pointed than the former : the root is blacke and lafting, hauing leaues both winter and Sommer, and hereupon it was ealled semper virens, and that very propetly, to diftinguifh it from the rent of this kinde, which are but annuall. $\ddagger$ 
B The leaues boyled among other pot-herbes do mueh preuaile in making the belly foluble, the being boyled in honicd water be alfo good againit the roughneffe of the throat, and hoarfenefie, as Galen teacheth.

C The leaues and floures of Borage put into Wine make men and women glad and merry, and dritre away all fadneffe, dulnefte, and melancholy, as Diofcorides and Pliny affirme.

D Syrrup made of the floures of Borage eomforteth the heart, purgeth melaneholy, and quieteth the phrenticke or lunaticke perfon.

E The floures of Borage made vp with fugar do all the a forefaid w ith greater foree and effect.

F Syrrup made of the ilyee of Borage with fugar, adding thereto pouder of the bone of a Stags heart, is good againt fivouning, the eardiacke paffion of the heart,againft melaneholy and the falling fickneffe. G The root is not vfed in medicine : the leaues eaten raw ingender good bloud, efpecially in thofe
that haue been lately freke.

\section{Cha p. 283. Of Buglofje.}

Tा The Kindes.

TIke as there be diuers forts of Borage, fo are there fundry of the Buglofies; notwithftanding after Diofcorides, Borage is the true Bugloffe : many are of opinion, and that rightly, that they
may.be both referred to one kinde; yet will we diuide them aecording to the eutome of our time, and their vfuall denominations.

I Buglog a vulgaris.

Common Bugloffe, or Garden Buglofte, Anchusa cion officinalis.

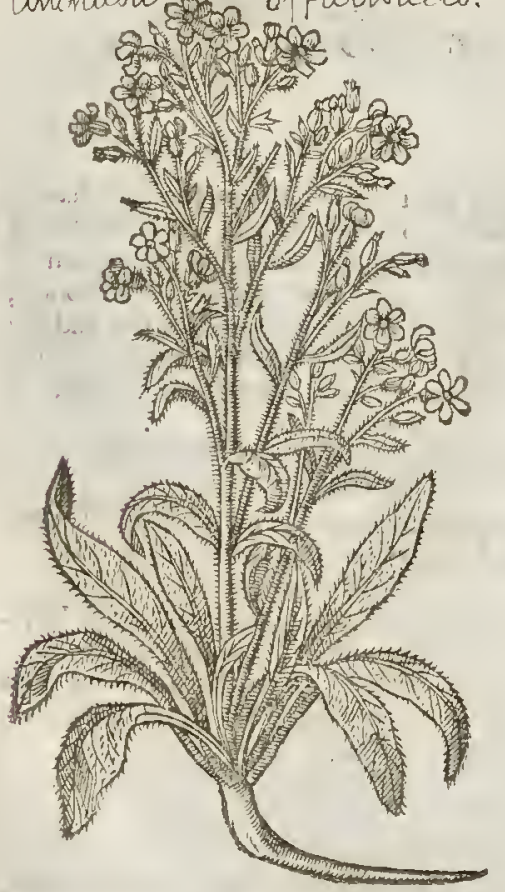

2 Bugloffum luteum.

P. Lang de beefe.

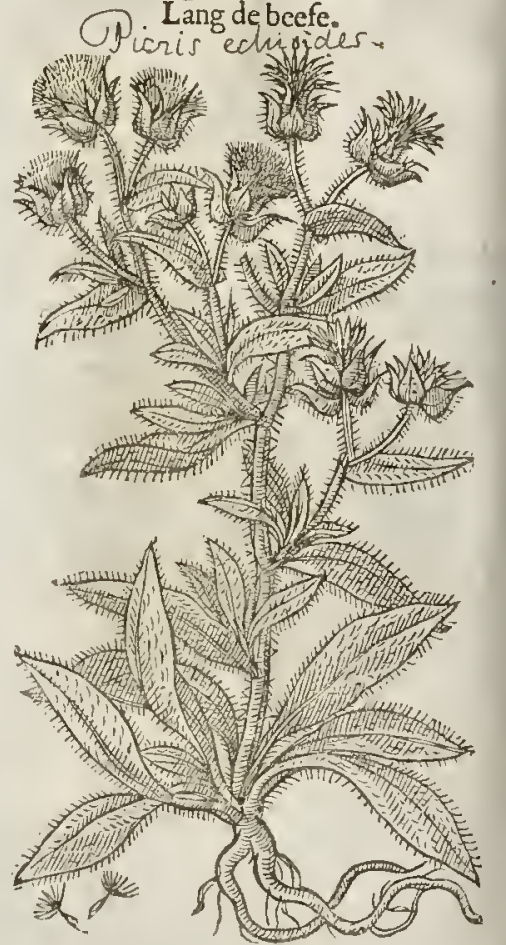

IT The Defcription:

- $7 \neg$ Hat which the A pothecaries call Bugloffe bringeth forth leaues longer than thofe of

Borage, tharpe pointed, longer than the leates of Beets, rough and hairy. The ftalke groweth vp to the height of two eubits, parted aboue into fundry branches, whereon are orderly placed blewifn floures, tending to a purple colour before they be opened,and afrerward more blew. The root is long, thicke, and groffe,and of long continuance. 


\section{1.8. 2. Of the Hiftorie of Plants.?}

$\$ 3$ Bugloffa fyluefleris minor. Small wilde Bugloffe. Sucopsis awensis. -

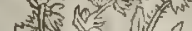
(n) , in in 1 , of 3)
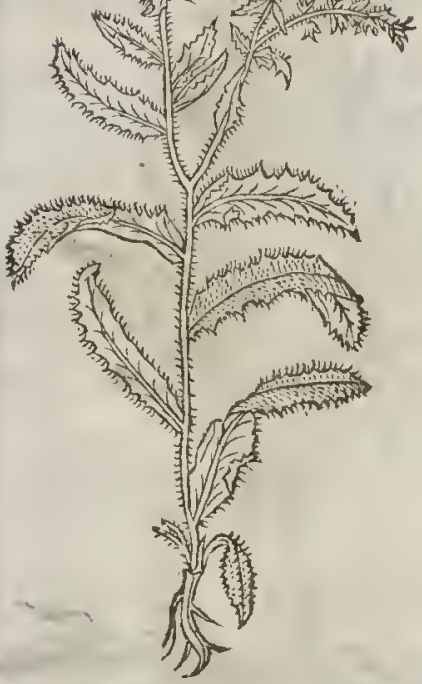

2 Lang de Beefo is a kinde hereof, altogether leffer,but the leaues hereof are rougher, like the rough tongue of an oxe or caw, whereof it tooke his neme. t The leaues of Lang-de-Becfe are very rough, the ltalke fome eubit and halfe high, commonly red of colour : the rops of the branches carty floures in ficdly rough heads : thefe floures are eompofed of many fmall yellow leaues in manncr of thofe of $D$ andelion, and flie away in down like as they do:the floures are of a verie bitter tafte, whence Lobel calls it Bsiglo. from echioides luteum Hier.rio cogratrm. Tabernamontamus hath fitly called it:Hieracium eclioides.

3 There is another wilde Bugloffe which Dodoneus hath by the name of Bugloffa filriefiris: it hath a fmall white root, from which arifes a flender ftalke fome foot and balfe high fet with final rough leaues finuated or cut in on the edges: the falkes at the top are diuided into three or foure fnall bran. ches, bearing frrall blew floures in rough huskes.

$$
\text { If The Place. }
$$

Thefe do grow in gardens emery where. $\neq$ The Lang-de-Beefe growes wilde in many places; as betweene Redriffe and Deptford by the waterie ditch fides. The little wilde Bugloffe growes vpon the drie ditch bankes about Piekadilla; and almoft euesy where. $\neq$

$$
\text { I) The Time. }
$$

They floure from May, or Iune, euen to the end of Sommer. The leaues perin in Winter,and new come vp in the $S$ pring.

gloffe.

T The Names.

Garden Bugloffe is called of the later Herbarifes Buglogsizand Bugloßa Domes.
Lane. Bugloffa fy lueftris, or wilde Bugloffe.

\# Snall wilde Bugloffe is ealled Boragofylueftris by $T$ ragus; Echium Germanicum Spinofun by Fuchlous ; and Bugloßa fylueftris by Dodone us. $\neq$

Tt The Temperature and Fertues:

The root, faith $D$ iofcorides, mixed with oile, eureth greenewounds, and adding thereto a little A barlev macale, it is a remedie againt Saint Anthonies fire.

It caufeth fwear in agues,as Plinie faith, if the iuiee be nixied with a little Aqurvits, and the bo- B dy rubbed therew ith.

The Phyfitions of the later time vfe the leates, floures, and roots in ftead of Borge, and pur C them both into all kindes of medieines indifferently, which are of foree and vertue to driue avay forrow and penfiueneffe of the minde, and to eomfort and it rengthen the heart. The leaucs are of like operation with thofe of Borage, and are ved as potherbes for the purpofes aforefaid, as wel Bugloffe as $L a n g-d \dot{b}-B c e f f_{\text {, and }}$ alfo to keepe the belly foluble.

\section{C н1 P. 284. Of Alkanet or wilde Buglofje.}

\section{ข1 The Defoription.}

Hefe herbes comprehended vinder the name of $u$ nehufa, were fo called of the Greeke word ayseran: (i) Illnere jucco, vel pigmentis, ihat is, to colour or paint any thing: whereupon thefe 


\section{$800 \quad$ Of the Hiftorie of Plants. LIB: 2.}

t I Anchufa Alcibiadion. Red Alkanet.

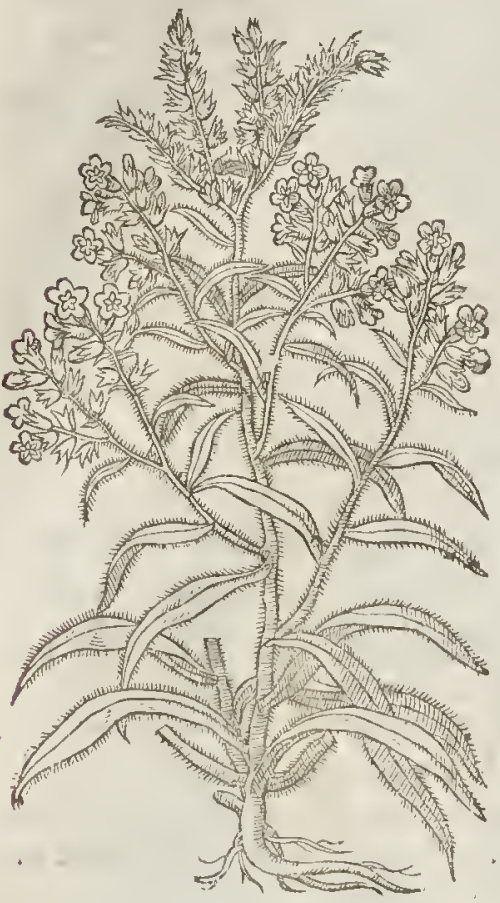

* 3 Anchujaminor. Small Alkanet.

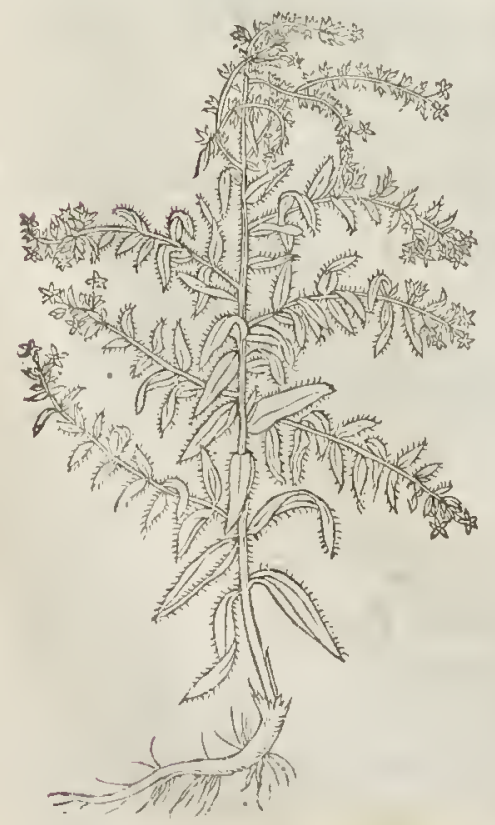

† 2 Anchuga lutea. Yellow Alkanet.

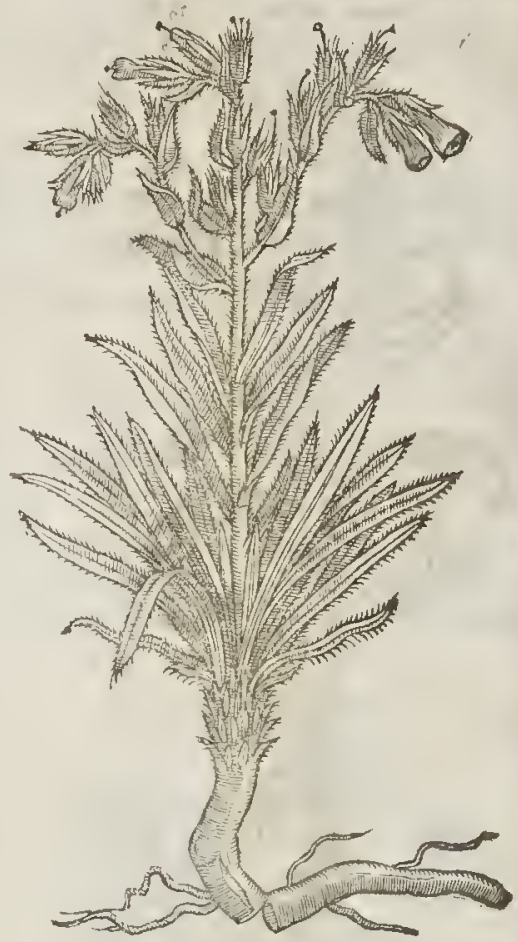

plants were called Unchufa of that flourithing and bright red colour which is in the root, euen as red as pure and cleere bloud: for that is the onely marke or note whereby to diftinguifh thefe herbes from thofe which be called $E$ chum, $L y \operatorname{cop} f i s$, and $B u g l o \iint a$, whereto they haue a great refemblance: I haue therefore expreffed foure differences of this plant Anchu/a ot Alkanet from the other kindes, by the leanes, floures, and bignefle.

I The firf kinde of Alkanet hath many leaues like Echium, or fmall Bugloffe, couered ouer with a prickie hoarineffe, hauing commonly butone falke, which is round, rough, and a cubite high. The cups of the floures are of a skie colour tending to purple, not vnlike the floures of Echium; the feed is fmall, fomewhat long,and of a pale colour : the root is a finger thicke, the pith or inner part thereof is of a wooddie fubfance, dying the hands or whatfoener toucheth the fame, of a bloudie colour, or of the colour of faunders.

2 The fecond kinde of Unchrea or Alkanet is of greater beaucie and eftimation than the firft; the branches are leffe and more buthie in the toppe: it hath alfo greater plentie of leaues, and thofe more woollie or hairie : the ftalke growetl to the height of two cubites : at the top grow floures of a yellow colour, far different from the other:the root is more thining, of an excellent delicate purplith colour, ath more full of iuice than the firf.

3 There 
3 There is a fmall kinde of Alkanet, whofe root is greater and more ful of iuice and fubfance than the roors of rhe otherkindes : in all other refpects it is lcffe, for the leaucs atenatrower, fmaller, tenderer, and in number more, very greene like vnto Boisge, yeelding forth many litrle render ftalks : the thoures are lefte than of the imall Buglofle, and red of colour : the feed is of an ante coIour, fomewhat loug and flendet, haung the tafte of Bugloffe.

4 There is alfo another kinde of Alkanet, whi h is as rhenthers before mentioned, a kiade of wilde bugloffe, now ithftanding for diftinctions fake I hane leparated and feured them. This lalt anchufuhth narrow leaues,much like vnto our common Sommer Sautric. The ftalkes are two handfuls high,bearing very fmal Houres, and of a blew inh or sk ie colour : the root is of a dark brownith red eolour, dy ing the hands little or nothing at all, and of a wooddie fubftanee.

$$
\text { 91 The Time. }
$$

Thefeplants do grow in the fields of Narbone, and about Montellicr and many other parts of Franee: I found thefe plants growing in the Ifle of Thanet neere vito the fea,berw ixt the houfe fometime belonging to Sir Henrie Crijpe,and Margate; where I found fome in their naturall ripeneife, yet fearcely any that were come to that beautifull eolour of Alkanet : but fuch as is fold for very good in our Apo:heearies thops I found there in great plentie.

$\ddagger$ I dout whether our Authour found any of thefe in the place heere fetdowne, for I haue fought it but failed of fuding; yet if he foun 1 any it was onely the firft deferibed, for I think the otner thee are ftrangers. $\neq$ of $T$ he $T$ m $m$.

The Alkanets 9oure and fourifh in the Sommet moneths : the roots doe yeeld their bloudie iuiee in harueft time, as Dinfcorides writeth.

\section{बा The 2 tames.}

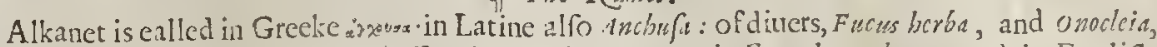
Buglofa Hiparica, or Spanifh Buglofe : in Spanth, Soggem: in French, orchanet: and in Engliph likewife Orehanet and Alkanet.

$$
\text { 9ा The Temperature. }
$$

The toots of Alkanet are eold and drie, as Galen wrirerin, and binding, and beeatre it is bitter it clenfeth away eholerieke humours : the leates bee not fo forecable, yet doe they likewife binde and dric.

of $T$ he vertues.

Diofcorid!s faith, that the root being made vp in acerote, or fearecloth with oile, is very good for $A$ old vlects; that with parched barley meale it is good for the leprey, and for tetters and ring-worms.

That being vfed as a perfaric it bringeth forth the dead birth.

The dceostion being inwardly taken with Mead ot honicd watet, euteth the yellow iaundife, $C$ difeafes of the kidneies, the fpleene and agues.

It is ved in ointments for womens paintings: and the leates dtunke in wine is good againft the D laske.

Diters of the later Phy fitions do boile with the root of Alkanet and wine, fweet butter, fueh as E hath in it no falt atall, vntill fuch time as it beemmeth red,which they eall red butter, and giue it not onely to thofe that late falne from fome high place, but alforeport it to be good to drite forth the meafels and fmall pox, if it be drunke in the beg inning with hot beere.

The roots of thefe are v fed to eolor firrups, waters, gellies, $\&$ fuch like eonfections as Turnfolc is. I rohn of Ardern hath fet down a compofition called Sanguis Veneris, which is mof fingular in deep G punetures or wounds made with thrufts, as follows:take of oile oliue a pint, the root of Alkanet two ounees, earth worms purged, in number twenty, boile them together \& keep it to the ve aforefaid.

The Gentlewomen of Franee do paint their faees with thefe roots, as it is faid.

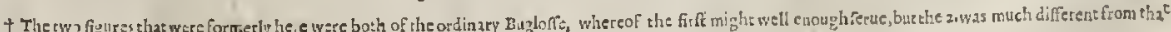
it thould hasueben.

\section{C н А י 285: Of Walland Vipers BuglojJe.}

$$
\text { बा The Defcription. }
$$

I Tcop/s Anglica, or wilde Bugloffe, foealled for that it doth not gtow foemmonlyeifewhere, bath rough and hairie leates, fomew hat leffer rhan rhe garden Englofle: the Houres grow for the mof part vpon the fide of the flender fealke, in futhion hollow like a little bell,whereof fome be blew, and others of a purple eolour.

2 There is anotlier kinde of Echim that hath rough and hairy leaues likewife, mueh like vnto the former; the falke is rough, charged full of little branches, which are laden on euery fide with diuers fmall narrow leaues, tharp pointed, and of a brown colour:among which leaues grow fn:tres, each foure being compofed of one leafe diuided into fue paits at the top, leffe, and not forride open as that of $L$ ycop (is; yet of a fad blew or purple colour at the firft, but when they are open they fhew to be of ar azire eolour, long and hollow, hauing certaine fmal blew threds in the nid ? I: the feed is malland black, fahioned like the head of a fnalse or viper:the toot is long,and red wirhnirr.

$$
\mathrm{x}^{\mathrm{x} \times 3} 3 \text { The }
$$




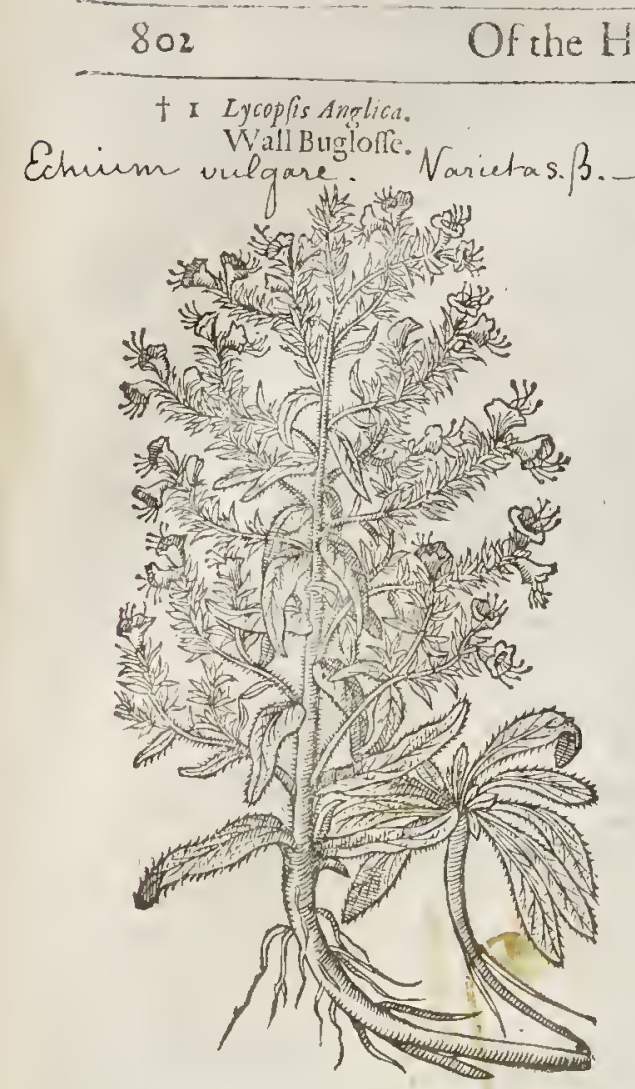

\$ 3 Echium pullo fore.

Rough Vipers Bugloffe

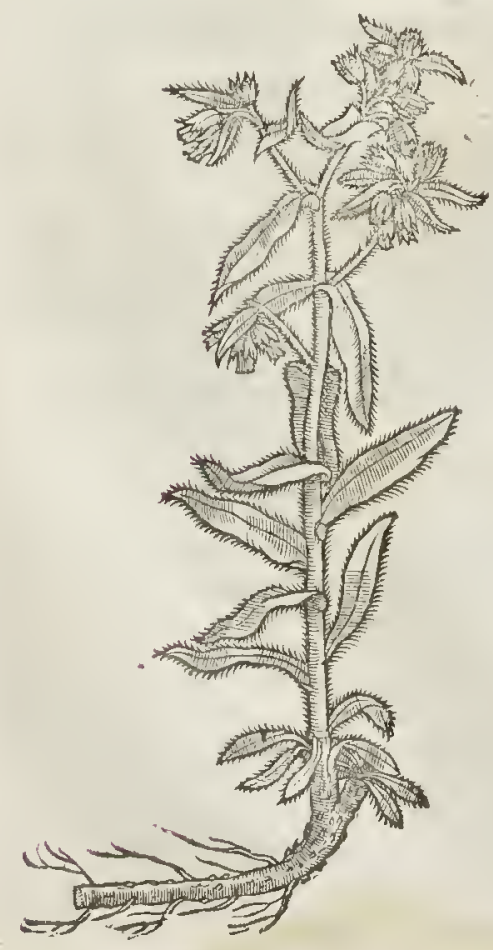

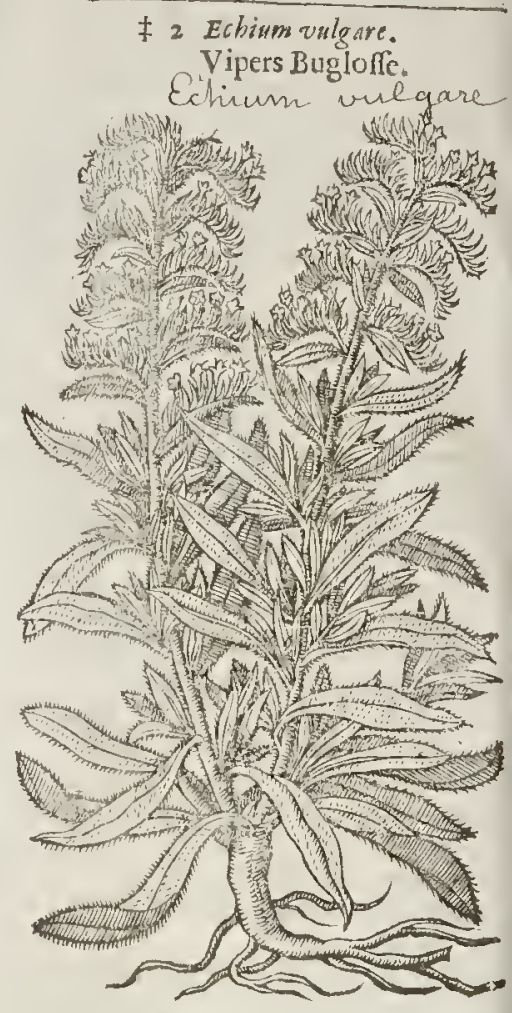

$\$ 4$ Echinm rubro fore.

Red floured Vipers Bugloffe:

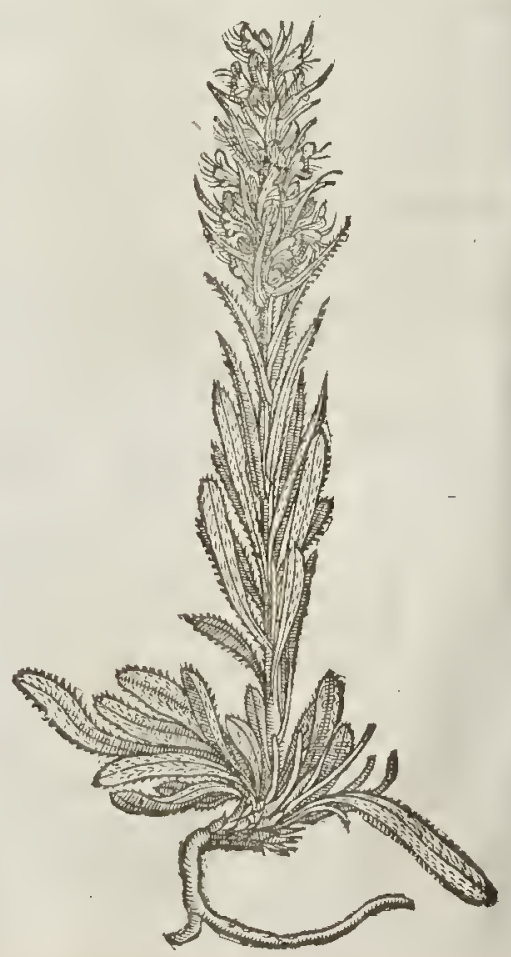


L 1 в. 2.

I Cynogloffum maius vulgare frise flore.

Hounds-tongue withour the foure.
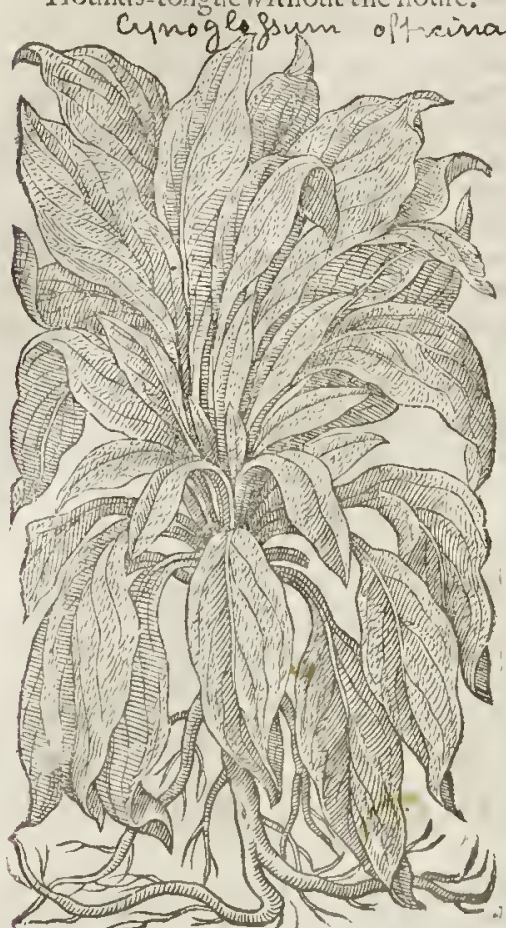

\$ 2 Cynoglofum Creticum $\mathrm{r}$.

The firft Candy Dogs-tongue. S

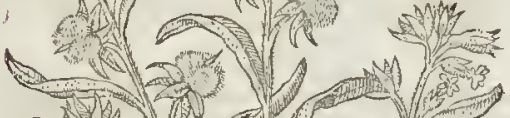

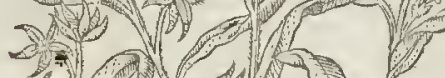

son

2)
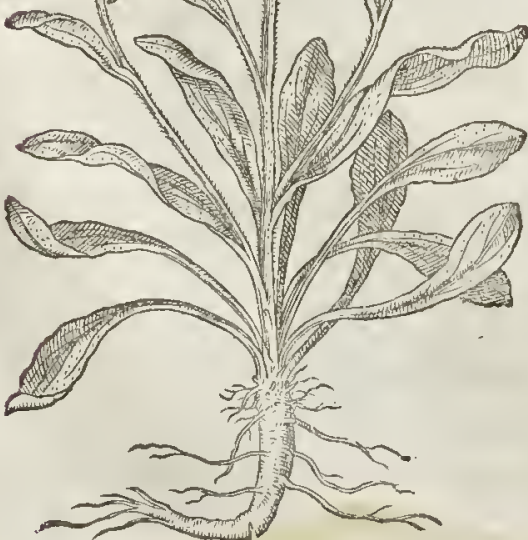

I Cynoglolfum maines cum fore or femme

Hounds-tongue with the flomreang feed.

cynigge Sinn ofticinate

की 1 19

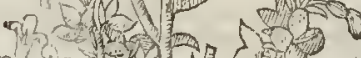

62 (1)

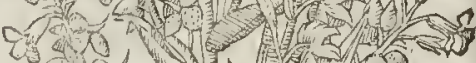

or.

binu周

Tol 1 (

(p. $<1.1$.

m.

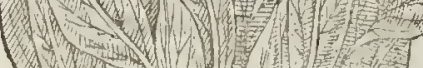

7 (

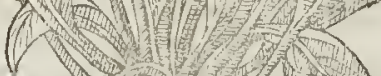

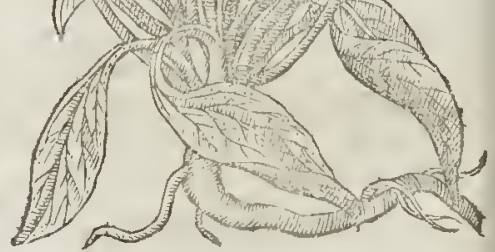

\$ Cynoglopum Creticusu al crmm.

The orher Candy Dogs-tongue.

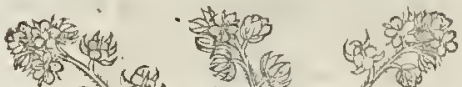

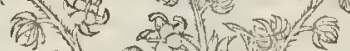

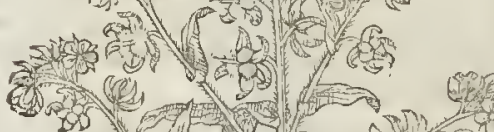

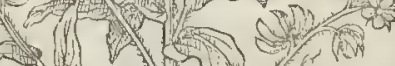

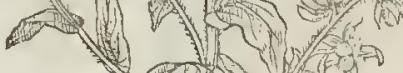

(1)

120 .

(1)

$(10-2)$

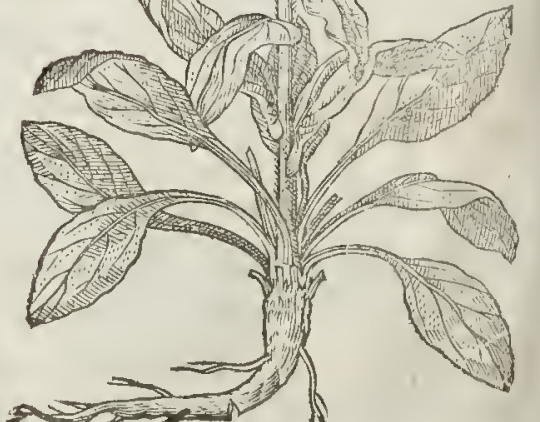


2 We haue recciued anothet fort hereof from the parts of Italy, hauing leaues like Woade, fomewhat rough, and without any manifelt fmell, wherein it diffeteth from, the common kinde. the feed hereof Gatie under tie fitle Cynorlofum Cretiam, Hounds-tongue of Candy. $\ddagger$ The floures are leffer and of a lighter eolour than thofe of the former; the feeds alfo are rough, and grow foure together, with a point comming our of the middle of them as in the eommon kind, but yet leffer; the root is long and whition. Clufues hach this by the name of Cynonloffum Creticum $\mathrm{I}$.

3 This fecond cynogloffum Creticum of Clefieus hath leaues fome handfull long, and fome ineh and better broad: among which, the next yeareafter the fowing, comes vp a ftalke fome cubit or more high, erefted, ft iffe, and ftraight, and fomewhat downy as are alfo the leawes, which grow vpon the fame, being fomw hat broad at their fetting on, and of a yellowifh greene colour. 'The top of the ftalke is dinided into fundry branehes, which twine or turne in their tops like as the Scorpion graffe, and earry thorter yet larger floures than the ordinarie kinde, and thofe of a whition eolour at the firf, with many fmall purplin veines, which after a few dayes beeome blew. The feeds are like the former in their grow ing, thape, and roughnefle. $\ddagger$

4 We haue another fort of Hounds-tongue likevnto the common kinde, fauing it is altogethet leffer : the leaues are of a fhining greene colour.

¥ 4 Cynogloffum minus foliovircnte.

Small greene leaued Hound[-tongue.

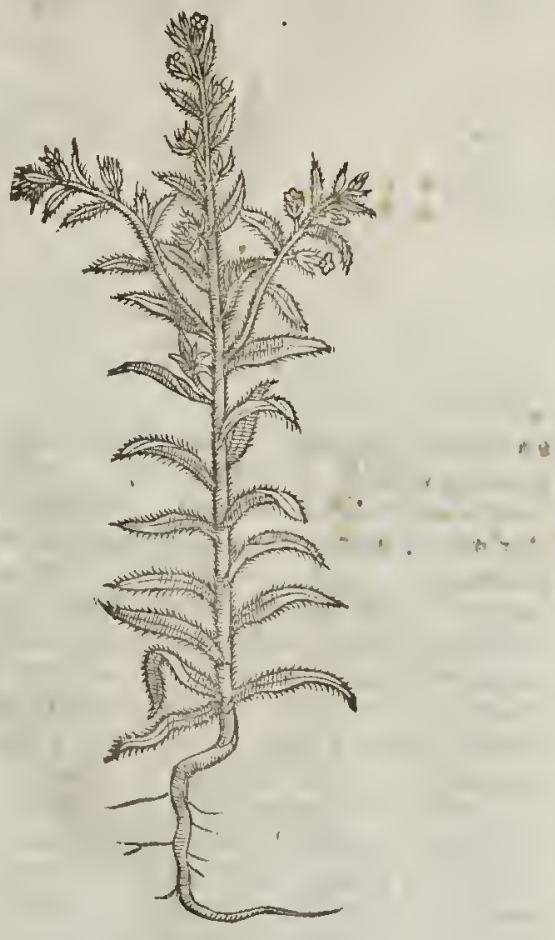

I The Place.

The great Hounds-tongue growes almof: euery where by high-wayes and vntoiled ground : the fmall Hounds-tongue groweth very plentifully by the waies fide as you ride Colehefter highway from Londonward, betweene Efterfotd and Wittam in Effex.

$$
\text { Tा The Time. }
$$

They floure in Iune and Iuly.

$$
\text { II The Names. }
$$

Hounds-tongue is ealled in Greeke; Kurghawar : in Latine, Lingua canis: of pliny; Cynoglofos; and he theweth two kinds theteof : in Englifh, Hounds-tongue, or Dogstongue, but rather Hounds-piffe, for in the world thete is not any thing fmelleth folike vnto Dogs-pifle as the leaues of this Plant doe.

9 The Nature.

Hounds-tongue, but efpecially his root, is cold and dry.

\section{बा The Vertues.}

The roots of Hounds-tongue rofted in the $A$ embers and layd to the fundament, healeth the hemorrhoides, and the difeafecalled $\mathrm{Ig}$ nis facer, or wilde-fire.

The iuyee boiled with honey of rofes and Turpentine, to the forme of an vnguent, is moft fingular in wounds and deepe vlcers.

Diofcorides faith, That the leates boyled C in wine and drunk, do mollifie the belly, and that the leaues ftamped with old fwines greafe ate good againit the falling away of the haite of the liead, which procecdeth of hot fharpe humots. Likewife they are a remedie againft fcaldings or burnings, and againft the biting of dogs, as the
fame Authot addeth.

\section{$\mathrm{C}_{\text {HA P. 287. Of Comfrey, or great Confound. }}$}

\section{T) The Defcription.}

I THe ftalke of this Comfrey is connered, thicke, and hollow like that of Sow-thiftle : it groweth two cubits or a yard high : the leaues that fpring from the root,and thofe that 
I Confolida maior flore purpureo.

Symphytim of picinale

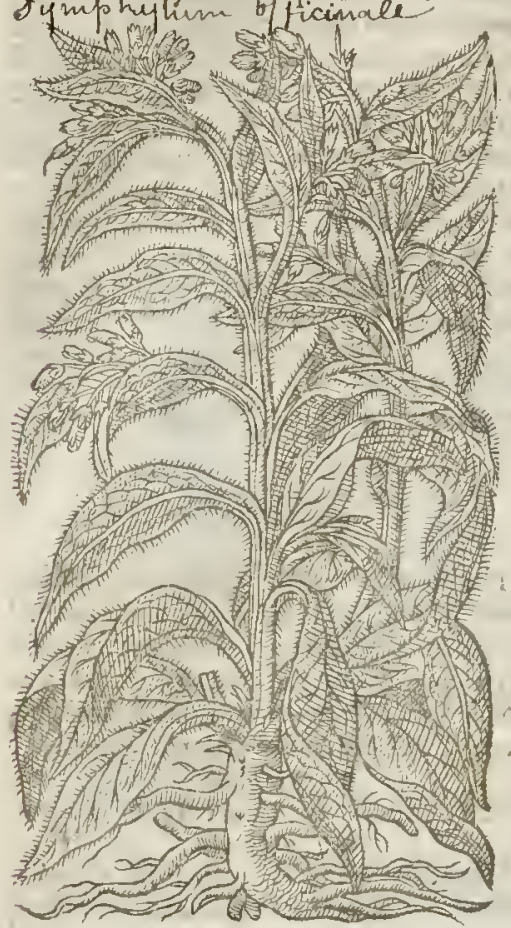

\# 4 Simphytum paresum Borcrinis fácie. Borage-floured Comfrey.

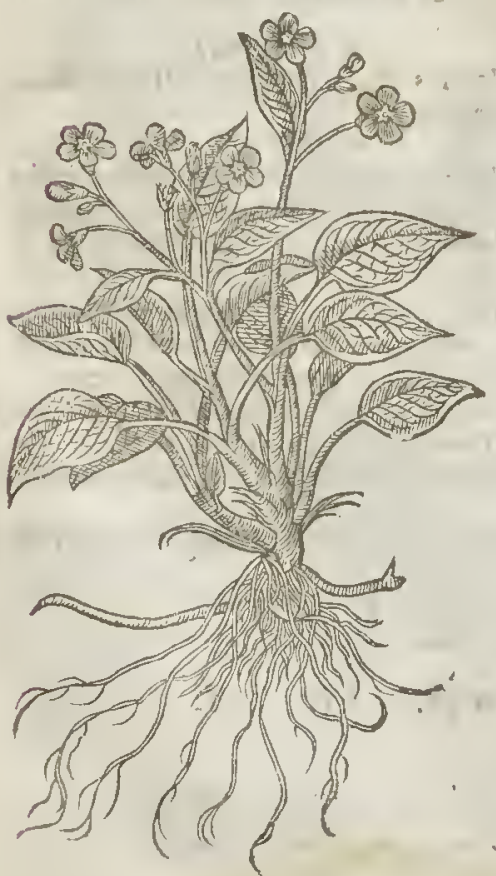

$3 \neq$ Sympliytumtuberofum.

Comfrey with the knobby root.
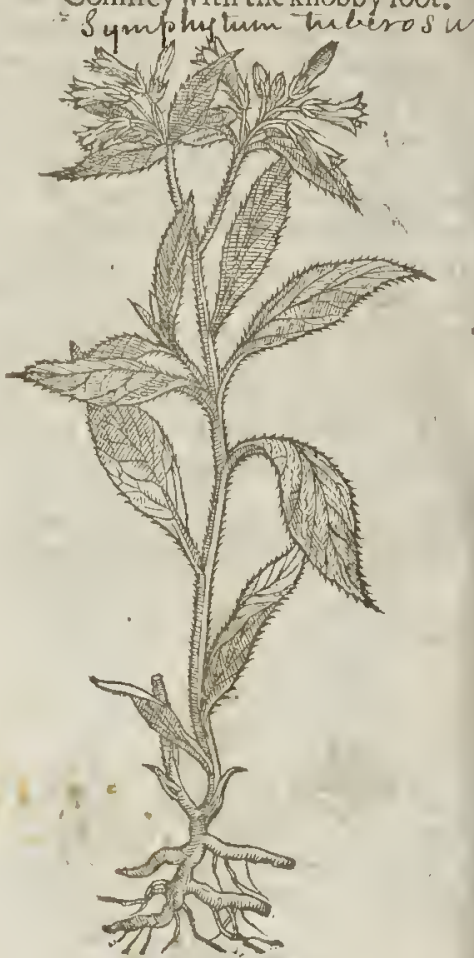

grow vpon the ftalkes are long, broad, rough, and pricking withall, fomething hairie; and being handled make the hands itch ; very like in colour and roughnes to thofe of Borage, but longer, and Tharpe pointed, as be the leaues of Elecampane: from out the wings of the ftalkes appeare the foures orderly placed, long, hollow within, of a light red colour:after them groweth the feed, which is blacke. The root is long and thick, blacke without, white within, hauing in it a clammy juice, in which root confiteth the vertue.

2 The great Comfrey hath rough hairy ftalks, and long rough leates much like the garden Bugloffe, but greater and blacker : the floures be round and hollow like littlc bells, of awhite colour : the root is blacke without, and white within, and very flimy. $\neq$ This differeth noway from the former but onely in the colour of the floure, which is yellowinh or white, when as the other is reddith or purple. $\neq$

3 There is anotherkinde of Comfrey which hath leaues like the former, fauing that they be Iefier: the falks are rough and tender : the floures bc like the former, but that they be of an oucrworn yellow colour : the roots are thicke, thort, blacke without, and tuberous, $\ddagger$ which in the figure are not expreffed fo large and knobby as they ought to have been. \$

4. This 
* 4. This pretty plant hath fibrous and blackifh roots, from which rife vp many leaues like thofe of Borage, or Comfrey, but much fmaller and greener, the ftalkes are fome eight inclies high. and on their tops carry ptetty floures like thofe of Borage, but not fo harpe pointed, but of a more pleafing blew colour. This floures in the fpring and is kept in fome choice Gardens; Lobell calls it Sympbytum pumilum repens Borraginis facic, fine Borrago minima Herbariorwm.

$$
\text { Tी The place. }
$$

Comfrey joyech in watery ditches, in fat and fruitfull medowes; they grow all in my Garden

They floure in Iune and Iuly. of The Time.

\title{
T) The Names.
}

It is called in Grecke simpuro: in Latine Symphytum, and Solidago : in Thops, Confolidat mior and Symphytum matus : of Scribonius Largus, Inula rafica, and Alus Gallica: of others, offocollon : in high

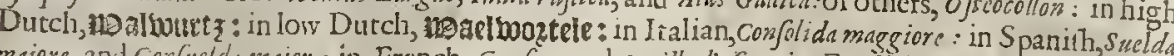

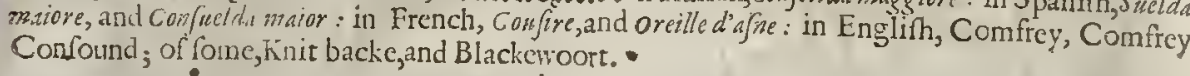

\section{T The Temperature.}

The root of Confrey hath a cold quality, but yet not much : it is alfo of a clammie and oluir noifture, it caufeth no itch at all, neither is it of a harpe or biting tafte,vnfauory, and without any qualitie that nuy be tafted; fo far is the tough and gluing moifture from the tharpe clammineite of the lea Onion, as that there is no comparifon betweene them: The leaues nay caufe itching not through heate ritharpcneffe, but through their ruggedneffe, as we hame already written, yet
tefle than thofe of the Nettle.

The rotertucs.

The rootes of Comfrey tamped, and the juice drunke with wine, helpeth thofe that fpit bloud,
nd healeth all inwaid wounds and burftings.

The fame bruifed and laid to in manner of a plaifter, doth heale all freth and greenewoundes, and are fo glutenatiue, that it will fodder or glew together meate that is chopt in peeces feething
in a pot, and make it in one lumpe.

- The rootes boiled and drunke, doc clenfe the bret from flegme, and cure the griefes of the lungs, efpecially if they be confect with fugar and fyrrup; it preuaileth much againft ruptures or
burftings.

The fimie fubftance of the root made in a poffet of ale, and giuen todrinke againft the paine in the backe, got ten by any violent motion,as wrafling, or ouermuch vfe of women, doth in foure or fiue daies perfeetly cure the fame:although the inuoluntary flowing of the feed in men be gotten
chereby.

The roots of Conifrey in number foure, Knotgraffe and the leaues of Clarie of each an hand full, being ftamped all together, and ftrained, and a quart of Mufcadell put thereto, the yolkes of three egges, and the powder of three Nutmegs, drunke firft and laft, is a moit excellent med icine againft a Gonorrhaz or running of the reines, and all paines and confumptions of the backe.

There is likewife a fyrrup made hercof to be vfed in this cafe, which faieth voiding of bloud : tem pereth the heate of agues:allaicth the fharpeneffe of flow ing humors:healeth vp vicers of the lungs, and heipeth the cough: the receit whereof is this: Take two ounces of the roots of great Comfrey, one ounce of Liquorice; two hand fulls of Folefoot, roots and all;one ounce anid an halfe of Pine-apple kernells; twenty iuiubes; two drams or a quarter of an ouncenf Mallow feed; one dram of the heads of Poppy; boile all in a fufficient quantitic of water, till one pinte remaine Atraine it, and and adde to the liquor ftrained fix ounces of very white fugar, and as much of the beft hony, and make thereof a yruxp that rutt be throughly boiled.

The fame fyrup cureti the vlcers of the kidnies, though they hatie been of long continuance; 6 and toppeth the bloud that commeth from thence. Moreouer, it ftaicth the oucrmuch flowing of the monethly fickeneffe, taken eucry day for cer-
saine daies together.

It is highly commended for woundes or hurts of all the reft alfo of the intrailes and inward parts, and for burfings or ruptures.

The root ftamped and applied vnto them, taketh away the inflammation of the fundament, $K$
out A

\author{
${ }^{B}$
} : . (n) 
I Pulmonariamaculofa.

Spotted Cow lips of Ierufalem. ilmonaria officinalis.

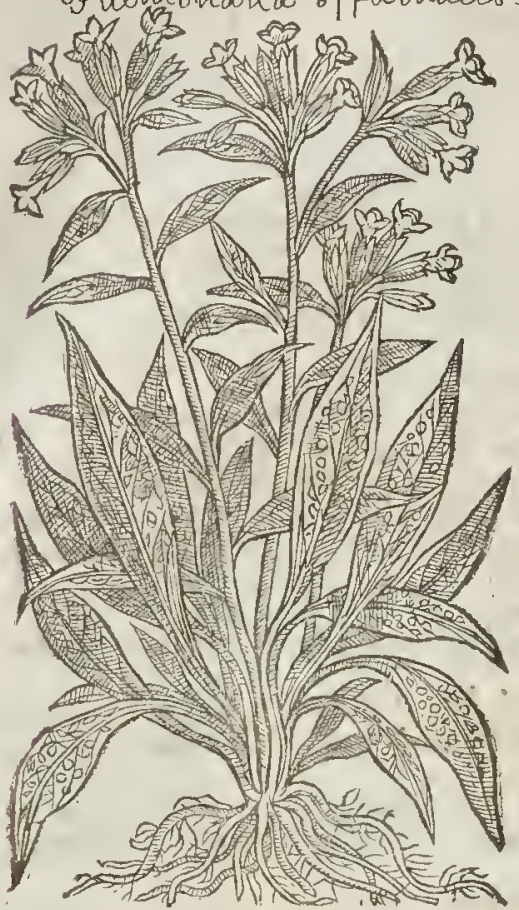

3 Palmoria angufifolia ä. Clufij.

Narrow leafed Cowflips of Ierufalem:

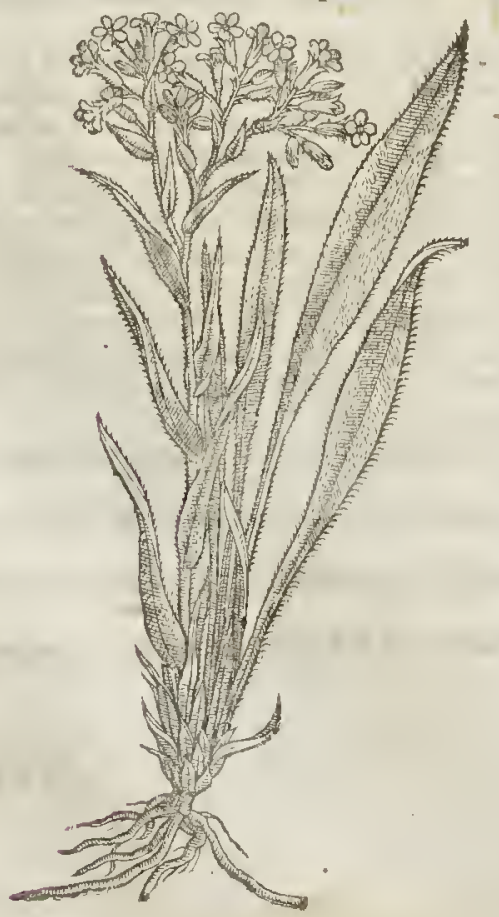

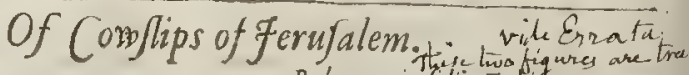
2 Pulmonariafoliys Ecbig Bugloffe Cowflips.

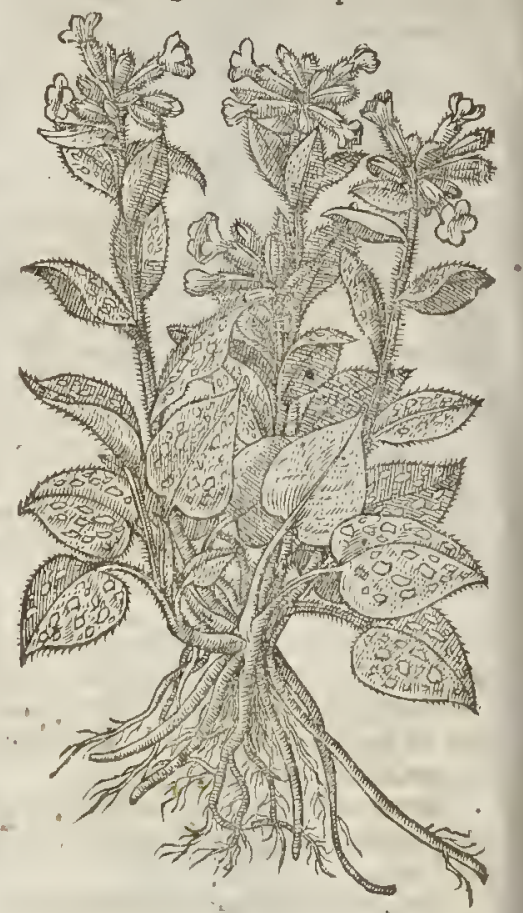

T The Defription.

- Cownips of Ierufalem, or the true and right Lungw or, hath rough, hairy, and la rge leaures, of a brown green eolor, confufedly fpotted with diuers fpots, or drops of white: $a$ mong ft which fpring vp certaine ftalkes, a fpan long, bearing at the rop many fine floures, growing together in bunches like the floures of eowflips, fauing that they be at the firftred, or purple, and fometimes blew, and oftentimes al thefe colours at onee. The floures being fallen, there come fmall buttons full of feed, The root is blacke and threddy. ₹ This is fomerimes found with white foures. $\ddagger$

2. The fecond kinde of Lungwort is like vnto the former, but greater in each refpect: the leaues bigger than the former, refembling wilde Bugloffe, yet fpotted with white fpots like the former: the floures are like the other, but of an exeeeding thining red colour.

3 Carolus Clufins fetteth forth a thirdkinde of Lungwoort, which hath rough and hairie leaues, like vnto wilde Bugloffe,but narrower: among which rifes vpa falke a foot high, bearing at the top a bundle of blew floures, in fathion like vnto th ofe of Bugloffe or rhelaft deferibed. 
Thefe plants do grow in moift thadowie woods, and ate planted almot euery where in gardens: $\$ M^{5}$. Goody $y$ found the Pulmonaria foly's Eclyy, being the fecond, May 25 . LAsno 1620 . flouring is a wood by Holbury houfe in the New Forret in Hampthire. $\ddagger$

They fioure for the moft part Tा The Time.

$$
\text { 9 The Names. }
$$

Cowflips of Ierufalem, or Sage of Ierufalem, is called of the Herbarifts of our time, pulmonoria, and Pulmonalis; of cordus, symphitum fytueftre, or wilde Comfrey: but feeing the orher is alfo of nature wilde, it may aptly be called Symphytum maculofum, or Maculatum : in high Dutch, Rung gentraut: in low Dutch, Onter Grouboen melctutit: in Englin, fpotted Comfrey, Sage of Ierufa lem, Cowtl ip of Ierufalen,,Sage of Bethlem, and of fome Lungwort; notwithntanding there is another Lungwort, of which we will intreat among the kindes of Moffes.

$$
\text { T) The Temperature. }
$$

Pulmonara fhould be of like temperature with the great Comfrey, if the roote of this were clammie : but feeing that it is hard and woody, it is of a more drying quality, and morebinding.

$$
\text { g) The Vertues. }
$$

The leaues are vfed among pot-herbes. The roots are alfo thought to be good againit the infirmities and vicers of the lungs, and to be of like force with the great Comfrey.

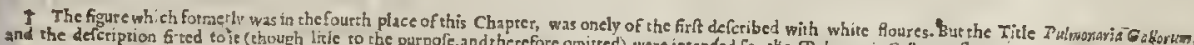

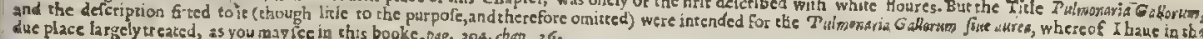

\section{C. in P. 289. Of Clote Burre, or Burre Docke.}

x Barduna maior.

The great Burre Docke. Arctimu Lappa

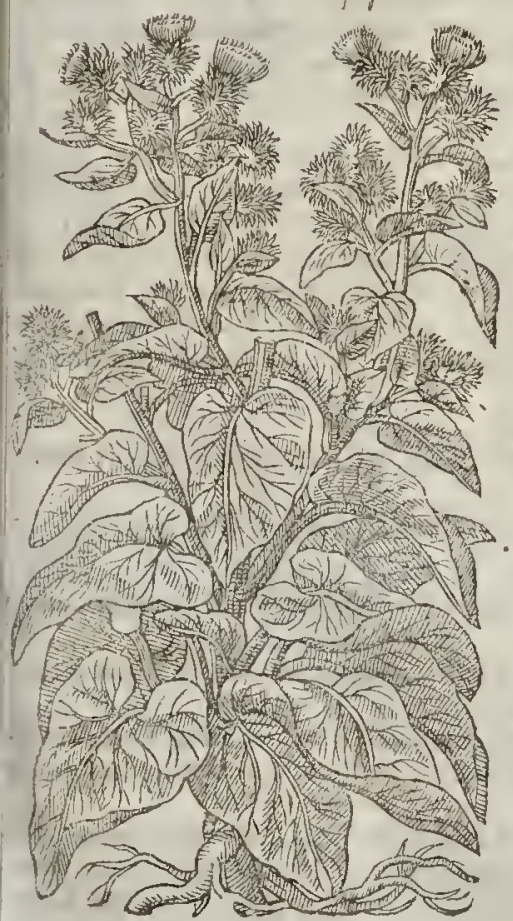

2 Bardana ininor.

Can The leffe Burre Docke.

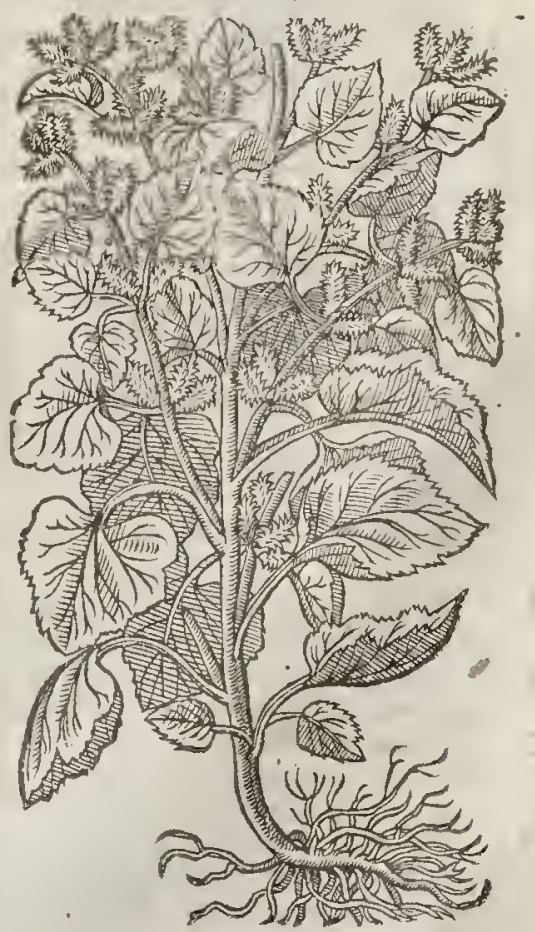




\section{बा The Defeription.}

t Lot Butre bringeth forth broad leanes and hairie, far bigger than the leaues of Gourds, and of greater compaffe, thicker alfo, and blacker, which on the vpper fide are of a darke greenecolour, and on the nether fide fomewhat white: the ftalke is cornered, thicke, befer wirh like leaues, but far leffe, diuided into very many wings and branehes, bringing forth great Burres round like bullets or balls, which are rough all ouer, and full of tharpe crooking prickles, taking hold on mens garments as they paffe by; out of the tops whereof groweth a foure thrummed, or all of threds, of eolour purple: the feed is perfected within the round ball or bullet,and this feed when the burres open, and the windebloweth, is catied aw ay with the winde : the root is long, white within, and blacke without.

$\ddagger$ There is another kinde lereof which hath leffer and fofter heads, with weaker prickles ; thefe heads are alfo hairy or downy, and the leaues and whole plant fomewhat leffe, yet orherwife like the fore deferibed; Lobell ealls this Artion montanum, and Lappa minor Galeni: it is alfo the Lappa minor altera of Mattbiolus. Lobell found this growing in Somerfetthire three miles from Bath, neere the houfe of one Mr. Iohn Cult.

2 The leffer Burre hath leaues farte fmaller than the former, of a grayith ouerworne colour like to thofe of Orach, nicked round about the edges : the ftalke is a foot and a halfe high, full of little blacke fjots, diuiding it felfe into many branehes: the floures before the Burres come fortl do compafie the finall ftalkes round about; they are but little, and quickly vade away : then follow the Burres or the fruit out of the bofome of the leaues, in forme long, on the tops of the branches, as big as an Oliue or a Cornell berry, rongh like the balles of the Plane tree, and being tonched cleaue faft vnto mens garments : they do not open at all, but being kept clofe fhut bring forth long feeds. The root is faftened withvery many ftrings, and groweth not deepe.

$$
\text { of The Place. }
$$

The firft groweth euery where : the fecond I found in the high way leading from Dtaitonto Iuer, two miles from Colbiooke, finee which time I haue found it in the high way betweene Stanes and Egham, ₹ It alfogroweth plentifully in Southwick (heet in Hamponire, as I hate been enformed by $\mathrm{M}^{\mathrm{t}}$. Goodyer. $\neq$

Their feafon is in Iuly and Augut.

$$
\text { T The Time. }
$$

$$
\text { बा The Names. }
$$

The great Burre is called in Grecke sperion: in Latine, Perforata,porfosatio, and Arcium: in fhops, Bardana, and Lappa maior : in high Duteh, $\mathbb{6} 20$ [skletten : in low Dutch, Groate cliften:in trench, Glouteron: in Englih, Great Burre,Burre Docke, or Clot Butre : A puleius befides thefe doth alto fet downe certaine other names belonging to Clot Burre, as Dardana, Bacchion, Elephantofis, Nephel; on, Manifolium.

The leffer Burre Docke is called of the Gracians aduror: in Latine, Xantbium : in thops, Lappa minor, Lappa unwer $(a$, and of diuers, Strumaria: Galcn faith it is alfo called, Phafganion, and Phafgumon, or herbe victory, being but baftard names, and therefore not properly fo called: in Englifh, Loufe Burre, Ditch Burre, and leffer Burre Docke : it feemeth to be called Xanthium of the effect, for the Burre or fruite before it be fully withered, being ftamped and put into an earthen veffell, and afterwards when need requireth the weight of two ounces thereof and fomewhat more, being fteeped in warne water and rubbed on, maketh the haires of the head red;yet the head is firft to be dreffed or rubbed with nitet, as $D$ iofcorides writeth.

\section{T The Teimperature.}

The leaues of Clot Burre are of temperature modcrately dry and walting; the root is fome. thing hot.

The feed of the leffer Burre, as Galen faith, hath power to digen, therefore it is hot and dry.

- The Vertues.

A The roots being taken with the kernels of Pine Apples, as Diofurides witneffeth, are good fot
them that foit blould and corrupt matter.

B Apeleiss faith that the fame being ftamped with a little falt, and applied to the biting of a mad dog, cureth the fame, and fo fpeedily fetteth free the fieke man.

C Healfo teacheth that the juice of the leatres giuen to drinke with hony,procureth vrine, and ta. keth away the paines of the bladder; and that the fame drunke with old winedoth wonderfully helpe againft the bitings of ferpents.

D Columella declareth, that the herbe beaten with falt and laid vpon the fearifying, which is made with the launeet or rafer, draweth out the poifon of the viper : and that alfo the root being ftamped is more auaileable againft ferpents, and that the root in like maner is good againft the Kings
euill. 
The ftalke of Clot-burre bcfore the burres come forth, thc rinde pilled off, being eaten raw with $F$ falt and pepper, or boyled in the broth of fat meate, is pleafant to bc eaten : being taken in that manner it increafeth feed and firrcth vp luft.

Alfo it is a good nourithment, efpecially boyled : if the kernell of the Pinc Apple be likewife F added it is the better, and is no leffe auailable againit the vleer of the lungs, and fpit ting of bloud, than the root is.

The root ftamped and ftrained with a good draught of Ale is a moft approned nedicine for a $G$ windic or cold ftomacke.

Treacle of Andromacluts, and the whites of egges, of each a like quantitie, laboured in a leaden $H$ mortar, and fpred vpon the Burre leafe, and fo applicd to the gout, hatre been proued many times molt miraculoully roappcare the paine thereof.

Diof corides commendeth the decotion of the root of Arcion, together with the feed, againft the I tooth-ache, if it be holden a while in the mouth : alfo that it is good to foment therewith both burnings and kibed heeles; and affirmeth that it may be drunke in wine againft the ftrangury arid paine in the lip.

Diofcorides reporteth that the fruit is very good to be laid vnto hard fwellings.

The root cleanc pieked, wathed, ftamped and frained with Malmefey, helpech he the reines, the whites in women, and ftrengthneth the backe, if there beadded thereto theyelits of egges, the pouder of acornes and nutmegs brued or mixed together, and drunkc firft and laft.

\section{Cна т. 290. Of Colts-foot, or Horfe-foot.}

I Tusilingo foreins. Colts-foot in floure. Tulsitug o Trarfar 1 Tupulagisis folia.

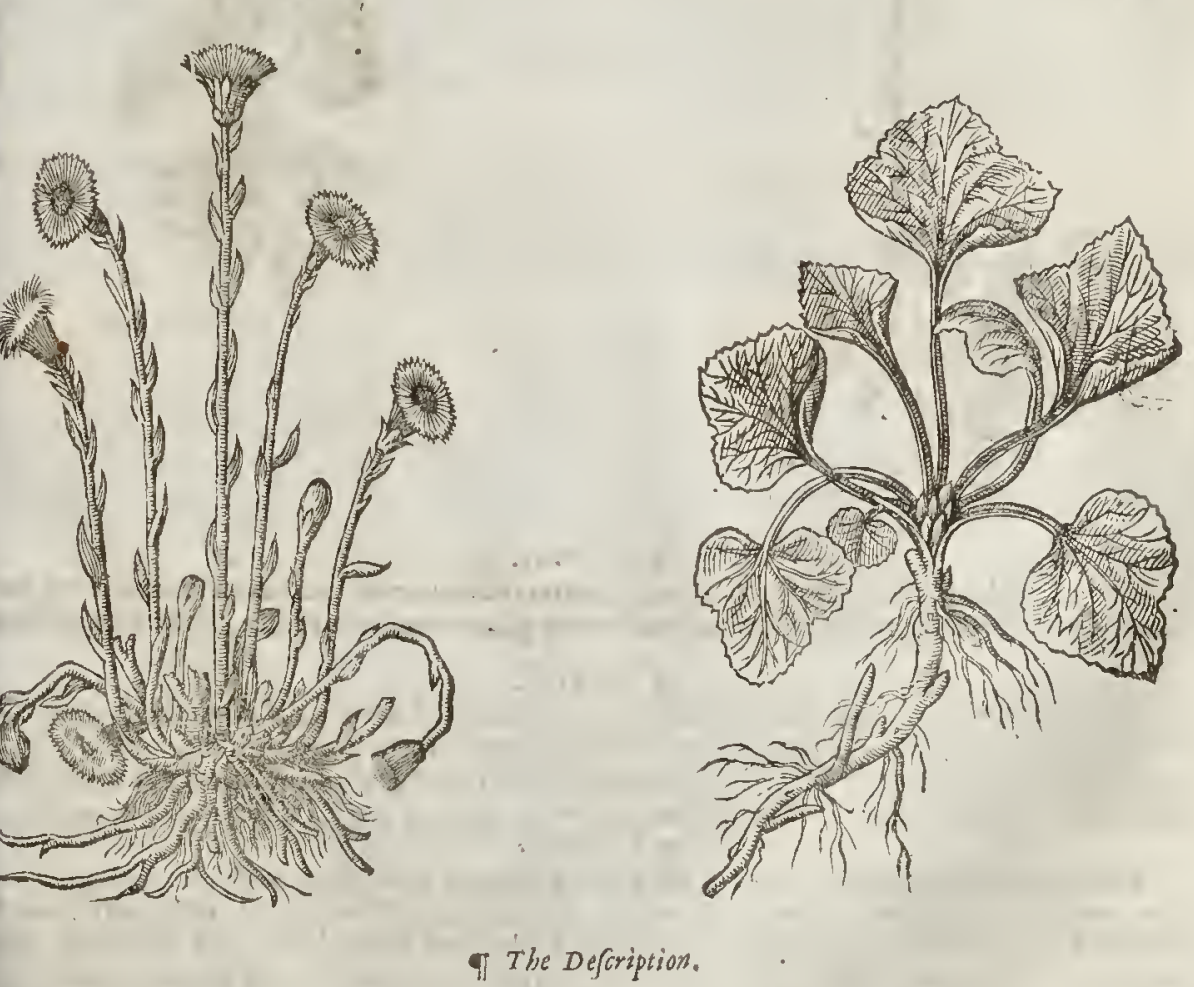

I TFkilago or Fole-foot hath many white and long creeping roots, fomewhat fat ; from which rife vp naked ftalkes (in the beginning of March and Aprill) about a fpanne long, bearing at the top yellow floures, which change into down, and are caried away with thewinde: when the ftalke and feed is perifhed, there appeare fptinging our of the earti 
many broad leaues, green aboute, and next the ground of a white hoarie or grayifh colour, fathioned like an horfe foot; for which caufe it was called Fole-foot, and Horfe-hoofe: feldome or neuer thall you find leaues and floures ar once, but the floures are palt before the leaues comc out of the ground; as may appeare by the firft picture, which fetreth forth the naked ftalkes and floures; and by the fccond, which pourtraiteth the leates onely.

¥ 2 Befides the commonly grorving and defcribed Colts-foot, there are orher two fmall mountaine Colts-feet defcribed by Clufius; the firft whereof I will here prefent you with, but the fecund you thall finde hereafter inthe chapter of $A \int_{a r} \mathrm{rum}$, by the name of Afarina cMatiholi. This here delineated hath fiuc or fix leaues not much vn like thofe of A lehoofe, of a darke thining green colour aboue, and very white and downy below : the ftalke is naked fome handfull high, hollow and down $y_{3}$ bearing one floure at the top compofed of purplith threds, and flying away in downe : after which thc talke falls away, and fo the leates onely remaine during the reft of the yeare : the root is fmall and creeping. It growes on the tops of the Auftrian and Stirian mountaines, where it floures in Iune or Auguft. Brought intogardens it floures in Aprill. Clufisus calls it TuSulago Alpina $\mathrm{r}$. and he bath giuen two figures thercof, both which I here give you by the fame titles as he hath them. ‡

$\neq 2$ Tußilago Alpina flore aperto. Mountaine Colts-foot full in floure.
‡ 2 Tufsilago Alpina flore evanido. Mountaine Colts-foot with the floure fading.
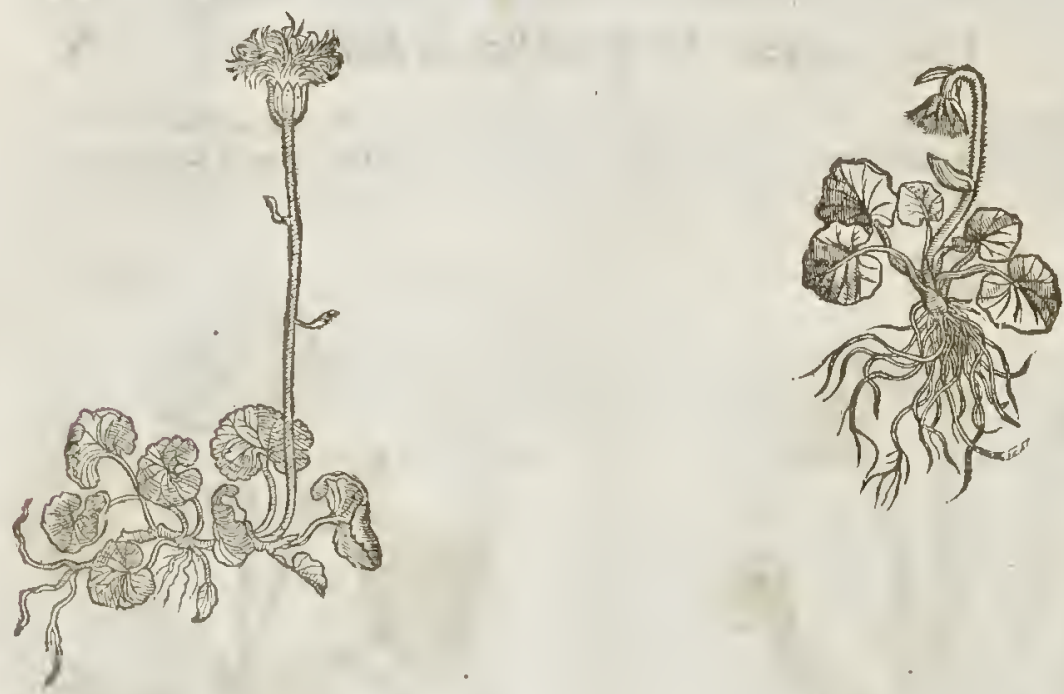

If The Place.

This groweth of it felfe neere vnto Springs, and on the brinkes of broakes and riuers, in wet furrowes, by ditches fides, and in other moift and watery places neere vnto the fea, almoft euery where.

T) The Time.

The floures, which quickly fade, are to be feene in the end of March, and about the Calends of Aprill, which fpeedily wither together with the ftems : after them grow forth the leaues, which remaine greene all Sommer long: and hereupon it came that Colts-foor was thought to be without foures; which thing alfo pling hath mentioned, in his fixe and twenticth booke, cap. 6 .

4 The Names.

Folefoot is called in Grecke sixur : of the Latines likewife Bcchion, and Tußslago: in fhops, Farfara, and Vngula Caballana : of diuers, pata equina : in Italian, Vnghiadi Cawallo: in Spanifh, vnhad" afno: in French, Pas d'afne : in Englinh, Fole-foot, Colts-foot, Horfe-hoofe, and Bull. foot. The fame is alfo chameleuce, which $P$ liny in his twenty eighth booke, and fifteenth chapter reporteth to be likewife called $F$ arfugrum, and $F$ arrimum, if there be not an error in the copy: which thing alfo Aëtius in his firft booke affirmeth, pretermitting the name of Bechium, and attributing vnto it all the vertues and faculties of Bechium or Colts-foot. Whofe opinion Orabafiss feemeth to be of, in his fifteenth bookeof his nedicinable. Collcctions, making nention of chamaleuce : only pliny 
alfo agreeth with them; thewing that fome thinke, that Bechiven is ealled by another name Chameleace, in his twenty fixth book c; cap. 6 . and it may be that $D$ iofcorides hath written of one and the felfe fame herbe in fundry places, and by diners names. Bechitum and $T$ us llago, which may alfo be Englinhed Cougliwort, fo called of the effeet, and Farfarm, of the white Poplar tree, row wh re leaves it is like, which was named of the Anticnts Forfarso, as Plautss wtiteth in his Comedie called I'cenulise.

$$
\text { fundasqua cos profterneban vt folia Farfari. }
$$

To the company I gaue both line burh and fling.

That to the ground as Poplar leaues I might them fling:

\$Dodoreus (from whom our Author tooke this) fets downe this place in Plautus as you finde it licre, but notwell; for the laft verfe thould be Fundafgue, co prefterneburt folia Farfari. Thus it is in moft cditions of $p l_{\text {ats }}$ tus , and that rightly, as the cnfuing words in that place declare. $\neq$

The white Poplar trec is called in Greeke sivw, and hereupon Bechion or Colts-footwas alfo cal led Chanaleuce.

$$
\text { 9) The Tempcrature and Vicrtues. }
$$

The leaues of Colts-foot being frefh and greene are fomething cold, and hate withall a drying $A$ qualitie; they are good for vlcers and inflammations : but the dried leates are hot and drie; and fomewhat biting. A decoction made of the grcens leaties and roots, or elfe a fyrtup theteof, is good for the cough $B$
that proceedeth of a thin rheume.

The green lenues of Fole foot pound with hony, docure and heale the hot inflammation called $\mathrm{C}$ Saint Anthonies fre, and all otlicr inflammations.

The fume of tredricd leaues taken through a funnell or tunnell, burned vpon coles, effecitually $D$ helpeth thofe that are troubled with the fhortne fe of breath, and ferch their winde thicke and of ten, and breaketly without perill the impoftumes of the brest. faid.

Being taken in manner as they take, Tobaco, it mightily pteuaileth againft the difeafes afote- E

$$
\begin{gathered}
\text { CHA P.29!. Of Butter-Burre. } \\
\text {. The Defoription: }
\end{gathered}
$$

1 R Vtter-Burre doth in like manner bring forth floures befote the leaties, as doth Coltsfoot, but they are fmall, mofie; tending to a purple colour; which being made vp into a big eare as it were, do quickly (togetherwith the ftem, which is thicke, full of fubftance, and brittlc) withet and fall away : the leaues are very great like to a round cap or hat, called in Latine Petafus, of fuch a wideneffe, as that of $i t$ fclfe it is big and large enough to keepe a mans head from raine, and from the heate of the Sunne : and therefore they be greater than the leanes of the Clot-burre, of colout fomewhat white, yet whiter vnderneath : euery ftem beareth his leafe; the ftem is oftentimes a cubit long, thicke, full of fubitance; vpon which ftandeth the leafc in the centrc or middlemoft part of the circum ference, or very neere, like to one of the greatet? Mufhroms, but that it hath a cleft that ftandeth about the ftem, efpecially when they are in perifhing: and withering away : at the firtt the vpper fuperficiall or out fide of the Murhroms inandech out, and when they are in withering ftandeth more in; and euen fo the leafe of Butter-bur hath on the outfide a certaine thallow hollowneffe : the root is thicke, long, blacke without, whitc within, of
itafte fomewhat bitter, and is oftentimes worme-eaten.

$$
\text { 91 The Place. }
$$

This groweth in moif places rieere vnto ritters fides, and vpon thie brinks and banks of lakes and ponds, almoft enery whore.

The eare with the floures flourih in A prill ot fooner : then come vp the !eatues, which continue till Winter, with new ones fill growing vp. 
I Petwites forens.

Butter-Burre in floure.

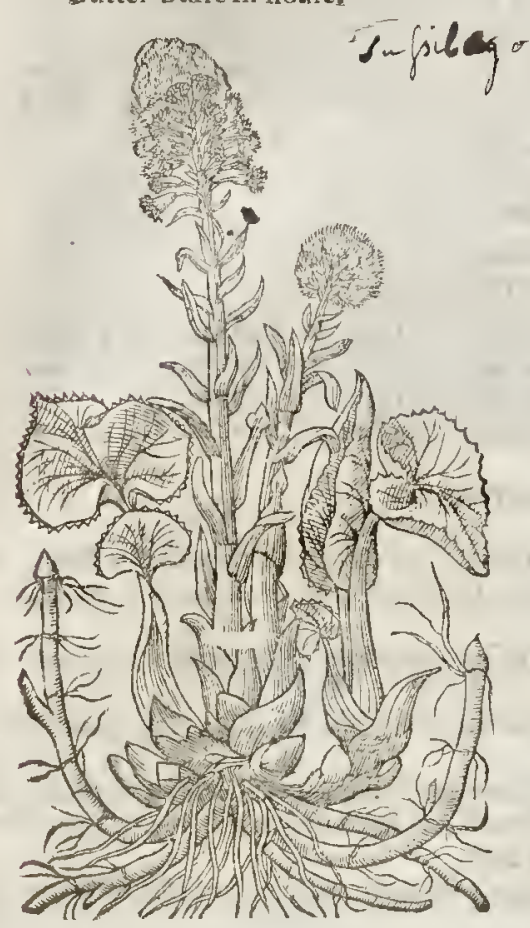

LIB.2.

I Petafet is folid.

The leaules of Butter-burre.

$$
\text { 2) The Names. }
$$

Butter-bur is called in Greeke martw, of the huvenefle of the leafe that is like to mirsm, or a hat :

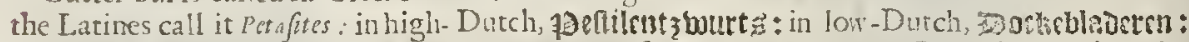
in Englifh it is named Butter-Burre : it is very manifeft that this is like to Colrs-fore, and of tre famekinde.

$$
\text { T The Tempcrature. }
$$

Butter-Burre is hot and dry in the fecond degree, and of thinne parts.

$$
\text { T } T \text { beVertues. }
$$

A The roots of Butter-burre famped with ale, and giuen to drinke in pentilutat and burning Feuers, mightily cooleth and abateth the heate thereof.

B

The roots dried and beaten to pouder, and drunke in wine, is a foucraigne mecticine againft the plague and peftilent feuers, becaufe it prouoketh fweat, and driveth from the heartall venome and ill heate : it killech wormes, and is of great force againft the fuffocation of the mother.

C The fame cureth all naughty filthy vlcers, if the pouder be ftrwed therein.

D The famekilis wormes in the belly: it prouokes vrine, and brings downe the monthly termes.

\section{\# C н а P. 292. Of Mountaine Horfe-foot.}

\section{If The Defcription.}

* 1 His plant (which the moderne Writers hane referred to the Cacalin of the Antients, 1 and to the kindes of Colts-foot) I hane thought good to name in Englin, Horlefoot, for that the leaues exceed Colts-foot in bigneffe,yet are like them in thape : and of this plant Clufus (whom I herechicfely follow) hath deferibed two forts : the firft of tlice hath many leaues almoft like vnto thofe of Colts-foot, but larger, very round, and finipt atout the edges, of a lighr greene coiour aboue, and loarie vnderneath, hauing alfo many veines ro nerues running vp and downe them; and thefe leates are of an vngratefull tafle, ahd grow vpon long purp!ifh crefted falkes : The femme is fome two cubits high, crefted likewife, and of a purplifh colour, fet,alfo at certaine fpaces with leauesvery like vnto the other, but lefer than tho'c 
¥ Cacalia incanofolio.

Hoarieleared Horfe-foot.

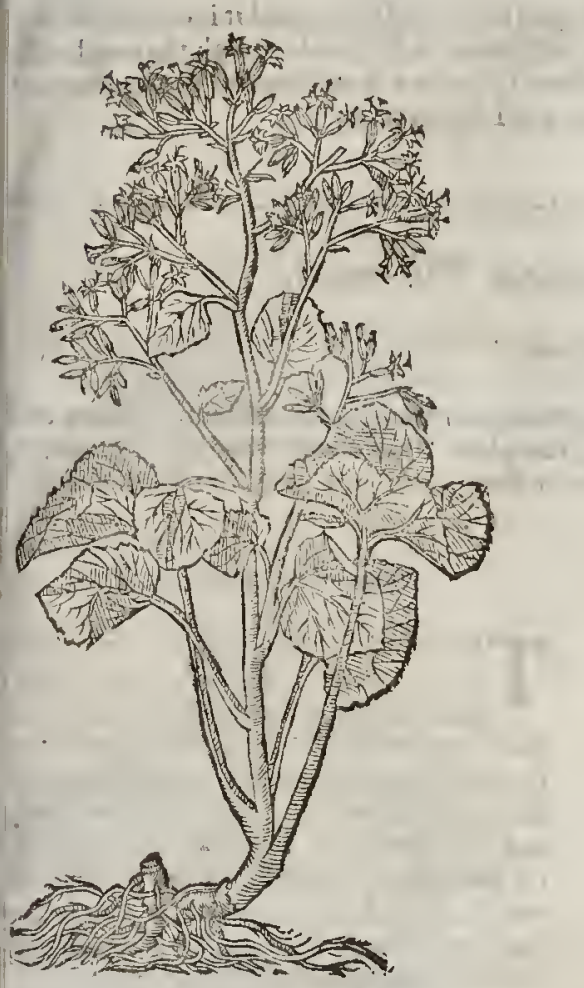

‡ 2 Cacaliafolio plabro.

Smosth leauel horfe-foot.

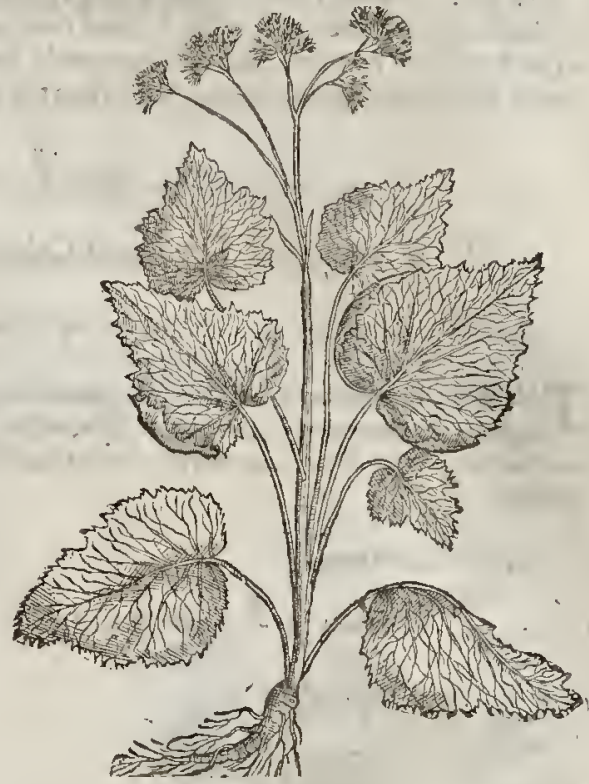

next the ground, and more cornered and tharper pointed; the tops of the ftalkes and branches caĩ rie bunches of purple Anures, as in an vmbell: and commonly in each bunch there are three lirtlo floures confifting of ioure leaues a peece, and a forked peftell, and thefe are of a purple colour, and a weakc, but not vnplealant fmell, and they at lengt turne into downe, amongftwhich lies hid a longifh feed : the ront, if old,fends forth diuers heads, as alfo ftore of long whitith fibres.

2 The leaues of this are more thin, tough and hard, and of a deener greene on the vpper fides, neither are they whitih below, nor come fo round or clofe whereas they are faftened to their falks (which are not crefted as thofe of the orher, but round and fmonth) they are alfo full of veines, and nickt about the edges, and of fomewhat an vngratefull hot an! bitter tafte. The ftalkes arealfo Imoother, and the floutes of a lighter colour.

\section{बा The Place.}

Both thefe grow in the Aufrian and Stirian Alpes vader the fictes of wools, among bufhes and fuch thadowieplaces : but not in England, that I haue yet heard of.

$$
\text { बा Thi Time. }
$$

I find it not fet downe when thefe floure and feed, but iudge it about the fame time that Colrf foot doth.

$$
\text { Ti The Names. }
$$

This by Clufius, Lob: $l$ and others, hath beene called Cacatia, and referred to that defcribed by $D i$ fcorides, li6.4.cap. $\$ 23$. which is thought to be that fet forth by Galcy by the name of cancanss. It i the Hiftoria Lugd.pag. 1052 . The later of thefe two here defcribed is figuted by the name of $T_{\text {uff:- }}$ lago Alpina fove montana, and the former is there,page $\mathrm{r} ; 08$, by the name of Cacalia, but the floures are not rightly expres: and ifmy iudgement faile me not, the figure which is in the fencnteenth page of the Appendix of the fame Authour,by the title of Aconitum Pardalianchesprinum, is of no orher than this very plant. But becaufe I haue not as yet feene the plant, I will not pofrtiuly atfirme it: but referre th is my opinion to thofe that are iudicious and curious to $_{2}$ know the plant that raifed fuch contronerfie between $M$ atthiolus and Gefner, and whereof neither Camerarius nor Earh hine, who haue fet forth $M$ atthiolus his Commentaries, haue giuen vs any certain or probable know led $y_{\text {es }}$ 
-1 The Temperature and Vertucs, out of the antients.

A The root of Cacalia is void of any biting qualitic, and moderately drics, and it is of a groffe and emplaiftieke fubftanee; wherefore fteped in wine and fo taken it lyelpes the cough, the roughneffe of rhe Arterie or hoarfnes, like as Tragacanth: neither if you ehew it and fwallow downe the iuiee doth it leffe auaile againft thofe effects than the iniee of Liquorice. $\neq$

\section{$\therefore$ Cна r.293. Of Fmall Celandine or Pile-moort. 9T The Kindes.}

1

Here be two kindes of Celandine, according to the old writers, mueh differing in forme and figure : the one greater, the orher leffer, whieh I intende to diuide into two diftinct ehapters, marthalling them as neere as may be with their like, in forme and figure, and firf of the fmall Ce. landine.

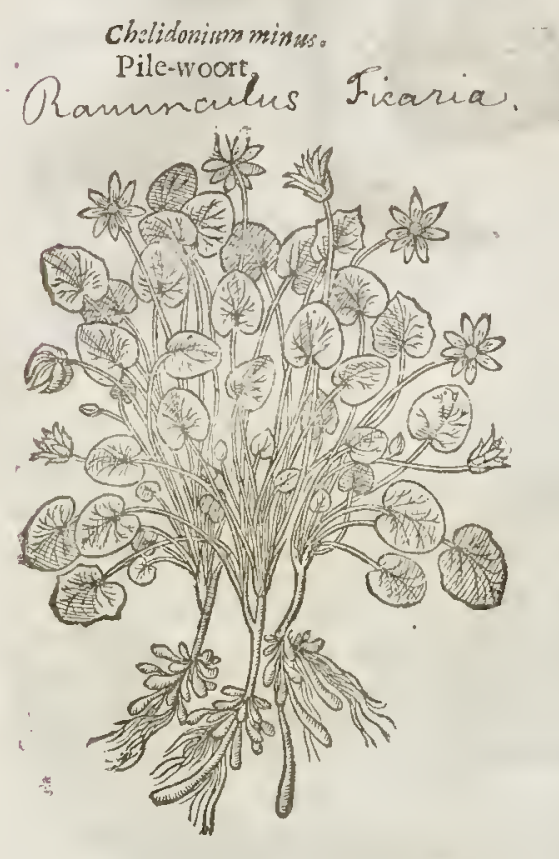

$$
\text { 4t The Defoription. }
$$

T He lefier Celandine hath greeneround leates, fmooth, flipperie, and fhining, leffe than the laucs of the Iuie: rlie ftalks are flender, hort, and for the mont part creeping vpon the ground: they bring forth little yellow flours like, thofe of Crow-foot, and after the loures there fpringeth vp a litthe fine knop or head full of feede : the root confiftech of flender ftrings, on which doe hang as it were certaine graines, 0 the bignes of wheat cornes, or bigger.

$$
\text { (f) The Place. }
$$

It groweth in medows, by eommon waies by ditches and trenehes, and it is commoneuery where, in moift and dankifh places.

$$
\text { of The rime. }
$$

It commetl forth about the Calends of Mareh, and flourcth a little afrer: ir beginnerh to fade away in A prill, it is quite gone in May, afterwards it is hard to be found,yea feareely the root.

$$
\text { of The Names. }
$$

It is ealled in Grecke xarsesur: of the Latines Chelidoniun minus, and Hirundinaria minor: of diuers, Scropluslaria miner, Ficaria minor: of Se-

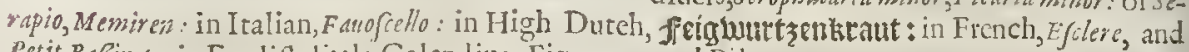
Petit Bapinet : in Englifh, little Celandine, Fig-woort, and Pile-woort.

Tा The Temperature.

$$
\text { T The Temperature. }
$$

It is hot and drie, alfo more biting and hotter than the greater : it commeth ncereft in facultie to the Crow foot.

\# This which is here, and by mof: Authours fet forth for Chelidonium minus, hath no fuch great heat and Aerimonie as Diofcorides and Galenaffirme to be in theirs; making it hot in the fourth degree, when as this of ours fearce exceedes the firft, as farre as wee may coniesture by the tafte. $\ddagger$

\section{T T he vertues.} B It prefently, as Galen and Diofrorides aff rme, exulcerateth or bliftereth the skin : it maketh rough
and corrupt nailes to fall away.

B The iniee of the roots mixcd with honie, and dratrne vp into the nofthrils, purgeth the head of fonle and filthie humours. 
The later age vfe the roots and graines for the piles, which being often bathed with the iuice $C$ mixed with w me, or with the fickmans vrine, are drawne together and dried $\mathrm{vp}$, and the paine quite
taken away.

There be alfo who thinke, that if the herbe be but cartied about one that hath the piles, the pain $D$ forthwith ceafeth.

\section{C н а P. 294. Of Marfh Marigold. \\ TI The Defription.}

I T Arih Marigold liath great broad leaues fomewhat round, fmoath, of a gallant greerie colour, fleightly indented or purld about the edges : among which rife rp thicke fat ftalkes, likew ife greene; whereupon doe grow goodly ycllow floures, glittering like. go'd, and like to thofe of $\mathrm{CrOw}_{\mathrm{f}} \mathrm{foot}$, but greater : the root is fniall, compofed of verie manie ftrings.

I Callba paluftris maior.

The great Marth Marigold. Caltha palustiris

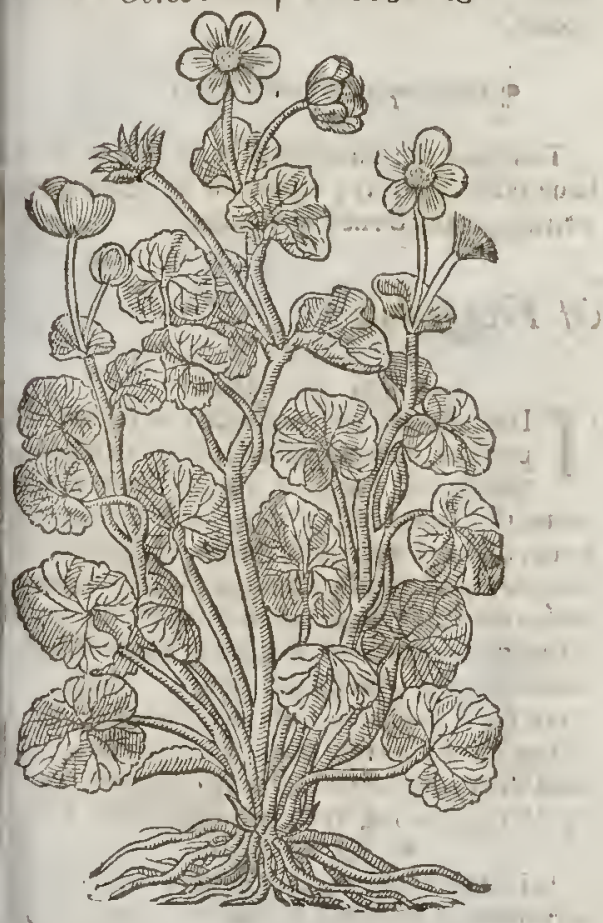

2 Calt hapaluftris minor.

The fmall Marth Marigold.

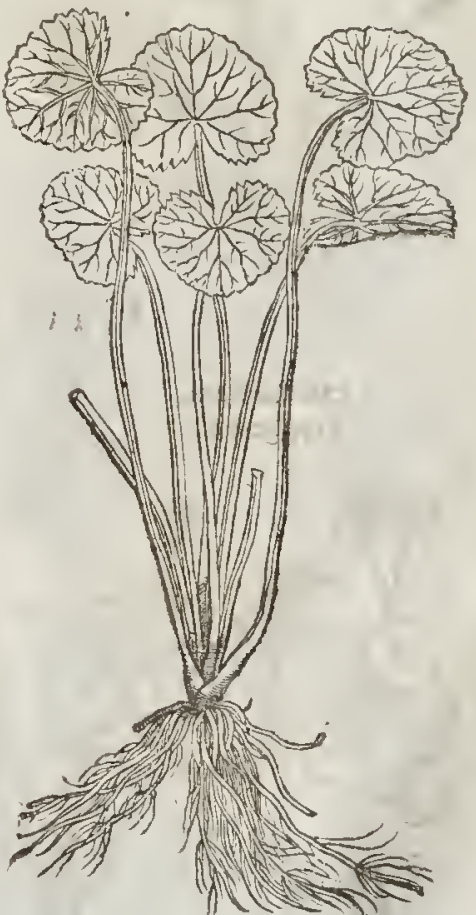

2 The fmalier Marnh Marigold hath many round leates fpred vpon the ground, of a darke greene colcur : among ft which rife vp diuers branches, charged with the like leaucs: the floures yrow at the toppes of the branches, of a moft mining yellow colour : the roor is alfo like the former.

3 The great Marh Marigold w ith double floures is a ftranger in England, his natiue Counitrey fhould feeme to be in the furtheft part of Germanie, by the relation of a man of thofe Countries that I haule had conference withall the which hee thus defcribed : it hath (faith hee) leaues, croots, and italkes like thofe of our common fort, and hath double foures like thofe of the garden Marigold, wherein eonfifteth the difference.

₹ Cammerarius writes iuft contraric to that which our Authour here affirmes ; for hee faith, In

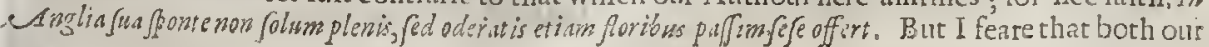


3 Calthapaluftris multiplex. Double floured Marn Marigold.

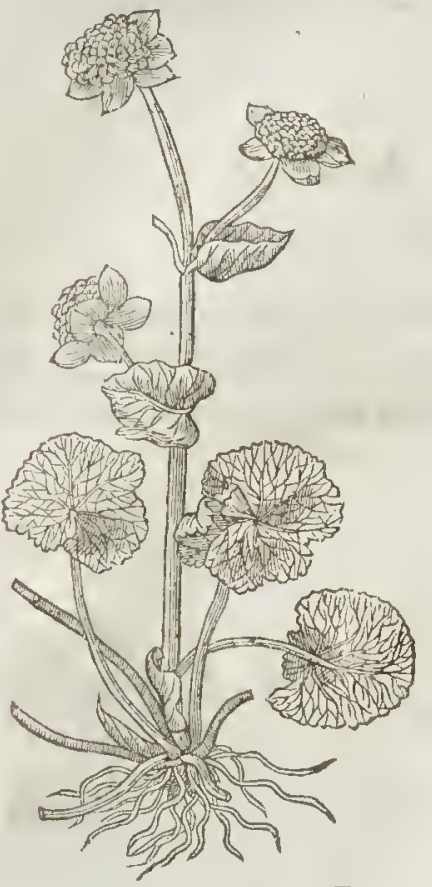

Chap. 295.

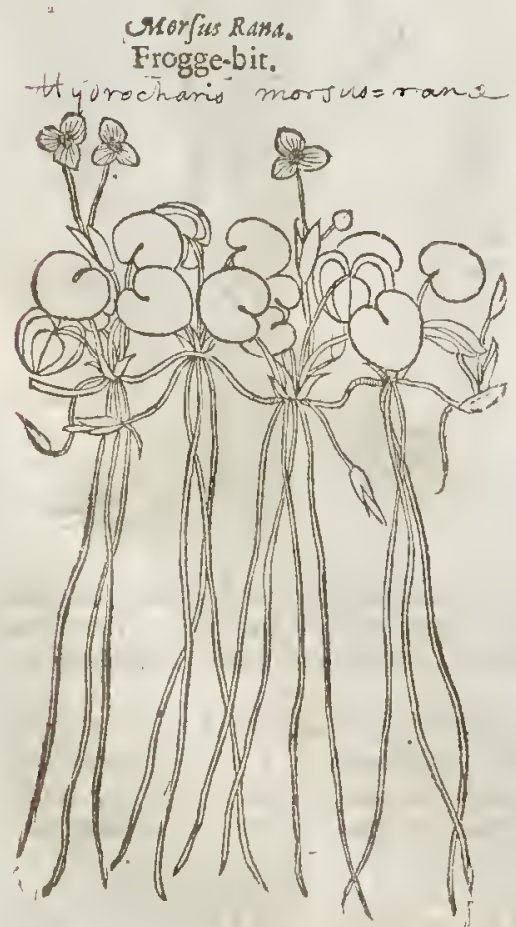

Authour and Camerarius were deceiued by trufing the report of fome lying, or elfe ignorant perfons, for I could neuer finde it growing wilde with double floures liere, nor Cameram there: yet I do not denie but by chance fome one with double floures may be found both lere \& there, but this is not euery where. $\neq$ The Platee.

They ioy in moift and marith grounds, and in watery medowes. ‡ I haue not found the double one wilde, but feene it preferued in diners gardens for the beautic of the foure. $\ddagger$

$$
\text { II The Time. }
$$

They "floure in the Spring when the Crowfoots doe, and oftentimes in Sommer : the leaues keepe their greeneneffe all the Winter long.

$$
\text { T The Niames. }
$$

Marfh Marigold is called of Vulcrius Cordus, Caltha paluftres: of Tabernahwontanus, Populdgo: but not properly : in Englifh, Marfh Marigolds : in Chentire and thofe parts it is called Bootes.

\section{Tा The Temperature and Veriucs.}

Touching the faculties of thefe plants, wee haue nothing to fay, either out of other mens writings, or our owne experiences

\section{Of Frogge-bit.}

$$
\text { T. The Defcription. }
$$

THere floreth or fwimmeth vpon the vpper parts of the water a tmallplant, which wee vfually call Frog-bit, hauing little round leaues, thicke and full or iuice, very like to the leaues of wall Peniwoort $:$ the floures grow vpon long ftems among the leaues, of a white colour, with a certaine yellow thrum in the middle, confifting of three leaucs : in ftead of roots it hath ncnder ftrings, which grow out of a thort and fmall head, as it were, from whence the leanes fpring, in the bottom of the water : from which head al fo come forth llopewife certaine ftrings, by which growing forth it multiplieth it felfe.

$$
\text { था The Place. }
$$

It is found fwimming or floting almoft in euery ditch, pond, poole, or ftanding water, in all the ditcles about Saint George his fields, and in the ditches by the Thames fide neere to Lambeth Marh, where any that is difpofed may fee it.

$$
\text { Ti'The Time. }
$$

It flourinicth and flouretl moft part of ail the ycare.

$$
\text { The Names. }
$$

It is called of fome Ranx morfus, and chorfus Rante and Nymphrentarua. 
It is thought to be a kinde of Pond-weed (or rather of Water Lillie) and to have the fame fa- A cult ies that belong vnto it.

\section{Char. 296: OfWater Lillie.}

\section{बi The Defcription.}

1 The white water Lillic or Nemuphar hath great round leaues, in thape of a Buckler, thick; fat, and full of itice, ftanding vponlong round and fmooth foot-italkes, ful of a f pungious fubftance; which leaues do fwim or flote vpon the top of the water : $v$ pon the end of each ftalk groweth one floure onely, of colour white, confifting of many little long tharpe pointed lcaues, in the middeft whereof bee many yellow threds : after the floure it bringeth forth a round head, in which lieth blackin glittering feed. The roots be thicke, full of knors, blacke withour, white and fpungie within, out of which groweth a multitude of itrings, by which it is faftened in the bottome.

I Nymplices alba.

White Water Lilieg

Nymphoa alla

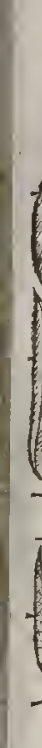
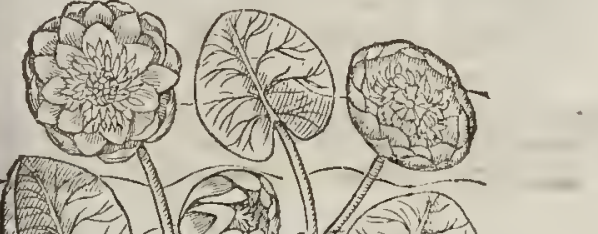

(E)

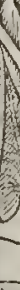

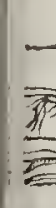

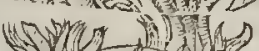

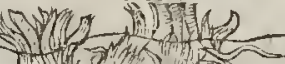

anivisusion

17

2 The leaues of the yellow water Lillic be like to the other,yet are they a litrle longer. The ftalkes of the Houres and leaues be like: the floures be yellow, confinting onely of fue litt le thort leaues fomething round, in the midft of which groweth a fmall round head, or button, tharpe towards the point, compaffed about with many yellow threds, in which,when it is ripe, liealfo glittering feeds, greater than tlofe of the other, and leffer than wheat cornes. The roots be thick, long, fet with certaine dents, as it were white both with in and without, of a fpurgious fubftance.

3 The fmal white water Lillie floteth likewife vpon the water, hauing a fingle root, with fome fue $w$ fibres faftened thereto: from which rifcth vp many long, round, fmooth, and foft foot-ftalkes, whe of which doe bring forth at the end faire broad round buckler leaues like vnot the prece- a Nymphanlutea.

Ycllow Water Lillie, Nymphaa intea.
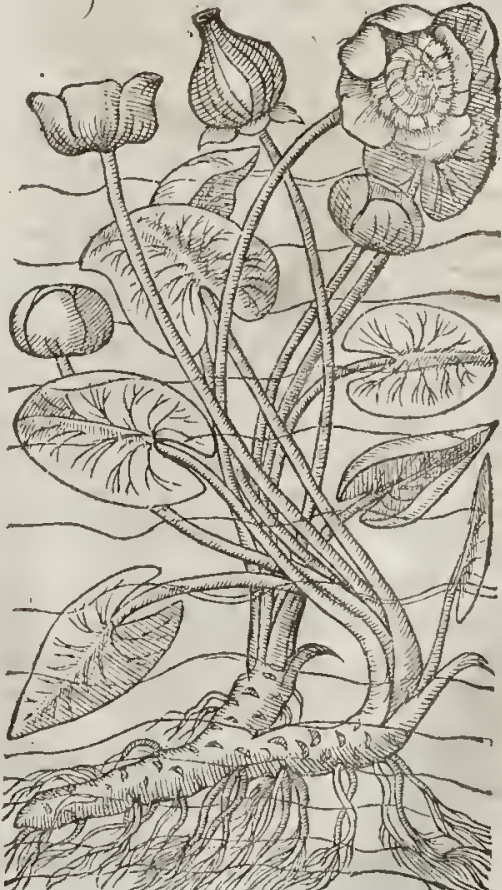
dent. 
dent, but leffer: on the other foot-ftalkes ftand pretric white flourcs, confifting of fiue fmall leaues apeece, hauing a little yellow in the middle thereof.

3 Xumphenalbirminor.

The finall white Water Lillie.
5 Nymplara lutea minima. Dwarfe Water Lillie.
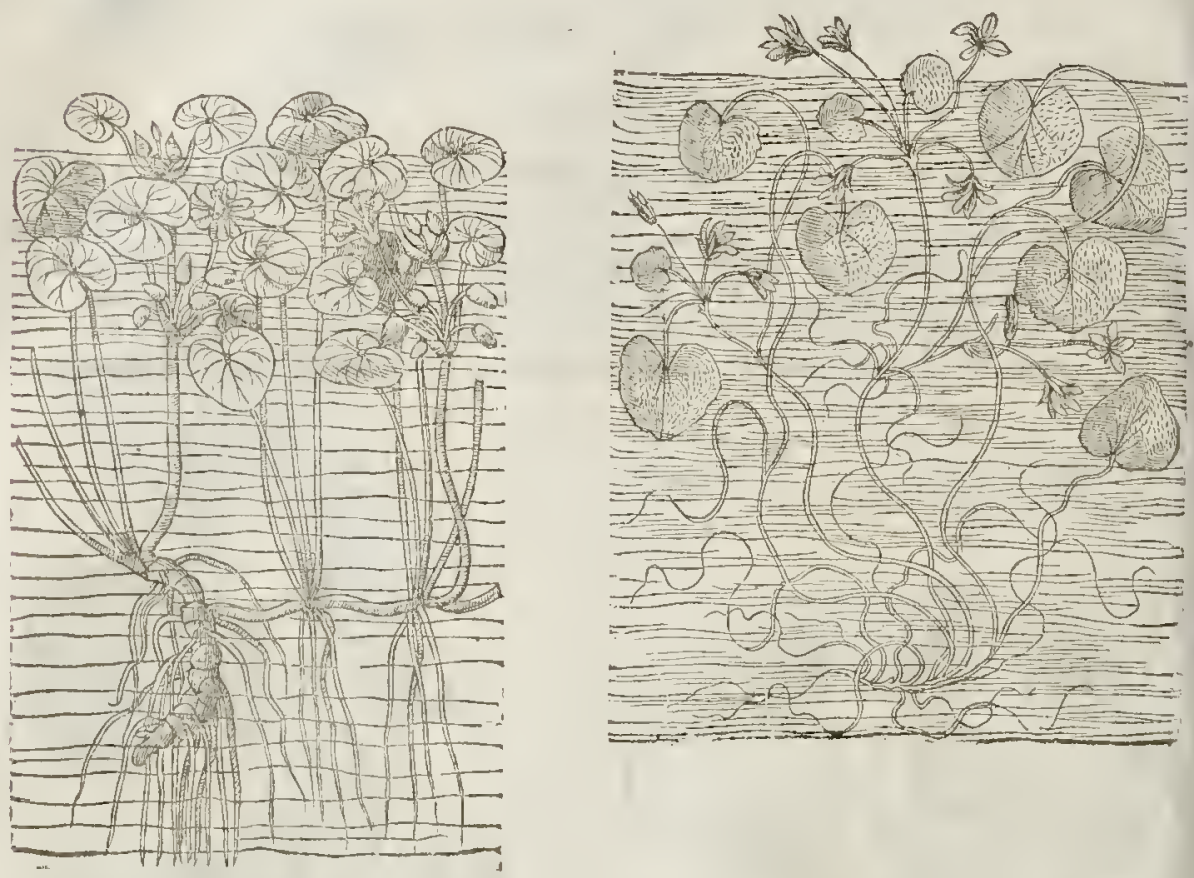

4 The fmail yellow water Lillie hath a little threddie root, ereeping in the bottome of the water, and difperfing it felfe far abroad : from which rife fmall tender ftalkes, fmooth and foft, whereon do grow little buskler leanes like the luft defcribed: likcwife on the other fimall ftalke ftandeth a tuft of many floures lik w w ife floting vpon the water as the orhers do $¥$ This hath the foures larger than thole of the next defcribed, wherefore ir may be fitly named Nymphail lutea manor fore amplo, +

5 This dwarfe water Lillie differeth not from the other fmall yellow water Lillie, fauing that, that this linde hath tharper pointed leates, and the whole plant is altogether leffer, wherein lieth the difference. $¥$ This ha $\mathrm{h}$ the foures much leffe than thofe of the laft deferibed, wherefore it is ficly for diftinction fake named Nymphasa latca minor flore parwo. $\neq$

$$
\text { If The Place. }
$$

Thefe herbes do grow in fennes, ftanding waters, broad ditehes, and in brookes that run flowly, and fometimes in great riuers.

$$
\text { They The Time. }
$$

They floure and flourith noit of the Sommer moneths.

$$
\text { Tा The Names. }
$$

Wrater Lillie is called in Greeke Nvorux :and in Latine alfo $N y$ mphoun, fo named becaufe it loutes

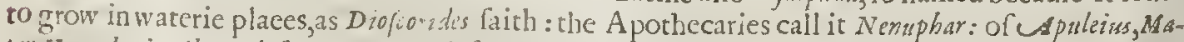

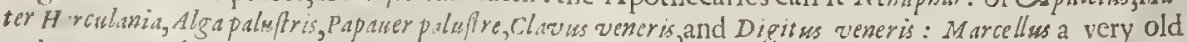
writer reporreth, that it is called in Latine Clawa Herculs: 113 French, Badittin : in high Dutch, 1Dafo

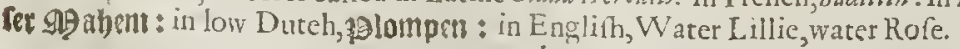

$$
\text { Tit The Temperature. }
$$

Both the root and feed of water Lillie hate a drying force without biting.

A Water Lillie is ith yellur foures ftoppeth laskes, the onerflowing of feed which commeth away by dreanes or otherwife, and is good for them that haue the bloudie flix. 


\section{1.2. Of the Hiftory of Plants.}

But water Lillic which hath the white floures is of greater force, infomuch as it ftaieth the $D$ whites:but both this and the other that hath the black root muft be drunke in red wine:they hane alfo a fcouring quality, therfore they both clenfe away the morphew, and be alfogoud againta the pilling away of the haire of the head; againft the morpherv they are fteened in water, and for the pilling away of the haire in Tarre: but for thefe things that is fitter which hath che black row, nnd for the other, that which hath the white toot.

Theopraftus faith, that being famped and laid vpon the wound, it is reported to ftay the blee- C ding.

The Phy fitions of our agedo commend the floures of white Nymphea againt the infirnities of the head which come of a hot caufe : and docertainely attirme, that the root of the yellow cureth hor difeafes of the kidnies and bladder, and is fingular good againft the running of the reines.

The root and feed of the great water Lillie is very good againft venery or flchly defire, if one E do drinke the decostion thereof, or ve the feed or roor in powder in his meates, for it dryeth vp the feed of generation, and fo cauferh a man to be chaft, efpecially vfed in broth with flefh.

The conferue of the floures is good for the difcafes aforefaid, and is good allo againt hot bur- I ning feuers.

The floures being made into oile, as yee do make oile of tofes, doth coo!e and refrigcite, caur fing fweate and quiet fleepe, and putterh away all venereous drcames : the temples of the herid ant palmes of the hands and fect,and the breft being annointed for the one, and tliegenisars vpois ais. about them for the other.

The greene leaucs of the great water Lillie, either the white or the yellow laid vpou the region iI of the backe in the finall, mightily ceafe the inuoluntary flowing away of the feed called Gonorrhea, or running of the raines, being two or three times a dxy remeoued, and freih applied thereto.

\section{C н а P.297. Of Pond-weed, or mater Spike:}

I Potsmogeiton latifolium. Broad leafed Pondweed.

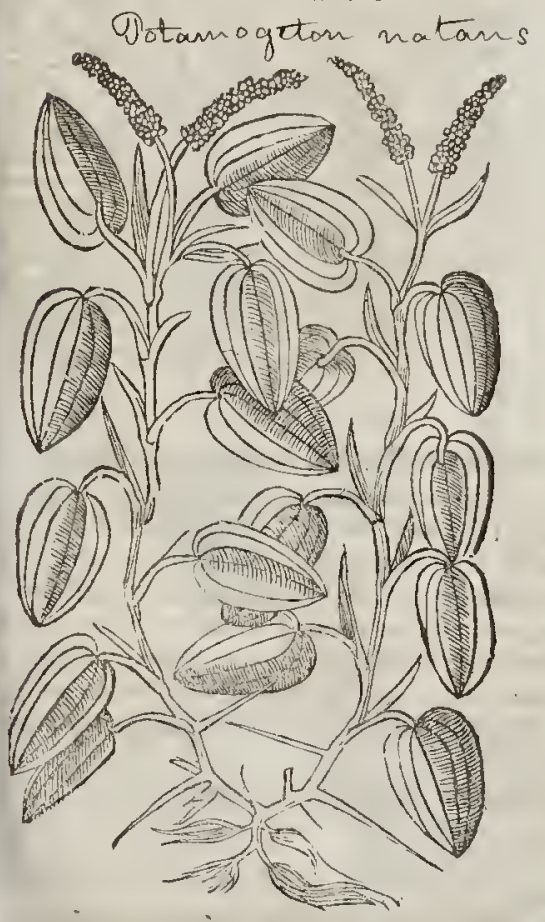

2 Potamogeiton angufifolum: Polu Narrow leafed Pondweed.

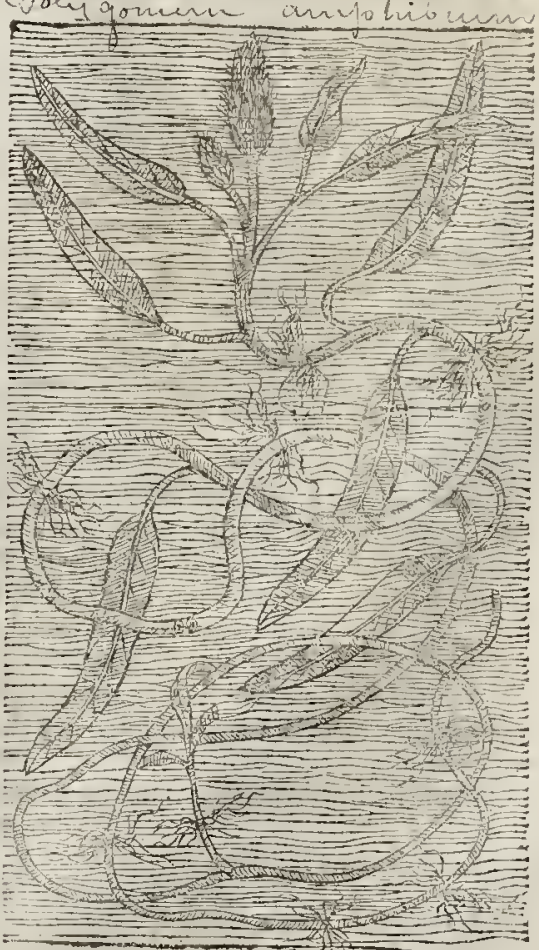

L $2 . Z$ 


\section{QT The D fription.}

I Ond-weed hath little fallies, flender, fpreading like thofe of the vine, and jointed : the leaues be long, fmaller chan che leaues of Plantaine, andharder,w th manifef veines run. niug a ong ft them as in Plantains, which ftandilig voon flcnder and long ftems or footftalkes, thew themfelues aboure the water, and lie flat along vpon the fuperfieiall or vpper part rhereof, as do the leanes of the water Lillie: the floures grow in thort eares, and are of a light red purple eolour, like tlufe of Red-thankes or Biftort : the feed is hard.

$f_{2}$ This (whofe figure was tormerly unfitly put by our A uthour to the following deferip. rion) hath longer,rarrower, and tharper fointed leaues rhan thofe of the laft deferibed, hauing the veines running from the middle rib to the fides of the leates, as in a willow leafe, which they lomewhat refenble; at the tops of the ftalkes grow reddifh fpikes or eates like thofe of the laft defcri bed : the root is long,jointed, and fibrous. ‡

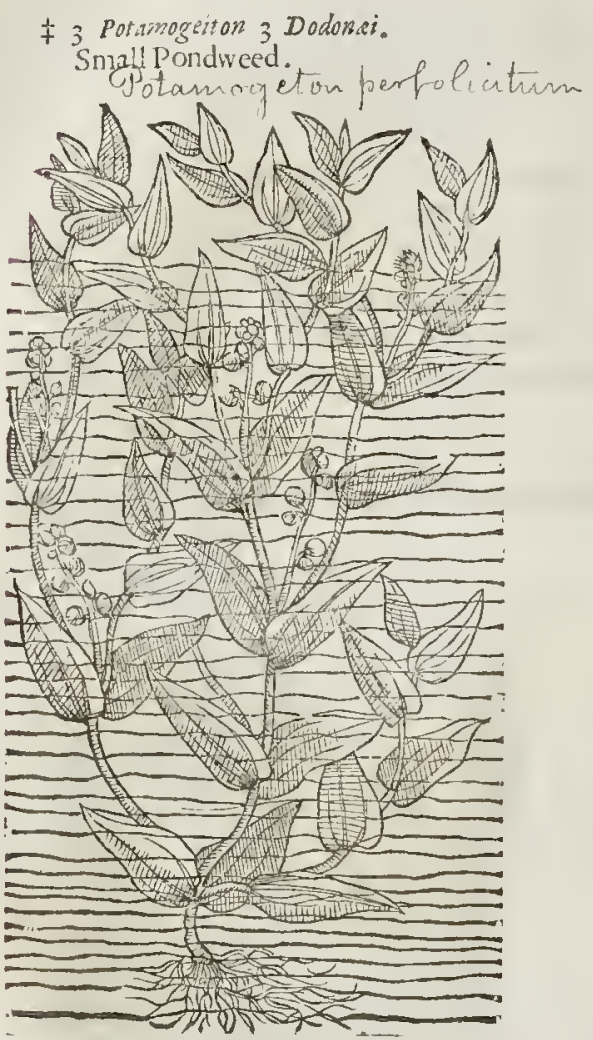

¥ 4 Potamogciton long is acut is folijs. Long tharpe leaued Pondweed.

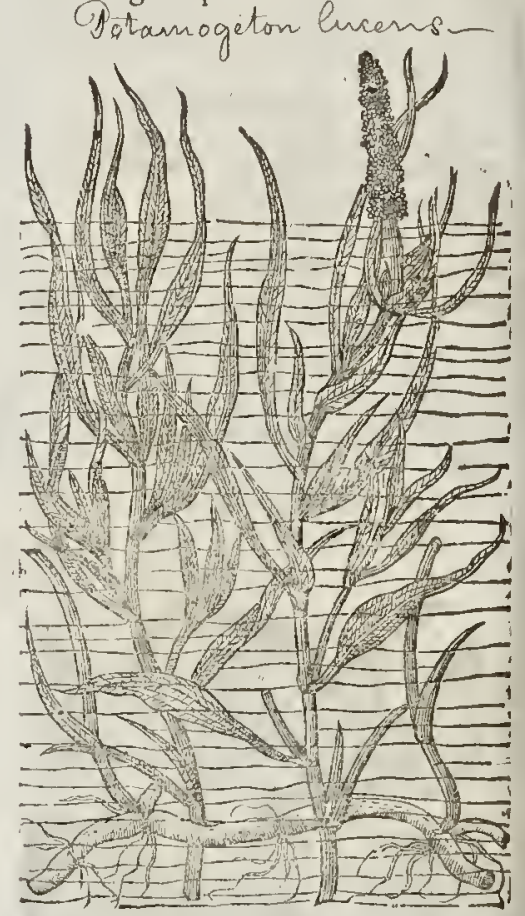

There is another Pondweed defcribed thus, it thooteth fotth into many flender and round ftems, which are diftributed into fundry branehes : his leaues are broad, long, and tharpe pointed, yet much le ffe than the firft linde:out of the bofomes of the branehes and leaues there fpring certaine little falkes which beare fundry fmall white mofie floures, which doe turne into plaine and round feeds, likethe common Tare or Vetch:his ront is fibrous, throughly faftened in the ground.

\# 4 There is alfo another Pondweed, whieh hath whitifh and jointed roots ereeping in the bottome of the water, and fending clowne fome fibres, but fending vp flender jointed and long fallies, fmall below, and bigger abour, hauing long narrow and very ftiffe tharpe pointed leaues. The foures grow in a reddin fpike like thofe of the firft deferibed. This is the Potamogeiton alrera of Dodoneus. $\ddagger$

The fe herbes do grow in ftanding waters, pooles, ponds, and ditches, almoft euery where.

They do floure in Iunc and Iuly.

$$
\text { of The Time. }
$$

a The Names.

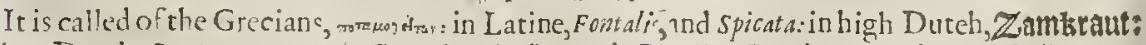
n loiv Dutch, fontcpnetupt: in Freneh, Efpi d'eane : in Englifh, Pondwced, and water Spike. 
T) The Temperature. than that of Knot-graffe.

9 The Vertues.

It is good againft the itch, and confuming or eating VIcers, as Diofcorides writeth.

Alfo it is good being applied to the inflammation of the legges, wherein I gnis factr hath gotten is the fuperioritie.

\section{С н а Р. 298. Of Water Saligot, water Caltrops, or water $\mathcal{N}$ (uts. I The Defription.}

$1 T$ Ater Calttops haue long flender ftalkes, growing vp, and rifing from the bottome of the water, and mointing aboue the fame: the root is long, liaung hereand there vnder the water certaine taffels full of fmall ftrings and threddie laires: the ftem towards the top of the water, is very great in refpect of that which is lower, the leaues are large and fornewhat round, not wnlike thofe of the Poplat or EIme tree leares, a litrle crevifed or notched about the edges : amongft and vnder the leaues grow eth the fruit, which is triangled, hard; tharpe pointed,and prickly: in thape like thofe hurtfull engines in the warres, caft in the paffage of the enemie to annoy the feet of theit horfes,called Caltrops, whereof this tooke its name : within thefe heads or Nuts is contained a white kernell, in tafte almoft like the Chef-nut, which is reported to be eaten gteene, and being dried and ground to ferte in ftead of bread.

\# Thereare two other plants which are found growing in many ponds and ditches of this kingdome,both about London and elfe-whete, and I will hete giue you the figures out of Lobel and clufius, and their deferiptions as they were fent me by $\mathrm{M}^{\mathrm{r}}$. Goodyer, who hath fatted me the labour of
defcribing them.

$$
\begin{aligned}
& \text { Tribulus aquaticus minor quercus floribus, Cluf.p. } 252 \text {, } \\
& \text { Pufillum fontila patbum, Lobely. }
\end{aligned}
$$

2 This water herbe bringeth forth from the root, thin, flas knottie ftalkes, of a teddith colour, iwo or three cubits long, or longer, accord ing to the depth of the water (which when they are drie are pliant and bowing) divided towards the top into many parts or branches, bearing but one leafe at eviery ioint, fometimies two inches long, and halfe an inch broad, thin, and as it were thining, fo wrinckled and crompled by the fides that it feemeth to be come, of a reddith greene colour : the foot-ftalkes ate fomething long and thicke, and rife vp from amongft tho fe leaues, which alvaies grow two one oppofit aga inft a nother, in a contrarie manner to thofe that grow below on the ftalk: neere the top of which foot-ftalke groweth fmall grape-like hushes, oit of which fpring very fmal reddin floures, like thofe of the Oke, euery floure hauing foure very fmall round topped leaues : after eucry floure commeth commonly foure tharpe pointed graines grow ing together, containing within them a little white kernell. The lower part of the ftalke hath at euery ioint fmall white threddie roots, fomewhat long, whereby it taketh hold in the mudde, and draweth nournithment vnto it. The whole plant is colnmonly coueted ouer with water. It foureth in Iune and thebeginning of Iuly. I found it in the ftanding pooles or finh-ponds adioyning to a diffolued Abbey called Durford, which ponds diuide Hampthire and Suffex, and in other ftanding waters elfwhere. This defctiption was made vpon fight of the plant the 2 .of I un ne, I 622 .

$$
\text { Tribuins aquaticus minor, mufcat ella foribus. }
$$

3 This hath not flat ftalkes like the other, but roind,kneed, and a lwaies bearing two leaues at eucry ioint, one oppofite againft another, greener, thorter and leffer than the othet, tharpe pointed, not mich wrinckled and crumpled by the edges. Clufus faith, that they are not at all crumpled. I neuer obferued any withou crumples and wrinckles : the floures grow on thort fmall footintalkes, of a whition green coloirr, like thofe of Mufcatella Cordi, called by Gerard, Radix cauta minima viridi flore: viz. two foures at the top of euery foot-ftalke, one oppofite againft another, euery floure containing foure fmall leaues : which two floures beeing paft there come up eight finall 


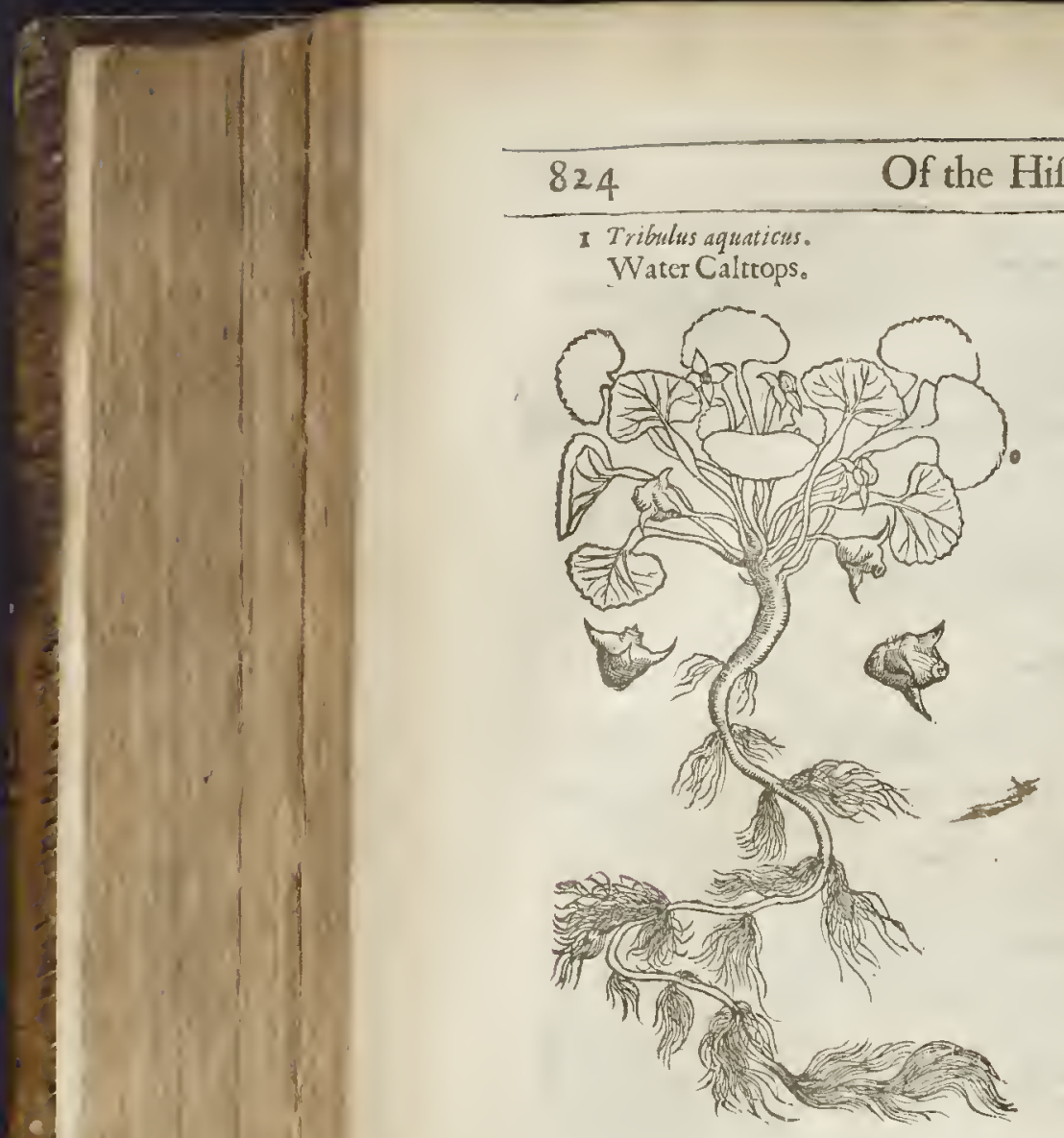

¥ 3 Tribulus aquaticus minor, Muf catella foribus. Small Frogs-Lettuce.

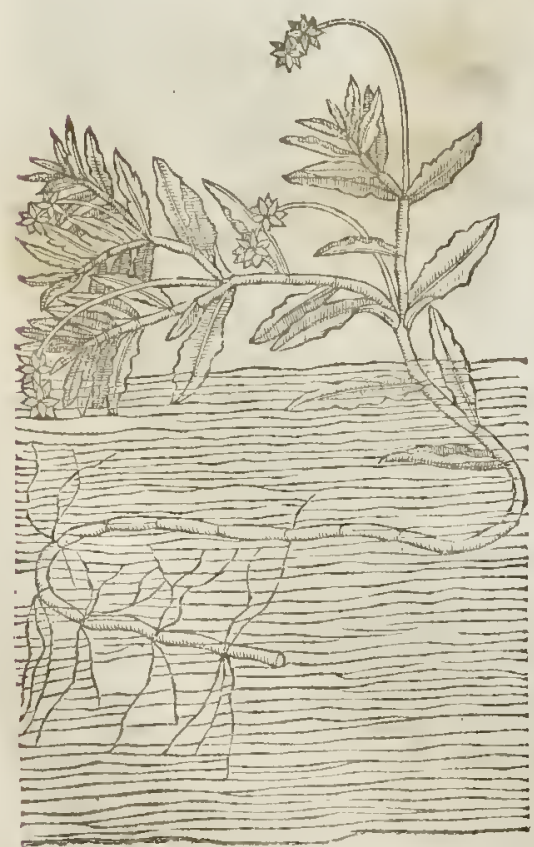

† 2 Tribulus aquaticus minor quercus floribus. Small water Calttops, or Frogs-lettucc.

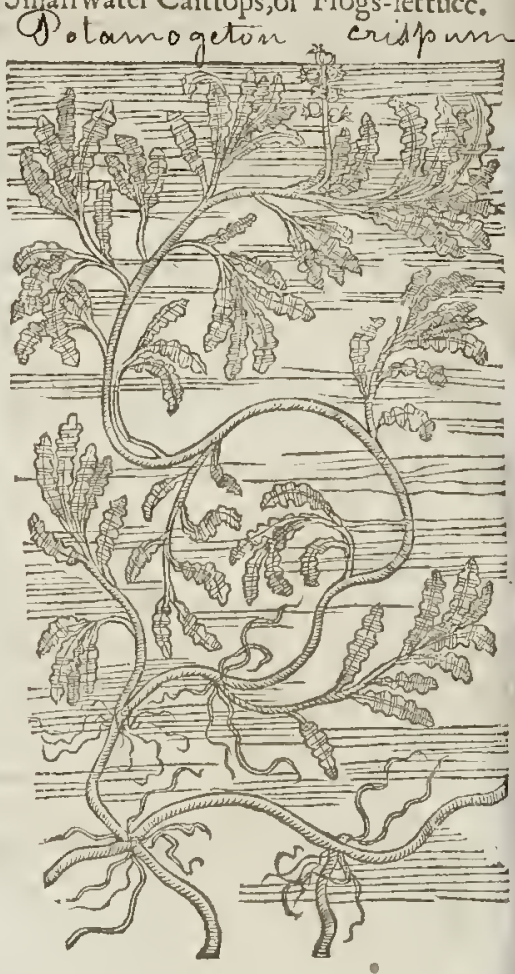

husks making fix feueral waies a fquare of flouts. The roots are like the formct. This gtoweth abundantly in the rituer by Droxfotd in Hampihire. It floureth in Iune and Iuly when the other doth, and continueth couered ourerwith water, greene, both winter and Sommer.Iohn Goodyer * \$

\section{The Place.}

Cordus faith that it groweth in Germany in myrie lakes, and in citie ditches that haue mud in them:in Btabant and in other places of the Low-countries, it is found of tentimes in ftanding waters, and fprings: Matthiolus wtitcth, that it groweth not only in lakes of fweet water, but alfo in certaine ditches by the fea neere vnto Vcnice.

$$
\text { If The Time. }
$$

It flourifheth in Iune, Iuly, and Aue guf.

$$
\text { ब The Tames. }
$$

The Grecians call it ropus srooss: the Latins, Tribulus aquatilis, and aquaticus, and Tribrelus lacintris : the A pothecaries, Tribulus marinus:in High Dutch, noafter nulz: the Brabanders, nater noten: and of the likenefte of yron nailes, gpinctiters: 
the Freneh men, Macres : in Englin it is named water Caltrops, Saligot, and Water-nuts :moft docall the frut of this Caltrops, Caftanea aquatiles, orwater Chef-nuts.

\section{The Temperature.}

Water Caltrop is of a cold nature, it confifteth of a moift effence, which in this is more wateric than in the land Caltrops, wherein an earthic cold is predominant, as Galen faith.

\section{T I he Vertues.}

The herbe vfed in manner of a pultis, as Diofcorides teacheth, is good againft all inflammations $A$ or hot fwellings: boiled with honie and water, it perfectly healeth cankers in the mouth, fore gums, and the Almonds of the throat.

The Thracians, faith Plimie, that dwell in Strymona, do fatten their horfes with the leaues of Sa- B ligot, and they themfelues do feed of the kernels, making very fweet bread thereof, which bindeth the belly.

The green nuts or fruit of Tribulus aquaticus, or Saligot, being drunke in wine, is good for them C which are troubled with the fone and grauell:

The famedrunke in like manner, or laied outwardly to the place, helpeth thofe that are bitten D with any venomous beaft,and refifteth all venome and poifon.

The leates of Saligot be giuen againf all inflammations and vlcers of the mouth, the putrifa. E ction and corruption of the iawes, and againft the Kingseuill.

A pouder made of the nuts is giuen to fuch as piffebloud, and are troubled with gtauell; and F it doth bind the belly very much.

\# The two leffer water Caltrops here defcribed are in my opinion much agreeable in temper $\mathrm{G}$ to the great one, andare much.firter Succidanes for it then Aron, which fone in the compofition of $r$ nguentum $u$ grippa haue appointed for it . $\neq$

\section{C н а Р. 299. Of water Sengreene, or frefth water Soldier.}

Militaris Aizoides.

Fren water Soldier.

Stratioles cleociden

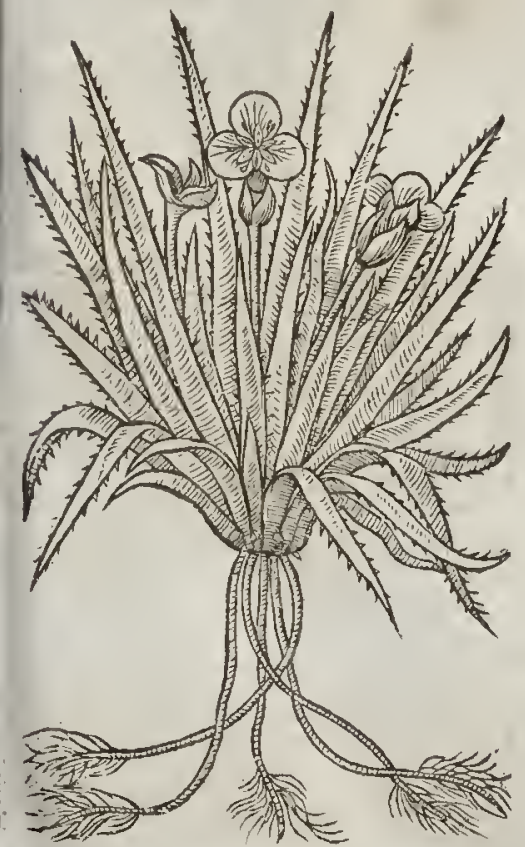

T The Defcription.

FReth water Soldier or water Houfleeké: hath leaues like thofe of the herbe Aloe, or Semper woum, but horter and leffer, fet round about the edges with certaine fific and hort prickles: amongt which commeth forth diuers cafes or huskes, verie like vnto crabbes clawes : out of which when they open grow white floures, confifting of three leaues, alto gether like thofe of Frogs-bit, hauing in the middle little yellowin threds : in ftead of roots there be long ftrings, round, white, verie like to great Harp-ftrings, or to long wormes, which falling downe from a hort head that brought forth the leaues, go to the botrom of the water, and yet be they feldome there faitened : there alfo grow froni the fame other ftrings aflope, by which the plant is multiplied atter the manner of Frogs-bit:

$$
\text { Tा The Place. }
$$

\# I found this growing plentifully in the ditches about Rotfey a fmal village in Holderneffe. And my friend M. William $B$ road obfertred it in the Fennes in Lincolne-fhire. $\neq$ The leaues and floures grow vpon the top of the water, and theroots are fent downe through the water to the mud.

$$
\text { qा The Time. }
$$

It foures in Iune, and fometimes in Augüft. 
- Tा $T$ be Names.

It may becalled Sedum aquatile, or water Sengreen, rhat is to fay, of the likeneffe of herbe Aloe, which is alfo called in Latine Sedum : of fome, Cancri chela, or Cancriforficula : in Englith, VVater Houleeke, Kuights Pondwoort ${ }_{3}$ and of fome,Knights water Sengreene, frefh watè Soldier,or wa ding Pondweed: it feemeth ro be Stratiotes aquatilis, or Siratiotes potamios, or Knights water Vi oundwoor, which may alfobenamed in Latine Militaris aquatica, and CMilitaris Aizoides, or Soldiers Yarrow; for it groweth in the water, and floteth vpon it, and if thole itrings which it fendeth to the bottome of the war er be no roots, ir alfo liveth wirhout roots.

This herbe is of a cooling nature and temperament:

$$
\text { GThe Temperature. }
$$

$$
\text { Tा I be Vertues. }
$$

'A This Houfleeke ftaieth the bloud which commeth from the kidneies, it keepeth green wounds' from being inflamed, and it is good againt S. Anthonies firc and hot fwellings, being applied vnto them : and is equall in the vertues aforefaid with the former.

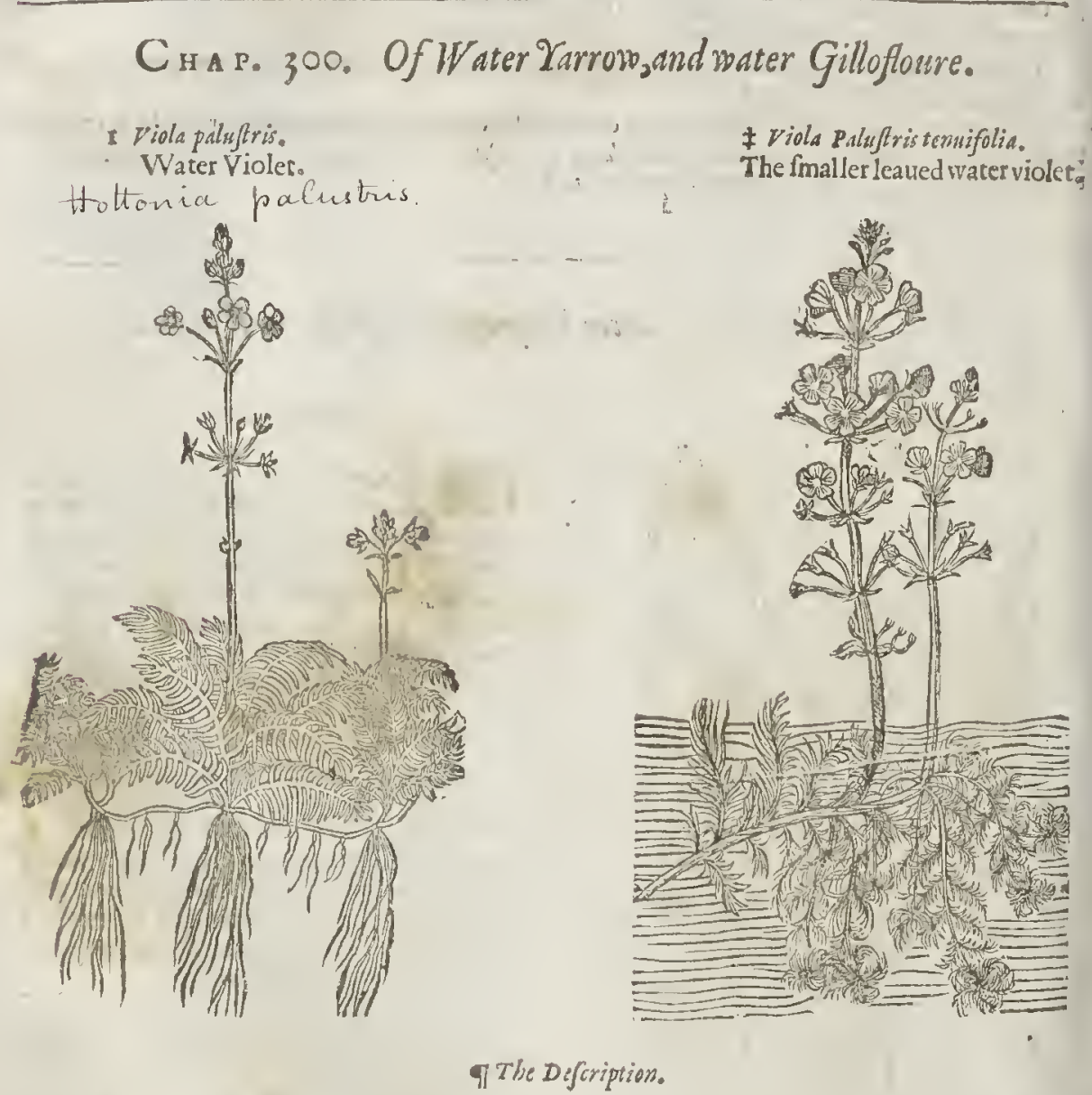

1 T Atet Violet hath long and great iagged leaues,very finely cut or rent like Yarrow: bur faller:anong which come vp fmall italkes a cubit and a halfe high, bearing at the rop fmall white floures like vn roftocke Gillofloures, with fome yellownes in the middle. The roots are long and fmall like blacke threds, and at the end whereby they are faftened to the ground they are whire, and thining like Chry fall.

$\ddagger$ There is anorher varieric of this plant,which differs from it only in that the leaues are much fmalleras you may fee then expreft in the figure. 
2 Water Milfoile, or water Yarrow hath long and large leaues deepely curwirh many divifons like Fennell, but finelier iagged, fwimming vpon the water. Tke root is fingle, long, and round, which brings vp a right fraight and flender ftalke, fet in fundry places with rhe like !eatues; but fmaller. The Aloures grow at the top of rhe ftalke tuff fafhion, and like vnto the land Yarrow.

3 This water Milfoile differeth from all the kindes aforefaid, hauing a root in the bottom of the water, made of many hairy frlngs, which yeeldeth vp a naked flender ftalke within rhe water, and the reft of the ftalke which floteth vpon the water diuideth it felfe into fundry other branches and wings, whioh arebedafnt with fine fmall iagged leaues like vnto Cammomill, or rather re. fembling hairy taffels or fringe, than leates. From rhe bofomes whereof come forth fmall and ten der branches, etrery branch bearing one floure like vnto water Crow-foot, white of colour, with a little yellow in the midet : the whole plant refenibleth water Crow-foot in all rhings faute in the btoad leaines,

+4 There is another kinde of water violet very like the forner, fauing that his leaues are much longer, fomewhar refembling the leates of Fennell, farhioned likevntowings, and the floures are fomewhat fmaller, yer whire, wirh yellowneffe in their middles, and thaped like thofe of the laft defcribed. And the feed alfo growes like vnto that of the Water Ranuniulws, laft deferibed.

5 There is alfo another kinde of water Milfoile, which hath leaues very like vnto water Violet, fmaller, and not fo many in number : the ftalke is fmall and tender, bearing yellow gaping foures fathioned like a hood or the fmall Snapdragon; which caufed $P$ ena to pur vnro bis name this additament Galericulatum, that is, hooded. The roots are fmall and threddy, with fome fer snobs hanging thereat like the founds of fith.

2 Millefoliunz aquaticum: Water Yarrow.

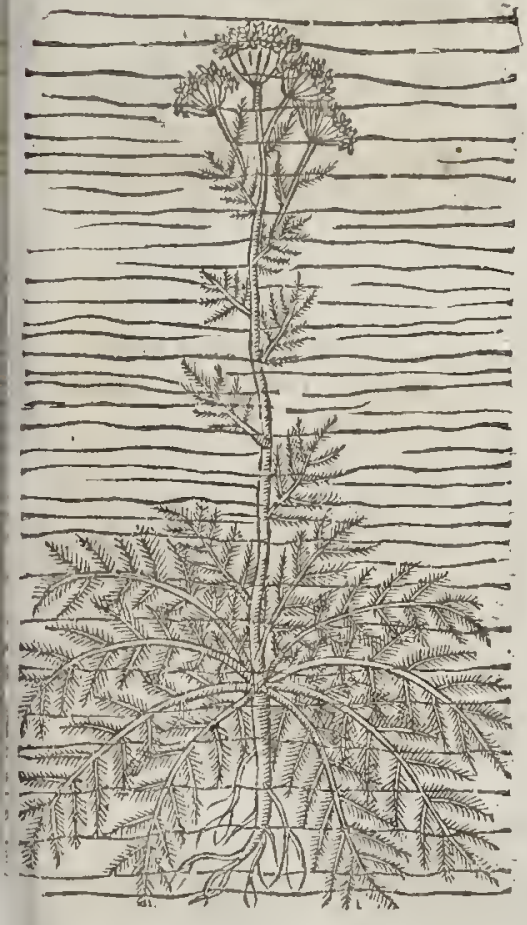

3 Millefolism, fue mar atriphyllon, flore do fewine Bamunculi aquatici, Hepatise facie.

Ramminculer or water Milfoile.

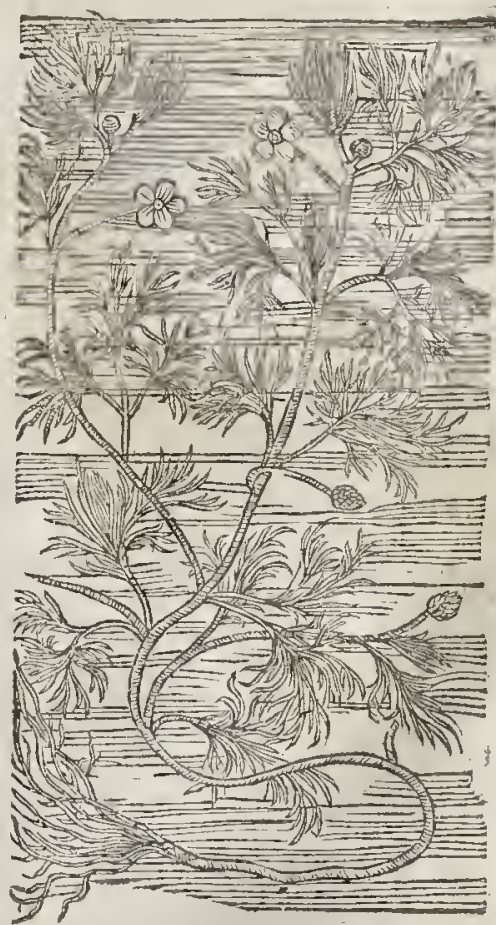

₹ 6 Tothefe may we adde a fmall water Milfoile, fet forth by clufius. It hath round greere ftalkes fet with many ioynts, whereoit come at rheir lower ends many haury fibres, whereby it taketh hold of rhe mud : the tops of rhefe ftems ftand fome handfull aboue the water, and ar eacls ioynt fand fue long finely winged leaues; very greene, and fome inch long; which wax leffe and 
leffe, as they ftand higher or neerer the top of the ftalke : and at each of thefe le anes about the top of the ftem grewes one fmall white floure confifting of fix little leaues 1oyned together, and rot opening themfelues : and thefe at length turne into little knobs, with foure little pointals ftanding out of them. Clufins calls this Myriophyllon aquaticum minus. F

$¥ 4$ cillefolium tenuifolium.

Fennell leaued water Milfoile.

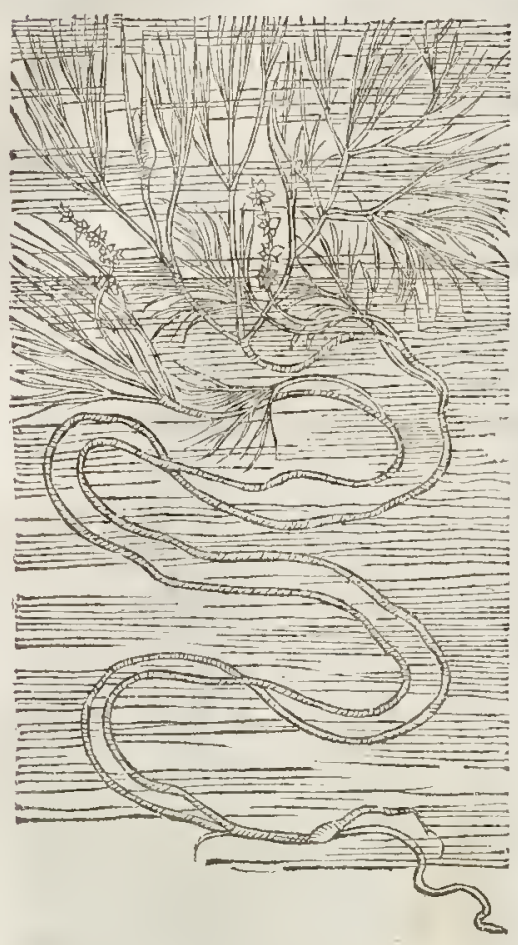

¥ 5 Millefol om palufregalericulatum. Hooded water Milfoile.

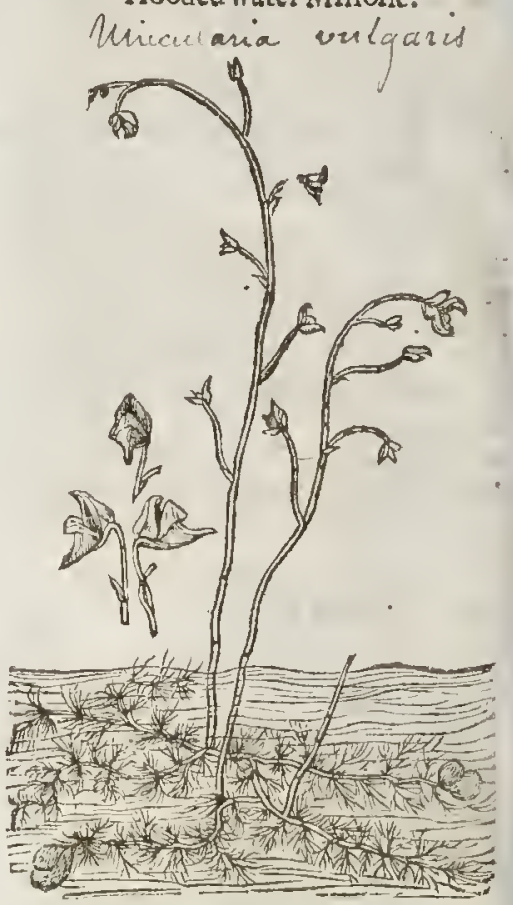

They be found in lakes and ftanding waters, or in waters that tun flowly : I haue not found fuch plenty of it in any one place, as in the water ditches adioyning to Saint Geotge his field neere London.

They floure for the mot patt in May and "une.

$$
\text { of The rime. }
$$

1) The Names.

The firn is called in Dutchwater tiolectan, that is to fay, Viola aquatilis : in Englifh, Water Gi".o'loure, or water Violet: in French, Gyroflees d" eake: Matthiolus makes this to be alfo Myrophylli $f: e s$, or a kinde of Yarrow, although it doth not agree with the defcription theteof; for weither Wath it one nalke onely, nor one fin le root, as Myrropbyllon or Yatrow is defcribed to have; for the roors are full of ftrings, and it bringeth forth many ftaikes.

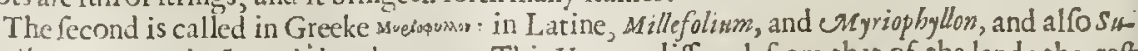
percilinm Ion:ris in thops it is unknowne. This Yarrow differeth from that of the land: the reft are fufficiently fpoken of in their tirles.

$$
\text { 9 The Nature and Vertues. }
$$

A Water Yarrow, as Diofcorides faith, is of a dry facultie; and by reafon that it taketh away hot inflammations and fwellings, it feemeth to be of a cold nature; for Diofcorides affitmeth, that water Yarrow is a remedie againft inflammations in greene wounds, if with vineger it be applied greene ordry : and it is giuen inwardly with vineger and falt, to thofe that haue fallen from a high place.

B Watet Gillofloure ot water Violet is thought to be cold and dry, yet hath it no vfe in phy ficke atall. 


\section{The Defcription.}

1 W Ater Crow-foot hath flender branches trailing far abroad, whereupon grow leaues vnder the water moft finely cut and iagged like thofe of Cammomill. Thofe aboue the water are formwhat round, indented about the edges, in forme not vnlike the fmal tender leautes of the mallow, but leffer: among which do grow the Houres, fmall, and white of colour, made of fine little leattes, with fome yellowneffe in the middle like the floures of the Straw-beriy, and of a fweet fmell : after which there come round rough and prickly knaps like thofe of the field Crowfoot. The roots be very fmall hairy ftrings.

\# There is fometimes to be found a varietic of this, with the leaues leffe, and diuided into three parts after the manner of an Iuy leafe; and the floures are alfo much leffer, but white of colour,with a yellow bottome. I queftion whether this be not the Ranuncul us bederaceus Dalegchampiy, pag. 103 1. of the biff. Lugd. ‡

2 There is another plant growing in the water, of fmal moment,yer not amiffe to be remembred, called Hederula aquatica, or water Iuie: the which is very rare to finde; neuertheleffe I found it once in a ditch by Bermondfey houfe neere to London, and neuer elfew here : it hath fmall threddy ftrings in ftead of roots and ftalkes, rifing from the bottome of the water to the top; whertunto are faftned fmall leaues fwimming or flocing vpon the water, triangled or three cornered like to thofe of barren Itie, or rather noble Liuerwort : barren of floures and feeds.

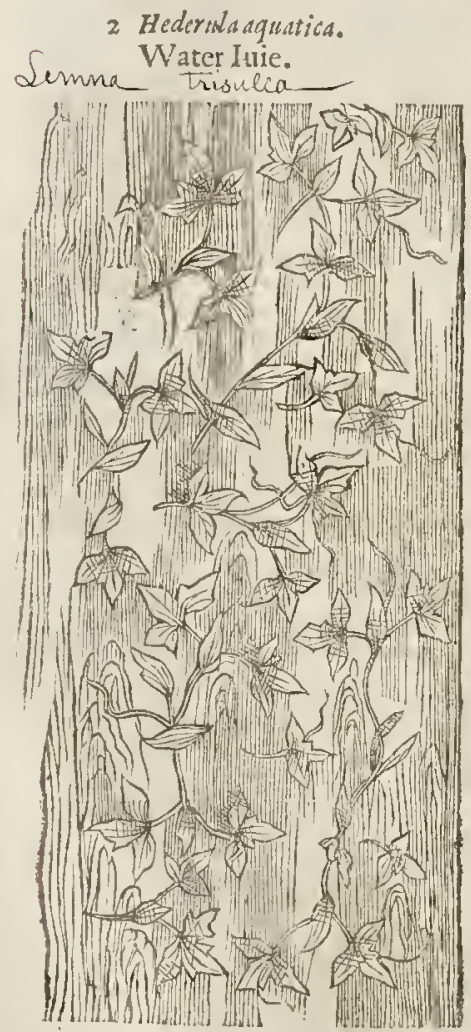

\$3 Stellaria aquatica.
Water Starwort.

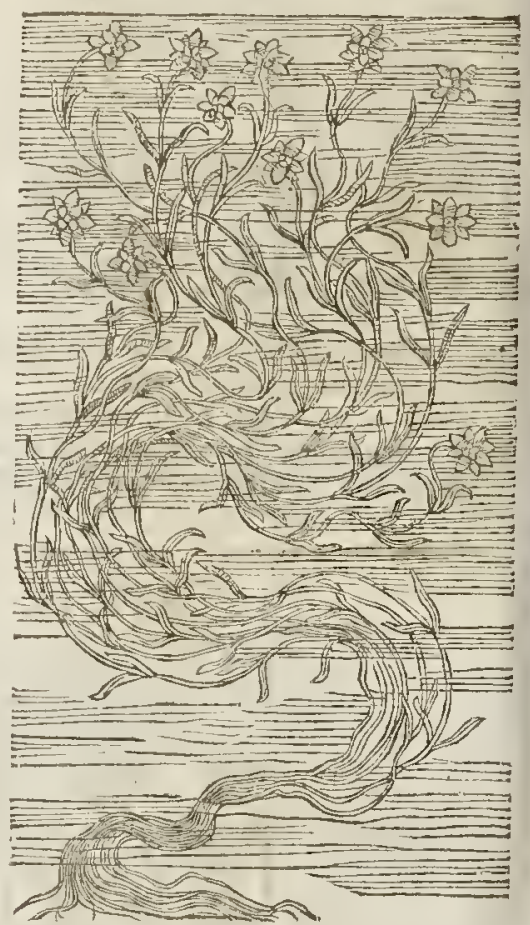

3 There is likewife another herbe of fmall teckoning that floteth vpon the water, called Stellaria a quatica, or water Star-worr, which hath many fmall graffie ftems like threds, comming from the bottome of the water vnto the vpper face of the fame: whereupon do grow fmal double floures of a greenifh or herby colour. \# I take this Stellarin to be nothing elfe but a water Chickeweed, which growes almoft in euery ditch, with two long narrow leaues at each ioynt, and halfe a dozen or more lying clofe together at the top of the water, in fafhion of a ftarre : it may be feene in this fhape in the end of A prilland beginning of May: I haue not yet obferued either the floure or feed
thereof. $\neq$ 


\section{The Place.} places.

Water Crow-foot groweth by ditehes and thallow Springs, and in other moift and plafhic

It The Time.

The Names.

Water Crow-fnot is called in Latine Ramunculus aquatilis, and Polyanthemum aquatile : in Englifh, Water Crow-foor, and whitewater Crow-foot : molt Apothecaries and Herbarifts do erroneoufly name it Heparica aquatica, and Hepatica alba ; and with greatererror they mix it in medicines in ftead of Hepatica alba, or graffe of Parnaffus, + I know none that eommit this great error here mentioned, neither hate I knowne either the one or the orher etrer vfed or appointed in medieine with vs in England, though Dodonaus (from whom our Author had this and moft elfe) doc blame his countreymen for this mitake and error. $\neq$

Water Ctow-foot is hot, and like to common Ctow-foot.

\section{Chа в. 303, Of Dragons.}

I Dracontium maius. Great Dragons.

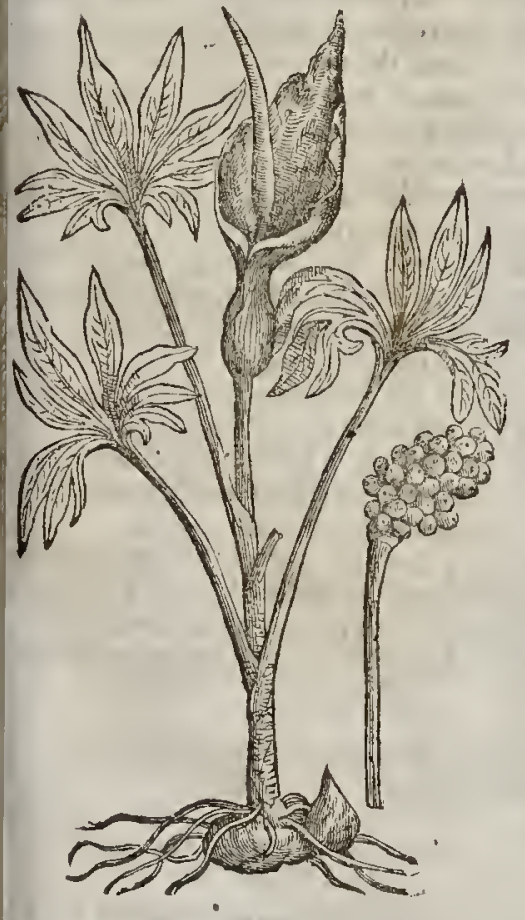

† 2 Dracostium minus. Small Dragons.

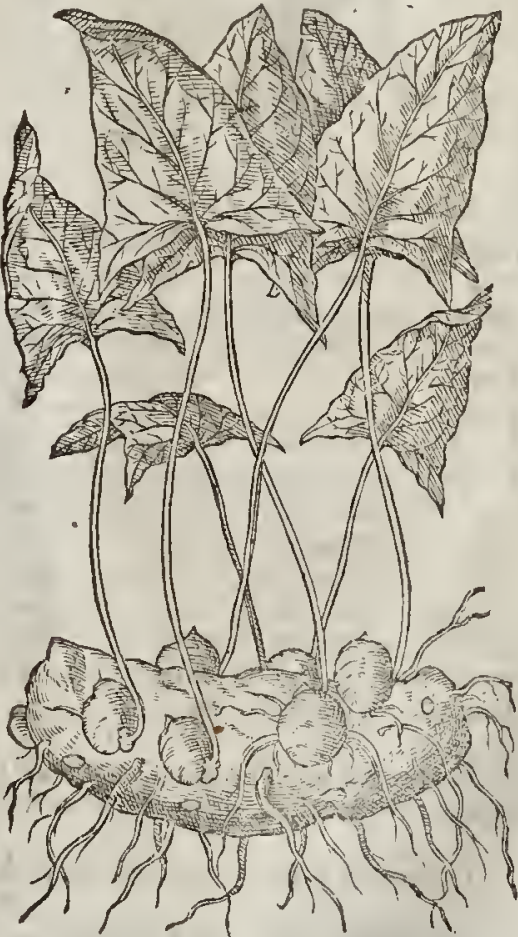

T) The Defription.

I 7 He great Dragon tifeth vp with a ftraight ftalke a eubit and a halfe highor higher, thicke, round, fmonth, fprinkled with lpots of diuers eolours, like thofe of the adder or fnake : the leaues are great and wide, eonfitting of feuen or more ioyned together in order; euery one of whieh is long and narrow, mueh like to the leaues of Doeke, fmooth and nipperic: out of the top of the ftalke groweth a long hore or huske greater than that of the Cueckow pintle, of a greenifh eolour without, and within erimfon, with his peftell whieh is blaekin, long, thicke, and pointed like a horne; the skin or filme wheteof when the feed waxeth big, being 

Water Dragons.

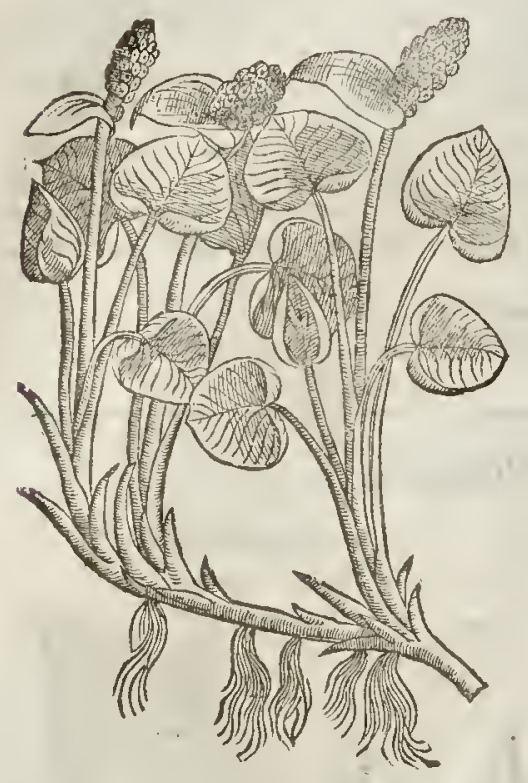

I Dracunculus aquations.

Atretched or broken afurder, there appearcth the fruit, like to a bunch or clufter of grapes: the berries where of at the firft be greene, afterwards red and full of iuyce; in which ; contained feed that is fomewhat hard : "Tho root continueth fre $h$, thicke, like to a knob. white, couered with a thin pilling, oftentimes. of the bigneffe of a meane apple, full of white little threds appendant thereunto.

2 The leffer Dragon is like Aronor wake Robin, in leaues, hofe, or huske, peftell, and berries, yet arc not the leaues fprinkled with blacke but with whitith fpots, which perith not fo foone as thofe of wake-Robin, but endure together with the berries euen vintil winter : thefe berries alfo be not of a deepered but of a colour enclining to Saffron. The root is not vnlike to the Cuckow-pint, hauing the forme of a bulbe, full of ftrings, with diuers. rude thapes of new plants, whereby it greatly encreafeth.

+ The figure which our Authour hecre gaue by the title of Dracuntium minus, was no other than of Aron, which is defcribed in the firft place of the next chapter: neither is the defcription of any other plant, than of that fort there of which hath leaues fpotted either with white or blacke fpots, though our Author fay onely with white. I laue giuen you Clufus his figure of Arum Byzantinum, in ftead of thatwlich our Aurhor gaue. $\neq$

3 The root of water Dragon is not round like a bulbe, but very long, creeping, and ioynted, and of meane bigneffe; out of the ioynts whereog arife the ftalkes of the leaues, which are round, fmóth, and fyongie within, and there grow downewards certaine white and flender frings. The fruit fprings forth at the topvpon a thort ftalke, together with one of the leatues, being at the beginning coucred with little white thred's, which are in ftead of the fioures : after that it groweth into a bunch or clufter, at the firft greene, and when it is ripe, red, leffer than that of Cuckow-pint, but not lefle biting : the leaues are broad, greenifh, glib, and fmooth, in Fathion like thofe of Iuy, yet leffer than thofe of Cuckow-pint; and that thing whereunto the cluftered fruit growes is alfo leffer, and in that part which is towards the fruit (that is to fay the vpper part) is white.

4 The great Dragon of Glattbialus bis defcription is a ftranger not onely in England, but: elfewhere for any thing that we can learne: my felte haue diligently encuired of mon frangers skilfull in plants, that haue reforted vnto me for conference fake, but no man can giue me any certaintie thereof; and therefore I thinke it amiffe to giue you his figure or any defcription, for that I take it for a feigned picture.

$$
\text { बा The Place. }
$$

The greater and the leffer Dragons are planted in gardens. The water Dracons grow inwatery and marifh places, for the molt part in fenny and ftanding waters.

The berries of thefe plants are ripe in Autumne.

$$
\text { - The Time. }
$$

$$
\text { बा Tlie Names. }
$$

The Dragon is called in Grecke spaxirmoy : in Latine, Drasunculus. The greatcr' is named Serpen. tarinmaior: of fome, Bifaria, and Colubrina: Cordus calleth it Dracunculus Polyphyllos, and Luph Cri-

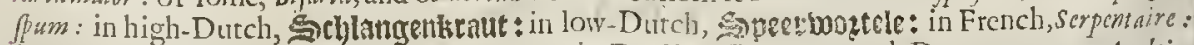
in Italian, Dragontea : in Spanifh, Taragontia : in Englinh, Dragons, and Dragon-wort. Apulcius calleth Dragon Dracontea, and fetteth downe many ftrange names thercof, which whether they agree with the greater or the leffer, or both of them, he doth not expound; as Pythonion, Anchomanes, Sauchromaton, Therion, Schonos, Dorcadion, Typhonion, I beriophonon, and Fminion. Atheraus iheweth, that $\mathrm{Dragon}$ is called Aronia, becaufe it is like to Aron. 'The Temperature.

Dragon, as $G$ alen faith, hath a certaine likeneffe with $A$ ron or wake-Robin, both in leates, and alfo in root, yet more biting and note bitter than ir and therefore lotter, and of thinner parts:it is 
alfo fomething binding, which by reafon that it is adjoined w ith the two former qualities, that is to fay, biting and bitter, is is made in like manncr a fingular medicine of very great efficacy.

If The Vertues.

The root of Dragons doth clenfe and fcoure all the entrailes, naking thinne, efpecially thicke $A$ and tough humours; and it is a fingular remedy for vicers that are hard to be cured, named in Greeke vasuition.

It fcoureth and clenfeth mightely, afirell fuch things as haue need of fcouring, as alfowhite and blacke morphew, being tempered with vineger.

The leattes alfo by reafon that they are of like qualitie are good for vlcers and greene wounds : and the leffedry they are, the fitter they be to heale, for the dryer ones are of a more tharpe or biting quality than is contenient for wounds.

The fruit is of greater operation than either the leaues or the root : and therefore it is thought $\mathrm{C}$ to be of force to confume and take away cankers and proud fiech growing in the noftrils, called in Greeke Polypus : al fo the juice doth clenfe aw ay webs and fpors in the eics.

Furthermore, Diofcorides writeth, that it is reported that they who haue rubbed the leatres of $D$ root vpon their hands, are not bitten of the viper.

Pliny faith, that ferpents will not come neere vnto him that beareth Dragons about him, and $\mathrm{E}$ thefe things are read concerning both the Dragons, in the two chapters of Diofcorides.

Galen allo hath made mention of Dragon in his booke of the faculties of nourinments, whete $\mathrm{F}$ he Yaith, that the root of Dragon being twice or thrice fod, to the end it may lofe all his acrimony or tharpenefle, is fometimes ginen as Aron, or wake-Robin is, when it is needfull to expell the more forceable thicke and clanmy humours that are troublefome to the cheft and lungs.

And Digfcorides writeth, that the root of the leffer Dragon being both fodde and roftwith $G$ honie, or taken of it felfe in nseate, caufeth the humours which fticke faft in the cheft to be eafily roided.

The juice of the garden Dragons, as faith Diofcorides, being dropped into the eies, doth clénfe H them, and greatly amend the dimnefle of the fight.

The diftilied water hath vertueagaint the peftilence or any pefilentiall feuer ot poifon, being I drunke bloud-ivarme with the beft treacic or mithridate.

The fnell of the floures is hurtfull to women newly conceiued with child.

\section{C на 304. Of Cockompint, or wake-Robiris}

\section{The Defription.}

1 A rm or Cockow pint hath great, large, fnooth, fhining, tharpe pointed leaues, befpotA ted here and there with blackifh fpots, mixed with fome blewneffe: among which rifeth up a falke nine inches long, befpeckled in many places with certaine purple fpots. It beareth alfo a certaine long hofe or hood, in proportion like the eare of an hare: in the middle of which hood commeth forth a peftle or clapper of a darke murrie or pale pur ple colour: whicl being pat, there fucceedeth in place thereof a bunch or clufter of berries in manner of $a$ bunch of grapes, greene at the firt, b tit after they be ripe of a yellowifh red like corall, and full of pith, with fome threddy additatnents annexed thereto.

2 There is in Egypta kinde of Arum which alfo is to be feene in Africa, and in certaine places of Lufitania, about riuets and floods, which differeth from that which groweth in England and other parts of Europe. 'This plant is large and great, and the leaties thereof are greater than thofe of the water Lillie : the root is thicke and tuberous, and toward the lowet end thicker and broader, and may be eaten. It is reported to be without floure and feed, but the increafe that it hath is by the fibres which runne and fpread from the roots. F This plant hath alfo peftells and elufters, of berryes as the common Aron, but fomervhat different, the leaues are not cut into the ftalke, but joined before the fetting thereto: the root alfo is very large. Thofe that defire to fee more of this plant, and the queltion which fome hatie morted, whither this be the Colocafar, or Faba estryptia of the Antients ? let tbem haue recourfe to the firft chapter of Fabius Colmma his Minus cogritarum fripizm pars altera, and there they fhal! finde fatisfaction; $\neq$

$$
\text { A a a is }
$$




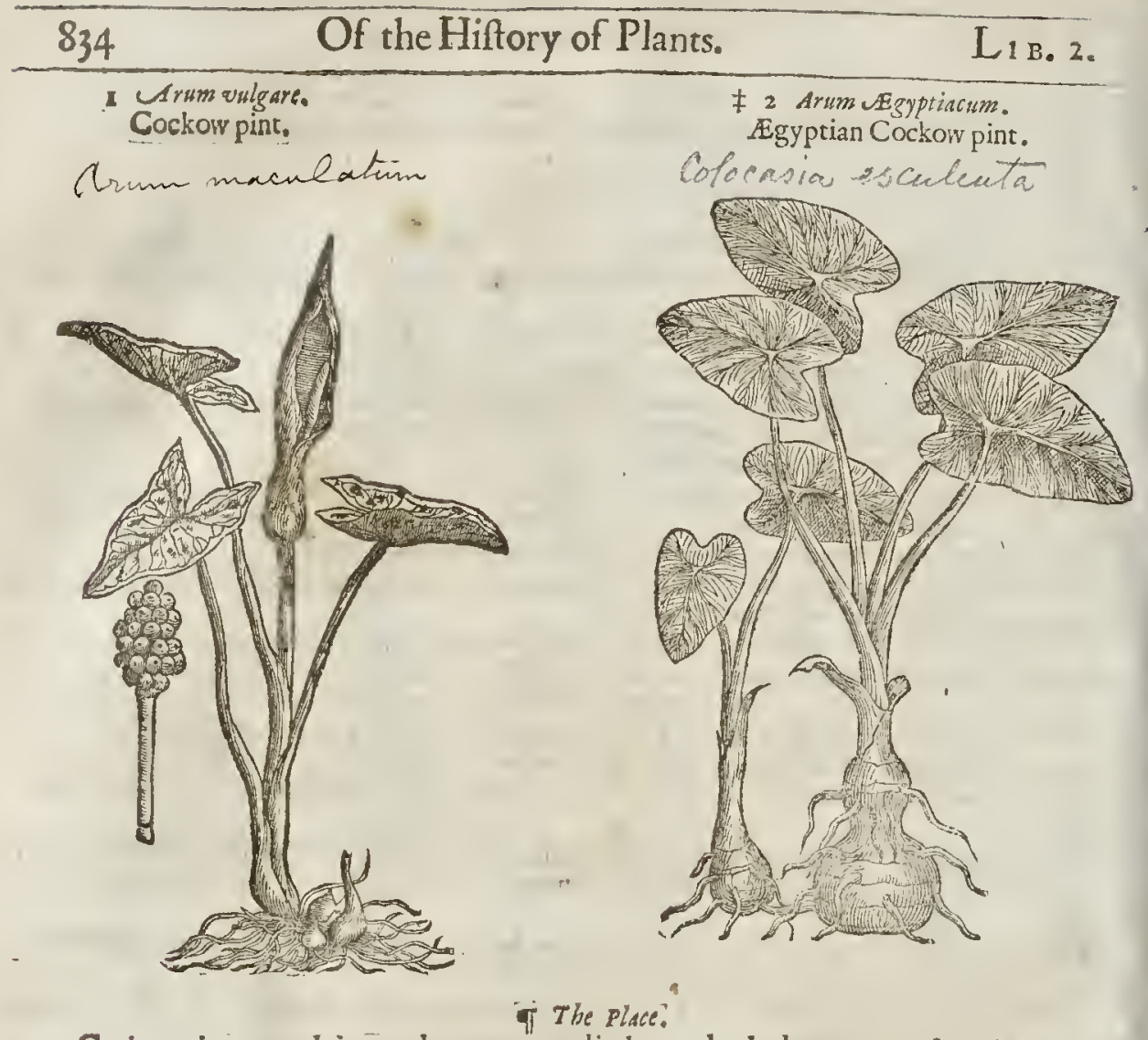

Cockow pint groweth in woods neere vnto ditches vnder hedges, etrery where in thadowie places.

$$
\text { It The Time. }
$$

The leaues appcare prefently after winter:the peftell theweth it felfe out of his huskc or theath in Iune, whileft the leaues are in withering : and when they are gone, the buneh or clufter ofberries beconmeth ripe,which is in Iuly and Augut.

$$
\text { Tा } T \text { be Names. }
$$

There groweth in Egypt a kinde of Aron or Cuckow pintwhich is found alfo in Afriea, and likewife in certaine places of Portingale neere vnto rituers and ftrcames, that differeth from thofe of our countries growing, which the people of Caftile call Manta de nueftrafenora: mont would haue it to be called Colocafia; but Diofcorides faith that Colocafia is the root of Faba Etgyptia, or the Beane of Egypt. $\neq F$ abius Columna (in the place formerly alledged) prooues this not to be the true Colocapia, and yet Proper Alpinus fince in his feeond booke de plant is extoticis, cap. 17. and i 8. 1abours to proute the contrary : let the curious hate recourfe to thefe, for it is too tedious for me in this place to infitt vpon it, being fo large a point of controuerfic, which hath fo much troubled all the late writers. $\neq$

The common Cuckow pint is ealled in Latine, Arum : in Greeke, agr : in thops, Iarm, and $B_{a}$ arbisAron: of others, pes vituli: of the Syrians, Laphas: of the men of Cyprus, Colocalinas as we finde among the baftard names. Pliny in his 24 . booke, I 6 . chapter, doth witneffe, that there is great difference betweene Aron and D racontinm, although there hath been fome controterfie about the fame among the old writers, affirming them to beall one : in high Duteh it is called, foaffen pint : in Italian, Gigora : in Spani(h, $Y_{\text {aro }}$ : in low Dutch, $\mathbb{C}$ alfsuoet : in French, Picd d'vedr: in Englifh, Cuckow pint, and Cuckow pintle,wake-Robin, Priefts pintle, Aron; Calfes foot, and Rampe;and of fome Stratchwoort,

$$
\text { TI The Temperature. }
$$

The faeulties of Cuckow pint doe differ aceording to the varictie of countries : for the root hereof, as Galen in his booke of the faculties of nourifhments doth affirme, is tharper and more biting in fome countries than in others, almoft as much as Dragons, eontrariwife in $\mathrm{Cyren}$ a city in Afrieke, it is generally in all places hot and dry, at the leaft in the firf degrce. 


\section{TI The Vertues.}

If any man would hatre thicke and tough humours which are gathered in the cheft and lings to be clenfed and voided out by coughing, then that Cuckow pint is beft that biteth moft:

It is eaten being fodden in two or three waters, and frefh put to, whereby it may lofe his acrimonic; and being fo eaten, they cut thicke humors meanely, but Dragons is better for the fame purpofe.

Diofcorides fheweth, that the leaues alfo are preferued to be eaten, and that they muit be eaten after they be dried and boyled; and writeth alfo, that the roor hath a pectiliar vertue againft the gout, being laid on ftamped with Cowes dung.

Beares after they haue lien in their dens forty dayes without any manner of fuftenance, butwhar they get with licking and fucking their owne feet, do as foone as they come forth eate the herbe Cuckow pint, through the windic narure whereof the hungry gut is opened and made fit againe to recciure fuftenance: for by abftaining from food fo long a time, the of t is thrunkc or drawne fo clofe togetlier, that in a manner it is quite fhut vp, as Ariftotle, etbianus, Plutarch, Pliny, and others dowrite.

The moff pureand white ftarch is made of the roots of Cuckowpint; but riolt hurtfull to the hands of the Laundreffe that hath the handling of it, for it choppeth, bliftereth, and maketh the hands rough and rugged, and withall fmarting.

\section{CH A. 305. "Of Eriers Conole, or booded Cuckowpint.}

1 Arifarumiatifolium.

Broad leaned Friers Cowlc.

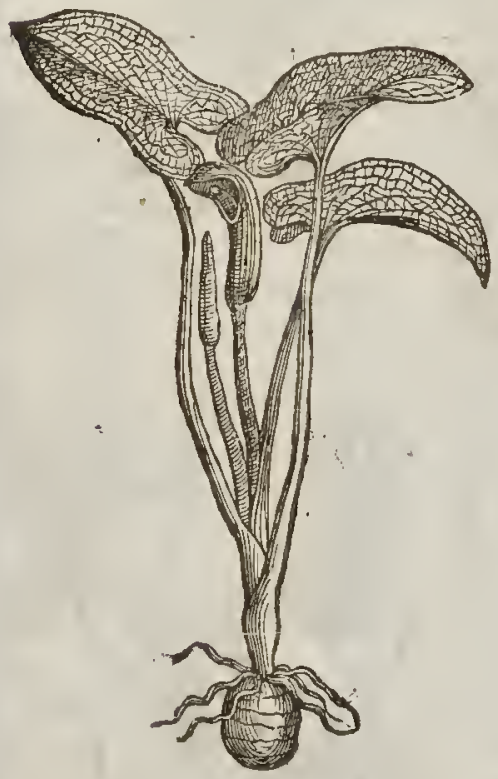

i Arifarturingufifolium:

Nárow leaued Friers Cowle.

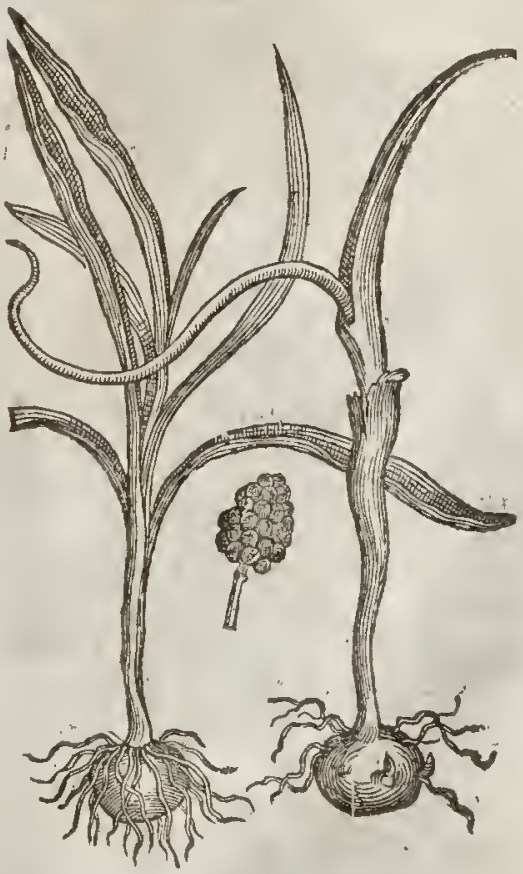

TT The Defription.

I RRoad leated Friers hood hath a leafe like Iuy, broad and tharpe pointed, but far leffe,approching necre to the forme of thofe of Cuckowpint : the ftalke thereof is fmall and flender: the huske or bofe is little; the peftel fmall, and of a blacke purplific colour; the clufter when it is ripe is red; the kernels fmall; the root white, hauing the formie of Aron or Cuckowpint, but leffer, whereof doubtleffe it is a kinde.

A่aล 2 
2 The fecond Friers hood hath many leaues, long and narrow, fmooth and glittering : The huske or hofe us narrow and long; the peftell that commeth forth of it is flender, in forme like a great earth worme, of a blackith purple colour, as hath alfo the infide of the hofe, vpon which, hard to the ground, and fometimes a little within the ground, groweth a certa ine bunch or clufter of berries, greene at the firft, and afterwards red: the roct is tound and white like the others.

$$
\text { It The Place. }
$$

Thefe plants are ftrangers in England, but common in Italy, and efpecially in Tufcane about Rome, and in Dalmatia, as Aloifins Anguillara witneffeth : notwithftanding I haue them in my Garden.

$$
\text { I The Time. }
$$

The floures and fruit of the fe come to perfection with thofe of Cuckowpint and Dtagons.

$$
\text { q) The Names. }
$$

Fricrs hood is called of Diofcorides, 'Aeiouen : in Latine, Arifarum : but Pliny calleth it 'Aers, or Aris: for in his twenty fouth booke, cap. 16. he faith, That Aris which groweth in Egypt is like Aron or Cuckow pint : it may becalled in Englin after the Latine name Arifarum, but in my opinion it may be more fitly called Friers hood, or Friets cowle, to which the floures feeme to be like; whereupon the Spaniards name it F raulillos, as Dalcfchampius noteth.

$$
\text { ब1 The Temperature. }
$$
faith.

Fricrs-Cowle is like in powet and facultie to the Cuckow-pint, yet is it more biting, as Galen

$$
\text { - The Vertues. }
$$

A 'There is nogreat vfe of thefe plants in phy ficke; but it is reported that they ftay running preating fores or vicers: and likewife that there is made of the roots certaine compofitions called in Grecke Collyrid, good againft fiftula's : and being put into the fecret part of any liuing thing, it totteth the fame, as D iofiorides writeth.

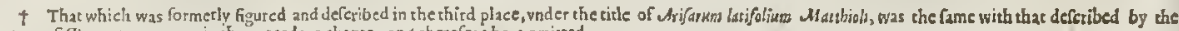 name of Draconsium muno, in the precedens chapter, and therefore hese omitted.}

\section{Снав. 306. Of effocabacca.}

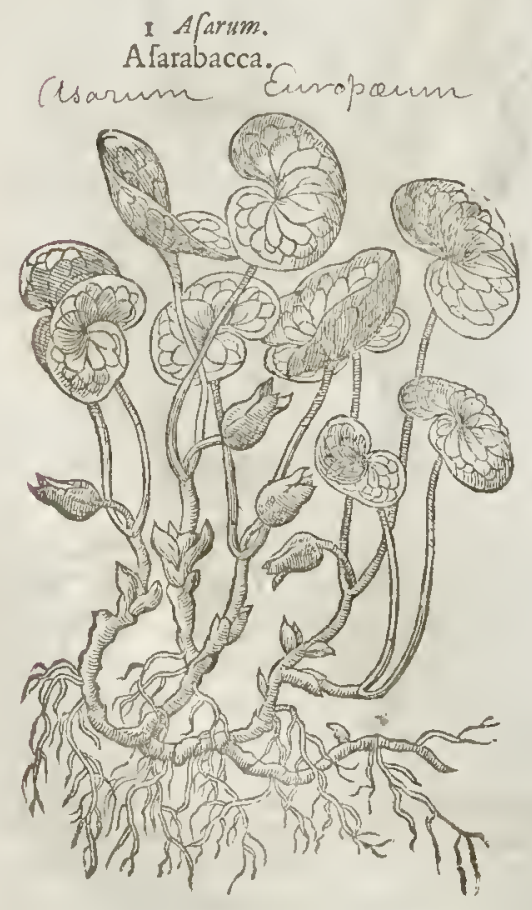

2 Afarina Matthioli. Italian A farabaeca.

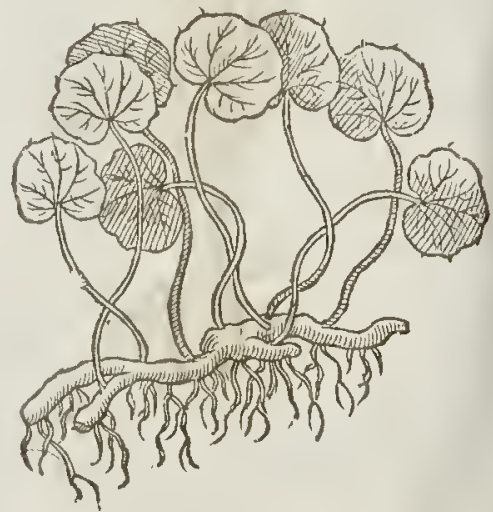




\section{IT The Defription:}

I THe leaues of A farabacca are fmoorh, of a deepe greene colour, rounder, jroader, and 1 tenderer than thofe of Iny, and not cornered at ali, not vnlike to thofe ot Sow-bread: the floures lie clofe to the roots, hid vider the leaues, ftanding rpon fiender footftalkes, of an ill fauoured purple eolour, like to the floures and husks of Heubane, bur lefle, whisein are contained fimall feeds, eornered, and fomewhat rough : the roots are many, finall and llender, growing allope vader the vpper cruft of the earth, one folded within another, of an vnpleafant tafte, but of a moft fweet and pleafing fmell, bauing withall a k inde of biting qualitie.

2 This ftrange kinde of A farabacea, which Mutthiolis hath fet forth creeping on the ground, in manner of our common Aftrabacca, hath leaues fomw hat rotinder and rougher, lleightly indented about the edges, and fet vpon long flender foot-ftalkes : rhe floures grow hard vnto the ground like vnto thofe of Cammomill, but much leffer, of a mealy or dufty colour, and not witl:our finel. The roots are long and flender, creeping vnder the vpper cruft of the earth, of a tharpe tafte, and bitter withall. \# This Afarina of cMatt hiolus, Clufinss (whofe opinion l here follow) hath iudged to be the Tus lago alpina 2. of his defcription; wherefore I giuc you his figure in ftead of that of our Author, which had the floures expreft, which this wants. $\ddagger$

$$
\text { of The Place. }
$$

It delighterh to grow in fhadowie plaees, and is very common in molt gardens.

$$
\text { बा The Time. }
$$

The herbc is alwaies greene; yet doth it in the Spring bring forth new leaues and fioures.

$$
\text { at The Names. }
$$

It is called in Grecke eraen, Afarum : in Latine, Nardiss ruffica: and of diuers, Perpenfa: Perpenfa is alfo Buccharis in Pliny, lib. 2 I.cap. 2 I. Maccr faith, That Ajarm is called $Y u l g a g o$, in thefe words:

$$
\text { Eft Afaron Crocì, Vulgago diat a Latizè. }
$$

This herbe, Afaron do the Grecians name;

Whercas the Latines Fulgago clepe the fame.

It is found alfo amongtt the baftard names, that it was called of the great learned Philofophers "as se ipras : that is, Martis fanguis, or the bloud of Mars : and of the French men Baccar; and thereupon it feemeth that the word Afarabaccacame, which the Apothecaries vie, and likewife the common peop'e : but there is another Baccharis differing from $A$ far um, yet nocrithiftanding Crateuas doth allo call Batchar is, Afarum.

This confufion of both the names hath been the caufe, that moft could not fufficiently expound themfelues coneerning $\mathcal{A} \int \mathrm{arum}$ and $B$ accharts; and that many things haute beene written amiffe in many copies of Diofcorides, in the chapter of Afarum : for when it is fet downe in the Greek copies a fwcet fmelling garden herbe, it belongeth not to the defcription of this $\mathrm{AJarum}$, but to that of Baicharzs. For Aftrum (as Pliny faith) is focalled, becaufe it is not put into garlands : arid fo by that meanes it came to paffe, that oftentimes the deferiptions of theold Writers were found corrupted and confufed: which thing, as it is in this place manifeft, fo oftentimes it cannot fo eafily bemarked in orher places. Furthermore, Afarum is called in French Cabaret : in highi. Durch, zelmutt : : in low -Dutch, $\$ 9$ ang $002 \mathrm{en}$ : in Englim, A farabacea, Fole-fcot, and Hazel-wort.

$$
\text { of The Temperature. }
$$

The leaues of A farabacea are hot and dry, with a purging qualicic adioyned thereunto; yet not without a certaine kinde of aftriation or binding. The roots are alfollot and dry, yet more than the leaues; they are of thin and fubtill parts : they procure vrine, bring downe the defired fieknes, and are like in facu'tic, as Galen faith, to the roots of $A$ cor uss, $^{1}$ but yet more forceable; and the roots of Acorus are alfo of a thinne effence, heating, attenuating, drying, and prouoking vine, as fic affirmeth : which rhings are happily performed by taking the roots oc $\Lambda$ rarabacea, ciether by then: felues, or mixed with other things.

$$
\text { \% The Vertues. }
$$

The leaucs draw forth by vomit, thicke phlcgmaricke and clonlericke huniours, and withail A moue the belly; and in this they are more forccable and of greater effect than the roots thenfelues.

They are thought to keepe in hard fivelling cankers that rhay encreafe not, or come to exulce- B sation, or creeping any farther, if they be outwardly applied vpon the fame.

The rosts are good againt the ftoppings of the liner, gail, and fplcene, againft wens and hard $C$ fwellings, and agues of long continuanee: but being taken in the greater quantitie, they purge flegme and choler not much leffe than the leaues (though Galen (ay no) by vomit efpecially, and alfo by fiege.

A. aลa 3

One 
$8_{3} 8 \quad$ Of the Hiftory of Plants.

L 1 B. 2 .

D Ore dram of the pouder of the roors giuen to drinke in ale or wine, groficly beaten, prouncth vomit for the purpoles aforefard; but being beaten into fine pouter, and fo giuen, it purgeth very little by vomit, but worketh molt by procuring much vrine; therefore the groffer the pouder is, fo much the better.

E But if the roors he infufed or boyled, then mut rvo, three, or foure drams be put to the infuron, and of the leaues cight or nine be fufficicnt: the iuyce of which famped with fone licuid thing, is to be gitren. The roots may be ftceped in wine, but more effectually in whay or lionied water, as Mcfics teacheth.

F The fame is good for them that are tormented with the Sciatica or gout in the liuckle bones, for thofe that haue the dropfie, and for fuch alfo as are vexed with a quarraine ague, who are cured and made whole by vomiting.

\section{Cha в. 30\%. Of Ser Binde-meed.}

i Soldarchamarina.

Sea Binde-weed.

Comoluubus Soldomella.

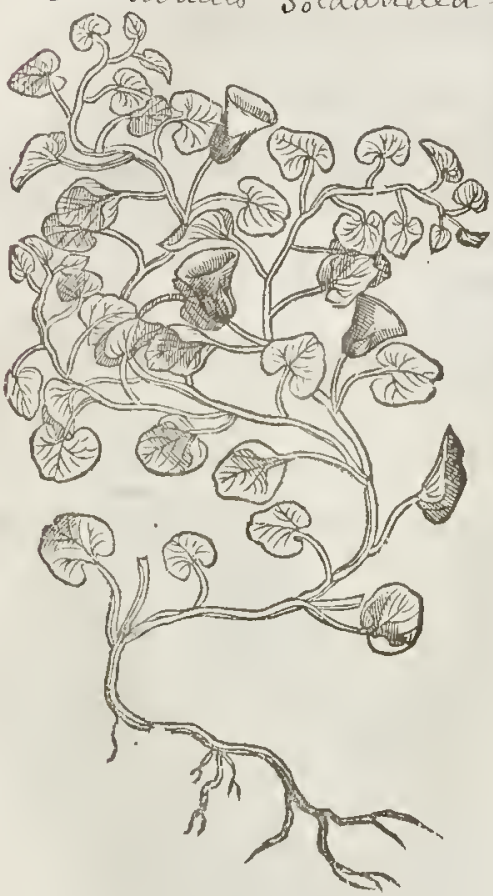

\$ Soldanella Alpinamaior. Mountaine Binde-weed.

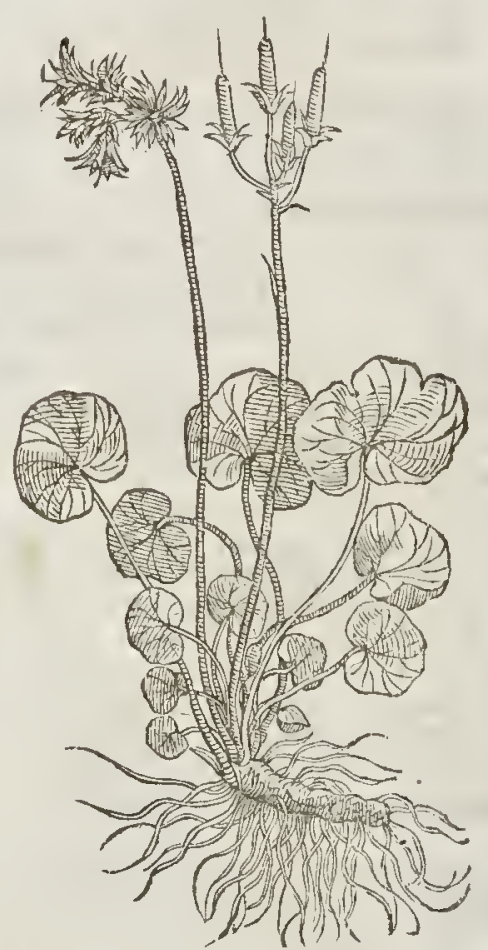

6) The Defcription.

I Coldanella or Sea Binde-weed hath many fmall branches, fomwhat red, trailing vpontle $\checkmark$ ground, beferwith fmall and round leaues, not much vnlike Afarabacca, or the leaucs of Arifolochia, but finaller; betwixt which leawes and the ftalkes come forth floures formed like a bell, of a briglet red incarnate colour, in cuery refpeet aniwering the fmall Bindeweed, whereof it is akinde, albeit I latic here placed the fame, for the reafons rendred in my Proeme. The feed is blacke, and groveth in round luskes : the root is long and finall, thrurting it felfe far abroad, and into the carth like the other Binde-weeds.

2 Soldasella or mountaine Binde-weed hath many round leaues fpred vpon the ground, not much vnlike the former, but rounder, and more full of veines, greener, of a bitter tafte like fea Bindeiveed: among which commeth forth a fmalland tender falke a handfull ligh, bearing at the top little foures like the fomil Bell-flowre, of a sky colour. The root is fmill and threddy. 
Li B.2. Of the Hiftory of Plants:

¥ 3 Soldanella Alpina minor. Small Mountaine Bindweed.

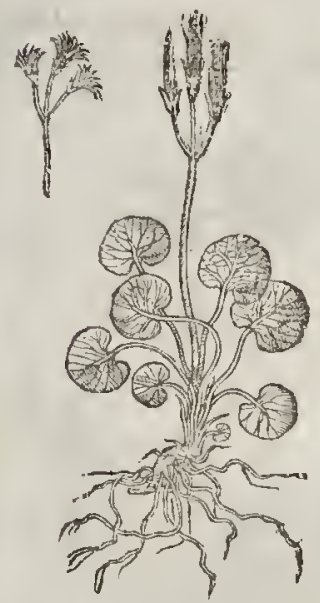

* 3 There is of this kinde another liauing all the parts fmaller, and the leaucs radder and rounder : the floures alfo blew, and connofed of one leafe diuided into futc parrs, and fuc cceded by a longith cod, round and tharp oointed. $\neq$

$$
\text { 9i The place. }
$$

The firit grows plentifully by the Sca hore in moft places of England, efpecially ncere to Lee in Effex, at Merfey in the furic comric, in mof places of the Inc of Thanet, and Shepry, and in many places along the Nort, eru conft.

The fecond groweth vpon the mountains of Germanie,and the Alpes; it groweth vpon the mountains of VVales, no: far fro.n Coivmers Meare in North-Wales.

$$
\text { बा The Timse. }
$$

Theteherbes do floure in Iune, and areg?thered in Auguit to be kept for medicine.

$$
\text { at The Nimes. }
$$

The firt called Soldanell $n$ is of the Apothecaries and the 1 ntients called Marina Brafien; that is to fay, Sea Co'cwoort : but whatrafon hath moued them fo to doe I cannot conceiue, vnleffe it be penurie and fcarfitic of names, and becaufe they know not otherwife how to terme it : of this I am fure, that this plunt and Braßica are no more likc than things which are mof valike; for Brafjaca Marina is the Sea Colcwoort, which doth mucl refemble the garden Cabbage or Colc, both in fhape and in nature, as I hauc in lis due place expreffed. A great fault and ouerfighr therefore it hach been of theold writers and their fuccef fors which hatie continued the cuttome of this error, not taking the paines to difinguifh a Bindeweed from a Cole-woort. But to auoid controuerfies, the truth is, as Thate before fhewcd, that this Soldanella is a Bindeweed, and cannot be efteemed for a Braffica, that is a Colewoott. The later Herbarifts call it Soldana, and Soldanella : in Dutch, Zectoind, that is to fay, Convolumlus cMarinus: of

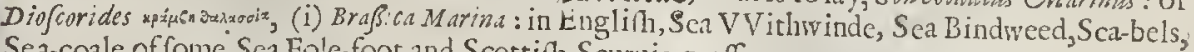
Sea-coale, of fome, Sea Fole-foot, and Scottifh Scuruie-graffe.

The fecond is called soldanellumontana: in Englin, Mountaine Bindweed.

$$
\text { 9 The } 2 \text { ature. }
$$

Seabindeweed is hot and drie in the fccond degree : the fecond is bitter and very aftringent. बा The Vertucs.

Soldanella purgeth downe mightily allkinde of watrifh humours, and openeth the ftoppings of $A$ the liuer,and is giuen with great profit againft the dropfie: but it inut be boiled wirh the broth of fome fat meat or fich, and the broth drunke, or elfe the herbe taken in poader worketh the like efrect.

Soldanella hurteth the ftomack, and typubleth the weake and delicate bodies which doe receitue it $B$ in pouder, wherefore aduice muft be taken to mix the faid pouder with Anuife fueds, Cinnmon, ginger,und futgar,which fpices do correet his malignitic.

Practitioners about Aufpurge and Rauifpurge(cities of Germanic) do greacly boat that they $C$ haue done wonders with this herbe Soldanella montana; faying, that rhe leaues taken andemplaifred upon the natell and fomewhat lower, draw forth water from their bellies that are hydroptike, that is, troubled with water or the droplie: this effect it worketh in other parts withoutheating.

It doth alfowonderfully bring fleth in wounds, and hralcth them.

Diofcorides witneffeth, that the whole herbe is an enemic to the fto nacke, biting and exirenely purging (both fodden, and taken with ment) and bringeti troublerone gripings thereusto, and doth oftentimes more hurt than gond.

₹ My friend $\mathrm{M}^{\mathrm{r}}$. Goodyer hath rold me, that in Hamplhite at Chicheter and thercabout they $\mathrm{E}$ make ve of this for Scuruie-grafle, and that not withour grent crrotras any that know the qualities mayealily perceine: 


\section{С на . 308. Of the Graffe of Parnafjus.}

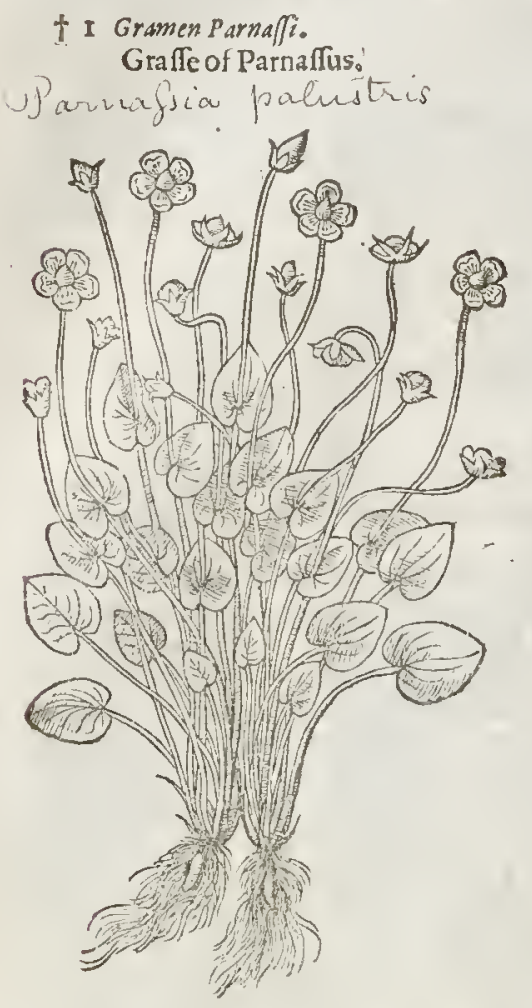

‡ 2 Gramen Parnaßi fore duplici.

Grafle of Parnaftus with double floures.

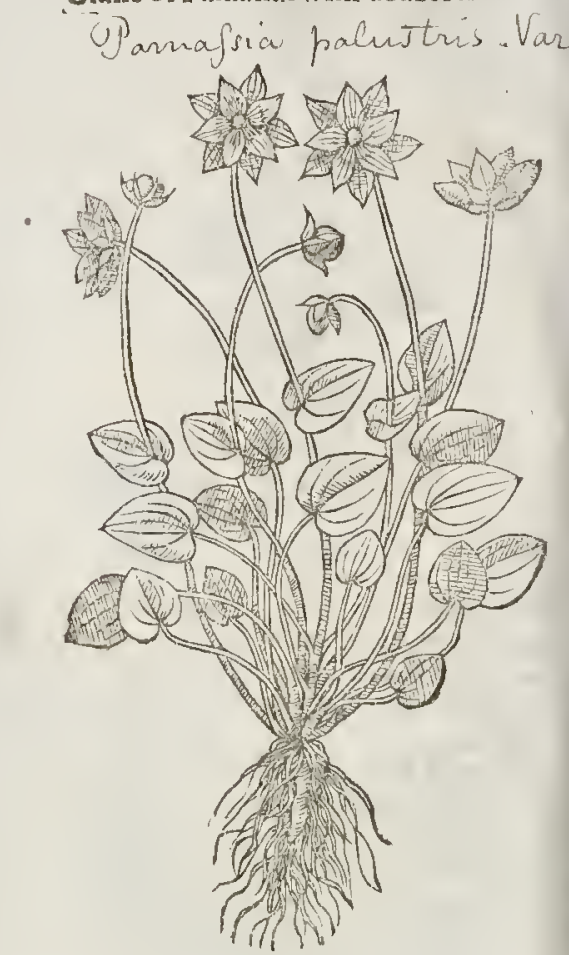

9) The Defcription.

I THe Graffe of Parnaffits hath fmall round leates, very much differing from any kind of

1 Graffe, much refenbling the leaues of Iute, or A farabaeca, but imaller, and not of fo darke a colour: among thefe leaues fpring vp imall ftalkes a foot high, bearing little white floures eonfifting of fiue round pointed leaues; which beeing falne and paft, there come vp round knops or heads, wherein is contained a reddifb feed. The root is fomew hat thieke, with many ftrings ancexed thereto.

2 The lecond kinde of Gramen Parnaffs doth anfwer the former in eaeh refpect, fauing that the leaues are fomewhat larger, and the floures double, otherw ife verie like.

I The Place.

The firt groweth very plentifully in Lanfdall and Crauen, in the North parts of England; at Doncafter, and in Thornton fields in the fame eountrie : moreouer in rhe Moore neere to Linton, by Cambridge, at Heffet alfo in Suffolke, at a place named Drinkftone, in the medow called Butchers mead. $\mp \mathrm{M}^{\mathrm{r}}$.Goodyer found it in the boggy ground below the red well of Wellingborough in Northampton fhire : and $\mathrm{M}^{\mathrm{r}}$. William Broad obferued it to grow plentifully in the Caftle fiedds of Berwieke vpon Tweed. $\neq$

The fceond is a ftranger in England.

Th The Time.

There herbes do floure in the end of Iuly, and their feed is ripe in the end of A uguft:

Valeritus Co: dus hath among many that hate writren of thefe hesbes faid fomerhing of them to good purpore, calling them by the name of Hepatica alla (w beteof without controuerfe they are kindes) in Englifh, white Liuewont : altlough there is arother plart called Hepatira alba, which 


\title{
L I B. 2. - Of the Hiftoric of Plants.
}

for difinction fake I have thought good to Englifh, Noble white Liu erwoort

The feeond may be called Noble white Liuerwoort with the double floure.

$$
\text { If The Nature, }
$$

The feed of Parnaffus Graffe, or white Liuer-woort, is drie, and of fubtill parts.

$$
\text { Tा The Vertues. }
$$

The decoction of the leates of Parnaffus Graffe drunken, doth drie and ftrengthen the feeble and moif ftomacke, ftoppeth the bellie, and taketh away the defire to vomite.

- The fame boiled in wine or water,and drunken, efpecially the feed thereof, prouoketh vrine, breaketh the ftone, and driueth it forth.

\section{C н а Р. 309. Of white Saxifrage, or Golden Saxifrage.}

\author{
If The Defription.
}

I THe white Saxifrage hath round leares fpred vpon the ground, and fomewhat iagged about the edges, not mueh vnlike the leaues of ground Iuie, but fofter and fmaller, and of a more faint yellowith greene : among which $n$ feth vp a round hairie ftalke a cubit high,bearing at the top fmall white floures, almoft like Stockgillo floures : the root is compact of a number of blacke ftrings, whereunto are faftened very many fmall reddith graines or round roots as bigge as peppercomes, which are vfed in medicine, and are called Semen Saxifrage albs; that is, the feede of white Saxifrage, or Stone-breake, although (befide thefe forefaid round knobbes) it hath alfo fmall feed contained in little huskes, following his floure as other herbes haue.

I Saxifraga abas.

White Saxifrage:

Saxifraga gramicata

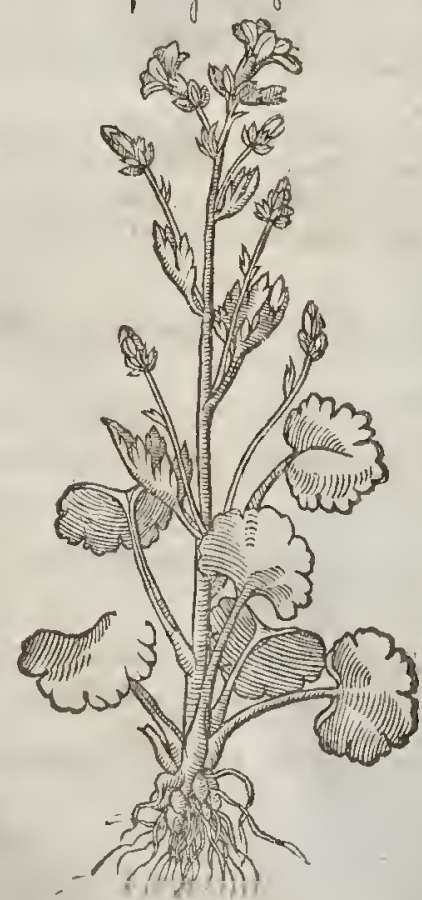

2 Saxifraga aureas.

Golden Saxifrage:

Chrysosplanium oppositifolieim

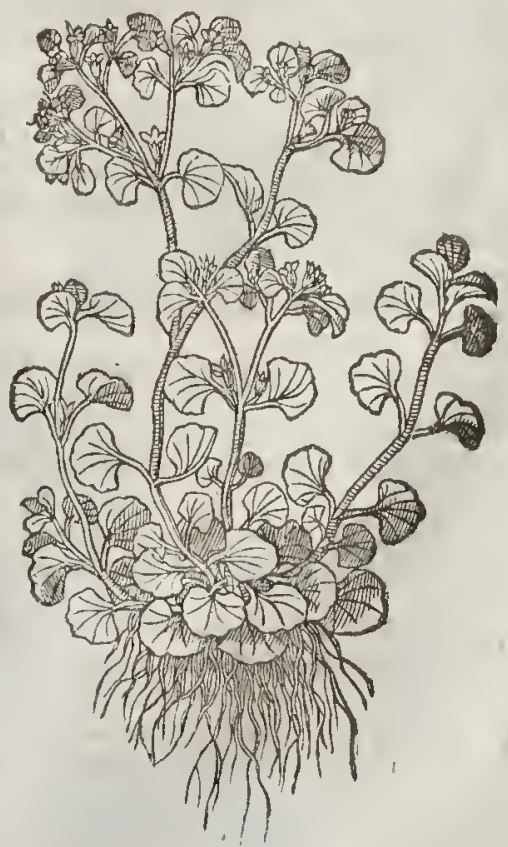




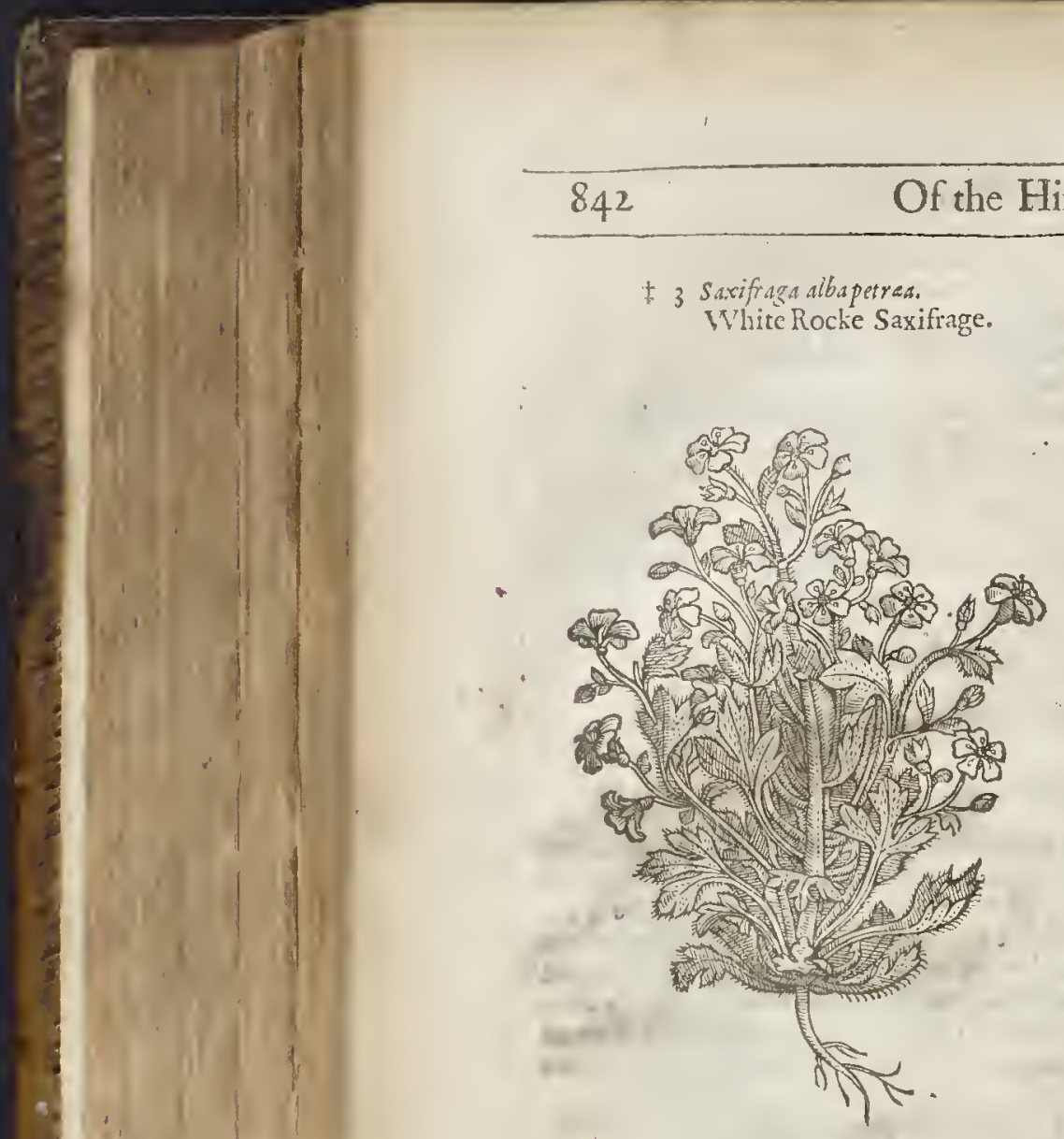

L 1 в. 2.

2 Golden Saxifrage hath round compar fed leaues,bluntiy indented abour the borders like the formet, among which rife vp ftalkes a handfull high, at the top whercof grow two or three little leaues togerher : out of the middle of them fpring fmall floures of a golden co'or, after whic li come little husks, wherein is contained the red feed,not vnlike the former: the roote is tender, creeping in the ground with long threds or haires.

* Pona hath fer forth this plat by the name of Saxifraga alba petrea, and rlorefore I haue placed it bere; though I thinke I might more fitly haue ranked him wich Paronychia $r u-$ taceo folio formerly deferibed. It hath a fmall fingle root from which arife diuers fat longifh Icaues, fomewhat hatry, and diuided into three parts : among ft thofe rifes vp a round knottie ftalke, roughith, and of a purplifh colour, fome Isalfe foot high, diuided into fundry branches, which carty white floures, confifting of fiue leates apiece, with fome yellowith threds in their middles : thefe falling, there remaines a cup containing a very fmall feed. It floures at the end of Iune in the thadowie places of the Alpes, whercas Pona fir ft obferued it. $\neq$

\section{T The Place.}

The white Saxifrage groweth plentifully in fundrie places of England, and efpecially in a field on the left hand of the high way, as you goe from the place of execurion called Saint Thomas Waterings vnto Dedford by London. Ir growet h alfo in the great field by Iflington called the Mantles: alfo in the greene places by the fea fide at Lee in Effex,among the rufhes, and in fundrie othet places thereabout, and elfe where. $\neq$ It alfo gtowes in Saint Geotges fields behinde Southwarke. $\ddagger$

The golden Saxifrage groweth in the moift and marifh grounds about Batheand Wels, alfo in the Moores by Botton and $W$ ishich in Lincolnfhire: $\neq$ and $M^{*}$.George Bosoles hath found ir growing indiuers woods at Chiffelhu: $\mathrm{ft}$ in Kent: $\mathrm{M}^{5}$. Goodyer aifo hath obferued it abundantly on the thadowie moift tockes by Mapledurham in Hamplhire : and I haue found it in the like places in Yorkthite. $\ddagger$

T The Time.

Thewhite Saxifrage floutcth in May and Iune : the herbe with his floute ate no more feen vntill the rext yeare.

The golden Saxifrage floureth in March and Aprill.

The Names.

The firft is called in Latine Saxifraga Alba: in Englifh,white Saxifrage, or white Stone-breake:

The fecond is called Golden Saxifrage,or golden Stone-breake. II The Nature.

The firf of thefe,efpecially the root and feed thereof, is of a warme or hot complexion.

Golden Saxifrage is of a cold narure,as the tafte doth manifeftly declare.

G) The Vertues.

A The root of white Saxifrage boiled in wine and drunken, prouoleth vrine, clenfeth the kidneis and bladder, breaketh the ftone, and driueth it forth, and is fingular good againft the ftrangurie, and all orher griefes and imperfections in the reines.

B The vertures of golden Saxifrage are yet vnto v's vnknowne, now itfanding I am of this rainde, that it is a fingular wound herbe, equalliwith Sanicle. 


\section{Cha P. 3 iо Of Sow-breid. \\ II The Defcription.} 1 He firt being the common kinde of Sowbread, culled in flops $P$ imi porcinus, and Arpart of the leaues are mixed here and there confufedly with white fpots, and vnder the leaues next the ground of a purple colour : among which rife ip litrle ftemmes like vnou the ftalks bf violets, bearing at the top fmall purple Houres, which turne themfelues backwert bueine full blowne) likea Turks cap, or Tulepan, of a fmall fent or fauour, or none ar all : which being pals there fucced little round knops or heads which containe flender browne feedes: thefekroppes

I Cyclamen or biculato folio.

Round Sowbread.

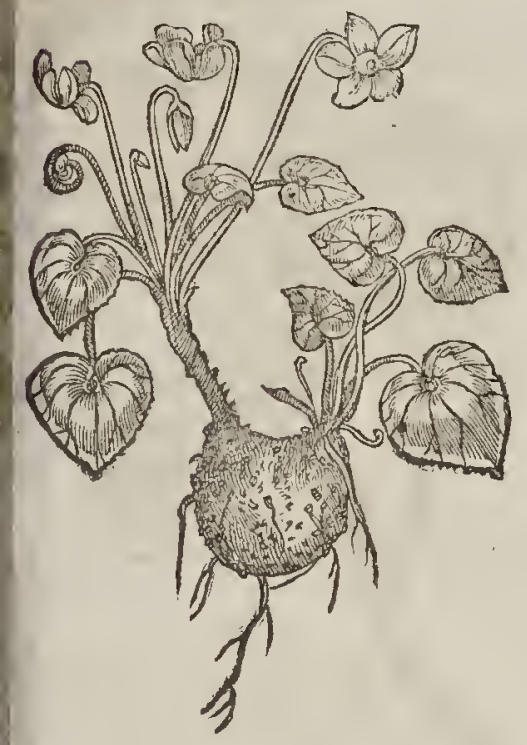

2 Cyclamen folio Hedcris. tuie Sowbread.

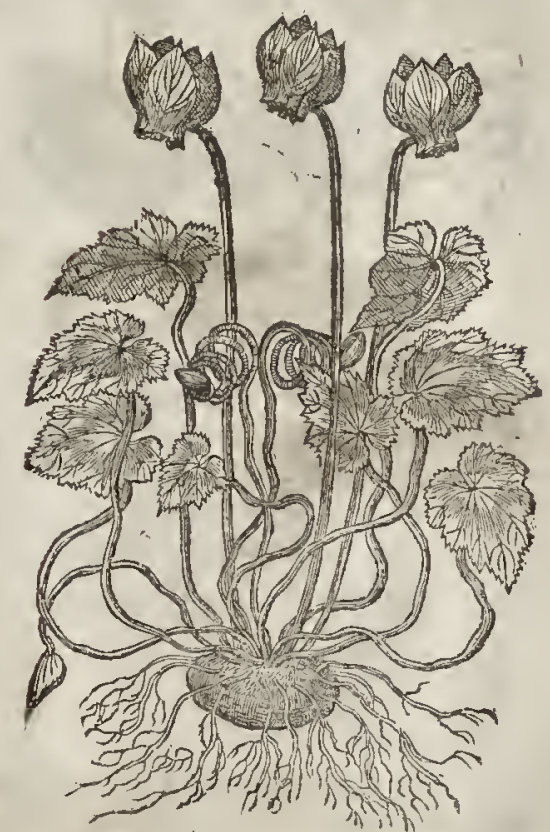

3 Cyclamen Vernum. Spring Sowbread.

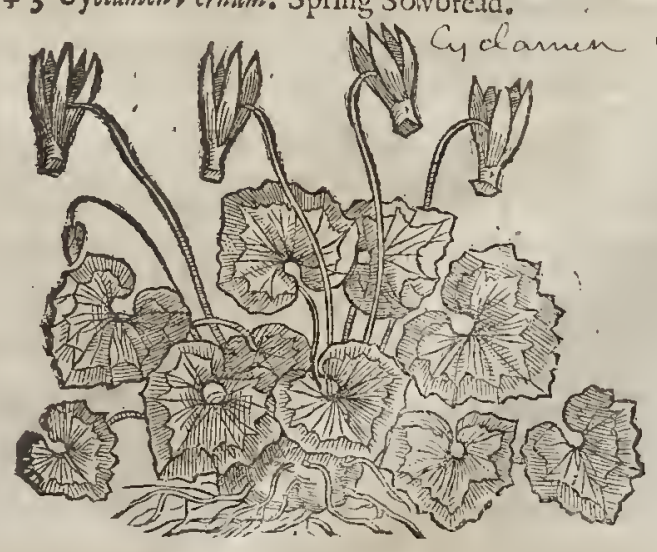

Europoum 
arewrapped after a few daies in the fmall ftalkes, as thred about a bottome, where it remaine th fo defended fron the iniuric of Winter clofe vpon the ground, eouered alfow th the greene leaues aforefaid, by which meanes it is kept from the frof, euen from the time of his feeding,, hieh is in September vntill Iune : at which rime the leaues do fade aw ay, the falkes and feed renaining bare and naked, whereby it inioyeth the Sun(whereof it was long depriued) the fooner to bring them unto maturitic: the root is round like a Turnep, blacke without and whitew ithin, with many fmal frings annexed thereto.

¥ Cyclamen F゙ чrnum album: White foured Sowbread:

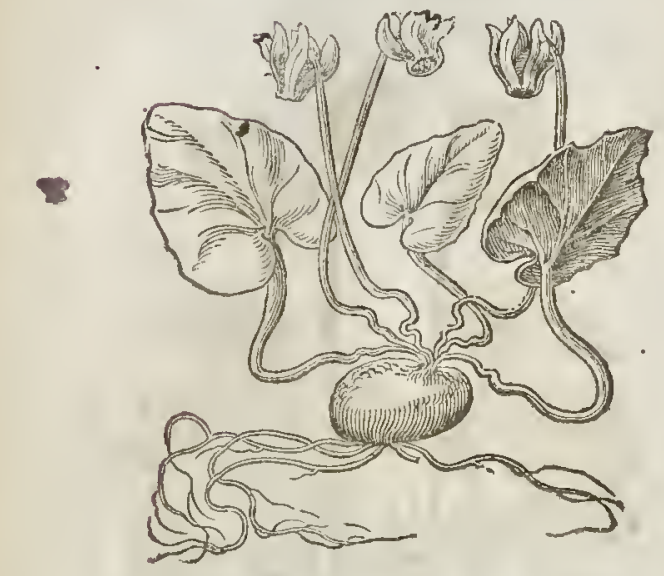

\$ Un Cyclaminos altera, bedcrace is folïs planta?

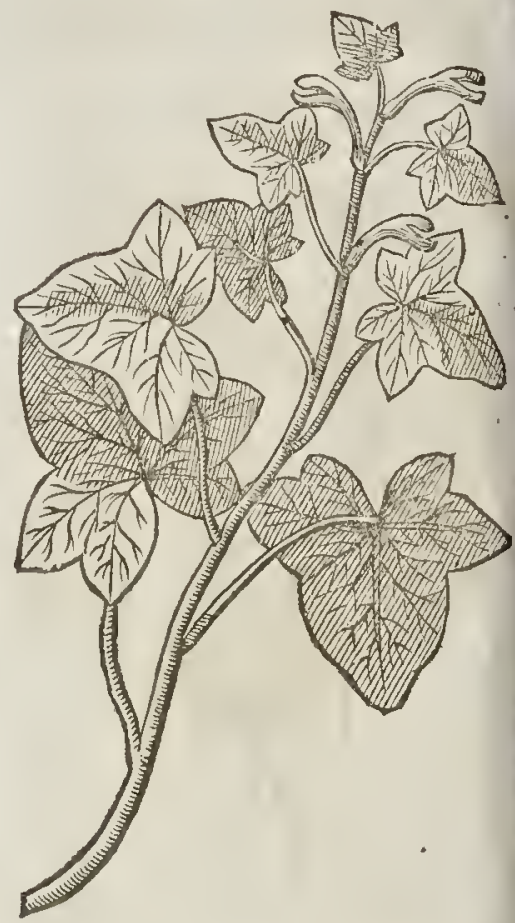

2 The fecond kinde of Sowbread, hatl bioad leaues fpred vpon the ground, tharpe pointed: fomewhar indented about the edges, of a darke greene eolour, with fome little lines or ftrakes of white on the vpper fide, and of a darke reddifh colour on that fide next the ground: among whieh rife vp flender foot-1talks of two nr three inehes long: at the tops whereof ftand fueh floures as the pre eedent, but of a fweeter fmell, and more pleafant colour. The feed is alfo wrapped vp in the ftalk for his further defence againft the iniurie of winter. The root is fomewhat greater,and of more vertue, as fhall be deelared.

3 There is a third kinde of Sowbread that hath round leaues without peaked corners,as the laft before mentioned, yct fomewhat fnipt about the edges, and fpeckled with white about the brims of the leaues, and of a blaekifh eolour in the middle:the floures are like to the reft, but of a deeper purpla:the root alfo like, but fmaller, and this commonly foures in the Spring.

$¥ 4$ This in leaues and roots is mueh like the laft deferibed, but the floures are frualler, fnow white, and fiwcet fmelling. There arediuers other varieties of the fe ulants, which I thinke it not neceffarie forme to infift vpon: wherefore I referre the eurious to rhe Garden of floures fet forth by $\mathrm{M}^{\mathrm{r}}$. Iolsn Parkir. fon, where they fhall finde fatisfaction. $\neq$

5 There is a plant which I haue fet forth in this place that may very well be called into queftion, and his place alfo,confidering that there hat heen great contention about the fame, and not fully determined on ei ther part, which hath moved me to plaee lim with thofe plan ts that moft do refemble one another, both in thape and name:this plant hath greene corncred leaues like to Iuie, 

long and fmall gaping floures like the fmall Snapdragon : more hath not been faid of this plant;
exther of ftalke or root, but is left vnto the confideration of the learned.

₹ The plant which our Author here would acquaint you with, is that whieh Lobel figures wuth this title whieh I here gine, and faith it was gathered amongft other plants on the hils of I taly, but in what part or place, or how growing he knew not; and he onely queftions whether it nay nor be the Cyclaminos altera of Diofcorides, lib.2.cap.1 95 . $¥$

\section{The Place.}

Sow bread groweth plentifully about Artoies and Vermandois in France, and in the Foreft of Arden,and in Btabant : but the fecond groweth plentifully in many places of I ta!ie.

It is reported unto mee by men of good credit, that cyclumen or Sow-bread growetli vpon the mountaines of Wales; on the hils of Lineolnthire, and in Somerfet thire by the houfe of a gentleman called $\mathrm{M}^{\mathrm{r}}$.Hales; vpon a Fox-borough al fo not far from $\mathrm{M}^{\mathrm{r}}$. Bamficlds, neere.to a towne called Harding ton. The firft two kindes clo grow in my garden,where they prof perwell. that this growes wilde in England. $¥$

\section{का The Time.}

Sow-bre.d floureth in Septcmber when the plant is without leafe, which dothafterwards fpring vp,continuing greene all the Winter, eouering and keeping warme the feede vntill Midfommer nexr, at what time the feed is ripe as aforefaid. The third foureth in the fpring, for whieh cafe it was called Cyclamen virnum:and fo doth alfo the foutth.

\section{T) The Names.}

Sow bread is called in Greeke weragurs : in Latine, Tubcr terra, and Terra rapum : of Martellsus, orbicularis : of Apulcius, Palalin, Rapum Porcinum, and Tcrramalum in thops, Cyclamen, Panis purcimus, and Artbanita: in Italian,Pan Porcino: in Spanirh, Mazan de Puerco: in High Dutch, Sebweinbrot: in Low Dutch, đletcking bzoot: in Freneh, Pain de Porceas : in Engliih, Sow-bread. Plsny calleth the colour of this floure in Latine, Coloßinus color: in Englin, Murrey colour.

Sow-bread is hot and drie in the third degree.

$$
\text { If The Nature. }
$$

T The Vertues.

The root of Sow. bread dried into pouder and taken inwardly in the quantitie of a dram and a $A$ halfe,with mead or honied water, purgeth downeward tough and groffe fiegme, and other harpe
humours.

The fame taken in wine as aforefaid, is very profitableagainft all poifon, and the bitings of ve- $B$ nomous beafts and to be outward ly applied to the hurt place.

The pouder taken as aforefaid, cureth the iaundife and the ftoppings of the liuer, taketh away $C$ the ycllow colour of the bodie, if the patient after the taking hereof be caufed to fweat.

The leaues itamped with bonie,and the iuice put into the eies, cleereth the fight, taketh away al fpots and webs, pearle or haw, and all impediments of the fight,and is put into that exeellent oint-

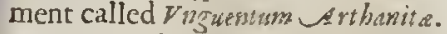

The root hanged about women in their extreame tranell with ehilde, caufeth them to be deli- E uered incontinent,and takerh away much of their paine.

The leaues put into the place hath the like effect, as my wife hath prooued fundrie times vpon $F$ diuers women, by my aduife and eommandement, with gocd fucceffe. The iuiee of Sow-bread dothopen the Hemorrhoids, and caufeth them to' How beeing applied
with wooll or flocks.

It is mixed-with medieincs that eonfume or wafte away knots, the Kings enill, and other hard $H$ fwellings:moreouer it clenfeth the head by the noftrils, it purgeth the belly being annointed therwith, and killech the childe. It is a ftrong medieine to deftroy the birth, being put vp as a peffarie.

It feoureth the skin, and takcth away Sun-burning, and all blemifhes of the face, pilling of the I haire, and marks alfo that remaine after the fmall poeks and mefels : and giuen in wine to drinke, it makcth a man drunke. The decotion thereof ferueth as a good and effectuall bath for members out of ioint, the gout, $\mathbb{K}$
aud kibed heeles.

The root being made hollow and filled with oile, elofed with a little wax, and rofted in the hot $L$ embers, maketh an excellent ointment for the gricfes laft rehearfed.

Being beaten and madevp into trochifches, or little flat eakes, it is reported robea good amorous $M$ medieine to make one in loue if it be inwardly taken.

$$
\text { The Danger. }
$$

It is not good for women with childe to toueh or take this herbe, or to come neerc vnto it, or ftride oncr the fame where it groweth; for the naturall attractiue vertue therein eontaincd is fuch, that without controuerfe they that attempt it in maner abouefaid, thall be deliuered before their 


\section{6 \\ Of the Hiftorie of Plants. \\ L I B.2.}

time: which danger and inconuenience to auoid, I haue (about the place where it groweth in nu garden) faftened iticks in the ground, and fome other ftickes I have faftenedalfocroffe-waies nue chem, left any woman thould by lamentable experiment finde my words to bee true, by their ftepping ouer the fame.

$¥$ I iudge our Author fomething toowomaninh in this, that is, led more by vain opirion tlan by any reafon or experience, to confirme this his affertion, which frequent experience fhcws tola vaine and friuolous, efpecially for the touching, ftriding ouer, or comming neere to this herbe. $\neq$

\section{Cна в. 3II. Of Birtbroourts \\ T The $\mathrm{K}$ indes.}

Drthwoort, as Diofcorides writeth, is of three forts, long, round, and winding : $P$ linie hath added a $\{$ fourth kinde called $\boldsymbol{P}$ ffolochia, or little Birthwoost. The later writers haute ioined vnto then a fifth, named Saracens Birthwoort.

1 Ariftolochialonga.

Long Burthwoort.

7

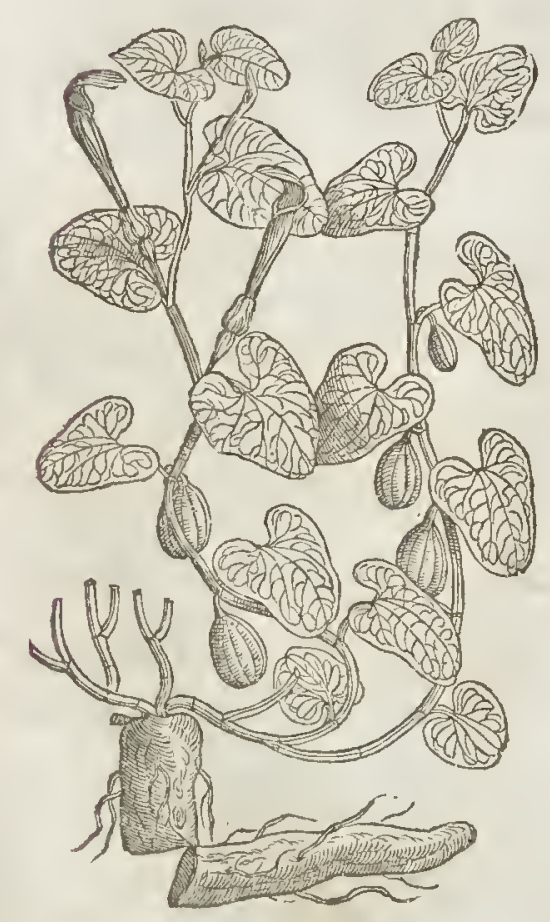

2 Arifolochiarotunda. Round Birthwoort.

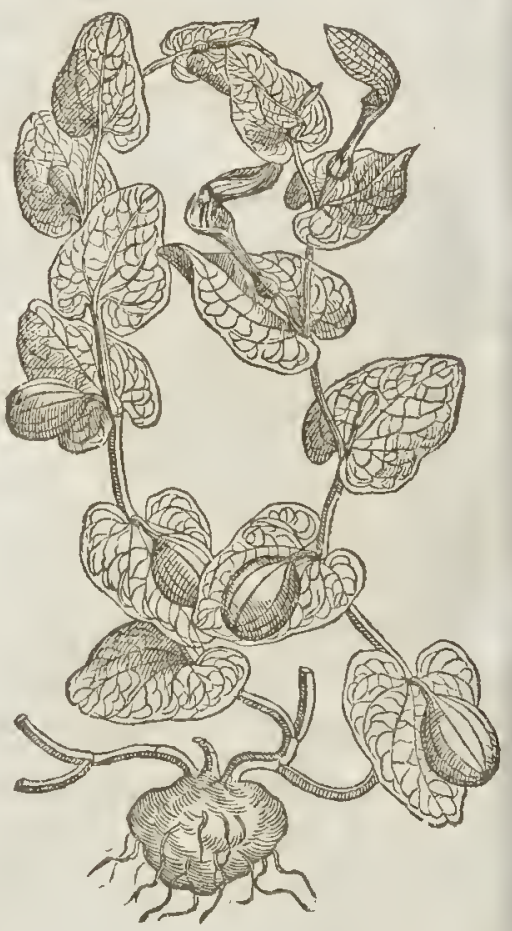

T) The Deferipion.

1 Ong Birthwoort hath many fmall long nender falkes creeping vpon the ground, tangling one with another very intricately, befet with round leaues not much vnlike Sowbread or Iuie, but larger, of a light or ouerworne greene colour, and of a grieuous or lothfome fmell and fauour : among which come forth long hollow floures, not much vnlike the floures of Aron, but without any peftell or clapper in the fame; of a dark purple colour : after which do follow fmall frut like vnto little peares, containing trangled feeds of a blackifh colour. The root is long, thicke, of the colour of box, of a ftrong faurour and bitter tafte.

2 The round Birthwoort in falkes and leaues is like the firft, but lis leates are rounder : the floures differ onely in this, that they be fomewhat longer and narrower, and of a faint yellowifh colour, but the fmall fiap or point of the floure that turneth backe againe, is of a darke or blacke pur- 
LI B. 2.

Of the Hiftory of Plants.

84

ple colour. The fruit is formed like a peare, tharpe toward the top, moteribbed and fuller than the former : the root is round like vnto Sow-bread, in tafte and fauour like the former.

3 Ariffolochiaclematitis. Climing Birthviroort.

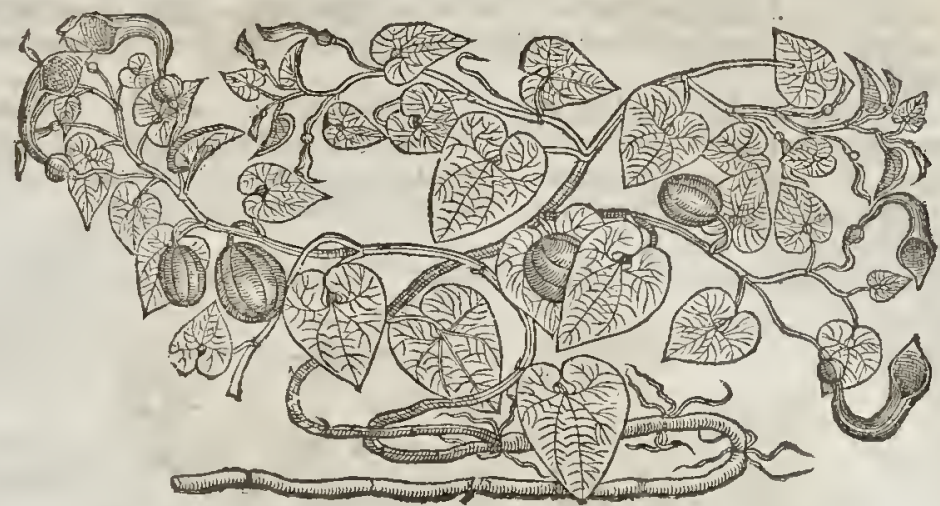

\# 4 Ariftolocbia Saracenica.

Saracens Birthwoort

Úvistocinia clemootrites

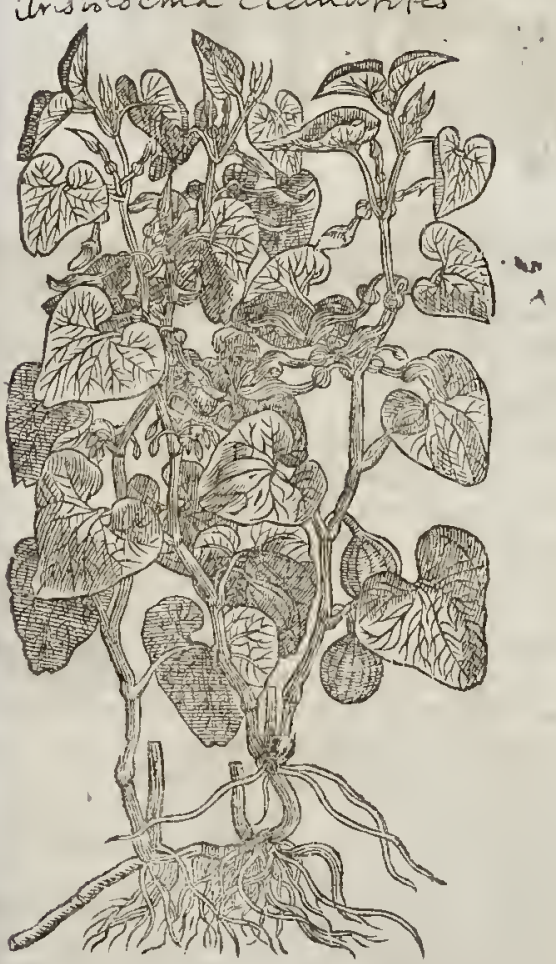

\$ 5 Piftolochia.

Small Birthwoort:

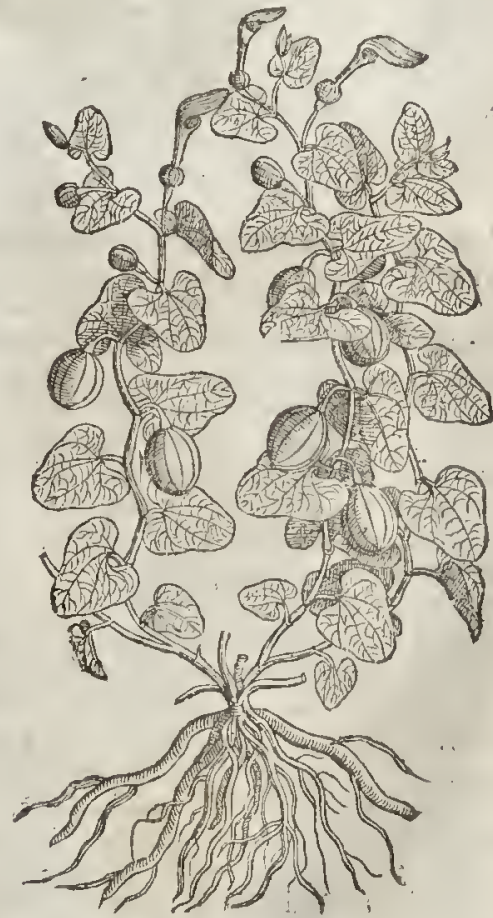

3 Climing Birthwoort taketh hold of any thing that is next vnto it,with his long and clafping Italks,which be oftentimes branched, and winderh it felfe like Bindweed: the ftalks of the leatres are longer, whofe leaues be fmooth, broad, tharpe pointed, as be thofe of the others: the floures Inkewife hollow, long,yellow, or of a blackinh purple colour : the fruit differeth not from that of the others : but the roots be flender and very long, fometimes creeping on the top of the earth, and sometimes growing deeper, being of like colour with the former ones.

4. There is a fourth kinde of $B$ irthwoprt refembling the reft in leaues and branched ftalkes, yet $\mathrm{Bbbb} 2$ 
higher,and longer than either the long or the round:the leaues thereofbe greater than thofe of $A$ farabacca; the floures hollow, long, and in one fide hanging ouer, of a yellowith colour: the fruit is long and round like a peare, in which the feeds lie feuered, of forme three fquare, of an ill fauored blackifh colour:the root is fomewhat long, oftentimes of a mean thickneffe, yellow like to the colour of Box, not inferior in bitterneffe eirher to the long or to the round Birthwoort : and fometimes the fe are found to be fmall and fender, and that is when they were but lately digged v and gathered: lor by the little parcels of the roots which are left, the young plants bring forth at the Leginning tender and branched roots.

5 Small Birthwoort is like to the long and round Birthwoort both in ftalkes and leaues, yet is it leffer and tenderer: the leames therenf are broad, and like thofe of Iuic : the floure is long, hollow in the vpper part, and on the outfide blackifh: the fruit fomerhing round like the fruit of round Birthwoort : in ftead of roots there grow fortl a multitude of llender ftrings.

\section{¥ 6 piflolochinCretica fiue Virginiana. Virginian Snake-root.}

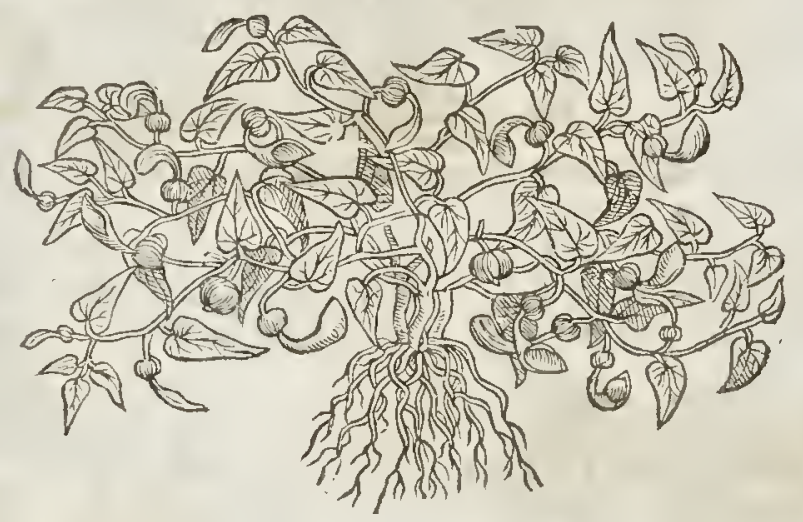

\# 6 Clufins figures and deferibes another fmal Pifolochia by the name of Pifiolochia Cretica, to which I thought good to adde the Epithite Virginiallo, for that the much admired Snakeweed of Virginia feems no otherwife to differ from it than an inbabitant of $C_{a n d y}$ from one of the Virginians,which none I thinke will fay to differ in pecie. I will firt giue cluf/us his defeription, and then expreffe the little varietic that I haue obferued in the plants tharwere brought from Viryinia, and grew here with ws: it lends forth many fleader ftalks a foot long,more or leffe, and thefe are cornered or indented,crefted, branched, tough, and bending towards the ground, or fpred thereon, and of a darke green colour : vpon which wirhout order grow leaues, neruous, and like thofe of the laft defcribed, yet much tharper pointed, and after a fort refembling the thape of thofe of Swilux afpera; but leffe, and of a darke and lafting greetue colour, faftened to longin $\mathrm{ntalkes}$ : out of whofe bofomes grow long and hollow erooked floures, in thape like thofe of the long Birtlwoort, but of a darker red on the outfide, but fomewhat yellowifh within : and theic are alfo faftened to pretty long ftalks; and they are fueceded by fruit, not vnlike, yet leffe than that of the long Birthwort. This hath abundance of roots, like as the former, but much fmaller, and more fibrous, and of a ftronger fmell. It floures in Iuly and Auguft. Thus Clufius deforibes his, to which that Snakeweed that was brought from Virginia, and grew with $\mathrm{M}^{\mathrm{t}}$. Iohn Tradef cant at South-Lambeth, An. I632. was agreeable in all points, but here and there one of the lower leaues were fomwhat broader and rounder pointed than thereft : the foure was long, red, crooked, and a little hairie, and it did not open the top, or fhew the inner fde, which I iudge was by reafon of the coldneffe and vnfeafonableneffe of the later part of the So mer when it floured : the ftalks in the figure fhould haue been expreft more crooking or indenting, for they commonly grow fo. How hard it is to indge of plants by one particle or facultie may very well appeare by this herbe I now treat of : for fome by the fimilitude the root had with $A$ farwm, and a vomiting qualitie which they attributed to it (which certainly is no other than aceidentall) would forthwith pronounee and maintaine it an Afarum: fomealfo refer it to other things, as to Primrofes, Vincitoxicum, \&c. Others morew arily naned it Serpentaria Virgimiana, and Radiv Virginiana, names as it were offering themfelues and eafilyto be fitted and impofed vpon fundry things, but yet too generall,and therefore not fit any more to be vfed, feeing the true and fpecifick denominarion is found. $\neq$

Tlimy theweth that the Birthwoorts grow in fat and champion places, the fieldes of Spane are
Plat 
full of thefethree long and round Birthwoorts: they are alfo found in Italie and Narbone or Languedock, a countrey in France. Petrus Bellonius writeth, that he found branched Birthwoort vpon Ida a mountaine in Candie : Carolus Clufizu faitl, that he found this fame about Hifpalis, and in many other places of Granado in Spain,among buthes and brambles : they grow all in my garden.

They Poure in May, Iune, and Iuly.

$$
\text { IT The Time. }
$$

$$
\text { TT The Names. }
$$

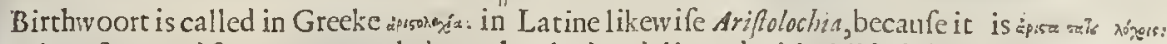
that is to fay, good for w omen newly brought a bed, or deliuered with clilde:in Englith, Birthworta Hartwoort, and of fome, Ariftolochia.

The firft is ealled Anistolochin longa, or long Birt hwoort, of the forme of his root, and likewife Ariftolocbia was, or male Birthwoort : the fecond is thought to be $F$ amina or fenale Birthwoort, \& it is called Rotunda Ariflolachia, or round Birthwoott : of diuers alfo Terra malum; the Apple of the earth: yet Cyclaminus is alfo called Terra malum, or the A pple of the earth.

$$
\text { It The Temperature. }
$$

All thefe Birthwoorts are of temperature hot and drie,and that in the third degree, hating bcfides a pow er to clenfe.

$$
\text { Q1 The vertues. }
$$

Diofcorides writeth, that a dram weight of long Birthwoort drunkew ith wine and alfo applied, is $\mathbb{A}$ good aga inft ferpents and deadly th ings : and that beng drunke with myrrhe and pepper, it expelleth what foener is left in the marrix after the childe is delinered, the flourcs alfo $\&$ dead children: and that being put vp in a peffarie it performeth the fame.

Round Birthwoort ferueth for all thefe things, and alfo for the reft of the other poifons: it is B likewife auaileable againft the ftufing of the lungs, the hicket, the fhakings or thitrerings of agues, hardneffeof the milt or fpleene, burftings, cramps, and couvulfions, paines of the fides if it be drunk with water.

It plucketh out thomes, fplinters, and fhiuers, and being mixed in plaifters, or pulteffes, it draws C forth fcales or bones, remoneth rottenneffe or corruption, mund ifieth and fcoureth foule and filthy vleers, and filleth them vp with new flefh, if it be mixed with Ireos and honie.

Galen faith,that branehed Birthwoort is of a more fweet and pleafant fmell : and therefore is v- D fed in ointments; but it is wea ier in operation than the former ones.

Birthwoort,as Pliny writerb, being drunk with water is a moll excellent remedie for cramps and $E$ convulfions, bruifes, and for fuch as haue falne from high places.

It is good for them that are hort-winded, and are troubled with the falling fickneffe. F

The round Ariftolochia doth beatitifie, clenfe, and faftcin, the teeth, if they be often fretted or rub- G bed with the pouder thereof.

\# The root of the Virginian Piffolochia, which is of a ftrong and aromaticke fent, is a fingular \& $\mathrm{H}$ much vfed Antidote againft the bite of the Rattle-fnake, or rather Adder or Viper, whofe bite is very deadly, and therfore by the prouidence of the Creator he harh v pon his taile a skinny dry fub. ftance parted into cels which containe fome loofe, hard drie bodies that rattle in them (as if one Thould put littleftones or peafe into a fiffe and very dry bladder) that fo he may by this noife gite warning of his a pproeh, the better to be awoided; but if any be bitten, they know, nor ftand 'in need of no better ant idote, thanthis root, which they chew, and apply to the wonnd, \& alfo fwallow fome of it downe, by which means they quickly ouercome the malignitic of this poifnous bite, which otherwife in a very hort time would prove deadly. Many alfo ommend the vfe of this againft the plague, fmall pox,meafels,and fuch like maligne and contagious difeafes. $\neq$

\section{C на в.312. Of Violets.}

$$
\text { The Kindes. }
$$

There might bedefcribed many kinds of fioures vnder this name of violets, if their differences thould be more euriounly looked into than is neceffarie:for we migh tioine hereunto the ftock Gillo loures, the Wall floures, Dames Gillofloures, Mar ians violets, and likervife fome of the bulbed Houres, becaufe fome of them by $T$ beophraftus are termed Violets. But this was nor our charges holding it fuffieient to diftingurin and diuide them as neere as may be inkindred and neighbourhood, addireffing my felfe vnto the Violets called the blacke or purple violets, or March Violets of the Garden, which hate a great prerogatiue aboue others, not onely becaufe the minde coneeiueth a certaine pleafure and recreation by fimelling and handling of thofemoft odoriferous flours, but alfo for that very many by thefe Violets reeeine ornament and comely grace: for there tee made of them Galands for the head, Nofe-gaies, and poefies, which are delightrfull to looke on, and pleafant to finell to, fpeaking nothing of their appropriate vertues; yea Gardens rhemfelues receilue by thefe tlue greateft ornament of all $I_{3}$ chicfeft beautic and moft gallant grace; and the're- 
creation of the minde which is taken hereby, cannot be but very good and honeft: for they admonith and fir vp a man to that which is eomely and lioneft; for foures througl rheir beautie, variety of colour, and exquifite forme, do bring to a liberall and gentle manly minde, the remembrance of honettie, comelineffe, and all kindes of vertues. For it would be an vnfeemely and filthic thing (as a certaine wife man fairh) for him that doth looke vpon and handle faire and beaurifull things, and who frequenteth and is conuerfant in faire and beautifull places, to haue his minde not faire, but filthie and deformed.

$$
\text { of The Defcription. }
$$

I THeblacke or purple Violet doth forthwith bring from the root many leaues, broad, fleightly indented in the edges, rounder than tlue leaues of Iuie: among the nidif wherof fpring ve fine flender ftems, and vpon etrerie one a beautifull floure fweetly fnelling, of a blew darkifh purple, confifting of fuc litrle leaues, the loweft whereof is the greatef; and after them doe appeare little hanging cups or knaps, which; when they be ripe, do open and diuide themfelues into three parts. The feed is fmall, long, and fomewhat round withall. The root confifteth of many threddie ftrings.

1 Violanigra five purpurea.

The purple Garden Violet.

Uiola odorata. a.

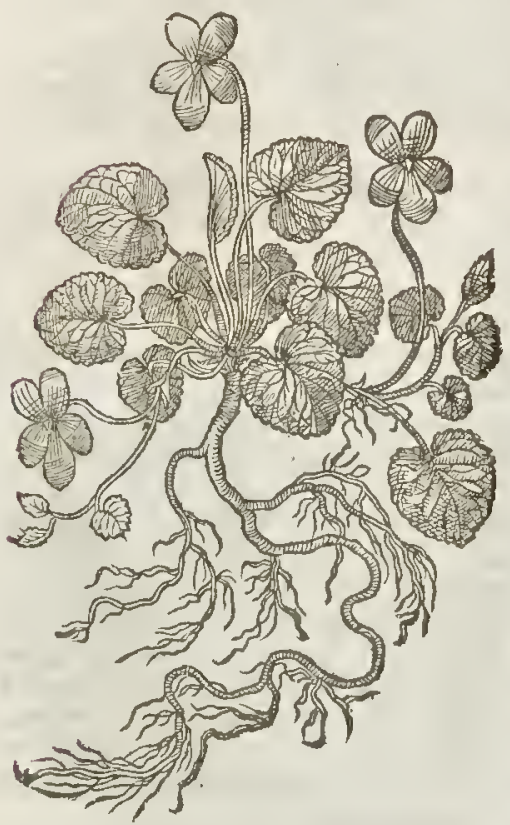

2 Viola flor albo.

The white Garden Violet. Viola odozata . V. B 


\section{1 в. 2. Of the Hiftory of Plants.}

3 Violamartia purpurea multiplex. The double garden purple Violet.

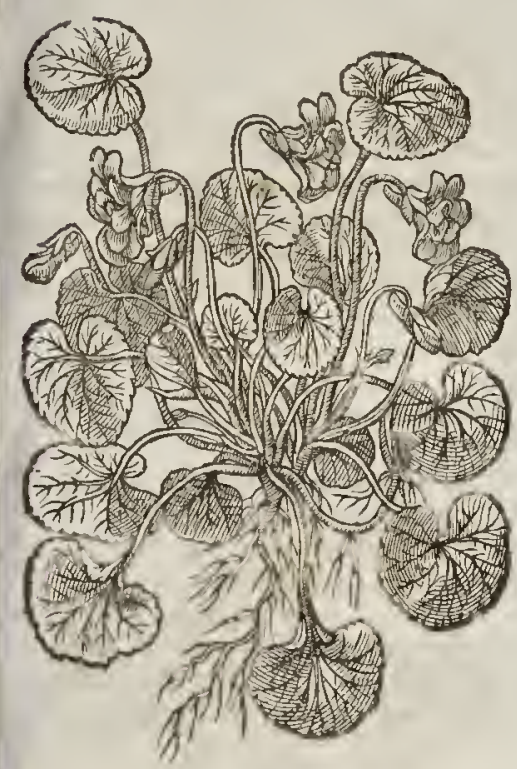

t 6 Violacrinina fylueftris.

Dogs Violets, or wilde Violets.

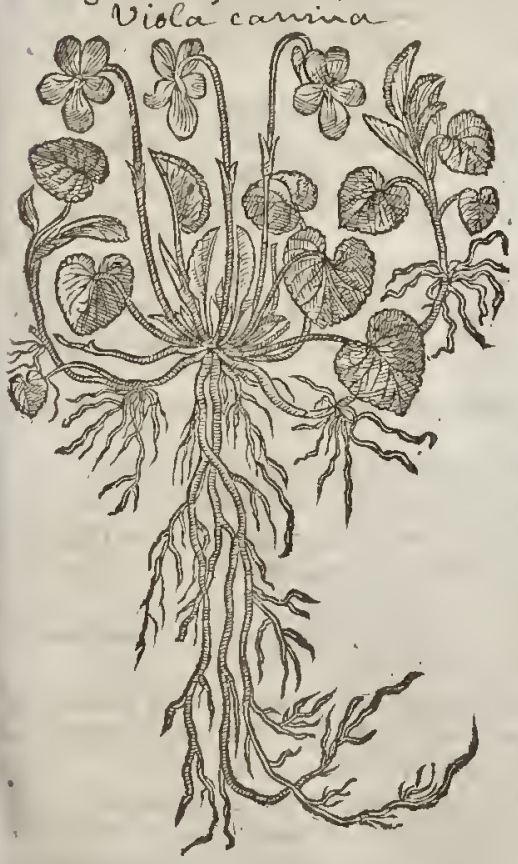

5 Fiula martialutea. Yellow Violets.
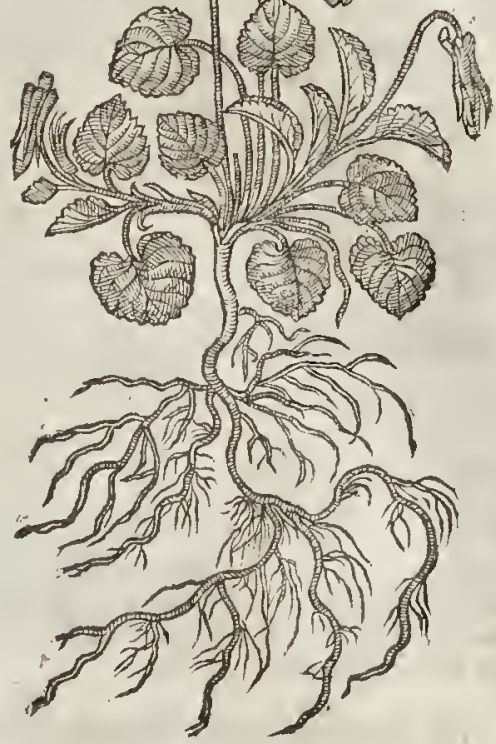

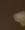

growing vpon the hills in Lancafhire, neere vnto a village called Latham; and though he brought them into his garden, yet they withered and pined. The whole plant is deferibed to be like vnto the ficld Violet, and differeth from it, in that this plant bringeth forth yelloiv floures, yet like in forme and figure, but without fmell.

6. The wilde field Vio'er with round leates rifeth forth of the ground fro $n$ a fibrous root, with long flender branehes, whereupon do grow round fmooth leaues. The floures grow at the top of the ftalkes, of a light blew eolour : $\ddagger$ and this growes eommonly in Woods and fuch like plaees, and floures in Iuly and Auguft. There is another varietie of this wilde Violet, which hath the leaues longer, narrower,and fharper pointed. And this was formerly figured and deferibed in this place by our Author, $\ddagger$

7 There is found in Germanie about Noremberg and Strasborough, a kinde of Violer which is altogether a franger in thefe parts. It hath (faith my Author) a thieke and tough root of a wooddy fub tanee, from which rifeth vp a falke diuiding it felfe into diuers branches, of a wooddy fubftanee; whereupon grow long iag. ged leaues like thofe of the Panfey. The floures grow at the top, eompact of fiue !caues apiecsof a watchet colous. 


\section{The Place.}

The Violet gtoweth in gardens almof cuery where: the othets whieh are ftangers have beene touched in their deferiptions.

$$
\text { or The Time. }
$$

The floures for the moft part appeate in Mareh, at the fartheft in A prill.

$$
\text { of } T \text { be Names. }
$$

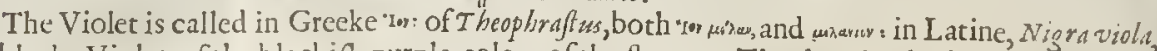
ot blacke Violet, of the blackin purple colout of the floures. The Apothecharies keepe the Latine name Viola, but they call it Herba Violaria, and MaterViolarum: in high-Dutch, 2Blan rivel: in low-Dutch, Jioleten : in French, Violette de Mars : in Italian, Violamammola : in Spanith, Vace ta : in Engligh, Violet. Nicander in his Geoponickes beleeueth, (as Hermolaus theweth) that the Grecians did call it "Io, becaufe eertaine Nymplis of Ionia gaue that foure firt to Irpiter. Orhers fay it was called Ion, bccaufe when Iupter had turned the young Damofell Io, whom he tendetly loued, into a Cow, the earth brought forth this floute for her food : which being made fot her fale, receitued the name from her; and thereupon it is thouglt that the Latines alfo called it Viola, as though they fhould fay itula, by blotring out the letter $t$. Scruius reporteth, That for the fame caufe the Latines alfo name it Vaccinium, alledging the place of $V$ irgil in his Bucolieks :

$$
\text { Albalignftra cadurt, vaccinia nigraleguntur. }
$$

Notwithtanding $I$ rirgil in his tenth Eclog fheweth, that $Y$ acciniam and $r$ iola do differ.

$$
\text { Eimigr.e viola funt, of vaccinia nigra. }
$$

+ Vitruviss alfoin his feuenth booke of Architedure or Building doth diftinguin Viola from $V$ uccimium : for he theweth that the colour called Sile Attucum, or the Azure of Athens, is made $\epsilon x$ Viola; and the gallant purple, ex Vacsinio. The Dyers, faith he, when they would counterfeit Szle, or Azure of A thens, put the dried Violets into a fat, kettle, or caldron, and boyle them with water; afterwards when it is tempered they poure it into a linnen ftrainer, and wringing it with the: hands, receiue into a mortar the liquor coloured with the Violets; and fteeping earth of Erethric in it, and grinding the fame, they make the Azure colour of Athens. After the fame manner they temper $V$ accinium, and putting milke vnto it, do makea gallant purple colour. But what Vaccinis ate we will el fewhere declare.

$$
\text { q The Temperature. }
$$

The foures and leaties of the Violets are cold and moif.

$$
\text { I The Vertues. }
$$

A The floures are good for all inflammations, efpecially of the fides and lungs; they take awis: the hoarfeneffe of the cheft, the ruggedneffe of the winde-pipe and iawes, allay the extream to. of the liter, kidneyes, and bladder; mitigate the fietic heate of burning agues; temper the fharpneffe of choler, and take away thirft.

B There is an oyle made of Violets, which is likewife eold and moit. The fame being anointed vpon the tefticles, doth gently prouoke lleepe which is hindred by a hot and dry diftemper : mixed or laboured together in awoodden difh with the yelke of an egge, it affivageth the pain of the fundament and hemorthoides : 1t is likewife good to be put into eooling clifters, and into pulteffes that coole and eafe paine.

C But let the oyle in which the Violets be fteeped be either of vnripe oliues, ealled omphacinum, or of fweet Alnonds, as Mefues fairh, and the Violets themfelues mult be frem and moift : For being dry, and hauing loft their moifture, they doe not coole, but feeme to haue gotten a kinde of heate.

D The later Pliyfirians do thinke it good to mix dry Violets with medicines that are to comfort and frengthen the heart.

E The leaues of Violets inwardly taken do coole, moiften, and make the belly foluble. Being outwardly applied, they mitigate all kinde of hot inflammations, both taken by themfelues, and alfo applied with Barley ffoure dried at the fire, after it hath lien foking in the water. They are likewife laid vpon a hot ftomacke, and on buming eyes, as Galenwitneffeth. Diof corides writeth, that they be moreouer applied to the fundament that is fallen out.

F They may helpe the fundament that is fallen out, not as a binder keeping baek the fundament, but as a fuppler and a mollifier. Befides, Pliny faith that Violets are as well vfed in garlands, as finelt vnto; and are good againft furfeting, heauinefle of the head : and being dried in water and drunke, they remoue the Squinancic or inward fwellings of the throat. They eure the falling fickneffe, efpecially in yong children, and the feed is good againft the ftinging of Scorpions.

$G$ There is a fyrup made of Violets and Sugar, whereof three or foute ounces being taken at one time, foften the belly, and purge choler. The manner to make it is as followeth.

H Firf make of clarified fugar by boyling a fimple fyrup of a good confiftence or meane thickeneffe, whereunto put the floures cleane picked from all mannet of filth, as alfo the white ends 
nipped away, $a$ quanticie according to the quantic ie of the fyrtip, to your owne diferetion, where in let them infufe or fteepe foure and rwenry houres, and fer vpon a few warme embers, then ftrain it, and put more Violets into the fame fyrup: thus do three or foure times, the oftner the better then fe: them vpon a gentle fire to fimper, but not to boyle in any wife: fo haue you it limply made of a moft perfect purple colour, and of the fmell of the Houres themfelues. Sone do adde hereto a lirtle of the iuyce of the floures in the boyling, which makerh ir' of berter force and vertue, Likewife fome do pur a litcle quantitic of the iuyce of Lymons in the boylng, which doch greatly encreafe the beauty thereof, but norhing at all the vertue.

There is likewife made of Violets and fugar cerrain plates called Sugar Violet, or Violer tables, or Plate, which is moft pleafant and wholefome, efpecially it comforreth the heart and the other inward parts.

The decoction of Violets is good againft hot feucrs, and the inflammarion of the liuer and all $\mathrm{K}$ other inward parts : the like propertic hath the iuyce, fyrrup, or conferue of the fame.

Sytrup of Violets is good againft the inflammation of the lungs and breft,againt the pleurifie $\dot{L}$ and cough, againft feuers and agues in yong children, efpecially if you pur vnto an ounec of Syrrup eight or nine drops of oy le of Vitrioll, and mix it together, and giue it ro the ehilde a poonefull ar once.

The famegiuen in manner aforefaid is of great efficacie in burning feuers and pefilent difeafes, greatly cooling the inward parts : and ir may feeme ftrange to fome, that fo tharpe a corroliue as oyle of Vitriol thould be giuen into the body; yet being delayed and gituen as aforefaid, fucking children may take it wirhout any, perill.

The fame taken as a forefaid cureth all inflammarions of the throat, mouth, uvula, fquinancie, $N$ and the falling euill in children.

Sugar-Violet harh power roceafe inflammations, roughneffe of the throar, and comforteth the heart, affivageth the paines of the head, and cauferh lleepe.

The leaues of Violets are vfed in cooling plaifters, oyles, and comfortable cataplafmes or pul- p tefles; and are of greater efficacie among other herbes, as Mercurie, Mallowes, and fueh like, in clifters, for the purpofes aforefaid.

\section{Chas. 3iz. Of Hearts-ege, or Panjies.}

\section{The Defcription:}

I He Hearts-eafe of Paunfie hath many round leates at the firft comming vp; afrerward they grow fomewhat longer, lleightly cut about the edges, trailing or creeping vpon the ground. The ftalkes are weate and tender, whereupon do grow foures in forme and figure like the Violet, and for the moft part of the fame bignefre, of rhree fundry colours; whereof it tooke the fyrname Tricolor, that is to fay, purple, yellow, and whitc or blew : by reafon of the beauty and brauerie of which colours they are very pleafing to the eye, for fmell they haue little or none at all. The feed is contained in little knaps, of the bignefle of a Tare, which come forth after the foures be fallen, and do open of themfelues when the feed is ripe. The root is nothing elfe but as it were a bundle of threddy ftrings.

2 The vpright Paunfe bringeth forth long leaues deepely cut in the edges, harpe pointed, of: a bleake or pale greene colour, fet vpon flender vpright ftalkes, cornered, ioynted, or knecd a foot high or higher; whereupon do grow very faire foures of three colours, vir. of purple, blew, and yellow, in thape like the common Hearts-eafe, but greater and faiter : which colours ate fo excellenty and orderly placed, that they bring great dele etation to the belolders, though they haue Jittle or no fmell at all. For oftenti mes it hapneth, that rhe vppermoft floures are differing from thofe that grow vpon the middle of the plant, and thofe varie from the lowermolt, as Nature lif todally with things of fuch beaty. The feed is like the precedent.

3 The wilde Paunfie differeth from that of the garden, in leates, roors, and tenderbranches: the foures of this wilde one are of a bleake and pale eolour, far inferiour in beauty to that of the garden, wherein confifteth the differenee.

4 Stony Hearts-eafe is a bafe and low plant: The leaires are rounder, and not fo much cut about the edges as the orhers: The branches are weake, and feeble,trailing vpon the ground: The floures are likewifc of three colours, that is to fay, white, blew, and yellow, void of fmell. The root perineth when it hach perfected his feed.

5 There is found in fundry plaees of England a wilde kinde hereof, bringing floures of a faint yellow colour, without mixture of any other eolour, yet haung a deeper yellow fpor in the lowe f: 
$L_{1}$ B. 2.

1 I'iolatricolor.

Hearts-eale.

viola tricolor $a$.

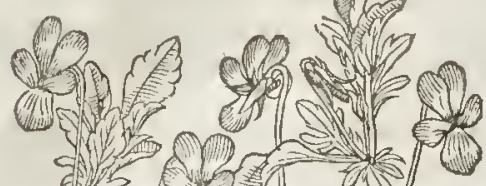

c. 5 OR z चै

wonl

(x)

2. 25 , 13

- 13 a d

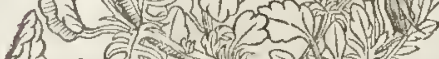

435 .

4. 31 .

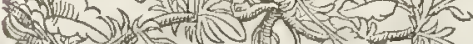

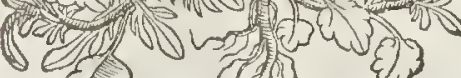

Es औ

......

s Violatricolor fyluefris.

Wilde Patinfies.

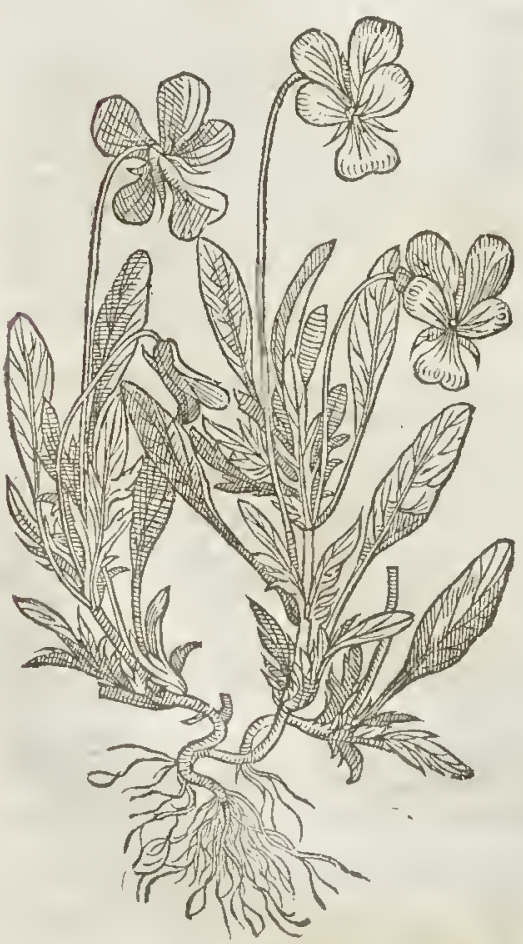

2 Viola ajfurgens tricolor. Vpright Hearts-eafe,

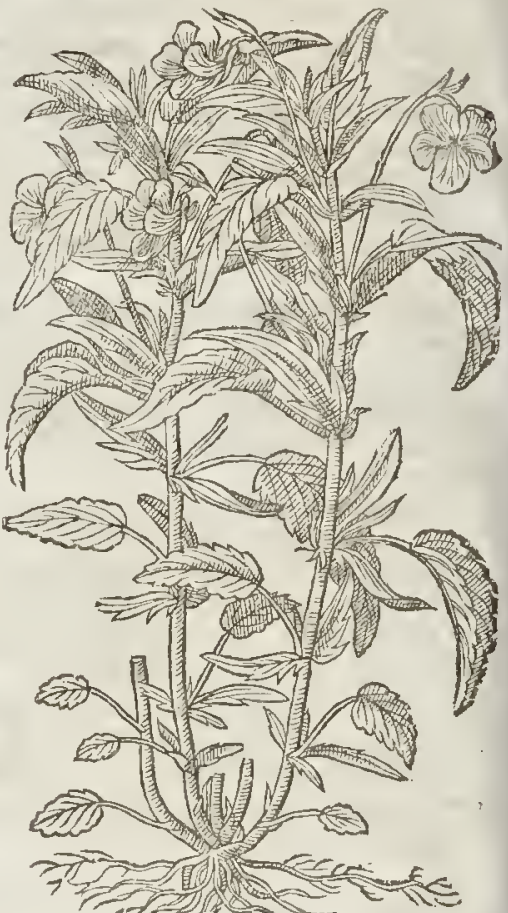

4 Violatricolor petrea.

Stony Hearts-eafe.

Violatricalon. Nars.

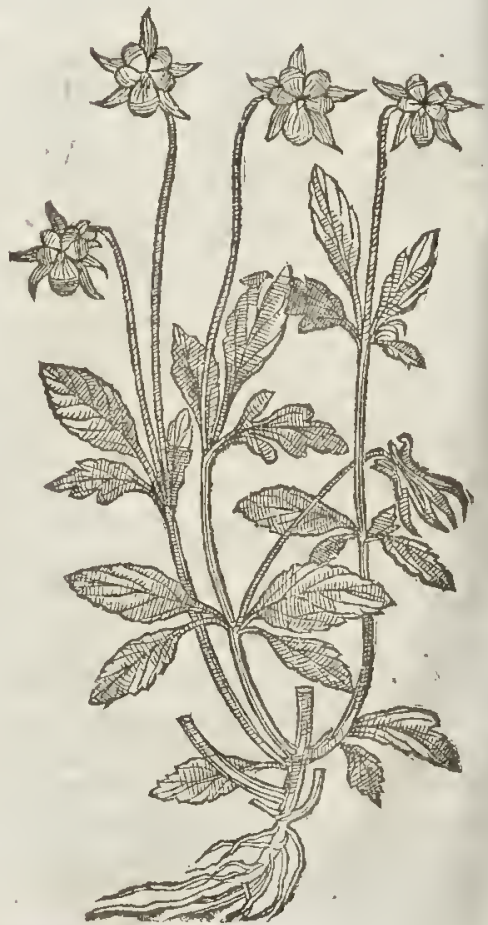


leafe with foure or fiue blackith purple lines, wherein it differeth from the other wilde kinde: and this hath beene taken of fome yong Herbarifts to be the yellow Violet.

\section{9) T be Place.}

The Hearts-eafe groweth in fields in many places, and in gardens alfo, and that oftentimes of it felfe: it is more gallant and beautifull than any of the wilde ones.

Matthiolus reporteth, that the vpright Paunfie is found on mount Baldus in Italy. Lobel faith that it groweth in Languedocke in France, and on the tops of fome hills in England; but as yet I haue not feene the fanc.

Thofe with yellow floures haue been found by a village in Lancafhire called Latham, foure miles from Kyrckhan, by $\mathrm{M}^{\mathrm{r}}$. Thomas Heskcth before remembred.

$$
\text { 9) The time. }
$$

They foure not oncly in the Spring, but for the moft part all Sommer thorow;enen vntill Autumine.

$$
\text { Fi The Names. }
$$

Hearts-eafe is named in Lacine riolis tricolor, or the three coloured Violet ; and of diuers, IAcea. (yet there is another Iacea fyrnamed Nigra: in Englim, Knatp-weed,Bull-weed, and Mat ful'on) of others, Herba Trinitatis, or herbe Trinitic, by rearon of the triple colour of the floures: of inme others, Herbuclaucllata: in French, Penfees: by which name they became knowne to the Brabal!ders and others of the Low-eountries that are next adioyning. It feemeth to be Vola flumver, which Theophrastus calleth wija, which is alfo called sigor: in Englifh, Hearts-cafe, Paunfies, Liue in idleneffe, Cull ine to you, and Three faces ina hood.

Thevpright Panfic is called not vnproperly Viola afjurgens, or Strrecta, and withall Tricolor, that is to fay, ftraight or vight Violet threc coloured: of fome, Viola arborefcens, or Tree Violet, for that in the multitude of branches and manner of growing it refembles a little tree.

$$
\text { The Temperature. }
$$

It is of temperature obfcurely cold, but more cuidently moift, of a tough and flimie iuyce, like that of the Mallow; for which caufe it moifnethand fuppleth, but not fo much as the Mallow doth.

It is good, as the later Phy fitions write, for fuch a's are ficke of an ague, efpecially children and $A$ infants, whofe convul fions and fits of the falling fiekneffe it is thought to cure.

It is commended again inflammations of the lungs and cheft, and againf $f$ cabs and itchings $B$ of the whole body, and healeth vleers.

The diftilled water of the herbe or floures giuen to drinke for ten or more dayes together, three $\mathrm{C}$ ounces in the morning, and the like quantitic at night, doth wonderfully eafe the paines of the Freneh difeafe, and cureth the fame, if the Patient becaufed to fiveat fundry times, as Cofteus reporteth, in his bouke de naturavinuerf. pirp.

\section{Cна р.314. Of Ground-fuy, or c Ale-boofe.}

$$
\text { (1) The Defcription. }
$$<smiles>[C]1CCCCC1</smiles>
Round Iuy is a low or bafe herbe; it creepeth and foreads vpon the ground hither and thither all about, with many falkes of an vncertaine length, flender, and like thofe of the Vine, fomething cornered, and fometimes reddin : whereupon grow leaues iomething broad and round, wrinkled, hairy, nicked in the edges, for the moft part two out of cuerie ioynt: amongft which come forth the floures gaping like little hoods, not vnlike to thofe of Germander, of a purplifh blew colour: the roots are very threddy : the whole plant is of a ftrong finell and bitter tafte.

\# 2 . Vpon the rockic and inountainous places of Prouinee and Daulph ine growes this other kinde of Ale-hoofe, which hath leaues, falkes, Houres, and roots like in mape to thofe of the former, but the floures and leaues are of a light putple colour, and alfo larger and longer. This by $L_{0}$ bel is called 1 garina, fue Saratilis bedera. $\neq$

$$
\text { The place. }
$$

It is found as well in tilled as in vntilled places, but moft commonly in obfcure and darke pla =

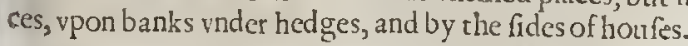

It remaineth greene not onely in Sommer, but alfo in Winter at any time of the yeare : it flois. reth from Aprill till Sommer be farfpent. 


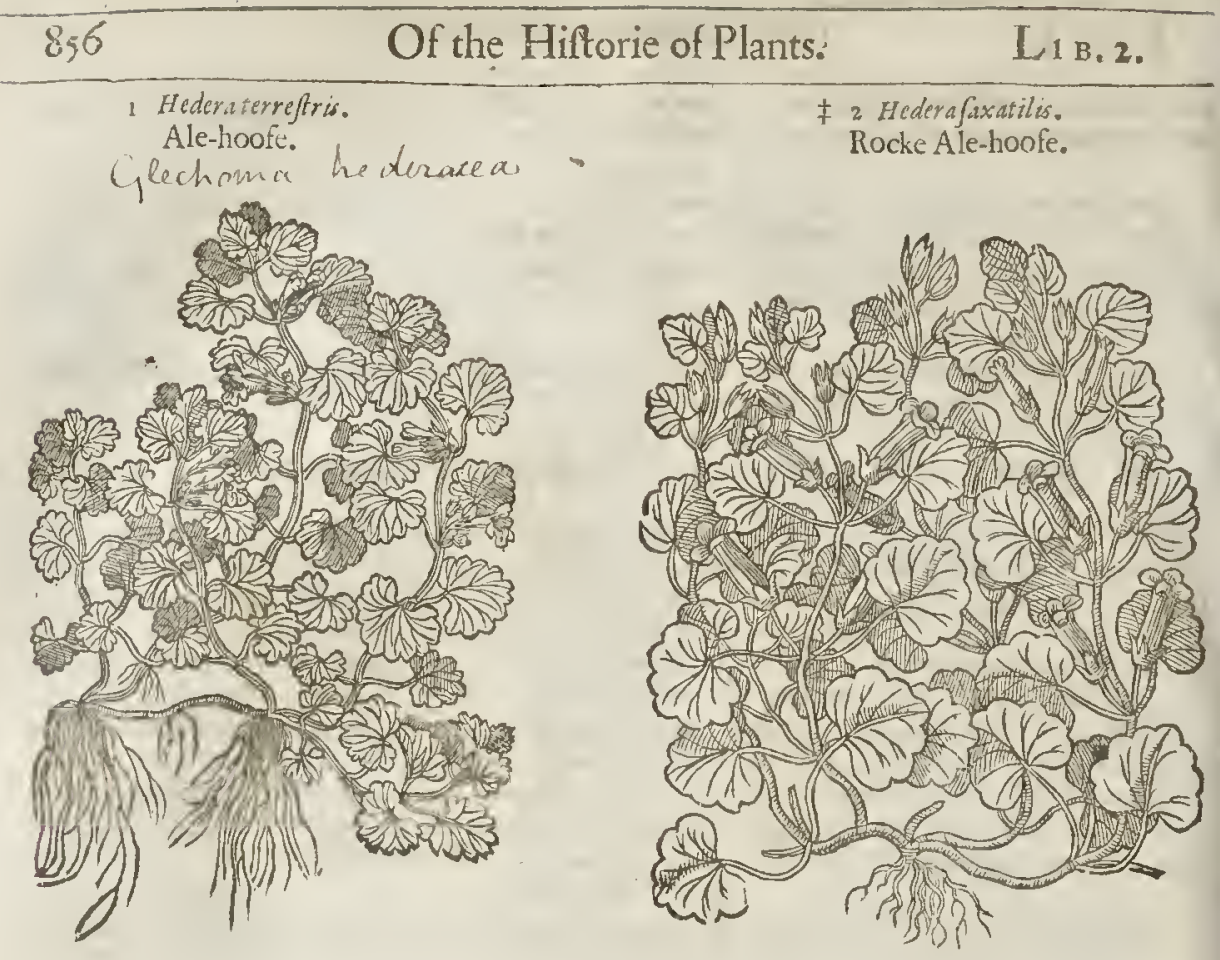

TI The Nimes.

It is commonly called Hederaterreftris : in Greeke, xamaxiars: alfo Corona terre : in high-Dutch, Bumoelecb: in low - Dutch, Dnoethaue: in French, Lierreterreftre: Hedera bumilis of fome, and Chumecifrum: in Englifh, Ground-Iuy, Ale-hoofe, Gill go by ground, Tune-hoofe, and Cats. foot. \$ Many yueftion whether this be the Ghamaijsas of the Antients: which controuerfie $D_{0}$. dowers hatl 3 largely handled, Pempt.3. lib.3. cap.4. $\$$

$$
\text { The Temperature. }
$$

Ground-Iuie is hot and dry, and becanfe it is bitter it fcoureth, and remoueth ftoppings out of the intrals.

$$
\text { The Vertues. }
$$

A Ground-Iuy is commended againft the humming noyfe and ringing found of the eares, being put in to them, and for them that are lard of hearing.

B Matholus write th, That the iuyce being tempered with Verdugreafe, is good againft fifulaes and Lollow vlcers.

C Dinforides teacheth, That halfe a dran of the leaues being drunke in foure ounces and a halfe of taire water, for fourty or fifty dayes together, is a remedie againft the Sciatica, or ache in the huckle bone.

D The fame taken in like fort fix or feten dayes doth alfo cure the yellow jaundice. Galen hath attributed (aswe haue faid) all the vertue vnto the floures : Secing the floures of Ground-Iuy (faith Iie) are very bitter, they renoue itoppings ont of the liuer, and are giuen to them that are vexed with the-Sciatica.

E

Ground-Iuy, Celandine, and Daifies, of each a like quantitie, ftamped and Atrained, and a little fugar and rofe water put thereto, and dropped with a feather into the ejes, taketh awayall manner of inflammation, fpots, webs, itch, fmarting, or any griefe whatfocuer in the eves, yea although the fight were nigh hand gone: it is proted to be the beft medicine in the world.

F The herbes ftamped as a forefaid, and mixed w ith a little ale and honey, and ftrained, takes away the pinne and web, or any griefe out of the eyes of horfe or cow, or any other beaf, being fquirred into the fame with a fyringe, or I might have faid the liguor iniested into the ejes with a fyringe. But I lift not to be oucr eloquent among Gentlewomen, to whom efpecially my Works are moft neceffarie.

G The women of our Northerne parts, efpeciallv about Wales and Chemire, do tunne the herbe Ale-hoof into their Ale; but the reafon thereof I know not: notwithftanding without all contro- 
uerfie it is moft fingulat againt the griefes aforefaid : being tunned vp inale and drunle, it alfo purgeth the head from rlumaticke humots flowing from the braine.

Hederaterreft ris boyled in water ftayeth the termes; and boyled in müton broth it helps weake I and aking backes.

They hauevfed to pur it into ointments againft burning with fire, gunpouder, and fuch like.

Hederaterreft ris being bound in a bundle, or chopt as herbes for the pot, and eaten or diunke as $I$ thin broth ftayeth tlue Hux in women.

\section{Cha P. 315. Of f $u$. \\ बI The Kindes.}

7 Here be twok indes of Iuy, as Thcophraft us witneffeth, reckoned among the number of thofe plants which haue need to be propped vp; for they ftand not of themifehes, but are faftned to ftone walls, trecs, and fuch like, and yet notwithftanding both of a wooddy fubfance, and yet not to be placed among the trees, hrubs, or buhes, bccaufe of the affinitic they haue with climbing herbes; as allo agreeing in forme and figurewith many other plants that climbe, and are indeed fimply to be reckoned among the herbes that clambervp. But if any will cauill, or charge me with my promife made in the beginning of this hiftorie, where we made our diuifion, namely, to place each plant as neere as may be in kindred and neighbourhood; this promife I haue fulfilled, if the curious eye can be content to reade without rathneffe thofe plants following in order, and not onely this climbing Iuy that lifteth her felfe to the tops of trees, but alfo the other Iuy that creepeth vpon the ground.

Of the greater or the climing I luy there are alfo many forts ; but efpecially thtee, the white, the blacke, and that which is called Hedera Helix, or Hedcrifterilis.

\section{The Defription.}

I $T$ Hegreater Iuy climbeth on trces, old buildings, and walls : the ftalkes thercof are wooddy, and now and then fo great as it feemes to become a trce; from which it fenarms it creepeth and wandercth far about : it alfo bringeth forth continually fine little roots, by which it faitneth it feife and cleaueth wonderfull hard vpon trees, and vpon the fmootheft ftone walls : the leanes are fmooth, thining efpecially on the vpper fide, cornered with tharpe pointed corners. The foures are very fmall and moffie; aftet which ficceed bundles of black berties, euery one hauing a fmall tharpe pointall.

There is another fort of great luy that bringeth foth white fruit, which fome eall Acharnicoms irriguam; and alfo another lefer, the which hath blacke berries. This Pliny calleth Selinizium.

We alfo finde mentioned another fort hereof fpred abroad, with a fruit of a yellow Saffron colour, called of diucrs Diony/sas, as Diofcorides writeth : others Bacibica, of which the Poits vifed to make gatlands, as Pliny teftifieth, lib.16.cap. 34 .

2 Barren Iuy is not much vnlike vnto the common Iuy a forefaid, fauing that his branches are both fmaller and tenderer, not lifting ot bearing it felfe vpward, but creeping along by the ground vnder moift and fhadowie ditch banles. The leaues are noft commonly three fquare, cornered, of a blackifh greene colour, which at the end of Sommer become brownifh red vpon the lower fide. Thewhole plant beareth neither foures nor fruir, but is altogether barten and fruitleffe.

$\neq 3$ There is kept for nouelties fake in diuers gardens a Virginian, by fome(though vnfitly) eetmed a Vine, being indeed an Iuy. The ftalkes of this grow to a great heighth, if they be planted nigh any thing that may futaine or beare them $v p$ : and they take firt hold by certaine fmall tendrels, vpon what body foemer tincy giow, whether ftone, boords, bricke, yea glafe, and that fo firmely, that of tentimes they will bring pieces with them if you plucke then off. The leaues are large, confifting of foure, fuce, or more particular leaues, each of them being long, and decply.notched about the cdges, fo that they fomewhat refemble the leaues of the Chefnut trec : the floures ;grow clutering together a ftet the manner of Iuy, but nener with v's fhew themfelues open, fo that we cannot iufly fay any thing of their colour, or the fruit that fucceeds them. It puts forth his leaues in A pril,and the ftalkes with the rud?ments of the foures are to be feene in Augurt. It may :as I faid be fitly called Hederavirginiand. 产

Iuy grorethconnonty of The Place.

Iuy groweth commonly about walls and trees; the white Iuy groweth in Greece, and the barren Iuy groweth vpon the ground in ditch b.mkes and fhalowie woods.

Ccec 

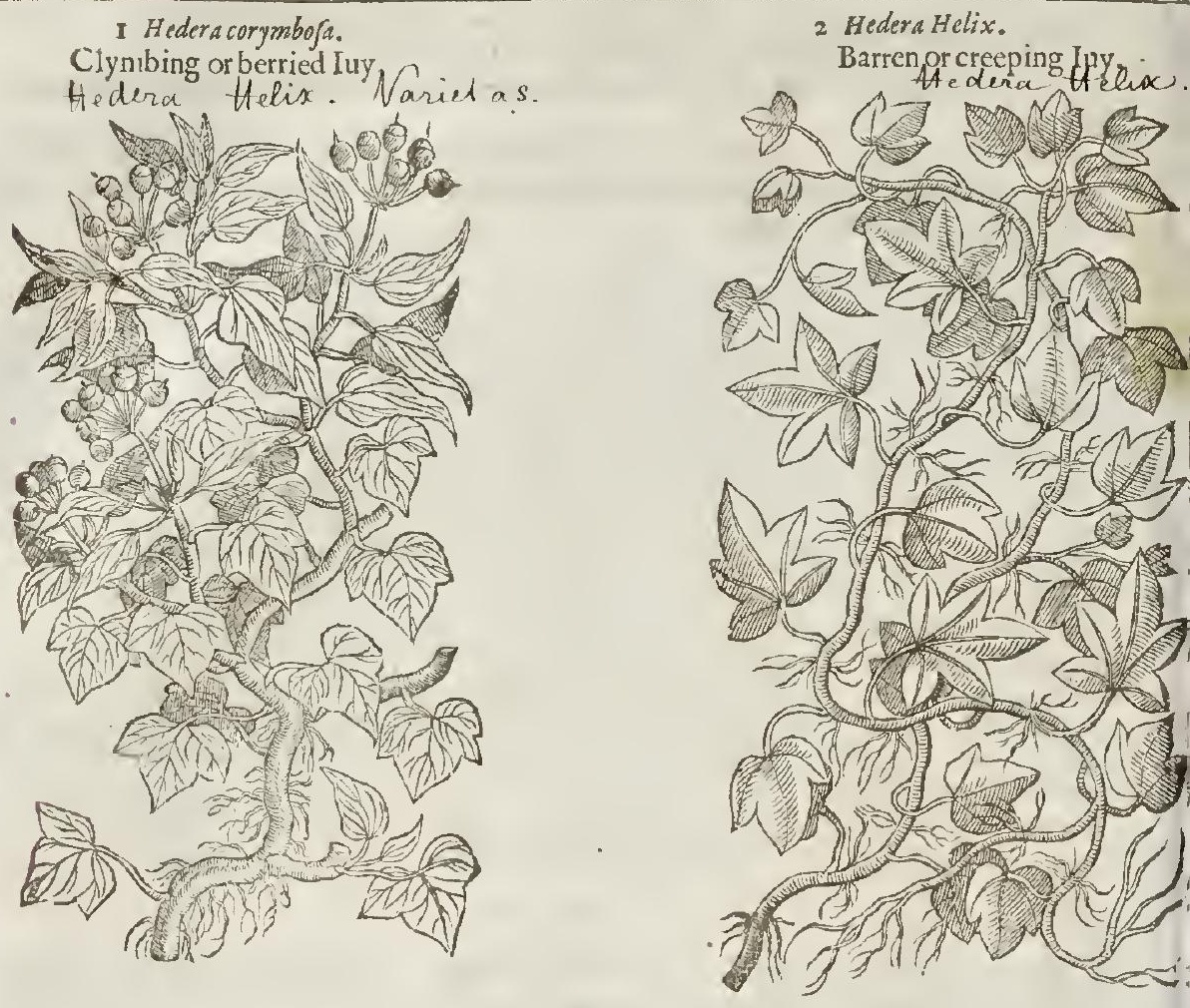

The Time.

Ituy flouritheth in Autumne : the berries are ripe after the Winter Solftice.

TT The Names.

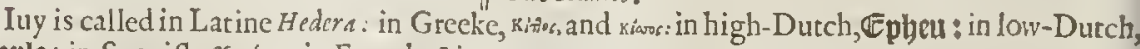
Jizeyle: in Spanifh, Yedra: in French, Liarre.

The greater Iuy is called of Theopliraftus itor Kians: in Latine, Hedira atsollens, or Hedera affurgens: Gaza interpreteth it Hedera excelfa. The later Herbarifts would have it to be Hedera arborea, or tree Iuy, becaufe it groweth vpon trees, and Heder a muralis, which hangeth vpon walls.

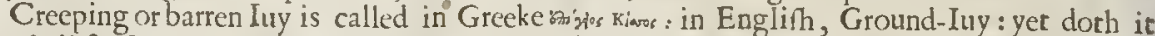
much differ from Hederaicrreftris, or Ground-Iuy before defcribed : of fonic it is called Clasicula, Hedera Helix, and Hederafterilis; and is that herbe wherein the Bore delighteth, according to Iohannes Khueniws.

q The Temperature.

Iuy, as Galen faith, is compounded of contrarie faculties; for it hath a certaine binding earthy and cold fubftance, and alfo a fubftance lomew hat biting, which euen the very tafte doth thew to be hor. Neither is it without a third facultic, as being of a certaine warme waterie fubftance, and that is if it be greene: forwhileft it is in drying, this watery fubftance being earthy, cold, and binding confumeth away, and that which is hot and biting remaineth.

\section{TI The Vextues.}

A The leatres of Iuy freh and greene boyled in wine, do heale old vlcers, and perfectly cure thore that haue a venomous and malicious quality ioyned with them; and are a remedy likew ife againft burnings and fcaldings.

B Moreouer, the leaues boyled with vinegcr are good for fuch as haue bad fpleens; but the floures or fruit are of more force, being very finely beaten and tempered with vineger, efpecially fo vfed they are conmended again burnings.

C The iuyce drawne or fnift vp into the nofe doth effe.tually purge the head, tryyeth the running of the eares that hath beene of long continuance, and healeth old vlcers both in the eares and alfo in the nothrils : but if it be too fharpe, it is to be mixed with oyle of Rofes, or fallad oyle.

D The gum that is found vpon the trunke or body of the old ftocke of Iuy, killeth nits and lice, and takerh away haire: it is of fo hor a qualitic, as that it doth obfeurely bume: it is as it were a 
L1 в. 2. Of the Hiftory of Plants.

certaine waterifh liquor congealed of thofe gummic drops. Thus farre Galen.

The very fame almoft hath Diefcorides, but yet al fo fomewhat more: for oucr and befides hee $E$ faith, that fite of the berries beaten fmall, and made hot in a Pomegranat rinde, with oyle of rofes, and dropped into the contrarie eare, doth eafe the tootli-ache; and that the berries make the haire blacke.

Iuy in our time is very feldonie vfed, faue that the leaues are layd vpon little vlcers made in the $F$ thighes, legs, or other parts of the body, which are called Iffues; for they draw humors and waterifh fib fance to thofe parts, and keepe them from hot fivellings or inflammations, that is to fay, the leates newly gathered, and not as yet withered or dried.

Some likewife affirme that the berries are effectuall to procure vrine; and are ginen vnto thofe $G$ that be troubled with the ftone and difeafes of the kidneyes.

The leaules laid in teepe in water for a day and a nights fpace, helpe fore and fmarting wate- $H$ rith eyes, if they be bathed and wathed with the water wherein they hate beene infufed.

\section{Снат. 3 I6. Of rougb Binde-weed.}

I Smilax Peruviena, Salfaparilla.

Rough Binde-weed of Peru.

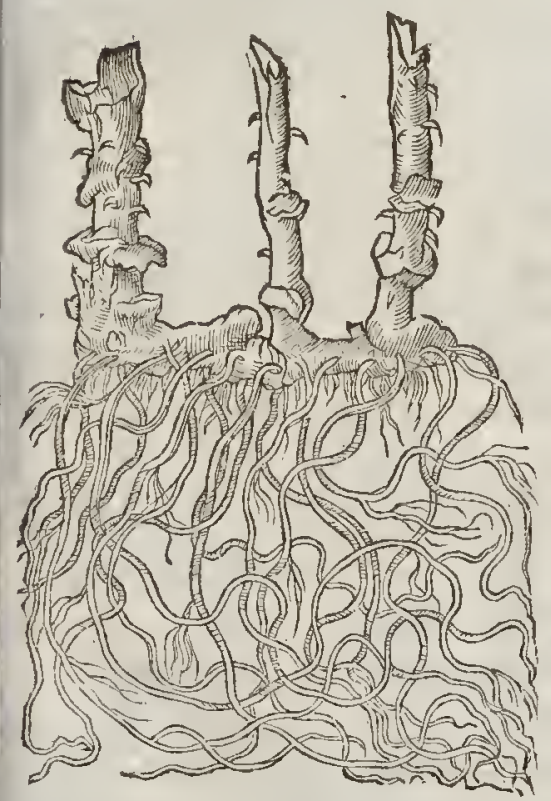

2 Smilaxapera.

Common rough Binde-weed.

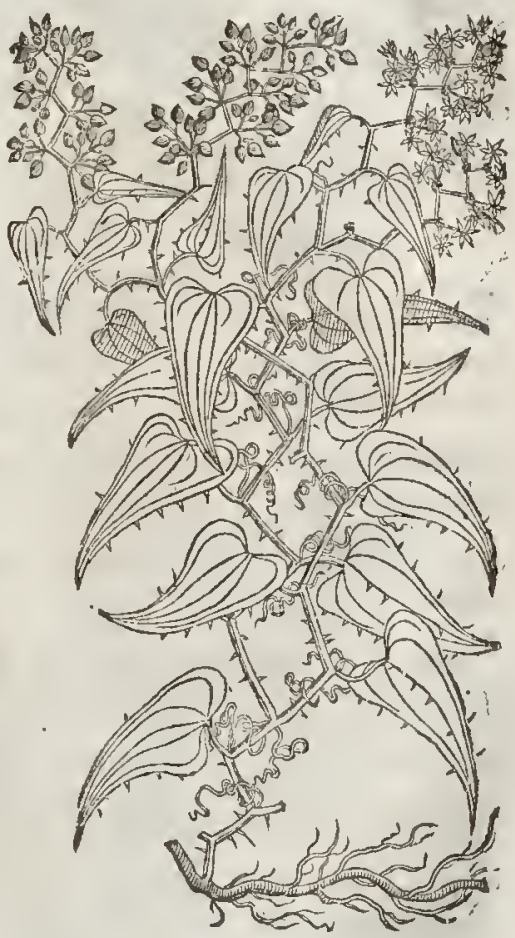

T) The Defiription.

1 Lthough we hatue great plenty of the roots of this Binde-weed of Peru, which we vfitally cally $Z_{a r} \approx a$, or $\operatorname{Sarf} a P_{\text {arill }}$, , wherew ith diuers griefes and maladies are cured, and that thefe roots are very well knowne to all; yet fuch hath beene the carelefneffe and fmall prouidence of fuch as haue trauclled into the Indies, that hitherto not any haue giuen vs inftruction fufficient, either concerning the leaues, floires, or fruit: Onely Monardus faith, that it hath long roots deepe thruft into the ground: which is as much as if a great learned man fhould tell the fimple, that our common carrion Crow were of a blacke colour. For who is fo blinde that feeth the root it felfe, but can eafily affirme the roots to be very long ? Nowwithftanding, there is in the reports of fuch as fay they haue feene the plant it felfe growing, fome contradiction or contrarietie: fome report that it is a kind of Bind-weed, and efpecially one of thefe rough Bindweeds':

$$
\mathrm{Cacc}_{2} \text { others, }
$$


3 Smalax appera Lufutanica. Rough Binde-rveed of Portugall.

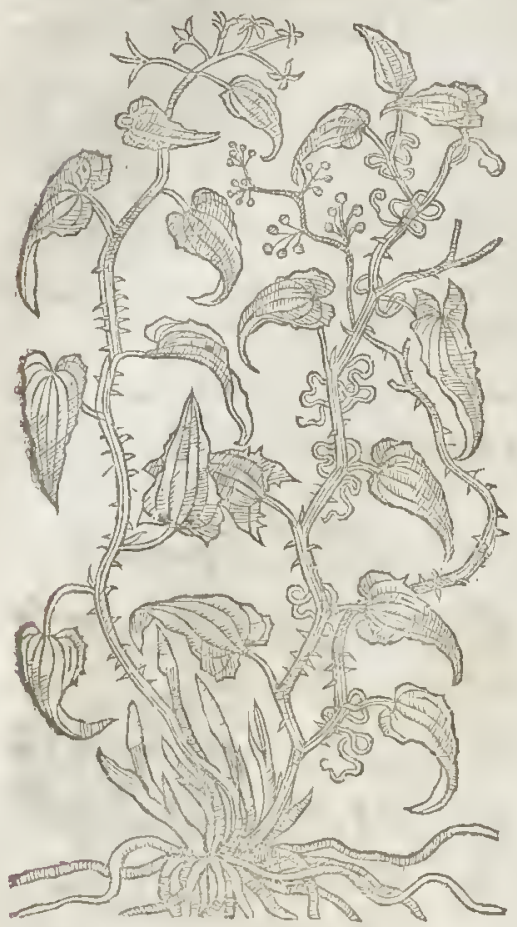

others, as one $\mathrm{M}^{*}$. White an exeellent painter who carried very many people into Virginia (or after fone Norembega) there to inhabit, at which time hee did fee thereof great plentie, as he himfelfe reported vnto me, with this bate defcription; It is (faith he) the root of a fimall ihrubbie tree, or hedge tree, fuch as are thofe of our conntry called Haw-thorns, hauing leaues refembling thofe of Iuy, but the floures or fruit he remembreth not. $\neq$ It is moft certaine, that Sara parilla is the root of the Americane smalax a/pera, both by eonfent of molt Writers, and by the relation of fuch as haue feene it growing there. $\neq$

2 The common rough Binde-rweed hath many branches fet full of litrle tharpe prickles, with certaine elafpong tendrels, wherewitl it taketh hold vpon ledges, fhrubs, and whatfoeurer ftandeth next vnto it, winding and clafping it fulfe about from the botrom to the top; iv hereon are placed at euery ioint one leafe like that of Itry, without coners, flarpe pointed, leffer and harder than thofe of fmooth Binde-reed, oftentimes marked with little whluite fpots, and garded or bordered about the edges with crooked prickles. The floures grow at rhe top of crooked ftalks of a white colour, and fiveet of finell. A fter commeth the fruit lihe thofe of the wilde Vine, greene at the firl, and red when they be ripe, and of a biting talte; wherein is contained a blackin feed in thape like tlat of hempe. 'The root is long, foncwhat hard, and parted into very many branches.

This rough Binde-weed, found for the moft part in the barren mountaines of Portugal, differeth not from the preedent in ftalkes and floures, but in the leaues and fruit; for the leaules are fofter, and leffe prickly, and fometines haue no prickles at all, and they are alfo oftentimes much narrower : the fruit or berry is not red but blacke when as it commeth to be ripe. The root hereof is one fingle root of a wooddy fubitanee, with fome fibres annexed thereto, wherein eonfifteth the difference.

$$
\text { 9i The Place. }
$$

Zurat parilli, or the prickly Binde-rweed of America, groweth in Peru a prouinee of Ameriea, in Virginia, and in diuers other places both in the Eaft and Weft Indies.

The others groiv in rough and vntilled places, about the hedges and borders of fields, on mountaines and vallics, in Italy, Languedoek in France, Spaine, and Germany.

$$
\text { Tा The Time. }
$$

They floure and fourith in the Spring : their frut is ripe in Autumne,or a little before.

$$
\text { 9) The Names. }
$$

Tt is named in Greeke swin rexke. Ga a (Theoploraftus his Tranflator) names it Hedera Cilicia; as likew ife Pliny, wholab.24.cap. 10 writeth, that it is alfo fynamed Nicophoron. Of the Hetrurians, Hedera Pprnofa, and Rubus cerisinus: of the Caftilians in Spaine, as Lacuna faith, Zarza parilla, as though they lhould fay Rubus vitioula, or Bramble little Vine. Parra, as Matthiolus interpreteth it, dorh fignifie a Vine; and Parill.t, a fmall or little Vine.

Diuers affirme rhat the root (brought out of Perua prouinee in America) which the later Herbarifts do call zurãa, is the root of this Bindeweed. Gurcias Lopius Lufutangs granteth it to belike thereunto, but yet he doth not affime that it is the fame. Plants are oftentimes found to be like one another, which notwiththanding are proted not to be the fame by fome little difference; the diters confitution of rhe weather and of the foile making the difference.

Zarzadrilla of Peru is at frange plant, and is brought vnto vs from the Countries of the new world called America; and fuch things as are brought from thence, a'though they alfo feeme and are like to thofe that grow in Europe, notwithlanding they doe often differ in vertue and operation : for the diucrfitie of the foile and of the weather doth not only breed an alteration in the form, 
but doth moft of all preuaile in making the vertues and qualities greater or leffer. Such things as grow in hot places be of more force, and greater funell; and in cold, ofleffer. Some things that are deally and pernitious, being remoued wax milde, and are mude wholeforme : fo in like manner, atthough Zurzaparilla of Peru be like torough Binde-weed, or to Spanih Zarza parilla, notwirh?ftanding by reafon of the temperature of the wearher, and aifo through the nature of the foile, it is of a great deale more force than that which groweth either in Spane or in Africke.

The roots of Zarza parilla of Peru, which are brought alone without the planr, be long and flender, like to the leffer roots of common liquorice, very many oftentimes hanging from one head, in which roors te middle Atring is harde?t. They hate little tafte, and fo fmall a fmell that it is not to be perceiued. Thefe are reported to grow in Honduras a prouince of Peru. They had their name of the likeneffe of rough $B$ inde-weed, which anong the inllabitants it keepeth; fignifying in Spanifh, a rough or prickly vine, as Garcias Lopius witneffeth:

$$
\text { T The Temperature. }
$$

The roots are of temperature hot and dry, and of thin and fubrill parts, infomuch as their decoetion doth very eafily procure fweat.

$$
9 \text { The Vertues. }
$$

The roots are a remedie againft long continuall paine of the ioynts and head, and againft cold A difeafes. They are good for all manner of infirmities wherein there is hope of cure by fwearing, fo that there be no agtie ioyned.

The cure is perfected in few dayes, if the difeafe be not old or great ; but if it be, it requireth a $B$ longer time of cure. The roots here meant are as I rake it thofe of $Z a v z a$ partlla, whereof this $5 \mathrm{~min}$ $l_{a x}$ appera or rough Binde-weed is holden for a kinde : notwith ftanding this of $S$ pain and the other parts of Europe, though it be counted leffeworth, yet is it commended of Diofcorrdes and Pliny againft poyfons. The 'eaues hereo, faith Diofcorides, are a counterpoyfon again lt deadly medicines, whether they be drunke before or after.

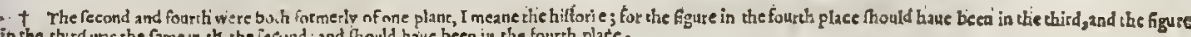
in the chird was the fame w th the iscund; and hould haue been ia the fourth place.

\section{CHA P. 317: Of Jmootb or gentle Binde-weed.}

1 Smilax lenis frue lavis maior.

Great fmooth Binde-weed.

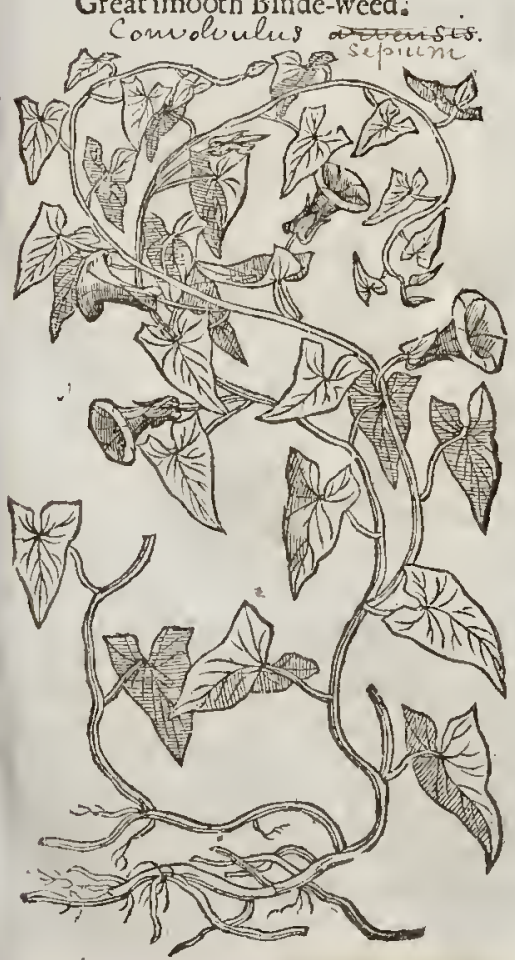

2 Smilax lenis minor. Small Binde-weed. Comvolunlus dpitana is

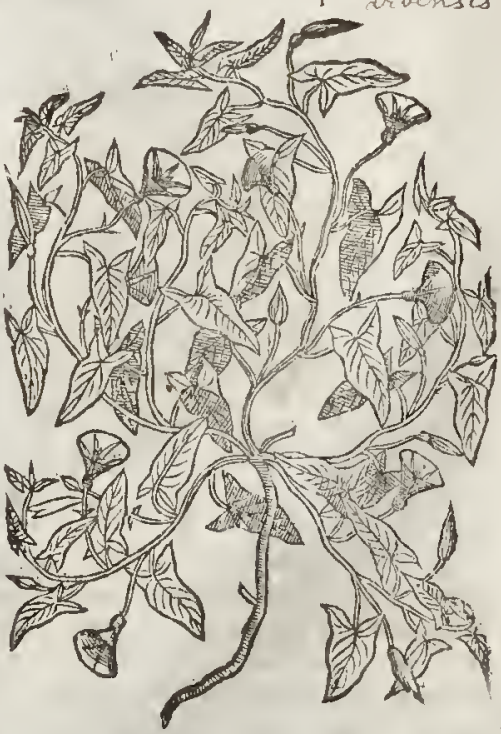



vnto any part of the forme of Smilax indeed. But we will leaue controuerfies to the further eonfideration of fueh as louc to dance in quag-mires, and come to this our eommon fmooth Smilax, ealled and knowne by that name among vs, or tather more truly by the name of Comnlvulus maior, or $V$ olubilis maior : Ir beareth the long branehes of a Vine, but tenderer, and for the lenoth and great fpreading, therof it is very fit to nake thadows in arbors : the leaues ate fmoth like Iuic, but fomewhat bigger, and being broken ate full of milke : among it which eome forth great white and hollow floures like bells. The feed is three eornered, growing in fmall huskes eonered with a thin skin. The root is fmall, white and long, like the great Dogs graffe.

2 Smilax lemis minor is mueh like vnto the former in Italkes, leaues, floures, feed, and roors, fauing that in all refpeets it is mueh fmaller, and ereepetl vpon the ground. The branches are fmall and fmooth : the little leaucs tender and foft : the floures like vnto little bells, of a purple eolour:
the feed three cornered like vnto the orhers.

3 Convolvulus minimus pica-folius.

Lauander leafed Binde-weed.

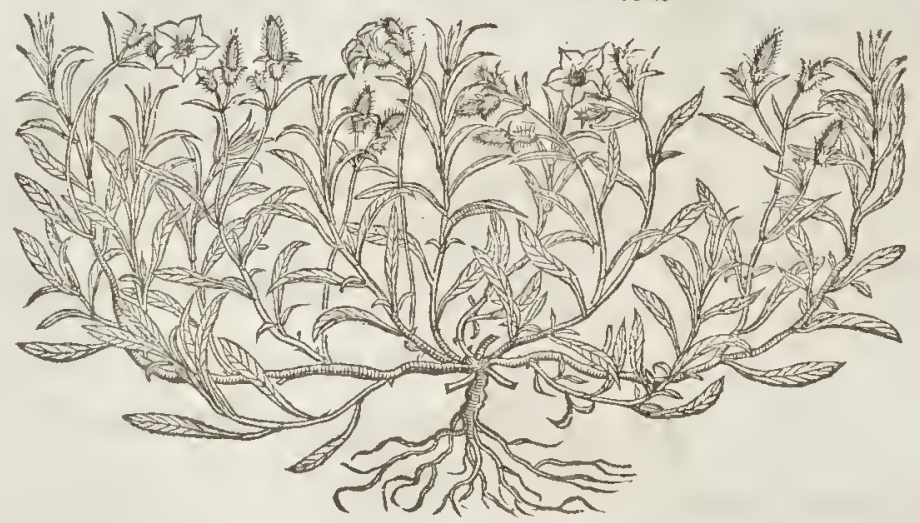

t 4 Convolvulass argentcus Althce folio.

Siluer leafed Binde-weed.

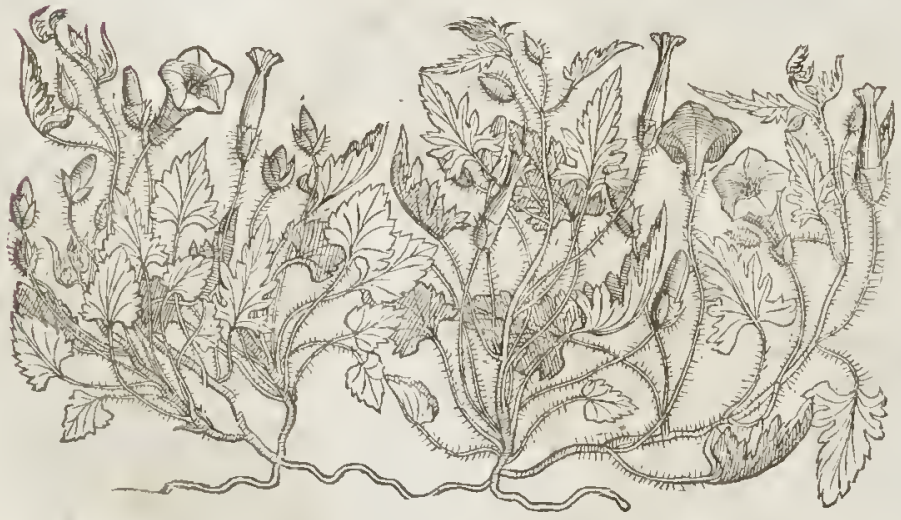

3 This Bindweed Pena faith he neucr faw but in the brinks of quieke-fets and Olinets in Prouence, Sautoy, and Narbone; notwithftanding I found it growing in the corne fields about great ounmow in Efrex, in fueh abundanee, that it doth much hurt vnto their eorne. This $k$ ind of Bindted or folded in the eompafte of the bell very orderly, mentioned, but it hath a finer floure, plaiopens it felfe the opens it felfe the welts are not fo much pereeitred) and it is of a darke purple eolour : the feed is thicke together, proeceding and flat, growing out of flender branehes which ftand vpright and bling Linariaboth in coly of a wooddy white root. The leates are long and narrow, refernling Luaria both in colour and hairineffe, in tatte drying, and formewhat heating. 
5 Volubilis nigra. Blacke Bindweed.

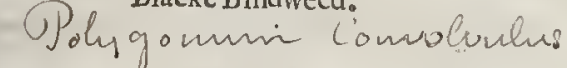

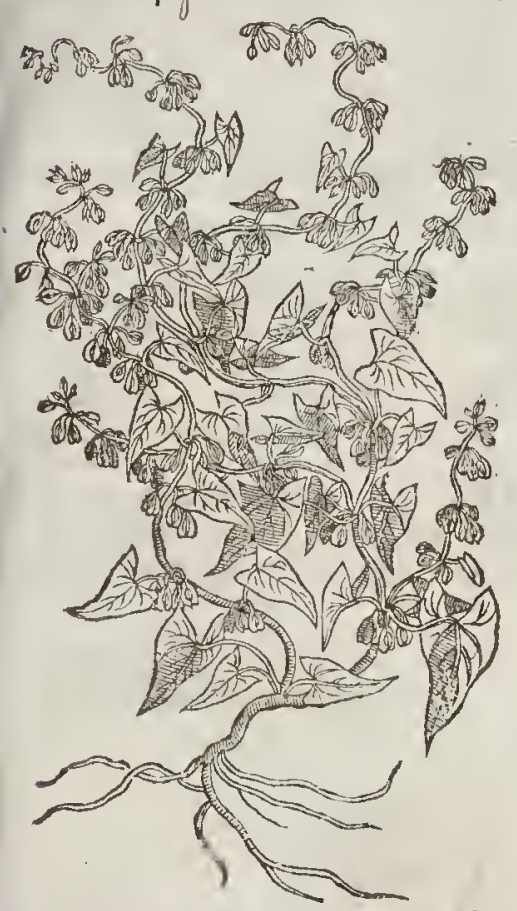

\$ 4 The ftalkes and branches of this are fome cubite long, flender,weake and haity, fö that they lie vpon the ground, if they haue nothing to fuftaine them: vpon thefe without any order grow leaues, Thaped like thofe of Luy, or the marh Mallow, but leffe, and conered ouler with a filuer-like downe or hairineffe, and diuided fomewhat deep on the edges, fometimes alfo curled, and otherwhiles onely fnipt about. The floure growes upon long italkes like as in other plants of this kinde, and confins of cne foldingleafe, like as that of the laft mentioned, and it is eicher of a whition purple, o- elfe abfolite purple colour: The root is frall and creeping. It growes in many places of Spaine, and there floures in March and A prill. Clutists calls this Convoluulus All he folio, and fath that the Portugals name it Verdezilla, and commend it as a thing moft effectuall to heale wounds. Our Authour gate the figure hereof (how fitly let the Reader iudge) by the name of Papaser cormutum luteum minus, making it a horned Poppy, as you may fee in the former Edition, $P d g$. 294. $\neq$

t 5 This kinde of Bindweed hath a tough root full of threddie frings, from which rife vp immediatly diuers trailingbranches, wherupon grow leanes like the common field Bindireed, or like thofe of Orach, of a black green colour, whereof it tooke his name:the floure are final, and like thofe of Orach: the feed is btack, three fquare, like, but leffe than that of Buck.wheat. The whole plant is not onely a huttfull weed, but of an euill fmell alfo, and ton frequenrly found

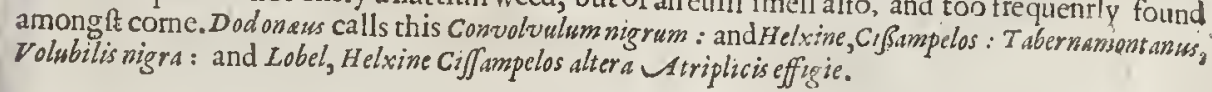

All thefe kindes of Bindweeds do The Place. and fouth excepted. $\neq$

They do floute from May to the end of 7 the Time.

They do floute from May to the end of Auguft.

Egineta, no prickles at all it is furnamed Leuis or fmooth, becaufe the ftalkes and branches thercof haure no prickles at all. Dolichus called alfo Smilax horten $j s$, or Kidney beane,doth differ from this: and irxewife Smilax the ttee, which the Latines call $T_{a x}$ us: in Englifh, the Yew tree. The later Hetbarifts do call this Bindiveed Volubilis maior, Campanella, $F$ wnis arborum, Convoluulus albus, and Smilax lewis maior : in like manner Pliny in his $2 \mathrm{r}$.booke, 5 .chapt.doth alfo name it Conuoluulus. It is thought to be Liguftrum, not the fhrub priuet, but that which Martial in his fitt booke of Epigrams fpea-
keth of, writing ggainft Procillus.

The fmall Bindweed is called convoluulus minor, and Smilax lauis minor, volubilis minor : in high Dutch, minderaut: in Low Dutch, nozange: in French, Liferon:in Italian, Vitucchio: in Spanifh,
Campanilla $Y$ erua : in Englioh, Withwinde, Bindeweed, and Hedge-bels.

Thefe herbs are of an hot and ary to The Nature.

$$
\text { If The Nature. }
$$

The leanes of blacte The Vertues.

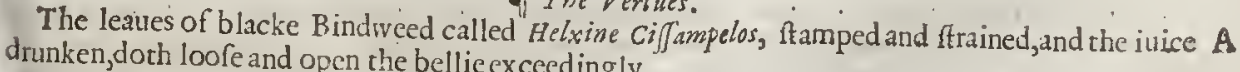
The leates poind and laid to bellie exceedingly.

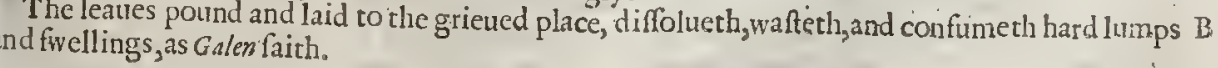




\section{4 \\ Ot the Hiltorie of Plants. \\ $\mathrm{L}_{1 \mathrm{~B} .2 .}$}

D The reft of the Bindweeds are not fit for medieine, but vnprofitable weeds, and hurtfull vnto cach thing that groweth next vnto them.

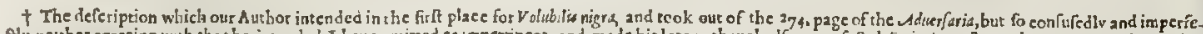

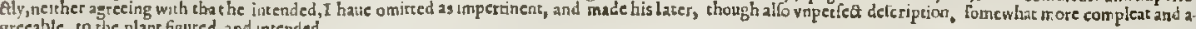
grecable to the plant figured and intended.

\section{CHA P.318. Of Blew Bindweed. \\ T The Defcription.}

I Rew Bindweed bringerh forth long, tender, and winding branehes, by which it climeth vpon things that ftand neere vnto it, and foldeth it felfe about them with many turnings and windings,wrapping it felfe againft the Sun,eontrary to all orher things what foever, that with theirelafping tendrels do embrace things that ftand neere rnto them; whereupon doe grow broad eornered leaues very like vnto thofe of Itic, fomerhing rough and hairy, of an ouerworne ruffet greene eolour : among which come forth moft pleafant foures tell fafbion, fomthing concred as are thofe of the eommon Bindweed, of a moft thining azure colour tending to purple: which being pait, there fueeeed round knobbed feed veffels, wherein is contained long blackifh feed of the bigneffe of a Tare, and like vnto thofe of the great hedge Bindweed. I he root is threddy, and peritheth at the firft approch of Winter.

I Consolvulus Caruleus.

Blew Binde.weed.

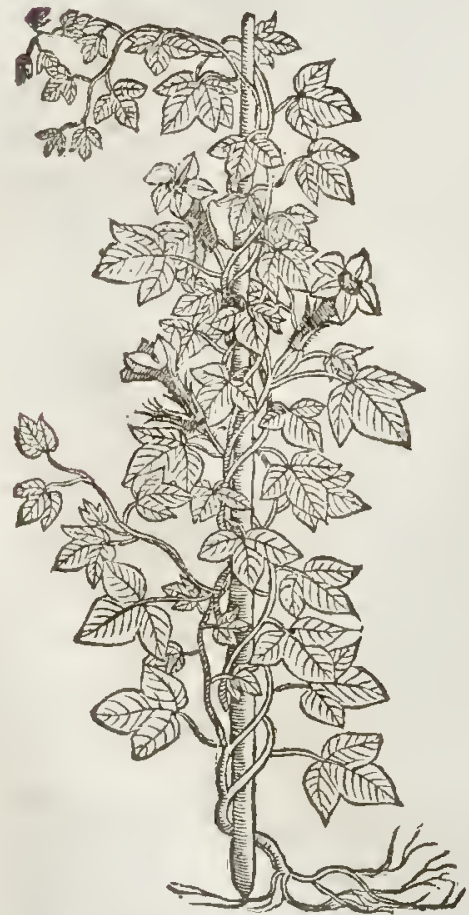

¥ 2 Convolvulus cervileus folio rotundo. Round leaued blew Bindweed.

\# 2 There arealfokept in our gardens two other blew foured Bindweeds. The one a large and great plant, the other a leffer. The great fends vp many large and long winding branches, like thofe of the laft defcribed, and a little hairie : the leaules are large and roundifh, ending in a tharpe point : the floures are as large as thofe of the great Bindweed, and in thape like them, tut blew of colour,with fue broad purplish veines equally diftant each from other : and the fe foures commonly grow three neere together vpon three feuerall falks fome ineh long, faltened to another 
\# 3 Convoluulus ceruleus minor, folio oblongo. Small blew Bindweed.

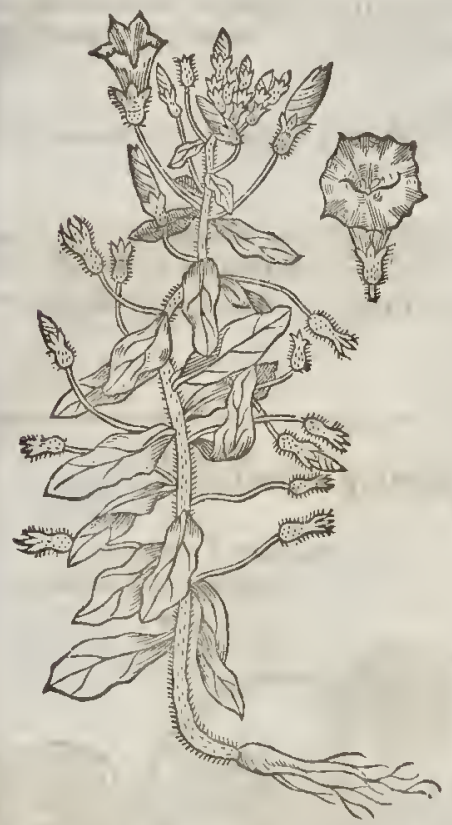

ftalkc fomc handfull long: the eupwhich holds the flourcs, and afterwards beeomes the iccd veffell, is rough and hairic:rhe feed is blacke, and of the Ligneffe of a Tare: the root is ftringic, and laits no longer than to the perfecting of the feed. I haue onely in ucn the figure of the leafe and firurc larecly expref, becaufe for the 100 and narncr of growing it refemblestic laft defcrited.

3 This fmall blew Bindweed fendech forth diuers long flender creeping hairic branehes, lying flat vpon the ground, in ieffe tharcbe fomcthing for it to reft vpon: rluc lcaues be longith and hairy, and out of their bofomcs (almolt from the bortonie to the tops of the ftalks) comc fmall foot-filies earrying beatifull fourcs of the bioncfe and ihape of the common fmal Birdrecd, but commonly of three eolours; that is, white in the verie bottome, yellow in the middle, and a perfect azurc at the rop; and thefe twine thcmfelucs vp,open and ihut in fue plaits like as moft orher flourcs of this kinde doe. The feed is contained in round knaps or heads, and is blaclic and cornercd: the root is fmall, and perifhes ctrery yeare. Eauhine was the firft that fet this forth, and that by the name of Convolvulus peregrinus. ceruleus folio oblongo. \$

$$
\text { 9. The Place. }
$$

The feede of this rare plant was fitt brought from Syria and other remote places of the world, and is a franger in theic Northern parts. yet haue I brought v and nourifhed it in my garden vnto flouring, but the whole plant perifhed bcfore it could perfeet his fecd.

\section{T The Time.}

The fced nuft be fowne as Mclons and Cucumbers ate, and at the fanc tine : it floured with me at the end of Auguft.

It is called Campana La ula, and Lavura: of the later Hetbarifts Cimpana Carulea, and alfo Convol: vulum Ceruleum: it is thought to be the Ligufrum nigrum; of which Columella in his tenth booke hath made mention.

\section{Fer calathis violam, of nigropermifta lingfiro Balfamacum Cafia nectens, dit.}

In baskets bring thou Violcts, and blew Bindweed w ithall, But nuixcd witli plcafant Baulme, and Caffia medicinall.

For if the greater fmooth Withwindc, or Bindwecd be Ligufrum, then may this be not vnproperly callcd Liguftrum nigrum : for a blcw purplc colour is oftcntimes called blackc,as hath bcene faid in the blacke Violct. But therc be fome thatwould haue this Bindweed to be Granum nil Anicems, of which he writeth in the 306 . elapter ; the which differcth from that $N$ il that is deferibed in the $5 \mathrm{I} 2$.chapter. For this is Ifat is Grecorum, or the Grccian Woad: but that is a frangeplant, and is brought from India, as both Auicen and Scycpio doe teftific: Auicen in this manncr: what is Gramum Nil? It is Cartamum Indum : and Serapio thus; Habali $V_{1}$, is Gronum Indicum, in cap. 283. where the famc is defcribed in thefe words : [ The plant thcrcof is like to the plant of $L$ eblab, that is to ay of conrolvulus, or Bindwced, taking hold of treeswith his tendcr ftalks : it hath bo h green branclics and leaues, and there commeth out by etiery leafe a purple flotrc, in fafhion of the Belflourcs : and when the floure doth fall aw ay, it yeeldeth a feed in fnall cods (I read little heads) 
in which are three graines, leffer than the feedes of Stanefaker] to which defcription this blew Bindweed is anfwerable.

There be alfo other forts of Bindweeds, which be referred to $\mathrm{Nil}$ Anicenn ; which no doubt may be kinds of $\mathrm{Nil}$; for nothing gainfaith it why they fhould not be fo. Therefore to conclude, this beautifull Bindeweed, which we call Convolvules Carulens, is called of the Arabians Nil: of Serapio, Hab al Nil : about Alepo and Tripolis in Syria the inhabitants call it Hafmifen: the Italians, Campama azurea : of the beautifull azured floures, and alfo Fior de notte, becaufe his beautie appeares molt in the night.

$$
\text { The Temperature. }
$$

Convolvulus Cermleus, or Nil,as Asicen faith, is hot and drie in the firft degree:but Serapio maketh it to be hot and drie in the third degree.

$$
\text { 9 The Vertues. }
$$

A It purgeth and voideth forth raw, thicke, flegmaticke, and melancholicke humours:ir driues out all kinde of wormes, but it troubleth the belly, and caufeth a readineffe to vomit, as Auicen faith : it worketh flowly, is Serapio writeth; in whom more hereof may be found, but to little purpofe, whereforewe thinke good to paffe it outer.
CHA P. 319.
Of Scammonie, or purging Bindweed:
Scammonium Syriacums
Syrian Scammonie.
t 2 Scamonea Valestina. Scammonie of Valentia.

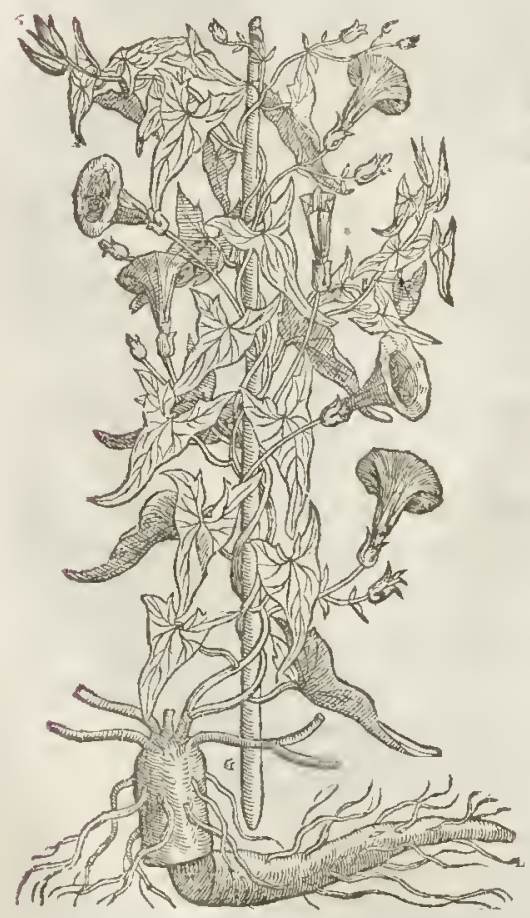


hardned, is greatly vied in Phyficke: for which confideration, there is not any plant growing vpon the earth, the knowledge whereof more concerneth a Phyfition, both for his mape and properties, than this Scammonie, which Pena calleth Lact aria fcarforiaque volvula, that is, milkie and climbing Windweed, whereof it is a kinde; although for diftinction fake I haue placed them as two feuerall kindes. And although this herbe be furpected, and halfe condemned of fome learned men, yet there is not any other herbe to be found, whereof fo fmall a quantitie will do fo much good : neither could thofe which have carped at it,and reproued this herbe, finde any fimple in refpect of his vertues to be put in his roome: and hereof infueth great blame to all practirioners; who hate not endeuoured to bee better acquainted with this herbe, chiefely to auoid the deceit of the craftic Drug-feller and Medicine-maker of this confected Scammonie, brought vs from farre places, rather to be called I feare infected Scammonie, or poifoned Scammonic, than confected. But to auoid the inconueniences hereof, by reafon of the counterfeiting and ill mixing thereof: I have therefore thought good to fet downe what I haue taken out of the diligent, and no leffe learned obferuations of Pena, concerning this plant, Anno 1561 , Or 1562 .Vid.adver $\int . p .5 .272$.

\section{¥ 3 Scammonium Monpelienfe. French Scammonie.}

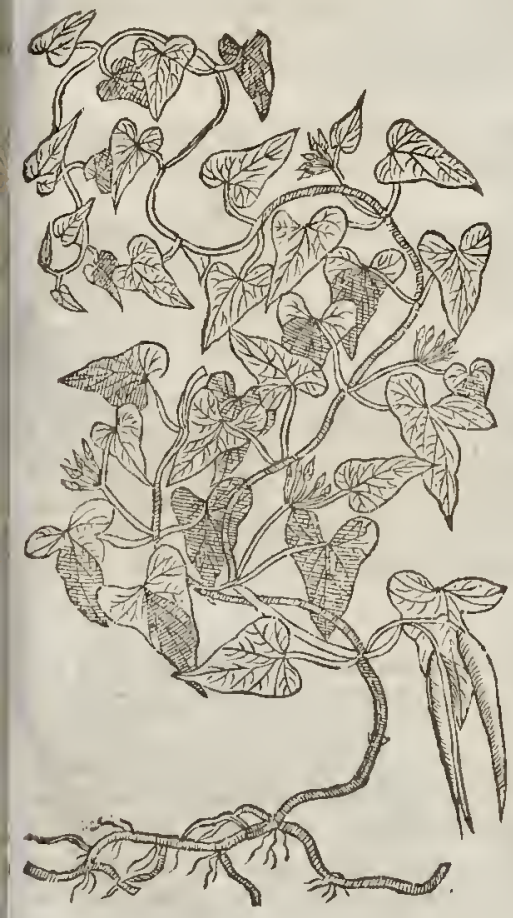

Sequinus Martmellus an Apothecarie of Ve: nice, being a moft diligent fearcher of Simples, that hemight hate the right Scammony of Antioch, trauelled into Syria, where from the citie of Alepo hee fent an 100. weight of the iuice of Scammonic of Antioch,prepared and hardned into a lumpe, at the making whereof he was prefent himfelfe. This man fent alfo of the feeds thereof, which in all points anfwered the cornered feed of volubilis; which being forvne in the beginning of the Spring at Padua and Venice, grew vp to the form of a braue \& goodly Convolvulus, in leanes, floures, and thew. fo like vnto our Cifaxapelos, that a man would baue ta: ken it for the fame without controuerfie, lauing that the rootwas great, and in bigneffe equall to the great Brionie, as a'fo in tenderneffe. The outward bark of the root was of a dusky colour; and whitewithin : the inner pith beeing taken forth feemeth in all mess iudgements to be the farme and the beft allowed Turbith officinarum : and yet it differeth from Turbith, in that, that it is more brittle, and will more eafily bee broken,though the pith in Scammonie bee no leffe gummie and ful of milkie iuice, than Turbith. Further Pena reporteth, that afterward hee fent of this feed vnto Antwerpe,whereit grew very brauely, the climing ftrings and branches growing vp to the height of fiue or fix cubites, not differing from that which was fowne in Ita. lie. Alfo William Dries of Antwerp,a moft excellent A pothecary, did cut of the branches of his Antwerpian Scammonie from the root, and conferred the fuperfuous branched roots with the Turbith of A lexandria, and could not find them to differ or difagree the one from the other in any point. But he that will know more concerning the making,difference, choice and vfe of Scammony, let him reade $P$ crain his chapter of Scammonie, in the place formerly cited, where he thall finde many excellent fecrets worthy the noting of thofe which would know how to vfe fuch rareand excellent medicines.

2 Scammony of Valentia (whercof I hate plentic inmy garden) is alfo a kinde of Bindweed, grow ing naturally by the fea fidevpon the grauelly fhore, by the mouth of the riuer Rhodanus, at the waters called Aquas Marianas, where the Apothecaries of Montpellier gather of it great plentie, who hate attempted to harden the milkie iuice thereof, to vfe it in ftead of Scammonie of Antioch. This plant bringeth forth many flender branches, which will climbe and very well run vpon a pole; as being fupported therew ith, and mounteth to the height of fiuc or fix cubits, climbing \& ramping like the firf kinde of $\mathrm{Scammonie.} \mathrm{The} \mathrm{leaues} \mathrm{are} \mathrm{greene,} \mathrm{fmooth,plaine,} \mathrm{and} \mathrm{fharpe}$ pointed, 
pointed, which being broken do yeeld abundanee of milke : the floures are white, fmall, and ftarrefathion : the roots white and many, thooting forth fundry other roots, whereby it mightily increa-
feth.

$\dagger 3$ This frange kindc of Scaminonic, which Cluf ius makcth rightly to be Periploce ßpecics. hath very many long branches ramping and taking hold of fuch things as do grow neerevnto them, of a darkith athe colour:whereupon do grow leaues tharp pointed, crooled at the fetring on of the falke like thofe of the blacke Bryonie, and likewife of an ahe colour, fet together by couples:from the bofome whereof thruft forth fmall tender foot-ftalkes, whereon are placed fmall white flotres ftarre-fathion: the feeds are contained in long coddes, and are wrapped vp in downe, like as thofe of Swallow-w ort. The root is very long, Ilender, and creeping, like that of the fmall Bindiveed fo that if it once take in any ground, it can hardly be deftroyed.

\section{T The Place.}

It doth grow in hot regions, in a fat foile, as in Mifia,Syria, and other like countries of A fia.it is likewife found in theiland of Candia,as Bellonius witneffes; from whenee I had fome feeds, of which feed I receiued two plants that profpered exceeding well; the one whercof I beftowed vpon a learned A pothecaric of Colchefter, which continueth to this day, bearing both floures and ripe feed. But an ignorant weeder of my garden plueked mine vp,and caft it away in my abience, in ftead of a weede: by which mifchange I am not able tow rite hecreof fo abfolttely as I determined: it likewife groweth necre vnto the fea fide about Tripolis in Syria, where the inhabitants doe call it Meudheudi.

91 The Time.

It floured in my garden about S. Iames tide,as I remember, for when I went to Briftow Faire, Ileft it in floure; but at my returne it was deftroyed as a forefiud.

$$
\text { बा The Names. }
$$

The Greckes call it avsusaia : the Latines, Scammonium, fonaming not onely the plant it felfe, bur alfo the hard and eondenfed iuice : of the Apothecaries, Scommonca, andwhen it is prepared, Diagri. dium : as though they thould fay, saxpidor: which fignificth a little tearc: both thclicrbe and iuice are named Scannony: of Rbafis, Coriziola.

\section{TT The Temperature.}

The iuice doth mightily purge by the ftoole, and is the ftrongeft purge whatfocuer; for as oribafius faith,it is in no part ouercome by thofethings which it ir and moue the body. It worketh the fame not vehemently by any liot qualitie, but by fome other hid and feeret propertic of the whole fubftance; for there is noextremitic of heat perceited in it by tafte : for with what liquor or thing focuer it is mixed, it gitteth vito it nobitterneffe, biting, or other vnpleafant tafte at all,and therefore it is not to be accounted anong the extreme hot medicines, but among thofe that are mode-
rately lot ant dric.

\section{A T Therertues.}

A It clenfeth and draweth forthefpecially choler : alfo thinne and waterith humours, and of tentimes Hegme, yet is it as $P$ aulus teacheth more hurtfull to the ftomacke than any other medi-
cine.

B uxefues thinketh that it is not onely trouble fome and hurtfull to the ftomacke, but alfothat it Thaueth the guts, gnawing and fretting the intrails; openeth the ends of the veins, and through the effence of his whole fubrtance, it is an enemy to the heart, and to the reft of the inward parts:if it be ved immoderately and in time not contenient, it caufeth fwounings, vomitings, and owerturnings of the ftomacke, fcouring, the bloudy fux and vlcers in the lower gut, which bring a continuall de-
fire to the ftoole.

C Thefe mifchiefes are prenented if the Scammonie be boiled in a Quinee and mixed with the flime or muci lage of $\boldsymbol{P}$ fillinm, called Fleaw oort, the pap or pulp of Prunes, or other things that haue a flimic inice, with a little Mafticle added, or fome other cafre binding thing.

D Plinie affrmeth that the hurt thereof is taken away if Aloes be tempered with it: [ Scammonie (faith he) ouerthroweth the ftomack, purgeth choler, loofeth the belly vnleffe two drams of A loes be put vnto one feruple of it] which alfo Oribafus alloweth of in the firft booke of his synopses, and
the fenenth booke of his medicinall Collections.

E Theold Phyfitions were alfo wont toboile Scammonie in a Quince, and to giue the Quince to be eaten, hauing eaft away the Scammonie: and this Quince fo taken doth moue the bellywithout any hurt.vnto the ftomacke, as Galen in his firft booke of the Facultics of Nourifhments doth fet downe, and likewife in his third booke of the Facultics of fimple Medicines.

F The Apothecaries dovfe Scammonie prepared in a Quince, which as we haue faid they name Diagridium, and do mix it in dincrs compofrtions. 
They keepe vfully in the ir thops two compofitions; or electuaries, the one of $P$ fillum or Flea - C woort, fet downe by $M e f u e$ : the other of Prunes fathered vpon Nicolaus, which were deuifed for the tempering and correction of Scammony, and be commended for hot burning agucs, and tertians, and for what difeafes focuer that procced of choler.

Galen hath taken Mafticke and Bdcllium out of the pilles called Cochie, which alfo conteine in $H$ them a great and fufficient quantitie of Scammonie, as we may reade in his firtt booke of medicines according to the places affected, which alfo we meane to touch in the chapter of Coloyuinrida, where we intend to intreat at large concerning mafticke, and other binding things, that are accuftomed to be mixed for the corre etion of ftrong and violent purgers.

The quantirie of Scammony, or of Diagridium it felfe, as $M$ cfuc writerl, is from fute graines to ten or twelue : it may bekept as the fame Author fheweth, foure yeeres: $P l i n g$ indgeth it to be after rwo yeeres little worrh : it is to be vfed, faith he, when it is two yeeres old, and it is not good before, nor after. The mixing or otherwife the vfe thereof, more than is fet downe, I thinke it not expedient to fer forth in the Phy ficall vertues of Scammony, vpon the receipt whercof many times death infueth:ny reafons are diters, for that the fame is very dangerous, either if too great a quantitie thereof be taken, or if it be giuen without correction; or taken at the hands of fome runnagate phy ficke-monger quach faluer,old women-leaches, and fuch like abufers of Phy ficke, and deceiuers of people. The vfe of Scammony I commit to the learned, nnto whome it efpecially and onely
belongeth, who canvery carefully and curiounly vfe the fame.

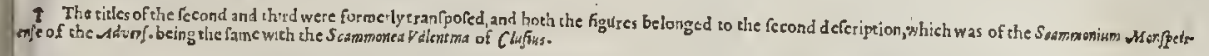

Сна в. зzо. Of Briony, or the white Vine.

9) The Kindes. There be two kindes of Bryony, the one white, the other blacke : of the white Briony as follow-
eth.

Bryonia alba.

White Bryonic: Bryorria diotic

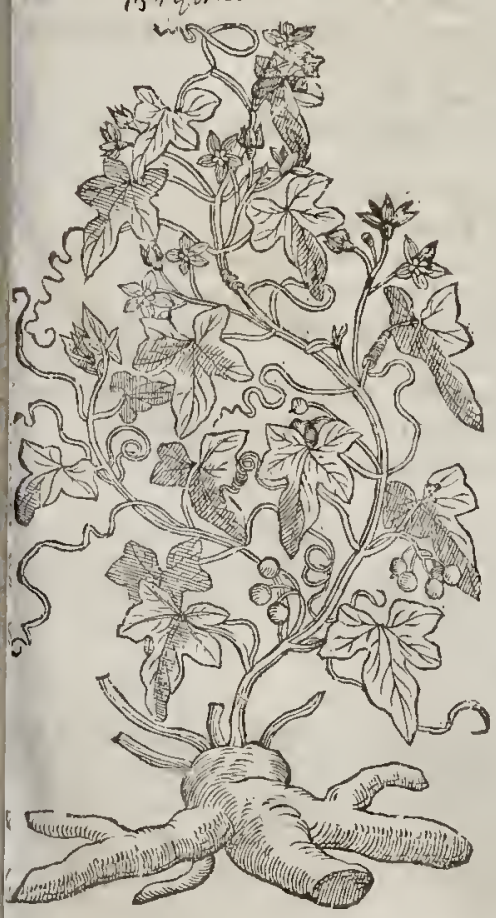

T) The Defcription.

W Hite Briony bringerh forth diuers long: and flender ftalkes with many clafpıng. tendrels like the Vine, wherewith it catcheth hold of thofe things that are next vnto it. The leaues are broad, fute comered, and indented like thofe of the Vine; but roughsr, more hairie, and whiter of colour. The floures be fmall and white, growing many together. The fruite. confifterh in little clufters, the berries whercof are at the firft greene, and red when they be ripe. The roote is very greate, long, and thicke, growing deepe in the earth, of a white yellowifh colour, extreame bittcr, and altogether of an vnpleafant tafte. The Qucenes chiefe Surgion $M^{r}$. William Godorous, a very curious and learned gentleman hewed mea root hereof, rhat waied halfe an hundred weight, and of the bigneffe of $a$ child, of a yeere old:

$$
\text { ot The place. }
$$

Briony groweth almoft cuery where among pöt-her'ses, bedge-buthes, and fuch like places.

$$
\text { -1 The Time. }
$$

It floureth in May, and bringeth forth his grapes in Autumne:

$$
\text { It The Names. }
$$

Bryony is called in Greek, simanhos an w: in Latine, Dddd 


\section{0}

Of the Hiftorie of Plants.

$\mathrm{L}_{1 \mathrm{~B} .2 .}$

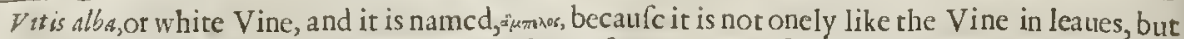
alfo for that it bringeth forth his fruite made vp after the likeneffe of a little cluftcr, although the berries ftand not clofe together: it is called of Pliny, Bryania, and Madon: of the Arabians, 1 iphefera: of Mattheus Sylvaticus, Ititicella: in the poore mans Treafure, Roraftrum : of Apuleius, Apiaftel. lum, vit is T amini, Vitis alga, and Vitalba : in high Dutch, Suchburt 3 : in low Dutch, 1Bitonte: in Englion, Bryony, white Bryony, and tetter :3errie : in French, Couleree : in Italian, Zucca Jylvatica: in Spanifh, Nuezablanca.

\section{T The Temperature.}

White Briony is in all parts hot and dry, excecding the third degrce, efpccially of heate, with an cxcceding great forcc of clenfing and fcouring, by rca fon whereof it purgeth and drawerh forth, not onely cholericke and flegmaticke humours, but alfo watric.

\section{T The Vertues.}

A Diofcorides writeth that the firft fprings or fproutings being boiled and eaten, do purge by fiege and vrine. Galen faith, that all men vfcaccuftomably to eate of it in the fpring time,and that it is a nourithment wholefomc, by reafon of the binding qualitie that it hath; which is to be vnderftood of thofe of the wilde Vine, called in Latine, $T$ amus; and not of the fproutings of this plant ; for the fproutings of the firft fprings of white Bryony are nothing binding at all, but do mightily purge the belly, and torment the thomacke.

B Diofcorides alfo affirmeth, that the juice of theroot being preffed out in the fpring, and drunke with meade or honied watcr, purgcth flegmc:and not onely the juice, but alfothe dccoction of the root ürawcth fortl flegme, choler, and.waterioh humours, and that very ftrongly; and it is withall ofrentimes fotroublefome to the ftomache, as it procureth vomite.

C This kindc of ftrong purgation is good for thofe that have the dropfie, the falling fickeneffe, and the dizzineffc and. fwimming of the braine and head, which hath continued long, and is hardly to be rcmooucd : yet notivithftanding it is not daýly to be giuen (as Diofcorides admoni(heth) to them that liaue the falling fickeneffe, for it will be troublefome enough to take it now and then: and it is (as we haue faid) an exceeding frong medicine, purging with violence, and very forceable for mans nature.

D The root put vp in manner of a peffary bringeth forth the dead child and afterbirth : being boiled for a bath to fit in, it workcth the fame effect.

E It fcoureth the shin, and takcth away wrinck les, freckles, funne burning, blacke marks, fpots, and fcars of the face, being tempered with the meale of vctches or Tares, or of Fenugreeke : or boilcd in oile tull it be confumed; it taketh away blacke and blew fpots, which come of ftripes:it is good againft Whitlowes:being ftamped with wine and applied it breaketh biles;and fmall apoltumes, it drawctl forth folinters and broken bones, if it be ftamped and laid therero.

F The fame is al fo fitly mixed with eating inedicines, as Diufcorides writeth.

G The frut is goodagainft fcabs and tlie leprie, if it be applied and annointed on, as the fame Authot affirmeth.

H Galen writeth, that it is profitable for Tanners to thicken their leather hides with.

I Furthermore, an electuary made of the roots and hony or fugar, is fingular good for them that are fhort winded, troublcd with an old cough, paine in the fides, and for fuch as are hurt and bur. ften inwardly : for it diffolucth and fatereth abroad congealed and clottered bloud.

K The root ftamped with falt is good to be laid vpon filthy vlcers and fcabbed legs. The fruite is likewife good to the famc inecnt if it be applied in manner aforcfaid.

L The root of Bryony and of wake-Robin famped with fome fulphur or brimfone, and made vp into a maffc or lump and wrapped in a linnen clout, taketh away the morphew, freckles, and fpots of the face, if it be rubbed with the fame being dipped firl in vineger.

\section{Cна р. 32т. Of blacke Brionie, or the wilde Vine.}

\section{T The Defcription.}

I THeblack Bryony hath long flcxible branches of a woodic fubfance, couered with a gaping or cloten barke growing very farre abroad, winding it felfe with his imall tendrels about rrces, hedges, and what elf is next vnto it, likc vnto the branches of the Vine. The leaues are like vnto thof $\mathrm{c}$ of Ituc or gardcn Night thade, tharpc pointed, and of a fhining greene colour:the fioures are white, fmall, and moftie; which being paft, there fucced little clufters of red 
I Bryonianigra. Blacke Bryonic.

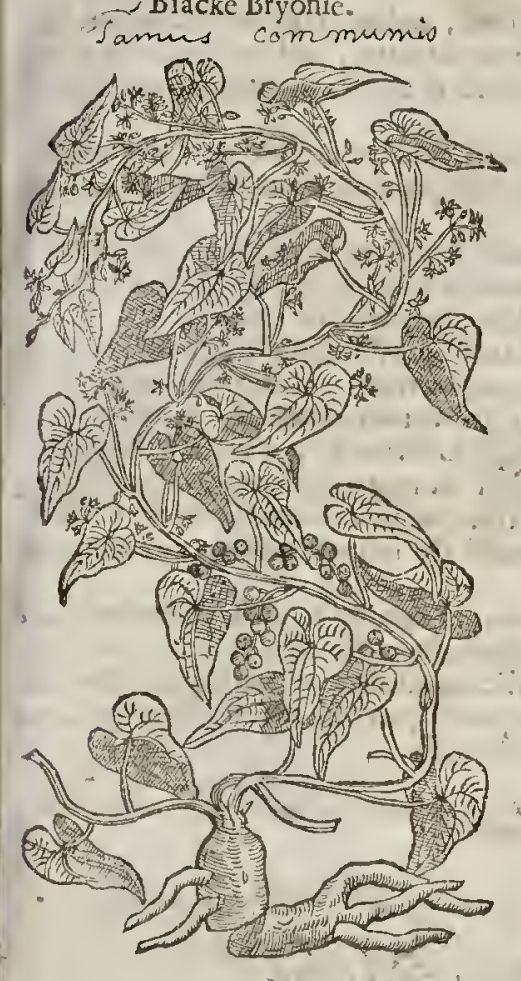

berries,fomwhat bigger than thofe of the fmall Raifons,or Ribes, which wee call Currans, or fmall Raifins. The root is very. great and thick, oftentimes as bigge as a mans legge, blackin withont, and verie clammie or flimie within which being but fraped with a knife, or any 0 ther thing fit fot that purpote, it feemeth to be a matter fit to fpread vpon cloth or leather in manner of a plaifter or Seare-cloth: which being fo fpread and vied, it ferueth to lay vpoh many infirmities, and vnto verie excellent purpofes, as thall bee declared in the propet place.

$2^{\prime}$ Thewilde Blacke Bryonie refeinbleth the former, as well in flender Vinie ftalkes as leaues; but clafping tendrels hath it none, neuerthelcfie by reafon of the infinite branches, and the tenderneffe of the fame, it taketh hold of thofe things that ftand next vnto it, although eafie to bee loofed, contrarie vnio the other of his kinde. The berries heereof are blacke of colour whent hey be ripe. The roor alfo is blacke without, and withn of a pale yellow colour like box, ‡ This which is here defcribed is the Bryonia nigra of Dodonews But Baubine calleth it Bryonia Ulba; and faith it differeth from the common white Bryonie, onely in that the root is of a yellowifh boxe colour on the in. ide, and the fruit ot berries are blacke when as tliey come to ripe. neffe.

\section{Bryonianigra fiovers non frudum ferens.}

3 This is altogether like the firf defcribed in roots, branclies, and leaues; onely the foot-1talks whereon the floures grow are about eight or nine inches long : the floures are fomething greater, hituing neither before or after their flouring any berries or therv thereof; but the floures and footffalks do fone wither and fall away : this I hauc heretofore, and now this Sommer, $162 \pi$, diligently obferued, becaufe it hath not beene mentioned or obfertued by any that 1 know. Iohs Goodyer. $\neq$

$$
\text { of The Place. }
$$

The firft of thefe plants doth grow in hedges and buthes almoft euery where:"

The fecond groweth in Heffia, Saxonic, Weftphalia,Pomerland, and Mifnia, where white Bryonie doth not grow, as $V$ alerius Cordus hath written, who faith that it growes vnder Hafell-trees, neer vinto a citie of Gernanie called Argentine,or Strawisborough.

\section{The Timic.}

They ipring in March,bring forth their flomres in May, and their ripe fruitin September.

$$
\text { of The Names. }
$$

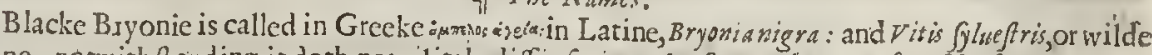
$V$ ine; notwith fanding it doth not a little differ from Labrufca, or $V$ it $v$ Vinefer a fylueftris, that is to fay, from the wilde vine, which bringeth forch wine,which is likewile called Ampelos agria: Why both thefewere called by one name, pliny was the caufe, who could not fufficiently expound them in his 23 . booke, firft chapter; but confounded them, and made them all one, in which errour are alfothe Arabians.

This wilde Vine alfo is called in Latine, $T$ amus, and the fruit thereof $V u a T$ aminia, pliny nameth it alfo Salicafrum. Ruellius faith that in certaine thops it is called Sigillsm B.Mariz;it is alfocalled. Cyclamines alt era but not properly: in Englifh,B Backe Bryonie, wilde Vine, and our Ladies -feale.

$$
\text { TT The Temperature. }
$$

The roozs of the wild Vine are hot and drie in the third degree: the fruit is of like temperatire, but yet nor fo forceable: both of them fcoire and walte away.

$$
D \mathrm{~d} d \mathrm{~d} \text {. }
$$




\section{T The Vertues.}

A

Diofcor:des faith, that the roots do purge waterifh humours, and are good for fuch as haue the dropfe; - if they be boiled in wine, adding vnto the wine a little fea water, and bee drunke in three ounces of faire freln water : he faith furthermore, that the fruit or berries doth take away the Sun. burveand other blemithes of the skin.

B The berries do not onely clenfe and remouc fuch kinde of fpots, but do alfo very quickly wafte and confume array blacke and blew marks that come of bruifes and drie beatings, which thing a! fo the ronts performe being laid vpon them.

C The young and tender fprourings are kept in pickle, and referued to be eaten witl meat as $D$ iof corides teacheth. Matbiolses writeth that they are ferued at mens tables alfo in our age in Tufcante: others report the like alfo to bedone in Andalofia, one of the kingdomes of Granado.

D I I is faid rhat fwine feelse after the roots hereof, which they dig vp and eat with no le fe delight

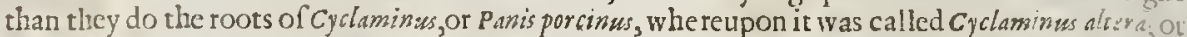
Sow-bread; if this reafon fand for good, then may we in like manner ione hereunto many otlier roots, and likewife call them Cyclamins's altera,or Sow-bread : for fwine do not feeke after the roors of this onely, digge them vp and greedily deuoure them, but the rosts of diuers other plants alfo, of which none are of the kindes of Sow-bread. It would therefore be a point of rafhneffe to affith Tamus or our Ladies-feale to be a kinde of Sowbread, becaufe the roots thereof are pleafant meat tofivine.

E The root fpred vpon a piece of theepes leather, in manner of a plaifter whileft it is yet frefh and green,takethaway blacke or blew marks, all fcars and deformitie of the skin, breaketh hard apoftems, draweth forth fplinters and broken bones, diffolueth congealed bloud; and being laid on and vfed vpon the hip or huckle bones, thoulders, armes, or any other part where there is great pain and ache, it taketl it away in fhort fpace, and worketh very effectually.

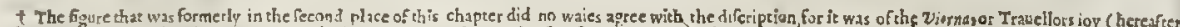

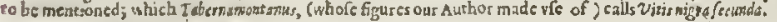

4
}

\section{CHAP. 322. OfBryonie of Mexico. T The Defcription.}

$\mathbf{I}$

That plant which is now called Mechoaran, or Bryonie of Mexico, commeth verie neere the kinds of Bindweeds, in leaues and trailing branches, but in roots like the Brionies; for there fhooteth from the root thereof many long flender tendrels, which do infinitly grafpe and clafpe about fuch things as grow or ftand next vnto them : whereupon grow great broad leaues tharpe pointed, or a darke greene colour, in thape like thofe of our Ladies-leale, fomwhat rough and hairic,and a little biting the tongue : among the leaues come forth the floures (as Nicolaus cMonardus writetl) not vnlske thore of the Orenge tree, but tather of the golden Apple of loue, confuting of fiue fmall leaues : out of the middeft whereof commeth forth a little clapper or peftell in manner of a round lumpe, as big as a Hafell nut; which being diuided with a thin skin, or membrane, that conmeth through it, openeth into two parts, in each whereof are contained two feeds, as bigse as Peale, in colour blacke and thining. The root is thicke and long, verie like vnto the root of white Bryonic, whereof we ma'ie this a kinde, although in the tafte of the roots there is fome differenee : for the root of white Bryonie hath a bitter tafte,and this liath little or no tafte at all.

2 'The Bryony, or Mcchoncan of Peru groweth vpwith many long trailing flexible branches, interlaced with diuers Vinie tendrels, which take hold of fuch things as are next or neere vnto them, euen in fuch manner of clafping and climing as doth the blacke Bryonie, or wine Vine, whereunto it is very like almolt in each refpect, fauing that his moffic floures do fmell very fweetly. The fruit as yet I have not obferued, by reafon that the plant which doth grow in my garden did not perfect the fame, by oceafion of the great rain and intemperate weather that hacned in $A m$.I 596 .but I am in good hope to fec it in his perfe.tion, \& rhen we thall eafily iudge whether it be that right $M \mathrm{M}^{-}$ choacan that hath been brought from Mexico and other places of the Weft Indies or no ? The root by the figure thould feeme ro anfwer that of the wilde Vine, but as yet thereof I cannot write cer. tainly.

\#3 There is brought to vs and into vfe of late time the root of another plant, which feemes 


\begin{tabular}{|ll}
\hline L I B. 2. Of the Hiftory of Plants. & 873 \\
\hline
\end{tabular}

\section{Mechoacan.}

Bryonic of Mexico?
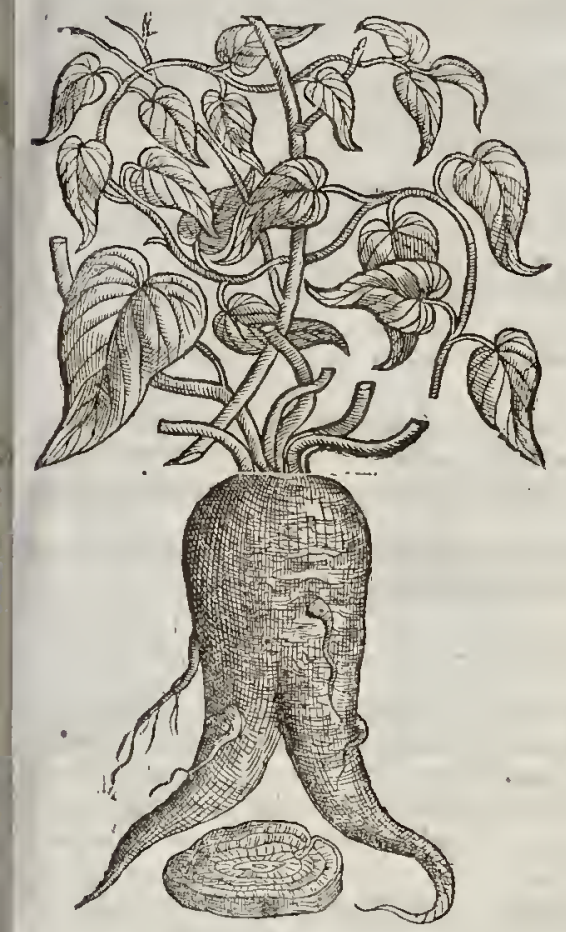

2 Mechoacan P̈erwviann. Bryonie of Pert.

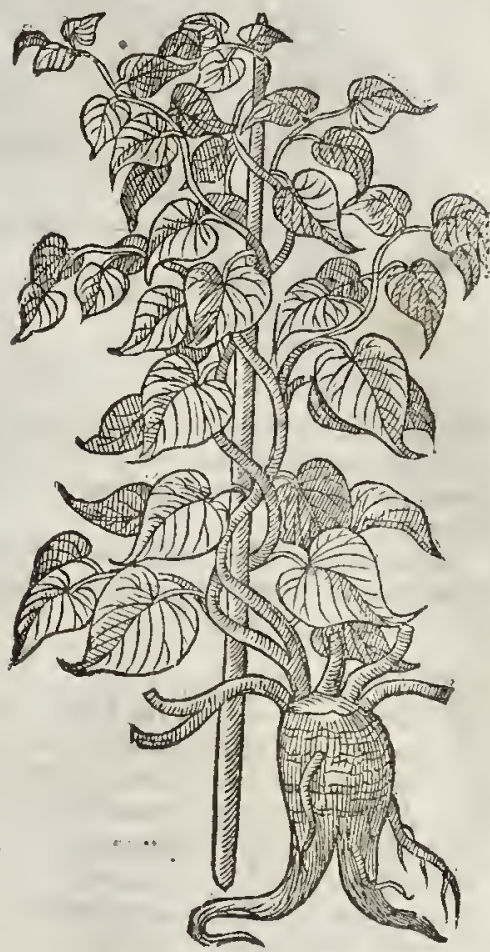

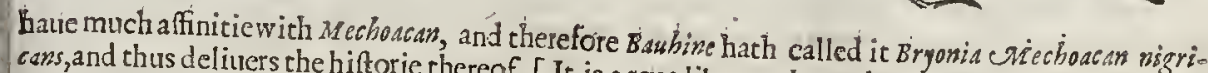
cons, and thus deliners the hiftoric thereof. [ It is a soot like Mechoncan, but contered with a blackith barke, and reddinh (or rather grayifh) on the infide: and cut into llices, it was brought fome yeares agone out of Ind ia by the name of Chelapa, or Gelapa: It is called by thofe of Alexandria and MarThe tafte is not vngratefull, and of thofe of Marfeilles it is thought theblacke or male Mecho.acan : quickly flames : it in facultie exceds nhe by reafon of the much gummineffe, put to the fire it neffe it more powerfully purgeth ferous common Mechoacan; for by teafon of the great gummithens the liuer and ftomacke, wherefore it is furs with a little griping, alfo it principally ftrengoperation without naufeouf houres before meat.] Thus much Bas vfually giten in Succorie water, or fome thin broth three before he fet forth his Prodromus, forthat, who faith it was firft brought to thefe parts eleuten yeres this ten yeares. $\ddagger$

Some write that Mechoscan w of Mexico ot Mexican,whereof it tooke bis in the Protince of New Spaine, neere vito the citie Indies called Nicaragua and Quito, whete is is the. It groweth likewife in a protince of the Weft

It beareth his name as is faid, of The Nomes. res, or to be a kinde of Bryonie : but feeing the in which it is found. Some take it to be Bryorta $\beta$ s:hath little agreenent with Bryonic ; for the rone rot is nothing bitter, but rather without taite, it bum, or white Rubarbe, but vnproperly, being noth of Bryonic is verie bitter. Diuers nane it Rha al: if I might yeeld my cenfure, it feemetheing nothing like - It commeth reere vnto Scammony, and monie of America. Scammonie creeperh, acamonium qrodd m A Americanum, ot a certain Scam"The toot is both white and thicke. lchoncan : it is called in Englicke: the iuice harh but little tafte, as alfo hath this of Me. onie:

$$
\text { Bidd }
$$


The root is of a mcane temperature between ho: and cold, but yet drie. T The Vertues.

A It purgeth by frege, efpecially flegme, and then waterifh humours. It is gituen from one ful dram weight to two, and that with w1ne, or with fome diffilled water(according as the difeafe requireth) or cls in flem broth.

It is to be giuen with good effect to all,whofe difeafes proceed of fiegme and cold humors. It is good again ft head -ache that hath continued long, old coughes, hardneffe ofbreathing, the colick, paine of the kidneies and ioints, the difeafes of the reines and belly.

\section{Син.323. Of the Manured Vine.}

$$
\text { ๆ The Kindes. }
$$

I.

He Vine may be accounted among thofe plants that hate need of taies and props, and cannoc ftand by themfelues; it is held vp with poles and frames of wood, and by thar meanes it fpreadeth all about and climbeth aloft : it ioyneth it felfe vnto trees, or whatfoeuer fandeth nexe vnto it.

Of Vines that bring forth wine, fome be tame and husbanded; and others that be wilde: of tame Vines there are many that are greater, and likewife another fort that be leffer.

$$
\text { If The Defcription. }
$$

T

He trunke or bodie of the Vine is great and thicke, very hard, couered with many barkes, and chofe full of cliffes or chinkes; from which grow forth branches, as it were armes, many waies fpreading, out of which come forth iointed thoots and fprings: and from the bofome of thofe ioints, leaues, and clafping tendrels: and likewife bunches or clufters filled ful of grapes: the leaues be broad, fomething round, fiue cornered, and fomewhat indented about the edges; among it which come forth many clafping tendrels, that take hold of fuch props or ftaics as do ftand next vnto it. The grapes do differ both in colour and greatneffe, and alfo in many other things, the whic h to diftinguifh feucrally were impoffible, confidering the infinite forts or kindes, and alfo thole which are tranfplanted from one region or climate to another, do likewife alter both from the forme and talte they had before, in confideration whereof it thall be fufficient to fet forth the figure of the manurcd grape, and fpeake fomewhat of the reft.

There is found in Grxcia and the parts of Morea, as Pantalaren, Znte, Cephalowia, and Petras (wherof fome are Iflands, and the other of the continent) a certaine Vine that hath a trunke or bodic of a woodd ie fubftance, w ith a fcaly or rugged bark, of a grayifh colour, whereupon do grow faire broad leaues, fleightly indented about the edges, not vnlike vnto thofe of the Marlh-mallow : from the bofome whereof come forth many fmall clafping tendrels, and alfo tough and pliant foot-ftalkes, whereon do grow verie faire bunches of grapes, of 2 watchet blewifh colour : from the which fruit commeth forth long tender laces or ftrings, fuch as is found among Sauoric: whereunon wee call that plant which hath it laced Sauorie, not vnlike that that groweth among, and vpon Flax, which we call Dodder, or Podary lini, whe reof is made a blacke wine, which is called Greeke wine, yet of the tafte ofSacke. The laced fruit of this Vine may be fitly termed $V u a b a r b a$, Laced or bear. ded grapes.

The plant that beareth thofe fmall Raifins which are commonly called Corans or Curtans, or rather Raifins of Corinth, is not that plant which among the vulgar people is taken for Currans, being a fhrubbe or buth that bringeth forth fmall clulters of berries, differing as much as may bee from Corans, hauing no affinitie with the Vine or any kinde thereof. The Vine that beareth fmall Raifins or Corans hath a bodie or ftocke as other Vines hauc,branches and tendrels likew ire. The leaues are larger than any of the others, fnipt about the edges like the teeth of a faw:among which come forth clufters of grapes, in forme like the other, but fmaller, of a blewifh colour, which being ripe are.gathered and laid vpon hurdles, carpets, mats, and fuch like, in the Sun to drie : then are they carried to fone houfe and laied vpon heapes, as we lay apples and corne in a garner, vntill the merchants do buy them : then do they put them into large Buts or otherwoodden veffels, and tread them downew ith their bare feet, which they call Stiuing,and fo are they brotight into thefe parts for our vfe. $\neq$ And they are commonly termed in Latine, Vue Corintbiace, and Paffulemi. mares. $\neq$ 
Vit is Vinifers.

The manured Vine.

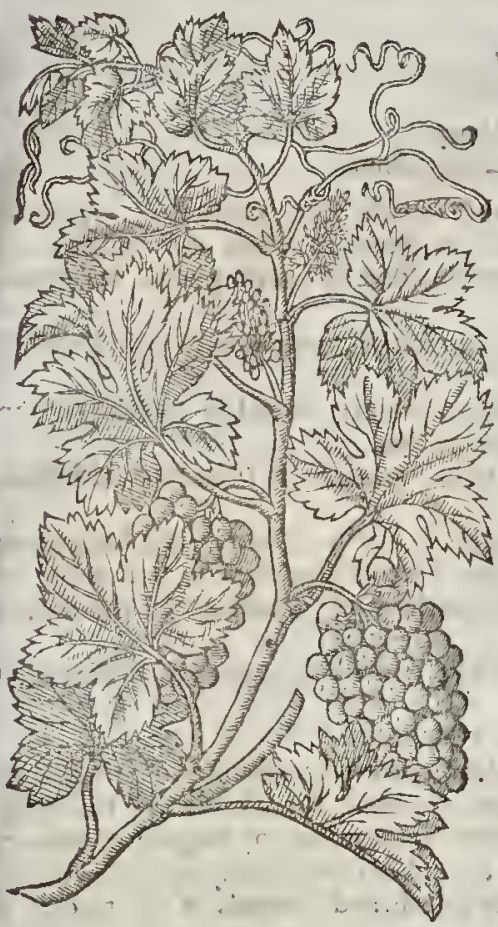

$\mp$ There is alfo another which bearcth exceeding faire grapes, whereof they make Raifins, whiter eoloured, and much exeeding the bicnefie of the eommon Raifin ot the Sunne : yer that Grape whereof rhe Raifin of the $S_{\text {un }}$ is male is a large one, and thought to be the $V u t Z i b i b i$ of the lat bians; and it is that which $T$ abernamontonus fivt1red vnder that name, who therein was followed by our Authour : but the figures being litrle to the purpofe, Ihaue thought good to onit them. $\neq$

There is another kinde of Vine, which hath great leaues very broud, of an oilerworne colout whereupon do grow great bunches of Grapes of a blewifh colour: rhe pulpe or meate whereof ficketh orcleauerh fo hard to the granes or little ftones, that the one is not eafily dituided from the other . refembling fome ftarued or withered berrie that hach been blated, whereof it was named Duracina.

There be fome vines that bring forth grapes of a whitith or reddifh yellow colour: orters of a deepered, bo:h in theoutward skinne, pulpe, and suyce w'ithin.

There be others whofe gripes are of a blew ealour, or fomething red, yet is the iuyee like thofe of the former. Thefe grapes do yeeld forth a wlice wine before they are put into the preffe, and a reddifh or paller Wine when they are trodden with the husks, and fo left to macerate or fermerit, with which if they remaine too long they yeeld forth a wine of a higher colour.

There be others which make a blacke and obfcure red wine, whereof fome bring bigger clufters, and confift of greater grapes; others of lcffer : fome grow more cluftred and clofer together, others loofer: fo me haue but one fone, others more : fome make a more aufere or harfl wine; others a more fweet : of fome the old wine is beft; ofditiers, the firft yeares wine is moft excellent : fome bring forth fruit foure fquare, of which forts or kindes we hate great plenty.

\section{The Place.}

A fit foile for Vines, faith Florentinus, is euery blacke earth, which is not very clofe nor clam. my, hauing fome moifture; notwithftanding Columella fuith that great recard is tobe had what kinde or fort of Vine you would nourith, according to the nature of the eountrey and foile.

A wife husbandman will commit to a fat and fruitfull foile a leane Vine,and of his own nature not too fruitfull : to a leane ground a fruitfull vine : to a clofe and compa.t earth a fpreading vine, and that is full of mutter co make branches of : to a loofe and fruitfull foile a Vine of ferv bran. ches. The fame Co'umella faith, that the Vine delighteth not in dung, of what kinde foeuer it be; but frefh mould mixed with fome thatings of horne is the beft tobedifpofed about the roots, to
caufe fertilitic.

\section{\$1 The Time.}

Columella faith, that the Vines mut be pruned before the young branehes bud forth. Palladiss writeth, in Februarie: if they be pruned later they lofe their nourihment wirh weepins.

G) The Vames.

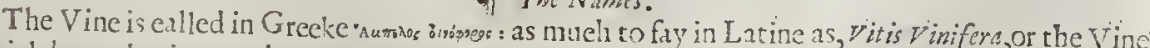

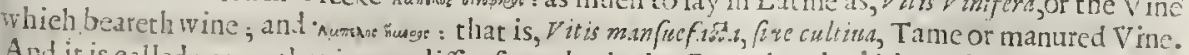
And it is ezlled someer, that irma differ fron both the Bryonies, the ivhite and the blaeke, and from Tiwnus, or our Ladies Seale, which be likewife named Apros. It is ealled $y$ it is, becauie inuita-

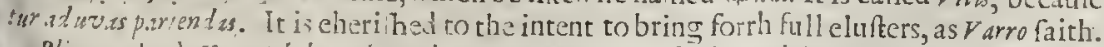

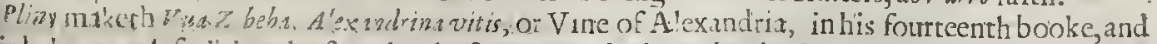
third chapter, defcribing the fa ne by thofe very worls that Theophraftus doth. Diofcorides fetteth

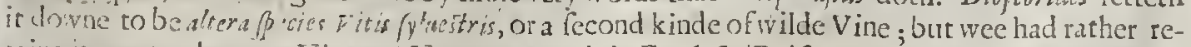

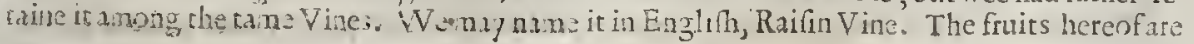


called in thops by the name of Paffularmm de Corintho : in Englifh, Currans, or fmall Raifins.

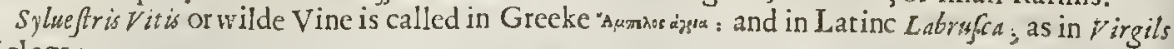
Eđlogs:

\section{- Adpice vt antram Sylueftris raris $\int$ ar fit labrufca rasemis.}

See how the wilde Vinc
Bedecks the caute with fparfed clufters fine.

To this wilde Vine doth belong thofe which Pliny in his fixteenth booke, chapter 27. reporteth tobecalled Trifera, or that bring three fundry fruits in one yeare, as Infana and mad bearing Vines, becaufe in thofe fome clutters are ripe and full growne, fome in fwelling, and others but flouring.

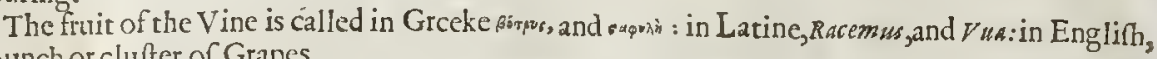
a bunch or clufter or Grapes.

The clufter of Grapes that hath been withered or dried in the Sun is named in Grceke sxpits: in Latine, $V$ ua paffa : in thops, $P_{a} \iint_{k} l_{a}:$ in Englith, Raifins of the Sun.

The berry or Grape it felfe is called in Latine Acinus, and alfo Gransm, as Democritus faith, fpeaking of the berry.

The feeds or ftones contained within the berries arc called in Latine, Vinacea, and fometimes Nuclei : in fhops, Arilli, as though they fhould fay Cridul, becaufe they are dry, and yecld no iuyce, notwithftanding Vinaces arc alfo taken in Colwmella for the droffe or remnant of the Grapes after they be preffed.

The ftalke, which is in the middle of the clufters, and vpon which the grapes do hang, is called of Galen, Giтpurs: of Varro, Scapus uvarum.

T) The Temperature and Vertues.

A The tender and clafping branches of the Vine and the lea ues do coole, and mightily bind. They ftay bleed ing in any part of the body : they are good againft thc laske, the bloudy tlix, the heartburne, heate of the ftomacke, or readineffe to vomit. It ftayeth the lufting or longing of women with childe, though they be but outwardly applied, and alfo taken inwardly any manner of waies. They be moreouer a remedie for the inflamnation of the mouth, and almonds of the throat, if
they be gargled, or the mouth wathed therewith.

$B$. Of the fame factilty be alfo the clufters gathered before they be ripe; and likewife the bunches of the wilde grape, which is accounted to be more effectuall againf all thofe infirmities.

C Diofrorides faith, That the liquor which falleth from the body and branches bcing cut, and that fometime is turned as it werc into a gum (which driueth forth ftones out of the kidnics and blad. der, if the fame be drunke in wine) healeth ring-wormes, fcabs, and leprie, but the place is firta to be rubbed with Nitre. Being often anointed or layd on it taketh away fuperfluous haires : but yet he faith that the fame is beft which iffucth forth of the greene and fmaller ftickes, efpccially that liquor which falleth away whileft the branches arc burning, which taketh away warts, if it be laid
on them.

D The ftones and other things remaining after the prefling are good againft the bloudy flix, the laske of long continuance, and for thofe that are much fubicet to vomiting.

E The athes made of the ftickes and drofle that remaine aftcr the prefling, being laid vpon the piles and hard fivellings about the fundament, doe cure the fame, being mixed with oile of Rue, or Hcrbe-gracc and vineger, as the fame Author affirmeth, it helpeth to ftrengthen members out of ioynt, and fuch as are bitten with any venomous beaft, and eafeth the paine of the fpleene or milt, being applied in manner of a plaifer.

F The later agedo vf to make a lie of the afhes of Vine fticks, in compofitions of caufticke and burning medicines, which ferue in ftead of an hot-iron : the one we cail a potentiall cauterie, and
the other actuall.

$$
9 \text { of Grapes. }
$$

$G \bigcirc$ Grapes, thofe that are eaten taw do trouble the belly, and fill the ftomacke full of winde; efpecially fuch as are of a fowre and auftere tafte, fuch kindes of gra pes doe vcry much hinder the concotion of the Atomacke; and while they are difperfed through the liuet and veins they ingender cold and raw iuyce, which cannot eafily be changed into good bloud.

H Sweet grapes and fuch as are thorow ripe,are leffe hurtfull ; their iuyce is hotter, and is eafilier difperfed. They alfo fooner pafie thorow the belly, efpecially being moif, and moft of all if the liquor with the pulpe be taken without the ftones and skin, as $G$ alen faith.

I The fub itancc of the ftones, although it be drier, and of a binding quality, doth defcend thorow 
all the bowels, and is nothing changed : as alfo the skins, which are nothing at all altered in the body, orvery little.

Thofe grapes which haue a ftrong tafte of wine are in a meane betweene foure and fweet.

Such grapes as haue little iuyee do nourith more, and thofe leffe thar haue more iuyee : but $B$ thefe do fooner defeend; for the body reeeiueth more nourifhment by rhe pulpe than by the iuice; by the iuyee the belly is made more foluble."

Grapes laue the preheminenee among the Aurumne fruits, and nourifh more than they all,but $\mathrm{C}$ yet not fomuch as figs : and they haue in then little ill iuyce, efpueially when they be thorow ripe.

Grapes may be kept thewhole yeare, being ordered after that manner as Toublimses Comerarius reporteth. You thall take (faith he) rhe meale of muftard feed, and ftrew in the bottome of any earthen por well leaded; whereupon you thall lay the faireft bunehes of the ripent grapes, : rhe which you thall eouer with more of the forefaid meale, and lay vpon that another fort of Grapes, fo doing vntill the porbe full. Then thall you fill vp the pot to the brimwith a kinde of freete Wine ealled Mutt. The pot being very elofe eouered thall be fet into fome Cellar or other cold place. The Grapes you may take forth at your pleafure, wafh ing them with faire water from the powder.

$$
\text { 11 Of Raifins: }
$$

FRaifins molt are fiveet ; fome haue an auftere or harh tafte. Sweet Raifins are horter; au- E ftere colder : both of them do moderately binde, but the auftere fomewhar more, which doe move ftrengthen the ftomacke. The fweet ones do neirher flacken the ftomacke,nor make rhe belly folubic, if they be taken with their ftones, whieh are of a binding qualitie: otherwife the ftones taken forth, they do make the belly loofe and foluble.

Raifins do yeeld good nourithment to the body, they haue in them no ill iuyce at all, but doe F ingender fomew hat a thicke iuyee, whieh notw ith fanding doth nourin the more.

There eammeth of fiveet and fat Raifins moft plenty of nourifhment : of which they are the beft that baue a thin skin.

There is in the fweet ones a temperate and fmoothing qualitie, with a power to clenfe mode- $H$ rately. They are good for the eheft, Iungs, winde-pipe, kidneyes, bladder, and for the ftomacke; for they make fmooth the roughneffe of the winde-pipe, and are good againft hoarfeneffe, thortneffe of breath, or diffieultic of breatling : they ferue to concost the fpittle, and to caufe it to rife moré eafily in any difeafe whatfocuer of rhe chett, fides, and lungs, and do mirigate the paine of the kidneyes and bladder, which hath ioyned wirh it heate and fharpeneffe of vrine : they dull and allay the maliee of tharpe and biting humors rhat hurt the mouth of the ftomacke.

Morcouer, Raifins are good for the liuer, as Galen writeth in his feuenth booke of medicines, I aecording to rhe places affected : for they be of foree to coneo.t raw humors, and to reftrain rheir malignitie, and they themfelues do hardly putrifie : befides, they are properly and of their owne fubftanee familiar to the intrals.and eure any diftemperature, and nourith much; wherein they are ehiefely to be eommended, for Raifins nourifh, ftrengthen, refift putrifaction, and if rhere be any diftemperature by reafon of moifture or coldne $\int_{e}$, they helpew ithout any hurt a the faid Galen alfirmeth.

The old Phy frians hatre taught vs to take forth the ftones, as we may fee in diuers compofiti- $\mathbb{R}$ ons of the antient writers; as in that eompofirion which is ealled in Galen, Arteriaca Mitbridatis, which hath rhe feeds of the Raifins taken fortl : for feeing that Raifns eoutaine in them a tlieke fubftance, rhey cannot eafily. paffe through the veines, but are apt to breed obftrustions and ftoppings of the intrals : whieh things happen the rather by reafon of the feeds ; for they fo much the harder paffe rhrough rhe body, and do quicklier and more eafily caufe obftructions, in that they are more aftringent or binding. Wherefore the feeds are to be taken out, for fo thall the ityce of the Raifins more eafily paffe, and the fooner be diftributed through the intrals.

Diof corides teporteth, Thar Raifins ehewed with pepper draw flegme and water out of the head.

of Raifns is made a pultefle good for the gout, rotrings about the ioynts, gangrens, and mortified vleers: being ftamped with the herbe All-heale it quickly rakes aw ay the nailes that are loofe in the fingers or toes, being laid thereon.

$$
\text { T of } M u f \text {. }
$$

$\mathrm{MVat}$, called in Latine $M u, t u m$, that is to fay, rhe liquor newly iffuing out of the grapes when they be trodden or preffed, dorh fill rhe ftomacke and intrals with winde; ir is hardly digefted; it is of a thicke iuyce, and if it do not fpeedily paffe through the body it becommeth more

liurtfull. 
hurtfull. It hath onely this one good thing in it (as $G$ alen faith) that it maketh the body foluble.

A That which is fweeteft and preffed out of ripe Grapes doth fooneft paffe through; but that which is made of foure and auftere grapes is worft of all :it is more windy, it is hardly eoneonted, it ingendreth raw humors; and althorgh it doth defeend with a loofeneffe of the belly, notwithftanding it oftentimes withall bringeth the collieke and paines of the fone : but if the belly be not mooned all things are the worfe, and more troublefome; and it oftentimes brings an extreame laske, and the bloudy flix.

B That firf part of the wine thateommeth forth of it felfe before the Grapes be hard preffed, is anfwerable to the Grape it felfe, and doth quick ly defeend ; but that which iffues forth afterward, hauing fome part of the nature of the ftones, ftalks, and skins, is much worfe.

\section{T of Cinte:}

C F Cute that is made of Muf, which the Larines call Sapa, and Defrutum, is that liquot which we call in Englifh Cute, which is made of the fweeteft Murt, by boyling it to a eertain thiekneffe, or boyling it to a third part, as Columella writeth.

D Pliny affirmeth, That Sapa and De frutum do differ in the manner of the boyling; and that $S_{\text {apa }}$ is made when the new wine is boyled away till onely a third part retraineth : and Defrutum till halfe be boyled.

E Sir eum (faith he in his fourteenth booke, sap.17.) which othets call iqum, and we Sapa, a worke of wit, and not of nature, is made of new wine boyled to a third part; which being boiled to halfe we eall Defrutum.

F Palladius ioyneth to thefe Caranwm, which as he faith is made when a third part is boiled away, and wo remaine.

G Leontius in his Geoponieks theweth, that Hep ems mult be made of eight parts of new wine,and an hundred of wine it felfe boyled to a third.

H Galen teftificth, that itww is new wine very much boyled. The later Phyfitians docall Hepfema or Sapa boyled wine.

I Cute or boyled wine is hot, yet nor fohor as wine, but it is thicker; yet not fo eafily difributed or earried through the body, and it flowly defcendeth by vrine, but by the belly oftentimes fooner; for it moderately maketh the fante foluble.

K It nourifheth more, and filleth the body quiekly; yet dorh it by reafon of his thiekneffe ftieke in the ftomacke for a time, and is not fo fit for the liwer or for the fpleene. Cute alfo doth digeft raw humors that fticke in the cheft and lungs, and raifeth them vp fpeedily. It is therefore good for the eough and hortneffe of breatb.

I The Vintners of the Low-countries (I will not fay of London) doe make of Cute and Wine mixed in a eertain proportion, a eompound and counterfeit wine,w hich they fell for Candy wine, commonly called Malmfey.

M Plinylib. I4. cap.9. faith, that Cute was firft deuifed for a baftatd hony.

$$
\text { I) of wine. }
$$

N Tro fpeake of wine, the inyee of Grapes, which being newly preffed forth is called as we haue 1 faid CM ftum or new wine: after the dregs and drofle are fetled, and now it appeareth pure and cleere, it is ealled in Grecke uroc: in Latine vinum : in Englith. Wine, and that not vnproperly. For eettaine other ityees, as of A pples, Pomegranats, Peares, Medlars, or Seruices, ot fuch as otherwife made (for examples fake) of barley and Graine, be not at all fimply ealled wines, buc with the name of the thing added whereof they do confift. Hereupon is the wine which is preffed forch of the pomegranat berries named $R$ hoites, or wine of pomegranats : out of Quinces, $C y d o$ mites, or wine of Q'inees : out of Peares, Apyites, or Perry : and that which is eompounded of barley is ealled Zythum, ot Barley wine: in Englinh, Ale or Beere.

0 And other ecrtaine wines haue borrowed fyrnames of the plants that haue beene fteeped or infufed in them , and yet all wines of the Vine, as Wormwood wine, Myrtle wine,and Hyffop wine, and thefe are all called artifieiall wines.

P That is properly and fimply called wine which is preffed out of the grapes of the vine, and is without any manner of mixture.

Q The kindes of wines are not of one nature, nor of one facultic or power, but of many differing one from another : for there is one differenee thereof in tafte, another in eolour; the third is referred to the eonfiftenee or fubftance of the wine; the fourth eonfifteth in the vertue and ftrength thereof. Galen addeth that whieh is found in the fmell, which belongs to the vertue and ftrength of the wine. 
That may alfo be ioyned vnto them which refpecteth the age : for by age wines beeome hotter A and iharper, and doe withall change oftentimes the eolour, the fubftanec, and rhe fmell : for fome wines are fweet of tafte; others auitete or fomerhing harf $h$; diuers of a rough tafte, or altogerher harm; and moft of them fufficient tharpe : there be likew ife wines of a middle fort, inelining ro one or other qualitie.

Wine is of colour eicher white or reddifh, or of a blackifh dcepe red, which is ealled blaeke, or B of fome middle colour betweenc thefe.

Some wine is of fub ftance altogether thin ; orher fome thieke and fat ; and many alfo of a mid- C dle confiftence.

Onewine is of great ftrengrh, and another is weake, whieh is called a waterith wine: a ful wine $D$ is ealled in Latine $y$ inofum. There be alfo among the fe very many rhat be of a middle ftrength.

There is in all wines, be they neuer fo weake, a certaine winie fubftance thin and hot. There be $E$ likewife waterie parrs, and allo diuers earrhy: for wine is not fimple,but (as $G$ alen tcftifieth in his fourth booke of the faeulries of medieines) confirteth of parts that haue diuers faeultics.

Of the fundry mixture and proportion of rhefe fubftances one wirh anorher there rife diuers and $F$ fundry faeulties of the wine.

Thar is the beft and fulleft wine in which the hot and winie parts do moft of all abound : and G the weakeft is that wherein the waterie haue rhe preheminenee.

The earthy fubftance abounding in the mixture caufeth the wine to be auftere or fomething $\mathbf{H}$ barfh, as a erude or raw fubftance doth make it altogether harfh. The earthy fub ftance being feuered fallerly downe, and in eonrinuanee of time finketh to the bottome, and becomes the dregs or lees of the wine: yet it is not alwaies wholly feuered, but hath both the taft and orher qualitics of this fubftsnee remaining in the wine.

All wines haue rheir heate, partly from the proper nature and inward or originall heate of the I vine, and partly from the Sun : for there is a double heare whiehripeneth not only the grapes, but alfo all other fruits, as $G$ alen reft ifieth; the one is proper and naturall ro euery thing; the other is borrowed of the Sun : which if it be perceiucd in any thing, ir is vndoubtedly beft and efpeeially in the ripening of grapes.

For the heare which proceeds from the Sun eoneosteth the grapes and the iuyee of the grapes, $\mathbf{K}$ and doth efpecially ripen rhem, ftirring vp and increafing the inw ard and narurall heat of the wine, which otherwife is fo ouerwhelmed with aboundanec of raw and waterifh parts, as it feemes to be dullcd and almolt without life.

For vnleffe wine had in it a proper and originall heate, the grapes could not be fo concotted by the force of the Sun, as that the wine rhould beeome hot; no leffe than many orher things naturally co ld, which although they be ripened and made perfeet by the beare of the Sun, do nor for all that lofe their originall narure; as the fruirs, iuyces, or feeds of Mandrake, Nightrhade, Hemloeke, Poppy, and of orher fitch like, which though they be made ripe, and brought to full perfetion, yet fill retaine their orve cold qualitie.

Wherefore feeing that wine through the heate of the Sunne is for the moft part brought to his $M$ proper heatc, and that the heate and foree is not all alike in all regions and places of the earth; therefore by reafon of the diuerfitic of regions and plaees, the wines are made not a littlc to differ in faeulrie.

The ftronger and fuller wine growcth in hot countries and places that lie to the Sun; the rawer i and weaker in eold regions and proninees that lie open to the North.

The hotter the Sommer is the ftronger is the wine; the leffe hot or the moifter it is, the leffe ripe is the wine. Notwithftanding not onely the manner of the weather and of the Sunne maketh the qualiries of the wine ro differ, but the natiue propertie of the foile alfo; for both the taft and other qualities of rhe $W$ ine are aceording to the manner of the Soile. And it is very well knowne, that not only the colour of the wine, but the tafte alfo dependeth v pon the dinerfity of the grapes.

Wine (as Galen wrireth) is hot in the feeond degree, and rhat which is very old in therhird; but new winc is bot in the firft degree: whieh things are efpecially to be vnderftood concerning the meane berweenc the ftrongeft and the weakeft; for the fulleft and mighrieft(being but Horna, that is as I take it of one yeare old) are for the moft part hot in the feend degree. The weakeft and the moft waterirh wines, alrhough they be old, do feldome exeed the feeond degree.

The drineffe is anfiverable to the heate in proportion,as $G$ alen faith in his booke of Simples:but in his bookes of the gouernment of health he fheweth, that wine doth not onely heate, but alfo moiften our bodies, and that the fame doth moiften and nourifh fuch bodies as are extreme dry : and both thefe opinions be true.

For the faeulties ofw ine are of one fort as it is a medicine, and of anorher as it is a nourifh- $R$ ment; which $G$ alen in his booke of the faeulries of nourithments doth plainly thew, affirming that thofe qualities of the wine which Hippocrates writeth of in his booke of the manner of diet, be not 
as a nourithment, but rather as of a medicine. For wine as it is a medicine doth dry, efpecially be. ing outwardly applied; in which cafe, for that it doth not nourioh the body at all, the drines doth more plainly appeare, and is more mantfeftly perceiued.

A Wine is a fpeciall good medicine for an vlcer, by reafon of his heate and modetate drying, as Galen teacheth in his fourth booke of the method of healing.

B Hippocrates writeth, That vlcers, what manner of ones foener they are, muft not be moift ned vnleffe-1t be with wine: for that which is dry (as Galen addeth) commeth neerer to that which is whole, and the thing that is moift, to that which is not whole.

C It is manifett that Wine is in power or facultie dry, and not in act, for Wine actually is moift and liquid, and alfo cold: for the fame caufe it likewife quencheth thirft, which is an appetite or defire of cold and moift, and by this a ctuall moifture(that we may fo terme it) it is if it be inward ly taken, not a medicine, but a nourifhment; for it nouritheth, and through his moifure maketh plenty of bloud; and by increafing the nourifiment it moiftneth the body, vnleffe peraduenture it be old and very ftrong: for it is made fharpe and biting by long lying, and fuch kinde of Wine doth not onely heate, but alfo confume and dry the body, for as much as it is not now a nourifhment, but a medicine.

$\mathrm{D}$

That wine which is neither fharpe by long lying,nor made medicinable, doth nourifh and moifen, feruing as it were to make plenty of nourithment and bloud, by reafon that through his actuall moifture it mote moifteneth by feeding, nourining, and comforting, than it is able to dry by $\mathrm{E}$ his power.

Wine doth refrefh the inwatd and naturall heate, comforteth the ftomacke, caufeth it to have an appetite to meate, muteth coucoction, and conueyeth the nourifhment through all parts of the body, increafeth ftrength, inlargeth the body, makcth flegme thinne, bringerh forth by vrine cholericke and waterie humors, procureth fiveating, ingendreth pure bloud, maketh the body wel
coloured, and turneth in ill colour into a better.

F It is good for fuch as are in a confimption by reafon of fome difeafe, and that haue need to hatue their bodies nourifhed and refrefhed (alivaies prouded they haue no feuer, ) as Galers faith in his feuenth booke of the Method of curing. It reftoreth ftrength moft of all other things, and that fpeedily : It maketh a man intetry and ioyfull : It putteth away feare, care, troubles of minde, and forrow : It mouth pleafire and luft of the body, and bringeth fleepe
gently.

G And thefe things proceed of the modetate vfe of wine : for immodetate drinking of wine doth altogether bring the contrarie. They that ate drunke are diftraughted in minde, become foolifh, and oppreffed with a drowfie leepineffe, and be afterward taken with the Apoplexy, the gout, or altogether with othet moft grieuous difeafes; thebraine, liner, lungs, ot fome other of the intrals being corrupted with too often and ouermuch drinking of wine.

H Morcouer, wine is a rcmedy againft taking of Hemlocke or green Coriander, the iuyce of black Poppy, Wolfs-bane, and Leopards-bane, Tode-ftooles, and other cold poyfons, and alfo againf: the biting of ferpents, and ftings of venomous beaft, that hurt and kill by cooling.

I Wine alfo is a remedieagainft the oure-fulneffe and ftretching out of the fides, windy fivellings, the greene fickneffe, the dropfie, and generally all cold infirmities of the ftonack, liver, milt,
and a!fo of the matrix.

$\mathrm{K}$ But Wine which is of colout and fubfance like water, through thining bright, pure, of a thin fubftance, which is called white, is of all wines theweakeft; and if the fame fhould be tem. pered with water itwould beare very little: and hereupon Hippocrates calleth it iaryoen, that is to fay, bearing little water to delay itwithall.

L This troubbleth the head and burtech the finewes leffe than others do, and is not vnpleafant to the ftomacke : it is eafily and quickly difperfed thorow all parts of the body: it is giten with far leffedanger than any otherwine to thofe that haue the Ague (except fome inflammation or hos fivelling be fufpected) and ofrentimes with good fucceffe to fuch as haute intermitting feuters; for as $G$ ale $, 1, i 6.8$. of his Method faith, it helpeth concoction, digefteth humors that be halfe raw, ptocurerh vrine and fweat, and is good for thofe that cannot fleepe, and that be full of care and forrow, and for fuch as are onerwearied.

M Blackewine, that is to fay wine of a deepe red colour, is thicke, and hardly difperfed, and doth not eafily pafe throngh the bladder : it quickly taketh hold of the braine, and makes a man drunk : it is harder of digeftion : it remaineth longer in the body; it eafily foppeth the liner and fplecne; for the moft part it bindes, notwith ftand ing it nourifheth more, and is more fit to ingender bloud: it filleth the body with flefh fooner than others do.

N That which is of a light crimfon red colour is for the molt part more delightfull to the taftc, fitter for the ftomacke; it is fooner and eafier difperfed : it troubleth the head leffe, it remains nor fo long vndet the thott tibs, and eafiliet de fcendeth to the bladdet than blacke wine doth : it doth 
alfo make the belly cotiue, if fo be that it be not ripe. For fueh erude and rough wines do oftentimes noleft weake ftomackes, and are troublelome to the telly.

Reddin yellow wine feemeth to be in a meane betweene a thin and thicke fubrtace:orher- A wife it is of all vines the hotteft; and fuffereth moft water to be mixed wirh it, as Hippocrucs ivriteth.

The oldvine of this kinde, being of a thin fubftanee and good fmell, is a fingular medicine for $\mathbb{B}$ all thofe that are much fubje $z$ to frouning, although the eaufe thereot proceed of eholer that hurteth the mouth of the ftomacke, as $G$ alen teftificth in the 12 , booke of his method.

Sweete wine the leffe hot it is, the leffe doth it trouble the head, and offend the minde; and it C better paffeth through the belly, making it of tentimes foluble: but it doth not fo eafily paffe or defcend by vrine.

Againe, the thicker it is of fublanee, the harder and flowlier it paftith through : it is good for $D$ the lungs, and for thofe that haue the cough. It ripeneth raw humours that ficke in the ebeft, and caufeth them to be eafilier fpit vp; but it is not fo good for the liwer, wherento it bingeth no fmall hurt when either it is: inflamed, orfehirrous, orwhen it is ftopped. It is alfo an eneny to the fpleene, it tieketh vnder the fhort ribs, and is hurfull to thofe that are full of eholer. For this kind of wine, efpeeially the thieker it is, is in them very fpeedily turned into choler:and in others when it is well eoneosto 1 , it inerea feth plenty of nourifhment.

Aufere wine, or that whieh is fonewhat harth in taft,nouritheth not nueh; and if fo be that it $E$ be thin and white, it is apt to prouoke vrine, it leffe troubleth the head, it is not quickly digefted, for which euufe it is the more to be thunned, as Galen faith in his 12 . bookc of his method.

That wine which is altogether harth or rough in taft, the leffe ripe it is, the neerer it eommerh $F$ to the qualities of Veriuiee made of fower grapes, being euidently binding. It Arengheneth a weake ftomacke; it is good a gainft the vnkindely lufting or longing of women with child ; it ftai. eth the laske, but it Ateketh in the bowels : breederh ltoppings in the liner and milt; it forvly defcendeth by vrine, and fomething troubleth the head.

- Old wine which is alfo made tharpe by reafon of age, is not onely troublefome to the braine, but alfu hurteth the finewes : it is an enemy to the entrailes, and maketh the body leane.

New wine,and wine of the firft yeere, doth eafily make the body to fwell, and ingendreth winde, $H$ it eaufeth troublefome dreames, efpeeially that which is not throughly refined, or thicke, or very fweet : for fuch do fooner ficke in the intrailes than others do. Cther wines that are in a meane in colour, fubltance, tafte, or age, as they do deeline in vertues and goodnefle from the extreames; fo alfo they be free from their faults and difeommodities. They come neere in faeulties to thofe wines whereunto they be next, either in colour,tafte, or fubftanee, or elfe in fmell or in age.

Wine is fitteft for thofe that be of nature cold and dry; and alfo for old men, as Gaten theweth I in his fifth booke of the gouternment of health : for it heateth all the members of their bodies, and purgeth away the watery part of the bloud, if their be any.

The beft wines are thofe that be of a fat fubftance: for thofe both increafe bloud, and nourith $K$ the body; both whieh commoditues they bring to old men, efpecially at fuel time as they haue no ferous humour in theirveines, and haue need of much nourimment. It happeneth that oftentimes there doth abound in their bodies a waterifh exerement, and then ftand rhey in moft need of all of fuehwines as do prouoke vrine.

As wine is beft for old men, fo it is worft for ehildren : by reafon that Leing drunke, it both moi- I fteneth and dryeth ouermuch, and alfo filleth the head with vapours, in thofe who are of a moift and hor complection, or who fe boties are in a meane betweene the extreames, whom Galen in his booke of the gouernment of health doth perfuade, that they thould not fo muel as tafte of wine for a very long time: for neither is it good for them to haue their heads filled, nor to be made moift and hor, more than is fufficient, beeaufe they are already of fuch a heate and moifure, as if you thould but little inereafe either qualitie, they would fortlwith fall into the extrene.

And feeing that euery exeeffe is to be thunned, it is expedient moft of all to thun this, by which $M$ notonely the body, but alfo the minde teeciuerh hurt .

Wherefore we thinke, that wine is not fit for men that be already of fullage, vnleffe it be mode- $N$ rately taken,becaufe is earietli them headlong into fury and luf, and troublethand dulleth the refonable part of the minde.

\section{If of the dilaying, or tempering of wine.}

TT was an ancient cuitome, and of long eontinuance in old time, for wines robe mixed with wa- $\mathrm{O}$ ter, as it is plaine and enident not onely by Hippocrates, but alfoby other old mens writings. Wine firft began to be mixed with water for health and wholefomenefle fake: for as Hippecra. is writech in his booke of aneient Phyficke, being fimply and of it felfe much drunke, it maEece

kech 


\section{2}

Of the Hiftorie of Plants.

$\perp 1 \mathrm{~B}, 2$

ketha man in fome fortweake and feeble: which thing oud, feemeth alfo to allow of wricing thus:

Vt Venus encruat vires, fic copia vini

Et tent ut gr.fWs, cie silitatque pedes.

As Venery the vigour fpends, fo ftore ofwine

Makes man to ftagger, makes ljis ftrength decline.

A Moreoner, wine is the fweeter, hauing water poured into it, as Athendus faith. Homer likewife commendetla that wine which is well and fitly allaied. Philocorus writeth (as Aibenaws reporteth) that Amphityon king of Arhens was the firft that allaied wine, as hauing learned the fame of Dio. nyfus: wherefore be faich, that thofe who in that manner drunke it remained in health, that before had their bodies feebled and ouerweakented with purc and vnmixed wine.

B The maner of minglingtertempering of wine was diuers: for fometimes to one part of wine, there were added two, and fometimes three or foure of water; or two parts of wine three of water: of a lefle delay was that which confifted of equall parts of wine and water.

C The old Comedians did thinke that this leffer mixture was fufficient to make men mad,among whom was Mnefithezs, whore words be extant in Athenews.

D Hippocrates in the fcuenth booke of his Aphorifmes faith, that this manner of tempering of wine and water by equall parts bringeth as it were a light plea fant drunkenteffe, and that it is a kindc of remedy againf difquietnefle, yawnings, and hiuerings; and this mingling belongeth to the ftrongeft wines.

E Such kinde of wines they might be which in times paft the Scythians were reported of the old writers to drinke, who for this caufe docall vnmixed wine the Scythians drinke. And they that drinke fimple wine fay, that they will'Scythizare, or coas the Scythians do; as we may reade in the tenth booke of Aib neus.

F The Scythians,as Hippocrates and diucrs other of the old writers affirme, be people of Germany beyond the floud Danuburs, which is alfo called Ifter : Rhene is a riuer of Scyrhia : and Cyrres hauing paffed outer Ifter is reported to haue come into the borders of the Scythians.

$G \quad$ And in this our age all the people of Germany do drinke vnmixed wir c, which groweth in their owne countrey, and likcwife other people of the North parts, who make no fcruple at all to drinke. of the ftrongeft wines without any mixture.

$$
\begin{aligned}
& \text { Tof the liguor which is deftilled out of wime, commonly } \\
& \text { called, A qua vitx. }
\end{aligned}
$$

H There is drawne out of Wine a liquor, which in Latine is commonly called Aqua vite, or wa: ter of life, and alfo Aqua ardens, or burning water, which as diftllled waters are drawne out of berbes and other things, is after the fame manner difilled out of ftrong wine, that is to fay, by certaine inftuments made for this purpofe, which are commonly called Limbeckes.

I Thiskinde of liquor is in colour and fubftance like vnto waters diftilled out of herbes, and alfo refembleth cleere fimple warer in colour,hut in facultie it farre differeth.

$\mathrm{K}$ It beareth the fyrname of life, becaufe that it ferteth to preferueand prolong the life of man.

L It is called Ardens, burning, for that it is eafily turned into a burning flame : for feeing it is not any other thing than the thinneft and ftrongeft part of the wine, it being put to the flame of fire, is quicklyburned.

M This liquor is very hot,and of moft fubtill and thin parts, hot and dry in the later end of the third degree, efpecially the puref fpirits thercof: for the purer $i t$ is, the hotter it is, the dryer, and of thinner parts : which is made more pure by often diftiling.

N This water diftilled out of wine is good for all thofe that are made cold cither by a long difeafe, or through age, as for old and impotent men : for it chcrilheth and increafeth naturall heate; vpholdeth ftength, repaireth and augmenteth the fame: it prolongeth life, quickeneth all the fenfes, and doth not only preferue the memory, but alfo recouereth it when it is loft: it tharpeneth the fight.

O It is fit for thofe that are taken with the Catalepfre (which is a difeafe in the braine proceeding of drineffe and co'd) and are fubject to dead flecpes, if there be no feucr joined; it ferueth for the weakeneffe,trembling, and beating of the hart; it frengtheneth and heateth a fet bleftomacke; it confumeth windeboth in the ftomacke, fides, and bowels; it maketh good concoction of mcatc, and is a fingular remedy againft cold poifons.

$P$. It hath fuch force and pow er, in frengthening of the hart, and ftirreth vp the inftruments of the 
fenfes, that it is moft effectuall, not onely inwardly taken to the quantitic of a little fpoonefull, but alfo outwardly applied : that is to fay, fet to the nofthrils, or laid vpon the temples of the head, and to the wrefts of the armes; and alfo to foment and bath fundry hurts and griefes.

Being held in the mouth it helpeth the rooth-ache:it is alfo good againft cold cramps and con- A vulfions, being chafed and rubbed therewith.

Some arebold to giue it in quartaines before the fit, efpecially after the height or prim of the $B$ difeafe.

This water is to be gituen in wine with great iudgement and diferetion ; for fecing it is extreme C hot, and of moft fubtill parts, and nothing elfe but the very fpirit of the wine, it moft fpeedily peirceth through, and doth eafily affault and hurt the braine.

Therefore it may be giuen to fuch as haue the apoplexic and falling fickneffe, the megrim, the $D$ headach of long cont inuance, the Vertigo, or giddineffe proceeding through a cold caufe :yer can it not be alwaics fafely given; for vnleffe the matter the cfficient caufe of the difeafe be fmall, and the ficke man of temperature very cold, it cannot be miniftred without danger : for that it fpredeth and difperfeth the humours, it filleth or ftuffeth the head, and makech the ficke man worfe : and if the humours be hot, as bloud is, it doth not a little increafe inflammations alfo.

This water is hurtfull to all that be of nature and complexion hot,and moft of all to cholericke $E$ men:it is alfo offenfue to the liter, and likewife vnprofitable for the kidnies, being often and plen-
tifully taken.

If I fhould take in hand to write of euery mixture, of each infufion, of the fundry colours, and euery other circumftance that the vulgar people doe gine vnto this water, and their ditiers vfe, I fhould fpend much time but to fmall purpofe.

\section{If of Argall, Tartar,or wine Lees.}

$\mathbf{T}$

he Lees of wine which is become hard like a cruft, and fticketh to the fides of the veffell; and Fi wine casks, being dricd, hard, found, and well compact, and which way be beaten into powder, is called in thops Tartarum : in Englih, Argall, and Tartar.

Thefe Lees are vied for many things; the filuer-Smiths polith their filuer herewith : the Diers $G$ ve it : and it is profitable in medicine.

It doth greatly dry and waft awày, as Panlus eEgineta faith: it hath withall a binding facultie; H proceeding from the kinde of wine, of which it commeth. The fame ferueth for moilt difeafes of the body : it is good for them that haue the greene fick-
nes and the dropfic, efpecially that kinde that lieth in the flefh,called in Latine, Lewcophlagmatica : being taken euery day fafting hálfe a penny weight or a full penny weight (which is a dram and nine graines after the Romanes computation) doth not onely dry vó the waterifh excrements, and voideth them by vrine, but it preuaileth much to clenfe the belly by fiege.

It would worke more effectually, if it were mixed either with hot fpices, or with other things $\mathrm{k}$ that brcake winde, or elfe with diuretickes, which are medicines that protoke vrine; likewife to be mixed with gentle purgers, as the ficke mans cafe fhall require.

The fame of it felfe, or tempered with oile of Myrtles, is a remedy againft foft fwellings, as $D_{i-} L_{2}$ of corides teachcth : it ftaieth the laske, and vomiring,being applied outwardly vpon the region of the ftomacke in a pultis; and if it be laid to the botcome of the belly and fecret parts, it foppeth the whites, wafterh away hot fwellings of the kernels in the flankes,and other places, which be not yet exulcerated : it affwageth great brefts, and dryeth vp the milke, if it be annointed on with vineger.

Thefe Lees are oftentimes burnt:if it beconc all white it is a figne of right and perfect burning, $M$ for till then it muft be burned : being fo burnt, the Grccians terme it, of han, as etgiget a faith : the A pothecarics call it, Tarlarmm uftum, and Tartarum calcinatum: that it to fay, burnt or calcined
Tartar.

It hath a very great caufticke or butning qualitie $:$ it clenfeth and throughly heateth, bindeth, $N$ eateth, and very much drieth, as Diofcorides doth write: being mixed with Rofin, it maketh rough and ill nailes to fall away: Paulus faith, that it is mixed with caufticks or burning medicines to increafe their burning qualitic : it muft be vfed whileft it is new made, becaufe it quickly vanitheth : for the Lees of wine burned, do foone relent or wax moift, and are fpecdily refolued into: liquor : therefore he that would vfe it dry, muft haue it put in a glaffe, or glaffed veffell well fopped, and fet in a hot and dry place. It melteth and is turned into liquor if it be hanged in a linnen bag in fome place in a cellervnder the ground.

- The A pothecaries call this liquor that droppeth away from it,oile of Tartar. It retaineth a cauficke and burning quality, and alfo a very dry facultic : it wery foon taketh away leprie, feabs, tetters, andother filth and deformitic of the skin and face: with an equall quantitie of Rofe watet added, 
added, and as mucin Corufe as is fuffieient for a liniment, wherewith the blenifhed or fpotted parts nutut be anointed ouer night.

$$
\text { T The briefeformme of that hat beearfaid of the r"ine. }
$$

A He ityce of the greene leaties, branches, and tendrels of the Vine drunken, is good for thofe 1 that vomit and ipit bloud, for the blondy flix, and for women with childe that vonite ouermuch. The kernell within the grapes boyled in water and drunke hath the fame effect.

B Wine moderately drunke profiteth much, and maketh good digeltion, but it hurteth and difempereth them that drinke it feldome.

C. Whitewine is good to be drunke before meate; it preferueth the body, and piercetl quickely into the bladder : but vpon a full ftomacke it rather maketh oppilations or ftoppings, bccaufe it doth fwiftly drive dow ne meate before Nature hath of her fel fe digefted it.

D Claret wine dorh greatly nourith and warme the body, and is wholefome with meate, efpecially vnto phlegmaticke people; but very vnw holefome for yong children, as Galer faith, becaufe it heateth aboure nature, and hurteth the head.

E Red wine ftops the belly, corrupteth the bloud, breedeth the ftone, is lurtfull to old people, and good or profitable to few, faue to fuch as are troubled with the laske, bloudy flix, or any other lourenefic of thebody.

F Sacke or Spanith winchath beeric vfed of a long time to be drunke after meate, to caufe the meate the better to diget, but common experience hath found it to be more beneficiall to the ftomacke to be drunke before meate.

G Likewife Malmfey, Muskadell, Baftard, and fuch like fweet wines haure been vfed before meat; to comfort the cold and weake ftomacke, efpecially being taken fatting : but experience teacheth, that Sacke drunke in ftead thereof is much better, and warmeth more effectually.

II Almighty God for the comfort of mankinde ordained Wine; bur dccreed withall, That it fhould be modcratly taken, for fo it is wholfome and comfortable : but when meafure is turned into exeeffe, it becommeth vin holefome, and a poyfon nint venomous, relaxing the finewes, bringing with it the palfey and falling ficlineffe: to thofe of a middle age it bringeth hot feuers, frenfie, and lecheric ; it confumeth the liuer and other of the inward parts: befides, how littlc credence is to be giuen to drunkards it is euident; for though they be mighty men, yet it maketh them monfters, and worfe than brute beafts. Finally in a word to conelude; this exceffuc drinking of Wine difhonoreth Noblemen, beggereth the poore, and more haue beene deftroyed by furfeiting there:
with, than by the fword.

\section{CHAP. 324. Of Hops. \\ The rinds:} Herebe two forts of Hops : one the manured or the Garden Hop; the other wildeor of the
hedge.

$$
\text { The Defeription. }
$$

- THe Hop doth liue and flourifh by embracing and taking hold of poles, pearches, and other things vpon which-it climeth. It bringerh forth very long ftalkes, rough, and hairie; alfo rugged leaues broad likc thofe of the Vine, or rather of Bryonic, but yer blaeker, and with fewer dented dunitions : the floures hang downe by clufters from the tops of the branches, puffed vp, fet as it were with fales likelittle canes, or fcaled Pine apples, of a whitifh colour tending to yellownefie, ftrong of fmell : the roots are flender, and diuerfly folded one with-
in another.

2 Thewilde Hop differeth not from the manured Hop in forme or farhion, but is altogethet leffer, as well in the clufters of floures, as alfo in the franke fnoots, and dorh not bring forth fuch ftore of floures, wherein cfpecially confifteth the difference.

The to The Place.

growethop ioyeth ina fat and fruitfull ground: ir profpereth the better by manuring : alfo it growerh among briers and thornes about the borders of fields, I meane the wilde kinde. 
1 Lupus faliftarius. Hops.

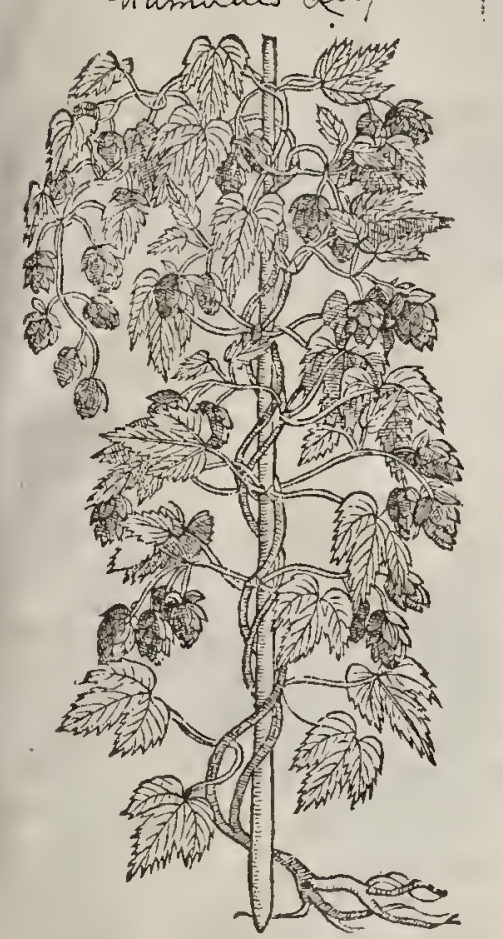

The Time.

The floures of hops are gathered in A uguft and September, and referued to be vfed in beere : in the Spring time cume forth new fhoots or buds:in the Winter onely the roots remaine aliue.

$$
\text { T Thi Names. }
$$

It is called in fhops and in all other places $L_{\text {it }}$ pulus: of fome, Lupusfalidarius, or Lapulsu falic7arius : in high-Dutch, Hoppe: in Spanifh, Hombrezillos : in French, Hossblon : in Engli h, Hops.

Pliny, li6.21. c.tp. 5 . maketh mention of Hops among the prickly plants.

$$
\text { } 1 \text { The Temperature. }
$$

The flomres of the hop are hot and dry in the fecond degree : they fill and ft uffe the head, and hurt the fame with their ftrong frmell. Of the fame remperature alfo are the leaues themfelues, which doe likewife open and clenfe.

$$
\text { of The Vertues. }
$$

Thebuds ot firit fprouts which come forth in $A A$ the Spring are vfed to be eaten in fallads; yetare they, as Pliny faith, more toothfome than nouriMing, for they yeeld but very fmall nourithment : notwithitanding they be good for the intrals, both in opening and procurung of vrine, and likewife in keeping the body foluble.

Theleaues and little tender ftalkes, and alfo the $B$ B floures themfelues remoue ftoppings our of the liuer and fpleene, purge by vrine, helpe the fpleene, clenfe the blour, and be profitable againft long lingering Agues, fcabs, and fuch like filth of the skin, if they be boyled in whay.

The iuyce is of more force, and doth not onely remouc obftuctions out of the intrals, but it is alfo thought to auoid choler and flegme by the ftoole. It is written, that the fame dropped into the eares taketh away the ftench and corruption thereof.

The floures are vied to feafon Beete or. Ale with, and too many do caufe birterne fe thereof, and are ill for the head,

The floures make bread light, and the lumpe to be fooner and eafilier leaucned, if the meale be $\mathrm{E}$ tempered with liquor wherein they haue been boyled.

The decostion of hops drunke openeth the ftoppings of the liwer, the fpleene, and kidneyes,and $\mathrm{F}$. purgeth the bloud fron all corrupt humors, caufing the fame to come forth with the vrine.

The iuyce of Hops openeth the belly, and driueth fort yellow and cholericke humours, and $G$ purgeth the bloud from all filthinefie.

The manifold vertues of Hops do manifenty argue the wholfomeneffe of beere abouic ale; for $\mathrm{H}$ the hops rather make it a phy icall drinke to keepe the body in health, than an ordinary drinke for the quenching of our thirf.

\section{Cнар. 325. Of Trauellers-foy. \\ ब The Defoription.}

J. TTe plant which Lobil fertech forth vnder the tirie of Viorns, Dodnsess makes F'itis alba, but not properly; whofe long wooddy and viny branches extend themfolues very far, and into infinire numbers, decking with his clafping tendrels and white ftarre-like fontres (being very fiveet) all the buthes, hed ses, and thrubs that arc ncere vnto it. It fends forth many brumclied ftalkes, thicke, tough, full of thoors and clafping tendrels, wheretrith ir foldeth it folfevpon the hedres, and taketh hold and climeth vpon euery thing trite ftandech nears vnto 
it. The leaues are faftncd for the moft part by fiues vpon onc rib or ftem, twonn cither fite, and one in the midft or point ftanding alonc; which lcaues are broad likc thofe of luy, but rot cornered at all : among which come forth clufters of white floures, and after them great tufts of that feeds, each feed hauing a finc whitc plume like a featlycr faftncd to it, which makech in the winter a goodly thew, conering the hedges white all ouer with his feather-like tops. The root is long, tough, and thickc, with many ftrings faftned thcreto.

2 Clufus hath fer forth a kind of clematis, calling it Clemat is Eetica, hauing a martellous long: fmall bianch full of ioynts, with many leates indented about the edges like thof cf the peare tree, but fiiffer and fmaller, comming from etrery ioynt; from whence alfo at each ioynt procced two fmall clafping tendrels, as alfo the fmall font-ftalkes whereon the fceds do ftand, grow ing in grear tufted plumes or farhers, like vnto the precedent, whereof it is a kinde. The foures arc not cxprefled in the figurc, nor feene by the Author, and thetefore what hath been faid fhall fuffice.

I Viorns.

The Tramelicrs Ioy.

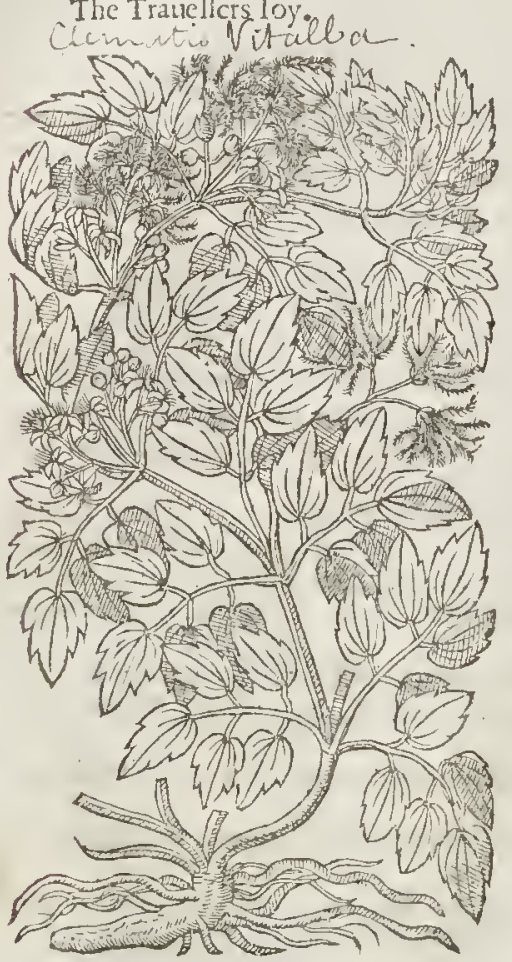

2 Clemat is Berica.

The Spanih Iratlers Ioy.
C. Cingrioso?

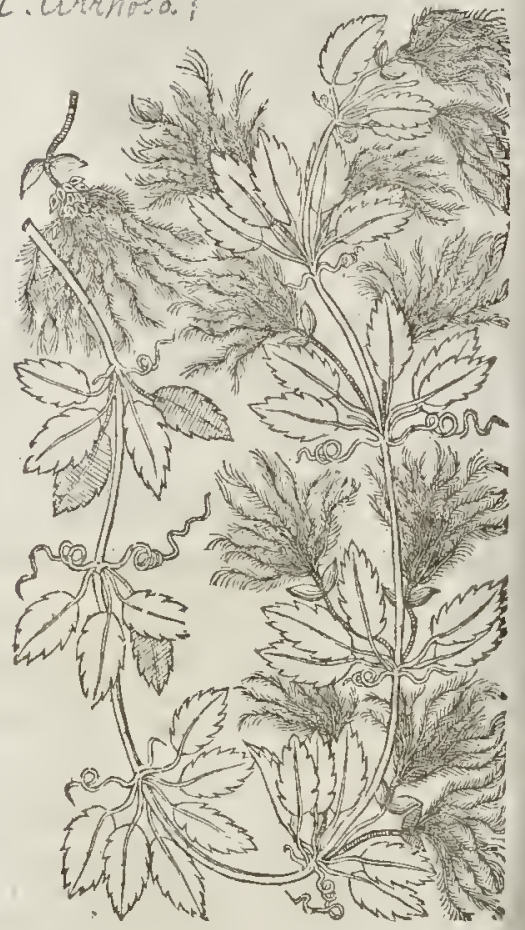

The Place.

The Tranellers loy is found in the borders of fields among thornes and bricrs, almoft in enerie hedge as you go from Grauefend to Cantubury in Kent; in many placcs of Effex,and in moft of thefe Southerly parts about London, but not in the North of England that I can heare of.

The fecond is a tranger in thefe parts : yer haue I found it in the Ine of Wight, and in a wood by Waltham abbcy.

$$
\text { The Time. }
$$

The floures come forth in Iuly : the beauty thercof appeares in Nonember and December. q The Nimes.

The firt is called commonly Viorna, quafi vias ornans, of decking and adorning waies and hedges, where people traucl; and thereupon I hauc named it the Traucllcrs Iov : of $F$ ruchfius it is called Vitis nigra: of Dodoness, Writalba: of Matthiolus, Clemat is altera: of Cordus, Vitis alba : of Diofcorides, Vitis fylueftris : of T heophrafus, Atragene: in Durch, Xinen: in Frcnch,as Ruclliws writeth,Viorne. 9) The Temperature and Vertues.

Thefe plants haue no vee in phy ficke as yet found our, but are efteemed onely for pleafure, by revfon of the goodly thadow which they makc with thcir thicke burhing and clyming, as alfo for the beaty of the floures, and the plcafant fent or fauor of the fame. 


\title{
Cha p. 326. Of Ladies Bower, or Virgins Bower.
}

\author{
If The Defcription.
}

1 Hat which Lobel defcribeth by the name Clemat is peregrina, hath very 'long and nender

1 ftalks like the Vine, which are iointed, of a darke colour; it climeth aloft, and taketh bold with his crooked clafpers vpon euery thing that ftandeth neere vnto it: it hath many leaues diuided into diuers parts; among whicli come the floures that hang vpon flender toot-ftalkes, fomething like to thofe of Peruinckle,confifting onely of foure leates, of a bleiv colour, and fometimes purple, with certaine threds in the middle : the feeds be flat,plaine,and sharpe pointed. 'The roots are flender, and fpreading all about.

$x=$ Clemat is peregrina Cerulea, five rubra. Blew or red Houred Ladies-bower. Criticcllas

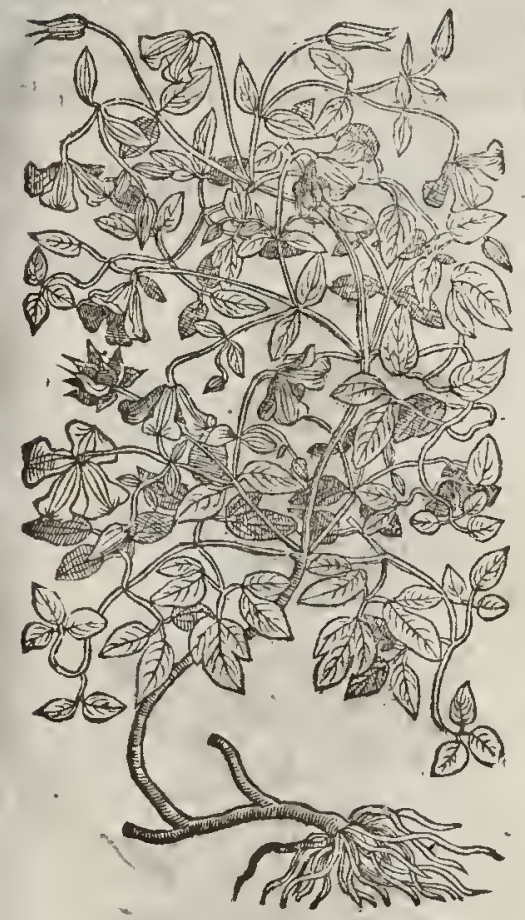

\# 3 Clemat is Carsilea fore pleno. Double floured Virgins-bowcr.

2 The fecond differeth not from the other, in leates, ftaikes, hranches nor feed. The onely difference confifterh in that, that this plant bringeth forth red floures, and the other blew.

$¥ 3$ There is preferued alfo in fome Gardens another fort of this Clematis, which in rootes, leaues, branches, and manner of growing differs not from the former: but the floure is much different, being co npofed of abundance of longith narrow leaues, growing thicke together, wich foure broader or larger leaues lying vnder, or bearing them vp, and thefe leaties ate of a darke blewith pu:ple colour. Clufius calls this Clemiat is alteraflore pleno. $\neq$ Tा The Place.

Thefe plants delight to grow in Sunnie places : they profper better in a fruitfull foile than in barren. They grow in my garden, whore they flourifh exceedingly.

The Time.

They floure in Iuly and Augut, and perfêt their feed in September.

बा The Names.

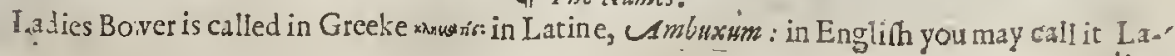


dies bower, which I take from his aptneffe in making of Arbors, Bowere, ard Ihadie couctures in gardens.

The Temperature and Vortues.

TI The T emperature and $V$ crtues.
Phy fieke is not yet linown.

\section{C н А P. 327. Of purging Perninckle.}

T The Defcription.

'1 Mong thefe plants whieh are called Clematides thefe be alfo to be numbred, as hatuing certaine affnitie,becaufe of the fpreading,branehing,and femblanee of the Vine; and this is ealled Flammula vrens, by reafon of his fierie and burning heare, be eaufe that being laid vpon the skin, it burneth the plaee,and makethan efeltar, chen as our common eauftich or corrafiue medieines do. The leaucs hereof anfwer both in eolour and fmoothneffe, Vinca, Per winca, or Peruinekle, growing vpon long elambring tender branehes, like the orher kindes of elin bing plants. The floures are very white, ttar-falhion, and of an exceeding fweet mell, nuch like vnto the fmell of Haw thorne floures, but more pleafant, and leffe offenfuce to the head : hauing in the middle of the floures certaine fmall chites or threds. The root is tender, and difperfeth it felfe far vnder the ground.

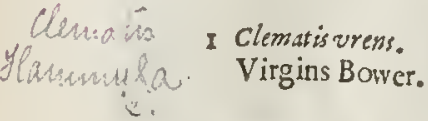

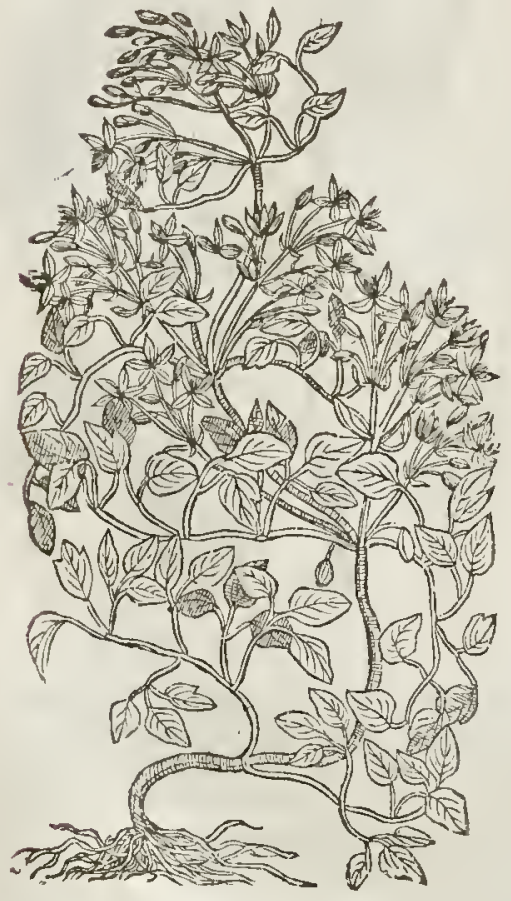

W $\mathrm{CO} 2$ Flammula Towis Jurrecta. Vprighe Virgins Bower.

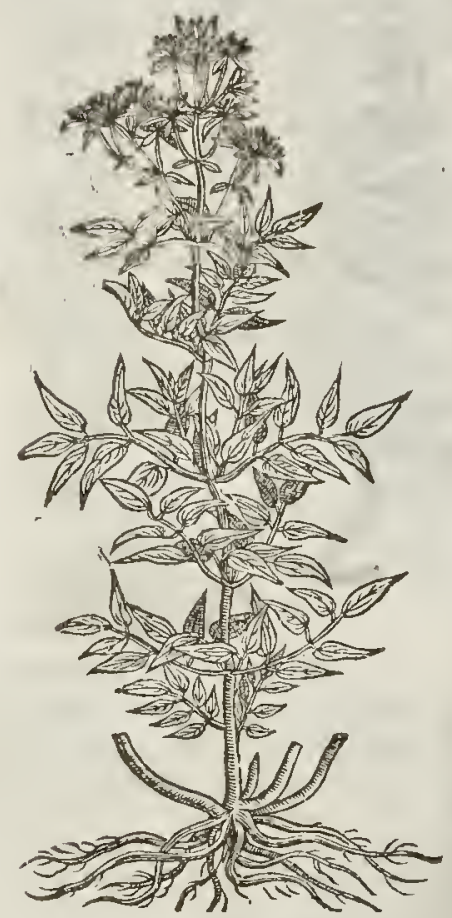

2 Vpright Clamberer or Virgins Bower is alfo a kinde of Clemstis, hauing long tough roots not vnlike to thofe of Lieorlec; from which rifeth vp a ftraight vpright ftalke, of the height of three or foure cubits, fet abour with winged leaues, compo fed of diuers fmall leaues, fet vpon a middle rib,as are thofe of the afhe tree, or Valerian,but fewer in number:at the top of the ftalks eome forth finall white floures, very like the precedent, but not of fo pleafant a fweer fmell; after whieh eome the feeds, flat and tharpe pointed. 


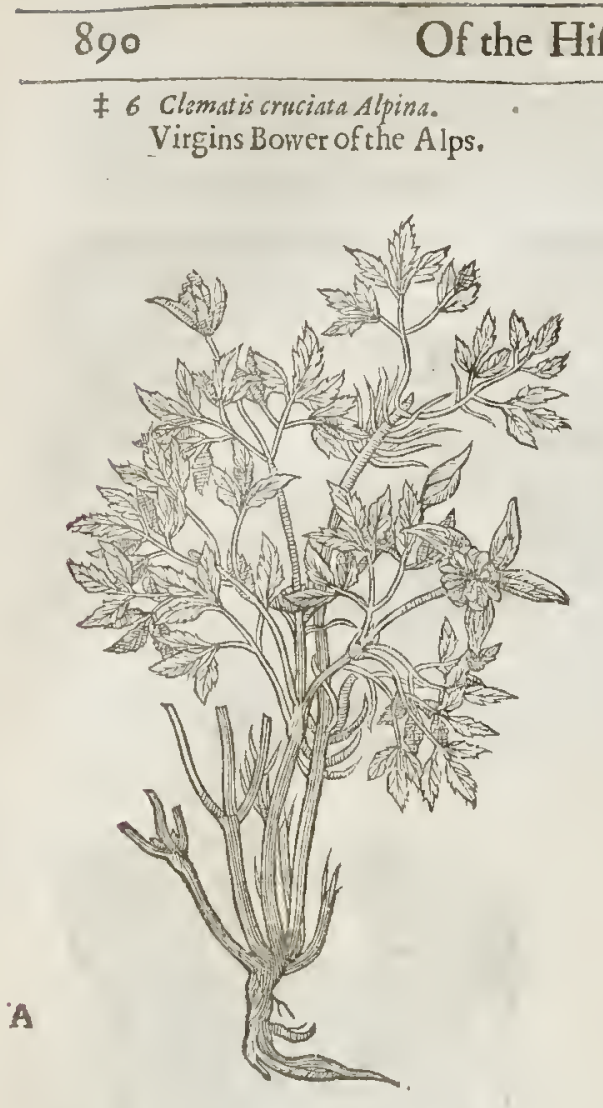

L1 в. 2.

6 Clomat is cruciatd Alpina.
Virgins Bower of the Alps. 
che floures of Woodbinde : many times it fallethout, that there is to be found three or foure futcers one aboue another, filled with flourcs, as the firk $k_{2}$, which hath caufcd it to be called double Hony-fuckle, or Woodbinde.

\section{Periclymenum.}

Woodbinde or Honifuckles.

Sonsera Perichimenum

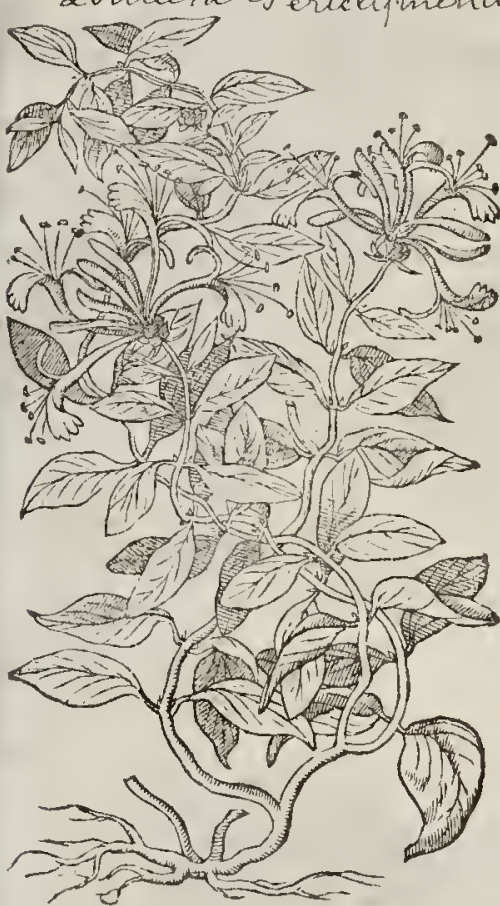

2 Periclymenums perfoliatum.

Loncera Caponifoluiom
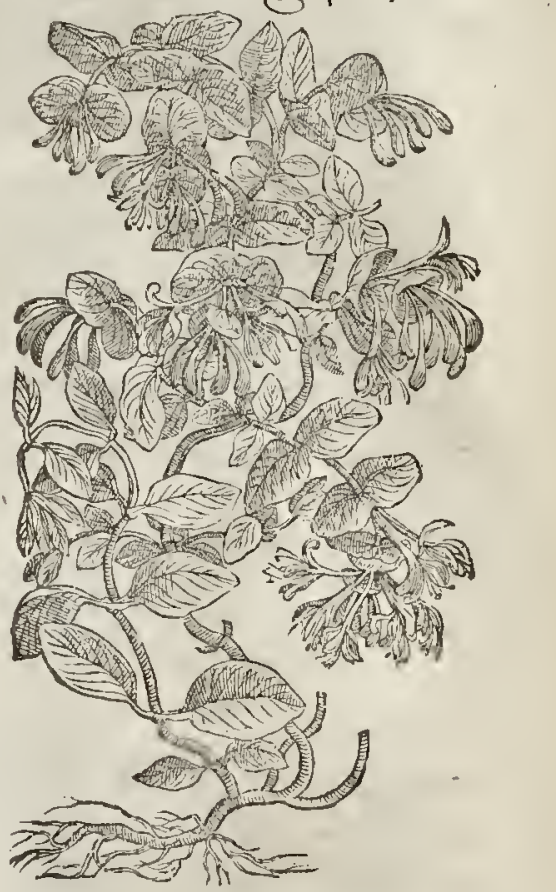

T The Place.

The VYoodbinde growerh in woods and hedges $s_{\text {, }}$ and vpon (hrubbes and buthes, oftentimes winding it felfe fo ftraight and hatd about, that it leauth his print vpon thofe things fo wrapped.

The double Honifuckle growerh now in my garden, and many others likewife in great plenty, although not long fince, vcry rare and hard to be found, except in the garden of fome diligent $\mathrm{Hcr}$ barifts.

The leaues come forth bctines in the fpring : the flourcs bud forth in May and Iune : the fruit is ripe in Autumne.

It is called in Greeke wesavum : in Latine, Volucrum maius : of Scriboniss Laygus, Sy'us mater: in thops, Caprifolium, and Matrifylua : of fome, Lilium inter pinas : in Italian, vincibofco: in High

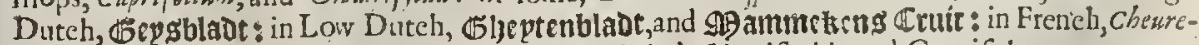
fuetle : in Spanih,Madrefelua : in Englih, V Voodbinde, Honifickle, and Caprifoly.

Tा The Temperature.

There hath an errout in times pant growne among ft a few, and now almoft paft recourie to bee called againe, being growne an errour vniucrfall, wh hich errour is, how the decoction of the leanes of Honifuckles, or the ditzilled water of the floures, are rafhly gituen for the inflammations of the mouth and throte, as though they were binding and cooling. But contrariwife Honifuckle is neither cold norbinding; but hrt, and attenuating or making thinne. For as Galen faith, both the fruit of VVoodbinde, and al fo the leaues, do fo much attenuate and heat, as if fomewhat too muich of them be drunke, they will caufe the viine to be as red as bloud, yet do they ar the firft onely prow tokevrine. 


\section{- The Vertues.}

A Diofcorides writeth that the ripe feed gathered and dried in the thadow, and drunke rntothe quantitie of one dram weight, fortie daies together, doth wafte and confume away the hardnc fle of the fpleene, remoueth wearifomneffe, helpeth the tho: tne ffe and difficultie of breathing, cureth the hicket,procureth bioudie vrine after the fixt day, and caufeth women to have freedie traucll in childe bearing.

B The leates be of the fame force: which being drunk thirty daies together,are reported to make men barren,and deftroy their natmall feed.

C The floures fteped in oile and fet in the Sun, is geod to annoint the bodie that is benumed, and growne verie cold.

D The diftlled water of the foures are giucn to be drunke with good fucceffe againf the piffing of bloud.

E A fyrrup made of the floures is good to be drunkeagainft the difeafes of the lungs and fpleene that is ftopped,being drunkewith a littlewine.

F Ncthwithptanding the words of Galcn(or rather of Dodonaus) it is certainely found by experience, that the water of Honifickles is good againft the foreneffe of the throte and uvula : and with the fame leaues boiled, or the leaues and foures diftilled, are made diuers good medicines againft cankers, and fore mouths, as well in children as elder people, and likcwife tor v!cerations and fcaldings in the priuie parts of man or woman; if there be added to the decostion hercof fome allome or Verdigreace, if the fore require greater clenfing outwardly, prouided alwaies that there be r.o Verdigreace put into the water that mut be iniected into the fccret parts.

\section{С н в. 329. Of fafmine, or Gellemine.}

1 Iafminum album.

VVhite Geffem inc.

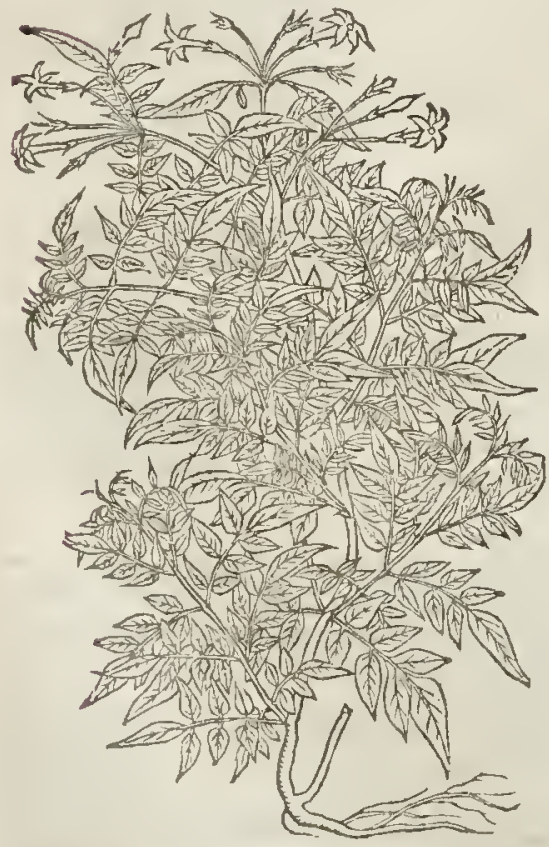

2 Iafmirum Candiflorum maiks. Great white Geilemine.

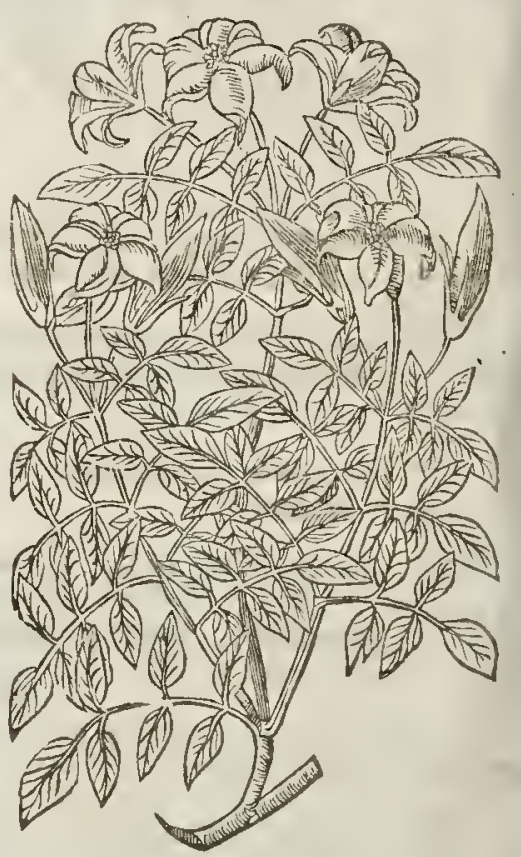

If The Defcription.

A Amine, or Gelfemine, ss of the number of thofe plants which haue need to te fipported for propped v $\mathrm{p}$ and yet notwithnanding of it felfeclafpeth not or windceh his faltic: a- 
3 Iafminum luteums. Yellow Iafmine.

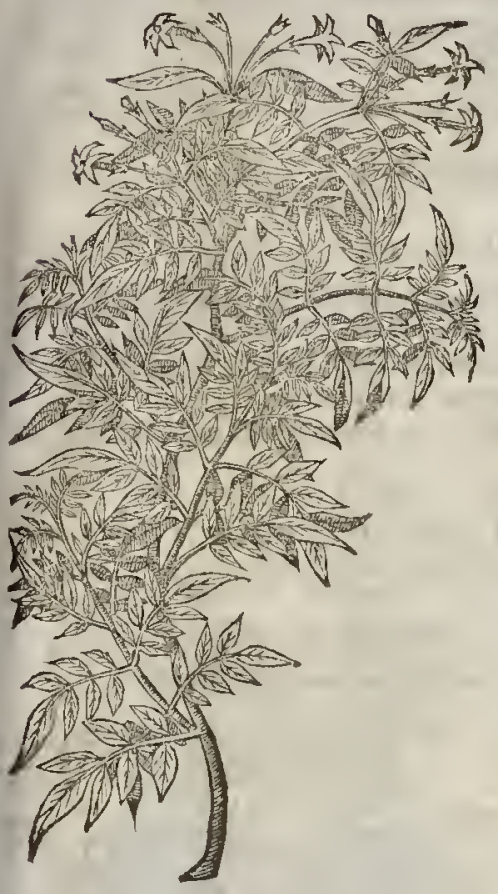

bout fueh things as fand neere vnto it, bat onely leaneth and lyctly voon thofe things that are prepared to futtainc it aboint arbors and banquiting houfes in gardens, by whieh it is ledit vp. The ftalks therof are long, round, branehed, ioinred or kneed, and of a green eolour, hauing with in a white fpangeous pith. The leaues ftand vpon a middle ribbe, fet together by couples lite thofe of the alhe tree, but mueh fmaller, of a deepe greene eolour. The foures grov at the vppermote part of the braneles, ftanding in a fmal tuft, far fet one from another, fivect in finel, of eolour white. The feed is flat and brosd like thofe of Lupines, which icldome come to ripeneffe. The root is tough and tlureddie.

2 Lobel reportetl that he faw in a garden at Bruxels, belonging to a reucend perlon called

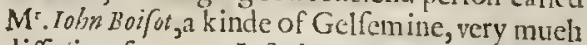
differing from our Iafmine, which lie nourithed in an earthen pot:it grew nor aboue, faith he, to the height of a eubit, diuided into diuers bran. ches, wherupond id grow leates like thofe of the common white Iafmine, but blacker and roundet. The floures to the fhew were moft beautiful, in thape like thofe of the eommon lafmine, but foure times bigger, gaping wide open, white on the vpper fide, and of a bright red on the vnder fide.

3 There is a kind hereof with ycllow flonres: but fome doe deferibe for the yellow Iafmine the fhrubbie Trefoile, ealled of fone Trifolum fruticans : and of others, Poicmonium. But this yel low Iafmine is one, and that is anothet plant, differing from the kindes of Iafmine, as thall be declared in his proper place. The yellow Iafmine differeth not from the common white Gefmine, in leaues, ftalks, nor fafhion of the floures : the oncly differenee is, that this plant bringeth forth yel-
low floures, and the or her white.

4 There is likewife another fort that differeth not from the former in any tefpect,but in the eolour of the floure; for this plant hath floures of a blew colour, and the others not fo, wherein confifteth the difference.

TI The Place.

Gelfemine is fortered in gardens, and is $v$ fed for arbors, and to coner banquetting houfes in gardens : it groweth nor wilde in Eng land that l ean vnderftand of, though $\mathrm{M}^{\mathrm{r}}$. Lyte be of another opi, nion: the white Iafmine is common in moft plaees of England: the teft ate ftrangers, and not feene in thefe parts as yet.

$$
\text { They the Time. }
$$

They bring foth theit pleafant floures in Iuly and Auguet.

$$
\text { T. The Names. }
$$

Among the Arabians Serapiowas the fitt that named Geftemine, Zambach : it is ealled Iafmio num, and Iefeminum, and alfo Gefsminum : in Englin, Ia fmine, Geffermine, and Iefie.

There is in Diofcorides a conpofition of oile of Ia finine, whieh he faith is made in Petfra of the white floures of Violets, wh hich Violets feeme to be none other than the floures of this Geffemine: for $D$ of corides oftentimes hith reekoned faire and elegant floures amongt the Violets; fo that it mun not fecine ftrange that he calleth the floures of Gefiemine Violets, efpecially feeing that the plant it felfewas vnknowne vnto him, as it is enident.

$$
\text { The Temperatsure. }
$$

Geffemine, and efpecially the floures thercof be bot in the beginning of the fecond degree, as scrapio teporterh out of Mc fisc.

The oile which is made of the floures hereof, wa a terth away raw bunors, and is good againt cold $A$ rhenmes; but in thine that are of a hot conftitution it eaufeth head-ache, and the otiermuch fincll thercof naket the nofe to bleed, as the fame Author affirmeth. It is vfed (as Diofcorides w riteth, 
and after him Aetirs) of the Perfians in their banquets for pleafure fake: it is cood to be nure ted after bathes, in thofe bodies that baue need to be fuppled and warmed, bur by reafon of tim it is not much vicd.

The leaues boiled in wine vntill they be foft, and made vp tothe forme of a pultis, and arth the diffolue cold fwellings ,wens, hard lumps, and fuch like outgoings.

$$
\begin{gathered}
\text { Сна Р. 330. Of Peruinkle. } \\
\text { I The Defoription. }
\end{gathered}
$$

I Eruinkle hath flender and long branches trailing vpon the ground, tak ing hold here ane there as it runneth; fmall like to rufhes, with naked or bare fpaces betweene ioint an ioint. The leaues are fmooth, not vnlike to the Bay leafe, but leffer. The foures grom hard by the leaues, fpreading wide open,compofed of fiue fnall blew leaues.

We haue in our London gardens a kinde hereof bearing white floures, which maketh it to differ from the former.

I Vinca Peruincaminor. Peruinkle.

Dunca minor

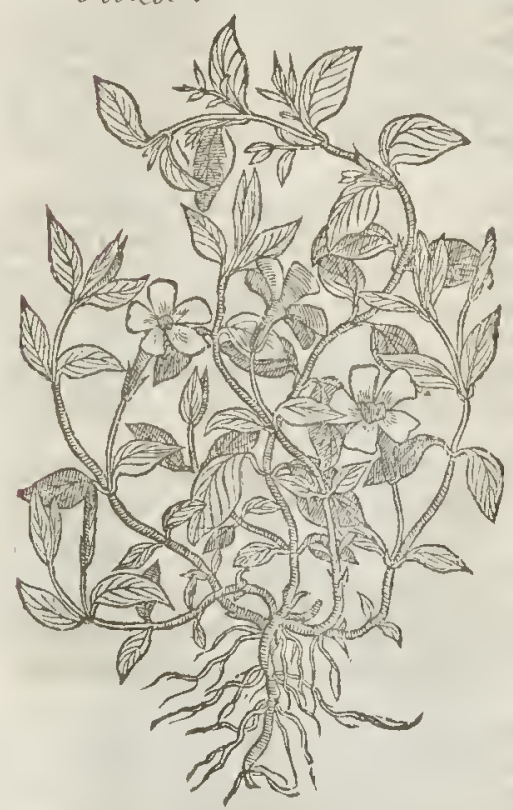

¥ 2 Clcmat is Daphnoides, fore Perninea maior Great Pcruinkle.

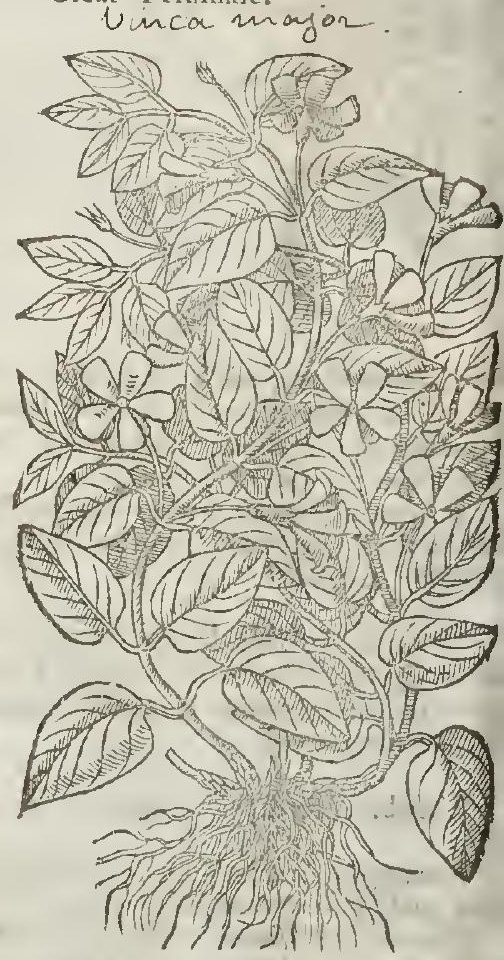

There is anotherwith purple floures; doubling it felfe fomewhat in the middle, with fmaller leates, wherein is the difference.

2 There is another fort, greater than any of the reft, which is called of fome Clemat us Daplinoides, of the fimilitude the leaues haue with thofe of the Bay. The leaues and floures are like thofe of the precedent, but alrogether greater; wherein confifteth the difference.

T The Place.

They grow in moft of our London gardens; they loue a moift and 'fhadow ie place : the branclies remaine alwa ies greene.

The floures of thern do flourinh in March, A prill,and May, and oftentimes later.

$$
\begin{aligned}
& \text { The Time. } \\
& \text { Aprill,and May, and oftentimes later. }
\end{aligned}
$$




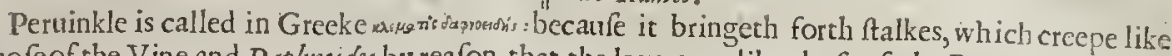
thore of the Vine, and $D$ apphoides by reafon that the leaues are like thofe of the Bay, as aforefaid. pliny calleth it Vinca Peruinca, and Chamedaphne: notwithftanding there is another Chamedaphowe, of which in his place. The fame Author likewife calleth it Centunculus : in High Durch, Jngrum: in

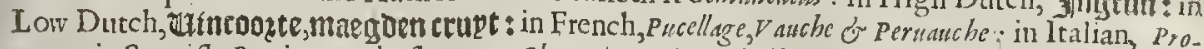
uenca: in Spanifh, Persingua : in thoppes, clematis peruinca : in Englin,Peruinkle, Peruinkle, and Periwinkle.

\section{If The Temperature.}

Peruink le is fomething hot, but wi thin the fccond degree, fomething drie and aftringent:

$$
\text { T The Vertues. }
$$

The leaues boiled in wine and drunken, ftop the laske and bloudic fix.

An handfull of the leates ftamped, and the iuice giuen to drinke in red wirie, ftoppeth the and bloudy flix, f pircing ofbloud twhich neuer faileth in any bodie, cith $\mathbb{B}$ wife ftoppeth the inordinate courfe of the monethly fickneffe.

\section{Cin а. 331. Of Capers.}

I The Kindes.

There be two forts of Capers efpecially, one with broad leanes fharpe pointed : the other with 1 rounder leaues. The Brabanders haue alfo another fort, called Capparis fabago, or Bean Capers.

I Capparisfolio acuto. Sharpe leafed Capers.

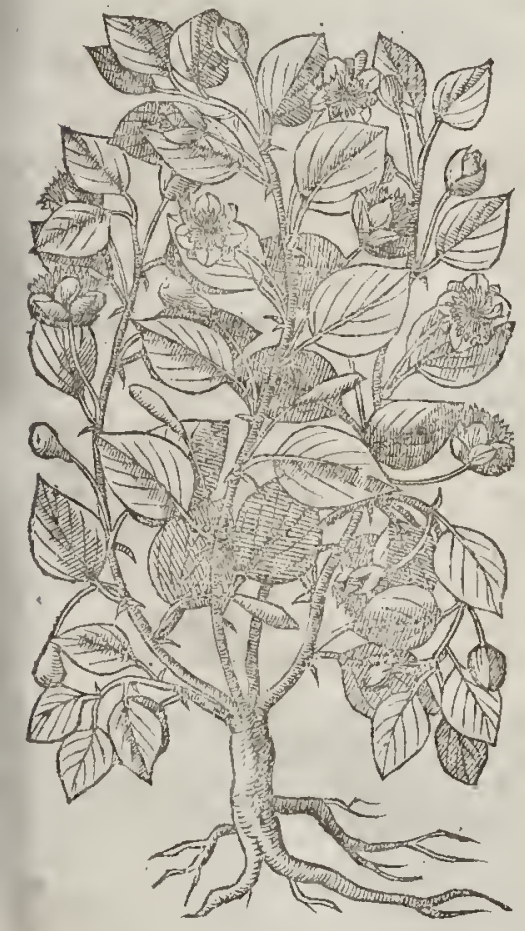

2 Capparis rotundiore folio. Round leafed Capers.

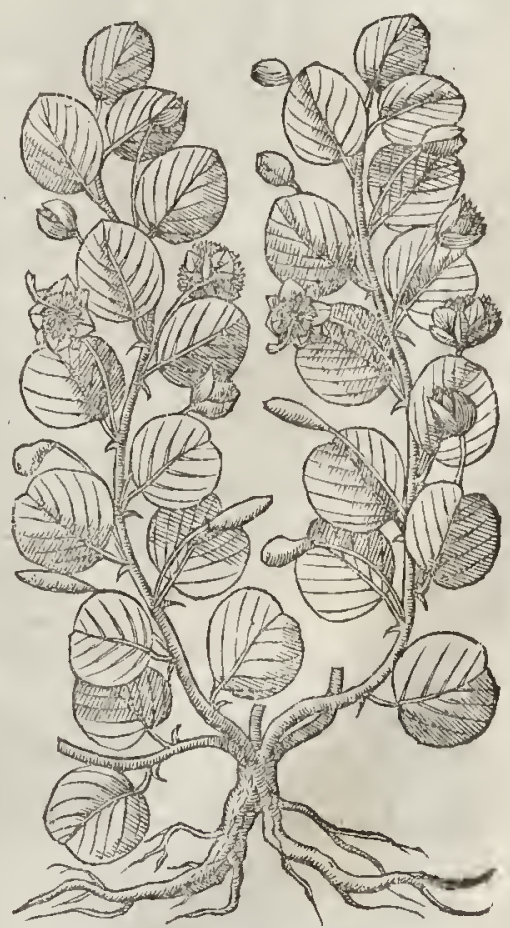

T) The Defcription:

I He Caper is a prickly fhrub, the thoots or branches whereofbe full of tharpe prickly thornes, trailing vpon the ground if they bee not fupported or propped vp: whereupon Ffff $z$ doe 
doe grom leates like rhofe of the Quinec.rree, but rounder; among ft the which come forth long flender foot-talkes, whereon do grow round hnoppes, which doe open or fpread abroad into faire floures, after which eommeth in place long fruit, like to an oliue, and of the fame colour, wherein is eontained flat rough feeds, of a duskic colutr. The root is wooddie, and couered with a thiek bark or rinde, which is much vfed in Phyfielie.

2 . The fecond kinde of Caper is likewife a prickly plant, mueh like the bramble bunh, hauing many flender branches fet full of tharpe prickles. The whole plant traileth vpon rhe place where it groweth, befet with round blackith leaues diforderly plaeed, in, fhape like thofe of Aftrabaec,a, but greater, approching to the formc of Fole-foot : among whieh eommeth forth a fmall and tender naked twig, charged at the end with a fmall knap or bud, whieh openeth it felfe to a fmall ftarlike fourc, of a plealant fiveer fmell, in place whereof comes a fmall fruir, long and round lite the Corncll berric, of a browne eolour. The root is long and wooddie, and eouered with a thieke barke or rinde, which is likewife vfed in medieine.

\section{of The rlace.}

The Caper groweth in Italy, Spaine, and other hot Regions without manuring, in a leane foyle, in rough plaees among ft rubbini, and vpon old walls, as Diofcorides reporteth.

Theophraftus writeth, that it is by nature wild, and refuferh ro be husbanded, yer in thefe our daies diucrs ve to cherifh the fame, and to fet it in dry and ftony places: my felfe at the impreffion hereof, planted fome feeds in the bricke walls of my garden, whieh as yet do fpring and grow green, rhe fieceffe I expeit.

q The Time.

The Caper floureth in Sommer, euen vntill Autumne. The knoppes of rhe floures before they open are rlofe Capers or fauce that wee eat, which are gathered and preferued in piekle or Salt.

$$
\text { T) The Names. }
$$

It is called in Greeke restraer: and in Latinc alfo Cappar is : but properly Cynosbatos, or Canirubus : whieh is alfo taken for the wilde Rofe; it is generally ealled Cappers in moft languages:in Englin, Cappers, Caper,and Capers.

T The Temperature.

Capers, or rhe foures not yet fully growne, be of temperature hot, and of thinne parrs; if rhey be eaten greene, they yceld very lictle nourithment, and much leffe if they be falted. And theiefore they be rather a fauce and nedieine, rhan meat.

$$
\text { I The Vertues. }
$$

A They ftir vp an appetiteto meat; they be good for a moif ftomack, and ftay the watering thereof, and elenfeth aw ay the flegme that cleauerh vnto it. They open the ftoppings of the liuer and milr,with meat ; they are good to be taken of thofe that haue a quartaine Ague, and ill fpleenes. They are eaten boiled (the falt firft wanhed off) with oile and vineger, as other fallads be,and fometimes are boiled with meat.

B The rinde or barke of the root eonfifteth of ditiers faeulties, it heateth, elenfeth, purgeth, cutteth and digefteth, hauing withall a eertaine binding qualitie.

C This barke is of a fingular remedie for hard fpleenes, being outwardly applied, and alfo inwardly taken, and the fame boiled in vineger or oxymel, or being beaten and mixed with other fimples: for after this manner it expellerh rhieke and groffe humours, and conucieth away the fame mixed with bloud, by vrine, and al fo by fiege, whereby the milt or fpleene is helped, and the paine of the huckle bones taken away : moreouer ir bringerh downe rhe defired fickneffe, purgeth and draweth Alegme out of the head, as Galen wrireth.

D The fame barke (as Diofcorides reacheth) dothelenfe old filthie fores, and feoureth away the thieke lips and erufts about the edges, and being ehewed it takerh aw ay the toorh-ache.

E Bcing ftamped with vineger, it feoureth away tetters or Ring-wormes, hard fwellings, and cures the Kings-enill.

F The barke of the roots of Capers is good againft the hardneffe and ftopping of the fpleene, and profiterh much if it be giuen ind-inke to fuch as haue rhe Seiatiea, the Palfie, and thofe that are burften or bruifed by falling from fome high plaee: it doth mightily prouoke vrine, infomuch that if it be vfed ouermuch, or giuen in ton great a quantity, it procureth bloud to come with the vrine. 


\section{Cha r. 332. Of Beane Capers.}

Capparis fabrgo.

Beane Capers.

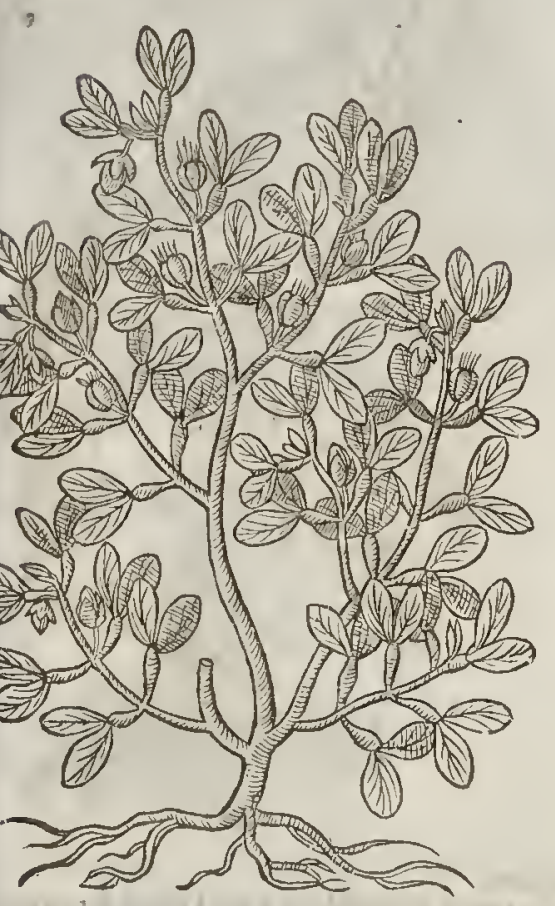

$$
\text { T The Defcription. }
$$

$\mathrm{T}$ His plantwhich the Germanes cal If $3=$ bagn, and Dodon erus fauoring of Dutch, calleth it in hiș laft Edition Catpares Fabago,and properly : Lobcl calletl it Cappar is Legruminofa $:$ betwcen which there is no great difference, who labour to refer th is plant vnto the kindes of Capers, which is but a low and bafe herbe, and not a fhtubbie burfh, as are the true Capers. It bringeth forth fmooth ftaiks tender and branched, whereupon doe grow long tlicke leaties, leffer than thofe of the true Capers, and notvnlike to the leaues of Purflane, comming out of the branches by couples, of a light greene colour. The floures before they be opened are like to thofe of the precedent, but when they be come to matutitic and full ripeneffe they waxe white, with fome yellow chites in the midt: which being paft, there appeare long cods, wherein is conrained fmall flat feed. Tlic root is tender, branching hither and thither.

$$
\text { T The Place. }
$$

It groweth of it felfe in corne frelds of the low Countries, from whence I haue receined feeds for my garden, where they floutith.

$$
\text { घ Therime. }
$$

It floureth when the Caper doth.

\section{T) The 2lames.}

It is called in Latine of the later Herbarifts Capparis fabago: of moft, Capparis Leguminofa: it is thought to be that herbe which Auicen de fetibeth in his 28. chapter, by the name of Ardifrigi: wee mady content our feltes that Capparis fabugo retaine that name fill, and feeke for none other, vnleffe it be for an Englioh name, by which it may be called afrer the Latine, Beane Capet.

Touching the faculties thereof we latie rotherature and Vertues.

$$
\text { T The Temperature and Vertues. }
$$

\section{Cin a. 333, of Swallow-wort.}

\section{If The Defcription.}

I Wallow -wort with white floures hath diucts vp right branclies of a brownith colout, of Sthe height of twocubits, befer with leates not vnlike to thofe of $D$ ulc.umar, ot wooddie Night-fhade, fomewhat long, broad, Tharpc-pointed, of a blackinh greene colour, and Itrong fauour : among which come forth very many fmall white floures ftar-falhion, hanging vpon little flender foot. ftalkes : after which come in place thereof long tharpe pointed cods, thuffed full of a mott perfeet white cotton refembling filke, as well in thew as handling; (our London Gentlewomen hate named it Silken Cinlie) among which is wrapped foft btownin feed. The roots are very many, white, threddic, and of a ftrong faurour.

2 The fecond kinde is oftentimes found with stalkes much longer, climing vpon props or fuch things as ftand neere vnto it, attaining to the height of fure r: fix cubites, ivrapping it felfevpon them with many and fundty foldings : the floures hereof are blacke: the leates, cods, and roois be like thofe of the former.

$$
\text { Ffff } 3
$$


I Asclepias fore albo.

White Swallow-woott.

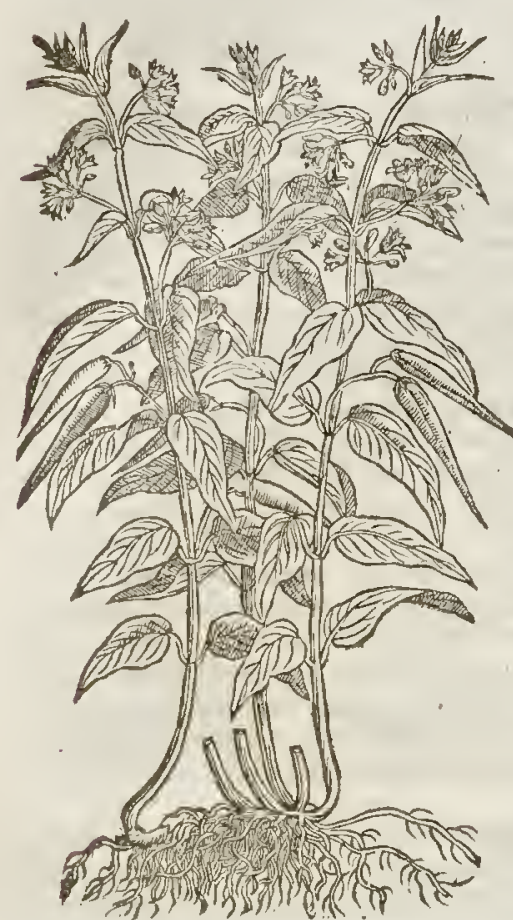

2 Afclepias flore nigro. Blacke Swallow-woort.

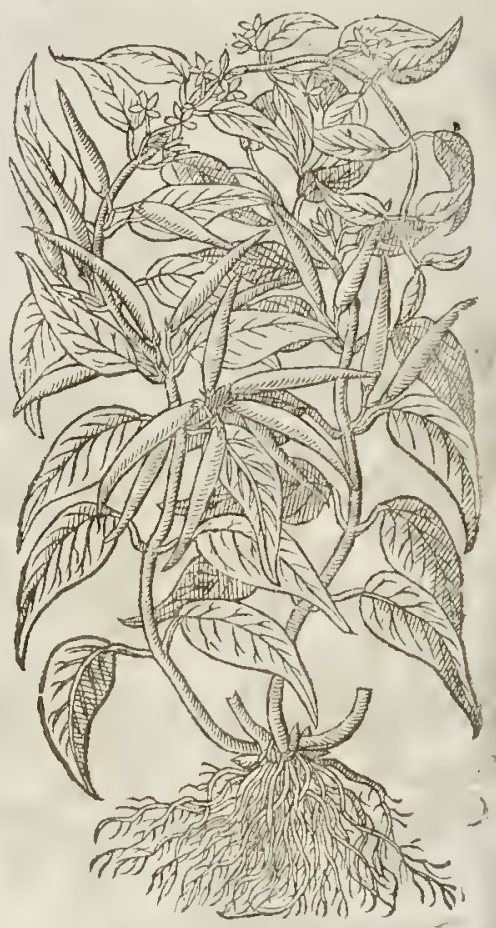

Tr The place.

Both thefe kindes do gtow in my garden, but not wilde in England;yet haue I heard it reported that it groweth in the fields about Nothampron, but as yet I am not certaine of it.

or The Time.

They floure about Iune, in Autumne the downe hangeth our of the cods, and the feed falleth to the ground.

$$
\text { T The N.smes. }
$$

It is calicd of the later Herbatifts Vincotoxicim: of Ruellius, Hederalis: in High Dutch, 5 burItwe motele, that is to fay in Latine Hirundmaria: in Englih, Swallow-woott: of our Gentlewomen it is called Silken Ciflic; Efculaoius (who is faid to be the firft inuenter of Phyficke, whom therefore the Greekes and Gentiles honored as a God)called it after his owne name Afclepias, or Efculapiros herbe, for that he was the firft that wrote thereof and now it is called in thoppes Hirun. din.iria.

Ti The Temperature.

The roots of Swallow-woort are hot and dry; they are thought to be good againft poifon. बा The Vertues.

A Diofcorides writeth, that the roots of Afclepias or Swallow-woort boiled in wine, and the decostion drunkc, are a remedic againt the gripings of the belly, the ftingings of Serpents, and againft deadly poifon, being one of the especialleft lierbes againft the fame.

B Theleaucs boiled and applied in forme of a pultis, cure the euill fores of the paps ot dugs,and matrix, that arc hard to be cured.

\section{C н А. 334. Of Fndian Swallow-swoort.}

\section{T) The Defription}

Meregroweth in that part of Virginia, or Norembega, where our Englim men dwelled (inrending thcre to erect a certaine Colonie) a kinde of Ufclepiss, or Swallow-woort, which 
the Saulages call wifanck ": there rifeth vp from a fingle crooked root one vpright ftalke a foor high, llender,and of a greenifh colour : whereupon do grow faire broad leates tharpe pointed,with many ribs or nertes ruming through the fame like thofe of Ribwort or Plantaine, fet together by couples at certaine diftances. The floures comc forth at the top of the ftalks, which as you are not obferued, by reafon the man that brought the feeds and plants hercof did not regard them. After which, there come in place two cods (1eldome more) Tharpe pointed like thofe of our Swallowwort, but greater, ftuffed fullof a molt pure filke of a fhining white colour: among which filke appeareth a fmall long tongue (which is the feed) refembling the tongue of a bird, or that of the herbecalled Adders tongue. The cods are not only full of filke, but enerie nerue or finew wherewith the leaues be ribbed are likewife moft pure filke; and alfo the pilling of the ftemmes, enen as Nax is torne from his ftalks. Thisconfidered, behold the iuftice of God, that as he hath fhut vp thofe people and nations in infidelity and nakedneffe, fo hath henot as yet given them vinderftanding tucuner their nakedneffe, nor natter wherewith to doe the fame; notwithftanding the carth is coured oner with this filke, which dayly thcy tread vnder their feet, which were fufficient to apparell many kingdornes, if they were carefullly manured and cherifhed.

IVifanck, fine r'incetoxicum Indianum. Indian Swallow-wort.
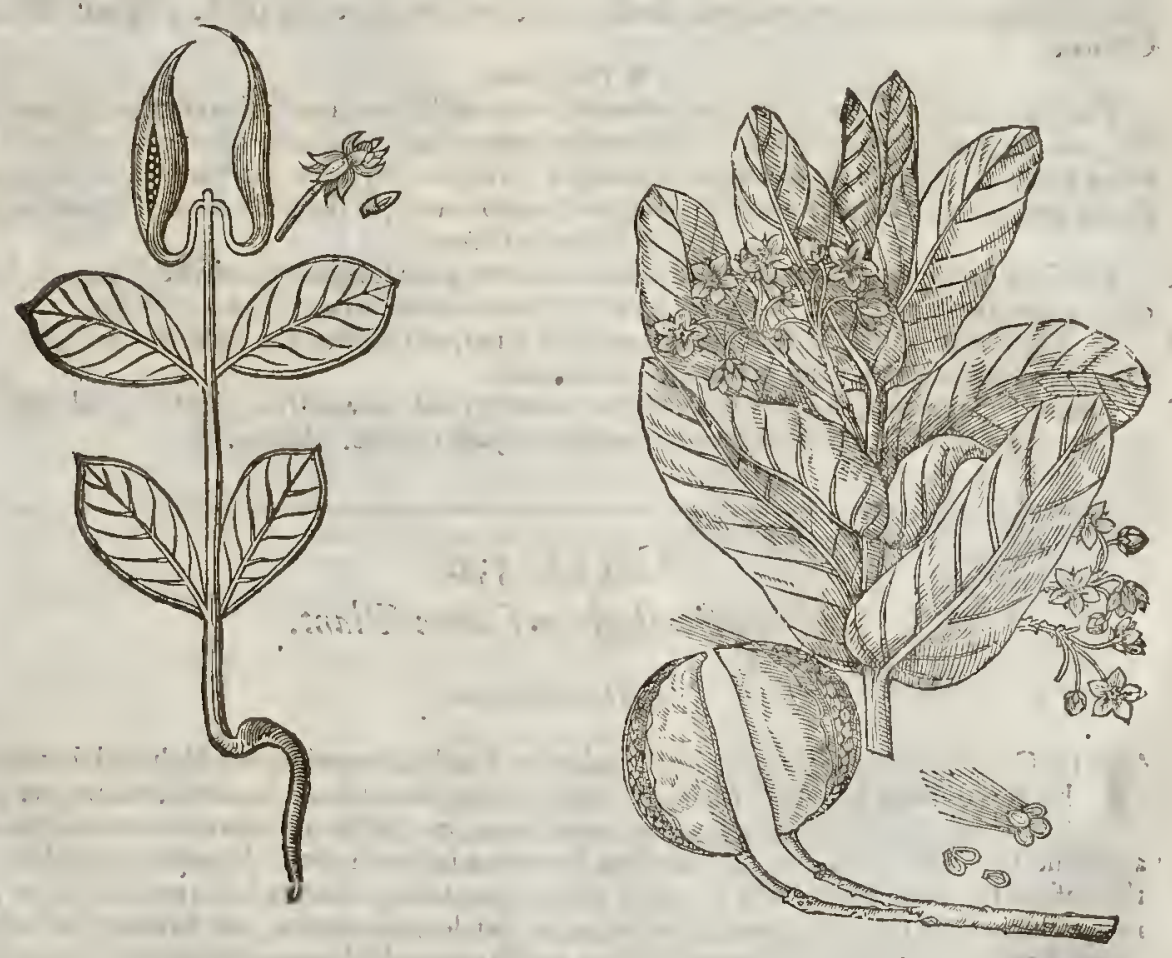

¥ This Plant, which is kept in fome gardens by the name of Virginia Silke Graffe, I take to be the fame, or very like the Beidelfar of Alpinus, and the A pocyrum Syriacsm of Clufaus: at Padua they call it Efula Indica, by reafon of the hot milky iuyce. Baubinus hath very vnfitly named it $L_{a}$ -

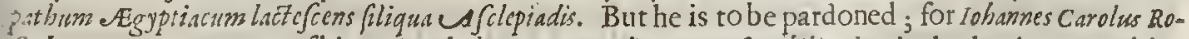
fenbergus, cap.16.p.46. Of his Animad. Jo Exerc. Medice, or Rofa nobilis iatrica, hath taken vpon him the credit and inuention of this abfurd denomination: I may call it abfurd, for that neither any way in thape or qualitic it refembles or participates any thing with a Docke. I haue giuen you the figure of our Authorwitl his title, and that of Cluffus with his : in the former the cods are only well expreft ; in the later the leaues and floures reafonably well, but that they are too few in numher, and fet too far a funder. Vpon the fight of the growing and flouring plant I tooke this defcription: The root is long and creeping; the ftalkes two or three cubits high, fquare, hollow, a finget thicke, and of a light greene colour, fending out towards the top fome few branches: vpon this at

cersaine 
certaine fpaces grow by couples leaues fome halfe foot long, and three inches broad,darke greene on their vpper fides, morewhitifh below, and full of large and eminent veines: at the top of the ftalke and branches it carries moft commonly an hundred or more floures, growing vpon footftalkes fome inch long, all clofe thruft together after the manner of the Hyacinth of Peru at the firft flouring : each floure is thus compofed, firft it hath fiue fmall greene leaues bending backe, which ferue for the cup : then hath it other fiue leaues foure times larger than the former, which bend backe and coner them; and thefe are greene on the vnder fide, and of a pale colour with fome redneffe aboute : then are there fiuc little graines (as I may fo terme them) of a pleafant red colour, and on their outfide like cornes of Millet, but hollow on their infides, with a little thred or chine comming forth of each of them : thefe fue ingirt a fmall head like a button, greenith vinderneath, and whitith aboue. I haue ginen you the figure of one foure by the fide of our Authors figure. The leaues and ftalkes of this plant are very full of a milky iuyce $\ddagger$

\section{If The place.}

It groweth, as before is reliearfed, in the countries of Norembega, now called Virginia by the honourable Knight Sir Walter Raleigh, who hath beftowed great furnmes of money in the difco. uerie thereof; where are divelling at this prefent Englifh men.

\section{T The Time.}

It fpringeth vp, floureth, and flourifheth both Winter and Sommer, as do many or moft of the plants of that countrcy. $\ddagger$ It dies downe with vs etrery Winter and comes vp in the Spring, and floures in Augutt, but neuter bringeth forth the cods with vs, by reafon of the coldneffe of our Climate. $\neq$

\section{T) The Names.}

The filke is vfed of the people of Pomeioc and other of the prouinces adioyning,being parts of Virginia, to coner the fecret parts of maidens that netrer tafted man; as in other places they vfe a white kinde of moffe Wifanck : we haue thought Afclepias Virgiwians, or Vincetoxicum Indianums fit and proper names for it : in Englim, Virginia Swallow-wort, or the Silkc-wort of Norembega.
T The Nature andVertues.

A Wc finde nothing by report, or otherwi fe of our owne knowledge, of his phy ficall vertues, but onely report of the aboundance of moft pure filke wherew ith the whole plant is poffefled.

B $¥$ The leates bearen either crude, or boyled in water, and applied as a pulteffe, are good againft fwellings and paines procceding of a coldcaufe.

C The nilky iuyce, which is very hot, purges violently; and outwardly applied is good againft tetters, to fetch haire off skins, if they be fteeped in it, and the like. Alpinus. $\neq$

$$
\begin{gathered}
\text { ChA P. 335. } \\
\text { Of the Bombafle or. Cutton-Plant. } \\
\text { The Defrription. }
\end{gathered}
$$

\section{$\mathrm{T}$}

He Cotton buth is a low and bafe Plant, hauing fmall ftalkes of a cubit high, and fomtimes higher; dinided from the loweft part to the top into fundry fmall branches, whereupon are fet confufedly or without order a few broad leaues, cut for the moft part into three fcetions, and fometimes more, as Naturc lift to beftow, fomewlrat indented about the edges, not vnlike to the leafe of the Vine, or rather the Veruaine Mallow, but leffer, fofter, and of a grayifh colour :among which come forth the floures, ftanding vpon flender foot-ftalkes, the brimmes or edges whereof are of a yellow colour, the middle part purple: after which appcareth the fruit, round, and of the bigneffe of a Tennife ball, wherein is thruft together a great quantitie of fine white Cotton wooll; among which is wrapped vp blacke feed of the bigneffe of peafen, in thape like the trettles or dung of a cony. The fruit being come to maturitic or ripeneffe, the huske or cod opens it felfe into foure parts or dinifions, and cafteth forth his wooll and feed vpon the ground, if it be not gathered in his time and feafon. The root is fmall and fingle, with few threds anexed thereto,and of a wooddy fub fance, as is all the rent of the plant.

$$
\text { qा The Place. }
$$

It groweth in India, in Arabia, Egypt, and in certaine Iflands of the Mediterranean fea, as $\mathrm{Cy}_{y-}$ prus, Cindy, Malta, Sicilia, and in other prouinces of the continent adiacent. It groweth abour Tripolis ind Aleppo in Syria, from whence the Factor of a worihipfull merchant in London, Mafter $\mathcal{A}$ icholas Lelc beforc remembred, did fend vnto his faid nuafter diuers pounds weight of the feed; whereof fome were conmitted to the earth at the impreffion hereof, the fucceffe we leaue to 
Goßipicum, fiue Xylon.

The Cotton buih.

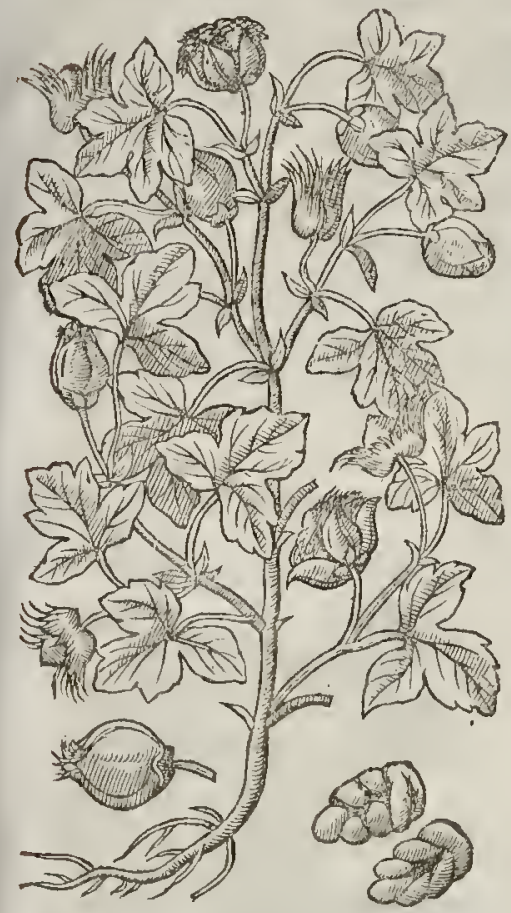

the Lord. Notwithftanding my felfe 3 yeares paft did fow of the feed, which did grow verie frankly, but perifhed before it came to perfection, by reafon of the cold frofts that ouertooke it in the time of flouring.

$$
\text { 9) The Time. }
$$

Cotron feed is fowen in plowed fields in the Spring of the yeare, and reaped and cut down in haruett, euen as corne with vs; and the ground mut be tilled and fowne new againe the nex yeare, and vfed in fuch fort at we do the tillage for corne and grain : for it is a plant of one yere, and perifheth when it hath perfected his fruit, as many orher plants do.

$$
\text { of The Names. }
$$

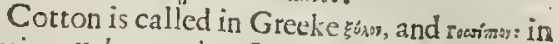
Latine, $x y l u m$, and Goßipium after the Greeke: in fhops; Lamigo, Bombax, and Cotum : in Italian, Bombagia : in Spanifh, Algodon: in high-Dutch, 2Baumbool: in Englith and French, Cotron, Bombafte and Bombaee.

Theophraftus hath made mention hereof in his fourth booke, sap. 9. but without a name; and he faith it is a tree in Tylus which beares wool. Ne1ther is it any maruell if he rook an vnknown fhrub or plant, and that groweth in Countries farre nff, for a tree: feeing allo in this age (in which very many things come to be better knownethan in times paft) the cotton or wooll hereof is ealled of the Germanes (as wee haue faid) Baunt wooll, that is, Wooll of a tree whereas indeed it is rather an herbe or fmall fhn taid) Baunt wooll, that is, Wooll of a tree, Of this Theoplaraftus writeth thus; It is reported that the to be numbred among trees.

forth many trees that beare wooll, it hich reported that the fame Ifland (viz. Tylus) doth bring Pliny writing of the fame, 16 . 19 .rap.

geth forth a fhrub whieh is called $G$ ofsipion, called Xylina. It is (faith he) the plant that or Xylon, and therefore the linnen that is made of it is which the Priefts of Egypt do weare.

\section{The feed of Cotton (according The Tcmperaturc.} hot and dry.

\section{The feed of The Tertues.} teth vp the luft of the body by increafing corghl, and for them that are fhort winded : italfo ftir- $A$

The oyle preffed out of the feed takng naturall fece, wherefore it furpaffeth.

The afhes of the ivooll burned taketh away freckles, fpots, and orher blemifhes of the skin. is Bole Armonicke, and is more refrieth the bleeding of wounds, ved in reftrictiue medicines, To fpeake of the commodities of the than Bole it felfe. and the dayly vfe and benefit we receiue wooll of this plant were fuperfluous, common experience forie to fpeake of the making of Fuftian, Bo thew them. So that it were impertinent to our hiwooll thereof.

\section{ChA P. 336. Of Dogs-barie. \\ iा The Kindes.}

Therebe two kindes of Dogs-banes ; the one a clymbing or clambering plant; the other an
vpright fhrub. 


\section{ब. The Defcription.}

I T Ogs-bane tifeth vp like vnto a fmall hedge burh, vpright and ftraight, vntill it haue attained to a certaine heighth; then doth it elafpe and climewith his tender branclies as do the Bindeweeds, taking hold vpon props ot poles, or whatfoemer ftandeth nex $\mathrm{r}$ to it : whereupon do grow faire broad leaues, fharpe pointed like thofe of the Bay tree, of a deepe greene colour. The floures eome forth at the top of the falkes, eonfilting of fue fmall white leaues : whieh being paft, there fueeeed long cods, fet vpon a flender foot-ftalke by couples, ioyning themfelues together at the extreme point, and likew ife at the ftalke, making of two pieces knit together one entire eod; whieh eod is full of fueh downy matter and feed as that of Afclepias, but more in quantity by reafon the eods are greater; which being dty and ripe, the filken cotton hangetli forth, and by little and little theddeth, vntill the whole be fallen vpon the ground. The whole ulant yeeldeth that yellow ftinking milky iuyee that the other doth, and fometimes it is of a white eolour, according to the climate where it groweth; for the more cold the eountry is, the whiter is the iuyee; and the mote hot, the yellowet. The root is long and fingle, with fome threds anexed thereto.

Periplocarpens anguftifolia.
Climing Dogs-bane.

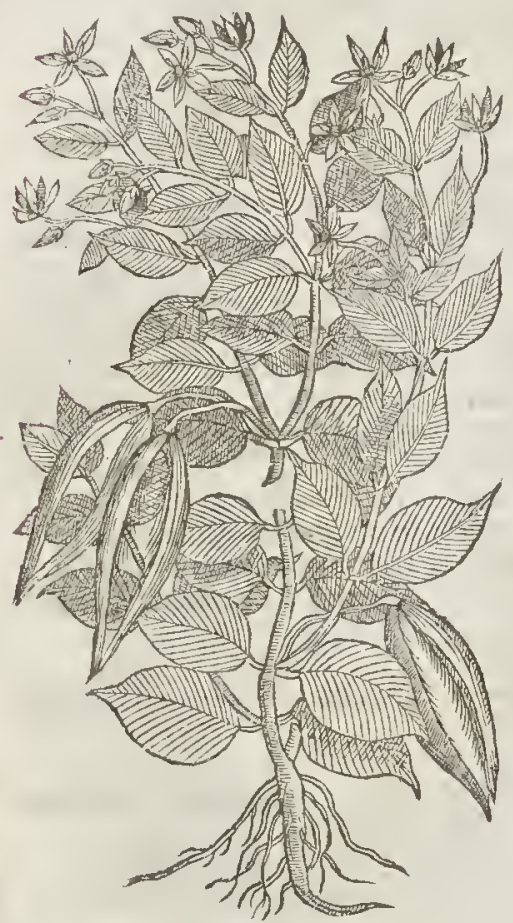

¥ 2 Periplocalatifolia: Broad leafed Dogs-bane.

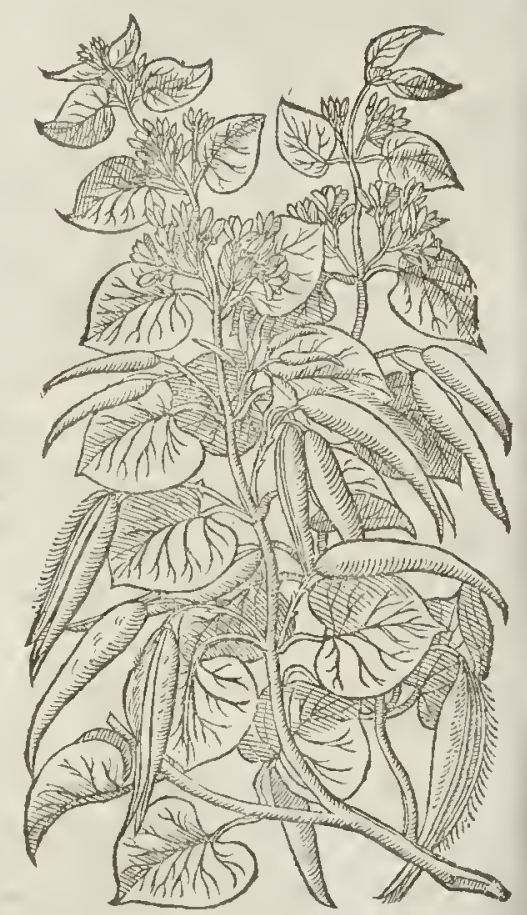

2 There is another Dogs-bane that hath long and flendet ftalkes like thofe of the Vine, but of a browne reddith eolour, wherewith it winderh it felfe about fuch things as ftand neere vnto it, in manner of a Bindweed : whereupon are fet leaues not vnlike to thofe of the Iuy, but not fo much cornered, of a darke greene eolour, and of a ranke fmell being bruifed betweene the fingers, yeelding forth a ftinking yellow milky iuyee when it is fo broken :among ft whieh come forth little white floures, ftanding fatteringly vpon little huskes: after the floures eome long cods, very like vnto afclepias or Swallow-wort, but greater, ftuffed with the like foft downy filke; among which downe is wrapped vp flat blacke feed. The roots are many and threddy, creeping all about within the ground, budding forth new thoots in fundry places, wheteby it greatly ineteafeth. \$1 The Place.

They grow naturally in Syria, and alfo in Italy, as Matthiolus teporteth : my louing friend Iohn Robin Herbarift in Paris did find me plants of both the kinds for my gatden, where they floure and flourifh; but wherher they grow in France, or that he procuted them from fome other region, as yet I haue no certaine knowledge. 
the floures of Lilly conuall : on the other fide when the floures be vaded there come forth round berries, which at the firft are greene, and of a blackecolour tending to blewnefle, and wlien thev be ripe be of the bigneffe of luy berries, of a very fweet and plealant tate. The roor is white and thicke, full ofknobs or ioynts, which in fome places refemble the marke of a feale, whereof I think it tooke the name Sigillum Solomons ; and is fweet at the firft, but afterward of abitter tafte, with fome tharpeneffe.

2 The fecond kinde of Polygonatum doth not much vary from the former, fauing in the leaves, which be narrower, and grow round about the ftalke like a fpur, in fathion like vnto W'oodroofe or red Madder:among the leaules come forth floures like the former, but of a greener white colour: which being paft, there fucceed berries like the former, but of a reddifh colour : which being paft, there fucced berries like the former, but of a reddih colour : the roots are thick and snobby like the former, with fome fibres anexed thereto.

3 Polygonatum latifolium 2. Clufij. Sweet fmelling Solomons Seale.

4 Polygonatumramorum. -ovi allaria Polygonatum Branched Solomons Seale.
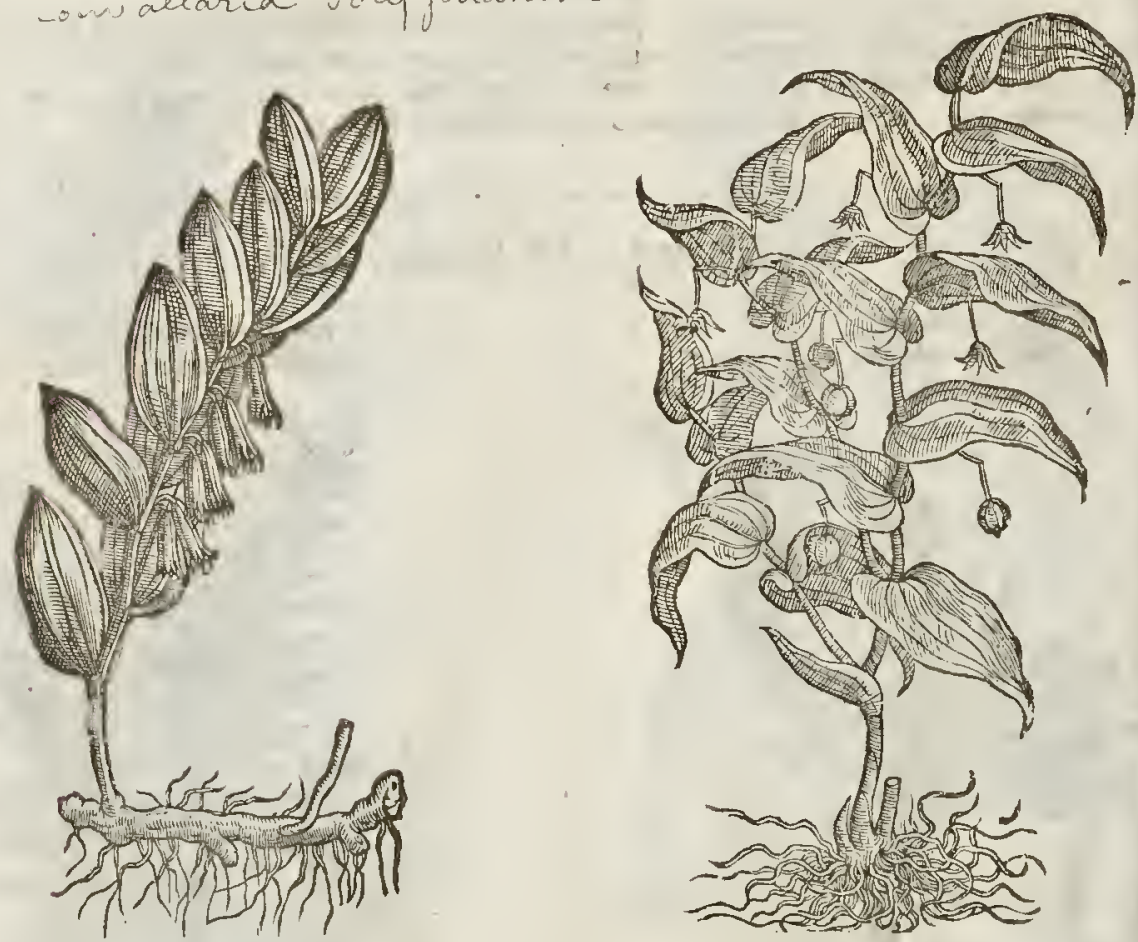

3 The third kinde of Solomons Seale, which Carolus Clufises found in the wooddy mountaines of Leitenberg, aboue Manderftorf, and in many other mountaines beyond the riuer Danubius, efpecially among the ftones, hee fent to London to $\mathrm{Mr}^{\mathrm{r}}$. Garth a worthipfull Gentleman, and one chat greatly delighteth in ftrange plants, who very louingly imparted the fame vnto me. This plant hath ftalkes very like vnto the common Solomons Seale, a foot high, befet with leaues vpon one fide of the ftalke like the firft and common kinde, but larger, and more approching to the bigneffe of the broad leafed Plantaine, the tafte whereof is not very pleafant : from the bofome of which leaues come forth fmall well fmelling greenifh white floures not much vnlike the firft : which being paft, there follow feeds or berries that are at the firft green, but afterward blacke, containing within the fameberries a fmall feed as big as a Vetch, and as hard as a ftone. The roots are like vnto the other of his kinde, yet not fo thicke as the firft.

4 The fourth kind according to my accuunt, but the third of Clufres (which he found alfo in the mountaines a torefaid) groweth a foot high, but feldome a cubit, differing from all the others of lis kinde; for his ftalkes diuide themfelues into fundry otherbranches, whicls are garnifhed with goodly leawes, larger and tharper pointed than any of the reft, which do embrace the falks abont after the manner of Perfoliata or Thorow-wax, yet very like vnto the kindes of Solomons Seale in 
Thew, faue that they are fomewhat hoarie vndcrneath the leatues; which at the firtt arc fircete in tafte, but fomewhat acride or biting towards the later end. From the backe part of che leaus thoot forth fmall long tenderand crooked ftems, bearing at the end little gaping w Lite foures no: nuch vnlike Lilium contullim, fauouring like Hawthorne floures, fpotted on the inner fide with blacke fpots : which being pat, there come forth three connered berries like the narrow leafed So' feale, greene at the firt, and red when thcy be ripe, containing many white hard graines. The roots differ from all the otherkindes, and are like vnto the crambling roots of Thalichrum, which the grat-
uer hath omited in the picture. .

5 Polygonatum anguftifolium ramofum.

Narrow leaued Solomons fealc.

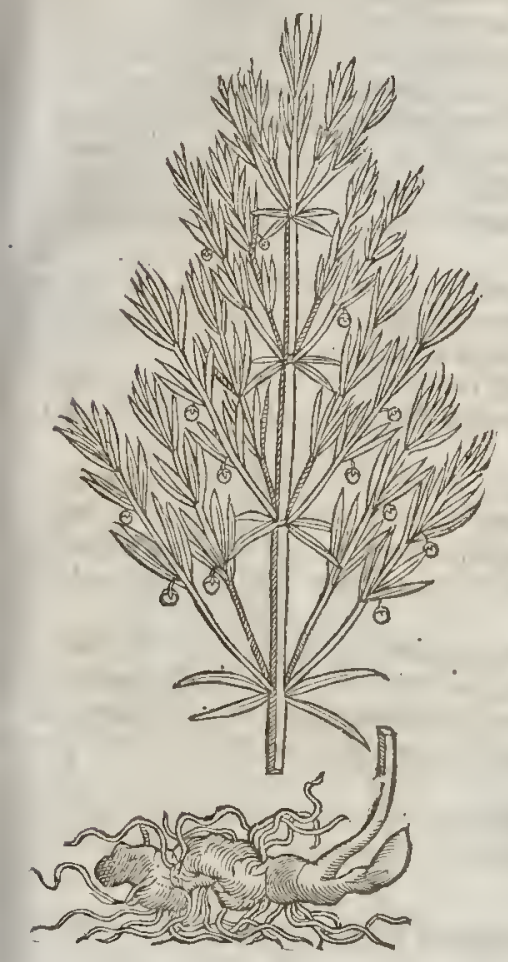

5 This rare fort of Solomons Seale rifes ve from bis tuberous or knobby rot, with a ftraight vpright ftalke ioynted at certannedi. fances, leaung betweene each ioynt a batc and naked falke, fmooth, and of a greenilh colour tending to yellownes; from the which ioynes thrue forth diuers malbranches, with foure narrow leaues fet about like a far or tle herbe Woodroofe : vpon which tender branches are fet about the falkes by cortaine fpaces long narrow leames inclofing the fame round about:among which lcaues cone forth fmall whition floures of little regard. The fruit is fmall, and of a red colour, full of pulpe or meate; among which is concained a hard ftony feed like that of the firf Solomons feale.

¥6 There is kept in our gardens, and faid to bebrought from fome part of $A$ merica another Polygonatum, which fends vp a italk fome foot and morehigh, and it hath leaues long, neruous, and very greene and thining, growing one by another without any order vpon the ftalke, which is fomewhat crefted, crooked, and very greene; bearing at the very top thereof, aboue the higheft leaf $c_{\text {, }}$ ipon littlc foot-ftalks, fome cight or nine little white floures, confifting of fix leaues apiece, which are fucceeded by berries, as in the former. This foures in May, and is vulgarly named Polygonatum Virginianum, or Virginian Solo-
mons feale. $\neq$

T) The Place.

The firfe fort of Solomons fealegrowes naturally wilde in Somerfet-thire, vpon the North fide of a place called Mendip, in the parith of Shepton Mallet : alfo in Kent by a village called Crayford, vpon Rough or Row hill : alfo in Odiam parke in Hamp?hire; in Bradfords wood, necre to a town in Wilthire foure miles from Bathe; in a wood neere to a village called Horflcy, fue miles from Gilford in Surrey, and in diuers other places.

That fort of Solomons feale with broad leaues groweth in certaine woods in Yorkflirecalled Clapdale woods, three miles from a village named Settle.

$$
\text { St The Time. }
$$

They fpring vpin March, and hew their floures in May : the fruit is ripe in September.

$$
\text { T The Names. }
$$

Solomons feale is called in Grecke nouprisay: in Latine likewife Polygonatim, of many, Knees, for fo the Grecke word doth import : in thops, Sigillum Salomonis, and scala cals: in Englifh like-

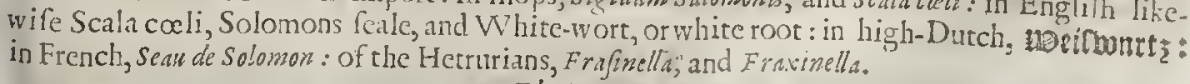

$$
\text { घा The Temperature. }
$$

The roots of Solomons feale, as Galen faith, haucboth a mixt facultic and qualiticalfo: For they liate (faith he) a certaine kinde of atriation orbinding, and biting withall, and likewife a certaine louthfome bitrerneffe, as the fame Author affrmeth: which is not tobs fornd in thofe that do grow in our climate.

$$
\text { Gggg }
$$




\section{The Vertues.}

A

Dioforides writeth, That the roots are exeellent good for to leale or clofe ip greerewounds, being ftamped and laid thereon, whereupon it was ealled Siguthum Salomones, of the lingular vertue that it hath in fealing or healing vp wounds, broken bones, and fueh like. Some haue thought it tooke the name Sigillum of the markes vpon the roots: but the firft reafon feenes to me mose probable.

B. The root of Solomons feale ftamped while it is freh and greene, and applied, takcth away in one night, or two at the moft, any bruife, blacke or blew fpots gotten by falls or womens wilfulneffe, in ftumbling vpon their halty husbands filts, or fueh like.

C. Galen faith, that neither herbe nor root hereof is to be gituen inwardly : but note what experienee lath found out, and of late dayes, efpeeially among the vulgar fort of people in Hamplhire, which Galen, Drofcorides, or any other that hate written of plants have not fo much as dreamed of; which is, That if any of what fex or age foeuer ehanee to hate any bones broken, in what part of their bodies foever ; their refuge is to ftampe the roots hereof,and gite it vnto the patient in ale to drinke: which fodoreth and glues together the bones in very fhort fpaec, and very ftrangely, yea although the bones be but flenderly and vnhand fomely placed and wrapped vp. Moreouer, the faid people do giue it in like manner vnto their cattell, if they ehanee to hatue any bones broken, with good fueceffe; whieh they do alfo ftampe and apply outwardly in manner of a pulteffe, as well vnto themfelues as their eattell.

D The root ftamped and applied in manner of a pulteffe, and layd vpon members that haue been out of ioynt, and newly reftored to their plaecs, driucth away the paine, and knitteth the ioynt very firmely, and taketh away the inflammation, if there chanee to be any.

E The fame famped, and the ityee giuen to drinke with ale or white wine, as aforefaid, or the decoation theteof made in wine, Lelps any inward brufe, difperfeth the congealed and elosted bloud in very thort fpace.

F That which might bewritten of this herbe as touching the knitting of bones, and that truely, would feeme vnto fome ineredible; but common experience teacheth, that in the world there is not to be found another herbe comparable to it for the putpofes aforefaid : and therefore in briefe, if it be for buifes inward the toots muft be ftamped, fome ale or wine put thereto, ftrained, and giuen to drinke.

G It muß be giuen in the fame manner toknir broken bones, againft bruifes, blaek or blew marks gotten by ftripes, falls, or fuch like; againft inflammation, tumors of fwellings that happen vn to members whofe bones are broken, or members out of ioynt, afrer reltaturation: the roots are to be ftamped fmall, and applied pulteffe or plaiferwife, wherewith many great works liatue beene perfotmed beyond eredit.

H Mattbiolus teaeheth, That a water is drawne out of the roots, wherewith the women of Italy ve to feoute their faces from funne-burning, freckles, morphew, or any fuch deformities of the skinne.

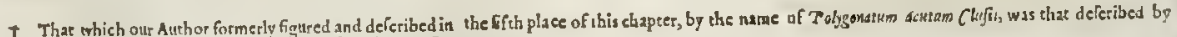
bim in the fourth place; but the figu:e was not fo well exprell.

\section{С на в. 338. Of Knee-bolme, or Butchers broome.}

If The Defcription:

$\mathrm{K}^{\mathrm{N}}$ Nee-holme is a low wooddy plant, hauing diuers fmall branches, or tather ftems, rifing inmediately ftom the ground, of the height of a foot; whereupon are fet many leanes like vnto thofe of the Box tree, or rather of the Myrtle, but tharpe and prieking at the point. The fruit groweth vpon the middle rib of the leafe, greeneat the fitft, and red as Cotall when it is ripe, like thofe of $A$ paragrs, but bigger. The roots are white, branehed, of a meane thickneffe, and full of rough fprouting thoots thrufting forth in other plaees, wheteby it grearly cneteafeth.

The Place.

It groweth plentifully in moft places in England in roughand barren grounds, efpeeially vpon Hampfed heath foure miles from London; in diuers places of Kent, Effex, and Barkfhire, almoft in enery copfe and low wood.

T The Time.

The young and tender fptouts come forth at the fitt of the Spring, whieh are eaten in fonrs 


\section{1 в. 2. Of the Hiftorie of Plants.}

plaees, as the yong tendet ftalkes of A fparagus and fuch like herbes. The berries are ripe in Auguft.

Ruf cus, frue Brufcus.

Knee-holne, or Butchets broome.

Rusins aculeates

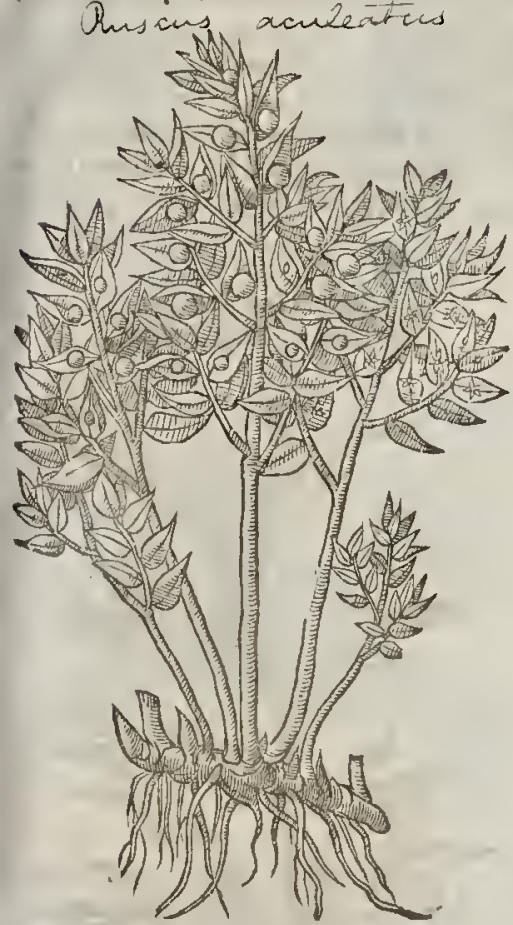

T. The Names.

It is called in Grecke is rpupmin, as though they fhould fay ucuta exyrtus, or pricking Myrtle; and Myrtusfyluefris, or wild Myrtle: in Latine, Rnficum, or Rufcus, in thops, Brufcus: of diuers, Scopa regia, as teftificth Marcellas Exapericus an old 'Writer : in hich Dutch,

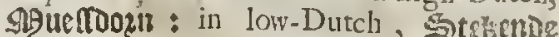
palım: in Italian, Rufco, and Pontogopi: in Spanim, Gilbarbeyra : in Englith, Knce-holme, Knee-huluer, Butchers broome, and Petigree.

There be fome (faith Pliny, li6.25. cap. 13.) that call it O.xymyrfune.

Serapio, cap.288. fuppofeth that Myrtus Agria, or wilde Myrtle, is the fane that Cubebe are: he alledgeth a rearon, becaufe $G$ alcm hath not defcribed Myrtus Agria, or Knee-holme; neither Diofcorides Cubebe. Which as it is a rcafon of no account, fo is it alfo without trutly: for $G$ alen doth no where make mention of Crbebs; and be it that he had, it thould not therefore follow that Knec-holme is Cubeba. Galen fpeaketh of Carpefium, which Auicen in his 137 ehapter maketh to be Crbebse:and that Carpefurm doth much differ from Knecholme, thofe things do euidently declare whieh $G a$ len hath left written hereof in his firt book of of Counterpoyfons. Carpefum (faith hee) is an herbe like in kinde to that which is called Phu, or Setwall,but of greatcr force, and more aromaticall or fpicie. This groweth very plentifully in Sida a city of Pampliilia. Alfo he faith further, that fome of the ftickes of Carpefinu are like to thofe of Cinnamon: there be two kinds thereof, one which is named Lairtium; and another that is called Ponticum. They botlu take their names of the mountaines on which they grow : but Pontict $m$ is the better, which is put into medicines in which the herbe $P$ bu ought to be put. For Carpefum, as I haue faid, is like voto Phu, or Setwall, yet is it ftronger, and yeeldeth a certaine aromaticall qualitie both in tafte and fmell. Thus far Galen. By which it plainly appeareth, that Knec-holne is not Carpeffum, that is to fay, $A$ uncenna his $C u b c b$, as fhall be further declated in the chapter of $C u b e b e$.

Hercin Serapiowas likewife deceiued; who fufpected it to be fuch a like thing ; faying, There be certaine fruits or graines called $C_{u b} b b_{c}$, not fticks : yet do they neither agree with Knee-holm, neither yet were they knowne vnto Galen.

Ifasc in the fecond booke of his Practife doth number it among the graines : and likew ife 7 aliz abbus in the fecond booke of his Practife alfo, num.162. The later Grecians, among whom is Nicolaus Myrepfus, call them Cubebs.

\section{Th Themperature.}

The roots of Kuce-holme, which be chiefely wfed, ate of temperature liot,and meanly dry, with a thinneffe of effenee.

$$
\text { G The Verties. }
$$

The decoetion of the roots of Knee-holme made in wine and drunken, prouoketh vrine, breaketh the ftone, driueth forth graucll and fand, and eafeth thofe that make theirwater with gteat paine.

Dioforides writeth the fame things of the leaues and berries, which morcouer (faith hee) bring $B$ downe the defired ficknefle, helpe the head-ache and the yellow jaundice. Ouer and befides, the roots do ferue to raife up gently tough and groffe flegm which ftieketh in the lungs and cheft, and do coneoct the fame. 


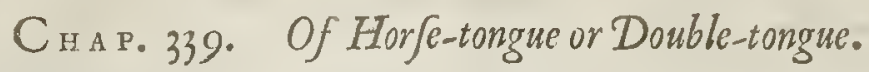

\author{
बा The Defcription.
}

I T Orfe-tongue fendeth fortlu round ftalkes of a fpan long; wherupon are fet long broad 1 and fharpe pointed leates, but not pricking as are thofe of Knee-holme, not vnlike to the leaues of the Bay tree, but leffer; greater than thofe of Knee-holm : out of the middle rib where of commeth forth another leafe, fharpe pointed alfo, but frnall, and of the bigneffe of the leafe of Knee-holme, refembling a little tongue. From the bofome of which two leates commeth forth a berry of the bigneffe of a peafe, of colour red when it is ripe, which is fometimes in a manner all hid vnder the leafe. The root is white, long, and tough, and of a fweet and pleafant finell.

I Hippoglo/fum mas.

The male Horfe-tongue.

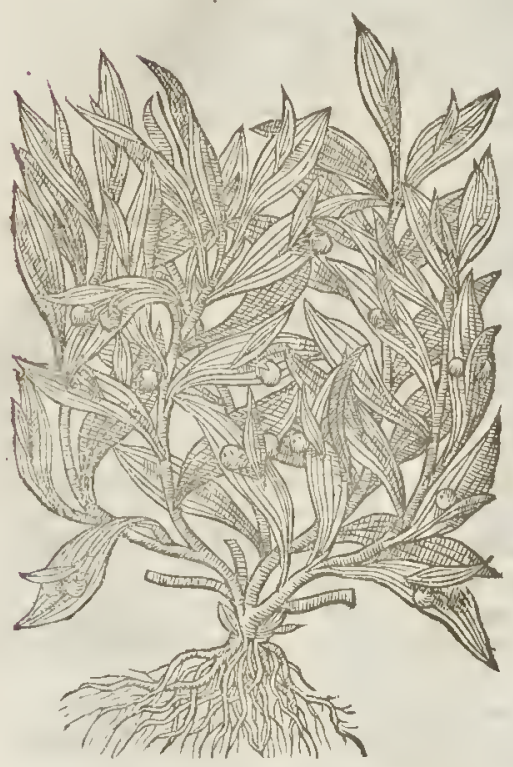

2 Hippoglof

The female Horfe-tongue,

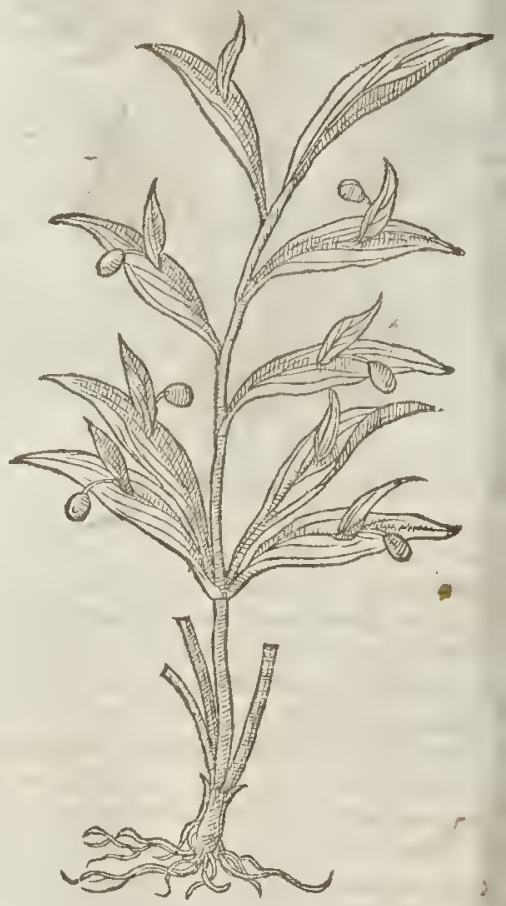

2 The female Horfe-tongue differeth not from the precedent but in ftature and colour of the fruit : it rifeth vp (faith my Aurhor) fourc or fiue handfulls high : the berries come forth of the middle part of the greater leafe, and the fetting on of the leffer, of a feint yellowi $h$ red colour, where in confifteth the difference, $\neq$ This is all one with the former: $\neq$

3 There is likewife anorher fort of Double-tongue fet forth by Matthiolus, which feemes vnto fome not to differ from the firft deferibed or beft known Horfe tongue, being in truth the felf fame plant without any difference:notw it hftanding I haue fet for th the figure, that it may appeare to be the fame, or very little different,and that not to be diftinguirhed: but Matthiolus may not efcape without reprchen fion, who knowing the vntrue tranflation of Rucllius, would fet forth fo falfe a pisture in his Commentarics.

† Our Author here, as in many other places, miftakes himfelfe; for Matthrolus did not fet forth that figurethat our A urhor gines in this place, for Hippoglof fum, but by the title of Lauras Alexandrina altcrat: and it thus differs from the common Horfe-tongue ; it hath fhorter and rounder leates, yet fharpe pointed, and the berries are not coucred with little leaues as in the other, neither lawe they any apparant ftalkes at all, but grow clofe to the leaues, as you may fee them expreft in the figure. \pm 
3 Hippogloffum Matthioli. Italian Horfe-tongue.

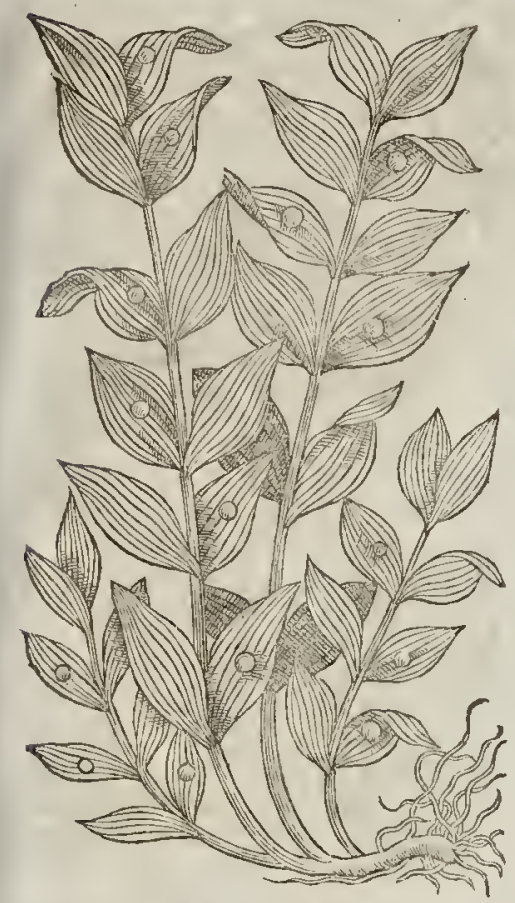

I The Place.

- They are found on the Alps of Liguria, and on the mountaines of Auftria. Bellontws writeth, that they dogrow very plentifully about the hil Athos.

The firft of the Horfe-tongues growes in my garden very plentifully.

$$
\text { ब) The rime. }
$$

That which groweth in my garden foured in the beginning of May : the fruit is ripe in the fall of the leafe.

$$
\text { T) The Names. }
$$

Horfe-tongue is called in Greck in izanawo : of the later Herbarifts, Bonifacia, Vvularia, Bifin gua, Lingun Pagma, and Vintoriola. The fame is alfo named ríqu isoy of Ida a mountaine of Troy, which is called Alcxanders Troy : of forme, $I$ aurus Alexmdrina, or the Bay of Alexandria, and Laurus Idear.

This Hippogloff:um Borzifacia is called in highDutch, Zaptintaratt : in low-Dutch, o ong= hertuladt: in Spanifh, Lengua de Catuallo: in Englifh, Horfe-tongue, Tongne-blade, Doubletongue, and Laurel of Alexandria.

$$
\text { G The'Tempcrature. }
$$

Horfe-tongue is cuidently hor in the fecond degree, and dry in the firf.

$$
\text { T The Vertues. }
$$

The roots of Double-tongue boiled in wine, $A$ and the decoetion drunke, helpeth the ftrangurie, pronoketh vrine, eafeth women that have hard trauell in childe-bearing. It expelleth the fecondine or after-birth. The root beaten to pouder, whereof fix drams ginen in fweetwine, doth helpe the difeafes aforefaid : it bringeth downe the termes, as Diofcorides teacheth. The like writeth $P$ liny alfo: adding further, That it caufeth women to haue fpeedy deliuerance, efpecially if halfe an ounce of the pouder of the root be giuen to drink in a dranglist of fiveet wine.

Eaptifta Sardus doth notably conmend this herb for the difeafes of the mother; by giuing, faith B he, a little fpoonfull of the pouder either of rhe herbe, the fruit, or of the root, to her that is tronbled with the mother, the is thereby forthwith recoucred. He alfowriteth, that the fanc is a fingul ar good medicine for thofe that be burften, if a fpoonfull of the pouder of the root be drunke in the broth of fleth certaine dayes together。

\section{II A s. 340. Of Cucumbers. \\ ब Thc Kindes.}

THere be ditiers forts of Cucumber; fome greater, others leffer; fome of the Garden, fome wilde ; fome of one fahion, and fome of another, as fhall be declared in the following chapters.

IT The Defription.

I THe Cucumber crecepes alongtt vpon the ground all about, with long rough branches whereupon do grow broad rough leates vneuen about the edges: from the bofome whereof come forth crooked clafping tendrels like thofe of the Vine. The Houres fhoot forth betweene the falkes and the leaues, fet vpon tender foot-ftalks compofed of fitie fmall yellow leaues : which being pat, the fritit fuccedeth, long, comered, rough, and fet with ccrtaine bumpes or rifings, greene at the firt, and yellow when they be ripe, wherein is contained a firme and follid pulpe or fubitance tranfparent or thorow-thining, which together with the feed is eaten a little before they be fully ripe. The feeds be white, long, and that:

$$
\text { Gggg } 3
$$


c. Cucumisvulgaris.

Common Cucumber.

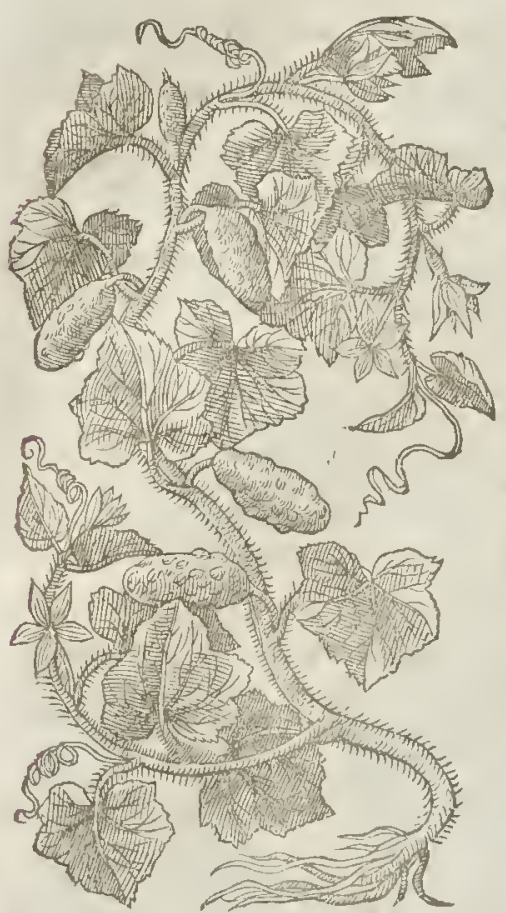

4 Cucumis ex Hipanica femine natus: Spanith Cucumber.

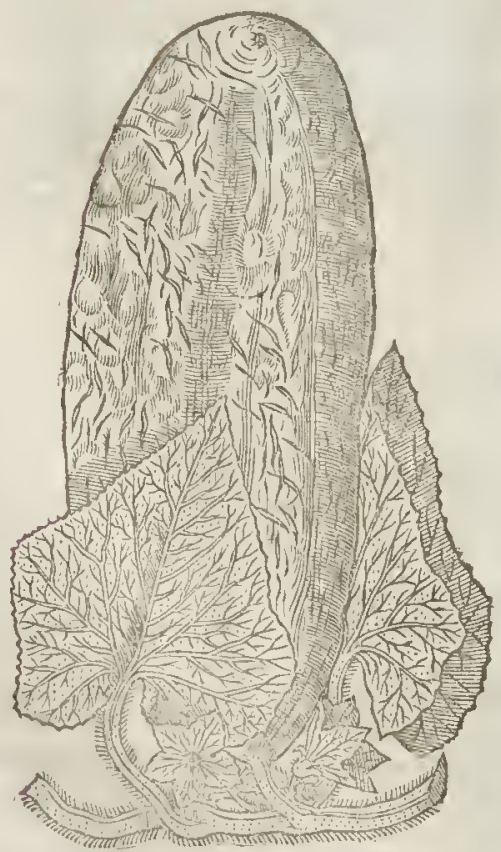

2 Crormis Anguina. Adders Cucumber.

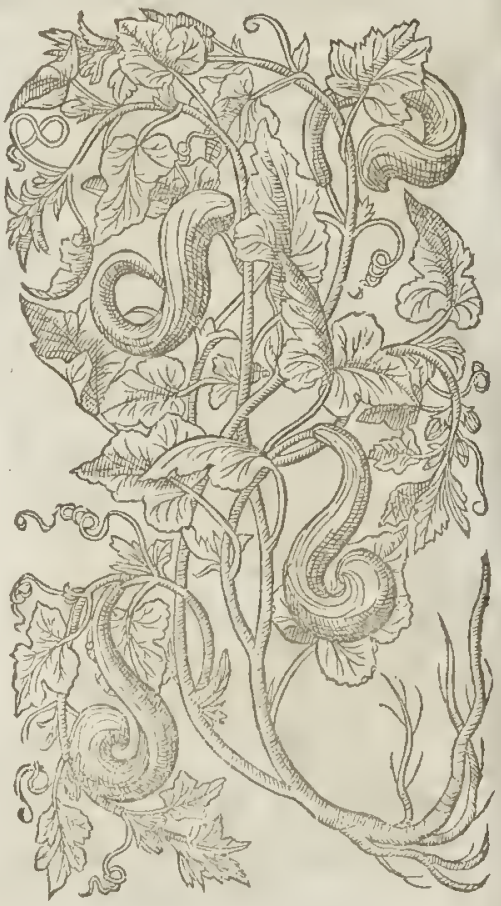

2 There be alfo certaine long cucumbers, which were firft made(as is faid) by art and manuring, which Nature afterwards did preferue: for at the firft, when as the fruit is very little, it is put into fome hollow cane, or other thing made of purpore, in which the cucumber groweth very long, by reafon of that narrow hollowneffe, which being filled vp, the cucumber encreafeth in length. The feeds of this kinde of cucumber being fowne bringeth forth not fuch as were before, but fuch as art hath framed. which of their own growth are found long, and oftentimes very crookedly turned : and thereupon they haue beene called Angrsini, or long Cucumbers.

3 The peare fafhioned Cueumber hath many trailing branches lying flat vpon the ground, rough and prickly ; whereon doe ftand at each ioynt one rough leafe, harpe pointed, and of an oucrworn green colour; among which come forth clafping tendrels, and alfo flender foot-ftalks, whereon do grow yellow ftare-like. floures. The frnit fuccecds, thaped like a peare, as big as a great Wardcn. The roor is threddy.

4 There hath bin not long fince fent out of $S$ pain fome feeds of a rare $\&$ bcautiful cucumber, inco Strausburg a city in Germany, which there brought forth long trailing branches, rough \& hairy, fet wirh very large rough leates thatp pointed, falhioned like vnto the leaues of 
the great Bur-docke,butmore cut in or diuided : amongft which come forth faire yellow floures growing nakedly vpon their tender foot-ftalks : the which beeing paft, the fruit commerh in place, of a foot in length,greene on the fide toward the ground, yellow to the Sun ward, fraked with many pors and lines of diuers colours. The pulpe or meat is hard and faft like that of our Pompion.

of The Place.

Thefe kindes, of Cucumbers are planted in gardens in moft countries of the world.

$$
\text { If The Time. }
$$

According to my promife heretofore made, I haue thought it good and conuenient in this place to fer dorvne not onely the time of fow ing and fetting of Cucumbers, Muske-melons, Citruls, Pom pions, Gourds, and fuch like, but alfo how to fct or fow all manner and kindes of other colde feeds, as alfo what foeuer ftrange feeds are brought vntovs from the Indies, or other hot Regions: widel.

Firft of all in the middeft of A prill or fomewhat fooner(if the weather be any thing temperate) you mall caufe to be made a bed or banke of hot and new horfe dung taken forth of the ttable (and not from the dunghill) of an ell in breadth, and the like in depth or thickneffe, of $w$ hat length you pleafe, according to the quantitic of your feed:the which bank you fhal couer with honps or poles, that you may the more conueniently couer the whole bed or banke with Mats, old painted cloth, ftraw or fuch like, to keepe it fron the iniuric of the cold froftie nights, and not hurt the tluings planted in the bed : then fhall you coner the bed all ouer with the moft fertileft earth finely fifted, lalfe a foot thich, wherein you thall fet or fow your feeds : that being done, calt your ftraw or other couerture ouer the fame; and fo let it reft without looking vpon it, or taking aw ay of your coutering for the fpace of feuen or eight daies at the moft,for commonly in that fpace they will thruft them. felues up nakedly forth of the ground:then muft you caft vpon them in the horteft time of the day fome water that hath ftood in the houfe or in the Sun a day before, becaufe the water fo caft vpon them new ly taken forth of a well or pumpe, will fo chill and coole them being brought and nourithed vp in fuch a hot place, that prefently in one day you haue loft all your labour, I mean not only your feed, but your banke alfo; for in this fpace the great heat of the dung is loft and fpent, keeping in memorie that enery night they muft be couered and opened when the day is warmed with - the Sun beanes : this mult be done fron time to time vntill that the plants haue foure or fix leaues a piece, and that the danger of the cold nights is paft: then muft they be teplanted verie curioufly, with the carth fticking to the plant,as neere as may bevnto the molt fruitfull place, and where the Sun hath moft force in the garden; prouided that vpon the remouing of them you muft couter them with fome Docke leanes or wifpes of itraw, propped vp with forked ftickes, as well to keepe them from the cold of the night, as alfo the heat of the Sun: for they cannot whileft they be young and newly planted, indure neither onermuch cold nor onermuch heat, vntill they are wel rooted in their new place or divelling.

Oftentimes it falleth out that fome feeds are more franker and forwarder than the reft, which. commonly do rife vp very nakedly with long necks not vnlike to the ftalke of a fmall murhrome, of a night old. This naked ftalke muft you couer with the like fine earth euen to the greene leaues, hauing regard to place your banke fo that it may be defended from the North-windes .

Obferue thefe inftrutions diligently and then you fhall not haue caufe to complaine that your feeds were not good, nor of the intemperancie of the climat (by reafon wherof you can get no fruit) although it were in the furtheft parts of the North of Scotland.

$$
\text { 9 T lo Names. }
$$

The Cucumber is named generally Cucumis : in fhops, Cucumer : and is taken for that which the Grecians call owot inpos: in Latine, Cucrmis fativures, or garden Cucumber: in High Dutch, Cutumen: in Italian, Concomero: in Spanith, Cogombro: in French, Concombre: in Low Dutch, Concommeren: in Englinh, Cowcumbers and Cucumbers.

\section{If The Temperature and Vertues.}

All the Cucumbers are of temperature cold and moift in the fecond degree. They putrifie foon $\mathbb{A}$ : in the ftomacke, and yeeld vnto the body a cold and moif nourifhment, and that very little, and the fame not good.

Thofe Cucumbers mut be chofen which are green and not yet ripe: for when they are tipeand $B$ yellow they be vnfit to be eaten.

The feed is cold, but nothing fo much as the fruit. It openeth and elenferh, prouoketh vrine, o. C peneth the ftoppings of the liner, helpeth the cheft and lungs that are inflamed; and being ftamped and outwardly applied in fead of a clenfer, it maketh the skin fmooth and faite,

Cucumber (fait h my Author) taken in meats, is good for the ftomack and other parts troubled D with heat. It yeeldeth not any nourifhment that is good, infomuch as the vnmeafurable vfe thereof filleth the veines with naughty cold humours.

The feed ftamped and made into milkelike as they dowith Almonds, or ftrained with milke or $E$ 
fweet wine and drunke, loofeth the belly gently, and is excellent againft the exulceration of the bladder.

F The fruit cut in pieces or chopped as herbes to the pot and boiled in a fmall pipkin with a piece of mutton, being made into potage with Ote-meale, euen as herb potage are made, whereof a meffe eaten to break-falt, as much to dinner, and the like to fupper; taken in this manner for the fpace of three weckes together wichout intermiffion, doth perfeclly cure all manner of fawce-fiegme and copper faces,red and thining ferie nofes (as red as red Rofes) with pimples,pumples, rubies, and fuch like precious faces,

G Prouided alwaies that during the time of curing you do vfe to wath or bache the face with this liquour following.

H Take a pinte of ftrong white wine vineger,pouder of the roots of Ireos or Orrice three dragtnes, fearced or bolted into moft fine duft, Brimmeftone in fine pouder halfe anounce, Camphire two dragnes, ftamped with two blanched Almondes, foure Oke Apples cut thorow the middle, and the iuice of foure Limons : put then all together in a trong double glaffe, hake them together very ftrongly, fetting the fame in the Sunne for the fpace of ten daies : with which let the face be wathed and bathed daily, fuffering it to dric of it felfe without wiping it away. This doth not only helpe fric faces, but alfo taketh away lentils, fpots, morplew, Sun-burne, and all other deformities of the face.

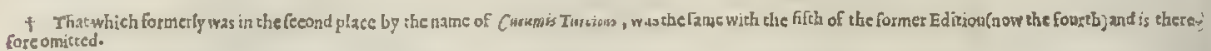

\section{Char. 341: Of Wilde Cucumber.}

Cucumisufinimus.

Wilde Cucumber.

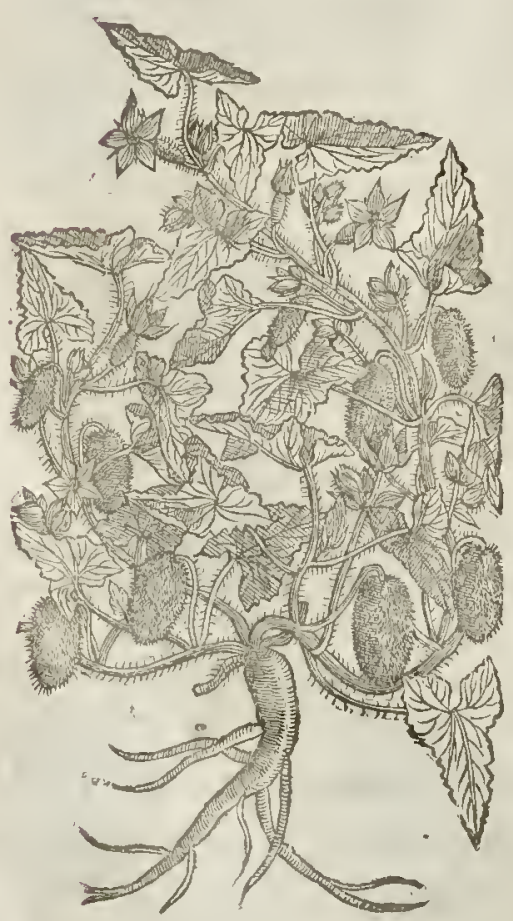

T $T$ lse Deforipion.

Fe wilde Cucumber hath many fat hairie" 1 branches, very rough and full of iuice,creeping or trailing vpon the ground, ${ }_{3}$ werupon are fet very rough leaues, hairy, tharp pointed, \& of an ouerworne grayinh greene colour : from the bofome of which come forth long tender footftalkes : on the ends whereof doe grow imall floures compofed of fiue fmall leaues of a pale yellow colour: after which commeth forth the fruit, of the bignes of the fmalleft pullets egge, but fomewhat longer, verie rough and hairy on the nut fide, and of the colour and fubftance of the ftalkes, wherein is contained very much water and fmalhard blackifh feeds alfo, of the big. neffe of tares; which bcing come to maturitie and ripeneffe, it cafteth or fquirteth forth his water with the feeds, either of it owne accord, or being touched with the moft tender or delicate hand neuer fo gently, and oftentimes ftriketh fo hard againft thofe that touch it (efpecially if it chance to hit againft the face) that the place fnuarteth long after: whereupon of fome it bath been called Noli me tangere, Touch me not. The root is thicke, white and longlafting. The Place.

It is found in moft of the hot countrics a: suong rubbith, grauell, \& other vntilled places: it is planted in gardens in the Low-countries; and being once planted, faith Dodoneus, it eafily commeth vp againe many yeares after (which is true:) and yet faith he further, that it doth not fpring againe of the root, but of the feeds fpirted or caf-about:which may likewife be true where he hath obferued it, but in my garden it is orherwife, for as I faid beforc, the root is long lafting, and continueth from yeare to yeare.

The 
-1 The Time.

It fpringeth vp in May, it floureth and is ripe in Autumne, and is to be gathered at the fame time, to make that excellent compofition called Elateritum.

\section{QT The Nomes.}

It is called in Greeke oixus à eros: in Latine, Agreflis, and Erraticus Cucumis: in hoppes, Cucumer afminus : in Italian, Cocomero. faluatico : in Spanih, Cogumbrillo amargo: in Englifh, wilde Cueumber, pirting Cucumbers, and touch me riot: in French, Concombres farvages.

9f The Temperature.

The leates of wilde Cucumbers, roots, and their rindes as they are bitter in tafte, fo they be likewife hot and elenfing. The inice is hot in the feeond degree, as Galer witne fleth, and of thin parts. It cleufech and waftech away. : i, 20 ; The Vertues.

The iuice ealted flut eritu doth purge forth choler, flegme, and waterie humours, and that with $A$ forec, and not onely by fiege, put fometimes alfo by voinit. The quantity that is to be tiken at one time is from fute grains to ten,according to the ftrength $B$
of the patient.

The iuice dried or hardened, and the quantitic of halfe a feruple taken, dritueth forth by fiege ${ }_{6}$ groffe flegme, cholericke humours, and preuaileth mightily againit the dropfie, and morneffe of eies.

The fame drawne vp into the nolthrils mixed with a little mill, takcth away the rednefle, of the $D$

The iuice of the root doth alfo purge flegme, cholericke and waterin humours, and is good for $E$ the dropfe:but not of fuch foree as Elaterium, which is made of the itrice of the fruit : the making Whereof commend to the learned and curious A pothecaries: among which number N: :William hath more exally performed the fame than any other what foeter that I hauc had know of it, and

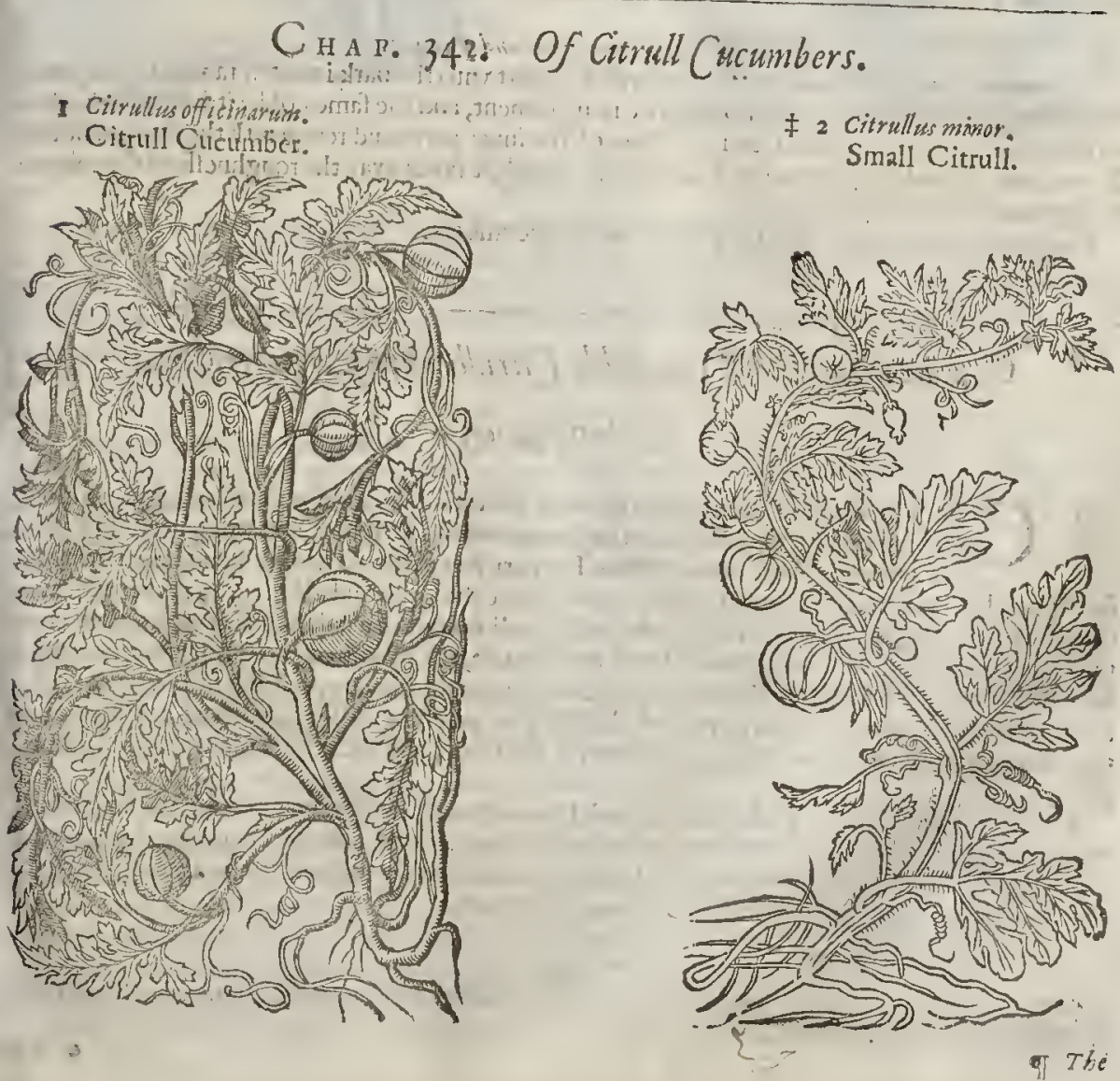


ब The Defoription.

1 THe Citrull Cucumber hath many long, flexible, and tender ftalkes trailing vpon the

ground, branched like vnto the Vine, fet with cercaine great leates dceply cut,and very much iagged : among which come forth long clufping tendrels, and alfo tender footflalkes, on the ends whereof dogrow Houres of a gold yellow colour : the fruit is fomewhat round, ftraked ot ribbed w itl certaine deepe furrowes a long th the fame, of a green eolour aboue, and vnderneath on that fide that lyeth von the ground fomething whitc: the outward skin whereof is vety fmooth; the meat within is iudiffercut hard, more like to that of the Pompion than of the Cucumber or Muske melon: the pulpe wherein the feed licth, is fpungic, and of a llimic fubftance : the feed is long, flat, and greater than tho fe of the Cucumbers : the fhell or outward barke is blackifh, fometimes of an ouctivorne reddith colour. The fruit of the Citrull dorh not fo cafily rot of puttifie as doth the Melon, which being gathered in a faire dry day may be kept a long time, efpecially being couered ina heape of wheat, as Mattholus fatl, but according to my practife you may keepe them much longer and better in a lieape of dry fand.

2 The feeond kinde of Citrull differeth not from the former, faing that it is altogether lef. fer, and the leaucs are not fo deepely eut or iagged, wherein confifteth the difference. oT The Place and Time.

(T. The Citrull profpereth beft in hot Regions, as in Sicilia, A pulia ${ }_{3}$ Calabria, and Syria, about Alepo and Tripolis. We haue many times fown the feeds, and diligently obferued the order preferi- bed in planting of Cueumbers.

The latter Herbarifts do call it Anguris : in hoppes, Citrullus, and Cutumus Citrillus : in Englifl, Citruls, and Cucumber Citruls, and the leed is knowne by the name of Semen Citrulli: or Citrull feed.But if Cucumis Citrullus, be fo called of the yellow colour of the Citton, then is the common Cucumber properly Cucumis Citrullus : which is knowne vnto all to be conttaric.

\section{9) The Temperature and Vertues.}

A The meat or pulpe of Cucumer Citrull which is next vnto the bark is eaten raw, but more commonly boiled : it yeeldeth to the bodie little nourifhment, and the fame cold : it ingendreth a waterinbloud, mitigateth the extremity of heat of the inner parts, and tempereth the fhatpneffe and feruent heat of choler: being rav and held in the mouth, it takes away the toughneffe of the tongue in Agues, and quencheth thirft.

B The feedsare of the like facultic with thofe of Cucumbets.

\section{Cin s. 343. Of the wilde Citrull called Colocynthis. \\ I The Defription.}

1 Oloyuntinta hath beene taken of many to be a kinde of the wild Gourd, it lieth along creeping on the ground as doe the Cucumbers and Melons,comming neereft of all to that which in thofe daies of fome Herbarifts is called Citrull Cucumber:it bringeth fotth vpon his long hranches fmal erooked tendrels like the Vine, and alfo very great broad leaucs deepely eut or iagged : among which come forth fmall floures of a pale yellow colour; then commeth the fruit round as a bowle; coucred with a thin rinde, of a yellow colout when it is tipe, which when it is pilled or pared off, the white pulpe or fpungie fubftance appeareth full of feedes, of a white or elfe an ouerwotne browne colour; the fruit fo pated ot pilled, is dtyed for medicine; the which is molt extreame bitter, and likewife the feede, and the whole plant it felfe in all his parts.

2 The fecond kinde of Coloquintida hath likew ife many long btanches and clafping tendrels, wherew ith it taketh bold of fuch things as are necre vnto it. It bringeth forth the like leaues, but not fo much iagged. The floures are finall and yellow: the ftuit is fanhioned like a peare, and theo. thet fort round, wherein the efpeciall difference confifteth.

$$
\text { 9 The Place. }
$$

Cotoquintida is fowne and commeth to perfection in hot regions, but fcldome or neuer in thefe Northerly and cold countries. 
Bdellimm, of thefe, Maftich hath a manifeft binding qualitie : but tough and clammie things are much better, which hate no altrict ion at all in rhem, or verv little.

D For by fuch binding or aftringent things, violent nedicines being reftrained and brideled, do af tenward work their operation with nore violence and trouble : but tuch as hate not binding rliugs mixed w ith them docafil ierworke, and with leffer paine, as be rhofe pils which khafs in his ninrh booke of Almanzor calleth illia : which are compounded of Coloquintida and Scamony, two of the ftrongeftmedicines rhar are; and of a third called gum sagapene, which through his clammineffe doth as it weredaube the intrails and guts,aud defend rliem from the harme that ruight liate come of either of them.

E Thewhich compofition, alrhough it be wonderfull frong, and not to be ved w itlout very great necefitic vrge thereunto, doth notwithfanding eafily purge, and without any great trouble, and with lefier torment than molt of the mildeftand gentleft medicins which hate Maftich and other things mixed with them thar are aftringent.

F And for this caufe it is very like that Galen in his firft booke of Medicines, according to the places affected, would not fuffer Maftich and Bdellium to be in the pilles, which are furnamed Corhis: the which notw ith1tanding his Schoolemafter Quint t:s was alfo woont before to adde vnro the fame.

G But Coloquintida is not onely good for purgations, in which it is a remedie for the diffineffeor the turning ficknefe, the megrim, continuall head-ache, the Apoplexie, the falling fichneffe, the ftuffing of the lungs, the gnawings and gripings of the guts and intrailes, and other moft dangerous difeafes, but alfo it dotls outwardly worke his operarions, which are not altogether to be reiceded.

H Common oile wherein the fame is boiled, is good againft the finging in the cares, and deafenes: the fame killets and driureth forth all manner of wormes of the belly, and doth of tentimes prouoke to the ftoole, if the nauell and bottome of rhe belly be therewirh annointed.

I Being boiled invineger, and the teeth wathed therewith, it is a remedie for the tooth-ache, as Mefues reacheth.

$\mathrm{K}$. The feed is very profitable to keepe and preferue dead bodies with; efpecially if Aloes and Myrrhe be mised wirh it.

L The white pulpe or fpungious pith taken in the weight of a fcruple openeth the belly mightily, and purgeth grofle flegne, and cho!erucke humors.

MI It hath the like force if it be boiled and laid to infufe in wine nr ale, and giuen to drinke.

$N$ Being taken after the fame manner it profireth the difeafes tefore remembred, that is, the A poplexie, falling ficknefie, giddineffe of the head, the collicke, loof eneffe of finewes, and places out of ioint, and all difeafes proceeding of cold.

O For the fame purpofes it may be vfed in clifters.

P The fame boiled in oile, and applied with cotton or wooll, taketh away the pain of the Hemorrhoides.

Q The decoction made in wine, and vfed as a fomentation or bathe, bringeth downe the defired ficknefle.

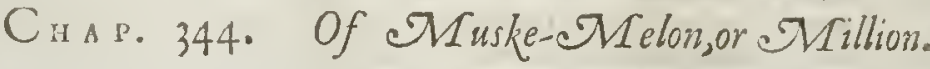

\section{The Kindes.}

Here be diuers forts of Melons found at this day, differing very notably in thape and propor1 rion, as alfo in tafte, according to the climate and countrie where they grow : but of the Antients there was onely one and nomore, which is that Melopepocalled of Galen, Cucumis, or Galens Cucumber : notw irhftandiug fome hate comprehended the Muske-Melons vnder the kindes of $\mathrm{Ci}$ truls, wherein they haue greatly erred : for doubtleffe the Muske-Melon is a kinde of Cucumber, according to the beft approued Authors.

\section{T The Defcription.}

I Hat which the later Herbarifts do call Muske-Melons is like to the common Cucumber in ftalks, lying flat vpon-the ground, long, branched, and rough. The leaues be much alike, yet are they leffer, rounder, and not fo cornered: the foures in like manner bee yellow:the fruit is bigger, at the firt fomwhat bairy, fom thing long, now and then fomwhat ramd; oftentimes greater, and many times leffer : the barke or rinde is of an ouerworne ruffet greene colours 


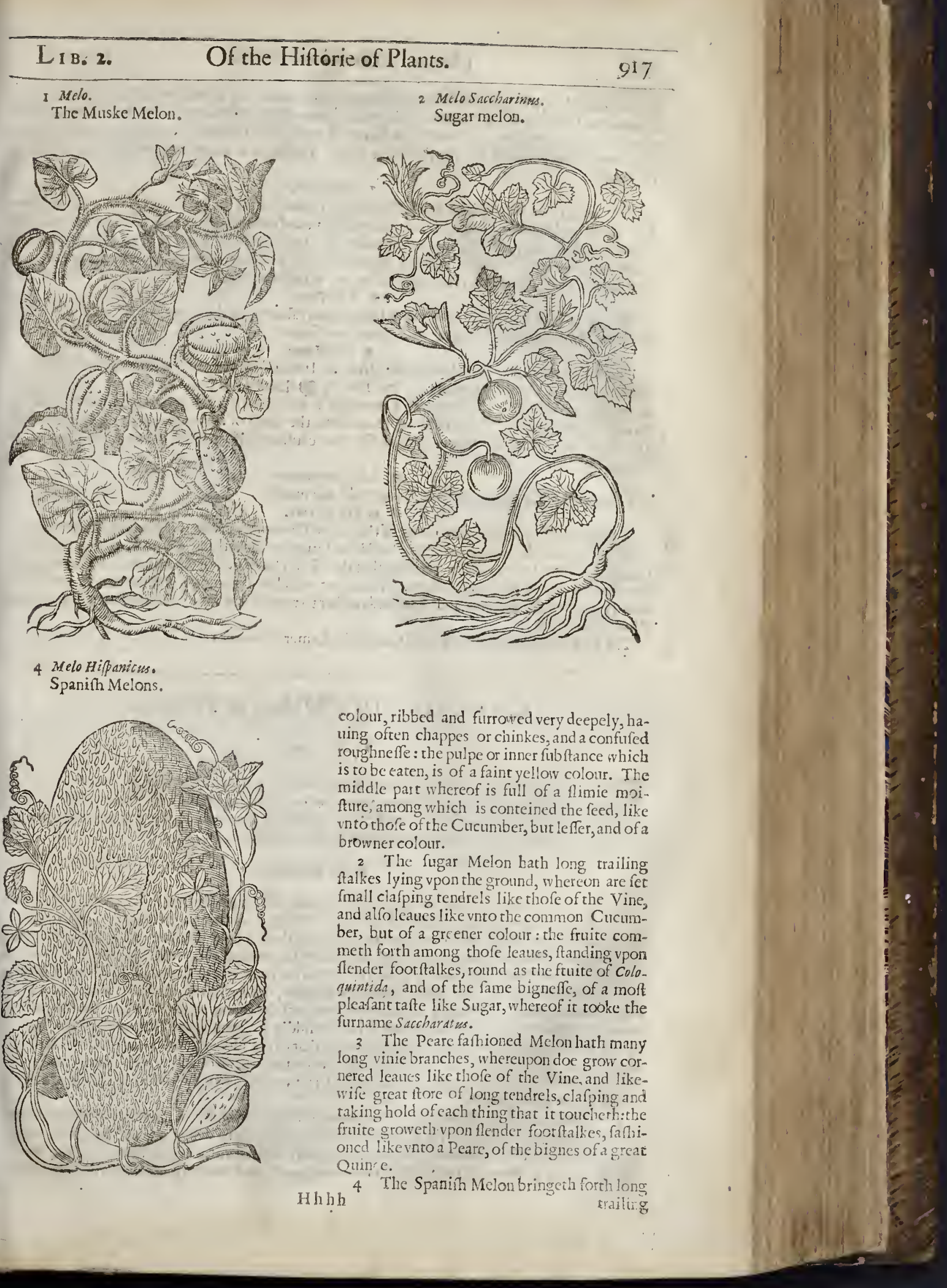


trailing branches, whereon are forbroad leaues flightly indented about the edces, not diuided at all, as are all the reft of the Melons. The fruire groweth neere vnto the ftalke, like vnto the conmon Pompion, very long, not crelted or furrowed at all, bur fpotted with very many fuch markes as are on the backefide of rhe Harts-tongue leafe. The pulpe or meate is not fo pleafing in tafte as the other.

\section{9t The Place.}

They delight in hot regions, notwirhftanding I haue feen at the Queenes houfe ar Saint Iames very many of the firft fort ripe, rbrough the diligent and curious nourithing of them by a sbilfull Genteman the keeper of the faid houfe, called $\mathrm{M}^{\mathrm{r}}$.Fowle, and in orher places neere rnto rhe right Honorable the Lord of Suffex houfe, of Bermondfey by London, where from yeere to yeere there is very great plenry, efpecially if the weather be any rhing remperate.

I The Time.

They are fer or fowne in Aprill as I haue already thewne in the chapter of Cucumbets : their fruite is ripe in rhe end of Alguft, and fometimes fooner.

\section{- The Names.}

The Muske Melon is called in Latine, Melo : in Italian, Mellone : in Spanifh, Melon : in French, Melons : in High Dutch, 99 elaun : in Iow Dutch, 9 eloenen : in Grecke, unas, which doth fignifie

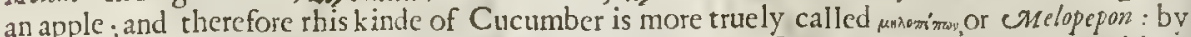
reafon that Pcpo hath the fmell of an apple, whereto the fmell of this fruit is like; hauing withail the fmell as it were of Muske : which for that eaufe are alfo named Melones Mufthatellini, or Muske Melons.

The meate of the Muske Melon, is very cold and moift.
There.

$$
\text { T The Vertues. }
$$

A It is harder of digention than is any of the reft of Cuembers : and if it remaine long in the ftomacke is putrifierl, and is occafion of peftilenr feuers : which thing alfo wëtizes wirnefferh in the firft booke of his Tetrabibles, wriring rhar the vfe of Cucumeres, or Cucumbers, breedeth pefti. lent feauers; for he alfo taketh Cucumis to be that which is eommonly called a Melon : which is vfually caten of the Italians and Spaniards rather to reprefie the rage of $l u f t$, than for any other Phy ficall vertue.

The feed is of like operation with that of rhe former Cucumbcr.

$$
\begin{gathered}
\text { ChA 345. Of Melons, or Pompions. } \\
\text { T The Kindes. }
\end{gathered}
$$

$\mathrm{T}$ Here be found diters kindes of Pompions which differ either in bigneffe or forme : it fhall be rherefore fufficient to defcribe fome one or two of them, and referre the reft vnco the view of the figures, which mont liucly do expreffe their differences; cofpec ially becaufe this volume waxeth great, the defeription of no moment, and I luaften to an end.

$$
\text { T The Defoription. }
$$

I The great Pompion bringeth forth thicke and rough prickly falkes, which with their clafping tendrells take hold vpon fuch things as are neere vnto rhem, as poles, arhours, pales, and ledges, which vnleffe they were neere vnto them would creepe along vpon rhe ground; rhe leaues bewilde, and great, very rough, and cut with certaine deepe gafhes, nicked alfo on the edges like a faw; rhe floures be very great like vnto a bell eup, of a yellow colour like gold, hauing fure comers fand ing out like teeth: rhe fruite is great, thicke, round, fet with rhicke ribbes, like edges fticking forth. The pulpe or meate whercof which is nexr vnder the rinde is white, and of a meane hardneffe : the pirh or fubfance in the middle is fpungie, and flimie : the feed is grear, broad, flat, fomerhing white, much greater rhan that of rhe Cucumber, otherwife nor differing at all in forme. The colour of rlue barke or rinde is of tentines of an obfcure greene, fometimes gray. The rinde of the greene Pompion is harder, and as it were of a woody fubitance : the rinde of the gray is fofter and renderer.

2 The fecond kinde of Melons or Pompions is like vnto rhe former in ftalkes and leaues, and alfo in clafping rendrels : but the gathes of the leaues are nor fo deepe, and the ftalkes be tenderer: the floures are in like manner yellow, gaping, and cornered at the rop, as be rlofe of the former: but the fruite is fomewhat rounder; fometimes greater, and many times leffer: and oftentimes 
3 Pepomaximus compreffus. The great flat bottommed Pompion.

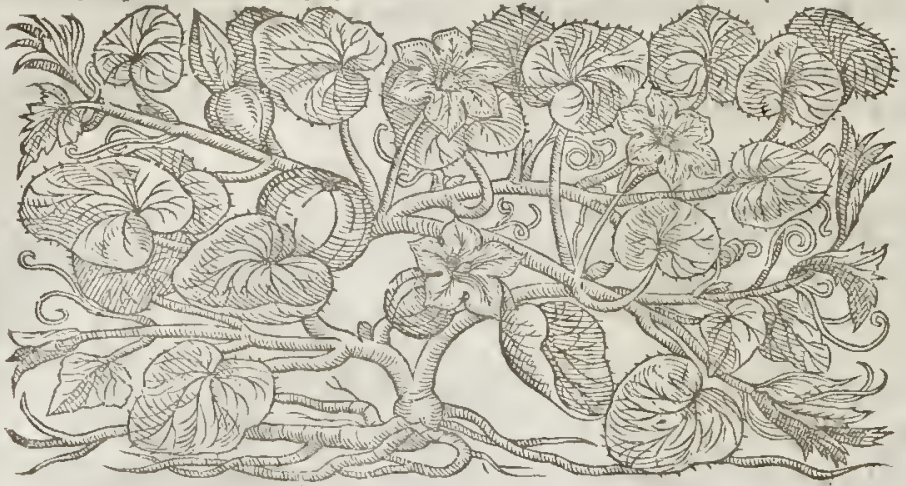

4 Pepomaximus clypeatus. The great buckler Pompion.
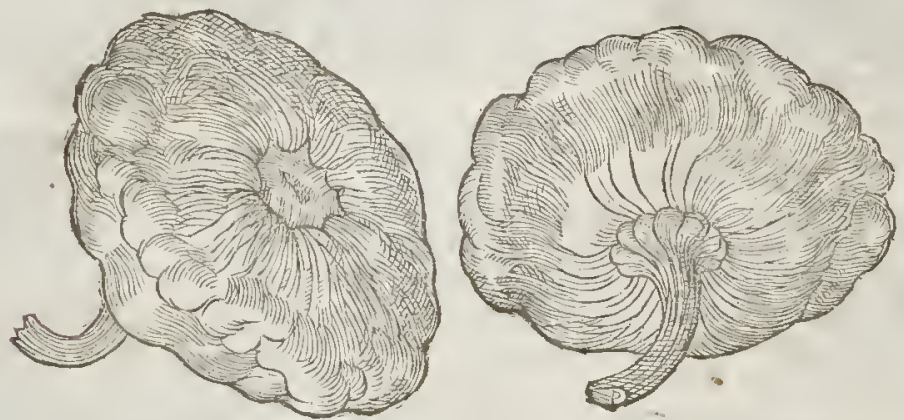

5 Pcpo Indicus minor rotundus.

The fmall round Indian Pompion.

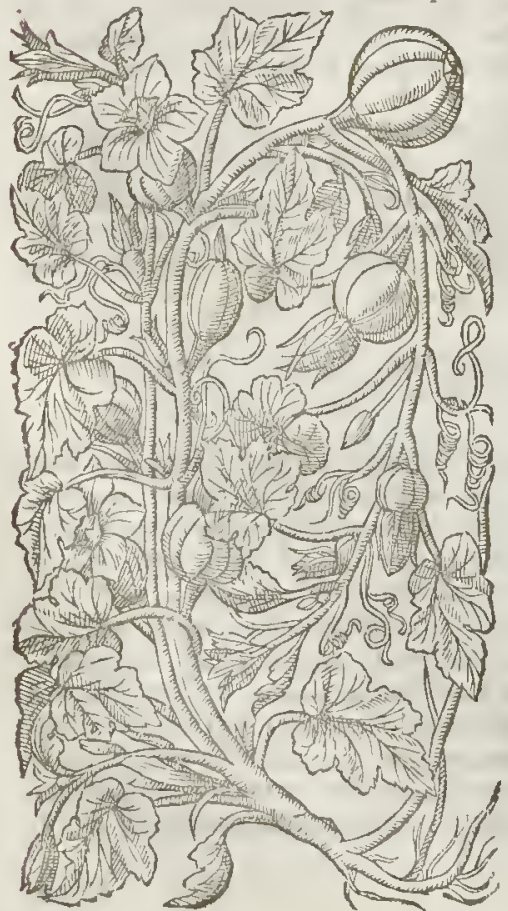

6 pepo Indicus angulofiss.

The cornered Indian Pompion.

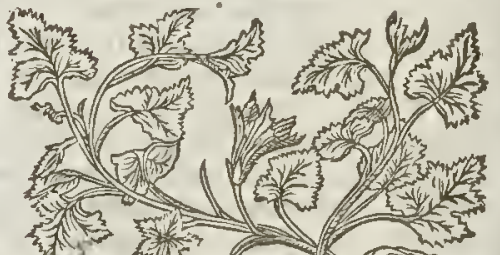

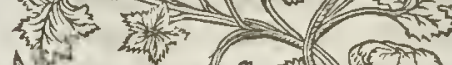

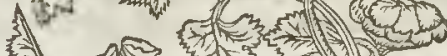

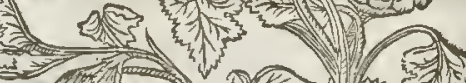
Mind

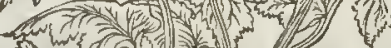
Eving s 积

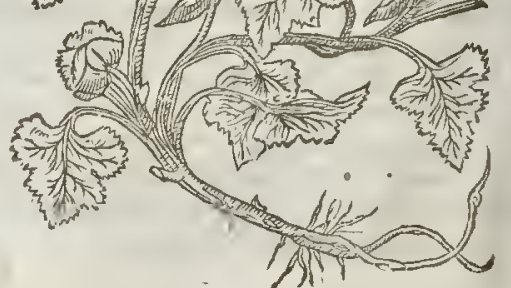


Mclones aquatici edulcs Virginiami.

The Virginian Water-Melon.

This Melon or Pompion is like and fully as bigge as the common Pompion, in freading, running, creeping branehes, lcaules, floures, and clafping tendrels : the fruit is of a very blackifh yreene colour,and extendeth it felfe in length neere foure inches long, and three inches broad, no bigger nor longet than a great apple, and groiv a longot the branches forth of the bofomes of the leates, not farre from the root euen to the toppes of the branches, containing a fubftanee, pulpe, and fiat feed, like the ordinary Ponpion: rhe root is whitith, and difperfeth it felfeverie farre abroad in the earth, and perifheth about the beginning of VVinter. Oftober the tenth, 1621 . Iohis Goodyer. +

\section{T The place.}

All there Melons or Pompions be garden plants : they iry beft in a fruitfull foile, and are common in England; except the laft defcribed, which is as yet a ftranger. बा Thc Time:

They are planted at the beginning of Aprill: they floure in Auguft: the fruit is tipe in Seprember.

The great Melon or Pompion is named in Greeke mimev : in Latine likewife Pepo: The fruits of them all when they be ripe are called by a conmon name in Greeke, rivess : in Englinh, Millions or Pumpion. Whereupon certaine Phyfitions, faith Galen, hate contended, that this fruit ought to be called onvosint tour, that is to fay in Latine, Pepo Cucremeralis, or Cucumber Pompion. Pliny in his ninth booke the fifth Chapter writech, that Cucumeres when they exceed in greatneffe are named Pepo. nes : it is called in High Duteh, 预luker: in Low Duteh, 19 spaenen: in French, Pompons.

Ail of The Temperature and Vertics.

All the Melons are of a cold nature, with plenty of moifture : they baue a certaine clenfing qua- A litic, by meanes whercof they pronoke irine, and do more freedily paffe through the bodie than do either the Gourd, Citruli, or Cueumber, as Galen hath witten

The pulpe of the Pompion is neuer caten sav, but boiled. For fo it doth more eafily defcend, B making the belly foluble. The nourifhment which commeth hereof is litrle, thin, moift and cold, (bad, faith Galers) and that efpecially when it is not well digefted : by reafon whereor it maketh a man apt and readic to fall into the difeafe called the Cholericke Paffion, and of fome the Felonie.

The feed clenfeth more than the meat, it provioketh vrine, and is good for thofe that are ttoubled C with the ftone of the kidnies.

The frut boiled in milke and buttered, is not oncly a good wholefome meat for mans body, but $D$ being fo prepared, is alfo a moft phy ficall medicine for fuch as hauc an hot ftomacke, and the inward parts inflamed.

The flefh or pulpe of the fame fliced and fried in a pan with butter, is alfo a good and wholfome E meat: but baked with apples in an oucn, it doth fil thebody with fatuous ot windie belchings, and is food viterly vnwholeforne for fuch as liue idlely but vnto robuftious and tuftick people nothing hurteth that filleth the belly.

\section{A A 346. Of Wilde Pompions.}

TI The Defription.

1 S there is a wilde fort of Cncumbers, of Melons, Citruls and Gourds, fo likewife there be ecrtaine wilde Pompions; that be fo of their owne nature. Thefe bring forth rough ftalksfer with tharp thony prickles. The leanes be likewife rough:the floures yellow as be thofeor the garden Melon, but cuery part is leffet. The fruit is thicke, round, and fharp pointed, hauing a bard greene rinde. The pulpe or meat whereof, and the middle pith,with the feed are like thofe of the garden Pompion, but very bitter in tafte. 2 The fecond is like vnto the former, but 'it is altogether leffer, wherein confinteth the diffe-
rence.

Hhh 3 
IPepomaior fylueftris.

The great wilde Pompion.

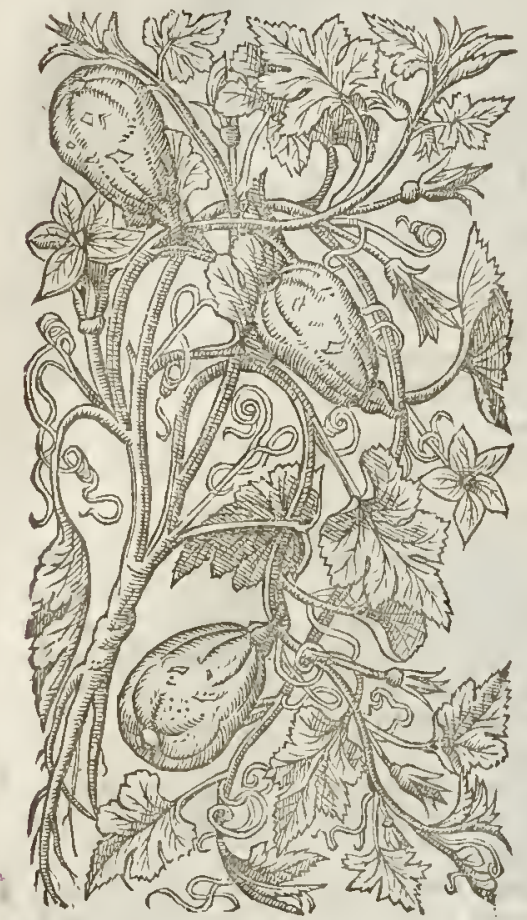

2 Pepo minar fylueftris. The fmall wilde Pompion.

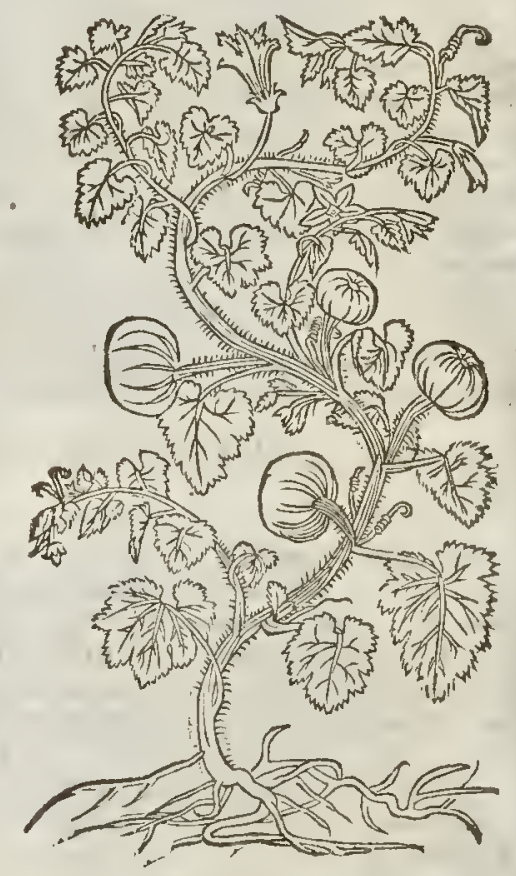

TT The Place.

Thefc Melons do grow wilde in Barbarie, A frica, and moft parts of the Eaft and Weft Indies? They grow not in thefe parts except they be fowne.

T The Time.

Their time of flouring and flourifhing anfwcreth that of the garden Pompion.

$$
\text { The Names. }
$$

Although the Antient Phyfitions haue made nomention of thefe plants,yet the thing it felfe doth fhew, that there be fuch, and ought to be called in Greeke mizoses äpos : in Latine, Pepones fyluefers : in Englifh,wildc Melons or Pompions.

T) The Temperatere.

Like as thefewilde Melons be altogether of their ow ne nature very bitter, fo be they alfo of tem" perature hot and drie, and that in the later end of the fecond degree. They haue likewife a clenfing facultie, not inferior to the wilde Cucumbers.

$$
\text { q The Vertues. }
$$

A The wine, which when the pith and feed is taken forth,is powred into the rinde, and harh remained fo long therein till fuch tine as it becommeth bitter, doth purge the belly, and bringeth forth flegmaticke and cholerick humors. To be briefe, the iuice hereof is of the fame operation that the wilde Cucumber is of; and being dried it may bevfed in ftead of Elaterium, which is the dried iutce of the wilde Cucumber.

$$
\text { C н А } 347 . \quad \text { Of Gourds. }
$$

T The Kindes.

There be aivers forts of Gourds, fome wilde, and others tame of the garden; fome bringing forth 1 fruit likevnto a bortle; others long, bigger at the end, keeping no certaine forme or fanhion; fome greater, others leffer. \pm will onely figure and defcribe two or three of the chiefeft, and fo paffe ouer the reft, becaufe each one vpon the firf fight of them knowes to what kinde to referre them. 


\section{Tt The Defription.}

I Te Gourd bringeth forth very long ftalkes as be thole of the Vine, cornered and pars ted into diuers branches, which with his clafping tendrcls taketh hold and clymeth vpon fineh things as ftand neere vnto it : thic leaues be very great, broad, and itarpe pointed, almoft as great as thofe of the Clot-Burre, but fofter, and fomewhat conercd as it were with a white frecfe, as bealfo the ftalkes and branches, like tholc of the marifh Mallow:the fourcs be white, and grow forth from the bofome of the leaues : in their places come vp the fruit, which are not all of one fafhion, for oftentimes they haue the forme of flagons or botrles, with a grcat large belly and a fmall necke. The Gourd (faith Pliny, lib.19. cap.5.) groweth into any forme or fafhion that you would baue it, either like vnto a wreathed Dragon, the leg of a man, or any cther Thape, according to the mould wherein it is put whileft it is young: being fuffered to elime vpon any Arbour wherc the fruit may hang, it hath beene feene to be nine foot long, by reafon of his great weight which hath ftretched it out to the length. The rinde when it is ripe is verie hard, wooddy, and of a yellow colour : the meate or inward pulpe is white; the feed long, flat, pointed at the top, broad below, with two peakes ftanding our like hornes, white with in, and fweet in
taftc.

2 The fecond diffcreth not from the preedent in ftalkes, Ieatres, or foures: the fruit hereof is for the molt part fafhioned like a bottle or flagon, wherein cfpecially confifteth the difference.'

I Cucurbita anguina. Snakes Gourd.

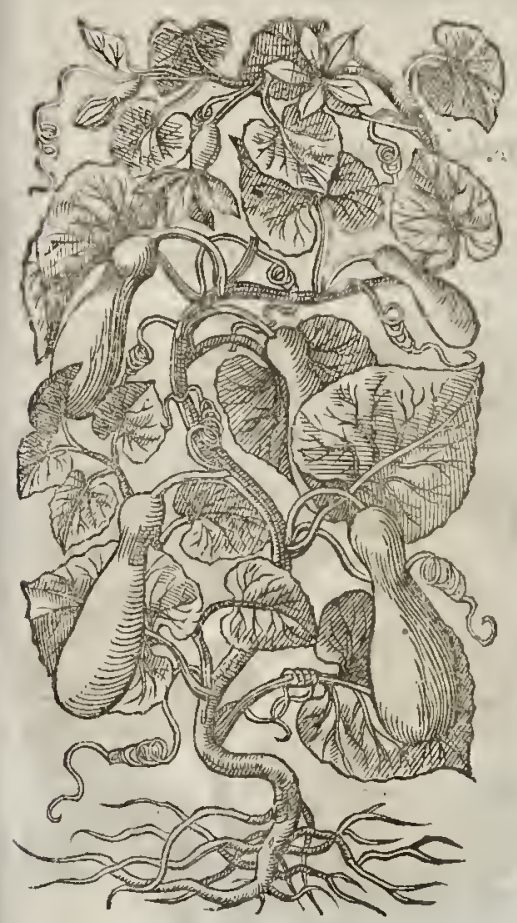

2 Cucurbitalagenaris. Bottle Gourds.

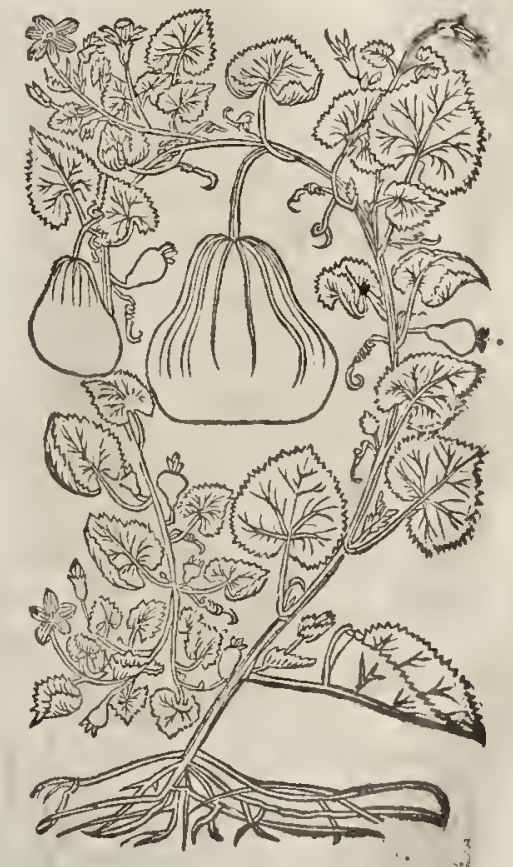

T. The Place.

The Gourds are elherifhed in the gardens of thefe cold regions rather for pleafure than for profit : in the hot countries where they come to ripeneffe there are fometimes eaten, but with fmall delight ; efpecially they are kept for the rindes, whercin they put 'Turpentine, Oyle, Hony, and alfo fcrue them for pales to fetch water in, and many other the like vfes.

$$
\text { गा The Time. }
$$

'They are planted in a bed of horfe-dung in A pril, eucn as we haue taught in the planting of cur-' cumbers : they flourith in I une and Iuly; the fruit is ripe in the end of Auguf.

The Gourd is called in Greeke knhoursa nipuer : in Latine, Cucurbita edulis, Cucurbitafatiun : of Plingy Cucurbita 
Cucurbita Cameraria, becaufe it elimeth vp, and is a eouering for arbours and walking plaees, and banguteting houfes in gardens : he calleth the other which elimeth not vp, but lyeth crawling on the ground, (ucurbutaplebera : in Italian, Zucca: in Spanioh, Calabaz $a$ : in Freneh, Cougge : in high Dutel, Hutbs: in low - Dutch, Cauboodorden: in Englin,, Gourds.

बा The Temperature.

The meate or inner pulpe of the Gourd is of temperature cold and moift, and that in the fecond degree.

$$
\text { The thertues. }
$$

A The ilycebeing dropped into the eares witl oyle of rofes is good for the paine thereof proceeding of a hot eaule.

B The pulpe or meate mitigateth all hor fwellings, if it be laid thereon in manner of a pultis,and being vred in this manner it taketh away the head-ache and the inflammation of the eyes.

C The fame Author affrmeth, that a long Gourd or elfe a Cueumber being laid in the eradle or bed by the young infant whileft it is afleepe and ficke of an ague, it fhall bevery quiekely made whole.

D The pulpe alfo is eaten fodden, but becaufe it hath in it a waterim and thinne iuyee, it yeeldeth fmall nourifhment to the body, and the fane cold and moift; but it eafily paffeth thorow, efpecially being fodden, which by reafon of the flipperinefte and moifneffe alfo of his fubstance molli. fieth the belly.

E But being baked in an ouen or fried in a pan it lofeth the moft part of his naturall moifture, and therefore it more flowly defcendeth, and doth not mollifie the belly fo foone.

F The feed allayeth the tharpneffe of vrine, and bringeth downe the fame.

\section{C н A P. 348. Of the wilde Gourd.}

I Cucurbita lagenaria fylucftris.

Wilde Bottle Gourd.

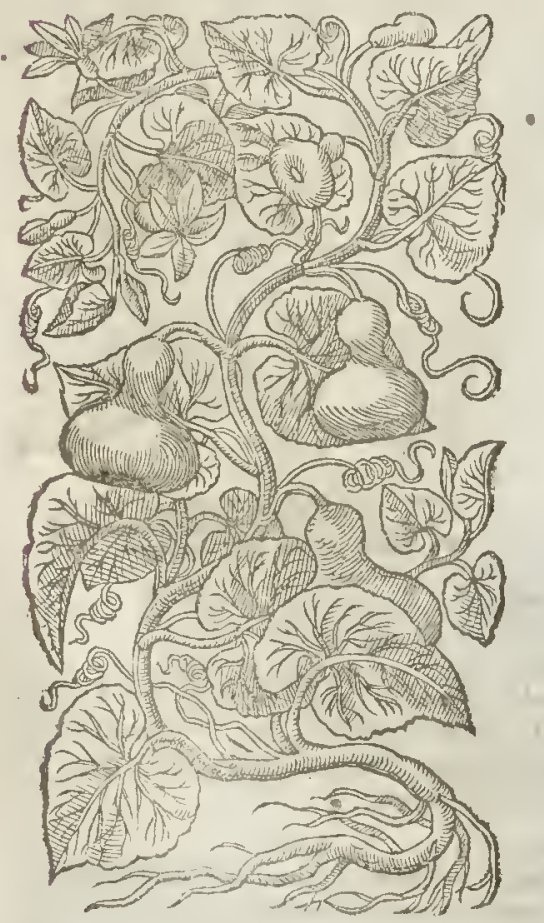

2 Cucurbita fyluefris fungiformis. Murhrome wilde Gourd.

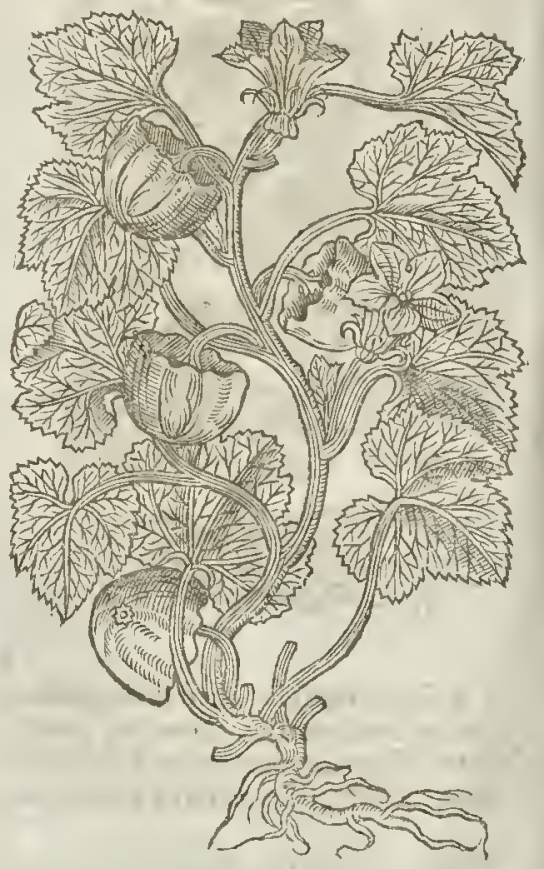




\section{I] The Defcription}

I THere is befides the former ones a certaine w ilde Gourd : this is like rhe garden Gourd 1 in clymbing ftalkes, clafping rendrels, and foft leaues, and as it were downy; all and cuerie one of which things being farre leffe : this alfo clymbeth vpon Arbours and binquetring houres : the fruit doth reprefenr the great bellied Gourd, and thofe that be like vnto borrles in forme, bur inbigneffe it is very farre inferiour, for it is fmall, and fcarfe fo great as an ordinarie Quince, and may be beld within the compaffe of a mais hand: the outward rinde at the firft is greene, afterwards it is as hard as wood, and of the colour thereof: the inner pulpe is moift, and very fu I of iuyce, in which lieth the feed. The whole is as bitter as Coloquintida, which hath made fo many crrors, one efpecially, in taking rhe fruit Coloquincida for the wilde Gourd.

2 The fecond wilde Gourd hath likewife many trailing branches and clafping rendrels, wherwith it takcth hold of fuch things as be neere vnto it : the leaues be broad, deepely cur into diuers fections, like thofe of the Vine, foft and very downy, whereby ir is efpecially knowne robe one of the Gourds: the floures are very white, as are alfo thofe of rhe Gourds. The fruit fucceederh, grow ing to a round forme, flar on the top like the head of a Munhome, whereof ir tooke his fyrname.

\section{IT The Place.}

They grow of themfeltes wilde in hor regions; they nener come to perfection of ripeneffe in thefe culd countries.

The time an fwereth thofe of the garden.

$$
\text { T. The Time. }
$$

$$
\text { IT The Names. }
$$

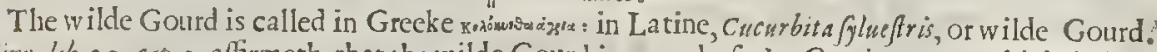
Plimy, 126.20. cap.3. affirmeth, rhat the wilde Gourd is named of the Greeians, oripos, which is hollow, an inch thicke, not growing but among ftones, the iuyce whercof being taken is very good for the ftomacke. Bur the wilde Gourd is not that which is fo defcribed, for tt is aboue an inch thicke, neither is it hollow, but full of iuyce, and by reafon of the extreme birterneffe offenfiue to the itomacke.

Some alfo rhere be rhat takc this for Coloquintida, but they are far deceited; for Colocynthis is the wilde Citrull Cucumber, whereof we haue treated in the chapter of Citruls.

The wilde Gourd is as hor and dry as Coloquintida, that is to fay, in the fecond degree.

$$
\text { I The Vertues. }
$$

Thewilde Gourd is extreme bitter, for which caulc it openeth and fcoureth the ftopped paffa-' A ges of the body; it al fo purgeth downwards as do wilde Melons.

Moreouer, rhe wine which hath continued all night in this Gourd likewife purgeth the belly $B$ mightily, and bringeth forth cholericke and flegmaticke humors.

\section{Ch а P. 349. Of Potato's.}

Sifarum Peruvianum, fuie Batata Hijpanorum. Potatus, or Potatos.

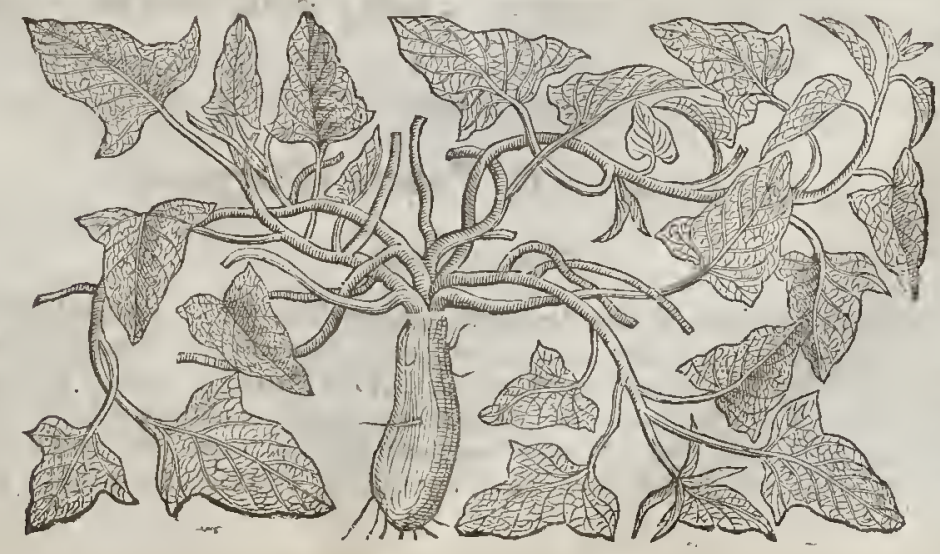




\section{T The Defcription.}

$\mathrm{T}$ His Plant (which is called of fome Sifarum Peruvianum, or Skyrrets of Peru) is generally of vs called Potatus, or Potatocs. It hath long rough flexible branches trailing vpon the ground like vnto Pompions; whereupon are fer greene three cornered leaues, very like vnto thofe of the wilde Cucumber. There is not any that haue written of this planthaue faid any thing of the floures : therefore I refer their defcription unto tho fe that thall hereafter haue further knowledge of the fame. Yet haue I had in my garden diuer's roots that haue flourifhed vnto the firft approch of Winter, and haue growne vnto a great length of branches, but they brought not forth any floures at all; whether becaufe the Winter cauled them to perifh before their time of flouring,or that they beof nature barren of floures, I am not cerraine. The roots are many, thicke, and knobbie, like vnto the roots of Peionies, ur rather of the white A fphodill,ioyned together at the top into one head, in maner of the Skyrrit, which being ditrided into diuers parts and planted, do make a great increafe, efpccially if the greateft roots be cut into diters goblets, and planted in good and fertile ground.

The Place.

The Potatoes grow in India,Barbarie, Spaine, and other hot regions; of which I planted diuers soots (that I bought at the Exchange in London) in my garden, where they flourifhed vatil Wina. ter, at which time they perifhed and rotted.

$$
\text { II The Time. }
$$

It flouritheth wnto the end of September : at the firft approch of great frofts the leaues together with the roots and falkes do perith.

The Namics. rades:

Clufines calleth it Battata, Camotes, Amotes, and Igrames : in Englifh, Potatoes, Potatus, and Poin

$$
\text { The Temperature. }
$$

The leaues of Potatoes are hot and dry, as may euidently appeare by the tafte. The roots are of a temperate qualitic.

$$
\text { a) The virtues. }
$$

A The Potato roots are among the Spaniards, I talians, Indians, and many other nations commoni and ordinarie meate; which no doubt are of mighty and nourifhing parts, and do ftrengthen and comfort nature; whofe nutriment is as it were a meane betweene flerh and fruit, but fomwhat windie; but being tofted in the embers they lofe much of their windinefe,efpecially being eaten fopped inwine.

B Of thefe ronts may be made conferues no leffe tooth fome, wholefome, and dainty than of the flerh of Quinces : and likewife thofe comfortable and delicate meats called in thops Morfelli, Placentule, and diuers other fuch like.

C Thefe Roots may ferue as a ground or foundation whereon the cunning Confectioner or Sugar-Baker may worke and frame many comfortable delicate Conferues, and reftoratiue fiveete meares.

D They are vfed to be eaten rofted in the afhes. Some when they be fo rofted infufe them and fop them in Wine; and orhers to giue them the greater grace in eating, doe boyle them with prunes, and fo eate them. And likewife others dreffe them (being firt rofted) with Oyle, Vineger, and falt, euerie man according to his owne tafte and liking. Notwithftanding how foeter they bee dreffed, they comfort, nourin, and frengthen the body, procuring bodily luft, and that with greedineffe.

\section{С н Р. 350. Of Potatoes of Virginia. \\ T) The Defcription.}

$\mathrm{V}$

Irginia Potato hath many hollow flexible branches trailing vpon the ground, three fquare, vnenen, knotted or kneed in fundry places at certaine diftances : from the which knots commeth forth one grear leafe made of diuers leaues, fome frmaller, and others greater, fet together vpon a fat middie rib by couples, of a fwart greene colour tending to redneffe; the whole leafe refembling thofe of the W inter-Creffes, but much larger; in tafte at the firft like graffe, but afterward tharpe and nipping the tongue. From the bofome of wlich leaues come forth long round 
round flender foot-ftalkcs, whereon do grow very faire \& plcafunt firoures, ma de of one entire who'e leafe, which is folded or plaited in fuch ftrangc fort, that it fecmeth to be a toure madc of fue fundry fmall leaues, which cannot cafily be pcrccited except the fame be pullat open. Tlic whole floure is of a light purple colour, ftriped downc the middle of cuery fold or welt with a light fhew of yellowneffe, as it purple and ycllow were mixed together. in the middle of the floure rhrulteth forth a thicke flat pointall yellow as gold, with a fmall tharpe grecne prickeor point in the middeft thereof. The fruit fuccedeth the floures, round as a ball, of the bigneffe of a little Bulleffe orwilde plum, greenc at the firft,and blacke when it is ripe; wherein is contained fmall white feed leffer than thofc of Muftard. The root is thicke, fat, and tuberous, not much differing cither in Thape, colour, or tafte from the common Potatoes, fauing that the roots hereot are not fo great nor long; fome of them are as round as a ball,fome onall or cgge-fanhinn; fome longer, and others horter: the which knobby roots are faftened vnto the ftalkes wirh an infinite nunber of threddie ftrings.

BattataVirginiana, fue Virginianorum, es Pappus.

Virginian Potatoes.
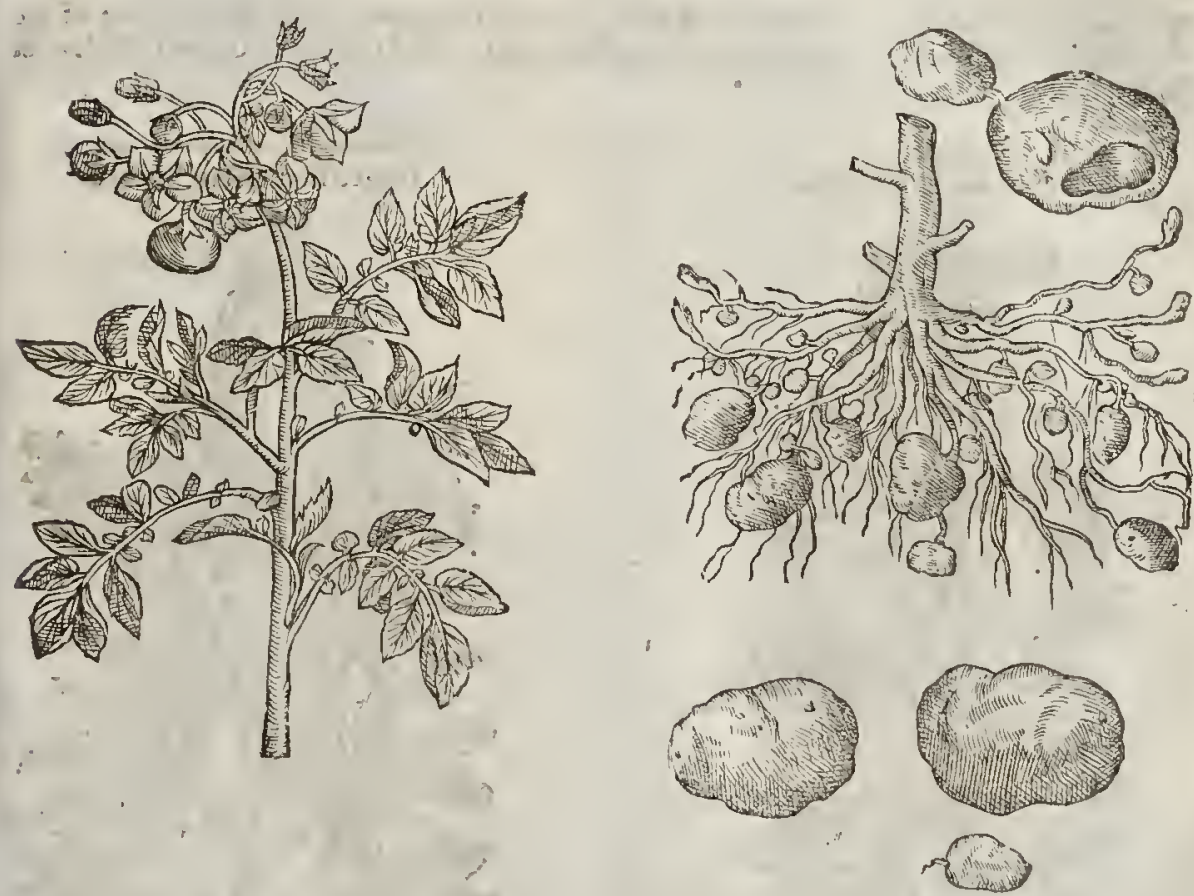

The Place.

It groweth natnrally in A merica, where it was firft difconered, as reports $\bar{C}$. Clufius, fince which time I haue receiued roots hereof from Virginia, otherwife called Norembcga, which grow and profper in my garden as in thcir owne natiue countrey.

\section{Tा The Time.}

The leates thruft forth of the ground in the beginning of May:the floures bud forthin Augurt. The fruit is ripe in September.

The Indians do call this plant $P$ appus, meaning the roots : by which nanie al fo the conrmon Potatoes are called in thofe Indian countries. We haue the name proper vnto it mentioned in the ticle. Becaufc it hath not onely the thape and proportion of Potatoes, but alfo the pleafant tafte and vertues of the famc, we may call it in Englifh, Potatoes of America or Virginia.

$\neq$ Clufius queftions whether it be not the Arachidina of Theophraftuss. Busubine hath referred it to the Night hades, and callcth it Solamum tuberofirm Efculcnum, and largely figures and deferibes it in his Prodromess, pag. $89 . \ddagger$ 
T) The Temperature asd Vertues.

A The remperature and vertues be referred vnto the conmon Potatoes, being likew ife a food, as alfo a meate for pleafure, equall in goodneffe and wholefomeneffe vnto the fame, being either rofted in rheembers, or boyled and eaten with oyle, vineger, and pepper, or dreffed any other way by the hand of fome eunning in eookeric.

B $\ddagger$ Buhine faith, Thar he heard that rhe vfe of thefe toots was forbidden in Bourgondy (where they eall them Indian Artichokes) for thar they were perfuaded the too frequent vfe of rhem caufel the leprofie. $\neq$

$$
\begin{gathered}
\text { C н A P. 35I. } \\
\text { Of the Garden Mallow called Hollibocke. } \\
\text { I The Kindes. }
\end{gathered}
$$

7 Here be diuers forts or kindes of Mallowes; fome of the garden : there be alfo fome of the 1 Marih or fea thore; others of the field, and both wilde. And firft of the Garden Mallow or Hollihoeke.

I Maluabortenfis.

Single Garden Hollihoeke.

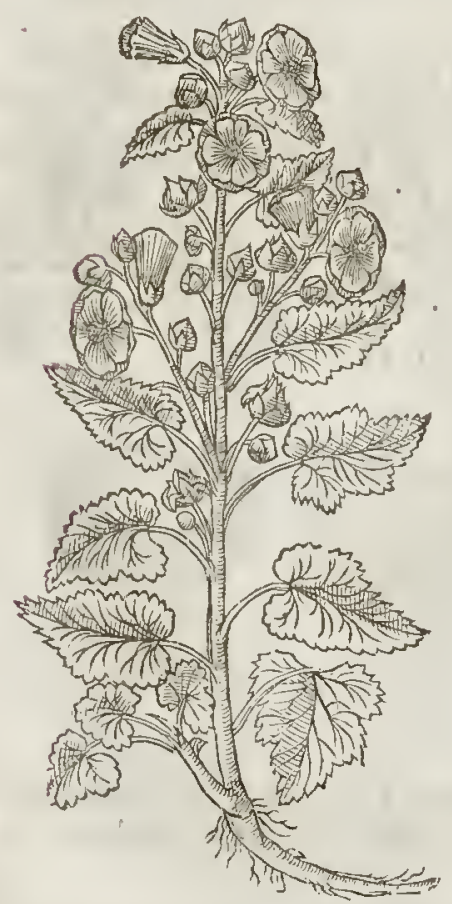

2 Maluarofea fimplex peregrina. Iagged Atrange Hollihocke.

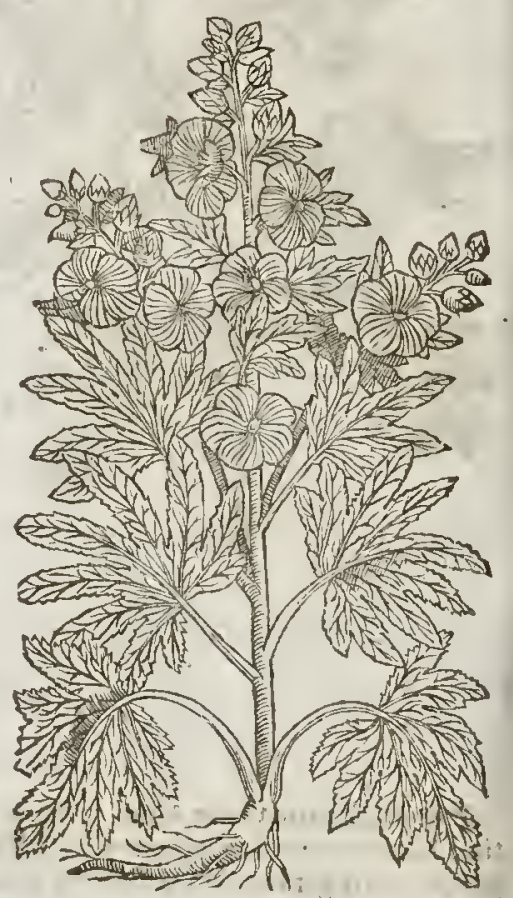

I The Defription.

I $T$ He rame or garden Mallow bringeth forth broad round leaues of a whitith greene co: lour, rough, and greater than thofe of the wilde Mallow. The falke is fraight, of the height of foure or fix cubits; whercon do grow vpon flender foot-falks fingle floures not much vnlike ro rhe wilde Mallow, but greater, confifting only of fiue leaues, fometimes white or red, now and then of a decpe purple eolour, varying diuerfly, as Nature lift to play with it : in their places growerh vp a round knop like a litrle eake, conpact or made vp of a multitude of fiat feeds like little eheefes. The root is long, white, tough, eafily bowed, and groweth decpe in the ground. 


\section{3 calua purpurea multiplex.} Double purple Hollihocke.

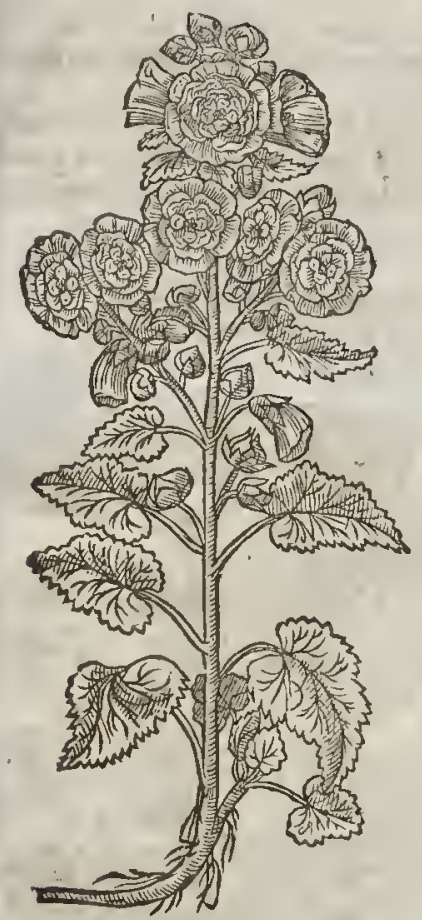

2 :The fecond being a ftrange linde of $\mathrm{Hol}$ lihocke hath likewife broad leaues, rough and hoarie, or of an ouerworne ruffet colour, cut into diucrs fe:tions emen to the middle ribbe, like thofe of Palma Chrifti. The floures are very fingle, but of a perfect red colour, wherein confifteth the greateft difference. $\ddagger$ And this may be called Malua rofea fimplex peregrina folio Ficus. lagged ftrange Hollihocke. $\neq$

3 The double Hollihocke with purple floures hath great broad leaues, confuredly indented about the edges, and likewife toothed like a faw. The ftalke groweth to the height of foure or fue cubits. The floures are double, and of a bright purple colour.

4. The Garden Hollilıcke wirh double floures of the collun offarler, groweth to the height of fue or fix cubits, liauing many broad leaues cut about the edges. The italke and roor is like the precedent. $\neq$ This may be called Thaived bortchfis rubram miliplex, Double red Hollillockes, or Ro fe mallow $\ddagger$

${ }^{5}$ The tree mallow is likewife one of the Hollihockes; it bringeth forth a great ftalke of the height of ten or twelue foot, growing to the forme of a fmall tree, whereon aie placed diuers great broad leaues of a ruffet greene colour, nor vnlike to thofe of the great Clot Burre Docke, deepely indented about the edges. The foures are very great and double as the greateft Rofe, or double Peiony, of a deep red colour tending ta blackneffe. The roote is great, thicke, aud of a wooddy fubftance, as is the reft of the plant. $\$$ This may be called Malua bortenfis atrorubente multiplicifore. $\neq$ T) The Place.

Thefe Hollihockes are fowne in gardens, almoft euery where, and are in vaine fought elfe where. If The Time.

The fecond yeere after they are forne they bring forth their floures in Iuly and Auguft, when the feed is ripe the ftalke withereth, the root remaineth and fendeth forth new ltalkes, leaues and floures, many yeres after.
The Hollihocte is called in The Namies.

Rofa byemelis or winte Rofe in Greche,

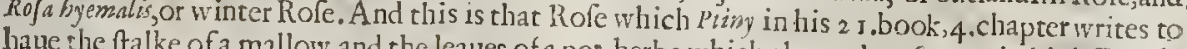
haue the ftalke of a mallow, and the leates of a por-herbe, which they cal Mofieuton: in high Dutch,

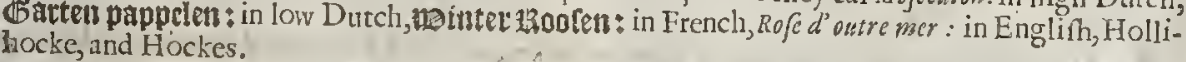

G The Temperature.

The Hollihockeis meetely hot, and alfo moift, but not fomuch as the wilde Mallow:it hath likewife a clammie fubftance, which is more manifet in the feed and root, than in any other part. T) The Vertues.

The decoction of the floures, efpecially thofe of the red, doth ftop the ouermuch flowing of the $A$ monthly courfes, if they be boiled in red wine.

The roots, leaues, and feeds ferue for all thofe things forwhich the wilde Mallowes do, which B are more commonly and familiarly vfed.

\section{CHA Р.352: Of the wilde $\mathrm{M}$ allowes,}

\section{T The Defription.}

I The wilde Mallow hath broad leaues fomewbat round and comered, nickt about the edges, fmooth, and greene of colour : among which rifevp many flender tough ftalkes

Jii i clad 
clad with the like leaues, but imaller. The floures grow vpon lirrle foorftalkes of a reddifh colour inixed with purple Itrakes, confifting of fiue leaues, fathioned like a bell : after which conumeth vp a knap or round burton, like vnto a flat cake, compact of many fmall feeds. The ront is white, rough, aud full of a flinic juice, as is all the reft of rhe plant.

2 The dwarfe wilde Mallow creepeth vpon the ground : rhe ftalkes are flender and weake, yet tough and flexible. The leautes be rounder, and more hoary rhan the other. The floures are fmall and of a white colour.

3 The crifpe or curled Mallow, called of the vulgar fort French Mallowes, hath many fmall vpright ftalkes, growing to the height of a cubit; and fometimes figher; whereon do grow broad leaues fomewhar round and fmoorh, of a lighr greene color, plaited or curled abour rhe brims like a ruffe. The floures be fmall and white. The root per: therh when it harh perfected his feed.

I Galua fyluefris."

The ficld Mallow.

inalva syluestris

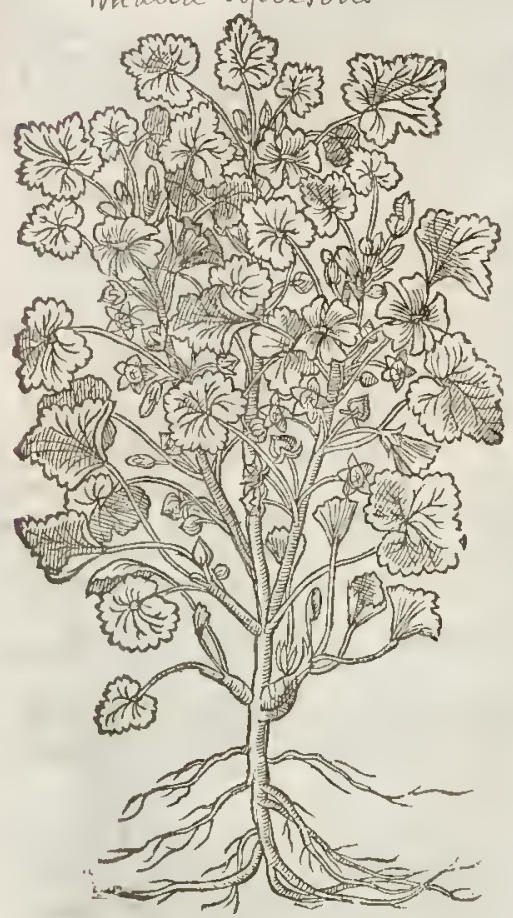

2 Malua glucftris pumila.

The wilde dwarfe Mallow. Malca atundifolia

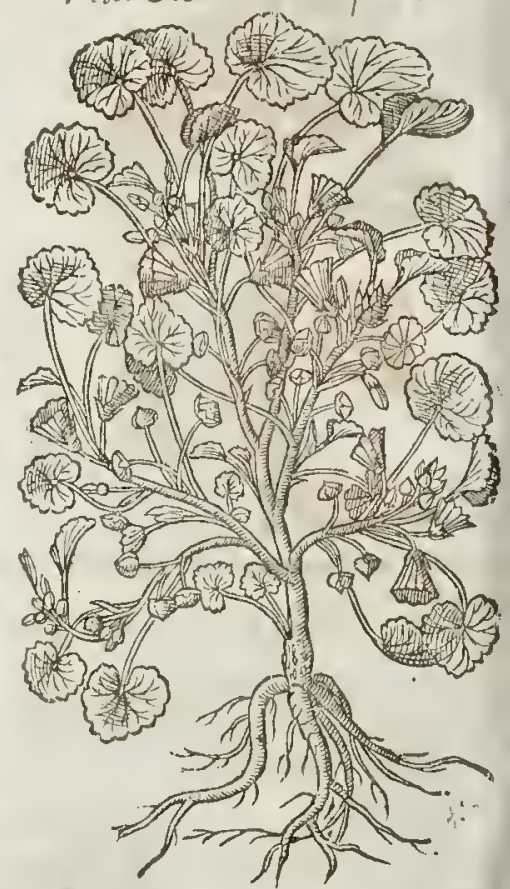

4 The Veruaine Mallow hath many ftraight ftalkes, whereon doe grow diuers leaues deepely cut and jagged etten ro the middle rib, nor vnlike to the leaues of Veruaine, whereof ir tooke his name : among which come forth faire and pleafant floures like vnto thofe of the common Mallow in forme, but of a more brighr red colour, mixed with ftripes of purple, which fetteth forth the beauric. The root is thicke, and conrinueth many yeeres. $\neq$ This is fometimes though more rarely found with whire floures. $\ddagger$

$\ddagger 5$ This annuall Mallow, called by clufizs, Malsatrimeftris, is very like our conmon Mallow fending vp flender branched ftalkes fome three foot high; the borrome leaues are round, thofe on the ftalkes more tharpe pointed, greene aboue, and whiter vnderneath ${ }_{3}$ the floures confift of fiue leaues of a light carnarion colour, the feed is like that of the ordinary mallow, but fmaller; and fuch alfo is the roor which perithes euery yeere as foon as the feed is ripe:it is fowne in fome gardens, and growes wilde in Spaine. $\ddagger$

The two firft mallowes grow in vnroiled places among pot-herbes, by high waies, and the borders of fields.

The French mallow is an excellent pot-herbe, for the which caufe it is forne in gardens, and is not to be found wilde that I know of. 
3 Malua cripa.

The French curled Mallow.

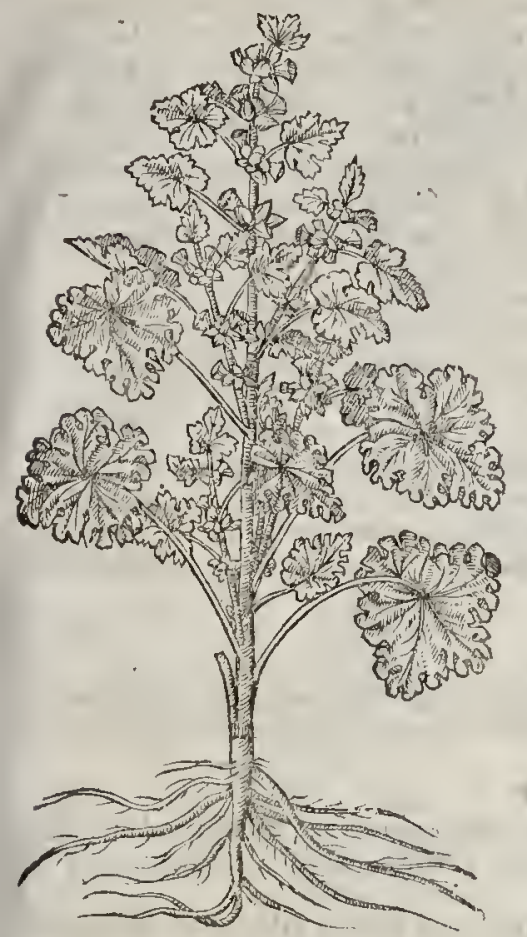

† Malua aftiun Hifpanica.

The Spanifh Mallow.

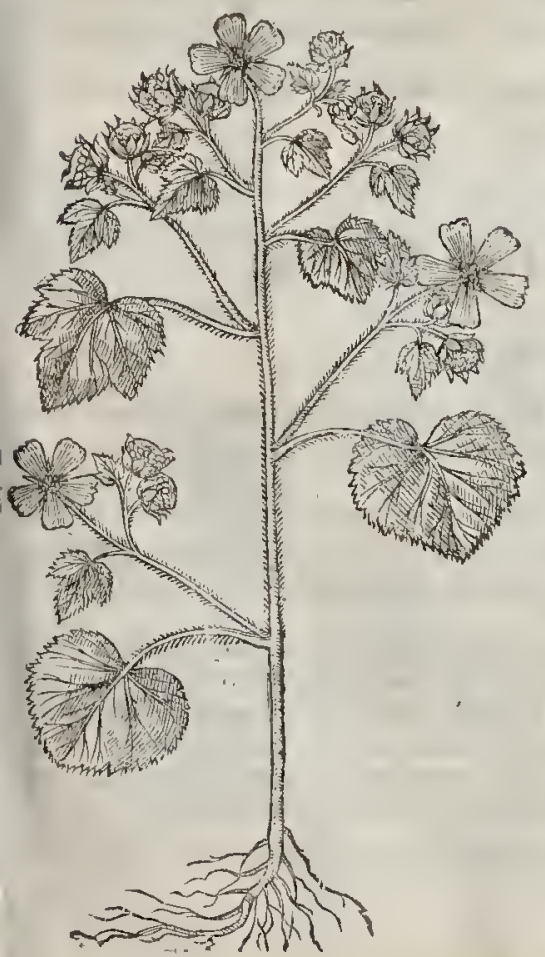

4 Malua verbenaca.

Veruaine Mallow.

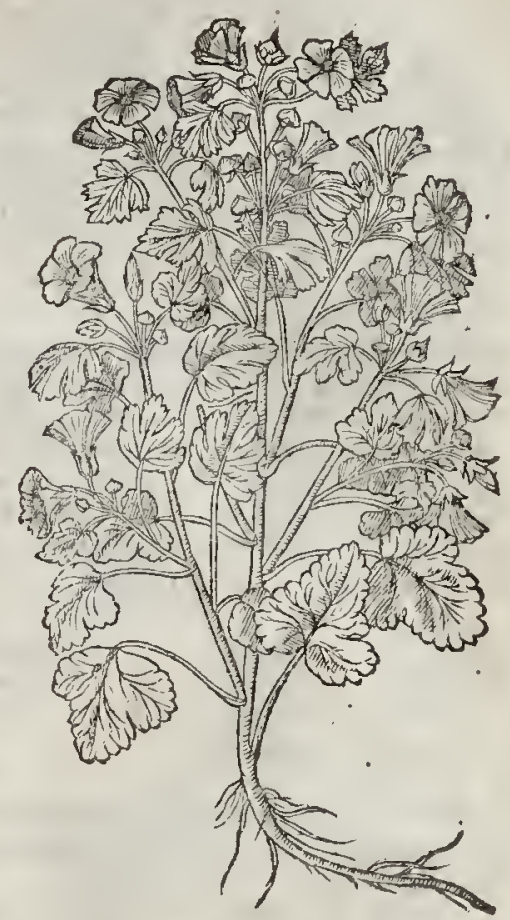

The Veruaine Mallow groweth not euerie where : it growes on the diteh fides on the left hand of the place of execution by London, called Tyborn : alfo in a ficld neere vnto a village fourteene miles from London ealled Bufhey, on the backe-fide of a Gentlemans houre named $M^{2}$. Robert Wylbrabam: likewife among ft the buthes and hedges as yout go from London to a bathing place ealled rhe Old Foord; and in the buthes as you go to Haekny a village by London, in the clofes next the town, and in diuers other places, as at Bafingburne in Hartfordhire, three miles from Roifton.

$\neq \mathrm{M}^{\mathrm{r}}$. Goodyer found the Veruain Mallow with white floures growing plentifully in a clofe necre Maple-durham in Hamprhire, ealled Aldercrofts. $\neq$

$$
\text { of The Time. }
$$

Thefe wilde Mallowes do floure from Iune till Sommer bewell fpent : in the meane time their feed alfo waxeth ripe.

$$
\text { Tt The Names. }
$$

The wilde Mallow is called in Latine Mal.

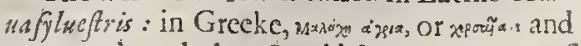
zxems, as though they fhould fay a mitigator of paine: of fome, ofiritca : in high-Dutch, taap= pelin: in Low-Duteh, gsatume, and Life = kens ctuit: in Englio, Mallow.

$$
\text { Ii ii } 2
$$


The Veruainc Mallow is callcd of Diofcorides, Alcea: in Greeke, waxia: of fomc, Herba Huñarica, and Herba Simeonis, or Simons Mallow : in Englifh, Veruaine Mallow, and iagged Mallow.

The name of this herbe Malua feemeth to come from the Hebrewes, who eall it in their tongue rits citalluach, of the 1altnefle, beeaufe the Mallow groweth in faltifh and old ruinous places, as in dung-hills and fuch like, which in moft aboundant manner yecldeth forth Salt-peter and fuel like matter: for o Melach fignifieth falt, as the Learned know. I am perfuaded that the Latine

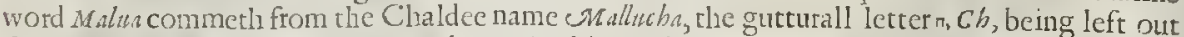
for good founds fake : fo that it were better in this word Maliva to reade $u$ as a vowell, than as a confonant : which words are vttered by the learned Doctor Rabbi Darid Kimbi, and feeme to carric a great thew of truth: in Englifh it is called Mallow; which name commeth as neereas may be to the Hebrew word.

$$
\text { Ti The Temperature. }
$$

Thewilde Mallowes haue a certaine moderate and middle heate, and moiftneffe withall: the iuyee thereof is limic, clammic, or gluing, the which are to be preferred before the garden Mallow or Hollihocke, as Diphilus Siphinus in Atbenews doth rightly thinke; who plainely theweth, that the wilde Mallow is better than that of the garden : although fome do prefer the Hollihocke, whereun to we may not confent, neither yet yeeld vnto Galen, who is partly of that minde, yet ftandeth he doubtfull : for the wilde Mallow w ithout controuerfie is fitter to be eaten, and"nore pleafant than thofe of the garden, except the French Mallow, which is gencrally holden the wholfommeft, and among ft the pot-herbes not the leaft commended by $\mathrm{H}$ gfiod: of whofe opinion was $\mathrm{Ho}_{0}$ race, writing in his fccond Ode of his Epodon,

$$
\begin{aligned}
& \text { Malue falubres corpori. } \\
& \text { érat }
\end{aligned}
$$

The Mallow (faith Galen) doth nourifh moderately, ingendreth grofle bioud, keepeth the bodie foluble, and loofeth the belly that is bound. It eafily defcendeth, not onely becaufe it is moif, but alfo by reafon it is limy.

$$
\text { at The Vertues. }
$$

A The lcaues of Mallowes are good againit the ftinging of Scorpions, Bees, ${ }^{\top} W$ afps, and fuch like: and if a man be firft anointed with the lcaucs famped w ith a little oyle, he thal not be fung at all, Diofcorides fititl.

B The decostion of.Mallowes with their roots drunken are good againft all venome and poyfon, if it be incontinently taken after the poyfon, fo that it be vomited vpagaine.

C The leaucs of Mallowes boylcd till they be foft and applied, do mollifie tumors and hard fwellings of the mother, if they do withall fit ouer the func theteof, and bathe themfelues therewith.

D The decostion vfed in clifters is good againft the toughneffc and fretting of the guts, bladder, and fundament.

E The roots of the Veruaine Mallow do healc the bloudy flix and inward burıtings;being drunke with wine and water, as Diofcorides and $P$ aw Eg ginet $a$ teftific.

\section{Cна в. 353. Of Marbo Mallow.}

\section{If The Defcription.}

I Arth Mallow is alfo a certainekinde of wilde Mallow : it hath btoad leates, fmall toward the point, foft, whitc, and frcefed or cortoned, and fleightly nicked about the edges : the ftalkes bc round and ftraight, thrce or fourc foot high, of a whitifh gtay colour; whereon do grow floures like vnto thofe of the wilde Mallowes, yet not red as they are, but commonly. whitc, or of a very light purplc colour out of the white : the knop or round button wherein the feeds lie is like that of the firft wilde Mallow. The root is thicke, tough, white within, and containeth in it a clammy and flimy inyee.

$\dagger 2$ This ftrange kinde of Mallow is holden among t the bef writers to bea kinde of marfh Mallow : fome exeellene Herbarifts haue fet it downe for Sida Theophraft, wherto it doth not fully anfwer : it hatl ftalks two cubits high, wheron are fet without order many broad lcaues hoaric and whitith, not vnlike thofe of the other marth Mallow : the floures eon filt of fue lcaues,and are latger than thofe of the marth Mallow, and of a purple colour tending to redneffe : after which there come round bladders of a pale colour, in thapc like the fruit or feeds of round Ariftochia, or Birthwort, wherein is eontained round blacke feed. The root is thickc and tough, much like that of the common Mallow. 
CIB. 2.

Of the Filtorie of Plants.

- I Althalbifors.

Marth Mallow on a

meting

-1

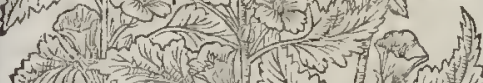
mild

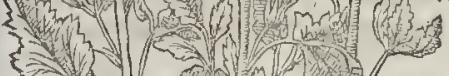
(1)
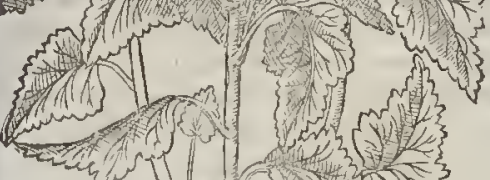

4 . 19 .

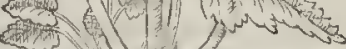

t

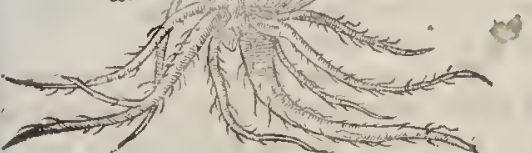

3 Altidic Arborefens:

Tree Mallow.

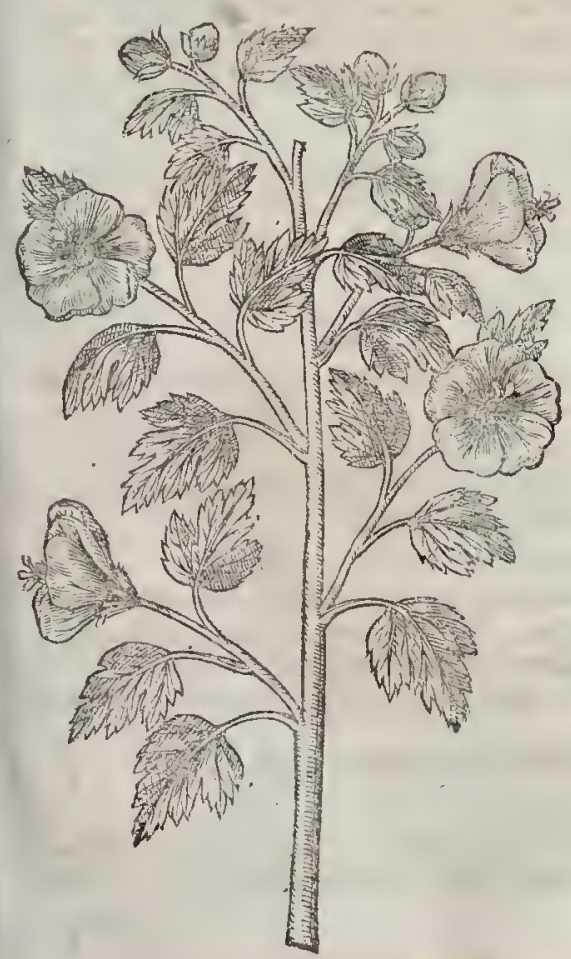

2 Althenpaluftris

V'ater Mallow

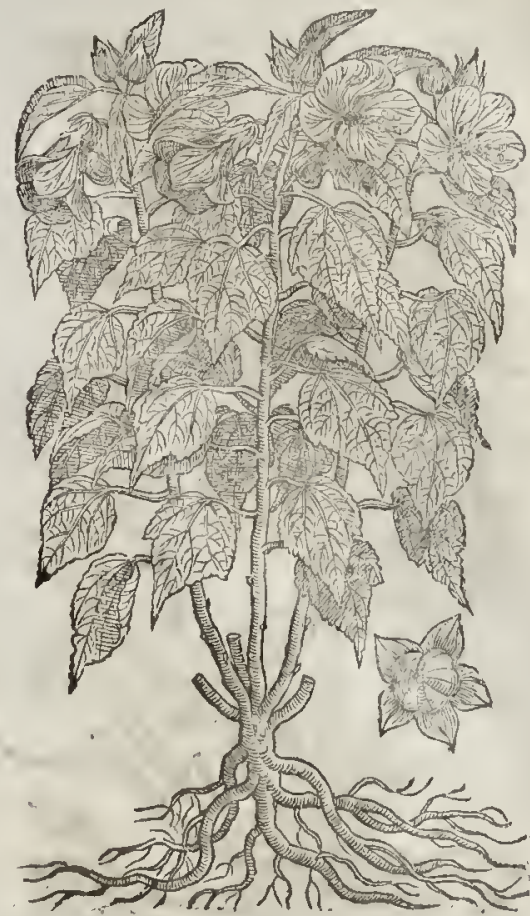

4 Althen frutex Cln/ij.

Shrubbed Mallow.

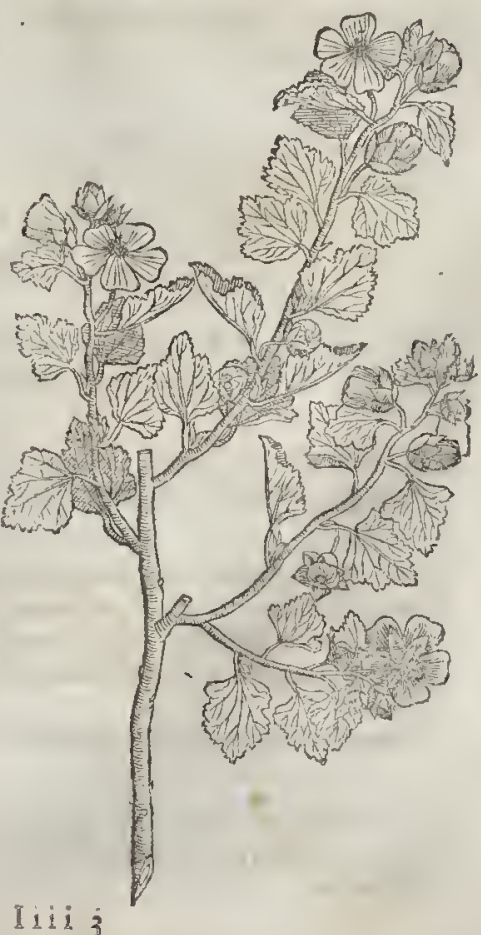




\section{Of the Hiftory of Plants. \\ Li в. 2.}

\$ Alcea fruticofa camabina.

Hempe-leancd Mallow.

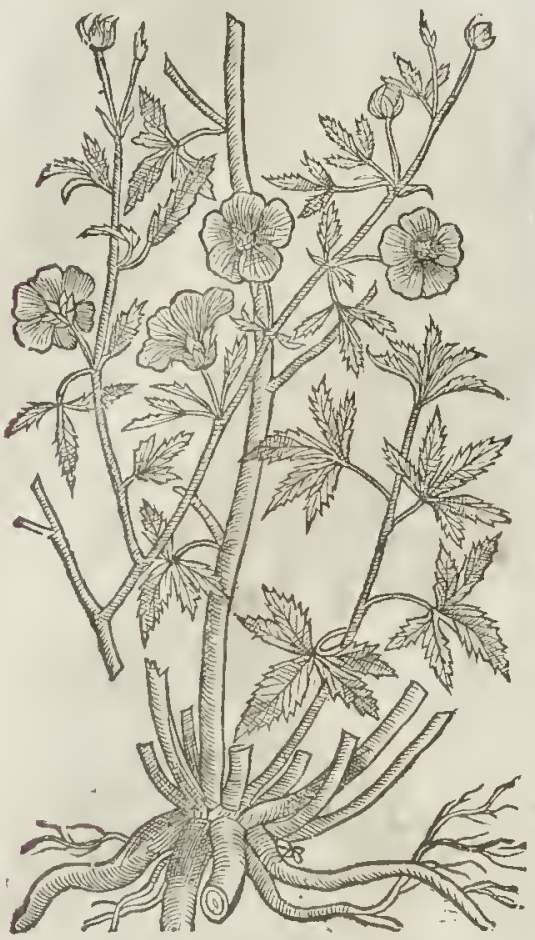

3 This wilde Mallow is likewife referred vito the kinds of marfh Mallow, called generally by the name of Alr bea, which groweth to the torm of a fmal hed ge tree, approching neerer to the fubfance or nature of wood than any of the other; wherewith the peopie of Olbia and Narbone in France doe make hedges, to fenet or diuide their garders and vineyards (euen as we doe with quiche-fets of priuet or thome) which continteth long : the ftalke whereof groweth vpright, very ligh, comming neere to the Willow in wooddinelle and fitbftance. The floures row along th the fanc, in fathion and colour of the common wild mallow.

4 The thrubby mallow riferh vp like vnto a hedge bum, and of a wooddy fublance, diuiding it felfe inco diuers tough and limber branches, coucred with a bakk of the colour of afhes; whereupon do grow round pointed leates, fomewhat nickt about the edges, very foft,not vnlike to thofe of the common marf mallow, and of an ouerwome hoary colour. The Houres grow at the top of the falks, of a purple colour, confifing of fue leaues, very like to the common wilde mallow, and the feed of the marth mallow.

5 We haue another fort of mallow, called of Pessa, Alcea fruticofior pentaphylla : it bringeth fotch in my garden many twiggy branches, fet vpon ftiffe ftalkes of the bignefle of a mans thumbe, growing to the height of ten or twelue foot : whereupon are fer very many leates deepely cut euen to the middle rib, like vnto the leates of hempe : the floures and feeds are like vnto the common mallow: the root is exceeding grcat, thicke, and of a wooddy fubltance. \# Clufius calls this Alcea fruticofacannabino folio: and it is with good reafon thought to be the Cannabis fylueftris defcribed by Diofrorides, ho. 3 .
cap. $266 . \neq$

$$
\text { T. The Place. }
$$

The common marth mallow groweth very plentifully in the marthes both on the Kentifh and Effex hiore alongft the riuer of Thames, about Woolvych, Erith, Greenhyth, Grauefend, TilbuIis, Lee, Colchefter, Harwich, and in moft falt marthes about London : being planted in gardens it profpereth well, and continueth long. The fecond groweth in the moift and fenuy places of Fertaria, betweene Padua in Italy, and the
rituer Eridanus.

The others are frangers likewife in England : notwithftanding at the imptefion hereof I haue fowen fome feeds of them in my garden, expecting the fucceffe.

$$
\text { 9) The rime. }
$$

They floure and flourinh in Iuly and Augut: the root fpringeth forth afreth eucry yeare in the beginning of March, which are then to be gathered, or in September.

$$
\text { The Names. }
$$

The common marth mallow is called in Greeke Axsma, and ieions : the Iatines retaine.the names Althea and $1 b_{i}$ fors : in thops, Bifmalua, and cMaluarifous; as though they fhould fay Malua Ibifous: in high-Dutch, 3 bifth: in low-Dutch, moitte 99 aluwe, and noitten bemft: in Italian and $S_{p 2}$ nifh, Malmus co : in French, Guimaulue : in Englih, marn mallow, moorith mallow, and white
mallow.

The reft of the mallowes retaine the names expreffed in their fenerall titles.

or The Temperature.

Marfh mallow is moderately hot,but drier than the other mallowes : the roots and feeds hereof are more dry, and of thinner parts, as Galen writeth; and likewife of a digefting, forming, or molli-
fying nature. 


\section{The Vertues.}

The leaues of Marfh Mallow are of the power to digent,mitigate paine, and to eoncost.

They be with good effect mixed with fomentations and pulteffes againft paines of tle fides; of 13 the ftone, and of tie bladder, in a bath alfo they ferue to take away any manner of paine.

The decotion of the leaues drunke doth the fame, which doth not only aftivare paine which $\mathrm{C}$ proceedeth of the ftone, but alfo is very good to caufe the fame to defcend more ealily, and to paffe forth.

The rooss and feeds are profitable for the fame purpofe: moreouer the decostion of the roots helpeth the bloudy fix, yet not by any binding qualitie, but by mitigaring the cripings and trettings thereof: for they doe not binde at all, although Galcn orberwife thought, but they cure the bloudy flix, by hauing things added vnto them, as the roots of Biftort, Tormentill, the foures and rindes of Pomegranates and fucl like.

The mucilage or fimie inice of the roots, is mixed very effecually with all oils,ointments, and $E$ plaifters that flacken and mitigate paine.

The roots boiled in wine, and the decoction gituen to drinke, expell the ftone and gratueli, helpe $\mathrm{F}$ the bloudy fix, fciatica,crampes, and convulfions.

The toots of Marfh Mallows, the leaues of common Mallowes, and the leaucs of Violets,boiled $G$ in water vntill they be verie foft, and that little water that is left drained away, ftamped in a ftone morter, adding thereto a certaine quant itic of Fenugteeke, and Linefeed in pouder; the root of the blacke Bryonie, and fome good quantitie of Barrowes greafe, ftamped altogether to the forme of a pultis, and applied vety warme, mollifie and foften A poftumes and hard fwellings, frellings in the ioints, and fores of the mother : it confumeth all cold tumors, blaftings, and windie outgrowings; it cureth therifts of the fundament; it conforteth, defendeth, and preferueth dangerous greene wounds from any manner of accidents that may happen thereto, it helpeth digeftion in them, and bringeth old vlcers to matutation.

The feeds dried and beaten into poudet and giuen to drinke, ftoppeth the bloudy flix and laske, $\mathrm{H}$ and all other iffues of bloud.

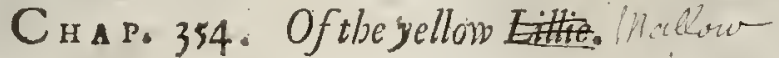

Althar Lutea.

Yellow Mallow.

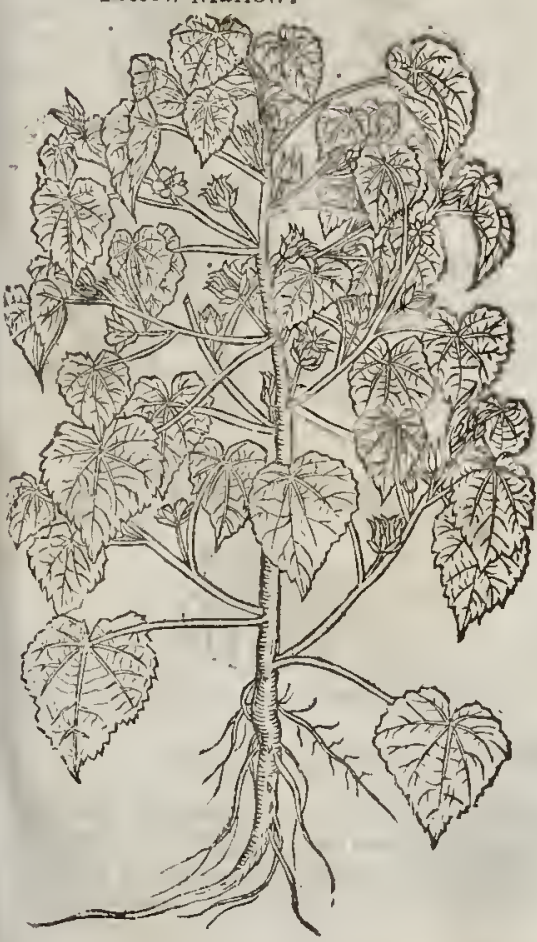

T The Defcription.

THe yellow Mallow ricth vpwith a tound ftalke, fomething hard or wooddic, three or foure cubits high, couered with btoad leaues' fomething round, but thatpe pointed, white, foft, fet with very fine haires like to the leaues of gourds, hang ing vpon long tender foot falks: from the bofome of whieh leaues come forth yellow floires, not vnlike to thofe of the eommon Mallow in forme : the knops or feed veffels are blacke, crooked, or wrinckled, made vp of many fmall cods, in whieh is black feed the root is finall,and dieth wlien it hath perfected his feed.

$$
\text { If The Place: }
$$

The feed hereof is brought vnto vs from Spaine and Italy : we doe yearely fow it in our gardens, the which feldom or neuer doth bring his feed to riperrefle : by rea fon whereof,we are to feeke for feeds againft the next yeare.

$$
\text { IT Thic Time. }
$$

It is fowne in the midft of Aprill, it brings forth his floures in September.

$$
\text { aा The Names. }
$$

Some thinke this to'be Abutilon: whereupon that agreeth which $A$ uien writeth, that it is like to the Gourd, thar is to fay in leife, and tubenamed Abutilon, an A Arblisilon : diucrs 
take it to be that Aithas or Marfh Mallow, vntowhich Theoplofafus in his ninth booke of the $\mathrm{Hi}_{\text {- }}$ ftorie of plants doth attribute Florem piaron, or a yellow floure : for the floure of the common Marfh Mallow is not jellow, but white; yet may Theophraftus his copie, which in diners places is fultie, and hath many cmptie and vnwritten places, be alfo faultie in this place; therefore it is hard ro fay, that this is Theophraftus marh Mallow, efpecially feeing that Theophraftus feemethalfo to atrribute vnto the root of Marn Mallow fo mueh fime, as that water may bee thickened rherew ith, which the roots of eommon Marn Mallow ean very well doe : but the root of Abutilon or yellow Mallow not at all : it may be ealled in Englin, yellow Mallow, and Auicen his Mallow.

बा The Temperature.

The temperature of this Mallow is referred vnto the Tree-mallow.

a. The Vertucs.

A Anicen Caith, that Abwtilon or yellow Mallow, is held to be good for greenewounds, and doth prefentivg glew together, and perfecty cure the fame.

F The feed drunke inwire preuaileth miglitily againft the fone.

C Bernutras P.ludarus of Anchufen reporteth, that the Turks do drinke the feed to prouoke fleepe and reft.

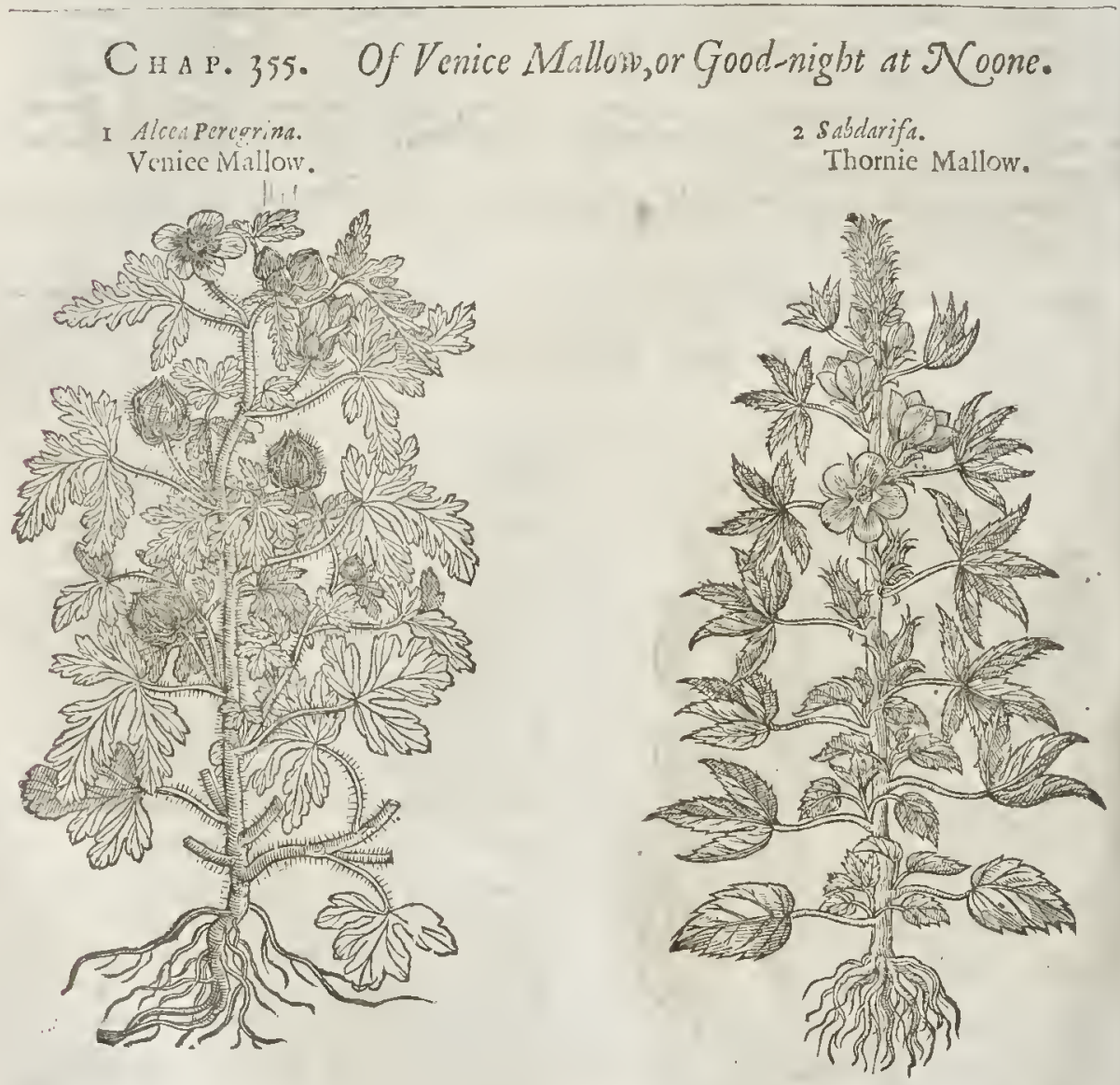

If The Defcription.

+ I Te Veniec mallow rifech vp with long,round, feeble ftalkes, whereon are fet vpon long

Is flender foor-ftalkes, broad iagged leaues, deepely eut curn to the middle rib : amongit which come forth very p!carant and beatifull foures, in thape like tho fe of the common mallow, 
$\neq 3$ Alcca efgyptia.

The Egyptian Codded Mallow.

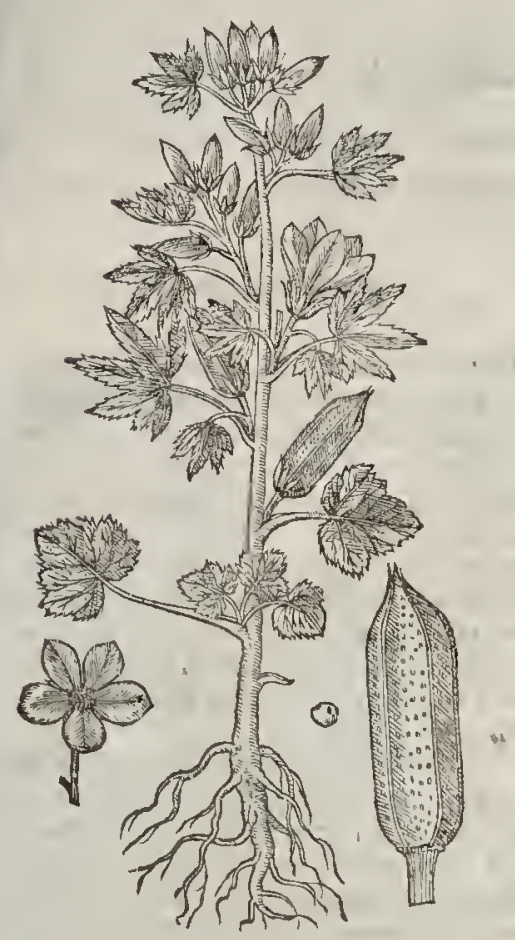

fomething white about theedges, bur in the middle of a fine purple : in the middeft of this floure ftandeth forth a knap or peftel, as yellow as gold: it openeth it felfe about cight of the clocke, and fhutteth vp againie at noone, about twelue a clockwhen it hath receiued the beams of the Sun,for two or three houres, wherean it thould feeme to reioice to look, and for whofe departure, being then vpon the poinr of declenfion, it feemes to griene, and fo thuts vp the floures that were open, and neucr opens them againe; whereupon it might more properly be called Malva horaria, or the Mallow of an looure: and this Columella feemeth to call Moloche, in this verfe;

Et Moloche, Frono fiquitur gree vertice folem:

The feed is contained in thicke rough bladders, whereupon Dodoneus calleth it Aliea $V^{\prime} \mathrm{C}$ ficaria:within thefe bladders or feed veffels are contained blacke feed, not unlike to thofe of Nigella Romana. The root is fmall and tender, \& peritheth when the feed is ripe, and muft be increafed by new and yearely fowing of the feed, carefully referued.

2 Thorn Mallow rifeth vp with one vpright ftalk of two ocubits high, diuiding it felfe into diuers branclies, whereupon are placed leaues deeply cut to rhe middle rib, and likewife fnipt abour the edges like a faw, in tafte like Sorrel the floures forthe moft part thruft forth of the trunke or body of the fmall ftalke, compact of fine fnall leaues, of a yellowifh colour, the middle part whereof is of a purple tending to redneffe:the husk or cod wherein the floure doth ftand is fee or armed with fharpe thornes : the root is finall,fingle, and moft impatient of our cold clymate, infomucls that when I had with great induftrie nourithed vp fome plants from the feed, and kept them vnto the midft of May; notwithftanding one cold night chancing among many, harh deftroied them all.

$\ddagger \quad 3$ This alfo is a ftranger cut leaued Mallow, which Cluf fus hath fet forth by the name of $\mathrm{Al}$ : cen eEgyptin: and Proper Alpinus by the title of Bammia the ftalke is round, ftraight, green, fome cubit and halfe high:vpon which without order grow leaues at the bottome of the ftalk, like thofe of Mallow, cornered and fnipt about the edges; but from the middle of the ftalke to the top they are cur in with fiue deep gafhes like as the leaues of the laft defcribed: the foures grow forth by the fides of the ftalke, in forme and colour like thofe of the laft mentioned, to wit, with fiue yellowinh leaues : after thefe follow long thicke fiue cornered hairy and tharpe pointed feed veffels, containing a feed like orobus, couered with a little downineffe : this growes in Egypt, where they eat the fruit thereof as we do Peafe and Beanes: Alpimus attribut es diuers vertues to this plant,agreeable to thofe of the common Marh-mallow. $\neq$

$$
\text { का The Place. }
$$

The feeds hereof haue been brought out of Spaine and other hot countries. The firft profpereth well in my garden from yeare to yeare.

$$
\text { 91 The Timse. }
$$

They are to be fowne in the mof fertill ground and funnie places of the garden, in the be: ginning of May, or in the end of Aprill.

$$
\text { of } T \text { be Names. }
$$

Their names haue beene fufficiently tonched in their feteral defcriptions. The firft may be called in Englifh, Venice-mallow, Good-night at noone, or the Mallow flouring but an houre: of Matthiolus it is called Hypecoon, or Rue Poppie, but vnproperly.

$$
\text { 9) The Temperature and Vertues. }
$$

There is a certaine clammie iuice in the leates of the Venice $V$ allow, wherenpon it is thought $A$ 


\section{$93^{8}$}

Of the Hiftorie of Plants:

L 1 в.2.

to come neere vnto the temperature of the common Mallow, and to be of a mollifying facultie:but his vfe in Phyficke is not yet knowne, and therefore can there be no certaintie affirmed.

\section{Cнан. 356. Of Cranes-bill. \\ ब The Kindes.}

THere be many kindes of Cranes-bil, whereof two were known to Diofcorides, onewith the knobby root, the other with the Mallow leare.

Geranium Columbirum.

Doties foot, or Cranes-bill.

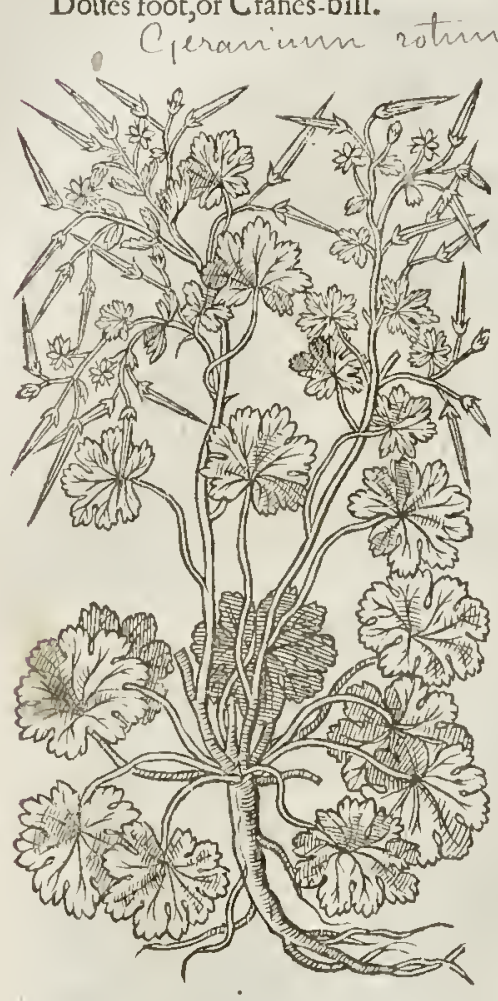

I The Defcription.

D Otues-foot hath many hairy ftalks, trailing or lcaning toward the ground, of a brownifh color, fomewhat kneed or iointed; wherupon do grow rough leaues of an oucrworne green colour, round, eut about the edges, and like vnto thofe of the common Mallow: amongft which come forth the floures of a bright purple color : after which is the feed,fet together like the head and bil of a bird; wherupon itwas callcd Cranesbill,or Storks-bill, as are alfo all the other of his kinde. The roor is thender, with fome fibres annexed thereto.

$\ddagger 2$ There is another kinde of this with larger ftalkcs and leaues, al fo the leaues are more deeply cut in and diuided, and the floures are either of the fame colour as thofe of the common kinde, or elfe fomewhat more whition. This may be called Geranium columbinum maizus difuctis foliis, Great Doures foot.

3 To this kinde may alfo fitly be referred the Geranism Saxatile of $\mathrm{T}$ halius : the root is f $\mathrm{mal}$ and threddy, the leanes are fmoother, redder, more bluntly cut about the edges, and tranfpa. rent than thofe of the firft defcribed, yet round; and otherwile like them : the Houres are fmall and red, and the bills like thofe of the former. Mafter Goodyer found it growing plentifully on the bankes by the high way leading from Gilford towards London, necre vnto the Townes end. $\ddagger$

- The Place.

It is found neere to common high waies, defart places, vntilled grounds, and fpecially vpon mud walls almoft euery where. Iune.

It fpringeth wp in March and Aprill : Aloureth in May, and bringeth his feede to ripeneffe in

$$
\text { T. The Names. }
$$

It is commonly called in Latine, Pes Columbinus : in High Dutch, Scatter kraut : in Low Dutch, Dupuetr boet : in French, Pied de Pigeon : hereupon it may be called Geranium Colimbinum. in Englifh, Dones-foot, and Pigeons-foot: of Dinfcorides, Geranism altersms: of fone, Pulmonia, and Gruina.

$$
\text { T The Temperature. }
$$

Doues foot is cold and fomewhat drie, with fome aftriction or binding, hauing power to foder or ioine together. A It Teemeth, faith my Author, to be good for g teene and bleeding wounds, and a fivageth inflam-
mations or hot fivellings. 
The herbe and roots dried, beaten into moft fine pouder, and giuen halfe a fpoonfull fafting, and $\mathrm{B}$ the like quantirie to bedwards in red wine, or old claret, for the fpace of one and twentie daies together, cureth miraculoufly ruptures or burftings, as my felfe bane often prooued, whereby I haue gotten crow nes and credit: if the ruptures be in aged perfons, ir thall be needfull ro adde rherero the powder of red fnailes (thofe whithout thels) dried in an onen, in number nisie; which forrifi. the herbs in fuch fort, rhat it neuer faileth, although the rupture be great and of long continuance: it likewife profireth much thofe that are wounded inro the body, and rhe decotion of the herbe made in wine,preuaileth mightily in healing inward wounds, as my felfe haue likcwife proued;

\section{Сан. 357. Of Herbe Robert.}

Geranium Robertianum:

Herbe Robert.

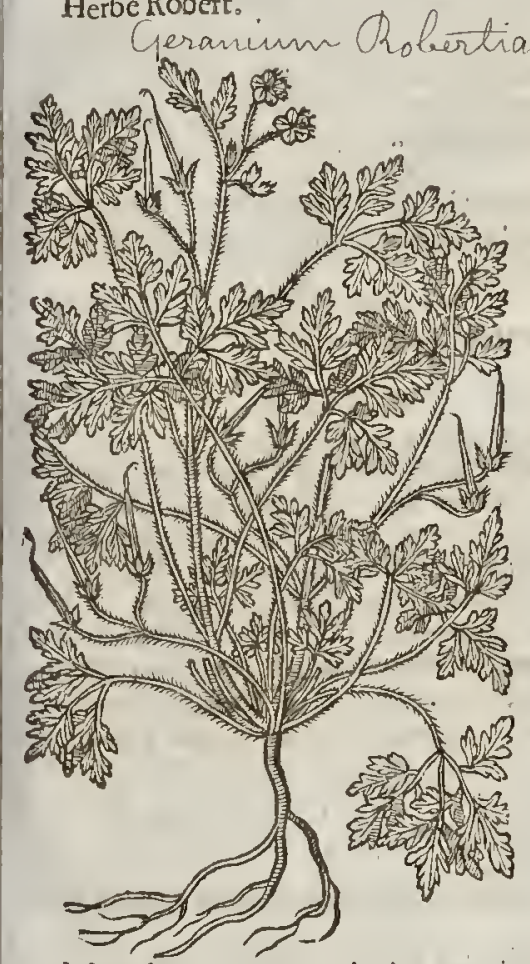

T The Defcription.

T. Erbe Robert bringeth forth flender weake 1 and britrle ftalks, fomewhat hairie, and of $a$ reddifh colour, as are of tentimes the leatues alfo, which are iagged and deepely cur, like vnto thofe of Cheruile, of a moft loathfome ftinking fmell. The floures are of a moft bright purple colour; which being paft, there follow cerraine fmal heads, wirh tharpe beaks or bils like rhole of birds: the root is fmall and threddic.

$$
\text { Tा } T \text { he Place. }
$$

Herbe Robert groweth vpon old walls, as wel thofe made of bricke and ftone, as thofe of mud or earth:it groweth likewife among rubbin, in the bodies of trees that are cut downe, and in moift and thadowie ditch banks.

T Tbe Time.

It floureth from Aprill till Sommer bealmoft fpent:the herbe is green in winter alfo, and is hardly hurt with cold.

$$
\text { T Tbe Names. }
$$

It is called in high Dutch, Lupuechts brat: in low Dutch, 230 ozechts itcuí: and thefeupon ir is named in Latine, Rubert $n_{2}$ and Roberti her$b_{a}:$ Ruellius calleth it Robertiana; and we, Rober. innum: of Tabernamontanu, Rupertinnum: in Englith, Herbe Robert. Hee rhat conferreth this Cranes bill with Diofcorides his third siderit is thall plainely perceiue, that they are borh one, and that this is molt apparently Sideritis 3. Diof coridis; for Dioforides fetteth downe three Sideriti des, one with the leafe of Horehound; the nexr with the leafe of Fearne; and the third groiveth in walls and Vineyards: the natiue foile of Herbe Robert agree thereunto, and likewife the leaues, being like vnto Cheruile, and not vnlike to thofe of Corlanders, according to Digfcorides defcrip:
tion. participating of mixt faculties.

\section{The vertues.}

It is good for wounds and vlcers of the dugs \& fecret parts, it is thought to ftanch bloud,which $A$ thing Diofcorides doth attribute to his third Sideritis: the vertue of this, fith he, is applied to heale vp bloudy wounds: 


\section{Cha P. 358 .}

Geranium tuberofum.

Knobbic Cranes-bill.

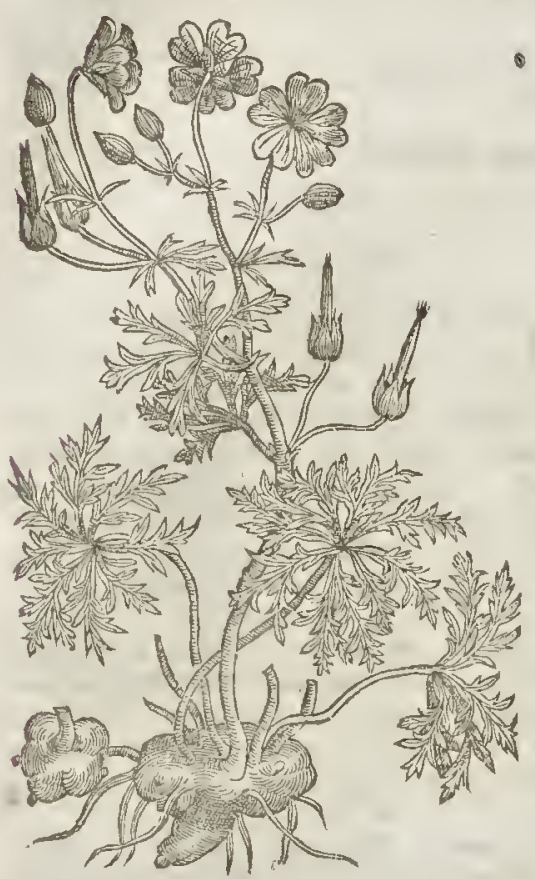

of knobbed Cranes-bill.

\author{
If The Defcription.
}

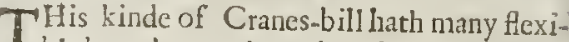
1 ble branches, weake and tender, fat, and fult of moifture, wheron are placed very great leaues cut into diuers fmall fections or diuifions, refembling the leaues of the tukerous Anemone, or Vinid-Houre,but fomewhat greater, of an outerworn greenilh colourramong which come fortls lóng foor-ftalks, whereon do grow faire floures, of a bright purple colour, and like vnto the fmalleft brier Rofe in forme: which being paft, there fucceed fuch heads and beaks as the reft of the Cranes-bill hauc : the root is thiek, bumped or knobbed, which we call tuberous.

$$
\text { IT The Place. }
$$

This kinde of Cranes-bill is a ftranger in England,notwithftanding I hatc it growing in my garden.

$$
\text { T The Time. }
$$

The time anfwereth the reft of the Cranesbills.

$$
9 \text { The Names. }
$$

Cranes bill is called in Greeke rup arion: in $\mathrm{La}$ tine, Gruinalis, commonly Roftrum Gruis, or Rofrum Cicorid : of the likeneffe of a Cranes-bill, or torkes-bill : of fome, wá cus mof cata:but that name doth rather belong toanother of this kind: it is alfo called Acus Pafforis : in Italian, Roftro

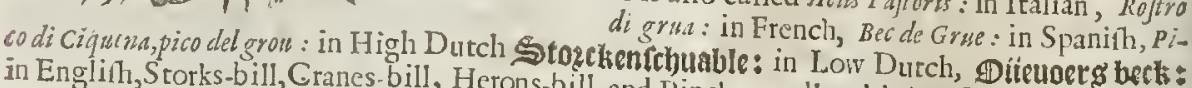
in Englinh, Storks-bill, Cranes-bill, Herons-bill, and Pinche-needle : this is alfo called for diftinor Diofcorides his firt. Cranes-bill.

The roots of this Che Temperature.

The roots of this Cranes.bill haue a little kinde of heat in them.

A The Viofreres.

A Diofcorides faith that the roots may be eaten, and that a dram weight of them drunk in wine dotlu walte and confume away the windineffe of the Matrix.

B Alfo Pliny affirmeth, that the roo hereofis fingular good for fuch as after weakneffe cratle to

C The rame Authorafimeth

is excellent good againft the Ptificke, weight of a dram of it drunke in wine thrce times in a day, is excellent good againft the Ptificke, or confumption of the lungs?

$$
\begin{gathered}
\text { CнAp. 359. Of OMusked Cranes-bill. } \\
\text { It The Defcription. }
\end{gathered}
$$

$\mathrm{M}$ Vsked Cranes-bil hatl many weake and feeble branches trailing vpon the ground, whereon the edges, of a pleafant firee many fmaller leates, fet vpon a middle rib, fript or cut abour the floures fet yppon tender foote-ftalkes, of a red colike to that of Muske: among whieh come fortl? which appeare fmall heads and poinced of a red colour,compact of fue fmall leaues apiece: after soot is fnill and threddy. 


\section{I в. 2. Of the Hiftorie of Plants.}

Geraniuris mofchatum.

Musked Cranes bill.
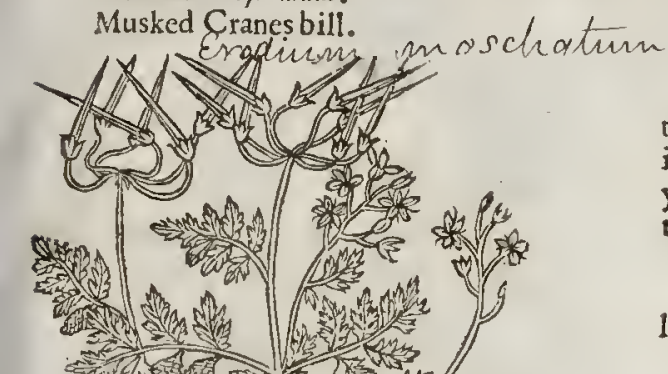

It is planted in Gatdens for the fweet fmell that the whole plant is poffeffed with, $\neq$ but if you cub the leaues and then frell to them, you shall finde them to haue a fent quite contraty to the formet. $¥$

$$
\text { T The Time. }
$$

It floureth and floutitheth all the fommer long.

\section{The Names.}

It is called Myrrkida Pliniy Roftrum Cicosid; sters mofchat a, in fhops, and Acusp preores, and likewife Geranium mofchatum : in Eng'in, Mufked Storkes bill, and Cranes bill, $\mathscr{M}$ fihatum, and of the vulgat fort Mufchato, and alfo Pickneedle.

$$
\text { If The Temperature. }
$$

This Cranes bill hath not any of his faculties found out or knownc: yet it feemcth to be colde and a litrle dry, with fome aftrietiones binding.

T) The Vertues.

The vertues are refetted vnto thofe of Doues foot, and are thought of Dioficorides to be good for greene and bloudy wounds, and hot fwellings that ate new ly begun.

\section{Cна P. 36о. Of Crow-foot Cranes-bill, or Gratia Dei.}

$$
\text { Tा The Difcription. }
$$

Rrow foot Ctanes bill hath many long and tender branches tending to tedneffe, fet with great leaues deepely cut or jagged, in forme like thofe of the fielde Crow foot, whereof it tooke his name; the floures are pretty large, and grorv at the top of the ftalkes vpon tendet footfalkes, of a perfea blew colour:which being paft, thete fucceed fuch heáds, beakes, and bils as the other Cranes bils.

I haue in my garden anorher fort of this Ctanes bill, bringing forth very faite white floures, which maketh it to differ from the precedent; in orher refpeats there is no difference at all.

$\$ 2$ This which is the Geranim 2. Batrachiodes mum of Clufus hath large ftalkes and leaues and thofe very much diuided or cut in ; the ftalkes alfo are diuided into fundry branches, which vpon long footfalkes carry floures like in thape, but leffe than thofe of the formerly defcribed, and not blew, but of a reddifh purple colour, hauing ten threds and a pointall comming foth of the middle of the floure; the beakes or bils which are the feed ftand vpright, and hang not downe their points as moft others do. The root is large and lines many yeares.

3 The ftalkes of this are ftiffe, greene, and haity, diuided at their tops into fundry branches which end in long foot:talkes, vpon which grow fioures commonly by couples, and they confift of fiue leaues apiece, and thefe of a darke rcd colour. The leaues are large, foft, and hairy, dinided into fix or feuen parts, and fnipt abour the edges; the roots are large and lafting. It is kept with vs in gardens, and floutes in May. Clufus calls it Geranizm r.prollo flöre.

4 This alfo hath ftalkes and leaues much like thofe of the laft defcribed, but fomewhat leffe: the florues are as large as thofe of the laft defcribed, but of a more light red, and they are conteined in thicker and thorter cups, and fuccecded by thortcr feeds or bills; and are commonly of a fweet muske-like fmell: The root is very long, red, and lafting. It foures in'the middert of May, and is 
942

Of the Hiftorie of Plants.

$\mathrm{L}_{1 \text { в.2. }}$

t I Geranium Batrachioides. Crow-foot Cranes-bill. pratense

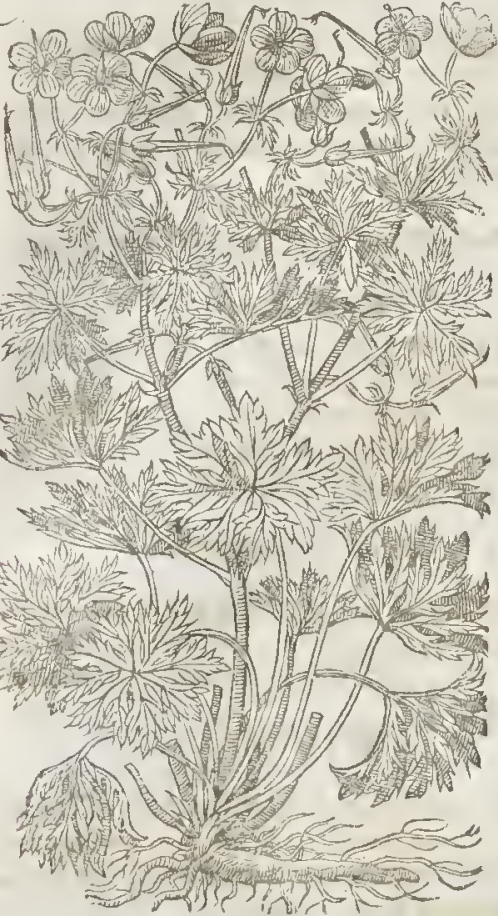

+ 3 Geramiom Batracbioides pullo fore. Duskig Cranes-bill. Jhoum - Gevan

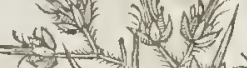
25. Wav at:

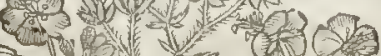
$67 \sqrt{3}$ a 1 हn

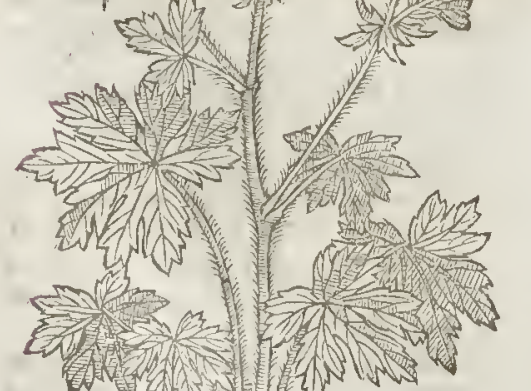
E) (14)
2 Geraniam Batrachioides alscrum. Small Crow-foot Cranes-bill.

Qon Geraninin sytuat En की

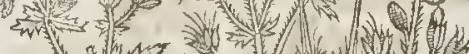
nully Eचत

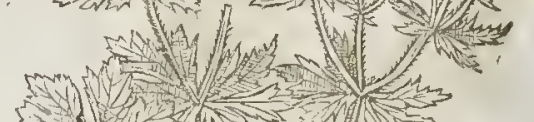

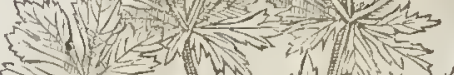

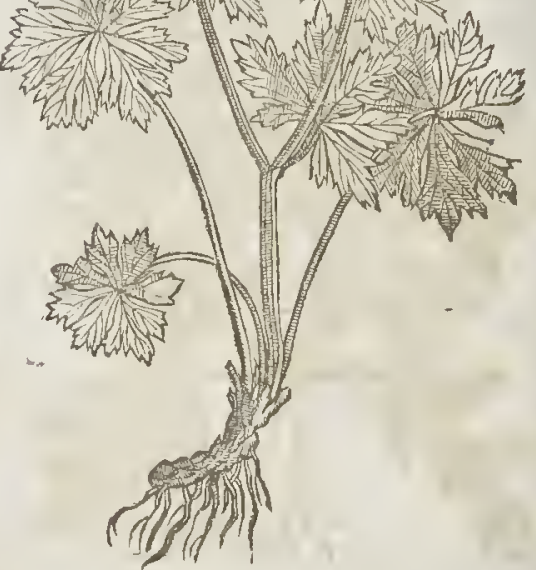

\$ Geranium Butrachioides longius radicatum? Long rooted Cranes-bill.

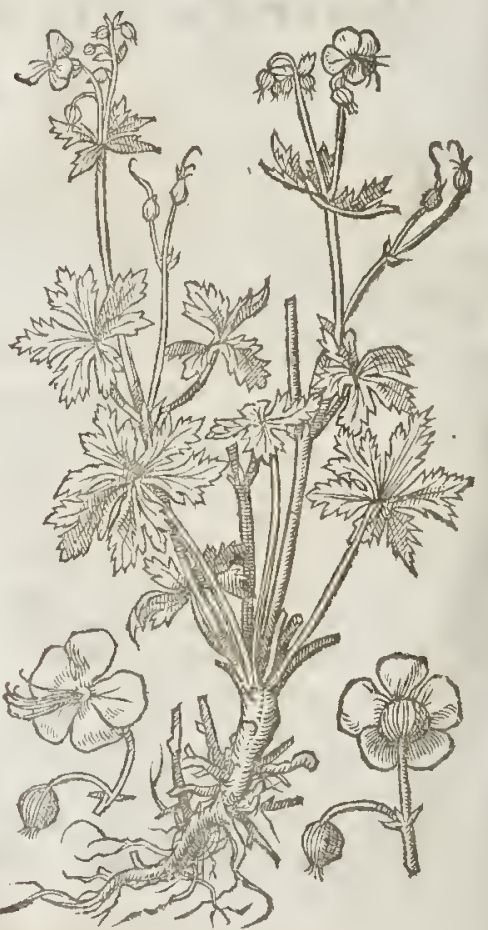


fections or cuts: among which come forth fowers compofat of fiue leanes apicee, of ablcwith or watchet colour, in the middle part whereof eome forrh a fow chines, and a fmall pointell of a purplifh colour: the head and beake is like to the teft of the Cranes bills, but greater: the root dicth when it hath petfected lis feed.

2 This Cranes. bill, being a baftard kinde of the former, laath long flender branehes groriing to the height of two or rhree cubits, fet about with very great leaues, not unlihe to thofe of Hollihocks, but fomewhat leffer, of an nuerworne greene colouramong whieh rife vp litrle foot-ftalks, on the ends whereof do grow fmall floures, leffer than thole of the preeedent, and of a murrcy colour: the head and feeds are like alfo,but much leffer : the roots doe likewife die at the finftapproch of W inter.

IT The Place.

Thefe are ftrangers in England, except in the gardens of fome Herbarifts: they grow in my gatdenvery plentifully.

$$
\text { จा The Time. }
$$

The time anfwereth the teft of the Cranes-bils,yet doth that of Candie floute for the mof part with me in May.

$$
\text { T) The Names. }
$$

There is not more to be faid of the names than hath been remembred in their feneral titles:they may becalled in Englifh, Cranes-bils, or Storkes-bils.

Their temperatute anfweteth that of Dones-foot.

T) The Temperature.

$$
\text { I The Vertues. }
$$

A Their facult ies in working are equall to thofe of Dones-foot, and vfed for the fame purpofes, (\& tight ly) fpeeially being ved in wound drinks, for the which it doth fat excel any of the Cranes bils, and is equall with any othet herbe whatfoeuet fot the fame purpofe.

\section{Cна P.362. Of diuers milde Cranes-bills.}

\section{If The Kindes.}

$T$

Here be diuers forts or kindes of Cranes-bils which haue not been remembred of the antient, nor much fpoken of by the later writers,all whieh I meane to comprehend vnder this chapter, making as it were of them a Chopter of wilde Cranes-bils, although fome of them late place in our London gardens, and that worthily, efpecially for the beautie of the foures: their names thall be expreffed in their feucral titles, their natures and faculties are refetred to the other Cranes-bils, or if you pleafe to a further confideration.

$$
\text { T The Defcription. }
$$

Potted Cranes-bill,or Storkes-bill, the whieh Lobel deferibeth in the tit Te thus, Geranium Fuf cum flore liuido purpurante, of medio Candicante, whofe leaues are like unto Crowfoot (beeing a kinde doubtleffe of Cranes bill, called $G$ ratia $D$ ci) of an oterworne duttie colour, and of a ftrong fauour, yet not altogether vnpleafant : the ftalkes are drie and brittle, at rhe tops whereof doe grow pleafant floures of a darke purple colour, the middle part of them tending towhiteneffe: from the flile or pointel thereof, commeth forth a tuft of fmall purple hairy threds. The root is thick and very brittle, lifting it felfe forth of the ground, infomuch that many of the faid roots lie aboue the ground naked without earth, euen as the roots of Floure-de-luces
doe.

3 Of thefe wilde ones Ihane another fort in my garden, which clufus in his Pannonickeobferuations liati called Geranium Hamatoides, ot fanguine Cranes bill: and Lobel, Geranium Grunum, Or Gruinale: it hath many fexible branches creeping vpon the ground: the leaues are much like vnto Doues foot in forme, but cut etren to the mislde rib - the floures are like thofe of rhe fmall wilde mallow, and of the fame bigneffe, of a perfect bright red colour, which if they be fuffered ro 
1.1 B. 2. Of the Hiftory of Plants.

945

I Geranism maculatum fine fufcum. Spotted Cranes bill.

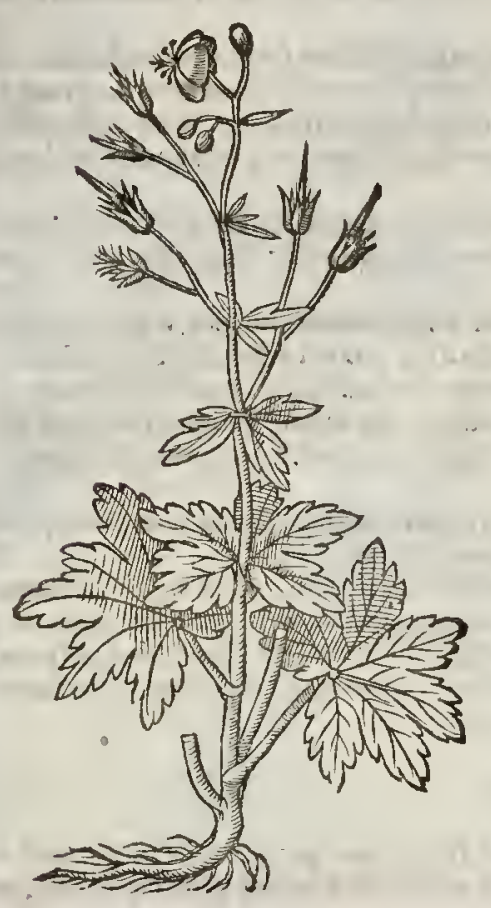

\section{Geranium Cicut a folio inodornms.}

Vnfauorie fielde Cranes-bill.
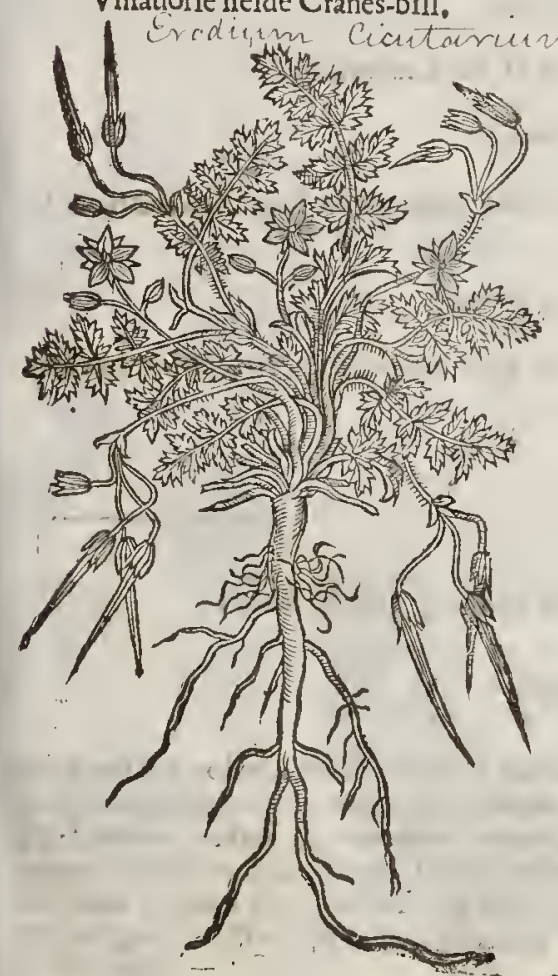

$\mathrm{Kkkk}$

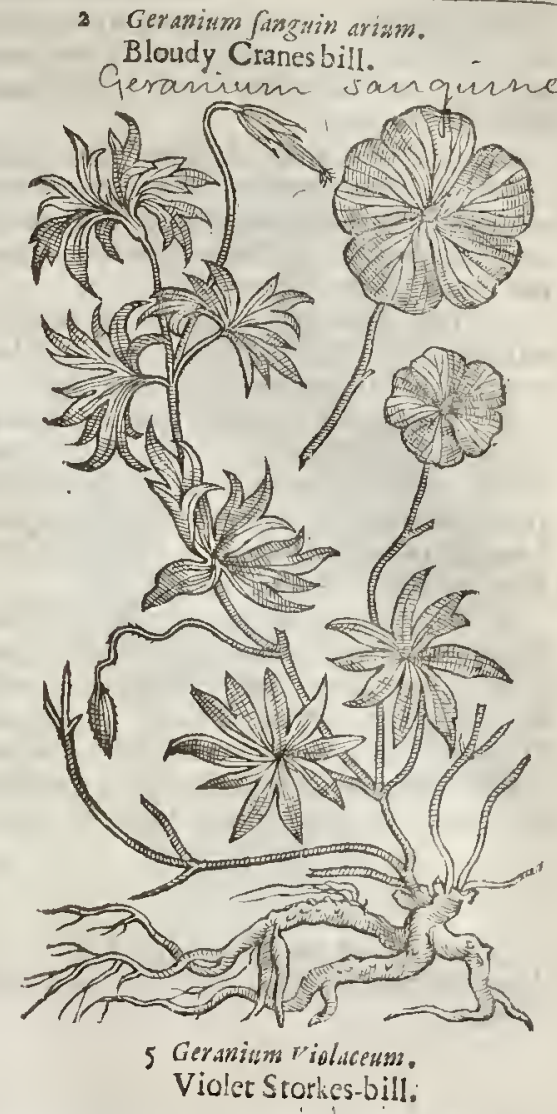

Gloudy Cranes bill.

$\cdot$

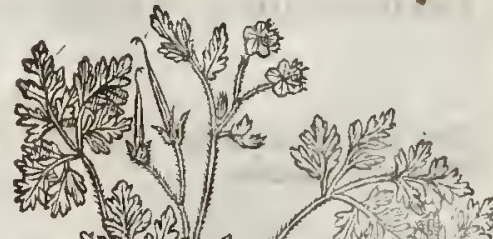
(a) 13 , m.1.2.

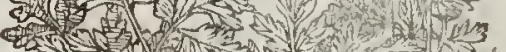

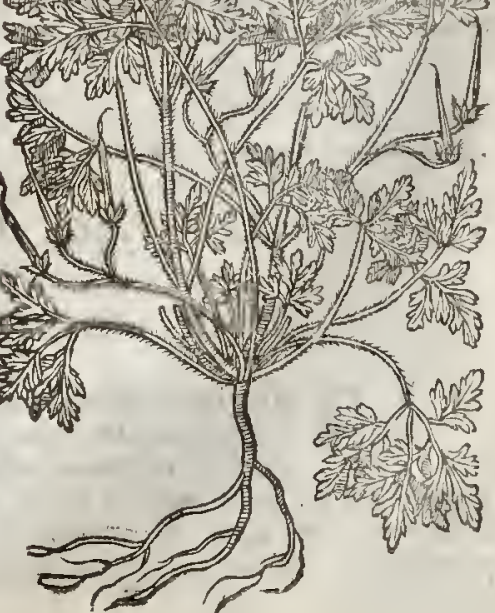
A 
grow and Itand vneill rhe next day, will be a murry colour; and if they tand vnto the third day, they will turne into a deep purple rending to blewneffe; rheir changing is fuch, that you hall finde at one time vpon one branch floures like in forme, but of diuers colours. The roor is thicke, and of a wooddic fubftance.

3 This wilde kinde of musked Cranes bill, being altogether without fauour or fmell, is ealled Myrrbida inodorum, or Geramum arven fe inodor wm, which bath many leaues fpred flat vpon the ground, enery leafe made of diuers fmaller leafes, and thofe cur or iagged abotir the edges, of no fmel at all: amongft which rife vp flender branches, whereon doe grow fmall floures of a light purple colour: rhe root is long and fibrous.

4 This is alfo one of the wilde kindes of Cranes-bills, agreeing with the laft deferibed in each refpeet, except the floures, for as the other lath purple floures, fo this plant bringeth forrh white floures, other difference there is none at all.

5 The Cranes-bill wirh violet coloured floures, hath a thicke wooddie toot, with fome few ftrings annexed thereto : from which rife immediatly forth of the ground diuers ftiffe ftalks, which diuide rhemfelues into other fmall branches, whereupon are fet confufedly broad leaues, made of three leaues apiece, and thofe iagged or cut about the edges: the floures grow at the rop of the branches of a perfect Violet colour, whereof it tooke his name: after which come fuch beakes or bils as rhe other of his kinde.

$\ddagger$ The figure that was put vnto this Defcription is the fame with Geraniwm Robertianum, and therefore I thought it not much amiffe ro pur it here againe. $¥$

6 I haue likew ife another fort that was fent me from Robinus of Paris, whofe figure was neuer fet forth, neither defcribed of any : it bringeth from a thicke tough root, with many branches of a brownifh colour:wherupon do grow leaues not valike to thofe of Gratia Dei,but not fo deeply cut, fomewhat cornered, and of a thining greene colour : the floures grow at the rop of the tender bran. ches, compofed of fixe fmall leaues, of a bright fcarlet colour.

$$
\text { If The Place. }
$$

The thirdand fourth of thefe Cranes. bills growe of themfelues about old VValls, and about the borders of fields, VVoods and copfes; and molt of the reft wee haue growing in our gardens.

$$
\text { I The Time. }
$$

Ther time of Houring and feeding anfwereth the reft of the Cranes bills.

q The Names.

Their feuerall titles thall ferue for their names, referring what might haue been faid more to a further confideration.

$$
\text { T. The Nature and Vertues. }
$$

IA There hath not as yet any rhing beene found either of their temperature or faculties, but may be referred vnto the other of rheir kinde.

\section{\# C на Р. 363. Of certaine other Cranes-bills. \\ T) The Defcription.}

7 I His which Chafus receiued from Do etour 7 homas Pennic of London, and fets forth by the fame title as you finde it here expreft, hath a root confifting offundry long ioynted, and red necte vnto the roote, and about the ioints : out of each of there ioyntes come two leaues which are faftened vnto fomewhat long foot-ftalkes, and diuided into fue parts, which alfo are fnipt about theedges : out of cach ofwhich ioints by the fetting on the foot. falkes 
\# I Geraniam bulbofum Pennei. pensies bulbous Cranes bill.

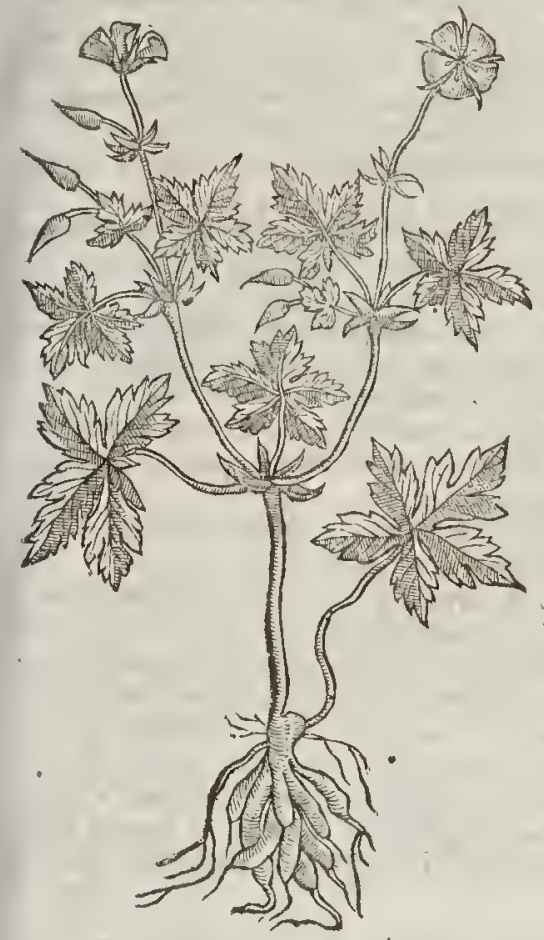

¥ 3 Geranium argenteum Alpinum.

Siluet leaued Mountaine Cranes bill.

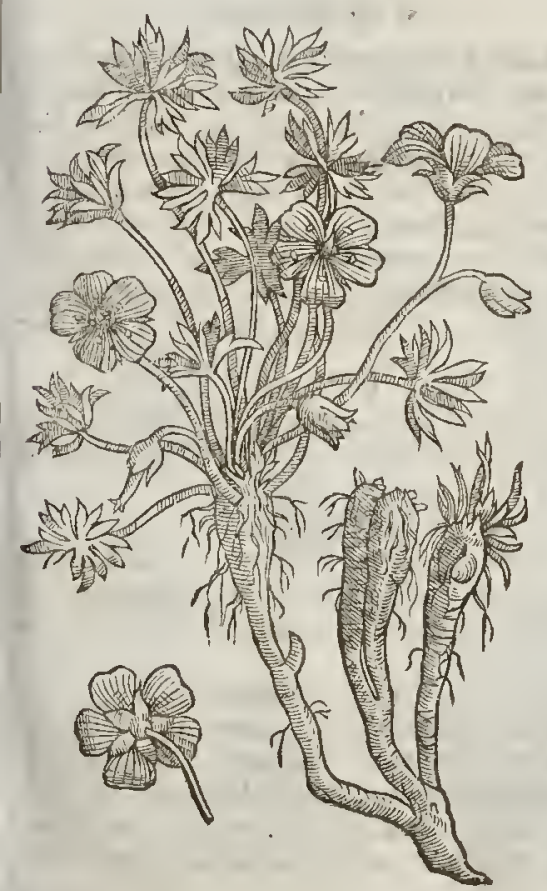

\$ 2 Gerarium nodofrem, Platcas. Knotty Cranes bill.

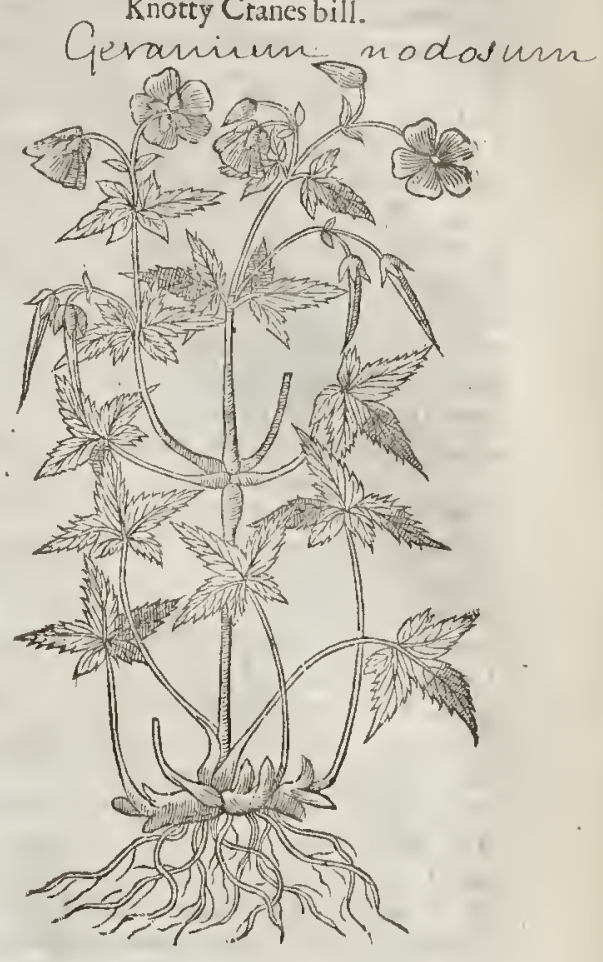

foot-ftalkes come forth fitue little tharpe pointed leaues : the floures grow by couples vpon the rops of the ftalkes, and are of a reddifh purple colour. It growes wilde in Denmark; whence D'. Turner brought it,and beftowed it vpon D'. Pemy before nentioned.

2 This hath ftalks fome foor high, iointed, and of a purplin colour : vpon which grow leaues diuided into three parts; but thofe below are cut into fiue, and both the one and the other are fnipt about the edges: the floures are compofed of fue reddith purple leaues of a pretty largenefic, with a reddith pointall in the middle; and falling, the feed follows, as in orher plants of this kind: the root is knotty, and ioynted, with fome fibres: it floures in May, and fo continuerh a grear part of the Sommer after. Chufus calls this Geranium 5. nodofum, Platean. This formtimes is found to carry tuberous excrefcences vpon the ftalkes, tow ard the later end of Sommer; whence Platems diftinguiined it from the orher, bur afterwards found it to be the fame: and cluffus alfo figures and defcriberh this larervariet ie by the name of $G \mathrm{era}$ mium 6. tubiriferum Flatedu.

3 The root of this is fome two handfuls 
long, blackewithout, and white within, and towards the top diuided into fundry parts; whence put forth leates couered ouer with a fue filuer dorne; and they are diuided into fiue part ts, each of which againe is diuided intothree others, and they are faftned to long flender and round footftalkes: the foures grow vpon foot-ftalkes thorter than thofe of theleaues; the foures in colour and thape are like thufe of the Veruaine Mallow, but much leffe; and after it is vaded there followes a thort bill, as in the other plants of this kinde. It floures in Iuly, and growes vpon the Alps, where Pona found it, and firft fet it forth by the name of Geranium Alpwan longuss raduatum.

4 The ftalkes of this pretry Cranes bill are fome foot or better high, whereon grow leaues parted into fite or fix purts like thofe of the Geranium fuf $(\mathrm{wm}$, but of a lighter greene colour : the floures are large, compofed of fute thin and foone fading leaues of a whitifh colour, all ouer intermixt with finc veines of a reddith colour, which adde a great deale of beauty to the Aloure: for thefe veines are very fmall, and curioully difperfed ouer the leaues of the Aloure. It $f$ atres in Inne,

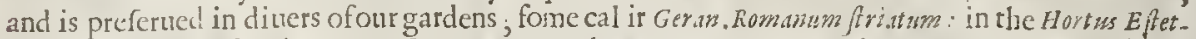
tenfis it is fet forth by the name of Geranium Anglicum variegatum. Bauline calls it Goranium batrachiodes flore wariegato. We may call it Variegated or ftriped Cranes bill.

5 There is of late brought in to this kingdome, and to our knowledge, by the induftry of $\mathrm{M}^{\mathrm{t}}$. To bn Tradefomt, another more rare and no lefte beautifull than any of the former; and he had it by the name of Geranism Indicum nocin odoratum : this hath not as yet beenew ritten of by any that $I$ know; therefore I will giue you the defcription thereof, but cannot as yet giue you the figure, becaufe I omitted the taking thereof the laft yeare, and it is not as yet come to his perfection. The leaues are larger, being almoft a foot long, compofed of fundry little leaues of an vnequal bignes, fet vpon a thicke and ftiffe middle rib; and thefe leates are much diuided and cut in, fo that the whole leafe fomew hat refembles that of Tanacetum inodorum and they are thicke, greene, and fomewhat hairy : the falke is thicke, and fome cubit high; at the top of each branch,vpon foot-ftalkes fome inch long grow fome eleucn or twelue floures, and each of thefe foures confifteth of fue round pointed leaues of a yellow in colour, with a large blacke purple fpot in the middle of each leafe, as if it were painted, which gines the floure a great deale of beauty, and it alfo hath a good fmell. I did fee it in Houre about the end of Iuly, r6;2. being the firf rime that it flomed with the owner thereof. We may fitly call it Sweet Indian Storks bill, or painted Storks bill : and in Latine, Geranium Indicum odoratum flore maculato. +

\section{С нат. 364. Of Sanicle.}

Sanicula, fue Diapenfia. Sanicle.

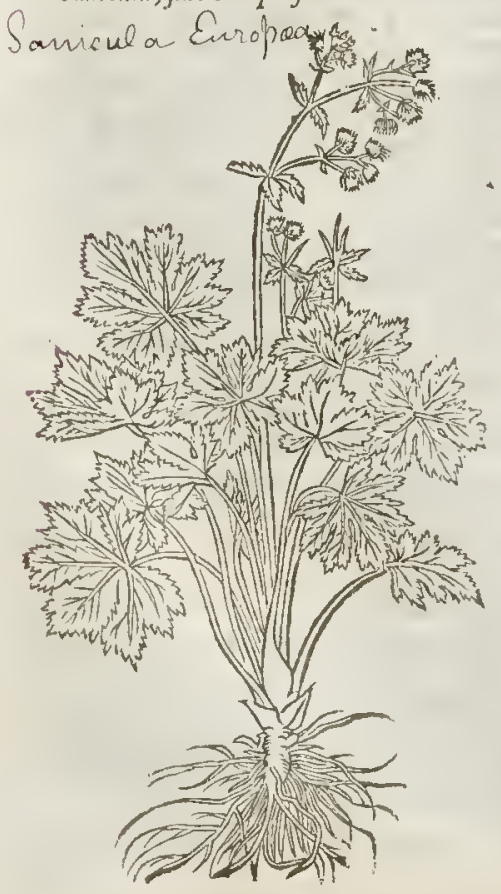

T The Defcription.

Anicle hatl leaues of a blackith greene colour, fmooth and thining, fomewhat round, diuided into fue parts like thofe of the Vine, or rather thofe of the maple:among which rife vp llender ftalkes of a browne colour, on the tops whereof ftand whire moflie floures $:$ in their places comevpround feed, rough, cleauing to mens garments as they parfe by, in manner of little burs : the root is blacke, and full of threddie Atrings.

$$
\text { 91 The Place. }
$$

It groweth in fhadowie wouds and copfes almott euerie where : it ioveth in a fat and fruitful moift foile.

$$
\text { ef The Time. }
$$

It foureth in May and Iune : the feed is ripe in Auguf: the leates of the herbe are greene all the yearegand are not burt with the cold of Winter.

$$
\text { T The Names. }
$$

It is commonly called Sanicula ; of diuers, $D i-$ apenfra : in high and low Dutch, 5 antitkel: in French, Sanicle : in Englioh, Sanickle, or Sani- kel : it is fo called, à fanandis wulneribus, or of healing of wounds, as Ruellius faith : there be alfo 
L I 8. 2. Of the Hiftory of Plants:

other Sanicles, fo named of moft Herbarifts, as that which is defcribed by the name of Dentaria or Coral-wort, and likewife $A$ uricula wr 3 , or Beares eare, which is a kind or Cow lip; and likervife another fet forth by the name of saniculagutitit, whereof we hatie entreated among the kindes of Beares eates,

of The Temperature.

Sanicle as it is in tafte bitcer, with a certane binding qualitic; fo befides that it clenfeth, and by the binding faculty ftrengthneth, it is hot and dry, and that in the fecond degree, and after fome Authots, hot in the third degree, and altringent.

$$
\text { बा The Vertues. }
$$

The iuyce being inwardly taken is good to heale wounds.

The decoction of it alfo made in wine or water is giten againfe fuitting of bloud, and the blo:ldie fix : alfo foule and filthy vicers be cured by being bathed therewith. The herbe boyled in water, and applied in manner of a pulteffe, doth diffolue and wafte away cold fwellings : it is vfed in porions which are called Vulnetarie potions, or wound drinkes, which maketh whole and found all invard wounds and outwatd hurts : it alfo helpeth the vlcerations of the kidnies, ruptures, or burftings.

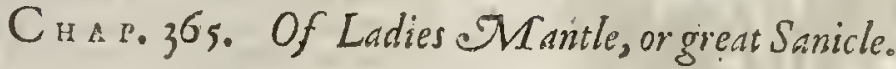

Alchimilla.

Lyons foot, or Ladies mantle.

dechemilla velgaris -

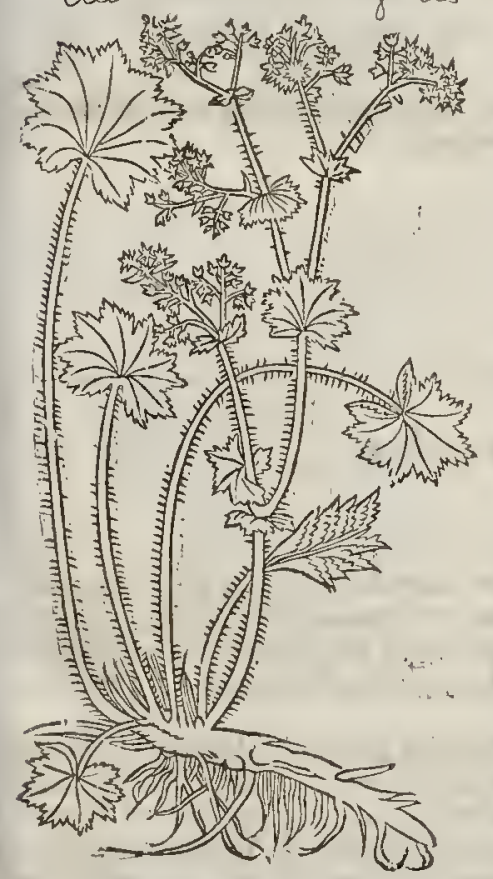

91 The Dafcription.

Adies manitlehath maty round leaves, with 1 fiue or fix corners fincly indented about the edges, which before they be opened are plaited and folded rogether, not vnlike to the leanes of Mallowes, but whiter, and more curled: among which rifeiviptender ftalks fet with the like leaues but much lefler: on the tops wheteof grow fmall moffie floutes clufteting thicke together, of a yellowith greene colour. The feed is fmall and yellow, inclofed in greene husks. The root is thicke, and full of threddy ftrings.

$$
\text { of The Place. }
$$

It groweth of it felfe wilde in diuers places, as in the toivne paftures of Andoner, and in many other places in Barkfhire and Hamplhire, in their paftures and copfes, or low woods, and alfo vpon the banke of a mote that inclofeth a houfe in Btthey called Bourn hall, fourteen miles from London, and in the high way from thence to Watford, a fmall mile diftant from it.

$$
\text { or The Time. }
$$

It floureth in May and Iune : it flourifheth in Winter as well as in Sommer.

$$
\text { बा The Names. }
$$

It is called of the later Herbarits Alchimilla : and of molt, Stellaria, Pes Leonis, Pata Leonts, and Sanculd maior : in high-Dutch, SEvnnaubi, and Dnter freathoen mantel : in French, picd de Lion: in Englinh, Ladies mantle, great Sanicle, Lyons foot, Lyons paw; and of fome, Padelyon.

$$
\text { If The Temperature. }
$$

Ladies mamle is like in temperature to little Sanicle, yet is it more drying and more binding.

$$
\text { if The Fertues. }
$$

It is applied rowounds after the fame manner that the fmaller Sanicle is, being of like efficacie : it toppeth bleeding, and alfo the ouermuch flo wing of the natural fickneff: : it keeps downe maidens papsoidugs, and when they be too great o: flaggy ir maketh them leff : or harder.

CHAP

\section{A}




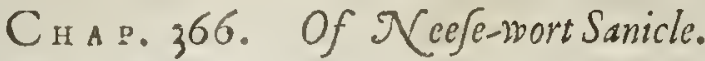

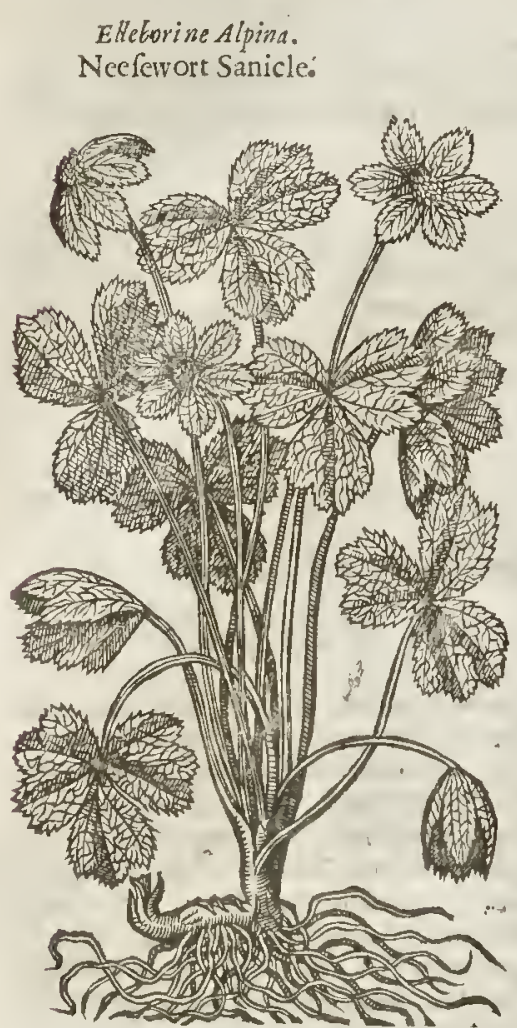

Tf The Defcription.

VHen I made mention of Helleborts albus, I did alfo fet downe my eenfure coneerning Elleborme, or Epipactis:but this Elleborme of the Alpes I put in this place, becaufe it approcheth neerer vnto Sanicle and Ranunculsus, as participating of both : it groweth in the mountaines and highedt parts of the Alpith bills, and is a ftranger as yet in our Englith gardens. The root is compact of many fmall twifted frings like black Hellebor:from thenee arife fmall tender falkes, fmooth, and eafie to bend; in whofe tops grow leaues wit's fue diuifions, fomewhat nickt about the edges like vnto Saniele : the floures confitt of fix leaues fomewhat fhining, in tafte fharp,yet nor vnpleafant. This is the plant which Pena found in the forreft of Efens, not fatre from Iupiters mount, and fets forth by the name of $A l p i n a \mathrm{El}$. leborine S anicula ó Ellcbori nigri fucie.

T The Nature and Vertues.

I have not as yet found any thing of his nature or vertues.

\section{Cна в. $3^{6} 7$. Of Crom-feet. \\ बा The Kindes.}

$T$ Here be diuers forts or kinds of thefe pernitious herbes comprehended vnder the name of $R_{b-}$ muncuíus, or Crowfoot, whereof moft are very dangerous to be taken into the body, and therefore they require a very exquifite moderation, with a moft exact and due manner of tempering,not any of them are to be taken alone by themfelues, beeaufe they are of mont violent force, and therefore hate the greater need of eorrection.

The knowledge of thefe plants is as neeeffaric to the Phyfitian as of other herbes, to the end they may fhun the fame, as Scribonisu Largus faith, and not take them ignorantly: or alfo, ifneeffitie at any time require, thiat they may vfe them, and that with fome deliberation and fpeciall ehoice, and with the ir proper correctiues. For thefe dangerous Simples are likewife many times of themfelues benefieiall, and oftentimes profitable : for fome of them are not fo dangerous, but that they may in fome fort, and oftentimes in fit and due feafon profit and do good, if temperature and moderation be vfed : of which there be foure kindes, as Diofcrides writeth; one with broad leaues, another that is downy, the third very fmall,and the fourth with a white floure: the later herbarifts haue obferued alfo many moe : all thefe may be brought into two prineipall kindes, fo that one be a garden or tame one, and the other wilde; and of thefe fome are eommon, and others rare, or forreigne. Moreouer, there is a differenee both in the roots and in the leates; for one hach a tumped or knobby root, another a long leafe as Speare-wort: and firft of the wilde or field Crowfeet, raferring the Reader into the end of the foeke and kindred of the fame, for the temperature
and vertues. 


\section{L1 B. 2. Of the Hiftory of Plants.}

I Ranunculas pratenfis, etiamque horten is. Common Crow-foot.

Rammaculus ratrena (1) a 2 vo NW no $\frac{1}{\sin _{2}} \mathrm{~N}$

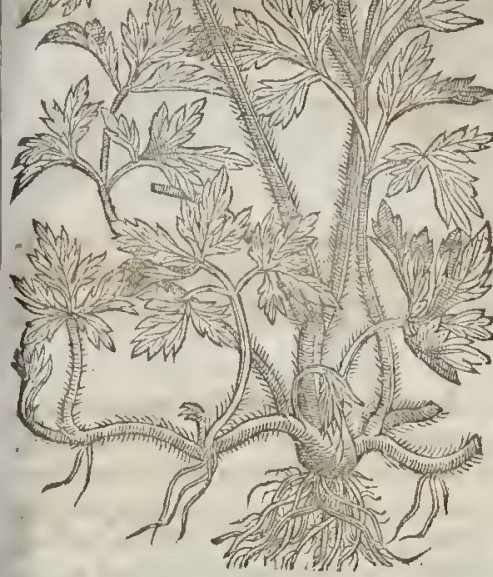

3 Ranunculus arunrum? Crow foor of the fallowed field: Rane nealus arvonsis.

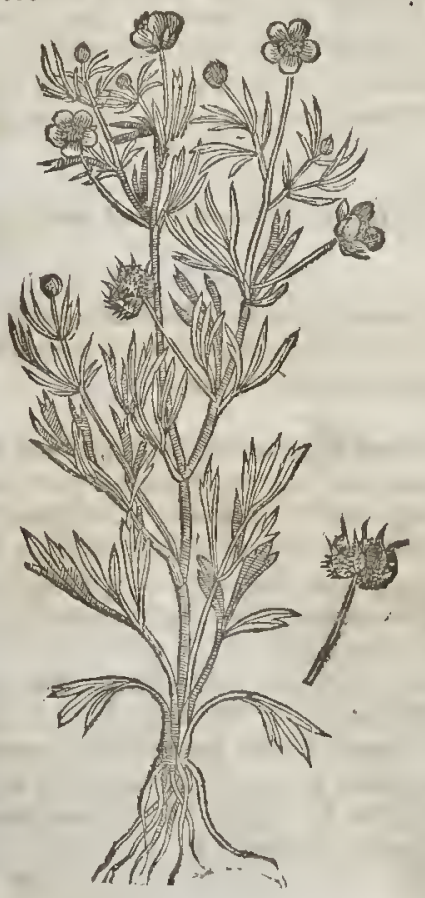

a Ranunculus furrect is cauliculis. Rammight Crow-foot.

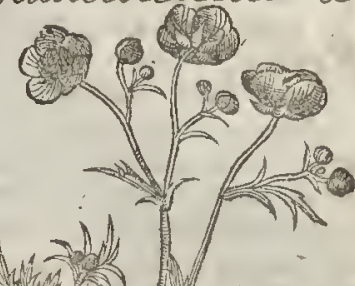

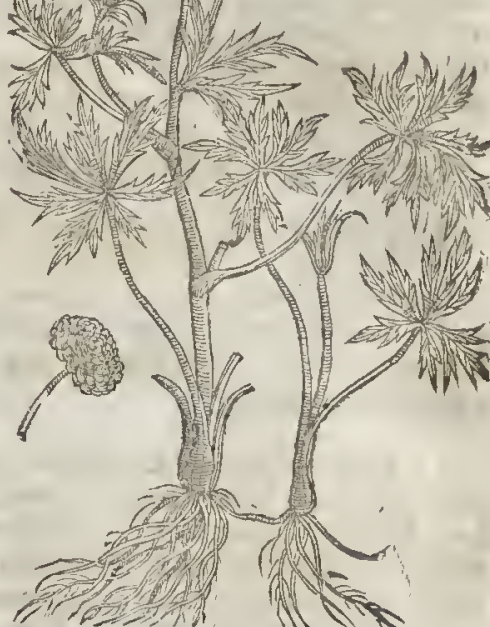

4 Ranunculus Alpinus albus.

White mountaine Crow-foot.

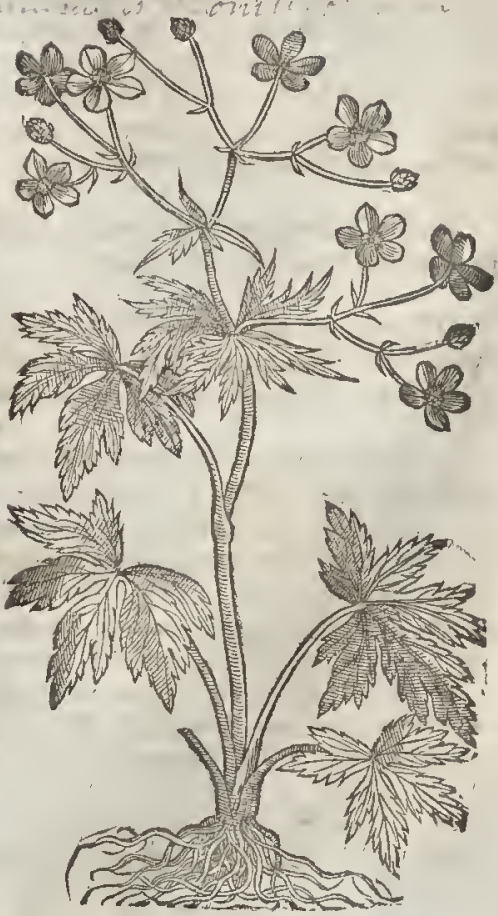




\section{-1 The Defcription.}

I Hecommon Crow-foot hath leaues diuided into many parts, commonly three, fome: times fiue, cut here and there in the edges, of a deepegreene colour, in which fand diuers white fpors : the ftalkes be round, fomething hairie, fomc of them bow downe toward the ground, and put forth many little roots, whereby it taketh hold of the ground as it trailethalong: fome of them ftand vpright, a foot high or higher; on the tops whereof grow fmall floureswith fue leaues apiece, of a yellow glittering colourlike gold : in the middle part of thefe floures ftand certaine fnall threds of like colour : which being paft, the feeds follow, made vp in a rough ball : the roots are white and threddy.

2 The fecond kinde of C row-foot is like vnto the precedent, fauing that his leaues are fatter, thicker, and greener, and his fmall tw iggy ftalkes ftand vpright, otherwife it is like : of which kind it chanced, that walking in the field next to the Theatre by London, in the company of aworthipfull merchant named $\mathrm{M}^{\mathrm{r}}$. Nicolas Lete, I found one of this kinde there with double foures, which beforc that time I had not feene.

$$
\text { The Place. }
$$

They grow of themfclues in paftures and medowes almoft enery where.

They floure in May and many moneths after.

$$
\text { T The Time. }
$$

$$
\text { T The Names. }
$$

Crow-foot is called of Lobel, Ranunculus pratenfis : of Dodoneu, Ramunculus hortenfis, but vnprow perly: of Pliny, Polyant hemum, which he faith diuers name Batrachen : in high-Dutch, $\$$ ochmalb bluom: in low Dutch, 250 ter blacmen : in Englih, King Kob, Gold cups, Gold knobs, Crowfoor, and Butter-floures.

\section{पा The Defcription.}

3 The third kinde of Crow-foot, called in Latine Ranumetus aruorums, becaufe it growes com: monly in fallow fields where corne hath beene lately fowne, and may be called Corne Crow-foot; hath for the moft part an vpright falkc of a foot high, which diuides it felfe into other branches: whereon do grow fat thicke leaues very nuch cut or iagged, refembling the lcaues of Sampire, bus nothing fo greene, but rather of an ouew orne colour. The floures grow at the top of the branches, compact of fiue fmall leaues of a faint yellow colour : after which come in placc clufters of rough and tharpe pointed feeds. The root is fmall and threddy.

4 The fourth Crow-foot,which is called Runumlus Alpinus, becaufe thofe that hate firft written thereof have not found it elferwhere but vpon the Alpifh mountains (notwithftanding it groweth in England plentifullywildegefpecially in a wood called Hampted Wood, and is planted in gardens) harh diuers great fat branches two cubits high, fet with large leanes like the common Crow-foot, but greater, of a deepe greene colour, much like to thofe of the yellow Aconite, called Aconitum luterm Ponticum. The floures confift of fiuc white leaues, with fmall yellow chiues in the niddle, finelling like the floures of May or Haw-thorne, but more pleafant. The roots are greater than any of the ftocke of Crow - feet.

$$
\text { T. The Place and Time. }
$$

Their place of growing is toucled in their defcription : their time of flouring and feeding an: firereth the other of their kindes.

$$
\text { T) The Names. }
$$

The white Crow-foot of the Alps and French mountaines is the fourth of Dioforides his defcription; for he defcribeth his fourth to haue a white floure: more hath not bin faid touching the names, yet Tabern. calls it Batrachium album : in Englifh, white Crow-foot.

$$
\text { IT The Defcription. }
$$

5 Among the wilde Crow-feet there is one that is fymamed Illyricus, which brings forth flen: der falks, round, and of a meane length: whereupon doe grow long narrow leauescut into many long gathes, fomthing white, and coucred with a certaine downineffe : the floures be of a pale yellow colour: the root confifeth of many fmall bumpes as it were graines of corne, or litele long, bulbes growing clofe together like thofe of Pilewort. It is reported, that it was firfe brought out of Illyria into Italy, and from thence into the Low-Countries : notwithftanding we haue itgrow. ing very common in England. $¥$ But only in gardens that I haue feene. $¥$

6 The fixth kinde of Crow-foot, called Ramunculus bulbofus, or Onion rooted Crow-foot, and round rooted Crow-fout, hath a round knobby or onion-fafhioned root, like vnto a fmall Turnep? and of the bigneffe of a great Oliue : from the which rifes vp many leaues fpred vpon the ground, like thote of the field Crow-foot, but fmaller,and of an ouerworne greene colour : among fe which rife vp flender ftalkes of the height ofa foot : whereupon do grow floures of 2 feint yellow colour. * This groweswilde in molt places, and floures at the beginning of May. 


\section{T The Place.}

It is alfo reported to be found not only in Illyria and Sclauonia, bur alfo in the Ifland Satdinia. ftanding in the Midland, or Mediteranian fea.

$$
\text { T T T Names. }
$$

This Illyrian Crow foot is naned in Greeke oixum a'vewr, that is, Apirm fylueftre, or wilde Smallage: alfo Herba Sardoa; it may be, faith my Author, that kinde of Crow foor ealled Apism rifus, and ynar qui ; and this is thought to be that Golotophillis, of which Pliny maketh mention in his 24 . booke, 17. chap. which being drunke, faith he, with wine and mytrh, caufeth a man to fee diucrs ftrange fights,and not to eeafe laughing till he hath drunke Pine apple kernells with Pepper in wine of the Date rrec, (I thinke he would haue faid vntill he be dead) becaufe the nature of laughing Crowfoot is thought to kill laughing, but wirhour doubt the thing is eleane contrary; for it caufeth fuch convulions, cramps and wringings of the mouth and jawes, that it hath feemed to fone that the partyes haue dyed laughing, whereas in truth they haue died in great torment.

5 Ranuncules Illyricus. Crowfoor of Illyria.

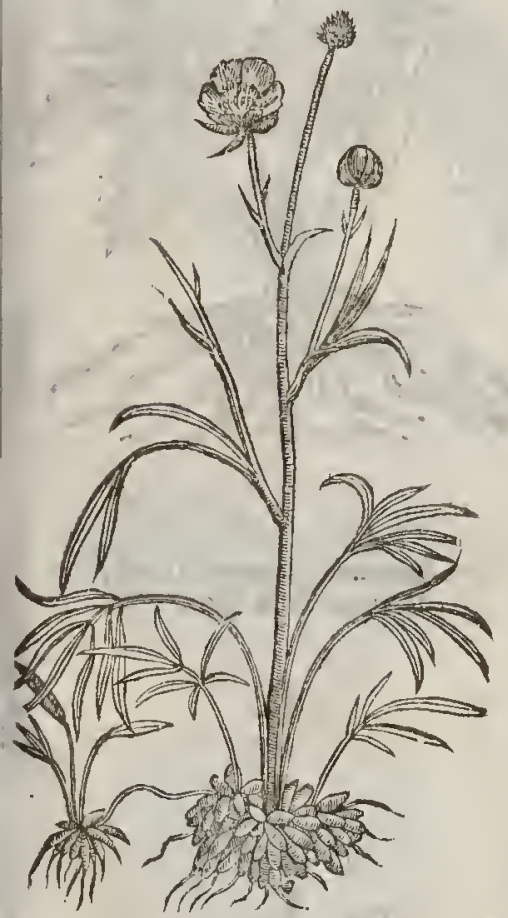

6 Ranusculus bulbofus. - Raminnculirs bullósus.

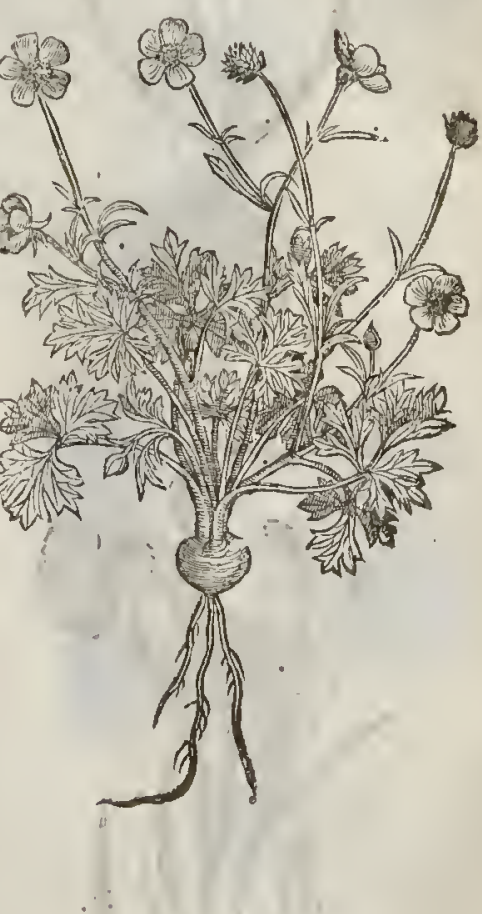

q The Defcription.

7 The feuenth kinde of Crowfoot, called Luricomus of the golden lockes wherewith the Houre is thrummed, hath for his root a great bufh of blackith hairy ftrings ; from which thoote torth fmall jugged leates, not much vnlike to Saniele, but diuided onely into three parts, yer fometimes in to fue; among which rife vp branched ftalkes of a foot high, whereon are placed the like leates but fmaller, ferabout the top of the ftalkes, whereon do grow yellow floures, fweet fmeliling, of which it hath been called Ranunom dulcis, Tragi, or Trugax his fweet Crowfoor. $\neq$ It growes in medowes and about the fides of woods, and Houres in Aprill. $t$

† 8 Frogge Crow foot, ealled of Pcna, Aconitum Batrachioides : of Dodonsus, Batrachion Apulei, is that formerly defcribed in the fourth place, whereto this is much alike, but that the ftalkes and leaues ate larger, as alfo the floures, which are white: the roo: is tough and threddy.

9 The ninth Crowfoote hath many grafie leates, of a deepe greene tending to blewneffe, fomewhat long, narrow and fmooth, very lilie vnto thofe of the finall Bifort, or Snakeweed: 
7 Ranunculus auricomus.

Golden-haired Crow-foot.

Rainunculus arisicomers.

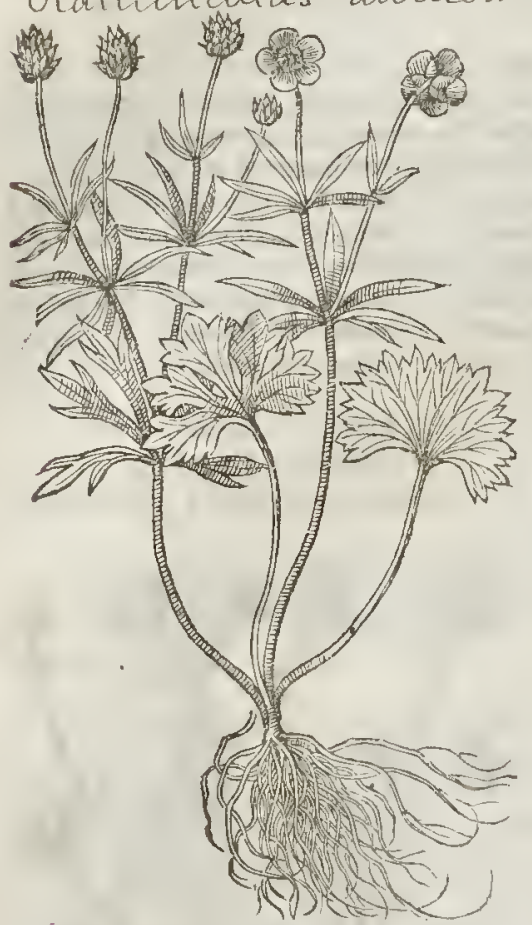

9 Ranunculus graminetus Lobcliy.

Graffie Crow-foot.

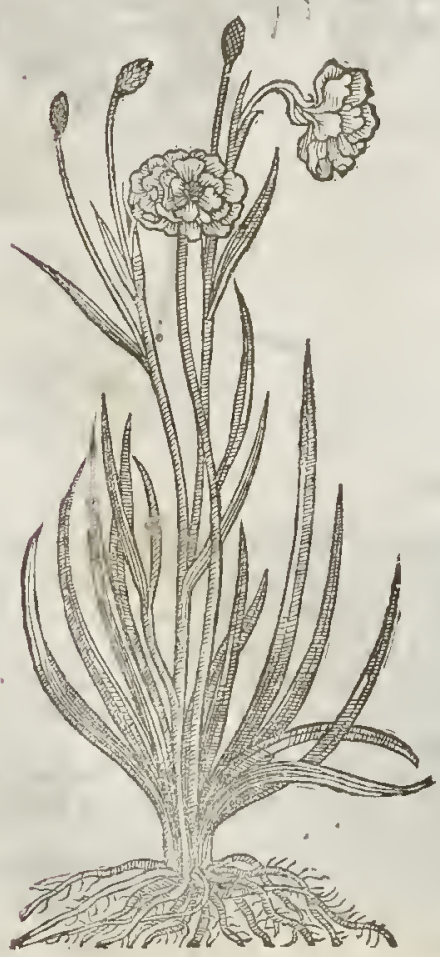

+8 Rananculus Aconiti folio. Frog Crow-foot.
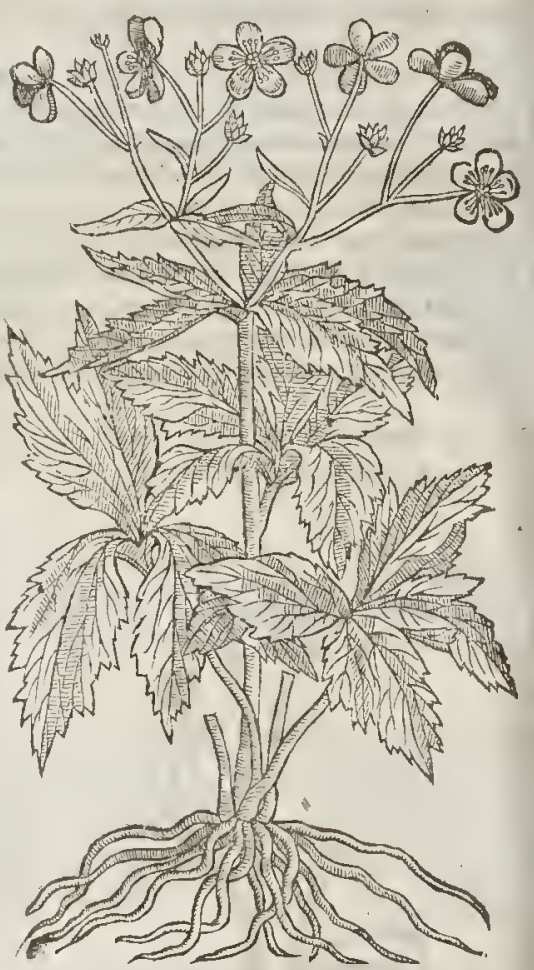

Io Ranunculus A utummalis Chufij. Winter Crow-foot.

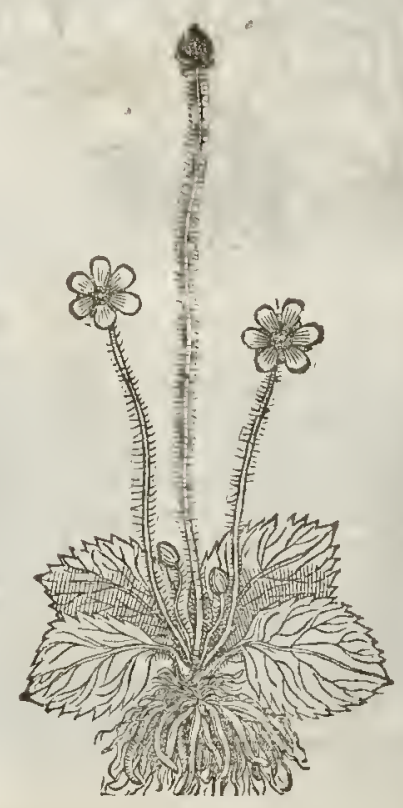


am ong which rife vp flender ftalkes, bearing at the top fmall yellow floutes like the other Crowfeet : the root is finall and threddy. \# There is a variery of this hauing double loures; and thaue giucin you the figure thereof in thead of the fingle that was formerly in this place. $\ddagger$

1o The Autumne or Winter Crow-foot hat h diners broad leaules fpred vpon the ground, fnipe about the edges, of a bright thining greene colour on the vpper fide, and hoary vnderneati, full of ribs or finewes as are thofe of Plantaine, of an vnpleafant tafte at the firft, afterward nipping the tongue: among which leaues rife vp fundry tender foot-ftalkes, on the tops whereof fand ycllow floures confiting of fix finall leaues apiece: after which fucceed little knaps of feed like to a dry or withered ftraw-berry. The root is compact of a number of limber roots, rudely thruft together in manner of the Afphodill.

II The Portugall Crow-foot hath many thicke clogged roots faftued vnro one head, very like thofe of the yellow A fphodıll : from which rife vp three leaues, feldome more, broad, thicke, and puffed vp in diuers places, as if it were a thing that were bliftered, by meanes whereof it is very vineuen. From the middle of which leaues rifeth vp a naked ftalke, thicke, fat, very tender, but yet fragile, or cafic to breake : on the end whereof ftandeth a faire fingle yellow floure, hauing in the middle a naked tundle of a gold yellow tending to a Saffron colour.

It Ramancultus Lufitanicus clufij. portugall Crow-foot.

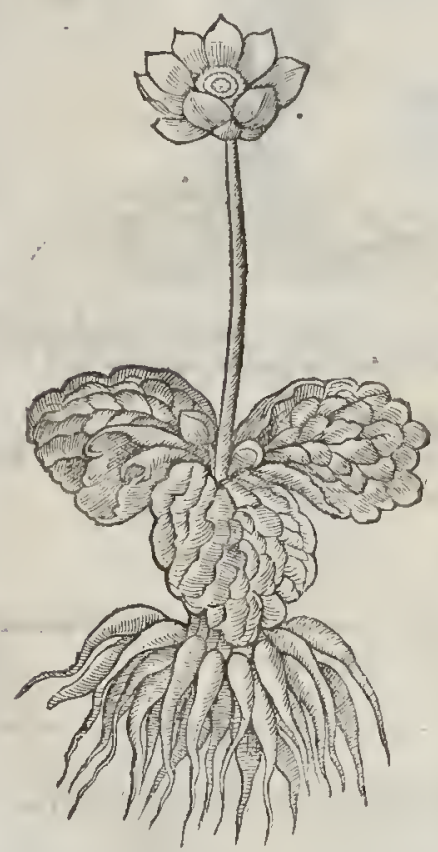

12 Ronunsulus globofus. Locker Gowlons, or G lobe Crowfoot.

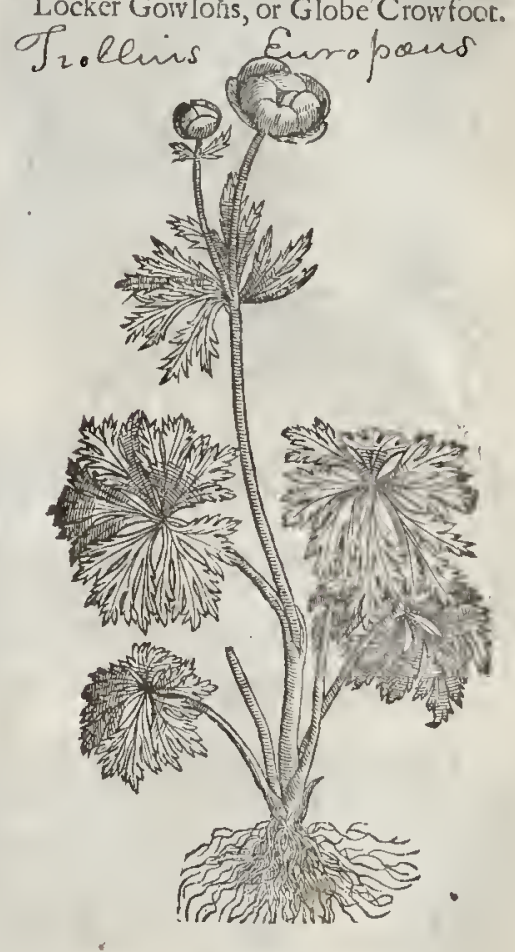

I2 The Globe Crow-foot hath rery many leaues decpely cut and iagged, of a bright greene colour like thofe of the field Crow-foot: among which rifeth vp a ftalke, diuided toward the top into other branches, furninhed with the like leaues of thofe next the ground, but fmaller: on the tops of which branches grow very faire yellow floures, confifting of a few leaues folded or rolled vp together like a round ball or globe: whereupon it was called Rarmunculsas globofus, or the Globe Crow-foot, or Globe floure: which being paft, there fucceed round knaps, wherein is blackin feed. The root is fmall and threddy.

¥ 3 This hath large leaues like thofe of the laft defcribed, but rough and hairy : the falk is ifome foot high : the floures are pretty large, compofed of fiue white fharpin pointed leaues. It Houres in Iuly, and growes in the Alps: it is the Ranusculi montani 2. pecies altern of Clufits.

14 This other hath leaues not vnlikethofe of the precedent, and fuch ftalkes alfo; but the floures confift of 5 round leaues,putplifh beneath ; the edges of the vpper fide are of a whitih purple, \& the refidue wholly white, with many yellow threds in the middle; it grotys in the nountain

$$
\text { Lil12 Lura, }
$$


I 3 Ramunculus hirfutus Alpians flo.albo. Rough white floured mountaine Crow - foot.

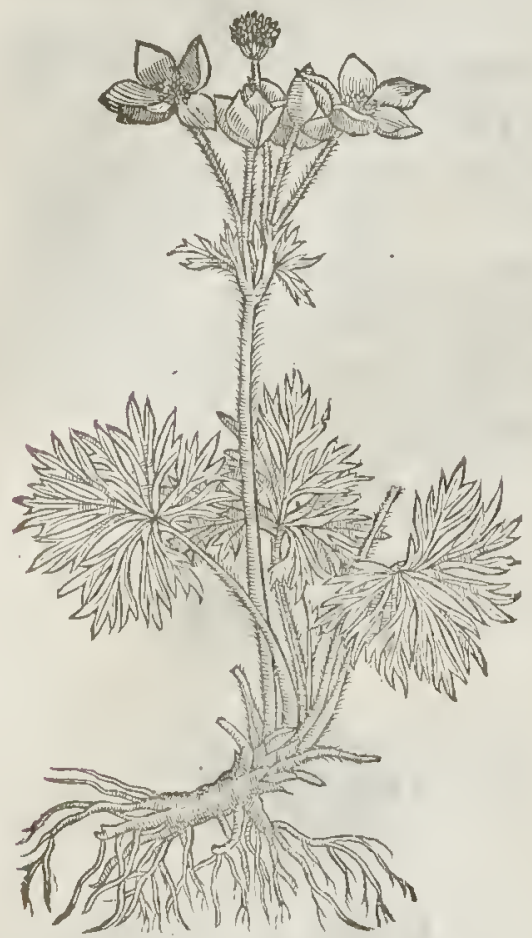

¥ 4 Ranunculus montanus hirfutus propureus. Rough purple floured mountain Crowfoot.

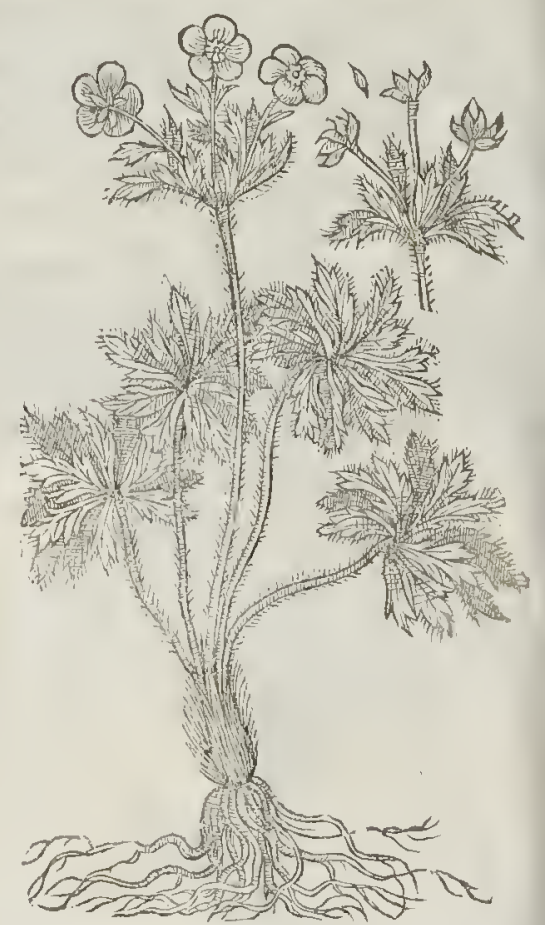

Iura, againft the city of Geneua, whereas it floures in Iune, and ripens the feed in Auguft. Clufus had the figure and defcription liete of from D: Penny, and he calls it Ranunculus montanus 3 . $\ddagger$

4 The Place.

The twelfth kind of Crow foor groweth in moft places of York-fhite and Lancathire, and other bordering thires of the North countrey, almoft in euery med ow, but not found wilde in thefe Southerly or Wefterly parts of England that I could cuer vnderftand of.

$$
\text { IT The Time. }
$$

It floureth in May and Iune : the fced is ripe in Augult.

$$
\text { a The Ninizs. }
$$

The Globe floure is called generally Ranninculus globofus: of fome, Flos Trolliws, and Ranunculus Alpinus : in Englifh, Globe Crow-foot, Troll Howres, and Lockron gowlons.

\section{$\mathrm{C}_{\mathrm{HA}} \mathrm{r} \cdot 3$ 68. Of Double yellow and wbite Batchelors Buttons. II The Defoription.}

$x$ THe great double Crow-font or Batchclors button hath many iagged leaues of a dcepe greene colour : among which rife vp ftalkes, whereon do grow taire yellow floures exceeding double, of a thining yellow colour, oftentimes thrufting forth of the middeft of the faid floures one other fmaller floure : the root is round,or fathioned like a Turnep the form whereof hath caufed it to be called of fome S. Anthonies Tumep, or Rape Crow - foot The feed is wrapped in a cluter of rough knobs, as are moft of the Crow-feet.

2 The touble yellow Crow-foor hath leaucs of a bright greene colour, with many weake branches trailing vpon the ground; whereon do grow very double yellow floures like vnto the precedene, but airozether leffer. The whole plant is likew ife without any manifert difference, fauing that thefe floures do neucr bring forth any finaller flourc out of the middle of the greater, as the other doth, and alfo hath no Turnep or knobby root at all, wherein confifts the greateit difference. 
T Kanunculns maximus Anglicus.

Double Crow-foot, or Batchelors buttons.

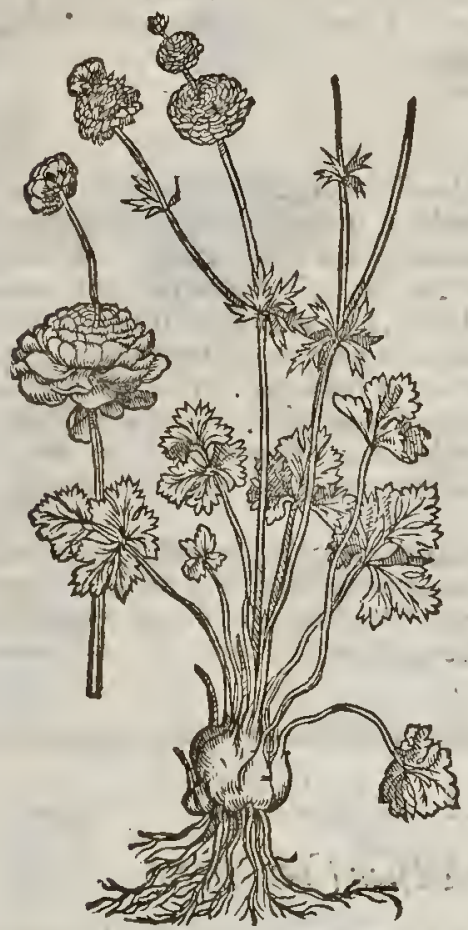

\section{Rastruculus albus multiflorins. Doublewhite Crow-foot:}

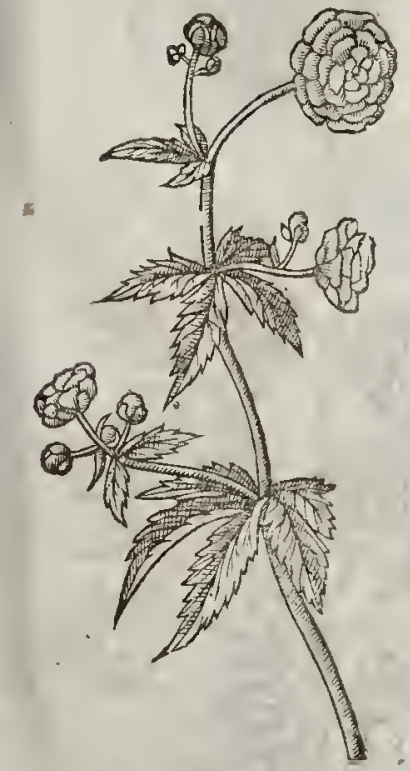

2 Ranunculus dilc is multiplet.

Double wilde Crow-foot.

3 The white double Crow-foot hath many great leaues deeply cut with great gafhes, anid thofe Inipt about the edges. The ftalks diuide themfelues into diuers brittle branches, on the tops whereof do grow very double floures as white as fnow, and of the bigneffe of our yellow Batchelors button. The root is tough, limber, and difperfeth it felfe farre abroad, whereby it greatly increafech.

$$
\text { T The Place. }
$$

The firft and third are planted in gardens for the beauty of the floures,and likewife the fecond, which hath oflate beene brought out of Lancahire vnto our London gardens, by a curious gentleman in the fearching forth of Simples, $M^{t}$. Thomas Hesketh, wh ho found it growing wilde in the towne fields of a final village called Hesketh, not farre from Latham in Lancalhire.

$$
\text { q The Time. }
$$

They floure from the beginning of May to the end of Iune.

$$
\text { The Names. }
$$

Dhofcorides hath made no mention hereof; but $A$ puleius hath fepatated the firit of thefe from the others, intreating of it apart, and naming it bya pe-" culiar name Batrachion; whereupon it is alfo called Apuleij Batrachoon, or Apuleius Crow-foot.

It is commonly called Rapum $D$. Anthonï, or Saint Anthonies Rape : ir may becalled in Englith, Rape Crow-foot: it is called generally about Londor, Batchelors buttons, and doible Crow-fox : in L $111_{3}$ Dutch, 


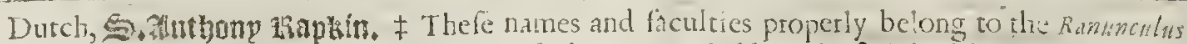
bulbolses, defcribed in the in t place ot the lat chapter; and al fo to the firit double one lere deferibed; for they wry litele but in colour, and the fingleneffe and doubleneffe of their tioures. $\neq$

The third is called of Lobel, Ranunculus visucus polyanhos: Of Iabern. Rinunculus allus multifiorus: in Englih, Doublew lite Crow-foot,or Ratchelori buttons.

Thefeplants dobite as the other Crow-feet do.

$$
\text { का The Temperature. }
$$

Thechiefef vertue is in the roor, which being ftanped with falt is guod for thofe that hulpe a plague fore, if it be prefently in the beginning tied to the thigh, in the middle betreen the groin or flanke and the knee : by meanes whereof the poy fon and malignir ic of the difeafe is drimn fom the inwatd parts, by the emunctoric or clenfing place of the tlanke, into thofe outward parts of leffe acconint : for it extucerateth and prefently raifeth ablifter, to what past of the body foetier it is applied. And if it chance that the fore hapneth under the arme, then it is requifite to apply it to the arme a little aboue tre elbow. My opinion 1s, that any of the Ciow-fect wilido the fane: my teafon is, becaufe they all and eucry of them do blifter and caufe paine, wlicrefoetier they be applied, and paine dotl draw vnto it felfe more paine; for the nature of paine is to refort vnto the weakeft place, and where it may finde paine; and likewife the poyfon and venomous qualutic of that difeafe is to te fott vnto that paincfull place.

Apuleivs faith further, That if it be hanged in a linnen cloath about the necke of him that is lu-

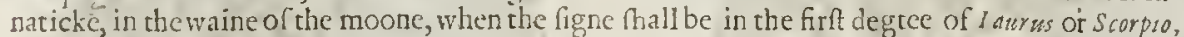
that then he fhall fotchwith be cured. Moreouer, the herbe Batraclion ftampedivith vineger, root and all, is vfed for them that haue blacke skars or fuch like marks on theit skins, it eats them out, and leautes a colour like that of the body.

The figure that for merly was in the firt olace of this chapter was the double one mentioned in the leeond defoription of the foregoing chapeer, where alfo you may fince a double flous expreft by the fide of the figure.

\section{С н в. 369. Of Turkie or effian Crow-feet.}

1 Ranunculus fanguineus multiplex. The double red Crow-foot.

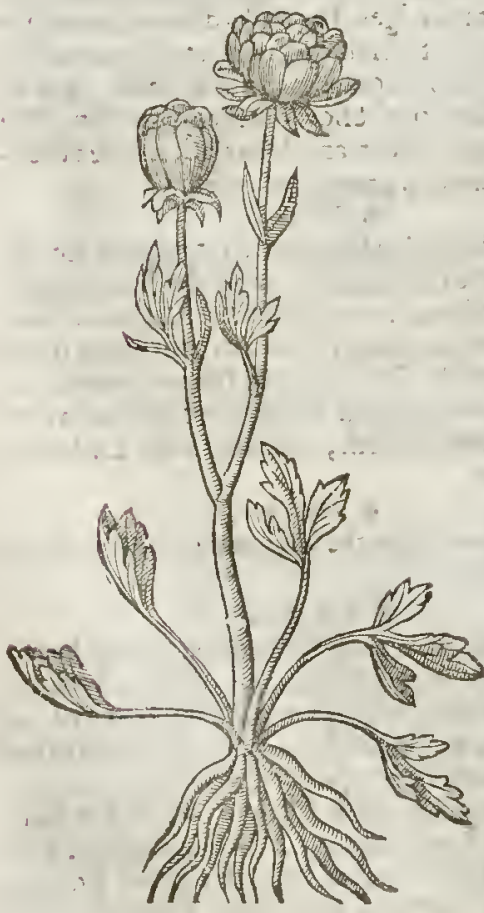

* 2 Ranunculus Aflaticus flo. pleno miniato. "The doubte Afian skarlet. Crow-foot.

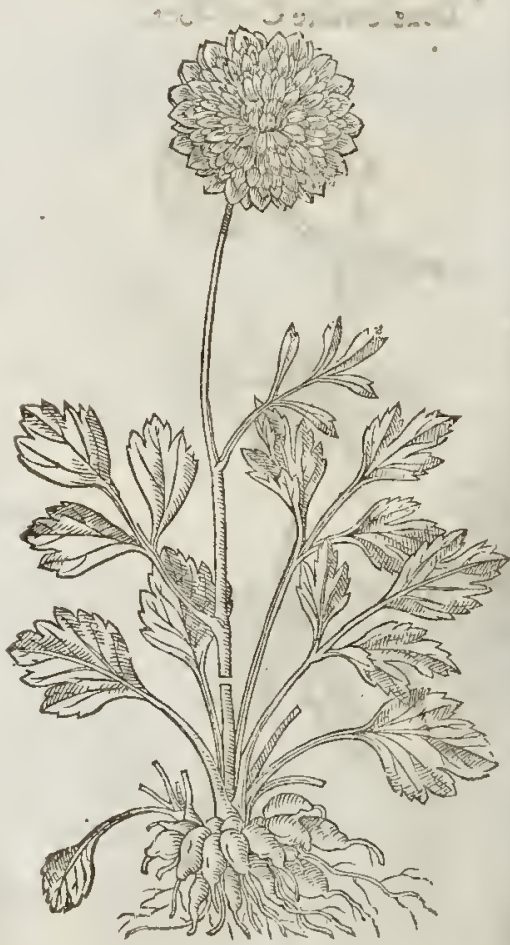




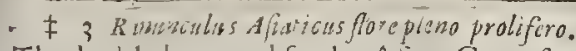

The double buetoned fearkt A isan Crow foot,

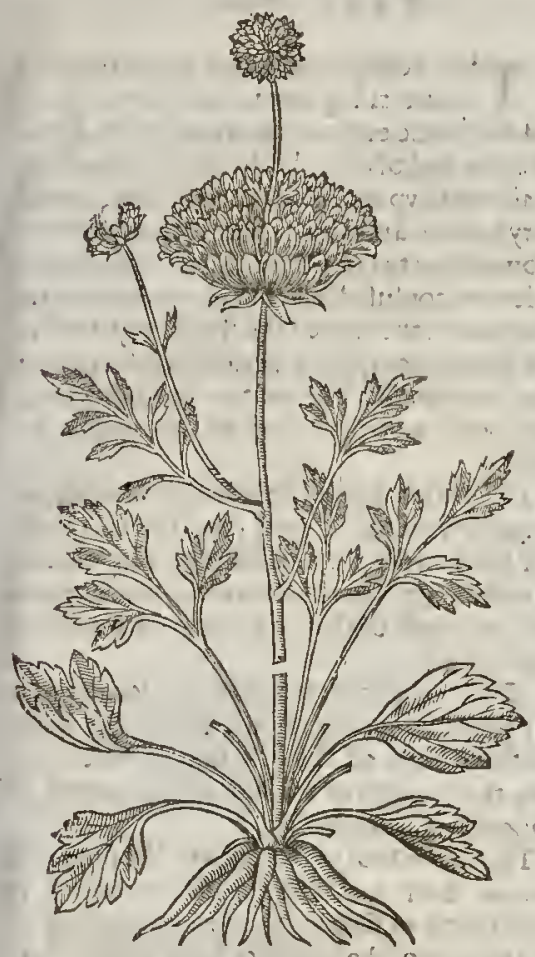

† 5 Ranunculus grunola radice ramolus: Branched red A fian Croiv-foot.

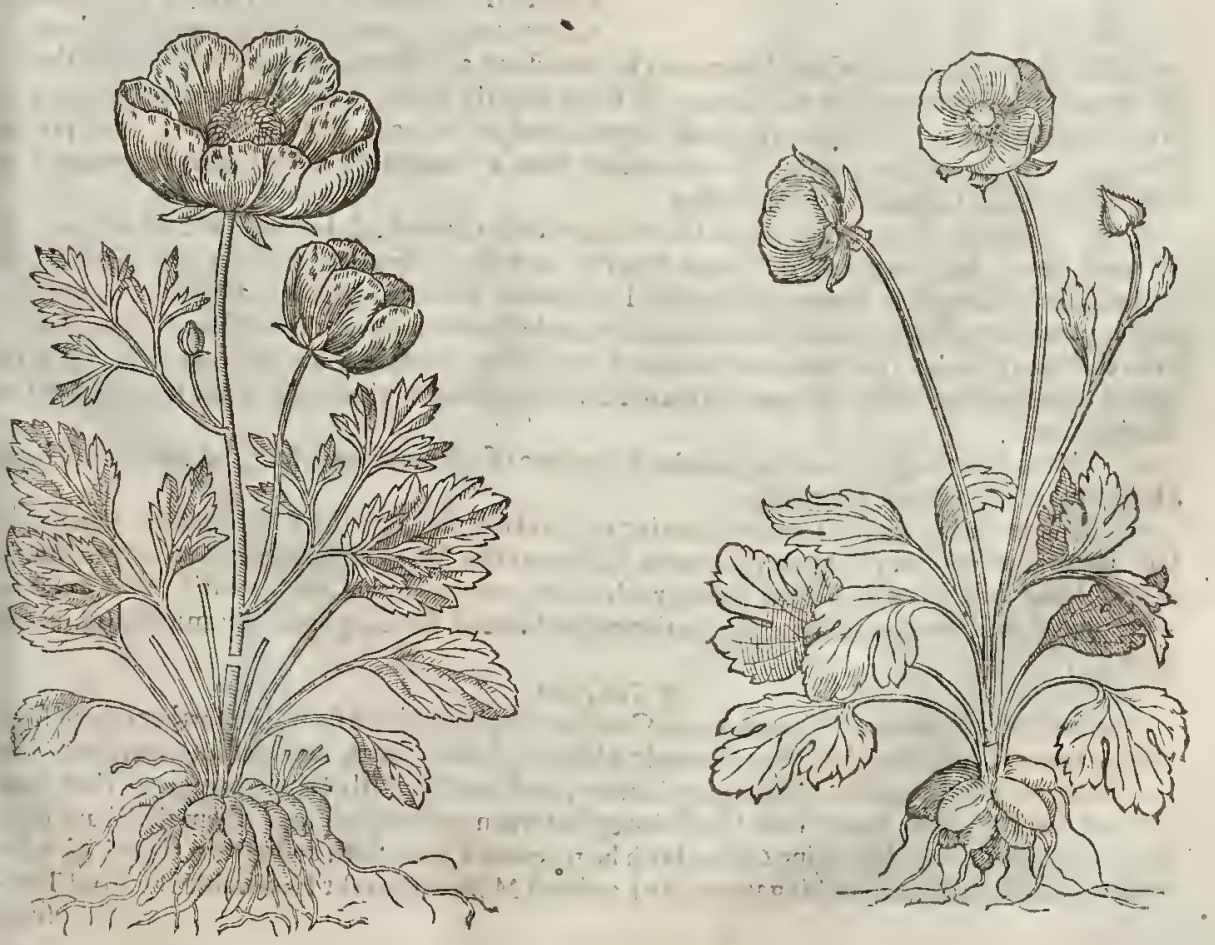

4 Ranunculus Tripolitanus. Crow-foot of Iripolie.

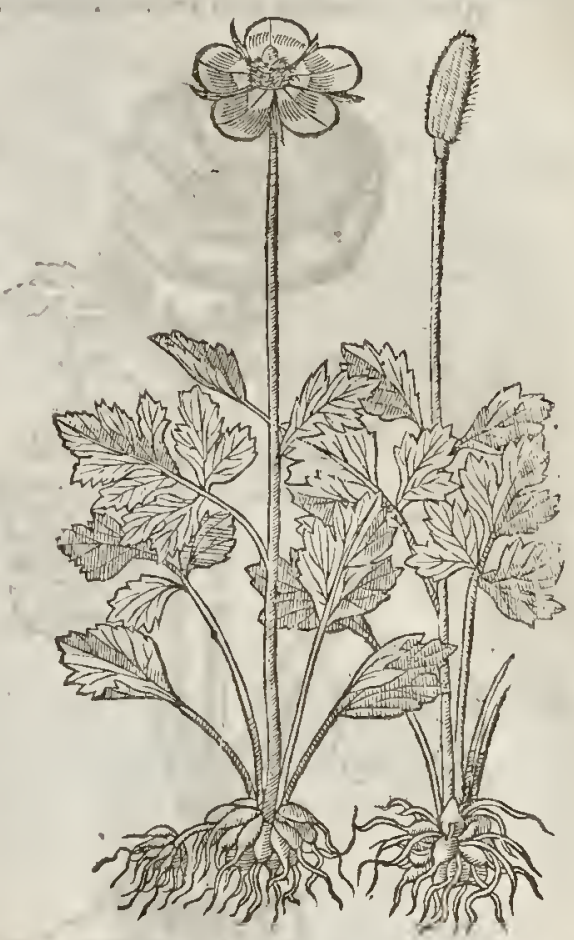

₹ 6 R.munculus Afraticns grumofa radice fo. allo. Whive foured Afan Crow-foor. 
¥ Rasunculus Afraticus grumofa radice flore flavorostio.

Afian Crow-foot with yellow ftriped floures.

$$
\text { If The Defription. }
$$

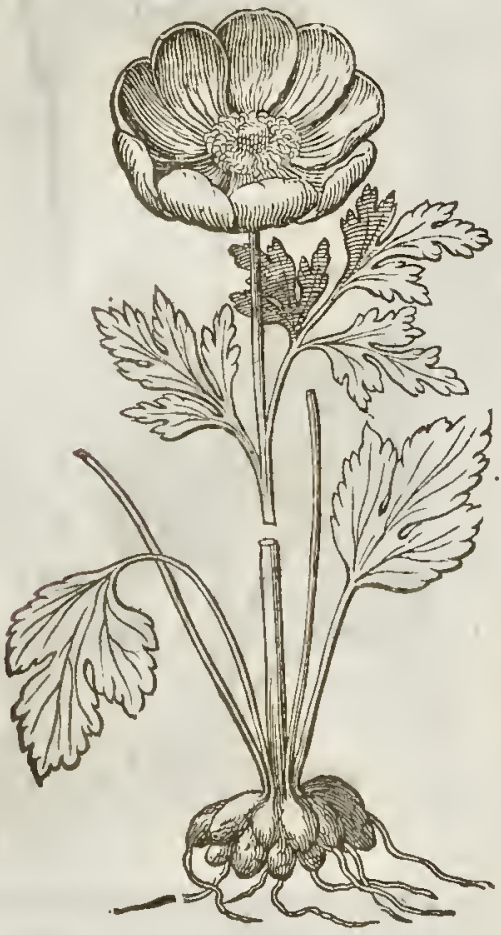

I THe double red Crow-foot hath a few

1 leaues rafing immediatly forth of the ground, cut in the edges with deepe gafhes, fomewhat hollow, and of a bright thining grecn colrur. The ftalk rifeth vp to the height of a foot, fmooth and very brittle, disiding it felfe into other branches,fometimes two,feldome three: whereon do grow leaties confufedly, fet witlout order : the floures grow at the tops of the ftalks, very double, and of great beauty, of a perfect fearlet colour. tending to redneffe. The root is compact of many long tough roots, like thofe of the yellow Afphodill.

\# 2 Of this kinde there is alfo abother, or other the fame better exprefl; for Clrofius the author of thefe nener fee the former, but makes it onely to differ, in that the floures are of a farguine colour, and thofe of this of a kinde of fcarlet, or red lead colour.

3 This differs nothing from the former, but that it fends vp anotluer toure fonew hat leffer, out of the middle of the firf floure, which happens by the ftrength of the root, and goodneffe of the foile where it is planted. $\neq$

4 The Crow-foot of Tripolis or the fingle red Rasumculzes hath leaues at the fitf comming vp like vnto thofe of Ground fwell : among which rifeth vp a ftalke of the height of halse a cubit, fon what hairy, wheron grow broad leaues deeply cut, euen to the middle rib, like thofe of the common Crow-foot,but greener: the flotre gruwsth at the top of the ftalke, confinting of fure leaues, on the out fide of a darke ouerw orne red co'our, on the in fide of a red lead colour, biight and fhining, in thape like the wilde corne Poppie:the knop or ftile in the middle which containeth the feede is garnifhed or bedeckt with very many fnall purp!e thrummes tending to blackneffe: the root is as it were a roundell of little bulbes or graines like thofe of the finall Celandine or Pilewoort.

¥ 5 There be dinets other A fian Crow -feet which clufius hath fet forth, and which grr w in the moft part in the gardens of our prime Florifts, and they differ little in their ronts, falkes, or leaues, but chiefely in the floures; wherefore I will onely briefely note their differences, not thitking it pertinent to tand vpon whole defcriptions, vnleffe they were more nectffary:th is fift differs from the fourth in that the ftalkes are diuided into fundry branches, which beare like, but 'effe floures than thofe which ftand vpon the main ftalke:the coloufr of thefe differs not from that of the laft defcribed.

6 This is like the laft defcribed, but the foures are of a pure white colour, and fometimes hauc a few ftreaks of red about their edges.

7. This in ftalkes and manner of growing is like the pracedent : the ftalke feldome parting it felfe into branches; but on the top thereof it carries a faire floure confining commonly of round topped le aures of a greeninh yellow colour,with diuers red veines here and there difperf. d and mnning alongft the leaues, with fome purple thrums, and a head ftanding vp in the middle as in the former. 市

$$
\text { If The Place. }
$$

The firft groweth naturally in and about Conftantinople, and in A fia on the further fide of Borphorus, from whence there hath been brought plants at diuers times, and by diuers perfons, but thev hatre perifhed by reafon of their long iourney, and want of skill of thofe bringers, that hate fuffered them to lie in a box or fuch like fo long, that when we haue receiued them they have been as dry as ginger, notw ith fanding $C l w$ fus faith he receined a plant frefh and greene, the which a domeftical theefe ftole forth of his garden.My Lord and Mafter the right Honorab le the Lord Trea- 
furer bad diners plants fent him from thence which were driebefore they camejas aforefaid. The other growerh in Aleppo and Tripolis in Syria naturally, from whence we haue teceiued plants fór our gardens, where they flourinh as in thcir owne countrey.

$$
\text { The Time. }
$$

They bring forth their pleafant floures in May and Iune,the feed is ripe in Augut:

$$
\text { of The Names. }
$$

The firft is called Ranunculus Confantinopolitnmus: Of Lobcl, Ranunculus fanguinems muliplex, Ranunculus Bizantinats, five Afuticus : in the Turkifh tongue, Torobolos, Catamer luile: in Engliph, the double red Ranunculus, or Crow - foot.

The fourth is called Ranunculus Tripolitanus, of the place from wlience it was firft brought into thefe parts : of the Turks, Turobolos Calamer, without that addition laile : which is a propicr word to all floures that are double.

$$
\text { बा The Temperature and Vcrtues: }
$$

Their temperature and vertues are referred to the other Crow-feet, whereof they are thought tobekindes.

\section{C на в. 370. Of Speare-woort, or Bane-woort.}

\section{9f The Defcription.}

I Peare-woort hath an hollow ftalke full of knces or ioynts, whereon do grow long leaues, a litrle hairy, not vnlike thofe of the willow, of a hining green colour : the floures are yery large, and grow at the tops of the ftalks, confitting of five leaues of a faire yellow colour, verie like to the field gold cup, or wilde Crow-foot: after which come round knops or feed veffels, wherein is the feed : the root is contract of diuers bulbes or long clogs, mixed with an infinite number of hairy threds.

I Ranunculus flammens maior. Great Speare-woort.

Rawninguevi Lingua

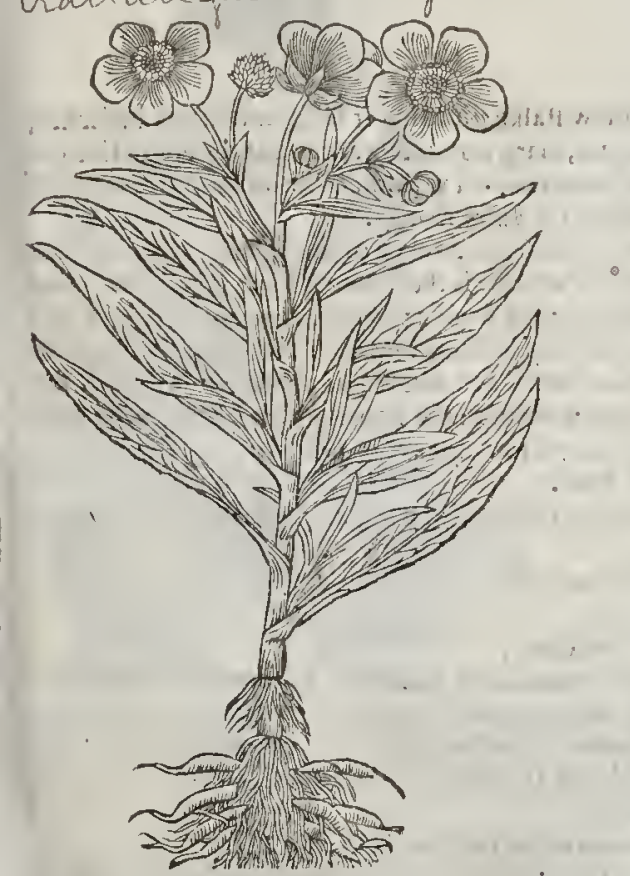

2 Ranunculus flammens minor.
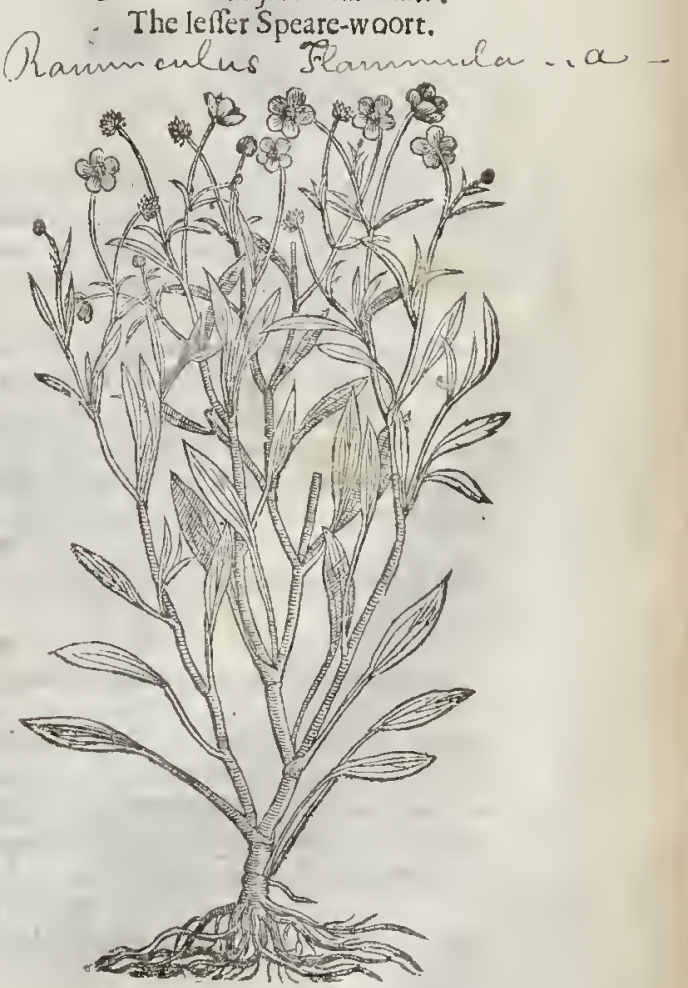


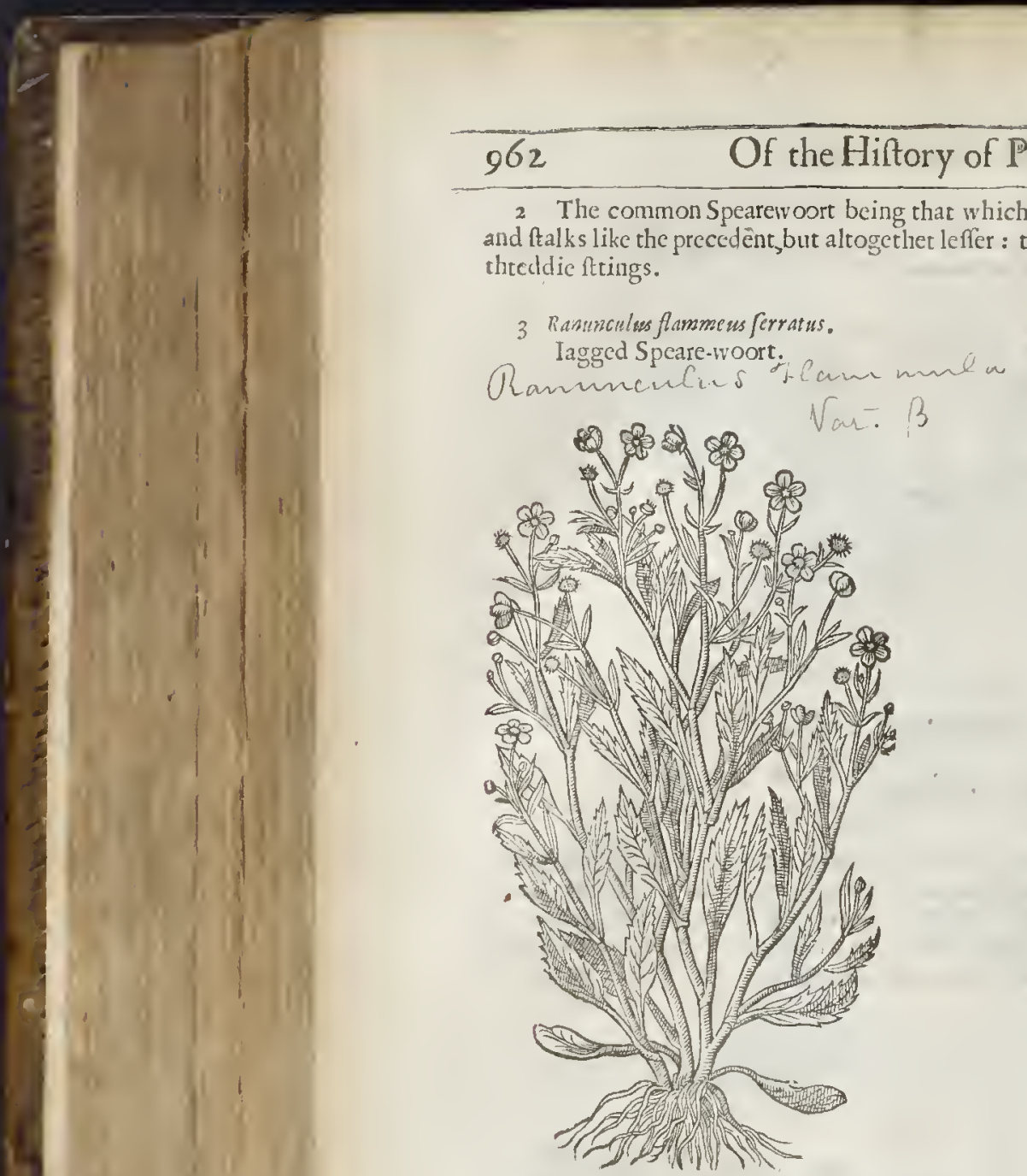

L 1 B. 2.

2 The common Spearew oort being that which we haue called the leffer, hath leaucs, foures, and ftalks like the precedent, but altogetliet lefier : the roote confifteth of an infinite number of theced ie ftings.

4 Rarunculus palsf fris roturdifolius. Marifh Ctow-foot, or Speare-worts.

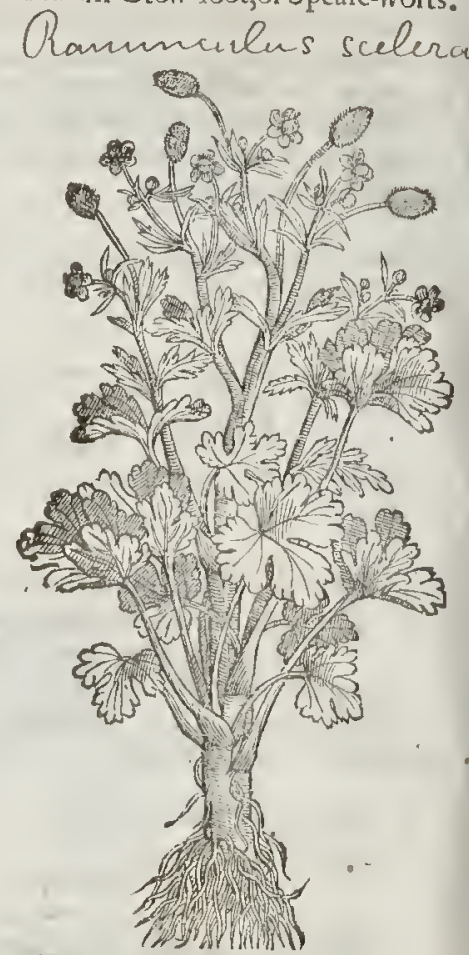

3 Iagged Speate-woort hath a thicke fat hollow falke, diuiding it felfe into diuers branches, whereon are fet fomtimeśby couples two long leaues, tharp pointed, \& cut about the edges like the teeth of a faw. The floures grow at the top of the branches, of a yellow colour, in form like thofe of the field Crowfost : the root confiteth of a number of hairy ftrings.

4 Marh Crow-foot,or Speare-woort (whereof it is a kinde, taken of the beft approned authors to be the trne Apium rifus, though diuers thinke that Pulfarilla is the fame: of fome itis called Apium hemorrboidarum) rifeth forth of the mud or waterifh mire from a threddic root, to the height of a cubit, fometimes higher. The italke diuideth it felfe into diuers btanches, whereupon doe grow leaues deeply cut round about like thofe of Doues-foot, and not vnliket the cut Mallow, but fomewhat greater, and of a moft bright nining green colour : the floures grow at the top of the branches, of a yellow colour, like vnto the other water Crow-feet.

$$
\text { qT The Place. }
$$

They grow in moift and dankifh places, in brinkes or water courfes, and fucl. like places alnoft euery where.

They floure in May when other Crow-feet do.

$$
\text { T The Time. }
$$

$$
9 \text { The Names. }
$$

Speare-woort is called of the later Herbarifts Flammula, and Ranuaculus Flammeus; of Cordus, RA:

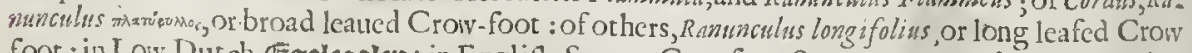
foot : in. Low Dutch, Egelcoolen : in Englinh, Speare- Crowfoot, Speare-woort, and Banewoort,becaufe it is dangerous and deadly for theep; and that if they feed of the fame it inflameth their li. uers, fretteth and bliftereth their guts and intrails.

T) The Temperature of all the Crom feet.

Speare woort is like to the other Ctow-fect in facultic, it is hot in the mouthor biting, it exulccrarcth 
Lr в.2. Of the History of Plants: $\quad 963$

cerateth and raifeth bliftets, and being taken inwardly it killeth remedilefe. Generally all the Crowfeet, as Galen faith, are of a very thorpe or biting qualities, in fomuch as they raileblifters with paine: and they are hot and die in the fourth degree.

\$t The Vertus of all the Crowfeet.

The leaves or roots of Crowfeet Ramped and applied unto any part of the body, eaufeth the A skin to fuel and blifter, and raifeth vp wlicales, bladders, caufeth fears, crufts, and org lie vices :it is laid vpon ragged warts, corrupt niles, and fitch like excrefences, to citufe them to fall away.

The leases tamped and applied mo non peftilentall or plague fore, or carbuncle, facet b the $B$ spreading nature of the banc, and caufeth the venomous or peltilentiall matter tobteath forth, by opening the parts and petites in the skin.

It preuilerly much to draw a plague fore from tic inward parts, being of danger, wo other re- $C$ mote places further: from the heat r, and other of the fpirituall parts, as hath benne declared in the defeription.

Many do vf to tic a little of the lice se tamped with salt vito any of the fingers, again ft the pain D of the recti; which medicine cleome daleth; for it eaveth greater paine in the finger than was in the too rh, by the manes whereof, the greater paine taketh away the lefter.

Cunning beggars dove to taupe the leaves, and lay it veto their legs and arms, which caufeth $E$ fuck filthy veers as we daily lee(among fuck wicked vagabonds) to moue the people the more to pattie.

The kind of Crow foot of Illyria, being taken to be Apian riffs of fore, yet others think Ace- $\mathrm{F}$ nit um Batrachioides to be it. This plant fpoileth the fences and vnderttand ing, and draweth together the finewes and muscles of the face in fish Arrange manner, that tho fe who beholding fuel as died by the taking hereof, have fuppofed that they died laughing, fo foreeably hath it draw ne and eontracked the nerves and finewes, that their faces hate been drawn awry, as.though they laughed, whereas contraviwife they hate died with great torment.

‡ на р. 37 т. Of divers other Crowfeet.

+ I Rimuncalus Crevices latifolus. Broad leaned Candy Crowfoot.

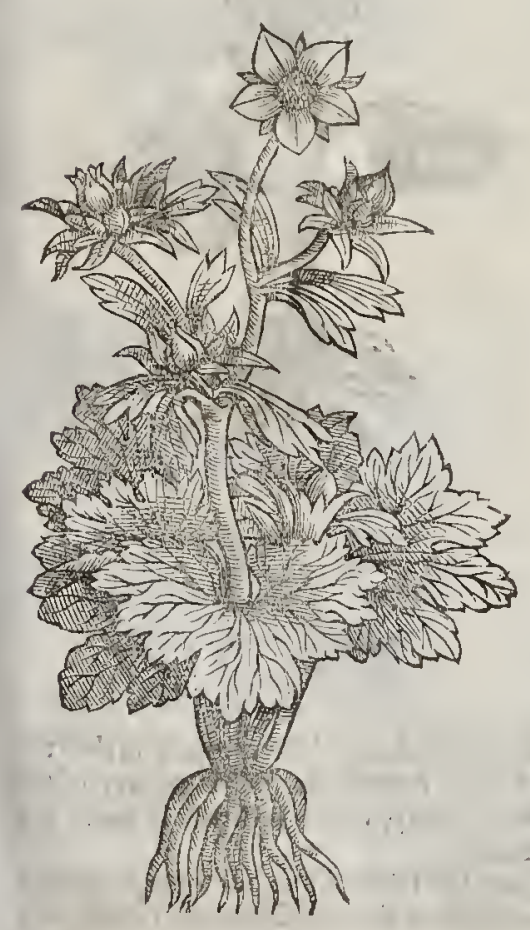

$\ddagger 2$ Ramuncuinsfolno Plantaziais. Plantain leased Crowfoot.

Ranunculus amplexicaulis.

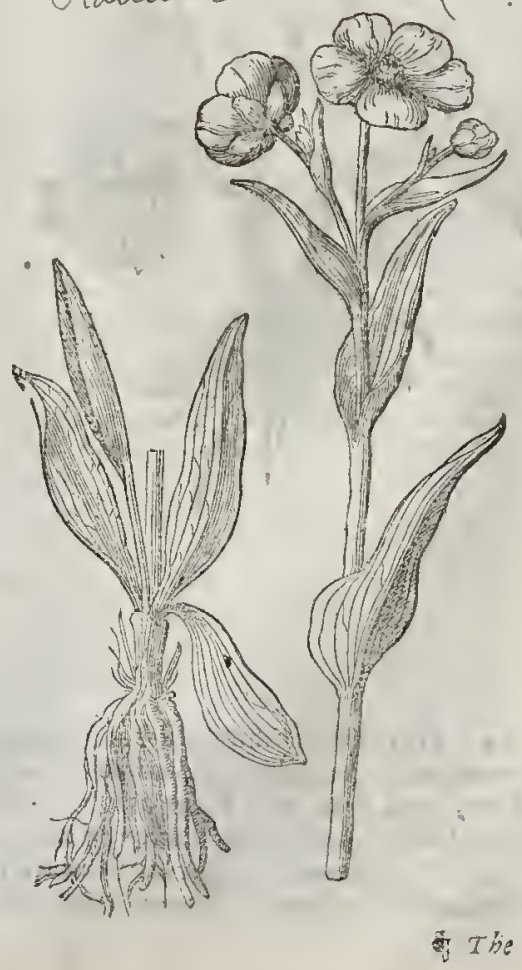




\section{The Defeription.}

+ I Heroots of this are fomwhat like thofe of the A fian Ramnculus: the leaues are verie large \& roundin, of a light green eolour, eut about the edges, \& here and there deeply diuided: the ftalke is thicke, round, and ftiffe, tiuided into two or three branches; at the ferting on of wh ich grow longith leates a little nickt abcut the end: the foures are of an indifferent bigneffe, and confift of fuic longith round pointed leaues, ftanding a little each from other, fo that the green points of the eups thew thenfelues between them : there are yellow threds in the middle of thefe floures, which eommonly fhew rhemfelues in Februarie, or March. It is found only in fome gardens, and Clufus onely hath fet it forth by the name we liere give you.

2 Thisalfo that eame from the Pyrenxan hills is made a Denizen in our gardens: it hath a ftalke fome foot high, fetwith nertous leanes, like thofe of Plantains, but thinner, and of the co. lour of Woad,and rhe y are fomerhing broad at their fetting on, and end in a tharpe poinr: at the top of the ftalke groti the floures; cach confitting of fiuc round flender pure white leaues, of a reafonable bignefle, with yellowifh rheds and a little head in the middle: the root is white and fibrous. It Houres about the beginning of May. Clufus alfo fet forth this by the title of Rumuculus Pyrencus albo flore.

3. The fame Author hath alfo gituen vs the knowledge of diners other plants of this kinde, and this hee calls Rominculus montanus I. It hath many round leaues, here and there deeply cut in, and fnipr about the edges, of a darke greene colour, and thining, pretty rhicke, and of a very hot rafte : amongftwhich rifes vp a flender, fingle, and Arort ftalke, bearing a white floure made of fue little leaues with a yellowith thrum in the middle:wlich falling, the feeds grow cluftering together s in other plants of this kinde: the ront is white and fibrous.

¥ 3 Ramusulus mont anus flo.minore.

Mounta in Crow foot with the leffer fioure.
¥ Ranunculus montanus flore maiore. Mountain Crow foot with the bigger floure:
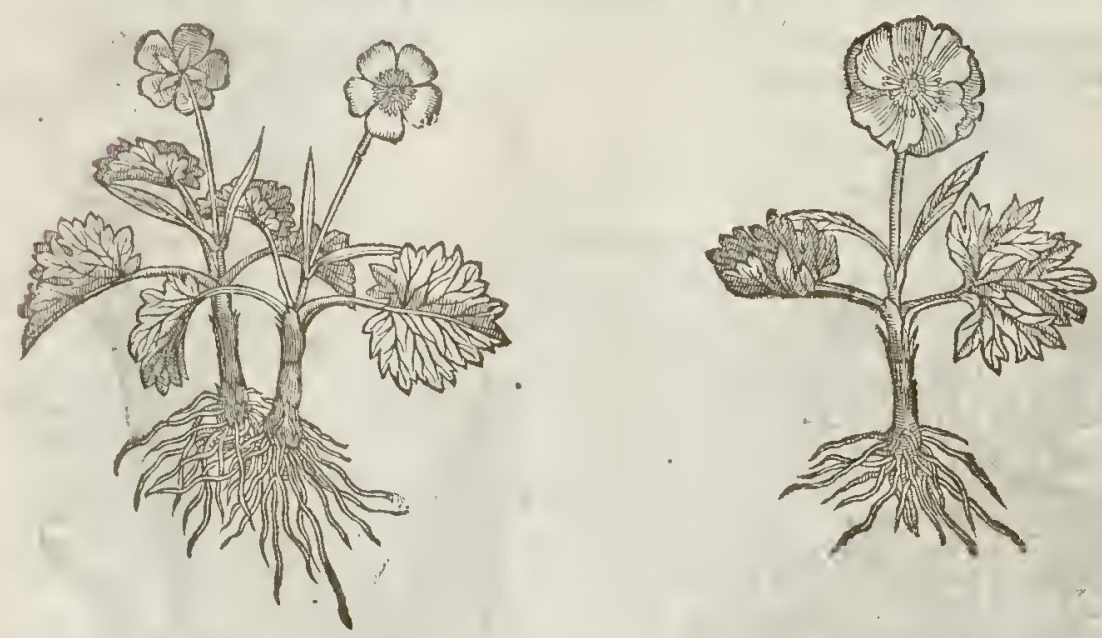

4 This alfo is nothing elfe but a varietic of the laft deicribed, and differs from it in that the floures are larger,and it is fometimes found with them double. Both thefe grow on the tops of the Alpes, and there they floure as foone as the fnow is melted away, which is vfually in Iune: but brought into gardens they floure vety early, to wit, in A prill.

5 'The leaues of this are eut or diuided into many parts, like tho fe of Rue, but fofter, \& greener (whence Clufius names it Ranunculus Rut a folio) or not much ynlike thofe of Coriander (whereupon 
which follow there fucced fiue or Gx tharpe pointed rough cods, conteining feed almoft like that of the former. $\ddagger$

\section{С нат. 372. Of Woolfes-bane. \\ T The kindes,}

There be diuers forts of Wolfes-bane: whercof fome bring forth flowers of a yellow colour; others of a blew, or tending to purple: among the yellow ones there are fome greater, orhers leffer, fome with broader leaties, and others with narrower.

I Thora Valdenfis.

Broad leafed V Volfes-bane.

Rammenlus Jhona. w.

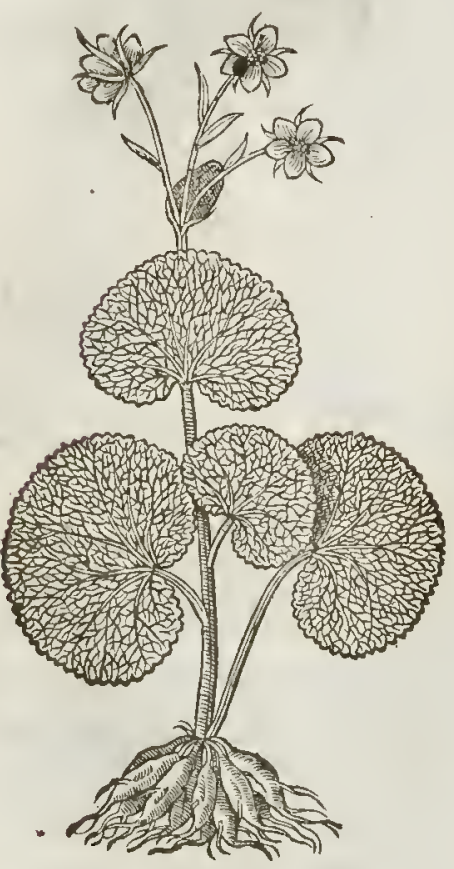

2 Thoramont is Baldi, fove Sabandica. Mountaine VVolfes-bane. Ranunculus J hora $N$ ar.

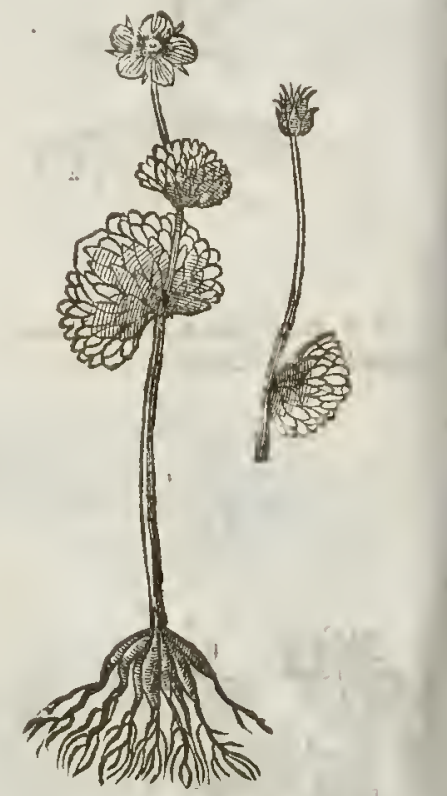

9 $T$ he Defcription.

I THe firt kinde of Acomite, of fome callcd $T$ hor , others adde therto the place where it groweth in great abundance, which is the Alps, and call it Thora Valdenfarm. This plant tooke his bame of the Greek word sopo, fignifying corruption, poifon, or death, which are the certaine effects of this pernicious plant : for this they vfe very much in poifons, and when they meane to infect their arrow heads, the more fpeedily and deadly to difpatch the wilde beafts, which greatly annoy thofe mountaines of the Alpes: to which purpofe alfo it is broughr into the Mart-townes neere vnto tbofe places to be fold vnto the hunters, the iuice thereof beeing prepared by preffing forth, and fo kept in bomes and hoofes of beafts, for the moft fpeedie poifon of all the Aconites; for an arrow touched therewith, leaneth the wound vncureable (if it but onely fetch bloud where it entereth in) except thar round about the wound the ferh bee fpecdily cut away in great 


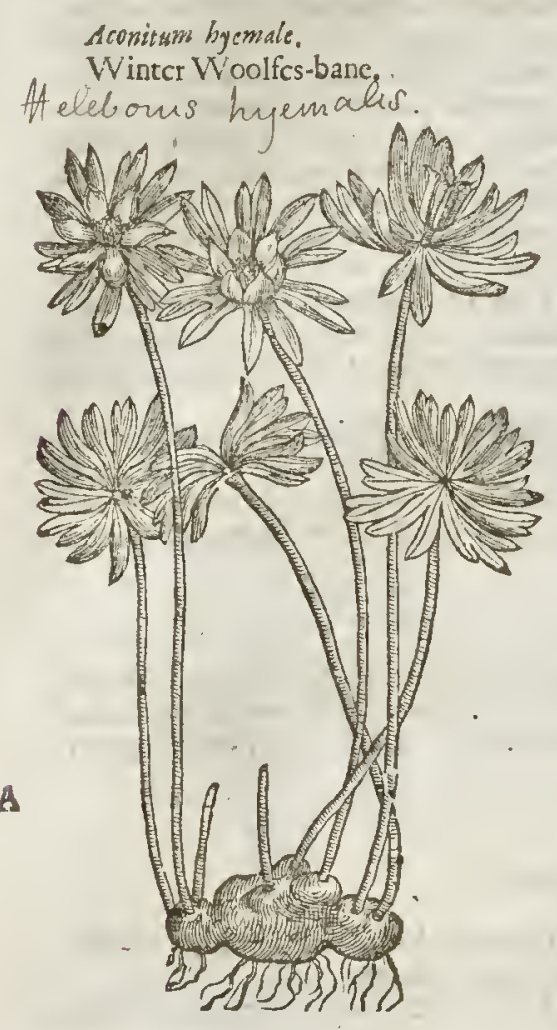

TI The Place.

It groweth vpon the mountaines of Germany:we hate grcat quantitic of it in our London gardens.

$$
\text { 9T The Time. }
$$

It fourcth in Ianuarie; the feed is ripe in the end of March.

$$
\text { T } T \text { he Names. }
$$

It is called Aconitum byemale, or Hiber-' nam, or winter Aeonite: that it is a kinde of Aconite or Woolfs-bane, both the form of the leates and cods, and alfo the dangerous faculties of the herbe it felfe do declare.

It is much like to Aconstum Theophrafti: which he defcribeth in his nint! booke, faying, it is a thort herbe hauing no merrit, or fuperfluous thing growing on it, and is withoutbranches as this plant is: rle root, faith

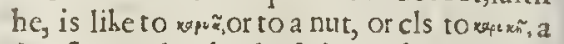
dry fig, onely the Icafe feemeth to make againft it, which is nothing at all like to that of Succoric, which he compareth it rnto.

- The Temperature and Vertues.

This herbe is counted to be very dangerous and deadly, bot and drie in the fourth degree, as Theoph. in plaire words coth teftifie concerning his ow ne Aconite; for which he faith that there was reucr found his Antidote or remedie : whercof Utherases and Theopompus write, that this plant is the moft poifonous herb of all others, which moued 0 wid ro fay 2uequanafcuntar dura vivatcin caute: notwithftanding it is not without his peculiar vertues. Iouchinas Camerarius now liuing in Noremberg faith, the water dropped into the eies ceafeth the pain and burning: it is reported to preuaile mightily againft thebitings of feorpions, and is of fueh force, that if the fcorpion pa ffe by where it growetly and touch the fame, prefently he bccommeth dull, heauy, and fenceleffe, and if the fame fcorpion by chance tonch the white Hellebor, he is prcfently deliuered from his drowfineffe.

\section{Cha P. 374. Of MitbridateWoolfes-bane.}

$$
\text { T) The Defcription. }
$$

This plantcalled Anthora, being the antidote againft the poifon of Thara, Aconite or wolfes bage, hath flender liollow ftalkes, very brittle, a cubit high, garnifhed with fine cut or iagged leaues, very like to Nigella Romana, or the common Larkes fpurre, called Corfolida Regalis: at the top of the ttalkes doe grow faire flowers, fathioned like a little helmet, of an ouerworre yellow colour ; afterwhich come fmall blackin cods, wherein is conceined blache fhining feed like thofe of Onions: the root confifteth of diuers knobs or tuberous lumpes, of the bigneffe of a sans thumbe.

$$
\text { Ti The Place. }
$$

This plant which in Greeke we may tcrmc armasope: groweth abundantly in the Alps, called Rhesici, in Sauoy, and in Liguria. The Ligurians of Turin, and thofe that dwcll neere the lake Lemane, hate found this herbe to be a prefent remedy againt the deadly poifon of the herb thora and the reft of the Aconites, prouided that when it is brought into the gardenthere to be kept for Ply $f \mathrm{cks}$ vfe, it munt not be planted neere to any of the Aconites: (or through his attractiue qualitie, it will 
Anthor afve Aconitum falutiferum.

Wholfome Wolfes.bane.

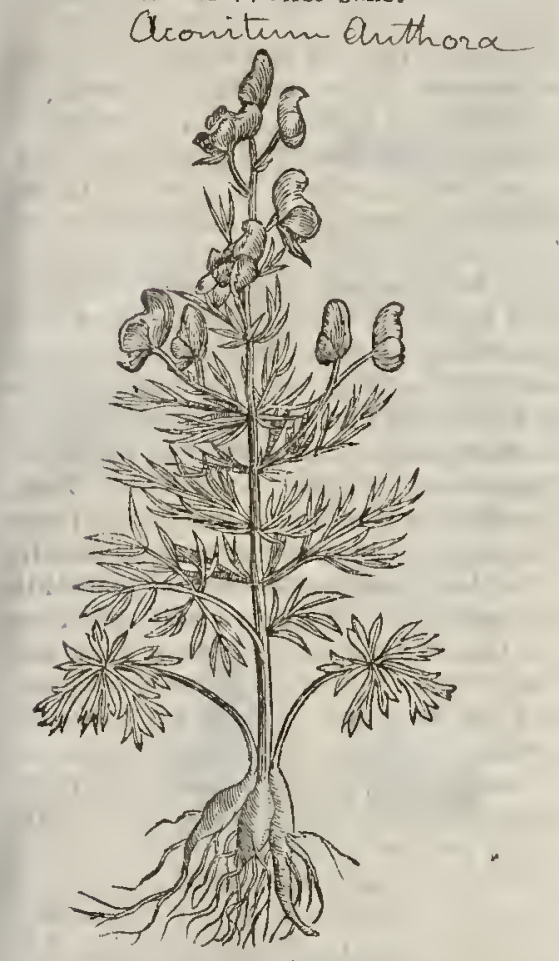

draw vnto it felf the maligne and venomous poifon of the Acunire, whereby it will become of the like qualitie, that is, to become poifonous likewife : but being kept far off, it retaineth his owne nattrall qualitie Atill.

$$
\text { T) The Time, }
$$

It floureth in Anguft, the feed is tipe in the end of September.

$$
\text { T The Names: }
$$

The inhabitants of the lake of Genena, \& the Piemontoife do call it Anthor a, and the common people Anthoro. wátucen ealletl a certaine herbe which is like to Monks Lood, as a remedy againt the poifon thercof, by the name of Napellus Moyfin, in the 500 ehap. of his feend booke, and in the 745.clap.he faith, that Zedoaria doth grow with Napellus or Monkes hood, and that by reafon of the neereneffe of the fame, the force and itrength thereof is dulled and made weaker, and that it is a treacle, that is, a counterpoifon againlt the Viper,Monks hood, \& all other poifons: and hereupon it followeth, that it is not only Napellus Moyfs, but all fo Zedoaria Auicen. n.e: notwithftanding tlie Apothecaries do fell another $Z$ edoarin differing from Anthosa, which is a root of a longer forme, which not without caufe is thouglit to be $A$ unicens and Serapio's Zerumbeth, or Zurumbeth.

It is called Airtbora, as though they fhould fay $A$ Antithora,becaufe it is an enemie to $T$ bo. $r a$, and a counterpoifon in the fame. Thore and Anthora, or $T$ ura and Amura, feeme to be new words, bur yet they are vfed in Marellis Empericus, an old writer, whoteacheth a medicine tobe made of Tura and Antura againft the pin and web in the cies : in Englifh, yellow Monks-iood, yellow Helmet floure, and Aconites Mithridate.

$$
\text { 7f The Vertucs. }
$$

The root of Anthora is wonderfull bitter, it is an enemie to all poifons : it is good for purgati- $A$ ons; for it voideth by the ftoole both waterie and flimic humours, killeth and dritetl forth all manner of wormes of the belly:

Hugo Solerius faith, that the roots of Anthora do largely purge, not onely by the flocle, but alfo $B$ by vomite : and that the meafure thereof is taken to the quantitic of $F$ afelus (which is commonly called a beane) in broth or wine, and is giten to ftrong bodies.

Antonius Gatanerius doth thew in his treatic of the plague, the fecond difference, the third chap- $C$ ter, that Axthora is of great force,yea and that againft the plague: and the root is of like vertucs, ginenwith Dittanie,which I haue feene, faith he, by experience : and lie further faith, it is an herbe that groweth hard by rhat herbe $T$ bor $a$, of which there is made a poifon, wherew ith rhey of Samoy and thofe parts adiacent doenuenome their arrowes, the more fpeedily to kill the wilde Goats, and other wilde beafts of rhe Alpin mountaines. And this root Antbora is the Bezour or counterpoifon to that $T$ hor, which is of fo great a venome, as that it killeth all liuing creatures with his poifonfome qualitie:and thus much Gwanerius.

Simon Ianuenfis hath alfo made mention of Anthora, and Arroldus Villanovanus in his treatie of D poilons : but their writings do declare that they did not well know Anthora.

\section{Chap.375. Of yellow Wolfes-bane.}

\section{T. The Defription.}

He yellow kinde of Wolfes-bane called Acorzitumi lateum Ponticum, or according to Dodonars Aconitum Lycottonon luteum maius : in Englifh,yellow Wolfes-bane, whereof this nur age hath found out fundry forts not knowne to D iofcorides, although fome of thie forts feeme to ftand 
Aconitum luteum Ponticum.

Yellow Woolfesbane.

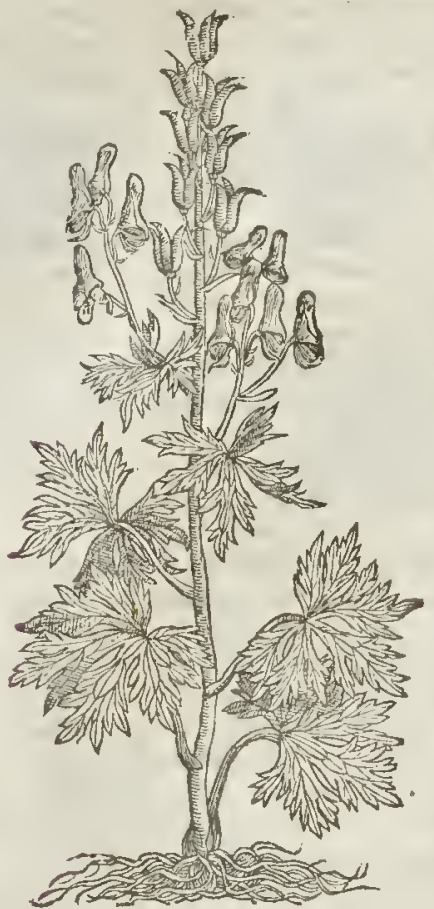

indifferent betweene the kindes of Rammenlur, Hellcborus, and Napellws; ) this yellow kinde I fay harh large ihining greene leaues fartioned like a vine, and of the lame bigneffe, decpely indented or cut, not much wnilie the leaucs of Gcranium Fr:fam, or blacke Cranes-bill: the falkes are bare or naked, not bearing bis leaues vpon the fame ftallies, ore oppofire aginint anorher, as in the other of his kinde: his ftalkes grow vp to the height of thre cubits, bearing very fine yellow tomes, fincaftically fathioned,and in fuch manner thaped, rhat I can very hardly defcribe rhem viro you. They are fomewhat like unto the helmet Monkes hood, open and liollow at one end, firme and thut vp at the other : his roors are many, compas of a number of threddy or blacke ftrings, of an ouerworne yellow colour, fpreat ing far abroad euery way, folding themfalues one within another very confufedly. This plant growed naturally in the darke hillic forrefts, and thadowie woods, which are not trauclled not haunted, but by wilde and famage beafts, and is thomght to be the ftrongeft and next vnto $T$ fora in his poifoning qualitie, of all the reft of the Aconites, or Woolfes banes-infomuch that if a few of rhe foures be chewed in the mouth, and frit fortl againe prefently, yet forthwith it burneth the jawes and tongue, cauling them to fwell, and making a certaine fwimming or giddineffe in the head. Th is calleth to my remembrance an hiftory of a certaine Genteman dwelling in Lincolnefhire, called Mabsve, the true report whereof my very good friend Mr. Nicholas Beffon, fometimes fellow of Kings Colledge in Cambridge, hath delitered vnto me: $\mathrm{M}^{\mathrm{r}}$. Mabesve dwelling in Bofton, a fudent in Phyficke, hatring occafiout to ride through the I ennes of Lincolnethire, found a root that the bogs had turned $v p$, which feemed vnto him very ftrange and vnknowne, for that it was in the fpring be fore the leaues were out, : this he tafted, and it fo infauned his mouth, tonguc, and lips, that it caufed rhem to fwell very extreamely, fo that be fore he could get to the towne of Bofton he could not fpeake, and no doubt had loft his life if that the Lord God had not bleffed thofe good remedies which prefently he procured and wed. I haue here thought good to expreffe this biftory, for two efpeciall caufes; the firft is, that fome indufrious and diligent obferuer of nature may be prouoked to feeke lorth that vencmous planr, or fome of his kindes : for I am certainely perfuaded that it is eirher the Thora Yaldenfum, or Acomitum lutewn, whereof this gentleman tafted, which two plants haue not at any time been thought togrow naturally in England:the other caufe is, for that I would warne orhers to beware by that genrlemans harne. $\neq I$ inn of oninion rhat this root which $\mathrm{M}^{\mathrm{L}}$. Malswe tated was of the Rumeulsu flumews maior, deferibed in the firt place of the $37^{\circ}$. chapter aforegoing; for that growes plentifully in fuch places, and is of a very hot tilte and hurtfull qualitic. $\ddagger$

$$
\text { 9. The Place. }
$$

The yellow Woolfes bane groweth in my garden, but not wilde in England, or in any other of thefe Northerly regions.

$$
\begin{aligned}
& \text { It flotreth in the Time. } \\
& \text { It of Iune, fomewhat afrer the other Aconites. } \\
& \text { का The Names. }
\end{aligned}
$$

This yellow Woolfes-bane is called of Lobl, Aconitum luteum Posticum,or Ponticlic Wonlfesbane. There is mention made in Diofcorides his copies of three Woolfes-bunes, of which the hulzters ve one, and Phyfitions the other two. Marcellus Virgilizs holdeth opinion that the vfe of this plant is vtterly to be refufed in medicine.

$$
\text { 1) The Texperature and Vertucs. }
$$

A The facultic of this A conite, as alfo of the other Woolfes-banes, is deadlv to man, and likewife to all other liuing creatures. 
L 1 в. 2. Of the Hiftory of Plants. It is vfed among the hunters which feek after wolues, the iuyce whereof they put into raw flelh,
which the wolues dc uoure, and are killed.

\section{C н А .376 . \\ Of other Wolfes-banes and Monkes-boods. \\ If The Defoription.}

I

THis kinde of Wolfes-bane (called Aconitum Lycoctonum: and of Dodonaus, CA conitume Lycuetorion fore Delphiny, by reafon of the Qhape and likenes that the fourre hath with Delphinium, or Larkes-fpur: and in Englifh it is called blacke Wolfes-bune), hath many large lcaues of a very deepe greene or onerworne colour, very deepely cut or iagged : among which riferh vp a ftalke two cubits high; whereupon do grow foures fahioned like a hood, of a very ill fauoured blewifh colour, and the thrums or threds within the hood are blacke : the feed is al fo blacke and three comered, growing in finall husks: the root is thicke and knobby.

I I Aconitum lycoctonon flore Delpliniz. Larks-heele Wolfes-bane.

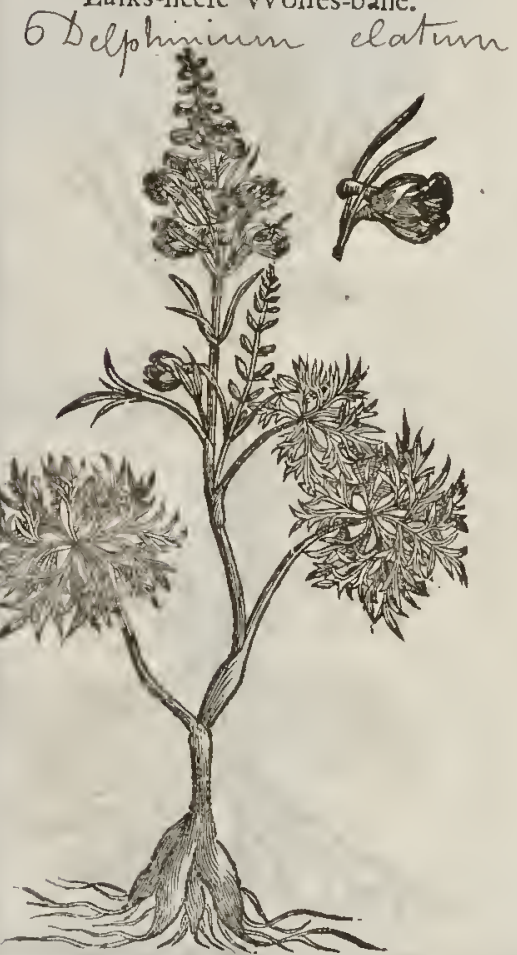

I 2 Aconitum lycoctonoricarulcum parvum Small blew Wolfes-bane. dconitum variegatum

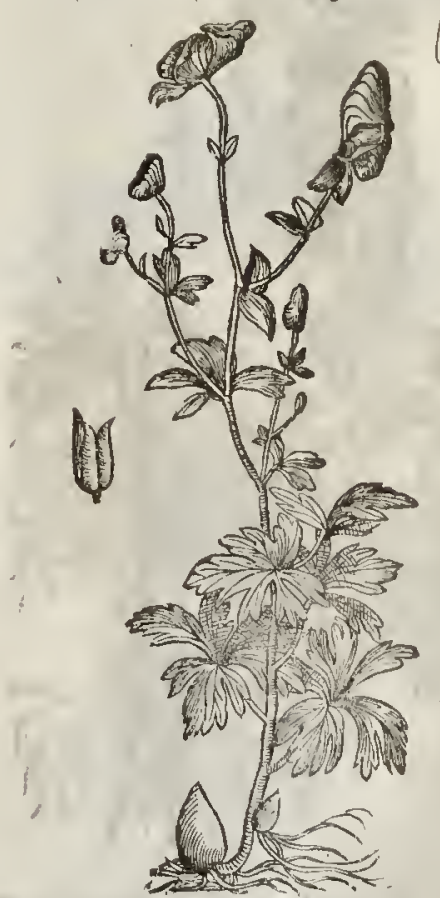

2 This kinde of Wolfes-bane, called Lycottonon cerulenos purvum, facie Napelli : in Englithfinall Wolfes-bane, or tound Wolfes-bane, hath many flender brittle ftalkes two cubits high, befet with leaues very much iagged, and likevnto Napellus, called in Englinh, Helmet-Houre. The foures do grow at the top of the ftalkes, of a blewin colour, fathioned alfo like a hood, but wider open than any of the reft : the cods and feed are like vnto the other : the root is round and fmall, fafhioned like a Peare or fmall Rape or Turnep: which moucd the Germanes to call the fame 1iapen-blae= men, which is in Latine, Flos rapaceus : in Englin, Rape-floure.

3 This kinde of Wolfes-bane, called Napellus verus, in Englifh, Helmet-floure, or the great Monkes-hood, beareth very faire and goodly blew floures in thape like an helmet; which are fo beautifull, that a man would thinke they were of forme excellent vertue, but non eft femper fides habendu fromti. This plant is vniuetally knowne in ont London gatdens and el few here; but natually. 
it groweth in the mountaines of Rhetia, and in fundry places of the Alps, whete you flatl find the graffe that groweth round it eaten vp with cattell, but no part of the herbe it felfe touched, except by certain Hies, who in fuch aboundant meafure fwarme about the fane that they couer the whole plant : and (which is very ftrange) although thefe flics do with great delight feed hereupun,yet of them there is confected an Antidote or moft auailable medicine againft the deadly bite of the fpider called Tarantala, or any other venomous beaft whatfoeuer; yea, an excellent remedie not onely againft the Aconites, but all other poyfons whatfoeuer. The medicine of the forefaid flies is thus made: Take of the flies which baue fed themfelues as is aboue mentioned, in number twentie, of Ariftolochia rotunda, and bole Armoniack, of each a dram.

4 There is a kinde of Wolfes-bane which Dodonass reports he found in an old written Greeke booke in the Emperors Libraric at Vienna, vider the the title of Aconitum lycocionum, that anfwereth in all poinrs vnto Diofcorides his defeription, except in the leaucs. It hath leaues (faith hee) like vnto the Plane tree, but leffer, and more full of iags or diuifions; a flender ftalke as Ferne, of a eubithigh, bearing his feed in long cods : it hath blacke roots in fhape like Creauifes. Hereunto agreetl the Emperors picture in all things fauing in the leaues, which are not fo large, nor fo much diuided, but notched or toothed like the teeth of a far.

3 Napellis verus coruleus.

Blew Helmet-floure, or Monks-hood.

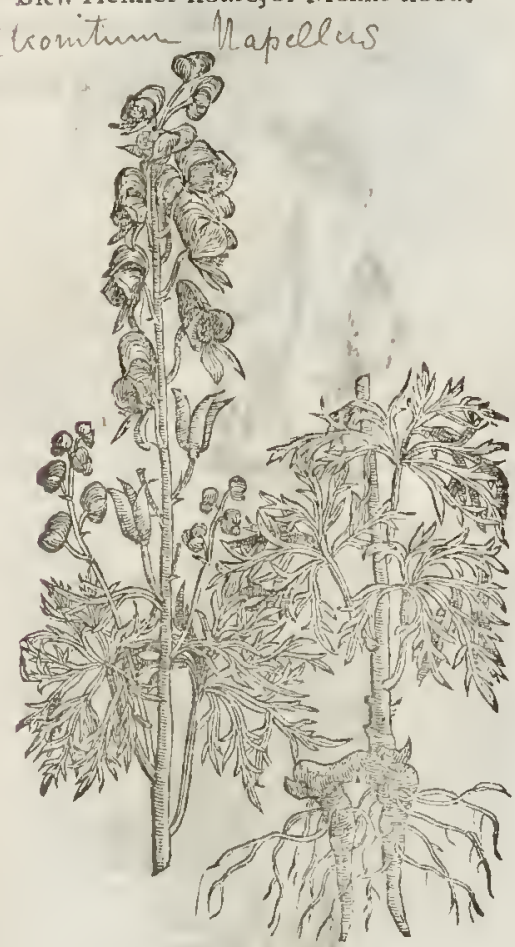

\# Aconisum lycoctonum ex Cod.Csfareo.

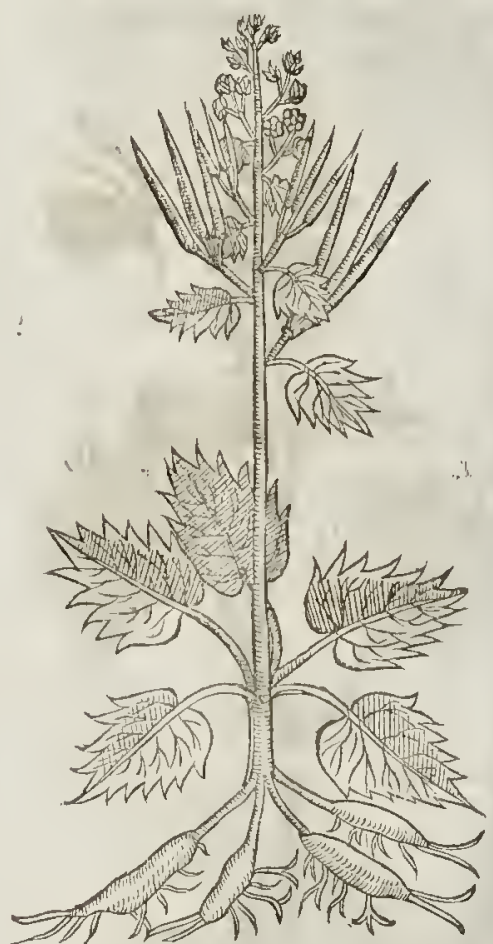

₹ 5 Befides thefe mentioned by our Authot there are fundry other plants belonging to this pernitious Tribe, whofe hiltorie I will briefely runne ouer: The frrft of rhefe is that which clufus hath fet forth by the name of Aconitum lycottonum flo. Delphiny Silefiacum: ir hath ftalks fome two or three eubits high, fmooth and hollow, of a greenith purple colour, and coured with a eertaine mealineffe : the leaues grow vpon long ftalks, being rough, and fathioned like thofe of the yellow Wolfes bane, but of a blacker colour : the top of the ftalke ends in a long fpike of fpurre-floures, which before they be open refemble locufts or little Lyzards, wi th their long and crooking tailes; but opening they thew fute leaues, two on the fides, two below, and one aboue, which ends in a crooked taike or horne : all thefe leaues are wrinckled, and purple on their outfides, but fmooth,and of an elegant blew within. Afrer the floures are paft fueceed three fquare cods, as in other Aconites, wherein is contained an vnequall brownifh wrinckled feed : the root is thicke,black, and tuberous. This growes naturally in fome mountaines of Silefia, and floures in Iuly and Augut. 


\section{$\mathrm{L}_{\mathrm{I} \text { в. 2. }}$ Of the Hiftorie of Plants.}

\# Aconitum lycoat. birfutum flo. Delphini.

Rough Larks-hecle Wolfes-bane.

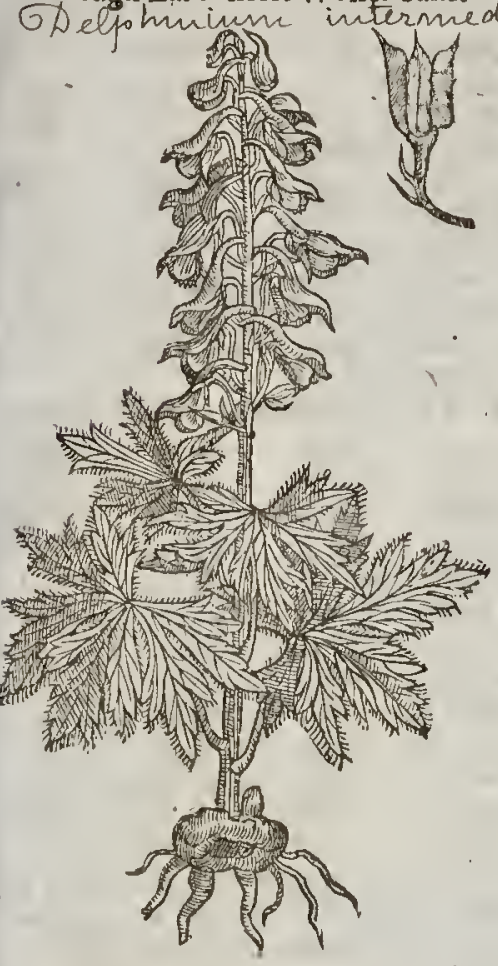

\$ Aconitum purpureum Noubergenfe. Purple Monks-hood of Newburg.

Aconitum neonoitainm
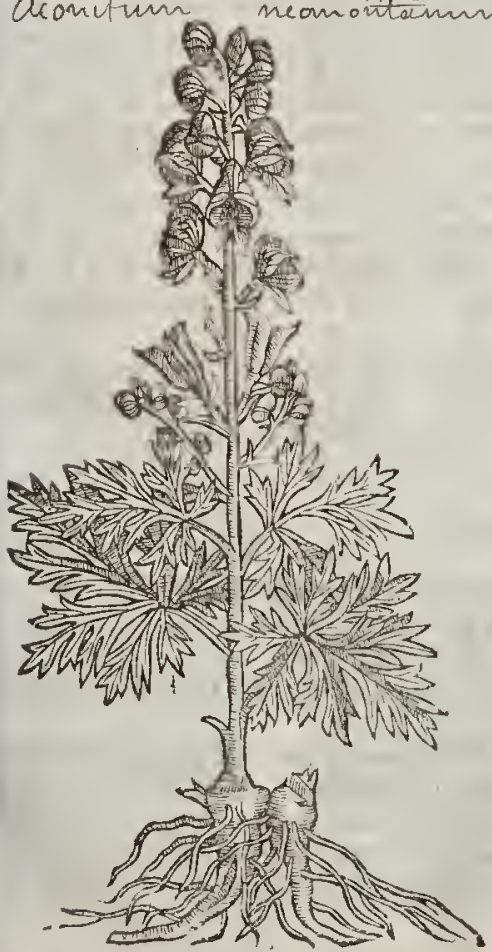

¥6 Aconiturn violaccum.

Violet coloured Monks hood.

aconityn Sarricim

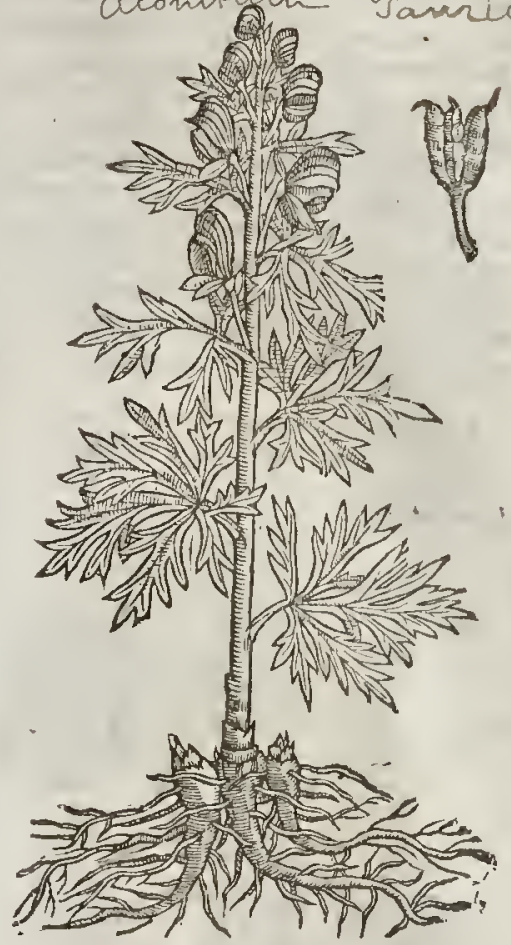

\$ Aconitum muximum Iudenbergenfe.

Large Poured Monks-hood.

Clonterm Cammarmm

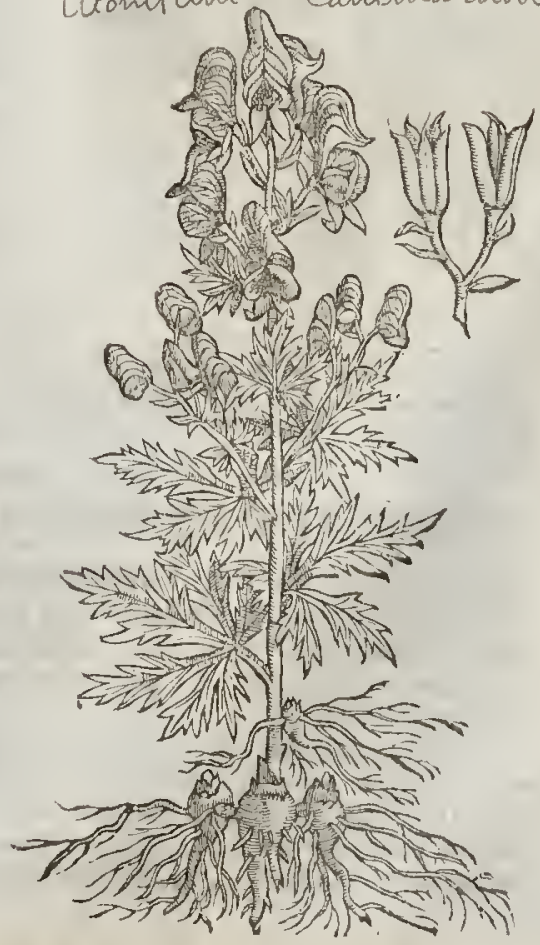


6 The leanes of this are fomwhat like, yet lefie chan thote of our common Monk s. liovd,blackith on the vpper fide and thining. The ftalke is fome cubit and latfoligh, tirme full of pith, fmooth, and hining; diuided towards the top into tome branches carying few toures, lite in forme to thofe of the vulgar Monks-hood, of a molt elegant and deepe viotet colcur : the feds are like the former, and roots round, thicke, and thort, with many fibres. It growes spon the lisls nic ] Saltsburg, where it foures in Iuly : but brought into gardens it foures looner than che reft of this kinde, to wit in May. Clafius calls this aconum lycoutonum 4. Taurickm.

7 This hath leaues broader than thofe of our ordinaric Monks. hood, yet like them : the ftalke is round, fraight, and firme, and of fome three cubits lieight, and of times toward the top diuided into many branches, which carry their floures f pike-tanhion, of a purple colour, abfolutely like thofe of the common fort, but that the thrummie mater in themiddeft of the Houres is of i? duskier colour. The root and reft of the parts are like thofe of the common kinde: it growes na turally vpon the Styrian Alpes, whereas it foures foricwhat after the common kinde, tow it, in

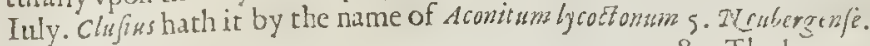

‡ Aconitum maximum nutante coma. Monkes-liood with the bending of nouding licat.

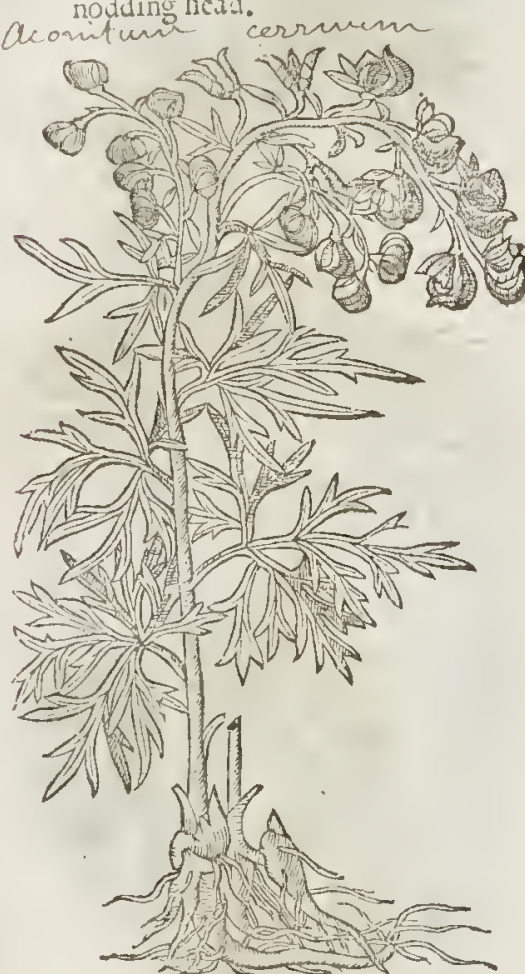

8. The leaues of this are alfo diuided into fiue pars, and fnipt abrut the edges, and doe very much refemble thofe of the Ima! Wolksbrane defcribed in the fecond place, but that the leanes of chat inine, when as thefe do not: the falke is twocubits high, aroucry thicke, yet firme and ftraight, of a rcenilh purple $\mathrm{co}$ lour; and at the top carries fiue or inx floures, the largeft of all the Monks Lioods, confifting of foure leaues, as in the reft of this kind, with a very large helmet ouer them, bcing fometimes an inch long, of an elegant blewift purple color : the feed-reffels, freds, and roors are like the reft of this kinde. This growes on Iudenberg, the higheit hill of all Stiria, and floures in Auguft; in gardens ahout the end of Iuly. Clufins names it Aconitum Lycoct. 9 . Iudenbergenje.

9 This rifes vp to the height of three cubits, with a flender round falke which is diuided into fundry branches, and commonly hangs downe the head; whence Clufurs cals it weonitum Iycoctonum 8. coma nutante. The floures are like thofe of the common Monkshood, but of fomewhat a lighter purple colour. The leaucs are larger and long, and much more cut in or diuided than any of the reft. The roots, feeds, and orher particles are not vnlike thore of the reft of this kinde. $\neq$

$$
\text { बा The Place. }
$$

Diuers of the fe Wolfs-banes grow in fome gardens, except Aconitum lycoetonow, taken forth of the Emperors buoke.

\section{Thefe plants do floure from May vnto the end of Augutt. \\ T $T$ be $N$ ames.}

The firft is Lycoctonipecics, or a kinde of Wolfes-bane, and is as hurtfull as any of the reft, and called of Lobel, Aconitum flore Delphinï, or Larke-1pur Wolfes-bare. Auicen fpeaketh licrcof in his fecond booke, and afterwards in his fourth bouke, Fen. 6 . the firft Treatife : haung his rcafons why and wherefore he hatl feparated this from conach adip, that is to fay, the WV olfes ftringier, or rhe Wo!fes bane.

The later and barbarous Herbarifts call the third Wolfes tane in Latire Napellus, of the fgure and thape of the roots of Naprs, or Nawet, or Nanew gentle : ut is likcrvife Aconutr lycoctorifperzes, or a kinde of Wolfes-bane: alfo ic may becalled Toxicum; for Toxicum is a deadly neclicire uherewirl the Huntcrs poyfon their f peares, darts, and arrowes, tl at brirg prefont death: to named of arrowes which the Barbarians call Toxcumat. and Toxa. Diofcoridis fetting cowre tle fymptones 
or accidents caufed by Toxicum, together with the temedies, reckoneth vp almolt the verie fame that Awicen doth concerning Napellus : notwithftanding Asisen writes of $N_{x p p e l l}$ ass and Toxicmm $\mathrm{fe}$ uerally; but not knowing what Toxicum is,as he himfelfe confeffeth: fo that it is not to be tharuelled, that hauing written of Napellus, he fhould afterward entreat againe of Toxisum.

9. The Nature and Vertues.

All thefe plants are hot and dry in the fourth degrec, and of a moft venomous qualitie.

The force and facultic of Wolfes-bane is deadly to man and all kindes of beafts : the fame was tricd of latc in Antwerpe, and is as yet freth in memorie, by an euident experiment, but moft lamentable; for when the leaues hercof were by certaine ignorant perfons ferued vp in fallads, ali that did eate theteof were prefently taken with moft cruell fymptomes, and fo died.

The fymptomes that follow thofe that do cate of thefe ceadly herbes are thefe; their lips and $B$ tongues fwell forthwith, their eyes hang out, their thighes are ftiffe, and their wits are taken from. them, as Auicun writeth in his fourth booke. The force of this poyfon is fueh, that if the points of darts or arrowes be rouched with the fame, it bringeth deadly hut to thofe that are wounded therewith.

Againt fodeadly a poyfon Autces reekoneth vp cettaine remedies, which helpe after the poy- C fon is vomited vp; and among thefe he maketh mention of the Moufe (as the copies eucry where haue it) nourinhed and fed vp with Napellus, which is altogether an enemic to the poyfonfome nature thereof, and deliuereth him that hath taken it from all perill and danger.

Antonius Gunncrius of Pauia, a famous phyfition in his age, in his treaty of poy fons is of opinion, that it is not a moufe that Auscen fpeakes of, but a fly : for he telleth of a certaine Philofopher that did vcry carefully and diligently makc fearch after this Moufe, and neither could find at any time either Moufe, or the root of Wolfes-bane gnawne or bitten, as he had read; but in fearching he found many flies feeding on the leaucs, which the fame Philofopher tooke, and made of them an Antidote or counterpoyfon, which he found to be good and effcetuall againit other poyfons, but efpecially the poyfon of Wolfes-bane.

This compolition confifteth of two ounces of $\tau$ erralemnia, as many of the berries of the Bay $E$ tree, and the likeweight of Mithridate, 24 of the flies that haue taken théir repalt vpon Wolfesbane, of honey and oyle Oliue a fufficient quantitic.

The fame opinion that Gunerius is of, Petrus Pena and Matthies de Lobel doe alfo hold; who affirme, that there was neuer feene at any time any Moufe feeding thercon, but that there be Flies which tefort vnto it by fwarmes, and feed not onely vpon the finures, bur on the herbealfo.

$$
\text { IT The Danger. }
$$

There hath bcene little heretofore fer downe conccrning the vettues of the A conites,but nuchi might be faid of the hurts that hauc come hereby, as the wofull experience of the lamentable example at Antwerpe, yet fren in memorie, doth dcelare, as we haue faid.

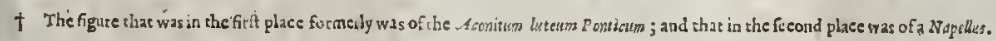

\section{Cнат. 377. Of blacke Hellebore.}

T. The Defoription.

\& THe firl kinde of blacke Hellebor Dodoraus fetteth forth vnder this title Viratrum nigrum; and it may properiy be called in Englinh,blacke Hellebor, which is a name moft fitly agreeing vnto the true and vadoubted blacke Hellebor, fot the kindes and other forts hereof which hereafter follow are falfe and baftard kindes thereof. This plant hath thicke and fat leanes of a deepe greene eolour, the vpper part whereof $\boldsymbol{k}_{\mathrm{s}}$ fomewhat bluntly nicked or toothed, hauing fundry ditifions or curs; in fome leates many, in others fewer, like vnto the female Peony, or Smyraium Creticum. It beareth Rofe fathioned floires vpon nender ftems, growing immediately out of the ground an handfull high, fomtimes vety white, and oftentimes mixed with a little thew of purple : which being vaded, there fucceed fmall huskes full of blacke feéds : thc roots are many, with long blacke ftrings comming from one head.

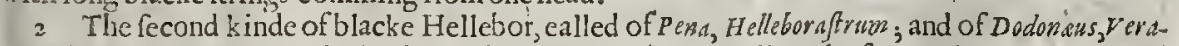
1 :rume focuradum (in Englifh, baftatd Hellebor) hath leaues muh like the formet, but natrower and blacker, each leafe being much iagged or toothed about the edgcs like a faw. The ftalkes grow to the height of a foot or more, diuiding themfelues intoother btanches towatd the top; whereon do grow floures not much vnlike, to the former in thew, fauc that they arc of a greenîn herby coInur. The roots are fmall and threddy, but not fo blacke as thic formet. 
I Helleborus niger verus. The true blacke Hellebor. Helleh ores niger.

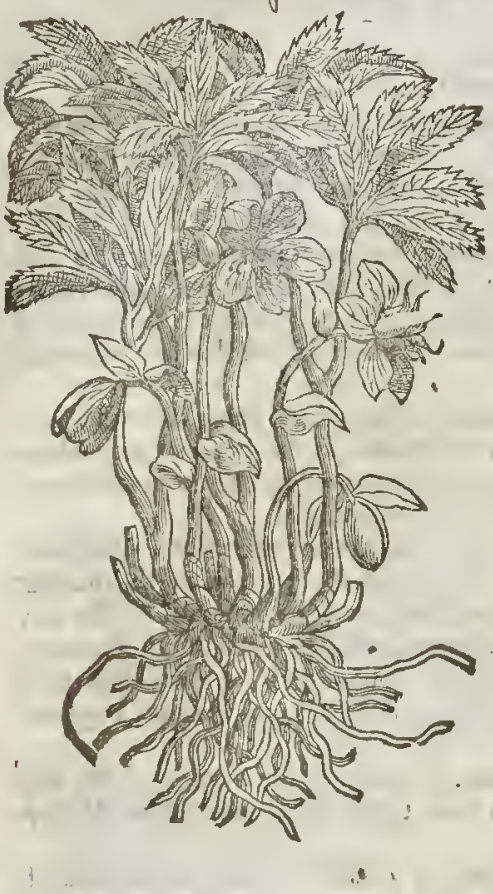

3 Helleborafter maximus. The great Ox-hecle. Adtebouns fotidius

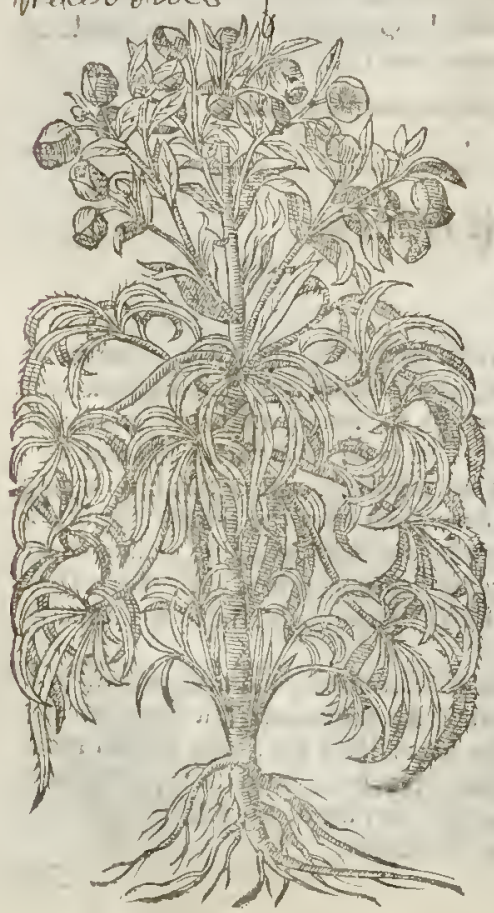

2 Helleboraftrum.

Wildeblackc Hellebor. Adel oms wiridis

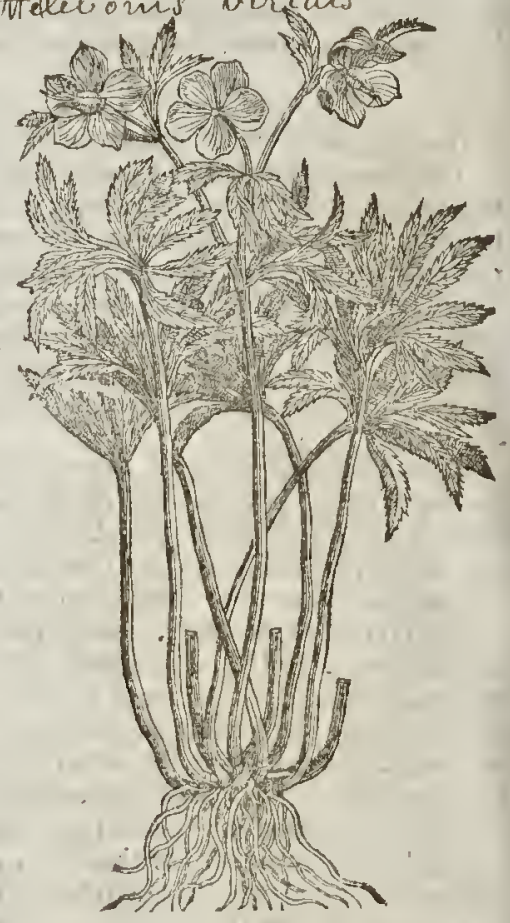

4. Confliga Rülly, ó Sefanoides magnum Cordi: Setter-wort, or Beare-foot.

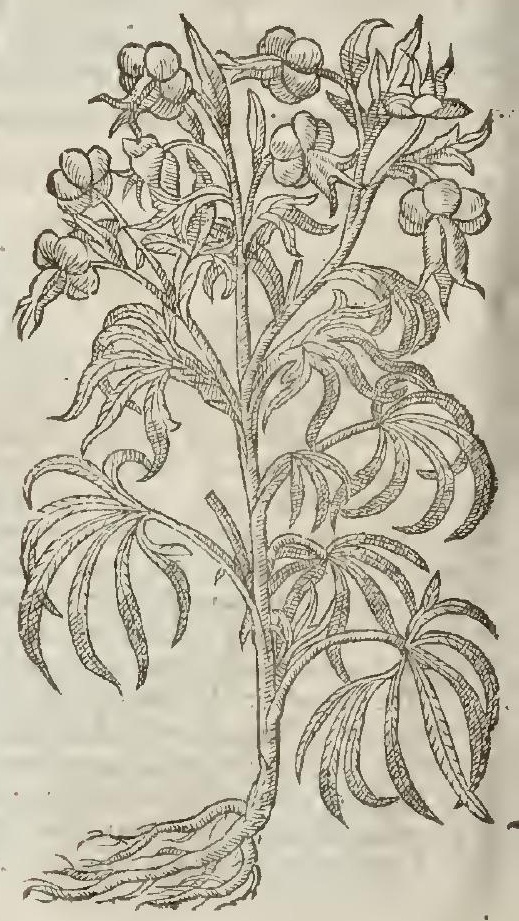


3 The third kinde of blacke Hellebor, called of Pena, Helleborafter maximus, with this addition, flore $\dot{\sigma}$ femine pragnans, that is, full both of tloures and feed, hath leaues fomewhat like the former wildc Hellebor, faue that they be greater, more iagged, and deepely cut. The ftalks grow vp to the height of two cubits, diuiding thcmfelues at the top into fundry fnall branches, whercupon grow little round and bottle-like hollow greene floures; after which come forth feeds which come to perfect maturitie and ripeneffe. The root confifteth of many fmall blacke ftrings, inuolued or wrapped one within another very intricately.

4. The fourth kinde of blackc Hellebor (called of $P$ ena and Lobel, according to the defcription of Cordus and Euellius, Sefrmoides magnum, and Conjiligo: in Englih, Ox-heele, or Setuter-woort ; which names are taken from his vertues in curing Oxen and fucl like cattell, as thall be thewed af terw ard in the names thereof) is fowell know ne vnto the moft fort of penplcby the name of Bcarefoot, that I thall not hate caufe to fpend much time aboit the defcription. $\$$ Indeed is was not much needfull for our Author to defcribe it, for it was the laft thing he did; for both thefe tivo laft are of one plant, both figures and defcriptions; the former of thefe figures exprefing it in floure, and the later in feed : but the former of our Author was wish fomewhat broader leaues,and the laterwith narrower. $\ddagger$

$$
\text { Tा The Place: }
$$

Thefe Hellebors grow vpon rough and craggy mountains : the laft growes wilde in many woods and thadowie places in England: we haue them all in our London gardens.

$$
\text { 4. The Time. }
$$

The firf floureth about Chriftmaffe, if the Winter be milde and warme: the others later : G The Names.

It is agreed among the later writers, that thefe plants are Verstranigra $:$ in Englifh,blacke Hel

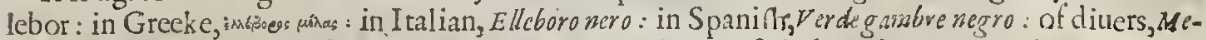
lampodium, becaufe it was firft found by cxelampos, whowas firft thought to purge therewith Pretus his mad daughters, and to reftore them to health. Dioforides writeth, that th is man was a thep-

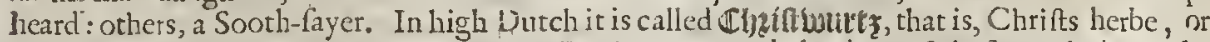
Chriftmaffc herbe : in low Dutch, birth of our Lord Iefus Chrift.

The third kinde was called of Fuchfus, $P$ feudohelleborws, and $t$ erutrum nigrum adulterinum, which is in Englifh, falfeorbaftard blacke Hellebor. Moft name it confiligo, becaufe the busbandmen of our time do herewith cure their cattell, no otherwife than the old Farriers or horfe-leeches ivere wont to do, that is, they cut a fit or hole in the dew-lap, as they terme it (which is an emprie skin vader the throat of the beaft) wherein they put a prece of the ront of Setterwort or Bcare-foor, fuffering it there to remaine for certaine dayes together : which manncr of curing rhcy do call Settering of their cattell, and is a manner of rowelling, as the faid Horfe-leeches doe their horfes with horfe haire twifted, or fuch like, and as in Surgerle we do vfe with filke, which in ftead of theword Seton, a certaine Phy fitian called it by the name Rowell; a word very vnproperly fpoken of a learned man, becaufe there would be fome difference betwixt men and beafts. This manner of fettering of cattell helpeth the difeafe of the lungs, the cough, and wheefing. Morener, in the time of peftilence or murraine, or any other difeafes affeiting cattell, they put the root into the place aforefaid, which draveth vnto it all the venomous matter, and voideth it forth at the wound. The whicli Abfyrtus and Hierocles the Grecke Horfe-leches haue at large fet downe. And it is called in Englith, Beare-foot, Setter-wort, and Setter-grafle.

The fecond is named in the German tongue, Lowratitaut, that is, Pcdiculwis, or Lov fiegrafe: for it is thought to deftroy and k1ll lice, and not onely lice but theepc and other cattell : and may be reckoned among the Beare-feet, as kindes thereof.

$$
\text { of The Temperature. }
$$

Blackc Hellebor, as Galen holdeth opinion, is hotter in tafte than the white Hellebor : in like manner hot and dry in the third degree.

$$
\text { T) The Vertues. }
$$

Black Hellebor purgeth downwards flegme, choler, and alfo melancholy efpecially, and all me- $A$ lancholy humors, yet not without trouble and difficultie: therfore it is not ro be giuen but to robuftious and ftrong bodies, as Mefuesteacheth. A purgation of Hellebor is good formad and furious men, for melancholy, dull, and heauy perfons, for thofe that are troubled with the falling ficknes, for lepers, for them that are ficke of a quartane Ague, and briefely for all thofe that are troubled with blacke cliolor, and molelted with melancholy.

The manner of gituing it (meaning the firft blacke Hellebor) faith Alturius in his firft booke, is $\mathrm{B}$ threc fcruples, little more or leffe.

It is giuen with wine of raifiss or oxymel, but for pleafantnes fake fome fweet and odoriferous $C$ 
feeds mult be put vnto it : but if you would haue it ftronger, adde thereunto a grain or two of $\mathrm{Sca}$ monie. Thus much Actuarizus.

D The firft of thefe kindes is beft, then the fecond; the reft are of leffe force.

E The roots take away the morphew and blacke fpots in the skin, tetters, ring-wormes, leprofies, and feabs.

F The root fodden in pottage with flch, openeth the bellies of fuch as hate the dropfie.

G The root of baftard Hellebor, called among our Englifh women Beare-foot, fteeped in wine and drunken, loofeth the belly euen as the true blacke Hellebor, and is good againft all the difeafes wheteunto blacke Hellebor ferueth, and killeth wormes in children.

H It doth his operation with more force and might, if it be made into pouder, and a dram theteof bereceined inwine.

I The fame boyled in waterwith Rue and Agtimony, cureth the jaundice, and purgeth yellow fuperfuities by fiege.

K. The leaues of baftard Hellebor dried in an ouen, after the bread is drawne out, and the pouder thereof taken in a figge or raifin, or ftrawed vpon a piece of bread fpred with honey and eaten, killeth wormes in children exceedingly.

\section{$\mathrm{C}_{\text {A }}$. 378 . Of Diofcorides bis blacke Hellebor.}

Aftrantianigra, fue VCratrum nigrum Diofcoridis, Dod. Blacke Mafter-worts, or Diofcorides his blacke Hellebor.

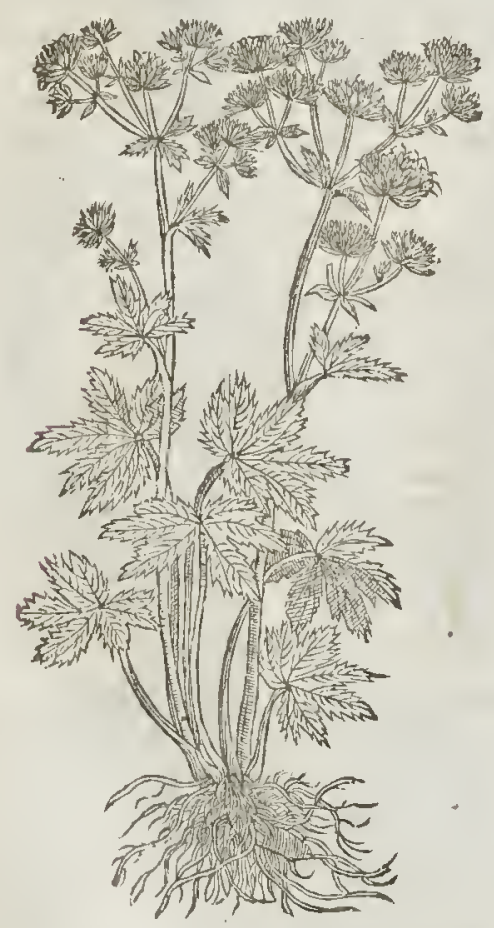
garden.
II The Defcription,

TTis kinde of blacke Hellebor, fet forth by Lobel vnder the name of Afrantianigra, agreeth very well in thape with the true $A$. Arantia, which is called Imperatorin: neuertheles by the confent of $D$ iof corides and other Authots, who haue expreffed this plant for a kinde of. $\nu e$. ratrum nigrum, or blacke Hellebor, it hath many blackifh green leaues parted or cut into fo ure or fiue deepe cuts, after the manet of the vine leaf: very like vnto thofe of Sanicle, both in greennes of colour, and allo in proportion. The fta'ke is euen,fmooth, and plain: at the top wherof grow floures it little tufts or vmbels, fer together like thofe of Scabious, of a whitifh light greene colour, dafhed oner as it were with a little darke purple : after which come the feed like vnto Carthamus or baftard Saffron. The roots are many blackifh threds knit to one head or mafter root. Tा The Place.

Blacke Helleb or is found in the mountains of Germany, and in othet vntilled and rough places: it profpereth in gardens.

Diofcorides writeth, That blacke Hellcbor growerh likewife in rough and dry places : and that is the beft which is taken from fuch like places ; as that (faith hec) which is brought ouc of Anticyra a city in Greece. It groweth in nyy.

का The Time.

Fis? This blacke Hellebor flowreth not in Winter, but in the Sommer moneths. The herb is green all the yeare thorow.

$$
\text { व The Names. }
$$

It is called of the later Hcrbarifts, Aframtia nigra : Of others, Sanicula famina : notwithftanding it diffeteth much from Aftrantia, an herbe which is alfo named Imperatoria, or Mafter-wort. The vulgar people call it Pellitorie of Spaine, but untruly : it may be called blacke Mafter-wort, yet doubtlefie a kinde of Hellebor, as the purging facultie doth thew : for it is certaine, that diuers experienced phyfitians can witneffe, that the roots hereof do purge melancholy and other bumors, 


\section{व The Nimes.}

It is ealled in our age chriftophorima, and $S$. Chriftophori herba: in Englith, Herbe Chriftopher: fone there be that name it Coftus nigir: others had rather haue it Aconitum batcifer um : it hath no likenes at all noraffinitie with coftus, as the fimpleft may perevine that doknow both. Bur doubtleffe it is of the number of the Aeonices, or Wolfs-banes, by reafon of the deadly and pernicious qualitie that it hath, like vnto Wolfes-bane, or Leopards-bane.

qा The Temperature.

The temperature of Herbe Chritopher anfivereth thofe of the Aconites, as we haue faid. q The Vertues.

I finde little or nothing extant in the antient or later writers, of any one good propertiewherewith any part of this plant is pofleffed: therefore I with thole that loue new medieines to take heed that this be none of them, beeaufe it is thought to be of a venomous and deadly qualitic.

\section{С на в. 380. Of Peionie. \\ T) The Kindes:}

THere be three Peionies, one male, and two females, deferibed by the Antients : the laterwriters haue found out foure more; one of the female kinde, ealled P eonia pumila, or dwarfe Peonie; and another ealled Pcomia promifura fue neutra, Baftard, Mif-begotten, or neither of beth, but as it were a plant participating of the male and female; one double Pcionie with white floures, and a fourth kinde bearing fingle white foures.

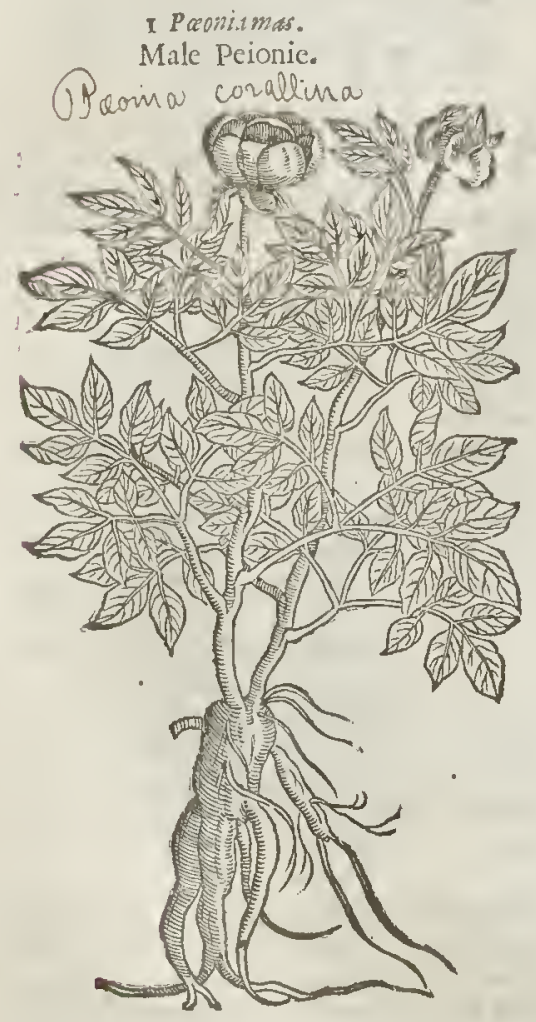

Preunia meas cumfemire.

Male Peionic in feed.

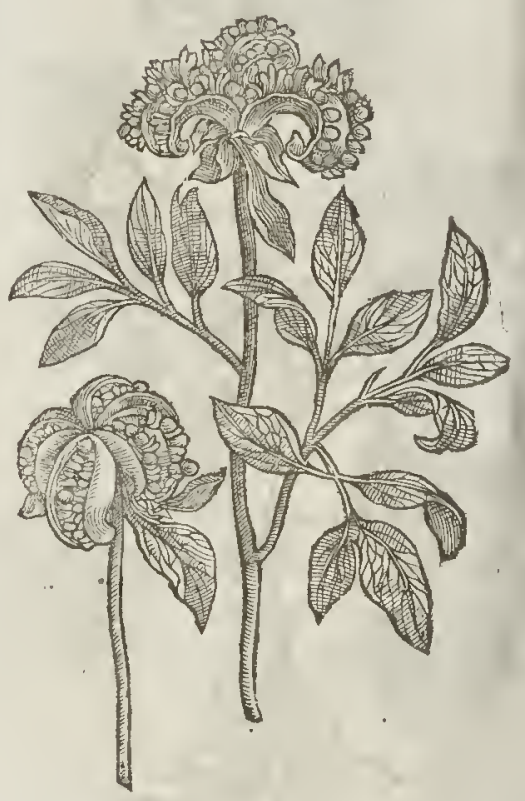

9f The Defoription.

I THe firf kinde of Pcionie (being the male, ealled Peomia mas : in Englinh, Male Peiony)

1 hath thicke red ftalkes a eubit long: the leaues be great and large, confifing of diuers leaues growing or ioyned together spon one flender ftemme or rib, not much vnlike the leaues of 
the Wall-nut tree both in fathion and greatneffe : at the top of the 'ftalkes grow faire large red floures very like rofes, hauing alfo in the midft yellow threds or thrums like them in the role called Asthera: which being vaded and fallen away, there come in place three or foure great cods or luskes, which do open when they are ripe; the inner part of which cods is of a faire red colour, wherein is contained blacke fhining and polithed feeds as big as a peafe,and betweene enery black feed is couched a red or crimfon feed, which is barren and empty. The root is thicke, great, and tuberous, like vnto the common Peionie.

2 There is another kinde of Peionic, called of Dodonaus, Paonia famina prior : of Label, Paoniat formina : in Engliih, female Peonie, which is fowell knowne vnto all that it needetla not any de-
fcription.

3 The third kinde of Peionic (which $P$ ena fettech forth vnder the name Pania famisa polyanthos: Dodonarus, Paonia famina multiplex : in Englifh, Double Peionie) hath leaues, roots, and floures like the common female Pcionic, faue that his leaues are not fo much iagged, and are of a lighter greene colour : the roots are thicker and more tuberous, and the floures much greater, exceeding double, of a very deep red colour, in fathion very like the great double rofe of Prouince, but greater and more double.

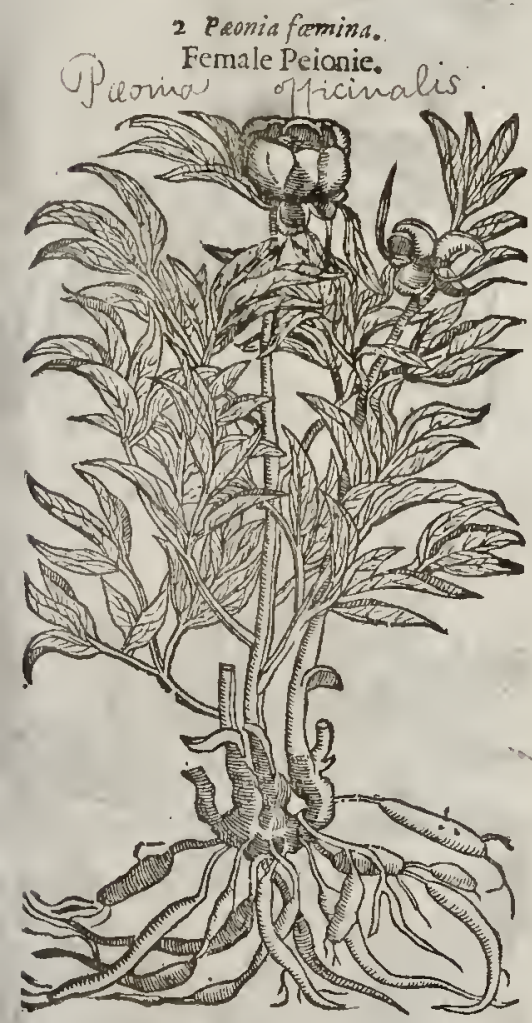

3 Pasniafomina multiplex.
Double red Peionie.

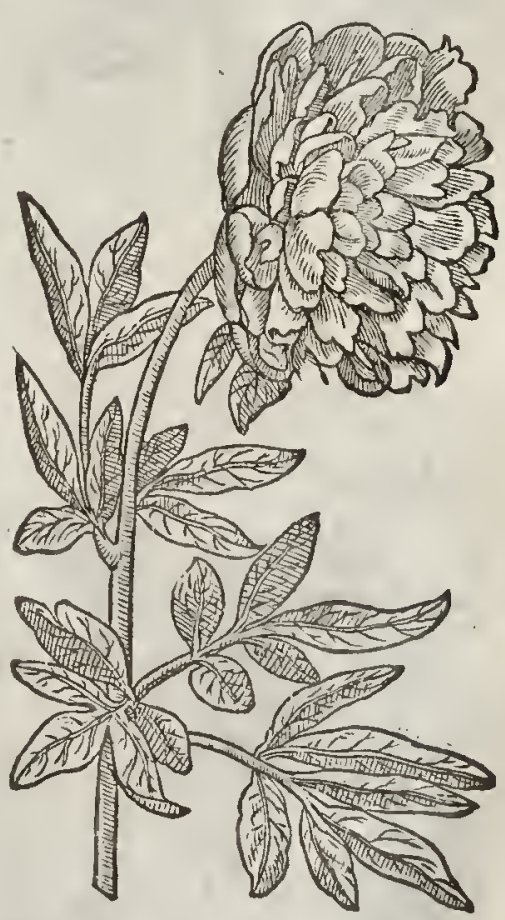

4 There is found another fort of the double Peionie, not differing from the precedent in ftalks; leaues, or roots : this plant bringeth forth white foures, wherein confitterh the difference.

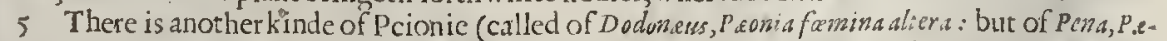
oxiapromil(cua, fuse neutra: inEngli(h, Maiden or Virgin Peiony) that is like to the common Peiony, fauing that his leaucs and floures are much leffe, and the ftalks thorter : it bearech red floures and feed alfo like the former.

6 We haue likewife in our London gardens another fort bearing foures of a pale whitifh colour; very fingle, refembling the female wilde Peiony, in orher refpetts like the double white Peiony, but leffer in all the parts thereof.

\# Clufius by feed fent him from Conftantinople had two other varieties of fingle Peionies; the one had the leaues red when they came out of the groind; and the floure of this was of a deep red colour : the orher hud them of a whiting greene, and the floures of this were fomewhak larger, and of a lighter colour. In the leaues \& other parts they refembicd the common double Peinny. 


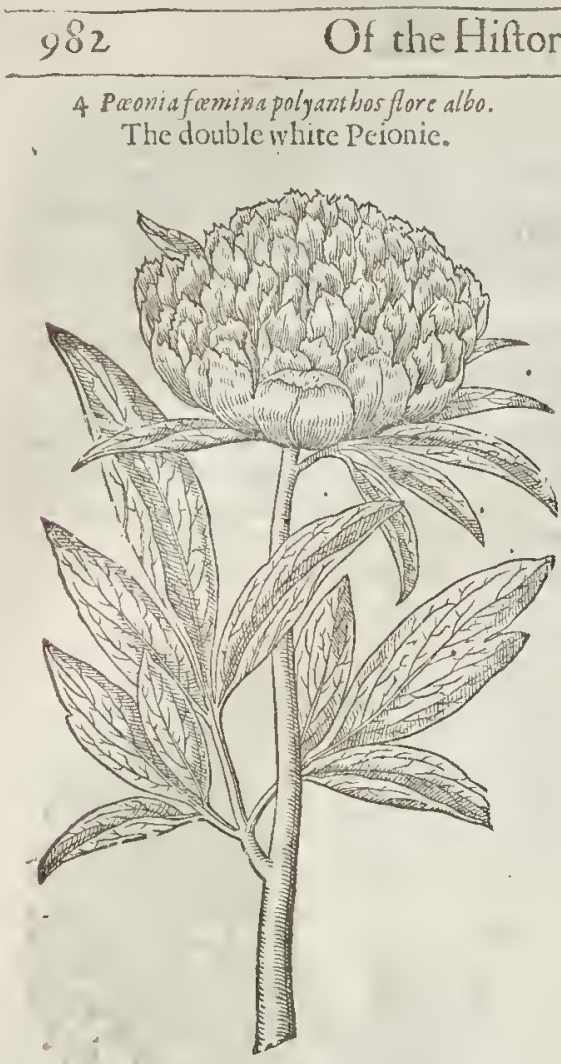

' 7 paonia feminapumila.

1) warfe female Peionie.

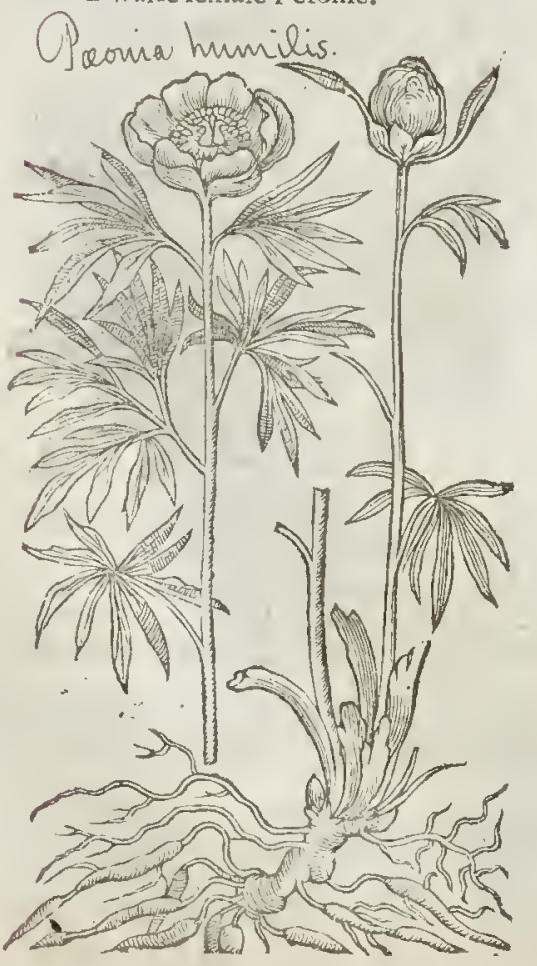

LIB. 2.

† 5 Pconia promifcua. Maiden Peionie.

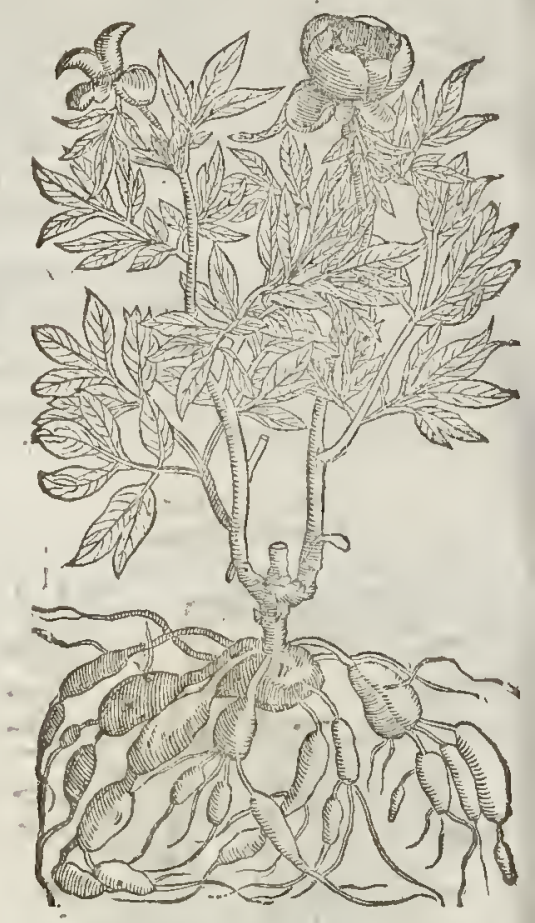

\$ Paronia By antina.

Turkih Peionic.

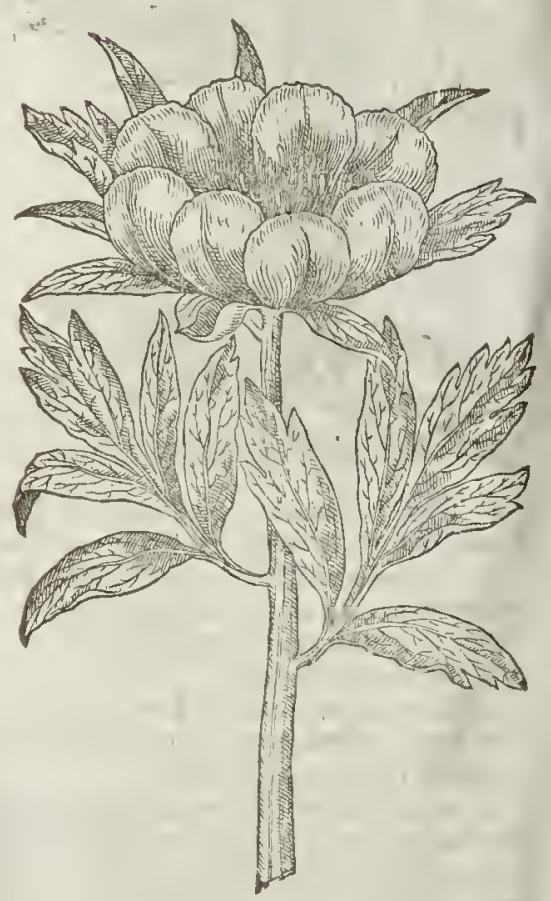


All of The rlace.

All the fotts of Peionies do grow in our London gardens, except that double Peiony with whita floures, which we do expect from the Low - countries of Flanders.

The male Peionie groweth wilde vpon a cony berry in Betfore, being in the parin? of Southfleet in Kent, two miles from Graucl-end, and in the ground fontimes belonging to a farmer there
called lobr Bradley.

₹ 1 haue been told that our Aurhor himfelfe planted that Peionie there, and afterwards feemed to finde it there by accident: and I do belecte it was fo, becauferone before or fince hatra euer feen ot heard of it growing wild fince in any part of this Kingdoms.

They floure in May: the feed is tipe in Iuly.

$$
\text { G The Time. }
$$

$$
\text { of } T \text { he Names. }
$$

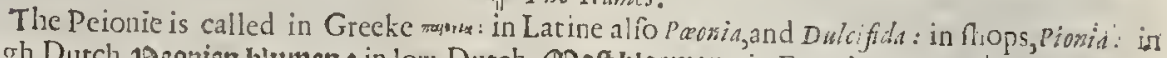

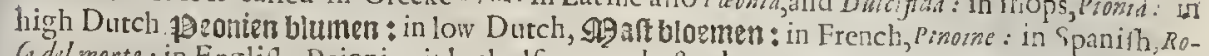

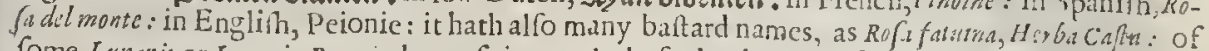
fome, Lunaris, or Lunaria Peonia:becaufe it cureth thofe that haue the falling ficlinefie, whom fome men call Lunaticos, or Lunaticke. It is called Ideus Dadylus : which agreethwith the female Peionie; the knobbie ronts of which be like to $D$ aetyli $I d w i$ and $D$ adtylt Idwz are cerraine precious ftones of the forme of a mans finger, growing in the Ifland of Candie: it is called of diuers Aglsophor:? or bright ly thining, taking his name of the fhining and glittering graines, which are of the colour of fcarlet.

There be found wo Aglaophotides, defcribed by eliamus in his 14 . Eoole; one of the fea, in the 24. Chapter : the other of the eartli, in the 2 7.chapter. Thar of the fea is a kindc of Fucus, or fea moffe, which groweth upon high rocks, of the bigneffe of Tamarisk, with the head of Poppy; which opening in the Sommer Solftice doth yeeld in the night time a certain fierie, and as it were fparkling brightneffe or light.

That of the earth, faith he, which by another name is called cyroplafitus, lieth hid in the day time among othet herbes, and is not knowne at all, and in the night time it is eafily feene : for it thineth like a ftar, and glittereth with a fierie brightneffe:-

And this Agluphotes of the earth, or Cynoppaftus, is Peonia; for Apulcies faith, that the feedes ot graines of Peionie thine in the night time like a candle, and that plenty of it is in the night feafon found out and garhered by the mepheards. Theophrast us and Pliny dro thew that Peionic is gathered in the night; which etianus alfo affirmeth concerning wglaophotss?

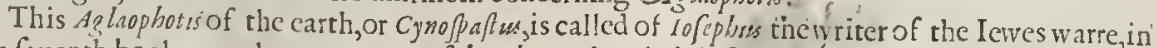
Iris feucnth book e, 25 . chapter, Baaras, of the place whesein it is found; which thing is plaine to him

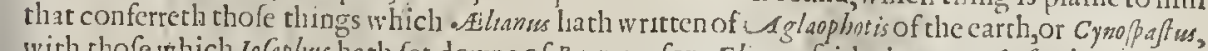
with thofe which Iofephus hath fet downe of Baaras : for wli anus fairh, that c yropa? fus is not plucked vp withour danger, and that it is reported how he that firt touched it, not k now ing the nature thercof,perifhed. Therefore a firing muft be fattned to it in the night, and a himgric dog tied therto, who being allured by the fnell of rofted fien fet towards him, may plucke it vp by the rootes. Iofephas alfo wrirerl, that Bizura doth thine in the euening like the day ftar, and rinat they who come neere, and would plucke it vp, can hardly do it, except that either a womans vine, or her menfes be poutred vpon it, and that fo it may be pluckt vp at the length.

Moreoner, it is fet downe by the faid Author, as alfo by pling and Theophrafisus, that of necefitice it muft be gathered in the night; for if any man thall pluck of the fuit in the day cime, being feene of the VVood.pecker, he is in danger to loofe his eies; and if he cur the root, it is a chance if his fundament fall not out. The like fabulous sale hath been fet forth of Mandrake, the which I hate partly touched in the fame chapter. But all the fe things be molt vaine and fritulous: for the root of Peionie, as alfo the Mandrake, may be temoued at any time of the yeare, day or houre whatfoener.

- But it is no maruell, that fuch kindes of trifles, and moft fuperftitious and wicked ceremonics are found in the books of rhe moft antient writers; for there were many things ita their time verie vainly feined and cogged in for nftentation fake, as by rhe Fyptians and orher comterfeit mates, as pliny doth truly teftife:an imitaror of whon in times paf, was one 4 s dreas a Plyfition, who, as Galen faith, conucied into the art of Phylick, 'ies and fubrill de'ufonl'. For whilich calle Galen commanded his Schollers to refraine fro $n$ the reading of him, and of all fuch lite lying and deceitfuil fycophants. It is reported that rhefe herbes too'se the nun of peinnis, o: $P$ e ry, of that execllent

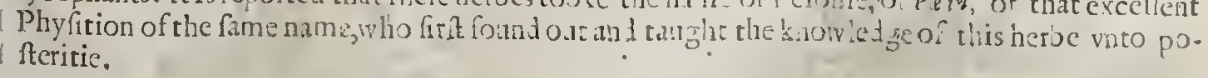


Ti The Temperature.

The root of Peionic, as Galen faith doth oently binde with a kinde of fiveetneffe : and hath alfo ioined with it acertaine bitterifh harpnefle : it is intemperature not very hot, little mone than meanly lot ; but it is drie,and of fubtill parts.

\section{- The Veriues.}

A Diofcorideswriteth, that the root of the Male Peionie being dried, is giuen to women rhat be not well elenfed after their deliuerie, being drunke in Mead or honied watcr to the quanritic of a bean; for it feowreth rhofe plants, appeafeth the griping throwes and torments of the belly, and bringerh downe the defired fickneffe.

B Galen addeth, that it is good for thofe that haue the yellow iaundife, and pain in the kidnies and bladder, it elenfeth the liuer and kidnies rhat are ftopped.

C It is found by fure and euident experienee made by Gaien, that the frefh root tied about the necks of children, is an effectuall remedie again th the falling ficlsneffe; but vnto thofe that are growne vp in more yeares, the root thereof muft alfo be minifted inwardly.

D It is alfo giuen, faith $p$ liny, againft the difeafe of the minde. The root of the male Peionie is preferred in this cure.

E Ten or twelue of the red berries or feeds drunke in wine that is fomething harth or fower, and red, do ftay the inordinate flux, and are good for the ftone in the beginning.

F The blacke graines (that is the feed) to the number of fifteene taken in wine or mead, helpes the ftrangling and paines of the matrix or mother, and is a fpeciall remedie for thofe rhar are troubled in the night with the difeafe called Ephialtes or night Mare, whieh is as though a heauy burthen were laid vpon them, and they oppreffed therewith, as if they were ouerenme by theirenemies,or oucrpreft with fome great weiglit or burthen; and they are alfo good againit melancholicke dreames.

G Syrrup made of the floures of Peionie helpeth greatly the falling fielnefle : likewife the extraction of the roots doth the fame.

\section{С н Р. 381. Of toothed Violets or Corall woorts.}

a Dentaria Bulbifera. Toothed Violet.

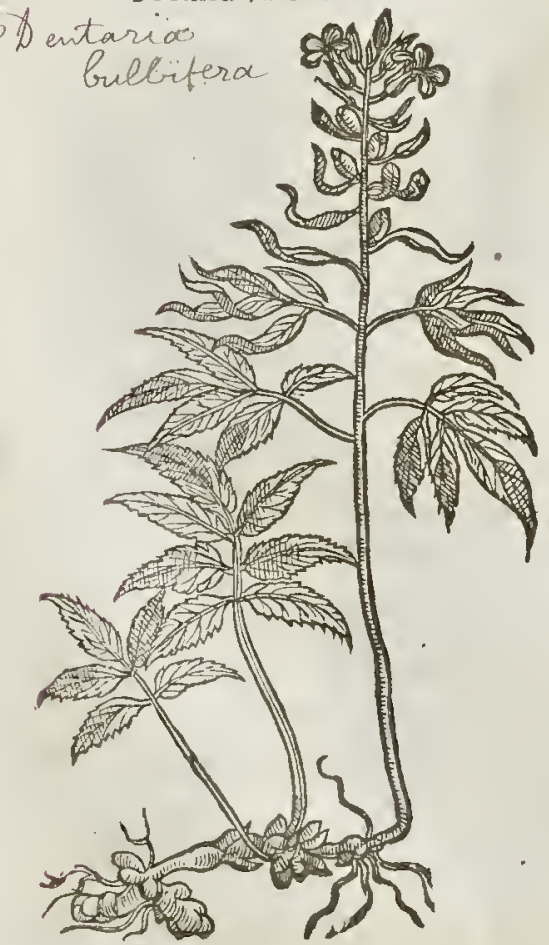

2 Dentarin Coralloide radice, fare Dent. Enneaphyllos: The Cotall toothed Violet.

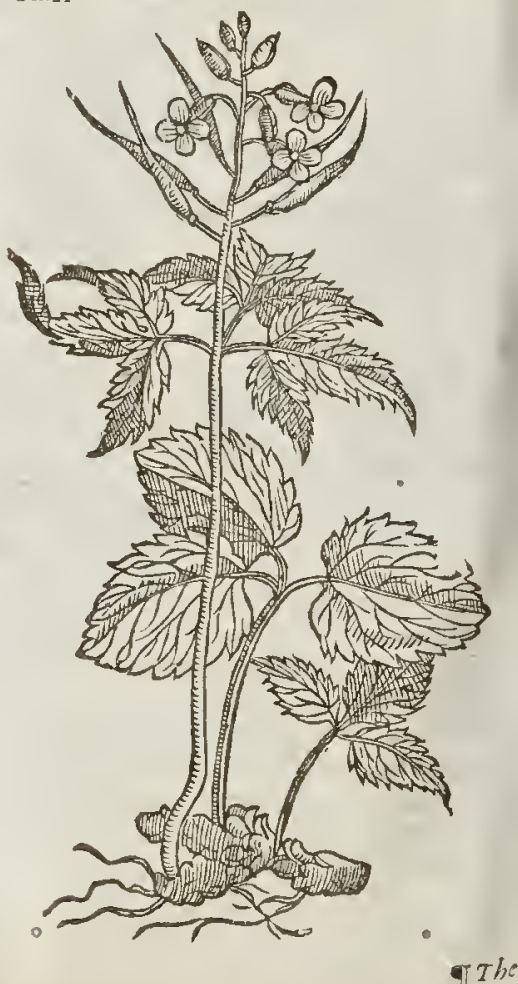


fomewhat like the cods of Queenes Gillofloures, wherein is contained fmall blackith feed: the root is like the former, but not in euery refpect much refembling Corall, yet white and tuberous notwithftanding.

3 Thethird kinde of Dogs-tooth Violet is called of Clufius, Dentaria beptaphyllos, that is, corrfifting of feuen leaues faftened vpon one rib, finew, or fmall ftem : of Lobel with this title, Alabaftrites altera, or Dentarnaltera : but Cordus calleth it Coralloides altera : in Englifh, Corall violet; it hath fall:es, Houres, and roots like vnto he firft of his kinde, fauing that the Houres are much fairer,and white of colour, and the roots haue a greater refemblance of Corall than the other.

4 The forrth kinde of Dogs-tooth violet, ealled in Englith Codded violet (which clufurs fettech forth vnder the title Dentaria Matthiols Pentaphyllos, whieh Pexa doth alfo expreffe vnder the ti tle of Nemoralis alpina Herbariorus Alabaftrites; Cordus calleth it Coralloides, and may very well bee called in Englin Cinkfoileviolet) hath leaues folike the greater Cinkfoile, that it is hard to know one from another; therefore it might very well haue been reckoned among the herbes called Pentaphy lla, that is, fiue leaued herbes. This plant groweth in the thadow ie forreft about Turin, and the mountain Sauena ealled Calcaris, and by the Khene not far from Bafill. The Atalks grow to the height of a eubit, befet witl a tuft of floures at the top like to that of the firf,but of a deeper purple colour:whiel being vaded, there fueceed long and flat cods like vnto Rocket, or the great Celandine, wherein is eontained a fmall feed. All thewhole plant is of a hot and bitter tafte. The roots are likevnto Corall, of a palewhitith colour : the leaues are tough and harth in handling and of a deep greene colour.

† Clufius gites s another varietic of Dentaria pentaply/los, whofe roots are more vneuen and knobby than the laf defcribed : the falke is fome foot high : the leates fue vpon a falke, but not fo rough,nor of fo deepa greene as thofe of the former, yet the floures are of a deep purple colour, like thofe of the lant defcribed. $\ddagger$

T The Place.

They grow on diuers hadowie and darke hills. Valerius Cordus writeth, that they are found about the fore? Hercinia,not far from Northufum,mont plentifully, in a far foile that hath quaries of ftone in it. The firft I laue in my garden. of The rime.

They floure efpecially in Aprill and May: the feed commeth to perfection in the end of Augut: 9 The Names.

The toothed Violet, or after fome, Dogs-tooth violet, is commonly ealled Dentaria: of Cordus, Coralloides, of the root that is in forme like to Corall. Mattholus placeth it inter Solidagines or Symprby. ta, among the Confounds and Comfries. Wee had rather call them Viole Dentaria, of the likeneffe the floures haue with Stocke-gillofloures. 'They may becalled in Englifh, Toothed Violets, or Corall-woorts.

A I have read of few or no vertues contained in thefeherbes, faung thofe which fome women haue experienced to be in the firtt kinde thereof, and which Matbiolus afcribeth vnto Pentaphy lla dentaria the fourtlikinde, in the fourth booke of his Commentaries vpon Diofcoridis, and in the chap.conterning $s$ ymphytum, where he faith that the root is $v$ fed in drinkes which are made againf Enterocele and inwayd wounds, but efpecially thofe wounds and hurts which haue entred into the hollow neffe of the breft.

$$
\begin{aligned}
& \text { С на Р. 382. Of Cinkefoile, or fiue finger Grafje. } \\
& \text { Tt The Defcription. }
\end{aligned}
$$

I "Me firt kinde of Cinkfoile is fo common and fo vniuerfally knowne, that I thinke ita needleffe trauell to ftand about the defcription. $\neq$ It hat h many long flender ftalks, lying fpred vpon the ground, out whereof grow leaues made of fiuc longin fnipt leaues faftened to one long foot-ftalke : the floures alfo grow vpon the like foot-ftalks, and are compofed of fiue yellow leames. The root is pretty large, of a reddith colour, and round; but dried, it becomes fquare. $\ddagger$

2 The feeond kinde of Cink foile or Quinquefoile hath round and fmal falks of a cubit high; the leaues are large;and very much iagged about the edges, very like the common Cinkfoile: the floures grow at the top of the falks, in fafhion like the common kind, but much greater, and of a pale or bleake yellow or elfewhitifh colour: the root is blacke without, and full of ftrings annexed thereto, and of a wooddie fubrtance. 


\section{L18. 2. Of the Hiftory of Plants.}

987

2uinquefolium vulgare.

Common Cinkfoile

Molentictar reptains. Q voras a.

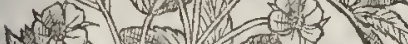
M. 1. ( $4(N)=0$ Q 81.

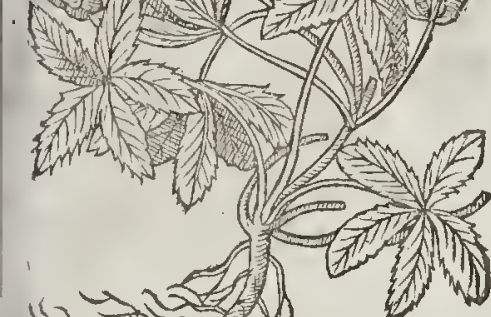
$(12-7+528$

3 Pentapbyllum purpureum. Purple Cinkfoile.

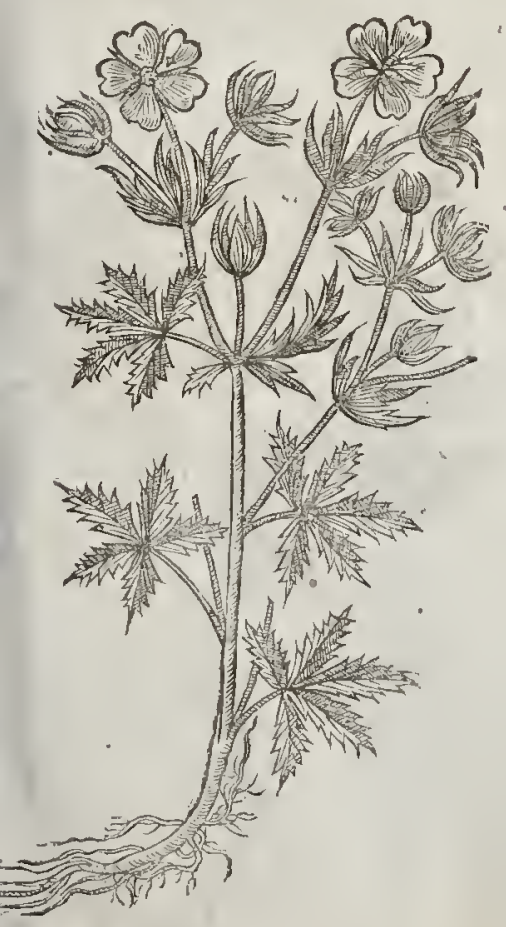

† 2 2uinquefoliwn mains rectum, Great vpright Cinkfoile.

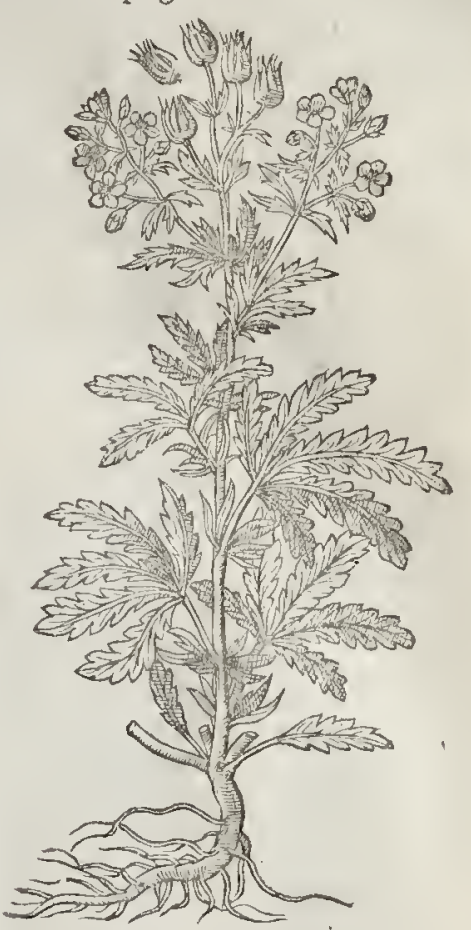

4 Pentaplyyllow rubram palagire.

Marfh Cinkfoile.

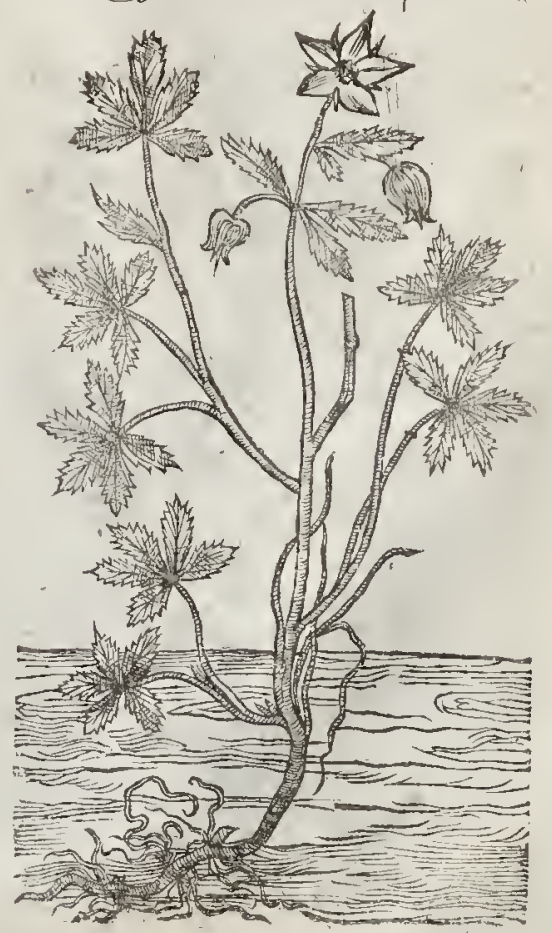


5 Pextaphyllampetrofurn, Heptaphyllum Clufy. Stone Cinktoile. alehemilea alpina -

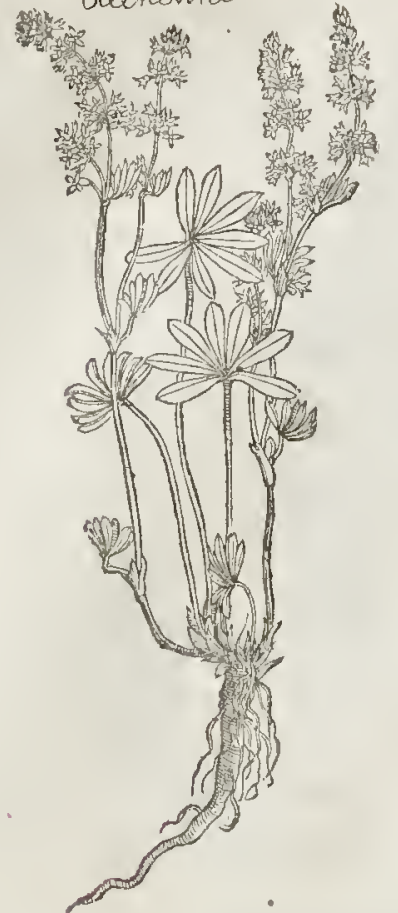

7 2uiniuefolium Tormentills facie. Wall Cinkfoile.

Motentilla aram tea - Alt ㅅ․ की 3. ogth बक्षे

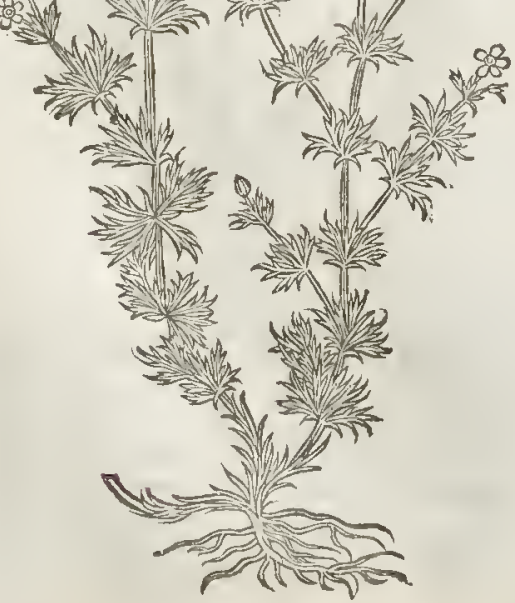

t 6 Pentaphylion fupinum Potentilla facic. Siluerweed Cinkfoile.

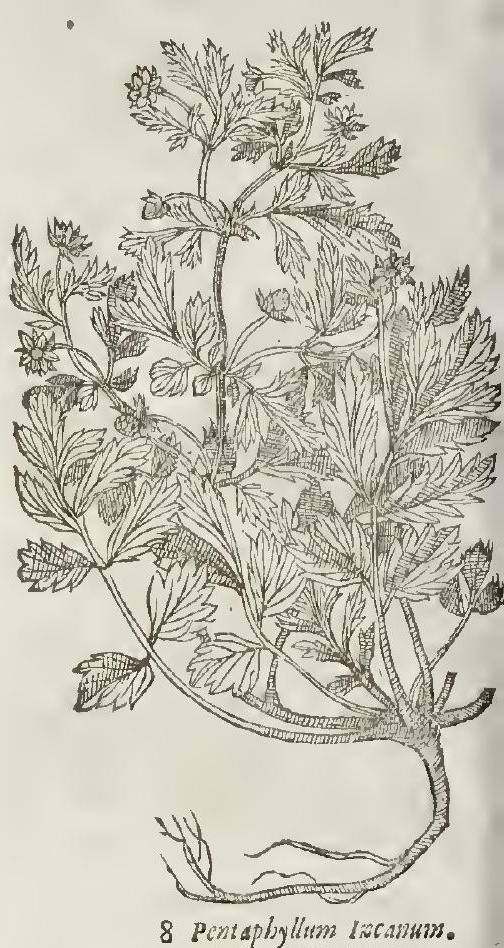
Hoiric Cinkfoile.

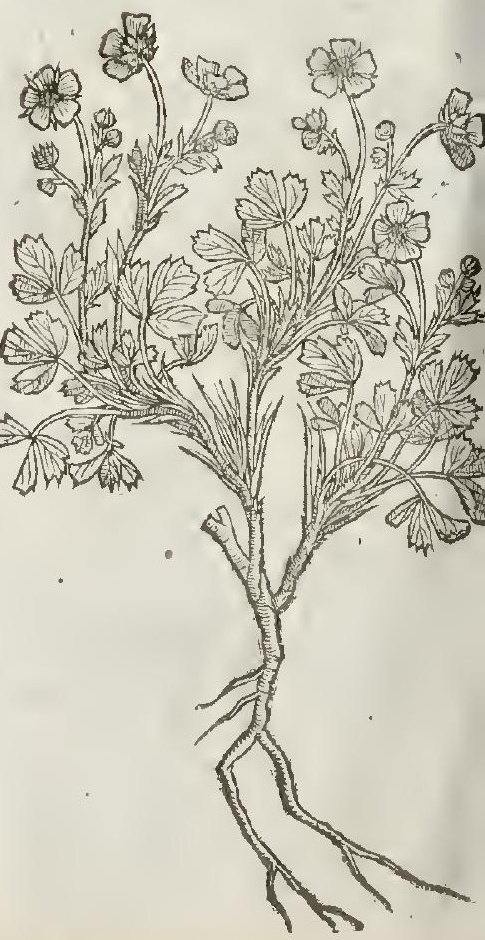




\section{B. 2. Of the Hiftory of Plants.}

t 3 The third kinde of Ginkefoile hath leaues like thofe of the lant defcribed, and his floures ate of a purple colour ; which being paft, there fucceedeth a round knop of feed like a Strawberry before it be ripe : the ftalkes are creeping vpon the ground : the root is of a wooddy fubitance, full of blacke ftrings appendant thereto. $¥$ This differs not from the laft defcribed, but in the colour of the'floures.

4 The fourth kinde of Cinkefoile is very like vnto the other, efpecially the great kinde: the ftalkes are a cubit high, and of a reddifh colour : the leaues confilt of fue parts, fomewhat fnipt about the edges : the floures grow at the tops of the ftalkes like vnto the orher Cinkefoiles, fauing that they be of a darke red colour : the root is of a wooddy fubftance, with fome fibres or threddy ftrings hanging thereat.

9 Pentaphyllum incanumininus repens.

Small hoary creeping Sinkefoile.

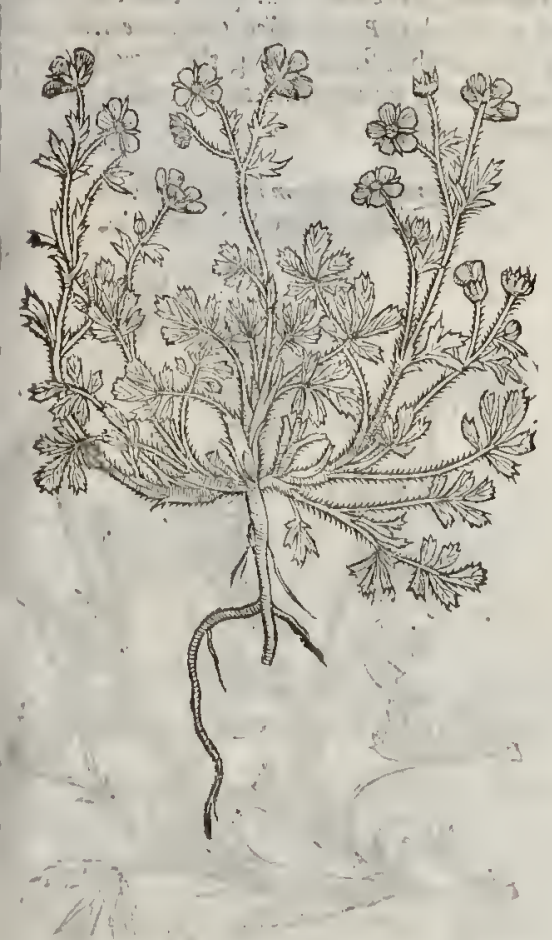

10 2uinquefulium (yluaticum majus fo. albo: Wood Cinkefoile, with whice floures: Potentilea alla

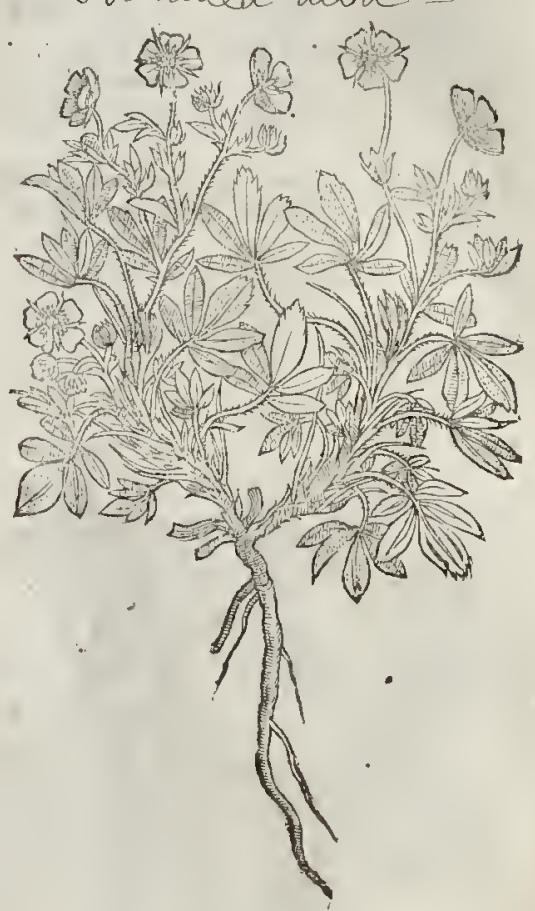

5. The fifth kinke of Cinkefoile groweth vpon the cold mountaines of Sauloy, and in the vallie of Auftenfic, and in Narbone in France, and (if my memory faile not) I hate feen the fame growing vpon Beetton cafle in Cliefhire:the leaues hereof are few, and thinne fet, confinting of fute parts like the other Cinkctoiles, oftentimes fix or feuen fet vpon one foot-ftalke, not finipt about the edges as the other, hut plaine and fmooth; the leafe is of a fhining white filuer colour; very foft and thining : the floures, grow like ftarres, vpon flender ftalkes by tufts and bunclies, of $a$ white colour, and fometimes purple, in fafhion like the floures of Alchimillit, or Ladies nuantle : the root is thicke and full of ftrings, and of a browne purple colour.

\# 6. This plant,whofe figure our Author formerly gate for Frazaria ferilis, \& in his defcription confounded with it, to auoid confufion, I thinke fit to giue you here anong th the Cmkefoiles, and in that place the Frag ariafterilis, as moft agreeable thereto. This feemes to challengekindred of three fetretall plants, that is, Cinkefoile, Tormentill, and Siluer-veed, for it hath the vpper deanes, the yellow floures, crecping branches, and root of Cinkeforle, but the lower leaues are of a darke greene, and grow many wpon one middle rib like thofe of Silner-weed; the fruit is like

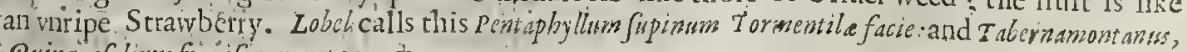
Qningucfulium frigg iforsm repens. 7

7 . The fenenth kinde of Cinkefoile, pena that diligent fearcher of Simples found in the Alpes of Rhetia, nere Clauena, and at the firlt fight fuppofed it to be a kinde of Tormentilla, or $P$ en-

$$
0000
$$

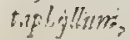


taphyllum, fauc that it had a more threddy root, rather like Germinm; it is of a darke colour outwardly, hauing fome fweet imell, reprefenting $G$ aryopbyllat $a$ in the fauor of bis roots:in leaues and floures it refembles Cinkefoile and Tormentill, and in thape of his ftalkes and roots Anens or Garyophyllata, participating of thcm all : notwithftanding it approcheth neereft vnto the Cinkefoiles, hauing ftalkes a foot high, whereupon grow leaucs diuided into fuc parts, and jagged round about the edges like the tecth of a faw, hauing the pale ycllow flourcs of Pentaphyllum or Tommentilla; within which are little moflic or downy threddes, of the colour of faffron, but leffer than the comnion Aucns.

8 The eighth kinde of Cinkcfoile (aecording to the opinion of diuers larned men, who haue had the view thereof, and liaue iudged ir to be the true Leucas of Diofcorides, agrecable to Dioforides his defeription) is all hoary, whereupon it tooke the addition Incanm. The falkes arc rhickc, wooddy, and fomewhat red, wrinckled alfo, and of a browne colour; which rife vnequall from the root, fpreading themfelues into many banches, fhadow ing the place where it growcth, befer with thickc and notehed lcaues like Scordum, or water Germander, which aceording to the iudgment of rhe learned is thoughr to be of no leffe force againft poifon than Pentaphyllon, or Tormentilla, being of an aftringent and drying qualiry. Hereupon it may be that fome trying the force hèrcof haue yeelded it vp for Leucas Diofcoridis. This rarc plant I neuer found growing naturally, but in the hollowncfie of the peakifh mountaincs, and dry grauclly vallies.

I I Quinquefolium jyluaticum minus flo. albo: Small white fourcd wood Cinkefoile.

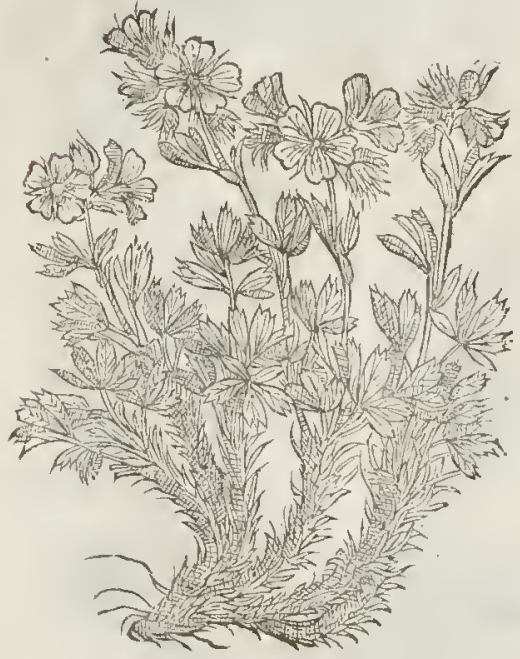

士 12 Quinquefolium minus fo. aureo: Small golden flotred Cinkefoile.

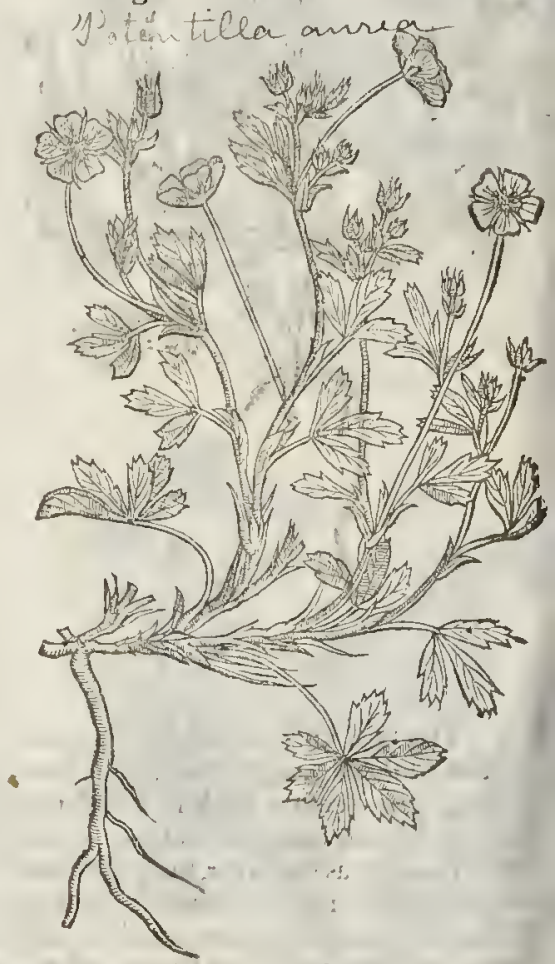

t This hath the likecreping purple branches as the laft defcribed:the leaues are narrower; morc hairy and dceper cut in: the foures are alfo of a morc golden colour, inother refpects they are alikc. $¥$

$\dagger$ ro Thewood Cinkcfoilc hath many leaues fpred vpon the ground, confifting of fiue parts; amcng which rife vp other lcaucs, fet vpon wery tall foot-ftalkes, and long in refpect of thofe that did grow by the ground, and fomewhat fnipt about the ends, and not all along the edges. The Aoures grow vpon flender ftalkes, confifting of fute white leaues. The root is thicke, with diuers fbres comming from it.

I I This alfo from fuel a root as the laftefcribed fends forth many fender branches not resping, but feanding vpright, and fet with little hoary leaues, finipt oncly at rle ends, like as 
* 13 Pentaphyllum fragiferum. Strawberry. Cink foilc. O) otentilla un pestris.

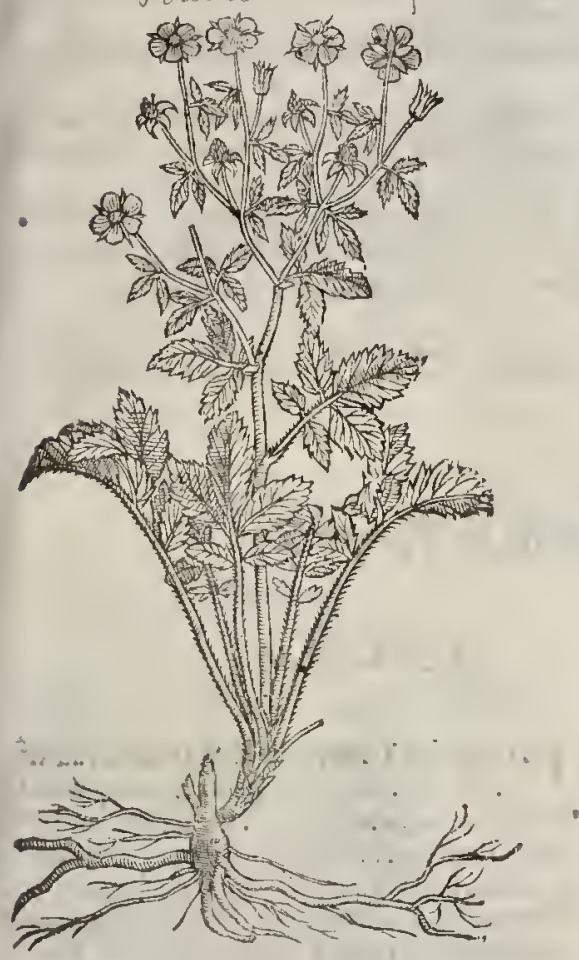

thofe of the latt defcribed: the tops of the branches carry pretty white floures like thof of the laft defcribed, whereofit feems to be a kinde, yet leffe in each refpect.

I2 This from a blacke and fibrous roor fends forth creeping branclies, fet with leaues like the common Cink foile, but leffe, fomewhat hoary and ihining; the ftalks are fome handfull high, and on their tops carry large floures in refpect of the fmalneffe of the plant,and thefe of a faire golden colour, w ith faffron coloured threds in their middle: the feedes grow after the manner of other Cinkfoiles: this floures in Iune, and it is Cluf rus his Quinque folium 3. aureofore. $\neq$

$\mathrm{r}_{3}$ There is one of the mountain Cink foiles that hath diuers flender brittle ftalks; rifing immediarly our of the ground; whereupon are fet by equall diftances certain iagged leaues, not vnlike to the fmalleft leaues. of Auens: the floures are white and grow at the top, hauing in them threds yellow of colour, and like to the other Cinkfoiles, but altogether leffer. The root is thicke, tough, and of a wooddie fitbince. $\neq$ The feedes grow cluftering together like little Strawberries, whence clufius calls it 2uinquefolium frogiferum.

$$
\text { Tf The Place. }
$$

They grow in low and moift medowes, vp. on banks and by high waies fides:the fecond is onely to be found in gardens.

The third groweth in the woods of Sauena and Narbon, but not in England : The fourth groweth in a marh ground adioining to the land called Bourne ponds, halfe a mile from Colchenter; from whence I brought fome plants for my garden, where they flourifh and profper well.

The fifth groweth vpon Beeftone cafte in Chefhire: the fixth vpon bricke and ftonewals about London,efpecially vpon the bricke wall in Liter-lane.

The place of the feuenth and eight is fet forth in their deferiptions.

$$
\text { T The Time. }
$$

Thefe plants do floure from the beginning of May to the end of Iune.

$$
\text { 9I The Nanzes. }
$$

Cinkfoile is called in Greeke merieprian: in Latine, 2uinquefulium: the A pothecaries vfe the Greek name Pentap hyllon: and fometime the Latine name. There be very many baftard names, wherewith I

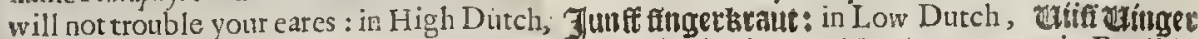

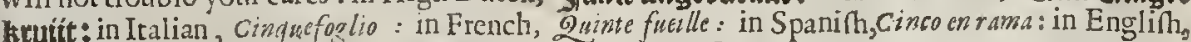
Cinkfoile, Fiue finger Graffe, Fiue leaued grafe, and Sinkfield.

$$
\text { o]. The Temperature. }
$$

The roots of Cinkfoile, efpecially of the firf,do vehemently drie, and that in the third degree, but without biting : for they haue very little apparant heat or tharpneffe.

$$
\text { q The Vertues. }
$$

The decoction of the roots of Cinkfoile drunke, cureth the bloudy flixe, and all other fluxes of $A$ thebelly, and Itancheth all exceffue bleeding.

The iuice of the roots while they be yong and tender, is giren to be drunke againft the difeafes $B$ of the liver and lungs, and all poifon.

The fame drunke in Mead or honicd water, or wine wherein fome pepper hath been mingled, cu- $\mathrm{C}$ reth the tertian or quartaine feucrs:and being drunken after the fame manner for thirty daics together, it helpeth the falling fickneffe.

The leaules vfed among herbes appropriate for the fame purpole, sureth ruptures and burfings D of therim,and guts falling into the cods. 
E The ituce of the leaues drunken doth cure the Iaundice, and comfortch the fomacke and liner.

F The decostion of the roots held in the mouth doth mitigate the paine of the teeth, ftaieth putrifaction, and all putrified vlcers of the mouth, helpeth the inflammations of the almonds, throat, and the parts adioining, it ftaicth the laske, and helpeth the bloudy flix.

$\mathrm{G}$ The root boiled in vineger is good againtt the thingles,appeafeth the tage of ftett ing fotes, and cankerous vicers,

H It is reported, that foure branches hereof cureth quattaine agues, three tertians, and one branch quotidians: which things are moft vaine and friuolous,as likewife many other fuch like, which are not onely found in Diofiorides, but alfo in other Authors, which wewillingly withftand.

I Ortolpho Morolto a learned Phyfition, commended the leaties being boilcd wi th water,and fome lignum vite added ther to, againft the falling fickneffe, if the patient be caufed to fweat vpon the taking thereof. He likew ife commendeth the extraction of the roots aga inft the bloudy fix :

4 Out Aullor formerly in his defcription, tidle, and place of growing mentioned that plant which he figured, and is yet kept in thefecond place; and in the fief place he figured the common Cinke. foile, atud made mention of it, yec without defesption in the Fecond. Thar which formerly uas in the fixh place, bythe

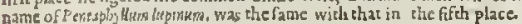

\section{С на з 383 . Of Setfoile, or Tormentill.}

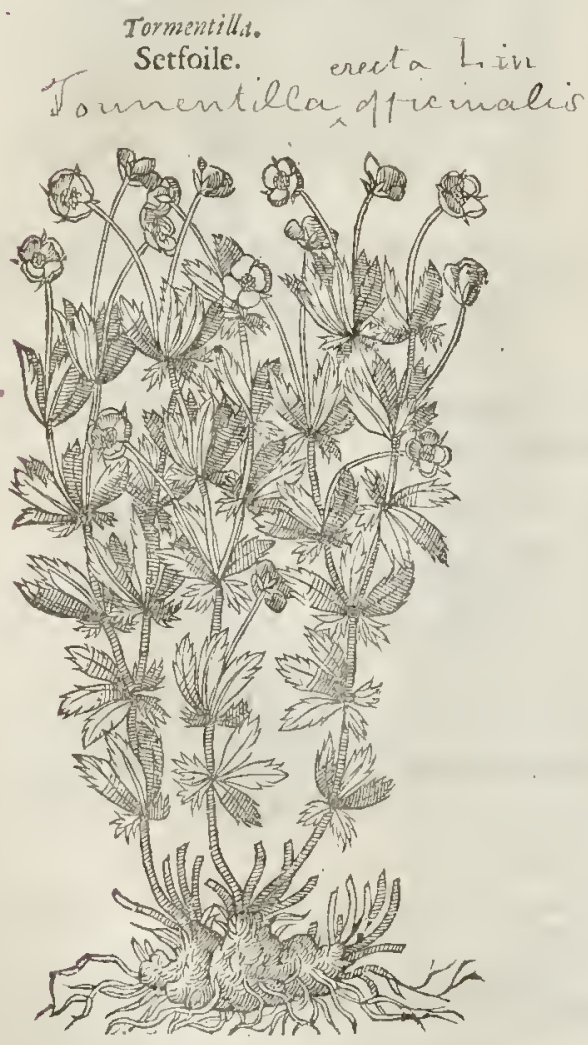

$T^{\text {His herbe Tormentill or Setfoile is ane of }}$ 1 the Cinkfoiles, it brings forth many ftalks flender,weake, , carfe able to lift it felfe vp, but rather lieth downe vpon the ground: the leaues beleffer than Cinkefoile, but moe in number, fomtimes fiuc, but commonly feuen, whereupon it tooke his nanje Setfoile, which is feuen leaules,and thofe fomew hat fnipt about the edges: the floures grow on the toppes of flender ftalkes, of a yellow colour, like thofe of the Cinkfoiles. The root is blacke withont, teddifh within, thicke, tubetous, or knobbic.

$$
\text { T The Place. }
$$

This plant loueth woods and thadowie places, and is likewife found in paftures lying open to the Sun, almoft euery where. guft.

It floureth from May, vnto the end of Au-

$$
\text { I The remes. }
$$

$$
\text { ข) The Names. }
$$

It is called of the later Herbarifts Tormentilla : fome name it after the number of the

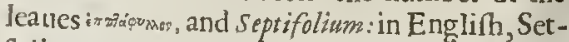
foile and Tormentill : in high-Dutch, 2Birk= bourtz: moft take it to be Chryfogonox; whereT The Temperature.

The toot of Tormentill doth mightily dry, and that in the third degree, and is of thin parts: it hath in it very litcle heat,and is of a binding quality.

$$
\text { i. The Vertues. }
$$

A Tormentill is not only oflike vertue with Cinkefoile, butalfn of greater efficacie: it is much ved againft peftilent difeafes: for it ftrongly refifteth putrifaction, and procurcth fireare. 
The leaues and roors boiled in wine, or the inice thereof drunken prouoketh fweat, and by that $B$ means driteth out all venome from the heart, expelleth poifon, and preferueth the bodie in time of peftilence from the infection'thereof, and all other infe trious difeafes.

The roots dried made ints pouder and drunke in wine doth the fame.

The fame pouder taken as a forefaid,or in the water of a Smiths forge in hot fteele hath been often quenched of purpofe,curcth the laske and bloudy flix, yea although the patient hauc adioined vnto his feouring a grieuous feuer.

It ftoppeth the fpitting of bloud,piffing of bloud, and all other iffues of bloud,as well in men as $E$ women.

The decoetion of the leaues and rootes, or the iuice thereof drunke, is excellent good for all $\mathrm{F}$ wounds, both outward and inward:ir alfo openeth and healeth the ftoppings of the liuer and lungs, and cutrèth tilectutundice.

The roor beaten into pouder, tempered or kneaded with the white of an egge and eaten, ftaieth G the defire to vomite, and is good againft choler and melaneholic.

\section{$\mathrm{C}_{\mathrm{H} \text { × }}$ 384. Of wilde Tonfie or Silwer-weed.}

\section{Argentina.}

Siluerweed, or wilde Tanfie. Potentilea Anserina

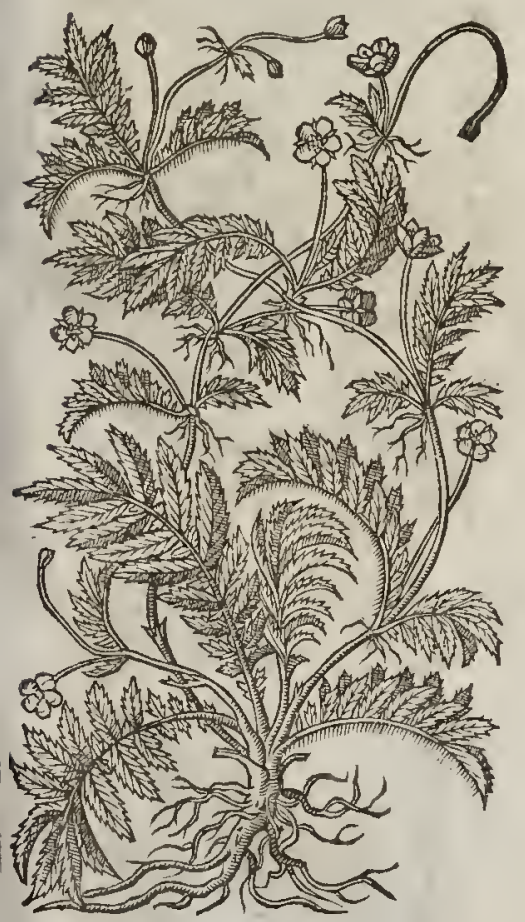

T) The Defcription.

W Ilde Tanfie creepeth along vpon the ground with fine flender ftalkes and clafping tendrels: the leaues are long made vp of many fmall leaues, like vnto thofe of the garden Tanfie, but leffer; on the vpper fide greene, and vnder very white. The floures be yellow, and ftand vpon flender ftems, as doe thofe of Cinkfoile,

$$
\text { T) The place. }
$$

It groweth in moift places neere vnto high waies and running brookes euery where.

$$
\text { T The Time. }
$$

It floureth in Itine and Iuly.

$$
\text { I The Names: }
$$

The later Herbarifts do eall it Argentina, of the filuer drops that are to be feene in the difilled water therof when it is put into a glaffe, which you thall eafily fee rowling and tumbling vp and downe in the bottome; 1 iudge it rather fo ealled of the fine thining Siluer eoloured leaues. $\neq$ It is likew ifecalled potentilli: of diuers, Agrimonia fy lueftris, Anferina, and $T$ anacetum fylueftre : in High Dutch, Genferich: in Low Dutch, Bantericts : in Frenel,, Argentine: in Englifh, Wilde Tanfie, and Siluerweed.

$$
\text { T The Temperature. }
$$

It is of temperature moderatly cold, and dry almoft in the third degree, hauing withall a binding faecultic.

The Vertues.

Wilde Tanfie boiled in wine and drunk, toppeth the laske and bloudy flix, and all other flux of $A$ bloud in man or woman.

The fame boiled in water and falt and drunke, diffolueth clottéd and congealed bloud in fuch $B$ as are hurt or bruifed with falling from fome high place.

The decoftion hereof mude in water, eureth the vlcers and cankers of the mouth, if fome honie $\mathrm{C}$ and allom be added thereto in the boiling.

Wilde Tanfie hath many other gocil vertues, efpecially againft the ftone, inward wounds, and D monds of the privie or feret parts, and clofeth vp all greene and freth wounds.

00003 
E The difilled water taketh away freckles, fpots, pimples in the face and Sun-burning; but the herbe laid to infufe or fteepe in whire wine is far better : but the beft of all is to fteepe it in ftrong white wine vinegre, the face being otten bathed or wathed therewith.

\section{Cнар.385. Of eAvens, or Herbe Bennet.}

1 Caryophyllata.

Auens or herbe Bennet.

Geum terlawnm

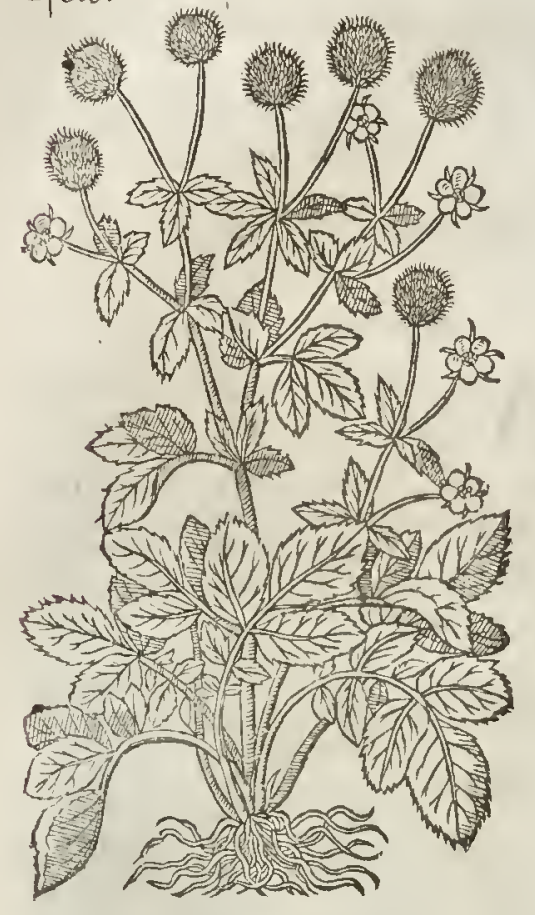

9T The Defcription.

1 Hecommon Auens hath leaues not vnlike to Agrinony, rough, blackifh, and much clouen or deepely cut into diuers gafhes: the ftalke is round and luairy, a foor high, diuiding it felfe at the top into diuers branches, whereupon dogiow yellow floures like thole of Cinkefoile or wilde Tanfeswhich being paft, there follow round rough reddith hairy heads or knops ful offeed, which being ripe wil hang ypon garmentz as the Burs doe. The root is thiche, redith within, with certaine yellow frings faftered thereunto, Imelling like vnto Clones or like vnto the roots of $\mathrm{Cy}$ perus.

2 The Mountain Atrens hath greater and thicker leaues than the precedent,rougher, and more hairie, not parted ints three, bur rather round, nicked on the edges: among which rifeth vp flender ftalkes, whereon a oe grow little longith fharpe pointed leaues: on the toppe of each ftalke doth
2 Caryophyllata montana. Mountaine Aliens.
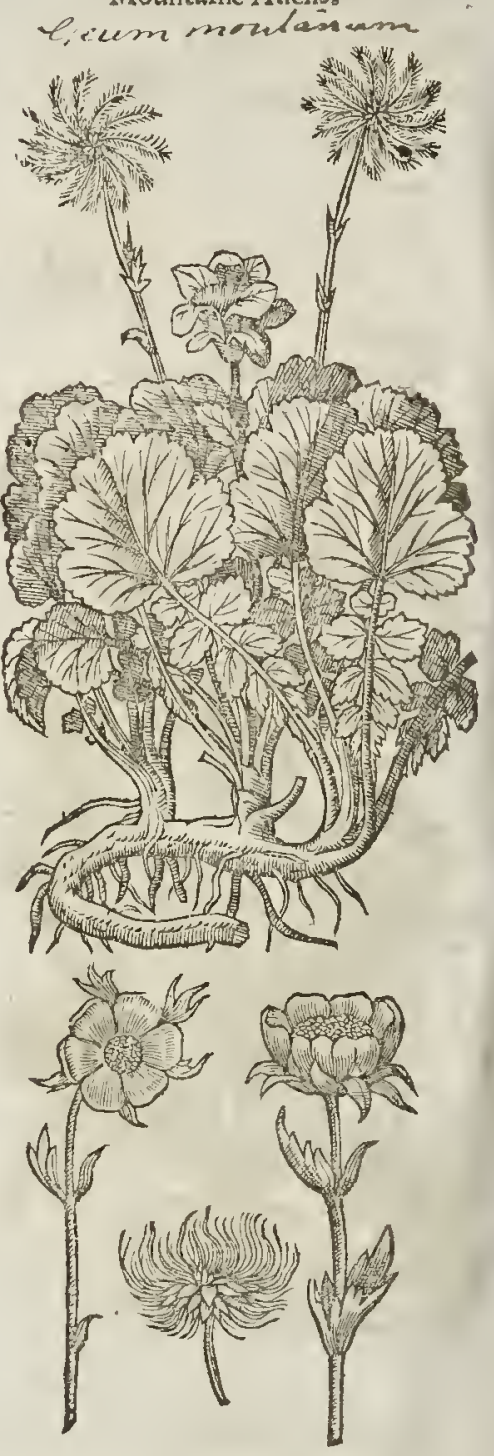
LI B. 2.

Of the Hiltoric of Plants.

995

3 Caryophyllata Alpinapentaphyllar. Fiue leaued Atiens.

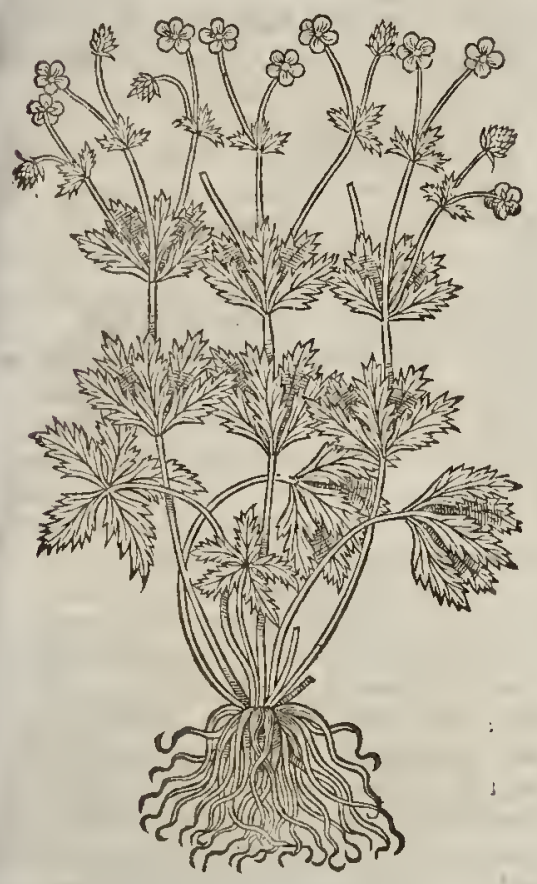

+ 5 Caryophyllata Alpinaminims?

Dwarfe mountaine Auens.
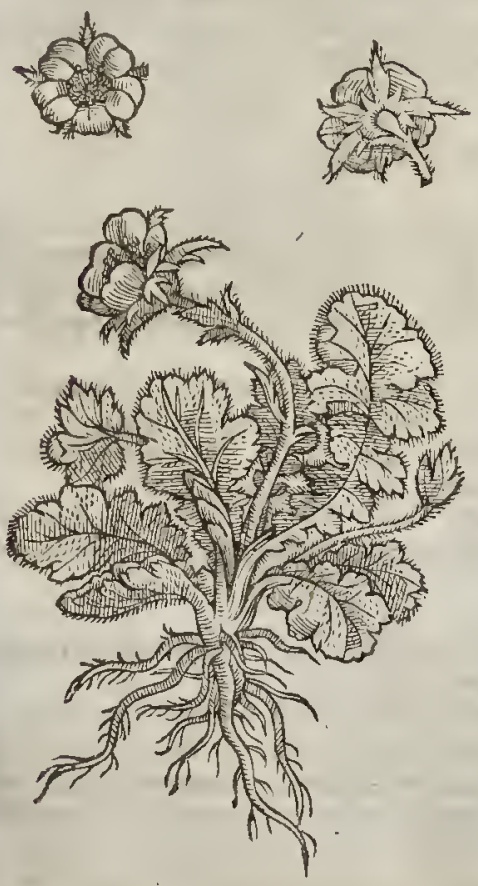

\# Caryophyllata montana parpurea. Red Houred mountaine Auens.
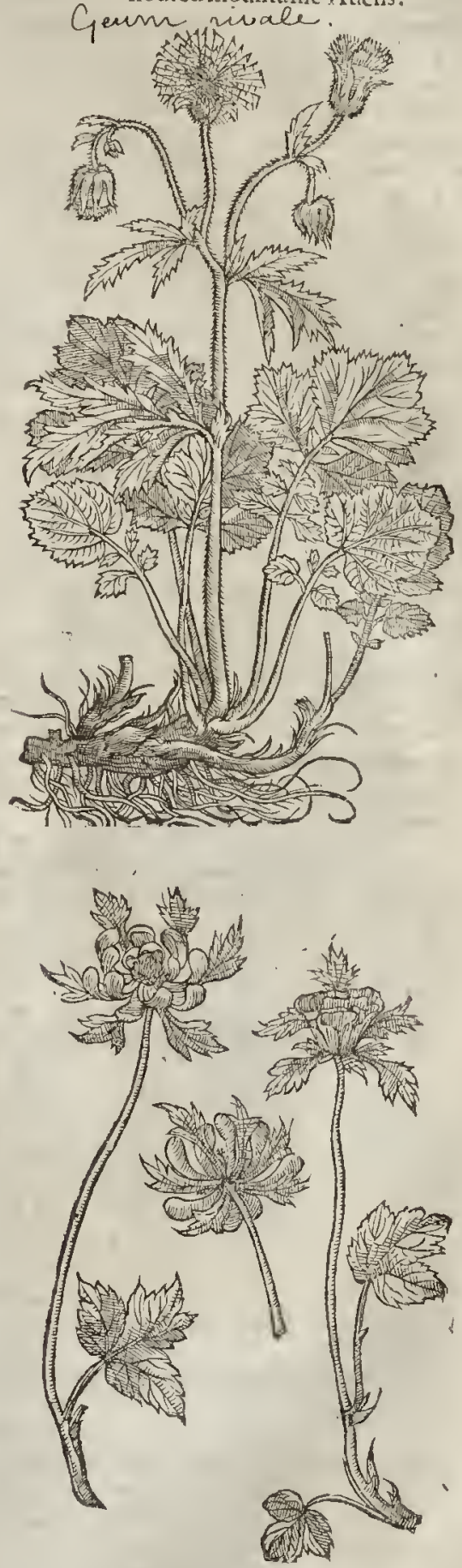
grow one floure greater than that of the former, which confifteth of fiue lit tle leaules as yellow as gold : afterwhieligrowes vp the feeds among long hairy threds. The toot is long,growirg anlope, Oomewhat thicke, with ftrings anexed thereto.

3 Fiue finger Auens hath many fmall leaues fpred vpon the ground, diuided into fiue parts, fomewhat fnipt about the edges like Cinkefoile, whereof it tooke his name. Anong which rife vp flender ftalkes diuided at the top into diuers branehes, whereon do grow fmall yellow floures like thofe of Cinkefoile: the root is compofed of many tough ftrings of the imell or Cloues, whiclu makes it a kind of Auens; otherwife doubtles it muft of neceffitie be one of the Cinkfoiles

$\mp 4$ This lath ioynted ftringy rooss fome finger thick, from whence rife vp many large and hairy leaues, compofed of diuers little leaues, with larger at the top, and thefe fnipt abuut the edges like as the conmon Auens: amongft the fe leaues grow vp fundry ftalkes fome foot or bettet high, whereon grow floures hanging dow ne their heads, and the tops of the ftalkes and eups of the floures are eommonly of a purplifh colour: the floures themfelues are of a pretty red colour, and are of diuers thapes, and grow diuers wayes; which hath beene the reafon that Cluffus and other haue iudged them feuerall plants, as may be feene is Clufus his Workes, where he giues you the floures, which you here finde expreft, for a different kind. Now fome of thefe Houres, euen the greater part of then grow with fue red round pointed leates, which neuer lic faire open, but only ftand ftraight out, the middle part being filled with a hairy matter and yellowith threds : orher-fome confift of feuen, eight, nine, or more leaues; and fome againe lic wholly open, with greene leaues growing clofe vnder the cup of the floure, as you may fee them teprefented in the figure; and fome few now and then may be found eompofed of a great many little leaues thick thruft together, making a very double floure. After the floures ate falne come fuch hairy heads as in other plants of this kinde, amongft which lies the feed. Gefner calls this Geum rivale: Thalius, Caryophyllata maior purpurea : Camerarisu, Caryophyllata aquatica: Clufius, Caryophyllatamoniana prima, or tertia.

5 . The root of this is alfo thicke, fibrous, and whitifh; from which arife many leaues three fingers high, refembling thofe of Agrimonie, the little leaues ftanding directly oppofite each againft other, fnipt about the edges, hairy, a little curld, and of a deepe greene colour:out of the midft of thofe, vpon a thort ftalk growes commonly on fingle floure of a gold-yellow colout, much like the mountainc Auens defcribed in the fecond place. It floures at the beginning of Iuly, and groweth vpon the Alpes. Pona was the firft that defctibed it, and that by the name of Caryophyllara Alpina omnium minima. $\ddagger$

\section{The Place.}

Thefe kindes of Auens are found in high mountaines and thicke woods of the Notth patts of England : we haue them in our London gardens, where they flourifh and encreafe in finitely.

I Thered floured mountaine Auens was found growing in Wales by my mueh honoured friend $\mathrm{M}^{\mathrm{r}}$. Thomas Glymn, who fent fome plants thereof to our Herbatifts, in whofe gardens it thritheth exceedingly. $\ddagger$

$$
\begin{gathered}
\text { They floure from the beginning of May to the end of Iuly. } \\
\text { T The Names. }
\end{gathered}
$$

Auens is called caryophyllat a, fo named of the fmell of Cloues which is in the roots, and diuers call it Sanamunda, Herbi benedicta, and Nardus ruftica: in high-Dutch, 2Beneoicten bozt?: in French, Galiot : of the Wallons, Gloriafilia: in Englin, Auens, and herbe Benet : it is thought to be Gewm Plinÿ, which molt do fufpect, by reafon he is fo briefe, Geum, faith Pliny, llb.26.cap.7. hath little flender roots, blacke, and of a good fmell.

The other kinde of Auens is called of the later Herbarifts, Caryophyllata montana, Mountaine Auens : it might agtee with the defcription of Bacchar is, if the floures were purple tending to whiteneffe; which as we haue faid are vellow, and likewife differ in that, that the roots of Auens fmell of Clotes, and thofe of Baccharis hate the fmell of Cinnamon.

$$
\text { T) The Temperature. }
$$

The roots and leaues of Aucns are manifeftly dry, and fomething hot, with a kinde of fcouting qualitie.

\section{q1 The Vertues.}

The decoction of Auens made in wine is commended againf cruditie or rawneffe of the ftomacke, paine of the Collicke, and the biting of venomous beafts.

The fane is likewife a remedie for ftitches and griefe in the fide, for ftopping of the liter ; it coneneteth raw humours, fcoureth away fuch things as eleaue to the intrals, wafteth and diffol-

th winde, cfpecially being boyled with wine: but if it be boyled with pottage or broth it is of

at efficieie, and of all other pot-hetbes is chiefe, not onely in phy ficall broths, but commonly levedinall.

li: anes and roots taken in this manner diffolue and confume clottered bloud in any inward 
L I в. 2. Of the Hiftory of Plants.

part of the body; and therfore they are mixed with potions which are drank of thofe that are bruifed, that are inwardly broken, or that haue fallen from fome high place.

The roots taken vp in Autumne and dried, do keep garments from being eaten with moths, and $F$ make them to hane an excellent good odour, and ferue for all the phyficall purpofes that Cinkefoiles do.

\section{Снар. 386. Of Straw-berries.}

\section{Tा The Kindes.}

THerebediners forts of Strawberries; one red, another white, a third fort greene; and likew ife a wilde Straw-berrie, which is altogether barren of fruit.

I Fragaria of Fraga.

Red Straty-berries,

Ifragaria vesca

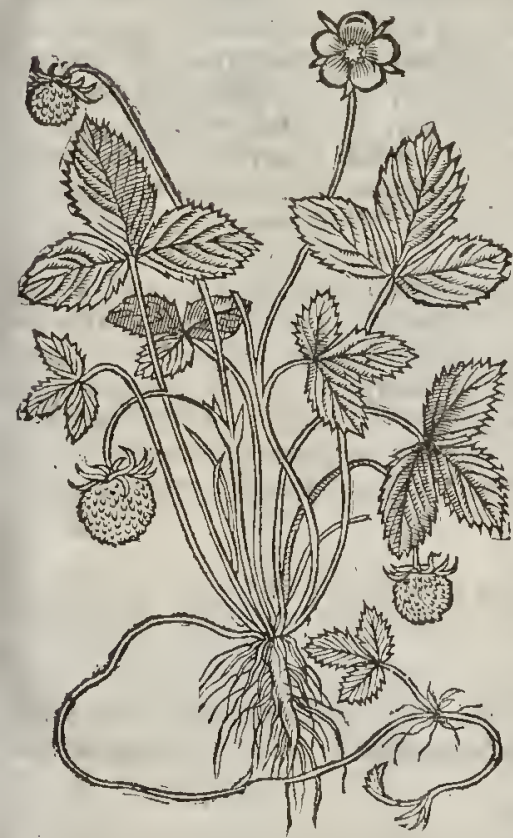

2 Fragaria \&o Fraga fuballa.

White Straw-berries.

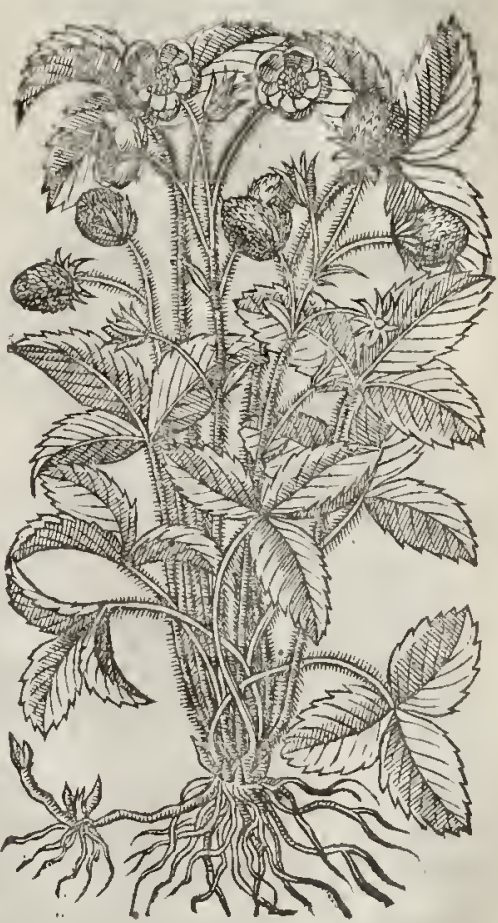

If The Defcription.

I T He Straw-berry hath leaues fpred vpon the ground, fomewhat fnipt about the edges, three fet together vpon one flender foot-ftalke like fhe Trefoile, greene on the vpper fide, and on the nether fide more white : among which rife up flender ftems, whereon do grow fmall floures, confinting of fiue little white leaues, the middle part fomw hat yellow, a fter which commeth the fruit, not vnlike to the Mulberrie, or rather the Rafpis, red of colour, hauing the tafte of wine, the inner pulpe or fubftancewhereof is moift and white, in whieh is contained little feeds : the root is threddy, of long continuance, fending forth manye ftrings, which difperfe themfelues far abroad, whereby it greatly increafeth.

2 Of thefe there is alfo a fecond kinde, which is like to the former in ftems, ftrings, leaues, and floures. The fruit is fomething greater, and of a whitifh colour, wherein is the difference.

There is another fort, which brings forth leaues, floures, and ftrings like the other of his kinde: The fruit is green when it is ripe, tending to redneffe vpon that fide that lieth to the Sun,cleaning 
fafter to the ftemmes, and is of a fwceter tafte, wherein onely confifteth the diffetence.

¥ There is alfo kept in our gardens (onely

† 3 Fragarianinimevefca, finefterilis. Wilde ot barten Straw-betry. Fragaria sterilis

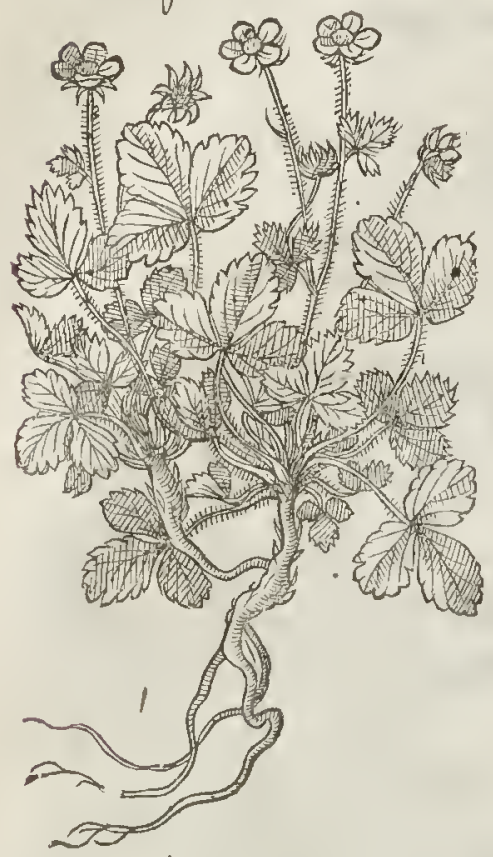
fot vatietie) another Strawberrie which in leates and growing is like the commonkinde; but the floure is greenifh, and the funit is harh, tough, and ptickely, being of a greenifh colout, with fome fhew of tedneffe. $\mathrm{M}^{\mathrm{r}}$. Io hn Tradefcant hath told me that he was the firit that tooke notice of this Straw-berry, and that in a womans garden at Plinouth, whofe daughter had gathered and fet the roots in her gatden in ftead of the common Straw-berty : but fhe finding the frut not to anfwer het expe.tation, intended to throw it away : which labor he pared ber, in taking it and beftowing it among the loners of fuch varieties, in whofe gardens it is yet preferued. This may be ealled in Latine, Fragaria fruct u hipido, The prickly Straw-berry. $\ddagger$

+3 This wild Strawberty hath leaues like the othet Straw-berry, but fomewhat leffe, and fofter, Alightly indented about the edges, and of a light greenecolour : among which tife vp flender ftems beating fireh floutes as the common Straw-berries doe, but leffer, which doewither away, leauing behinde a barren or chaffic head, in thape like a Straw-berrie, but of nowoth or value: the root is like the others.

It The Place.

Straw-berries do grow vpon hills and vallies, likewife in woods and other fuch places that be fomewhat thadowie : they profper well in "Gatdens, the firft eutery whete, the orher two more tare, and are nor to be found faue only in gardens.

$\neq \quad$ The barren one growes in diuets places, as vpon Blacke heath, in Greenw ich parke,\&rc. $\neq$

The Time.

The leates continue greeneall the yeate: in the Spring they fpred furthet with their ftrings, and floureafterward: the berries are tipe in Iune and Iuly. $\neq$ The batren one floures in April and May, but netrer carries any berties. $\ddagger$

97 The Nimes.

The fruit or berries are called in Latine by Virgil and ouid, Fraga : neither haue they any other name commonly knowne : they are called in high-Duteh erdberen: in luw-Dutch, Cettbefien: in French, Fraijes : in Engliph, Strawberries.

\section{The Temperature.}

The leaues and toots docoole and dry, with an aftriction otbinding quality : but the berries be coklel and moift.

$$
\text { 9 The Fertues. }
$$

A The leaues boyled and applied in mannet of a pultis taketh away the burning hcate in wounds : the decoction there of ftrengthneth the gumames, faftneth the teeth, and is good to be held in the mouth, both againit the inflammation or burning heate thereof, and alfo of the almonds of the throat : they ftay the oucrmuch flowing of the bloudy flix, and other iffies of bloud.

B The berries quench thirf, and do allay the inflammation or heate of the ftomack : the noutifhment which they yeeld is Iittle, thin,and waterifh, and if they happen to putrifie in the ftomacke, their nourifhment is naught.

C The diftilled water drunke with whitc Wine is good againtt the pafion of the heart, reuiuing the fpirits, and making the heart merry.

D The difilled water is reported to feoure the face, to take away fpots, and to make the face faire and fmooth; and is likew ife drunke with good fitee ffe againft the ftone in the kidnies.

E The leatresate good to be put into Lotions or walhing watets, for the mouth and the priuie patts. 


\section{Li B.2. Of the Hiftory of Plants:}

The ripe Straw-berries quench thirt, coole heat of the ftomack, and inflammation of the liuer, F take away (if they be often wed) the redneffe and heate of the face. ":-

t That figure which formerly was in this place, and lome parz of the defcription were (as I haue formerly noted) of the Peataphyllum fupinum Totentills facie, which yor mav finde defribed among?t the Cind foiles in the fixch place.

\section{$\mathrm{C}_{\text {HA P. }} 387$. Of eAngelica.}

\section{T. The Kindes:}

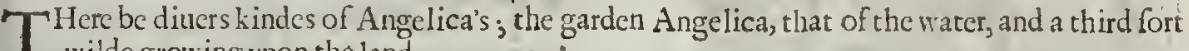
wilde growing rpon the land.

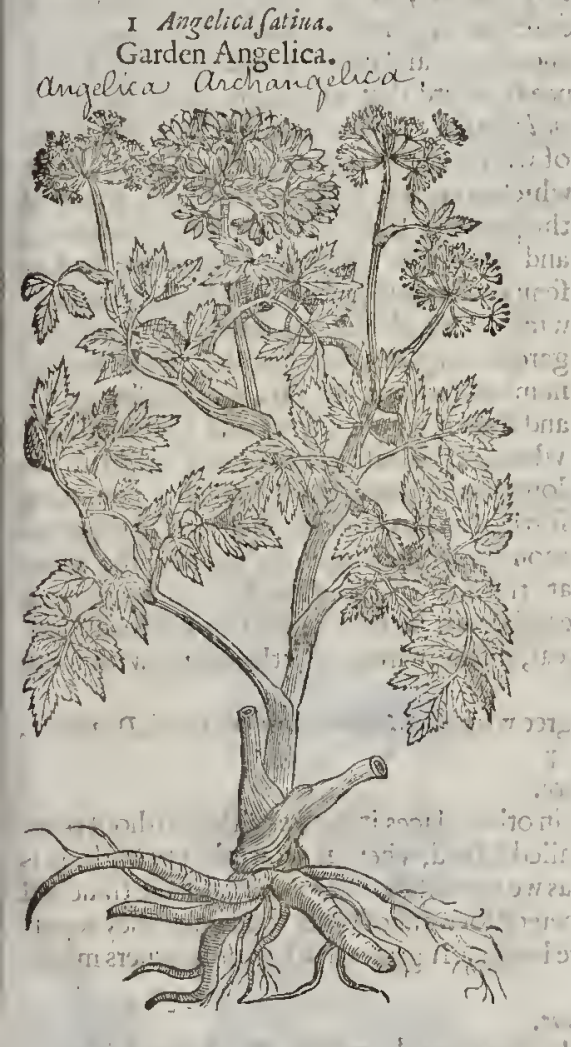

2 Angelica fylueftris.

Wilde Angelica:

Angelica syluestris.

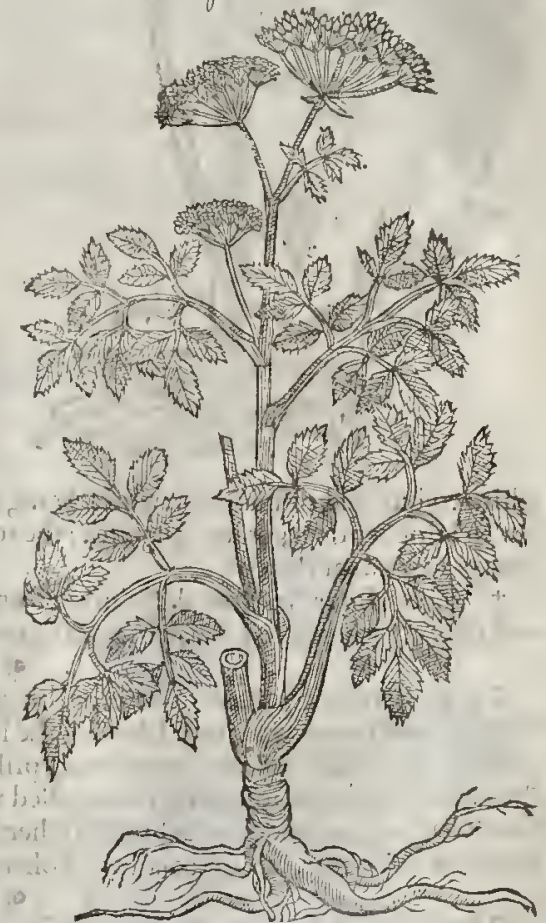

II The Defription.

1

Concerning this ylant Angelicathere hiath bin here tofore fome contention and contro. ueffie, Cordes calling it Smyminm: fome later writers, Coftus nizer but to auoid ca- uilli, thic controuerfic is foone dee ided, fithit and noother doth afluredly retaine the name Angelica. It hath great broad leatres, dituided againe into other leates, which are indented or fnipt about much like to the vpectmolt' lcatiès of Spliondylitum, but lower, tenderer, greener, and of a : fronger fauor: aniong which leaues. fpring vo the ftalkes, very great, thicke, and hollow, fixe or I feuch foot high, ioynted or knced : from which ioynts proceed other armes or brancines, at the top i whereof grow tufts of whitiph floures like Fennell or Dill : the root is thicke, great, and oilous, out i of which iffucth, if it be cut or broken, an oylie' liquor': the whole plant, as well leaues, ftalkes, as roots, are of a reafonable pleafant fauour,' not much vnlike Petrolcum.

There is anotherkinde of true Angelica found in rur Englin gardens(which I hauc obferued) being like vnto the former, fruing that the roots of this kinde are more fragrant,and of a more aromaticke fauor, and the leaues next the ground of a purplifh red colour, and the whole plant lefer. 


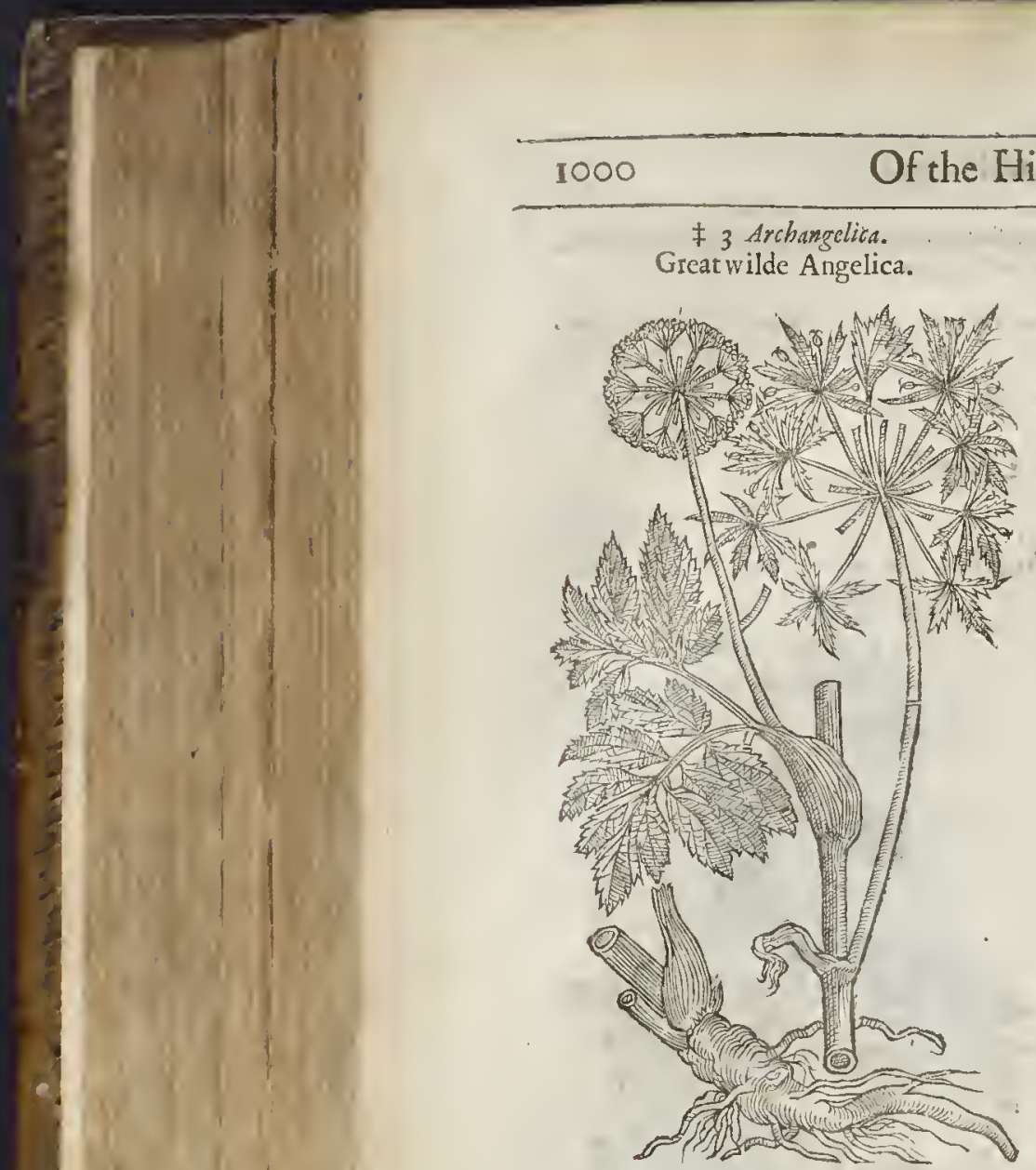

L 1 B. 2.

\$ Archangelica.

Great wilde Angelica.
2 The wilde Angelica, which feldome growes in gardens, but is found to grow plentifully in water foken grounds and cold moift medowes, is like to that of the garden, fauce that his leaues are not fo deepely cut or iag. ged; they be alfo blacker and narrower: The ftalkes are much flenderer and horter, and the floures whiter : the root much fmaller, and hath more threddy ftrings appendant thereunto, and is not fo ftrong of fauour by a great deale.

3 Muthiolus and Gefier hane made men'tion of another kinde of Angelica, but we are very flenderly inftructed by their infufficient defcriptions : notwithftanding for our better knowledge and more certain affurance I mult needs record that which my friend $\mathrm{M}^{\mathrm{r}}$. Bredwell related to me concerning his fight thereof, who found this plant growing by the mote which compaffeth the houfe of $\mathrm{M}^{5}$. Munke of the parifh of Iuer, two miles from Colbrook; and fince that I haue feene the fame in low fenny and marihy places of Effex, about Harwich. This plant hath leaues like vuto the garden Angelica, but fmaller, and fewer in number, fet von one rib a great falke, groffe and thicke, whofe ioynts and that fmall rib whereon the leafe growes are of a reddith colour, hauing many long branches comming forth of an husk or cafe, fuch as is in the common garden Parfnep: the floures doe grow at the top of the branches, and are of a white colour, and tuft fafhion: which being pat, there fucceed broad long and thicke feeds, longer and thicker than garden Angelica : the root is great, thicke, white, of little fauour, with fome ftrings appendant thereto.

₹ 'This of our Authors defcription feemes to agree with the'Archangelica of Lobel, Dodoneus? and $c$ luf frus; wherefore I haue put their figure to it. $\neq$

$$
\text { T The Place. }
$$

The firf is very common in our Englifh gardens $:$ in other places it growes wilde without-plawting; as in Norways and in an Ifland of the North called Ifland, where it groweth very high. It is eaten of the inhabitants, the barke being pilled off, as we vnderftand by fome that haue tratrelled into Ifland, who were fometimes compelled to cate hereof for want of other food; and rhềy report that it hath a good and pleafant talte to rhem that are hungry. It groweth likew ife in diuers mountaines of Germanie, and efpecially of Bohemia.

$$
\text { T The Time. }
$$

They floure in Inly and Augunt, whofe roots for the moft part do perifh after the feed is ripe: yet haue I with often cutring the plant kept it from feeding, by which meanes the root and plant hane continued fundry yeares together.

$$
\text { It The Names. }
$$

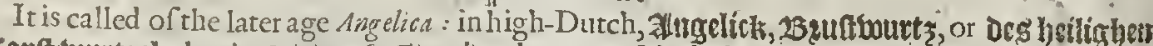
Gepft bututżl, that is, Spiritus farti radix, the root of the holy Ghol, as witneffeth Leonbartus Fuchfus : in low-Durcl, alngelíika : in French, Angelic : in Englịh alfo Angelica.

It feemeth to be a kind of Laferpitinem; for if itbe compared with thofe things which Therphraftus at large hath written concerning silpbium or Laferpitium, in his fixth boake of the hiftorie of plants, it thall appeare to be anfwerable thereunto. But whether wild Angelica be that which Theophraftus calleth Magydaris, that is to fay, another kinde of Laferpitium, we leaue to be examined and confidered of by the learned Phyfitians of our London Colledge.

$$
\text { of The Temperature. }
$$

Angelica, efpecially that of the garden, is hot and dry in the third degree; therefore it opencth; attenuateth or maketh thin, digelteth, and procureth. fireat. 


\section{Ti The Vertues.}

The roots of garden Angelica is a fingular remedy againft poifon, and againft the plague, and A all infeetions taken by euill and eorrupt aire; if you do but take a peeee of the root and hold it in your mouth,or ehew the fame between your teeth, it doth mof certainely driue away the peftilentiall aire,yea although that eorrupt aire hate poffeffed the hart,yet it driueth it our agan by vine and fwear, as Rue and Treacle, and fuch like Antipharmacado.

Angelica is an enemy to poifons: it cureth peftilent difeafes if it by veed in feafon:adram $B$ weight of the pouder hereof is giuen with thin wine,or if the fetrer be vehement, with the diftlled water of $C$ arduxs bencdictus, or of Tormentill, and with a little vineger, and by it felfe alfo, or with Treacle of Vipers added.

It openeth the liuer and fpleene : draweth downe the termes,driucth out or expelleth the feeon- C dine.

The deeotion of the root made in wine, is good againft the eold thiucring of agues.

It is reported that the root is auaileable againft witeheraft and inchantments, if a man earry the $E$ fame about, them, as Fuchfius faith.

It attenuateth and maketh thin, groffe and tough flegme: the root being vied greene, and while $F$ it is full of juiee, helpeth them that be afthmatieke, diffoluing and exnectorating the ftufings therein, by eutting off and clenfing the parts affeeted, reducing the body to health againe; but when it is dry it worketh not fo effeetually.

It is a moft fingular medieine againft furfeting and loathfomenefle to meate : it helpeth con- $G$ cotion in the ftomacke, and is right beneficiall to the hart : it cureth the birings of mad dogges, and all other venomous beafts.

The wilde kindes are not of fuch force in working, albeit they haue the fame vertues attributed $H$ vato them.

\section{С нат. 388. Of Maftermorts and berbe Gerard.}

I Imperatoria.

Mafterwoorts. is inperatonca Ostrutinimu.

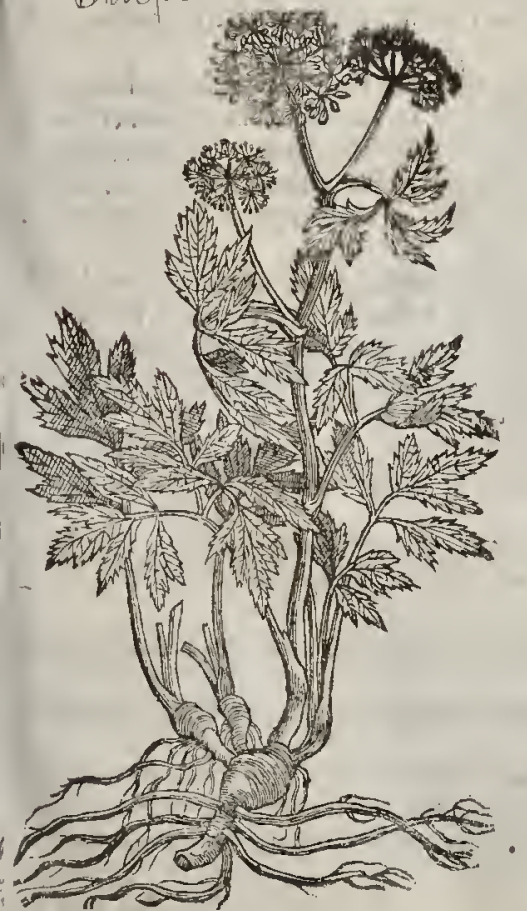

2 Herba Gerardi.

Herbe Gerard, or Ainh-weed: Acaobodium Ujodagraria

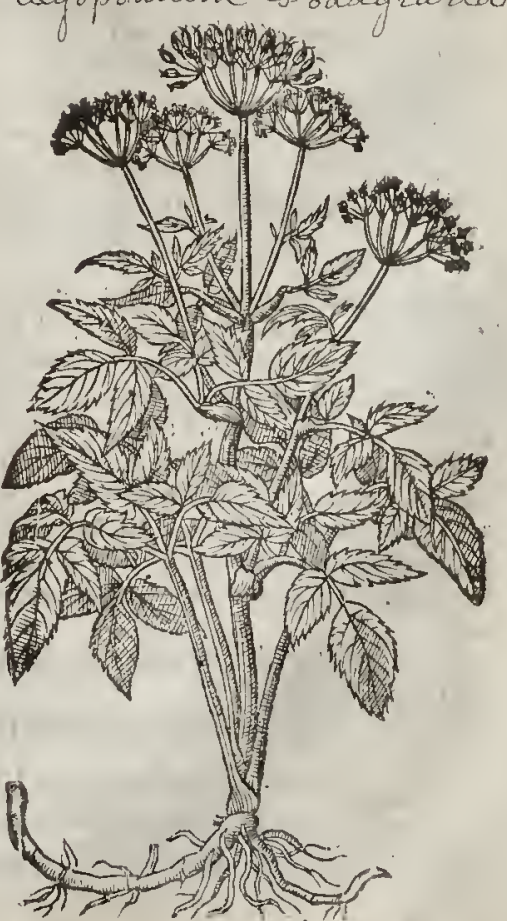




$$
\text { 4. The Defription. }
$$

I Mperatoria or Mafterwoot hath great broad leates not much vnlike wilde Angelica, but

fmaller,and of a deeper greene colout, in fatior like Angelica, and cuery leafe duided into fundry other litrle leaues: the tender knotted italkes are of a reddith colour, bearing at rhe top round fpokie tufts with white floures: the feed is like the feed of Dill : the root is thicke, knotty and tuberous, of a good fautour, and hot or biring vpon the tongue, which hath mooued the viskilfull to eall it Pellitory of Spaine, but very vnfirly and vntruely.

2 Herba Gerardi, which Penadoth alfo call Imperatoria and oftrutium : the Germaines Podagraria, that is, Gour-woort:in Englim, herbe Gerard, or wilde Maiterwoor, and in fome plaees after Lyte, Afhweed, is very like the other in leaues, floures, and roots, fauing that they be fmaller, growing vpon long ftems : the roots tenderer, whiter, and not fo thicke or tuberous. The whole plant is of a reafonable good fauour, but not fo ftrong as Mafterwoort.

$$
9 \text { The Place. }
$$

Imperatoria groweth in darke woods and defarts; in my. Garden and fundry orlers very plentifully.

Herbe Gerard groweth of it felfe in gardens without fetring or fowing,and is fo fruitfull in his increafe, that where it hath oneetaken root, it will hardly be gotten ont againe, fpoiling and getting euery yeere more ground, to the annoying of better herbes.

They floure from the beginning of Iune to the beginning of Augult.

$$
\text { 9ा The Names. }
$$

Imperatoria, or Afrantia, is called in Englim, Mafterwoort, or baftard Pellitory of Spaine.

Herba Gerardi is called in Englifh, Herb Gerard, Aifhweed, and Goutwoortin Latine alfo PodsgrariaGermanica.

9) The Nature.

Imperatoria, efpecially the root, is hot and dry in the third degree. The wilde Imperatoria, or herbe Gerard, is almoft of the fame nature and quality, but not fo ftrong.

$$
\text { T The Veritus. }
$$

A Imperatoria is not onely good againft all poifon, but alfo fingular againft all cortupt and naughty aire and infection of the peftilenee, if it be drunken with wine.

B The roots and leaues ftamped, diffolue and cure peftilentiall carbuncles and botches, and fueh other apoftunations and fivellings, being applied rherero.

C The root drunke in wine cureth the extreme and rigorous cold fits of agues, and is good againft the dropfie, and prowoketh fiveat.

D The fame taken in manner a forefaid, comforteth and ftrengthneth the famack, helpeth digeftion,reftoreth appetite, and diffolueth all ventofities or windineffe of the ftornacke and other parts.

E It greatly helpeth fuch as haue taken great fquats, brufes, or falls from fome high place, diffoluing and fcattcring abroad congealed and clotted bloud within the body: the roor with his leaues ftamped and laid vpon the members infected, curcth the bitings of mad dogs, and of allother venomous beafts.

If Herbe Gerard with his roots ftampecl, and laid vpon members that are troubled or vexed with the gout, fwageth the paine, and takcth atway the fivellings and inflammation thereof, which occafroned the Gemaines ro giue it the name Podag aria, bceaufe of his vertues in curing the gout.

G It curethalfo the Hemorrhoids, if the fundament be bathed with the decoction of theleaues and roots, and the foft and tender fodden herbes laid thereon very hot.

H Falfe Pellicory of Spaine attenuatieth or maketh thin, digefteth, pronoketh fweate and r rine, concosteth groffe and colde humors, wraftcth away windireffe of the entrailes, ftomacke and matrix: it is good againft the collicke and ftone.

1 Onedram of the root in pouder gitlen. certaine daies together, is a remedy for them that haue the dropfic, and alfo for thofe that are troubled with convulfions, cramps, and the falling fickeneffe.

$K$ Being giuen with winc before the fit come, it cureth the quartaine ague, and is a remedy againft peftilent difeafes.

L The fame boiled in flatpe or fower w ine, eafe th the tooth-aeh, if the mouth be wathed therewith very hot.

M Being chewed it draweth forth wat er and flegme out of the mouth (which kinde of remedies in Latine are called Apophlermatifimi) a nd disburdeneth the braine of phlegmaticke humours, and are likewife vfed with gond litcceffe in apoplexies, drow fie fleepes, and other like infirmities. 


\section{C'на P. 389 . \\ Of Hercules Wound-wort, or All-beale. \\ 9 The Kindes.}

PAnax is of fundry kindes, as witneffeth Theophrafus in his ninth booke; orie groweth in Sy+ia, 1 arid likewife other three, that is to fay, Chironium, Heraclium, and Afrilapium, or Chirons Aliheale, Hercules All-heale, and Afculapius All. heale. Befides thefe there is one Plaiyphyllon, or broad leafed; fo that in Theophraftus there are fix kindes of Panax: but Diofcorides deferibeth only three, Horasleum, Aflepium, and Chironium : whereunto we haue added another fort, whofevertues wee found out by meanes of a husbandman, and for that caufe haue named it $P$ anax Coloni, or Clownes wort.

I Panax Herálcum.

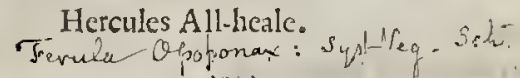

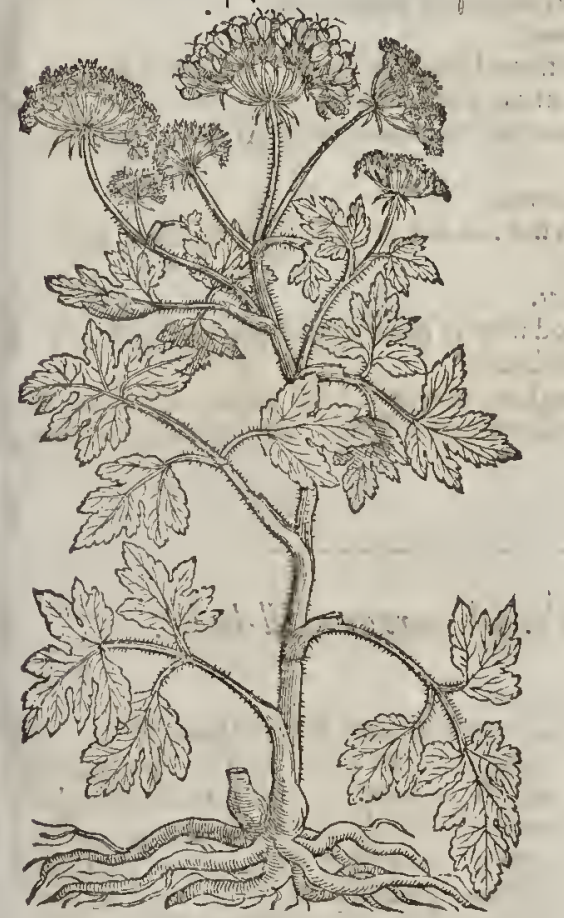

2 Panax Aeracham maius.

Hercules great Wound-ifort.

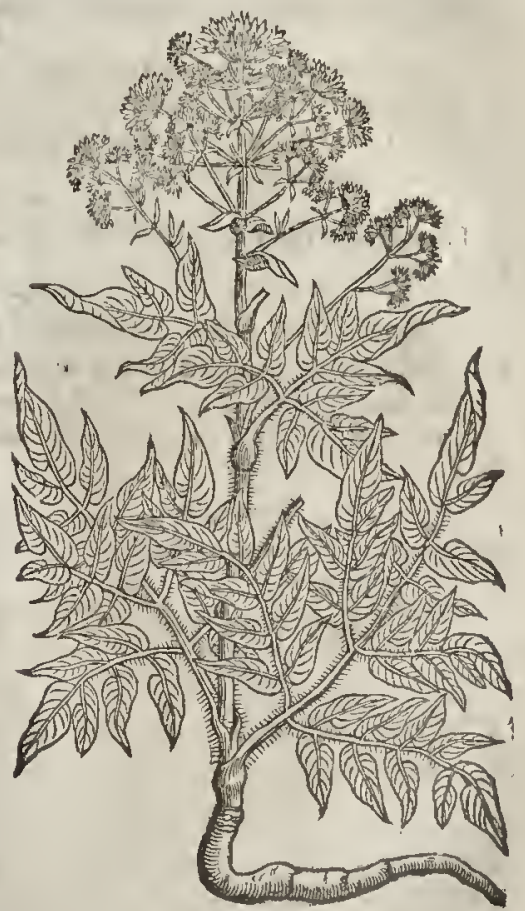

Til The Deforigrion.

I Tremles All-heale or Wound-wort hath many broid le mes firead poon tise ground;

1 very roug! and hairy, of an ouerworne greene co!oun, and decpely cut into ditiers featons like thofe of the Cow Parfenep, and not vnlike to the fig leaines anong the which rifeth vp a very ftrong ftalke coucred ouer with a rough hairinefle, of the height of foure or fuceubits. Being wounded it yeeldeth forth a yellow gunmie invee, as dorh cuery part of the plant, whieh is that preeious gum called opopanax : at the top of whieh falks ftand great tufes or vimbels of yellowith floures, fet together in fpoky rundles like thofe of Dill, wheh turn into feed of a fruv eolour, tharpeand hot in tafte, and of a pleafing fauour : the root is very thicke, fat, and full of inyee, and of a white colour.

2 The great Wound'wort, which the Venetians nowith in their gardens, hath gre ur !age leanes fomewht rough or hirie, eonfiting of diuers fma!l leates fut rogether vpona midd'crib, whieh mate one encire leafe ioyned togetier in one, whereofereh co'htera!l or fide leafe is long

$$
\mathrm{P}^{\prime} \mathrm{PP}=
$$


and tharpe pointed: among which rifct vp a knotty ftalke threeos foure cebits high, diuic ing it felfe into diuers branches; on the tops whereof do grow fpolie tufts or rundles like 1 lec precedcit, but the foures are commonly white: the feed is flat and plaine: the root long, ihicke, and white, which being broken orwounded, yeeldeth forth liquor like that of the former, of a liorard brit g taite.

$$
\text { Tा The Place. }
$$

Thefe plants grow in Syria; the firt of them alfo in my garden : but what Panax of Syria is, Theophraftus doth not expreffe: Pliny in his 12 booke, Chap. 26 . fairh, that the leates are round, and of a great compaffe: but it is fufpected rhat thefe are drawne from the defcription of Hercules Panax.

Brosd leafed Pankx is thought to be the great Centory : for pliny wirnefleth, that Panax which Chiron found out is fyrmamed Cchtaurium, Centoric.

Matbiolus faith it growes of it felfe in the tops of the hills Apennini, in the Cape Argentaria, in the fea contts of Siena, and it is cherithed in the gardens of Italy : but he cannot affirme, That the liquor hereof is gathered in Italy; for the liquor opopanax which is fold in Venice is brought, faith be, out of A lcxandria a city in Egypt : it groweth alfo in Syria, Boctia, and in Phocide,ci. ries of Arcadia.

$$
\text { 9. The Time. }
$$

They floure and flourih from the firft of May vnto the end of Scprember. Ti The Names.

Thatwhich is is called tras in Greeke, is likewifenamed Pandx in Latine : and that Pandr He:zwhich Divforides fetteth downe is called in Latine, Panax Heraculasim, Or Hercsleum, or acules Panax : it nay be called in Englih, Hercules his Wound-wort or All-heale, or Opopa:dx wort, of the Grecke name.

$$
\text { T) The Temperature. }
$$

The barke of the root of Hercules Wound-wort is hot and dry, yet leffe than the iuyce, as Galen teacheth.

\title{
T The Vertues.
}

A The feed beat to ponder and drunke in Wormwood wine is good againft poyfon, the biting of mad dogs, and the ftinging of all manner of venomous beafts.

$B$ The leafe or root itamped with honcy, and brought to the forme of an Vnguent or Saluc, cureth wounds and vlcers of great difficultie, and couereth bones that are bare or naked without
flefh.

\section{C н A 390 . Of ClownesWound-wort or CAll-beale.}

\author{
The Defription.
}

Lownes All-Leale, or the Husbandmans Wound-wort, hath long flender fquare ftalks of the height of tw cubits, furrowed or chamfered along the fame as it were with fmall gutters, and fomewhat rougli or hairy : whe reupon are fet by couples one oppofite to another, long rough leaues foncwhat narrow, bluntly indented about the edges like the tecth of a faw, of the forme of the leaues of Speare-mint, and of an cuerworne greene colour : at the top of the ftalkes grow the floures fpike fathion, of a purple colour mixed with fome few fpots of white, in forme like to little hoods. The root confifteth of many finall threddy ftrings, whereunto are annexed or tied diuers knobby or tuberous lumpes, of a white colour tending to yellownefe : all the whole plant is of an vnpleaf fant fauour like Stachys or ftinking Hore-hound. ‡ The root in the Winter time and the beginning of the Spring is fomewhat knobby tuberous, and ioynted, which after the Ralkes grow vp become fiaccide and hollow, and fo theold ones dccay, and then it putrerh forth
new ones. $f$

The Place.

wher fide's of ditches, and likewife in fertile fields that are fonwhat moif, almoit euery where; efpecially in Kent about South-fleer, ncere to Graucfend, and likewife in the medowes by Lambeth necre London.

$$
\text { It floureth in Augut and The Time. }
$$

It floureth in Auguft, and bringeth his feed to perfection in the end of September.

$$
\text { T) The Names. }
$$

'That which hath bin faid iu the defcription thall fuffice touching the names, as well in Latine as Englin. 
P.nax Coloni.

Clownes All-heale.

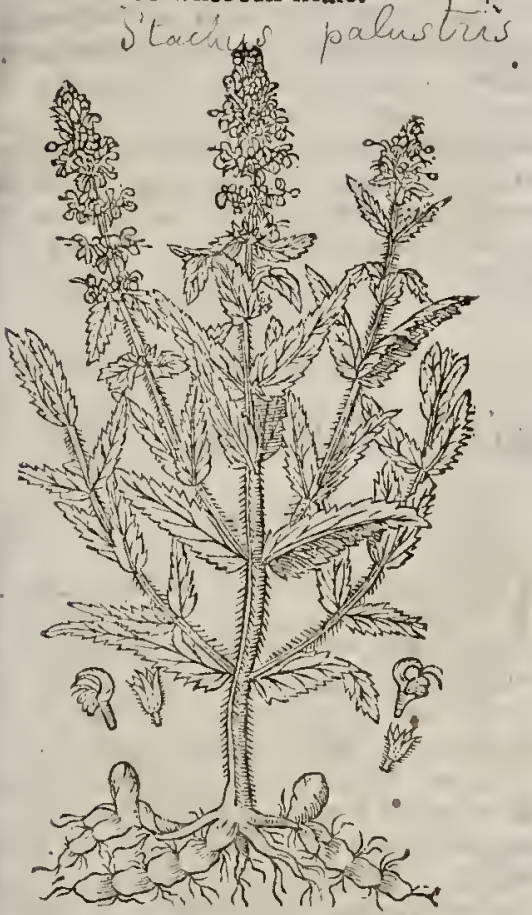

₹ This plant by Geforitits called stachys

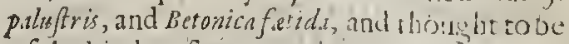
of the kinde of Herba Inditica, or Sidiritis ; to which indeed I thouid, and T buthers hath refer.

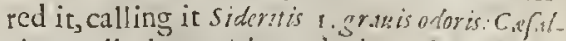
pinus ealls it Tcrtiola ; and giues this reaton, quod Tertianas fanet, becaufe it eures Tertians. Tabernamontan. ealled it Stachys atuatica, whofe figurewith a defcription our Authour in the former edition gatte,pag. $56 \mathrm{~g}$. by the name of charrubium aquaticum nemturn; yec (is it feemetl) erther not knowing, or forgetting what he had formerly done,he liere againe fetteth it forth as a new thing, vnder another title: but the former figure of Thtern. being in my iudsment the better, I haue here giuen you, with addition of the iointed tuberous joots as they are in Winter : yet by the Curuers fault they are not altogether fo exquifitely expret as I intended. $\ddagger$

\section{T) The Temperature.}

This plant is hot in the feeond degree, and dry in the firft.

$$
\text { T) The Tiertues. }
$$

The leanes hercof ftamped with Axungic or A hogs greafe, and applied into greene wounds in manner of a pultefie, healcth them in thort time, and in fuels abfolute manner, that it is hard for any that liaue not had the experience thereof robelecue : for being in Kent about a Patient, it chanced that a poore man in mowing of Peafon did cut his leg with a fithe, wherein he made a wound to the bones, and withall very large and wide, and alfo with great effufion of bloud; the poore man crept vnto this herbe, whieh he bruifed with his hands, and ried a great quantity of it vnto the wound witl a piece of his thirt, which prefently ftanched thebleeding; and eeafed the paine, infomueh that the pore man prefently went to his dayes worke againe,and fo did from day to day, without refting one day vntill hewas perfectly whole; whielı was accomplithed in a few dayes, by this herbe ftamped with a little hogs greafe, and fo laid vpon in nanner of a pulteffe, whiel did as it were glew or foder the lips of the wound torether, and heale it aceording to the firf intention, as we terme it, that is, without drawing or bringing the wound to fippuration or matter; which was fully performed in feuen dayes, that would haue required forty dayes with bal. fam it felfe. I faw the wound, and offered to heale the fame for clarit ic; which he refufed, faying that I could not heale it fuwell as himfelfe : a elownith anfwer I eonfeffe, withont any thankes for my goodwill whereupon I haue named it Clownes Wound-wort, as aforcfaid. Since which time my felfe haue cured many grieuvus wounds, and fome mortall, with the fame herbe; one for example done vpon a Gentleman of Grayes Inne in Holborne, M'. Edmund Cartwright, who was thruft into the lungs, the wound entring in at the lower part of the Thorax, or the breft-blade, euen chrough that eartilaginous fubfanee ealled Gucronata Cartilago, infomucl that from day to day the frothing and puting of the lungs did fpew forth of the wound fuch exerements as it was porfeffed of, befides the Gentleman was mof dangeroully vexed with a double quotician feuer; whom by Gods permiftion I perfeetly cured in very thort tine, and with this Clomes experi. ment, andfome of my foreknowne helpes, whieh were as followeth.

Firft I framed a llight vnguent hereof thus: I ron'se foure lundfulls of the herbe ftanped, anul put them into a pan, whereuntes I added foure ounces of Barrowes greafe, halfe a pinte of oyle $O$. liue, wax threc ounces, which I boyled vnto the confumption of the iuyee (which is known when the fuffe doth not bubble at all) then did I ftraine it, putting it to the fre againe, adding therto two ounces of Turpentine, the which I fuffered to bovle a lietle, referuing the furne for iny vec.

The which I warmed in a faveer, dipping therein fmall foit tents, which I put inco the wound, C defending the parts adioyning with a plaiter of Calcitheos, relented wirl ovle of rofes: which nantner of drefing and preferming I ved enen vintill the wound was parfietly whole : notwithltanding osce in a day I gau him two fponfulls of this deco rion follo ving.

I toxkea quare of gox Claret Wine, wherein I boyled at mandill of the leaves of solidro

$$
\text { Ppp? }
$$$$
\text { Sariccricit, }
$$

.



Saracenica, and Saraeens Confound, or foure ounces of honey, whereof I gaue him in the morning
two fpoonfulls to drinke in a fmall draught of wine tempered with a little Sugar.

E In like manner I cured a Sloo-makers feruant in Holburne, who intended to deftroy himfelfe for caufes knowne vnto many now liuiug : but I deemed it better to couer the fault, than to put the fame in print, which inight moue fuch a graceleffe fcllow to attempt the like : his attempt was thus; Firft, he gate himfelfc a molt mortall wound in the throat, in fuch fort, that when I gaue him drinke it came forth at the wound, which likewife did blow out the candle : anorher deep and grieuous wound in the breft with the faid dagger, and alfo two orhers in Abdomine or the nether belly, fo that the $Z$ irbus or fat, commonly called the caule, iffued forth,w ith the guts likevife: the which mortall wounds, by Gods permiffion, and the vertues of this herbe, I perfestly cured within twenty dayes : for the which the name of God be praifed.

\section{Cн а в.391. Of Maggydare, or Lafer-wort.}

\section{+ Laferpitium.}

Lafer-wort.

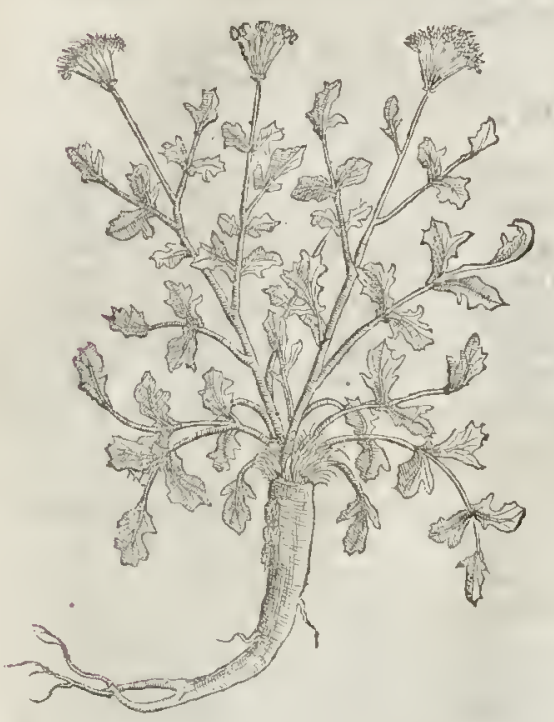

T The Defcription.

T T feemeth that neither Diofcorides nor yet Theophiraftus haue euer fecne Laferpitium, Sayapersum, or any other of the gummiferous ropts, but haue barely and nakcdly fer downe their iudgments vpon the fame, either by hearc-fay, or by reading of other mens Workes. Now then feeing theold $\mathrm{W}$ riters be vnperfect herein, it behooueth vs in this cafe to fearch with more diligence the truth hereof; and the rather, for that very few haue fet forth the true defcription of that Plane which is ealled Laforpitium, that is indeed the true Laferpitium, from the roots whereof flow that fap or liquor called $L_{a}$ er. This plant,as Pena and Lobel them felues fay, was found out not far from the Inles which $D$ iojcorides calls Stcechades, ouer againft Maffilia,among fundry other rare plants. His ftalke is grcat and thiche like Ferula, or Fennell gyant : The leatles are like vnto the conmon Smallage, and of an vnpleafant fauour. The foures grow at the top of the ftalkes, tuft-fa hion like Ferula or Fonnell : which being paft, there fuc-
ceed broad and flat feeds like Angcliea, of a good fauour, and of the colour of Box. The roots are many, comming from one head or chiefe root, and are couered ouer with a thicke and fat barke. Thefe roots and ftalkes being fcarified or cut, there floweth out of them a ftong liquor, which be-
ing dried is very medicinable, and is called $\Sigma$ afer.

\section{9) The Place.}

There be fundry forts of Lafer, flowing from the roots and fealkes of Laferpitium, the goodneffe or qualitic whcreof varieth aecording to the countrey or clymate wherein the plant groweth. For the beft groweth vpon the high mountaines of Cyrene and Africa, and is of a pleafant fmell : in Syria alfo, Media, Armenia, and Lybia; the liquour of which plant growing in the fe places is of a moft ftrong and deteftablc fauour. Lobel reporteth, that Iacobus Rainaudus an A porhecaric of Maffilia was the firft that made it knowne, or brought the plants thereof to Montpellier in France, unto the learned Rondeletius, who right well beholding the fame, concluded, that of all the kindes of Ferula that he had euer feene, there was not any fo anfwerable vnto the true Laferpitium as this
onely plant.

$$
\text { 9T The Time. }
$$

This Plant floureth in Montpellier about Midfommer, 
या The Names.

It is called in Latine Laferpitium : in Englifh, Lafcrwoort, and Magydare: the gum or liquour that iffueth out of the fame is called Lafor, but that whieh is gathered from thofe plants that doe grow in Media and Syria, is ealled Afa fatida.

T) The Naiure.

Laferpitium,efpecially the root; is hot and drie in the third degree: Lafer is alfo hot and drie in the third degree, but it exeeedeth much the heate of the leaucs, Palkes, and rootes of Laferpiitum.

9. The Vertues.

The toot of Laferpitium well pounded, or ftamped with oile, feattereth elotted bloud, taketh a. way blacke and blew markes that come of bruifes or ftripes, eureth and diffolueth the Kings-euill, and all hard fivellings and botehes, the places being annointed or plaiftered therewith.

The fame root made into a plaifter with the oile of Ireos and wax, doth both affwage and eure the Sciatica, or gout of the hip or luckle bone.

The fame holden in the mouth and ehewed, doth affwage the tooth-aehe; for they are fuch roots as draw from the braine a great quantite of humors,

The liquour or gum of Laferpitium, efpecially the Lafer of Cyrene broken and diffolued in water and drunken, taketh away the hoarfeneffe that eommeth fuddenly : and being fupt vp with a reare egge, eureth the eough : and taken with fome good broth or fupping, is good againf an old pleurifie.

Lafer eureth the iaundies and dropfie, taken with dried figs : alfo being taken in the quantitie of a fcruple,wich a litcle pepper and Myrrhe, is very good againft thrinking of finewes, and members out of ioint.

The fame taken with honic and vineger, or the fyrrup of vineger, is very good againft the fall ing fiekneffe.

It is good againtt the flux of the belly comming of the debilitie and weakneffe of the ftomacke (called in Latine Caliacus morbus) if it be taken with raifons of the Sun.

It driueth away the thakings and thiuerings of agues, being drunke with wine, pepper, \& white Frankineenfe. Alfo there is made an electuarie thereof ealled Antidotus cxjucco Cyrenuico, wh ich is a fingular medieine againft feuer quartaines.

It is exeellent againft the bitings of all venomous beafts, and venomous thot of darts or arrowes, not onely taken inwardly, but alfo applied outwardly vpon wounds.

It bringeth to maturation, and breaketh all peftilentiall impofthumes, borches and carbuncles ${ }_{j}^{2} K$ being applied thereto with Rue, Salt-peter, and honie : after the fame manner it taketh away corns after they hauc been fcarified with a knife.

Being laied to with Copperas and Verdigreafe, it taketh away all fupetflous outgrowings of the fle h, the Polypus that happeneth in the nofe, and all feuruie mangineffe.

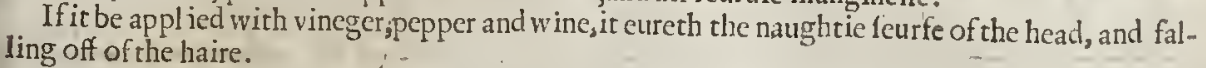

The gum or liquour of Laferpitium which groweth in Armenia, Lybia and fundry other places, is that ftinking and lothfome gum ealled of the Arabian Phy fitions $A / A$ and $A / \int$, as alfo with vs in Shoppes "Afafatida : but the $L$ afsipitium growing in Cyrene is the beft, and of a reafonable pleafant fmell, and is ealled Lafer to diftinguioh and make differenee betweene the two iuices; though 1 fa fortidabe good for all purpofes aforefaid, yer is it not fo good as Lafer of Cyrene: it is good alfo to fmell vnto, and to be applicd vnto the nauels of women vexed with the choking, or rifing of the mo.
cher.

\section{Cна \\ T) The Defcription.}

A Ntient writers have added vnto this common kinde of Louage, fecond fort, yet knowing that the plant fo fuppofed is the true Siler montanum, and not Lewifticum, though others haue alfo deemed it $L$ aferpitiam. Thefe two fuppofitions are eafily anfweted, fith they bee. fundrie kindes of plants, though they be very neere in thape and faculties ane vato another. This plant 


\section{Of the Hiltorie of Plants. \\ L 1 в. 2.}

t Lenificam vulgare. Common Louage.

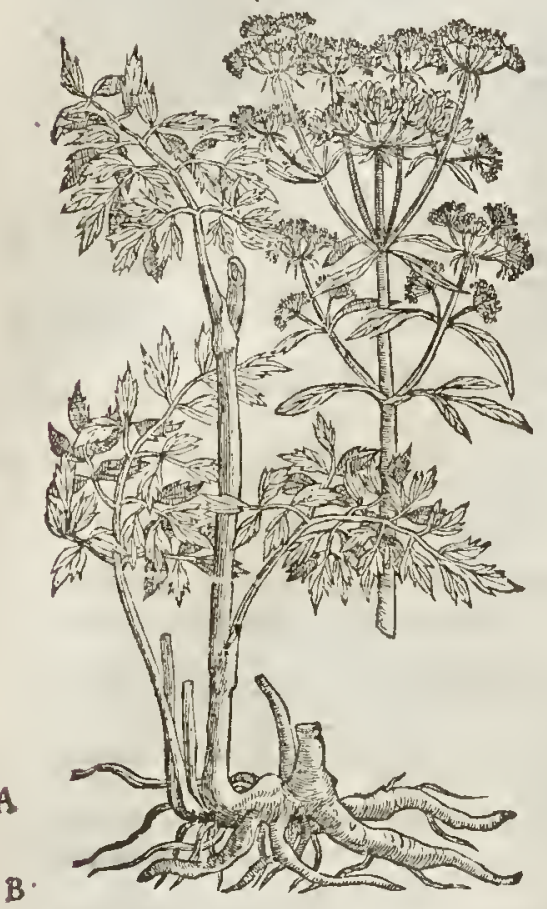

being our common garden Louge, lath lare and broad leaues, almoft like to fmallage. Tl c ftalks are round, hollow and 'knottic, 2.cubits high, hau ing fpoky tufts,or burhy rundles;and at the top of the ftalks of a yel'cw co'our, a round, flat, and browne feed, like the feede of Angelica : the root is long and thicke, ard bringeth forth enery yeare new ftems.

\section{Th The Place.}

The right Leuifticum or Louage groweth in fundry gardens, and not wild (as far as I k..CW) in England.

\section{The Time.}

Louge floureth moft commonly in Iuly and Augurt.

\section{The $\mathrm{T}$ amcs.}

It is called in Latine Lenifticm: and by fome, Liguficum: of other fomc, Silcr montanum, but not truly: in High Dutch, Litfors kel: in French, Liuifche: in Low Dutch, lata Hetre : in Englifh, Lonage.

\section{वा $T$ ' he Nature,}

This plant is hot and drie in the thisd de. gree.

\section{The Yeriues.}

The roots of Loulage are very gcod for all inward difeafes, driuing away inrofities or windineffe, efpecially of the ftonacke.

1 he feed thereof warmeth the formack,telpeth digeftion; wherefore the people of Gennes in times paft did vfe it in their meates, as wce doc pepper,according to the tertimonie of Ant. CXufa.

C The diftilled water of Lonage cleareth the fight, and putceth aw ay all fpots, lentils, freckles, and redneffe of the fac c, if they be often wafhed therewith.

t The Ggure which was here was of che Siler moneman, or seffi off iviuerkmo

\section{C на P. 393. Of Cow Parrnep. \\ If $T$ be Defcription.}

$\mathrm{T}$ His plant Sphiondylium groweth in all Countries, and is knowne by the name of wilde Parfnep or Sphondylium, whereunto it effectually anfwereth, both in his gricuous and ranke fauour, as alfo in the likeneffe of the root, wercupon it was called sphoxdyliwm; and of the Germanes, Acanthus, but vntruly :the leaues of this plant are long and large, not much valike the leaucs of wilde Parfnep, or Panax Heracieum; deepely notched or cut about the edges like the teeth of a faw, and of an ouerworne greene colour. The floures grow in tufts or rundles, like vnto wilde Parfneps: the root is like to Henbane: this herbe in each part thereof hath an euill fauour, and differeth from the right Acantbium, not onely in faculties, but enen in all other things.

$$
\text { T The Place. }
$$

This plant growerh in fertile moift medowes, and feeding paftures, very commonly in a ll parts of England, or elfewhere, in fuch places as I hatue trauelled.

sphondylium foureth in Iunc and Iuly.

$$
\text { IT The Time. }
$$

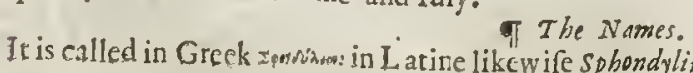




\section{† Sphondylium.}

Cow Parfnep.

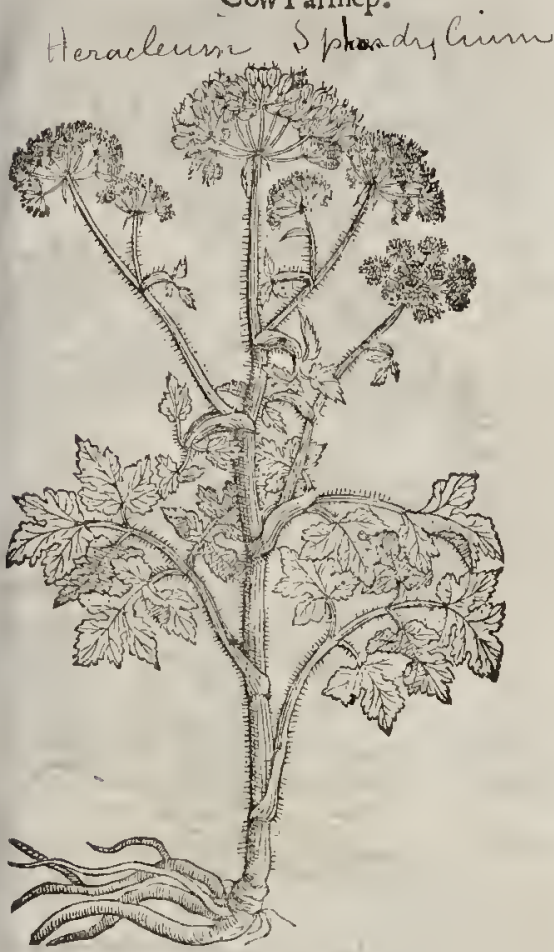

many Branca vrfina, who vnaduifedly in times palt hauc vfed it in clyfters, in ftead of Brancke Vrfine, and thcreupon lazic named it 2Bstuclaw: in Englith, Cow Parfinep, ms. dow Parfnep, and Madncp.

$$
\text { of The Nature. }
$$

Cow Parfnep is of a manifent warm $\mathrm{cmm}$. plexion.

\section{The Fertucs.}

The leaues of this plant do crinfume and diffoltic cold fivellings if they be bruifed and applied thereto.

The people of Polonia and Lituania ufe to make drinke with the decoetion of this herbe, and leuen or fome other thing made of meale, which is vfed in Atead of beere and other ordinarie drinke.

The feede of Cow parfnep drunken, fcoul- C reth out Hegmaticke matter through the guts, it healeth the iaundice, the falling fickneffe, the ftrangling of the mother, and them that are fhort winded.

Alfo if a man be falne into a dead ncepe, $D$ Or a $f_{w} O_{\mathbf{l}}$ ne, the fume of the feed will waken him ag a ne.

If a $\mathrm{p}^{\mathrm{i}}$ hrenticke or melancholicke mans head bee annointed with oilewherein the leaues and roots haue beene foddèn, it helpeth him very much,and fuch as be troubled with the head ache and the lethargie, or fickneffe called the forgetfull etill,

\section{CHA P. 394. Of Herbe Frankincenfe. \\ If The Defeription.}

$x$ Here hath beene from the beginning diuers plants of fundry kindes, which men baut termed by this glorious name Libanot is, onely in refpect of the excelleni and frestane f mell which they hate yeelded vnto the fences of man, fomewhat refembling Frank ir cenfe. Tlee fent and fmell Diofcorides doth afcribe to the root of this fir? kindc, which bringeth forth a long ftalk with ioints like Fennell, whereon grow lcanes almolt like Clcruill or Henilocks, fauing that I they be greater, broader, and thicker : at the top of the ftalkes grow fpok ie tafels bearing whitith floures, which do turne into fweet fmelling feed, fomewhat flat, and almo it like the feed of Arigeli$\mathrm{ca}$. The root is blackewithout, and white within, hairic aboue, at the parting of the root and t talke like vnto Mesm or Pencedanum, and fatoreth like vhro Rofine, or Frankincenfe.

2 The fecond kinde of Libanot is hath alfo a ftraight ftalkc, full of knots and ioints: the lcatics are like vnto Smallage : the floures grow in taffels like vnto the formcr, and bring forth great, long and veucin feed of a tharpe tafte: the root is like the former, and fo is the whole plant very like, it leffer.

3 The third kinde of $L i b$ won is differeth fomerv hat from the others in forme and ficipe, yet is agreeth with them in fmel l, which in fome fort is like Fran'sinfence: the leaues are whiter, longer, and rougher than the leates of $S$ mallage: the ftalks do grow to the heighe of two cubits, bearing at the top the frokie tufts of Dill, fonewhat yellow : the root is like the frimer, but thicker, nei-

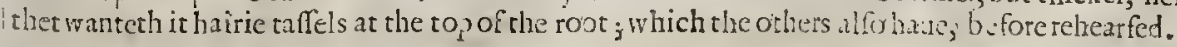


I Libanot is Theophraftimaior.

Great herbe Frankinfence.
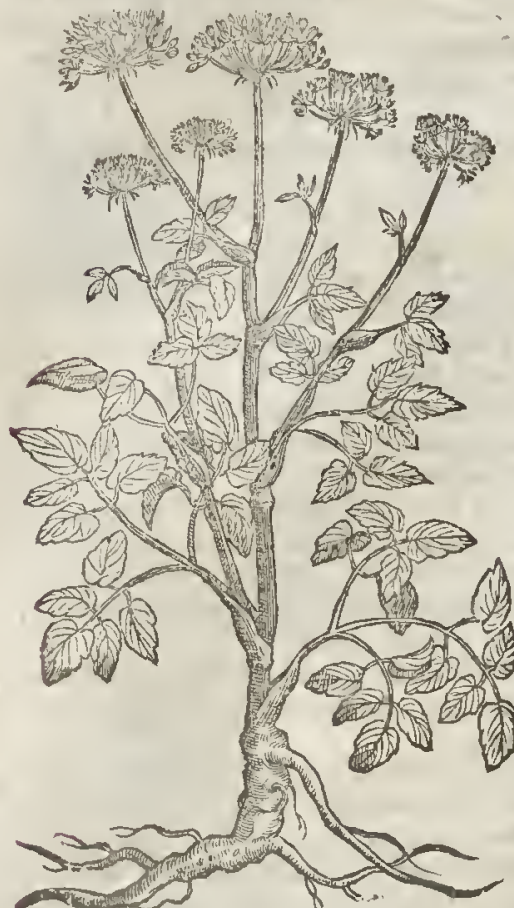

2 Libanot is Theophraftinigra. Blacke herbe Frankinfence, Siansticum Corvaria.

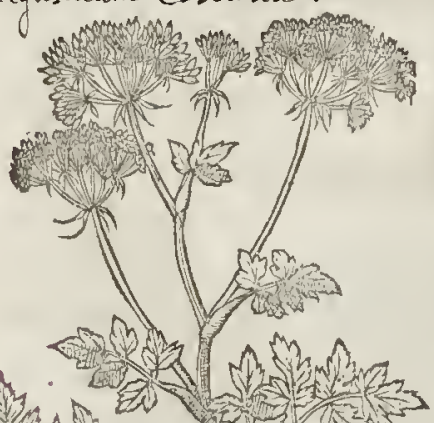

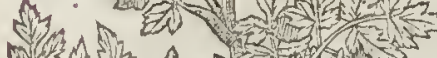

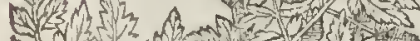

(M)

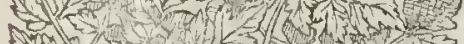

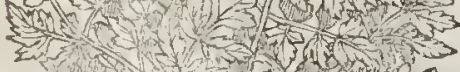

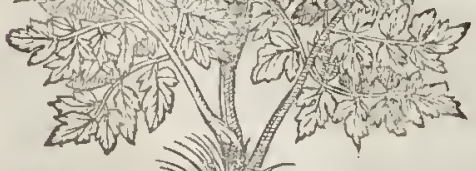

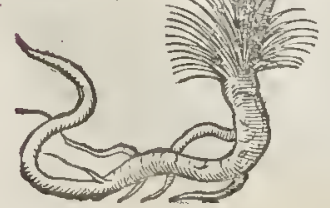

2 Libanot is $T$ beopbraftiminor. Small herbe Frankinence.

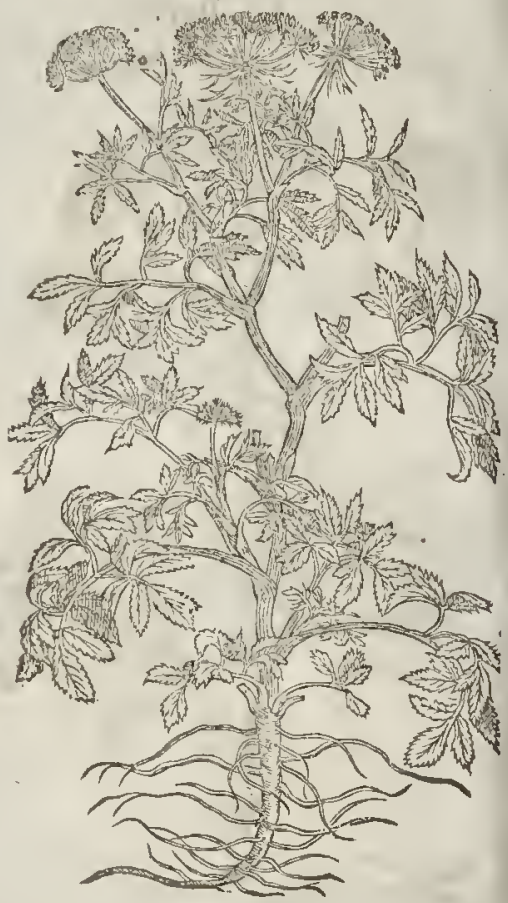

4'Libanotis Galeni, Cachrys verior: Rofemaric Frankincenle.

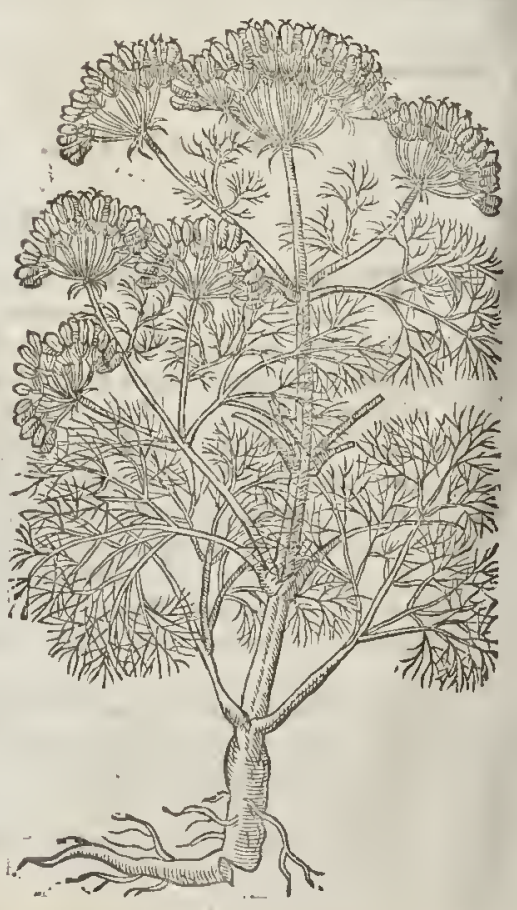


4 I cannot finde among all the plants called Libanosides, any one more agreeable to the truc and right Libanot is of Diofcorides than this herbe, which arifeth vp to the height of fiuc or fix cubirs with the electe fhining ftalks. of Ferula; diuiding it felfe from his knottie ioints into fundryarms or branehes, fet full of leaues like Fennell,but thieker and bigger, and fatrer than the leaues of $C_{0-}$ tula fatida, of a grayion greene colour, bearing at the top of the ftalks the tufts of Ferula, or racher of Carrots, full of yellow floures:which being paft there fueceedeth long flat feed like the feed of the Afh tree,fmelling like Bofin, or Ftank ineenfe,which being chewed filleth the mouth with the taft of Frankineen fe, but tharper : all the reft of the plant is tender, and fomewhat hot, but not vnpleafant : the plaut is like vnto Ferula, and aboundeth with milke as Ferula doth, of a reafonable gocd faubur.

$$
\text { 9 The Place. }
$$

I haute the two laft kindes growing in my garden; the firft and leeond gtow vpon the high Deferts and mountaines of Germanie.

Thefe herbs do floure in Iuly and Auguft.

$$
\text { I The Time. }
$$

The Names.

This hetbe is called in Greeke cisurn', beeaufe their roots do fmell like ineenfe, whieb is eal led in Greekexicxor : in Latine, Rofmarinus; the firft may be Englifhed great Frankincenfe Rofe. marie; the fecond fmall Ftankineenfe Rofemarie; $M^{5}$. Lite ealleth the third in Englih, blacke Hart-root; the fourth white Hart-root : the feed is ealled Cachrys or Caxchrys.

$$
\text { T) The Nature. }
$$

Thefe herbes with their feeds and roots are hot and dtie in the feeond degree, and ate of a dige fting, diffoluing, and mundifying qualitic.

The Vertucs.

The leaues of Libanot is pounded, ftoppe the fluxe of the Hemothoides ot piles, and furple $t$ ? fwellings and in flammations of the fundament ealled Condilomata, concost the fwellings of th throat called Strum, and ripen botches that will hardly bee brought to fupputation or to ripe neffe.

The iuice of the leaues and roots mixed with honie, and put into the eies, doth quicken the fighr, and clecreth the dimneffe of the fame.

The feed ming led with honic,doth feoure and clenfe rotten vleets, and being applied vntocold r: and hard fwellings confumeth and wafteth them.

The leaues and roots boiled vntill they be foft, and mingled with the meale of Datnelland vineget,aflivageth the paine of the gout, if they beapplied theteto.

Moteouet being receiued in wine and pepper,it helpeth the iaundice, and ptouoketh fweat, and being put into orle and ved as an ointment, it eureth ruptures alfo.

It purgeth the difenfe ealled in Greeke A, sos : in Latine, Vituligo, or Impetigo, that is, the white fportines of the skin, ehaps, or rifts in the palms of the lands and foles of the fect,and by your patienc coufin german to the fcab of Naples, tran fported or trans ferted into Franee, and prettily well fprir kled oucr our Northern coafts.

When the feed of Libanot is is put intoreecits, you mutt vnderftand, that it is not meant of the feed of Caehris, becaufa it doth with his tharpeneffe exafperateor make rough the gullet ; for it bath a vety heating qualitie, and doth drie very vehemently,yea this feed being taken inwardly, o: the herbe it felfe, caufeth to purge vpward and downewatd very vehemently.

\section{C.на г. 395. Of Corianders:}

$$
\text { If The Defeription. }
$$

I THe firft or common kinde of Coriander is a very ftinking herbe, fmelling like the ftin king wormecalled in Latine Cimex : it hath a round ftalke full of branches, two foor long. The leates are of a faint greene éolour, very much cut ot iagged : the leaues that grow loweft, and fpring firft, are almolt like the leaues of Cheruill or Parley, but thofe which come forth afterwatd, and grow vpon the ftalks, aremore iagged, almoft like the leaues of Fumitorie, though a great deale fmaller, tenterer, ${ }_{3}$ and more iagged. The floures are $w$ hite, and do grow in round taffels like vnto Dill. The feed is round, bollow within, and of a pleafant fent and fauour when it is drie. The toot is hard, and of awooddie fub tance, which dieth when the fruit is ripe, and forverh ir felfe 
from yeare to yeare; whereby it mightily increaferh.

1 Coriandrum.

Coriander.

Coriandrum sotivam

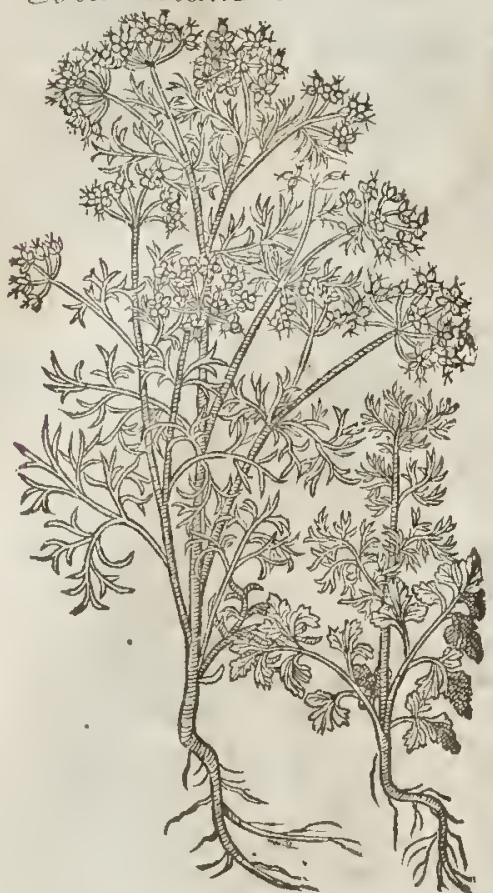

₹ 2 Coriandrum alterum misus odorum: Baftard Coriander.

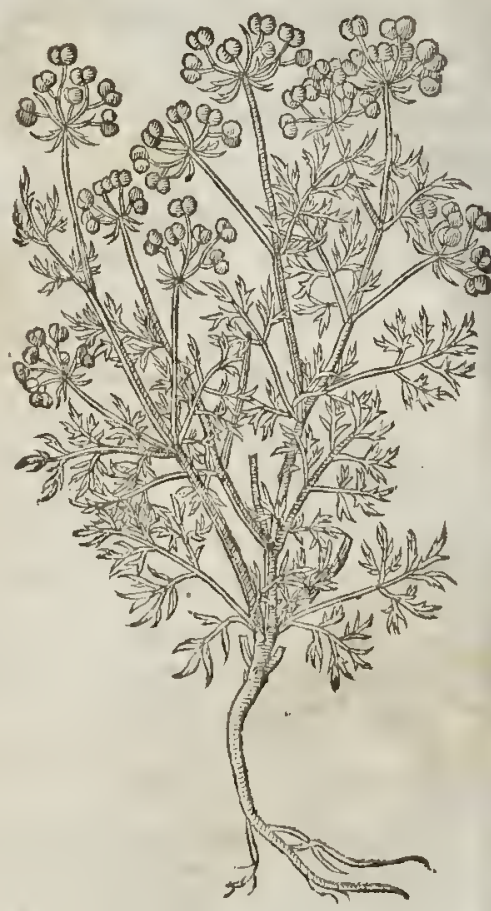

2 There is a fecond kinde of Coriander very like vnto the former, fauing that the bottome leaues and ftalks are fmaller:the fruit thereof is greater, and growing together by couples, it is nor fo pleafant of fauour no tafte, being a wilde kinde thereof, vnfit eitherfor meat or medicine.

I The Place.

Coriander is fowne in fertile fields and gardens, and the firt doth come of it felfe from time to time in my garden, though I neuer fowed the fame but once. if The Time.

They floure in Iune and Iuly, and deliuer their feed in the end of Augun. The fir is The Names. rum,wilde Corianders.

The greene and finking learesof $\mathrm{Co}$ ot The Temperature. vnwholefome and hurffull to the body.

The drie and pleafant well fauouring feede is warme, and very conmenient to fundrie purpofes.

A Coriander feed prepared and couered with fugar, as comfits, taken after meat clofeth vp the mouth of the ftomacke, ftaieth vomiting, and helpeth digeftion.

B The fame parched or roited, or dried in an ouen, and drunk with wine, killeth and bringeth forth wormes, floppeth the laske, and bloudy flix, and all other extraordinarie iffues of bloud.

\section{The maance how to prepare Coriander, both for meat and medicine.}

C Take the feed well and fufficiently dried, whereupon poure fome wine and vineger, and fo leaue them to infufe or fteepe foure and twentic houres, then take them forth and drie them, and keepe
them for your vfe. D The greene leaues of Coriander boiled with the crums of bread or barly meale, confimeth all 
hot fivellings and infammations : and with Beane meale diffolucth the Kings euill, wens; and hard lumpes.

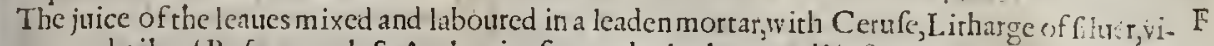
neger, and oile of Rofes, eureth $S$. Anthonies fire, and taketh away all inflammat ions what foctier.

The juice of the greene Coriander leaues, taken in the quantitic of foure dragmes, killeth and $G$ prifoneth the body.

The feeds of Cotiander prepared with fugar, preuaile much againft the gour, raken in fome $H$ fmall quantitic before dinner vpon a fafting ftomacke; and after dinuer the like without drinking immediately after the fame, or in three or fourre houres. Alfo it the fame be taken after fupper it pretaileth the more, and hath more fuperiority ouer the difeafe.

Alfo if it be taken with meate fafting, it eatfeth good digeftion, and hutteth vpthe ftonselie, I keepeth away fumes from rifing vp out of the fame : it taketh away the founding in the cares, drieth vp the rheume, and eafeth the fquinancy.

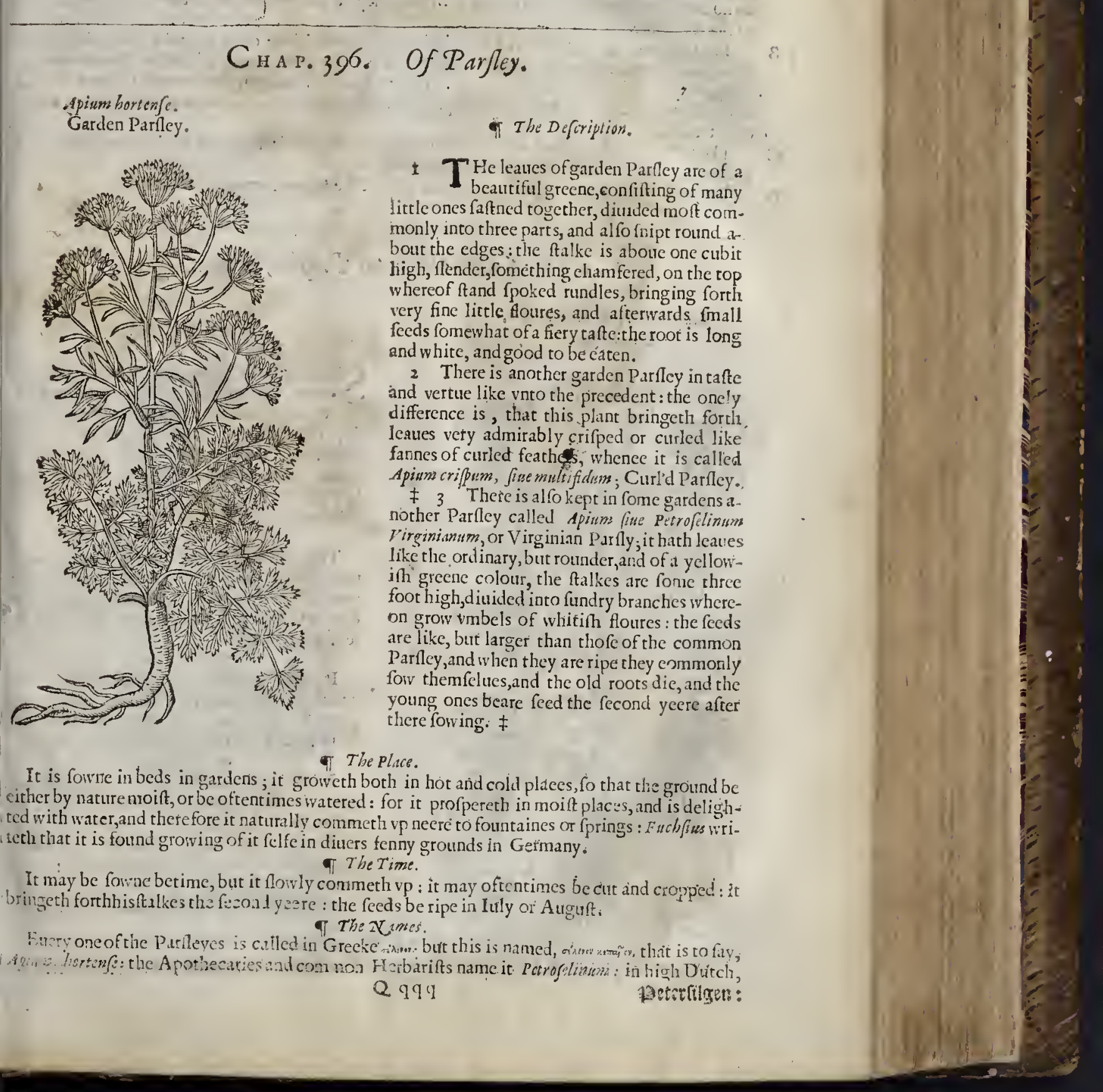




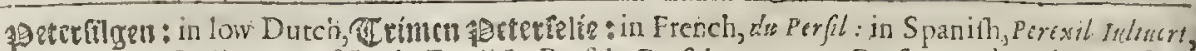
and $S_{a l f a}$ : in Iralian, Petrofello in Englith, Perfele, Parfely, conmon Parfley, and carden Parncy. Yct is it not the rrie and right Petrcfelmm which grow eth a mong roekcs and ftones, whereupon it tooke his name, and whereot the bctk is in Macedonia: thcreforc thcy are dec siued who rhinkc that garden Parlley doth not differ from ftone Parfley, and that sthe onely difference is, for that Garden Parlley is of leffe force than the wilde; for wilde herbes are more if rong in operation than thofe of the garderi.

$$
\text { 9i The Temperature. }
$$

Garden Parfley is hot and dry, but the feed is more hot and dry, which is hot in the fecond degree,and dry almoft in the third : the root is alfo of a moderate heatc.

$$
\text { q: The vertaes. }
$$

A The leaues arc pleafant in fauces and broth, in which befides that they give a pleafarit tafte, they be alfo fingular good to takc away ftoppings, and to pronoke vrine:which thing the roots likewife do norably performe if they be boiled in broth: they be alfo delightfull to rhe tafte, and agrecable to the ftomacke.

B The fceds are more profitable for medicine; they makc rhinne, open, prouoke vrine, diffolue the ftone, breake and wafte aw ay winde, are good for fich as hatc tise dropie, draw downe menfes, bring away the birth, and after-birth : they be commended alfo againft the cough, if they be mixcd or boiled with medicines made for that purpofe : laftly they refift poifons, and therefore are mixed with treacles.

C The roots or the feeds of any of them boiled in ale and drunken, caft forth itrong tenome or poifon, but the feed is the ftrongeft part of the berbc.

D They are alfo good to be put intoclyfters againit the ftone or torments of the guts.

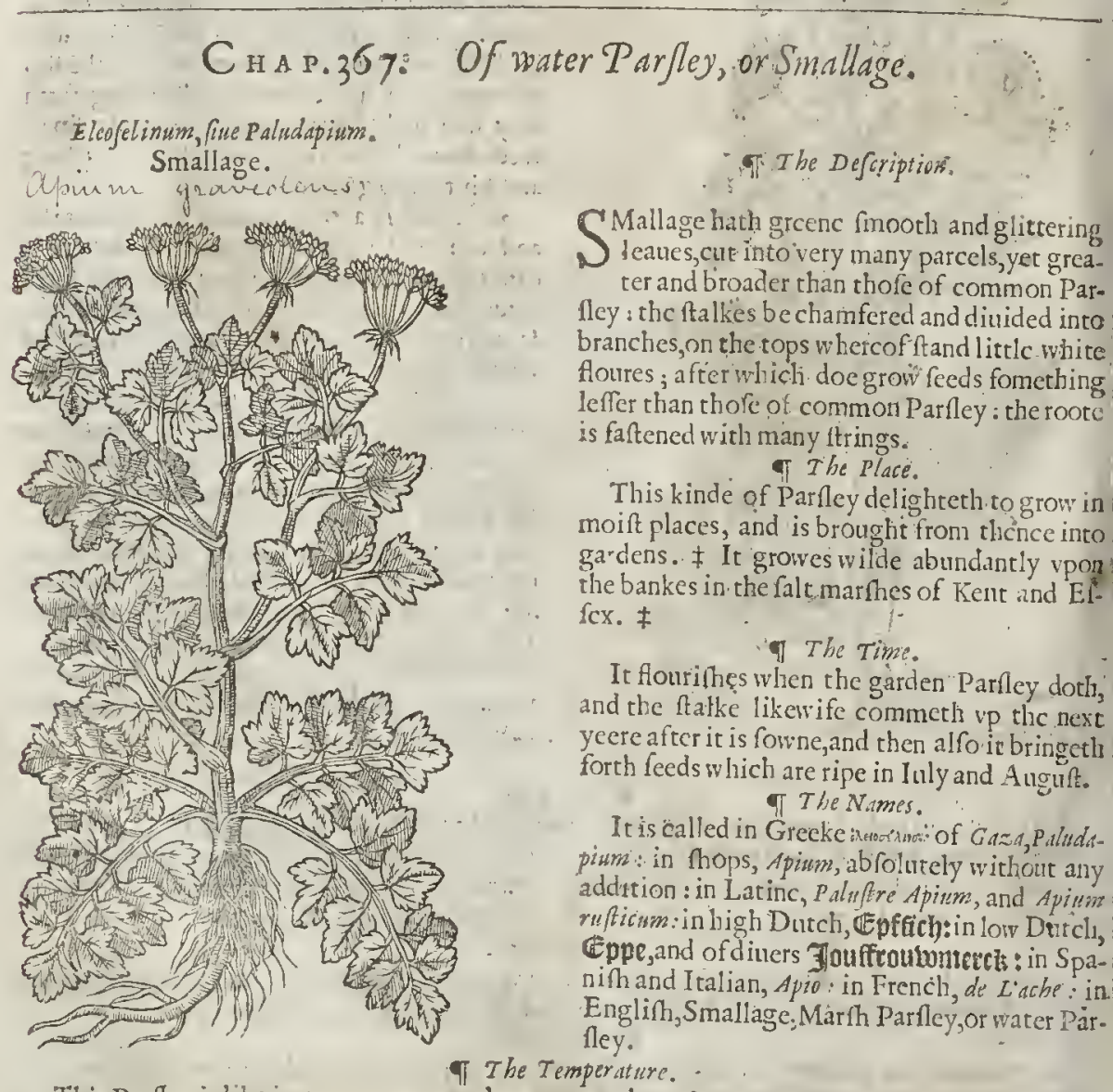

Tlin Parfley is like in temperature and -vertues to that of the garden, but it is both hotser and drier, 
driet, and of more force in mott things: this is feldome eaten, neither is it comnted good for fauee, but it is very profitable for medicine. .:

$$
\text { का The Vériues. }
$$

The juice thereof is good for many things, it clenfeth, openeth, attenutet or makeri thin; it remooueth obftuctions, and prouoketh vinie, and therefore thore fy rrups which hauc this mixed with them, as that which is called syrupus Bizinutinus, open the ftoppings of the liucr and fplecne, and ate a temedy for long lafting agues, whether they, be tertians or quartains,and all other which ptoceed both of a cold caufe and al fo of obftuctions ur floppings, and are very good againftcthe yellow jaundife.

The fame juice doth perfectly cute the malicious and venomousvlcers of themouth, and of the $B$ almonds of the throat with the decoction of Barly and $\mathrm{Mcl}$ Rof arim, or hony of Rofes aulded, if the parts be wafhed therewith : it likewife helpethall outward vlcers and foule wounds: with liony it is profitable alfo for cankers exulcetated; for al though it cannot cure then, yet it doth keep them from purtrifation, and prefenth them from ftinking : the feed is good for chofe things for which that of the Gatden Parley is: yet is not the vfe thereof fo fafe, for ic hurteth thofe that are troubled with the falling fickeneffe, as by euident proofes it is very wellknowne.

Smallage, as Pliny writeth; hath a pectisiar vertue againft the biting of venomous fiders.

The juice of $S$ mallage mixed with hoiy and beane floure, doth nake an excellent mundifica- 1 titu for old vlcers and malignant fores. and ftaieth alfo the weeping of the cut or hurt fincwes in fimple membets, which are not very fatty or flefhie, and bringeth the fane to perfes digeftion.

The leaues boiled in hogs greata, and made into the forne of a pultis, take away the paine of $E$ felons and whitlowes in the fingers, and ripsti and healethem.

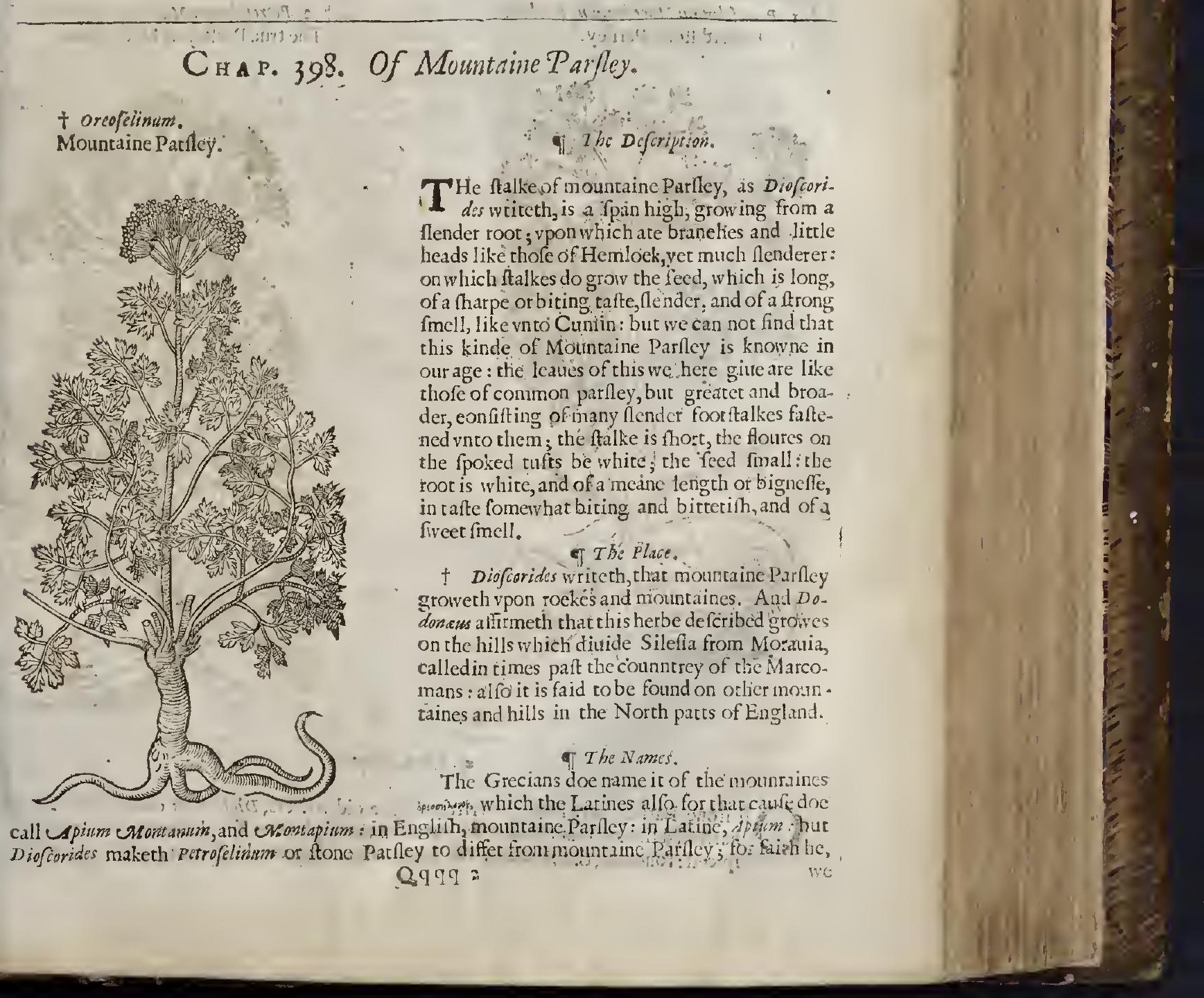


we mut not be deceitted, taking mountaine Parfley to be that which groweth on rockes : for rocke Parflcy is another plant, of fome it is called, Jeflgutta : in Latinc, Citultitona, (in Engli(h, much good: ) for it is fromamed becaufe it is good, and profitable for many things : and this is not altogether unproperly terned Orefelinum, or mountaine Parfley; for it groweth as we hauc faid on mountaines, and is not unlike to ftone Parfley : the feed is not like to that of Cumin, for af it were fo: who would deny it to be oreofelinum, or Diofcorides, his mountaine Parley.

The Temperature and Vertues.

A orcofelinum, or mountaine Parfley is, as Galen faith, like in faculty unto Smallage; but more effeEtuall; Dioforides writeth that the feed and root being drunke in wine prouoke vrine, bring downe the menfes, and that they are mixed with counterpoifons, diuteticke medicines, and medicines that are hot.

B The root of $V$ eelguita, or much good, is alfo hot and dry, and that in the later end of the fecond degree, it maketh thin, it cutte th, openeth, prouoketh, breaketh the ftone and expelleth it,openeth the ftoppings of the liuer and fpleene, and cureth the yellow jaundife:being chewed it helpeth the tooth-nch, and bringeth much water out of the moutl.

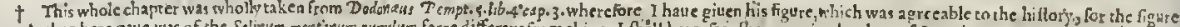

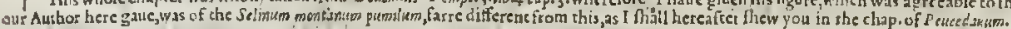

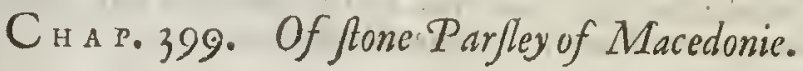

f $x$ Petrofelinum Macedonium, Fuchsiy. Baftard ftone Parliey.

Sison Amomurine:
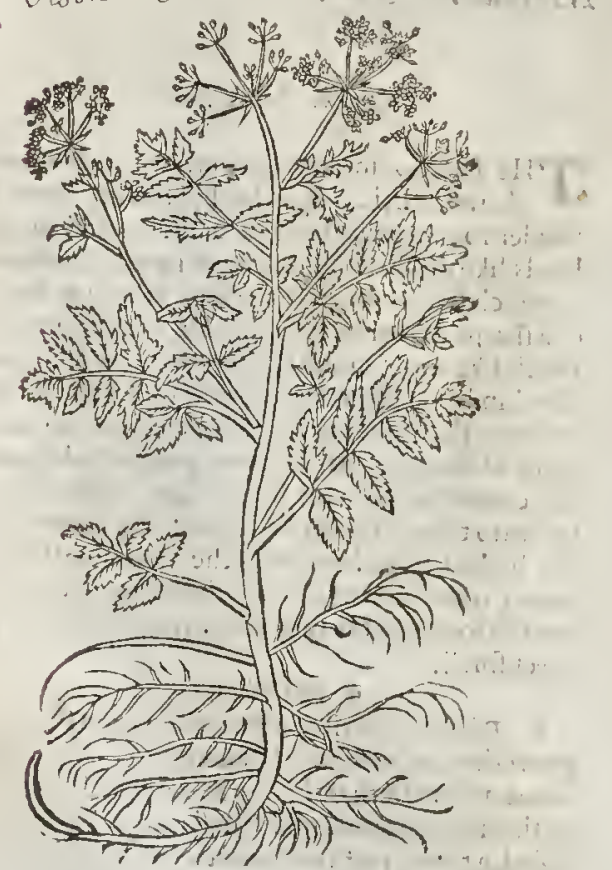

T. The Defription? t 2 Petrofelinum Macedonicum verum. The true Parfley of Macedonia.

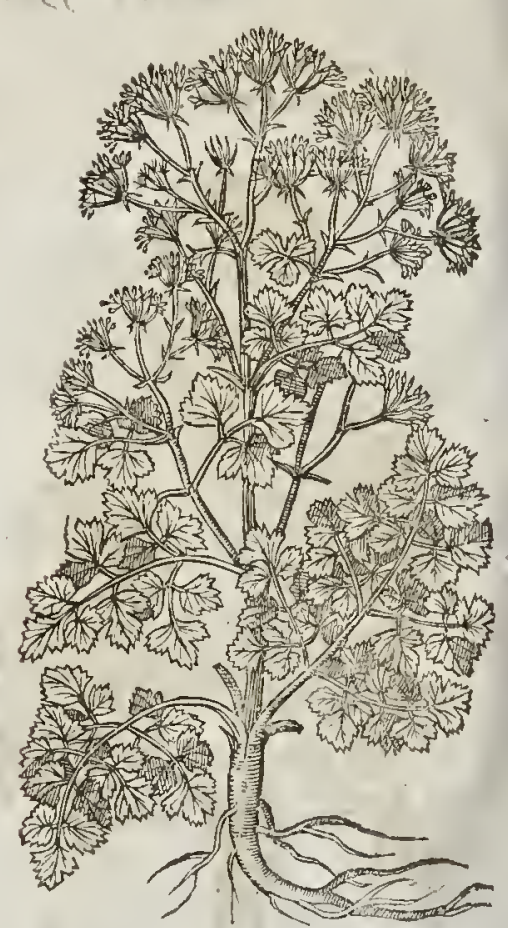$$
\text { , Tr. The Defrription. }
$$

$\mathrm{O}$

F ftone Parfley very little is written of the old writers, Diofcorides onely faith that this hath feed likc to that of Lmes; bur of a more pleafant fmell, fharpe, aromaticall, or fpiced : touching the forme of the leaues, the colour of the floures, and fathion of the 
root he writcth nothing at all : and Pling is more briefe; as for Thcopbraftus he doth no: 5o much as name it,making mention oncly of Parfley, A lexander, Smallage, and noustaine Parfley.

F For ftone Parfley Leonhartus Fuchfisus hath fet down a plant, hauing leaues not fpred and cut after the manner of garden Parfley, but long, and fripped round about, made vp and faftened to a rib or ftem in the midnt,fomething like, but yet not altogether, to the firft laanes of the lefter Saxifrage; the ftalke is flender, and a cubit and a halfe high; the floures on the fpokie tufts are white: the feed fomething blacke, like to that of A meos, and g,arden Parlley, very fweet of fmell, fomething tharpe or biting : the root is flender and full of itings.

2 Lobil alfo in ftead of the right ft one Parfley defcribeth anothet, which the Venetians call ftone Parley of Macedonia this hath leanes like thofe of garden Parfley,or rather of the Venetinn Saxifrage which is the blacke herbe Frankincenfe formerly deferibed : the ftalke is a cubit high the fpokie tufrsfomething white: the feed fmall, quickely vading (as he faith) inferiour to thit of garden Parfley in tempetature and vertues:but whether this be the true and right ftone Parfley, he
addetli, he is ignorant.

$$
\text { Tा The rlace. }
$$

It groweth on craggy rocks, and among ftones: but the beft in Macedonia, whercupon it beareth the furname Macedonicum, of Macedonia.

It finureth in the fommet moneths.

$$
\text { Tा The rime. }
$$

If The Names.

It is called in Greeke, msoidren, of the ftony places where it groweth : in Latine, Petrapium, and Petroflinum Macedonicum: in Englim, ftone Patfley: the Apothecaries know it not : they are farre deceiued that would hate the hetbe which Fuchfins piqureth to be Amomum : for Amomum differeth from this, as it is very plaine by the defeription theteof in $D$ tofcorides : but we hold this for the true ftone Parfley, till fuch time as we may leatne fome other more like in leaues to the Patflies, and in feed, fitch as that of ftone Parfley ought to be : and the very feed it felfe may caufe is to hold this opinion, being fo agreeing to the defeription as no herbe more; for it is fharpe and biring, and of a fweetet fmell than is that of Ameos, and of a more fpicy fent; yet do not the ?eaues. gainefay it,which though they haue not the petfect forme of other Parfleyes, yet notwith ftanding

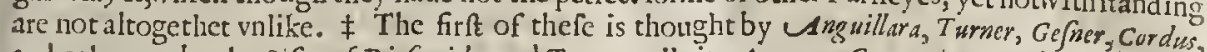
and others, to be the Sifon of Diofcerides, and Tragus calls it, Amomum Germanicum, and the feeds in fhops retaine the name of $s \mathrm{~cm}$. Amomi. The fecond is thought by Columna to be the fecond $D_{\text {anu. }}$ cus of Diofcorides. $\neq$

The feed of ftone Patlley which is moft commonly vfed, is hot and dty, hauing withall a cutting quality.

T The Vertues.

It prouketh vrine, and biingeth downe the floures $:$ it is profitable againft winde in the ftomacke, and collicke gut, and gripings in the belly: for it is, as Gulen faith, ftet or confumer of winde : it is a remedy againft paine in the fides, kidnies, and bladder, it is alfo
mixed in counterpoifons: $D$ iofcorides.

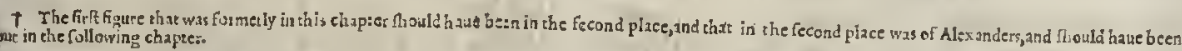

\section{‡ CHa p. 400. Of Carne Tarlley, or Hone-wort.}

\section{T. The Deforiptios.}

$\mathrm{T}$

${ }^{-1}$ His herbe commeth vp at the firt from ieed like Purflev, with two fmall Long narrow Ieaues, the next that fpring are two fmall round fmooth leaues nickt about the edges, and fo for two or three couples of leanes of the next growth there are fuch round leaties growing on a middle rib by couples, and one round mne, alfo at the top; after as more leates fpring vp, fo the falI thion of them alfo change, that is to fay,etrery leafe hath about eight or nine fmall fimooth greene leates, giow ing on each fide of middle rib one oppofite againft another, and one growing by it felfeat the top, and ate fincly finipt or indented about the edges, in forme refenting thofe of Siumodoratsm Trazi, but not fo bigge, long, or at all brownih, among ft which rife vp nuany fmall round ftraked ftalkes or branches, about two foot long, now and then aboure twenty from one root, fonstimes frowing vprighr, fometimes crceping not farte from the ground, joynted or kneed, 


\section{\# Selizsum Sö folïs.} Honewoott.

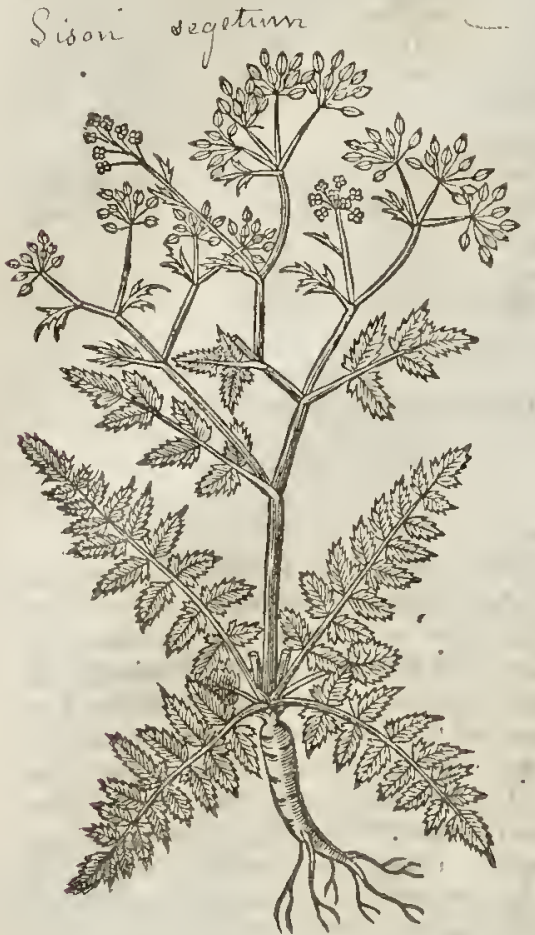

and diuiding thentelues into vety many branches, at euery joynt groweth one liate fmaller than the former, which together with the lowermoft perifh, fo that thue is feldome one greene leafe to be feen on this herbewhen the feed is ripe; the fouires are white, and grow moft sommonly at the tops of the branches, fometimes at molt of the joynts euen from the carth, in uneuen or vnorderly vmbells, cuery floure hauing fiuc exceeding fmall leaues, flat, and broud at the toppe, and in the middle very frnall cheiues with purple tops, the whole foure ror much cxcecding the bigneffe of a fmall pins head, which being pate there conmeth vp in the place of enery floure two fmall gray crooked ftraked feeds, like Parfley feeds, but bigger, in tafte hot and aromaticall. The roo is fmall and whition,with many threds not fo big as Parlley roots. It beginneth to floure about the beginning of Iuly, \& fo continues flouring a long time; part of the feed is ripe in Augurt, and fome farre in the beginning of October, mean while fome falleth, wherby it renueth it, felfe, and groweth with flourlfhing greene leaues all the winter.

I tooke the defcription of this herbe the yeere, 1620. but obferted it long before, not knowing any name for it : firit I tefeted it to Sium, calling it, Sium terreftre, and sium $c_{6-}$ getum of agrorum; afterwards vpon fight of Selinum peregrinum primum clufil, which in fome tefpects refembleth this herbe, I named it Selinum Sijfoliy; yet wanting an Englifh name, at length about the yeere 1625.I faw Miftris Vrfula Leigh(then fertuant to Miftris Bilfon of Mapledurham in Hampfhite, and now (5. Marcï 1632. wife to Mafter William Mooring Schoolemater of Petersfield, a Towne neere the faid Mapledurham) gathet it in the wheate ermes about Mapledurham aforefaid (where in fuch like grounds it ftill groweth,efpecially in clay grounds) who told me it was called Honewott, and that her Mother mift tis Cbaritie Leigh late of Brading in the Inte of Wight deceafed, taught her to vfe it after the mannet heere expreffed, for a fwelling which thee had in her left cheeke,which for many yeeres would once a yere at the leaft arife there, and fwell with great heat, redneffe, and itching, vatil by the vfe of this herbe it was perfectly cuted, and rofe no more nor fwelled, being now (5. Martï 1632) about twenty yeeres fince, only the fcar remaineth to this day. This fwelling her mother cal led by the name of a Hone, but asking whether fuch tumors werein the faid Ine vfually called Hones the could not tell, by reafon theewas broughe from Brading afotefaid young, and not being aboue twelue yeeres old when thee vfed this medicine.

$$
\text { it The vertues. }
$$

A Take one handfull of the greene leaues of this Honewort, and ftampe tbem, put to it about halfe a pinte or more of becre, itraine it,and drinke it, and fo continue to drinke the like quantity euery morning fatting till the fwelling doth abate, which with or in hetwas performed in the fpace of two weekes at the moft. Auguif, 18.1620. Iobn Goodyer: ¥

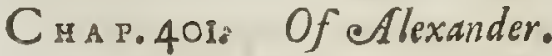

Tf The Defription.

$\mathrm{T}$

He leaues of Alexander are cut into many pateells like thofe of Smallage, but they be nueh greatet and broader, fmooth alfo, and of a deepe greene colour : the ftalke is thicke, oftentimes a cubit high: the floures be whitc, and grow vpon fpokie tufts : the feed is thicke, 
long, blacke fomething bitter, and of an aromaticall or fpicy fmell : the roor is thicke, blacke whout, whitewichin, like to a little Radifh,and is good to be caren.out of which beins brhlien or sut, there iffterh forth a juice that quickely waxeth thicke, hauing in it a tharpebittcrncffe like in tafte vnco Myrrhe : which thing allo Theophraftus hath noted, rhere iffueth our of it, faith be, a juice like Myrrhe.

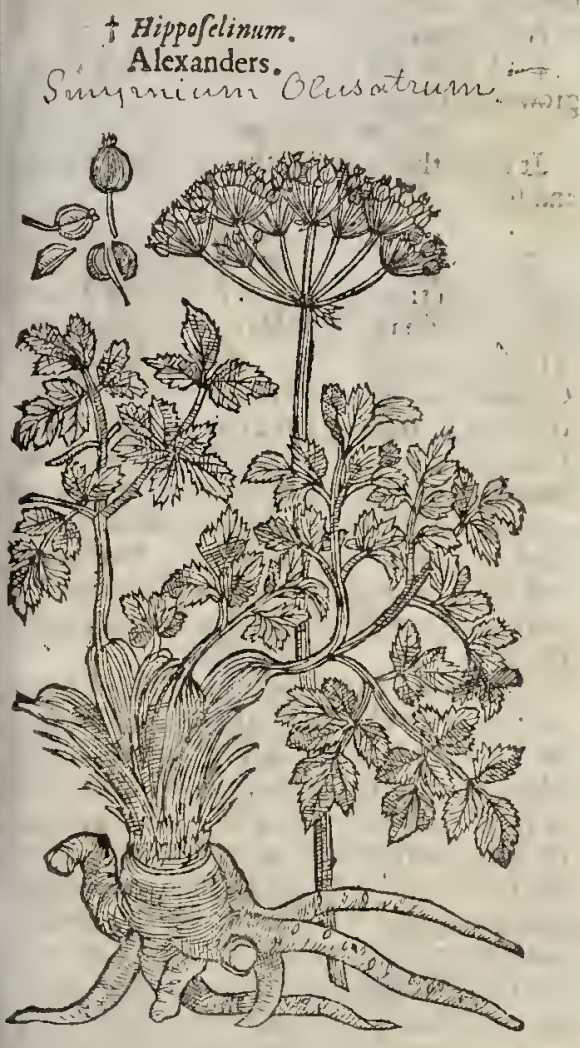

I The Place.

Hippojelimum.

anciuna Ocusatrume.

The Viertues.

Diofcorides faith, that the leatues and ftalkes are boiled and eaten, and drefled alone by themfelues, or with fines: that rhey are preferued raw in pickle: that the roor eaten both raw and fod, is good for the ftomacke: the root hereof is alfo in our age ferued to the table raw for a fallade

The feeds bring downe the floures, expell the fecondine, breake and confume winde, prouoke mine, and are good againft che ftrangury the decoction alfo of the root doth the farie, efpecially if it be made with winc.

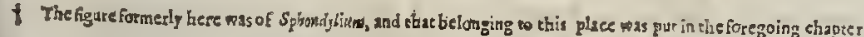

A lexanders or gteat Parfley groweth in

The feed waxeth ripe the fecond yeere, in the Moneth of A uguft.

It is called in Greeke, of the greanneffe wherein, it excellerh the orher Parlieyes in $\pi_{000}$ : wion, or Horfe Parlley; of Gn?a, Equapium : it is alfo named olsus atrum, or the blacke potPare; and of diuers sylueftre Apium; or wilde Darney; of Galen and certainc others, qui syser, by that is, as we have faid, like vnto Myrrhe, which is called in Greeke omportor: there is alfo another Smyrnium of mount Aman, of which we dow rite in the 404.chapter: the Aporhecaries cal it Petrofelinam Macedonicum : others, (tho Germaines, ecelelie ban 9 acedonion: in Spanifh, Pcrex. if Macedonico : the French, and Englifhmen, Alexandre,Alexanders.

The feed $8 x$ root of A lexanders, are no leffe loo and dry than are thofe of the Garden Pardey, they clenfe and make thinne,being hot and dry in the third degree.

\section{B}

\section{TI The Defcriptiox.}

$T$ His is like to the kindes of Parleyes in the fundry cuts of rhe leaues, and alfo in the bignelfe for they be broad and cue into diuers parcels : the ftalkes are round, chamfered, fet with cer: taine joints, hollow within, a cubit high or higher, two or three comming forth together out of one roor, and in the nether part many times of a darke reddifh colour. The floures be white, and grow vpon fpokie turfs : the feed is round, flat, like rhat of Dill: the roor is white within, and diuided into many branches and ftrings. Thisplane in whas part foeter it be cut or broken, yeeldeth forth a milky juice, 


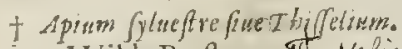

Wilde Parfley. Shyselinum palustre: Systiveg. Sch". of The Plice.

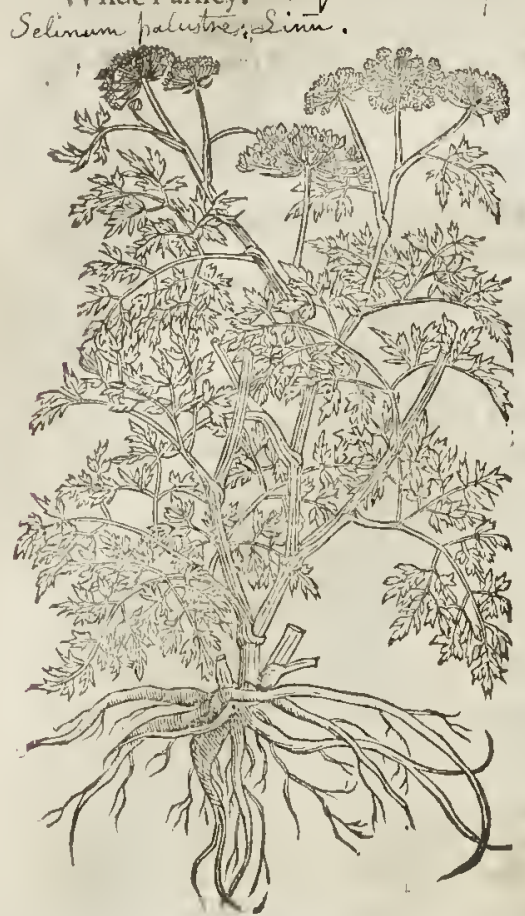

It is found by pords fides in moift and cian. kith plaees, in dicles alfo, hauing in them ftanding waters and oftentinucs by oid ftoches of Alder trees.

$¥$ I haue not as yet obferued this plant growing wilde with vs. $\neq$

$$
\text { - The Time. }
$$

It fourcth and brirgeth forth feed in Iuse and Iuly.

$$
\text { बI Tlie Nature. }
$$

'The 1 ops of the Low countrics haue mifcalled it in times patt by rle name of $M \mathrm{cum}_{\text {, }}$ and wed it for the right Mcri, or Spikr el wort. The Germaires name it Dlfenith: Valeriws Cordus,olfnichim : diuess in t:e Low Countries call it miloe efppe: that is to lay in Latine, Apir myluflre, or wilde Pat 1 ey :and fcme, loater $\mathbb{E}$ ppe: that is, Hydofelinch, Or Uprnm aquatile, water Parfley : ar doftcntimes is itramed, aswe have alrcady written, Elcofelinim, and Sium. It may be more rightly termed in Latine, Apism fylucftre, and in Englifh, wilde Parlley.

Drofcorides hath made mention of wilde Parley in the chapter of $D$ asum or wilde Car-

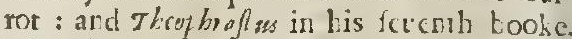
where be maketh the Parfeyes to differ bot in leaucs and falkes, and ficwcth that fome haue white ftalkes, others purple, or elfe of fundry colours, and that there is alfo a certainc wilde Parley; for he faith that tl ofe which haue the purple ftalkes, and the falkes of diuers colours, come ncerelt of all to the wilde Parfley. And therefore fecirg that olfcrichism, or wildc Parfley, hath the lower part of the ftalkenf a purplith colour,and like in Jcaues ro Parflcy, which in times palt we thought good rather to call Apium fylueftre, or wilde Parfey, than to erre with tle Apcthecaries, and to take it for Mew. And after when we now krow rlat it was licld to be 7 by felium plit. miy, and that we could alledge nothing to the contrary, we al fo fetled cur felwes to be of theiropinion; and rhe rather, beeaufe the faculties are agrecable. Thyffelium, faith Pliny, h6. 25. chaprer 1 I. is not valike to Parflcy : the root hereof purgeth flegme out of the hrad; which thing alfo the root of olfcnichum doth effectually performe, as we will forthwirh deelase. The name alfo is agreeable, for it feemeth to be called swinem, becaufe it extendeth it felfe, in Greeke, rian, tharow Desious, or marifh places.

The root hereof is hot and dry in the third degree.

$$
\text { T The Temperature. }
$$

$$
\text { T The Vertues. }
$$

A The root being chewed,bringeth by the mouth flogme out of the head, and is a remedy for the toorh-ach, and there is nodoube but that it alfo makes thin, eutreth and openeth, prot ok eth vrine, and bringeth downe the floures, and doth likewife no le? ?e but more effectually per forme thofe things that the reft of the Parfleyes do.

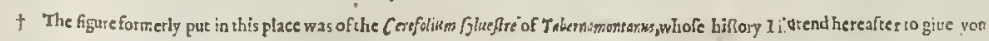

\section{C н А Р. 403. Of baftard Parfley. \\ The Defcription.}

1 He firft kinde of baftard Parfley is a rough hairy herbe, not much volike to Carrots: the leaues are like tothofe of Corianders, but parted into many fmall jagges :at the top of the branches do grow hadowie vmbels, or fpokic ruadles, confifting of many fmall white 
I Caucalis albis floribus.

Baftard Parfley with white flourcs.

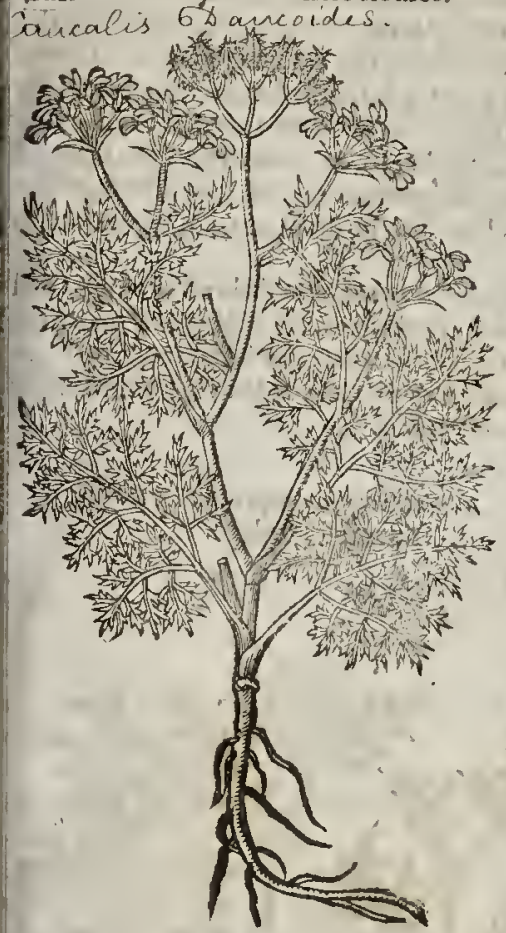

\section{* 36 ausalis Peucedang follo: Hogs Parlley}

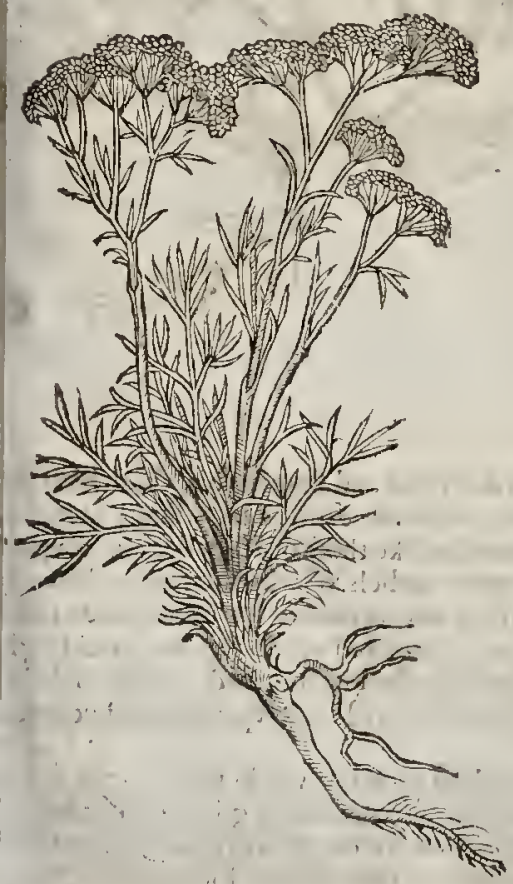

¥ 2 Caucalis diy foliys flore rubro. Bafard Parlley with red Houres.

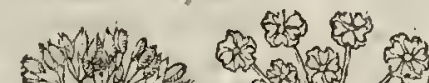

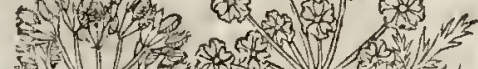
政

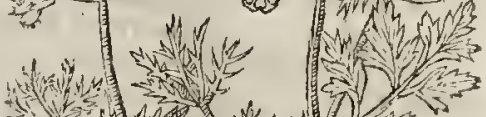

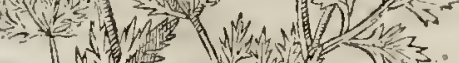

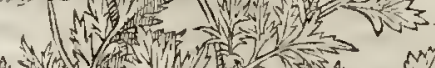

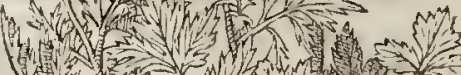

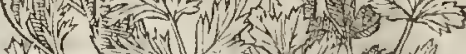
Silu $\Rightarrow 1$ man

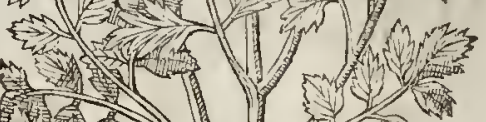

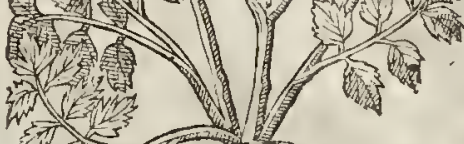

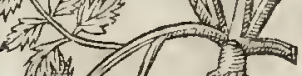
证 vi a d on

$\$ 4$ Casucalis maior Cluf. Great rough Parfley.

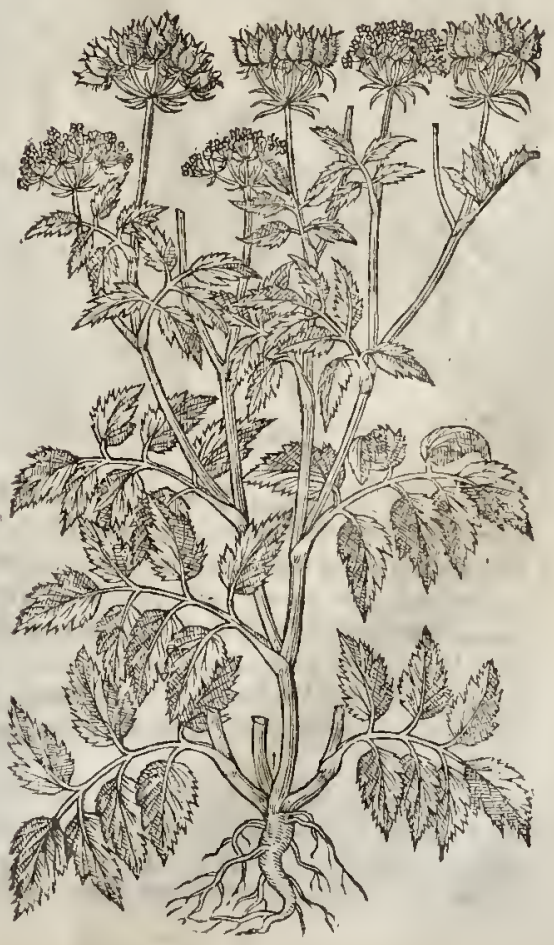


floures : the feed is long and rough, like the feed of Carrots, but greater : tle scot is f raight and fingle, growing deepe into the ground, of a white colour,and in tafte like the Parfiep. ' Utu. 2 There is another fort like vnto the former, fauing that the leaues tliteol ate bioader, and the floures are of a reddifh eolour: there hath great controuer fie rifen about the true determiration of Caucalis, beeaufe the Latine interpretation of Diofcorides is greatly fuffeed, ecresning in it felfe mueh fuperfluous matter, not pertinent to the hiftory : but wee decme that this plant is the true Caueales, the notes fer downe deelare it fo to be : the floures, faith he, are reddifh : the fecus eoucrca with a rough buske fet aboutwith priekles, which eleaue vnto garments that it toucheth, as doc Burs;whleh roughneffe being pilled off, the feed appeares like vnto hulled Otes, rot inpleafant in tafte, all which do thew it tobe the fame.

3 There is likewife another fort that hath a long fingle root, thrummed about tievereret with many thrummy threds of a browne eolour : from which rifcth vp diuers ftalkes full of joynts or knees, eouered with a fheath or skinnie filme, like vnto that of $M$ cum : the leaties are fincly eut or jagged, refembling the leaues of our Englim Saxifrage:the floures grow at the top of the falke in fpoky rundles like Fennell : the feed is fmall like that of Parfley.

₹ 5 Cascalis minor fof culis rubentibus. Hedge Parlley.

$$
\text { Canioulis Unthriscus }
$$

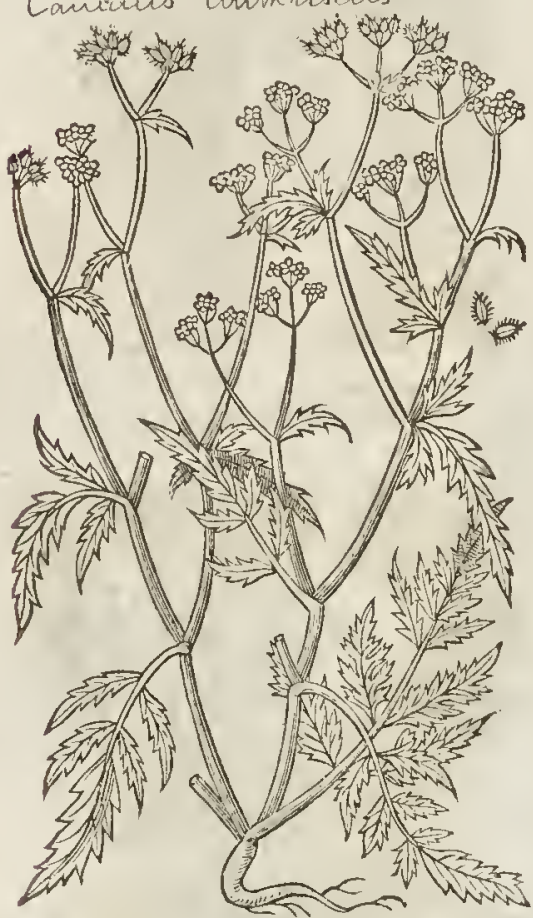

₹ 6 Caucalis nodofacchinoto fermine. Knotted Parley. 
Smyrnimm Creticum.

Candy Alexander.

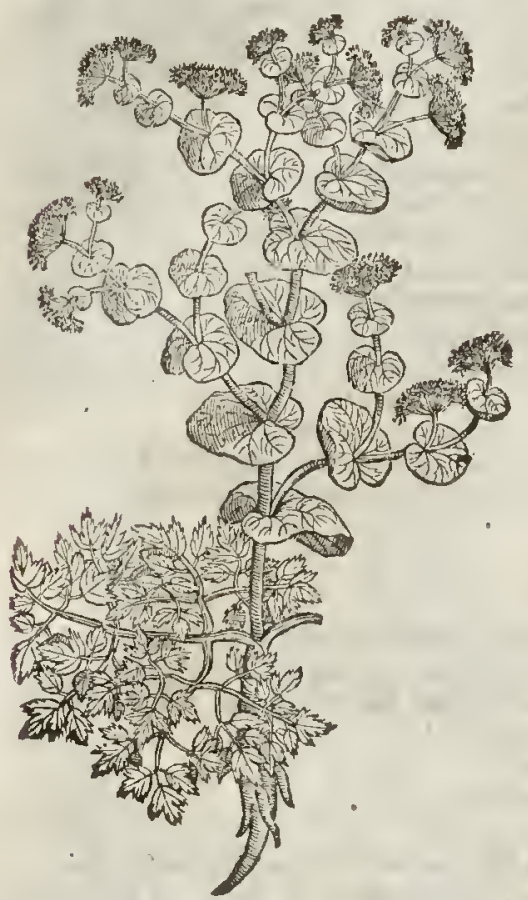

at the top of the ftalkes doe grow round ffokie tufts of a yellow eolor, after which com meth round and blacke feed like Coleworrs, of a tharpe and bitter tafte like Myrrhe:the root is white and thiekc, contrary to the (1pinion of Dodosans, who faith it is blacke without,but I fpeake thatwhich I haue feen and prooued.

$$
\text { q The Place. }
$$

Smyrnium groweth naturally vpon the hils and mountaines of Candy, and in my garden alfo in great plenty:alfo vpon the mountain Amanus in Cilicia.

$$
\text { 9 The Time. }
$$

Smyrnium floureth in Iune, and the feed is tipe in Auguft.

$$
\text { 9) The Numes. }
$$

This plant is called in Latine, smyrnitum. in Greeke, qúprm, in Cilieia, Petrolelinum, and as Galen teftifieth, fome haue called it, Hippofelonum agrefte : in Englioh, Candy Alexaadets, or Ihorow bored Parfley.

$$
\text { 9) The Nature. }
$$

Smyrnium is hot and dry in the third degree.

\section{T) The Vertues:}

The leaues of Smyrnium diffolue wens and hard fwellings, dry vp vlcer's and exeori ations, and glew wounds together.

B The feeds are good againft the ftoppings of the fpleene, kidnies, and bladder.

C. Candy A lexanders hath foree to digeft and waft away hard fwellings, in other things it is like to garden Parfley, and ftone Parlley, and therefore wevfe the feed heereof to prouoke the defired fickeneffe, and vrine, and to helpe thofe that are fuffed in the lungs, as Gales writeth.

D The root is hot, fo is the herbe and feed, which is good to be drunke againft the biring of ferpents : it is a remedy for the eough, and profitable for thofe that eannot take their breath vnlefle they do fit or fand vpright : it helpeth thofe that ean hardly make their water: the feed is good againft the infirmity of the fpleene or milt, the kidnies and bladder : it is likewife a good medicine for thofe that have the dropise, as Diofcorides writeth.

$$
\begin{gathered}
\text { Cina } .405 . \text { Of Parfneps. } \\
\text { The Defription. }
\end{gathered}
$$

I THe leaues of the tame or Garden Parfneps are broad, confitting of many fmall leaucs fattened to one middle rib like thofe of the afh tree: the ftalke is ipright, of the height of a man : the floures ftand vpon fpokic tufts, of colour yellow ; afterwhich commeth the feed fiat and round, greatet than thofe of Dil : the root is white, long, fweet, and good to be cateri.

2 The wilde Parfnep is like to that of the Garden, in leaues, italke, tuft, yellow floures, flat and round feed, but altogether leffer : the root is fmall, hard,wooddy, and not fit to be eaten.

\section{T The Place.}

The garden Parfoep recuireth a fat and loofe earth, and that that is digged vp deepe.

The wilde Parfnep groweth in vntoiled places, efpecially in the falt marfhes, vpon the bankes and borders of the fame : the feed whereof being gathered and brought into the garden, and for ed 
I Paftinaca latifolia fativd: Garden Parfneps.

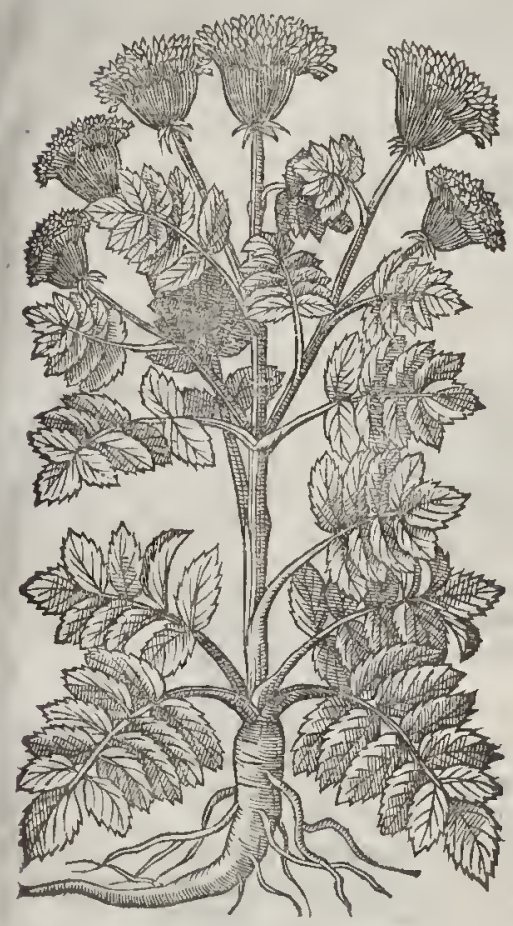

2 Paftinacalatifolia gyluchris.

Wilde Parfneps. Pastinaca sativa

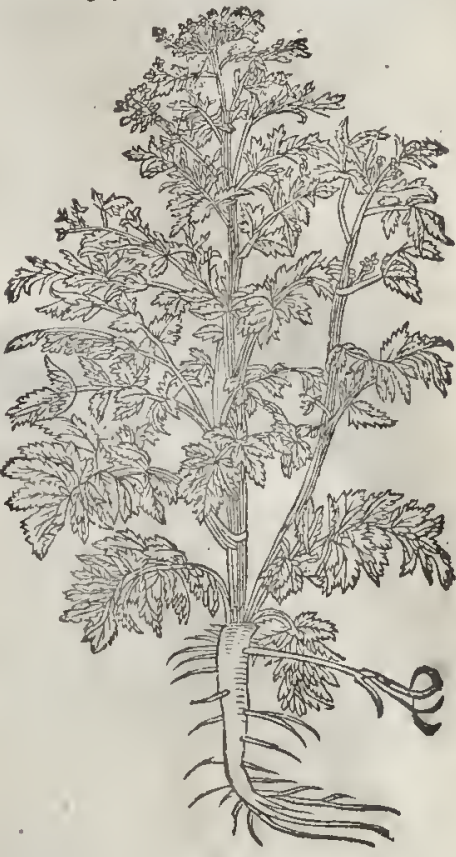
in fertillground, do proue better roots, fweeter and greater than they that are fowne of feeds gathe-
red from thofe of the garden.

They floure in Iuly and Augut, and feed the fecond yeare after they be forne.

$$
\text { T) } T \text { be } 2 \text { ames. }
$$

The Herbarifs of our time do call the garden Parfneps susunivos. and $P_{a}$ ftinaca, and therefore wee haue furnamed it Latifolia, or broad leafed, that it may differ from the other garden Parfnep with narrow leaues, wh ich is truly and properly called Staphylinu, that is, the garden Carrot. Some Phy. fitions doubting, and not knowing to what herbe of the Anticnts it fhould be referred, haue fained the wilde kinde hercof to be $P$ anacis pecies, or a kind of A healc:diuers haue named it Buncia; others, Branca Leonim, but if you diligently marke and confer it with Elaphobofoum of Diofcorides, you fhal hardly finde any difference at all: but the plant called at Montpelier $P$ abulum Ceruinwm: in Englihh, Harts fodder, fuppofed there to be the true Elaphobo foum, differeth much from the true notes thereof. Now Bascin, as Iacobus Manlius reporteth in Luminari maiore, is Divforides, and the old Writers Paftinata, that is to fay, $T$ enuifolia, or Carrot : but the old writers, and efpecially Diofcorides haue called this wilde Parfnep by the name of Elaphobofoum: and wee doe call them Parfneps and Mypes.

The Parfnep root is moderately hot, and moredrie than moi

\section{The Vertues.}

The Parfneps nourih more than doe the Turneps or the Carrots, and the nourithment is fome - $A$ what thicker, bur not faultie nor bad; notwithftanding they be fornwhat windy:they paffe through the bodie neither flowly nor fpeedily: they neither binde nor loofe the belly: they prouoke vrine, and luft of the bodie: they be good for the Atomacke, kidneies, bladder, and lungs.

There is a good and pleafant food or bread made of the roots of Parfneps, as my fricnd $\mathrm{M}^{\mathrm{r}}$. $P$ lat $\mathrm{B}$ hath fet forth in his booke of experiments, which I haue made no triall of, nor meane to do. winde

The feed is hotter and drier euen vato the fecond degree, it moouctli vrine, and confuneth $\mathrm{C}$

$$
\text { RTrs }
$$




\section{Of the Hiftory of Planits.}

D It is reported, faith Diofcoridcs, that Deare are preferued from bitings of Serpents, by eating of the herbe Elaphobof cum, or wilde Parfnep, wherupon the feed is giuen with wine againft the bitings and fingings of Serpents.

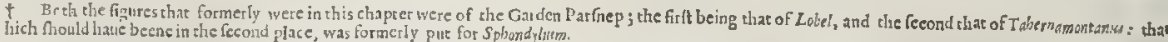

\section{Cin в. 406. Of Skirrets.}

Sifarum. Skirrets.

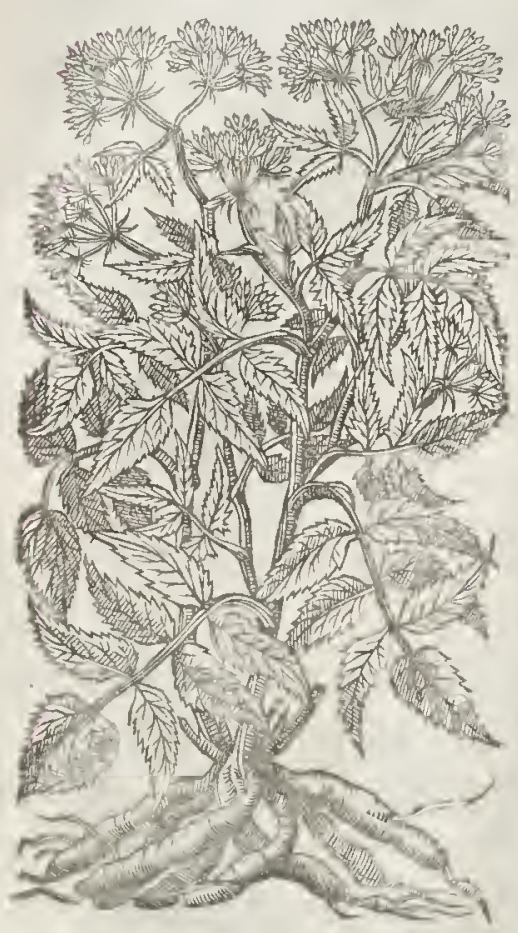

IT The Defcription.

THe leanes of the Skirret do likewife confift 1 of many fmall leaues faftened to one rib, $\mathrm{e}-$ uerie particular one whereof is fomething nic$\mathrm{ked}$ in the edg es, but the y are leffer, greener, and fmoother than thofe of the Parfnep. The falks be fhort, and feldome a cubit high; the floures in the fpoked tufts are white, the roots be many in number, growing out of one head an hand bredth long, moft commonly not a finger thick, they are fwces, whitc, good to be eaten, and moft pleafant in tafte

$$
\text { IT The Place and Time. }
$$

This Skirret is planted in Gardens, and efpe: cially by the root, for the greater and thicker ones being taken away, the leffer are put into the earth againe:which thing is heft to be done in March or Aprill, before the ftalks come vp, and at this timc the roots which be gathered are eaten raw, or boiled.

\section{- The Names.}

This herbe is called in Latin sifarum, and al fo in Greekc orows ; the Latines do likervife call it Sifer; and diuers of the later Herbarifts, Seruillum or Cherwulum, or Seruilla. the Germans name it Sieclin: Tragres, Zaun garten Xapuntielen: in the Low-countries, Supcket woptelen, that is to fay, Sugar roots, and oftentimes $\$$ erilletr: in Spanih, Cherinia: inIralian, $S_{1} \int_{a}$ o: in French, Cheraty: in Englifh, Skirret and Skirwort. And Emperour commanded to be comueied vntolim from is that Sifer or Skirret which Tiberius the
as Pliny reporteth in lib. 19 .cap. 5. The Skirrer is a caftle about the rituer of Rhene, as Pliny reporteth in lib. 19 .cap. 5. The Skirret is a medieinable herb, and is the fame that the forefaid Emperour did fo much commend, infomuch that he defired the fame to be brought vnto him ten in his 8 g. chiapter: for Secacul is defcribed by the fe, Serapio his Secacul, of which he hath writCMatthiolus Syluaticus expounderh it: and it bringerh fore of Iulben, that is to fay, of the peafe, as peafe, full of moifture, and of a fweer tafte, bringeth forth a black fruit of the bigneffe of a Cichthe leafe of the peafe, neither doth it bre, which is called Granum Culcul: But the Skirret hath not nifent, that the Skirret doth very much differ from Serapio his Secacul: fo farre is it from becing the
fame.

\section{Tf The Nature and Vertues.}

A The roots of the Skirret be moderately hot and moift they be eafily concoeted, they nourith meanly, and yeeld a reafonable good iuice : but they are fomething windie, by reafon whereof they
alfo protoke tuft.

They be caten boiled, with vineger, falt, and a little oile, after the manner of a fallad, and often the cooks, wh the tafte of the eater, and alfo dreffed aftet other farhions, according to the skil of 
Thewomen in Sucria, faith Hieronymss Heroldus, prepare the roots hercof for their husbands, and C know full well wherefore and why, \&ec.

The iuice of the roots drunke with goats milke ftoppeth the laske. The famedrunde with wine D putteth away windineffe out of the ftomacke, and gripings of the belly, and helpeth the hicket or yeoxing. They ftir vp appetite, and prowoke vrine.

\section{Cнар. 407. Of Carrots.}

\section{T) The Defcription.}

I He leaues of the garden Carrots are of a deepe g reene colour,compofed of many fine Fennel I-like leaues, very notably cut or iagged; among which rifeth vpa ftalk ftraight and round, foure cubits high, fomw hat hairic and hollow, hauing at the top round fpoked tufrs, in which do grow little whire floures : in cheir places commeth the feed, rough and hairie,of a fweet fmell when it is rubbed. The root is long; thicke and fingle, of a faire yellow colour, pleefant to be eaten, and very fiveer in talte.

I Paftinatca fativatenuifolia. Yellow Carrot.

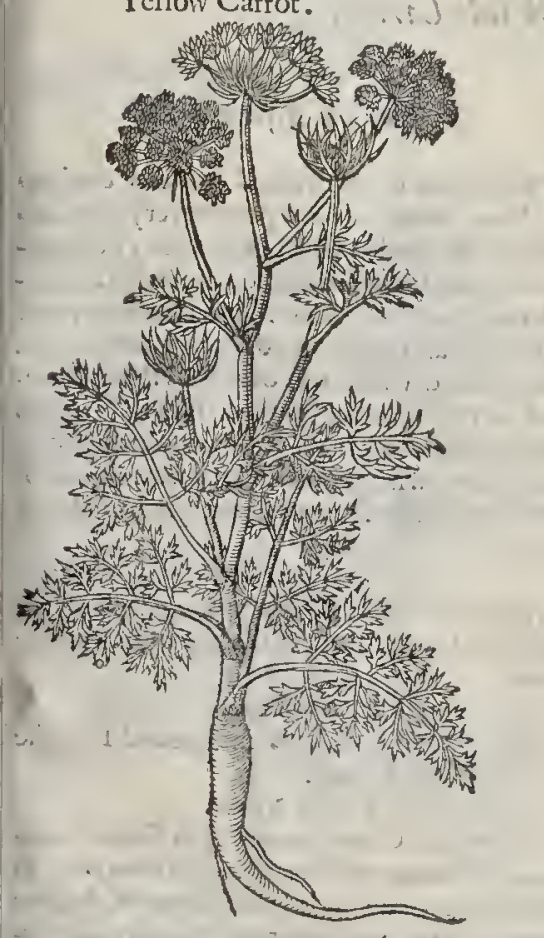

\$ 2 Paftinacajatiua atrourubers. Red Carrot.

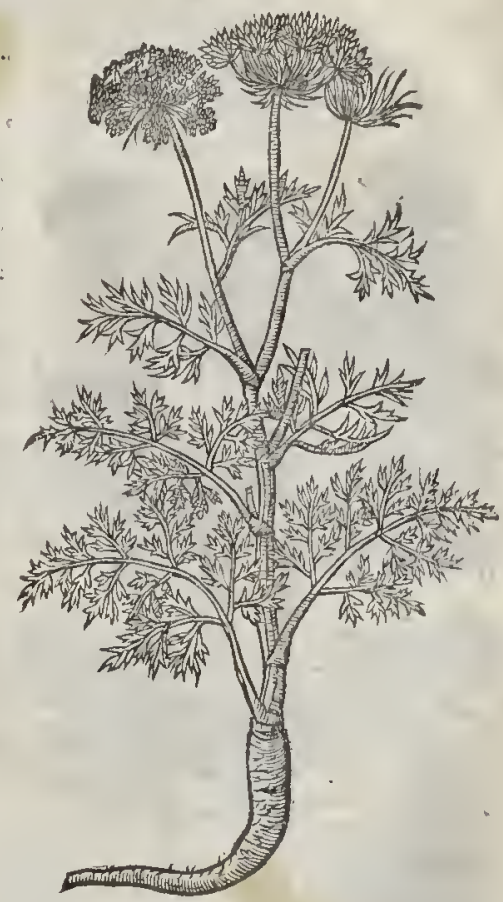

2. There is another kinde hetcof like to the former in all parts, and differeth from it only in the colour of the root, wh ich in this is not yellow, bui of a blackinh red colour.

If The Place.

Thefe Carrots are fowne in the fields, and in gardens where other pot herbes are: they require 2 loofe and vell manured foile.

They are tobe fowne in Aprill; theybring forth their floures and feed the yeare after they be fowne,

The Carrot is properly called in Greeke om of The for that which we have termed in Larine by the 
name of Paftuna lationis foly, or the Garden Parfaep, is defcribed of the old writers by another name:this Carrot is called in Latine likewile, Paftinuta farivn, but with this addition tenuifolia, that it may differ from the garden Pirfinep with broad leaues, and white roots. Theopls ast us in the ninth booke of his biftorie of plants nameth this staphylmus, or Carror, daixos, and writeth that it growcrly in Areadia, and faith that thebeft is found in Spartey? Achaia, but doubtleffe he meant that $D$ aucus which we call Cretch is, that may be numbred among the Carrots : Galen in his booke of the faculcies of Simple medicines doth alfo make it to be Dancus, but yet not fimply Dancus; for he ad.

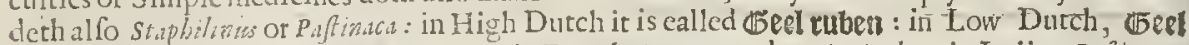

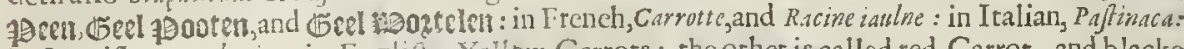
in Spanifl, Camaboria : in Englin, Yallow Carrots : the orher is called red Carrot, and blacke Carrot.

$$
\text { T) The Temperature and Vertues. }
$$

Theroot of the yellow Carrot is moft commonly boiled with fat flefh and eaten : it is tempeA rately hot and fomethng noift. The nourihment whieh eommeth thereof is not mucl, and not veric good : it is fomething windie, but not fo much as be the Turneps, and doth not fo foon as they paffe through thebodic.

$\mathrm{B}$

The red Carrot is oflike facultic with the yellow. The feed of them both is hot and drie, it breas kethand confumetl windineffe, prouoketh vrine, as doth that of the wilde Carrot.

\section{Cha p. 408. Of Wilde Carrot.}

Paftinatat fliteftris tenuifolia.

Wilde Carrot, or Bees-neft.

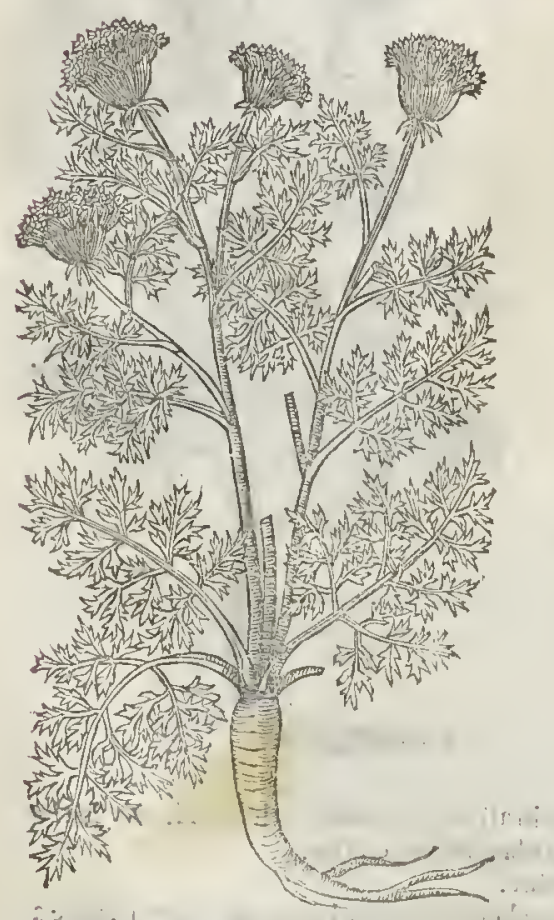

\section{Ti The Defription?}

THe leaues of the wilde Carrot are cut into 1 diuers flender narrow parcëls, very like vnto thofe of the garden Carrots, but they be fornewhat whiter,and more baitic : the ftalks be likewifellairie and fomewhat rough : the floures are little, and ftand vpon broad fpoked tuftes, of a white color, of which tuft of floures the middlemoft part is of a deep purple : the whole tuft is drawn togerther when the feedis ripe, refembling a birds neft; whereupon it hath been named of fome Birds-neft : the root flender, and of a mean length:

$$
\text { I The Place. }
$$

It groweth of it felfe in untoyled places, in fields, and in the borders thereof, almoft euerie where.

$$
\text { - The Time. }
$$

It foures and flourifhes in Iune and Iuly, the feed is ripe in Auguft.

$$
\text { of The Names. }
$$

The wilde Carrot is ealled in Greeke sapurs. yos àpus : in Latine, Paftinacafylucftris tenuifolia: in thops, Darcess : and it is ved in ftead of the true $D$ asers, and net amiffe, nor vnprofitably : for $G a-$ lenalfo in his time doth teftificthat it was taken for Darsus, or baftard Parfly, and is without doubt $D$ awci $y$ lucftris genus, or a wilde kinde of baftard Parfly, fo called of $T$ heophrastus: in high!

Dutch it is named noilo 19 aftenen, dogol neft : in Low Dutch, rogelg neft, and moilde Catoten croolicne ctupt: in Frencl, Paftenade Sauvige: in Englifh, wilde Carrót,and after the Dutch, Birds-tiets, and in fome plizes Bees-nef:

Aibenews eiting Diphilus for Lis Author, faith, that the Carrot is called oinpon, becaufe it ferueth for lone marters; and orphew, as Pliny writeth, faid, that the v fe hereof winneth loue: which things: 
be written of wilde Carrot, the root whereof is more effe etuall than that of the garden, and containeth in it,as Galen faith,a eertaine force to proeure lunt.

T The Tomperature and Vertues.

The feed of this wild Carrot,and likewife the root is hot and drie in the fecond degree, and doth $A$ withall open obftructions.

The root boiled and eaten, or boiled with wine, and the decoction drunke, pronoketh vrine, $\mathrm{ex}-\mathrm{B}$ pelleth the ftone, bringeth forth the birth; it alfo procurech bodily lust.

The feed drünke bringeth downe the defired fickneffe, it is good for them that can hardly make $\mathrm{C}$ water, it breaketh and diffolueth winde, it remediath the dropfie, it eureth the colliek and ftone, be
ing drunke in wine.

It is alfo good for the paffions of the morher, and helpeth coneeption: it is good againft the bi- D tings of all manner of venomous beafts: it is reported, faith Diofcorides, that fueh as haue firft taken of it are not hurt by them.

\section{Cна в. 409. Of Candie Carrots.}

Daurus Cretenfis verus:

Candie Carrots.

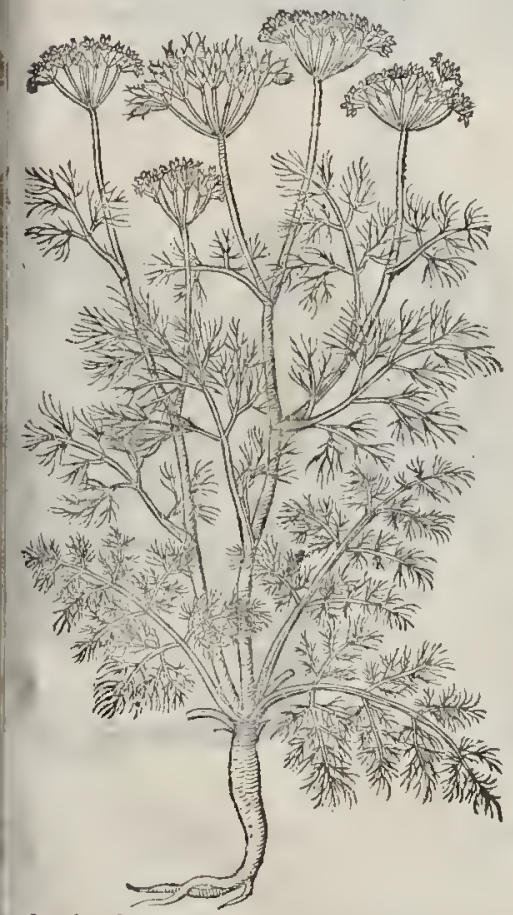

If $T$ be Defoription. the third degree : but the feed of the wilde Carrot is hot and drie in the feeond degre.

His Dancus Cretenfis, being the true Dancus of Diofcorides, doth not grow in Candy only, but is found upon the mountaines of Germany, and vponthe hills and rockes of Iura about Geneua, from whenee it hath beene fent and eonteied by one friendly Herbarift vnto anorher, into fundrie regions: it beareth leaucs whieh are fmall, and very finely iagged,refembling either Fennel or wild Carrot : among which rifeth vp a talke of a cubic high, hauing at the top white fpokie tufts, and the floures of Dill:which being paft, there come great plentic of long feed,well fmelling, not vnlike the feed of Cumin, faue that it is whitifh, with acertaine mofline ffe, and a tharpe tafte, and is in greater ufe than any part of the plant. The roor alfo is right good in medicine, being leffer than the root of a Parfnep, but hotter in tafte, and of a fragrant
fmell.

$$
\text { बा The Time. }
$$

This floures in Iune and Inly, his feed is ripe in Augute.

\section{9) The Names.}

There is fufficient fpoken in the defeription as touching the name.

$$
\text { T) The Nature. }
$$

Thefe plants are hot and drie, efpecially tice The is hot and drie in the feeond degree. The feed of $D$ aucus drunken is good againft the ftrangurie, and painfull making of water, it pre- $A$
uaileth againft the grauell and ftone, and prouoketh vrine.

Itaffwageth the torments and gripings of the belly,diffolueth windines, cureth the collick, and $B$
ipeneth an old congh. Theth an old congh.

poifon.'

The feed of $D$ ancus Creticus is of great efficacic and verune being put into Treacle, Mirhridate, D or any antidotes, againft poifon or péftilenee. 
E The root thereof drunke in wine ftoppeth the laske, and is alfo a foueraigne remedie again fe venome and poiron.

\section{C н A. 410. Of ftinking and deadly Carrots. IT The Defoription.}

I THe great finking Carrot hath very great leaues, fpread abroad likewings, refembling 1 thofe of Fennell gyant (whereof fome haic taken it to be a kinde, but vnproperly) of bright greene colour,fomewhat hairie: among whieh rifeth vp a falk of the height of two cubits, and of the bigneffe of a mans finger; holiow, and full of a fpungious pith; whereupon are fet at certaine ioints, leaues like thofe next the ground, but fmaller. The floures are yellow, ftanding at the top of the ftalkes in fpokie rundles, like thofe of Dilliafter whieh commeth the feed, flat and broad like thofe of the Parfnep, but much greater and broader. The root is thicke, garnithed at the top with certaine eapillaments or hairy threds, blacke without, white within, full of milkie inice, of a moft bitter, tharpe, and lothfome tafte and fmell, infomuch that if a man do ftand where the wind doth blow from the plant, the aire doth exuleerate and blifter the face, and euery other bare or na. ked place that may be fubie et to his venomous blaft,and prifonous qualitic.

I Thap fal latifoiia Cluriy. Stinking Carrots.

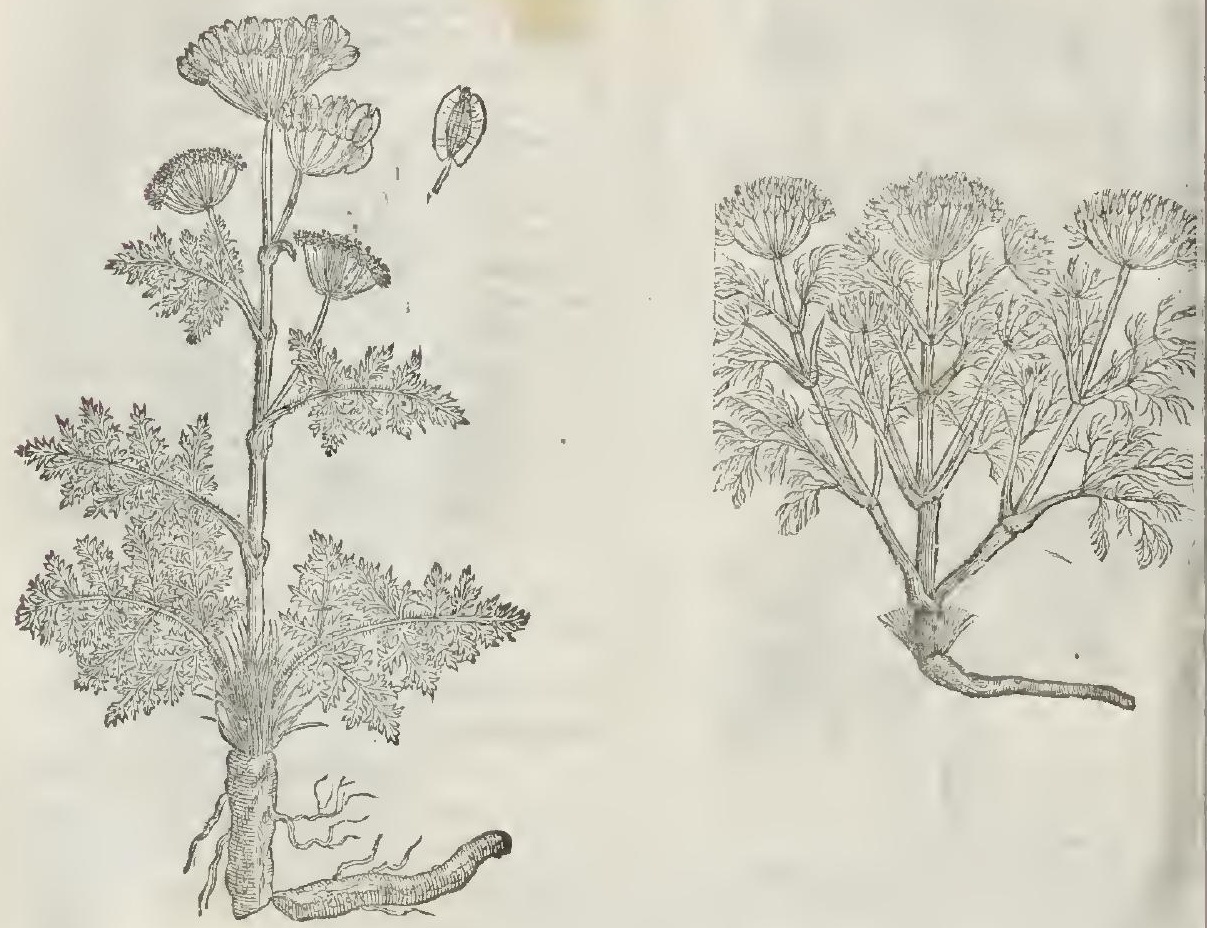

2 Thappiatemifolia. Small leafed ftinking Carrot.

2 This fmall kind of ftinking or deadly Carrot is like to the laft defcribed in cach refpect, fauing that the leaues are thinher and more finely minced or iagged, wherein confifts the difference.

3 The common deadly Carrot is like vnto the precedent, fauing that he doth more necrely refemble the ftalkes and leates of the garden carrot, and is not garnifhed with the like bufh of haire about the top of the ftalks : otherwife in feed,root, and euill fmell, tafte and qualitie like.

ot The Place.

Thefe pernicious plants delight in ftonie hills and mountaines : they are ftrangers in England. 
3 Thapfin vulgaris.

Deadly Carrots.

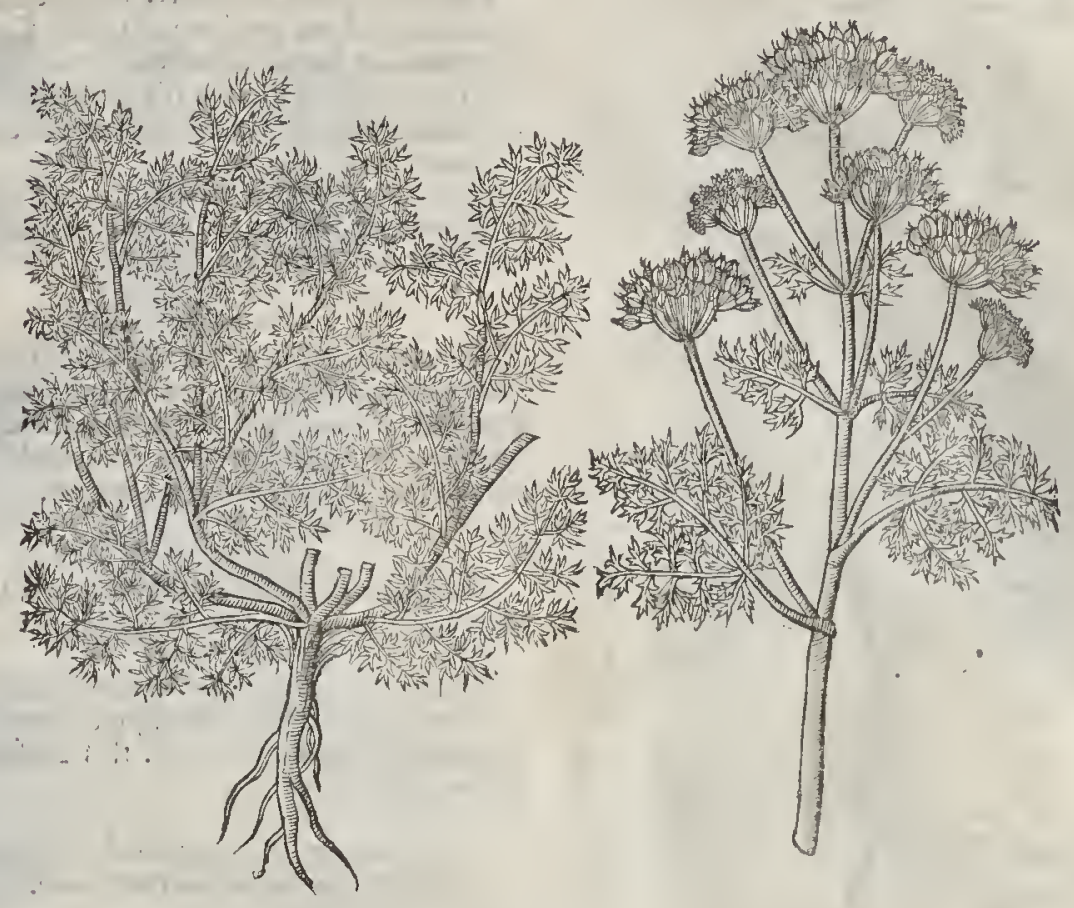

They floure in Auguit, or fomew lut after.

9) The Time.

9. The Names.

The French Phyfitians hane aecepted the root of $T$ hapfia for a kinde of Turbith, calling it $T$ Hr petum Cineritium; notwithtanding voon better confideration they hase left the vfe thereof, efpecially in purging, for it mightily hurteth the prineipall parts, and doth often eaufe enell gripings in the guts and belly, with convulfions and eramps : neuertheleffe the venomous qualitic may bee taken away with thofe eorregtiues which are vfed in mitigating the extreme heate and virulent qualitie of Sarcocolld, Hammoniacum, and Turpetum : but where there be fo many wholefome Simples, and likewife compounds, they are not to be vfed.

Of fome it is ealled Turpetum Grifeum : it is ealled Thapfar, as fome thinke, of the Inand Thap. fus, where it was firft found ; or as we deeme, of the likeneffe it hath with Carrots. Of the people of Sieilia and Apulia it is ealled Ferulacoli, where it doth grow in great aboun-
dance.

$$
\text { 9) The Temperatureandvertues. }
$$

The temperature and faculcies in working haue been touched in the defçription, and likewife in the names.

\section{CHA P. 4II. Of Fennell.}

T) The Defoription.

THe firt kinde of Fennell, called in Latine Faniculum : in Greeke, Meparm, is fo well knowne among ft vs, that it were but loft labour to deferibe the fame.

2 The fecond kinde of Fennell is likewife well knowne by the name of Sweet Fennell, fo cailed beeaufe the feeds thereof are in rafte fweet like vnto Annife feeds, refembling. the common Fennell, fauing that the leaues are larger and fatter, or mote oleous : the feed greater and whiter, and the whole plant in each refpeet greater. 


\section{Of the Hittorie of Plants.}

Foniculum vulyare.

Common Fenuell. Anethum fonculum

A

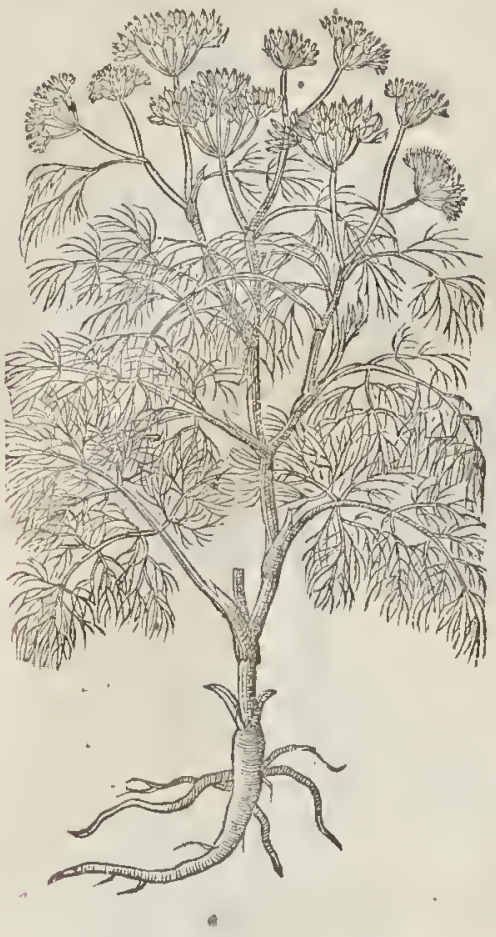

The Place.

Thefe herbs are fet and fowne in gardens; but the fecond doth not profperwell in this Countrey : for being fownc of good and perfect feed, yet in the fecend yeare after his fowing it will degenerate from the right kindc, and become common Fennell.

$$
\text { I T the Time. }
$$

They foure in Ime and Iuly, and the feed is ripe in the end of Augult.

\section{T The Names.}

Fennell is called in Greeke mapastoos : in Latine, cMarathrum, and Foniculum; in high Dutch, fenckell : in low-Dutch, denckell : in Italian, Finocchio: in Spanifh, Hinoio: in French, $F \in$ noil : in Englifh, Fennell, and Fenckell.

\section{Tा The Nature.}

The feed of Fennel is hot and dry in the third degree.

\section{बi The vertues.}

The pouder of the feed of Fennell drunke for certaine dayes together fafting preferuech the cye-fight : whercof was written this Diftichon following:

\section{Feniculus, Rofa, Verbena, Chelidonia, Ruta,}

Ex his fit aqua que lumina reddit acuta.

Of Fennell,Rofes, Veruain, Ruc,and Celandine, Is made a water good to cleercthe fight of eine.

B The grecne leates of Fennell eaten, or the feed drunken made into a Ptifan, do fill womens breftswith milke.

C The deco.tion of Fennell drunke eafetl the paines of the kidnies, caufeth one to autoid the ftone, and prowoketh vrine.

D The roors are as effectuall, and not onely good for the intents aforefaid, but againft the dropfie alfo, being boyled in wine and drunkcn.

E Fennell feed drunke affivageth the paine of the ftomacke, and wambling of the fame, or defire to vomit, and breaketh winde.

$\mathrm{F}$

The herbe, feed, and root of Fennell are very good for the lungs, the liner, and the kidneyes, for it openeth the obftructions or ftoppings of the fame, and comforteth the inward parts.

$G$ The feed and herbe of fireet Fennell is equall in vertues with Annife feed.

$$
\begin{gathered}
\text { Cha P.4L2. Of Dill. } \\
\text { The Defription. }
\end{gathered}
$$

Ill hath a little ftalke of a cubit high, round and ioynted; whereupon doe grow leaues verie finely cut, like to thofe of Fennell, but much fmaller : the floures be little and yellow, ftanding in a fpokic tuft or rundle : the feed is round, flat and thin : the whole plant is of aftrong fmell : the root is threddy.

It is fowne in gardens, and is alfo fometimes found wilde. 
Anethum.

Dill.

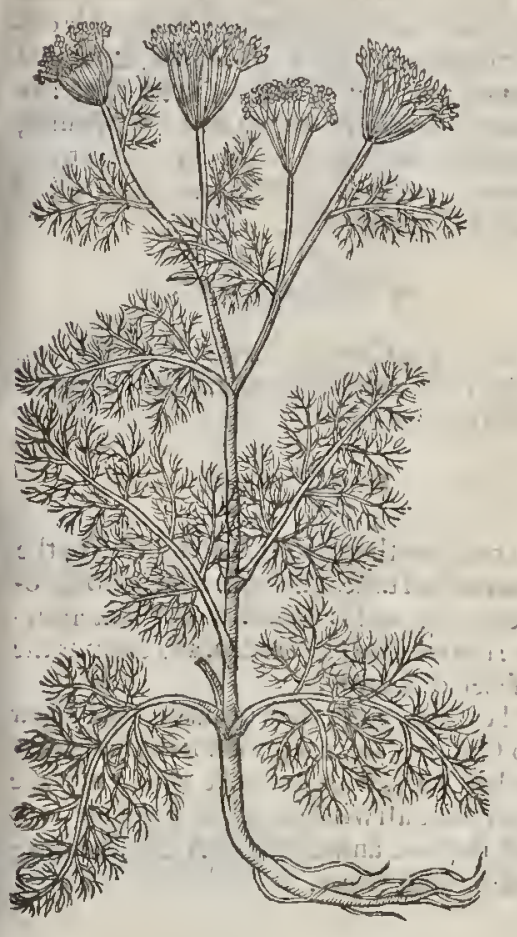

9) The Time.

It bringeth forrh floures and feed in Auguft.

$$
\text { II The Natres. }
$$

Dil is called in Greek Amyg: : in Larine likewife Anetbum, and Anetums : in high-Dutch, Dovllen : in low-Burch, Doille : in lralxan, Anetho: in Spanifh, Eneldo: in French, Aret: in Englin, Dill, and Aner.

$$
\text { of The Temperature. }
$$

Dill, as Galen fairh, is hor in the end of the fecond degree, and dry in rhe beginning of the fame, or in the end of rhe firnt degree.

$$
\text { The Vertues. }
$$

The decoction of the tops of dried Dil, and likewife of rhe feed, being druake, ingendrerh milke in the brefts of nurfes, allayeth gripings and windinefle, prouoseth vrine, increafeth feed, ftayeth the yeox, hieker, or hiequer, as $D i_{2}$. ofcorides teacheth.

The feed likewife if it be fmelled vnroftay- B eth the hicket, efpecially if it be boyled in wine, bur ehiefely if ir be toyled in Wormewood Wine, or Wine and a few branches of Worme-wood, and Rofe leaues, and the ftomacke barhed rherewirh.

Galen fairh, thar being burnt and layd vpon moif vicers, it curetl rhem, efpecially rhofe in the fecret parts, and likewife thore fub Praputio, though they be old and of long continuance.

Common oyle, in which Dill is boyled or funned, as we do oyle of Rofes, doth digeft, mitigate paine, procureth fleepe, bringeth raw and vnconco, ted humors to perfe $e$ digeftion, and prouoketh bodily luft.

Dill is of grear force or efficacic againft the fuffocation or ftrangling of the mother, if the woman do reeitue the fume thereof being boyled in wine, and put under a clofe ftoole or hollow foat fit for the purpofe.

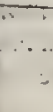

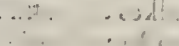

$$
\text { CHA . 413. Of Carhivaies。 }
$$

$$
\text { I. The Defcription. }
$$

Aruwaies haue an hollow ftalke foure fquare, of two cubirs high, full of knors ot ioynts; from which proeed fundry other fmall branches, fet full of leaues very fincly cut or iagged, like vnto thofe of Carrots or Dill : at the top of théftalkes grow fpokie white rufr's like thofe of Dill : after which commerh the feed, tharpe in eating, yet of a pleafant rafte : rhe root is like that of Parfley, ofrenwhite, feldome yellow, and in tafte like vnto the Carrot.

\section{-1 The Place.}

It groweth almoft euery where in Germanie and in Bohemia, in fat and fruitfull fields, and in medowes that are now and rhen ouer-run with water : ir groweth alfo in Caria, as Dinforides fhewetll, from whence it tooke his name.

It floureth and feedetin from May to the end of Augurt: 
qा The Names.

It is called in Greeke rier : in Latine, Carums and Carcum : in fhops, Carui. Simean Zethy calleth it Carnabadion : in high-Dutch, lanm, and knumund : in low-Dutch, Caruy faet : in Frencl, du Caray : in Italian, Caro : in Spanifh, Caranea, and an article being ioyned vnto it, Alkar auca : in Englifh, Caruwaie, and the feed is called Caruwaie feed.

\section{If The Temperature.}

The feed of Caruwaics, as Galen faith, is hot and dry in the third degrce, and hath a moderate biting qualitie.

\section{If The Vertues.}

It confumeth winde, it is delightfull to the Itomacke and tafte, it helpetl concoction, prouoketh vrine, and is mixed with counterpoyfons : the root may be fodden, and eaten as the Parfenep or Carrot is.

The feeds confected, or made with fugar into Comfits, are very good for the fomacke, they helpe digettion, prouoke vrine, affwage and diffolue all windineffe : to conclude in a word, they are anfwerable to Anife feed in operation and vertues.

\section{Char. 414. Of eAnnie.}

Tt The Defcription.

1 THe ftalke of Annife is round and hollow, diuided into diuers fmall branches, fet with leatles next the ground fomewhat broad and round : thofe that grow higher are more lagged, like thofe of yong Parncy, but whiter: on the top of the ftalkes do ftand fpokie rundles or tufts of white floures, and a fterward feed, which hath a pleafant tafte as euerie one doth know.

$\ddagger 2$ This other Amnife (whofe vmbels Clufius had out of England from Mafter Morgan the oueencs Apothecarie, and Iames Garret; and which were brought from the Philippines by $\mathrm{M}^{\mathrm{r}}$. The.Candifb in his voyage when he incompaffed the world) is thus defcribed by Clufius : The vmbcls were large, no lefie than thofe of the Arehangeliea, made of diuers thicke ftiffe foot-ftalks, each whereof carried not double feed as the common Annife, but more, in a round head fome inch ouer, made of cods fet ftar-fahion, fix, 8, or more, of a dusky colour, wrinkled, diuided into two equall parts, and open aboue: moft of thefe huskes were empty, yet fome of them contained one fmooth fhining afh-eoloured feed, of the bigneffe of that of orobus ; the tafte and fmell was the famc with our common Anife fecd, wherefore they which fent it to Clufurs called it Anife : yet in the placewhere it grew it was called Damor; for $\mathrm{M}^{\mathrm{x}}$. Candigh had the name fo written in the China charaeters, after their manner of writing. $\neq$ :

$$
\text { बा The Place. }
$$

It groweth plentifully in Candy, Syria, Egypt, and other countries of the Eant. I haue often. fowne it in my garden, where it hath brought forth his ripe feed when the yeare hath fallen out to be temperate. 
I036 Of the Hiftorie of Plants.

$\mathbf{L}_{\text {I B: } 2 \text { : }}$

\section{C н А P. 4I4. \\ of Bithops Weed, Herbe-William, or eAmeos. \\ Ti The Defcription.}

I THe conmon Ameos, efpecially with vs here in England, hath round greene falks, with diuers boughes and branches, and large long leaues, diuided into diuers other narrow long and fmall leaues, dented or fnipt about the edges, hauing at the top of the ftalke white floures in great fpoky tufts, which bring forth a little fharpe and bitter feed : the root thercof is white and threddie.

2 This excellent and aromaticall Ameos of Candy hath tufts and leaues like Daucus Creticus? and a root like vnto the garden Carrot, of a yellow colour,and hot feed like origamum, of an excellent fpicie fauour or fmell, growing in fpoky tufts or roundles like Carum : it liath beene brought from Candy and Syria into Venice, and from Venice into France, Flanders, and England, where we haue often fowne it ; but without doubt we haue beene beguiled therein by the deceitful drugmafters, who liaue firt boyled it, or vfed fome other falfe and deceitfull deuice, to bring greater admiration vnto the Venice treacle, for the confection whereof this feed is a chiefe and molt principall ingredient.

\section{Ammi vulgare. \\ Common Bihops-weed.}

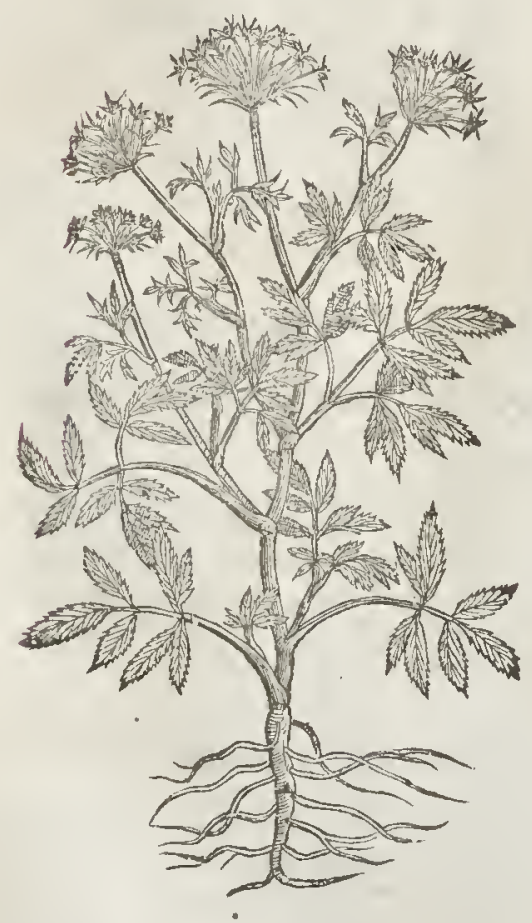

t 2 Ammi Creticum.

Candy Bihlops-weed.

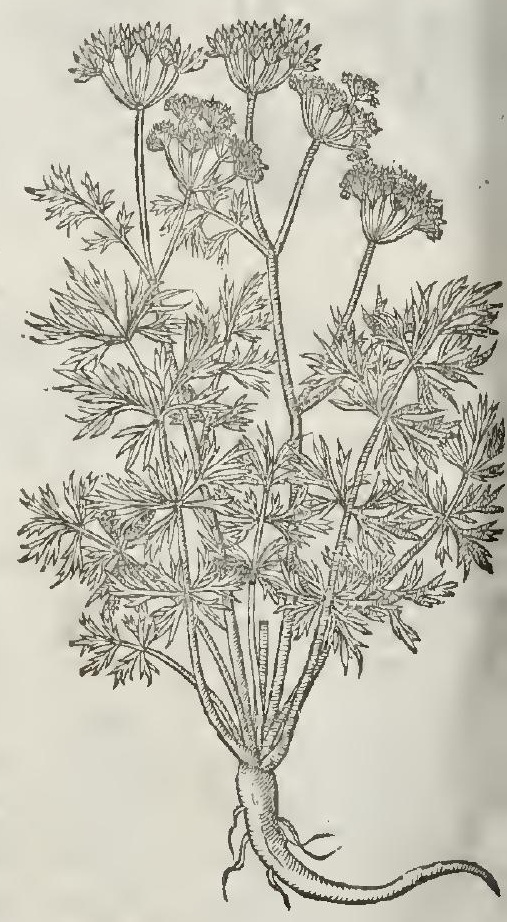

3 There is another kinde of Ameos, which is an herbe very fmall and tender, hauing ftalkes a foot and a halfe high, very fmall and tender, befet with leaues like vnto Dill, finely iagged, and fomewhat flender; and at the top of the ftalkes grow little tufts or fpokie white rundles, which afterwards do turne into fmall gray feed, hot and tharpe in tafte. The root is fmall and flender. If The Place.

Thefe plants do all grow in my garden, except Ammi $_{2}$ creticum, whereof hath beene fufficiently fpoken in the defeription. 
$\ddagger 3$ Ammiperpufillum.

Small Bifhops-weed.

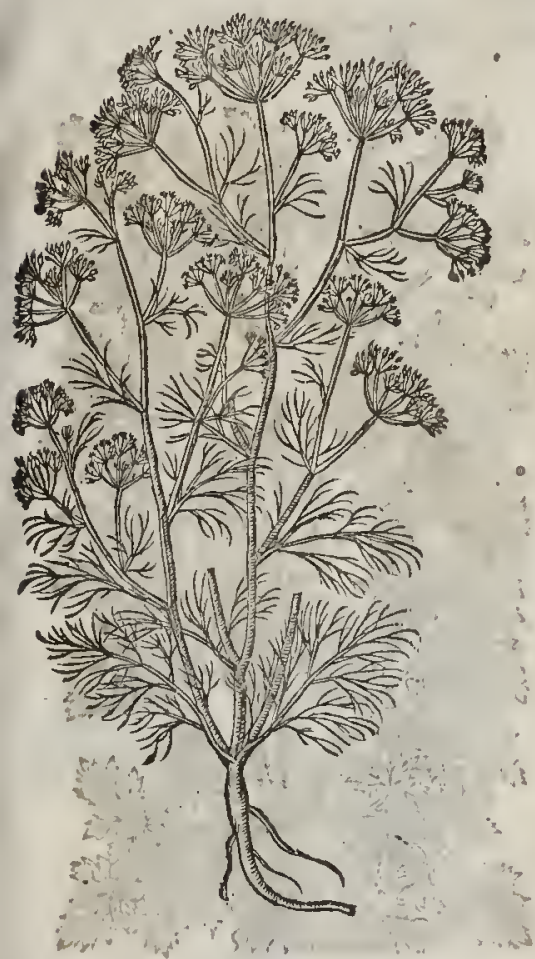

9) The Time.

They flowre in Inne and Iuly, and yecid their feed in the end of Augut.

$$
\text { बi "The Names." }
$$

The Grecians call it"sus: the Latines alfo Ammi diucrs call it Cuminum ethropicims : others, Cuminum Regium, or Comin Royall : in thops, Ammios, or Ameos in the Genitive eafe: the Germanes, Rmep : in Englilh, Ameos, or Anmi : of fome, Herbe-William, Bull-wort, and Bilhops-weed.

$$
\text { T The Temperature. }
$$

The feed of Ameos is hotand dry in the later end of the third degree. ${ }^{4}$

\section{T The Vertuis:}

It auaileth againft gripings of the belly in A making of vrine,againft the biting of ferpents taken in wine, and alfo it bringeth downe the floures : being applied with honey it takerh avay blacke and blew fpots which cone of fripes: the feed of sifondoth alfo the like, for it is hot and dry, and that in the third degree; likewife of thin parts, prouoking vrine, and bringing downe the defired fickneffe.

The feed or A nicos is good to be drunken $B$ in wine againft the biting of all manner of venomous beafts,and hath power againft all maner of poyfon \& peltilent feuers, or the plague, and is vfed in the correcting of Cantharides, whereby thofe flies aremade medicinable to be applied to the body wichout danger.

Ameos brayed and uingled with honey fcattereth congealed bloud, and putteth away blacke $\mathrm{C}$ and blew markes whicl come by ftripes or falls, if it be applied thereto in manner of a plainter.

\section{Char.415. Of Cheruill:}

\section{If The Defription.}

I THe leaues of Cheruill are flender, and diuerfy cut, fomething hairy, of a whitifh green: the ftalks be thort, flender, round, and bollow within, which at the firft rogether with the leaues are of a whitith green, but tending to a red when the feeds are ripe: the floures be white, and grow vpon fcattered tufts. 'The feed is long, narrow, flender, harpe pointed : the root is fill of frings.

$\ddagger_{2}$ There is found in Iune and Iuly, almolt in euerie hedge, a certaine plant which $T$ aber. nmont and $B$ aubine fitly cal Cherophyllum, or Cerefolium (flueftre and the figurewas vnfity giuen by our Auchor for Thy felinum : It hath a whitifi wooddy root, from w hich arife round red and hairy ftalkes fome two cubits high, fometimes more, and oft times fomewhat big and fivolne about tlie ioynts, and they are not hollow but full of pith : toward the top it is diuided into fundry branches, whicl on their tops carry vmbels of fmall purc white little floures, which are fucceded by longith feeds. The leattes are vftally parted into three chiefe parts, and thefe againe fubdituded into fiue, and they are finpt about the edges, foft and hairy, of a darke greene or elfe reddinh colour. It flotireth in Iune and Iuly, and then ripens the feed. $\neq$

3 Grear Cheruill hath large leates deepely cut or tagged, in fhèv very like vnto Hémlótis, of a very good and pleafant fmell and tafte like vnto Cheruill, and fomething hairy, wh ich hath canfed vs to call it fivect Cheruill. Anong thefe leaues riferh vp a ftalke fomw hat ereftrd or furrowed, of the height of two cubits, at the top whereof grow fpoky tufts or rundles with white 
flourcs, which do rurne into long browne crefted and thining feed, one feed bcing as big as foure Fennell feeds, which being grecne do tafte like Anife fced. The root is great, thicke, and long, as big as Enula Campana, exeeeding fweet in fnell, and tafting like vnto Anife fceds.

1 Cerefoliumvulgarefativum. Common Cheruill.

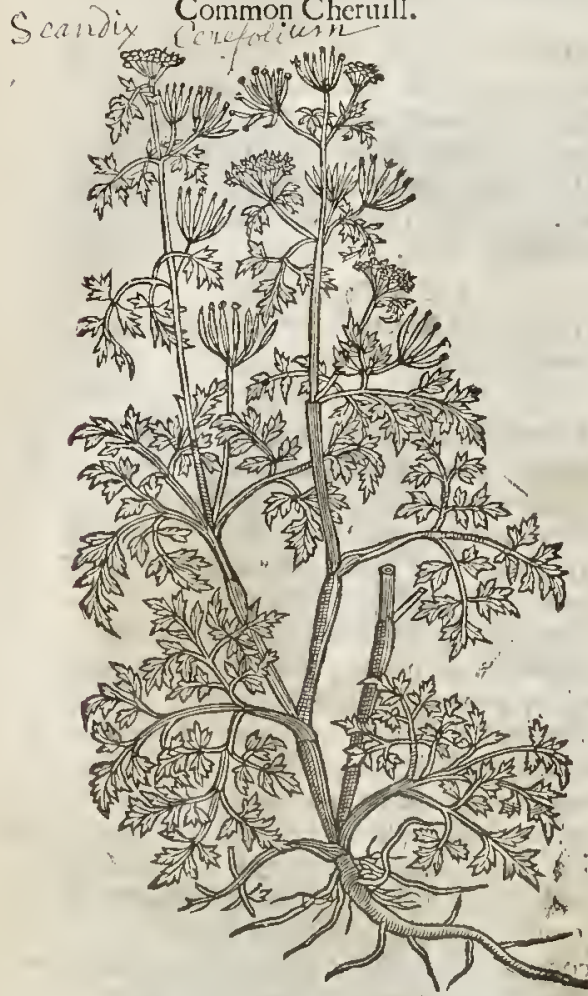

t 2 Cerefulium fyluefire. Char Hedge Cheruill. Lemulentin

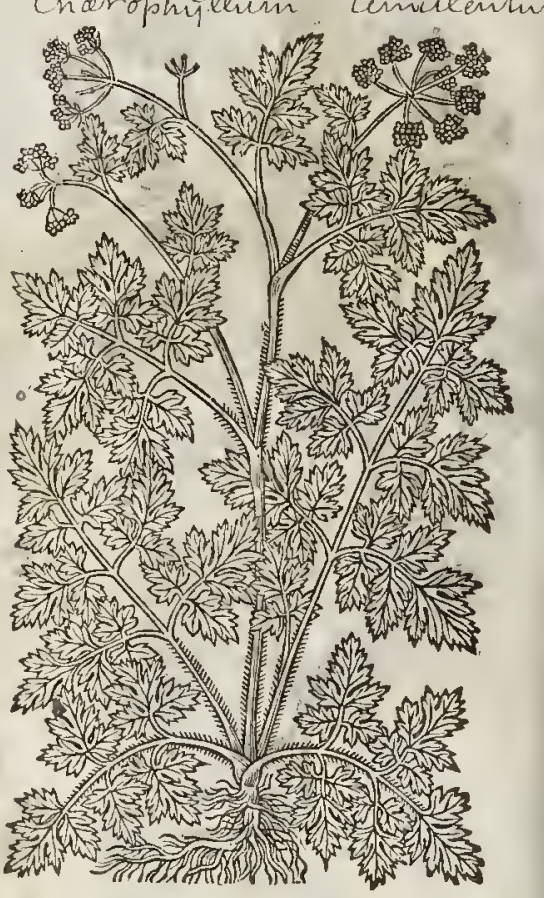

* 4 There is found in fome parts of the Alps, as about Geneun and in other places, another Myrrbis, which in the lcancs and vimbels is like that of the laft defcribed, but the whole plant is lcfie; the feed is long, fmall, fmoorly, and thaped like an Oat, and in tafte fomewhat like that of the Daucus Creticus. Lobel hath this by the fame name as we here gine it you.

5. About mud walls, higli-wayes, and fuch places, here about London, and in diuers orher places, is found growing a fimall plant, which in all things but the fmell and height agrecs with that referred to this kinde by $F$ abius Columna, and ealled Myrrhis eEquicolor wm nour. The root hereof is fmall and white, pcrining cucry yeare when it hath perfected his feed : the ftalks are flender, holluw, fmooth, and not hairy, feldome exeeeding the height of a cubit, or cubit and halfe; it is diuided into fundry branehes, vpon the fides whereof againt the fetting on of the leaues, or out of their bofomes, grow forth the ftalks, whieh carry vmbels of fmall white floures: after which follow the feeds, growing two together, and thefe longinh, rough, round, and hairy, ab oit the bigneffe of : Anife feeds. The leaues are fmall, and finely eut or diuided like thofe of Hemlock, but of a whitifh colour, and hairy: it eomes vp in Mareh, floures in May, and ripens his feed in Iune. In Italy they eate the yong leaues in fallads, and call it wilde Cheruile : we may in Englin for diftinctions fake call it fmall Hemloeke Cheruill.

6 To thefe we may fitly adde that plant whieh in the bift. Lugd. is called Cicut arin alba, and by Camerarius, Cicut arin paluftris; for it floures at the fame time with the laft mentioned, and is found in foure and feet in May and Iune very frequently almoft in all places; but afterwards his ftalkes die downe, yet his roots liue, and the leaues are greene all the yeare. The root of this is very large, and diuided into fundry parts, white alfo and fpungie, of a pleafing ftrong fmell, with a bot and biting tafte : the ftalks grow wp in good ground to be fome three cubits high, and they archollow, ioynted, pretty thickc, greene, and much crefted, fending for th of the boromes of the lcaucs many branehes, which vpon their tops earry vmbels compofed of many white foures, cach floure confiffing of fiue little leaues, whereof the loweft is twiee as big as the reft, rhe two fide-ones leffe, and the vppermoft the leaft of all. The leaues are large like thofe of $M y r r b i x$, but of a dark green eolour. 
and thofe that grow about the tops of the ftalkes are eommonly diuided into into three parts, and thefe fubdiuided into fundry long tharpe pointed and fnipt leaues like as in crityrhits. The feeds grow two together, being longin,round, fharpe pointed,blacke, and hining. We may fitly ternie this plant, wilde Ciecly, for that it fo much refembles the Myrrhis or garden Cicely, arke onely in thape, but (if $I$ be not deceiued) in vertues alfo. $¥$

3 Cerefolism magum, fue Myrrhis. Great Chertiill or Myrrh.

Scaridix MMMid

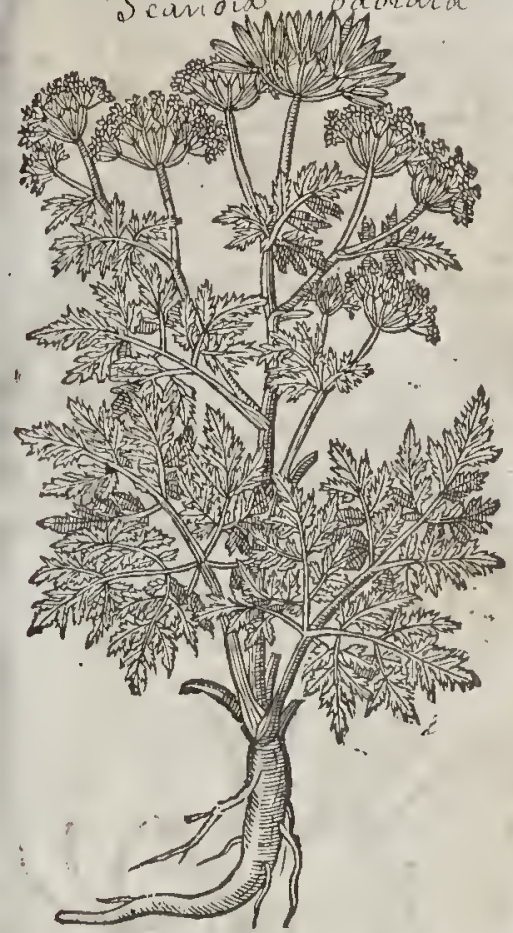

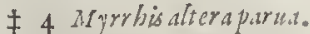
Snall fweet Cheruill.

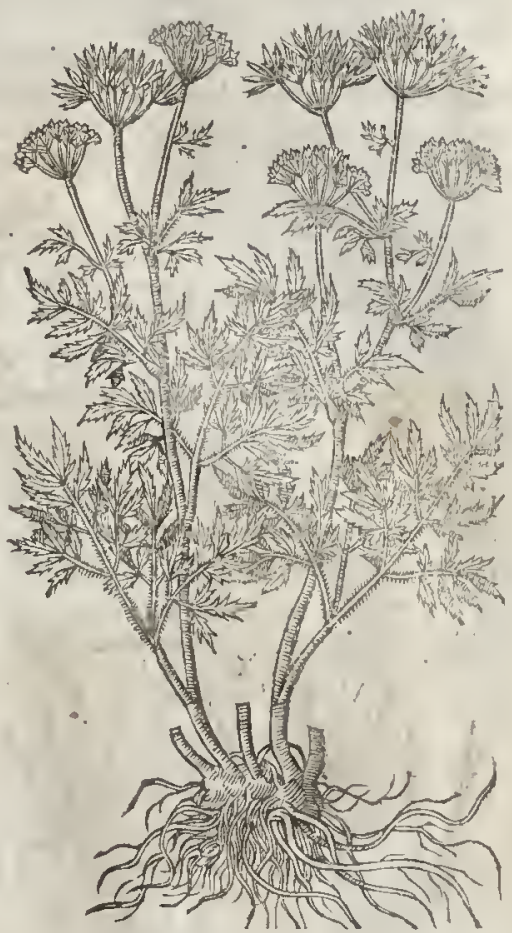

The Place.

The eommon Cheruill groweth ingatdens with other pot-herbes : it profpers in a ground that is dunged and fomewhat moift. The great fweet Cheruill groweth in ny garden, and in the gardens of other men who haue been diligent in thefe matters.

\section{The Time.}

Thefe herbes do floure in May, and their feed is ripe in Iuly.

$$
\text { T The Names. }
$$

Cheruill is commonly called in Latine Cerefolium, and as diuers alfirme, Cherofolium, witho in the feeond fyllable. Columella nameth it Cherephyllsum, and it is thought to be fo called beeaure it delighteth to gtow with many leaues, or rather in that it eaufeth ioy and glaclnes : in high-Duteh,

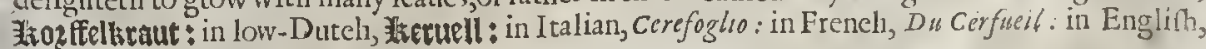
Cheruell, and Cheruill.

Myrrhes is alfo called Myrrha, taken from his pleafant fatiour of Myrrh : of fome, Corila, as is is found nored among the baftard names. It is alfo, by reafon of the fimilitude it hath with Hemloeke, ealled by moft late writers, Cicutaria. Of this, Pliny maketh mention,lib.24.cap. T6. where he reporteth that it is ealled Smyrrbiza : in Englith it is ealled Cheruill, fweet Cheruill, or fivect Eicely.

\section{The Temperature and $V$ critues.}

Cheruill is held to be one of the pot-herbes, it is pleafint to the ftomacke and tafte: it is of a A temperate heate and moderate drineffe, but nothing fo muels as the Parlleyes.

It pronoketh vrine, efpecially being boyled in wine, and applied hot to the thare or nethermont $B$ part of the belly, and the wine drunke in which it was boyled.

It hath in it a eertaine windineffe, by meanes whereof it proeureth luft.

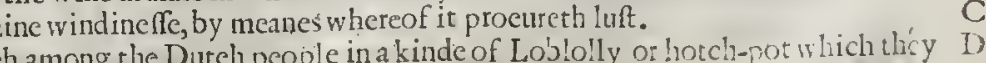
do eate, eilled Warmus.

$\operatorname{ser} 2$ 
The leaues of fweet Cheruill are exceeding good, wholefome, and pleafant,among other fallad herbs, giuing the talte of Anife feed vnto the reft.

F The root, faith $G$ alen, is hot in the fecond degree, hauing a thinneffe of fubltance ioined with it.

G Diofcorides teacheth, that the root drunke in wine is a remedie againtt the bitings of the venomous fpiders called in Latine Phalangia; and that it bringeth downe the menfes and fecondines and being boyled and drunke it is good for fuch as haue the pryfick or confumption of the lungs.

H The feeds caten as a fallad whileft they are yet greene, with oyle, vineger, and pepper, exceed all other fallads by many derrees, both in pleafantneffe of tafte, fweetneffe of fmell, and wholfomnefle for the cold and fecble ftomacke.

The roots are likewife moft excellent in a fallad, if they be boyled and after dreffed as the cunning Cooke knoweth how better than my felfe : notwithitanding I doe vfe to cate them with oile and vineger, being firft boyled; which is very good for old penple that are dull and without courage; it reioyceth and comforteth the heart, and increafeth their luft and ftrength.

\section{Cна Р. 417. Of Shepbeards needle or wilde Cheruill. \\ T) The Defcription.}

$1 S$

Candix, or Pedten Veneris, doth not much differ in the quantitie of the falks, leaues, and floures, from Cheruill ; but Scardix hath no fuch pleafant fmell as Cheruill hath : the leaues be leffer, more finely cut, and of a browne greene colour : the floures grow at the top of the ftalkes in Imall white tufts ; after which come vp long feeds very like vno pack-needdles, orderly fet one by another like the great teeth of a combe, whereof it tooke the name Pecten Veneris, or Venus combe, or Venus needle: the root is white, a finger long.

I Pecten Veneris, fue Scandix.

Shepheards needle, or Venus combe.

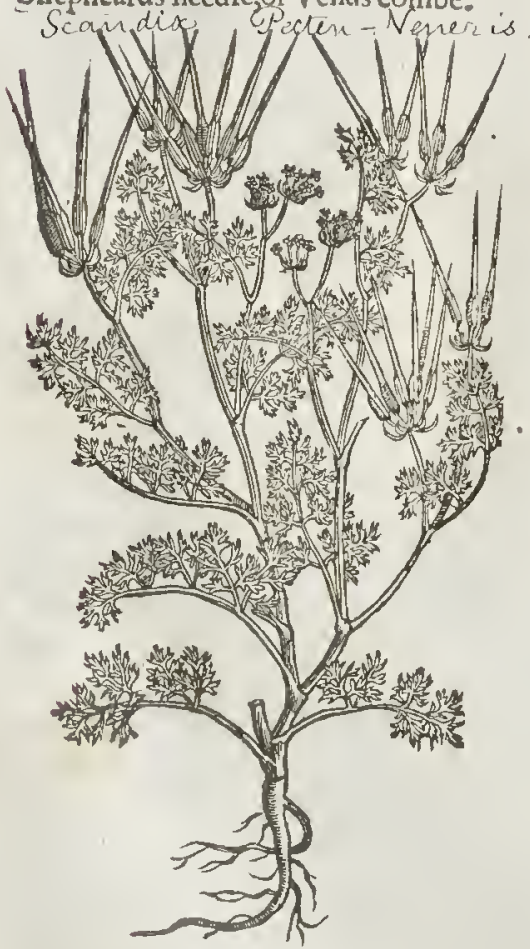

* 2 Scandix minor, fue Antbrifous. Small Shepheards needle.

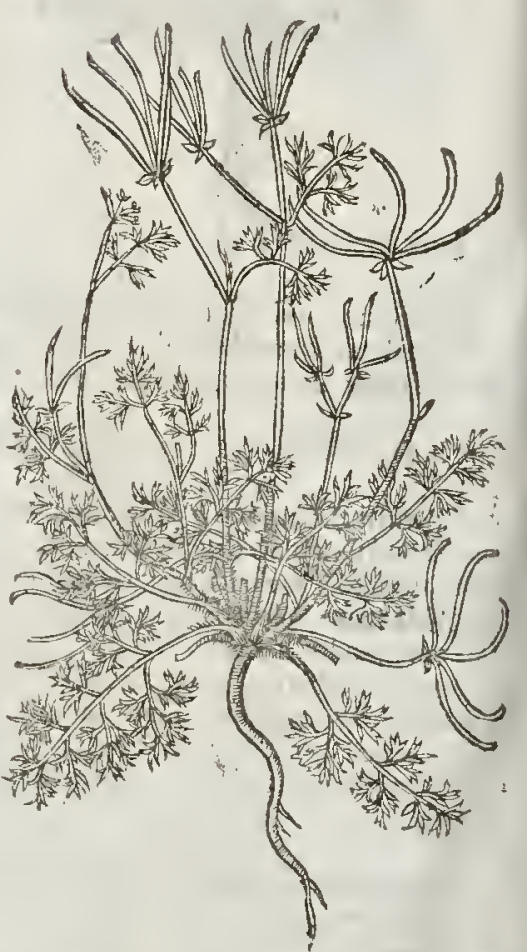

\# 2 This from a flender long and whitith root fends vp many fmall leaues like thofe of the laft defcribed,but of a pleafing fmell and tafte fomething like that of the common Cheruill ; amongft thefe leaues grow vp flender ftalks a little hairy, diuided into fhort green and flender branches carrying little vmbels, confiting of fure, $\left[1 x_{2}\right.$, feuen, or eight Imal white floures, compofed of fiue leaucs apiece. 
apiece, with a darke purplith chiue in the middle : the floures are fucceeded by, or racher grow vpon long flender cods, which become fome inch long, and refemble thofe of the laft deferibed. It floures in Iune, as Clufus affirmeth, who gines vs the hiftory of it; and he receiued it from Honos ritss Bellus out of Candy; whowrites, that in the Spring rime it is nutch ved in fallads, and defired, for that it much excites to Venery. He alfo thinks this plant to be the Ansbrifoss of $P$ liny, and by the fame name Clufuns fets it forth: Columna hath called it Anifo-marathrum, becaufe the finell and tafte is betweene thar of Anife and Fennell. $\neq$

$$
\text { 9f The Place. }
$$

It groweth in molt corne ficlds in England, efpecially anong wheate and barley:

$$
\text { T) The Time. }
$$

It floureth in May : the feed is ripe in Auguft wirh corne.

$$
\text { Qf The Names. }
$$

The Latines eall it Scandix, hauing borrowed that name of the Grecians, who call it zuárom : we finde among rhe battard words, that the Romans did eall it Scanaria, and Acula, of the feed that is like vnto a needle. Finclizus defcriberh it vnder the name Pedten Feneris : of others, Acus Veneris, and

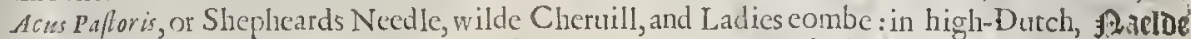
Hiatuel: This is that herbe (fairh tliny, lib.22.cap.22.) whieh Arifophanes obiested in fport to the Poet Euripides, that his mother was wont to fell no right pot-herbe but $s$ candix, or Shepheards needle, meaning, as I rake it, Vifnga, wherewith the Spaniards doe picke rheir teeth when they hauc caten no meate at all exeept a few oranges or fuch a like trifle, called alfo Scandix.

\section{The Temperature.}

Shepheards needle, faith Galen, is an herbe fomewhat binding, and bitter in tafte, infomuch that it is hot and dry either in the later end of the fecond degree, or in the beginning of the thitd.

\section{- TheVertues.}

Diofcorides faith it is eaten both raw and boyled, and that it is an wholefome pot-herbe among $A$ the Greekes; but in thefe dayes it is of mall eftimarion or value, and taken but for a wilde Wort, as appeareth by Ariftophanes taunting of Euripides, as a forefaid.

The decontion thereof is good for the bladder, kidneyes, and liuer; but as I deeme hee meant $\mathbf{B}$ Cheruill, when he fer the fame downe to bevfed in phy fiére.

\section{Cн A . 4I8. Of Tootb-picke Cberuill. \\ T. The Defcription.}

1 The firft of thefe Tooth-picke Cheruils beareth leaues likewilde Turneps, a round ftalke furrowed, ioynted, blackinh, and hairy, diuided into many branches, on the tops whereof grow fpokie tufts, befet round about with many fmall leaues. The toures thereof are whitilh : after commeth the the feed,which being once ripe do clutter and are drawne together, in a round thicke ruft like a fmall birds neft, as be thofe of the wilde Carrot; whofe feeds whofo toucheth, rhey will cleate and ftieke to his fingers, by reafon of the glutinous or flimie matter they are polfeffed with. Tho root is fmall and whitifh, bitter in tafte, as is all the reft of the plant.

2 The Spanith Tooth-pieke hath leaues, floures, and knobby ftalkes like vnto wilde carrots, faung rhat the leaues are foméwhat finer, cut or iagged thicker, and tenderer, but not rough or hairy at all as is the former, of a bitter tafte, and a reafonable good fmell : among which rife vp bufhic rtindles or fpok ie tufrs like thofe of the wilde Carrot or Pirds neft, clofely drawne together when the feed is ripe; at what time alfo the tharpeneedles are hardned, fit to make Tooth-pickes and fuch like, for which purpofe they do very fitly ferte:

$$
\text { qा The place. }
$$

Both of rhem grow in Syria, and molt commonly in Cilicia : the later is to be found likewife in Spaine almoftetiery where; and I haue it likewife in my garden in great plentic.

$$
\text { If The Time. }
$$

They floure in my garden about Augut, and deliuer their feed in Ostober.

$$
\text { T. The Names. }
$$

That which the Grecians eall wors, the Latines do likewife name Gingidium : and it is ealled in Syria Lepidium: yet is there another Lepidium. It is reported among the baftard names to be cal. led by the Romans, Bifucutwm : of which name fome thew remaines among the Syrians, who commonly call the larer, Gingidium, rifraga : this is named in Englifh, Tooth-picke Cheruill.

$$
\operatorname{sif} 3
$$




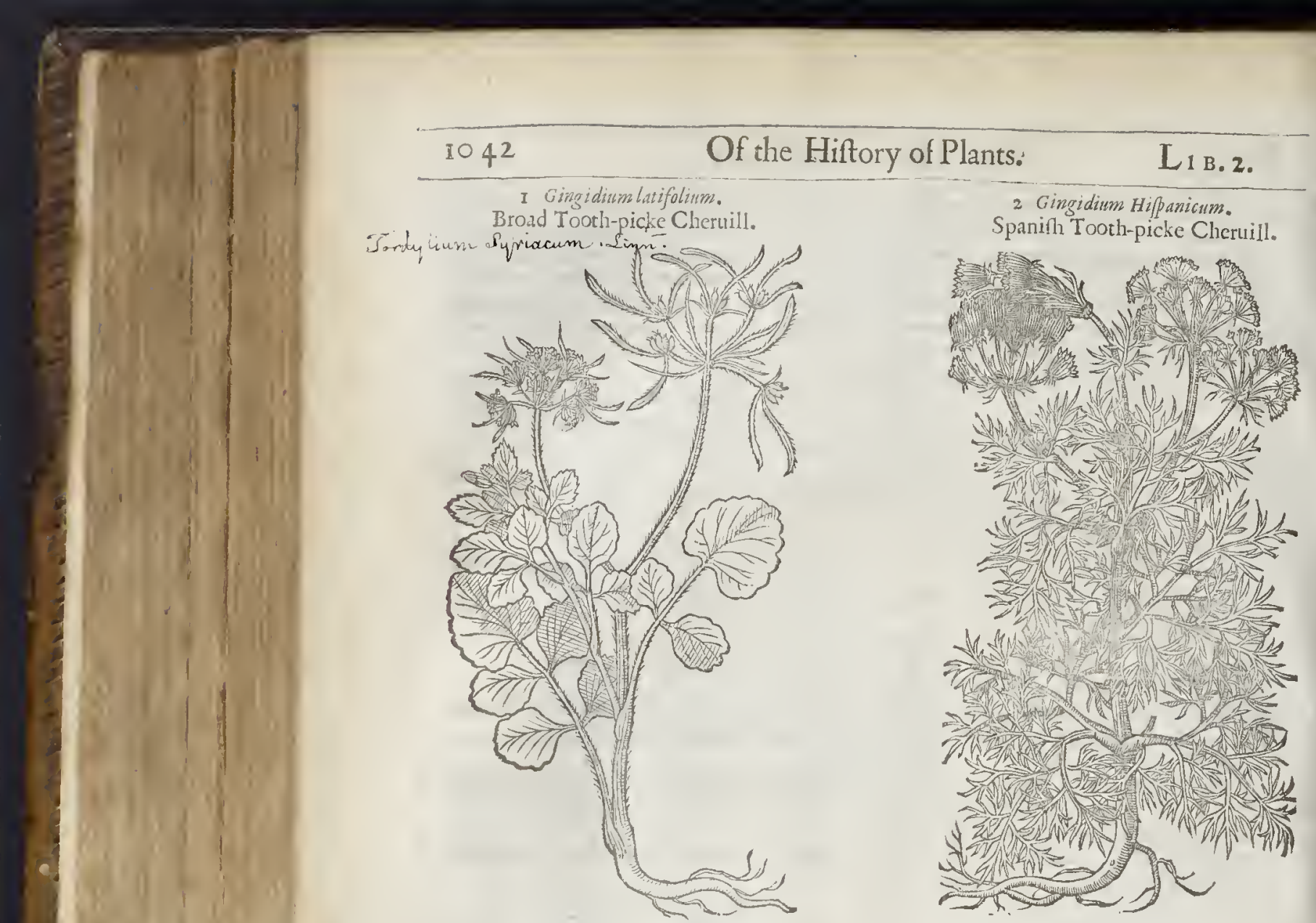

बा The Temperature and Vertues.

A There is, faith Galen, great incrcafe of Gingidum in Syria, and it is eaten no otherwife than Scandex is with vs at Pergamum : it is, faith he, very wholefome for the ftomacke, whether it be eaten raw or boyled; notrvithfanding it is euident that it is a medicine rather than a nourifhment. As it is bitter and binding, fo is it likew ife of a temperate heate and drineffe. The heate is not very apparant, but it is found to be dry in the later end of the fecond degree,as alfo the faid Author alledgeth in his difcourfe of the faculties of frmple medicines.

B Diofiorides dorh alfo write the fume: This pot-herbe (faith he) is eaten raw, fodden, and preferued with great good to the ftomacke; it prouoketh vrine, and the decoction thereof made with wine and drunke, is profitable to fcoure the bladder, prouoketh vrine, and is good againft the gra-
uell and ftone.

C The hard quills whereon the feeds do grow are good to cleanfe the teeth and gums, and do eafily take away all filth ant baggage fticking in then, without any hurt vnto the gums, as followeth after many orher Tooth-picks,and they leaue a good fent or fautor in the mouth.

\section{C н а .4T. Of Mede-freet, or Queene of the Medowes. बा The Defcription.}

I His herbe lath leaues like thofe of A grimonie, confifting of diuters leaues fet vpon a midon the inner fide, and on the vper fide crumpled or wrinkled like vnto thofe of the Elme, Thee. whereof it tooke the name I murria, of the fimilitude or likeneffe that the leaues haue with the Elme leaues. The ftalke is three or foure foot high, rough, and very fragile or eafie to bee broken, of a reddin purp'e colour : on the top whereof are very many little floures cluftering and growing togethe; of a white colour tending to yellowneffe, and of a pleafant fivecte 
I Rcginaprati.

Qucene of the Medor. - spirar vilmaria ats sir ses
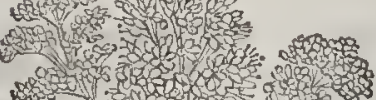

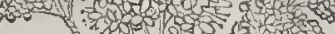

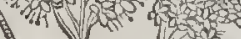
$\rightarrow$
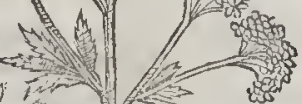

\section{8} de

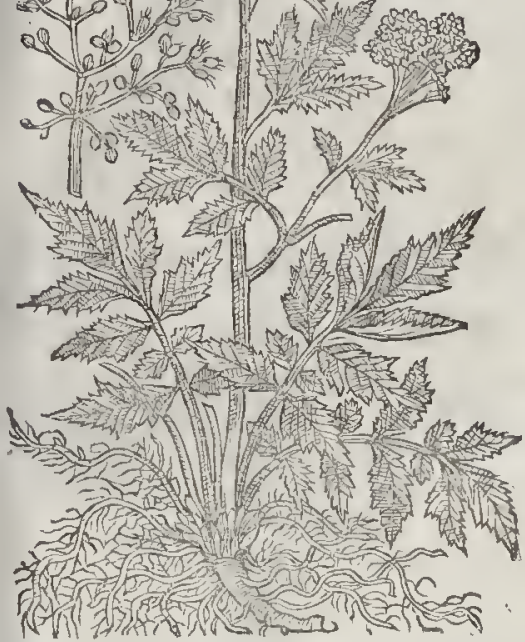

fmel, as are the lcanes likewife: after $w$ hich come the feeds, fmall, crookedly turning or winding one with another, made into a fine little head. The root hath a fweet fmel, fpreding far abroad, blacke without, and of a darkifh red colour withn.

$\ddagger 2$ Thete is alfo another which by Fuchfurs, Tragus, Lonucerwi, Gefrer, and others, is called Barba Capri : it hath large wooddic rootes, leaues of the bigneffe, and growing fomewhat after the manner of the wild Angelica : the ftalks are ctefted, and diuided into fundry branches, which carry long bending fpikes or eares of white floures \& feeds fome what like thofe of the common kinde. This floures at the fame time as the forme?, and I haue not yetheard of it wildewith vs. but onely feene it growing with $\mathrm{M}^{\mathrm{r}}$. Tradsf cant. $\ddagger$

$$
\text { Tा The place. }
$$

It groweth in the brinhes of wateric ditches and riuers fides, and alfo in medowes: it liketh waterie and moift places, and groweth almoft eucry where.

\section{oा The Time.}

It foureth and flouritheth in Iune, Iuly, and Auguft.

\section{9) The Names.}

It is called of the later age Reginaprati, \& Butba Capri:of fome, Vlmaria, à foliorsm Vlmi fimilitudine, from the likeneffe it harh with the Elme tree leafe: in high Dutch, Seithatc, It is called Barba Hirci, which name belongeth to the plant which the Grecians do call Tragopogon: of Anowillara, Potentilla maior. It hath fome likeneffewith Rhodora Plinï, but yet we cannot affirme it to be the fame. It is called in low Dutch 1iejinette: in French, Barbe de Cheure, Reine des Praiz: in Englifh, Meadef-fweet, Medow-fweet, and Q!necne of the medowes. Camerarins of Noremberg faith it is called of the Germanes his countrimen, noutme klaut : becaufe the roots, faith he, feen to be eaten with wormes. I rather fuppore they call it fo, becaufe the antient hackny men and horfleaches do grue the decoation therof to therr horfes and affes, againft the bots and wormes, for the which it is greatly commended.

\section{Tा The Tempcrature.}

Mede-fweet is cold and drie, with an euident binding qualitie adioined.

$$
\text { ब The Vertucs. }
$$

Theroot boiled, or made into pouder and drunke, helpeth the bloudy fix, ftaieth the laske, and $\mathbb{A}$ all other fuxes of bloud in man or woman.

It is reported, that the flourcs boiled in wine and drunke, do take away the fits of a quartaine a- $B$ gue, and make the heart merric.

The leaues and floures fare excell all other ftrowing herbes, for to decke vp houfes, to fraw in C chambers, halls, and binqueting houfes in the fommer time; for the fmell thereof makes the heart merric, delighteth the fenfe's : neither doth it caufe head-ache, or lochfomeneffe to meat, as fome other fweet fmelling herbes do.

The diftilled water of the floures dropped into the eies, taketh away the burning and itching $\bar{D}$ thereof, and clearcth the fight.

\section{C н а . 420. Of Burnet Saxifrige.}

- The Defcription.

I Tis great kinde of Pimpinell, or rather Saxifrage, hath great and long roots, fantioned like a Parfnep, of an hot and biting tafte like Ginger : from which rifeth vp an hollow ftalke 
ttalke with inints and knees two cubits high, befet with large leaues, which do more neerely reprefont Smallage than Pimpernell, or rather the garden Parfnep. This plant confifterh of many fmall leates growing vprn one ftem, fnipt or dented about the edges like a faw : the foures do grow at the top of the falkes in whte round tufts : the feed is like the common Parfley, fauing that it is hotter and biting vpon the tongue.

F There is a bigger and leffer of th is kinde, which difier little, but that the ftalkes and veins of rhe leaues of the leffer are of a purplith colour, and the root is hotter. Our Authour formerly gaue the figure of the leffer in the fecond place, in ftead of that of Bipinella. $\neq$
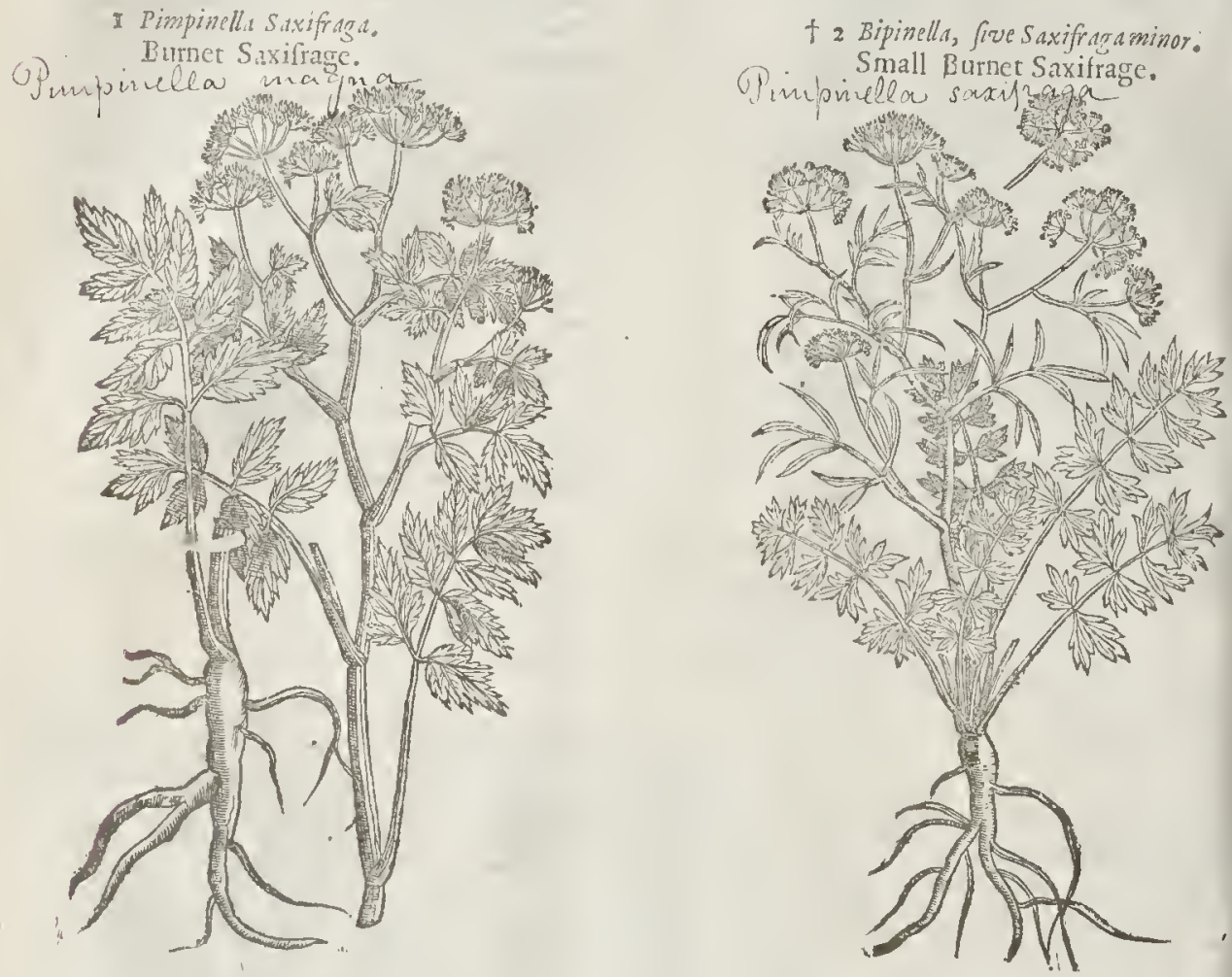

2 Bipinilld is likevife a kinde of Bumet or Pimpinell, vpon which Pera hath beftowed this addition Suxifraya minor: vnderwhich name $S$ axifrag a are comprehended diuers herbs of diuers kinds and the one very vilike to the other : but that kinde of Saxifrage which is called Hircina, which is rough or hairie Saxifrage, of others Bipinalla, is belt knowne, and the beft of all the reft, like vnto the fmall Burnet, or common Parfley, faung that it is void of liaires, as may appeare by the old Latine
verfe.

\section{Pimpineili buluct pilos, Saxifrat a tron babet wllos.}

Pinpinell hath haires fome, but Saxifrage hath none.

Notwithitanding, I haue found a kinde hereof growing in our paftures adioining to London, the leaues whereof if you take and tenderly breake with your hands, you may draw forth fmall threds, like the web of a fpider, fuch as you may druw from the leaucs of Scabious. The ftalke is hollow, ditiding it felfe from the ioints or knces, into fundry other fmall branches; at the top whereofdoe grom imall tuftes or pokic rundles, of a white colour : after which commeth the feed like to carti, or Caruwaies, of a fharpe tafte: the ront is alfo tharpe and hot in tafte.

T The Place.

$$
\text { They floure from Iunc to the end of Auguft. }
$$$$
\text { If The Time. }
$$

of Saxifragedothnore foetuer: 
focuer: wherein the Phy itions of Puris hate been deceitued, calling or fuppoting the medrw Rus to be the right $P$ bellundrum, whereunto it is not like either in thape or facultic : tor it is nerthing 10 effectuall in breaking the tone, or protoking of vrine, as cither of thefe plants, efpecially pumpinit. la Hircinat,which is not fo called, becaufe it hath any ramminh fnell of a gout, but becaufe pratitioners hauc ved to feed gouts with it, whofe $\mathrm{Herh}$ and bloud is finguldrgood againtt the trone; but we rather take it to be named Hircina, of Hircinia fylu, where it doth grow in great abundance, the fauour of the herbe not being vnplealant, fomewhat refembling the finell and tafte of $D$ aucus, Ligre-

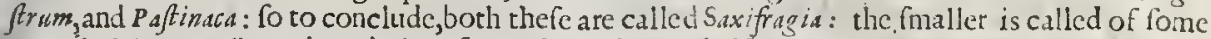
Petrefindula, Bipinella, and Bipenula: of BaptiftaSardus, and alfo of Leonardus Fuchfies, Prmpincllum:lior : wherefore diuers call it Pimpinella Saxifraza: for there is alfo another Pimpinclla, called Pimpinella Sanguiforba : notwith ftanding the verfe before rehearfed fhewerh a difference betweene Prmpinella and Saxifraga: in high Dutch, it is called 2Bibernel : in Low Dutch, 23 auenaet: in Englih the greater may be called grcat Saxifrage, and the other finall Saxifrage.

Bipinella is called Saxifragiaminor: in Englifh,Small Saxifrage,as Pimpinella is called great Saxifrage. $\ddagger$ Columna iudges it to be the Tragium of Diofcorides. $\neq$

\section{The Nature.}

Saxifrage of both kindes, with their feed, leaucs, and roots, are hot and drie in the third degree, and of thin and fubtill parts.

\section{T) $T$ he Vertues.}

The feed and root of Saxifrage drunken with wine, or the decostion thereof made with wine, $\mathbb{A}$ caufeth to piffe well, breaketh the ftone in the kidnies and bladder, and is fingular againft the itrangurie, and the ftoppings of the kidnies and bladder : whereof it tooke the name Saxifr.tgia, or break c itone.

The iuice of the leaues of Saxifrage doth clenfe and take away all fpots and freckles of the face, B and leaueth a good colour.

The diftilled water thereof mingled with fome vineger in the diftillation, cleareth the fight, and $\mathbf{C}$ ealseth away all obfcuritie and darknefle of the fame.

\section{C н А т. 42 г. Of Burnet:}

I Pimpinela hortenfis: terivin Burnet.

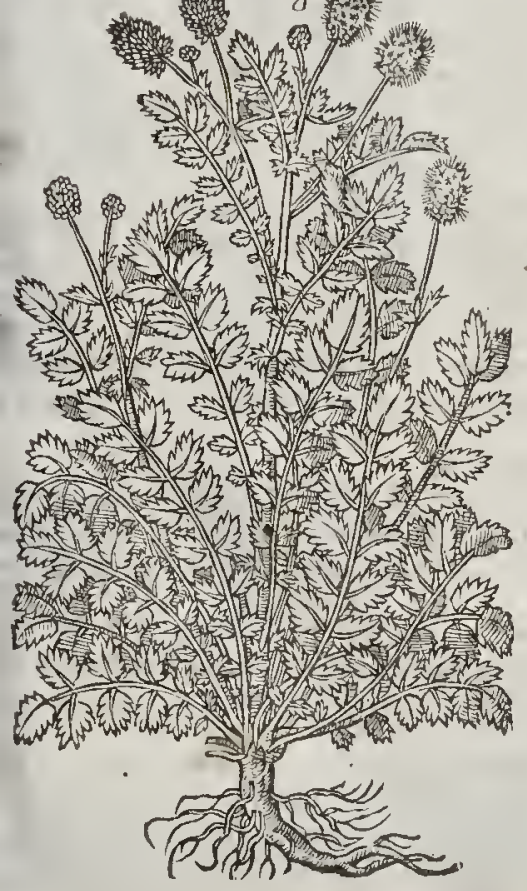

2. Pimpinella fylueffris.

Wilde Buynet:

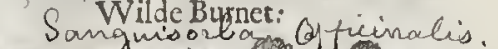

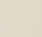




\section{- The rina's.}

Drnet of which wewill intreat, cloth difer from Pimpinella, which is alfocalled srivifraga. One of the Bunnets is leffer, for the moft part growirg in gardens, rorwithetanding ir growerh in barren fieldes, where it is mueh fmaller: the otter greater, is altogitherwilde.

$$
\text { T) The Defcription. }
$$

I

Arden Burnet hath long leases made vp togetler of a great many vi on one fem, cue. ry one whereof is fomething round, nicked on tle cdges, fomm har liarre:arnong tlefe rifeth a filke that is not alrogerber without leaues, fomethisg chantered: ifon the tops whereof grow litelc round heads or $\mathrm{k}$ naps, which bring forth fmall floures of a bsow ne purple colour, and after them cornered feeds, which are thruft vp together. The root is long : thewhole plant dorh fmell fomething like a Melon,or C ucumber.

2 Wilde Burnet is greatcr in all parts, it hath wider and bigger leaues than thofe of tic former : the ftalke is longer, fometimes two ctibits high : the knaps are greats $r$, of a darke jurple colour, and the feed is likew ife cornered and grsater:the root longer, but this Eurcer bath ropleafant fmellatall.

$\ddagger 3$ There is kept in fome gardens another of this kinde, with rery large leaues, fta!kes, and beads, for the heads are fome inch and halfe long, yet but flender confidering the length, and the fourcs (as I rementer) are of a whitifh colour: in other refpeits it differs not from the precedent: it may titly be called pimpinella Janguiforba hortenfis maxima, Great GardcrBurnet. $\neq$

\section{T The Place.}

The finall Pimpinell is commonly planted in gardens, notwithfanding it dotl grow wille vp. on many barren hearlis and paftures.

The great wilde Bumetgrowerh(as $\mathrm{M}^{\mathrm{r}}$. Lyte faith) in dry nedowes about Viltiord, ard my felfe bate found it growing vpron the fide of a caufey which croffeth the one halfe of a field, whereof rlie one part is earable ground, and rbe other partmedow, lying between Paddington and Lyfon gireen neere vnto London, vpon the highway.

They floure from Iunc, vnto the end of Auguft.

\section{The Time.}

of The Nantes.

The later herbarilts doe call Burnet Pimpinella fanguifor ba, that it may difter from the other, and yet it is called by feterall names, Sanzuiforba, and Sanguinaria: Gefper had rather it fhould becalled peponell af of efmell of Melons or Pompions, to which it is like, as we haue faid : of others it is na-

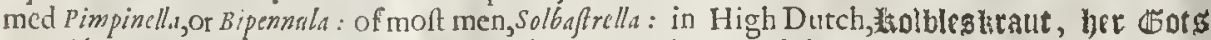
2Bartlin, Blutheaut, megelticaut: in French, Pimpennelle, Sangmiforbe: in Englinh, Burcet. It agrectl cum alter a Diofcorides Sidcritide; that is to fay,witl Diofcorides his fecond Iron-moort:ele leafe (and efpecially that of the leffer fort) which we hate written to confift of many nicks in the edges of the Ieaues, and this may be the very fame which Pliny in his 24 book, ehapter 17 .reporteth to be named in Perfia, Siffitiepteris, becau fe it made then merry; he alfo callerh the fame Protomedia, and Cafir nera, and likewife Diony/roxymphas, for that it doth maruelloufly agree with wine; towlich alfo this Pimpinella (as we haue faid) doth gitue a pleafant fent : neither is that repugnant, that Pliny in arother place harh written, De Sideritibus, of the Iron-woorts, for it often falleth out that he intreateth of one and the felfe fame plant in diuers places, vnder diuers names:which thing then hapneth fonner when the writers thenfelues do not well know the plant, as that Pliny did not well know Sideritis or Iron-woort, it is euen thereby manifeft, becaufe he fetretl not downe his owne opinion hereof,but other mens.

Burnet,be ficles the drying and binding facultic that it hath, doth likew ife meanly coole:and the leffer Burnet hath likewife wirhall a certaine fuperficiall, fleight, and temperate fent, which when it is pur ine the wine it dorh leaue behind it : this is not in the dry herbe, in the iuice, nor in the decoction.

$$
\text { 9 The Vertues. }
$$

A Burnet is a fingzular good herb for wounds (which thing Diofcorides doth attribure to his fecond Ironwoors) and commended of a number : it itancheth bleeding, and therefore it was named $S_{n m-}$ zwa forba, as well inwardly raken, as outwardly applied.

B Either the iuice is giuen,or the decotion of the pouder of the drie leaues of the herbe, beeing bruifed, it is outwardly applicd, or elfe put among other exicrnall medicines.

C It taieth the laske and bloudy flix: it is alfo mot: effectuall to ftop the montlaly courfe.

D The leffer Bumet is pleafant on be caten in fallads, in which it is thought to make the he art mer-

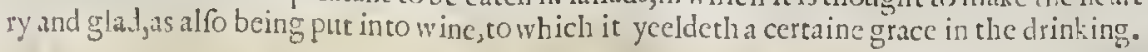




\section{L1 B. 2. Of the Hiftory of Plants. 1047}

The decoction of Pimpinell drunken, cureth the bloudy flix, the fpitting ofbloud, and all other $\mathrm{F}$ uxes of bloud in man or woman.

The herbe and feed made into pouder, and drunke wirls wine, or water wherein iron harh beene " $G$ tenched doth the like.

The lcaues of Pimpinell are very good to heale wounds, and are teceiued in drinkes that are madc $\mathrm{H}$ or inward wounds.

The leaves of Burnet feeped in wine and drunken, comfort the heart,and make it metry, and are I ood againft the trembling and Thaking theteof.

\section{С н Р. 422. Of Englifh Saxifrage。}

\section{T The Defeription.}

I Tis kinde of Saxifrage our Englin women Phyfitions have in great ve, and is familis arly knowne vnto them, vouchfafing that name vnto it of his vertues againft the ftone:it lath the leaues of Fennel, but thicker and broader, very like vnto Sejeli pratenfe, Monjpelienfurum (which ddition Pena hath beftorved vpon this our Englim Saxifrage) among which rifeth vp a ftalke, of a ubit high or more, bearing at the top fpokie, rundles befet with whitin yellow floures : the root sthickc, blacke without, and white within, and of a good fauour.

t isaxifraga Anglicana facie Sefeli pratenfis. Englinh Saxifrage.

if isciedumum Silans.

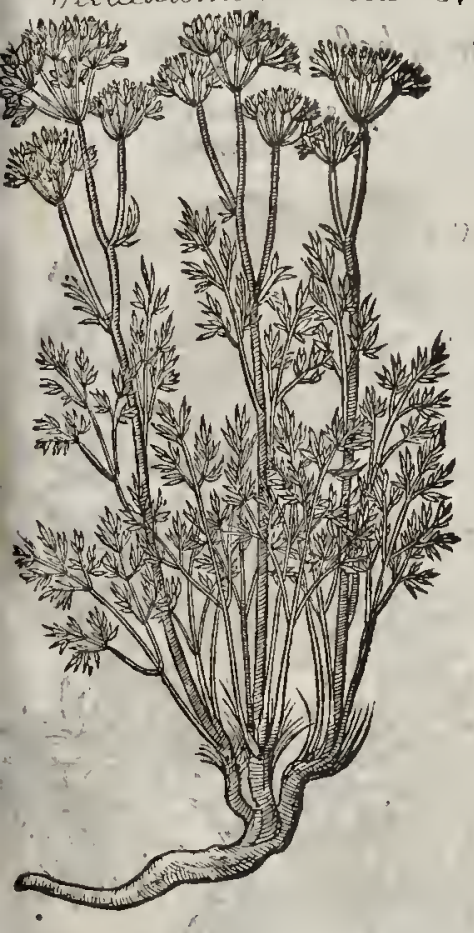

₹2 Saxifraga Pannonica Clufy. Auftrian Saxifrage.

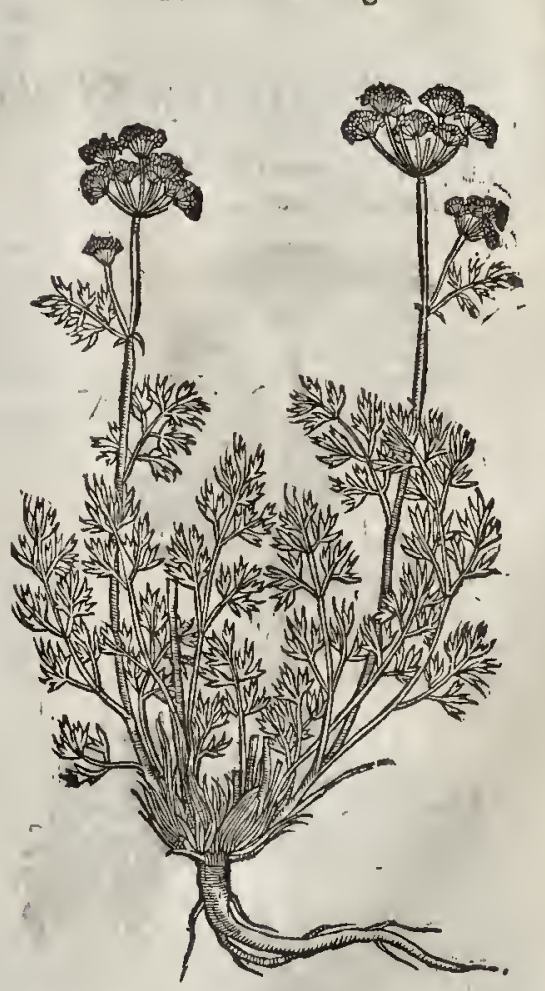

$\#^{* * *} 2$ Chaf i us hath fet forth another plant not much different from this our common Saxifrage, and called it Saxifraga pannenica, which I haue thought fit here to infert: the leatis, fairh he, ate much fhorter than thof of Hogs-Fennell, and fomewhat like thofe of Fumitorie : rhe ftalkes are fome font high, flcnder, hauing fome few fmall leaues, and at the top carrying an vmbel of white floures: thic roor is nor much vnlike that of Hogs-Fennel, but fhorter and more acridejit is hairic at the top 
thereof, whenee the ftalkes and leates come forth: it growes vpon fome hils in Hungarie and Auftria, and floures in Itrly. $¥$

$$
\text { I The Place. }
$$

Saxifrage groweth in moft fields and medowes euery where throughout this ourkingdome of England.

It floureth from the beginning of May to the end of Auguft.

$$
\text { T The Names. }
$$

Saxifraga Anglwana is ealled in our mother tongue Stoné-breake or Englifh Saxifrage : Pena and Lobel eall it by this name Saxifraga Anglicana : for that it groweth more plentifully in England than in any other countrey.

$$
\text { T The Nature. }
$$

Stone-breake is hot and dric in the third degree? $10 \ldots, \ldots, \ldots$

$$
\text { T The Vertues. }
$$

A A decoction made with the feeds and roots of Saxifrage, breaketh the ftone in the bladder and kidneies, belpeth the ftrangurie, and eaufeth one to piffe freely.

B The root of Stone-breake boiled in wine, and the decoction drunken, bringeth dow ne, womens fickneffe, expelleth the fecondine and dead childe.

C The root dried and made into pouder, and taken with fugar, comfortethand warmeth the ftomack, cureth the gnawings and griping paines of the belly.

D It helpeth the collicke, and driteth away ventofities or windineffe:

E Our Englifh women vfe to put it in their running or rennet for cheefe, efpecially in Chefhire where I was borne) where the beft eheefe of this Land is made."

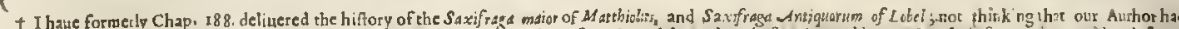
t Thaue fornety chap.

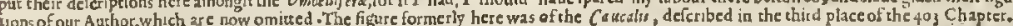

\section{Cи а т. 423. Of Siler Mountaine or baftard Louage.}

I I Siler mont ansm officinarum. Baftard Louage.

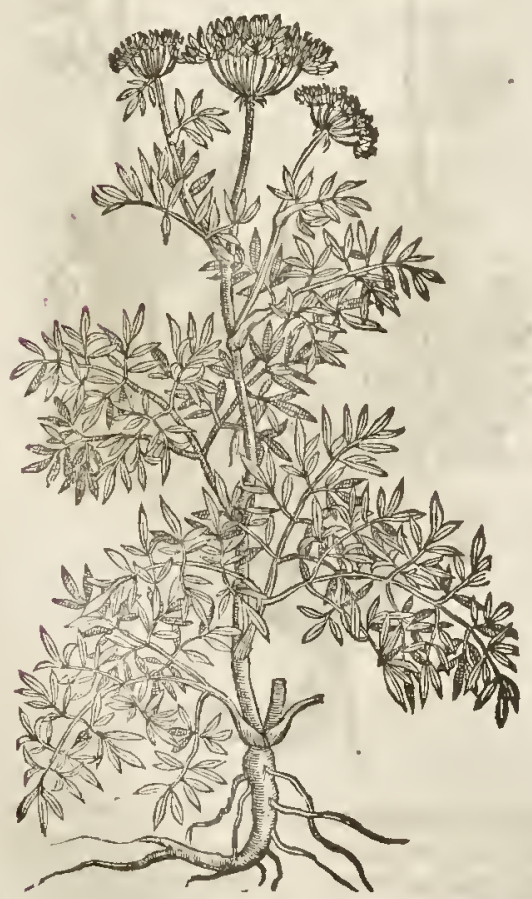

t 2 Sefolipraterfe Monpelienfiumn.

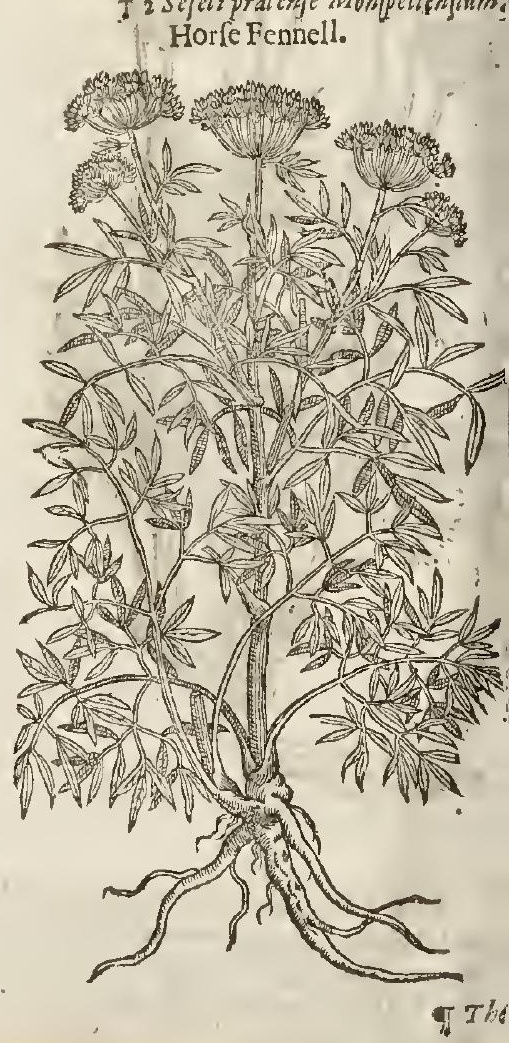




\section{TT The Defcription.}

I THe naturall plants of sefeli, being now bettcr knowne than in times paft, efpecially among out Apothecaries, is called by them Siler montanum, and Sefcleos: this plant they hate retained to rerygood purpofe and confideration; but the errour of the name hathcaufed diuers of our late writers to erre, and to fuppofe that Siler montanum, called in hops, Sefeleos, was no other than Scfolimafilien fuum of Diofiorides. But this plant containeth in his fubfeance much more acrimony, ,harpeneffe, and efficacy in working, than any of the plants called Sefelios. It hath falkes like Ferrila two cubits high. "The root fmelleth like Ligufficum: the leates are very much cut or diuided, like the leaues of Fennell or Sefeli Mafsilienses, and broader than the leaues of Peadedansm. At the top of the ftalkes grow fpoky tufts like Angelica, which bring forth a long and leafic feed like Cumine, of a pale colour; in tafte feeming as though it were condited with figar, but withall fomewhat fharpe, and fharper than Sefeli pratenfe.

2 There is a fecond kinde of Siler which Pena and Lobel fet forth under the title of Sefeli pratenfo chompeliew fum, which Dodoneus in his" laft edition calleth siler pratenfe alterum, that is in thew very like the former. the ftalkes thereof grow to the height of two cubits, but his leaucs are fomcwhat broader and blacker : there are not fo many leaues growing vpon the italke, and they are leffc diuided than the former, and are of little fauour. The feed is fmaller than the former, and fauouring very little or nothing. The root is blackc without, and white within, diuiding it felfc into fun. dry diuifions.

\section{The Place.}

It groweth of it felfe in Liguria, not far from Genua in the craggy mountaines, and in the gar dens of diligent Hcribarifts.

$$
\text { T The Time. }
$$

Thefe plants do flourc from Iune to the crd of Auguft.

$$
\text { 9. The Names. }
$$

It is called commonly Siler Montanum: in French and Dutch by a corrupt name Ser-Montain: in diters thops, Sefelcos, but vntruly : for it is not Sefeli,nor a kinde thereof: in Englifh, Siler moun taine, after the Latine name, and baftard Louage. $\neq$ The firt is thought to be the Ligufticum of the Antients, and it is focalled by crattbiolus and others. $\neq$

\section{If The Nature.}

This plant with his feed is hot and dry in the third degree.

$$
\text { of The Vertues. }
$$

The feeds of Siler drunke with Wormewood wine, or wine wherein Wormcwood hath been fodden, mooueth womens difeafes in great abundance:curcth the fuffocation and ftrangling of the matrix, and caufeth it to returne vnto the naturall place againe.

The root ftamped with hony, and applied or put into old fores, doth cure them, and coner bare and naked bones with flem.

Being drunke it prouoketh vrine, eafeth the paines of the guts or entrailes proceeding of crudi- $\mathbf{C}$ tie or rawneffe, it helpeth concostion, confumeth winde, and fwelling of the ftomackc.

The root hath the fame vertue or operation, but not fo effectuall, as not being fo hot and dry.

The figare which ormetly wis here was of the Sefeli Ma silimfe defcribed in the sext chanter in the fourth place, and thet which belonged to this place

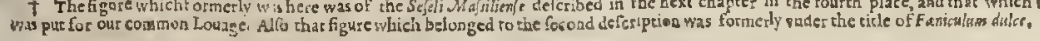

\section{C н А P. 224. Of Sefelios, or Harte-morts of Candy. \\ - The Defcription.}

I His plant being the Sefli of $C_{a n d y}$, and in times paft not clfewhere found, tooke his furname of that place where it was firf found, but now adaies it is to be feen in the corne fields about Narbon in France, from whence I had feeds, which profper ivell in my garden. This is but an annuall plant, and incrcafeth from yeere to yeere by his owne fowing? The leaues grow at the firft euten with the ground, fomewhat hairy, of an ouerworne greene colour, in thape much like vnto Cheruill, but thicker : among which rifeth vpan hairy rough ftalke, of the height of a cubit, bearing at the top fpokie tufts with white floures: which being vaded, there followeth round and flat feed, compaffed and cunningly wreathed about the edges like a ring. 
The feed is flat like the other,ioyned two together in one, as you may fee in the feed of Ferula on Angeliea, in thape like a round target, in talte like Myrrhis. Matbiolus did greatly miftake this plant.

2 There is a kinde of Sefeli Creticum, ealled alfo Tordylion : and is very like vnto the former, fauing that his leaues are more like vnto common Parfneps than Cheruil,and the whole plant is big. gerthan the former.

I Sefelicreticum minus:

Small Sefeleos of Candic.

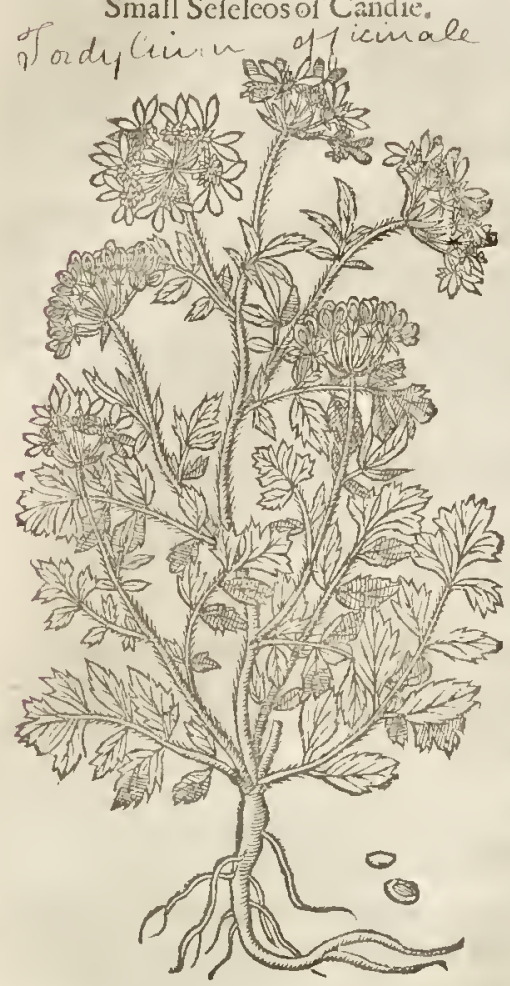

$¥ 2$ Sefeli Creticum maius. Great Sefelios of Candic! Jordyhim , 200 moxine

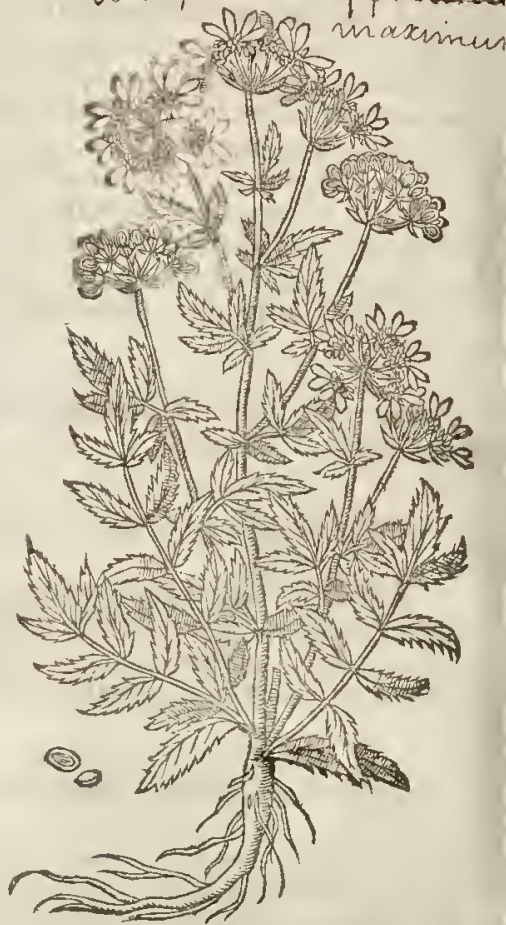

3 There is likewife a kinde of sefeli that hath a root as big as a mans arme, efpecially if the plant be old, but the new and young plants beare roots an ineh thieke, with fome knobs and tuberous fprouts, about the lower part, the root is thieke, rough, and eouered ouer with a thicke barke, the fub tance whereof is firft gummic, aftenvard tharpe, and as it were full of fpattle; from the vpper part of the root proeed many knobs or thicke fwclling roots, ont of which there iffueth great and large wings or branches of leaues, fome whereof are notched and dented round about, growing vnto one fide or rib of the lea fe, ttanding alfo one oppofite vnto another, of a darke and delaid green colour, and fomew hat fhining abouc, but vnderneath of a grayith or afhe colour : from amongft thefe leates there arifeth a ftraked or guttered ftalke, a cubit and a halfe high, fometimes an ineh thieke, hauing many ioints or knees, and many branches growing about them, and vpon eaeh ioint leffer branches of leaues. At the top of the ftalkes, and vpper ends of the branehes grow little cups or vmbels of white floures; which being vaded, there eommeth in plaec a feed, which is very like Siler monsanum. $\neq$ I take this here deferibed to be the Sefeli montanum r of Clufus, or Liguftickrs alterum Belgarum of Lobci: and therefore I have ginen you Clufurs his figure in this plaee. $\neq$

There is alfo a kinde of Sefeli, whieh Pena fetteth forth for the firft kinde of Daucus, wherof I take it to be a kind e,growing enery where in the paftures about London, that hath large lcaues, growing for a time enes with the earth, and fpred thereupon, and diuided into many parts, in manner almoft like to the former for the moft part in all things, in the round fpokie tufts or vmbels, bearing ftiffe and faire white floutes in thape like them of Cinkefoile; in fnell like Sambucus or Elder. When the floure is vaded, there commeth in place a yellow guttered feed, of a fpieie and very hot anfe. The root is thiel:s, and blucke without, which rottethand perifheth in the ground (as wee 


\section{С н г. 425. Of Spignell, Spicknell, or Mewe. TThe Defeription.

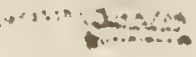

I Signell hath ftalkes rifing vp to the height of a cubit and a halfe, befec w ith leaues refem bling Fennell or Dill,but thicker,more burhic, and more finely iagged; and at the top of the ftalkes do grow fpokic tufts like vnto Dil. The roots are thick, and full of an oleous fubltance, fmelling well, and chafing or heating the rongue, of a reafonable good faurour.

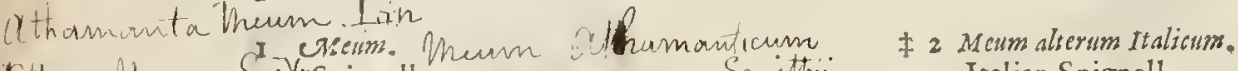

$$
\begin{aligned}
& \text { Etruga heum Sys vegsignell. } \\
& \text { Smithie } \\
& \text { Italian Spignell. }
\end{aligned}
$$
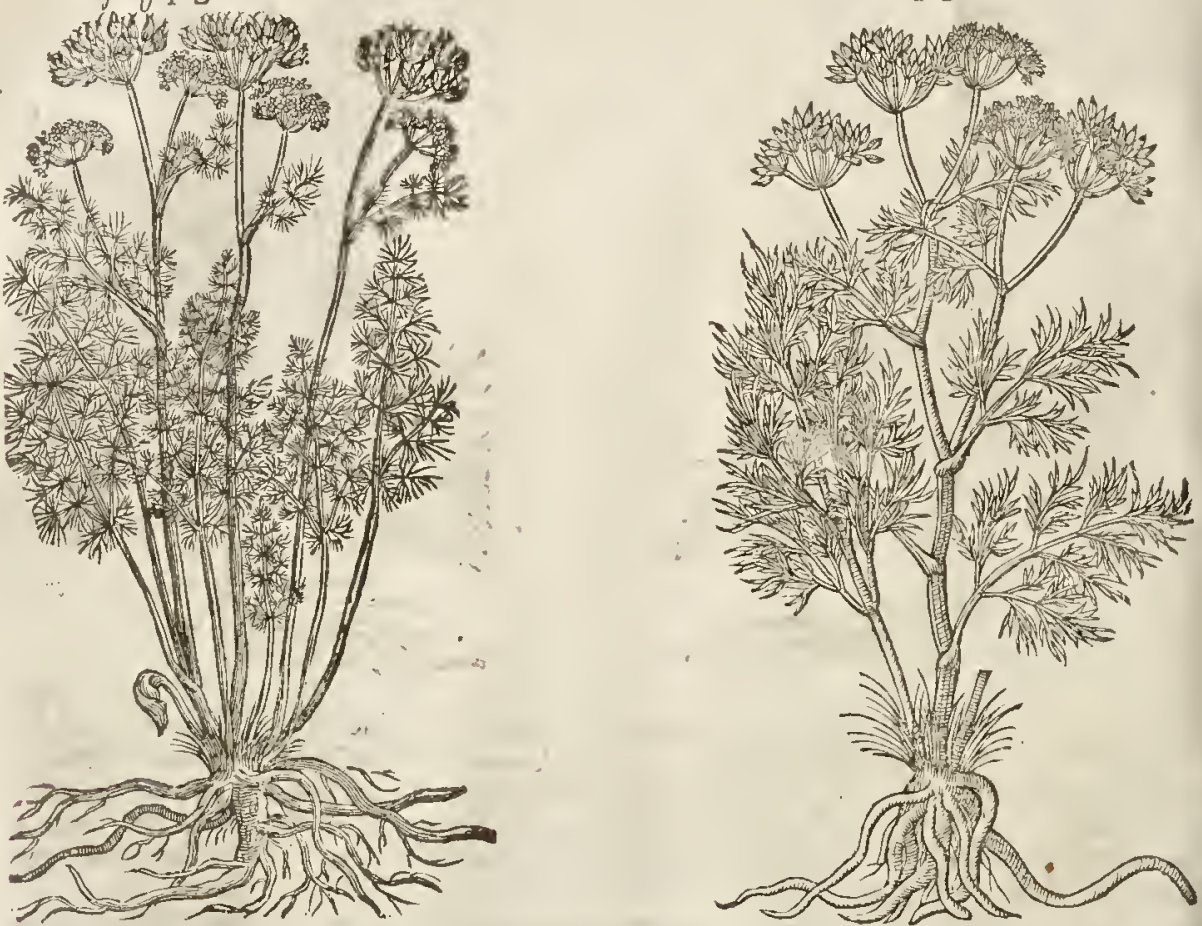

There is a baftard kinde of Spignell like vnto the former, fauing that the leaues are not fo fincly cut or liagged : the floures are tufted more thicker than the former: the roots are many,thick, and full of fap.

$$
\text { The Place. }
$$

Mew, or Mcon groweth in Weftmerland, at a place called Round-twhat betwixt Aplebie and Kendall, in the parith of Otton.

Baftard Mewc, or Meum, groweth in the wafte mountaines of Italie, and the Alps, and (as it hath been told me) rpon Saint Vincents rocke by Briftow, where I fpent two daies to feeke it, but it was not my hap to find it, therefore I make fome doubt of the truth thereof.

IT The Time.

Thefe herbes doe floure in Iune and Iily, and yecld their feed in Auguft.

T The Names.

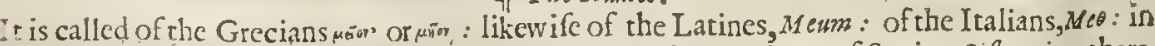
A $P$. ia, as Mathiolus declareth, it is called Imperatrix : in diuers places of Spaine, Siftra: in others, $\%$ : in High Dutch, 23eecemuets: in French, siftre: Ruelliw faith that it is named in France thesro tortwoyim, and fylueftre, or writhed Dil, and wilde Dill : alfo it is called in Englifh, Spignel, Spicknell, of fome Mew, and Bearewoort.

The fecond may be called battard Spicknell. 
4 The Temperature.

Thefe herbes, efpecially the roots of right Mcon, is hot in the third degree, and drie in the fecond.

The Vertues.

The roots of Meon, boiled in water and drunke, mightily open thic ftoppings of the kidnies and bladder, prouoke viine and bodily luft,eafe and helpe the trangurie, and confume all windineffe and beichings of the ftomacke.

The fame taken witl honie doth appeafe the griefe of the belly, and is exceeding good a- B gainf all Catarrhes, rheumes, and aclies of the 1ointes, as alfo any phlegme which falls vi on the Lungs.

If the fame be laied plaifterwife vpon the bellies of childien, it maketh them to pife well.

They clenfe the entrails, and deliuer them of obftructions or ftoppings : they prouoke virine, D driue forth the ftone, and bring downe the floures : but if they be taken more than is requifite, thicy caufe the head-ache; for feeing they haue in then more heat than drineffe, they carry to the head raw moifture and windie heat, as Galen faitl.

\section{С н г. 426. Of Horeftrange, or Sulpburwoort. \\ If $T$ he Defcription.}

I Vylphurwoort or Hogs-fennell hath a ftiffe and hard ftalke full of knces or knots, befet with leaues like vnto Fennell,but greater.comining neerer vnto Ferula,or rather like the leaues of wilde Pine-tree, and at the top ot the falkes round fpokie tufts full of little yellow floures, which do turne into lroad browne feed. The root is thicke and long : I haue digged vp roots thereof as big as a mans thigh, blacke without, and whitc within, of a ftrong and grievous fmell; and full of yellow fap or liquour, wibich quickly waxeth hisd or dry, fmelling not nuch vnlike brimftone, called Sulphur; which hath induced fone to calint Sulphurwoort; hauing alfo at the top toward the vpper face of the carth, a certain buth of haire, of a browne colour, among which the leaucs and falkes do fpring forth.

2 The fecond kinde of Peucedonum or Hngs-fennell is very like vnto the former, fauing that the leaues be like Ferula : the roots are nothing fo great as the former, but all the reft of the plant doth far exceed the other in greatneffe.

3 There is another kinde of $P$ sucedanum or Hogs Fennell, which $P$ ena found vpon Saint Vincents rock by Brifow, whofe pioture he hath fet forth in his Aduer far ia, which that famous Englion Phyfition of late memorie, D. Turner found there allo, fuppofing it to be the right and true Percedanum, whereof no doubt it is a kinde : it groweth not aboue a foor high, and is in thape and leaues like the right $P$ eucdamum, but they be fhorter and lefer, growing formw hat iike thewrithed Fennell of Maffilua, but thebranches are more largely writhed, and the leaues are of the colour of the branches, which are of a pale greene colour. At the top of the branches grow fmall white tufts, hauing feed like Dill,but fhorter and flenderer, of a good tafte, fomewhat tharpe. The ront is thieker than the fmalneffe of the herbewill well beare. Among the peopleabout Briforw, and the rocke aforefaid, this hath been thought good to eat.

$\ddagger$ The figure of this our Authour formerly gaue (yet vnfitly, it not agreeing with that deferipcion) for o reofelinum : it may be he thought it the fame with that of Dodon. his defcription, beeaufe be found it vider the fame title in Tabernomontanus. This is the Selinum montanum pumilum of Clufiess; and the Peucedani facie profilla planisa of Pena and Lobel; wherfore Baubine was miltaken in his Pinat, whereas he refers that of Lobel to his third Pencedanum : the root of this is black withour, and white within, but thort,yet at the top about the thickneffe of ones finger: the leaues are fimall arid green, commorly diuided into fiue parts; and thefe againe fubdiuided by threes: the Atalke is fome fixe inches or halfe a foot high, ditided into fundry branches, crefted, broad, and at the toppes of the branches, euten when they firtt thoot vp, appeare little vmbels of white floures very fimall, and confiftung of fite leaues apiece. The feed is blacke, th ining and round, two being ioined together, as in noft vmbelliferous plants. It floures in May, and riperis the feede in Iuly : I receitued in luly $16_{3}$, , fome plants of this from Briftow, by the meanes of my oft mentioned friend Mafter George

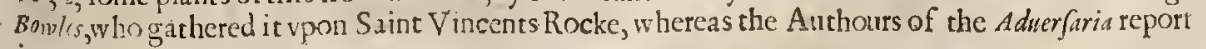
it to grow. t 


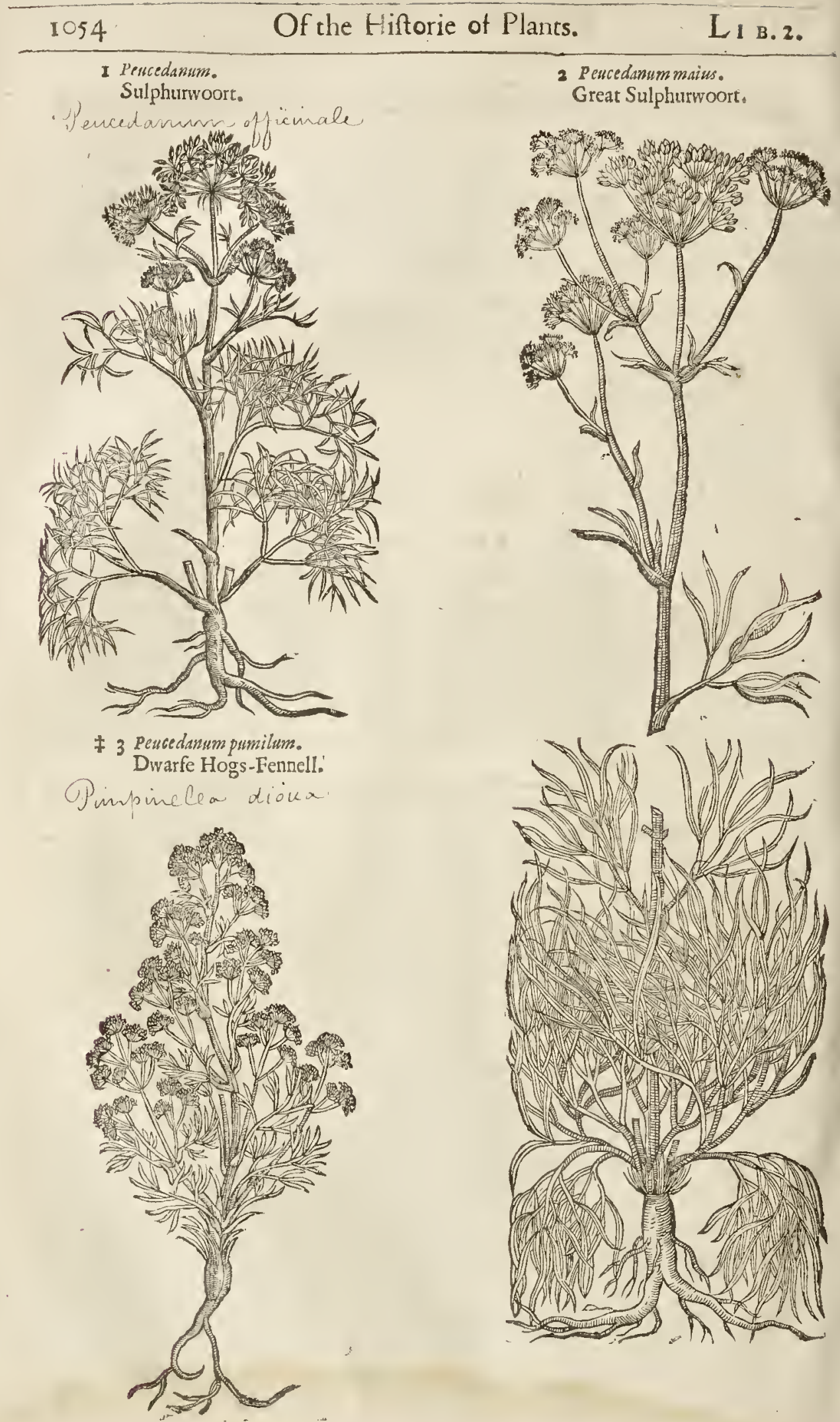


बi The Place:

The firft kinde of Pcucedawm or Hogs Fennell groweth very plentifully on the South fide of a wood belonging to Waltham, at the Nafe in Eflex by the high-way fide; alfo at Whirfable in Kent, in a medow neere to the fea fide, fonctime belonging to Sir Henry Cripe, and adioyning to his houfe there. It groweth alfo in great plenty at Feueriham in Kent, neere vnto the hauen vpon the bankes thereof, and in the medowes adioyning.

The fecond kinde groweth vpon the fea codts of Montpellier in France, and in the coafts of Italy.

Thefe plants do floure in Iune, Ituly, and Auguf.

IT The Names.

The Grecians call it moxidxoc : the Latines in like mannet $P$ eucedanos, or Peucedinum, and alfo $P$ imuftellum : noft of the fhops, and likewife the common people name it Feniculum Porcinum : of diuers, Stataria : of the Propliets, zussis sximen : that is to fay, a good Angell or Ghof : in high-Dutch,

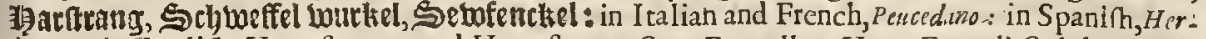
batum : in Englifh, Hore-1trange, and Hore-1trong, Sow-Fennell, or Hogs Fennell, Sulphur-wort, or Brimftone-wort. It is called Pencedanum and pinaftellwm, of the Greekeand Latinewords, miss. and Pinus.

T The Temperature.

"The fe herbes, efpecially the yellow fap of rhe root, is hot in the fecond degree, and dry in the beginning of rhe third.

T The Vertues.

The yellow fap of the root of Hogs Fennell, or as they call it in fome places of England, Hore- $\mathbb{A}$ frange, taken by it felfe, or with bitter almonds and Rue, is good again the thortnefle of breath, it affwageth the griping paines of the belly, diffolueth and driteth aw ay ventofitie or windineffe of the ftomacke; it watteth the fwelling of the milt or fpleene, loofeth the belly gently, and purgeth by fiege both flegmc and choler.

The fame taken in manner aforefaid prouoketh vtine, eateth the paine of the kidneyes and blad- B der, caufeth eafie deliuerance of childe, and expelleth the fecondine, or after-birth, and the dead childe.

The fap or inyce of the root mixed withoyle of Rofes, or Vineger, and applied, eafeth the pal- $C$ fie, crampes, contraction or drawing together of finewes, and allold cold difeafes, efpecially the Sciatica.

It is vfed with good fuccefle againft the rupture or burftings in yong children, and is very good $D$ to be applied vnto the nauels of children that ftand out ouer much.

The decostion of the root drunke is of like vertue vnto the ityce, but not altogether fo effecti- $\mathbf{E}$ all againft the forefaid difeafes.

The root dried and made into pouder doth mundifie and clenfe old ftinking and corrupt fores $\mathbf{F}$ and vlcers, and healeth them: it alfo draweth forth the corrupt and rotten bones that hinder the fame from healing, and likewife fplinters and other things fixed in the flefh.

The faid pouder or iuyce of the root mixed with oyle of Rofes, caufeth one to fweat, if the body $G$ be anointed therewith, and therefore good to be put into the vnction or ointmenr for the French difeafe.

The congealed liquor tempered with oyle of Rofes, and applied to rhe head afrer the manner of $\mathrm{H}$ an ointment, is good for them that haue the Lethargie, that are franticke, that haue dizzineffe in the head, rhat are troubled with the falling fickneffe, that haue the palfie, that are vexed with convulfions and crampes, and generally it is a remedie for all infirmities of the finewes, with Vineger and oyle, as Diofcurides teacheth.

The fame being fmelt vnto reuiuth and calleth them again that be ftrangled with the mother; I and that lie in a dead fleepe.

Being taken in a reare egge it helpeth the cough and difficultic of breathing, gripings and win- $K$ dineffe, which, as $G$ alen addeth, proceedeth from the groffeneffe and clammineffe of humors.

It purgeth gently, it diminifheth the fplcene, by cutting, digefting, and making thin humours $L$ that are thicke : it caufeth eafie traucll, and openeth the matrix.

A fusall piece of the root holden in the mouth is a prefent remedie againft the fuffocation of $M$ the mother. 


\section{Cна н. 427. of Herbe Ferula, or Fennell Gyant. \\ If The Kindes.}

$\mathrm{D}$ Iofcorides maketh mention of a Ferula, out of which is gathered the Gum Sagapene; and alfo he declareth, that the Gums Galbanum and Amminincum are liquors of this herb Ferula : but what difference there is in the liquors, according to the clymat or countrey where it growcth, he doth not fet downe; for it may be that out of one kinde of Ferula fundry iuyces may be gathered, that is to fay, according to tile diuerfitie of the countries where they grow, as we have faid: for as in Lafer, the inyce of Laferwort that groweth in Cyrene doth differ from that liquor which groweth in Media and Syria ; fo it is likely that the herbe Ferula doth bring forth in Media Sagaperum, in Cyrene Ammoniacum, and in Syria Galbanum. Theophraftus faith that the herbe Ferula is diuided into mo kindes, and he calleth one great, by the name of Ferula; and another little,by the name Ferulago.

I Ferulit.

Fennell Gyant.
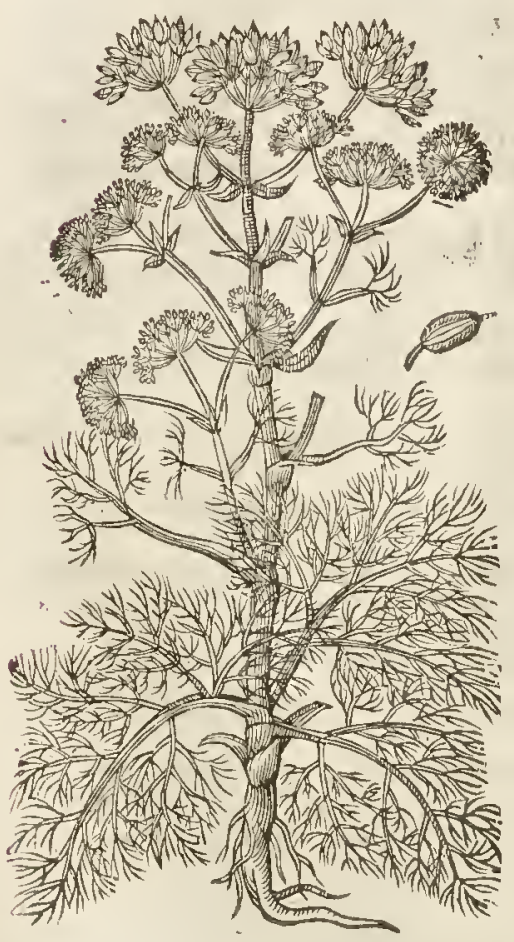

$\ddagger 2$ Ferulago.

Small Fennell-Gyant.

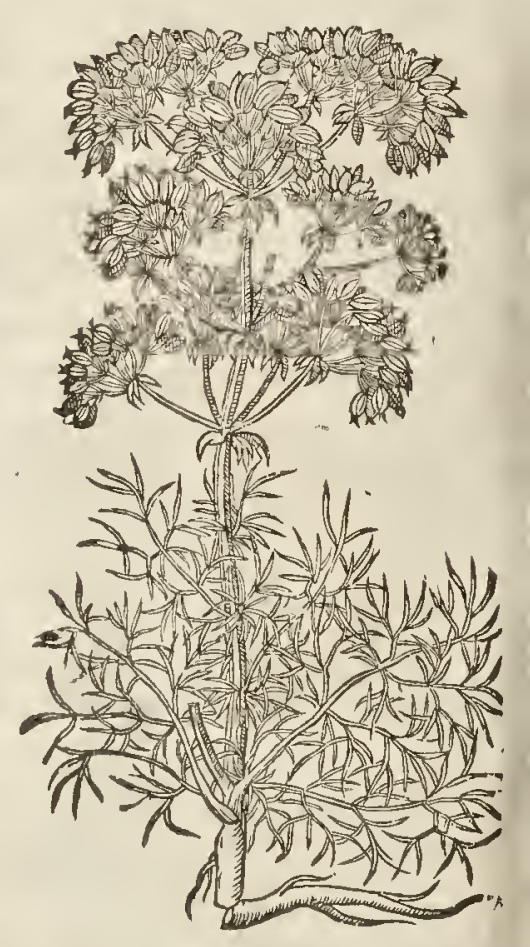

TI The Defcription:

I E Erula, or Fennell Gyant, hath very great and large leaues of a deepe greene colour, cut $\mathrm{H}^{-1}$ and iagged like thofe of Fennell, fpreading themfelues abroad like wings: among?t which rifeth vp a great hollow ftalke, fomewhat reddifh on that fide which is next vinto the Sun,diu ided into certaine fpaces, with ioynts or knees like thofe of Hemlocks or Kexes, of the bigneffe of a mans arme in the wreft, of the height of foure or fue cubits where it groweth naturally, as in Italy, Greece, and other hot countries; notwithftanding it hath attained to the heiglit of fourteene or fiftecne foot in my garden, and likewife groweth fairer and greater than from whence it came, as it fareth with orher plants that come hither from hot regions: as for example our great Artichoke, which firftwas brought out of Italy into England, is become (by reafon of the great moifture which our countrey is fubiect vnto) greater and better than thofe of Italy; infomtich 
infomuch that diuers Italians hate fent for fome plants of our Artichokes, deeming thein to be of another kinde; neterthelefte in Italy they are finall and dry as they were before. Euen lo it hapneth to this Fertla, as we haue faid. This forefuid ftalke dituideth it felfe toward the rop into diuers orher fmaller branelies, whereon are fet the like leaues that grow next the ground, but nuch leffer. At the top of the brunches at the firt budding of the floures appeare certaine bundles inclofed in thin skins, like the yolke of an egge, whieh diuers eall Corculum Ferula, or the litrle heart of Ferula; which being brought to maturitic, open themfelues into a tuft or umbel like that of Dil, of a yellowith colour: after which come the feed, in colour and fafhion like thofe of the Parfnep, but longer and greater, alwaies growing two together, foelofely ioyned, that it cannot be difeerned to be more than one feed vntill they be ditided: the root is very thicke and great, full of a certaine gummic iuyce, that floweth forth, the root being bruifed, broken, or eut ; which being dried or hardned, is that gum which is called Sagapenam, and in fome fhops Serapinum.

\$ 3 Panax Afclepium Feruldefacie. Asfoulapius his All-heale.

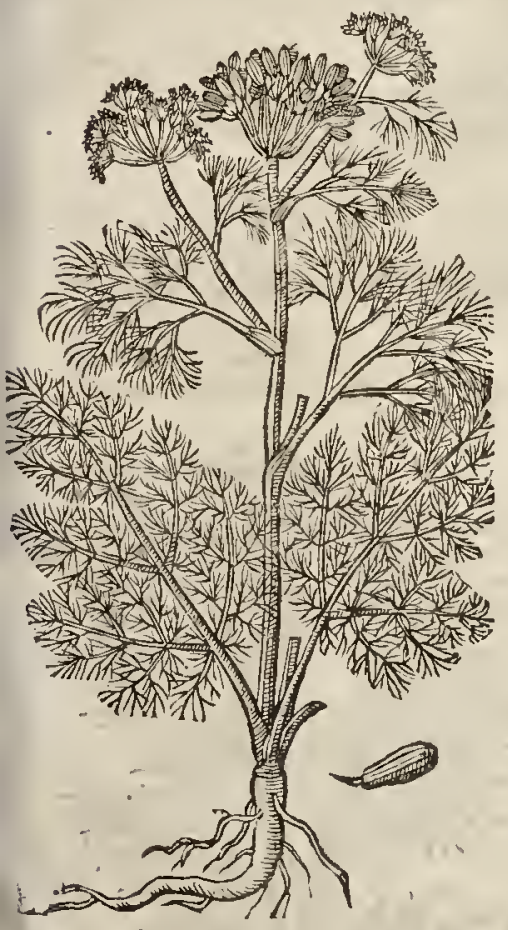

2 There is likewife another fmaller Ferula like vito the former in each refpeot, fauing that it is altogether leffe : the root likewife being wounded yeeldeth forth a fap or inyee, which when it is hardned is called Galbanum: of the Affyrians, cMetopium.

I haue likewife another fort fent mee from Paris, with this title Fertlanigra; which profpereth exceeding well in my garden, but difference I cannot finde any from the former, $f_{a}$ that the leaues are of a more blacke or fivart colour.

\# 3 I know not where more fitly than in this place to gine you the hiftorie of that $F e$ rude or Ferulaceous plant that Dodoneus, Lobel, and others haue fet downe vnder the name of Panax cifclepinim: The ftalke hereof is Ifender, a cubir high, crefted and ioynted, and from thefe ioynts proceed leates bigger than thoie of Fennell, and alfo rougher, and of a ftrong fmell : at the tops of the branches grow vmbels of yellow floures : the feed is flattinh, like that of the other Feruld : the root long, white, and of a ftrong fmell. This growes naturally in Iftria. $\neq$

$$
\text { If The Place. }
$$

Thefe plants are not gtowing wilde in Eng. land; I haue them all in my garden.

$$
\text { I The Time. }
$$

They floure in Iune and Iuly; they perfect their feed in Scptember; not long after, the ftalkewith his leaucs perith : the root remai. neth frefh and greene all Winter.

I The Names.

- The firt is called in Greeke Mápons : in Latine, Ferula $:$ in Italian, Feroln: in Spanifh, Camanheia: in Englinh, Herbe Ferula, and Fennell Gyant.

If The Temperature.

Thefe plants with their Gums are hot in the third degree, and dry in the feeond.

$$
\text { - The Vertues. }
$$

The pith or marrow, called Corcultum Ferula, as Galen teacheth, is of an aftringent or binding A qualitie, and therefore good for them that fpit bloud, and that are troutbled with the flix.

Diofcorides faith, that being put into the nofthrils it ftayeth bleeding, and is giten in Wine to $B$ thofe that are bitten wirh Vipers.

It is reported to be eaten in A pulia rofted in the embers, firtt wrapped in leaues or in old clouts, C with pepper and falt ; which, as they fay, is a pleafant fweer food, that ftirreth vp luft, as they report.

The feed doth heate, and attenuate or make thinne : it is a remedie againft cold fits of an $A$ gue, D by procuring fiveat, being mixed with oyle, and the body anointed therewith.

A dram of the iuyce of Fcrula which beareth Sagapenum, purgeth by fiege tough and nimie thu- E nuors, 
mors and all groffe flegme and choler, and is alfo good againft all old and cold dufeafes which are hard to be cured; it purgeth the brain, and is very good againft all difcafes of the head, againft

F the Apoplexie and Epileprie.

Eeing taken in the fame manner, it is good againft crampes, palfies, fhrinkings and paines of.

$\mathrm{G}$ the finewes.

It is goodagainft the fhortneffe of breath, the cold and long cough, the paine in the fide and

$H$ breft, for it mund ifieth and clenfeth the breft from all cold flegme and rheumaticke humors.

Sagapenum infufed or fteeped in vineger all night, and fpread vpon learher or clouth, feattereth, diffolucth, and driucth away all hard and cold fwellings, tumors, botehes, and hard lumpes growing about the ioynts or elfewhere, and is excellent good to be put into or mingled with all oynt-

I ments or emplaifters which are made to mollifie or foften.

The iuyce of Ferula Galbanifera, called Galbanum, drunke in wine with a little myrrh, is good againft all venome or poyfon that hath beene taken inwardly, or hot into the body with venomous $\mathbb{K}$ darts, quarrels, or arrowes.

It helps womens paineful trauel, if they do take therof in a cup of wine the quantitic of a bern.

L The perfume of Galbanum helpeth women that are gricued with the rifing of the mother, and is good for thofe that hate the falling fiekneffe.

M Galbanum foftneth, mollifiech, and draweth forth thornes, fplinters, or broken bones, and confumeth cold and fegmaticke humors, feruing in fundry ointments and emplaifters for the $\cdot v$ fe of Surgerie, and hath the fame phyficall vertues that are attributed vnto Sarapenum.

\section{C н а. 428. Of Drop-wort, or Filipendula.}

I Filipendula.

Spria Drop-wort olipendula.

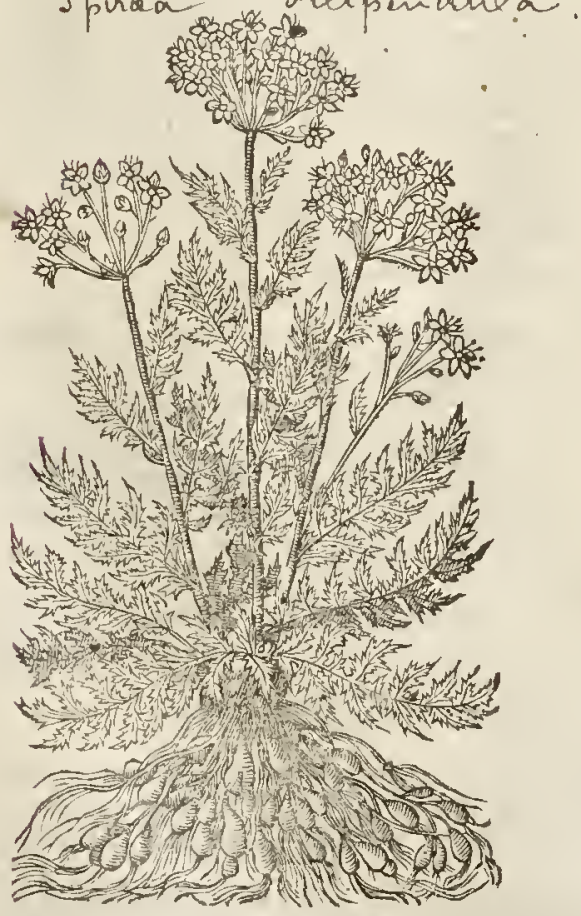

2 Filipindula montana.

Mountaine Drop-wort.

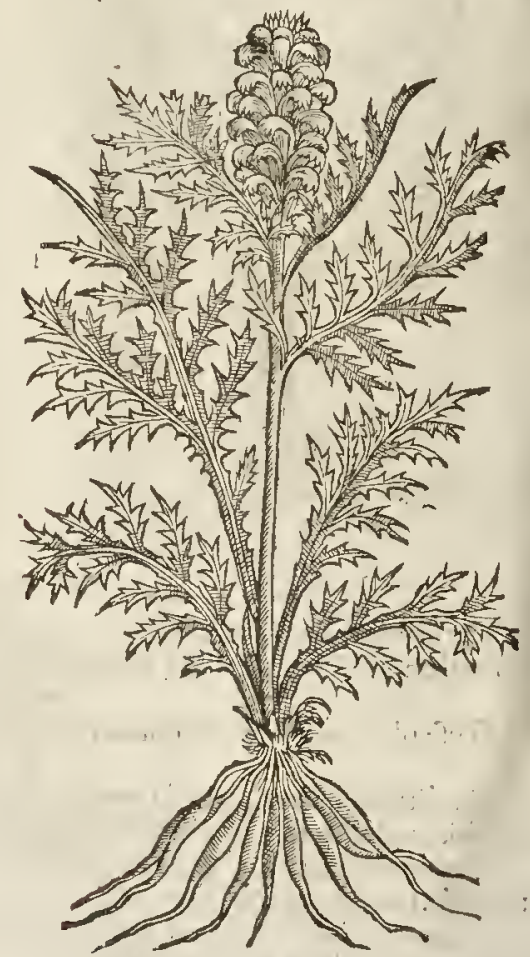

The Kindes:

7 Here bediuers forts of D. rop-worts, fome of the champion or fettill paftures, fome of mork moint and dankifh grounds, and fome of the mountaine. 


\section{The Defcription.}

1 THe firf kinde of Filipendula hath leaues growing and fpred abroad like feathers, eaeh leafe confinting of fundry fmall leaues dented or fnipt round about the edges, grow ing to the italke by a fmall and flender ftem : there leates refemble wilde Tanfe or Burner, but tliar they be longer and thicker, fer like feathers, as, is aforefaid: among thefe rife vp ftalkes a cubit and a halfe high, at the top whereof grow many faire white floures, cach fmall Houre confifting of fix flender leaues, like a little ftar,bufhing together in a tuft like the floures of Medefweet, of a foft fweet fmell : the feed is fmall, and groweth together like a button : the roots are fmall and blacke, whereupon depend many little knops or blackepellets, much like the roots of the female Peonie, fatuing that they be a great deale finaller.

2 The feeond linde of Filipendula, called of $P$ ena in his Obferuations, Oenunthe, fute philipendula altera montana, is neither at this day very well knowne, neither did the old writers hererofore oncewrite or fpazke of it : but Pent that painefull Herbarif found it growing naturally in Narbone in France, neere vnto Veganium, on the top of the high hills called $p$ aradifus $D e i$, and neere vnto the mountaine Calcaris : this rare plant hath many knobby long roots, in thape like to $A$ phodelus lutens, or rather like the roots of Corruda, or wilde Afparagus, from which rifeth vp a ftalke a foot high, and more, which is thicke, round, and chanelled, befet full of leaues like thofe of common Filipendula, but they be not fo thicke fer or winged, but more like vnto the leaties of a Thifte, confifting of fundry fmall leaues, in fathion like to Coronopus Ruclly, that is, Ruellius his Bucks horne : round about the top of the ftalke there groweth a very faire tuft of white flutres, refembling fine fmal! hoods, growing clofe and thicke together like the floures of Pedicularis, that: is, Red Rattle, called of Carolus Clufius, Alectorolophos, wherenflue maketh this plant a kinde, but in my iudgement and opinion it is rather like Cynoforchis, a kinde of Satyrion.

3 Filipendula anguffifolia.

Narrow leafed Drop.worto' Enarthe Sencedomifolia.

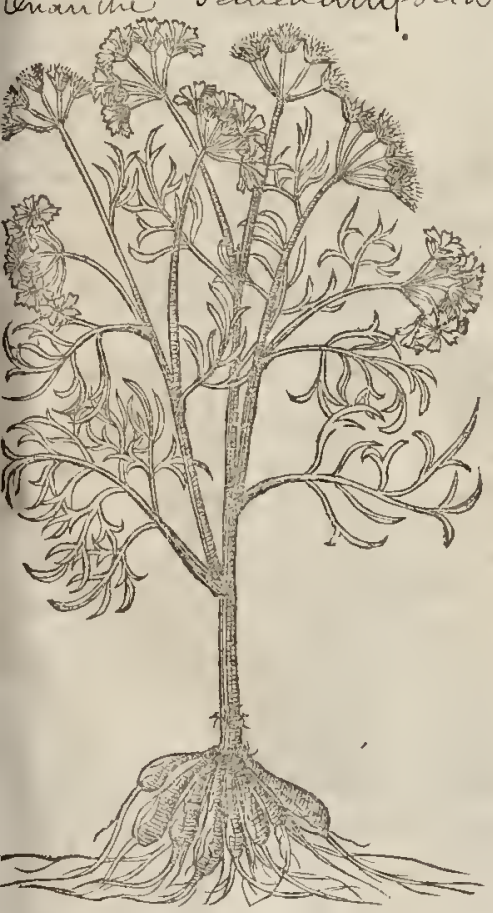

' 4 Filipendula Cicutafacie. Hemlocke Drop-wort. Enuthe erocata

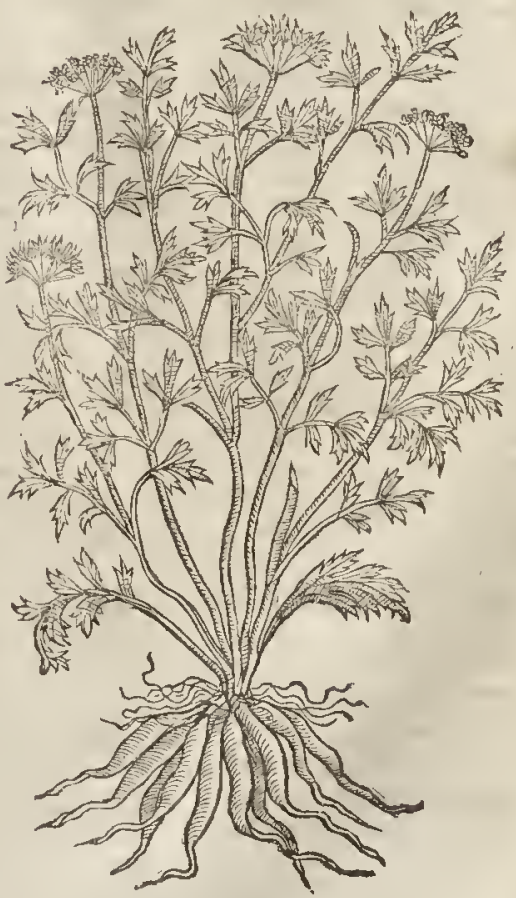

3 There is another kinde of Filipendula fet forth vnder the name of o mant he, that hath many tuberous and thicke roots. like thofe of Drop-wort, but white of colour, and euety one of thofe knobs hath a certaine ftring of fibre anpexed thercto from whence arifeth a crefted ftalk two foos high, 
5 Filipendula aquatica.

Water Diop-wort.

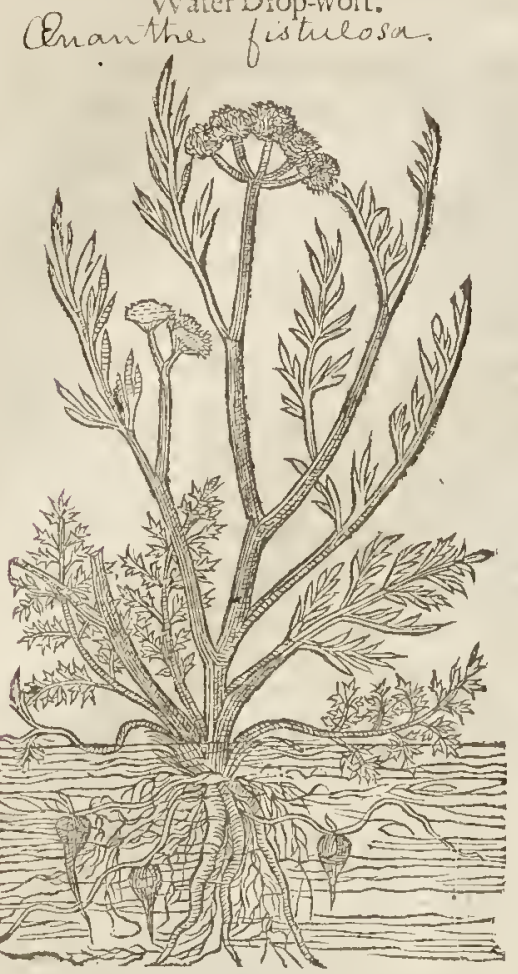

high, diniding it felf toward the top into fur dry armes or branches: from the hollow plac or bofome of etery ioynt (out of which do grow thofe branches) the leanes doe alfo pro ceed, very much cut or iagged like Fennell : a the top of thofe branches come forth fpokie rundles of white floures fathioned like itars.

+4 The fourth hinde of Filipendula is a ftrange a plant as the former, efpecially wit] vs here in England, except in the waterie pla. ces and rilles in the North, where Paludapium or water Smallage groweth; wheremnto it leaues it is not vnlike, but more like Ruta pra $\operatorname{ten}$ (3s : It hath many large branches, a naught fauror, and in colour and thape like Cicuta, tha is, Hemlocke. The falkes are more than two cubirs high, comming from a rootwhich ex. ceedingly multiplies it felfe into bulbes, like Aphodeles albus. The finell of this plant i: ftrong and grienous; the tafte hot and biting it being full of a iuyee, at firft milky, but after wards turning yellow. The fpoky tufts or run. dles growing at the top are like Cicuta, yea, $\mathrm{i}$ much refembleth Hemlocke in propertie anc nitalities, and fo doe they affirme that haue proued and feene the experience of it : for being eaten in fallads it did well nigh poyfor: thofe which ate of it, making them giddie in their heads, waxing very pale, ftaggering and reeling like drunken men. Beware and take good heed of this and fitch like Simples ; for there is no Phy fitian that will gime it, becaufo there be many orher excellent good Simpleswhich God hath beftowed vpon vs from the preuenting and curing of difeafes. F Pernitious and not excufable is the ignorance of fome of our time, that haue bought and (as one may probably coniecture) vfed the roots of this plant in ftead of thofe of Peionie; and I know they are dayly by the ignorant women in Cheape-fide fold to people nore ignorant than themfelues, by the name of water Louage; Caweat Emptor. The danger that
may enfue by $v$ fing them may be gathered by that which our Author hath here fet downe, being
taken out of the Aduerfaria, pay. 326 . aken out of the Aduer faria, pay.326. 末

5 The fifth and laft kinde of Filipendula, which is the fourth according to Matthiolus his account, hath leaucs like water Smallage, which $P$ ling calleth sylaus, the leaues very much refembling thofe of Laner Cratere : among which rifeth vp a fmall ftalke deepely furrowed or crefted, bearing at the top thereof fpolie or buthy rundles of white floures thicke thruft together. The roots are compace of very many filaments or threds, a among which come forth a few tuberous or knobbie roots like vnto the fecond. $\quad$ The Place and Time.

The firt groweth plentifully vpon fonic rockes or mountaines, and rough places, and in fertile paftures.I found great plenty there of growing in a ficld adioyning to Sion houfe, fomtime a Nunnerie, neere London, on the fide of a medow called Sion Medow.

The fecond hath been fufficiently fpoken of in the defeription. The third groweth neere unto brookes and riters fides. The fourth groweth betweene the plowed lands in the moift and wet furrowes of a field belonging to Batterfey by London. ‡ It alfo groweth in great aboundance in many places by the Thames fide; as amongft the oyfiers againft Yorke houfe, a little aboue the Horfe-ferrey, againft Lambeth, \&c. \# The fifth groweth neere the fides of riuers and waterftreames, efpecially neere the riuer of Thames or Tems,as in S. Georges fields, and about the Bifhop of Londons houfe at Fulham, and fuch like places.

They floure from May to the end of Ime.

4) The Names.

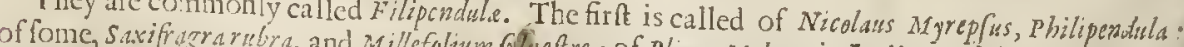
dula : in Englin, Filipendula and Dom Jyluefre : of Pliny, Molon : in Italian and Spanifh, Filipenocrantbe aquaticu, and silews Pliniy. 
The fourth, whofe leaues are like to Homloeks, is as fome thinke ealled of Coidus, olferachium: Englifh Homlozke Filipendula:

\section{- The Nature.}

Thefe kindes of Filipendula are hot and dry in the third degree, opening and elenfing, and yet ith a little aftriction or binding. All the kindes of Oenanthes haue the fame faculcie, except the ourth, whofe pernitious facultic we hate formerly touched.

oा The Vertues.

The root of common Filipendula boiled inwine and drunken, is good againft all paines of $A$ he bladder, caufeth one to make water, and breaketh the ftone. The like Diofcorides hath written f Oenanthe; the root, fath he, is good for them that piffe by drops.

The powder of the roots of Filipendula often vfed in meate, will preferte a man from the fal- $B$ ing fickenefle.

The fioures

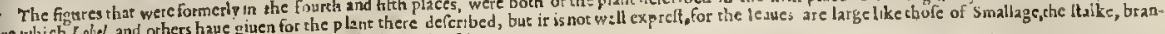

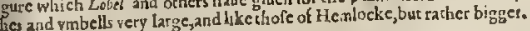

\section{С н а Р. 429. Of Horrilocks, or berbe Bennet.}

\section{The Defcription.}

$1 \rightarrow H e$ firftkinde of Hcmlocke hath a long ftalke, fiue or fix foot high, great and hollow, full of joints like the ftalkes of Fennell, of an herby colour; poudered with fmall red pots, almoft like the ftems of Dragons. The leaues are great, thicke, and fmall eut or jagged like the leaues of Cheruill, but much greater, and of a very ftrong and vnplea fant fauor." The Houres are white,growing by tufrs or fpokie tops, which do change and turne into a white flat feed: the root isthort, and fomewhat hollow within.

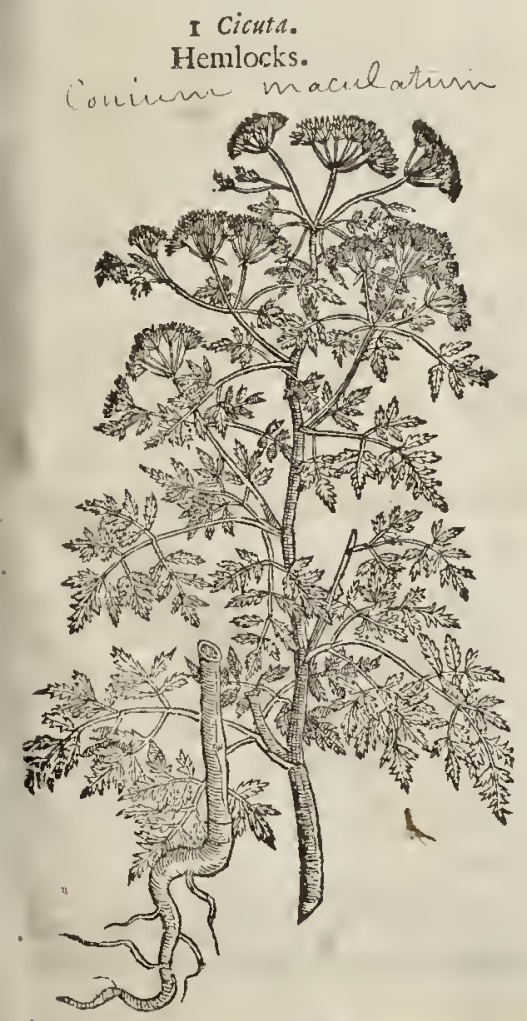

2 The Apothecaries in times paft not knowing the right Sefeli Peloponnenfe, baue erronioully taken this Cicustalafolia for the fame. The leaues whereof are broad, thicke, and like vnto Cicutaria, yet not the fame; they called it Sefeli Peloponnen $\int e \mathrm{cum}$ folio cicute, the faculties whereof deny and refuec that affertion and opinion, yea and the plant it felfe, which being touched, yeeldeth or breatheth out a moft virulent or lothfome finell : thefe things fuffie iciently argue, that it is not a kinde of Sefel, befides the reafons following : Sefeli hath a reafonable good fauour in the whole plant, the root is bare and fingle, without fibres, like a Carrot - but cicuts hath not onely a lotbone fmell, but his roots are great, thicke, and kno'sby, like the roots of cicyrrbis : the whole plint doth in a manner refemble the lextes, Ptalkes and floures of Myrrbis odorati, whole finall ivhite floures doc turne into long and crooled feeds, growing at the top of the branches three cubits high.

$\neq 3$ This in leatres, ftalkes, and roors is larger than the latt deferibed, the ftalkesequalling or exceeding the height of a man; the fmell is ftrange and greiusus, and in all the parts thereof it is like to the other plant s of this kinde. Lobel figtres it by the name of $C i$. cutaria maxima Brancionis, and queftions whither it be not Thapfatertia Salamanticenfum of clufurs; but Clufius denies it fo to be. $\ddagger$ 
2 Cicutalatifolia fatidisima.

Broad lcafed ftinking Hemlocks.

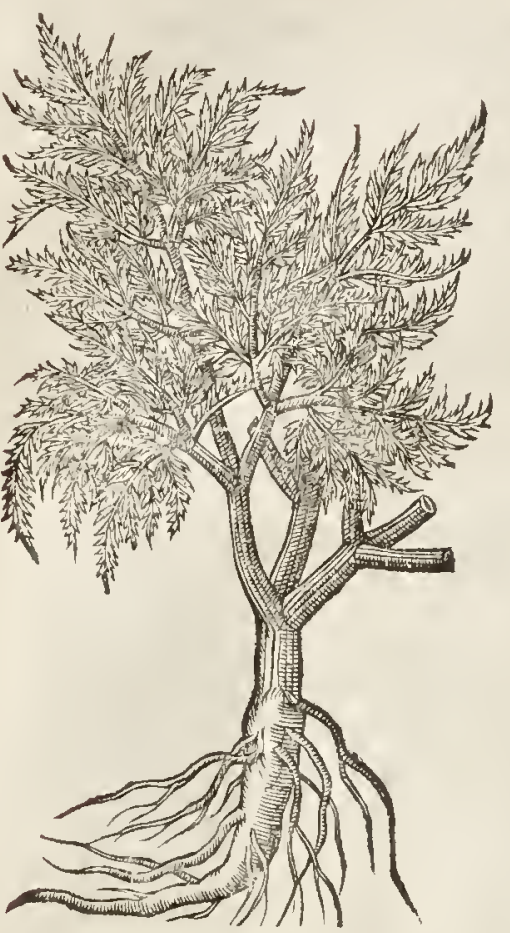

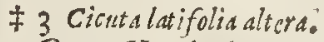
Gyant Hemlocke.

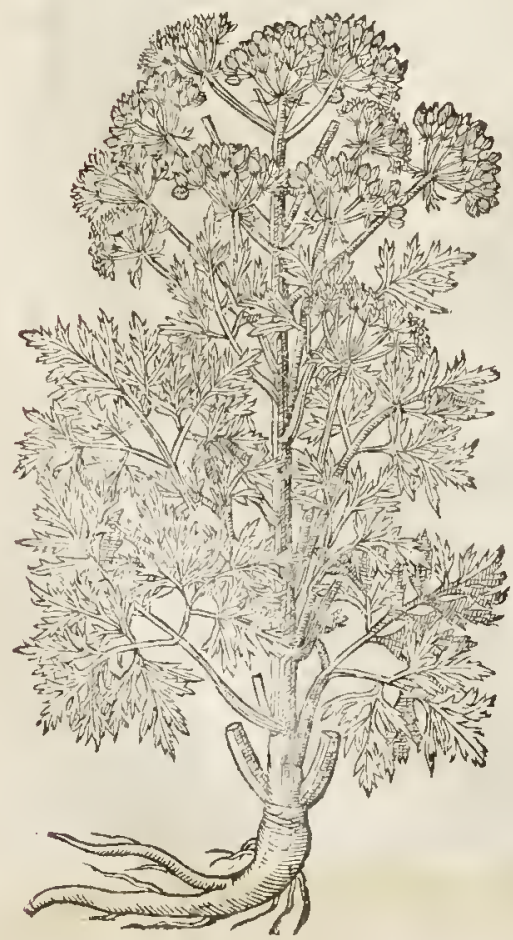

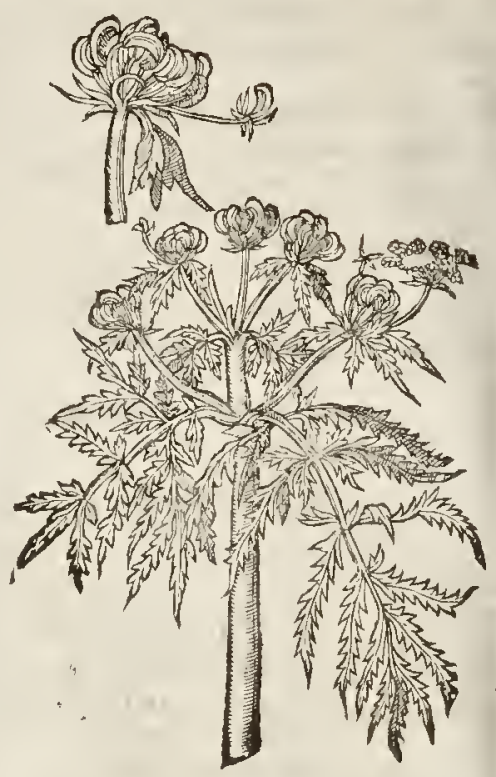

I The Place.

Common Hemiocke groweth plcntifully about towne walls and villages in thadowie places, and fat foiles necre ditches.

The fecond groweth vion mountaines and defart places, and is a ftranger in England; yet I have plauts thercof in my garden.

\section{T The Time.}

They flourith and feed in September.

9f The Names.

Homlocke is called in Greeke romer : in La: tine, cicuta - in high Dutch, Scbirling: in low Dutch, Schreclinck: in Spanifh, Cegutay $\mathrm{Ca}_{-}$ nabera in French, Crgue. in Englifh, Hemlocke, Homlocke, Kcxe, and herbe Benner.

The fecond is called Cicuta latifolia, and $\mathrm{Ci}_{-}$ cutaria latifolia, and Sefeli Peloponnenfe quorun. dam - in Englifh,great Hemlockes, and garden Homlocke.

-1 The Tempcrature.

Galn faith, that Homlocke is extreme cold in operation, euen in the fourth degree of coldnefle. 
furrowed, of a yellowith grecne colour : the leaues thoot forth of the ioynts and branches, fike vilto wilde Henilocke, but much thicker, fatter, and oileous, very firely cut or iagged, al mont lihe thole of the fmalleft $V$ ifraga, or Spanifn Tooth-pickes : the foures ftand at the top of the ftalkes in fmall whitifh rufts : the feed followeth, blackin, of the bigneffe of Anife feed, and of a fwect fauour : the root is thicke and long, within the water, very foft and tender, with very many frings faftned thereto.

$$
\text { T) The Place. }
$$

I This growes among ftoncs and rubbith, by the walls of ciries and towns almott enery where.

The orher groweth in the midft of water ditches and ftanding pooles and ponds, in raoit plaees of England : it groweth very plentifully in the ditches by a caufey, as you goc from Redriffe to Detford neerc London, and in many other places.

$$
\text { qा The Time. }
$$

They floure and flourith in Iuly and Augut.

$$
\text { 9 The rames. }
$$

¥ I This is Petrofolini vitium of Tragus; and Dawci inutilis genus of Gefner: Thalius calls it A. pium cicutariun : Lobel, Cicutariafatua : Tabernamontanus, Petrofclinum canimum; which name wc may fit'y make Englin, and call it Dogs-parfley.

$\because$ This is Ligufticum fyl. O Fariculum fyl. of Tragus : Cicutaria paluftris of Lobel and others: Dodonam thinkes it Plinzes $P$ he $D_{\text {andrion }}$; and Cefalpinus iudges it his Silaus. $¥$

$$
\text { T) The Temperature arid Fertucs. }
$$

Their temnerature and faculties are anfwcrable to the common Hemlockc, which hauc ro vfe in phyficke, as we haue faid.

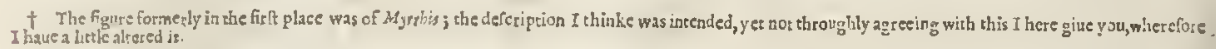

\section{Ch A P. 43 I. \\ Of Eartb-nut, Eartb Cheft-nut, or Kipper-nut.}
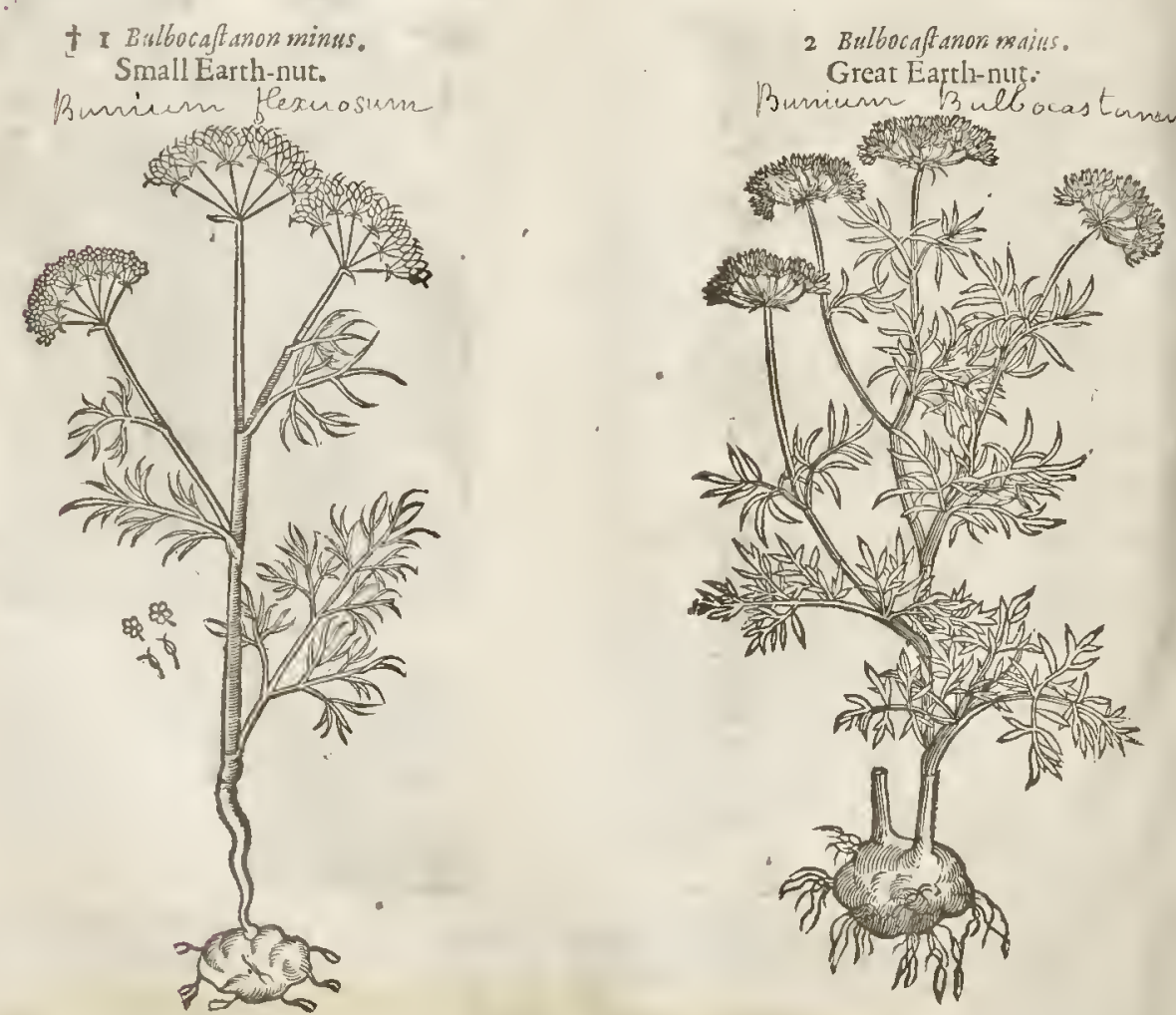


\section{TI The Defeription.}

I Firth-nut or Kipper-nut, called after Lobelius, Nucrla terreftris, hath fmall euen erefted 1 flalkes a foot or fomewhat more high: whereon do grow next the ground leaues like thofe of Parlley, and thofe that doe grow higher like vno thofe of Dill; the white floures doe ftand on tlic top of the ftalkes in fpokie rundles, like the tops of Dill,whieli turne into fmall feed, growing together by couples, of a very good fmell, not vnlike to thofe of Fennell, but much fmaller : the toot is round, knobbed, with eertaine eminenees or bunclings out ; browne without, white within, of a firme and follid fubstanee, and of a tafte like the Cletle- nut ot Cheftnut, whereof it tooke his name.

2 There is alfo another Earth-nut that hath ftalkes a foot hight, whereon doe grow iagged leaues like thole of Engluth Saxtrage, of a bright greene colour : the floures grow at the top of the branches, in fmall fpokie tufts eonfifting of little white floures : the soot is like the other, bulbous farhion, with fome few ftrings hanging at the botrome, of a good and pleafant tafte. $¥$ This differs from the former, in that the leaues are larger and greener: the root alfo is not fo far within the ground, and it alfo fends forth fome leaucs from the bulbe it felfe; whereas our eommon kind hath only the end of a fnall root that earries the ftem and leaues vpon it, faftened vnto it as you fee it expreft in the former figure. $\ddagger$

$$
\text { Tf The Place. }
$$

Thefe herbes do grow in paftures and eorne fields almolt euery where : there is a field adioining to High-gate, on the right fide of the middle of the village, couered ouer with the fame; and likewife in the next field vnto the conduit heads by Maribone, ncere the way that leadeth to Paddington by London, and in diuets other places. $¥ \mathrm{I}$ haue not yet obferued the fecond to grow wilde with vs. $\ddagger$

$$
\text { T) The Time. }
$$

They floure in Iune and Iuly : the feed eommeth to petfection afterward.

$$
\text { The Names. }
$$

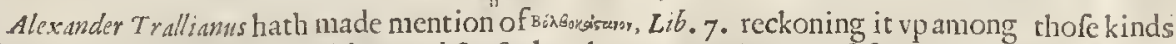
of meate or fuftenanees which be good for fuch as haue rotten lungs: of fome it is ealled Agriocaftanom.

Gminterius thought the word was cortupted, and that Balanocaftanon fhould be tead : but this is as It range a word as Bolbocaft anon, which was deriued of the forme of a bulbe, and the tatt of a Cheftnut : of fome, Nuculaterreftris, or the little Earth-nut : it is thought to be Bunium Diofooridis of fome; but we thinke not fo: of Dr. Turner, Apios; yet there is another Apios, being a kinde of $T_{i-}$

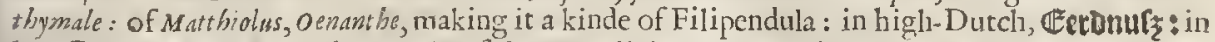
low Duteh, Eertnoten: the people of Sauoy call it Fucrottes : in Englifh, Eatth-nuts, Kippernuts, and Earth Chelt-nuts.

\section{T The Temperature.}

The roots of Earth-nuts are moderately hot and dry, and alfo binding : but the feed is both hor: ter and drier.

$$
\text { I The Vertues. }
$$

The feed opencth and pronoketh vrine, and fo doth the root likew ife.

The toor is good for thofe that fpit and piffe bloud, if the toor be eaten raw, or rofted in the embers.

The Dutch people doe vfe to eate them boyled and buttered, as we doe Parfeneps and Carrots, whieh fo eaten comfort the ftomacke, and yeeld nourithment that is good for the bladder and kidneyes.

There is a plaifter made of the feeds hereof, whetcof to write in this placc wete impertinent to our hiftoric.

\section{H P. 432 . Of Cumin.}

9) The Defeription.

THis garden Cumin is a low or bafe lerbe of a foot high : the ftalke diniderly it felfe into diuers fmall branehes, whereon doe grow little iagged leaues very finely cut into frmall parcels, like thofe of Fennell, bur more finely eut, thorter and leffer : the fpoky tufts grow at the top of the branehes and ftalkes, of a red or purplifh colour : after which come the feed, of a ftrong or raneke fmclland a biting tafte: the root is flendet, which perifheth when it hoth tipened his feed. 
Cuminum Satioum Diofcoridi: Garden Cumin.

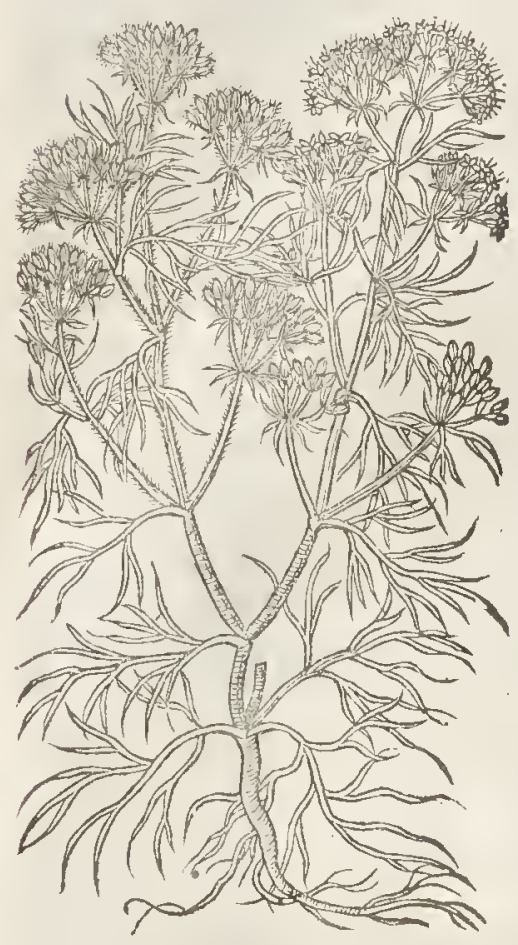

T The Place.

Cumin is husbanded and fown in Italy and Spain, and is very common in other hot countries, as in $Æ$ thiopia, Egypt, Cilicia, and all the leffer A fia.

It delights to grow efpecially in putrified and hot foiles: I have proucd the feeds in my garden, where they haue brought forth ripe feed much fairer and greater than any that commeth from beyond the feas .

$$
\text { The Time. }
$$

It is to be fown in the middle of the fpring; a thewre of raine prefently following dorh much hinder the growth thercof, as Ruelliws faith.

My felfe did fow it in the midef of May, which fprung vp in fix days after: and the feed was ripe in the end of Iuly.

$$
\text { Tा The Names: }
$$

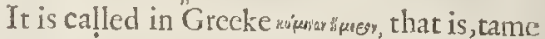
or garden Cumin, that it may differ from the wlde ones : it is named in Latine Cuminum: in forop, Cyminum : in high-Dutch. 1200mif= che tepmmid: in Italian, Comino: in Spanifh, Cominctios: in French, Comin: in Englinh, Cumin.

$$
\text { 91 The Temperature. }
$$

The feed of garden Cumin, as Galcn faith, is hot and dry in the third degree: Dipfcorides faith that it hath in it alfo a binding qualitic.

\section{ot The Vertues.}

A The feed of Cumin feattcreth and breaketh all the windineffe of the ftomacke, belly, guts, and matrix : it is good againft the griping torments, gnawing or fretting of the belly, not onely receiued inwardly by the mouth, but alfo in clifters, and ontwardly applied to the belly with wine and barley meale boyled together to the forme of a pultis.

B Being handled according to art, cither in a cataplafine, pultis, or plaifter, or boyled in wine and fo applied, it taketh away blattings, fwellings of the cods or genitors : it confumeth windie fwellings in the ioynts, and luch like.

C Being raken in a fupping broth it is good for the cleft and for cold Iungs, and fuch as are oppreffed with aboundance of raw humors.

D It ftancheth bleeding at the nofe, being tempered with vineger and fmelt vnto.

E. Bcing quilted in a little bag wirh fome fmall quantitic of Bay falt, and made hor wpon a bedpan with fire or fuch like, and fprinkled'with good wine vineger, and applied to the fide very hor, it taketh arvay the fitch and paines thereof; and eafeth the pleurifie very much.

\section{Снав. 433. Of wilde Cumin.}

The rindes. Here be diuers plants differing very notably one from another in fuape, and yet all compre:
hended vnder the title of wilde Cumin.

T) The Defeription.

I THe wilde Cumin hath fnall white roots with fome fibres thereto appendant; from the which arife fundry little iagged leaues, confirting of many leffer leanes, finely dented about the edges, in fafhion like the fmalle? leaues of wilde Parfnep : among which fpringeth vp a flender bending ftalke a foot high, like vnto Peiten Veneris, bearing at the top thercof white round 
LIв.2.

Of the Hiftory of Plants:

I Cuminum fylueftre.

Wilde cunin.
2 Cuminum filiquofum:

Codded wilde Cumin.

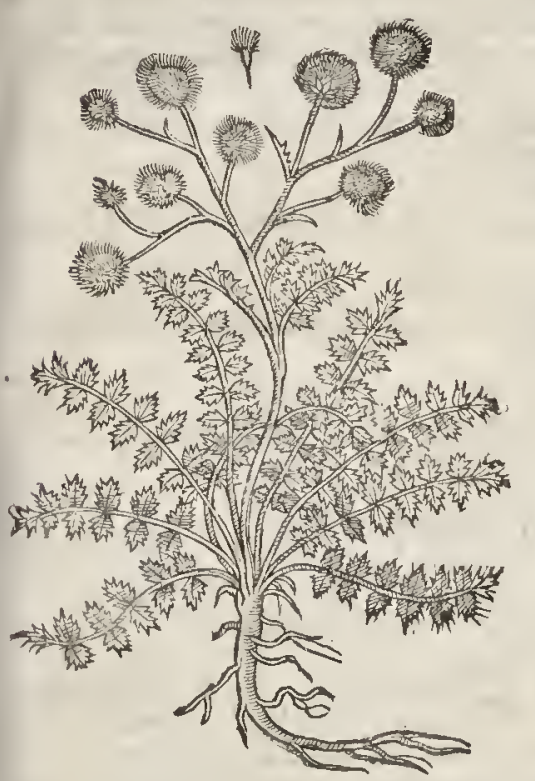

3 Cuminum Corniculatum, (ive Hypecoum Clufy. Horned wild Cumin.

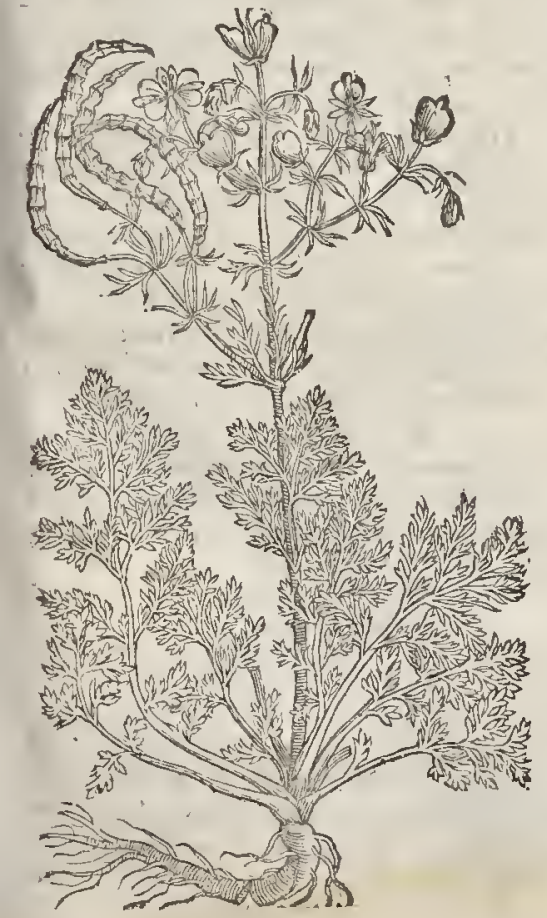

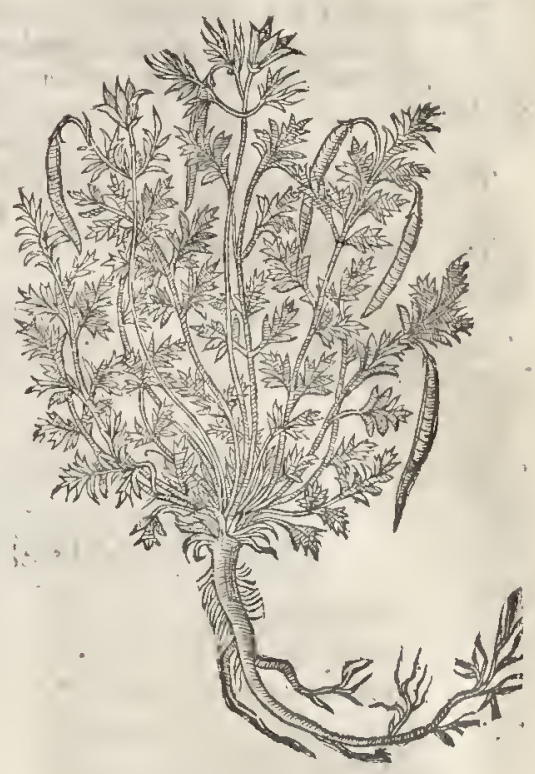

round and hairie buttons or knops, like $A r$ Etion, as D.ofcorides hath right well obferued: within which knoppes is contained a tender downie fitbftance, among which is the feed, like the leed of Dens Leonis, but mueh leffer.

2 The fecond kinde of Cumin is verie like vnto the forefaid vilde Cumin, fauc that it beareth a number of horned or erooked coits, after the mauner of Scorpioides, but thicker, and leffe erooked, and the reedes within the cods are feuerally diftinet and feparated one from another by equall partitions, in fruall eroffes, yellow of colour, \& fomewhat long : the ftalkes are little and tender, befet with leanes mueh like vnto the fmall leaues of Carui, or Pecten Vencris: and at the top of the ftalks there do grow pretty ycllow foures, like thofe of great Celindine or Rocket, fauing that they be fom: what lefler.

+3 The third kinde of Cumin is very like vnto the laft before mentioned, but the leaues are much greater, more flender, \&x more finely cur or iagged, like che leaties of Sefeli of Mafylia : anong whieh rifeth vp a ftalke a eubir high or fomewhat morc, very fmooth and whitih: at the top whereof fpring forth fine yellow tloures, not like the former, but confining of $f(x$ leaues apicce; 
whereof two are large, and edged with greene on the outfide: the other foure are fmall ones, and grow two on a fide betweene the two larger leates : thefe floures being vaded, there fucceed croo. ked cods, great er, and morc full of knots or diuifions than the former, whercin is contained a fmall and flat yellow feed like Galeg a the root is long, thicke,and fingle.

\section{T The place.}

Thefe wilde Cumins do grow in Lycia, and Galatia, a prouince of Afia, and in Carthage a citie of Spaine; feldome feene in thefe Northerne parts: notwithftanding at the impreffion hereof, the laft did floureand flourith in my garden. $\neq$ Thefe grow in Prouince in France,and in diters parts of Spaine. $\neq$

\section{था The Time.}

They floure in Augut, and perfect their feed in September.

$$
\text { of The Names. }
$$

Their names hate been touched in their titles in as ample manner as hath been fet down by any Author.

$$
\text { 9 The Temperature asd Vertues. }
$$

Thcir temperature and vertues are referred to the garden Cumin; notw ithftanding I cannot reade in any Author of their vie in Phy ficke.

\section{С на т. 434. Of Flixweed.}

I Soplia Chivurgorum.

Flixwced.

Sisumbinime Soph ha

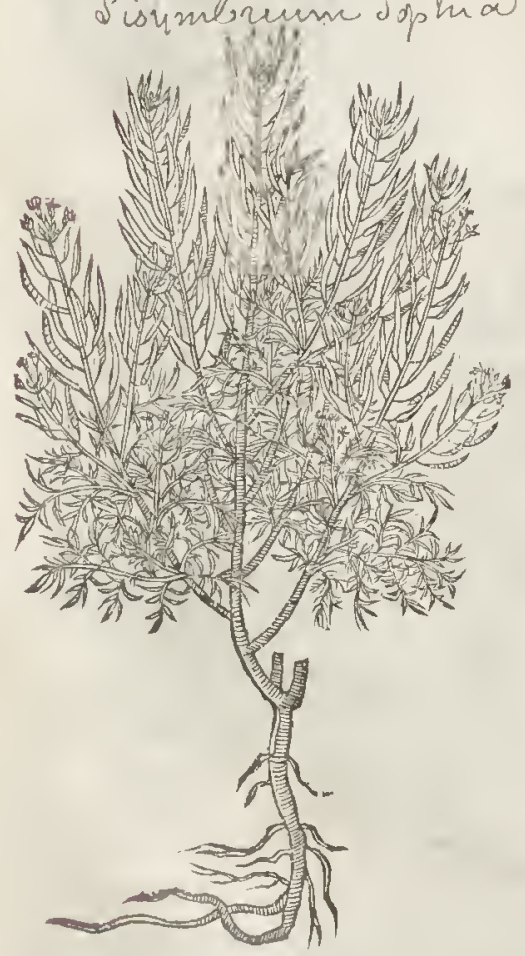

बा The Defcription:

I Flixweed hath round and liard ftalks,a cubit \&xa halfc high, wheron do gr ow lcaues moft finely cut and ditided into in numerable fine iags, like thofe of the fea $\mathrm{W}$ ormewood called Seriphium, or Abfint hium tcinifolium, but much finer and fmaller, drawing neere vnto the fmalleft leaues of Corianders, of an outerworne greene colour : the floures grow along ft the tops of the fpriggie branches, of a dark yellow colour : after which come long eods full of fmall red feeds : the root is long, ftraight,and of a w ooddie fub fta nee:

2 The fecond fort differeth not from the precedent, fauing that the leaues of this plant are broader, wherein efpecially confifteth the differenee; notwithftanding in minc opinion Tabernamontanus found this feeond fort growing in fome fertill plaee, whereby the lcaucs did grow broader and greater, whieh moued him to make of this a fecond fort, whercas in truth they are both but one and the felfe fame plant.

$$
\text { -T The Place. }
$$

This Flixeweede groweth in moft places of England, almoft euery where in the ruins of old buildings, by high waies, and in filthie obfeure bafe plaees.

\section{The Time:}

It foureth and feedeth from Iune to the end of Septen ber.

बा The Names.

Flixweed is called Thalietrum; and of fome, Thalictrum, but vnproperly; for Thalictrumbelong: eth to Englifh Rubarbe : the Paracelfians do vaunt and brag very muteh of an herbe ealled Sophia, adding thereto the furname $P$ aracel $/ 2$, wherewith they inagine to do wonders, whether this be the fame plant it is difputable, the controuerfic not as yet deeided; neuertheleffe we muft be content 
L1 B. 2. Of the Hiftory of Plants.

roacept of this for the true Sophia,vntil fome difciple or other of his do fhew or fit frethen $1:$ e

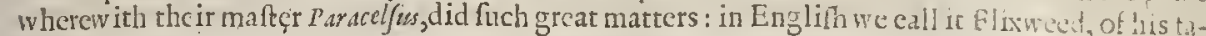
cultieagainft the flix.

$$
\text { का The Temperature. }
$$

$$
\text { 9 } \text { The Vertues. }
$$

The feed of sophia or Flixweed drunkewith wine, or Smithes water, ftoppeth the bloukly fix, the A laske, and all other iflues of bloud.

The herbe bruifed or put into vnguents, elofetl and healeth vicers, or old fores and wounds, as 3 Paracelfus faith, and that becaufe it dricth without acrimonic or tharpneffe.

\section{C.н A P. 435: Of the great Celandine, or Swallow-woort. T The Defcription.}

I He great Celandine hath a tender brittle falke, round, hairie, and full of branches, each whereof hath diuers knees or knottie ioints, fetwith leaues not vnlike to thofe of Columbine, but tenderer and decper cut or iagged, of a grayinh grecne vnder, and greene on the other fide tending to blewnefle: the floures dogrow at the top of the ftalkes, of a gold yellow colour, in Thape like thofe of the Wall-floure : after which come long cods, full of bleake or pale feeds : the whole plant is of a ftrong fmell,nothing pleafant, and yeeldeth a thicke iuice of a milkic fibftance, of the colour of Saffron : the root is thicke and knobbie,with fome thred's annexed thereto, which being broken or bruifed, yeeldeth a fap or iuice of the colour of gold.

I Chelidoniummaius.

Great Celandine.

Chelidonium majus.

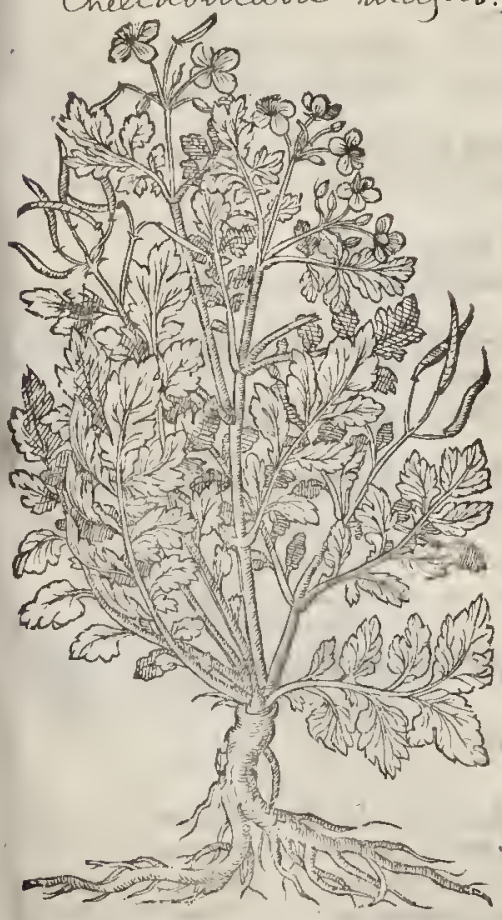

$\neq 2$ Chelidonium majus folio magis diffecto.

Great Celandine with more cut leates.

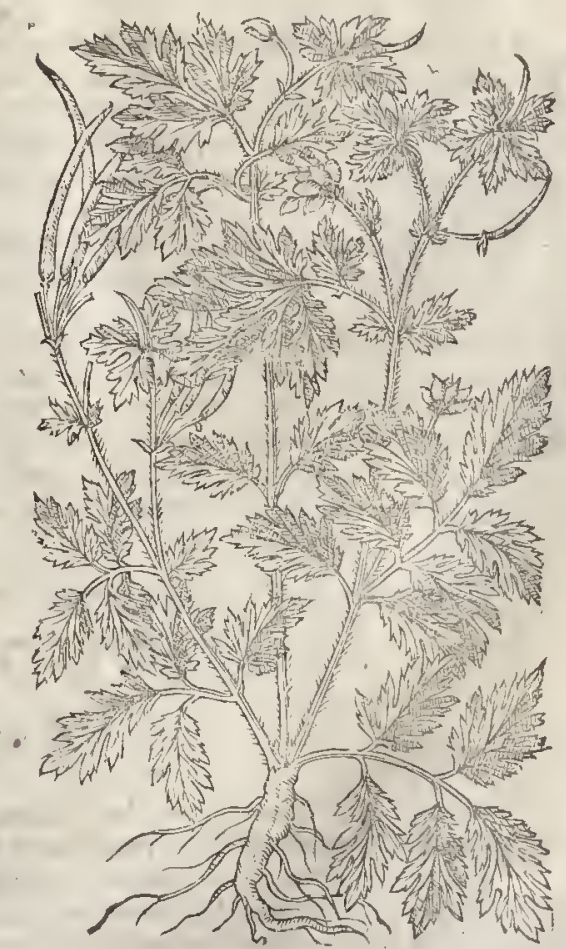

\pm 2 This other doth not in forme and magnitude differ from the former, but in the leaires, twhich are finelier cut and iagged, and fomewhat in their fhape refenble an Oken leafe : the floures 
alfo are a little iagged or eut about the edges : and in thefe two partieulars confifts the whole difference. Clugus ealls it Chelidoniwm mains laciniato fore; and Baubine, Chelddonium manus folýs quernis. $\neq$

$$
\text { T The Place. }
$$

It groweth in vntilled places, by common way fides, among briers and brambles, about old wals, and in the fhade, rather than in the Sun.

$$
\text { T The Time. }
$$

It is greene all the yeare, it floureth from A prill to a good part of Sommer, the coddes are perfeeted in the meane time.

$$
\text { 9T The Names. }
$$

It is ealled in Greceke xardinor : in Latine, Chclidonium maius, and Hirundinariamajor: among ft the Apothecaries, Cholucioria : diuers mifeall it by the name Celidonitum : it is named in Italian,Celi-

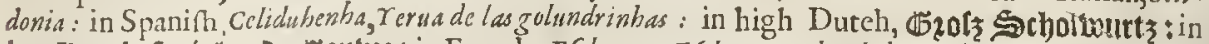
low Duteh $\mathcal{G}$ tinkende $\mathscr{b}$ outwe: in French, Efclere, or Efclayre, and celidome: in Englinh, Celandine, or great Celandine, Swallow-woort,and Tetterwoort.

It is called Celandine, not becaufe it then firft fpringeth at the eomming in of the Swallows, or dieth when they goe away: for as we haue faid, it may be found all the yeare, but becaufe fome. hold opinion, that with this herbe the dammes reftore fight to their young ones when their eies be out:thewhich things are vaine and falfe; for Cornelius Celfos in his fixth booke doth witneffe, that when the fight of the eics of diuers young birds be put forth by fome outward meanes, it will after a time be reftored of it felfe, and fooneft of all the fight of the Swallow, wherupon (as the fame Author faith) that the tale or fable grew, how thorow an herbe the dams reftore that thing, whiel healeth of it fel fe : the very fame doth. Ariflotle alledge in the fixt booke of the hiftorie of Liuing erea tures: [The eies of Swallowes (faith he) that are not Aledge, if a man do prieke them out, do grow, againe, and afterwards do perfectly recouer their fight.]

\section{T) The Temperature.}

The great Celandine is manifently hot and drie, and that in the third degree, and withall fco:ires and clenfeth effectually.

\section{The Vertues.}

A The iuice of the herbe is good to tharpen the fight, for it elenfeth and confumeth away flimie things that cleate about the ball of the eie, and hinder the fight,and efpeeially being boiled with honic in a brafen veffell,as Diofcorides teacheth.

B The root cureth the yellow iaundife, which commeth of the ftopping of the gall, efpecially when there is no ague adioined withit, for it openeth and deliuereth the gall and liuer from ftoppings.

C The root being chewed, is reported to be good againtt the tooth-ache.

D The iuice muf be drawn forth in the beginning of Sommer, and dried in the Sunne, faith Diofcorides.

E The root of Celandinc boiled witl A nnife-feed in white wine, openeth the foppings of the liuer and cureth the iaundies very fafely, as hath been of ten proned.

F The root cut in fmall pieces is good to be given vnto Haukcs againft fundry difeafes, whereun: to they are fubies, as wormes, craie, and fuch like.

G \# I haue by experienee found (faith clufius) that the iuice of the great Celandine dropped in colmall greene wounds of what fort foeuer,wonderfully cures them.

\section{С а р. 436. Of Coxcombe, or Yellow Rattle.}

T The Defcription:

\footnotetext{
RijftaGalli, or Crifta Gallinuced, hath a ftraight vpright ftalke, fet about with narrow leates, fript round about the edges: the floures grow at the top of the ftems, of a yellow eolour; after which come vp little flat pouches or purfes, conered ouer or contained within a little bladder, or flat skin, open beforclike the mouth of a fifh, wherein is contained flat yellowifh feed,whieh being ripeand drie,will make a noife or satling when it is thaken or moued, of which propertie it tooke the name yellow Rattle.
} 
It is cold and drie and aftringent.

$$
\text { I) The Temperature. }
$$

1. The Vertues.1

'A It is held to be good for Fiftulaes and hollow vlcers, and to ftay the ouermuch flowing of the menfes, or any other fux of bloud, if it be boiled in red wine and drunke.

\section{C. \\ TI The Defcription.}

$\mathbf{I}$

Onimon Yarrow hath very many ftalkes comming vp a cubit high,round, and fomewhat hard: about which ftand Jong leaues, cue in the fides fundry wife, and as it were made vp of many fmall iagged leaues, euery one of which feeme to conie neere to the fender leates of Coriander : there ftand at the top tufts or fpoked rundles : the flotires where of are either white or purple, which being rubbed do yeeld a frong fmell, but vnpleafant; the root fendeth downe many ftrings.

I Millefolium terrestre vulgare.

Common Yarrow.

tehilles optiarmica

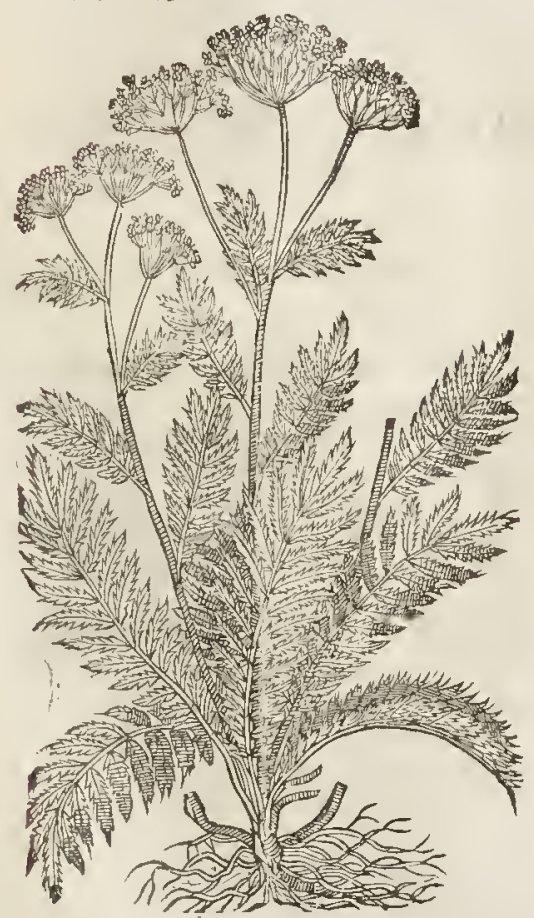

cille folium flore rubro. lied foured Yarrow.

2 The fecond kinde of Milfoile or Yarrow harlı ftalkes, leaues and roots like vnto the former, fauing that his fpokie tufts are of an execllent faire red or crimfon eolour, and being a little rubbed in the hand, of a reafonable good fauour.

$$
\text { T The place. }
$$

The firt groweth eucry where in drie paftures and medowes : red Milfoile groweth in a field by Sutton in Kent ealled Holly. Deane, from whence I brought thore plants that do grow in my Garden; but it is not common euery where as the other is.

They Houre from May to the end of Ostober.

$$
\text { I The Time: }
$$


बा The Names.

Yarrow is ealled of the Latine Herbarifts Millefolium : it is Dioforides his ixiwes: in Latine, Achil. lea, and Achillo foleritis; which thing he may very plainely fee that will conapare with that defcription which Dofcorials hath fet downe : this was found cut, faith Pling in his 25 . booke, chap.5. by

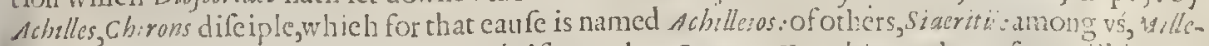
foltum : yet be therc otlier Sideritides, and alfo another Panaces Herablem, whereofwe will intreat ill another place: Apuleits fetteth downe diuers names hereof, fome of which are alfo found among the baftard names in Diofcorides . in Latine it is called Militaris, Supercilimm Feneru, Acrism,

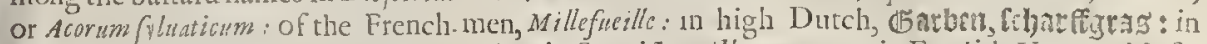
low Duteh, ש5ecuwi:in Italian, Millefoglio : in Spanilh, Milhoyas yerua, in Englib, Yarrow, Nofebleed,common Yarrow, red Yarrow, and Milfoile.

\section{था Tlic Tempcraiure.}

Yarrow, as Galen faith, is not vnlike in temperature to the Sideritidis, or Iron worts, that is to fay, clenfing, and meanely eold, but it moft of all bindeth.

\section{9) The Vertues.}

The leaus of Yarrow doe elofe vp wounds, and keepe them from inflammation, or fiery fwel- $A$ ling: it fancheth bloud in any part of the body, and it is likew ife put into bathes for wonen to fic in : it ftoppeth the laske, and being drunke it helpeth the bloudy flixe.

Mof men fay that the leaues chewed, and efpecially greene, are a remedy for the tooth-ache.

The leaues being put into the nofe, doeafe it to bleed, and eafe the paine of the merrim.

It cureth the inward exeurations of the yard of a man, comming by reafon of pollucions or extreme Alowing of the feed, although the iffuc do caufe inflammation and fwelling of thofe fecret parts and though the fpcrmaticke matter do come downe in great quantity, if the juice be injected with a fyringe, or the de costion. This hath been pronued by a eertain friend of mine, fomecimes a Fellow of Kings Colledge in Cumbridge, who light ly brufed the leaues of eommon Yarrow, with Hogs-greafe, and applicd it warme vnto the pritic parts, and thereby did diuers times helpe himfelfe,and others of lis fellowes, when hew as a fudent and a fing le man liuing in Cambridge.

One dram in powder of the herbe giuen in wine, prefently raketh away the paines of the colicke. E

\section{С н т. 439. Of yellow Yarrom, or Milfoile.}

I Millcfoliumluteum. Yellow Yarrow.

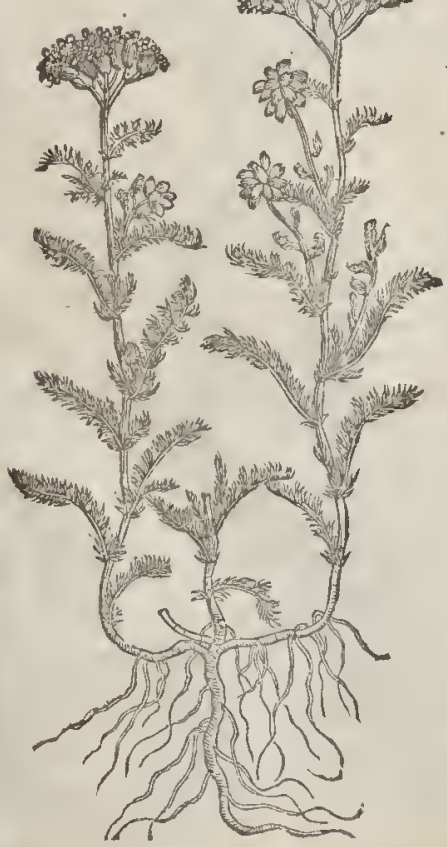

† 2 Achillea, fuc Mille fo liwm nobile. Achilles Yarrow.

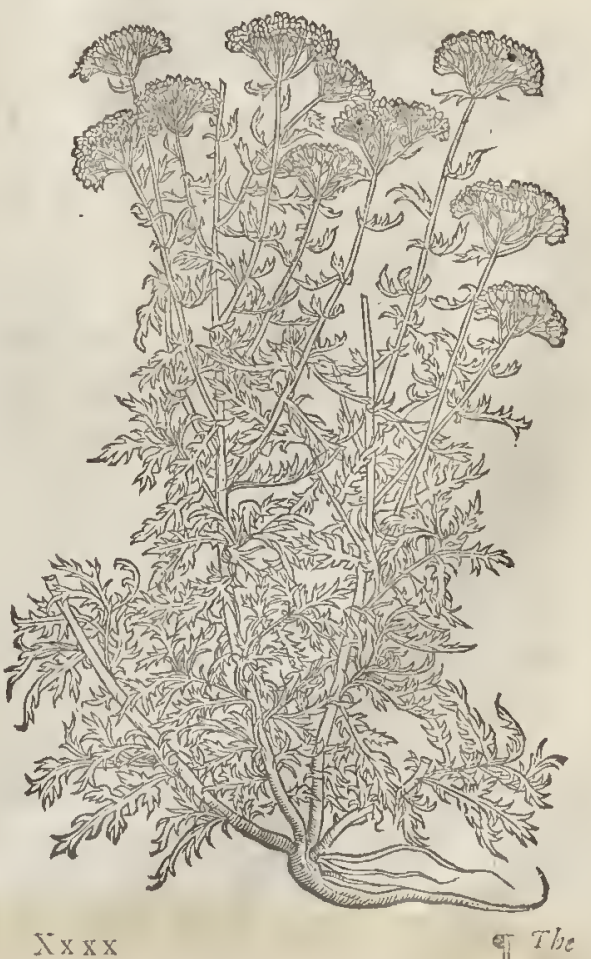


T The Defcription.

$1 \mathrm{Y}$ Ellow Yarrow is a fmall plant feldome aboue a fpan high: the ftalkes whereof are co. uered with long leaues, very finely cur in the edges like feathers in the wings of littlo birds: the tufts or fpokie rundles bring forth yellow floures, of the fame thape and forme of the common Yarrow : the root confifteth of threddy ftrings,

2 Achilles Yarrow, or noble Milfoile, hath a thicke and tough root, with ftrings faftened there to: from which immediately rife vp divers ftalkes, very greene and crefted, whereuron doe grow long leaues compofed of many fmall jagges, cut euen to the middle rib : the foures ftand on the top of the ftalkes with fpokie vmbels or tufts, of a whitifh colour, and pleafant fmell.

$$
\text { T) The Place. }
$$

Thefe kinds of Yarrow are feldome found : they grow in a fat and fruitfull foile, and fometimes in medowes, and are ftrangers in England.

They foure from May vntill Atginf.

$$
\text { I The Time. }
$$

\section{The Names.}

Diofcorides defcription doth fufficiently declare, that this herbe is Stratiotes cMillefolinm : in Greeke, sexmins $x^{20}$ siqumos: the height of the herbe theweth it, the forme of the leanes agree ; there is fome ambiguity or doubt in the colour of the floures, which Diofcorsdes deferibeth to bewhite, as the vulgar copies haue; but Andreas Lacuna addeth out of the old booke, of a yellow colour : it is named of the later age, Millefolium minus, or little Yarrow, and Millefolium luteum, yellow Yarrow, or Nofe-bleede : the A pothccaries and common people know it not.

Yarrow is meancly cold and fomewhat binding.

$$
\text { If The Temperature. }
$$

$$
\text { T The vertues. }
$$

A It is a principall herbe for all kinde of bleedings, and to heale vp new and old vlcers and greene wounds : there be fome, faith Galen, that vfe it for fiftulaes.

B This plant Achillea is thought to be the very fame wherewith schilles cured the wounds of his fouldiers, as before in the former chapter.

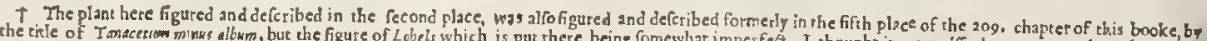

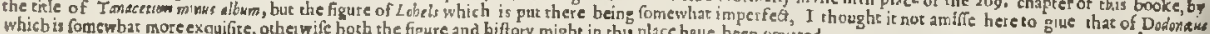

\section{- Cha p. 440. Of Valerian, or Setwall. \\ T) The Defription.}

I Te tame or garden Valerian hath his firft leates long, broad, fmooth, green, and vndi. uided; and the leaues vpon the ftalkes greater, longer, and deepely gafhed on either fide, like the leaues of the greater Parfnep, but yet leffer : the ftalke is aboute a cubit high, fmooth, and hollow, with certaine joints farre diftant one from another: out of which joints grow forth a couple of leaues, and in the tops of the ftalkes vpon fpokic rundles ftand floures heaped together, which are fmall, opening themfelues out of a long little narrow necke, of colour whitifh, and fometimes withall of a light red : the root is an inch thicke, growing aflope, faftned on the vper part of the earth by a multitude of frings, the moft part of it ftanding out of the
ground, of a pleafant fweet fmell when it is broken.

2 The greater wilde Valerian hath leaues diuided and jagged, as thofe of the former; thofe about the ftalke hereof are alfo fmooth, hollow, and jointed, and abone a cubit high : the floures ftand on fpokie rundles like to thofe of the former, but of a light purple colour : the roots are flen-
der, and full of ftrings and fmall threds, not altogether without fmell.

3 The other wilde one is much like in forme to the garden Valcrian, but farre leffer : the firft leates thereof be vndiuided, the other are parted and cut in funder : the ftalkes a fpan long: the floures which ftand on fpokie rundles are like to thofe of the others, of a light whitim purple colour : the roots be flender, growing aflope,creeping, and full of fine fmall threds, of little fmell.

4 There is a fmall Valerian growing vpon rockes and ftony places, that is like vnto the laft defcribed, fauing it is altogether leffe. $¥$ The ftalk is fome halfe foot higl, and ftrait, diuiding it felfe into branches toward the top, and that alwaies by couples : the bottome leaues ate who!e, the top 
LIB. 2.

I Valeriana hortenis.

Garden Valerian,or Setwall.

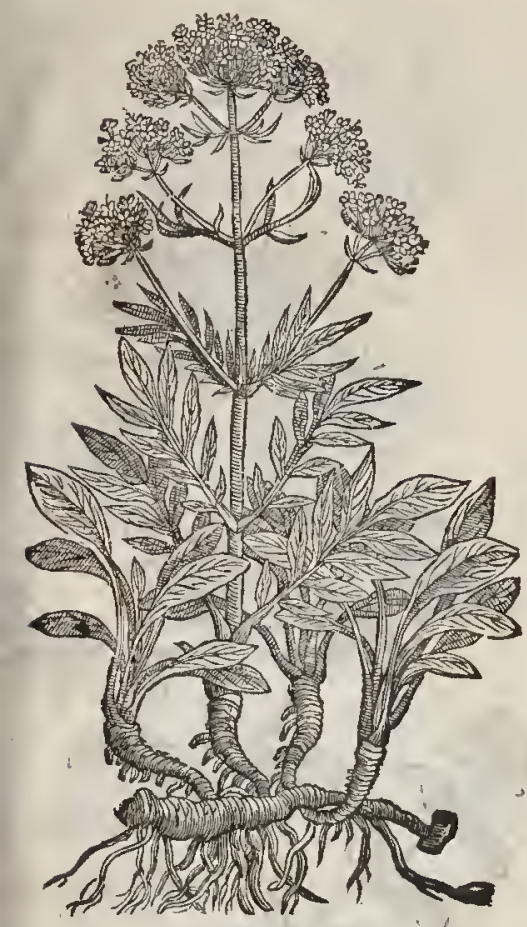

3 Valerianaminor?

Small Valerian.

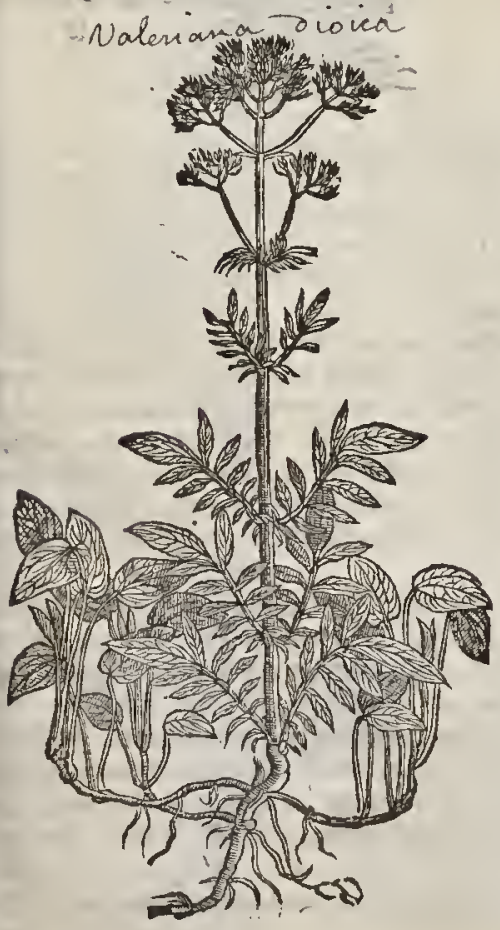

107.5

2 Valerianamaior fyluefrus.

Great wilde Valerian.

Nalerian a officinalis

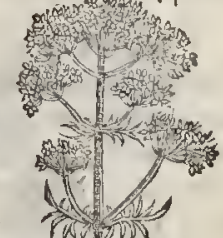

-
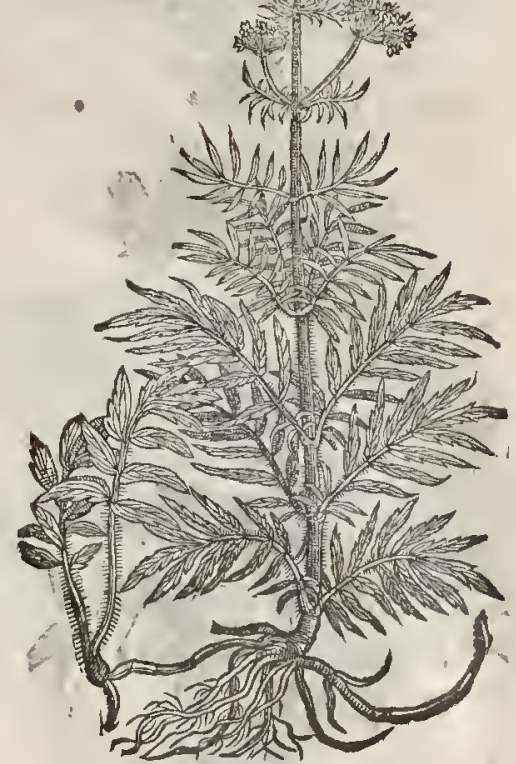

4. Valeriina Petrea.

Srone Valcrian.

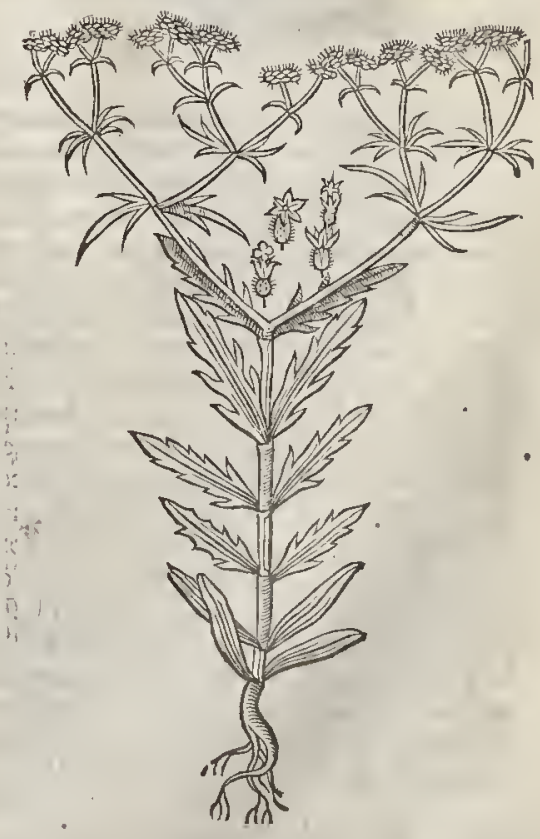


leanes mueh diuided, the floures are fmall, of a whitifh purple colour,parted inio fute, and flanding vpon rcund rough heads, which when the floures are falne, become fat-fantioned, diuided into fix parts : it floures in Iune, and is an annuall plant. $\neq$

5 Taleriana Graca.
Greebih Valerian.
Dolemioniam coruleuma

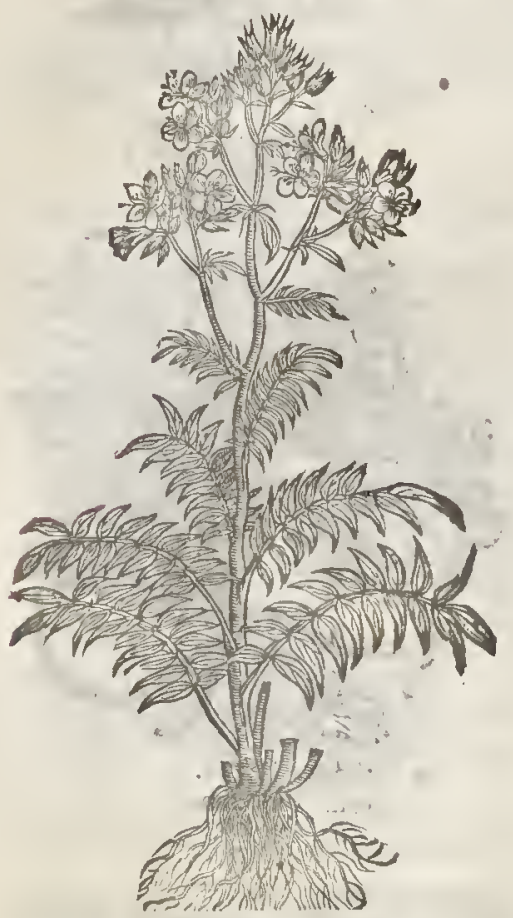

\# Valeriana Mexicana. Indian Valctian.

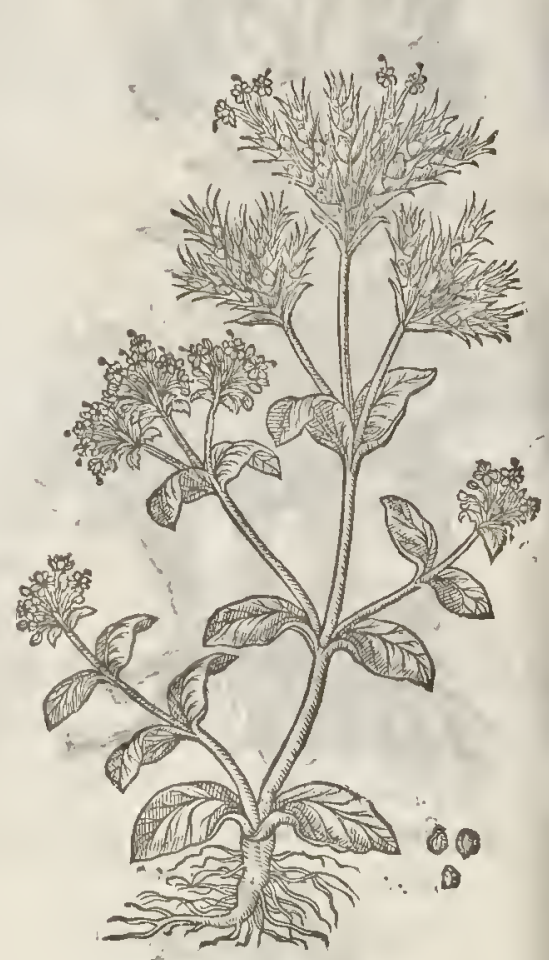

5 The ffth fort of Valerian hath diuers fmall hollow ftalkes, foot high and foncwhat more, garnined with leaues like vnto thofe that do grow on the vpper part of the falks of common $\mathrm{Va}$ Jerian, but fmaller, cut of iagred almoft to the middle rib: at the top of the ftalkes doe grow the floures cluftering togetler, of a blew colour, confitting of fiue leaues apiece, hauing in the middle therent finail white threds tipped with yellow : the feed is fmall,growing in little hushes or feed veficls : the root is nothing elfe but as it were all of threds.

6 I hawe another for of Valerian(the feed whereof was fent me from that teuctend Piny fition Bernard $p$ alsuane, wider the title of Valcyiana Mexicana: $>$ hauing fmall tenter ftalkes trailing vpon the rround, veryweake and britte : whereupon doe grow fmooth grecinh leaues like thofe of Come Sallade (iv hicliwee hate fet forth amongft the Lettuee, vnder the ritle Latfuca Agnira, or - Lambs Lettuee: ) among the leaues enme forth the floures eluftering together, like vnto the great Vabrian in forme, but of a deepe purple colour : the root is very fmall and threddie, which perifh. etla with the reft of the plant, when it hath brought his feed to maturitic or tipeneffe, and muft bee fowne ancw the bext yeare in May, and not before.

7 There is alfo another fort orkinde of Valerinn ealled by the name Pbyteuma, of the learned Phyfitions of Montpelier and others (fet forth vnder the ftocke or kind red of the Valerians, refembling, the atorefaid Conn- Iallad, which is called of fome Prolifera, from the Greeke title $\boldsymbol{P}$ byteuma; as if you thou'd fay, gond to make coneeption.and to proeute loue:) the loweft leanes are like thofe of the fmall Valerian, or 7 yellowith eolour : the vpper leaues become more ingged: the ftalks are an hudfull hivl : on the topswhereof do ftand fmall round fpokie tufts of whire floures; whiel being paft, the feels apperre like fmall round pearles, wh ich being ripe, grow to be fomewhat fat, buxing in the muldle nfeach feed the pt int of an hole, as it were grauen or bored therein. The root is fanll and hin-?e.rith fome fibres annexed therero.

+ $\mathrm{Thi}$, fcnds forth from a white and wooddic root many leaues fpred tpon the ground;green, 
\$ $\mathrm{V}$ aleriana annu, Clur. Annuall Valerian.

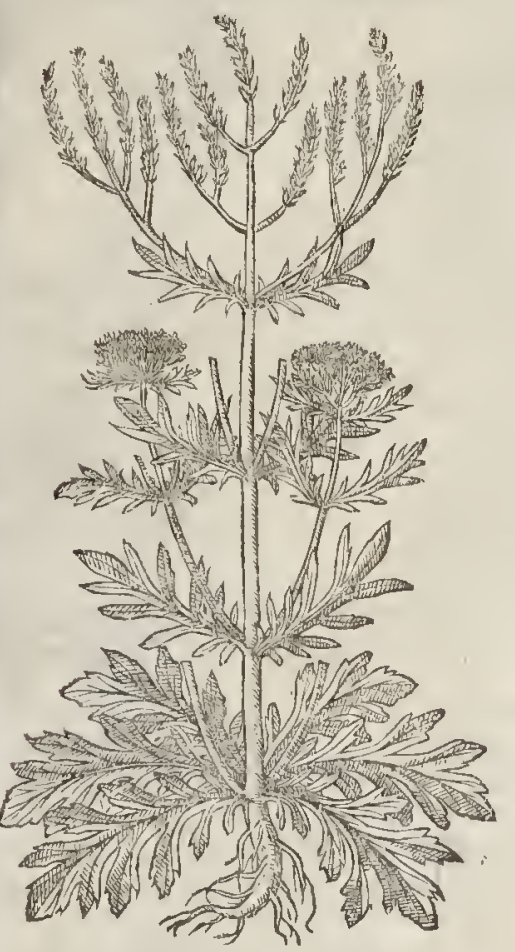

\# Io Daleriana Alpina airgufiffolis. Small Alpine Setwall.

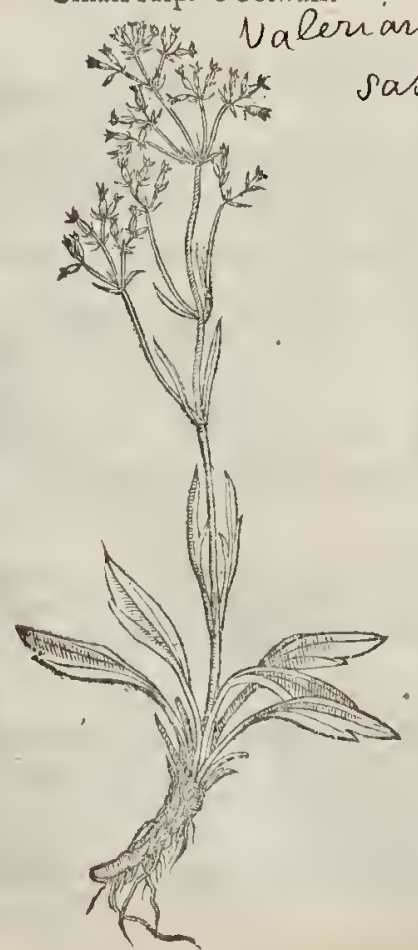

$\ddagger 9$ Valeriana Alpinalutifolia. Broad leated Setwall ot the Alps

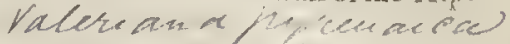

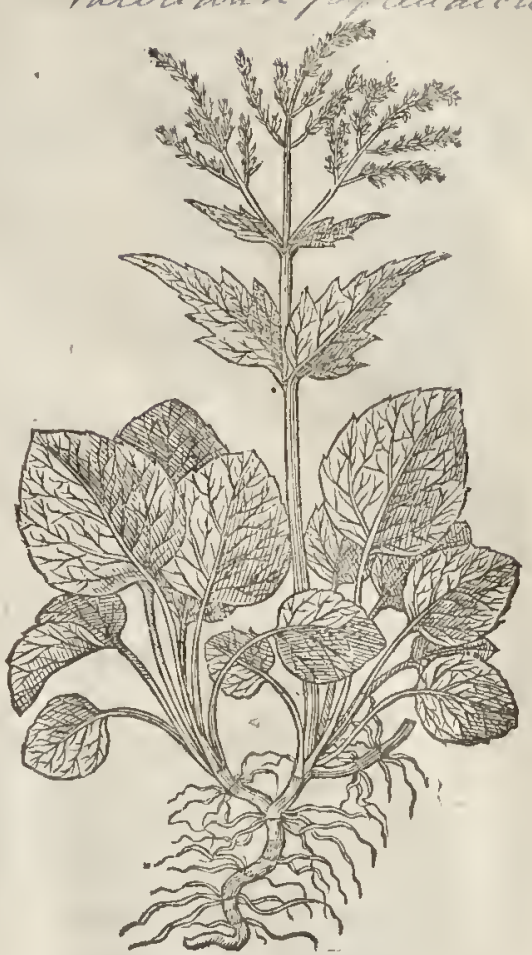

and not vnlike thofe of the Star-Thifte:among thefe rife vp fome round hollow branehed italks two cubites high : at cach ioint grow forth two leaues lefter, yet like the lower: at the tops of the branches grow the floures as it were in little vmbels, confinting of fue leates apiece; and thefe of a light red, or Hefh colour : and then thefe as it were vinbels grow into longifh branches bearing feed almolt like, yet leffe than the red Valcrian : it floures in Iuly, and peritheth when it hath ripened the feed. Clatias hath fet chis forth by the name of $v$ alcriatianmualtera.

9 The lame Author hatinalfo giuenvs the hiftorie of fome other Plants of this kind; and this he cals $V$ aleriana fyl. Alpina I latifol, the flalk bereof is fome foot high, round, yreene, and crefted: vpon which tand leaues longith, fharpe pointed, and ent in with two or three deepe gaShes : but the bottome leaues are more rotnd and larger, comming neere to thele of $T$ racbelis ism,yet lefler, flenderer, and bitter of tafte : the floures which arewhite of colour, and the feed, are like thofe of the other Valerians: the root is fmall, creeping, fibrous, white and atomatick: it growes vpon the Alpes, and flomres in Ime and Itily.

Io This fendes forth leaues like thofe of the mountain Daifie: att of the midt of which $\mathrm{X} \times \mathrm{x} \times 3$ vifeth. 
rifeth vp a ftalk fome foot high, iointed, and at the top diuided into little branclses, carrying white floures like the other Valerians : the root is as aromaticke as that of the lant mentioned; and grows in the chinkes of the Alpine rockes, where it Houres in Iune and Iuly. Clufius harh it by the name of Fulcrianafylueslitis Alpmo 2. Saxatilis. $\ddagger$

$$
\text { T The rlace. }
$$

The furft and likewife the Greeke Valerian are planted in gardens; the wilde ones are found in moift places hard to rimers fides, ditches, and waterie pits; yet the greater of thefe is brought into gardens where it flourifheth, but the leffer hardly profpereth.

$$
\text { -1 The Time. }
$$

Thefe floure in May, Iune, and Iuly, and mott of the Sommer moneths.

$$
\text { 9T The } 2 \text { ames. }
$$

Generally the Valerians are called by one name, in Latine, Yaleriana : in Greeke, os : in Thoppes alfo $P$ hw, which for the noft part is meant by the garden Valerian, that is called of $D i o C_{0}$ raposs $\dot{\alpha}_{2 p r a}$ in Latine, Sylucfiris, or Rufica Nardus : of Pliny, Nardus Cretica: which names are rather referred to thofe of the next chapter, although the fe be reckoned as wilde kindes thereof: of certaine in our

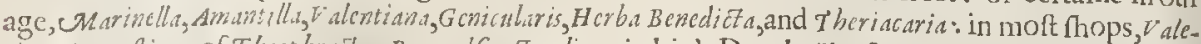

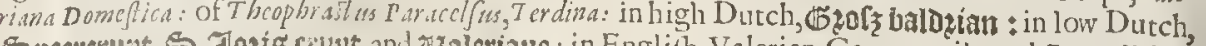

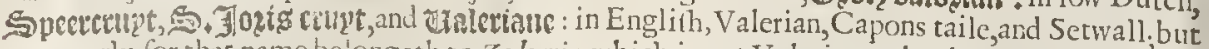
unproperly, for thac name belongeth to Zedoaria, which is not Valerian : what hath been fet downe in the titles thall ferte for the diftinetions of the other kindes.

$$
\text { The Temperature. }
$$

The garden Valerian is hot, as Diofcorides faith, but not much, neither the green root, but the dried ones; for the green is eafily perceiued to hawevery little heate, and the dried to be liotter, which is found by the tafte and fincll.

A The dric root, as Diofcorides teacheth, prouoketh vrine, bringeth downe the defred fickneffe, hel peth the paine in the fides, and is put into counterpoifons and medicines preferuatiue againft the peftilence, as are treacles, mithridares, and fuch like: wherempon it hath heen had (and is to this day among the poore people of our Northerne parts) in fuch veneration among ft ticm, that no broths, pottage, or phy ficall meats are worth any thing, if Setwall were not at an end : wheretspon fome woman Poet or other hath made tizefe verfes:

They that will hate their heale, Muft put Setwall in their keale.

B. It is vied generally in fleight cuts, wounds, and frall hurts.

C The extraction of the roots giten, is a moft fingular medicine againft the difficultie of making

D Wilde Valerian is thought of the later Herbarifts to be good for them that are burfen, for fuch as be troubled witl the crampe and other convulfons, and alfo for all thofe that are bruifed with falls.

E The leates of thefe and alfo thofe of the garden, are good againft vlcers and forenes of the mouth and gums, if the deco ftion therc of be gargarized or held in the mouth.

F Some hold opinion that the ronts of wilde $V_{\text {at }}$ !erian dried and poudered,and a dramme weight thereof taken with wine, do purge vpward and dow neward.

\section{С н т. 441. Of M Mountaine Setwall, or $\mathcal{X}$ ardus. T The Dcfeription.}

I 7 He Nardus named Celtica, but now by fome, Liguftica Nardus, flouritheth in high mounto be Salivilca ; neither do.I doubt, but that it is the fame call it Selliga; whence Gefner thought it

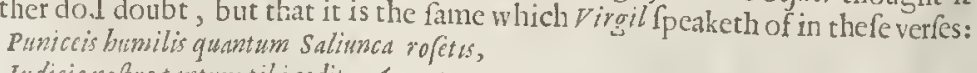
Iudicio nof tro tantum tibicedit 4 Amintas.

For it is a very litrle herbe ereeping on the ground, and afterward lifting vp it felfe with a falke of a handfull high; w wereupon from the lower part grow finall thin leaues, firft green, but afterwards fomewhar yellowith : vpm ihe roughneffe of the root there are many fales, platted one vpon another; but vider the rone there are many browne ftrings and hairy threds, in fmell like the roots of Uf frabacca, or rather the wilke nzountaine Valerian, whereof it feemes to be a kinde, in tafte harpe and bitcer. The flotues grow along the yper branches, white or yellow ilh, and rery fmall. 
tranflating of Garcias the Luftanian Phyfitian, he fetteth it forth with a light defcription, faying, It is a bafe and low herbe two handfulls high, bringing forth leaues without any ftalkes at all, ¥ very hairy about the root, and blackin, hauing no pleafant fent at all. The leaues chewed yeeld no aromaticke tafte, but are clammie, or vifcide; whereas the leaues of Celticke Narde are hot, with a little aftriotion, and of a plcafant fincll and tafte. $¥$

4 Mountaine Spikenard hath a great thicke knobbed root, fer here and there with fome tender fibres, of a pleafant fiveet fmei; from the which come forth three or foure fmooth broad leaues, and likewife iagged leaues deepely cut euen to the middle rib : among which rife vp naked ftalks, garnifhed in the middle with a tuft of iagged leaues. The foures grow at the top of the ftalks, in an vmbel or tuft like thofe of the wilde Valcrian in fhape and colour, and fuch alfo is the feed. $¥ I$ haue given you the figure of the root and whole leates as they fhew themfelues when they firft appeare, as it was taken by clufius. $\neq$

5 Rardius Indica.

Indian Spikenard.

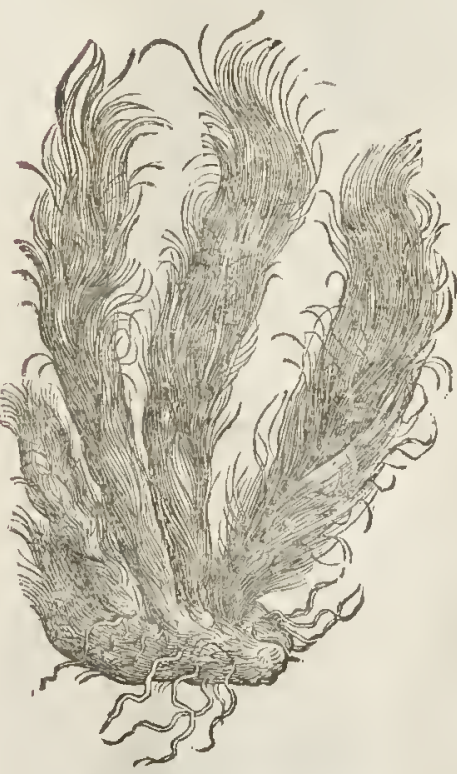

6 Nardus Narbonenfis. French Spikenard.

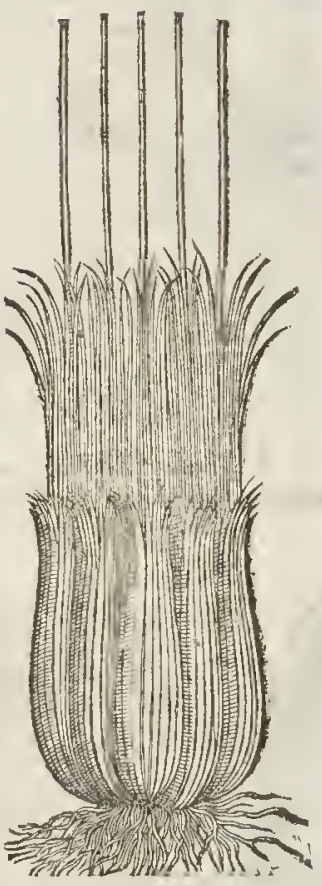

5 The Spikenard of India is a low plant, growing clofe vnto the ground, compored of many rough browne hairy cloues, of a ftrong, yet not vnpleafant fmell. The root is fmall and threddie.' ¥ It hath certainly ftalkes, foures, and feeds ; but none of our Indian Writers or Trauellers haue as yet defcribed them. I haue feene little pieces of flender hollow ftalkes fome two inches long fantned to the roots that are brought to vs.

+ 6 This French Spikenard, being a baftard kinde, groweth clofe vpon the ground like the precedent, compact of fcaly rough leaues: in the middle whereof commeth forth a great buin of round greene ftiffe and rufhy leaues : among the which thoot vp dituers round ftalkes a cubit high, fet from the middle to the top with greenifh little cods, ftanding in chaffic huskes like thofe of Schonanth. The root is fmall and threddy: the whole plant is alrogether without fmell, which Theweth it to bea baftard kinde of Spikenard.

\section{T) The Place.}

Thefe plants [the firft fourc] are ftrangers in England, growing in great plent ie vpon the mountaines of Iudenberg and Heluetia, on the rockes among the moffe, and in the mountains of Tiroll and Saltzburg.

The firft and fecond, if my memoric faile me not, do grow in a field in the North part of Eng. 
land, called Crag elofe, and in the foot of the mountaine called Ingleborow Fels. "F The foutl: may be found in fome gardens with vs. The fifth growes in rhe Eait Indies, in the prourinces of Mandou and Chito in the kingdome of Bengala and Decun. The latt growes in Prouinee in France, neere a little city called Gange. $\ddagger$ - The Time.

The leates grow to withering in September, at which time they finetl more pleafantly than when they floutihed and were greene.

\section{The Names.}

N.ydus is ealled in Pannonia or Hungarie, of the eountrey people, Speick : of fome, Bechi fin: that is, the herbe of Vienna; becaufe it doth grow there in great aboundanee, from whence ir is brouglit into other countries: of Gefner, Saluma : in Englith, Celtiche Spikenard: of the Valletians, Selliga, and Nordus Celtica.

\section{9] The Temperature and Vertues.}

Celticke Narde mightily prouokes vrine, as reeorderh Rondeletius; who trauelling through the A defart countrey, chanced to lodge in monafterie where was a Chanon that could not nake his water, but was prefently helped by the decoction of this herbe, through the aduice of the faid rom deletius.

$\neq$ The true Spikenatd or Indian Nard hatls a heating and drying faeultie, being (according to ' $B$ Galen) liot in the firft degre [yet the Greeke copy hath the third] and dry in the fecund.It is co:npofed of a fufficiently aftringent fubftance, and not much aeride heace, and a eertaine light bi:terneffe. Confinting of thefe faculties, according to reafon, both inwardly and ourwardly ved it is coutuenient for the liuer and ftomacke.

It prousketh vrine, helps the gnawing paines of the ftomacke, dries vp the defixions that ttotble the belly and intrals, as alfo thofe that moleft the head and bref.

It ftayes the fluxes of the belly, and thofe of the wombe, being vfed in a peffarie, and in a bath it helpes the inflammation thereor.

Drunke in cold water, it helpes the naufeoufneffe, gnawings, and windineffe of the ftomacke, $E$. the liuer, and the difeafes of the kidneyes, and it is much ved to be put into Antidotes.

It is gool to caufe haire to grow on the eye lids of fuch as wint it, and is good to be fterved vp- $F$ on any part of the body that abounds with fuperfluous moi fture, to dry it vp.

The Celticke-Nard is good for all the forementioned vfes, but of leffe efficacie, vnleffe in the G prouoking ofvrine. It is alfo much ved in Antidotes.

The mountaine Nard hath al fo the fame faculties, but is much weaket than the former, and not invfe at this day that I know of. $\neq$

\section{Cна в. 442. Of Larkes becle or Lurkesclaw.}

\section{T) The Defription.}

I The garden Larks fpur hath a round Item ful of branches, fet with ten ler iagged leaues very like vnto the fmall Sothernwood : the floures grow along t rhe ftalks roward the tops of the branehes, of a blew colour, confifting of fiue little leaues which grow to. gerher and make one hollow foure, hauing a taile or fpur at the end turning in like the fpurte of rode-flax. After cone the feed, very blacke, like thofe of Leekes : the root perifherh ar the firt approch of Winter.

2 The fecond Latks fpur is like the precedent, but fomewhat fmaller in ftalkes and leaues: the floures are alfo like in forme, but of a white colour, wherein efpecially is the diffurenee. Thefe flourcs are fometimes of a purple eolour, fometimes white, murrey, carnation,and of fundry other colours, varying infinitely, according to the foile or countrey wherein they line.

¥ 3 Larks fpur with double floutes hath leaues, falkes, roots, and feeds like the other fingle kinde, but the floures of this are double; and hereof there are as many fenerall varieties as there be of the fingle kinde, to wit, white, red, blew, purple, biuh, \&cc.

4 There is alfo another varictic of this plant, which harh taller ftalkes and larger leaties than the common kinde : the floures alfo are nore double and larger, wirh a leffer heele: this find alfo yeeldeth vfually lefic ieed than the former. The colour of the flomre is as various as thar of the former, being either blerv, purple, white, red, or blufh, and fometimes mixed of fome of the fe. $\ddagger$

5 The wilde Larks fpur hath moft fine iagged leaues, eut and hackt into diuers parts. confufealy fet vpon a fmall middle tendrell : among which grow the floures, in thapelike theothers, but 
I Confolidareo alis fatiua.

Garden Larks heele.

Obephinium Consohida

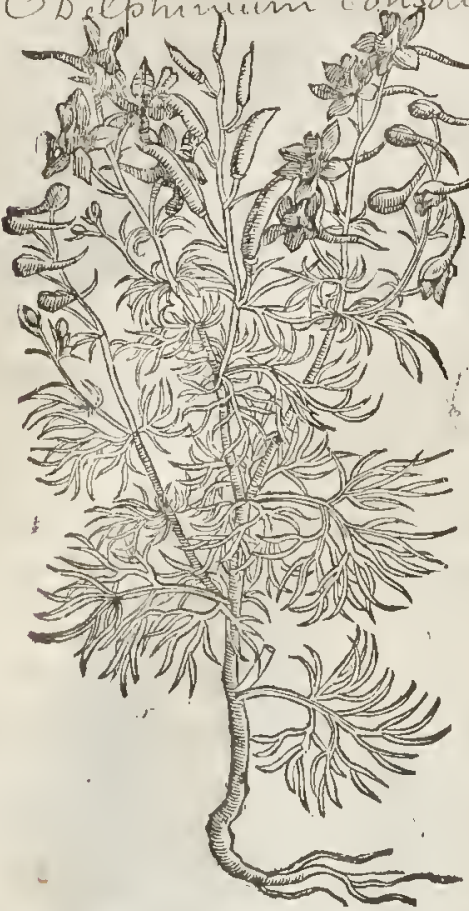

\# Conjolidaregalis fore displici. Double Larks fpur.
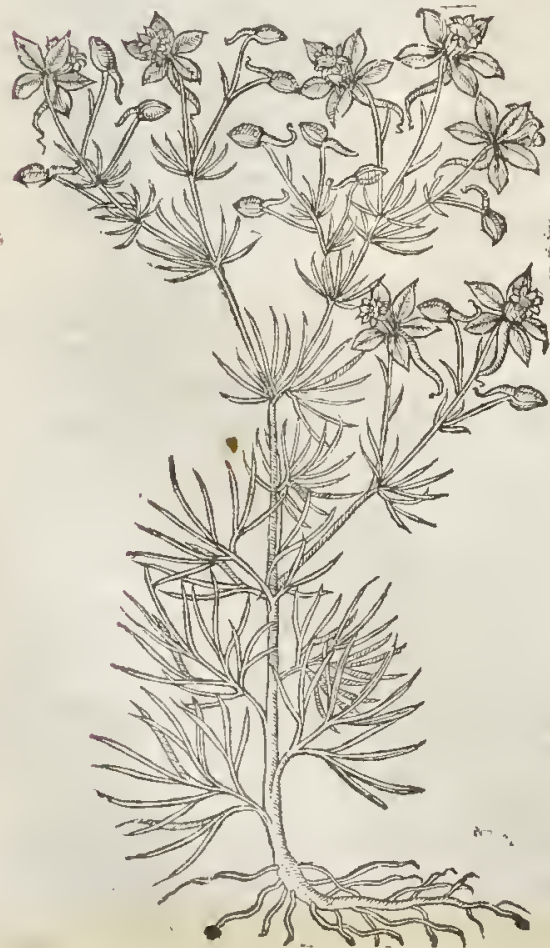

2 Crnfolida fatiza fore alluect rubro.

White or red Larks fpur.

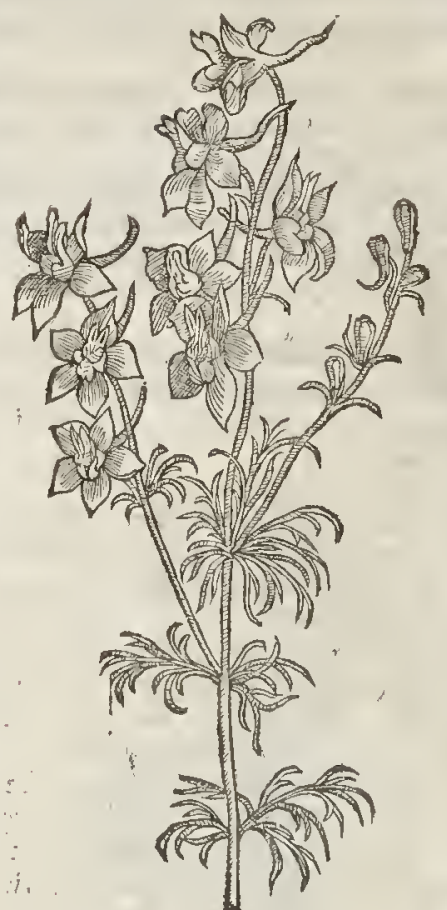

* ${ }_{4}$ Confolidareg el atior fo.pleno. Great double Larks fpur.

4 군

Mha

2) 401

N10 - r 0

D10 n

$+2 \times 150$

$-7.15$

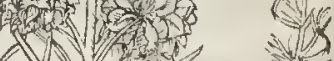

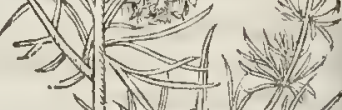
A N NWW $=$

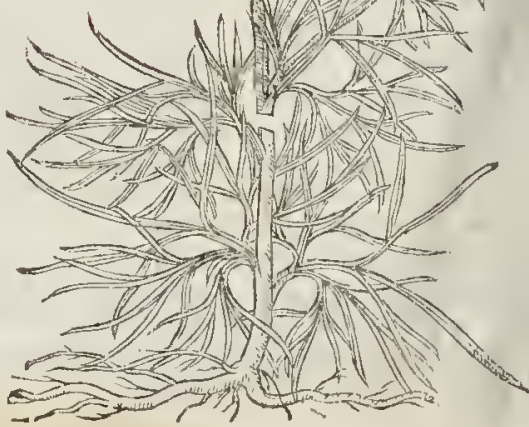


a great deale le ffer, fometimes purple, otherwhiles white, and often of a mixt eolour. The root is fmall and threddy.

; Confolidaregalis fylueftris. Wilde Larkes heele.

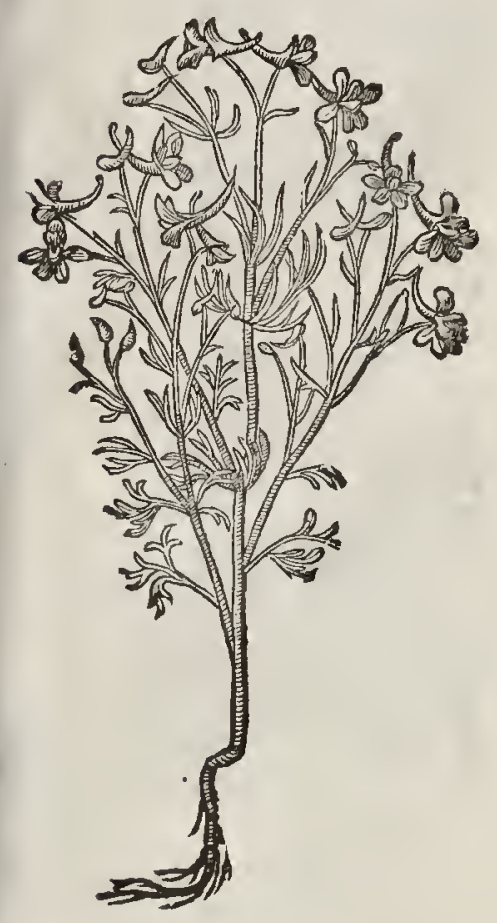

fi The Place.

Thefe plants are fet and fowne in gardens : the laft groweth wilde in eorne fields, and where corn hath grown, $\neq$ but not with vs, that I haue yet obferued; though it be frequently found in fich plaees in many parts of Germanic. $\neq$

$$
\text { 9 The Time. }
$$

They floure for the mort part all Sommer long, from Iune to the end of Auguif, and ofttimesafter.

$$
\text { I The Names. }
$$

Larks heele is ealled Flos Regius of dituers, Confolida regalis; who make it one of the Confounds or Confreyes. It is alfo thought to be the Delpbinium which Diofcorides deferibes in his third booke; wherewith it may agree. It is reported by Gerardus of Veltwijcke, who remained Lieger with the great Turke from the Emperor Charles the fifth, That the faid Gerard faw at Conftantinople a copy which had in the ehap. of Delphinium, not leaues but floures like Dolphines : for the floures, and efpeeially before they be perfected, haue a certaine hew and likeneffe of thore Dolphines, which oild pictures and armes of eertain antient families haue expreffed with a erooked and bending figure or fhape; by which figne alfo the heauenly Dolphine is fer forth. And it skilleth not, though the ehapter of $D$ elphinium be thought to be falfified and counterfeited, for although it be fome other mans, and not of Diofcorides, it is notwithftanding fome one of the old Writers, out of whom it is taken, arid foifted into Diofcorides hisbookes: of fome it is called Bucinus, or Bucinum : in Englin, Larks fpur,Larks heele, Latks toes, and Larks claw : in high-Dutch, kitoder fpoozen; that is, Equitis calcar, Knights fpur : in Italian, Sperone : in Freneh, Pied d' alouttte.

\section{Thefe herbes are temperate and warme of nature. \\ T) The Vertues.} T) The Temperature.

We finde little extant of the vertues of Larks heele, either in the antient or later writers, worth the noting, or to be eredited, for it is fet downe, that the feed of Larks fpurdrunken is good againft the ftingings of Scorpions; whofe vertues are fo foreible, that the herbe onely thrown before the Seorpion or any other venomous beaft, eaufeth then to be without foree or flrength to hurt, infomueh that they eannot moue or ftirre vntill the herbe be taken away : with many other fuch trifling toycs not worth the reading.

\section{С на 443 . Of Gith, or Nigella.}

The Kindes.

$T$ Here be diuers forts of Gith or Nigella, differing fome in the colour of the floures, others in 1 the doubleneffe thereof, and in fmell of the feed.

\section{The Defcription.}

I THe firt kind of Nigella hath weake and britrle ftalks of the height of a foot, full of branehes, befet with leatues very much eut or iagged, refembling the leaues of Fumiterie, but much greener: the floures grow at the top of the branches, of 2 whitin blew colour; each floure 
$1084 \quad$ Ot the Hiftory o! Plants.

I Melanthium.

Garden Nigella.

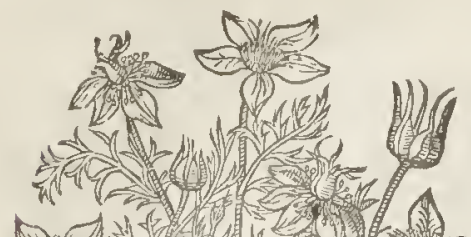

0.74 年

$50-13$

* 3

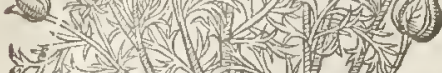

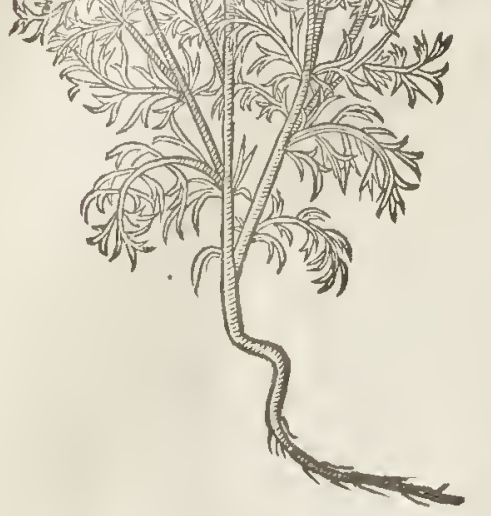

3 Melanthium Damafcenum.

Damaske Nigella.

Miqula Gbanyascena.

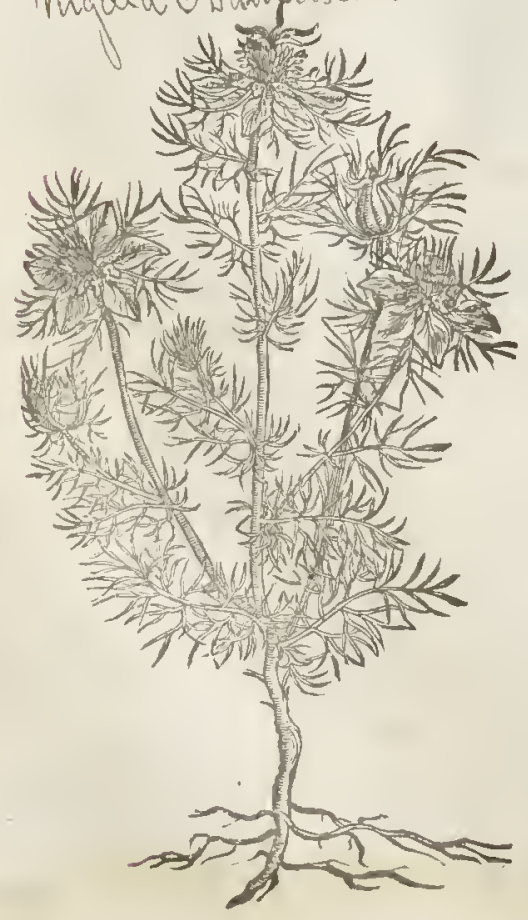

L. 1 B. 2.

2 Gredanhum fulugtre.

Wilde Nigclla.

migella arvensis.

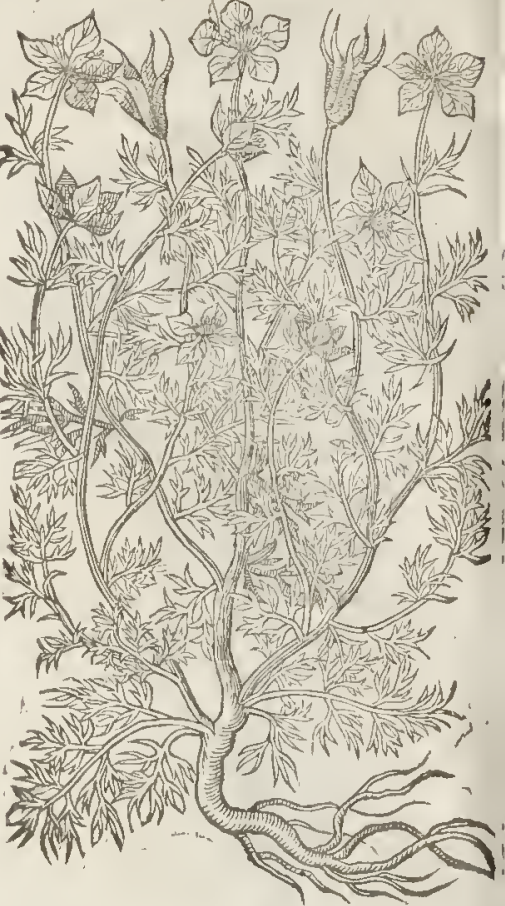

\$ Melint bium Darafcenum flo. pleno. Double floured Damaske Nigella.

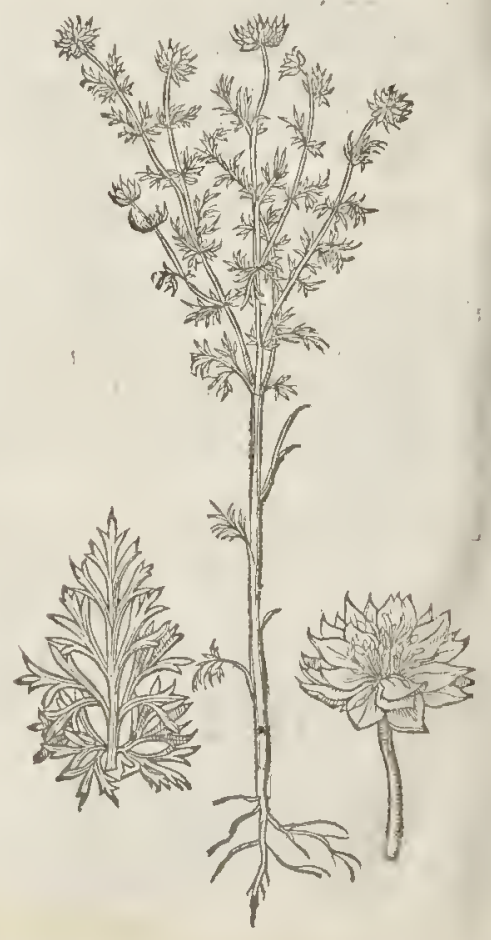


being parted into fute fmall leates, ftarre fathion : the floures being vaded, there eonie vp frai? knots or heads, hating at the end thereof fue or fix little fharpe hornes or pointalls, and ctr: ry knob or head is diuided into findry friall cels or parcitions, wherein the feed is contcined, which is of a blackinh eolour, very like vnto Onion feed, in tafte harpe, and of an execllent fiveet fanour.

2 The wilde Nigella harli a ftreaked ftalke a foot or more high, befet full of grayinh 'caures, very fincly jagged,almoft like the leaues of Dil : the floures are like the former, faue that they are bicwer : the eods or knops are like the heads or huskes of Columbines, wherein is ennteined tre fiveet and pleafant feed, like the former.

5 Nigella fiore albo multiplici. Damaske Nigella.

higelear sativia
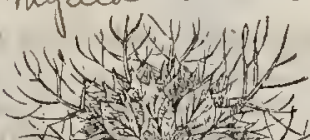

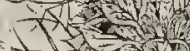

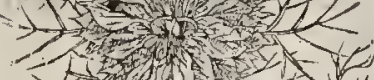

ST (1)

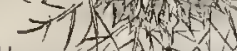

Nive
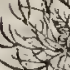

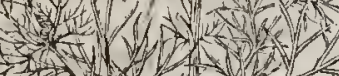

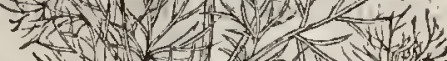

-1 ,

Dition

d)
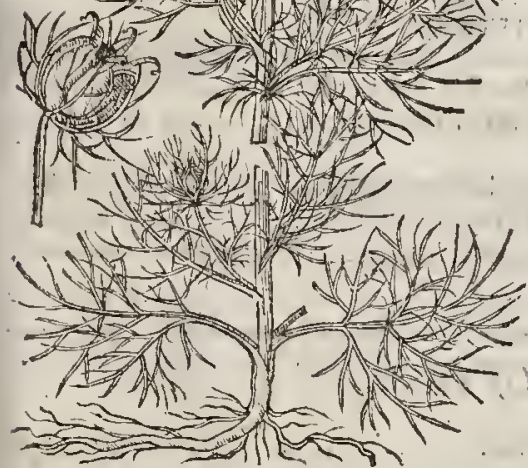

\$ Nigella Hijpanica flore ampls. Great Spanifh Nigella,

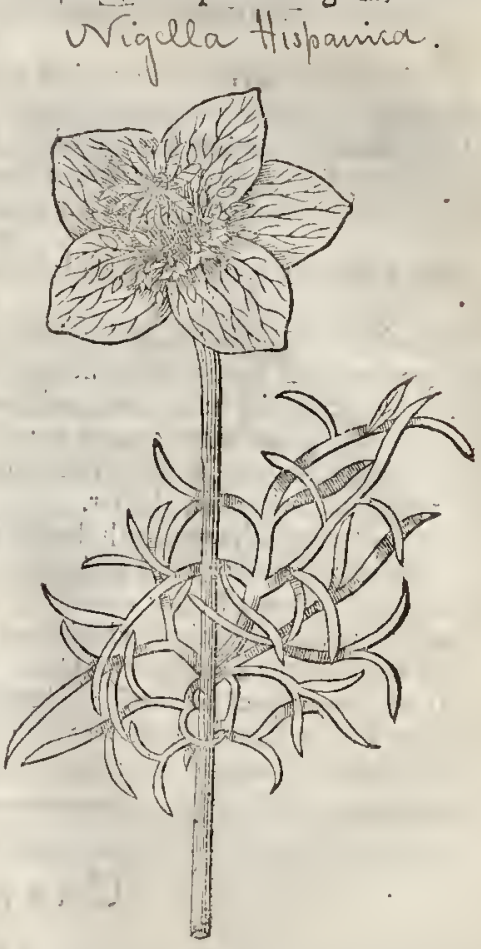

3 The third kinde of Nigella, whieh is both faire and pleafant,ealled Damaske Nigella, is ve. ry like vnt $n$ the wilde Nigella in his imall eut and jagged leaues, but his ftalke is longer:the floures are like the former, but greater,and euery floure hath fiue fmall greene leaues vider liim, as it were to fupport and beare him vp: which floures being gone, there fteceed and follow knops and feed dike the former, but without fmell or fatour.

\# 4 This in the fmalneffe, and fhape of the lcaures and the manner of growing is like to the Lalt defcribed hauing fmal leaues growing vnder the floure, which is not fingle, as in the laft defcribed, bur double, eonfifting of fure or more rankes of little blewi ih leaues, wh hich are fueceeded by fuch conered heads as thofe of the former, hauing in them a blacke feed without any manifert finell. $\ddagger$

5 The fifth kinde of Nigella hath many finall and flender ftalkes, fet full of fiender and thin leawes deepely cut or jagged, of a fainc yellowith greene eolour : the foures grow at the top of the ftalkes, of a whirifh colour, and exceeding double : which being vaded, thiere fucceed bowles or knobs, full of fweet blaeke feed like the former: ths root is fmall and tender.

$\neq 6$ The rox of this is flender, and yellowith; the ftalke fonre cubit ligh, iound, green, erefted, and toward che top diuided into fundry branches, the leaues toward the bottone are fonewhat fma!l cur, but fo newinat larger vpon the ftalkes. The floure is much latger than any of the tormer, compofed of fue leaues, of a light blew aboue, and fomewhatwhition onterncath, wirh 
large veines sunaing about them : in the middle ftands vp the head, eceonjpdfal wirh blackinh threds, and fome 7. Or 8 . little gaping blewifh floures at the bottomes of them; the leares of the floures decaying the head becomes bigger, hauing at the tops thereof 6. 7.0r.8. Longith twined hornes growing, in a ftar fahion; the infide is parted into cels conteyning a yellowith green, or elie

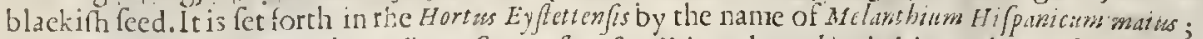

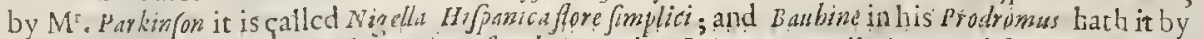
the name of Nigella latifolia flore matore fimplici cerulco. It is an annuall plant, and thoures in Iuly; it is fometimes to be found in the gardens of our Florilts. F

$$
\text { The Place. }
$$

The tame are fowne in gardens: the wilde ons do gtow of themfelues among corne and other graine, in dituers countries beyond the feas.

4 The rime.

The feed mutt be forme in Aprill : it floureth in Iuly and Auguft. :

$$
\text { If The Names. }
$$

Gith is called in Greeke wavisur in Latine alfo Mclanthium in thops, Nigell, and Nigcll.t Romana . of diuers, Gith, and Salufandria, and fome among rhe former baftard names, papacr vigrmm - in ligh

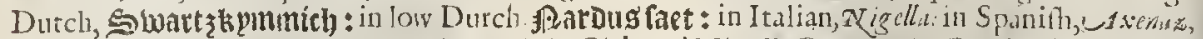

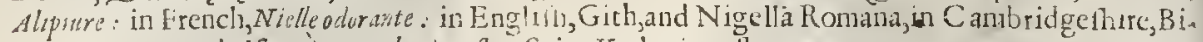
fhops woort : and alfo Diue Catharing flos, Saint Katharines Houre.

of The Temperature.

The feed of the garden Nigella is lot and dry in the third degree, and of thin parts.

$$
\text { of The Verines. }
$$

A The feed of 2 igella Romana drunke wirh wine, is a remedy againft the fhortnes of breath, diffo!ueth and putteth forth windineffe, pronoketh vrine, the menfes, inerealeth milke in the brefts of nurfes if it bedrunke noderately; otherwife it is not onely burfull to them, but to any that take thereof too often, or in tongreat a guantity.

B The feed killetl and driueth forth wormes, whether it betaken with wine or watet, or laid to the nauell in manner of a plaifter.

C The oile that is drawne forth thereof bath the fame property.

D The feed parched or dried at the fire, brought into pouder, and wrapped in a piece of fine lawne or farcenet, cureth ail murs, catarrhes, rheunes, and the pofe, drieth the braine, and reftoreth the fence of fmelling vnto thofe which hate loft it, being often fmelled vnto froni day to day, and made warme at the fire when it is vied.

E It takes away freckles, fcurfs, and hard fwellings, being laid on mixed with vineger. To be briefe, as Galen faid, it is a moftexcellent remedy where there is need of clenfing, drying, and heating.

It fertetl well among other fiveets to put into fweet waters, bagges, and odoriferous powders.

t The figures of the thidand fourth of rhe former edition were tratcpoled.

$$
\begin{aligned}
& \text { CH A P. 444. Of cockle. } \\
& \text { 9ा The עefcription. }
\end{aligned}
$$

Ockle is a common and hurtfull weed in our Corne, and very well knowne by the name of

Cockle, which Pan calleth Pfeudomelanthium,and Nigellaftrum, by which names Dodoneus and - Fubhfus doulforerne it ; Mornus calleth it Lolium; and Tragus calleth it Lychnoraes fegetum. This planr hath fraight, flender, and hairy ftems, garnifhed with long hairy and grayifh leaues, which grow to sether by couples, inelofing the ftalke round about : the Houres are of a purple colour, declining to reduefre, eonlifting of fue fmal! leaues, in ptoportion very like to wilde Camplons; when the flonres be vaded there follow round knobs ot heads full of blackinh feed, like vgto the fect of Nigellat, but without any finell or fauour at all.

$$
\text { of The place and Time. }
$$

The place of his growing, and time of his flouring, are bettet knowne then defised.

$$
\text { of The Names. }
$$

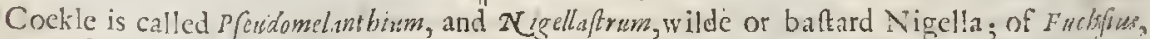

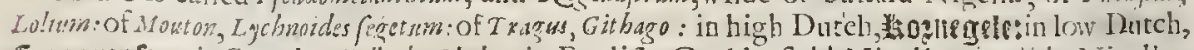

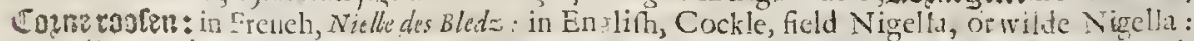
in Italian, Gubone; whereupon mof Herbarifts being monued with the likenefta of the word, hate rhouglut it robethe true Gith or Milanthim; but how farre they are deceived it is betrer knowne, than needfull ro be confured : for it doth not onely differ in leates from the true Gith, but al!n in uther properries,and yet it is ealled Githor Melambium, and that is of the blackenes of the

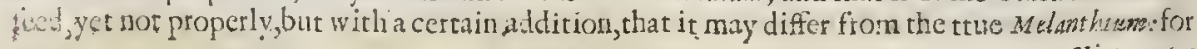




\section{1 B. 2. Of the Hiftroy of Plants.}

Pfendomelantbium.

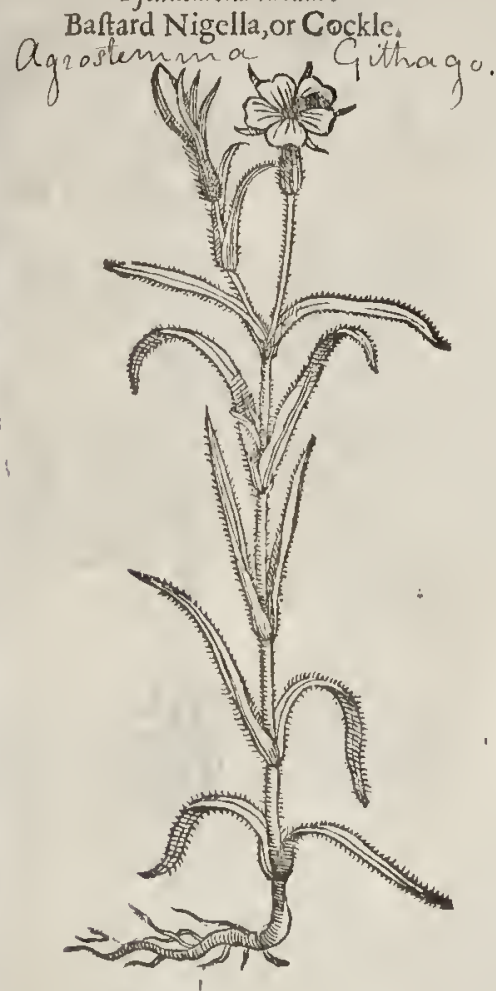

Hippocrates callech it Melantbitum ex Tritico, of wheate: octanius Horatianus calleth that Gith which groweth among Corne: and for the fame caufe it is named of the learned of this our time Nigellaftrum, Gi. gat bo, and P feudomelantbium: Rucllius faith it is called in French Niele, and Flos CMiiancales.

-I The Temperature.

The feed of Cockle is hot and dry in the later end of the fecond degree.

- The Vertues.

The feed made in a peffaric or mother $A$ lippofitorie, with honey pur vp, bringeth dewne the defired ficknefle, as Hippocrates in his booke of womens difeaies doth witnefie.

octanius Horatianus giteth the feed par- B ched and beaten to pouder to be drunke againft the yellow jaundice.

Some ignorant people haue vfed the C feed hereof for the feed of Darnell, to the great danger of thofe who haue receiued the fame : what hurt it doth among come, the fpoyle vnto bread, as well in colour, tafte, and vnwholefomnes, is bettcr known than de fired.

\section{Cha}

- The Kindes.

7 Here be diuers herbes comprehended vnder the title of Fumitorie; fome wilde, and others of 1 the garden; fome with bulbous or tuberous roots, and others with fibrous or threddy toots : and firft of thofe whole roots are nothing but ftrings.

\section{TI The Defription.}

I TVmitoric is a very tender little herbe : the ftalkes thereof are 1lender, hauing as it were - little knots or ioynts full of branches, that farfe grow vp from the ground without proppings, but for the molt pirt they grow fidelong: the leaues round about are fmall, cut on the edges as thofe of Coriander, which as well as the 1talkes are of a whitith greene: the Ho:tres be made vp in clufters at the tops of the fmall branches, of a red purple colour : then rifevp liuskes, round and little, in which lieth the fmall feed: the root is llender, and groweth fraight downe. $¥$ This is alfo found with floures of a purple violet colour, and alfo fomtimes with them white. $\neq$

- 2 The fecond kinde of Fumitoric hatl many fmall long and tender branches, wherupon grow little leaues, commonly fet together by threes or fues, in colour and tafe like vntorhe former; hauing at the top of the brancises many fmall clafping tendrels, with which it taketh bold vpon hedges, bufhes, and whatfocuer growech next vnto it : the floures are finall, and cluftering together of a white colour, with a little fpot in their middles; after which fucced cods containing the feed : the root is fingle, and of a fingers lengtl.

3 The third kinde of Fumitorie hath a very fmall root, confifting of diuers little ftrings ; from which arife fmall and tender branches trailing here and there vpon the ground, befet with many frnall and tender leaues mott finely cut and iagged, iike the little leaues of Dill, of a deepegreene colour tending to blewnefie: the floures ftand on the tops of the branches, in birnches or clufters thicke thruft to sether, like thofe of the medow C auer, or three leafed grafle, of a moft bright red coiour, and very beaurifull to behold : the rune is very fmatl and threddy,

$$
\text { ryyy } z
$$


I Fumumapurpurea.

Common or purple Eumitory.

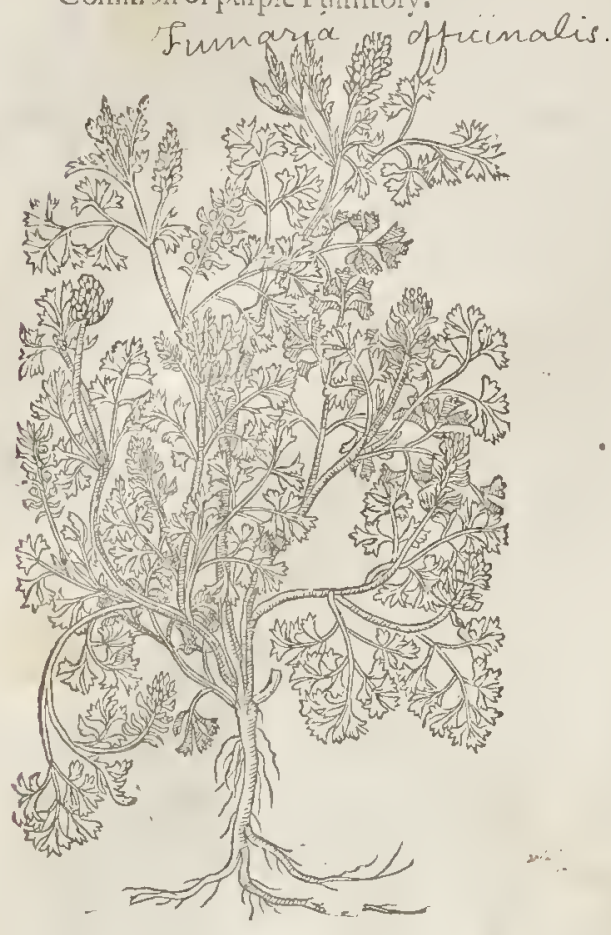

3 Fumariatenuifolia.

Fine leafed Fumitoric.

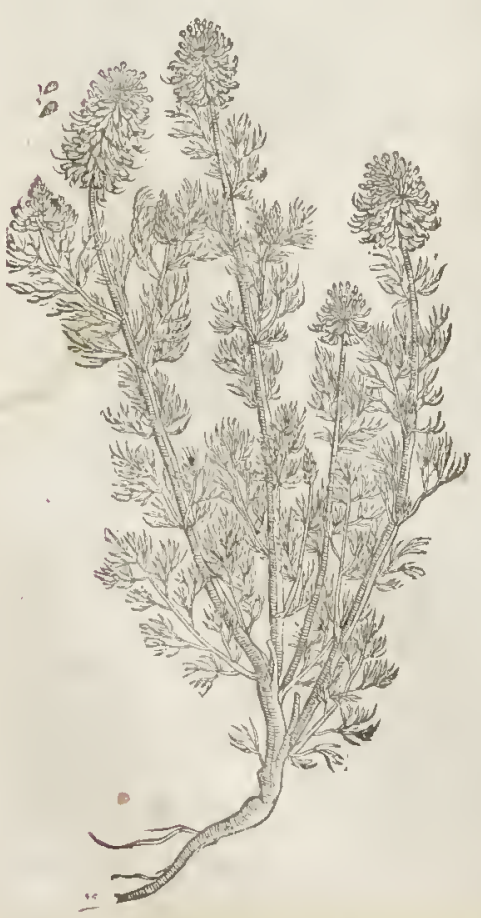

† 2 Fumariaalba latifolia clawiculata. White broad leafed Fumitoric.

of maria clavicul

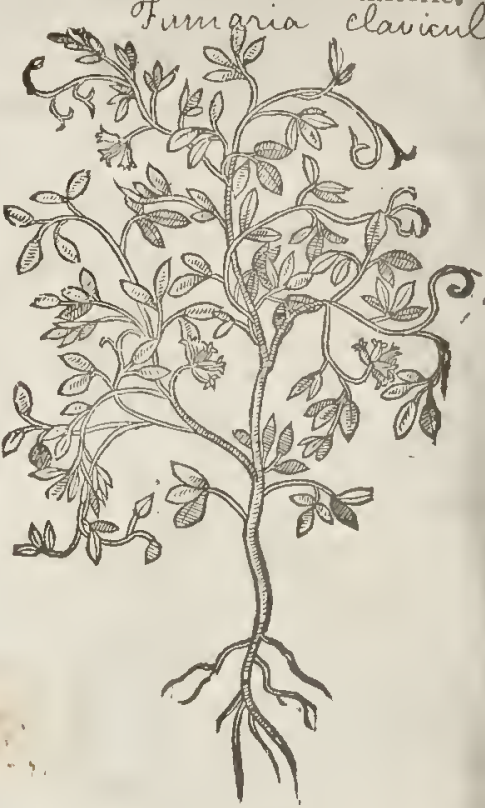

i

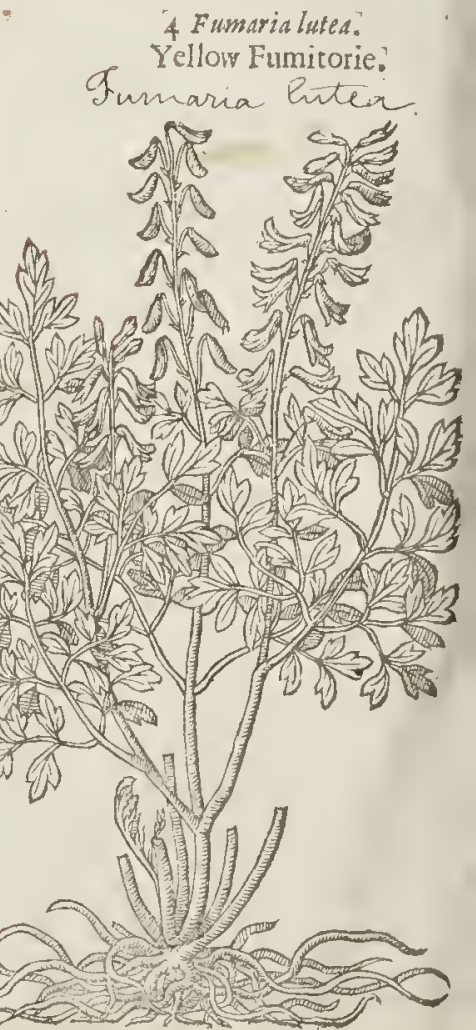


4 The ycllow Fumitoric hath many crambling threddy roots, forinewhr thicke, grofte, and fit, like thofeof $A$ paragus : from which rife diuers vpright falkes a cubit high, diu dus shemfelues toward the top inco other fmaller branches, wheron as conturedly placed leatic iske thofe of Thalidtrum, or Englifh Rubarb, but leffer and thinner : along th the tops of the branches grow yellow floures, refembling thofe of Sage: which being paft, there followerh finall feed litic vnto dutt.

\section{- The Place.}

The Fumitories, grow in corne ficlds among Barley and other graine; in vineyards, gariens, and fuch like nuanured p.aces. I found rhe fecond and third growing in a corne field betweene a firall village called Charleton and Greenwich.

\section{T The Time.}

Fumitorie is found with lis floure in the beginning of May, and fo continues to rhe end of fo:nmer. When it is in floute is the beft time to gather it to keepedry, or to diftill.

T) The Names.

Fumitorie is called in Greeke Kemis, and Kaxyu, and often Kastims : in Latine, Fumaria : of Pliny, Cap-

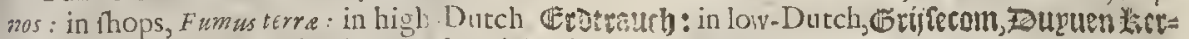
tel: in Spanilh, Palomilsa : in Freuch and Englifh, Fumiterre.

$$
\text { a) The Temperature. }
$$

Funitoric is not hot, as fome haue thought it to be, but cold and fomething dry ; it openeth and clenfeth by vrine.

$$
\text { - i he Vertues. }
$$

It is good for all them that hauc eirher fcabs or any othet filth growing on the skinne, and fot $A$ them alfo that haue the French difeafe.

It temoueth ftoppings from the liuer and $\mathrm{fp}^{\prime} \mathrm{eene}$ : it purifieth the bloud, and is of times good for them that late a quartane ague.

1. The decoetion of the herbe is vfed to be giuen, or elfe the fyrrup that is made of the iuyce: the $\mathbf{C}$ diftilled water there of is alfo profitable againft the purpofes aforcfaid.

It is oftentimes boyled in whay, and in this manner it helpeth in the end of the Spring and in D Sommer time thofe that are troubled with fabs.

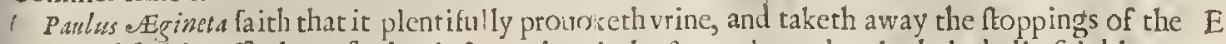
liuer, and fcebleneffe thereof; that it frengthneth the ftomacke, and makcth the belly foluble.

Diofcorides afirmeth, that the iuyce of Fumitoric, of that which groweth among Barley, as ets- F ginet a addeth, with gum Arabicke, doth take awav voprofitable haires that pricke the eyes, growing vpon the eye lids, the haires that pricke being firft plucked away, for it will not fuffer others to grow in their places.

The decotion of Funitotic drunken dritucth forth by vrine and ficgeall hot cholericke burnt $G$ and hurtfull lummors, and is a molt lingular cigefter of falt and pituitous humors.

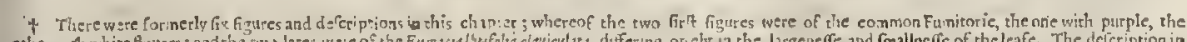

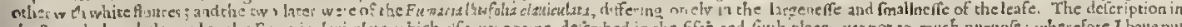

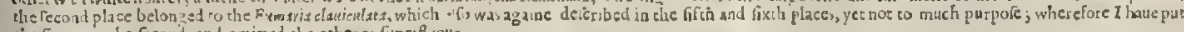
tisc figure to the fiscond, and omitted the ocher as fupethisous, .

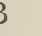
政 D

$$
\mathrm{B}
$$
F 
4 The fmall white Hollow-root likew ife agreeth with the fotmer in eacl refpect, fauing that this plant bringeth white floures, and the other not fo.

I Radix caua maior purpurea.

Great purple Hollow-root.

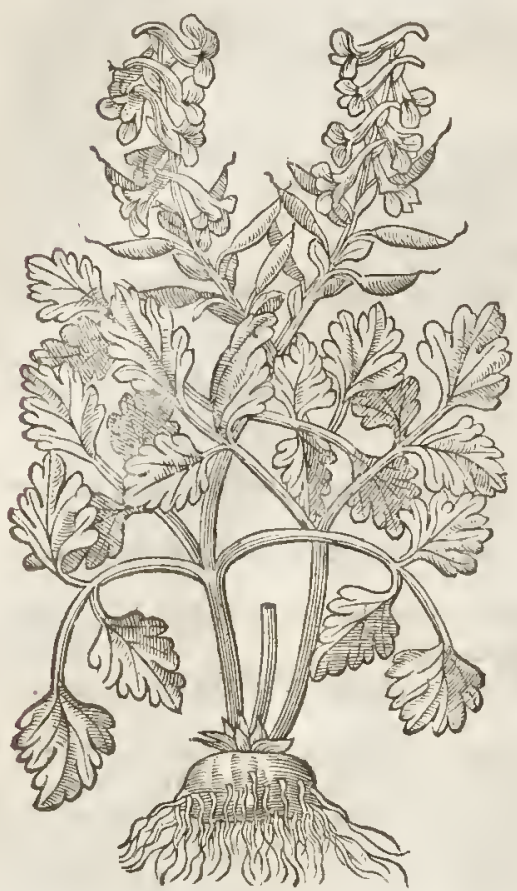

2 Radix cana maior allia.

Great white Hollow-root:

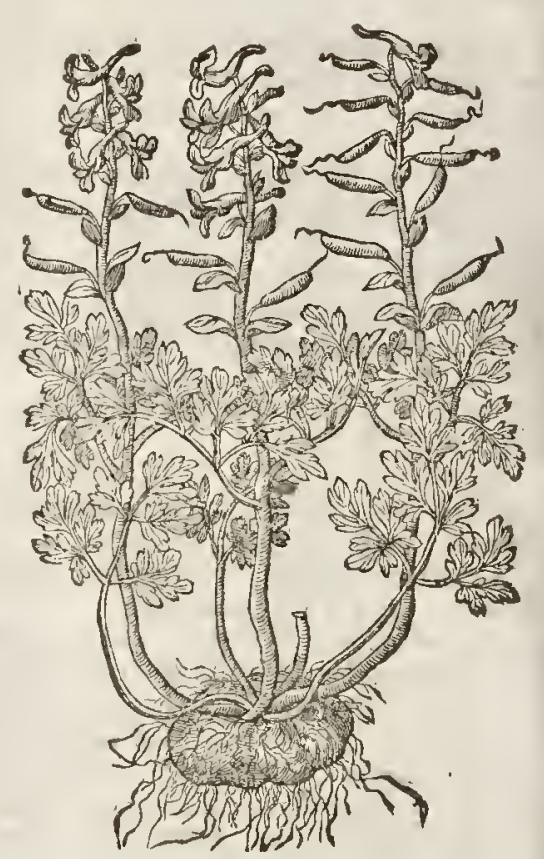

5 This kinde of Hollow-root is alfo like the laft deferibed, fauing that the foures hereof ate mixed with purple and white, which maketh it to differ from the others.

6 There is no difference in this, that can poffibly be diftinguifhed, from the laft deferibed, fauing that the floures hereof are of a mixt eolour,white and purple,with fome yellow in the hollowneffe of the fame, wherein confifteth the differenee from the preeedent.

7 This thin leafed Hollow-root hath likewife an hollow root,couered oner with a yellow pitling, of the bigneffe of a tennife ball : from which thoot vp leaues fpred vpon the ground, very like unto the Jeaues of Columbines, as well in forme as eolour,but much thinner, more iagged, and altogether lefer : among which rife vp fnall tender ftalkes, weake and feeble, of an handfull high, bearing from the middle thereof to the top very fine floures, fathioned vnto one piece of the Columbine floure, which refembleth a little bird of a purple colour.

8 This other thin leafed Hollorr-root is like the precedent, fauing that this plant brings forth white floures tending to yeliowneffe, or as it were of the eolour of the field Primrofe.

9 Sunmpkens holmotele, as the Dutch men doe eall it, hath many fmall iagged leates growing immediately from the ground, among which rife vp very flender ftalkes, whereon doe grow fuch leaues as thofe next the ground : on the top of the branches ftand faire purple floures like vnto the others $n$ f his kinde, faung that the floures hereof are as it were fmall birds, the bellies or lower parts whereof are of a white colour, wherein it differeth from all the reft of the Hollow-soots.

ro The laft and fmall hollow-root is like the laft deferibed, fauing that it is altogether leffe, and the foures herc of are of a greene eolour, not vnike in thape to the floures of Cinkefoile. \# This plant, whole figure our Author here gaue with this fmall defcription, is that which from the fnuel of muske is called Mof chatella, by Cordus and others : it is the Denticulat $n$ of Dalef champirus:

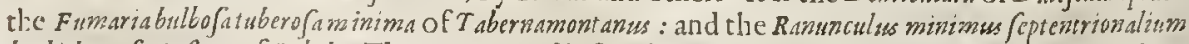
herbido mufcopo fore of Lobel. The root hereof is fmall and toothed, or made of little bulbes refenbling teeth, and ending inwhite hairy fibres : it fendeth vp dituers little branches fome two 
L1 B. 2. Of the Hiftroy of Plants.

or three inches high: the leaues are fomewhat like thofe of the yellow Fumitorie, or Radixenus, but much leffe: the floures grow cluftering on the top of the ftalke, commonly five or feuen together,each of them made of foure yellowith green leaues with fome threds in the $n_{\text {; }}$ it floures in 9 prill,and is to be found in diters places amongft bufhes at that time, as in Kent about Chinchurft; efpecially in Pits his wood, and at the further end of Cray heath,on the left hand vader a hedge a: mong bryers and brambles, which is his proper feat. $\neq$

9 Radix caua minor.

Bunnikens Holwoort:

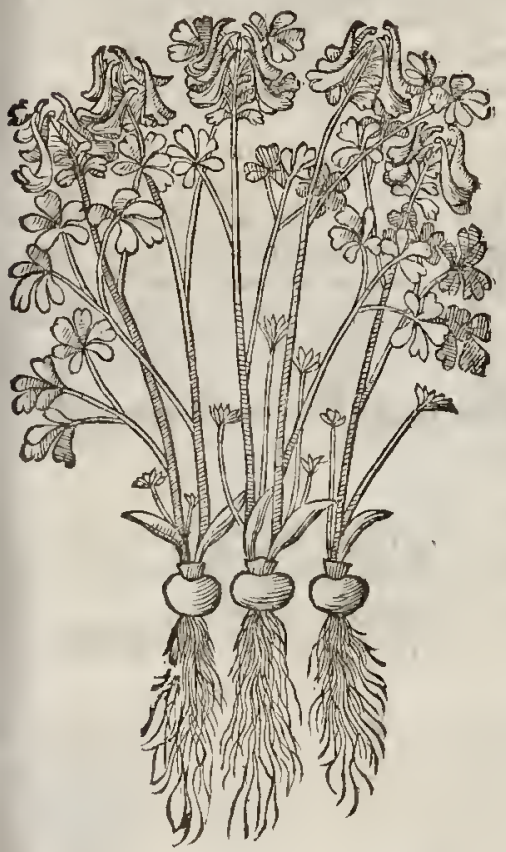

Io Radix cand minima viridi flort. Small Bunnikens Holwoort.

Adoxa thosch atcleina

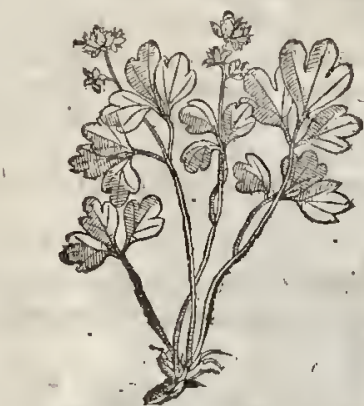

T the pilate.

Thefe plants do grow about hedges, brambles, and in the borders of fields and vineyards, in low and fertile grounds, in Germanic and the Low-countries, neuertheleffe the two firlt, and alfo the Ewo laft defcribed dogrow in my garden.

$$
\text { T The Time. }
$$

Thefe do floure in March, and their feed is ripe in Aprill : the leaties and ftalkes are go'n in May, and nothing remaining fauc oncly the roots, fo little a while do they continue.

\section{The Names.}

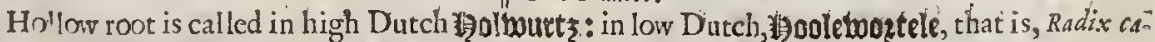
ta: in Englin, Hollow root, and Holewoort : it is ved in thops in fteed of Ariftolochia, or round Brrthwoort; tr hich errour is better knowne than needfull to be confuted : and likew ife their errour' is apparant, who rarhly iudge it to be Piffolochia, or little Birthwoort. It fhould feem the old Writers knew it not; wherefore fome of our later Authors haue made it Leontopetali pecies, or a kinde of Lions Turnep: others, Eriphinm : and orherfome, $T^{\prime}$ befum: moft men, Capros Chelidosin: it fee:meth to agree with Leontopet alon in bulbed roots, and fomewhat in leaues, but in no other refpeits, as may be perceived by Diofcorides and Plinies defcription of Leontopetalon. And if Eripbium haue

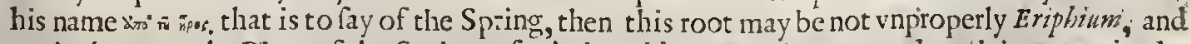
Veris planta : Ot the Plant of the Spring : for it is euident that it appeareth and is greene in the Spring onely: fo ne thinke it hath beene called Eriphium, $a^{b} H a d o$, or of the Goat: but this Eriphion is quite another plant, as both Apulcius writeth, and that booke alfo mentioneth which is attributed to Galen, and dedicated to Psternianus. In the booke which is dedicated to Paternianus, there be read thefe words ; [Eripbion is an herbewhich is found vpón high mountaines, it hath leaues like Simllage, a fine floure like the Violet, and a root as great as an Onion: it hath likewife other rnors whicly 
which fend forth roots after roots. Whereby it is cuident that this reot whercof we intreac is not this kinde of Eripbium. Concerning Thefium the old W riters hauewriten but little: Theophra fi $u$ faith, that the root thereof is bitcr, and being ftamped furgeth the belly. Pliry in his 21 . bocke, chap. 17. hewerh, that the root which is called Thefism is like the bulbed plants, and is rough in tafte: Athenaus citing Timachida for an Authour, faith, that Thefum is callec a foure, of which iri. adnes garland was made. Thefe things feeme well to agreew ith Hollow roor; for it is bumped or bulbous, of tafte bitter and auftere or fomething rough, which is alfo thought to lurge : but what certaintie can beaffirmed, feeing the old writers are fobriefe? what manner of herbe Capros chelidonia is, which growerh by hedges, and hereupon is furnamed parizums, Aetius doth rot expound, onely the name there of is found in his fecond Tetrab. the third booke, chap. 1 10. in Marlians his Collyriwm, and in his Tetrab. 3.booke, 2. chap.among fuch things as flrengthen the liuer. But if Capros Chelidomia be that which pliny in his 25 . booke,chap. I 3.doril call Prima Capros, or the firnt Capnos, and commendeth it for the dimneffe of the fight, it is plainenough that Radix caua, or the Hollow root, is not Capros Cheledonia for Plinies firtt Capnos is branched, and foldeth it felfe vpon ledoes:but Hollow roor harh no fuch branches growing on it, and is a low lierbe, ard is rot held w with props, nor needeth them. But if Actius his Capnos Chelidonia be another herb differing from that of $P$ liny (which thing perchance was the caufewhy it Thould bee furnamed Chclidonia) there is fome reafon why it thould be called Capros Chelidonin; for it is fomcwhat like Fumitorie in leates, though greater, and commeth vp at the firt fpring, which is about the time when the Swallowes do cone in; ncuerthelcffe it doth not follow, that it is irue and right Capnos Chclidonia for there be alfo orher herbs com. ming vp at the fame feafon,and perifh in thort time after, which rorwithanding are not called chelidonit.

$$
\text { वा) The Temperature. }
$$

Hollow root is hot and drie,yet more drie than hot, that is to fay, dry in the third degree, and hot in the fecond; it, bindeth, clenfeth, and fomewhat wafterh.

\section{The Vertues:}

A Hollow root is good againft old and long lafting fwellings of the Almonds in the throat, and of the iaves: it likewife pretaileth againt the paines of the hemorrhoides, which are fwolne and painefull, being mixed with the ointment of Poplarbuds, called Vng. Populeon.

B It is reported that a dram weight hereof being taken inwardly, doth purge by fiege, and draweth forth flegne.

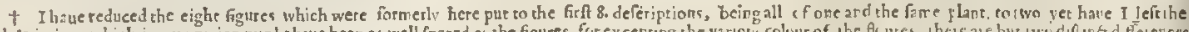

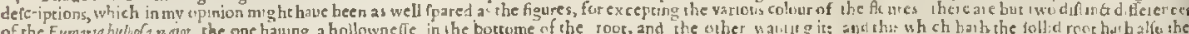

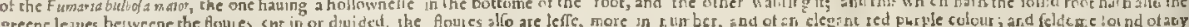
other colour, whereas the orher varies much in the colour of the Hou es.

\section{C нат. 447. Of Columbine.}

\section{T) The Defcription.}

I

1 He blew Columbine hath leates like the great Celandine, but fomcrhat rounder,in=dented on the edges, parted into diters feetions, of a blewifh greene colour, which being broken yeeld forth little iuice or none at all : the ftalke is a cubit and a halfe high, flenter, reddifh, and fleightly haired : the flender fprigs whereofbring forth euerie one one foure with fitc little hollow hornes, as itwere hanging forth, with fmall leaues ftanding vpright, of the thaje of litt'e birćs.the fe floures are of colour fomtimes blew, at other times of a red or purple, oftcri whe, or of mixt colors, which to diftinguinh fetrerally would be to fmal purpofe, being chings fo tamiliarly knowne to all : after the floures grow vp cods, in which is contained little blackeand glittering feed: che roots are thicke, with fome ftrings thereto belonging, which continue manic yeares.

2 The fecond doth not differ fauing in the colour of the floures; for like as the others are defcribed to be b lew, fo thefe are of a purple red, or horfe-fleth colour, which mak eth the difference.

2 Tle double Columbine hath ftalks, leaues, and roors, like the former.the floures liercof are ver: 'ouble, that is to fay, many of thofe little floures (haung the forme of birds) are thruftone intor t e belly of another, fometimes blew, often white, and other whiles of mixt colours, as nature

to play with her little ones, differing fo infinitely, that to diftinguifh the m a part would require 
LIв. 2.

Of the Hiftory of Plants:

1093

I Aquilegia carrulex.

Blew Colmmbines.

Aquileqia vie Cqaris

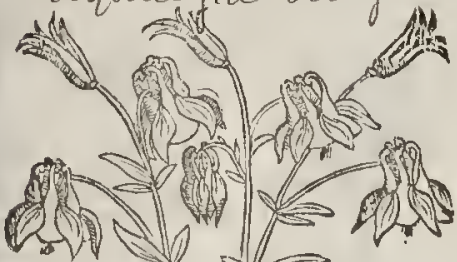

(2) $\Rightarrow$ (it) $\Rightarrow$

त्यो $42 x+3$

trin

stmenter

दि

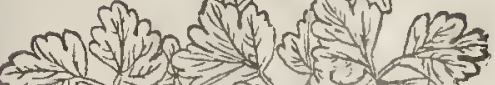
(व) 6.ins i
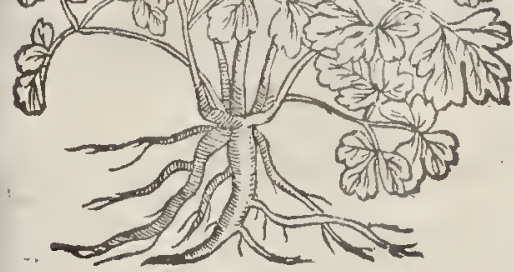

3 Lquilina multiplex.

Double Columbines:

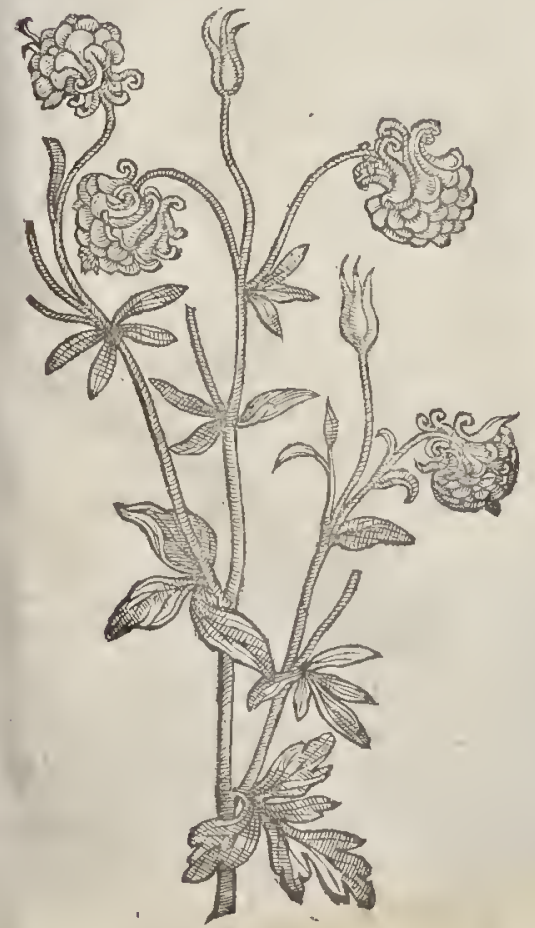

2 Aquilein rubra.

Red Columbines

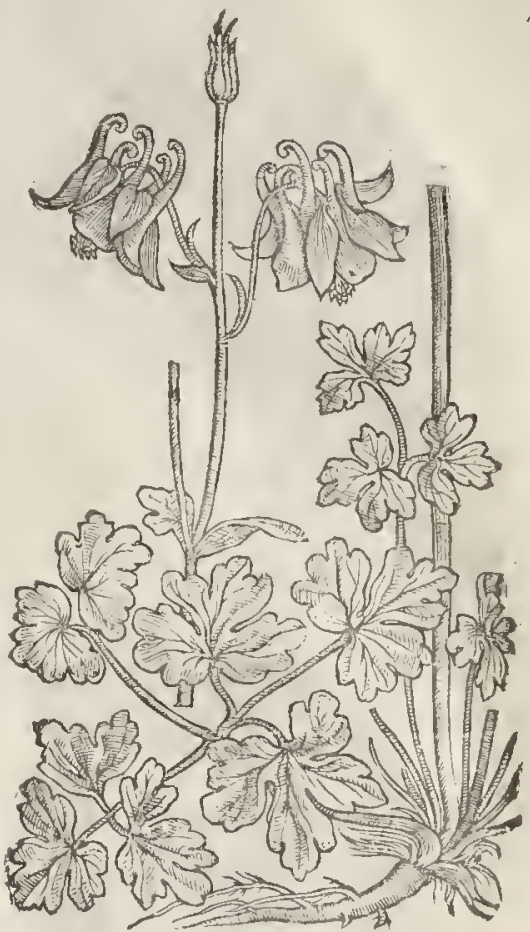

* 4 Aquilegia variegata. Variegated Columbins.

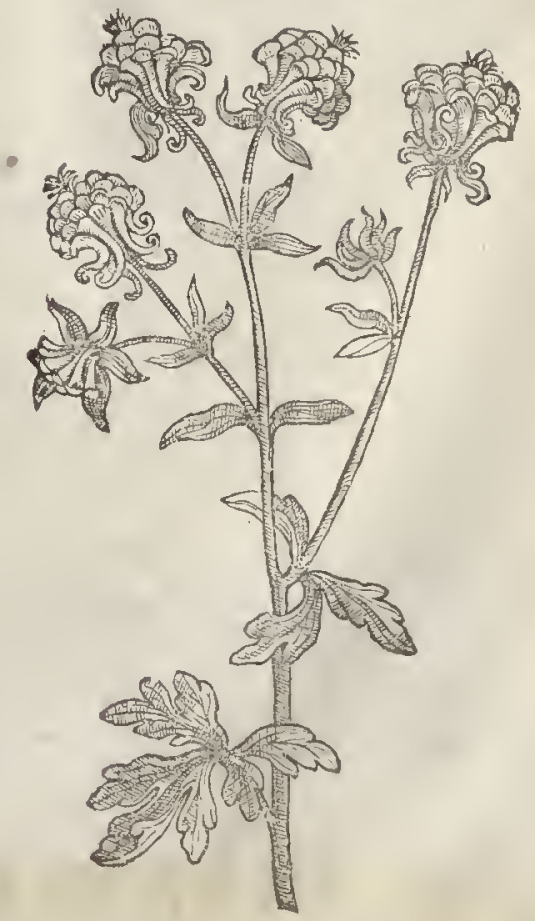


\$ Aquilestia flo.inverforubro.

Columbine with the inuerted red floure.

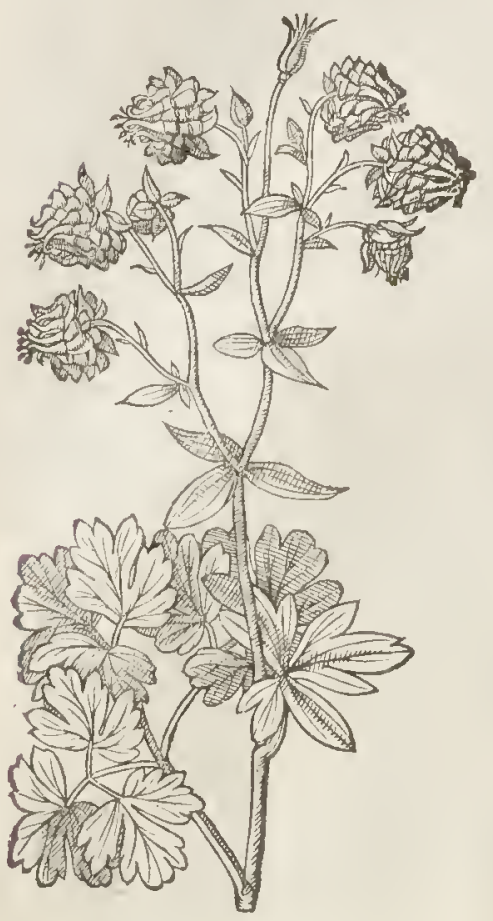

¥ 7 Aquilegiaflore rofeo. Rofe Columbine.

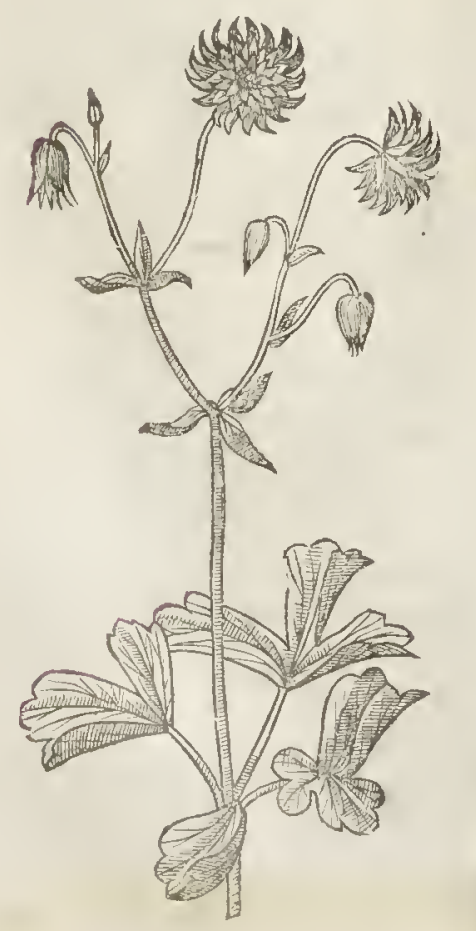

¥6 Aquilegiafo. inverfo albo.

Inuerted Columbine with the white foure:

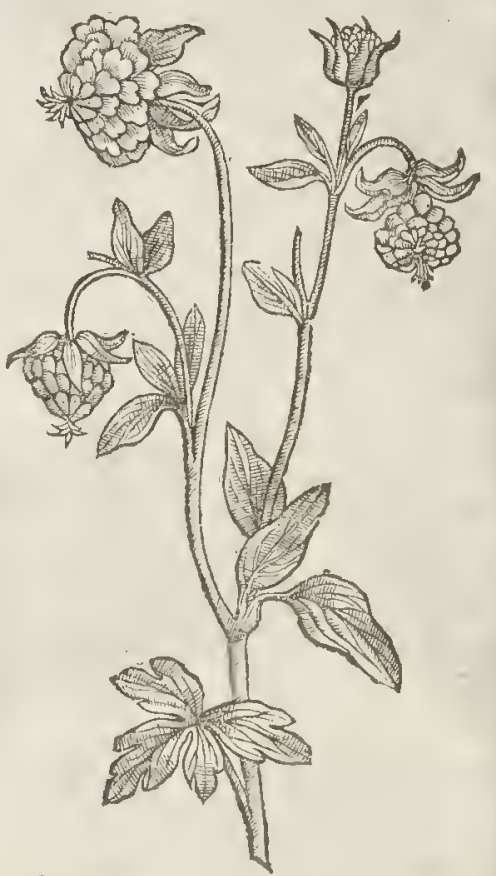

\$ Aquilegiádegener. Degenerate Columbine.

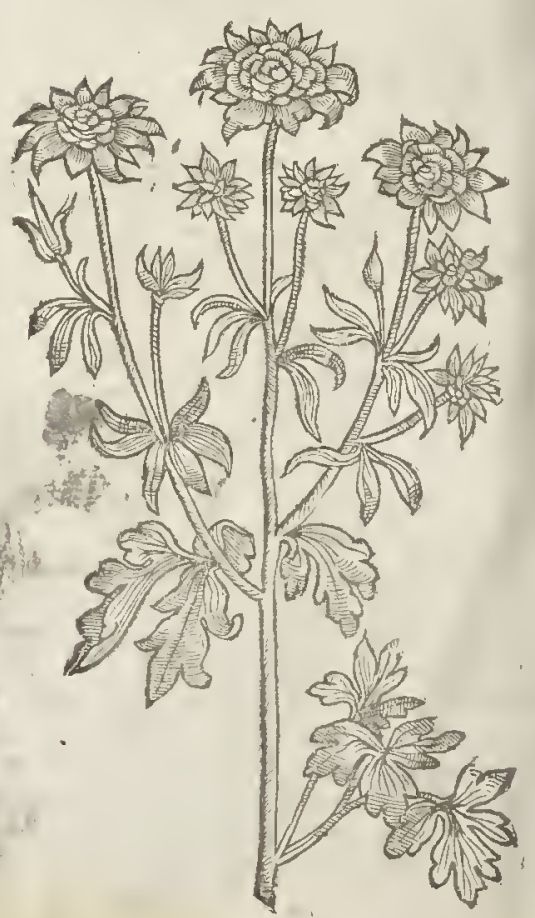




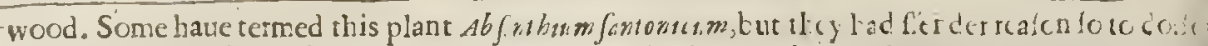

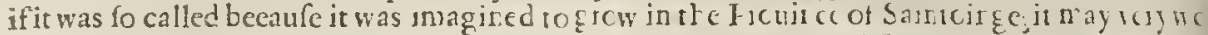
appeare to the contrarie; for in the Alpes of Calatia, accentrey in A fis marer, It gucuchl ing:ta

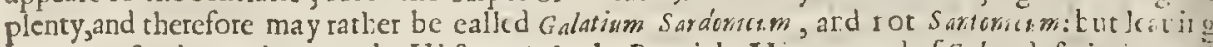
controuerfies impertinent to the Hi ftory, it is the Fonticke Woun w cod of $G$ alens defcripticn, a d fo holden of the learned Palwdane (who for his fingular kr.cwledge in plants is worthy triple lor $n$ ) and likewife many others.

I Abfint bium latifolium five Ponticum. Broad leafed Wormivood.

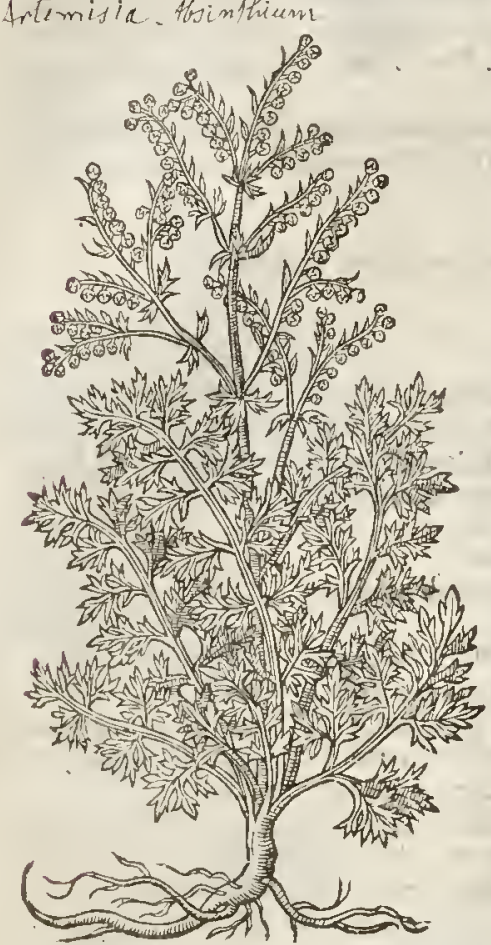

t 2 Alfinthinmetruifolism Ponticum Galcri: Small Ponticke VVormwocd.

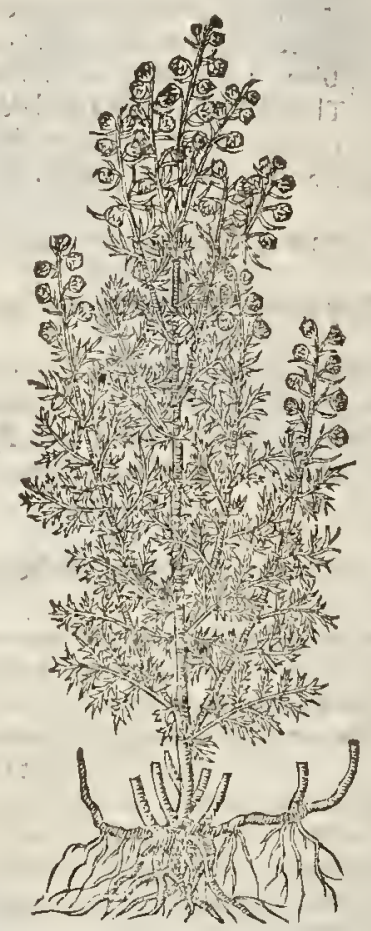

-1 The Place.

This broad leafed Wormewood delighteth to grow on recks and mountaines, and in untlled places; it groweth much vpon dry bankes, it is common euery where in all countries the beft, faith Diofcorides, is found in Pontus, Cappadocia, and on mount Taurus : Pliny writeth, that Ponticke Wormwood is better than that of Italie: Onid in thefe words doth declare that Ponticke Wormwood is extreme bitter.

$$
\begin{aligned}
& \text { Trupia deformes gignunt Abfint hiacampi, } \\
& \text { Terraque de fruitu, quam fit amara docet. }
\end{aligned}
$$

Vntilied barren ground the lothfome Wormwood yeelds, And knowne it's by the fruit how bit ter are the fields.

And Bellonius in his firft booke of Singularities, chap.76.doth thew, that there is alfo a broad leafed Wormwood like vnto ours, growing in the Prouinees of Pontus, and is vfed in Confantinople by the Phyfitions there; it is likewife found in eertain cold places of Switzerland, which by reafon of the ehilneffe of the aire rifeth. not vp, but ereepeth vpon the ground, whereupon diuers cal it creeping Wormwood.

$$
\text { I The Time. }
$$

The litcle flours and feeds are perfected in Iuly and Auguft, then may Wormwood be gathered and laied $v$ for profitable vfes.

It is ealled in Greeke atisor: it is named of Apuleiws, Abfixthium ruficum, countrey Wormmood, 
H It helpeth them that are ftrangled with eating of Mufhroms, or toad ftools, if it be drunk with vineger.

I And being taken with wine, it is good againft the poifon of $I x i a$ (being a vifcous matter proceeding from the thiftle Chamslion) and of Hemlock, and againf the biting of the fhrew moufe, and of the Sea Dragon: it is applied to the fquincic or inflammations of the throat with honie and niter.and with water to night wheales, and with heny to fwartiph markes that come vpon brufes.

It is applied after the fame manner to dim eies, and to mattering eares.

L Joacbimus Camerarius of Noremberg commendeth it greatly againft the iaundiee, giuing of the floures of Wormwood, Rofemarie, Sloes, of each a fmall quantitie, and a little faffron, boiled in wine, the body firft being purged and prepared by the learned Phyfition.

t The fioure which formerly was in the fecond place, was of a fmall wormwood, not differentefom the common kinde, but only in the fmalnere, atid more a-

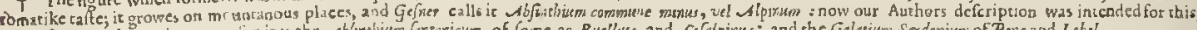

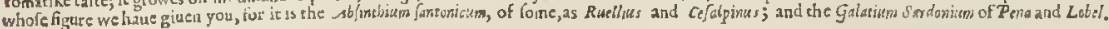

\section{Cи а .449.}

Abfint hium tenuifolium Anfriacum. Aultrian:Wormewood.

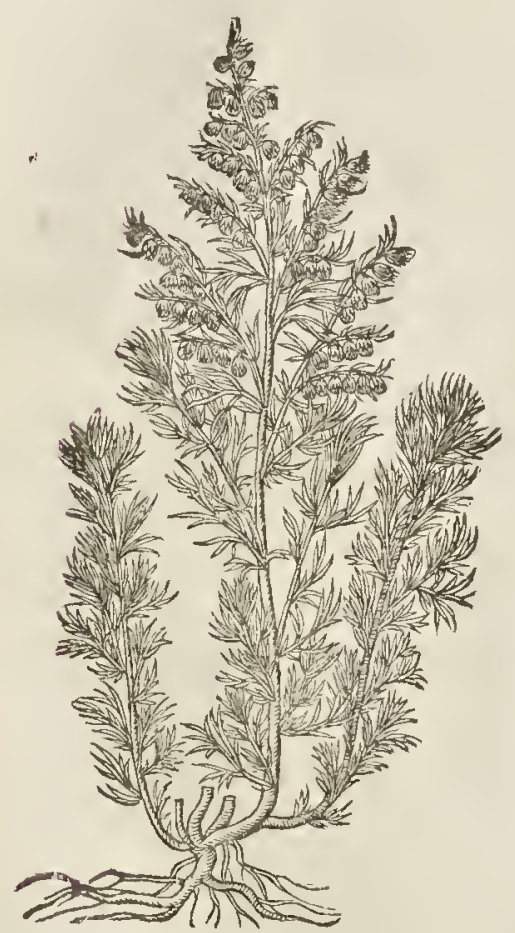

\section{Of Sirall leafed Wormewood.}

$$
\text { If } T \text { be Defcription. }
$$

SMall leafed Wormwood bringeth forth ve: ry many little branches,flender, a fpan or a foot high, full of leaues, leffe by a great deale, and tenderer than the former, molt finely and nicely minced: the floures like thofe of the former, hang vpon the little branches and fprigs : the roots are fmall, creeping ouer twhart, from whenee do rife a great number of yong fprouts: this VVormwood alfo is fomewhat white, and no leffe bitter than the broad leafed one, and hath not fo ranke, or fo vnpleafant a fmell, but rather delightfull.

$$
\text { Tf The Place. }
$$

It grows plentifully in Myfia, Thracia,Hungarie, and Auftria, and in other regions neere adioining $:$ it is alfo found in Bohemia, and in many vntilled places of Germanie; it is a garden plant in the low Countries, and in England.

$$
\text { T) The Time. }
$$

It bringeth forth floures and feed in Autumne : a little while after when winter commeth, the herbe witlyereth away, but the roote remaineth aliue, from which leaues and ftalks do come againe in the fpring.

$$
\text { g) The Names. }
$$

\# This Lobel calls Abfinthium Ponticum Tridentinum Herbariorum : Cluffus , Abfint hium tenuifolium Auftriacum: Tabernamontanus, Abfinthium Nabatheum Auicenne : wee may call it in Englifh,fmall leaued Wormwood. $\neq$

Tा The Temperature.

Small leafed VVormwood is of facultie hot and drie, it is as bitter alfo as the broad leafed one, and of like facultie.

The faculties are referred unto the common Thertwes. 
heard that the later growes wilde in any place with vs in England. $\neq$ का The Time.

Thefe bring forth flourcs and feeds when the other Wormwoods doe. $¥$ The later fearce fecdes with vs, it floures fo late in the yeare.

$$
\text { T. The } 2 \text { umes. }
$$

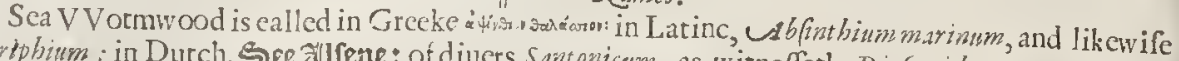

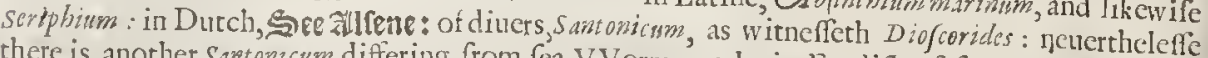
there is another Santomum differing from fea VVormwood: in Englifh of fome women of the
countrey, Gardcn Cypreffe.

$$
\text { 9) The Timperature. }
$$

Sea VVormwood is of nature hot and drie, but not fo much as the common.

$$
\text { T The Vertues. }
$$

A Diofcorides aflirmeth, that being taken of it felfe, or boiled with Riec, and eaten with hony, it kil leth the fmall wormes of the guts, and gently loofeth the belly, the whieh $P$ liny doth alfo affirmc.

B The iuice of fea VV ormw ood drunke with wine refiftech poifon, efpecially the poifon of Hemlockes.

C The leates ftamped with figs, falt peter, and the meale of $\mathrm{D}$ arrel $\mathrm{l}_{3}$ and applied to the belly, fides, or flankes, telp the dropfie, and fuch as are fplecenticke.

D The fame is fingular againft all inflammations, and heat of the ftomacke and liter, exceedino all the kindes of V Vormwood for the fame purpofes that common V Vormwood ferueth.

E It is reported by fuch as dwell neere the fea fide, that the cattell which do feed where it growcth become fat and lufty very quickly.

F The herbewith his ftalks laid in clictes, pteffes, and watd-robes, keepeth clothes from moths and other vermine.

\section{Cнар. 451. Of Holy Wormewood.}

Sementina.

Holie V Vormewood.

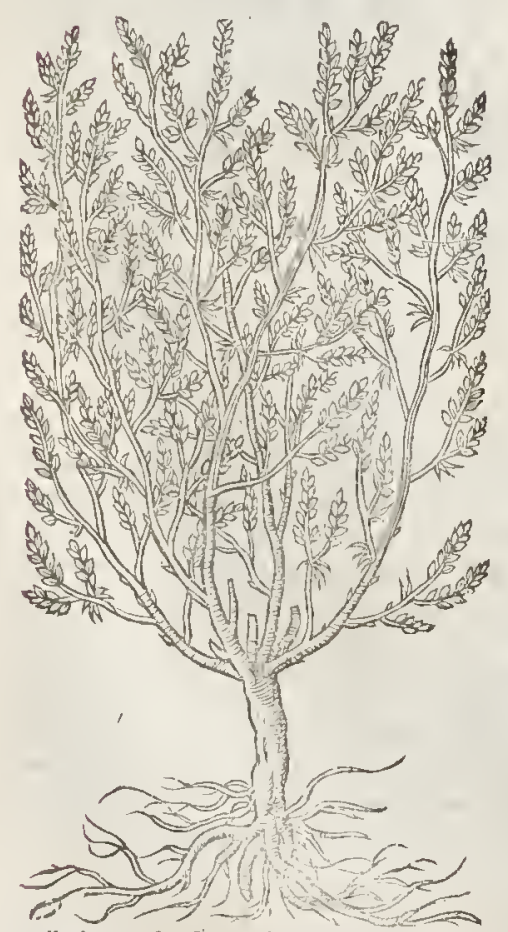

T The Defoription.

THis Wormwood called sementina, and $S_{e-}$ menfinctum, whichwe haue Englined, Holy, is that kinde of Wornuwood which beareth that feed which wc haue in $v$ fe, called VV ormefeed: in fhops, semen Stmtolinurs: abour which there hath been great controucrfic among ft writers: fome holding that the feed of Suntonicum Galatium to be the true V Vormfeed : others deeming it to be that of Romanum Abfinthism : it doth much refemble the firft of the fea VVormwoods in frape and proportion : it rifeth vp with a wooddie ftalke, of the height of a cubite, diuided into diuers Branehes and wings; whereupon are fet very finall leaues : among which arepla. ced clufters of feeds in fuch abundanee, that to the firft view it femeth to be a plant confifting all of feed.

\section{T The Place.}

It is a forcine plant : the feeds being forvne in the gardens of hot regions doe profper well; in thefe eold countries it will not grow at all. Neuertheles there is one or two companions about London, who haue reported vnto niee that they had great ftore of it growing in their gardens yearely, which they fold at a great price vnto our London Apothecaries, and gained much money thereby; one of the men dwelleth by the Bagge and Bottlc ncere London, whofe name is Cornewith; into whofe gatden I was brought to fee the thing that I would not belceue; for being of ten 


\section{4) The Defription.}

+ I $\triangle$ Efinthium album hath ftraight and vpright falkes, a foot high, beftwith broad leaues, but very decply cut or clouen, in hewlike vnto thofe of the great Daify, but white of colour : at the top of the ftalkes, out of fealy heads, as in an vmbell grow Alourcs, compact of fix fmall white lcaues : the root is long, with fome fibres annexed vnto it.

2 This kinde of Wormwood Gefner and that learned A pothecarie Valerandus Donraz, called Abfinthium Egyptium: the leaues of this plant are very like to the Jeaues of Trichomanes, which is our common Maiden haire, of a white colour, euery fmall leafe ftanding one oppofite againf another, and of a ftrong fauour.

3 This VVormwood, which Dodonens calleth Abfinthium inodorum, and Infpidum, is very like vnto the fea VVormwood, in his fmall and tender leaues: the ftalke bcareth flowers alfo like unto the forefaid Sea-Wormwood,but it is of a fad or deep colour, hauing neither bitter tafte, nor any fauour at all; whereupon it was called, and that very fitly, Abfinthium inotorum, or $A$ bfint hium infipi. dum : in Englin, foolin, or vnfauory wormwood. $\ddagger$ Dodonews faith not that his Alfint hium infipidum is like the fea wormwood, but that it is very like our common broad leaued VVormwood, and fo indeed it is, and that to like, that it is hatd to be difcetned therefrom, but onely by the want of bitterneffe and fmell. +

3 Abfint birem inodorum.

Vnfauorie VVormwood.

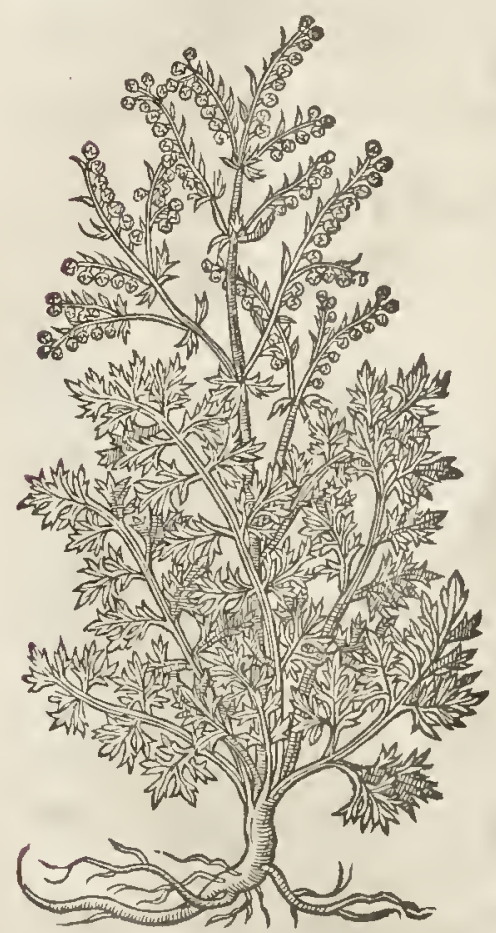

4 Abfint bium marimum, Labrotani fa mina facie. Small Latander Cotton.

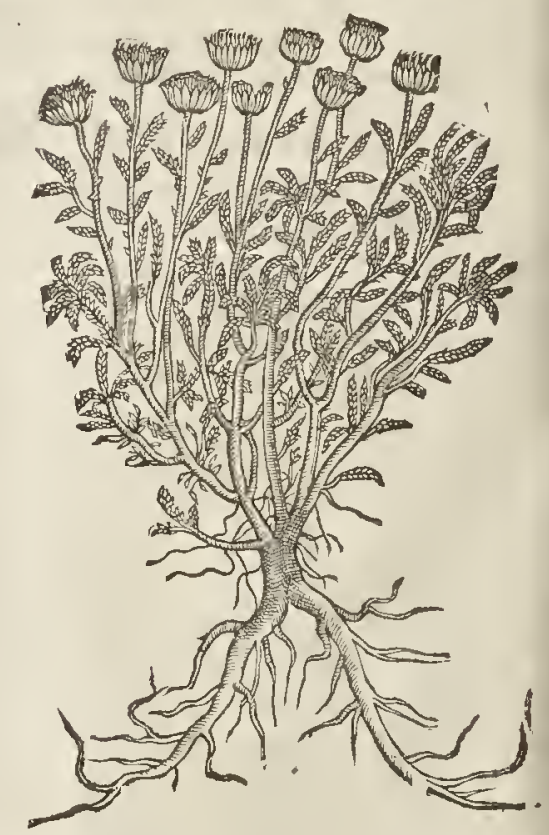

4 This kinde of Sea-wormwood is a Thrubby and wooddie plant, in face and fhew like to Lauander Cotton, of a ftrong fmel, hauing floures like thofe of the common wormwood, at the firft fhew like thofe of Lauander Cotton:the root is tough and wooddie.

T The Place.

Thefe plants are ftrangers in England, yet we hate a few of them in Herbarifts gatdens.

I The Time.

The time of their flouring and feeding is referred to the other wormwoods. Tा The Names.

The white wormwood Conradus Gefnerus nameth Seripbium femina, and faith, that it is commonly called Herba alba, or white herbe : another had rather name it Santonicum; for as Diofcorides faith, Santonicum is found in France beyond the Alpes, and beareth his name of the fame 
3 Artemifamarina. Sea Mugwort. Atrenvisia covulisens

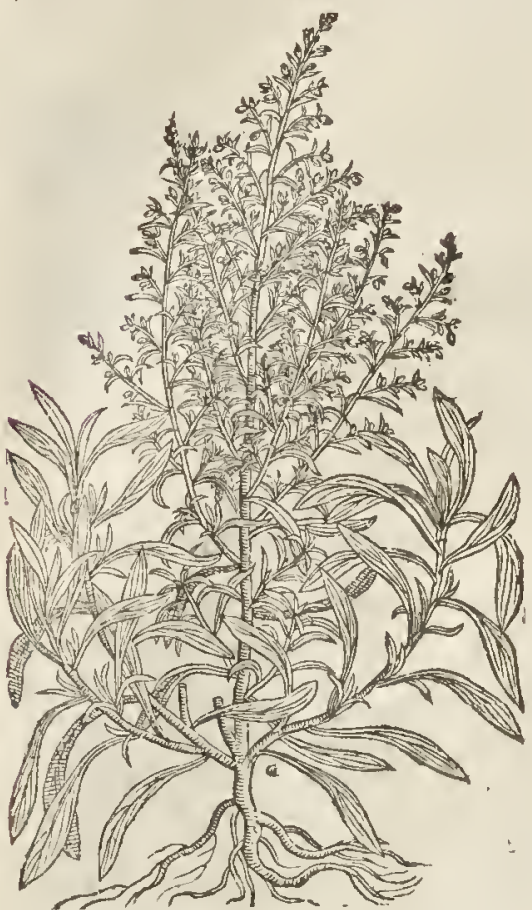

+ Artemifie marineramulus, fol a integra of difrecta exprimess.

A branch fhewing the cut and vncut leaues.

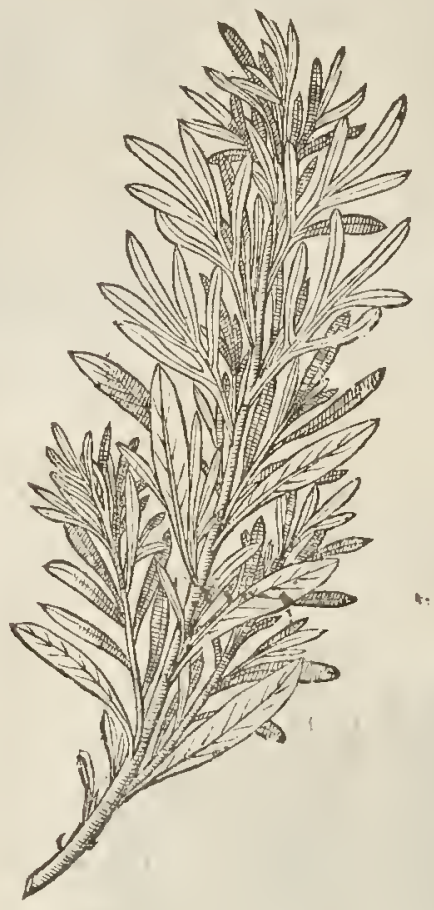

The Place.

The common Mugwort groweth wilde in fundry places about the borders of fields, abcut high waies, brooke fides, and fuch like places.

Sea Mugwort groweth about Rie and Winchelfea cafte, and at Portmouth by the Ifle of Wight.

They floure in Iuly and A uguit.

T) The Time.

The Names.

Mugwort is ealled in Greek e Aprnara : and alfo in Latine Artemiffa, which name it bad of cortemifra Queene of Halicarnaffus, and wife of noble Maufolus King of Caria, who adopted it for her owne herbe : before that it was called nosine, Parthervis, as Pliny writeth. Apuleins affirmeth that it was likew ife ealled $P$ arthenion; who hath very many names for it, and many of them are placed in Diofcorides among the baftard names : moft of thefe agree with the right Artemifia, and dituers of them with other herbes, which now and then are numbred among the Mugworts: it is alfo ealled Mater Herbarum : in high. Dutch, 25eifuts, and Sant Jolyantis fruttell : in Spanifh and Italian, Artem:fia : in French, Armoifa : in low -Dutch, 23ijuoet, Sint Jants krupt: in Englifh, Mugwort, and common Mugwort.

Mugwort is hot and dry in the fecond degree, and fomewhat aftringent.

$$
\text { T The rertues. }
$$

Pliny faith that Mugwort doth properly cure womens difeafes.

B Dioficrid's writeth, that it bringetlidowne the termes, the birth, and the after-birth.

B And that in like mannet it helpeth the mother, and the paine of the matrix, to beboyled as bathes for women to fit in ; and that being put vp with myrrh, it is of like foree that the bath is of. And that the tender tops are boiled and drunk for the fame infirmities; and that they are applied in manner of a pulteffe to the thare, tobring downe the monethly eourfe.

Pliny faith, that the ttauclier or wayfaring man that hath the herbe tied about him feeleth no wearifomneffe.at all ; and that he who hath it about him can be hurt by no poyfonfome medieines, norby any wilde bealt, neither yet by the Sun it felfe; and alfo that it is drunkeagainft opium, or 
3 Abrotanum bumile.

Dwarfe Sothernwood.

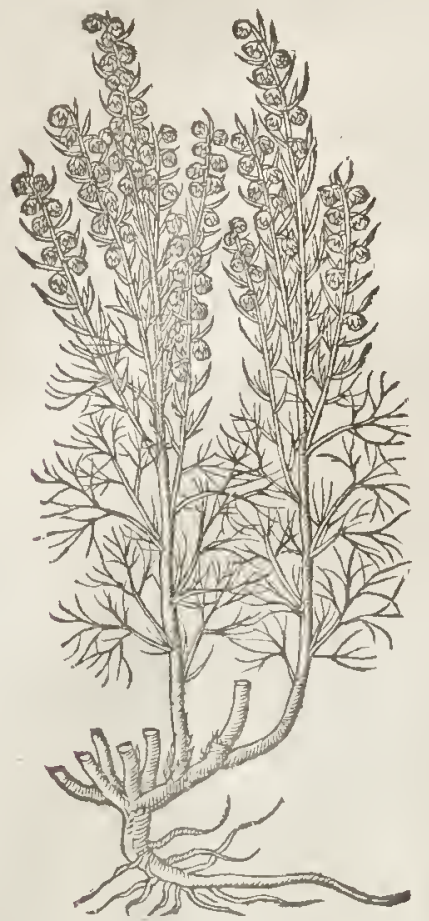

5 Abrotanumcampeftre.

Wilde Sothernwood. Artensia ia casrpesir

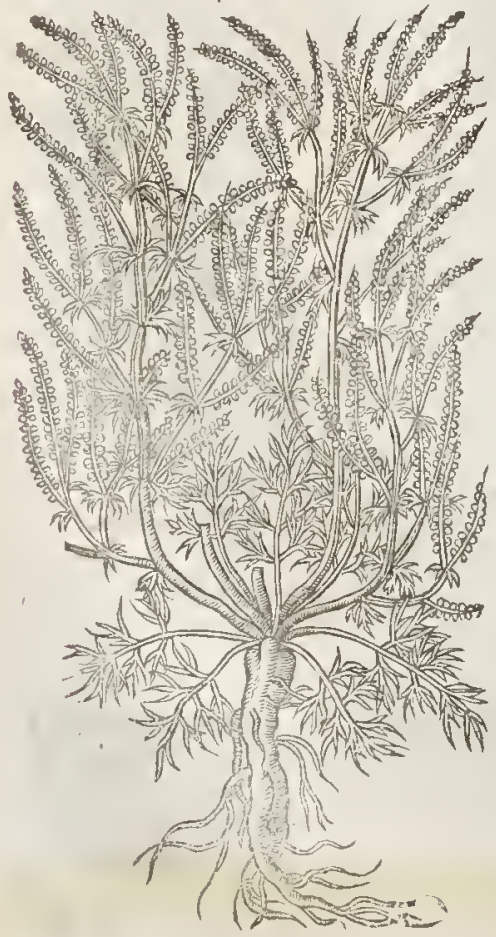

4 Abrotanum inodorum.

Vnfauorie Sothernwood.

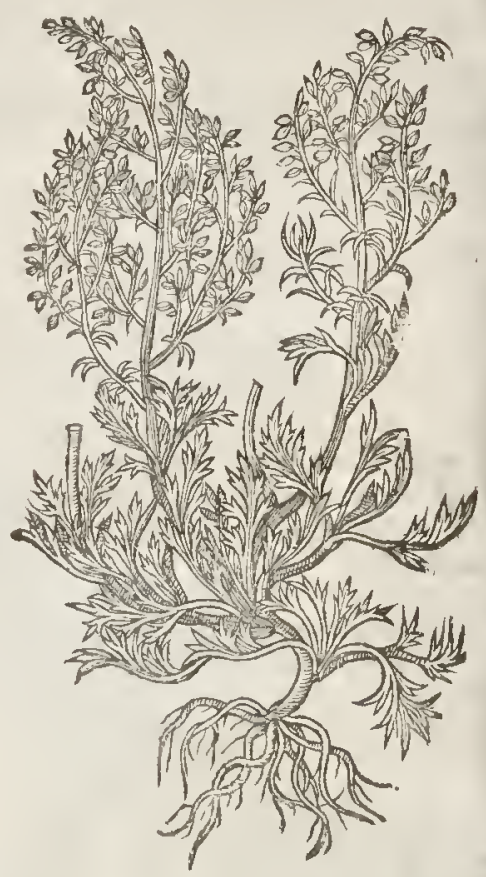

2 The leffer Sothernwood groweth low, ful of litt le fprigs of a woody fubftanee: the leaues are long, and fmaller than thofe of the former, not fo white : it beareth eluftering buttons vpon the tops of the ftalks : the root is made of many ftrings.

3 The third kinde is alfo thorter: the leaues hereof are iagged and deeply eut after the maner of the greater Sothernwood, but they are not fo white, yet more fweet, wherein they are like vnto Lauander cotton. This kinde is very full of feed: the buttons ftand alongtt on the fprigs, euten to the very top, and be of a glittering yellow. The root is like to the reft.

4 The vnfauorie Sothernwood groweth flat vpon the gromd, with broad lcaues deepely ent or ingged in the edges like thofe of the eommon Mugwort : amongivlich rife vp weake and feeble falkes trailing likewife rpon the ground, fet confufedly here and there with the like leates that grow next the ground, of a grayin or hoary colour, altogether without finell. The floures grow alongft the ftalkes, of a ycllowifh colour, fmall and chaffic: the root is tough and wooddy, with fome frings anexed thereto.

5 This wilde Sothermood hath a sreat long thicke roor, tough and wooddy, eotrered 
ouer with a fealy barke like the fealy baeke of an adder, and of the fame colour : from wh ieh rife very many leaues like thofe of Fennell, of an ouerworne greene eolour : anong which grom fmall twiggy branehes on the tops, and alongft the ftalkes do grow fmall eluftering floures of a yellow colour : thewhole plant is of a darke colour, as well leaues as ftalkes, and of a ftrong vnfurourie fimell.

$$
\text { 4 The Place. }
$$

Theophraftus faith that Sothernwood delighteth to grow in placesopen to the Sun : Diofcorides affirmeth that it groweth in Cappadocia, and Galatia a countrey in Afia, and is Hicrapolis a city in Syria: it is planted in gardens almolt etrery where:that of Sieilia and Galatia is moft commended of Pliny.

$$
\text { 9) The Time. }
$$

The buttons of Sothernwood do flourifh and be in their prime in Augut, and now and then in September.

$$
\text { Tा The Names. }
$$

It is ealled in Grecke 'Aperom : the Latines and Apothecarics kecpe the fame name Abrotanum: the Italians and diucrs Spaniards eall it Abrotano : and other Spaniards, rerwa lombriguera : in high

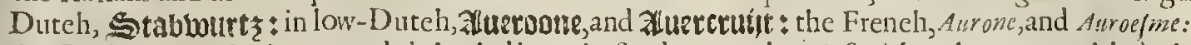
the Englith men, Sothernwood: it hath ditiers baftard names in Diofcorides; the greater kinde is Diof corides his Fernina, or female Sothernwood; and Pliny his Montanum, or mountaine Sothernewood: the mountaine Sothernwood we take for the female, and the champion for the male. There be notwithftanding fome that take Lauander Cotton to be the female Sothernwood; grounding thereupon, beeatfe it bringeth forth yellow floures in the top of the fprigs like elufter buttons: but if they had more diligently pondered Diofcorides his words, they would not hate been of this opinion: the leffer Sothernwood is $M$ at, the male, and is alfo elinies champion Sothernwood; in Latine, Campefre. The third, as wehaue faid, is likewife the female, and is commonly ealled fiveet Sothernwood, becaufe it is of a fweeter fent than the reft. Diofcorides feemeth to eall this kind Sisulum, Sieilian Sotherntvood.

$$
\text { T) The Temperature. }
$$

Sothernwood is lot and dry in the end $\delta$ the third degree : it hath alfo foree to diltribute and to rarifie.

The tops, floures, or feed boyled, and ftamped raw with water and drutke, helpeth them that A cannot take their breaths without holding their neekes fraight vp and is a remedie for the eramp, and for finewes Thrunke and drawne together; for the feiatiea alfo, and for them that can hardly make water ; and it is good to bring downe the termes.

It killeth wornes, and driueth them out : if it be drunke with wine it is a remedic againt dead- $B$ ly poyfons.

Alfo it helpeth againft the ftinging of feorpions and field fpiders, but it hurts the ftomacke. C Stamped and mixed with oyle it taketh away the fhitering eold that eommeth by the ague fits, D and it heateth the body if it be anointed therewith before the fits do come.

If it be pounce with barley meale and laid to puihes it taketh them away.

It is good for inflammutions of the cyes,with the pulpe of a rofted Quince,or with erummes of $\mathrm{F}$ bread, and applied pultis wife.

The a hes of burat Sothernrood, with fome kinde of oyle that is of thin parts,as of $P$ alma Chri- $G$ fii, Radith ovle, oyle of fweet Maricrome, or Organie, eureth the pilling of the haire off the head, and makech the beard to grow quickly : being ftrewed about the bed, or a fume made of it vpon hot embers, it dritueth away ferpents: if but a braneh be layd vnder the beds head they fay it prouokethvenerie.

The feed of Snthernwod made into pouder, or boyled in wine and drunke, is good againit the diffieultic and ftopoing of vrine; it expelleth, watteth, eonfumeth, and digeftetl all eold humors, tough flime and flegme, whieh do vfually ftop the fpleene, kidneyes, and bladder.

Sorhernwood drunke in wine is good againit all venome and poy fon.

The leaues of Sothernwood boyled in water vntill they be foft, and itamped withballey meale $\mathrm{K}$ and barrowes greafe vinto the forme of a plaifter; diffolue and wafte all eold tumors and fivellings, being applied or laid thereto.

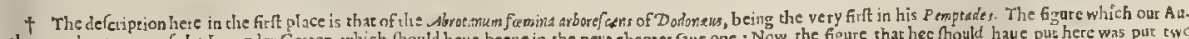
uhor pue thereco was of the Launaler Coston, which thould haue beene in the next chapter fane one : Now the figure that hee fhould have put here was pur two

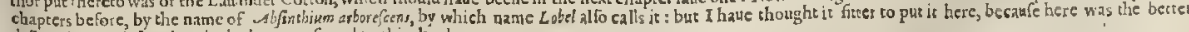
defirtption, and the plant is the berer 8 feferest to this binde. 


\section{Ch a P. 455. \\ Of Oke of ferualem, and Oke of Cappadocia.}

I Botrys.

Oke of Icrufalem.

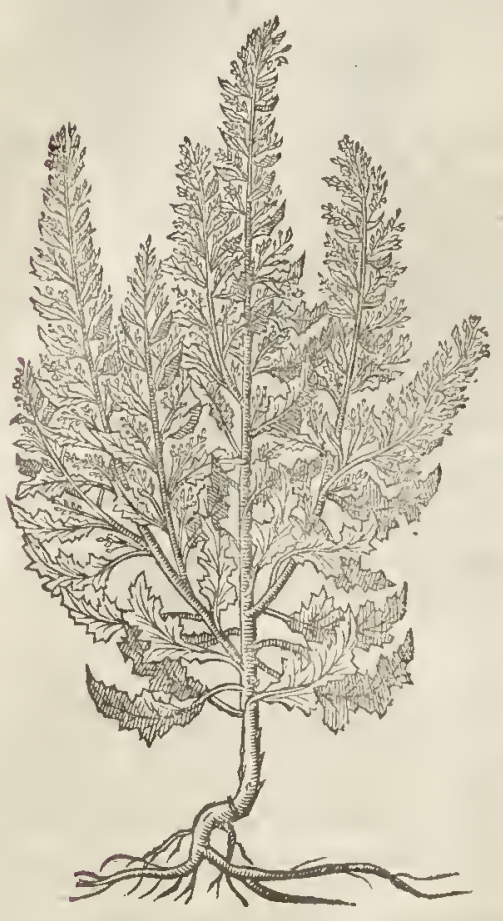

2 Ambrofia. Oke of Cappadocia.

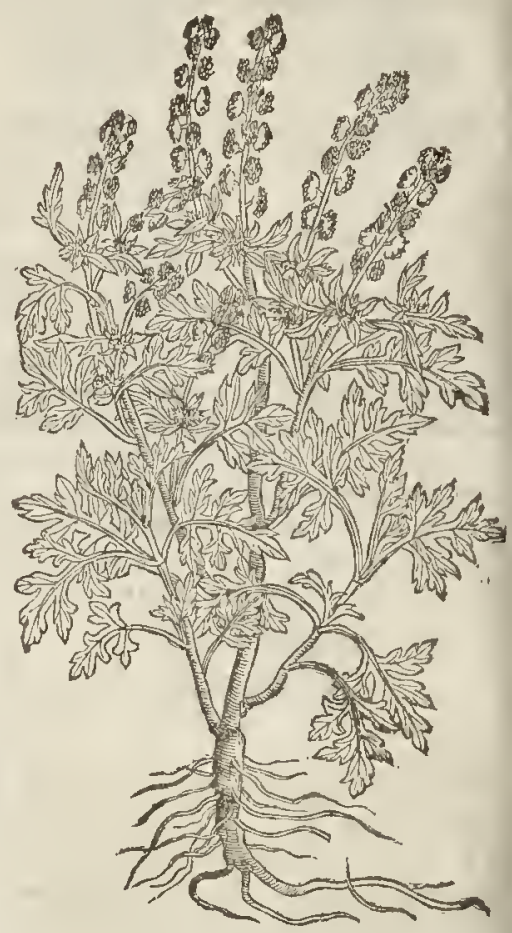

T) The Defcription.

I

( ke of Ierufalem, or Botrys, hath fundry fmall ftems a foot and a halfe high, diniding themfelues into many fmall branches, befet with fmall leates deeply cut or iagged, call it Oke of Ierufalem t the vpper fide of $\mathrm{f}$ of an Oke, which hath caufed our Englifh women to hairy, but viderneath it is of a darke reddif leafe is of a deepe greene, and fomewhat rough and abour the branches, like a darke reddinh or purple colour : the feedie floures grow cluftering the whole herbe is of a pleafint cluters or blowings of the Vine : the roor is fimalland threddy: plane dieth when the feed is ripe.

2 The fragrant finell that this kind of Ambrofia or Oke of Cappadocia yeeldeth, hath moued the Poets to fuppofe that this herbe was meare and food for the gods : D iofcorides faith it groweth crooked and ftreaked branches, diuiding the cubits, yeelding many weake from the middeft to the Wormwood, ftandiug one beforcanot many moffic yellowifh floures not much vnlike common ouer with bran or a like vnto Tribulus terret tris w wherein is conraned be into fmall prickly cornered buttons, much fmell: the leaues are in thape like the leaues of Mucke round feed, not vnpleafant in tafte and wholeplant is hoary, and the approcl of Winter.

Thefeplantsarebron The Place.

They floure in 1 ugurt, and the feed is ripe in Seprember.

$$
\begin{aligned}
& \text { Thond the leas, efpecially from Spaine and Italy. } \\
& \text { The Time. }
\end{aligned}
$$


lonce it is ealled in the Aduer.. Abrotanum percgrinum cupreffi folÿs. The fifth hath not the ftalkes growing y pright, but creeping : the leaues are toothed, more rhicke and hoary than the reft; in orher refperts alike. Bashine calls it Abrotanum fomina repens canefocns. $¥$

$$
\text { of The Place. }
$$

Latrander Cotton groweth in gardens almoft euery where.

They floure in Iuly and Auguft.

$$
\text { of The Tinze. }
$$

T The Names.

They are called by one name Santolina, or Lauander Cotron : of moft, Chamecypariffus. But Pliny concerning Chamacypariffus is fo thort and briefe, that by hin their opinions can ncither be reiected nor reeciued.

They are doubtleffe mueb deceiued that would haue Lauander Cotton to be Abrotanum fami. $n a$, or the female Sothernwood: and likewife they are in the wrong who take it to be Seriphium, fea Wormewood; and they who firft fer it abroch to be a kinde of Sothernwood we leaue to their errors; beeaufe it is not abfolutely to be referred to one, but a plant participating of Wormewood and Sothernwood:

$$
\text { T The Tempcrature. }
$$

The feed of Lauander Cotton hath a birter tafte, being hot and dry in the third degree.

$$
\text { of The Vertues. }
$$

A Pliny faith, That the herbe Chamacypariffus being drunke in wine is a good medieine againft the poyfons of all ferpents and venomous beafts.

B

It killeth wormes either giuen greene or dry, and the feed hath the fame vertue againft wormes; but auoideth them with greater force. It is thought to be equall with the vfuall wotme-feed.

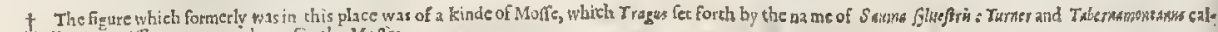
led it Chamecyparighes. Seo morc chercolin the Morles.

\section{C н А. 457 .}

1 Lsparagus fativus. Garden Sperage.

Asparagus officmakes

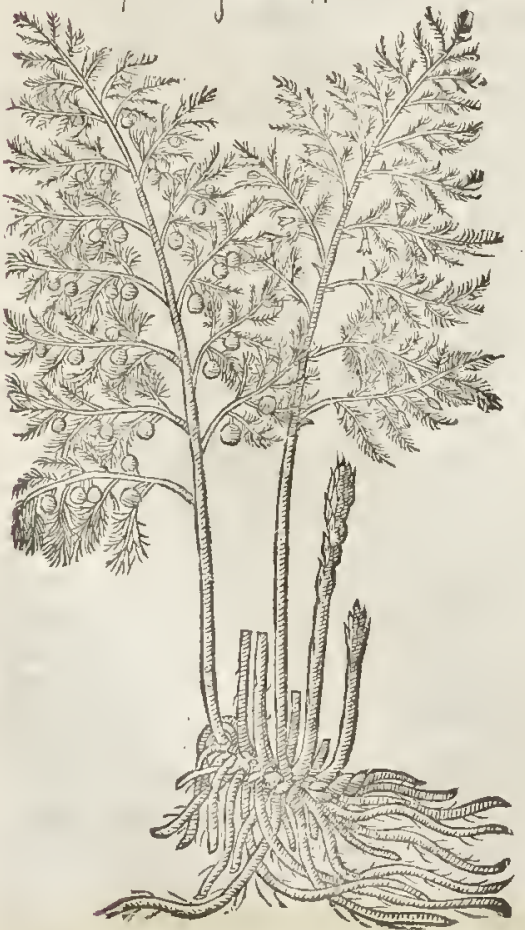

Of Sperage, or eAparagus.

2 Aparagus petrisus. Stone or mountaine Spetage.

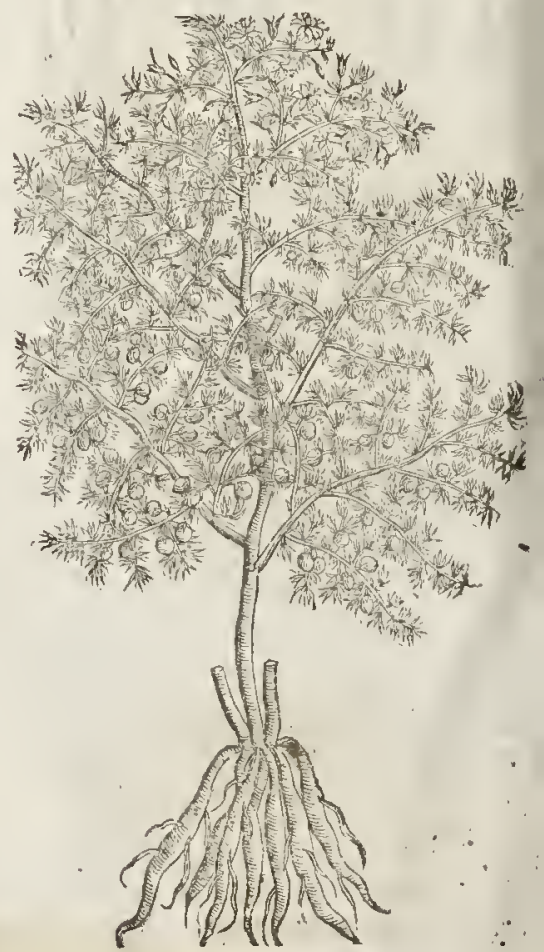




\section{T) The Defcription.}

I THe firf being the manured or garden Sperage, hath at his firft rifing out of the ground thicke tender thoots very foft and brittle, of the thickeneffe of the greateft fivans quil in tafte like vnto the greene beane, hauing at the top a certaine faly lof ft bud, which in time groweth toa branch of the height of two cubits, diuided into diuers other fmaller branches, whereon are fet many little leates like haires, more fine than the leaucs of Dill : among which come forth fmall moffic ycllowith floures, which yceld forth the fruit, greene at the firft, aftervard red as $\mathrm{Co}_{\mathrm{O}}$ rall, of the bigneffe of a mall peafe; wherein is contained groffe blackifh feed exceeding hard, whieh is the eaufe rhat it lieth fo long in the ground after the fowing, before it do fpring vp. The roots are many thicke fott and fpongie ftrings hanging downe from one head, and fpred themfelies all about, whereby it greatly increafeth.

2 We haue in our marihin and low grounds ncere vnto the fea, a Sperage of this kinde, which differeth a lietle from that of the garden, and yet in kinde there is no difference at all, but only in manuring, by which all thitgs or mof things are made more bcautifull,and larger. This may be called Afparaguzs palufiris, marih Sperage.

4 Alparazus fyluefris aculeatus.

Wilde prickly Sperage.
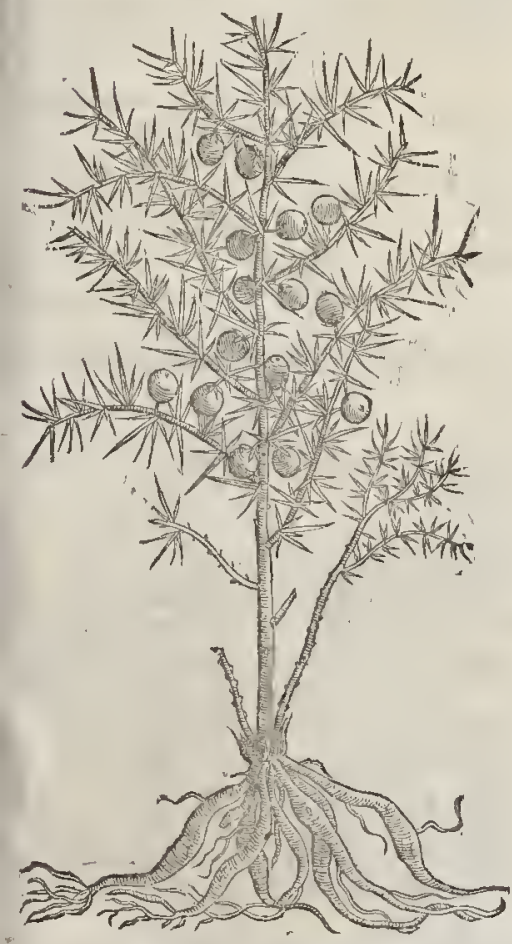

5 Apparagus fylugftris spinafus Clufil:

Wilde thornie Spcrage.

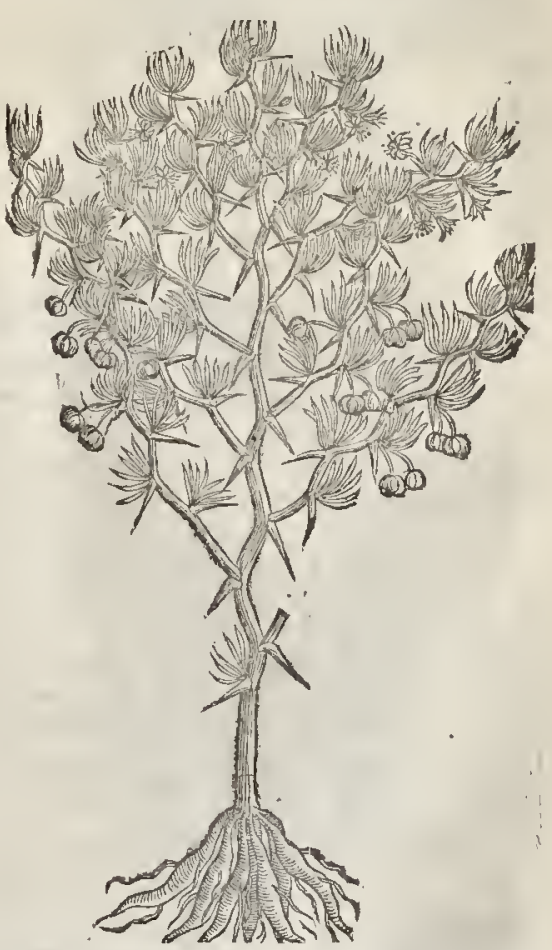

3 Stone or mountaine Sperage is one of the wilde ones, fet forth vnder the title of Corrisda? which Lobelealicth Apparaguspetreus; and Galen, Myacant binus, that doth very well refemble thofe of the garden, in ftalkes, roots, and branches, fauing that thofe fine hairy leaues which are in the garden Sperage be foft, blunt, and tender; and in this wilde Sperage, fharpe hard and pricking thomes, though they be fmall and flender : the root hereof is round, of the bigneffe of a pcafe, and of a blaekcenlost? the roots are long, thicke, fat, and very many.

4. This fourti kinde difiereth from the laft deferibed, being a wilde Speragc of Spaine and Hungarie: the plant is altngether fet with tharpe thomes (three or foure comming forth together) as are the branehes of Whinnes, Gofe, or Furfen : the fruit is blaeke when it is ripe, and full of a greenifh pulpe, wherein lie liard and blaeke feeds, fometimes one, orherwhiles two in a berry: the roots are like the others, but greater and to:ngher. 
$\ddagger 6$ Drypis.

Sperage Thiftle.

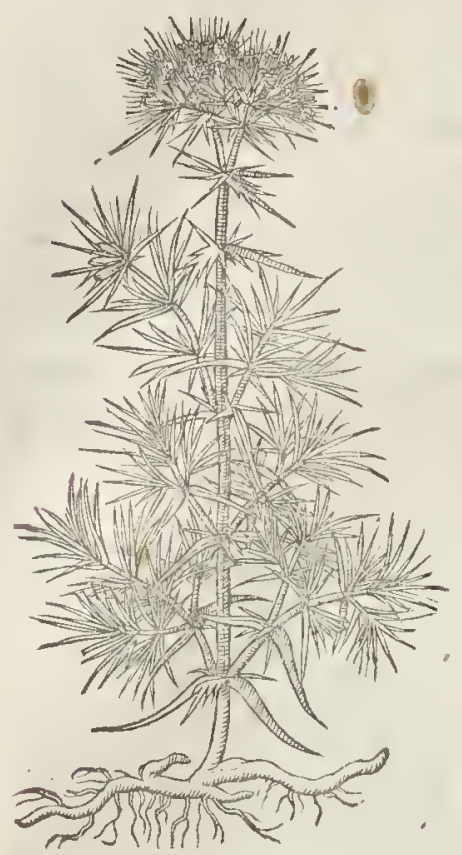

5 Carolus Clufus defcribeth alfo a eertain wilde Sperage with inarp prickles allalong $\Omega$ the ftalkes, orderly placed at euery 1oynt one, hard, fiffe, and whition, the poinrs of the thornes pointing downward: from the which ioynts alfo doe grow out a few long greene leaues faftned together, as alfo a litrle yellow floure, and one berry three cornered, and of a blacke colour, wherein is contained one black feed, feldome more: the roots are like the other:

6 Drypis being likewife a kinde hereof, hath long and fmall roots, creeping in the ground like Couch graffe; from whieh fpring vp branches a cubit high, ful of knotty ioints: the leaues are Imall like vnro Iuniper, not much differing from Corruda or Nepa : the floures grow at the top of rhe falke in fpokic tufrs or rundles, of a whice colour, clofely thruft togerher : the feed before it bee taken out of rhe huske is likevnto Rice; being taken out, like that of Melilot, of a faffron colour.

$$
\text { बा The Place. }
$$

The firf being our garden Afparagus growerh wild in Eflex, in a medow adioining to a mill, beyond a village called Thorp; and alfo at Singleton nor far from Carbic, and in the medows neere Moulton in Lincolnfhire.

Likewife it groweth in great plentie neere vnto Harw ich, at a plaec called Bandamar lading, and at North Moulton in Holland, a part of Lincolnfhire.

The wilde Sperages grow in Portugal and Bifeay among ftones, one of the which Petrus Bellonius doth make mention to grow in Candie, in his firft booke of Singulariries, cap. 28.

$$
\text { बा The Time. }
$$

The bare naked tender thoots of Sperage fpring vp in Aprill, at what time they are caten in fallads; they floure in Iune and Iuly; rhe fruir is ripe in Seprember.

$$
\text { oा The Names. }
$$

The garden Sperage is ealled in Grecke'Awriexzs : in Latine likewife Afparagus : in thops, sparagus, and Speragus : in high-Durch, Spargen : in low-Duteh, alpaege\$, and Cozalcenit; that is ro fay, Herba Corall, or Corall-wort, of the red berries, which beare the colour of Corall: in $S$ panifh, Aparragos : in Italian, Aparago : in Englifh, Sperage, and likewife A Cparagus, after the Latine name : in Freneh, $A / p e r g e s$. It is named $A / p$ arguts of the excellencie, becaufe apparagi, or the fprings hereof are preferred before rbofe of orher plants whatfoeuer ; for this Latine word $A$ paragus doth properly fignifie rhe firft fpring or fprout of euerie plant, efpecially when it is tender, and before it do grow into a hard ftalke, as are the buds, tendrels, or yong fprings of wild Vine or hops, nnd fuch like.

Wilde Sperage is properly called in Grecke Minessor, which is as much ro fay as Moufe prickle,

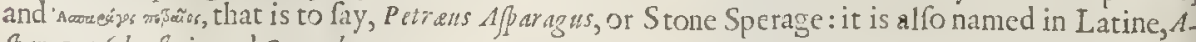
spargus fylueftris, and Corruda.

\section{The Temperature.}

The roots of the garden Sperage, and alfo of rhe wilde, doc elenfe without manifert heate and drineffe.

\section{If The Vertucs.}

A The firf fprouts or naked tender thoots hereof be oftentimes fodden in flefh brorly and caten, or boyied in fare water, and feafoned with oyle, vineger, falr, and pepper, then are ferued ar mens tables for a fallad; they are pleafanr to the ratte, cafily concocted, and gently lonfe the belly.

$B$ They fon what prouke vrine, are good for the kidnies and bladder, but they yeeld ynro the body lirtle nourifhinent, and the fame moif, yet not faultic: rhey are thought to increafe feed, and Atir vp luft.

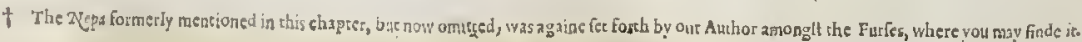




$$
\begin{gathered}
\text { Cн а г. } 458 \text {. } \\
\text { Of Horfe-taile, or Shaue-graje. } \\
\text { T The Defription. }
\end{gathered}
$$
Reat Horfe-taile rifeth wp with a round talke, hollow within like a Reed, a cubit high, compact as it were of many fmall pieces, one put into the end of another, fometimes of a reddith colour, very rough, and fet at eutery ioint with many ftiffe ruth-like leaues or rough briftles, which maketh the whole plant to refemble the taile of a horfe, whereof it tooke his name: on the top of the ftalke do ftand in ftead of floures cluftered and thicke Catkins,nor vnlike to the firft thoots of Sperage, which is called Myacantha: the root is ioynted, and creepeth in the ground:

2 This fmall or naked Shaure-graffe, wherewith Fletchers and Combe-makers do rub and polith their worke, rifeth out of the ground like the firtt thoots of Afparagus, iointed or kneed by certaine diftances like the precedent, but altogether without fuch briftly leaues, yet exceeding rough and cutting : the root groweth aflope in the earth, like thofe of the Couch-graffe.

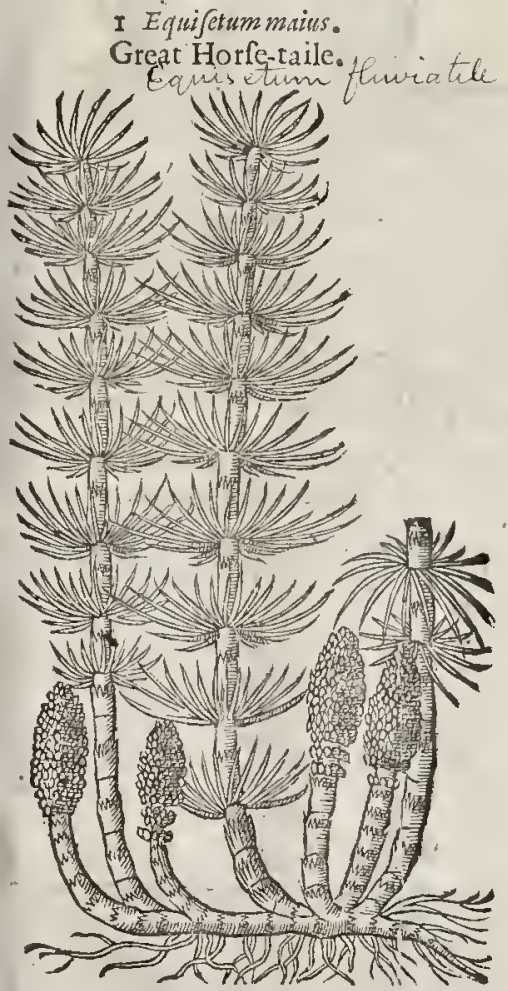

$$
\begin{aligned}
& 2 \text { Equifetum nudum: } \\
& \text { Naked Horre-raile: } \\
& \text { Equiseturn it yemale }
\end{aligned}
$$

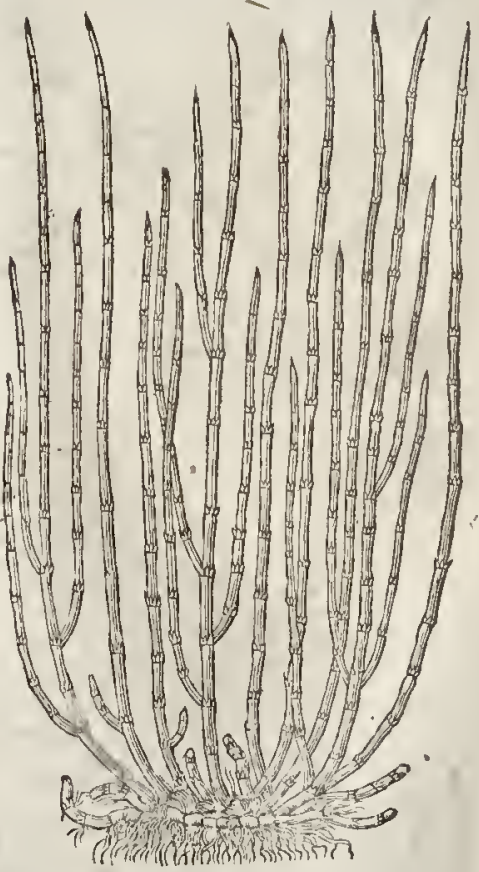

3 Horfe-tailewhich for the moft part groweth among corne and where corne hath been, hath a very flender root, and fingle; from which rife vp diuers iointed ftalkes, whereon doe grow verie long rough narrow iointed leaues, like vnto the firft defcribed, but thicker and rougher, as is the reft of the plant.

4 Water Horfe-taile, that growes by the brinks of riuers and running freams, and often in the midet of the water, hath a very long root, according to the deptli of thewater, groffe, thicke, and iointed, with fome threds anexed thereto : from which rifeth vp a great thick iointed ftalke, whereon do grow long rough ruthy leaues, pyramide or fteeple fantion. The whole plant isalfo rough, hard, and fit to thate and rub wooden things as theother.

5 This kinde of Horfe-taile that growes in woods and thadowie places, hath a fmall root, and fingle, from which rifeth vp a rough chamfered ftalke ioynted by certaine fpaces, hau ing at eacl ioynt cwobufhes of rough brifty leates fet one againft another like the other of his sinde. 
3 Equifetum fegetale.

Corne Horfe-taile.

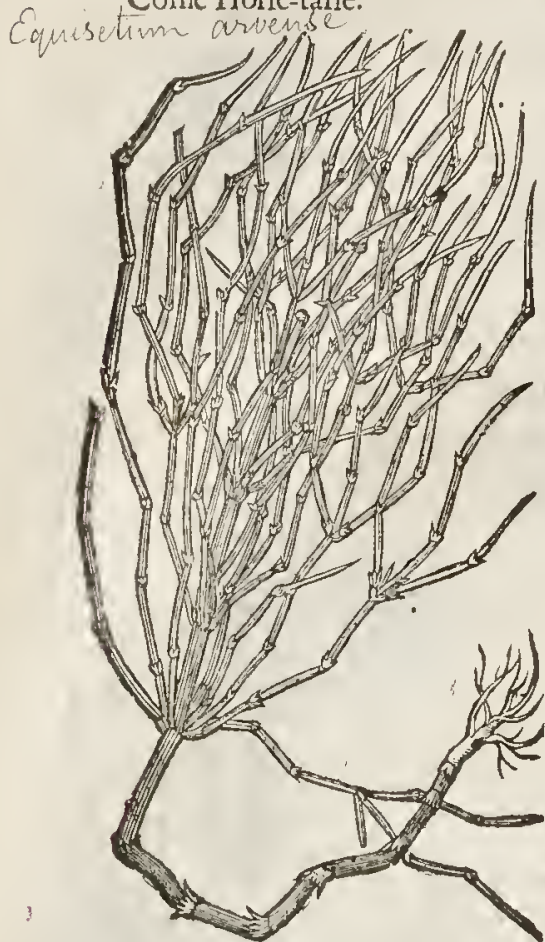

5 Equifetum fy luaticuns:

Wood Horfe-taile.

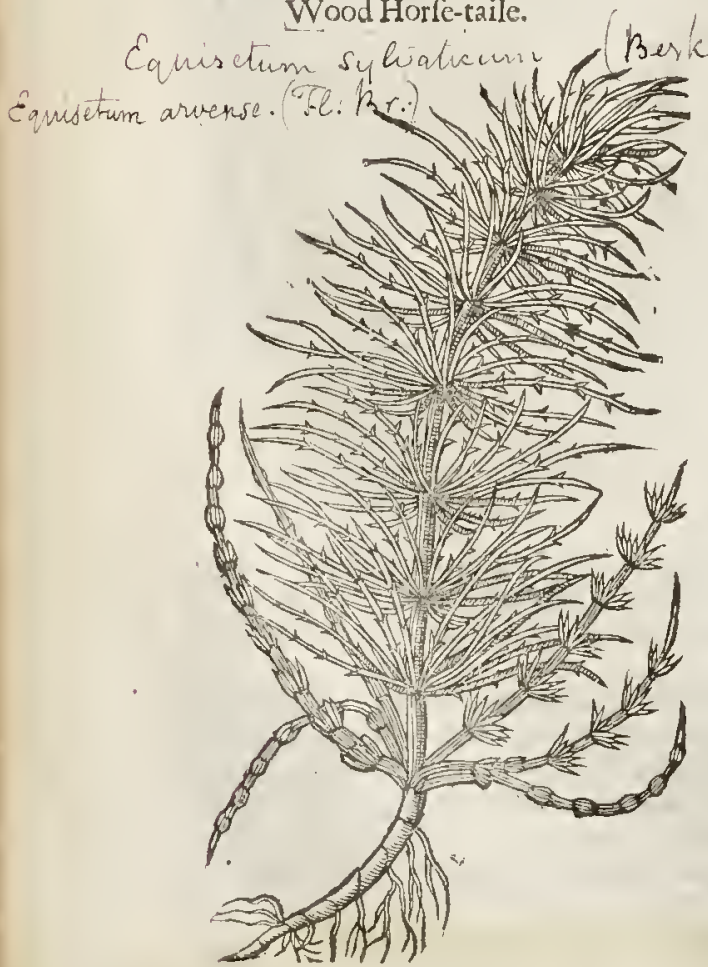

4 Equijctum paluftre.

Water Horfe-taile.

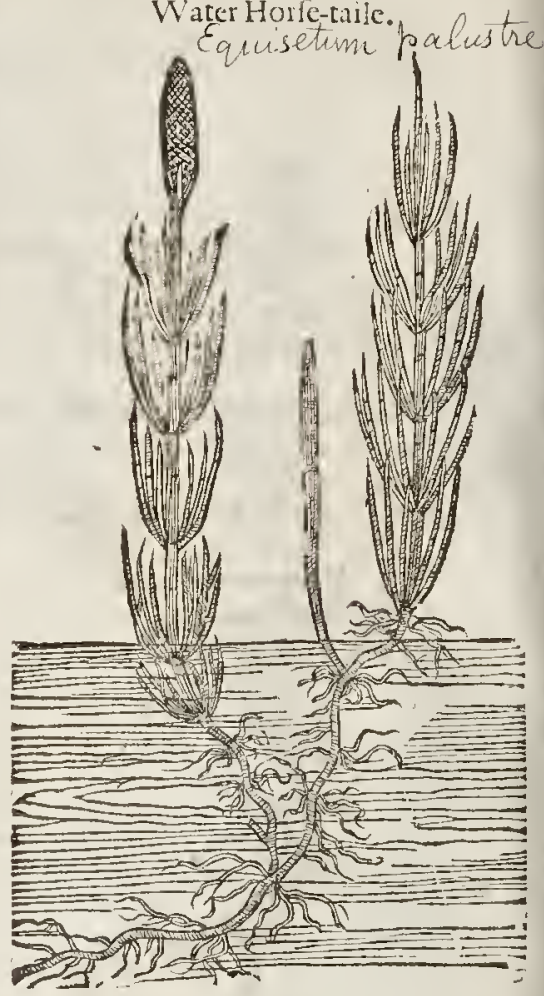

6 Cauda cquina fomina.

Female Horfe-taile.
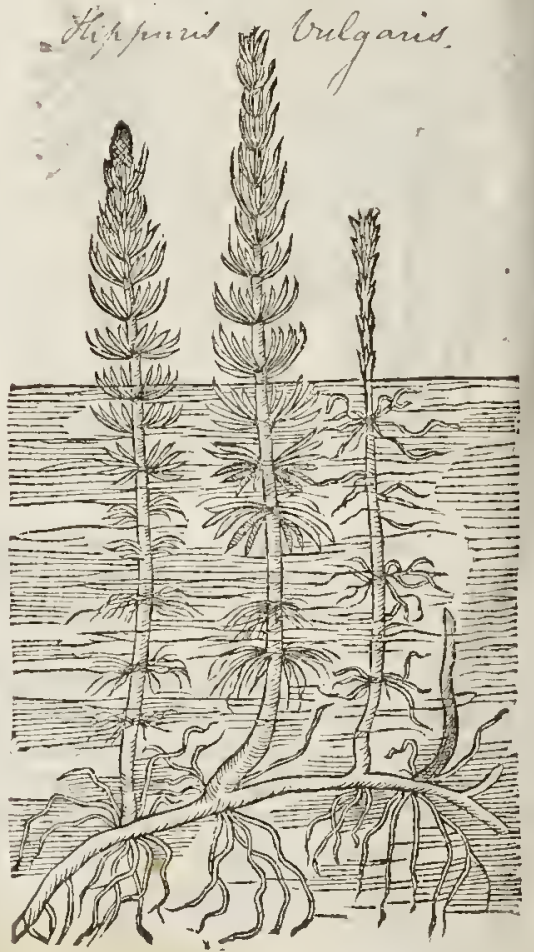


\section{T. The Place.}

The titles and defcriptions thew the plaec of their growing : the laft Belionius reporteth to grow in diucrs vallies of the mountaine Olympus, and not far from Ragufa a citie in Sclauonia.

They flotre from Aprill to the end of Sommer.

$$
\text { The Time. }
$$

9f The Names.

Horfe-taile is called in Greeke ixлинs, Mippuris : in Latine, Equiftum and Equinalis : of plinic in his 15 . booke, 3 chap. Equfctis, of the likenefle of a horfe haire: of fome, Salix cquina: in hoppes,

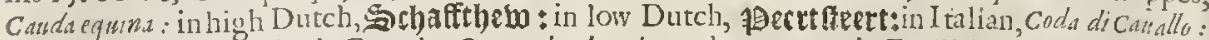
in Spanihh,Codade mula: in French; 2ucue de cheual: and Caqueue : in Englifh, Horfe-taile, and Shaue-graffe.

Shauc-graffe is not without caufe named Ajprella, of his ruggednefie, which is not vnknowne to women,who fcoure theis pew ter and woodden things of the kitchin therewith:which the German

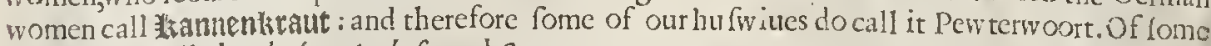
the tenth is called Ephedira, Anobafis, and Caucon.

\section{Tा The Temperature.}

Horfe-taile, as Galen faith, hath a binding faenltie, with fome bitterneffe, and therefore it doth mightily dry, and that without biting.

$$
\text { बा The Vertues. }
$$

A Diofcorides faith, that Horfe-taile being ftamped and laied to, doth perfectly curewounds, yea though the finewes becut in funder, as $G$ alen addeth. It is of fo great and fo fingular a vertue in healing of wounds, as that it is thought and reported for truth, to cure the wounds of the bladder, and other bowels, and helpeth ruptures orburftings.

B The herbe drunke either with water or wine, is an excellent remedy againft blceding at the nofe, and other fluxes of bloud. It faieth the ouermuch flowing of womens floures, the bloudy flix, and the other fluxes of the belly.

C The iuice of the herbe taken in the fame manner can do the like, and more effectually.

D Horfe-taile with his roots boiled in w ine, is very profitable for the vlcers of the kidnies\& bladder, the cough and difficultie of breathing.

\section{Cir A.. 459. Of Sea-Clufter,or Sea Raifon.}

I I Vuamarinaminor. Small Sea Grape.

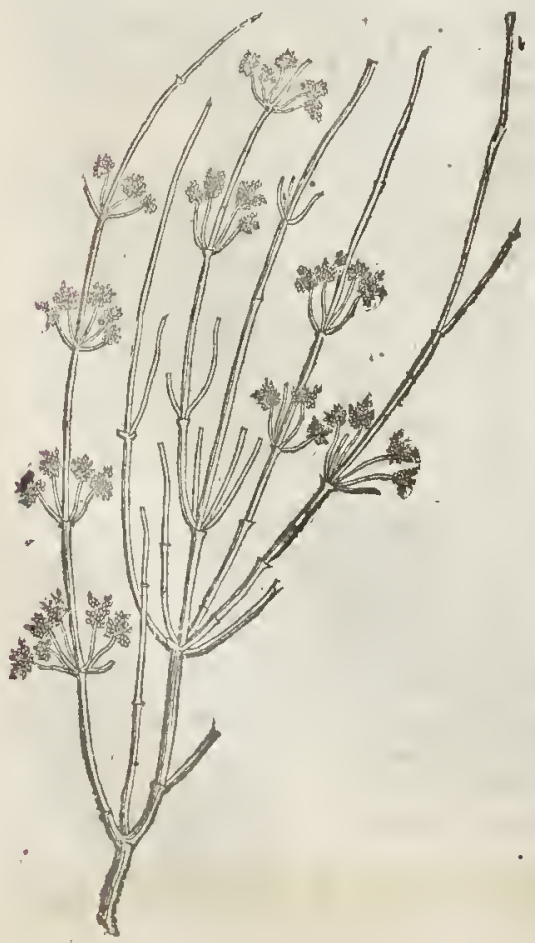

I Mall Sea Grape is not vnlike to horfT) The Defcription. taile: it bringeth forth flender ttalk: almof like ruthes, fetwith many little ioints, fuch as thofe are of the Horfe-taile, and diuided into many wings and branches; the tops whereof are tharpe pointed, fomew hat hard and pricking:it is without leaues: the flours grow in clufters out of the ioints, with little ftems, they are fmall and of a whitih green colour : the fruit confiftcth of many little pcarles, like to the vnripe berries of Rafpis, or Hind-berry:when it is rif it is red with a faffron colour, in tafte fweet and pleafant: the feede or kernell is hard, three fquare, tharpe on cuery fide, in tafte binding: the root is iointed, long, and crecps aflope : the plant it felfe alfodoth rather lic on the ground than ftand vp: it groweth all full of fmall flalkes and branches, cafting themfelues all abroad.

2 Carolus clufius hath fer forth another fort of fea Grape, far different from the precedent; it rifethyp to the height of a man, bauing inanic branches of a wooddie fubftanec, in form like to Spaninh Broome, without any leaues at all:wherupon doe grow clufters of floures vpon flender foot-ntalks, of a-yellowith molfie or herby colüur, like thofe of the Cornell tree: after which come the fruit like vnto tlye mulberric, of a reddifh co. lour and fower tafte, wherein licth hid one or two ferds 
fecds like thofe of Millet, blaeke without, and white within : the root is hard, tough, and wooddie,

2 Vuamarixamaior.

Great Thrubbie fea Grape.

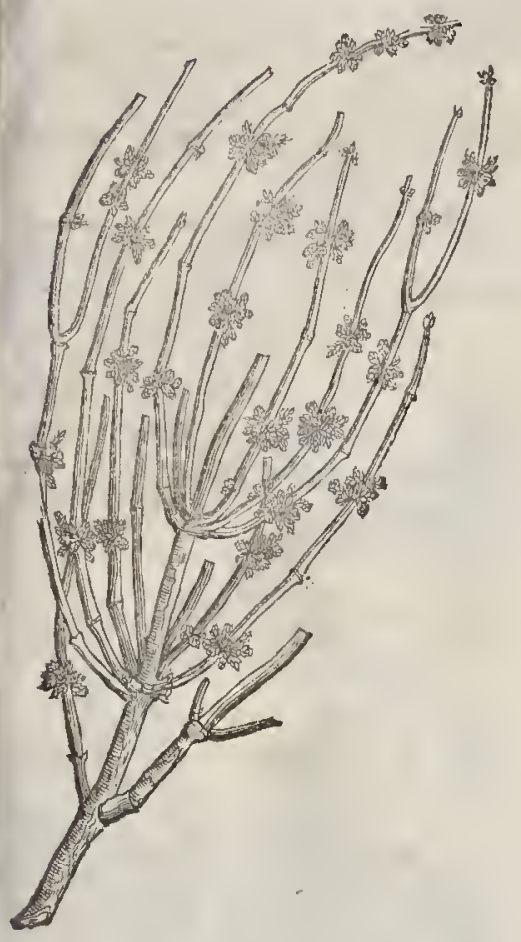

3 Tragos cuatthioli. Bartard Sea Grape. Salsola Kali

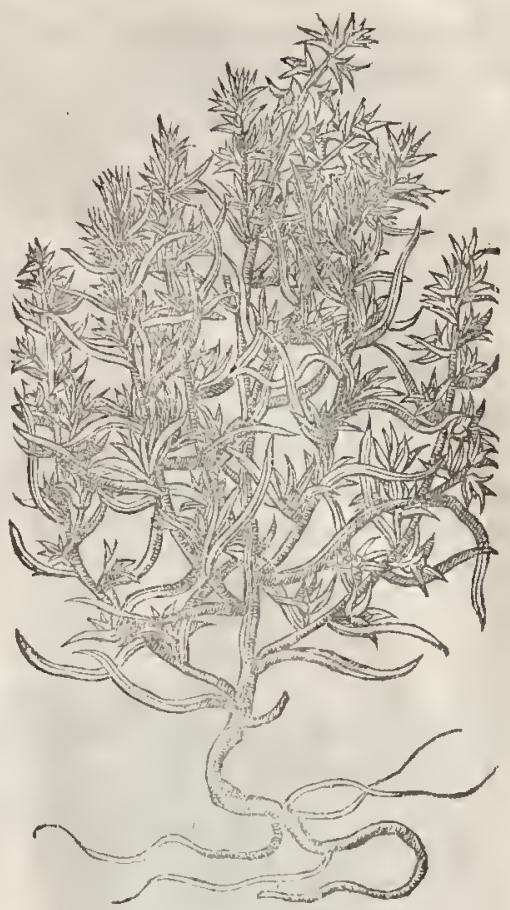

3 Trasoz Matthioli, or rather Tragos improsus, Matthioli, which he vnaduifedly called $T$ ragon, is without controuer lie nothing el fe but a kinde of $K$ ali : chis plant rifeth vp out of the ground with ftalks feldome a eubite high, diuided into fundry other groffe, thicke, and writhen branehes, fet, or armed with many pricking leaues, of the colour and thape of $d$; $a 0$ n, and fomewhat thicke and flethie: among which come forth fuch prickley bures, as are to be feen in Tribulus tcreftris, as that it is hard for a man to touch any part thereof without pricking of the hands : the foures are of an herbie colour, bringing forth flat feed like vnto $K$ ali : the root is flender, and fpreadeth vnder the turfe of the earth: the whole plant is full of clammic iuice, not any thing aftringent, but fomewhat faltifh, and of no fingulatvertue that is yet knowne : wherefore I may couelude, that this cannot be Tragos Dioforidis, and the rather, for that this Tragon of $M$ attbiolus is an herbe, and not a thrub, as I haue before fpoten in $V$ vam mina, neither bearech it any berries or graines likewhear, neither is it pleafant in tafte and fraell, or any thing aftingent, all which are to be found in the right $T^{\prime}$ ragos before expreffed; which (as Dinfcorides faith) is without leanes, neicher is it thorney as Tragus improbus Mut thioli is:this plant I have found growing in the Inle of Shepey, in the trat leading to the houfe of Sir Edivard Hobby, ealled Slierland.

$$
\text { का The Place. }
$$

It louerh to grov ypon dry banks and fandy places neere to the fea:it is found in Languedocke, not far from Montpeliur,and in other plaees by the fen fide, and is a franger in England,

$$
\text { था The Time. }
$$

When it growetly of it felfe the fruit is ripe in Autumne, the plant it felfe remaineth long green for all the cold in Winter.

$$
\text { बT The 2Tames. }
$$

It is called of the later Herbarift, Vuamarima : in French, Raifn de Mer, of the pearled fruit, and the likeneffe thar it hath with the Rafpis berrie, which is as it were a Raifon or Grape,eonfifting of many little ones : it is named in Greeke spizs, but it is not called Tragres, or Trazanos, of a Goat (for fo fignifieth the Grecke word) or of his ranke and rammin finell, but bceaufe it bringeth forth 
fruit fit to be eaten, of the Verbe $\pi p^{2} y_{\mu}$, which fignificth to cat : it may be called Scorpion, becaufe the frrigs thereof are fharpe pointed like to the Seorpions taile.

बा The Tcmperature.

The berries or Raifons, and efpecially the feed that is in them liate a binding quality, as we haue faid, and they are drie in the later end of the feeond degree.

बा The Vertucs.

A when they much abound.

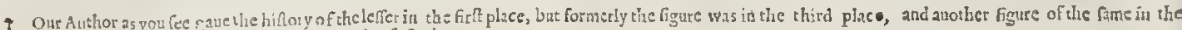
ccond piace, and the fiome of the grence: was in the firn place.

$$
\begin{gathered}
\text { CHAs. 460. Of Mradder. } \\
\text { Tt The kindes. }
\end{gathered}
$$

7 Here is but one kinde of Madder oncly which is manured ot fet for $v$ fe, but if all thofe that aro 1. like vnto it in leates and manner of growing were referred thereto, there fhould be many forts: as Goofe-graffe, foft Cliucr,our Ladies Bedfiraw, Woodroofe, and Croffe-woort,all which are like to Madder in leates, and therefore they be thought to be wildekinds thereof.

I Rubiatinctortm. Red Madúc:

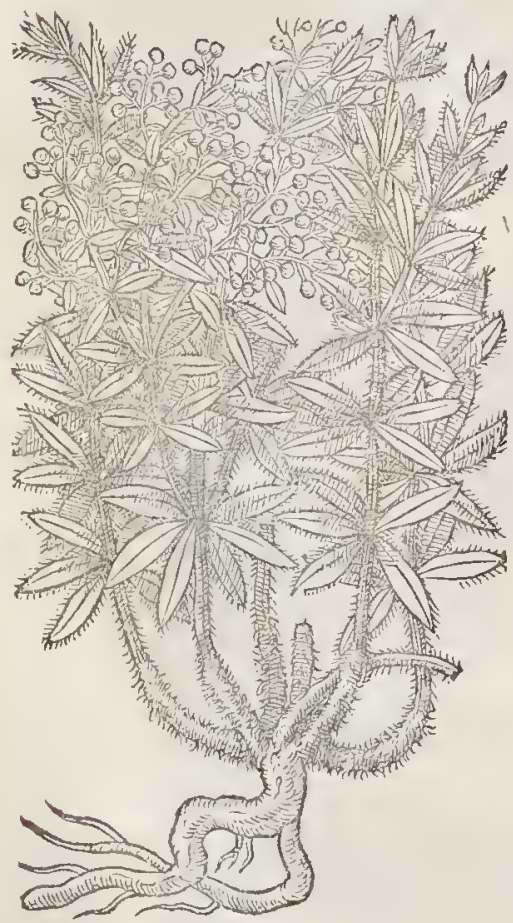

2 Rubiafylueftris. Wilde Madder Galium Mollugo-

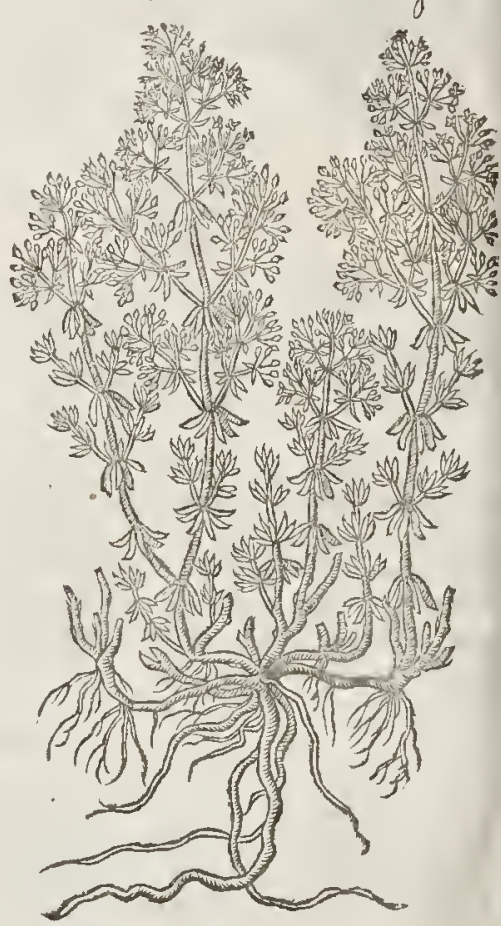

\section{GT The Defcription.}

I THe garden or mantred Madder hath long falks or trailing branches difperfed farre a1 broad vpon the ground, fquare, rough, and full of ioints; at etrery ioint fet round with greene roagh leaues, in manner of a ftarre, or as thofe of Woodroofe : thic flonres grow at the toppe 


\section{Synanchica LItg.p.II85.}

Asherula 5 Theroot is crooked, blackin without,yellow vnderneath the skinne, white within that and wooddic ; about fue or fix inehes long, with many hairy ftrings : from the root arife many fourefquare branehes trailing vpon the ground, fometimes reddifh towards the root : the leaues are fmall and fharpe pointed, like thofe of $G$ allium, and grow along the ftalke, on eertaine knees or ioints, foure or fite together,fometimes fewer:from thofe ioints the ftalk diuideth it felfe towards the rop into many parts, whereon grow many floures, each floure hauing foure leaues, fometimes white, fometimes of a fleth colour, and cuery leafe of thefe flefh eoloured leaues is artifieially ftraked in the middle, and neere the fides with three lines of a deeper red, of no pleafant fmell : after which commeth the feed fomething round, growing two together like ftones. It floureth all the Sommer long, and groweth in drie Chalkie grounds aboundantly. Auguft 13. I 6 I 9. Iohn. Goodyor. \$ : :..

\$ 6 Rubia minima.

Dwarfe Madder.

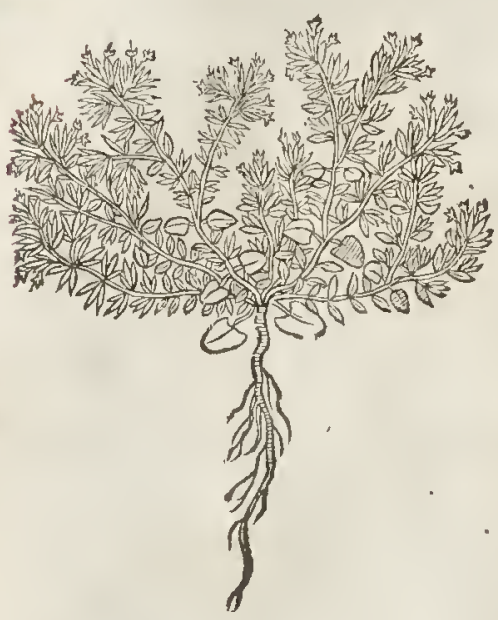

* 6 Lobel thus deferibes this Dwarfe Madder : there is another (faith hee) which I gathered, growing vpon Saint Vincents rocks not farre from Briftow: the leaues are of the bigneffe of thofe of Rupture-woort, fharpe pointed, and growing after the manner of thofe of Madder, vpon little creeping ftalkes, fome inch and halfe high, whereon grow yellowith fmall floures. The root is fmall and of the co: lour of Corall. $\neq$

$$
\text { T) The Place. }
$$

Madder is planted ingardens, and is verie. common in moft places of England. Mafter Gcorge Bowles found it growing wilde on Saint Vineents roeke; and out of the Cliffes of the rockes at Aberdovie in Merioneth thire.

The fecond groweth in moift medowes, in moorifh grounds, and vnder buthes almoft etrerywhere.

3 This grows by the fea fide in moft places: $\neq$ The fourth growes onely in fome few gardens with vs, but the fifth may bee found wilde in many places : I found it in great plenty on the hill beyond Chattam in the way to If The Time.

They Hourinh from $\mathrm{N}$ ay vnto the end of Auguft : the roots are gathered and dried in Autumne? and fold to the ve of Diers and Medicine.

\section{T The Names.}

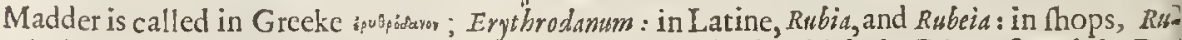
bia tincterum : Paulus eEginetn theweth that it is named Thayfor which the Diers vfe, and the Romanes eall it Herba Rubia: in Italian Rubbia, and Robbia: in Spanifh, Ruvia, Roya, and Granza: in

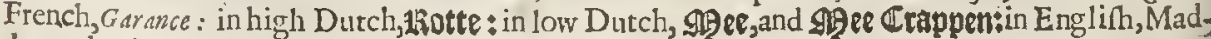
der,and red Madder.

\section{T The Temperature.}

Of the temperature of Madder, it hath beene difputed among the learned, and as yet not cenfir: red, whether it doe binde or open;fome fay both; diuers diuerlly deeme:a great Phyfition(I do nor fay the great learned) ealled me to account as touching the faculties heereof, although he had no commiffion fo to doe, norwithftanding I was content to be examined vpon the point, what the na. ture of Madder was, bceaufe I haue written that it performeth eontrary effects, as thall be thewed: the roots of Madder, which both the Phyfitions and diers doe vfe, as they haue an obfcure binding 
power and fnee; fo be they likewife of nature and temperature co!d and dry: they are withall of diuers thin parts, by reafon whercof there colour doth eafily picree: yec haue they ar the tirts eertain litrle fweetnes, with an harh binding quality prefently following it; which wat onely we our felues hane obferued, but alfo Auicenthe prinec of Phytitions, who in his 58. Chaper hath written, that the root of Madder hath a rough and harfh tafte : now $\mathrm{M}^{2}$. Doctor, whether it binde or open I luate anfwered, attending your eenfure : but if $I$ haue erred, it is not with the multitude', but with thofe of the beft and beft learned.

$$
\text { of The Vertues. }
$$

The decostion of the roots of Madder is euery where commended for thofe that are burnen, $A$ brufed, wounded, and that are fallen from high places.

It ft eneheth blecting, mitigaterh iniamnations, and helpeth thore parts that be hurt and $B$ brufed.

Tor the fe eatufes they be mixed with potions, which the later Playfitians eall wound drinkes $:$ in which there is fuch foree and vertuie, as Matthiolus al fo reporteth, that there is lihervife great hope of euring of deadly wounds in the cheft and intrails.

Our opinion and judgement is eonfirmed by that moft expert man, fometimes Phy fition of D Louaine, lohannes Spirsang w, who in his Rapfodes hath noted, that the decocion of Madder gituen with Triphera, that great eompofition is finguldr good to ftay the reds, the hemorrhoides and bloudy flixe, and the fame approoued by diters experiments : which confirmetl Madder to be of an attringent and binding qualitic.

Of the fame opinion as it feemeth is alfo Eros Iuliaher freed man (eommonly called Trotutu) E who in a compofition agaiuft vntimely birth doth vec the fame: for ifhe had shought that Madder were of fueh a qualitic as Diofcorides writeth it to be of, hewould not in any wife hate added it to thore medicines which are good againft an vntimely birth.

For Diofcorides reporteth, that the root of Madder doth plentifully prouoke urine, and that $\mathrm{F}$ groffe and thicke, and otrentimes bloud alfo, and it is fo great an opener, that being bur onely applied, it bringeth dow ne the menles, the birth,and after-birth : but the extreme redines of the vrine deeciued him, thac immediately followerh the raking of Madder, which redueffe eame as he thought, from bloud mixed therewith, which notwith fanding eommeth no otherwife then from the colour of the Madder.

For the root hereof taken any maner of way doth by \& by make the vrine extreme ted:no orherwife than Rubarb doth make the fame yellow, not ehanging in the meane time the libitanee thercof, nor making it thicker than it was before, whieh is to be vnderftood in thofe which are in perfect health, which thing doth rather fhew that it doth not open, but binde, no otherwife th..n Rubatbe doth: for by teafon of his binding quality the warerilh humors do for a while keepe their colour. For eolours mixed with binding things do longer remaine in the things erloured, and do not fo foone vade: this thing they will know that gather colours out of the juices of flo'ures and herbes, for with them they mixe allume, to the end that the colour may be retained and kept the longer, whieh otherwife would be quiekely loft. By thefe things it manifertly appeareth that Madder dorh nothing vehemently either elenfe or open,and that Diofcorides hath rafhly attributed vnto it this kinde of qualitie, and after him $G$ alen and the reft that followed, ltanding ft iffely to his opinion.

Pliny faith, that the ftalkes with the leates of Madder, are vfed againft fernents.

The root of Madder boiled in Meade or honied water,and drunken, opene th the ftcpping of the liuer, the mile and kidnies, and is good againt the jaundife.

The fame taken in like maner prouoketh vrine vehenent ly, infomuch that the of ten vfe thereof $K$ caufeth one to piffe bloud, as fome haue dreamed.

Langius and other exeellent Phyfitions hate experimented the fame to amend the lothfome colour of the Kings-etrill, and it helpeth the vleers of the mouth, if vnto the cecostion beadded a little allume and hony of Rofes.

$\neq .5$ The fifth being the Symanchica of Dalefchampius, dries without biting, and it is exeellent $M$ againft fqinaneies, either taken inwardly, or applied outwardly, for which eaufe they hatre ca!led - it Synanchica, Hift. Lugd. $\ddagger$

\section{Cин г. 46I. Of Goofe-graffe, or Cliwers. The Defoription:}

I A Parine, Cliuets or Goofe-graffe, harh many fmall fiquare branclies, rough and thatpe, foll of joints, befer at cuery joint with frmall leaues ftar falhion, and like vnto fma!l M.t.dder: $\mathrm{Bbb} b \mathrm{~b}$ 
the fontes are very little and white, pearking on the tops of the fprigs : the feeds are finall, round, a little hollow in the middett in maner of a nauell, fet for the molt part by couples : the roots flender and full of ttrings : the whole plant is rough, and his ruggedneffe taheth hold of mens veftures and woollen garments as they paffe by : being drawne along the tong ue it fetcheth bloud: Diofrorides reports, that the theepheards in ftead of a Cullender do vfe it to take haires out of milke, if any remaine therein.

2 The great Goore-graffe of Pliny is one of the Moone-worts of Lobel, it hath a very rougl] tender falt e, whereupon are fet broad leaues fomewhat long, like thofe of Scorpion graffe, or Alyffor Galeni, Galens Moone. woort, very rough and hairy, which grow not about the joints, but three or foure together on one fide of the ftalke: the foures grow at the top of the branches, of a blew colour : after which commeth rough cleauing feeds, that do fticke to mens garments which touch it : the root is fmall and fingle.

$$
\text { it }
$$

Aparine.

Goofe-graffe or Cleuers.

$$
\text { Galium Aparine }
$$

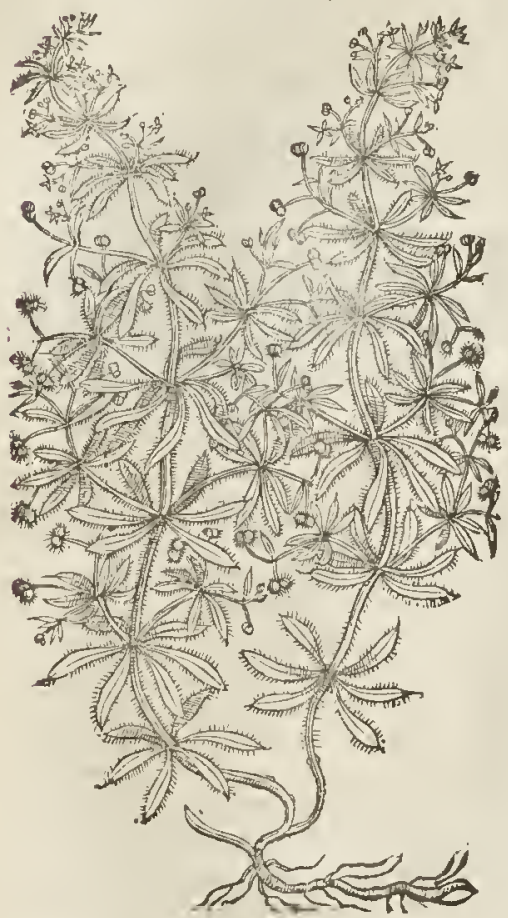

2 Aparine maior Pliny. Great Goofe-grafle. llspersya peocumbens.

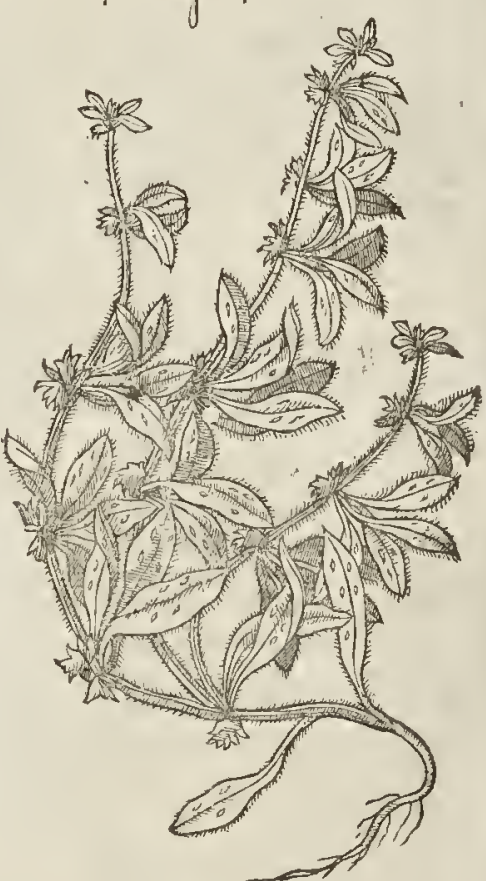

T The Place.

Goofe-graffe growetl neere the borders of fields, and oftentimes in the fields themfelues mixed with the corne alfo by conmmon waies, ditches, hedges, and among thornes: Theophraftus and Galen write, that it groweth among Lentles, and with hard embracing it doth choke it, and by that meanes is burdenfome and troublefome vnto it.

It is found plentifully euery where in fummer time.

$$
\text { का The Time. }
$$

\section{The Names.}

It is named in Greeke amasis: Apparine : in Latine, Lappaminor, but not properly : Pliny affirmeth it to be Lappaginis feciem: of fome, Philant hropos, as though he fhould fay, a mans friend, becaufe it taketh hold of mens garments; of diters alfo for the fame caufe, philadelphos : in Italian, Speronella: in Spanith, Prefera, or amor ai Ifortaiano: in high Dutch, 估lecb ktaut : in French, Reble, on Grateron: in low Dutch, 位ecferupt: in Englifh, Goofe-fhare, Goofe-grafle, Cleuer, or Clauer.

\section{Tा The Temperature.}

It is,as Galen faith,moderately hot and dry, and fomewhat of thin parts. 
T. The Vertues.

The inicewhich is preffed out of the feeds, ftalks, and leaues,as Diofcorides writeth, is a remedie $A$ for them that are bitten of the poilonfome fpiders called in Latine Phalangia; and of vipers if it be drunke with wine.

And the herbe ftamped with fwines greafe wafteth away the kernels by the throte.

Pliny teacheth that the leaues being applied do alfo ftay the aboundance of bloud iffuing ofwounds.

Women do vfually make pottage of Cleuers with a little mut ton and Otemeale, to caufe lank - D nefle, and keep them from fatneffe.

\section{Cна р. 462. Of Croffe-noort. T The Defcription.}

I Roffe-woort is a low and bafe herbe, of a pale greene colour, hauing many fquare feeble rough ftalks full of ioints or knees, couered ouer with a foft downe: the leaues are little, fhort, \& fmal, alwaies foure growing together, and ftanding croffewife one right againit another,making a right Burgunion croffe: toward the top of the ftalke, and from the bofome of thofe leaues come forth very many fmall yellow floures, of a reafonable good fauour, each of which is alfo fhaped like a Burgunion crofle: the roots are norhing elfe but a few finall threds or fibres.

1 Cruciata.

Groffe-woort.

Gahim conciation

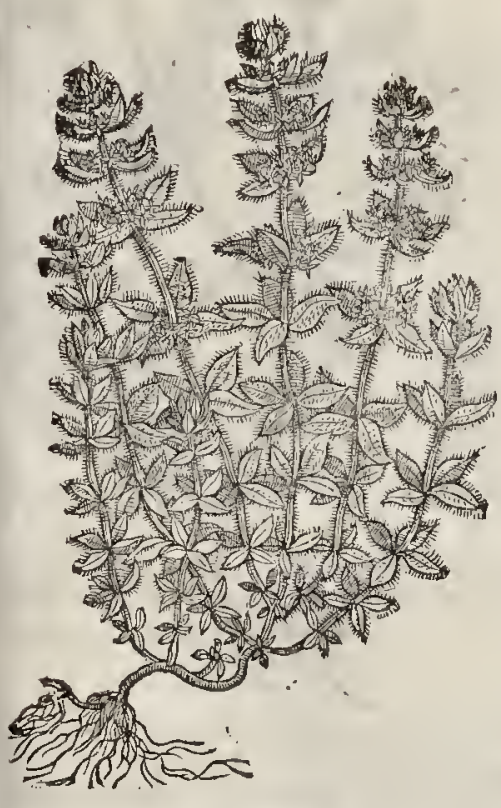

₹ Rubia Cruriata levis.

Croffe-woort Madder:

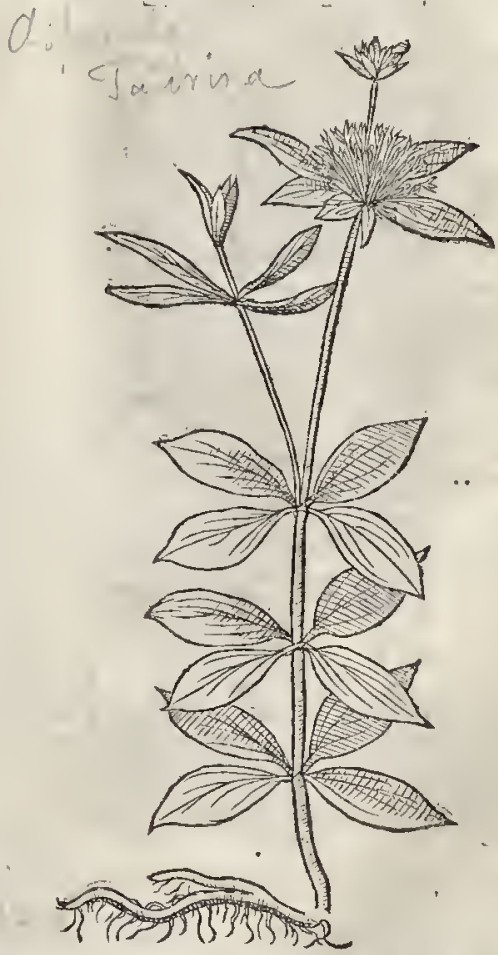

$¥ \check{z}^{*}$ This in mine opinion may be placed here as fitly as any where els; for hath the leaules ftanding croffe-waies foure at a ioint, fomew hat like thofe of the largeft Chiekweed : the ftalkes arebetweene a foot and a halfe and two cubites high. "The white Starre-falhioned foures ftand in roundles about the tops of the ftalks. It growes plentifully in Piemont, on the hills not firre from Turine. Lobel fets it forth by the name of Rubia Lavis.T asrinenfium. $\neq$ 


\section{The Place.}

Cruciata, or Croffe-woort, groweth in moift and fertile medowes; I fourd the famegrowing in the Churchyard of Hampltead neere London, and in a pafture adioining thercto, by the mill : alfo it groweth in the Lane or high way bey ond Charlton, a fmall village by Greerwich, and in fundry other places.

It fioureth for the moft part all Sommer long.

$$
\text { 9I The Time. }
$$

\section{Tा The Names.}

It is called Cruciata, and Cruciat is, of the placing of the leates in manner of a Croffe: in Englifh, Croffe-woort,or Golden Mugweet.

\section{Croffewoort feemeth to be of a binding The Temperature.}

7 The Vertues.

A Croffewoort hath an excellent propettie to heale, ioine, and clofewounds together,yea it is very fit for rhen, whet her they be inward or outward, if the faid herbe be boiled in wine and drunke.

$B$ The decoetion thereof is alfo minifted with good fucceffe to thofe that areburften : and fo is the herbe,being boiled vntill it bee foft, and laied vpon the burften place in manner of a pultis.

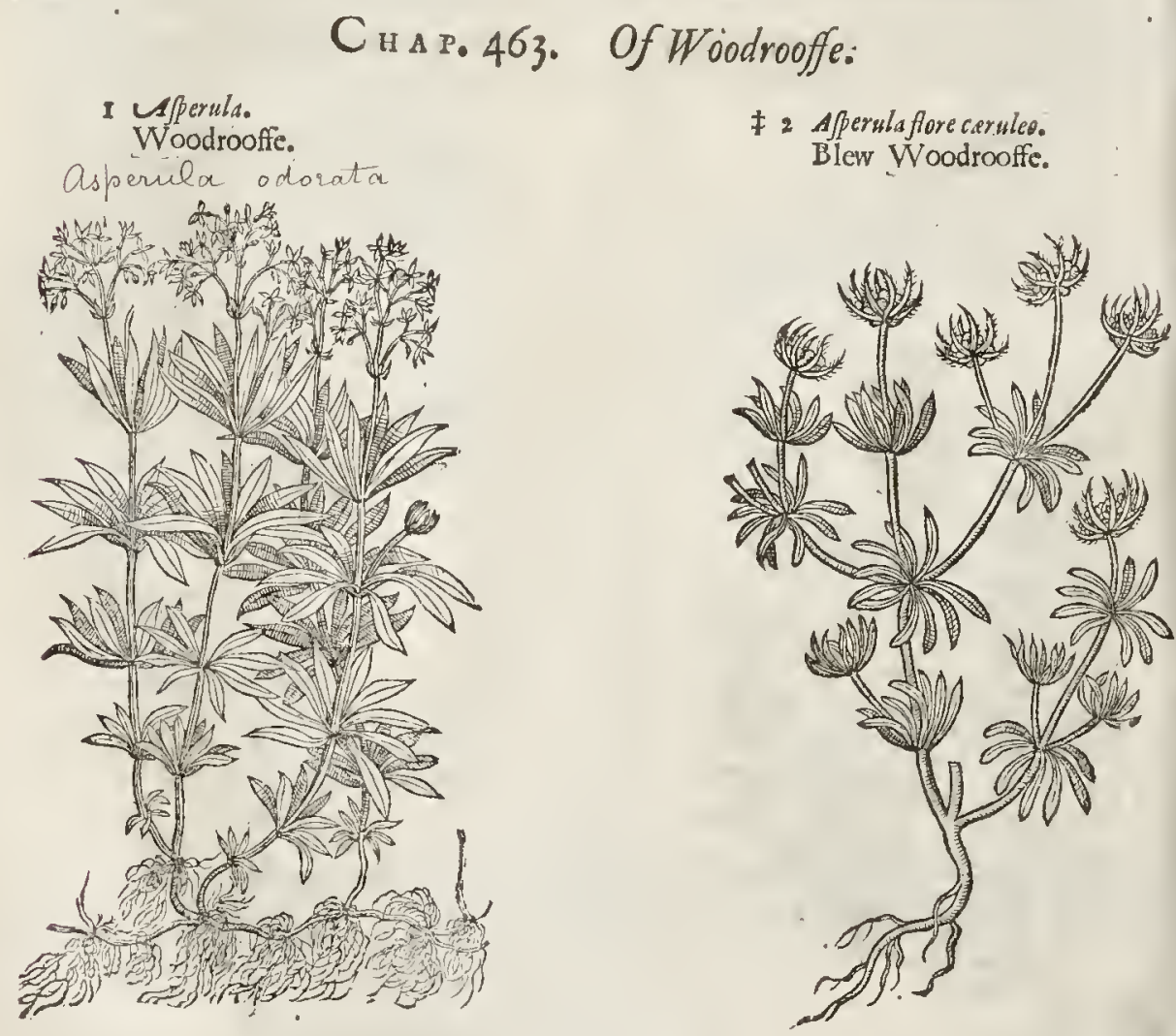

\section{The Defcription?}

I T T Oodrooffe hath many fquare ftalkes full of ioints, and at euety knot ot ioint feuen or eight long nar row leaues, fet round about like a ftar, or the rowell of a furre:rhe floures grow at the top of the ftems, of a white colour, and of a very fweet fmell, as is the reft of the herbe, which being made vp into garlands or bundles, and hanged vp in houfes in the heat of Sommer, dorh very wel attemper the aire, coole and make frem the place, to the delight
and comfort of fuch as are therein. 
$¥ 3$ isagina Spergula. Spurrye.

Spergule arvensis

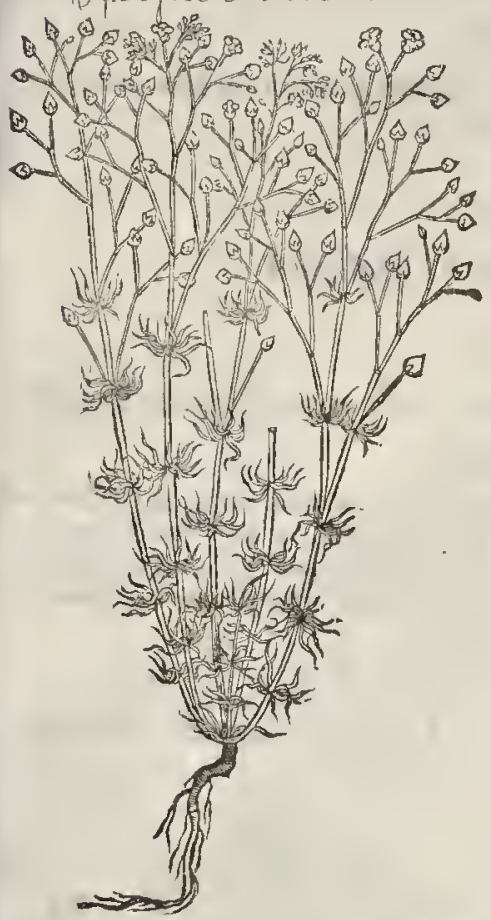

2 There is anorher fort of Wondrooffe called Aperula Cerulea, or blew Woodrooffe; it is an herbe of a foot high, fof t, hairy, and fomething branched, with leaues 8 it alks like thore of white Woodrooffe: the floures thereof are blew, ftanding vpon fhort ftems on the tops of the ftalks : the feed is fmall,round, and placed togerher by couples : the root is long, and of a red colour.

3 There is another herb called sagine per. gula, or Spurry, which is fown in Brabant, $\mathrm{Hol}$ land, and Flanders, of purpole to fatten cattel. and tocaufe them to gine much inilke, and there called Spurrey, and Franke Spurrey: it is a bafe and low herbe, very tender, hauing many iointed falks whereupon do grow leaues fet in round circles like thofe of Wnodrootfe, but leffer and fmoother, in forme like the rowell of a Pur:at the top of the falks do grow fmall white floures;after which come round feed like thofe of Turneps : the root is fmall and thred die.

$\ddagger 4$ There are one or two plants more, which may fitly be here mentioned : the firft of them is the Spergula marina of Dalechampiur, which from a pretty large wonddy and roughith root fends vp iointed ftalks fome font ong: at each ioint come forrh two long thick round leaues, and out of their bofomes orher leffer leaues:the top of the falks is diuided into fundry branches, tearing floures of a faint reddith colour,compofed of fiue little leaues, with yellowith threds in the middle: after which follow cups or feed veffe $I$, which open into foure parts, and containe a little flat reddinh feed : it grows in the falt marthes about Dartford, and orher fuch places, floures in Iuly and Augurt, and in the meane fpace ripens the feed. We may call this in
Englifh, Sea Spurrie.

5 This other hath a large root, confidering the fmalneffe of the plant : from which arife many weak flender branches fome three or foure inches long, fomtimes mote, lying commonly flat on the ground, hauing many knots or ioints : at each whereof vfually grow a couple of white fcaly leaues, and out of their bofomes other fmall tharpe pointed little greene leaus : at the tops of the branches grow little red floures, fucceeded by fuch,yet leffer heads than thofe of the former : it floures in Iuly and Auguft,and growes in fandy grounds, as in Tuthill-fields nigh Wefminfer:the figure

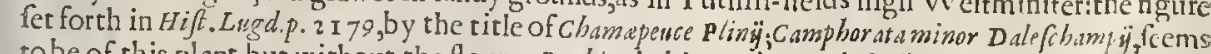
to be of this plant, but without the floure: Banbine in his Prodromus defcribes it by the nane of $A l$ fine Spergule facie. This may be called Chickweed Spurrey,or fmall red Spurrey. $\neq$

$$
\text { T The Place. }
$$

White Woodroofe groweth vnder hedges, and in woods almofteury where : the fecond grows eth in many places of E fex, and diuers other parts in fand y grounds. The third in Corne fields.

They floure in Iune and luly.

$$
\text { If The Time. }
$$

$$
\text { of The Names. }
$$

Mot haue taken Woodrooffe to be Pliny his Aly Sos, which as he faith, doth differ from Erythrow dinzum, or Garden Madder, in leaues onely, and leffer ftalks : but fuch a one is nor onely this, but alro that with blew floures:for Galen dorh attribute to Alyfos, a blew floure: notwithetanding Galens and Plinics Aly fos are thought to differ by Galens owne words, writing of Aly fos in his fecond booke of Counterpoifons, in Antontus Cous his compolrion, in this maner:Alyfos is an herb very like vnto Horehound, but rougher and fuller of prickles about the circles : it beareth a floure
tending toblew.

Woodrooffe is named of diuers in Latine Aperuls odorata, and of molt men Aperouladisrata: of

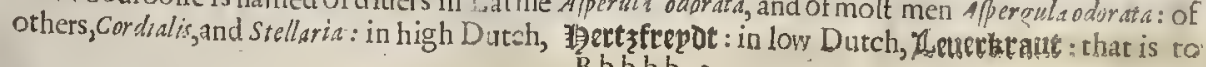
$\mathrm{Bb} b \mathrm{bb} 3$ 
fay Iecoraria, or Hepatica, Lituerwoort : in Freneh, enaguet: in Englih, Woodrooffe, Woodrowe, and Woodrowell.

of The Temperature.

Woodrooffe is of temperature fomething like vnto our Ladies Bed ftraw, but not fo ftrong, being in a meane between heate and drineffe.

A It is reported to be put into wine, to make a man merry, and to be good for the heart and liuer:it preuaileth in wounds, as Cruciatn, and other vulnerarie herbes do.

\section{C н ${ }^{\circ} \mathrm{P} \cdot 464$. Of Ladies Bedfraw. \\ If The Kindes.}

THere be diuers of the herbes ealled Ladies Beditraw, or Cheefe-renning; fome greater, others 1 leffe; fome with white floures, and fome w ith yellow.

\section{7 he Defription.}

T Adies Bedftraw hath fmall round eucn ftalkes, weake and tender, ereeping hither and thither vpon the ground : whereon doe grow very fine leaues, cut into fmall iags, finer than thofe of Dill, fet at certaine fpaces, as thofe of Woodrooffe: among which come forth floures of a yellow colour, in clufters or bunches thieke thruft together, of a ftrong fiveet fmel but not vipleafant:the root is fmall and threddie.

I Gallium lutcum.

Yellow Ladies Bedfraw.

Galium verum

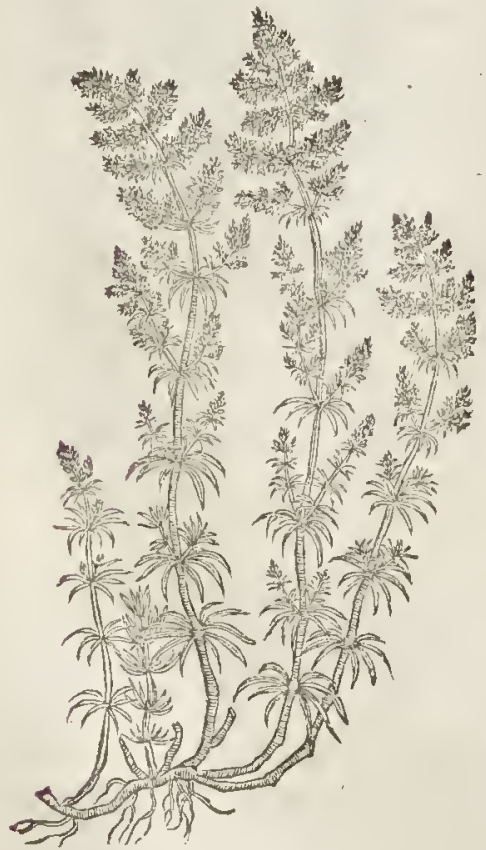

Gallium album.

Ladies Bedftraw with white floures.

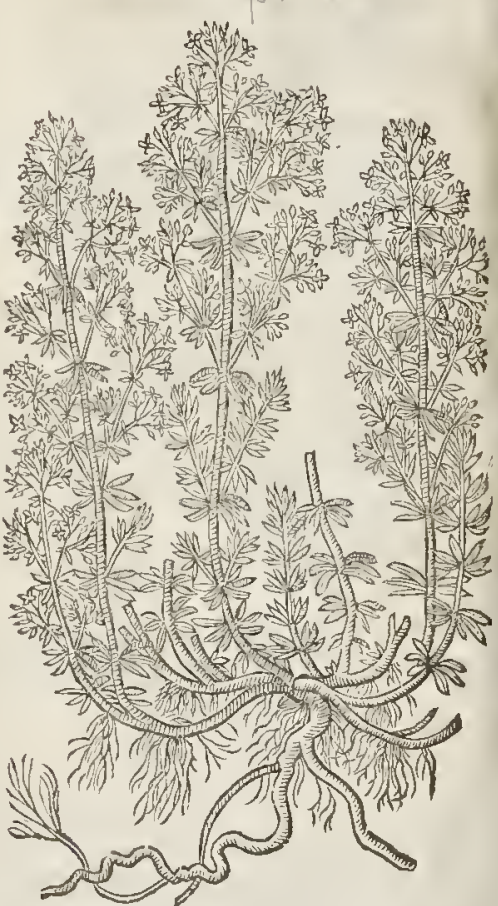

2 Ladies Bedftraw with white floures is like vnto Cleauers or Goofe-graffe, in leaues, ftalkes, and manner of growing,yet nothing at all rough, but fmooth and foft:the floures be white, the feed round : the ronts flender, creeping within the ground: the whole plant rampeth vpon burhes, fhrubs and all other fuch things as ftand neere vnto it:otherwife it cannot ftand, but muft reele and fall to the groud. 
3 This fnall $G$ allium, or Ladies little red bed-ftrow, harh been taken for a kind of wild Madder; neuertheleffe it is a kinde of Ladies bed-ftrow, or eheefe-renning, as appeareth both by his vertues in turning milke to eheefe, as alfo by his forme, being in eaeh refpect like vnto yellow $\mathrm{Gal}$ lium, and differs in the colour of the floures, which are of a dark red colour, with a yellow pointal in the middle, confifting of foure fmall leaues: the feed hereof was fent me from a Citifen of Straufburg in Germanie, and it hath not been feen in thefe parts beforethis time.

4 There is likewife another fort of Gallinm for diftinctions fake ealled Mollugo, which bath ftalks that need not to be propped vp, but of it felfe ftandeth vpright, and is like vnto the common white Gutlinm, but that it hath a fmoother leafe. The foures thereof bealfow hite, and very fmall. The root is blackinh.

\section{† 3 Gallium rubrum.}

Ladies Bed-ftrow with red flourcs.

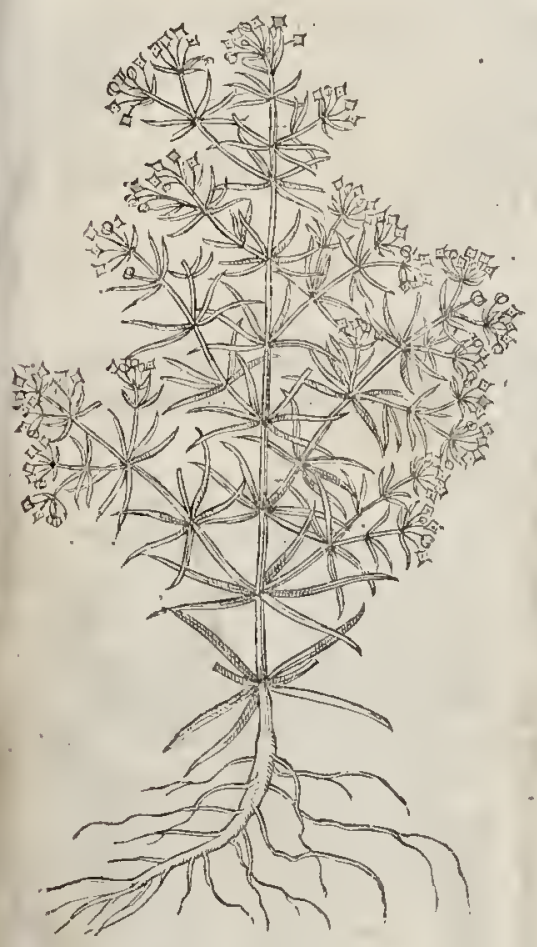

4 Gallium, fine Crolluro montana. Great baftard Madder.

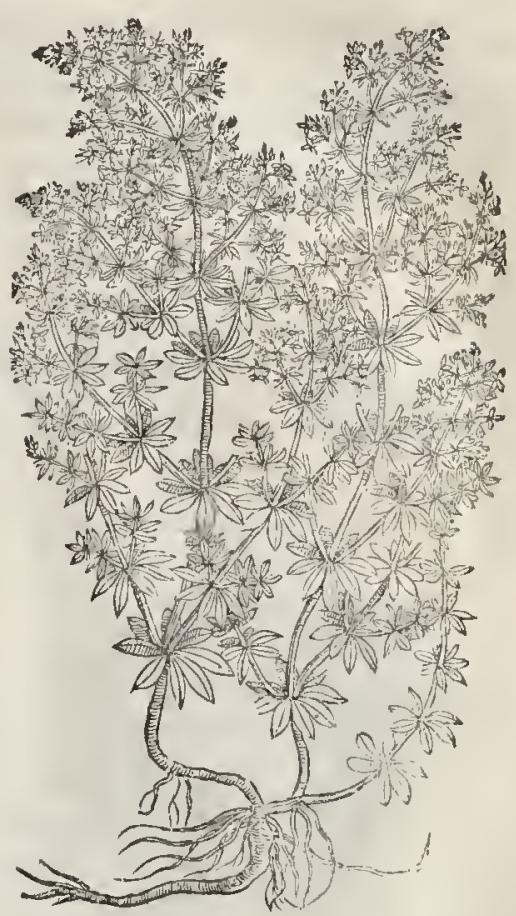

T. The Place.

The firft groweth wpon funnie bankes neere the borders of fields, in fruitfull foiles almolt euery where.

The fecond groweth in marifh grounds and other moift places.

The third groweth vponmountaines and hilly places, and is nor yet found in England.

The fourtl and laft groweth in hedges anong buthes in moft plaees.

They floure moft of the Sonmer monetlis.

$$
\text { GT The Time. }
$$

न $T$ be Names.

The firft is ealled in Greeke ra $\alpha^{2} m$ : it hath that name of milke, ealled in Greeke s'a $^{2}$, intowhich, it is pur as ehee fe-renning : in Latine likewife Galliwm : in high-Duteh, 9 gagerktatt, noaltteoo: in low-Duteh, nalltroo: in French, Petit Muguet : in Italian, Galio : in Spanih, Cosialeche yerua: in Englifh, our Ladies Bed-ftrow, Cheefe-renning, Maids haire, and pery Mugwet.

The others are Species Lapp.rainis, or kindes of fmall Burres, fo taken of the Antients: The Iaft; of the foftneffe and fmoothneffe of the leaues, is eommonly ealled Mollugo: diuers take it for a kinde of wilde Madder, naming it Rubiufylueftris, or wilde Madder.

If The Temperature.

Thefeherbes, efpecially that with yellow floures, is dry and fomething binding; as Galen faith. 


\section{The Vertues.}

A The floures of yellow Maids haire, as Diofcurides writeth, is vfed in ointments againft burnings, and it ftancheth bloud : it is put into the Cerote or Cere-cloath of Rofes : it is fet a funning in a glaffe, with Oyle Oliue, vntill it be white: it is good to anoint the wearied Traueller: the root thereof drunke in wine ftirreth vp bodily luft; and the floures fmelled vnto worke the fame effes.

B The herbe thereof is vfed for Rennet to make cheefe, as cMattbiolus reporteth, faying, That the people of Tufcanie or Hetruria do vfe to tume their milke, that the Cheefe which they make of Sheeps and Goats milke might be the fweeter and more pleafant in tafte, andalfo morc wholfome, efpecially to breake the fone, as it is reported.

C The people in Chethire, efpecially about Namptwich, where the beft cheefe is made, do vfe it in their Rennet, efteeming greatly of that cheefe aboue other made without it.

D We finde nothing extant in the antient writers, of the vertues and faculties of the white kindes but are as herbes neuer had in vfe either for phyficke or Surgerie.

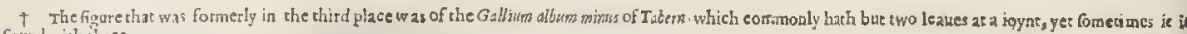
found with thise

\section{C на в. 465. Of Ferne.}

T) The Kindes.

THere be diuers forts of Ferne, differing as well in forme as place of growing; whereof there be two forts according to the old writers, the male and the female; and thefebe properly called Ferne: the others liaue their proper names, as thall be declared.
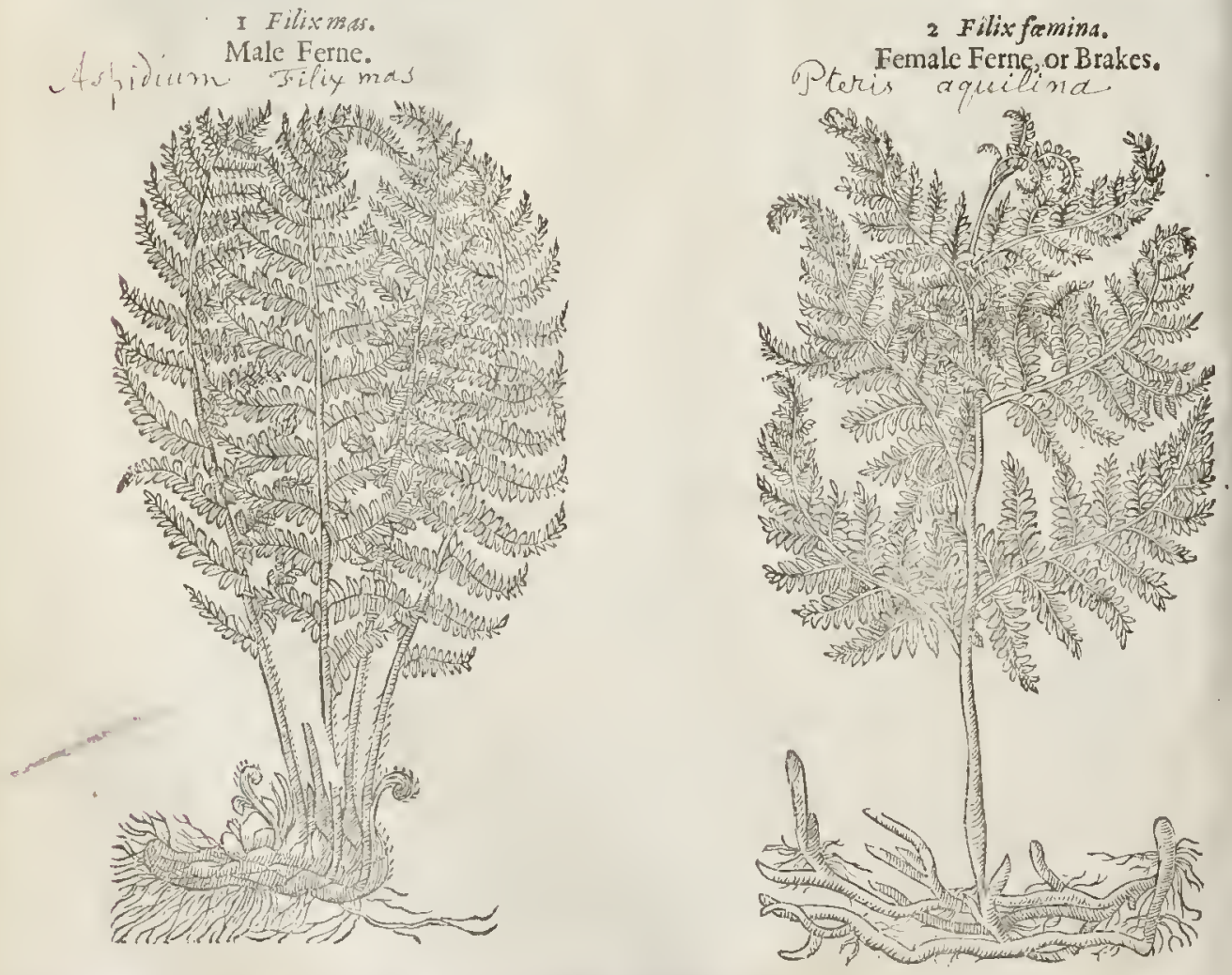


\section{9f The Defcription.}

1 He male Ferne bringeth forth prefently from the root broad leaues and rough, fomewhat hard, eafie to be broken, of a light greene colour, and ftrong fmcll, more than a cubit long, fpred abroad like wings, compounded as it were of a great number fanding vpon a middle rib, euerie one whereof is like a feather, nicked in the edges, and on the baekefide are fprinkled as it were with a very fine earthy-coloured duft or fpors, which many rathly haue taken for feed : the root confifteth of a number of tufts or threds, and is thicke and blacke, and is without ftalke and feed, and altogether barren.

\section{$¥$ Filicis (vulgo) maris varietates of differentia.}

Differences of thic male Ferne.

1 haue obferued foure forts of Ferne, by moft writers efteencd to be the male Ferne of $D$ iofcorides: by Anguillura, Gefner, Cafalpinus, and Cluffrss, accounted to be the female, and fo indeed doe I thinke them to be, though I call them the male, with the multitude. If you looke on the fe Fernes according to their feuerall grow ths and ages, you may make many more forts of them than I haue done; which I am afraid hath beene the occafion of defcribing more forts than indeed there are in nature. Thcfe defcriptions I made by them when they were in their perfect growths.

\section{Filix mas ramofa pinnulis dentat is.}

The roots ate nothing but an aboundance of fmall blacke hairy ftrings, growing from the lower parts of the maine ftalkes (for ftalkes I will call them) where thofe ftalkes are ioyned together. At the beginning of the Spring you may perceiue the leaues to grow forth of thcir folding clufters, conered with brownifh fcales at the fuperficies of the eartll, very clofcly ioyned together: a young plant hath but a few leaues; an old one, ten, twclue, or more : each falke at his lower end neere the ioyning to his fellowes, at his firft appearing, before he is an inch long hauing fome of thole blacke fibrous roots for his fuftenance. The leaues being at their full growth hath each of them a three-fold diuifion, as hath that Ferne which is commonly called the female : the maine ftalke, the fide branches growing from him, and the nerues growing on thofe fide branches bearing the leaues : the maine ftalke of that plant I defcribe was fully foure foot long (but there are viually from one foot to foure in length) full of thofe brownifh fcales, efpecially toward the :ooi, firme, one fide flat, the reft round, naked fully one and twenty inches, to the firt paire of fide branches. The fide branches, the longeft being the third paire from the root, were nine inches long, and thorter and fhorter towards the top, in number about twenty paire; for the moft part towards the root they grow by couples, almoft oppofite, the neerer the top the further from oppofition : the nerues bearing the leaues, the longeft were two inches and a quarter long, and fo fhorter and Ahorter toward the tops of the fide branches; about twentie in number on each fide of the longeft fide branch. The leaues grow for the moft part by couples on the nerue, eight or nine paire on a nerue; each leafe being garhed by the fides, the garhes ending with fharpe points, of a deep green on the vpper fide, on the vnder fide paler, and each leafe hating two rowes of duify red feales, of a browne or blackilh colour : toward the top of the maine falke thofe fide branches ehange into nerues, bearing only the leates. When the leaues are at their full grow th,you may fee in the middeft of them at their roots the faid fcaly folding clufter; and as the old leates with their blacke threddy roots wholly perinh, they fpring vp; moft yeares you may finde many of the old leates grecne all the Winter, efpecially in warme placcs. This groweth plentifully in the boggy that dowie moores neere Durford Abbey in Suffex, and alfo on the moitt hadowic rockes by Mapledurham in Hampihire, ncere Peters-field; and I hatc found it often on the dead putrified bodies and ftems of old rotten okes, in the faid moores; neere the old plants I haue obfertued verie many fmall yong plants growing, whieh came by the falling of the feed from thofe difty fcales : for I beleetre all herbes haue feeds in themfelues to produce their kindes, Gen.r. II. \& I 2 .

The three other hate but a twofold ditifion, the many ftalks and the neruss bearing the leates. Theroors of them all are blacke fibrous threds like the firft, their maine ftalks grow many thicke and elofe together at the root, as the firftoth : the differenee is in the fafhion of their leaues, and manner of growing, and for diftinctions fake $I$ haue thus called them :

2 Filix mas non ramofa pinnulis lat is denfis minutim dentat is.

The leanes are of a yellowifh greene colour on both fides, fet very thick e and clofe together n! 
the nerue, that you cannot fee betweene them, with marticllous fmall niches by chcir fic'es, and on their round tops : cach leafe hath alfo two rowes of dufty feed fcales; the figures. fet forth by Lo. bal, Tabern. and Gerard, vnder the title of Filix rnas, do well refemble this Ferne. This growes plentifully in moft places in thadowie woods and copfes.

\section{Filix mas non ramofa pinnulis anguft is, raris, profunde dentatis.}

The leaues are of a deepe greene, not clofely fet together on the the nerue, but you may far off fee betwixt them, deeply indented by the fides, ending with a point not altogether fharpe : each leafe hath alfo two rowes of dufty feed feales. I haue not feerie any figure well refembling this plant. This groweth allo in many places in the thade.

$$
4 \text { Filix mas non ramofapinnules lat is auriculat is pinojos. }
$$

The leatres are of a deeper greene than either of the two laft deferibed, placed on the nerue not very clofe together, but that you may plainly fee between them; each leafe (effecially thofe next the ftalke) hauing on that fide fartbeft off the ftalk a large eare or outgrowing erding, witl a hasp pricke like a haire, as doth alfo the top of the leafe: fome of the fides of the leaties are alfo nicked, ending with the like pricke or haire. Each leafe bath two rowes of dufty feed fcales. I his I take to be Filix mas aculeatamior Babini. Neither hate I feene any figure refembling this plant. It grow. eth abundantly on the thadowic moift roekes by Maple-durham neere Peters-field in Hampinire. Iobr Goodyer. Inly 4. 1633. ‡

2 The temale Ferne hath neither floures nor feed, but one only ftalke, chanfered, fomething edged, hat ing a pith within of diuers colours, the which being cut allope, there appeareth a certain forme of a fpred-Earle : about this ftand very many leaues which are winged,and like to the leaues of the male Ferne, but lefier : the root is long and blacke, and creepeth in the ground, being now and then an inch thicke, or fomewhat thinner. This is alfo of a frong fmell, as is the malc.

$$
\text { 9ा The Place. }
$$

Both the Ferncs are delighted to grow in barren dry and defart places : and as Horace teftifietl;

$$
\text { Neglect is vrenda Fulix innafcitur agris. }
$$

It comes not vp in manured and dunged places, for if it be dinged (as Theophraft us, lik.8. cap.8. re: porteth) it withereth away.

The male ioyeth in open and cham pion places, on mountaines and ftony grounds, as Diofcorides faith. $\ddagger$ It growes commonly in thadowie places vnder hedges. $\ddagger$

The femalc is often found about the borders of fields vnder thornes and in thadowic woods.

$$
\text { T The Time. }
$$

Both thefe Fernes wither away in winter: in the fpring there grow forth new leaues, which continue greene all Sommer long.

$$
\text { I The Names. }
$$

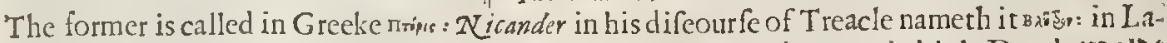
tine Filix mas : in Italian, Felce; in Spanifh, Helecho, Falguero, and Feyto : in high-Dutch, wanlbc

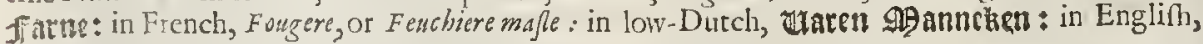
mule Eerne.

The fecond tinde is ealled in Greeke murmips, that is, Filix formina, or female Ferne : in Latine, as Diofcorides noteth among the baftard names, Lingna cervina: in high-Dutch, toalot farn wei $=$

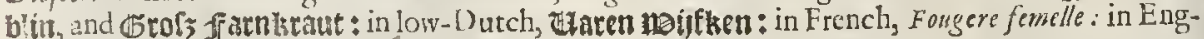
lih, Brake, co:mmon Ferne, and female Ferne.

\section{- The Temperature.}

Both the Fernes are hot, bitter, and dry, and fomething binding.

$$
\text { T The Vertues. }
$$

A The roots of the male Ferne being taken to the weight of halfe an ounce, driueth forth long flat wormes out of the belly, as Drofcorideswriteth, being drunke in Mede or honied water; and more cffectually, if it be giuen with two fcruples or two third parts of a dram of Scamonie, or of blacke Hellebor : they that will vfe it, faith he, muft firft eate Garlicke. After the fame manner, as Galers addeth, it killeth the childe in the motherswombe. The root hereof is reported to be good for them that hatue ill fpleenes: and being ftamped with fwines greafe and applied, it is a remedie againft the pricking of the reed: for proofe hereof, Diofcorides faith the Ferne dieth if the Reed be planted about it; and contrariwife, that the Reed dieth if it be compaffed with Ferne : which is vaine to thinke, that it hapneth by any ant ipathic or naturall hatred, and not by reafon this Ferne profpercth not in moif places, nor the Reed in dry.

D The funale Ferne is or like operation with the former, as Galen faith. Diofcorides reports, That this bringeth barrenneffe, efpecially to womien; and that it caufeth women to be deliuered before their time : he addcth, that the pouder hcreof finedy beaten is laid vpon old vlcers, and healeth 
the galled neekes of oxen and other eattell : it is alfo reported, that the root of Ferne can into an hoghead of wine keepeth it from fouring.

The root of the male Ferne folden in Wine is good againt the hardneffe and ftopping of the milt: and being boyled in water, ftayeth the laske in yong ehildren, if they be fet oner the decoction thereof to eafe their bodies by a clofe ftoole.

\section{С н IT The Defcription.}

V. Ater Ferne hath a great triangled ftalke two cubits high, befet vpon each fidewith large leaues fpred abroad likewings, and dented or cut like Polypodie : thefe leaues are like the 1. large leaues of the Ath tree; for doubtleffe when I firft faw them a far of it caufed me to wonder sthereat, thinking that I had feene yong A fhcs growing vpon a bog; but beholding it a little necrer, I might eafily diftinguifh it from the Afh, by the browne rough and round graines that grew on the top of the branches, which yet are not the feed thereof, but are very like vnto the feed. The root is great and thicke, folded and couered ouer with many fcales and interlaeing roots, hauing in the middle of the great and hard wooddy part thercof fome fmall whiteneffe, which hath beene called the heart of of mund the water-man.

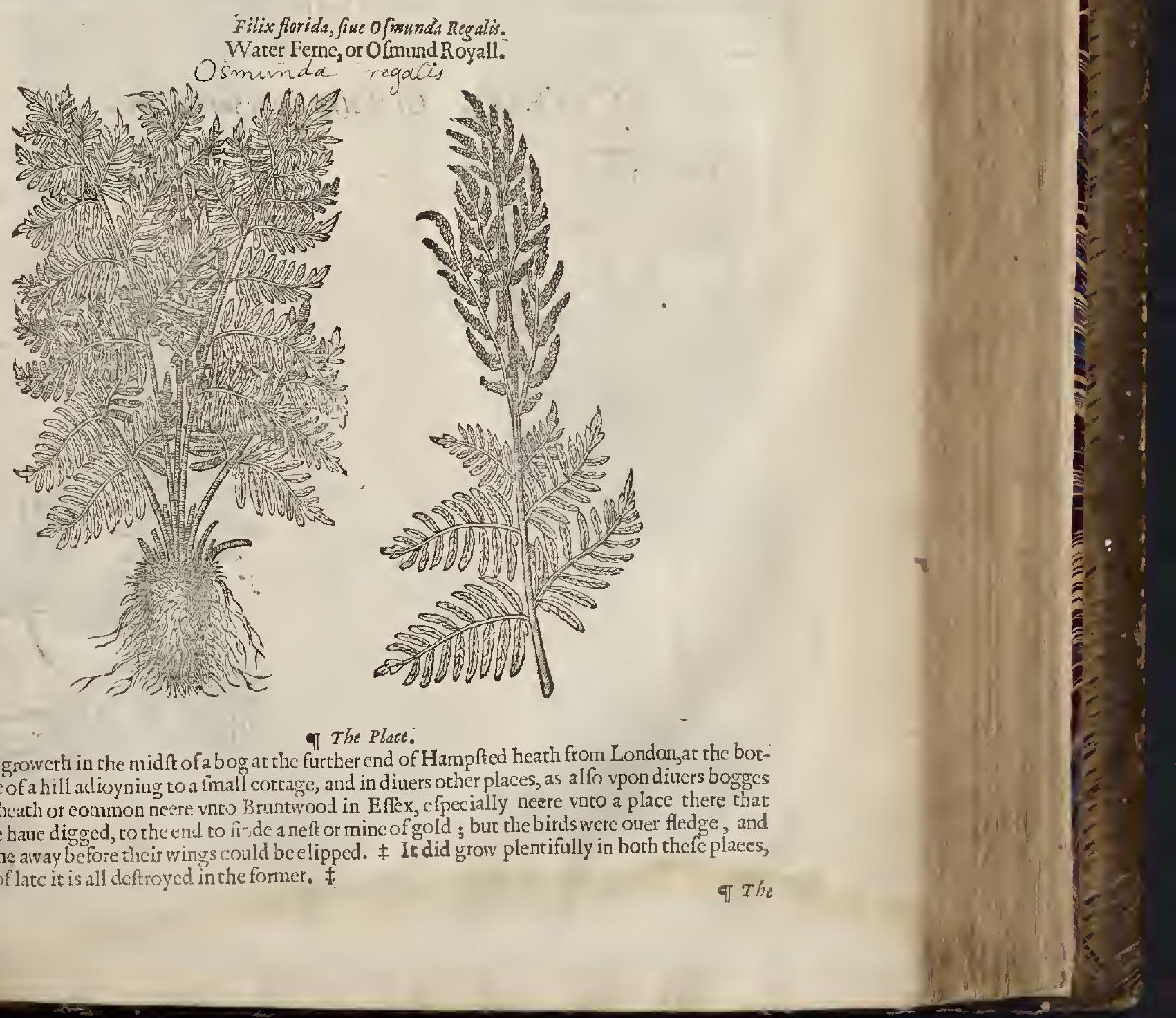




$$
\text { बा The Time. }
$$

It flourifheth in Sommer, as the former Fernes : the leates decay in W' intcr: the ront continueth freth and long lafting; which being brought into the garden profpereth as in lis natiue for!e, as my felfe hate proued.

$$
\text { If The Names. }
$$

It is called in Latine ofmunda : it is more truly named Filix paluftris, or aquatilis : fome terme it by the name of Filicaftrum: moft of the Alchimits call it Lunaria maior: $V$ alcrins Cordus nameth

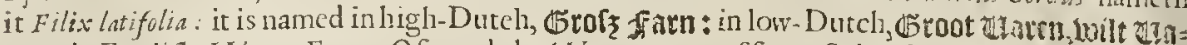
ren : in Englih, Watcr-Ferne, Ofmund the Water-man : of fome, Saint Chriftophers herbe, and Ofmund.

\section{it The Temperature.}

The root of this alfo is hot and dry, but leffe than thcy of the former ones.

\section{The Vertues.}

A The root, and efpecially the heart or middle part thereof,boiled or clfe ftanped, and taken with fome kinde of liquor, is thought to be good for thofe that are wounded, dry-bcaten, and bruifed; that laue fallcn from fome high place : and for the fame caufc the Empericks do put it in dceoctions, which the later Phyfitians do call wound-drinks : fome take it to be fo effcotuall, and of fo great a vertuc, as that it can difolue cluttered bloud remaining in any inw ard part of the body, and that it alfo can cxpell or driue it our by the wound.

B The tender fprigs thereof at thcir firft comming forth are excellent good vnto the purpofes $a$ foreraid, and are good to be put into ba!mes, oyles, and confolidatives, or healing plaifers, and into vnguents appropriate vnto wounds, punctures, and fuch like.

\section{Chas.467: Of Polypodie or wall-Ferne.}

I Polypodium.

Wall Ferne, or Polypodic of the wall.

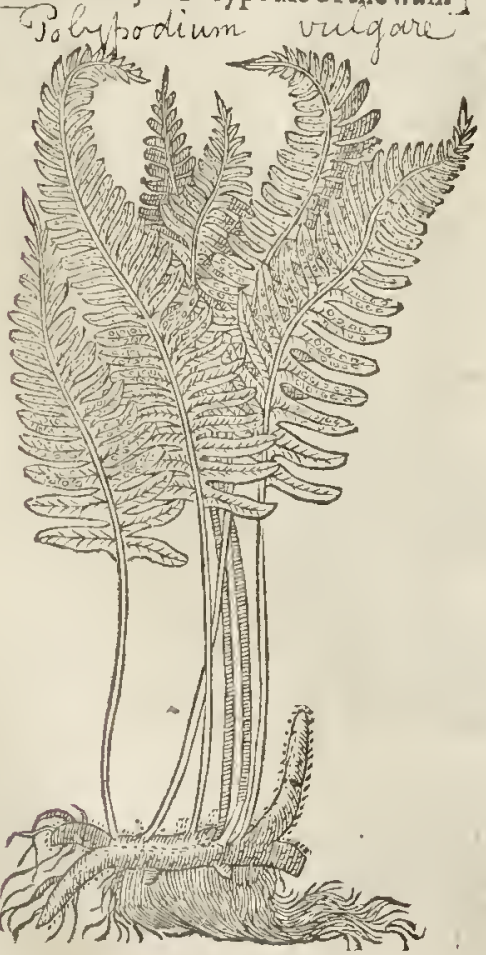

2 Polypodium quercinum: Polypodie of the Oke.

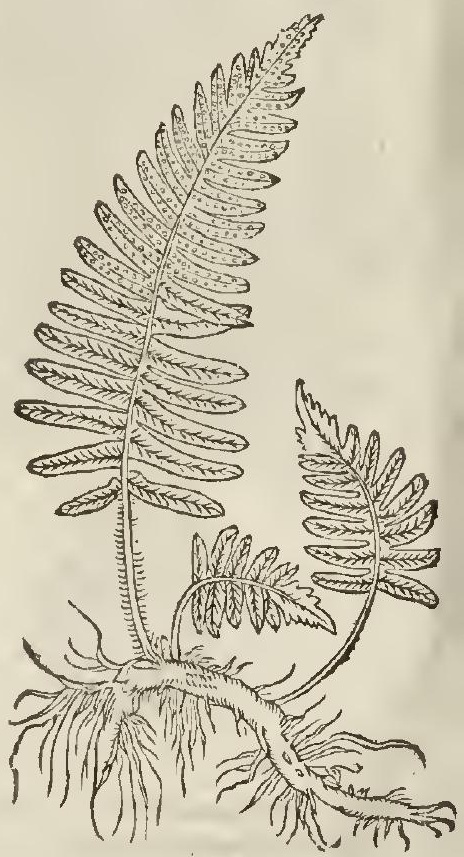


A Diofcorides writeth, that it is of power to purge and to draw forth choler and flegme. Aatuarius addeth, that it likewife purgeth melaneholy : other fuppofe it to be without any purging force at all; or elfe to haue very little : of the fame minde is alfo lobannes Monardus, who thinketh it purgeth very gently; which thing is confirmed by Experience, the miftris of things. For in very dced Po. lypody of it felfedoth not purge at all, but onely ferueth a lit tle to make the belly foluble, being boiled in the broth of an old cocke, with Bectes or Mallowes, or other like things that mooue to the ftoole by their flipperines. Ioaxnes Mefue reckoneth vp Polypodie among thofe things that do efpecially dry and make thin : peraduenture he had refpect to a certaine kinde of srthritis, or ache in the joints: in which not one only part of the hody, but many together moft commonly are rouched: for which it is very mueh commended by the Brabanders and other inhabitants about the riuer Rhene, and the Maze. In this kinde of difeafe the hands, the feet, and the joints of the knees and elbowes do well. There is joined withall a feeblenesin moouing, through the extremity of the paine:fometimes the vpper parts are leffe grieued, and the lower more. The humors do alfo eafily run from one place to another, and then fettle. Againft this difeafe the Geldres and Cletrelanders do vfe the decoction of Polypodic, whercby they hope that the fuperfluous humours may be wafted and dried vp, and that not by and by, but in continuance of time: for they appoint that this decoction thonid be taken for certaine daies together.

B But this kinde of gout is fooner taken away either by bloud letting, or by purgations, or by both, and afterwards by fiveate; nether is it hard to be cured if thefe generall remedies be vfed in time : for the humors do not remaine fixed in thofe joints, but are rather gathered together than fetcled about then.

C Therefore the body muft out of hand be purged, and then that which remaineth is to be wafted and confumed aivay by fuch things as procure fweate.

D Furthermore, Diofcorides faith, that the root of Polypody is very good formembers out of joint, and for chaps betweene the fingers.

E The root of Polypodie boiled with a little honie, water, and pepper, and the quantitie of an ounce giuen, enptieth the belly of cholericke and pituitous humours; fome boile it in water and wine, and giue there of to the quantitie of three ounces 'for fome purpoles with good fuc. .cefle.

\section{Cin в. 468. Of Oke-Ferne.}

* Vr Author here (as in many other places) knit knots, fomewhat intricate to loofe, for firft he confounds in the names and nature the Polypody of the Oke, or leffer Polypodie wirh the Dryopteris, or Oke-Ferne; but that I haue now put backe to the former chapter, his fit place; then in the fecond place did he gine the Defcription of the Dryopteris of the $\mathbf{A} d$ zerf. taken from thence, par. 263. Then were the place, times, names, src. taken ont of the chapter of Dryopteris Candida of Dodoneus, being, Pcmpt. 3.lib. 5. cap. 4. But the figure was of the Filacula formina petran 4 . Of $T$ abcrnamontanus. Now I will in this chapter giue you the Dryopteris of the Aduer faria, then that of Dodoncus, and thirdly that of Tragss ; for I take them to be different; and this laft to be that figured by our Author,out of $\tau_{\text {abernamontanus. } \ddagger}$

$$
\text { Tा The Defeription. }
$$

I THis kinde of Fernecalled Dryopteris, or Filix querna, hath leaues like wnto the female Fernebefore fpoken of, but much leffer, fmaller, and more finely cut or jagged, and is not aborie a foot high, being a very flender and delicate tender herbe. The leaues are fo finely jagged that in thew they refemble feathers, fet round about a fmall rib or finew; the backe fide being fprinckled, not with ruffet or browne markes or fpecks, as the other Fernes arc, but as it were painted with white fpots or markes, not ftanding out of the leaues in fcales, as the fpots in the male Ferne, but they are double in each leafe clofe vnto the middle rib or finew. The root is long, brownc, and fomewhat halry, very like vnto Polypody, but much flenderer, of a fharpe and cauficke tafte. $\neq$ Rondeletims affirmed that he found the vfe of this deadly, being put into medicines in ftead of Polypody by the ignorance of fome Apothecaries in Dauphenye in Franee. Mr. Goodyer hath fent me an acurate defeription together with a olant of this Ferne which I haue thought good here alfo to fet forth, $\neq$ 
L18. 2.

\# Dryopteris Aduerf. True Oke Ferne.

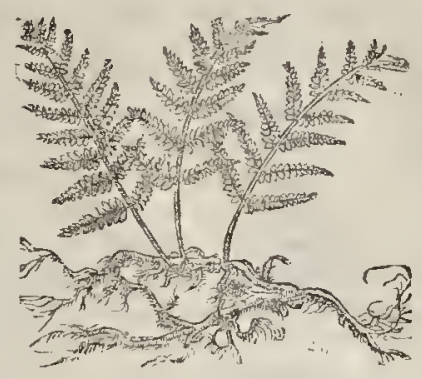

* 2 Dryopteris alba Dod. White Oke-Ferne.

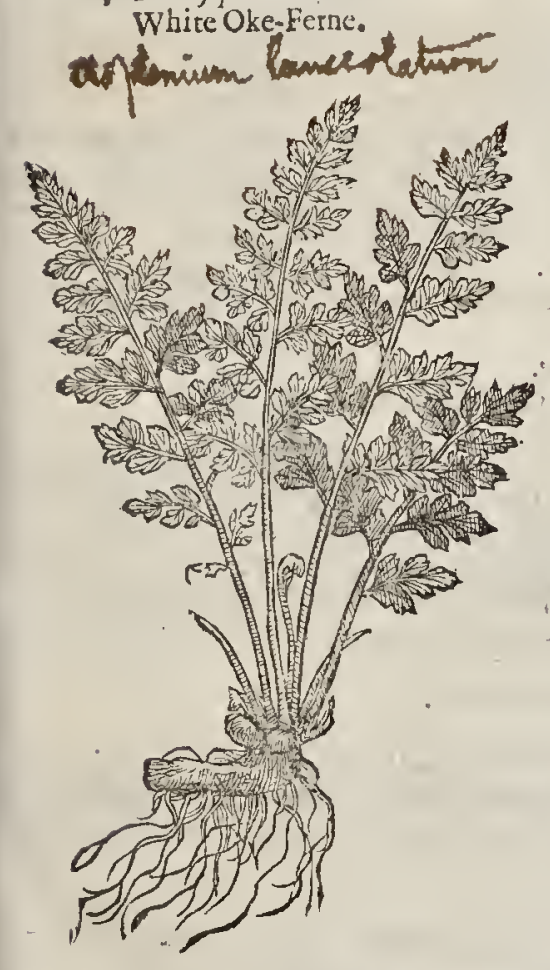

* 3 Dryopteris Tragi. Tree Ferne.

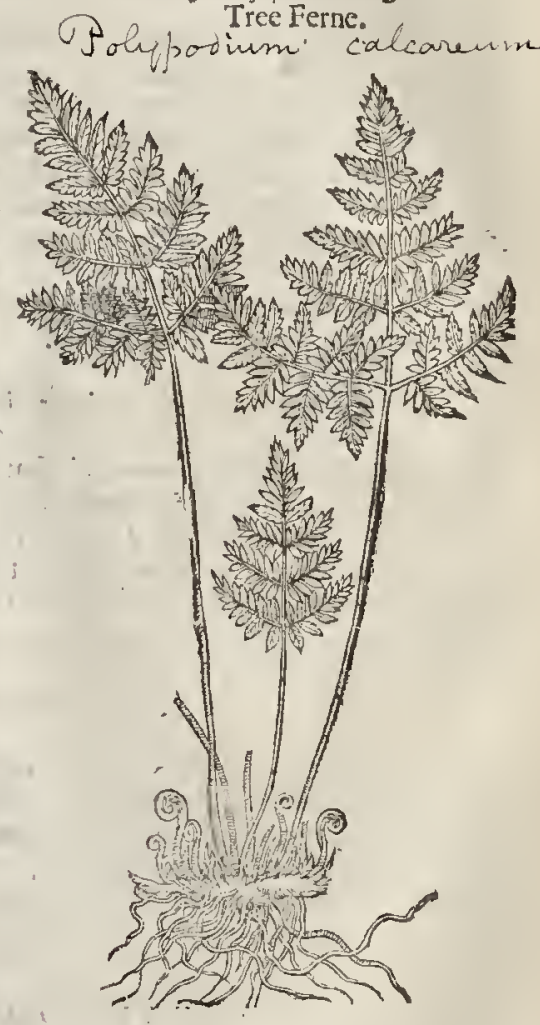

Dryopteris Pind o Lobeliy.

The roots crepe in the ground or mire, neere the tutfe or vpper part thereof, and fold anong fit themfelues, as the roots of Polypodiums do, almoft as big as a wheat ftraw, and about fiue, fix, or feuen inches long, colc blacke witlout, and white within, of a binding tafte inclining to fweetneffe, with an innumerable conpunie of fmill blacke fibres like haires growing thereunto. The ftalkes fpring from the roots in feterall places, in nu n'ber variable, according to the length and encre sfe of the roor; I haue feene fnall p'ant: h ue but one or two, and fome biguer plants haue fourcene or fiftens: they hute but a two-fo't diuifion, the ftalke growing from the root, and the nerue bearing the leaues : the ftalke is about fure, fix, or feten inches long, no bigget that a bennet or finall grafe tzalke, oxe itde $\mathrm{Hz}$, as are the mile Fernes, the reft round, finooth, and grecn. The firte paire onzrites grow a'out three inches fron the roor, and fo do all the reft grow by couples, almolt exasty one arainft another, in number abo.t eight, nine, of ten couples, the longeft feldo ne excedeng an inch in length. The leates grow on thore nerues alfo by conples, eightor nine curles on

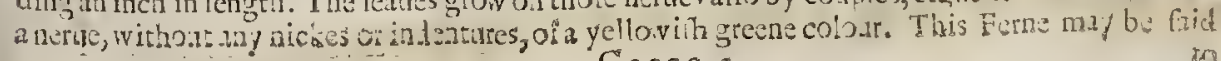


to je like Polypodium in his creeping root, like the male Ferne in his ftalke, and lihe the fomale Ferne in his nerues and leaucs. I could finde no feed-feales on the backefices of any of the leates of this Ferne. Many yeares paft I found this fame in a verywet moore or bog, being the land of Rlchard Auften, called Whitrow Moore, where Peate is now digged, a nile fron Petcrs-field in Hamphire; and this fixth of $1 u l y, 1633$, I digged vp there many plants, and by them made this defcription. I neuer found it growing in any other place : the leaues perifh at Winter, and grow vpagaine very late in the Spring. Ioln Goodyer. Inly 6. 1633.

${ }_{2}$ Dodoneus thus defcribes his: Dryopteris (faith he) doth well refemble the male Ferne, but the leaues are much fmaller, and more finely cut, fmooth on the forefaid, and of a ycllowith green together with the ftalkes and middle nerues; on the backe it is rough as other Fernes, and alfo liueth without ftalke or feed. The root confifts of fibres intricately folded together, of an indifferent thickneffe, here and there putting vp new buds. This is the Adianthum of the eAduer. who affirme the vfe thereof to be fafe, and not pernitious and deleterie, as that of $D$ ryopteris. It thus differs from the former; the leaues of this are not fet direstly one oppofite to another, the diuifions of the leaues are larger and more diuided. The root is more threddy, and creepes not fo much as that of the former.

3 This (which is Clufus his Filix pumila faxatilis prima, and which I takeso be the Dryopteris or

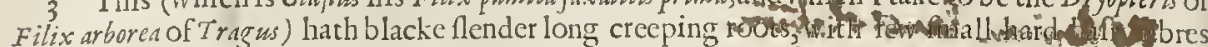
faftened to them, of a very aftringent tafte : from thefe rife vp fundry ltalkes a foot high, duided into certaine branches of winged leates, like to thofe of the female Ferne, but much leffe, tenderer and finer cut, and hating many blackifh fpots on their lower fides. This differs from the two former, in that the leaues arebranched, which is a chicfe difference; and Baubinus did very well obferue it, if he had as well followed it, when he diuided Filix into ramofa o non ramofa. $\ddagger$

$$
\text { I The Place. }
$$

It is oftentimes found in funny places, in the vallies of mountains and little hils, and in the tops of the trunks of trees in thickewoods.

$$
\text { Tा The Time: }
$$

The leaues hereof perith in Winter ; in the Spring new come forth.

$$
\text { I The } 2 \text { ames. }
$$

This is called in Greeke sevainir : in Latine, Querna Filix : Oribafius in his eleuenth book of phy: Iicall Collections calleth it Bryopteris, of the moffe with which it is found; for, as Diofcorides writeth, it groweth in the moffe of Okes. The Apothecaries in timcs paft mifalled it by the name of Adiantum: but they didworfe in putting it in compound medicines in thead of Adiastum. $V$ alerius Cordus calleth it Pteridion: in low-Dutch, Cijcken baten: the Spaniards, Helecho de Roble : it is named in Englifh, Oke-Ferne, Petty-Ferne; and it may moft fitly be called MoffeFerne.

$$
\text { The Temperature and Vertues. }
$$

Oke-Ferse hath many taftes, it is fweet, biting, and bitter, it hath in the root a harfh or choking tafte, and a mortifying qualitie, and therefore it taketh away haires. Diofcorides faith further, that Oke-Ferne ftamped roots and all is a remedie ro root vp haircs, if it be applied to the body after fweating, the fweat being wiped away.

\section{C на Р. 469: Of blacke Oke-Ferne.}

$$
\text { T The Defoription. }
$$

I THere is alfo a certaine other kinde of Ferne like to the former Oke-Ferne of Docionars his defcription, but the falkes and ribs of the leaues are blackifh, and the leaues of $a$ deeper greene colour : this groweth out alfo immediately from the root, and is likewife diuet fly, but not fo finely indented : the root is madevp of many ftrings, not vnlike to the male Ferne, but much leffer.

2 The female blacke Ferne is like vnto the male, fauing his leaues are not fo tharpe at the points, morewhite and btoad than the male, wherein confifteth the difference.

$$
\text { If The Place. }
$$

They grow likcwife vpon ttes in thadowic woods, and now and then in thadow ie fandy banks, and videt ledges. 
I Onopterismas:

The maleblacke Ferne.

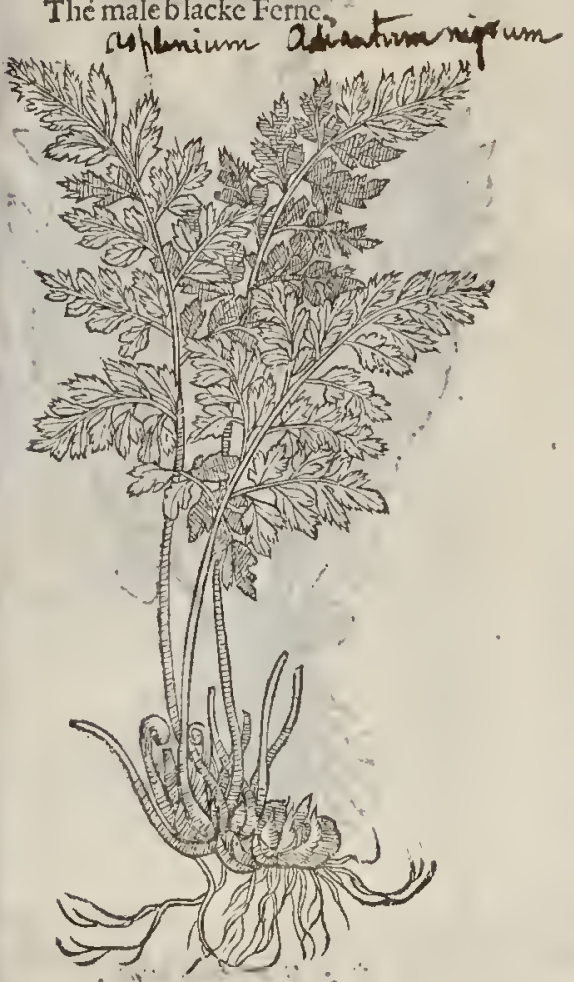

9 Tloc Time.

They remaine greene all the yeare long; otherwife than Polypodic \& Maidens haire do; yct do they not ceafe to bring forth new leaues in Summer: they are deftitute of floures and feed, as is the former.

$$
\text { T The Namis. }
$$

This is called of diuers of the later Herbarifts, Dryopteris nigra, or blacke Oke-Ferne, of the likeneffe that it lath with Dryopteris; which we haue called in Englin, Oke-Ferne, or moffe Ferne : of others, Adumum nigrtum, or blacke Maidens haire, that it may differ from the former, which is falfly ealled. $A d$ antum. There are of rhe later Herbarifts who would haue it to be Lonchutis apera, or rough Spleen-wort; but what likeneffe hath it with the lcaues of Scolopendrium? none at all:therfore it is not Lonchitis apera, mueh leffe $A d$ iantum Pliniy, which differeth not from $A$ diantum Thcophrafis, for what he hath of eidiantum, the fame he taketh out of Theophra. ftus : the right Adrantum we will defcribe hereafter., Notwithftanding blacke Oké Fernewas vfed of duers vnlearned Apothecaries of France and Germany for Adiantum, or Maiden-haire of Lumbardy : but thefe men did erre in doing fo; yet not fo much as they who take Polypodie of the Oke for the true Maiden-haire.

I The Temperature and Vertues.

The blacke Oke. Ferne bath no ftipticke qualitic at all, but is like in facultie to Trichomancs, or Englifh Maidenthaire.

$$
\begin{gathered}
\text { Cна Р. 470. Of Harts-tongue. } \\
\text { वा The Defription. }
\end{gathered}
$$

I Th common kiinde of Harts-tongue, ealled $P$ hyllitis, that is to fay, a plant confifting on-

I' ly of leaues, bearing neither italke, floure, nor feed, refembling in thew a long tongue, whereof it hath been and is called in hops Lingua cerwina, that is, Harts tongue: thefe leates are a foct long, fmooth and plaine vpon one fide, but $v$ pon that fide next the ground ftraked outerthwart with certaine long rough markes like fnall wormes, hanging on the back fide thereof. The root is blacke, hairy, and tw ifted, or fo growing as though it were wound together.

2 The otber kind of Fene, called Phyllitis milt fid a, or Laciniata, that is, iagged Harts rongue, is very like vnto the former, fauing that the leates thereof are cut or iagged like a mans hand, or the palme and browantles of a Deare, bearing neither falke, foure, nor feed.

3. There is another kinde of Hart s-tongue called Hemionitu, wh wich hath bred fome contronerfieamong, writers : for fome haue tooke it for a kinde of Harts-tongue, as it is indeed; others deferibe it as a proper plant by it felfe, ealled Hemionitus, of inemos, that is, Mulser, a Mule, becaufe Mules do delight to feed thereon: it is barren in feeds, ftalkes, and floures, and in thape it agreeth very well with our Harts-tonguc: the roots are compact of many blackifh haires : the leates are fpotted on the backfide like the common Harts-tongue, and differ in that, rhat this Henionitus in the bafe or lowct parts of the leaues is arched after the manncr of a new Moone, or a forked arrow, the yongett and frmalleft leaues being like vnto rhe great Binde-weed, called rolubtlis.

4 There is a kinde of Fernecalled likewife Itemionit is fterilis, which is a very fonall and bafe herbe not aboue a finger high, hauting foure or fiue fmall leaues of the fame fubftance and colour, fpotted on the backe part, and in tafte like Harts-tongue; but the leaues beare the thape of them of Tot abona, or good Henry, which many of our A pothecaries do abufituely take for Mercurie: The roots are very many, fmooth, blacke, and threddic, bearing neither ftalke, fhourc, nor fecd : whis plant. 
I Phyllitis.

Scolobarts-tongue.

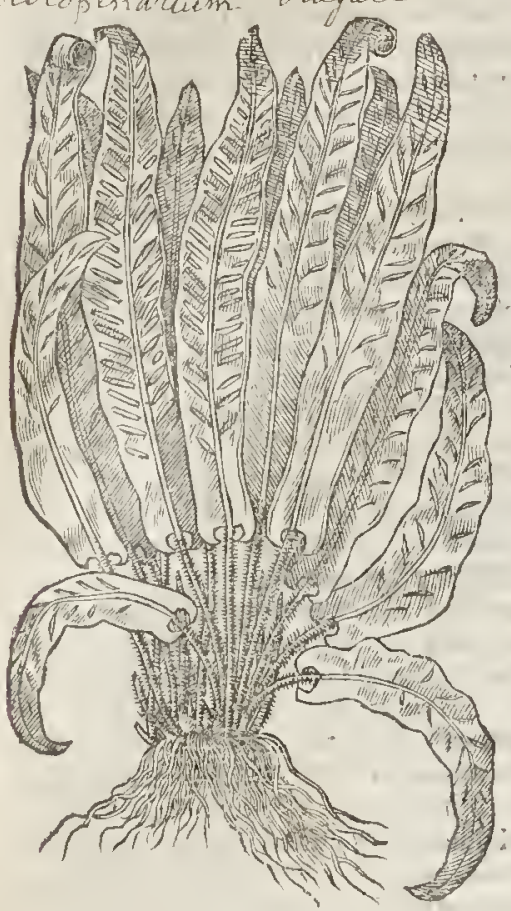

* Henionitis mior.

Mules Ferne, or Moone-Ferne.

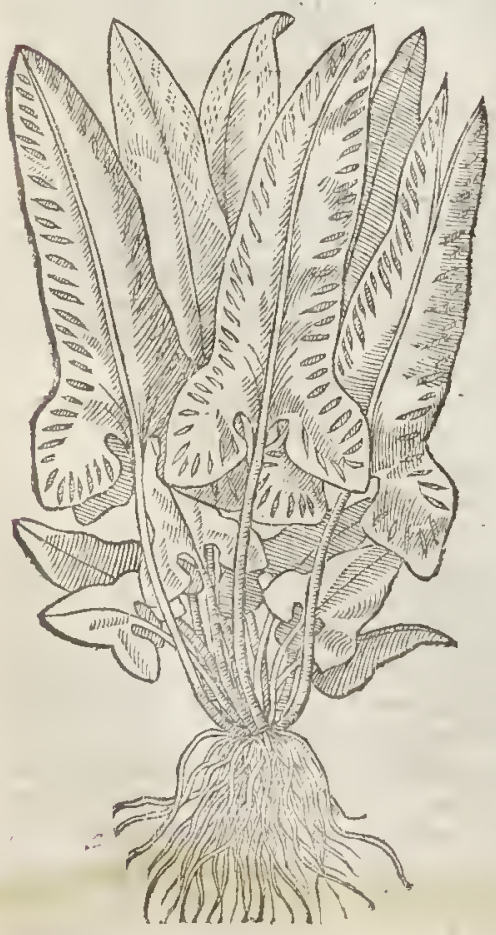

2 Pbyllivis multifida.

Finger Harts-tongue.
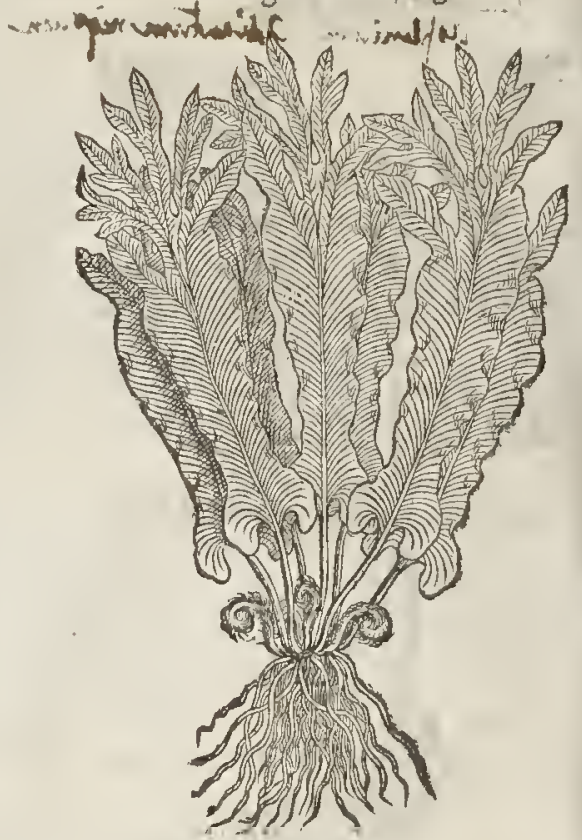

¥ Heraionitis minar. Small Moone-Ferne.

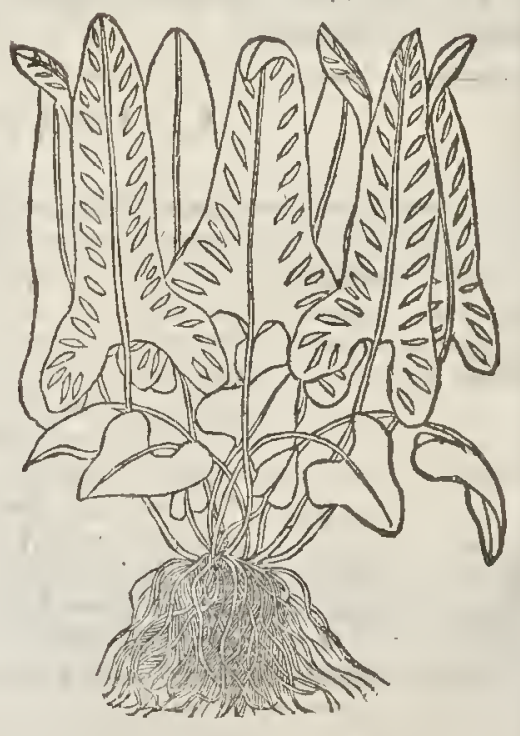




\section{\$ 5 Hemionitispergerina, . Handed Moon-Feñ.:}

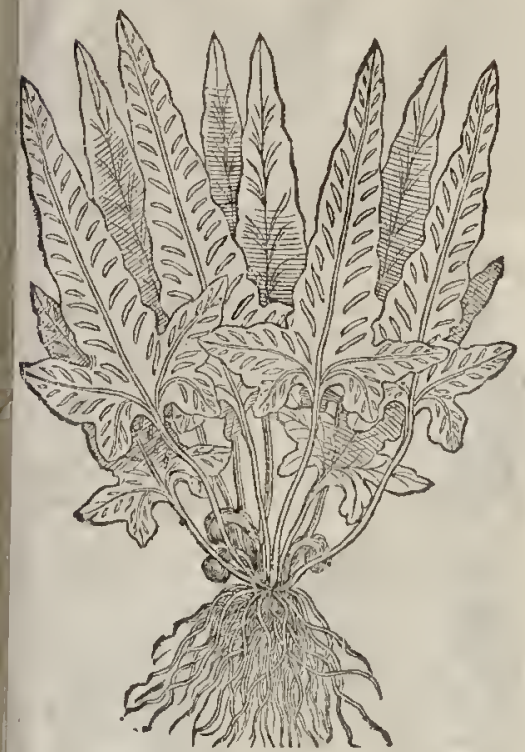

my very good friend $\mathrm{M}^{\mathrm{x}}$. Nicholas Belfon found in a grauelly lane in the way leading to Oxey parke neere vnew Watford, fifteenè miles from London: it growes likewife on the ftone walls of Hampton Court, in the garden of $\mathrm{M}^{\mathrm{T}}$. ' $\mathrm{H}_{\text {ugr }}$ gens, keeper of the faid houfe or pallace.

5 There is a kinde of Ferne called al fo He. mionit is, but with this addition Peregrina, that is very feldome found, and hath leatles very like to Harts-tongue but that it is palmed or brancled in the part next the ground, almoft in manner of the fecond Phillit is, at the top of the leames; 0 therwife they refenble one another in nature and forme.

$$
\text { Tा The Place. }
$$

The common Harts-tongue growerh by the waies fides as you trauell from Lonton to Ex. ceter in great plenty, in hadowie places, and moift ftonie vallies and wels, and is mucli plan. ted in gardens.

The fecond I found in the garden of Mafter Crampich a Chirurgion dwelling at Mtuch-dunmow in Effex, who gaue me a plant for my garden.

$\neq \mathrm{M}^{\mathrm{r}}$.Guodyer found it wilde in the banks of a lane neere Swaneling, not many miles from Southampton. $\neq$

It groweth vpon Ingleborongh hils, and di. uers other mountains of the North of England. T The Time.

It is greene all the yeare long, yet lefiè greene in winter: in Sommer it now and then bringeth forth new leanes.

T The Names.

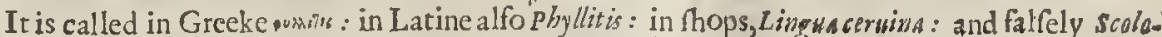
pendria, for it differeth much from the right Scolopendria, or Stone Eerne : it is called in high Dutcl,

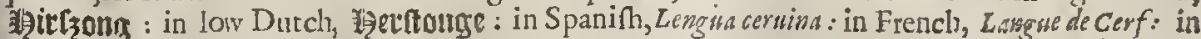
Englin, Harts-tongue : of fome, Stone Harts-tongue : Apuleiws in his 83 . Chapter nameth it $\mathbb{B}_{3}$ diolus.

It is of a binding and drying facultic.

$$
\text { T The Temperature. }
$$

\section{The vertues.}

This common Harts-tongue is commended againt the laske and bloudy flix : Diofcarides teacheth, that being drunke in wine it is a remedie againlt the bitings of ferpents.

It doth open the hardneffe and ftopping of the fpleen and liter, and all other griefes proceeding of oppilations or ftoppings what foeuer.

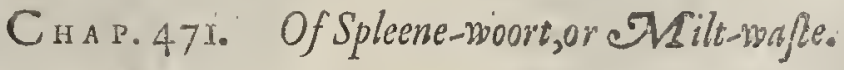

$$
\begin{aligned}
& \text { IT The Defcription. }
\end{aligned}
$$

CPleenc-woort being that kinde of Ferne called $A$ plelensim, or Citerach, and the true ScolopersoSdria, hath leaues a fpan long, iagged or cut vpon both fides, eners hard to the middle ribbe; euery cut or incifure being as itwere cut halfe round (whereby it is knowne from the rough Spleene-woort ) not one cut right againft another,but onebefides the other, fet in fenerull order,being flipperie and greene on the vpper fide, foft and downie vnderneath; which when they be withered are folded vp tngether like a fcrole, and hairie without, much like to the rough Beareworme wherewith men bait their hookes to catch filh : the root is fmall,blecke,and rough, much platted or interlaced, haung neicher ftalke, flourę, nor feeds. 
I Aplcnimm froc Cetcrach. Spleenewoort or Miliwalte.

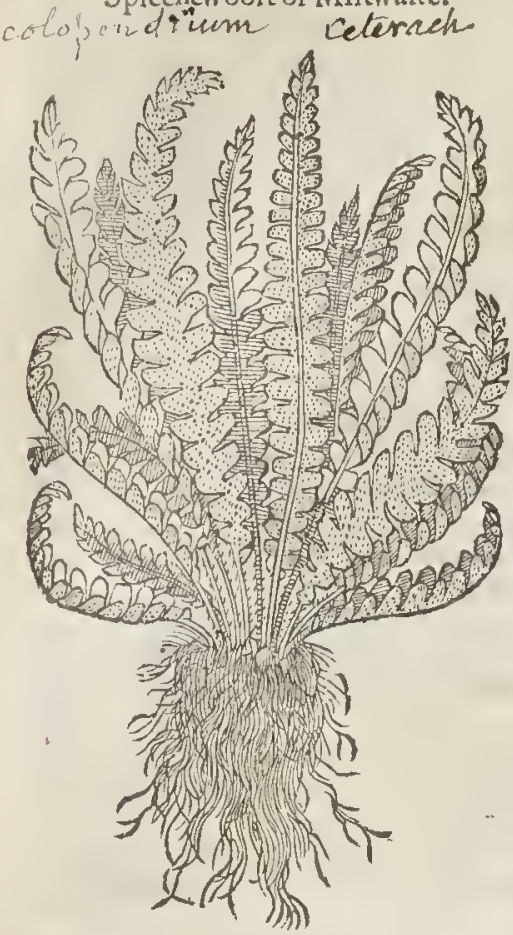

+3 Lonchitis apperamaior. Great rough Spleene-woort; Aspidium Sonchitis

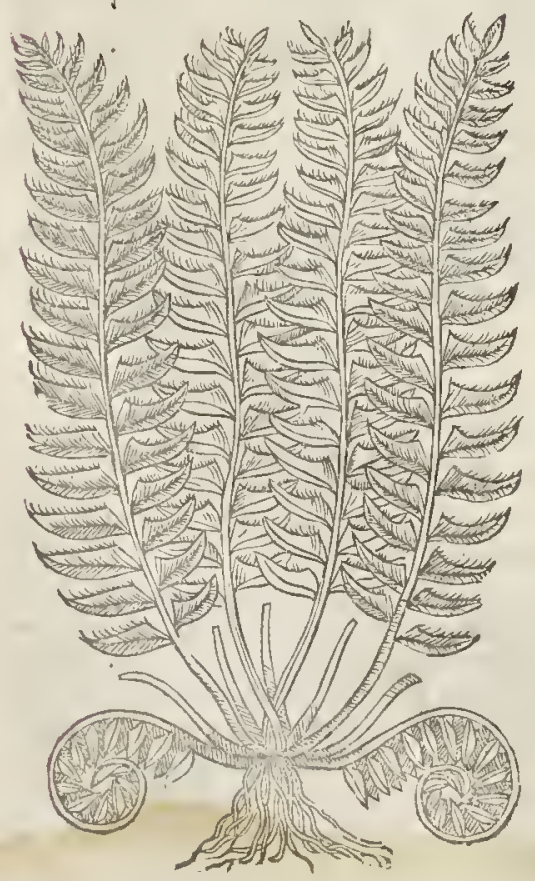

2 Lonchitis apera: Blechnum Rough Splcenewogrt.

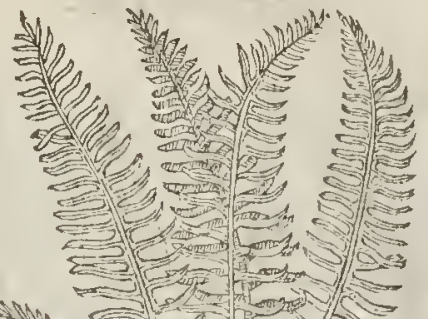
Ditul $\Rightarrow$ D.

S 20 -

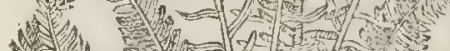
13 年 W t

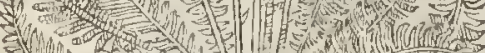

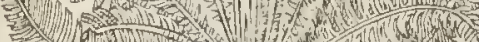
(1)

I 4 Lonchitis Marsmthe. Baftard Splecne-woort.

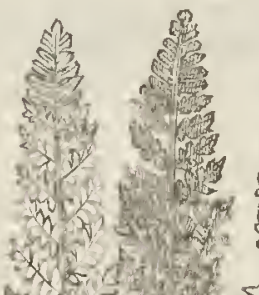
Nis mo

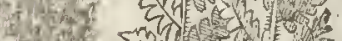

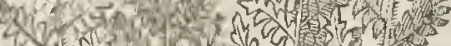
Q a s. है

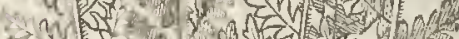

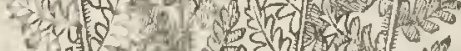

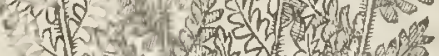
shin son

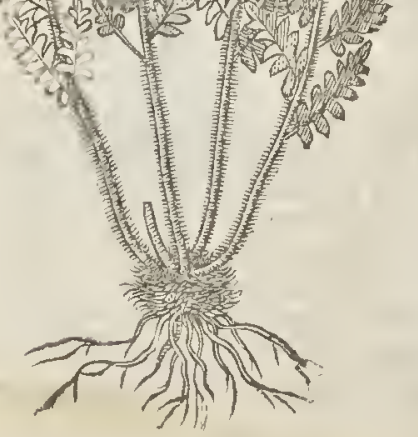


2 Rough Spleenewoore is partly like the other Fernes in thew, and bearcth neither falke nor feed, hauing narrow leaues a foot long, and fomewhat longer, flafhed on the edges euen to the middle rib, fmooth on the vpper fide, and of a fwart greene colour; vnderneath rough, as is the leaues of Polypodie : the root is blacke, and fet with a number of flender ftrings.

¥ 3 This greater 'Spleenwoort hath leaues like Ceterach, of a fpanne long, fomewhat refem. bling thole of Polypodie, but that they are more diuided, fnipt about the edges,and tharpe pointed : the root is fibrous and ftringie. This growes on the rockes and mountainous places of Italy, and is the Lonchit is aperamaior of Matthiolsw and others. $\neq$

4 This kinde of Splecnewoort is not onely barren of ftalks and feeds, but alfo of thofe fpots and marks wherew ith the others are fpotted : the leaues ate few in number, growing pyramidis or fteeplewife, great and broad below, and harper toward the top by degrees : the root is thick, blach, and buhic, as it were a Crowes neit.

$$
\text { The Place. }
$$

Cetcrach groweth vpon old ftone walls and rockes, in darke and thadow ie places throughout the Weft part of England; efpecially vpon the ftone walls by Briftow, as you go to Saint Vincents Rocke, and likewife about Bathe, VVells, and Salisburie, where I hate feene great plentie thereof.

The rough Spleenwoort groweth vpon barren heaths, drie fandiebankes, and thadowie places in moft parts of England, but efpecially on a heath by London called Hampftead heath, where it groweth in great abundance.

$$
\text { ब The Names: }
$$

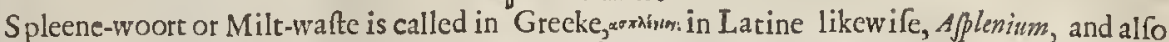
Scolopendria : of Gaza, esula berba : in thops, Ceterach : in high Dutch, Stepufatn : in low Dutch, Stevnuacen, and $\$ 9$ iltcrupt : in Englifh,Spleenwoort, Miltwafte, Scaleferne, and Stoneferne: it is called Aplenion, becaufe it is fpec:all good againft the infirmitics of the Spleene or Milt, and scolopendria, of the likeneffe that it bati: with the Beare-worme, before remembred.

Rough Miltwafte is called of diuers of the laterwriters Ajplenium fylueftre, or wilde Splcenwoott: of fome, Afplenium magrum, or great Spleene-woort: $V$ alerius Cordus calleth it Strutiopteris: and $D_{i-}$ of corides, Lonchitis apera, or rougl Spleene-woort : in Latine according to the fame Authour, Longin a, and Calabrina: in Englifh, rough Splecn-wort,or Miltwafte.

\section{T The Temperature.}

Thefe plants ate of thin parts, as Galen witneffeth,yet are they nothot, but in a meane.

\section{T The Vertues.}

Diofcorides teacheth, that the leaues boiled in wine and drunk by the fpace offorty daies, do take $A$. away infirmities of the fpleen; help the frangurie, and yellow iaundice, caufc the ftone in the bladder to moulder nnd paffe away, all which arc performed by fuch things as be of thinne and fubtill parts: he addeth likew ife that they ftay the hicket, or yeoxing, and alfo hinder conception,either inwardly taken,or hanged about the partie, and therefore, faith Rliny, Spleenewoort is not to be giuen towomen, becaufe it bringeth barrenneffe.

There bc Empericks or blindc practitioners of this age, who teach, that with this herbe not one- $B$ ly the hardneffe and fwelling of the Spleene, but all infirmities of the liuer alfo may be effectually, and in very thort time remooued, infomuch that the fodden liter of a beaft is reftored to his former conftitution againe, that is, inade like vnto a raw liuer, if it bee boyled againe with this herbe.

But this is to be reckoned among the old wiues fables, and that alfowhich Diofcorides telleth of, touch ing the gathering of Spleenewoort in the night, and other moft vaine things, which are found here and there fcattered in old book' : from which moft of the later Writers do not abftaine, who many times fill vp their pages with lies and frimolous toies, and by fo doing do not a little deceitue yong ftudents.

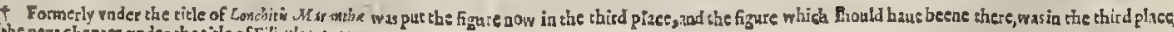
Def ule aext cliapres, inder the title of Filigula petres ma. 


\section{С н Р. 472. Of diuers Jmall Fernes. \\ IT The Defription.}

THis fmall or dwarfe Ferne, which is feldome found except in the tanks of ftony fountaines, wells, and rockes bordering vpon ritiers, is very like vnto the common Brakes in leauss, but altogether lefer: the root is compofed of a bundle of blacke threddic Atrings.

2 The fernale, which is found likewife by running ftreames, wells, and fountaines, vpon rockes, and ftonie places, $i$ s like the precedent, but is a great deale fmaller, blacker of colour, fewer :ootes, and Thorter.

I Filicula fontanamas.

The male fountaine Ferne.

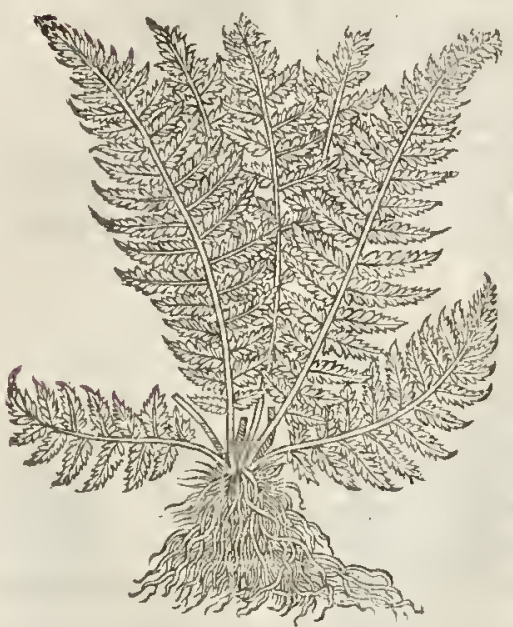

† Filicula petreamas.

The male dwarfe ftone Ferne.

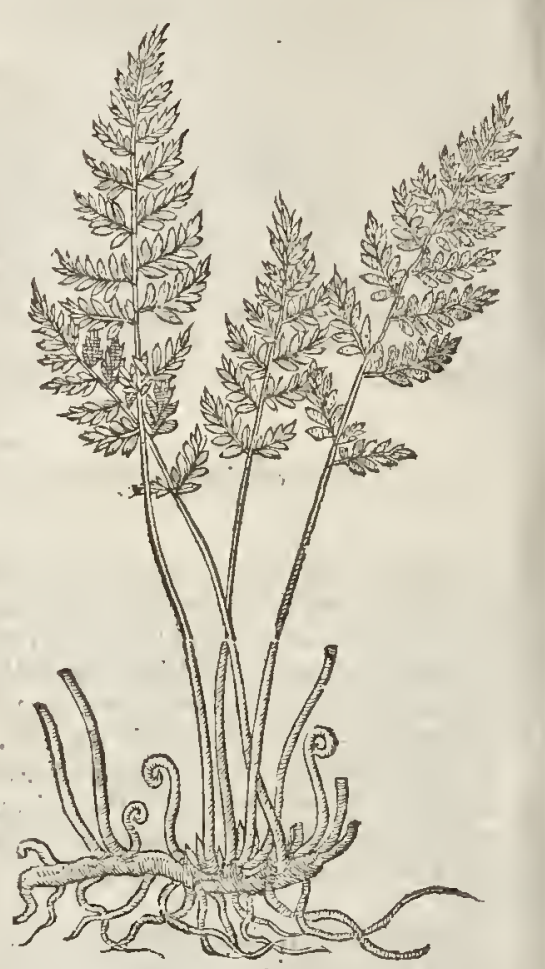

3 The male diwarfe Ferne that groweth vpon the ftonic mountaines of the North and Weft pares of England, efpecially tow ard the fea, and alfo in the ioints of ftone walls among the morecr, harh fmall lcaues deepely cut on both fides, like unto ceterach or Spleene wort, barruborly of feeds and ftalks, as alfo of thofe fpors or markes that are to be feene vpon the backe part of the 0 rher Fernes : the root creepeth along, fetwith fome few hairie ftrings, refembling thofe of the Oke Ferne, called Dryopteris.

4 The female ftone Ferne hath diuers long leaues tifing from a threddy ront, contrarie to that of the male, compofed of many fmal! leaues finely minced or cut like the teeth of a faw, $1^{6}$ a w hi tith green colour, wirlinut any fpots or marks at all, feeds or ftalks, which groweth vnder fha low io rocks, and craggic mountaines in moft places. ‡ From a fmall root compofed of manv blacke. hairie, and intricatcly fo'dung Arings come vp many leaues two on three inches high, fiffe, thicke darke greere, and thining: in the ditifion,growth, pofition, fhape and tafte, it refembles the nale Eernegand hath alforutie fpots on the backe : the middle ribbe and talke is of a hining brow- 
Filicula petraa famina, five Chamafilix marina he female dwarfe ftone Ferne. (unglica. adplenium maninum.

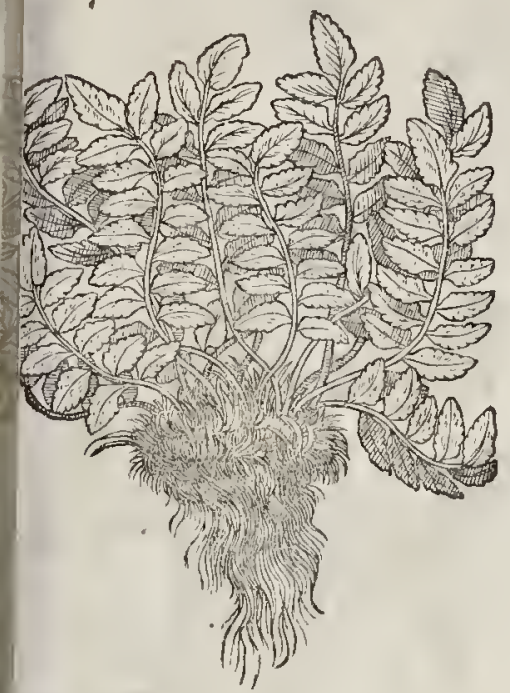

nifh filken colour: it growes in the ebinkes of the roekes by the Sea fide in Cornewall. The Place.

The place is fufficiently touehed in the defeription.

$$
\text { 9I The Time. }
$$

They flourin both Winter and Sommer, for when the leaues wither by reafon of age, there arife young to fupplie the place, fo rhat they are not to be feene without greene and withered leaues both at onee.

\section{The Names.}

It fuffieeth what hath bin faid of the names in their feuerall titles: notwithftanding the lat deferibed we haue ealled Chameflix marina Anglica : whieh groweth vpon the roekie eliffeneere Harwieh, as alfo at Douer, among the Sampire that there groweth.

\section{TT The Temperature and Vertues.}

Their temperature and faculties inworking $A$ are referred vnro the kindes of blaeke Oke Fernes,ealled Dryopteris, and onopteris.

- Te ishard ofay what

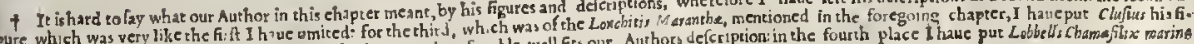

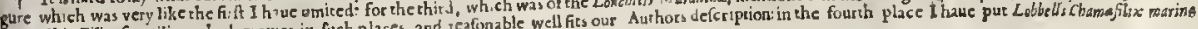
gureof his Filie faxedtits 2 . Which growes, in fach places, and

\section{Cнат. 473. Of true Maiden-baire.}

Ti The Rindes.

$T^{H e o p h r a f t u s}$ and $p l i n y$ haue fet downe two Maiden-haires, the blacke and the white; whereunto; of wewill intreat.

I Capillus Veneris verus.

hiantum Cafidens Veneris.

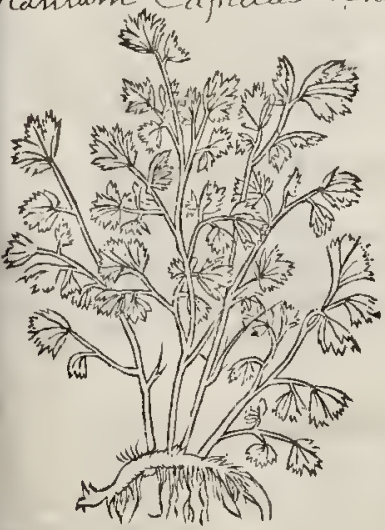

WV

T 7 Horo will follow the variable opinions of writers eoneerning the Ferne ealled Adianthum verum, or Capillus Feneres verus, mutt of neeeffitie be brought into a labyrinth of doubts, confidering the diuers opinions thereof:but this 1 know that Venus-haire,or Maiden. haire, is a low herb growing an hand high, fmooth, of a darke erimfon colour, and glitering withall : the leaues be fmal, eut in funder-and nieked in the edges fomething like thofe of Coriander, eonfufedly or without order plaeed, the middle rib whereor is of a blacke thining eolour : the root confifteth of manie fmall threddie ftrings.

2 This Affrian Maiden-haire is likewife a bafe or low herbe, hauing leaucs, fat, fmooth, and plaine; fet vpon a blackith middle rib, like vnto that of the other Maiden-haire, eut or notched in the edges, nature keeping no eertaine forme, but making one leafe of this fartion, and another far different from it : rhe root is tough and threddie.

3 This plant whieh we haue inferted among the Adianthes as a kinde thereof, may witl nut errour fo paffe, whieh is in great requent in Flanders and Germanie, where the practitioners in Phy. ficke dovfe the fame in tead of Capillus Veneris, and with better fucceffe than any of the Capillare 
herbs,although exatthiolus and Diofcorides himfelfe hath made this wall Rue to be a kinde of $P$ aronychia, or Nailcwoort:notw ithftanding the Germanes wil not leaue the ve thereof,but recciue it as the true Adianth, efteeming it equal, if not far better, than either Geterach, Gapillus Veneris verss, $2 \mathrm{p}^{2}$ Tricomanes, ealled alfo Polytrichon : it bringeth forch very many leaues, round and flender, cut in to two or three parts, tery hard in handling, fmooth and greene on the out fide, of an ill fauroured dead colour vnderneath, fet with little fine fpots, which etridently theweth it to be a kinde of Ferne: the root is blackc and full of ftrings.

2 Capillus Veneris Syriaci.

Alfyrian Maiden haire.

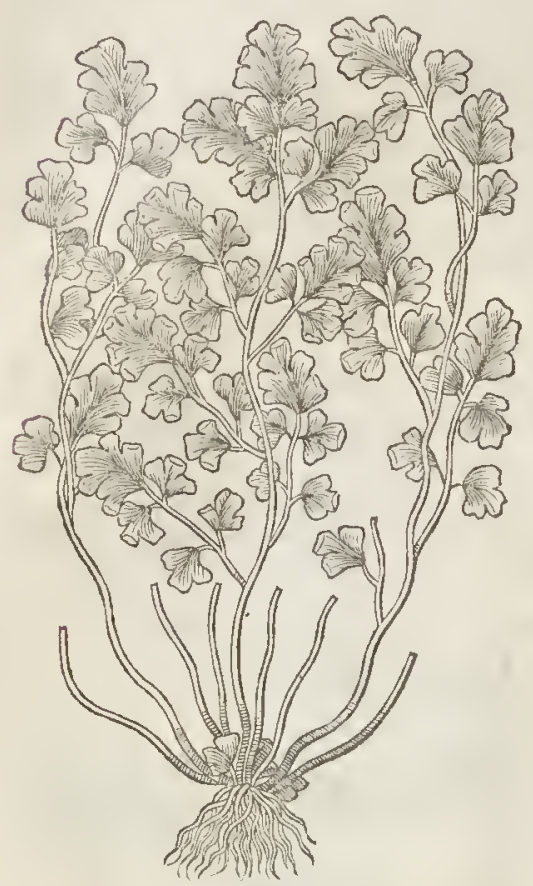

3 Ruta muraria, fove Saluiavite. Wall Rue, or Rue Maiden-hire. A.jeemine Ruta-murarie

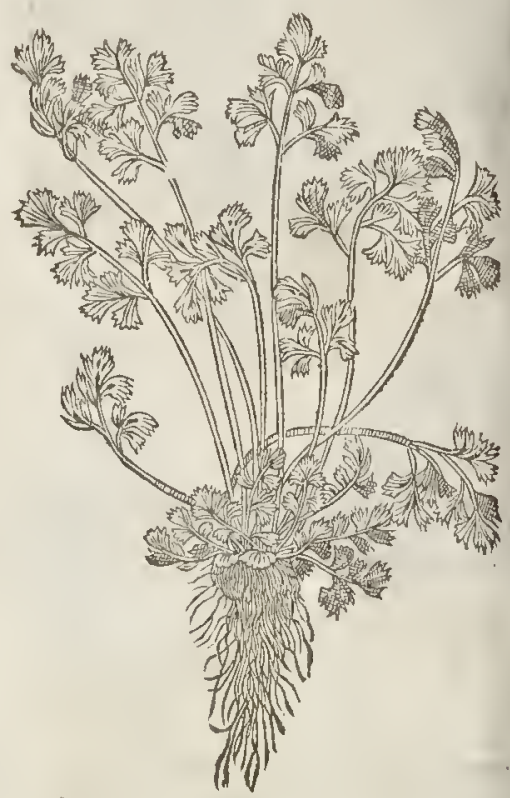

Q The Place.

The right Maiden-haire groweth vpon walls, in ftonic, hadowie, and moift places, necre vnto fountaines, and whcre water droppeth : it is a ftranger in England: notwithftanding I haue heard it reported by fome of good credit, that it groweth in diuers places of the Weft countrey of England. Europe.

The Affyrian Maiden-haire taketh his furname of his natiue countrey Aflyria it is a Aranger in

Stone Rue groweth vpon old walls necre vnto waters,wells, and fountaines: I found it vpon the wall of the churehyard of Dartford in Kent, hard by the riuer fidewhere people ride through, and alfo vpon the walls of the Churchyard of Sittingburnc in the fame Countie, in the middle of the towne bard by a great lake of water, and al fo vpon the Church ivalls of Railey in Effex, and diuers other places.

9 The Time.

Thefe plants are greene both winter and fommer, and yet haue neither floures nor feed.

Tl The Names.

Maiden-haire is ealled in Greck Asár ray : Theophrastus and pliny name it Adismtumnigrum,orblack Maiden-haire : for they fet downe two Maiden-haires, the blackcand the white, making this the

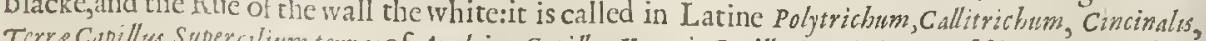
Terre Capillus, Superalium terre: of Apuleiw, Capillus Veneris, Capillaris, Crinita: \& of diucrs, Coriandrum putei: the Italians keepe the name Capillus Veneris : in Englilh, blache Maiden haire, and Venus haire, and it may be called our Ladies haire. 
It is called Adianton becaufe the leafe, as $T$ heophraftis faith, is neuer wet, for it cafteth off water that falleth thereon, or being drowned or courered in water, it temaineth fill as if ir were dry, as $P$ ling likewife writeth; and is termed Callitricon and Polytricon, of the effect it hath in dying haire, and maketh it to grow thicke.

VVall Rue is commonly called in Latine, Rutamuraria, or Rutamuralis: of fome, Salua vite, bus wherefore I know not, neither themfelues, if they were liuing of rhe A porhecaries of the Low Countries Capillus Veneris, or Maiden haire, and they haue vfed it a long t ime for the richt Maiden haire; it is that kinde of Adrantum which Theophraftus termed Adiantum Candidum, or whire Maiden haire, for he maketh two, one blacke, and theother white, as we haue faid. Pliny dorh likewife fet

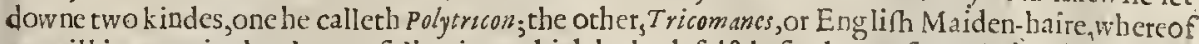
we will intreate in the chapter following, which he hath falfely fet do:vne for a kinde of Adiantum, for Tricomancs doth differ from $A$ diantum.

Some rhere be that thinke, Wall-R!re is Paronychia Diofcoridis, or Dioforides his Whitlow-wort, wherein they haue becn greatly deceiued : it is called in high Dutch, g9autranten:in lo:v Dutch, Stecuenut : in Frencl, Rue de marsille : in Englifh, Wall-Rıe, and white Maiden-baire.

\section{If The Temperature and Vertues.}

'The true Maiden-haire, as Galens teftifieth, doth dry, make rhin,ivafee away, and is in meane be- A tweene heate aud coldneffe: $M$ efues theweth that it cunfilteth of vnlike or difagreeing parts, and that fome are watery and earthy, and the fame binding, and another fuperfieially bot and thinne: And that by this tt taketh away obftuctions or ftoppings, maketh things thinne that are thicke, loofeneth the belly, efpecially when it is frefh and greene: for as this part is thin, fo is it quickly sefolued, and that by reafon of his binding and earthy parts : it ftoppeth the belly, and fayeth the laske and other fuxes.

Being drunise it breaketh the ftone, and expelleth not onely the ftones in the kidnies, but alfo thofe which fticke in rhe pafiages of the vrine.

It raifeth vp groffe and himie humors out of the cheft and lungs, and alfo thofe which ficke in $\mathrm{C}$ the conduits of the winde pipe, it breaketh and raifeth them out by fpetting, if a loch or licking medicine be made thereof.

Mrreouer, it confumeth and wafteth away the Kings-euill, and other hard fivellings, as the $D$ fame Author affirmeth, and it maketh the haire of the head or beard to grow that is fallen and pilled off,

Diofcorides reekoneth vp many vertues and operations of this Maiden-haire, which do not onely $E$ differ, but are alfo contrary one to another. Among others he faith, that the fame fancheth bloud: and a little before, that it draweth away the fecondines, and bringeth downe the defired fickenes : which words do confound one another with contrarieties; for whatfoeuer things do ftanch bloud, the fame do alfo ftay the termes.

He addeth alfo in the end, that it is fowne about theepe-folds for the benefit of the theepe, but $E$ what that benefit hould be, he therveth not.

Befides, that it eannot be fowne, by reafon it is without feed, it is euident, neither can it fitly be $G$ remooucd. Therefore in this place it feemeth that many things are tranfpofed from other places, and fally added to this ehapter : and peraduenture fome things ate brought hither out of dif courfe of Cytifus, or Milke Trefoile, whereof here towrite were to frnall purpofe.

Wall-Rue is not much vnlike to blacke Maiden-haire in temperature and facultie.
Wall-Rue is good for them that haue a cough, that are fhort winded, and that betroubled with I ftitehes and paine in their fides.

Being boiled, ir eaufeth concodion of raw humors which ficke in the lungs; it taketh away $K$ the paine of the lidnies and bladder, it gent ly prouoketh vrine, and driueth forth ftones.

It is commended againft ruptures in young children, and fome affitme it to be excellent good, $L_{\text {; }}$ if the powder thereof be taken continually for forty daies together.

\section{С н а . 474. Of Englifh, or common Maiden-baire.}

\section{The Defcription:}

I $\mathrm{Hg}$ !ifh Maiden-haire hath long leaues of a darke green colour, confining of very many fmall round leaues fet vpon a middle rib, of a hining blacke colour, darhed on the nether fidewith fmall tough markes or fpeckes, of an ouerworne colour: the roots are fmall and threddy. 


\section{6 \\ Of the Hiftory of Plants. \\ L1 в. 2.}

I Trichomanes mas.

The Male Englin Maiden-baire.

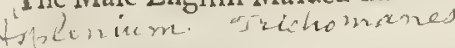

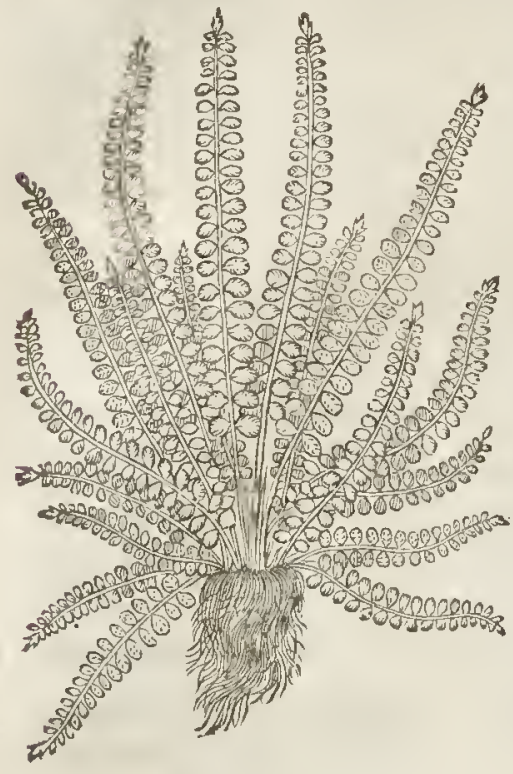

2 The female Englifh Maiden-haire is like vnto the precedent, fauing that it is leffer, and wanteth thofe fpots or markes that are in the other, wherein confifteth the difference. $\ddagger$ Our Authors figure was of the Trochomanes famina of Tabernamontanus, which expreffes a variety with branched lcaues, and thercin only was the differcnee. $\neq$

\section{T The Place.}

It growes for the moft part nere vnto fprings and brookes, and other moift places, vpon old ftone walls and rockes: I found it growing in a fhadowie fandie lane in Betfome, in the parith of Southfleet in Kent, vpon the ground whereas there was no ftones or flony ground necre vnto it, whıch before that time I did neuer fee; it groweth likewife vpon fone walls at her Majefties palaee of Riehmond, $8 x$ in moft ftone wals of the Weft and North parts of England. ¥ $\mathrm{M}^{\mathrm{r}}$. Coodyer faith, that in Ianuary, 1624 . he faw enough to lade an horfe growing on the bancks in a lane, as he rode betweene Rake and Headly in Hampthire ncere Wollmer Forreft. $\neq$

$$
\text { Tा The Time. }
$$

It eontinueth a long time, the coldneffe of winter doth it no harme, it is barren as the other Fernes arc, whereof it is a kinde.

\section{The Names.}

It is called in Greeke, rexiowns: in Latine, Filicula, as though we fhould fay, Parua Filex, or little Ferne, alfo Capillaris: in thops, Capillus Veneris. Apulcius in his .51 chapter maketh it all one with Gallitrichos : of fome it is called Polytrichon: in Englifh, common Maiden-haire.

\section{T The Temperature and Vertues..}

\section{A}

Thefe, as Diofcorides and Galen do write, hauc all the faeulties belonging to Adiantum, or blacke Maiden-haire.

The deeoction made in wine and drunke, helpeth them that are fhort winded, it helpeth the cough,ripeneth tough flegme, and auoideth it by fpitting.

The lie wherein it hath been fodden, or laid to infufe, is good to wath the head, caufing the,

$\mathrm{C}$ feurfe and fcales to fall off,and haire to grow in places that are pild and bare.

\section{Cна в. 475. Of Thiftes. \\ Tा The Kindes:}

T

He matter of the Thiftes is diuers, fome Thifles ferue for nourifhment, as the Artichoke without prickles,and the Artichoke with prickles; otlıer for medicine, as the root of Carline which is good for many things; the bleffed thiftle alfo, orherwife ealled Cardiuzs benedictus; Sea Huluer, and diuers others : fome are poifon fome, as Chamaleon niger; one fmooth, plaine, and without prickles, as the Thifte called Beares Breech, or Acsnthus fatiuns, whereof there is another with priekles, whieh we make the wilde, of the which two we intend to write in this chapter.

$$
\text { Tा The Defeription. }
$$
Eares breech of the garden hath broad leaues, fmooth, fomewhat blaeke, gafhed on both
the edges,and fetwith many cuts and fine nickes:betwecne which rifeth vp in the midit a big ftalke brauely deckt with floures, fet in order from the middle vpward, of colour white, of forme long, which are armed as it were with two earkins, one higher, another lower : after then grow forth the huskes, in which is found broad feed : the roots be blacke without, and white with- 
Branke Vrfinc, and reporteth it to be a citie herbe, and to ferue for arbors : fome name it $E$ rancaVrfma (others vfe tucal Cow-parfnep by the name of Brania Vrfina, but with the addition Germanica:) the Itahans call it Acantho,and Brunca Orfina: the Spaniards, Y erua Giguate: the Ingrauers of old timc werew ont to carue the leaues of this Branke Vrline in pillers, and other works, and alfo vpon the eares of pots; as among others Virgill teftifieth in the third Eclog of his Bucolicks:

$$
\begin{aligned}
& \text { Etnobis idcm Alcimedon duo pocula fecit, } \\
& \text { Etmolli circum eftanfas amplexus Acantha. }
\end{aligned}
$$

\# I take Firgils Acantbus to be that which we now commonly call pyracantha, as I thall hereafter thew when I come to treat thereof. $\ddagger$

The other Branke Vrine is named in Greeke dipeos cxansos:and in Latinc, Sylueftr is Acanthus, or wilde Branke Vrfine, and they may becalled properly Acantha, or Spina,a prickle; by which nane it is found called of inoft Herbarifs, fantbus : yet there is alfo another $A$ canthus a thornie thrub:the

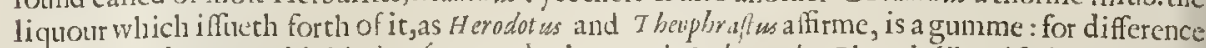
wherof peraduenture this kinde of $\omega$ cambisus is nmed $H . ; .16 a n t b a$ : There is likew ife found anong the baftard names of Acawthus the word Mamolaria, and alfo crepula, but it is not expreffed to which of them, whether to the wilde or tame it ought to be referred.

The Temperature.

Theleaues of the garden Branke Vrfine confilt in a meane as it were betruccne hot and cold, being fomwliat moif, wivith a mollifying and gente digeft ing facultie, as are thole of thc Mallow, and therefore they are profitably boyled in clyfters, as well as Mallow leaues. The root, as Galen teachctl, is of a more diying ptalitic.

$$
\text { 9 T The Vertucs. }
$$

A Diofcorides firth, that the roots are a remed ie for lims that are burnt with fire, and that hauc been out of ioint, if they be laicd thereunto: that being drunke they prouole vrine, and ftop the belly: that they helpe thofe that be broken, and be troubled with the crampe, and be in a confumption of the lungs.

B They are good for fuch as haue the ptificke and fpet blond withal, for thofe that liaue faln from fome high place, that are bruifed and dric beaten, and that haue ouer frained themfelues, and they are as good as the roots of the greater Comfrey, whereunto they are vcrie likc in fubfance,tough iuicc, and qualitic.

C Of the fame root is made an excellent plaifter againft the ache and numneffe of the hands and feet.

D It is put into clyfters with good fuccefic againft fundry maladies.

\section{Сиат. 476. Of the Cotton Thifte.}

\section{IT The Defcription.}

1 THe common Thifle, whereof the grcatcet quantitic of down is gathered for diuers pur-. pofes, as well by the poore to ftop pillowes, cufhions, and beds for want of feather , as alfobought of the riel $V$ pholfters to mixe with the feathers and downe they do fell, which deceit would be looked vnto : this Thiftic lath great leaues, long and broad, gathed about the edges, and fet with tharp and ftife pricliles all alongtt the edges, conered all ouer with a foft cotton or downe: out from the middeft wherenf riferl vp a long ftalke aboue two cubits high, cornered, and fct with filmes, and alfo full of prickles : the heads arc likewife connered with prickles, and bring foorth floures eonfifting of many whitilh thred s: the feed which fucceederth them is wrapped vp in down; ir is long, of a light crimfon coiour, and leffer than the feede of baftard faifron: the root groweth deep in the ground, being white, hard, wooddie, and not without ftrings.

2 The lllyrian eotron thifte hath a long naked root, befet about the top with a fringe of many fmall threals or iags:from winich ariferh a very large and tall ftalkc, hioher than any man, rather like atree than an annull herbe or plant: this ftalkc is garnifned with fcroles of thinne leaues, from the botrome to the top, fer full of moft horrible tharpe prickes, and fo is the falke and euerie part of the plant, fo that it is impoffible for man or beaft to touch the fame without great hurt or darsger: his leanesarevery great, far broader and longer thanany other thifle whatfoeuer, coucred withan hoatie enten or downe like the former: the flotres doe grow at the top of the ftalker, 
L 1 B: 2. Of the Hiftoric of "lants.

which is diuided into fundry branches, and arc of a purple colour, fet or armed round about with the like, or rather tharper thornes than the aforefaid.

I Acantbium Album.

The white Cotton Thille:

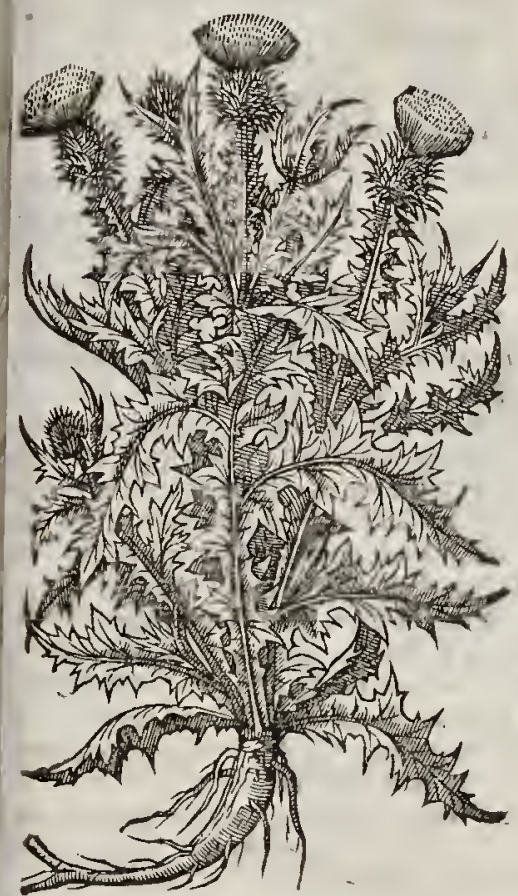

2 Acanthium illyricum purpureum. The purpie Cotton Thiftle.

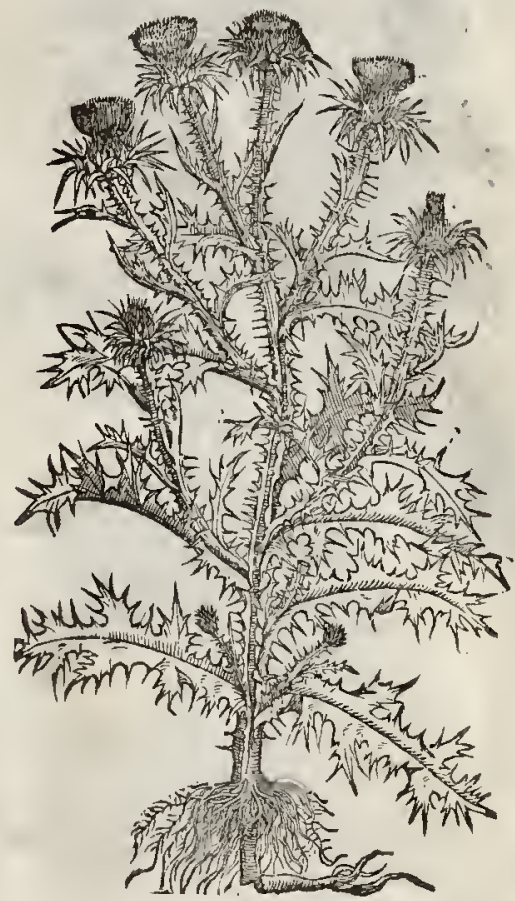

The Place.

Thefe Thiftles grow by high waies fides, and in ditches almoft euery where?

II The Time

They floure from Iune vntill Augut, the fecond yeare after they be fown:and in the mean time the feed waxeth ripe,which being thorow ripe the herbe perifheth, as doe likewife molt of the ether Thiftles, which lue no longer than till the feed be fully come to maturitie.

\section{Tा The rames.}

This Thifte is taken for that which is called in Greekeingatson, which Diofcorides defcribeth to hatue leaues fet with prickles round about the edges, and to be coured with a thin downe like a copweb, that may be gathered and fpun to make garments of, like thore of filke in high Dutch it is called neriftwege oiftll : in Low Dutch, nettee neech Diftel: in French, Chardon argent in : in Englifh, Cotton-Thifle,white Cotton-Thiftle, wilde white Thiftle, Argentine or the Siluet Thifle.

Tा The Temperature and Vertues.

Diofcorides faith, that the leatles and roots hereof are a remedy for thofe that haue their bodies $A$ drawne backwards; thereby Galen fuppofeth that thele are of tempcrature hot.

\section{$\mathrm{C}_{\text {н }}$ P. 477. Ofour Ladies-T biflle。 \\ TI The Defcription.}

$\mathrm{T}$ He leaues of our Ladies Thithle are as bigge as thofe of white Cotton. Thifile:for the leatier thereorbe great,broad, large, gathed in the edges armed with a multitude of it iffe and tharpe prickles, as are thole of Ote-Thiftle, but they are without down,altogether nippery, of a light 


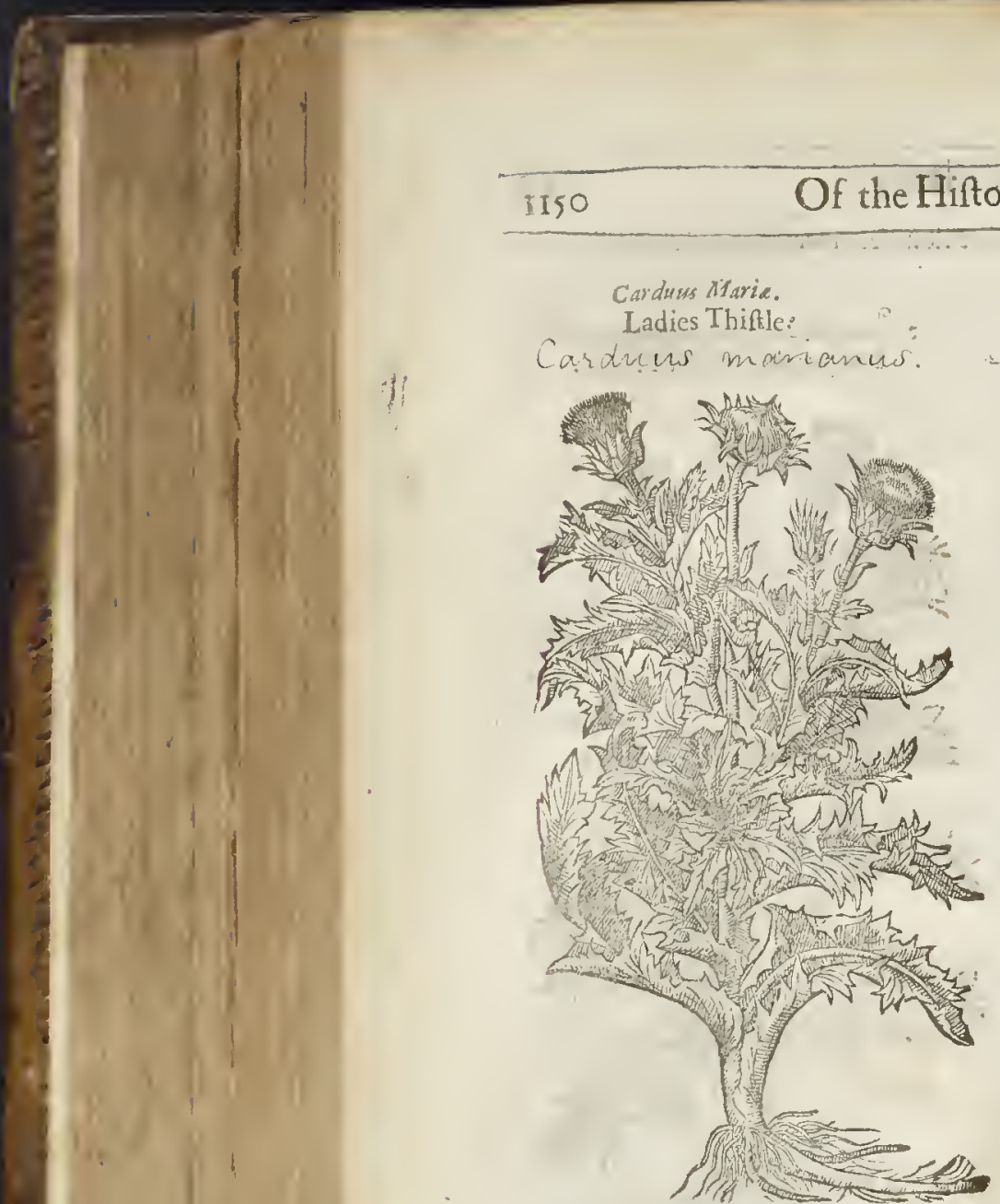

A Galenwriteth, that the roots of Spina alba do drie and moderately binde, that therefore it is good for thofe that be troubled with the lask and the bloudy flix, thar it ftaieth bleedings, waftetl away cold fwellings; cafeth the paine of the teeth if they bee wafhed with the decoetion thereof.

B The feed thereof is of a thin effence and hot facultie, therefore he faith that it is good for thofe that be troubled with cramps.

C Diofcorides affirmeth that the feeds being drunke are a remedie for infants that baue their finews drawne together, and for thofe that be bitten of ferpents : and that it is thought to driucary for pents, if it be but hanged about the necke.

$$
\begin{gathered}
\text { Cна } .478 . \text { Of the Globe Tbiftle. } \\
\text { T The Defcription. }
\end{gathered}
$$

Lobe Thifle hath a very long ftalke, and leaues iagged, great, long, and broad, deeply gafhed Jitrong of fmell, fomewhat greene on the vpper fide, and on the nether fide whiter and downy the floures grow forth of a round bead like a globe, which ftandeth on the tops of rhe ftaikes they are wite and fmall, with blew threds in the midit: the feed is long, with haires of a meane length : the root is thicke and branched.

2 There is another Globe Thifle that hath lefler leaues, but more full of prickles, with round heads alfo: but rhere growe h out of them befides the foures, certaine long and ftifie priclies.

3 There is likew ife another kinde refembling the firft in forme and figure, but much luffer, an the floures thereof tend more to a blew.

4. There is alfo anorher Globe Thifte, which is the leait,and luath the fharpeft pricliles of al the reft : the head is imall; the floures whereof are white, like to thofe of the firft. 


\section{Li B. 2. Of the Hiftory of Plants:}

I Cardrius globofus.

The Globe-Thiftle.

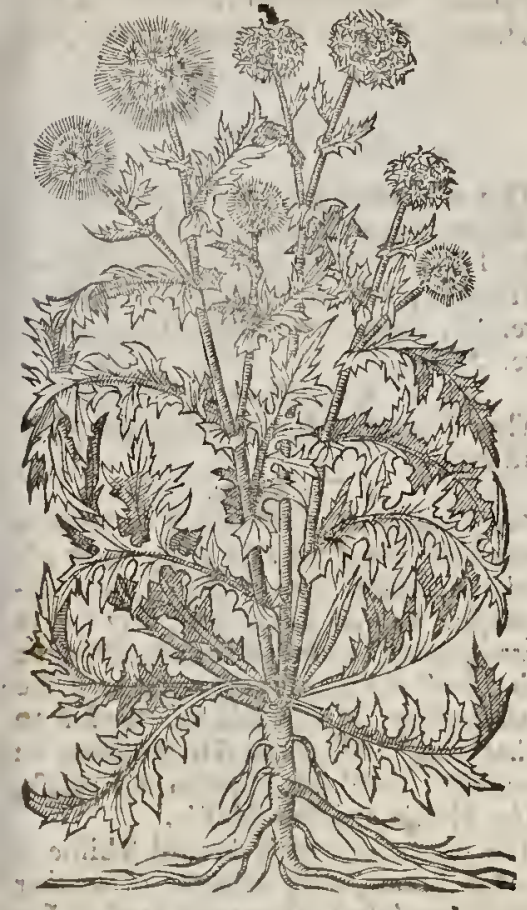

* 3 Carduns globofus minor. Small Globe-Thifle.

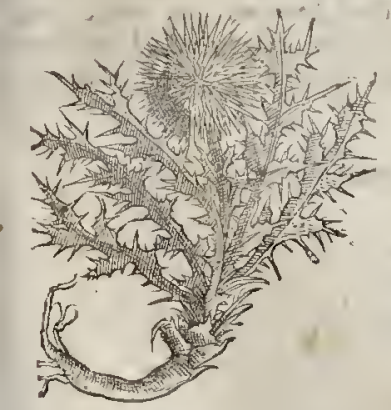

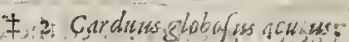

Prickly headed u obe- Thitle.

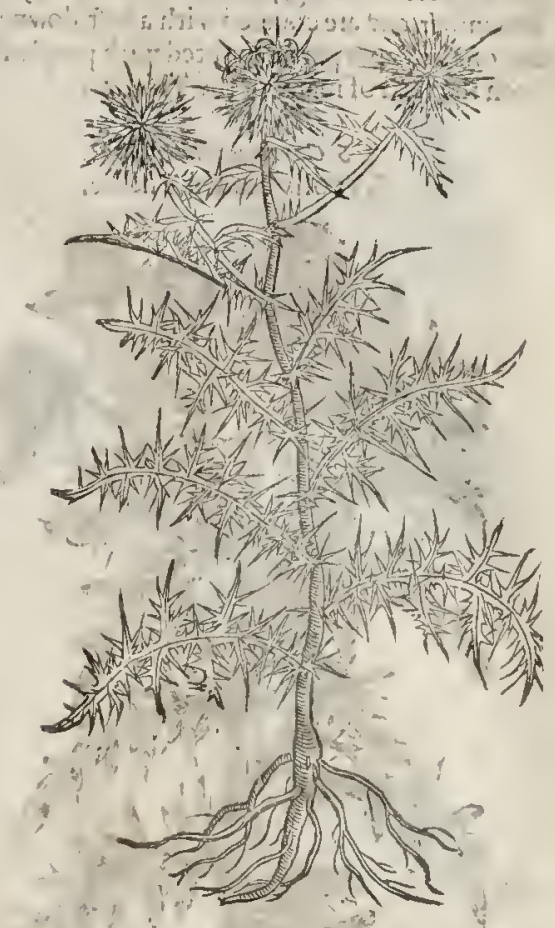

+ 5 Cardisies globo fus capitulo latione. Flat headed Globe-Thiftle.

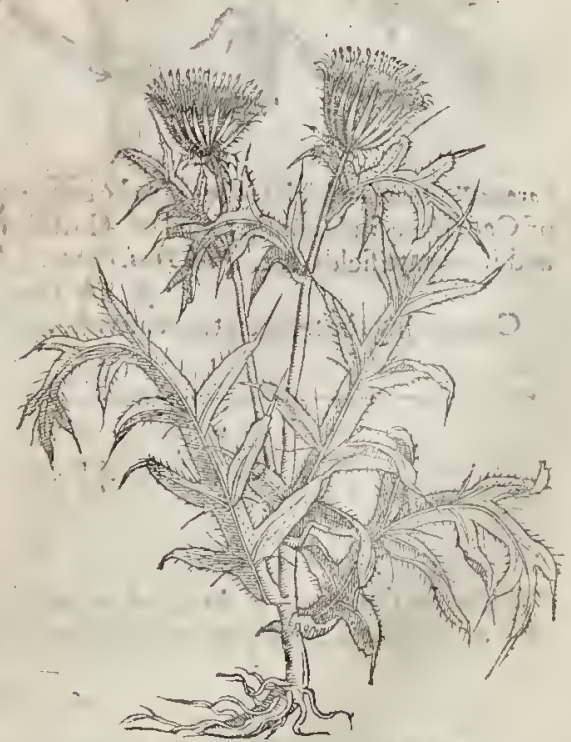

5 There is a certaine other kinde hereof, yet the head is not fo round, that is ro fay, flatter and broader aboue; ont of which fpring blew floures : the falke hereof is flender, and coviered with a white thin downe: the leates are long, ganhed likewife on both fides, and armed in encry corner with harpe prickles:

6. There 
6 There is another called the Down-Thiftle,which rifeth vp with thicke and long ftalks. The leaues thereof are iagged, fet with prickles, white on the nether fide : the heads be round and many in number, and are couered with a foft downe, and tharpe prickles ftanding forth on cuerie fidc, being on the vpper part fraughted wirh purple floures all of frings : the feed is long, and thineth, as doth the fecd of many of the Thiftles.

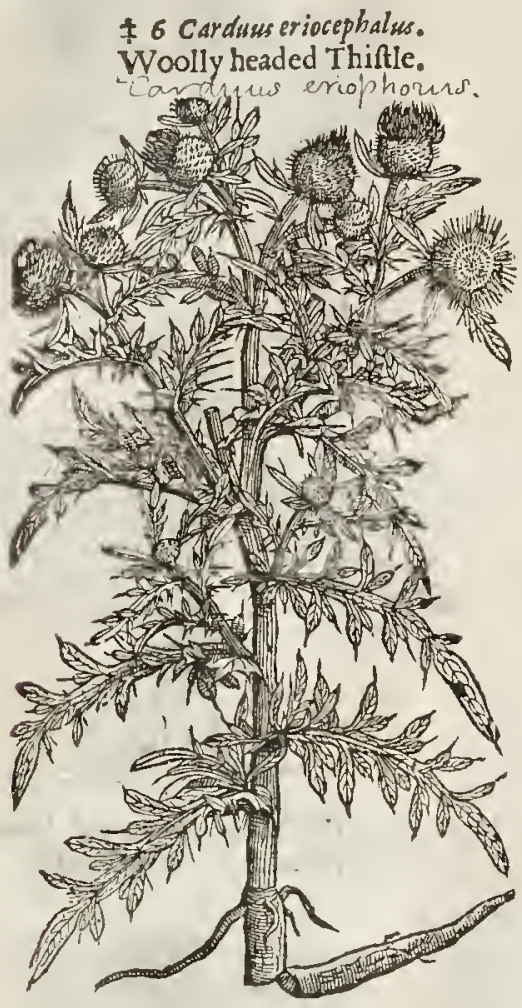

If The Place.

They are fown in gardens, and do not grow in thefe countries that we can finde.

\# I haue found the fixth by Pocklington and in other places of rhe Woides in YorkeShire. $M^{:}$. Goudyer alfo found it in Hamp. Shire. $\neq$

TI The Names.

They floure and flourith when the other Thiltles do.

\section{The Names.}

Fucbiries did at rhe firft take it to be $C b_{a}$ meleon niger; but afrerwards being better aduifed, he named it Spina peregrina, and Cardus us globofus. Valerius Cordus doth firly call it spherocephalss: the fame name doth alfo agree with the reft, for they laue a roand head like 2 ball or g lobe. Moit would haue the firft to be that which crattbiolus fetteth downe for spina alba : this Thinte is called in Englin, Globe Thiftle, and Ball-Thiftle.

The downe or woolly headed Thiftle is called in Latine, being deftitute of another name, Eriocephalus, of the woolly head : in En. glith, Downe Thifte, or woolly headed Thifile. It is thought of diuers to be that which Bartholomeus V, beveteranus and Angelus Palea, Francifcan Friers, report to be called Corona Fratrum, or Friers Crowne : but this Thiftle doth far differ from that, as is euident by thofe things which they hate written concerning Corosa Fratrum; which is thus : In the borders of thekingdome of Aragon towards the kingdome of Caltilewe frnde another kind of Thifte, which groweth plentifully there, by common wayes, and in wheate fields, \&c. Vide Dod.Pempt.5. lib.5.cap.5.

-1 The Teaperature andVcrtues.

Concerning the temperature and vertues of thefe Thiftles we can alledge nothing at all.

\section{C н i P. 479: Of the Artichoke. \\ F The Kindes.}

7 Here be three forts of Artichokes, two tame or of the garden; and one wilde, which the Italian efteemeth greatly of, as the beft to be caren raw, which he calleth cardume

Q The Defcription.

I He leates of the great Artichoke, called in Latine Cinara, are broad.great, long, fetwith deepe gafhes in the edges, wirh a deepe channell or gutter alongft rhe middle, bauing no prickles at all, or very few, and they be of a greene afh colour : the falke is aboue a cubit high, and bringeth forth on the rop a fruit like a globe, refembling at the firft a cone or Pine apple, that is to fay, made vp of many fcales; which is when the fruit is great or loofed of a greenifh red colour within, and in the lower part full of fubltance and white; but when it opens it felfe there growes 
Creator in his fecret wifedome did ordaine thofe furrowes, euen from the extreme point of the leafe ro the ground where it is fanted to the root, for noother purpofebut to guide and leade that water which falls fir off, vnto the root; knowing that w ithout fuch ftore of water the whole plant would wither, and the fruit pine away and come to nothing.

$$
\text { था The Time. }
$$

They are planted for the moft part about the Kaleids of Nouember, or fomewhat fooner. The plant nut be fet and dunged with good ftore of alhes, for that kinde of dung is thought beft for planting thereof. Encry yeare the flips muft be torne or flipped off from the body of the root,and chefe are to be fet in Aprill, which will beare fruit about Auguft following, as Columella, Palladius, and conmon experience teacherh.

$$
\text { बI The Names. }
$$

The Artichoke is called in Latine Cinara, of Cinis, Afhes, wherewith it louth to be dunged. Galen calleth it in Greckc kover, but with $k$ and $v$ in the firft fyllable : of fome it is called Cactos: it is named in Italiu, Carcroffi, Archoccht : in Spanifh, slcarrbofa: in Englioh, Arcichoke:in Frencl,

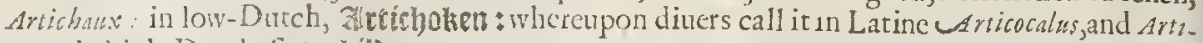
coca : in hish-Duceh, sotrobiionon.

The orler is numed in Latine eommonly not onely Spinof a cinara,or prickly Artichoke, but alfo of Palladist, Cardurs : of che Italians, Cardo, and Cardino : of the Spaniards, Cardos: of the Frenel men, Charduns : Lonburius Fuchjous and mont writers take it to be Scolymus Dioforidis; but Scolymus Diofcorides hath the leafs: of Chamelcon or Spina albo,with a ftalke full of leaues, and a prickly head: but neither is Cinara the Arrichole which is without prickles, nor the Artichok wirli priekles any fuch kinde of lierbe; for though the head hath prickles, yet the ftalke is not full of leaues, but is many times without lenes, or elfe harh not paft a leafe or two. Cinara doch betrer agree with that which Theophroftus and Pliny call kains, Cactus, and yet it doth notbring forth falkes from the root creeping alongft the ground: it hath broad leaues fetwith prickles; rhe middle ribs of the leames, the skin pilled off, are good to be eaten, and likewife the fruit, the feed and down taken away; and that which is under is as tender as the braine of the Date tree: which things Theophroftus and Pliny report of Cactus. That which they write of the falkes, fent forch immediately from the root vpon the ground, which are good to beeaten,is peraduenture the ribs of the leaucs:euerie fide taken away (as they be ferued vp at the table) may be like a falke, except eucn in Sicilia, where they grew only in Theoplsraftus time. It bringeth forth both certaine ftalks that lic on the ground, and anotheralfo ftunding ftraight vp; but alterwards being remoued and brought into Italy or England, it bringeth forth no more bur one vpright : for the foile and clyme do much preuaile in altering of plants, as not onely $T$ beophrafus teacheth, but alfo enen experience it felfe declareth: and of Cactus, Theoplraftus writeth thus; k kems (Cactus) growerh oncly in Sicilia : it bringeth forth prefently from the root talkes lying along von the ground, with a broad and prickly leafe : the ftalkes being pilled ate fit to be eaten, being fomewhat bitcer, which may be preferued in brine: it bringeth forth alfo another ftallie, which is likew ife good to be eaten.

4 The Temperature and Vertues.

A Thenailes, that is, the white and thicke parts which are in the bottome of the outward feales or Alakes of the fruit of the Artichote, and alfo the middle pulpe whereon the downy feed ftands, are eaten both raw with pepper and falc, and commonly boyled with the broth of far fleth, with pepper added, and are accounted a dainty difh, being pleafant to the tafte, and good to procure bodily luft : fo likewife the middle ribs of the leaues being made white and tender by good cherithing and looking to, are brought to the tible as a great fertice together with orher junkets : they are eaten with pepperand falt as be the raw Artichokes : yet both of them are of ill ilyce; for the Artichoke enntuneth plenty of chrolericke iuyec, and hath an hard fubtance, infomuch as of this is ingendred melancholy iuyce, and of that a thin and cholerick bloud, as Galcn teacherh in his book of the Faeulries of nourifhments. But it is beft to eate the Artichoke boyled: the ribbes of the leaves are altogetiner of an hard fubfarce : they yeeld to the body a raw and melanclioly iuice,and containe in them great ftore ofwinde.

B It fayeth the inuoluntaric courfe of the naturall feed either in man or woman.

C Somewrite, that if the buds of yong Artichokes be firft fteeped in wine, and eaten, they prouoke vrine, and ftir vp rhe luft of the body.

D I finde moreotier, that the root is good againft the ranke fmell of the arme-holes, if when the pith is tuken arvay the fame root be boyled in wine and drunke: for it fendeth forth plenty of ftinking vrine, whereby the runke and rammih fauor of the whole body is much amended. 


\section{Cин н.480. Of Golden Thiftles. \\ If The Defcription.}

I THe ftalkes of Golden Thintle rife vp forthwith from the root, being many, round, and branehed. The leates are long, of a beautifull green, with deepe gathes on the ed,es; and fet with molt tharpe prickles : the floures come from the bolome of the leaues, fet in a facite chatfie knap, very like to Sueeorie floures, but of eolour as yellow as gold : in their places come vp broad flat and thin feeds, not great, nor wrapped in downe : the root is long, a finger thieke, fiveet; foft, and good to beeaten, wherewith wine are mueh delighted : there iffueth forth of this thiftle in what part foener it is ent or broken, a inyee as white as milke.

\# There is fome varietic of this Thittle ; for it is found muel larger about Montpelier than it is in Spaine, wrth longer branehes, but fewer floures: the leaues alfo are fpotted or ttreaked with white like as the milke Thifle: $w$ henee Clufius, whom I here follow, harl giren two figures thereof the former by the name of Scolymus Thenphrafti Hi/panicus; and the other by the title of Scolymus Theophrafti Narbonenfis. This with white fpots I faw grow ing this yere with $\mathrm{M}^{\mathrm{t}}$. Tradefcarit at Soutli Lambeth. $\ddagger$

I Cardurs Chryfonthemus Hipanicus. The Spanim golden Thittle.

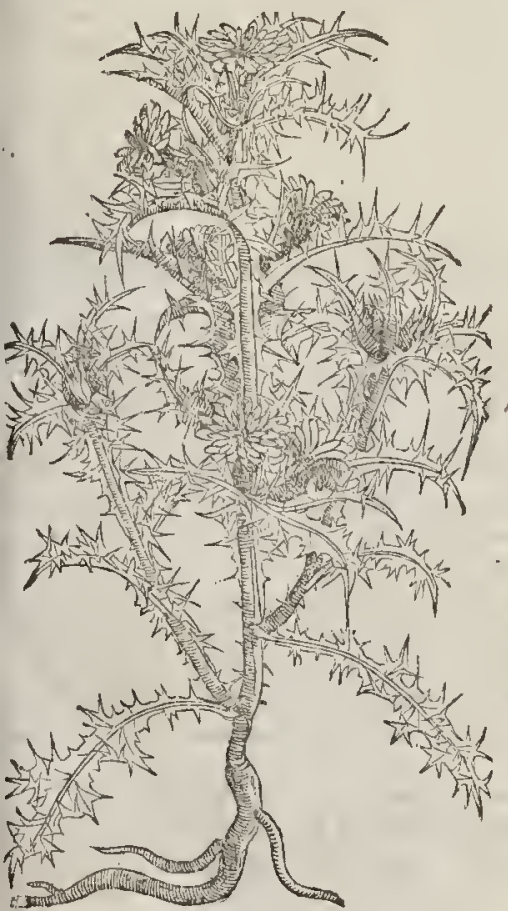

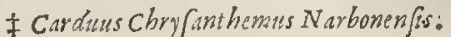

The French golden Thittle.

2 The solden Thittle of Peru, called in the Weft Indies, Fique del Inferno, a friend of mine brought it unto mo from an Ifland there ealled Saint Iolns Ifland, among other feeds. What reafon the inhabitants therehate to eall it fo, it is vnto me unknowne, vnleffe it be becaufe of his fruit, which doth mueh refemble a fig in thape and bigneffe, but fo full of tharpe and venomous prickles, that whof netrer had one of them in his throat, doubtleffe it would fend him packing cither to heaten or to hell. This plant hath a finglewooddy root as big as a mans thumbe, but fomwhat long : from which arifeth a brittle ftalke full of ioynts or knees, diuiding it felfe into fundry other fmall branches, fet full of leaues like vnto the milke Thifte, but much fmaller, and ftraked with many white linesn: ftreakes : and at the top of the italks come forth faire and gondly yellow floures, very like vnto the fea Poppy, but more elegant, and of greater bcauty, hauing in the midet 
thereof a fmall knop or boll, fuch as is in the middle of our wild Poppy, but full of tharpe thorns, and at the end thereof a ftaine or fpor of a deepe purple : after the yellow floures be fallen, this forefaid knop groweth by degrees greater and greater, vntill it come to full maturitie, which openeth it felfe at the vpper end, fhew ing his feed, whieh is very blaeke and round like the feeds of muftard. The whole plant and each part there of doth yeeld verie great aboundance of milkie iuyee, which is of a golden eolour, falling and tffuing from any part thereof, if it be eut or bruifed : the whole plant perifheth at the approch of Winter. The vettues hereof are yet vnknowne vnto me, wherefore I purpofe not to fet downe any thing thereof by way of eonie:tute, but thall, God willing, be ready to deelare that whieh certaine knowledge and expericnce either of myne owne or others, thall make manifet vnto me.

$$
\text { T The Place. }
$$

The golden Thiftle is fowne in gardens of the Low. Countries. Petrus Bellonius writes, That it growetin plentifully in Candy, and alfo in moft places of Italy : Clufurus reporteth that he found it in the fields of Spaine, and of the kingdome of Caftile, and about Montpelier, with ferver branches, and of a higher growth.

The Indian Thifle grow cth in Saint Iohns Ifland in the Weft Indies, and profpeteth very well in my garden.

$$
\text { Tा The Time. }
$$

They floure from Iune to the end of Augut : the feed of the Indian golden Thiftle muft be fowne when it is ripe, but it doth not grow vprntill May next after.

\section{9i The rames.}

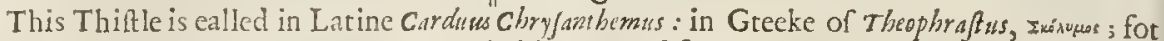
thofe things which he writeth of Scolymus in his fixtb and feuenth bookes doe wholly agree with this Thift le Chry faxt benzus : which are thefe; Scolymus, dorh floure in the Sommer folftiee, braulely and a long time together; it hath a rnot rhat may be eaten both fod and raw, and when it is broken it yeeldeth a milky iuyce: $G$ ata namcth it $C$ ardutus. Of this Pliny alfo makes mention, lib.21,ca, 16 . Scolymus, faith he, differs from thofe hindes of Thiltles, viz. scarna, and Atractilis, beeaufe the root thereor may be eaten boyled. Againe, $L \cdot b .2$, . Cap.22. The Eaft Countries vfe it as a meate : and he calleth it by another name nmusirer. Which thing alfo T beophraftus feemeth to affirme, in his fixt booke; for when he reekoneth vp herbes whofe leaues are fet with priekles, he addeth scolymus, or Limonia.

Notwirhftanding, pliny maketh mention likewife of another Scolymus, whieh hee affirmeth to bring forth a purple floure, and betweene the middle of the ptickes to wax white quiekely, and to fall off with the winde; in his twenticth booke, cap.2 :. Which Thifte doubtleffe doth not agree with Carduus Chryfant bemus, that is, with Theophrafus his scolymus, and with that which we mentioned befote: fo that there be in Pliny two Scolymi; one with a root that may be eaten, and another with a purple floure, turning into downe, and that fpeedily waxeth white. Scolymus is likcwife defcribed by Diofcorides; but this differs from Scolymus Theophrafti, and it is one of thofe which Pliny reekoneth vp, as we wil more at large deelare hereafter. But let vs eome againe to Chry fant herrus : This the inhabitants of Candy, keeping the marks of the old name, do eall Afcolymbros : the Italians name it Anconitani Rinci : the Romans, Spira borda: the Spaniards, Cardon lechar : and of diuers it is alfo named Glycyrrhizun, that is to fay, dulcis Radix, or fweet Root: it is called in Englin, golden Thiftle : fome would haue it to be that whielı Vegetius in Arte Veterinaria ealls Eryzgiums : but they are deceited ; for that Eryngium whereof Vegetius writeth is Erynginm mavinum, or fea Hulucr, ofwhich we will intreat.

The golden Thiftle of Indin nay be ealled Carduts Chryfant hemus, of his golden colour, adding thereto his native countrey Indianus, or Peruakus, or the golden Indian Thiftle, or the golden ThiAtle of Peru : the feed eame to my hands by the name Fique del Inferno : in Latine, Ficus infernalis, the infernall fig, or fig of hell.

\section{T The Tomperature and Vertues.}

A The root and tender leates of this Scolymas, which are fomcrimes caten, are good for the ftomaeke, but they eontaine very little nourihment, and the fame thinne and waterie, as Galen teacheth.

B Pliny faith, that the ront heteof was eommended by Eratof hemes, in the poore mans fupper, and that it is reported alfo to prounke vrine cfpeeially; to heale tetters and dry fcurfe, being taken wrll vineger; and with Wine to ftir vp Hefhly lutt, as Hefrod and Alcaus teftifie; and to take away the ftench of the arme-holes, if an ounee of the root, the pith picked out, be bovled in three parts of wine, rill one patt be wafted, and agood dtaught taken fafting after a bath, and likewife after meat: whicl: 
which later words Diofcorides likewife harh concerning his Scolymoss : out of whon Pliny is thought to haue borrowed thefe things.

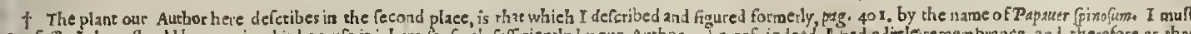

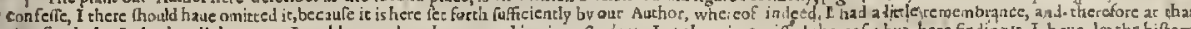
time foughu has Index by all the nanes I could remernber, but not making it a Cardies, I at that eime miffed thereof ; bur here finding ic, I haue les the fiftory ftand as it $w 2 \delta_{8}$ and onely omitted the figure which you may finde before, and fomeching alro is the hiftory not here deliuered.

\title{
С н а F. 48I. Of wbite Carline Thiftle of Diofcorides.
}

\author{
If The Defcription.
}

I The leaues of Carline are very full of prickles, cut on both edges with a multitude of deepe gafhes, and fet along the corners with ftiffeand very tharpe prickles; the middle ribs whereof are fomerimes red: the italke is a fpan high or higher, bringing forth for the molt part onely one head or knap being full of prickles, on the outward circum ference or compaffe like the Vrchin huske of a chefnut : and when this'openeth at the top, there groweth forthabroad floure, made vp in the niddle like a flat ball, of a great number of threds, which is compaffed about with litrle long leaues, oftentimes fomewhat white, very feldome red : the feed vnderneath is flender and narrow, the root is long; a finger thicke, fomething blacke, fo chinked as though it were fplit in funder, fweete of fmell, and in tafte fomewhat bittcr.

\# I Carlinacaule cens magno fore. Tall Carl ine Thift le.

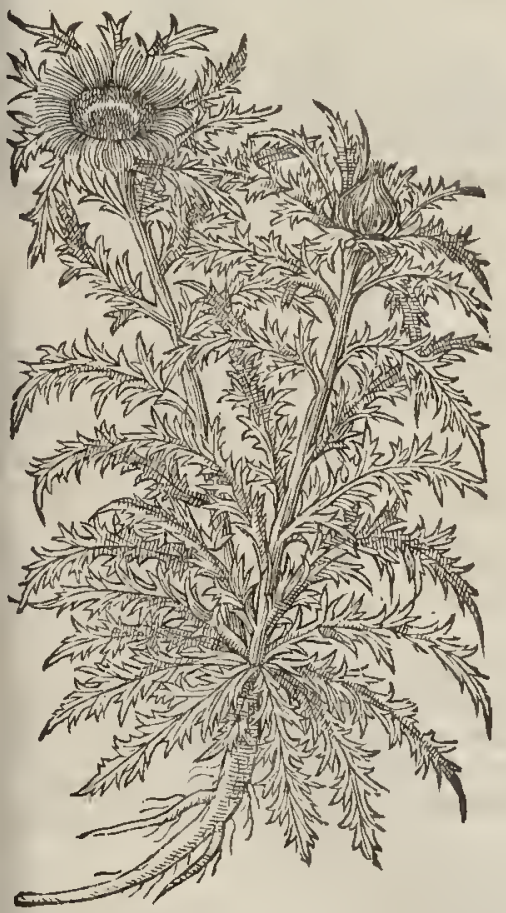

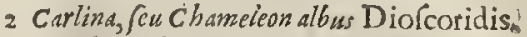
The white Carline Thiftle of Diofcordes with the red floure.

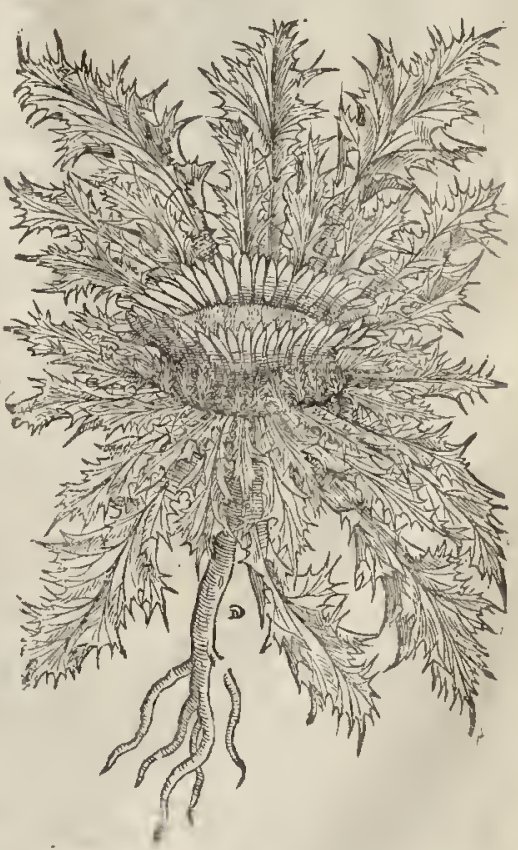

2 There is alfo anothet hereof without a ftalke, wirh leanes alfo very full of prickles, like almolt to thofe of the other, lying flat on the ground on etrery fide: among which there groweth forth in the middle a round head or knap, fet with prickles without after the fame maner, but greater:the floure whereof in the middle is of ftrings, and paled round about with red leaues, and fometimes with white, in faire and calme weather the floures both of this and alfo of the other laie 
3 Carlina acarlos minor flore purp. Dwarfe Carline Thiftle.

Cardens acoulis.

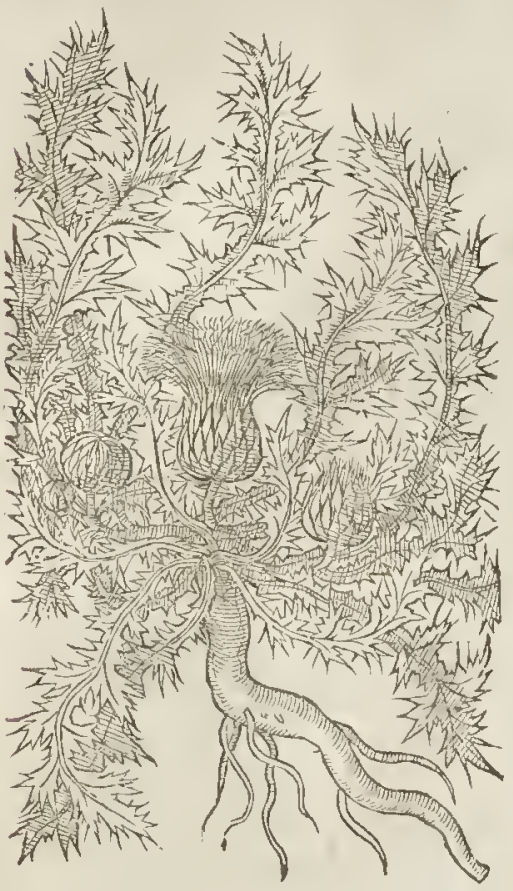

themfelues wide open, and when the weather is foule and mifty, are drawne clofe together : the root hereof is long, and fweet of fmell, white, found, not nicked or fplitted as the other.

\# 3. This fmall purple Carline Thiftle hath a prety large root diuided of times at the top into diuers branches, from which rife many green leaues lying fpred vpon the ground, deeoly eut and fetwith nharpe prickles; in the mid? of thefe leaucs come vp fometimes one, butotherwhiles more fcaly heads, which carry a pretty large floure compofed of many purple threds, like that of the Knapweed, but larger, and of a brighter colour ; thefe heads grow vfually clofe to the leaues, yet fometimes they ftand vpon ftalkes three or foure inches high:when the Houre is palt they turne into downe, and are car ried away with the winde : the feed is fmall and grayith. This growes vpon Blacke-Hcath, vp. on tlue chalky hills about Dartford, and in many fuch places. It floures in Iuly and Augurt. T ra $g$ gus calls it Chamilon albus, vel exigurs; Lobel, Cardutus acaulis, Septentrionalium, and Chameleon albus, Cordi; Cluf (ius, Carluna minor purpureo flore, and he faith in the opinion of fome, it feemes not vnlike to the Chamaleon whereof Theophy aftus makes mention, lib.6.cap. 3. Hifl. plint. $\neq$

$$
\text { If The place. }
$$

They both grow vpon high mountaines in defart places, and oftentimes by high way fides:
but that which bringeth forth a ftalkc groweth enery where in Germany, and is a franger in Eng-
land. land.

\section{They floure and feed in Iuly and Augut, and many times later. T The Names.}

The former is called in Latine, Carlina, and Cardopatium, and of diners, Carolina, of Charlemaine the firft Romane Emperor of that name, whofearmie(as it is reported) was in times paft through the benefit of this root delitered and preferted from the plague :it is called in high Dutch Hetbrmurtz: in low Dutch, Frencl, and other languages, as likew ife in Englifh, Carline, and Carline Thifle: it is Diofcorides his Lcucacant ba the ftrong and bitter roots thew the fame; the faculties alfo are anfiverable, as forthwith we will declare: Leucacamth a hath alfo the otber names, but they are counterfeit, as among the Romanes Gniacardus; and among the Thufcans, Spira alba, or white Thiftle, yet doth it differ from that Thiftle which Diofcorides calleth Spina alba, of which he allo writting apart, doth likewife attribute to both of them their owne proper faculties and operations,
and the fame differing.

The later writers do alfo call the other Carlina altera, and Carlima humilis, or minor, low or little Carline: but they are much deceited who go about to referre them both to the Chamæleons; for for many, Petrus Bellowius, in his fift booke of Sinanixlcons do neurer grow, as there is one witneffe for many, Petrus Bellowins, in his fift booke of Singularities, who fuificiently declareth what diffeby the defeription of the Chamxleons.

\section{T The Temperature and Vertups.}

A The rnot of Carline, which is chicfely vfed, is hor in the later end of the fecond degree, and dry in the third, with a thinnes of parts and fubitance; it procureth fweate, it dritech fortl all kinde of wormes of the belly, it is an enemy toall maner of poifons, it doth not onely drite away infections
of the plague, but alfo eute th the fame, if it te drunke in time.

B Bcing cherved it helpeth the tooth-ache ; it openeth the ftoppings of the liter and fplecae.

C It prouloketh vrine, bringeth downe the menfes,and cureth the dropfic.

D. And it is giuen to thofe that haue been dry beaten, and fallen from fome high place. 
The like operations Diofcorides hath concerning Leucacantha : Leucacantha (faith he) hath a root $\mathrm{E}$ like Cyperus, bitter and ftrong, which beng chewed eafeth the paine of the teeth : the decoction thereof with a draught of wine is a remedie againft paines of the fides, and is good for thofe that haue the Seiatica or aele in the huekle bones, and for them that be troubled with the crampe.

The iuyce alfo being drunke is of like vertues.

\section{C на г. 482. Of wilde Carline Thifle. \\ The Defription.}

I THe great wilde Carline Thitle rifeth vp with a falke of a cubit high or higher, diuided

1 into certaine branches: the leaues are long, and very full of prickles in the edges, like thofe of Carline: the floures giow alfo vpon a prickely head, being fet with threds in the middeft, and paled round about with a little yellowifh leates : the root is flender, and hath a twinging talte.

2 Carolus Clufus defcribeth a ccrtaine other alfo of this kinde, with one onely ftalke, flender, fhort, and not aboure a hand full high, with prickly leaues like thofe of the uther, but leffer, both of them coucred with a certaine hoary downe: the heads or knaps are for the molt part two, they haue a pale dow ne in the mid $t$, and leates Itanding round about, being fomewlat ftiffe and yellow: the root is flender, and of a reddih yellow.

1 Carlinafylueftris maior.

The great wilde Carline Thitle. Parlina vulqaris

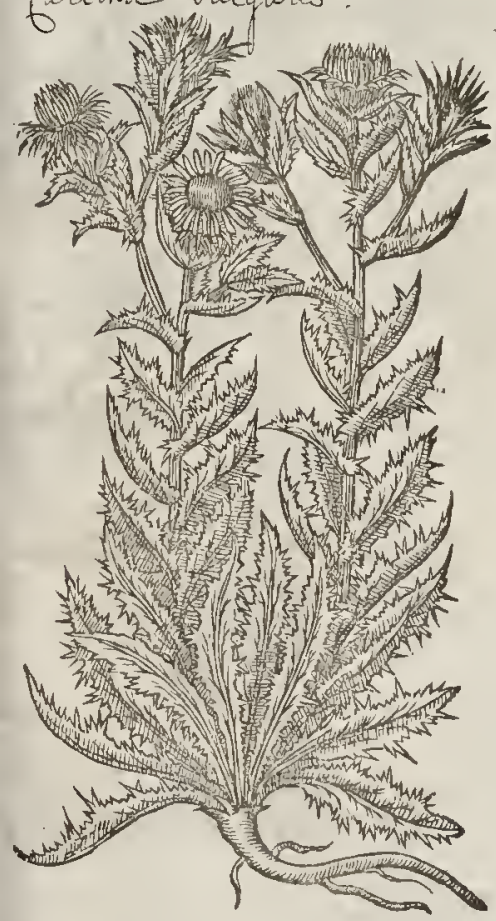

2 Carlina fluefris misor. The little wilde Carline Thi@le.

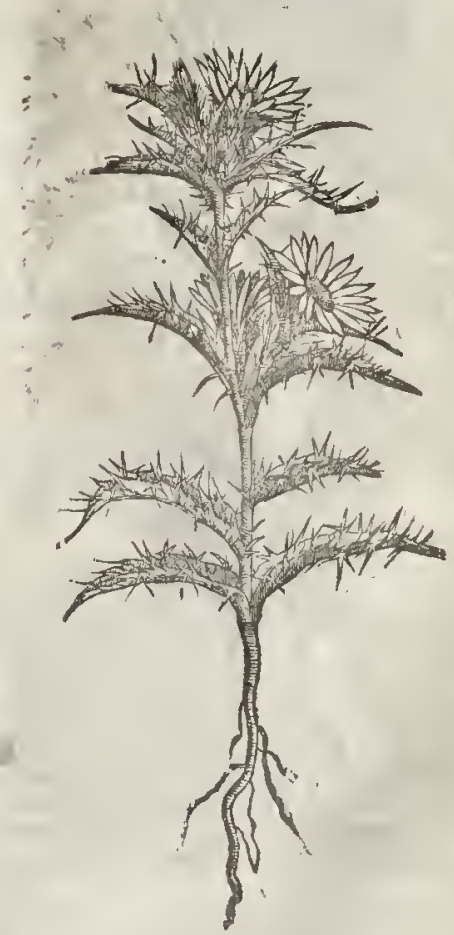

If The Place.

The oreat Carline is found in vntoiled and defart places, and oftentimes vpon hills. $¥$ It grows etl: ypon Blacke Heath, and in many other places of Kent. $\ddagger$

'The leffer Carline Carolus Clufaus writeth that he found growing in dry itony and defart places.' about Salmantica a city of Spaine.

Eeece 2 
They foure and flourith in Itne and Iuly.

$$
\text { q The Time. }
$$

$$
\text { (7) The Names. }
$$

It is commonly called in Latine, and that not vnfitly, Carlina fylueftris for it is tike to Carline in flotres, and is not very vnlike in leaues. And that this is $\mathrm{Ampm}_{\mathrm{m}}$, it is fo muteh the harder to affirme, by how mueh the briefer Theophraflus hath written hereof, for he faith that this is like baftard faffron, of a yellow eolour and fat iuyee : and Acoma differs from LA curna; for LAcama, as Hefychans faith, is the Bay tree; but Acorna is a priekly plant.

T) The Temperature and vertues.

It is hot, efpeeially in the root, the twinging tafte thereof doth declare; but fecing it is of no ufe, the other faculties be vnfearehed out.

\section{C на г. $483^{\circ}$ Of Chamaleon Thiftle. \\ I The Kindes.}

THere be two Chamxleons, and both blacke : the vertues of their roots do differ, and the roots themfelues do differ in kinde, as Theophrafus declareth.

t 1 Chamaleonniger.

Theblacke Chamxleon Thiftle.

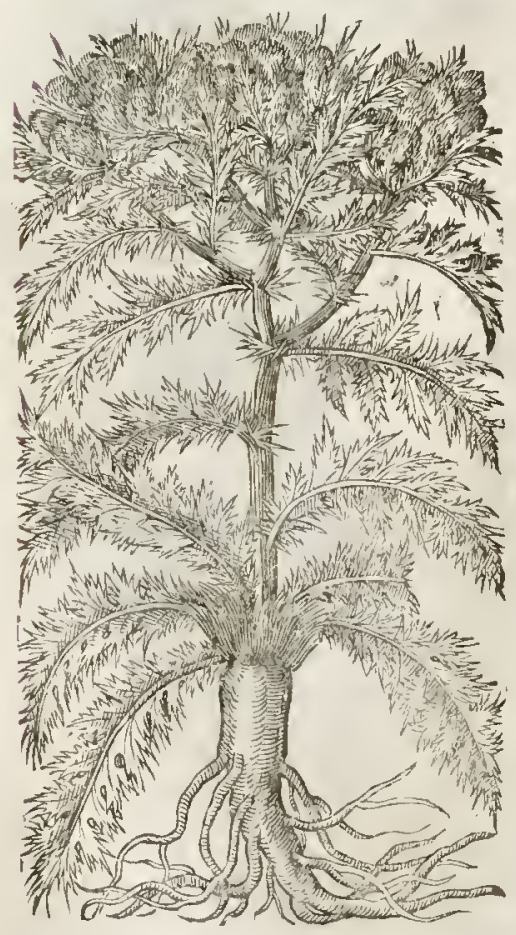

2 Chameleon niger Salmanticenfis. The Spanifi blacke Chamxleon.

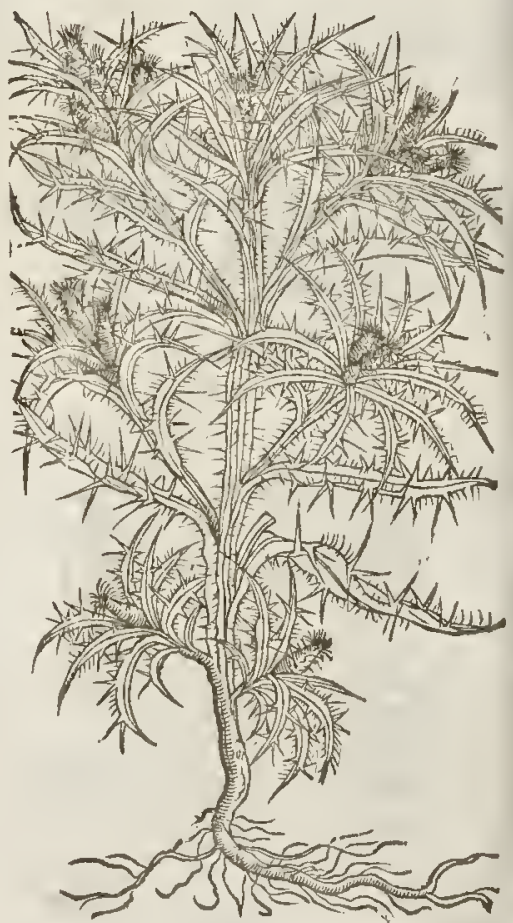

The Defcription.

I Heleaues of blacke Chamæleon are leffer and flenderer than thofenf the prickely Artielsoke, and fprinekled with red fpots : the ftalke is a cubit high, a finger thicke, and fonewhat red : it beareth a tufted rundle, in which are flender priekely floures of a blew colour like the Hyaeinth. The root is thicke, blacke without, of a elofe fubftanee, fometimes eaten away, which being cut is of a yellowifh colour within, and being chewed it bites the tongue. 
2 This blacke Cham greene, in a manner white: the ftalke is chamfered, a foot high, and diuided into branches, on the tops whereof ftand purple floures growing forth of prickly heads : the root is blacke, and fiveet in raftc. This is defcribed by Clufus in his Spanilh Obferuations, by the name of Chame'eon Salman. ticenfis, of the place wherein he found it : for he faith that this groweth plentifully in the territory of Salmantica a city in Spaine : but it is very manifeft that this is notblacke Cham elcon,neither doth clufins affirme it.

$$
\text { The Place }
$$

It is very common, faith Bellonius, in Lemnos, where it beareth a floure of fo gallant a blew, as that it feemeth tocontend with the skie in beaticie; and that the foure of Blew-Botrle bcing of this colour, feemes in comparifon of it to be but pale. It groweth alfo in the fields necre Abydim, and hard by the riters of Hcllefpont, and in Heraclea in Thracia.

Chamelcon Salmanticengs groweth picntifully in the territoric of Salmantica a city in Spaine,

$$
\text { q The Time. }
$$

They flourc and flourith when the other Thiftes do.

\section{The Names.}

The blacke Chame?'con is caller' in Grecke xaman pixas : in Latine, charseleon niger : of the Ro: mans, Cartizus niger, and I crnilas : of fone, Crocodilion: in Englifh, the Chamaleon Thifte, or the Thille that changeth it fere into nany thapes and colours.

\section{The Temperature andrertues.}

The roothereof, as Galen faith, containeth in it a deadly qualitic : it is alfoby Nicander num- $A$ bred among the poyfonous herbes, in his booke of Treacles; by Diofcorides, li6. 6 . and by Paulus Egineta : and thctefore it is vfed only outwardly, as for fcabs, morphewes, tettcrs, and to be briefe, for all fuch things as ftand in necd of clenfing: moreouer, it is mixed with fuch things as doe diffolue and mollific, as Galen faith.

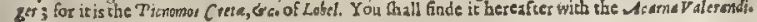

\section{Cha p. 484: Of Sea Hilly. \\ QT The Kindes.}

Iofcorides maketh mention oncly of one fea Holly : Pliny, lib. 22. cap. 7. fecmes to acknow: lcdge $t w o$, one growing in rough places, another by the fca fide. The Phyfitians after thern hatic obfcrued more.

\section{The Defeription:}

I Ea Holly hath broad leates almon like to Mallow leaucs, but cornered in the cdges, and fet round about with hard prickles, fat, of a blcwinh white, and of an aromaricall or fpicie taftc : the ftalke is thicke, aboue a cubit high, now and then fomewhat red bclow : it breaketh forth on the tops into prickly or round hcads or knops, of the bignefle of a Wall-nut, held in for the moft part with fix prickely leaues, compaffing the top of the ftalke round about : which lcaules as wel as the heads are of a gliftring blew : the floures forth of the heads are likcwife blew, with white threds in the midft: $t^{\prime} \mathrm{g}$ roor is of the bigneffe of a mans finger, very iong, and fo long, as that it cannot be all plucked vp, vnleffe very feldome; fet here and there with knoss, and of tafte fiweet and pleafane.

2 The leaties of the fecond fea Holly are dituerfly cut into fundry parcels, being all ful of prickles alongft the edges : the ftalke is diuided into many branches, and bringeth forth prickly heads, but lefier than thofe of the other : from which therc alfo grow forth bletw foures, feldome yellow : there ftand likew ife vnder enery one of thefe, fix rough and prickly leates like thofe of the uther, but thinner and fmaller : the root hereof is alfo long, blacke without, wh tre within, a finger thicke, of rafte and fimell like that of the other, as bcalfo the leatucs, which arclikewife of an aromaricail of fricic tafte, which being new fprung vp, and as yet tender, be alfo good to be eaten, 

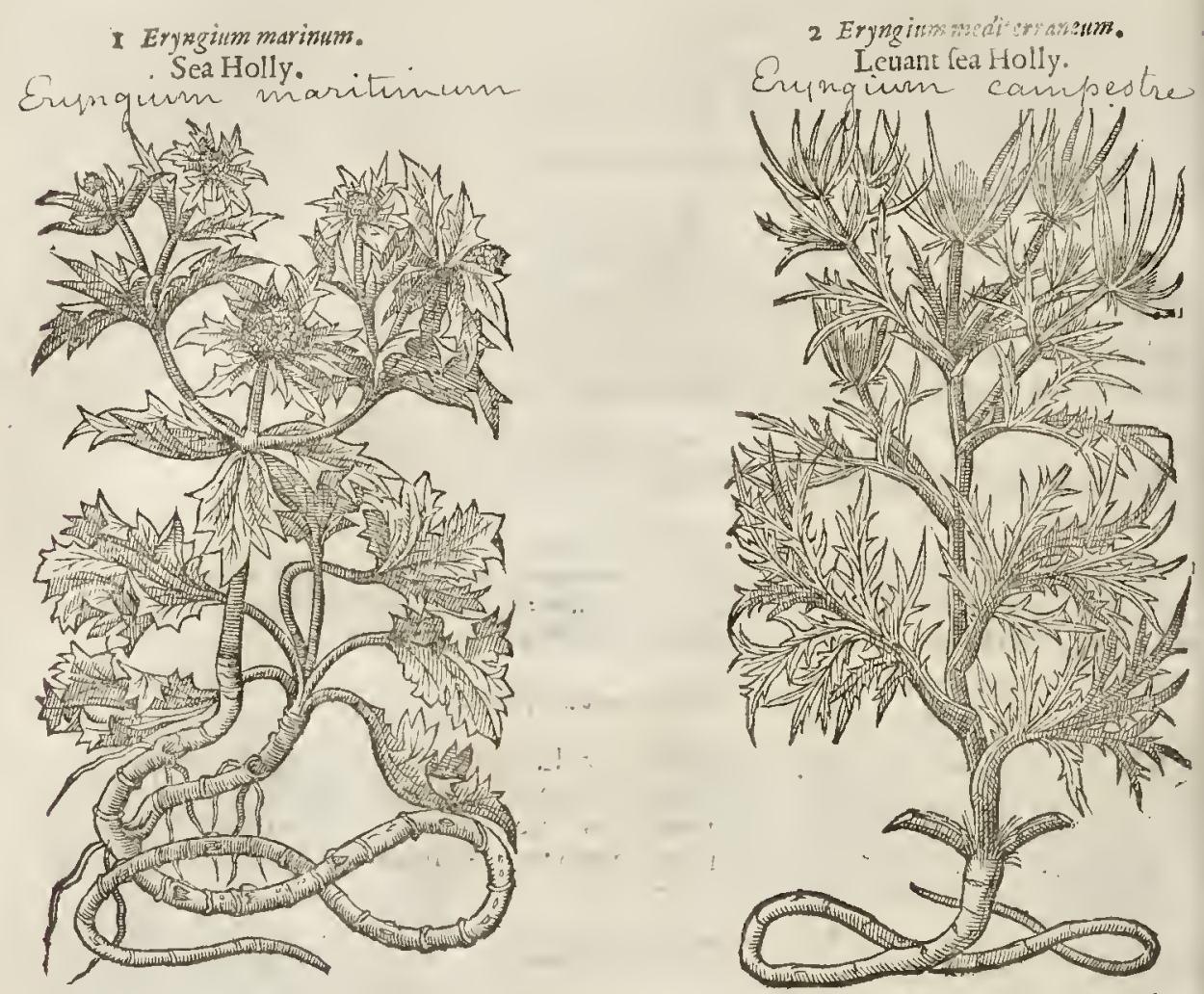

T The Place.

Eryngium marinum growes by the fea fide vpon the baich and ftony ground : I found it growing plentifully at Whitfable in Kent, at Rie and W inchelfea in Suffex, and in Effex at Landamer la. ding, at Harwich, and vpon Langtree point, on the other fide of the water, from whence I hatre brought plants for my garden. ivife.

Eryngium Campeftre groweth vpon the fhores of the Mediterranean fea, and in my garden like-

Th The Time.
Both of them do floure after the Sommer folftice, and in Iuly.

Tा The Names:

This Thiftle is called in Greeke 'Eprosior : and likewife in Latine Eryngium : and of Pliny alfo $E$ rynge : in thops, Eringus; in Englin, Sea Holly, fea Holme, or fea Huluer.

The firf is called in Latine Eryngium marinum : in low-Dutch euery where, $\mathbb{C r p u g}$ diftl, $\mathbb{E}$ in: Deloog, 9herwotele: in Englifh, fea Holly.

The fecond is named of Pliny, lib.22.cap. S. Centum capita, or hundred headed Thiftle : in high-

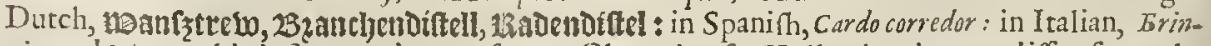
gio, and Iringo: this is lymamed Campeftre, or Champion fea Holly, that it may differ from the other.

\section{The Temperature:}

'The roots of them both are hot, and that in a mean; and a little dry alfo, with a thinneffe of fub: ftance, as Galen teftifieth.

A The roots of fea Holly boyled inwine and drunken are good for them that are troubled with the Collicke, it breaketh the ftone, expelleth grauell, and helpeth alfo the infirmities of the kidnies, prouoketh vrine, greatly opening the paffages, being drunke fifteene dayes together.

B Tbe roots themfelues haue the fame propertie if they be eaten, and are good for thofe that be liuer-ficke, and for fuch as are bitten with any venomous beaft : they eafe cramps, convulfions, and the fulling ficknefre, and bring downe the termes. 
The roots eondited or preferued with fuyar, as hereafter followcth, are execeding gool to be gi- $\overrightarrow{\mathrm{C}}$ uen vnto old and aged people that are confumed and withered with age,and which want naturall unoifure : they are allo good for other forts of people that haue no delight or appetic to venerie, nourifhing and reftoring the aged, and amending the defects of parure in the younger.

TI The manner to condito Eryngos:

Refine figgar fit for the purpofe, and take a pound of it, the white of an egge, and a pint of cleere $D$ water, boile them together and feum it, then let it boile vntill it be come to good ftrong fyrup, and when it is boiled, as it cooleth, adde thereto a faucer full of Rofe-water, a fpoone full of Cinnamon water,and a graine of Muske, which haue been infufed together the night beforc, and now ftrained; into which fyrrup being more than halfecold, put in your roots to foke and infufe vneill the next day; your roots being ordered in manner hereafter following :

Tliefe your roots being wathed and pieked, mut be boiled in fairewacer by the fpace of foure $\mathrm{E}$ houres, vntill they be foft, then muft they be pilled cleane, as ye pill parfneps, and the pith muft bee drawne out at the end of the root; and if there be any whole pith eannot be drawne out at the end, then you muft flit them, and fo take out the pith: thefe you mut alfo keepe from much handling, that they may be cleane, let them remaine in the fyrrup till the next day, and then fot them on the fire in a fare broad pan vntill they be verie hot, but let them not boile at all : let them there remaine ouer the fire an houre or more, remoouing them eafily in the pan from one place to another with a woodden flice. 'This done, haue in a readineffe great cap or royall papers, whereupon you muft ftraw fone Sugar, vpon which lay your roots after that you haue taken them out of the pan. Thefe papers you muft put into a Stoue, or hot houfe to harden; but if you haule not fuch a place, lay them before a good fire. In this manner if you condite your roots, there is not any that can prefcribe you a betrer way. And thus may you condite any other root whatfoeuer, which will not onely bec exceeding delicate, but very wholefome, and effectuall againft the difeafes aboue named.

A certaine man affirmeth, faith Aetises, that by the continual ve of Sea Holly, he neuer afterward F voided any ftone, when as before he was very often tormented with that difeafe.

It is drunke, faith Diofcorides, with Carrot feed againtt very many infirmities in the weight of a $\mathrm{G}$ dramme.

The iuice of the leaues preffed forth with wine is a remedie for thofe that are troubled with the $H$ running of the reines

They report that the herbe Sea Holly, ifone Goat take it into her mouth, it caufeth her firft to I fand ftill, and afterwards the whole focke, vntill fuch time as the Shepheard take it forth of her mouth,as Platarch writeth.

\section{Сна т. 485. Of baftard Sea Hollies. \\ 91 The Defcription,}

THis Eryngium which Dodoneus in his laft edition calleth Eryngium planum ; and Pens 1 more fitly and truely, Eryngium Alpinum caruleum, liach ftalkes a cubite and a halfe high, hauing fpaces betweene eury ioint : the lower leaues are greater and broader; and notched about the edgcs, but thofe aboue are leffer, compaffing or enuitoning cach ioint ftar-fähion, befet with prickles which are foft and tender, not much hurtful to the hands of fuch as touch them; the knobs or heads are alfo prickley, and in colcur blew. The root is bunchie or knottie, like that of Helenizm, that is, Elecampane, blackewithout, andwhitewithin, and I Ike the Eringes in fweenefic and tafte.

2 The fecond baftard Sea Holly, whole picture is fet forth in Dodoneus his laft Edirion veric gallantly, being alfo a kind of Thiftle, hath leaues like vnto the former Erynges, buit broader next the rootes than thofe which grow next the ftalkes, fomewhat long,greenifi, folt, and not prickley, but lightly creuifed or notehed about the edges, greater than Quince leaues. The ftalks grow more than a cubit high; on the tops where of there hang downwards fiue or fix knobs or heads, in colour and Houres like the other ; lauing three or foure whitifh roots of a foot long.

3 The thirdkinde of baftard Eryngium hath his firft leaues (which grow next the Elound) grear, broad, and foft,growing as it were in a rundle about the root. The falke is fm.ll and Render, diuided into fome branches, which beare nany little leaues, turning or fanding many waics, whicl 
1164

Of the Hiftorie of Plants.

L13.2.

1 Eryngium caruleum. Blew Sea Holly.

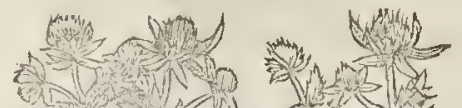
2ne

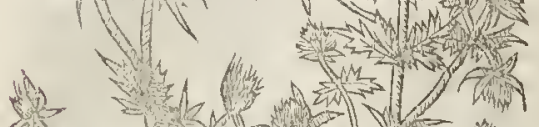
$25+120$ - not

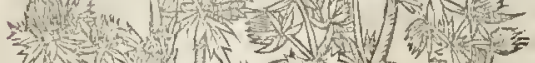

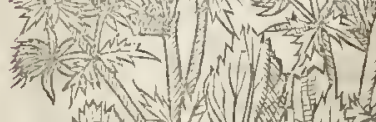

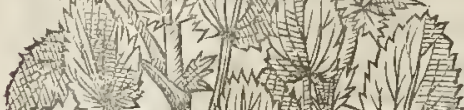
how $=5$ (N)

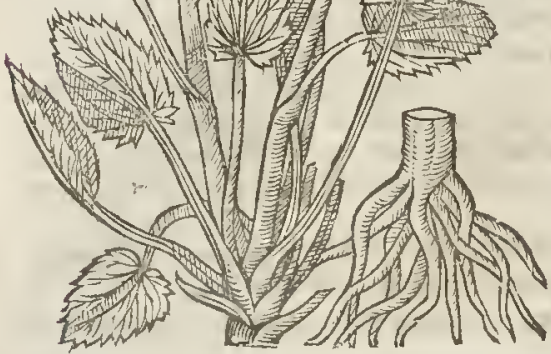

3 sryrigium pumilum cing. Dwarfe Sea Holly.

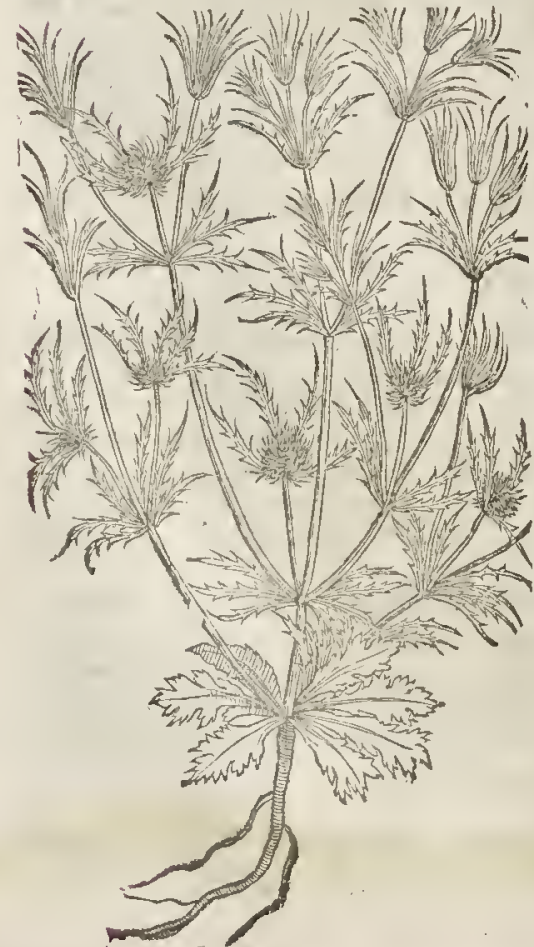

2 Eryngium puriumu frim, um Docictids. Baltard Sea Holly.
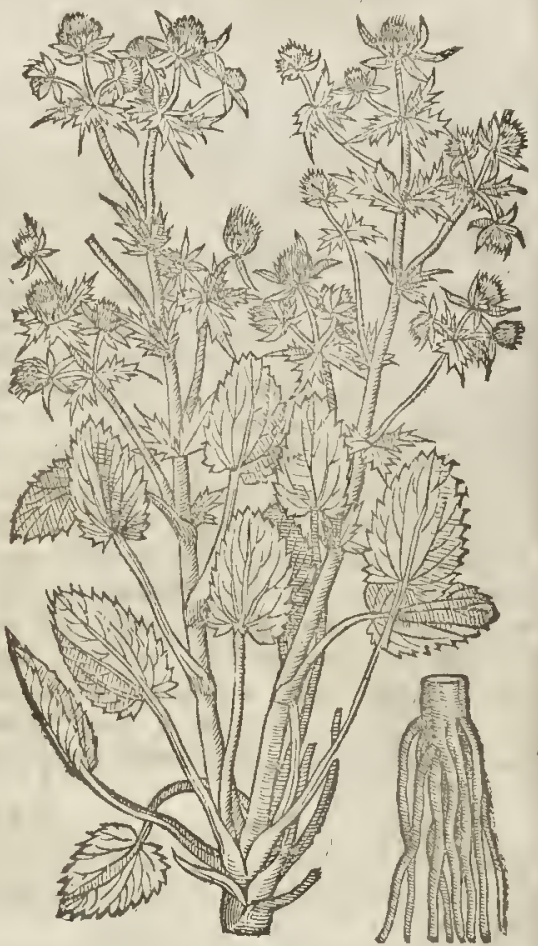

4. Eryngium Montannm. Mountaine Sea Holly.

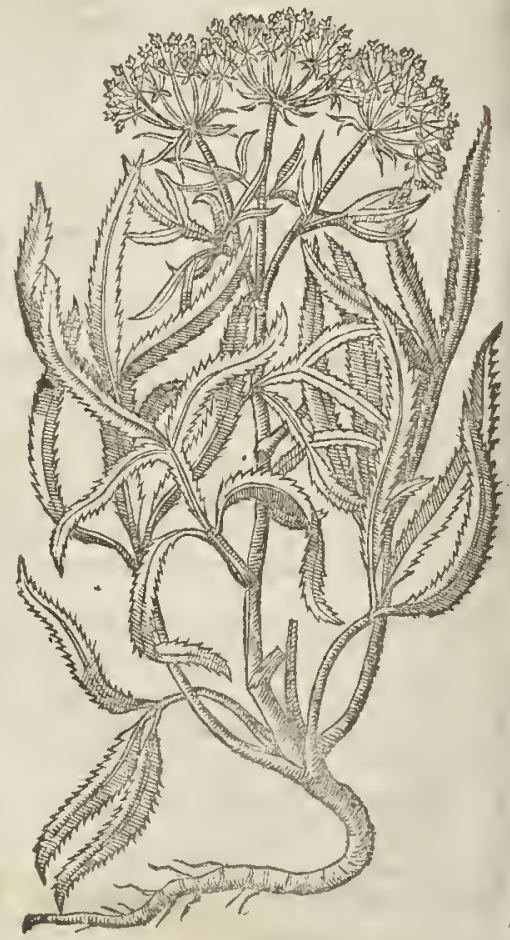




\section{‡ 5 Eryngium fufillum planum.} Small fmooth Sca Holly.

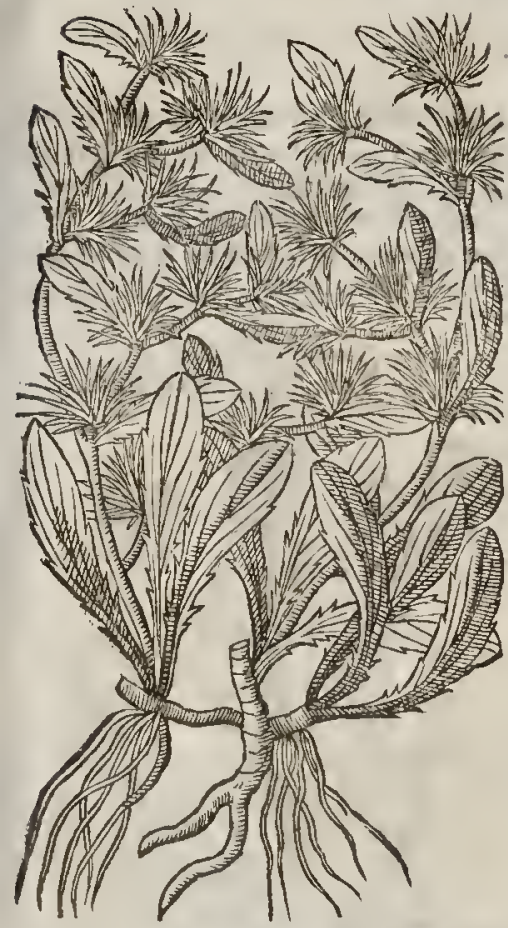

bc alfo flender, prickly, and ferabour the ftalks ftar-farhion. The knops or heads growing at the tops of the branches are round and prickly, bedring little blew floures and leaues, which compafle them about: the root is Iender,and lafteth buit one yeare.

4 The fourth kinde of baftard Sea Holly, which Pens calleth Eryogium montanum recentsorum, and is the fourth according to Dodoners his account, is like to the Erynges, not in filate but in tafte : this beateth a very fmall and $1 \mathrm{~h} n$. der ftalke, of a meane herght ; whereupon ove grow three or foure leaues, \& feldom fitie, made of diners leaues fet vpon a midd'e rib, narrow, long, hard, and of a darke greene colour, dented on both edges of the leafe like a faw: the ftalke is a cubit ligh, iointed or knced, and diuiding it felfe into many btanches, on the tops whereof are round tufts or vmbels, wher in are contained the floures, and after they be vaded, the feedes, which are fmall, fomew hat lons well fmelling, and harpe in tafte: the roor is white and long, not a finger thicke, in tafte fiveet hur afrerwards foncwhat tharpe, and in fent and fatour not vn. pleafant:when the root is dricit, it may be crumbled in pieces, and theretore quickly braicd.

\# 5 This is a low plant prefently trom the root ditided into fundry branches, Aender round \&ly ing on the ground:at cach ioint grow leaues without any certain order, broad row ard their ends, and narrower at their fetting on, fripe about their edges: rofe rext the root were Inme inch broad, and two or more long, of a yellowifh grecne colour : the ftalkes are parted into findry branches; and at each ioint haue little leaues, and rough and greene heads, with blewifh floures in them : the roots crecpe,and are fomewhat like thofe of $A$ par igus. This neither Clufius nor Lobel found wilde; bur it grew in the garden of Ioln exouton of Tourney, a learned A pothecarie, veric skilfull in the knowledge of plants : whereupon they both called it Eryngium pufillum planwm Coutoni. $\ddagger$

TI The Place:

Thefe kindes of fea Holly are ftrangets in England: we haue the firt and fecond in our Londor gardens.

They floute and flourith when the Thifles do.

$$
\text { बT The Time. }
$$

If The Names.

Thefe plants be Erymgia $\beta$ miri, or baftard Sea Hollies, and are lately obferued:and therefore they liate no old natmes,

The fitfe may bece called in Latine Eryngium Borufficum, or Non fpinofum : Sea Hollie without prickles.

The fecond is called by Matthiolus, Eryngium planum, ot flat Sea Holly: othets had rathet name it Alpenum Eryngium,or Sea Holly of the Alpes.

The third is rightly called Eryngium pumilum, little Sea Huluct.

criatliolus maketh the fourth to be Crillomum quartum, or the fourth kinde of Sampier: and athets, as Dodoncus and Lobel, hauc made it a kinde of Sea Huluer.

T) The Temperature and Vertues.

Touching the faculties here of we haue nothing to fet downe, fceeing they haue as yet no vfe in medicine, nor vfed to be eaten. But yet that thcy be hot, the very tafte doth declare. 


\section{Cи а в. 486. Of Star-Tbiftle. \\ II The Defcription.}

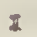

TMHe Star-Thifle, called cardus ftellatus, hath many foft frizled leaues, deepely cut or gafht,altogether without prickles : among which rifeth vp a falke, diuiding it felfe into many other branches, growing two foot high; on the tops whereof are fmall knops or heads like the other Thiftes, armed round about with many tharpe prickles, fathioncd like a blafing ftar, which at the beginning are of a purple co!our,but afterwards of a pale bleak or whitifh colour : the feed is fmall, fiat, and round; the root is long, and browne w ithout.

I Carduns frellatus.

Centaure Car-Thiftle.

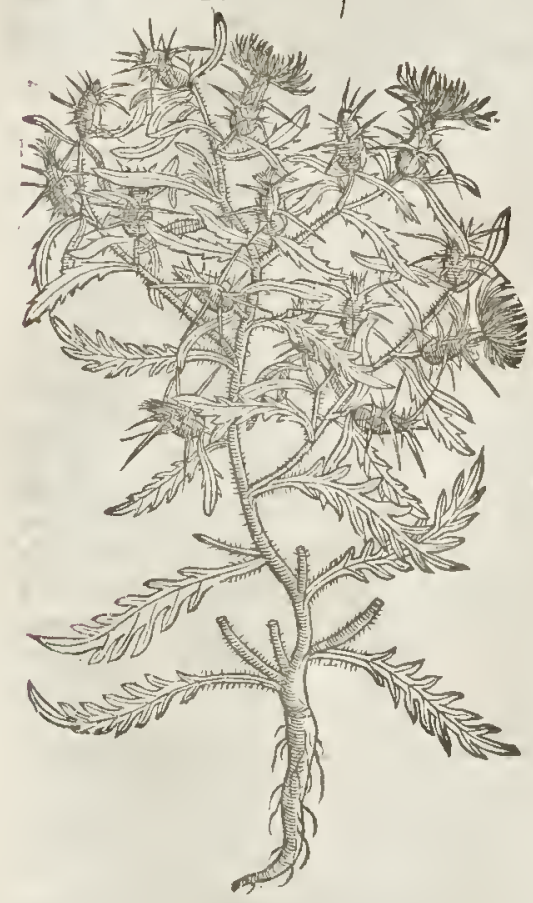

+2 Carduus Solstitialis. Certau red Saint Barnabiess Thittle.

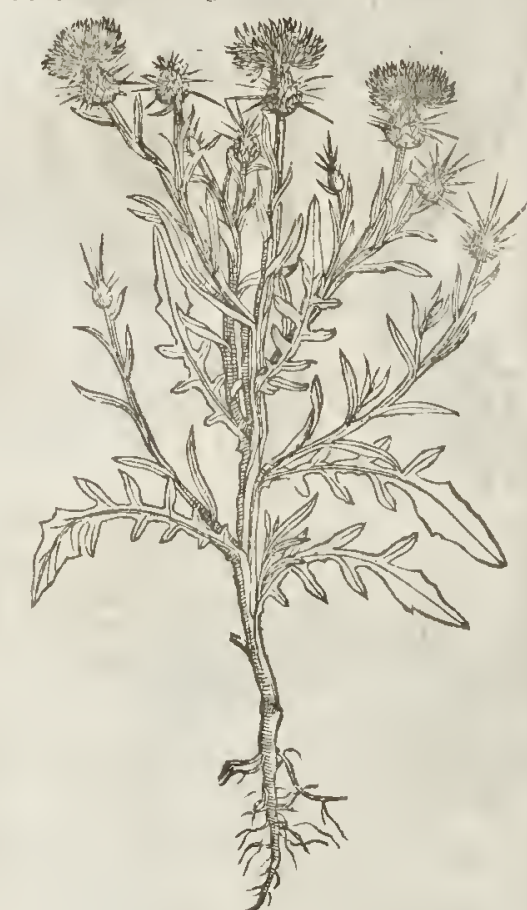

2 Saint Barnabies Thiftle is another kinde of Star-Thiftle; notwithftanding it hath prickles no where fane in the head onely, and rhe prickles of it ftand forth in manner of a far : the ftalks are two cubits high, parted into diuers branches fofter than are thofe of ftar-Thiftle, which ftalks have velnes or thin skins cleauing vnto them all in length, by which they feeme to be foure-fquare: the leaues are fomew bat long, fet with deep gathes on the edges: the foures are yellow, and confift of threds : the feed is little; the root long and fender.

\section{or The Place.}

The two firf do grow vpon barren places neere vnto cities and townes, almoft euery where,

$$
\text { बा The Time. }
$$

They floure and flourifh efpecially in Irly and Auguft.

$$
\text { at The Names. }
$$

The firft is called in Latine, Stellaria ; as alfo Carduns Stellatus, and likewife Carduns Calcitrapa but they are deccined, who take it to be Erynginm, or Sea-Hollv, or any kinde thereof. Mattholus faith rhat it is called in Italian Calcatrppa : in high Dutch, noallen Diftel: in low Dutch,, Diftell: in French, Chaure trappe : in Englih, Star-Thiftle.

S.Barnabies Thifte is called in Latine Solfititalis Bina, becaufe it foureth in the Sommer Sol- 
L 1 B. 2. Of the Hittroy of Plants.

Itice,as Gcfncr faith, or rather becaufe after the Solitiee the priekles thereof be tharpeft: of Guillais dimus, Eryngium, but not properly, and Stcllaria Horaig Augcry, who with gcod fuceeffe saue it again the ftone, dropfies, greene fiekneffe, and quotidian feuers. It is called in Englifh as aboue faid, $S$ aine Barnabies Thiftle.

The Star-Thiftle is of hot nature.

$$
\text { T. The Temperature. }
$$

$$
\text { The Fertues. }
$$

The fed is commended againft the ftrangurie : it is reported todritie forth the fone, if it bee $A$ drunke with wine.

Baptifta Sardus affumeth, that the difilled water of this Thiftle is a remedie for thofe that are in- B fected with the French Pox, and that the vfe of this is good for the liner, that it takcthaway the 1toppings thereof.

That it elenfech the bloud from eorrupt and putrified humours.

That it is giuen with good fuceeffe againft intermitting fcucrs, whether they bequotila $\mathrm{C}$ terrian.

As touching the faculties of Saint Barmabies Thifte, which are as yet not found out, we haue E nothing to write.

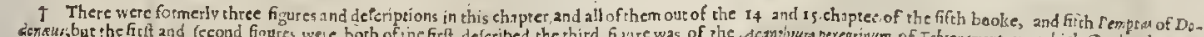

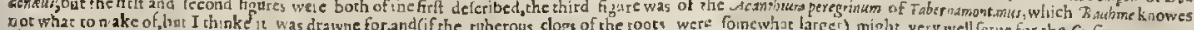

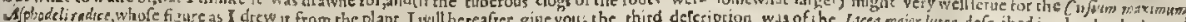
she 349 . Chap pas. 727

\section{C н A P. 487 Of Teafels.}

\section{q) The Kindes.}

Vrage hath fet downe two kindes of Teafels: the tame, and the wilde. Thefe differ not fauc on ly in the husbanding; for all things that are planted and manured doe more flourifh, and bes come for the molt part fitter for mans vfe:

I Dipfacusfativus: Garden Teafell.
Ot is sacre
Snutionum
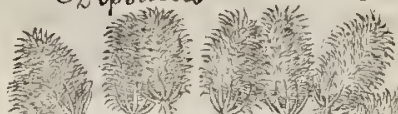

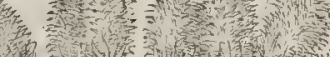

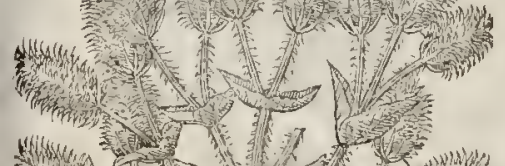

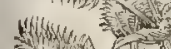
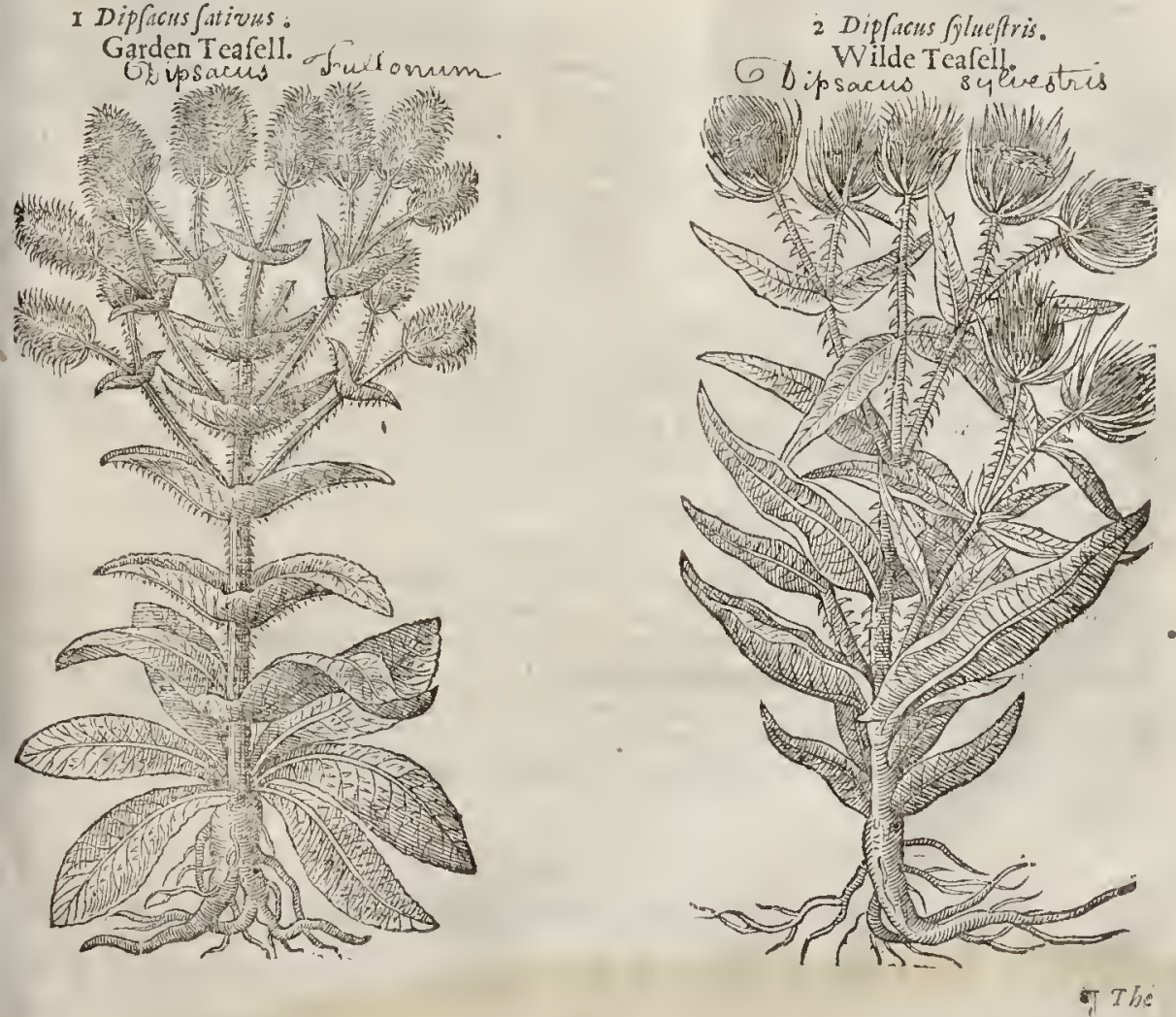
\$ 3 Dipfacus minor, five Virgapaforis. Sheepheards-rod.

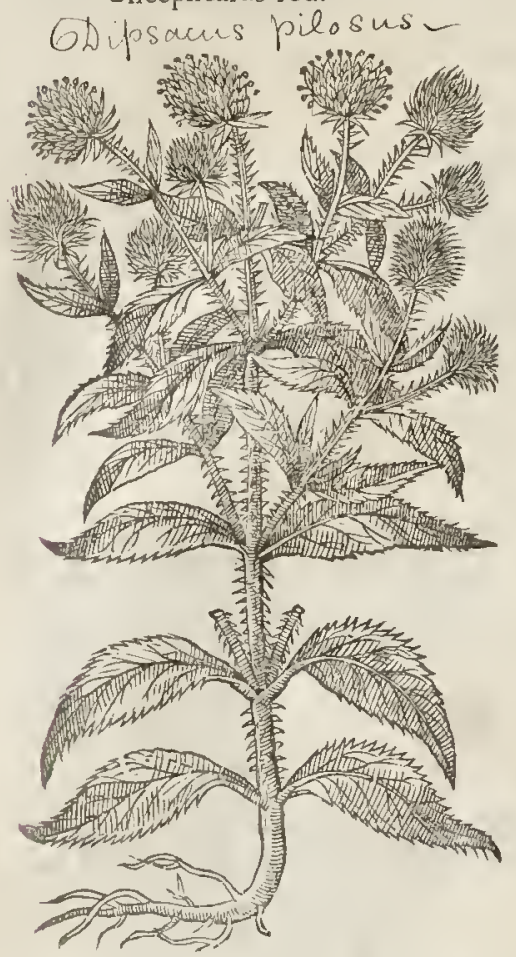

T) The Defcription.

I

G

Arden Teafel is alfo of the number of the Thiftles; it bringeth forth a ftalke that is titraight, very long, iointed, and ful of priekles: the leaues grow forth of the ioints by eouples, not onely oppofite or fet one right againft another,but alfo eompaffing the ftalke about, and faftened together; and fo faftened, that they hold dew and raine water in manner of a little bafon : thefe be Inng, of a light greene colour, and like to thofe of Lettice, but full of prickles in the edges, and hate on the outfide all a longt the ridge fitfer prickles: on the tops of the ftalkes ftand heads with fharpe prickles like thofe of the Hedge-hog, and crooking backward at the point like hookes: out of which heads grow litrle floures: The feed is like Fennell feed, and in tafte bitter: the heads wax white when they grow old, and there are found in the midft of them when they are cut, cerraine little magots : the root is white, and of a meane length.

2 The feend kinde of Teafell which is alfo a kinde of Thiftle, is very like vntorhe former, but his leates are fmaller \& narrower:his floures of a purple colour,and rhe hooks of the Teafell nothing fo hard or tharpe as the other, nor good for any vfe in dreffing of cloath.

3 There is anotiner kinde of Teafell, being a wilde kinde therof, and aceounted among thefe Thiftles, growing higher than the reft of his kindes; but his knobbed heads are no bigger than a Nutmeg, in all other things elfe they are like to the other wilde kindes. $¥$ This hath the lower leates decply eut in with one gath on each fide at the botrome of the leafe, which little ears are 0 mitted in the figure: the leaues alfo are leffe than the former, and narrower at the fetting on, and hold nowater as the two former do: the whole plant is alfo much leffe. $\neq$

T) The Place.

The firft called the tame Teafell is fowne in this countrey in gardens, to ferue the vfe of Fullers and Clothworkers.

The fecond kinde groweth in moift places by brookes, rituers, and fuch like plaees.

The third I found growing in moift places in the high way leading from Braintree to Henning:ham eaftle in Effex,and not in any other plaee exeept here \& therea plant vpon the high way from Much-Dunmow to London. $¥$ I found it growing in great plentie at Edgecombe by Croyden, clofe by the gate of the houfe of my much honoured friend Sir Iobn Tunstall.

Thefe floure for the moft part in Iune and Inly. 9ा The Time.

TT The Names.

Teafell is ealled in Greeke sidawe, and likew ife in Latine, Dipfacus, Labrum Veneris, and Cardurs Veneris : it is termed Labrum Veneris, and Lawer Laxacrum, of the forme of the leaues made vp in fa- fhion of a bafon, which is neuer without water : they commonly call it Virga paftoris minor, and Carduus fullonum : in high Dutch, ltatden Diftell : in low Duteh, Caeroen : in Spanifh,Cardencha: and Cardo Penteador: in Italian, Diffaco, and Gardo: in Freneh, Chardon de foullon, Verge àbergier: in Englifh, Teafell, Carde Teafell, and Venus bafon.

The thira is thought to be Galedragon Plinij : of which he hath written in his 27 . book the tenth Chapter.

A 9 The Temperature.

The roores of thefe plants are drie in the feeond degree, and haue a certaine clenfing facultic. 
There is fmall vfe of Teafell in medicines : the heads (as we haue faid) are vfed to dreffewoollen cloth with.

Diofcorides writeth, that the root being boiled in wine, $8 \times$ ftamped till it is come to the fubftance $B$ of a faluc, healeth chaps and fiftulaes of the fundamint, if it be applied thereunto; and that this me. dicine mutt be referued ina box of copper, and that alfo it is reported to be gocd for all kindes of warts.

It is needleffe here to alled ge thofe things that are added touch ing the little wormes or magors $C$ found in the heads of the Teafell, and which are to behanged about the necke, or to mention the like thing that Pliny reporteth of Galedragon : for they are nothing elfe but moft vaine and trifling toies, as my felfe haue proned a little before the impreffion hereof, hauing a moft grienous ague, and of long continuance: notwithftanding Phy ficke charmes, thefe worms hanged about my neck, fpiders put into a walnut thell, and diuers fuch foolith toies that I was conftrained to take by fantafticke peoples procurement; notwithftanding I fay,my helpe came from God himfelfe, for thefe medicines and all other fuch things did meno good atall.

\section{Cha r. 488. Of Baftard Saffrom.}

+ I Carthams foue Cricus. Baftard Saffron.

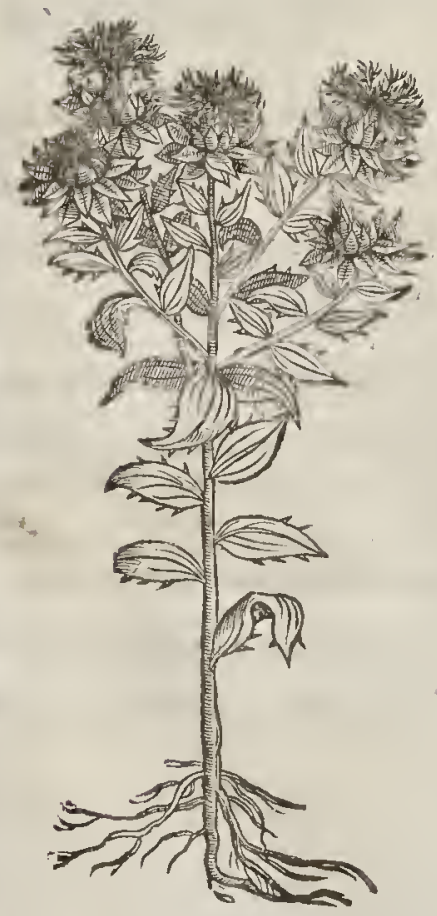

t 2 Cniciss alter ceruleas. Blew floured Baftard Snffron:

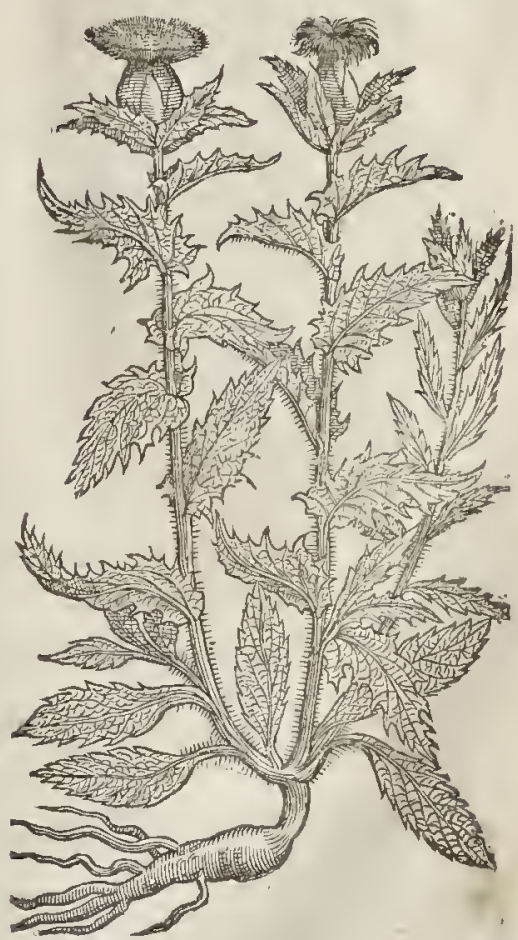

If The Defoription.

I Nicus, called alfo baftard Saffron, which may very wel be reckoned among the Thiftles: rifeth vp with a ftalke of a cubite and a halfe high, ftraight, fmooth, round, hard, and wooddy ${ }_{3}$ ix branched at the top: it is defenderd with long leaues, fomathing broad, tharp 
pointed; and with prickles in the edges : from the tops of the ftalks ftand out little heads or knops of the bigneffe of an Oliuc or bigger, fet with many tharpe pointed and prickly fcales:out of which come forth floures like threds, clofely compact, of a deepe yellow thining colour, drawing necre to the colour of Saffron: vinder them are long feeds, fmooth, white, fomewhat corncred, bigger than a Barly corne, the huske whereof is fomething hard, the inner pulpe or fubfance is fat, white, frect in tafte: the root flender and unprofitable.

2 There is alfo another kinde of Baftard Saffron, that may very well be numbred among ft the kindes of Thiftes, and is very like vnto the former, fauing that his fockie or threddic foures, are of a blew colour : the root is thicker, and the ivinole plant is altogether more fharpe in prickles:the ftalks alfo are morecrefted and hairic.

\section{of The Place.}

It is fowne in diuers places of Italy, Spaine, and France, both in gardens and in fields : Pling, 7ib. 25. cap. I 5. Caith, that in the raigne of Vefpafran this was not knowne in Italy; being in Egypt onely of goot account, and that they vfed to make oile of it, and not meat.

$$
\text { I) The Time. }
$$

The floures are perferted in Iuly and Auguft : the root after the feed is ripe, the fame yeare it is fowne witheretl away.

\section{TI The Names.}

It is called in Grecke rrixos: in Latine alfo Cnicus, or Cnecus: in fhops, Cartamus, or Carthamum : of diuers, Crocus horten fs, and Crocus Saracencus: in Italian, Z affarano Saracine (co, and Zaffarano faluatico: in Spanifh, Alafor, and Semente depapaginios: in high Duteh, noilien Zaffean: in French, Safran Saunage: in Englith, Baftard Saffion. of fome; Mocke Saffion, and Saffron D'orte, as though you thould fay Saffron de horte, or of the garden. Thcoploraftus and Pliny call it Crecus vrbana, and fatiun,or tame and garden baftard Saffron, that it may differ from A Aractilis, which they make to be a kinde of Cricus fyluefris, or wilde Baftard Saffron, but rather a peciss of the Holy Thifle.

$$
\text { T The Temperature. }
$$

We vie faith Gulen, the feed onely for purgations: it is hot, and that in the firft degree, as ersefuec writeth.

The Tertues.

A The iuce of the feed of baftard Saffon bruifed and ftrained into honied water or the broth of a chicken, and drunke, prouoketh to the ftoole, and purgeth by fiege flimy flegme, and fharp humors: Morcouer it is good againft the collicke, and difficultic of taking breath, the cough,and ftopping of the breft, and is fingular againft the dropfie.

B The feed ved as a forefaid, and ftrained into milke, caufeth it to curdle and yeeld much cruds, and maketh it of great force to loofe and open the belly.

C The floures drunke with honied water open the liuer, and are good againt the iaundice:and the floures are good to colour meat in ftead of Saffron.

D The feed is very hurtfull to the ftomacke, caufing defire to vomite, and is of hard flow digeftion, remaining long in the fomacke and entrailes.

E Put to the fame feed things comfortable to the ftomacke, as Annife feed, Galingale, or Maftick, Ginger, Salgemme, and it thall not hurt the ftomacke at all, and the operation thereof thall be the more quicke and fpeedy.

F Of the inward pulpe or fubftance hereof is made a moft famous and excellent compofition to purge water with, commonly called Diachartamon, moft fingular and effe stual purgation for thofo $t$ hat haue the dropfic.

G The perfect defcription hereof is extant in Guido the Surgion, in his firft Dootrine, and the fixe Traftate.

H We haue not read, or had in ve that Baftard Saffon with the blew floure, and therefore can fay nothing of his vertues.

t The figurc formetly w 25 of the Cninus cesulests.

$$
\begin{gathered}
\text { Cн а Р. 489. Of Wilde Baftard Saffron: } \\
\text { वा The Defription. }
\end{gathered}
$$


word, Cardo-bcnedictus : it is moftplaine, that it is species Alractyludw, or a kind of wil de baftard Saf-

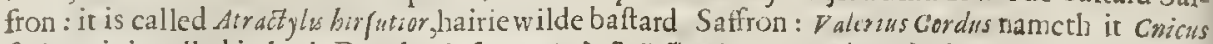

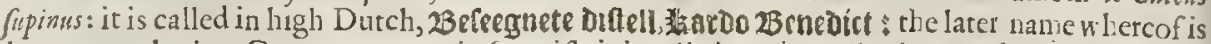
knowne to the low Countrey men: in Spanifh it is called Cardo Sanito. in French, chardon beraiff, or bencift: in the Ifle Lenmos, Garderacantha: in Englifh, Bleffed Thifte, but more commonly by the Latinc namc Carduus Benedictus.

\section{II $T$ be Temperature.}

Wilde baftard Saffron doth drie and moderately digent, as Galen witneffeth.

As Curdurs Benedictus is bitter, fo is it alfo hot and drie in the fecond degree, and withall clenfing and opening.

\section{The Vertues.}

A The tops, feed, and leaues of Atractylis, faith Diofcoridcs, being beaten and drunk with pepper and wine, are a remedie for thofe that are ftung of the fcorpion.

B Bleffed Thifte taken in meat or drinke, is good for the fwimming and giddineffe of the head, it frcngthneth memorie, and is a fingular remedic againft deafenefle.

C The fame boiled in wine and drunke hot, healeth the griping paines of the belly, killeth and expelleth wormes, caufeth fweat, prouoketh vrine, and driueth out gramel; clenfeth the flomack, and is very good againtt the Feuer quartaine.

D The iuice of the faid Curdurs is fingular goodagainft all poifon,as Hierome Bocke witnefleth, in what fort foeuer the medicine be taken; and helpeth the inflammation of the liuer,as reportetl I vachimus Camerarius of Norcmberg.

E The pouder of the leaues miniftred in the quantitic of halfe a dtam, is very good againft tlue peAilence, if it be receitud within 24 -houres after the taking of the ficknes, and the party iwcat veou the fame : the like vertue hath the wine, wherein the herbe hath been fodden.

F The green herb.pounded and laid to, is good againtt all hot Iwellings, as Eryfipeles, plague-fores, and botches, efpecially thofe that proceed of the peftilence, and is alfo good to be laied vponthe bitings of mad dogs, ferpents, fpiders, or any venomous beaft what focuer; and fo is it likewife if $i$ be inwardly raken.

G The diftilled water thereof is of leffe vertue.

H It is reported that it likew ife cureth ftubborne and rebcllious vicers, if the decoction be taken for certaine daies together; and likew ife Arsoldus do villa noun reporteth, that if it be ftamped with Barrows greafe to the form of an vnguent, adding thereto a little wheat floure, it doth the fame, be. ing applied twice a day.

I The herbe alfo is good being ftamped and applicd, and fo is the iuice thareor.

K. The extraction of the leates draw ne according to Art, is exccllent good againft the French difeafe, and quartaine agues, as reporteth the forefaid Camerarius.

L The fame Author reporteth, that the diftilled water taken with the water of Louage, and Dod. der, helperh the fauce-flegme face, if it be drunke for certaine daies together.

\section{С н Р. 490. Of Tbifleopon Thifle, and diwers otber Wilde Thifles. \\ i) $T$ be Defoription.}

1 Mong all the Thornes and Thiftles, this is moft full of prickles; the ftalks thereof are 1 verie long, and leem to be cornered by reafon of certaine thin skins growing to them, being fent downe forth of the leaues : the leaues are fer round about with many deep gathes, being very full of prickles as well as the italks : the heads are very thicke fet in euery place with ftiffe prickles, and confift of a multitude of fcales; out of which grow purple floures, as they do out of orher Thittles, feldome white:the root is almott traight, but it groweth not deep.

2 To this alfo may be referred that which Lobel writeth to be named of the Iralians Leo, and Car: duus ferox, for it is fo called of the wonderfull tharpe and fiffe prickles, wherewith the whole plant aboundetl : the ftalke thereof is fhort, fcarce a handfull high: the floure groweth forth of a prickly head, and is of a pale yeliow colour, like that of wilde baltard Saffron, and it is alfo inuironed and fet round about on euery fidewith long hard thornes and prickles.

3 The third groweth feldome abone a cubite or two font high: it bringeth forth many round ftalkes, parted into diuers branches; the leates are like tho'e of white Cotton Thiftle, but leffer, and blacker, and not coucred with downe or Cotton: vpon the tops of the falks grow little lieads 
L 1 B. 2.

Of the Hifiory of Plants.

t I Polyacanthos.

Thifle von Thifle.

Cardums acanthoudes (1)

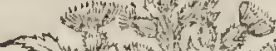

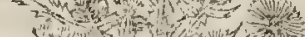

wo s t

- x

14.

Hon

1. 3 .

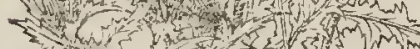

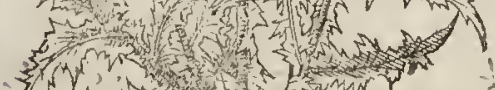

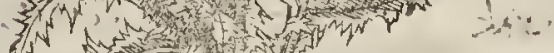

150,0

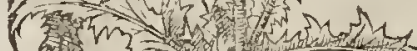

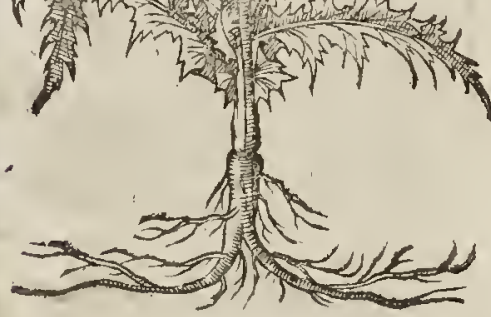

I 3 Carduns A fininus five o nopyens?

The Altes Thilte, or Affes bos:

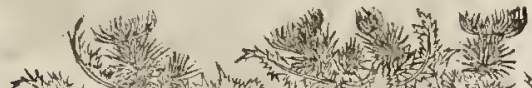

matr.

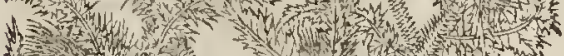

约

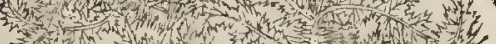
in

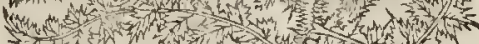

舟

3.

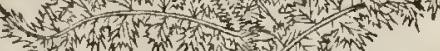

An

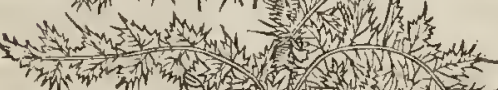

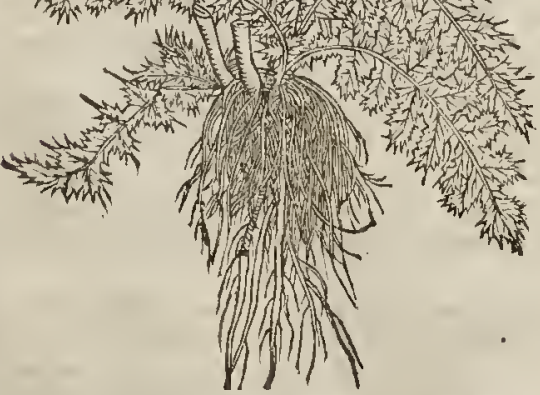

2 Cardus firox.

The cruell Thitle.
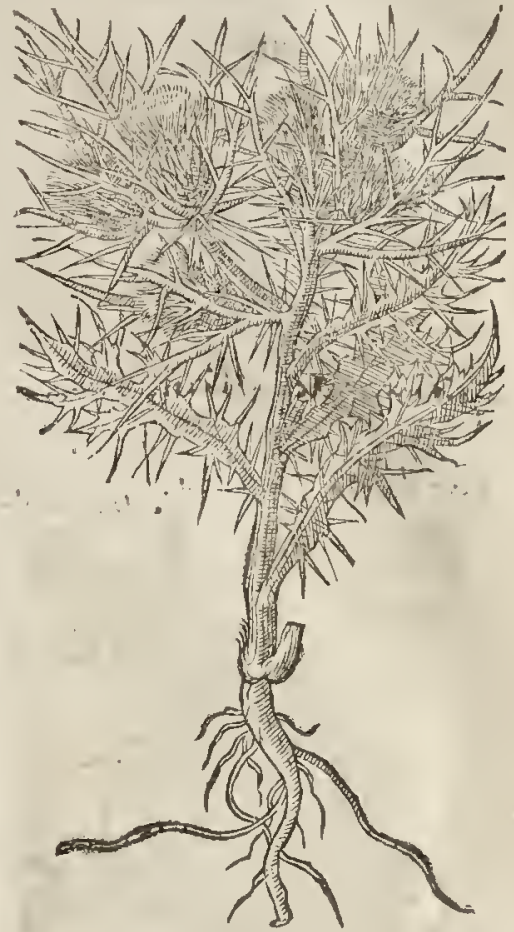

* Carduas vulsatipirnus viarum. The Way Ihifle,

- Cardrunos arveirsis.

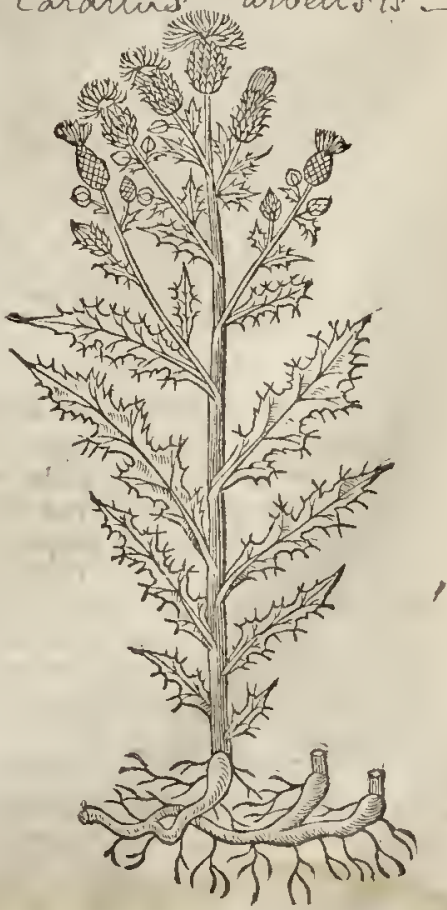




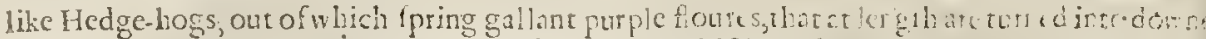
leaung teedes behinde then like rhole of the orler Thifies : the root confiferly of many that Arings.

4 The fourth rifeth vp with an higher ftake, now and then a yard long, roud and rot fo fult fof branches nor leates, which are tharpe and full of prickles, but lefer and narrower : rhe heads bestfo leffer, longer, and not fo full of ftiffe prickles : the foures are of a white eolcur, and vanifh irto davne : the root is blacke, and of a foot long.

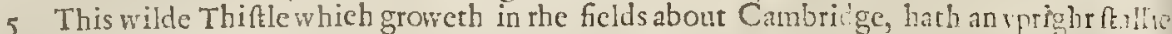
whereon do grow broad prickley leaues : the floures grow on the tops of the branches, confitting wh a flockiedowne, of a white colour tending to purple, of a molt pleafant freet fncil, ltriungwit the fauour of muske: the root is fmall, and peritheti at the approch of Winter. I I had no tisu: $t$ directly fitting this; wherefore I put that of Dodondus his onopordon,which may well fertu for it, if the leaties were narrower, and more diuided. $\neq$

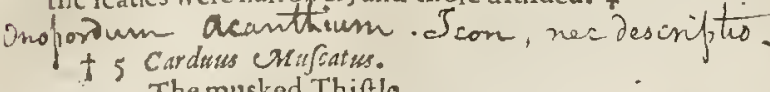

Cardinus mitams.

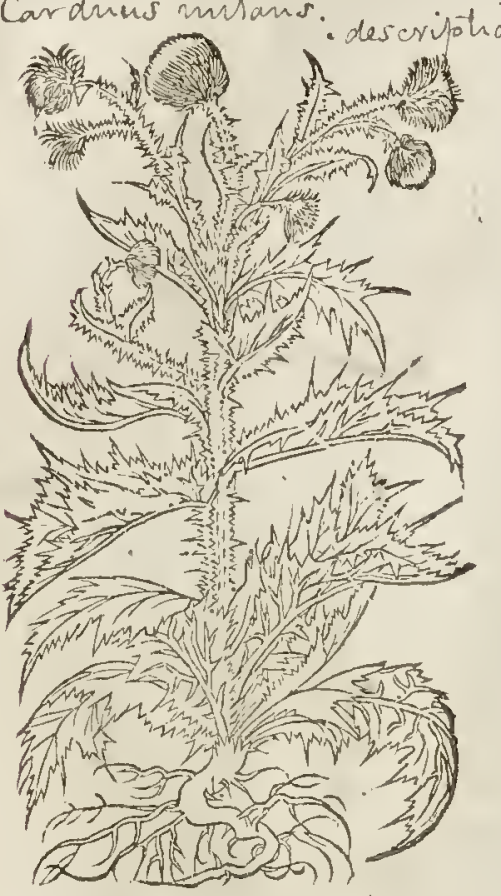

nec jorn
$x \times 0 \times 0 \times 0 \times 1$

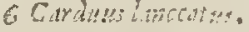

The Speare Thifle.

Cardinus lanceolatins.

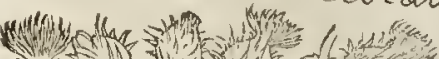
* 3. mbram

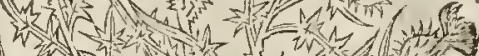

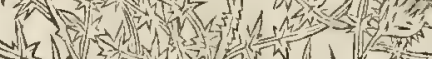

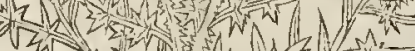

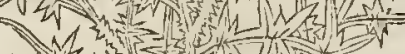
16. an 1 m

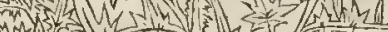

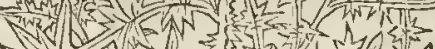

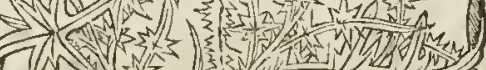

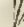
19

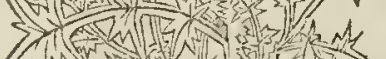

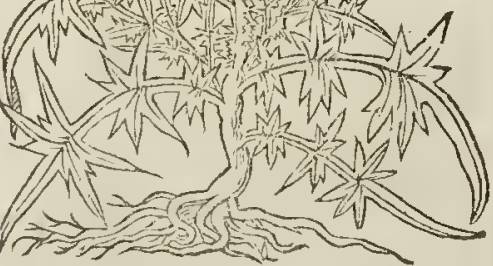

6 The Speare Thifle hath an vpright falke, gart ifhed with a skinnie membrane, full of molt tharpe priekles: whereor do grow very long leates, dided into diuers partswith tharp prickles; the point of the leanes are as the point of a fpeare, $w$ te teof ir tooke his name:the floures growon the tops of the branches, fet in a fcaly prickly head, like vntc' the heads of Knapweed in forme, confifting of many threds of a purple colour : the root confifteth of many tough ftrings.

7 Theophrafus his fin Thiftle called Ucarna, which was b rought fron Illyria to Venice, by the learned $v$ alerandus Donrez, deferibed by $T$ heophraf $\mathrm{s}$, hath hor 1 ible tharpe yellow prickles, fee vpon is is acene indented leaues, which are eotered on rhe backe fide with an hoariedowne (as all the reft of the plant) haung a ftalke of a cubit and a halfe high, and at rhe top certaine fealy knops containing yellow rhrummie floures, armed or fenced with horrible flarp prickles:the root is long and tiredaic.

8. The other kinde of fifh Thiftle, beingalfo another Acarna of Valcrandus defeription, hath long and large leaues, fet ful of harpe prickles, as thougl it were fet full of pins:all the whole plant is couered w ith a ecraine hoarineffe, like the former : there arifeth vpa falke nine inches long, yea in fome fertile grounds a cubite high, bearing the floure of Cardwus besidictus, ftanding thicke together, but leffer. 


\section{d The Time.}

Thefe kindes of Thiftes do floure from the beyinning of Iune vat ill the end of S $\mathrm{S}$ prember. बा The N.imes.

Thefe Thiftes comprehended in this prefent ehapter are by one generall name ealled in Larine Cardut fy'ueftres, orwilde Thiftles; and that which is tbe feeond in order is named Siolymas: but not that scolymus which theophr. deelareth to ycekl a milky iuyee (of which wee haue written before) but one of thofervhieh Pliny in his twenticth booke, c.p.23. deferibeth: of fome they are raken forkindes of Chamxleon: their feterall tit'es do fet futh their feucral Lacine numes, and aito the Englioh.

¥ There was formerly much confufion in this chapter, both in the figures and hiftorie, which I will here cndeatour to amend, and gitue as mueh light as I ean, to the obfeuritic of our Authour and fome others; to whieh end I haue made choice of the names as the fitteft place.

I This defeription was taken out of Dodonaws, and the title alfo of Onopordon whichwas formerly put ouer the figure, and they belong to the Thitle our Author before deferibed by the name of Acantusm purp. Illyrum, cap.476. I hate therefore elanged the title, yet let the defeription ftand, for it reafonablewel! agrees with the figure which is of the carduzes prnofifomus vulguris of Lobel, and Polyacantha T beophraftz of Tabern. Of this Thiftle I obferue three kindes: the firft is a Thiftle fome two eubits and a halfe high, with many flender falkes and branches exeeeding pric'sly, hating commonly fite prickly welts runaing a ongtt the falks. the leaues on the vpper fides as alfo the italkes are of a reafonable freth greencen'our, but the vnderfide of the leafe is tomwat whitifh: the heads confift of fundry luary greene threds which looke like priekles; but they are weake, and not prickly: the floure is of the bignetfe, and of tive like co'our and thape as the eonxmon Knapweed, yet Comwhat brighter: it growes on diteh fides, and floures in Iuly. This I take to be the Aculeofa Gale of the Aduerf.pag. 34 . but not that which Lob.l figures for it in his Iconts. This is that which Tabernamontanus figures for Polyatantha, and our Autlor gaue his figure in this place. The fecond of thefe I take to be thut which Lobel hath figured for Poly icantha, and Dodomets

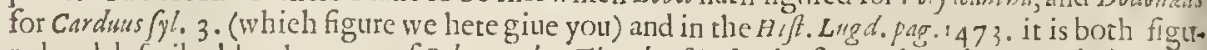
red and deferibed by the name of Polyacanibos Throphrafti. In the figure tlere is little difference: in the things themfelues this; the ftalkes of this are as high as thote of the laft, hut fenderer,with fewer and ftraighter branches, and commonly edged with futre large welts, which haue fewer, yet longer prickles than thofe of the former: the leaves and thalkes of this are of a grayin or whition colour : the heads are longifh, but much fmaller than thofe of the former, and rhey feldom open or fpred abroad tleir floures, but onely thew the tops of diuers reddin threds of a feint eolour. This grnwes as trequently as the former, and commonly in the fane plaees. The third, which I thinke may fit'y be referred vnto thefe, growes on wet heaths and fuch like places, hauing a fallie fometimes foure or finc cubits high, growing ftraight vp, with few branches, and thofe thort ones : the floures are of an ind ifferent bignefle, and commonly purple, yet fometimes white. I thinke this may be the onopyios alicr Lugdunenf. or the Carduns paluftris deferibed in Baubinus his Prodromus, par. 196 .

2 The feeond, whieh is a Aranger with vs, is the Phanix, $L$ co \& Cardus ferox of Lobel and Dod. Bauhin horl? reford it to Acarna, ealling it L carna minor caule non foliogo.

3 The third defeription was alfo out of Doduneus, being of his Carduss fyluffris primus, or the onopyros Doavei of the Hifl. Lugd. The figutes formerly both in the third and fourth place of this chapt rwere of the Acanthium Illyricum of Lobel; or the Onopordon of Dodonats, formerly men. cioned.

4 Thisderetiption alfo was out of Dodonems, being of his Carduus fylueftris alter, agreeing in all things but the colour of the floures, which fhould be purple. Lobel in his Obferuations deferibeth the fame Thiftle by the name of Carduus wulgatisimus viarum : but both he and Dodon. give the figure of carlinafylueftris for it : but neither the floures not the heads of that agree with that deferirtion. I iudge this to be the Thiftle that $F$ abius Columna hath fet forth for the Ceanothos of $T$ beopliraftus; and $T$ abern. for Carduus arvenfis : and our Author, though vnfitly, gate it in the next place for carduus mu catus.

5. The Muske-Thiftle I haue feene growing about Deptford, and (as far as my memory fertes me) it is very like to the third here defcribed : it growes better than a eubit high, with reafow able large leaues, and alfo heads which are a litrle foft or downy, large, with purple floures : the heads before the floures open fmell ftrong of muske. I haue found no mention of this but only in Gefner de colletione in parte, where he hath thefewords; Carduus arven is maior purpureo fore (gui fl re inns)

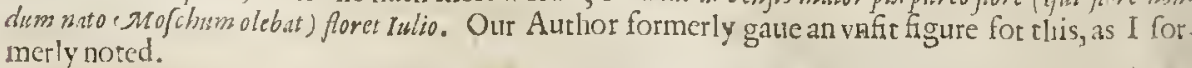

There is fufficient of the reft in their titles and defcriptions: $\neq$ 


\section{The Temperature and Vertues.}

Thefe wild Thiftes (accotding to Galen) are hot and dry in the fccond degree, and that thtough $A$ the propertie of their effence they driue forth ftinking vrine, if the roots be boyled in Wine and drunke; and that they take away the ranke fmell of the body and arme-holes.

Diofcorides faith, that the root of the common Thifle applied plaifterwife cotrecteth the filthy $B$ fmell of the arme holes and whole body.

And that it wotkes the fame effect if it be boyled in wine and drunke, and that it expelleth plen- C tie of ftinking vrine.

The fame Author affirmeth alfo, that the herbe being as yet greene and tendet is vfed to be eaten among other herbes after the manner of Afparagus.

This being ftamped before the floure appeateth, faith Pliny, and the iuyce pteffed forth, canfeth E haire to grow where it is pilled off, if the place be bathed with the iuyce.

-The root of any of the wilde Thiftles being boyled in water and drunke, is reported to make $F$ them dry that drinke it.

It ftrengthneth the ftomacke; and it is repotted (ifwe beleeue it) that the fame is alf good for $G$ the matrix, that boyes may be ingend red: for fo Chereas of Athens hath written, and Glaucres, who is thought tö write moft diligently of Thiftles.

This Thifle being chewed is good againft ftinking teath. Thus farre Pliny, in his twentieth H booke, cap. 23 .

\section{С н А P. 49I. Of the Melon or Hedge-bog Thifle.}

Melocarduus Echinatus Pence \&o Lob.

The Hedge-hog Thiftle.

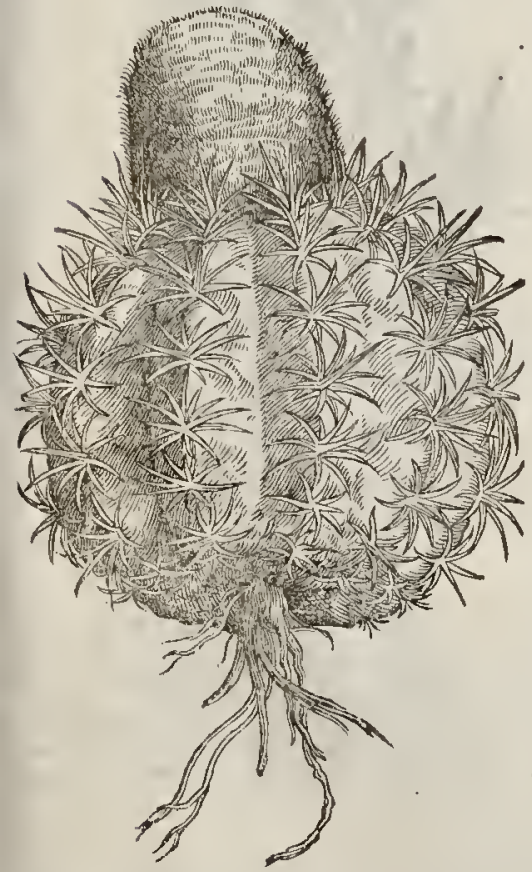

The Defeription.

V Ho can but maruel at the tare and fin:gulat workmanfhip which the Lord God alminhty hath thewed in this Thiltle, called by the name Eibirio-Melocactos, or Me10. car disus Echinatus? This knobby ot bunchy mate or lump is ftrangely compact and context togethet, containing in it fundry thares and formes, participating of a Pepon or Melon, and a Thiftle, both being incorporate in one body; which is made after the forme of a conck of hay, btoad and flat below, but fharp toward the top, as big as a mans body from the belly vpward : nn the out fide hereof are fourteene hard ribbes, defeending from the crowne th the loweft part, like the bunchy or out fivelling rib of a Melon ftanding nur, and chanelled betweene : at the top ne crowne of the plant ifficth forth a fine filken cotton, wherewith it is full ftaught; within which cotton or fiockes lie hid certain fmal theaths or cods, tharpe at the point, and of a deep fanguine colour, anfwering the cods of capficum or Indian Pepper, not in thew only, but in colour, but the cods are fomewhat fmallet. The furrowed or chanelled ribs on the outfide are garni hed or rather armed with many prickly ftars, ftanding in a compaffe like thatpe crooked hornes or hookes, each ftar confifting of ten or twelue pricks, wherewith the nutward barke or pilling is garded, fo that withnut
s hard, thicke, and like vno Aloes, of the co. hurt to the fingers it cannot be touched : this rinde is hard, thicke, and like vnro Aloes, of the co-
lour of the Cucumber : the fieth or inner pulpe is white, fat, waterith, of tafte foure, vnfaunry, and cooling, much like vnto the meate of a raw Melon or Pompion. This plant groweth withnut leafe ot ftalke, as our Northerrie Thiftle doth, called Cardus uscasles, and is bigger than the largeff

Rempion: 
Pompion: the roots are fmall, fpreading farre abroad in the ground, and confifting of blacke and cough twigs, which cannot eadure the inurie of our cold clymate. or The place.

This admirable Thifte groweth vpon the cliffes and gratelly grounds neere vnto the fẹa fide, in the Iflands of the Wett Indies, called S. Margarets and S. Lolws Ifle, neere vnto Pserto rico, or Por:o rico, and other places in thofe countries, by the relation of diuers traullers that haue iournied into thofe parts, who haue brought me the plant it felfe with his feed; the which would not grow in my garden by reafon of the coldneffe of the clymate.

\section{cT The Time.}

It groweth, flourech, and flourifheth all the yeare long, as do many other plants of thofe Countries.

\section{The 2 kanses.}

It is called Carduss Echinatus, Melocarduses Echinatus, and Ecbino Melocactos: In Englith, the Hedge-hog Thiltle, or prickly Melon Thifle. \$ Such as are curious may fee more hereof in $\mathrm{Clu}$ fius his Exoticks, lab.4. cap. 24. $¥$

$$
\text { II The Temperature and Vertues. }
$$

There is not any thing extant fet forch of the antient or of the later writers, neither by any that haue traulled from the Indies themfelues therefore we leaue it to a further confideration.

\section{C н $\Delta .492$. Of the gummie Thifle, called Euphorbium.}

\section{Euphorbium.}

The poyfonous gum Thifle.

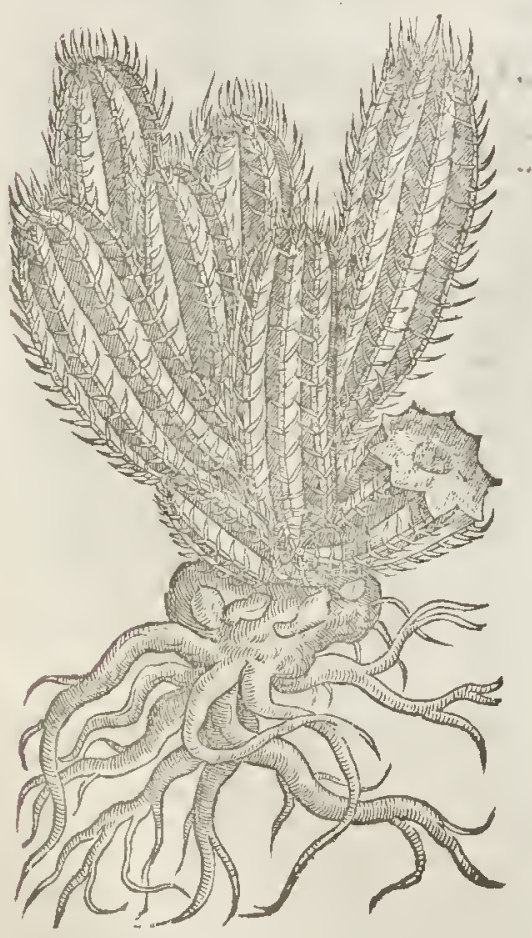

2 Anteupiborbinm.

The Antidote againft the poy fonous Thifte,

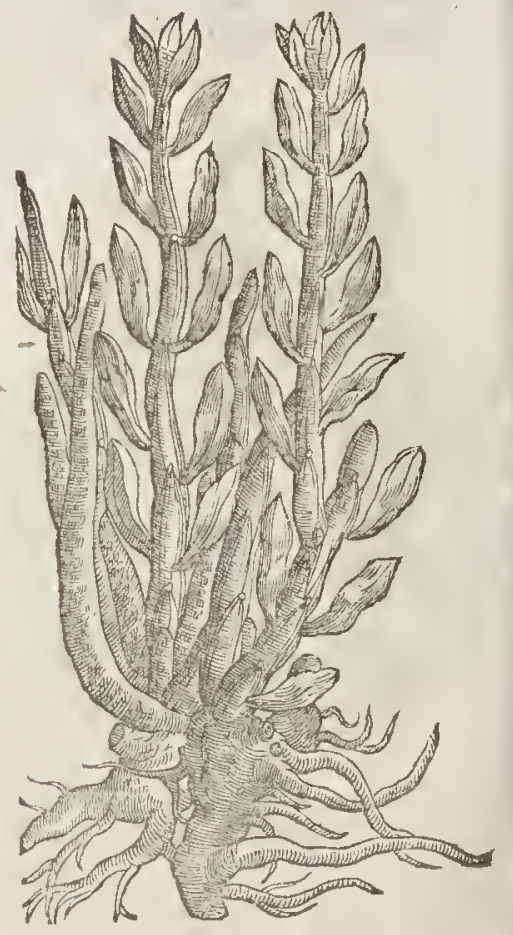

T) The Defcription:

1 TVphorbium (whereout that liquor or gum called in thops Euphorbium is extrafted) hath

- very great thicke groffe and fpreading roots, difperfed far abroad in the ground: from which arifelong and round leaues, almolt like the fruit of a great Cucumber, a foot and a halfe long, ribbed, walled, and furrowed like vnto the Melon : thefe branched ribs are fet or armed 
floures grow at the top ot extreme point of the plant : after which follow fruit in thape like a fig, full of a red iuyee, which being touched ftaineth the hands of the colour of red leade: the tafte is not vinpleafant.

4 There hath been brought from the Indies a prickly teed of the bigneffe of a good big faf, of the length of fix or eigint foor, chamfered and furrowed, hauing vpon two fides growing vnto it an vnetien membrane or skinny fubfance, as it were a iag or welt fet vpon the wing of a garment, and vpon the very point of eucry cut or iagge armed with moft tharpe prick les: the whole trunke is filled full of a fpongeous fubftance, fuch as is in the hollownes of the brict or bramble; among f the which is to be feene as it were the pillings of Onions, wherein are often found liuing things, that at the firft feeme to be dead. The plant is ftange, and brought dry from the Indies, therefore we cannot write fo abfolutely hereof as we defire; referring what inore might be faid to a furcher confidetation or fecond cdition.

$$
\text { T) The Place. }
$$

Thefe plants grow vpon Mount Arlas, in Libya, in moft of the Iflands of the Meditertanear. fea, in all the coaft of Barbarie, efpecially in S.Ctux neere vnto the fea fide, in a barren place thete called by the Englifh men Halte Hanneken; which place is appointed for Merchants to confor of their bufineffe, euen as the Exchange in London is : from which place my friend $\mathbf{M}^{\mathrm{r}}$. Will ams Martin, a right expert Surgeon, did procure me the plants of them for my garden, by his feruant that he fent thither as Surgeon of a thip. Since which time I haue receiued plants of diuers others that hate tramelled into other of thofe parts and coafts : notwirhftanding they haue not endured she cold of our extreme Winter.

$$
\text { I The Time. }
$$

They put forth their leaues in the Spring time, and wither away at the apptoch of Wintet.

\section{a) $T$ be Names.}

It is called both in Greeke and Latine 'Euqopkros, Euphorbium : Pliny in one place putteth the herbe in the feminine gender, naming it Euphorbia: the iuyce is called alfo Euphorbion, and fo it is likewife in thops: we are faine in Englinh to vfe the Latine word, and to call both the hetbe and iuyce by the name of Euphorbium, for other name we hauenone: it may be called in Englifh, the Gum Thifle.

9 $T$ be Temperature.

Euphorbirm (that is to fay, the congealed iuyce which we vfe) is of a very hot, and, as Galess teftifieth, caufticke or burning facultie, and of thinne patts : it is alfo hot and dry in the foutth degree.

A An emplaifter made with the gumme Euphorbium, and twelue times fo nu'ch oyle, and a little wax, is very fingular againft all aches of the ioynts, lamenefle,palfies,crampes,and forinking of f $_{\text {- }}$ newes, as Galen, lib.4. de medicament is fecusdum genera, declareth at latge, which to tecite at this prefent would but trouble you ouermuch.

B Euphorbium mingled with oyle of Bay and Beares greafe cureth the fcurfe and fcalds of the head, and pildneffe, caufing the haire to grow againe, and other bare places, being anointed therewith.

C The fame mingled with oyle, and applied to the temples of fuch are very fleepie, and troubled with the lethargie, doth awaken and quicken their fpirits againe.

D If it be applied to the nuque or nape of the necke, it bringeth their fpeech againe that hatreloft it by reafon of the Apoplexic.

E Euphorbium mingled with vineger and applied taketh away all foule and ill fauouted fpots, in what part of the body foeuer they be.

F Being mixed with oyle of Wall-Houres, as Mefues faith, and with any other oyle or ointments, it quickly heaterh fuch parts as are ouer cold.

G It is likewife a remedie again tt old paines in the hucklebones, called the Sciatica.

H Hetius, Purus, Actuarius, and cMefue docteport, That if it be inwatlly taken it purgeth by fiege water and flegme; but withall it fetteth on fire, fcortcheth and fretteth, not onely the throat and mouth, but alfo the ftomacke, liner, and the reft of the intrals, and inflames the whole bodie.

I For that caufe it muft not be beaten fmal,and it is to be tempered with fuch things as allay the heate and tharpeneffe thereof, and that make glib and flipperie; of which things thete mutt be fuch a quantitie, as that it may be fufficient to couer all ouet the fuperficiall or outwatd part thercof.

K But it is a hard ching fo to couer and fold it vp, or to mix it, as that it will not burne or fcortch. For thougl: it be tempered with neuer fo much oyle, if it be outwardly applied it raiferh blifters, efpecially in them tha: haue foft and tender flel $\mathrm{h}$, and therfore it is better not to take it inwardly. 
It is troublefome to beate it, vnleffe the nottrils of him that bents it be earefully foned and

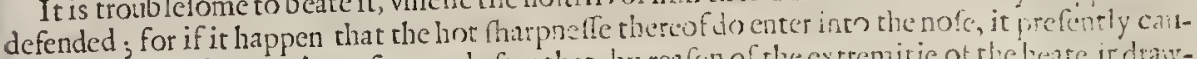
feth itehing, and moueth neefing, and after that, by reafon of the extremitie of the lyeate, ir draireth out aboundance of Alegme and filth, and laft of all bloud, not without great quantity of reares.

But againf the hor tharpneffe of Euphorbizm, it is reported that the inhabitants are remedied $M$

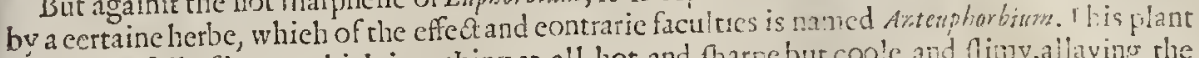
likewife is full of inyee, which is nothing at all hot and tharne butcoo!c and fliviy, allaying the heate and tharpneffe of Euphorbium. We haue not yer learned that the o'd writers hate fee downe any thing touehing this herbe; notwithtanding it feemeth to be a kinde of Orpine, whien is the antidote or counterpoy fon againft the poyfon and venome of Euphorbium.

\section{‡ С н а . 493: Of foft Thiftes, and Tbifle gentle.}

‡ There are eertaine other plants by moft writers referred to the Thifles; which being o. mitted by our Author, I have thought fit here to give you.

‡ Cirfummaximum $\cup$ phodeli radice. Great foft bulbed Thifle.

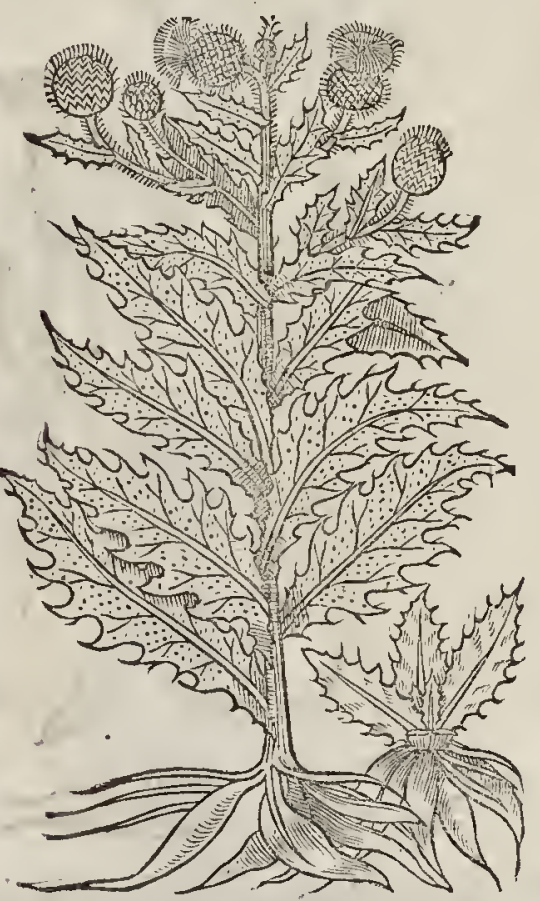

2 Cirfirmmaiusalicrum. Grear foft Thitle.

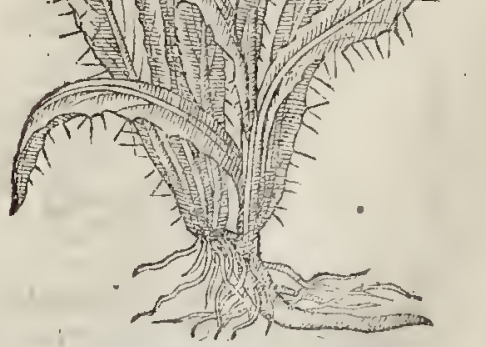

\$ The Defcription.

- Te firf and largeft of thefe harh routs confifting of great longin bulbes like tliofe of the Afphndill: from whenee arifemany large ftalkes three or foul cubits hiph, crefed and downy : the leaues are very long ant large, inyeie, greenifin, and cut abo:tr theedges, and fet witl foft priekles. At the tops of the ftalkes and branches grow heads romel and large, out whereof eome floures confifting of abounidanee of threds, of a purple eolour, which flie away in downe. This growes wilde in the mountainous medowes and in fo me wer plaees of Autria. I hatu feene it growing in the garden of $\mathrm{M}^{\mathrm{r}}$. Iolue Purkinfon, and with $\mathrm{M}^{\mathrm{r}}$. Tuggye. It

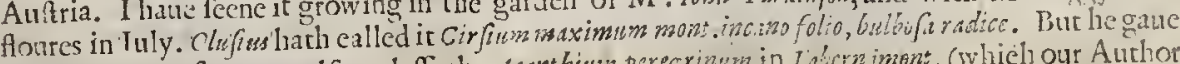

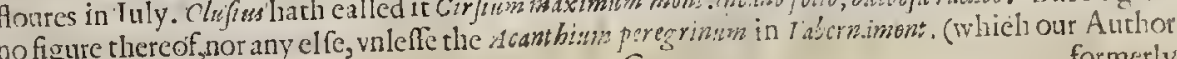
G $\pi \sigma^{\circ}$

formerly 


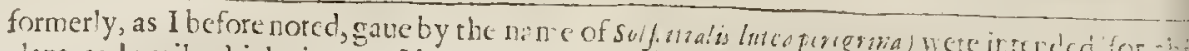
plant, as I verily thiske itwas. I haue gutucn you a figure wicli I dicw fome veares aco bor in plant it felfe.

2 The root of this is long yet fending forth of the fides creeping fibres, lut not bulbous a lie leaues are like thofe of the latt mentioncd, but leffe, and armed with $n$ arpe prick'es of a grecrith

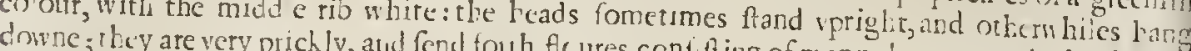
Atulkes are thicke, crefted and wel ed many egant prirpie threds. Tl. fea confts of Zecland, Flanders, and Holland it ing of the leates. T his grones wilde vi on tle of Dodonass; and Cirfiem maius of Lobel.

3 This whofe ront is fibrous and liuing, fends forth leffer, narrower, and fofter leates than thofe of the former, not lagged or cut about their edges, nor hoary, yet fet about with prick'es:

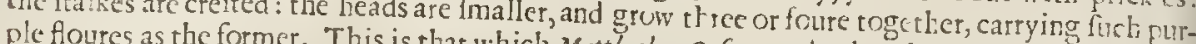
sm : Dodoness, for Cirfum 2. and Clufus hath Mattbiolus, Gefner, and otlers have fet forth for Corfi-

\# Cirfum foliysnon hirfutis. Soft imooth leaucd Thifle.

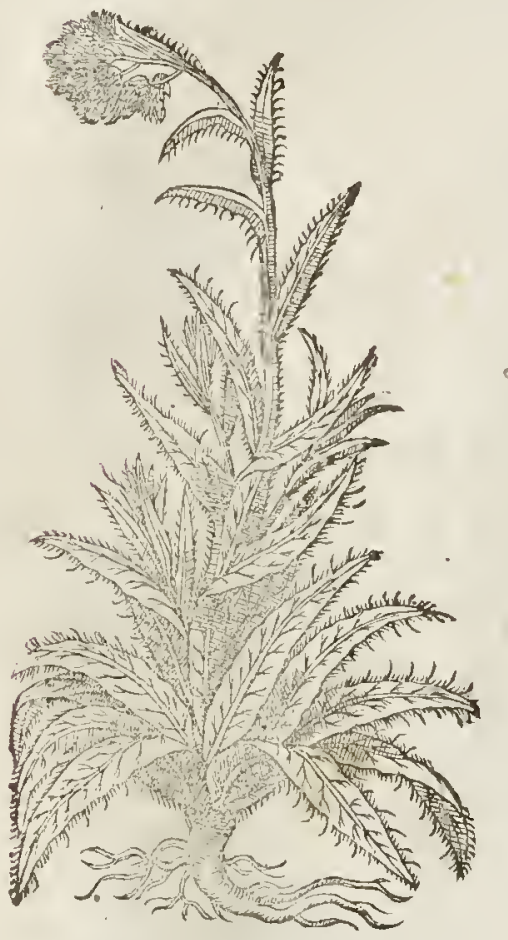

\$ Cirfum montamum capitulisparuis. Small Burre Thiftle.

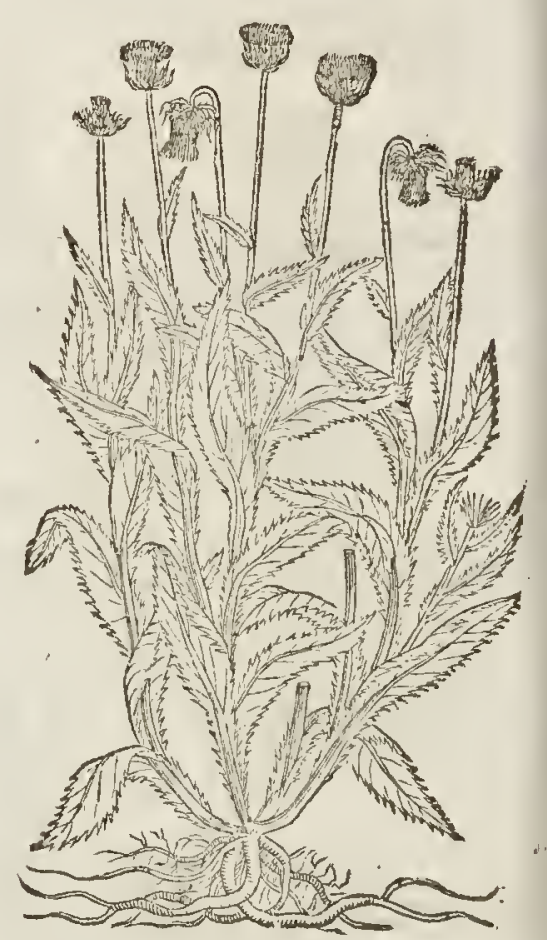

4 The leaues of this are fomewhat like thofe of the laft defcribed, but larger, and welting the fome two cubits her fetting on : they are alfo fet with prickles about the edges : the otalks are roigh pricklv heads, length turne into downe. anter the toures come to perfertion doe hang downewards, and at the diverswonddv p'aces of Hungatwich lies hid a fmooth thining feed. This groweth whic in

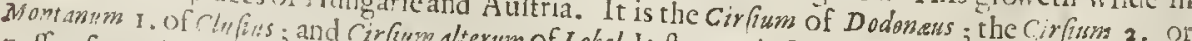

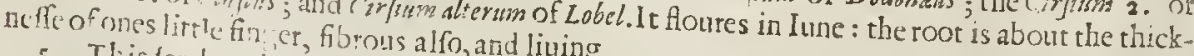
i Tlisterids w

oc the middeft of thefe leaues orowes les, hairy, and fet about the edges with flender prickles : out der, itifie, and downv: ipon whicl ip a talke fometimes a font, otherwhiles a cubit ligh, fler: a little nicked or cut in : this ftalke fometimes hat wat broad at theirfetring on, and thetc it? flender ones, at the tops whereof gtow out of fath no branches, otherwhics rwo or thrce lon? 


\section{L1 B. 2. Of the Hiftroy of Plants.}

1133

\$ 5 Cirfum montanum anglicrm. Single headed Thittle.

cardunu pratein $s$ is

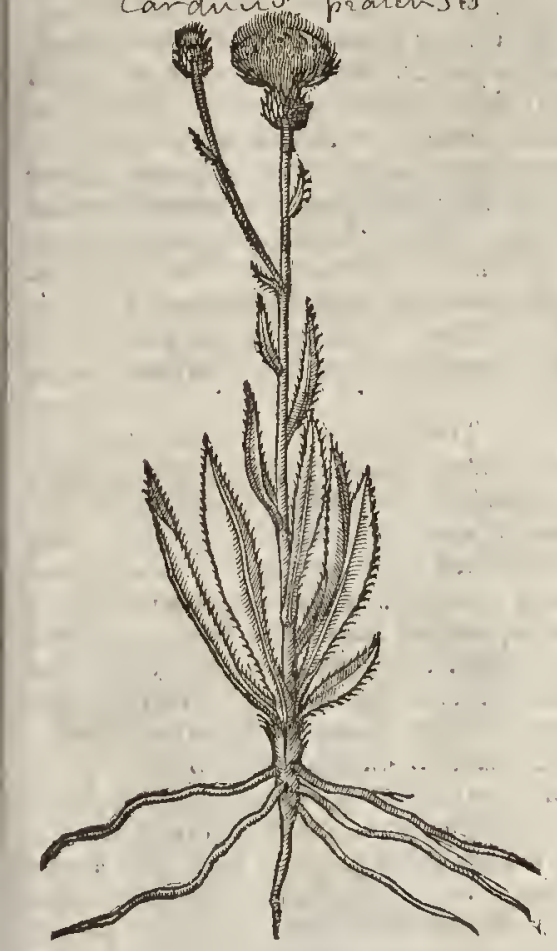

\# Cirfij Anglici Icon Lobeliy.

Lobels figure of the fame.

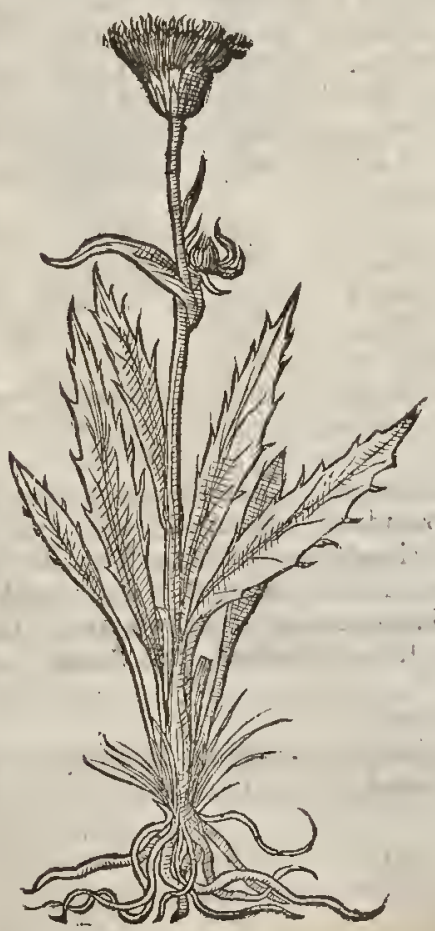

¥ Cirfij Anglicialia Icon Penkei.

Pennies figure of the fame.

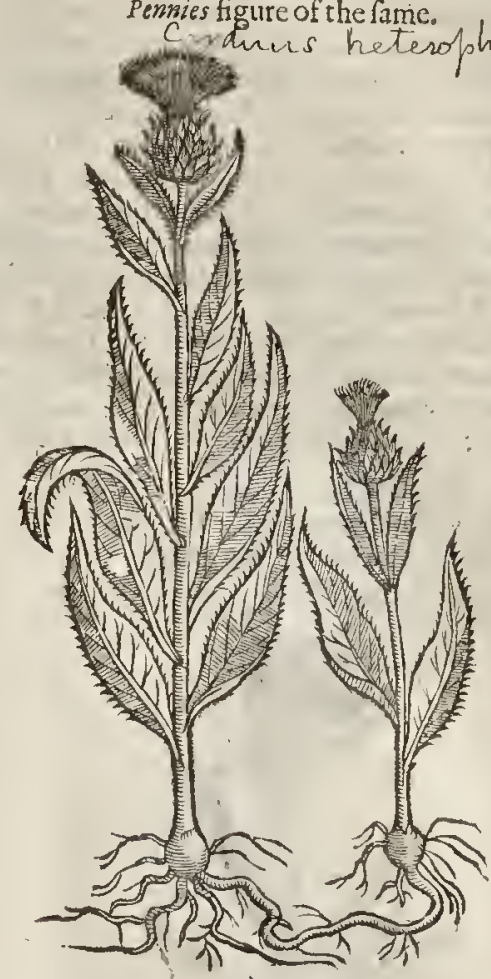

* 6 carduns mollis folys diffect is. lagged leaued Thiftle gentle.

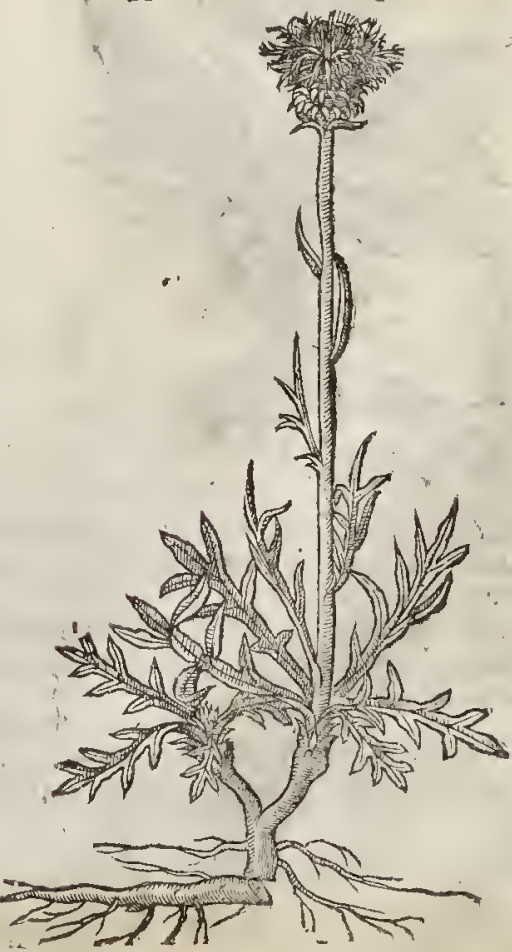


which at leng th tutne into downe; among which lies hid a fmall fhining feed like the other plants of this kind. The root is made of diuers thieke frbres, which run in the ground, and here and there put vp new heads. This plant wants no fetting forth; for Clufus giules vs the figureand hiftorie thereof, firft by the name of Cirfum Pamonicum $\mathrm{x}$. pratenfe; then he gives another hiftorie thereof, with a worfer figure, (which he receiued of $D^{r}$. Thomas penny of London) by the name of Cirfoum Anglicum 2. Lobel alfo deferibed it, and fet it forth with a figure expteffing the floure alreadic faded, by the name of Cirfium Anglicum. Bunbine in his Pinax, deceiued by thefe feuerall expreffions, hatli made thrée feuerall plants of this one; a fault frequent in many Writers of plants. Cluffus found it growing in the mountainous medowes alongt the fide of the Danow in Auftria: Penny, in the medorwes at the foor of Ingleborow hill in Yorke-fhire: Iobel, in the medowes at a place ealIed Acton in Glocefter-thire. I found this onely once, and that was in a medow on this fide Highgate, hauing beene abroad with the Companie of Apothecaries, and returning that way home, in the companie of M". Iames Walfall, William Broal, and fome others. I haue giuen you both the figures of Clufurs his owne in the firft place, and that of D'. Penny in the fecond, but the former is the better : I haue alfo giuen you that of Lobel.

7 Carduns mollis folys Lapathi. Dockie leaued Thiftle-gentle.

$$
\text { Serratula alpoina. }
$$

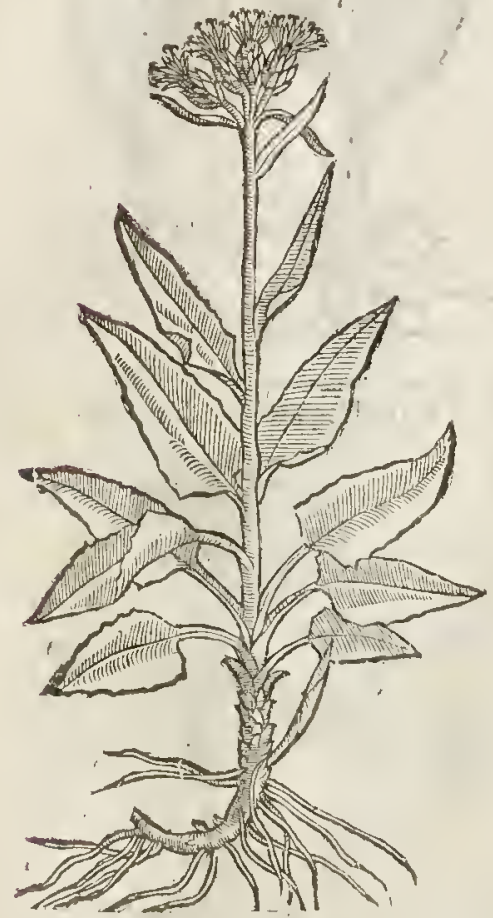

6 Thefe alfo chufiss (whom I herein follow) addeth to the kindes of Thiftles. This iagged leafed one, which he calleth Carditus mollior primus, hath many leates at the root, both fpred vpon the gtound, and alfo fanding vpright; and they are eouered with a white and foft downineffe, yet greene on the vpper fide : they are alfo much diuided or cut in euen to the middle rib, like to the fofter or tenderer leaues of the Statre Thiftle : they haue no ptiekles at all vpon them : out of the middeft of thefe leaues grow vp one or two ftalkes, round, erefted, purplifh, hoarie, and fome cubit or better high. The leaues that grow vpon the lower parr. of the ftalke are diuided, thofe aboue not $\mathrm{fo}$; the tops of the ftalkes fometimes, yet very feldomc, ate parted into branches, which cary faly heads containing elegant floures made of many purple ftrings. The floure deeaying, there fuceeeds a cornered feed: the root lomtimes equalls the thickeneffe of ones finger, brownith, long, and fomewhat fibrous. It floures in May, and growes vpon the hilly places of Hungarie.

7 The ftalke of this is fome foot or better high, thicke, crefted, and fomwhat hairy: the leaues about the root are fomwhat large, aud in thape like thofe of Bonus Henricus, (abufiuely called in Englifh, Mereurie) fomewhat finuated about the edges, and fet with harmeleffe prickles, greene abouc, and verie hoarie vnderneath, like the leaues of the white Poplar : thofe that grow vpon the ftalke ate leffer and narrowet: out of whofe bofomes towards the tops of the ftalke grow out little branches which carry three, foure, ot more little fcaly heads like thofe of the Blew-Bottle, ot Knapweed, whereout grow threddy blewih purple floures : the feed is wrapped in downe, and not vnlike that of Blew-Bottle: the root is blacke, hard, and liuing, fending forth fhoots on the fides. It growes vpon the higheft Auftian Alpes, and floures in Iuly. Clufins calls this Cardwas mollior Zapathi folio.

T The Temperature and Vertues.

Thefe plants feeme by their tafte to be of a moderately heating and drying facultie, but none of them ate vfed in medicine, nor hauc their vettues fet downe by any Author. 


\section{C н А Р. 494: \\ Of three leafed Grafse, or CMedow Trefoile. \\ The Kindes:}

Thete be diuers forts of three leafed Graffes, forne greater, others leffer, fome beare floures of 1 one colour, fome of another: fome of the water, and others of the land: fome of a fweet fmel, others ftinking : and firft of the common medow Trefoiles, called in Irin Shamrockes.

1 Trifoliumpratenfe. Medow Trefolle. Jirtolinir repens. descr: mala.

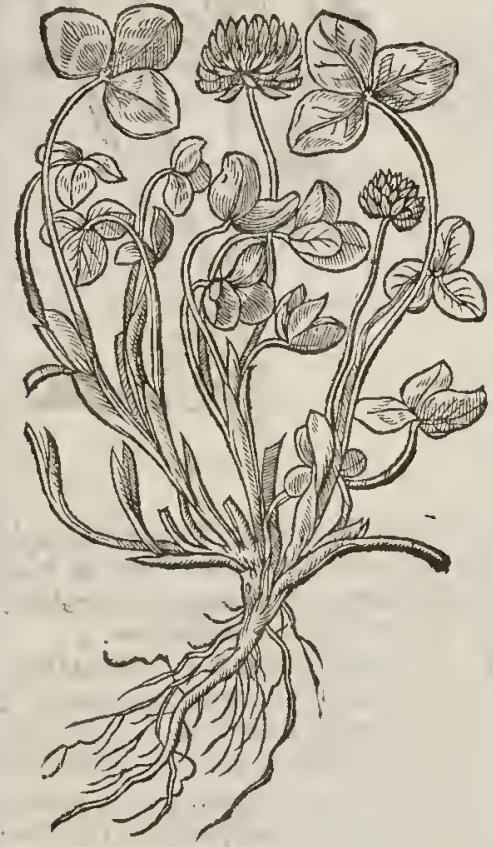

$\$ 3$ Trifolinm mains for albo: Great white Trefoile.

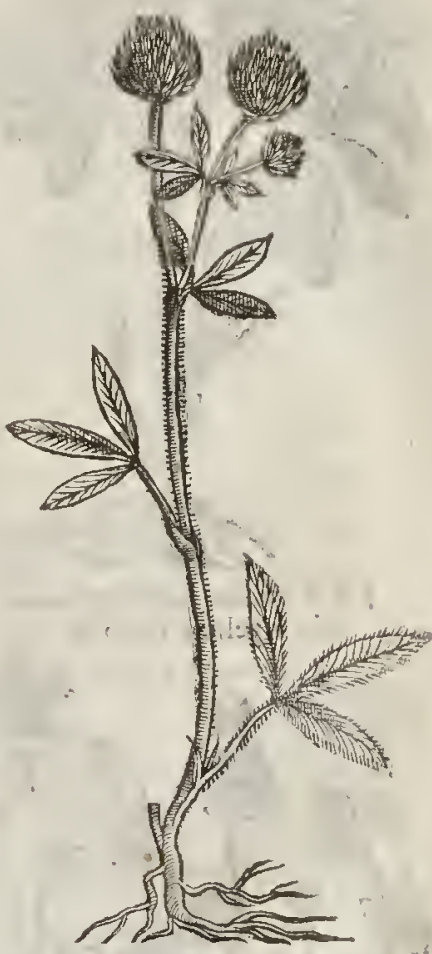

If The Defcription:

I Edow Trefoile bringeth forth ftalkes a cubit long, round, and fomething hairy, the 1. greater part of which creepeth vpon the ground; whereon dogtow leates confifting of three ioyned together, one ftanding a little from another; of which thofe that are next the ground and roots are tounder, and they that grow on the vpper part longer, hauing for the - moft part in the midit a w hite fpor like a halfe moon. The floures grow on the tops of the ftalkes in a tuft or fmall Fox-taile eare, of a purple colour, and fweet of tafte. The feed groweth in little huskes, round and blackin : the root is long, woodd y, and groweth deepe.

2 There is another of the field Trefoiles, differing from the precedent efpecially in the colour of the floures; for as thofe are of a bright purple, contrariwife thefe are very white, which maketh the difference. The leaues, floures, and all the whole plant is leffe than the formet.

3. 4. There is alfo a Trefnile of this kinde which is fowne in fields of the Low-Countries, in Italy and diters other places beyond the feas, that commeth vp ranker and higher than that which groweth in medorves, and is an excellent food for cattell, both to fatten them, and caufe them to gitiegreat ftore of milke.

$\mp$ Of this there is one more with white floures, which hath ftalks fome foor high, and narrow hairy leaues, with a root of the thickneffe of ones little finger. This is Chufus his Trifolium maius 
\# 4 Trifolium maius flo. purpureo. Great purple Trefoile.

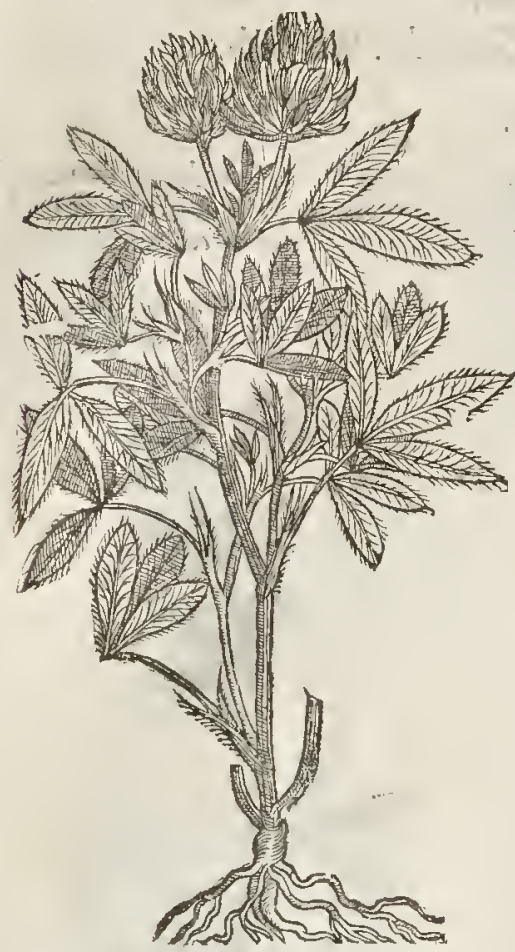

\$ Trifolium luteum minimum.

Little yellow Trefoile.

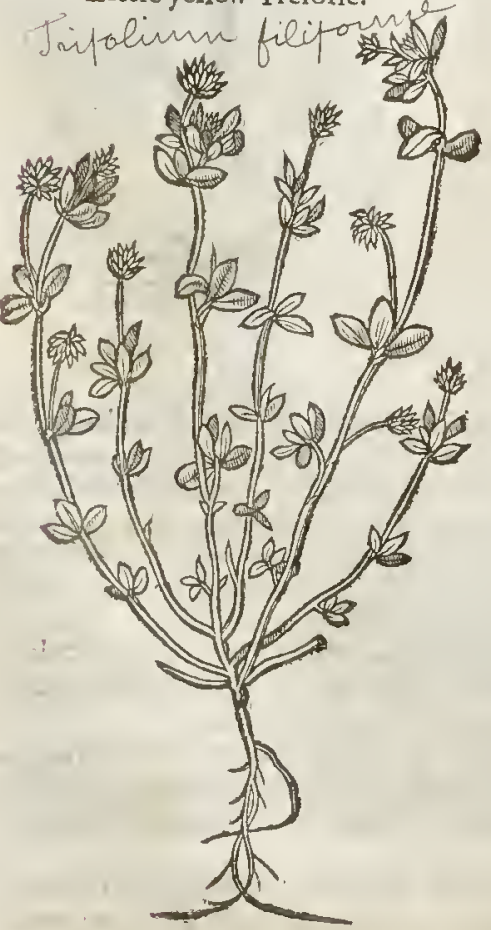

‡ 5 Trifolium luteum Lupulinum.

Mrediop Trefoile.

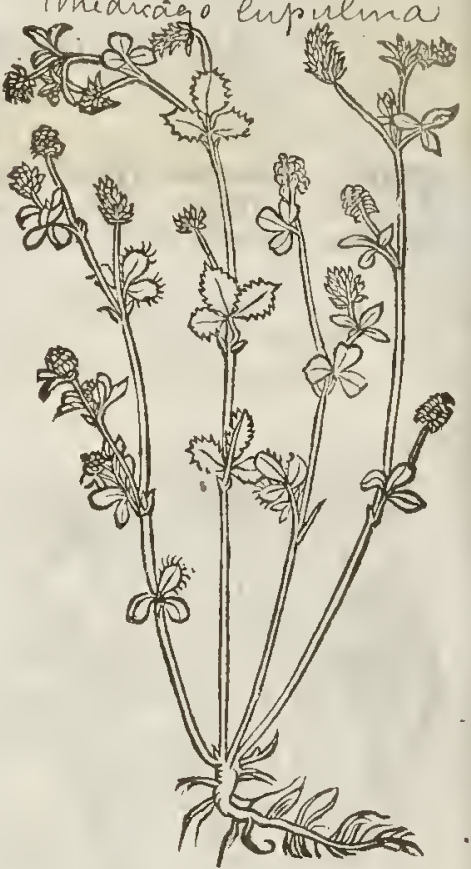

primiun. The other hatlu falkes fome cubit high, with larger ioynts and leaues : the floure or lead of floures is alfo larger, of an elegant red colour. This cluffus calls Trifolium mains tertium. $¥$

5. 6. Likewife we haue in our fields a fmaller Trefoile that bringeth forth yel low foures, a greater and a leffer, and diuers others alfo, differing from thefe in diuers notable points, the which to diftinguifh apart would greatly inlarge our volume, and yet to fmall purpofe : therefore we leaue them to be diftinguirhed by the curious, who may at the firft view eafily perceiue the difference, and alfo that they be of one ftocke or kindred.

$\neq$ The greater of thefe yellow Trefoiles hath prety large yellow heads, which afterwardbecome of abrownifh eolour, and fomewhat refemble a Hop:whenee $T$ halius called it Lupulus fyluaticus, or Irifolium luteum alterum lupulinum : Dodoncus cals it Trifolium agrarium. The leaues are fmall, and lightly niekt about the edges. The lefter hath fmaller and far leffer yellow heads, which are fucceeded by many little erooked cluftring feeds:the leaues of this are fmall, and alfo fnipt about the edges:both this \& the other haue two littleleaues clofe by the faftning of the foot-ftalkes of the leanes to the main ftalks; wherfore I refer them to the Medicks, and vfually cal this later,Medica $\int \mathrm{em}$. racemofo. It is the Trifol. luteum minimum of Pena and Lobel; and Trifolium arven $\int e$ of Tabern. $\neq$ 


\section{T The Place.}

Common Medow Trefoile groweth in medowes, fertile paftutes, and waterith grounds; 'The others loue the like foile.

They floure from May to the end of Sommer.

$$
\text { 97 The Time. }
$$

\section{The Names.}

Medow Trefoile is called in Latine Trifoltum pratenfe: in High Dutch, Hotentlee:in Iow Dutch, Claueten : in Freneh, Treffle and Trainiere, and Vifumarus, as Marcellus an old writer teftifieth: in Englifh, Common Trefoile, Three-leafed graffe: of fome, Suckles,and Honi-fuckles, Cocksheads; and in Irith, Shamrocks.

The leaues and filoures of Medow Trefoiture.
Thes are cold and drie. if The Vertues.

The decotion of three leaued Graffe madewith honie, and vfed in a clyfter, is good againft the $A$ ' fretrings and paines of the guts; and driueth forth tough and llimie humours that cleaue vnto the guts.

The leaues boiled w ith a little barrowes greafe,and vied as a pultis,take away hor fwellings and $\mathrm{E}$ inflammations.

Oxen and other eattell do feed of the herbe, and alfo calues and young lambs. The floures are $\mathrm{C}$ acceptable to Bees.

$P$ liny w riteth,and fetteth it downe for certaine, that the leaues hereof do tremble, and ftand right $\mathrm{D}$ vpagainft the eomming of a ftorme or tempeft.

The medow Trefoile (efpecially that with the blacke halfe Moon vpon the leafe) ftamped with E a little honie, takes away the pin and web in the eies, ceafeth the paine and inflammation thereof, if it be ftrained and dropped therein.

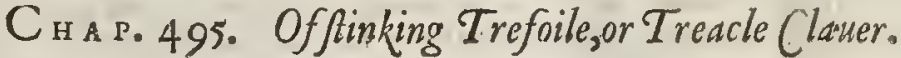

Trifolium bituminofum, Treacle Clauer:

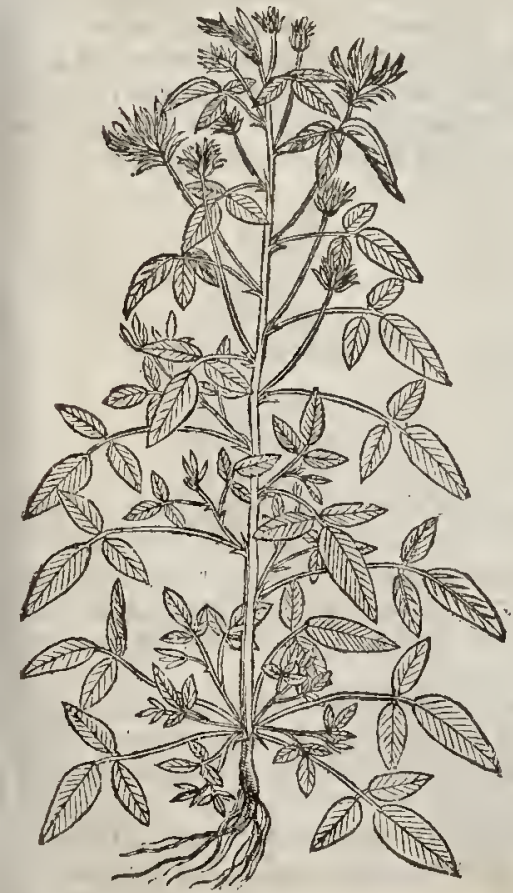

\section{T The Defoription.}

TReacle Clauer. groweth vpright like a Ihrubbie plant, with ftalkes of a cubit and a halfe high, whereupon do grow next the ground broad leates, 3 ioined together, thofe vpon the falkes are longer and narrower. The talks are eouered ouer with a rough etill colouredhairinefle: the leaues are of a dark black greene eolour, and of a loth fome fmell, like the pitch called Butumen ludaicum, whereof it took his name: the floures grow at the toppe of the ftalks, of a darke purplifh colour tending vnto blewneffe, in thape like thofe of Seabious : the feed isbroad, rougl, long, and marpe pointed: the rcor is fmall and tender, and eannot indure the coldnefle of our winter, but perithethat the " firft approch thereof.

$$
\text { of The Place. }
$$

It groweth naturally, faith Hippocrates Hippiatros, not Cous, in rough places, as Ruellius tranflateth it : in Germanie, France and England if neuer commeth vp of it felfe, but mutt be forwn in gardens, as my felfe haue proued diuers times, and was confrained to fow it yearely, or elfe it would not eome $v p$, neither of his owne fow ing or otherwife:

$$
\text { 1) The Time. }
$$

It floureth not in my garden vntil the end of Augut. 


\section{T Te Names.}

Nicander calleth this Ttefoile stamnin: in Latine, Trifolium acutum, or tharpe pointed Trefoile: of Pliny, Trifolium odoratum, but not properly; of orhers, Trifolium Afphalteum, five Bitumnnofum, or Stone Pitch Trefoile.

Aucen calleth it Tarflon, and not Handacocha: Auicen doth comprehend Diofcorides his Loti, that is to fay, Lotus vrbana Jylueftris, and Esyptia ${ }_{3}$ which Dioferides confoundeth one with another in one chapter: in Englith it is called Clauer gentle, Piteh Trefoile,ftinking Trefoile, \& Treacle Clauer. of The Temperature.

This Trefoile, called $A \int p h$ alt enm, as Galen faith, is hot and drie, as Bitumen is, and that in the third degree.

4 The Vertues.

A Being drunke, it taketh away the pain of the fides, which commeth by obltuctions or ftoppings, ptomoketh vrine, and bringeth downe the defired fickneffe.

B Hippocrates writeth, that it doth not onely bring them downe, but likewife the birth, not onely inwardly taken, but alfo outwardly applied. If a woman, faith he, be not well clenfed after her ehild bearing,giue her this Trefoile to drinke in white wine.

C Diofcurides faith, that the feeds and leaues being drunke in water, are a remedie for the pleurifie, difficultie of making water, the falling fickneffe, the drop fie when it firt beginneth, and for rhofe that are troubled with the mother: the quantity to be taken at onee is three drams of the feeds, and foure of theleaues.

D. The leaues drunke in Oxymel, or a fyrtup ofvineger made with honie, is good for thofe that are bitten with ferpents.

E Some affime that the decoetion of the whole plant, root and leaues, taketh away paine from thofe whom ferpents haue bitten, if they. be walhed therewith; but if any other man hauing an v!eer be wathed with that water wherw ith he was bathed that was bitten of the ferpent, they fay that he flall be troubled in the fame manger that the ftinged partie was.

F Some alfo giue with wine three leaues,or a fmall quantitie of the feed in tertian agıses, and in quarraine foure, as a fure remedic againft the fits.

$G$ The root alfo is put into antidotes or eounterpoifons, faith Diofcorides : but other antient $P$ tions do not onely mix the root with theui, but alfo the feed,as we may fee in Galen, by a greac ma ny eompofitions in his 2. booke of Antidotes; that is to fay, in the Treacles of Eleus Gallus, $Z$ cru Laudoceus, Claudius Apollonius, Eudemus, Heraclides, Dorotheus, and Heres.

H The herbe ftamped and applied vpon any entenomed wound, or made with poifoned weapon, it dtaweth the poifon from the depth moft apparantly. But if it be applied vpon a wound where there is no venomous matter to work vpon, it doth no leffe infeet that part, than if it had been bitten with fome fetpent or venomous beaft: which wonderfull effect it doth not performe in refpect of any vitious qualitie that it hath in it felfe, but beeaufe it doth not finde rhat venomous matter to work vpon, which it nat:urally draweth (as the Load-ftone doth iron)wherupon it is conftained through his attractiue qualitie, to draw and gather togethet humours from far vnto the place, whereby the paine is greatly inereafed.

\section{С н м. 496. Of diuers otber Trefoiles.}

$$
\text { TI The Defiription. }
$$

27 Hree leauedgraffe of A meriea hath diuets erooked round ftalks, leaning this way and that way, and diuided into diuers branehes : whereon do grow leaues like thofe of the medow Trefoile, of a blaek greene colour, and of the fmel of Pitch Trefoile, or I reacle Clauet : the floures grow at the top of the btanehes, made vp in a long fpiked ehaffie eate, of a white eolour: afrer which commeth the feed, fomewhat flat,almof like to thofe of Tares : the roots ate long ftrings of a wooddic fub fanee.

2 This three leafed graffe (which Dodoneus in his laft Edition ealleth Trifolium cochleatum primum : and Lobel, Fant:m Burgundiacum) hath diuers round vpright ftalks, of a wooddierough fubftance, yet not able of it felfe to ftand without a prop ot ftay: which ftalks are diuided into diuers fmall branches, whereupon do grow leaues ioined thtee together like the other Trefoiles, but ofa darke fwart greene colour : the floures grow at the top of the falks in thape like thofe of the cod. ded Ttefoile, but of a datke purple eolout: the feede followeth, contained in fmall wrinckled 


\section{L1B. 2. Of the Hiftroy of Plants.}

1 Trifolium Amcricum.

Trefoile of America.

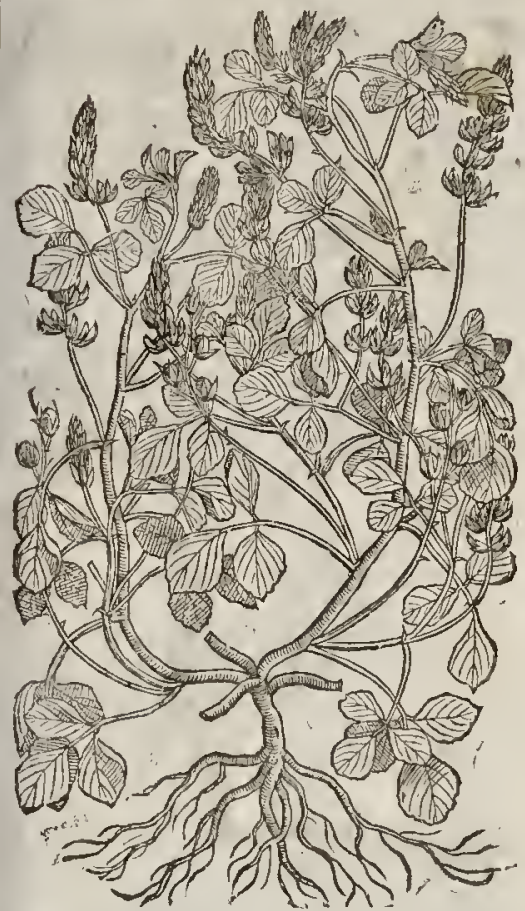

+2 Irifolium Burgundiacum. Burgundie Trefoile.

Medicena soitiva.

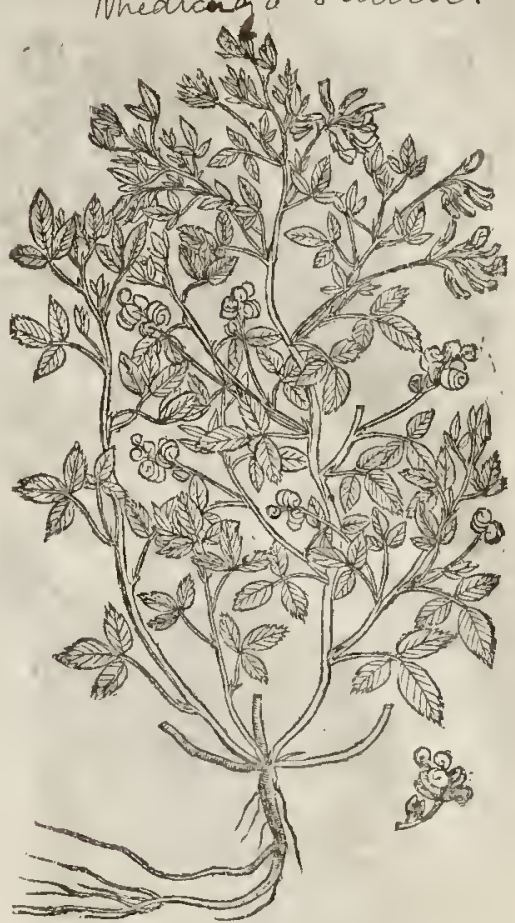

3 Trifolim Salmatitum. Portingale Trefoile.

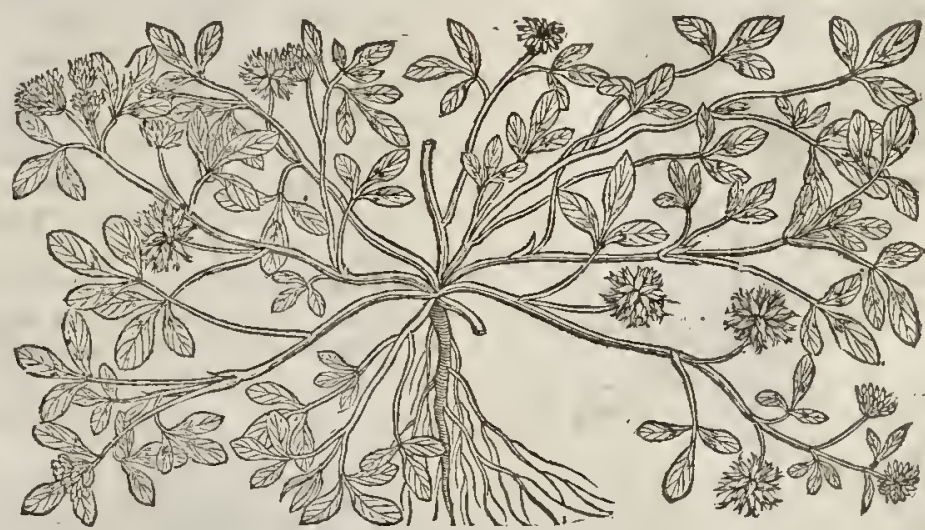

Buskes turne? round,after the manner of a water fnaile:the root is thick, compofed of diuers rough threddie ftrings, and lafteth long in my garden with great increafe.

3 This three leaucd graffe of Salmanca, a citie as I take it of Portingale, differeth not much from our field Trefoile : it hath many branches weake and render, trailing vpon the ground, of two cubites and a halfe high: whereupon doe grow leaues fet togerher by three vpon a ftemme, from the bofome whereof thruft forth tender foot-ftalkes, whereon doe ftand moft fine floures of $a$ bright red tending vnto purple: after which come the feed wrapped in fmall skinnes, of a red colour.

4 The Hart Trefoile hath very many flexible branches, fer vpon a flender falke, of the length of two or three foot, trailing hicher and thither : whereupon doe grow leaues ioined together by three 


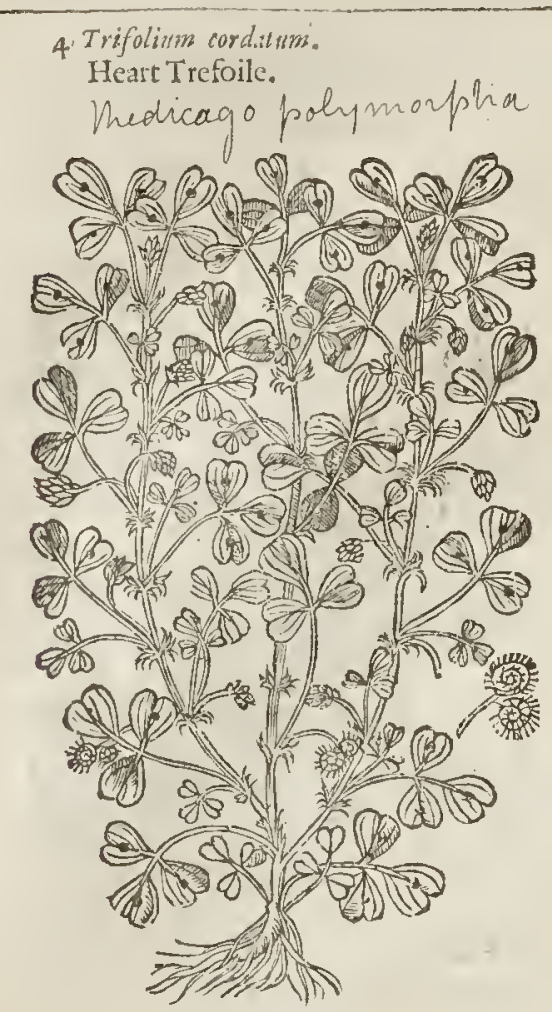

Trifolium corditum.

Heart Trefoile.

Wedicago polymorpha

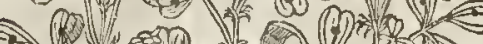

(1)

Qu(B) (a)

(2) $0 \mathrm{NO}$ ?

7010

¥ 6 Coronopus ex Codice Cefareo. Crow-foot Trefoile.

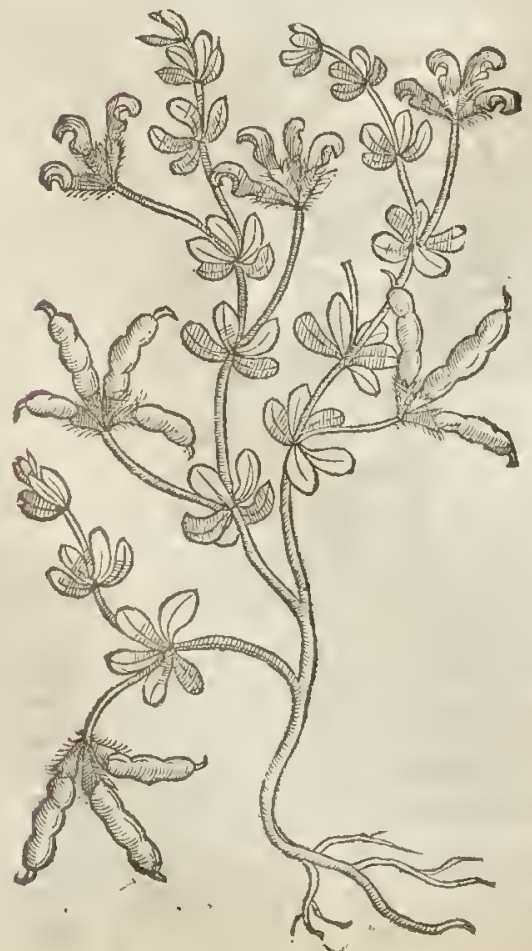

5 Trifolium filiguofum minus. Small codded Trefoile. Lotirs couniculatirs.

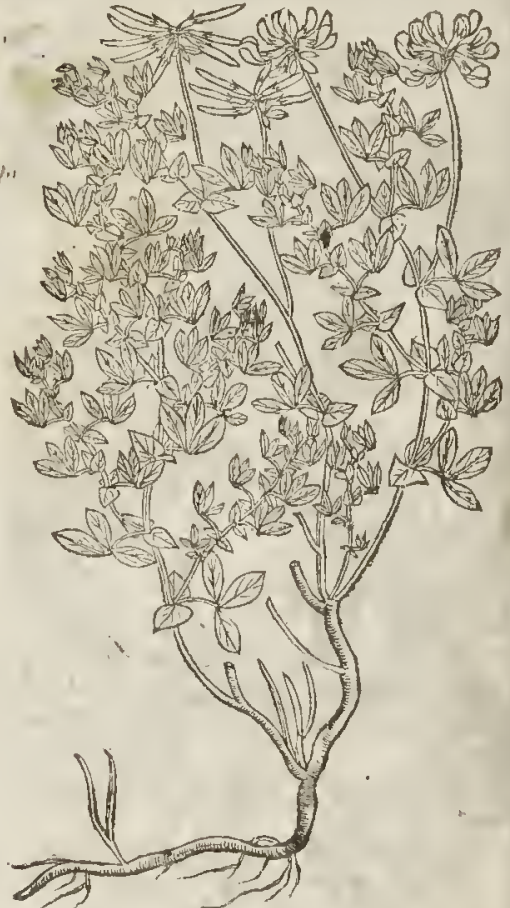

three on little flender foot-ftalks, euery little leafe of the fathion of a heart, whereof it took his name: among which come forth fcalie, or chaffie yellow floures: the root is thick and threddie. $\neq$ I take the plant which our $\mathrm{Au}$ thour here figured and intended to defcribe vnto v9, - to be of that Medica which Camerarius calls Arabica, which growes wilde in many placeswith vs, hauing the leaues a litrle dented in at the ends, fo that they refemble the vulgar figure of a heart; and each leafe is marked with a blackifh, or red fpot: the foures be fmall and yellow : the feeds are contained in rough buttons,wound vp like the other Snaile Trefoiles, whereof it is a kinde. I hatue giuen you the figute a little more exquifite, by the addition of the fpots and cods. $\neq$

5. This kinde of tince leaued graffe is a low herb, creeping vpon the ground:the leates are like thofe of the comnon Trefoile, but leffer, and of a grayinh greene colotir : the floures are faire and yellow, fafhioned like thofe of broome, but leffer : after come three or foure couls, wherein is contained round feed:the root is long and reddith. $¥$ This is the Trifolism comiculatum, or Melilotus Coronat a of Lobal: Lotus pentaphyllos of Ge fner. $\neq$

This codded Trefoile is like vnto the laft defcribed in euery refpect, fauing that this plant is altogether larger, hauing falks a cu- 


\section{LIB.2.}

bite and a halfe high : the leates are alfo fourc times as large,two roundinh leaues gro ving hy the ftalke, and three longith ones growing vpon a hort foot-falke conming forth bitwcere the two roundith leaties: both the ftalke and leates hate a litte fofr downineffe or hairneffe on them:the floures grow cluftering together on the taps of the ftalks, in fhanc, bigneffe and colour like thathe the laft defcribed, but cominonly more in number : they are alfo fucceded by fuch cods as thofe
of the former.

6 The figure which Dodon rus hath fet forth our of an old Mamfeript in the Emperors Library, being there figured for Coronopurs, feemes to be of the lat deferibed, or fome niantvery is tie thereto, though the fute leaues at each ioint be not put in fucl order as thev fhould be, yet ail the natts are well expret, according to he irawing of tho e times, for you thall funde few anticnt expreffons
come fo neere as thisdoth. $\neq$.

$\rightarrow$ There is a kinde of Clauer growing airsur Narbone in France, that hatl many twiggie tough branches comining from a wooddy root, whereon are fer leaues three to yether, afrer the ma ner of the other Trefoiles, fo newhat long, hairy, and of a hoarne or ouerworne greene colour. The floures are yellow, and grow at the tops of the branches like tho fe of Broome.

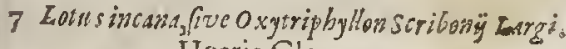
Hoaric Clatuer.

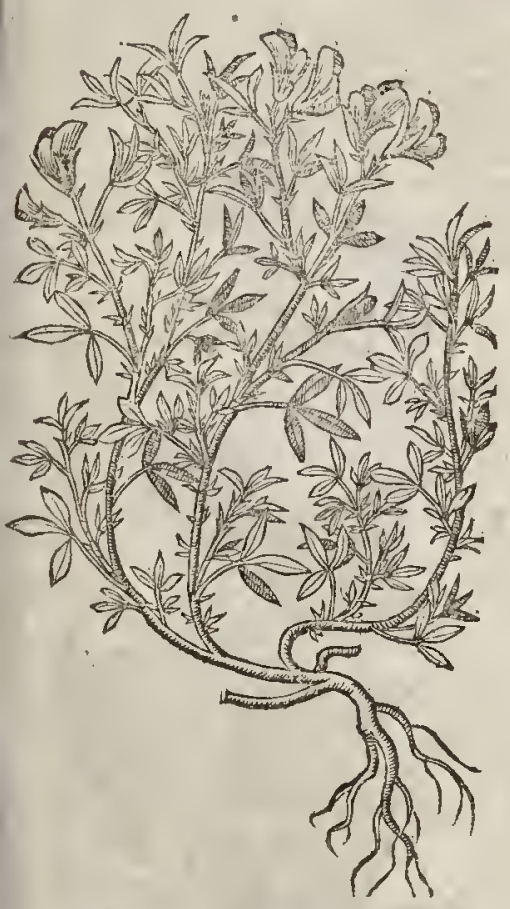

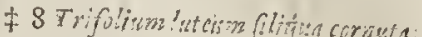
Yellow homed Trefoile. Medicago tabeata.

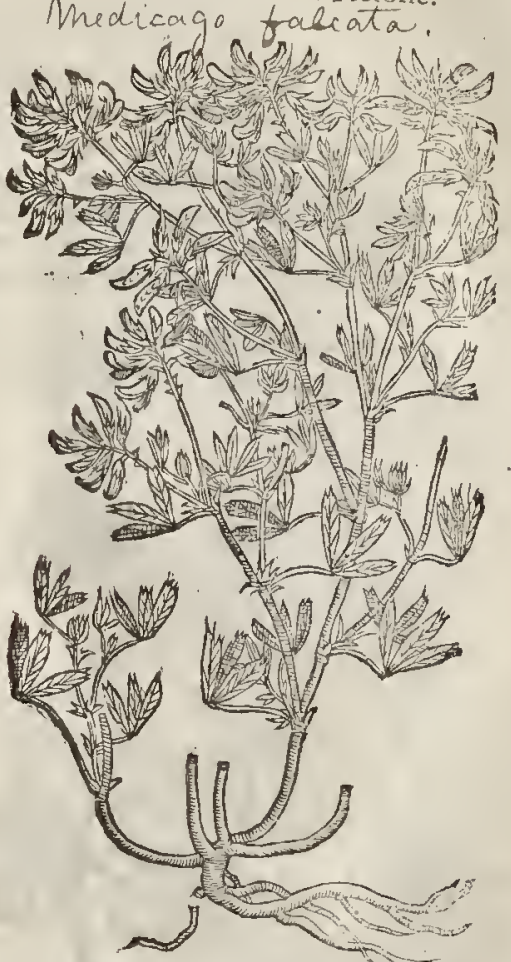

7 This fends vp many branches from one root, fome cubit or more long, commonly lying a long vpon the ground, round, flexable, and diuided into fundrie branches: the leates ftand to jechen oy threes, and are like rhofe of the true Medica, or Burgundie Trefoile, bur much lefie: the toures Srow clutering toget her on the rops of the branches, like in thape to thore of the former s of a vel Ow colour, and not withour fmell : they are fucceeded by fuch, yee narrower cronted coldes, as the eeds like thofe alfo of that Trefoile and futh not wel exprefled them: ) in thefe coils are containe

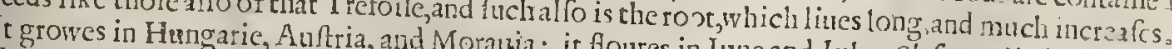

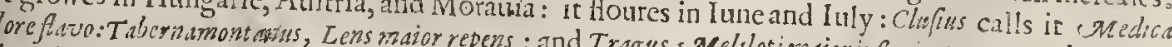

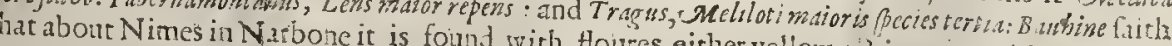
lacke, or mixed of bley and it is found with Houres either yellow, white, greene,blew, purple, aredicofrutefiens:" 
बा The Place.

The feverall titles of moft of thefe plants fet forth their naturall place of yrowing the rett grow in moft fertile fields of England.

$$
\text { बा The Time. }
$$

They foure and flourith moft of the fommer moneths.

$$
\text { It The Names. }
$$

There is not much to be faid as touching their names, more than hath beene fet dow ne.

$$
\text { If The Tempicrature and Vertues. }
$$

The temperature and faculties of thele Trefoiles are referred vnto the common medow Tie. foiles.

7 The figure formerly pat in the fecond place was of the lefier yellow Tiefoile deferibed in the laft chapter faucone.

\section{Cн А P. 497. Of the great Trefoiles, or minged (lamers. If The Defcription.}

I T He great Hares foot being a kinde of Trefoile, hath a hard and wooddie root, full of blacke threddie flrings: from whence arife diuers tough and fecble branches, wherempon dogrow leaues, fer together by threcs, making the whole plant ro refemble thofe of the Medow Trefoile: the floures grow at the top of the ftalks, compofed of a bunch of gray baites: among the which foft matter conmeth forth fmall floures of a moft bright purple colour, fomw hat refembling the fioures of the common medow Trefoile, but far greater. Lobel ealls this Lagopus maximus folio, o facie Trifoly pratenfis : Dodonats, Lagopus maior folio Trifoliy.

\# I Lagopus maximus.

The great Hares foot Trefoile.

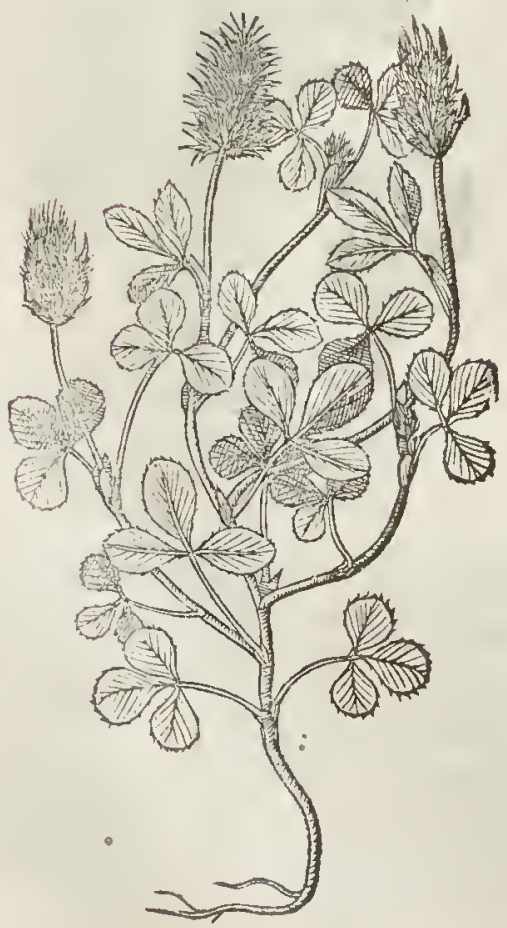

* 2 Lagopus maior (picalongiore. Gieat large leaded Hares foot.

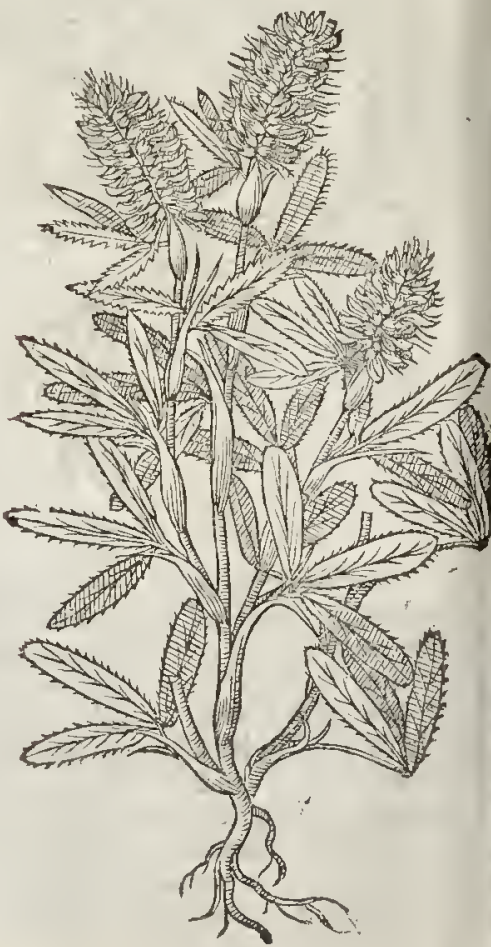




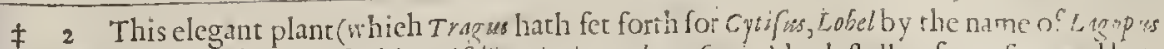
alter a folio primato and Clufius for his Trifoly maloris 3 . altera (peizes) hath ftalkes fone fuor and better high,whereon grow leaues fet together by thres, in zg, houry and lightly fnipt abo it the edges, witl elegant nerues orveines, running from the middle rib to the fides of the leaues, shich are molt confpicuous in hot Countries, and ehietly then when the leafebegins to decay. Atrletops of the branches, in long and large heads grow the floures, of an elergant fanguine colour. This floures in May and lune, and growes wilde vpon fome mountaines of Hungary and Auftria; I haue feenethem, both this and the former, growing in the gardens of fome of our Fiorifts.

3 This other great kinde of Hares-foot fends forth one flender,yet Atife falke, wherenn grow leaues whofe frot-italkes are large at the fetting on, encompafing the ftalkes : the leaties themfelues grow by threes, long, narrow, and tharpe pointed, of a grayifh colour like thofe of the common Hares-font; the fpike at the top is foft and downy, with little reddifh floures amnogt the whition hairinefle. This growes wilde in Spaine : Clufinus calls it Lagopus anguftifolivar Iripanicus maior.

There is another fort of this defcrbed by Lobel and Pena in the Aducr.whofe leaucs are longer and narrower than this, the whole plant alfo is oft times leffer : they eall it Lagoprs alfera ang"flit folia. $\neq$

\# Lagopres anguftifoinis Hifpanicus.

Narrow leafed Spanih Hare-foot.

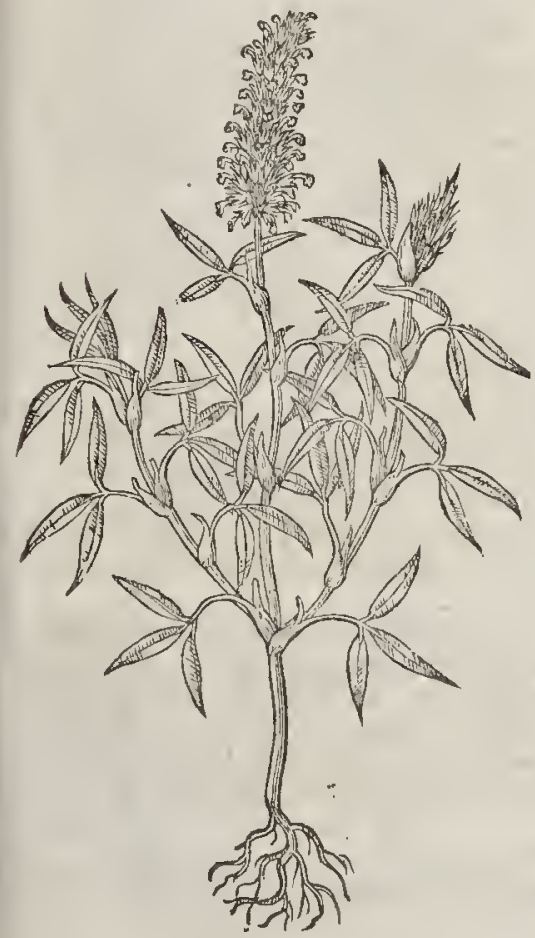

4 Lagopodium, Pesleporis. Little Hares-fodt Trefoile.

Tritolinive sense

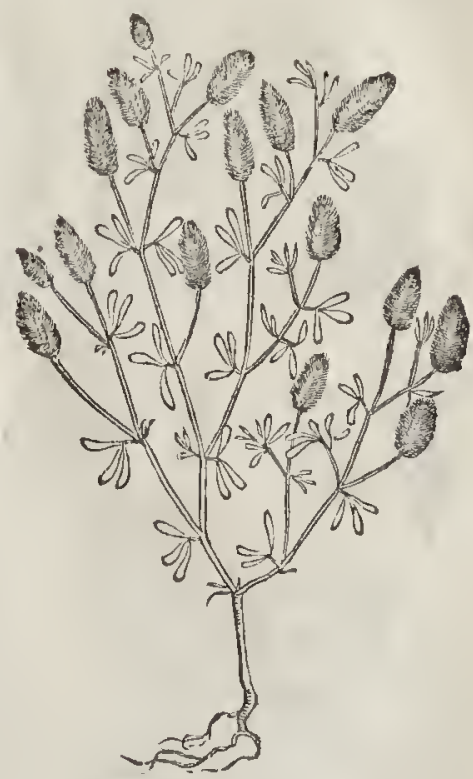

4 'The fimall Hares-foot hath a round rough and haity ftalke, diuiding it felfe into diucts other branches; whereupon dogrow fmall leanes, three joined together, like thofe of the fmall yellow Trefoile : the Aloures grow at the very point of the ftalkes, eonfifting of a rough knap or bufh of haires or downe, like that of Alopecuros, or Fox taile, of a whitifh colnur tending to a light blufh, with little white Ro:rres among the downinefle: the rnot is fmall and hard.

The firt groweth in the fields of France and Spaine, and is a Atranger in England;yet it groweth in my garden.

The fmall Hare-foot groweth among corne, efpecially among Barly, and likewife in barren patures almoft euery where.

They floure and flourifh in Iune, Iuly, and Auguft.

$$
\text { The Time. }
$$




\section{a The Names.}

The great Hare-foot Trefoile is ealled of Tragus, Cytifus: of Cordus, Trifoliwn magnum-of Lou:liths, Eagopum maximum, and Lagopodiums : in Grecke, ^azsтои: in Englih, the grear Hares-foor

The laf, being the fmalleft of thefe kindes of Trefoiles, is called Litgopus, arid $P$, $s$ Leporis : in Duteh, foot.

$$
\text { बा The Tempcraturc snd Ireriues. }
$$

A The temperature and faeulties are referred vnto the other Trefoiles, wherefticearekindes: notwithltanding Dofcorides faith, that the fmall Harcs-foot doth binde and dry. It fopperb, faith he, the laske, if it be drunke with red wire. But it muft be gituen to fuch as are feuterth with warer.

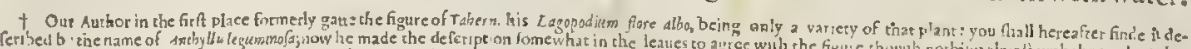

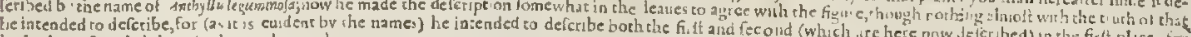

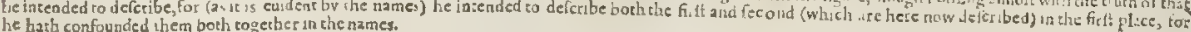

\section{С нағ. 498. OfWater Trefoilo, or Bucks Beanes.}

Trifoliun patudofum. Marih Trefoile

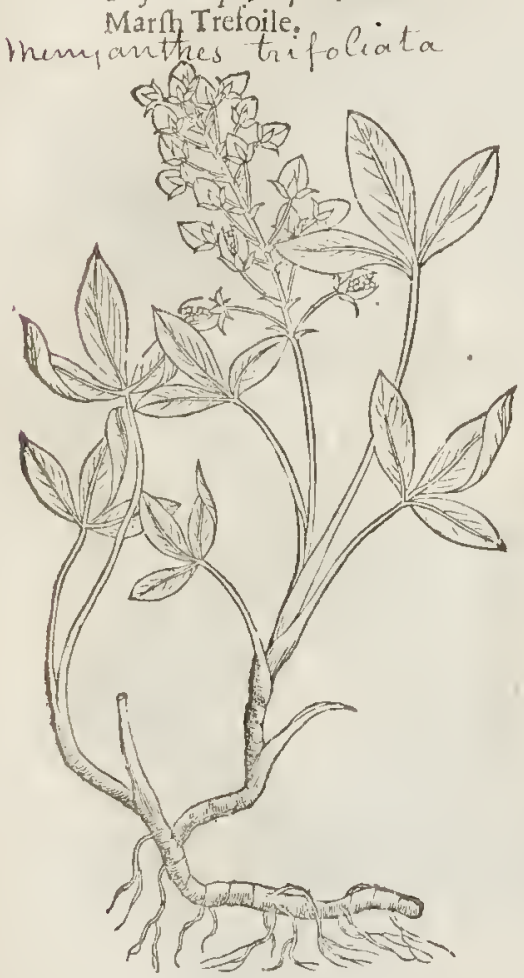

II The Defeription.

I THegreat Marth Trefoile hath thicke - fat italkes, weake and tenter, full of a fpungious pith, very fnooth, and of a cubit lon?: whereondo grow leates like to thofe of the garden Beane, fet vpon the falkes three joined together like the orher Trefoiles, fmooth, fhining, and of a deepe greene eolout : among which toward the top of the ftalkes ftandeth a bulh of feather like floures of a white coluur, dafht ouer flizhty with a wah of light earnation after wheh the feed followeth, contained in frnall burrons, or knobby huskes, of a brnivne yellowith eolour like vnto Millet, and of a bitter tafte: the ror:ts eteepe diuers wairs in the middle marith ground, being full of joints, white withit, and full of pores, and fpungie, bringing forth diuers by-fhonts, ta aikes; and leatres, by which meanes ic is eaftly inereafed, and largely multiplied.

2 The fecond differeth not from the precedent, fauing it is altogether leffer, wherein con. fifteth the differenee, if there be any: for do:ibeleffe I thinke it is the felfe fame in each refpect, and is made grearer and leffer, according to his place of growing, elymate, and eountrcy.

$$
\text { I The Place. }
$$

Thefe grow in marifh and Fenny places, and vpon boggie grounds almotteucry where.

\section{T) The Time.}

'They foure and flourith from Iune to the erid of Augurt.

9) The N $N^{\top}$ ames.

Marith Trefnile is ealled in high Dutel, 2Bibrthlee, that is to fay, Calloris Trifotium, or Trifolim

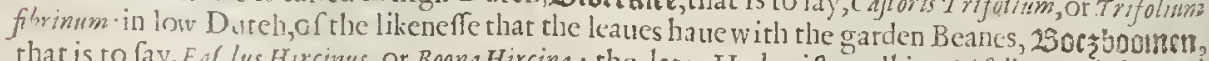
that is in fay, Fof lus Hurcimus, or Boona Hircina: the later Herbar:fts call it Trifolium galufre, and Puludrym of fome, ljopyrum : in Englinh, marh-Clauer, marh-Trefoilc, and Buckes-Beanes.

$$
\text { I) The Temperature and Vertues. }
$$

A The feed of Ifopyrum, faith Diof orides, if it be taken with meade or honied water, is good again fo the cough and paine in the chef:

$B$ It is alfor remedy for thofe that hate weake liners and fpet bloud, for as Galen faith it clen feth and cutteth tough humours, hauing alfo adjoined with it an altringent or binding quality.

CHAP. 


\section{C н а . 499 Offweet Trefoile, orgarden Clauer.}

\section{Trifolium odoratum.}

Sweet Trefoile.

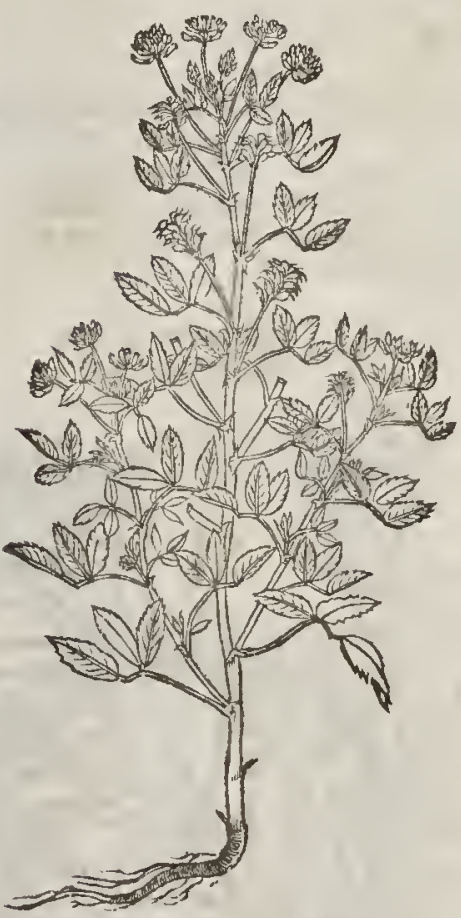

The Defoription.

Weet Trefoile hath an vpright Aalk, hollow, and of the height of two cubits, diuiding it felfe into diue s branches : whereon do grow leaues by three and three like to the other Trefoiles, flcightly and fuperficioufly nicked in the edges:from the borom wherof come the floures, enery one ftand ing on his owne fingle foot-ftalk; confifting of little chaffie husk s, of a light orpale blew in colour a fter which come vp little heads or knops, in which lieth the feed, of a whitifh yellow colour, and leffer than that of Fenu-greeke: the root hath diters ftrings: the who'e plant is not onely of a whitith green colour, but alfo of a fweet fmell, and of a ftrong aromaticall or fpicie fent, and more fwect when it is dried:which fmel in the gathcred and dried plant doth likewife continue long: and in moift and ra inie weather, it fmelleth more than in hot and drie weathes: and alfo when it is yet freth and gieene it loferh and recouereth againe his fmell feucn times a day; whereupon the old wines in Germanie do call it Sicuen gezeiten besut, that is, the herbe that changeth feuen times a day.

$$
\text { 9ा The Place. }
$$

It is fowne in gardens not onely beyond the feas, but in diuers gardens in England.

$$
\text { I The Time. }
$$

It is forve in May, it floureth in Iune and $\mathrm{Iu}$ ly, and perfecteth his feed in the end of Augutt, the fame yere it is fowne.

q The Names.

It is commonly called in Latine Trifolium odcratura: in high Dutch as we hatie faid secuen ge: zeiten: in low Dutch, Seuenghetiicutit, that is to fay, an hab of fenen tincs : it is callcd in Spanish, Trcbolreal: in French, Treffe oderifernat : in Englinh, Sweet Trefoile, and garden Claucr : it feemeth to be Lotus Vrbana, or atiua, of which Diofcorides writeth in his fourth booke:ncuerthelefle diuers Authors fet downe Melilot, for Lotus vrbana, and Trifolium odoratum, but not properly. $\neq$ The Gardincrs and herbe women in Cheapfide commonly call it, and know it by the name of Balfam,or garden Balram. ‡

$$
\text { T) The Temperature. }
$$

Galen faith, that fwect Trcfnile doth in a meanc concost and drie, and is in a meane and temperate facultic betwcene hot and cold : the which faculties vndoubtedly are plainely perceiued in this fwcet Trefoile.

$$
9 \text { The Vertucs. }
$$

The iuice prod forth, faith Diofrorides, with hony added thercto, clenfeth the vlcers of the cics, $\mathbb{A}$ callcd in Latine Argcma, and takethaway fpots in the fame, callcd 1 lbugines, and remooueth fuch things as doe hinder the fight.

The oilcwhrein the floures arc infufed or ftceped, doth perfectly cure greene wounds in very fhort fpace; it appcafeth the paine of the gout, and all other aches, and is highly conumended againft ruptures, and burftings in young children.

The iuice gitucn in white wine cureth thofe that have fallen from fome high place, auoideth $\mathbf{C}$ congcaled and clotted bloud, and al fo helpeth thofe that do piffe bloud, by meanes of fome grcat bruife, as was prooued lately vpon a boy in Fanchurch ftreet, whom a cart went oner, where- 


\section{Of the Hiftorie of Plants.}

upon he did not onely piffe bloud, bur alfo it moft wondetfully gurhed fot th, both at his nofe and mouth.

D The dtied hetbe laied among gatments keepeth them from Mothes and othet vetmine.

\section{Cна Р. 500. Of Fenugreeke. \\ If The Defription.}

- Enugreekc hatl a long flender trailing ftalkc, greenc, hollow within, and diuided into diuers fmall branches: whereon dogrow leaues like thofe of the medow Trefoile, but rounder and lcffer, greene on the vpper fide, on the lower fide tending to an afh colour : among which come finall white floures, after them likewife long fender narrow cods, in which do lie fmall vneuen feeds, of a yellowith colour: which being dried, haue a ftrong fmell, yet not vnpleafant : the root is fmall, and peritheth when it hath perfected his feed.

I Fonumgractom.

Fenugreekc.
\$2 Ferrungracum fylueftre.

Wilde Fenugreeke.
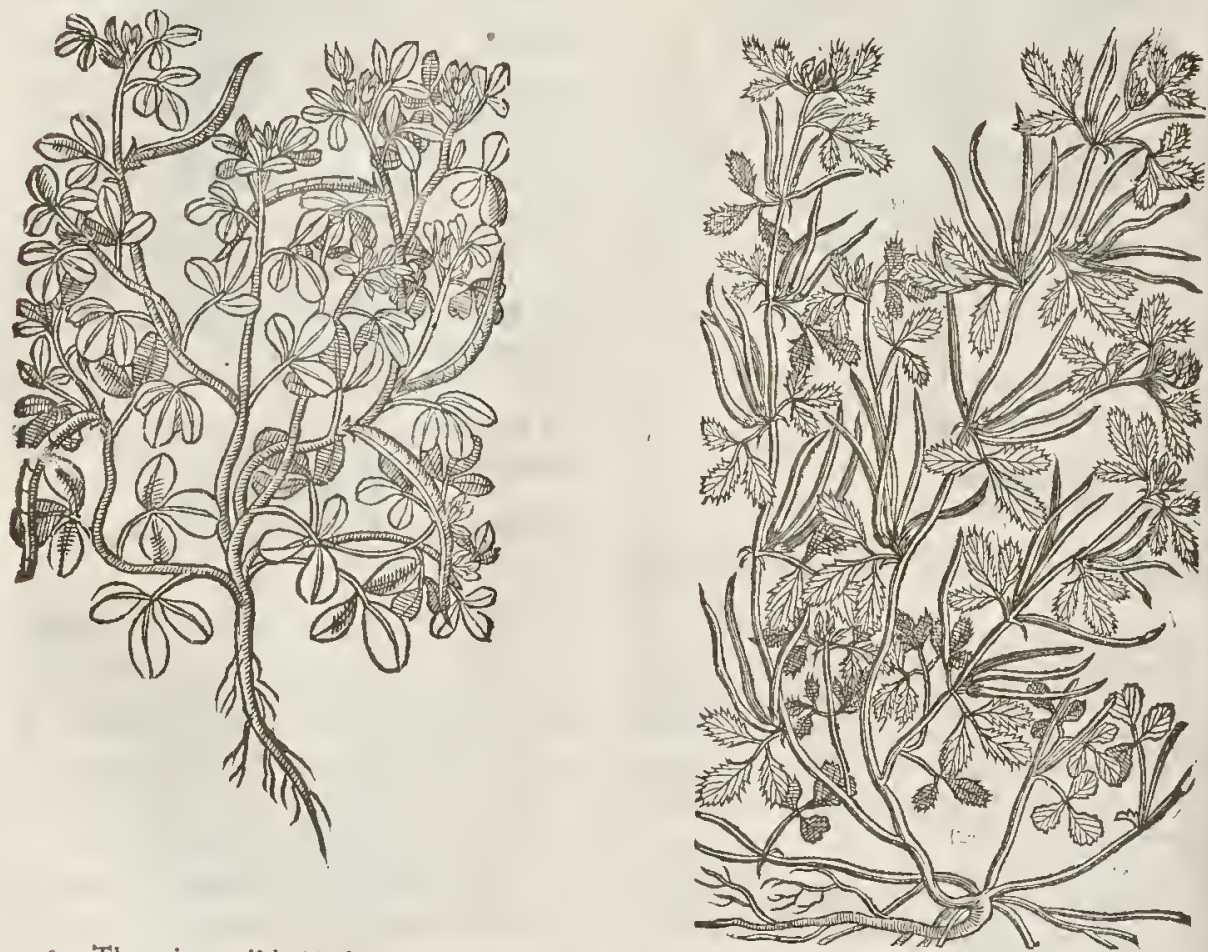

2 Thete is a wilde hinde hereof feruing to little vfe, that hath fmall round branches, full of knecs or ioints : from each ioint proceedeth a fmal tender footftalk, whereon do grow three leatues and no morc, fomewhat fnipt about the edges, like vnto thof of Burgundic Haie: fom the bofoms whereof come forth fmall yellow floutes, which turnc into litrle cods : the roor is thickc, tough,
and pliant.

Fenugrcekc is fowne in fields beyond 9 The Place. out gardens.

Tl The Time.

it is fowne that it may ferue for fodderding to Columella, ofwhich one is in September, at what time ginning of Februarie, norw ith forder againft in inter; the other is in the end of Ianuatie, or the be- 
T The Names.

It is called in Grecke rixs, or as it is found in Pliny his copies Carphos: in Latine, Fenum Gre. ckm: Columella fairh that it is called Siligua : in Plinywe read silicia : in Varro, Silicula: in high Dutch, bocklbotte : in Iralian, Fiengreco: in Spanith, Alfornas: in Fiench, Fenegrec : and in Englin, Fenegreeke.

\section{The Temperature and Vertues.}

It is thought according to Galen in his booke of the Faculties of nourifhments, rhat it is onc of $\mathbf{A}$ thofe fimples which do manifeftly heat, and that men dovfe it for food, as they do Lupines; for it is taken with pickle ro keep the body foluble, and for this purpofe it is more agrecable itan Lupines, feeing ir hath nothing in his owne proper fubftance, rhat may hinder the w orking.

The iuice of boiled Fenegreeke taken wirh honie is good to purge by the ftoolc all manner of $B$ corrupr humors that remaine in rhe gurs, making foluble through his flimineffe, and mirigaring paine through his warmnelie.

And becaufe ir bath in it a clenfing or fcouring facultic, it raifeth humors out of the cheft : but C there muft be added vnto it no great quantirie of hionie leaft the biring qualirie thould abound.

In old difeafes of the cheft wirhout a feuer, fat dates are to be boiled with it, bur when you haue D mixed the fame iuice preffed ont with a great quanririe of hony, and hane againe boiled it on a foft fire to a mean rhickneffe, then muft you ve it long before mear.

In his booke of the Faculties of fimple medicines he faith, that Fenegreek is hor in the fecond $E$ degree, and dry in the firft : therefore it doth kindle and make worfe hot inflammarions, but fuch as are leffe hot and more hard are thereby cured by being wafted and confuned away.

The meale of Fenegreeke, as $D$ iofcorides faith, is of force to mollifie and wafte away:being boiled $F$ with mead and applied it taketh aw ay inflammations, as well inward as nurward

The fame being rempered or kneaded with niter and vineger, doth folten and wafte away the G hardneffe of the milt.

It is good for women that hane either impofthume, vlcer, or fopping of the matrix, to bathe and $\mathbf{H}$ fit in the deco:tion thereof.

The iuice of the deco tion preffed forth doth clenfe the haire, taketh away dandraffe, fcoureth running fores of the head, called of the Grxcians axems:being mingled with goofe greale, and put vp in manner of a pcffarie, or mother fuppofititorie, it doth open and mollifie all the parts, about the morher.

Greene Fenegrecke bruifed and pounded with vineger, is a remedie for weak and feeble parts,and $\mathrm{K}$ that are without sk in, vlcerated and raw.

The decostion thereof is good againft vlcers in the low gut, and foule ftinking excrements of $\mathbf{L}$ thofe rhat hane the bloudy flix.

The oile which is preffed out thereof fcoureth haires and fcars in the primie parts.

The decoction of Eenegreeke feed, made in wine, and drunke wirh a little vineger, expelleth all $\mathrm{N}$ euill humors in rle ftomacke and gurs.

The feed boiled in wine wirh dares and hony, vnto the form of a fyrrup,doth mindifie and clenfe 0 the breaft, and eafe th the paines thereof.

The meale of Fenegreek boiled in mead or honied water, confumerh and diffolueth all cold hard $P$ impolthumes and fwellings, and being mixed wirl the roors of Marth Mallows and Linfeed effeiteth the fame.

Ir is very good for women that haue any griefe or fivelling in the matrix, or other lower parts, if $Q$ they bathe rhofe parts with the decostion thereof made in wine, or fit ouer ir and fweat.

Ir is good towarh the head with the decoction of the feed, for it taketh away the fcurfe, fcailes, $\mathbf{R}$ nits, and all orlser fuch like imperfections.

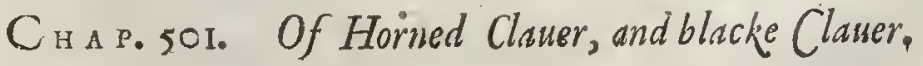

$$
\text { The Defcription. }
$$

I The horned Clauer, or codded Trefoile,groweth wp with many weake and flender ftalks lying von the gromnd : about which are fet white leanes, fomewhat long, leffer, aud nars rower rhan any of rhe other Trefoiles: the floures grow at the tops, of the farnion of thofe of Peafon, of a fhining yellow colour: after whych come certain ftraighit cods, bigger than thofe of Fenegreek, hur blunter at rheir ends, in which are contained little round feed the root is hard and wooddic, and fendeth forrb young fprings euery yeare.

Hhhh 3

2. This 


\section{8}

Of the Hiftorie of Plants.

L 1 в. 2.

I Lotus trifolia corniculata.

Horncd or codded Clauer.

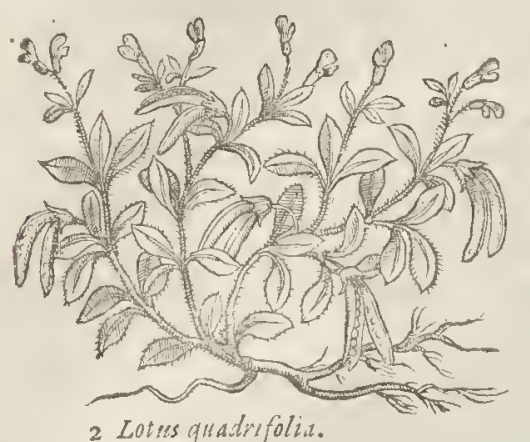

Foure leafed graflc.

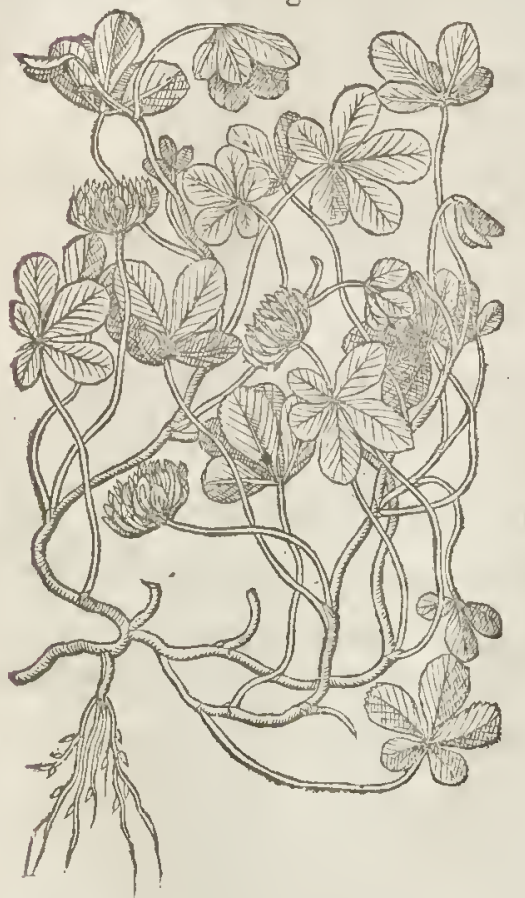

2 This kinde of three leafed graffe, or rather foure leafed Trefoile, hath leaues like vnto the common -Trefoile, fauing that they bee leffer,and of a biowne purplifh colour, knowne by the name of Purple-wort, or Purple-graffe; who $c$ flotres are in thapclike the medow Trefoile, but of a duftieo ue rworn colour tending towhiteneffe; the which doth oftentimes degenerate, fometime into three lcaues, fometimes in fiue, and alfo into feuen, and yet the plant of his natur chathbut foure leaues \& no more. I I do not thinke this to be the purple leaued Trefoile with the white floure, which is commonly called Purple-grafle; for I could neuer obferue it to haue more leaues than three vpon a ftalke. $\neq$

\pm 3 The root of this is fmall and white, from which arife many weake hairie branches fome cubir long:wheron grow foft hairyleaues three on one foot-ftalke; with two little leatses at the root therof, \& out of the bofoms of thefe vpon likc footfalkes grow three leffer leaues, as alfo floures of the bignes and thape of thofe of a Verch, but of a brane deep crimfon veluet colour : after thefe are paft come cods ferwith. foure thinne welts or skins which make them feem foure fquare; whence Camerarius called it Lotus pulcherrimatetragonolobus: the feed is of an afh colour, fomewhat leffe than a peafe. It floures moft of the Sommer moneths, and is for the prettineffe of the floure preferucd in many Gardens by yearely fowing the feede, for it is an annuall plant. Clufins hath it by the name of Lotus filiguows rubello flore: and hee faith the feeds were diucrs times fent out of Italy by the name of Sandalida. It is alfo commonly called in Latine Pifums guadratum $\neq$

\section{TI The Place.}

The firft groweth wilde in barren ditch bankes, paftures, and drie Mountaincs.

\# 3 Lotiss filigua qandrata. Squarc crimfon veluct pcafe.

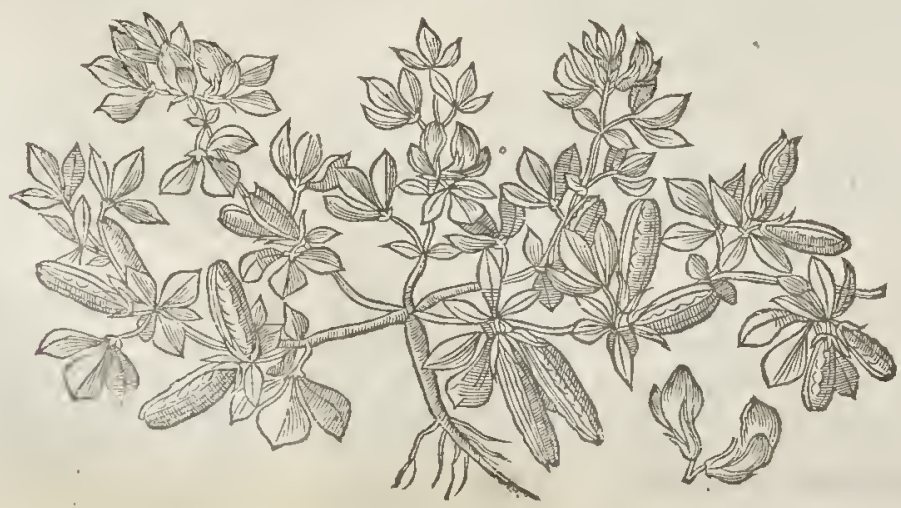


The fecond groweth likewife in paftures and fields, but not fo common as the other; and is planted in gardens.

They floure in Iuly and Auguit.

$$
\text { TI The Time. }
$$

The Names.

The fecond is ealled Lotus Trifolis : in Englih, horned Clauer, or eodded Trefoile.

The other is called Lotus quadrifolia, or foure leafed Graffe, or Purple-wort : of Pena and Lobel, Quadrifolism pheium fufcum hortorum.

T) The Temperature and Vertues.

Their faeulties in working are referred vnto the medow Trefoiles :notwithftanding it is repor- A ted, that the leates of Purple-wort ftamped, and the iuyee giuen to drinke, eureth young ehildren of the difeafe called in Englin the Purples.

\section{С н Р. 502. Of Medicke Fodder, or fnaile Clamer. TI The Defcription.}

i His kinde of Trefoile, called Medica, hath many fmall and flender ramping branehes, crawling and creeping along vpon the ground, fet full of broad leaues flightly indented about the edges: the foures are very fmall, and of a pale yellow colour, which turne into round wrinkled knobs, like the water Snaile, or the fith called Periwinckle: wherein is contained flatfeed fafhioned like a little kidney, in colonr yellow, in tafte like a Vetch or peafe: the rool is fmall, and dieth when the feed is ripe : it growes in my garden, and is good to feed cattell fat.

I Trifolium Cochleatum.

Medicke Fodder.

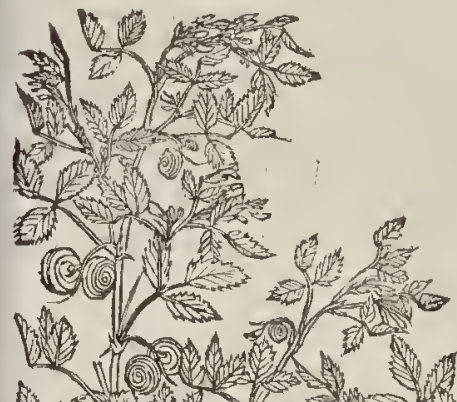

.

,<smiles>C1[Si][Si]1</smiles>

. v.<smiles>[SiH2]</smiles>

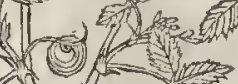
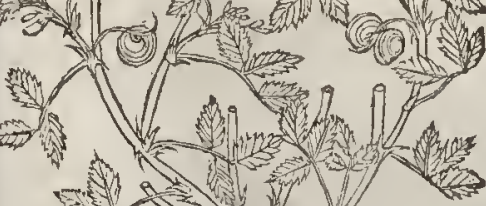

सily
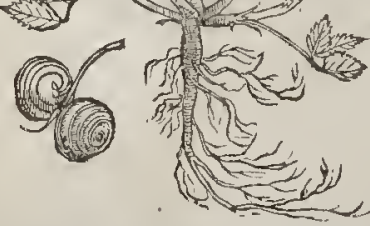

$¥ 2$ Medica fructu cochleato pinofo. Prickly Snaile Trefoile.

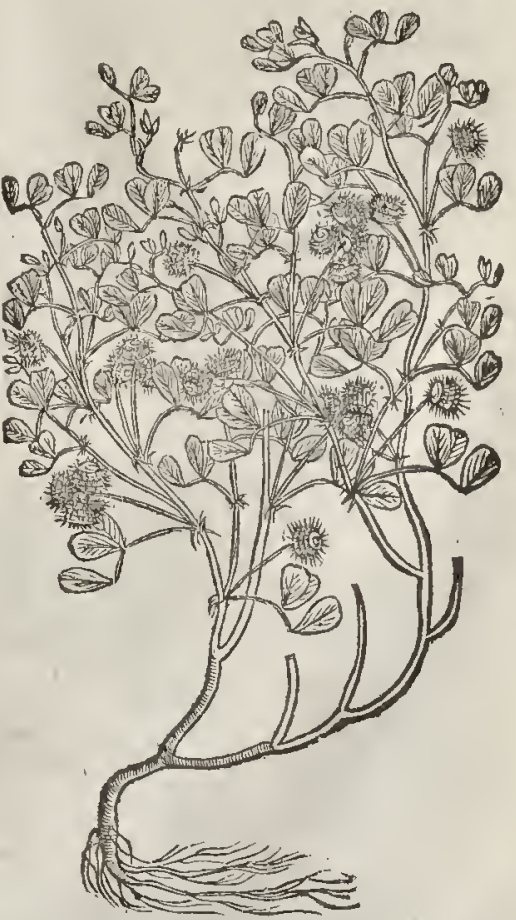

\# There are many varieties of thefe plants, and they chiefely confitt in the fruit; for fome are fmoots and Hat, as this firftefcribed: other fome are rough and prickely, fome with leffer, and 
orher fome with bigger prickles; as al fo with them ftanding diuers wayes, fome are onely rough, and of thofe fome are as big as a fmall nut, other fomc no bigger than a pcafe. I giue you here the defcriptions of three rough ones, (as I rcceiued them from $\mathrm{M}^{5}$. Goodyer) whereof the laft is of the fca, which, as you may fee, our Author did but fuperficially defcribe.

2 Medice maior is Batice peciesprima, pinulis intort is.

This hath foure fquare reddifl, ftreaked hairy trailing branches, like the fmall Englifh Medica, greater and longer, foure or fue foot long: the leaues are alfo fmooth, growing threc together, ncither tharpe pointed, nor yet fo broad at the top as the faid Englin Medica, but blunt topped, with a fmall blacke fpot in the midf, not crooked : thc floures arc alfo yellow, three, foure, or fue on a foot-ftalke: aftcr commeth a round writhed fruit fully as big as a hafell nut, with fmall prickles not ftanding fore-right, but lying flat on the fruit, finely w rappcd, plaited, folded, or interlaced together, wherein lieth wrapped the fced in fathion of a kidney, very like a kidney beane, but foure times fmaller, and flatter, of a thining blackc colour without, like polithed Ieat; containing a white kerncll within : the root is like the former, and perifheth alfo at Winter.

$$
\text { Credica maioris Betica pinofa pecies altera. }
$$

The branches alfo creepc on the ground, and are ftraked fmooth foure fquare, reddith here and therc, three or foure foot long : the lcates are frmonth, finely norched about the edges, tharp pointed, without blacke fpots, very like Medica pericarpio plano: the fioures are fmall and yellow like the other : the fruit is round, writhed or twined in alfo, fully as big as a hafell nut, fomewhat cottonie or woolly, with thort tharpc prickles: wherein "lycth alfo wrapped a fhining blackekidney-like feed, fo like the laft defcribed, that thcy are not to be difcerned apart: the root is alfo alike, and perifheth at Winter.

\section{Medice marine Jpinefa/pecies.}

The branches of this are the leaft and , Thorteft of all the reft, little exceeding a foot or two in length, and arc fourc fquare, grecnc, fomewhat hairie, and trailing on the ground : the leaues are like to thofe of Medica pericar pro plano, not fully fo tharpe pointed, without blacke fpots, foft, hairy, three on a foot-ftalke: the floures grow alnng the branches, on very fmall foot-ftalkes, forth of the bofomes of the leanes, (not altogether on or ncere the tops of the branches) and are very fmall and yellow, but one on a foot-ftalkc: after commeth fnall round writhed fruit, nobigger than a peafc, witl very thort tharpe pricklcs, whcrein is contained ycllowith fecd of the farhion of a kidney like the former, and is the hardeft to be plucked forth of any of the reft: the root is alfo whitifh like the roots of the other, and alfo perifheth at Winter. Ang. 2. 1621 . Iohn Goodyer. t.

\section{Trifolium Cochleatummarinum.} Medick Fodder of the fea.

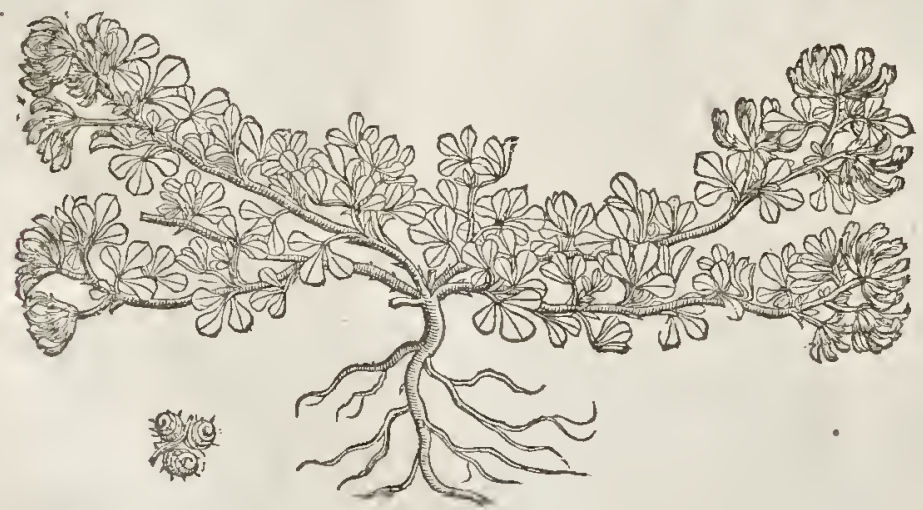

3 This kinde alfo of Trefoile, (called Medica marina : in Englifh, fea Trefoilc, growing naturally by the fea fide about Weftchciter, and vpon the Mcditerranean fea coaft, and about Venice) hath leates very like vnto the common medow Trefoile, but thicker, and cousred ouer with a 
flockie hoarineffe like Graphalium, after the manner of moft of the fea herbes : the floures are yellow : the feeds w rinkled like the former, but in quanti tie they be leffer.

\section{T The Place:}

The firft is fowne in the fields of Germanie, Italy, and other eountries, to feed their eattell, as we in England do Bueke-wheat : we haue a fmall quantitie thereof in our gardens, for pleafures fake

The third growech neere vnto the fea fide in diuers places.

$$
\text { T The Time. }
$$

Medica muft be fowne in Aprill; it floureth in Iune and Iuly : the fruit is ripe in the end of Augult.

\section{The Thames.}

Mediek fodder is ealled of fome Trifolium Cochleatum, and Hedica : in Freneh, L'berbe à Limaffon : in Greeke,'Musw: : in Spanith, Mirlguas : of the Valentians and Catalons, Alfafa, by a word either barbarous or Arabieke : for the chiefe of the Arabian writers, Auicen, doth call Medicn, Cot, Alafelcti, and Alfasfara.

The other is ealled Sea Clauer, and Mediek fodder of the fea.

\section{a) The Temperature and $v$ crtues.}

Mediek foddcr is of temperature cold, for whieh eatre it is applied greene to fuch inflammati. A ons and infirmities as haue need of eooling.

\section{H A. 503. Of Wood Sorrell, or Stubwort.}

I Oxys alba.

White wood Sorrell.

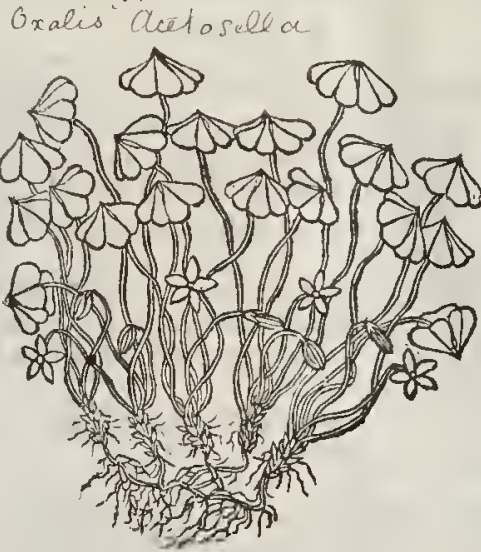

II The Defcription.

Xys Pliniana, or Trifoliuma acctofum, being a kind of three leafed graffe, is a low and bafe herbe without ftalk; the leaues immediately rifing from the root vpon thort' ftems at their firft comming forth folded together,but afterward they do fpred abroad, and are of a faire light greene colour, in number three, like the reft of the Trefoiles, but that each leafe, hath a deepe eleft or rift in the middle : amongft thefe leaues come vp fmall and weake tender ftems, fuch as the leaues do grow vpon, which beare fmall ftar-like floures of a white colour, with fome brightnes of earnation dafht ouer the fame : the floure eonfifteth of fue fmall leaties; after which come little round knaps or huskes full of yellowith feed : the root is very threddy, and of a reddith eolour : the whole herbe is in tafte like Sorrell,but mueh tharper and quieker,and maketh better greene fauee than any other herbe or Sorrell whatfoener.

$\neq$ My of mentioned friend $\mathrm{M}^{*}$. Gcorge Bewles fent me fome plants of this with very faire red floures, which he gathered in Aprill laft, in a wood of Sir Thomas Walfing bams at Chiffelhurft in Kent,ealled Stockwell wood, and in a little round wood thereto adioyning. $\$$

2 The feeond kinde of $0 x y$ s or wood Sorrell is very like the former, fauing that the floures are 


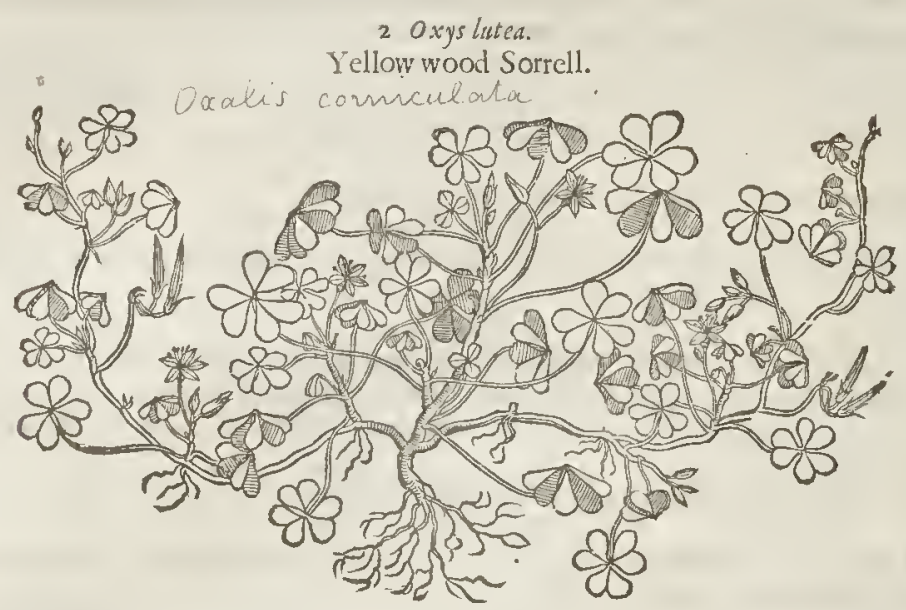

of a yellow colour, and yeeld for their feed veffels fmall and long horned cods; in oiher refpects alike.

$$
\text { T) The Place. }
$$

Thefe plants grow in woods and vnder bufhes, in fandie and fhadow ie places in euery countrie. ‡ I haute not as yet found any of the yellow growing with vs. ‡

$$
\text { of The Time. }
$$

They floure from the beginning of A prill vnto the end of May and midft of Iune.

$$
\text { The Names. }
$$

Wood Sorrell or Cuckow Sorrell is called in Latine Trifolium acetofum : the A porhecaries and Herbarifts call it Allcluyn, and Panis Cuculi, or Cuckowes meate, bccaufe either the Cuckow feedeth thereon, or by reafon when it fpringeth forth and floureth the Cuckow fingerh mont, at which time al fo Allelinya was wont to be fung in Churches. Hicronymus Fracaftoriss nameth it Lujula. Alexander Benedictus faich that it is called Alimonis : in high-Dutch, Sautelklee: in Low-Dutch, Coectrecertbzoot: in French, Pan de Cocu : in Englinh, wood Sorrel,wood Sower, Sower Trefoile, Stubwort, Alleluia, and Sorrell du Boss.

It is thought to be that which Pliny, lib.27. cap.?2. calleth oxys; writing thus: Oxys is three leafed, it is gool for a fecble ftomacke, and is al fo eaten of thofe that are burften. But $G$ alen in his fourth booke of Simples faith, that $O x y s$ is the fame which oxalis or Sorrell is :and $O x y s$ is found in Pliny to be alfo Iunci ßpecies, or a kinde of Ruth.

Thefe herbes are cold and dry like Sorrell.

$$
\text { T The Natwre. }
$$

$$
\text { 9f The Vertues. }
$$

A Sorrell du Bois or wood Sorrell ftamped and ved for greene fatice, is good for them that have ficke and feeble ftomackes; for it ftrengthneth the ftomacke, procureth appetite, and of all Sorrel fauces is the beft, not oncly in verture, but alfo in the pleafantneffe of his tafte.

B It is a remedie againt putrified and ftinking vlcers of the mouth, it quencheth thirft, and coo: leth mightily an hot peftilentiall feuer, efpecially being made in a fyrrup with fugar.

\section{Cha r. 50t. Of noble Liner-wort, or golden Trefoile.}

\section{aा The Defeription.} Oble Litierwort hath many leaues fpred vpon the ground, three comered, refembling the three leaued graffe, of a perfect graffe greene colour on the vpper fide, but grayin underneath : among which rife vp diuers fmall tender foot-ftalkes of three inches long; on the ends whereof ftands one fmal fingle blew floure, confinting of fix little leaures, hauing in the midd le a ferv whice chines : the feed is inclofed in little round knaps, of a whitih colour; which being ripe do fart forth of themfelues : the root is llender, compofed of an infinite number
of blacke ftrings.

2 The fecond is like rn to the precedent in leaues, roots, and feeds : the floures hereof are of a thining red colour, wherein confifteth the difference. 


\section{The Vertues.}

A It is reported to be good againft the weakeneffe of the liuer which proceedeth of an lot caure; for it cooleth and frengthneth it not a little.

B Baptiftasardus commendeth it, and writeth that the chicfe vertue is in the root; if a ffoonfull of the pouder thereof be given certaine dayes together witl wine, or with fome kinde of broth, it profiteth much againft the difeafe called Exterocele.

\section{С н в.505. Of Melilot, orplaifter Clauer. \\ I The Defoription.}

I THe firftkinde of Melilot hath great plenty of (mall tough and twiggy branches, and 1 ftalkes full of ioynts or knees, in height two cubits, fet full of leaues chrce together, like vnto Burgondie hay. The floures grow at the top of the ftalke, of a pale yellow colour, ftanding thickly fet and compact together, in order or rowes, very like the floures of Sccurdaca altera: which being vaded, there follow certaine crooked cods bending or turning vpward with a fharpe point, in fathion not much vnlike a Parrets bill, wherein is contizined feed like Fenugreele, bu't flatter and flenderer : the whole plant is of a rea fonable good fmell, much like into honey, and very full of ityce : the root is very tough and pliant.

I cuelilotus Syriaca odora. Aflyrian Clauer.

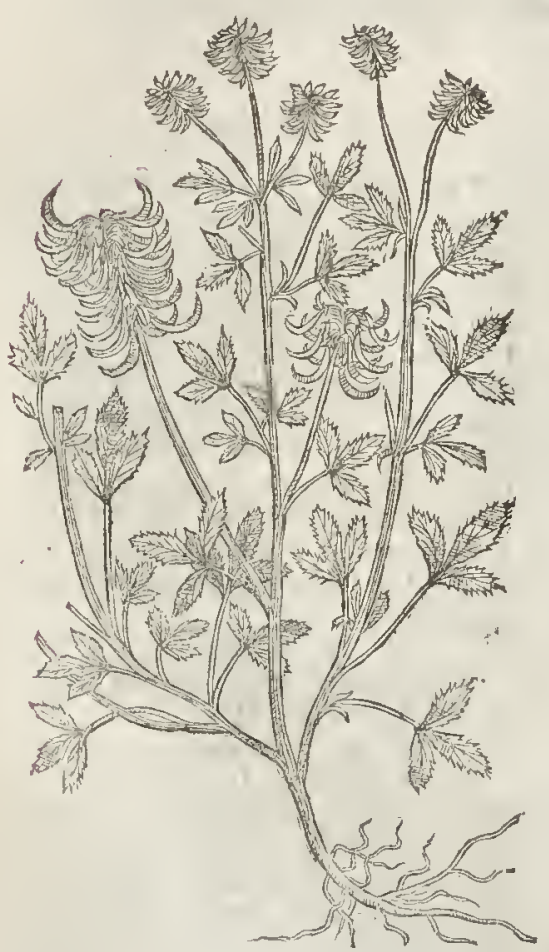

2 Mclilotus Italica or Patanisa. Italian Clauer.

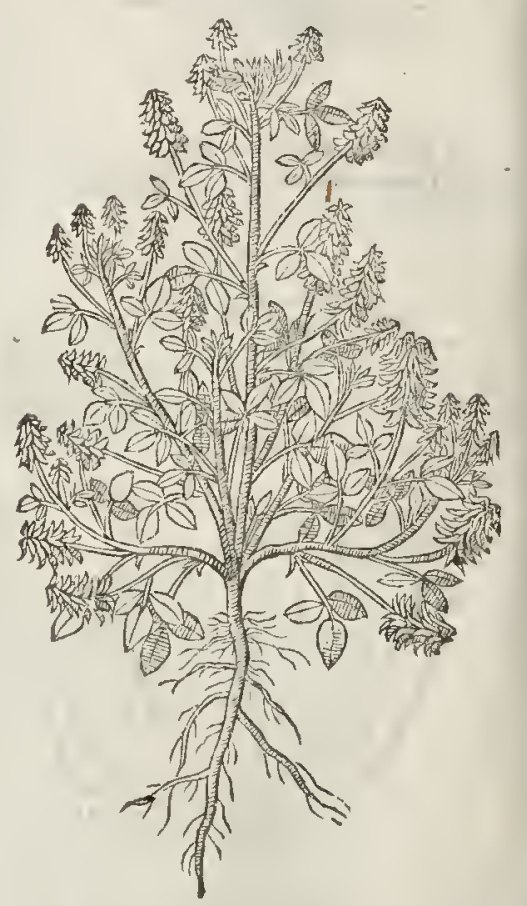

2 'The fecond kinde of Melilot hath fmall and tender vpright ftalkes, a cubit high, and fomewhat more, of a reddith colour, fet full of round leaues three together, not finipt about the edges like the other Trefoiles; and they are of a very deepe greene colour, thicke, fat, and full of iuyce. The floures grow alongft the tops of the ftalkes, of a yellow colour, which turne into rough round feeds as big as a Tare, and of a pale colour. The whole plant hath alfo the fauour of honey, and reritheth when it hath borne his feed. 
3 The third kind of Melilot hath round falks and ingged leatues fet round about, no: nuch vn. like the leaues of Fenugreeke, alwaies three growing rogether like the Trefoiles, and of cencimes couered aner w ith an hoatineffe, as though mealc hud been frewed vpon them. The floures be yellow and fmall, growing thicke together in a tuft, which turne into little cals, wherein the feed is contained: the toot is fmall, tough, and pliant.

4 The fourth kinde of Melilot growes to the height of three cubits, fet full of leaues like the common Melilot, and of the fane fauour: the floures grow alongft the top of the falks, of a white colour, which turne into fmall foft huskes, rhetein is contained little blackith feed : the root is alfo tough and pliant.

\section{Melilotus Coronata. Kings Clauer.}

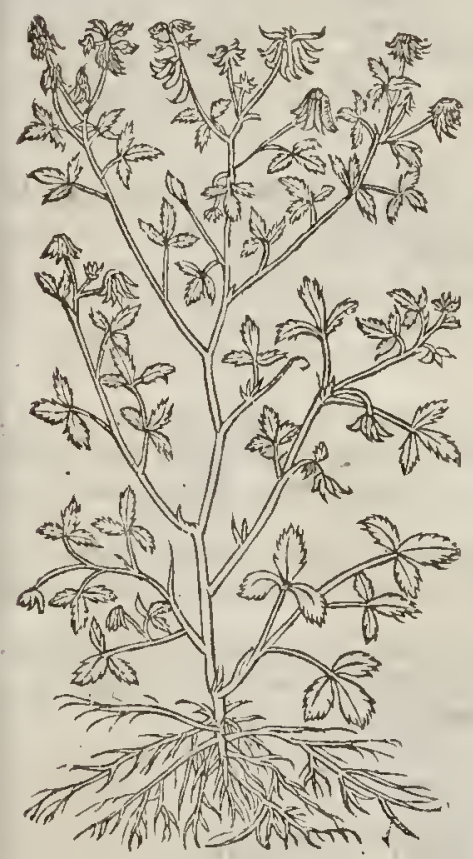

4 Melilutus Germanicd. Germane Clatuer.

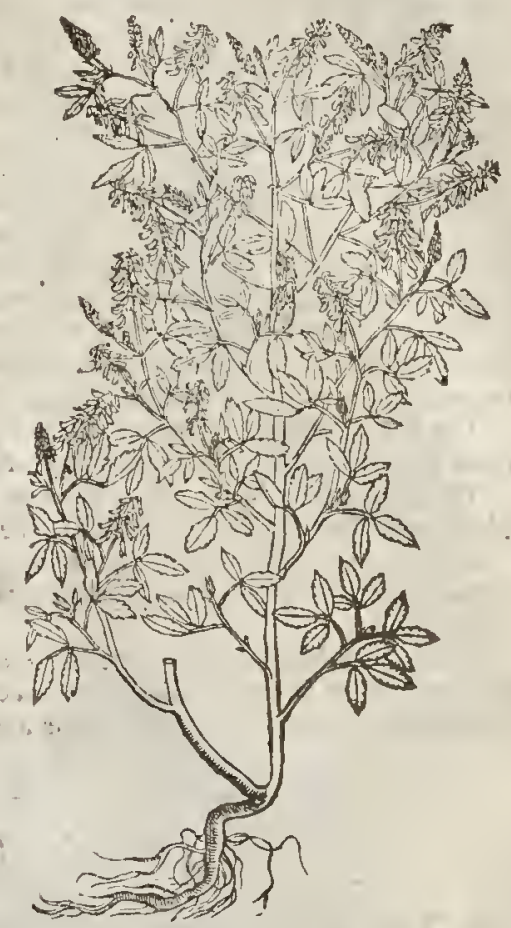

¥ Although our Author intended this laft defcription for our ord inatie Melilor, yet he made it of another which is three times larget, grow ing in fome gardens (where it is oncly fowne)aboue two yards high, with white floures and many btanches : the whole thape thereof is like the common kinde, as far as I temember. The common Melilot hath weake eornered greene ftalkes fome two foot and better ligh; whereon grow longirh leaues fnipt and oftentimes eaten about the edges, of a frefh gteene colour : out of the bofomes of the lealles come little ftalkes fome handfull long, fet thicke on their tops with little yellow floures hanging downe and turning vp again, each floure being compofed of two little yellow leaues, whereof rhe vppermolt turnes vp again,and the vndermoft feemes to be parted into three. The floures pat, there fucceed little cods whercin is the feed.

\section{of The Place.}

There plants grow in my garden : the common Englifh Melilot Psna fettech forth foi Melilot us Gerinanica : but for certaintieno part of the world doth cnioy fo great part thercof as England, and efpecially Effex ; for I haue feene betweene Sudbury in Suffolke, and Clare in Effex, and from Clare to Heningham, and from thence to Ouendon, Bulmare, and Pednarih, very many acres of earable pafture overgrowne with the fame; infonuch that it doth not onely fpoyle their land, but the conne allo, as Cockle or Darnel, aid as a weed that genetally fpreadeth oucr that corner of the Shire.

$$
\text { giili } \text { of } T \text { th }
$$


Thefe herbes do foure in Iuly and Auguft.

$$
\text { T Tle Time. }
$$

T' The Names.

Plaifter Clauer is called by the generall name, Melilotus of fome, Trifolizum odorat m yet there, is

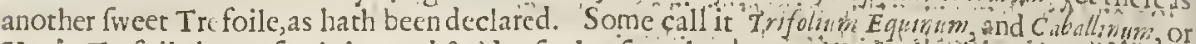

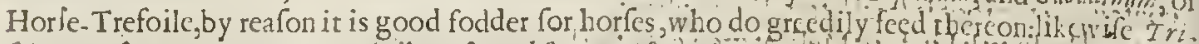

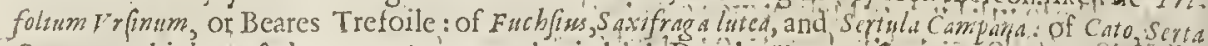
Compana, which mot do name Corona Regia in high Dutch, Dzocte Strcnteucren: of the Romaties and Hetrurians, Tribolo, as Mathiolws writeth : Englih, Melifot, and PJafler-Claver in Yorkefhire, Harts-Clauer.

\section{- The Temperature.}

Melilote, faith Galco, hath more plenty of hot fubftance than cold (that is.to fay, Lat and dry in the firf degree) it hath alfo a certaine binding qualitie. befides a watting and jugning facultie. Diofcerides theweth, that Mchilore is of a bindingand mollifying qualitic, bur the mollifying qualiric is not proper vnto it, but in as much as it walt th away, and digefteth humors gathered in hor fwellings, or orherwife : for fo far doth it mollifie or fupple that thing which is hard, which is not properly called mollifying, but digetting and watting away by vapors: which kinde of quality the Grecians call diaspenuxi。

$$
\text { Tा The Veriues. }
$$

A Melilote boilcd in fweet wine vntill it be foft, it you adde thereto the yolke of a rofted egse, the meale of Fenegreeke and Linefeed, the roots of Marfh Mallowes and hogs greace ftamped togcther, and vfed as a pultis or cataplafma, plaifterwife, dotl affwage and fofren all manner of fwellings, efpecially aisout the matrix, fundament and genitories,being appliced vato thofe places bot.

B With rhe juice hercof,oile, wax, rofen and turpentine, is made a mort foueraigne healing and drawing emplafter, called Melilote plaifter, retaining both the colour and faunour of the herbe, being artificially made by a skilfull Surgion.

The herbe boiled in wine and drunke prouoketh wrine, breaketh the ftone, and affwageth the paine of the kidnies, bladder and belly, and ripeneth flegmé, and caureth it to be cafily caft forrh.

D The juice thereof dropped into the eies cleereth the fight, confugtal, diffolucth, and cleane taketh away the web; pearle, and fpot in the cies.

Melilote alone with water healeth Recentes melicerides, a kinde of wens or rather apontems conteyning matter like honey; and alfo the running vlcers of the head, if it be laid to with chalke, wine and galls.

F It likewife mitigateth the paine of the eares, if the juice be dropped therein mixed with a little

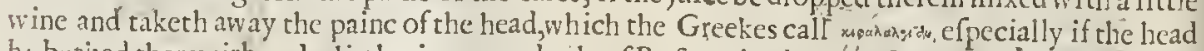
te batised therewirh,and a little vineger and oile of Rofes mixed anóng

\section{${ }_{\ddagger}$ C н а р. 506. Of certaine otber Trefoiles.}

¥ Tofe Trefoiles being omitted by our Author, I haue thought good to put into a chapter by themielues, though they haue little affinity wirh one another, the two laft excepted.

$$
\text { It The Defcriprion: }
$$

I THe firft of thofe in roots, ftalkes, and manner of growing is like the Medickc or fnaire Trefoiles formerly deferibed:the leaucs are hairic; the floures yellow and fimall âter which follow crooked flat cods, of an indifferent bredth, wherein is contained fecds made after the

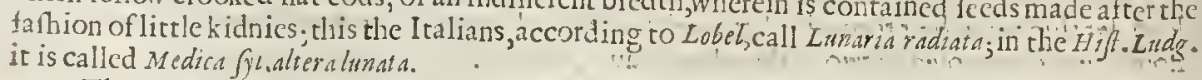

2 The roor of this is long and thicke, couered with a yellowith rinde, and hau ing a white fwcet pith in the infide, concred with a bairineffe on the rop, and fending forth fundry fibres : from this rife up many wealic long foot-ftalk's, whereon grow leaues fer together by threes, long, narrow, fmooth, lightly nickt on the edges: amongt thefe rifes vp commonly one falke (yet fometimes two) fmooth and naked, threc or foure inches long; on the top thereof grow fpilic farhion, 8 .or ten pretty large light purple floures, eacli of them being fet in a cup diuided into 5 . parts. This growes von diuers parts of the Alpes: and Pena in his Mons Baldus fer it forth bv the name of Trifolnm

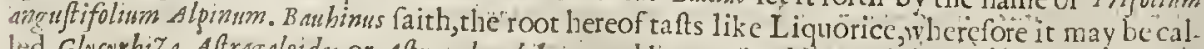
led Glycyrbiza Aftragaloider, or Aftragalus dillos: and lie receitued it out of Spainc by the name of Glycyrhiza. He calls it in his Prodromus, Trifolinm Ulpinum fore magno radice dustci. 
1 18. 20

Of the Hiftoric of Plants.

1207

+ I Trifolium filiqualuant. Moone Trefoile.

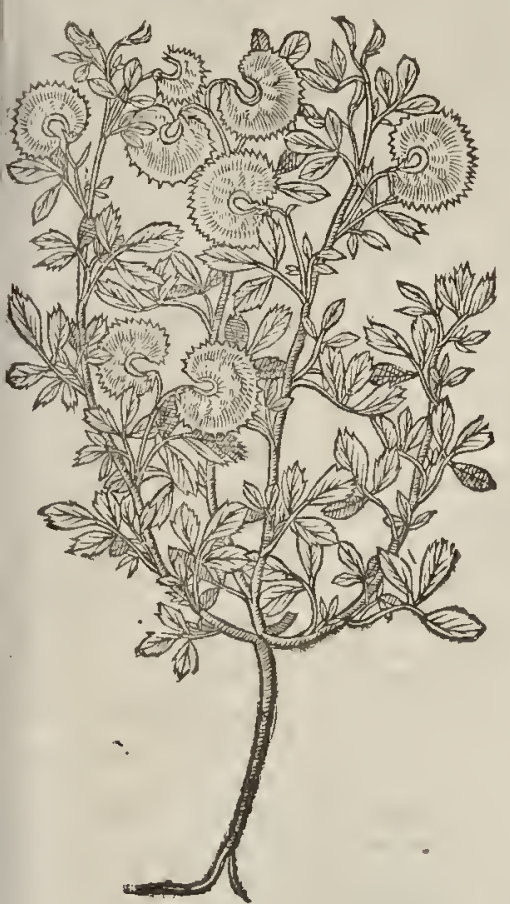

+ 2 Trifol. angufifol. Alsinum. Liquorice Trefoile.

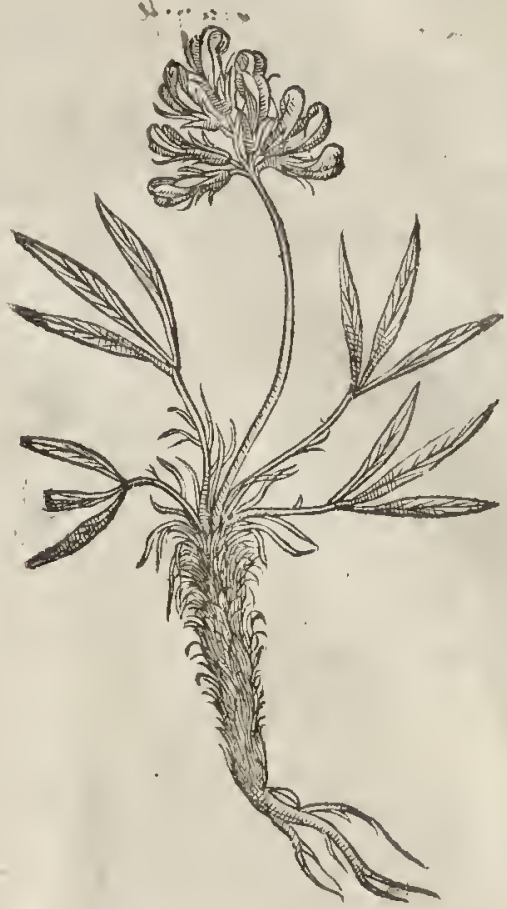

+ 3 Trifolium/pinofum Creticumi o Prickly Trefoile.

3 This thomie Trefoile hath a long threddy root, from which arife nany fhort branched ftalkes fome two handfulls higli, connered, and fpred vpon the ground, the ioynts, whieh are many, are commonly red, and armed with foure fharpe prickles, and out of each of thent, von thort footitalkes grow two trifoile leaties, greene, longih, and ending in a little prickle: out of thefe ioynts alfo grow little foot-ftalkes, which earry lingle lloures made of fiue little leaues, of the thape and colour of the littleblew Bell-floure, with ten chiues in the middle tint with yellow : after thefe follow fuc comered tharpe pointed heads, containing a fingle flat red feed in eaeh eorner. Clufins fet forth this by the name of Trifolnum pinofun Creticum : the feedwas fent out of Candy by the name of ip arvoprov : he queftions whether it may not be the true Tribulas terreftris of Diofcorides,

4 The roots, halkes, and leaies of this pietty Trefoile do not much ditfer from the common Ii i i 2

white 
₹ 4 Trifolium fragifersm.

Straw-berry Trefoile.

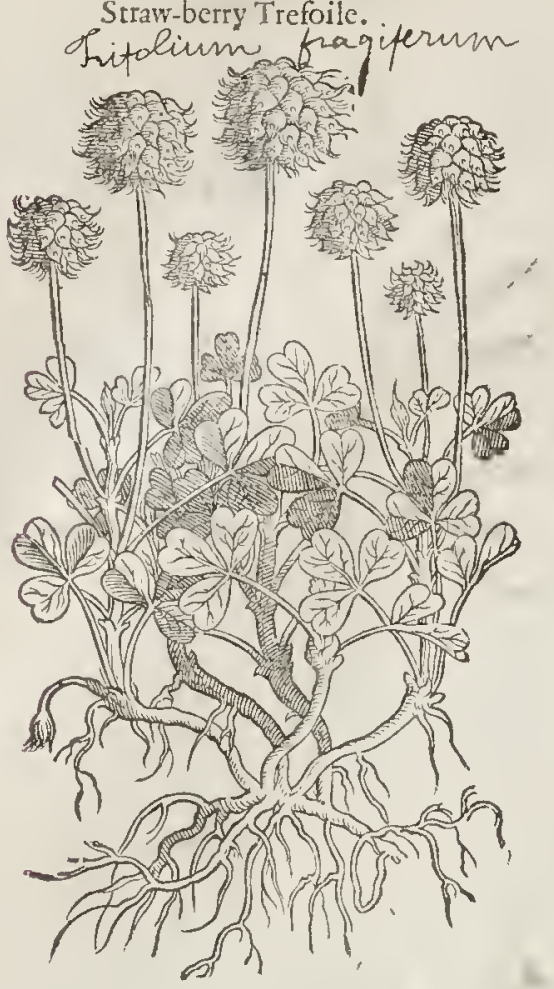

white Trefoile,but there is fome difference in the floures and feed; for the floures of this are fmall, grow rhick rogether, $\&$ are of a whitith blum colour : afrer which follow heads made of lirtle bladders or rhinne skins, after fuch a manner as they refemble a Strawberrie or Rafpas, and they are of a grayinh colour, here and there marked with red: the ftalkes feldome grow aboue three inches high. It growes in mort falt marimes, as in Darrford falr marifh, in thofe below Purfleet, and fuch like: it floures in Iuly and Augurt. Claserses hatl fer it forth by the name of Trifolium from siferum Frificum : fome had rather call it Trifolium veficarium, Bladder Trefoile.

* 5 There are two other Trefoiles with which I thinke good to acquaint you, and thofe by the fimilitude of the cups, which containe the floures, and become the feed veffels, may be fitly called stellata; and thus Baubine calls the firit Trifolision ftellatuns; wherero for diftinctions fake I adde hirfutum, calling it Trufol. ftellatum hirfutsm, Rongl ftarrie hea. ded Trefoile: it hath a fmal long white root, from which arife ftalkes fome foot high, round, flender, hairie, and reddifh, hauing few leaues or branches : the leaues ftand three on a ftalke, in orher Trefoiles, fmooth on the vpper fide, and hairy below the floures are fmall and red, like in thape to rhofe of the common red Trefoile, but leffer; and they ftand each of them in a cup reddim and rough below, and on the vpper part cut into fiue long tharpe leaues ftanding open as they commonly figure a farre: the floures fallen, thefe cups dilate themfelues, and haue in themiddle a longin tranfuerfe whirifh fpot. I faw this Houring in May in the garden of $\mathrm{M}^{\mathrm{r}}$. Tradefcant, who did firft bring plants hereoffrom Fermentera a fmalI Inand in the Medirerranean fea.

6 This orher(which for any thing that I know is not figured nor defcribed by any)hath ftalks fometimes a foor, orherwhiles little aboue an inch high, hairy, and diuded but into few branches: the leaus, which ftand by threes. are fafned to long foot-ftalkes, and they themfelues are fomewhat longith, hauing two litrle tharpe pointed leanes growing at the ferting on of the footftalkes to the tialkes : they are greenc $o^{f}$ colour, and not fnipt about the edges. The heads that grow on the roos of the falkes are round, Morr, and greene, with fmall purple or elfe whitifl floures like thote of the common Tretor!e, but leffer, ftanding in cups diuided into fuc parts, which when the floures are $f_{d}$ 'm $\mathrm{n}$ bernme fonewhat bigger, harfher, and more prickly, but open not themfelues fo mucb as rhofe of It. trmer : rhe feed is like that of Miller, bur fomwhat roun. der. This foures in iune, and the fest sripe in Iuly. I firft obferued it in Darfford falt marifh, the rentli of Iune, 1633 . I haile named this Trifolium fellatum glabrum, Smooth ftarrie headed Trefoile. $\ddagger$

$$
\text { *: The Temperature and Vertuses. }
$$

Thefe, cfpecially the rhree laft, feem: to be of the fame temper and vertue as the common Medow Trefoilcs, bur none of rhem are ar rhis day vfed in Phy ficke, or knownc, vnleffe to fome few. * Iritolimur mav thimum

\section{Cиар. 597. Of Pulfe.}

चा The rindes. Here be diuers forts of Pulfe, as Beanes, Peafon, Tares, Chiches, and fuch like,comprehended inder this rit le Pulfe: and firft of the great Beane, or garden Beane. 
LIB. 2.

Of the Hiftory of Plants.

\section{The Defcription.}

I He grear Beane rifeth vp with a foure fquare ftalke, fmoorh, hollow, withour ioynts; long and vpright, which when it is thieke fowne hath no need of propping, but when it is fowne alone by it felfe it foone falleth downe to the ground: it bringeth forth long leaues onc ftanding from anorher, confifting of many growing vpon one rib or ftem, eucrie one wheren is fomewhat fat, ferw ith veines, flipperie, more long than round. The floures are eared, in forme long, in eolour either white with blaeke fpors, or of a blackith purple: after them come vp long cods, thicke, full of fubitance, flenderer below, frized on the infide with a certaine whire wooll as it were, or foft floekes; which before they he ripe are greene, and afterwards being dry they are blacke and fomewhat hard, as be alfo the cods of broome, yet they be longer than thofe, and greater : in which are contained tlurce, foure, or fiue Beanes, feldome more, long, broad, flat, like almolt ro a mans naile, great, and oftentimes to the weight of halfe a dram; for the moft part white, 110 w and then of a red purplifh colour; which in their vpper part haue a long black nauell as it were, which is coured with a nuile, the eolour whereof is a light greene $:$ the skin of the fruit or beane is clofely compacted, the inner part being dry is hard and found, and eafily eleft in funder; and it hath on the one fide an euident beginning of fprouring, as haue alfo the litrle peafe, great Peafe, Cielies, and many other Pulfes. The roors hereof are long, and faltned with many ftrings.

I Falumaior hortentis.

The great garden Beane.

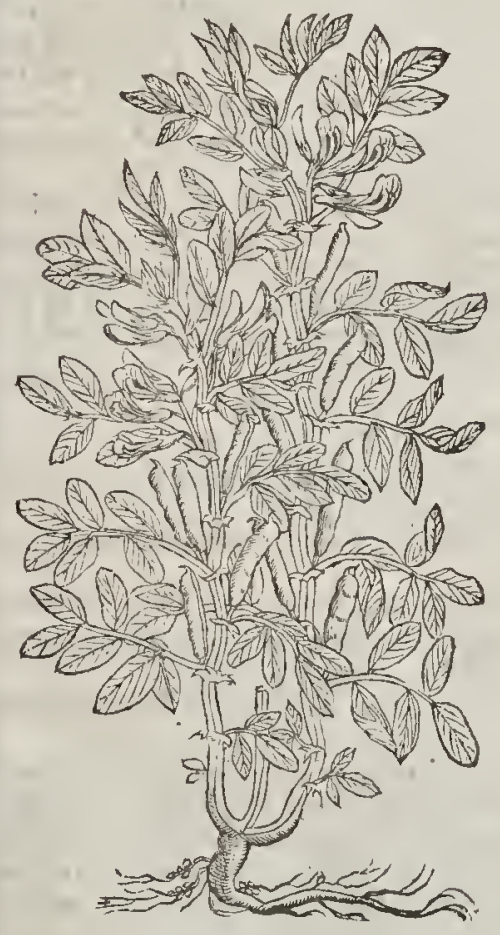

2 Fabafylueftris.

The wilde Beane.

2 The fecond kinde of Beane (which Pen ferteth forth vnder the title of Syluefris Grecorum Faha, and Dodonitss, Bona flueftris; which may be called in Englifh Greeke Beanes) hath fquare hollow Ralkes like the garden Beanes, but frnallct. The leaues bealfo like the common Bcane, faung that the ends of the rib whereon thofe leaues do grow haue at the very end fmall tendrels or clafpers, fuch as the peafe leaues haue. The floures are in fathion like the former, but of a darke red colnur: which being vaded, there fueceed long euds which a re blacke when they be ripe, within which is inclofed blacke feed as big as a Peafe, of an vnpleafant tafte and fauour, 
¥ 3 The common Beane in ftalkes, leaues, floures, and cods is like the former great garden Beane, but leffer in them all; yet the leaues are more, and grow thicker, and out of the bofomes of the leaues vpon little foot-1talkes grow the floures, commonly fix in number,vpon one ftalk, which are fucceeded by fo many cods, leffer and rounder than thofe of the former : the beans themfelues are alfo leffe, and not fo tlat, but rounder, and fomewhat longifh : their colour are either whitifh, yellowith, or elfe blacke. This is fowne in moft places of this kingdome, in corne fields, and known both to man and beaft. I mucli wonder our Author forgot to mention fo common and vulgarly knowne a Pulfe. It is the Bana or Fafclas minor of Dodoneus; and the Faba minor of Pena and Lobel. $\ddagger$

$$
\text { 9ा The Place. }
$$

The firf Beane is fowne in fields and gardens euery where about London.

Thisblacke Beane is fowne in a few mens gardens who be delighted in varietie and ftudy of herbes, whereof I haue great plenty in my garden.

$$
\text { If The Time. }
$$

They foure in Aprill and May, and that by parcels, and they be long in flouring : the fruit is ripe in Iuly and Auguft.

$$
\text { The garden Beane is called in Latine } F \text { a } T \text { T be Names. }
$$

he fame kinde and name alth in Latine $F a b a:$ in Englinh, the garden Beane : the field Beane is of the fame kinde and name, although the fertilitie of the foile hath amended and altered the fruic into a greater forme. \# The difference betweene the garden and field Beane is a fpecificke difference, and not an accidentall one caufed by the foile, as euery one that knoweth them may well perceiue. $¥$

'The blacke Beane, whofe figure we haue fet forth in the fecond place, is called Fabafylueftris : of forne thought to be the true phy ficke Beane of the Antients; whereupon they haue named it $F$ aba Veterum, and alfo Faba Grecorum, or the Greeke Beane. Some would haue the garden Beane to be the true Phafeolus, or Kidncy Bean; of which number Dodoneus is chiefe, who hath fowrangled and ruffled among his relatiues, that all his antecedents muft be caft out of dores : for his long and tedious tale of a tub we haue thought meet to commit to obliuion. It is called in Grẹe rouera whereupon the Athenians feaft dayes dedicated to Apollowere named noxitir, in which Beans and Pulfes were fodden : in Latine it is al focalled $F$ aba fre $f a$ or fracta, broken or bruifed Beane.

$\neq$ Dodonaus knew well what he did, as any that are either iudicious or learned may fee, if they looke into the firft chapter of the fecond booke of his fourth Pemptas. But our Authors words are too iniurious, ef pecially being without caufe, \& a gainft him, from whom he borrowed all that was good in this his booke, except the figures of Tabernamontanus. It may be $D^{r}$. Pritft did not fit his tranflation in this place to our Authors capacitie, for Dodoners did not affirme it to be the Phafeolus, but $P$ halclus, diftinguifhing betweene them.

\section{T The Temperature and Veriues.}

A The Beane before it be ripe is cold and moift : being dry it hath power to bind and reftraine, according to fome Authors : further of the temperature and vertues out of $G$ alen.

B The Beane (as Galen faith in his booke of the Faculties of nourifhments) is windie meate, although it be neuer fo much fodden and dreffed any way.

C Beanes haue not a clofe and heauy fubftance, but a fpongic and light, and this fubftance hath a fcouring and clenfing facultie; for it is plainly feene, that the meale of Beanes clenfeth away the filth of the skin; by reafon of which qualitie it paffeth not flowly through the belly. C And fecing the meale of Beanes is windie, the Beanes themfelues if they be boyled whole and
eaten are yer much more windie.

E If they be parched they lofe their windineffe, but they are harder of digeftion, and doe flowly defcend, and yeeld vinto the body thicke or groffe nourifhing inyce; bur if they be eaten green before they be ripe and dried, the fame thing hapneth to them which is incident to all fruits that are eaten before they be fully ripe; that is to fay, they giue vnto the body a moift kinde of nourifh. ment, and therefore a nourifhment more fullib 6 excrements, not oncly in the inward parts, but alfo in the outward, and whole body thorow : therefore thofe kindes of Beans do leffe nourifh, but they do more fpeedily paffe thorow the belly, as the faid Author in his booke of the Faculties of fimple Medicines faith, that the Beane is moderately cold and dry.

F The pulpe or meate thereof doth fomewhat clenfe, the skin doth a little binde.

$G$ Therefore diuers Phyfitians haue ginen the whole Beane boyled with vineger and falt to thote that were troubled with the bloudy flix, with laskes and vomitings.

H It raifeth flegment of the eheft and lungs : being outwardly applied it drieth without hurt the watery humors of the gont. We haue oftentimes vfed the fame being boiled in water, and fo mixed
with fwines greafe. 
We haue laid the meale therof with Oxymel, or fyrrup of vineger, both vpon bruifed and woun - I ded finewes, and vpon the wounded parts of fuch as haue been bitten or ftung, to take away the fierie heat.

It alfo maketh a good plaifter and pultis for mens ftones and womens paps:for thefe parts when $K$ thiey are inflamed, haue need of moderate cooling, efpecially when the paps are inflamed through the cluttered and congealed milke contained in them.

Alfo milke is dried vp with that pultis.

The meale thereof (as Diofsorides further addeth) being tempered with the meale of Fenugreek $M$ and hony, doth take away blacke and blew fpots, which come by drie beatings, and wafteth away kernels vnder the eares.

With Rofe leaues, Frankincenfe, and the white of an egge, it keepeth backe the watering of the $\mathrm{N}$ eies; the pin and the web, and hard fwellings.

Being tempered with wine it heale th fuffurions, and ftripes of the eies.

The Beane being chewed without the skin, is applied to the forehead againft theumes and fal- 0 ling downe of humours.

Being boiled in wine it taketh aw ay the inflammation of the ftones.

The skins of Beans applied to the place where the hairs were firft plucked vp, wil not fuffer them $R$ to grow big, but rather confumeth their nourifhment.

Being applied with Barly meale parched and old oilc, they wafte away the Kings euill.

Thedecoction of them ferueth todie woollen cloth withall.

This Beane being diuided into two parts (the skin taken off) by which it was naturally ioined $V$ together, and applied, ftancheth the bloud which doth too much iffue forth after the biting of the horfeleach,if the one halfe be laied vpon the place.

The blacke Beane is not vfed with vs at all, feeing, as we haue faid, it is sare, and fowne onely in a $X$ few mens gardens, who be delighted in varietie and fudie of herbes.

\section{С на р. 508. Of Kidney Beane.}

\section{Tा The Kindes.}

\section{T}

He ftocke or kindred of the Kidney Bean arewonderfully many; the difference efpecially con:

fifteth in the colour of the fruit: there be other differences, whero f to write particularly would greatly ftuffe our volume with fuperfluous matter, confidering that the fimpleft is able to diftin. guifh apart the white Kidney Beane from the blacke,the red from the purple, and likewife thofe of mixt colours from thofe that are onely of one colour: as alfo great ones from little ones. Wherefore it may pleafe you to be content with the defcription of fome $\mathrm{few}$, and the figures of the reft, with their fetterall titles in Latine and Englifh, referring their defcriptions vnto a furtherconfide. ration, which otlerwife would be an endleffe labour, or at the leaft needleffe.

$$
\text { It The Defription. }
$$

1 The firft kinde of Phafcolus or garden Smilax hath long and fmall branches growing very high, taking hold with hisclafping tendrels vpon poles and ftickes, and whatfoeuer ftandeth neere vnto him, as doth the hop or vine, which are fo weake and tender, that without fuch props or fupporters they are not able to fuftaine themfelues, but will run ramping on the ground fruitleffe: vpon the branehes do grow broad leaues almoft like Iuie, growing together by three, as in the common Trefoile or three leaued Graffe: among which come the floures, that do vary and differ in their colours, according to the foile where they grow, fometimes white, fometimes red, and oftentimes of a pale colour : afterwards there come out long cods, whereof fome are crooked, and fome are ftraight,and in thofe the fruit is contained, fmaller than the common Bcane, fomwhat flat, and fathioned Itke a Kidney, which are of diuers colours, like wnto the floures : whereto for the moft part thefe are like.

2 There is alfo another Dolichus or Kidney Beane, lefier, horter, and with fmaller cods, whofe floures and frut are like in forme to the former Kidncy Beanes, but much leffer, and of a blacke colour.

3 There is likewife another ftrange Kidney Beane, which doth al fo winde it felfe about poles and props neere adio ining,that hath likew ife three leaues hanging vpon one ftem, as hane the other Kidney Beans, but euery one is much narrower and alfo blacker:thecods be fhorter, plainer, and flatter, and containe fewer feeds. 
I Phacolus albus.

White Kidncy Beane:

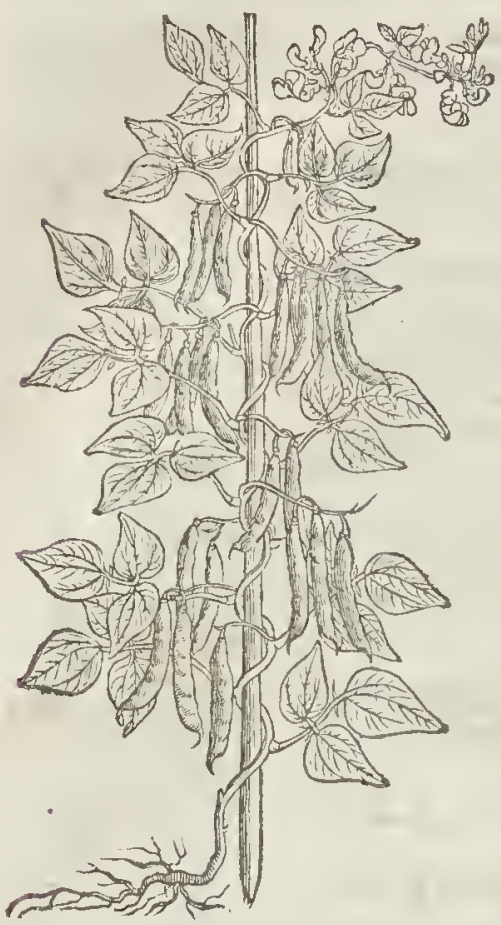

3 Smilax bortenfis rubra.

Red Kiduey Beane.

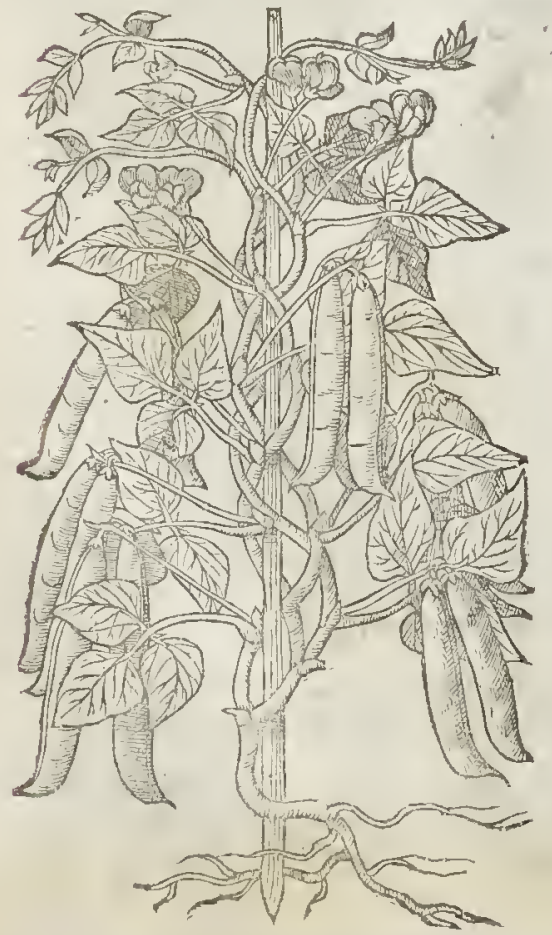

2 Phafeolus niger. Blacke Kidncy Beane.

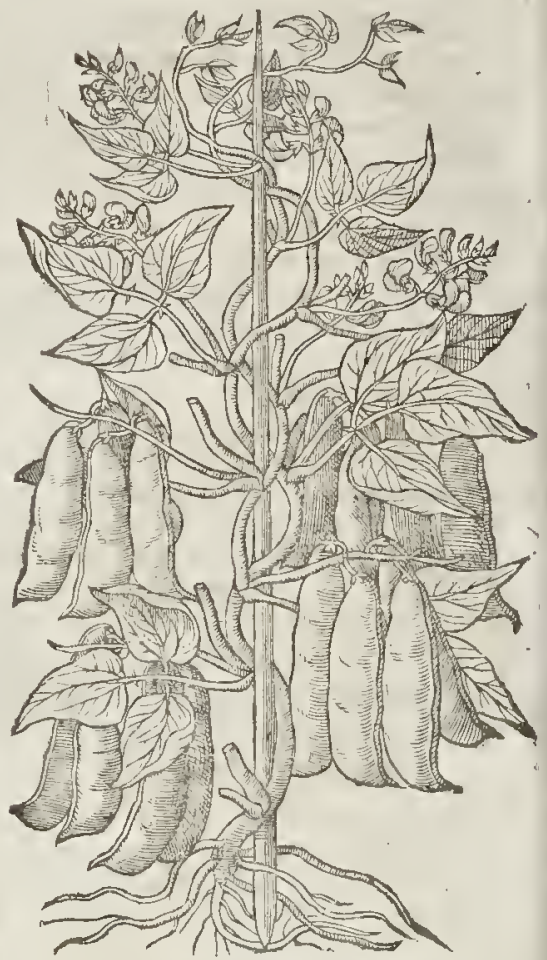

4 Smilax bortenfis flava.

Pale yellow Kidncy Beane.

Yt 50 Gos

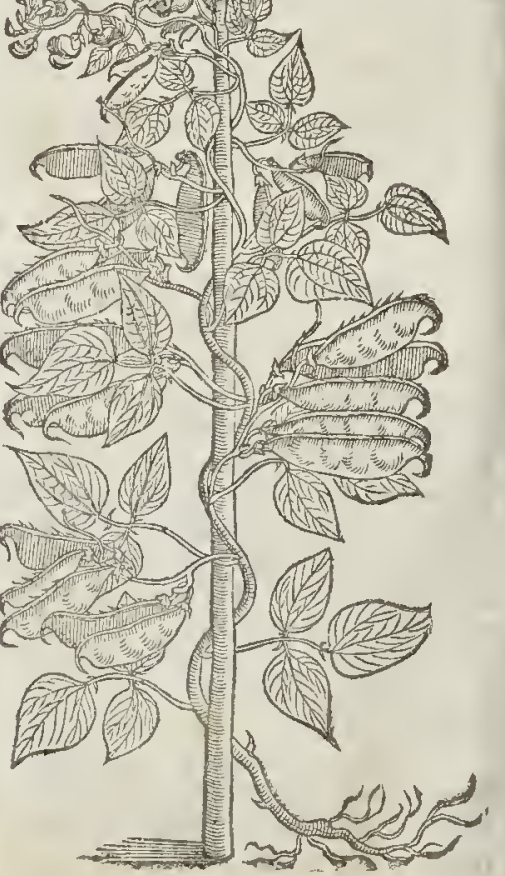


\# Phafeolus peregrinus fructu minore albo. Indian Kidney Beane with a fmall white fruit.
¥ 6 Phafcolus peregrinus frudt a minore frutefcens Indian Kidney Beane with a fmall red fruit

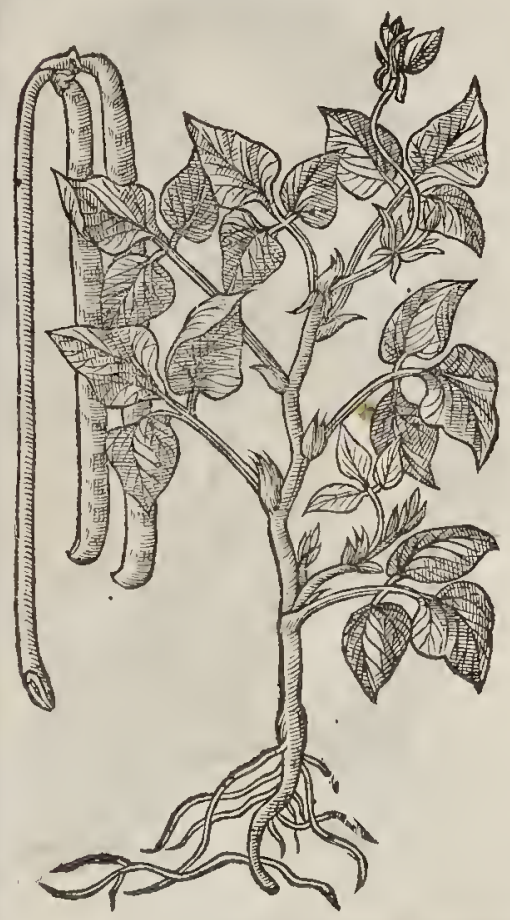

\# 7 Phafeolus peregrinus anguftifolius: Nartow leafed Kidney Beane.

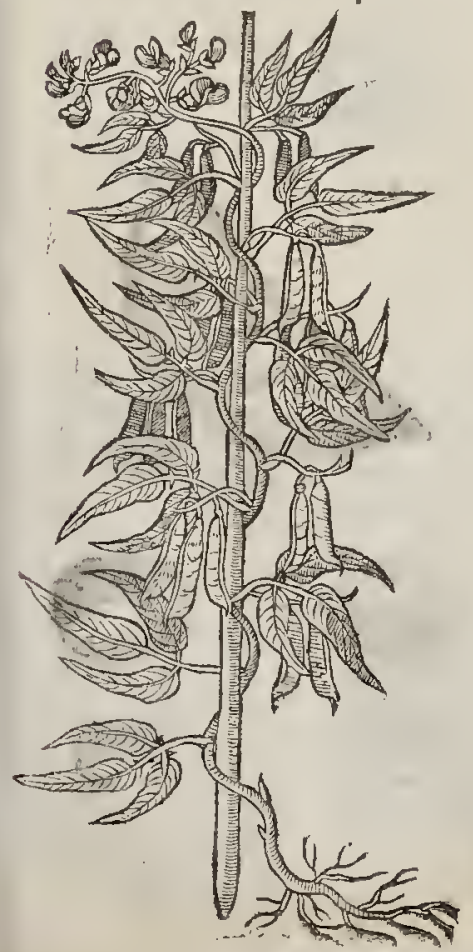

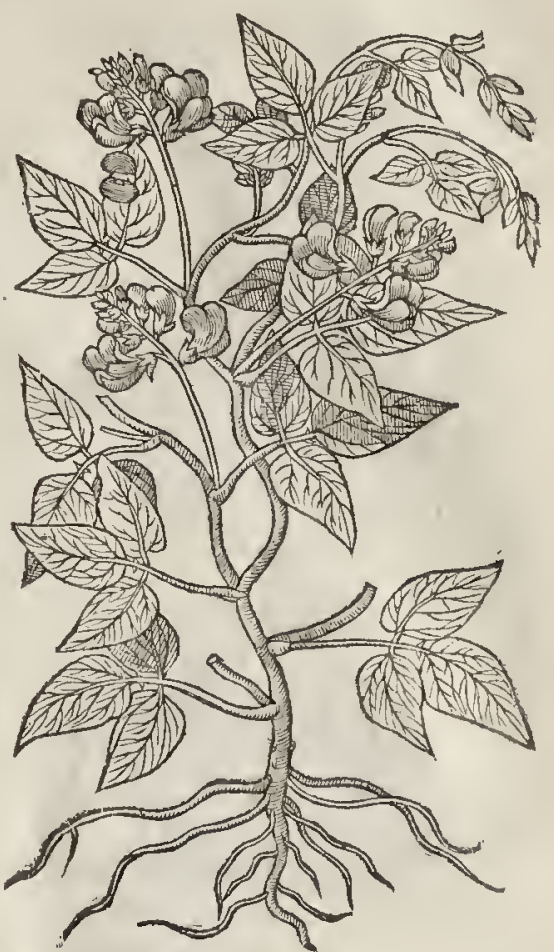

4 This Kidney Bean differeth not from the others, but onely in the colour of the fruit,which are of a pale yellow colour, wherein confitterlx the difference.

$\ddagger$ Befides the varieties of thefe Kidney Beans mentioned by our Author, there are diters other reckoned vp by Clufurus, which haue been brought out of the Eaft and Weft Indies, and from fome parts of Africa; I will only gine you the figures of two or three of them outo $C$ lufins, wich the $\mathrm{CO}_{2}$ lours of their floures and fr uit.

5 The ftalke of this is low and fiffe, the floures of a whicifh yellow on the outfide, and of a violet colour within: the fruit is fnow white, with a blacke fpot in the eye : This is phafeolus peregrinus 4. of Cluzgus.

6 Thishath leaues like the Marfh Trefoile, floures growing many together, in thape and magnitude like thore of common Peafe:the conds were narrow and contained three or foure feeds which were fmall, nobigger than the feeds of $L a-$ burrum; the Painter expreffed two of them in the leafe next vnder the vppermolt tuft of fioures: this is Clufus his $P$ bafeolusperegrinus.5.

7 This growes high,winding about poles or other fupporters: the leaues are narrower than the former:the fruit leffer and flatter,of a reddifh colour. This is the phafeolus perggrinus c. of
clafins. 8 This rindes about poles, and growes to a 
8 phafeolus Brafilianus. Kidney Beane of Brafile.

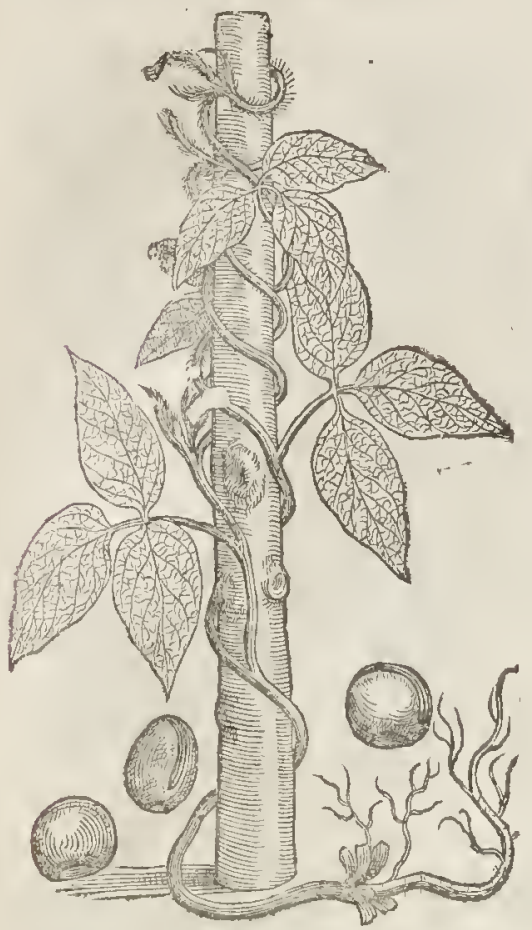

8 Phafeolt Brafil ans ad vivum. The Brafile Kidney Bean in his ful bigneffe?

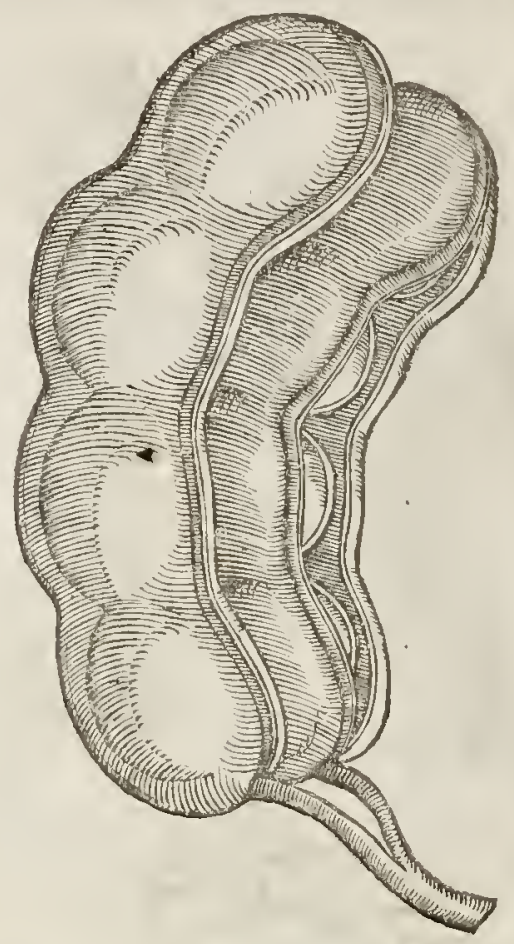

9 Plafcolss eAtgyptiacus. The party coloured Deane of Egypt.
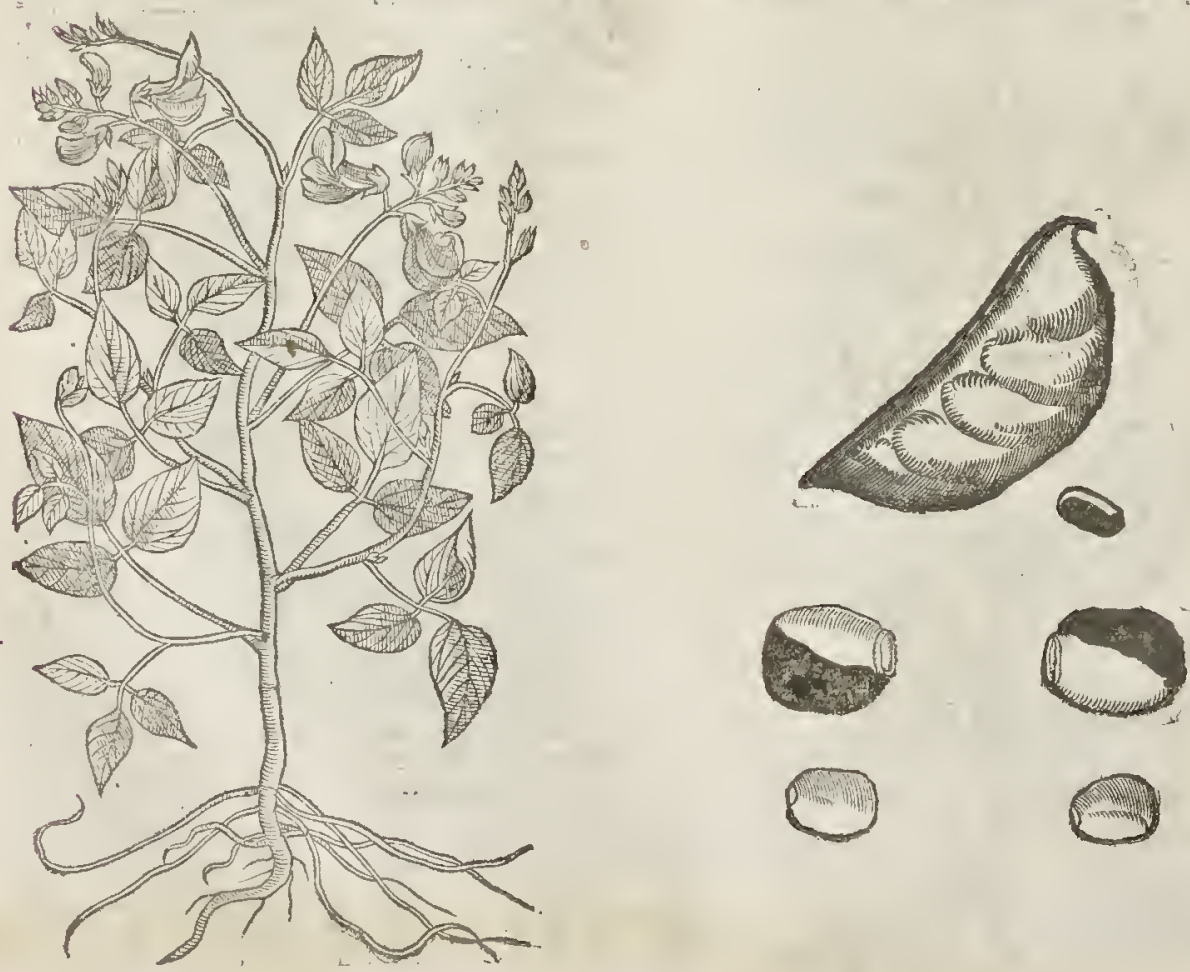
10 Pbajeoli Americipurgantes.

Purging Kidney Bean of America.

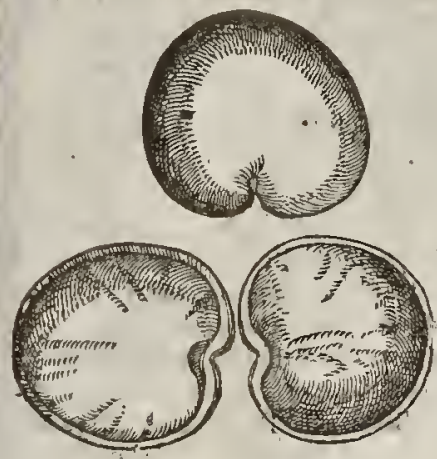

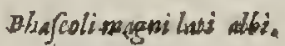
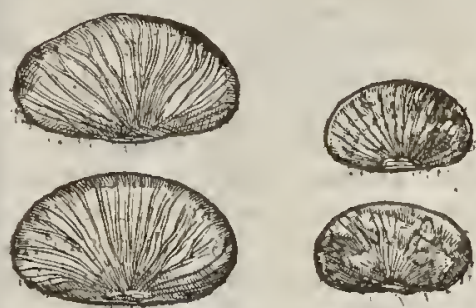

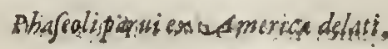
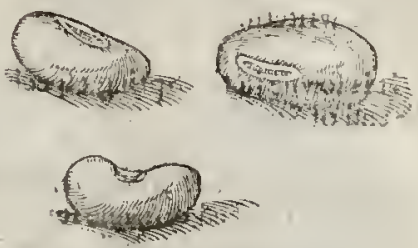

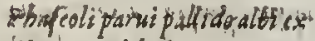
stamericadelatio

(1)

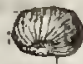

tist

Profedilinbrio

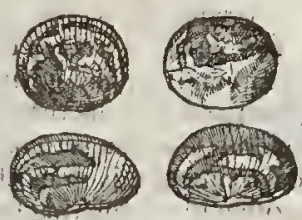

Ahagadirubrik Indianiduriffint:

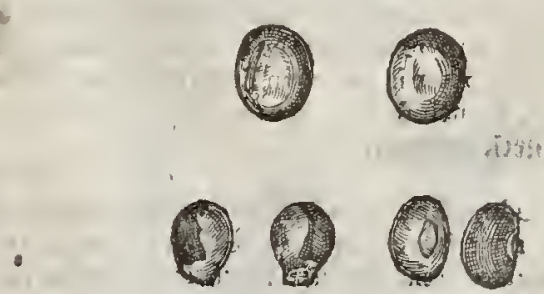

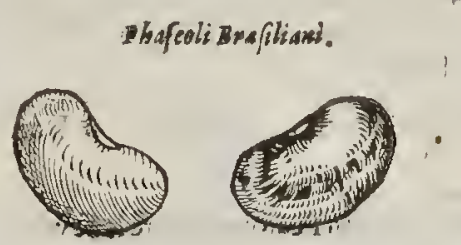

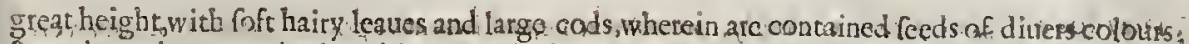
fonetimes they ate red,otherwhiles of a whitith ath colour, foinetimes wholly blacks and-other whiless Fpotted

9. The Egyptian Beane is fomowhat like the other Kidnew Beanes in his gedwing : his fritio is. of the bigneffe of a imall Hafell nut, blacke on one fide and ofra golden yellow of Orenge colour's
on the orber.

Befides the fe you finde here figured, and diuers others deferibed by Clufuss, $\mathrm{T}$ think it not amiffe to mention two more. The firft of thefe, which was procured by $M^{*}$. Tradefant, and growes in our Gardens, is a large plant, not differing in unanner of grovth from the former Iñdian Kidney Beanes, but his floutes are large, many, and afan elegant fearlet colour: whenee it is vulgarly ter med by our Flourifts, the Searlet Beane. The other thate feerne grow th alittle height, but it would not indure; but the cods of it which were brought to vs wete fo ne three inehes long, and couered with a lairie downe of a reddith colour, which pue vpon the hands or skin in any part of the boty would fting like a Nettle, and this was called the Stinging Beane: I thinke it came from fome partof the Eagh Indies, tiv 
af The Plice.

Kidney Beanes doe eafily and foone fpring vp, and grow into a wery great length, Leing fevie

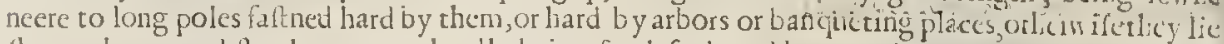

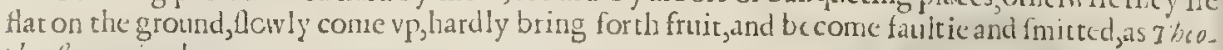
plitalius ivriterh.

T The Time.

It is fowne in the Spring, efpecially in the midft of April, but not before : the frut is rige about the end of So:nmer.

$$
\text { G) The Nimes. }
$$

Hippocrates, Divelis, Theophraftus, and moft of the other old Writcess do call it dira: : diucrs of ilie

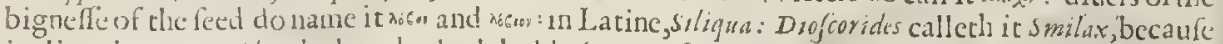
it climeth vp as Smilax doth, and taketh loold of props, ftaic s,and fbrubbes fanding necre into it :

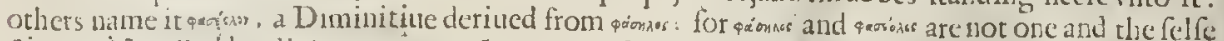
fame pulfe called by diuers names, as fome fuppofe, but fundry fruits one differing from the other, as $G$ alen $1 \mathrm{l}$ his firft booke of the Facultics of Nourifhmenes cloth fifficicutly declare, where lie intreateth of them both. For firlthe difputeth of Phafeli and Ochri, Beans, and Peafe : then afterward others comung betwceac, hewriteth of Dolichus, which alfo is naned Phafcolus: and though hee may bethought to doube what manner of pulfe that is which Theoplorafus ealleth Dolichus; rotwithfanding he gathereth and eoncludeth that it is a fruit of a garden plant in' Italy, and in Caria, growing in the fields, whieh is in forme longer than the Ciehlings, and was commonly ealled in his

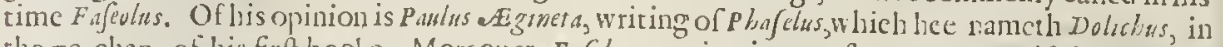
the 79 . chap. of his firf booke. Morcouer, Fagelus was in cimes paft a connon pulfe in Italy and Rome, and Dolichus a frange pulfe; for Columilla and $P$ alladius, writers of husbandry, hauemade mien-

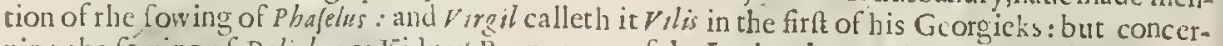
ning the fowing of Dolichus or kidney Beane, none of the Larines haue, written, by reafon that the famewas rare ill ltaly, and fowne onely in gardens, as $G$ alez hath affirmed, naming it oftentimes a garden plant,and thewing that the fame, as we haue faid, is fowne in Caria; and likewife Diofcorides nameth it orine xnsu', that is to fay, Smilax hortenfis, or garden Smilax, becaufe it groweth in Eardcns: who alfo writing of this in another fetcrall chapter, heweth plainely, that Smila borterfis, or Doltchus is another plant diftering from Fafelus, which he nameth phafolus.

Fot which caufes ir is not to bedoubted, but that Phafiss with three fyllables, differeih from Fafeoius witli foure fyllables, no otherwife than Cicer, Cicercula, and Cicera ditier, which notwithotanding, be neere one to another in names : and it is not to be doubted but that they are deceiued, who thinke it robe one and the felfe fame Pulfe called by fundry names.

This plant is named in Enghth, Kidney Beane, Sperage Beanes : of fome, Fafelles, or long Peafon, Frencl Beanes, gatreden Smilax, and Romane Beanes; in French, Fetes de Romme : in Duteh, (1) Utikgboonen.

\section{T) The Temperature.}

Kictney Beanes, as Diofiorides teacheth, do more loofe the belly than Peafon; they are leffewindy, and nourifh well, and no lefte than Peafon, as Diocles faith: they be alfo without ingendring windineffe atall : the Arabian Phy fitions fay that they are hot and moift of nature.

$$
\text { T The Vertues. }
$$

A The fruit and cods of Kidney Beanes boiled together before they be ripe, and buttered, and fo eaten with their cods, are exceeding delicate meat, and do not ingender winde as the other Pulfes
doe.

B They doe alfo gently loofe the belly, pronoke vrine, and ingender good blond reafonably well; but if you cat them when they be ripe, they are ncither toothiome norwholfoms. Therefore they are to be taken whileft they are yet greene and tender, which are firft boiled vntill they be tender; then is the tib or finew that doth run alongit the cod to be taken away; then mult they be put into a fone pipkin, or fome other veffell with butrer, and fet to the fire againe to ftew, or boile gently: which meat is very wholfome, nourithing, and of a pleafant tafe.

\section{Char. sog. Of the flat Beane called Lupine.}

\section{If The Defcription.}

I The tame or garden L kpine hath round hard ftems, which of themfelues do f and visright without any fuccour, help or ftay : the leaues confift of fue, fix, or feuen ioined to 
gether, like thofe of the Chaft tree,green on the vpper fide, and on the nether fide whiteand dow: ny; and in the enening about the fetting of the Sun they hang flagging downwardsas though they were withercd:among thefe there commeth vp a tuft of floures of a pale or light bluth colour, which turne into great rough cods, wherein is the fruit, which is flat and round like a cake, of a white colour, and bitter in tafte : and where they cleane vnto the cod, in that part they haue a certaine dent like a little matell. This Lupine hath but one root, which is flender and wooddie, haung hanging
on it a few fmall threds like haires.

2 The yellow Lupine is like to the garden one in ftalke and leares, yet both of thefe leffer and thorter. It hath beautifull floures of an exceeding faire gold yellow colour, fweet of fmell, made up into an eare, of the colour of the yellow violet, and fomewhat of the fmell : the coddes are fmall, hard, fomew hat hairy : the fceds be little, flat, tound, in tafte ex treme bitter, of fundry colours, ill fanored, far leffer than the tame one.

3 The blew Lupines are longer than the yellow, and diuided into more wings and branches: the leaues be leffer and thinner : the floures finall, and leffer than the yellow, of a blew colour:the feeds be alfo of diuers colours, bitter, and leffer than any of them all.

\# 4 There is alfo another blew Lupine, whofe leates, ftalks, floures, and cods are like, but lar? ger than thofe of the firt defcribed : the floures are of colour blew, with fome whiteneffe here and
there intermixt.

\section{बा The Place and Time.}

They require(faith Theoploraf ws) a fandy and bad foile : they hardly comevp in tilled places, be ing of their owne nature wilde : they grow in my garden, and in other mens gardens about London. They are planted in Aprill, and bring forth the ir fruit at two or thrce fundrie times, as though is did floure often, and bring forth many crops:tle firf in May, the fecond in Iuly, the laft in Septem.
ber, but it feldone commeth to ripeneffe.

This $T$ he Names.

This pulfe is named in Greeke s:pers supes : in Lacine, Lupinus, and Lupinus fativus : in high Dutch, freigbonen : in Italian, Lupino dcmefico : in Spaniph, Entramocos: in the Brabanders languagc, thtith onaten, and Lupinem : in French, Lupins : in Englih, Garden Lupine, tame Lupire, and of fome
after the German name Fig-beane.

T) The Temperature and Vertues.

A The feed of the garden Lupine is modizsury, that is to fay, much and often vfed,as Galen faith in his books of the Faculties of Nourithments: for the famc being boiled and afterwards feeped in faire water,vntill fuch time as it doth altogether lofe his naturall bitrernes, and laftly being feafoned with a reafonable quantitie of falr, it' is caten with pickle. The Lupine is of an hard and earthy fubflance, wherefore it is neceffarily of hard digeftion, and containeth in it a thicke inice; of which being not perfectly concocted in the veines, is ingendred a bloud or iuice which is properly called crude, or raw:but when it hath lof all his bitternes by preparing or dreffing of it (as aforefaid) it is ing fo prepared, it is, as $G$ alen writeth in as without relinh, which is perceined by the tafte; $8 x$ beemplait ickes or clammers.

B But whileft the naturall bitterneffe dorh as yet remaine, it hath power toclenfe and to confume or wafte away, it killech wormes in the belly, being both applied in manner of an ointment and gi-
ten with hony to licke on, and alfo drunke with water and vineger.

C Moreoner, the decoction thereof inwardly taken, voideth the wormes; and likewife if it be fundry times outwardly v fed as a bath, it is a remedy againft the morphew, fore heads, the fmall Pox, wilde fcabs, gangrenes, venomous vlcers, partly by clenfing, and partly by confuming and drying without biting; bcing taken with Rew and Pepper, that it may be the pleafanter, it fcoureth the li-
uer and milt. D It bringeth downe the menfes, and expelleth the dead childe if it be layed to with myrh and
honie.

E Moreouer, the meale of Lupincs dothwafte or confume aw ay without any biting qualitie, for it doth not onely take away blacke and blew fpots that come of dry beatingś, but alfo it cureth $c$ csradas, and $P$ hymat : but then it is to be boiled either in vineger or oxymell, or elfe in water and vineger, and that according to the temperature of the grieued parties, and the diuerfities of the difeafes, 2uod exvfu eft cligendo: and it alfo taketh away blew marks, and what thing foeuer elfe we haue

F Thefe Lupines, as Diofcorides doth furthermorewrite bcing borforme.

a certaine creame, are good to clenfeand beaurifie the bcing boiled in raine water till they yceld

$G$ They cure the feabs in theepe with theroot of bace. with the warme decoction. 
The root boiled with water and drunke, prouoketh vrine.

The Lupines being made fweet and pleafant, mixed with vineger and drunk, takc away the loth- I fomneffe of the ftomaeke, and eaufe a good appetite to meat.

Lupines boiled inthat ftrong leigh which Barbars do ve, and fome Wormwood, Centorie, and $\mathbb{K}$ bay falt added thereto, ftay the running and fpreading of a Gangrena, and thofe parts that are depritued of their nourifhment and begin to mortific,and ftaieth the ambulative nature of running and fpreading vleers, being applied thereto very hot, with ftuphes of eloth or tow.

\section{Cha P.510. OfPeajon. \\ T) The Kindes.}

THerc be diuers forts of Peafon, differing very notably in many refpects; fome of the garden, and 1 others of the field, and yet borh counted tame: fome with tough skinnes or membrares in the cods, and or hers have none at all,whofe eods are to be eaten with the Peafe when they be young, as thofe of the young Kidney Beane : others earrying their fruit in the tops of the branches, are efteemed and taken for Seottifh Peafon, which is not very common. There be diuers forts growing wild, as fhall be declared.

I Pifrm maiks. Rownciuall Peafe.

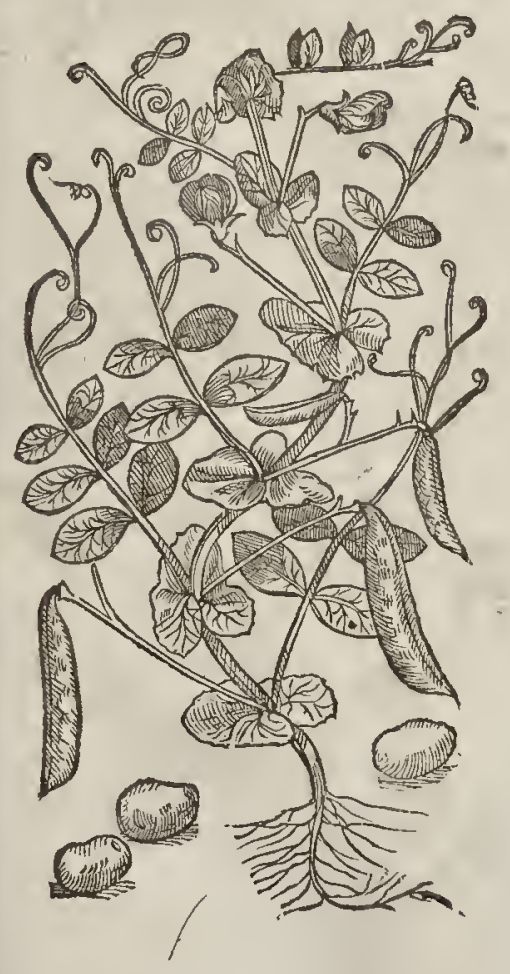

2 pifum minus.

Garden and field Pcafe.

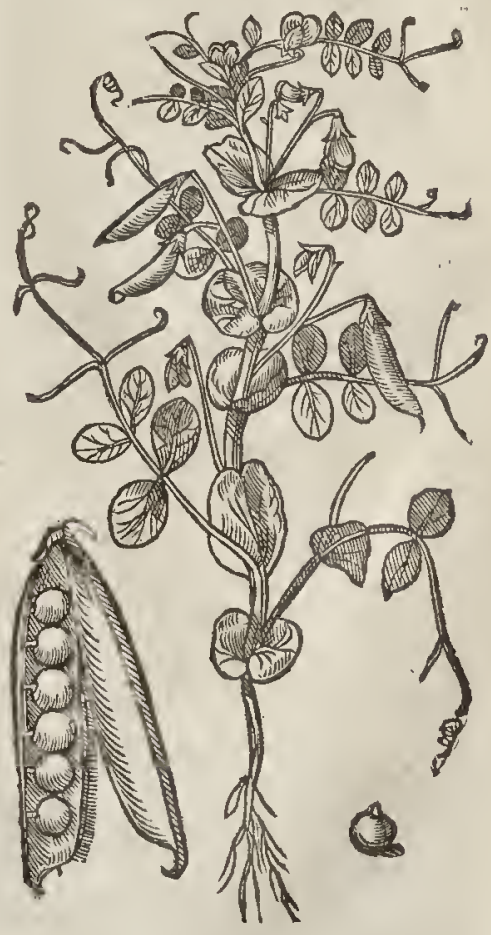

T) The Defcription.

2 He greac Peafe hathlong ftalks, hollow, brick le, of a whitith green colour, branched, and

1 fpread ipon the ground, vnleffe they be held vp with proppes fet neere vnro them: the leafe there of is wide and long, made vp of tnany litrle leaues which be fimoath, whire, growing vpon one lirrle ftalke or ftem, and fet one righe againft anorher : ir hath alfo in the vpper part long elarping tendrels, wherewith it foldeth it felfe vpon props and ftaies ftanding next vnro 
3 Pifum vmbellatum.

Tufted or Scottifi Peale,

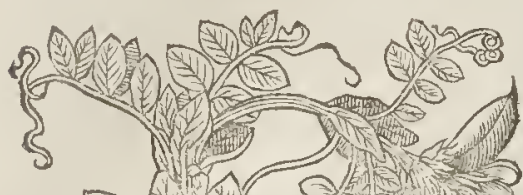

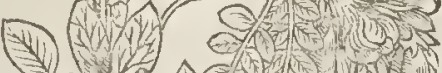

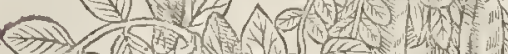

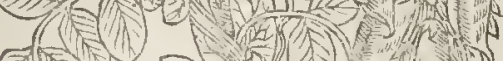

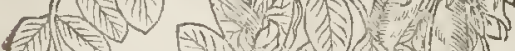

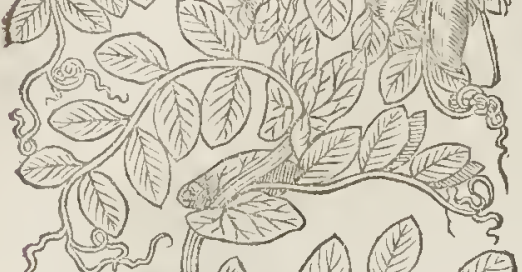

3.

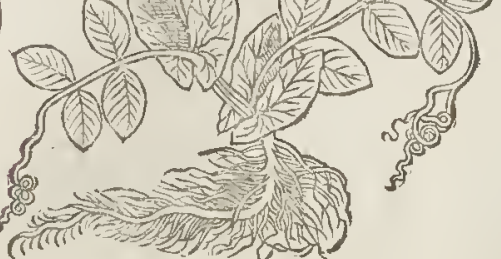

5 pifum fylueftre.

Wilde Peafe.

(12) (1) 0.093

(1. 泟

3 s

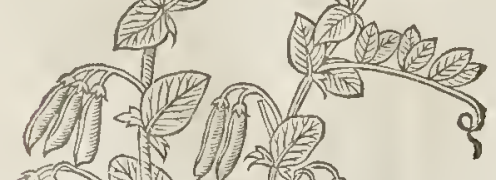

S

Whilline

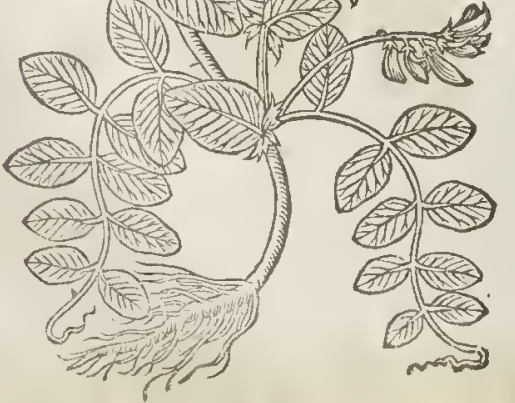

4 Pifum excorticatum.

Peafe without skins in the cod.

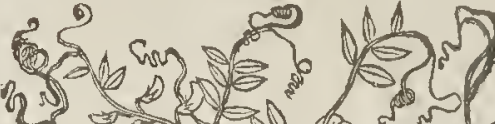
25 , enc 0 . 120 s

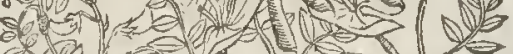
196 206 I.

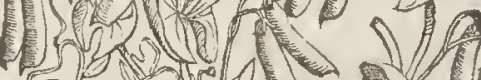
o 1 - 12 $\xi \in(-1)$. gov $(1) d$

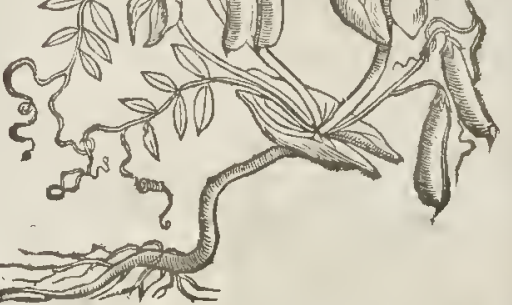

6 Pifum perennefylucftre.

Enerlafting wilde Peafe.

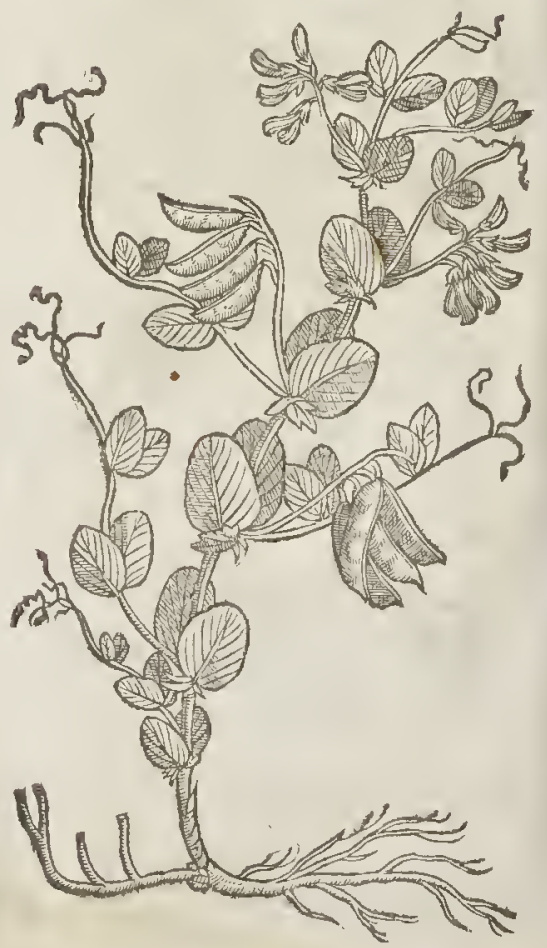


it : the flourc is white and hath about the middle of it a purple fpot: the cods be long, round $c t$ driforma : in which are contained feeds greatcr than ochri, or little Pealon, which being dric a cornered, and that vnequall, of colour fomcrimes white and fometimes gray : the roots are Imall.

2 The ficld Peafe is fo, very well hnowne to all, that it were a needlefte labour to focind time abotit the defcription.

3 Tufted Peafe are like vnto thofe of the field, or of the garden in each refpeet, the difference confifteth onely in that, that this plant carrieth his foures and frtit in the tops of the bruncles in a round tu fe or vmbel, contrary to all other of his kinde, which bring forth their fruit in the midft; and along f the ftalks : the ront is thicke and fibrous.

4 Peafe without skins, in the cods differ not from the precedene, fating that the cods hereof want that tough sh inny membranc in the fanie, which the hogs cannot eat by rea fon of the toughneffe: whereas the other may be eaten cods and all the reft,euen as kidney beanes are : which being fo dreffed are exceeding delicate meat.

5 The wilde Peafe differeth not from the common feld Peafe in ftalke and leaues, fauing that this wilde kinde is fomewhat leffer : the floures are of a yel'ov colour, and the fruit is much leffer.

6 The Peafe whofe root nevier dies differeth not from the wilde Peale, onely bis continiting without fowing,bcing once fowne or planted, fetteth forth the difference.

$$
\text { of The Place: }
$$

Peafe are fet and fown in gardens, as alfo in the fields in all places of England. The tufted Peafe are in reafonable plerty in the W Weft part oc Kent,about Sennocke or Seuenock, in other places not roconinion.

The wilde Peafe do grow in paftures and earable Gelds in diuers places, fpecially about the ficld bclonging vnto Bithops Hatfield in Hartor l/hire:

$$
\text { TI The Timee. }
$$

They be fowne in the Spring timic, like as he alfonther pulfes, which are ripe in Summer : they profper beft in warme weather, and eafily take har ne by cold, efpecially when they foure.

$$
\text { The Nimes. }
$$

The great Pcafe iscalled in Latine P Jum Romanum, or P. fum maius: in Englith, Roman Peafe, or the greater Peafe, alfo garden Peafe: of Inme, Branch Peafe, French Peafe, and Rounfuals. Theopbrafas and other old W' riters do ca'] it in Greeke siru: in Latine alfo Pifum: in low Dutch,130omfebe petwiten : in French d's Poir. The little Pcafe is called of the A porthecaries euery where Ptfum, and Pifum minas: it is culled in Englifh, litt'e Peafe, or the conmon Pcafe:

$$
\text { Tा The Temp rature and vertues. }
$$

The Peafe, as Hippocrates faith, is leffe windie than Beans, but it paffeth foner through the belly. A Galen writeth, that Peafon are in their whole fubftance like vnto Beanes, and be eaten after the fame manner that Beans arc, notwithftanding they differ from then in thefe two things, both becaule they are not fow ind ie as be the beanes, and al fo for that they haue not a clenfing faculty, and therefore they do more florly de [eend t'rous sh the bellv. They hue no effe 'unll qualutic manifeft, and are in a meane betwecn thofe thin ss which ire of gond and bad itwike, that nourith much and litrle, that be windic and without winde, as Galen in his booke of the Faculties of Nourifhments hath written of thefe and of beans.

\section{Cha p. sil. Of the time or Garden Cicte:}

$$
\text { The Defcription. }
$$

Arden Giche bringeth forth round italks, branched and fomewhat hairy, leaning on the onc Tide : the leaues are made of many little ones growing vpoin one ftem or rib, and fet one right agrinftanorher: of which enery one is fmall,broad, and nicked on the edges, leffer than the leates of wilde Germander : the floures be frial, of eolour either white, or of a reddith purple:after whieh come vp lire' thort cods, puffed vp as it were with winde like little bladders, in which doe lie twn or at the mont thee feeds cornered, friall tow ards the end, with one tharp coiner, not much vnlike to a Rams head, of co'our cither white, or of a reddith blacke purple; in which is plainly feers?

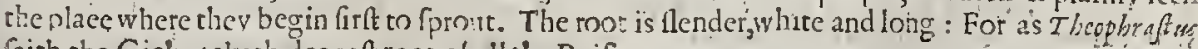
Eaith, the Ciche taketh deepelt root of all the Pu fes.

$$
\text { T The Place. }
$$

It is fowen in Ttaly, Spaine and Franec, etery wherc in the fieds. It is fremen in our tondon gardens, bur noteninmon. 
Cicter atizum.

Garden Ciche.

A

B

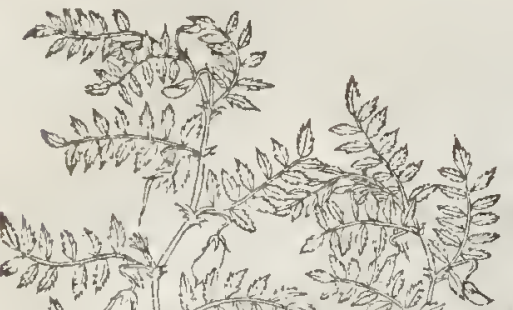

c

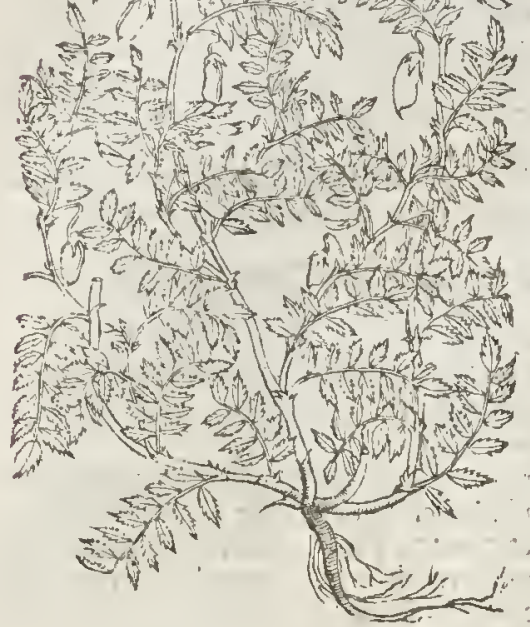

q) The Time.

It is fowne in Aprill, being firft ftecped in wa. ter a day before : the fruit is ripe in Auguilt. The Names.

It is called in Giecke polsenrexpits: in Latine, Cicer ar.etwum, or hams Ciches, \&z of the blackifh purple co'our, Cicer nitrum, zel rubrum, blacke or red Ciche: and theother is named Cundidum ys album Cicer: orwhire Ciclse: in Englifh, Common Cich, or Cicles, red Cich, ofbome, Stieepes Ciche Peafe, or Shcepes Ciche Peafor.

I The Temperature ind vertues!

The Ciche, as Calen writeth in his bonke of the Faeulties of nourinments, is no lefferwindie than the rtue Bean, but it yeelder a ftronger nourifhment than that dorli : ir protioleth luft, and it is thought to ingender feed.

Some gine the fame to italion Lorfes.Moreoner, Ciches do foure more than do the true Beanes: infomuch as certaine of them donaniteftly diminifh orwafte anay the ftones in the Kidneycs: thofe be the blacke and little Ciches called' $\mathcal{L}$ rittind, or Rams Ciches, but it is better to drinke the brath of them foiden in water.

Both the Rams Ciches, as Diofcorides faitli; the white and the blacke prounke rrine, it the decoction therof be made with Rof mary, and givenvino thofe that hate either the 'Dropfienr yellow iaundice; bit they are hurtfull vnto the bladder and Kidneies that hauc viccrs in thein.

\section{Cha p. siz. Of wilde Cicbes.}

9 The Kindes.

Me wilde Ciche is like to the tame(faith Dioforidss)but it differeth in feed: the later writers hatte fet downe two kindes hereof,as thall be declared.

\section{If $T$ be Defoription.}

I Te firftwilde Cich bringerh forth a great number of ftalks branehed, lying flat on the garden Ciche, but : about which be the leaues, confinting ot many vpon one rib as co thole of the forth faftned on fmall ftemed in the edges, n orc like to the leares of Axcich: the flours co ne eares:in heir on matl ftems, which grow clofe to the ftalks, of a pale yellow colour, and like vnto

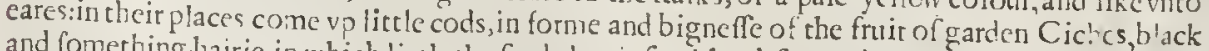
and fomething hairie in which lieth the feed, that is fmal, hard, flat, and glittering, in tafte like tlut of Kidney Beane : the rnot groweth deepe, faftened with many ftrings.

2 There is another kinde of wilde Cich that hath alfo a great rumber of $\mathrm{fta}$ 'ks lving vron the ground, about which ftand foft leaucs, fomething hairy and white, confinting of threc broadleaues ft ariding vpon a midale rib, the leaft of which ftand neereft to the ftem, and the greateft at the very ron: the floures come forth at the bottome of the leanes many together, of co! our vellow ; after Which grow fnall long buskes, foft and hairy, in euery ane whereof is a little cod, in which lie two
feeds like little Cichlings. 
1 Cicer fylueftre.

The wilde Cich.

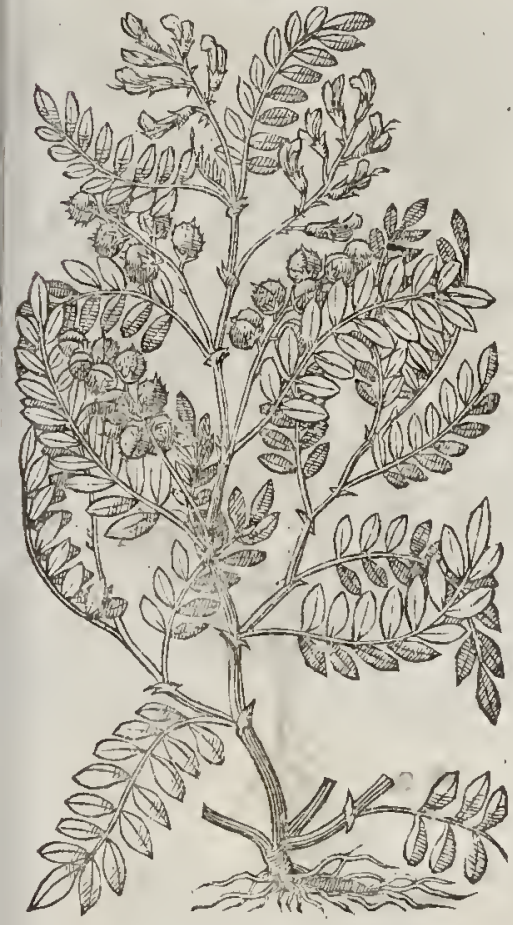

2 Cicer fyluse? rowint foliam. Broad leafedivilite Cicli.

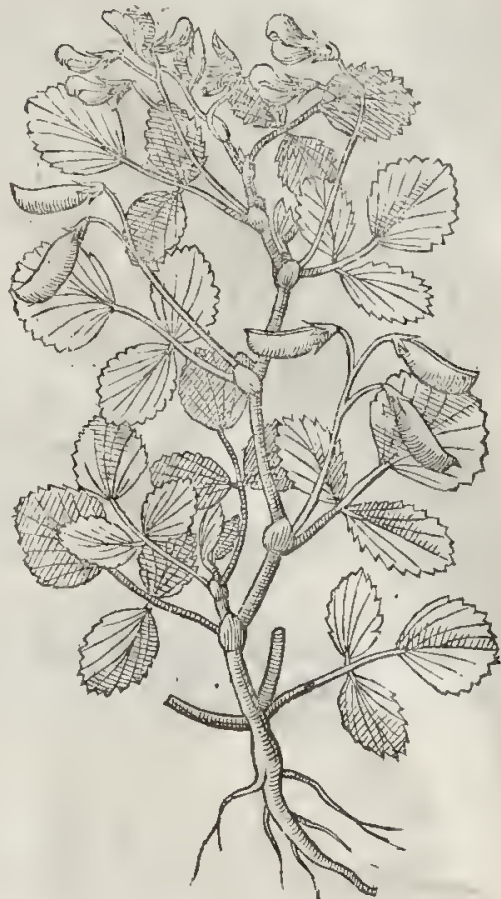

The Place."

Thefe plants are fownc in the parts bey'ond the feas for to feed their cartell with in winter,as we do tares, vetches, and fuch other bafc pulfe.

of The Time.

The time anfwerech the Vetch or tare.

The Names:

The wild Cich hath no other name in Latine but Cicer fylmeftre : the later writers haue not found any name at all.

q The T'emperature and Vertues.

Their temperature and vertues are referted to the garden Cich, as Theophraftus affirmes; and $\mathrm{Ga}$ len faith that the wilde Cich is in all things like vnto thar of rhe garden, but in Phy ficks vfe more effectuall, by reafon it is more hotter and drier, and alfo more biting and bitter.

\section{Cна Р. 513. Of Lentils. \\ e The Defcription.}

1 He firt Lentil growes vp with flender ftalks, and leaues which be fomwhat hard, growing aflope from both fides of the rib or middle ftalke, narrow and many in number like hofe of Tares, but narrower and leffer : the floures be fmall, tending fomewhat towards a purple: the cods are little and broad : the feeds in thefe are in number three or foure, little, round, plane, and flat : the roots are finall and threddy.

The fecond kinde of Lencill hath fmall render and pliant branches a cubit high, wheron lo grow leates diuided or confiting of fundry other fmall leates, like the wilte Vetch, ending at the middle rib with fome clafping tendrels, wherewith it takerh lold of fuch things as are neere vr:to it : among thefe come forch little brownith floures mixe $\mathrm{d}$ with white, which turne into fmall flat cols, containing little browne flat feed, and fometimes white. 


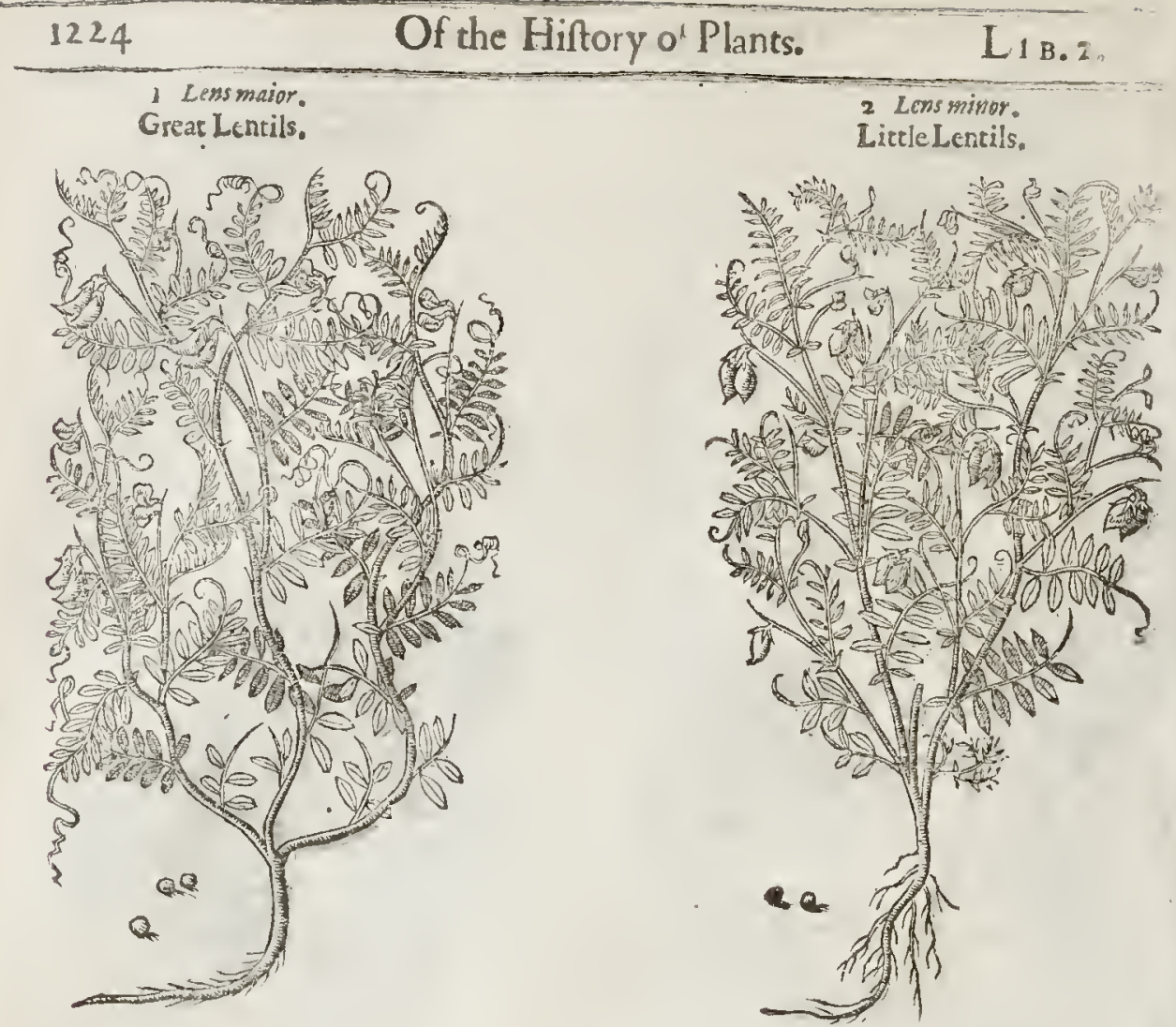

T The Place?

Thefe Pulfes do grow in my garden; and it is reported vnto me by thofe of good credit, that about Watford in Middlefex and other placs of England the husbandmen do fow them for their cattell, cuen as othcrs do Tates.

They borb floute and wax

9 The Time.
and Auguit.

IT The Names.

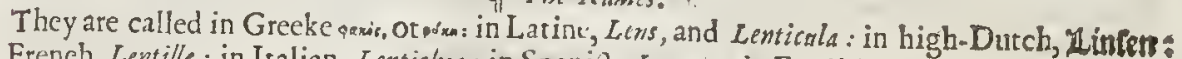
in French, Lentille : in Italian, Lentichra: in Spavioh, Lenteza : in Englioh, Lentils.

Lentils, as $G$ aten faith, are in a meane betweene hot and cold, yet are they dty in the fecond degree: their skin is attingent or binding, and the meate or fubftance within is of a thicke and eatthy iuyce, hauing a qualitic that is a little auftere or fomething harfh, much more the skin theteof; but the inyee of them is quite contraric to the binding qualitie; wherefore if a man thabboile them in faire water, and afterwards feafon the water with falt and piekle, att cam ip jas oleo condrens, The f r ke it, the lame drinke doth Jonfe the belly.

The firt decostion of Lentils doth lonfe the belly ; but if they be boyled againe, and the fitt decostion caft dway, then doe they binde, and ate good againit the bloudy fixe ot dangerous

They do their operation more effe etually in ftopping or binding, if all or any of thefe following Serue be

$\mathrm{D}$

The meale of Inre Peares, Qunces, Ptantaine leanes, Galls, or the berries of Sumach.

fores, filling the

E The Lentil hauing the skin or coar taken off ands.

The Lentil haulug the skin or coat taken off, as it loreth that ftrong binding qualitie, and thofe

F

aecidents that depend on the fame, fo doth it more nourifh than if it had the skin on.

It ingendreth thicke and naughty iuyce, and flowly pafteth thorow the belly, yet doth it not ftay the loofnefe as that doth which hath his çoat on; and therefore they that vfe to eat ton muel 
L1B. 2. Of the Hittroy of Plants.

1225

thereof do neeeffarily beeome Lepers, and are muels fubiect to eankers, for thieke and dry nourifhments are apt to breed melaneholy.

Therefore the Lentill is good food for them that through waterin humours be apt to fall into $G$ the dropfie, and it is a moft dangerous food for dry and withered bodies; for which caufe it bringeth dimoffe of fight, though the fight be perfect, through his exeeffue drineffe, whereby the fpirits of the fight be warted; but it is good for them that are of a quiteeontraric conftitution.

It is not good for thofe that want their termes; for it breedeth thieke bloud, and fuch as llowly $\mathrm{H}$ paffeth through the veines.

But it is lingular yood to ftay the menfes, as Galen in his booke of the faeulties of nourinments I affirmeth.

It eaufeth troublefonc sreames (as Digforides doth moreoucr write) it hurteth the head, fi- $\mathbb{K}$ neves, and luigs.

It is good to fivallow downe thirty graines of Lentils thelled or taken from their husks, againft $L_{\text {, }}$ the ottereafting of the ftomacke.

Being boyled with parched barly meale and laid to, it affwageth the paine and ach of the gout. $M$

With honey it filleth w hollow fores, it breaketh afehares, clenfeth vleers : being boyled in $N$ wine ir watterl away wens and hard fwellings of the throat.

With a Q:inee, and Melilot, and oyle of Rofes it helpeth the inflammation of the eyes and fun- $O$ dament but $11 \mathrm{ggreater}$ inflammations of the fundament,and great deep vleers, it is boyled with the rinde of a pomurranat, dry Rofe leaues, and honey.

And a fter the fa ne maner againft eating fores that are mortified, if fea water be added; it is alfo $P$ a remedic argainfe purhes, the hingles, and the hot inflammation ealled $S$. Anthonies fire, and for kibes, in fiel, manner as we hate written: being boyled in fea water and applied, it helps womens brefts ia whieh the milke is cluttered, ánd eannot fuffer too great aboundanee of milke.

\section{Cas. 5i4. Of Cicbortrue Orobus.}

orobus receptus Herbariorum.

The true Orobus.

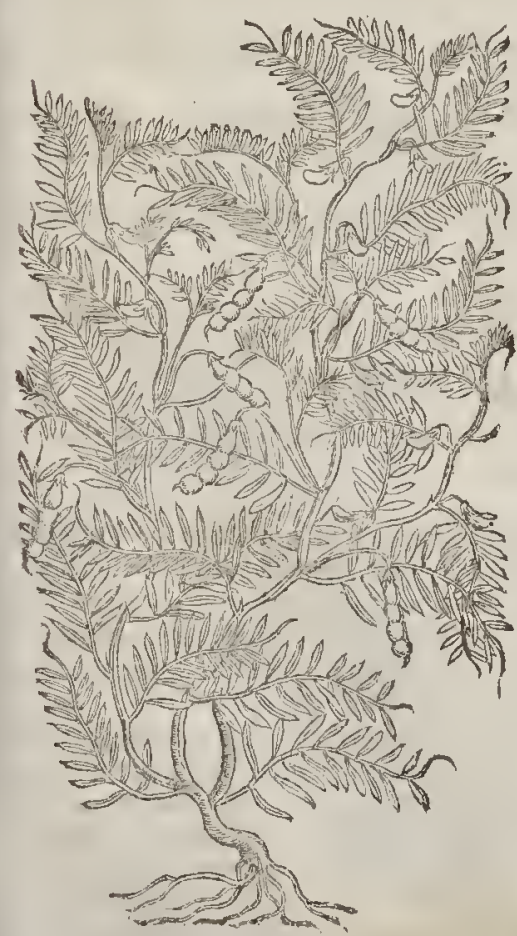

IT The Defcription.

His Pulfe, which of molt Herbarifts is taken 1 for the true Orobus, and ealled of fome, bitter Fiteh, is one of tle Pulfes whofe tender branehes traile vpon the ground, as $T$ broppratf tus faith, and whofe long tender branehes fpred far abroad, whereon doe grow leanes like thole of the field Veteh : anong which grow white floures; after which come long eods, that appeare bunehed on the out fide againft the placewhere the feeds do lic, whieh are fmali, round, ruffer of eolour, and of a bitter tafte : the root is fmall and fingle.

$$
\text { \&ा The Place. }
$$

It profpereth bett in a leane foile, aecording to colmuclla: it groweth in woods and eopfes in fundry places of Spaine and Italy, but here only in gardens.

$$
\text { 4T The Time. }
$$

This is fowne early and late, but if it be fowne in the fpring it eafily commeth vp, and is pleafant ${ }_{5}$ and vnpleafant if it be fowne in the fall of the leafe.

$$
\text { बT The Retmes. }
$$

This is ealled in Greeke Derpos: the fhoos of Germanie haute kept the name orobus: the Italians cal it Macho : the Spaniards, Yerio, and Yeruos: in Englinh it is ealled bitter Veteh, or bitter Fiteh, and Orobus, after the Latine name. Of fome Ers,after the French name.

का I 
4. The Temperature and Vertues.

A Galen in his firft booke of the Faculties of nourifhments faith, That men do altogether abftaine from the bitter Vetch, for it hath a very unpleafant tafte, and naughty inyce; bur Kinc in Afra and in moft other countries do eate thereof, being madc fweet by ftecping in water; notwithftanding men being compelled through neceffitie of great famine, as Hippocrates alfo hath written,do oftentimes fecd thereof; and we alfo dreffing them after the manner of Lupines, vfe the bitter Vetches with honey, as a medicine that purgeth thicke and groffe humors our of the cheft and lungs.

B Moieoucr, among the bitter Vetches the white are not fo medicinable, but thofe which are neere to a yellow, or to the colour of Okar; and thofe that haue beene twice boyled, or fundrie times foked in water, lofe their bitter and vnpleafant tafte, and withall their clenfing and cutting qualitie, fo that there is onely left in them an earthy fubftance, which ferues for nourifhment, that drieth without any manifeft bitterneffe.

C And in his booke of the Faculties of fimple medicines he faith, Thatbitter Vetch is dry in the later end of the fecond degree, and hot in the firf: moreoner, by how much it is bitter, by fo much it cienfeth, cutteth, and remoneth ftoppings : but if it be ouermuch wed it bringeth forth bloud by rrinc.

D Diofcorides writeth, that bitter Vetch caufeth head-ache and heauy dulneffe, that it troubles the belly, and driveth forth bloud by vrine; notwithikanding being boyled it ferueth to fatten Kine.

E Thcre is made of the feed a mcale fit to bo vfed in medicinc, after th is maner : the full and white graines are chofen out, and being mixed together they arc ftecped in water, and fuffered to lie till thcy be plumpe, and afterwards are parched till the skinne bebroken; then are they gtound, and fearfed or thaken thorow a mealc fieuc, and the mcale referued.

F This loofeth the belly, pronoketh vrinc, maketh one well coloured : being onermuch eaten or drunkc it drawcth bloud by the ftoole, with gripings, and al fo by vrine

G With honey it clenfeth vlcers, takcth away freckles, fun-burnes, blacke foots in the skinne, and maketh the whole body faire and cleane.

H It ftayeth running vicers or hatd fwellings, and gangrens or mortificd fores; it fofteneth the hardneffe of womens breafts, it taketh away and breaketl cating vlcers, carbuncles, and fores of the head : being tempered with wine and applicd it healeth the bitings of $\mathrm{dog} s$, and alfo of venomous beafts.

I With vineger it is good againft the ftrangutic, and mitigateth paine that commeth thereof.

$\mathrm{K}$. It is good for them that are not nourithed after their meat, bcing parched and taken with hony in the quantitie of a nut. $\mathrm{L}$ The decortion of the fame helpcth the itch in the wholc body, and taketh away kibes, if they
be wath,cd or batled therewith.

M cicer boylcd in fountaine water with fome o robus doth affwage the fivelling of the yard and priuie patts of man or woman, if they be wafhed or bathed in the decostion thereof; and the fubftance hereof may alfo be applied plaifterwife.

N It is allo vfed for bathing and wa hing of vlcers and running fores, and is applied vnto the fcurfe of the head with great profit.

\section{CHA P. 5I5. Of the Vetchor Fetch.}

\section{T) The Defoription.}

I Te Verch hath flender and foure fquared falkes almoft three foot long : the Ieaues be long, with clafping tendrels at the end made vp of many little leaues growing vpot one rib or middlc ftem; cuery one whereof is greater, broader, and thicker than that of the Lentil : the floures are like to the floures of the garden beane, but of a blackc purple colour : the cods be broad, fmall, and in cuery one are contained fiue or fix graines, not round,but flat like thofe of the Lentil, of colour blacke, and of an vnpleafant taftc.

$\$ 2$ There is another of this kinde which hath a crecping and liuing root, from which it fen. deth forth crefted falkes fome cubit and halfc high: the leaues are winged, commonly a dozen growing vpon one rib, which ends in a winding tendrel : each peculiar leafe is broader toward the botrome, and tharper towards the top, which cnds not flat, but fomewhat round. Out of the bofomes of the leates towards the tops of the ftalkes, on hort foot-ftalkcs grow two, thrce or more prety large peafe-fathioned blewith purple floures, which are fucceeded by fuch cods as the former, but fomewhat lefier; which when they grow ripe become blacke, and fly open of themfclues, 
¥ I ricia.

Tare, Vetcil, or Fetch,

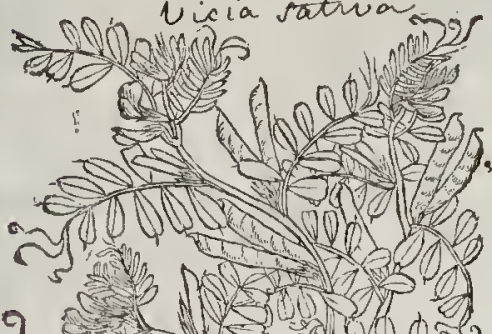

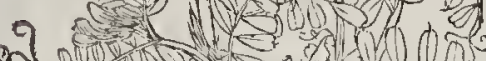
G.0104 का $5 \sqrt{\pi} C^{2}, 10$

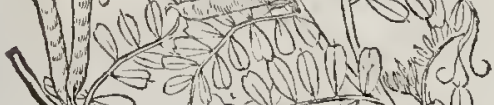
$4(2,2)=010$

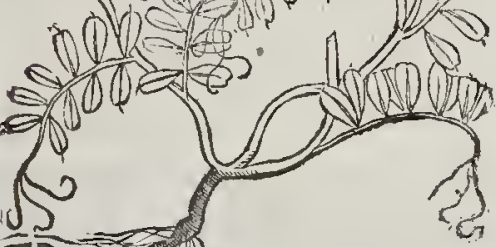

+ z Viciafyl.fo, albo.

White floured Vetch.

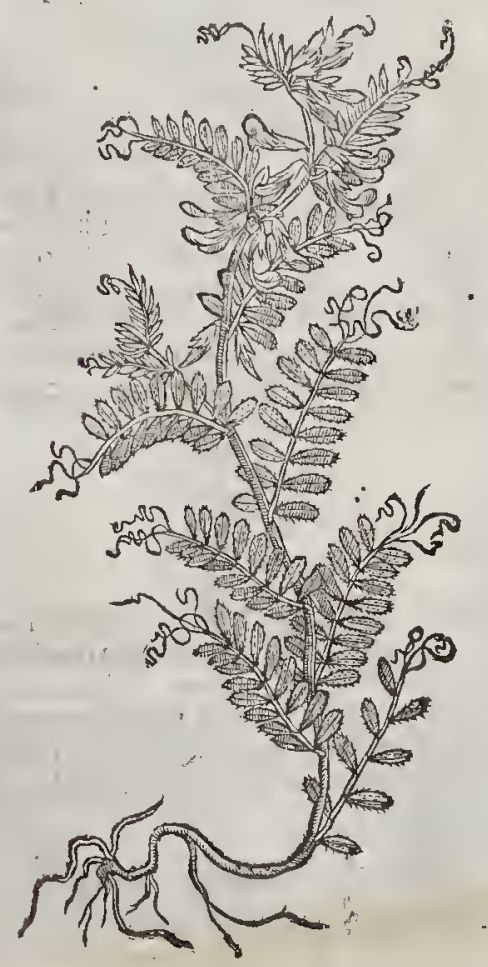

t 2 Viciamaxima dumsetorum. BuIh Vetcls.

bicia spium -

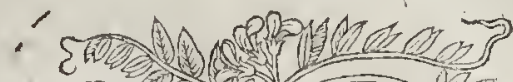
एक से वे वो

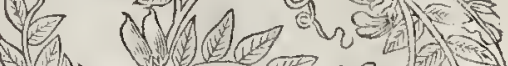
(E) (1) B. 2u as

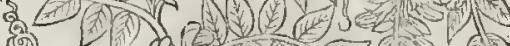

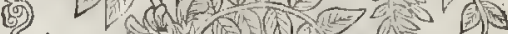
(AM $A$ (E)

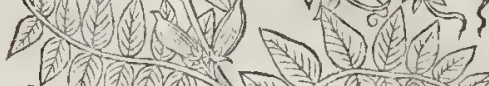

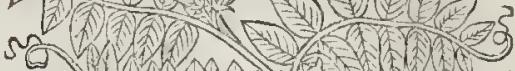

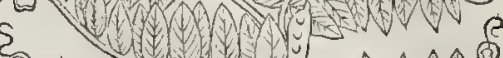
A A A N NAMO

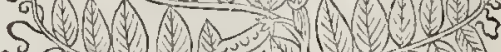
3 a a a (

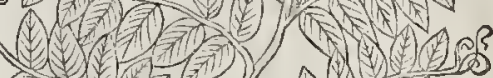
(x)

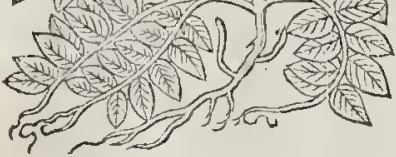

4 viciafylueftris, fue Craccimaior. Srangle Tare, Tine, or wilde Ferch.

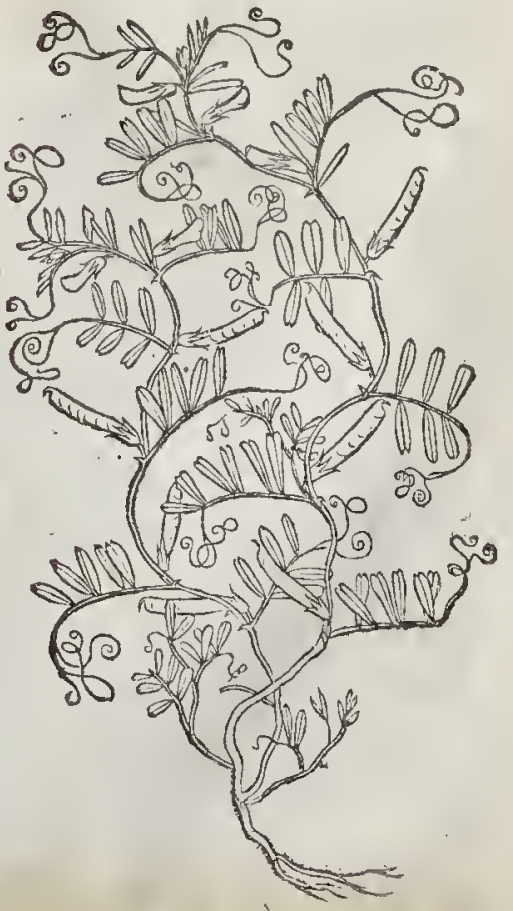


and fo fatter their feed. This growes in many places wilde anıong bufhos, both hete and in Ger-

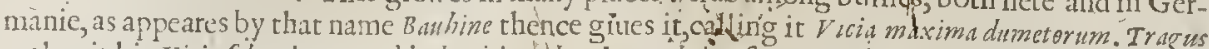
makes it his Ficia fyl. altera; and iudges it tobe the Aphrice of Diofcordes; and he faith the Latines call it Os mmadi : the high-Dutch, $\$$, Crifoffels tituut, and Schwatts Xinfen. Tabern.calls it Craccinatior.

\# riciafyl. func Cracca minima.

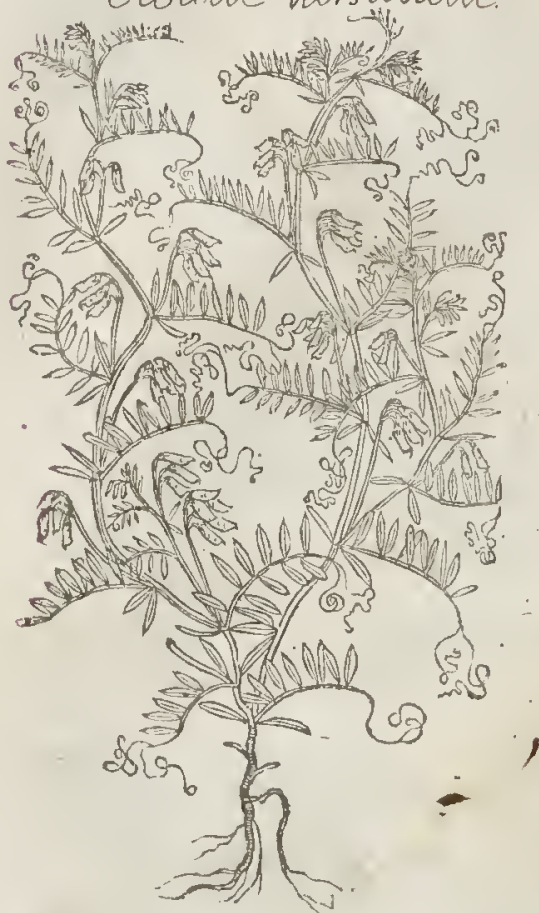
Ereunill wilde Tare.

1 3 "This alfo hath a lafting root, which fendeth pround crefted branches, a foot and fomtimes a cubit high, whereon grow fuch leaues as thofe of the former, bur more white and downie : the floures, which grow on thort footftalkes, out of the bofomes of the leaules, toivards the top of the ftalks, are of a whirifh colour, with veines of a dusky colour, diuaricated -onet the vpper leafe : the cods are like thofe of the common Fetch. Clizfius found this in fome wilde places of Hungarie; it floured in May: he calls it Viciafylueftris albo flore $\neq$

4 Strangle Tare, called in fome countries Tine, and of others wilde Vetch, is a ramping herbe like vnto trie common Tare, ramping and clymbing among corne where it chanceth, that it plucketh it downe to the ground, and ouergroweth the fame in fucl fort, that it fpoileth and killeth not only wheat, but all other oraine whatfocuer : the herbe is better known thandefited, therefore thefe $f(w$ lines fhall fuffice for the defcription, $¥$ This groweth pretty long, with many flender wcake branches : the leaucs are much fmaller than the former, and end in clafping tendrels : the floures ate of a purple colour, and commonly grow but one at a ioint, and they are fucceeded by flat fharpe pointed cods which containe fome nine or ten feeds apiece.

5 This alfo growes a good height, with flenderer ftalks than the former, which is diuided into fundry branches : the leaucs grow
but very flendet foot-ftalkes, fometing al fo in clafping tendrels : the floures grow vpon pretty long but very flendet foot-ltalkes, fometimes two or three, otherwhiles more, very fmall, and of a whitith colour inclining to blewneffe : which are fucceeded by little thort flat cods, containing combel ; but I queftion whether it be that which colour : this is the Arachus, fue Craccaminima of Ioling it Vicialegetum cum fliquis plurimis hirfutis . for in his. Pinax hath made the fame with it, cally agrees with this figure of Lobel and that defcriprion thich I hauc defcribed, and which exactout any hairineffe at all. This floures moft corne fields and nedowes. $\ddagger$.

The Tare is forne in The Place.

The Tare is fowne in any ground or foile whatfocuer.

It flourcth in May, and perfecteth his If The Time.

It

TT The Names.

It is called in Latine $F^{*}$ icia , i vinciendo, of binding or wrapping, as $V$ arro noteth, becaufe, faith he, it bath likewife chafping tendrels fuch as the vine hath,by which it crawles vpward vpon the ftalks of the weeds which are next vito it: of fome, Cracca, and Arachus; and alfo Yphaca: it is called in

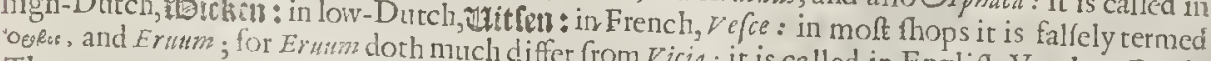
The countrey men lay vp this Vetch with differ from Vicia : it is called in Englinh, Vetch, or Fetch. their cattell.

A Notwithfanding I 5 The Temperature and Fertues.

ally in the fpring, it being but greene; yet is it hard of who in time of famin hatre fed hereof,efpeciTherefore 
L 1 B. 2.

Of the Hiftory of Plants.

1229

Therefore feeing it ilof this kinde d nature, it is manifeft that the nourifhment which comes thereof hath in it no good iuyee at all, but ingendretl a thieke bloud, and apt to beeome melancholy.

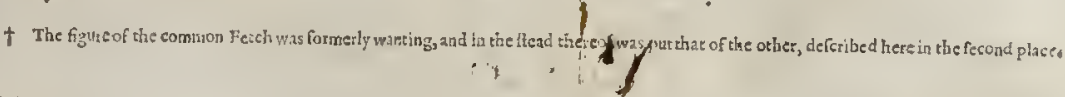

Cна т.516. Of Chichlings, Peafe, and Tare eucrlafing.

ף. The Defoription.

I Here is a Pulfe growing in our high and thieke woods, hauing a very thieke tough and wooddy root, from which rife vp dituers long weake and feeble branehes, eonititing of a tough middle rib, edged on both fides w ith a thin skinny membrane, fmosth, and s a graffe greene colour; w hereon do grow atcertaine diftanees fmall flat ftems, vpon which ftand two broad leatues ioyning together at the bottome: from betwixt thofe leaues enme forth tough clafping, tendrels which rake hold of fueh things as grow next vnto them: from the bofome of the ftem, whereon the leaues do grow, thooteth forth a naked fmooth foot-falke, on whieh doe grow molt beautifull foures like thufe of the Peafe, the middle part whereof is of a light red, tending to a red Purple in graine; th outward leaues, ake fomewhat lighter, inelining to a blun colour; whieh being paft, there fueeced long round eods, wherein is eontained feed, of the bigneffe of a Tare, but roundcr, blackith without, and yellowish within, and of a bitter tafte.

\$ Lathyrus maior latifolius. Peafc enerlafting.

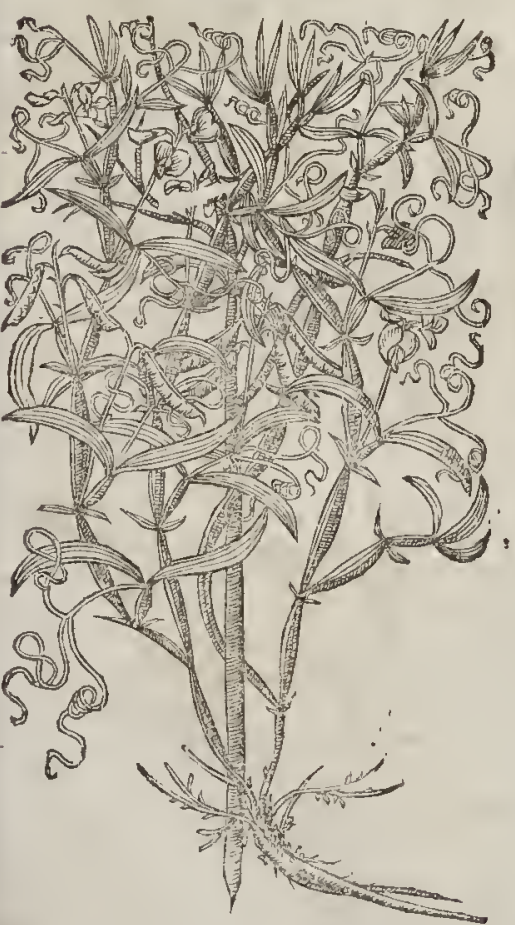

$\mp=$ Lathyrus angufifolius flore albo. White floured Chiehelings.

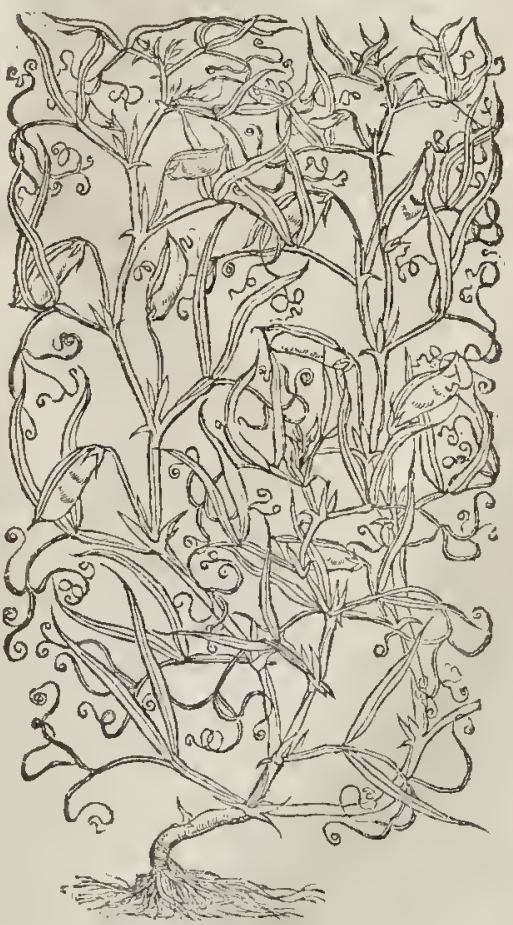

† 2 Of which kinde there is likewife another like vnto the preeedent in each refpe?t, fauing that the leates hereof are narrower and longer, and therefore ealled of moft which fet forth the deteription, Latbyrus anguft folia : the flonres of this atewhite, and futh alfo is the eolour of the fruit: theroot is fmall, and nor lafting like that of the former.

\# 3 The ftalks, leaues, and floures of this are like thofe of the precedent, but the floures are of areddifh purple colour : the cods are leffer than thofe of the former, and in them are contained 
leffer, harder, and rounder feeds, of a darke or blackinh colour. This gipwes not wildewith vs, but is fometimes fowne in gardens, where it floures in Iune and Iuly.

4 This Egyptian differs not in thape from the reft of his kinde, but the floures are of an elegantblew on the infide, but of an ath colour inclining to purple on the outfide : the cods grow vpon long foot-ftalkes, and are a little winged, onwelted, and containe but two or three little cornered feeds fpotted with blacke fpots. This floures in Iune and Iuly ; and the feed thereof was fent to Cluf lus from Conftantinople, hauing been brought thither out of Egypt.

\# Latbyrus anguffifol. flo.purp. Purple Houred Chichelings.

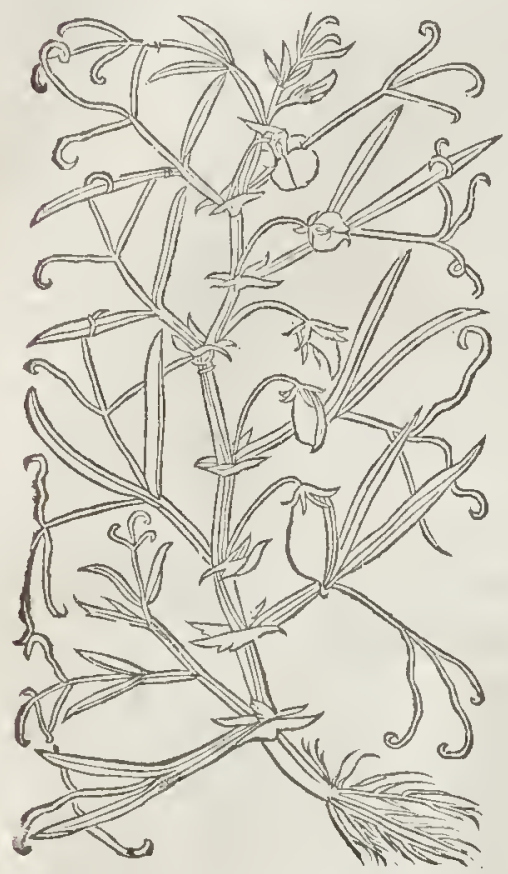

$¥ 4$ Lathyrus eEgyptiacus. Egyptian Chichelings.

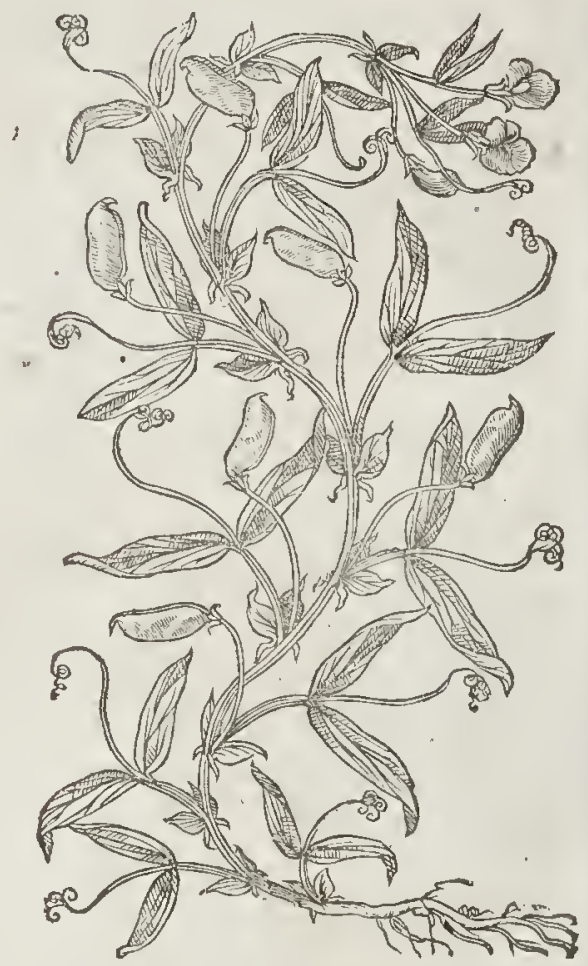

5 The ftalkes of this are fome two or three foot long,winged, weake, and lying on the ground vnleffe they haue fomewhat to fupport them. Vpon the fe at certa ine diftances grow winged leaues with two little eares at their fetting on to the flalke: thefe leaues confift of fix long and narrow greene leaues like thofe of the other plants of this kinde; and thefe fix leaues commonly ftand vpright, by couples one againft another; otherwhiles alternately : the footfalke whereon thefe ftand ends in clafping tendrels : the foures are in thape like the former, but the outer leafe is of a faire red or crimfon colour, and the inner leafe white : after the floures come the cods, containing fome foure or fiue pretty large Hat feeds, which fwell out of the cods where they lie, which in the fpaces betweene cach feed are depreft, like that of orobus. This is only a garden plant with vs, and floures in Iune and Iuly, the feed is ripe in Augurt. I haue for this giuen you Lobels figure of his Lat hyris angufiore graminco folio; which may feruc, if you but make the leaues and cods to agree with this defcription.

6 The ellow wilde Tareor Fetch hath dituers very fmall ramping ftalkes, tough, and leaning this way and that way, not able to ftand of it felfe without the helpe of props or things that ftand. by it: the leanes ate very thin and tharpe pointed : the floures grow along ft the leaues in fafhion of the peafe foures, of a bright yellow colour : the roots are very fmall, long, tough, and in number infinite, infomuch that it is impoffb!c to root it fortl, bcing once gotten into the ground, vnlefle the earth be digged vp with the roots, and both calt into the riuer, or burned. Doubtleffe it is the moft pernicious and hurt full weed of all others, vato all manner of greene whol fome herb es or any wood whatfoewer. 


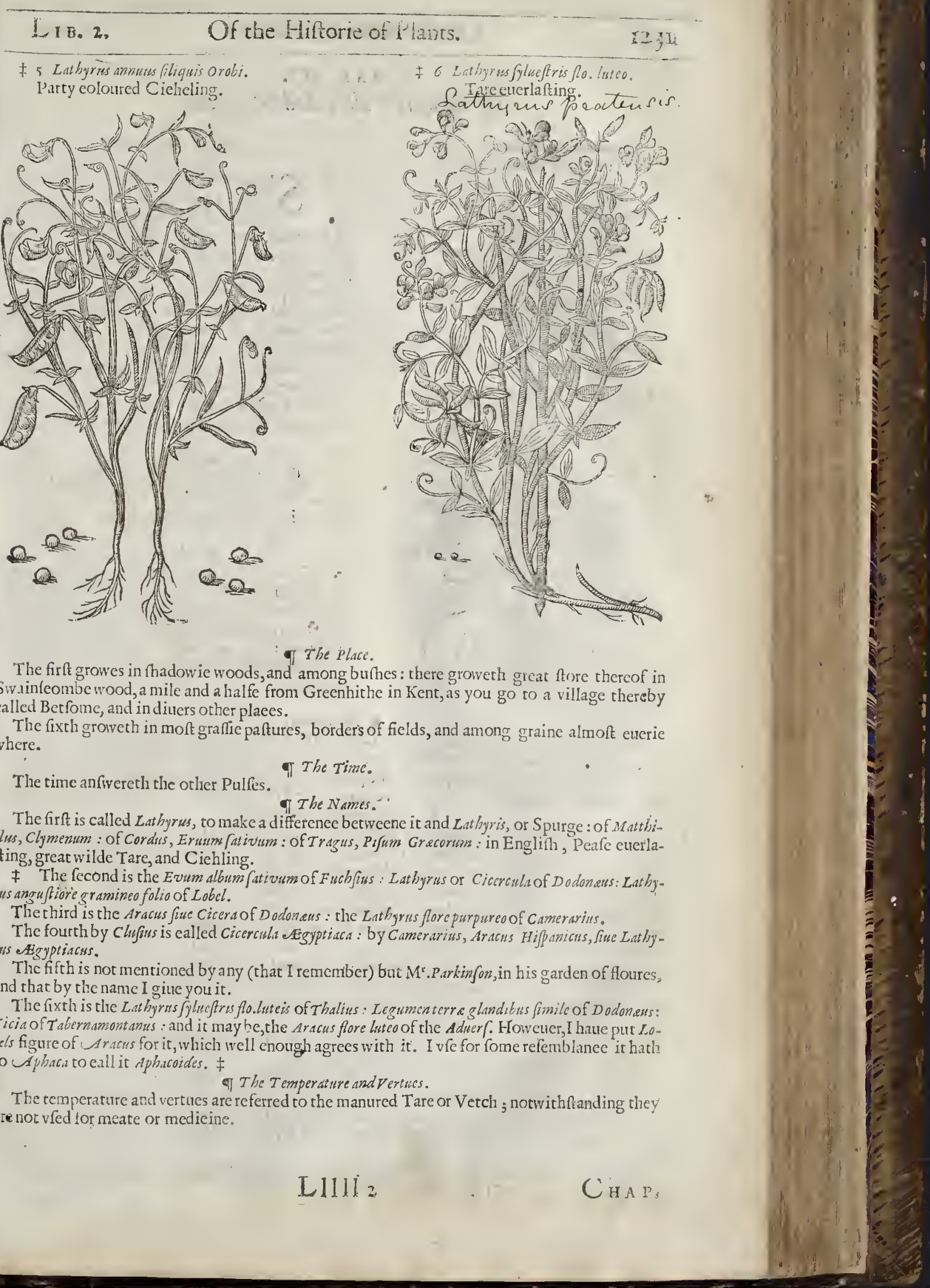




\section{Ch А P. 517. Of the oylie $\mathcal{P}$ ulfe called Sefamum.}

Sefamam, frue Sifamum. The Oylie Graine.

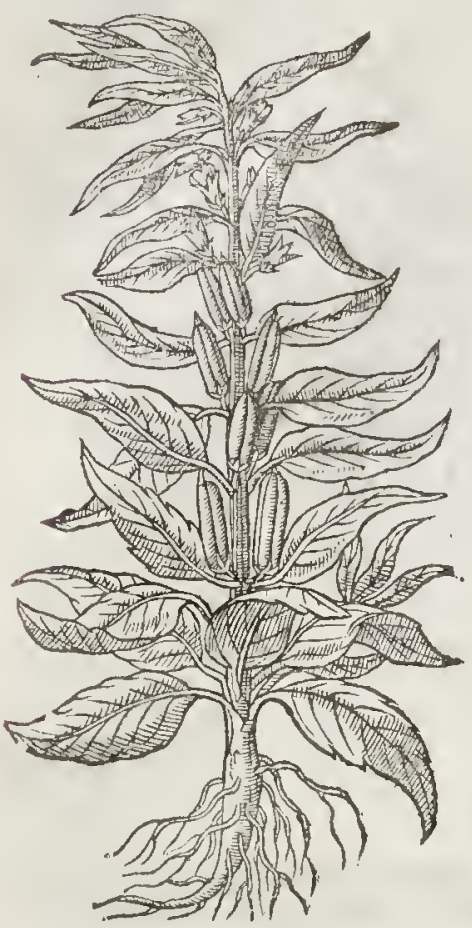

T) The Defcription.

+ Efamum hath a thicke and fat vpright

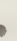
$\circlearrowleft$ lalke a cubit and a halfe high, gamiThed with leaues much like the Peach or Almond, but rougher, and cut in with fomwhat deepe gathes on their fides: among ft thefe leaues come forth large white or elfe red foures, fomewhat thaped like thore of Foxgloues, which turne into round long crefted cods, contining white flat oileous feed. Theophraftus affimeth that there is a kinde thereof which is white, bearing only one root. Nokinde of beaft will cate this plant while it is greene, becaufe of his bitterneffe; but being withered and 'dried, the feed thereor becommeth fweet,and the cattell will feed on the whole plant.

\section{T The Place.}

It groweth both in Egypt and in India : Sefama, faith Iliny, came from the Indies; they make an oile of it. It is a franger in England.

\section{T The Time.}

It is one of the Sommer grains, and is fowne be fore the rifing of the feuen ftarres, as Pliny writuth yet Columella faith, that Sefamum muft be fowne after the Aurumne Equino etial, ngainft the Ides of October : they require for the moft part a rotten foile, which the husbandmen of Campania do call a blacke mold.

\section{T The Names.}

The Grecians cal this grain ziraves : the Latines alfo Sefamum, and Sifamum, and often in the foe. minine gender Sefama: we are conftrained for want of an Englifh name to vre the Latine: it is vnknowne to the A pothecaries, efpecially the plant it felfe; but the feed and oyle thercof is to be found among them in other countries : we may call it Turky Millet.

\section{If The Temperature and $V$ crtues.}

A According to fome it is hot and dry in the firft degree : the feed thereof,as Galen faith, is fat, and therefore being layd $v$ it commeth to be oylie very quickly; wherfore it fpeedily filleth and ftuffeth vp thofe that feed thereof, and ouerthroweth the fomacke, and is flow of digeftion, and yeeldeth to the body a fat nourifhment : therefore it is manifeft that it cannot ftrengthen the ftomack, or any part thereof,as alfo no otherkind of fat thing : and the iuice that commeth thereof is thick, and therefore it cannot fpeedily paffe thorow the veines. Men do not greedily feed of it alone, but makecakes thercof with honey, which they call znoasess: it is alfo mixed with bread, and is of an hot temperature, for which caufe it procureth thirft : and in his booke of the faculties of fimple Medicines he faith, that Sefamm is not a little clammy and fat, and therefore it is an emplafticke, and foftner, and is moderately hot : the oilewhich commeth thercof is of like temperature, and fo is the lecotinn of the herbe alfo.

B Digfcorides writech, That Sefamum is an enemie to the ftomacke, it caufeth a f inking breath, ifit remainefticking betweene the teeth after it is chewed.

C It waftech away groffenes of the finewes; it is a remedic againft bruifes of the eares, inflammations, burnings and fealdings, pains of the ioynts, and biting of the poyfonfom horned ferpent calied Ceraftes. Being mixed with oile of Rofes it takes away thehead-ache which commeth of heate.

Of the fame force is the herbe boyled in wine, but it is efpecially good for the heate and paine if rheeyes.

Of the herb is made an oile ved of the Egyptians, which as $P$ liny faith is good for the eares. It is a remedie againft the founding and ringing of the eares. 


\section{HA P. 518. Of Hatchet Fetch.}

\section{The Defcription.}

I He firlt kinde of Hatchet Fetch hath many fmall branches trailing hercand therevp on the ground: vpon which grow fmall leaues fpred abroad like the leaues of the wilde Fetch; among which come forth clutters of fmall ycllow floures, which fade away; and turne into litt le flat thin and browne cods, wherein is contained fmall reddirh feed of a bitter talte.

2 " The fecond kinde of hatcher Fetch hath many round tough and flexible branches, trailing vpon the ground: whereupon do grow leaues like the former, but more like the leaues of Liquo rice, and hating the talte of the Liquorice root; which hath giten occa fion to fome to deeme it a kinde of Liquorice : among thefe leaues come forth pale yellow floures, after which there fucceed fmall crooked cods, turning their points inwardly, one anfwering another like little hornes, containing fuall flat feeds foure comered, and fathioned like a little wedge : the root is tougl, of a wooddy, fubfance, and doth conținue fruitfull a very long time:

T. Hcdyformmins.

Hatchet Fetch.

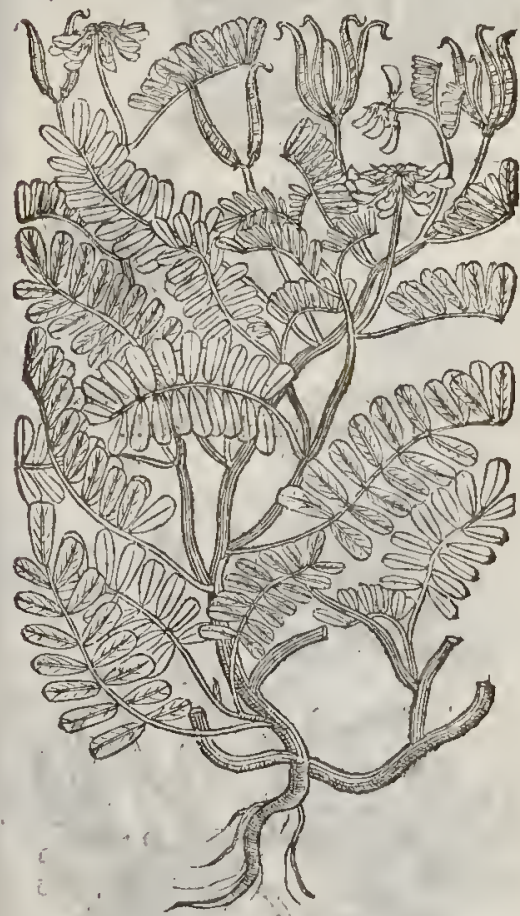

¥ 2 Hedyfarum Glycyrhizatum.

Liquorige hatchet Fetch.

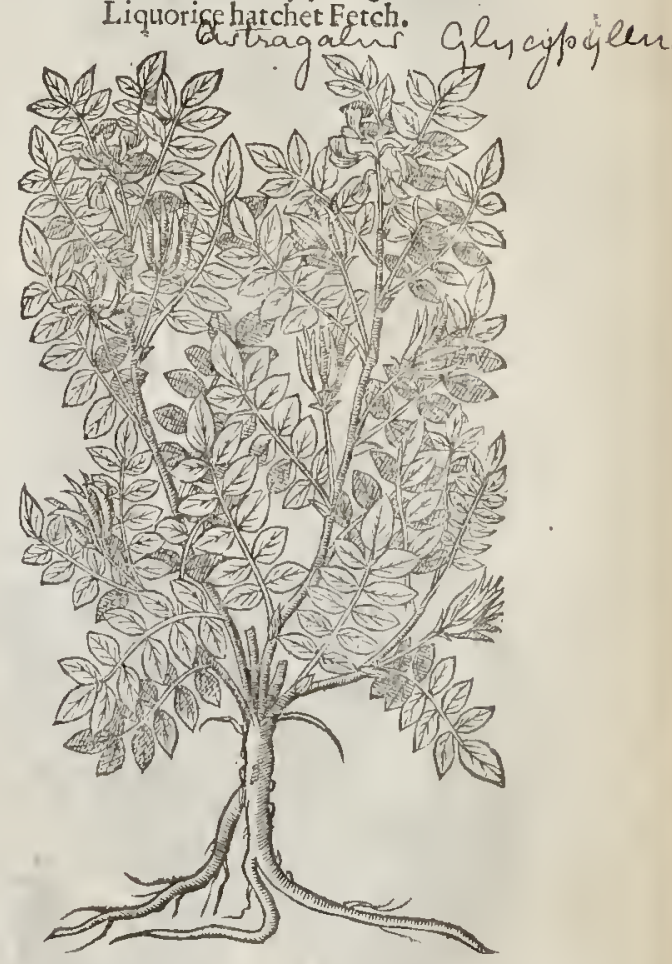

3 There is another kind of securidaca or hatchet Fetch, which hath branches, leaues, and roots like the laft before remembred, and differeth in that, that the fioures of this plant are nixed, and do vary into funury colours, being on the vpper part of a Heh colour, and on the Iniver of a white or fnowie colour, with a purple Storks bill in the middle : the leaues are in taltc bitter: the cods are fmall like thofe of Birds foot, and not much vnlike the cods of orobus.

4 There is likewife another kinde of Securidaca or hatcliet Fetch, which is dedicated vnto $\mathrm{Ca}$ rolus clufius by the aforenamed Dr. Penny, who found it in the North parts of England, haung leates, roots, and branches like vnto the former : but the floures of this arc white, and mixed with fome purple, and bitter alfo in tafte : the cods are like the claw of a crab, or (as Clufus faith) like the knife which thoo-makers do vfe in Flanders; in which cods are contained fmall reddin feed: this root alfo is of long continuance. $\neq$ Clufrus doth not fay that $D^{r}$. Pemy found this in the Nort of Englind, but in the territorie of Geneta not far from Pontetremile, among ft the buthes, and no
where elfe.

$$
\text { Ellti? } 5 \text { This }
$$


¥ 3 Hedy faram maius filigus articulatis. Hatchet Ferch with ioynted cods.

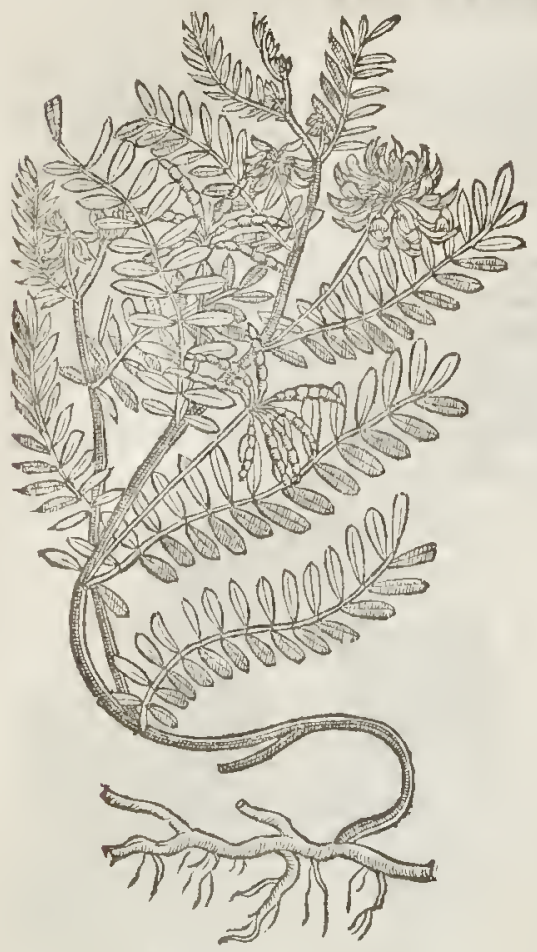

\# 5 securidaca minor lutea. Small yellow hatchet Fetch.

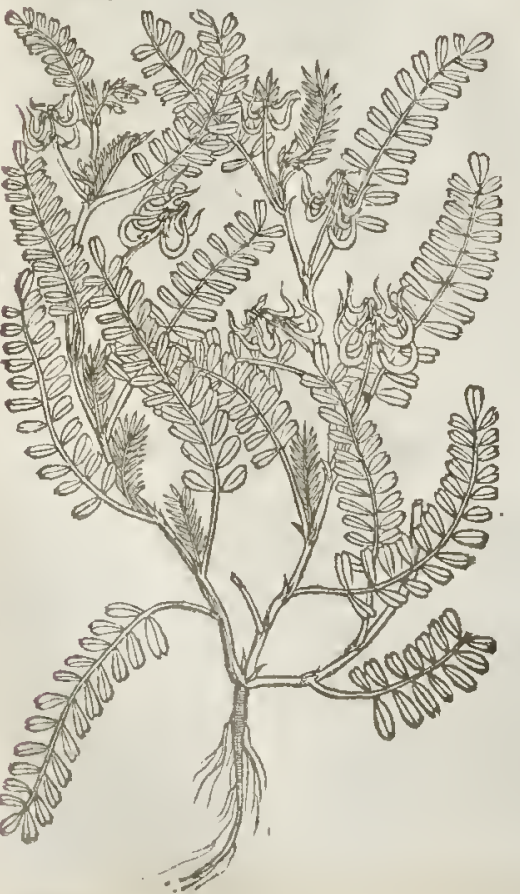

\#4 Securidaca minor pallide carulea. Small blcw floured hatchet Fetch.

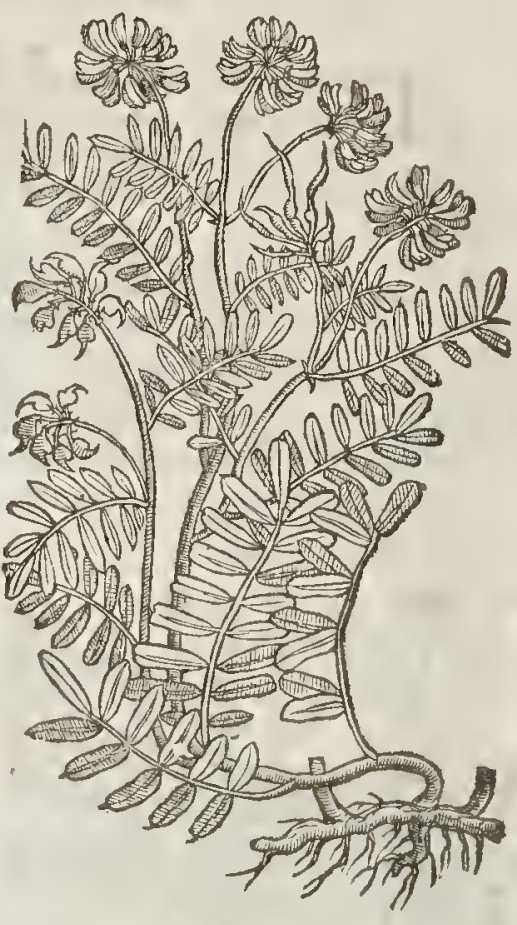

* 6 Securidaca filiguis planis dentat is. Indented hatchet Fetch.

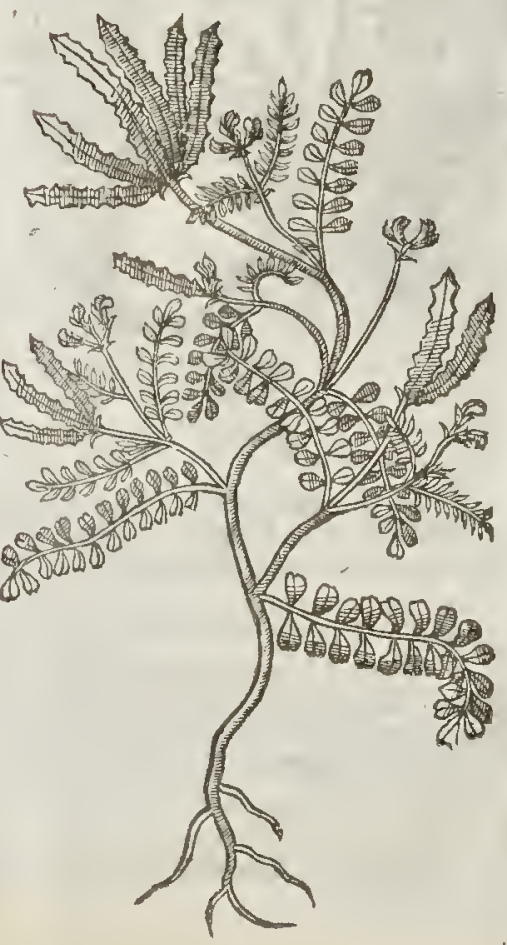


¥ 5 This in the ftalks, leaues, colour, and thape of the floures is like, yet leffe than the firft defcribed; thecods ate alfo fmaller, leffer, and more crooked: and herein onely confifts the chiefe difference, it is an annuall plant, and grows onely ir fome gardens. Matthiolus, Lobcl, Dodonnews, and other, make rhis their Hedyfarrm, or Securidaca minor.

6 This hath many crefted branches, whereon great winged leaues, that is, fome twentie or more faftened to one rib : the floures are like thof of the other plants of this kinde; but the cods are of an inch long, flat,or indented or toothed on their fides. But of what colour the floures and feeds are of it is not expreft by clufins, who onely fet this forth by a pieture, and fome pieces of a dried plant thereof, which he rcceiued from Cortis fus, by the name of Scolopersdria leguminga, or Hedyfarum peregrinum : Cortufus bad it from Honorius Bellws, who obferued it grow ing vpon the Rocks at Sebetico,a citic of Lllyria. I

7 There is alfo another fort of Harchet Fetcl, which hath very long and tough branches trailing vpon the ground.befet with leaues like the former, but much greater : the floures lo grow at the top of rhe branches, of a pale colour, and turne into rough round and flat cods, fafhioned like little bucklers : rhe root of this (as of the firft)dieth at the firtt approch of winter, as foone as the feed is ripe: $\$$ The ftalks of this are ftiffe and crefted, growing to the height of two cubits, with leaues as large as thofe of Liquorice : the floures are of a faire bright red colour : the cods are made as it were of many rough buckler.like feeds, or rather feed veffels wherin are contained fmal brow feeds. F

$\ddagger 7$ Hedyfarmm Clypeatum. French Honyfuckle.

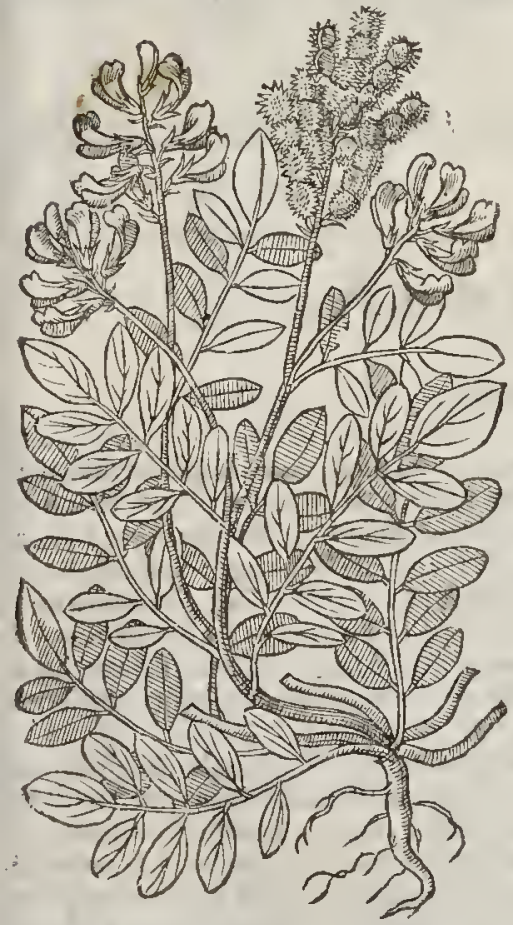

8 Ferrum Equinum. Horfe-fhoo.

8 Horfe-fhoo hath many ftalks flender and lying vpon the ground : the leares be thinne, and leffer than thofe of Axfeed : the floures along the ftalks are little: after which come vp long cods formething broad, and a little bowing; which haue vponthe one fide geepe round and indented cuts, like after a fort to an Horfe-fhoo: the root is fomewhat long.

$$
\text { II The Place. }
$$

Thefe plants do grow iu my garden : the fecond kinde I found growing in Suffolke, in the high way on the right hand, as you goe from Sudbury to Corner Church, about an hundred paces from the end of the towne, as alfo in fundry other places of the fams countrey and in Effex abour Dun- 
mow, and in the townes called Clare and Hennyngham. ₹ Alfo it growes by Purfleet, about the foot of the hill whereon the Wind-mill ftands; and in diuers parts of Kent. $\neq$

Horfe-fhooe commeth vp in certaine vntilled and funic places of Italy and Languedocke : it groweth likewife in my garden.

Thefe plants do floure in Iune, and their fced is ripe in Auguft:

If The Names.

The Grecians name this, whether it be a pulfe or an infirmitie among corne, iNowan : the Latines, of the forme of the feed, Securidaca, and Hedyfarum : in Englifh, $A_{\perp}$ xeed, Axwoort, Ax-fitch, and Hatcher Fitch : it is vnknowne to the Apothecaries.

$\neq$ The fecond is the Fenugrecum fylueftre of Tragus and Dodonsus: the Glycyrbiza fylueftris of Gefner; and the Glawx vulgaris of Lobel. \#

Horfe-thooe is commonly called in Italian $S$ fcrro de caullo : you may name it in Latine Ferrum equinum : in Englifh, Horfe-fhooe.

If The Temperature.

The feeds of thefe plants are hot and drie of complexion.

$$
\text { The Vertues. }
$$

"A . Being drunke it is acceptable to the ftomacke, and remouth ftoppings out of the intrailes, and $\because$ of like vertue be the new leaues and tender crops of the whole plant.

B - Diofcorndes theweth that it is allogood for the ftomacke being taken in drink, and is mixed with counterpo ifons.

C And it is thought to hinder conception, if it be applied with honie before the act.

D The feed of Axwoort opencth the ftoppings of the liuer, the obstruction of the foleen, and of all the inward parts.

E Horfe-thooe is bitter and like in nature to Axfeed.

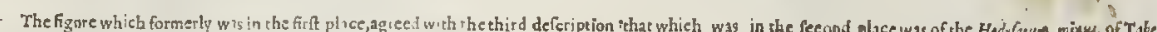

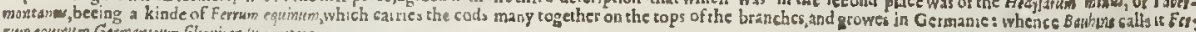

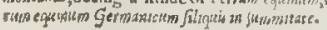

\section{Grap. 5ig. Of Peaje Earth-D (ut.}

T The Defoription.

T Te Peale Earth nut, commeth vp with flender and weake ftalkes:the leanes be thin, and b littie, growing vpon tender ftens, with clafping tendrels at the ends, with which it imbraceth and takech hold of fuch things as itand neere vnto it:the floures on the tops of the falkes are like to thofe of Peafe, but lefter,of a red purple colour, in fmell not vupleafant : in their places come vp long cods, in which are three or foure round feeds:the roots be thicke, long, like after a fore to acorns, butmuch greater, blacke without, gray wirhin, in tafte like to the Cheffe-nut : out of which beneath doth hang a long flender ftring: there grow out of the fame alfo other ftrings, hard to the fetting on of the ftalk, vnto which creeping a flope do grow other kernelled roots whilft the plant doth thus multiplie it telfe.

\# 2 Thisivith Thalius in his Sylun Harcynia, fet forth by the name of Afragalus fyluaticus, was by our Author taken for, and confounded with the Terraglandes, and therefore I haue put it with it, that the difference might the better appeare, which is not a lirtle to fuch as heedfully obferue it: But our Author in this is to be p.rdoned, feeing Dr. Turner, a man more exquifite in the knowledge of plants, and who had feene the true Terre glandes in Germany, miftooke this for it, as may appeare by that litrle Tract of his of the names of plants in Latine and Engliih, fet forth Ammo, i 548 ; for there he faith, I I have feene this herbe of late in Come parke more aftringent than it of Germany: ] and indeed this growes there, and is much more aftringent and wooddic than that of Germany, and no wife fit to be eaten. The roor confifts of many blaeke tuberous partucles, here and there fending forth fibers:from hence arife cormered ftalks fome foot high, fmal below, \& fomwhatlarger aboue: the leaues grow forth of the ftalks, confifting fometimes of two, \& otherwhiles of 4 . longith narrow leaues faftned to one foot talk, whichar the ferting on hath two little leaues or eares: forth of the bofomes of thefe leaues grow ftalks fome two inclies long, each of which vfually carry a couple of Peafe-fathioned thoures of a purple colour:which fading, vfually become blew : after thefe follow cods, ftraight, round, and blacke; and in each of them are commonly contained nine or ten white round 
ound feeds : it floures moft part of Summer,and perfects the feed in Inly and Augut. $\neq$

I Terraglandes. Peafe Earth-nut.

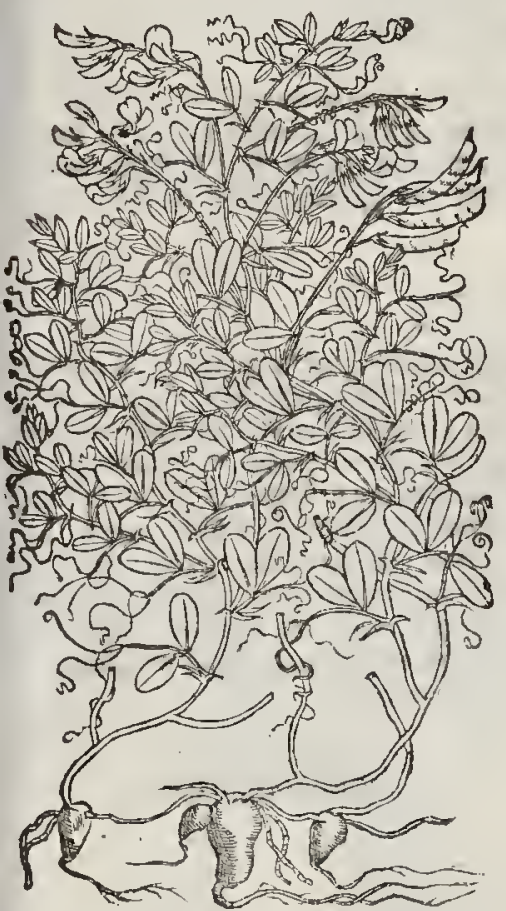

†.2 Aftragalus fyluaticus. Wood Peafe, or Heath Peafe. Orobustiberosus.

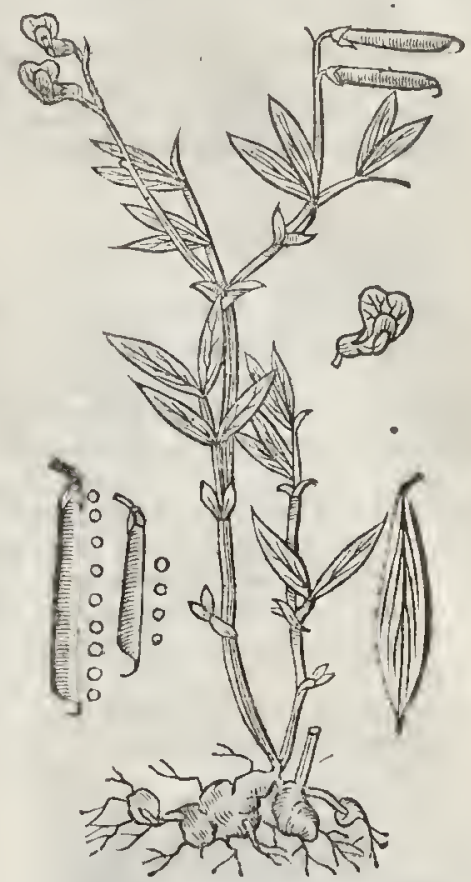

T) The Place.

+ I This groweth in coine fields, both with the corne it felfe, and alfo about the borders of fields among briets and brambles $:$ it is found in diuers places of Germany, but not with vs that I can yer learne.

This is found in the woods and paftures of England, efpecially in Hampftead wood neere London: it groweth in Richmosd Heath,and in Come parke likeivife.

\section{9) The Time.}

It floureth in I une and Iuly, the nuts after harueft be digged vp and gathered.

$$
\text { T) The } 2 \text { esmes. }
$$

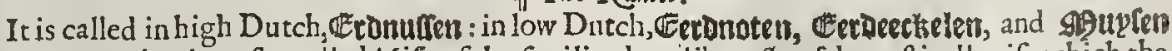
mettectem, that is to fay, tailed Mife, of the fimilitude or likenefle of domefticall mife, which the blacke, round, and long nnts, with a piece of the flender ftring hanging out behind, do reprefent: the

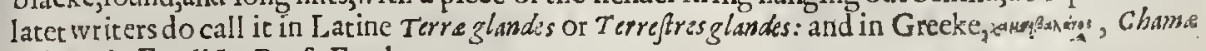
balani : in Englinh, Peafe Earth nut.

\section{- $T$ he Temperalure and Vertues.}

The Nuts of this Peafe being boiled and eaten, are bardlier digefted than be cither Turneps or $A$ Parfneps, yet do they nourith no leffe than the Parfneps : they are not fo windie as they, they doe more flowly paffe through the belly, by reafon of their binding qualitie, and being eaten raw they be yet harder of digettion,and do hardlier and flowlier defcend.

They be of temperature meanly hot,and fomewhat dric, being withall not a littlebinding:wher $=B$ upon alfo they do not onely ftay the furxes of the belly, but alfo all iffues of bloud, efpecially from the mother or bladder.

The root of Peafe Earth-nut ftoppeth the belly, and the inordinate courfe of womens ficknefe. $C$ 


\section{Ch а т. 520. Of Milke Vetch.}

\section{If The xindes.}

breach of promife made in the contained vnder the title of Aftrag alus; whether I may, without plants, it is doubtfull : but feeing theginning, infert them among the $L$ cruminu, pulfes, or herbic to paffe, vintill fome other thall finde a place is difutable, I think it not amiffe to fuffer them thus bourhood.

$$
\text { TI The Defription. }
$$

17 He firlt kinde of Aftragalus bath reddifh ftalks, a cubit high, a fingerthicke, fomewhat crefled or furrowed, and coucred ouer with an hairy moflincs; which diude iticnifelucs into fundry fmal branches, befet with leaucs confifting of fundry little leaues fet vfon a middle rib, like the wi!de Vetch, placed on the fmall pliant branches like fearhers, which are likewife coucred oucrwith a woollie hoarineffe, in tafte aftringent at the firf, but afterw ards burning hot : among thefe leaues come forth many fmall white flcures, in fafhion like the floures of Lupines, which before theiropening feeme to be fomewhat yellow : the root is marticllons great and large, confidering the fmalnefle of the plant; for fometimes it groweth to the bigneffe of a mans arme, kecping the fanc bigneffe for the fpace of a fpan in length, and after dividech it felfe into two or more forks or branches, blacke without, and wrinckled; white within, hard and wooddie, and
in tafte vnpleafant, whlicli being dried becommeth harder than an borne.

I Aftragalus Lufitanicus Clufij. Portingale milke Vetch.

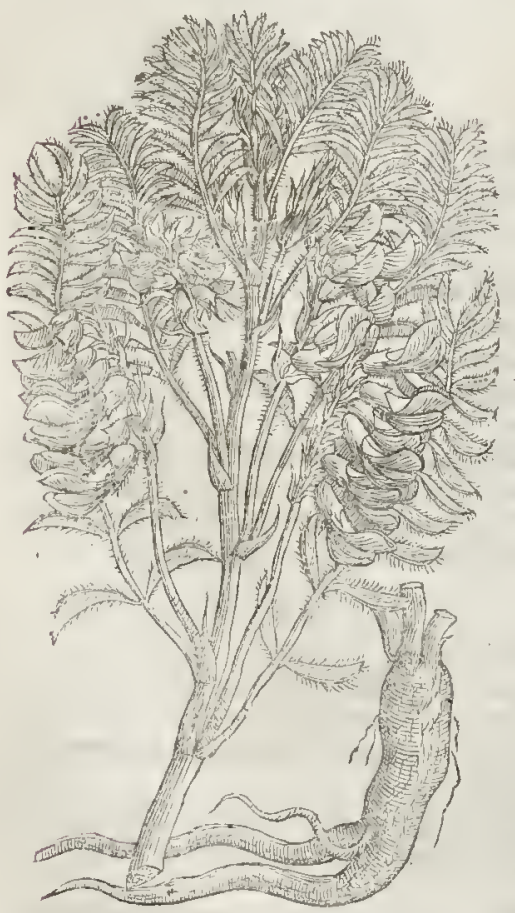

2 Lefragalus Syriacus. Affyrian milke Vetcli.

2 The fecond kinde of Aftragalus is a rare and gallant plant, and may well be rermed Planta Legumino fa, by reafon that it is accounted for a kinde of Aft ragalus, refembling the fame in the fimilitulc of his falkes and leaues, as alfo in the thickneffe of his rootes, and the creepine and folding; 
Tा The Names.

A

Milke Vetch is called of Matthiolus, Polygala, but not properly: of moft it is called Afragalus: in Spanifh, Garanancillos: in the Portingales tongue, Alphabeca: in Dutch, Clepne Ciceren.

Afragalus, as Galen faith, hath aftringent or binding roots, and therefore it is of the number of thofe fimples that are not a litele drying; for it glueth and healeth vp old vlcers, and faieth the flux of the belly, if they be boiled in wine and drunke : the fame things alfo touching the vertues of $A$ fragalus Diofcorides hath mentioned:the root, faith he, being drunke in wine Raieth the laske, and prouoketh vrine, being dried and caft vpou old vlcers it cureth then : it likewife procureth grear $B$ ftore of milke in eattell that do eat thereof, whence it tooke his name.

It ftoppeth blecding, but it is with much ado beaten,by reafon of his hardneffe,

\section{Cна р. 52 I. Of Kidney Vetch.}

If The Defcription.

I Idney $\mathrm{V}$ etch hath a ftalke of the height of a cubit, diuiding it felfe into other branches. whereon do grow long leaues, made of diucrs leaues, like tholc of the Lentill,couered as it were with a foftwhite downineffe : the floures on the tops of the ftalks of a yellow colour, verie many ioined together, as it were in a fpokie rundle: after which grow vp little cods, in which is contained fmall feed : the root is llender, and of a wooddie fubftance. $\neq$ This is fometimes found with white floures: whereupon Tabernamontanus gaue two figures, calling the one Lagopodium flore luteo, and the other $L$ agopodium flo.albo. Our Author vnfitly gaue this later mentioned figure in the chap. ter of $L$ agopus, by the name of Ligopum maximum. $\neq$

I Antbyllis Ligumingafa.

Kidney Vetch.

Anthyllir vilararia

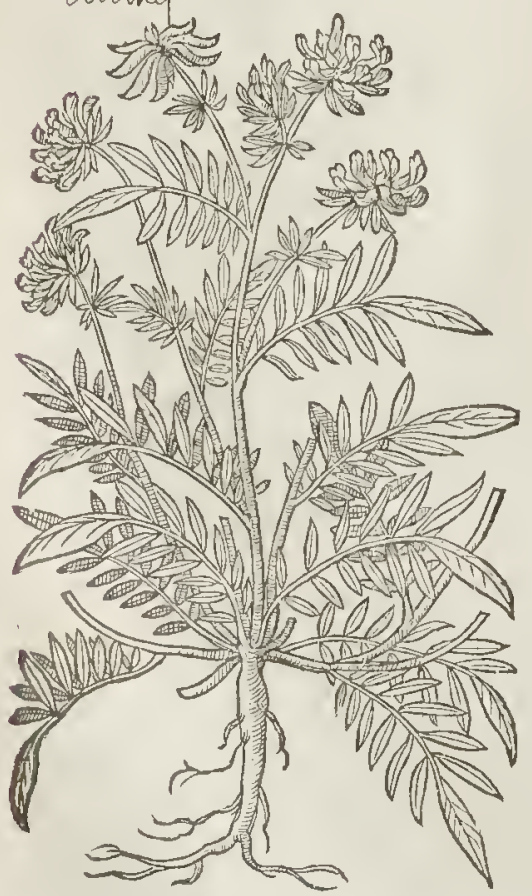

2 Stella leguminofa.

Starry Kidney Vetch.

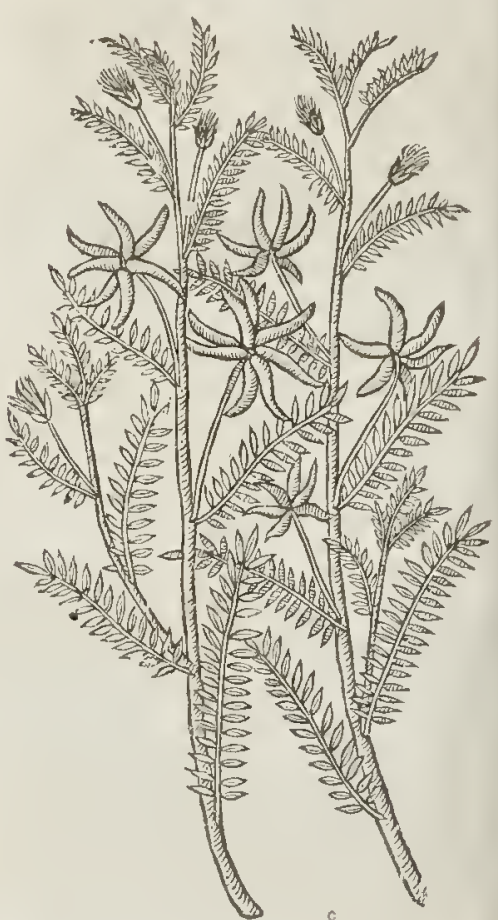

2 The Starry Kidney Vetch, called Stella lgominiofa, or according to cortufus, Arcturo hath 
many fruall flexible tough branches, full of fmall knots or knees, from each of which fpringeth forth one long fmall winged leafe, like birds foot, but bigger : from the bofome of thofe leaues conc forth little render ftems, on the ends whereof do grow fmall whitinh yellow floures, which are very flender, and foone vaded, like vnto them of Birds-foot : thefe foures turne into fmall tharpe pointed cods, ftanding one diftant from another, like the diuifions of a 1 tar, or as thongh it confifted of litrlc hornes; wherein is contained fmall ycllowith feeds : the toot is tough, and deep-
ly growing in the ground.

3 There is anorher fort of Kidney Verch called Birds-foot, or ornithopodium, which hath very many fmall and render branches, trailing lere and there clole vpon the ground, fet full of fmall and foft leaues, of a whiting greene, in fhape likc the leaues of the wilde Vetch, but a great dcale leffer, and finer, almot like fmall feathers amongtt which the floures doe grow, that are very fmall, yellowifh, and fometimes whitih; whichbeing vaded therc come in place thereor little crooled cods, fite or fix growing together, which in thet and hape are like vnto a fmall birds foot, and each and eucry cod refembling a claw; in which are inclofedfmall feed like that of $T$ ur:
neps.

\section{$\ddagger 3$ Ornithotodition maizus.}

The great Birds. foot.

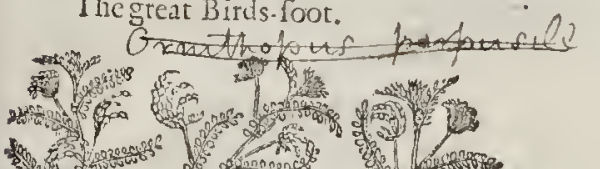

\section{

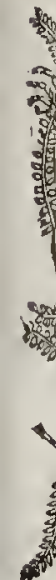

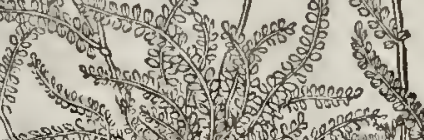

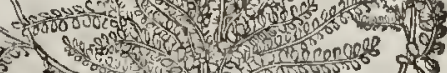

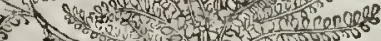

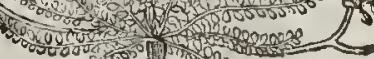
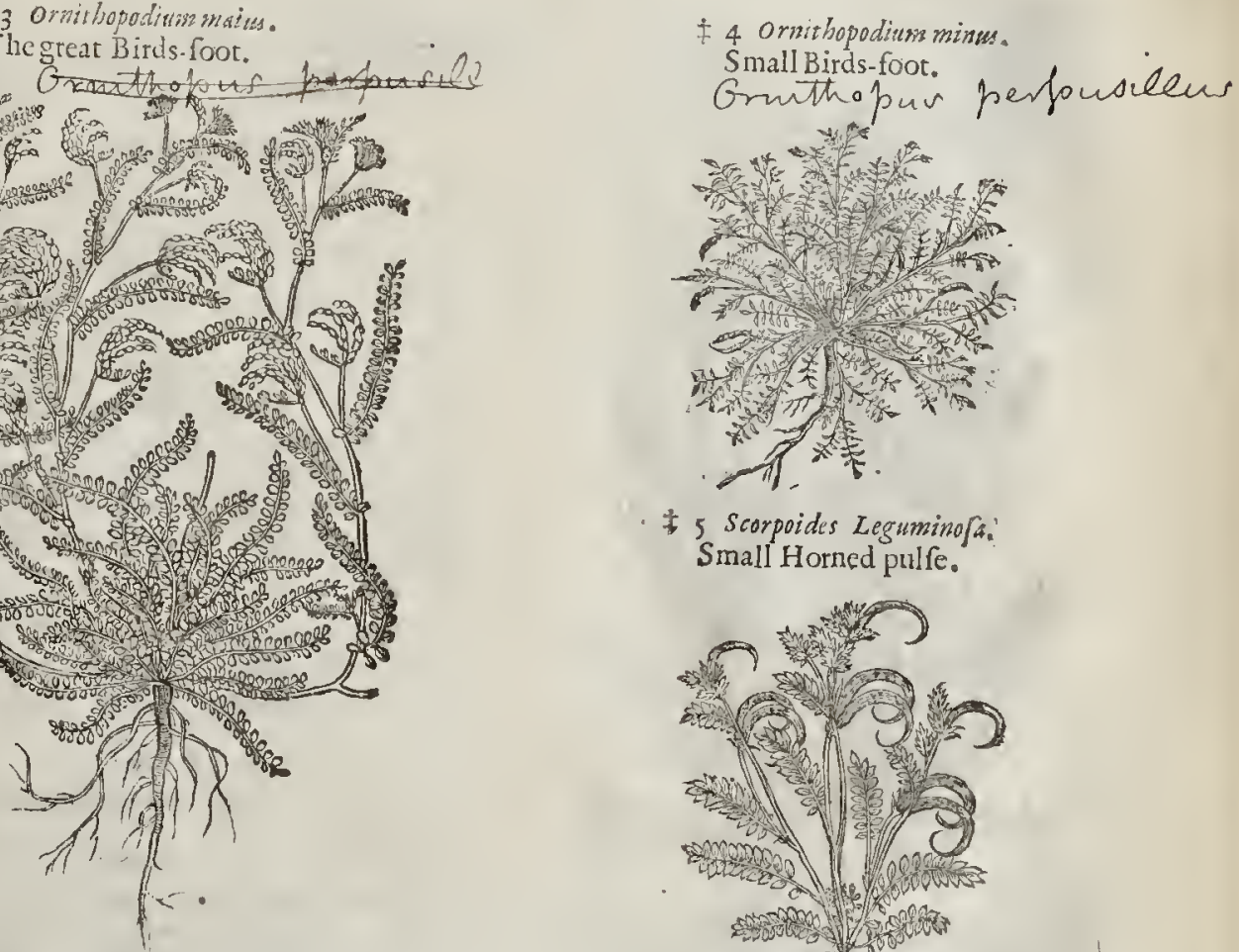

* 5 Scorpoides Leguminofa. Small Horned pulfe.

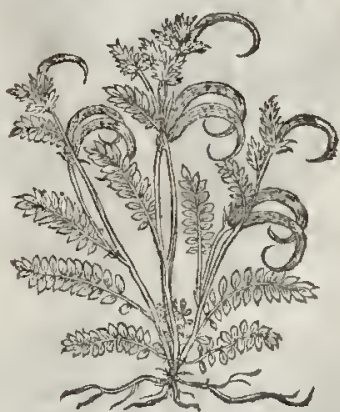

4 Therc is al fo another kinde of ormit nopodinm, or Birds-foot, called fmall Birds-foot, which is very like vnto the firlt, but that it is much fmaller: the branches or fprigs grow not aboue a hand or lualfe an band in length, fpreading themfelues vpon the ground with his fmall leaues and branches, in maner of the leffer Arachis: the floures are like vnto thofe of the former, but very fmall, and
of a red colour.

$\ddagger-5$ This finall horned pulfe may fitly here take place: The root thereof confilts of many little fibres, from which arife two or threc little flender ftraight ftalkes fome handfull and halfe or foot high: at the tops of thefe grow little tharpe pointed crooked homes, rounder and flenderer than thofe of Fenugrecke, turning their ends inwards like the tailes of Scorpions and fo jointed the flomes are fmall and yellow; the leates little, and winged like thofe of Birds-foot. Pena and Lobel found this amongt the corne in the fields in Narbon inFrance, and they fet it fortls by the name as I haue here gitsen you ir. $\ddagger$

I. 3. 4. Thefe plants I found growing vpon Hamplead Heath neere London, right againfe $\mathrm{Mmnmm}$ 
the Beacon, vpon the right hand as you go from London, neere vnto a grauell pit : they grow alfo vpon blacke Heath, in the high way leading from Greenw ich to Charleton,within halfea mile of the towne.

$$
\text { T) The Time. }
$$

They floure from Iune to the middle of September.

The Names.

¥ This Gefner calls Vulnerariaruffica:Dodonets, Lobcl,and Clufurs, call ir Lnthyllis, and Anthyllis leguminofa. $¥$

3. 4. I cannot finde any other name for thefe plants, but ornithopoditum : the firft is called in Englinh,great Birds-foot; the fecond fmall Birds-foot.

\section{बा The Nature and Vertucs.}

Thefe berbes are not vfed either in meate or medicine, that I know of as yet; but they are very good food for cartel, and procure good ftore of milke, whercupon fome haue taken them for kindes of polygala.

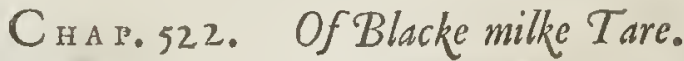

Glawx Diofcoridis.

Diofcorides his milke Tare.

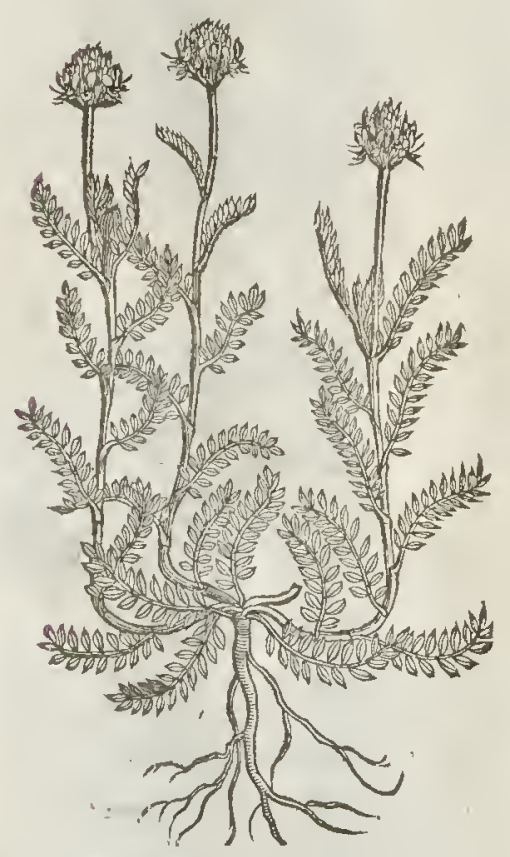

T The Defcription.

THe true Glasx of Diofcorides hath very many tough and wooddy branches trailing vpon the ground, fet full of fmall winged leaues, in thape like the common Glaux, but a great deale fmaller, refembling the leaues of Tares, but rather like Birds-foor, of a very gray colour : amongt which come forth knobby and fcaly, or chaffie heads, very like the Medow Trefoile, of a faire purple colour: the root is exceeding long and wooddy, which the figure doth not expreffe and fer forth.

$$
\text { Tा The Place. }
$$

The true Glaux groweth vpon Barton hill, foure miles from Lewton in Bedfordhire, vpon both the fides of the declination of the hill.

\section{ब The Time.}

Thefe plants do floure and fourifh about Midfommer:

\section{T) The Names.}

Thefe plants hate in times paft been called Glaux, i. folia babcns glauca, fure pallentia ; that is, hauing skie coloured, or pale leaues.

Sithens that in times paft, fome hane counted Glaux among the kindes of Polygala, or Milkewoorts, ive may therefore call this kinde of Glawx, blacke Milke-woort.

Thefe herbes are dry in the fecond degree.

$$
\text { It The Nature. }
$$

Tा The Vertues.

A The feeds of the common Glaux are in vertue like the Lentils, but not fo much aftringent : they ftop the flux of the belly, dry vp the moifture of the ftomacke, and ingender ftore of milke.

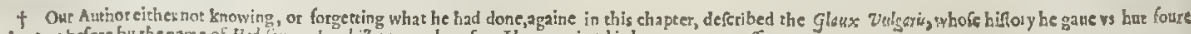

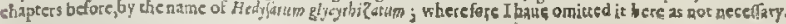




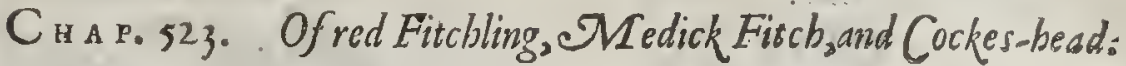

\author{
91 The Defcription.
}

I T He firte kinde of onobrychis hath many fmall and twiggie pliant btanches, ramping and creeping through and about buthes, or whatfoetet it groweth neete vnto : the leavies and all the teft of the pulfe or plant is very like to the wilde Vetch ot Tare:the floutes gtow at the top of fmall naked ftalks, in thape like the peafe bloome, but of a purple colour layed oner with blew, which turne into fmall round ptickly husks, that are nothing elfe but the feed, st

I Onobrychis, five Caput Gallinaceum. Medick Fitchling, ot Cockes-head.

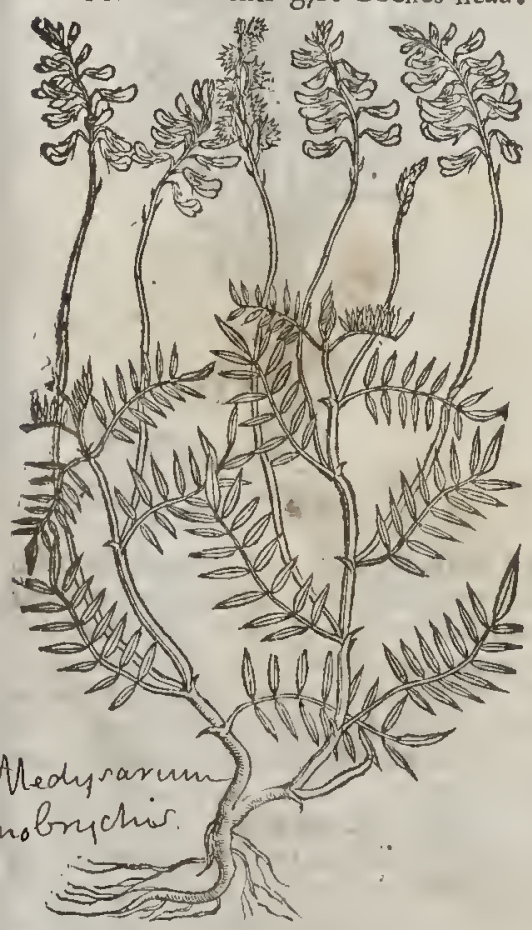

2 Onobrychis flore purpureo. Purple Cackes-head.

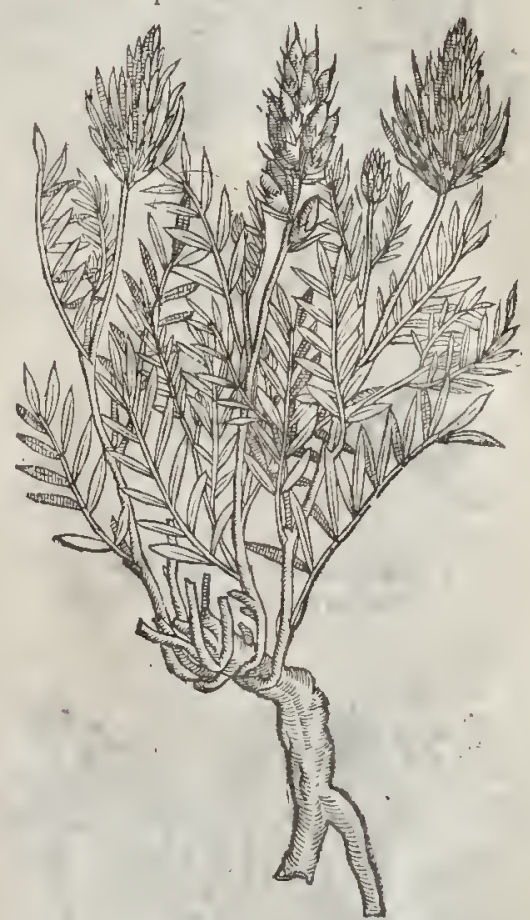

2 The fecond kind of Fitchling or Cocks-head, of Clufius his defctiption, hatb very many ftalks? efpecially when it is growne to an old plant, tound, hard, and leaning to the ground like the other pulfes; and leaues very like Galega, rr the wilde Verch,of a bitter tafte and lothfome fauour : among which come forch fmall round ftems, at the ends whereor do grow floures Ipike falhıon, three in ches long, in thape like thofe of the great Lazopus, or medow Trefoile, but longer, of an excellent thining purple colour, butw ithour fmell : after which there follow fmall coddes, containing little hard and blacke feed, in tafte like the Vetch. The root is grear and long, hard, and of a wooddy fubftance, fpreading it felfe far abroad, and growing very deep into the ground.

3 The third kinde of Fitchling or Cocks-head hath from a tough frnal and wooddic roor, many twiggie btanches growing a cubit high, full of knots, ramping and creeping on the ground. The leaues are like the former, bur fmaller and horter: anong which come forth imal tender ftemmes: whereupon do grow little floures like thofe of the Tare, but of a blew colour tending to purple:tlie floures being vaded, there come the fmall cods, which containe litrle blacke feed like a Kidney, of ablacke colour.

4 The fourth kinde of Fitchling hath firme green lard ftalks a cubit and a halfe high,whereupon grow leates like to the wilde Tare or $G$ aleg $a$, but fmallet and fomewhat hairie, bitter and vnpleafant in tafte,and in the end fomewhat fharpe. At the top of the ftalks come forth long fpiked 
3 Onobrychis 2: Clufy. Blew Medicke Fitch:

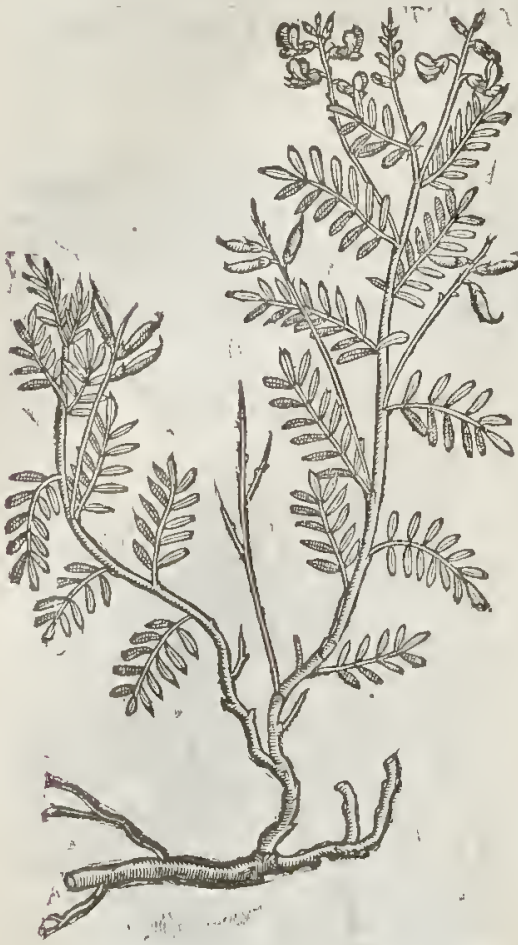

5 Onobrychis montana 4 . Cluf $\ddot{y}$ : Mountaine Medick Fetch.

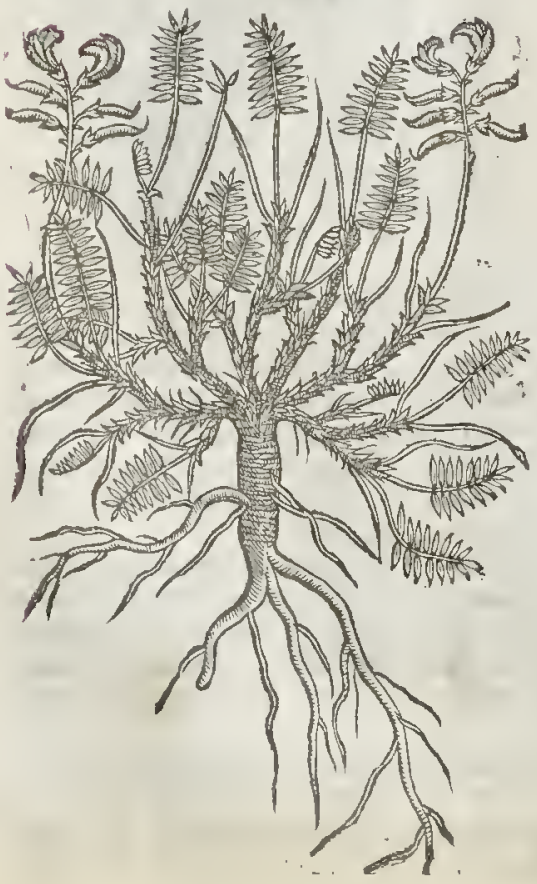

4 onobrychis 3. Cluf $\ddot{y}$ flore pallido. Pale coloured Mediche Fitch.

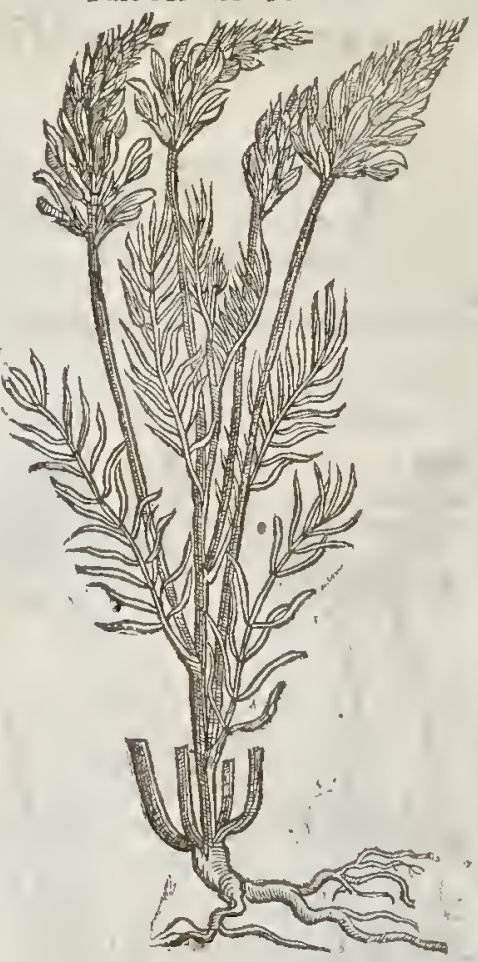

Houres, of a pale colour, and in thape like thofe of the fecond kinde; which being vaded, there follow fmall bottle cods, wherein is contained little blacke feed like the feed of Fenegreek, but fmaller. The root is thicke and hard, and of a wooddie fubftance, and lafting very long.

5 The fifth kinde of onobrychis hath many groffe and wooddie ftalks, proceeding immediatly from a thick, fat, and flerhie tough root: the vpper part of which are fmall, round, and pliant, garnithed with little leaues like thofe of Lentils, or rather Tragacant ba, fomewhat foft, and couered outer with a woollie hairineffe: amongf which come forth little long and naked ftems, eight or nine inches long, whereon do grow ma ny fmall floures of the fathion of the Verch ot Lentill, but of a blew colour tending to purple; and after them come (mal cods, wherein the feed, is contained.

\section{g) The place.}

The firft and fecond grow vpon Barton hill, foure miles from Lewton in Bedfordfhire, vpon both the fides of the hill:and likewife vpon the graffiebalks between the lands of corn two miles from Cambridge, neere to a water mill towards London; 82 dituers other places by the way from London to Cambridge: the reft are ftrangers in England.

\section{बा The rime.}

Thefe plants do flcure in Iuly, \& their feed is ripe thortly after. 
q $T$ he Names.

It is dimpust, or without a name among the later writers : the old and antient Ply fitions do call it inspo $x^{\prime}$ : for all thofe things that are found written in Dioforides or Pliny concerning Onub ychis, doe efpecially agreehereunto. Diofcorides writeth thus; Onobrychis hath leaucs litic a Lentill, but longer; a ftalk a fpan high; a crimfon floure; a little root : it groweth in moift and vntilled placcs:and Pliny in like manner; Onobrychis hath the leaues of a Lentill, fomwhat longer, a red flome, a finall and flender root:it groweth about I prings or founta ines of water.

All which hings and cuery particular are in this armuse, or nameleffe herbe, as it is manifeft: and therefore it is not to be doubted at all, but that the fame is the Onobrychis of the old W'rircrs:it maybe called in Englifh red Fetchling, or as fome fuppole Medick Fitch, or Cockes- liead.

$$
\text { T The Temperature. }
$$

Thefe herbs as Galen hath written in his books of the Faculties of fimple Medicines, do rarife or make thin and wafte away.

Therefore the leaues thereof when it is greene, being but as yet layed vpon bard fwellings, wax- A en kernals, in manner of a falue, do wafte and confume them away, but beeing dried and drunkc in wine they cure the ftrangurie; and laied on with oile it procureth fweat.

Which things alfo concerning Onobrychis, Diofcorides hath in thefewords fet downe: the luerbe $\mathrm{B}$ ftamped and applied wafteth away hard fellings of the kernels; butbeeing drunkewith wine it helpeth the ftrangurie, and rubbed on with oile it caufeth fwcatings.

\section{Cнa p. 524. OfBaftard Dittanie.}

Fraxinella.

Baftard Dittanie:

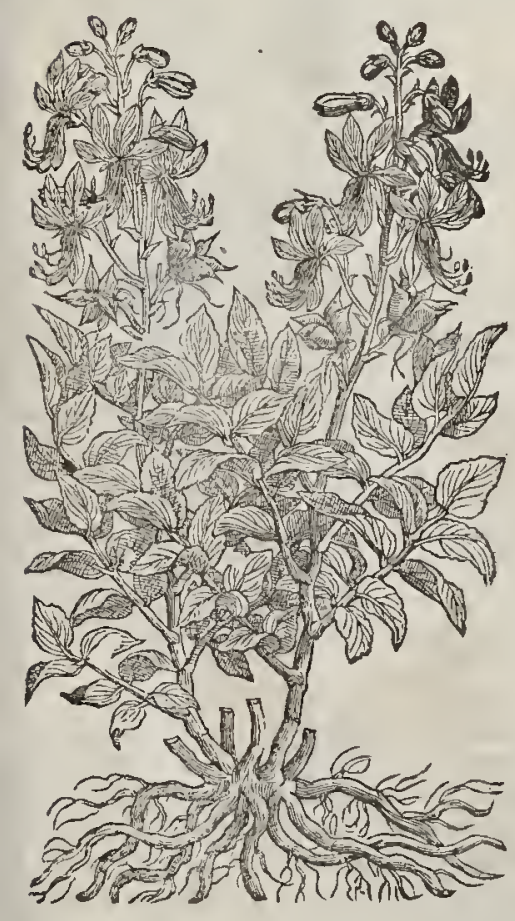

T The Defcription.

B Aftard Dittanie is a very rare and gallant plant,hauing many browne ftalks, fonwwhat rough,diuided into fundry fmall branches, garnihed with leaues like Liquorice, or rather like the leaucs of the A th tree, bur blacker, thicker,and more ful of iu ice, of an vnplca fant fauor: among which grow flourcs, confinting of fiue whition leaues ftripped with red, whereof one which groweth vndermoft hangeth downe low; but the four which grow vppermolt grow more ftiffe and vpright:out of the midtt of this floure commeth forth a taffell, which is like a beard, hanging alfo downwards, and fomcw hat turning vp at the lowerend: which beeing vaded, there come in place foure huskes ioined together, much like the husks or coddes of Columbines, fomewhat rough without, flimic to handle, and of a lothfoine fauour,almolt like the fmell of a goat; whereupon fome Herbarifts haue called ic Tragiwm: in the cods are contained fmall black thining feeds like Peonic feeds in colour : the roots are white, a finger thickc, onc twifting or knorting within another, in taft fo mw hat bitter.

There is another kindc here of groming in my garden, not very much differing: the leaues of the one are greatcr, grecner, harder, and tharper pointed: of the other blaeker, not fo hard, nor fo' Tharpe pointed: the foures alfo kereof be fonlthing more brighe coloured, and of the orher a little redder.

Ti The Place.

Baftard Dittany groweth wilde in the monntaines of Italy and Gernunic, and thatie it crow. ing in my garden. A 
बा The Time.

It floureth in Iune and Iuly : the fecu. is ripe in the end of Auguft.

4f $T$ be Names.

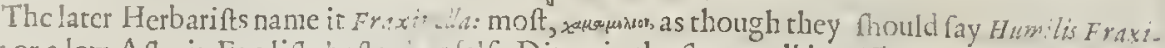
mus or a low Afh : in Englifh, bafter ., f falfe Dittanie:the fhops eall it Dictamum, and Diptumum, but not truly, and ve oftentimes il : cots leceof in ftead of the right Dittanie. That it is not the right Dittanie it is betterknon tet an necdfull at all to be eonfuted; and it is as cuident that the

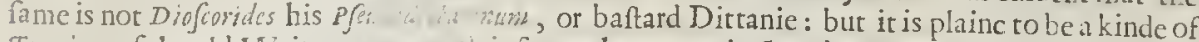
Tragism of thc old Writers 1 . with it feemeth to agree in thew, but not in fubftance.

$\ddagger$ The root of this is one." aci $m$ hops, and thete knowne by the name of $\mathrm{Rad} x \mathrm{x}$ Diptamni, or Diclamni.

The root of baftard D: and opcning faetltic.

A It The Vertues.

T) The Temperature.

A Ir bringeth cowne th: $\ldots . . .$. alfo bringeth away the birth and after birth; it helpeth eold difcares of the matrix : and it $s: \ldots$. . is to be good for thofe that haue ill ftomaekes and arc thort
winded.

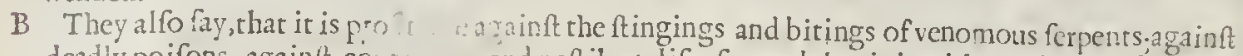
dcadly poifone, againtt critas, $1 \%$ and peftilent difeafes, and that it is with good lucecfe mixed with counterpoifnos.

C The feed of Baftard Ditranic ral cn in the quantitic of a dram is good againtt the ftrangury,prouoketh vrine, brcaketh the fo: in the bladder, and dritueth it forth.

D The like vertue hath the !eaies and iuice taken after the fame fort, and being applicd outwardIy, it draweth thornes and folintc: snut of the Alefh.

E The root taken with a litte Rubarb killerh and driueth forth wormes.

F Diofcorides reporteth, that the wilde Goats being ftricken with darts or arrowes, will eat DiEt am, and thereby caufe them to fall nut of their bodies; which is meant of the right $D_{i} i Z_{\text {am }}$, though $D_{0}$ doneus reporterh that this plant will co the like(which I do notbelecue) $\ddagger$ nor $D$ odorates affirme. $\ddagger$
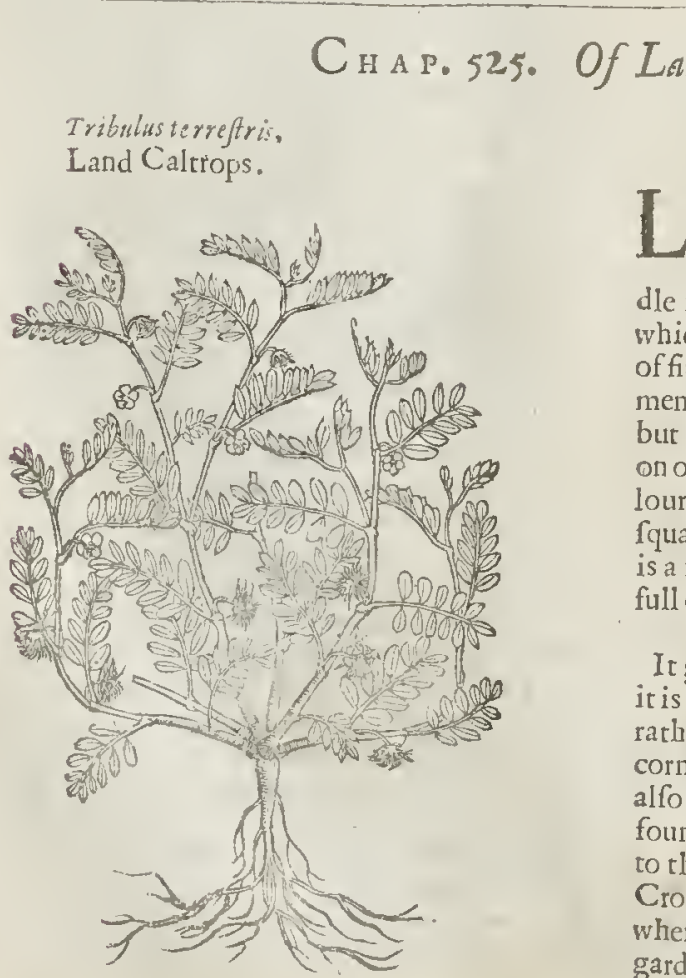

L

And Caltrops hath long branehes full of ioints, fpred abroad vpon the srouthd, garnifhed with many leaues fer vpon a middle rib, a fter the manner of Fctches; among ft which grow little yellow bramehes, enfiting of fiuc fmal leaues, like vnto the floures of Tormentill : I neuter faw the plant beare yellow, but white floures, agrecing with the deferipti. on of $D$ odoncus in each refpce, faue in the colour of the floures, which doe turne into fmall fquare fruit,rough, and full of prickles, whercin is a fmall kernell or feed : the root is white, and full of frings.

\section{का The Place.}

It groweth plentifully in Spain in the fields: ir is hurtful to corne, bur ycr as Pliny faith, it is rather to be aecounted among tlie difcafes of corne, than among the plagues of the earth:ir is alfo found in moft plaees of Iraly \&r Franee; I found it growing in a moift medow adioyning to the wood or Park of Sir Francis Carew, necre Croidon, not far from London, and not elfewhere; from whenee I brought plants for my garden. 
It Alourech in Iune and Iuly : the fruit is ripe in Auguft
बा The Names.

It is called in Greeke reisurs : and in Latine Tribulus:and that it may differ from the orler which groweth in the water, it is named reisune \%erouros, or Tribulus terreftris : it may be called in Englin, land Caltrops, of the likeneffewhich the fruit hath with Caltrops, that are inftruments of Warre caft in the way to annoy the feet of the Enemies horfes, as is before remembred in the Water S.2ligot.

eq The Temperature and $V$ crtues.

Inthis land Caltrop there is an earthy and cold qualitic abounding, which is allo binding, as A Galen faith.

The fruit thereof being drunke wateth away ftones in the kidneyes, by reafon that it is of thin $B$ parts.

Land Caltrops, faith Diofcorides, being drumke to the quantitie of a French crownew eight, and C fo applied, cureth the bit ings of the Viner.

And if it be drunke inwine it is a remed ie againft poyfons : the decoftion thereof fprinckled D about killeth fleas.

* С н а . 526. Of Spring or mountaine Peafeor Vetches.

$\ddagger$ I Orobus Venetus.

Venice Peare.

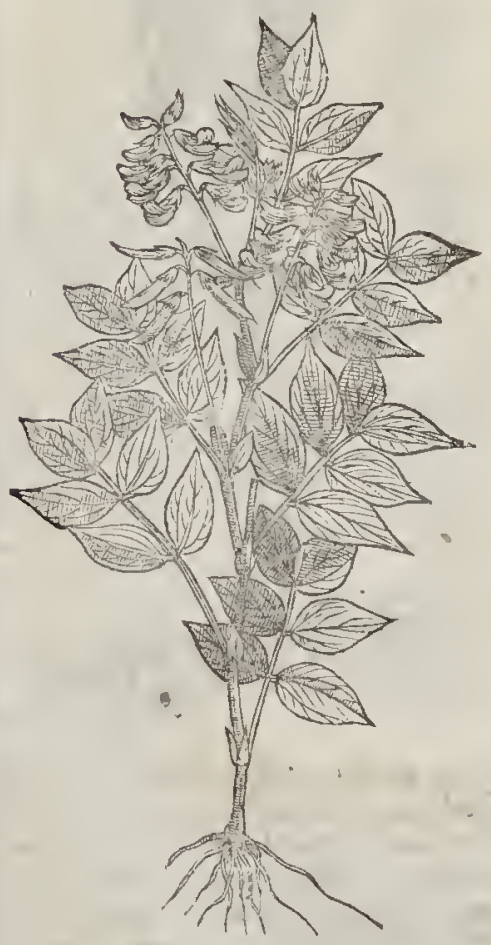

\#2 orobus fyluaticus vernus. Spring Peare.

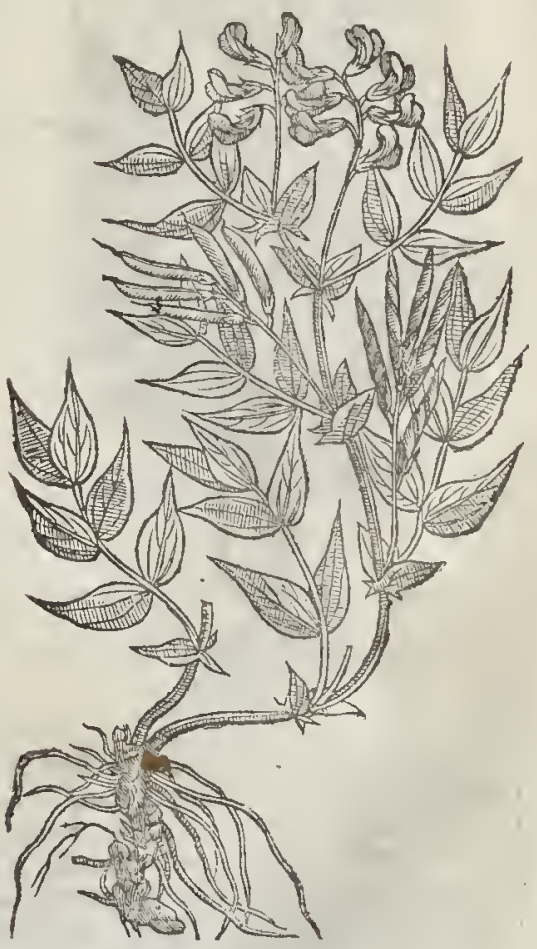

9) The Defription.

I THis, which Chufus calls o robus venetws, hath many cornered ftalkes fome foot long 1 whercongrow winged leates, foure or fix faftned to one rib, ftanding by couples ne againft a nother,without any odde leafe at the end : thefe leaues are of an indifferent largeneffe, 
and of a light greene colour : the floures grow vpon long foot-ftalks comming fort h of the tofons of the leaucs, many rogether, hanging downe, fmall, yet haped like thole of other Pulfes, and of a purple colout : after thefe follow cods almoft like thofe of Fetehes, but rounder, rcd $w$ ben ihey be ripe, and containing in them a longith white feed : the root is hard and wooddy, rumning diuers wayes with many fibres, and luuing fundry yearcs : this varies fomtimes with yellow er grecn leaues and white floures. It floures in May, and growes onely in fome few gardens with vs.

2 The ftalkes of this alfo are a foot or more high, ftiffe, cornered, and grcen; on thefe do grow winged leaues fix or eight on a rib, after the manner of thofe of the laft dcicribed : each of thefe leaues hath three veines running a longtt it: the floures in fhape and manner of growing are like thofe of the former, but of a moft elegant purple colour: which fading, they become blew. The floures are fueceeded by fuch eods as the former, wherein are eontained longith fmall variegated feed : which ripe, the eods fly open, and twine themfelues round, as in moft plants of this kinde: the root is blacke, hard, cuberous and wooddy, fending forth each yearencw houts. This foures in April and May, and ripeneth the feed in Iune. This wasfound by Clufurs in diuers mountainous wooddie places of Hungarie : he calls it orobus Pannonicus I.

$\$ 3$ Orobus montanus foo albo.

White mountaine Peafe.

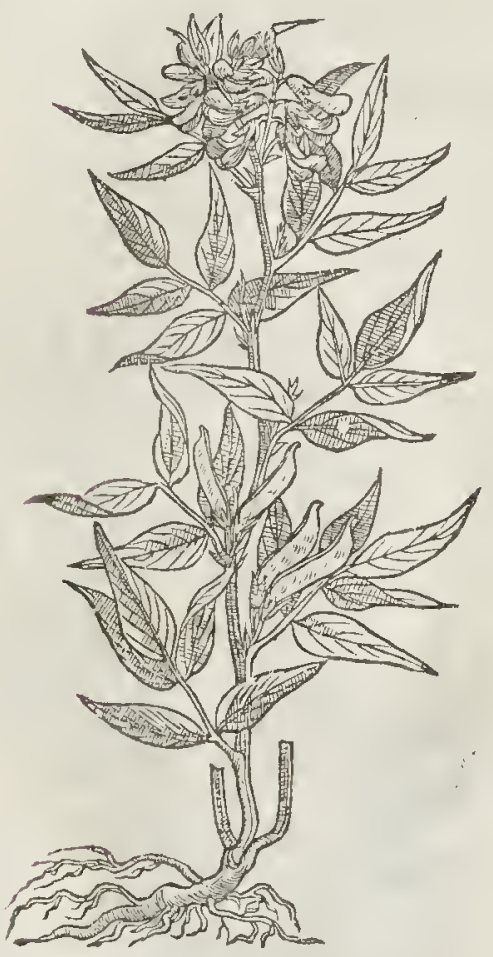

$¥ 4$ orobus montanus angufifolius. Nartow leafed mountaine Peafe.

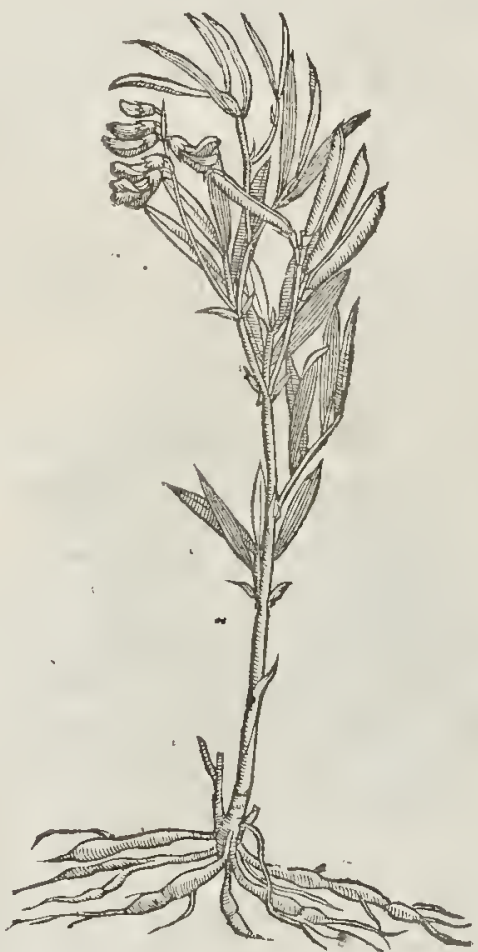

3 This hath ftalkes fome cubit high, ftiffe, ftraight, and ctefted; wheteon by turnes are faftned winged leaues, con fifting of foure fufficiently large and tharpe pointed leates, whcre to fometimes at the very end growes a fift : the veines in thefe run from the middle rib towards their edges : their tafte is firft fomewhat fourith, afterwards bitterion. The floutes grow vpon hort falks comming forch of the bofomes of the leaues, fue or fix together, like thofe of the Fetch, but of are like thofe with fome little yellowneffe on the two little leaues that turne ipwards. The cods otherkindes. This is a feribed, and containe in them a brownith feed, larger than in any of the giues vs this by the name of o robus plant, and perifhes as fooneas it hath perfected the feed. Clufurs

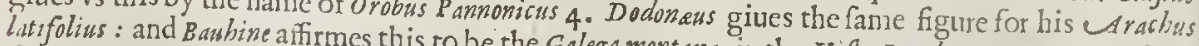
ferme to be of two feucrall plants to be the Galega montana, in the Hift. Lugd.pag. I I39. But thefe alfo that in the Hift. Lugd. to be : yer Chons a fitmes his to haue a liuing root, and fueh feemes 
them. The floures are like thofe of other Pulfes, of colour white : the cods are fome inch and halfe long, containing fome halfe dozen darke yellow or blackifh fmall Peafe : thefe cods grow one at a ioynt, on thore foot-ftalkcs comming forth of the bofomes of the leaues, and are welted on their broader fide, which ttands towards the maine italke. This growes with vs only in gardens, Dodonous, Pent, and Lobel call it ochrus fylueftris, fue Ervilia.

2 The ftalkes of this grow vp fometimes a cubit high, being very flender, diuided into bran. clies, and fet vnorderly with many graffe-like long narrow leaues : on the tops of the ftalkes and branches, vpon pretty long foot-ftalkes grow pretty peafe-fathioned floures of a faire and pleafant crimfon colour : which fallen, there follow cods, long, fmall, and round, whcrein are nine, ten, or more round bard blacke hining graines : the root is fmall, with diuers fibres, but whether it die when the feed is perfeeted, or no, as yet I haue not obf rued. This growes wilde in many places with vs, as in the pafture and nodow grounds about Parcridgc Church. Lobeland Dodon.call this Eroun fylueftre; and they both partly iudge it to be the firft Catanance of Diofcorides, and by that name it is vfually called. It foures in Iune and Iuly, and the feed is ripe in Auguf.

3 This alfo, though it be not frequently found, is no ftranger with vs; for I haue found it in the corne ficlds about Darfford in Kent and fome other places. It hath long flender ioyntederee. ping falkes, diuided into fundry branches, whereon ftand pretty greene thrce cornercd leaucs two at a ioynt, in fhape and bigncle like thore of the leffer Binde-weed. Out of the brofomes of thefe leaues at each ioyst comes a clafping tendrcl,

$\ddagger 3$ Aphaca.

Small yellow Fetch. Lativinis aphaca

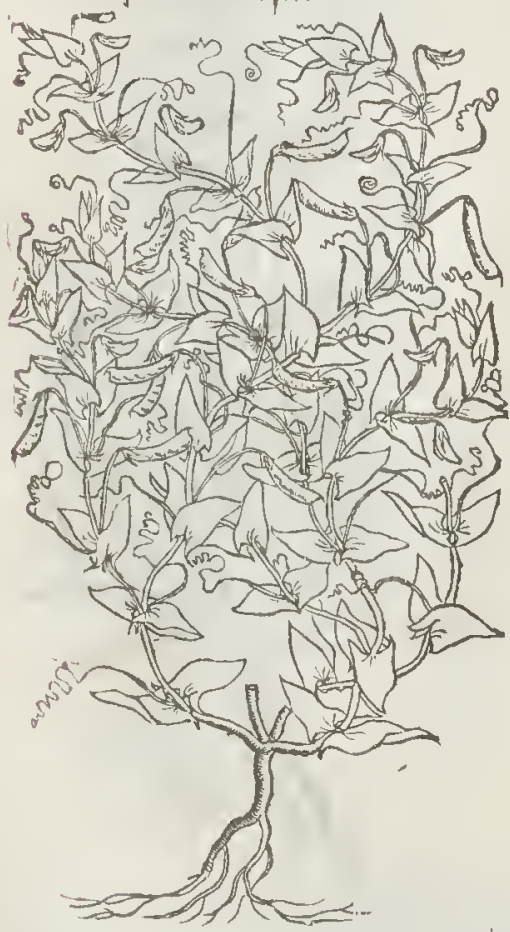

and commonly together with it a foot-falke fome inch or more long, bearing a pretty little peafe-fathioned yellow floure; which is fucceeded by a fhort flattifh cod containing fix or fetren little feeds. This flotres in Iutte, luly, and Augut, and foripens the feed. It is by Lobel and others thought to be the Aphace of $D$ ioforides, Galen, and Pliny : and the Pitine of Theo. plsraftus, by $\cup$ ingwillara.

I finde mention in Stowes Chronicle, in Amo I 555, of a certainc Pulfe or Peafe,as they term it, wherewith the poore pcople at that time, there being a great dearth, were miractloufly helped : he thus mentions it; In the moneth of Auguit(faith he) in Suftolke, at a placeby the fea fideall of hard ftonc and pibble, called in thofe parts a fhelfe, lying betweene the towncs of Orford and Aldborough, wherc ncither grew graffe, nor any earth was cuer feene; it chanced in this barren pliacc fuddenly to fpring vp without any tillage or forving, great aboundance of Peafon, whereof the poore gathered (as men iudged) aboute an hundred quarters, yet remained fome ripe and fome bloffoming, as many as euer there were before: to the which place rode the Bithop of Norwich and the Lord Willoughby, with others in great number, who found nothing but hard rockie ftone the fpace of three yards vader the roots of thefe Peafon : which roots were great and long, and very fwcet.

Gefneralfo, de Aquatilibus, lib.4.pag.256.making mention, out of $D^{r}$. Cajus his letters, of the fpotted Englin Whale, taken about that time at Lin in Norfolke, alfo thus mentions thofe peale: Pifa (faith he) in littore noftro Britannico quod o rie $a t c m$ Jpectat, certo quodam in loco Suffolcie, inier Alburnum or ortfordism oppid.t, faxis infidentia (miribile dictu) nulla terra circumfu $a$, autumali tem. pore Anso 1555 , B ponte nat a funt, adeo naggna copia, wt fufficerent vel millibus bominum. Thefe Peale, which by their great encreare did fuch good to the poore that yeare, without doubt grew there for many yeares before, but were not ob ferued till. [Mngifter art is, ingenique largitor Venter] hunger made them take norice of them, and quickned their inuention, which commonly in our people is very dull, efpecially in finding out food of this natire, 
My Worthipfull friend Dr. Argent hath told me, that many yeares ago he was in this place, and caufed his man to pull aw ay the beach with his hands, and follow the roots folong, vntill hee got fome equall in length vinto his height, yet could come to no ends of them: hee brought thefe vp with him to London, and gaue them to Dr. Lobel, whowas then liuing; and he caufed them to be drawne, purpofing to fet them forth in that Worke which he intended to haut publined; if God had fpared him longer life. Now whether thefe Peafe be truly fo called, and be the fame with the Pifum fylueftre periwnt, or different; or whether they be rather of the ftocke of the Lashyrus maior, or of fome other Pulfe here formcrly defcribed, I can affirme nothing of certaintie, becaufe I haue feene no part of them, nor could gatlier by any that had, any certaintie of their thape or figure: yet would I not paffe them ourer in filence, for that I hope this may come to be read by fome who lite thereabout, that may by fending me the things themfelues, giue me certane knowledge of them; that fo I may be made able, as I am alwaies willing, to impart it to others.

$$
\text { T) The remperature andVertues. }
$$

I hate not liate not found any thing w ritten of the faculties of the two firft; but of Aphate, Galen aith it hat an afringent faculcie like as the Lentill, and alfo is ved to be caren like as it, yet it is

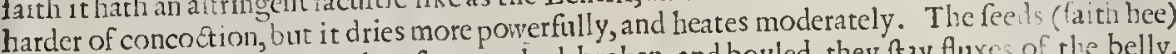
haue an aftringent facultic; wherefore parched, broken, and boyled, they ftry fluxes of the belly. We know (Gich Dodonets) by certaine experience, that the Aphace here defcribed hath this a ltringent force and facultie.

\section{С на р. 523. Of buftard Rubarb.}

Thalietrum, fue T balictrum maius: Great baftard Rubarb.

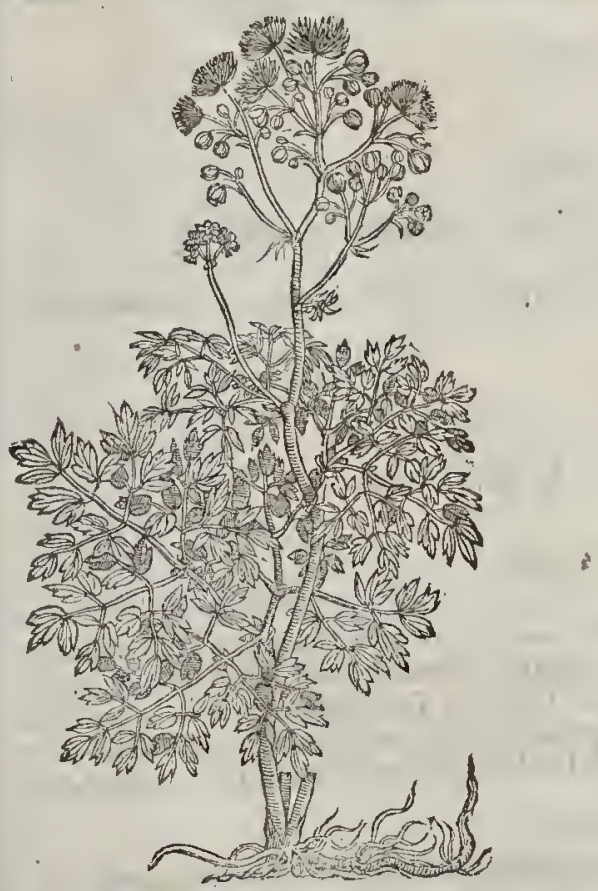

- Thalidtrum minus. Small bafard Rubtib. Shalictrum mums.

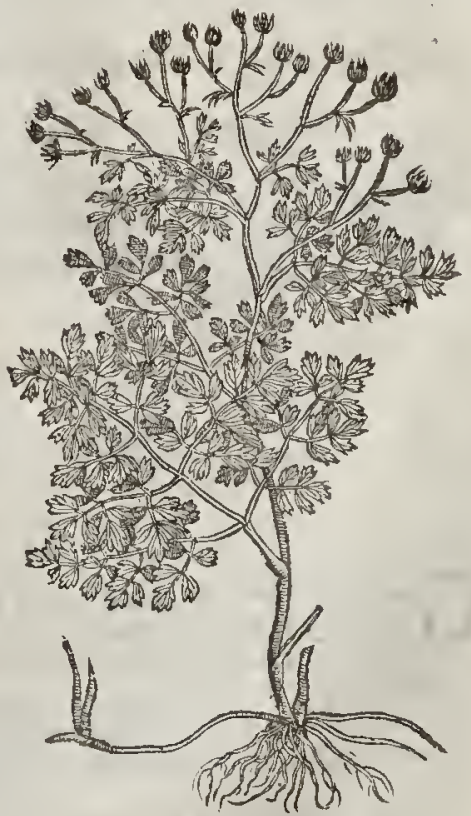

ซf The Defription.

7 He great $T$ halictrum or baftard Rubarb hath large leaues parted or diuided into diuers other fmall leaues, fomewhat fnipt about the edges, of a blacke or darike green colour: 
the ftalkes are crefted or ftreaked, of a purple colour, growing to the height of two cubits : at the top whereof grow many fmall and hairy white floures, and after them come fmall narrow huskes like little cods, foure or fiuc growing together : the root is yellow, long, round, and knotty, difper fing it felfe far abroad on the vpper cruft of the earth.

2 Tlic fmall baftard Rubarb is very like vnto the precedent, but that it is altogether leffer: his ftalkcs are a fpan or a foot long: his leauses be thin and tender; the root fine and flender: the little foures grow together in fmall bundles or tufts, of a light yellow colour, almoft white, and
are of a gricuous fauour.

\# 3 There is kept in fome gardens a plant of this kinde growing vp with large falkes to the height of three cubits : the leaues are very like thofe of Columbines: the floures are made of many white threds: it floures in Iune, and is called Thaliftrum maius Hifpanicum, Great Spanifh Ba-
ftard Rubarb. ‡

If The Place.

Thefe Plants doe grow alongft the Ditch fides leading from Kentiph freetvnto Saint Thomas a- Waterings (the place of Execution) on the right hand. They grow alfo vpon the bankes of the Thames, leading from Blacke-wall to Woolwich, neerc London, and in fundry other pla-
ces alfo.

$$
\text { T The Time. }
$$

The foure for the moft part in Iuly and Augut.

$$
\text { T The Names. }
$$

Diuers of the later Herbarifs do call it Pigamum, as though it were nifwor, that is, Rue; whereupon moft call it Ruta palreftris, or Fen Ruc : others, $P$ Peudo. Rhabarbarum, and $R$ habarbayum Monachorum, by rafon of the yellow colour of the root. But neither of their iudgements is greatly to be efteemed of : they indge better that would haue it to be Thalietrum, which Diofcorides defcribeth to have leaucs foncthing flatter than thofe of Coriander; and the ftalke like that of Rue, vpon which the lcaues doe grow. Pena calleth it Thalictrum, T halictrum, and Rutapraicnfis: in Englifh, baftard Rubarb, or Englifh Rubarb : which names are taken of the colour, and rafte of the roots.

Thefe herbes arc hot and dry of complexion.

$$
\text { IT The Temperature. }
$$

$$
\text { Tा The Vertues. }
$$

A The leates of baftard Rubarb with other pot-herbes do fomewhat mone the belly.

B The decontion of the root doth more effectually. they dry without biting.

\section{Cha r. 529. Of Goats Rue.}

$$
\text { The Defcription. }
$$

QT

Alega or Goats Ruc hath round hard ftalkes two cubits or morc high, fet full of leaues der rib, refembling the leaues of leafe confifting of fund rie fmall leaues fet vpon a flenfloures grow at the top of the ftalke, cluft the field Vetch or Tare, but greater and longer. The light skie colour, which turne into long cods together after the manner of the wilde Vetch, of a root is grcar, thicke, and of a white colour.

Itgroweth plentifully in The Place. wilc in my garden.

It flourcth in Inly and Augurt.

The Iralians call it Golega, and outo of $T$ he Names.

$$
\begin{aligned}
& \text { का The Time. } \\
& \text { of The Numes. }
\end{aligned}
$$

Ruta Cspraria; diucrs name it corruptly Gralega: Hieronymus Fracaforiu 
Galega. Goats Rue.

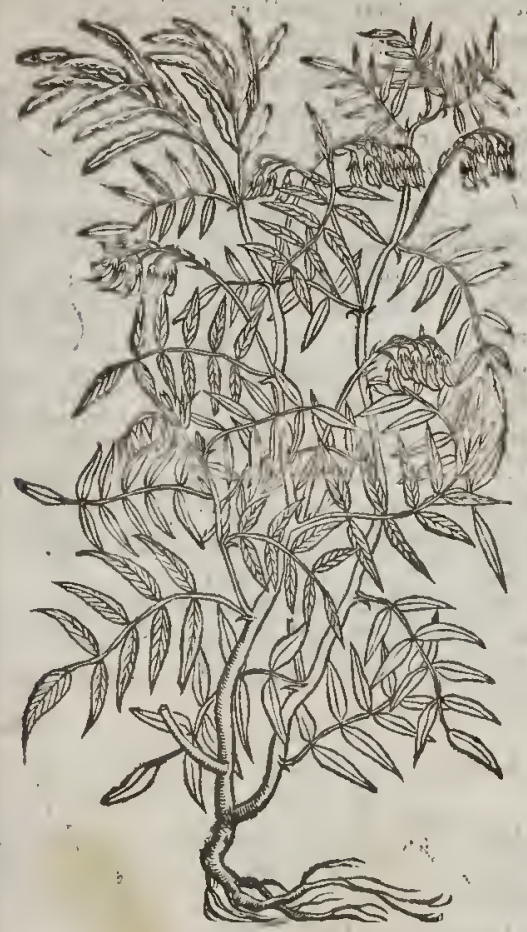

Fracaftorius calleth it Herba Galleca : the Herufucians, Lauanefe; and it is alfo ealled by dituers other names in fundry places of Italy,

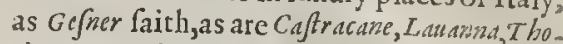
rina, or Taurina, Martanica, Sarracena, Caprazina, Herbanefi, Foenum grecum fyluefire, and as $B r d-$ faulus witneffetll, Grarga.It is named in Englinh, Iralian Fitch,and Goats Rue.

Some iudge that the o'd Phyfitions were wont to eall it Onob,ychu:others, Glauce:di. uers would hauc it to be Polemonium, but not fo mueh Petr. Wnd. Mat hrotws in his eommentaries, as euery one of the deferiptions mentioned by Diofcorides dogainfay them; as alfo thofe, who thinke that Galega, is Polygalon, \& that the name of Galega came of Polygalon, the very defeription alfo of Polygalon is againft them : for Galega is ligher and greater than that it may be called a little fhrub oncly of an hand bredth high.

$$
\text { 9. The Temperature. }
$$

This plant is ina meane temperature be: tweene hot and eold.

$$
\text { T The Vertues: }
$$

Goats Rue is a fingular herbe againft all vcnome and poifon, and againft wormes, to kill and driue them forth, if the juice be giuen to little children to drinke.

It is of like vertue if it be frycd with $B$ Linefecd oyle, and bound vpon the childes natell.

It is minifted vnto children which are poffeffed with the falling euill, a f poonefull etrery mor- G ning in milke.

Being boiled in vineger, and drunke with a little Treacle, it is very good againt the infe oion of the plague, efpecially if the medicine be taken within tw clue houres.

The herbe it filfe is eaten, being boiled with ferh, as we vfe to eate Cabbage and otherwoorts, and likewife in fallades, with oile, vineger and pepper, ${ }^{\prime}$ as we doeate boiled Spinage, and fueh like; Which is moft excellent being foeaten, againft all poifon and peftilence, or any venomous infirmitie whatfocuer, and procurech fweat.

It alfo helpeth the bitings and Ringings of venomous beafts, if either the juice or the herbe $\mathrm{F}$ ftamped be laid vpon the wound.

Halfe an ounce of the juice inwardly taken is reported to helpe thofe that are troubled with convulfions, erampes, and all other the difeafes aforefaid.

The feedes do feed pullen exeecdingly, and caufe then to yeeld greater ftore of egs than or- $H$ dinary.

$¥$ The juice of the leaues, or the leaties themfelues bruifed and applied to any part fwollen I by the fting of a bee or wafpe, mitigate the paine, and are a prefent renedy, as $\mathrm{M}^{\mathrm{r}}$. Cannon a louter of Plants, and frind of mine, hath aftured me he hath feen by frequent cxperienee. $\neq$

\section{C н A . 550. Of Pliny bis Leadwoot. - The Defcription.}

D Entaria or Dentiliaria hath offended in the fuperlatiue degree, in that hehath hid himfelf $\mathrm{e}$ like a runnagate fouldier, when the affault ghould haue been giten to the plant Lepidiusm, whereof doubrleffe it is a kinde. But if the fault be mine, as without queftion it is, I erane pardon for the ouerfight, and do increate thee gentle teader to cenfure me with fautour, whliereby I may more boldiy infert it in this place, rather than to leaue it vntouehed. The learned of Nar: bone(efpecially Rondelet tws) haue notwithout good eaule accounted this goodly plant for a kinde

\section{D}

\section{.}




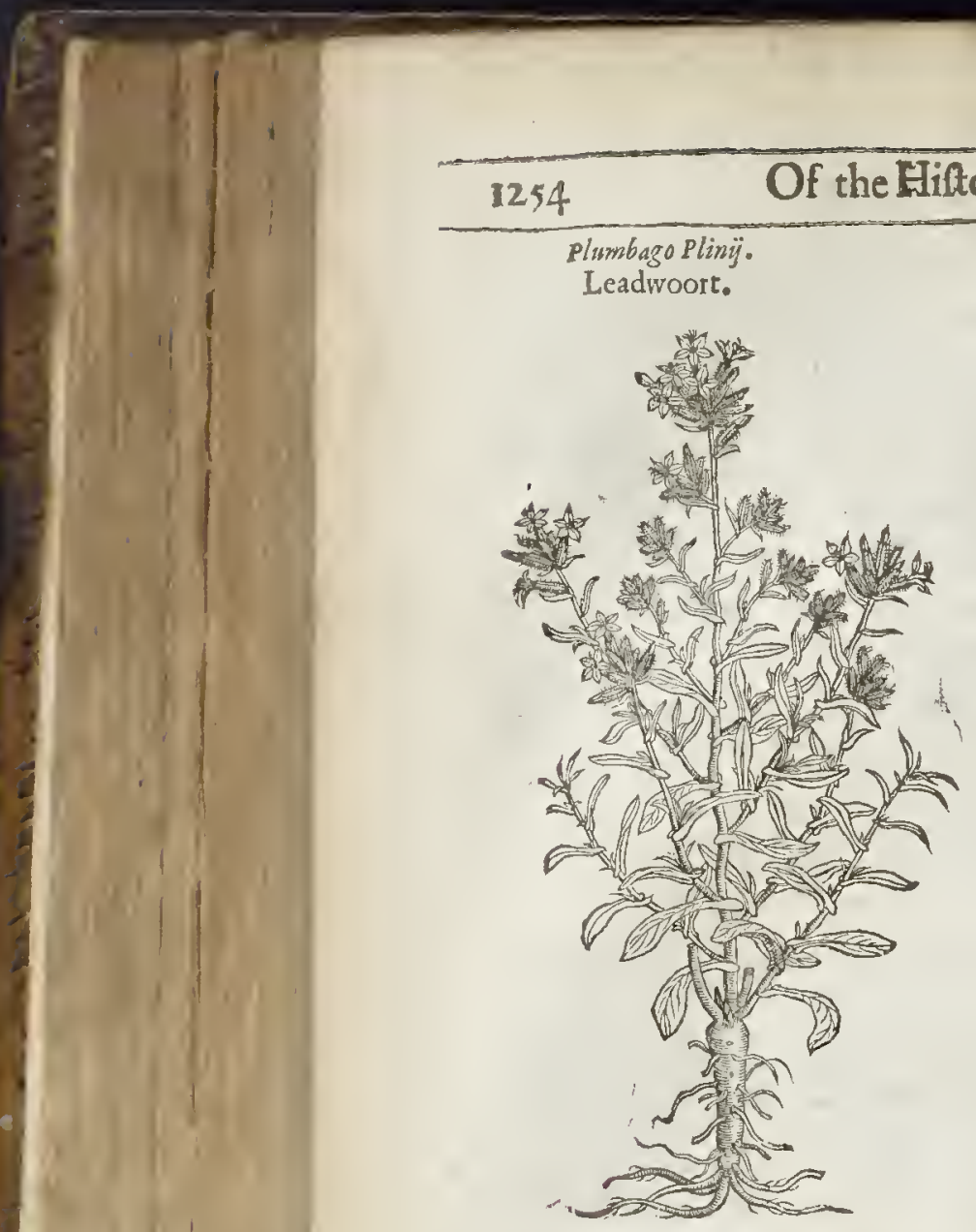

thereof,becaufe the whole plant is of a biting tafte, and a burning faculty, and that in fuch extremity, that it will raife blifters vpon a mans hand: for which caufe fome of the learned fort haue accounted it Plinies Molybdena, or Agineta his Leprdium : but the new Herbarifts call it Dentaria, or Dentillaria Rondeletij, who made the like vfe hereof, as he did of $p y$ rcthrum, \& fuch burning plants, to appeafe the immoderate pain of the roorh-ache and firch like. This plant hath grear thicke tough roors, of a wooddy fubitance, from whence fpring vp long and rough falkes two cubits bigh, confufedly garnithed and befer with long leaues, in colour like Woad, of a fharpe and biting tafte. The fioures grow at the top of the ftalkes of a purple colour; which being paft, there fucceed clofe gliftering and hairy huskes, wherein is contained fmall blackifh

Dentillaria is of a caufticke qualicy. If $T$ he Temperature. feed.

of The Place.

Pend reporteth that Dentillaris groweth a: bout Rome, nigh the hedges and corne fields: ir likewife groweth in my Garden in greac plenty.

\section{It floureth in Iuly and Auguft.$$
\text { 9) The Names. }
$$

Leadwoort is called Molybdana, Plumbago Plinü, \& Dentillaria Rondelet $y$ : in Italian, Crepanclla, rhe Romanes, Hcrba S. Antonë: : in Illyria, Cucurda : in Englin, Leadwoort.

T The Vertucs:

A Ir helpeth the toorh-ache, and that as fome fay if it be holden in the hand fome fmall while:

$x$

Thi Arden Rue or planted Rue, is a frub full of branches, now and then a yard high, o: Thigher: the ftalkes whereof are couered wirh a whitifh barke, the branches are more green:the leaues hercof confift of diuers parts, and be diuided into wings, abour which are certaine little ones, of an odde number, fomething broad, more long than round, fmooth and formewhat fat, of a gray colour,or greenifh blew : the floures in the top of the branches are of a pale yellow, confiting of foure little leates, fomething hollow : in the middle of which fandeth vp a little head or butron foure fquare, feldome fue fquare, containing as many litrle coffers as it hath corners, being compaffed about with diuers litrle yellow rhreds: out of which hang pretie fine tips of one colour; the feed groweth in thc litrle coffers: the root is wooddy, and faftned with many ftrings : this Rue hath a very ftrong and ranke fmell,and a biring tafte.

2 The fecond being the wilde or mountaine Rue, called Ruta fylueftris, is very like to garden Rue, in ftaikes, leaues, floures, feed, colour, tafte, and fauour, fauing that euery little leafe hath finaller cuts, and is mucl narrower : the whole plant dieth at rhe approch of winter, being an annuall plant,and muft either ftand till it do fow himfelfe, or elfe muft be fowne of others. $¥$ This fecond is a variety of rhe garden Rue differing from the former onely in fmallneffe. $\neq$

This plont is lik ewife a wilde kinde of Rue, and of all the reft the fmalleft, and yet morc visulent, biting, and ft inking than any of the reft: the whole plant is of a whitifh pale greene, agreeing with the laft before mentioned in cach refpect, faue in grearneffe, and in that the venomous fumes or vapors that come from rhis fmall wilde Rue are more noifome and hurtfull than the former. $\$$ The leaucs lie fpred vpon the ground, \& are very finely cut and diuided:the whole plant is of 
1 Rutshortenfis: Garden Rue.

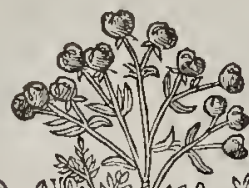

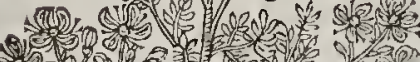
(1) 50 , Ian

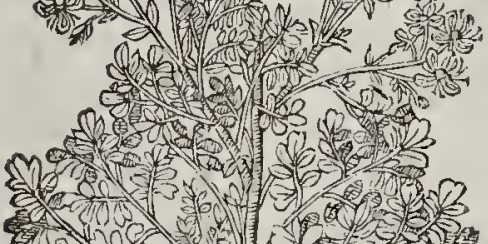
祭政 E⿰ \% \& 00 v

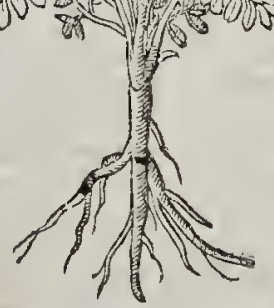

\section{Ruta mostars:} Mountaine Rue!

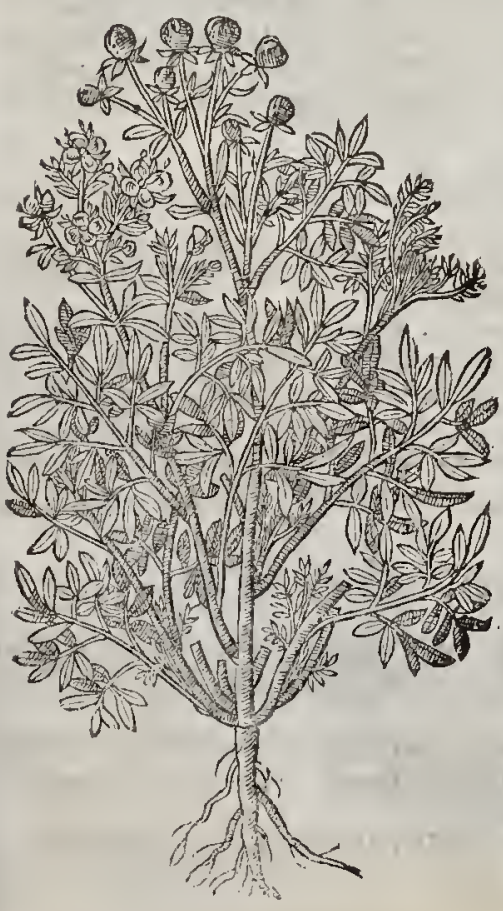

3 Rutafylucfris minima.

The fmalleft wilde Ruc.

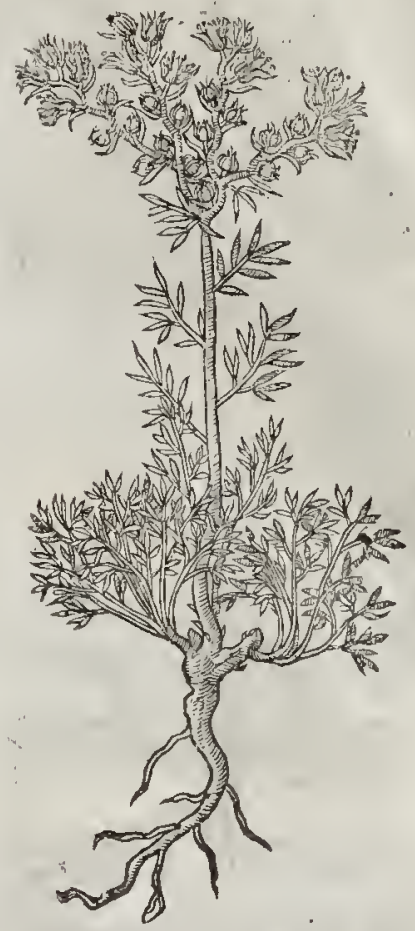

5 Hitarmala.

Wilde Rue with white floures.

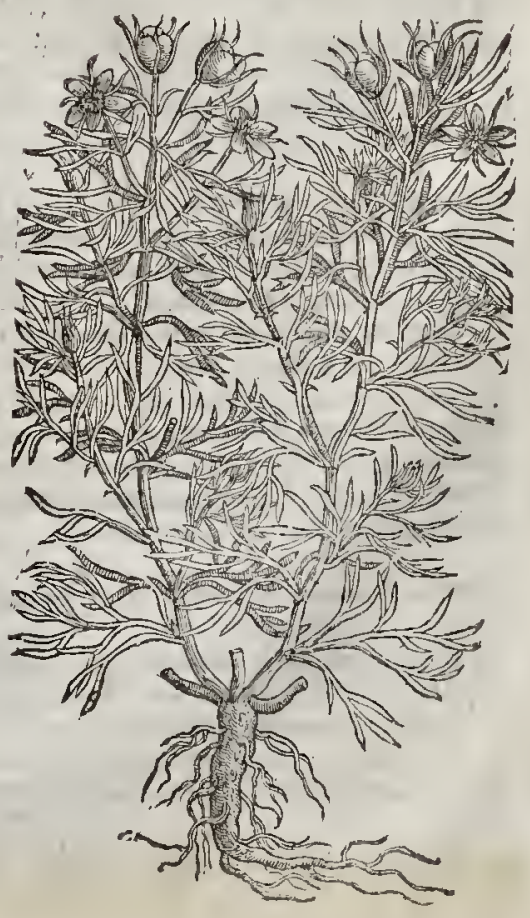


$\ddagger 6$ RutaCanina. Dogs Rue.

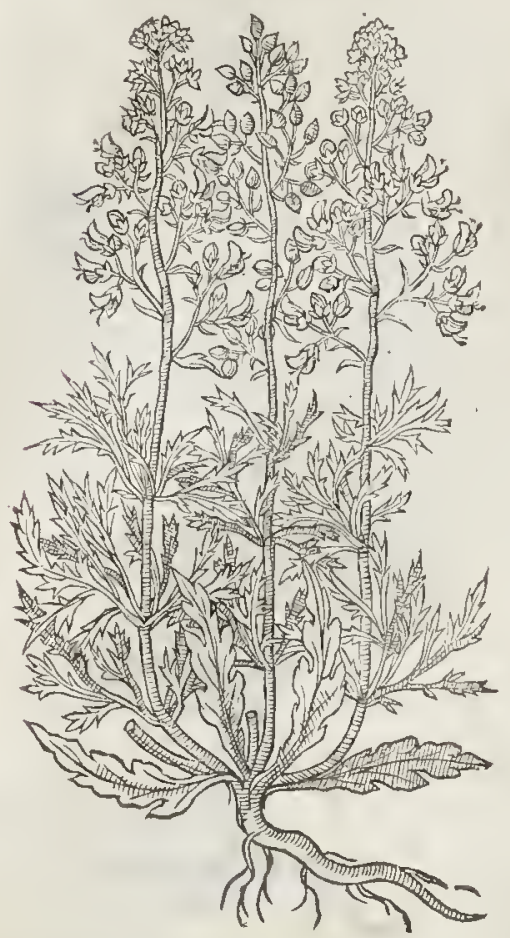

fuchacrimonic, that clufus fuith he hath oftner than onee obferued it ro picree througl three paire of gloues to the hand of the gatherer; and if any one rub his face with his hand that hath newly gathered it, forthwith it will mightily inflame his face. He tells a hiftory of a Duteh Student of Mompelicr that went with him a fimpling, who putring fome of it betweene his hat and his head to leepehim the cooler, had by that meanes all his face prefently inflamed and blifted wherefocuer the fweat ran downc. $\neq$

4 There is another wilde Rue growing vpon the mountaines of Sauoy and other places adioyning, hauing a great thicke ropt, from which do arife great thoots or ftalkes; wheron do grow leaues very thicke and fat, parted into diuers longith fections, otherwife refembling the leaues of the firft deferibed, of a ftrong and ftinking fmell : the floures grow on the rops of the ftalkes, confifting of foure fmall yellow lcaues : the feeds are like the other.

5 Harmel is one of thewilde Rues:it bringeth forth immediatly from the root dituers little ftalks of a cubit high; whereupon do grow greene leaues diuerfly cur into long pieces, longer and narrower than thofe of thewild ftrong fmelling Rue : the floures be white, compofed of fure white leatses : the fruic is three fquare, bigger than that of the planted Rue, in which the feed lieth : the root is thick, long; and blackith : this Rue in hot countries hath a maruellous ftrong fmell, in cold Countries not fo.

$¥ 6$ This, which Matthiolus gaue for Sideritis 3 . and Lobel, Clufus, and others for Rut a canina, hath many twiggy branches fome cubit and halfe high; whereon grow leaures refembling thofe of the Papawer hhas or $A$ Agemone, leffer, thicker, and of a blackifh greene : the floures are of a whitifh purple eolour, fathioned fomewhat like thofe of Antirrhinm : the feed is fmall, and contained in fuch veffels as thofe of Rue, or rather thofe of Blattaria. Thewhole plant is of a ftrong and vngratefull fmell : it growes in the hot and dry places about Narbon in Franee, Raucnna and Rome in Itraly. $\neq$

$$
\text { T The Place. }
$$

Garden Rue ioyeth in funny and open places : it profpereth in rough and brickie ground, and among alhes : it cannot in nowife away with dung.

The wilde are found on mountaines in hot countries, as in Cappadocia, Galatia, and in diuers protinees of Italy and Spaine, and on the hills of Laneathire and Yorke.

Pliny faith that there is fuch friend hip betweene it and the fig trce, that it profpers no where fowell as vnder the fig tree. The beft for phy ficks vfe is that which groweth vnder the fig tree, as Diofcorides faith : the eaufe is alledged by Plutarch in the firft booke of his Sympofiacks or Feafts, for he faith it becommeth more fwect and milde in tafte, by reafon it taketh as it were fome part of the fweetnes of the fig tree, whereby the ouer rancke quality of the Rue is allayd; vnlefie it be that the fig tree whileft it draweth nourifhment vnto it felfe, it likewife draweth away the ranckneffe of the Rue.

$$
\text { q The Time. }
$$

They floure in thefe cold countries in Iuly and Auguft; in other countries fooner.

$$
\text { T. The Names. }
$$

The firt, which is Hortenfis Rut a, garden Rue: in high-Dutch, 2hauten: in low-Dutch, lisutite: the Italians and Apothecaries keepe the Latine name: in' Spanith, Aruds : in French, Rue de 1ardin: in Englifh, Ruc, and Herbe-Grace.

Wilde Rue is called in Greeke niyum, Peganon : in Latine, Rutafylueftris, or wilde Rue : in Galatia and Cappadocia, wixu: of diuers, Harmala : of the Arabians, Harmel : of the Syrians,Befara.. The Temperature.

Rue is hot and dry in the later end of the third degree, and wild Rue in the fourth : it is of thin 
and fubrill parts : it wafts and confumes winde, it eutteth and digefteth gtoffe and tough humors.

$$
\text { 4) The I"crtucs. }
$$

Rue or Herbe-Graee prouokes vrine, brings downe the ficknes, expels the dead ehild and after- A birth, being inwardly taken, or the deeosion drunie; and is good for rhe mother, if but fmelled to.

Plin.lib.20.6a: 3 . faith it opens the matrix, and brings it into the righr plaee, if the belly all ourer $B$ and the fhare(che bre ft fay the old falfe eopies) be anointed therewith: mixed with hony it is a remedie aganft the inflammation and fwelling of the ftones, proeecd ing of long abfinenec from vencrie, ealled of our Englin Mountebanks the Colts euill, if it be boyled with Barrowes greafe, Bay leaues, and the pouders of fenugreeke and Linfeed be added therero, and applied pultis wife.

It takes alvay erudity and rawnefie of humors, and alfo windines and old paines of rhe tomaek.

Boiled with vineger it eafeth paines, is good againft the ftiteh of the fide and eheft,and thortnes of breath von a ejid earle, and alfo againft the paine in the ioynts and huekle bones.

The oilc of it furtes for the purpofes laft reeited: it takes away the eollieke and pangs in the E guts, not only in a clifter, butallo anointed vpon the places affected. But if this oile be made of the oile preffed out of $\mathrm{Linefeed}$ it will be fomueh the better, and of fingular foree to take away hard fwellings of the fpleene or milt.

It is vfed with gooul fuccefle again the dropfic called in Greeke worapre, being applied to the $F$ belly in manner of a pultis.

The herb a little boiled or fealded, and kept in piekle as Sampier, and caten, quickens the fight, G

The fame apolied with honey and the iuyee of Fennell is a remedie againnt dim eyes.

The iuyee of Rue nude hor in the rinde of a pomegranat and dropped uto the eares, takes away the paine thereof.

$S$. Anthonies fire is guenehed therewith : it killeth the fhingles, and rumning vlecrs and fores in $K$ the heads of yong ehildren, if it be tempered with Cerufe or white Lead, vineger, ant oile of rofes, and made into the forme of $N$ utritum or Triapharmacon.

Diofcorides faith, that Rue put vp in the nothrils fayeth bleeding.

Of whofe opinion Pliny alfo is; when notw thfanding it is of power rather to procure bleeding $M$ through the fharpe and biting qualitie that it harh.

The leates of Rue beaten and drunke withwine, are an antidote againft poifons, as Pliny faith.

Diofcorides write th, that a rwelue penny weight of the feed drunke in wine is a eounterpoy fon againft deadly medieines or the poy fon of Wolfs-bane, Ixi., Muthroms, or Tode-ftooles, rhe biting of Serpents, ftinging of Scorpions, fpiders, bees, hornets, and wafps; and it is reported, that if a man be anointed with the iuyee of Rue thefe will not hurt him; and that the Serpent is driven away at the fmell there of when it is burned, infomueh that when the Weefell is to fight iv ith the Serpent, the armeth her felfe by eating Rue againt the might of the Serpent.

The leaues of Rue eaten with the kernels of wallnuts or figs ftamped together and made into a $P$ maffe or pafte, is good againft all euill aires, the peftilenec or plague, refifts poy fon and all venom.

Rue boiled with Dil, Fennell feed,and fome Sugar, in a fuffieient quantitie of wine, fwageth rhe torments and griping paines of the belly, the paines in the fides and breat, the difineulty of breathing, the cough, and ftopping of the lungs, and helpeth fueh as are deelining to a droprie.

The ityee taken with () ill,as aforefaid, helpeth the eold fits of a gues, and alters their eourfe : it $R$ helpeth the inflammation of the fundament, and paines of the gut called Rectum inteftinum.

The iuyee of Rue drunkewith wine purgeth women after their deliueranee, driuing forth the $S$ fecondine, the dead ehilde, and the vnnaturall birth.

Tue vfed very often either in meate ordrinke, queneheth and drieth vp the naturall feed of ge- 'T nerarion, and rhe milke of rhofe that giue fueke.

The oile wherein Rue hath beene boyled, and infufed many dayes logether in the Sun warmeth $V$ andehafech all eold members if they be anointed therewith: alfo it prouokech vrine if the region of rhe bladder be anointed therewith.

If it be minifted in elifters it expells windineffe, and the torfion or gnawing paines of the guts. $X$

The leaues of garden liue boiled in water and drunke, eaufeth one to make water,pronoketh the $Y$ termes, and ftoppeth the Jaske.

Rutafylueftris or wilde Rue is mueh more vehement both in finell and operation, and therefore the more virulent or pernitious ; for fomt imes it functh out a vapororaire fo hurtfull that it feoreheth the faee of him thar lookcth vpon it, raifing v plifters, wheales, and other aee idents : it venometh their hands that toueh it, and will infect the faee alfo, if it be touched with them before they be e seane wathed; wherefore ic is not to be admitted vn to meate ot medicine.

\section{The end of the fecond Booke:}




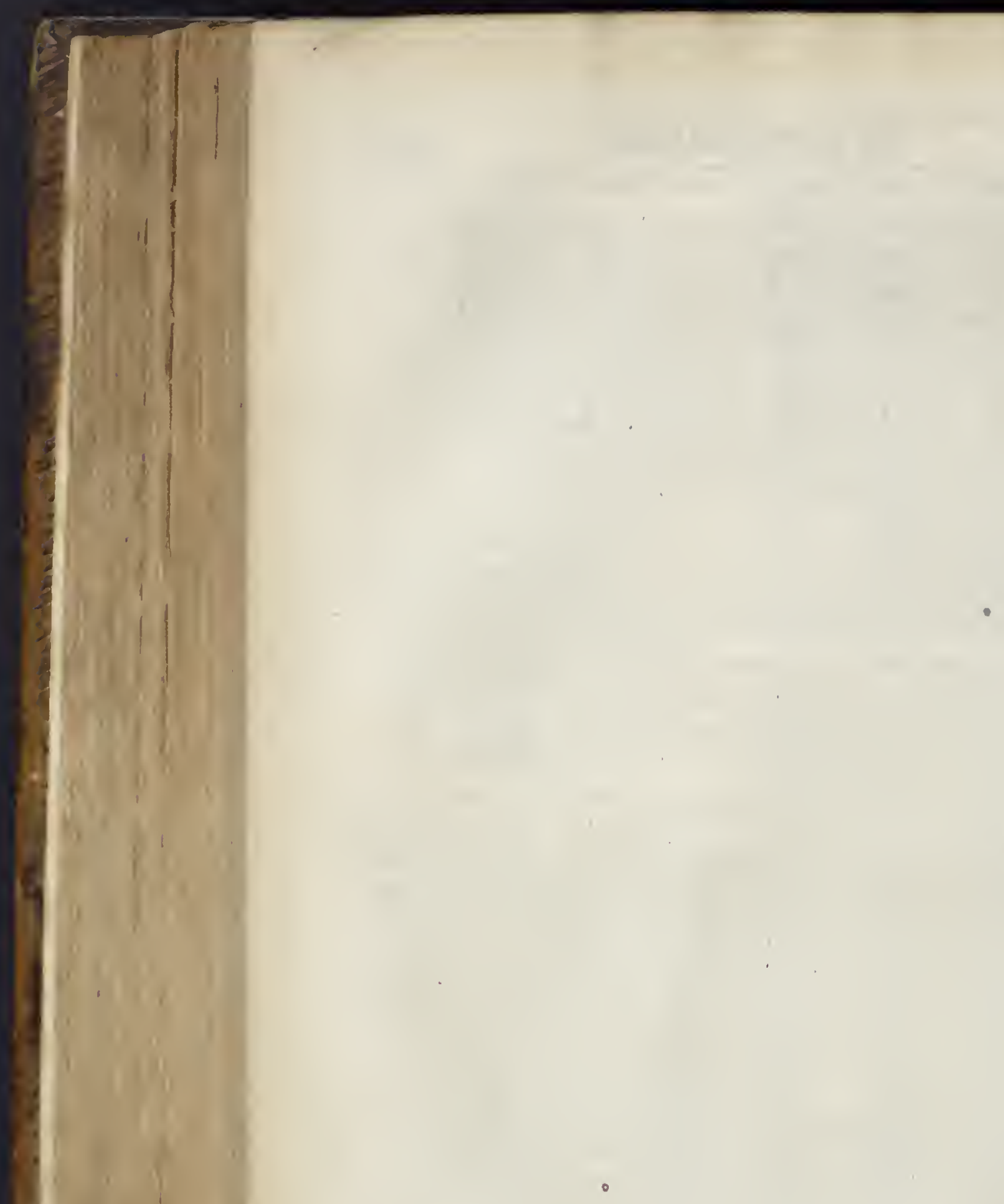


L 1 в. 3 .

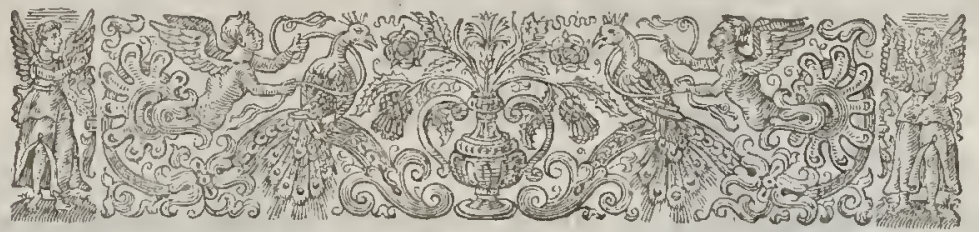

\section{THE THIRD BOOKE OF THE HISTORIE OF PLANTS.}

Containing the Defcription, Place, Time, $\mathcal{N}$ ames, $\mathcal{N}$ ature, and Vertues, of Trees, Sbrubs, Bufhes, Fruit-bearing Plants, Ro/ins, Gums, Rofes, Heath, Q Yoffes: fome Fndian Plants, and otber rare Plants not remembred in the Proeme to the firft Booke. Alfo Mithromis, Corall, and their fenerall kindes, erc.

\section{The Proeme.}

Fen Aung finifhed the Treatife of Herbes and Plants in generall, vfed for meat, medicine, or 4 weet fmelling $v \int e$, onely fome few omitted for want of perfert inftuetion, and alfo being hindered by the flackeneffe of the Cutters or Grauers of the thofe; which wants we intend to fupplic in this third and laft part. The Tables as well genetall as parricular fhall be fet forth in the end of this prefent Volume.

\section{Cнат. т. Of RoJes.}

T) The Kindes.

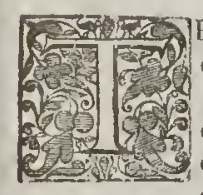

He Plant of Rofes, rhough it be a fhrub full of prickles, yet it had been moie fit and conuenient to haue placed it with the moft glorious. floures of the $w$ orld, than to infert the fame hete among bafe and thornie fhrubs : for the Rofe doth deferue the chicfent and moft principall place among all foures whatfoeuer; beeing not onely efteemed for hisbeatie, vertues, and his fragrant and odoriferous fimell; but alfo becaufe it is the honotr and ornament of our Englifh Scepter, as by the coniunction appeareth in the uniting of thofe two moft royall hou fes of Lancafter and Yorke. Which pleafant floures deferue the chicfeft place in Crownes and garlands, as Anacrcon T hiss a moft antient Greeke Poet (whom Henricus Stephasws lath tranflated in a gallant Latine verfe) affirmes in thofe verfes of a Rofe, beginning thus

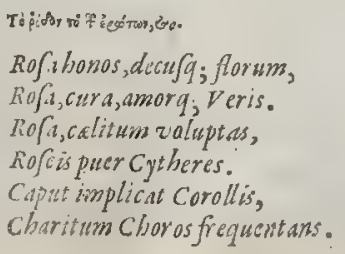


The Rore is the honour and beautie of floures,

The Rofe is the care and loue of the Spring,

The Rofe is the pleafure of th'heauenly powres;

The Boy of faite Fenus, Cytheras darling,

Doth wrap in his liead round with garlands of Rofe,

When to the dances of the Graces he gocs.

Augerius Busbeckits fpeak ing of the cfimation and honor of the Rofe, reporteth that the Turks can by no meanes indure to fee the leaues of Rofes fall to the ground,becaufe that fome of them haue dreamed, that the firft or moft antient Rofe did fpring of the bloud of $V$ en ss; and others of the Mahumetans fay, that it fprang of the fweat of Mabumet.

But there arc many $\mathrm{k}$ indes ofRofes differing either in the bigneffe of the floures, or the plant it felfe, roughneffe or fmoothneffe, or in the multitude of the floures, or in the fewneffe, or elfe in colour and imell : for ditters of them are high and tall, others fhort and low ; fomc haue fiue leaues, others very many. Theophraftus telleth of a certaine Rofe growing about Philippi, with an hundred leates, which the inhabitants brought forth of Pangxum, and planted it in Campania, as Pliny faith; whiel wee hold to be the Holland Rofe, that diuers call the Prounce Rofe, but not properly.

Moreouer, fome be red, others white, and moft of them or all, fweetly fmelling, efpecially thofe of the gardent.

I Rofalbit. The White Rofe.

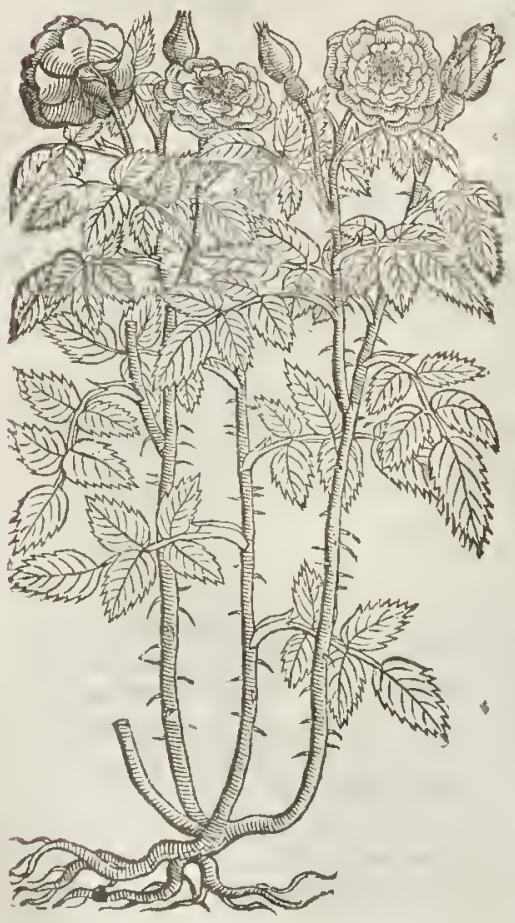

\section{Tf The Defoription.}

I

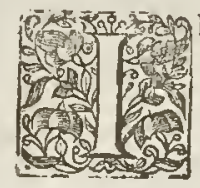

F the curious could fo be content, one general defcription mighe ferue to diftinguin the whole focke or kindred of the Rofes, beeing things fowell knowne: notwithftanding I thinkc it not amiffe to fay fomething of them fenerally, in hope to fatisfie all. The white Rofe hath very long falkes of a wooddie fubitance, fet or armed with diuers marpeprickles: the branches whereof are likewife full of prickles, whereon doe grow leaues confriting of fure leaues for the moft part, fet vpon a middle rib by couples; the old leafe ftanding at the point of the fame, and euery one of thore finall leaues fomewhat fnipt about the edges, fomewhat rough, and of an ouerworne green colour : fron the bofom wherof fhoot forch long foot-ftalks, whereon do grow very faire double floures, of a white colour, and very fiveet fmell, hauing in the middle a few yellow threds or chiues; whieh being paft there fucceedeth a long fruit,grcene at the firft, but red when it is ripe, and ftuffed with a downie choaking matter, wherein is contained feed as hard as ftones. The root is long, tough, and of a wooddie fubftance.

- 2 The Red Rofe groweth very low in refpect of the former : the ftalkes are fhorter, fmoother, and browner of colour: the leaues are like, yet of a worfe duft ie colour : the floures grow on the tops of the branches, confifting of many leaucs, of a perfeet red colour:the fruit is likewife red when it is ripe : the root alfo wooddie.

3 The common Damaske Rofe in ftature, prickley branches, and in other refpects is like the 
2 Rofa rubra.

The red Rofe.

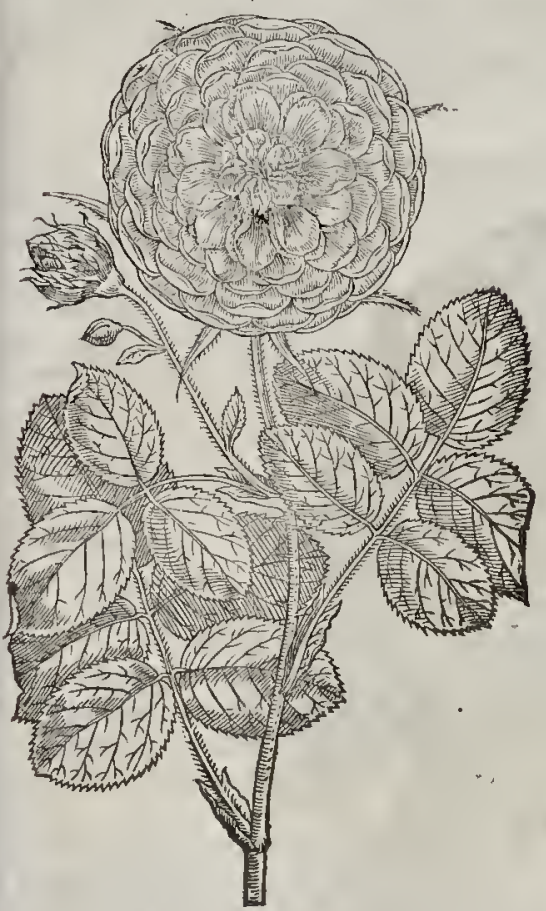

5 Rofa fine pinis.

The Rofe without prickles,

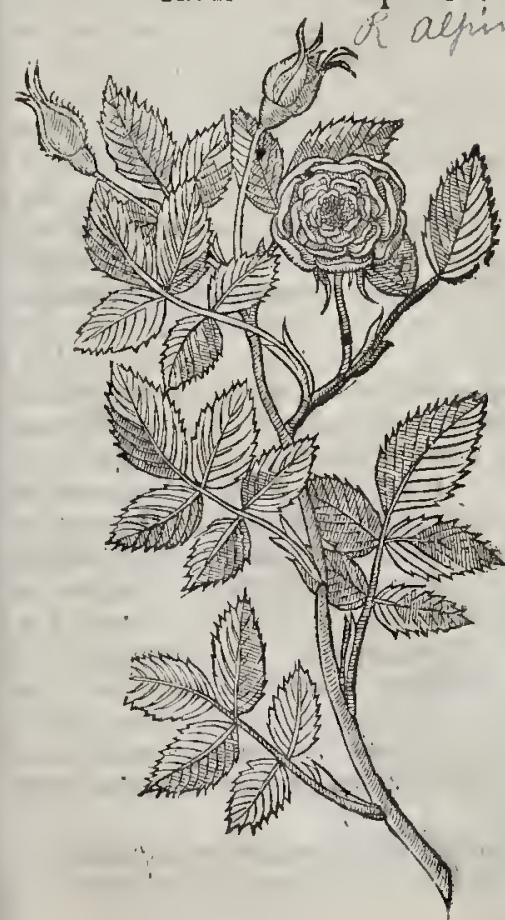

3 Rofa Prouincialis, five Dism recrio

The Prouince, or Damaske Rofe.

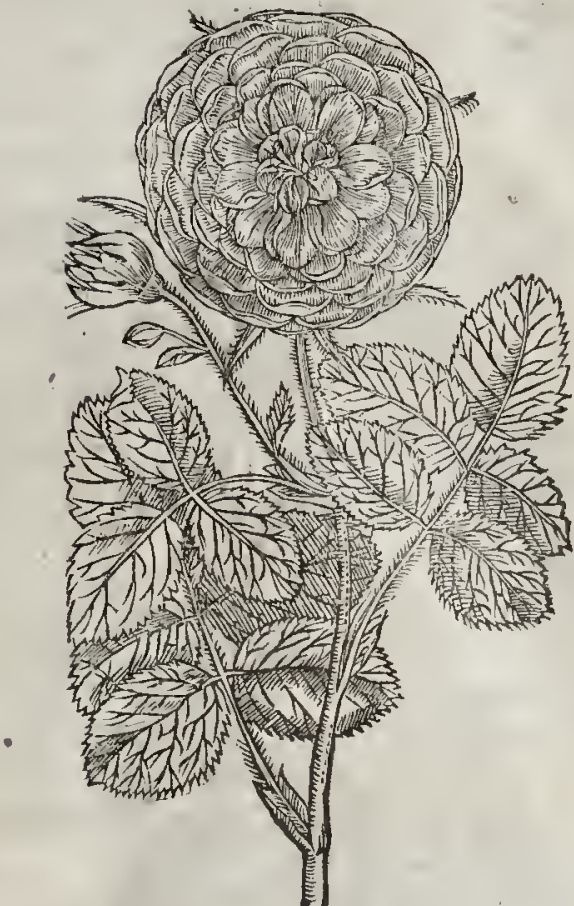

white Rofe; the efpeciall difference confifteth in the colour and fmell of the floures; for thefe are of a pale red colour, and of a more pleafant fmell,and fitter for meate or medicine:

4 The Rofa provincialis minor, or lefier Prouinse Rofe differeth not from the former; but is altogether lefler:the floures and fruit are like: the vfe in phyfick alfo agreeth with the precedent.

5 The Rorewithout prickles hath many young thootes comming from the root, ditriding themfelues into diuers branches; totgh, and of a woody fub ftance as areall the reft of the Rofes, of the hight of two or three cubites, fnooth and plaine without any roughneffe or prickles at all; whereon do grow leanes like thore of the Holland.Rofe, of a fhining deepe greene colour on the vp. per fide, vnderneath fomewhat hoaric and hairy. The floures grow at the toppes of the branches, confifting of an infinitenumber of leaties, greater than thofe of the Damaske Rofe, more double, and of a colour betrreene the Red and Damaske Rofes, of a molt fwecr fmell. The fruit is round, red when it is ripe, and ftuffed with the like flockes and feeds of thofe of the Damask Rofe. The root is great, sqaoddie, and far fpreading. 
6 The Holland or Pronince Rofe hath diners fhoots proceeding from a wooldic root, fullo tharpe prickles, diuiding it felfe into diucrsbranehes, whercon do grow leates confifting, of leaues fet vpon a rough middle rib, and thofe fnipt about the edges: the floures grow on the tops o the branches, in fhape and colour like the Damaske Rofe, but greater and more double, infonucl fweet as ollow chitues in the middle are hard to be feene; of a reafonable good fmell, but not ful fo fweet as the common Damaske Rore : the fruit is like the other of his kinde.

\section{Rofa Hollandica, (ive Bataus.}

The great Holland Rofe, commonly ealled the great Prouinee Rofe.

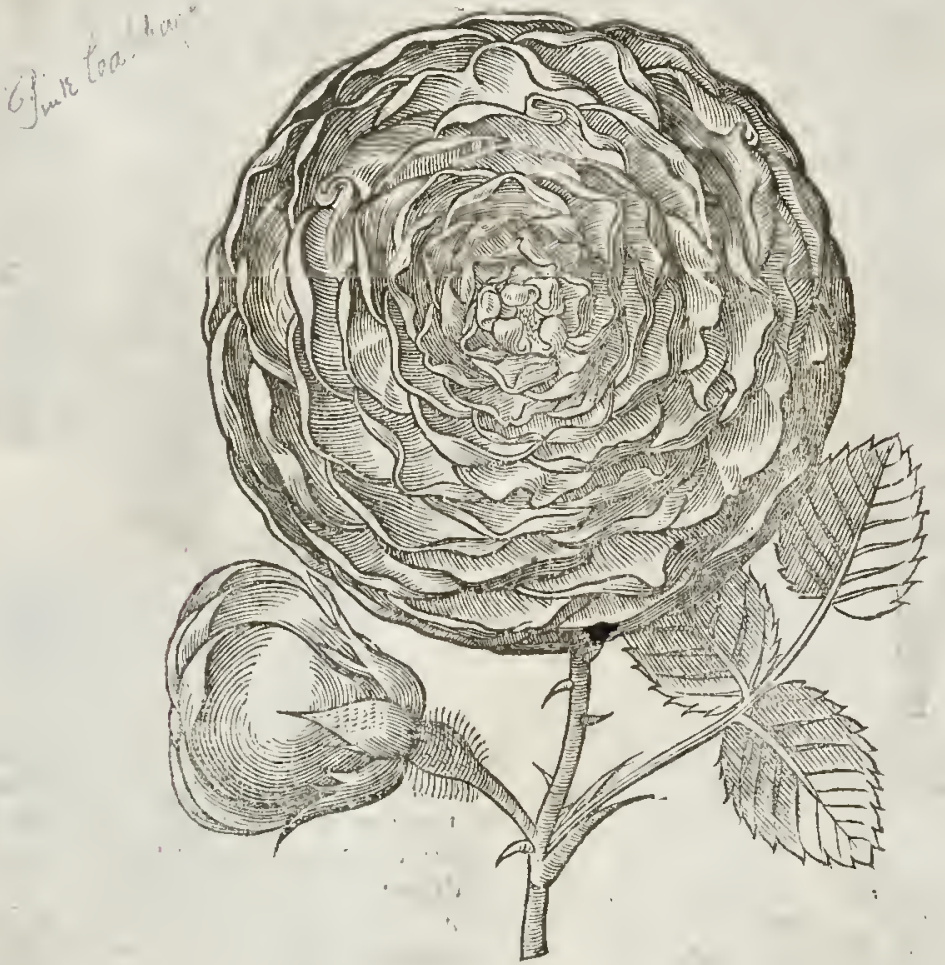

We have in our London gardens one of the red Pofes, whofe floures are in quantitie and beauty equal with the former, but of greater eftimation,of a perfect red colour, wherein efpecially it differed Rofe.

All the fe forts of Rofeswe of Te Place.

as yet is a ftranger in Eofes we haue in our London gardens, except that Rofe without prikles, which thite in great abundance,euen The double white Rofe doth grow wilde in many hedges of Lancathe countrey called Lcyland, and in a place called in thefe Southerly parts, efpecially in a place of the faid Leyland fields doth growy our a are called Roughford, not far from Latham. Moreover, in fuch abrodanee, that there grow our garden Rofe wilde, in the plowed fields among the corne in with the beft garden Rofe in each gathered daily, during the time, many buncls of Rofes, equall field in the place aforefaid each refpect : the thing that giueth great caufe of wonder is, that in a yeare the field will be fored ouer wirh Rofield, enery yeare that the field is plowed for cone, that then fhall there be but few Rofes to be gat and when it lyeth as they call it ley, and not plowed,

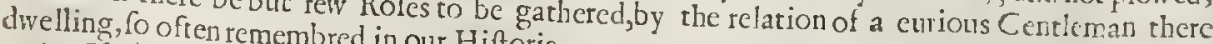
$\neq$ I baic heard that he in our Hiftoric.

is plowed, are no other than Rofes which grow in fireh plenty in Gloners field,cuery yeare the ficld

Thefe floure from the endof The Time.

cops and fuperfuous branches are cus to the end of Auguft, and diuers times after, by reafonthe fou re euen untillo etober, and after. 
qT The Names.

The Rofe is called in Latine Rofa : in Greeke poss: and the plant it felfe poskis: (which in Latine keepeth the fame name that the floure hath) and it is called Rodon (as Plutarch faith) becaule it fendeth forth plenty of fmell.

- The middle part of the Roles, that is, the yellow chines, or feeds and typs, is called Amthos, and Flos Rolo, the floure of the Rofe: in thops, Anthera, ot the blowing of the rofe.

The white parts of the leaues of the floure it felfe, by which they are faftened to the cups, he named $V n g u$ s o nails. That is called $C_{a}$ lix, or the cup, which containeth and holdeth in together the yellow part and leaues of the foure.

Alabuftri,are thofe parts of the cup which are deeply cut, \& that compaffe the finure clofe al: out before it be opered, which be in number fue, two haue beards and two haue ro! e, and the fift hath but halfe one : molt do call them Cortices Rof $\mathrm{rrm}$, or the husks of the rofes: the thoots of the plant of rofes, Strabo Gallus in his little garden doth call viburna.

The white Rofe is called Ro/a alba : in Englih, the white Rofe : in high Durch, Uecirs Loofen:

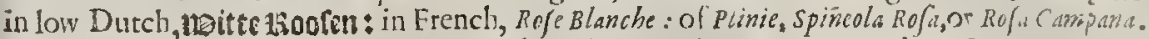

The red Rofe is called in Latine, Rola rubra: the Frenchmeir, Roje Frasche, Rufe de Proums, a towne in Campaigne: of Plinie, Trachinia, or Preneftina.

The Damaske Rofe is called of the Italians Rofa incarnata: in high Dutch, Leibfacbige 1900fer:

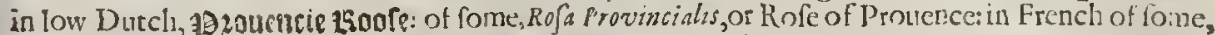
cMelefia : the liofe of Melaso, acitie in Afia, from whence fome hate thought it was firft brought into thofe parts of Europe.

The great Role, which is generally called the great Prouence rofe, which the Dutch men cannot endure; for fay they, it cane firft ont of Holland, and therefore to be called the Holland Role : but by all likelihood it came from the Damaske role,as a kinde thereof, made better and fairer by art which feemeth to agree with trutl.

The rofe without prickles is called in Latire. Rosa fine $\beta$ inis, and may be called in Euglin, the rofewithout thornes, or the rofe of Aufrich,becaufe it was firtt brought from Vienna, the Metro. politan citie of Auftrich,andgiue nto that famous Herbarift Carolus Clufurs.

\section{बा The Temperature.}

The leaues of the floures of rofes, becaufe they doe confift of diuers parts, hauc alfo diuers and fundry facultics:for there be in them certain that are earthy and binding, others moift and watery, and fundrie that are fpirituall and a irie parts, which notwithlanding are not all after one fort, for in one kinde thefe excell, in another thofe, all of them haue a predominant or nuer rul ing cold temperature, which is neerct to a meane, that is to fay, of fuch as are cold in the firt degree, moift, airie, and fpirituall parts are predominant in the Wibiterofes, Damaske and Muske.

$$
\text { at } 7 \text { he Vrrtucs.. }
$$

The diftilled water of rofes is good for the ftrengthning of the heart, \& refrething of the fpirits, $\mathbf{A}$ and likewife for all things that require a gentle couling.

The fame being put into iuketting dihes, cakes, fluces, and many other pleafant things, gitueth $\mathbf{B}$ a fire and delectable tafte.

It mirigateth the paine of the cies proceeding of a hot caufe, bringeth fleep, which alfo the freth C rofes themfelues prounlie through their fwect and plea fant fmell.

The ituice of thefe rofes, efpecially of Damask, doth moue to the ftoole, and maketh the belly fo- D luble:but moft effe.Atually that of the Musk rofes:next to them is the iuice of the Damask,which is more common'y, fed.

The infufion of then doth the fame, and alfo the fyrrup made thereof,called in Latine Drofatum, E or Scrupiurn : the A pothecaries call it Syrrup of rofes folutiue, which muft be made of the infufion in which a great number of the lesues of thefe freth rof's are diwers and fundry times teeped.

It is profitable to make the belly loofe \& foluble,when as either there is no need of other fton. F; ger purgat inn, or that it is not fit and expedient to $\mathrm{vfe}$ it : for befides thofe excrements which ftick to the bowuls, or chat in the firft and neereft veines remaine raw, flegmaticke, and now and thers cho'ericke, it purgetl no other excreınents, vnleffe it be mixed with certaine other ftronger medicines.

This fyrrup doth moiften and coole, and therefore it alayeth the extremitic of heat in hot bur- $G$ ning feuers, mitigareth the inflammations of the intrails, and quencheth thirftit is fcarce good for aweake and moit ftoracke, for it leaueth it more flacke and weake.

Of like vertuc alfo are the leaties of thefe preferued in Sugar,efpecially if they be onely bruifed $\mathrm{H}$ with the hands, and diligently tempered with Sugar,and fo heat at the fire rather than boiled.

बा The Temperature of Red Rofes.

There is in the red Roles, which are common etery where, and in the other that be of a deep purple, called Prouence rofes, a mote earthic fubsance, alfo a dtying and binding gualitie, yet not 
without certaine moifture ioined, being in them when they are as yet freth, whieh they lofe when they bedried : for this caufe their iuice and infufion doth alfo make the bodie foluble,yet not fo mueh as of the others a forefaid. Thefe rofes being dried and their moifture gone,dobind and dry; and likewife coole, but leffer than when they are freih.

K They ftrengthen the heart, and helpe the trembling and beating thereof.

They gitue ftrength to the liter, kidneies, and other weake intrails; they dry and comfort a weak ftomacke rhat is flathie and moift; ftay the whites and reds, ftaneh bleedings in any part of the body, ttay fweatings, binde and loofe, and moiften the body.

I. And they are put into all manner of counterpoifons and other like niedieines, whether they be to be ourwardly applied or to be inwardly taken, to which they giue an effectuall binding, and cer'taine ftrengthning qualitie.

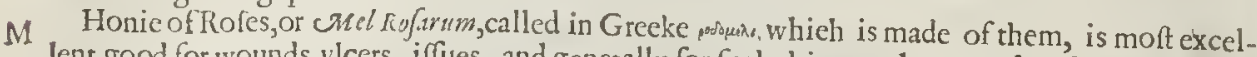
lent good for wounds,vlcers, iffues, and genetally for fuch things as haue need to be clenfed and
dried.

N The oile doth mitigate all kindes of heat, and will not fuffer inflammations or hot fwellings to rife, and being rifen it doth at the firlt affwage rhem.

$$
\text { Tf The Tempcrature and Vertues of the parts. }
$$

O The floures or bloom ings of Rofes, rhat is to fay, the yellow haires and tips, do in like maner dry and binde, and that more effectually than of the leaues of the rofes themfelues:the fame temperature the cups and beard; be of; but feeing none of rhefe haue any fweet fmell, they are not fo profitable, nor fo familiar or benefieiall ro mans nature : notwithftanding in fluxes at the fea, it fhall auaile rhe Chirurgion greatly, to earry fore thereof with him, which doth there preuaile much
more than at the land.

P The fame yellow ealled Anthera, taieth not onely thofe lasks and bloudy fluxes which do happen at the fea,but thofe at the land alfo, and likewife the white flux and red in women, if they bee dried,beaten to pouder, and two fcruples thereof giuen in red wine, with a little powder of Ginger added thereto : and being at the fea, for want of red wine you may vfe fuch liquour as you ean get
in fueh extremitie.

Q The little heads or burtons of the Rofes, as $P$ liny writeth, do alfo ftanch bleeding, and ftoppe the
laske.

$\mathrm{R}$ The nailes orwhite ends of the leaues of the floures are good for watering eies.

S The iuiec, infufron, or decostion of Roles, are to be reekoned among thofe tnedicines whieh are foft, gentle, loofing, opening and purging gently rhe belly, which maybe taken at all times and in all places, of entery kinde or fex of people, both old and yong, without danger or perill.

I The fyrrup made of the infufion of Rofes, is a moft fingular $\&$ gentle loofingmedieine, earrying dow nwards cholerieke humors, opening the ftoppings of the liuer, helping grearly the yellow iaundies, the trembling of the heart, $\&$ taking away the extreme heat in agues and burning feuers which
is thus made:

$V$ Take two pound of Rofes, the white ends cut away, put them to fteepe or infufe in fix pintes of warme water in an open vefiell for the fpaee of twelue houres:then ftraine them out, and pus thereto the like quantitie of Rores, and warme the water again, fo let it ftand the like time: do thus foure or fiue times; in the end adde vnio that liquor or infufion, foure pound of fine fugar in powder; then boyle it vnto the forme of a fyrrup, vpon a gentle fire, eontinually ftirring it vntill it be cold; then ftrdine it, and keepe it for your vfe, whereof may be taken in white wine, or other liquour, fron
one ounce into two.

X Syrrup of the iutice of Rofes is very profitable fot the griefes aforefaid, made in this manner :

Y Take Rofes, rhe white nailes cut away, what quant itie you pleafe, ftampe them, and fraine out the itice, the which you thall put to rhe fire, adding thereto fugar,aceording to the quantity of the iuice: boiling rhem on a gentle fire vnto a good eonfiftenee.

Z Vnro thefe fyrrups you may adde a few drops of oyle of Vitriol, which giueth it a nolt beautifull colour, and alfo helpeth the force in eooling hot and burning feuers and agues: you liketvif: may adde thereto a fmall quantitie of the iuice of Limons, which doth the like.

A The conferue of Rofes aswell that which is erude and raw, as that which is made by ebullition or boiling, taken in the morning fatting, and laft at night, ftrengthneth the heart, and taketh away the fhaking and rrembling thereof, ftrengthneth the liuer, kidneies, and other weake intrails, comfortet h weake ftomacke that is moift and raw; ftaieth the whites and reds in women,and in a word is rhe molt familiar thing to be ved for the purpofes aforefaid, and is thus made:

B Take the leaues of Rofes, the nails cut off, one pound, put them into a clean pan; then put thetet: a pinte and a halfe of fcalling ivater, ftitting them togethet with a woodden flice, folet them ftand 
to macerate, clofe couered fome two or three houres; then fet them to the fire flowly to boyle, ad. ding thereto three pounds of fugar in poivder, letting them to fimper together aecording to difcre tion, fone houre or more; then keepe it for your vfe.

The fame made anotherway, but better by many degrees: take Rofes at your pleafure, pur them $C$ to boyle in faire.water, hauting regard to the quantity; for if you haue many rofes, you may take the more water; if fewer, the leffe water will ferue: the which you thall boyle at the leaft three or foure lioures, euen as you would boyle a piece of meat, vntill in theeating they be very tender, at which time the rofes will lofe their colour, that you would thinke your labour lont, and the thing fpoyled. But proeed, for though the Rofes haue loft their co'our, the water hath gotten the tin eture thereof; then thall you adde vnto one pound of Rofes, foure pound of fine fugar in pure powder, and fo according to the reft of the rofes. Thus thall you let them boyle gently after the Sugar is put therto,continually firring it with a woodden Spatula vntill it be cold, whereof one pound weight is worth fix pound of the crude or raw conferue, as well for the vertues and goodneffe in taftc, as alfo for the beautifull colour.

The making of the erude or raw conferue is very well knowne, as alfo Sugar rofet, and diuers D other pretty things made of rofes and fugar,which are impertent vnto our hiftorie,becaufe I intend neither to make thercof an A pothecaries fhop, nor a Sugat bakers ftorehoure, leauing the reft for our cunning confectioners.

\section{С н а т. 2. Of the Muske Rofes.}

\section{Tा the Kindes.}

There be diuers forts of Rofes planted in gardens, befides thofe written of in the former chap-

ter, which are of molt writers reckoned among the wilde tofes, notwithftanding we thinke it conuenient to put them into a chapter betweene thofe of the garden and the brier rofes, as indifferent wherher to make them of the wilde rofes, or of the tame, feeing we hawe made them denizons in our gardens for diuers refpectsyand that worthily.

I Rofa Mofchatafimplicifore: The fingle Muske rofe.

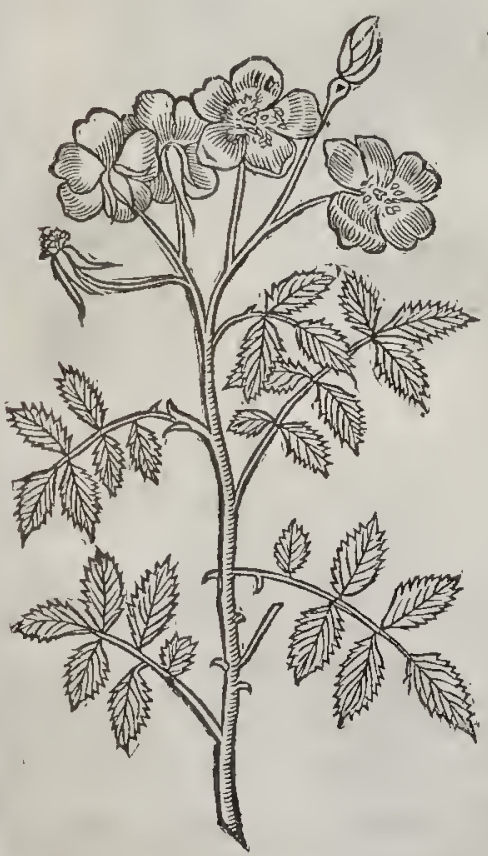

2 Rofa Mofchara multiplex.

The double Muskerofe.

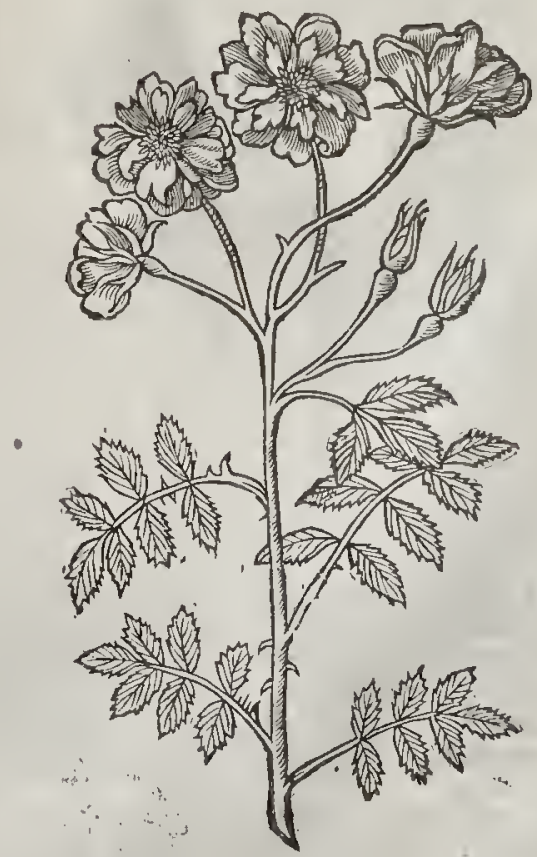

00000 
T The Defcription.

I THe fingle Muske Rofe hath diuers long thoots of a greenifh colour and wooddie fubfance,armed with very tharpe prickles, diuiding it felfe in to diuers branches : whereon do grow long leaues, fmooth $\&$ thining, made of diuers leates fet vpon a middle rib, like the orher rofes: the floures grow on the tops of the branches, of a white colour, and pleafant fircet fme!l, like that of Muske, whereof it tooke his name : hauing certain yellow feeds in the middle, as the reft of the rofes haue : the fruit is red when it is ripe, and filled with fuch chaffie flocks and feeds as thofe of the other rofes: the root is tough and wooddie.

2 The double Muske rofe differeth not from the precedent in leaues, italks, and roots, nor in the colour of the floures, or fweetnefle thereof, but onely in the doublenefie of the foures, wherein confifterh the differenee.

3 Of thefe rofes we haue another in our London gardens, which of moft is called the biuth rofe, it floureth when the Damaske rofe doth : the floures hereof are very fingle, greater than the orher Muske rofes, and of a white colour, datht ouer with a light wath of carnation, which maketh that colour which weecall ablurh colour : the proportion of the whole plant, as alfo the fmell of tha floures, are like the preecdent.

3 Rofecuofchatafpecicsmior. The great Muske rofe.

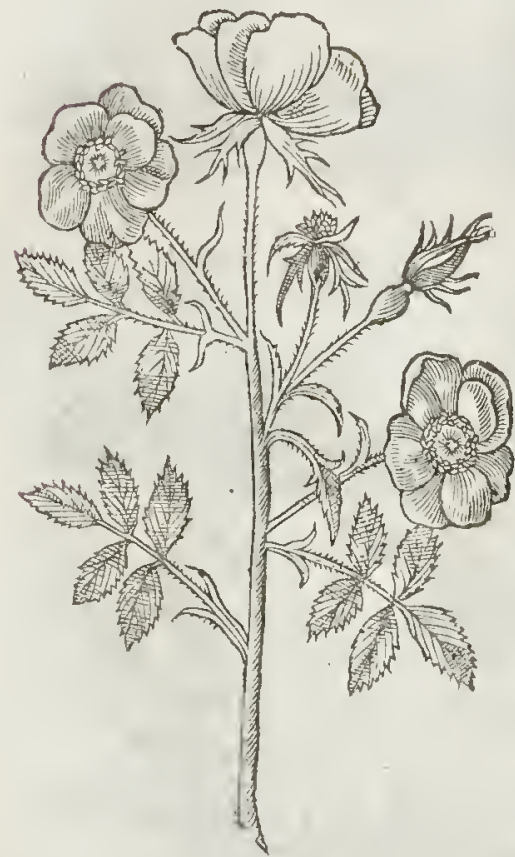

4 Roja Holofericea. The veluet rofe.

4 The Veluet fofe groweth alwaies very low, like vnto the red rofe, hauing his branchcs couered with a certaine hairie or prickley matter, as fine as baires, yet not fo harpe or ftiffe that it will harme the moft tender skin that is: the leaues are like the Ieaues of the white rofe:the floures grow at the top of the falks, doubled with fome yellow thrums in the midnt, of a deepe and blacke red floures be vaded the others.

5 The yellow rofe which (as diuers do report) was by Art fo coloured, and altered from his firft eftate, by graffing a wilde rofevpon a Broome ftalke; whereby (fay they) it dotly not onely change his colour, but his fmell and force. But for my part I hauing found the contrarie by mine owne cxperience, cannot be induced to belecue the ieport: for the roots ard off-fprirgs of this rofe haue 


\section{LIB. 3 \\ Of the Hittroy of Plants. \\ 1267}

brought forth yellow rofes, fuch as the maine ftocke or mother bringeth out, which cuent is not to be feen in all other plants that hauc been graffed. Moreouer, the feeds of yellow rofes hauc brought forth ycllow rofes, fiuch as the flourc was from whence they were taken; which they would not do by any conie eturall reafon, if that of themfelues they were not a naturall kind of rofe. Laftly, it were contrary to that true prineiple, Naturefequitur femina quodque fus: that is to fay;

Euery feed and plant bringeth forth fruit likevnto it felfe, both in fhape and naturc : but leauing that errour, I will proceed to the defcription : the yellowv rofe hath browne and prickly ftalks or fhoots, fiue or ix cubits high, garnifhed with many leaues, like vnto the Muske rofe, of an excellent fiveet fmell, and more plcalant than the leanes of the Eglantine : the floures come forthamong the leaues, and at the top of the branches of a faire gold yellow colour : the thrums in the middle,are alfo yellow:which being gone, there follow fuch knops or heads as the other rofes do beare.

5 Rofaluted.

The ycllow rolc.

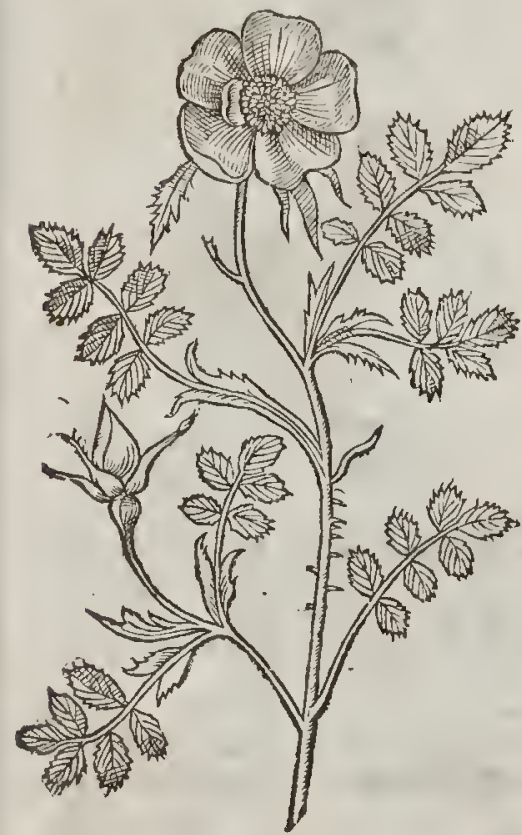

\#6 Rora Lutcamultiplex. The double yellow rofe.

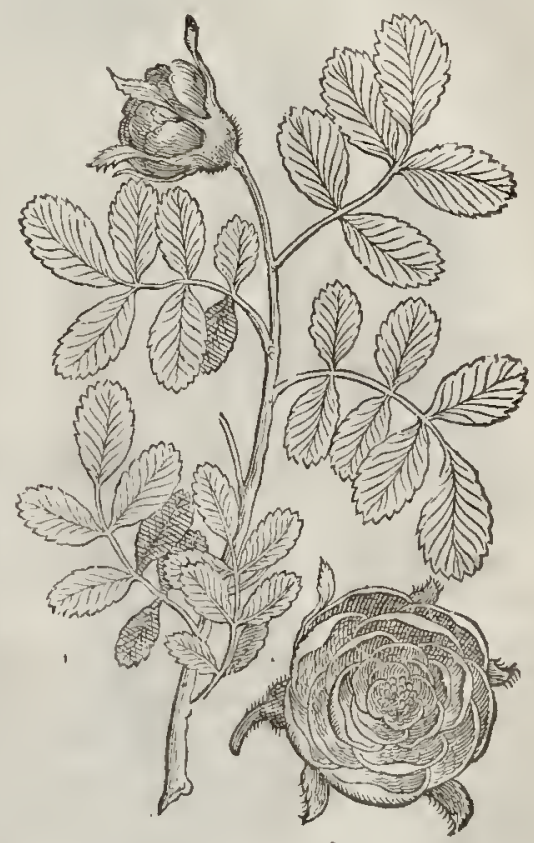

¥ 6 Of this kinde there is another more rare and fet by, which in Palks, leaues, and other parts is not much different from the laft deferibed,oncly the floure is very double, and it feldome fairl $y$ fhewes it felfe about London, where it is kept in our chiefe gardens as a prime raritie. $¥$

7 The Canell or Cinnamon rofe, or the rofe fmelling like Cinnamon, hath fhoots of a brown colour, foure cubits bigh, befer with thorny prickles, and leaules like vnto thofe of Eglantine, but fmaller and greener, of the fauour or fmell of Cinnamon, whereof it tooke his namc, and not of the fmell of his hourcs (as fome hate decmed) which haue little or no fauour at all : the floures.be exceeding double, and yellow in the middle, of a pale red colour, and fometimes of a carnation : the root is of a wooddic fubftance.

8 We hate in our London gardens another Cinnamon or Canell rofe, not differing from the laft deferibed in any refpect, but onely in the floures; for as the other hath very double floures, contrariwife thefe of this plant are verie fingle, wherein is the difference. 
7 Rofa Cinnamomea pleno flore. 'The double Cinnamon Role.

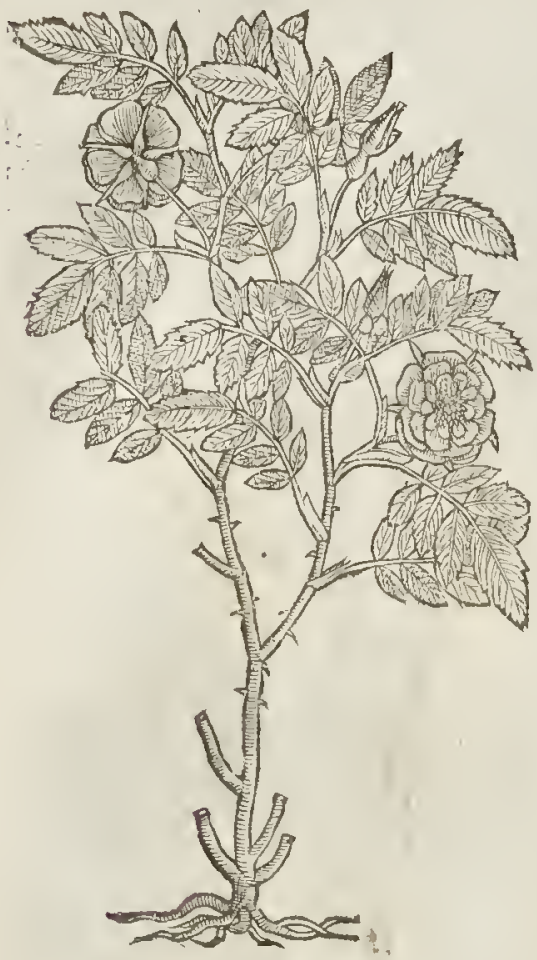

$\ddagger 8$ Rofa Cimsamomcafore fimplici. The fingle Cinnamon Rofe.

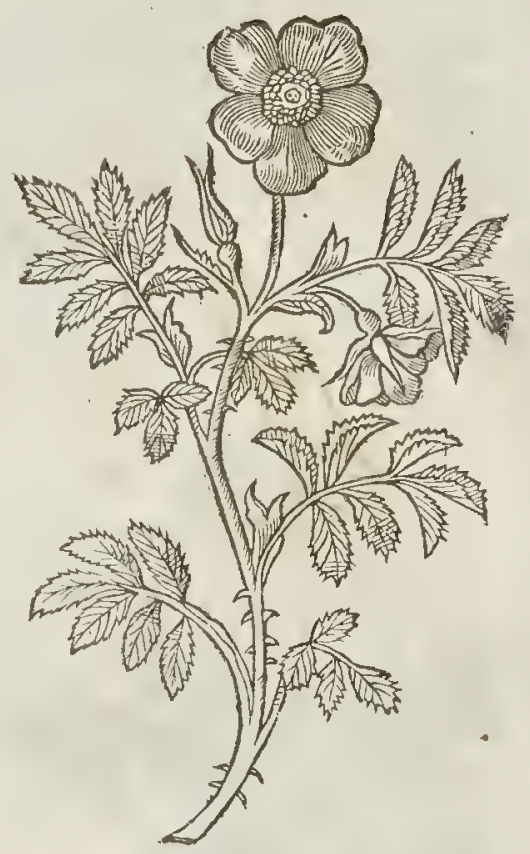

9 The Place: land.

Thefe Rofes are planted in our London gardens, and elfewhere, but not found wilde in Eng-

$$
\text { T The Time. }
$$

The Muske Rofe floureth in Autumne, or the fall of the leafe : the reft floure when the Damask and red Rofe do.

$$
\text { Ti The } \mathcal{2} \text { ames. }
$$

The firt is called Rofa Mofchat a, of the fmell of Muske, as we have faid : in Italian, Rofa Mofchetta:

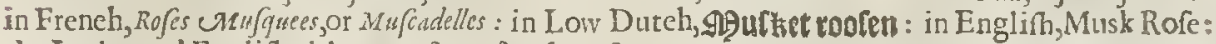
the Latine and Englifh citles may ferue for the reft.

$$
\text { बा The Temperature. }
$$

The Muske rofe is eold in the firft degree, wherein airie and fpiritual parts ate predominant:the reft are referred to the Brier rofe and Eglantine.

$$
\text { T The Vertics. }
$$

A Conferue or fyrmp nuade of the Muske rofe, in manner as befote told in the Damaske and red rofes, doth purge very nightrily waterifh humors, yet fafely, and without all danger, taken in the quantitic of an ounee in weight.

B The leates of the floures eaten in the morning, in manner of a fallad,with oile, vineger and pepper,or any other way aceording to the apperite and pleafure of them that hall eat it, purge very notably the belly of watcrith and eholericke humors, and that mightily, yet without all perill or paine at all,infomuch as the fimpleft nay vfe the quantitic, aceording to their owne faneie; for if they do defire many ftooles, or fieges, they are to eat the greater quantity of the leaues, iffewer, the leffe quantitic; as for example:the leaues of twelue or foureteene floures giue fix or eight ftooles, and fo inereafing or diminifhing the quantitie,more or fewer, as my felfe haue often proued.

C The white leates ftamped in a wnodden difh with apeece of Allum and the iniee ftrained forth into fome glafed veffell, tried in the thadow, and kept, is the moft fine and pleafant yellow colour that may be diuifed, notonly to limne or wafh pietures and Imagerie in books, but alfo to colour meates and fauces, which notwithfanding the Allum is very wholfome. 
L18. 3. Of the Hittory of Plants.

There is not any thing extant of the others, but are thought to be equall with the white Muske Rofe, whercof they are taken and holden to be kindes.

\section{Cha в. 3. Of the wilde Rofes:}

\section{T The Defcription:}

I The fweet Brier doth oftentimes grow higher than all the kindes of Rofes; the thoots of

it are hard, thicke, and wooddie; the leaues are glittering, and of a beautifull greene colour, of fmell molt pleafant : the Rofes are little, fiue leaued, moft commonly whitifh, feldom tending to purpie, of little or no fmell at all:the fruit is long, of colour fomewhat red, like a little oliue ftone, and like rhe little heads or berries of the others, but lefler than thole of the garden : in which is contained rough cotton, or liairie downe and feed, folded and wrapped vp in the fame, which is fmall and hard at there be likewife found about the flender thootshereof, round, foft, and hairie fpunges, which we call Brier Balls, tuch as grow about the prickles of the Dog-rofe.

I Rofafylueftris odora: The Eglantinc, or fwect Brier. Rosa uliginosa
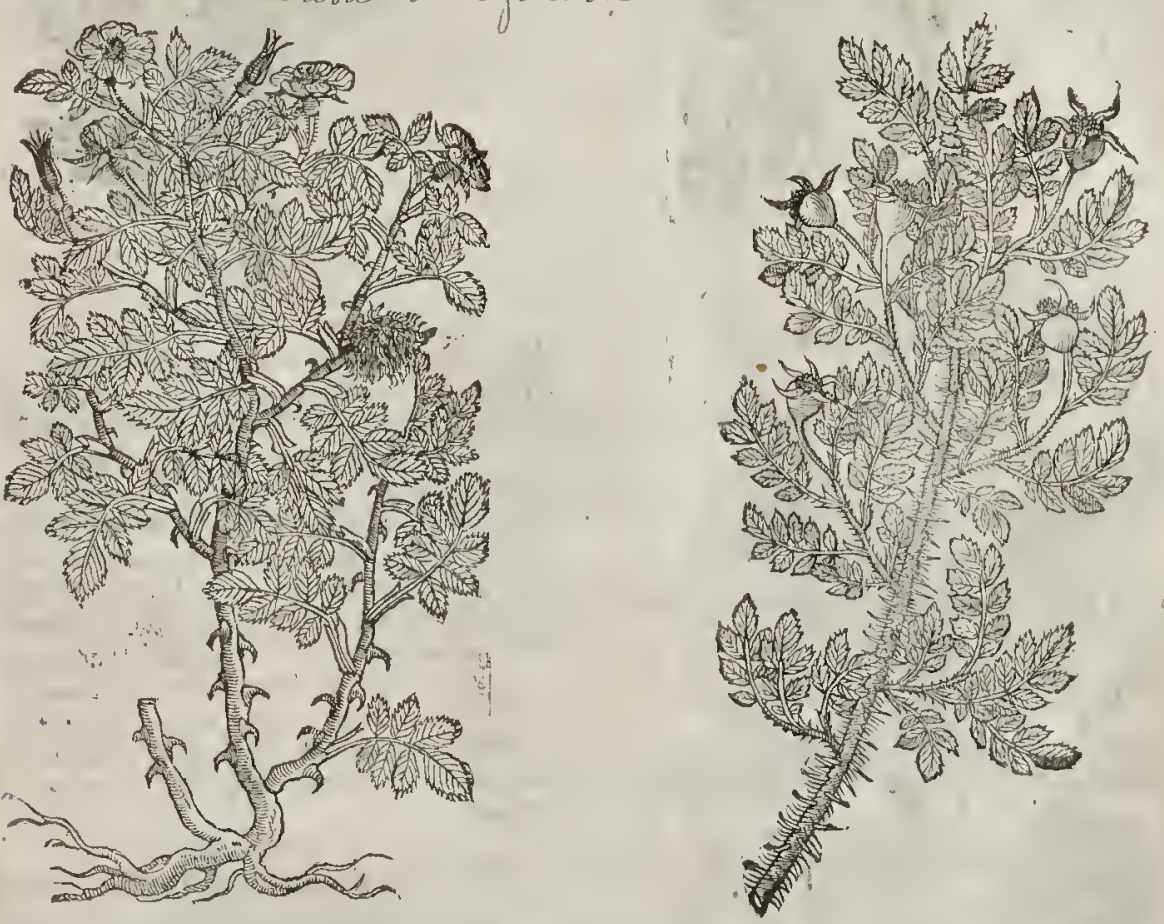

2 We hate in our London gardens another fweet Brier, hauing greater leaues, and much fwee: ter: the floures likewife are greater, and fomewhat doubled, exceeding fweet of fmell, wherein it differeth fro $n$ the former.

3 The Brier Burh or Hep tree, is alfo called Rofa canima, which is a plant fo commonand well knotvne, that it were to fmall purpofe to vfe many words in the defcription thereof:for eten children with great delight eat the berries thercof when they be ripe, make chaines and other prettie gewgawes of the fruit : cookes and gentlew omen make Tarts and fuclx like difhes for pleafure thereof, and therefore this thall fuffice for the defcription.

4 The Pimpinell rofe is likewife one of the wilde ones, whofe ftalks fhoot forth of the ground in many places, of the height of one or two cubits, of a browne colour, and armed with fharpe pric- 


\section{0 \\ Of the Hiftorie of Plants. \\ L 1 в. 3.}

+ 2 Rofa jylodora flore duplici. The double Eglantine.

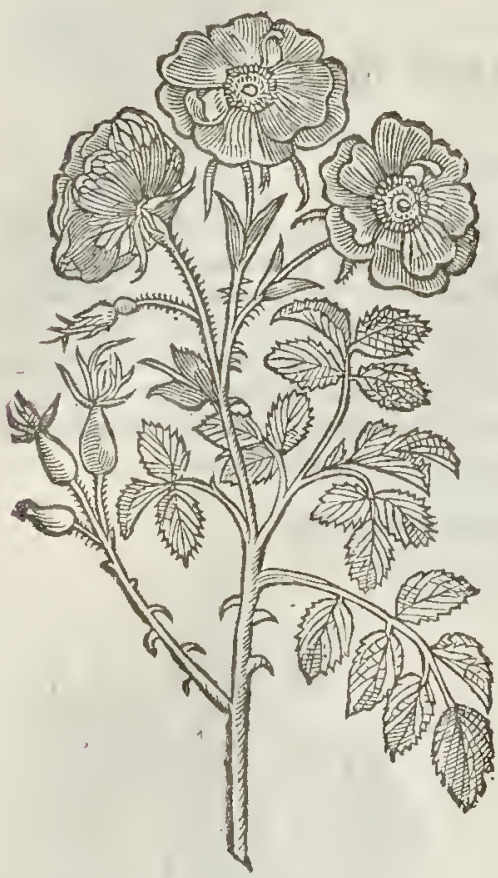

4 Rofisimpinells folio. The Pimpinell kofe.

Q opunozisima Pyoth

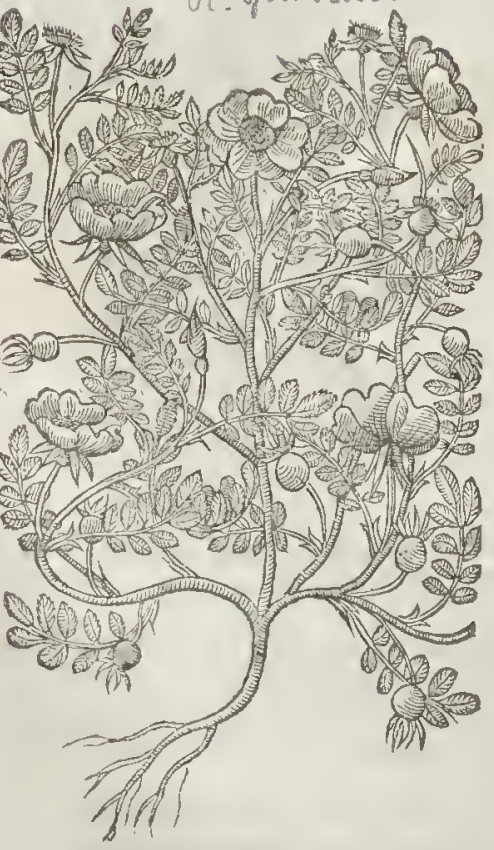

3 Rofa Caminainodora. The Brier Rofe, or Hep tree.

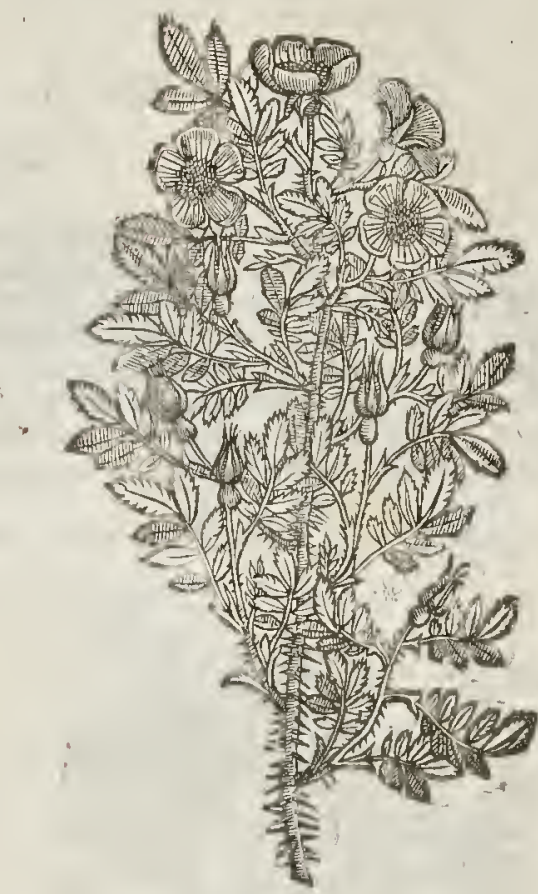

kles, which diuide themfelues torvard the tops into diuers branches, whereon doe grow leaues confifting of diuers fmall ones, fet vpon a mid. dle rib like thofe of Burnet, which is ealled in Latine Pimpinella, whereupon it was ealled Rofa Pimpinella, the Bumet Rofe. The floures grow at the tops of the branches, of a white colour, very fingle, and like vnto thofe of the Brier or Hep tree: after which cone the fruit, blacke,contra. rie to all the reft of the rofes, round as an apple; wherempon fome baue called it Rofa Pomifera, or the Rofe bearing apples : wherein is contained feed, wrapped in ehaffie or Hoekie matter like that of the Brier: the root is tough and wooddie:

$$
\text { T The Place. }
$$

Thele wilde Rofes dogrow in the borders of fields and woods, in mof parts of England. The laft $g$ oweth very plentifully in a field as you go from a village in Effex, eailed Graies (vpon the brinke nf the riuer Thames) vnto Horndon on the bill, infomuch that the field is full fraught therewith all oner.

It groweth likewife in a pafure as you goe from a village hard by London ealled Knights bridge,vnto Fulham, a village thereby, and in many other plaees.

Ve hatie them all except the Brier Bufh in our London gardens, which we thinke vuworthy the place. 
They flourc and flourith with the other Rofes.

$$
\text { The Time. }
$$

TI The Names.

The Englantine Rofe, which is Cynorrhodi, or Carine Rofa/pecies, a kinde of Dogs Rofe:and Rofa fylueftris, thewild Rofc: in low-Dutch, $\mathbb{E}$ glantiet: in French, Efglentine; and as Ruellius teftifies, Eglenterium : who alfo fufpects it to bc Cynosbaton, or Ganirubus: of which Dioforides hath written in thefe words; Cynosbatus, or Caxirubuss, which fomc call oxycart ba, is a thrub growing like a trce, full of prickles, with a white floure, long fruit like anoliue ftonc, red when it is ripe, and downie within : in Englifh wc call it Eglantine, or fwcet Brier.

The fpongicballs which arc found vpon the branches arc moft aprly and properly called "stongiole fylueftris $R \theta f e$, the littlc fponges of the wildc Rore. The fhops mittake it by the nane of Bede-

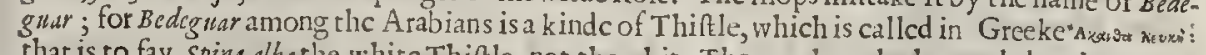
that is to fay, spine albat the whitc Thitte, not the white Thorne, though theword doe import fo
mucll.

The Bricr or Hep trec is called Sylucftris kofa, the wilde Rofe : in high-Dutch, moilden liolen: in French, Rofes faurages: Pliny, lib.8. cap.25. Farth that it is Rofa Canina, Dogs Rofe: ofditers, Canina fent is, or Dogs Thornc: in Englifh, Brier bufh, and Hep trec: the latt hath been touched in the
defcription.

The faculics of the Temperature and Vertues. The facultics of there wilde Rofcs arc reforred to the manured Rofe, but not vfed in phyficke A
where the ol her may bc had : notwithftanding Pliny affirmetl, that the.root of the Brierbuth is a fingular remedic found out by oraclc, againt the biting of a mad dog, which he fets downe in his
eighth booke,clap. $4 \mathrm{I}$.

The fame Author, li6.25.cap. 2. affirmeth, that the little fpongie Brier ball ftamped with honey B and a hes caureth haircs to grow which arc fallen through the difeafe called alopcria, or the Foxes etill, in plaine tcrncs the French pocks.

Fuchfius affirnics, that the fpongic excrefcence or ball growing wpon the Brier are good againft $\mathbf{C}$ the ftone and itrangurie, if they be beaten to pouder and inwardly taken.

They arc good not as they be diureticks or prouokers of wrine, or as they are wearcrs away of the $D$ ftone, but as ccrtaine other binding medicines that ftengthen the weake and feeble kidneycs; which do no morc good to thofe that be fubie ft to the ftone, than many of the diuretickes, efpecially of the ftronger fort; for by too much vfing of diurcticks or piffing medicines, it hapneth that the kidneyes arcoucr-wcakened, and often times too much heatcd, by which meancs not only the ftones are not diminifhed, worne aw ay, ordriten forth put oftentimes are alfo increafed and made morc liard: forthcy feparate and takc away that which in the bloud is thin, waterie, and as it wcre wheyifh; and the thicker part, the ftronger forts of diuretickes do draw together and make hard: and in likc maner alfo otliers that are not fo ftrong, by the oucrmucl v fing of them,as Galen.lib.5. of the facultics of fimple medicincs reportetls.

The fruit when it is ripc makcth moft plafant meats and banqueting difhes, as tarts and fuch $\mathbf{E}$ like; the making whercof I commit to the cunning cookc, and tceth to eat them in the rich mans
mouth.

\section{Cha.p. 4. Of the Bramble or black-Berry bulto}

IT The Defription.

He common Bramble bring cth forth flender branches, long, tough, eafily bowed, tan-
ping among hedges and what foeuer ftands ncere vnto it, armed with hard and fharpe ping among hedges and what focuer ftands ncere vnto it; armed with hard and tharpe
priekles, whereon doe grow leaues confinting of many fet voon a rough grcene on the vpper fidc, and vnderncath fomewhat whitc: on the tops of vpon a rough middle rib, flourcs, in thape likc thofe of the Brier Rofe, but leffer, of colour white, and fomctimes wafht onter with a little purplc : the fruit or berry is like that of the Mulberry, firtt red, blackewhen it is ripe, in tafte betweene fwect and foure, very foft, and full of grains : the root creepeth,and fendeth forth
here and there yong fprings.

$\ddagger 2$ This hath a round of $¥$ Rubus repens fruthu cafio. crecpeth on hedges and low buthes of a great length,on the and very tharpe pricking thornes, and crecpeth on hcdges and low buthcs of a great length,on the vpper fide of a light red colour,and vn-
derncath greene, and taketh root with thic tops of the trailing branches, whereby it doth mightily 
- encreafe : the leaucs grow without ordcr, compofed of thrce lcaues, and fometimes of fiue, or elfc the two lower leates are diuided into two parts, as Hop lcaues are now and then, of a light greene colour both aboue and vnderneath. The floures grow on the tops of the branches, racematim, many together, fomerimes white, fometimes of a very light purplc colour, enery flourc containing fiuc leaues, which arc crompled or wrinkled, and do not grow plaine : the fruit followes, firft green, and afterwards blew, euerie bérry compofed of one or two graines, feldome obouc foure or fiue growing together, about the bignefle of corans; wherein is contained a ftony liard kerncll or feed, and a iuycc of the colour of Claret wine, contraric to the common $R$ ubu or Bramble, whofe leaues are white vndernenth : the berries being ripe are of a hining blacke colour, and eucry berry containes vfually aboue forty graines clofely compacted and thruft together. The root is wooddy and laiting. This growes common enough in moft places, and too common in ploughed fields. Sept.6. 1619. Toln Goodyer. †

3 The Rafpis or Framboife buh hath leaucs and branches not much vnlike the common Bramble, but not fo rough nor prickly, and fometimes without any prickles at all, hauing onely a rough hairineffe about the ftalkes: the fruit in fhape and proportion is like thofe of the Bramble, red when thcy be ripe, and coucred oner with a lite downineffe; in tafte not very pleafant. The root creepeth far abroad, whereby it greatly encreafeth. ‡ This growcs cither with prickles vpon the ftalkes, or elfe without them: the fruit is vfually red, but fometimes white of colour. $\neq$

\section{Rubus.}

The Bramblebufh

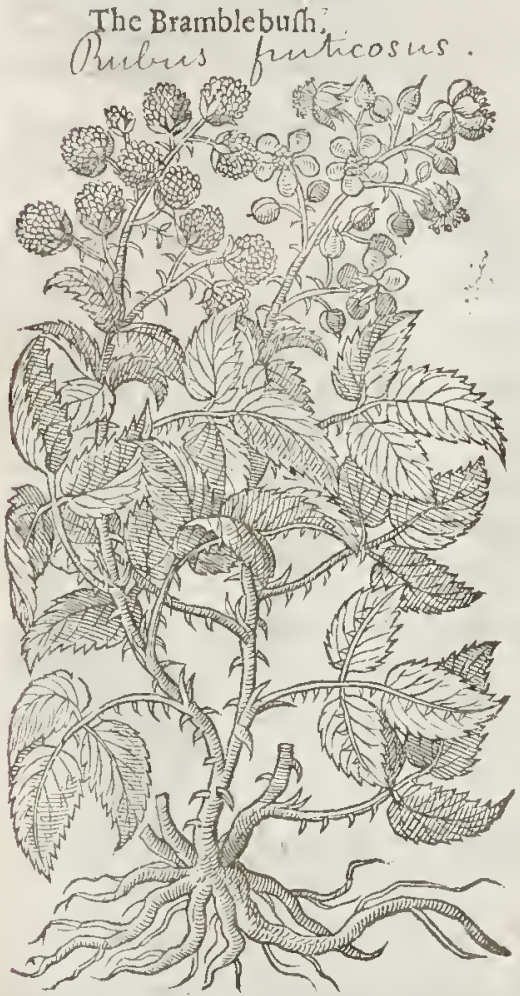

2 Rubus Idews.

The Rafpis buth or Hinde-berry. Quilus 3 doxa

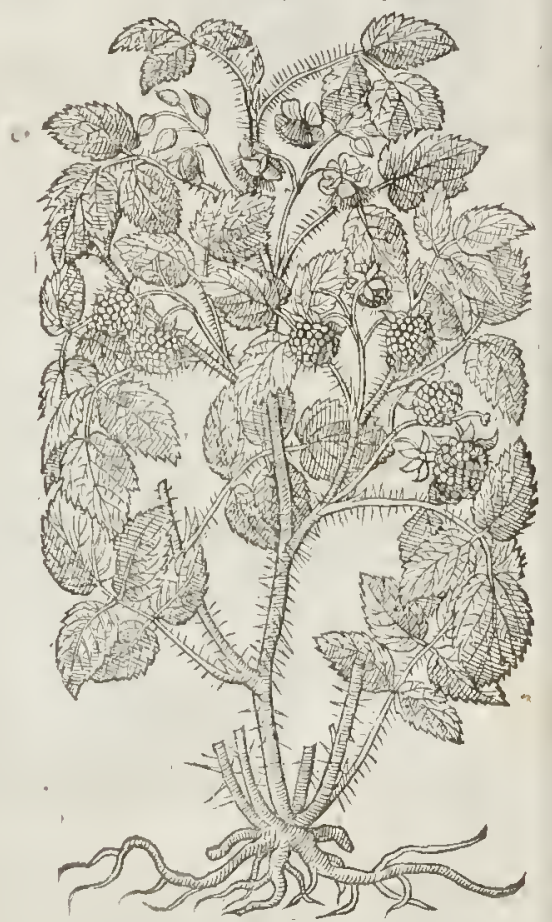

4 Stone Bramble feldome groweth aboue a foot high, hauing many fmall flexible branches without prickles, trailing wpon the ground, coucred wit' a seddifh barkc, and formwhat hairy: the leates grow three together, fet vpon tender nakea foot 1 alkes fomew hat fniptabout the edges: the floures grow at the end of the branches, confiting of foure fmall white leaues like thofe of the Cherry tree: after which come fmall Grape-like fruit, confifting of one, two, or three large tranfparent berries, fet together as thofe of the common Bramble, of a red eolour when they be ripc, and of a pleafant tafte, but fomewhat aftringent. The roots creepe along in the ground very farre abroad, whereby it greatly inereafeth.

4 Chumemores (ealled in the North part of England, where they efpecially doe grow, Knotberies, and Inought-berries) is likewife one of the Brambles, though without prickles:it brings

forth 
forth fmall weake branches or tender ftems of a foot high ; whereon do grow at certaine diftances rough leaues in thape like thofe of the Mallow, not vnlike to the leaues of the Goofeberrie burh : on the top of each branch ftandeth one flourc and no more, confifting of fiue fmall leatres of a dark purple colour : which being fallen, the fruit fucceedeth, like vnto that of the Mulberric, whereof it was called Chamamorus, dwarfe Mulberry; at the frrft white and bitter, after red and fomwhat pleafant : the root is long, fonething knotty; from which knots or ioynts thrutt forth a few threddie frings. $\neq$ I take that plant to which our Author hereafter hath allotted a whole chapter,and called Vaccinia nubis, or Cloud-berries, to be the fame with this, as I fhall fhew you more largely in that place. $\neq$

4. Rubus Saxatilis.

Stone blacke-Betry bunt.

Oubus saxatilis.

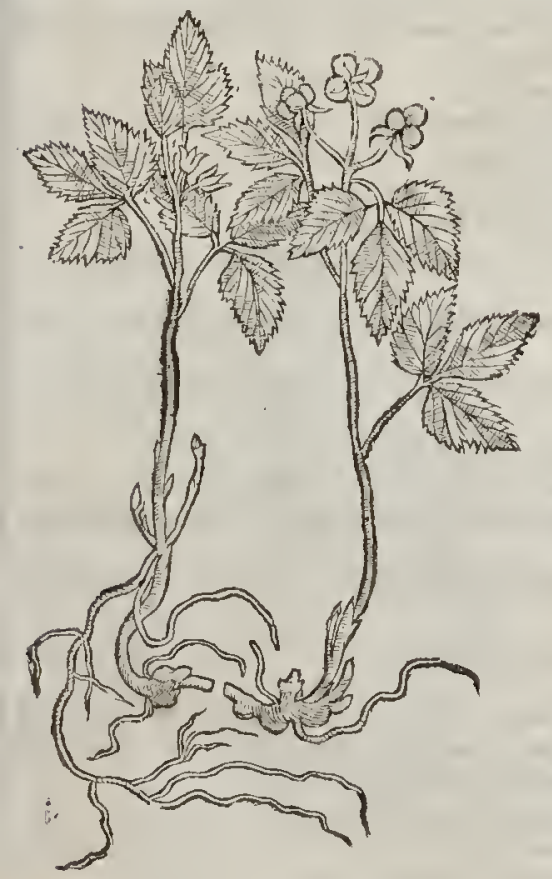

5 Chamimorus. Knot berry bunt.

Aulus Chamamous.

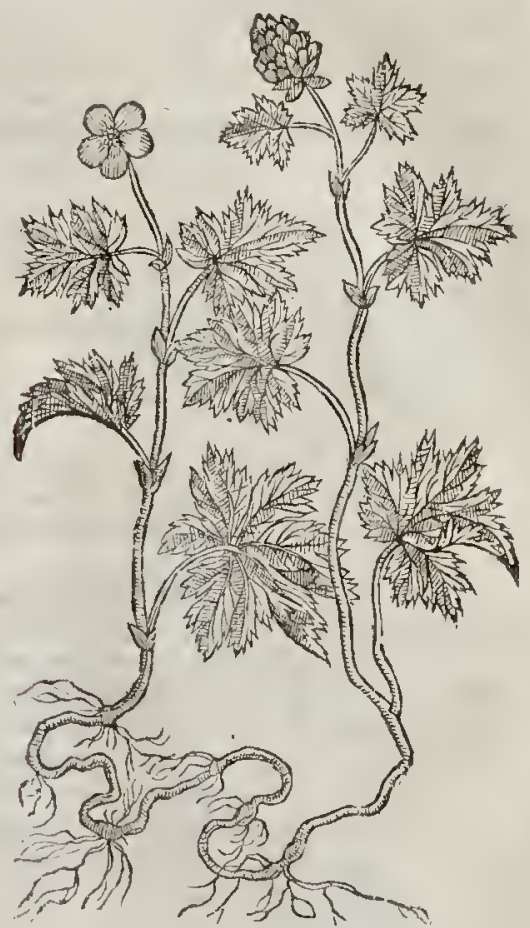

The Place.

The Bramble groweth for the moft part in euery hedge and bufh.

The Rafpis is planted in gardens : it groweth not wilde that $\mathrm{I}$ know of, except in the field by a village in Lancalhic called Harwood, not far from Blackburne.

I found it anong the buthes of a caufey, neere vnto a village called Wifterfon, where I went to Choole, two miles from the Nantwich in Chefhire.

The ftone Bramble I hate found in diuers fields in the Ifle of Thanet, hard by a village called Birchinton, neere Queakes houfe, fometimes Sir Henry Cripes dwelling place. $¥$ I feare our Author miftooke that which is here added in the fecond place, for that which he figured and deicribed in the third (now the fourth) which I know not yet to grow wilde with vs. $\neq$

Knot-berries do louc open fnowie hills and mountaines; they grow plentifully vpon Ingleborow hils among the heath and ling,twelue miles from Lancarhire, being thought to be the higheft hill in England.

They grow vpon Stane-more betweene Yorkfhirc and Weftmerland, and vpon other wet Fells and mountaines.

Thefe floure in May and Iune with the Roles : their fruit is ripe in the end of Augunt and Sep. tenber. 
I The Names.

The Bramble is ealled in Greeke raros: in French, Rorges, Loi Duyts Brelneers : in Latine, Rubus, and sentrs,and Vepres, as Ouid writeth in his firft booke of Metamorpho fis.

Aut Leporiqui vepre latens boftilia cernit
Ora canum.

Or to th' Hare, that vnder Bramble clofely lying, fpies

The hoftile mouthes of Dogs.

Of diuers it is ealled Cynosbatus, bur not properly; for Cynosbatus is the wild Rofe, as we haue written : in high-Duteh, 2Bzenren: in low-Duteh, 2Bzeemen: in French, Rouce : in Italian, Garza: in Englinh, Bramble buh, and Black-berry buth.

The fruit is named in Latine Morum rubi; and as $F$ uchfous thinketh, Vacinizm, but not properly: in fhops, Mora Bati : and in fueh Thops as are more barbarous, Gaora Baßi: in Englifh, Blackeberries.

The Rafpis is ealled in Grecke saxrsisaja : in Latine, Rubus Idreus, of the mountaine Ida on which it groweth : in Englith, Rafpis, Framboile, and Hinde-berry.

बा The Temperature and veriues.

A The yong buds or tender tops of the Bramble buth, the floures, the leaues, and the vnripe fruit, do very mueh dry and binde withall : being ehewed they take away the heare and inflammarion of the n:outl, and almonds of the throat: they ftay the bloudy flix, and other fluxes, and all maner of bleedings: of the fame foree is their deeoction, with a litrle honey added.

B They heale the eyes that hang out, hard knots in the fundament, and ftay the hemorrhoids, if the leaues be layd thereunto.

C The iuyec whieh is preffed out of the ftalks, leaues, and vnripe berrics, and made hard in the Sun, is more effectuall for all thofe things.

D The ripe fruit is fiveet, and containeth in it mueh iuyce of a temperatc heate, therefore it is not vnpleafant to be eaten.

E It hath alfo a certaine kinde of aftriction or binding qualitic.

F It is likewife for that caufe wholfome for the ftomaek, and if a man eat too largely therof, faith Galen, he thall hate the head-ache : but being dried whileft it is yet vnripe it bindeth and drieth more that thẹ ripe fruit.

G The root befides that it is binding containeth in it much thin fubftance, by reafon whereof it wafteth away the ftone in the kidnies, fairh Galen.

H Pliny writeth, that the berries and flouresdo proucke vrine, and that the decoetion of them in wine is a prefent renedie againft the ftone.

I The leates of the Bramble boiled in water, with honey, allum, and a littlewhite wine added thereto, make a moft exeellent lotion or wafhing water to heale the fores in the mouth, the prinie parts of man nit woman, and the fame decection faftnetlu the teeth.

$\mathrm{K}$ The Rafpis is thought to be like the Bramble in temperature and vertues, but not fo much binding or drying. The Rafpis, faitl $D$ iofcorides, performeth thofe things whieh the Brambledoth. The fruit is good to be giuen to thofe that have weake and queafie ftomacks.

\section{Cir a P.5. Of Holly Rofes, or Ciftus.}

\section{T) The Kindes.}

Ciftus liati becn taken of diuers to be a kinde of Rofe: the old Writers haue made two forts 1 thereof, male and female; and likewife a third fort, which is called Ledum : the later Herbas rifts batue difcouered diuers more, as thall be declared.

\section{If A gencrall Defcription, whercin all the forts of Ciftus are corsprifed.}

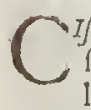

Iftus and his kindes are wooddy thrubs full of branehes, of the height of two or three cubits:

fome hiaue broad leates, others rough, voeuen, wrinkled, fomewhat downy, and moft like the

leatres of Sage; although fone haue the leaues of Rofenary, others the forme of thofe of the Poplar tree : the floures grow on the tops of the branches, like vnto the wild Rofe, yet fuch as very quiekly fade, perin, and fall away : thofe of the male are moft of a reddith blew or purple colour; and of the female white: in their plaees come vp little heads or knops fomwhat round, in which is contained fmall feed : the roots of then all are wooddy. 
3 Ciftus mas dentatus.

Toothed or fnipt male Cifus.

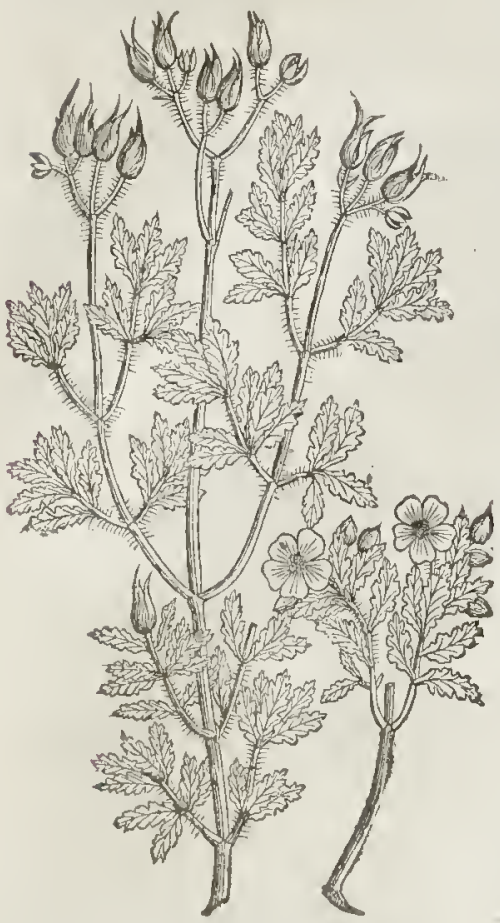

5 Ciftus famina.

The female Cirtus.

Cistus salrvolus.

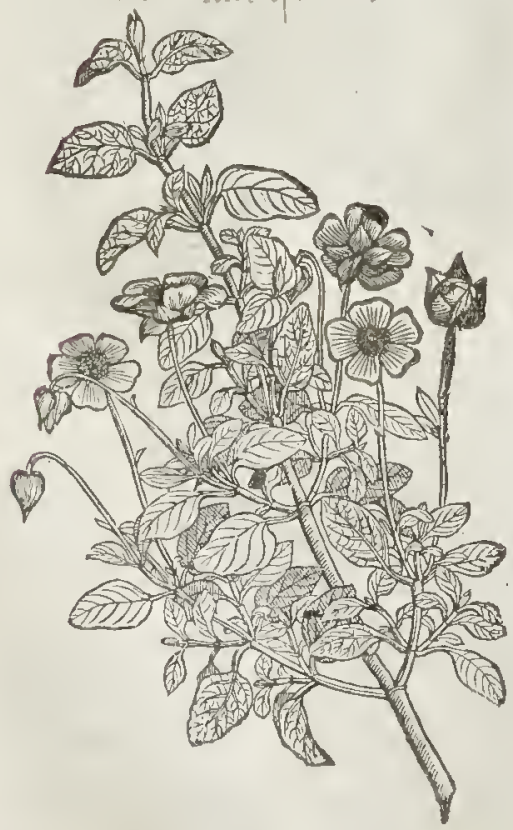

4 Ciflus mas tenuifolius.
Thin leafed Ciftus.

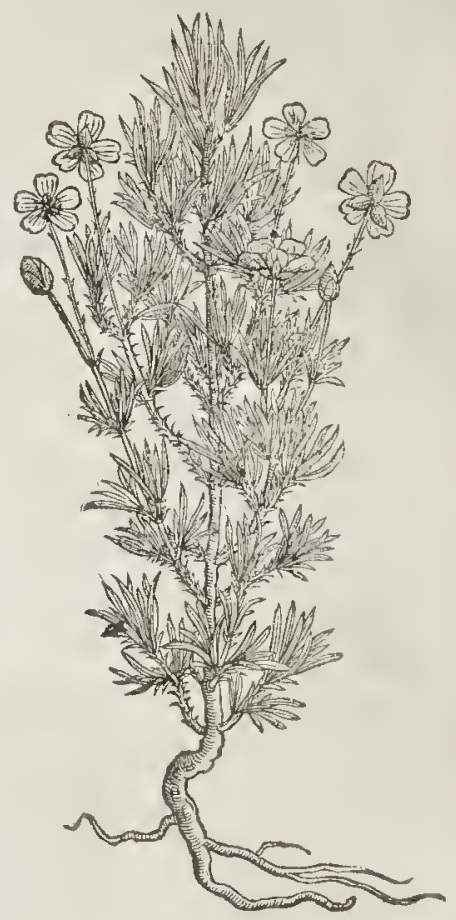

7 Ciftus folio Halimi.

Cifus with leaues like Sea Putlane.

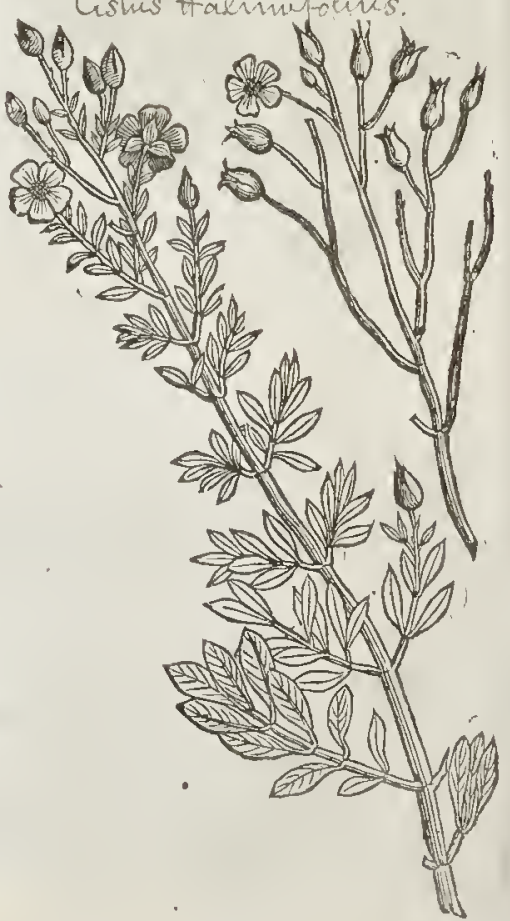


5 The firft of the females is like vnto the male Cintus in each refpert, faung that the floures hereof are of a white colour, with diuers yellow thrtmmes in the middle, and the orhers purple,
wherein confifteth tho difference.

6 The fecond female of Matthiolus defcription luth many hard and wooddie ftalks, branched with diucrs armes or wings : whereon are fet by couples rough hoary and hairy leates, of a darke ruffet colour : among which come forth fmall white floures like vntó rhofe of the Iafrnin:the root is rough and wooddy. F This I itdge all one with the former, and therefore hatie omitted rhe figure as impertinent, although our A uthour followed it, making the floure fo litcle in his defeription. $\ddagger$

+7 The feuenth fort of Ciftus growerh vp to the height of a fmall hedge bufh, hauing diucrs brittle branches fill of pith : whereon are fer leaues by couples, like thofe of fea Purlane, that is to fay, foft, hoary, and as itwere conered oner with a kinde of mealineffe : the floures are yellow, and leffe than thofe of the former.

8 cifus folio Lausadu's.

Latuindor leaned Ciftus.

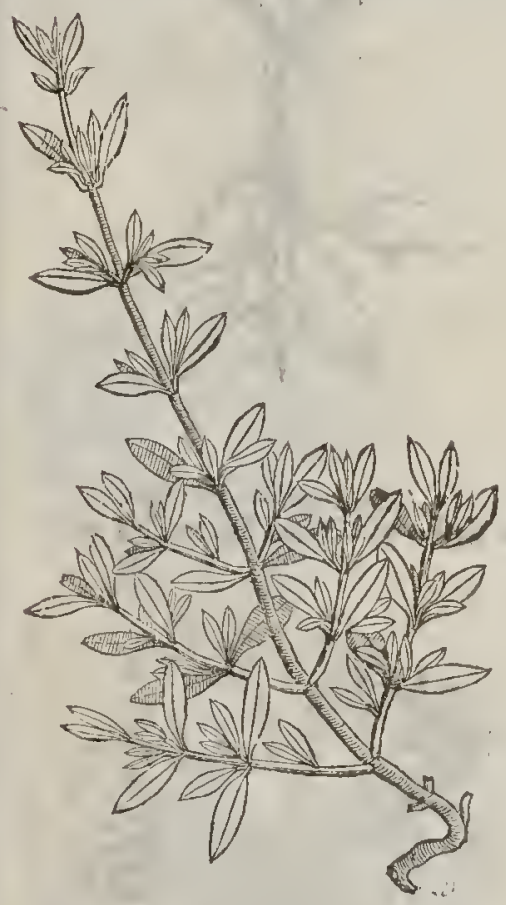

5. Ciflus folio Tiymi.

Ciftus wirh the leaues of Tyme.

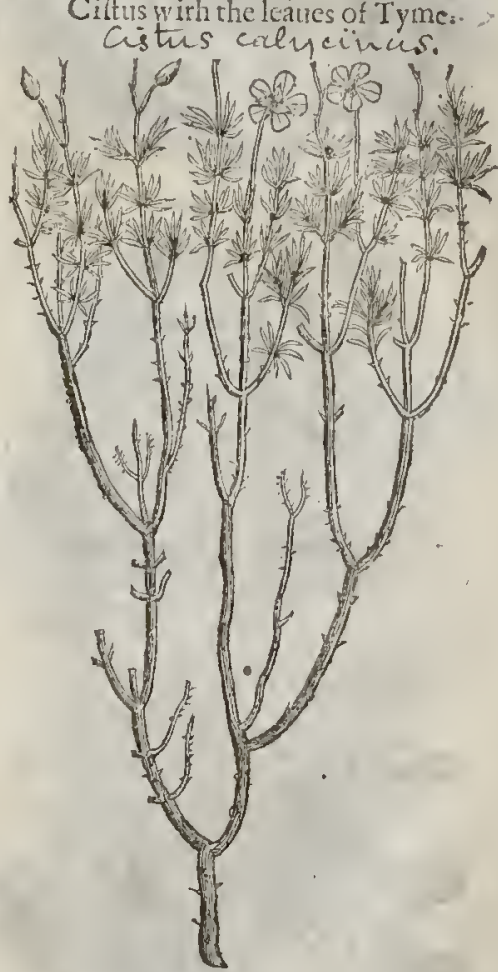

3 The eighth Cittus liath likew ife thrubbie ftalks in maner of a hedge tree, whereon do grow at ccrtaine diftances diuers leaues clofe ioyned together at the ftalke, like thofe of the former, but fomewliat lower and narrower: the floures we haue nomexpreffed in the figure, by reafon we haue no certaine knowledge of them.

9 This ninth Ciftus is likewife a wooddy fhrub fome foot high : the ftalks are very britrle, as are all the reft of his kinde, wherenn do grow very fmall leaties like thofe of Tyme: the floures are white, which makerh it one of the females.

10 The low orbafe Ciftus with broad leaues, growerh like a finall fhrub, of a wooddy fubftance: the leaules are many, of a darke greene colour : the floures are in forme like the orher, but of a yellow colour : the roots are likewife wooddy.

I This narrow leafed low Ciftus hath diuers tough branches leaning to the ground, whereon do grow without order many fmall narrow leaues fomewhar long, of a gummy tafte at the firf, af terwards bitter : the floures grow on the tops of the branches, of a yellow colour, confifting of fite leates, wirh certaine chiues in the middle; after which follow three fquate cods or feed-veffels:the root is tough and wooddy.

$$
\text { PPPPF Tล ThE }
$$


io Cifus bumilis latifolines.

L. ow Giftus with broad leaucs.

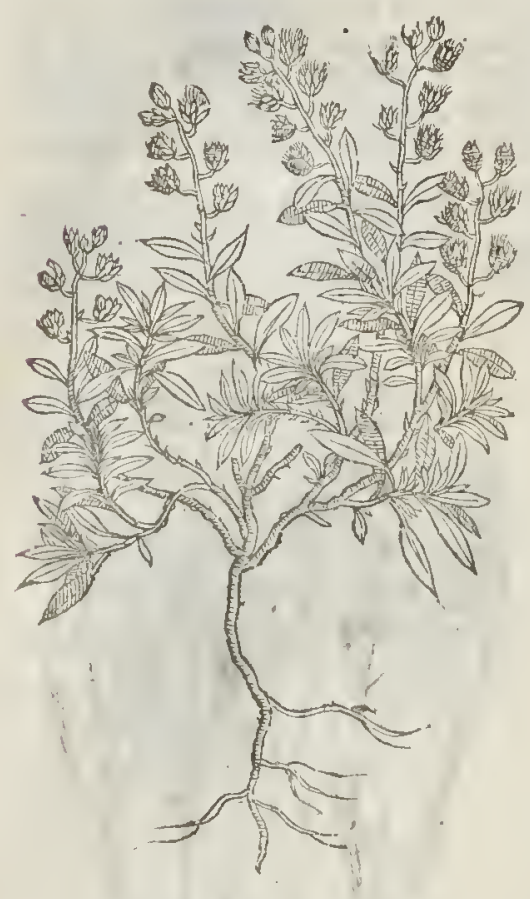

12 Ciftus bumilis Auftrinca Clufi]. Low Ciftus of Auftria.

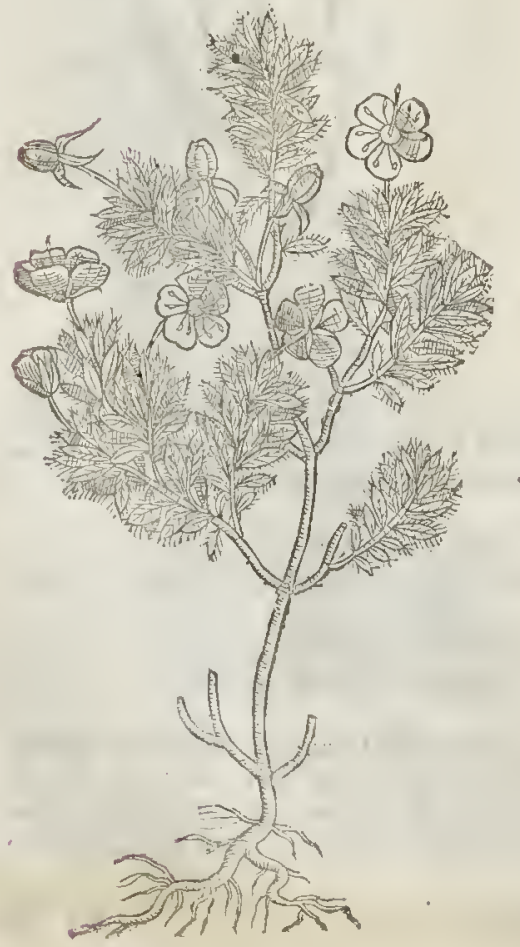

II Ciffus humsilis anguftifolius. Low Ciftus with narrow leanes.

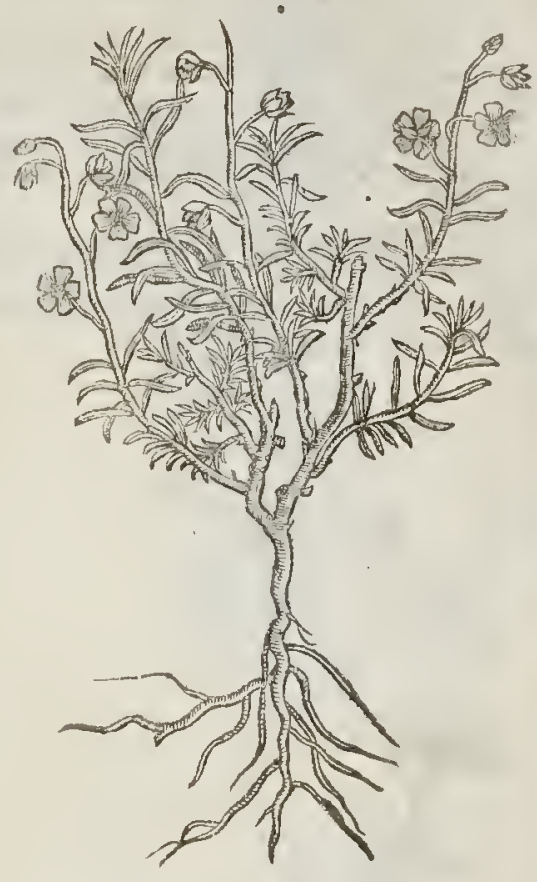

11 Ciffus buwilis ferpilli folio.

Low Ciftus with leaues likewilde Tyme.

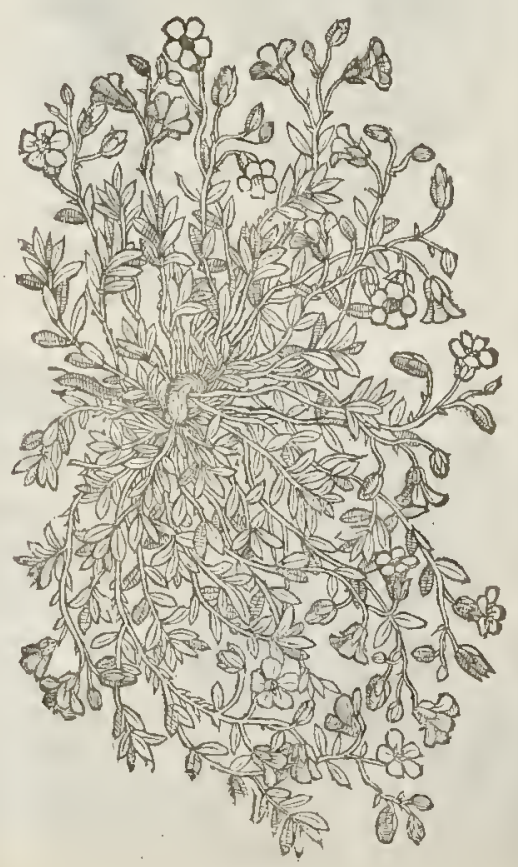


I B. 3 .

Of the Hiltory of Plants.

12 The low or bafe Ciftus of Aufria groweth likewife leaning to the ground, hauing nany wonddy branches very firme and tough, coitered with a blackith barke; whereon do grow very many rough and hairy leaues in thape like thofe of the fmall myrtle, of a thining greene on the vpperfide, and of an aftringent tafte : on euery branch ftandeth one floure, feldome trvo, in forme like the other, but confifting of one leafe deeply diuided into fiue parts, and of a white colour tending to a flerh colour.

I 3 This low fort of Ciftus hath many long tough branches trailing vpon the ground, of a reddith colour, whereon do grow fmall leaues like thofe of wilde Tyme, of a darke green colour, very thicke and fat, and fomewhat hairy : the floures grow at the top of the branclies, of a yellow gold colour, confifting of fiue fmall leailes of a very fweet fmell. The root is thicke, hard, and vooddie.

14 This ftrange and rare plant of Lobels obferuation I hate thought meet to be inferted amongft the kindes of Ciftus, as a friend of theirs, if not one of the kinde : it hath leaues like vnto the male Ciftus (the firft in this chapter defcribed) but more hairy, bearing at the top of his branches a fmall knop in thape like a rotten Strawberry, but not of the. fame fubftance; for it is compact of a fcaly or chaffie matter fuch as is in the middeft of the Camomill Houres, and of a ruffet colour.

14 Ciftus exolicus Lobelij.

Lobcls ftrange Ciftus.

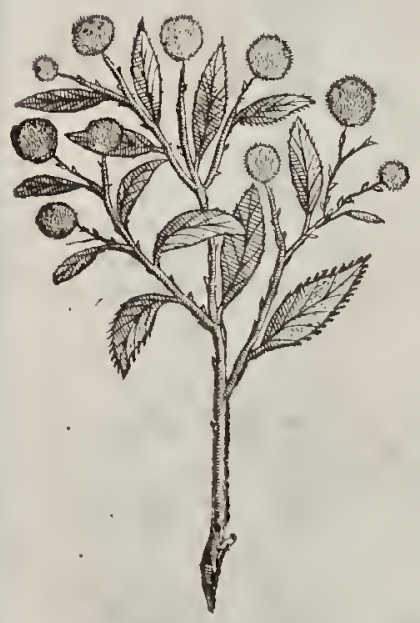

I6 Myrtociftus Tho.Pennei Angli. D. Pemn his Ciftus.

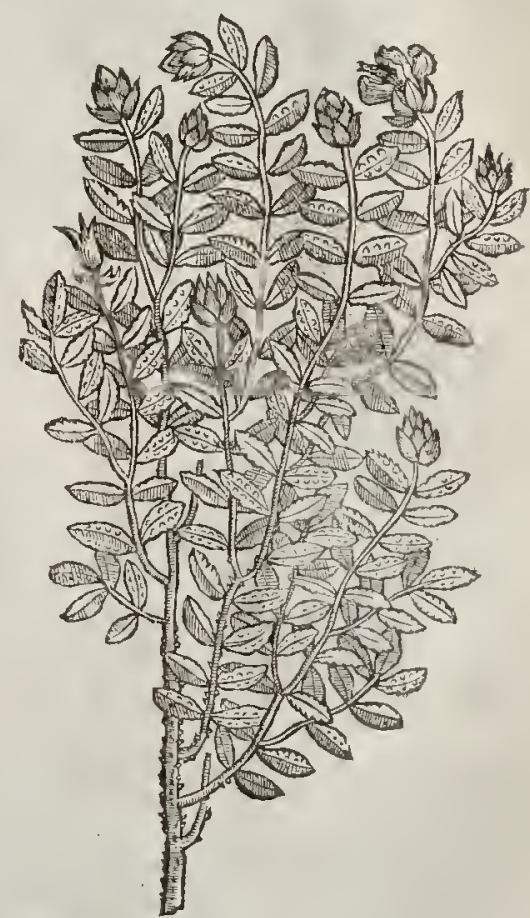

15 This adultetine or counterfeit ot forged Cifus growes to the height of a hedge buth : thic branches arc long or brittle, whereon do grow long leaues like thofe of the Willow, of an ouerworne suffet colour : the foures are fmall, confifting of fiue little yellow leaues : the whole plant being well viewed feemeth to be a Willow, but at the firft fight one of the Ciftus : fo that it is a plant participating of both: the root is wooddy. $¥$ Baubine indges this (which our Author out of Tabern. figured and named ciflus adulterinus) to be the Ciftus fer forth in the eighth place of the next chapter faue one : but I rather iudge it to be of the Ledsm Silefacum fet forth in the eleuenth place of that chapter, and againe in the twelf th, where you may finde more thereor. $¥$

I 6 This kinde of Ciftus, which $\mathrm{D}^{\mathrm{r}}$. Pemay (a famous Phyfitian of London deceafed) did gdther vpon the Iflands of Majorica or Majorca, and called it by the name suprosiso, in Latine, cMyrtociftus Balearica, is a fhrub growing to the heightofthree cubits, hauing a very rough barke, befet round abour with rough and fcabbed warts; which bark wil of it felfe eafily fall aw ay from the 


\section{0}

old branches or boughes $\theta$ f the tree. The leaues of this tree are almoft like them of Myrtus, very roug hinderneath like the branches aforefaid; but the leaues that grow higher, and tew ard the top of the branches, are fmooth, growing about the branches very thicke together, as in the other kindes of Citus. The floures are yellow, growing on the top of the twigs, confifting of fiue long leaues full of many very long chiues within. When the floures be vaded, there followeth a verie long and fiue fcuare head or huske full of feed. The whole tree is very fweer, out of which iffucth a gum or rofine, or rather a thicke clantmy and fat iuyce, fuch as commeth forth of the kindes of - Lctury.

17 'This arnual Ciftus groweth vp from feed with one vpright ftalke to the height of a cubit,' of times uimiued into or ier fnall branches; whereon grow rough leaues fomwhat long, of a dark

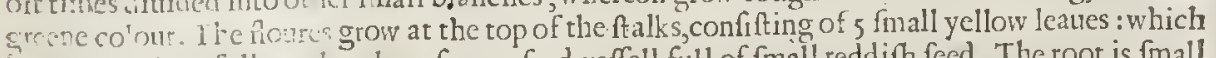
i in wait l.u. Followeth a three fquare feed veffell full of fmall reddifh feed. The root is fmall - orthr, and perificth when the feed is perfeited.

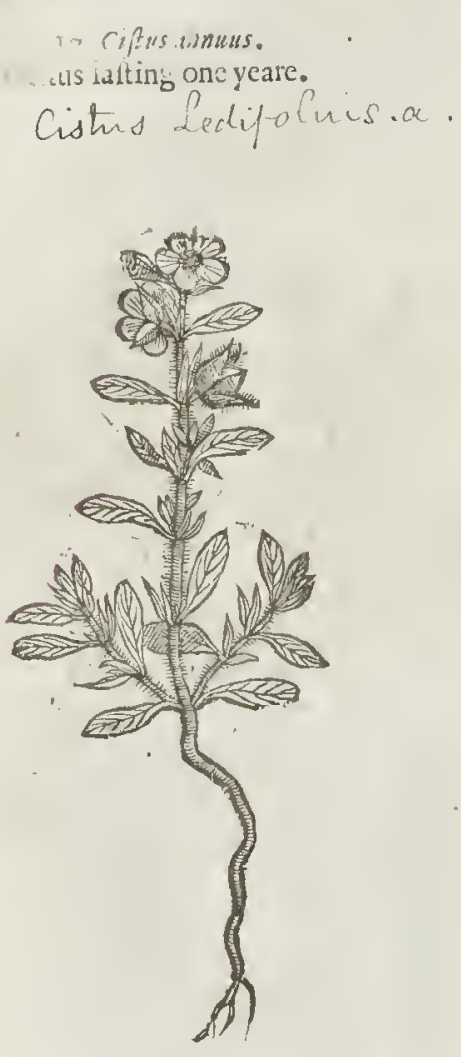

I8 Cistus anmus longifoliss Lobelï.

Long leafed yearely Ciftus.
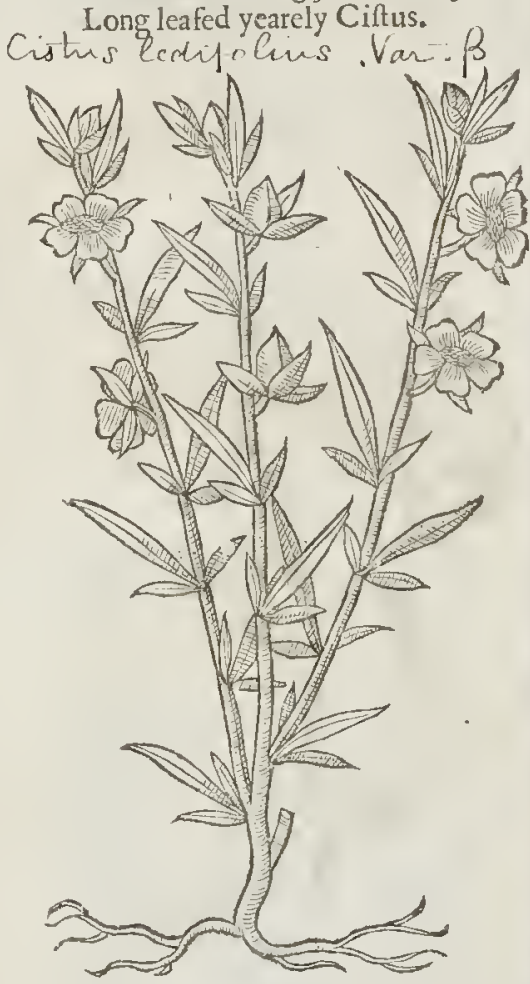

IS This other Ciftus that lafteth but one yeare hath long ftalks diuided into other branches of the height of two cubits; whereon do grow long rough leaues, fet three together at certain diftances, the middlemoft whcreof is longer than the other two : the floures grow on the frdes of the b: nnches, like the female Ciffus, of a white colour : the root is of a wooddy fubftance, as arc all the reft of his kin?

f Is This growes fome foor high, with a fquare rough greenith ftalke, whereon by couples at certaine fpaces ftand little longifh rough leaues, yet toward the top of the ftalk they ftand fomrimes three together: vpon the top of the little branches grow floures like thofe of the other $\mathrm{Ci}$ ftus, of colour yellow, with a fine fanguine fpor vpon each leafc of the floure. It groweth in fome parts of France, as alfo on the Alps in Iraly. Clnfius defcribes it by the name of Ciftus annums 2. Pona in his Mons Baldus calls it Cifus apruus fore guttato.

20 This hath many flender branches whereon grow fmall roundifh leaues, hoarie, and fomewhat like thofe of Marjerome, fomwhat lefe, with the middle rib ftanding out. The floures grov vpon the tops of the branches, and confift of fiue white lcaues, with a darke purple fpor in the mid dile of each leafe ; the threds in the middle of the Houre are of a yellow colour $:$ their feed-veffels 
L1 B. 3 .

Of the Hiftory of Plants.

I28 I

are of the bigneffe of thofe of flax, but three fquare, containing a feed of the bigreffe of that of Henbane. Chafrus found this in diuers parts of Spaine, and fets it fortiby the name of ciftus folio Sampfuchi. $\neq$

\# Ig Ciffus annuses flor e maculato. Spotted annuall Ciftus.
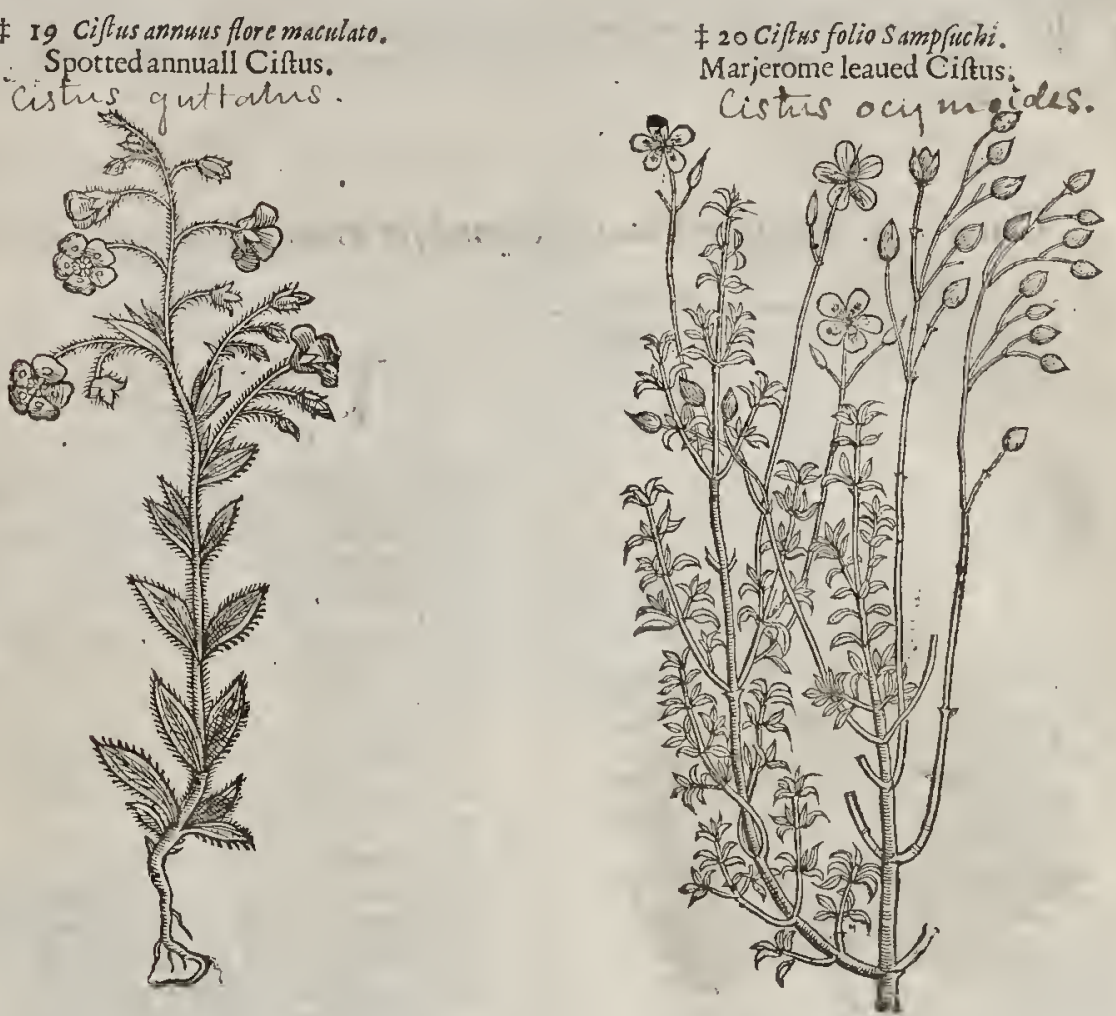

91 The Place.

Holly Rofes grow in Italy, Spaine, and Languedoc, and in the countries botdering vpon the riuer Padus, in all Hetruria and Maffiles, and in many other of the hotter proninces of Europe, in dry and ftony places, varying infinitely according to the diuerfitie of the regions where they doe grow; of which I haue two forts in my garden, the firft, and the Ciffss armuss.

They floure from May to September.

The Time.

\section{T The Names.}

The Holly Rofe is called in Greeke *isor, or xiars: in Latine alfo Ciffus, and Rofa fyluatica : of diuers, Rofa Canina, as Scriboxius Largas writeth, but not properly: in Spanifh, Eftepa: of the Portugals, Rofella $\cdot$ in Englih, Holly Rofe, and Ciftus, after the Greeke name. The fungous excrefcence growing at the root of Ciftus, is called in Greeke ismists, becaufe it groweth vnder the fhrub Ciftus : it is alfo called Limodoron: fome call it wimos: among whom is Paulus e Egineta, who allo dorh not call that Hypocift is which groweth vnder the fhrub Ciftus, but the iuyce hereof; whereupon might grow the word Hypociftis, by which name the Apothecaries call this ityce when it is hardned : of fome it is called Erithanon, Citinus, and Hypoquiftidos.

If The Temperiature.

Ciftus, as Galen faith, doth greatly dry, neere hand in the fecond degree, and it is of that cold. neffe, that it hath withall a temperate heate : the leaues and the firft buds being beaten do only dry and binde, in fuch fort as they may clofe vp vicers, and ioyne together greene wounds:

$$
\text { Th The vertues. }
$$

The floures are of moft force, which being drunke with wine are good againft the bloudy flix, $A$ wreakeneffe of the ftomacke, fluxes, and onerflowings of moift humors.

They cure putrified vlcers being applied in manner of a pultis : Diofcorides teacheth that they $B$. are a remedie for eating vlcers, called in Greek simg, being anointed therewith; and that they cure burnings, fcaldings, and old vilcers.

$$
\text { PрPिё } 3 \text { Hypocifis }
$$


C. Hypocift is is much more binding $:$ it is a fure remedic for all infirmities thar conte of fluxes, as voiding of bloud, the whites, the laske, and the bloudy flix : but if it be requifit to ftrengrhen that part which is ouerweakned with a fuperfuous moifture, it doth notably comfort and fit rengthen the fame.

D

D It is excellent to be mixed with fomentations that ferue for the ftomacke and liver.

It is put into the Treacle of Vipers, to the end it thould comfort and ftrengthen weake bodies, as:Galen writeth. in :...

\section{$\mathrm{C}_{\text {H }}$ А . 6. Of other Plants reckoned for dnarfe kindes of Ciftus.}

1. 2. Heliantbenum Anglicum luteum vel album. Englin yellow or white dwarfe Ciftus.

Listus, ttelionthemum

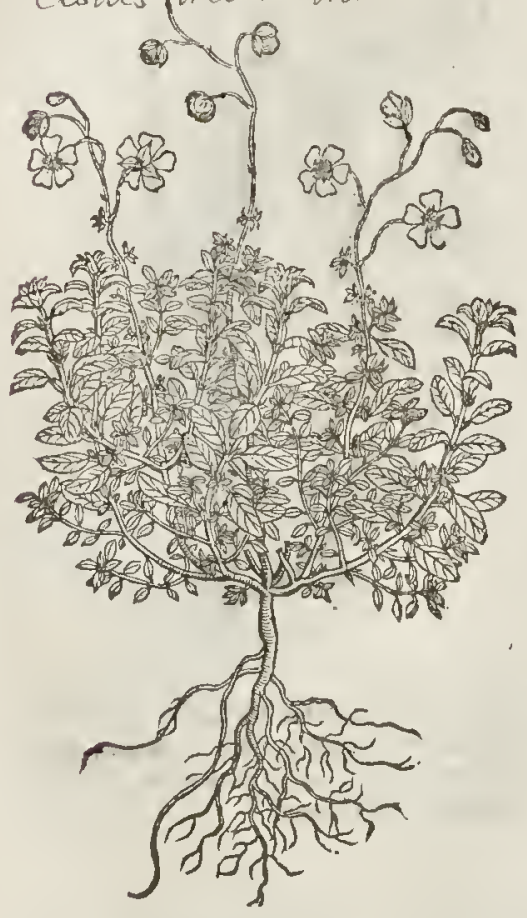

T The Defcription.

1 THe Englifhdwatfe Ciftus, called of Lobel, Pumax Chironiums (but rhere is another $P$ anute of Clisroms defcription, which I hold to be the true and right $P$ anax, notwithftanding he lath inferted it amongft the kindes of Ciftus, as being indifferent to ioyne witle vs and others for the infertion) is a low and bafe plant crecping vp. on the ground, lauing many funal tough branches, of a browne colour; whercupon do grow little leaues fet rogether by couples, thicke, fat, and ful of fubstance, and coucred oner with a fort downe : from the bofome whereof come forth other leffer leaues: the floures before they be open are mall knops or buttons, of a browne colour mixed with yellow ; and being open and fpred abroad are like thofe of the wild Tanfie, and of a yellow colour,withfome yellower chiues in the middle: the root is thicke, and of a wooddy fubftance.

2 The fecond is very like vnto the precedent, fauing that the leaues are long, and doe not grow fo thicke thruft togecher, and are more woolly: the floures are greater, and of a white colour, wherein the efpeciall difference confifteth. The root is like the former.

3 Hcliwthemum luteum Germanicum. The yellow dwarfe Ciftus of Germanie.

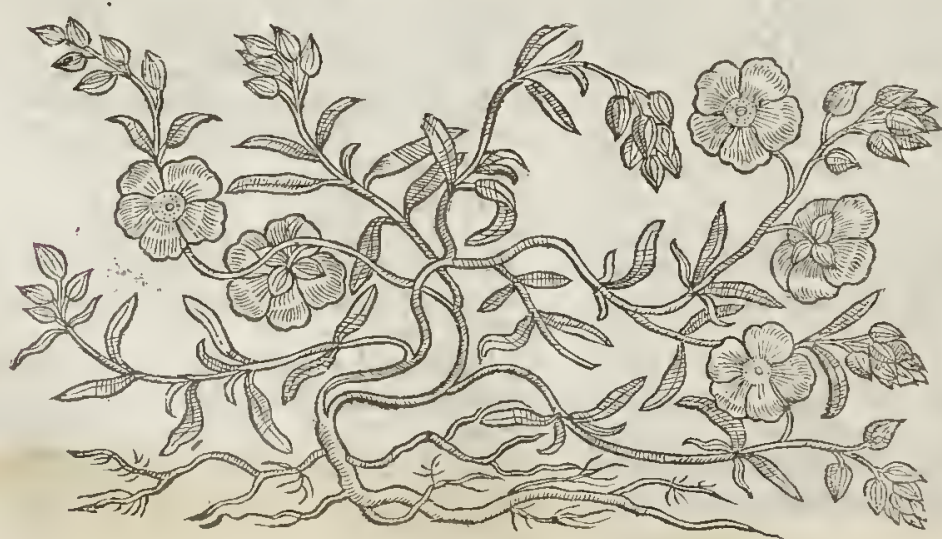




\section{1 B. 3 .}

\section{Of the Hiftory of Plants.}

$12 S^{3}$

3 There is found in Germanie, a certaine plant like to Ciftus, and Ledon, but much leffer, creeping vpon the ground, vnleffe it be propped vp, hauing a multitude of twiggie branches, flender, and fine : whereupon do grow leaues leffer than thofe of Ledon or Ciftus,very like to thas of our Englifh white dwarfe Ciftus, of a full fubtance,fleightly haired, wherein is contained a tough iuice: the floures are finall like little Rofes, or the wilde Tanfie, of a yellow colour : the roots be flender? wooddic, and fonething red.

4 Helianthemuns album Germanicuan: The white dwarfe Ciftus of Germanie.

$$
\text { Cistus apencourimes:" }
$$

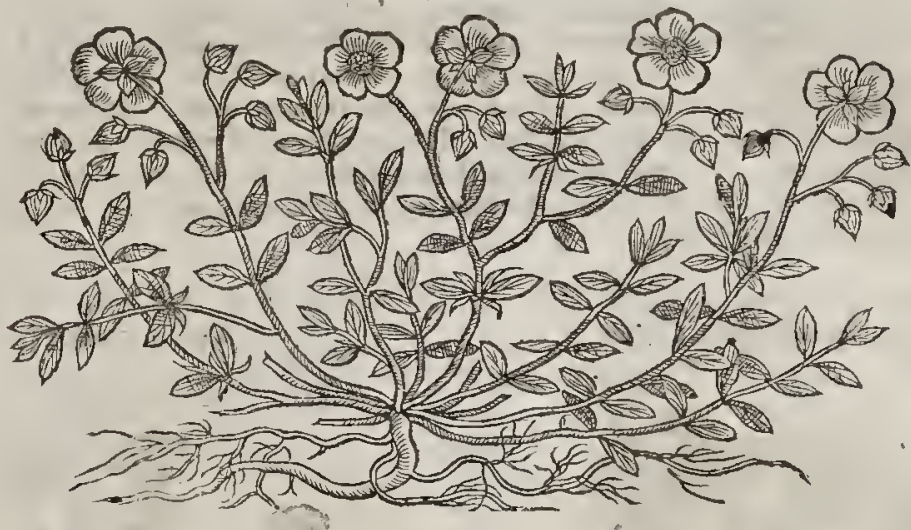

5 Helianthemem Sabardicums.

The dwarfe Ciftus of Sawoy.
6 Helianthusum anguftirolium. Narrow leufed dwarfe Ciftus.
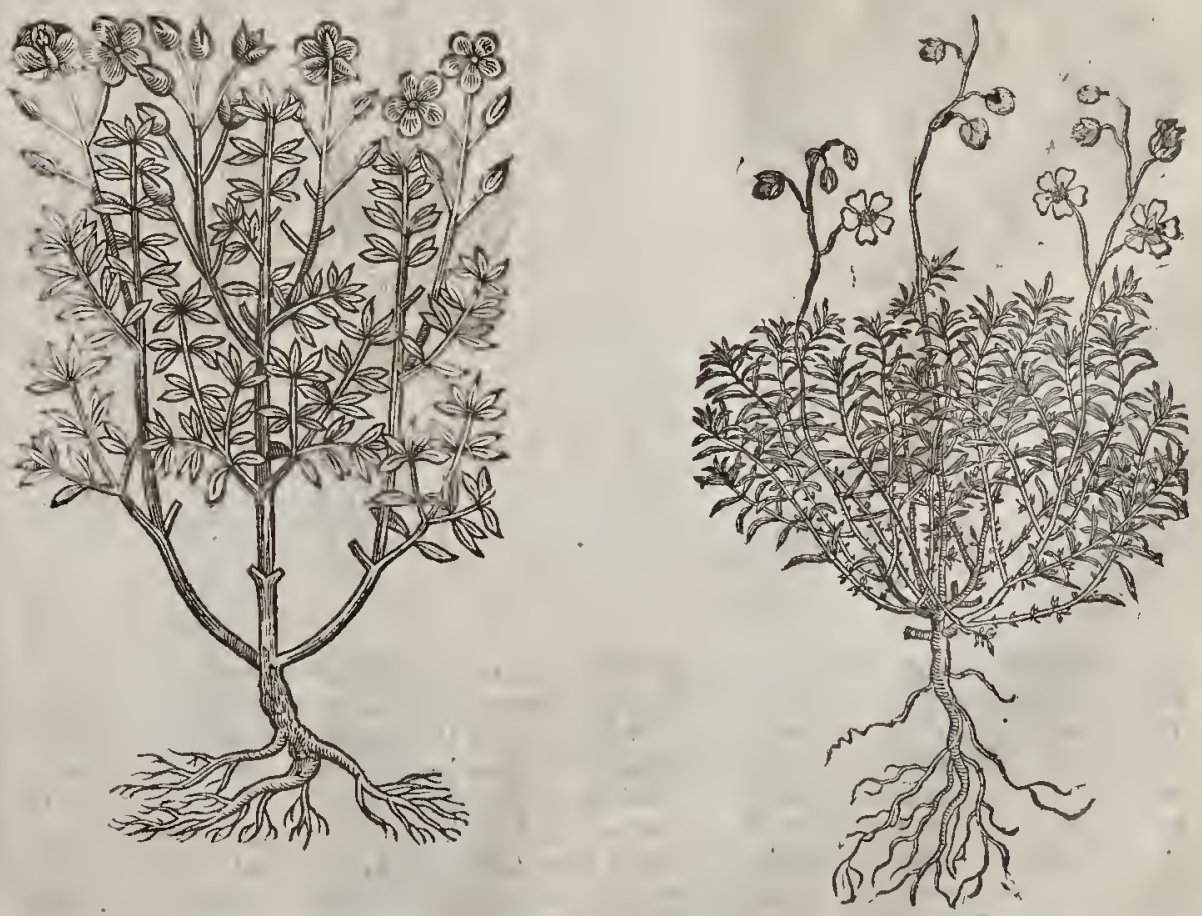

4 This differeth mot from the laft defcribed, fauing that the floures hereof are very white, and the orhers yellow, wherein they cfpecially differ. 
5 The $D_{\text {warfe }}$ Ciftus of Sauoy hath diuers tough branches, of a reddinh colour, very tough and wooddy, diuided into diuers other branches : whercon are fer fmall leaues, foure together, by certain fpaces; the floures grow at the top of the branches like thofe of our yellow Dwarfe Ciftus, of a yellow colour : the root is very wooddic.

6 This dwarfe Ciftus with narrow leaues, hath very many fnall Rexible brancbes, of a browne colour, very fmooth, and ramping vpon the ground; whereon do grow fmall, long, narrow leaues, like thore of Time of Candie, from the boforne whereof come forth diters other frnaller leaues: the floures grow on the rops of the branches, of a bleak yellow colour:the root is likew ife wooddy.

$\neq 7$ To thefe I may fitly adde two more:the firft of thefe hath creeping ftalks, fome foot or two long,blackinh, and diuided into fundry fmaller branehes: the lcaues grow thick and many together, fet by couples (though the figure do not wel expreffe fo much:) thefe leaues are fmal, of the bignes of thofe of Tinze, thick, green aboue, and whitish vnderneath, and of a bitter taft : at the ends of the branches grow two or foure floures neere together, very fmall,compofed of five little leaues, of a kinde of fieth colour: to thefe fucceed heads opening themfelues when they come to ripeneffe into fule parts, and containing a very fmall feed : the root is hard and wooddie, fending out certaine fibres : alfo the branches here and there put forth fome fibres. This plant dryed hath a pretty pleafing fmell. This growes vpon the higheft Auftrian and Styrianalpes, and is fet forth by Clufius by the name of Chamaciftus feptimus.

\section{$¥ 7$ Chamaciftus ferpillifolius.} Tyme leaned dwarfe Ciftus.

Azialea procumzeni

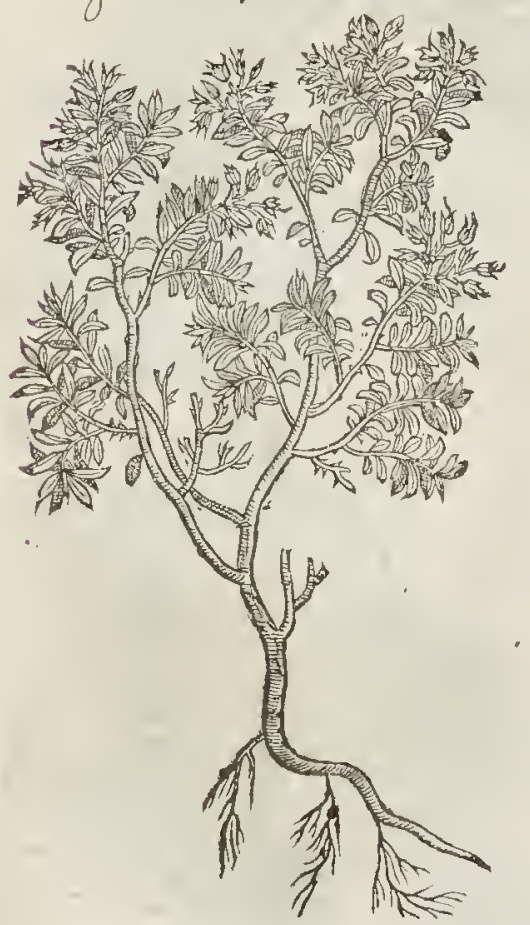

\$ 8 Chamaciftus Frificus. Frifian Dwarfe Ciftus. Saxipaqe Hirish hos

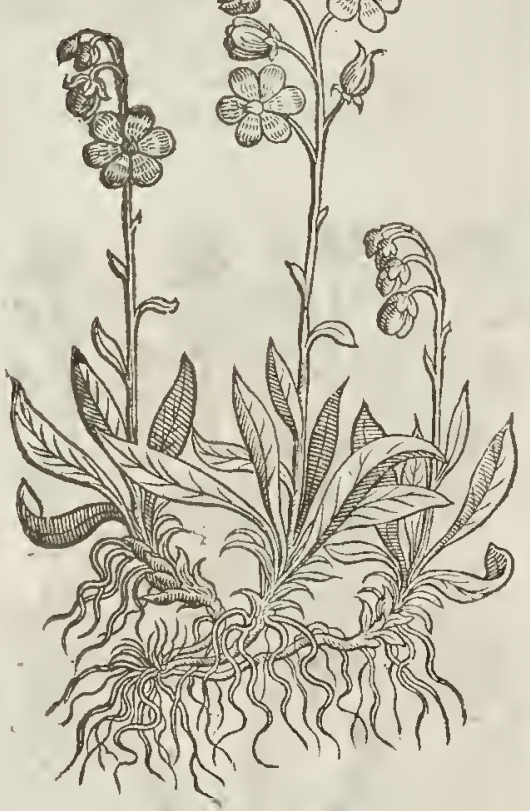

8 The fame Author alfo in his Cure pofteriores giues vs the hiftorie of this, which he receitued with fome orher rare plants from Iohn Dortman, a famous and learned A pothecarte of Groeningen: This little plant is in leafe and root almont like and neere of the fame bignefie with the Celticke Nard, yet the ftalks are vnlike, which are fmall, fet with a few long inh leanes, and at the tops they carry fite or fix pretty floures like thofe of Crow feet, confiftung of fix leaues apicce, of a yellow colour,yer with fome few fpots of another colour,and thefe fet in a double ring a bout the middle; a fter thefe follow heads or feed veffels with forked tops, filled with a chaffe feed : the whole plant finells fomewhat ftrong. It growes together with Gramen Pernaffi in rotten moorifh places about a village in the county of Drent.Dortman called this Hirculus Frificus : Clufines addes, qui Chamecifti
s,enus. $\neq$ 


\section{The Place.}

Their feucrall citles hauc touched their naturall countries: they grow in rough,dric, and funnie places, in plaine fields and vpon mountaines.

Thofe of our Englih growing, I haue found in very many places, efpecially in Kent, vpon the chalkie bankes about Grauel-end, Southfleet, and for the molt part all the way from thence vn. to Canturburicand Douer.

They floure from Iuly to the end of Augurt.

$$
\text { 9. 'The Time. }
$$

Tragus calleth dwarfe Ciftus in the high Dutch tongue, but therc is another herbe called alfo of the later Herbarifts Gratıa Der, which is Cratiola: Valerius Cordus llameth it Helisnthemum, and Solis flos, or Sunne floure: of Chifirs, Chameciftus, or Dwarfe Cintus.

Pliny writeth, chat $I$ cliant he groweth in the champion countrey Temifcyra in Pontus, and in the mountaincs of Cilicia neere to the fea : and he faith further, that the wife men of thofe countries, and the kings of $\mathrm{Per}$ fia do annoint their bodies herewith,boiled with I.ions fat, a little Saffron, and winc of Dates, that rlev may feene faire and beautiful; and there fore haue they called it Helsocali. den, or the beautic of the Sun: Matthiolus faith, that Heliawtbemum is taken of fome to be Panaces Chironium, or Chirons All-heale: but it is nothing likely, as we baue faid.

$$
\text { IT The Temperatureand Vertues. }
$$

The faculties and temperaturc are referred to the kindes of Ciftus, for it healeth wounds, ftarcheth bloud,and ftoppeth the fpittings of bloud, the bloudie flixe, and all other iffues of bloud.

The fame boiled in wine healeth vicers in the mouth and prinie parts, if they be wathed there- $\mathrm{B}$ with : to be briefe, it ioineth together and ftrengthnetl : which things doe plainely and euidently Thew, that it is not onely like to Ciftus and Ledon in forme, but in vertues and facultiesalfo, and therefore it is manifeft, that it is a certaine wilde kinde of Ciftus and Lecion.

\section{С н р. 7. Of Cifus Ledon, and Ladanum.}

T The Kindes:

1.i. B

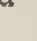


I Ciftus Ledon 1.Clufy.

The firft Ciftus bringing Ladanum.

Cistits Badaniferis.

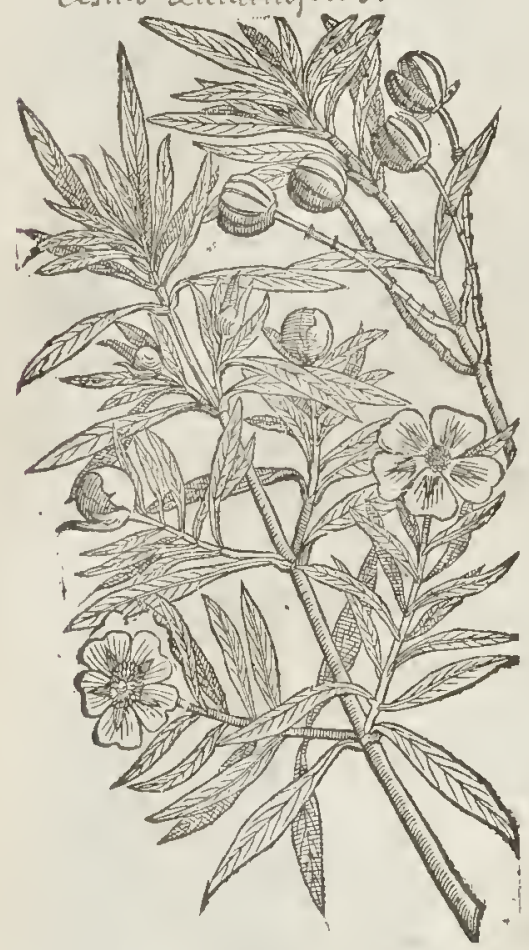

3 Ciflus ledon populea fronde.

Ciftus ledon with leatucs like the Poplar.

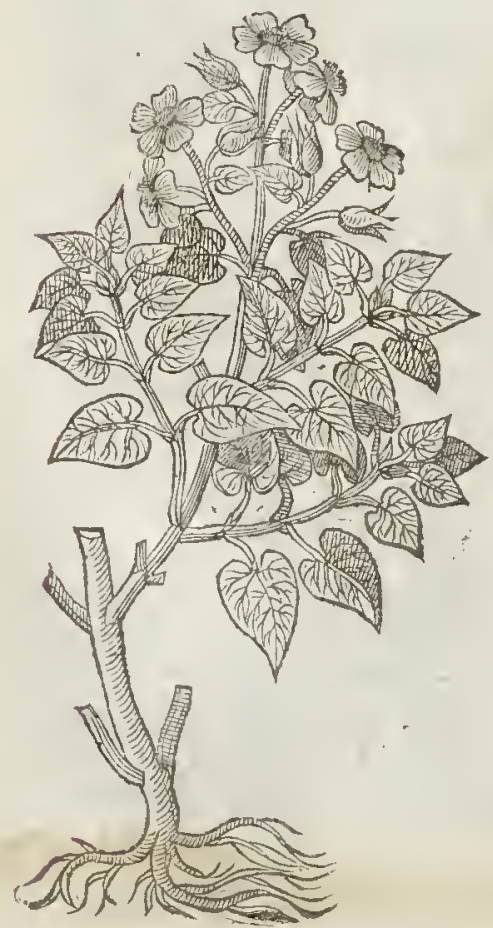

2 Cistus. ledon 2.Clusiy.

The fecond gum Ciftus.

Cistus poobulitolins. a

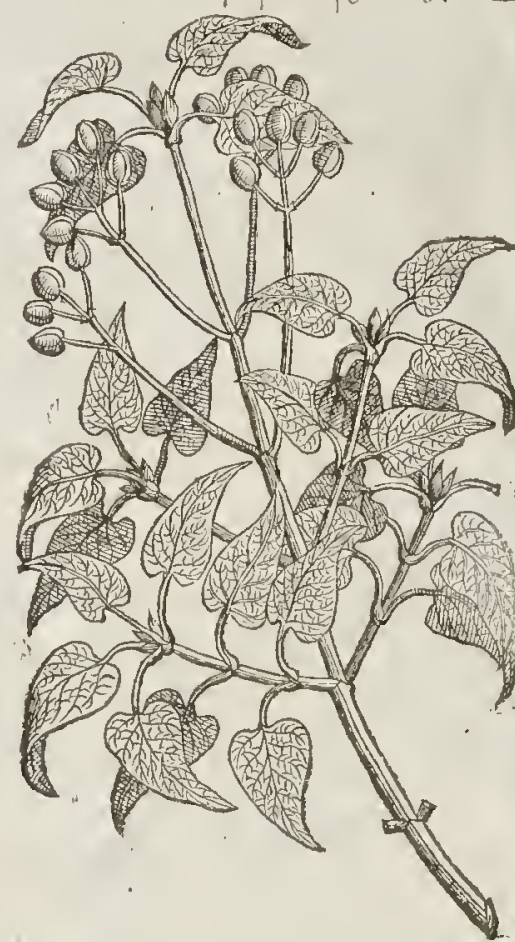

4 Ciftus ledon 4. Clufiy.

Cint is ledon, the 4 . of Clug fus:

Ciatus imocus.

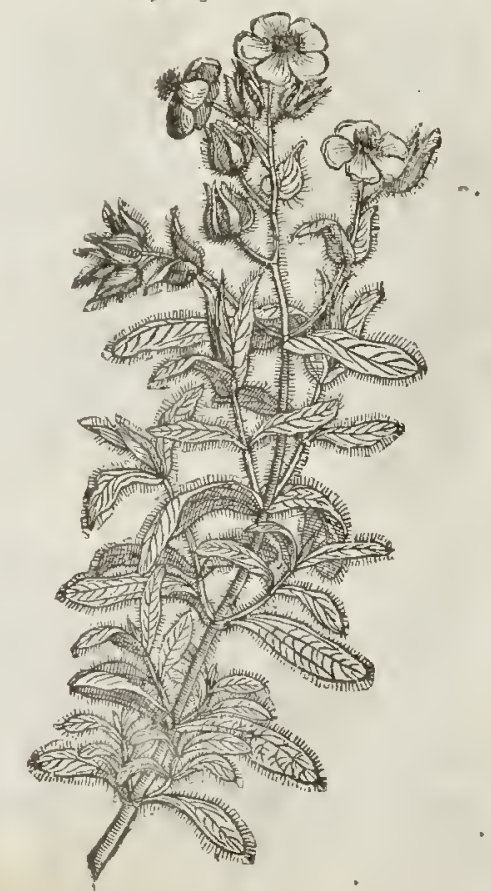




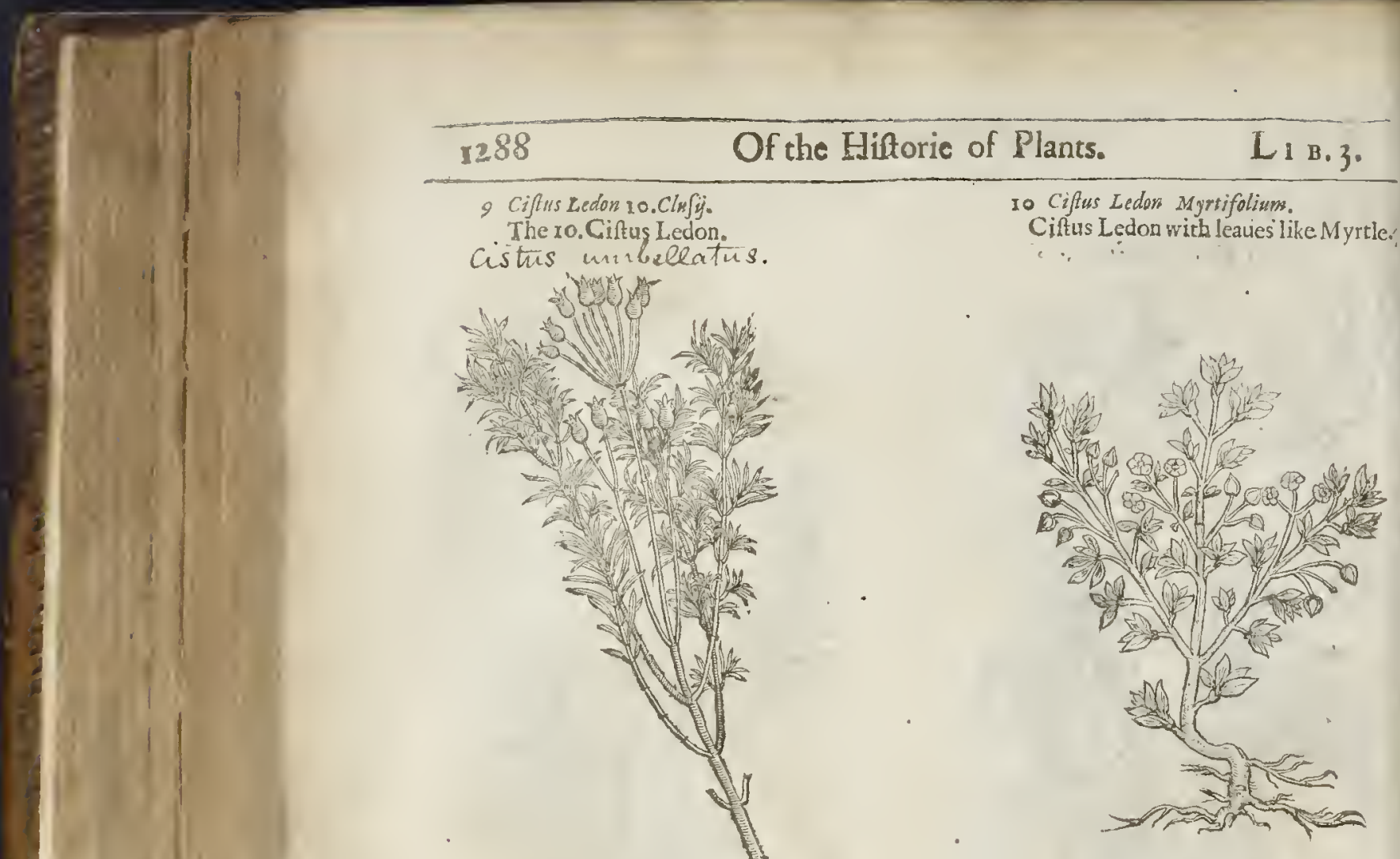


8 - The eighth grovath vp like a little hedge buh, 'hauing leaues like the common fumaic Ciftus, fuing thut thofe of this plant are fprinckled ouer with that clammy moifurc, and the other not fo: the homes and feed ate alfo like. From the root of this plant commeth fuch like excrefcence called Lim, toron, orobsuche, or Hypocifi is, as there doth from the firft male Ciltus, wherein it differeth fron all tha relt vnder the name Ledon.

9 The ninth hath diuers trittle ftalkes of an ath colour tending to a rufer; wheresn are fet very many leaues like thole of Thymz, of an ouerworne colour : the floutes are white, with certaine yellow chives in the middle, which the grater hath omit ted in the figure.

Io The tenth groweth vp like a fmill thrub, hauing britele ftalkes, conered with a blackith barke, and diuided into diuers branches; whereon are fet vpon fhort truncheons or fat foot ftalkess foure or fiue like thore the Myrtle tree, of a ftrong Imell : the floures are likewife of a white colour.

12 Ciftus Ledum Rorifmurinifolio. Ciftus Ledon with leaues like Rolemarie.

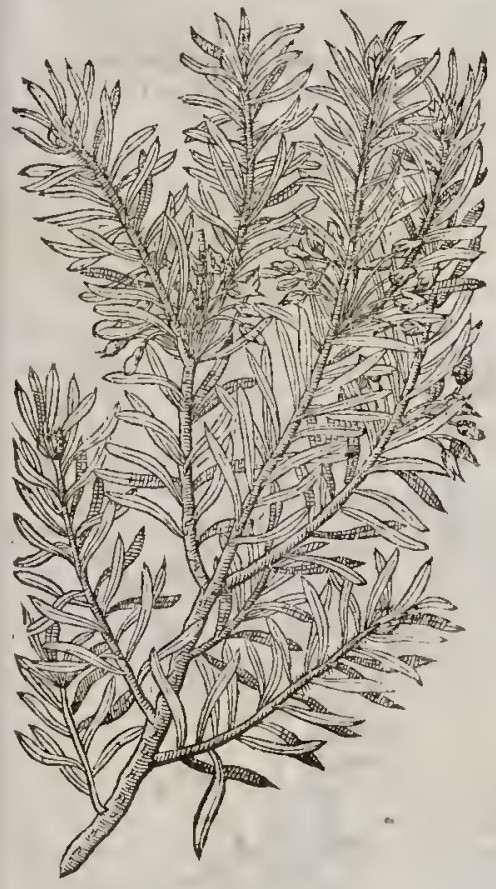

I 3 Cifus Ledum Maltioli.

Ciftus Ledon of Matshiolus defeription.

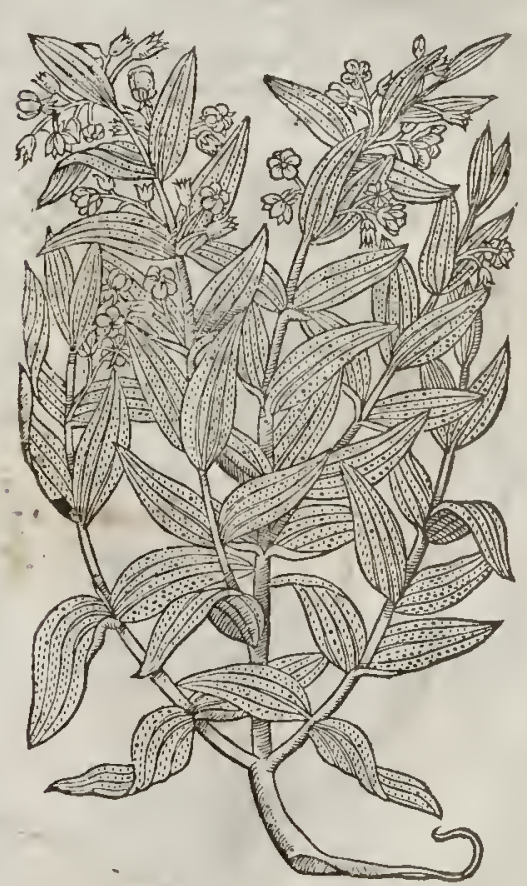

11. 2. The twelfth kinde of Ciftus Ledon groweth wpright with a ftraight body or ftocke, bringeth at the top many fmall twigs or rods of a cubit long, couered with a barke of the colour of aines, which diuide themfelues into other branches, of a purplifh colour, befec with long and narrow leaues, not much vnlike to Rofemary, but longer; of a greene colour aboue, but vinderneath hauing as it were a long rib, made or compact of wooll or downe ; of a fweet and pleafant fmell, and fomewhat tharpe in tafte : on the tops of the branches grow knops or heads, compact as it were of many feales, of an iron or ruftie colour : our of which commeth and proceedeth a cetaine round and long mane, or hairy panickled zufr of Aloures, w ith many long, tender, grecne, and fomerr hat woolly ftalkes or twigs growing vnto them, of a fweet fent and fimell : the fioures confift of fute little white leaues, within which are contained ten white chines with a long ttile or pointal in the midft of the floure: when the foures be vaded, there fucceed long knops or heads which are fiue cornered, in thape and bignefle like vnto the fruite and berries of Cormus; which being greene, are befpeckled with many filuer fpots, but being ripe, are of a red colour; conteining within them a long yellow feed,w wicl is fo rmall and flender, that it is like to the durt or powder that fallet hout of worme holes. $\neq$ This is the Ledum Sileflucsm of Clufui; and the Ledum Rorifmarinifolio of Taber.

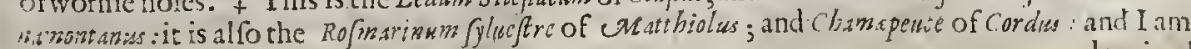
Qq११९ deceived 
ceceiued if the figure which $T$ abernamont anus and our Author out of him gaue by the name of $C_{i-}$ ftus adulterinus, were not of this. $¥$

I3 Among the fhrubby buthes comprehended vnder the title of Ciftus Ledum, $M$ at hiolus hath fet forth one, whereof to write at large were impolfible,confidering the Author is fobriefe, and of our felues we have not any acquaintancewith the plant it felfe: Drofcorides to helpewhat may be, faith, that it is a thrub growing like vnto the ftocke or kindred of the Cifti: from whofe leaties is gathercd a clammy dew which maketh that gummie matter that is in fhops called Lapdum $:$ it groweth, faith he, in hot regions (but not with vs:) the Mauritanians call the juice or clamny matrer, Leden, and Laden : of fome, Ladano, and Odano: in Spanifh, Xara: and further faith, it groweth in Arabia, where the buth is called chafus: thus much for the defcription. $¥$ Our Author here feems to make Diofcorides to comment vpon Matthiolus, which thewes his lcarning, and how well he was exercifed in reading or vnderftanding any thing written of Plants. But of this enough; The plant here figured which Matthiolus iudges to be the true Ledon, or Cistus Ladanifera of Diofcortdes, hath large ftalkes and branches, whereon grow very thicke leaues, broad alfo and long, with the nerues running along t the leaues, the floure of this confifts of fiue white leates, and the feed is contained in a three cornered feed vefiel. $\ddagger$

14 Ciftus Ledum Alpinum Clufij. The Mountaine Ciftus.

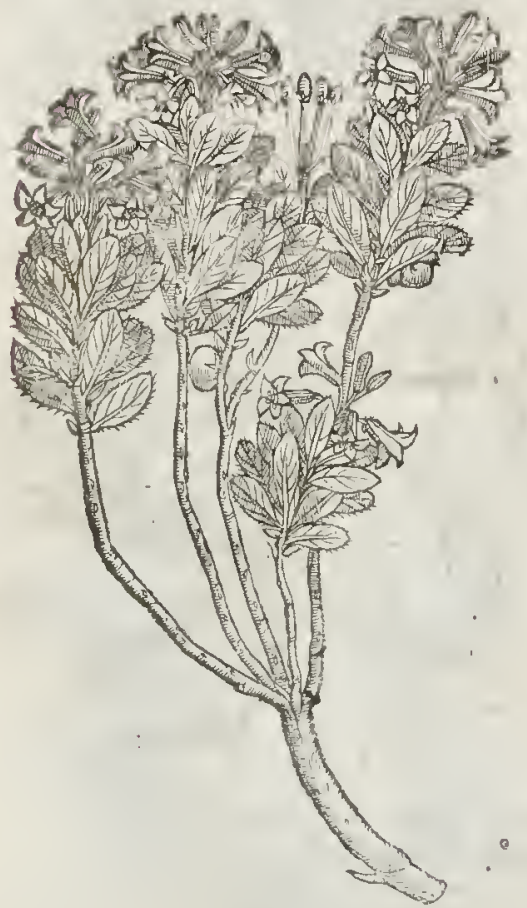

* 15 Ciftus Ledon folys Rorifmarini. Rofemary leaucd Cifus Ledon.

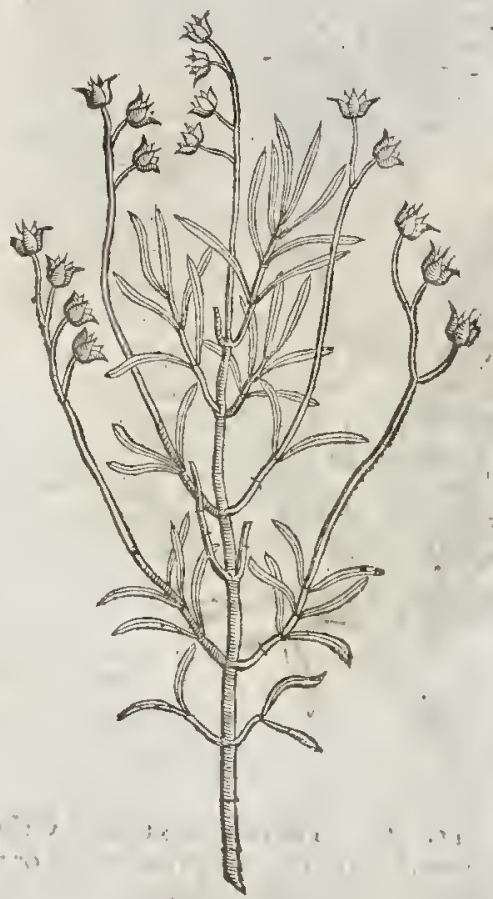

I4 The foureteenth Ciftus, being one of thofe that do grow vpon the Alpifh mountaincs, which Lobel fetteth downe to be Balfamum alpinum of Gefner: notwithftanding I think it not amiffe to infert it in this place,hauing formy warrant that famous Herbarift Carolus Clufius: : this plant is one of beautifulleft, differing in very notable points, and yet refembleth them in the wooddy branches and leaues:it rifeth vp hauing many weake branches leaning to the ground,yct of a wooddy fubftance, eouered oucr with an afh coloured barke: the leaues are broad, and very rough, of a thining grecne colour, and a binding tafte: the foures grow at the tops of the branches like little bcls, hanging downe the ir heads, diuided at the lips or brims into fiue diuifions, or a deepe red color on the out fide,and dafht outer here and there with fome filuer fpots; on the infide of a bright fhining red colour, with cerraine chiues in the middle, and of very fwect fmell, as is all the reft of the plant; a fter which eome fmall heads or knaps, full of feed like duft, of a very ftrong fmell, making the head of them to ake that fmel thereto:thc root is long, hard, and very woody:oftentimes there is 
found vpon the trinke or naked part of the ftalks certaine excrefcences, or out-grow ings in manner of galls, of a fungous fubftance, liketholc of Touchwond, white within, and red without, of an aftringent or binding tafte:

\# 15 This growes fome cubite and betrer high, and hath long narrow glutinous leates like in thape to thofe of Rofemarie, fet by couples, but not very thick : the branehes whereon the floures dogrow are llender, and the feed veffels are diuided into fue parts as in other plants of thus kinde. This Clufius found in Spaine, and fets forth for his Ledum ronum $¥$.

$$
9 \text { The Place. }
$$

Ciftus Ledon groweth in the Ifland of Candie, as Bcllonius doth teftifie, in vntilled places euery where : it is alfo found in Cyprus,as Plony theweth,and likewife in many places of Spaine that lie open to the Sun : moreouer both the forme and bigneffe of the leaues, and alfo of the plants themfelues, as well of thofe that bring forth Ladumw, as the other Ciftus, do varie in this wonderful maber, according to the diuerfitie of the places and countries where they grow : they are ftrangers in thefe Northerly parts, being rety impatient of ourebld clymate.

$$
\text { ithe Timae. }
$$

They foute for the molt part from May to the end of Augut:the clammie matter which falleth tpon the leaires, which is a liquid kinde of Rofen of a fweet fmell, is gathered in the Spring time'as Diofcorides \{aith: but as Petrus Bellonizus affirmeth (being an eye witnes of the gathering) in the mid't of fommer, and in the extreme heat of the Dog-daies, the which in our time not without great care and diligence, and as great labour, is gathered from the whole plant (with certain inttruments made in manner of tooth pickes, or eare pickes, which in their tongue thcy call Ergaftiri) and not gathezed from the beards of Goats, as it is reported in the old fables of the lying Monks themfelues,calIed Calohieros, that is to fay Greekin Monkes, who of very mockeric hane foifted that fable anıong others exrant in their workes.

₹ I thinke it not amiffe for the better explanation of the matter here treated of,as alfo to thew you after what manner our Author in diuers places gaue the teftimonies of fundry Writers, and how well he underftood them, here to fer dow ne in Englinh the words of Bellowrus concerning the gathering of $L$ sdamsom, which are thefe. [ The Greekes (Saith he) for the garhering of Ladanum, prouide a peculiar inftrument which in their vulgar tongue they terme Ergaftrri: This is an inftrumenc like to a Rake without teech, to this are faftened fundry thongs cut out of a raw and vntanned hide; they gently rub the fevpon the Ladamum bearing Thrubs, that fo the liquid moifture concrete about the leanes may fticke to them, which afterwards with kniues they fhaue off thefe thongs in the heat of the day. Wherefore the labour of gathering Ladanum is exceeding great, yea intollerable, feeing they mu ft of neceffitie ftay in the mountaines all the day long in the greateft heat of the Dogdaies: neitber vfually thall you finde any other who will take the paines to gather it, befides, the Calohieroi, tlat is the Greeke Monkes. It is gathered no where in the whole. Ifland of Candy in greater plenty, than at the foot of the mountane Ida at a village called Cogualino, and at Milopotamo.ł]

$$
\text { T The Names. }
$$

The thrub it felfe is called in Greeke sesor, ot aros : the Latines keep the name Ledon or Ladon, and is a kinde of Ciffus or Hollie Rofes: the fat or clammie matrer which is gathered from the leaues, is named Ladanon and Ledanon, according to the Greeke: the Apothecaries corruptly call it Lapdanum : Diofcorides counteth that to be the beft which is fweet of fmell, and fomewhat greene; that eafily waxeth foft, is fat, without fand, and is not eafily broken, but very full of Rofine or Gumme.

$$
\text { T. The Temperature. }
$$

Ladanum, faith Galen, is hot in the later end of the firlt degrec, hauing alfo little aftrictineor bin: ding qualitie; it is likewife of a thin fubftance, and therefore it fofteneth, and withall doth modesately diget, and alro concoct.

\section{The Vertues.}

Ladanum harh a peculiar property againft the infirmities of the mother, it keepeth haires froin $A$ falling; for it watteth aw ay any fetled or putrified humour that is at their roots.

Digfcorides faith, that Ladanum doth bind, heat, fouple, \& open,being tempered with wine, Myrrhe, B and oile of Myrtles; it keepeth haires from falling ,being: annointed therewith; or laied on mixed with wine, it maketh the markes or fcars of wounds faire and well coloured.

It taketh away the paine in the eares if it be poivred or dropped therein, mixed with honied wa. C ter, or with oile of Roles.

A fume made thereof draweth fotth the afterbirth, and taketh alvay the hardneffe of the ma. trix. 
E It is with good fucceffe mixed with mollifying plaifters that mitigate paine.

Fi Being drunke with wine, it ftoppeth the laske, and prouoketh vrine.

$G$ There is made hereof diuers forts of Pomanders, chaincs, and bracelets, with other fweets mix. ed therewith.

\section{С на в. 8. Of Rojemarie. \\ T The Defription.}

1 Ofemaric is a wooddie thrub, growing oftentimes to the height of three or foure cum bits, efpecially when it is fet by a wall : it confffeth of flender brittle branches, wheron do grow vcrie many long leaues, narrow, fomewhat hard, of a quicke fpicy taftc, whitith vnderneath, and of a full greene colour aboue, or in the vpper fide, with a plcafant fweet ftrong fmell; among which comc forth little floures of a whitim blew colour: the feed is blackinh : the ronts are tough and woody.

I Rofmarioum Coroxarimm: Gatden Rolemaric.

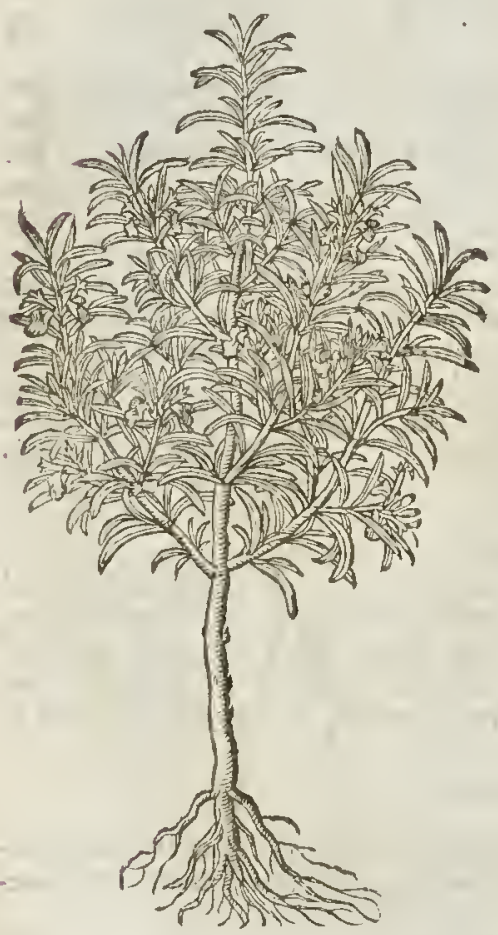

2 Rofmarimum flinefire. WildeRofemarie.

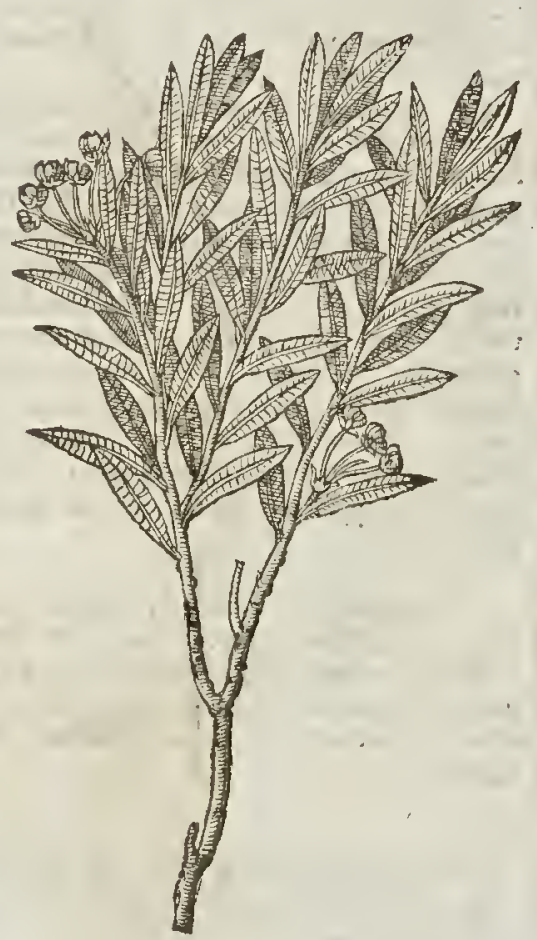

2 The wilde Rofemarie clufus hath refetred vnto the kindes of Ciftus Ledon.we haue as poore kinfman thereof inferted it in the next place, in kinred or neighbourhood at the leaft. This wildc Rofemarie is a fmall wooddic thrub, growing feldome aboue a foot high, hauing hard branches of a reddifh colour, diuiding themfelues into other fmaller branches of a whitifh color:wheron are placed without order diucts long leaues, greene aboue, and hoarie vnderneath, not vnlike to thofe of the dwarfe Willow, or the common Rofemarie, of a drie and aftringent tafte, of littlc fmel fifting of fue fre tl lires ftand on the tops of the branches, fet vpon bare or naked foot falks, confull of fmall feed : the reo a reddifh colour, fomewhat thining; after which appeare little knaps

3 This plant grows yp like an licdge thrub of a woddie fubftance, to the height of two or three 
3 Cafia Poetica, Lobeliy.

The Poets Rofemarie or Gardtobe.

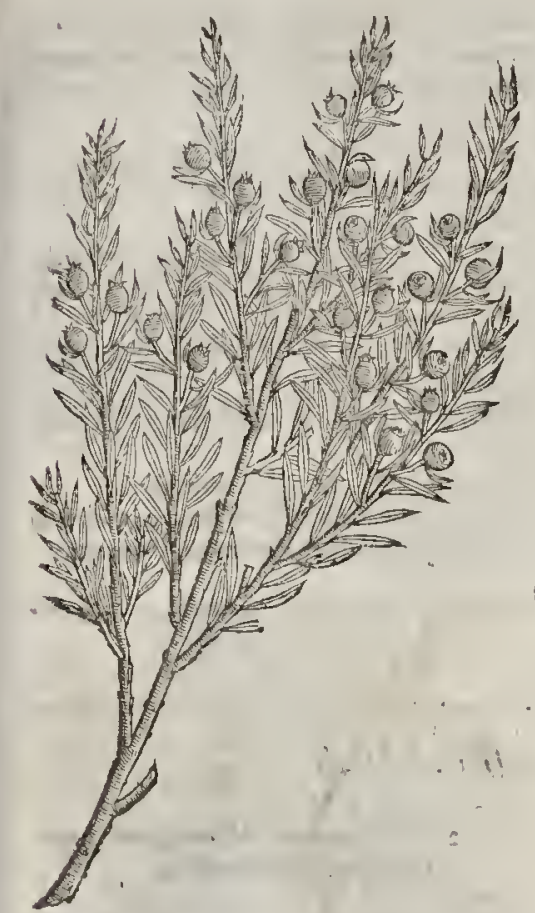

cubits; hauing many twiggie branches of a green colour:w herupon do grow narrow leautes like vnto Linaria or Toad-Hax, of a bitter tafte; among which come forth fmall moflie floures, of a grecnifh yeliow colour like thore of the Cornell tree, and of the fmell of Rofemarie: which hath monedne to placeit with the Rolemaries as a kinde thereof, not finding any other plant fo neere vnto it in kinde and neighbourhood : after the floures be pait, there fueeed fruit like thoie of the Myrtle tree, greene at the firt, and of a fhining red colour when they bee ripe, like Corall,or the berries of $A$ p a aragus, foft and fwcet intafte, leauing a certaine acrimonie or tharpe tafte in the end : the ftone within is liard as is the nut, wherein is contained a fmal white kernel, fweet in taft:the root is ofa wooddie fubftanee : it floureth in the Sommer; the fruit is ripe in the end of Oetober : the people of Granade, Montpelier, and of the kingdom of Valentia, doe vfe it in their preffes and Wardrobes, whereupon they call it Gurrdalobo. $\neq$ This in Clufius his time when lie lined about Montpelier was called ofyris; but afterwards they called it Cafrat thinking it that mentioned by the Poet Virgil; the which it cannotbe, for it hath no fiveet fmell. $P$ ena and Lobel ind ge it to be the Cafse of Theophraftus, wherewith alfo is dothnor well agree. $\neq$

$$
\text { G) The Place. }
$$

Rofemarie growcth in France, Spaine, and in other hotcountries; inwoods, and in vntilled places : there is fuch plentic thercof in Languedocke, that the inhabitants burne fcaree any other fuell: they make hedges of it in the gardens of Italy and England,being a great ornament vnto the fame: it growerh ncither in the fields not gardens of the Eafterne cold countries; but is catefully and curioully kept in pots, fet into the ftoues and fellets, againtt the iniuries of their cold Winters.

Wilde Rofemarie groweth in Lancafhire in diners places, cfpecially in a field called Little Reed,amongit the Hurtleberries, neere vnto a fmall village called Maud fley; there found by a learned Gentleman often remembred in out hiftorie(and that wortliily) Mr. Thomss Hesketh.

$$
\text { T The Time. }
$$

Rofemarie flcureth twice a yeare, in the Spring, and after in Auguts.

The wilde Rofematie floureth in Iune and Iuly.

$$
\text { It The Tames. }
$$

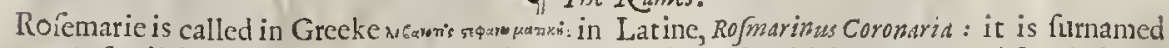
Coronaria, for difference fakebetweene it and the other $L i b a n o t z d e s$, wh ich are reckoned for kindes of Rofemarie, and al fo becaufewomen hauc keen accuftomed to make erownes and garlands thereof: in Italian, Rofmarino coronario : in Spanifh, Romcro : in French and Dutch Rofinarin.

Wilde Rofemaric is called Rofinarinus fylueftis: of Cordus, Chamepence.

$$
\text { T The Temperature. }
$$

Rofemarie is hot and drie in the fecond degree, and alfo of an afteingent or binding quality, as being compounded of diturs parts, and taking more of the mixture of the earthy fubftance.

$$
\text { of The vertues. }
$$

Roremarie is giten againft all fuxes of bloud; it is alfo good, efpecially the floures thereof, for $\mathbf{A}$ all infirmities of the heat and braine, proceed ing of a cold and moift callfe; for they dry the brain, quieken the fences and memorie and ftrengthen the finewie parts.

Serapiowitnefferh, that Rofenaric is a remedie againft the ftuffing of the head, that commeth B through eoldneffe of the braine, if a garland thereof be put about the head, whereof sbin cuefrua gineth teftimonic.

Dioficrides teaeheth that it cureth him that hath the yellow iaundice, if it be boiled in water and $\mathbf{C}$ drunk before exetcife, \& that after the taking therof the patient muft bathe himfelfe \& drink wine. 
D The diftiled water of the floures of Rofemarie being drunke at morning and euening firft and laft, taketh away the fteneh of the mouth and breath, and maketh it very fweet, if there be added thereto, to fteep or infufe for cettaine daies, a few Cloues, Maec, Cinnamon, and a little Annife reed.

E The Arabians and other Plyyfitions fueeceding, dowric, that Rofemaric comforteth the brain the memoric, the inward fenfes, and reftoreth fpeeeh vnto them that are poffeffed with the dumbe palfie, efpeeially the conferue made of the floures and figar, or any other way eonfected with fugar,being taken eucry day fafing.

F The Arabians, as Serapio witneffeth, give thefe properties to Rofemaric : it heateth, fay they, is of fubtill parts, is good for the eold rheume whieh falleth from the braine, driueth away windines, promoketh vrine, and openeth the foppings of the liuer and milt.

$G$ Tragus writeth, that Rofemarie is fpiee in the Germane Kitehins, and other eold countries. Further, he fath, that the wine boiled with Rofemarie, and taken of women troubled with the mother, or the whites, helpeth them, the rather if they faft three or foute houres after.

$H$ The floures rinade vp into plates with fugar after the manner of Sugar Rofet and eaten, comfort the heart, and make it merry, quieken the fpirits and make them more limely.

I The oile of Rufemarie ehimiealiy drawne, ecmforteth the cold, weakeand feeble braine in moft wonderfull maner.

K The people of Thuringia dovfe the wilde Rofemarie to prouoke the defred fiekneffe.

L Tholc of Marchia vfe to put it into their drinke the fonner to make their elients drunke, and allo do put it intis chelts and prefles among clothes, to preferue them from mothes or othervermine.

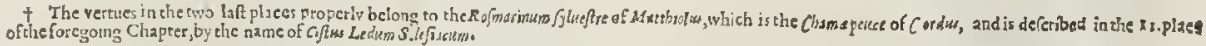

\section{Cнат. 9. Of VprigbtWood-binde.}

I Periclymenum rectum Sabaudicum. Sawoy Honifuekles.

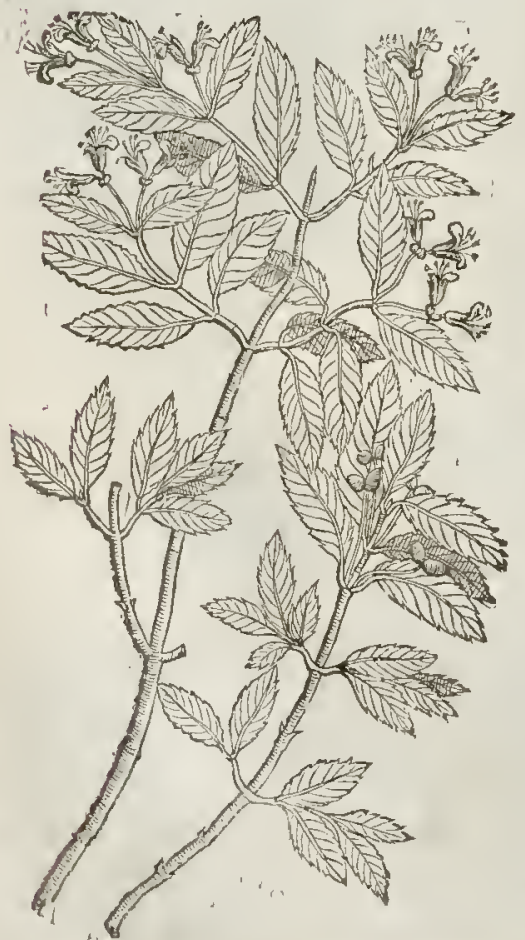

2 Periclymenum rectum Germanicum: Germane Honifuckles. ini-zer ?

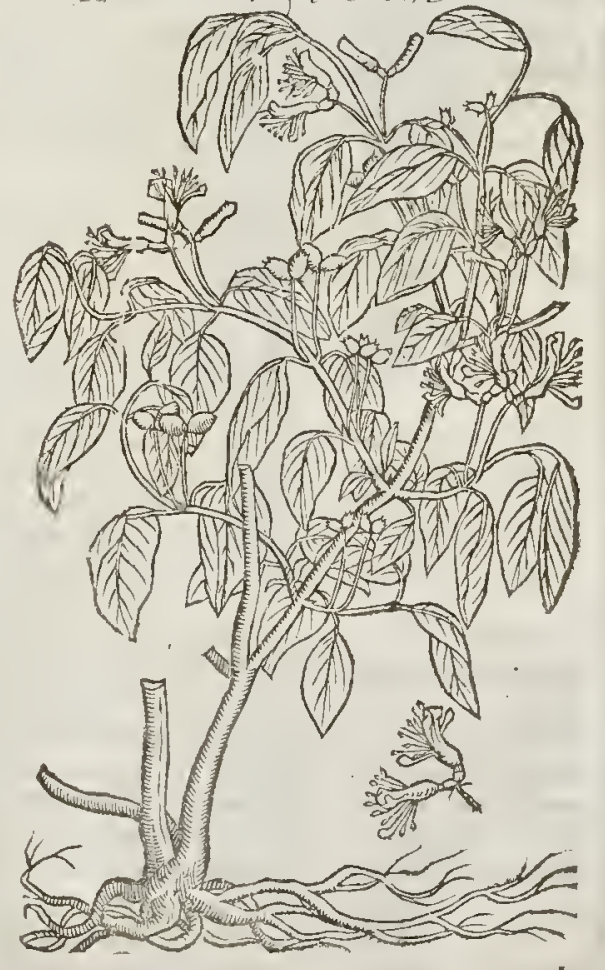

II The 
L18. 3. Of the Hiftory of Plants:

\section{IT The Defcription.}

I This ftrange kinde of Hony-fuckle, found in the woods of Sauroy, reprefents vnto vs that firub or hedgc-burh called Cornus frmina, the Dog-berry tree, or Pricke-timber tree, hauning lcaues and branches like the common Wood-binde, fauing that this doth not clamber or clymbe as the others do, but contrarivife growcth vpright, without leaning to one fideor other, like a fmall trce or hedgc-buth: the floures grow vpon the render fprayes or twiggic branches, by couples, not vnlike in thape and colour to the common Wool-binde, but altogether lefler, and of a white colour, hatuing within the fame many hairy chines like the other of his kinde : after which comc red bcrries ioyned together by couples : the root is tough and wooldy.

2 The ftalkes of the fecond be oftentimes of a meane thickneffe, the wooddy fubftance fomwhat whitin and foft : the branches be round, and couered with a whition barke, notwithftanding in the beginning when the fprayes be yong they are fomewhat reddith. The leates be long, like thofe of the common Hony-fuckle, foft, and of a white greene : on the lower fide they be whiter, and a little hairy : the floures be leffer than any of the Wood-bindes, but yce of the fame fathion, and of a whitinh colour, ioyned together by couples vpon feuerall flender foot-ltalkes, like little wilde Cherries, of a red colour, the one leffer oftentimes than the other.

3 Periclymenum rectum fructu carulco. Vpright Wood-bindewith blew berrics.

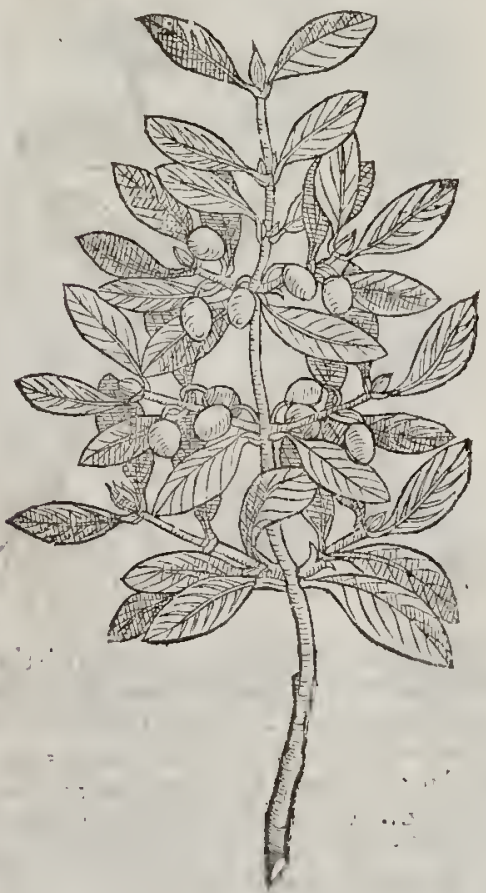

4. Periclyminum rectum fructu rubro? Charry Wood-binde.

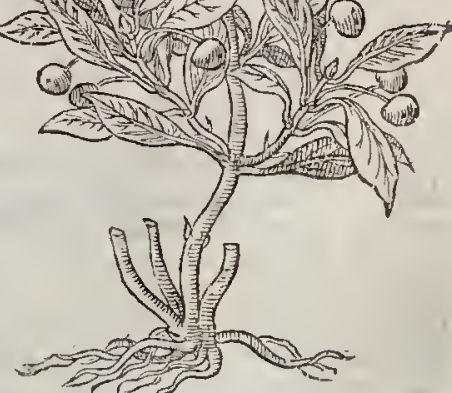

i This ftrange kinde of Wood-binde, which Carolus Clufurs hath fet forth in his Pannonicke Obferuations, rifeth vp oftentimes to the height of a man, enen as the former doth; which ditides it felfe into many branches, couered with a rough b lacke barke, that choppetly and gapeth in fundric clefts as the barke of the Oke. The tender branches are of a whitin greene colour, conered with a woolly hairineffe, or an ouerwornc colour, whereupon do grow leaues fet by couples onc againft the other, like vnto rhe common Wood-binde, of a drying bitter tafte : the floures grow by couples likewife, of a whitifh colour. The fruit fucceedeth,growing like little Cherrics, each one on his owne foot-ftalke, of a bright and thining blew colour; which being bruifed, doe dic the hands of a reddifl colour, and they are of a tharpe winie tafte, and containe in them nany fmall flat fecds. The root is wooddy, difperfing it felfe far abroad, 
4 This kind of vpright Wood-bind groweth vp likewife to the height of a man,and oftentimes more high, like :o the laft deferibed, but altogether greater. The berries hereof are very blaeke, wherein efpecially is the differenee. $\neq$ The leaues of this are as large as Bay leaues, fharpe pointed; greene aboue, and whicifh vndernearh, but not hairy, nor fnipt about the edges: the floures grow by eouples, of a whitifh purple, or wholly purple : to thefe paires of floures there eommonly fueeeds but one berry, larger than any of the former, of the bignefle of a little cherry,and of the fame eolour, hauing two marks vpon the top therof, where the floures ftood, $\neq$

Periclymeni $3 \cdot d$. flores.

The floures of the third and fourth.

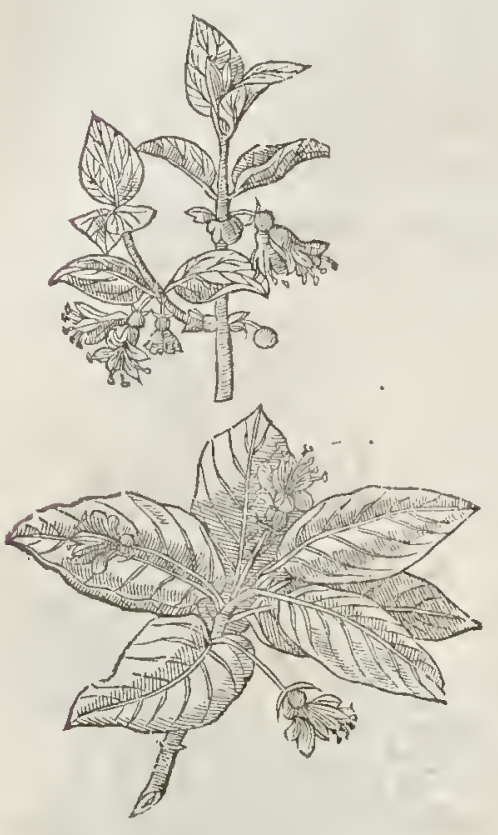

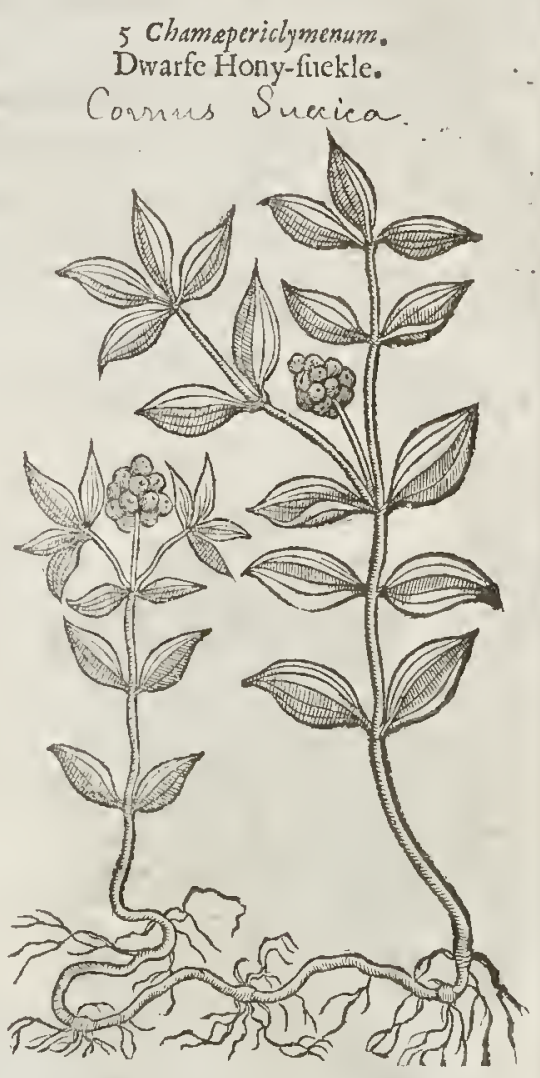

5 Chamsericlymenum. Dwarfe Hony-finckle.

5 To the k indes of Wood-bindes this plant may likew ife be referred,whofe picture with this defeription was fent vnto Chrfiss long fineeby that learned Doctor in phy fieke Thomas Penny (of are fet by eouples faire broad leaues one :) it rifeth vp with a ftalke of a foot high; whereupon thofe of Plantaine, fharpe pointed, and font againft another, ribbed with eertaine nerues like the bofome of whieh leaues eome forth fmath hollowed in the middle like Spoon-wort : from whieh The root is tough and very flender, ereeing it oceupieth mueh ground.

$$
\text { Tा The Place. }
$$

Thefe plants are ftrangers in England: they grow in the woods and mountaines of Switzerland, Germany, Satoy, and other thofe parts tending to the Eaft, Eaft North-Eaft, and Eaft and by
South.

I haue a plant of the firft kinde in my garden : the reft as yet I haue not feene, and therefore eannot write fo liberally thereof as I eould with.

‡ The dwarfe Hony-fuekle growes in the maritime parts of Norway and Sweden, \& the eountries thereabour. $\neq$

They foure for the noft part when is ripe in September. 


\section{The Names.}

Vprighe Wood-binde or Hony-fuekle is called Periclymenum ftans, and periclymenam rectum, or spright Wood-binde : of Dodonats, Xylofterm : in high-Duteh, nwm Ccrafa, or Dog Cherries. The Englith names are expreffed in their feuerall tirles. It hach bin called Chamecerafus, but not truly.

q The Temperature and Vertues.

Touching the temperature and vertues of thefe vpright Wood-bindes, we haue no experience at all our felues, neither hate we learned any thing of others.

\section{Сан. 10, Of Sene.}

Serat foläsoubiafis.

Italian Sene.

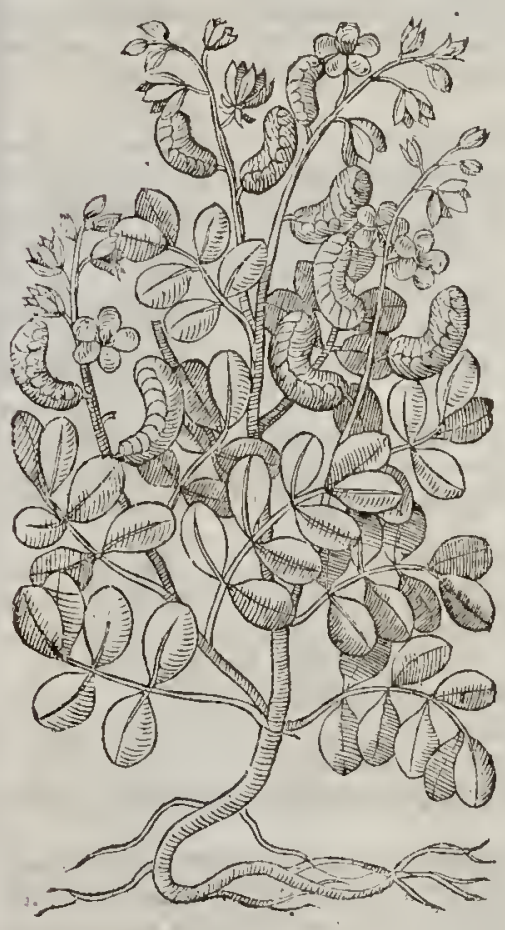

TT The Defription.

Ene bringeth forth ftalks a eubit high, fet with dimers branches : the leaues are long, winged, confinting of many fmall leaues like thofe of Liquorice, or of battard Sene: the floures eome forth of the bottom of the wings, of colour yellow, ftanding vpon flender footftalks; from which after the floures be gone hang forked cods, the fame bowing inward like a halfe-moone, plain and flat, in which are contained feeds like to the feeds or kernells of grapes, of a blackifh colour. The root is flender, long, and vnprofitable, which perifheth when the leaues are gathered for medicine, and the feeds be ripe, and mutt be fowne againe the next yeare, euren as we do corne.

There is another kinde of Sene growing in Italy, like the other in each refpect, fauing that it is greater, and hath not that foree in purging that the other hath. of The place and Time:

This is planted in Syria and Egypt, alfo in Italy, in Prouinee in France, in Languedoc. It hardly groweth in high and low Germany, neither in England: it profpereth in hor Regions, and eannot away with cold; for that eaufe it is in I taly fowne in May, and eontinteth no longer than Autumne:the beft is brought from Alexandria and Egypt. The Arabians were the firft that found it qut.

T The Names.

The Perfians call it Abalyemer, as crefue his copy teacheth: the Apotheearies Sena, by which name it was knowne to 4 cturarins the Greeian, and to the later Latines : it is called in Engling; Sene.

T The Temperataye.

Sene is of a meane temperature, neither hot nor cold, yet inelining to heate, and dry almon in the third degree : it is of a purging facultie, and that by the ftoole, in fuch fort as it is not much troublefome to mans nature, hauing withall a certaine binding qualitie, which it leauth after the purging.

\section{The Vertues.}

It voideth fortlı fiegmatieke and cholericke humors, alfo grolic and melancholike, if it be helped with fomething tending to that end.

It is a fingular purging medieine in many difeafes, fit for all ages and kindes.
Tt purgeth without violenec or hurt, efpecially if it be tempered with Anife feed or other like $\mathrm{B}$
C fweet fmelling things added, or with gentle purgers or lenitiue medicines. It may be giuen in pouder, but commonly the infufion thereof is ved. 
D) The quantitie of the pouder is a dram weight, and in the infufion, foure, fiue, or more. It may be mixed in any liquor.

E It is in the deco.tion or in the infurion tempercd with cold things in burning agues and other hot difeafes : in cold and long infirmitics it is boyled with hot opening fimples and fuch like; ot elfe it is fteeped in wine, in which manner, as familiar to mans nature, it draweth forth gently by the ftoole, almoft without any kinde of paine, crude and raw humors.

F . Moft of the Arabians conmend the cods, but our Phyfitions the leaues rather; for vnleffe the cods be full ripe they ingender winde, and caufe gripings in the belly. For they are oftentimes gathered before they be ripe, and otherwife eafily tall away being thaken downe by the wind, by reafon of their weake and flender ftalks.

G Some alfo thinke that Sene is hurt full to the ftomacke, and weakncth the fame, for which caufe they fay that Ginger or fone fweet kinde of fpice is to be added, whereby the ftomacke may be frengthned. Likewife eMefue noteth that ir ${ }^{3}$ is flow in operation, and therefore Salgem is to be mixed with it. Morenuer, Sene purgeth pö fo fpecdily as ftronger medicines do.

H Notwithftanding it nay be helped not only by Salgem, but alfo by otherpurging things mixed? therewith, that is to fay with fimple medicines, as Rubarb, Agaricke, and others; and with compounds, as that which is callcd Catholicon, or the Electuarie Diaphanicon, or that which is made of the ityce of Roles, or fome other, according as the condition or qualitie of the difeafe and of the ficke man requireth.

I The leaues of Sene are a familiar purger to all people, but they are windic, and do binde the bodie afterwards, very nuch difquicting the ftomack with rumbling and belching : for the auoiding of which inconuenience there muft be added Cinmanon, Ginger, Annife feed, and Fennell feed, Raifins of the Sun, and fuch like that do breake winde, which will the better help his purging qua-
litic.

K Senedoth better purge when it is infured or fteeped, than when it is boyled : for doubtleffe the more it is boiled the lefle it purgeth, and the more windie it becommeth.

L Take Borage, Bugloffe, Balme, Fumitoric, of each threedrams, Sene of Alexandria very wel prepared and pouned, two ourices, itrow the pouder vpon the herbes and diftill them : the water that commeth thereof referte to your ve to purge thofe that liue delicately, being miniftred in white wine, with fugar, in condited confections, and fuch dainty waics, whercin delicate and fine people do grcatly delight : you may alfo(as was faid before) adde hereunto according to the maladie, di-
uers purgers, as A garicke, Mirobalans, \&c.

M The pouder of Sene after it iswell prepared two ounces, of the pouder of the root of Meclioacan foure drams, pouder of Ginger, Anife feeds, of each a little, a fpoonfull of Anife feeds, but a very little Ginger, and a modicum or fmall quantitie of Salgemma : this hath beene proued a ve. rie fit and familiar medicine for all ages and fexes. The patient may take one fpoonful or two therof fafting, either in pottage, fome fupping in drink, or white wine. This is right profitable to draw
both fegme and melancholy from the breft and other parts.

The leaucs of Sene and Cammomil are put in baths towafh the head. Sene opens the inward parts of the body which are ftopped, and is profitable againft all griefes
of the principall members of the body.

P. Take Sene prepared according to art one ounce, Ginger half a quartcr of an ounce, twelue cloues, Fenell feed two drans, or in ftead thercof Cinnamon and Tartar, of cach halfe a dram, pouder all thefe; which done, take thercof in white wine one dram before fupper, which doth maruelloufly
purge the head.

Q Handle Sene in maner aboue fpecified, then take halfe af ounce thereof, which don,adde thereto fixty Raifins of the Sumne with the ftones pickt out, one fpoonfull of Anife feeds braied; boile thefe in a quart of alc till one halfe be watted, and while it is boiling put in your Sene : let it ftand fotill the morning, then ftraine it and put in a little Ginger : then take the one halfe of this potion and put thereunto two fpoonfulls of fyrrup of Rofes : drinke this together, I meane the one halfe of the medicineat one time, and if the patient canot abide the next day to receite the other halfe,
then let it be deferred vitil the third day after.

R Sene and Fumitorie (as Rafis affirmeth) do purge aduft humors, and are excellent good againft fcabs, itch, and the ill affection of the body.

$S$ If Sene be infufed in whey, and then boyled a little, it becommeth good phyficke againft me. lancholy,clenfeth the braine and purgeth it, as alfo the heart, liuer, milt, and lungs, caufeth a man to looke yong, ingendreth mirth, and taketh away forrow : it cleareth the fight, ftrengthnet hearing, and is very good againft old feucrs and difeafes arifing of melancholy.

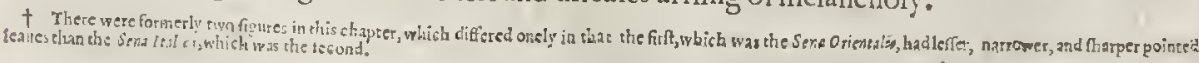


3 Coluted forpioides humilis. Dwarfebaftard Sene.

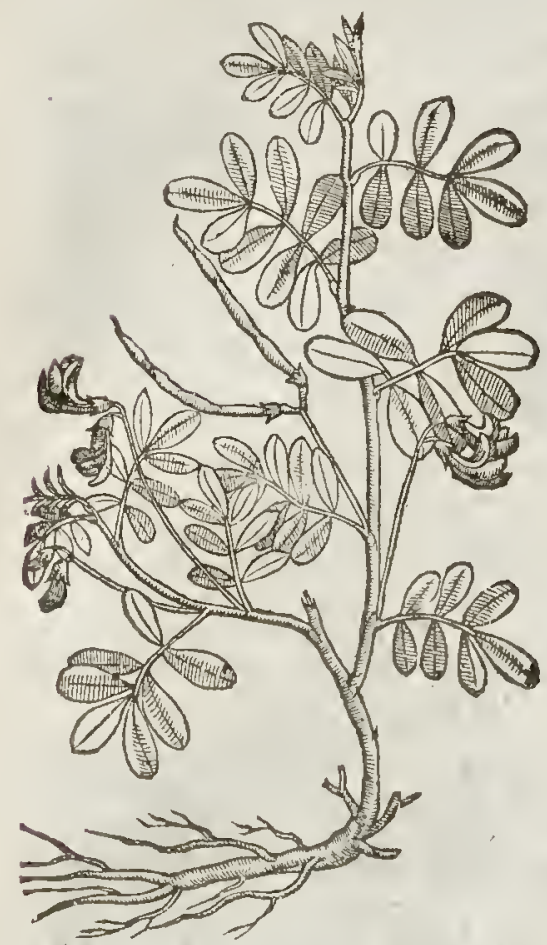

5 Colutea minima, fine Coronilla. The fmalleft baitard Sene.

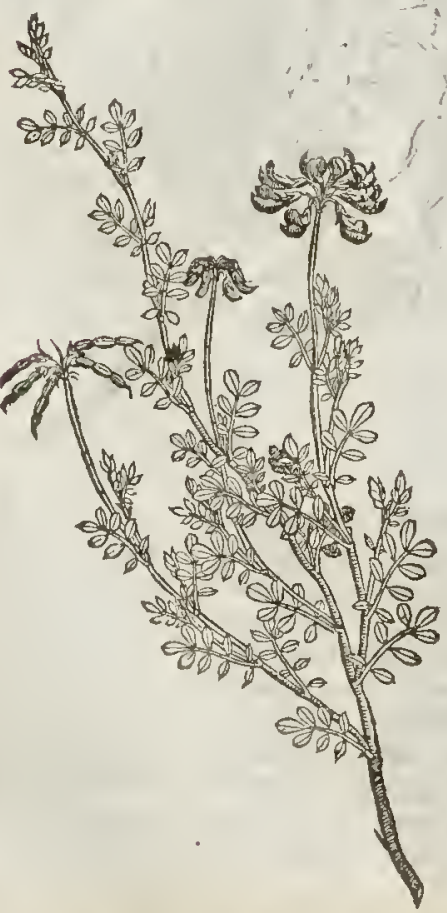

4 Colutea fcorpioides montama $\mathrm{Cl}_{u[}[3]$. Mountaine baftard Sene.

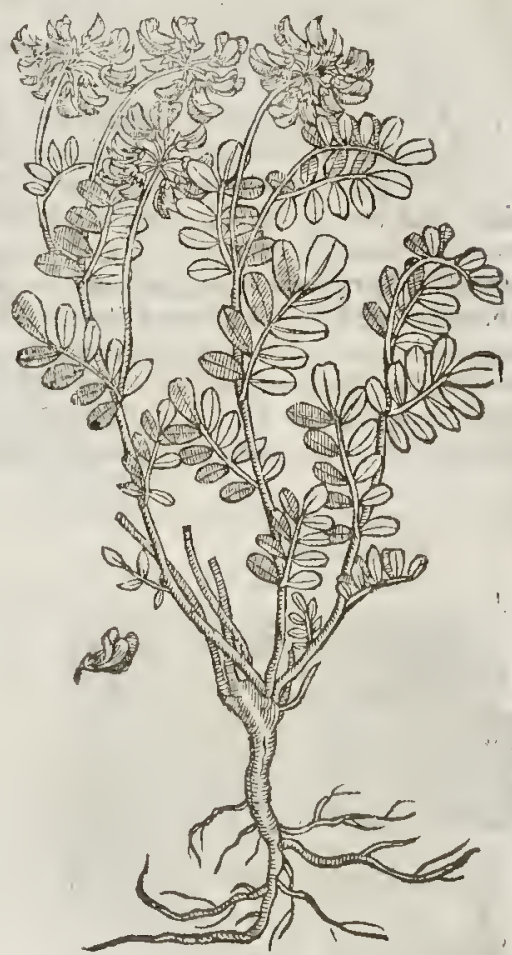

flender foot-ftalkes, long and naked like thofe of the Peafe, and of a yellow cotour, of little or no fmell at all, and yet that little nothing pleafant : after which come forth long cods, wherein is contained fmall feed like thofe of the Strangle Tare.

4 This mountaine baltard Scne hath ftalks, Icaues, and roots like the laft defcribed. The Houres grow on the tops of the branches in $\mathrm{ma}$ ner of a crowne; whereupon fome have called it Coronilla : in fhape like thofe of the peafe,and of a yellow colour: the cods as yet we hate not feen,and therefore not expreffed in the figure.

5 This fmall baftard Sene groweth like a Emall thrub creeping vpon the ground, halfe a cubit high, bringing forth many twiggic branches, in maner of thofe of the Spanioh broome; wherupon do grow leaues like thofe of Lentils or the Strangle Tare, with many fmal leaues fet. vpon a middle rib, fomew hat fat or full of iuice, of the colour of the leaues of Rue or Herbegrace, of au aftringent and vnpleafant tafte : the foures grow at the tops of the branches, of a yellow colour, in thape like thofe of the fmalleft broome: after which come litcle crooked códs like the clawes or toes of a bird, wherein is contained feed fomwhat long, blacke, and of an vnfauorie rafte : the roor is long, hard, tough, and of a wooddy fubfance. 
6 There is alfo found another fort hereof, not much differing from the former, fauing that this plant is greater in each refpect, wherein efpecially confifteth the difference.

I The Place.

Colutea or baftard Sene groweth in diuers gardens, and commeth vp of feed; it quickly commeth to perfeetion, infomuch that if a fticke thereof be broken off and thruft into the ground, it quickly taketh root,yea although it be done in the middle of fummer, or at any other time,euen as the fticks of Willow or Elder,as my felfe haue often prooued; the which bring forth floures and fruit the next yecre after.

The fecond with Scorpion cods groweth likewife in my garden: the laft doth grow in diuers barren chalky grounds of Kent towards Sirtinbourne, Canturbury, and about Southfleet; I haue not feene then elfewhere: the reft are ftrangers in England.

ब The Tinse. reed.

They foure from May till fummer be well fpent, in the meane feafon the cods bring forth ripe

$$
\text { The Names. }
$$

This fhrub is called of $T$ heophraftus in Giecke unavow with the diphthong $w$ in the fecond fillable : in Latine, as Gaza expoundeth it, Coloutes or Colutes: in high Dutch, neelleb linfen: in French, Baguenardicr: they are deceiued that thinke it to be Sena, or any kinde thereof, although we haue followed others in giving it to name Baftard Sene, which name is very vnproper to it : in low Dutch it is called Sere boom: and we may vfe the famename Sene tree, in Englifh.

This Calutea, or baftard Sene, doth differ from that plant mane with $v$ in the fecond fyllable, of which Colytra, T heophraft we writeth in his third booke. $\neq$ The fifth is the Polygald Valentina of Cowfius. $\neq$

If The Nature and Vertues.

Theophrafter, neither any other hath made mention of the temperature or faculties in working A of thefe.plants, more than that they are good to fatten cattell,efpecially theepe.

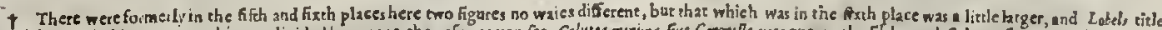

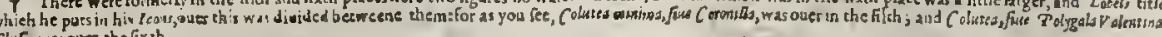
cluffis was our the lixth.

\section{C н Р. I2. Of Liquorice.}

I The Defcription.

I THe firft kinde of Liquorice hath many wooddy branches, rifing vp to the height of two or three cubits, befet with leaues of an ouerworne greene colour, confinting of many fmall leaues fet vpon a middle rib, like the leaues of Colutea, or the Maftich tree, fomewhat glutinous in handling : among which come fmall knops growing vpon thort ftems betwixt the leaues and the branches, cluftering together,and making a round forme and hape: out of which grow fmall blew floures, of the colour of an Englinh Hyacinth; after which fucceed round, rough, prickly heads, confifting of diuers rough or fcaly buske s clofely and thicke compact together; in which is contained a flat feed: the root is Atraight, yeliow within, and browne without : of a fweet and pleafant tafte.

2 The common and vfuall Liquorice hath ftalkes and leaues very like the former, fauing that his leaues are greener and greater, and the flourcs of a light fhining blew colour : but the floures of this are fucceeded by longish cods that grow not fo thicke cluftring together in round heads as the former, but fpike fashion, or rather like the wilde Vetch called onobrychu, or $G_{\text {aleg }} \cdot$ the conds arc finall and fat like vnto the Tare : the rootsare of a broming colour without,and yellow within like Box, and fweeter in tafte than the former.

\section{The Place.}

Thefe plants do grow in fundry places of Gernany wilde, and in France and Spaine, but they are planted in gardens in England, whereof I hate plenty in my garden : the poore people of the North parts of England do manure it with great diligence, wherby they obtain great plenty thereD), replanting the fame once in thece or fonre yeares.

T The Time.

Li prorice floureth in Iuly, and the feed is ripe in Septembcr. 
\$ 2 G'yigrbizavulusu.

Coinmon Licticu.

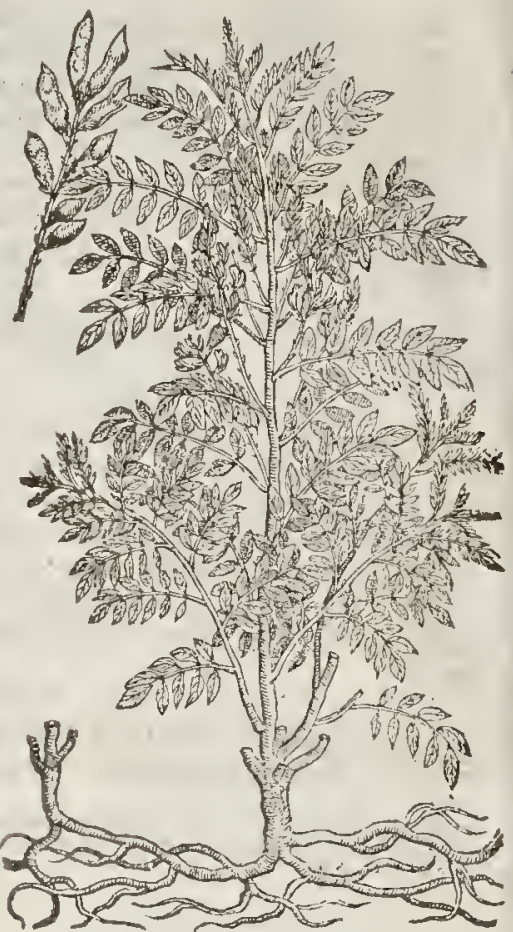

G) The Names.

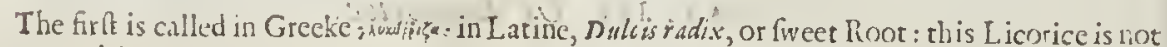
knowne cither to the A pothecaries or to the vulgar people: we call te in Englifh, Diofcorides his Licorice.

It is moft euident that the other is Glycyrrhiza,or Licorice : the Apothecaries call it by a corruptword, Liguirtita : the Italians, Regaltia : the Spaniards, Regeliza and Regalitia : in hich Dutch,

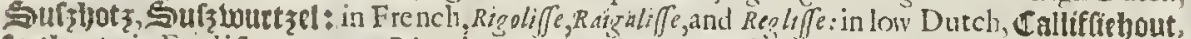
cuethout: in Englifh, common Licorice : Pliny calleth it Scythicaberla ; it is named scythice of the countrey Scythia, where it groweth.

\section{G The Temperature.}

The Nature of Diofcorides his Licorice, as Galen faith, is familiar to the temperatute of ourbo. dies, and feeing it hath a certaine binding quality adiomed, the temperature thereof fo much as is hot and binding, is fpecially of a warmebuality, comming reereft of all to a meane temperature; befides, for that it is alfo fweet, it is likervife meancly moift.

For as much as the root of the common Licorice is fiveet, it is alfo temperately lon and moift; notwrthitanding the barke thereof is fomething bitter and hot, but this muft be feraped away; the frefh root when it is full of juice doth moilten more than the dry.

$$
\text { वा The Vertucs. }
$$

A. The root of Licorice is good againft the rough barthneffe of the thrnat and breft; itopeneth the pipes of the lungs when they be ftuffed or ftopped, and ripeneth the cough,and bringeth forth Alegine.

B The inice of Licorice made according to Art, and hardned into a lumpe, which is called Succus Liquiritis, ferueth well for the purpofes aforefaid, being lolden vnder the tongue, and thete fuffered to melt.

C Moreour,with the juice of Licorice, Ginger, and other fpices, there is made a certaine bread or cakes:called Ginger-bread, which is very good againft the cough, and all the infirmitics of the lungs and breft: which is caft inte moulds, lome of one farhion, and fome of another.

I) The iuice of Licorice is proficable againt the heate of the tomacke, and of the mouth. 
$L_{1 \text { B } 3}$.

Of the Hiftorie of Plants.

The fame is drunkew irls wine of Raifons againft the infirmities of the liuer and eheft, fcabs or $\mathrm{E}$ fores of the bladder, and difeafes of the kidneyes.

Being melted under the tongue it quencheth thirf : it is good for greenewounds being layed $F$ thereupon, and for the ftomacke if it be ehewed.

The deeoction of the freih roots ferueth for the fame purpoles.

But the dried root mot finely poudered is a fingular remedie for a pin and a web in the eye, if it $\mathbf{H}$ be ftrewed thereupon.

Diofcorides and Pliny alforeport, that Liquorice is good for the ftomaek and vleers of the mouth, I being caft vpon them.

It is good againt hoarfeneffe, difficultie of breathing, inflammation of the lungs, the pleurifie, $K$ fpitting of bloul or matter, confumption or rottennes of the lungs, all infirmities and ruggednes of the eheft.

It takes away inflammations, mitigatetli and tempereth the tharpneffe and faltnes of humors ${ }_{2} L$ concosteth raw humors, and proetreth eafic fpitting.

The decotion is goot for the kidnies and bladder that a re exuleerated.

It eureth the ftranguric, and generally all infirmities that proceed of fharpe, falt,and biting hu- M mors.

Thefe things eoneerning Liquorice hath alfo $T$ heopbraf us : vit. that with this and with cheefe $N$ made of Mares milke the Seythians were reported to be able to liue eleuen or twelue dayes.

The Scytlian root is good for fhortnefle of breath, for a dry cough, and generally for all infi- 0 mities of the cheft.

Moreouer,with honey it healeth vleers, it alfo queneheth thirft if it be held in the mouth : for $\mathrm{P}$

which eaufe they fay that the Seythians do liue elemen or twelue dayes with it and Hippace, which is cheefe made of Mares milke, as Hippocrates witneffeth.

Pliny in lis twenty fifth booke, chap. 8. hath thought otherwife than truth, that Hippace is an $\mathbf{Q}$ herbe focalled.

$t$ Both the figuresformerly were of the fith defcribed.

\section{С н м. 13. Of Milke Trefoile or Sbrub Trefoile. \\ The Kindes.}

THere be diuers kindes or forts of the fhrubby Trefoile, the which might very well haue paffed among the three leaued Grafes, had it not beene for my promife in the procme ofour firt part, That in the laft booke of our Hiftory the fhrubbie or wooddy plants thould be fet fortheuericone as neere as might be in kindred and neighbourhood.

\section{बा The Defoription.}

t r THe firt kinde of Cytifus or thrubby Trefoile growes to the forme of a frmall thrub orwooddy buth two or three eubits high, branehing into fundry fmall boughes orames, fet full ofleaues like the fmall Trefoile, darke greene, and not hairie, three growing alwaies together : among thefe come forth fmal yellow floures like them of Freneh Broome, whieh doe turne into long and flat eods, eontaining fmall feed of a blackith colour.

2 The feeond kinde of cytifus is likewife a fmall hrub, in thape after the manner of the former $_{2}$ but that the whole plant is. altogether fmaller, and the leaues rounder, fet together by couples, and the fmall cods hairy at theends, which rets forth the differenee. $\ddagger$ The leates of this are almoft round, and grow three together elofe to the ftalke: they are fmooth, of a frefh greene, and the middlemoft leafe of the three is the largent, and ends in a tharpe point : the floures are of the bigneffe and colour of the Trifolium corsiculatum : it floures in May. $\neq$

$3^{-}$The root of this third kinde is fingle, from whenee fpring vp many fmooth brittle ftalks dinided into many wings and branehes, whereon grow greene leaues fmaller than thofe of medow Trefoile : the floures are yellow, leffer than Broome floures, otherwife very like, growing about the tops of the twiggie branehes, diuided into fpoky tufts : which being vaded, there follow thinne long narrow eods, leffer than thofe of the Broome, wherein is contained fmall blacke feed. The root is long, deeply growing into the ground, and fometimes waxeth erooked in the earth. $¥$ This alfo hath fmooth green leaues, and differs little (if any thing at all) from the firft deferibed, where fore I thought it needleffe to gịte a figure. Our Author ealled it Cytifus filiquofus, Codded fhrub Trefoilc, beeaufe one of the branches was fairely in the figure expreft with cods; I know no other reafon, for all the cytigi aie codded as well as this. $\neq$ 
I Cytifus.

The firf ihrub Trefoile.

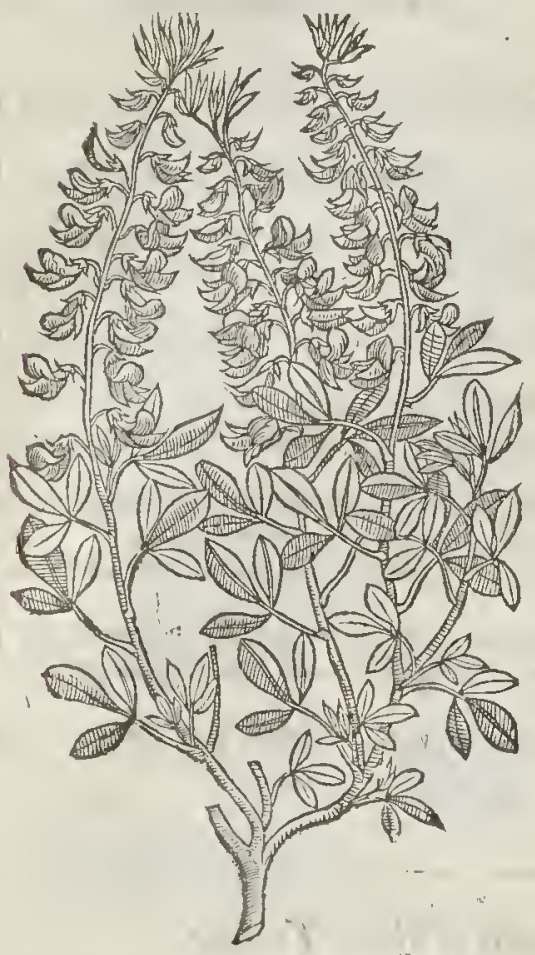

4 Cylfusbirfulas.

Ilairy lhrub Trefoile.

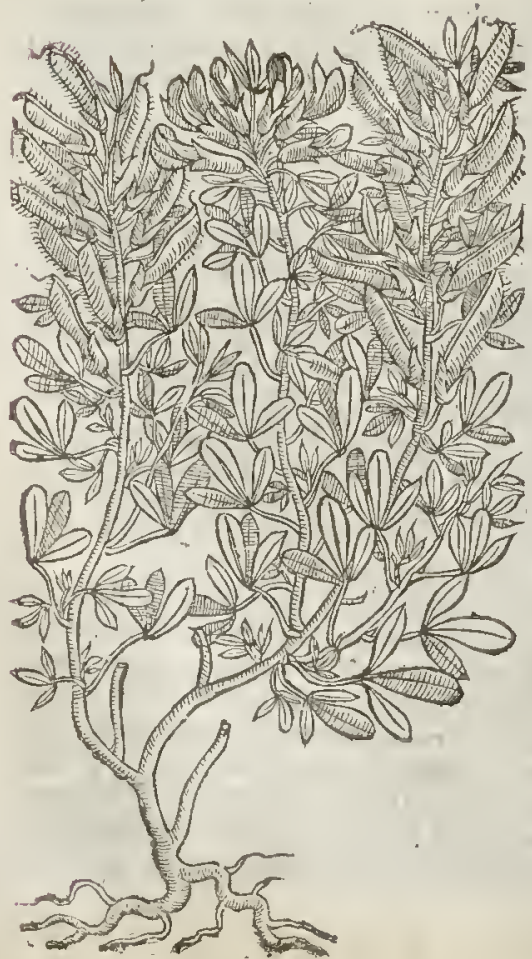

2 Cytifus.

The fecond thrub Trefoile.

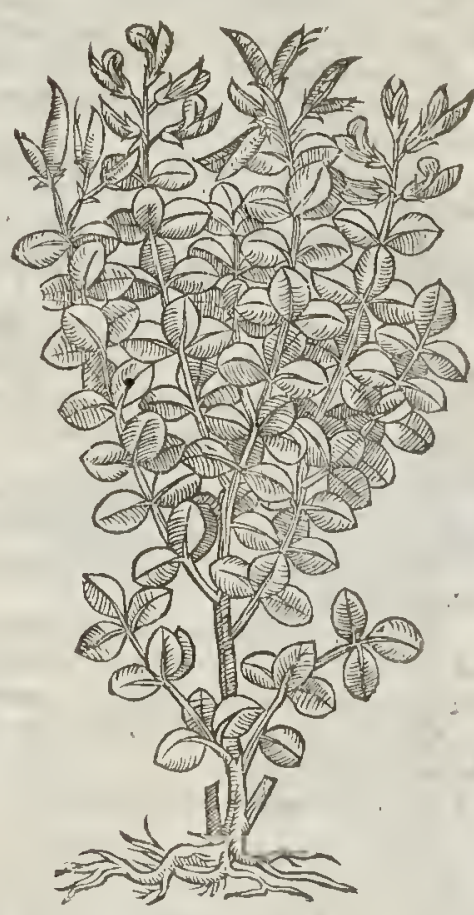

5 Cyigus incarus.

Hoary hrub Trefoile.

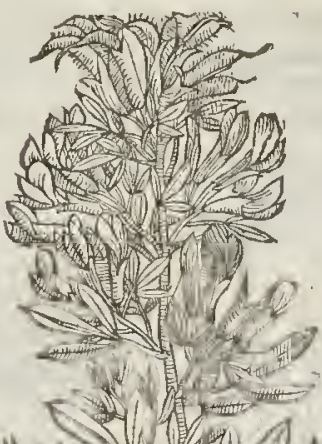

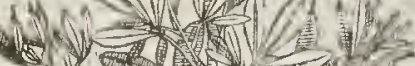

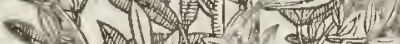

- a s I 01100

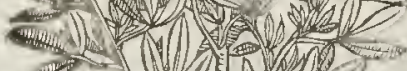

and

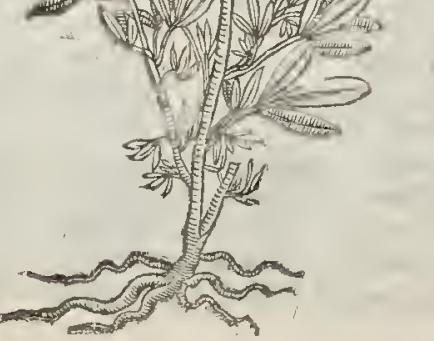


LiB.3. Of the Hiftory of Plants:

4 The fourth kinde of $C y t i f$ w hath a great number of fmall branches and falkes like the former, but it is a lower plant, and more woolly; whofe ftalks and branches grow not very high, but yet very plentifully fpred about the fides of the plant : the leates are greater than the former, but leffer than thofe of medow Trefoile : the floures grow c lofe together, as though they were bound vpor compa it into one licad or fpokic tuft fomewhat greater than the former : the cods are alfo greater, and more hairy : the root groweth very deepe into the ground, whereunto are adioyned a fer fibres: it falleth out to be nore hairy or woolly in one place than in another,and the more hairie and woolly that it is, the whiter it waxeth; for the roughnefie bringeth it a certain whition colour. † Thebranclies of this oft times lie along vpon the ground: the leaues are fonootl and grecne aboue, and hourie vnderneath : the foures ycllow, which fading fometimes become orange coloured : the ends are round, and feeds brownin. ‡

5 The fifth kinte of cytifus groweth to the height of a eubit or more, lauing many flender twiggy branches like Brome, Itreaked and very hard: whercupon grow leanes very like Fenugreelic, yet all hoary, three together : from the bofome of which, or betweene the leates and the Italkes, en me forth yellorv floures very like Broome, Spurtum, or Peafe, but fmaller : the cods be like vnto Broome cods, of an afl colour, but fenderer, rougher, and Aatter; in the feueral eels or diuifions whercof are contuned bright fhining feeds like the blacke feeds of Broonc: all the whole plant is houric like Rhamas or Halymus.

6 Cyifus Pinnities.

tVinged fhrub Irefoile.

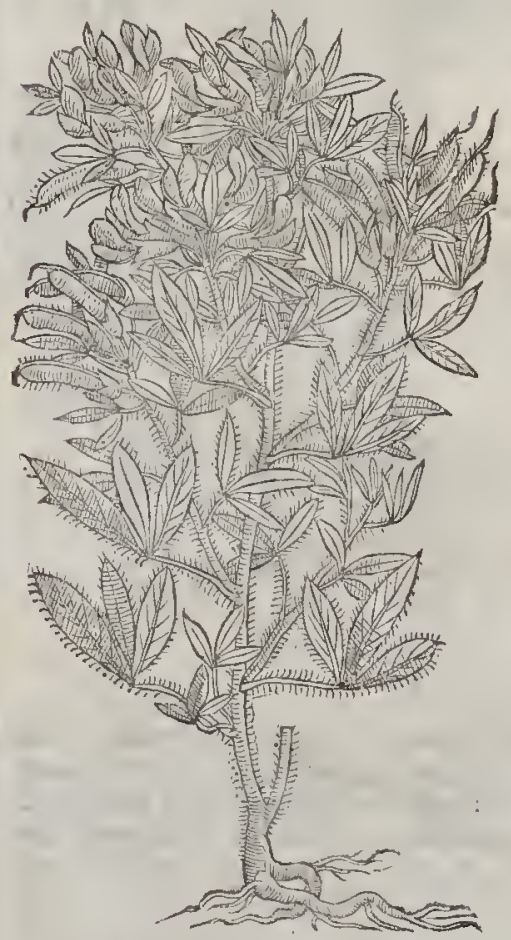

7 Cytifus 7.Comutus.

The Horned Shrub Trefoile.

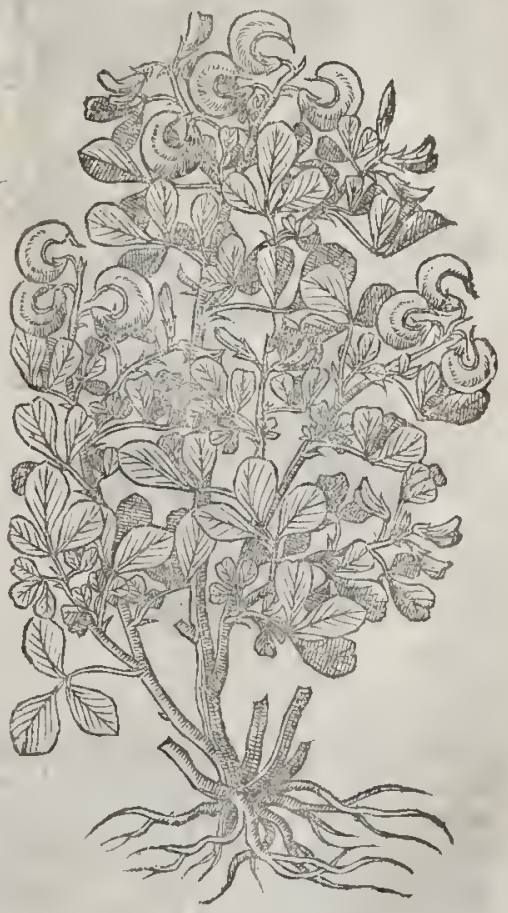

6 The fixth kinde of cyifius or buth Trefoile groweth to the height of a tall man, with long falkes entured oner with a blackith barke, and a few boughes or branches, befet or garnifhed with leancs like the common Trefoile, but finaller, growing alfo three together, whercof the niddlemont of the three lenues is twice as long as the two fide leaues; the vpper fide whereof is green, and the lower fide fomw har reddih and hairie: the flomres grow along the ftalks almoft from the bottome to the top, of a giden yellow colour, farhioned like the Broome floure, but greater than any of the reft of bis kinde, and of a reafonable good fauour: the feed hath the pulfie tafte of Cicer.

7 The feuenth kinde of rytif tus hach many tough and hairy branches rifing from a wooddie ruot, foure or fue eubits high, wh ich are diuided into fundry finaller branches befet with leaues like the medow Trefoiles; among which come forth yellow Houres like Broome, that turne into 
erooked flateods like a fiekle; wherein is eontained rhe feed tafting like cicer or Legumen. The whole planr is hoarie like $R$ bammus, and being broken or bruifed fmelleth like Roeker.

8 This eighth kinde of $C y t i f u s$, which $P$ era fetteth forth, is doubtleffe anorher kinde of $C y t i$ furs, refembling rhe former in leaues, floures, and eods, fauing that the fmall leaues (which are alwaies three roger her) area little fnipt about the edges: the whole plant is flenderer, fofrer,and greener, rather refembling an herbe than a fhrub : the root is fmall and fingle.

9 This baftard or mif-begorten fhrub 'Trefoile, or baftard Cytifess, groweth vp like a fhrub, but not of a wooddy fubftane, hauing tender ftalks fmoorh and plaine : whereon do grow hairy leates like the orher, diuers fer vpon one foot-ftalke, contraric to all rhe reft : rhe floures grow along the ftems like thofe of rhe ftocke Gillofleures, of a yellow colour : rhe root is tough and wooddy.

\section{Cytifus 8.}

The eighrh Mrub Trefoile.

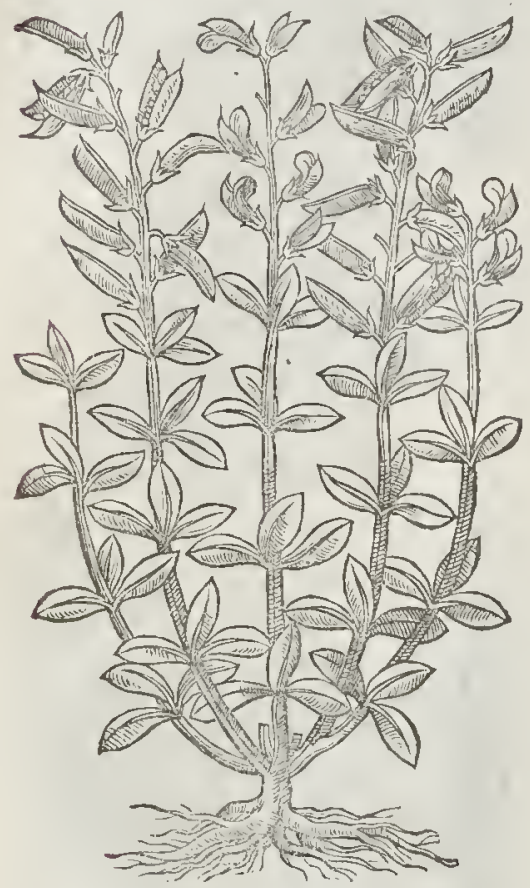

9 Cytifus adulterinus, fiue Aly) fon fruticans. Baftard flurub Trefoile.

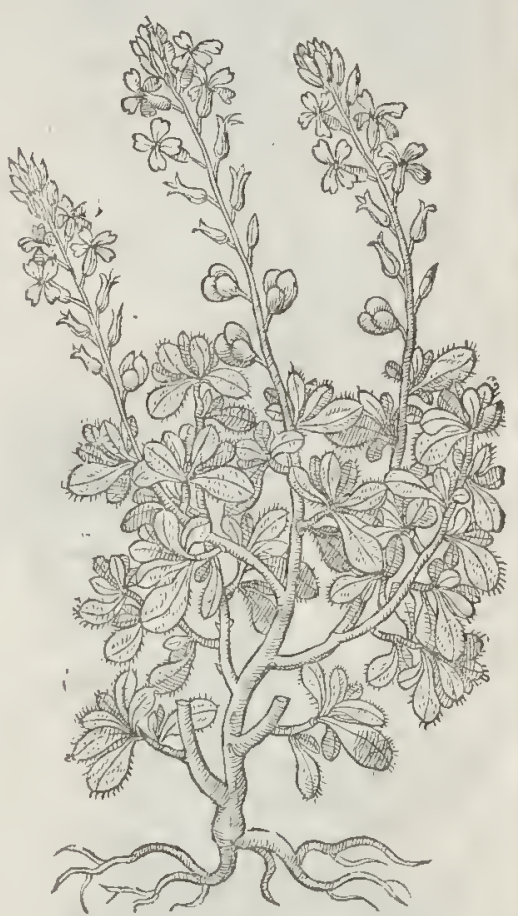

4. The Place.

Thefe planrs were firt brought into Italy and Greee from one of the Ifles of Cyelades, called Cynrho or Cynrhufa, and finee found in many places of Franee, as about Montpelier, Veganium, and orher places : rhey are ftrangers in England, rhough they grow very plentifully in Scotland, as it is reported; whereof I haue rivo forrs in my garden, that is to fay, Cytifus cMaram he, or the horned Cytifus, and likervife one of the fmalleft, that is to fay, the third in number. $¥$ The fecond groweth in the garden of $\mathrm{M}^{\mathrm{r}}$. 10 his T radefcant. $\neq$

$$
\text { of The Time. }
$$

'Thefe plants floure for rhe moft part in May, Iune, and Iuly, and fome afrer : the feed is ripe in September.

$$
\text { T The Names. }
$$

'The Greeians and Latines do call this Thrub wmoss, of Cynthufa an Ifland before mentioned, in which place they are in great eftimarion for that rhey do fo wonderfully feed eatrell, and enereafe milke in their dugs, nourith meepe and goats, which bring yong ones good for ftore and inereafe. One Author doth eall rhefe plants in Greeke ku isxy, rhat is to fay in Larine Facundum farnm, fertile or fruitfull Hay, for rhar the kindes hereof caufe milke to enereafe, nakerh good bloud and iuice, augmenteth freng th, and mulriplieth the narurall feed of generation : they may be called in Englifh, milke Trefoile, of the ftore of milke which they encreafe. 


\section{L18. 3. Of the Hiftory of Plants.}

ot The Temperature.

The leaues of milke Trefoilc do coole, as Diofrorides writeth; they affwage fwellings in the beginning, if they be ftaniped and laid unto them with bread: the decoetion thereof drunke prouoketh vrine: Galen teacheth, that the leaues of Milke Trefoile haue a digefting orwafting qualitie mixed with a waterie and temperate facultie, as hate thofe of the Mallow.

\section{The Vertics.}

Women, faith Columella, if they want milke muft fteepedry milke Trefoile in fairewater, and A when it is throughly foked, they nuft the next day mix a cutrt or thereabouts of the fame preffed or ftrained forth with a little wine, and fo let it be giuen vnto them to drinke, and by that meanes they themfeltes thall receiue ftrength,and their children comfort by abundance of milke.

Hippocrates reckoneth vp Milk-Trefoile among thofe things that encreafe milke, in his booke of $\mathrm{B}$ the Nature of women, and of womens difeales.

Alfo Ariffomactures of Athens in Pliny, commandeth togiue with wine the dry plant,and the fame C likewife boiled in water, to nurfes to drinke when their milke is gone.

Democritus and Arifomachus do promife that you thallwant no Bees, if you hane milke Trefoile D for them to feed on: for all writers with one confent do conclude (as Galen faith) that Bees doe gather of the floures of Milke Trefoile very great ftore of lonie.

Columella teacheth, that Milke Trefoile is notable good for hennes, Bees, Goats, Kine, and all E kinde of Cattell, which quickely grow fat by eating thereof,and that it yeeldech very great ftore of milke.

The people of Berica and Valentia (where there is great ftore of Cytifus) doevfe it very much $\mathrm{F}$ for the Silke Worms to lang their web vpon after they haue been well fed with the leates of Mulberries.

Milise Trefoile is likewife a maruellous remedie againft the Sciatica, and all other kindes of G gouts.

7 The defcription that formerly was in the fuft place belonged to that deferibed and figured in the feuenth.

\section{Снат. 12. OfBaftard onilke-Trefoiles.}

\section{The Defcription:}

I $T^{\text {His rifetl }}$ vp with little ftalks from the root, brittle, very many in number, parted into wings and branches,about which grow many leaues lefier than thofe of the medow Trefoile, of colour greene : the foures about the tops of the twigs be orderly placed in maner like ears, of colour yellow, leffer than thofe of broon, otherw ife all alike:in their places grow vp nender cods long, narrorv, and leffer than the cods of Broome: rough alfo and hairy; in which do lie listle blackin feeds: the root is long, and groweth deepe, and of tentimes creepetlianope.

2 The-fecond kinde of baftard Milke--Trefoile is like vnto the former in plentifull ftalkes and twigges, but that it is lower and more downie; neither doe the ftalkes thereof ftand vpright, but rather incline to the one fide:the leates alfo are fomewhat grcater, but yet leffer than thofe of the medow Trefoile, wholly white, and they neuer open them felues out, but keep alwaies folded with the middle rib ftanding out:the foures likew ife be clofelier ioined together, and compacted as it were into a little head,and be al fo formething greater : the cods in like manner are a little bigger and hairy, and of a blackith purple or murrey : the root groweth decpe in the ground, being diuided ineo a few fprigs ; it oftentimes happeneth to grow in one place more hairic or downie than in another : the more hairie and downic it is, the more white and hoarie it is; for the hairineffe doth alfo breng with it a certaine whitith colour.

3 The third kinde of baftard Milke Trefoile bringeth fortl a companie of young noots that are fomew hat writhed and crooked, long leaues of a faire greene colour : the floures are clofed together, long, white, ot elfe galbineous, fiveetly fmelling, that is to fay, hauing the fmel of honie: the fhrub it felfe is alwaies greene both Sommer and Winter. $\neq$ This growes fome foot or better high, with nender hoarie branclies, fet with leaues three ftanding together vpon a very fhort ftalke, and the middle leafe is as long againe as the other two; they are very white and hoarie, and the yellow floures grow out of the bofomes of the leaues all alongtt the falks. This is that nentioned in the vertues of the former chapter a: $F$ for the Silke wormes to worke vpon. $\neq$

4 The fourth fhrub is likewife one of the wilde kinde, though in face and ftature like the mas 
I Perudocytifus $\mathbf{I}$.

The firt baftard fhrub Trefoile.

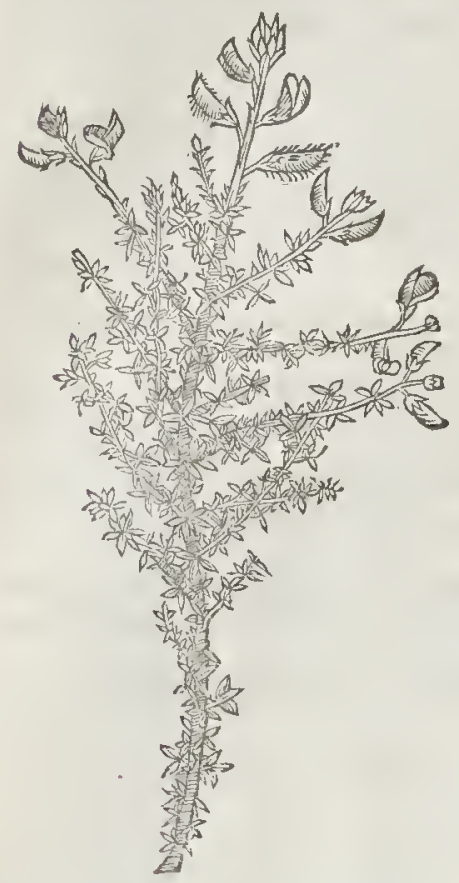

3 Cytifus fempcroirens.

The euer-greene fhrub Trefoile.

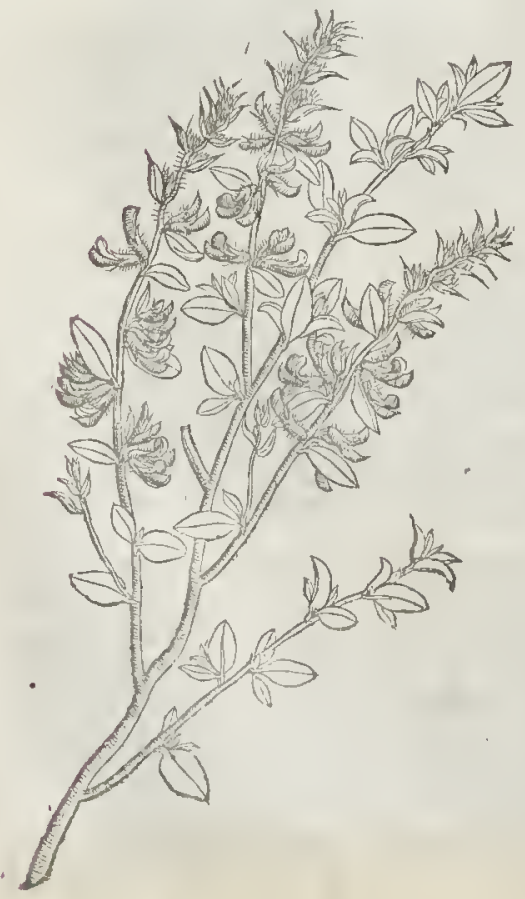

2 PSeudocytifus 2.

The 2.baftard fhrub Trefoile.

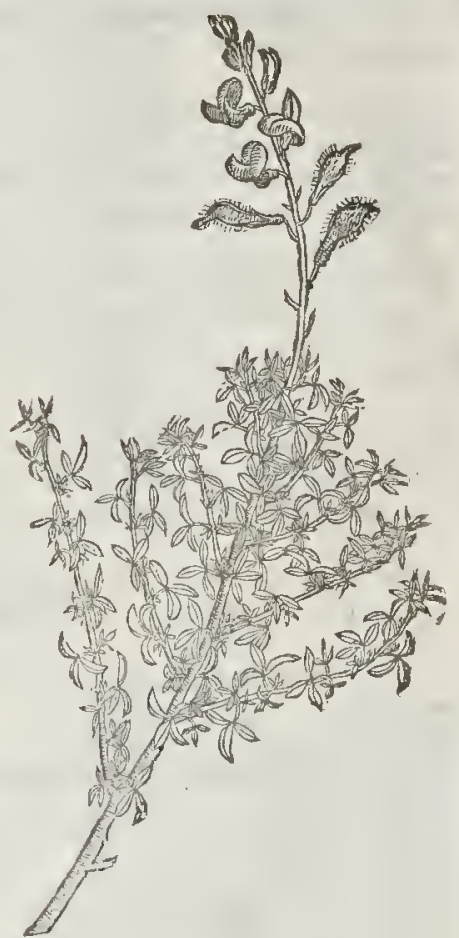

4 Pendocytifus hirfutus.

The hairie baftard tree Trefoile.

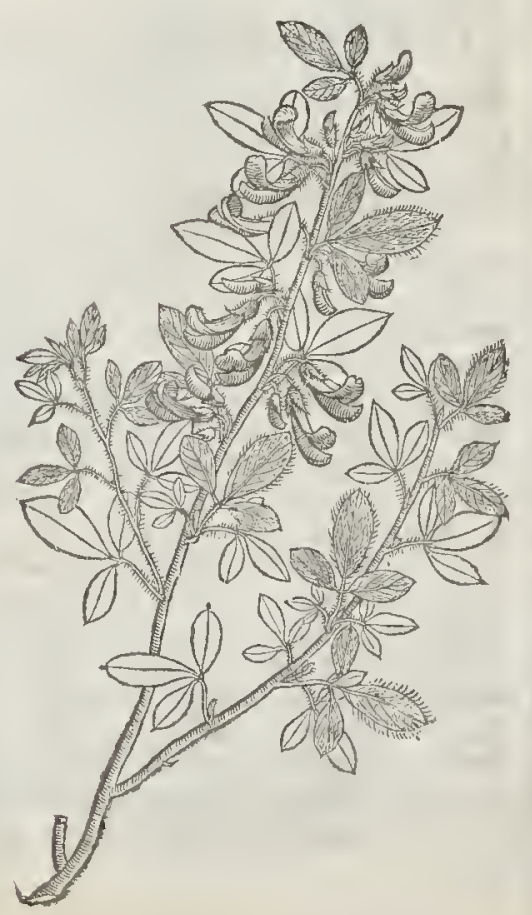


Li B. 3. Of the Hiftory of Plants.

nured Cytifus : It groweth vp like a frmall thrub or hedge buht to the height of two or three yards on whofe branches do grow three rough or hairie leaues, fet vpon a flender foot-ftalke, of a graffe greene colour abone, with a reddith hairineffe below: the floures grow along the ftalks from the middle to the toppe, of a bright fhining yellow eolour : the root is likew if wooddie.

If The Place.

Thefe kindes of Milke Trefoiles are found in Morauia, fo called in our agt, which in times paft was named cMarcomannorum prouincia, and in the vpper Pannonia, orherwife ealled Auftria, neere to high waies,and in the borders of fields; for they feeme after a fott to ioy in the thade. $t$ Thefe grow (aceording to Chry fuss) in fundry parts of Spairie.

They floure efpecially in Tune and Iuly.

T The Time.

-T The Names.

It is enident enough that they are battard kindes of Milke Trefoiles, and therefore they may be called and plainly termed Pfendocytifi, or baftard Milke Trefoiles, or Cytifi fylueftres, that is to fay, wilde Milke Trefoiles.

What temperature rhefe The Temperature and Vertues. as yet found out by our owne hrubs are of,or what vertues they haue we know not, neither haue wee Milke-Trefoiles.

\section{Cна Р. I5. Of the venomons Tree Trefoile.}

I I Dorycnium Monfplienfum.

The venomous Trefoile of Montpelier.
2 Dorycnium Hipanicum.

The venomous Trefoile of Spain。
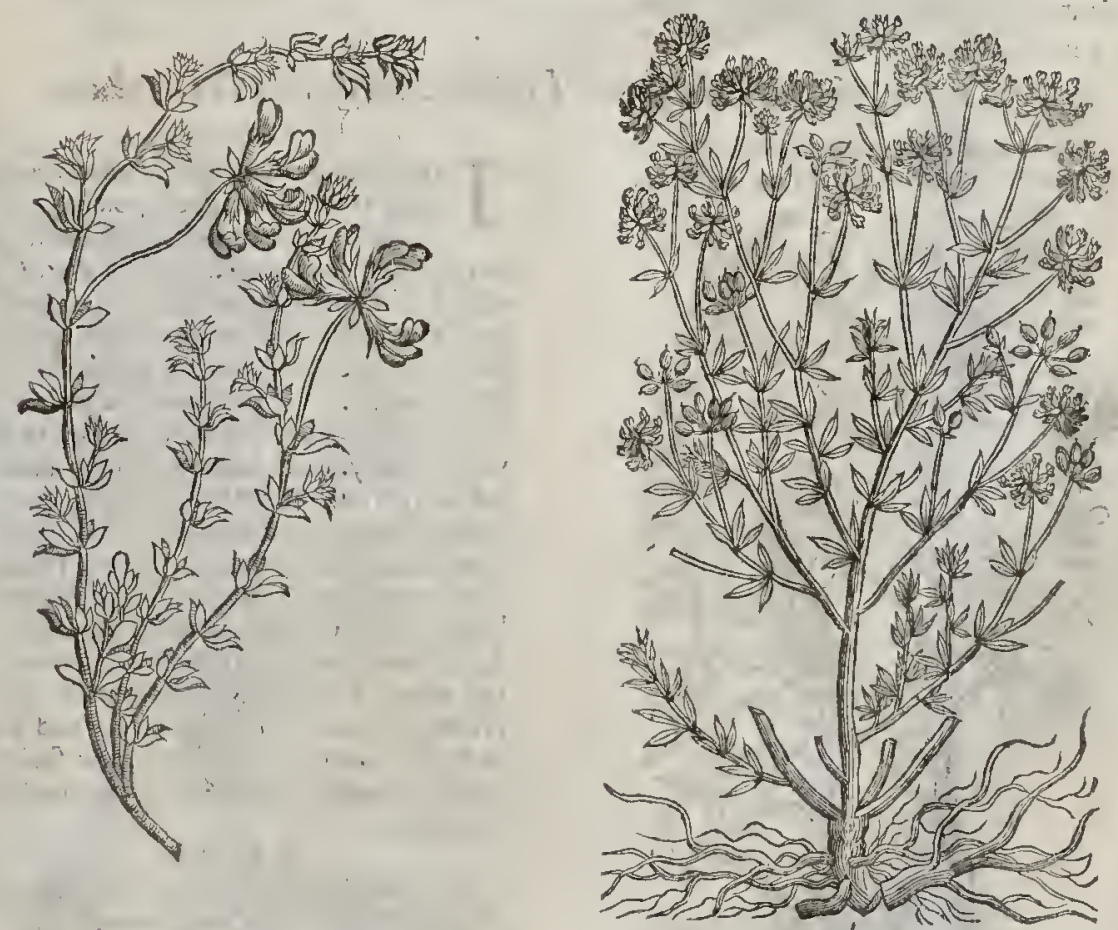

T) The Defcription.

Hevenomous tree Trefoile of Montpelier hath magy tough and pliant ftalkes, iwoor
threecubits high, diuided into fundry frall tw iggiebraunches, befes with leaues three rògethet 
together, placed from ioint to ioint by fpaces, fomewhat hoarie, very like vnto the leaues of $C$ tif fus $_{\text {; }}$; or Rue : anong which come forth many fmall moffie white floures, tuft farhion, in fmall bundles like Nofe-gaies, and very like the floures of the Oliue or Oke tree, which turne into fmall roundifh bladders, as it were made of parchment: wherein is contained blacke feed like wilde Lotus, but in tafte like the wilde tare: the whole plant is of an vnfauorie fmell; the root is thicke, and of a wooddie fubltance.

2 The Spanifh venomous Trefoile hath a wooddie ftalke, rough and hoary, diuided into other fnuall branches, whereon do grow leaues like the precedent: the floures grow on the tops of the branches, whereon do grow leaues like thofe of the Peafe, and of a yellow, or rather greenifh colour, wherein it differeth from the precedent.

$$
\text { q The Place. }
$$

Thefe venomous Trefoiles grow in Narbone, on the barren and ftonie craggie mountaines, at Frontignanas and about the fea coats, and are ftrangers in England.

They flourith from May to the cnd of I une.

$$
\text { IT The Time. }
$$

$$
\text { q The Names. }
$$

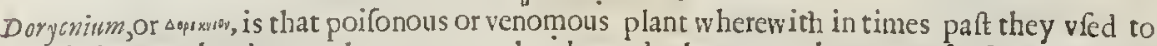
poifon their atrow heads, or rather weapons, thereby to do the greater hurt vnto thofe whom they did aftaile or purfie, whereupon it tooke his name: great controuerfie hath been among Herbarifts, what manner of plant Dorycritum fhould be; fome faying one thing, and fome another: which controuerfies and fundry opinions are very well confuted by the true cenfure of Rondeletizs, who hath for a definiriue fentence fet downe the plant defcribed for the true Dorycnium, and none other, which may be called in Englifh,Venomous tree Trefoile. \$ Thefe plants do not fufficiently an. fwer to the defcription of Diofcorides, neither cars any one fay certainly, that they ate poifonous. $\neq$

Dorycinium is very cold, wi thout moitning.

$$
\text { T) The Temperature. }
$$

$$
\text { Ti The Vertwes. }
$$

A Venomous Trefoile hath not one good qualitie that I can teadeof, but it is a peltilent venomous plant, as hath been faid in the defcription.

t The figures were formerly rsaripoited.

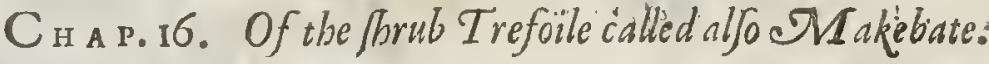 \\ Polemonium five Trifolium fruticans: \\ - The Defription.}

Shrubby Trefoile, or yellow Iafmine.

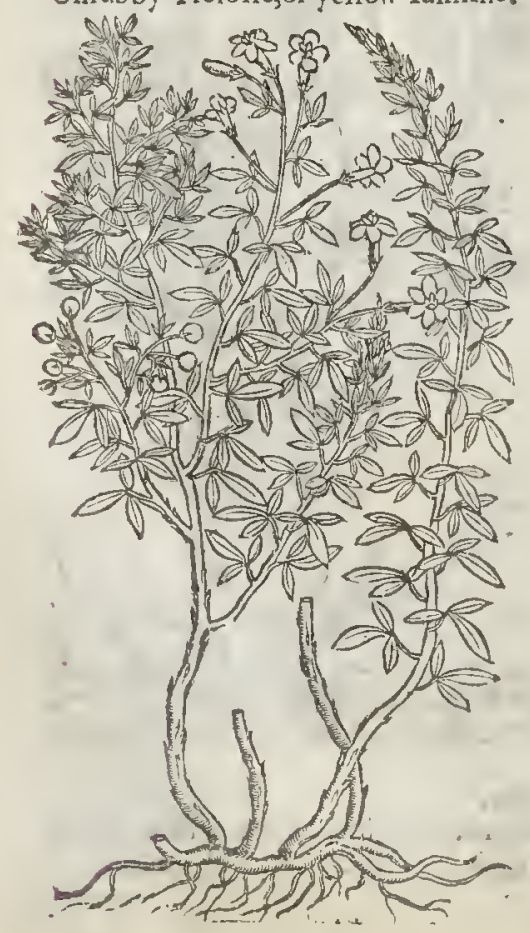

7 His thrubby plant called $P$ olemonium, hath many wooddie twigges, growing vito the height of foure or fite cubits, hauing fmal twiggie branches, of a darke green colour, garnifhed with fmall leaues of a deepe greene co-

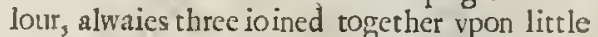
foot Atalks, like the Cytifus buth,orthe field Trefoile, but fmaller : the floures be yellow; and round, diuided into fue or fix parts, not much vnlike the yellow Iafmine, which hath caufed many to call it yellow lafmine, eten vnto this day : when the floures be vaded, there fucceed fmall round berries as big as a Peale, of a black purplifh colour when they be ripe, which being broken will die or colour the fingers like Elder Berries: within thefe berries are contained a finall flat feed, like vnto Lentils: the root is long and fmall, creeping hither and thither voder the earth, putting forth new fprings or fhoots in fundry places, whereby it wonderfully increafeth.

\section{If The Place.}

It groweth plentifully in the countrey of Montpellier at New Caftle vpon the drie hills, and hot banks of the Oline fields, and in the fto. ny fields and wood of Gramuntium : it growes in my garden, and in other Herbarifts gardens in England. 
LI в. 3.

Of the Hiftory of Plants.

at The Time.

It floureth in Sommer : the feed is ripe in Autumne; the fhrub it felf is alwites greene, and bath a lafting root.

T The Numes.

Moltocall it Cytifus, but we had rather name it Trifolum fruticans: for it doth not agree with Cytifus or Milk-Tr efoile, asin the chapter before it is plaine enough by his defeription, vnleffe it be Cytifus Marcelli, or Marcellus his Milke-Trefoile, with which peraduenture it might be thought to haue fome likeneffe, if the floures which are yellow werewhite, or zalbineous, that is to fay, blew.

There be diuers alfo that take this Trefoile to be Polemonsum, forafmuch as the leaues heref feeme to be fomewhat like thofe of common Rue, but Polcmonium hath not the leafe of common Rue, otherwife called Herb-grace, but of the other, that is to fay, of S. Iolnns Rue: it is called in Englin, (hrubby Trefoile, or Make-bait.

Tा The Temperature.

Polcmonitm is of temperature dry in the fecond degree, with fome Acrimonic or tharpneffe. 9 The Vertues.

This fhrubby plant hath fo many fingular and excellent vertues contained in it, thar fome haue $A$ called it by the name Chiliodunansis, that is, hauing an hundred properties.

It is very effe funH againtt the ftinging of Scorpions, and (as fome write) if a man hold it in his $B$ hand, he cannot be hurt with the biting of any venomous beaft.

Being taken in vineger it is very good for thofe that are fpleneticke, and whofe fpleen or Milt is C affected with oppilations or ftoppings.

If the root be taken in wine it hel peth againft the bloudy flix, it prouoketh vrine being drunke $D$ with water, fcoureth away gratiell,and eafeth the paine and ache called the Sciatica.

\section{Cras. 17. Of Broome, and Broome Rape.}

I Genifta.

Broome.

Spathime Scoparium

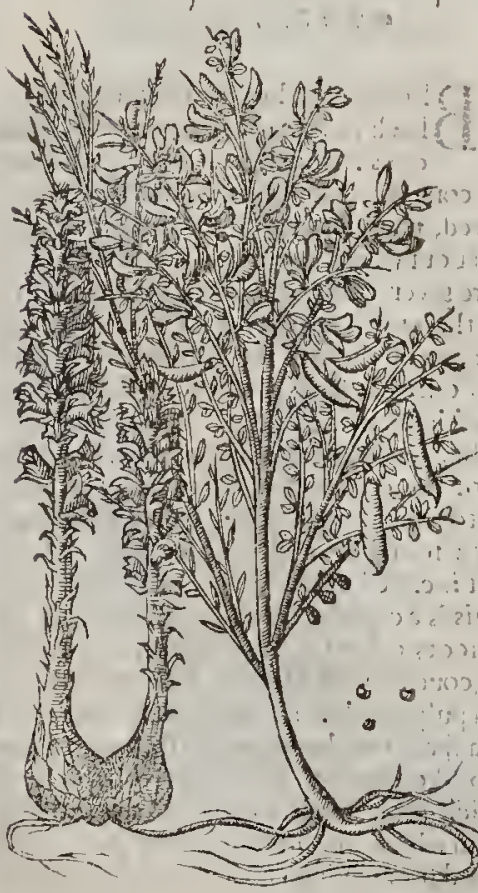

2 Rupum Genifte, $\sqrt{i v e}$ Orobanche. Broome Rape,or Orobanch.

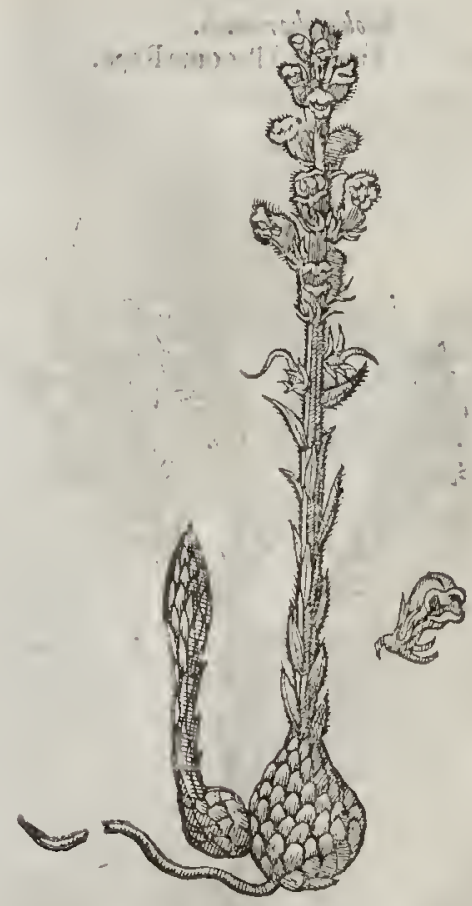

T $T b_{c}$ 
* Orobanche sempeliacs fo. oblongis. Long floured Broome Rape.

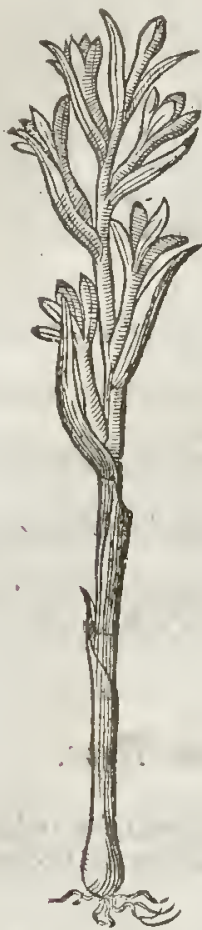

\# Orobaxeberawoja.

Branched Broome Rape:

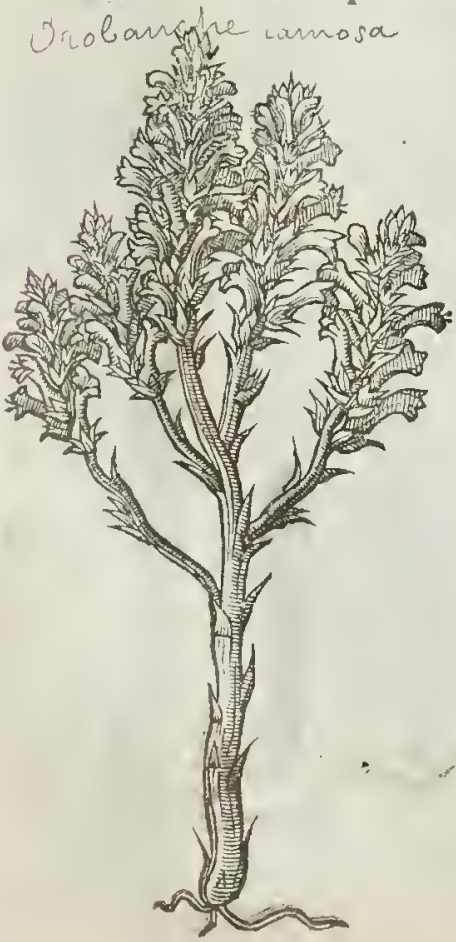

¥ orobanche florc maiore.

Great floured Brcome Rape.

(")ibanche Corulea
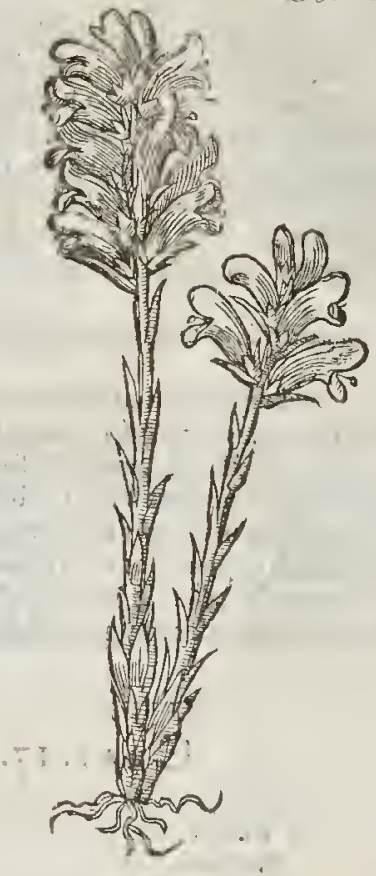

TI Te Defcription.

- DRoome is a bufh or fhrubby plant, it hath ftalkes or rather wcoddic branches: from which do fpring flender twigs, cornered, greene, tough, and that be earily bowed, many rimes diuided into fmall branches: about which do grow little leaues of an obfcure grecn colour, and braue yellow fioures; and at the length flat eods, which being ripeare blacke, as be thofe of the common Veteh, in which do lic flat feeds, hard, fomething brownirh, and leffer than Lentils:the root is hard and wooddie, fending forth djuers times another plant of the colour of an Oken leafe, in thane like vinto the baftard Orchis, ealled Birds neft, hauing a root like a Turnep or Rape, where. upon it is called Rapum Genifta, or Broom Rape. 2 This is a certaine bulbed plant growing vnto the roots of broome, big below, and fmallcr a boue, coured with blackinh feales, and of a yelowirh pulpewithin : from which doth rife a ftalke a fpan long, hauing whitifh houres about the top, like almoft to thofe of Dcad Nettle: afrerwhich grow forth long, thicke, and round husks, in which are conrained very many feeds, and good for nothing : the who'e plart is of the colour of the Oten leafe. 


\section{$\mathrm{L}_{\mathrm{I} 8: 3 .}$ Of the Hiftorie of Plants.}

3 Genifta Hipanica.

Spanila Broome.

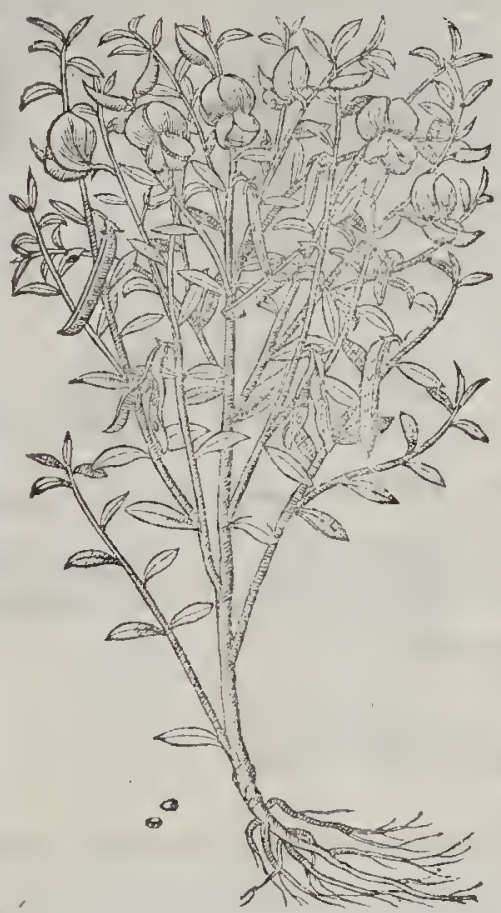

6 Chamegenista Pannonits.

Dwatfe broome of Hungaric.

Gensta pilosa

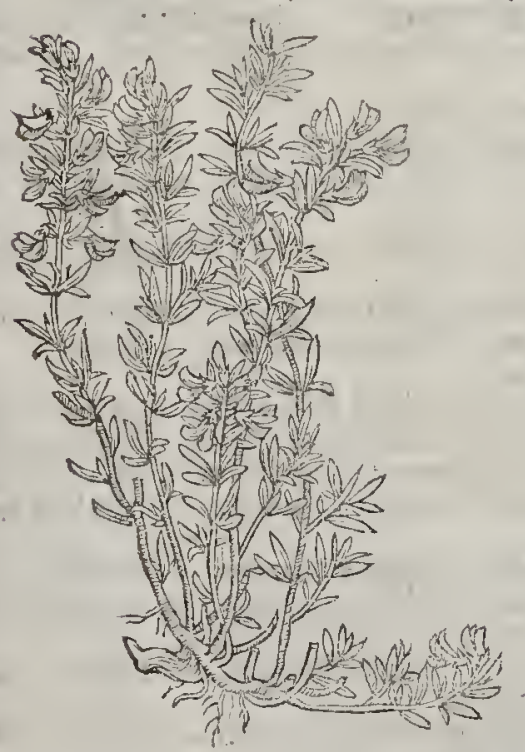

5 Chamagenifar Amglicto.

Englifh Drvarfe Broome.

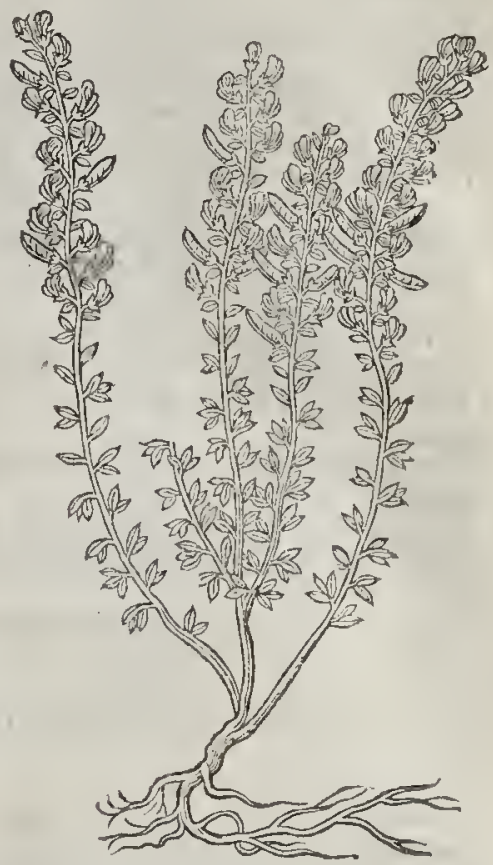

\# Of this Orobanche or Broome Rape there are fome varieties obferued and fet forth by $L_{0}$ bel and Clufuss: the firft of thefevarieties hath longer and fmaller floures than the ordinaric. The fecond hath larger floures, and thofe of a blewith colour, and is fomerimes found among eorne. The third is parted towards the top into fundry branches; the floures of this are either blew, purplifh, or elfe white, and it willingly growes among hempe. $\ddagger$

3 The Spanifh Broome hath likewife wonddy fems, from whenee grow vp flender pliant twigs, which be bare and naked without leaues, or at the leat having but few fmall leates, fet here and there far diftant one from another, with yellow floures not much vnlike the floures of eommon Broome, but greater, which rume into fmall long eods, wherein is conteined browne and flat feed: the roote is tough and wooddy.

4 Small leafed or thin leafed Broome lyath many tough pliant fhoots rifing ont of the ground, which grow into hard and tough italks, which are diulided into diuers rwiggy branches whereon doe grow very fmall thin leaues, of a whitifh colour; whereupon fome haue called it Genifta alar, white Broome : the floures grow at the top of the ftalkes, in thape like thofe of the common Broom, but of a white colour, wherein it fpecially differeth from the other Bromes. serfe

5 Englih 


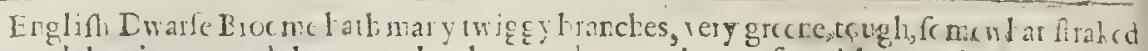
or eornered, leaning tow ard tle gipurd : $\mathrm{l}$ crec n do grow leaucs fet willout ioder, Fometinics two together, and often three or foure growirg faft together, like rnto the ceninion Biccme, greene on the vpper fide, hoary inderrcath, ard of a bitrcr tafte: arrong whieh leaves eome forth yellow floures like thofe of cummon Broome, but leffer, of little or ro fmell at all: after which appeare fmall cods fomcr hat hairy, wh crin is cont airc d fmall feed:the root is tough and wcoddy. $¥$ Baubinc judges thefe two laft defcribed to be onely varieties of the ec mmon Btcome; towlore opinion I do mueh incline, yet I have let o ur Authrs defeription ftand, togetler with the figure of this later,which fecmingly expreffes the greatc diffcrence. $\ddagger$

6 The Dwarfe Broome of Hungary hath ftalkes ard yellow foures like tl ofe of the laft deferibed : the leaues hereof are different, they are longer, and more in number: the whole plant is altogether greater, wherein efpecially confifteth the differenee.

\section{T) The Place.}

The common Broome groweth almoft euery where in dry paftures and low woods.

The Broome Rape is not to be found but where Broome deth grow ; it groweth in a Broome field at the foot of Shooters hill next to London; vpon Hamplead Heath, and in divers orher places.

Spanifh Broome groweth in diters kingdomes of Spaine and Italy; we hate it in our London gardens.

The White Broome groweth likewife in Spaine and other hot regions; it is a franger in England; of this Titus Calpburnius makes mention in his feeond Eelog of bis Bucolicks, writing thus:

Cernis vt, ecce pater, quas tradidit ornite vacce

Molle fub bir fut a latwes cxplicucre genifta.

Sce father, how the Kine ftretch out their tender frde

Vndẹ the hairy broome, that growes in fields fowide.

\section{of The Time.}

Broome floureth in the end of Aprill or May, and then the young buds of the floures are to be gathered, and laid in pickle or falt, which af terwards-being wa fhèd or boy!ed, "ure vfed for fallads, as Capers be, and be eaten with no lefie delight: the cods and feeds beripe in Augutf; the Rape
appeareth and is feene efpecially in the moneth of Iune.

The Spaninh Broome doth floure fooner, and is longer in fouring.

$$
\text { of The Names. }
$$

This Mrub is called in Latine, Genifta, or as fome would haue it Gencfta : in Italian, Geneflra : in

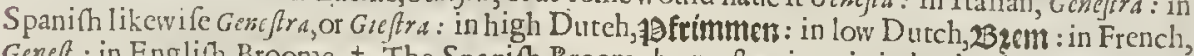
Gemeft - in Englith, Broone. $\neq$ The Spanim Broome by molt writers is iudged to be the Spart um
of Diofcorides. $\neq$

\section{T) The Temperature and Vertucs.}

A The twigs, floures, and feeds of Broome are hor and dry in the fecond degree: they are alfo of a thin effence, and are of force to clenfe and open, and efpecially the feed, which is dryer and not fo
full of fuperfuous moifture.

B The deeoction of the twigs and tops of Broome dotl clenfe and open the litter, milt, and kidnies.

C It driteth away by the foole watery humours, and therefore it is wholefome for them that hate the dropfie, efpecially being made with wine; but better for the other infirmities with water.

D The feed alio is commended for the fame purpores.

E There is alfo made of the afhes of the ftalkes and branches dryed and bumt, a lie with thin white wine, as Rhenifh wine, which is highly commended of diuers for the greene fickeneffe and dropfie, and this doth mightily expell and driue forth thin and watery humors together with the vrine, and that by the bladder; but withall it doth by reafon of his tharpe quality many times hurt and
fret the intrailes.

F Mefue faitl, that there is in the floures and branches a eutring moifture, but full of exerements, and therefore it caufeth vomit: and that the plant doth in all his parts trouble,cut, attenuate, and violently purseth by vomit and ftoole, flegme and raw humours out of the ioints.

G But thefe things are not written of Broome, but of spattum, which purgeth by vomit, after the manner of Hellebior, as both Diofcorides and Pliny do tentifie.

H Mefue alfo addeth, that Broome doth breake the ftone of the kidnies and bladder, and fuffereth not the matter where of the ftone is made tolie long,or to become a ftone. I The young buc's or little floures preferued in piekle, and eaten as a fallad, ftir vp an appetitc to, 
The fame being fully blowne, ftamped and mixed with fwines greafe,do eafc the paine of the $L$ gout.

And crefue writeth, that this tempered with honic of Rofes, or with an egge, doth confume a- M way the Kings-euill.

The Rape of the Broom or Broome Rape, being boyled in wine, is commended againft the pains $\mathbf{N}$ of the kidnics and bladder, pronoketh vtine, breaketh the ftone, and expelleth it.

The iuice preffed forth of Broom rape hcalcth green wounds, and clenfetls old and filthy vicers: $O$ the latet Phyfitions do affirmc that it is alfo good for old venomous and malicious vicers.

That worthy Prince of famous memoric Henry 8 . King of England, was woont to drinke the di- $\mathrm{P}$ ftilled water of Broome floures, againft furfets and difeafes thercof arifing.

Sir Thomas Fitzherbert Knight,was woont to cure the blacke iaundice with this drinkc onely. Q

Take as many handfuls (as yout thinke good) of the dricd leaues of Broom gathered and brayed $\mathbb{R}$ to pouder in the moneth of May, then take vnto each handfull of the dried Icaucs,one fpoonful and a halfe of the feed of Broom btaied into pouder: mingle thefe together, and let the ficke drinke thereof cach day a quantitie, firft and laft, vntill he finde fomecafe. The medicine mutbe continued and fo long vfed, vntil it be quite extinguifhed: for it is a difeafe not vety fuddenly curad, but muft by little and little be dealt withall.

Orobanch or Broom rape fliced and put into oyle Oline,to infufe or macerate in the fame,as yeS do Rofes for oile of Rofes, fcoureth and putteth away all fpots, lentils, frcckles, pimples, wheals and puthes from the face, or any part of the body, being annointed therewith.

Digfcorides writetb, that Orobanch may be caten either raw ct boiled, in mannet as we vee to eat $\mathrm{T}$ the fprigs or young thoots of Aparagus.

The floures and feeds of Spanith Broome are good to be drunke with Mead ot honied watet in V the quantitic of a dram, to caufe one tovomite with great forcc and violence, euen as white Hellebor, or licefing pouder.

If it be taken alone, it loofeneth the belly, driteth fotth gteat quantitic of watetic and filthie $\mathrm{X}$ humouts.

$$
\begin{aligned}
& \text { Cна . I8. Of baje Broome or greening meed. } \\
& \text { T The Defcription. }
\end{aligned}
$$

I T His bafe kinde of Broom called Greene weed or Diets weed, hath many tough branches proceeding from a wooddic root: whercon do gtow grear fote of leaues, of a deep green colour, fomervhat long like thofe of Flax : the floures grow at the top of the branches not much vnlike the leaucs of Broome, but frialler, of an exceeding faire yellow colout, which turne into fmal! flat cods, wherein is contained a little flat feed.

2 Carolis Cluf fus fetteth forth anoshet kinde of Broome, which Dodonsus calleth Genifatinctoria,being anothet fort of Diers weed : it groweth like the Spanith Broome: vpon whofe branches dogrow long and fmall lèanes like Flax, greene on the vpper fide, and of an hoatie fhining coiour on the other. The floures grow at the top of the ftalks, fike farhion, in forme and colour like the former : the roots ate thicke and wooddie.

3 Carolus Clnfius fetteth forth two kindes of Broome. The firft is a low and bafe plant,creeping and lying flat $v$ pon the ground, whofe long branches are norhing clfe, but as it wete ftalkes confifting of leates thicke in the middeft, and thinne about the edges, and as it were diuided with fmall nicks; at which placcit beginneth to continue the fame leafe to the end, and fo from leafe to leafe, vntill it hauc increafed a gteat fort, all which doe as it were make one ftalke; and hath none other leates, fating that in fome of the nicks or diuifions there commeth forth a fmall leafe like a little eare. Át the end of thofe flat and leafed fallis come forth the floutes, much like the floures of the common Gteening weed, but leffer, and ofa yellow colour,which turne into fmall cods. The roots are very lorig, tough, and wooddie, ful of fibtes, clo fing at the top of the roor, from whence they proceed as from one body.

4 This kinde of Greenweed called of fome Chamafpartium, hath a thicke wooddic root: from which rife vp diuters long leaues, confiting as it were of many pieces fet together like a paire of Beads (as may better be perceiucd by tlie figure, than expreffed by words) greencon the vpper fide, and whitifn vnderneath, very tough, and as is were of a ruthie fub ftance: among which rife vp very fmall naked rufinie fta!kes; on the top whereof groweth an eare or f pike of a chaffie matter hauing here and there in ris faid eare diuers yellow toures like Bropme, but very frall or listle.

$$
\text { sifir } 2
$$


I Gcriftella tinctoria.

Greeneweed or Diersweed.

Ciemsta tinctiona.

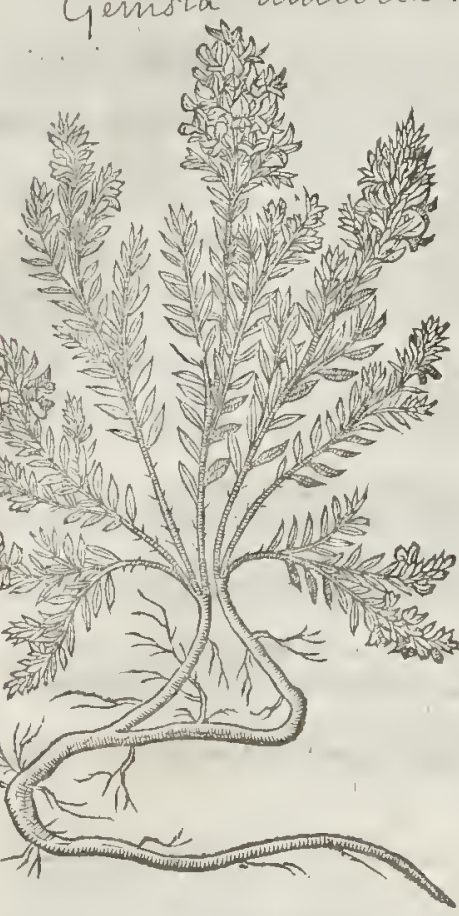

3 Genifellapinnata.

Winged Greeneweed.

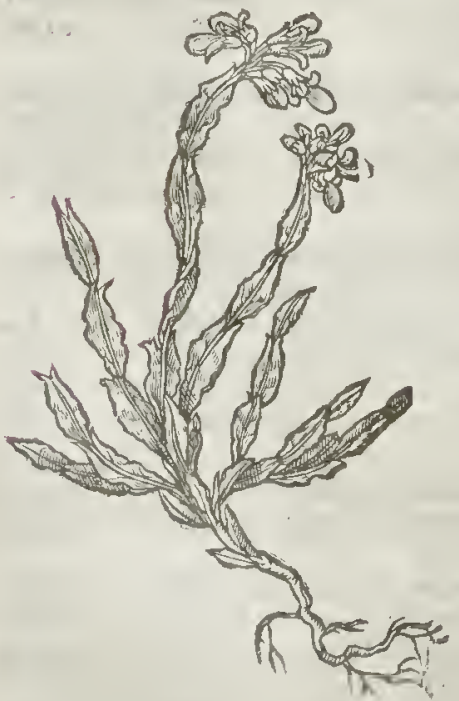

2 Geniftellainfectoria.

Wooddie Diers weed.

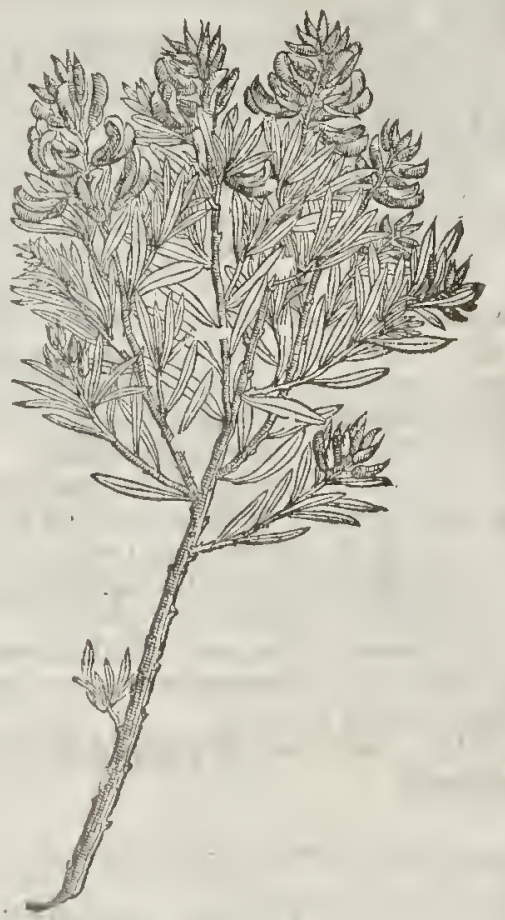

4 Geviftella glabulata?

Globe Greene weed.

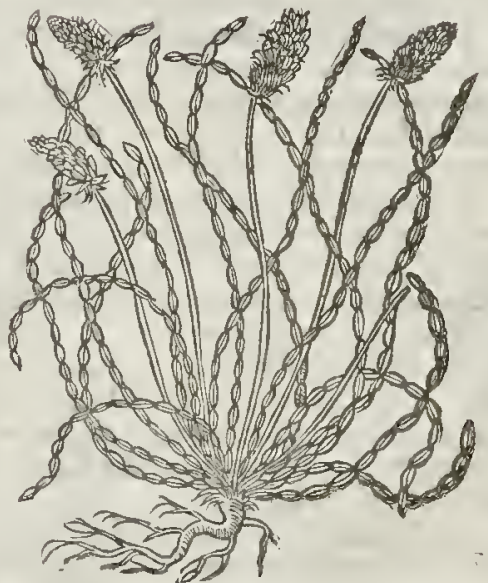


L 1 B. 3 . Of the Hiftory of Plants.

1317

5 The fift Greeneweed hat h wooddie tough root, w th th eertaine ftrings annexed thereto: from which rife v p diters long, flat leaues, tough, \& very hard, confifting as it were of many little leaues, fet one at the end of another, making of many one entire leafe, of a greene coloir : among f which come forth diuers naked hard ftalks, very fmall and ftiffe, on the tops whereof fand fpikic eares of yellow Aloures, like thofe of Broome, in fhape like that great three leafed graffe, enlled Lagopus, of like the Fox-taile grafe : after which come flat cods, wherein is inelofed fmall feed like to Tares both in tafte and forme.

5 Geniftella Lagopoides maior.

Hares foot Greeneweed:

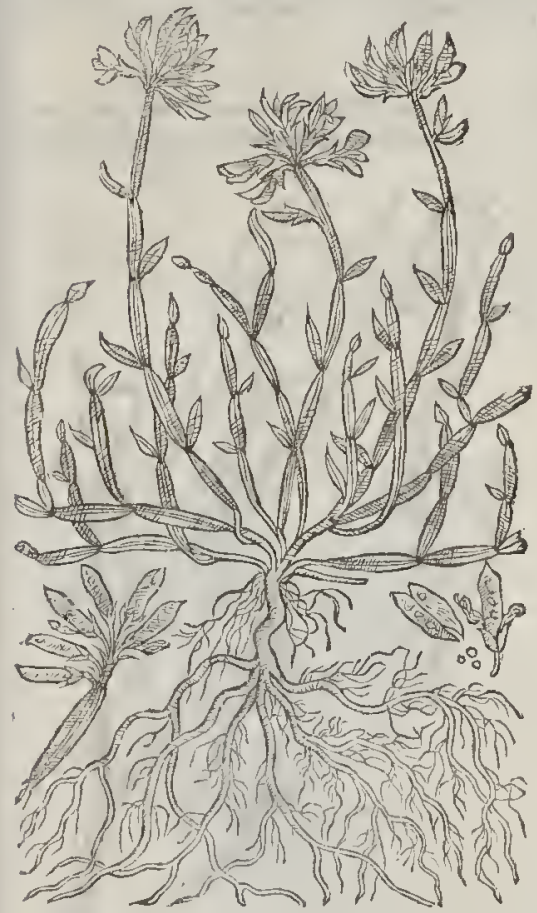

6 Geniftella Lagopoides minor.

Sinall Greenweed with Hares foot floure:

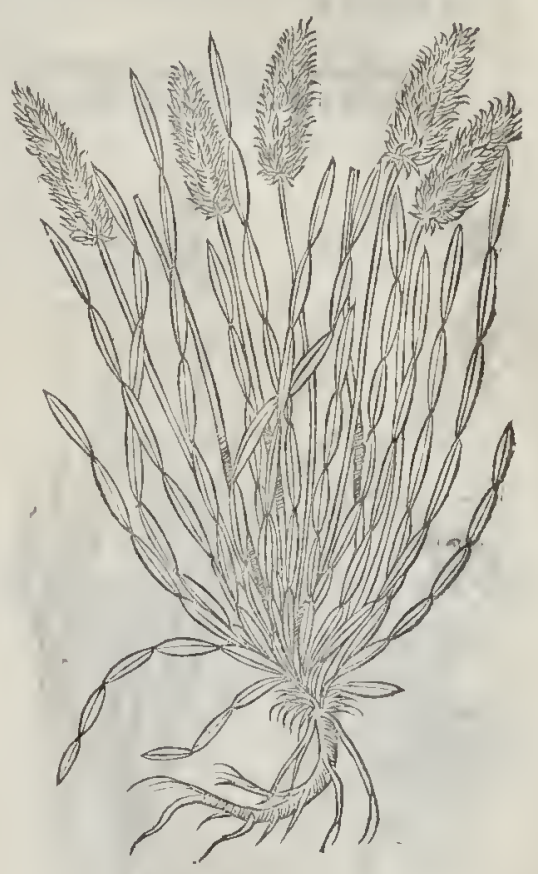

6 This differeth not from the preedent in ftalks, roots and leaues: the floures confilt of a floc: kie froft matter,not vnlike to the graffie tuft of Foxtaile, refembling the floure of $L_{a}$ op pus, or Haresloot, but hating fmall yellow fioures leffer than the former, wherein it ehiefely differeth from the other of his kinde.

$$
\text { T The Place. }
$$

The firft being our eommon Diers-weed, groiveth in molt fertile paftures and fields almoft euery where. The reft are ftrangers in England.

They floure from the beginning of Iuly to the end of Augut.

$$
\text { बा } T \text { bc Names. }
$$

The firft of thefe Greenweeds is named of moft Herbarifss Flos Tinetorius, but more rightly, Ge: niffa Tinctoria, of this Pliny hath nade mention [ The Greenweeds, faith he, do grow to dye eloths wirh] in his 18 booke $\mathbf{1 6}$. Chapter. It is ealled in high Duteh, ffetblumen, and Zllkerbzem : in Italian, Cerretta, and Cofaria, as eacatthiolus writeth in his ehapter of Lyfim.achia, or Loofe-ftrife: in Englifh, Diers Greening weed,bafe Broome, and Woodwaxen.

The reft we refer to their feucrall titles.

$$
\text { 9T The Temperature and Vertues. }
$$

Thefe plants are hke vnto common Broome in bitterneffe, and therefore are hot and drie in the $A$ fecond degree : they are likewife tho:ight to be in vertues equall, notwithftanding their vfe is not fo well knowne, and therefore not vfed at all where the other may be had: we hall not need to fpeak of that vfe that Diers make thereof, being a matter impertinent to our Hiftorie.

$$
\text { S ffff } 3
$$

$\mathrm{CHAF}$ 


\section{Cна т. I9. Of Spanijhbaje Broomes. \\ T) The Defription.}

f I THis growes to the height of a cubit,and is conered with a crefted and rough barke? and diuided into many longi in branchescrefted \& green, which at their fir it fpringing vp haue fome leanes vpon them, which fall away as foon as the plant comes to floure : from the fides of the branches come forth long foot-ftalks whereon hang fome fmall yellow floures, which arc fucceeded by fhort round yellowith red cods which commonly containe but one feed, feldome two, and thefe hard and blacke, and like a little Kidney, which when it is ripe will rattle in thecod being thaken. $\neq$

I Pfeudolpartum Hifpanicum Aphyllum. Spanifh Broomc without lcaues.

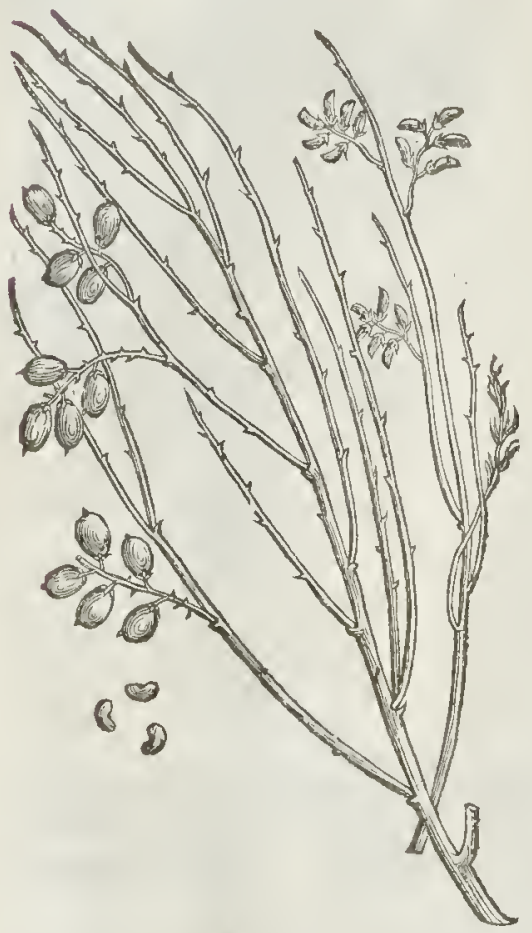

2 Pfeudopartum album Apbyllum: The white leafe-leffe Spanifh broom:

2 This naked broome growcth vp to the height of a man :the ftalk is rough, and void of leaues very greene and pliant, which diuideth it felfe into diuers twiggie branches, greene, and tough, like rufhes : the floures grow all a long the ftalks like thofe of broome, but of a white colour, wherein it diffcreth from all the reft of his kinde.

$$
\text { If The Place. }
$$

Thefe grow in the prounecs of $S$ paine, and are in one placchigher and more burhic, and in an otherlower.

t The fire flourcsin May, and the fecond

‡ The firft flourcs in May, and the fecond in Februarie. $\neq$

$$
\text { Tा The Names. }
$$

Thefe bafe Spanith broomes may bercferred to the true, which is called in Greeke avoprt: the Latines v fe the fame name, calling it fometimcs Spartsm, and Spartism: in Spanifh, Retama: in Englifh, Spanifh broome, and baltard Spanifh broome.

$$
\text { Tा The Temperature and Vertues. }
$$

A Both the feeds and iuice of the branches of thefe bafe broomes, whercwith they in $S_{p a i n c}$ and other hot regions do tie their vines, do mightily draw, as $G$ alen writcth. 
LI B. 3. Of the Hiftory of Plants.

Dioforides faith, that the feeds and floures being drunke in the quantitic of a dram, with Mede or honied water, doth caufe one to vomit Atrongly, as the Hellebor or neefing pouder dorlh, but yet without icopardie or danger of life: the feed purgeth by ftoole.

The iuyee which is drawne from out of the branches fteeped in water, being firft bruifed, is a remedic for thofe that are tormented with the Sciatiea, and for thofe that be troubled with the Squineie, if a draught thereof be drunke in the morning; fome vfe to fteepe the branches in fea water, and to giue the fame in a elifter, whieh purgeth forth bloudy and flimic exerements.

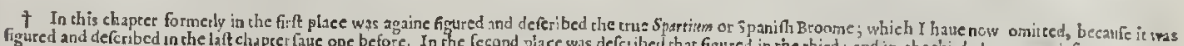

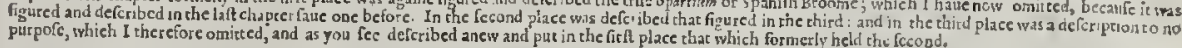

\section{С н а: 20. \\ Of Furzes, Gorfse, Whin, or prickley Broome. \\ 9T The Kindes.}

THerebe diucrs forrs of priekly Broome, ealled in our Englifh tongue by fundry names,according to the fpeech of the countrey people where they doe grow : in fome places, Furzes; in others, Whins, Gorffe, and of fome, Prickly Broome.

+ Genifrapinoja vulgaris.

Great Furze buih.

veex Enropeis

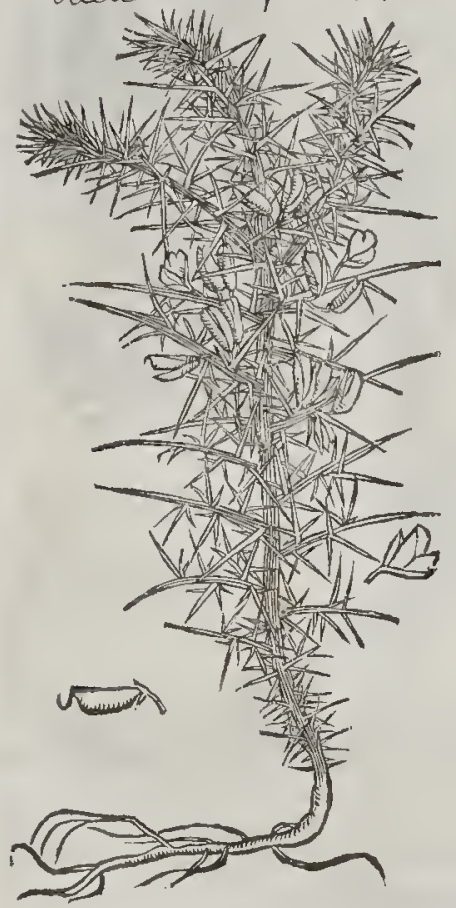

2 Genifta pinofaminor.

The fmall Furze buth.

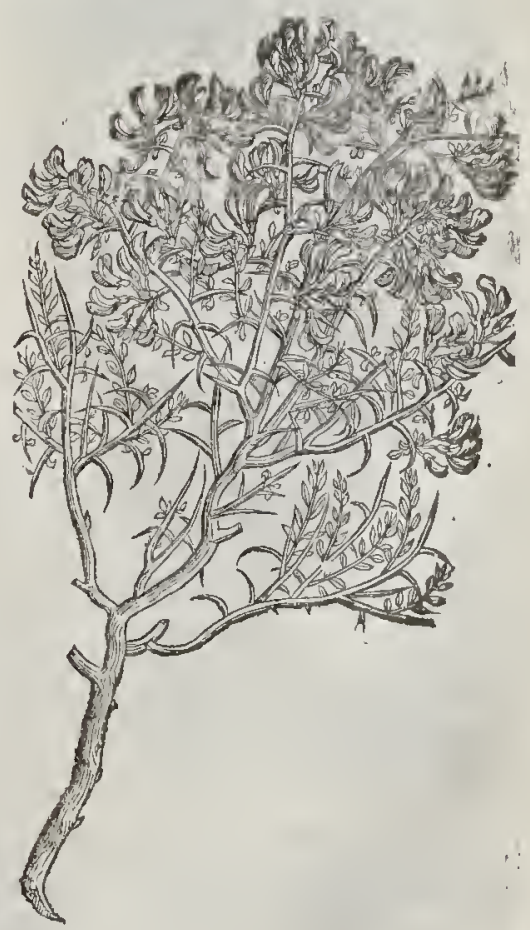

II The Defcription.

I THe Furze bufh is a plant altogether a Thorne, fully armed with molt tharpe priekles, without any leaues at all exeept in the fpring,and thofe very few and little, and quiekly falling away : it is a bufhy thrub, of fen rifing vp with many wooddy branches to the height of foure or fiuc eubirs, or higher, aeeording to the nature and foile where they grow : the greatelt and highelt that I did eter fee do grow about Excefter in the Weft parts of England, 
where the great fialks are dearely bought for the better fort of people, and the finall thorny fpraies for the poorer fort. From thefe thorny branches grow little floures like thofe of Broome, and of a yellow colour, which in hot Regions vinder the extreme heare of the Sunne are of a very perfect red colour : in the colder commeries of the Eaft, as Danziclie, Brunfwicke, and Poland, there is not any branch hereof growing, except fome few plants and feeds which my felfe haue fent to Elbing, 0 therwife called Meluin, where they are nolt curioully kept in their faireft gardens, as alfo our common Broome, the which I have fent thither likewife, being firft defired by diuers earnelt letters : the cods follow the foures, which the Grater hath omitted, as a German who liad neuer feen the plant it felfe, but framed the figure by heare-fay : the root is ftrong, tough, and wooddy.

We hauc in our barren grounds of the North parts of England a nother fort of Furze, bringing forth the like prickley thornes that the orhers haue : the onely difference confiftech in the colour of the flutes; for the others bring fortl yellow floures, and thpfe of this plant are as white as fnow.

+2 Tothis ma bc invned another kinde of Furze which bringeth forth certaine branches that be fome cubithigh, ftiffe, and fet round about at the firf with fmall winged Lentill-like leaues and litrle harmelefe prickles, which after they luauc been a yeare old, and the leaues gon, be armed onely with moft hard harpe prickles, crooking or bending their points downwards. The floures hereof are of a pale ycllow colour, leffer than thofe of Broome, yet of therame forme : the cods are fmall, in which do lie little round reddith feeds : the root is tough and wooddy.

+ 3 Geniffa spinofaninor filigua rotunda. Small round colded Furze.

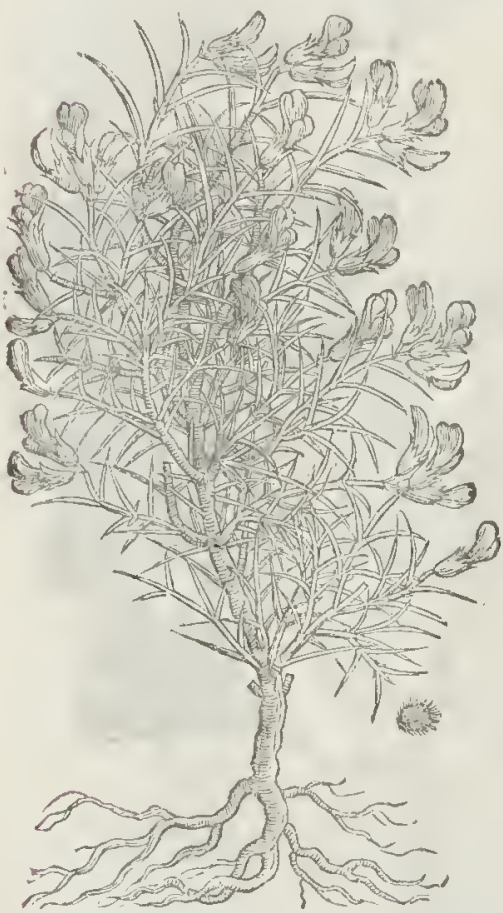

4 Geniffella aculeata.

Needle Furze or petry Whin.

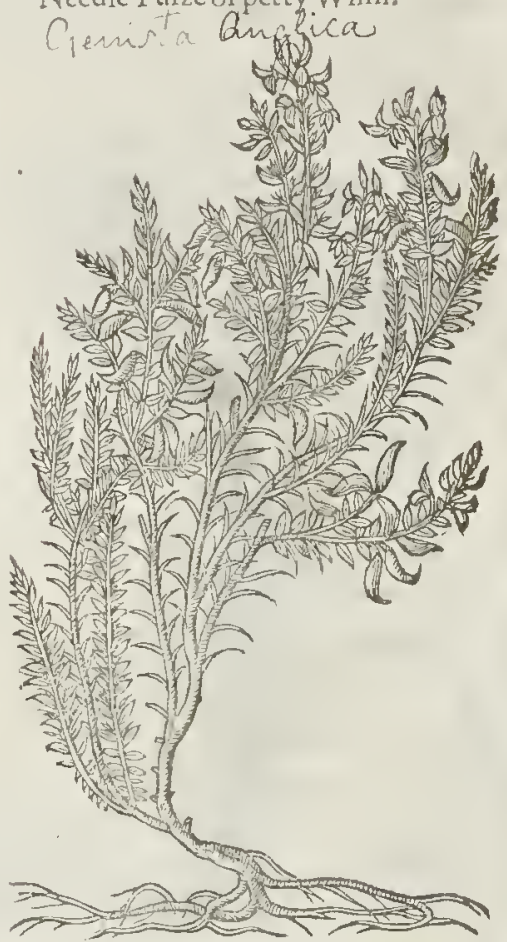

Of this Clufus reckons vp three varieties : the firft growing fome cubit high,with deepe yelLow floures : the fecond growes higher, and hath paler coloured floures : the third groweth to the Ineight of the firt, the floures alfo are yellow, the branches more prickly, and the leates hairy; and the figure I giue you is of this third varictic.

This feldome exceds a foot in height, and it is on eterie fide armed with tharpe prickles, which grow not confufedly, as in the common fort, but keepe a certaine order, and ftill grow forth by couples : they are of a lighter greene than thofe of the common Furze: on the tops of each of the branches grow tw or three yellow floures like thofeof the former; which are fucceeded by little round rowgh hairy cods of the bigneffe of Tares. This floures in March, and groweth in the way betwecn Burdeaux and Bayoue in France, and vpon the Pyreneat mountaines. Clufins makes it bis Scorpius 2.0: [econd fort of Furze: Lobel calls it Genista parting pinofum alterum. f 
for befides this scorpius of whieh he hath made mention, lib.25. cap.5. fetting dow ne Theophraftus his words, where he maketh Acositum Thelyphonon to be Scorpins, li6.23. cap.10. and likewife other plants under the fame title, but vnproperly.

$$
\text { If The Temperature and Vertues. }
$$

A There is nothing written in Theophraftus eoncerning the faeulties of Scorpius $\beta$ inefus, or Furze: pliny feemeth to attribute unto it the fame vertues that $S$ corpioides hath : notwithftanding the later Writers duagree that it is hot and dry of complexion : the feeds are vfed in medicines againft the ftone, andftaying of the laske.

+ This chaptex hath rndergone a gieat aiceration : as thus; the firft, elhid, and fourth defcriptions belonged to the third figure : the feeond and fifth deferip-

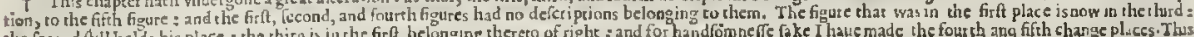
wesa alio in the fixth placestas formetly mentioned by olir Author (but now ornisted) in the chagrer of Af pasagur.

\section{C н а P. 2I. \\ of Cammucke Furze, Reft-Hirrow, or Petty Whinne. \\ I) The Kindes.}

THere be diuers forts of Reft-Harrow, which fome haue inferted among the fmooth Broomes; others, among thofe with priekles, whereof fome hauc purple floures and likewife ful of prickles; others, white floures;and tharpe thornes : fome alfo purple floures, others white, and alfo yelIow, and etery of them void of prickles.

I Unonis, fiue Refta Bonis.

Cammocke, or Reft-Harrow.

Onomis arvens is.

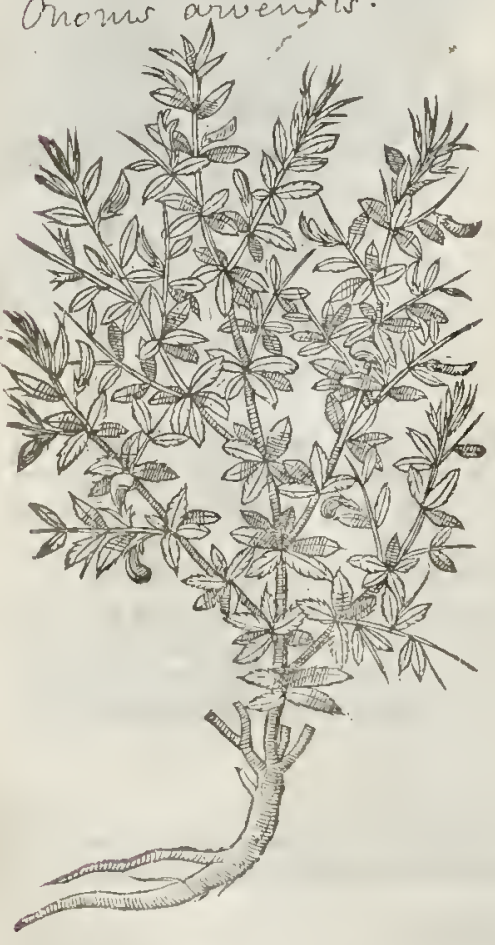

3 Anonis now pinofapurpurea, 'Purple Reft-Harsow without prickles.

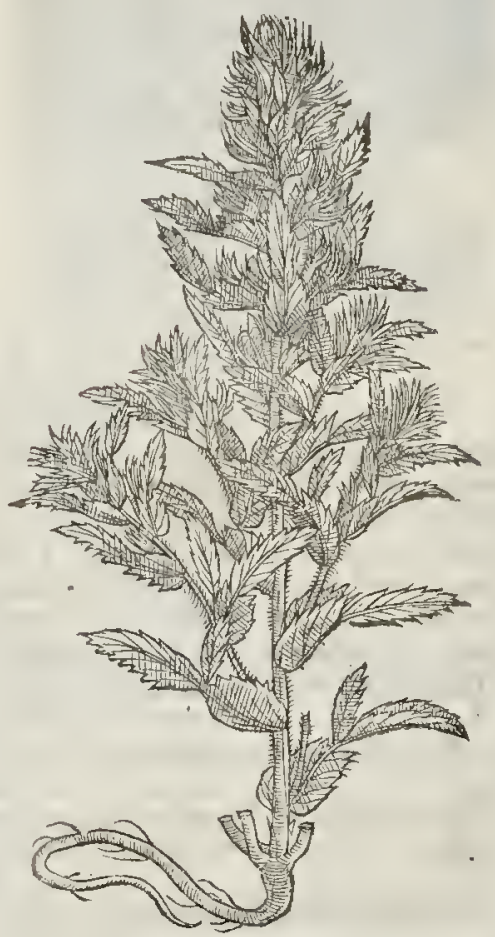

The Dofription.

* Ammoeke or ground Furze rifeth vp with ftalkes a cubit high, and often higher, fet with diuers ioynted branches, tough, pliable, and full of hard tharpe thornes : among which do grow leaues in forme like thofe of S. Lohns wort, or rather of the Lentill, of 2 


\section{C на P. 22. \\ of Goofe-berrie, or Fea-berry Bu/h. \\ G The Kindes.}

IT

Here be diuers forts of the Goofe-bcrrics; fomc grcater, others leffe: fomc rousd, others long, and fome of a red colour : the figure of one thall ferue for the reft.

\$ I will not much infift vpon diuerfities of fruits, becaufe my kinde friend M?. Tohn Parkinfon hath fufficiently in his late Worke difcourfed vpon that fubicet; oncly becaufe I indge many wil be defirous to know their names, and where to get them, I will briefcly name the chicfe varicties our Kingdome affords; and fuch as are defirous of them may finde them with $\mathrm{M}^{\mathrm{T}}$. Iobn evillen liuing in Old-ftrect.

The forts of Goorc-berries arc thefe : the long grecne, the grat ycllowifh, the blew, the gre?t round red, the long red, and the prickly Goofe-berrie.

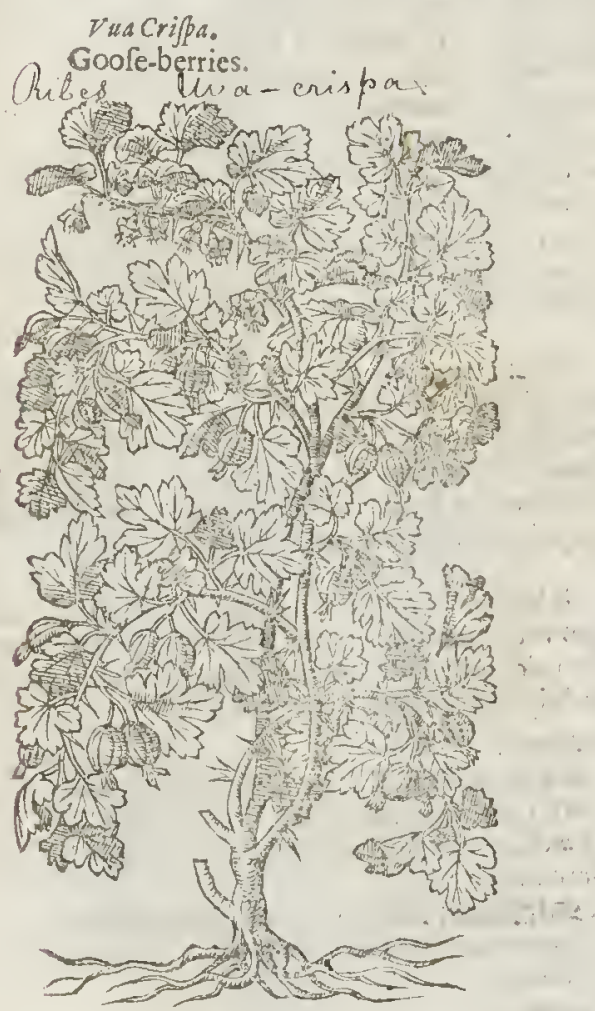

T The Defription.

$\mathrm{T}$ Hc Goofe-berry buth is a thrub of three or foure cubirs high, fet thiche with molt Tharpe prickles : it is likewife full of branches, flender,wooddy, and prickly : whercon doc grow round leaues curwith decpe gaThes into diuers parts like thofe of the Vine, of a very grecne colour : the floures be very fnual, of a whitih greene, with fome little purple dafhed here and thcre: the fruit is round, growing fcatteringly vpon the branches, greenc at the firf, but waxing a littlcycllow through maturitie, full of a winic inyce fomewhat fweet in tafte when they be ripe; in which is contained liard feed of a whitifh colour: the root is woodic, and not without ftrings anexed thercto.

Therc is another whofe fruit is almoft as big as a fmall Chery, and very round in forme: as alfo another of the like bignefle, of an inch in length, in taftc and fubftance agrecing with the common fort.

We baute alfo in our London gardens another fort altogether without prickles: whofe fruit is very fmal, Ieffer by much than the com. mon kinde, but of a perfect red colour, whercin it differeth from the reft of his kindc. of The Place.

Thefe plants do grow in our I.ondon girdens and elfewhere in great aboundanec.

d The Time.

The leaues come forth in the beginning of A prill or foner : the fruit is ripe in Iunc and Iuly. TI The Names.

This thrub had no name among the old Writers, whoas we deeme kncw it not, or clfe eftccmed it not : the laterwriters call it in Latine Croffularis : and of tentimes of the bcrries, Vua Cripa, Vua

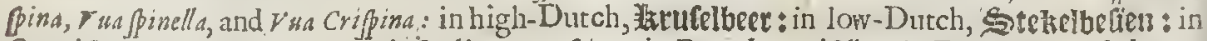
Spanifh, Vua Cripa, or Epina: in Italian, Vuapina: in French, Groifelles: in Englifh, Goofc-bcrry, Goofe-berry burh, and Fea-berry buth in Chefhirc, my natiue countrey.

\section{The Temperature.}

The berries of this buth before they beripe are cold and dry, and that in the later end of the fecond degree, and al o binding.

$$
\text { Tा The Vertues. }
$$

The fruit is ved in diucrs fauccs for meate, as thofe that are skilfull in cookcrie can better tcl than my felfe. 
L18.3. Of the Hittory of Plants.

'They are vfed in broths in ftead of Veritice, which maketh the broth not onely pledfant to the $B$ tafte, but is greatly profitable to fuch as are troubled with a hot burning ague.

They are diuerfly eaten, but how foeuer they be eaten they alwaies ingender raw and eold blo:id: C they nourith nothing orvery little: they alfo ftay the belly, and tench bleedings.

They ftop rhe menfes, or monethly fiekenes, exeept they happen to be taken into a cold fto- D mack, then do they not helpe, but rather elog or trouble the fame by fome manner of fix.

The ripe berries, as they are fweeter, fo doe they alfolitte or nothing binde, and are fomething $\mathrm{E}$ liot, and yecld a little more nourithment than thofe that be not ripe, and the fame not erude or raw; but thefe are feldome eaten or vfed as fauce.

The ituce of the greene Goofeberries cooleth all inflammations, Eryfipel.es, and Saint Antho. I nies fire.

They pronoke appetite, and coole the vehement heate of the ftomackeand liuer.

The young and tender leaues eaten raw in a fallad, prouoke vrine, and driue for th the ftone $G$ and grauell.

\section{Cна 2. 23.: Of Barberíries. The Kindes.}

There de diuers forts of Barberries, fome greater, ochers leffer, and fome without fones.

$$
\text { Spina acida, fiuc oxyucantha. }
$$

The Barberry buh.
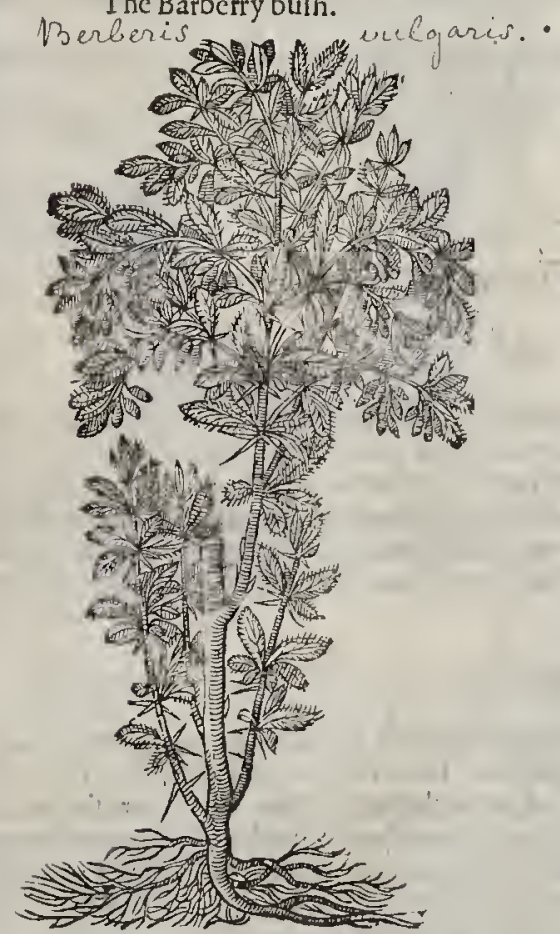

$$
\text { T The Defription. }
$$

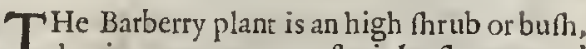
hauing many young fraight thootes and branches, very full of white and prickly thornes; the rinde whereof is mooth and thin, the wood it felfe yellow: the leaues are long, very grecne, llightly nicked about the edges, and of a fow re tafte : the floures be yellow, ftanding in cluAtcrs vpon long ftemmes: in their places come vp long berries, flender, red when they be ripe, with a little hard kernell or ftone within; of a fow re and tharpe tafte: the root is yellow, difperfeth it felfe farte abroad, and is of a wooddy fubfance.

Wee haue in our. London gardens another fort, whofe fruite is like in forme and fubftance, but one berry is as bigas three of rhe eommon kinde, wherein confifteth the differenee.

We haue likewife another withoutany ftone, the fruite is like the re ft of the Barber ries, both in fubftance and tafte.

$$
\text { T The Place. }
$$

The Barberric buth groweth of it felfe in vntoiled plaees and defart grounds, in woods, and the borders of fields, cfpecially about a Gentlemans houfe ealled $\mathrm{M}^{\prime}$. Moxke, dwelling in a village called Iuer, two miles from Colcbroole, where moft of the hedges are nothing elfe but Barberry buthes.

They are planred in gardens in mof places of England.

$$
\text { Tा The Time. }
$$

The leaues fpring forth in Aprill : the floures and fruite in September.

$$
\text { I The Names. }
$$

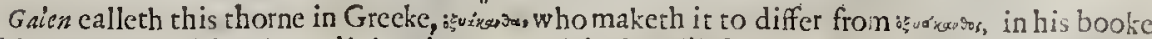
of the Faeulties of fimple medicines:but more plainely in his booke of the Faculties of Nourifhments; where he reckoneth vp the tender fprings of Barberries among the tender fhoots that are 
tobeeaten, fuch as Oxyacanthus or the Haw thorne bringeth not forth, wherein he plainely made a difference, Oxyacanthathe Barbery buth, and Oxyacanibis the Haw thorne tree.

Dioferides hath not made mention of this Thorne; for that which he calleth 0 xyacaniba in the Fominine gender, is Galens Oxyacanthus in the Mafculine gender.

Awicen fecmeth to containe both thefe Thrubs vnder the name of Amyrberis, butweknow they ate neither of affinitie or neighbourhood, al though they be both prickly.

The fhrub it felfe is ealled in thops Barbaries, of the corrupted name Amyrberis, of the later writers Crefpinus : in Italian, Crefpino in Spanifh, Efpino de maiuclas : in high Dutch, paiflelbeer:

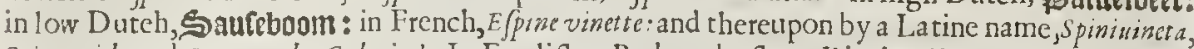
spima acidil,and Oxyacantha Galeni. \& In Englin, a Batbery burh, or Piprige Tree,according to D: Turner. $\neq$

T The Tomperature.

The leames and berries of this thorne ate cold and dry in the fecond degrec : and as Galen alfo affirmeth, thcy are of thin parts, and haue $a$ certaine cutting qualitie.

T The Vertues.

A The leaues arc vfed of diuers to feafon meate with, and in ftead of a fallad, as be rilofe of Sorrell.

B The decostion thereof is good againft hot burnings and cholericke agues : it allaicth the heate of the bloud, and tempercth the ouermuch heate of the liuer.

C The fruite or berrics are good for the fame things, and be allo profitable for hot laskes. and for the bloudy flixe, and they ftay all manner of fuperfluous bleedings.

D The greene leaues of the Barbery buth ftamped, and made into awce, as that made of Sorrell, called greene fauce, doth coole hot ftomackes, and thofe that are vexed with hot burning agues, and procureth appetite.

E The conferue made of the fruite and fugar performeth all thofe things before remembred, but with better force and fucceffe.

F The roots of the tree fteeped for cettaine daies together in ftrong lie, made with athes of the ath-tree, and the harrc of ten moifned therewith, maketh it yellow.

G Thebarke of the roots is alfo ved in medicines for the iaundife, and that with good fuccelfe. $\neq$

\section{С н P. 24. Of the mbite Thorne, or Hawthorne Tree.}

TI The Kindes.

$\mathrm{T}$

Here be two forts of the white Thorn Ttees deferibed ot the later writers, one rety common in moft parts of England: there is another very rare, and not found in Europe, except in fome few rare gardens of Gernanic; which differeth not from our common Haw thorne, fauing that the fruithere of is as yellow as Saffron:we haue in the Weft of England one growing at a place called Glaftenburie, which bringeth forth his floures about Chriftmas, by the reporr of diuers of good credir, who hate feen the fame; but my felfe halie not feen it; and thereforc leaue it to be better examined.

$$
\text { T The Defoription. }
$$

I Hewhite Thorne is a great thrub growing oftent imes to the height of rhe Peare-tree the trunke or body is great : the boughes and branches hard and wooddy, fet full of long tharpe thornes: the leaues be broad, cut with deepe gafhes into diuers fections, fmooth, and of a gliftering greene colour : the floures grow vpon fpokie rundles, of a pleafant fiveet fmell, fonctimes white, and often dafht oucr with a light wafh of purple; which hath moucd fome to thinke fome difference in the plants:after which come the fruit, being round berries, green at the firft, and red when they beripe; wherein is found a fof fweer pulpe, and certaine whirith feed : the root groweth deepe in the ground, of a hard wooddy fubfance.

2 The feeond and third hatuc been touched in the firft title, notw ithfanding I haue thought it not vnfit to infert in this place a plant perticipating with the Hawthorne in floures and fruit, and with the Sertice tree in leates, and not vnlike in fruit alfo.

7 beophraftus hath fet forth this tree under the name of writ, which groweth wnto the forme of a frall tree, delighting to grow in our thadowic woods of Cumberland and Weftmerland,and many orher places of the North country, where it is to be found in great quantitic:but feldome in 


\section{The Temperature.}

The fruit of thc Haw-thorne tree is very aftringent.

\section{If TheVertues.}

A The Hawes or berries of the Haw-thorne tree, as Diofcarides writeth, do both tay the laske, the menfes, and all other fluxes of bloud : Fome Authors write, that the ftones beaten to pouder, and giuen to drinke are good againft the ftone.

\section{$\mathrm{C}_{\text {н }}$ р: 25. OfGoits Thorne.}

\section{T The Defription.}

I THe firf Tragagantha or Goats-thorne hath many branchie boughes and twigs, flender and pliant, fo fpred abroad vpon eterie fide, that one plant doth fometimes occupie 2 great fpaec or roome in eompaffe : the leates are fmall, and in thape like Lentill leaues, whitifh, and fomewhat moffic or hairy, fet in rowes one oppofite againft another: the floure is like the bloffome of the Lentill, but much leffer, and of a whitifh colour, and fometimes marked with purple lines or ftreaks : the feed is inclofed in fmall cods or husks, al moft iike vrto the wilde Lotus or horned Trefoilc: the whole plant on enery fide is fet full of harpe prickely thornes, hard, white, and ftrong : the roots run vnder the ground likc Liquoriee, roots, yellow within, and blacke without, tough, limmer, and hard to breake; which being wounded in fundry places with fome iron toole, and laid in the Sun at the higheft and horteft time of Sommer, iffueth forth a certain liquor, whieh being hardned by the Sun, is that gum which is called in fhops Tragacant ha : and of fomc, though barbaroully Dragagant.

I Tragacantha, fuc Jpina Hirci. Goats Thorne.

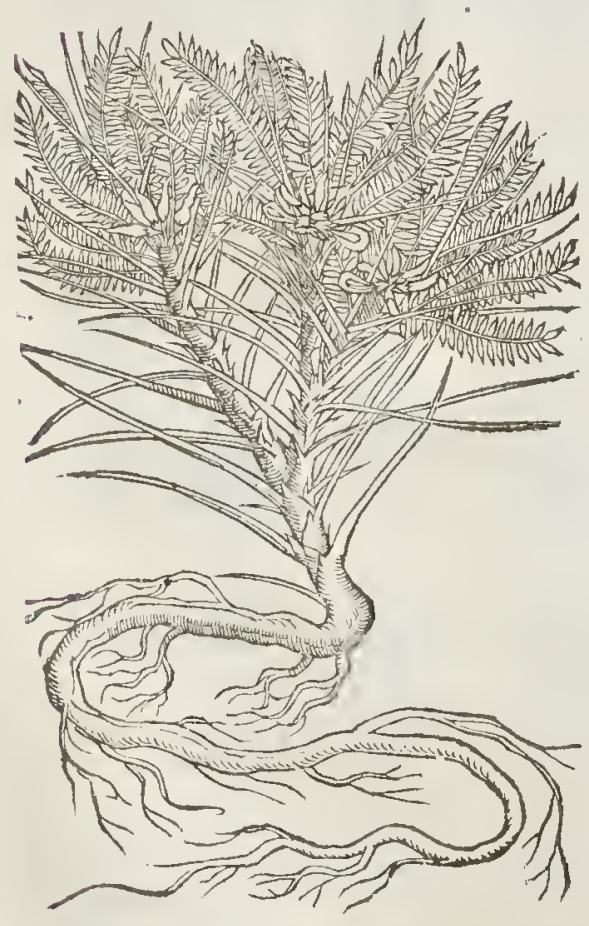

2 Spina Hirciminor.

Small Goats Thorne.

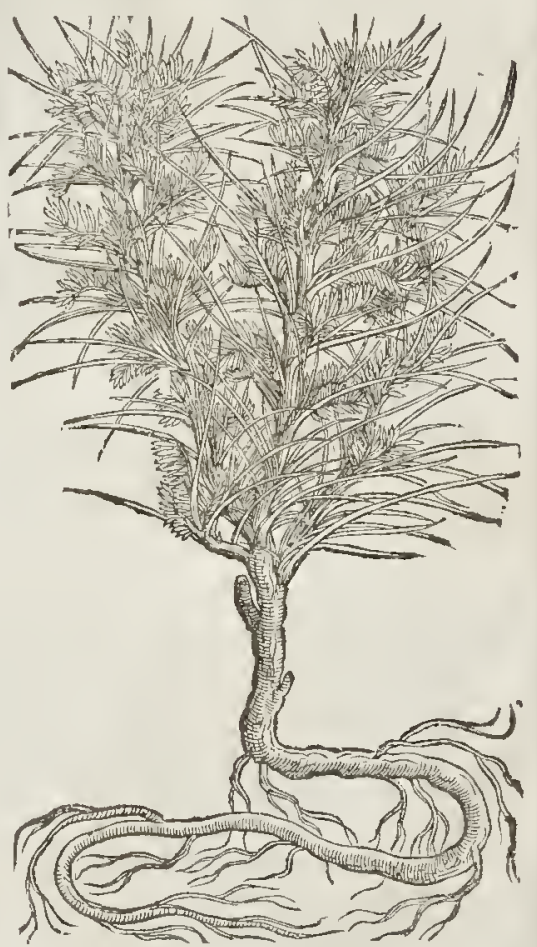

2 The fecond kinde of Trugacartha is a low and thieke fhrub, hauing many thoots growing from one turfe: of a white or grayifh colour, about a cubit high, ftiffe and wooddy : the leaues are like the former, and garded with mont itiffe pricks not very fafely to be touehed : among the thornie leaues come forth many floures in fmall tufts like Geniffella, but that they are white: the cods 
are many, fraight and thorny like Geniffella, wherein are many fmall white and chree cornered feeds as big as muftard feed. + This differs from the former in that it is fmaller, and lofeth the leaues euery Winter, when as the former keepes on the leaues vntill new ones come in the Spring. The middle rib of the winged leaues ends in a pricke, which by the falling of the leaues becommeth a long and naked thorne. I hane ginen you a more accurate figure hereof out of Clufins, wherein the leaues, floures,cods, and feeds are all expreffed apart. $\ddagger$

3 The Grecians baue called this plant Noveyide, becaufe it is good for the finewes : it thould feeme it tooke the name 1'otcrion, of Potrix, becaufe it loueth a watry or fenny foile : it hath fmall branches, and leates of $\tau$ ragacantha, growing naturally in the tract of piedmont in Italy: it fpreadeth abroad like a fhrub : the barke or rinde is blackifh, and dry without great moifture, very much writhed or wrinkled in and out as that of Nepa or Corruda : the fharpe pricks ftand not in order as Tragacantha, but confufedly, and are fine: and three times leffer than thofe of Tragacantha, growing much after themanner of $A$ frragalus : but the particular leaues are greene aboue, and white below, fhaped fomewhat like Burnet : the feed is fmall and red, like vnto Sumaeh, but leffer.

* Tragacanth.e minoris icon accuratior.

A better figure of the Goats-thorne.

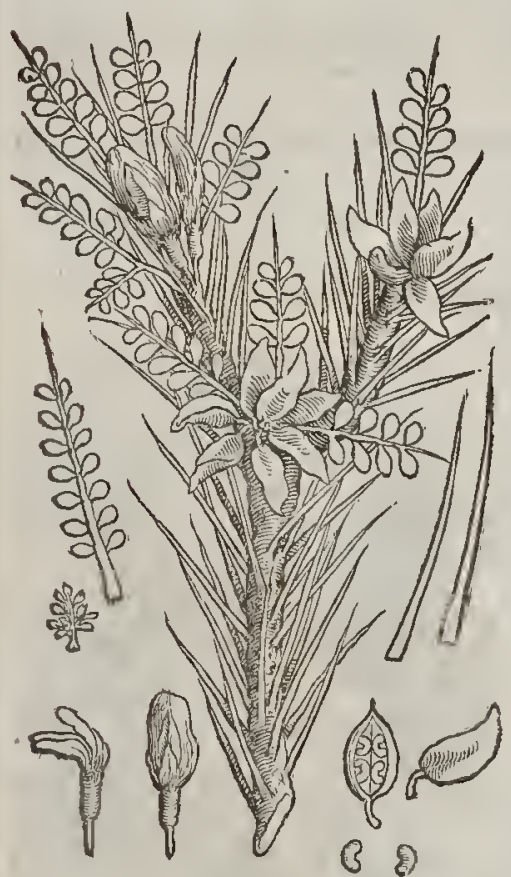

t 3 Poterion Lob. fue Pimpinclla pinofa Camer? Burnet Goat s-thorne.

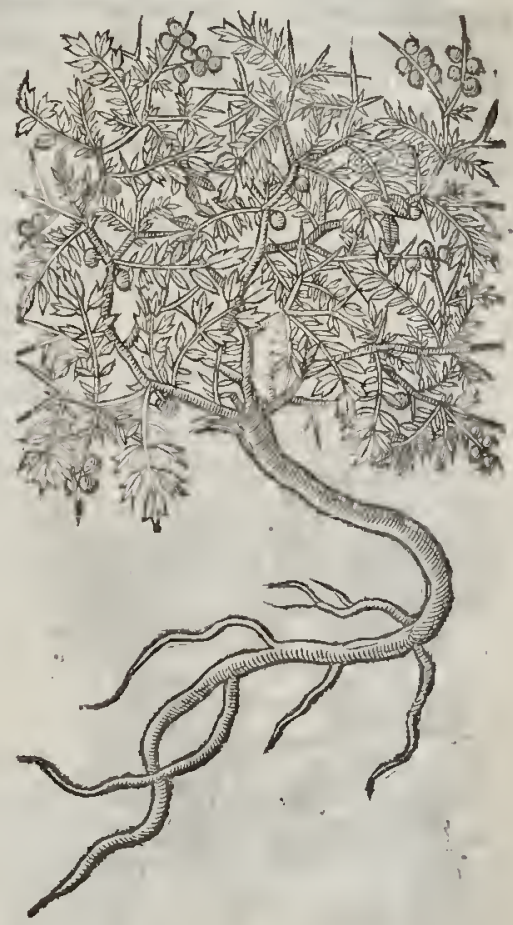

बT The place.

Petrus Bellonius in his firt booke of Singularities reports, that there is great plenty hereof grow: ing in $C$ andy vpon the tops of the mountaines. Theophraftus faith thar it was thought to grow no where but in Candy; but now it is certaine that it is found in Achaia, Peloponeffus, and in Afra: it doth alfo grow in Arcadia, which is thought not to be inferiour to that of Candy. It is thought by Lobel to grow in Languedock in France, whereof $T$ beophr. hath written in his ninth booke, that the liquor or gum iffueth out of it felfe, and that it is not needfull to hauc the root broken or cur. The bef is that, faith Diofcorides, which is through-fhining, thin, fmooth, vnmixt, and fweet of fmel and tafte.

$$
\text { Ti The Time. }
$$

They floure and flourin in the Sommer monech: I hate fowne the feed of Poterion in Aprill: which I reeeiucd from Ioachimus Camerarius of Noremberg, that grew in my garden two yeares tos gethet, and after perifhed by fome mifchanee. 
TI The Names.

Goats-thorne is called in Greeke saysensa : of mott Herbarifts likewife Tragacantha : we may cal it in Latine Spma Hirci : in French, Barbe Renard: and in Englifh for want of a better name, GoatsThorne: the liquor or gum that iffueth forth of the roors beareth the namealfo of Tragacanibs: it is called in thops Gunmi Tragacanthe; and in a barbarous manner Gummi Tragacanthi : in Englin, Gum Dragagant.

if The Tempcrature.

This plant in each part thereof is of a drying facultie without biting. It doth confolidate or glew together finewes that be cut : but the ronts have that facultie efpecially, which are boyled in wine, ard the decoetion giuen vnto thofe that have any griefe or hurt in the finewcs.

Gum Dragagant hath an emplafticke qualitic, by reafon whereof it dulleth or allayeth the fharpne ffe of humors, and doth alfo fomthing dry.

\section{ब] The Vertues.}

A The Gumme is fingular good to belicked in with honey againft the cough, roughneffe of the throat, hoarfeneffe, and all tharpe and thin theumes or diftillations : being laid vnder the tongue it taketh away the roughneffe thereof.

B Being drunke with Cute or the decoetion of Liquorice it taketh away and allayeth the heat of the vrine: it is alfo vfed in medicines for the eyes.

C The greateft part of thofe artificiall beades, fweet chaines, bracelets, and fuch like pretty fweet things of pleafure are made hard and fit to be worne by mixing the gum hereof with other fweets, being firft fteeped in Rofe water till it be foft.

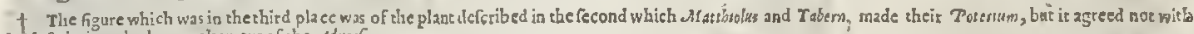
the defeription which was taken out of the Adues:s.

\section{Ch A P. 26.}

I Acacia Diofcoridis. The Egyptian Thorne.

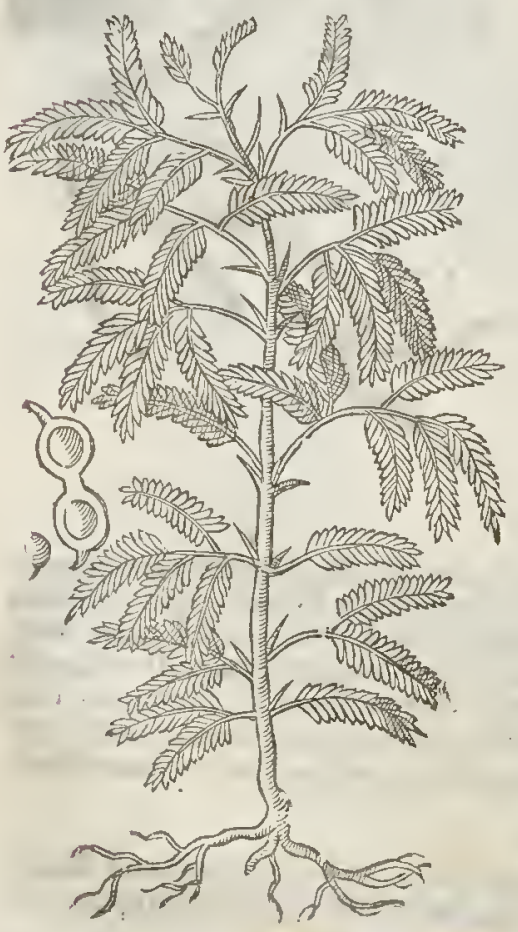

Of the Egyptian Thorne.

† 2 Acaciaalteratrifolia.

Thorny Trefoile.

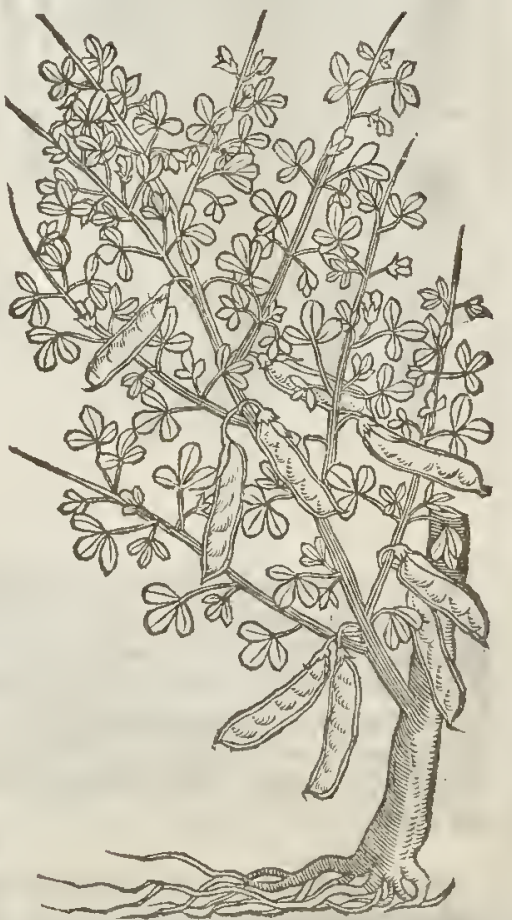




\section{The Defcription.}

I Dofcorides maketh mention of Acacia, whercof the firft is the true and right Acacia, which is a thrub or hedge tree, but not growing right or fraight vp as other fmall fmall trees do:his btanches ate wooddie,befetwith many hard and long Thorns; about which grow the leaues compact of many fmall leaues cluftering about one fidc, as in the Lentill: the floures are wirifh, the husks or eods be plaine and flat,yea very broad like vnto Lupines, efpecially on that fidewhere the feed gtowes, which is eontained fontetimes in one part,and fontimes in two parts of the husk gtowing together in a narrow neeke: the feed is fmooth and glittering. There is a blacke iuiee ${ }_{2}$ ken out of the fe huskes, it they be dried in the Thadow when they betipe; but if when rley are nor ripe, then it is fomewhat red: fome dowring out a iuce out of the leaues and fruit: there fow eth alfo a gum out of this tree, which is the gum of Atabia, called Gum A rabicke.

2. Diofcorides hauing deferibed Spina Acatia, fetterl downe a fecond kinde thereof, ealling it Acacia alter, which hath the three leaues of Ruc or Cytifs, and coddes like thofe of Gcnifiella, but fomewhat more blunt at the end, and thieke ar the baeke like a Rafor, and fill groweth forward narrower and narrowcr, vntill it come to lawe a fharpe edge: in thefe eods are eontained thtee or foure flat feeds like Genflella, whieh before they wax ripe are yellow, but afterwards blacke : the whole plant groweth to the height of Genift a pinofa,or Gorffe, both in Thape, height, and refemblanee, and noc to the height of a tree, as $\pi$ talthiolus would perfuate vs, but full of tharpe Thornes
like the former.

The true Aeaeia groweth in Egypt, Paleftina, Lombardic, and Syria, as Dioforideswriteth : among the fhrubs and rrees that remaine alwaics greene, Acacia is noted for one by Petrus Belloni. mus, in his firlt booke of Singularities, chap. 44.

The other Aeaeia groweth in Cappadocia and Pontus, as Diofcorides writeth : it is alfo found in Corfiea, and ou diucrs mountaines of Italy, and likewife vpon all the coaft of Liguria and Iom. batdie, and vpon the Narbone coalt of the Mediterranean fea.

Thefe floure in May, and their fruit is ripe in the end of Auguft.

$$
\text { Tा The Names. }
$$

The tree Acacia is named of the Grxcians vinum, yea etcen in our timc, and likewife of the Latins Acacia : it is a! focalled efigyptia pina : this frange thorne hath no Englifh name thar I can learn, and therefore it may leep ftill the Latine name Acacia, yet I latie named it the Egyptianthorne: the iuice is ealled alfo Aeaeia after the uame of the plant: the Apothecaries of Germanie dovfe in fead hereof, the iuice that is preffed forth of floes or fnags, which they thereforc eall Acacia Ger. maxuca : Mat hiolus piatureth for Acacia the tree which the later Herbarifts docall Arbor Iude, to which he hath vntruly added Thorns, that hemight belic Acacia, and yet he hath not made it agtee
with Diofioradis his defeription.

Thev eall this impen argine in Latine Acacia altera, or the other Acacia, and Pontica Acacia, or Ponticke Acacia.

$$
\text { 9. The Nature. }
$$

The iuice of Aeacia, as Galen faith, confffteth not of one only fubltanee, but is of fubfanceborh cold and earthie, towlich alfo is coupled a eertaine waterie effenee, and it likewife hath thin and hot parts difperfed in it felfe: therefore it is dry in the third degree, and eold in the firft if it benor waihed; and in the fecond, if it be walhed : for by wafhing it lofeth his fharpe and biting quality
and the hot parts. luntarie iffue ealled Gonoribs if It tralet the blaftings and inflac drunke in red wine.

It tealet the blaftings and inflammations of the eies, and maketh the skin and palmes of the $\mathrm{E}$ hands fmooth after the liealing of the serpigo: ithealeth the bliftets and extreme heat in the mouth, and maketh the baires blacke that arewafhed therewith

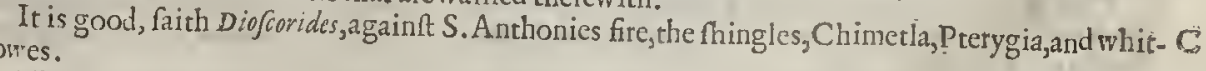

'The gum doth binde and fomcwhat coole : it hath alfo ioined vnto it an emplaiftiek quality, by 1 which it duileth or alayeth the tharpneffe of rhe medicines wherewith it is mixed: Being applied with the white and yolk of an egge, it fuffereth not blifters to rife in burned or fealded parts. Diof $c_{\text {. }}$

The iuice of the other, faith Diofcorides, doth alfo binde, but it is not foeffectuall nor fogood in $\mathrm{E}$

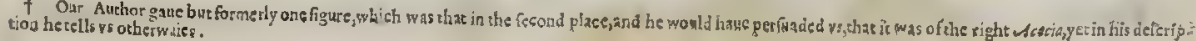




\section{II P. 27. Of box Thorne, and the inice tbereof called Lycium. बा The Defcription.}

I

Box Thorne is a rare plant, in fhape not vnlike the Box tree, whereof it hath beene recko. ned for a wilde kinde, hauing many great branches fet full of round and thicke leaues, very like that of the common Box tree : among t which grow forth moft tharpe pricking thornes : the floures grow among the leaues, which yeeld forth fmall blacke berries of a bitter taft, as big as a pepper corne : the iuice where of is fomewhat oilie, and of a reddin colour; which bitter itice being fet on firc, doth burne with a maruellous cracking and fpark ling; the arhes thereof are of ared colour : it hath many wooddic roots growing aflope.

I Lycium, five Pyxacantha. Box Thorne.

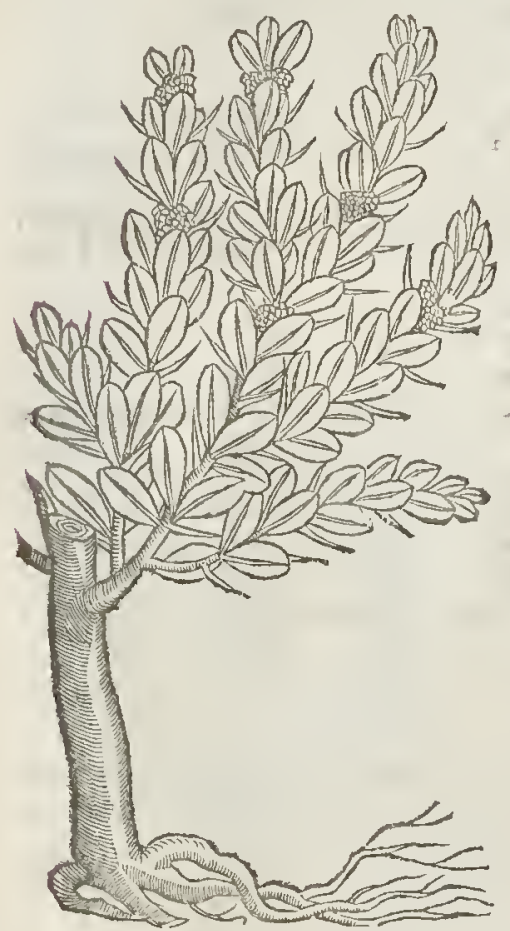

* 2 Lycium Hipanicum. Spanin Box Thorne;

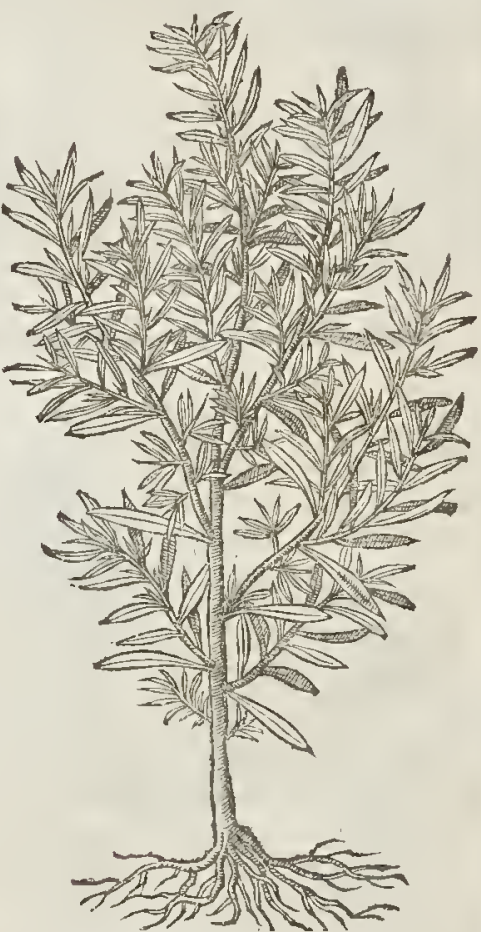

2 The other kinde of Py:acanth or Lyritm, groweth like vnto the common Priuet, bauing fuch like leaues, but fomew hat narrower : the tops of the lender fprigs are furnifhed with prickles: the root is tough, and of a wooddie fubftance.

\section{Tा The Place.}

They grow in Cappadocia and Lycia, and in many other countries : it profpereth in rough pla: ces, it hath likewife been found in Languedoc, and Prouence in France: Bellonius writeth that hee found it in Paleftina.

Matthiolus pictureth for Box Thorne, a plant with box leaues, with very many boughes, and certaine thornes ftanding among then : but the notable Herbarift Anguillar a and others, hold opinion, that it is not the right; with whom we alfo do agree.

There is drawne out of the leaues and branches of box Thorn, or as Pliny faith,out of the bough and roots being throughly boiled, a inice, which is named Lycium.

Diofcorides fait b, that the leaues and branches muft be braied, and tha infufion made many daies 
in the decostion thereof, after which the feees or wooddie ftuffe muft becaft away, and that which remaineth boiled againe till it become as thicke as honie: Pliny faith, that the roots and branehes are very bitter, and for three daies together they muft be boiled in a copper veffell, and the wood and ftieks often taken out till the deeodion be boiled to the thickneffe of honie,

$$
\text { T) The Time. }
$$

They floure in Februaric and Mareh,and their fruit is ripe in September,

$$
\text { of } T \text { bo Names. }
$$

It is named in Greeke woskrow, which a man may eall in Latine Buxea ppina : and in Englih, Box Thorne: of fome, Affes Box Tree, and prickley Boxe: it is alfo named Lycium, of the iuice which is boyled out of it: the inice is properly ealled num, and retaineth in Latine the fame name Lycium: it is termed in Englin Thorne box. But it feemeth to me, that the originall name $L$ yctum is fitter, being a ftrange thing, and knowne tovery few : the A pothecaries know it not, who in ftead thereof do vfe amiffe the itice of the fruit of Woodbinde, and that not without great errour, as we haue already written. $¥$ It is vnknowne in our thops, neither is there any thing ved for it, it being wholly out of vfe, wherefore our Author might here well haue fpared Dodoncus his words.

Diofcorides teacheth to make a zerarne of Sumach which is good for thofe things that Lycizrm is and is ved when Lycium is not to be had, and it is fit to be put in all medicines in ftead thereof.

$$
\text { oा The Temperature. }
$$

Lycium, or the inice of Box Thorne, is as Galen teacheth, of a drying qualitie, and compounded of diuers kindes of fub ftances, one of thinne parts digenting and hot; another earthie and cold, by which it enioyeth his binding faenltie : it is hot in a meane, and therefore it is vfed for feuerall pur. pofes.

\section{T The Vertues.}

Lycium eleareth the fight, faith Diofcorides, it healeth the feuruie fented fores of the eye lids, the $A$ : iteh, and old fluxes, or diftillations of humors; it is a remedie for the running of the eares; for $v$ lcers in the gu mmes, and almonds of the throat, and againft the chappes or gallings of the lips and fundament.

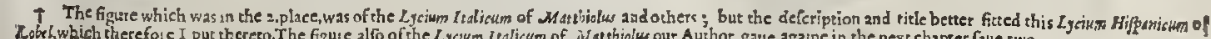

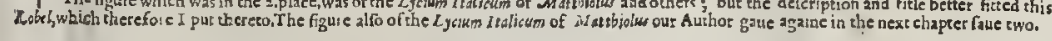

\section{Cна P. 28. Of Ramme or Harts Tborne: \\ Ti The Kindes.}

A Fter the opinion of $D$ iofiorides there be three forts of $R$ hammu, one with long, flat \& fort leatues: the other with white leaues; and the third with round leaues, which are fomewhat blackifh Theophraftus and Pliny affirme that there are but two, the one white, and the otherblack, both whieh do beare Thornes: but by the labour and indutry of the new and late writers there are found fundry forts moe, all which and enery one of them are plants of a wooddie fubftanee, hauing alfo many ftraight twiggie and pliant branches, fet with moft tharpe pricking thornes.

$$
\text { af The Defcription. }
$$

I THis is a fhrubbe growing in the hedges, and bringing forth ftraight branches and hard 1 thomes, like tothofe of the Hawthome, with little leaues, long, fomething fat and fort: and this hath that notable learned man Clufus deferibed more diligently in thefe words : the Ram is a fhrub fit to make hedges of, with ftraight branches, parting it felfe into many twigs, white,and fet with ftiffe and ftrong thornes, hauing leaues, which for the moft part grow by foures or fiues at the root of euery Thorne, long, fomething fat, like to thofe of the Oliue tree, fomew hat white, but tender and full of iuice; which in Autumne doe fometimes fall off, leauing new growing in their plaees : the floures in Autumne are fomething long, whitifh, durided at the brims into fue parts: in the ir places is left a feed, in thew as in Gelfemine: notwithftanding it was neuer my chance to fee the fruit : the root is thicke and diterfly parted.

¥ I obferued another (faith the fame Aurlor) almont like to the former,but lower,and diuided into more brançhes, with leffer leaues, more thick and falt of tafte, and whiter alfo than the former: the floures are like, in all things but their colour, thofe of the former which in this are purple.

2 This hath more flexible ftalks and branches, and thefe alfo fet with thornes : the leanes are narrow, and not fo thicke or flethie as thofe of the former, yet remaine alwaies greene likeas they do: the foures are fruall and moffie, of a greenin eolour, growing thicke about the branches, and they are fueceeded by a round fruit, yellowith when it is ripe, and remaining on the fhrubbe all the 
+ I Rhamnus r. Clufijflo.albo: White floured Ram-thorne.

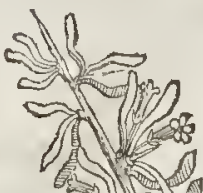

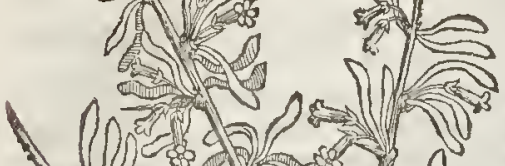

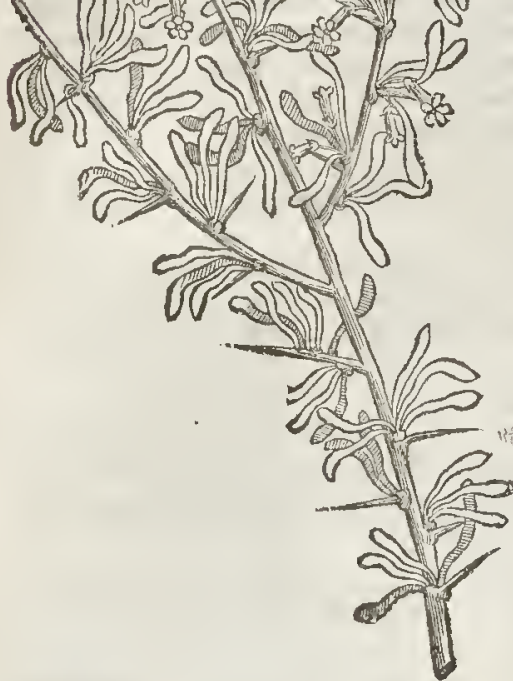

¥ 2 Rbammus 2. Clufy.

Sallow-Thome.

Avisorirae hlum noiden

tiv $\cong$

$1 \rightarrow 0,120$

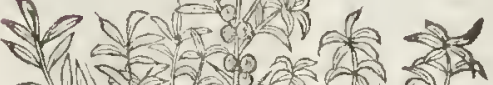
En W a हत d

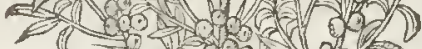
$M=1(n) \times 60$. If

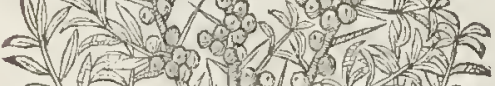
$\leftarrow 1 \mathrm{~s}=0$ ( 10 (3) NWW +1103 C.

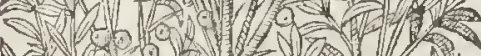

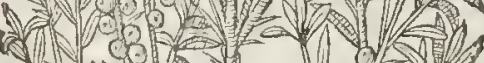
*a 30 - 201 Evano $\Rightarrow$ aco 1 at

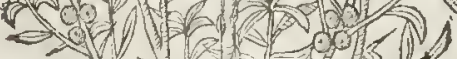
sth

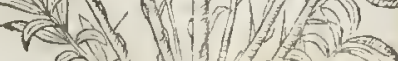
ris - 1. 110902

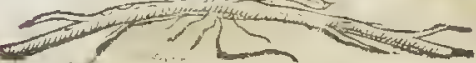

* Rhamnus alter Cluf flore purpurea? Purple floured Ram-thorne.

2es

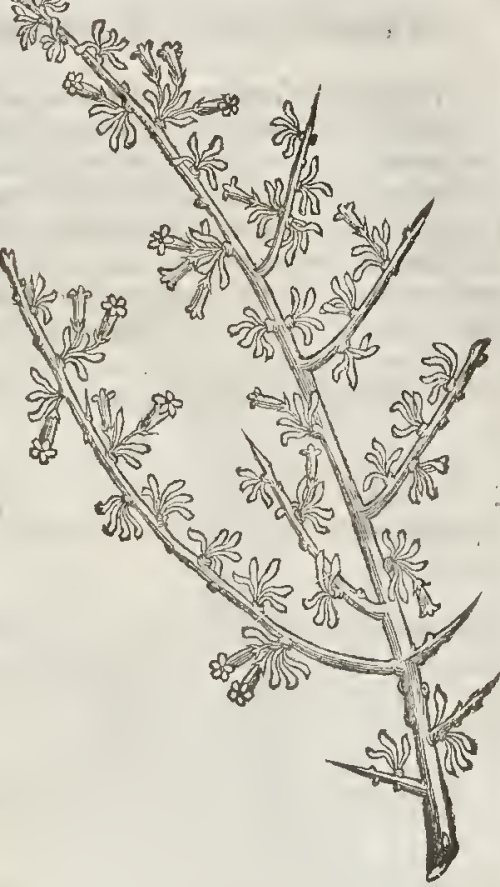

3 Ramuss tertise Clufiy.

Ram or Harts-Thorne.

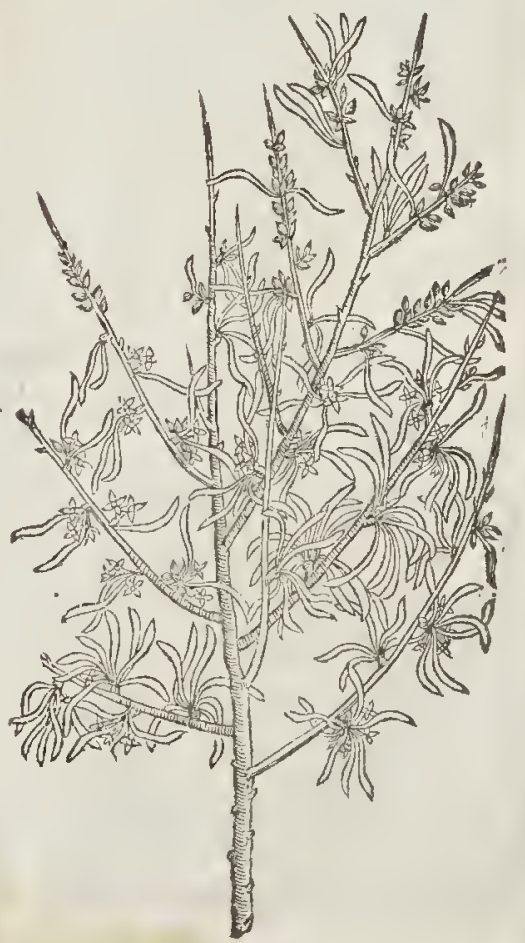




\section{B. 3. Of the Hiftory of Plants.}

Winter: The whole fhrubbe lookes as if it were fprinckled ouer with duft.

3 To thefe may be added another growing with many branches to the height of the Sloc tree or blacke Thorne, and thefe are couered with a blackifh barke, and armed with long.prickles: the leaucs, as in the firft, grow forth of certaine knots many together, long, narrow, flefhic, greene, and continuing all the yearc: their tafte is aftringent, fomew hat like that of Rhabarb : the floures thew them felues at the beginning of the Spring, of a greenifh colour,grow ing thicke together, and necre the fetting on of the leaues; in Summet it carries a blacke fruit almoft like a Sloe, round, and harfh of tafte.

$$
\text { T The Place. }
$$

The firft of thefe growes in fundry places of $S$ paine, Portugall, and Prouince : the orther varietie thereof Clufius faith he found but onely in one place, and that was neere the citie Horivela, called by the Antients Orcellis, by the riuer Segura, vpon the borders of the kingdome of Valentia:the fecond growes in many maritime places of Flanders and Holland, and in fome vallies by riuers fides. The third growes in the vntilled places of the kingdome of Granado and Murcia. $\ddagger$

$$
\therefore \text { T The Time. }
$$

This Ram is euer greene together with his leaues : the fruit or berrics remaine on the fhrub, yea euen in Winter.

\section{T) The Names.}

The Grecians call thisthorne izus : the Latines alfo Khammus and of diuers it is alfo named

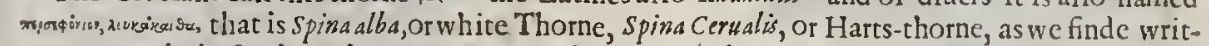
ten among the baftard words. Marcellus nameth it Spina falutaris, and Herbafalutaris; which hath, raith he, as it were a grape. I $\tau$ is called in Italian Crarruca and Rhamno: in Spanilhs Scambrones: in Englihh, Ram,or Harts Thorne.

If The Temperature.

The Ram, faith Galen, doth drie and digeft in the fecond degree, it coolethin the latet end of the firtt degrec, and in the beginning of the fecond.

\section{The Vertues.}

The leaues, faith Diofcorides, are layed pultis wife vpon hot cholericke inflammations, and Saine $A$ Anthonies fire, but we mutt vfe them whileft they be yet but tender, as Galen addeth.

$\neq \quad$ The leaues and buds or young thoots of the firt, are eaten as fallads with oile, vineger, and $B$ falt,at Salamanca and other places of. Caftile, for they haue a certaine acrimonie and acidicie which are gratefull to the tafte. A decoction of the fruit of the third is good to foment relaxed: and weake or paraly ticke members, and to eafe the paine of the gout, as the Inhabitants of Grana:do told Clufurus. $\ddagger$

\section{Cusir:29. Of Chrifts Thorne.}

II The Defcription.

C

Hrifts Thorn or Ram of Lybia, is a very tough and hard thrubby burn, growing vp fometimes vnto the height of a little tree, hauing very long and tharpe priek lie branches : but the thomes that grow about the leaues are leffer, and not fo prickly as the former. The leates are fmall, broad, and almoft round, fomewhat tharpe pointed; firt of a darke greene colour, and then fomwhat reddifh. The floures grow in clufters at the top of the ftalks, of a yellow colour : the husks wherein the feeds be contained, are flat and broad, very like unto fmall bucklers as hard as wood, wherein are contained three or foure thin and flat feeds, like the feed of Line or Flax.

$$
\text { IT The Place. }
$$

This Thorne groweth in Lybia; it is better efteemed of in the countrey of Cyrene than is their Lote tree, as Pliny affirmeth. Of this fhrub Dipbilus Siphnius in Athenaus in his fourcteenth booke makech mention, faying, that hee did verie often eat of the fame in Alexandria that beautifull Citie.

Petrus Eellonises who trauelled oner the Holly Land, faith, that this fhrubbic thorne Paliurus was 


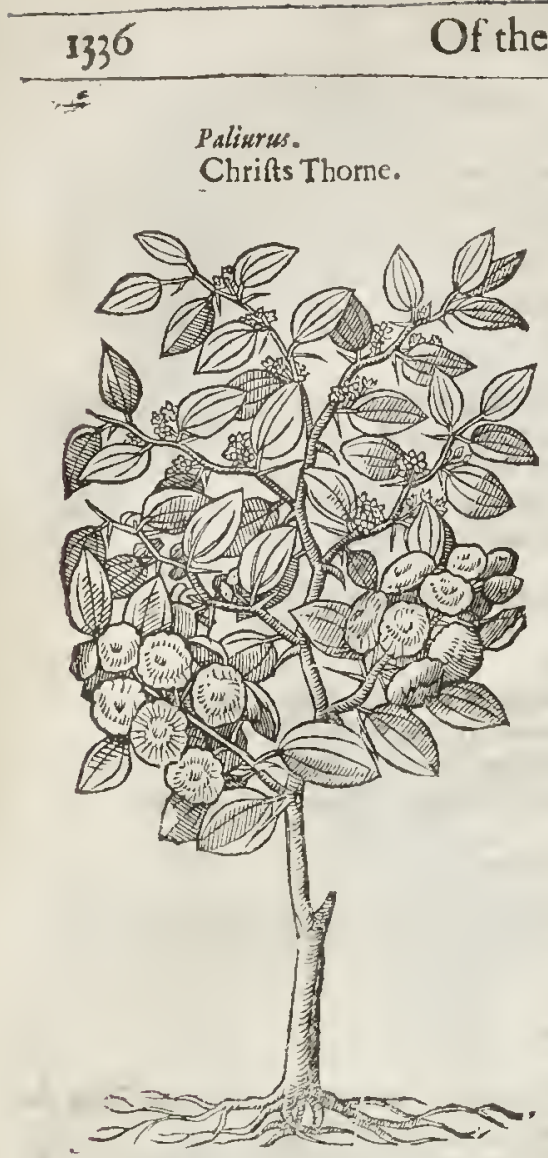

Liв. 3.
Paliurus.

Chrifts Thome. y of Plants.

the thorne wherwith il ey cron rcd cur Sauio ur Chrift : his reafon for the proof hereof is this, that in Iudxa there was not any thoine fo comm on, fo pliant, or fo fit for to make a crown or garland of, nor any fo full of cruell tharpe prickles, It groweth hroughout rhe whnle countrey in fuch aboundance, that it is their common fucll roburne; yea fo common wich them there, as our Gorffe, Brakes, and broome is here with vs. Iofephus in his firt booke of Antiquities, and I I.chap. Gairh, rhar this Thorie hath the moft fharpe prickles of any orher; and therefore that Chrift might be the more tormented, the lewes rather rooke this than any other. Of which I have a fmall tree growing in my garden, that I haue brought forth by fowing of the feed.

The Time.

The -leaues fall away and continue not al. waies green, as do thofe of rhe Rams:it buddetl forth in the Spring,as Pliny teftifieth.

$$
\text { - } T_{1} \text { T he } N \text { ames. }
$$

This Thornic forubbe is called in Greeke aturegs : the Itatines and Italians retaine rhe fame name Paliurus : for wanr of an Englin name, it may be termed Ramme of Lybia, or Chrifts Thorne: $P$ liny reporteth, thar the feed is called zura.

$$
\text { Tा The Temperatere. }
$$

The leaues and root of Chrifts Thorne doe euideritly binde and cut.

\section{The Vertues.}

A By vertue of rh is cutting quality the feed doth weare away the ftone,and caufe tough and limy bumors to remoue out of the cheft and lungs, as Galen faith.

$B$ The decoetion of the leaues and root of Chrifts Thiftle, as Diofcorides writcth, ftoppeth the belIy, prouoketh vrine, and is a remedy againft poifons, and the bitings of ferpents.

C. The root doth wafte and confumeaway Phymata, and oedemata if it be ftamped and applied.

D The feed is good for the cough, and weareth away the ftone in the bladder.

\section{Cнар. 30. Of Buck-T borne, or laxatiue Rrm. \\ T The Defription.}

DVck-thorne groweth in manner of a thrub or hedge tree; his trunke or body is ofren as big as a mans thigh; his wood or timber is yellow within, and his barke is of the colour of a Chentnut, almoft like the bark of a Cherry tree. The branchesare befet wirh leaucs that are fornewhat round, and finely fnipt about the edges like the leaues of the Crab or Wilding. trce : among which come forth Thornes which are hard and prickly:the floures are white and fmal, which being vaded rhere fucceed little round berries, greene at the firft, bur afterwards black, wherof that excellent greene co lour is made, which the Painters and Limners docall Sap-grcene; but thefe berries before they be ripe do make a faire yellow colour,being fteeped in vineger.

‡ 2 Befides the common kinde Clufius mentions two orher: the firn of which hath branches fome two cubits long, fubdiuided into diuers others, couered with a fmooth barke like that of rhe former, which, the vpper rinde being taken off, is of a yellowith greene colour, and bitrerifh tafte: the branches have fome few prickles vpon them, and commonly end in them:the leaues are almont like thofe of the common kinde, but fmaller, narrower, and fomewhat refembling thofe of lie blacke Thorn, hauing fonewhat a drying tafte : the floure confins of foure leaues of a yellowin 
* I Rhankus folmtivas.

Olharmuns contharticus.

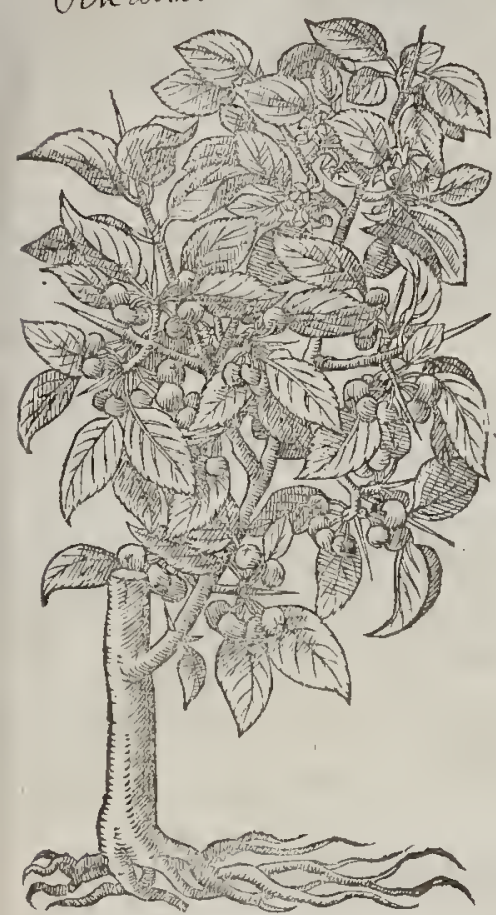

I 3 Rhammus folutivns pumilus. Dwarfe Buck-thorne.

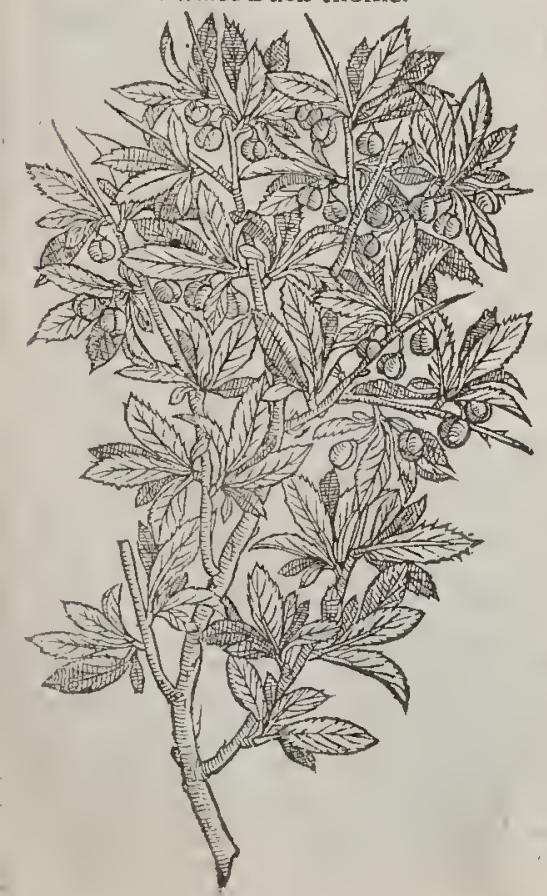

+2 Rhamuns folutivusminor. Middle Buck-thorne.

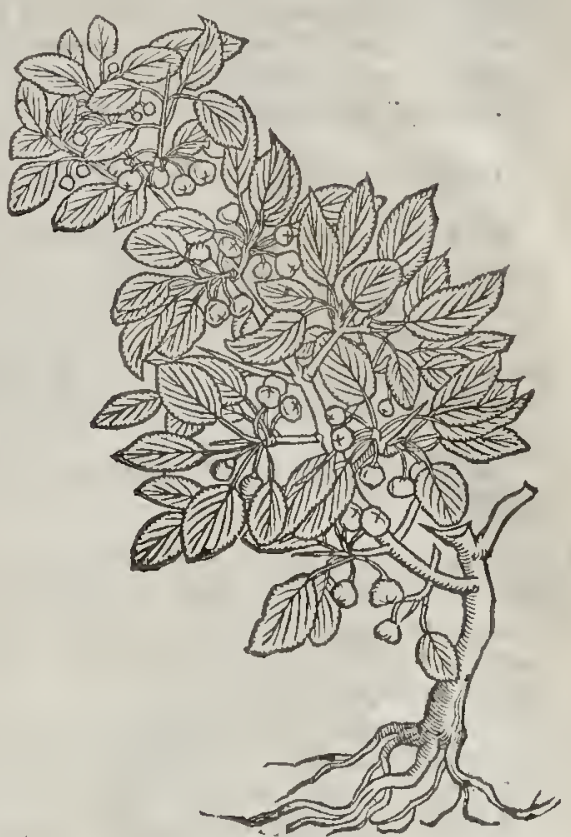

greene colour : the root is wooddie as in other Thrubs: Clufius found this growing in the moun tanous places of Auftria, and calls it Spinainfe. itoriapumila.

3 This other hath branches forre cubite long, and of the thickneffe of ones little finger, or leffer, couered with a blacke and fhriuelled barke: and towards the top diuided in to little boughs, which are coured with a thin $8=$ fnioother barke, and commonly end in a tharp thorn: the leaues much refemble thofe of the Slo-tree yet are they horter and leffer, greenealfo, and fnipt about the edges; firft of an aftringent, and afterwards of fomewhat a bitterifh tafte; the floures which grow a mong t the lcaues are of an herby colour, and confift of foure leaues : the fruit is not much vnlike that of the former; but diftinguifhed with two, \& fomtimes with three crefts or dents, firft green, and then black when it is ripe: the root is thicke, wooddie and hard. Clufus found this on the hill aboue the Bathes of Baden, hee calls it Spina infedtorinpumila 2. This Mathbiolus and others cal! Lycium Iialicum : and our Aurhor formerly gauc the figure of Matthiolis and Tabernamont anss, by the name of Lycium Hipanicum, and here againe another for his Rhamnus folutivus, whicl miade nee to keepe it in this chapter, and omit it in the former, ic being deferibed in neicher. $\neq$

$$
\text { Vuแuแ }
$$

त) $T h$ 
${ }_{133} 8$ Of the Hiftory of Plants.

L18.3.

91 The Place.

Buek-thorne groweth neere rhe borders of fields, in hedges, woods, and in other intoiled plaees: ir delighterh to grow in riuers and in warer ditehes : it groweth in Kenr in fundry places,as ar Farningham vpon the cony burrowes belonging fomerime to $\mathrm{M}^{\mathrm{r}}$. Sibil, as alfo vpon eony burrowes in Southfleer, efpecially in a fmall and narrow lane leading from the houfe of $\mathrm{M}^{\mathrm{r}}$. William $5 \mathrm{w}$ an vnto Longfield downes, alfo in the hedge vpon rhe right hand ar $\mathrm{D}$ artford townes end rowards London, and in many places more vpon the chalkie bankes and hedges.

of The Time.

It floureth in May, the berries be ripe in the fall of the leafe.

१ The Namics.

The later Herbarifts call ir in Latine Rhamnus folutivus, beeaufe it is fetwith thornes, like as the Ram,and beareth purging berries. Matthiolus namethit Spina infectoria; $\boldsymbol{V}$ alcrius Cordus, Spina Cerui, and diuers call it Burgifpina. Ir is termed in high Dutch, Greukbeet begbionn : in Iralian, spino Merlo, Spino Zcrlino, Spmo Ceruino: in Englirh, Laxatiue Ram, Way-rhorne, and Buck-tlorne: in low Durch rhey eall the fruir or berries toljinbetien, that is, as though you thould fay in Latine, Bacce Rhesarse: in Englifh, Rheirberries : in French, Nerprun.

9) The Temperature.

The berries of this Thorne, as they be in tafte bitter and binding, fo be they alfohot and dry in the fecond degree.

A The fame do purge and void by the foole rhicke flegme, and alfo eholericke humors : they are gituen being beaten into pouder from one dram to dram and a halfe:diters do nutuber the berries, whogiue to ftrong bodies from fifteene to twenty or moe; but ir is better robreakechem and boile

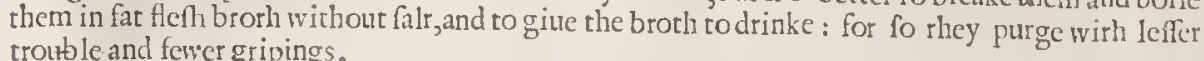
troible and fencr gripings.

B There is preffed forth of rhe ripe berrics a inice, whieh being boyled with a lirtle Allum is vfed of painters for a deep greene, which they do eall Sap grecne.

C The berries which be as yet vnripe, being dried and infufed or fteeped inwater, do make a faire yellow colour; but if they be ripethey make a greene.

\section{C н A P. 3. Of tbe Holme, Holly, or Huluer tree.}

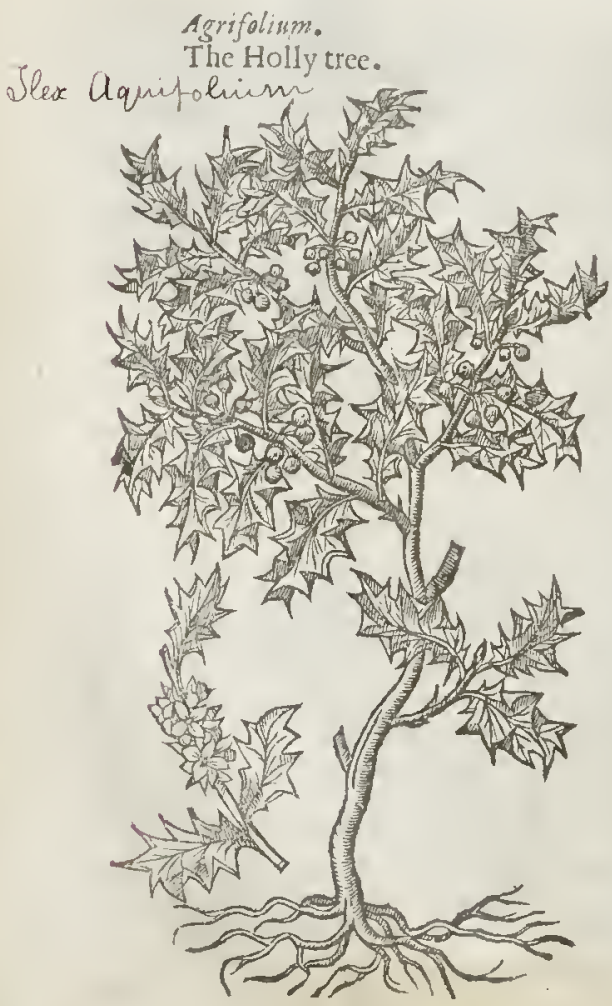

$$
\text { The Defeription. }
$$

7 He Holly is a fhrubbie plant, notwithltanding it oftentimes growes to a rrec of a reafonable bigneffe : rhe boughes whereof are tough and flexible, conered with a mooth and green bark. The fub ftanee of rhe wood is hard and found, and blackinh or yellowith within, which doth alfo finke in the water,as doth the Indianwood which is called Guaiaum: rhe leaues are of a beautifull green colour, fmoorh and glib, like almoft the bay leaues, bur leffer, and corncred in the edges with harp prickles, which notwithfanding they want or hatle few when the tree is old: the floures be white, and fweet of fmell:the berries are round, of the bigneffe of a little Peafe, or not much greater, of eolour red, of taft vnpleafant, with a white ftone in the midft,whieh do not eafily fall away, but hang on the boughes a long time: the root is wooddie.

There is made of the fmooth barke of this tree or thrub, Birdlime, which the birders and counrry men do ve to take birds wilh:they $\mathbf{m l}$ off the barke, and make a ditch in the ground, pecially in moift, hoggy, or foggy earrh, wherinto they put this bark, eourering the diteh with boughes of trees, lerring it remaine there rill is be rotten and putrified, whichwill be done in 
the fpace of twelue daics or thetcabout : which done,thcy takc it forth, and beat in morters vatill it be come to the thickneffe and clammineffe of Lime:laftly, that they may cleare it ftom pieces of barke and other filthincfe, they do warh it very often : aftcr which they adde vnto it a little oyle of nuts, and after that do put it vp in earthen vcffells.

$$
\text { ขा The Place. }
$$

The Holly treegroweth plentifully in all countries. It groweth green both winter and fommer, the berries ate ripe in September, and they do hang vpon the trce a long time after. $\mp$

$$
\text { T) The Names. }
$$

This ttce or thrub is called in Latine Agrifolium : in Italian, Agrifoglio, and Agtifoglio: in Spa: nifh, $A$ zebo: in high Dutch, naalobiftell, and of diuers Stecpalmeri : in low Dutch, French, Hous and Hortfon : in Englifh, Holly, Hulucr, and Holmc.

$$
\text { T. The Temperature. }
$$

The bcries of Holly are hot and drie, and of thin parts, and wafte away winde.

$$
\text { If The Vertues. }
$$

They are good againt the collicke : for ten ot twelue being inwardly taken bring away by the $A$ ftoole thicke fiegmaticke humors, as we haue learned of them who oftentimes made triall thcreof.

The Birdlimc which is made of the barke heteof is no leffe hurt full than that of Miffeltoe, for it $B$ is matuellous clammie, it glueth vp all the inttails, it fhutteth and draweth together the guts and paffages of the excrements, and by this meanes it bringeth deftuction to man, not by any qualitie, but by his glewing fubfance.

Holly beaten to pouder and drunke, is an expetimented medicinc againft all the fluxes of the $\dot{C}$ bclly, as the dy fenterie and fuch like.

\section{CHA . 32. Of the Oke.}

I 2uercus vulgaris cum glande \& musco fuo.

The Oke Tree with his Acornes and Moffe.

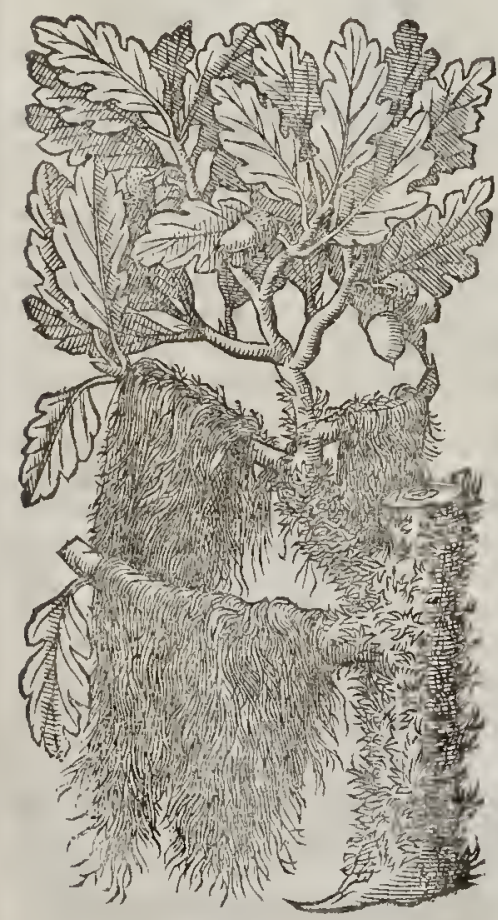

$$
\text { T) The Defription. }
$$

I THe common Okc groweth to i grcat tree; the trunlie ot body wherof is conered oner with a thicke tough batke full of chops or rifts : the armes or boughs are likewife grear, difperfing themfelues farte abroad: the leaues are bluntly indented abour the edges, fmooth, and of a fhining greene co. lour, whereon is often found a moft fiveet dew and fomewhat clammie, and alfo a fungous excrefcence, which we call Oke Apples. The fruit is long, conered w ith a brownc hard and tough pilling, fct in a rough fcaly cup or husk: there is often found vpon the body of the tree, and alfo vpon the branches, a certaine kind of long white mote hanging downe from the fane :and fonietimes another wooddie plant, which we cal Miffel toe, being either an excrefeence ot outgrow ing from the trec it felfe, or of the doung (as it is reported) of a bird that hath eaten a certaine berrie. $\neq$ Befides thefe there are about the roots of old Okes within the eartl eertaine other excrefcences, which Babbine and others haue called vwe quercince, becaufe they commonly grow in clufters together, after the manner of Grapes and about their bignes, being fometimes round, Sc other. whiles cornered, of a woody fubltance, hollow within; and fountimes of a purple, otherwhiles of a whitilh colour on the outfide : their tafte is aftringent, and vfe fingular in all Dyfente: 
rieș and fluxcs of bloud, as Excelins affirmes, Cap. 51 . de Lapid. \& Gem. ¥

3 Carolus Clusfus repotteth that hee found this bafe or low Oke not far from Lisbone, of the height of a cubite, which notwithitanding did alfo bcate an acorne like that of our Oke trce, fating that the cup is fmoother, and the Acorne much bitteter, wherein it differeth from the reft of his akinde.

2 2uercus vulgaris cum excrement is fungofis:

The common Oke with his Apple or greene Gall.

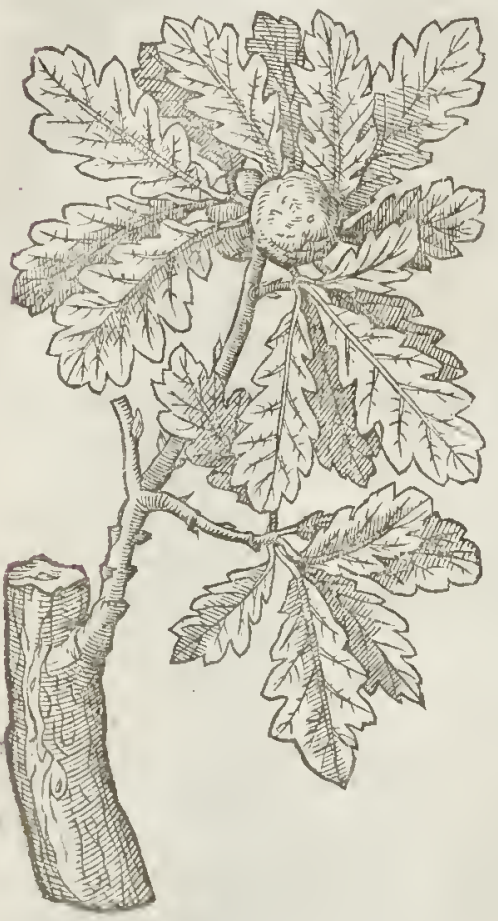

3 2uerces bumilis. The dwatte Okc.

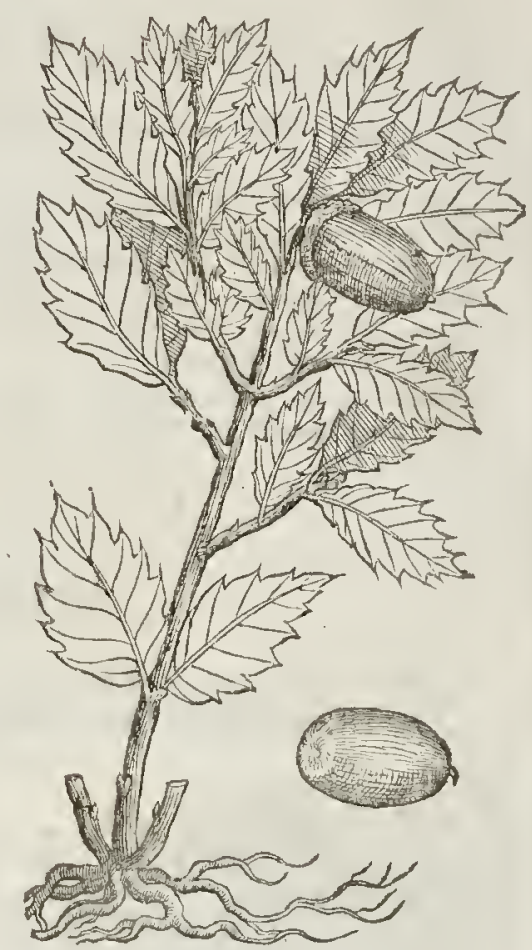

Thete is a wilde Oke which rifeth vpoftentimes to a matuellows hcight, and reacheth very far with his armes and boughes, the body wherof is now and then of a mighty thickneffe, in compaffe two or three fathoms : it fendeth forth great fpreading armes, diuided into a multitude of boughs. The leaues are finooth, fomcthing, hard, broad, ong, gafhed in the cdges, grecne on the vpper fide: the Acotnes are long, but thorter than thofe of the tamer Oke; euery one taftened in his oivne cup, which is rough withont : they are couered with a thin rinde or thell: the fub ftance or kenell within is ditided into two parts, as are Beans, Peale, and Almonds:the bark of the yong Okes is fmooth, glib, and good to thicken sk ins and hides with, but that of the old Okes is rigged, thicke, hard, and full of clops : the inner fubftance or heart of the wood is fomthing ycllow, hard and found, and the older the harder: the white and outward patt next to the batke doth eafily rot, being futb ie to to the worne, cfpecially if the tree be nor felled in due time: fome of the roots grow deepe into the earth, and otherfome far abroad, by which it ftiffely ftandeth.

$$
\text { Ti The Place. }
$$

The Oke doth fearcęly refufe any ground; for it groweth in a drie and barren foile, yet doth it profper better in a frutfull giound. it growcth vfon hills and mountaines, and likewife in vallies: it commethveuery where in all parts of England, but is not fo common in other of the South and hot regions.

\section{\&ा The Time.}

The Oke dotican lis leaues for the molt part about the end of Autumne: fome keepe their leaues on, but dry all winter long, vntill they be thruft off by the new fpring.

$$
\text { बा } 7 \text { he } 2 \text { eames. }
$$

The Oke is callcd in Greeke dius: in Latine, Quevcus: of fome, Placida; as Gaza trandateth it. It may

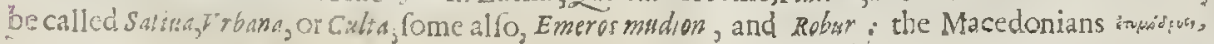


as though you thould fay Veriquercus, as $G a z$ expo undeth it, or Vere 2 wercss, the true Oke. We

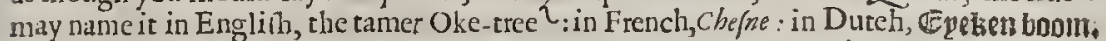

The fruit is named in Greeke Baxars in Lat ine, Glans : in high Dutch, Eichel : in low Dutch, Ees fol : in Spanifh, Bellot us : in Italian, Chiande : in Englifh, Acorne and Maft.

Tlie cup whercin the Acorne ftandeth is named in Greeke ikpanis, as Paulus afgineta in his third booke, 42 chapter teftifieth, faying, Omphacis is the hollow thing out of which the Acorne groweth: in Latine, Calix glandis; in Thops, Cupula glandis : in Englith, the Acorne cup. oा $\mathcal{T}$ be Temperature and Vertues.

The leaucs,barke, Acornecups, and the Aeornes themfelues, doe mightily binde and drie in the A third degrec, being fomew hat cold withall.

The beft of rhem, faith Galen, is the thin skin which is vnder the barke of the tree, and that next, B which lietlu necret to the pulpe, or inner fub tanee of the Acorne; all thefe ftay the whites, the reds, fpitting of bloud and laskes : the decoction of thefe is giuen,or the pouder of them dried, for the purpofes a forchaid.

Acornes if they be eaten are hardly concocted, they yeeld no nourifhment to mans body, but $\mathrm{C}$ that which is grofte, raw, and cold.

Swine are fatred herewith, and by feeding hereon haue their flerh hard and found.

The A corns prowoke vrine, and are good againf all venome and poilon, but they are not of fuch $E$ a ftopping and binding facultie as the leaues and barke.

The Oke apples are good againft all fluxes of bloud and lasks, in what manner foeter they be ta - F ken,buc the beft way is to boile them in red wine, and being fo prepared, they are good alfo againft the exeeflue moifture and fwelling of the iawes and almonds or kernels of the throat.

The decoction of Oke apples ftaieth womens difeafes, and eatfeth the mother that is falne $G$ downe to returne againe to the naturall place, if they doe fit outer the faid decoetion being very hot.

The fame fteeped in ftrong white wine vineger, with a littlc pouder of Brimftone, and the root of $\mathrm{H}$ Ireos mingled together, and fet in the Sun by the fpace of a moneth, maketh the haireblacke, confumeth proud and fuperfuous fleth, take th away fun-burning, freckles, fpots the morphew, wirhall deformities of the face, being walhed therewith.

The Oke Apples being broken in funder about the time of their withering, do forefhew the fe- I quell of the yeare,as the expert Kentith husbandmen haue obferued by the liuing things found in them: as if they findc an Ant, they foretell plenty of graine to infuc: if a white worme like a Gentill or Magot, then they prognofticate murren of beafts and eattell; if a fpider, then (fay they) wee Shall have a peftilenee or fome fueh like fickneffe to follow amongft men: thefe things the learned alfo haue oblerued and noted; for $M$ atthiolus writing vpon Dioforides fairh, that before the batre an hole through them, they containe in them either a flie, a fpider, or a worme; if a flie, then war infueth, if a ereeping worme, than fcarcitic of victuals; if a running fpider, then followeth great fickncffe or mortalitic.

\section{C н a p. 33. Of the Scarlet Oke.}

\section{The Kindes.}

A Lthough Theophraftus hath made mention but of onc of thefe Holme or Holly Okes onely,yet A hath the later age fet downe twokindes thereof;one bearing the fearler grain,and the other onIy the Acorn:which ching is not contrary to Diofcorides his opinion, for he intreareth of that which beareth the Acorne, in his firf booke, among sivir or the Okes; and the other hee deferibeth in his. fourth booke, vnder the title arixas RaquxmorCoccus Baphice.

\section{T The Defription.}

THe Oke which bearctl the fearlet graine is a fmall tree, in manner of a hedge tree, of a meane bigneffe, hau ing many faire branches or boughes fpread abroad: whereon are fet leaues,gre en aboue, white underncath, fnipr about the edges, and at euery eorner one tharpe prickle, in manner of the fmoother Holly : among which commeth fometimes, but not often, fmall Acornes, Itanding in litrle cups or husks,armed with prickes as tharpe as thornes, and of a bitter tafte. Befides the Acornes, there is found eleauing unto the wooddie branches, a certaine kinde of berries, or rather an excrefeenee, of the fibftance of the Oke Apple, and of the bigneffe of a Peafe, at the firft white, and of the colour of aneswhen they be ripe, in which are ingendred little Maggots, which feeme 
Ilex Coccinera.

The Searlet Oke.

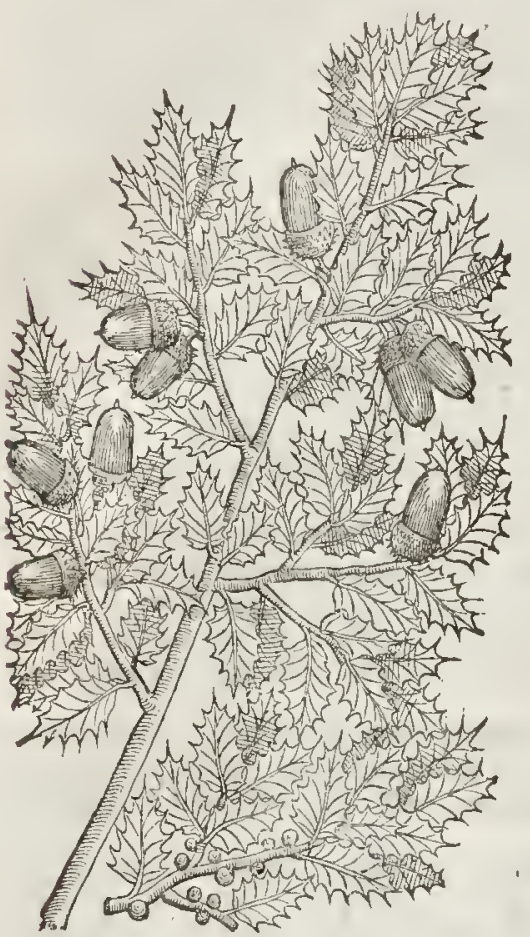

to be withour life vntill they fecle th $\mathrm{c}$ heat of the fun, and then they ereep, and feeke to flic a. way. But the peoplc of the countrey (which make a gaine of (hem) doewatch the time of their flying, euen as we doe Bees, which they then take and put into a linnen bag, wherein they thake and boult them vp ard downe vntil they be dead, which they make vp into great lumpes oftentimes, and likewife fcll them to diers a part, euen as they were taken forch of the bag, whereof is made the moft perfect Scarler. of The Place.

This Oke groweth in Languedocke, and in the countries thereabout, and alfo in Spain:but it bcareth not the fcarlct grain inall places, but in thofe efpecially, which lic towards the Mid. land fea, and which be fubiest to the fcorching heat of the Sun, as Carolus Clu (Ius witneffeth; \& not there alwaies, for when the tree waxer hold it growes to bc barren. Then do the peoplc eut and lop it downc, that after the young hoors hate arcained co two or three yeares growt h, it may become fruitfull againe.

Petrus Bellonius in his books of Singularicies Thewcth, that Cocous Baphicus or the Scarlet graine doth grow in the Holy land, and neere to the lakew hich is ealled the Sea of Tiberias, and that vpon lictle trces, whercby the inhabitants get great ftorc of wealth, who fepcrat the husks from the pulpe or Magors, and fell this being made vp into balls or lumpes, much dearerthan the emptic fhels or husks.

Of this graine alfo Paufanias hath made mention in his tench booke, and fheweth, that the trec which bringeth forth this graine is not great, and alfo groweth in Phocis, which is a countrey in Maecdonia neere to the Boetians, not far from the mountain Parnafus.

Theophafus writcth, that atus, or the Scarlet Oke, is a greac tree, and rifeth vp to the height of the common Oke: amongft which writers there are fome contrarietic. Petrus Bellonits reporteth it is a little tree, and Theophraftus a great one, which may chance according to the foylc and climate; for that vpon the ftonie mountaines cannot grow to that grearnefle as thofe in the fertill grounds.

$$
\text { of The Time. }
$$

The little graines or berries which grow about the boughes begin to appeare efpecially in the Spring, when the Southweft windes do blow : the foures fall and are ripe in Iune, togerherwith the Maggots growing in them,which recciung lifeby the heat of the Sun, do fortlwwith flie away (in manner of Moth or Burterfie) vnleffe by the care and diligence of the keepers, they be killed by much and of ten thaking them together, as aforefaid.

The tree or fhrub hath his leates alwaics greene: the Acornes be very late beforc they be ripe, feldome before new come vp in their place.

\section{T $T$ be Names.}

The Scarlet Oke is called in Grceke apim: in Lacine Ilex : the later writers, Ilex Coccigera, Or Coccifera; in Spani(h, cofcois: for want of a fit Englith name, we hate thought good to call it by the name of Scarlet Oke, or Scarlet Holme Okc: for Ilex is named of fomc in Englifh, Holne, which fignifieth Holly or Huluer. But chis Ilex, as well as thofe that follow, might be called Holm Oke, Huluer Oke, or Holly Oke, for difference from the fhrub or hedge tree Agrifolium, which is fimply called Holme, Holly, and Hulucr.

The graine or berric that feructh to die with is properly called in Greekc anxes famas: in Latine, Coccus infectoria, or Coccum infectorium : pliny alfo nameth it Cufculium: or as moft men doe reade it, Quffuilium: the fame Author faich, that ic is likewife named Scolecion, or Maggot berrie.

The Arabians and the Apothecaries doeknow ic by the namc of Chefmes, Chermes, and $\boldsymbol{K}$ ermes: They are deceiued who thinke that Chefmes doth differ from Infectorium Cocom : it is called in Ita-

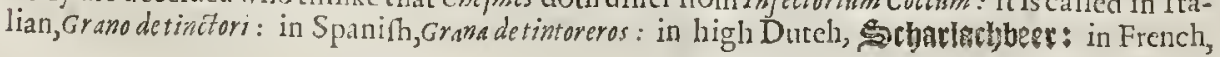


Fermillon, and Graine d'efcarlate: in Englin, after the Duteh, Searlet Berry, or Scarlet graine, and after the A pothecaries word, Coccus Baphocus : thic maggot within is that which is named Cuteho-
nele, as moft do deeme.

Theophraftus faith the Acorne or fruit bereof is called of diuers; "Awadr. Acylum.

If The Temperature and Vertues.

This graine is aftringent and fomwhat bitter, and alfo dry without thatpneffe and biting, there- A fore, faith Galen, it is good for great wounds and finewes that be hurt, if it be layd thereon : fome
temper it with Vineger; others with Oxymel or fyrrup of vineger.

It is eommended and giten by the later Phylitians to ftuy the Menfes : it is alfo counted among $B$ thofe Simplewhich be cordials, and good to itreng then the heart. Of this graine that noble and famous eonfection Alkerszes, made by the Arabians, hath taken his name, which many doe bighly commend againft the infirmities of the heartmotwithtanding it was chiefly demfed in the beginning for purging of mclane holy; whieh thing is planly perceitued by the great quantitic of Lapis La: ulus added thereto: and therefore feeing that this ftone hath in it a venomous quality, and likewife a property to purge melaneholy, it canot of it felfe be good for the heart, but the other things be good, which be therefore added, that they might defend the heart from the hurts of this ftone, and correat the malice there of.

This eompofition is commended againft the trembling and thaking of the heart, and for fwounings and mclancholy palfions, and forrow proceeding of no euident eatufe : it is reported to recre-
ate the minde, and to make a man merry and ioy full.

It is therefore gond againtt melaneholy difeafes, vaine Imaginations, fighings, gtiefe and for- D row without manifenteaufe, for that it purgeth away melancholy humors : after this maner it may
becomfortable for the heart, and delightfull to the minde, in taking away the materiall caufe of forrow : neiticr can it otherwife ftrengthen a weake and feeble heart, vnleffe this ftone ealled Lapis
cyaneus be quite left out.

Therefore he that is purpofed to vfe this compofition againft beatings and throbbings of the $E$ heart, and fwounings, and that not as a purging medicine, thall do well and wifely by leauing out the ftone Cyaseus; for this being taken in a little weight or fmall quantitie, cannot purgeat all, but may in the meane feafon trouble and torment the ftomacke, and withall thorow his tharpe and venomois qualitic (if it be oftentimes taken) be very offenfule to the guts and intrailes, and by this meanesbring more harme than good.

Morcoter, it is not neecffarte, no nor expedient, that the briftle died with Cochenele, called F Chefmes, as the A pothecaries terme ir, (hould be added to this compofition; for this brifle is not died without Auripigmentum, called alfo Orpinent, and other pernitious things ioyned therewith, whofe poy fonfome qualitiess are added to the iuyces tojether with the colour, if either the briftle or died filke be boyled in thein.

The berries of the Cochencle mut be taken by themfelues, which alone are fufficient to dy the $G$ iuices, and to impart vnto them their vertue : neither is it likewife needfull to boile the raw filke together with the graines, as moft. Phy litians thinke: this may be left out, for it maketh nothing at all for the ftrengtlining of the heart.

\section{Ci a P. 34. Of the great Skarlet Oke.}

If The Defcription. mon Matt trees : the timber is firme and found : the leaues fre feteading like the Acorne or eomedyes, like thofe of the former Skailt Oke : the leaues when the tree waxeth old baue on them no priek les at all, but are fomivliat bluntly eut or indented about the edges, greene on the vpper fide, and gray vnderneath : the Acone ftandeth in a priekly cup like our common Oke Acone, which when it is ripe beconineth of a browne colour, with awhite kernel with in of tafte not vnpleafant. Thete is found vpon the branebes of this tree a certaine kinde of long hairy moffe of the colour of afhes, not vnlike to that of our Englin Oke. $¥$ This tree is cuer greene, and at the tops of the branehes about the end of May, here in England, carrieth diuers long eatkins of moffie yellow floures, which fall away, and are not fucceeded by the acornes, for they grow out vpon other ftalks. Cluf fus in the yeare 551 obferued two trees; the one in a garden aboue the Bridge, and the other in the priuat garden at White. Hall, hauing leffer leaues than the former. The later of thefe is yer fanding, and euery yeare beares finall Acornes, which I could nener obferue to come to any ma. euritic. $\ddagger$ 
Ilex maior Glandifera. The great Skarlet Oke.

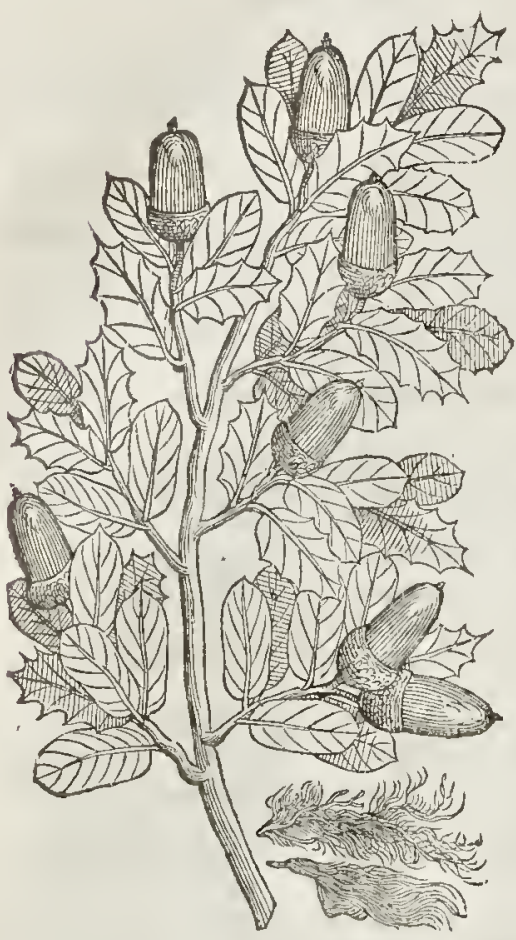

* Ilicis ramus floridus.

The floures of the great Skarlet Oke, 
$\mathrm{L}_{\mathrm{IB}}$ 3. Of the Hiftorie of Plants.

to haue the leafe of the Oline tree: but suber in Greeke,called Phellos, or the Corke tree, hath a little lafe.

T) The Temperature and Vertues.

The leaues of this Okc haute forcc to coole and repell or keepe backe, as haue the leaues of the $A$ Acornes or Malt trees : being ftamped or beaten, and applied, they are good for foft fwellings,and Arengthen weake męmbers.

The barke of the root boiled in water vatill it be diffolued, and layd on all night, maketh the $B$ haire blacke, being firf fcoured with Cimolia, as Diofcorides faith.

Clufius reporteth, that the Acorne is eftecmed of, eaten, and brought into the market to be fold, in the eity of Salamanca in Spaine, and in many other places of that countrey; and of this Acorne Pliny alfo hath peraduenture written, li6, 16. cap.5. in thefe words: Morcoter, at this day in Spain the Acorne is ferued for a fecond courfe.

\section{C н а 1. 35. Of the great Holme-Oke.}

I Cerrismaiorc Glande.

The Holme Oke witingreat Acornes.

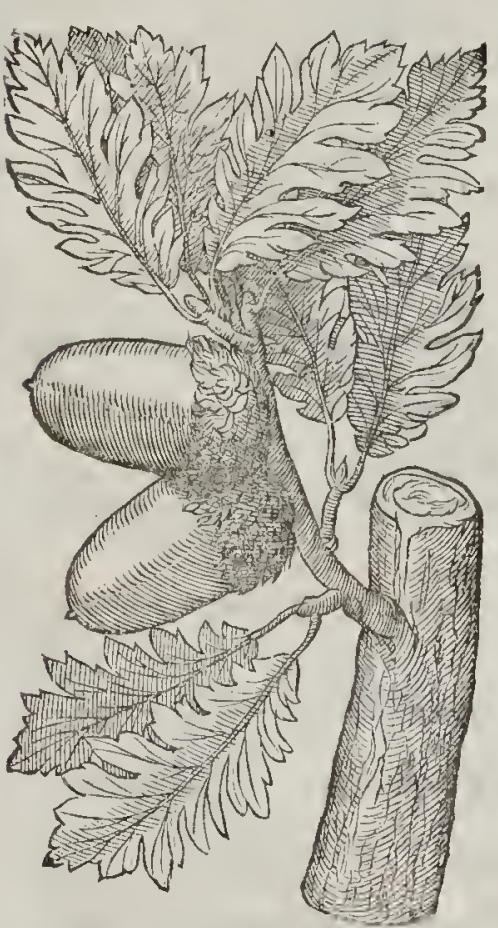

2 Cerris minore Glande.

The Holme Oke with leffer Acorns. $B$ (1) 


\section{Of the Hiftory of Plants. $\quad$ L $_{18} 0_{0}$.}

† Cerri minoris ramalus gum fore.

A branch of the fmaller Holme Oke with floures.

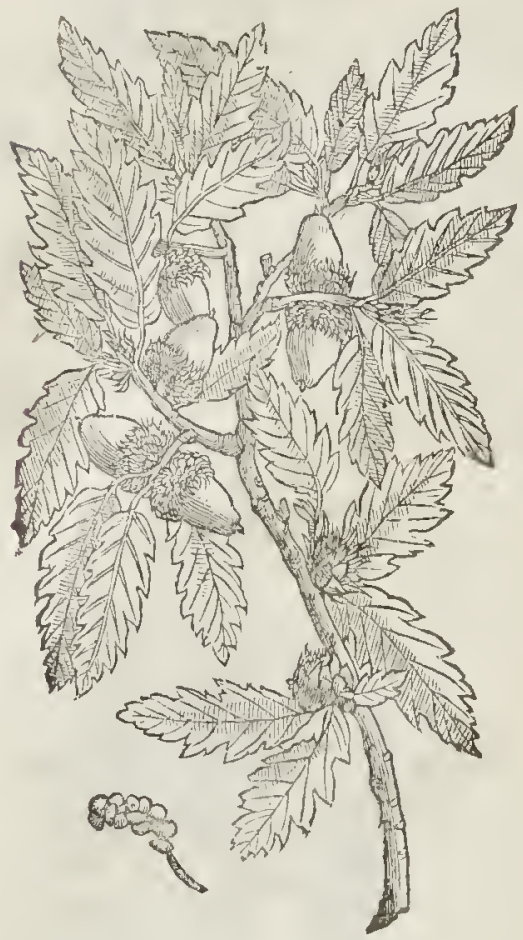

bringeth forth oft times a certain fmooth kinde of Gall not altogether vnprofitable: This Oke likewife bringeth forth another kinde of cxcrefence, which the Graucr hath omitted in the figure, which is called in Greeke qireon: Gaza nameth it Penir. Th: $p_{\text {enis }}$ or pricke is hollow, mofie, hangit downe halfe a yard long, like a long rag $c$ linnen cloath.

2 The fecond is altogether like the firft, fauing that this beareth fmaller A. cornes, and the whole tree is altogether leffe, wherein confifteth the difference.

$\mp$ Both this \& the former cary floures cluftering vpon long ftalkes, like as in the comminn Oke; but the fruit doth not fucceed them, but groiv forth in orher places. $\ddagger$

$$
\text { gi The Place. }
$$

This Oke groweth in vntoiled places, it. is feldome times found, and that but in Woods onely : it is for the molt part unknowne in Italy, as Pliny reporteth.

$$
\text { of The Time. }
$$

They bring forth their fruit or Acornes in the fall of the leafe.

$$
\text { 9i The Names. }
$$

This Oke is called in Greeke 'A izinat: in Latine, Cerrus : yet doth Plizy make mention both of Eigrlops, and alfo of Cerrus: A izina $_{1}$ is likewife one of the difeafes of corne, called in Latine $F e f t u c a$ : in Englinh, wilde Otes, and far differing from the tree eEgisops.

That which hangeth from the boughs, Pliny, lib.16.cap.8. calleth Pamu onely : that acorne tree named . Egilops bringech forth $P$ anos arestes, withered prickes, couered with white moffie iags hanging downe, not only in rhe barke, but alfo from the boughes, halfe a yard in bigneffe, bearing a fweet fmell, as we haue faid, among ointments.

$$
\text { T) The Temperature and Vertues. }
$$

We finde nothing written of the faculties of this tree among the old Writers, neither of our owne experience.

$$
\begin{gathered}
\text { Cha P. 36. Of the Corke Oke. } \\
\text { T The Defription. }
\end{gathered}
$$

I THe Corke tree is of a niddle bigneffe like vnto Ilex, or the barren skarlet Oke, bue with a thicker body, and fewer boughes: the leaues be for the moft part greater,broader, rounder, and more nicked in the edges : the barke of the tree is thicke, very rugged, and full of chinkes or crannies that cleaueth and diuideth it felfe into pieces, which vnlefe they be taken away in due time do giuc place to another barke growing vnderneath, which when the old is remoued is martellous red, as though it were painted with fome colour : the Acorne ftandeth in a cup, which is great, brifted, rough, and full of prickles: this Acorne is alfo aftringent or binding, more vnpleafant than the Holme Acorne, greatcr in one place, and leffe in ano-
ther.

2 The Corke tree with narrow leates groweth likewife to the height and bigneffe of a great tree; the trunke or body whereof is conered with a rough and feabbed barke of an ouerworn blackifh colour, which likewife cleateth and cafterh his coat when the inner barke groweth fomwhat thiche: the branches are long, toigh, and flexible, eafie to be bowed any way, like thofe of the

Oziar; 
LI В. 3 . Of the Hiftory of Plants.

Oziar; whereupon do grow leaues like thofe of the preeedent, but longer, and little or nothing indented about the edges : the fruit groweth in fmall cups as the Acomes dos: they are leffer than thofe of the other kinde, as is the reft of the tree, wherein is the eliefeft differenee. $\neq$ This varies in the leafe, (as you may fee in the figure) whieh in fome is fnipt about the edge, in other fowe not at all.

r. 2. Suberlatifolism ơ anguflifolinm.

The Corke tree with broad and narrow leanes.

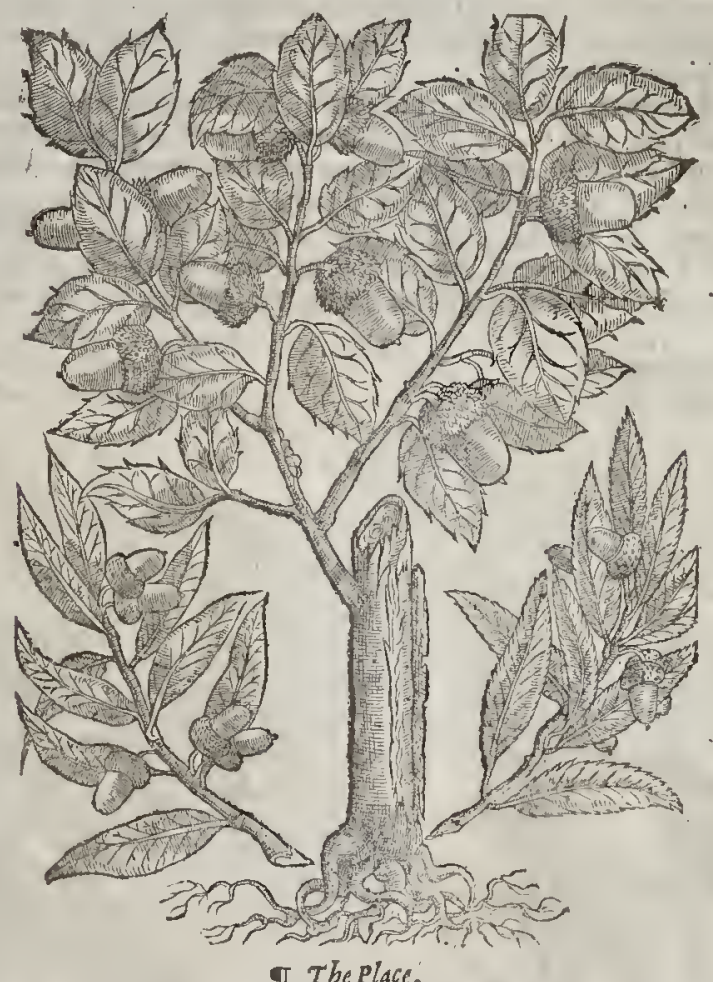

ฯ The Place.

Ir groweth in the colntrey of Aquitania,ncere to the mountaines called Pyrenxi : it alfo grow cth plentifully in the kingdomes of Spaine, differing fomewhat from that of A quitania, as Cluf iut declarech : it is likewife found in Italy, and that in the territorie of Pifa, with a longer leafe, and tharper pointed; and about Rome with a broader, and cut in the edges like a faw, and rougher, as Matibiolus teftifieth.

\section{T The Time.}

The leaues of the firft are alwaies greene in Spaine and Italy, about the Pyrenxan mountaines they fallaway in Winter.

\section{The Names.}

This tree is called in Greeke woms : in Latine Suber : in Freneh, Liere : in Italian, sugaro : the fame names do alfo belong to the barke : the Spaniards eall the tree Alcornoque : the Englifhmen, Corke tree and the barke, Corcha de Alcornoque; whereupon the Low-countrey men and Englith men alfo do eall it Corke; and yet it is ealled in low-Duteh alfotitlotyout,

$$
\text { 9 The Temperature and Vertucs. }
$$

This barke doth manifectly dry, with a binding faeultic.

Being beaten to pouder and taken in water it itancheth bleeding in any part of the body. The Corke whieh is taken out of wine veffels, faith $\boldsymbol{P}$ aslus, being burnt, maketh athes which do mighrily dry, and are mixed in compofitions diuifed againft the bloudy thix.

Corke is alfo profitable for many things : it is ved (fairh pliny) about the anchors of thips, Fi. thers nets, and to ftop veffels with ; and in $W$ inter for womens fhooes, whieh ve remaines with vs cuen to this day : fithermen hang this barke vpon the wings of their nets for feare of finking. and thoo-makers pit it in lhooes and pantofles for warmeffe fake.

CHAP. 


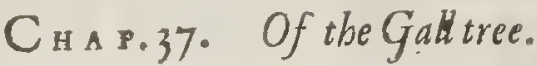 \\ IT The Kindes.}

F trees that bring forth $\mathrm{Galls}$ there be diucrs forts, as may appeare by the diuers formes ard forts of Galls fet forth in this prefent chapter, which may fcrue for their fetretalldiftinctons, where of fome bring for th Acornes likewife, and fome nothing but Galls : the figures of fome few of the trees thall give you fufficient knowledge of the reft : for all the Acone or Maft trees bring forth Galls, but thofe trees whofe figures we haue fet forth do beare thofe Galls fit for medicine, and to thicken skins with.

Diofcorides and Galen make but two forts of Galls; the one little, yellow, full of holes, and mne fpongie in the inncr part, both of them round, hauing the forme of a little ball, and the orher fmoorh and cuen on the out fide : fince, the later wrirers haue found moe, fome hauing certain little knobs fticking forth, like in forme to the Gall, which doth alfocleawe and grow without ftalke to the leafe. There is alfo found a certainc cxcrefcence of a light greene colour, fpongicand waterie, in the middle whereof now and then is found a little flie or worme: which fot ball in hot countries doth oftentimes become hard, like the little fmooth Gall, as Theophraft wa faid.

1 Galla, fue Roburmains. The great Gall ttee.

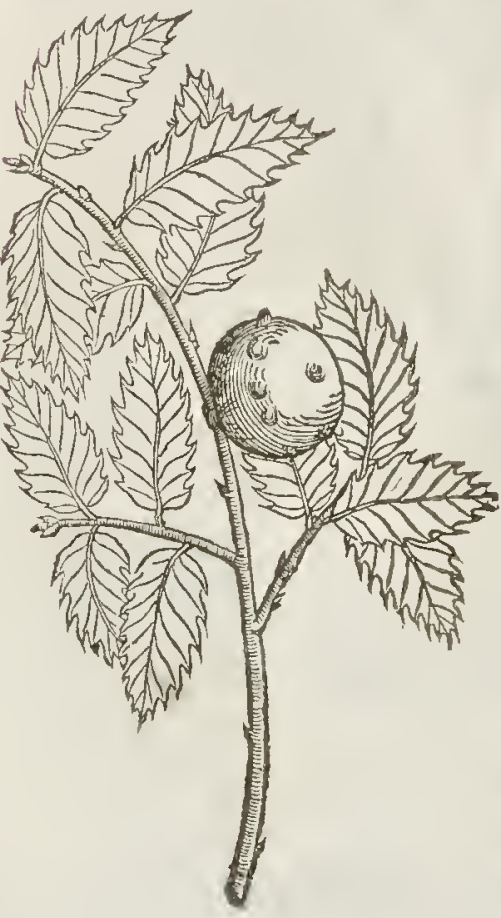

¥ 2 Robur, fiuc Galla mitior aliera. Another great Gall tree.

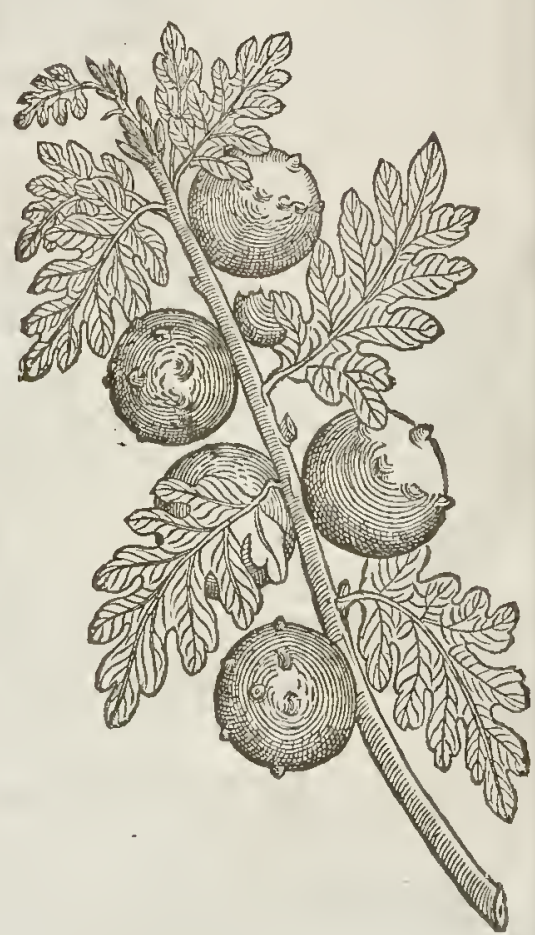

T The Defoription.

1

M He Gall tree gtowes vp to 2 fufficient height, hauing a very faire trunk or body, whereon are placed long twiggy branches bringing forth very faire leaues, broad, and nic ked in the edges like the teeth of a faw : among which come forth acornes, although the figure expreffe not the fame, like thofe of the Oke, and likewtfe a wooddy excrefcence, which we name thc Gall, hauing certaine fmall eminences or bunches on the out fide, growing for the moft part vpon the flender branches wirhout ftalks, and fomtimes they grow at the ends thereof; which by the heate of the Sun are harder, greater, and more follid in one countrey than another, according torhe foile and clymat. 
LiB. 3 .

3 Galluminar.

The little Gall tree.

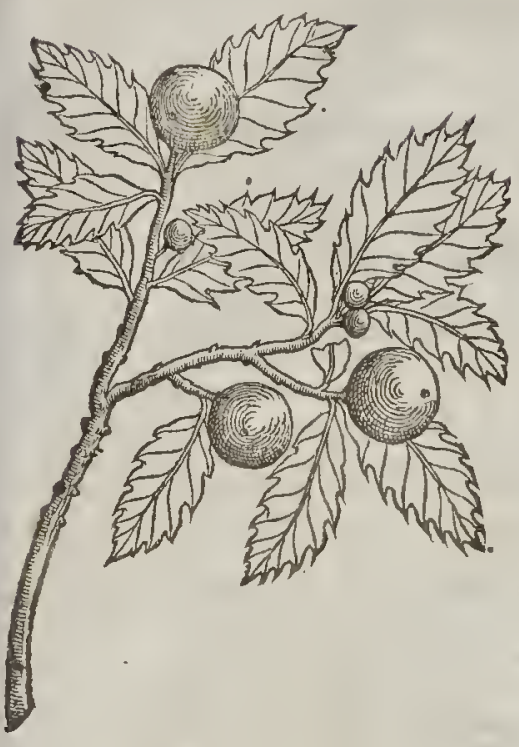

\section{Of the Hiflory of Plants.}

- $\neq \neq$ This growes [o the licight of a tall man, hauing leatres deepe'y diuided on the eatges like the Oke, and they we green abo:te, but hary and houry telow : it carties a great Gall of the bignele of a litrie Apple, and that in great plenty, S without al:v order. This groweth indiuers parts of old Caftile in Span, and in all the mountainous woods about Vichat in Aufria.t

3 The leffer Gall tree diftere:h not from the former, fating that it is altorether leffer: the fruit and Gall is likevife lerfer, whereinefpecially confifteth the diffetence.

$$
\text { दा The Place. }
$$

The Galls are found in Italy, Spaine, and Bohemia, and moft of the hor tegions.

$$
\text { of The Time. }
$$

The Gall, faiti Pliny, appeareth or commeth forth when the Sun commeth out of the figne Gemini, and that generally in one night.

$$
\text { of The Names. }
$$

The Gall tree is called guercas, Robur, and Galle arbor: the Gall is called in Greeke anxis: the Apothecaries and Italians kecpe the name Galla for the fruit : in high-Dutch, $\mathbb{B}$ blopftel: in low-Durch, Galmoten: in Spanilh, ngabs Galha, and Bugalhas: in French, Noix de Galle: in Englin, Gaules, and Galls.

\section{of The Temperature and vertues.}

The Gall called omplaciris, as Galenwriteth, is dry in the third degree, and cold in the fecond: it is a very harth medicine, it faftneth and draweth together faint and flackc parts, as the onergrowings in the fle $T_{2}$ : it repellcth and keepeth backe rheumes and fuch like fuxes, and dorh effectually dry up the fame, cfpecially when they haue a defcent into the gums, almonds of the throat, and
other places of the mouth.

The other Gall doth dry and alfo binde; but fo much Ieffer, hy how much the har th or choking qualitie is diminifhed : being boyled, beaten, and alf applied in manner of a plaifter is laid with good fuccerfe vpon the inflammations of the fundament, and falling downe thercof : it is boiled In water if there be need of a little aftrietion, and in wine, efpecially in auftere wine, if more need
require. Galls are very profitable againft the Dy fenterie and the Coliacke paftion,being drunk in wine, $C$
or the pouder thereof itrewed vpon meats.

Galls are vfed in dying and colouring of fundry things, and in nuking of inke.

Laft of all, burnt Galls doe receiue a further facultic, namely to tanch blow parts, and of a greater vertue to dry than be thofe that are not burnt : they bloud, and are of thin $E$ burning coles vntill they come to be thorow white, and chen they : they muft be layd vpon hot and wine.

Moreouer, Galls are good for thofe that are troubled with the bloudy flix and common laskes, F being taken in wine or water, and alfo applied or vfed in meats : finally, thefe are to be vfed as oft as
need requireth to dry and binde. force.

Oke Apples are much of the nature of Galls, yet are they far inferiour to them, and of leffer $G$

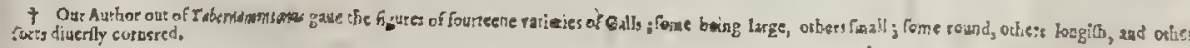



3 There is found alfo another plant growing vpon the boughes or branches of trees, in maner as our Miffeltoe doth, and may very well be reckoned as a kinde thereof : the plant cleaueth vnto the branches, being fet thereto as it were with the pillings of the fea onion, of the bredth of a mans hand toward the bottome, and fomewhat hollow : the tops whereof are very fmall and runy, hollow likervife,and of a purple colour : amiong which comes forth a branch like that of Hafula Regi $i_{a_{3}}$ or the King's Speare, refembling the bufh of Otes, couered with a white filke, fuch as is to be found in $A$ clepias, of a falt and nitrous tafte, and very vnpleafant.

9 The Place.

The firft kinde of Miffeltoe groweth vpon Okes and diuers other trees almoft enery wluere; as for the other two they are ftrangers in England.

$$
\text { The Time. }
$$

Miffeltoe is alwaies greene as well in Winter as in Sommer : the berries are ripe in Attumne; they remaice all Winter thorow, and are a food for diuers birds, as Thruhes, Blacke-birds, and Ring-dolies:

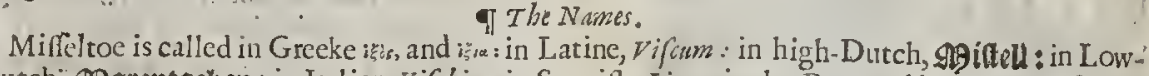
Dutch; \$Dacentacken : in Italian, Vifchio: in Spanilh, Liga: in the Portugal language,Vifgo: in Englifh,Miflel, and Miffeltoc.

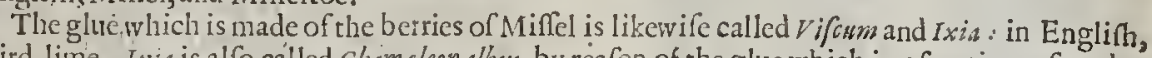
Bird-lime. Ixia is alfo called Cham clcon albus, by reafon of the glue which is oftentimes found about the root thereof. Thisword is alfo afcribed to Chameleon niger, as we reade among the baftard names." Ixia is likewife reckoned vp by Diofiorides, lib.6. and by Pawlus Egineta,,$i b$. 5 .amorig. the poyfons : but what this poyfonfomeand venomous $I x i n$ is it is hard and doubtfull to declare: many would haue it to be Chameleon nigr : others, the glue or clammy fubttance which is made of the berries of Miffel-toe; who do truly thinke that Ixia differeth from Chamaleon niger : for Paulus Aggineta, lib.5. cap. 30. in rectioning vp of fimple poyfons hath firft made mention of cham aleon niger, then a little after of $r_{x i a}$ : and whileft he doth particularly difcourfe of euery one, he intreateth of Chameleonniger, cap. 32 . and of Ixia (which hee alfo nameth Vlophonon) cap. 27. and telleth of the dangerous and far differing accidents of them both. And Diofcorides himfelfe, lib.6. where he fetteth downe his iudgement of fimple poyfons, intreateth firft of Chamaleon niger, and then a littleafter of Ixia. Thefe things declare that Chamelconniger doth differ from Ixia, which is reckoned among the poyfons. Moreouer, it can no where be read that Chumelcon niger beareth Birdlime, or hath fo ghtinous and clammy a fubftance as that it ought to be called Ixis: therfore Ixia, as it is one of the poyfons, is the glue that is made of the berries of Miffeltoe, which becaufe it is tharpe and biting, inflameth and fetteth the tongue on fire, and with his flimie and clammy fubftance doth fo draw together, fhut, and glue vp the guts, as that there is no palfage for the excrements, which things are mentioned among the mifchicfes that Ixia bringeth.

* I can by no meanes approue of, oryeeld to this opinion here deliuered out of Dodonsus by our Author; twhich is, That the Bird-lime made of the berries of Mifleltoc is poyfon; or that Ixid fet forth by Diofcorides and Nicander for a poyfon is meant of this : for this is manifetly treated of in Diofcorides, lib.3.cap.103. by the name of igis: when as the other is mentioned, h6.6.cap. $2 \mathrm{r}$. by the name of $i \xi i x$. Alfo dayly experience thewes this plant to haue no maligne nor poifonous, but rather a contrarie facultie, being frequently vfed in medicines againtt the Epilepfie. Sych as would fee more concerning Ixia or Ixias, let them haue recourfe to the firft chapter of the firft part of $F a=$. Gius Colsmm, de Stirpib.min.cognitis or rarioribus, where they fhall finde it largely treated of. $\ddagger$ The Temperature and Vertues.

The leates and berries of Mifieltoe are hot and dry, and of fibtill parts:the Bird-lime is hot $A$ and biting, and confifts of an airy and waterie fubftance, with fome earthy qualitie; for according to the iudgement of $G$ alen, his acrimony oucrcommeth his bitterneffe; for if it bevfed in outward applications it draweth humors from the decpeft or moft fecretparts of the body, fpreading and difperfing them abroad, and digefting them.

It ripeneth fwellings in the groine, hard fwellings behinde the eares, and other impoltumes, be: B ing tempered with rolin and a little quantitic of wax.

With Frankincenfe it mollifieth old vlcers and malicious impoltumes, being boyled with vn- $\mathbf{C}$ flaked lime, or with $G a g a t e$ lapide, or $A$ fio, and applied, it wafteth away the hardnes of the fpleene.

With Orpment or $S$ andaraca it taketh away foule ill fauoured nailes, being mixed with vnflaked $D$ limeand wine lees it receiucth greater force.

It hath been moft credibly reported vnto me, that a few of the berries of Miffeltoe bruifed and $E_{\text {; }}$ ftrainedinto Oyle, and drunken, hath prefently and forthwith rid a grieuous and fore ftitch. 


\section{C н $а$ P. 39. Of the Cedor tree.}

\section{If The Kindes. \\ $T^{1}$ Iuniper. \\ Cedrus Libani. \\ The great Cedat tree of Libanus. \\ great bearing \\ $\mathrm{T}$}

"Cones, the other fmall bearing betties like thofe of

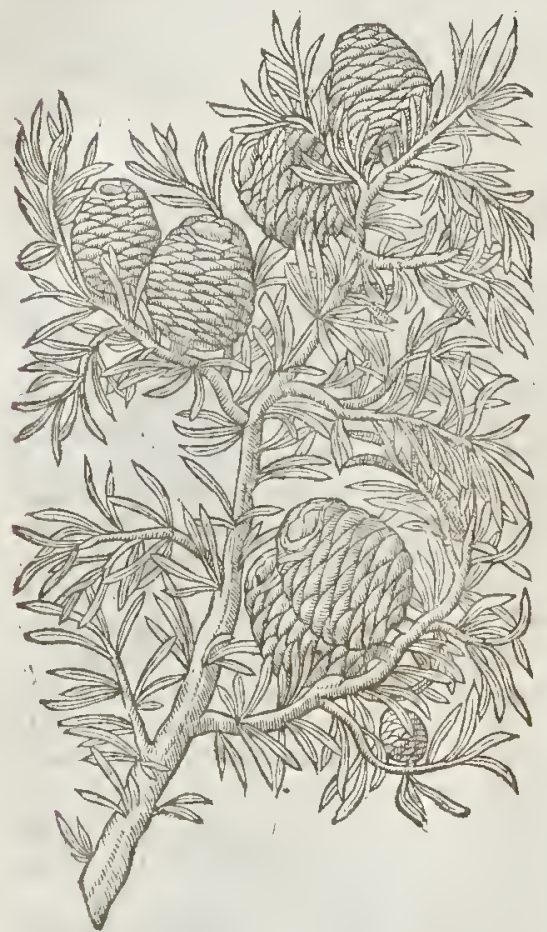

\section{Tा The Defcription.}

tree, not onely exceeding all other refruit lite tres, and thole which beare frit the but in his talne and largeneffe farre furmounting all othet trees: thebody or trunke thereof is commonly of a mighty bigneffe, infomuch as foure men are not able to fathome it, as Theophraftus writeth : the barke of the lower part, which proeeedech out of the earth, to the firft yong branches or thoots, is rough and harh; the reft which is among the boughes is fmooth and glib : the boughes grow forth almoft from the bottome, and not farre from the ground, euen to the very top, waxing by de. grees leffer and fhorter ftill as they grow higher, the tree beating the forme or thape of a Pyramide or Thatpe pointed fteeple: thefe compa fic the hody tound about in maner of a circle, and ate fo orderly placed by degrees, as that a man may clymbe vp by them to the very top as by a ladder : the leaues be fmall and round like thofe of the Pine tree,but fhorter, and not fo tharp pointed; all the cones or clogs are far horter and thieker than thofe of the Firre tree, eompaat of foft, not hard feales, which hang not downewards, but ftand vpright vpon the boughes, whereunto alfo they are fo ftrongly fantned, as they can hardly be plueked off
withoutbreaking of fome part of the branehes, as Bellonius writeth : the timber is extreme hard, and rotteth not, nor waxeth old : there is no wormes nor rottenneffe ean hurt or take the hard matter or heart of this wood, which is very od oriferous, and fomewhat red : Solomon King of the lewes did therefore build Gods Temple in Ierufalem of Cedar wood : the Gentiles were wont to make their Ditels or Images of this kinde of wood, that they might laft the longer.

\section{IT The Place.}

The Cedar trees grow vpon the fnowie mountaines, as in Syria vpon mount Libanus, on which there remaine fome euen to this day, faith Bellonius, planted as is thought by Solomon himfelfe: they are likewife found on the mountaines Taurus and Amanus, in eold and ftony plaees:the merchants of the fattoric at Tripolis told me, that the Cedar tree groweth vpon the declining of the mountaine Libanus, neere vnto the Hermitage by the eity Tripolis in Syria ; they that dwel in Sy-
ria vfe to make boats thereof for want of the Pine tree.

$$
\text { 9f The Time. }
$$

The Cedar tree remaineth alwaies greene, as other trees whieh beare fueh manner of fruit: the timber of the Cedar tree, and the images and other workes made thereof, feeme to fweat and fend forth moifture in moilt and rainy weather, as do likewife all that haue an oylie iuyce, as Theophira-
ftus witneffeth.

This hure and michty thee Names. dar, and Cedar tree. Pliny, lib. 24 . cap in Grecke rónes : in Latine likewife Cedrus : in Englifh, CeCedrina obies, Cedar Finy, lib.2 4. cap. F. nameth it Cedrelate, as though he thould fay, Cedrus abies, or Cedrina abies, Cedar Firre; both that it may differ from the little Cedar,and alfo becaufe it is very
like to the Firre tree. 
The Rofin hath no proper name, but it may be fyrnamed cedrina, or Cedar Rofin.

The pitch which is drawne out of this is properly called wise : yet Pliny writeth, that alfo the liquor of the Torch Pine, is named Cedrium. The ben, faith Diofcorides, is fat, thorow fhining, and of a trong fmell; which being poured out in drops vniteth it felfe together, and doth not remaine fenered.

$$
\text { बा The Tcmpcrature and Foctues. }
$$

Cedar is of temperature hot and dry, with fuch an exquifite tenuitie and fubriltie of parts, that it feemeth to be hot and dry in the fourth degree, efpecially the Pitch or Rofin thereof.

There iffueth out of this tree a Rofin like vnto that which iffueth out of the Fir tree, very fweet $B$ in fmell, of a clammy or cleauing fubftance, the which if you chew in your teeth it will hardly be gotten forth againe, it eleauech fo faft : at the firft it is liquid and white, but being dried in the fim it waxeth hard: if it be boiled in the fire an excellent pitch is made thereof, called Cedar Pitch.

The Aigyptians were wont to coffin and embalme their dead in Cedar, and with Cedar pitch, $\mathrm{C}$ although they wed alfo other meanes, as Herodotis recordeth.

The eondited or enbalned body they call in thops Cxumia, but very unfitly; for crumia a- D mong the Arabians is that which the Grecians call Piffafphalton, as appeareth by Asiccn, cap. 474 . and out of Serapio, catp.393.

He that interpreted and tranflated Serapiowas the caufe of this error, whotranflated and inter- E preted Mumia aecording to his owne fancic, and not after the fence and meaning of his Author Se- rapio, faying that this cumia is a compfition made of Aloes and Myrrh mingled together with the moifture of mans body.

The gum of Cedar is good to be put in medicines for the eyes, forbeing anointed therewith it $F$ cleareth the fight, and elenfeth them from the Haw and from ftripes.

Cedar infufed in vineger and put into the eares killeth thewormes therein, and being mingled $G$ with the decoction of Hyffop, appeafeth the founding, ringing, and hiffing of the eares.

If it be wance or infufed in vineger, and applied vnto the teeth, ir cafeth the tooth-ache.

If it be put into the hollowneffe of the teeth it breaketh them and appeafeth the extreme. II thereof.

It preuaileth againft Angina's, and the infammation of the TonGls, if a Gargarifme be made $K$ thereof.

It is good to kill nits and liee and fuch like vermine : it eureth the biting of the ferpent ceraftes, I! being layd on with falt.

It is a remedie againft the poy fon of the fea Hare, if it be drunke with fweetwine.

It is good alfo for Lepers : being put vp vnderneath it killeth all manner ofworms, and draweth $N$ forth the birth,as Diofcoridas writeth.

\section{C н $\mathrm{A}$ P: 40 . Of the Pitchtree.}

$$
\text { 4ा The Defoription. }
$$

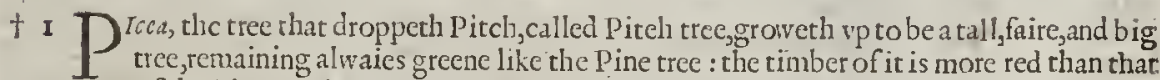
of the Pine or Firte : it is fet full of boughes not onely about the top, but much lower, and alfo beneath the middle part of the body, which many times hang downe, bending toward the ground : the leaues be narro:w, not like thofe of the Pine tree, but fhorter and narrower, and fharpe pointed like them, yet are they blacker, and withall couer the yong and tender twigs in manner of a circle, like thofe of the Firre tree; but being many, and thicke fet, grow forth on all fides, and not onely one right againf anorher, as in the Yew tree : the fruit is fealy, and like vnto the Pine apple, but fmaller : the barke of the tree is fomewhat blacke, tough and flexible, not brittle, as is the bark of the Firre tree: vnder which next to the wood is garhered a Rofin, which many times ir. fieth forth, and is like to that of the Lareh tree.

\# 2 Of this fort (fairh Clufius) there is found another that neuer growes high, but remainetli dwarfith, and it carries eertaine little nugaments or catkins of the bignefle of a fmall nut, compofedof feales lying one vponanother, but endıng in a prickly leafe, which in time opening fhew certaine emptic eauities or eels : from the tops of thefe fometimes grow forth branches fet with many thort and pricking litrle leaues: all the Thrub hath fhorter and paler coloured leaues than the former : I obferued neither fruit nor floure on this, neither know I whether it carry any. Dalechampires feemes to haue knowne this, and to hate called it Pirus Tubulus or Tibulus. $\neq$

$$
X \times x \times+3
$$




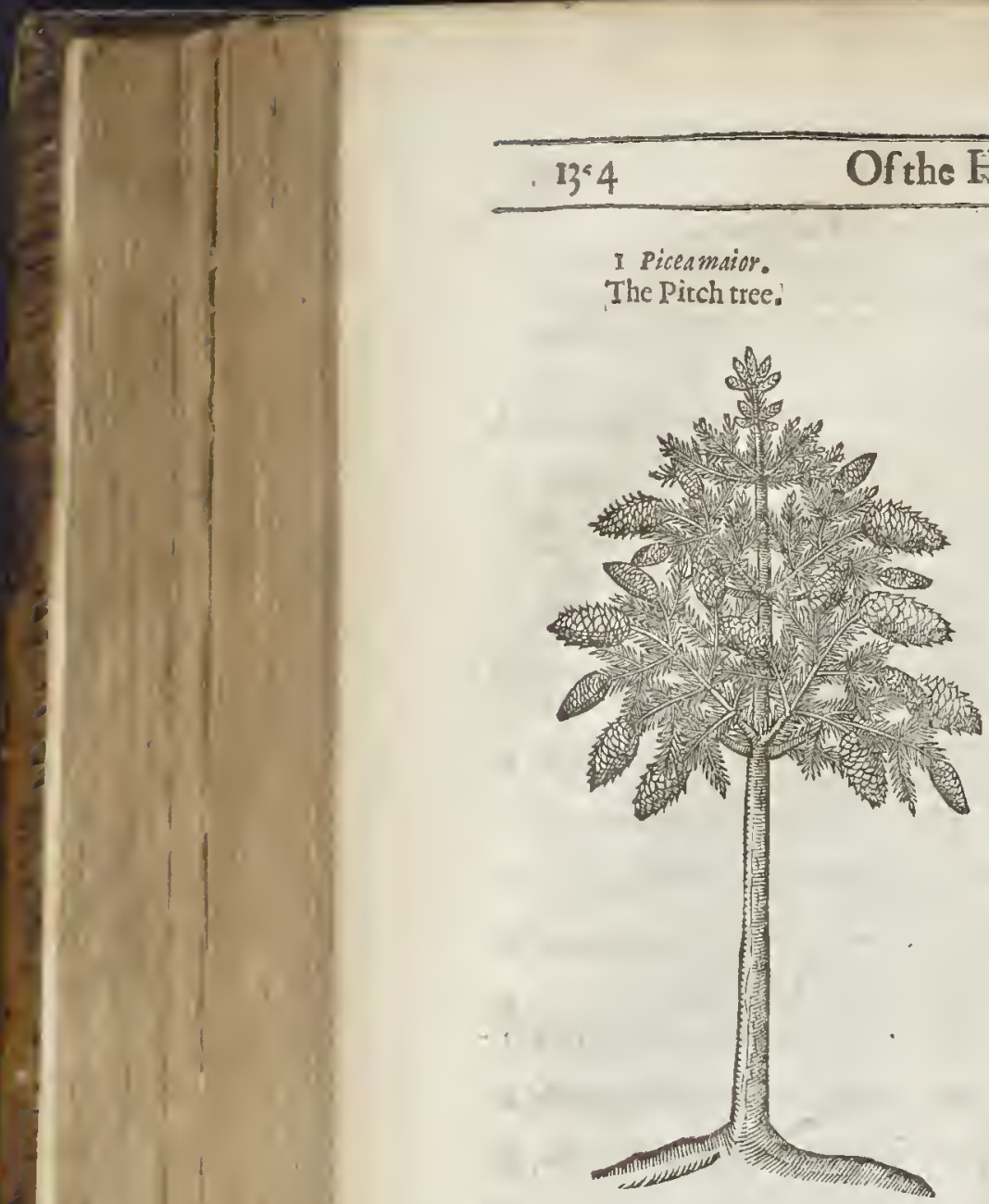

1 Picenmaior.

The Pitch tree.
¥ 2 Picea pumila: The dwarfe Pitch tree.

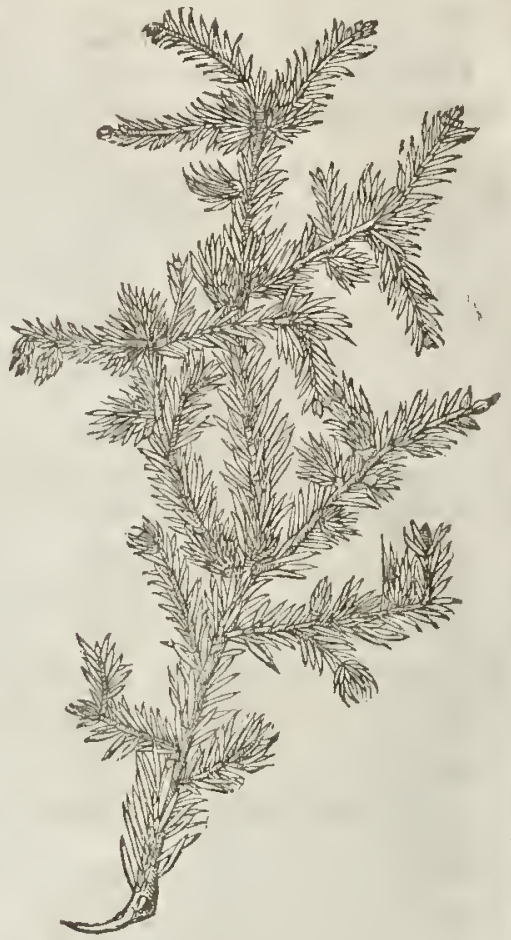

T The Place: Ruffia.

The Pitch tree groweth in Greece, Italy, France, Germanie, and all the cold regions euten vnto T) The Time.

The fruit of the Pitch tree is ripe in the end of September.

9) The Names.

The Grecians call this Cone tree mitus: the Latines, picea, and not Pinus ; for Pinus or the Pine tree, is the Grecians mix, as thall be declared : that miru is named in Latine Picea, Scribonius Largus teftifieth, in his 20 r Compofition, writing after this manner; Refinde Petuina, id eft, ex Picea arbore, which fignifies in Engliih, of the Rofin of the tree Pitys, that is to fay, of the Pitch tree. With him doth Pliry agree, $l i 6.16$. cap. Io. where he tranflating Theophraft tus his words concerning Peuce and Pitys, doth tranflate Pitys, Picea, although for Peuce he hath written Larix, as fhall be declared. Pliny writeth thus; Larix vffis radicibus norr repullulat : and the Larch tree doth not fpring vp againe when the roots are burnt: the Pitch tree fpringeth vp againe, as it hapned in Lesbos, when the wood Pyrthsus was fer on fire. Moreoner, the wormes Pityocamp a are farce found in any tree bue onely in the Pitch tree, as Bellonius teftifieth : fo that they are not rafhly called Pityocampis, or the wormes of the Pitch tree, although moft Tranflators name them Pinorum eruce, or the the wormes of the Pine trees : and therefore Pttys is firnamed by $T$ heophraftus, qs wermos, becaufe wormes and nagots are bred in it. But forfomuch as the name pitys is common both to the tame Pine, and alfoto the Pitclu tree, diuers of the late writers do for this caufe fuppofe, that the Pitch tree is named by

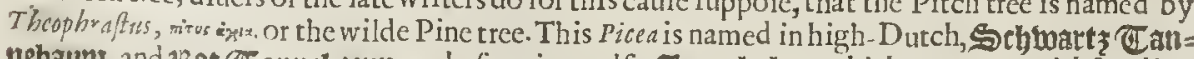

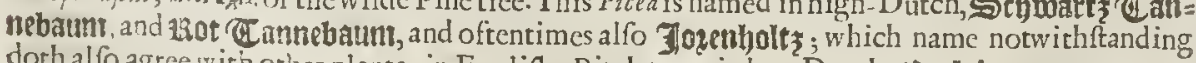
doth alfo agree with other plants : in Englih, Pitch tree: in low-Dutch, 看eck boom.

If The Temperature and Vertues.

The leanes, barke, and fruit of the Pitch tree, are all of one nature, vertue, and operation, and of the fame facultie with the Pine trees. 


\section{C н a P. 41. Of the Pine Tree:}

The Kindes.

$\mathbf{T}$ He Pine Tree is of two fotts, according to Theophraftus; the one $\tilde{\mu}_{\mu, w}$, that is to fay, tame, or of the garden; the other inss, or wilde: he faith that the Macedonians do adde a third, which isereparos or barren, or without fruit, that vnto vs is vnknowne : the later writers haue found moe as hall be declared.

Pinus fativa, fove domeftica.

The tame or manured Pine tree.

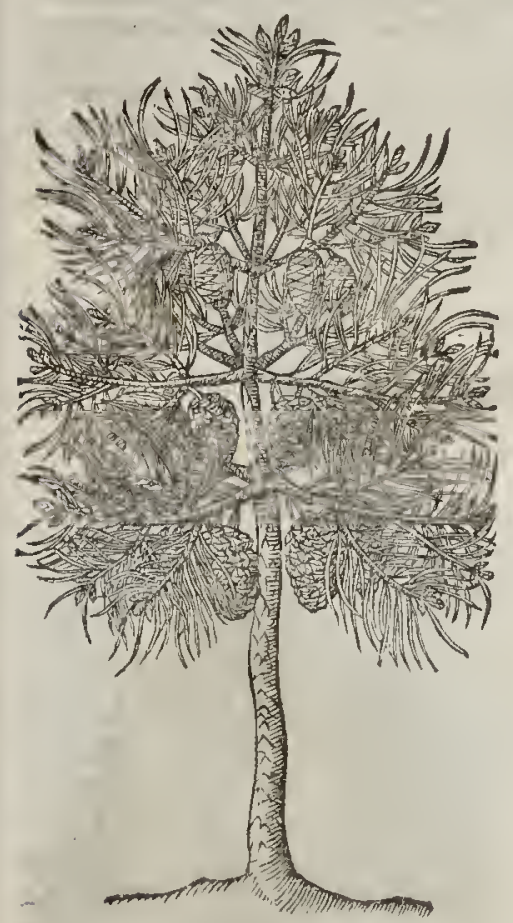

$$
\text { I The Defription. }
$$

7 He Pine tree groweth high, and great in the trunk or bodie, which below is naked, but aboue it is clad with a multitude of boughes, which diuide themfelues into diuers branches, whereon are fet fmall leaues, veric Atraight, narrow, fomwhat hard and tharp pointed : the wood or timber is hard, heaty, about the heart or middle ful of an oileous liquor, \& of a reddith colour: the fruit or clogs are hard, great, and confift of many found wondy fcales, vnder which are included ccrtaine knobs, without thape,couered with a woodden Thell, like fmall nuts, wherein are white kernels, long, very fweet, and couered with a thin skin or $\mathrm{mcm}$. brane, that eafily is rubbed off with the fingers; which kernell is ved in medicine.

$$
\text { If The Place. }
$$

This tree groweth of it felfe in many places of I talie, and efpecially in the territorie of Rauenna,and in Languedock, about Marfiles, in Spain, \&z in other regions,as in the Eaft countries:it is alfo cherithed in the gardens of pleafure, as well in the Low-countries as England.

$$
\text { T The Time. }
$$

The Pine trec groweth grcene both winter and Sommer: the fruit it commonly two yeres before it be ripe:wherfore it is not tobe found without ripc fruit,and alfo others as yet vcrie fmall, and not come to ripeneffe.

T The Names.

It is called in Latine, Pinus, and Pinus fatiua, $V$ rbara,, or rather Manfuet $a:$ in Englifh, tame and gar-

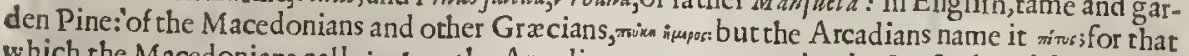
which the Macedonians call miven imestr the Arcadians name m'rus,as Theophraftus faith, and fo doth the tamc Pine in Arcadia,and about Elia change her name: and by this alteration of them it happens that the fruit or Nuts of the Pine tree found in the Cones or Apples, be named in Greeke by Diofcorides, Galen, $P$ aulus, and others, wrist, as though they hould terme it $P$ Pinos frutzus, or the frtit of the
Pine tree.

There is alfo another minus: in Latine Piced, or the Pitch tree, which differeth much from thic Pine tree : but $P$ yt is of Arcadia differeth nothing from the Pine tree, as we hate faid.

The fruit or apples of thefe be called in Greeke vertor, and in Latine Comi notwith fanding Conos is a common name to all the fruits of thefe kind of trees: they alfo be named in Latine, Nuces pinea:

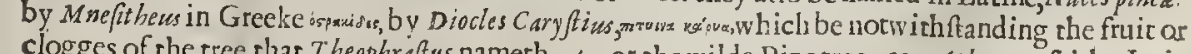
clogges of the tree that Theophraftus nameth misn, or the wilde Pinc tree, as Atheneus faith. It is thought that the whole fruit is called by Galen in his 4 . Commentarie vpon Hipocrates Bookes of Diet in tharpe difeares, Strobilos: yet in his 2. booke of the Faculties of Nourifhments hee doth not call Conos or the apple by the name of strobilos, but thc nuts contained in it. And in like manner in his fetenth book of the Faculties of Simple medicines ${ }_{j}$ the Pine Apple fruit, faith he,which 
they call Cocculus, and Strobilus, as wc late faid before, that thefe are named in Greeke $\pi$ rusisen. This apple is called in high Dutch, ZZetbel: in low Dutch, foim appel: in Englinh, Pine apple, Clogge, and Cone.

The Temperature and Vertues.

A The kernels of thefe nuts do concoct and moderately heate, being in a meane betweene cold and hot : it maketh the rough parts fmooth; it is a remedy againft an old cough, and long infirmities of the cheft, being taken by it felfe or with hony, or elfe with fome other licking thing.

B It cureth the Ptificke, and thofe that pine and confume away through the rottenneffe of their lungs : it recouereth ftrength, it nourifherh and is reftoratiue to the bodie.

It yeeldeth a chicke and good iuice, and nouriheth much, yet is it not altogether eafie of digefition, and therefore it is mixed with prefertes, or boyled with fugar.

C The fame is good for the itone in the Kidneies, and againft trettings of the bladder,and fealding of the vrine, for it alayeth the fharpneffe, mit igateth paine, and gently prouoleth vrine: morconer, it increafeth milke and feed, and therefore it alfo prouoketh fichly luft.

D The whole Cone or Apple being boyled with freth Horchound, faith Galen, and afterwards boiled againe with a little hony til the decoction be come to the thickneffe of hony, maketh an excellent medicine for the clenfing of the cheft and lungs.

E The like thing hath Diofcorides; the whole Cones, faith bee, which are newly gathered from the trees; broken aud boiled in fweet wine are good for an old cough, and confumption of the lungs, if a good draught of that liquour be drunle enery day.

F The falles of the Pine apple, with the barke of the tree, do ftoppe the laske and the bloudy flixe, they prouoke vine; and the decoction of the fame hath the like propertie.

\section{Cи а г. 42. Of the Wilde Pine tree.}

3 Pirus fylueftris.

The wilde Pine tree.

5 inims injuestins

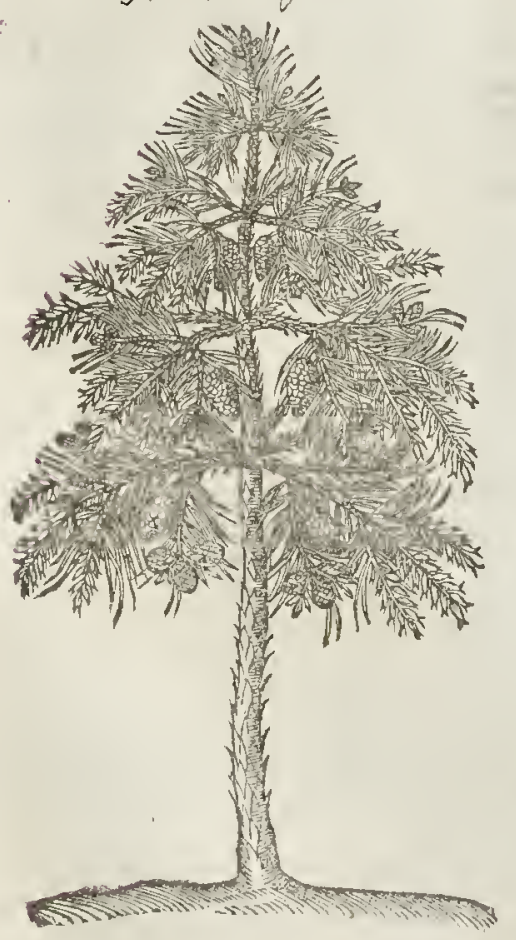

2 Pinus fylueftris mugo.

The low wilde Pine tree:

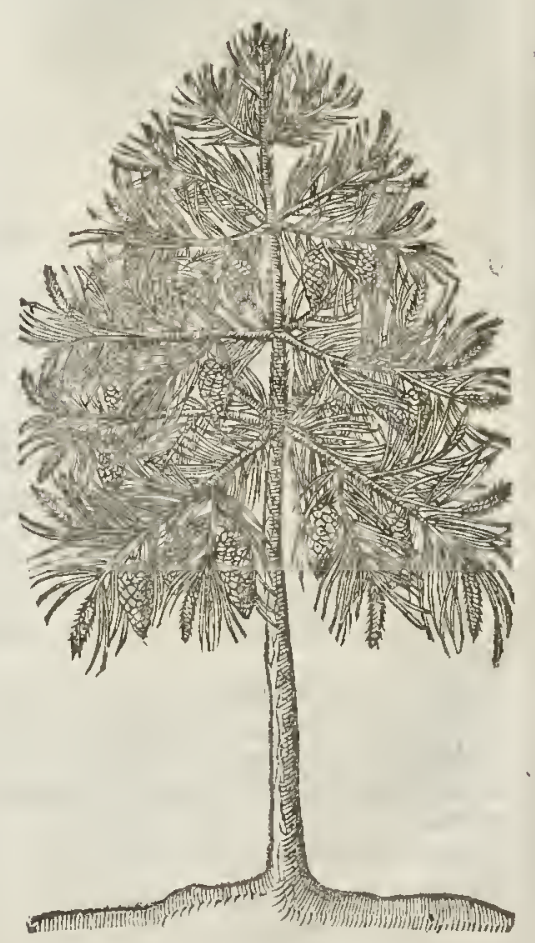




\section{LIB. 3. Of the Hiftory of Plants.}

\section{बा The Defcription. .}

I The firft kinde of wilde Pine tree groweth very great,but not fo high as the former, being the tame or manured Pine tree; the barke thereof is glib : the branches are fpread $a$. broad, befer with long tharpe pointed leaues: the fruit is fomewhat like the tame Pine tree, with forme Rofine thercin, and fweet of fmell, which doth eafily open it felfe, and quickely falleth from

2 The fecond kinde of wilde Pine tree groweth not fo higl as the former, neither is the ftem growing ftraight vp, but yet it bringeth forth many branehes, long, llender, and fo cafie to be bent or bowed, that hereof they make Hoops for wine Hogs-heads and Tuns:the fruit of this pine is greater than the fruit of any of the other wilde Pines.

3 The third kinde of wilde Pine tree groweth ftraight vpright,and waxeth great and high,yet not fo high as the other wilde kindes:the branehes do grow like the pitch tree: the fruit is long and big,almof like the fruit of the faid Piteh tree; wherein are contained fmal triangled nuts, like the nuts of the Pine Apple rree, but fmaller, \& more brittle, in which is eontained a Kennell of a good tafte, like the kernell of the tame Pine apple:the wood is beautiful and fweet of fmell,good to make
tables and other workes of.

4 There is another wilde Pine of the mountaine, not differing from the precedent but in ftature, growing for the moft part like a hedge tree, wherein is the difference.

.3 Pinus fylueftris montana.

The mountaine wilde Pine tree.

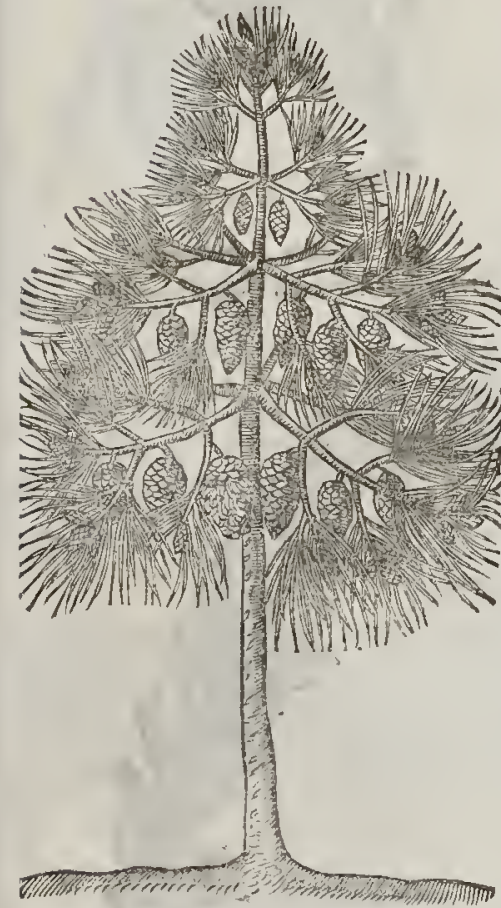

4 Pinus montana minor:

The fmaller wilde Pinetree?

5 This kinde of Pine, called the fea Pine tree, groweth not about the height of two men, hal uing leates like the tame Pine tree,but fhorter: the fruit is of the fame forme; but longer fomewhat fathioned like a Tumep : this tree yeeldeth very mueh Rofine. $\neq$ Bawhine iudges this allone with the third. $\neq$

6 The fixt kinde of wilde Pine being one of the Sea Pines, groweth like an hedge tree or fhrub feldome exceeding the height of a man; with little leaues.like thofe of the Larch tree, but alwaies continuing with a very little cone,and fine fmall kernell.

7 The baftard wilde Pine tree groweth vp to a meane height; the trunke or bodie, as alfo the 


1358 Of the Hittory of Plants:

5 Pinus maritimamaior.

The great Sea Pine tree.

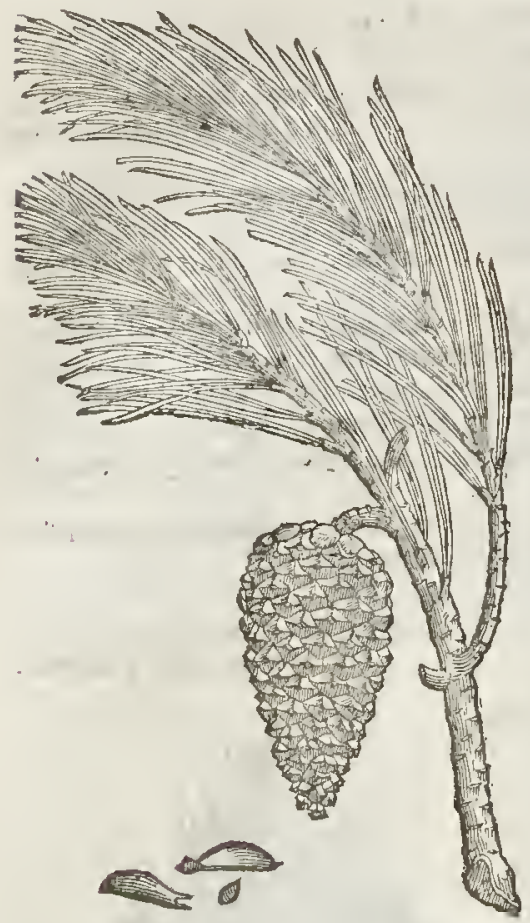

7. T eda five p eudopinus:

The baftard wilde Pine.

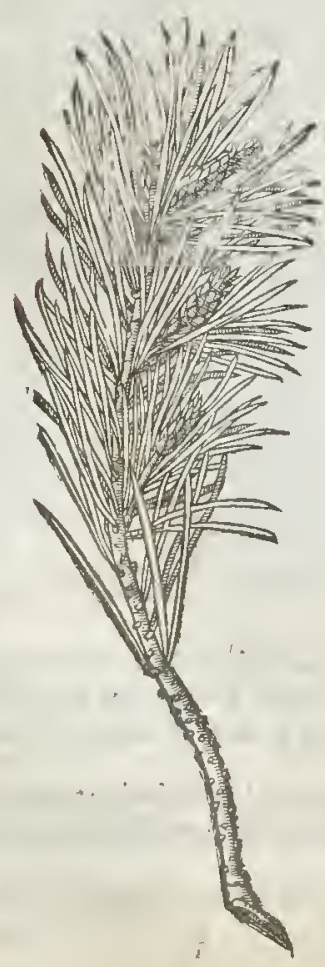

L1 B. 3:

6 Pinus fylueftris monor.

The little Sea Pine Tree.

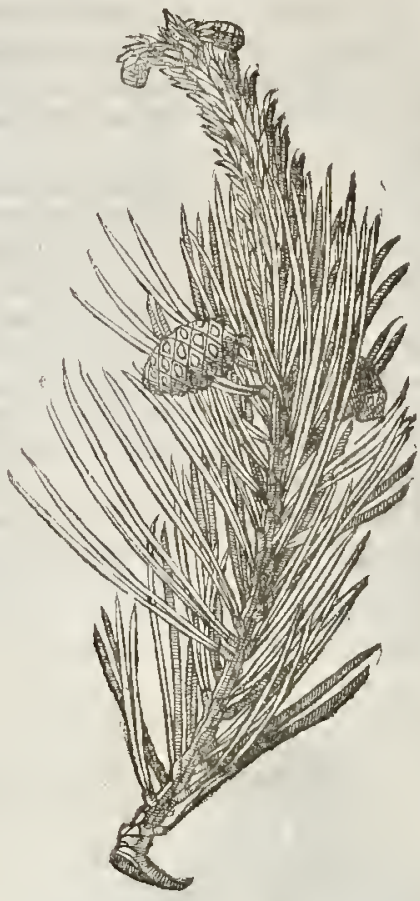

8 Piwafer Aupriacus?

Dwarfe Pine with vpright Cones:

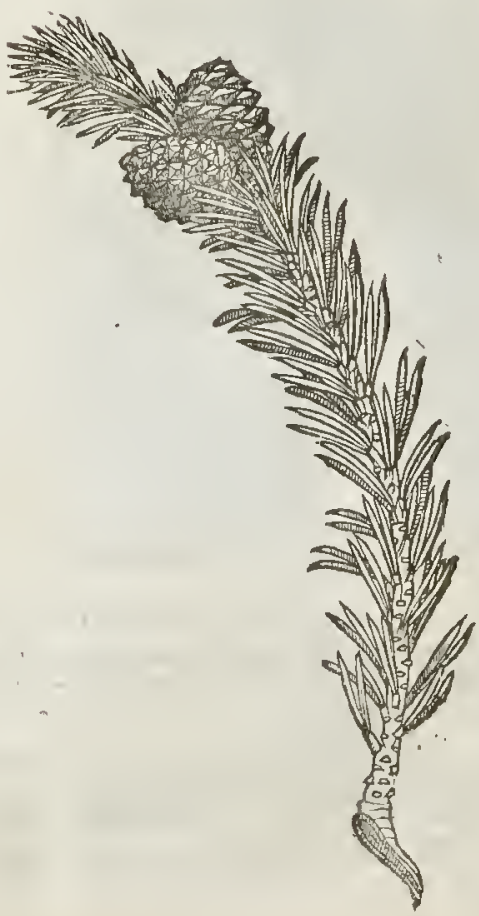


L I B. 3. Of the Hiftorie of Plants.

\section{$\$ 9$ Pinafer maritimus minor:}

Dwarfe Sea Pine.

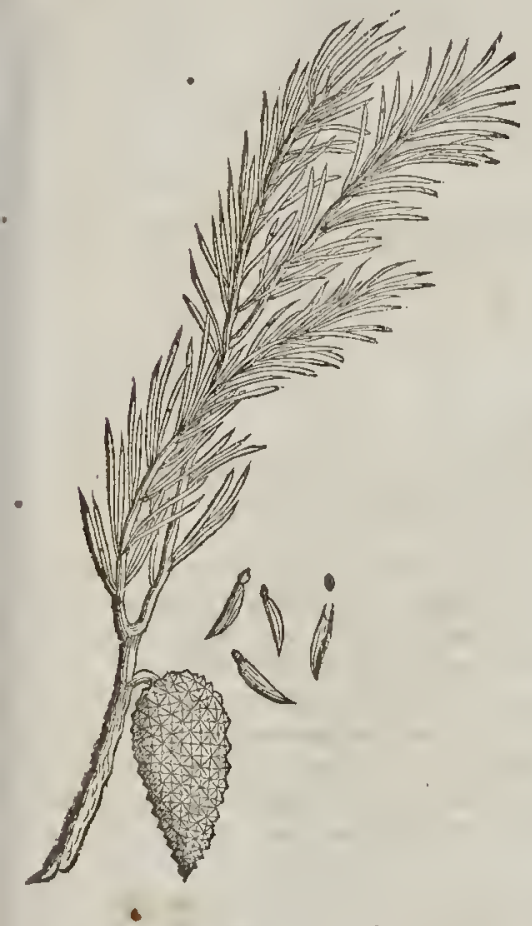

ches $\&$ leaues are like vnto tiofe of the manured Pine tree : the ondy difference is, that fome yeares it refembleth the Pine it felfe; and the other yeares as a wilde hedge tree, varying often, as nature lifteth to play and fport her felfe among th her delights, wirliother plants of lefie monent: the timber is foft, and not fit for building, but is of the fub. ftance of our Birch tree : the fruit is like thofe of the other wilde Pines, where of this is a kinde.

¥8 This dwarfe Auftrian Pine exceeds not the height of a man, but immediately from the root is diuided and fpread abroad into tough, bending, pretty thicke branches, coured oucr with a rough barlic: the leaues, as in the former, eome two out of one hofe, thicker, fhorter, blunter pointed, and morc greene than the former: the cones or elogs arc but fmall, yet round, and compact, and hang not dow ew ards, but ftand vpright : the root is tough and wooddie like other plants of this kinde: It growes on the Auftrian and Styrian Alpes. Clufius fets it forth by the name of Pinaffer 4. Anffriacus.

9 This other Dwarfe is of the fame height with the former,with fueh tough and bending branches, which are ncither fo thick nor clad with forough a barke, nor fo much fpread. The leanes alfo are fmaller, and not vnlike thofe of the Larix tree, but not fo foft, nor falling cuery yeare as they do. The cones are little and 』ender, the kernell fmall,blackifh, and winged as the reft. Clufius found this onely in fome few places of the kingdome of Murcia in Spaine, wherefore he calls it, Pinafter 3 . Hijparicus. Dodoricus calls it Pinus maritima minor. ‡

\section{T The Place.}

There wilde Pines doe grow vpon the cold mountaines of Lituonia,Polonia, Noruegia, and Ruffia, efpecially vpon the Ifland called Holland within the Sownd,beyond Denmarke, and in the woods by Narua, vpon the Liefeland fhore, and all the tract of the way,being a thourand Werits, (each Werft containing three quarters of an Englifl mile) from Narua vnto Mofcouia, where I haue feene them grow in infinite numbers.

\section{The time.}

The fruit of thefe pine trees is ripe in the end of September:out of all thefe iffueth forth a white and fweet fmelling Rofine: they are alfo changed into Teda, and out of thefe is boiled through the force of the fire, a blacke Pitch : the Pitch tree and the Lareh tree be alfo fometimes changed into $T e d a$; yet very feldome, for $T e d a$ is a proper and peculiar infirmitie of the wilde Pine tree. A tree is faid to be changed into Teda, when not onely the heart of it, but alro the reft of the fubitance is turned into fatneffe.

$$
\text { It The 2tames. }
$$

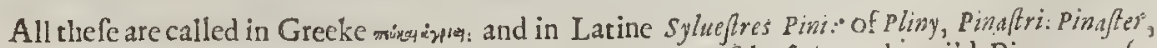
faith he in his I 6. bookc. ro chapter, is nothing elfe but Pinus fylueftris, or the wiid Pine tree, of a leffer height, and tul of boughes from the middle, as the tame Pine tree in the top, (moft of the copies haue falfely) of a marucllous height : they are far deceiued wr ho thinke that the Pine tree is called in Greekc mitur, befides the tame Pine which notwithftanding is focalled not of all men, but onely of the Arcadians (as we haue faid before) miru; all men do name the wilde muin; and therefore Teda, or the Torch Pine, hereof is faid to be in Latine not Pigea, Eut $P$ inea, that is, not the Pirch-tree, but the Pine tree,as ouid doth planly teftifie in his Heroicall Epitles; 
Vt vidi, at per y, 3 nec not is ignibus ar $f_{3}$ Ardet vi al magnos pinca Tedadeus.

Alfo in Faftorum as.

Illic accendit gemiras pro lampade Pines:

Hinc Cereris facris nunc quoque Teda datur.

The fame doth rirgill alfo fignifie in the feuenth of his Eneid.

\section{Ip fainter medias, fag rant cm foruida Pisum \\ Suftines.}

Where in ttead of Flagrantem Pinum, Seruius admonitherh vs to vndetftand. Teda Pinca. Catulins alfo confenteth with them in the marriage fong of Islia and crallius.

$$
\text { - } \quad \text { pincam quatc tedam. Manu }
$$

And Prudentius in Hymno Corei Pafchalis.

\section{Seu Ponus piceams fert alimoniom.}

Moteover, the herbe Peucedanos, or Hureftrong, fo named of the likenefic of amv, is called alfo in Latine Ptnaffellum, of $\boldsymbol{P}$ iwus the Pine tree:all which things do euidently declare that min is called in Latine not Picea,but Pinus.

The firtt of thefe wilde kindes may be Idea Theophrafti, or Theophraftus his Pine tree, grow ing on mount Ida, if the apple which is fhorter were longer: for he nameth two kindes of wilde Pines, the one of mount ida,and the orher the Sea Pine with the round fruit : but we hold the contrarie, for the fruit or apple of the wilde mountaine. Pine is thorter, and that of the Sca Pine longer. This may more truly be Macedonum mas, or the Macedonians maje l'ine, for they make two forts of wilde Pines, the male and the female, and the male more writhed and harder to bew rought vfon, and the female more ealie ; but the wood of this is more writhed,and nor fo much in requeft for workes, as the other, and therefore it feemeth to be the male. Fhis wilde Pine tree is called in high Dutch, Hartz̧baum, and moilder Caras.

The fecond wild Pine tree is named commonly of the Italians Tridentinis, and Ananienfibus, Cemsbro, and Carmolo; it feenech to differ nothing at all from the Macedonians wilde f fcmale Pine, for the wood is eafie to be wrought on, and feructh for diuers and fundry workes.

The third they call Mugo: this may be named not without caufe cenominu, that is to fay, Humilis pinus, or Dwarfe Pine : yet doth it differ from Chamapeuce the Herbe called in Englin, Ground Pine.

The fourth wilde Pine is named in Greeke mapalamusu in Latine, Maritima, and Marima Pinus: in Englin, Sea Pine.

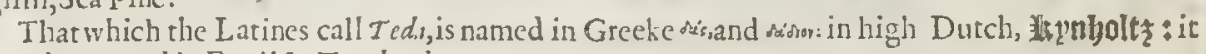
may be termed in Englith, Torch-pine.

Pliny is deceined, in that he fuppoferh the Torch pine to bee a tree by it felfe, and maketh it the fixth kinde of Cone-trec; as likewife he erreth in taking Larix, the Larch tree, for mixx, the Pine Tree. And as Diofcorides maketh fo little difference as fearfe any', betweene misy and miruse and fuppofeth them to beboth of one kinde, fo likewife he fetteth downe faculties common to them both.

$$
\text { T The Temperature and Vertues. }
$$

A The barke of them both, fa ith he, dotl binde ; being beaten and applied it cureth Merigals, and alfo thallow vicers and burnings if it be layed on with Litharge and fine Frankincenfe.

B) With the Cernte of Myrtles it healeth vlcers in tender bodies : being beaten with Copperas it staicth tetters, and creeping vlcers: it draweth aw ay the birth and after birth, if it be taken vnder in a fume : being drunke it foppeth the belly, and promoketh vrine.

C Galcn hathalmoft the fame things, but he faith, that the barke of the Pine tree is more temperate tlian that of the Pitch tree; the leaues ftamped take away hot fwellings and fores that come therent.

1) Being ftamped audboyled in vineger, they affwage the paine of the treth, if $t / \mathrm{g}$ be warhed with this decoetion hot : the fame be alfo good for thofe that haue bad liwers, being drunke with water or mead.

E Of the fame operation is likcwife the barke of the pine nuts; but $G$ alen affimcth that the Core 
or apple, although it feeme to be like thefe is notwithftanding of leffer force, infonich as it cannot effeculully performe any of the aforefaid vertues, but hath in it a certaine biting qualitie, which hurteth.

The Toreh Pine cut into fmall picces and boiled in vineger, is a remedy likewife againt the $F$ toorh-aehc if the tecth be walhed with the decostion.

Of this there is made a profitable fpather or flice to bevfed in making of compound plaifers $\dot{G}$ and peffarics that eafe paine.

Of the fmove of this is made a blaeke which ferueth to make inke of,and for cating fores in the $H$ comers of eics, and againft the falling aw ay of the haire of the cie lits, and for watering and bleere eies, as Diofcorizes teacheth.

\section{Of Rofins. \\ T The Kindes.}

1 Vt of the Pine trees, efpecially of the wilde kinds, there iffucth forth a liquid, whitith and fweet funclling Rofin, and that many times by it felfe; but more plentifully either out $c$ if the cut and briken boughes, or fortly of the body when the rree commeth to be a Torch Pine.

2 there iffueth alfo forth of the craekes and chinkes of the barkc, or out of the cut boughes,a certainedry Rofin, and that forth of the Pine Tree or Firre Tree.

There is likervife found a certainc eongealed Rofin vpon the eones or apples.

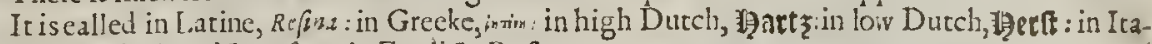
lian, R.zzi.t: in Spanih, Refim: : in Englioh, Rofin.

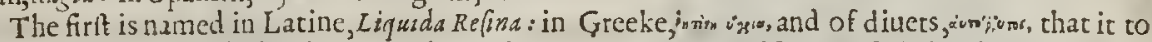

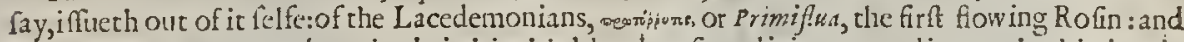
in Cieilia, Ka muxition, as Galer writeth in his third booke of medicines according to the kindes : in thops R? fin. Pini, or Rofin of the Pine tree, and common Rofin. It hapneth of tentimes through the negligent and carelcfe gathering thereof, that certaine finall pieces of wood, and little ftrones be found mixed with it : this kinde of Rofin Galen furnameth ajmusu, as thougu he thould fay, confufed, which bcing melted and clenfed from the droffe becommeth hard and brittle.

The like hapneth alfo to another liquid Rofin, which after it is melted, boiled, and cooled againe, is hard and brittle, and may likewife be beaten,ground, and fearced; and this Rofin is named in Greeke quvm: in Latine, Frifta, and many times Colophonia, in Greeke, sonowa : which name is vfed among the .. pothecarics, and may ftand for an Englifh name; for Galen in his third booke of Medicines aceording to their kindes faith, that it is called FriEz.r, and of fome Colophonia. that, faith he, is the drieft Rofin of all, which fome call Frifta, others Colophoniz: becaule in times palt, as Diofrorides writech, it was fetched from Colophon, this being yellow or blacke in comparifoin of the reft, is white when it is beaten:Pliny in his $r 4$.booke, 20 .ehapter.

The fecond Rofin is named in Grecke intis $\xi x e$, fpecially that of the Pitch tree without fatneffe, and that foone waxeth dry, which Galen in his 6. bookc of Medieines according to the kindes, caltleth properly qum mas mos: that which in Afia is made of the Pitch trec being very white, is called Spagas, as pling teltifieth.

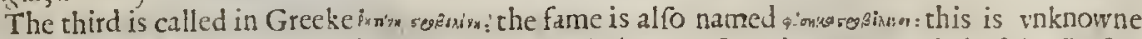
in thops. Yet there is to be fould a certaine dry Rofin,but the fame is compounded of the Rofins of the Pine tree, of the eones or clogs, and of the Firte tree mixed al together, which they call $G$ ar:pot : this is vfed in perfumes in Read of Frankincen fe, from which notwithrtanding it farrediffereth.

\section{T. The Temperature and Vertues.}

All the Rofins are hot and dry, but notall after one manner : for there is a difference among them : they whieh be tharper and more biting, are hotter, as rhat whieh conmeth of the cones, - being of Rofins the hotteft, becaulc it is alfo the Tharpelt : the Rofin of the Pitch Tree is not fo much biting, and therefore not fo hnt : the Rofin of the Firre tree is in a meane between them both; the liquid Rofin of the Pine is moifter, comming neere to the qualitic and facultie of the Larch Rofin

The Rofins which ate burnt or dricd,as Dioforides teftifieth,are profitable in plaifters, and compolitions that eafe wearifoneneffe; for they do not onely fupple or mollific, but alfo by reafon of the thinneffe of their parts and dryneffe, they diget : therefore they both mollifie and waft away fivellings, and through the fame facultie they cure wearifomnefte, bcing vfed in compound medi. cines for that purpof:.

The licyuid Rolins are very fitly mixed in ointments, eommended for the healing vp of greene woinds, for they both bring to fuppuration,and do al fo glne and inite them together. 
D Moteouter, there is gathered out from the Rofins as from Frankencenfe, a congealed fnoke, called in Latine Fuligo; in Greeke kyws: and in Englih, Blacke, which feruth for medicines that beautifie the eie lids, and cure the fretring fores of the corners of the eies, and alfowatering eies, for it dtieth without biting.

E There is made hereof faith Diofcorides, writing inke, but in our age not that which we write withall, but the famewhich ferueth for Printers to ptint their bookes with, that is to fay, of this blacke, ot congealed moke, and other things added.

\section{of PitchandTar. \\ The manner of drawing forth of Pitch.}

Out of the fatteft wool of the Pine tree changed into the 'Torch Pine, is drawne Pitch by force of fire. A place mutt be paucd with flone, or fome other hard natter, a little higher in the middle, about which there muft alfo be made gutters, into which the liquor thall fall; then out from them other gutters are to be drawne, by which it may be receiued; being reeeiued, it is put into barrels. The place being thus ptepared, the clouen wood of the Toreh Pinc nutf be fet vpright; then mut it be coured w ith a gteat number of Fir and Pitch boughes, and on euery part all about with much lome and earth : and great heed mut be taken, leaft therc be any eleft or clinke remaining, onely a whole left in the top of the furnace, thorow which the fire may be put in, and the flame and fmoke may pafie out: when the fire burncth the Pitch runrech forth, firft the thin, and then the thicker.

This liquor is called in Gteeke riare: in Latine, Pix : in Englith, Piteh, and the moifture, euen the fame that firft runneth is named of Plunie in bis 16. booke, $3 \mathrm{I}$. elapter, $C$ edria. There is boyled in Eutope, faith he, from the Torch Pine a liquid Pitch veed about thips, and feruing for many other purpofes; the wood being clouen is burned with fire, and fet round about the funaces on euery fide,after the manner of making Charcoles : the fir it liquor runueth thorow the gutur like water: (this in Syria is called Cedrum, which is of fo gteat vertue, as in Fgypt the bodics of dead men are preferued, being all conered ouer with it) the liquor follow ing being r.ow thicker, is made Pitch. But Diofcoridswriteth, that Cedria is gatheted of the great Cedariree, and rameth the liquot drawne out of the Torch tree by force of firc, miar vipts: th is is, that which the Latines call pis liquida : the Italians, Pcceliquida : in'high Dutch, Merich bach : in low Durch, (Ceet: in Ftench, Poix foudire: in Spanioh, Pex liguida - certaine A potheearies, Kutran : and we in Engliht, Tar.

And of this when it is boiled is made a harder Pitch : this is named in Grecke axex riare: in La-

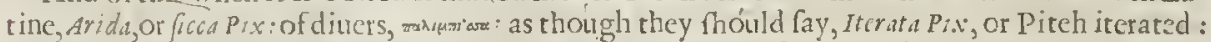
becaufe it is boiled the fecond time. A ceraine kinde hereof being made clammie or glewing is nanjed Borvis: in thops, Pix nawalis; or Ship Pitch : in high Duteh, 23ach:in low Dutch, Stetnpech: in Italian, Pece fecca : in French, Poix feche : in Spanith, Pez feca : in Englinh, Stone Pitch.

\section{The Temperature andVertues.}

A Pitch is hot and dry, Tarre is hotter, and ftone pitch more dtying,as Galenwriteth. Tat is good againft inflammations of the almonds of the thtote, and the uvula, and likewife the Squincie, being outwardly applied.

$B$ It is a remedie for mattering eares with oile of Rofes : it healeth the birings of Setpents, if it bc beaten with falt and applied.

C With an equall portion of wax it taketh away foulc ilfanoured nailes, it wafteth away fwellings of the kernels, and hard fwellings of the mother and fundament.

D With barly meale and a boies vine it coufumeth xorros, or the Kings enill : it fta ieth eating vlcers, if it be laid unto them with brimftone, and the barke of the Pitch Tree, or with btanne.

E. If it be mixed with fine Frankincenfe, and a cetote made theteof,it healeth cliops of the fundament and feet.

F Stone Pirch dorh mollifie and foften hatd fwellings : it ripens and maketh maticr, and wafteth away hard fwellings and inflammations of kernels : it fillethvp hollow vlcers, and is fitly mixed with wound medieines.

G What vertue 'Tarre hath when it is inwardly taken we may reade in Dioforides and Galen, but we fet dow ne nothing thereof, fot that no man in our age will eafily vouchfafe the taking.

H There is alfo made of Pitch a congealed froke ot blacke, which fetteth fot the fame purpoles, as that of the Rofins doth. 
LIB. 3. Of the Hiftory of Plants.

\title{
Си а. 43. Of the Firre or Deale Tree.
}

\author{
T) The Defription.
}

I THe Firre tree groweth very high and great, hauing his leaues euer greene; his trunke of body fmooth, euen and ftraight, without ioints or knots, vntill it hath gotten branches which are many and very faire, befer with leaues, not much vnlike the Ieaues of the Ewe tree, but fmaller : among which come forth floures vpon the taller trees, growing at the bottomes of the leaues like little catkins, as you may fee them expreft in a branch apart by themfelues : the fruit is like vnto the Pine Apple, but fmaller and narrower, hanging downe as the Pine Apple: the timber hereof excelleth all other timber for the malting of hips, pofts, rails, dcale boords, and fundry othes purpores.

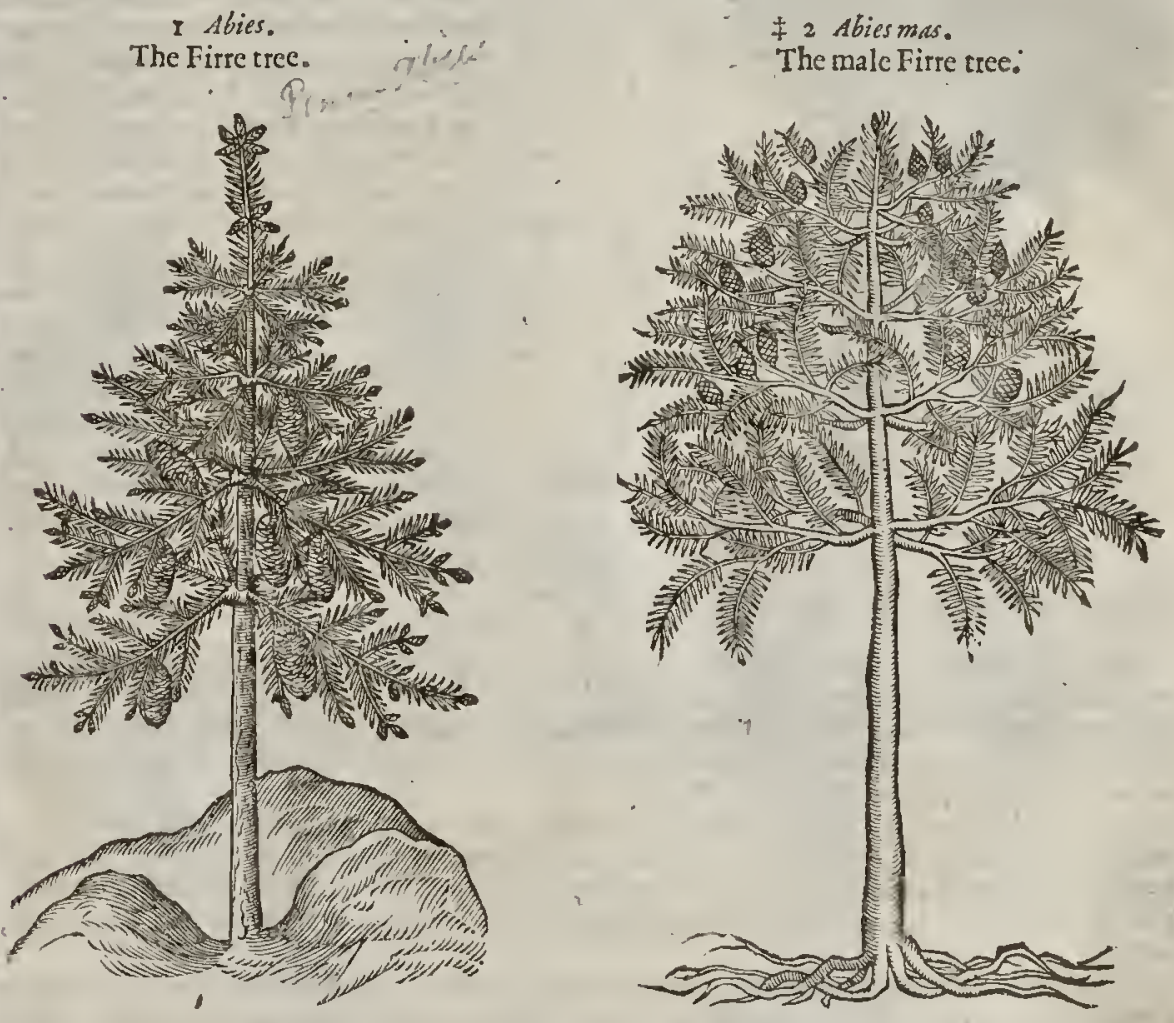

2 There is another kinde of Firretree, which is likewife a very high and tall tree, and higher than the Pine : the body of it is ftraight without knots below, waxing fmaller and fmaller enen to the very top: about which it fendeth forth boughes, foure together out of one and the felfe fame part of the body, placed one againft another, in manner of a croffe, growing forth of the foure fides of the body, and obferuing the fame order euen to the very top : out of thefe boughes grow others alfo, bur by two and two, one placed right againit another, out of the fides, which bend downwards when the other beare vpwards : the leates compaffe the boughes round about, and the branches thereof: they be long, round, and blunt pointed, narrower, and much whiter than thofe of the Pitch tree, that is to fay, of a light greene,and in a manner of a white colour : the cones or clogs be long, and longer than any others of the cone trecs, they confift of a multitude of foft fcales, they hang downe from the end of the twigs, and doe not eafily fall downe, but remaine on the tree a very long time : the kernets in thefe are fmall,not greater than the kernels of the Cherrie Itone,with a thinne skin growing on the nne fide, very like almolt to the wings of Bees, or great Flies: the timber or fubftance of the wood is white, and clad with many coats, like the head of an Onion.

Ү УуУу 2

of The 
† Abiet us ramus cum julis.

A branch with Catkins or floures.

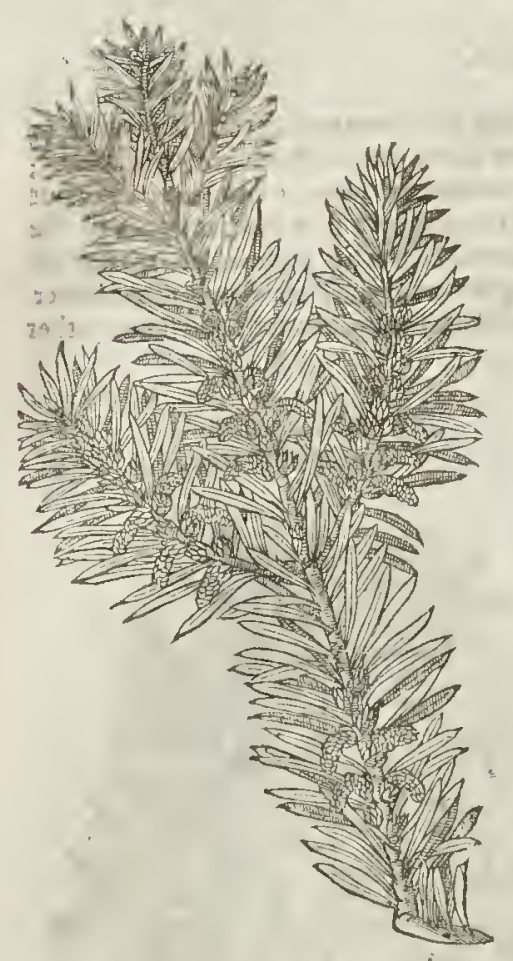

91 The Place.

The Firre trees grow vpon high mountains, in many woods of Germany and Bohemsa, in which it continuetl alwaies greene; it is found alfo on hils in Italy, France, \& orher countries, it commeth downe oftentimes into the vallies: they are found likewife in Prufe, Pomerania, Liefeland, Ruffia, \& efpecially in Norway, where I haue feene the goodlieft trees in the world of this kinde, growing vpon the rockie and craggie mountaines, almoft withour any earth about then, or any other thing, fauing a little mofre about the roots, which thruft them felues here and there into the chinkes and cra. nies of the rockes, and therefore are cafily caft downewith any extreme gale of winde. I haue feen the fe trees growing in Chefhire, Staffordthire, and Lancathire, where they grew in great plenty, as is reported, before Noubs floud : but then being onerturned and ouerwhelmed have lien fince in the moffes and waterie moorifh grounds very frefh and found vntill this day, $\&$ fo full of a refinous fubitance, that they burne like a Torch or Linke, and the inhabitants of thole countries do call it Fir-wood, and Firewood unto this day : oit of this tree iffueth the rofin called Thus, in Englifh, Frankinfence:but from the young Fir trees proeecdeth an excellent cleare and liquid Rolin, in tafte like to the peelings or outward rinde of the Pomecitron.

It The Time.

The time of the Fir tree agreeth with the Pine trees.

$$
\text { -T The Names: }
$$

The tree is called in Latine Abies : in Greeke, inaw : amongft the Græcians of our time the fame

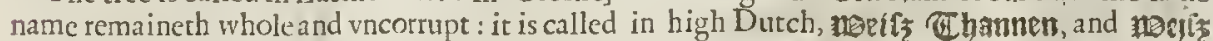
Chatumen batm : in Low Dutch, poitte lian, Abete : in Spanifh, Abeto : in Englifh, Firre-tree, Maft-tree, and Deale-tree. The firft is called in trench, dil Sap, or Sapin : the other is Suiffe.

The liquid rofin which is taken forth of the barke of the young Firre-trees, is called in Greeke

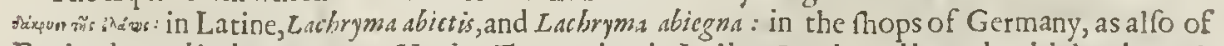
England, Terebint hina Veneta, or Venice Turpentine: in I talian, Lagrimo : diuers do thinke that $D i$ ofcorides calleth it indusoss inniw, oleafa Ke fina, or oile Rolin,but oile Rofin is the fame that Pix liquida, or'Tar is.

Arida Alictwm Refina, or drickofin of the Fir trees, is rightly called in Greeke purm iazrix, and in Latine, Abicgna Refina ; it hath a fweet fmell, and is oftentimes vfed among other perfumes in ftead of Frankincenfe.

$$
\text { 9i The Temperature. }
$$

Thebarke, fritit, and gums of the Fir tree, arc of the nature of the Pitch tree and his gums.

$$
\text { of The Vertues. }
$$

A The liquid Rofin of the Fir tree called Turpentine, loofeth the belly, driueth forth hot cholerick humours, clenfeth and mundifieth the kidnies, protoketh vrine, and driucth forth the flone and grauell.

B :- The famc taken with Sugar and the pouder of Nutmegs, cureth the ftrangurie, ftaieth the Gororrhœa or the intoluntary iffue of mans nature, called the running of the rains, and the white flux in women.

C It is very profitable for all green and frefh wounds, efpecially the wounds of the head:for it healethand clenfeth mightily, efpecially if it bewafhed in Plantaine water, and afterward in Rofewater, the yolke of an egge put thereto, with the poirders of olibanum and Mafticke fincly fearced, adding thereto a little Saffron.

CHAP. 


\title{
C H A P. 44. Of the Larch Tree.
}

\author{
बा The Defcription.
}

1. THe Larch is a tree of no fmall height, with a body growing f raight vp:the bark wherof in the nether parr beneath the boughes is thicke, rugged, and full of chinks; whick being ent in funder is red within, and in the other part aboue fmooth, llipperie, fomething whitew ithout : it bringeth forth many boughes diuided into orher leffer branches, which be rough and pliable. The leaues are fmall,and eut into many iags, growing in clufters thicke together like taffels, which fall away at the approch of Winter : the floures or rather the firft fhewes of the conics or fruit be round, and grow out of the tenderent boughes, being at the length of a braue red purple colour : che eones be fimall, and like almoft in bigneffe to thofe of the Cypreffe tree, but longer,and made vp of a mulcitude of thin feales like leaues : vnder which lie fmall feeds, hating a thin velme grow ing on then very like to the wings of Bees and wafps :the fubftanee of the wood is very hard, of colour, efpeeially that in the midn, fomewhat red, and very profitable for workes of long continuance.

I Laricis ramula:

A branch of the I arch trec.

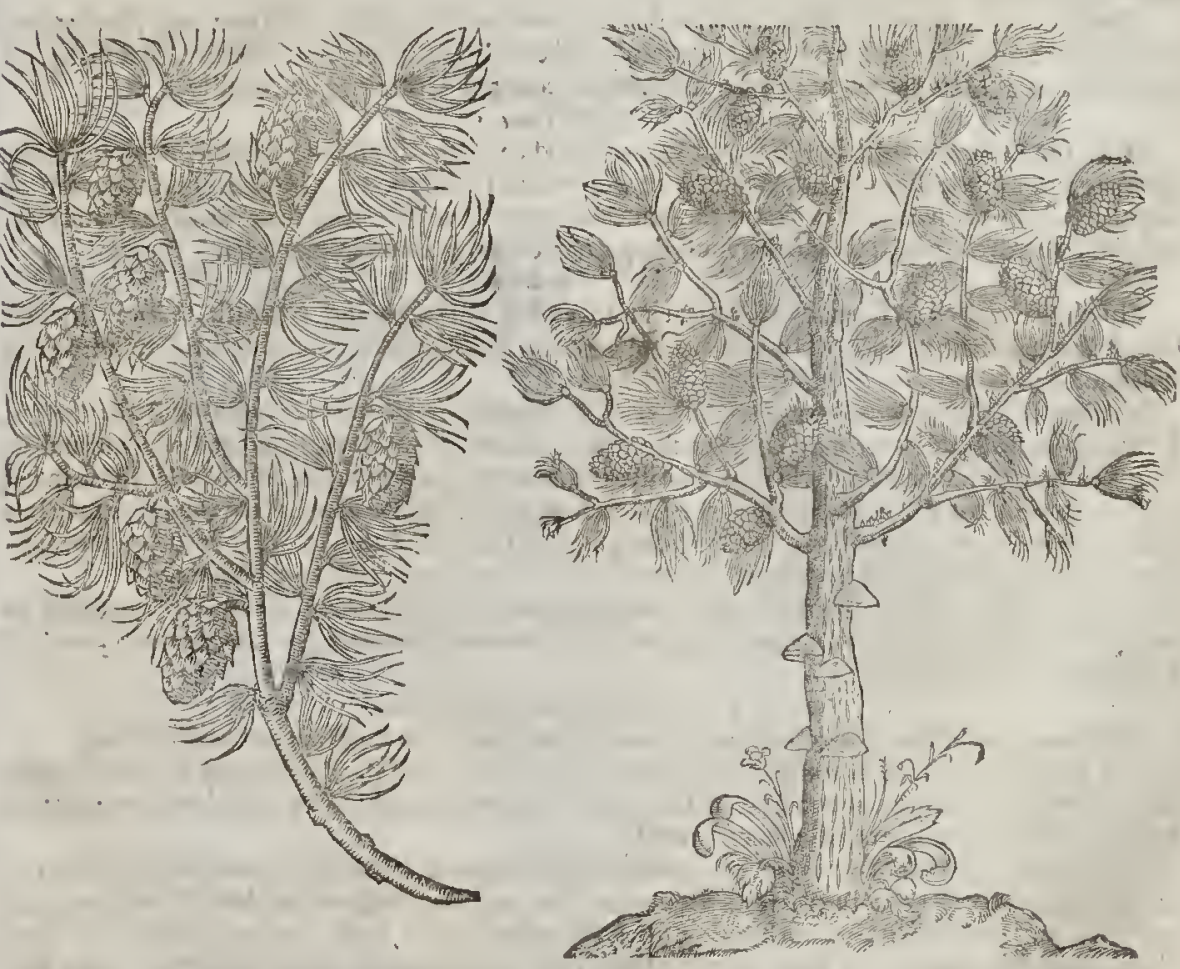

2 Larix cum Agaricofuo.

The Lareh tree with his Agarick:

It is not true that the woul of the Lareh tree tree eannot be fet on fire, as Vitruvius reporteth of the caftle made of Larch wood, which Cafar befieged; for it burneth in ehimneies, and is turned in to coles, which are very profitable for Smithes, as Matthiolus writeth.

There is alfo gathered of the Larch tree a liquid Rofin, very like in colour and fubftanee to the whiter hony, as that of Atbens or of Spaine, which notwithitanding iffueth not forth of it felfe, but runneth ont of the ftecke of the tree, when it hath been bored enen to the heart with a great and long auger and wimble.

Galcw writeth, that there be afrer a fort two kindes hereof, in his 4. booke of Medicines, according to the kinds, one like vnto Iurpentine, the other more tharper than this, hotter, more liquid 
of a ftronget fmell,and in tafte bitterer and hotter : but the later is thought not to be the Rofine of the Lareh, but of the Fir-tree, which $G$ alen beeaufe it is after a lort like in fubftance, might haue ta. ken for that of the Larch tree.

There groweth alfovpon the Larch tree a kinde of Mufhrum or excrefeence,not fueh as is vpon other trees, butwhiter, fofter, more loofe and fpungie than any other of the Murhrurns, and good for medieine, which beareth the name of Agaricus,or Agarieke: I find that Pliny fuppofeth all the Mafticke trees,and thofe that beare Galls, dobring forth this $A g$ aricum: wherein he was fomewhat deceiued, and efpecially in that he took Glandifer a for Conifer a, that is, thofe trees which beare maft or A cornes, for the Pine apple trees: but among all the trees that beare Agaricus, the Larch is the chiefe, and bringech moft plenty of Agarick.

\section{T) The Place.}

The Lareh tree groweth not in Greee, or in Macedon, but ehiefely vpon the Alpes of Italy, not far from Trent, hard by the riucrs Benacus and Padus; and alfo in other places of the fame mountaines : it is likewife found on hils in Morauia, which in times paft was called the countrey of the Mareomans: Fuch fus writeth, that it groweth alfo in Silefia : others, in Lufatia, in the borders of Poland: it alfo groweth plentifully in the woods of Gallia Cefalpina.

Pliny hath faid fomewhar hereof, contradicting the writings of otlers, in his I 6 book, 8 chaptet? where he faith, that fpecially the Acorne trees of France do beare A garieke, and not only the aeorn. trees, but the Cone trees alfo; among whieh, faith he, the Larch tree is the ehiefe thatbringeth forth Agarieke, and that not onely in Gallia, which now is ealled France, but rather in Lumbardy and Piemont in Italy, where there be whole woods of Larch trees, although they be found in fome fmal quantitic in other countrics.

The beft Agariek is that which is whiteft, very loofe and fpungie, which may eafily be broken, and is light, and in the firft tafte fweet, hard, and well compact: that which is heauy, blackifh, and containing in it little threds as it were of finewes, is counted pernicious and deadly.

I The Time.

Ofall the Cone trees onely the Larch tree is found to be without leaues in the Wintet : in the Spring grow freth leaues out of the fame knobs, from which the former did fall. The cones are to be gathered before winter, fo foone as the leaues are gone: but after the feales are loofed and opened, the feeds drop away : the Rofine muft be gathered in the Sommer moneths.

I $T$ he $N$ ames.

This tree is called in Greeke apre : in Laticealfo Larix, in Italian and Spanifh, Larice: in bigh Dutch, Letchenbaum : in low Dutch Lozkenboom : in French, ckelefe : in Englifh,Larch tree, and of fome Larix tree.

The liquid Rofin is named by Galcn alfo anders: the Latines call it Refina Larigna, or Refina Laricea. Larch Rofin : the Italians, Larga : the Apothecaries, Terebinthina, or Turpentine, and it is fold and alfo mixed in medieines in ftead thereof: neither is that a thing newly done; for Galen likewife in his time reporteth, that the Druggers fold the Lareh Rofine in ftead of Turpentine : and this may bee done without errour; for Galen himielfe in one place vfeth Larch Rofin for Turpentine; and in ano. ther, Turpentine for Larch Rofine, in his booke of medicines according to the kindes.

The Agarieke is alfoealled in Greeke likewife in thops: the Italians, Spaniards, and other nations do imitate the Greeke word; and in Englin we call it Agaricke.

\footnotetext{
of The Temperature and Vertues.
}

A Theleaues, barke, fruit and kernell, are of temperature like vnto the Pine,but not fo ftrong.

$B$ The Lareh Rofin is of a moifter temperature than all the reft of the Rofines,and is withall with: out fharpneffeor biting, much like to the right Turpentine, and is fitly mixed with medicines which perfectly eure vlcers and greene wounds.

C All Rofins, faith Galen, that hane this kinde of moifture and clammineffe ioined with them,do as it were binde together and vnice dry medicines, and beeaufe they haue no euident biting qualitie, they doe moiften the vlcers nothing at all : therefore divers haue very well mixed with fuch compound medieines either Tur pentine Rofin, or Lareh Rofin:thus far Galen. Moreoner,Lareh Rofin performeth all fueh things that the Turpentine Rofin doth, vnto which, as we haue faid, it is much likc in temperature, which thing likewife Galen himfelfe affirmeth.

D $\Lambda$ garicke is hot in the firft degree and dry in the feeond, aceording to the old writers. It cutteth, maketh thin,elenfeth,taketh away obfruations or ftoppings of the intrailes, and purgeth alfo by Atoole.

E Agarickecureth the yellow iaundice proceeding of obftructions, and is a fure remedie for cold Thakings, which are eaufed of thieke and cold humors.

F The fame being inwardly taken and outwardly applied, is good for thofe that are bir of venomous beafts which hurt with their cold poifon. 


\section{L1 в. 3. Of the Hiftory of Plants.}

It prouoketh vrine, and bringeth downe the menfes : it maketh the body well coloured, driteth $G$ forth wormes, cureth agues, efpecially quotidians and wandring feuters, and others that are of long continuance, if it be mixed with fit things that ferue for the difeafe: and thefe things it performes by drawing forth and purging away groffe, cold, and flegmaticke humors, which caufe the dif eafes.

From a dram weight,or a dram and a halfe, to two, it is gitien at once in fubftance or in potider : $\mathbf{H}$ the weight of it in an infufion or decoction is from two drams to fute.

But it purgeth flowly, and doth fomew hat trouble the ftomacke; and therefore it is appointed that Ginger thould be mixed with it, or wilde Carrot feed, or Louage feed, or Sal gem, in Latine, Salfoßilis.

Galen, as Mefue reporteth, gaue it with wine wherein Ginger was infufed: fome vfe to giue it $K$ with Oxymel, otherwife called fyrrup of vineger, whieh is the fafeft way of all.

A garicke is good againt the paines and fwimming in the head, or the falling Euill,being taken I with fyrrup of vineger.

It is good againit the thortneffe of breath, called Aft bma, the inueterate congh of the lungs, the $M$ ptyfieke, confumption, and thofe that fpet bloud: it comforteth the weake and feeble ftomacke, caufeth good digettion, and is good againft wormes.

\section{С н р. 45. Of the Cypreffe tree.}

Cuprefjas fatiua of fylueftris.

The Garden and wild Cypreffe tree.

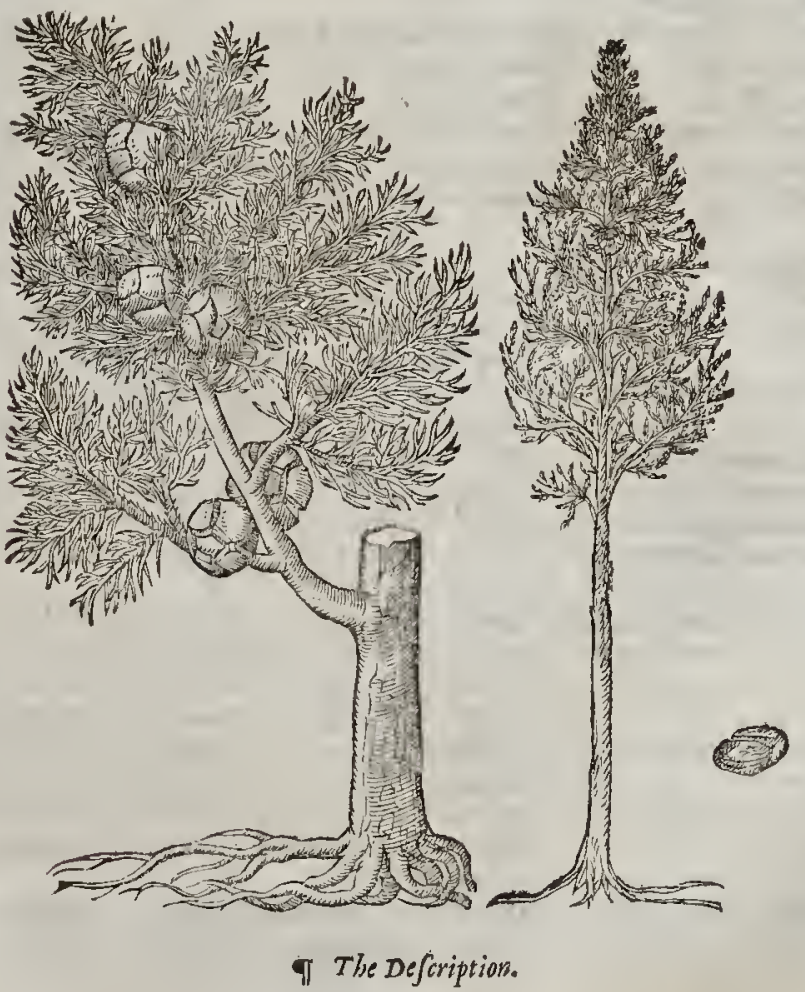

"He tame or manured Cypreffe tree hath a long thicke and Araight body; whereupon many flender branehes do grow, which do not fpred abroad like the branches of other trees, but grow vp alongt: the body, yet not touching the top : they grow after the fafhion of a fteeple, broad below, and narrow toward the top : the fub ftance of the wood is hard, found, well compact, fireet of fmell, andfomewhat yellow, almoit like the yellow Saunders, but not altogether foyellow, nei- 
ther doth it rot nor wax old, not cleaueth or choppeth it felf. The leatues are long, round like thofe of Tamariske, but fuller of fubstance. The fruit or nuts do hang vpon the boughes, being in manner like to thofe of the Larch tree, but yet thicker and more clolely compas : whieh being ripe do of themfelues part in funder, and then falleth the feed, which is maken out with the winde : the fame is fmall, Hat, very thin, of a fwart ill fauoured colour, which is pleafant to Ants or Pifmires, and feructlo them for food.

Of this diuers make two kindes, the female and the male; the female batren,and the male fruitfull. Theophraftus reporterh, that diuers affirme the male to come of the female. The Cypteffe yeelds forth a certaine liquid Korn, like in fubstanee to that of the Larch tree, but in tafte maruellous fharpe and biting.

The wilde Cypreffe, as Theophraftus writeth, is an high tree, and alwaies greene, fo like to the other Cypreffe, as it feeneth to be the fame both in boughes, body, leaues, and fruit, rather than a certaine wilde Cypreffe : the matter or fubftanee of the wood is found, of a fweet fmell, like that of the Cedar tree, which rotteth not : there is nothing fo crifped as the roor, and therefote they vfe to make precious and coftly workes rhereof.

$\neq$ I know no diffetence berweene the wildeand tame Cypreffe of our Author,but in the hand. fomneffe of their growth, which is helped lomewhat by art. $\ddagger$

$$
\text { aा The Place. }
$$

The tame and manured Cypreffe groweth in hot countries, as in Candy, Lycia, Rhodes, and alfo in the territoric of Cytene: it is reported to be likewife found on the hills belonging to Mount Ida, and on the hills called teuci, that is to fay white, the töps whercof be alwaics conered with fnow. Bellonius denie th it to be found vpon the rops of thefe hills, but in the bottoms on the rough parts and ridges of the hills : it groweth likewife in diuers places of England where it hath beene planted, as at Sion a place neere I-ondon, fometime a houfe of Nunnes : it groweth alfo at Greenwieh, and at other places, and likewile at Hanplted in the garden of $\mathbf{M}^{\mathrm{r}}$. Wade, one of the Cletkes of her Maicfies priuy Councell.

Thewilde kinde of Cypreffe tree groweth hard by Amzmons Temple, and in other parts of the countrey of $\mathrm{Cyrene}$ pon the tops of mountaines, and in extreme eold eountries, Bellonius affir. meth, that rhere is found a certaine wilde Cypreffe alfo in Candy, which is not fo high as other Cypreffe trees, nor groweth tharpe toward the top, but is lower, and hath his boughes fpred flat, round about in compaffe : he faith the body thereof is alfo thicke: but whether this be $T$ hy $d$, of which Thcophraftus and pliny make mention, we leaue it to confidetation.

$$
\text { बi The Time. }
$$

The tame Cypres tree is alwaies greene; the fruit mày be gathered turice a yeare, in Ianuatie; May, and Septenber, and therefore it is fyrnamed Trifora.

The wilde Cypres tree is late, and vety long before it buddetl.

$$
\text { I The 2kames. }
$$

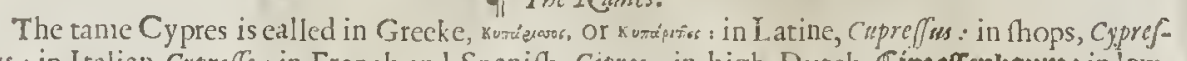
fus : in Italian, Cypreffo: in Ereneh and Spanith, Cipres : in high-Dutch, Cipzeftenbaun : in lorvDutch, Ceperfe boom : in Englifh, Cypres, and Cypres tree.

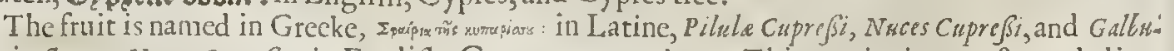
li: in thops, Nuces Cyprefs: : in Englifh, Cypres nuts or clogs. This tree in times paft was dedicated to $P$ luto, and was faid to be deadly; whereupon it is thought that the fhadow thereof is vnfortunatc.

The wilde Cypres tree is ealled in Greeke, sim or sin, and sion : from this doth differ siks, being a name not of a plant, but of a mortar in which dry things arebeaten: Thya, as Pliny writeth, lib. I 3 . cap. :6.was well knowne to Homer: he theweth that this is burned among the frveet finells, which Circe was nuch delighted withall, whom he would haue to be taken for a goddeffe, to their blame that eall fweet and odoriferous fmells, etien all of them, by that name; becaufe he doth efpecially make mention withall in one verfe, of Cedrus and $T$ hya : the eopies hatie fally Larix, or Larch tree, in which it is manifent that he fpake onely of ttees: the verfe is extant in the fift booke of $0 d_{y} m_{s}$, where he mentioncth, that Mercuric by lupiters commandement went to calyp wu den, and that he did fmell the burnt trees Thya and Cedrus a great way off.

Theophraftus attributeth great honot to this tree, fhewing that the roofs of old Temples became famous by reafnn of that wood, and that the timber thereof, of which the raftersare made is euctlafting, and it is not hut there by rotting, cobweb, nor any other infirmirie or corruption.

a) The Tempcrature.

The fruit and leaues of the Cypres ate dry in the third degree, and aftringent.

$$
\text { बा Thefortiks. }
$$

A The Cypresnuts being thamped and drunken in wine, as Dig corider writeth, ftoppeth the laske and bloudy fir, it is gopdagain? the fpiting of bloud and all othet ifrues of bloud. 
L 1 . 3. Of the Hiftory of Plants.

They gluc and hicalc vp grcat vlcers in hard bodies : they fafcly and without harme foke vp and $B$ confume the hid and fecret moifture lying deepc and in the buttome of weake and moift infirmitics.

- The lcaues and nuts are good to cure thc rupture, to takc away the Polypus, being an excrefcence 6 growing in the nofc.

Some do vfe the fame againft carbuncles and eating fores, mixing themwith parched Barley $D$ meale.

The leates of Cypres boyled in fwcct wine or Mede, helpes the Atrangurie and difficulty of mâking water. wife.

It is reported, that the fmoke of the leaucs doth driuc away gnats, and that the clogs do folike- F

The thaungs of the wrod laid among garments preferucth them from the moths : the rofin kil- $G$ leth Moths, little wormes, and magots.

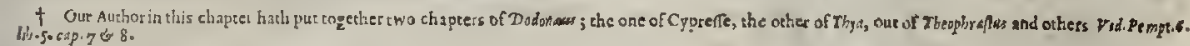

\section{C на в. 46. Of the Tree of Life.}

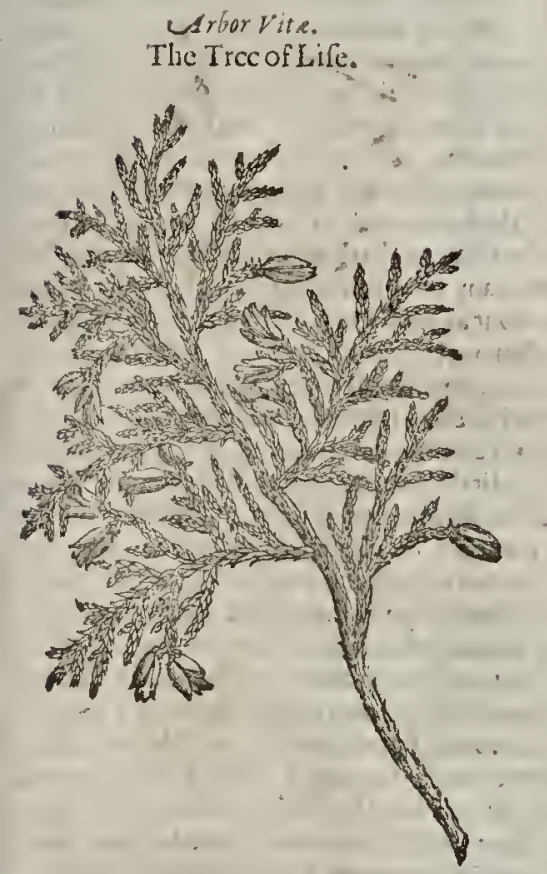

$$
\text { बा The Defoription. }
$$

THe tree Tree or Life groweth to the height of a fmall trce, the barke being of a darkc reddith colour : the timber very hard, the branches fpreading thenfclues abroad, hanging down toward the ground by reafon of the weakeneffe of the twiggie branchcs furcharged with very oileous and ponde. rous leaues, cafting, and fprcading themfelues like the feathers of aw ing, refembling thole of the $\mathrm{Sa}_{\mathrm{a}}$ uine tree, but thicker, broader, and more ful of gummic or oileons fibftancc: which being rubbed in the hands do yeeld an aromatick, fpicie,or gummie fauor,very pleafant and comfortablc : among ft the Ieaues comc forth fmall yellowin floures, which in my garden fall away withour any fruit: but as it hath beene rcported by thofe that have fecne the fame, there followeth a fruit in hot regions, much like vnto the fruit of the Cypres tree, but finaller, compact of little and thinne fcales clofely pact one vpon another, which my felfe hauc not yet feene. The branches of this tree laid downe in the eartla wil very cafily take root, encn like the Woodbinde or fome fuch plant; which I hatue often proued,and thereby hauc greatly multiplied thcfe trees.

\section{qा The Place.}

This tree growcth not wilde in England, but it growcth in my garden very plentifully. If The Time.

It endureth the cold of our Northernc clymat, yct doth it lofe his gallant grcenes in thewinter moneths : it floureth in my garden about May.

$$
\text { 97 The Names. }
$$

Theophraftus and Pliny, as fome thinke, hauc callod this fwcet and aromatical tree Thusia, or $T$ hya: fomccall it Cedrus Lycit: the new writers do termc it Arbor wit $:$ in Englih, the tree of life, I doe not meanc that whercof nsention is made, Gen.3.22.

Borli theleaucs and boughes be hot and dry.

$$
\text { If The Temperatire. }
$$

q $T$ he Vertues.

A mong the plants of the New-found land, this Tree, which I keophraftus calls Thris, or Thud, 
is the moft principal, and best agreeing vnto the nature of man,as an excellent cordial,and of a very. pleafant fmell.

\section{С на а. 47. Of the Yew tree.}

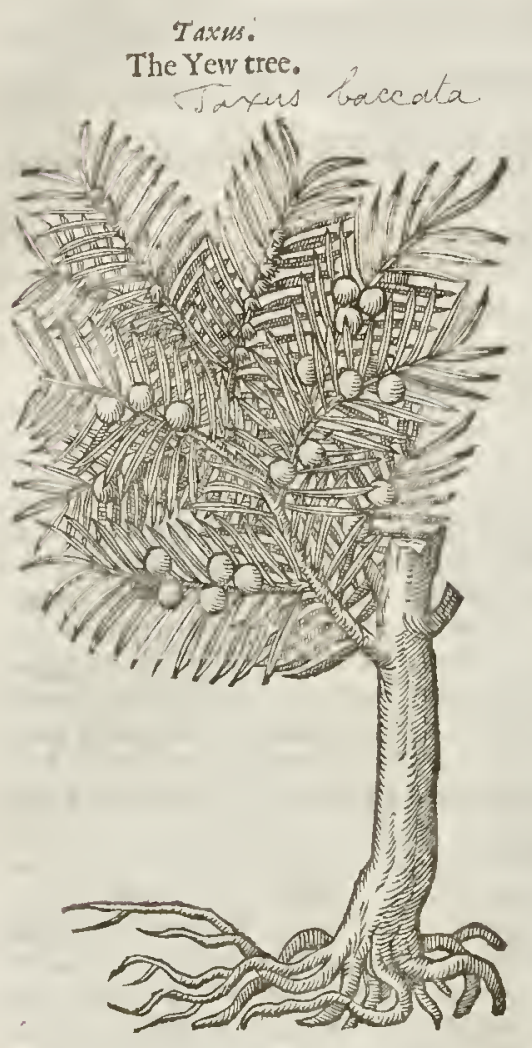

\section{The Defcription.}

* IN fead of the defcription and place mentioned by our Author(which were not amife) give me leaue to prefent you with one much more accurate, fent me by $\mathrm{M}^{\mathrm{r}}$. Iolin Goodyer.

Taxus glandifera bactiferáque.

The Yew bearing Acornes and berries.

$\Gamma^{H e r}$ He Yew tree that beareth Acornes and berries is a great high tree remaining alwaies greene, and hath vfually an huge trunke or body as big as the Oke, couered ouer with a fcabbed or fealy barke, often pilling or falling off, and a yong fmootl barke appearing vnderneath ; the timber hereof is fonewbat red, neere as hard as Box, vniuerfally coured next the barke with a thieke white fap like that of the Oke, and hath many big limmes ditided into many fmal fpreading branches : the leates be about an inch long, narrow like the leaues of Rofcmary, but fmooth, and of a darker greene colour, growing all alongt the little twigs or branclies clofe together, feldome one oppofite againft anorler, often hauing at the ends of the twigs little branches compofed of many leaues like the former, but fhorter and broader, clofely compan or ioyned together:amongtt the leaues are to be feene at all times of the yeare, fmall nender buds fomewhat long, but neuer any floures; which at the very beginning of the Spring grow bigger and bigger, till they are of the fanhion of little Acornes, with a white kernell within : after they are of this forme, then groweth vp from the bottomes of the Acornes a reddifh matter, making beautiful reddifh berries more long than round, fmooth on the out fide, very clammie within, and of a fweet tafte, couering all the Acorne, onely leaning a little hole at the top, where the top of the Acorne is to be feene : thefe fallen, or denoured by birds, leaue bchinde them a little whition huske made of a few fcales, appearing like a little floure, whicls peraduenture may deceine fome, taking it to be fo indeed: it feemes this tree, if it were not hindred by cold weather, would a lwaies haue A cornes and berries on him, for he hath alwaies little buds, which fo foone as the $S$ pring yeelds but a reafonable heate, they grow iuto the forme of Acornes : about the beginning of Auguft, feldome before, you fhall finde them turned into ripe berries, and from that time till Chriftmafle, or a little after, you may fee on him both Acornes and red berries.

Taxus tartum florens.

The Yew which only floures.

The Yew whicl onely beareth floures and no berries, is like the other in trunke, timber, barkc; and leaues, but at the beginning of Noutember, or before, this tree doth beginne to be very thicke fet or fratght on the lover fide or part of the twigs or little branches, with fmall round buds, verie neere as big, and of the eolour of Radifh feed, and do fo continue all the Winter, till about the beginning or middle of Februaric, when they open at the top, fending forth one fmall tharpe pointall, little longer than the huske, diuided into many parts, or garnifhed towards the top with many 
Imall dufty things like floures, of the eolour of the lusks; and if you fhall beate or throw ftones into this tree about the end of Februaric, or a good fpace after, there will proceed and fly from thefe floures an aboundance of duftie fmoke. Thefe dufty floures continue on the trecs rill about haruent, and then fome and fome fall away, and thortly after the round huds come vp as aforefaid.

$$
\text { का The Place. }
$$

Thefe trees are both very common in England: in Hampthire there is good plentie of them growing wilde on the chalkie hills, and in Church-yards where they haue been planted.

\section{T The Time.}

The time is expreffed in their defetiptions. Dec.19.162 I. Yohn Goedyer. $\neq$ T The Names.

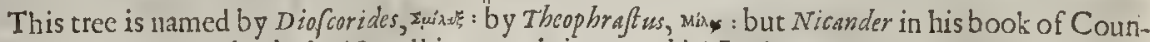
terpoy fons, sunos: Galcn doth alfo call it xexse: it is named in Latine Taxus : in high-Dutch, $\mathbb{C} \psi=$ benbaum : in low-Durch, Jbenboom: in Italian, Tafo: in Spanifh, Toxo, and Taxo : in Freneh, Yf: in Englifh, Ewe, or Ycw tree : in the vnlearned thops of Germany, if any of them remaine, it is called $T$ amarifous; where in times palt they wete wont not without great etror, to mix the bark hereof in compound medicines, in ftead of the Tamaristebarke.

$$
\text { T The Temperature. }
$$

The Yew tree, as $G$ alen reporteth, is of a venomous qualicie, and againft mans nature. $D$ iof corides wtiterh, and generally all that heresofore haue dealt in the faeultie of Herbarifme, that the Yew tree is very venomous to be taken inwardly, and that if any doe flecpe vnder the fhadow thereof it caufeth frekneffe and oftentimes death. Moreouer, they fay that the fruit thereof being caten is not onely dangerous and deadly vnto man, but if birds do eat thereof, it eaufeth them to eaft their feathers, and many times to die. All which I dare boldly affirme is altogether unrrue : for when I was yong and went to fchoole, ditiers of my fehoole-fellowes and likewife my felfe did eat our fils of the berries of this tree, and haue not only flept vnder the thadow thereof, but among the branches alfo, without any hurt at all, and that nor one time, but many times. Theophraftes faith, That Aisupa, animalia, Gaja tranflates them Iumenta, or labouring beafts, do die, if they do cat of the leaues; but fuch eattell as chew their eud reeeiue no hurt at all thereby.

Nicander in his book of Counterpoifons doth reekon the Yew tree among the venomous plants, fetting downe alfo a remedie, and that in thefe wotds, as Gorraus hath tranflated them.

Parce venenat a Taxo, qua furgit in Octa
Abictibus fimilis, let hoque abfumit acerbo
Niprater morem pleno cratere meraca
Fundere vina pares, cum primum fentiel ager
Aritariobstruct as fauces animague casalem.

$\ddagger$ Shun th' poys'nous Yew, the which on Oeta growes,

Like to the Firre, it caufes bitter death,

Vnlefle befides thy vie pure wine that flowes

Ftom empty'd cups, thou drinke, when as thy bteath

Begins to faile, and paffage of thy life

Growes ftrait.

Fena and Lobelalfo obferued that which our Author hete affitmes, and dayly experience thewes it to be true, that the Yew tree in England is not poy fonous : yet diuers affitme, that in Prouinee in France, and in moft lot eountries, it hath fuch a maligne qualitie, that it is not fafe to lleepe ot long to reft vinder the fhadow thereof. $\neq$

\section{$\mathrm{C}_{\text {н A P. }} 48$. Of the funiper tree. \\ The Kindes.}

A Mong the Iuniper trees one is lefier, anothet greater, being a ftange and forteine ttee : one of thefe bringeth forth a floute and no fruit ; the other fruit and no toures.

\section{ฯ The Defcription.} 1 He common luniper tree groweth in fome parts of Kent vnto the ftasureand bignes of tree 


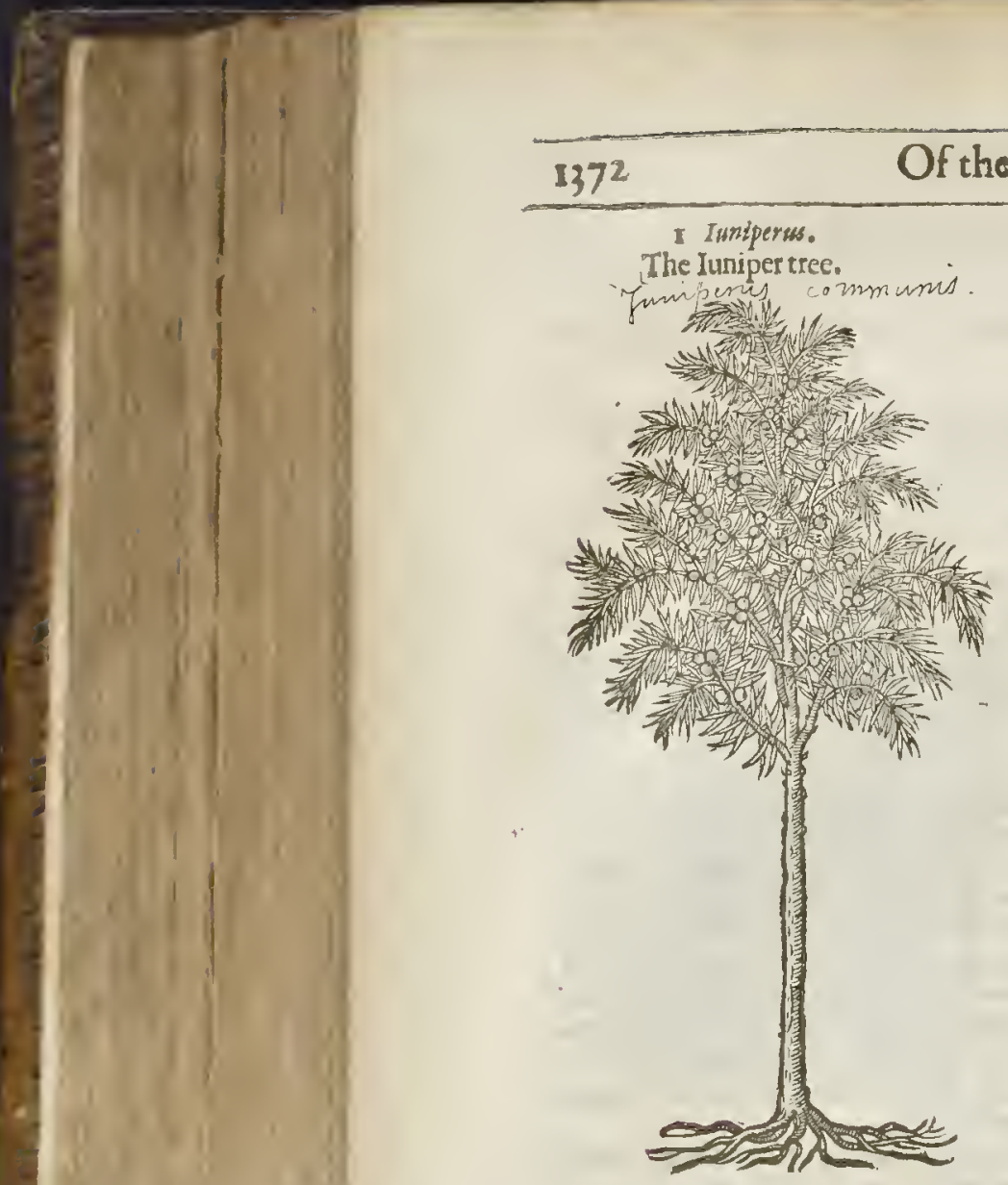

$L_{1}$ B.3.

I Litiperus.

The Iuniper tree.

* 3 Inniperus Alpina minor. Small Iuniper of the Alps. Juni

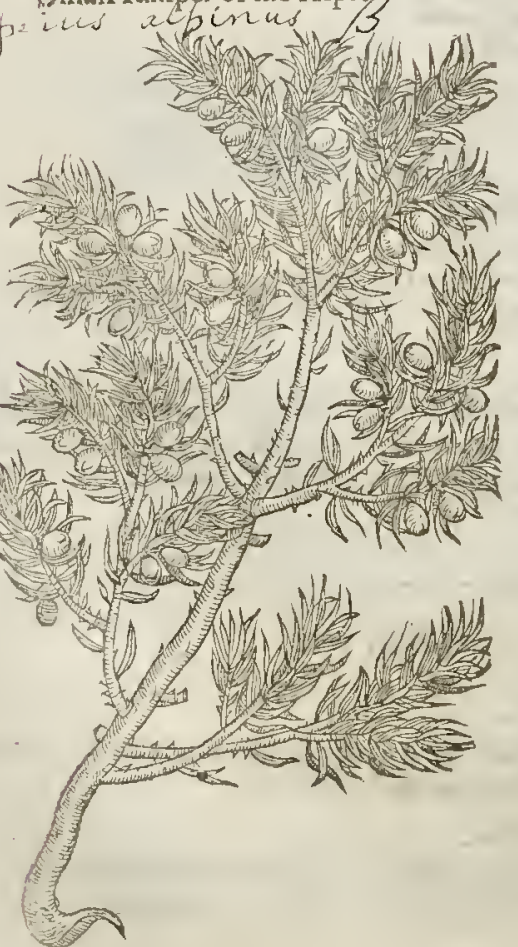

2 Iuniperus maxima.

The great Iuniper trec.

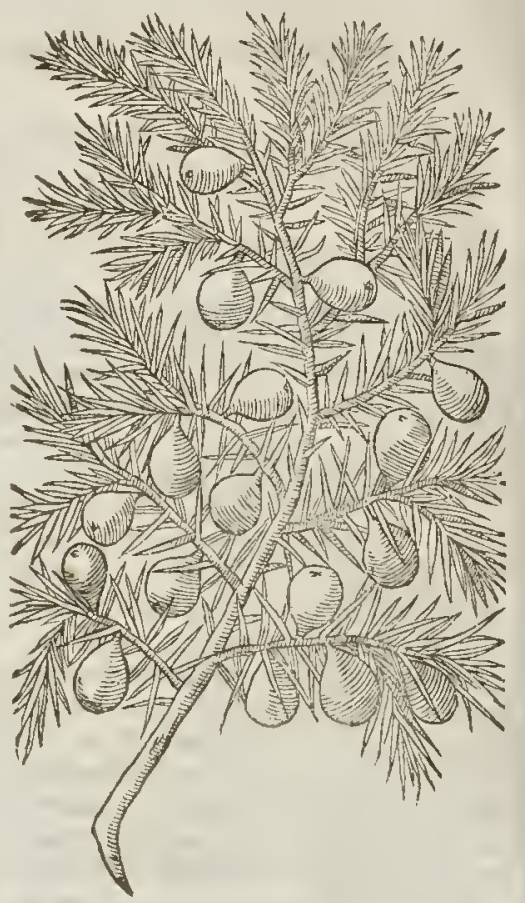

rrec hath a thin bark or rinde, which in hot regions will chop and rend it felf into many cranies or pieces : out of which rifts iffuctli a certaine gum or liqquour much like vnto Frankincenfe : the leaues arevery fmall, narrow, and hard, and fomw hat prick ly, growing cucr green along the branches, thicke together : among $f$ which come forth round ard fmall terries, grecne at the firt, but afterward blacke declining to blewnefle, of a good faros, and fwect in tafte, which do wax fomw hat bitter after they bedry and withered.

2 The great Inniper tree cumes ncw and then to the height of the Cypres tree, with a greater and harder lcafe, and alfo with a fruit as big as Oliue berrics, as Belloyius writeth, of an excecding fairc blcw colour,and of an excellent fireet fauor.

$\neq 3$ This exceeds not the beighr of a cubit, but growes low, and as it were crocps voun the ground, and confints of furdry thicker and thorter branches than the common kind, toug h alfo, writhen, and hard to breake; 3 leates alwaies growing at equall diftances, as in the common, but yet broader, fhorter, and thicker, neither leffe pricking than they, of a whitith grecne colour on the infide, and green withour, incompaffe the tender branches. Clufus, who giucs vs this figute and hiforie, nbfrurcl rot the floure, but the fruit is like that of the ordi- 

nary, but yet fomcwhat longcr; It growes vpon the Auftrian Alpes, and ripens the fruite in Auguft
and September. $\neq$

Tf The Place.

The common Iuniper tree is found in very many places, efpecially in the South parts of England.

Bellonius reporteth, that the greater groweth vpon mount Taurus : Uloifars Ungulldurawriteth, that it is found on the fea thores of the Ligurian and Adriatucke fea and in Illyycsing, bringing forth great berries : and others fay that it growes in Prouence of France : it commeth vp for the moft part in rough places and neere to the fea, as Diofrorides noteth.

I The Time.

The Iuniper tree floureth in May; the floure whereor is nothing elfe but as it werc a little yel lowith duft or powder ftrowed vpon the boughes. The fruit is ripe in September,and is feldome found either winter or Sommer without ripe and vnripe berries, and all at one time.

q) The Names.

The Iuniper tree is called in Greekcapuvers: the Apothecaries keepe the Latinc name Iuriperm the Arabians call it Archonas and Archencas: the Italians, Ginepro : in high Dutch, noechbolter: in Spanifh, Enebro, Ginebro, and Zimbro: the French men and bafe A lmaines Geneue: in Englith,
Iuniper tree.

The leffer is named in Grecke apxzoser: in Latine, Imniperas. The great Imiper Tree is called as

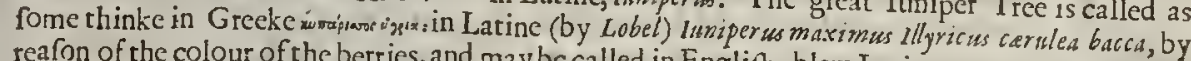
reafon of the colour of the berries, and may bc callecd in Englith, blew Iuniper.

The berries are called Grana Immiperi : in Grceke, wimu wis, although the Tree it felfe alfo is of rentimes called by the fanie name sewers: it is termed in high Dutch, wrametbeer, noectibolierber: in low Dutch, Ø̋eneforebefien: in Spanifh, Neurinas : in Englith, Iuniper berries.

The gum of the Iuniper tree is vfially called of the Apothecaries $\nu^{\prime}$ ernix : in Latine, Lachryma Inniperi: Scrapio nameth it $S_{\text {and }}$ ax and $S_{\text {andarachaj }}$ but there is another $S_{\text {andarach. }}$ among the Grecians, being a kinde of Orpment, which growes in the fame minerals wherein Orpment doth, and th is dorh farre differ from Vernix,or the Iuniper gum. Pling in his i i . booke, 7 .chapter maketh

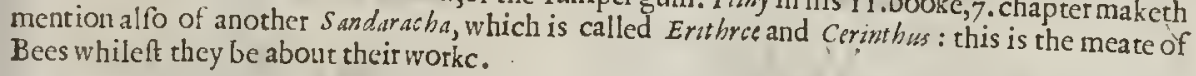

Iuniper is hot and dry, and that in The Temperature. but not altogether fo dric : the guin is hot and dry in the fales teacheth; the berries are allo hot, T The Vertues.

The fruite of the Iuniper tree doth clenfe the liner and kidnies, as Galen teftifieth : it alfo maketh thin clammie and groffe humors : it is vfed in counterpoyfons and other wholefome medicines : being ouer largely taken it caufeth gripings and gnawings in the ftomacke, and makcth the head hot : ir neither bindeth nor loofeth the belly : it prouoketh vrine.

Diofcorides reporteth, that this being drunke is a remedy againt the infirmitic of the che coughes, windines; gripings and poifons, and that the fame is good for thofe that be of the cheit, cramps, burftings, and with the difeafe called the morher. It is molt certaine that the deco ation of thefe berries is

againt that with which children are now and then extrem is fingular good againft an old cough; and which they vfe torife ve them.

Diters in Bohemia do take in ftcad of other drinke, the water wherein thofe berries have been 'D ftecped, who liue in wonderfull good heal th.

This is al fo drunke againft poifons and peft ilent feners, and it is not vnpleafant in the drinking: $E$ when the firft water is almoft fpent, the veffell is againe filled vp with frefh.

The fmoke of the leaues and wood driucth away ferpents, and all infection and eorruption of $F$ the aire, which bring the plague,or fuch like contagious difeafes : the iusce of the leaues is laid on with wine, and alfo drunkc again th the bitings of the viper.

The athes of the burned barke, being applied with water, take away fcurffe and filth of the

The powder of the wood being inwardly taken, is pernicious and deadly, as Diofcorides vulgar $H$ copies do affirme; but the true copies veterly deny it, neither do any of the old writers affirme it.

The fume and fmoke of the gum doth ftay flegmaricke humors that diftill out of the head, and ftoppeth the rheume : the gun doth ftay raw and flegmaticke humors that fticke in the ftomacke It killeth all mancrof raken, and al fo drinke:

mended alfo againft fpitting of in the belly, it ftaieth the men fes, and hemorrhodes : it is com- $\mathrm{K}$ be cafe chro ditlech them with flefh, if it

\section{.}


I. There is made of this and of oile of Linefeed, mixed together, a liquor cal'ed Vernifh, which is vfed to beautifie pictures and painted tables with,and to make iron gllfter, and to defend it from the ruft.

\section{Cн а F. 49. Of the prickly Cedar, or Cedar Iuniper. \\ T The Kindes.}

THe prickly Cedar tree is like ro Iuniper, and is called the fmall or little Cedar, for difference from the great and tall Cedar, which bringeth Cones; and of this thereare two kindes, as Theophraftes and Pliny do teftifie, that is to fay, one of Lycia, and another crimfon.

\section{T) The Defription.}

1 T He Crimfon or prickly Cedar feemeth to be very like to the Iuniper tree in body and boughes, which are writhed, knotty, and parted into very many wings : the fub. ftance of the wood is red, and fweet of finell like that of the Cypreffe; the trec is couered ouer with a rugged barke : the leaues be narrow and tharpe pointed, harder than thofe of Iuniper, tharper and more pricking, and ftanding thinner vpon the branches : the fruite or berry is fometimes as big as a hafell nut, or,as Theophraftus faith, of the bigneffe of Myrtle berries, and being ripe it is of a reddifh yellow, or crimfon colour, fweet of fmell, and fo pleafant in tafte, as euen the countrey-men now and than do eate of the fame with bread.

I Oxycedrus Phanicia.

Crimfon prickly Cedar.

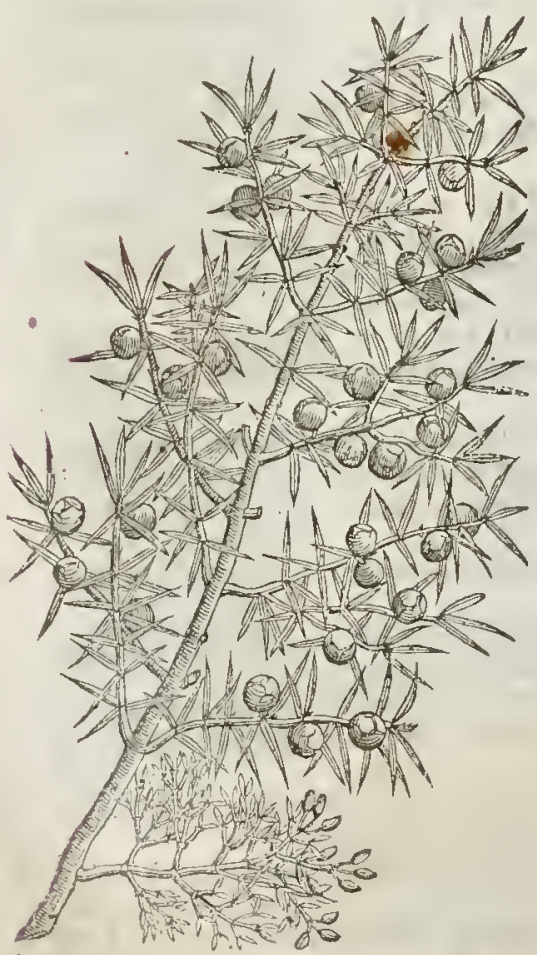

3 Oxycedrus Lycia. Rough Lycian Cedar.

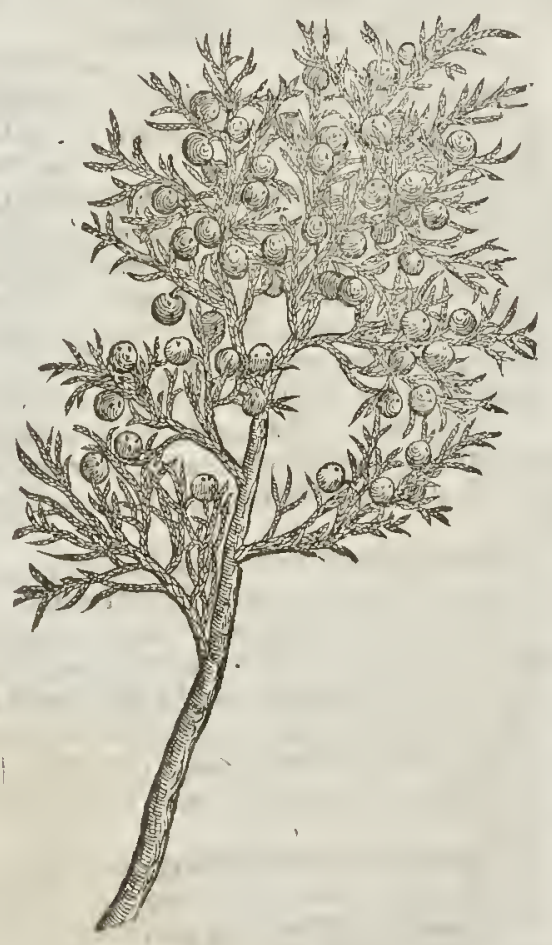

2 The other low Cedar which growes in Lycia is not fo high as the former, hauing likewife a writhed body as big as a mans arme, full of boughes; the barke is rough, yellowith without, and red within: the leaues ftand thicker, like at the firft to thofe of Iuniper, but yet fomewhat fhorter, and in the third or fourth yeere thicker, long and round withall, comming neere to the leates 
\pm 3 Codrus Lycia altera. The other Lycian Cedar.

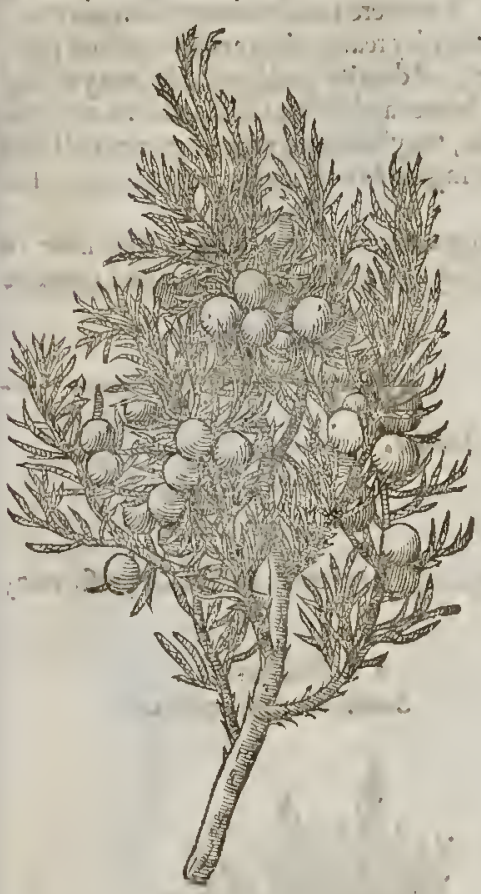

of the Cypres ttee, or of the recond Sauine, that is, blunt, and not pricking at all, which being bruifed betweene the fingers do yeeld a very pleafant fmel: fo doth one and the felfe fame plant bring forth below tharpe and prickly leaues, and a botre thick and blunt ones, as that notable learned Hetbarift Clufius harh moft diligently obferued : the fruit ur berry is round like that of Iuniper, of colour yellow when it is ripe, inclining to a red, in tafte fomw hat bitter, but fweet of fmell.

¥3 This alfo hath Cypreffe-like leaues, not vnlike thofe of the lalt defcribed, yet fomwhat thicker and broader : the fruit is alfo much larger, being as big as Hafell nuts, and of a red or skarlct colour; whencc Lobct calleth it Cedrss Phanicia altera. $\ddagger$

$$
4 \text { The Place. }
$$

The prickely Cedat with the crimfon colour commeth vp higher and greater in certaine places of Italy, Spaine, and A fra, and in other Countries; for that which grows on mount Garganus in A pulia is much higher and broader than thofe that grow elfewhere, and bringeth forth greater berries, of the bigneffe of an hafell nut, and fweeter, as that mort diligent writer Bellonius reporteth. Carolus Clufus Theweth, that the prickely Cedar and the Iuniper tree be of fo great a growth in diuers places of Spaine, as he hath obfetued, as that the body of them is as thicke as a man.

The Lycian Cedar is found in Prouence of France, not far from Maffilia, and groweth in a great part of Greece, in Lllyricum and Epirum.

The Time.

Both of them are alivaies greene, and in Winter allo full of fruit, by reafon that they continually bring forth berries, as when the old do fall new come in their places : in the fpring grow vp new buds and beginnings of berries : in Autumne they wax ripe the fecond yeare, as doe the berries of Iuniper.

$$
\text { The Names. }
$$

They are called in Latine, Minores, and Humiles Cedri, little and low Cedars, for difference from the tall and great Cedar which beareth Cones.

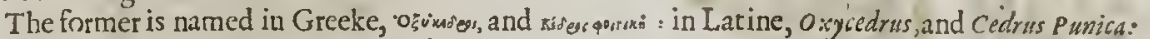
in Englirh, Prickly Cedar, and Crimfon Cedar: Pliny fyrnameth it Pharnicea, of the crimfon colour of the fruit : the Spaniards call this alfo Encbro, as Clrefus teftifieth, euen by the fame name which they giue to the Iuniper : wherein likewife they are thuught to imitate diuers of the old Writers, who hate not by names diftinguithed the Iuniper from the Cedar, but haue,as Theophrafus noteth, called them Cedros, Cedar trees; yet with an addition, 'ogrumess, or prickly Cedar.

The otherwith the blunt leafe is named by Theophraftus, súma Kiser:s of Pliny allo, Lycia Cedrus : in Piouince of France, Morucinc : diuers name this Sabina, and vec it in ftead of Sauine,which they want; as the Apothecaries of Epidaurus, and in ditiers cities of Greece, and al fo in Illyricum and Epirum, as Bellonius teftifieth. Some would hate it to be six, Thya; but Thya, according to $T$ heoplorafus, is like, not oncly in body, leaues, and boughes, but in fruit alfo, to the Cypreffe tree, but the fruit of this is nothing like to the Cypreffe Cones.

The fruir of this Cedar is named by Thcophraftus, Kispis, Cedris : notwithitanding Cedrus, as hee himfelfe doth alfo teftifie ( $G$ a a nameth it Credula) is a cerraine little fhrub which neuer groweth toa tree.

The gum or liquor which iffueth forth of the prickly Cedar is alfocalled' $r$ ernix, and is fold in fead thereof.

$$
\text { or The Temperatureand Vertues. }
$$

The little Cedar, as Galen writeth, is hotand dry in a manner in the third degree : the matter or $A$ fubitance thereof is fweet of fmell, like that ol Iuniper, and is vfed for perfumes and odoriferous Imells togethet with the leaues, 


\section{Of the Hiftorie of Plants.}

L I B.3.

B. The berries or fruit of the low Cedar haue the facultics not fo ftrong, as the fame Author teftificth, infomuch as that they may alfobe eaten, yet if they be taken too plentifully, they caufe head-ache, and breed heate and gnawings in the ftomacke. Yet there is a difference between thefe two Cedarberrics; for the crimfon ones are not fo hot and dry, by teafon they arc fweeter and pleafanter to the tafte, and therefore they are better to be eaten, and do alfo yeeld vnto the body a kind of nourifhment: but the berries of that of Lycia are biting, hotter and drieralfo than thofe of Iuniper, from which they differ efpecially in the biting qualitie; they bring no nourithment at all,and though a man cate neuer fo few of them he thall feele gnawings in his ftomacke, and paine in his head.

C The Peafants do feed thereon rather to fatisfie their huuger, than for any delight they haue in the tafte, or the phyficall vertues thcreof; albeit they bc good againft the ftrangurie, and prouoke vrine.

\section{С н а: 50: Of Sauin.}

If The Kindes.

7 Herebe two kindes of Sauin; one like in leafe to Tamariske, the other to the Cypreffe tree; whereof the one bcareth berries, the othcr is barren.

I Sabimafterilis.
'Barren Sauin.

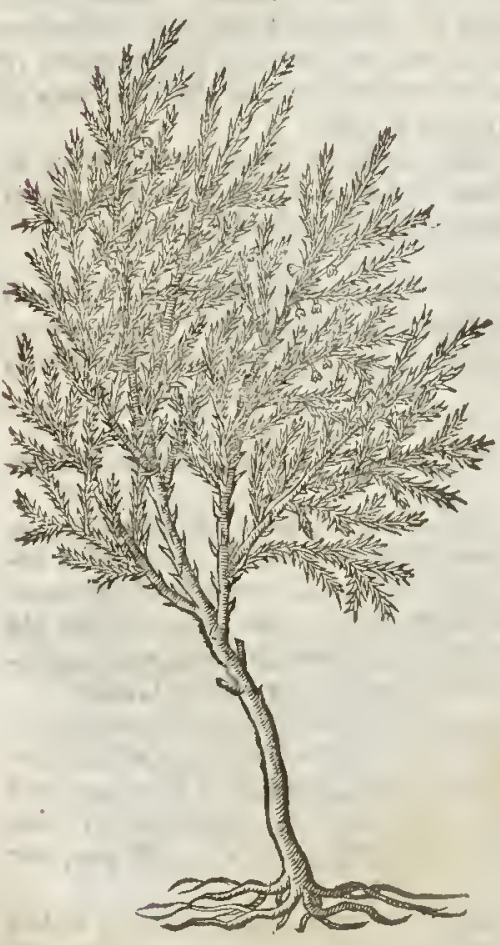

2 Sabinabaccifera. Sauin bearing berries.

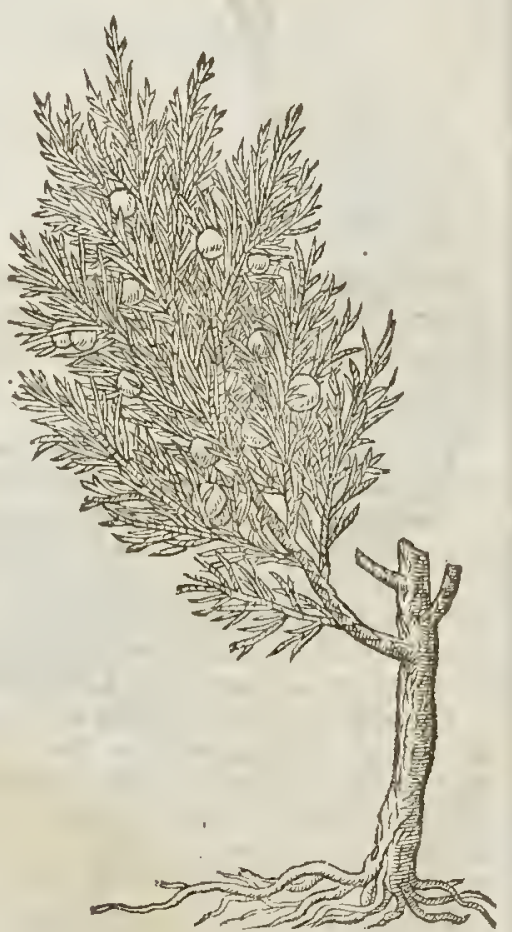

I The Defcription:

1 He firt Sauin,which is the common kind, and beft of all knowne in this country, groweth in manner of a low thrub or trce : the ftem or trunke whereof is fomtimes as big as a mans arme, diuiding it felfe into many branches fet full of fmall leaues like vnto Cypres, or Tamariske, but thicker, and morc tharpe or prickely, remaining greene $W^{\prime}$ inter and Sommer, in fmell ranke or vcry ftrong, barten both of floures and fruit. 


\section{1 B. 3. Of the Hiftory of Plants.}

¥ 3 Sabina baccata altéra.

The leffer berry-beating Sauin.

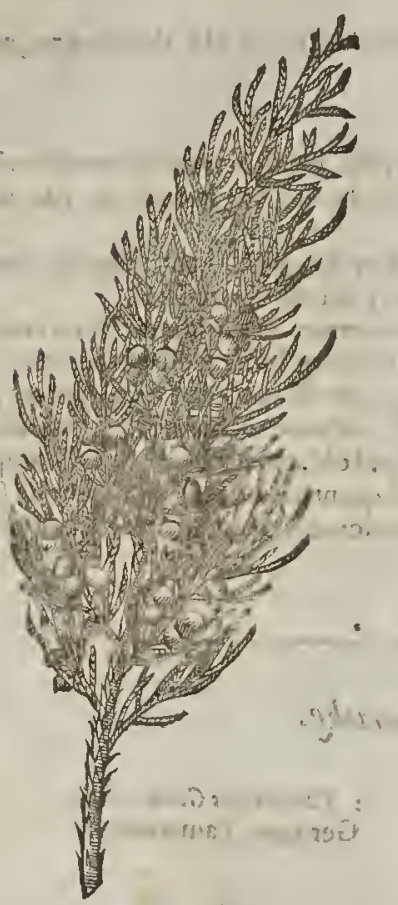

2 The orher Sauin is an high tree, as Bellomius faith,as tall as the Almond tree, and much like to the tame Cypreffetre: the.bodic is writhed, thieke, and fometimes of fo great a compaffe as that it cannot be fathomed; the fubftanee of the wood is red within, as is that of the Iuniper, and of the prickely Cedar : the barke is not very thicke, and it is of a yellowifh red : the leaues are of a maruellous gallant greene eolour, like to thofe of the Cypres tree, yer thicker or more in number ; in tafte bitter, of a fpicie fmell, and like Rofin : the boughes are broader, and thicke fet as it were with wings, like thofe of the Pitch tree and of the Yew tree: On which grow a grear number of betries, very tound like thofe of the little $\mathrm{Ce}$ dars, which at the firftare green, but when they be tipe they are of a blackinh blew. Out of the roothereof iffueth oftentimes a rofin, which being hard is like to that of the Iuniper ttee, and doth alfo crumble in the chewing.

$\neq 3$ There is anothet, whieh differs from the latedefcribed onely in that the leaties are fmaller and leffe prieking than thofe of the fortater, as alfo the branehes leffer : Lobcl calls this Saunina baccata altera. ¥

$$
\text { T) The Place. }
$$

Both of them grow vpon hills in woods, and in other like vntoiled places, as in $\mathrm{Candy}, \mathrm{My}$ fia, and el rewhere. $P$. Belloniss reporteth that he found them both vpon the tops of the mountaines Taurus, Amanus, and Olympus.

The firt is planted in our Englifh gardens almofe euery where : the feeond is planted both by the feed and by the alip : the flips mutt be fet in a ground that is meanly moift and thadowie, till they haue taken root: the thrubs whieh grow of thefe deeline toward the one fide, retaining ftill the nature of the bough : but that Sauin which is planted by the feed groweth more vpright; this in eontinuanee of time bringeth forth feeds, and the other for the moft part remaines batren: both thefe grow in my garden.

$$
\text { q The Time. }
$$

They both eontinue alwaies greene: the one is found to be løden with tipe fruit commonly in Winter, but it hath fruit at all times; for before the old betries fall, new ate come vp.

$$
\text { 9 The Names. }
$$

Sauine is called in Gtceke spross, or Bpitu : in Latine, Sabina.

The firt is commonly ealled in the Apotheearies Thops by rhe name Sauina : of divets, Savime: $r a$ : the Italians and Spaniards keepe the Latine name: it is ealled in high-Duteh, Siben baum: in low-Duteh, Samel boom: in Freneh, Sascrier : in Englin, common Sauine, or garden Sauine.

Some name the other Cupreffus Cretica, or Cypres of Candy, as Pliny faith, lib.1 2. Cap. 7 7.making mention of a ttee ealled Bruta: fome there are that take this to be alter a Sabina, or the feeond $S_{a-}$ uin, and to be read Brut $A$ for spas, Brat bu, by altering of the vowels. For it is deferibed by Plin.li.12. cap.17. to be like the Cypteffe tree, in thefe words; They feeke in the mountaine Elimxi the tree Bruta, being like to the broad Cypres tree, hauing white boughes, yeelding a fiveet fmell when it is fer on fire; whereof mention is madewitl a miracle, in the fories of Claudius Cefar. It is reported that the Patthians do vfe the leaues in drinks; that the fmell is very like to that of the Cypres tree, and that the finoke thereof is a remedie againft other woods. It groweth beyond Pafitigris, necre vnto the towne Sittaca, on mount Zagrus. Thus far Pling.

The mountaines Elimxi are deferibed by Strabo in the countrey of the Affyrians, next after the mountaine Sagrus aboute the Babylonians; by Ptolomarus not far from the Perfian gulfe : therefore it - is hard to fay that Bruta is Sabina altera, or the feeond Sauine, feeing that fo great a diftance of the place may vndoubtedly eaufe a differenee, and that it is not largely but briefely defetibed. It feepucth that Thya mentioned by $T$ hcophraftus is more like vnto Sauine : but yet forafmuch as $T$ bya is like in frut to the Cypres tree, and not to the ftuit or berries of the little Cedats, it is alfo verie 
manifeft, that the fecond Sauine is not $T$ bya, neither Vit a arbor, fo called of the later Herbarifts: it is likewife named by Lobel, Sabina genuina baccifora, atrocerulea, that is, the true Salline that beareth berries of a blackith blew colour.

\author{
T) The Tomperature.
}

The leaues of Sauine, which are moft vfed in medicine, are hot and dry in the third degree, and of fubtill parts, as Galen faith.

$$
\text { The Tertues. }
$$

A The leates of Sauin boyled in Wine and drunke pronoke vrine, bring downe the menfes with force, draw aw ay the after-birth, expell the dead childe, and kill the quicke: it hath the like ver. tue receilled vnder in a perfume.

3 T he leates ftamped with honey and applied, cure vlcers, ftay fpreading and creeping vlcers? fcoure and take away all fpots and freckles from the face or body of man or woman.

Theleates boyled in oyle Oliue, and kept therein, kill the wormes in children, if you anoint their bellies therewith : and the leaues potdered and giuen in milke or Murcadell do the fame.

D

The leaues dried and beate into fine pouder, and ftrewed vpon thofe kindes of excrefcences fut preputio, called Caroles, and fuch like, gotren by dealing with vncleane women, take them away perfectly, curing and healing them : but if they be inueterate and old, and haue been much tampered withall, it thall be neceffarie to adde vnto the fame a frnall quantitie of Auripigmentum in fine pouder, and vfe it with difcretion, becaufe the force of the medicine is greatly increafed thereby. and made more corrofitie.

\title{
CHap. S1: Of Tamariske:
}

I Tamarifous Narbonenfis? French Tamariske?

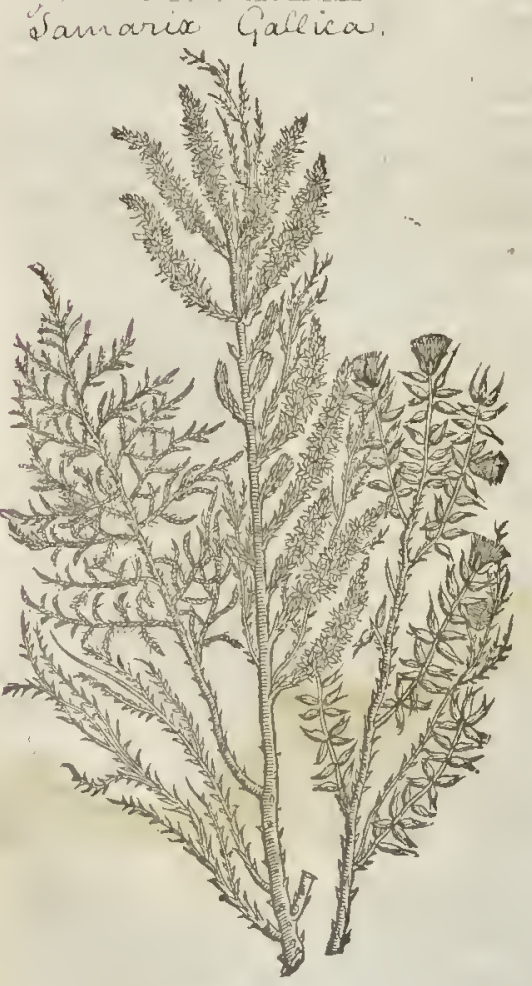

2 Tamarifous Germanica! Germane Tamariske.

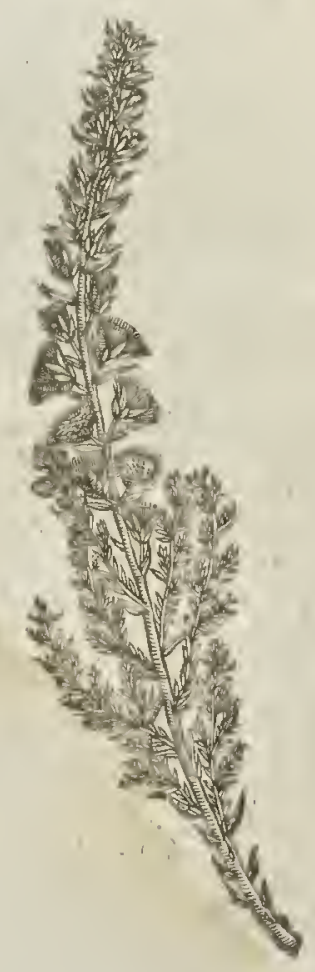




\section{T The Defcription:}

I THe firft kinde of Tamariske groweth like a fmall hedge tree, couered with a reddifh barke, hauing many branches fet and bedeckt with leaues, much like vnro Heath:among which come forth finall moffie white floures declining to purple, which,rurne into a pappous or downie feed, that flieth away wirh rhe winde, as that of Willow doth: the root is wooddie as the toots of orher fhrubs be, and growerh diuers waies.

2 The Germane Tamariske hath many wooddie branches or fhoots rifing from the root, with a white bark, hauing his leaues thicker and groffer than the former, and not fo finely iagged or cut: The floures are reddith, and larger rhan rhe former, growing not vpon foot-ftalkes, many thick eluftering together, as thofe of the former, but each a pretty, diftance fron another on rhe rops of the branches foike fafhion, and begin to floure below:which do turne into feed, that is likewife carried away with the winde.

$$
\text { T. The place: }
$$

Tamariske groweth by running ftreames, and nnany times by riuers that breake forth, and not feldome about femny grounds, commonly in a grauelly foile, for ir beft profpereth in moift and ftony places : ir is found in Germany, Vindelicia, Italy, Spaine,and alfo in Greece.

The Tamarisks do alfo grow in Egypr and Syria, as Diofcorides writeth, and likewife in Tylus an of marix IGand in Arabia, as Theophraftus noterh: rhe wood wher of, fairh he, is not weak as with vs in Greece, ovientalis bur ftrong like wpsion, or timber, or any other ftrong thing : this Tamariske Diefcorides dorh call Emsk:F.E ipups, that is to fay, tame, or planred, and faith that it bringeth forth fruit very like to Galls, in tafte rough and $b$ inding.

Petrus Bellonius in his fecond booke of fingularities reporreth, that hee faw in Egypt very high Tamarisks and grear like other trees, and that fometimes in morf places by riuers fides, and many times alfo in dry and grauelly grounds where no orher trees did grow, which now and then did beare hanging on the boughes fuch a multitude of Galls, that the inhabitants call Chermafel,as being ouer loden,they were ready to breake. Both thefe grow and profper well in gardens with vs here in England.

Thefe trees or fhrubs floure in May, and in the larer end of Auguft, theirfeed is carried away with the wind.

$$
\text { T } T \text { be Nutmes. }
$$

They are called in Greeke merx: and in Latine alfo Myrica, and $T_{\text {amarix }}$ : in thops, $T$ amarifcus: of Oefautus Horatianus, Murica: Diofcorides makerh that whiel groweth in Greece and Italy to be aypra, orwilde Tamariske: ir is named in high Dutch Camatífenen bolk, and j9o2k: in low Dutch, J benboom, Tamatlfthboome: in Italian, Tamarggto : in Spanih, Tamargura,and Tamariz: in French, Tamarts : in Englifh, Tamariske.

$$
\text { T The Temperature and Vertues. }
$$

Tamariske hath a clenfing and cutring facultie with a manifeft drying; it is alfo fomewhat $A$ aftringent or binding, and by reafon of thefe qualiries ir is very good for an hard fpleen, being boyled with vineger or wine, eirher the root or leaues, or tender branehes, as $G$ alen writeth.

Moreouer Diofcorides teaeherh, that the deeoction of rhe leaues made wirh wine, doth wafte the $B$ fpleene, and rhat rhe fame is good againft rhe tooth-aehe, if the mouth be wathed therewirh : that it bringeth downe rhe Menfes, if the patient fit therein; rhar it killerh lice and nits, if the parts be bathed rherewirh.

The afhes of burnr Tamariske bath a drying facultie, and greatly fcouring withall, and a little $C$. binding.

The floures and downie feed of the greater Tamariske dorh greatly binde, infomuch as it com- D merh very neere to the Gall naned Galla O mphacit is, bur that the roughneffe of tafte is more euident in the Gall; rhe which flourcs a:e of an vnequall temperature, for rhere is ioined ro the nature therof a great thinnefic of parts, and clenfing faculrie, which the Gall harh not,as Galen writeth.

Thcfc foures we firly vfe (faith Diofcur.) in ftead of Gall, in medic ines for the eies and mouth:

It is good to ftaneh bloud, and to ftay rhe laske and womens whires, it helpeth the yellow iaun. F diec, and al fo curerh thofe rhar are bit of the venomous fpider called phalang ium; the barke fetweth for the fame purpofes.

The leaues and wond of Tamariske haue great power and vertue againft the hardneffe and ftop- $G$ ping of the fpleene, efpecially rhe leaues being boiled in water, and the decoction drunke, or elfe in fufed in a finall veffell of Ale or Beere, and continually drunke : and if it bee drunke forth of a cup. or difh made of the wood or timber of Tamariske, is of greatet efficacie, 
Here be dituers forts of Heath, fome greater,fome leffer; fome with broad leaucs,and fome nar: tower : fome bringing forth berries, and others nothing but floures.

\section{T) The Defription.}

I The common Heath is a low plant, but yet wooddie and Thrubby, fcarce a cubit high:ie I bringeth forth many branches, whereupon do grow fundry little leaues fomew hat hard and rough,very like to rhofe of Tamariske, or the Cypreffe tree: the floures are orderly placed a* long t the branches, fmall, foft, and of a light red colour tending to purple : the root is alfo wooddie, and creepeth vnder the vpper cruft of the eatth:and this is the Heath which the Antients tooke to be the right and true Heath.

I. Erica vulgaris, five Pumila. Common or dwarfe Heath. Enca vulgaris.

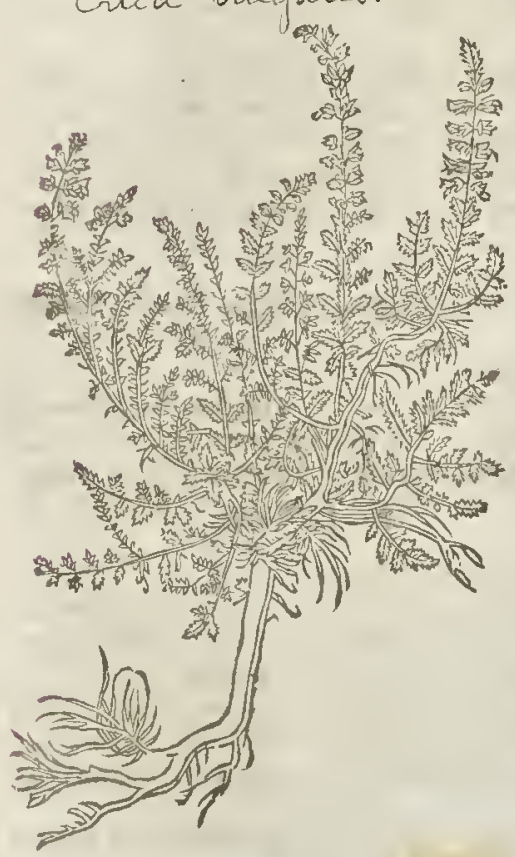

Ericavulgaris birfuta. Rough leaued Heath:

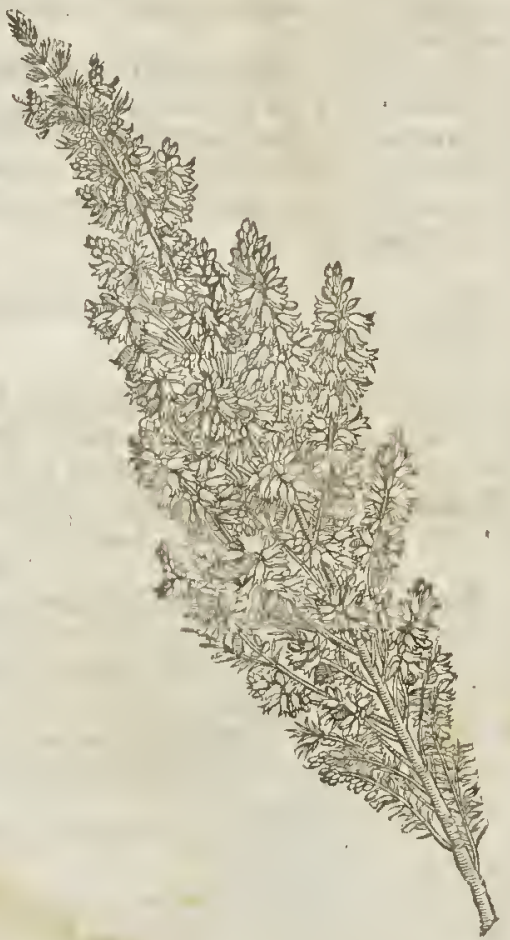

There is another Heath which differeth not from the precedent, fauing that this plant bringeth forth floures as white as fnow, wherein confifteth the difference: wherefore we may call it Erroapumila alba, Divarfe Heath with white floures.

2 The great Heath, (which Carolus Clufurs at his being in England found in the barren grounds about Windfor, which in his Spanith trauels he maketh the firft kinde) :groweth to the height of two cubits, feldome higher, full of branches, couered with a blackith barke : whereon are fet in very good order by couples, fmall, rough, fquareleaues finer than thofe of Tamariske or Cypreffe. The floures inclofe the litrle twiggie branches round about at certaine diftances, from the lower part to the tor fathinned like little bottles, confifting of foure parts, of a thining purple colour, very beautifull ro bu bold, and the rather to be efteemed becaufe it floureth twife in the yeare:the root is like. miferooldie. 
$\mathrm{L}_{1 \mathrm{~B}: 3 .} \quad$ Of the Hiftorie of Plants.

138 I

+3 Erica maior fore albo Cluyjy.

The great Heath with white floures.

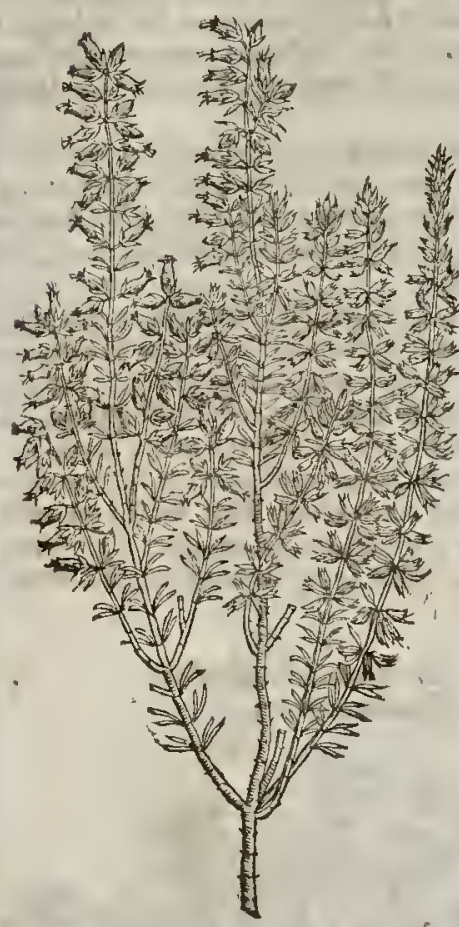

t5 Erica cruciata?

Croffed Heath.'

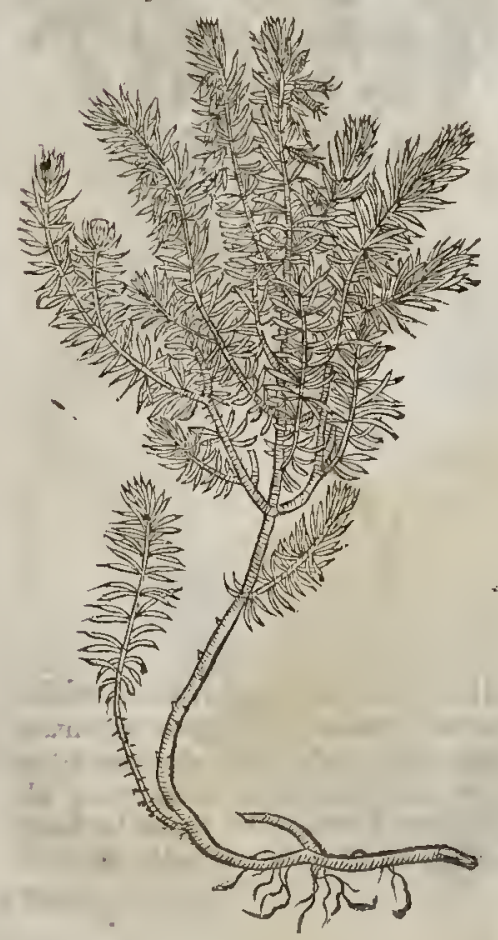

4 Ericamaior flore purpureo.

Grear Heath with purple floures:

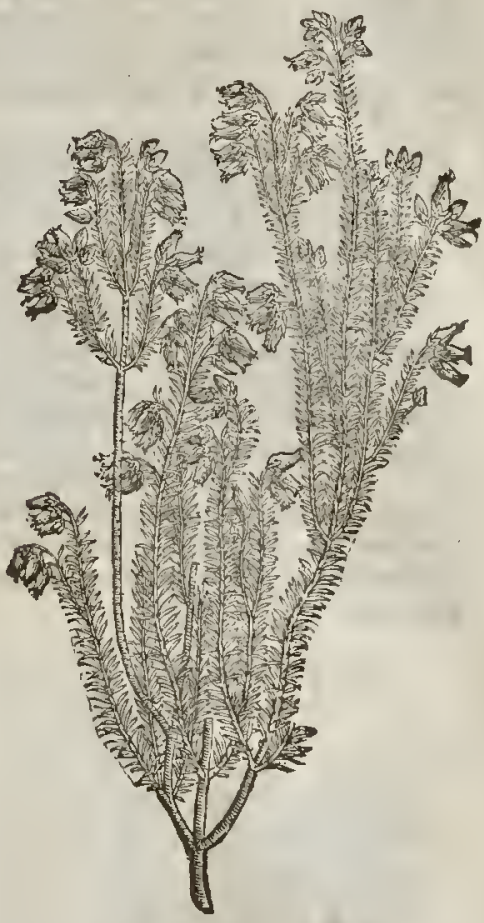

6 Erica Pyramidalis. Steeple Heath.

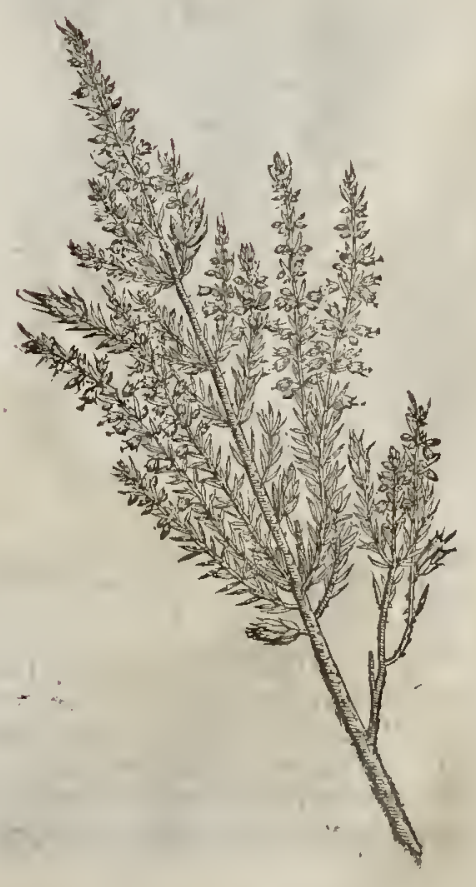


\# 3 This, faith clufures, which is the largeft that I haue feene, fometimes excceds the height of a man, very thrubby, hatuing a hard and blackith red wood: the leaues are fmall and thort, growing about the branches by foures, of a very aftringent tafte : it hath plentiful ftore of tloures growing all alongft the branches, fo that fomtimes the larger branches hate floures for a foot in length: this floure is hollow and longifh,well fmelling, white and beautifull. It growes betweene Lis bone and the Vniuerfity of Conimbrica in Portugal where it floures in Nouember, December, and Ianuarie. $\ddagger$

4 Of this kind there is another fort witl whition purple floures, more frequently found than

other fort, which floures are formw hat greater than the former, but in forme like, and flouring

fame time. $\ddagger$ Theleaues alfo are harry, and grow commonly by foures: the hollow floures

: cultering together at the very tops of the branches, and are to be found in Iuly and Au$i$ it it gin is on diucrs heathy places of this kingdome. $\ddagger$

Coiled Heath groweth to the height of a cubit and a halfe, full of branches, commonly Iyng dong von the ground, of a fwart darke colour:whereon do grow fmall leaues, fet at certaine fprees by two vpon one fide, and two on the other, oppofite, one anfwering another, euen as doe the leaues of Croffe-wort. The foures in like manner ftand alongtt the branches Croffe fafhion, of a darke overworne greenith colour. The root is likewife wooddy, as is all the teft of the plant.

This Steeple Heath hath likewife many wooddy braunches, garnifhed with fmall leaues which eafily fall off from the dryed ftalks; among which come forth diters little moffie greenifh foures of fmall moment. The whole buth for the moft part groweth round together like a lirtle coeke of hay, broad at the lower part, and Tharp aboue like a Pyramide or Atceple, whereof it tooke his name.

7 Ericatenuifolia.

Small leafed Heath.

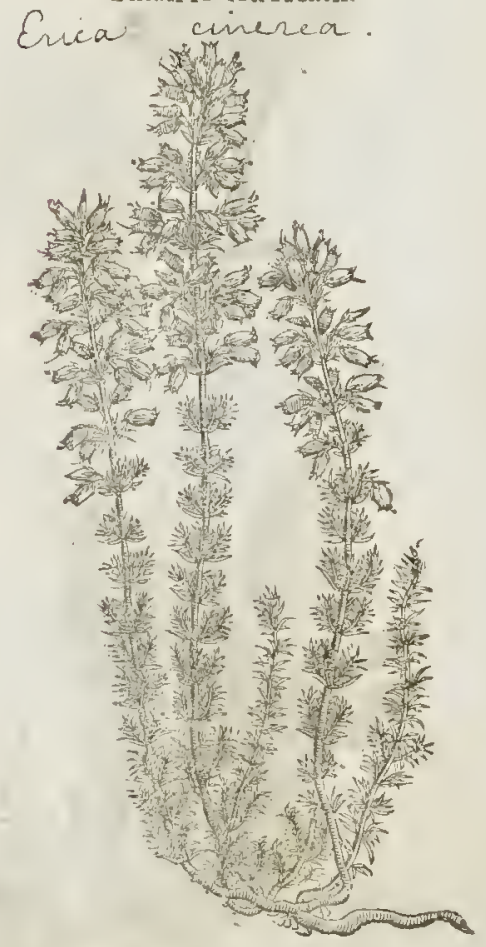

8 Ericatenuifolia caliculata. Challice Heath.

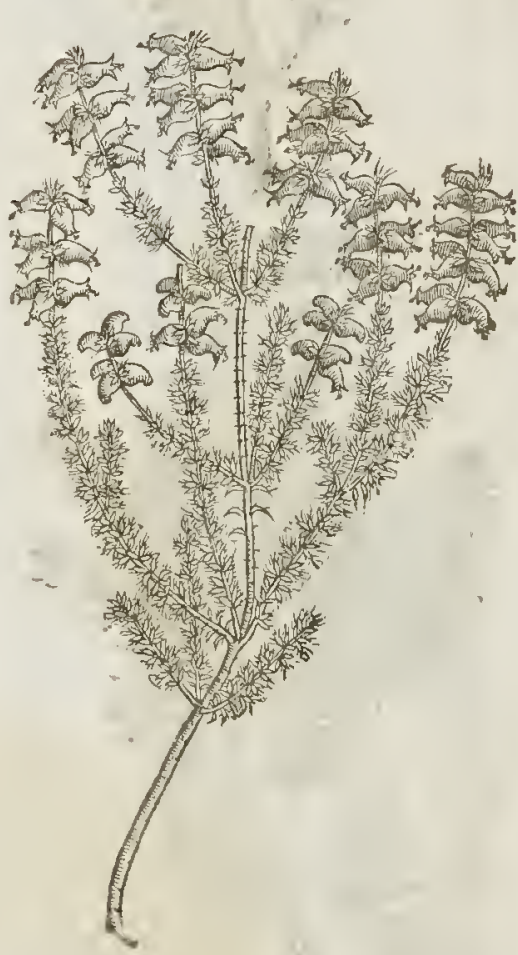

7 This fmall or thinne leafed Heath is alfo a low and bafe fhrub, hauing many fmall and flen der thoots comming from the root, of a reddirh browne colour; whereupon doe grow verie manie fmall leaues, not vnlike to them of common Time, but much fmaller and tenderer:the floures grow in tufts at certaine fpaces, of a purple colour. The root is long and of a wooddie fubftance. $\ddagger$ The branches of this are commonly whitin, the leaues very green : the floures are fmalleft at both ends and biggett in the middeft, hollow, and of a faire purple colour, which doth not eafily decay : it 
L1 B. 3. Of the Hiftory of Plants.

Aloures moft part of Stimmer, and growes in many Heathie grounds. $\ddagger$

8 Challiee Heath hath alfo many wooddy branches growing from the roots, flender, of a red. difh browne colour, a foot and a halfe high, garnithed with very licte lcaues, leffer than thofe of Time : the floures grow on the tops and vpper parts of the branches, and be in number, fiue, fix or moe, hanging downewards, in fafhion long, hollow within like a litte cunnell or open cup or challice, of a light purplifh colour : the root creepeth and putteth forth in diuers places neiv fprings or hoots.

9 The Heath that bringeth forth berries hath many weakeand flender brariches of a reddirh colour, which trailing vpon the ground do take hold thercof in fundry places, whereby it mightily increafeth : the leawes are fomcwhat broad, of a thicke and flefhie fubftance, in tafte fomthing dryIng at the firf, but afterwards fonewhat tharpe and biting the tongue: among which come forth fmall flotres of an herbie colour:which being vaded there fucceed fmall round berries, that at the firft are greene, and afterward blacke,being as big as thofe of I uniper ; wherciu is contained purple iuice like that of the Mulberry:within thofe berries are contained alfo fmall three cornered grains: the root is hard, and of a wooddy fubfance. $\ddagger$ I found this growing in great plenty in Yorkfhire on the tops of the hills by Gisbrough, between it and Rofemary-topin (a round hill fo called)and fome of the people thereabouts told me they called the fruit Crake berries. This is the fame that urat-

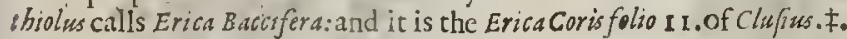

$¥$ ๑ Ericabacciferaprocimbens. Heath bearing Berriés. Einotrum migrum

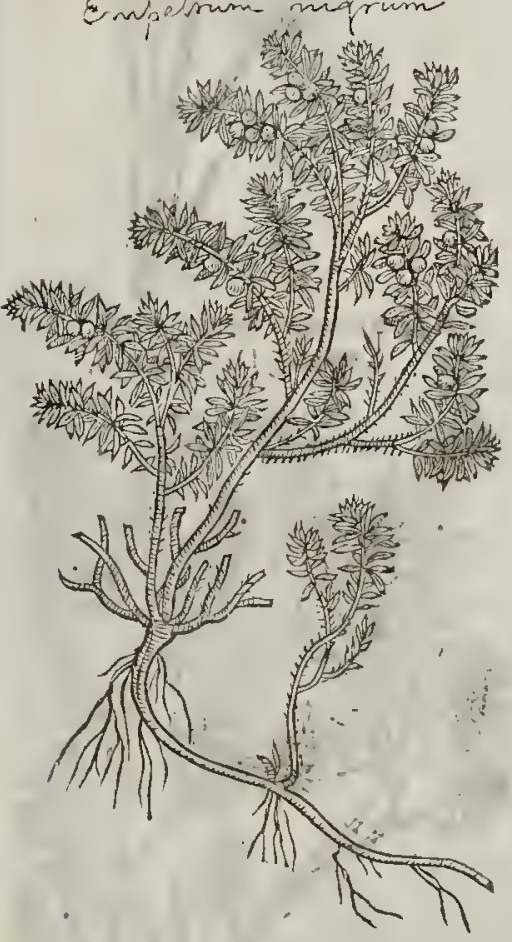

Io Ericabacciferatenufolia.

Small leafed Heath with Berries.

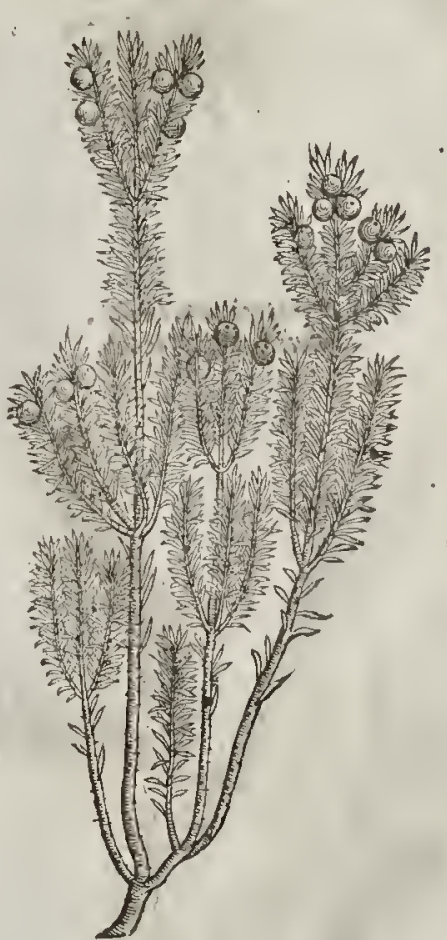

\# To This which our Authour figured as you feec in the tenth place/putting the defcription of the former thereto) hath brittle branches growing forne cubit high,conered with a barke blacker than the reft: the lcanes are like thofe of the former, but blacker and fmaller,growing about the ftalks by threes, of hottih tafte with fomeaftriction. In September and October it carries a fruit on the rops of the branches different from the reft, for it is very beautifull, white, tranfparent, refernbling dusky and vneuten pearles in formẹ and colour, fucculent alfo, and of an acide talte, commonly containing three little feeds in each berty: in Nouember this fruit becomes dry, and falls away of it felfe. Clufus onely ob ferticd this in Portugall, and at the firft fight a far off tooke the white berries to haue been graines of Manna. He calls it Erica Coris folio 10.

I I I remember ( Gith Dodossès) tliat I ob ferued another Heath which grew low; yet fent forth 
+ 11 Ericapumila,3.Dod. Dodonews his Dwarfe Heath.

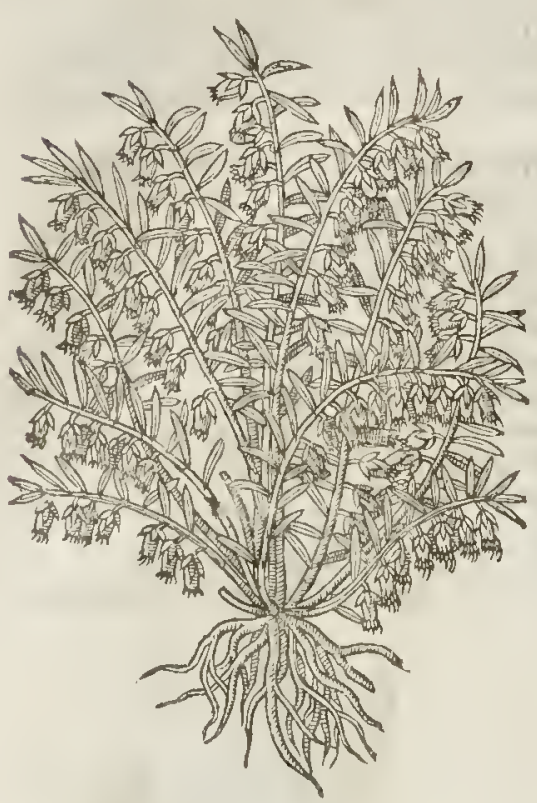

\section{\$3 Ericaperigrina Lobely.} cobels trange Heath.

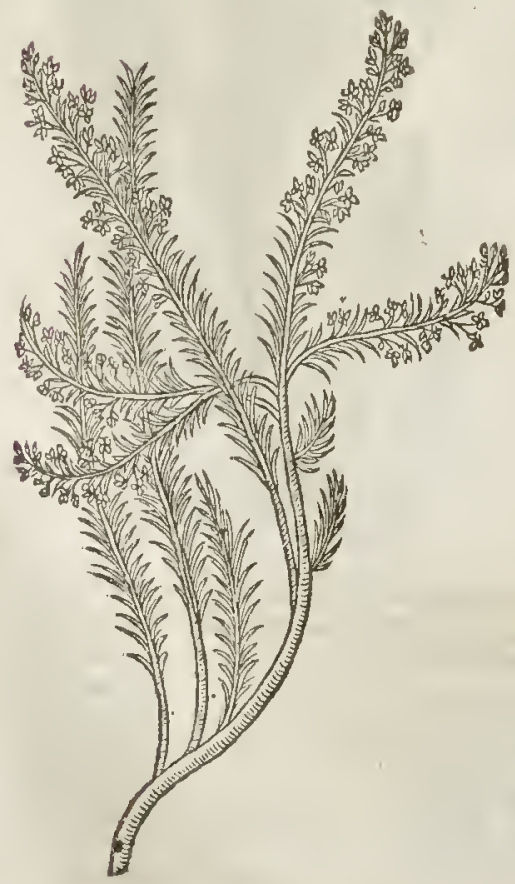

¥ 2 Ericat ternisper intervalla ramis. - Heath with three branches at a ioint.

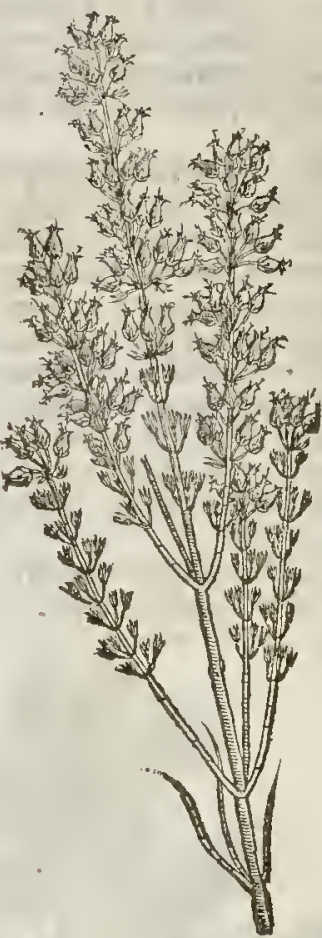

14 Evica Corisfolio 7. Clufyj. ..... Creeping Dutch Heath.

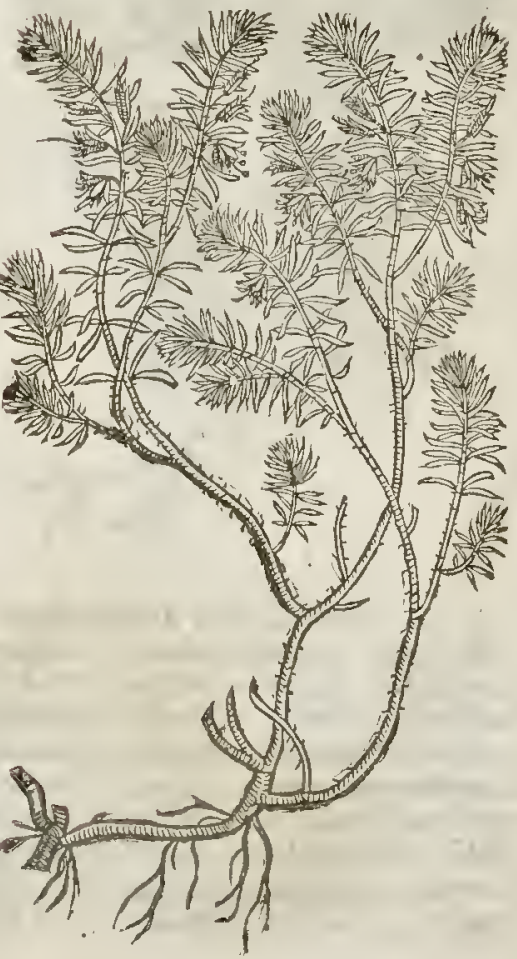


I 5 Erica Coris folio. 9. Clufij. Small Auftrian Heath.

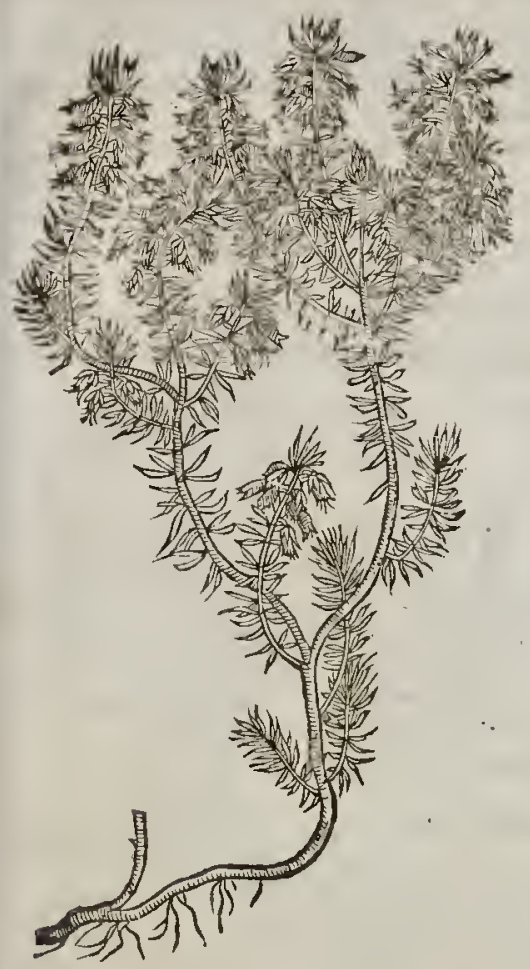

many wooddy and twiggy branches, hauing vpon them little narrow and longith leates; on thefe ftalkes fpike fathion to the tops of them, yet but on one fide, grow elegant redde floures, pointed with blacke. This growes in that tract of Germany which leads from Bohernia to Noremberg on dry and untilled places, and neere woods. It foures in Aprill.

I 2 This Rrubby Heath is commonly fone cubir high, hauing fender branches which come out of the maine ftemmes commonly three together; and the leaues alfo grow in the fame order; the tops of the branches arc adorned with many floures of a darke purple colour, hollow, round, biģgeft below, and itanding vpon long footitalks. Clufses found this growing in the vntilled places of Portingale abouc Lisbone, where it floured in December ; he calls it Erica Corus folio, 5 .

I 3 Befides all there (faith Lobel, hauing firft treated of ditiers plants of this kinde) there is a certaine rarer fpecies growing like the reft after the manner of a thrub in pots, in the Garden of $\mathrm{M}^{\prime}$.John Brancion: the leafe is long, and the purple floures, which as far as I remember confifted of foure little leaues apiece.grow on the tops of the branches. I know not whence it was brought, and therfore for rhe rarity I call it Erica peregrima, that is, Strange, or Forreine Heath.

I4 This hath many round blackin purple branches fome foot or cubit ligh, lying oft timies along vpon the ground : thefe are befet with many narrow little leaues, almoft like thofe of the third defcribed, yet fomew hat longer, commonly growing foure, yet fometimes fiue together, of
an aftringent tafte; the little floures grow on the top of the branches, longith, hollow, and of a light purple colour, comming out of foure little leaues almoft of the fame colour; when thefe are ripe and dryed they containe a blackinh and fmall feed; the root is hard, wooddy, and runnes diuers waies; the weake branches alfo that lie vpon the ground now and then take root againe. Cluf ims found this growing plentifully in diuers mountanous places of Germany where it floured in Lume, and Iuly.

I5 The weake ftalkes of this are fome foot high, which are fet with many fmall greene leates growing commonly together by threes; the tops of the branches are deckt with litrle hollow and Iongin floures dinided at their ends into foure parts, of a fen colour, together wi th the foure little lcaues out of which they grow, hauing eight blackinh little threds in them, with a purplifh pointall in the middle. The feed is blacke and fmall; the root wooddy as in other plants of this kinde.Clufius found this in fome mountanous woods of Auftria, where it floured in Aprill and May. $\ddagger$

\section{The Place.}

Heath groweth vpon dry mountaines which are hungry and barren, as vpon Hampfteed Heath necre London, where all the forts do grow, except that with the white floures, and that whicli beareth berries. $\neq$ There are not abouc three or foure forts that I could euer obferue to grow there. $\neq$

Heath wirh the white floures groweth vpon the downes neere vnto Granefend.

Heath which bearcth berries groweth in the North parts of England, namely, at a place called Crosby Raulenfwaith, and in Crag clofe alfo in the fame countrey: from whence I haue receiued the red berries by the gift of a learned Gentlemancalled $\mathrm{M}^{\mathrm{r}}$. Iames $T$ h bwaites.

$$
\text { बा The Time. }
$$

Thefe kindes or forts of Heath do for the moft part floure all the Sommer, enen vntill the lan of September.

$$
\text { If The Names. }
$$

Heath is called in Greeke, ipsien : in Latine alfo Erica diuers do fally name it Myrica: in high and low Dutch, laciben: in Italian, Erica: in Spanih,Brefo Quirro: in French, Bruyre: in Englifh, Heath, Hather, and Linge. 


\section{The Temperalure.}

Heath hath,as Galen faith, a digefting facultie, confuming by va ors ahe foures and leaves arc to be vfed.

$$
\text { The Vertues.. }
$$

A The tender tops and Aloures, faith Diofcorides, are good to be laid vpon the bitingsard finjigs of any venomous beaf : of thefe foures the Bees do garher bad hony.

B . The barke and leaues of Heath may be vfed for, and in the fame caufes that Tamarishe is ved.

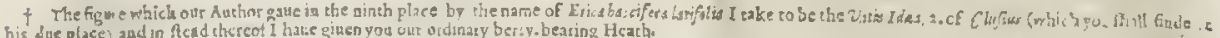

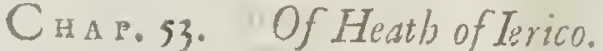

Tofa Hierieontesmaior.

The Heath Role of Ierico.

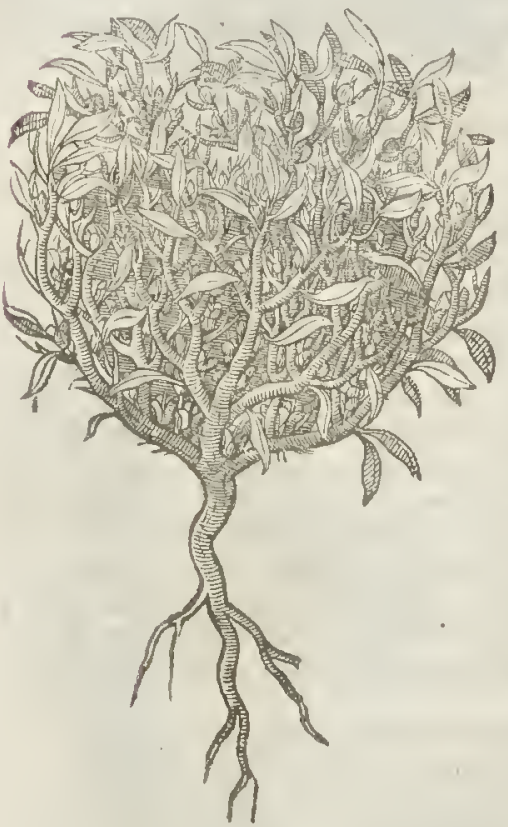

Tा The Deforiphes.

I. THiskinde of Heach which of the later writers hath been called by the name Rofa Haricontea; the coiner fpoiled the name in the mint, for of all plants that have bin written of, there is not any more vnlike varo the Rofe, or any kinde thereof than this plantwhat moued them thereto I know not:but thus much of my owne knowledge, it hath neither hape, nature, nor facultie agrecing with any Role: the which doubtleffe is a kinde of Heath, as the barren foile, and that among Heath, doth euidently thew, as alfo the Hearhie matter wherewith the whole plant is pofleffed,agreeing with the kindes of Heath in very notable points. It rifeth vp out of the ground, of the height of four inches, or an hand breadth, compact or made of fundry hard Atickes, (which are the ftalkes) clafping or fhuting it felfe together into round forme, intricately weauing it felfe one Ricke ouer thwart another, like, a little net:vpon which wooddy ftickes do grow lcaus not vnlike to thofe of the Oliue tree, which maketh the whole plant of a round forme, and hollow with. in; a mong the leaues on the infide grow fmalt mofre foures, of a whitinh herbie colour, which

2 Rofa Hierigontea ficcata. The Heath Rofe of Terico dricd.

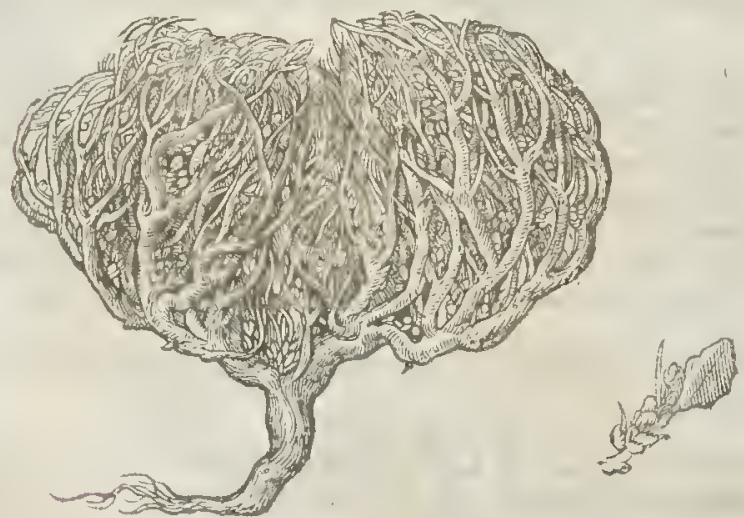


$\mathrm{L}_{1 \text { в. 3. }} \quad$ Of the Hiftory of Plants. turn into little feed, like the feed of Rocket, but leffer : the whole plant is of the fubftance of heath,
and wooddie.

2 The fecond figure fettecth forth the dried plant,as it is brought vntovs from beyond the feas: which being fet into a difh of warme water, for halfe an houre, openeth it felfe in forme, as whei it did grow, and taken forth vntill it be drie, returneth thut vp againe as before.

$$
\text { बा } T \text { be Place. }
$$

It groweth in the barren grounds of France, and other hot regions, among the Heath and fuch like plants : it is a ftranger in England, yer dried we haue them in great plenty. $\neq I$ haue not read nor heard that this grows wilde in France; but Bellonius faith it growes in Arabiadeferta : Baukne faith it eafily grew and flourifhed many yeares in his garden at Bafill. $\ddagger$

$$
\text { 7. The Time. }
$$

The feed being fowne in our cold climate, is fowne in A prill ; it perifheth when it is fprung vp, and bringeth neither floures nor feed.

$$
\text { T) The Names. }
$$

This kinde of Heath is called Rofa Hiericontea, or de Hiericho, the Rofe of Ierico: of fome, the Rofe of Ierufalem, and alfo Rofa UAaria : in Englifh, the Heath Rofe.

\section{The Temperature and Vertues.}

There is not any of the antient nor later writers that hate fet downe any certaintie of this plant $A$ as touching the temperature and faculties, but onely a bare picture with a Aender defeription.

\section{Cha P. 54. Ofthe Chafte Tree.}

I Vitex, five Agnus Caflus.

The Chafte tree.

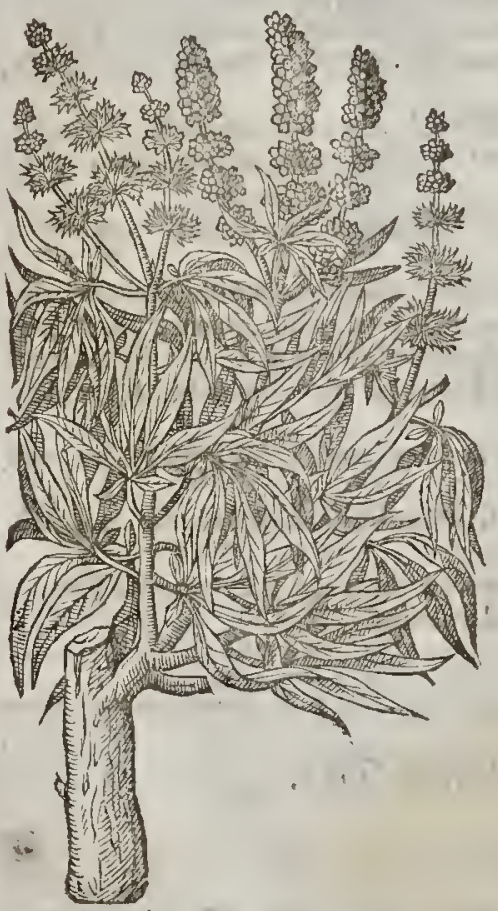

\# 2 Vitex latiore forrato folio.

Chafte tree with cut leates;

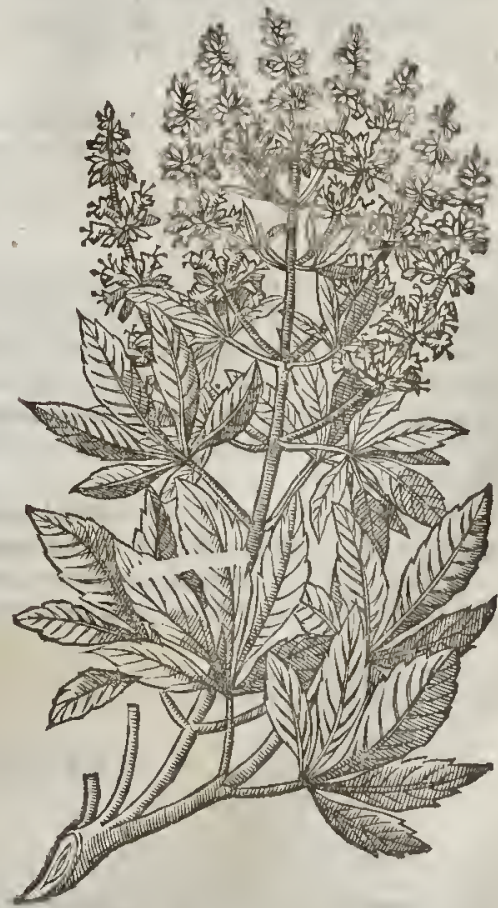




\section{If The Defription.}

I 7 Itex, or the Chafte tree, growetl after the manner of a burfie fhrub or hedge tree, hauing many twiggic branches, very pliant and ca fie to be bentwithout breaking, like to the willow:the leaues are for the moft part diuided into fute or feuen fections or diuifions, much like the leaues of Hemp, whereof each part is long and narrow, very like vnto the willow leafe, but fmaller : the floures do grow at the vppermoft parts of the branches, like vn to fpikie eares, cluftering together about the branches, or a light purple or blew colour,and very fweet fmel: the fruit is fwall and round, like vnto the graines or cornes of pepper.

$¥ 2$ Lobel mentions ano ther varietie hereof that differs from the former onely in that it hath broader leaues, and thefe alfo fnipt about the edges. $\ddagger$

I The Place.

Vitex groweth naturally in Italy, and other hot regions, by water courfes and running frcames: Ihaue itgrowing in my garden.

$$
\begin{aligned}
& \text { ritex beginneth to recourer his laft leaues in May;, and the floures come forth in Augurf. } \\
& \text { a) } T \text { he } \mathcal{X} \text { ames. }
\end{aligned}
$$

$\dagger$ The Grecians call this thrub arros, and roger: Agnos (i.) Caftus, Chafte : becaufe, faith Pliny in his 24.booke,9. Chapter, the Athenian Matrons in their fealt called $\tau$ hefmophoria dedicated to the honour of $C$ cres, defirous to keepe themfelues chafte, doc lay the leaues in their bedsvnder them : the Latines name it $V$ itex, and of diuers it is termed, as wee finde among the baftard and counterfeit names, ${ }^{*}$ wow: in Latine, Salix marina, or Salix Amerina, and piper Agrefte: in high Dutch, 5 chaff $\Rightarrow$

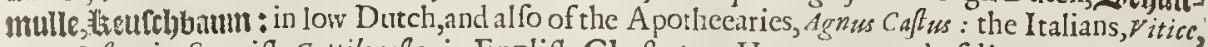
Agno Cafto: in Spanith, Gattilecafto: in Englifh, Chafte tree, Hempe trec, and of diuers Agnus cajtrs. $\mp$ The name $A$ grus $C$ aftus comes by confounding the Greeke name Agnos with Caftus, the Latine interpretation thereof. $\ddagger$

\section{Tा The Temperature.}

The leaves and fruit of Agmas caftus are hot and drie in the third degree: they are of very thin parts, and watte or confume winde.

The Vertues.

A Agrus Caftus is a fingular medicineand remedie for fuch as would willingly liue chafte, for it with frandeth all vncleanneffe, or defre to the fleth, confuming and drying vp the feed of generation, in what lort foeter it be taken, whether in pouder onely, or the decoction drunke, or whether the leaties be carried about the body; forwlich caufe it was called Caftus; that is to fay, chafte; cleane,and purc.

B The feed of Agnus Caftus drunken, driueth away, and difolueth all windineffe of the ftomaeke, openeth and cureth the ftoppings of the liter and fpleen, and in the beginning of dropfies, it is good to be drunke in wine in the quantitic of a dram.

C The leaues ftamped with butter, diffoltuand affwage the fwellings of the genitories and cods? being applied thereto.

D The decotion of the herbe and feed is good againft pain and inflammations about the matrix, if women be caufed to fit and bathe their priuy parts therein: the feed being drunke with i Penny: roiall bringeth downe the menfes, as it dothalfoboth in fume and in a peflary: in a Pultis it cureth the head-ache, the Phrenticke, and thofe that haue the Lethargie are woont to be bathed herewith,oileand vineger being added thereto.

E The leaucs vfed in a fume, and alfo frowed, driueaway ferpents; and beeing laycd on doe cure their bitings.

F The leed laied on with water doth heale the clifts or rifts of the fundament; with the leaues, it is a remedic for lims out of ioint, and for wounds.

$G$ It is reported that if fuch as iourney or traucll do carry with them a branch or rod of $A g$ mus $C a$ ftus in their land, it will keep them from Merry-galls, and wearinefle: Dioge.

\section{Cuas. 55. Of the Willow Tree.}

\section{The Defcription.}

I THe common Willow is an high tree, with a body of a meane thickneffe, and rifeth $v p$ as high as other trees doe if it be not topped in the beginning, foone after it is planted; the barke 
LIB. 3. Of the Hiftory of Plants.

1389.

barke thereof is fmooth,tough, and fexible : the wood is white, tough, and hard to be btoken : the Icaues are long, leffer and narrower than thofe of the Peach tree, fomewhat greene on the vpper fide and flipperie, and on the nether fide fofter ahd whiter: the boughes be couered either with a purple, orelfe with a white barke: the carkins which grow on the toppes of the branches come firft of all forth, being long and mofie, and quickly tutne into white and foft downe, that is carried away with the winde.

$$
\text { I salix. }
$$

The common Willow.

$$
5 x-4 \text { a } 36 x
$$

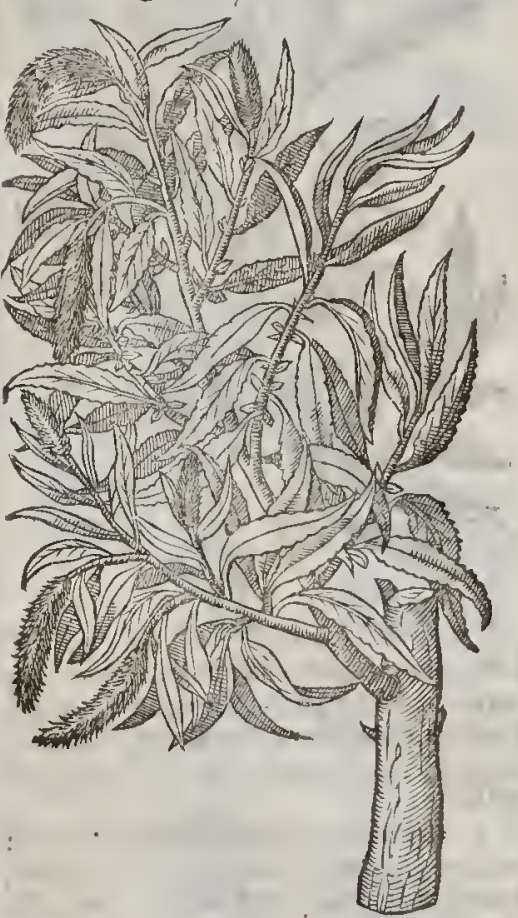

2 Salix aquatica.

The Oziat or watet Willow.

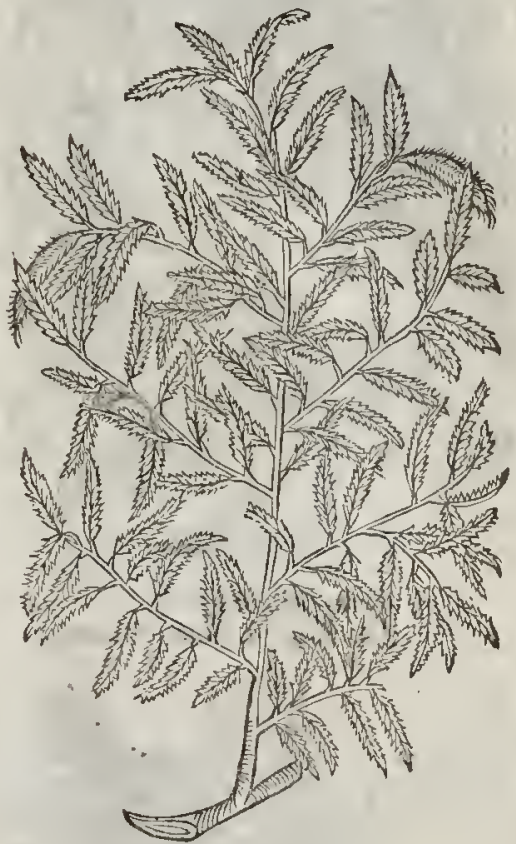

2 The leffer bringeth forth of the head, whieh ftandeth fomewhat out, flender wands or twigs, witls a reddith or Greene barke, good to make baskets and fuch like workes of: it is planted by the twigs or rods being thruft into the earth, the upper part where of when they are growne vp, is cur off, fo that which is called the head increafeth vnder them, from whence the flender twigs doe grow, whieh being oftentimes cut, the head waxeth greater: many times alfo the long rods or wands of the higher $\mathrm{W}^{\prime}$ trhy trees be lopped off and thruft into the ground for plants, but deeper, and aboue mans height : of which do grow great rods, profitable for many things, and commonly for bands, wherewith tubs and easks are bound.

2 The Sallow tree or Goats Willow, groweth to a tree of a meane bigneffe:the trunke or bo$\mathrm{dy}$ is foft and hollow timber,coured with a whitith rough barke: the branches are fet with leaues fomewhat rough, greene abone, and hoarievnderneath : among which come forth round catkins, or aglets that turne into downe, whieh is carried away with the winde.

4 This other Sallow tree differeth not from the precedent, but in this one point, that is to fay; the leaues are greater and longer, and euery part of the tree larger, wherein is the difference. $\ddagger$ Both thofe laft deferibed haue little roundifh leaues like little eares growing at the bottoms of the footftalkes of the bigger leates, whereby they may bee diftinguiihed from all orher Planes of this kinde. $\ddagger$

5 The kofe Willow groweth vo likewife to the hetght and bigneffe of a thrubby tree; the body whereof is conered with a lcabbed rong h barke : the branches are many, whereupon do grow very many tw igs of a reddith eolour, garnifhed with fmall long leaues, fomewhat whitifh: among ft which come forth litrle floutes, or tather a multiplieation of leaues, ioined together in forme of a 


\section{0 \\ Of the Hiftorie of Plants. \\ L: 18.3 .}

3 Salix Caprearotundifolia. The Goat round leafed Willow.

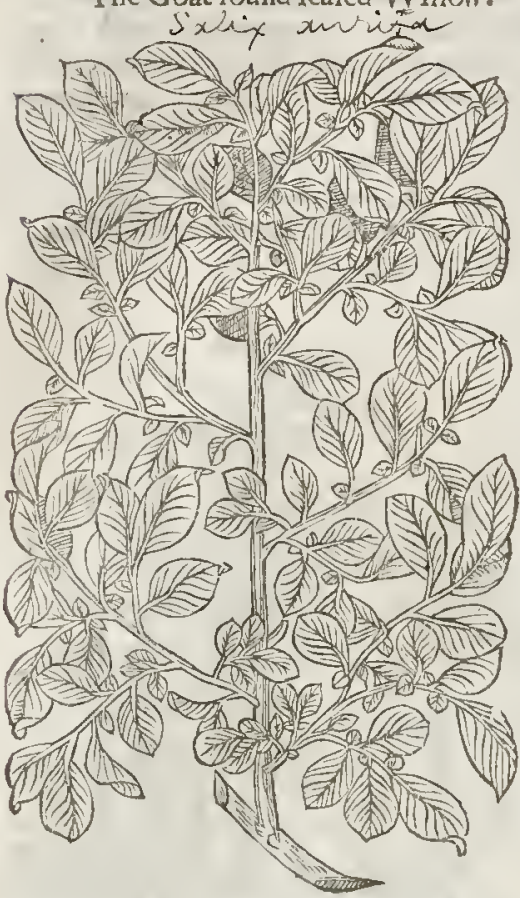

's Sulix Rofea Anglica.

The Englith Rofe Willow:

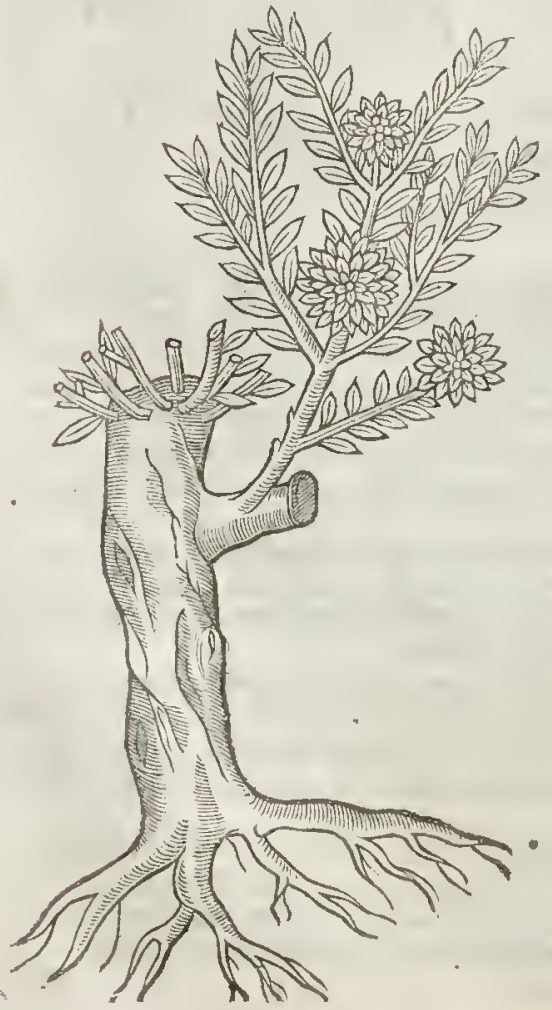

4 Salix Caprea latifoliz.

- The Goat broad leafed Sallow:

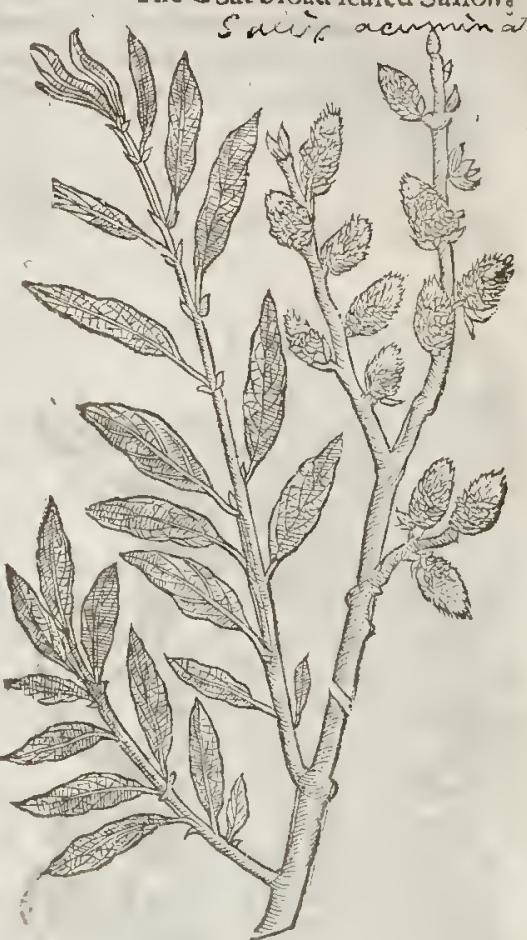

Rofe, of a greenifh white colour, which doe not only make a gallant thew, but alfo yeeld a moft cooling aire in the lieat of Sommer, being ret vp in houfes, for the decking of the fame

6 - The low or bafe Willow groweth but low, \& leaneth weak Iy vpon the ground, hauing many fmall and narrow leaues, fet vpon limber and pliant branches, of a darke or blackith greene colour : amongft which come forth long flender ftems full of moffie flotres, which turne into a light downie fubftance that flierh away with the winde.

7 The dwarfe Villow hath very fmall and nender branches, feldome times aboue a foot, but neuer a cubit high, couered with a duskifh barke, with very little and narrow leaucs, of a greene colour aboue, and on the vpper fide, but vnderneath of a hory or oucrworne greenifh colour, in bigneffe and faThion of the leaues of garden Flax : among which come forth little duskilh floures which doe turne into downe that is carried away with the winde: the root is fmall and threddy, of the bigneffe of a finger,and of a blackinh colour.

8 There is another kinde of willow like co the former, and differeth from it in that, the leaues of this kinde are fmaller and narrower, as big as the leaues of Myrtle, hauing fmall knobbie floures of a duskin co-

lotry 
$\mathrm{L}_{1 \mathrm{~B} 63 .} \quad$ Of the Hiftorie of Plants.

1391

6 Salix humilis.

The low Willow.

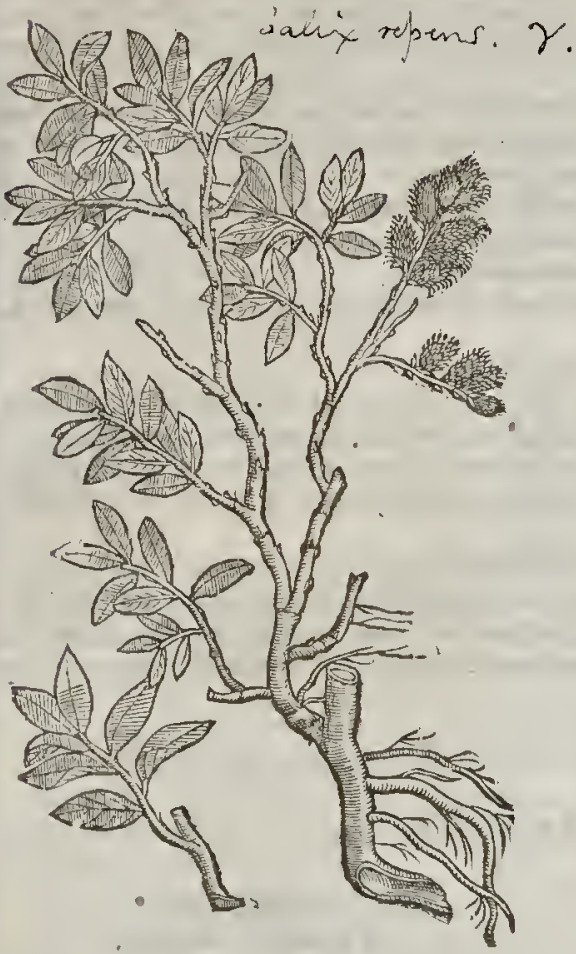

\$ Salix humilis repens:

Creeping dwarfe! Willow:

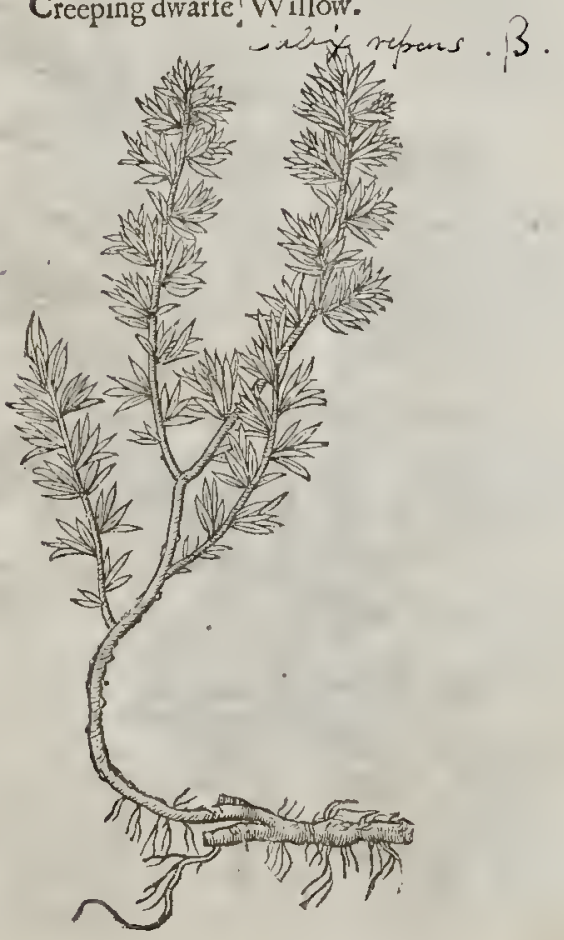

7 Chamaitca, fure Salix pumila. Thedwarfe Willow.

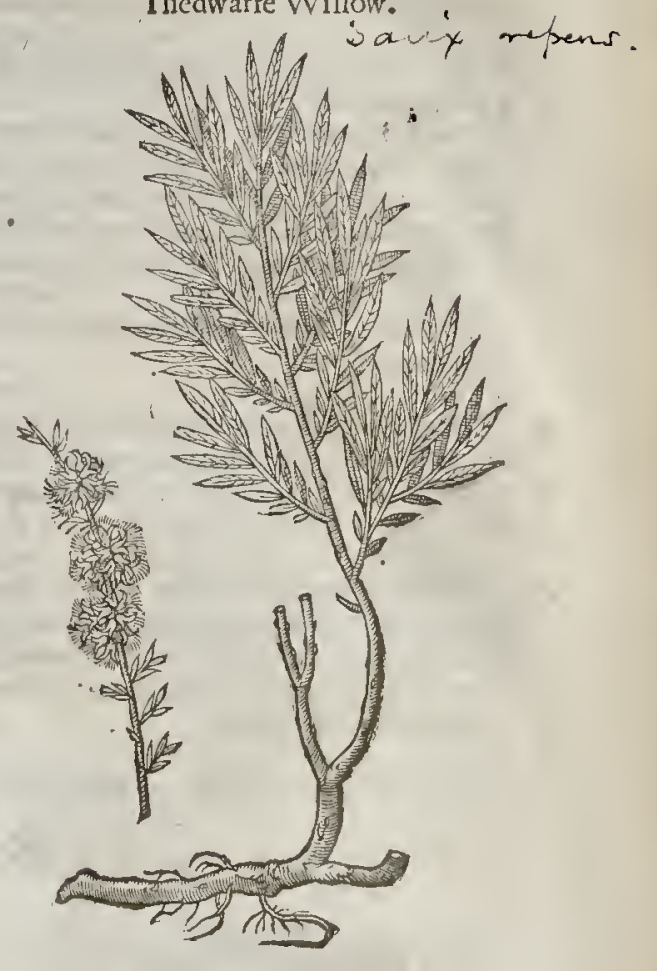

colour, which turne into downe that flyeth away with the winde : the root is fmall and limber, not growing deep, but running aiong vpon the vpper eruft of the earth.

$$
\text { of The Place. }
$$

Thefe Willowes grow in diuers places of England: the Rofe-Willow groweth plentifully in Cambridge fhire, by the riuers and ditches there in Cambridge towne they grow aboundantly about the places called Paradife and Hell-mouth, in theway from Cambridge to Grandchefter: I found the dwarfe Willowes grow ing neere to a bog or marifh ground at the further enci of Ha.npfted heath vpon the declining of the hill, in the ditch that inclofeth a finall Cottage there, not halfe a furlong from the faid houfe or cottage.

$$
\text { बT The Time. }
$$

The willowes do floure at the beginning of the Spring.

$$
\text { T The Names. }
$$

The Willow tree is called in Greeke 'Ifrx: in Latine, Salix : in high-Dutch, nepoen: in low-Durch, noilgen: in Italian, Sallce, Salcio : in French, Saux: in Spanin, salsueiro, Salzer, and Sauz : in Englinh, Sallow, W ithie, and Willow. 
The greater is ealled in Latine Sulix perticalis, common Withy, Willow, and Sallow, efpecial. ly thar which being often lopped fendeth out from one head many boughs : the kinde hereof with the red barke is called of $T$ bcophraft us, blacke Withy; and the other, white: Pliny calleth the black Greca, or Greeke Withie (the red, being the Greeke Withy, faith he, is eafie to be eleft) and the whiter, Amcrina.

Theophraftes writeth, that the Areadians do eall the leffer 'Earn', not 'Ir's : Pliny alfo naneth this Helice : both of them do make this tobeSalcis tertia pecies, the third kinde of Sallow : the fame is likewife called in Latine, Salixpumila, Salix viminalis, Gallica Salix, and by Columella, Sabina, whieh he faith that many do terme smerina: irfhigh-Dureh, klleyn noevoen : in low-Duteh, naimen: in Englifh, Ofier, fmall Withy, Twig Withy: Petrus Crcjcentus nameth it Fincus.

The Temperature.

The leaues, floures, feed, and barke of Willowes are eold and dry in the feeond degree, and a. fringent.

The Vertues.

A The leaues and barke of Withy or Willowes do ftay the fpitting of bloud, and all other fuxes of bloud whatfeuer in man or woman, if the faid leaues and barke be boiled in wine and drunke.

B The greene boughes with the leaues may very well be brought into ehambers and fet about the beds of thofe that be fieke of feuers, for they do mightily eoole the heate of the aire, which thing is a wonderfull refrefhing to the ficke Patienrs.

C The barke hath like vertues: Diofcorides writeth, that this being burnt to afhes, and fteeped in vineger, takes away cornes and other like rifings in tie feet and toes : diuers, faith $G$ alen, doe flit the barke whileft the Withy is in fouring, and gather a ecrain iuice, with which they vic to take aw ay things that hinder the fight, and this is when they are confrained to vfe a elenfing medicine of thin and fubtill parts.

\section{Chap. 56. Of the Oliue Tree.}

I oleafativa.

The manured Oliue tree.

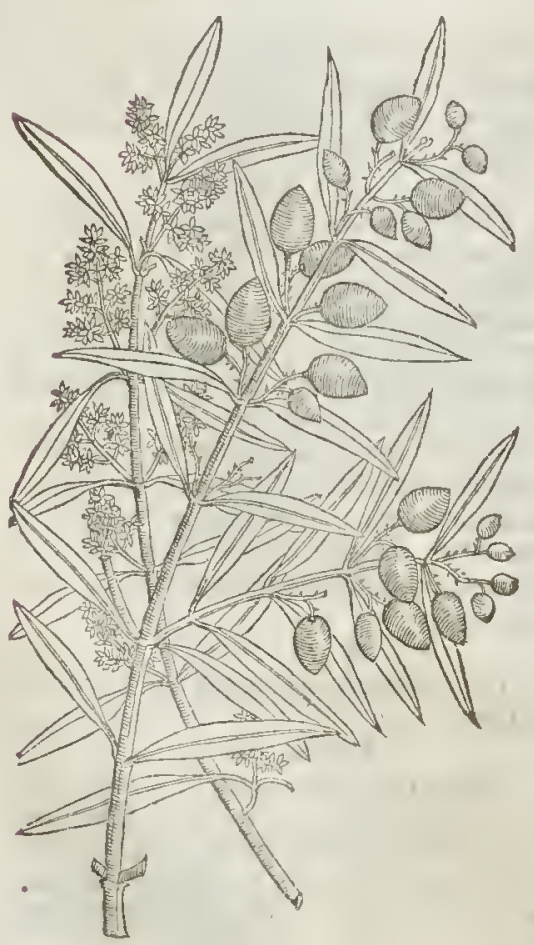

2 Oleafyluefris."

The wilde Oliue tree.

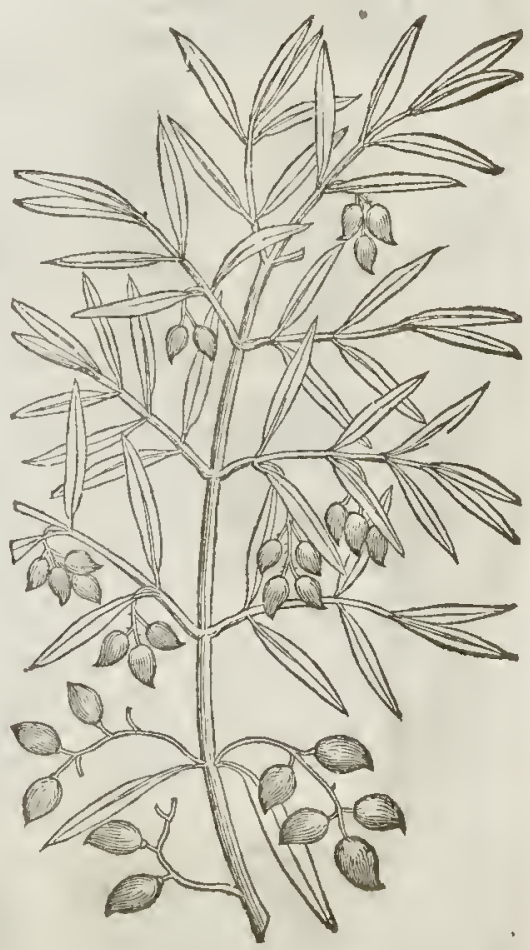




\section{It The Defription:}

I THe tame or manured Oliue ttee groweth high and gteat with mány branches, full of

1 long narrow leates not much vnlike the leaues of Willowes, but narrower and fraaller: the floures be whire and very fmall, growing vpon elufters or bunehes : the fruit is long and round; wherein is an hard ftone: from whieh fruit is preffed that liquor which we call oyle Oliue.

2 The wilde Oliue is like vnto the tame or garden Olitie tree, fauing that the leaues are fomething fmaller : among which fometimes dogrow many priekely thotnes : the fruit hereof is leffer than of the former, and moe in number, which do feldome come to maturitie or ripenes in fomuch that the oilewhich is made of thofe berties continueth enet green, and is called Oile Omphacine, or oile of vnripe Olines.

$$
\text { -I The Place. }
$$

Botl the tame and the wilde Oliue trees grow in very many places of Italy, Franee, and Spaine, and alfo in the Iflands adioyning: they are teported to loue the fea coafts; for moft do thinke, as Colmmell wrriteth, that aboue fixty miles from the fea they either dy, or elfe bring forth no fruit: but the bef, and they that do yeeld the moft pleafant Oyle are thofe that grow in the Ifland called Candy.

$$
\text { T The Time. }
$$

All the Olitie trees floure in the moneth of Iune : the fruit is gathered in Nonember or Deeem: ber: when they be a little dried and begin to wtinckle they are put into the preffe, and out of them is fqeezed oile, with water added in the preffing : the Oliues which are to be preferued in falt and pickle mutt be gathered before they be tipe, and whileft they are greene.

\section{The rames.}

The tame or garden Olitue tree is called in Greeke 'Exein, and 'Exia inmers : in Latine, oles fatiua, and vrbana : in high-Dutch, Delbaum : in low-Dutch, Wliffboome: in Italian, olino domeftico : in Fteneh, oliwier : in Spanifh, oliwo, and oliwera : in Englifh, Oliue tree.

The berty is called olwa: in Grecke alfo 'raxia : in Spanifh, Azeytuma : in French, Dutch, and Englim, Olite.

Oliues prefertedin brine or pickle are called Colymbades.

Thewilde Oline tree is named in Greeke, 'Ayenaix : in Latine, olen fylueftris, oleafter, Cotinus, olen exthiopica : in Duteh, naald Delbaum: in Italıan, olino Jaluatico: in Spanifh, Arebuche, Arambutheyro: in Fteneh, oliwier futurge': in Englinh, wilde Oline tree.

\section{Th The Temperature and $v$ ertucs.}

The Oliues which be fo ripe as that enther they fall off themfelues, or be ready to fall, which are named in G reeke, suvmuis, be moderatly hot and moift, yet being eaten they yeeld to the body little nourihment.

The viripe oliues are dry and binding.

Thofe that are preferued in pickle, called Colymbades, do dry vp the ouermuch moifture of the $\stackrel{\mathrm{C}}{\mathrm{C}}$ ftomacke, they remoue the loathing of meate, f tirre vp an appetite; but thete is no nourithment at all that is to be looked for in them, mueh leffe good nourifhment.

The branches, leaues, and tendet buds of the Oliue tree do coole, dry, and binde, and efpecially of the wilde Oliue; for they be of greater force than thofe of the tame : therefore by rea fon they be milder they ate bettet fot eye medieines, which have need of binding things to be mixed with them.

The famedo ftay S. Anthonies fire, the fhingles, epiny fides, night wheales, carbuncles, and ea- $E$ ting vlcers: being laid on with honey they take away efchares, clenfe foule and filthy vlcers, and quench the heate of hot fivellings, and be good for ketnels in the flanke : they heale \& skin wounds in the head, and being chewed they are a remedie fot vlcers in the mouth.

The inyce and decoetion alfo are of the fame effect: moteonet, the iuice doth fay all manet of F bleedings, and alfo the whites.

The inice is preffed forth of the ftamped Ieaues, witli wine added thereto (which is better) or $\mathbf{G}$ with water, and being dried in the Sun it is made vp into little eakes like perfumes.

The fiveat ot oyle which iffictl forth of the wood whileft it is in burning healeth tettets, feurfs $\mathrm{H}$ and fcabs, if they be anointed therewith.

The fame which is preffed forth of the vnripe Oliues is as eold as it is binding.

The old oile which is made of fweet and ripe Oliues, bcing kept long, doth withall become hotter, and is of greater force to digeft or wafte away; and that oile which was made of the unripe $\mathrm{O}$. liue, being old, doth as yet retaine fome part of his former aftriction, and is of a mixt faculty, that is to fay, partly binding, and partly digefting; fot it hath got this digefting ot confuming faculty by age, and the othet propertic of binding of his owne natute. 
I. The oile of ripe Olines mollifieth and affwageth paine, diffolueth tumors or fwellings, is good for the ftiffeneffe of the ioints, and againft cramps, efpecially being mingled according to art,with good and wholefome herbes appropriate vnto thofe difeafes and griefes, as Hypericon, Cammomill, Dill, Lillies, Rofes, and many orhers, which do fortifie and increafe his vertues.

The oile of unipe Oliues, called omphacinum oleum, doth ftay, repreffe, and drine away the beginning of tumors and infammations, cooling the heate of burning vlcers and exulcerations.

\section{C на P. 57. Of Prinet or Prin Print.}

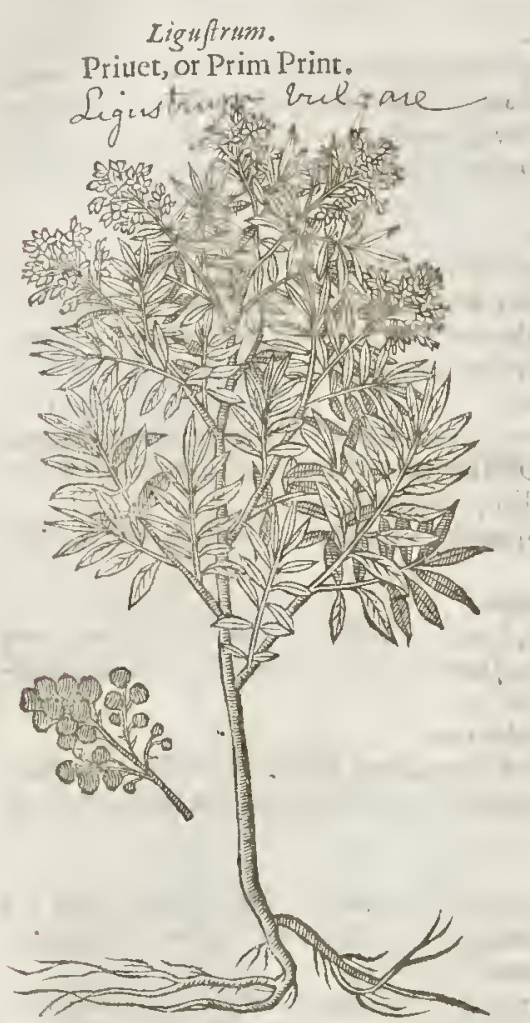

$$
\text { बा The Defoription. }
$$

Riuer is a fhrub growing like a hedge tree; rhe branches and twigs wherof be ftraighr, and courered with foft gliftring leaues of a deepe green colour, like thofe of Permincle, but yet longer, greater alfo than the leaues of the Oliue tree: the floures be white, fweet of fmell, very little, growing in clufters; which being vaded there fucceed clufters of berrier, at the firft greene, and when they be.ripe black like a little clufter of grapes, which yeeld a purple inice : the root groweth euery way aflope.

\section{a $1 .$. The Place.}

The common. Priuet groweth naturally in enery wonl, and in the hedge rowes of our London gardens : it is not found in the countrey of Polonia and other patts ad iacent.

$$
\text { The Time. }
$$

It floureth in the end of May, or in Iune : the berties are ripe in Autumne or about Winter, which now and then continue all the Winter long; but in the meane time the leaues fall away, and in the Spring new come vp in their places.

$$
\text { 9f The Names. }
$$

It is called in Latine, Liguftrum : in Italiar at this day, Guiftrico, by a corrupe word drawne from Liguftrum : it is the Grecians om pisa, and in no wife woes: for Cyprus is a hrub that growerh naturally in the Eaft, and Priuet in the Weft. They be very like one vnto another, as the deferiptions doe declare, but yet in this they differ, as witneffeth Bellonius, becaufe the leaues of Priuet do fall aivay in winter, and the leanes of Cyprus are alwaies greene : moreouer, the leaues of Cyprus do make the haire red, as Diofcoriates faith, and (as Bellonius reporterh) do giue a yellow colour : but the leaues of Priuet haue no vfe at all in dying. And therefore Pliny, lib.24.Cap.10. was deceiued, in that he iud ged Pritet to be the felfe fame tree which Cyprus is in the Eaft : which thing notwithftanding he did not write as hee himfelfe thought, but as other men fuppofe; for, lib.12. cap. I 4. he writeth thus : Some (faith he) affirme this, vit. Cyprus, to be that treewhich is called in Italy, Lignftrum; and that Liguftrum or Priuet is that plant which the Grecians call asuvere, the defcription dorh declare.

P billyrat, faitly Diofcorides, is a tree like in bigneffe to Cyprus, with leaues blackerand broader than thofe of the Oline tree : it hath fruit like to that of the Maftick tree,blacke,fontething fweet, ftanding in cluters, and fuch a tree for all the world is Pritet, as we haue before declared.

Serapro the Arabian, cap.44. doth call Primet Mabaleb. There is alfo another Mabaleb, which is a graine or feed of which Auicen maketh mention, cap.478. that it doth by his warme and comfortable heate diffolte and affirage paine. Serapio feemeth to intreat of them both, and to containe di-

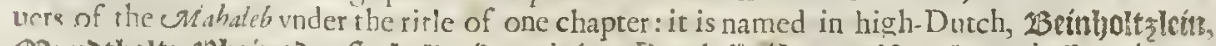

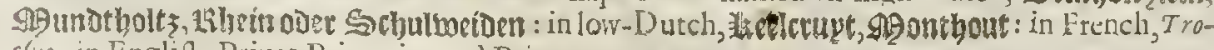
efre : in Englih, Priues, Primprint, and Print, 
L18.3. Of the Hiftorie of Plants.

Some there be that would hate the berries to be called Vaccinia, and Faccinium to be tin at of which Vitruvius hath made mention in his feuenth booke of Architecture the art of birilding.? chap. 14. of purple colours:after the fame manner, faith he, they temper $r$ asciminm, and putring milke vnto it do make a gallant purple : in fuch breuitic of the old writers what can be curaineiv determined.

The leaues and fruit of Privet are cold, dry, and aftringent.

\section{The Vertues:}

The leaues of Priuet do cure the fwellings, apoftumations, and wicers of the mouth or throat, being gargarifed with the iuyce or decostion thereof, and therefore they be excellent gond to be pur into lotions, to wath the fecret parts, and the fcaldings with women, cankers and fores in childrens mouthes.

\section{С н р:58. Of Mocke-Prinet.}

1 Phillyreangufifolia.

Narrow leaued Mock-Prituet.

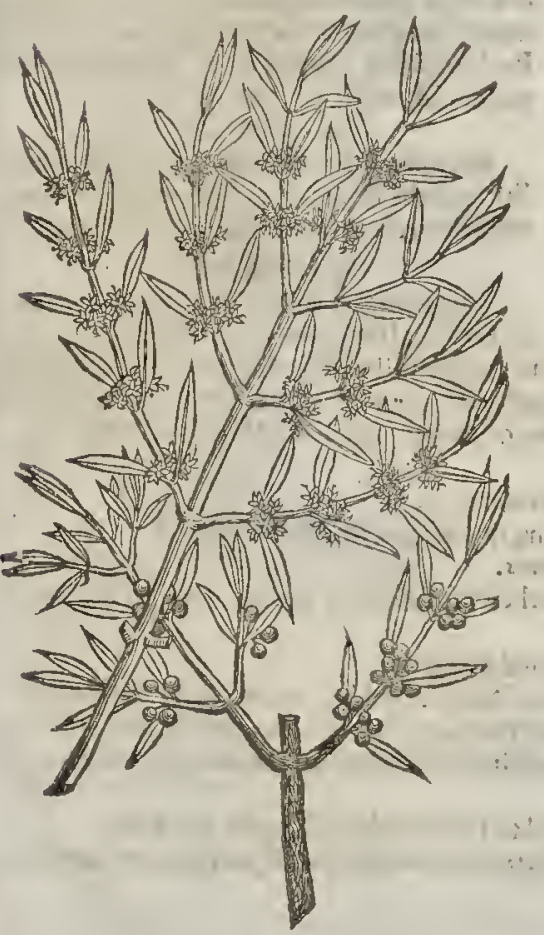

2 Phillyrealationefolio. The broader leaued Mock-Priuet.

The Deforipition.

Y Yprus is a kinde of Priuer, and is called phillyred, which rame all the forts or kindes therenf do retaine, though for diftinctions fake they paffe vnder fundry titles. This plant groweth like an hedge tree, fometimes as big as a Pomegranat tree, befet with flender twiggy boughes which are garnithed with leaues growing by couples, very like the leaues of the Oliue tree, but broader, fofrer, and of a greene colour : from the boromes of the le leaties come fortl great bunches of fmall white floures, of a pleafant fweet fmell : which being vaded, there fucced clifters of blacke berries very like the beiries of the Alder tree:

2. The fecond Cyprus, called alfo Phillyrea latifolia, is very like the former in body, branches, 


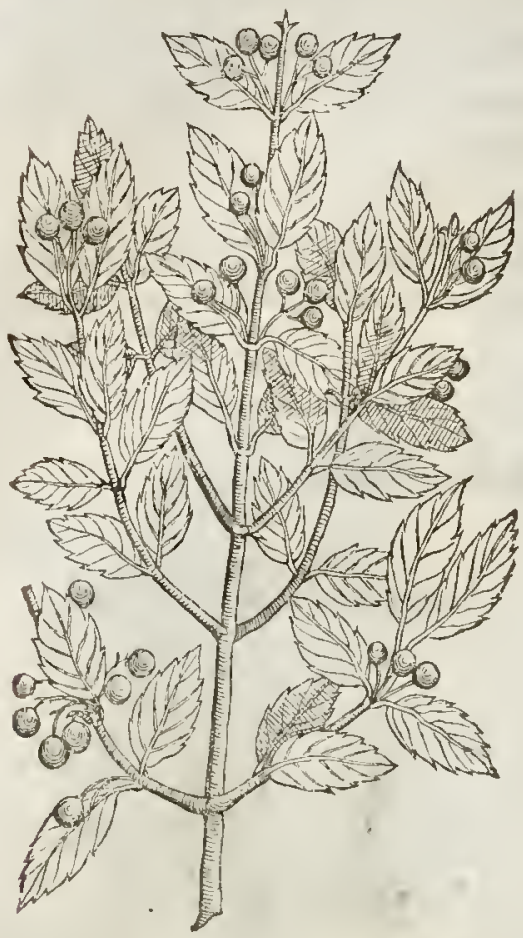

3 phillyreaferrata 2. Clufij.

The fecond toothed Privet of clufius.

leaues, floures, and fruit; and the difference is this, that the leaues of this plant arebrodder, but in facultie they are like.

3 This kinde of Priuet rifeth vp like an hedge birfh, of the height of fitueor fix cubits : the branches are long, fragile or brittle, couered with a whicin barke; wheteon are fet leanes fomwhat broad, iagged on the edges like the teeth of a faw, and of a deep green colour:among which come forth the floures, which neither my Author nor my felfe haue feene : the berries grow vpon fmall footftalks, for the moft part three together, being round, and of the bigneffe of pepper graines, or Miyrtle berries, of a blacke colour when they be ripe.

\section{The Place.}

Thefe plants do grow in Syria neere the city Afcalon, and were found by our induftr1ous Pena in the mountaines neere Narbone and Montpelier in France : the which $I$ planted in the garden at Barn-Elmes neere London, belonging to the right Honourable the Earle of Effex : I hane them growing in my garden likewife.

$$
\text { I The Time. }
$$

The leaues thoot forth in the firft of the Spring : the floures fhew themfelues in May and Iune : the fruit is ripe in September.

$$
9 \text { The Names. }
$$

This Princt is called in Greeke, wiragr, and in Latine al fo $C_{y p r u s}$; and may be named in Englioh, Eafterlin Prituet, and Mocke-Priuet, for the reafon following: they are deceiued who taking Pliny for their Author, do thinke that it is Liguftrum, or our Wefterne Priuet, as wee baue Thewed in the former chap. it is the Arabians Alcamna, or Henne : and it is alfocalled of the Turks Henre euen at this prefent time.

11 The Temperature.

The leates of thefe kindes of Priuet haue a binding qualitie, as Diofcorides writeth.

$$
\text { I The Vertues. }
$$

A Being chewed in the mouth they heale the vlcers thereof, and are a remedic againft inflammations or hot fwellings.

B The decoetion thereof is good againft burnings and fcaldings.

C. The fame being ftamped and fteeped in the inice of Mullen and laid on, do make the haire red, as Diofcorides noteth. Bellonius writeth, that not only the haire, but allo the nether parts of mans body and nailes likewife are coloured and died herewith,which is counted an ornament among the Turks.

D The floures being moifted in vineger and applied to the temples affwageth head-ache.

E There is alfo made of thefe an oile called oleum Cyprinum, fweet of fmell, and good to heate and fupple the finewes.

\section{Cis s P. 59. Of baftard Prinet. \\ T The Defription.}

I THis thrubby tree, called Macaleb, or Mabaleb, is alfo one of the Prinets : it rifeth vp like vnto a fmall hedge tree, not vnlike vnto the Damfon or Bullefle tree, hauing many vpright ftalks and fpreading branches : whereon do grow leaues not vnlike thofe of the Phityrea of Clufins defcription: amongit which come forth moflic floures of a white colour, and of a perfect 


\section{1 B. 3. Of the Hiftory of Plants.}

fweet fmell, growing in clufters, many hanging vpon one ftem, whiel the Grauer hath onitred: after whiel come the berties, greene at the firft, and blacke wher they be ripe, with a little hard ftonewith in, in wh iel! licth a kernell.

2 Gefner and Matthiolus liate fet forth another Macalbb, being alfo another bafard Pritec. It groweth to a fimall hedge tree, hauing many greene branches fet with round leaues like tlofe of fruit or raec, omw hat nipt about the edges : the floures are like thofe of the preedent: The ning blactec colour , whieh coreol, is as hard as a beade of Corall, fomewhat round, and of a thi-

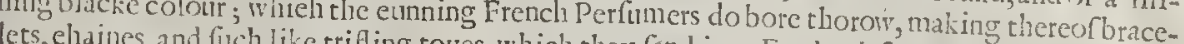
odde fweet and the England, fmeared oucr with fome for rare and ftrange Pomanders, and they are here fold vinto our eurious Ladies and Gentlewomen

\section{Plitlyrea arbor, verior Ruactcb.} Baftard Pritet.

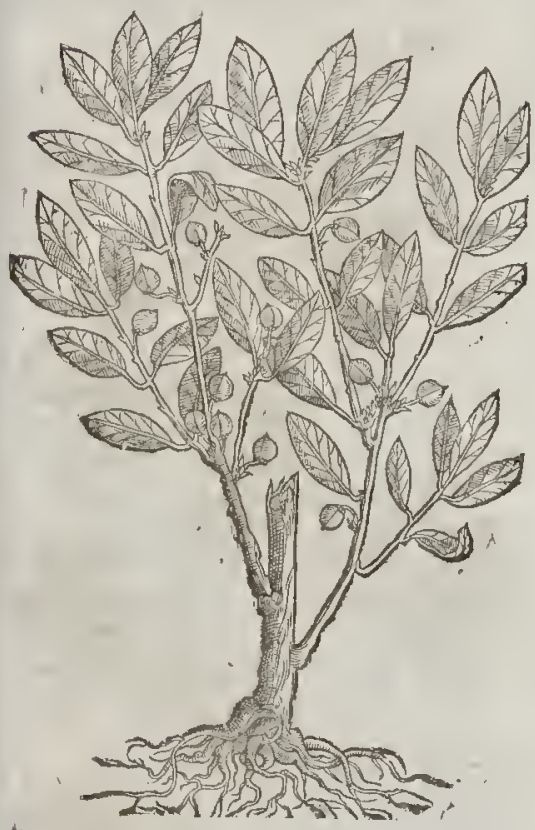

2 Azacaleb Gefoeri. Corall Priuct.

The fe trees grow in diters placesofer

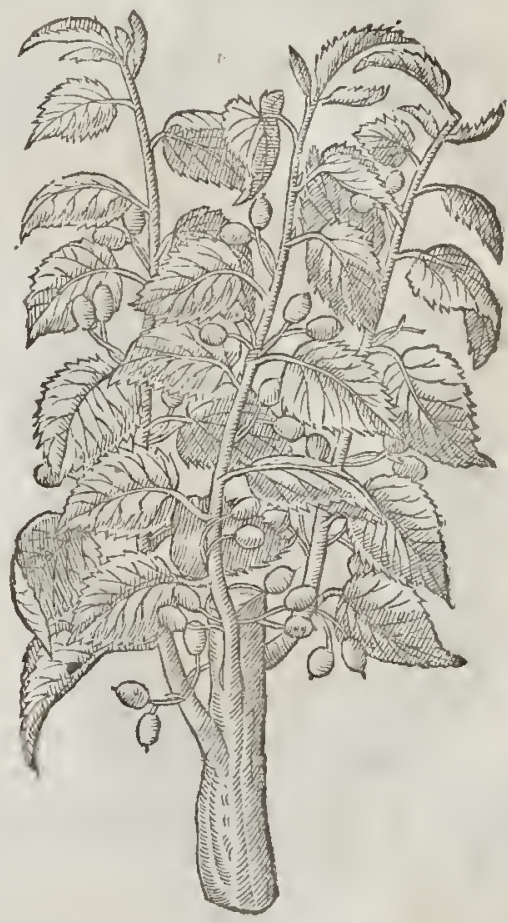

बा The Place. are ftrangers in England.

The floures bud forth in thie $S$ ping

This baftard Priuet is that tree which diuers fufpect to be thit Mabaleb or Macaleb of which $A$ -

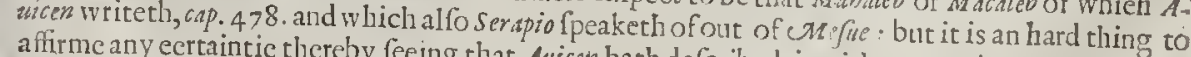
aftrme any ecrtaintic thereby, feeing that Auicen hath deferibed it without markes : notwith itanbaftard Prinet, or Corall, or Po of moft writers, and thofe of the beft : we may eall it in Englifh, Conster thereof

Conecrning this baftard Prit The Temperatuye and Vertues.

$$
\text { -T The Temperaturcand Vertues. }
$$

which are found in the frones or frute haue learned as yet no vfe thereof in Pbyficke. The kernels anfwerable to them in tones or fruit, as they be like in tafte to thof-of Cherries, fo be they alfo and be therefore good for the fure; for they are of a temperat heate, and do gently protroke vrine, feription. 


\section{C н а . 6о. Of the fruitlefse Primet. \\ 9f The Defcription.}

1 His fhrubby buth, called of Pliny and Carolus Clufus, Alaternus, groweth vp to a fmall hedge tree, in forme like vntu a baftard Priuet; but the leaucs are more like thofe of Ilex, or the Freuch Oke, yet itiffer and rounder than thofe of Macaleb : amongtt which come forth tufts of greenifh yellow floures like thofe of the Lentiske tree : vnder and among the leaucs come forth the berrics, like thore of Lantrus $T$ inus, in which are contained two kernels like to the Acines or ftones of the Grape.

I Alaterons Plinï.

Fruitleffe Priuet.

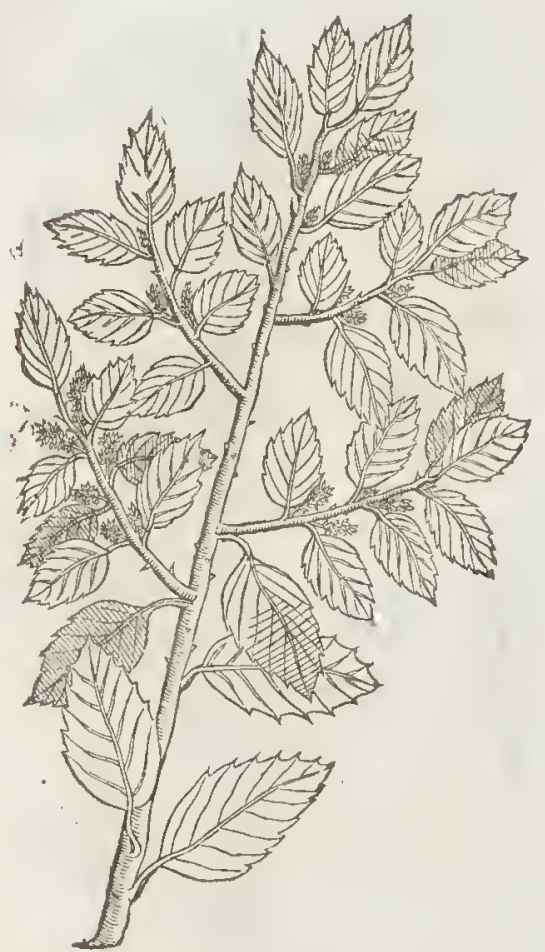

2 Alaternus hursilior.

The lower fruitleffe Prinet.

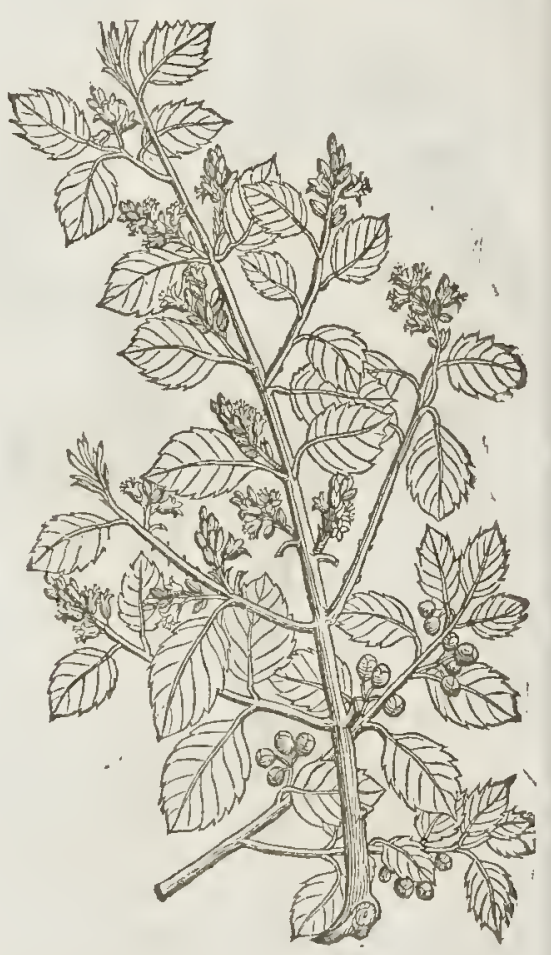

2 The fecond kinde of Alaternus is likew ife a fruitleffe kinde of Priuct, haning narrow leauces fomewhat fnipt about the edges: from the bofomes whereof come forth fmall herby coloured floures; which being vaded, there fucceedeth the fruit, whereof Auicen fpeaketh, calling it by the name Fagaras, being a fruit in bignefle and forme like thofe in thops called Cocculus-indi, and may be the fame for any thing that hath been written to the contrarie. This fruit hangeth as it were in a darke afh-coloured skin or huske, which incloreth a flender ftiffe fhcll like the thell of a nut, couered with a thin or blacke filme, whether it be the fruir of this plant it is not cenfured; notwithftanding yout fhall finde the figure hercof among the Indian fruits, by the name Fagaras.

$\neq$ This hath thorter branches and rounder leaues than the former $:$ the flourcs are larger and greener ; to which fucceed fruit cluftering together, firft greene, then red, and afterwards blacke and confifting of three kernclls : it floures in Februaric and the beginning of March, and growes in fundry places of Spainc. The fruit of this is not the Fagaras, neither doth the Fagar as mentioned by our Author any way agree with the Cosculus Indi of the fhops, as fhall be fhewed hereafter in their fitplecs. $\ddagger$

Thefe plants do grow in the thadowie woods of France, and are ftrangers in England. 
L1 в. 3. Of the Hiftory of Plants. 1399

The time anfwereth the reft of the Prituets.

qा The Names.

'Alaternus of Pliny is the fame Phillyrca which Theopbrafus hath written of by the name Philyca, and Bellonim alfo, $h 6$. 1.cap.42. Of his Singularities, and the people of Candy call it Elceprinon : the Portugals, Calca: in French, Dalader, and Sungin blane: in Englioh, barren or fruicleffe Priuet: notwithftanding fome hate thought it to beare fruit,which at this day is called Fazaras: with vs, Cocculus-Indi, as we haue faid. $¥$ I can by no meanes approue of the Englim nane here giuen by our Aurhor; but iudgethe name of Euer-greene Priuct, (giuen it by $\mathrm{M}^{\mathrm{r}}$.Parkinfon) to be nuch more fitting to the thing. $\neq$

TI The Temperature andrertues.

Whether the plant bevfed in medieine I cannot as yet learne : the filhermen of Portugall do A vfe to feethe the barke there of in water, with the which decoetion they colour their nets of a reddifh colour, being very fit for that purpofe : the wood alfo is ved by Dyers to dye a darke blacke withall.

\section{Сна г. 6г. Of the white and blew Pipe-Priuet.}

I syringanalba.

White Pipe.

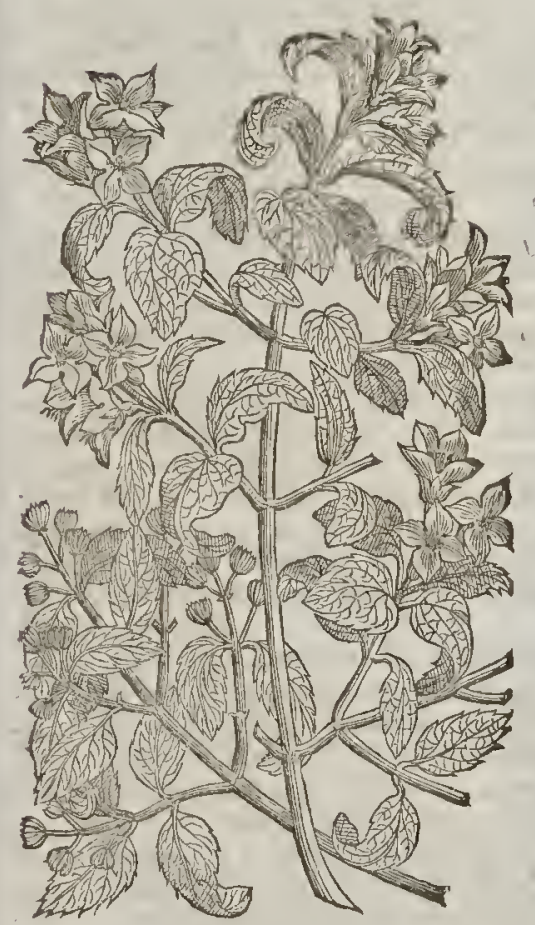

2 Syringacerulex, Blew Pipe.

T) The Defcription.

I Hewhite Pipe groweth like an hedge tree, or buthy fhrtb : from the root wherof arife many fhoots, which in thort time grow to be equall with the old ftocke, whereby in little time it increafeth to infinite numbers, like the common Englith Primor Pri'uer, wherenfdoubtleffe it is a kinde, if we confider enery circumftance : the branches are coured with a rugged gray barke: the timber is white, with fome pith or fpongie matter in the middle like Elder, but leffer in quantitie. Thefe little branches are garnifhed with fmill crumpled leaues of the thape and bigneffe of Peare tree leanes, and very like in forme: anong which come forch $\mathrm{Bbbbbb} \approx$ 


\section{$¥ 3$ Syringa Lrabica. Arabian Pipe.}

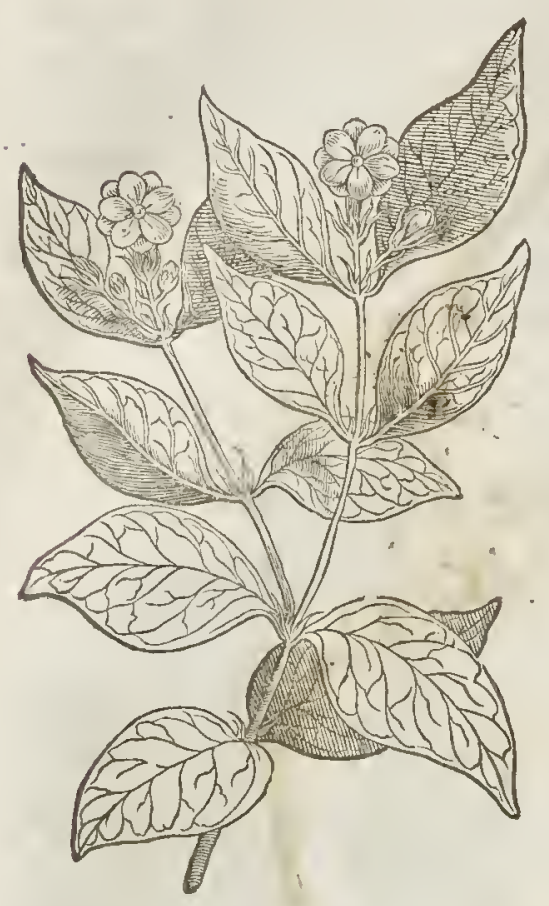

4 Balanus Myrepfien, fiue Glans vnguentaria. The Oylie Acotne.
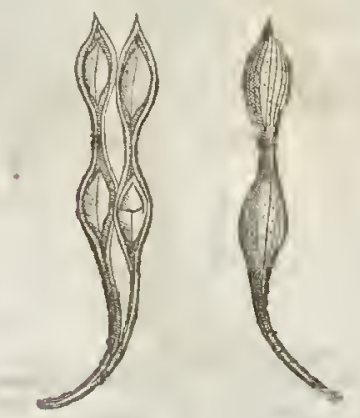

the Houtes, growing in tufts, compact of foure fmall leaues of a white colour, and of a pleafant fweet fmcll; but in my iudgement they ate too fweet, ttoubling and molefting the head in vety ftrange manner. I once gathered the flourcs and laid them in my Chamber window, which fmelled more ftrongly after thcy had licn together a few houres, with fuch an vnacquainted fauor, that they awaked me out of my leepe, fo that I could not take any reft till I had caft them out of my chamber. When the floures be vaded then followeth the furit, which is fmall,curled, and as ic were compact of many littlc folds, broad to. watds the vpper part, and narrow towards the ftalk, and black when it is ripe, wherin is contained a flender and long feed. The root hereof fprcadech it felfe abroad in the ground, aftet the manner of the toots of fuch fhrubbie trecs.

2 The blew Pipe groweth likewife in maner of a fmal hedge tree, with many fhoots rifing froin the root like rhe former, as our common Priuet dotl, whereof it is a kinde: The branches hame fomc fmall quanritie of pith in rhe middle of the wood, and are courred with a darke blacke greenish barkc or rinde. The leaues are excecding greenc, and crumpled or turned vp like the brimmes of an bat, in thapcvery likc vnto the leaues of the Poplar tree : among which come the floures, of an excceding faire blcw colour, compat of many fmall floures in the forme of a bunch of grapes: each foure is in thew like thofe of Valeriana rubra Dodorai, confifting of fourc parts like a lirrle ftar, of an exceeding fweet fauor or fmel, but nor fo ftrong as the former. Whon thefe floures be gone, there fucced flat cods, and fomewhat long, which being ripe are of a light colour, with a thinne membranc or filme in the mid ft, wherein are feeds almoft foure fquare, narrow and ruddy.

$\ddagger 3$ This (which clufus fettcth fotth by the name of lafminum Arabicum, or Syrin. ga Urabica) growcth fomc rwo or three cubirs high, diuided into many fender branches, whercon by couples at each ioint ftand leaucs likcthofe of the firft defcribed, but thinner, and not fnipt about the edges: on the tops of the branches gtow the floures, wholly white, confifing of nine,ten, or twelue leaues fet in two rankes: thefe floures are very fweet, hauing a fent as it werc compounded of the Spanifh Iafmine, and Otange floutes. It is a tender plant, and may be graffed vpon the common Iafmine, whereon it thriues ivell, and floures moft part of the Sommer. It growcth plentifully in Egypt; and Proper Alpinus is thought tomention this by the name of Sambac Arabum, fiue Gelfenimum Arabicum. I

4 Glans vngucrat aria, or the oylie Acorne, is the fruit of a tree like Tamariske, of the bigneffe of an Harcll Nut; out of the kernell whereof, no otherwife than out of bitter Almonds, is preffed an oylie iuyce which is vfed in pretious Oyntments, as Diofcorides affirmeth : neither is it in our timewholly teiected; for the oyle of this fruit mixed with fiveet odours fetueth to perfume 
gloues and diuers other things; and is vulgarly knowne by the name of Oyle of Ben.

बा The Place.

r. 2. Thefe trees grow not wilde in England, bur I haue rhem growing in my garden in very grcar plenty.

I) The Time.

They floure in Aprill and May, but as yet they haue not borne any fruit in my garden, though in Italy and Spane rheir fruit is ripe in September.

का The Names.

The later Ply fitians eall the firft Syring a, or rather ziprys" thar is to fay, pipe, beeaufe the ftalks and branehes chereof, when the pith is taken out, are hollow like a pipe : it is alfo many times fyrnamed Candida, or whire, or Syringa candido fore, or Pipew irh a whire Houre, beenufe it fhould differ from Lillach, which is fomerimes named Syringacarulea, or blew Pipe: in Englinh, White Pipe.

Blew Pipe the larer Phy fitians, as we haụe faid; do name Lillacb jir Lilac : of fome, syringa crerulea, or blew Pipe: moft do expound the word Lillach, and call it Berms Scrapio's and the Arabians

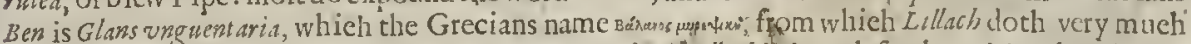
differ : among other differenees it is very apparant, rhat 'Jillach bringerh forth no Nur, howfoeuer Matthiolus dorh falny pieture ir with one; for thatlionly a little eod, the feed whereof hath in ir no oile at all. The figure of rhe Balanus Myrepfica we hatue thought good to infert in this ehapter, for want of a more conuenient roome.

$$
\text { बi The Temperatureand Vertues. }
$$

Concerning the vfe and faeulties of thefe fhrubs neither we' our felues haue found out any rhing $A$ nor learned oughr of others.

$\mp$ The Balanss Myrepfica raken in the quantitie of a dram, caufetls vomit; drunk with Hydromel B it purges by ftoole, but is hurtfull to the ftomacke.

The oile preffed out of this fruir,which is vfually termed oyle of Ben,as it liath no gond or plea- C fing fmell, fo harh it no ill fenr, neither dorh it become rancide by age, whieh is the reafon that it is much vfed by perfumers.

The oile fmoothes rhe skin, forrens and diffolues hardneffe, and conduces to the cure of all cold D affects of rhe finewes; and it is good for the paine and noife in the eares, being mixed with Goofegreafe, and fo dropped in warme in a fmall quantitie. $\ddagger$

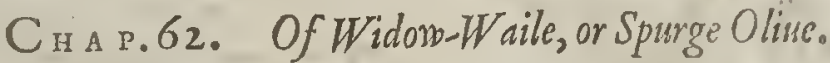

\section{Tा The Defcription.}

W Idow-waile is a mall forub abour two cubits high. The ftalke is of a wooddy fub ftanec, branched with many fnall twigs, full of litrle leaues like Priuet, but fmaller and blac$\mathrm{ker}$, on the ends whereof grow fmall pale yellow floures : which being palt, there fireceedeth a rhreecornered berrie like the Tithymales, for which eanfe it was ealled Tricoccos, that is, three berried chamelea : rlefe berries are greene ar the firft, red afterward, and browne when they be withered, and eonraine in them an oylie fatneffe like that of the Oliue, being of an hot and biting tafte, and that doe burne the mouth, as do both the leaues and rinde. The root is hard and wooddy.

$$
\text { T) The Place. }
$$

It is found in moft vntilled grounds of Italy and Languedoc in France, in rough and defart places. I haue ir growing in my garden.

It is alw a

$$
\begin{aligned}
& \text { The Time. } \\
& \text { Aurumne. } \\
& \text { T The Names. }
\end{aligned}
$$

The Grecians eall it xuridur, as though they fhould fay, low or fhort Oliue tree : the Latines, oleago, and oleafellus, and likewife Citocucium : ir is alfo named of dieners, oliwella, as Matthiolus Syh unticus fairh : it is called in Englioh, Widow-Waile, quia facit viduts.

The fruit is named of diuers, Kixxos sisteos : in Latine, Coccits cridifus : but he is deceined, faith Diofcorides, that namerh the fruit of Spurge-Oliue, Coccus Cnidifys : Auicen and Serapio call Chamelen, or Spurge Oliue, exezerton : vnder which name notwirhftanding they haue alfo eonrained both the Chanaleons or Carliaes; and fo haue they confounded Chamelea or Spurge Oliue with the.Carlines, and likewife Thymalea, or Spurge Alax.

$$
\mathrm{Bbb} b \mathrm{~b}
$$



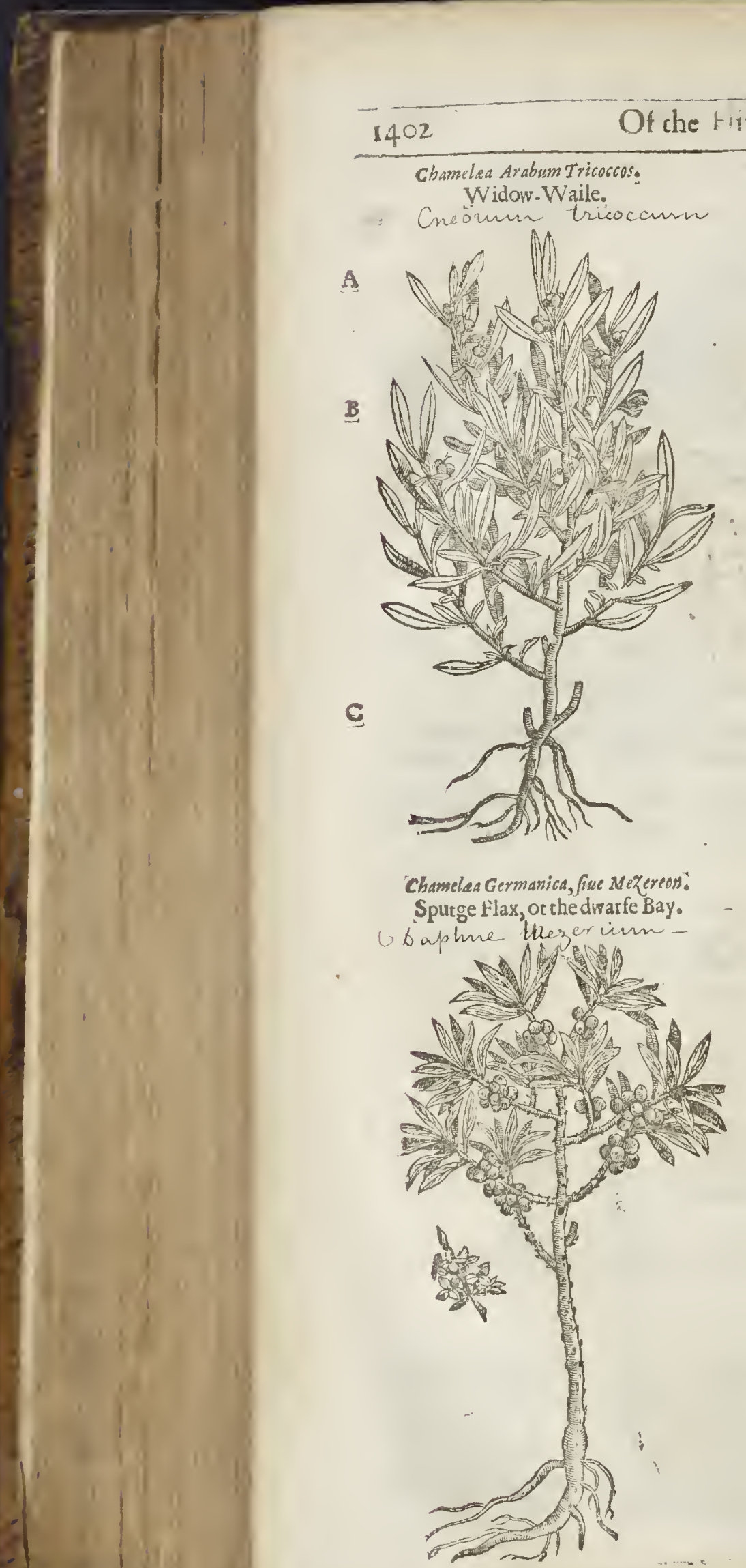

4) The Temporature.

Both the leaues and fruit of Spurge-Oliue, as we haue faid, are of a burning and ext rme hot temperature.

\section{T) The Vertues.}

The leaues, faith Diofcorides, purge both flegme and cho'er, efpecially taken in pills, fo that wo parts of $\mathrm{W}$ ormewood be mixed with one of Spurge Oliue, and made vp into pils witly Mede or honied water. They nelt not in the belly, but as many as be taken are voided whole.

(Mefue likewife hath a defcription of pills of the leaues of Mezereon, that is, Charnelea, or Spurge-Oliue (yet Syluius expoundeth it $T$ hy. melea,or Spurge-Flax) but in ftead of Worm. wood he taketh the outward fubfance of the yellow Mirobalans and Cepula Mirobalans, and maketh them vp with Tereniabin, that is ro fay, with Manna and foure Dares, which they call Tamarinds, diffolued in Endiue water; and appointeth the fame leaues to be firft tempered with very ftrong vineger, and to be dried.

Thefe pills are commended againft the Dropfie, for they draw forth watery hunzours, but are violent to nature, therfore we mult vie them as little as may be. Moreoner, Diofiorides addeth, that the leaues of Spurge Oliuebeaten with bony do clenfe filthy or crufted vicers.

\section{CHAP. 63. \\ OfGermane Oliue Spurge.}

Tा The Defcription.

7 Hedwarfe Bay tree, called of Dutch men Mezereon, is a fmal thrub two cubits high: the branches be tough, limber, \& eafie to bend, very foft to be cut; whereon grow long leates like thole of Priuet, but thicker and farter The floures appeare before the leaues, oft times in Ianuarie, cluftring together about the ftalks at certain diftances, of a whitith colour rending to purple, and of a moft fragrant and pleafant fweet fmel : after come the fmall berries, green at the firft,but being ripe, of a thining red colour, and a frerward wax of a dark black colour, of a very hot and burning tafte, inflaming the mouth and throat, being tafted, with danger of choking. The root is wooddy.

$$
\text { Tा The Place and Time. }
$$

This plant grows naturally in the moiftand Thadowy woods of moft of the Eaft countries, efpecially about Meluin in Poland, from whence I have had great plenty thereof for my garden, where they floure in the firft of the Spring,and ripen their fruit in Auguat.

9 The Names.

It is vfually called in high-1)utch.ZZetlant,

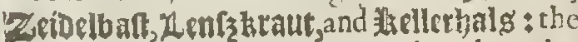
Apothecaries 
Apothecaties of our countrey nane it $M$ zereon, but we had rather call it Chamolat Germanica. in Englith, Dutch Mezereon, or it may be called Germane Oliue Spurge. We haue heard, thar thwers Italians do name the fruit there of Piper Momanum, Mountaine Pepper. Somc fay that Latircolat or Spurge Laurell is this plant, but there is another $L$ averela, of which we will hereafter treat : but by what name it is called of the old writers, and whether they knew it or no, it is hard to tell. it is thought to be Cneoron allum Theoplsrafti, but by reafon of his brenitic,we can affirme no certainty.

There is, faithhe, tw o kindes of Cneoron, the white and the blacke, the white hath a leafe, long, like in forme to Spurge Oliue: the black is ful of fubftance like Mirtle; the low one is more white; the fame is with finell, and the blacke without fmell. The root of both which groweth deee, is great : the branclies be many, thicke, wooddie, immediatly growing out of the carth, or little aboue the earth, tongh : wherefore they ve thefe to binde with,as with Oziars. They bud and Houre when the Autumne Equinostiall is par,and a long time after. Thus much T heophraftus.

The Germane Spurge Oline is not much vnlike to the Oline tree in leafe: the floure is fiveet of fmell : the buds whercof,as we hate writen, come forth after Autumne : the branches ate wonddy and pliable : the root long.grow ing deepe : all which fhew that it hath great likeneffeand affinity with Cneoron, if it be not the very fame.

\section{The Temperature.}

This plant is likewife in all parts cxtreme hot: the truit, the leaues, and the rinde are very tharpe and biting : they bite the tongue, and fet the throte on fire.

\section{T The Vertues.}

The leatres of Mezercon do purge downeward,flegme,choler, and waterith humours with great $A$ violence.

Alfoif a drunkard do eat one graine or berty of this plant, hee cannot be allured to drinke any $B$ drinke at that time; fuch will be the heat of his mouth and choking in the throat.

This plant is very dangerous to be taken into the body, \& in nature like to the Sea Tithymale, C leaning (if it be chewed) ruch an heat and burning in the throat, that it is hard to be queoched.

The thops of Germany and of the Low-countries dowhen need require vfe the leaues hereof D in ftead of Spurge Oliue, which may be done without errour; for this Germane S purge Oline is like in vertue and operation to the other, therefore it may be vfed in ftead therof, and prepared after the like and felfe-fame manner.

\section{C на P. 64. Of Spurge Flix.}

1 Thymelas.

Spurge Flax, or mountaine Widow waile.

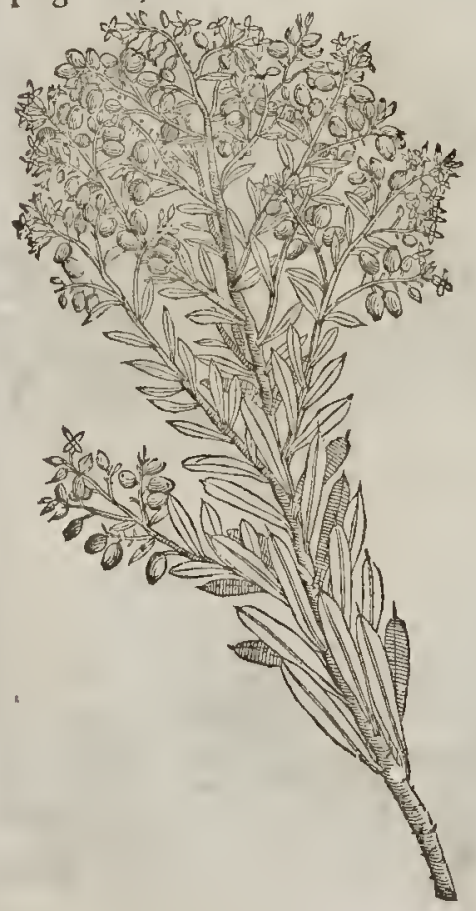

9 The Deferiptiox.

Curge Flax bringeth forth many llender branched fprigs abone a cubite high, couered round with long and narrow leaues like thofe of flax, narrower \& leffer than the leatues of Spurge Olite. The floures are white, fmall, fanding on the vpper parts of the fprigs: the fruit is round,greene at the firft, but red when it is ripe, like almoft to the round berries of the Haw thorne, in which is a white kernel coured with a blacke skinne, very hot and burning the mouth like Mezereon : the toot is hard and wooddie.

$$
\text { T The Place. }
$$

It groweth in rough mountains, and in vntoiled places in hot regions. It groweth in my garden. It The Time.

It is greene at any time of the yeare, but the fruit is perfected in Autumane.

$$
\text { Tा The Names. }
$$

The Grecians call it swentaxt: the Syrians, as Diofcorides witneffeth, Apolinon: dituers alfo Chamelea, but not properly !but as Diofcorides faith, the leafe is properly called Creoron, \& the fruit Coccos Cridios; notwithftanding thofe which Theophraft us calleth Cneord feem to differ fro m $T$ hymelea, or Spurge Flax, vnlefie $\mathrm{Ni}$ grum Cncoron be $T$ hymela a or Theophraftus faith 
thac ihere be wo kindes of Cnearon; the one whute, the other blacke: this may be called in Englifh, Spurge $12 x$, or mountaine Widow Wayle : the feed of Thymclen is called in thons, Gronmm Gnim dium.

$$
\text { 9t The Temperature. }
$$

Spurge Flax is naturally both in leaues and fruit extreme lot, biting, and of a burning qualitie. it The Fortues.

A The graines or berries, as Diofcorides faith, purge by fiege choler, flegme and water, if twenty graines of the inner part be drunke, but t bumeth the mouth and throat, wherefore it is to be eiuen witl fine floure or Barly meale, or in Raifons, or comercd with clarified hony, that it may be fwallowed.

B The fame being ftamped with Niter and vineger, fermeth to annoint thofe with, which can hard. ly fweat.

C The leaues muft be gathered about haruct, and being dried in the fhade, they arc to be layed vp and referued.

D They that would giue them muf beat them, and take forth the ftings:the quantity of two ounces and twodrams put intowine tcmpered with water, purgeth and draweth forth watery humors : but they purge more gently if they be boiled with Lentils, and mixed with por-herbes chopped.

E The fame leaues beaten to pouder and made vp into trochifces or flat cakes, with the iuice of fower grapes are referued forvfe.

F The herbe is an enemy to the ftomacke, which alfo deftroyeth the birth if it be applied.

+ Our Author formetly following Tabersdmontatu gatue two figüres and defcripcions in this Chapter, but being both of one thing I onitred the worfer fiatre and Ueicriprion.

\section{Cha p. 65: Of Spurge Laurell.}

Larrela florens.

Laurell,or Spurge Laurell flouring:

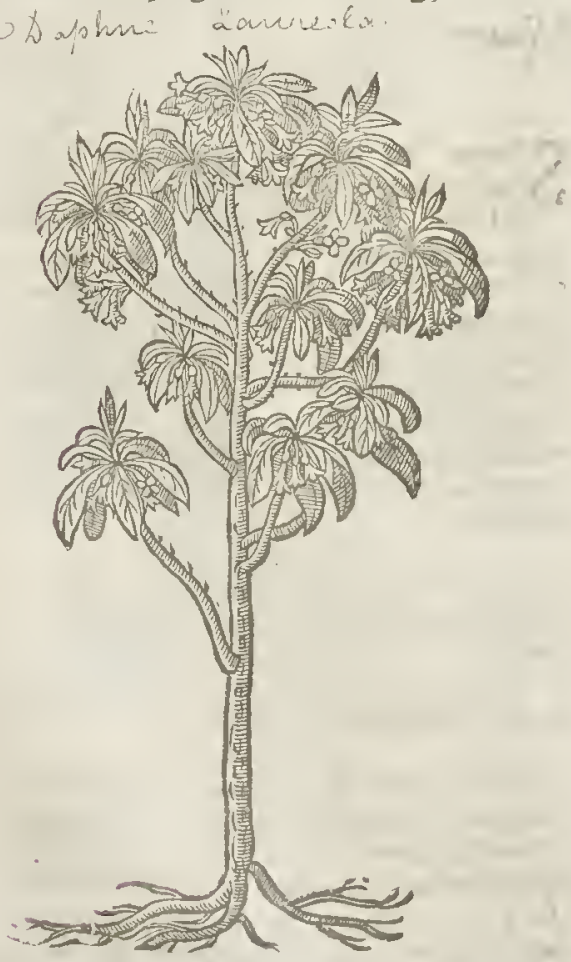

Laureola curs fructu.

Laurell wich his fruit.

ODaplune Lameda

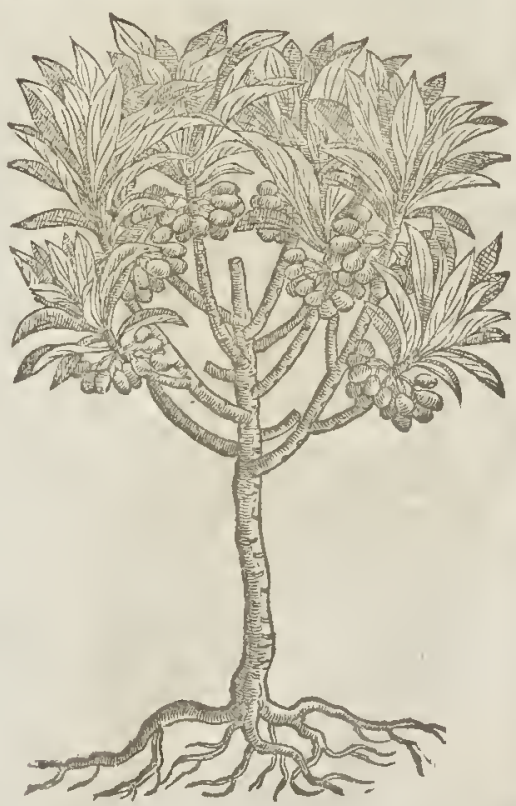




\section{Tt The Defcription.}

Surge Laurell is a fhrub of a cubit high, oftentimes alfo of two, and fpreadeth with many little

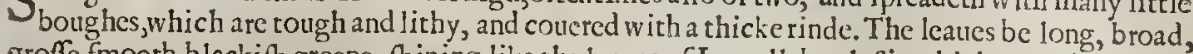
groffe, fmooth, blackifh greene, thining, like the leaues of Laurell, but lefler, thieker, and without imell, very many at the top, cluftering together. The floures be long, hollow, of a whitifh greene, hanging beneath and among the leaues : the berries when they be ripe are blacke, with a bard kernell within,which is a lirtle longer than the feed of Hempe : the pulpe or inner fubftance is wh ite: the root wooddic, tough, long, and diucrfly parted, growing deepe: the leaues, fruit and barke, as wel of the root as of the little boughes, doe with their tharpneffe and burning yualitic bite and fet on fire the tongue and throat.

$$
\text { T The place. }
$$

It is found on mountaines, in vntilled, rough, fhadowie, and wooddic places, as by the lake of Lo: zanna or Geneua, and in many places neere the riuer of Rhene and of the Maze. $\ddagger$ It gtowes abundantly allo in the woods in the moft parts of England. $\neq$

$$
\text { T) The Time. }
$$

The floures bud very foon, a litrle after the Autume Equinodiall:they are full blown in Winter, or in the firt Spring: the fruit is ripe in May and Iune: the plant is alwases greenc, and indureth
the eold 1tormes of winter.

It is callat in The Nomes.

It is called in Greeke sayorsts, of the likeneffe it hath with the leates of the Laurell or Bay treen in Latine likews (e Daphnoides : the later Latinifts for the fame eaufe name it Laureola, as though they thould fay Minor Laurss, or little Laurell. it is called zaupropm, ard mimas, notwithftanding there is another Chamedaphe, and another Peplion. This fhrub is commonly called in Englin, Spurge
Laurellof diuers, Laurell or Lowry.

Some fay that the Italians name the berries herenf Piper montarum, or Mountaine Pepper, as alfo the berries of Durch Mezereon : others affirme then to bee called in High Duteh alfo, ZZZei=
lant.

It may be Theophraitus his Cncoron : for it is much like to a Mirtle in leafe, it is alfo a brauched plant, tough and pliable, hauing a deep root, without fmell, with a blacke fruit.

$$
\text { T) The Temperature. }
$$

It is like in temperature and facultie to the Germane Spurge Oliue, throughout the whole fub: fance biting and extreme hot.

$$
\text { T) The Vertues. }
$$

The dric or greene leaues of Spurge Laurell, faith Dioforides, purgeth by fiege flegmarieke hu- A mors; it procureth vomite and bringeth downe the menfes, and being chewed it drawethwater out of the head. tion.

It likewife caufeth neezing; moreoner, fifteene graines of the feed thereof drunke, are a purga- $\mathbb{E}$ :

\section{Снар. 66. Of Rofe Bay, or Oleander. \\ ff The Defription.}

I R Ofe Bay is a fmall thrub of a gallant thew like the Bay trec, bearing leaves, thieker, greater, Ionger and rougher than the leaues of the Almond tree:the floures be of a faire ied colour, diuided into fiue leaues, not much vnlike a little Rofe : the cod or fruit is long, like AfElepias, or Tincetoxicum, and full of fuch white downe, among whieh the feed lieth hid. den: the root is long, fmooth, and wooddic.

2 The fecond $k$ inde of Rofe bay, is like the firt, \& differeth in that, that this plant hath white floures; but in other refpects it is very like. 


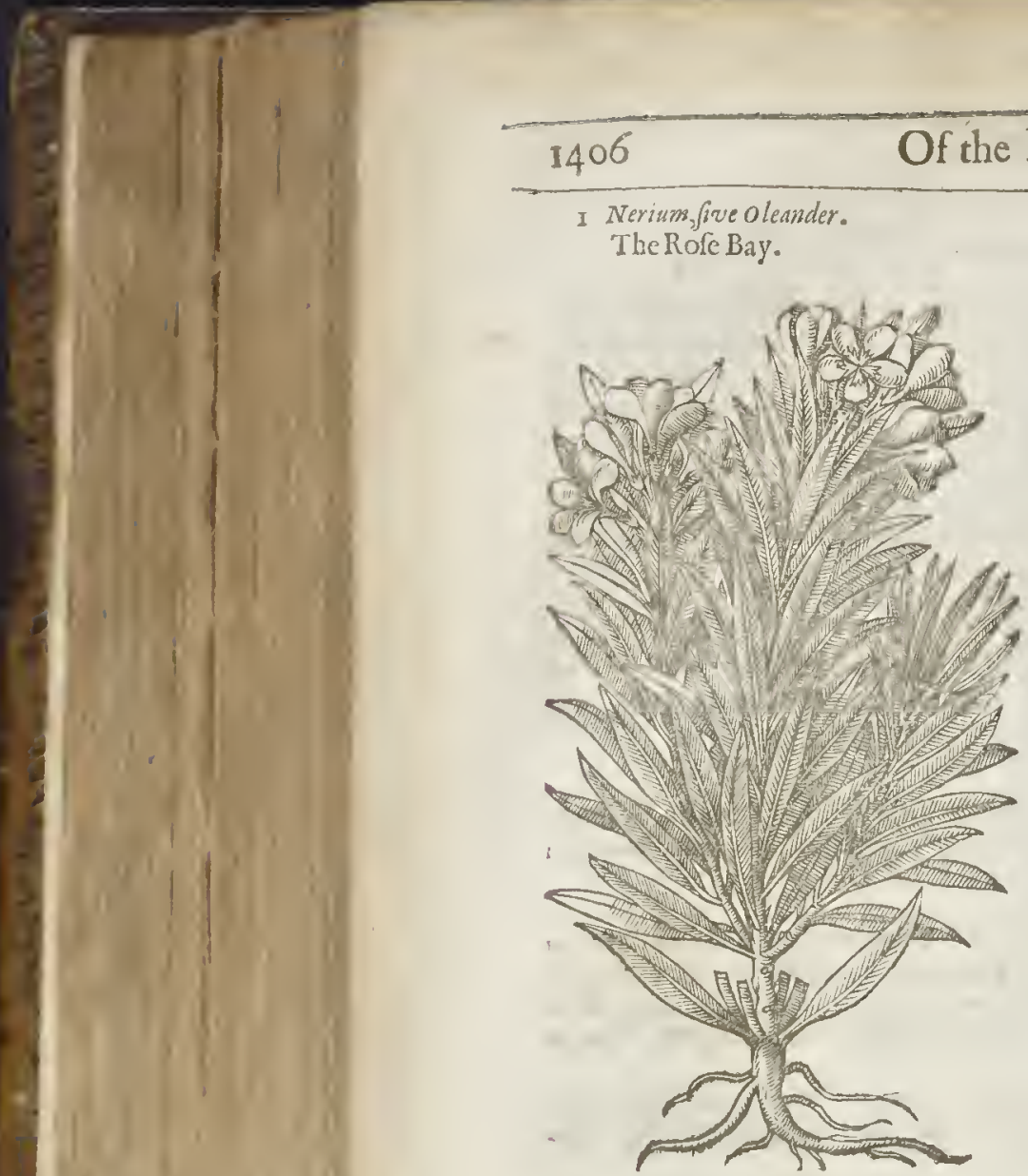

$\mathbf{L}_{1 \mathrm{~B} .3 .}$

The Rofe Bay.
2 Nerium fore albo.

The Rore Bay with white floures

Thefe grow in Italy and other hot regions, by riuers and the Sea fide: I haue them growing in my garden.

Tा The Time.

In my garden they floure inluly and Auguf : the cods be ripe afterwards:

The Names.

This plant is named in Greeke wem,by Nicander, Nues: in Latine likewife Nerion, and alfo Rhodo: 'dendron, and Elododaplone, that is to fay, Rofea arbor, and Rofia Laurus : in Thops, oleander : 'in Italian, oleandro : in Spanifh, Adelfa, Eloendro, and Alcndro ; in French, Rofagine : in Englifh, Rore tree, Rofe Bay, Rofe Bay tree and Olcander.

\section{T The Temperature and vertues.}

A This treebeing ontwardly applied, as $G$ alen fatth, hath a digefting facultie: but if it be inwardly taken it is deadly and poifonfome, not only to men,bur alfo to moft kindes of beafts.

$B$ The floures and leaues kill dogs, affes, nules, and very many of other foure footed beafts : but if men drinke them in wine they are a remedy againft the bitings of Serpents,and the rather if $R$ ue be added.

C The weaker fort of cattell,as meep and goats, if they drinke the water wherein the leaues haue been fteeped, are fure to dic.

$$
\begin{gathered}
\text { Cha . 67. Ofdwarfe Rofe Bay. } \\
\text { T The Defcription. }
\end{gathered}
$$

Warfe Ncrum, or Rofe Bay, hath leates which for the moft part are alwaies green, rough, and fmall, of a pale yellow colour like Box, far leffer than Oleander : the whole plant is of a fhrubbie ftarure, leaning this way and that way, as not able to ftand vpright without helpe; his branches are coured and fet full of fmall floures, f a hining fcarlet or crimfon colour; growing vpon 


\section{L1 в. 3. Of the Hiftory of Plants.}

1407

I Chamarhododendros Alpigena. Dwarfe Role Bay.

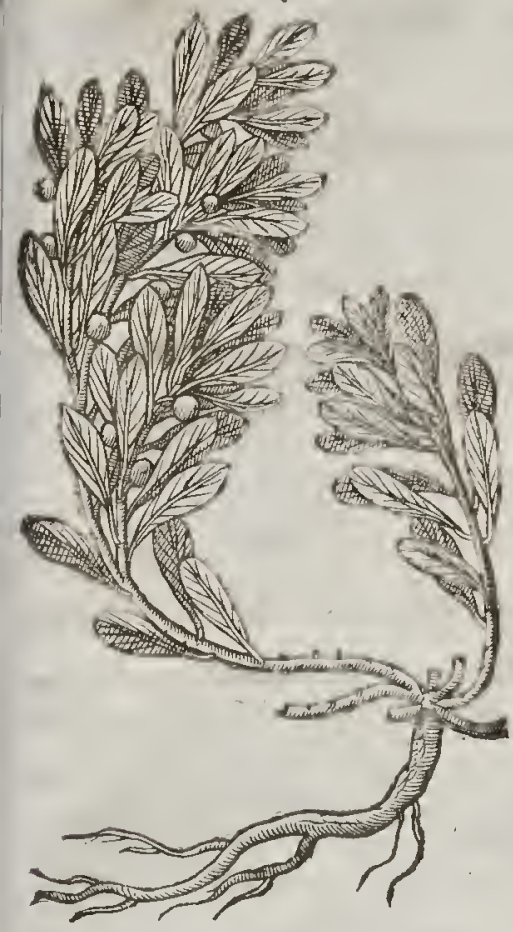

Larus:

The Bay tree.

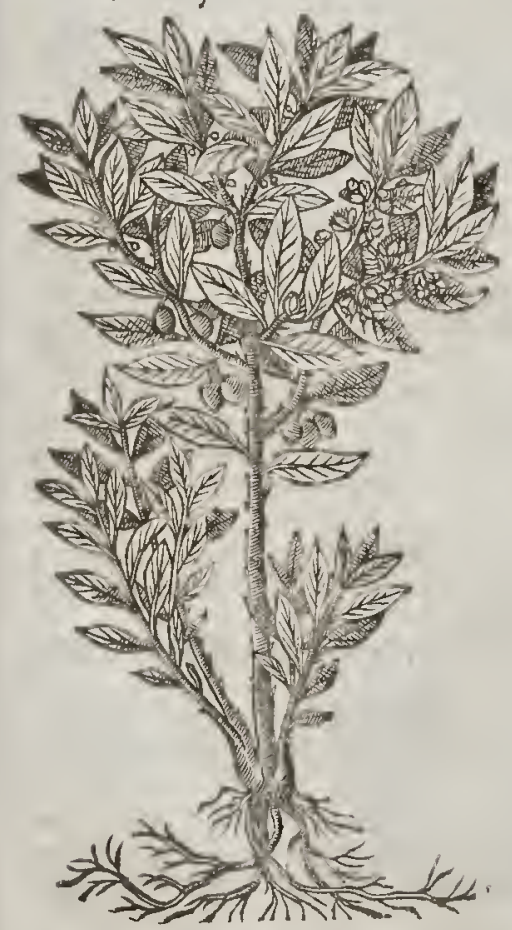

the hils as ye go from Trent to Verona, which in Iune and Iuly are as it were couered with a Icarlet coloured carpet, of an odoriferous fauor, and delectable afpect, which being fallen there commeth feed and faire berries like $A$. jparagus.

$$
\text { Tl The Place. }
$$

The place and time are expreffed in the de: fription.

$$
\text { II The Names. }
$$

This may be called in Englifh, Dwarfe Rofe Bay of the Alps. I find not any thing ex tant of the vertues, fo that I am conftrained to leaue the reft vnto your ow ne difcretion.

1. The orher planeour Author formerly deferibed in this chepter in the s.place by the name of Chamerododematros montsma, I hauc here omitted, becaulc

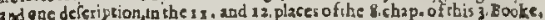

\section{C n A. 68. Of the Bay or} Laurell tree.

\section{If The Defcription.}

1 Te Bay or Laurell tree commeth 1 oftentimes to the height of a tree or a mean bigneffe; it is full of boughes, couered with a greene barke : the leaues thereof are long, broad, hard, of colour greene, fweetly fmelling, and in tafte fomw hat bitter : the floures along ft the boughes and leanes are of a greene colour : the berries are more long than round,and be couered with a black rind or pill : the kernell within is clouen into two parts, like that of the Peach and Almond,and other fuch, of a browne yellowinh colour, fweet of fmell, in tafte fomewhat bitter,with a little fharpe orbiting qualitie.

2 There is alfo a certaine other kinde hereof more like to a fhrub, fending forth out of the roots many off frings, which notwith. ftanding groweth not fo high as the former, and the barkes of the boughes be fomewhat red: the leaues be alfo tenderer, and not fo hard : in other things not vnlike.

Thefe two Bay trees Diofcorides was not ignorant of, for he faith, that the one is narrow leafed, and the other broader leafed, o: zather harder leafed which is more like.

$$
\text { If The Place. }
$$

The Laurell or bay tree groweth natural-

.

.

(1)

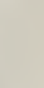


$I_{y}$ in Spaine and fuch hot regions;we plant and fet it in gardens, defending it from cold at the be. ginning of March efpecially. hatic not feene any one tree thereof growing in Denmarke, Sweuia,Poland, Limonia, or Ruffia,
or in any of thofe cold countries where 1 hate tratelled.

$$
\text { ๆ The Time. }
$$

The Bay trec groweth greene wintet and Sommer : it floureth in the Spring, and the black fruit is ripe in October.

$$
\text { ๆ The Names. }
$$

This tree is ealled in Greekesiom: in Latine, Laurus : in Italian, Lauro - in high Duteh, Zlooet: bectbaum: : in low Dutch, Lautus bogute: in French, Lumier: in Spanifh, Laurcl, Lorel, and Lourciro: in Englifh, Laurell,or Bay tree.

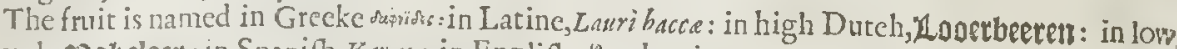
Durch, 203tiflect: in Spanith, Vayas : in Englinh, Bay berries. loute.

The Poces faine that it tooke his name of Daphne, Lado his daughter, with whom Apollo fell in

$$
\text { I The Temperature andVirtues, }
$$

A The Berries and leatues of the Bay tree, faith Galen, are hot and very drie, and yet the berries more than the leaues.

B

The barke is not biting and hot,but mere bitter, and it hath alfo a certaine aftrictiuc or binding qualitic.

C Bay Berries with Fony or Cutc,are good in a licking medicine, faith Diofcorides, againft the pthifiekc or Confumption of the lungs, difficulty of ureathing, and all kinde of fluxes or rheumes about the elsef.

D Bay Berries taken in wine,are good againft the bitings and ftingings of any venomous beaft, and againit all venome and poifon: they clenfe away the morphew : the itice prefled out hereof is a re. medy for painc of the cares,and deafeneffe, if it be dropped in with old wine and oile of Roles: this is alfo mixed with ointments that are good againft wearifomneffe, and tlat heate and difcuffc or walte away hunuors.

E Bayberrics are put into Mithridate, Treacle, and fuch like medicines that are made to refrefh fuch people as are growne fuggifh and dull by meanes of taking opiate medicines, or fuch as haue any venomous or poifoned quality in them.

I They aregood alfo againft cramps and drawing together of finewes.

G We in our time do not vfe the berries for the infirmities of the lungs, or che ft, but minifter tham againft the difeafes of the ftomacke, liuer, fpleene, and bladider: they warme a cold ftomacke, caufe coneo tion of raw humours, ftirre vp a decaied appetir, rake away the loathing of meat, open the ftopping of the liuer and fpleene, prouoke vrine, bring down the menfes, and driuc forth the feeons dine.

H The oile preffed out of thefe, or drawne forth by decoction, doth in thort time take away feabs and fitch like filth of the skin.

I It cureth them that are beaten blacke and blew, and that be bruifed by fquats and falls, it remoo: ueth blacke and blew fpots and congealed bloud, and digefteth and walteth away the humors ga thered about the grieucd part.

K Nioforides faith, that the teates are good for the difeafes of the motler and bladder, if a bath be made hereof to bathe and fit in : that the greene leaucs do gently binde, that being applied, they are good againft the ftingings of wafpes and Bees, that with Barly meale parched and bread, they aftwage all kinde of inflammations, and that being taken in drinke they mitigate the paine of the ftomacke, but procure vomite.

L The Berries of the Bay trec famped with a little Scammonic and Saffron, and laboured in a mostar with vineger and oile of Rofes to the forme of a liniment, and applied to the temples and forepart of the head, do greatly ceafe the paine of the Megrim.

M It is reported that common drunkards were accuftomed to eat in the morning faiting twolcattes thereof against drunkenneffe.

$N$ The later Plyy fitions docoftentimes vfe toboyle the leaues of Laurell with diucrs meats, efpeci ally fithes, and by fo doing there happeneth no defre of vomiting: but the meat feafoned herew ith beenmmeth more fauorv and better for the fomacke.

O The barke of the ront of the Bay tree,as Galen writeth, drunken in w ine prousctl vrine, breakes the ftone, and driucth forth graucll : it openeth the ftoppings of the liuer, the fpiecne and all other ftopping s of the inward parts': which thing alfo Diofcorides affirmeth, who likewife addeth that it killeth the ehilde in the mothers wombe. 
L 1 B. 3 .

Of the Hiftory of Plants.

It helpeth the dropfie and the iaundife, and procureth vnto women their de fired fickneffe.

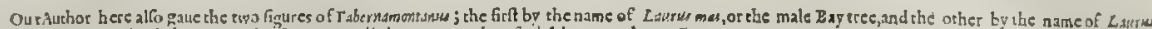

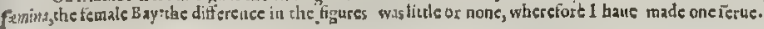

\section{A s. 69. Of the Wilde Bay tree.}

\section{The Defoription.}

I Aurus Tinus, or the wilde Bay tree, groweth like a fhrub or hedge bufh, hauing many tough and pliant branches, fet full of leaues very like to the Bay leaues, but fmaller and more crumpled, of a deepe and fhining greene colour : among whicl come forth tufts of whitin floures, turning at the edges into a light purple : after which follow fmall berries of a blew colour, containing a few graines or feeds like the ftones or feeds of grapes : the leaues and all the parts of the plant are altogether without fmell or fauour.

1 Laurus Tinus.

The wilde Bay tree.
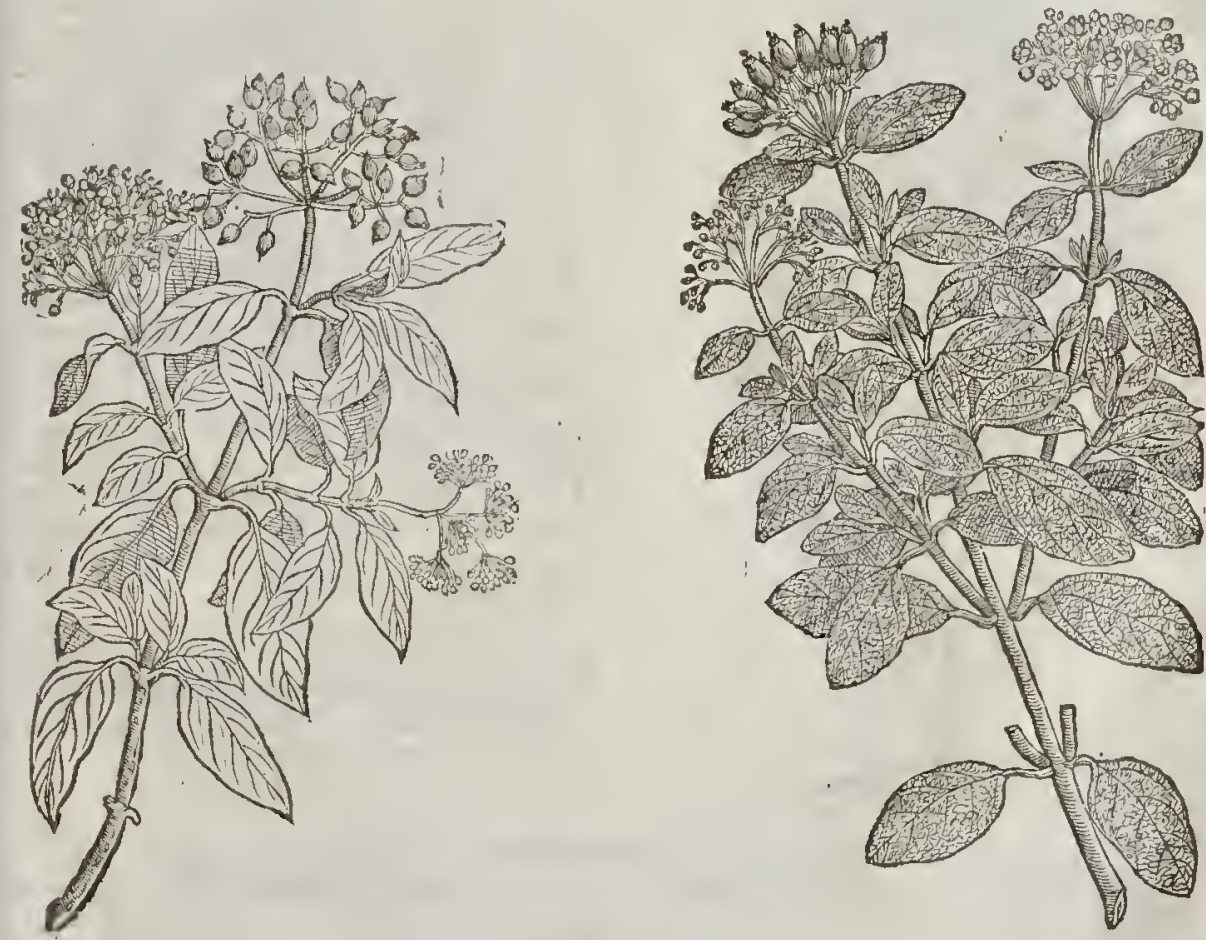

2 Tinus Luffit anica groweth verie like to Cornus Famina, orthe Dog-berry tree, but the branches be thicker,and more ftiffe, couered w ith a reddifh barke mixed with greene : che leaues are like the former, but larger, hauing many finewes or vaines running through the fame like as in the leaues of Sage: the foures hereof grow in tufts like the precedent,but they are of colour more declining to purple: the fmall branches are likew ife of a purple colour: the leaues haue no fmell at all, either good or bad : the berries are fmaller than the former, of a blew colour declining to blackneffe. T The Place.

The wilde Bay groweth plentifully in euery field of I taly, Spain, and other regions, which differ according to the nature and fcituation of thofe countries: they grow in my garden and profper verywell.

C c c c c

githe 


\section{T. The Time.}

The wilde Laurell is euer greene, and may oftentimes be feene moft part of thewinter, and the beginning of the fpring, with the floures and ripe berries growing both at one feafon.

$$
\text { T The Names. }
$$

It is called in Latine Tinus, and Laurus fyluefris: in Greeke, siqu draw: Cato nameth it Lakrus fyludo tica: in Italian, Lauro fyluatico: in Spanifh, $V$ ua de Perro, otherwife Follado; and of diuers, $D$ urillo: in Englin wilde Bay.

$$
\text { T) The Temperature and vertues. }
$$

Pliny nor any other of the Antients haue touched the faculties of this wilde Bay, neither haue we any vnderftanding thereof by the later writers, or by our owne experience.

\section{Cнар.70. Of the BoxTree.}

Buxius.

The Box tree.

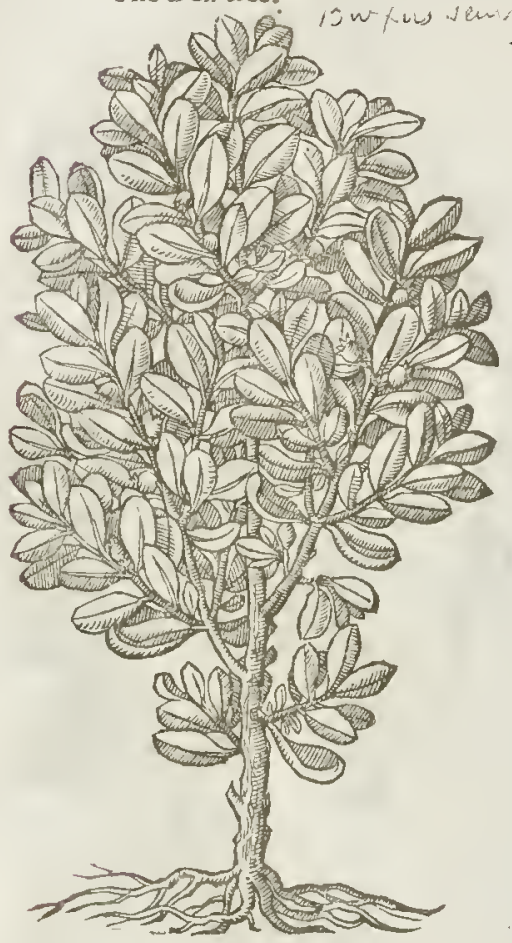

9] The Defeription.

7 He great Box is a faire tree, bearing a great body or trunke: rhe wood or timber is yellow and very hard, and fit for fundry workes, hatuing many boughes and hard branches, befer with fundry fmall hard green leaues, both winter and Sommer like the Bay tree: the floures are very litrle, growing among the leaues, of a greene colour : which being vaded there fucceed fmall blacke $h$ ining berrics, of the bignes of the feeds of Corianders, which are inclofed in round greenith huskes, hauing three fect or - legs like a braffe or boiling pot: the root is likewife yellow, and harder than the timber, but of greater beauty, and more fit for dagger haftes, boxcs, and fuch like vfes, whereto the trunke or bodv ferueth, than to make medicines; though foolith empericks and women leaches, do minifter it again th the A poplexie and fuch difeafes: Turners and Cutlers, if I miftake not the matter,do call this wood D udgeon, wherw ith they make Dudgeon hafted daggers.

There is alfo a certaine other kinde hereof, growing low, and not abouc halfe a yard high, but it fpreadeth all abroad : the branches hereof are many and very flender: the leaties bee round, and of a light greene.

\section{The Place.} dens.

Buxus, or the Boxtrec gioweth vpon fundry watte and barren hils in England, and in diuers gar.

$$
\text { q The Time. }
$$

The Box tree groweth greene winter and Sommer : it floureth in Februarie and March, and the feed is ripe in September,

$$
\text { TI The } 2 \text { ames. }
$$

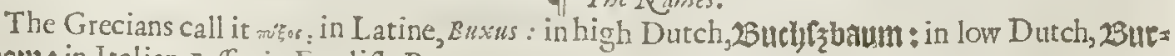
boom: in Italian, 5 a f $f_{0}:$ in Englifh, Box trec.

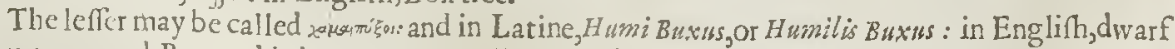
Box, or ground Box, and it is commonly called Dutch Box.

$$
\text { The Tomperature and Vertues. }
$$

A The leaucs of the Box tree are hot, drie, and aftringent, of an euill and lothfome finell,not vfed in medicine, but onely as I faid before in the defeription. 


\section{С а т. 7r. Of the Myrtle Tree.}

\section{T The Defcription.}

1 Te firft and greateft cryrtus is a fmall tree, growing to the height of a man, hauing ma ny faire and pliant branches, couered with a browne barke, and fet full of leawes mueti like vnto the Laurell or Bay leafe, but thinner and fmaller, fomewhat refembling the leaues of Peruinele, which being bruifed do yeeld forth a moft fragrant fmell,not mueh inferiour vato the fmell of Cloues,as all the reft of the kindes do : among thefe leaues come forth fmall white floures, in Thape like the floures of the Cherry trec, but mueh fmal ler, and of a pleafant fauour,which do tutn into fmall berties, greene at the firft, and afterwatds blacke.

I Myrtus Laurea maxima. The Mytle tree.

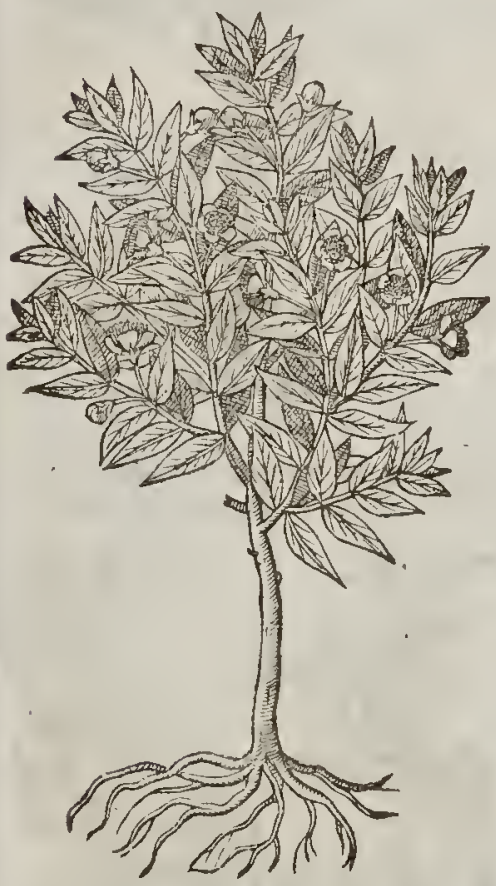

$\ddagger 2$ Myrtus Batica latifolia. Great Spanilh Myrte.

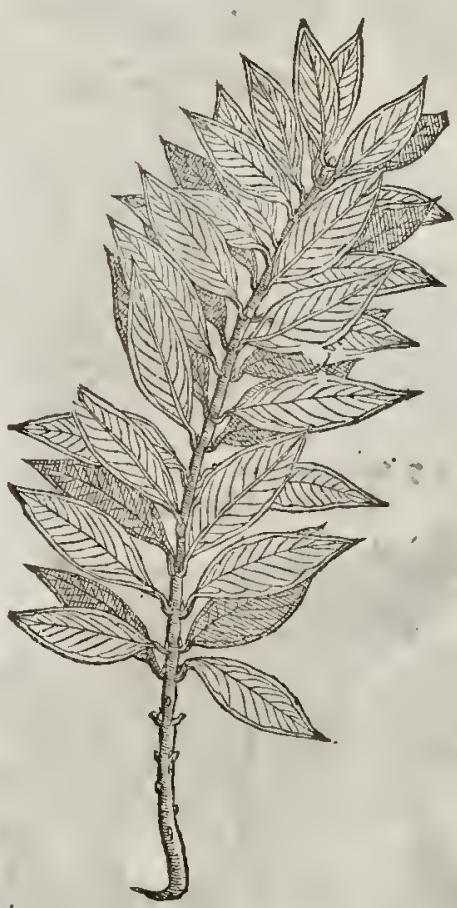

2 There is alfo another kind of Myrtus called cuyrtus Betica latifolid, according to Clufins Myr tus Lavre, , that hath leaues alfolike. Bay leaues, growing by eouples vpon his ple fant greene brant ches, in a double row on both fides of the ftalkes, of a light greene colour, and fomewhat thieker than the formet, in fent and fmell fweet : the floures and fruit are not much diffeting from the firft kinde.

3 There is likewife another kinde of cryrtus called Exotica, that is ftrange and noc common: it groweth vpright vnto the height of a man like vato the laft before mentioned, but that it is replenithed with greater plenty of leaues, which do fold in them felues hollow and almoft double,broader pointed, and keeping no order in their growing, but one thrulting with in anorber, and as it were crofing one another eonfuredly; in all other points agreeing with the precedent.

4 There is another for like vnto the formar in floures and branehs, but the leatres are fmooth, flat an 1 plaine, and noc erunsled or folded at all, they are alfo much fnaller than any of the former. The fruit is iu th tpe like the other, but that it is of a white colour, whereas the fruit of the other is blaeke.

5 Tha: is allo ansthar kin la of Myrtle, ealled Myrtus minor, or noble Myrte,azbeing rhe 
\# 2 Myrtus exotica. Strange Myrtle.

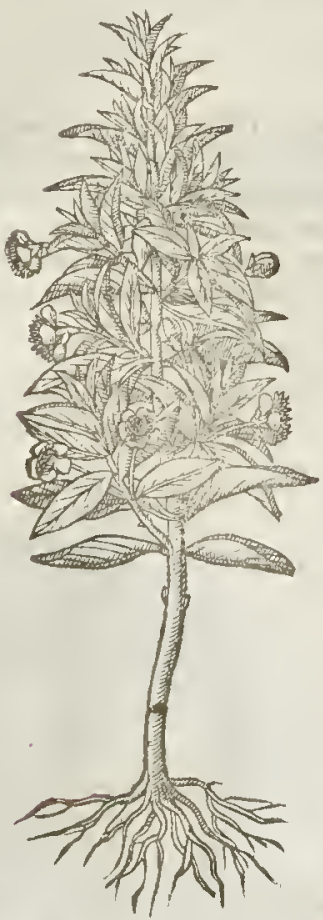

\$ 5 ayrtus minor.

The little Myrtle.

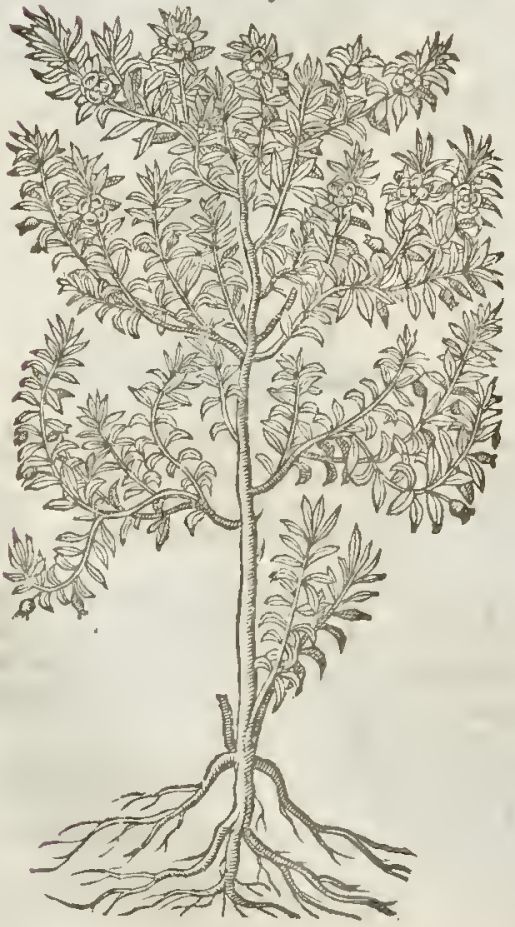

$\ddagger 4$ Myrtses fruttualbo. Myrtle with white berries.

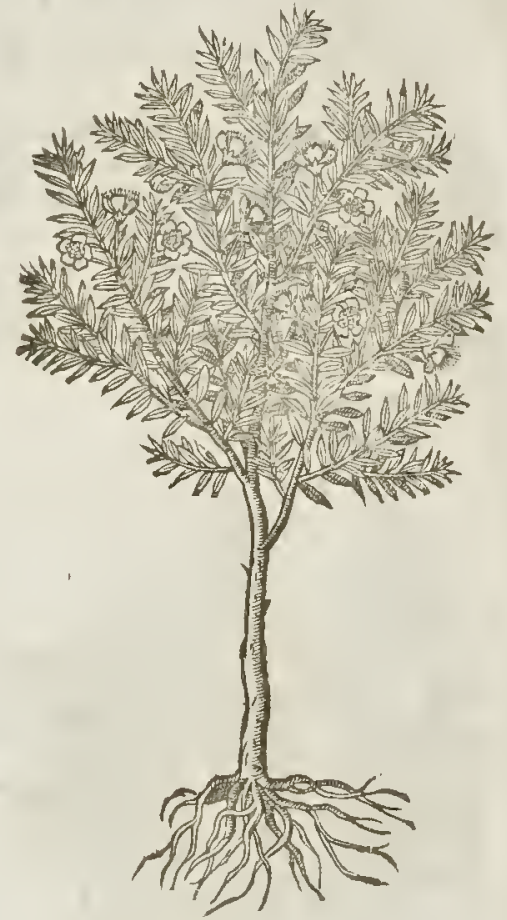

* 6 Myrtus Betica(ylueftris? Wilde Spanin Myrtle.

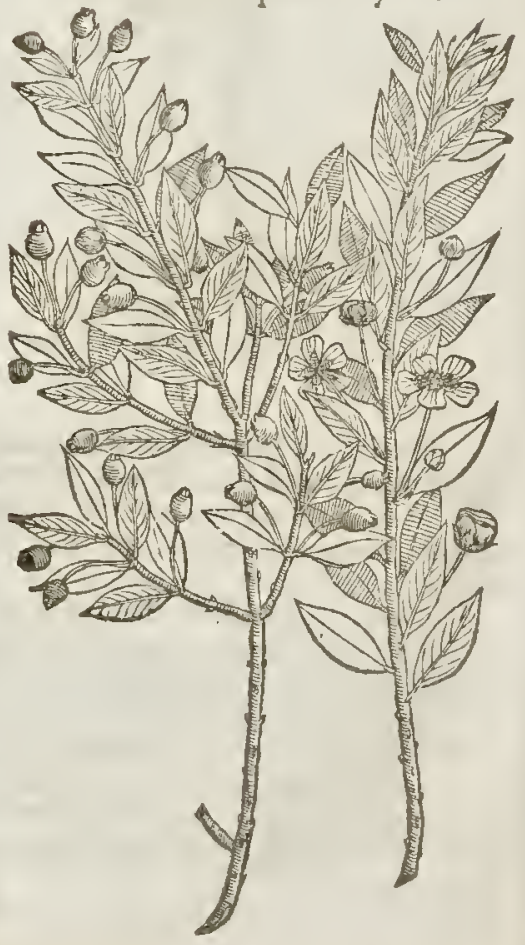


chiefe of all the teft (although moft common and beft knowne) and it groweth like a little fhrub or hedge bufh,very like vnto the former, but much fmaller : the leaues are fmal and narrow, very mueh in Shape refembling the leaues of Mafticke Time called $M$ arum, but of a frefher greene eolour : the floures be white, nothing differing from the former fauting in grearneffe, and that fometimes they are more double.

$\ddagger 6$ This growes not very high,neither is it fo thrubby as the former: the branehes are fmall and brittle : the leates are of a middle bigneffe, fharpe pointed, ftanding by couples in two rowes, feldome in foure as the formcr, they are blackith alfo and wel fmelling. the floure is like that of the reft : the fruit is round, growing vpon long ftalks out of the bofomes of the leaues, firft greene, then whitin, laftly blacke, of a winy and pleafant tafte with fome aftriction. This growes wilde in diuers places of Portugall, where clufus found it fouring in October : he ealls it Myrtus Betzca Jylueforis. ‡

$$
\text { It The Place. }
$$

Thefekindes of Myrtles grow naturally vpon the wooddy hills and fertill fields of Italy and Spain. $\neq$ The two laft are nourihed in the garden of Miftreffe $T_{\mathrm{g} g} g y$ in Weftminter, and in fome orher gardens. $\ddagger$

$$
\text { If The Time. }
$$

Where they ioy to grow of them felues they floure when the Rofes do:the fruit is ripe in Autumne: in England they neuer beare any fruit.

$$
\text { I) The rames. }
$$

It is ealled in Greeke pupann: in Latine, Myrtus : in the Arabieke tongue, Alas : in Italian, Myrto: in Spanifh,Arrayban: in the Portingale language, Murta,and Mrrtella: other Nations doe almoft keepe the Latine name, as in Englinh it is called Myrt'e, nr Myrtle tree.

Among the Myrtles that which hath the fine little leafe is furnamed of $p$ liny, Tarentina; $8 x$ that which is fo thieke and full of leaues is Exotica, ftrange or forreine. Nig' a Myrtus is that which hath the blacke berries : Candida, which hath the white berries, and the !eaucs of thıs alfo are of a lighter greene : Satima, or the tame planted one is eherifhed in gardens and orehards : Sylueftris, or the wild Myrtle is that which groweth of it felfe; the berries of this are oftentimes leffer, and of the other, greater. Pliny doth alfo fer downe other kindes; as Patritia, Plebein, and Coning als : but what manner of ones they are he doth not deelare : he al fo placeth among the Myrtles, Oxymyrfine, or Kneeholm, which notwithftanding is none of rhe Myrtles, but a thornie thrub.

rltryy in his 14. book, I 6 .chap. faith, that the wine whieh is made of the wilde Myrtle rree is called Myrtid.mum, if the eapie be true. For Diofcorides and likewife Sotion in his Gcoponikes report, that wine is made of Myrtle berries when they be thorow ripe, but this is called Vinum Myrtewm, or Myrttes, Myrtlewine.

Moremer, there is alfo a wine nade of the berries and leaues of Myrtie ftamped and fteeped in Munt, or wine new preffed from the grape, which is ealled, as Diofcorides faith, Myrfinite virum, or wine of Myrtles.

The Myrtie tree was in times pait eonfecrated to Venus. Pling in his 15 . booke, 29. ehapter, faith chus, There was an old Alter belonging to Venus, whieh they now call Murtia.

$$
\text { of The Temperature and Vertues. }
$$

The Myrtle confifteth of contrary fub ftanees, a cold earthinefre bearing the preheminence; it $\mathbf{A}$. hath alfo a certaine fubtill heat, therefore, as Galen faith, it drieth notably.

The leaues, fruit, buds, and iniee do binde, both outwardly applied and inwardly taken: they ftay $B$. the fpitting of blond, and all other ilfies thereof: they ftop both the whites and reds in women, if chey fit in abath made therewith : after which manner and by fomenting alfo they ftay the fuper: fluous courfe of the henorrhoides.

They are a remedy for laskes, and for the bloudy flix, they queneh the fiery heat of the eies, if $\mathbf{C}$ they be laid on with parehed Barly meale.

They bealfowith gond fuceeffe ourwardly applied to all infammations newly beginning, and D alfo to new paine vpon fome fall, ftroke or ttraine.

They are whollome for a moift and watery ftomaeke : the fruit and leates dried prouoke vrine: $\mathrm{E}$ for the grecne leates eontaine in them a ceartaine fuper flous and hurtfull moifture.

It is good with the decoetion herof made with wine, to bathe lims that are out of ioint,and bur- F ftings that are hard to be cured, and vicers alfo of the ourward parts: it helpeth fpreading tetters, feourcth away the dandrafe and fores of the head, naketh the haires blacke, and keepeth them

$$
\operatorname{seccc} 3
$$

from 
from fhedding; wi thiftandeth drunkenneffe, if it be taken fafting, and preuaileth againft poifon,and the bitings of any venomous beaft.

G There is drawne ont of the green berries thereof a iuce, which is dried and refertred for the foreCaidvfes.

$\mathrm{H}$ There is likewife preffed out of the leaues a inice, by adding vnto them either old wine or raine water, which muft be ved when it is new made, for being once drie it putrifieth, and as Diofeorides faith,lofeth his verrues.

\section{Chн т. 72. Offweet Willow or Gaule.}

Myrtus Brabanica, irve Elatgnus Cordi.

Gaule, fiveețillorv, or Dutch Myrtle tree.

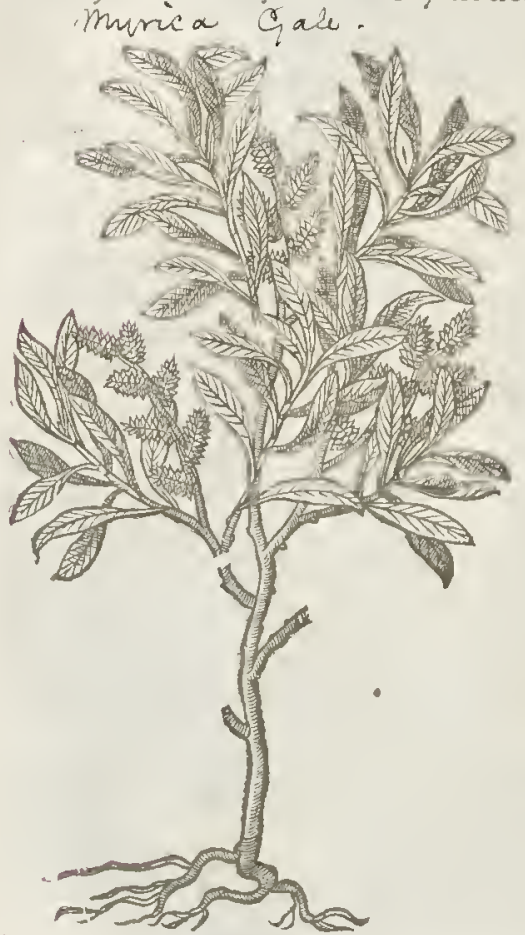

$$
\text { 9) The Defcription. }
$$

T Aule is a low and little hrubor wooddy T plant.hauing many brown \& hard branches:whercupon doe grow leaues fomewhat long, hard, thicke, and oileous, of an hot faucur or fmell fomewhat like Myrtus: among the brarches come forth other little ones, wherufon do grow many fpokie eares or tufts, full of fmall fioures, and atter them fucceed great ftore of fquare feeds cluftering together, of a ftrung and bitter tafte. The root is hard, and of a wooddie fubftance.

$$
\text { of The Place. }
$$

This Gaulegroweth plentifully in fundry places of England, as in the Ile of Ely, \& in the Fennie countries thereabouts, wherof there is fuch ft ore in that comntrey, that they make fagots of it and theaues, which they call Gaule heaues, in burre and heat their onens. It growcth alfo by Colebrooke, and in fundry other places.

\section{The Time.}

The Gaule floureth in May and Iune, and the feed is ripe in Augutt.

$$
\text { Th The Names. }
$$

This tree is called of diuers in Iatine, $2 / 4 y \mathrm{r}$ tus B rabantica, and $\boldsymbol{P}$ feudomyrfine; and Cordus calJeth it Eleagnus, Chameleagmus, and MyrtusBra. Gantica. Eleagnus is defcribed by Theophraftus to be a fhrubbie plant like vnto the Chafte tree, with a folt and downie leafe, and with the floure of the Poplar tree; and that which we haue defcribed is no fuch plant. It hath no name among the old writers for ought we know, vnleffe it be Rhus fylueftris Pliniy, or Pliny his wilde Sumach, of which hee hath written in his $24 . \mathrm{book}$, I I chap. [There is, faith he, a wilde herbe with fhort falkes, which is an enemy to poifon, and a killer of mothes.] Ir is called in low Dutch, 6 bagel: in Englin, Gaule.

$$
\text { If The Temperature. }
$$

Ganle or the wilde Myrtle, efpecially the reed, is hot and drie in the third degree : the leaues be hot and drie, but not fo much.

$$
\text { Tा The vertues. }
$$

A The fruit is troublefome to the brain; being put into beere or aile whileft it is in boiling(which many vfe to do) it maketh the fame heady, fit to make a man quickly drunke.

13 The whole thrub, fruit and all, being laied a mong clothes, keepeth them from moths and worms. 
L 1 . 3. Of the Hiftory of Plants.

\section{Си ар: 73. Of Worts or Wortle berries。}

The Kindes.

Accinia, or Worts, of which we treat in this place differ from Violets, neither are they efteeWriters.

1 Vaccinia nigra.

Blacke Worts or Wotcle berries.

$$
\begin{aligned}
& \text { Blacke Worts or Wotrle berries, } \\
& \text { Orceir inm Imy tilens. }
\end{aligned}
$$

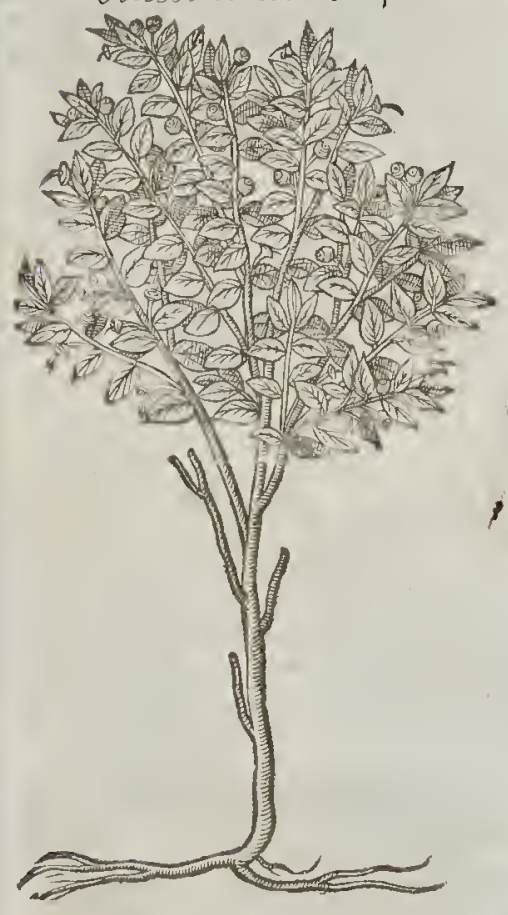

12 Yracinia rubra.

Red Worts or Wortle berries. : Naccinium Vitis-3 dicea

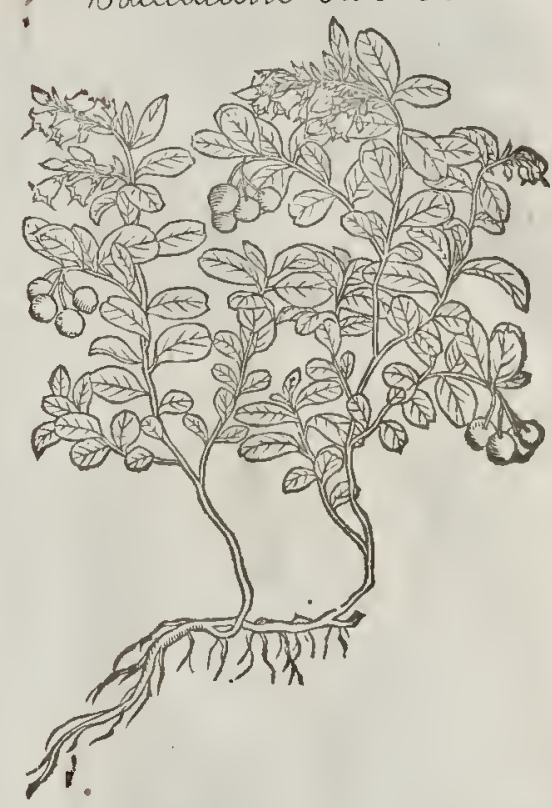

9) The Defiriptions.

I TAccinia nigra, the blacke Wortle or Hurtle, is a bafe and low thrub or wooddy plant, bringing forth many branches of a cubit high, fct full of fmall leaues of a dark greene colour, not much vnlike the leaues of Box or the Myrtle tree : amongit which come forth little hollow floures turning into fmall berries, greene at the firt, afterward red, and at the laft of a blacke colour, and full of a pleafant and fweet inyce : in which doe lie dituers little thinne whitifh feeds : thefe berries do colour the mouth and lips of thofe that eate them,with a black colour : the root is wooddy, flender, and now and then creeping.

2 Vaccinia rubra, or red Wortle, is like the former un the manner of growing, but that the leatues are greater and harder, almoft like the leates of the Box tree, abiding greene all the Winter long : among which come forth fmall carnation floures, long and round, growing in clufters at the top of the branches: after which fucceed finall berries, in theiv and bigneffe like the former, but that they are of an excellent red colour, and full of iuyce, of fo orient and beautifull a purple to limnewithall, that Indian Lacca is not to be compated thereunto, efpecially when this iuyce is prepared and dreffed with Allom according $t o$ art, as my felfe haue proued by experience : the tafe is ruugh and aftringent: the root is of a wooddy fubltance.

3 Vaccinia alba, or the white Wortle, is like vnto the former, both in fta lks and leaues, bur the berries are of a white colour, wherein confiftech the difference.

‡ The figure which our Author here gitues in the third place hath need of a better defcription, 
3 Vaccinia alba.

The white Worts or Wortle berries.

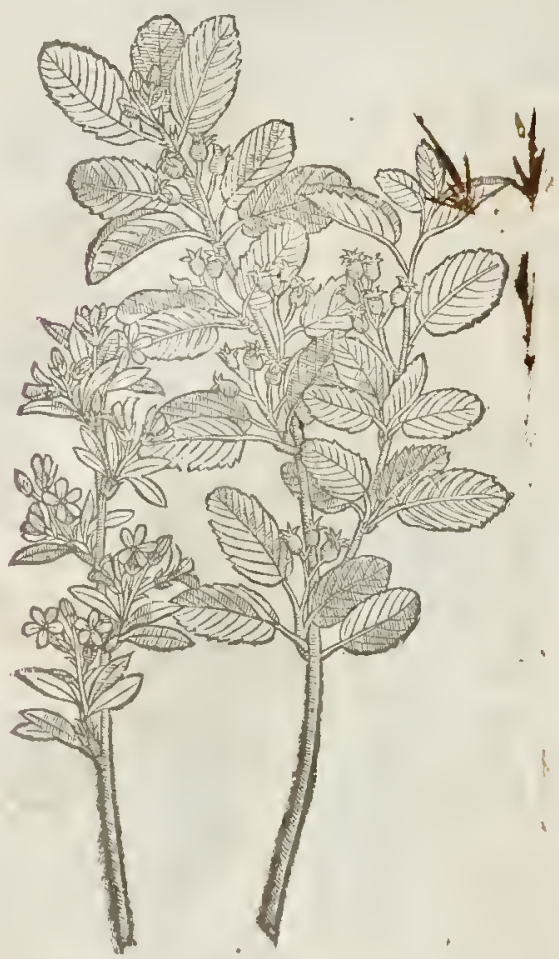

5 Vaccinia Vrfi, fue Vua Vrfi apud Cluflum.

Beare Wortle berries.

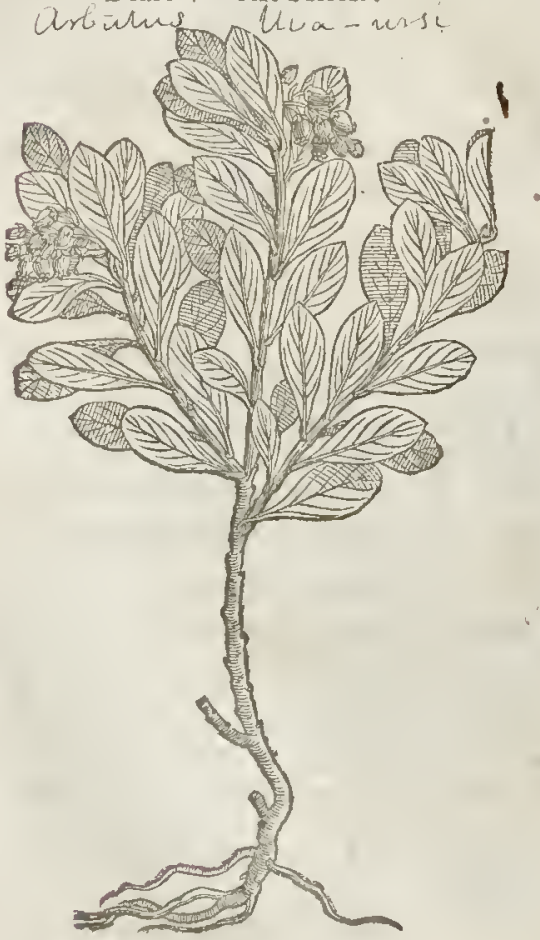

4 Vaccinin Pannonica, fue Vitis Idea. Af Hungarie Wortle berries.

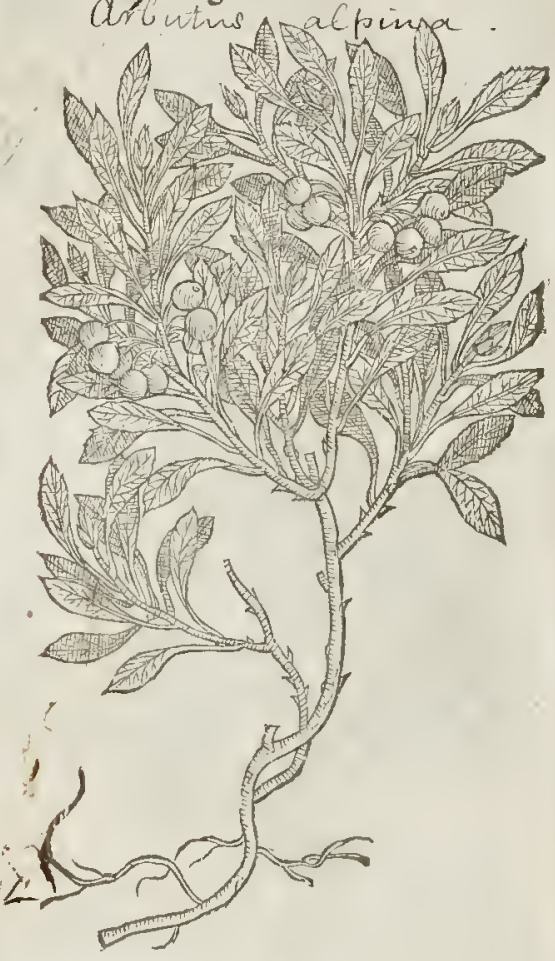

+ 6 Vit is Idea folyjs fubrotundis maior. Great round leaued Wortle berries. vaccinum Vlig inosym

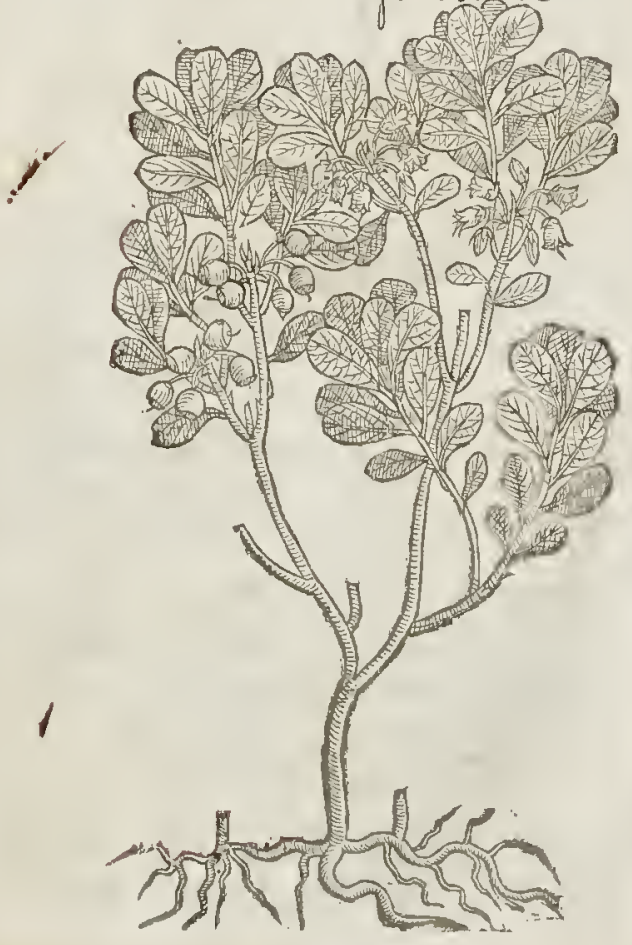


for the difference is not onely in the colour of the berries. This differs from rhe former in forme and bignefle; for it fends forth many ftalkes from the root, and the fe three, foure, or fiue cubits bigl, thicke, and dituided into fundry branches, conered for the moft part with a blackith barke : at tre beginning of the Spring from the buds at the fides of the branches ir fends forth leaucs all horie and hairy vnderneach, and greene about : from the midit of thefe; vpon hittle foor-ftalkes fand cinftering together many little floures, confifting of fucw hite leaues apiece withour finell; and then the leaues by little and little vnfold themighies and caft off their doyninefre, and beeome fniptabout the edges. The fruit that fucceeds the floures is round, blacke, fomewhat like, but bigger than a Haw, full of iuyce of a very fweet tafte w herein lies tea or more longith finooth blaekifh feeds. It growes vpon the Autrian and Stician Alps, where the fruir is ripe in Auguft.

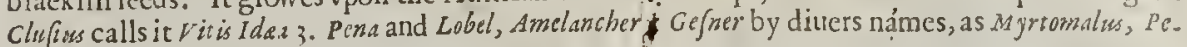
tromelis, Pyrus cersinus, \&ेc. $\ddagger$

4 Carolus Clufses in his Pannonicke Obferuation hatls fet downc another of the Wortle berries, vnder the wame of $V$ it is Idax, which differeth from the other Worto berries, not onely in fta. ture, but in leaues and fruit alfo. \$ The leaues are long, narrow, tharpe pointed, full of veines, a lirtle hairy, and lishtly fnipt about the cdges, greener apoue than below : the fruit growes from the tops of the branches of the former yeare, hanging voon long foot-ftalkes, and being as big as litt'c Chirries, firft greene, then red, and lanly blacke, furll of iuyce, and that of no vnpleafant tafte, containing no kernels, but flatwhite teeds commonly fue in number : the ftalkes are weake, and commonly lie vpon the ground: Chifrus found it vpon rhe Auftrian mountaine Snealben, with the fruit partly ripe, and partly vnripe, in Auguft. It is his Vits Ider r. $\neq$.

5 The fame Author alfo fetteth forth another of the Wortle berries, vnder the title of $V$ is Vrfa, which is likew ifea thrubby plant, hauing many feeble branches, whereon grow long leanes blunt at the poinrs, and of an ouerw orn green colour : among which, at the tops of the falks come forth elutters of bottle-like floures of a herby colour: the fruit followeth, growing likewife in clufters, green at the firft, and blacke whehrey be ripe : the root is of a wooddy fubftance. $\neq$ This is alwaies greene, and the floures are of a whition purple colour. $\ddagger$

$6 \neq$ This differs from the fecond, is that the leaues are thinner, more full of veines, and whiter vndern ath:the floure is like the common kind, whitifh purple, hollow, and diuided into fue parrs: the fruicalfo is blacke, and like that of the firf: defcribed. This growes ondiuers mountainous flaces of Germany, where Clugins obferued it, who madc it his Vitis Idea 2. ‡

$$
\text { Tा The Place. }
$$

Thefe plants profner beft in a lean barren foile, and in vntoiled wooddy places : they are now and then found on high hils fubient to the winde, and vpon mountaines : they grow plenrifully in tork the Germanies, Bohemia, and in diucrs places of France and England; namely in Middlefex on Hampfted heath, and in the woods thereto adioyning, and alfo vponthchills in Cherhire called Broxen hills, neere Beefton caftle, feuen miles from the Nantwich; and in the wood by Highgate called Finchley wood, and in diuers other places.

The red Wortle berry groweth in Weftmeland at a place called Crosby Rauenfivaith, where alfodoth grow the Wortle with the white berry, and in Laneafhtre alfo vpon Pendle hills.

$\neq \quad I$ hate feene none of thefe but only the firft defcribed, growing vpon Hamplted heath. The white formerly mentioned in the third defeription, and here againe in the place, feems only a varietic of the fecond hauing white berries, as far as I can gather by our Author; for it is moft certaine, that it is not that which he figured, and I haucdefcribed in the third place. $\ddagger$

$$
\text { T The Time. }
$$

The Wortle berries do floure in May, and their fruit is ripe in Iune.

$$
\text { वा The Names. }
$$

VVorcle berrics is called in high-Dutch, epoltuecen: in low-Duteh, Italsebefien, becanfe they nake a certaine cracke whileft they be broken betweene the teetls: of diuers, 1 auetuefien: the French men, Airelle, or Aurelle, as Iohannes de Choul wrireth: and we in England, VVorts, VVhortleberries, Blacke-berries, Bill-berries, and Bull-betries, and in fome places, VVin-berries.

Mot of the thops of Germany docall them Myrtill;, but properly CMyrtilis are the fruit of the Myrrle tree, as the A pothecaries nume rlem at this day. This plant hath no name for ought wee can learne, either among the Greekes or antient Latines; for whereas moft doe take it to be vit is $I d y$, or the Corinth tree, which Pliny fyrmameth Alexandrina, it is vntrue; for $V$ it is $I d a z$ is nor on. ly like to the common Vine, hut is alfo a kinde of Vine : and Theophraftus, who hath made mention

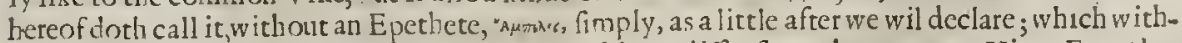
out doubt hewould not baue done if he had found it ro differ from the common Vine: For what things focuer receiue a name of fome plant, the fame are expreffed with fome Epethit added ro bc known to differ from others : as Luurus Alexandrina, Vit is alba, Vitis nigra, Vit is fylueftris, and fuch like.

Moreoucr, thofe things which haucborrowed a name from fome plant are like theremn, if not wholly 


\section{8}

Of the Hiftory of Plants.

L1B.3.

wholly, yet eithet in leafe or fruit, ot in fome other thing. $V$ it is alba of nigra, that is, the white and blacke Bryonies, haure leaues and elafping tendrels as hath the common Vine, and elyme alfo after the fame manner : Vit is fylueftris, or the wilde Vine, hath fuch like ftalks as the Vine hath,and bringeth forth fruit like to the little Grapes. Laurus Alexandrina, and Clsamedaphne, and alfo Daphnoides, are like in leaues to the Laurell tree : sycomorus is like in fruit to the Figtrce, and in leaues to the Mulberry tree: Chamedrys hath the leafe of an Oke; Peucedanus of the Pine tree : fo of others which haue taken their names from fome other : but this low fhrub is not like the Vine either in any part, or in any orber thing.

This Vitis Idea groweth not on the vppermol and fnowie parts of mount Ida (as fome would haue it, but about Ida, euen the hill Ida, not of Candy, but of Troas in the leffer A fia, whieh Prolomie in his fifth booke of Geogiaphic, ehap. 3. doth call Alexandr: Troas, or N lexander his Troy: whereupon it is alfo aduifedly named of Pliny, l16. I 4. cap.3. Vitis slexandrina, no otherwife than Alexandrinu Laurus is faid of Theophrafus to grow there: Laurus, fyrnamed Alexandrina, and Fucus gusedam, or a ecrraine Fig tree, and Asemios, that is to fay the Vine, are reported, faith be, to grow properly about Ida. Like vnto this Vine are thofewhieh Philoftratus in the life of Apollunius reportcth to grow in Mxonia, and Lydia, feituated not far from Troy, eomparing them to thofe vines whielı grow in India beyond Caucafus : The Vines there, faith he, be very fmall, like as be thofe that do grow in Maonia and Lydia, yet is the wine which is preffed out of them of a maruellous pleafant tafte.

This Vine which growes necre to mount Ida is reported to be like a thrub, with little twigs and branehes of the length of a eubit, about $w$ hich ate grapes growing alope, blacke, of the bignes of a beane, fwect, hating w ithin a certainc winic fubftance, foft : the leafc of this is round, vneut, and little.

This is deferibed by Pliny, lib. I 4 , cap. 2. almoft in the felfe fame words : It is called, faith he, $A$ lexandrinavits, and groweth neere vnto Phalacra: it is fhort, with branehes a cubir long, with a blacke grape of the bignes of the Latines Beane, with a foft pulpe and vety little, witbiery fweet clufters grow ing allope, and a little round leafe without euts.

And with this defeription the little fheub which the Apotheearies of Germany docall Myrtillus doth nothing at all agree, as it is very manifent; for it is low, featee a cubit high, with a few ihort branches not growing to eubit in length: ir dorh not bring forth elufters or bunehes, not yet fruit like nto grapes, but berries like thofe of the Yew tree, not fweet, but fomew hat foure and aftringent, in whichalfo there are many littlcwhite flat feeds : the leafe is not round, but nore long than round, not like to that of the Vine, but of the Box ttee. Moreover, it is thought that this is not found in Italy, Greece, or in the leffer A fia, for that Matthio/us affirmeth the fame to grow no where but in Germanie and Bohemia ; fo far is it from being ealled ot accounted to be $V$ it is Idea or Alexandrina.

The fruit of this may be thought not without caufe to be named $V$ accinia, fith they are betries; for they maybe termed of $B a c c_{2}$, berries, Vaccima, as though they fhould be ealled Baccinia. Yet this lettech not that rhere may be alfo other Vaccinia's: for Vaccinia is maionus ditio, or a word of diuers fignifieations. Virgil in the fitf booke of his Bucolicks, Eclog. I0, affirmeth, that the written Hyacinth is named of the Latines, Vaccinium, ttanlating into Latine $T$ heocritus his verfe which is taken out of his tenth Eidyl.

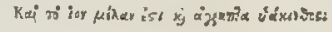

$$
\begin{aligned}
& \text { Virgil: } \\
& \text { Et nigr.e Viola, font or V accinia nigra. }
\end{aligned}
$$

Titruvius, lib.7. of his Arehitecture doth alfo diftinguifh Vaccinium from the Violer, and fheweth, that of it is made a gallant purple; which feeing that the written Hyaeinth eannot do, it muft needs be that this Vaccinmm is another thing than the Hyaeinth is, bccaufe it ferues to gite a purple dye.

Pliny alfo, lib. I6.cap. I 8. hath made mention of $V a c c i n i$, which are vfed todye bond-flaues garments with, and to giue them a purple eolour.

But whether thefe be our Vaccinin or Whortleberties it is hatd to affime, efpecially fecing that rliny reckoneth vp $T$ accinia amongft thofe plants which grow in waterie places; but ours grow on high plaees vpon mountaines fubieet towindes, neither is it certainly knowne to grow in Italy. How foener it is, thefe our Whortles may be called $Y$ accinia, and do agree with Plinies and $r$ ity rius his Vaccinia, becaufe garments and linnen eloath may take from thefe a purpledie.

The red Whortle berries haue their name from the blaeke Whortles, to which thev be in form

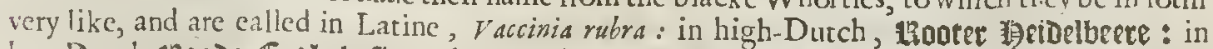

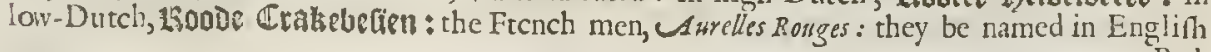




\section{LiB.3. . Of the Hiftory of Plants.}

Red Worts, or red Wortle berries. Conradus Gefnerus bath called th is plant Vit is Idea rubr un anis: but the growing of the berries doth thew, that this doth farre leffe agree with Vitse Ides, than the blacke; for they do not hang vpon the fides of the branches as do the black (which deceited thent that thought it to be Vitis $I d, 2$ ) but from the tops of the fprigs in clufters.

As concerning thenames of the other they are touched in their feucrall defcriptions.

$$
\text { q The Temperature. }
$$

Thefe raccinin or Wortle berries are cold cuen in the later end of the fecond degrec, and dry alfo, with a manifeft atriction or binding qualitue.

Red Wortle berrics are cold and dry, and alfo binding.

$$
\text { 9) The Vertues. }
$$

The inyee of the blacke Wortle berries is boyled till it become thicke, and is prepared or kept $A$ by adding hony and fugar vnto it : the A pothecaries eall it kob, whieh is preferred in all things before the raw berries themfelues; for many times whileft they be eaten or taken raw they are offenfiue to a reake and cold fomaeke, and fo far are they from binding the belly, or ftaying the laske, as that they alfo trouble the fame through their cold and raw qualitie, which thing the boiled iuyce called Rob doth not any whit at all.

They be good for an hot ftomacke, they quench thirft, they mitigate and allay the heate of hot B burning agues, they ftop the belly, ftay vomiting, cure the bloudy flix proceeding of choler, and helpe the felonie, or the purging of eholer vpwards and downwards.

The people of Chefhire do eate the blacke wortles in ereame and milke, as in thefe South parts we eate Strawberries, which ftop and binde the belly, putting away alfo the defire to vomit.

The red Wortle is not of fuch a pleafant tafte as the blacke, and therefore not fo much vfed to D be caren; but (as I faid before) they make the faireft carnation colour in the world.

\section{Cна в. 74. \\ Of the $\mathrm{M}$ arifh Worts or Ferne-Berries.}

Vacciniapalufria.

Marifh Wores.

Naccioinus oxycocus

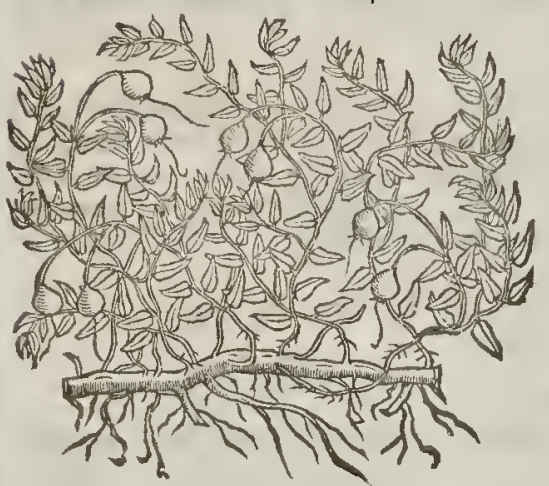

T) The Defription.

5 He Marifh Wortle berries grow vpon the bogs in marith or moorith grounds, creeping tlicreupon like vnto wilde Time, hauing many fmall limmer and tender ftalkes layd almoft flat vpon the ground, befet with fmal narrow leaues fathioned almoft like the leaues of Thyme, bur leffer: among which come forth little berries like vnto the common blacke Wortle berrie in thape, but fomewhat longer, fonctimes all red, and fometimes fpotted or fpecked with red fpots of a deeper colour : in tafte rough and aftringent.

$$
\text { 9] The Place. }
$$

The Marifh Worcle growes vpon bogs and fuch like waterifh and fenmy places,efpecially in Che hire and Staffordhire, where I have found it in great plenty.

\section{The Time.}

The Bersics are ripe about the end of Iuly, and in Auguf.

I The Names.

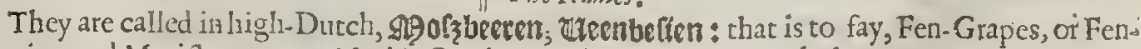
Berries, and Marilh-worts, or Marilh-Berries. Valerius Cordus nameth them Oxycoccon: wee haue ealled them reciniapaluftrin, or Marith Wortle berries, of the likeneffe they hate to the other berries : fome alfo call them Moffe-Berries, or Moore-berries.

$$
\text { T The Temperature. }
$$

Thele Wortle berries are enld and dry, hauing withall a certain thinneffe of parts and fubftanee, with a certaine binding qualitic adioyned. 
T Ihe Fertucs.

A They take away the heate of burning agues, and alfo the drought, they quench the furious heate of choler, they ftay vomit ing, reftore an appetite to meate which was lon by reafon of cholericke and corrupt humors, and are good againft the peftilent difeafes.

B The iuice of thefe alfo is boyled till it be thicke, with fugar added that it may be kept, which is good for all things that the berrics are,yea and far better.

I I haue brousht this Chapter and the next following from the place ithey formetly held, and leated them here amongft the reft of their kindred.

\section{Снар. 75. Of Cloud-berry.}

Vaccinia Nubis.

Clond-berrics.

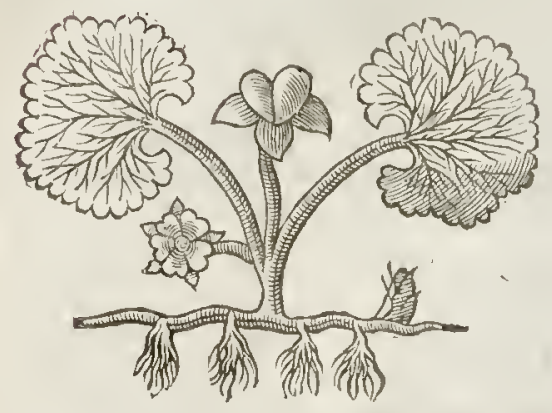

T) The Dcfoription:

7 He Cloud.berrie hath many fmall threddy roots, creeping farre abroad vnder the vpper crult of the earth, and alfo the moffe, like vnto Couch-grafte, of anouerworn reddifh colour, fet here and there with fmal tufts of hairy itrings: from which rife vp two fmall italks, hard, tough, and of a wooddy fubftance (neuer more nor lefic) on which loe ftand the leaues like thofe of the wilde Mallow, and of the fame colour, full of fmall nerues or finewes runring in each part of the fame : between the leaues commeth vp a ftalke likewife of a wonddy fublarce, wher on doth grow a fmall floure confifing of frue leaues, of an herby or yellow' th green colour like thofe of thewilde Auens. After commeth the fruit, greene at the firft, afrer yellow, and the fides next the Sun red when they be ripe; in forme almoft like vnto a little heart. nuade as it were of two, but is no more but one, open abouc, and clofed together in the bottom, of a harm or fharpe tafte, where. in is contained three or fouse little white feeds.

\section{T The Place.}

This plant groweth naturally vpon the tops of two higli mountaines(among the moflie places) one in York thire called Ingleborough, the nther in Lancafhire called Pc ndle, two of the higheft mountaines in all England, where the clouds are lower than the tops of the lame all Winter long, whereupon the people of the countrey haue called them Cloud-berries, found there by a curious gentleman in the knowledge of plants, called $\mathrm{M}^{\mathrm{r}}$. Hesketh, ofren remembred.

$$
\text { T The Time. }
$$

The leates fpring vp in May, at which time it floureth: the fruit is ripe in Iuly.

The fruit is cold and dry, and very aftringent.

$$
\text { T) The Temperature. }
$$

T The Vertucs.

A The fruit quencheth thir $\mathrm{f}$, cooleth the ftomacke, and allayeth infammations, being eaten as Worts are, or the decoftion made and drunke.

$\uparrow$ Mipfriend M. Pimble of Matribone zeeeined a plant hereof out of $L$ ancalhire: and by the fhape of the leareI contd not iudge it to differ from the $C$ bamamoin

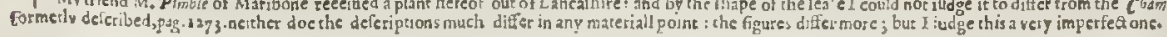

\section{C н в. 76. Of Jbrub Hectrt-Wort of Ethiopia. If The Defoription.}

Mis kind of Sefely, being the Athiopian Sefely, hath blackinh ftalks of a wooddy fubfance: this plant diuidech it felfe into fundry other armes or branches, which are befer with thicke fat and oileous leaues, falhioned foncwhat.like the Wood-bindeleaucs, but thicker, and more 


\section{$\mathrm{L}_{1 \mathrm{~B}: 3 .} \quad$ Of the Hiftorie of Plants.}

Sefeli Nethiopicum frutex.

Shrub Sefely, or Hart-woort of Ethiopia,

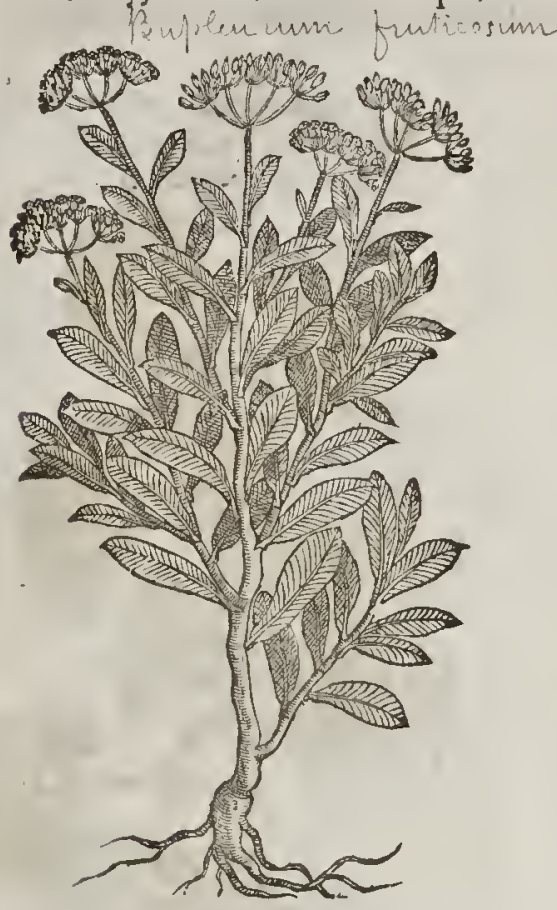

more gummic, approching very neere vnto the leaues of Oleander both in fhape and fubftance, being of a deepe or darke green eolour, and of a very good fauour and fmell, and continueth greene in my garden both winter and Sommer, like the Bay or Laurell. The foures do grow at the tops of the branehes in yellow rundles like the floures of Dill; which being patt, there fueeeedeth a darke or duskie feed refembling the feed of Fennell, and of a bitter tafte. The root is thieke and of a wooddy fubitance.

$$
\text { I T be Place. }
$$

It is found both in ftony places, and on the fea eoafts not farre from Marfilles, and likewife in other plaees of Languedoeke: it alfo groweth in Ethiopia, in the darke and defart woods : it groweth in my garden.

$$
\text { I The Time. }
$$

It flourifheth, floureth and feedeth in Iuly and Auguft.

$$
9 \text { The Names. }
$$

The Greeians call it Aisumnkrosas: the Latines likewife etthiopicum Sefeli : the Egypo tians, worers qpikn: that is, Dogs horrour : in Englifh, Sefely of Erhiopia, or Ethiopian Hart; woort.

T) The Temperature and Vertues.

Sefely of Ethiopia is thought to have the fame facultics that the Sefely of Marfilles hath; $A$ whercunto I referit.

\section{С на . 77. Of the Elder tree. \\ T The Kindes.}

THere be diuers forts of Elders, fome of the land, and fome of the water or marifh grounds ? fome with very jagged leaues, and others with double floures, as fhall be declared.

$$
\text { 9. The Defcription. }
$$

I

7 He common Elder groweth vp now and then to the bigneffe of a meane tree, cafting his boughes all about, and oftentimes remaineth a fhrub:the body is almoft all wooddie, hauing very little pith within; but the boughes and efpeeially the young ones whieh be iointed, are full of pith within, and haue but little wood without : the barke of the body and great armes is rugged and full of chinks, and of an ill fatroured wan colour like athes : that of the boughes is not very fmooth,but in colour almoft like; and that is the outward barke, for there is another vnder it neerer to the wood, of eolour greene : the fubftanee of the wood is found, fomewhat yellow, and that may be eafily cleft : the leaues confift of fue or fix partieular ones faftened to one rib, like tlinfe of the Walnut tree, but etery particular one is leffer, nieked in the edges, and of a ranke and ftinking fmell. The floures grow on fpokie rundles, which be thin and feattered, of a white colour and fweet fnsell : after them grow vp little berries, greene at the firf, afterwards blacke, whereout is preffed a purple juice, which being boiled with Allom and fueh like things, doth ferue very well for the Painters vfe, as alio to colour vineger: the feeds in thefe are a little flat, and fomewhat long. There groweth oftentimes vpon the bodies of thofe old trees or fhrubs a certaine exerefeence ealled Luricula Iude, or Iewes eare, whieh is foft, blackifh, eouered with a skin, fomewhat like now and then to a mans eare, which being plucked off and dryed, 
Thrinketh together and becommeth hard. This Elder gtoweth eucry whete, and is the common Elder.

2 There is another alfo which is rare and Itrange, for the berries of it are not blacke, but white: this is like in leates to the former.
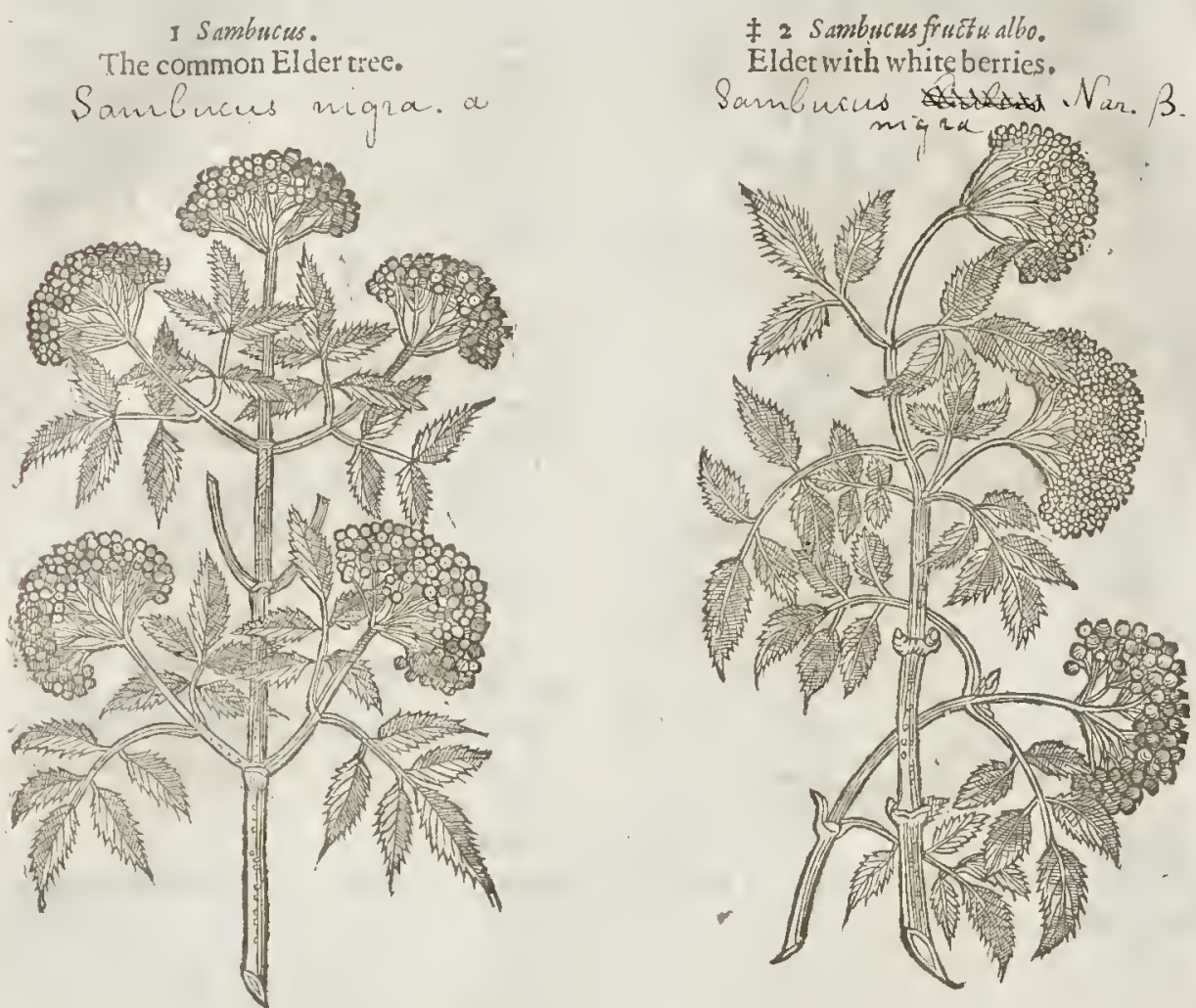

3 The jagged Elder tree groweth like the common Elder in body, branches, Thootes, pith; floures, fruit, and ftinking fmell, and differeth onely in the fafhion of the leaues, which doth fo much difguife the tree, and put it out of knowledge, that no man would take it for a kinde of EIder, vntill he hath fmelt thereunto, which will quickely thew from whence he is defcended: for thefe ftrange Elder leaues are very much jagged, rent or cur euen vnto the middle rib. From the trunke of rhis tree as from others of the fame kinde, proceedeth a certaine flefhie excrefcence like vnto the eare of a man, efpecially from thofe trees that are very old.

4 This kinde of Elder hath floures which are white, bur the berries redde, and both are not contained in fpokie rundles, but in clufters, and grow after the manner of a clufter of grapes:in leaues and other things it refembleth the common Elder, faue that now and then it groweth higher.

It The Place.

The common Elder groweth euery where : it is planted about conie-burrowes for the thadow of the Conies; but that with the white berries is rare: the other kindes grow in like places; but that with the cluftered fruit growcth vpon mountaines; that with rhe jagged leaues groweth in my garden.

$$
\text { 91 The Time. }
$$

Thefekindes of Elders do floure in Aprill and May, and their fruit is ripe in September.

$$
\text { I The Names. }
$$

This tree is called in Greeke, : inm : in Latine and of rhe Apothecaries, Sambucus: of Guillielmus

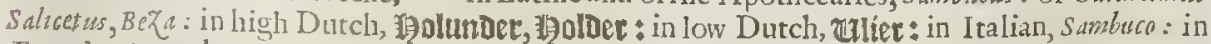
French, Has and Suin : in Spanifh, Sauco, Sauch, Sambugucyro : in Englifh, Elder, and Elder tree: that with the white berries diners would hate to be calied Sambucus fyluefris, or wilde Elder, bur crathiolus calleth it Montana, or mountaine Elder. 
3 Sambucus laciniatis folijs.

$S$ The iagged Elder tree.

Sanducus higra. Var. $\gamma$.

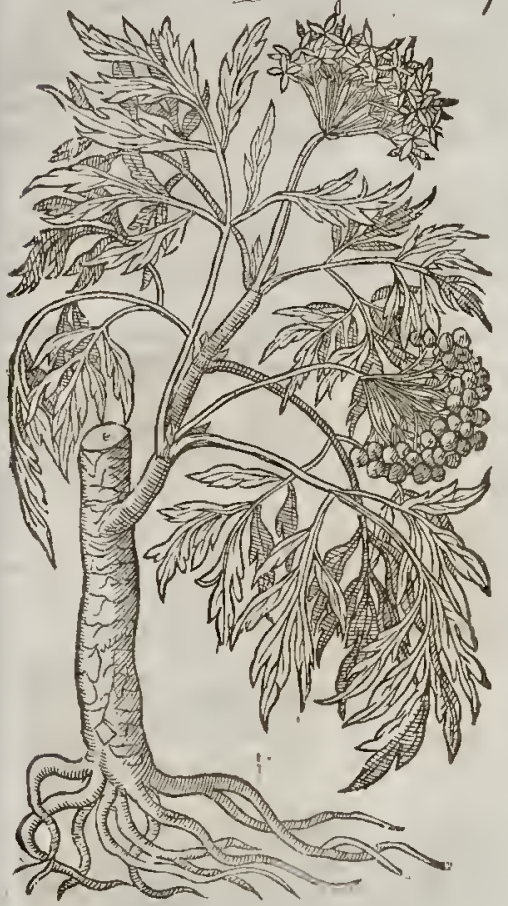

4 Samburus racemofa, vel Ceruins. Harts Elder, or Clufter Elder:

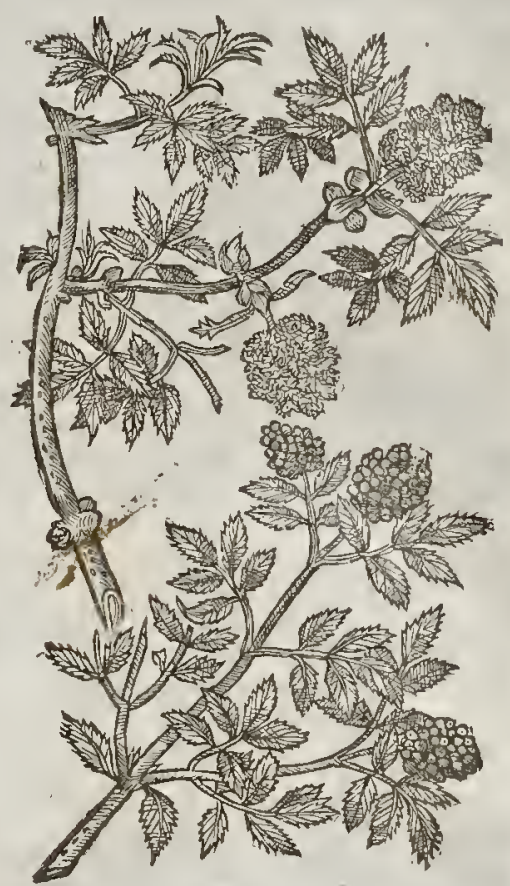

\section{The Temperature and Vertues.}

Galen attributeth the like facultie to Elder that he doth to Danewoort, and faith that it is of a drying qualitie, gluing, and moderatly digefting : and it hath not only thefe faculties, but others alfo; for the barke, leaues, firft buds, floures, and fruit of Elder, do not only dry, but allo heate, and haue withall a purging qualitie, tut not without trouble and hurt to the ftomaeke.

The leaues and tender crops of enmmon Elder taken in fome broth or pottage open the belly, B purging both n limie flegme and eholerieke humors: the middle barke is of the fame nature, but Atronger, and purgerh the faid humors more violently.

The feeds eontained within the berries dried are good for fuch as haue the dropfie, and fiteh as are too fat, and would faine be leaner, if they be taken in a morning to the quantity of a dram with wine for a certaine fpace.

The leaues of Elder borled in water vntill they be very foft, and when they are almoft boiled enough a little oile of fweet Almonds added thereto, or a little Linefeed oile; then taken forth and laid vpon a red cloath, or a piece of fcarlet, and applied to the hemorrhoides or Piles as hot as ean be fuffered, and fo let to remaine vpon the part affeeted, vntill it be fomewhat eold, hauing the like in a readineffe, applying one after another vpon the difeafed part, by the fpace of an houre or more, and in the end fome bound to the place, and the parient put warmea bed; it hath not as yet failed at the firft dreffing to eure the faid difeafe; but if the Patient be dreffed twice it muft needs doe good if the firt faile.

The greene leaues pouned with Deeres fuet or Bulls tallow are good to be laid to hot fwellings E and tumors, and doth affwage the paine of the gout.

The inner and greene barke doth more foreibly purge : it draweth forth choler and waterie hu- F mors ; for which eaufe it is good for thofe that haue the dropfie, being ftamped, and the liquor preffed out and drunke with wine or whay.

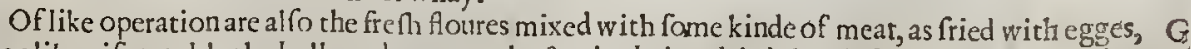
they likewife trouble the belly and mone to the ftoole : being dried they lofe as well their purging qualitic as their moifture,and retaine the digefting and attenuating qualitie, 
H The vinegar in which the dried floures are fteped are wholfome for the ftomaeke: being vfed with neate it ftirretl vp anappetite, it eutteth and attenuatech or maketh thin groffe and raw humors.

I The faeultic of the feed is fomewliat gentler than that of the othet parts: it alfo "moueth the belly, and draweth forrh waterie humors, being beaten to pouder,and giuen to a dram wcight: being new gathered, fteeped in vineger, and afrerwards dried, it is taken, and that effectually, in the like weight of the dried lees of wine, and with a few Anife feeds, for fo it worketh without any maner of trouble, and helpeth thofe that haue the dropfie. But it mult be giuen for eertaine daies together in a little wine, to thofe that haue need thereof.

K The gelly of the EIder, otherwife ealled Tewes care, hath a binding and drying qualitic : the in: fufion thereof, in whicli it hath bin fteeped a few houres, taketh away in flammations of the mouth, and almonds of the throat in the beginning, if the mouth and throat be wafhed therewith,and doth in like manner helpe rhe uvula.

I. Diofcoridis faith, that the tender and gteene leaues of the Eldet tree, with barley meale parched, do remone hot fwellings, and are good for thofe that are burnt or fealded, and for fueh as be bitten with a mad dog, and that they glew and heale vp bollow vleers.

M The pith of the young boughes is with out qualitie: This being dried, and fomewhat pteffed or quathed together, is good to lay ppen the narrow orifices or holes of fintula's and iffues, if it be put therein.

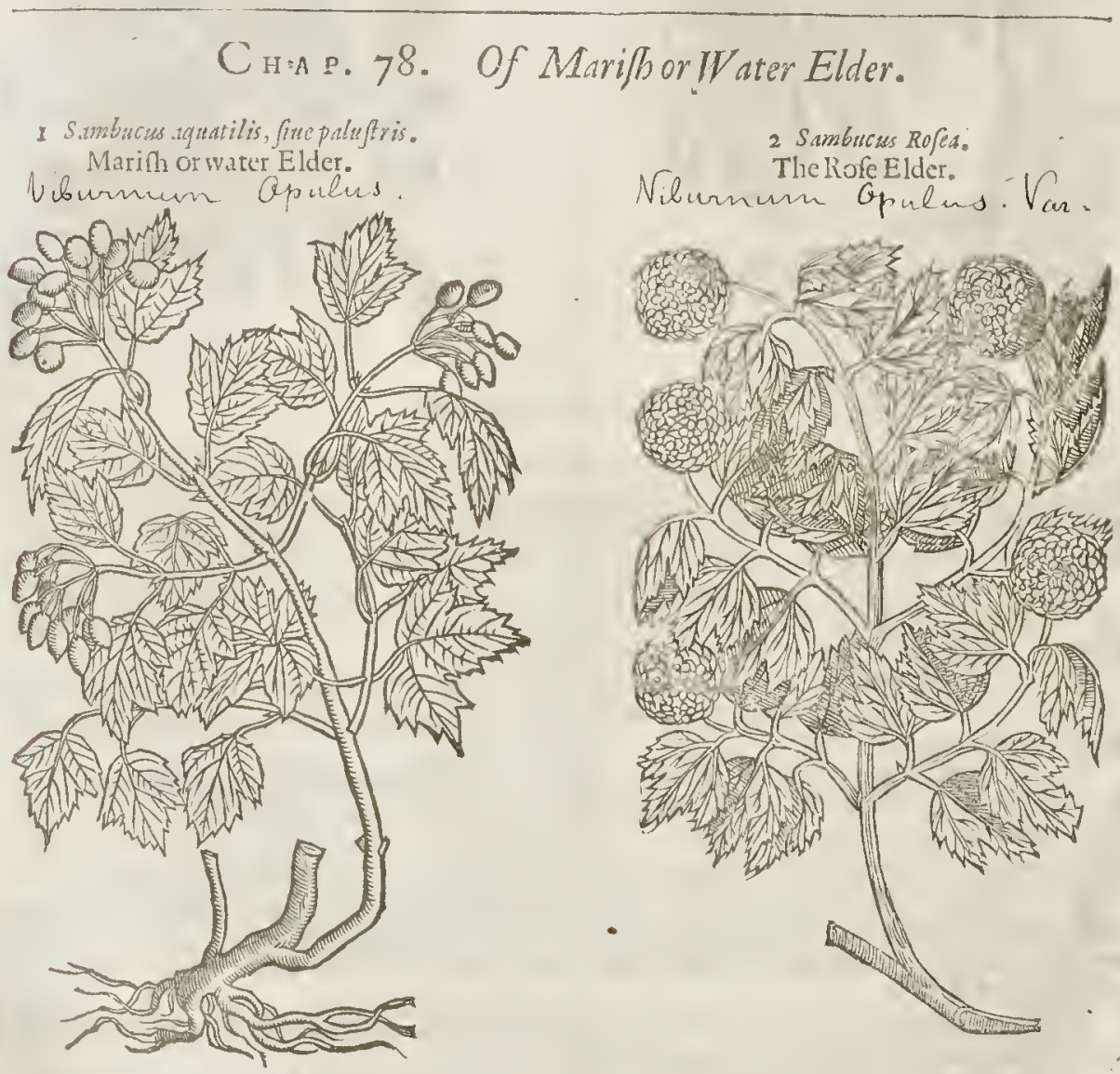

II The Defoription? Arith Elder is not like to the common Elder in leaues, but in boughes: it groweth
after the manner of a little tree: the boughes are coured with a barke of an ill fauoured Afh colour, as be thofe of the common Elder : they are fet with ioints by

certaine 
LI B. 3 .

Of the Hiftory of Plants.

certaine diftanees, and haue in them great plenty of white pith, therefore they haue leffewood whieh is white and brittle : the leaues be broad, eornered, like almont to Vine leaues, but leffer and fofter : among which come forth fpoked rundles which bring forth little floures, the vttermoft whereof along th the borders be greater, of a gallant white eolour, euery little one confiting of fiue leatues : the other in the midftand within the borders be fmaller, and it floures by degrees, and the whole tuft is of a mon fweet fmell : after whieh come the fruit or berries, that are round like thofe of the common Elder, but greater, and of a thining red eolour, and blacke when they be withered.

2 Sawbucm Fofea, or the Elder Rofe groweth likean hedge tree, hauing miny knotty branehes or thoots eomming from the root, full of pith like the common Eider : the leatres are like the vine leaues; among which come fortl goodly floures of a white eolour, f rinkled and dafhed liere and there with a light and thin Carnation eolour, and do grow thieke and elofely empaet together, in quantitic and bulke of a mans hand, or rather bigger, of great beauty, and fauoring like the floures of the Haw-thorne : but in my garden there groweth not any fruit vpon this tree, nor in any other place, for ought thar I ean vnderftand.

3 This kinde is likewife an hedge tree, very like vnto the former in ftalks and branehes, which are iointedand knotted by diftanees, and it is full of whire pith : the leaues be likew ife eornered : the floures hereof grow not out of fpoky rundles, but ftand in a round thicke and globed tuft, in bigneffe alfo and fathion like to the former, fauing that they tend to a deeper purple colour,wherin only the differenee conlifts.

बा The Place.

Sambucus paluftris, the water Elder,growes by running ftreames and water courfes, and in hedges by moift ditch fides.

The Rofe Elder groweth in Gardens, and the floures are theredoubled by Art, as it is fup. pored.

$$
\text { वा The Time. }
$$

Thefe kindes of Elders do flourc in Aprilland May, and the fruit of the water Elder is ripe in September.

$$
\text { T The Names. }
$$

The water Elder is called in Latine, Sambucus aquatica, and Sambucus paluftris : it is ealled opulus, and Plat anus, and alfo chameplatanus, or the dwarfe Plane tree, but not properly: Valerus Cordus maketh it to be Lycoftaphylos: the Saxons, faith $G e f n e r$, doeall it Vua Lupina; from whenee Cordus

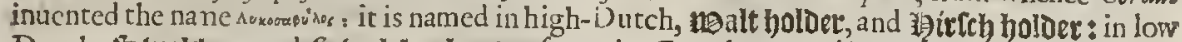

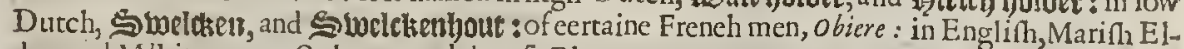
der, and Whitten tree, Ople tree, and dwarfe Plane tree.

The Rofe Elcer is ealled in Latine, Sambucus Rofea, and Sambucus aquatica, being doubtles a kind of the former water EIder, the floures being doubled by art, as we haue faid: it is called in Dutch, Bheloetche zisuce: in Englith, Gelders Rofe, and Rofe Elder.

$$
\text { T The Temperatureand Vertues. }
$$

Coneerning he faculties of thefe Elders, and the berries of the Water Elder, there is nothing found in any wrter, neither ean we fet downe any thing hereofofour owne knowledge.

$$
\begin{gathered}
\text { Снар. 79. } \\
\text { Of Dane-Wort, Wall-Wort, or Dwarfe Elder. } \\
\text { Tा The Defription. }
\end{gathered}
$$

Ane-wort, is it is not a fhrub, neither is it altogether an herby plant, but as it were a Plant participating of both, being doubtles one of the Elders, as may appeare both by the leaues, Houres, and fruit, as alfo by the fmell and tafte.

Wall wort isvery like vnto Elder in leaues, fpoky tufts, and fruit, but it hath not a wooddie ftalke; it bringet forth only greene ftalks, whieh wither away in Winter : thefe are edged, and full of ioynts, lile to the yong branches and thoots of Elder: the leaues grow by couples, with difances, wide, anl eonfift of many fmall leaues whieh ftand vpon a thicke ribbed falke, of which euery one is loig broad, and eut in the edges like a faw, wider and greater than the leaues of the common Elder tee : at the rop of the ftalkes there grow tufts of white floures tipt with red, with fue little ehiuesin them pointed with blaeke, which turne into blacke berries like the Elder, in the which be little ling feed : the root is tough, and of a good and reafonable length, better for Plyyfieks ve than thdeaues of Elder.

$$
\text { Ddd d }
$$


Ebulus, fuc Sambucns humilis.

Dane-wort, or dwar fe Elder.

Samburus Guas us.

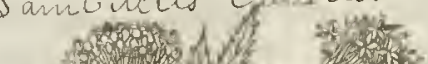

sin.

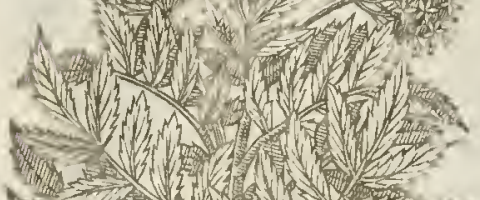

$\rightarrow 2-1$
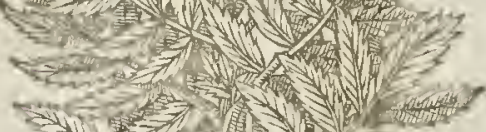

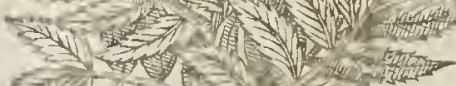

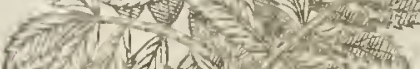

201

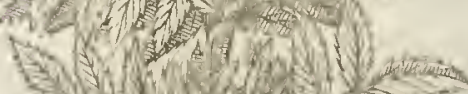

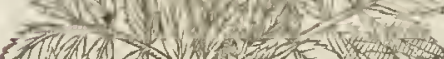

z)

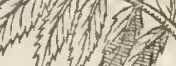

约到
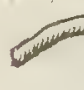

A

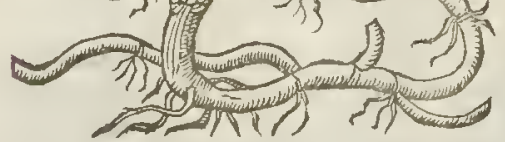

If The Place.

Dane-wort growes in vntoiled places neere common waies, and in the borders of fields : it groweth plentifully in the lane at Kilburne Abbey, by London : alfo in a field by S. Ioans neere Dartford in Kent : and alfo in the highway at old Branford townes end next London, and in many other places.

\section{If The Tinae.}

The floures are perfected in Sommer, and theberries in Autumne.

\section{T) The Names.}

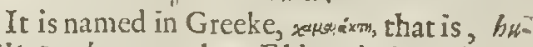
milis Sambucus, or low Elder: it is called in Latine, Ebulus, and Ebulum : in high-Duteh, alttich : in low-Dutch, 解ich: in Italian, $E$ bulo: in French, Hicble : in Spanifh, $\gamma_{e} \approx$ gos : in Englifh, Wall-wort, Dane-wort, and dwarfe Elder.

$$
\text { बा } T \text { be Temperature. }
$$

Wall-wort is of temperature hot and drie in the third degree, and of a fingular qualitie, which Galen dosh attribute vnto it, to waft and confume; and alfo it hath a ftrange and fpeciall facultie to purge by the ftoole: the roots be of greateft foree, the leaues haue the ehiefent ftrength to digeft and confums.

$$
\text { IT The Veriucs. }
$$

The roots of Wall-wort boiled in wine and drunken are good againft the dropfie, for they purge downwards watery humors.

B The leaines do confume and walte away hard fwellings if they be applied pulti-wife,or in a fomentation or bath.

C Diofcorides faith, that the roots of Wall-wort doe foften and open the matrix, and alfo correat the infirmities thereof, if they be boiled for a batl to fit in ; and diffolue the fwelings and paines of the belly.

D The itriec of the root of Dane.w ort doth make the haire blacke:

E The yong and tender leafe quencheth hot inflammations, being applicd witl Barly meale: it is with good fueceffe laid vpon burnings, fealdings, and vpon the bitings of mad dogs.; and with Bulls tallow or Goars fuet it is a remedic for the gout.

F The feed of Wall-wort drunke in the quantitie of a dram is the moft excellen: purger of waterie humors in theworld, and therefore moft fingular againt the dropfie.

$G$ If one fcruple of the feed be bruifed and taken with fyrrup of Rofes and a littl Seeke, it cureth the dropfie, and cafeth the gout, mightily purging downwards waterifh humors, seing once taken in the weeke.

$$
\begin{gathered}
\text { C н а 8. 80. Of Beane Trefoile. } \\
\text { It The Defription. }
\end{gathered}
$$

1 THe firt kinde of Anagyris or Laburnum groweth like vnto a fmall tre', garnifhed with many fmall branehes like the fhoots of Oziars, fet full of pale greele leaues, alwaies three together, like the Lotus or medow Trefoile, or rather like the laues of Vitex; or the Cyrifus buth: among which come forth many tufts of floures of a yellow colur, not mueh vnlike the floures of Broome : when thefe floures be gone there fueceed fmall flat :ods, wherein are. contained feeds like Galega or the Cytifus bufh : the whole plant hath little ono fauour at all: the root is folt and gentle, yet of a wooddy fubftance. 
LIB. 3. Of the Hiftory of Plants.

2 Stinking Trefnile is a thrub like to a little tree,rifing vp to the height of fix or eightcubits, or fometimes higher :it fendeth forth of the ftalks very many flender branches; the barke whereof is of a deep greene colour : the leaues ftand alwaies three together, like thofe of Lotus or medow Trefoile, yet of a lighter greene on the vpper fide : the floures be long, as yellow as gold, very like to thofe of Broome, two of three alfo ioined together after them comevp broad cods, whercin do lie hard fruit like Kidney Beanes, but leffer, at the firft white, afterwards tending to a purple, and laft of all of a blackin blew:the leaues and floures hereof haue a filthy fmell, like thofe of the finking Gladdon, and fo ranke withall, as euen the paffers by are annoied therewith.

I Anagyris. Beane Trefoile.

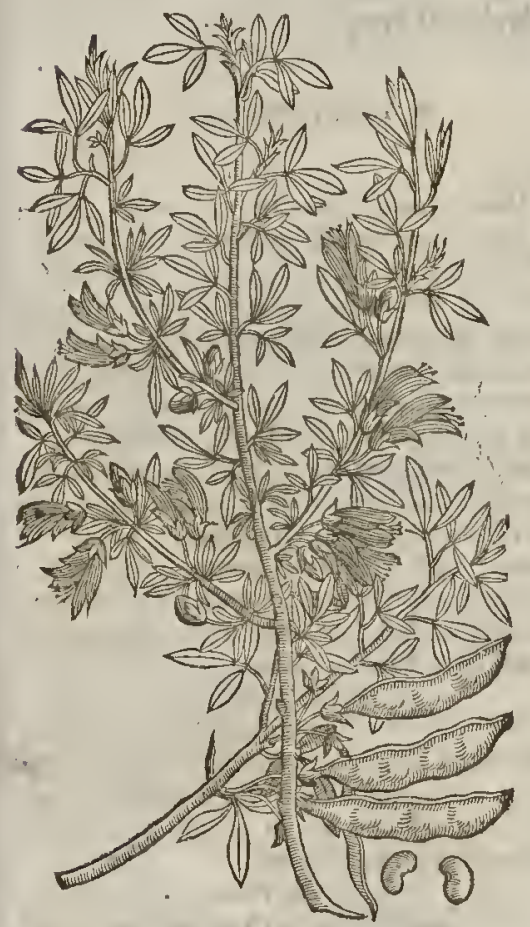

2 Anagyrisfatida.

Stinking Beane Trefoile:

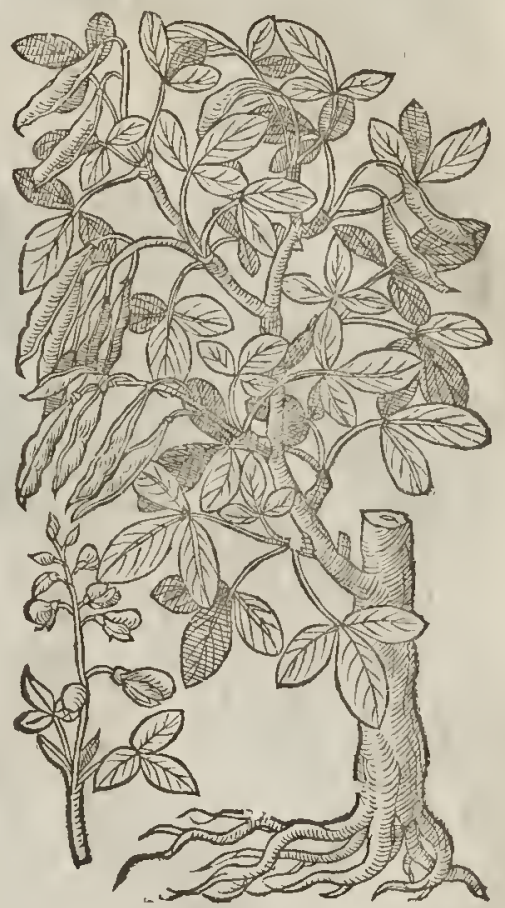

$¥$ Of Anagyris there are foure kindes, two with finking leautes; the one with longif leaules, the other with rounder.

Two other whofe leates do not ftinke; the one of thele hath fometimes foure or fute leatues on one ftalke, and the leanes are long and large. The other hath them leffer and narrower. $\neq$

IT The Place.

The fe grow of them felues in moft places of Languedocke and Spaine, and in other countries alfo by high waies fides, as in the IRe of Candy, as Bellowius writeth: the firft I haue in my garden; the other is a ftranger in England. $\neq$ Mafter Tradifcant hath two forts hereof in his garden. $\neq$

They floure in Iune, and the feed is ripe in September.

If $T$ he Nomes:

The Beane Trefoile is called in Greeke waviprs, which name remaineth vncorrupt in Candy enten to this day : in Latine al fo Anagyris, and Laburnum : of the people of Anagui in Italy named Eghelo, which is referred unto Lalwrnum, of which Plny writeth in his I6.booke, I8. chapter. In Englin, Beane Trefoile, or the Peafcod tree.

$$
\text { T The Temperature. }
$$

Beane Trefoile,as $C$ alen writeth, hath a hot and digefting faculty. 


\section{9ा The Vertues.}

A The tender leaues, faith Diofcorides, being ftamped and layed vpon cold fwcllings, do waftcaway the fame.

B They are drunke with Cute in the weight of a dram againft the oftuffing of the lungs, and doe bring downe the menfes, the birth, and the afterbirth.

C They curc the head-ache being drunke with wine; the iuice of the root digefteth and ripeneth, if the feed be eaten it procureth vomite, which thing, as crattbiolus writcth, the feed not onely of ftinking Bcane Trefoile doth effect, but that alfo of the other likewife.

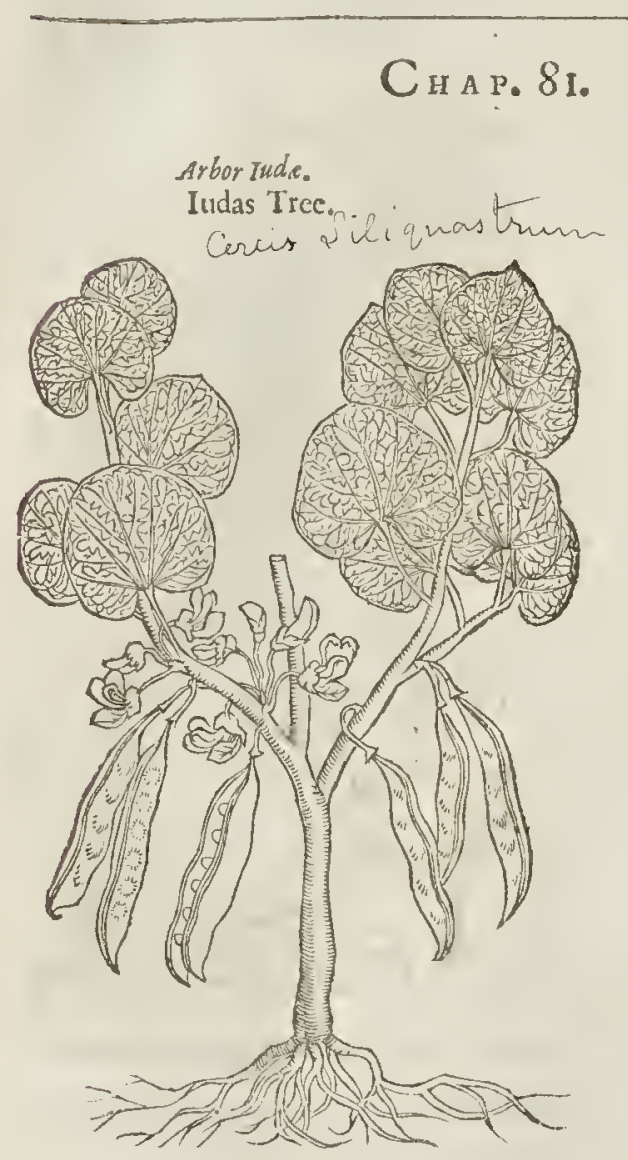

Of Iudas Tree.

of The Defcription.

TVdas tree is likewife one of the hedge plants.: it growcth vp vnto a tree of a realonable bignefle, couercd with a dark colou. red barke, whereon doe grow many twiggie tough branches of a brown colour, gannihied with round leaues, Iike thofe of round Birthwoort, or Sowbread, but harder, and of a deeper greene colour : among which come forth fmall floures like thofe of Peafon, of a purple. colour,mixed with red, which turn into long flat cods, preffed hard together, of a tawny or wancolour, wherein is contained fmall flat feeds, like the Lentill, or rather like the feed of Medica, fafhioned like a little kidney: the root is great and wooddie.

$$
\text { 9ा The Place. }
$$

This thrub is found in diuers prouinces of Spaine, in hedges, and among briers $8 \mathrm{cbram}$ bles: the mountaines of Italy, and the fields of Languedocke arc not without this fhrub: it groweth in my garden.

$$
\text { of The Time. }
$$

The floures come forth in the Spring, and before the leatues: the fruit or cods be ripe in Sommcr.

$$
\text { Tा The } 2 \text { ames. }
$$

It is commonly named in Latinc Arbcy Ith$d_{d}$ : fome haue called it Sycomorus, or Sycomore tree, and that becaufe the floures and cods hang downe from the bigger branches : but the right Sycomore trec is like the Fig-tree in fruit, \& in leaues to the Mulberrie tree, wherupon it is fo named. Others takc it to be upsis: of which Theophraftus writeth thus, Cercis bringeth forth fruit in a cod; which words are all fo few, as that of this no certaintie can be gathered, for there be more fhrubs that bring forth fruit in cods. The French men call it Guainier, as though they fhould fay, $V$ aginula : or a little theath : moft of the Spaniards do name it Alyorouo loco, that is, siliqua fylueftris or fatua, wilde or foolith cod: others, Arbol d' amor, for the braueneffe fake : it may becalled in Englifh, Iudas tree, for that it is thought tobe that wher eon Iudas did hang himfelfe, and not vpon the Elder tree, as it is vulgarly faid.

\section{Tा The Temperature and Vertues.}

The te mperature and vertues of this nhrub are vnknowne, and not found out:for whereas Matthiolus maker $h$ this to be 1 cacin, by adding falfely thornes vnto it, it is but a furmife. 
Li B. 3. Of the Hiftory of Plants.

\section{Cна т. 82: Of the Carob tree, or Saint Iobns Bread.}

$$
\text { The Defcription. }
$$

$T$

He Carob tree is alfo one of thofe that beare cods ; it is a tree of a middle bigneffe, very full of

boughes : the leaues long, and confift of many fet tngether vpon one middle rib, like thole of the Alh, but enery particular one of them is broader, harder and rounder : the fiuit or long eods in fome places are a foot in length, in other places horterby halfe, an inch broad, fnooth, \& thick; in which do lie flat and broad feeds: the cods themfelues are of a fweet tafte, and are eaten of diuers, but not betore they be gathered and dried; for being as yet green, though ripe, they are vnplea. fant to be eaten by reafon of their ill fawoured tafte.

Ceratia filiqua, five Ceratonia.

The Carob tree. ceratomia viluqua

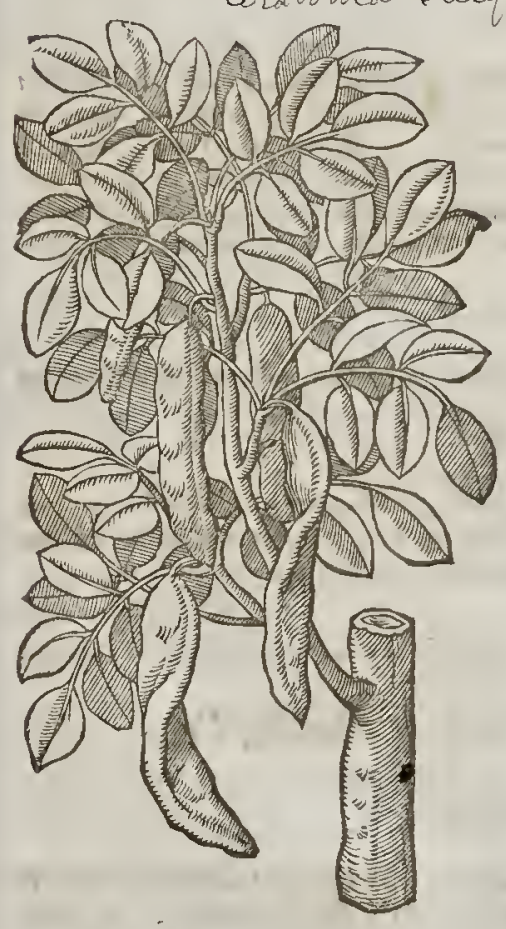

T) The Place.

This groweth in Apulia, a Pronince of the kingdome of Naples, and alfo in diuers vntoiled places in Spaine : it is likewife found in Ind ia and other counrries Eaftw ard, where the cods are fo full of fweet iuice as rliat it is vfed to preferue Ginger and other fruites, as Matthiolus fheweth. Straboli6.1 5. faith, that Ariftobulus reporteth how there is a tree in India of no great bignes, which hath great cods, ten inches long, full of hony; guas qui cderent non facile feruari, which rhing peraduenture is onely to be vnderftood of the greene eods, \& thofe that are not yet dry: it is very wel known in the coafts of Nicea and Liguria in Italy, as alfo in all the tracts and coalts of the Wert Indies, and Virginia. It groweth alfo in fun. dry places of Paleftine, where there is fuch plenty of it, that it is lefe vnto fwine and other svilde beatts to feed vpon, as our Acornes and Beech maft. Moreouer, both young and old feed thereon for plealure.and fome haue eaten thereof to fupply and help the neceffary nou. rithment of their bodies. This of fome is cal. led Saint Iohns bread, and thought to be that which is tranflated Locufts, whereon S. Iolyz did feed when he was in the wildernefie, be. fides thewilde hony whereor he did alfo eat but there is fnall certainty of this : but moft certaine that the people of that countrey doe feed vpon thefe cods, in Greeke called Rrexims: in Latine, silique : but Saint Iobns food is called in Greeke autoss: which word is often vfed in the Reutelation written by Saint $I 0 h n$, and tranflated Locufts. Now wee mult alfo remember that this Greeke word hath two feucrall interpretations or fignifications, for taken in the good part, it fignifieth a kinde of creeping creature, or flie, which hoppeth or skippeth vp and down, as dorh the grafhopper; of which kinde of creatures it was lawfull to ear, Lemit, 11.22 . and Mat. 3. 4. It fignifieth alfo thofe Locults which eame out of the fmoke of the bottomles pitmentioned Apoc.9.v.3.4.8x which were like vnto horfes prepared forbattell. The Hebrew word which the Englin tranlators have turned Grathoppers, Tremclius daresnot give the name Locuft vnto it, but callcth it by the Hebrew name $A r b$ is a fter rhe letters and Hebrew name, faying thus in the note vpon the 22 . verfe of the I r.ehapter of Leuit. Thefe kindes of ereeping things neither the Hebrews nor the Hiftoriogra. phers, nor our felues do know what they meane : wherefore we ftill retaine the Hebrew words, for all the foure kindes thereof: but it is certaine that the Eaft countrey Grafhoppers and Loeufts were fometimes ved in meat, as Math. 3.4. and Marc.I,6.Plin lib, 1 IoNatur, Hiffor, cap 26 . and 29. 
Thus far Tremelius and Imnus. By that which hath been faid it appeareth what S. Iobn the Baptift fed of, vnder the title Locufts : and that it is nothing like vnto this fruit Ceratia filiqua : I rather take the husks or thells of the fruit of this tree to be the cods or husks whercof the prodigall childe would haue fed, but none gaue them vnto him, though the fwine bad their fill thereof. Thefe cods being drie are very like beane eods, as I haue often feen. I haue fowne the feeds in my garden, whete they have profpered exeeeding well.

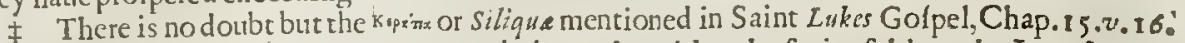
were the eods or fruit of this trce. I eannot belecue that either the fruit of this or the Locufts, were the axisiss mentioned in the third ehapter of Saint Mat.v.4. But I am of the opinion of the Greeke

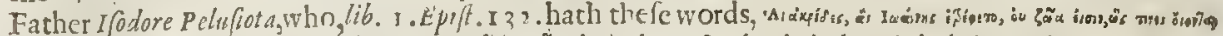
- A. murv, $O c$. That is : The Acrides which $10 \mathrm{hn}$ fed vpon are not liuing creatures like to Beetles, as fome vnlearnedly fuppofe, farre be it from vs fo to thinke; but they are the tender buds of herbes and plants or trees; neither on the other fide is the Mels agrion any herbe focalled, but mountaine hony gathered by wilde Bees, \&ce. $\neq$

$$
\text { of The Time. }
$$

The Carob tree bringetl forth fruit in the beginning of the Spring, which is noc ripe till Alat tumne.

$$
\text { TI The 2ames. }
$$

The Carob trec is called wigrona : in Latine likewife, Ceratonia : in Spanifh, Garouo: in Englifh; Carob tree; and of fome, Beane tree, and Saint lohns Bread:the fruit or cod is named xuman: in Latine Siliqua, or Stliqua dulicis: in diuers n:ops, Xylocaracta : in orher fhops in Italy, Carobe, or Civobole: of the Aporhecaries of Apulia,salequa : it is called in Spanifh, Alfarobas, or Algarovas: and without an article Garouas: in high Dutch, $\mathbf{S}$. Johang bzot: that is to fay, Sanzti Iohan.panis, or S.Iohns Bread, neither is it knowne by any other name in the Low-countries: Some call it in Englifh, Carob.

$$
\text { I The Temperature. }
$$

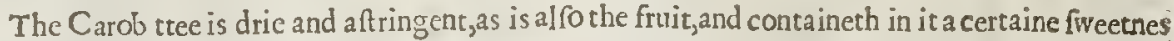
as Galen faith.

$$
\text { If } 7 \text { he vertues. }
$$

A The fruit of the Carob Tree, beeing eatwhen it is greene, doth gently loofe the belly; but beeing dry it is hard of digeftion, and ftopperh rhe belly, it prounketh vrine, it is good for the fto: macke,and nourifheth well, and much better than when it is greene and fre?h.

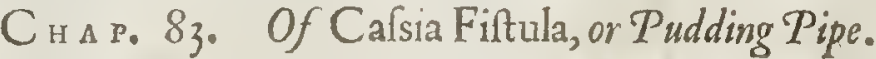 IT The Defcription.}

C Affia purgatrix, or Caffa fifuld, groweth vp to be a faire tree, with a tough barke like leather, of the colour of Box,whereupon fone haue fuppofed it to take the Greeke name kigus, in Latine, Coriaceus: the armes and branches of this are fmall and limber, befet with many goodly leaues, like thofe of the Wall-nut tree : among which come forth fmall floures of a yellow colour, eom. pact or confifting of fix little leaues, like the floures of Chelidonium mmas, or Pile-woort:after thele be vaded, there fueceed goodly blaeke round, long cods, whereof fome are two foot long, and of a wooldy fub tanee : in thefe coddes are contained a blacke pulpe, very fweet and foft, of a pleafant tafte, and feruing tomany vfes in Phy ficke, in which pulpe lieth the feed couched in little cels or partitions : this feed is flat and brownith,not vnlike the feed of Ceratia Siliqua, and in other refpeets very like vnt's it alfo.

$$
\text { T) The Place. }
$$

This trec groweth much in Egypt,efpeeially about Memphis and Alexandria, and moft parts of Barbaric, and is a ftranger in thefe parts of Europe.

$$
\text { I The Time. }
$$

The Caffa tree groweth green winter and fommer:it fheddeth his old leaues whennew are come; by meanes whereof it is neuer void of leawes : it floureth early in the fpring, and the ftuir is ripe in Autumne. 
Cafja fiftula.

Pudding Pipe tree.

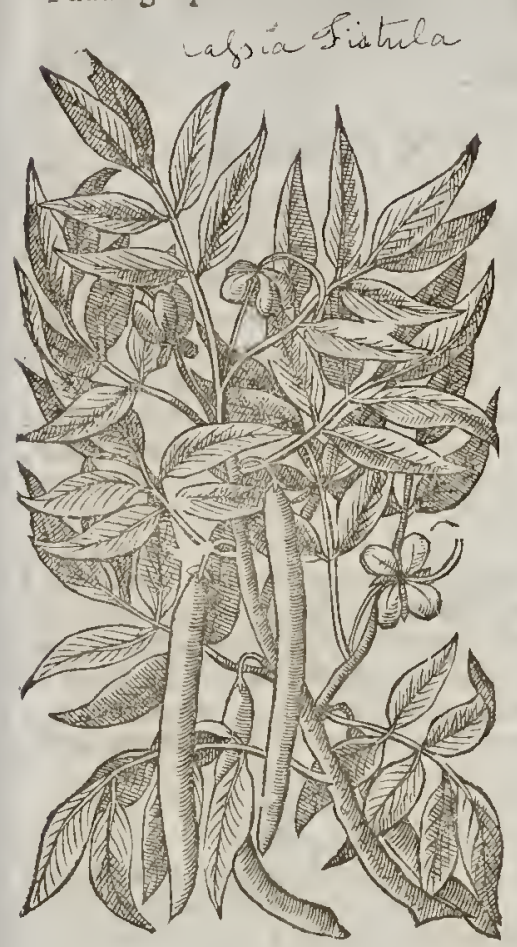

I) The Names.

This tree was vnknowne to the old writers, or fo little aceounted of, as that they liaue made no mention of it at all : the A rabians were the firft that eitcemed of it, by reafon they knew the vfe of the pulpe which is found in the Pipes:and a fter them the later Grecians, as Actuarius \& 0 .

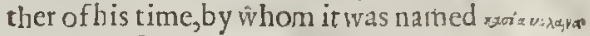
that is to fay in Latine, Cafin nigra. The fruit thereof, faith Attwarius in his fift booke, is like a long pipe, hauing within it a thicke humotir or moifture, which is not congealed all alike thorow the pipe, but is feparated and diuided with many partitions, being thin wooddy skins. The A potheearies call it Calfafifuln, and with a dou-

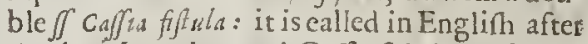
the A potheearies word, Caffia fiftula, and may alfo be Englifhed, Pudding Pipe, becaufe the cod or Pipe is like a pudding: but the old Caffia filtula,or aipts in Greeke, is that fiveet and odoriferous barke that is rolled together, after the manner of a long and round pipe, now named of the A pothecaries Cafjia lignea, which is a kinde of Cinamon.

\section{The'Temperature.}

The pulpe of this pipe which is chicfely in requef, is moin in the later end of the firf de. gree,and little more than temperatly hot.

The Vertues.

The pulpe of Cafia fifula extracted with violet water, is a molt fweet and pleafant medicine, and $\mathrm{A}$ may be giuen without danger to all weak people of what age and fex foeuer they be, yea it may be minifted towomen with childe,for it gently purgeth cholerieke humours and flimie flegme, if it be taken in the weight of an ounee.

Cafia is good for fuch as be vexed with hot agues, pleurifies, iaundice, or any other inflammation $B$ of the liner, being taken as afore is thewed.

Caffia is good for the reines and kidneies, driueth forth granell and the ftone, efpecially if it bee $\mathbf{C}$ mingled with the decodtion of Parley, and Fennell roots, and drunkc.

It purgeth and purifieth the bloud, making it more cleane than before, breaking therewith the D acrimonie and tharpneffe of the mixture of bloud and choler together.

It diffolucth all phlegnons and in flammations of the bret, Jungs, and the rough artery called $\mathbf{E}$ Trachea arteria, eafing thofe parts excecding well.

Caffia abateth the veliemencic of thirft in agues, or any hor difeafe whatfoener, efpecially if it be $F$ taken with the inice of Int ybum, cichoreum, or Solsnum, depured according to Art :it abatech alfo the intemperate heat of the reines, if it be receitred with diureticke imples, or with the decosti on of $\mathrm{L}$ icorice onely, and will not fuffer the ftone to grow in fuch perfons as do receive and vfe this medicine.

The beft Cafia for your vfe is to be taken out of themoft ful,moft heauy, \& faireft cods, or canes, $G$ and thofe which do thine without,and are full of foft pulpe within; that pulpe which is newly ta: ker forth is better than that which is kept in boxes, by what Art foeuer.

Caßia being outwardly applied, taketh away the roughneffe of the skin, and being laid vpon hot $H$ fivellings, it bringeth them to fuppuration.

Many fingular compounded medicines are made with this Cafja, which herc to recite belongs I not to my purpofe or hiftory.

Chap: 


\section{Cна P. 84. Of the Lentiske, or M M afiake tree. T) The Defcription.}

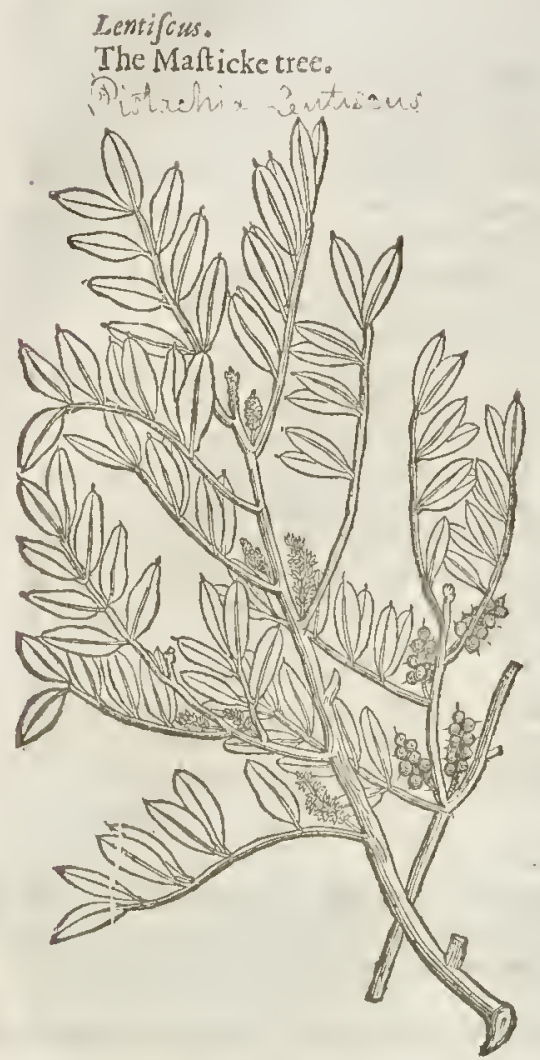

If The Defeription.

THe Maftick tree growe th commonly like a 1 Thrubwithout any great body, rifing vp with many fprings and thoots like the $\mathrm{Hafell}$; and oftentimes it is of the height and bigneffe of a meane tree: the boughes thereof are tough, and flexible; the barke is of a yellowith red colour, pliable likewife, and hard to be broken : there ftand vpon one rib for the moft part 8 leaues, fer vpon a middle rib, much like to the leaues of Licorice, but harder, of a deepe greene colour, and oftentimes fomewhat red in the brims, as alfo hauing diuers vains running along of a red colour, and fomthing ftrong of fmel: the floures be moffie, and grow in clufters vpon long ftems: after them come vp the berries, of the bignefle of Verches, greene at the firft, afterwards of a purple colout, and laft of all, black, fat, and oily, with a hard black ftone within; the kernel wher of is white, of which alfo is made oile, as Diofcorides witne ffeth:ir bringeth forth likewife cods befides the fruit (which may be rather termed an excrefence, than a cod)writhed like a horn; in which lieth at the firft a liquour, and afterwards when this waxeth ftale, little liuing things like vnto gnats, as in the Turpentine hornes, and in the folded leates of the Eim tree, There commeth forth of the Maftick tree Ro fin, but dry, called Mafticke.

\section{4) The Place:}

The Mafticke tree groweth in many regions, as in Syria, Candy, Italy, Languedocke, and in moft Prouinces of Spaine : but the chiefeft is in Chios an Ifland in Greece, in which it is diligently and fpecially looked vnto, and that for the Mafticke fake, which is there gathered from the husbanded Mafticke trees by the inhabitants euery yeare moft carefully, and is fent from thence into all parts of the world.

$$
\text { I The Time. }
$$

The floures be in their pride in the fpring rime, and the berrics in Autumne:the Maftick muft be gathered about the time when the Grapes be.

$$
\text { Tा The Names: }
$$

This tree is named in Greelecris: in Latine, Lentifcus : in Italian, Lentifque : in Spanifh, Masaz and Arcoyra : in Englifh, Malticke tree; and of fome, Lentiske tree.

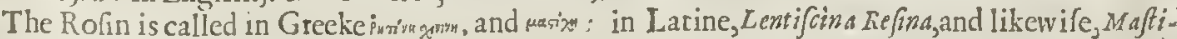
che : in Thops,Maftix : in Italian,Maftice : in highand low Dutch and French alfo, Maffic: in Spanith, Almaftiga, Maflech, and Llmccega: in Englifh, Mafticke. Mata.

Chrfors writeth, that the Spaniards call the oile that is preffed out of theberries, $\mathcal{A}$ zeyte de

$$
\text { T The Temperature. }
$$

The leaues, barke, and gum of the Mafticke tree are of a meane and temperate heate, and are drie in the fecond degree, and fomewhat aftringent.

$$
\text { of The Vertues. }
$$

A The lcaties and barke of the Mafticke trce ftoppe the laske, the bloudy fixe, the fpitcing of bloud, 
L. B. 3.

Of the Hiftory of Plants.

bloud, the piffing of bloud, and all othet fluxes of bloud: they ate alfo good againfthe falling fickeneffe, the falling downe of the mother, and comming forth of the fundament.

The gum Maftieke hath the famevettue, if it be relented in wine and giuen to be drunke.

Maftieke eliewed in the mouth is good for the ftomaeke, ftaieth vomiting, inereaferl appetite, B comforteth the braines, ftaieth the falling downe of the themmes and watery humors, and maketh a fweet breath.

The fame infufed in Role water is excellent to walh the mouth withall, to faiten loofeteeth, D and ro comfort the iawes.

The fame fpred vpon a piece of leathet ot veluet, and laid plaifterwife vpon the temples, ftaich $E$ the theume from falling into the inwes and teeth, and eafeth the paines thereof.

It preuaileth mueh againt vleers andwounds, being put into digeftiues and healing $\mathrm{V} n$ - $F$ gurents.

It dtaweth flegme forth of the head gently and without ttouble.

It is alfo ved in waters whiel ferue to elenfe and make faire the faee with.

The decoction of this filleth vp hollow vleers with fle h if they be bathed therewith.

It knitteth broken bones, ftaicth eating vleers, and prouoketh vtine.

G

$\mathrm{H}$

I

\section{Cна в. 85. Of the Turpentine Tree:}

I Tercbintblus.

The Tutpentine tree.

Distachic Terelinitus.

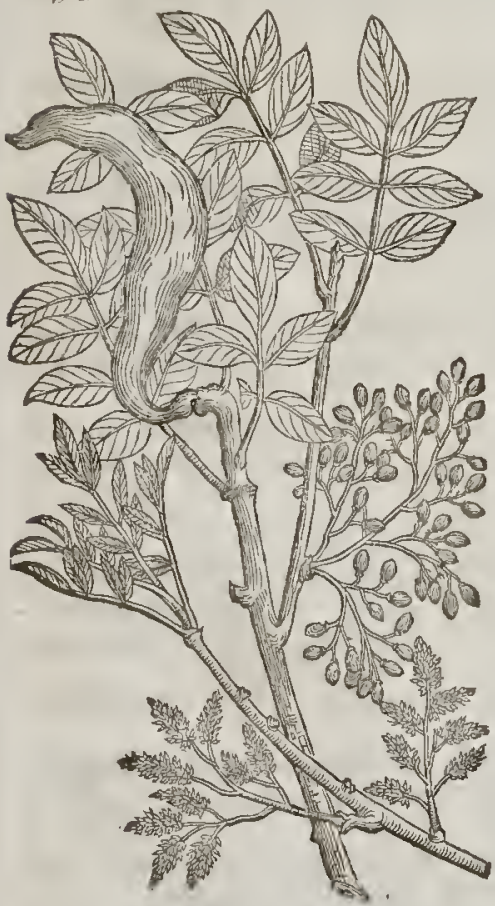

2 Terbinthus latifolia.

The btoad leafed Tutpentine trae.

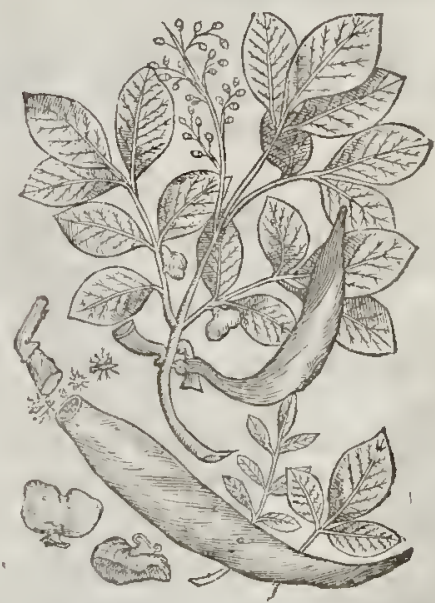

9) The Defription.

I THe firft Turpentine Tree groweth to the height of a tall and faite ttee, hauing many long boughes or branches, difperfed abroad, befer witl long leaues, confinting of fundry other finall leaues, eaeh whereof refemuleth the Bay leafe, growing one againft another vpon a little ftem or middle rib, like vnro the leaues of the Ath tree:the floures be fraall \& reddifh, growing vpon clufters or bunches that turne into round berries, which at their beginning are greene, afterwards reddilh; but being ripe wax blaeke, or of a darke blew colour, clammie, full of fat 
and oilous in fubftance, and of a pleafant fauour : this plant beareth an emptycod, or crookcd horne fomewhat reddith, where in are found inall flies, wormes nr gnats, bred and ingendrect of a certane humorous matter, which cleateth to the inner fides of the faid cods or hornes, which wormes hate no phyficall vee at all. The right Turpeutinc iffueth out of the branches of thefe trees; if you do cut or wnund them, the which is faire and cleere, and better than that which is gathered from the barke of the 1 -irre tree.

2 The fecond kind. of Turpentitie tree is very like vinto the former, but that it groweth not fo great: yet the leaues are greater and broader, and of the fame fathion, but very like to the leaues cif the Piftacia crec. The berries are firft of a fearlet colour, and when they be ripe of a skie co. lour. The great horned coits are hatrpe pointed, and fomewhat cornered, confifting as it werc of tihe fubftance of griftles. And our of thofe bladdets being brokcn, do creepc and come fmall flies orgnats, tred of a fuligitous excrement, and ingendred in thofe bladders. The trec doth alto yceld his Turpentine by dropping like the forms $r$.

$$
\text { T The Plact. }
$$

Thefe trees grow, as Dioforides faith, in Iurie, Syria, Cyprts, Africke, and iti the IDands called Cyclades. Bellonius reporath that there are found great ftore of them in Syria, and Cilicia, and are broughe from thence to Damafcus to be fold. Clufus faith, that ir growcs of it felfe in Langucdocke, and in very many places of Portingale and spaine, but for the moft part like a hrub, and wrthout bearing Turpentiue.

Theophraft us writeth, that it gtoweth about the hill Ind, and in Macedonia, fhort, in manner of a fhrub, and writhed, and in Damafcus and Syria great, in manncr of a fmall tree : he also fetterh downe a ccraine male rurpentine rree, and a female : the male, faith he, is barren, and the female fruitful1. And of thefe he maketh the onc with a berry red at the firt, of the bigneffe of a Lentill, which cannot come to ripenes; and the other with the fruit greene at the firt, afterwards fomewhat of yellowing red, and in the end blacke, waxing ripc in the fpring, of thcbigneffe of the Grecians Beane, and rofenny.

He alfo writeth of a certaine Indian Turpentine tree, that is to fay, a tree like in boughes and leaues to the right Turpentine tree, but differing in fruit, which is likc vnto $\Lambda$ luonds.

$$
\text { I The Time. }
$$

The floures of the Turpencine tree come forth in the fpring together with the new buds : the berries are ripe in September and October, in the time of Grape gathering. The hornes appeare
about the fame timc.

$$
\text { बा The Names. }
$$

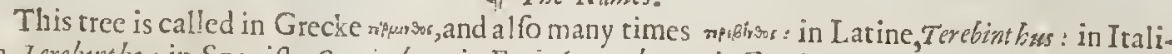
an, 1 crebrnt ho : in Spanifh, Cornicabra: in French, 7 crebute : in Englifh, Turpentine trce : the Arabians call it Botin, and with an article 4 lbotin.

The Rofin is furnamed tremes: : in Latine, Terebinthina : iri high Dutch, Termintim : in Englifh, Turpentine, and right Turpentine: in the Arabian language Albotim, who notne the fuit Granum viride, or greene berries.

\section{T The Tcmperature andVertues.}

A The barke, leaues, and fruit of the Tuspentine trce do foncwhat binde, they are hot in the fecond degree, and being grcene they dry moderately; but when they are diycd they dry in the fecond degeee; and thc frut approacheth more neere to thofe that be dry in the third degree, and allo hotter. This is fit to be eaten, as Diofcorides faith, but it hurteth the ftomacke.

$B$ It provoterh v:ine, helpeth thofe that haue bad fplcenes, and is drunke in wine againft the bitings of the poyfonfrsme fpiders called $P$ balangia.

C The Rofin of rhe Turpentine tree excelleth all other Rofins, according to Diofcorides his opininion: but $G$ alen writeth, that the Rofin of the maftickc trec beareth the preheminence, and then
the Turpentine.

D This Rofin lath alfo an aftring ent or binding facultie, and yer not fo much as mafticke : but it hath withall a cerrainc bitterneffe iovned, by reafon whereof it digefteth more than that of the Mafticke rree : thorow the fame qualitic there is likewife in it fo great a clenfing, as alfo it healeth $f$ c.ros, in his $\delta$. booke of the facultics of fimple medicines; but in his booke of medicines according to the kindes, he maketh that of the Turpentine tree to be much like the Rofins of the Larch tree, which he affirmeth to be moifter than all the reft, and to be withour both fharpneffe and bi-
ting.

E The fruit of rurpentine prouokcth vrine and ftirreth vp flefhly lutt.

F The Rofine of this tree, which is the right Turpentine, loofeth the belly, openeth the ftoppings of the litrer and fpleene, prouoketh vrine, and driucth forth grauell, being taken the quantitie of
two or three Beanes. 
L 1 в. 3.

Of the Hiftory of Plants.

1435

The like quantitie wathed in water diuers times vntill it be white, then muft be put thereto th ${ }^{\mathrm{e}} \mathrm{G}$ like quantity of the yolk of an egge, and laboured together adding thereto by little and little(concinually ftirring it) a (mall draught of poffit drinke made of white wine, and giuen to drink in the morning fafting, ithelpcth moft fpeedily the Gonorthrea, or running of the reines, commonly at the firft time, but the medicine neuer faileth at the fecond time of the taking of it, which gitues ftooles from foure to eight, according to the age and frength of the patient.

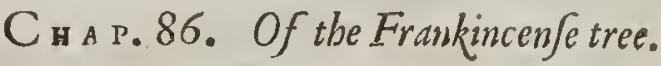

9 The Defcription.

7 He rreefrom which Frankincenfe floweth is but low, and hatb leatres like the Maftick tree jet fome are of opinion that the leafe is like the leafe of a Peare tree, and of a graffie colour : the rinde is like that of the Bay tree, whereof there are two kindes : the one groweth in mountains and rockie places, the other in the plaine: but thofe in the plaines are muchworfe than thofe of the mountaines : the gum hereof is alfo blacker, fitter to mingle with Pitch, and fuch other ftuffe to trim Ihips, than for other ves:

\section{Arbor Thurifera.}

The Frankincenfe trce.

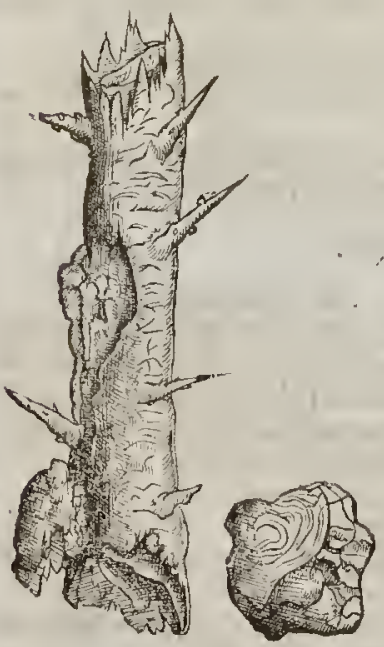

Thuris Limpidifolium Lobeliy. The frippofed leafe of the Frankincenfe tree.

Theuet in his Cofmographie faith, that the Frankincenfetree doth refemble a gummic or rofiny Pine tree,which yeeldeth a iuice that in time groweth hard, and is called Thus, Frankincenfe, in whom is found fometime certaine fmall graines like vnto gratell, which they call the Manna of Frankineenfe.

Of this there is in Arabia two other forts, the one, the gum wherof is gathered in the Dog daies when the Sun is in Leo,which is white, pure, cleare,and fhining. Pera writeth that he hath feene the cleare Frankincenfe called Limpidsm, and yeelding a very fweet fmell when it is bumt, but the leafe hath been feldome feene; which the Phyfition Launanus gaue to $P_{c}$ mand Lobel, together with to ne pieces of the Ro?ine, whieh he had of certaine mariners, but he could affirme nothing of certaintie whether it werc the leafe of the Frankincenfe, or of fome other Pine tree, yeelding the like iuice or gum. It is, faith he (which doth feldom happen in other leaues) from the lower part or foor of the leafe, to th: vppar end, as it were doubled, confinting of two thin rindes or coats, with a theath a fpu and a halfs lo ag, at the top gaping open like a hou 1 or fooles encombe, and as it were couered with theln st, which is athing fe!do.nz Feene in a leafe, bur is proser to the floures of $N$ sp:llus, 
or Lonchitis, as writers affirme; the other is gathered in the fpring, which is reddirh, w or fer than tl e other in price orvalue, becaufe it is not fo well concoeted in the heat of the Sunne. The Arabians wound this tree with a knife, rhat the liquour may flow out more abundantly, whercof fome trees yeeld threefcore pounds of Frankinfence.

$$
\text { 9] The Place. }
$$

Diofcorides faith it groweth in Arabia, and efpecially in that quarter wich is called I hurifera, the beit in that countrey is called Stagomas, and is round, and if it be broken, is far within, and when it is burned doth quickly yeeld a fmel:next to it in goodnes is that which groweth in Smilo, leffer than the other, and more yellow.

The time is already declared in the defcription.

$$
\text { T) The Time. }
$$

बा The $N_{\text {ames. }}$

It is called in Greckericams : in Latine, Thus: in Italian, Incenjo:in Dutch, Uucitauch:in Spanifh, Encenfo: in French, Enceus : in Englich, Frankincenfe, and Incenfe : in the A rabian tongue, Louar, and of fome few, Condir. $¥$ The Rofin carries the fame name; but in thops it is called olibamm, of the Greeke name and article put before it. $\neq$

$$
\text { The T cmperature and Vertues. }
$$

It hath,as Diofcorides faith, a power to heate and binde.

A It driucth away the dimnefle of the eye-fight, filleth wp hollow vlcers, it clofes raw wounds, ftaiB ethall corruptions of bloud, although it fall from the head.

C Galen writeth thus of $i t ; T$ hes doth heate in the fecond degree, and drie in the firft, and hath fome imall aftriction, but in the white there is a manifeft aftriction; the rindedoth manifefty bindeand dry exceedingly, and that moft certainly in the fecond degree, for it is of more groffer pasts than Frankincenfe, and not fo tharpe, by realon whereof it is much ved in fpitting of bloud, fwellings in the mouth, the collicke paffion, the fiux in the belly rifing from the ftomacke, and bloudy fixes.

D The fume or fmoke of it hath a more drier and hotter quality than the Frankincenfe it felfe, being dry in the third degree.

E It doth alfoclenfe and fill wp the vlcers in the eies, like vnto Myrrhe: thus far $G$ alen.

F Dioforides faith, that if it be drunk by a man in health, it driueth him into a frenfie : but there are few Greekes of his minde.

G A Arcen reporteth that it doth helpe and ftrengthen the wit and underfanding, but the often taking of it will breed the head-ache, and if too much of it be drunke with wine it killeth.

$$
\text { Снар.87. Of Fificke } \mathcal{N} \text { (uts. }
$$

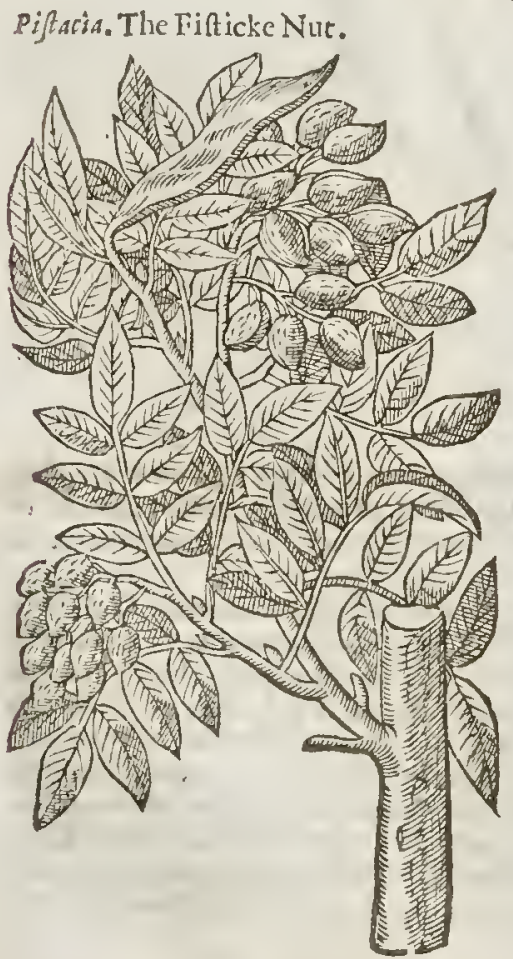

\section{The Defription.}

7 He trce which beareth Fifticke Nuts is like to the Turpentine tree: the leaues here of be greater than thofe of the Mafticle tree, but fet after the fame maner, and in like order that they are, being of a faint yellow colour out of a green; the fruit or Nuts do hang by their ftalks in clnfters, being greater than the Nirs of Pine Apples,and much leffer than Almonds : the husks without is of a grayin colour fometimes reddifh, the fhell brickle and white; the fubftance of the kernell greene; the tafte fweet, pleafant to be eaten, and fomething fwect of fincll.

$$
9 \text { The Place. }
$$

Fiftelse Nuts grow in Perfa, Arabia, Sy ria, and in India; now they are made free Denizons in Iraly, as in Naples and in other Prouinces there.

$$
\text { e) The Time. }
$$

This tree doth floure in May, and the fruit is ripe in Seprember.

$$
\text { 7. The Names. }
$$

This Nut is called in Greekemsimar in Athe neus: Nicander Colophonius in his booke of Trea. cles nameth it witiaxur: Pr.fJidonius nameth it Burrixus: others, $\phi_{15 a_{2}}$ or: the Latines obferuing the fame termes, haue named it Piffacion, Biftacion, or Phi. facion. 
Lis.j. Of the Hiftory of Plants.

facion : the Apochecaries, Fiftici : the Spaniards, Alhocigos, and Fifticos : in Italian, Poflacchi: in Englith, Fifticke Nut.

T The Temperature and Vertues.

The kernels of the Fifickc Nuts are oftentimes eaten as be thofe of the Pinc Apples; they be of temperature hot and moit; they are not fo eafily concocted, but much ea fier than common nuts: the ivice is good,yet fomewhat thicke; they yeeld to the body no fmall nourifhment, they nourio bodies that are confumed:they recouer ftrength.

They are good for thole that haue the phthifick, or rotting away of the lungs.

They concout,ripen, and elenfe forth raw humours that cleaue to the lights and chef.

They open the ftoppings of the liuer, and be good for the infirmities of the kidncies; they alfo remotre out of the kidneies fand and gratell; and affwage their paine:they are alfogood for vlcers.

The kernels of Fifticke nuts condited, or made into comfits, with fugar, and earen, doe procure bodily lut, vnttop the lungs and the breft, arc good again th the thortneffe of breath, and are an exccllent prefertutiue medicinebeing minifted in wine againft the bitings of all manner of wilde bcalts.

\section{С нат. 88 . Of the Bladder $\mathcal{N} u t$.}

Nur veficaria.

The Bladder Nut.

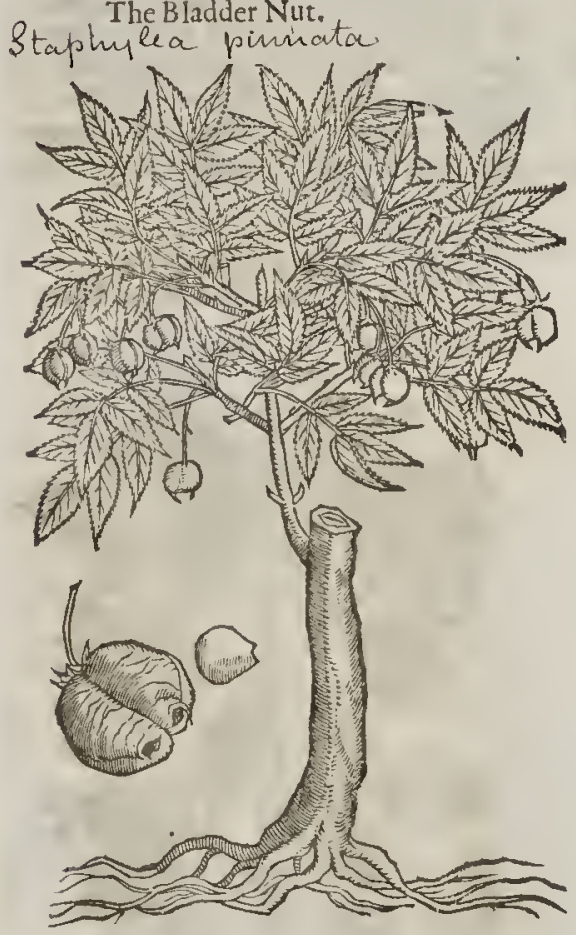

I I De Deription.

His is a low tree, hauing diuers young fprings growing forth of the root: the fubftanceof the wood is white, very hard \& found; the barke is of a light greene : the leaues confift of fure little ones, which be nicked in the edges like thofe ') the Elder, but leffer, not fo greene nor ranke of fmell. It hath the plearant whirith houres of Bryonic or Labrufa, both in fmell and thape, which turne into fmal corneredbladders of winer Clerries, called Alka kengie,but of an ouerworne greenifh colour: in thefe bladders are contained two little nuts, and Tometimes no more but one, leffer than the Hafell nut, but greater than the Ram Cich,with a wooddic thel and fomewhat red: the kernell within is fomething green; in tafte at the firft fweet, butafterwards lothfome, and ready to prouloke vomit.

$$
\text { II The Place. }
$$

It groweth in Italy, Germany and Franee; it groweth likewifeat the houfe of fir Walter Culpepper neere Flimmewell in the Weild of Kent, as alfo in the Frier-yard without Saint Paules gate in Stamford, and about Spalding Abbey, and in the garden of the righthonourable the Lord Treafurer my very good Lord and Mafter, and by his houfc in the Strand. It growethalfo in my garden, and in the garden hedges of fir Francis Carem neere Croydon, $1 \mathrm{e}_{\mathrm{J}}$ uen miles from London.

The Time.

This trce floureth in May, the Nuts beripe in Augutt and September.

T The 2 ames.

It is commonly called in high Dutch, 19 impetnur 3 , which fignificth in low Dutch 19 impetmo: ten: diters call it in Latine Piffacrum Germantcum: we thinke ic beft tocall it $\mathcal{N}$ u veficarta. Matthio'ss in his Epiftes doth iudge the Turks Coulcoul and Hebulben to agree with this: Gulielmus Quacelbenus affirmeth, Coulcoul to be vfed of diuers in Conftantinople for a daintie, efpecially when iney be new brought out of Egypt. This plant hatli no old name, vnlelfe it be Staphylodendron Plinï:

Eeeec 3 
torwhich it is taken of the later writers and Pliny hath written of it in his $16.600 k, 16$. chap. There is alfo (faith he) beyond the Alpes a tree, the timber whereof is very like to that of white Maple, and is called Staphylodendron, it beareth cods, and in thofe kernels, hauing the taite of the Hafel nut, It is called in Englith, S. Anthonies nuts,wilde Piftacia, or Bladder nuts:the I talians call it Piftachio Saluatrcke : the Freneh men eall it $B$ aguenaudes a patre noftres, for that the Friers do vfe to make beads of the nuts.

The Temperature and Vertues.

A Thefe nuts are moift and ful of fuperfuous raw humours, and therefore they eafily procure a readineffe tovomite, and trouble the ftomacke, by reafon that withall they be fomewhat binding, and therefore they be not to be eaten.

B

They hatre as yet novfe in medieine,yet notwithftanding fome haue attributed vnro then fome vertues in prouoking of Veneric.

\section{Cha P. 89. Of the Hajell tree.}

\section{The Defeription.}

I THe Hafell tree groweth like a thrub or fmall tree, parted into boughes without ioints, 1 tough and pliable:the leaues arebroad, greater and fuller of wrinckles than thofe of the Al fer tree,cut in the edges like a faw, of colour greene, and on the backfide more white, the bark is thin: the root is thicke, ftrong, and growing deep; in ftead of fioures hang downe eatkins, aglets, or blowings, flender, and well compact : afterwhich come the Nuts ftanding in a tough cup of a greene colour, and iagged at the vpper end, like almoft vnto the beards in Rofes. The thell is fmooth and wooddie: the kernel within confifteth of a white, hard, and found pulpe, and is couered with a thin skin, oftent imes red, moft commonly white; this kernell is fweet and plea fant vnto the tafte.

I Nux Auellana, ive Corylus. The Filberd Nut.

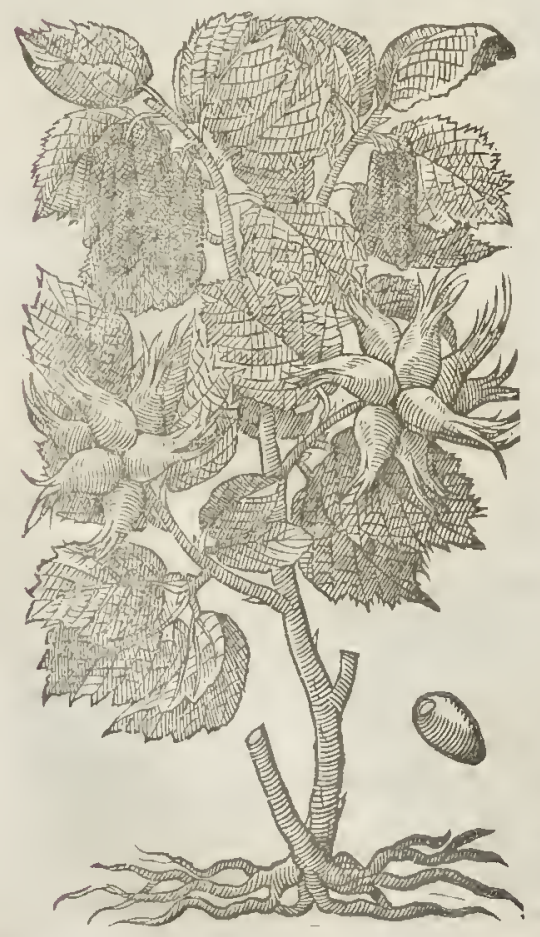

2 Corylus fylueftris:

The wilde hedge Nut: Coritin Chillans 
LAB. 3. Of the Hiftory of Plants.

2 Corylus fylusftres is our hedge Nut or Hafell Nut ttee, which is very well knowne, and thete fore needeth not any defctiption : whetcof there are alfo fundry forts, fome great, fome little, fome rathe ripe, fome later, as alfo one that is manuted in our gardens, which is very great, bigger than any Filberd, and yet a kinde of Hedge nut : this then that hath beene faid thall fuffice for HedgeNits.

¥ 3 The fnall Turky Nut tree growes but low, and the leates gtow without order,vpon the twigs, they are in thape like thole of the fotmer, but fomewhat longer : thechiefe difference confilts in the fruit, which is fmall, and like an Hafell Nut, but thortet : the huske, wherein fomtimes one, otherwhiles more Nits are contained, is very large, tough, and hard, diuided both aboure and below intn a great many iags, which on euery fide couter and hold in the Nuts, and thefe cups are very rough without, but fmooth on the infde. Clufus firf fet this foth (hauing receiued it from Conftantinopic) by the name of suellana pumila By?antina. $\neq$

3 Uuellana pumila Byzantina cum fuo fructu:

The Filbetd Nut of Conftantinople.
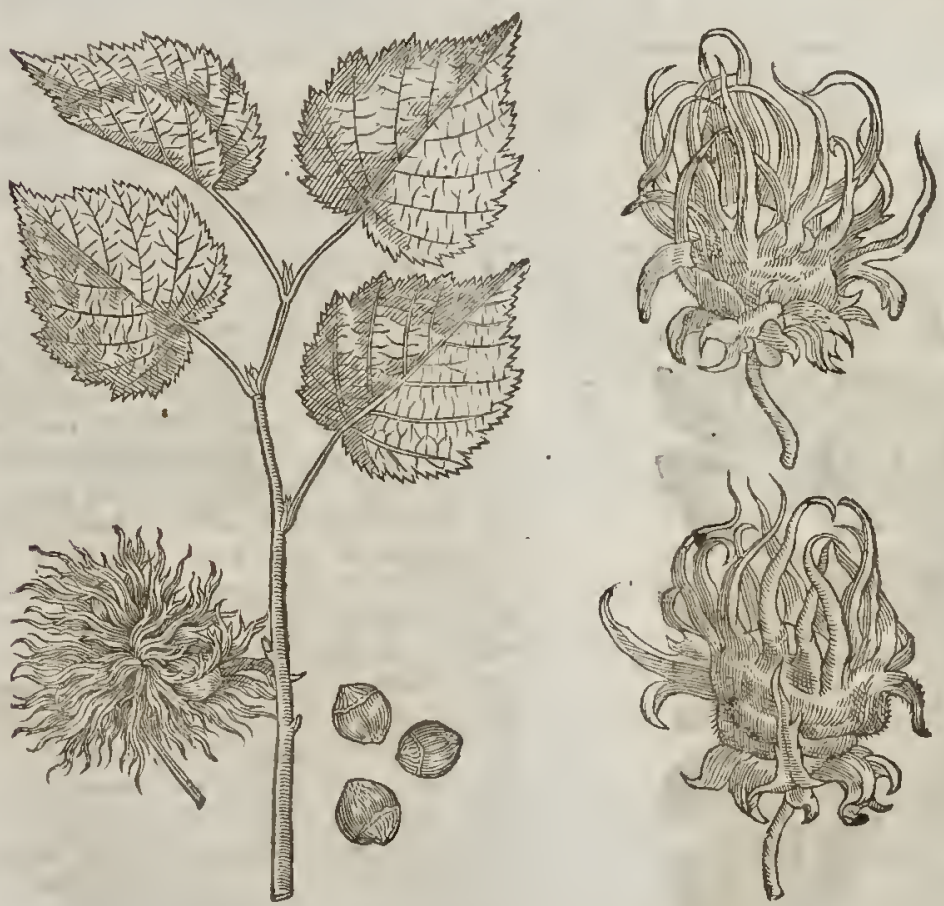

The Place.

The Hafell trecs do commonly grow in Woods and in dankifh vitoiled places : they ate alfo fet in Otehards, the Nuts whereofare better, and of a fwectet tafte, and be moft commonly red within.

If The Time.

The catkins ot aglets come foth vety timely, before winter be fully paft,and fall aw ay in March or Aprill, fo foone as the leaues come forth : the Nuts be ripe in Augut.

The Names.

'This fhtub is called in Latine, Corylus : in Greeke, wavartonnx, that is, Nux Pontica, or Ponticke

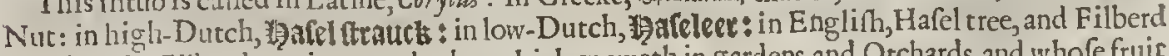
tree; but the Filberd tree is properly that which gtoweth in gardens and Otchards, and whole fruic is commonly wholly courered ouer with the huske, and the fhell is thinner.

The Nut is named in Latine, $N u x$ Pontica, tennis $N u x$, parta $N u x$; it is alfo called $2 u x$ Praneft: n.t, Nux If racleotica, and commonly $N$ ux auellana, by which name it is vitally knowne to the A por

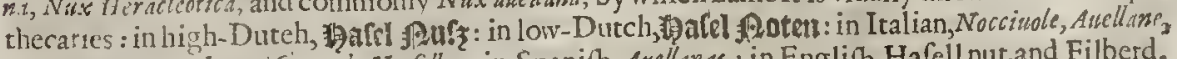

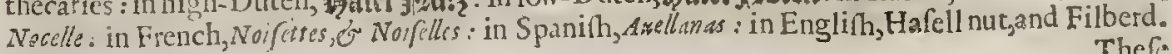

Thef: 
440

Of the Hiftory of Plants.

Thefe Nuts that haue their skinnes red are the garden and planted Nuts, and the right Pontick

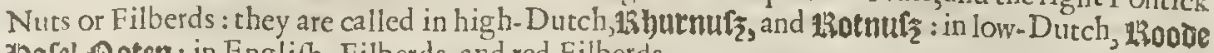
䄱alel Poter : in Englih, Filberds, and red Filberds.

The other Nuts which be white are indged to bewilde.

$$
\text { I The T emperature and Vertues. }
$$

A Hafell Nuts newly gathered, and not as yet dry, containe in them a certaine fuperfluous moifture, by reafon whereof rhey are wind ie: not onely the new gathered Nuts, but the dry alfo,be very hard of digettion; for they are of an earthy and cold effence, and of an lard and found fubftance. for which caufe alfo they very flowly paffe thorow the belly, therefore they aretroublefome and clogging to the ftomacke, caufe head-ache, efpecially when they be eaten in too great a quantitie.

$B$ The kernells of Nuts made into milke like Almonds do mightily bind the belly, and are good for the laske and thebloudy flix.

C The fame doth coole exceedingly in hot feuers and burning agues.

D The catkins are cold and dry, and likewife binding : they alfo ftay the lask.

E $\ddagger$ The kernels of Nuts rather caufe than cute the bloudy flix and lasks, wherefore they ate nor to bevfed in fuch difeafes. $\neq$

\section{- Ch а p. 90.}

Nux Iuglans.

The Walnut tree.

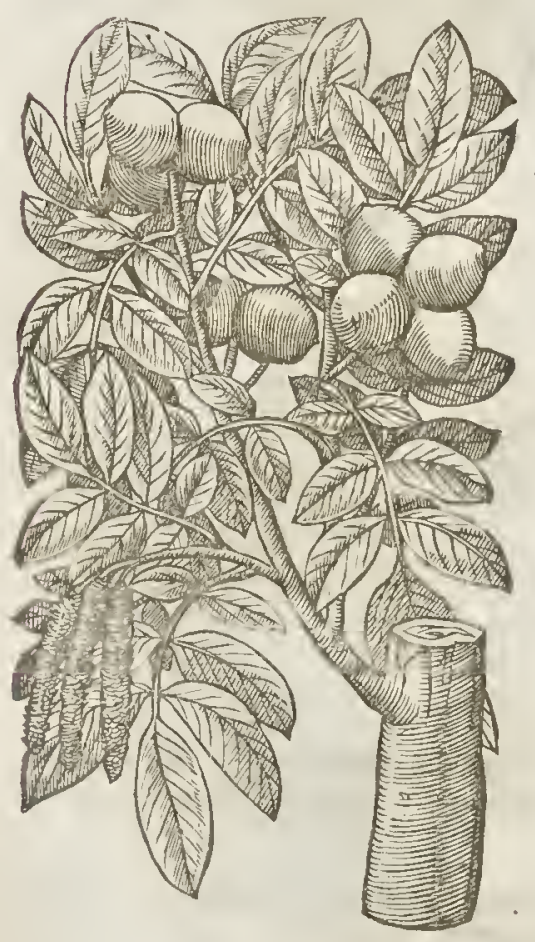

\section{Of the Wall-nut tree.}

$$
\text { II The Deforiptios. }
$$

T His is a gtcat tree with a thicke and tall body: the barke is fomewhat greene, and tending to the colour of arhes, and of tentimes full of clefts : the boughes fpread themfclues far abroad : the leaues confift of fiue or fix faftned to one rib, like thofe of the Afh tree, and withone ftanding on the top, which be broader and longer than the particular leaues of the Afh, fmooth alfo, and of a ftrong fmell: the catkins or aglets come forth before the Nuts : thefe Nuts do grow hard to the falke of the lea ues, by couples, or by rhree \& three; which at the firft when they be yet but tender haue a fweet fmel,and be courered with a green huske: vnder that is a wooddy thell in which the kernell is contained, being couered with a thin skin, parted almoft into foure parts with a woody skin as it were : the inner pulp whereof is white, fweet and pleafant to the taft; and that is when it is new gathered, for after it is dry it becommethoily and ranck.

$$
\text { 9ा The Place. }
$$

The Wainut tree groweth in fields neere common high-wayes, in a fat and frutfull ground, and in orchards : it profpereth on high fruitfull bankes, it loueth not to grow in waterie places.

\section{बा The Time.}

The leaues together with che carkins come forth in the Spring : the Nuts are gathered in Au-
gurt.

$$
\text { T The Names. }
$$

The tree is called in Greeke, $x_{p p v x}:$ in Latine, $N u x$, which name doth fignifie both the tree and

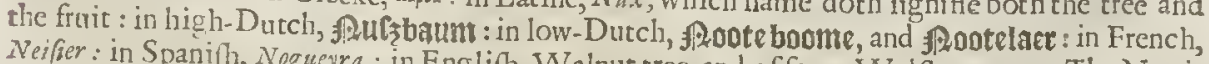
Neifer : in Spanifh, Nogueyra : in Englin, Wainut tree, and of fome, Walfh nut tree. The Nut is called in Greeke, Kepurareanixis, that is to fay, Nux Regia, or the Kingly Nat : it is likewife named 
$N_{H x}$ Inglans, as though you thould fay Iouis glans, lupiters Acorne; or Iuvans glans, the helping A.

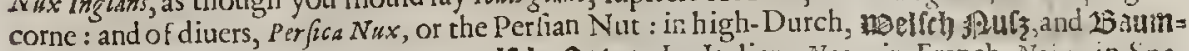

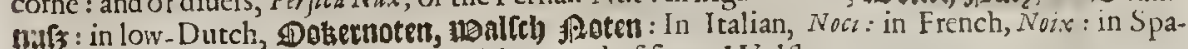
nith, Nuezes, and Nous : in Englirh, Walnut; and of fome, Walih nut.

If The Temapcrature andrortues.

The freith kernels of the nuts newly gathered are pleafant to the tafte : they are a little cold, and $A$ hate no fmall moifture, which is not perfectly coneocted : they be hard of digeftion, and nourilh little : they flowly defcend.

The dry nuts are hot and dry, and thore more which become oily and tanke : thefe be very hurt- $B$ full to the ftomacke, and befides that they be hardly concoited, they increafe choler, eaufe headache, and be hurt full for the eheft, aud for thofe that be troubled wirh the cough.

Dry Nuts taken fafting with a fig and a little Rue withftand poyfon, preuent and preferue the 'C body from the infection of the plague, and being plentifully eaten they driue wormes forth of the belly.

The greene and tender Nuts boiled in Sugar and eaten as Suckad,are a moft pleafant and deleD

cablemeare, comfort the ftomacke, and expell poyfon.

The oilc of $\mathrm{W}^{r}$ alnuts made in fuch manner as oile of Almonds, maketh fmooth the hands and $\mathrm{E}$ face, and taketh away fcales or fcurfe, blackeand blew marks that come of ftripes or bruifes.

Milke made of the kernels, as Almond milke is made, cooleth and pleafeth the appetite of the $F$ languihing ficke body.

With onions, falt, and hony, they are good againft the biting of a mad dog or man, if they be $G$ laid vpon the wound.

Being both eaten, and alfo applied, they heale in thort time, as Diofcorides faith, Gangrens, Car- H buncles, $x$ gilops, and the pilling away of the haire: this alfo is effectually done by the oile that is preffed out of rhem, which is of thin parts, digefting and heating.

The outward greene huske of the Nuts hath a notable binding facultie. The outward greene huske of the Nuts hath a notable binding facultie.
Galen deuifed and taught to make of the iuyce thereof a medicine for the mouth, fingular good $\mathrm{K}$
again ft all inflammarions thereof.

The leatses and firt buids haue a certaine binding qualitie, as the fane Authour theweth; yet $L$ there doth ahound in them an hot and dry temperature.

Some of the later Phyfitions vfe thefe for baths and lotions for the body, in which they hate a $M$ force to digeft and al fo to procure fweat.

\section{C $\mathrm{HA}$ P. 9I. Of the Cheftnut tree. T) The Defcription.}

I THe Cheitnut tree is a very great an high tree: it ealtetl fortl very many boughes : the body is thicke, and fometimes of fo great a compafic as that two men can hardly fathom ir: the timber or fubitance of the wood is found and durable: the leaues be great, rough, wrinkled, nicked in the edges, and greater than the parricular leaues of the Walnut ree. The blowings or catkins be flender, long, and greene : the fruit is inelofed in round a rough and prickly huske like to an hedge-hog or Vrchin,which opening it felfe doth ler fall the ripe fruit or Nut. This nut is not round, but flat on the one fide, fmooth, and tharpe pointed: ir is couered with a hard thell, which is tough and very fmooth, of a darke browne colour : rhe meate or inner fubfance of the nut is hard and white, and couered with a thin skin which is vnder the thell.

2 The Horfe Cheftnut groweth likewife to be a very great tree, fpreading his great and large armes or branches far abroad, by which meanes it maketh a very good coole hadow. Thefe branches are garnithed with many beautifull leaues, cut or dinided into fiue, fix, or feucn fections or diuifions, like to the Cinkfoile, or rather like the leaues of Ricinus, but bigger. The floures grow at the top of the ftalks, confifting of foure fmall leaues like the Cherry bloffome, which turne into round rough prickly heads like rhe former, but more fharpe and harder : the nurs are alfo rounder. + The floures of this, faith Clu (2us (whofe figure of them I here giue you) concout of the bofon of the leafe which is the vppermort of the branch, and they are many in number growing vpon prettic long foot-ftalkes, confifting each of rhem of foure whire leaues of no great bignefie; the trwo vppermof are a little larger than the reft, hauing round purple fpots in their middles : our of the middle of the floure eome forth many yellowifh threds with golden pendants. Tlye fruir is contained in a prickly huske that opens in three parts, and it is rounder and not fo harpe pointed as 


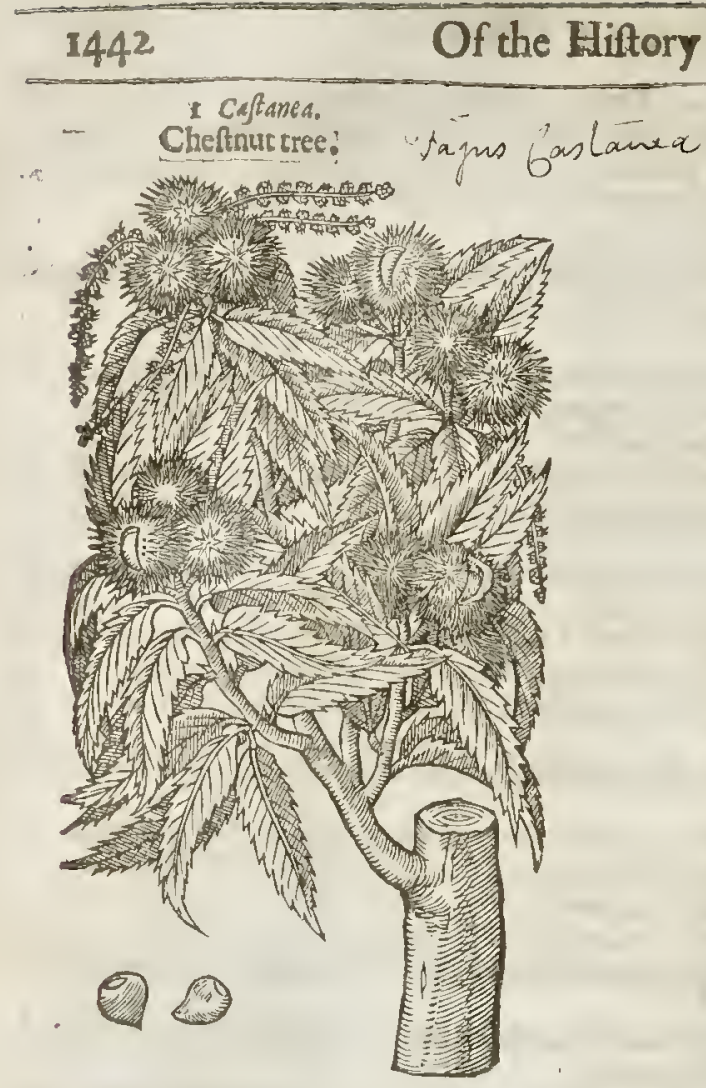

L 1 B. 3.

of Plants:

2 Castanea Equina cum flore. Horfe Cheftnut tree in floure,

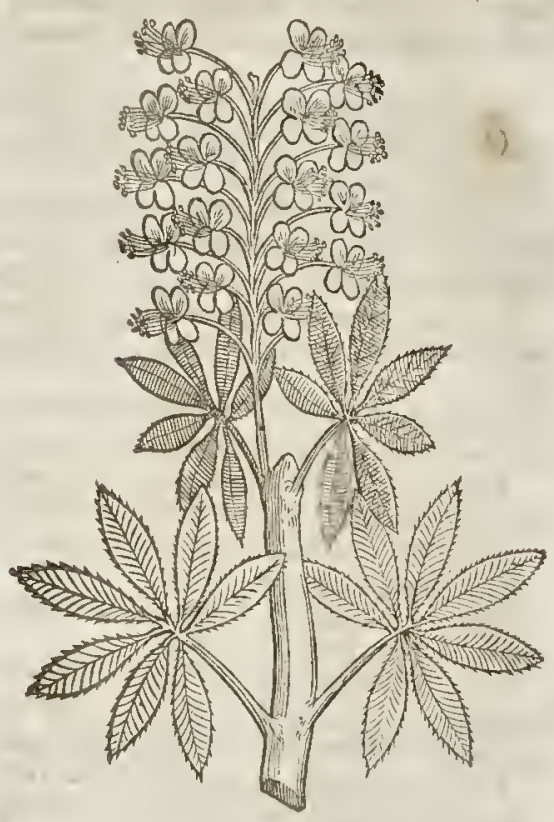

Eafonea Equira fratiws?
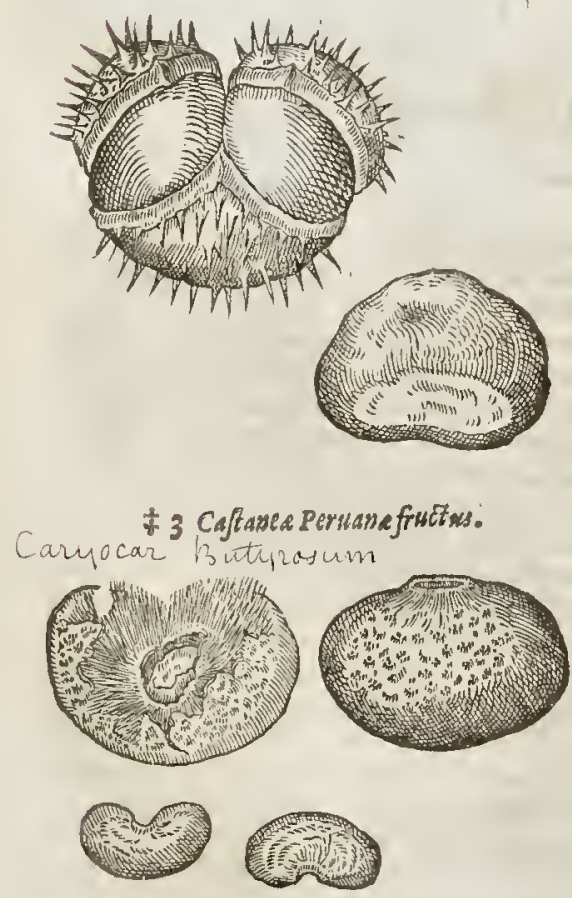

the ordinary Chefnut, neither vader the vtter coat hath it any peeling within as the other hath, neither is it of 10 good a tafte. $\ddagger$

$¥ 3$ This Americane Cleftnut is almof round, but that it is a little flatted on the fides, efpecially whereas it is faftned to the falke : the viter coat is fufficiently thicke, yet brittle, and as it were fungous, of a brownifh yellow colour : vnder this are aboundance of fmall yet fiffe priclles, faft ficking to the thell that containes the kernell : the thell it felfe is brownifh, not thick, - but tough and hard to breake, fmooth and thining on the infide, wherein is contained a kernel of the bigneffe and colour of an lares kidney, white within, and fweet in tafte like an almond or the common Cheftnut. Clufius cals this Caftanca peruana, or Chentnut of Peru; and hee faith hee had it from the famous Geographer Abratuam Ortelius, who had it fent himby Benedictus Arias Monta. nus. The figure is exprent wnder that of the Horfe Cheftnut. $\ddagger$

$$
\text { T The place. }
$$

The firft growes on mountaines and thadowie places, and many times in the vallies: they loue a foft and blacke foile. There be fundry woods of Cheitnuts in England, as a 
mile and a lualfe from Feuerham in Kent, and in fundry other places : in fome countries they be greater and pleafanter: in others fmaller, and of worfe taite.

The Horfe Chefnut groweth in Italy, and in fundry places of the Eaf countries. + It is now growing with $\mathrm{M}^{\mathrm{r}}$. Iradefcant at South Lambeth. ‡

$$
\text { पा The Time. }
$$

The blowings or aglets come forth with the leaues in Aprill; but the Nuts later, and be nof ripé till Autumne.

$$
\text { Tा The Names. }
$$

The Cheftnut treebcares the name of the Nut both in Greeke and Latine : in high-Duteh, $x_{\text {be }}=$ ftenbaum, and Hattatibaum: in low-Dutch, Caftaniboom: in French, Caftaignicr: in Engli1h, Cheftnut tree.

The Nut is called in Greeke, xeraney : in Latine, Caftanea, Tonis glans, Sardiniaglans : in ligh-Dutch . Feften : in low-Dutch, Caftanien : in Italian,Caft.gne: in French,Chaftaigne: in Spanifh, Morones, Caftanas : in Englith, C. heitnut : the greater Nuts be named of the Italians, Marroni : of the French men and of diters bafe Almaines, Marons.

The Horfe Cheftntt is ealled in Latine, Equira Cafanea : in Engli(h, Horfe Cheftnut, for that the people of the Eaft countries do w ith the fruit thereof cure their horfes of the cough, thortricffe of breath, and fucli like difeafes.

The Temperatureand Vertues.

Our common Chefnuts are very dry and binding, and be neither hot nor cold, but in a mean be- $A$ tweene both : yer hate they in them a certaine windinefle, and by reafon of this, vnleffe the fhell be firft eut, they skip fuddenly with a cracke out of the fire whileft they be rofting.

Of all the Acornes, faith Galen, the Cheitnuts are the chiefent, and doe onely of all the wilde $B$, fruits yeeld to the body commendable nourithment; but they fowly defeend, they be hardly concoefed, they make a thickebloud, and ingender winde: they alfo ftay the belly, efpecially if they be eaten raw.

Bcing boiled or rofed they are not of fo hard digeftion, they more cafily defcend, and are leffe $\mathrm{C}$ windy, yet they aifo make the body coftiue

Some affirme, that of raw Cheftnuts dried, and afterwards turned into meale, there is made a $D$. kinde of bread : yet it muff needs be, that this fnould be dry and brittle, hardly eoncocted, and verie now in pafing thorow the belly; but this bread may be good againit the laske and bloudy flix.

An Electuarie of the meale of Cheftnuts and hony is very good againt the cough and fpitting E ofbloud.

Thebarke of the Cheftme tree boiled in wine and drunke, ftops the laske, the blourdy flix, and F a!l other iffues of bloud.

\section{С н Р. 92. Of the Beechtree. \\ T) The Defcription.}

$\mathrm{T}$

He Beech is an high tree, with boughes fpreading oftencimes in manner of a circle, and with a thickebody hauing many armes : the tarke is fmooth $:$ the timoer is white, hard, and verie profitable : the lcaues be fmooth, thin, broad,and leffer than thofe of the blacke Poplar : the catkins or blowings bealfo leffer and horter than thofe of the Birch tree,and yellov : the fruit or Maft 1 contained in a huske or cup that is prickly, and rough briftled, yee not fo much as that of the Cheitnut : whieh fruicbeing taken forth of the thells or vrehin husks, be couered with a foft and fmooth skin like in colour and fmoothneffe to the Cheftnuts, but they be much leffer, and of another forme, that is to fay, triangled or three cornered: the kernell within is weet, with a certaine aftriction or binding qualitic : the roots be few, and grow not deepe, and little lower than vinder the turfe.

$$
\text { T The Place. }
$$

The Beech tree loteth a plaine and open countrey, and groweth very plentifully in many Forrefts and defart places of Suliex, Kent, and fundry other countries.

\section{T The Time.}

The Bech floureth in A prill and May, and the fruit is ripe in September, at what time the Decre do eate the fame very greedily, as greatly delighting therein; which hath caufed forrefters and hunt men to call it Buck-maft. 


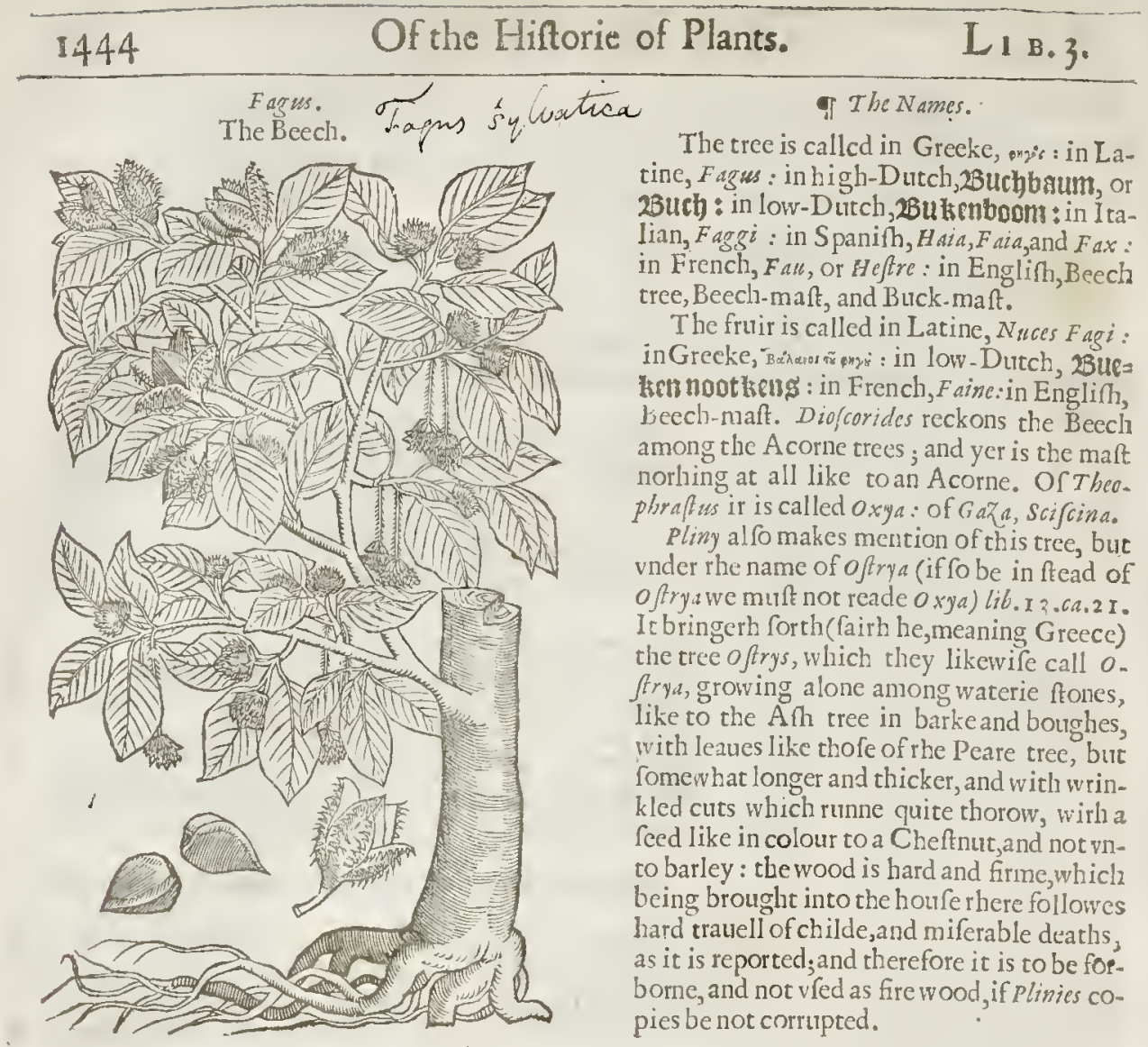

The Timperature.

The leanes of Beecli do coole : the kernell of the Nut is fomw hat moin.

बा The Vertues.

A The leaues of Beech are very profitably applied nnto hot fivellings, blifters, and excoriations; and being chewed rhey are good for chapped lips, and paine of the gurms .

B The kernels or maft within are reported to cafe the paine of the kidneyes proceeding of the ftone, if they be eaten, and to caufe the grauell and fand the eafier to come forth. With thefe,mice and Squirrels are greatly delighred, who do mightily encrea fe by feeding thereon : Swine alfo be fatned herewith, and certaine other beafts : alfo Deerc do feed thereon very greedily : they be likewife pleafant to Thrufhes and Pigeons.

C Petrus Crefcentizus writeth, That the afhes of the wood is good to make glaffe with.

D The water that is found in the hollowneffe of Beeches cureth rhe naughty fcurfe, tetters, and fcabs of men, horfes, kine, and heepe, if they be wafhed therewith.

\section{II A . 93. Of the Almond tree. \\ T The Defcription.}

THe Almond trec is like to the Peach tree, yet is it higher, bigger, of longer continuance : the leates bevery long, tharpe pointed, fnipt about the edges like thofe of the Peach tree: the foures be alike : the fruit is alfo like a peach, hauing on one fide a cleft, with a foft skinwithout, and coured wirh a thin cotton ; bur vnder this there is none, or very little pulp, which is hard like agriftle not earen : rhe nut or ftone wirhin is longer than that of the peach, not fo rugged, but fmooth; in which is conrained rhe kernel, in tafte fweet, and many times bitter : the root of the tree groweth deepe : the gum which foketh our hereof is like rhat of the peach rree.

$\neq$ There are diuers forts of Almonds, differing in largenes and tafte: we commonly haue three or foure forts broughr ro vs a large fiweet Almond, vulgarly termed a lordan almond; and a leffer, called a Valence Almond : a birrer Almond of the bigneffe of the Valence almond, and fomtimes another bitter one leffe than it. 
Amygdalus.

The Almond tree.

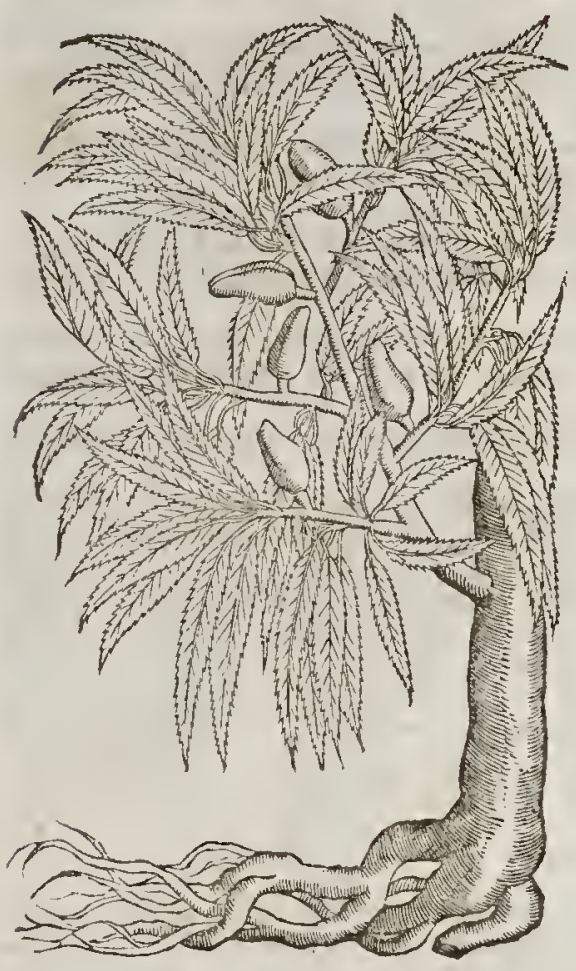

TI The Place.

The natural place of the $A$ lmond is in rie hot regions, yet we haue rhem in our London gardens and orehards in great plenty.

$$
\text { The Time. }
$$

The Almond foureth betimes with the Peach : the fruit is ripe in Augurt. 9 The N.rmes.

The tree is called is Greek, 'Amyst : in T.a. tine, Amygdilus : in French, amandier:iu Englith, Almond tree.

The fruit is eat!ed in Greeke, 'Anuzana: in Latine, Lamygdalum $\cdot$ in fhops, 1 imygdala: in high-Duteh, gandor : in low.Dutch, $\mathfrak{z}=$ manoclen: in Iraiian, cMandole : in Spanith, Almendras, fimelles, and rmendoas : in French, Amardes : in Englifh, Almond.

I The Temperature and Vertues.

Sweet Almonds when they be dry be moderatly hot; but the bitter ones are bot and dry in the feeond degree. There is in borh of them a cerraine fat and oily fubftance, whieh is drawne out by prefling.

Sweet Almonds being new gathered are pleafant to the tafte, rhey yecld fome $k$ ind of nourithment, but the fame grofle and earthy, and groffer than thole that be dry, and not as yet withered. Thefe do likewife llowly defcend, efpecially being caten without their skins; for euen as the huskes or branny parts of eorne doe ferue to driue downe the grofle excrements of the belly, fo sioe likewife the skins or husks of the almonds : therefore thofe that be blanehed do fo flowly defeend, as that they dowirhall binde the belly; whereupon they are giuen with good fueee fle to thofe that haue the laske or the bloudy flix.

There is drawne nut of fweet A Imonds, with liquor added, a white iuice like milke, which ouer and befides that it nourinerh, and is good for thofe that are tromsled with the laske and bloudie flix, it is profitable for thofe that haue the pleurifie and fpitvp fithy matter, as Alexander Tralizanus witneffeth : for there is likewife in the Almonds an opening and conencting qualitie, with a certaine elenfing faeulty, by wh ieh they are medicinable to the cheft and lungs,or lights, and ferue for the raifing vp of tlegme and rotten humors.

A Imonds taken before meate do ftop the helly, and nourif but litt!e, notwithranding many excellent meates and medieines are therew ith made for fundry griefes, yea very delieat and whol, fome meates, as Almond butter, ereame of Almonds, marchpane, and fueh like, which drv and ftay the belly more than the extrasted iuyce or milke; and they are alfo as good for the clueft and lungs.

They do ferue alfotomake the Phyfreall Barley water, and Barley Creame, which are giten in hot Feuers, as alfo for other ficke and teeble perfons, for their further refrefhing and nourihments.

The oile whieh is newly pee Ted out of the fweet Almonds is a mitigarer of paine and all maner of aches. Ir is giuen to thofe that haue the pleurifie, being firt let bind; but efpecially to thofe that are troubled $w$ ith the ftone of the kidnies, it flackens the naffajes of rhe vrine, and makerh them glib or flipperic, and more ready to fuffer the ftone to haue frue pafiage : ic maketi the belly foluble, and therefore it is likewife vfed for the collicke.

It is good forwonen that are newly deliuered; for it quickly remoucth the throwes which te- $G$ maine after their deliuery.

The nile of Almonds makes fmooth the hands and raee of delieat perfons, and clenfeth rhe skin $H$ from all fpots, pimpics, and lentils.

Bitce A inonds doe make thmme and open, they remoue ftoppings out of tise liver and fpleene, I

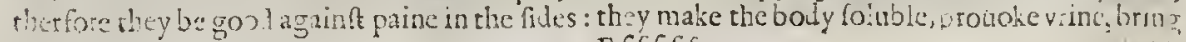

\section{A.}


downe the menfes, helpe the ftrangurie, and clenfe forth of the cleet and lungs clammiehumn s it rhey be mixed with fome hinde of looch or medicine to licke on: with farch they ftay the f pit-
ting of bloud.

L And it is reported that fiue or fix being taken fafting do kcepe a man.from being drunke.

M Thefe alfo clenfe and take away fpots and blemithes in the face, and in other parts of the body; they mundifie and make cleane foule eating vlcers.

N With hony they are laid vpon the biting of mad dogs; being applied to the temples with vineneger or oile of Roles, they take away the head-ache, as Dof corides wtiteth.

O They are alfo good againft the cough and thortneffe of winde.

$\mathrm{P}$ They are likewife good for thofe that fpit bloud, if they be taken with the fine fioure of $\mathrm{Am}$. $\mathrm{lm}$.

Q Thcre is alfo preffed out of thefe an olle which prouoketh vrine, but efpecially if a few fcorpi. ons be drowned, and fteeped therein.

$\mathrm{R} \quad$ With oile it it fingular gond for thofe that haue the ftone, and cannot eafily make watet but with extremitic of paine, it the thate and place betweene the cods and fundament be anoynted therewith.

$S$ Diofcorides faith, that the gum doth heate and binde, which qualities notwithftanding are not perceiued in it.

I It helpeth them that fpit bloud, not by a binding facultie, but thorow the clammineffe of his fubftance, and that is by cloling vp of the paffayes and potes, and fo may it alfo cureold coughes, and mitigate extreame paines that proceed of the ftone, and efpecially take away the tharpeneffe of vrine, if it be drunke with Baftard, or with any other fweet potion, as with the decnet ion of Licorice, or of Raifons of the funne. The fame doth likewife kill tctters in the outward parts of the bodie (as Diofcorides addeth) if it be diffolucd in vineger.

\section{Cin a P. 94. Of the Peachtree.}

\section{The Rindes.}

$\$$ Here are diners forts of Pcaches befides the fourc here fet forth by our Author, burt the trees to nor much differ in thape, but the diffcrence chiefely confifts in the fruit, whereof I will giue you the names of the choice ones, and fuch as are to be had from my friend $\mathrm{M}^{\mathrm{r}}$. Mul. len in Old-ftreet,which are thefe; two forts of Nutmeg Peaches; The Queenes Peach; The Newington Peach; The grand Carnation Peach; The Carnation Peach, The Blache Peach; the Melocotone; the White; The Romane; The Alberza; The Inand Peach; Peach du Troy. I hefe are all good ones. He liath alf of that kinde of Peach which fome call Nuciperfica or Nc8 orirs, thefe following kindes; the Roman red, the beft of fru:ts; the baftard Red; the little dainty green; the yellow; thewhite; the ruffet, which is not fo good as the reft. Thofe that would fec any fuller difcourfe of thefe may hauc recourle to the late worke of $\mathrm{M}^{\mathrm{r}}$. Iohn Perkinfon, where they may finde more varieries,and inore largely handled, and thetefore not neceflar ie fot me in this place to infilt vpon them. $\ddagger$

\section{Tा The DCfcription.}

I THe Peach tree is a tree of no great bigneffe: it fendeth forth diuers boughes, which be fo brittle, as oftentimes they are broken with the weight of the fruit or with tle winde. The leaues be long, nicked in the edges, like almoit to thofe of the Walnut tree, and intafte bitrer : the floures be of a light purple colour. The fruit ot Peaclscs be round, and haue as itwere a chinke or cleft on the one fide; they are coucred with a foft and thindr wne nr hairie cotron, being white without, and of a pleafant tafte; in the midd!e whereof is a rough or rugged ftone,where in is contained a kernell like vnto the Almond; the meate about the ftone is of a white colour. The ront is tough and yellowith.

3 The red Peac tree is likewife a ttee of no gteat bigneffe: it alfo fendeth forth diners boughes or branclies, which be very brittle. The leaues be long, and nicked in the edges like to the precedent. The foures be alfo like unto the former; the fruite or Peaches be round, of a red co'bur on the out fide; the meate likewife about the ftone is of a gallant ted colout. Thefekindes of Peaches are very like tn wine-in tafte, and therefore matuellous pleafant.

3 Perfica precocia, or the d'aunt Peach rree is like vnto the former, but his leates are greater and larger. The fruit or Peaches be of a ruffet colour on the one fide, and on thenther fide next vnto the fun of a red colour, but much greater than the red Peach : the ftones whereof are like unto the formet : the pulpe or meate within is of a golden yellow colout, and of a pleafant tafte. 
Li в. 3. Of the Hiftory of Plants. 1447

Perficaalba.

The white Peach.

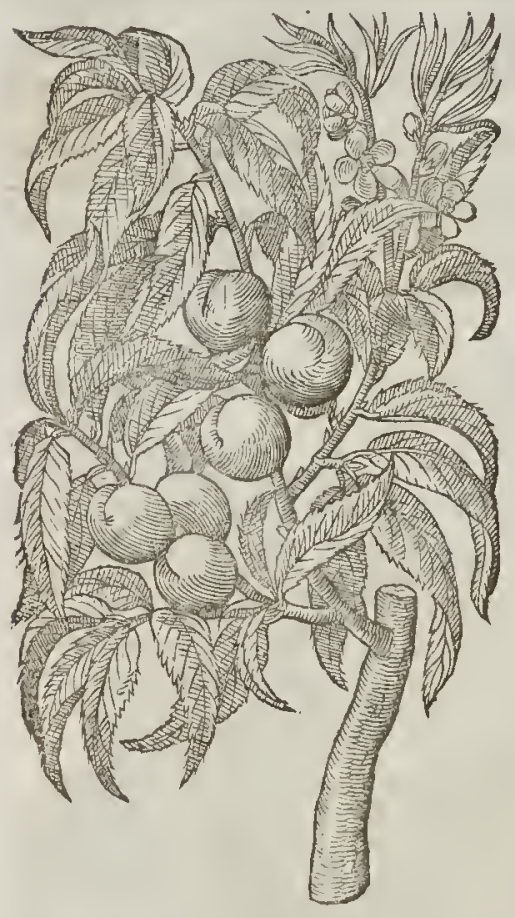

4 Perjaca lutea, or the yellow Peach tree, is like vnto the former in leaues and floures : his fruit is of a ycllow colour on the outfide, and likewife on the infide, harder than the rct ; in the middle of the Peach is a wooddy, hard, and. roush ftone, full of crelts and guters, in which doth lie a kernell much like to that of the Almond, and with fuch a like skin: the fubftance within is white, and in tafte fomething bitter. The fruic hercof is of greateft pleafure, and beft tafte of all the other of his kinde; altho!ng thete be found at this day diuers other forts that are of very good tafte, not remembred of the ancicnt, or fet doivne by the later writers, whereof to fpeake particularly, woul I no be grearly to our pretended purpore, confidering we halten to an cnd.

$\$ 5$ There is alfokcpt in fome of nur choife gardens a kind of Peach which hath a very double and beautiful foure, bur it is feldome fucceeded by any fruit; they call this, Perfica flore pleno, The double bloffomed Peach. $\neq$

\section{GT The Place.}

They are fet and planted in gardens and vineyards: I haue them all in my garden, with many other forts.

$$
\text { q The Time. }
$$

The Peach tree foone commeth vp: it beares fruit the third or fourth yeere after it is planted, and it foone decaicth, and is not of long concinuance, it floureth in A prill, or a little while after that the leaues appeare, and hath his fruit ripe in Scptember.

I The Nimes.

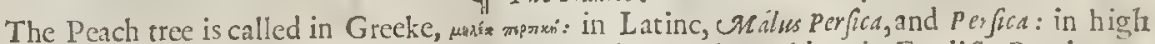

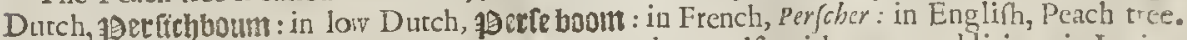

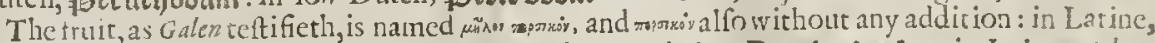
Malum Perficum, and Perficum . in high Dutch, 19 ferfing : in low Dutch, peefen : in Italy, fefche: in Spanifh, Pexegos : in French, Pifches : in Englioh, Peach.

$$
\text { T The Temperature and Vertues. }
$$

Peaches be cold and moift, and that in the fecond degree, they haue a juice and alfo a fub ftance A that doth eafily putrific, which yeeldeth no nourifhment, but bringeth hurt, efpecially if they be caten after other meates; for then they caufe the other meates to putrifie. But they are leffe hurtfull if they be taken firft; for by reafon that they are moift and lippery, they eafily and quickly defeend and by making the belly lippery, they caufe other meates to lip downe the fnoner.

The kernels of the Peaches be hot and dry, they open and clenfe; they are good for the ftop- B pings of the liuer and fpleene.

Peaches before they be ripe do ftop the laske, but being ripe they loofe the belly, and ingender naughty humor, for they are foone cormpted in the ftomacke.

The leaues of the Peach tice do open the ftopping of the liter, and do gently loofen the belly: and being applied plaiferwife vnto the naucll of young children, they kill the wormes, and driue them forth.

The fame leaucs boiled in milke, dokill the wormes in children very fpeedily.

The fame being dried, and cat vpon greene wounds, cure then. Atrained, and more floures put to the faid liquor to infufeafter the fame manner, and fo iterated fix or eight times, and ftrained again, then as much fug ar as it will require added to the fame liquor and boiled vnto the confiftenceor thicknes of a fyrmip, and two fpoonefulls hereof taken, doth fo fingularly well purge the belly, that there is neither Rubarbe, Agaricke, nor any other purger comparable vnto it ; for this purgeth downe waterin humors mightily, and yet without griefe or trouble, eicher to the ftomacke, or lower parts of the body. 


\section{Of the Hittorie of Plants. $\quad$ I I . 3.}

H The kernell within the Peach ftone ftamped fmall,and boiled with Vineger vntill it be brought to the forme of an ointment, is good to reftore and bring again the haire of fuch as be troubled with the Alopecin.

I There is drawne forth of the kernels of Peaches, with Peniroyall water, a iuice like vnto milke? which is good for thofe that haue the Apoplexy: if the fame be of tentimes beld in the mouth it drawe th torth water and reconereth the fpeech.

$\mathrm{K}$ The gum is of a meane temperature, but the fubftance thereof is tough and clammy, by reafon whereof it dulleth the tharpnes of thin humors : it ferueth in a looch or licking medicine for thofe that be troubled with the cough, and haue rotten lungs, and ftoppeth the fpitting and raifing vp of bloud, and alfo ftayerh orher fluxes.

\section{Cн А P. 95. \\ Of the A precockeor Abrecocke tree.}

- Armeriaca malses maior.

The greater Aprecocke tree.

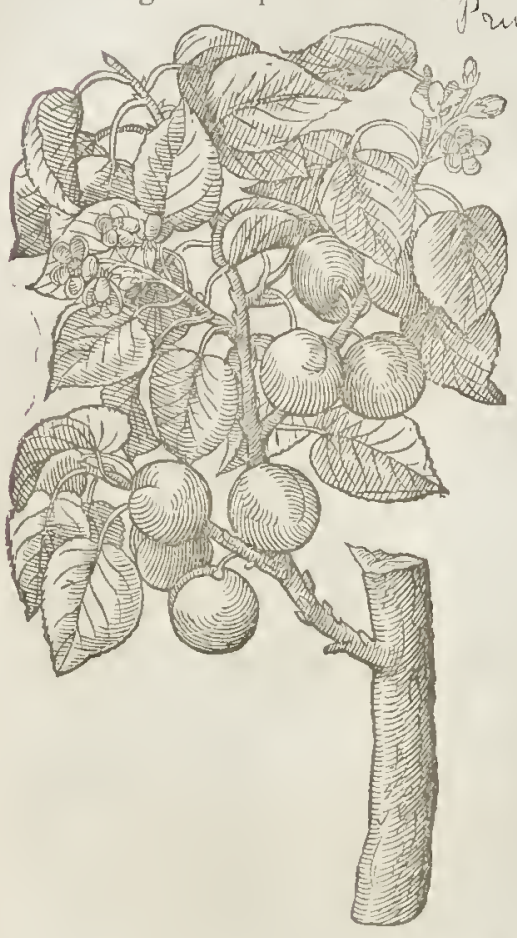

2 Armerracamalass minor. The leffer A precocke tree.

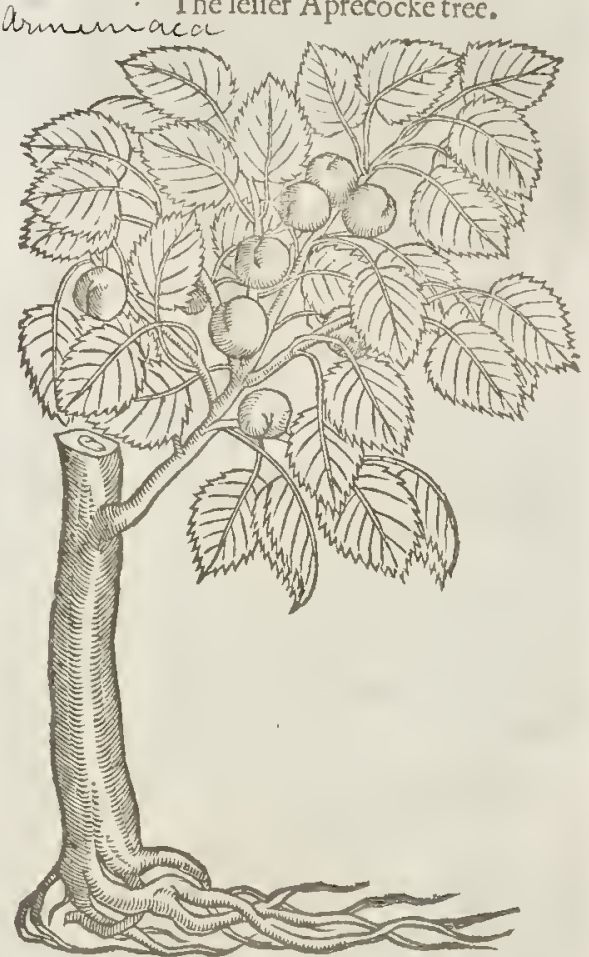

T) The Defcription.

17 His tree is greatur than the Peach tree, and hath a bigger body, it lafteth longer,efpe? cially if it be grafted or inoculated : the leaues hereof are broad, and fharpe pointed like thofe ofblacke Poplar, but leffer,and comming more neere to the leaues of birch, nicked in the edges : the floures are fomewhat white : the fruit round like a peach, yellow withir and without, in which doth lic a browne ftone, nothing rough at all as is that of the Peach, thorter alfo, and leffer, in which is included a fweet kernell.

2 We hate another fort of Aprecocke, whofe trunk or body is equall with the other in grearnefle, it is like alfo in leaues and brittle branches : his time of fouring, flourifhing, and manner of growing accordeth : the only point wherein they differ is, that this tree bringeth forth leffe fruit, and not fogood in tafte; in enery other refpect it is like.

$\ddagger$ Of this alfo $M$. Parkinfon hath fet forth diners varieties; and my forementioned friend $M$ : Millsn hath thefe fiue forts; the common, the long and great, the Muske, the Barbary, and the early Aprecocke. $\neq$ 
L 1 в. 3. Of the Hiftory of Plants.

of The Place.

Thefe trees do grow in my garden, and now adaies in many other gentlemiens gardens throughout all England.

T The Tinae.

They floure and flourifh in Aprill, and their fruit is ripe in Iuly.

If The Names.

This tree is called in Greeke, wnkit Apurtaxn : in Latine, M.slus Armeniaca : in Englith, Abrecockc tree, and A precocke tree.

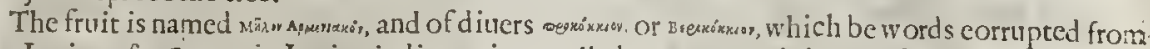
the Latine; for Precox in Latine is diuers times edled Preroqun it is named realum A.menia-

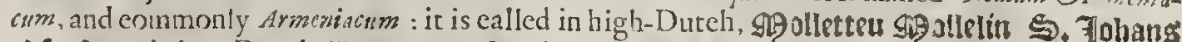

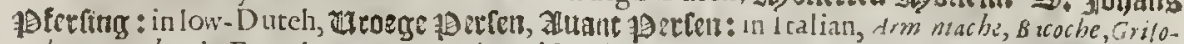
melc, Monache. in French, 15r,coz: In Spanilh, Alawircoques, Aluarchigas, and Albercocs: in Englinh, Abreencke, and of fome. Apreeocke, and Aprecox.

Galen fecricth to make a differenee betweene irecocia and Armeniaca, in his booke of the Faculties of nourithments, preferring Precocia before Armeniaca; yet he doth confeffe that both of them be ealled Armen'aca : others pronounee them Armenia with foure fyllables. And in his booke of the faculties of fimple medicines he affirmeth, that both the fruit and the tree are called aysuxuor : diters of the later Phyfitions do hetween thefe alfo make a difference, faying, 1 hat the greater ones and thole that are grafed be Asmeniaca (which the French men eall Alumt Perfes) and the leffer Pracocia: in Freneh, Albicoz.

$$
\text { T) The Temperature and Vcrtucs. }
$$

A preeocks are eo' $d$ and moif in the fecond degree, but yet not fo moift as Peaches, for which $A$ eaufe they do not fo fone or exfily putrifie, and they are alfo more wholefome for the ftomaeke, and pleafant to the tafte; yet do they likewife purrifie, and yeeld but little nourifh thent, and the fame cold, moitt, and full of exeruments : beitur takerr after meate they corrupt and putrifie in the Itomacke; being firft eaten before other mearc they eafily defeend, and eaufe the other meates to paffe downe the fooner, like as alfo the Peaches un.

The kernell with in the fame is fweet, and nothing at all like in faeul tic to that of the Pcach:

The vertues of the leaues of this tree are not as yet found out.

$$
\begin{gathered}
\text { Cнар: 96. Of Pomegranat tree. } \\
\text { I The Kindes. }
\end{gathered}
$$

A $S$ there be fundry forts of Apples, Peares, Plums, and fich like fruits; fo there are two forts of Pomegranates, the garden and the wilde, and a thurd is "w which is barren and fruitles : the fruit of the garden Ponegranat is of three forts; one bauing a fure iuyee or liquour ; anotler hauing a very liweet and pleafant liquor, and the third the tatten W Vine : of the wilde alfo there be two forts, and the differenee betweene them is no more than he twixt erabs and weildings, wheh are both wilde kindes of Apples : therefore the defeription of the garden Pomegranat thal fuitiee for the reft.

\section{The Defcription.}

$x$ He manured Pomegranat tree groweth vp to the height of a hedge tree, being fetien or eight cubits high, hauing many pliant and twiggy branehes, very limbor, tough, and of a browne enlour: whereon are fet very many leaues in thape like thofe of the Priuet, but more like thofe of the Myrtle tree, of a bright thining greene enlour tending to yellowneffe : anongt which there ftand certaine tharpe thornes confufedly fet, and likew ife hollow thoures like vnto the hedge $\mathrm{Rofe}$, indented on the edges like a ftarre, of a Carnation colour, and very fingle : after which commeth the fruit, couered with a hard barke, of an onerworne purplinh colour, tull of graines and kernels, which after they be ripe are of a gallant erimfon colour, and fuL of inyec, whieh differeth in tafte aceording to the foile, elymat, and eountrey where they grow; fome be fweer, others foure, and the third are in a middle betweene them both, hauing the tafte of Wine.

$$
\text { Efffff } 3
$$




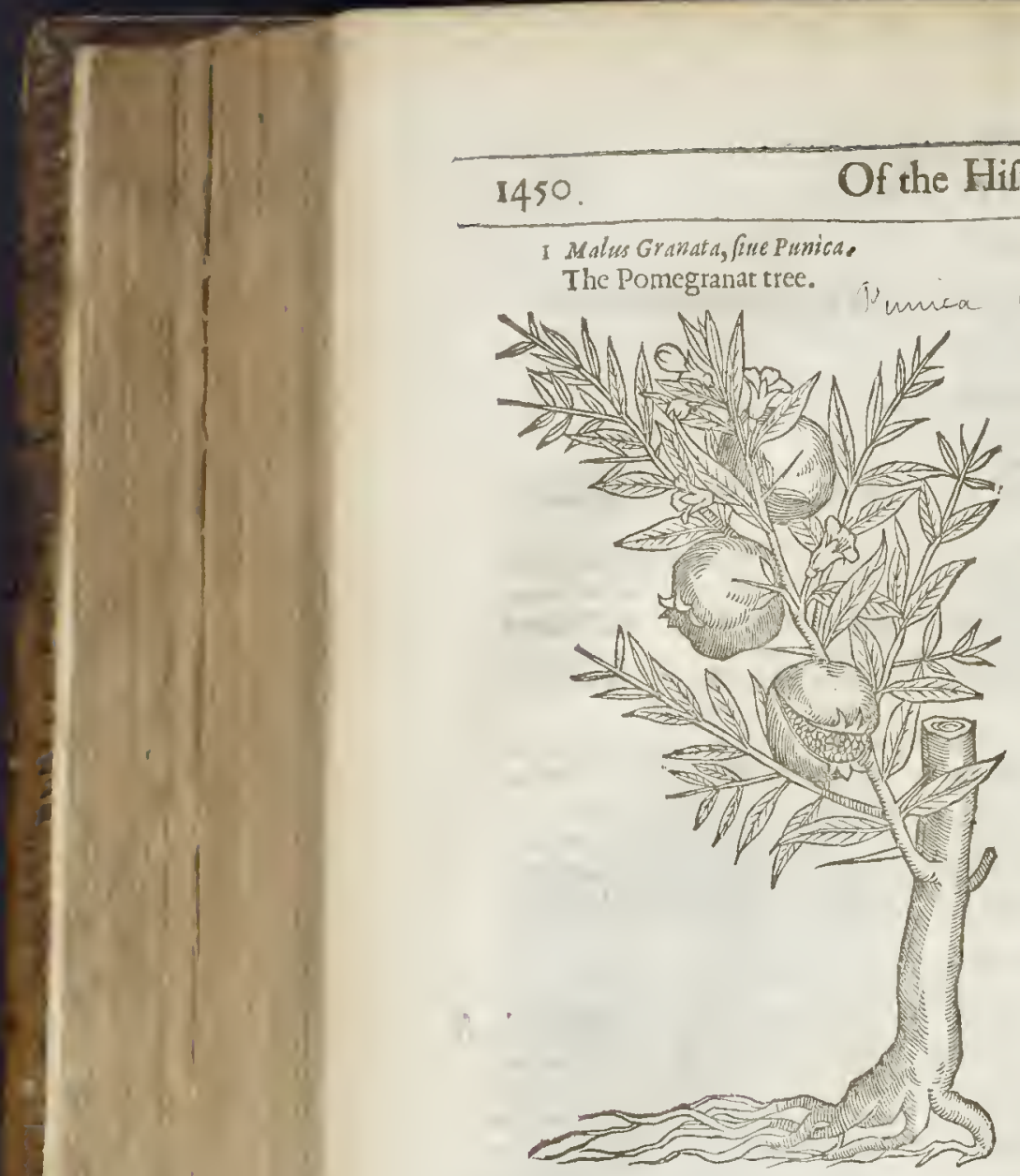

Balauftia, fine Pleni fores Gran.fyl.

The double floures of wild Pomegranat.
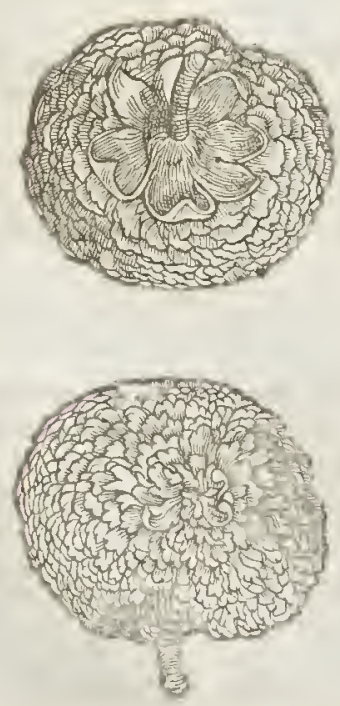

2 Malus Punica fylueftris.

The wilde Pomegranat.

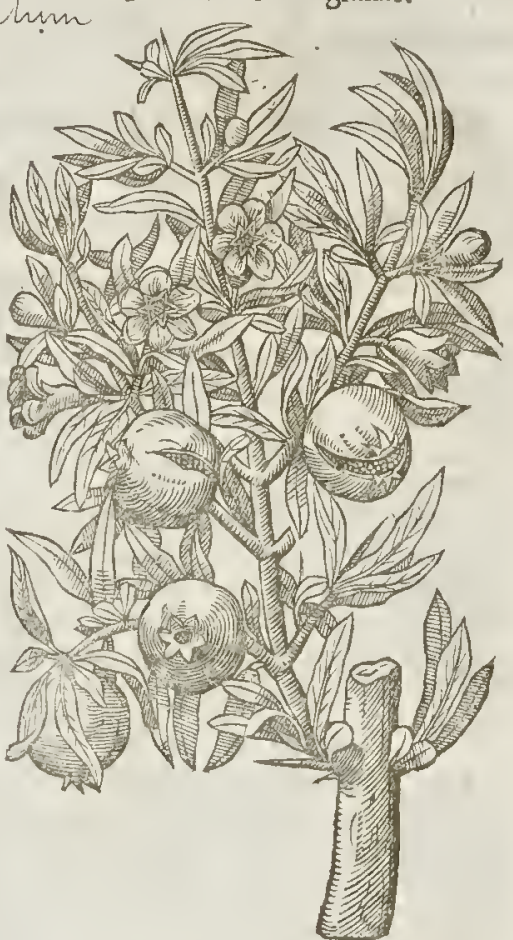

+2 The wilde Pomegranat tree is like the orher in leaues and twiggy branches, but it is more prickly and horrid: of this there are two forts, the one hauing fuch floures \& fruit as the tame Ponzgranat; the other bearing floures very double, as may appeare by the figure, which wither and fall away, leauing no fruit behind them, as the double floured Cherry doth, and diuers other herbes and trees alfo; $8 z$ it is altogether barren of fruit: of this Drofcorides makes fundry forts, differing in colour : one is white, faith he; another yellowifh red,and a third fort of the colour of the Rofe: this with red floures is beft knowne among the Apothecaries. g The Place.

Pomegranats grow in hot countries toward the South, in Italy, Spaine, and chiefely in the kingdome of Granado, which is thought tobe fo named of the great multitude of Pomgranats, which be commonly called Grainta they grow in a number of places alfo without manuring: yet being manured they profper better; for in gardens, vineyards, orchards, and orher like husbanded grounds they comevp more cheerefully: I haue recourered diters yong trees hereof, by fowing of the feed or grains, of the height of three or foure cubits, attending Gods leifure for floures and fruit.

$$
\text { II The Time. }
$$

The Pomegranate floureth in the moneths of May and Ime : the fruit is ripe in the end of Augut.

i. The 


\section{The Names.}

The Pomegranate tree is ealled in Latine, Malus Punica: in Gteeke, of the Athenians, $; 0 x$, and

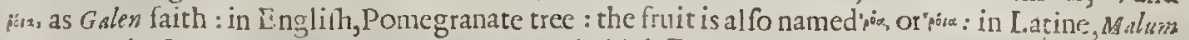
Punicum : in Thops, Malun, or Pornu Granatum : in high Duteh, Eranatopffel : in low Duteh, 6 ra $\approx$ tappel: in Italian, Meligramo, and Pomo Granato: in Spanilh, Grasada; and Romanas : in French, Pommes Gramdes : in Englih, Pomegranate.

The floure of the fruit full Pomegranate tree is ealled of the Grecians, *utwos: which is notwithftand ing properly the eup of the floure : the Latines name it alfo Cytznus.

The Houre of the wilde and barten Pomegranate tree is ealled Bxarusta : the A potheearies doe likewife terme it Balaustiuns.

The pill or rinde of the Pomegranate which is fo mueh in vfe, is named in Greeke orra: in Latinej Malicorium, and Sidium: in Chops it is called Cortex granatorum, or Pomegranate Pill.

\section{9! The Temperature and Pertues.}

The ituicie grains of the Pomegranate are good to be eaten, hauing in them a meetly good iuice: $\mathbf{A}$ they are wholefome for the ftomacke, but they all eontaine in them a thin and imall nourifhment, or none at all.

The fivect ones be not fo cold as the teft, but they eafily eaufe hot fwellings to arife, and they $\mathbf{B}$ ate not fo much eommended for agties.

The fourc ones, and efpecially if they be withall fomething har $h_{3}$ doecuidently enole, dry, and $C$, fomething biude.

They are good for the heart burne, they repreffe and ftay the outermueh vomiting of eholer, D called the Felonie: they are a remed ie againt the bloudy flixe,aptnefle to vomite, and vomite it Selfe.

There is made of the iuice of thefe foure Pomegranats a fyrrup, whieh fetueth for the fame pur - E pofes,and is alfomany times very profitable againft the longing of women with ehilde, vnlefle the coldneffe of the ftomacke be a hinderance thereunto.

The feeds of the graines, and efpeeially of the fower pomegranat, being dried,do likewife coole $\mathrm{F}$ and binde.

They ftop the fix, 1tay vomiting, and ftanch the fpitting vp of bloud, they frengthen the Ato- G. maeke.

Of the fane effect te the floures, both of the tame and wilde Pomegranate tree, being like to the $\mathbf{H}$ feeds in temperature and vertues.

They faften the teeth, and frengthen the gums, if the fame bewafhed therewith.

They are good again $\mathrm{t}$ burftings that eome by falling downe of the guts, if they be ved in pla. $K$ fers and applied.

The rinde or pill is not onely like in faeuit ie to the feeds, and both the forts of floures, but alfo I: more auail cable; for it eoolech and bindeth mote foreeably: it bringeth downe the hot fwellings of the almonds in the throat, being vfed in a gargarifme or a lotion for the throat, and it is a fugular remedy for all things that need cooling and binding.

Diofcurides writeth, that there is alfo gathered a iuiee out of both thofe forts of floures, which is $M$ very like in faeultie and vertue to Hypocifts, as the fame Author affirmeth.

The blofiomes of the tame and wilde Pomegranates, as alfo the rinde or thell thereof made into $M$ pouder, and drunke in red wine, or boyled in red wine, and the deeoction drunke, is good againt the bloudy fix, and all other iffues of bloud; yea it is good for women to fir ouer, \& bathe themfelues in the deeoction hereof: thefe forefaid bloflomes and fhels are good alfo to put into reftraining pouders, for the ftanehing of bloud in wounds.

The feeds or ftones of Pomegranats dried in the Sun, and beaten to pouder, are of like operati- 0 on with the floures : they ftop the laske and all iffues of bloud in man or woman,being taken in the mannet aforefaid.

\section{C н а . 97. Of the Quince Tree. \\ TI The Kindes:}

olumella maketh three kindes of Quinces, struthia, Chryfomeliana, and Muftela, but what manner ones they be hee doth not deelare, notwithtanding wee finde diuers forts differing as well in forme, 
forme, as tafte and fubftance of the fruit, wher of fome haue much core and many kernels, and others fewer.

Malus Cosonea.

The Quince tree.

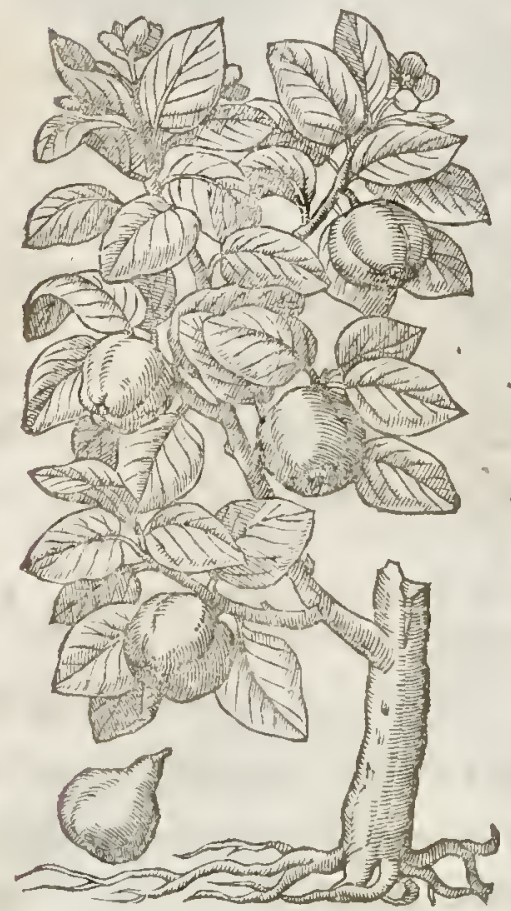

If The Defcription.

$T$ He Quince tree is not great, but groweth 1 low, and many times in maner of a fhrub: it is couered with a rugged barke, which hath on it now and then cerraine fcales : ir fprea. deth his boughes in compaffe like other trees; about which ftand leaues fomewhat round, like thofe of the common Apple tree, greene and 'Tmooth aboure, and vnderneath Ioft and white : the floures be of a white purple colour the fruir is like an apple, fate that many times it hath certaine embowed and fivelling diuifions:it differeth in farhion and bigneffe; for fome Quinces areleffer and round truft $\mathrm{p}$ together at the top with wrinkles, orhers longer and grearer: the third fort beafter a middle manner betweene both; they are all of them fer with a thin cotton or freeze, and be of the colour of gold, and hurtfull to the head by reafon of their ftrong fmell, they all likewife haue a kinde of chnking rafte : the pulp within is yellow, and the feed blackin, lying in hard skins, as doe the kernels of other apples.

\section{Q1 The Place.}

The Quince tree groweth in gardens and orehards, and is planted ofrentimes in hedges and fences belonging to gardens \& vineyards: it delighteth to grow on plaine and euen grounds, and fomew hat moift withall. Tt The Time.

The fe apples be ripe in the fall of the leafe, and chicfely in Oetober.

$$
\text { II } T \text { he Names. }
$$

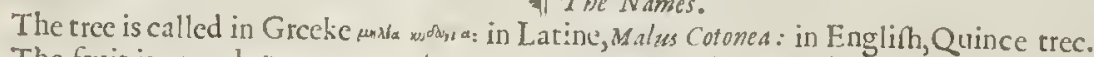

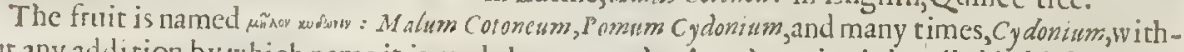
ort any addition; by which name it is made known to the Anothecaries: it is called in high Dutch,

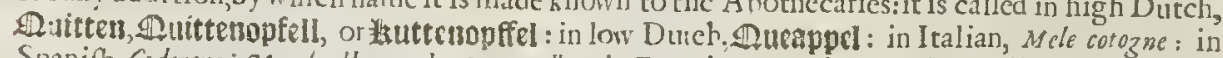
Spanifh, Codoyons, Exembrilbos, and cxarmellos: in French, Porme de coing : in Englifil, Quince.

$$
\text { ब The Temperature and Veriues. }
$$

A Quinees be cold and dry in the fecond degree,and al fo very much binding, efpecially when they be raw : they haue likewife in them a certaine fuperftous and excrementall moifture, which will not fuffer them to lie long without rotring : they are feldom eaten raw: being rofted or baked they be more pleafant.

B They ftreng then the ftomacke, ftay vomiting, ftop lasks, and alfo the bloudy flix.

C They are gond for thofe that fir v p loud, or that vomitbloud; and for women alfo that hate too grear plenty of their rionethly courfes.

D Simeon Sel $h_{2}$ writeth, that rhe woman with childe, which earech many Quinees during the time of her breeding, nall bring forth wife children, and of good vnderftanding.

E The Marmalade, or Cotiniate, made of Qunces and fugar, is good and profitable for theftrengthening of the ftomacke, that it may retaine and keepe the meat therein vntill it be perfectly digefted :it likewife ftayeth all kindes of fluxes, both of the belly and orher parts, and alfo of bloud: which Cotiniate is made in this manner:

F Take frire Quinces, pare them, cut them in pieces, and caft away the core, then put unto euery pound of $Q$ rinces a pound of fugar, and to euery pound of fugar a pinte of water : thefe muft bec boiled togerher ouer a fill fire till chey be very foft, then let it be ftrained or rather rubbed through a Atrainer, or an hairy fieue, which is better, and then fet it oner the fire to boile againe, vntill it bc Itiffe, 
L 1 B. 3. Of the Hiftorie of Plants.

ftiffe, and fo box it vp, and as it coolcth put thercto a littlc Rofe watcr,and a few graines of Muske, well mingled together, which will giue a goodly tafte vnto the Cotiniat. This is the way to nake Marmaladc:

Takewholc Quinces and boile them in water vneill they be as foft as a fealded codlingorapple, $G$ then pill off the skin, and cut off the fle $h$, and ftampe it in a ftone morter; rhen ftraine it as youd did the Cotiniate, afterward put it into a pan to drie, but not to feeth at all : and vnto cuery pound of the flefh of Quinces, put threc quarters of a pound of fugar, and in the cooling you nay put in rofe water and a little Muske, as was faid beforc.

There is boiled with Q ces, which wc vfe, faith Digfeorides, fo oft as we have need of a binding thing.

The fecd of Quinces tcmpered with water, dorh makea mufcilagc, or a thing likc iclly, which I being heid in the mouth, is marucllous good to takc away the roughnefe of the tongue in lio:burning feners.

The fame is good tobe layed vpon burnings or fealdings, and to be put into clifers again the $K$ bloudy fix; for it eafeth the paine of the guts, and alaieth the tharpncffe of biting humors.

Many other excellent, dainty and wholc fome confections arc to be made of $Q$ inces, as ielly of $L$ Quinces, and fuch odde conceits, which for brcuitic fakc I do now let pafie.

\section{С на р. 98. Of the cMedlar Tree.}

\section{TT The Kindes.}

THerc are diucrs forts of Medlars, fome greater, others leffer: fomc fweet, and others of a more lharh tafte : fome with much core, and many great ftony kernels, others fewer:and likewife one of Naples called Aronia.

\section{x MCspilnesfotivd.}

The manured Medlar.
¥ Mefpilus fativa altera: The other Gatden Medlar:

Thespiens Germanica.
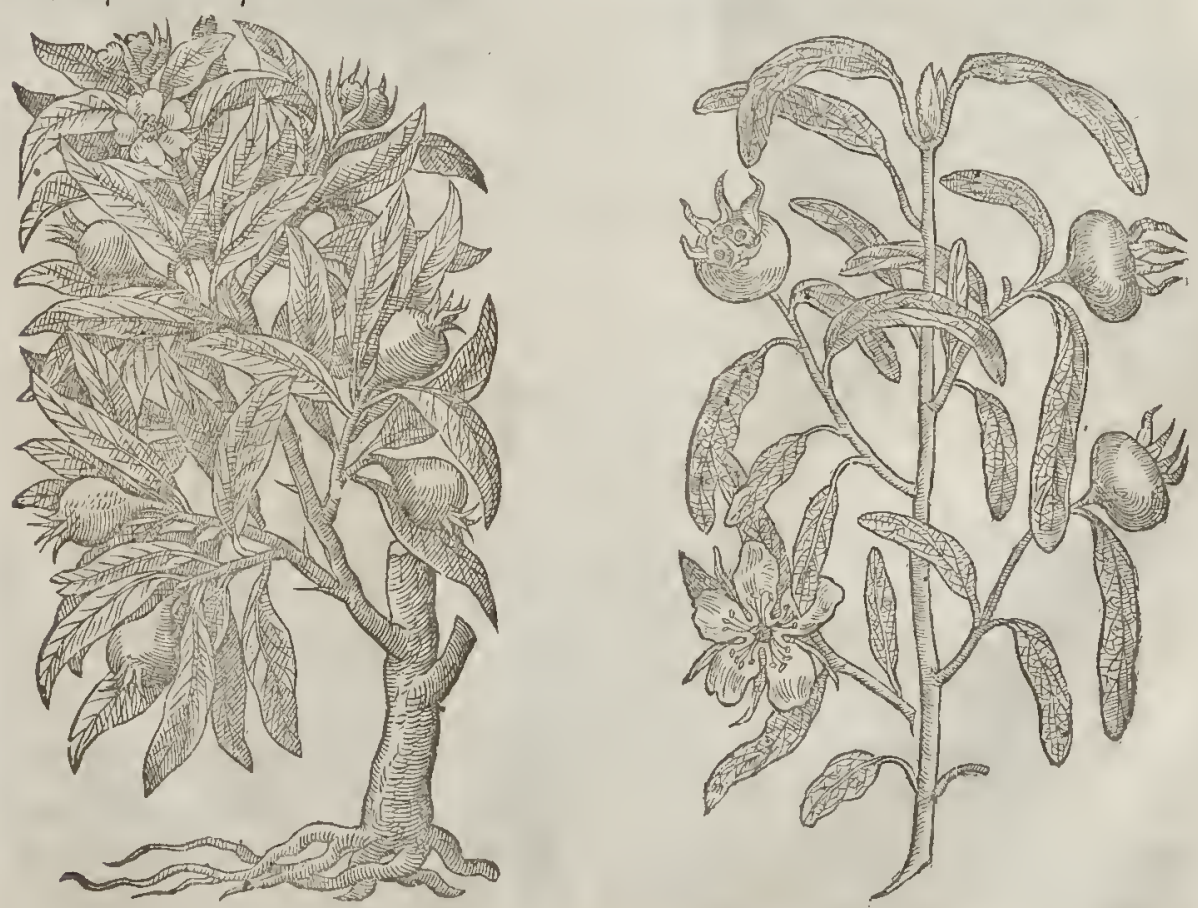


\section{If The Defcription.}

I THe manured Medlar tree is not great, the body whereof is writhed, the boughes hard, not ealie to be broken : the leaues be longer, yet narrower than thofe of the apple tree, darke,greene aboue, and fomew hat whiter and hairy below : the foures are white and great,hauing fiue leaues a piece: the fruic is fmall, round, and hath a broad compaffed naull or erowne at the top : the pulpe or meat is at the firft white, and fo harfh or choking, that it eannot be eaten before it beeome foft; in which are contained fiue feeds or ftones, which be fat and hard.

$\ddagger 2$ There is another whieh differech from the laft deferibed, in that the leaues are longer and narrower, the ftoeke hath no priekles vpon it : the fruit alfo is larger and teeter tafted:in other refpects it is like to the laft defcribed. This is the Mepulus fructupreftantiore of Tragus, and Mejpilus Domeftica of Lobel. $\ddagger$

3 The Neapolitane Medlar tree groweth to the height and greatneffe of an Apple tree, hauing many tough and hard boughes or branehes, fer with tharp thornes like the white Thorne, or Hawthorne: the leaues are very much cut or iagged like the Hawthorne leaues, but greater, and more like Smallage or Parley, which leaues before they fal from the tree do wax red:among thefe leaues come forth great tufts of floures of a pale herby colour:w hich being paft, clice fucceed fmall long fruit, leffer than the fmalleft Medlar, which at the firft are hard, and greene of eolour, bur when they be ripe, they are both foft and red, of a fweet and pleafant tafte : wherein is contained three fmall hard ftones, as in the former, whicli be the kernels or feeds thereof.

3 Mepilus Aronia.

The Neapolitane Medlar.

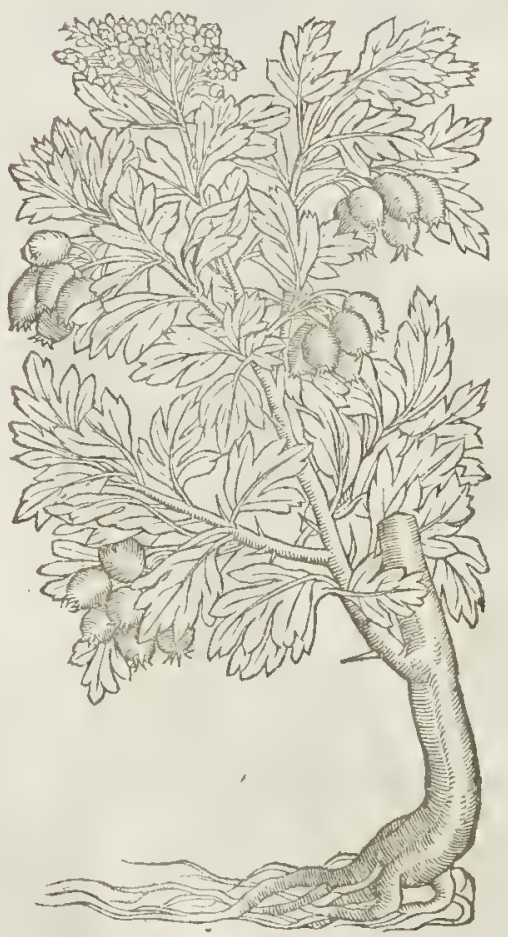

\$4 Chamemepilus.

Divarfe Medlar:

4 There is a dwarfe kinde of Medlar growing naturally vpon the Alpes, and hils of Narbone, and on the roeks of Mome Baldus nigh Verona, whieh harh been by fome of the beft learned efteemed for a kinde of Medlar : nchers, whofe iudgements eannot ftand with truth or probability, haue fuppofed it to be Enonymus, of the Alpes : this dwarfe Medlar groweth like a fmill hedge tree, of four or fuce eubits high,bearing many fmal twiggic wands or crops, befet with many flender leaues green aboue, and of a skie colour vnderneat b, in fhew like to a dwarfe Apple tree, but the fruit is 
very like the $\mathrm{Haw}$, or fruit of the white Thorne, and of a red colour. I The foures eome forth in the Spring three or foure together, hollow, and of an herbie colour, it growes in diuers places of the

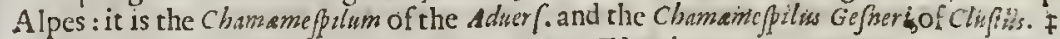

\section{The Place.}

The Medlantrees do grow in Orehards,and oftentimes in hedges among Briars and Brambles; being grafred in a white Thorne it profpereth wonderfull well, "and bringeth forth fruit twife or thrrfe bigger than thofe that are not grafted at all,almoft as great as little apples: we haue diucres fotts of them in our Orchards.

$$
\text { 91 The Time. }
$$

It is very late before Medlars be ripe, which is in the end of O fober, but the floures come forth timely enough.

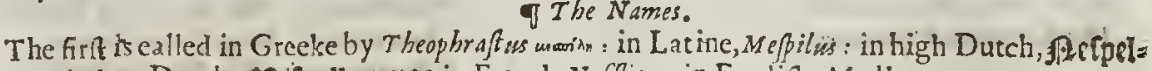
baum : in low Duteh, 9 ifpelboome: in French, Nefflier: in Englifh, Medlar tree.

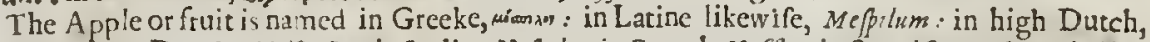
fperpel,unlow Dutch, ggifpele : in Italian,Neßpolo : in French, Neffe : in Spanifh, Nefperss: in Englith,Medlar.

Diofcorides affirmeth, that this Medlar tree is called mumes, and of diuers, Sitanion: Galen alfo in his booke of the faeulties of fimple medicines nametla this Eprmeles, whieh is called, as he faith, by the countrey men in Italy, $V$ nedo, and groweth plentifitly in Calabria ; for vnder the name of $M e f p$ im lus, or Medlar tree, he nicanoth no other than Tricoccus, which is alfes named aronia.

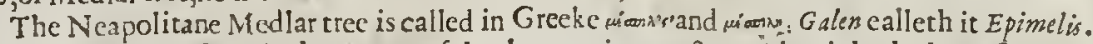

The fruit hereof is called $T$ ricoccos, of the three graines or ftones that it harh:they of Naples call it A2arolo: and we may name it in Englinh, three graine Medlar,orNeapolitane Medlar,or Medlar of Naples.

I The Temperature.

The Medlars are cold, drie,and aftringent; the leaues are of the fame nature : the dwarfe Medlas is dry, tharpe, and aftringent.

The Vertues.

Medlars do ftop the belly, efpecially when they be greengand hard, for after that they haue been $A$ kepta while, fo that they beeome foft and tender, they doe not binde or ftop fo much, but are then more fit to be eaten.

The fruit of the three grain Medlar, is eaten both raw and boiled, and is more wholefome for the $B$ ftomacke.

Thefe Medlars be oftentimes preferued with fugar or hony:and being fo prepared they are plea. C fant and delight full to the tafte.

Moreoucr, they are fingular good for women with childe : for they ftrengthen the ftomacke, and ftay the lothfomneffe thercof.

The ftones or kernels of the Medlars, made into pouder and drunke, doe breake the ftone, expell grauell, and proeure vrine.

\section{Cha P. 99. Of the Peare tree. \\ The Defription.}

$\mathrm{T}$

Ovrite of Peares and Apples in particular, would require a partieular volme : the ftocke or kindred of Peares are not to be numbred:etery country hath his peeuliar fruit:my felfe knows one etrious in graling and planting of fruits, who hath in one picee of ground, at the point of three feore fundry forts of Peares, and thofe exceeding good, not doubting but if his minde had been to fecke after multitudes, be might haue gotten together the like number of thofe of worfe kinds:befides the diuerfiries of thofe that be wilde, experienee theweth fundry forts: and therefore I thinke it not a miffe to fet downe the figures of fome few with their feuerall titles, as well in Latine as Englinh, and nne generall defeription for that, that might be faid of many, which to deferibe apart, were to fent an awle to Arlens, or to number thofe things that are wirhout number.

* Our Author in this chapter game eight figures with feuerall tirles to them, fo I pluekt a peare from each tree, and put his title to it, but not in the fame order that he obferued, for hee made the Katherine peare tree the feucnth, which T haue now niade the firtt, beeute the figure expreffes the whice tree. $\mp$ gा The 
q The generall de foreption.

7 He Peare tree is fot the mof part higher than the Apple tree, hauing boughes not fpreada1 broad, but growing vp in height. the body is many times great.the timber or wood it felfe is very tractable or eafte to bewrought vpon, exceeding fit to make moulds or prints tobe yrauen on, of colnur tending to yellowneffe:the leafe is fomew hat broad, finely nicked in the edges, greene aboue, and fo:newhat whiter underneach:the foures are white: the Peares, that is to fay, the fruit, are for the moft part long, and in forme like a Top; but in greatnes, colour, to me, and taft very much differ ng a mong themfelues; they be alfo couered with skins or costs of fundry colours:the pu pe or meat differeth, as well in colour as taftithere is contained in them kernels,blacke when they beripe:the ront groweth ttrait downewith fome braunches running allope.

Pirses fuperba, fue Katberina.

The Kathesine Peare tree.

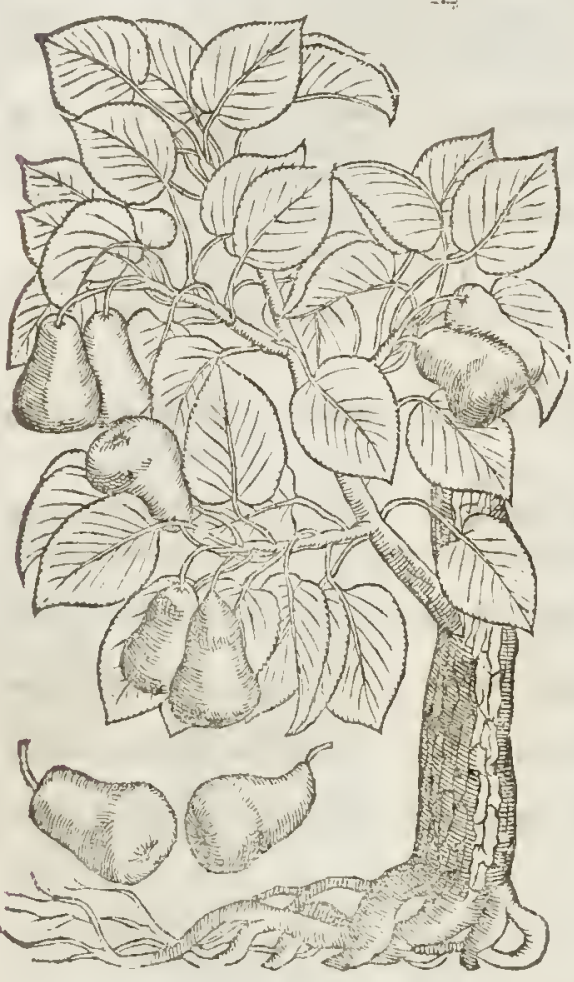

I Pyra Pracocia. The Ienneting Peare. 2 Pyra Lacobara. Saint Iames Peare. 3 Pyrumrgalc. The Peateroyall.
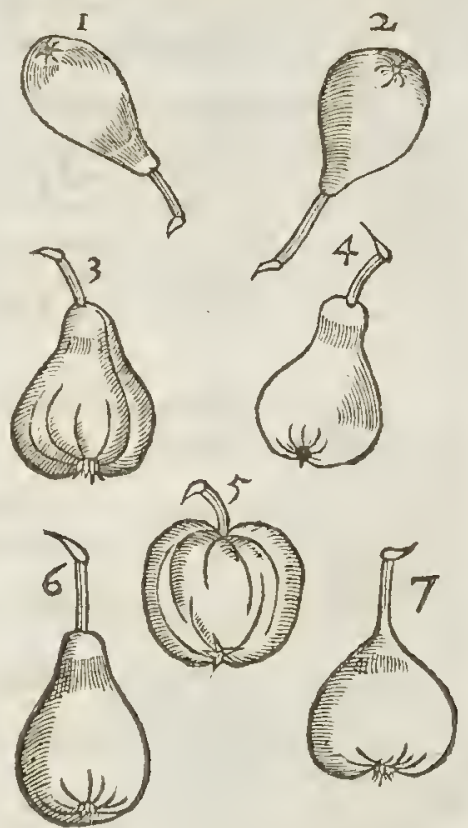

4 Pyrum Palatinum. The Burgomot Peare. 5 Pyrum Cydonium. The $Q$ ince peare. 6 Pyrum Fp foupatum. The sithops peare. 7 Pyrum by male. The Winter peare.

\section{Tा $T$ he Place.}

The tame Peare trees are planted in Orchards, as be the apple trees, and by grafting, though up. on wilde ftockes, come much varietie of gond and pleafant truits. 111 thefe before fpecified, and many forts more, and tho'e moft rare and good, are growing in the ground of Mafter Richard Po,nter, a molt cunning and curious graffer and planrer of all manner of rare fruits, dwelling in a fmall village neere London called Tw ickram; and alfo in the ground of an excellent graffer and painfull planter, M'. Henry Bawbury, of Touthill ftreet neere Weltminfter, and likewife in the ground of a diligent and molt affectionate louer of plants $\mathrm{M}^{5}$. Warner neere. Horfey downe by London, and in diuers orher srounds about London. I Moft of the beft peares are at this time to be had with $\mathrm{M}^{\mathrm{r}}$. John Millen in Old-ftreet, in whofe nurfery are ro be found the choifeft fruits this $k$ ingdom yeelds. $f$

\section{- The Time.}

The floures do fo: the moft part come forth in Aprill, the leaues afterwards : all peares are not ripe at one time: fome be ripe in laly, othets in Auguit, and diuets in September and later.

\section{T The alames.}

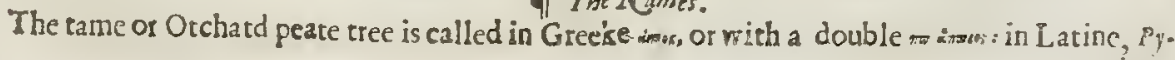




\section{Lre. 3. Of the Hiftorie of Plants.}

urbana, or Cultina : of 7 aremtinas in his Geoponikes andos: in high Dutch, Bithantim, in low Dutch, zoeetboom : in French, Porrier.

The Peare or fruir ir felfe is ca!led in Greeke amm : in Latise, Pyrum : in high Darch, 2 bitn: in low Dutch, 19 ecee : in Italian,Pere : in French, Poyre : in Spanifh, Peras : in Englih, Peare.

I The'Temperatureand Verixes.

Leauing the diuers and fundry lunames of Peares, let vs come to the faculties which the Phy fi- $A$ tions ought toknow; which alfo varis according to the differenees of their tattes: fur fonse l'cares are fweet, diuers fat and vnctuous, others foure, and moft are harfh,efpecially the wilde peares, and fome confift of diters mixtures of tates, and fome hauing no tafte at all, but as it were a waterifh taftc.

All Pears are cold, and all have a binding qualitic and an earthie fubltance: bur the Choke pcars $B$ and thofe that are harth be more earthicgind the fweet ones leffe: which fubltanee is fo full of filperfluous moifure in fome, as that they annot beeaten raw. All manner of Peares doebindeand ftop the belly, efpecially the Choke and harh ones, which are good to be eaten of thofe that hauc the laskeand the bloudy flix.

The harth and auttere Peares may with god fucceffe be laied vpon hot fivellings in the begin- $\mathrm{C}$ ning, as may be the leaues of the tree, which o both binde and coole.

Wine made of the iuice of peares called irEnglith, Perry, is foluble, purgeth thofe that arenor $D$ accuftomed to drinke thereof, efpecially whent is naw; notwithftanding it is as whollone a drink being taken in fmall quantiric as wine; it comfureth and warmeth the ftomacke, and eaufeth good digeftion.

\section{Cna p. 100. Of be wilde Pearetree.}

$$
\text { Tा The sindes. }
$$

S there be fundry kindes of the manured Peares, frare there fundry wilde; wherof to write apart were to fmall purpofe:therefore one defcription wh their feuterall titl s $s$ hall be fuftieient for theit diftin tions.

Pyrum franzulatorium maius.

The great Choke peare.

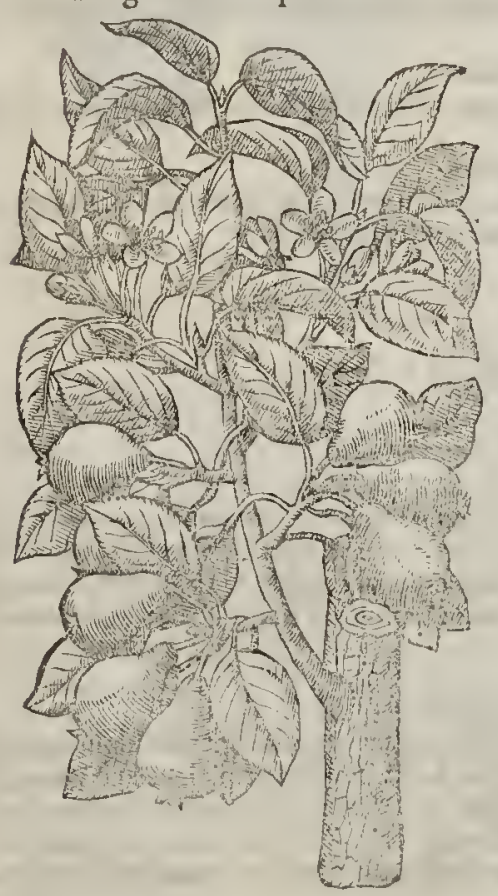

I The generall Defoription.

Thiwilde Pearetreegrows $11 \mathrm{kcw}$ ir $y$...., vpight, full of branches, for the moft part Pyramles like, or of the fathion of a ${ }^{1}$ teeple, not fpred abroad as is the Apple or Crab tree: the rimbr of the trunke or body of the tree is very firmand follid, and likewife finoorh, a rood veryfit to make diuers forts of inftrisments of azlfo the hafts of fundry tooles to worke withi; and likew ife feruech to be eut into many kinles of noulds, not only fuch prints as thefe figurs tre made of, but al fo many forts of prerty toies, fo coifes, breft-plares, and fuch like,vfed among ur Englifh gentlewomen:the branches are fmoth, coucred with a blackith barke, very fragileor eafie to break, wherenin do grow leaues, in fone greater, in otlier lefier:the foures are like thoe of the manured Pear-tree, yetfome whiter that otluers: the fruit differ not in thape, yet fome treater than others; but in tafte they differ arnong themfelues in diuers points, fome are tharpt, foure, and of an auftere tafte; fone more pleafant, others har h and bitter, and fome of fuch a dioking tafte, that they are not to be eaten of hogs $8 \mathrm{z}$ wild beafts, mulh leffe of men : they alfo difier in colour, etery cireumftance whereof to distinguifh apast would great ly enlarge our volume, and bring ro the Reader fnall profit or commodirie.

$\mathrm{Gggggg}$ 
I Pyrum ftrangulatorium maius.

The gteat Choke peate.
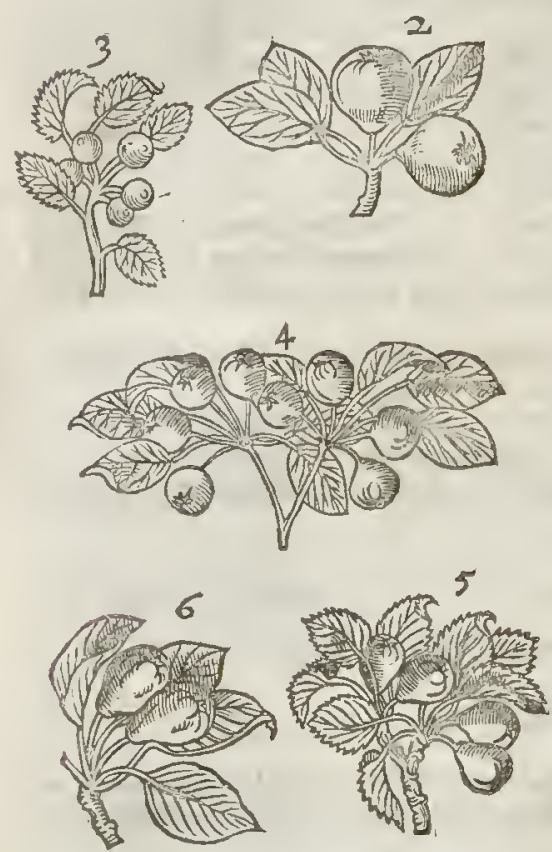

2 Pyrum frangulatorium minus, The fmall Choke peare.

3 Pyrns flusefrito. Oyzus cominamis. The walle hedge Peare tree.

4. Pyrw fylueftris minima. The wilde Crab peare tree.

5 Pros pedecularia. The Low fie wilde peate.

\section{6 pyrus Corrina.}

The Ctow peare tree.

\section{If The Place.}

The wilde peares grow of themfelues w ithout manuring in moft places, as woods, or in the borders of fields, and neere to high waies.

\section{T The Time.}

The time of wilde peares anfwereth the tame or manured peare, notwith ftanding for the moft part they are nor ripe much before Winter.

\section{T) The rames.}

The wilde peare tree is called in Latine, Pyrus fylueftris and Pyrafter: in Greeke, "Xas: by which name both the fruit and tree are knowne. Peares haue diters fyrnames among the antient Writers, and fpecially in Pliny, in his 5 .booke. 15 .chapter, none of whia are knowne to the later W riters (or not defired:)eurery citie or eury countrey haue names of timfelues, and peares haue allo diuers names aceording to to the places.

The Temperature.

All peares are of a eold temperatıe, and the moft part of them of a binding qualitic and an earthie fubftance.

\section{The Vertues.}

The vertues of the wilde peares re referred vnto the garden peares as touching their binding faeultie, but ate not to be eaten, be aufe their notringment is little and bad.

\section{Ca в. 10I. Of the Apple tree.}

\section{T The Kindes.}

THe Latine name Malis reachetb far among the old Writers, and is eommon to many trees, bur we will bricfely firt ntreat of $M$ ali, properly ealled Apple trees, whofe ftocke or kindred is fo infinite, that we baue thughts it nor amiffe, to vfe the fame order or method with A pples thatwee hate donew ith peares: $t$ hat is, to giue them feuerall titles in Latineand Englifh, and one generall defcription for the wlole.

\section{The Defcription.}

The Apple tree lath a body or truneke commonly of a meane bigneffe, not very high, hauing 1 long arnes or tranches, and the fame difordered: the barke fomewbat plaine, and not verie rugged: the leaues bee alfo broad, more long than round, and finely nieked in the edges. The floures are whitith tend ing vnto a bluth colour. The fruir or Apples doe differ in greatnefte, forme, colour, and tafte; fome cowered with a red skinne, others yellow or greene, varying infi- 
L 1 в. 3. Of the Hiftory of Plants.

1459

nitely aecording to the foyle and climate, fome vety great, fome littie,and many of a middle fort; fome are fivcet of tafte, or fomething foure; moft be ot a middle tafte betweene fweet and foure, the which todiftinguith I thinke it impoffible; notwithftanding I heare of one that intendeth towrite a peculiar volume of Apples, and the vfe of them; yet when he hath done what hec can doe, hee bath done nothing toueling their feucrall kindes to diftinguilh them. This that hath beene faid thall fuffice for our Hiftorie.

\# Our Author gaue foure figures more out of Tabernamontanus, with thefe titles. 3. MMalum reginale, the Queening or Queene of Apples. 5 Platumela five P'yra aftiun: The Sommer Peatemaine, 6 Platurchapia five Pyra hycmalia : the Winter Pearemaine. F

I Mains Carbosiatiat:

The Ponse Water tree.

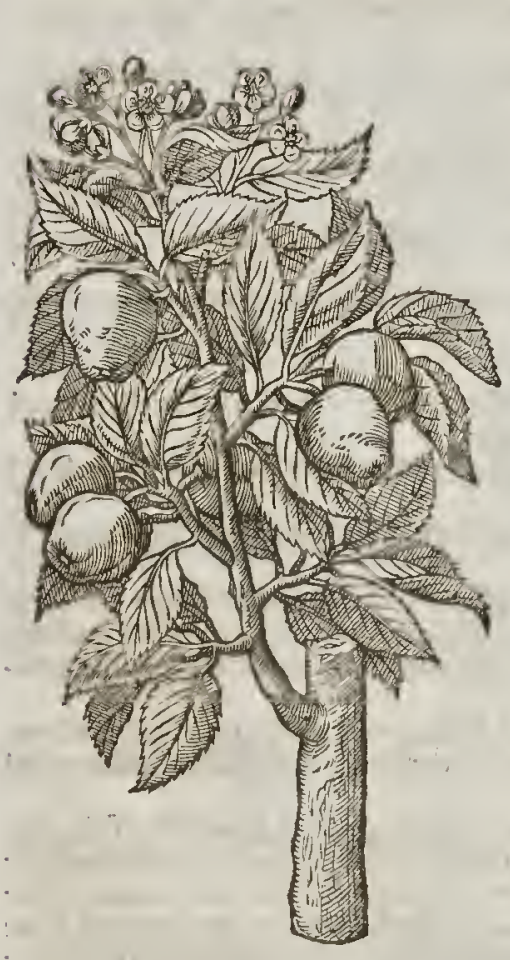

2 Malus Carbonarialongofructu. The Bakers ditch Apple tree,

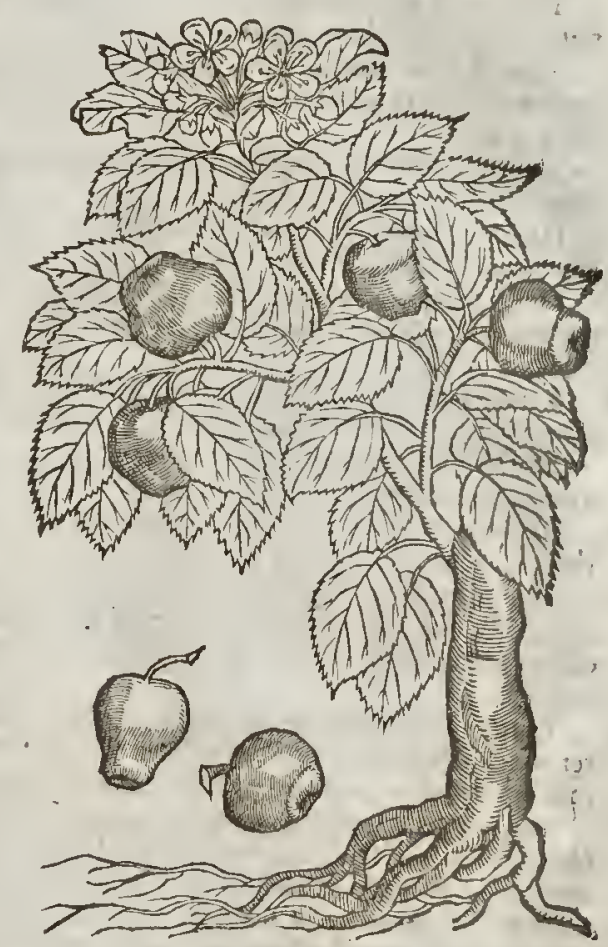

of The Place.

The tame and graffed Apple trees are planted and fet in gardens and orchards male for that putpofe : they delight togrow in good and fertile grounds: Kent dorh abound with apples of moft forts. But I haue feene in the paftures and hedge-rows about the ground of a worthipful gentleman dwelling two miles from Hereford called Mafter Eoger Bodnome, fo many trees of all forts, that the feruants drinke for the moft part no otherdtinke but that whieh is made of App!es; The quantity is fueh, that by the report of the Gentleman himlelfe, the Parfon hath fortithe many hogtheads of Syder. The hogs are fed with the fallings of them, which are fo many, that they make choife of thofe Apples they doeat,whowill not tafte of any but of the beft. An example doubtles to be followed of Gentlemen that hate land and liuing: but enuie faith, the poure wil break down out hedges, and we thall hate the lealt part of the fruit) but forw ard in the name of Gnd, graife, fet, plant and nourith vp trees in enery corner of yout grounds, the labour is fmall, the en? is nothing, the commoditie is great, your felues thall haue plenty, the poore thall haue fomewhat in time of want to relieue their neeeffitie, and God fhall reward your good mindes and diligence.

\section{If $T$ he Time.}

They bloom about the end of Aprill, or in the beginning of May. The forward apples be tipe about the Calends of Iuly, others in September. 


\section{T The Names.}

The Apple tree is called in Grecke $\mu$ axi: in Latine, Malus and Poms : in high Duteh, Dpffel bฉum : in low Duteb, alppeiboom: in French, Pommicr : in Englich, Apple-trce.

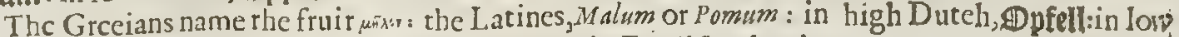
Dutch, Zlppel : in French and Spanirh, Marlanas. in Englifh, Apple.

\section{The Temperature.}

All Apples be of temperature cold and moift, and hate ioined with them a certaine excremen: tall or fupcrfuous mot fure: but as thcy be not all of like coldnefte, fo neither hate they like quan.' titic of fuperfuous moifture. They are foonelt rotten that haue greatelt ftore of moifture, and they may be longer kept in wlieh there is leffe ftore: for the abundanee of excrementall moifture is the caufewhy rhey ror.

Sweet Apples are not fo cold and moilt, wh ich being rofted or boyled, or orherwife kept, retaine or kecpe the foundnefle of their pulpe.

They yeeld more nourihment, and not fo moift a nourithment as do the other Apples, and doe not fo eafily paffe through rhe belly.

Soure Apples are colder and alfo moifter : the fubltance or pulpe of thefewhen they bc boiled doth run ab road, and retaineth not bis foundneffe : they yeeld a leffer nourifhment, and the fame raw and cold.

They do eafily and fpeedily paffe through the belly, and therefore they do mollifie the bclly, cfpecially being raken before mcat.

Harf or Auftere Apples bcing vnripe, are cold; thcy ingender grofte bloud, and great ftore of winde, and ofren bring rhc Collicke.

Thofe Apples whieh bc of a middle taftc containe in them of tentimes two or three forts of tafts; and yet do they retaine the faeulries of the orher.

A Rolted Apples are alwaies better than the raw, the liarm whereof is both mended by the fire, and may allo be corrected by adding vnio rhem feeds or fpices.

B Apples bc good for an hot fomaclit: rhofe that are auftere or fomewhat harfh doe frengthen a weake and feeble ftomacke proeeding of heat.

C Apples are alfogond to all infiammations or hot fwellings, butefpecially for fuch as are in theirbegining, if ilie fame be ourwardly applted.

D The iuice of Apples which fe cweet and of a middle tafte, is mixed in compolitions of diuers medieines, and alfo tor the rempering of melancholy hu, nours, and likewife to mend the qualities of medieines that are dry:as are Serapium expomes Reg is Saporis, Confectio Alkermes, and fuch like compofitions.

E There is likewife made an ointment with the pulpe of Apples and Swines greafe and Rofe wa: tcr,which is vfed to bcautifie rne face, and to take away the roughnefle of the skin, whicb is called in thops Pomatum: of rhc Apples whercof it is madc.

F The pulpe of the rofted apples, in number foure or fiue, aecording to the greatneffe of the Apples, cfpeeially of the Pomc-water, mixed in a wine quart of faire water, laboured together vntill it comc to be as apples and Ale, which wee call Lambes Wooll, and the wole quart drunke laft at night, within the fpace of an houre, doth in one night cure thofe that piffe by droppes with great anguith and dolour; the ftrangurie, and all other difcafes procecding of the difficultie of making water.but in rwife taking it, it neuer faileth in any: oftentimes there happeneth with the forefaid difeafes the Gonorrhxa, or running of the Raines, which it likcwife healeth in thofe prtfons, but norgenerally in all; which my felfe have often prout, and gained thereby both crownes and credit.

$G$ Thc leaues of the tree do coole and binde, and bealfocounted good for inflammations, in the beginning.

H Apples cut in pieces, and diftillcd with a quantitie of Camphere and butter-milke, take away the markes and fcarres gorren by the fmall pockes, being wafhed therewith when they grow vnto their ftate and ripenefr: : prouided that you giue vnto the patient a little milk and Saffron,or milk and mithridate to drinke, to expell to the extreme parts that venome which may lie hid, and as yet not feene. 


\section{C н а т. 102 of the Wilding or Crab tree:}

If The Kindes.

Tke as there be diuers manured Apples, fo are there fundry wilde Apples, or Crabs, whereof to $L_{\text {write apart were to fmall purpofe,and therefore one defeription fhall fuffiee for the reit. }}$

Malus fylueftris.

The wilding or Crab tree.' Oyur Mahes.

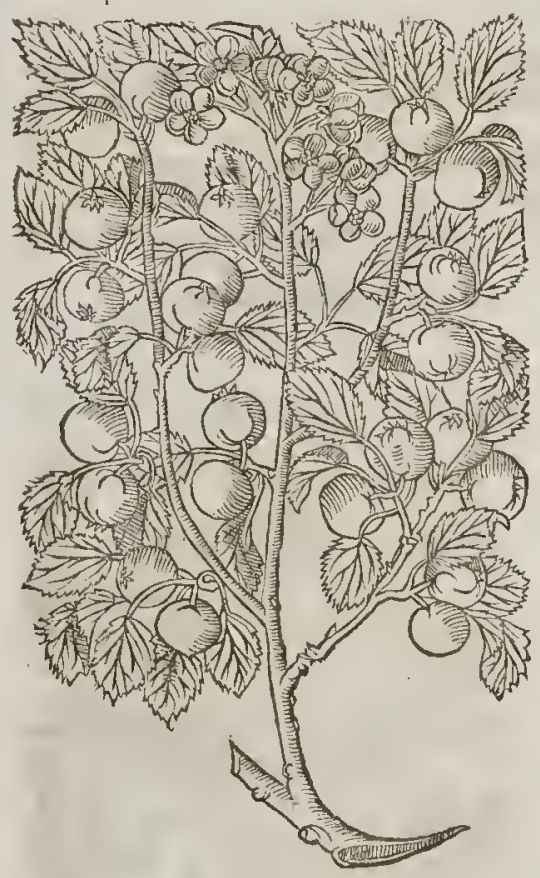

T) The generall Defcription.

THere be diucrs wilde Apple trees not hufbanded, that is to fay, not grafted; the fruit whereof is harfh and binding: for by grafting both Apples and Peares beeome more milde and pleafant. The rab or wilding tree growes oftentimes to a reafonable grearneffe, equalf with the Apple tree : the wood is hard, firme, and follid; the barke rough; the branehes or boughes many; the floures and fruit like thofe of the apple tree, fome red, orhers white, fome greater,others leffer : the differenee is known to all, therefore it thall fuffiee what hath beun faid for their feterall dittnetions : we hane in our Londongardens a dwarfe kinde of fweet Apple,called Chamemalus, the dwarfe apple tree, or Paradife applc, which beareth apples very timely without grafring.

\# Our Author herc allo (out of Tabernats montanus) gaue foure figures, whereof I onely retaine the bef, with their feueral tit!es. $\mathrm{c} \mathrm{M}_{\mathrm{s}}$ lus Jy lueftris rubens. The great wilding or red Crab tree: 2 cMalus fytueftris alba. The white wilding or $\mathrm{Crab}$ trec : 3 Malus fylteftris minor. The fmaller Crab tree: 4 Malus duracina fy luefris. The ehoking leane Crab-tree. $\neq$

$$
\text { of The Place. }
$$

The Crab tree groweth wilde in woods and hedge rowes almoft euery where.

The time anfwereth thofe of the garden.

ขा The Time.

qा The Namzes:

Their titles doth fet forth their names in Latine and Englifh.

\section{बT The Tempcrature.}

Of the temperature of wilde apples hath beene fufficiently fpoken in the formet Chapter.

\section{The Vertues.}

The iuice of wilde Apples or erabs taketh away the heate of burnings, fea!dings, and all inflam- A mations : and being laid on in fhort time after it is fealded, it keepeth it from bliftering.

The iniee of crabs or Veriuice is aftringent or binding, and hath withall an abfterfue or elenfing $B$ qualitie, beeing mixed with hard yeeft of Ale or Beere, and applied in manner of a cold ointment, that is, fpread vpon a eloth firf wet in the Veritiee and wrung out, and then laid to, taketh away the heat of Saint Anthonies fire, all inflammations what foetier, healeth fcab'd legs, burnings and fealdings wherefortet it be. 


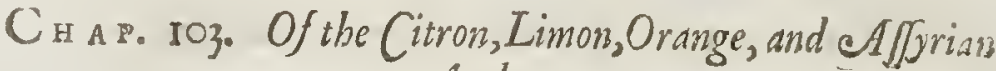 Apple trees.}

\section{T The Kindes.}

T He Citcon tree is of kindred with the Limon tree, the Orange is of the fame houfe or ftocke? and the Affyrian Apple tree claimeth a place as neereft in kinted and neighbouthood: where: ote I intend to comprehend them ali in this one chapter.

$$
\text { T The Defcription. }
$$

I. Te Citron tree is notvery great, hauing many baughes or branches, tough and pliable, ry fmooth, and fweec of mell like thofe of the Bay grow greene leaues, long, fomewhat broad, vecertaine prickles, fet far in funder : from the bay tree: among which come forth here and there fue litrle laues of fue little leaues, of a white colour tending to purple, with certaine threds like haires growing in the middle : the fruit is long,greater many times than the Cuctumber, often leffer, and not nuch

I cralus medica.

The Ponc Citton tree. Citins thedrea

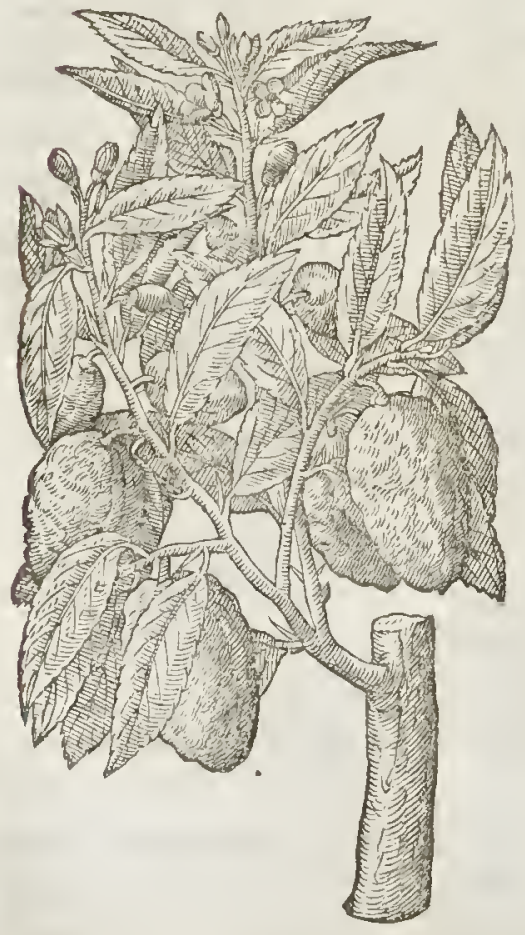

2 Malus Limonia. The Limon trec:

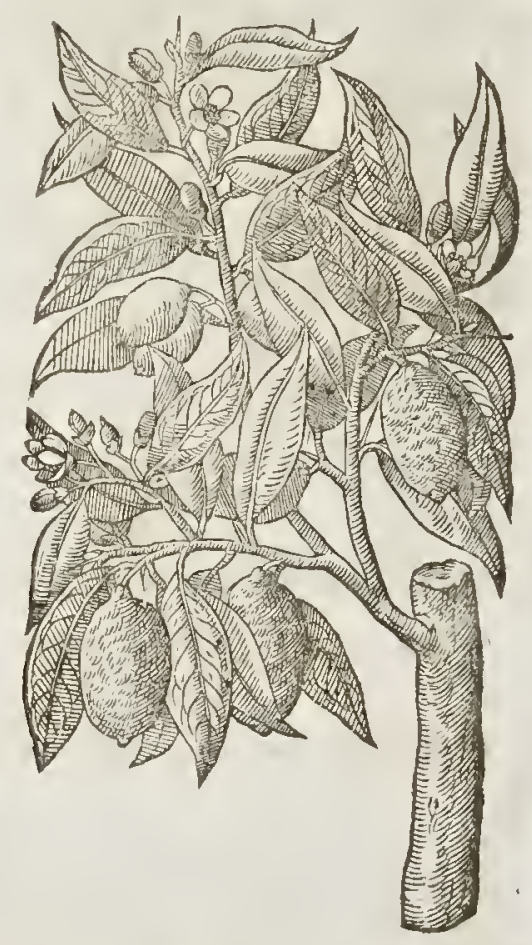

greater than the Limon : the batke or tinde is of a light golden colour, fet with diuers knobs or bumps, and of a very pleafant fmell : the pulpe or fubftance next vnto it is thick, white, hard, hauing a kinde of aromaricall or fpicie finell,almott without any tafte at all : the fofter pulpe within that is not fo firme or folid, but more fpungie, and full of a fower iuice, in which the feed licth hid, grea ter and thicher than a graine of Barley.

2 The Limon tree is like vato the Pome Citron tree in gtowth, thorny branches,and leautes of a plearant 
L 1 B. 3. Of the Hittorie of Plants.

a pleafant fweet fmell, like thofe of the Bay-tree: the floures hereof are whirer than thofe of the Cirron tree, and of a moft fwect fmell : the fruit is long and thicke, leffet than the Pone Cirron: the rinde is yellow, fomewhat bitter in tafte, and fweet of fmell : the pulpe is white, more in quantitic than that of the Citron,refpecting the bignes; in the middle patt whereof is conteined mote foft fpungie pulpe, and fuller of foure juice : the feeds are like thofe of the Pome Citron.

3 The Orenge tree groweth vp to the height of a fmall Peare tree, hauing many thornie boughes or branches, like thofe of the Citron tree : the leaues are alfo like thofe of the Bay-tree, ¥ but that they differ in this, that at the lowerend next the ftalke there is a leffer leafe made almoft afser the vuigar figure of an heart, whereon the bigger leafe doth fand, or is falt ned: $\$ \&$ they are of a fiveet fu.cll : the floures are white, of a moft pleafant fweet fmell alfo: the fruit is round like a ball, euery circumftance belonging to the forme is very well knowne to all ; the tafte is foure, fometimes fweet,and often of a talte betreene both : the feeds are like thofe of the Limon.

2 Malus arintit.

The Orange tree.

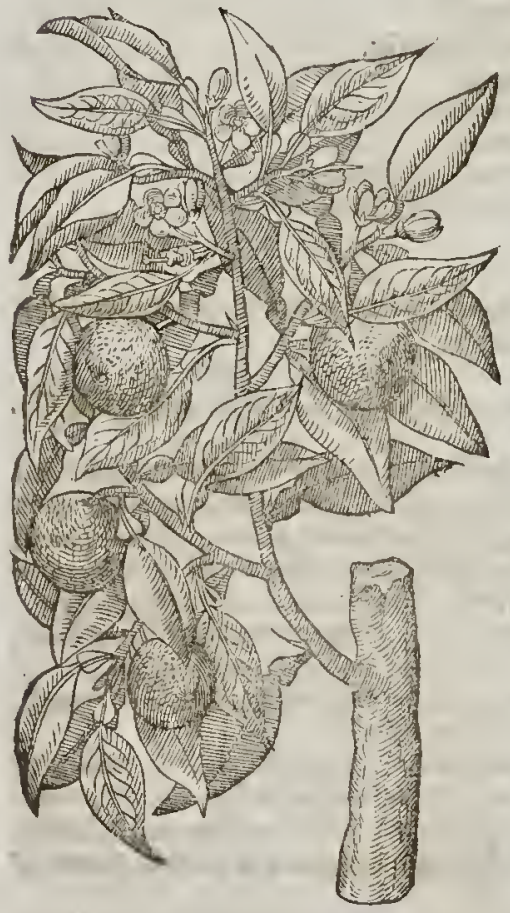

4 Malus us syria.

The Affyrian Apple tree.

4 The Affyrian Apple tree is like vnto the Orangetre : the branches are like : the leatues are greater : the floures are like thof of the Citron ttee: the fruit is round, three times as big as the Orange : the barke or peeling is thicke, rnugh, and of a pale yellow colout, wherein appeare often as it were fmallclifts or crackes : the pulpe or inner fubftance is full of iuice, in tafte thatpe, as that of the Limon, but not fo pleafant : the feeds are like thofe of the Citton.

of The Place.

The Citron, Limon, and Orange trees do grow efpecially on the fea coafts of Italy, and on the Iflands of the Adriaticke Turhene, and alfo $\mathrm{E}$ gæan Seas, \& likewife on the maine land, necr vnto meeres and great lakes : there is alfo great ftore of them in Spaine, bur in places eipecially ioining to the fea, or not farre oft : they are alfo found in certaine prouinces of Francewhich lie voon the midland fea. They were firf brought out of Media, as not onely Plinie wtiteth, but alfo the Poet $y$ irgil affirmeth in the fecond book of lis Georgickes, writing of the Citron tree aftet this manet : 


$\pi_{4} b_{4} \quad$ Of the Hiftory of Plants: $\quad \mathrm{L}_{18} \mathrm{~B}^{3}$

Mi) cueruxtque herbas, of non imoxiaverba, Auxilium verit, ac membris agit atravenena. Ipfaingers arbos, faciefque fimillima Lauro; $E t$, fi non alum late zait aret odorem, Laurus erit; folia haud vllis labertia vent is: Flos apprime tenax. Animas \& olentia Medi Or fouent illo, of fenibus medicantur anhelis:

The Countrey Media beareth iuyces fad, And dulling taftes of happy Citron fruit, Than whieh, no helpe more prefent can be had;

If any time ftepmothers worfe than brute hate poy fon'd pots, and mingled berbs of fure With hurt full eharmes : this Citron fruit doth chafe Blacke venome from the body in euery place, The tree it felfe in growth is large and big, And very like in thew to th' Laurell tree; And would be thought a Laurell, leafe and twig, But that the fnell it eafts doth difagree:

The floure it holds as fart as floure may be :

Therewith the Medes a remedir do finde For ftinking breaths and mouthes a cure moft kinde, And helpe uld men which hardly fetch their winde.

\section{T The Time.}

Thefe trees be alwaies greene, and do, as $P$ liny faith, beare fruit at all times of the yere, fome fals: ling off, others waxing ripe, and others newly comming forth.

$$
\text { The Names. }
$$

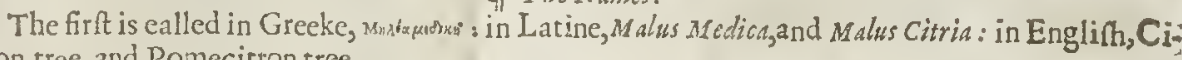
tron tree, and Pomecitron tree.

The fruit is named in Greeke, Minopusteds : in Latine, Maltm Medicum, and Malum Citrium : and Citromalum. Aimlyanus in Athenews theweth, that Iwba King of Mauritania hath made mention of the Citron, who faith that this Apple is named among rhem, Malsem Hejpericum : Galen denieth it to beealled any longer Malum Meducum, but Citrism; and faith, that they who call it Medicum do it to the end that no man thould vnderftand what they fay: the A pothecaries eall the feapples $C_{i=}$. Eroscs: in high-1)utch, Citcin opffell, Citrinaten : in low-Duteh, Citroenen: in Italian, Citrom, and Cedri : in Spanih, Cidras : in Freneh, Catrons : in Englith, Citron Apple, and Citron.

The fecond kinde of Citron is called in Latine, Limonium Malum; in Thops, Limones : in French, Limons - in low. Dutch, Limonen: in Englith, Limon, and Lemon.

The third is named in Latine, Malum anaramtum or anerantum : and of fome Lurantium : of others, Aurengitm, of the yellow eolour of gold: fome would haue them ealled Arantis, of Arantiwm, a towne in A chaia or A rania, of a countrey bearing that name in Perfia : it is termed in Italian

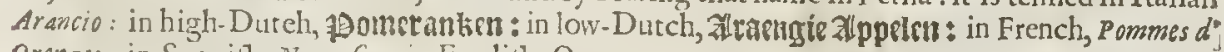
Orenges: in Spanith, Naranfes : in Englith, Orenges.

The fourth is named of diuers, Pormum Afyrium,or the Citron of Aftyria,and may be Englifhed Adans Apple, after the Italian name; and among the vulgar fort of Italians, Lomie, of whom it is alfo ealled Ponum Ad mi, or Adams Apple; and that came by the opinion of the common rude people, whu chinke it to be the fame Apple which Adam did eate of in Paradife, when he tranfgreffed Gods commandment; whereupon alfo the prints of the biting appeare therein, as they fay:but: other's fay that rhis is not the Apple, but that which the Arabians do call Mufa or Mofa, whereof $A$ uicen, c.2p. 395 . maketh ment ion : for disers of the Iewes take this for that through which by eating, Adam offended, as Andrew Thewet theweth.

$$
\text { TT The Temperature and Vertwes. }
$$

A All thefe fruits confift of vnlike parts, and mucb differing in facultie.

B The rindes are fweet of fmell, bitter, hot, and dry.

C The white pulpe is cold, and containeth in it a grofe iuice, efpecially the Citron.

D The inner futhance or pap is foure, as of the Citrons and Limons, cold and dry, with thinneffe of parts.

E The feel becaufe it is bitter is lot and dry. The rinde of the Pomeeitron is good againft all poyfons, for which caufc it is put into treacles
and fuch like confections. 


\section{L $1 \mathrm{~B}_{0} 3 . \quad$ Of the Hiftory of Plants.}

It is good to be eaten againft a ftinking breath, for it makcth the breath fweet; and being fo ta - $G$ ken it comforteth the cold ltomacke exeedingly.

The white, found, and hard pulpe is now and then eaten, but very hardly conented, and ingen * $H$ dreth a groffe, cold, and phlegmaticke iuyce, but being eondite with fugar, it is both pleafant in tafte, and eafie to be digelted, more nourilhing, and leffe apt to obftruction and binding or ftopping.

Galen reporteth, that the inner iuice of the Pomecitron was not wont to be eaten, but it is now ved for fauee; and being often vfed, it repreffeth eholer which is in the ftomaeke, and procures ap. petite : it is exeellent good alfo to be giuen in vehement and burning feuers, and againft all peltilent and venomous or infectious difeafes: it comforteth the heart, eooleth the inward parts, eutteth, diuideth, and maketh thin, grolle, tough, and fimy humors.

Of this forefaid tharpe iuice there is a fyrrup ptepared, which is ealled in thops, syrupus de Ace $\mathrm{K}$ to fit ate Citri, very good againft the forefaid infirmities.

Suclia firrup is alfo prepared of the harpe iuice of Limons, of the fame quality and operation, It fo that in ftead of the one, the other will ferue very well.

A dozen of Orenges eut in flices and put into a gallon of watet, adding therets an ounce of $M$ Mereurie fublimate, and boiled to the confumption of the halfe, curcth the iteh and mangineffe of the body.

Men inold time (as Theophrafus writeth in his fourth booke) did not cate Citrons, but were $N$ contented with the fnull, and to lay them amongft eloathes, to preferue them from Moths.

As often as need required they vied them againit deadly poyfons; for which thing they wcre 0 efpecially commended cuen by Virgils verfes, which we hauc before alledged.

Atbencus, $i b .3$. hath extant a ftory of fome that for certaine notorious offences were eondemned to be deftroyed of Serpents, who were preferued and kept in health and fafetie by the eating of Citrons.

The diftilled water of the whole Limons, rinde and all, drawne out by a glaffe Still, takes away tetters and blemithes of the skin, and maketh the face faire and fmooth.

The fame being drunke prouoket vrine, diffolueth the ftone, breaketh and expelleth it.

The rinde of Orenges is mueh like in faeultie to that of the Citrons and Limons, yet it is fo much the more lint as it is more biring and bitter.

The inner fubftanec or forre pap which is full of iuice is oflike facultie, or not mueh inferiour to the facultie of the pap of Cirmns or Limons; but the fwect pap doth not much coole or drie, but doth temperatly heate and moiften, being pleafant to the tafte: it alfo nouritheth more than doth the foure par, but the fame rnurinment is thin and little; and that which is of a middle taft, hatuing the fmacke of wine, is after a middle fort more cold than fiveet, and leffer cold than foure: the fweet and odoriferous floures of orenges be vfed of the perfumers in their weet fmelling ointments.

Two ounces of the inice of Limons, mixed with the like quantitie of the fpirit of wine, or the $y$ bett Aqua vit (but the fpirit of wine rectified is mueh better) and drunk at the firft approch of the fit of an ague, taketh away the thaking prefently : the medicine feldome faileth at the fieond time of the taking thereof perfectly to cure the fame; but neuer at the third time,prouided that the $\mathrm{Pa}$ tient be couered warme in a bed, and eaufed to fiveat.

There is alfo diftilled out of them in a glafie ftill, a water of a maruellous fweet finell, which be- $\boldsymbol{X}$ ing inwardly taken in the weight of an ounce and a halfe, moueth fiveat, and healeth the ague.

The feed of all thefe doth kill wormes in the belly, and driucth them forth: it doth alfomigh- $Y$ tily refift poy fon, and is good for the ftinging of feorpions, if it be inwardly taken.

Tliofe which be called Adams Apples are thought to be like in faculties to the foure iuyce, Z efpecially of the Limons, but yet they be not foeffestuall.

\section{CH а. I04. Of the Cormell tree. \\ T) The Defcription.}

7 He tame Cornell tree groweth fomtime of the height and bignefle of a mal tree, with a great number of fprings : it is couered with a rugged barke: the wood or rimber is very hard and dry, without any great quantity of fap therein : the leaues are like vnto the Dog berry leaues,crumpled rugged, and of an ouerworne eolour : the Houres grow in fmall bunches before any leaues do appcare; of colour ycllow, and of no grcat value (they are fo fmall) in fhew like the floures of the 


$1466 \quad$ Of the Hiftory of Plants. $\quad$ L 1 8. 3.

Cornus mas.

The male Comel tree.

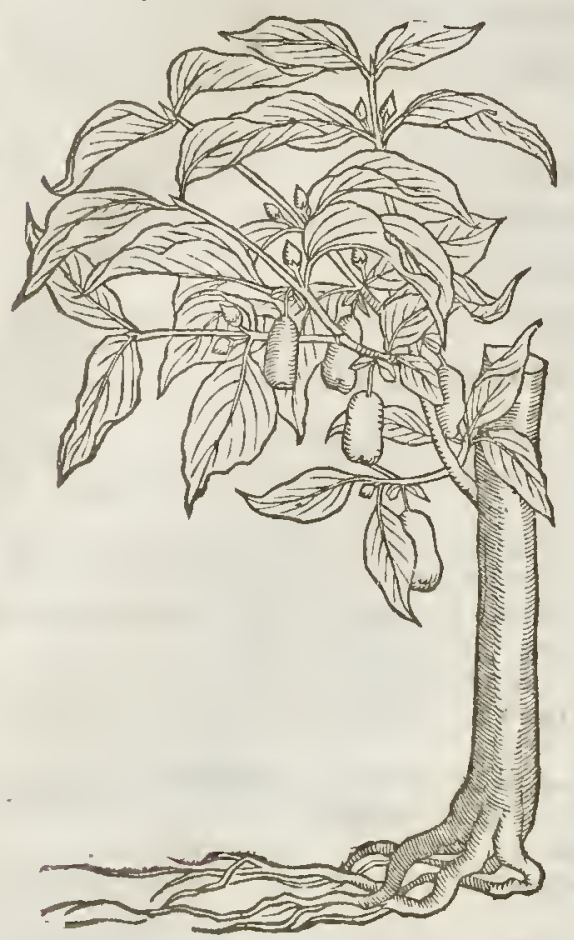

Oliue tree:which being vaded, there come fmall long berries, which at the firft bee greene, and red when they be ripe; of an auftere and harfh tafte, with a certaine foureneffe : within this berry is a fmall ftone, exceeding hard, white within like that of the Oliue, wherunto it is like both in the fafhion and oftentimes in the big: nefle of the fruit.

\section{T The place.}

This groweth in moft places of Germa nie without manuring :it growes not wild in England. But yet there befundry trees of them growing in the gardens of fuch as loue rare and dainty plants, whereof $I$ haue a tree or two in my garden.

$$
\text { 9) The Time. }
$$

The tame Cornell tree floureth fome: cime in February, \& commonly in March, and afterwards the leaues come forch ass an vntimely birth: the berrics or truit are ripe in Auguf.

$$
\text { T The Numes. }
$$

The Grecians call it kaviz : the Latines, Cornus : in high-Dutch, Goznelbaum : in low-Dutch $\mathbb{C o z r i t o d l e ~ b o o m : ~ t h e ~ i t a l ı a n s , ~}$ Corniolo: in French, Cornillier: in Spanifh, Cornizolos: in Englifh, the Cornell tree, and the Cornelia tree; of fome, long Chetrie tree.

The fruit is named in Latine, Cornum: in high-Dutch, Coznell: in low-Dutch, Cotnoele: in Italian, Cornole : in Englih, Cornel berties and Cornelian Cherries.

This is Corrus mas Theophrafti, or Theophraftus his male Cornell tree; for he fertethdowne two forts of the Cornell trees, the male and the female : he maketh the wood of the male to be found, as in this Cornell tree; which we both for this caufe and for others allo haue made to be the male. The female is that which is commonly called Virga fanguinea, or Dogs berry tree, and Cornus fyluefris, or the wilde Comell tree, of which we will treat in the next Chaprer following."

$$
\text { वा The Temperature and } V \text { critues. }
$$

'A The fruit of the Cornell tree hath a very harlh or choking talte : it cooleth, drieth,and bindeth; yet may it alfobecaten, as it is oftentimes.

B It is a remedic againft the laske and bloudy $f l i x_{3}$ it is hurtfull to a cnld ftonacke, and increafeth the rawneffe thereof : the leaues and tender crops of the tree are likewile of an harth and choking tafte, and do mightily dry.

C They heale greene wounds thàt are great and deepe, efpecially in hard bodies, but they ate not fo good for fmall wounds and tender bodies, as Galen writeth.

$$
\begin{aligned}
& \text { C на p. 105. } \\
& \text { Of the female Cornell or Dog-Berry tree. } \\
& \text { IT The Defcription. }
\end{aligned}
$$

$\mathrm{T}^{\prime}$

Hat which the Italians call $y$ irga fanguinea, or the bloudy Rod, is like to the Cornel tree, yet it groweth not into a tree, but remaineth a fhrub : the yong branches thereof are iointed, and be of an obfcure red purple: they haue within a white fpongic pith like that of Elder, but the old ftalks are hard and ftiffe, the fub tance of the which is alfo white, and anfwerable to thofe of the Cornell tree : the leaues are alfolike, the middle rib whereof as alio the brittle foot-ftalkes are fomewhat reddifh: at the top whereof itand white floures in fpoky rundles, which turne into berries, 


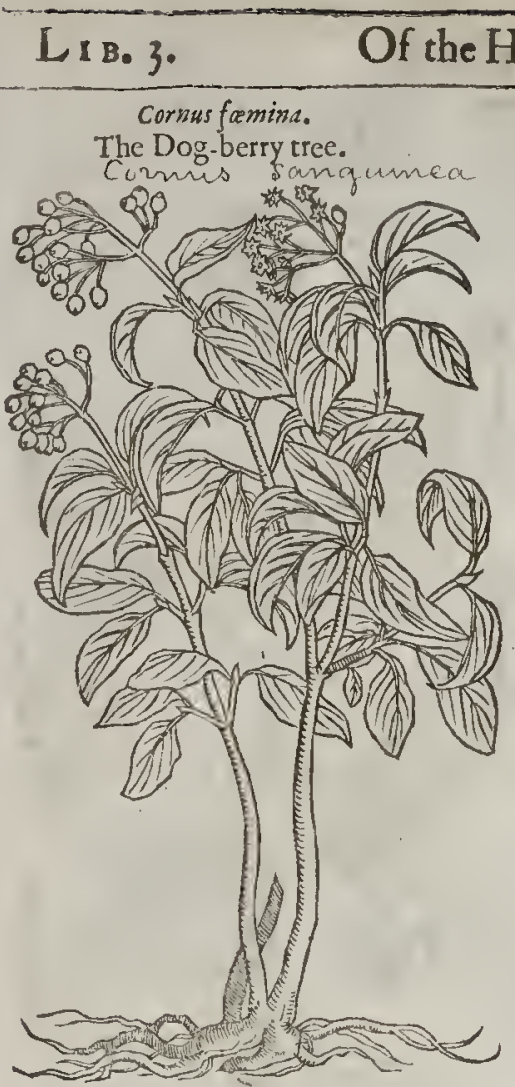

1467

greene at the firt, and of a thining black colo:ir when rhey be ripe, in tafte vapleafant, and nor cared for of the birds.

$$
\text { T The place. }
$$

This thrub groweth in hedges and buthes in every countrey of England.

$$
\text { TI The Tine. }
$$

The floures come forth in the Spring in the moneth of Aprill : the berries are ripe in Au. tumne.

$$
\text { If The Names. }
$$

The Iralians do commonly call it Saxguino, and Sanguinello: Petrus Crefcentius termes it Sarguinus; and CMatrbiolus, Virga fanguines: Pliny, lib.24. cap. Io. hath written a little of $V$ irga $S$ an. gumed : Neither is rirga Sanguimea, faith bee, counted more happy 3 the inner barke whereof doth breake open the fcarres which they before hauc healed. It is an hard thing, or peraduen. ture a rafh pars, to affirme by the fe few words, that Pliny his Virga Sanguinea is the fame that the Italian Sanguino is. This is called in highDureh, noelle, that is to fay, Cornus fylucftris, or wilde Cornell tree: and in French, Corncllier fasuage: in Englifh, Hounds tree, Hounds berry, Dogs berry tree, Pricke-Timber : in the North countrey they call it Gaten tree, or Gater tree; the berries whereof feem to be thofe which Chaucer calleth Gater berries: Valerius Cordus nameth it weosoreatix, that is to fay, Falja or Spuria Cornous, filfe or baltard Cornell tree : this feemeth alfo to be Theophraft us his rrivumaig, or Cornus femina, female Cornell tree. This hath little branches hauing pith within, neither be they hard nor found, like thofe of the male : the fruit is $\mathrm{A}^{\mathrm{g}}, \mathrm{morr}$, that is, not fit to be eaten, and a late fruit which is not ripe till after the Autumne Equinoctiall ; and fuch is the wildc Cornell tree or Gater trec, the yong and tender branches whereof be red, and haue (as wee haue written) a pith within : the fruit or berries be vnpleafant, and require a long time before they can bc ripe.

$$
\text { T The Temperature. }
$$

Theberries hereof are of vnlike parts; for they haue fome hot, bitter, and clenfing, and very many cold, dry, harn, and binding, yet they haue no vfe in medicine.

$$
\text { T The Vertues. }
$$

Matthiolus writeth, that out of the berries firft boiled, and afterwards preffed, there iffueth an A oylewhich the Anagnian countrey people dovfe in lamps: but it is not certaine, nor very like, that the barke of this wilde Comell tree hath that operation which Pliny reporteth of Virga Sang uinea; for he faith, as we haue already fet downe, that the inncr barke thereof doth break and lay open the fcars which they before haue healed.

\section{C н а р. 106. Of Spindle tree or Pricke-wood.}

$$
\text { IT The Defcription. }
$$

$I$

Rickewond is no high thrub, of the bigneffe of the Pomegranat tree : it fpreadeth farre with his branches : the old ftalks hate their barke fomewhat white; the new and thofe that be lately grownebegreene, and foure fquare: the futbitance of the wood is hard, and inixed with a light yellow : the leaues be long, broad, flender, and foft : rhe floures be whire, many ftanding vpon one foor-ftalke, like almoft to a fpoked rundle : the fruit is forre fquare, red, and containing foure white feeds, euery one whereof is conered with a yel low coat, which being taten ofr giucti a yellow die. 


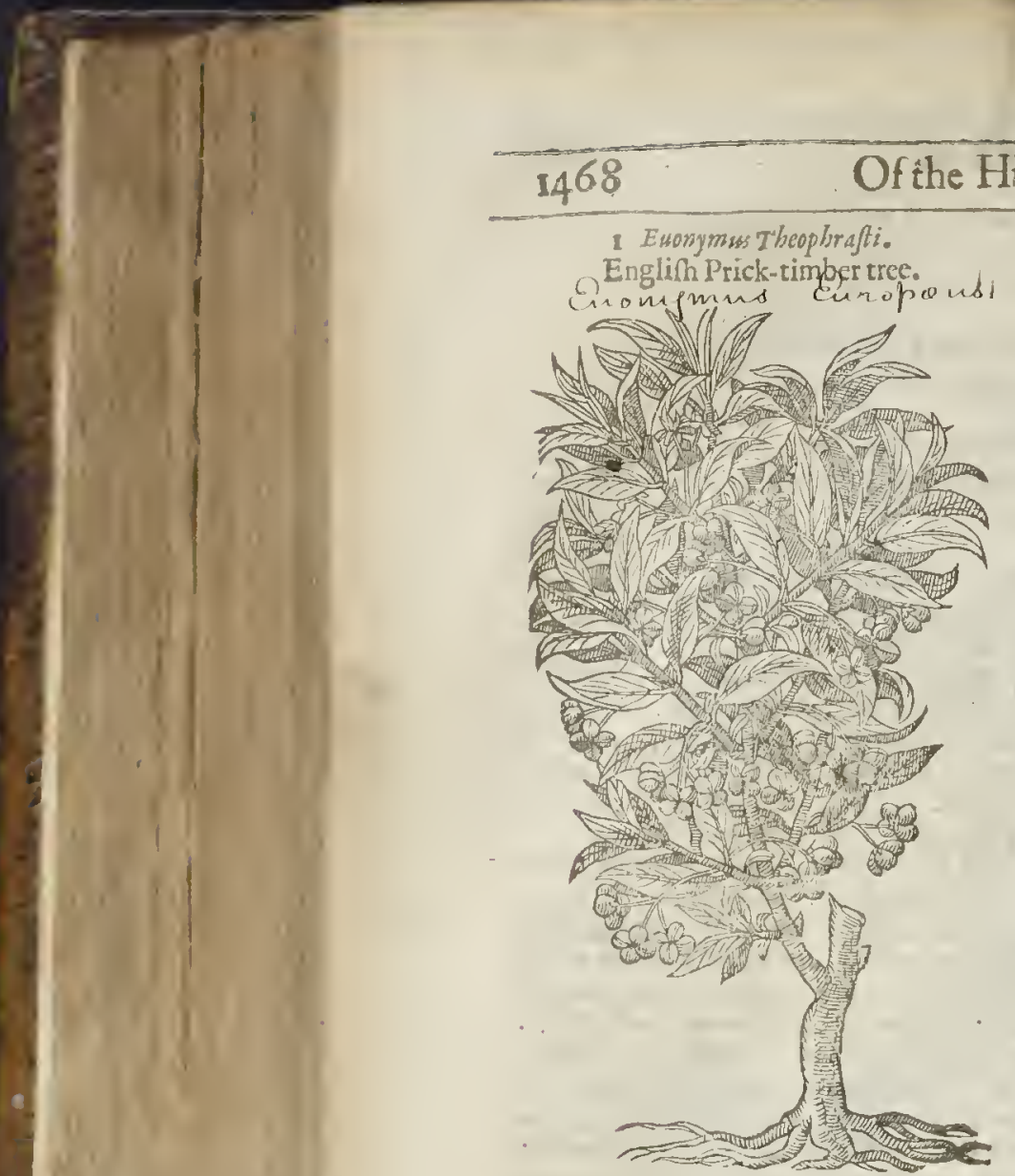

3 Exonymus Pannonicus.
Hungarie Spindle tree.

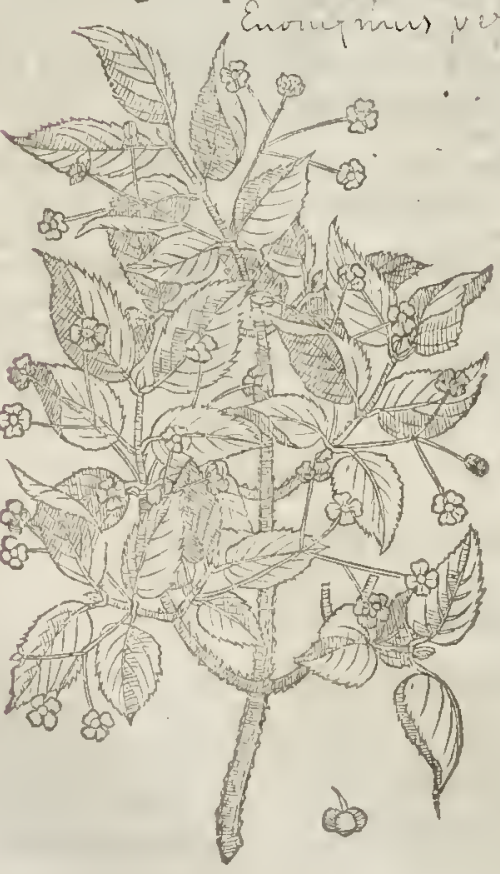

2 This other fort of Ewowymus groweth to the forme of an hedge tree, of a meane bignefle, the trunke or body whereof is of the thicknefle of a mans leg, couered with' a rough or fcabbed barke of an ouerworn ruffet colour. The branches thereof are many, flender, and very etren, coucred with a greene barke whileft they be yet young and tender; they arealfo verybrittle, with fome pich in themiddle like that of the Elder. The leates are few in number, full of nerues or finues difperfed like thofe of Plantaine, in thape like thore of the Pomecitron tree, of a lothfome fmell and bitter tafte: amonght which come forth flender foot ftalks very long and naked, whereondo grow fmall floures confifting of fourefmall leaues like thofe of the Cherrie tree, but leffer, of a white colour tending to a blufh, with fome yellowneffe in the middle: after commeth the fruit, which is larger than the former, and as it were winged, parted commonly into foure, yet fomtimes into fiue parts; and opening when it is ripe, it fheweth the white graines filled with a yellow pulpe. The root is tough and wonddy, difperfing it felfe farre abroad vnder the vpper cruft of the earth. 
3 The fame Author fetteth forth another fort which he found in the mountaines of Mnrauia and Hungary, hauing a trunke or flocke of the height of three or foure cubits, conered with a bark greene at the firft, afterward fprinkled ouer with many blacke fpots : the boughes are diui. "ed to tvard the top into diuers fmall branches, very brittle and cafie to breake, whereon-are placed leaues by couplesalfo, one oppolite to another, fomewhat fnipt about the edges, in thape like thofe of the great Myrtle, of an aftringent tafte at the beginning, after fo newhat hot and bitter : among which come forti fmall floures fanding vpon long naked foot-ftalkes, confilting of loure little leates of a bright thining purple colour, haung in the middle fome few fpots of yellow : afrer commeth the fruit, foure cornered, not vnlike to the commonkinde, of a pon ious fu'sfance, and a gold yellow colour : wherein is contained not red berries like the orher, but blacke, very like to thofe of Fraxinella, of a thining blacke colour like vnto burnithed horne; which are deuoured of birds when they be rine, and the rather becaufe they fall of themfelues out of their huskes, otherwife the bitterneffe of the husks would take away the delight.

$$
\text { 91 The Place. }
$$

The firft commeth vp in vntoiled places, and anong thrubs, vpon rough bankes and heapes of arth : it ferueth alfo oftentimes for hedges in ficlds, growing among? Brambles and fuch orher Thornes.

The other forts Carolus Clufius found in a wood of Hungarie beyond the riticr Drauts, and alfo vpon the mountaines of Morauia and other places adiacent.

$$
\text { oा The Time. }
$$

The foures appeare in Aprill ; the fruit is ripe in the end of Auguft, or in the moneth of Sep: rember.

T The Names.

Theophraftus calleth this thrub 'sumues, and deferibeth it in his third booke of the Hiftorie of Plants : diuers alfo fallny reade it Anonymos: Pctrus Crofcentius calleth it Fufanum, becaufe fpindles be made of the wood hereof; and for that caufe it is called in high-Durch, Spindelbaum, yet mnft of them 1 anboolin : in low Dutch, 7 apenbout : in Iralian, Fu ano: in French, Fufin, and Bonnet deprestre : in Englioh, Spindle tree, Prick-wood, and Prick-timber.

\section{T The Temperature and Pertues.}

This thrub is hurtfull to all things, as Thiophraflus writeth, and namely to Goats : hee faith the fruit hereof killeth; fo doth the leaues and fruit deftroy Goats efpecially, vnleffe they fcoure as wel vpwards as downwards: if three or foure of thefe fruits be giuen to a man they purge both by von,
mit and ftoole.

\section{Cна Рі то\%. Of the blacke eAller tree. T The Defoription.}

7 He blacke Aller treebringeth forth from the root feraight ftalkes diuided into diuers branches : the outward barke wherc of is blacke, and that next to the wond yellow, and giueth colour as yellow as Saffron : the fubftance of the wood is white and brittle, with a reddif pith in the midf : the leaues be like thofe of the Alder tree, or of the Cherry tree, yer blacker, and a little rounder : the floures be fomewhat white : the fruit are round berries, in which appeare a certaine rift or chinke, as though two were ioined together, at the firt greene, afterwards red, and laft of all blacke: in this there be two little ftones : the root runneth along in the earth.

$$
\text { 9ा The Place. }
$$

The Aller tree groweth in moift woods and copfes : I found great plenty of it in a wood a mile frnm Inington, in the way from thence toward a fmall village called Harnfey, lying vpon the right hand of the way ; and in the woods at Hampted neere London, and in moft woods in the parts a:
bout London.

The leates and floures appeare in the beginning of the Spring; and the berries in Autumne? of The Names.

This thrub is called Alnus nigra, or blacte Alder: and by others, Frangula: Petrus Crefcentius nameth it Aworms: in low - Dutch, Sparkenbout, and oftentimes pgillyout, becaufe boies make for themfelues arrowes hereof : in high-Dutch, Faulbaum : it is called in Englifh, blacke Allef tree; and of diuers Butchers pricke tree.

Hhhhh of $T$ igt 
Alnus nigra, furc Frangulds.

The blacke Aller tree.

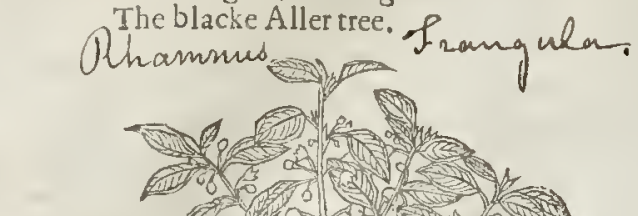

A

B

$\subseteq$

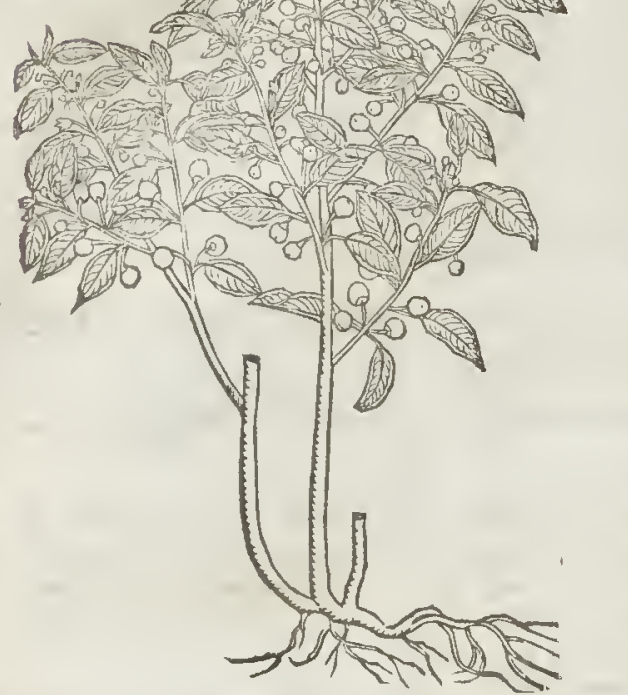

9) The Temperature.

The inner barke of the blacke Aller tree is of a purging and dry qualitie.

\section{qi TheVertues.}

The inner barkehereof is $v$ fed of diuers country men, who drink the infufion thereof when they would be purged: it purgeth thicke phlegmaticke humors, and alfo cholericke, and not only by the ftoole, but many times alfo by vomit, not without great trouble and paine to the ftomacke : it is therefore a medicine more fit for clownes than for ciutill people, and rather for thofe that fced groffely, than for dainty people.

There be others who affirme that the dried barke is more gentle, and caufeth leffer paine: for the greene bark (fay they)which is not yet dried containeth in it a certaine fuperfluous moifure which caufeth gripings and vomitings, and troubles the ftomacke.

The fame barke being boiled in wine or vineger makes a lorion for the tooch. ache and is commended againft frabs and filthi neffe of the skin.

The leaues are renorted to be good fodder for cattell, efpecially for kine, and to caufe them to yeeld good fore of milke.

\section{Cн а г.108. Of the Seruice tree.}

TI The Defoription.

1 He Service trec groweth to the height and bignefie of a great tree, charged with many grear armes or boughes which are fet with fundry fmall branches, garnithed with many great leaties fonew hat long like thofe of the Afh : the floures are white, and ftand in clufters, which turne into fmall browne berries fomewhar long, which are ror grod to be eaten wntill they have lien a while, and untill they be foft like the Medlar, wheco it is like in tafte and operation.

3 The common Seruice tree groweth likewife to the height of a great tree, with a ftraight body of a brownith colour, full of branches, fet with large difplayed leanes like the Maple or the White-Thorne, fauing that they are broader and longer: the floures are white, and grow in tufts; which being fallen, there come in place thereof fmall round berries, browne vpon one fide, and reddith toward the Sun, of an vnpleafant tafte in refpect of the former: in which are contained little blackin kernels.

$$
\text { T The Place. }
$$

Thefe trees are found in woods and groues in moft places of England : there be many fmal trees thereof in a little wood a mile beyond lflington from London: in Kent it groweth in great aboundance, efpecially about Southflect and Grauefend. ‡ The later of thefe I haue feene growing wilde in ditters plazes, but not the former in any place as yet. $\ddagger$

$$
\text { T The Time. }
$$

They flourc in March, and their frut is ripe in September.

$$
\text { If The Names. }
$$

The firft is called in Greeke, in, and oin: in Latine, Sorbus : in high-Dutch, seperberbaum: in low-Durch, Sogtobusotit: in French, Cormier : in Englifh, Seruice tree, and of forne affer the Latines, Sorbe trec. 
fimell, and niched round about the edges : out of the yonger fort of the boughes, hard to the fetting on of the leatles, grow forth hanging together many long narrow and flat cods, as it węre like almolt to diuers vircis tongues, wl ere the leed is perfected, which is of a bitter tafte: the roots be - many, and grow deepe in the ground.

\section{Fraxinus.}

The Alh tree.

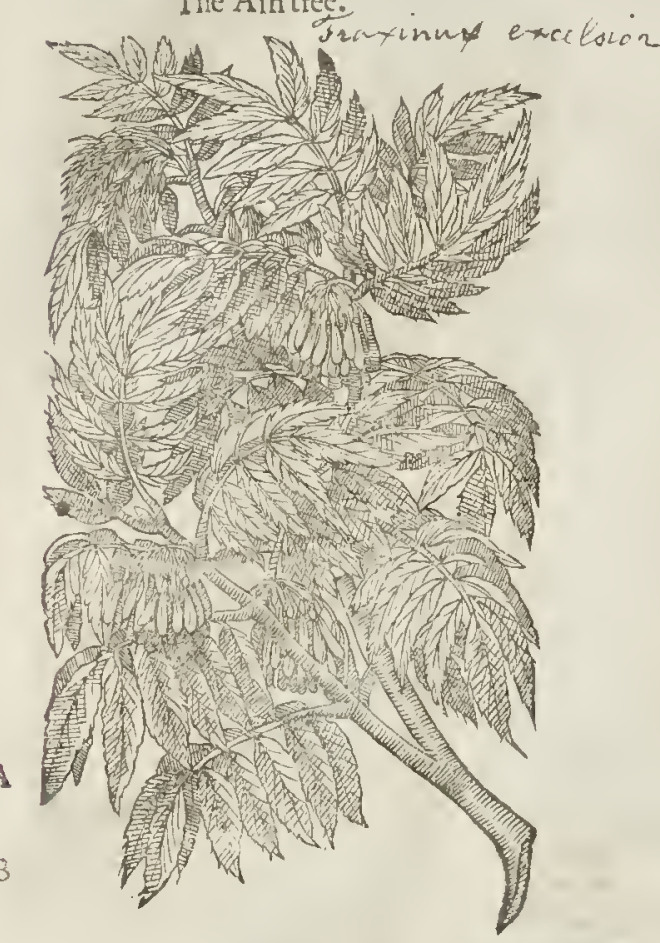

I The Place.

The Afh doth better profper in moift phces, as about the borders of Medowes and Riuer fides, than in dry grounds.

$$
9 \text { The Time. }
$$

The leanes and keyes come forth in Aprill and May, yet is not the feed ripe before the fall of the leafe.

$$
\text { of The Names. }
$$

This tree is called in Greeke, $\mu_{\mathrm{A} \lambda \boldsymbol{A}, \mathrm{a}}$ and of diters, maxs : in Latine, Fraxinus : in highDutch, ECrbetnbaum, (ECtyernbolt Stepnefcbert : in low-Dutcli, Elitben, and EIfhenboom: in Italian, Fraßsmo: in French, Frefne: in Spanifh, Frefno, Fraxino, and Frei. $x_{0}:$ in Fnglith, Am tree.

The fruit like vnto cods is called of the Apothecaries, Lingua Auis, and Lingua Pafferina: it may be named in Greeke, Oprws;rawer : yet fome would haue it called orneogloff rm : 0 thers make ornus or the wilde An to be callad orreoglo/f $\mathrm{wm}$ : it is termed in Englih, A ih keyes, and of fome, Kite-keyes.

$$
\text { If The Temperature and Vertues. }
$$

The leaues and bark of the An tree are dry and moderatly hot : the feed is tot and dry in the fecond degree.

The iuice of the leaues or the leates themfelues being applied, or taken with wine, cure

C The leates of this tree are of fo great vertue againf ferpents, as that they darc not fo much as touch the morning and euening thadowes of the tree, but fhun them afar off, as $P$ liny repnits, $l i .16$. cap. I 3. Ile alfo afirmeth, that the ferpent being penned in with boughes layd round about, will fooner run into the fire, if any be there, than come neere the boughes of the A th : and that the Afh doth floure before the Serpents appeare, and doth not caft his leaues before tirey be gon againe.

D Wewrite (faith he) vpon experience, that if the ferpent be fet within the circle of a fire and the boughes, the ferpent will fooner run into the fire than into the boughes. It is a wonderfull courtefie in nature, that the Afh frould floure before thefe ferpents appeare, and not caft his leaues before they be gon againe.

E Both of them, that is to fay the leaues and the barke, are reported to ftop the belly : and being boiled with vineger and water, do ftay vomiring, if they be laid vpon the ftomacke.

F The leases and barke of the Afh tree boiled in wine and drunk, do open the ftoppings of the liuer and fpleene, and do greatly comfort them.

$G$ Three or foure leaues of the Afh tree taken in wine each morning from time to time, doe make thofe leane that are fat, and keepeth them from feeding which do begin to wax fat.

The feed or kite-keyes of the Ath tree protoke vrine, increafe naturall feed, and ftirre vp bodily uft, efpecially being poudred with nutmegs and drunke.

The wood is profitable for many things, being exalted by Homers commendations, and Achilles fprare, as Pliny writeth. The thauings or fmall pieces thereof being drunke are faid to be pernici-
Ous and deadly, as Diofcorides affirmetl.

The Leewhich is made with the Afhes of the batke cureth the white fcurfe,and fuch other like toughneffc of the skin, as Pliny teftifieth. 
L18. 3. Of the Hiftory of Plants.

1473

\section{CHAP. IIO: \\ ${ }_{11}$ Of the wilde $A / h$, otberwife called Quicke-Beame or Quicken tree. \\ $\therefore$ Sorbusfyluctris, faue Fraxinus Bubula. \\ Tा The Defcriptios.} The Quicken tree, wilde Afh,or wilde Seruice tree.

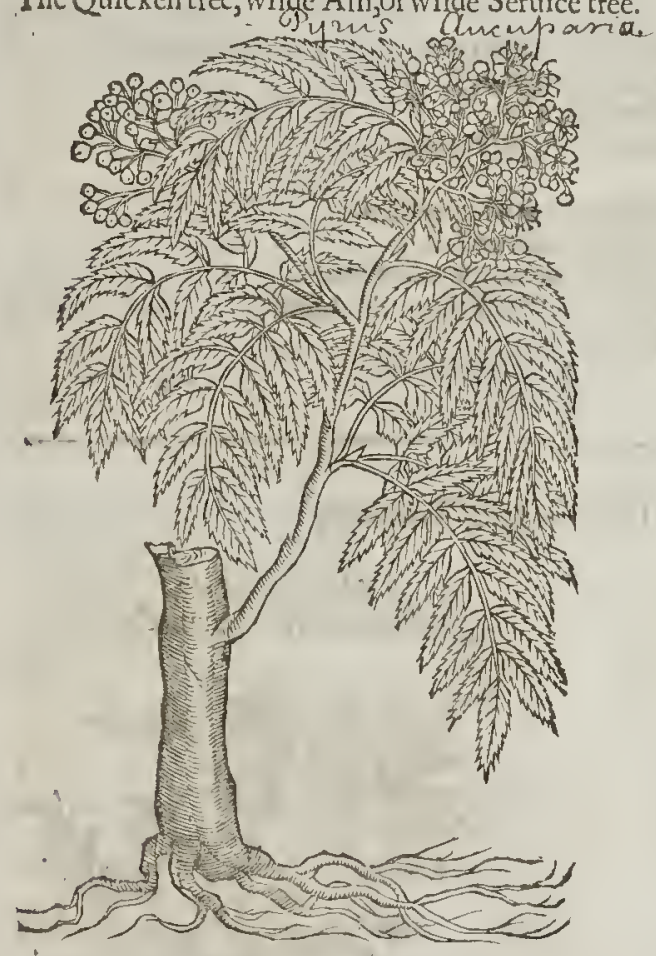

If The Names:
"THewilde Afh or Quicken Tree 1 Peni fetteth forth tor the wilde Sertice: this tree groweth feldome or neuer to the ftature and height of the Ath tree, notwithftanding it growes to the bignes of a large tree: the leaues be great and iong, and fcarcely be difcerned from the leaucs of the Seruice trec: the floures bee white, and fweet of fmell, and grow in tufts, which do turne into round berries,greene at the fir?, but when they be ripe of a decpe red colour, and of an vnpleafant tafte : the branches are as full of inice as the Ofiar, which is the caufe that boyes doe make Pipes of the barke thereof as thcy doe of Willowes.

$$
\text { The Place. }
$$

The wilde Afh or Quicken tree growcth on high mountaines, and in thicke high woods in moft places of England, efpecially about Namptwich in Clicihire, in the Weilds of Kent, in Suffex and diucrs other places.

$$
\text { I The Time. }
$$

The wild Afh floures in May, and the berries are ripe in September.

The Latines call this tree ormus, and oftentimes Sylueftris Fraxinus, or wilde Afh : and it is alfo Fraxim jecies, or a kinde of Afh; for the Grecians (as not only Pling writeth, but alfo Theophraffus) hath made two kindes of Alh, the one high and tall, the other lower : the high and tall one is Fra-

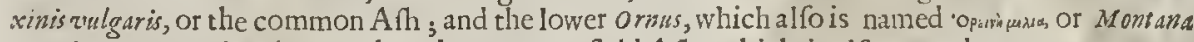

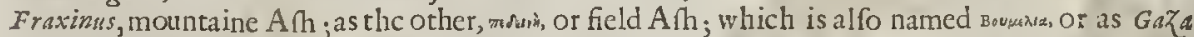
tranflateth it, Bubula Fraxinus, but more truly Magna Fraxinus, or great Ath; for the fyllable Bo is a figne of bigneffc : this Ornus or great Afh is named in high-Dutch, Glalbauin : in low-Dutch,

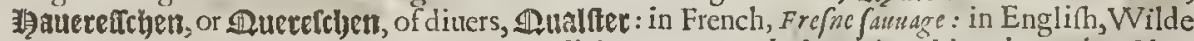
Afh, Quieken tree, Quick-beame tree, and Wicken tree. Mattbiolus makes this to be Sorbus fy Iue. ftris, or wilde Seruicetrec.

$$
\text { e) The Temperature and Vertues. }
$$

Touching the faculties of the leaues, barke, or berries, as there is nothing found among the old, $A$ fo is there nothing noted among the later writers : but Pliny feemeth to makc this wilde Afh like in faculties to the common Afh; for lib.16. cap. I 3. where hewrites of both the Afhes, hee faitlr, that the conmon Ath is Cripa and the mountaine Arh Spif $a$ : and forthwith he addeth this: The Grecians write, that the leates of them do kill catcell, and yet lurt not thofe that chew their eud; which the old writers hate noted of the Yew tree, and not of the Am tree. Pliny was deceived by

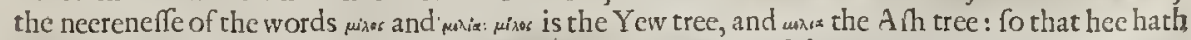
fally attributcd that deadly facultie to the Arh tree, which doth belong to the Yew tree.

The leates of the wilde Afh tree boiled in wine are good ayainft the paine in the fides, and the $\mathbf{B}$ ftopping of the liuer, and affwage the bellies of thofe that hate the tympanie and dropfie.

Benedictus Curtius Symplioryanus is deceined in the hiftorie of ornus, when he thinkerh out of vir. gils Georgicks, that o rous hath the floure of the Peare tree; for out of $V$ irgils verfes no fuch thing at Hhhhh 3 
all can be gathered : for he in intreateth not of the forms of trees, but of the graffing of diuers into others, vnlike and differing in nature; as of the graffing of the Nut tree into the Strawberry tree; the Apple into the Plane tree, the Beech into the Cheftnut tree; the Peare into the wilde Afh or Quick-beame tree, the Oke into the Elme tree : and is this refpeet hee writeth, that the Plane tree bringeth forth an Apple, the Beech tree a Cheftnut; the wilde Afh tree bringeth forth the white floure of the Peare tree, as is molt manifent out of Virgils owne words, after this manner, in the fecond booke of his Georgicks:

$$
\begin{aligned}
& \text { Inferitur wero ex fotu nuicus Arbutus borrida, } \\
& \text { Et feriles Platani malos geffere valentes, } \\
& \text { Caftanee Fagos: Ornus incanuit albo } \\
& \text { Flore Pyri,glandémque Jues fregere fub Vlmis. }
\end{aligned}
$$

The Tree-Strawb'ry on Walnuts ftocke doth grow, And barren Planes faire Apples oft haue borne;

Cheftnuts, Beech-Mant; the Q'icken tree doth fhew

The Peares white floure; and lwine oft times th' Acors

Haue gathered vnder Elmes.

\section{C.H A P. II. Of Coriars Sumuch.}

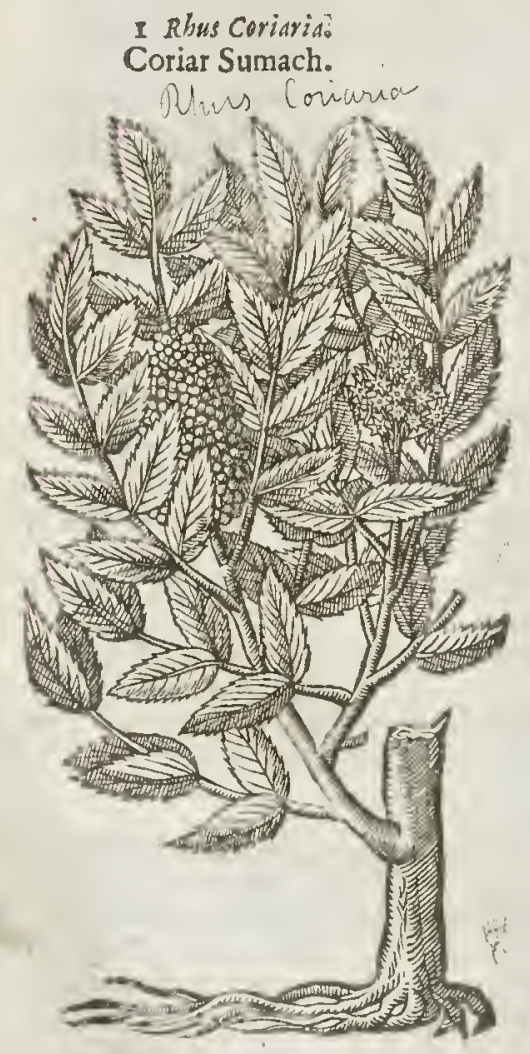

2 Rhus Mrytifolia?

Wilde or Myrtle Sumach: Coriaria myttiptic

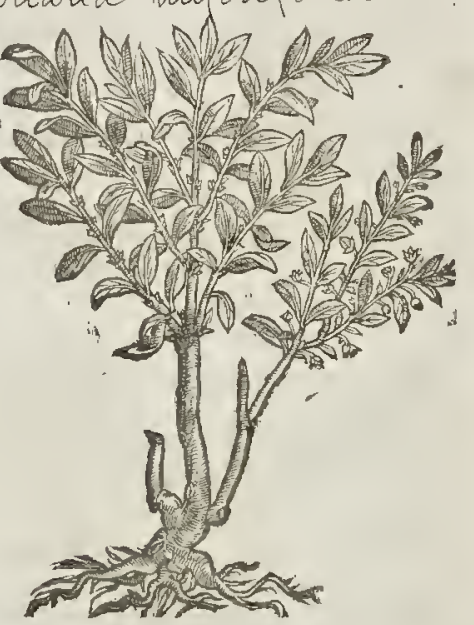

\section{The Defription?}

\&

Oriars Sumach groweth vp vnto the height of a hedge tree, after the manner of the Fider tree, bigger than Diofcorides reporteth it to be, or others, whoaffirme that $R$ hws groweth two cubitshigh : whofe errors are the greater : but this Rhus is folike to the 


\section{$\mathrm{L}_{1 \mathrm{~B} .30} \quad$ Of the Hiftory of Plants.}

Seruice tree in thape and manner of grow ing, that it is hatd to know one from the other, but that: the leates are foft and hairy, hauing a red finew or rib thotow the midf of the leafe: the floures grow with the leanes vpon long ftems clufteting together like cats taile, or the carkins of the nut trec, but greater, and of a whiti ih green colout : after which comc clifters of round berries, growing in bunches like grapes,

2 Pliny his Sumach, or the Sumach of plinies defcription, groweth like a fmall hedge tree, ha? uing many flender twiggie branches, garnihhed with little leaues like uxyrtus, or rather like the leaues of the Iuiube tree; among which come forth flender moffe floures, of no great account or va. lue, which bring forth fmall feeds, inclofed within a cornered cafe or huske, fa fioned like a fpoon: the trunke or body of both thele kindes of Sunlach being wounded with fome iron Inftument, yeeldeth a gum or liquour.

T) The Place.

Sumach groweth,as Diofcorides faith, in ftony places : it is found in diuets mountaines \& woods in Spaine,and in many places on the mount Apennine in Italy, and allo neere vnto Pontus, Archigenes in Galen, in the 8 . book of medicines according to the places affected, theweth, that it gtoweth in Syria, making choice of that of Sytia.

\section{Tl The Time.}

The floures of Sumach come forth in Inly, the feed with the berries are tipe in Autumne.' q $T$ be Names.

This is called in Greekeirs: Rlsus, faith Pliny, hath no Latine name $y e t$ Gaz $a$ after the fignificati: on of the Greeke word, faineth a name,calling it Fluida: the Arabians name it Sumach : the I talians, Sumacho : the Spaniatds, Sumagre: in low Dutch,by contra ating of the word they cal it 5 mact or Sumach: in Englith, Sumach, Coriars Sumach,and Leather Sumach: the leaues of the thrub be called "prís pupoodetuen: in Latine, Rhus coriaria, or $R$ hoe.

The feed is named Eruthros: and 'pou's azi va : in Latinc, Rhus Culinaria, and Rhus obfoniorum: in En: glih, Meat Sumach, and Sauce Sumach.

T The Temperature. The ftuit, leaues, and feed hereofdo very much binde, they alfo coole and dtie : dtie they are in
she third degree, and cold in the fecond, as Galen tcacheth.

\section{T) The Vertues:}

The leaues of Sumach boyled in wine and drunken, do ftop the laske, the inordinate coutfe of $A^{1}$ womens fickneffes, and all other inordinate iffues of bloud.

The feed of Sumach eaten in fauces with meat, ftoppethall manner of fuxes of thebelly, the B bloudy flix, and all other iffues, efpecially the whire iffues of women.

The decontion of the leaues maketh haires blacke, and is put into ftooles to fume vpwatd into the bodies of chof that hane the Dyfenterie, and is to be giuen them alfo to drinke.

The leates made into an ointmcnt or plailter with hony and vineger, faith the fprcading nature

The drie leaues fodden in water vntill the decoction be as thicke as hony, yecld forth a cettaine oilineffe, which performeth all the effects of Licium.

The feed is no leffe effectuall to be ftrowed in poudet vpon theit meats which are Coliaciot $D y-E_{j}$
tenterici. The fccdes pouned, mixed with honie and the powder of Okcn coles, healeth the Hemor- $G$ ]
rhoides.

There iffueth out of the fhrub a gin, which being put into the hollowneffe of the teeth, taketh $I$ away the paine, as Diofcorides w tite th.

\section{C н А Р. 112: Ofred Sumach. \\ T. The Defcription:}

1. THele two figures ate of one and the felfe fame plant; the fitt theweth the thtub being in floure: the other when it is full floured with the fruit growne toripeneffe, notwithftanding fome haue deemed them to be of two kindes, wherein they wete deceiued.

$t$ This excellent and mottbeautifull plant Coggygra (beeing teputed of the Italians and the Venetians for a kind of $R$ hus ot Sumach, becaufe it is vfed fot the fame purpofes wheteto Rhus fernetb. 
wech and therein dotly farre excell it) is an hedge plant growing not abone the height of foure or fue cubits, hauing tough and pliant ftalks and twiggie branches like to Oziers, of a brown colour. The leaues be round, thick, and ftiffe like the leaues of Capparis, in colour and fauror of Piffaci.tleaues, or T crebuthss; a mong which arifech a fmall vpright fprig,bearing many fmal cluftering little greenin yellow floures, vpon long and red ftalks. Afterwhich follow fmall reddinh Lentill-like feeds that earry at the tops a moft fine woolly or flockie tuft, erifped and eurled like a curious wrought filken Heece, which eur!eth and foldeth it felfe abroad like a large burh of haires.

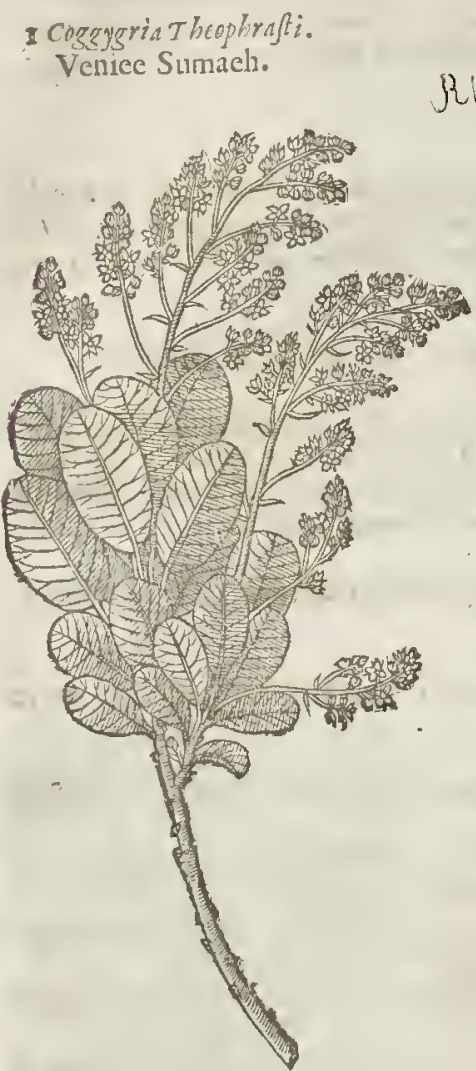

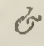

or

Rhis cotivend

Cotinus Coriariss Pliniy. Red Sumach.

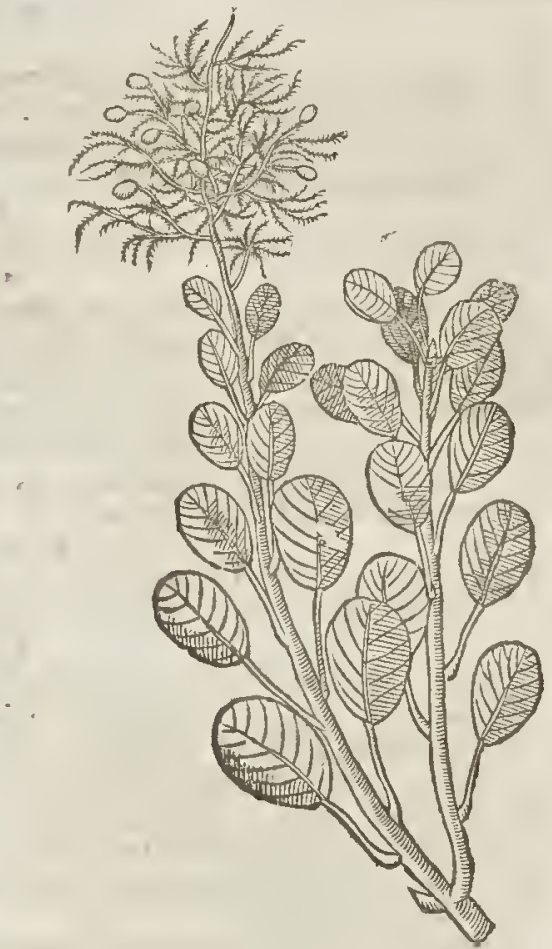

T The Place.

Cogzygria groweth in Orleans neere Auignion, and in diucrs places of Italy, vpon the Alpes of Styria, and many other places. It growethon moft of the hils of France, in the high woods of the vpper Pannonia or Auftria,and alfo of Hungaria and Bohemia.

They floure and flourin for the moft part in Iuly. I' The Time.

The firt is called Coggygria, and Cocrygria - in Englinh, Venice Sumach, or Silken Sumaeh; of Pli. ny, Cotinus, in bis I6.booke, 18 . chapter. There is, faith he, on mount A pennine a thrub which is called Cotinus ad lineamenta modo Conchylï coloreinfignis, and yet cotinus is oleaster, or oled fylueftris, the wilde Oliue tree, from which this fhrub doth much differ; and therfore it may rightly be ealled $\mathrm{C}_{\mathrm{O}}$ tinus Coriaria. Diuers would haue named it Scotinus, which name is not found in any of the old writers. The Pannonians do call it Farblauff : it is alfo thought that this fhrub is Coggygra Plzmï, of which in his $\mathrm{I}$. booke, 22 .chapter he writech in thefe words:Coggysria is alfo like to Vnedo in leafe, not fo great; it hath a property to loofe the fruit with downe, which thing happeneth wnto no other tree.

Ti The Temperature.

The leaues and flender branches together with the feeds are very much binding, cold and drie as the otherkindes of Sumach are. The Vertues.

A The leaues of Coggygra, or Silken Sumach, are fold in themarkets of Spaine and Italy for great fummcs 


\section{LIB.3. Of the Hiftory of Plants.}

fummes of money, vnto thofe that dreffe Spanifn skinnes, for which purpofe they ate verie excellent.

The root of Cotinus, as Anguillara notech, ferueth to die with, giuing to wooll and cloth a zeddith $B$ colour, which Pling knew, fhewing that this mrub (that is to fay the root) is ad lineamcnta modo Corm chyly colore infignis.

\section{Cна а. II3. Of the eAlder Tree.}

$$
\text { I The Defcription. }
$$

I THe Alder tree or Aller, is a great high tree hating many brittle branches, the barke is of a browne colour, the wood or timber is not har 1 , and yet it will laft and indure verie long vnder the water,yea longer than any other timber whatfoeuer:wherefore in the fenny and foft marith grounds they do vfe to make piles and pofts thereof, for the ftrengthening of the walls and fuch like. This timber dnth alfo ferue very well to make troughes to conuey witer in ftead of pipes of Lead. The leatres of this tree are in hape fomewhat like the Hafell,but they are blacker 8 more wrinckled, very clammie to handle, as though they were fprinckled with honie. The bloffome or floures are like the aglets of the Birch tree:which being vaded, there tolloweth a fcaly fruit clofely growing together,as bigas a Pigeons egge, which toward Auturnne doth open, and the feed falleth outand is lont.

I Linus.

The Alder tree.

Asetula Alnus

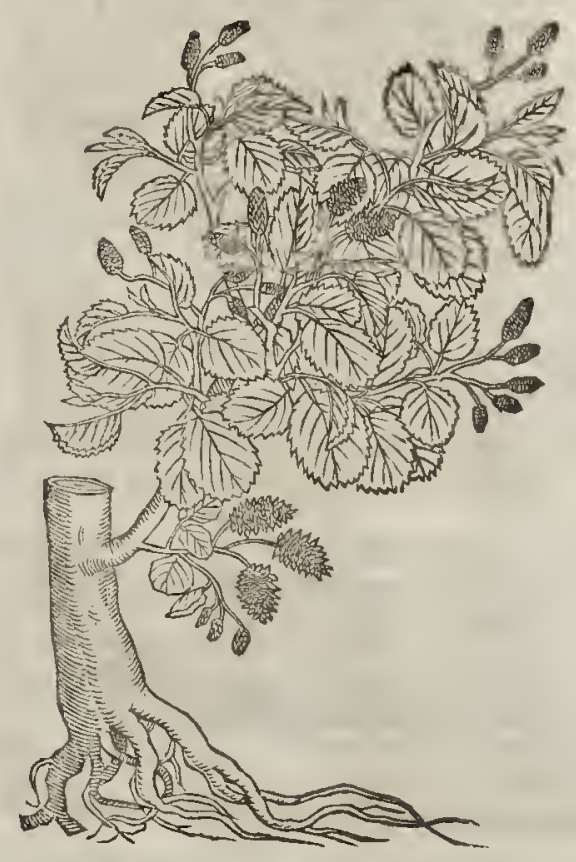

$\$ 2$ Alnushirfuta.

Rough leaued Alder.

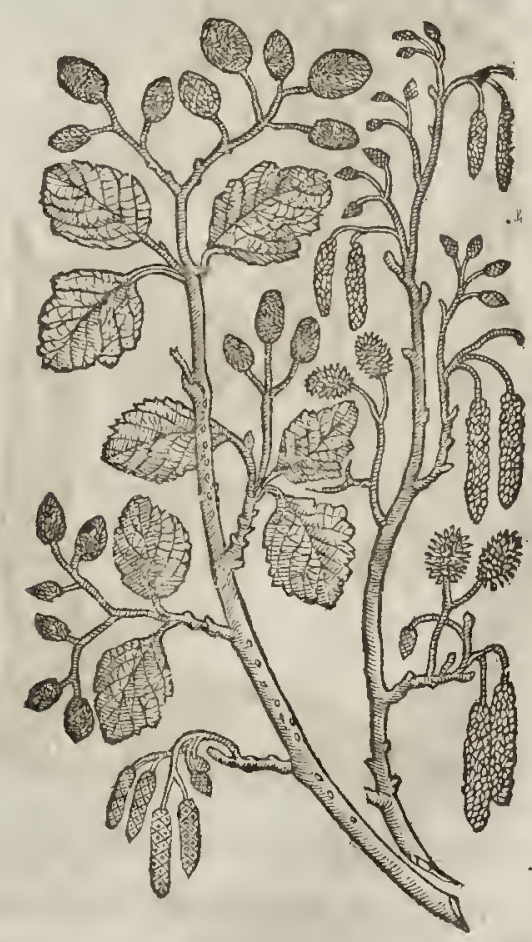

\pm 2 Chafous and Bashine haue obferued another kinde of this which differs from the ordinary, in that it hath larger and more cut leaues, and thefe not thining aboue, but hoary vnderneath: the carkins, as al fo the rough heads are not fo large as thole of the former: the barke alfo is whiter. Clyfous .makes ic his Alnus altera; and Babine, his Lalnus birfutus, or folio incano. 
The Aller or Alder tree delighteth to grow in low and moift waterin places.

\author{
It The Time.
}

The Aller bringeth forth new leates in Aprill, the fruir whereof is ripe in September.

$\checkmark$ The Names.

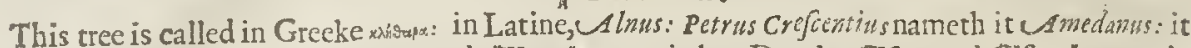
is called in high Dutch, Erlenbatum and Elletrbaum: in low Dutcb, GIrr and Elren.bont: in Italian, Alno: in French, Aulne ; in Englinh, Alder and Aller.

The leates and barke of the Alder trce are cold, drie, and aftringent.

$$
\text { of The Vertues. }
$$

A The leates of Alder are much vfed againft hot fwellings, vlcers, and all inward inflammations, efpecially of the Almonds and kernels of the throat.

The barke is mucli vfed of poore countrey Diers, for the dying of courfe clotly, cappes, hof, and

B fuch like into a blacke colour, whereunto it ferueth very well.

\title{
Cin a II . Of the Birchtree.
}

Betala:

The Birch trẹe.

jotimia ecia

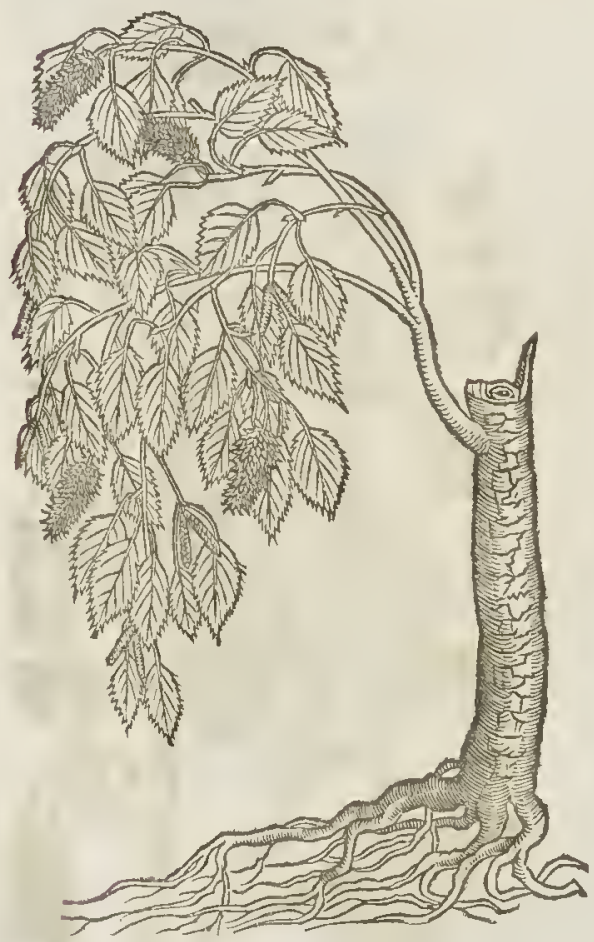

9) The Defcription.

THe comnon Birch tree waxeth likewife 1 a great tree, hauing many boughes befet with many fmall rods or twigs, very limber and pliant : the barke of the young twigs and branches is plaine, fmooth, and full of fap, in colour like the Cheft nut; but the rind of the body or trunk is lard without, white, rough, and vneuen, full of chinkes or creuifes:vnder which is found another fine barke, plaine, fmooth, and as thin as paper which heretofore was vled in ftead of paper, to write vpon, before the making of paper was knowne: in Ruffia and thefe cold regions it ferueth in ftead of tiles and flate to coner their houfes withall : this tree bearerh for his foures certaine aglets like the Hafell tree,but fmaller, wherein the feed is contained.

$$
\text { q) The Place. }
$$

This common Birch tree grows in woods, fenuy grounds, and mountaines, in moft places of England.

$$
\text { बा The Timse. }
$$

The catkins or aglets do firft appeate,and then the leaues, in Aprill or a little la ter. बा The Names.

Theoply af us callecth this tree in Greeke, onwerda dituers, orpus: Others onipes:it is named in Latine, $B$ ctald ; diuers alfo write it with a double Il Betulla, as fome of Plinies copies haue it:it is called in high Dutch, Birkenbaum: in low Dutcl, 2Berettenboom : in Italian, Betu la: by them of Trent, Bedallo: in French, Boulear : in Englifh, Birch tree.

IT The Temperature and Vertues.

Concerning the medicinablevfe of the Birch tree, or $h$ is parts, there is norhing exwat either in the old or new writers.

This tree, faith Pliny in his 16 -booke, 18 . chapter, Mirabili candore of tcrmitate terribilis magifra. mum virgis : for in times paft the Magiftrates roddes were made heereof: and in our timealfo the Schoolemafters and parents do terrifie their children with rods made of Birch.

It ferueth well to the decking vp of houfes,and banquetting roomes, for places of pleafure, and beautifying of ftreets in the croffe or gang weeke, and fuch like.

CHAP. 


\section{Cн ар. IIs. Of the Hornebeame, or Hard beame Tree.}

Betul us, five Carpinus.

The Hornebeame tree.

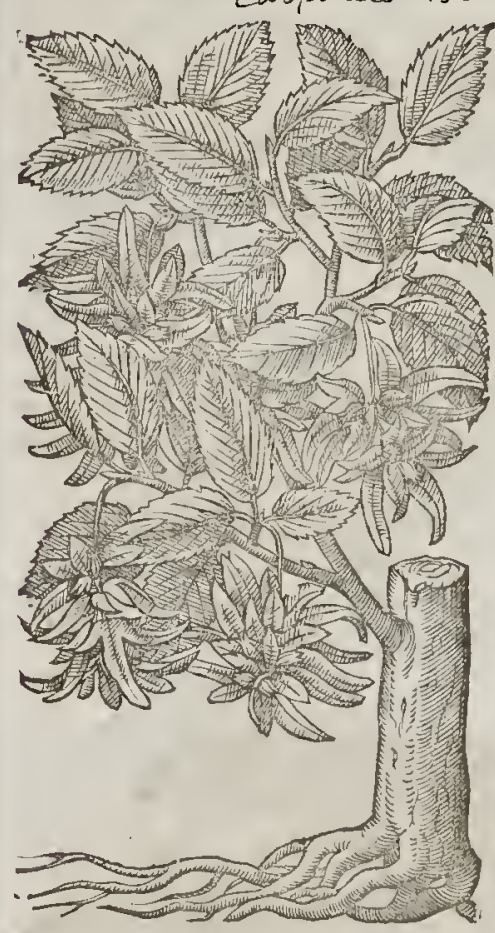

T The Defcription.

Etulus, or the Hornebeam treegrows great, and very like vnto the EIme, or Wich Hufel tree, hauing a great body : the wood or timber whereof is better for arrowes and Thafts, pulleies for mills, and fuch like deuifes, than E!me or Wieh Hazell; for in time it waxeth fo hard, that the toughneffe and hardneffe of it may be rather compared vnto horn than vnto wood, and therefore it was ealled Hornebeame, or Hardbeame: the leaues hereof are like the EIme, fauing rhat they be tenderer : among thofe hang certaine triangled things, vpon which be found knaps,or little heads of thebigneffe of Ciches, in which is eontai ned the frutor feed : the root. is frong and thieke.

$$
\text { it The place. }
$$

Betilus or the Horncbeame tree growes plentifully in Northamptonfhire; alfo in Kent by Grauefend,where it is commonly taken for a kinde of Elme.

$$
\text { T The Time. }
$$

This tree doth fpring in Aprill, and the feed is ripe in September.

$$
\text { बा } T \text { be Names. }
$$

The Hornebeam tree is ealled in Greek לurit. which is as if you thould fay Coniu alts, or belonging to the yok , becaufe it ferueth well to make sujim of, in Latine, Iuga, yokes wherewith oxen are yoked together, which are alfoetten at this time made thereof, as witneffeth Benedictus Curtius Symphorianus, and our felues haue fufficient knowledge thereor in our owne eountrv:and therefore it may be Englifhed Yoke Elme.It is called of fome, Carpinus and $Z_{u g i n}:$ it is allo called Betuitus, as if it were a kinde of Birch, but my felfe bet ter like that it thould be one of the Elmes : in high Dutch, zligozme: in Freneh, Carne: in Italian, Carpino : in Englifh, Hornebeame, Hardbeame, Yoke Elme, and in fome places, Witch.hafell. or The Temperature and Vertues.

This tree is not vfed in medieine, the vertues are not expreffed of the Antients, neither haue wee $\mathbf{A}$ any certaine experiments of our owne knowledge mure than hath beene faid for the vfe of Huf bandric.

\section{Cи ат. i16. Of the Elme tree.}

\# Vr Author onely defcribed two Elmes, and thofe nnt fo accurately but that I thinke I thall gitue the Reader content, in exchanging them for better receiued from $\mathrm{M}^{\text {: }}$. Goodyer; which are thefe.

\section{$V$ lmus rulgatifima folio lat o fabro. The common Elme:}

THis Elme is a very great high tree, the barke of the young trees, and boughes of the Elder, which are vfually lopped or thred, is fmooth and very tough,and wil frip or pil from the wood a great length without breaking:the bark of the body of the old trees as the trees grow in bignefle, teares or rents, which makes it very rough. The innermoft wood of the tree is of tedding yellors 
J 788 . Of the Hiftorie of Plants.

L I B. 3 .

yellow or brownith eolour, and curled, and after it is drie, very tough, hard to cleauc or rent, whereof aues of Carts are molt com non!y made: the wood next the barke, which is called the fap, is white. Before the leaues come forth the Anoures appeare, about the end of March, which grow on the twigs or branehes, elofely eompated of thruft together, and are like to the chiues growing in the middle of moft flourcs, of a reddith colour: a ferwhich come flat feed, more long than broad, not much vnlike the garden Araely feed in forme and bigneff, and doe for the moft part fall away before or fhortly after the leaues fpring forth,and fome hang on a great part of the Sommer:the leaues grow on the twigges, of a darke greene colour; the middle tize whereof are two inches broad, and three inches long, fome are longer and broader, fome narrower and fliorrer, rougl or harfh in handling on both fides, nickt or indented about the edges, and nany times crumpled, hauing a nerue in the middle, and many fmalier nerues growing from $\mathrm{him}$ : the leafe on nne fide of thenerue is alwaies longer than on theother. On thefe leaues oftentimes growblifter; or fmall bladders, in which at the fpring are litrle wormes, about thebignefle of Eed-fleas. This Elme is common it all parts of England, where I hauc trauelled.

Vlmus min or folio angufto fabro.

The Narrow leaued Elme.

2 This tree is like the other, but much leffer and lower, the leaues arevfually about two inches and a hal fe long, and an ineh or an inch and a quarter broad, nick tor indented about the edges, and hath one fide longer than the orher, as the firft hath, and are allo harm or rough on both fides, the

I Vlnus vilgatiff. folio lat o fabro. The common Elme tree. Uema: Camjoritis a a

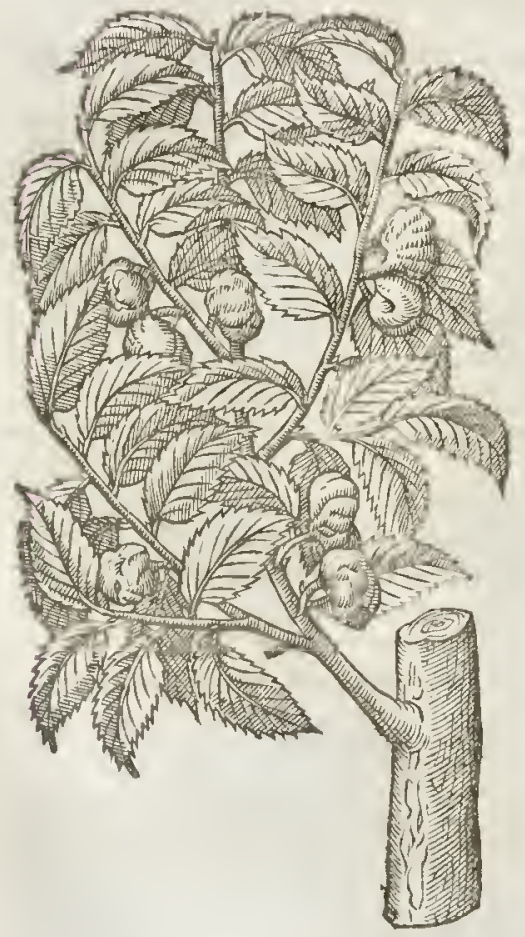

$\ddagger 2$ Vlmes minor folio augrito fabro.

The narrow leaued Eime.

quanes Canprestris - Var. $\beta$

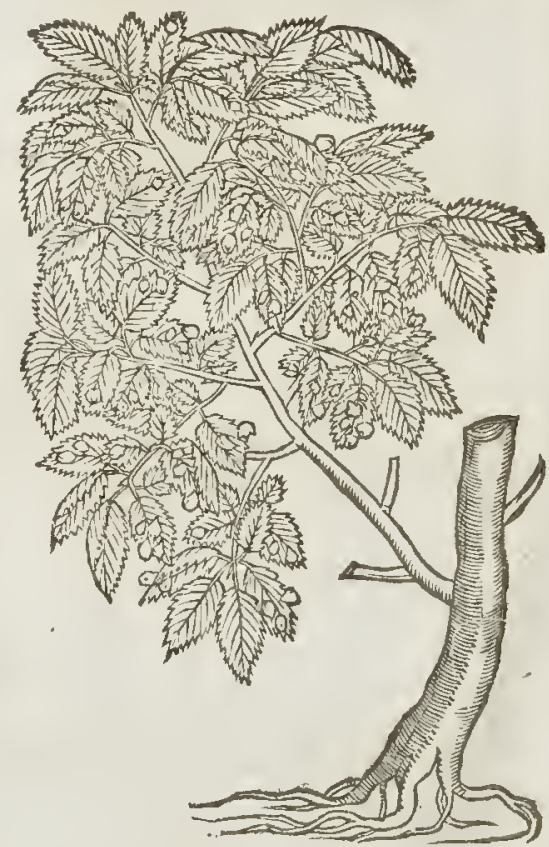

barke or rindewillalifo frip as the firft doth : hitherto $I$ haue not obferued either the foures or feed, or blifters on the leaues, nor have I had any fight of the timber, or heard of any vfe thereof This kinde I hatue feene growing but once, and that in the hedges by the high way as I rode betweene Chrif Church and Limmington in the New Forref in Hampthire, 
L $1 \mathrm{~B} .3$ Of the Hiftory of Plants.

about the middle of September 1634 . from whence I brought fo ne fnall plants of it, not a foos in length, which now, 1633 . are rifen vp ten or twelue foot high, and grow with me by the firt kinde, but are cafily to be difcerned a part, by any that will looke on both.

\# 3 Plinus folio latifimo frabro.

Witch Hafell, ot the broadelt leaned Elme. Ulmons effusa. Mriedenow. Sp:De-

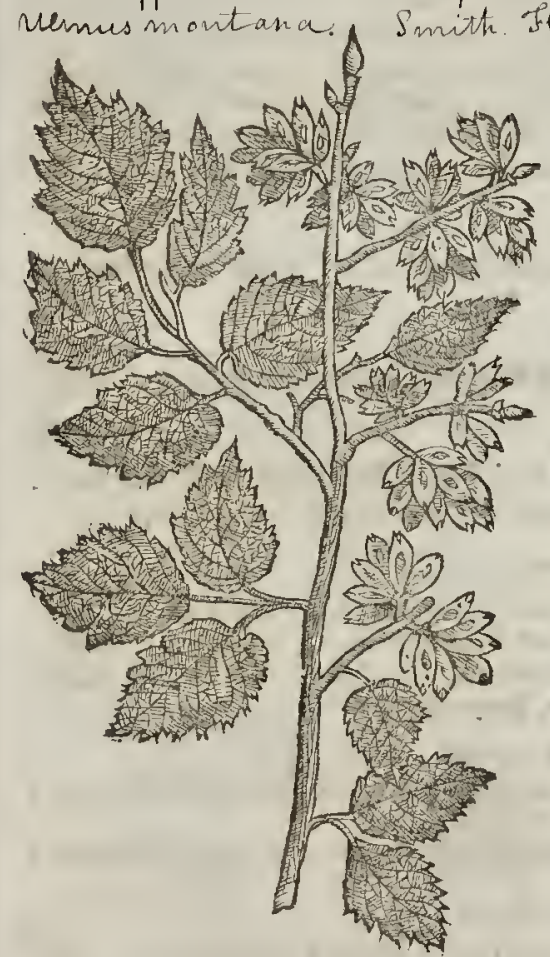

4 Vimus foliog glabro.

Witch Elme, or fmooth leaued Elme; ulems effusa. Wilden. Sp PR. $\beta$

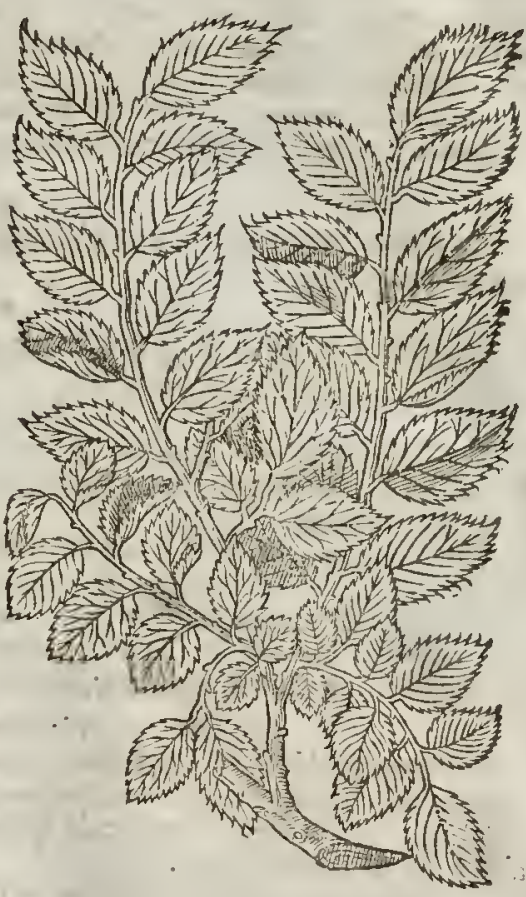

Vlmiss folio lat:fimo fabro.

Witch Halell, or the broadent leaued Elme.

3 This groweth to bea very great tree, and alfo very high, efpecially when he groweth in woods amongft other trecs: the barke on the ourfide is blacker than that of the firf, and is alfo very tough, fo that when there is plenty of fap it will frip or pecle from thewool of the boughes from the one end to the orther, a dozen fost in length or more, without breaking, whereof are often made cord's or ropes : the timber hercof is in colour neere like the firftit is nothing fo firme or ftrong for natres of Carts as clse fruit is, but will more eafily cleaue; this timber is alfo courered with a white fappe next the barke: the branches or young boughes are gro fer and bigger, and do fpread themfelues brolder, and hang more downewards than tho?e of the firft; the floures are nothing but chiues, very like thofe of the firf kind: the feed is alfo like, but fonething bigger : the leaues are nu:rch brouder and loajer than any of the kindes of Elma, vfully three or foure inches broxd, and fue or fix inches long, alfo rough or harih in handling on both fides, fnipt or indented abour the edges, necre refem'Jling the leaues of the Hatell: the one fide of the leaues are alfo noft con no:ly lonzer than the other, alfo on the lea:tes of this Elma are fo natin:3 blifters or bladders like tho e on the firt kinde. This profpereth and naturally groweth in any foile moift or dry, on high hills and in lorvallies in goud plenty in mot places in Humplhire, wher it is commonly calleJ V Vitch $\mathrm{H}$ afell. Old men affirme, that when long boughes were in greas we, there were vary many nude of thewond of this tree, for which purpore it is mantioned in the fratutes of Eng 9 nd by the name of V Vitch Hafell, as $8 . E l$. 10. This hath little affinicie with Carpiniss, which in Effex is called VVitch Hafell. 


\section{Vlmus folio glabro. \\ VVitch Elme, or finooth leauen Elme.}

4. This kinde is in bigneffe and height like the firft, the boughes grow as thofe of the VVitch Hafell doe, that is hanged more downewards than thofe of the common E!me, the barke is blacker than that of the firft kinde, it will alfo peele from the boughes : the fioures are like the firft, and fo are the feeds: the leaucs in torme are like thofe of the firlt kinde, tut are fimcoth in handing on both fides. My worthy friend and excellent Herbarift of happy momorie $M^{2}$. ' $W i M_{i m}$ am Coys of Stubbers in the parin of Northokington in Effex told me, that the woud of this kinde was more defired for naues of Carts than the wood of the firft. I obferued it growirg very plentifully as I tode between Rumtord and the faid Stubbers, in the yeere 1620 . intermixed with the frift kinde, but eafily so be arfccrned apart, and is in thofe parts vftally called VVitch Elme. $\ddagger$

$$
\text { T The Place. }
$$

The firt kinde of Elat g groth plentifully in all places of England. The reft are fet foth in their defcriptions.

$$
\text { बा The Time. }
$$

The feeds of the Elme fheweth it felfe firt,and befote the leaucs; it falleth in the end of Aptill, at what time the leaues begin to fpring.

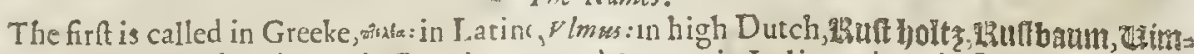
baum : in low Dutch, Dimen : in French, orme, and o me ast : in Italian, Olms. in Spanin, Ylimo : in Englim, Elme tree.

The feed is named by $r$ linit and Columella, samera. The little wotmes which are found with the ligino within the fmall bladders be named in Greeke, ufms; in Latine, Culices, and Muliowes.

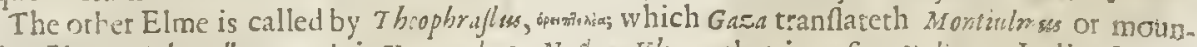
taine Elme Columell, nameth it Vernacula, or Noftras Vlmess, that is to fay, Italica, or Italian Elne : it is called in low Dutch, ertelcer, and in fome places,

a) The Temperatureand Vertues.

The leaues and barke of the Elme be moderately hot, with an euident clenfing facultie; they have in the chewing a certaine clammie and glewing qualitie.

B

The ieaucs of Eline glew and heale vp greene wounds, fo doth the barke wrapped and fwadled abour the wound like aband.

C The leaues being ftamped with vineger do take away fcurffe.

$\mathrm{D}$ geth flegme.

E The decoction of Elme leaues, as alfo of the batke or root, healeth broken bones very fueedily, if they be fomented or bathed therewith."

The liquor that is fornd in the blifters doth beautifie the face, and fcouterh away all foots, freckles, pimples, fpreading tetters, and fuch like, being applied thereto.

G It healeth greene wounds, and cureth ruptutes newly made, bcing laid on with Spleenwoort and the truffe clofely let into it.

\section{CHA P.I17. Of the Line or Linden Tree:}

$$
\text { Ti The Defiripion. }
$$

I He female Line or Linden tree waxeth very great and thicke, fpreading forth his bratr ches wide and farre abroad, being a tree which yeeldeth a moft pleafant thadow, tndes and within whofe boughes may be made braue fommer hou fes and banqucting arbors, becaufe the more that it is furcharged with weight of timber and fuch like, the berter it doth fourifh. The barke is brownin, very fmooth, and plaine on the out fide, but that wlicb is next to the timber is white, moift and tough, feruing very well for ropes, ttafes, and halters. The timber is whitith, plaine and without knots, yea very foft and gentle in the cutting or handling. Better gunpouder is made of the coles of this wood than of VVillow coles. The leaues are greene, 


\section{$\mathrm{L}_{1 \mathrm{~B} .30}$ Of the Hiftory of Plants.}

1483

fmooth, hining and large, fomewhat fnipt ot toothed about the edges: the floures are little, whi tim, of a good fauour, and very many in number, growing cluftering together from out of the middle of the leafe: out of which proceedeth a fmall whitifh long natrow leafe : after the floures fucceed cornered harpe pointed Nuts, of the bigneffe of Hafell Nuts. This tree feemeth to be a kinde of Elme, and the people of Efex abour Heningham (wheras great plenty gtowethby the way fides) do call it broad leafed Eilme.

I Tiliafemina.

The fernale Line ttec.

Silia Europea.

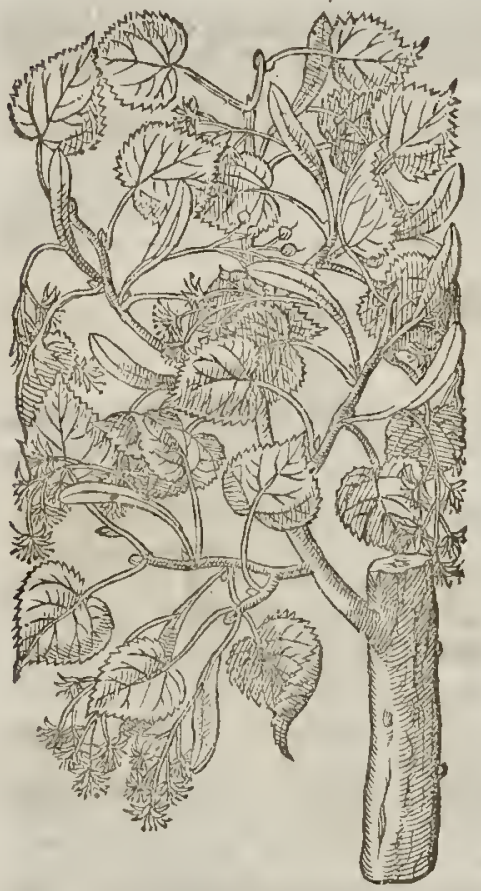

2 Tilia mo:

The male Line ttee.

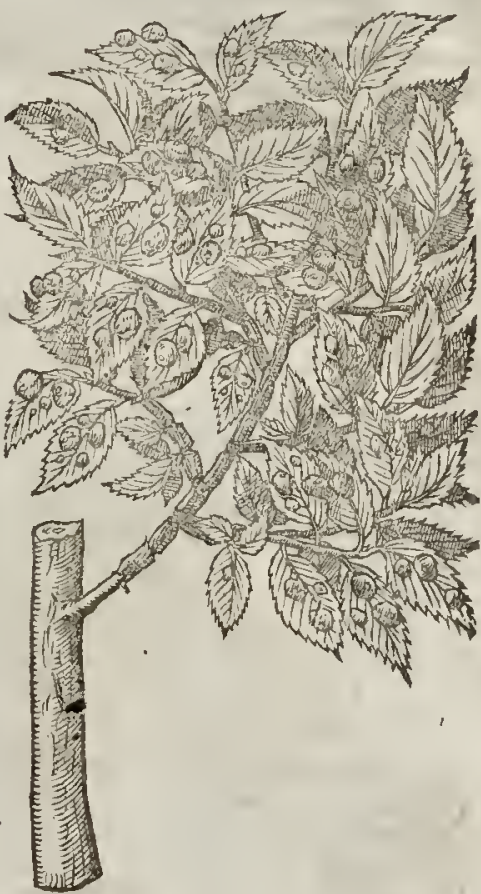

2 The male Tilia ot Line tree groweth alfo very great and thicke, fpreading it felfe fat abroad like the other Linden ttee: his bark is very tough and pliant, and ferueth to mate cords and halters of. The timber of this tree is much harder, mote knottie, and more yellow than the timber of the other, not much differing from the timber of the Elme tree: the leaues hereof are not mirch vnlike Iuy leaues, not very greene, fomewhat finipt about the edges: from the middle whereof come forth clufters of little white floutes like the formerwhich leing vaded, there fucceed fmall round pellets, growing cluftering together, like Iuy berries, within which is contained a little roundb lack in feed, which falleth out when the berry is tipe.

\section{T The Place.}

The female Linden tree groweth in fome woods in Northampton fhire; alfo neere Colchefter, and in many places alongt the high way leading from London to Henningham, in the countie of
Efrex.

The male Linden tree groweth in my Lord Treafurers garden at the Sttand; and in fundry other places, as at Barn.elnes, and in a garden a 3 aint Katherines neere London. $\neq$ The female gtowes in the places here named, but I haue not yet obferted the male. $\neq$

$$
\text { It The Time }
$$

Thefe trees floure in May, and their fruit is ripe in Auguft.

$$
\text { of } T \text { he resmes. }
$$

The Linden tree is called in Greeke wasp: in Latine, Tilia: in high Dutch, Linder, and Minden: baum : in low Dutch, Linde, and limbenboom : the Italians, Tilis : the Spariards, Teia in French, Tilet and $\tau$ iheerl: in Englih, Liaden tree, and Line trce.

$$
\text { Iiiisi }
$$


1484

Of the Hintory of Plants:

L18. 3.

Ti The Timperature.

The barke and leaues of the Linden or Line tree, are of a temperate heat, fomewhat drying and afringent.

\author{
बi The Veriucs.
}

A The leanes of $\mathcal{A}$ ilia boiled in Smithes water with a piece of Allom and a little honey, cure the fores in childrens mouthes.

B The leaues boiled vntill they be tender; and pouned very fmall with hogs greafe, and the pouder of Fenugreeke and Linefeed, take away hot fwellings and bring impoftumes to maturation. being applied theretovery hot.

C The foures are commended by diuers againft paine of the head proceeding of a cold caufe: againftiffinelfe, the Apoplexie, and alfo the falling fickneffe, and not onely the floures, but the difilled water thereof.

(D) The leaues of the Linden (faitl $T$ beophraftus) are very fweet, and be a fodder for moft kinde of cattle: the fruit can be caten of none.

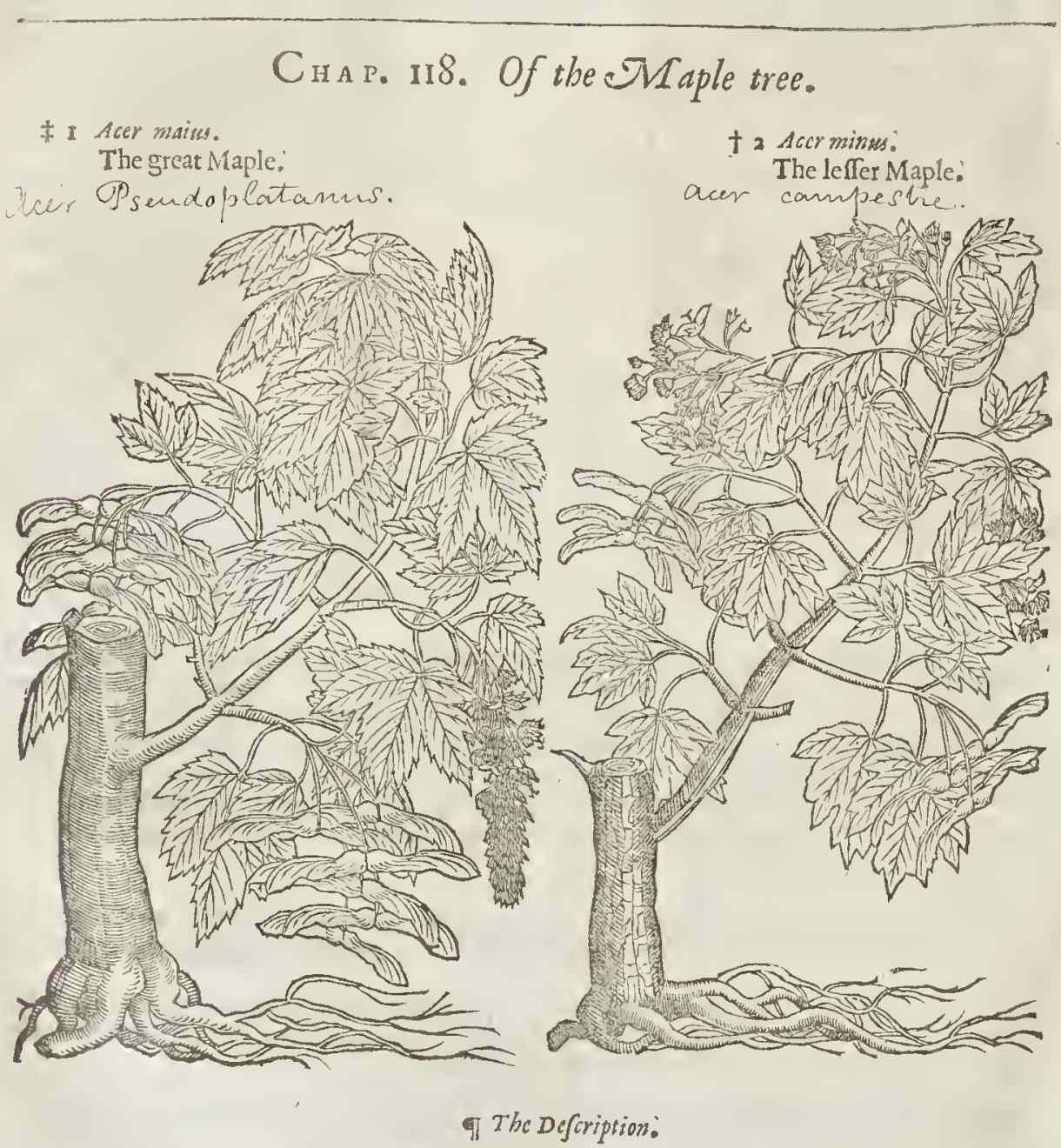

THe great Maple is a beautifull and high tree, with a barke of meane fmoothnelfe : the fub. 1 Aance of the wood is tender and eafie toworke on; it fendeth forth on euery fide very many goodly boughes and branches, which make an excellent hadow againt the heate of the Sun; vpon 
whieh are great, broad, and cornered leaues, much like to thofe of the Vine, hanging by long reddith ftalks : the floures hang by clufters, of a whitifh greene colour; after them eommeth vp long fruic faftened together by couples, one right againft another, with kernels bumping out neere to the place in which they are combined: in all the ocher parts flat and thin like vnto parehment, or refembling the innermoft wings of grafhoppers : the kernels be white and little.

2 There is a fmall Maple which doth oftentimes come to the bignes of a tree, but mont eommonly it groweth low afrer the maner of a hrub : the barke of the young thoots hereof is likewife fmoo:h; the fubftanec of the wood is white,and eafie to be wrought on: the leanes are enrnered like thofe of the former, lippery, and faltened with a reddifh ftalke, but mueh lefler, very like in bignes, and fmoothnes to the leafe or Saniele, but that the euts are deeper: the floures be as rhofr of the former, greene, yet not growing in clufters, but vpon fpoked roundles: the fruit ftandeth by two and two vpon a ftem or foot-ftalke.

\section{Tt The Place.}

The fmall or hedgeMaple groweth almoft euery where in hedges and low woods.

The great Maple is a franger in England, only it groweth in the walkes and plaeesof pleafure of noble men, where it efpecially is planted for the thadow fake, and vnder the name of Sycomore tree.

$$
\text { 9) The Time. }
$$

Thele trees floure about the end of Mareh, and their fruit is ripe in September.

$$
\text { If The Names. }
$$

This tree is ealled in Grecke orisoun : in Latine, Acer : in Englith, Maple, or Maple tree.

The great Maple is called in high Dutch, Hozme, and maloeschetne: the French men, Grand Erable, and $P$ tafrac abufutely, and this is thought to be properly called optsansos: but they are far deceiued that takc this for Platamus, or the Plane tree, being drawne into this errout by the neereneffe of the French word; for the Plane tree doth much differfrom this. $\neq$ This is now eommonly (yet not rightly)called the Syeomore tree. And feeing vle will have it fo, I thinke it were notvafit to eall it the baftard Syeomore. $¥$

The other is ealled in Latine, Acer minor : in high Duteh, moafinolder:in low Duteh,2Booghout: in Freneh, Erable : in Englioh, fimall Maple, and common Maple.

\section{If The Temperature and Vertues.}

What we the Maple hath in medicine we finde nothing written of the Greeians, but Pliny in his $A$ 14. booke,8.chapter affirmeth, that the root pouned and applied, is a fingular remedy for the paine of the liuer. Sercnus Sammonicus writeth, that it is drunke with wine againt the paines of the fide.

\section{Si latus immeritums morbotentatur acuto, Acceinfsmbinges lapidem ftridentibus wndis. Hinc bibis: aut Aceris radiccm tundis, \&u vns: Cum vino capis : hoc prafens medicamen babeur.}

Thy harme'effe fide if fharpe difeafe inuade, In hifling water quench a heated ftone: This drinke. Or Maple root in pouder made, Take off in wine, a prefent med'eine knowne.

\section{C н в. IIg. Of the Poplartree.}

$$
\text { If The Kindes. }
$$

Here be diuers trees vider the ticle of Poplar,yet differing very notably, as thall be declared in the deferiptions, whereof one is the white, another the blacke, and a third fort fee downe by $P l i$ 2ty, which is the Afpe, named by him Lybica;and by Theopbraftus, Rerkis: likewife thete is another of America, or of the Indies, which is not to befound in thefe regions of Eutope. 


\section{बi The Defcription.}

I The white Poplar tree commeth foone to perfection, and groweth high in thort time, full of boughes at the top: the barke of the body is fmooth, and that of the boughes is likewife white withall : the wood is white, eafie to be cleft : the leaues are broad, deeply gained, \& cornered like almoft to thafe of the Vine, but much leffer, fmooth on the vpper fide, glib, and fomwhat greene; and on the nether fide white and woolly : the catk ins are long, downy, at the firlt of a purplith colour : the roots fpread many waies, lying vnder the turfe, and not grow ing deepe, and therefore it tappeneth that thefe trees be oftentimes blowne downe with the wande.

I Populus alba.

The white Poplar trees oprivins alba.

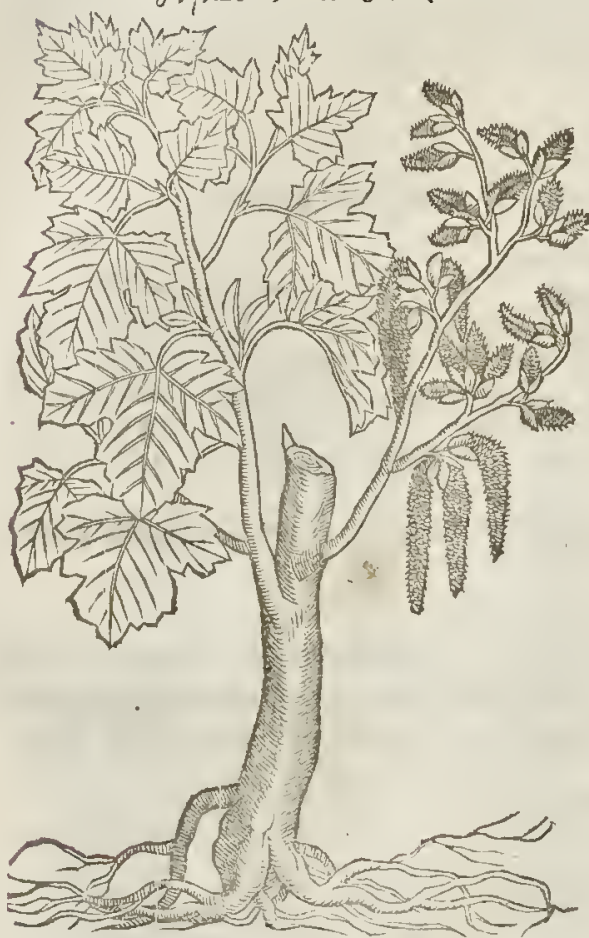

2 Populus nigra. The blacke Poplar tree.

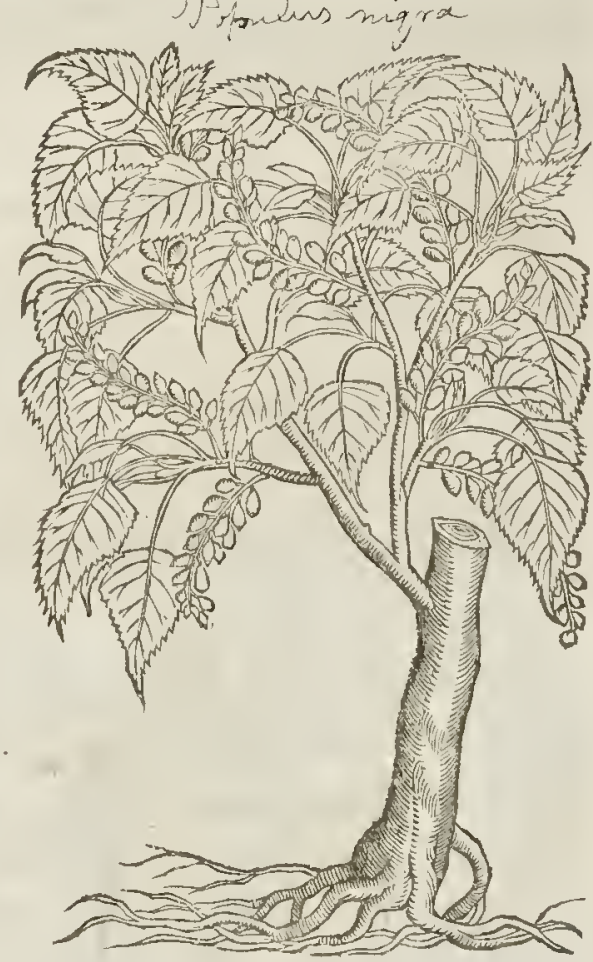

2 The black Poplar tree is as high as the white, and now and then higher, oftentimes fuller of boughes, and with a thicker body : the barke thereof is likewife fmooth, but the fubftance of the wood is harder, yellower, and not fo white, fuller of veines, and not fo eafily cleft:the leaues be fomwhat long, and broad below towards the ftem, tharp at the point, and a little fnipt about the edges, neither white nor woolly, like the leaues of the former, bur of a pleafant greene colour : amonget which come for th long agiers or catkins,which do turne into clufters : the buds which thew themfelues before the leaues fpring out, are of a reafonable good fautour, of the which is made that pro-
fitablcointment called Vnguentum Pepulcon.

3 The third kinde of Poplar is alfo a great tree: the barke and fubftanee of the wood is fomewhat like that of the former : this tree is garnifhed with many britrle and tender branches, fer full of leaues, in a manner round, mueh blaeker and harder than the blaeke Poplar, hanging vpon long and flender ftems,which are for the moft part ftil watering, and make a great noife by being beaten one to another, yea though the weather be calme, and fearee any winde blowing; and it is knowne by the name of the Af, en tree: the roots hereof are ftronger, and grow deeper into the ground than
thofe of the white Poplar.

4 This ftrange Poplar,which fome do call Populus rotund, folit, in Englin, the round leafed Poplar of India, waxecth a great tree, bede et with many goodly twigg ie branches, tough and limmer like 


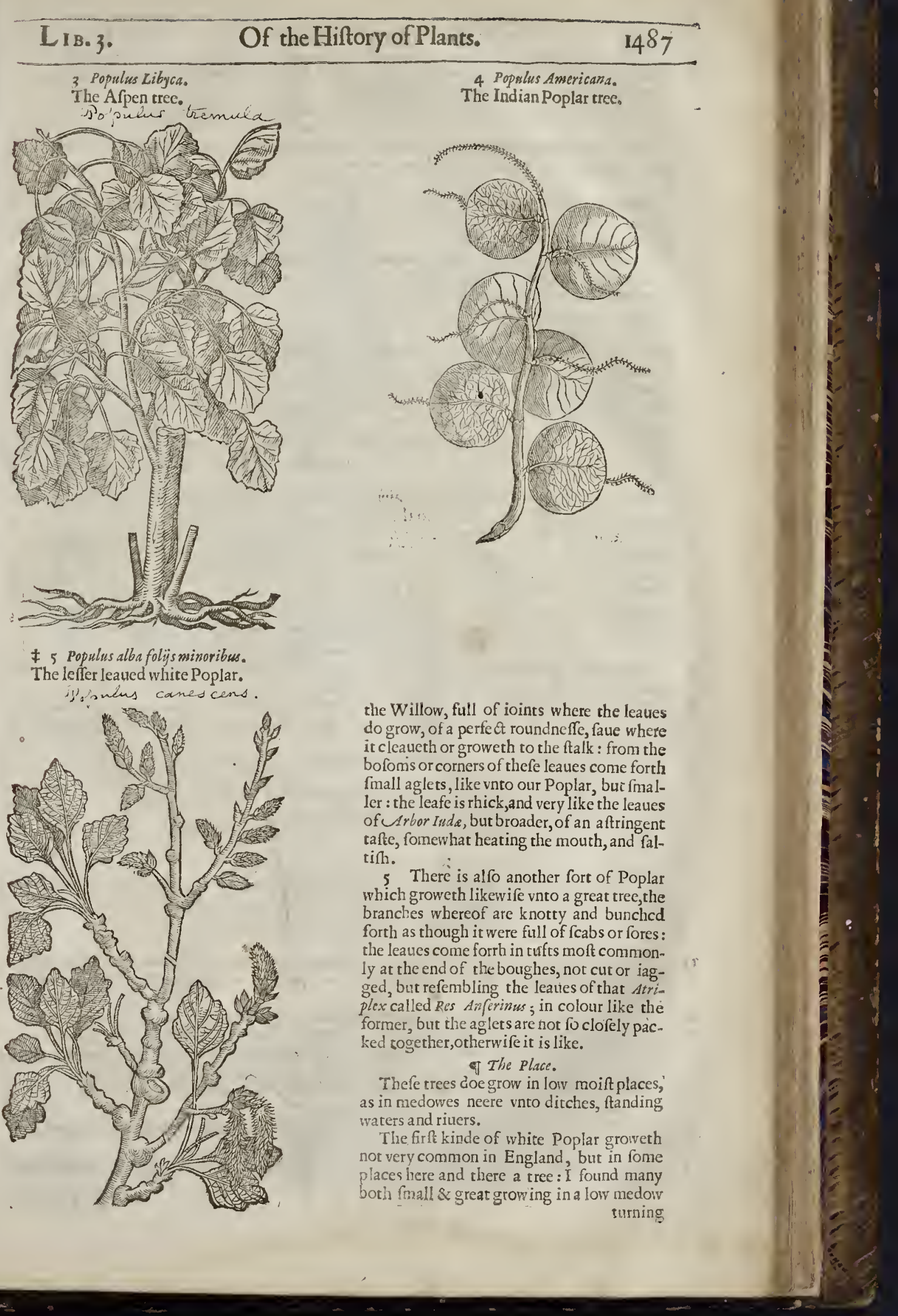


trung vp a lane at the farther end of a village called Black-wall, from London; and in Eflex at a place called Ouenden, and in diuers other places.

The Indian Poplar groweth in mont parts of the Iflands of the Wcet Indies. -1 The Time.

Thefe trees do bud forth in the end of March and beginning of A prill, at which time the buds mutt be gathered to ferue for Vrguentum Yopuleon. of The Names.

The white Poplar is calied in Greeke, Aturn : in Latine, Poprulus alba : of diuers, Farfarus, as of Plautus in his Comedie Pcrulhis, as you may fee by his words fet downe in the chap. of Colts-foot, pas. 813.

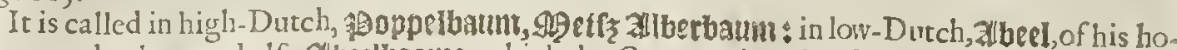
rie or aged colour, and alfo Zlbeeloosme; which the Grammarians doe fally interpret 4 bies, the Firre tree : in Italian, Popolonero : in French, Peuplier blane, Aubel, Obel, or Aubent : in Englifh, white Poplar tree, and Abeell, after the Duteli name.

The fecond is called in Greeke, Airmer: in Latine, Populus nigra : by Petrus Crefcentius, Alburus: in high-Dutch, alfpen : in low-Dutch, foppulier : in Italian, Popolo nero : in French, Peupliernoir : in Spanifh, Llamo n:gallho : in Engliih, Poplar tree, blacke Poplar, and Pepler. The firft or new fprung buds whereof are cal!ed of the A pothecaries, o culi Popul, Poplar buds : others chufe rather to call it Gemma Populz : fone of the Grecians name it zming : w whereupon they grounded their error, who rafh ly fuppofed that thofe rolenny or clammy buds are not to be put or vfed in the compofition of the ointment bearing the namc, of the Poplar, and commonly called in Englifh, Popilion and Pompillion, but the berries that grow in clufters, in which there is noclammineffe at all.

They arealfo as far deceiued, who giuing credit to Poets fables, do beleeue that Ambercommeth of the clammy rofin falling into the riter Poo.

The third is called of diners, fopulus tremula, which word is borrowed of the French men, who name it $T$ remble : it alfo receitued a name amongft the low-Countrey men, from the noife and rat-

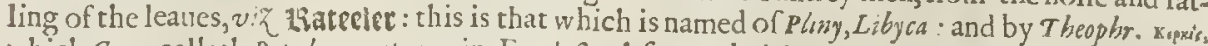
which Graacalleth Poprlus montans, in Englin, Afpe, and Aipen tree, and may alfo be called Tremble, after the French name, confidering it is the matter whereof womens tongues were made, (as the Poets and fome others report) which feldom ceafe wagging.

$$
\text { of The Temperature and vertues. }
$$

A The white Poplar hath a clenfing facultie, faith Galen, and a mixt temperature, confifting of a waterie warme effence, and al $\delta$ a thin earthy fub ftance.

B The barke, as Diofcorides writeth, to the weight of an ounce (or as others fay, and that more truly, of little more than a dram) is a good remedie for the Sciatica or ache in the huckle bones, and for the ftrangurie.

C That this barke is good for the Sciatica, serenus summonicus doth alfo write:

Sapius occultus victa coxendice morbus

Perfurit, \& greffus dirolanguore moratur:

Populus alba dabit medicos de cortice potus.

An hidden difeafe doth oft rage and raine,

The hip ouercome and vex with the paine,

It makes with vile aking one tread flow and thrinke;

The barke of whitc Poplar is helpe had in drunke.

D The famebarkc is alfo reported to make a woman barren, if it be drunkewith the kidney of a Mule, which thing the leawes likewife are thought to perform, being taken after the foures or reds
be ended.

E The warme itice of the leates being dropped into the eares doth take aw ay the paine thereor.

I. The rofin or clammy fubftance of the blacke Poplar buds is hot and dry, and of thin parts, atte. nuating and mollifying : it is alfo fitly mixed acopu for malagmat is : the leaues haue in a manner the like operation for all thefe things, yet weaker, and not fo effe atuall, as $G$ alen teacheth. G The leaues and yong buds of blacke Poplar doe affwage the paine of the gout in the hands or

H The ointment made of the buds is gond againft all inflammations, brufes, fquats, falls, and fuclt like : this ointment is very well knowne to the A pothecaries.

I Panlus eEginet a teacheth to make an oile alfo hereof, called Egyrinum, or oile ofblacke Poplar. 


\section{$\mathrm{C}_{\mathrm{Ha}} \mathrm{P}, 120$. Of the Plane tree.}

Platanus.

The Plane tree.

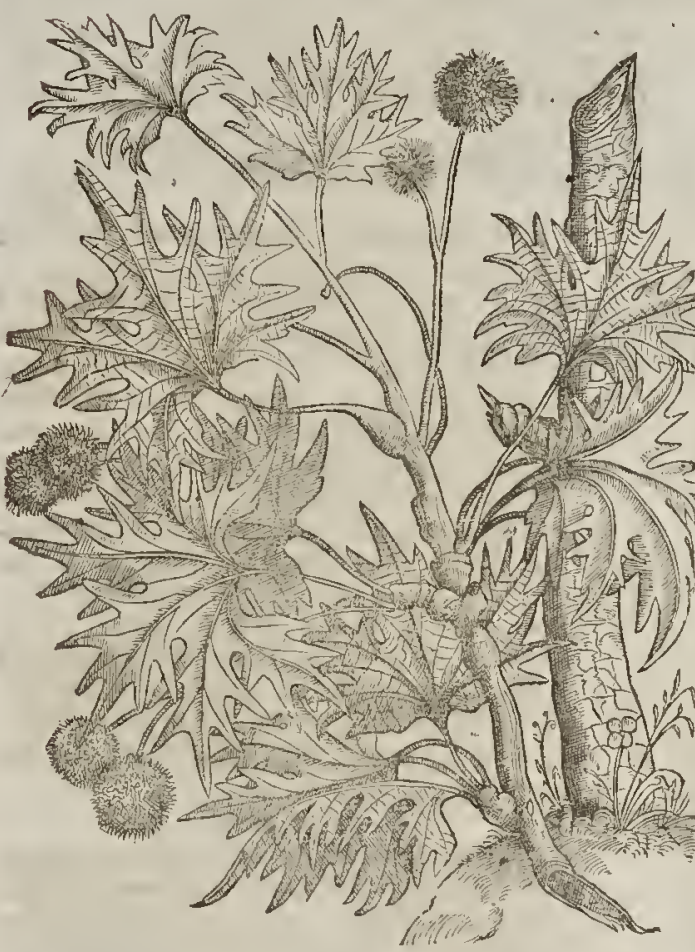

ब1 The Defription.

He Plane is a great tree, hauing very long and farre fpreadino boughes calting a wonderfull broal thadow, by reaton wherof it was highly commended and eiteemed of among the old Romans: the leaues are cornered like thofe of Palma Chrift, greater than Vine leaues, and hanging vpon little red foot-falkes : the foures are fmall and mofite, and of a pale yel. lowith colour : the fruit is round like a ball, rugged, and fomewhat hairy; but in A fia more hairy and greater, almolt as bigas a Walnut: the root is great. difperfing it felfe far abroad.

$$
\text { q) The Place. }
$$

The Plane tree delighteth to grow by fprings or riuers : Pliwy reports that they were wont to be cherinhed wich wine: they grew a fterward(faith he) to be of fo great honour (meaning the Plane trees) as that they were cherifhed and watered with wine: and it is found by cxperience that the fame is very comfortable to the roots, and ivee hatie alseadie taught, that trees defire to drinke wine. This tree is frange in Italy, it is no where feene in Germany, nor in the low-Countries: in A fia ic groweth plentifully: it is found alfo in Candy, growing invallies, and neere vinto the hill Athos, as Petrus Bellonius in his Singularities doth declare : it groweth in many places of Grecee, and is found planted in fonce places of Italy, for pleafure rather than for profit. My feruant Walliam CMar/hall (whom I fent into the Mediterra. nean fea as Surgeon vnto the Hereules of London) found diuers trees hereof growing in Lepantn, hard by the fea fide, at the entrance into the towne, a port of Morea, being a part of Greece, aud from thenee btought one of thofe rough buttons, being the fuit thereof. $\ddagger$ There are one or two yong ones at this time growing with $\mathrm{M}^{\mathrm{r}}$. Tradefcailt. $\ddagger$

The Plane trces eaft their leaves in Winter, as Ecllonius teftifieth, and therefore it is no maruel that they keepe away the Sun in Sommer, and not at all in Winter : there is, faith Pliny, no greater commendation of the tree, than that it kecpeth away the Sunne in Sommer, and entertaineth it io Winter.

$$
\text { 9 } T \text { he Names. }
$$

- Thistree is ealled in Grecke, mirar: and likewife in Latine Platanus : it beareth his name of the bredth : the French mens Plagnedoth far differ from this, which is a kind of Maple: this tree is naned in Englih, Plane tree.

$$
\text { था Tlie Temperature and F"crues. }
$$

The Plane tree is of a cold and moifteffenee, as Galen faith : the greene leanes are good to be $\mathbb{A}$ laid vpon hot fwellings and inflammations in the beginning.

Being boiled in wine they are a remedie for the running and thewatering of the eyes, if they be $B$ applied.

The barke and balls do dry :the barkeboiled ia vineger helpeth the tooth-ache,

The fruit of the Plane tree drunke with wine lselpeth the bitings of mad dogs and ferpents, and $\mathrm{C}$ mixed with hogs greafe it maketh a good ointment againft burning and fealding. - The burned barke doth mightily dry, and feoureth withall; it remoueth thewhite fcurfe, and cu- D reth moif vlcers. 
F The duft or downe, faith Galen, that lieth on the leaues of the tree is to be taken heed of, for if it be drawne in with the breath, $i$ is offenfue to the winde-pipe by his extreme drineffe, and making the fame rough, and hurting the voice, as it doth alfo the fight and hearing, if it fall into the eyes or cares. Diofcorides doth not attribute this to the duft or downe of the leaucs onely, but alfo to that of the balls.

\section{Cha p. I2I.}

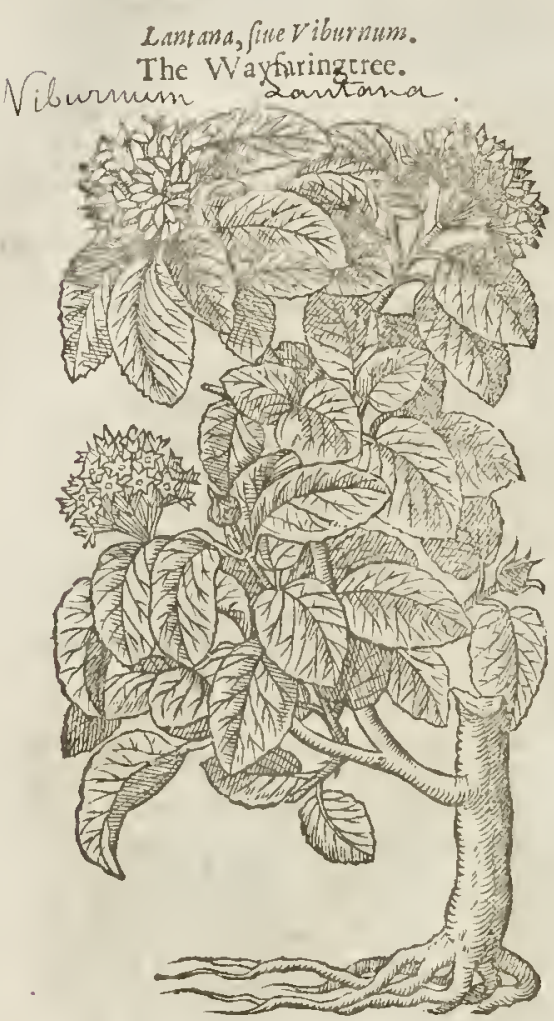

\section{Of the Wayfaring Tree.}

\section{If The Deforiplion,}

T. He Wayfaring mans tree growes vp; to the 1 height of an hedge tree, of a mean bignes: the trunke or body thereof is conercd with a ruffet barke : the branches are long, tough, and cafic to be bowed, and hard to be broken, as are thofc of the Willow, couered with a foft whitin trarke, whereon are broad leaues thicke and rough, flejghtly indented about the edges, of a white colour, and fomew hat hairy whileft rhey. be frefhasd grcen; but when they begin towither and fall away, they are reddifh, and fet together by couples one oppofit to a nother. The floures are whire, and grow in clufters : aftcr which come cluters of fruit of the bigneffe of a peale, fomewhat fiat on both fides, at the firf greene, after red, and blacke when they be ripe: the root dilperfeth it felfe far abroad vnder the vpper cruft of the earth.

$$
\text { a) The Place. }
$$

This tree groweth in moft hedges in rough and ftony places, vpon hils and low woods, efpecially in the chalky grounds of Kent about Cobham, Southfleet, and Gramefend, and in all the tract to Canturbury.

$$
\text { of The Time. }
$$

The floures appeare in Sommer : the berries arc ripe in the end of Autumnc, and new leaues comc forth in the Spring.

This hedge tree is called Viurn of Ruellius : in French, Viorne, and Fiorna : in Italian, Lantama : it is reputed for the trec Viburnum, of which Virgilmaketh mention in the firft Eclog, whcre hee commendeth the city Rome for the loftineffe and ftatelineffe thereof, abouc other Cities, faying, that as the tall Cypres trees do thew themfelues aboue the low and Thrubby Viorn, fo doth Rome aboue other cities lift vp hor head very bigh ; in thefc verfes:

\section{Verum bactantion alias inter cuput exulit orbes, Quantum lenta folent inter viburna cupresi.}

But this all other citics fo excels, As Cyprcffe, which 'mong t bending Viornes dwels.

¥ I iudge Viburnum not to be a name to any particular plant, but a generall name to all low and bending thrubs; among $\mathrm{t}$ which this here dcferibed may take place as one. I enquired of a countrey man in Effex, if he knew any name of this: he anfwered, it was called the Cottontree, by. reafon of the foftneffe of the leaues. $\ddagger$

बI The Temperature.

The leates and berries of Lantana arc cold and dry, and of a binding qualitie. 
L 1 เ. 3.

\section{The Dertues.}

The decottion of the leaues of Lantana is very good to be gargled in the mouth againt al fwel- A lings and inflammations thereof, againft the fcuruic and other difeafes of the gumsyand faftneth loof teeth.

The fame boiled in lee doth make the haires blacke if they be bathed ur wafhed therewith, and $B$ fuffered to dry of it felfe.

The berries are of the like facultie, the pouder whereof when they be dried ftay the laske,all if $\mathrm{C}$ fues of bloud, and alfo the whites.

It is reported, that the barke of the root of the tree buried a certaine time in the carth, and after- $D$ wards boiled and famped according to art, maketh good Bird-lime for Fowlers to catch Birds with.

\section{Chap.122. Of the Beade tree.}

\section{Zizyphacandida. \\ Melia The Besdetree}

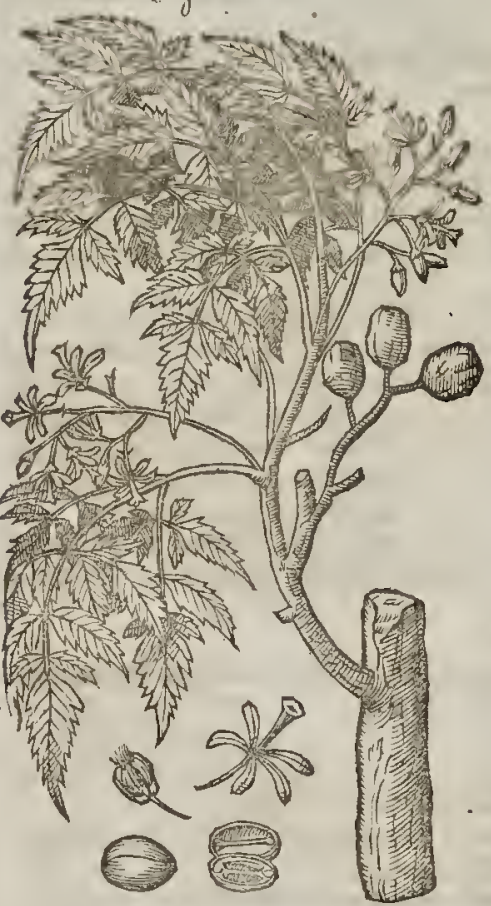

₹ Zinypha Cappadocica.

The Beade tree of Cappadocia.

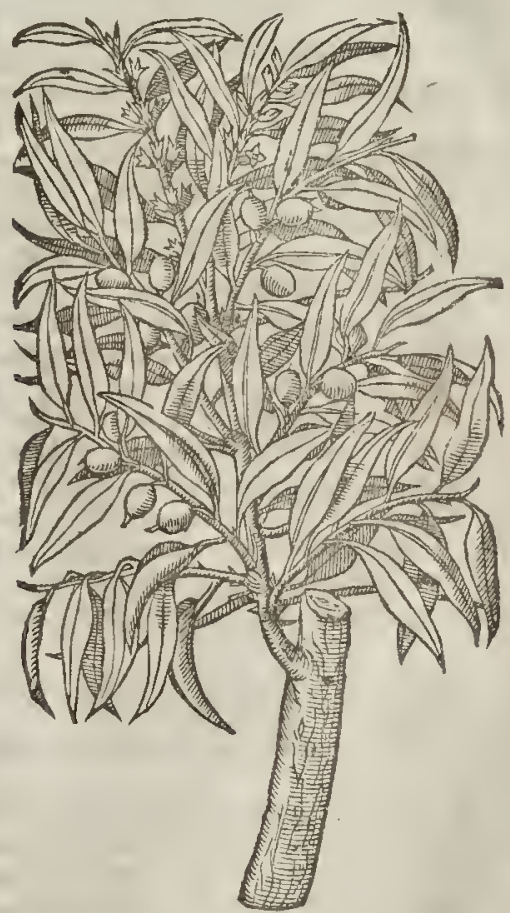

बा The Defcription.

I THis treewas called Zizypha candidaby the Herbarifts of Montpellier; and by the Vene: 1 tians and Italians, sycomorus, but vntruly : the Portugals have termed it Arbor Paradizo: all which and each whereof haue erred together, both in refpeet of the fruit and of the whole tree : fom hatc called it $z i \approx y p h a$, though in facultie it is nothing like, for the tafte of this fruit is very vnpleafant, virulent, and bitter. But deciding all controuerfies, this is the tree which Atsices calleth. Azeder.ach, which is very great, charged with many large armes, that are garnithed with twiggie branches, fet full of great leates confiting of fundry fmall leates, one grow ing right oppofite to another like the leaves of the Afh tree or Wicken tree, but more deepely cut about the cdges like the teeth of a faw : among which come the floures, confifting of fiue fmall blew leates laydabroad in manner of a ftarre: from the middeft whereof growerh forth a imall hollow cup refembling 
refembling a Chalice: after which fucceedech the fruic, couered with a brownith yellow thel, very like vnio the fruic of luiubes (whereof $D$ odonews in his laft edition maketh it a kind $*$ ) of a raneke, bitter, and vnplealant tafte, with a fix cornered ftone within, which being drawne on a ftring, ferneth to make Beades of, for want of other things.

2 Zizyphus Cappadocica growerli not lo great as the former, but is of a meane ftature, and full of boughes:the barke is fmooth and cuen, and that which growcth vpon the trunke and great boughes is of a fhining fcarlet colour: out of the fe great armes or boughes grow lender twigges, white and foft, which are fet full of whitim leaues, but more white on the contraric or backe part, and are like to the leaues of Willow, but narrower and whiter: among thefe leaucs come forth fmall hollow yellowith floures, growing at the ioints of the branches, moft commonly three together, and of a pleafant fanour, with fome few threds or chives in the middle thereof. After which fuccedeth the fruit, of the bigneffe and fathion of the fmallef Oliue, white both within and without, wherein is contained a fmall ftone which yecldeth a kernell of a pleafans tane, and very fiveet.

$$
\text { The Place. }
$$

Matthiolus writetl, that Zizyphus candida is found in the cloifters of many monafteries in Iraly; Lobel faith that it groweth in many places in Venice and Narbon; and it is wont now of late to be planted and cheriohed in the goodlieft orchards of all the low -Countries.

Zizyphus Cappadocica groweth likewife in many places of Italy, and fpecially in Spainc: it is alfocherithed in gardens both in Germany and in the low-Countries. \& It groweth alfohere in rhe garden of $\mathrm{M}^{\mathrm{r}}$. Io hri Parkinfon. $\ddagger$

\section{T The Time.}

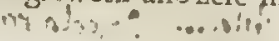

Thefe trees foure in Itune in Iraly and Spain ; their fruit is ripe in September; but in Gunany and the low-Conntries there doth no fruit follow the floures.

\section{T The Names.}

Zizyphus candida Auicen calleth $A$ zederach, or as diuers read it, Aqederaeih:and they name it, faith he, in Rechi, Arbor Mirobalanorum, or the Mirobalane tree, but not properly, and in Tabraften, and $\mathrm{Kien}$, and Thihich. The later writers are far deceiued in taking it to be the Sycomore tree; and they as much, that would hauc it to be the Loteor Nettle tree: it may be named in Englin, Bead tref, for the caufe before alledged.

The other is alter a pecies Zizyphi, or the fecond kinde of Iuiube tree, whieh Columella in his ninth booke and fourth chap. dothcall $z_{i z y p h s s}$ alb $a_{3}$ or white I uiube tree, for difference from the other that is fyrnamed Rutila, or glittering red. Pliny calleth this 2 izyp ninth chapter, where he entreaterh of the honour of rariands, of which he faith there be two forts, whereof fome be made of floures, and orbers of leaues: I would call the floures (faith he)brooms, for of thole is gathered a yellow floure, and Rljodederdron, alfo Zizypha, which is called Cappadocica. The floures of the fe are fweet of fmell, and lil e Oliue foures. Neither doth Colunella or Pliny vnaduifedly take this for Zizyphrs, for both the kaucs and foures grow out of the tender and yong fprung twigs, as they likewife do our of the former: he foures are very fweet of fmel, and calt their fauor far abroad: the fruit allo is like thac of the former.

\section{The Tempersture.}

Auicen writing and intreating of $A$ zadaracth, faith, that the foures thereof be hot in the third degree, and dry in the end of the firn.

$Z$ izyplous cappadocica is cold and dry of complexion.

\section{9) The Verises.}

A The floures of $Z$ izyphus, or $A$ zadurath open the obftuctions of the braine.

B The difilled water thereof killerh nits and lice, preferueth the haire of the head from falling. cfpecially being mixed with whirewine, and the head bathed with it.

C The fruit is very hurtfull to the cheft, and a troublefome enemic to the ftomacke; it is dange-
rous, and praduenture deadly.

D Moreouer, it is reported, that the decoetion of the barke and of Fumitorie, with Mirobalans added, is good for agues proceeding of flegme.

E The iuice of the vppermoft leaues with honey is a remed ic againft poifon.

F The like alfo hath $R$ hafis : the Beade tree, faith he, is hot and dry : it is good for ftoppings of the head, it maketh the hairelong; yet is the fruit thereof very offenfue to the fomacke, and of tentimes found to be pernitious and deadly. Mattholus writeth, that the leaues and wond bringeth death euen vnco beafts, and that the poy-
fon thereof is refifted by the fame remedies that 0 loander is.

H $Z$ iz vphus Capprdocica preuaile th againft the difeafes a forefaid, but the decontion thercof is verie good for thofe whofe water fcaldeth them with the continuall iffuing thereof, as alfo for fuch as hate the running of the reines and the exulcerations of the bladder and priuy parts. 
L1 $3.3 . \quad$ Of the Hiftory of Plants.

A looch ot licking medieine made thereof or the fyrrup, is exeellent good againft fpitring of $G$ bloud proceeding of the difillations of tharpe or falt humors.

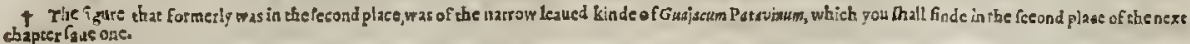

\section{Cha P. I23. Of the Lote, or $\mathcal{X}$ (ettle tree.}

Lotus arbor.

The Nettle tree.

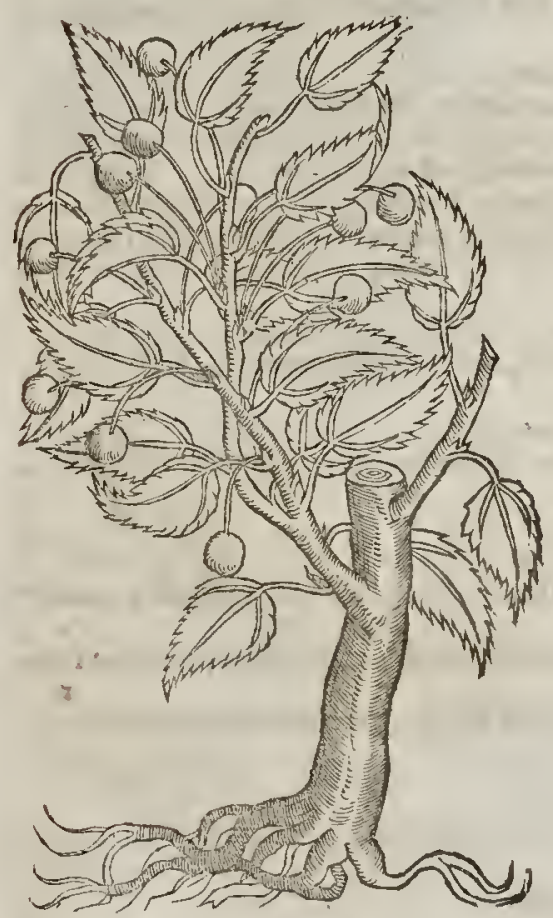

9ा The Defripcion.

$T^{H e}$ Lote whereof we write is a tree as big as a Peare tree,orbigger and higher: the body and armes are very rhieke; the barke whereof is fmooth, of a gallant green colour tending to blew neffe : the boughes are long, and fpread themfelues all about : the leaues be like thofe of the Nettle, Tharpe pointed, and nieked in the edges like a faw, and dath here and there with ftripes of a yellowin white colour : the berries be round, and hang vpos long ftalkes like Cherries, of a yellowith whitecolour at the firft, and after. wards red, but when they be ripe they be fomerwhat blaeke.

$$
\text { 9) The Place. }
$$

This is a rare and ftrange tree in both the Germanies : it was brought out of Italy, where there is found fore thereof, as $M$ ats $h$ iolus teftifieth: I haue a fmall tree thereof in my garden. There is likewife a tree chereof in the garden vnder London wall, fometime belonging to $\mathrm{M}^{\mathrm{r}}$. Gray, an Apotheeary of London; and another great tree in a garden neere Coleman ftreet in London, being the garden of the Queenes Apotheearieat the impreffion hereot, ealled $M^{r}$, Hugh Morgan, a curious conferuer of rare fimples. The Lote tree doth alfo grow in Africke, but is fomewhat differeth from the Italian Lote in fruit, as Pling in plaine words doth thew in his thirteenth booke, feventeenth ehapter. That part of $A$ rieke, faith he, that lieth towards vs, bringeth forth the famous Lote tree, which they eall Celt is, and rhe fame well knowne in Iraly, but altered by the foile : it is as big as the Prare tree, although 2 epos Cornelius reporreth it to be fhorter : the leaues are full of fine euts, otherwile they be thought to be like thofe of the Holme tree. There be many differenees, but the fame are made efpecially by the fruit: the fruit is as thig as a Beane, and of the colonr of Saffron, but before it is thorow ripe, it ehangerh his color as dorth the Grape. It growes thicke among the boughes, after the manner of the Myrtle, not as in Italy, after the manner of the Cherry; the fruit of it is there fo fweet, as it hath alfo giten a name to that countrie and land, too hofpitable to ftrangers, and forget full of their owne eountrey.

It is reported that they are troubled with no difea fes of the belly that eate it. The better is that whieh hath nokernell, whieh in the other kinde is ftony : there is alfo preffed out of it a wine, like to a fweet wine. which the fame Nepos denieth to endure aboue ten daies, and the berries ftamped with $A$ lica are referued in veffels for food. Moreoter we haue lieard fay, that armies haue been fed therewitl, as they haue pafted too and fro thoro: Africke. The eolour of the wood is blacke: they ve to make futes and pipes of it : the root ferueth for kniues hafts, and other fhorr workes: this is there the nature of the tree : thus farre Pliny. In the fame plaee he faith, that this renowmed trec doth growaboat Syrtes and Naramon: and in his 5. booke, 7. ehapter he fhewerh that there is not far from the lefer Syrcis, the Ifland Menynx, firnained Lotoph agitios, of the plenty of Lote trees.

$$
\text { Kktkkk strsto }
$$

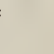

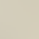




\section{4 \\ Of the Hiftory of Plants. \\ L18.3.}

Strabo.in his I 7 . booke affirmetl, that not onely Menynx, but alfo the leffer syntis is faid to be Lotophrgitis : firft, faith he, lieth Syrtis a certaine long Inland by the name Cercinna, and another leffer, called Circinnitis; next to this is the leffer Syrtis, which they call Lotophagitis Syrt is: the compaffe of this gulfe is almoft 1600 . furlongs; the bredth of the mouth 600 . By both the capes there be Iflands ioined to the maine land, that is, Circinna and Menynx, oflike bigneffe: they thinke that Menynx is the countrey of the Lotophagi, or thofe that feed of the Lote trees of which countrie $H$ omer maketh mention, and there are certaine monuments to be feen, and $V l y f$ f fes Altar, and the fruit is felfe; for there be in it great plenty of Lote trees, whofe fruit is wonderful
fweet : thus faith Strabo.

This Lote is alfo defcribed by $T$ heophraftus; in his fourth booke he faith, that there be very many kindes, which be feuered by the fruit : the fruit is of the bignes of a beane, which when it waxeth ripe doth alter his colour as grapes do : the fruit of whicli the Lotophayi do eate is fweet, pleafant, harmeles, and wholefome for the belly, but that is pleafantcr which is without kernels,
and of this they make their wine.

This Lote tree, as the fame Author affirmeth, is by nature euerlafting : as for example, the Lote trees whereof pliny hath written in his 16 . booke, 44 . chapter. At Rome, faith he, the Lote tree in Lucinas court, linw much elder it was than the church of the citie, built in the yeere which was without magiftrates, 469 . it is vncettaine : there is no doubt but that it was elder beeaufe $L$ ucina bate the name of that $L$ rucus or grouc. This is now about 450 .yecres old. That is elder which is furnamed Capillata, or hairic; bccaufe the haire of the ventall virgins was brought vnto it: but the other Lote tree in $V$ ulcans church, which Romulus built by the victory of tenths is taken to be as old as the citie, as Mafjurius watneffeth.

$$
\text { Tt The Tine. }
$$

They lofe their leaucs at the firft approeh of winter; and recouer them againe in Aprill : the fruit is ripe in September.

Tा The Names.

This tree is called in Greeke, ,arar in Latine by Pliny, Celt is. in Italian, Perlaro: by thofe of Trent. Bagolaro: and in Englirh,Lote tree, and Nettle tree.

\section{The Ternpcrature and rertues.}

A The Lote tree is not greatly binding as Galen faith, but of thin parts, and of a drying nature.: -

B The decottion of the wood beaten fmall, being eitherdrunke or vfed clifterwife, is a remedy for the bloudy fix; and for the whites and reds.

C It ftoppeth the laske, and maketh the haire yellow, and as Galen addeth, keepeth haites from falling.

D The fhiucrs o: fnall pieces thereof, as the fame Author alleageth, are boiled fometimes in water, fometimes in wine, as need fhall require.

$$
\begin{aligned}
& \text { Of Iralian wood of Life, or Pocke wood, vulgarly called Lignum vitx. } \\
& \text { Tा The Defcription. }
\end{aligned}
$$

1 Talian Lignum vite, or Wood of Life, groweth to a faire and beautifull tree, hauing a frraight and vpright body, coucred oucr with a fmooth and darke greene barke, yeelding greater beautie, and fomewhat broader : among whoodly leates, like thofe of the Peare tree, but of the branches, almoft without ftalkes: this fruir is round it is ripe,as big as Cherries, of an excellent frit is round, and at the firft greene, but blacke when Lignum Santrom, or Guaiasum, whereof kind therof, firft planted in the common bowles and phyficall drinkes be made, but it is a baftard to be the right Guaiacum.

$¥ 2$ The leaues of this are longer and narrower than the former, but firme alfo and nervous like as they are; the fruit is in mape like Sebeftens, but much leffe, of a blewifh colour when it is ripe, with many little ftones within; the tafte hereof is not vnpleafant. Matthiolus calls this P Perdo-

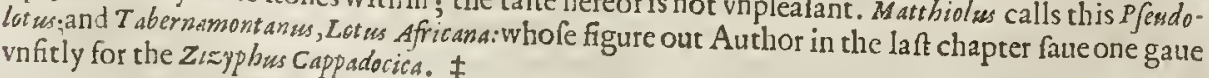

$$
\text { Guaiacum Patauisum growech plentifully The Place. }
$$

Guaiacum Patauinum groweth plentifully about Lugdunum, or Lions in France :I planted it in 


\section{$L_{1 B} 3_{0} \quad$ Of the Hittory ot Plants.}

1495

the garden of Barne-Elmes neere London two trees: befides, there groweth another in the garden of $\mathrm{M}^{\mathrm{r}}$. Gray an Apothecarie of London, and in my garden likewife.

I Guaiacum Patauinum latifolium.

Broad leafed Italian Wood of life:

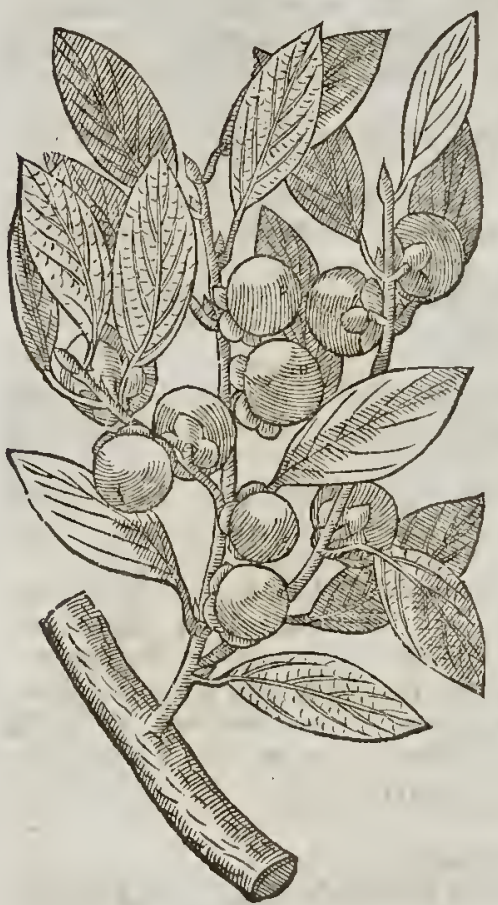

2 Guaiacum Patarizum angufifol. Narrow leafed Italian Guaiacum.

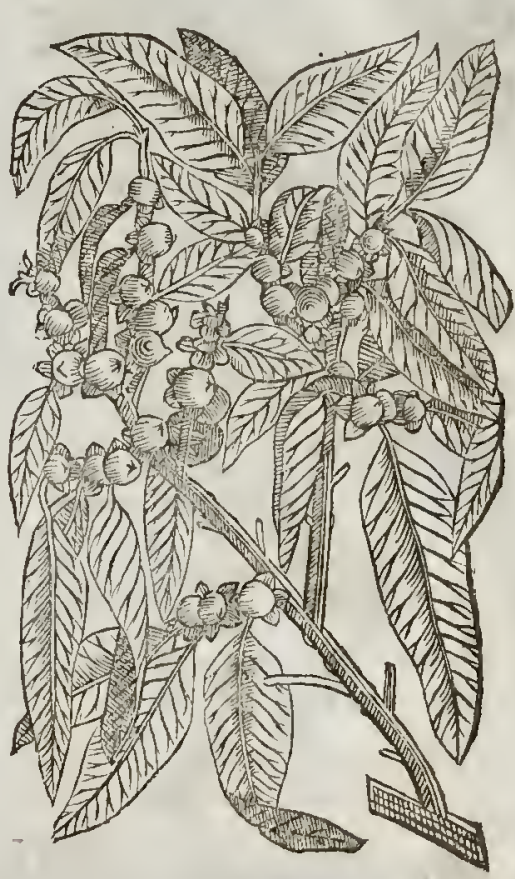

The Time.

It floureth in May, and the fruit is ripe in September.

I The Names.

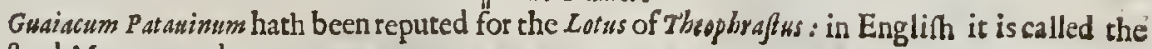
baftard Metryawood.

\# This hath noaffinitie with the true Indian Guajacum which is frequently ved in medicine. $\neq$

9) The Temperature and Vertues.

\# The fruit of this is thought to be of the fame temper and qualitie with that of the Netrlearee. 7

\section{C m a P. I25. Of the Stramberry tree. \\ I The Defcription.}

$\mathrm{T}$ He Strawberry tree groweth for the molt part low, very like in bigneffe to the Quince tree (whereunto Diofcorides compareth it.) The body is couered with a reddifh barke, both rough and fealy : the boughes ftand thieke on the top, fomewhat reddith: the leaues bee broad, long, and fmooth, like thofe of Bayes, fomewhat nieked in the edges, and of a pale greene colour : the floures grow in clufters, being hollow and white, and now and then on the one fide fomewhat of a purple colour : in their plaees come forth certaine berries hang ing downe vpon little long frems like vnto Strawberries, but greater, without a ftone within, but onely with little feeds, at the firft greene, and when they be ripe they are of a gallant red colour, in tafte fomew hat harhyand in a manner without any relith; of which Thrurhes and Black-birds do feed in Winter. 


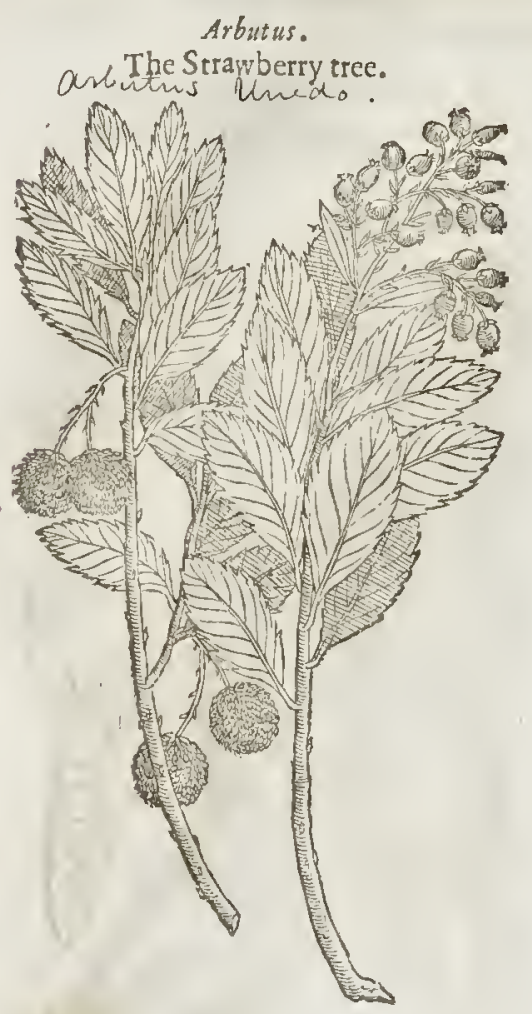

IT The Place.

The Strawberry tree groweth in moft Countries of Greece, in Candy, Italy, and Spainc, alfo in the vallics of the mountaine Athos, where, being in ather places but little, they become great huge trees, as $\boldsymbol{P}$. Bellosius writeth. Iuba alfo reporteth, that there be in Arabia of them fifty cubits high. They grow only in fome few gardens with vs.

$$
\text { I The Time. }
$$

The Strawberry rree floureth in Iuly and Auguft, and the fruit is ripe in September, after it bath remained vpon the tree by the fpace of an whole yeare.

\section{Tा The Nomes.}

This trec is called in Greek, кimser : in Latine, Arbutus : in Englinh, Strawberry tree, and of fome, Arbute tree.

The fruit is named in Creeke, mpsimuner, or as others reade it, muginsor : in Latine, CMemacylum, and Arbutiss; and Pling calleth it Vkedo: Ground Strawberries (faith he)hawe one body, and vnedo, $^{2}$ much like vnto them, another body, which onely in apole is like to the fruit of the earth: The Italians call rhis Strawberry Albatro the Spaniards, Madrono, Medronbeyro, and Medronbo : in French, Arboutes, Arbous : It may be termed in Englinh, Tree Stràwberry.

\footnotetext{
T) The Temperature and Vertues.
}

A The fruit of the Strawberry trec is of a cold remperature, hurting the ftomacke, and caufing head ache; wherefore no wholefome food, though it be eaten in fome places by the poorer fort of people.

\section{Cha 126. Of the Plum tree. \\ T. Thi Kindes.}

T.O write of Plums particularly would require a peculiar volume, and yet the end not to be at tained vnto, nor the flocke or kindred perfectly knowne,neither robe difting uifhed apart : the number of the forts or kindes are not knowne to any onc comntrey : encry Clymat hath his owne fruit, far different from that of other countries . my felte haure three fcose forts in my garden, and all ftrange and rare : there be in othar placts many more common, and yet yearely commeth to our hands others nor before knowne, therefore a few figures thall ferue for the reft. $\neq$ Let fuch as require a larger hiftorie of thefe varieties hane recourfe to the of menrioned Worke of $\mathrm{M}^{t}$. Par. kinfon: and luch as defirc the things themfelues may finde mofe of the beft with $\mathrm{M}^{*}$. Iobn Millen in Old ftreet. :

$$
\text { T The Deforition. }
$$

I T.He Plum or Damfontree is of a meane bigneffe : it is conered with a fmooth barke: the branches are long, whereon do grow broad leaues, more long than round, nicked in the edges : the floures are white: the Plums do differ in colour,famion, and bignes, they all confitt of pulpe and skin, and alfo of kernell, which is fhut vp in a fhell or fone. Some Plums are of a blackinh blcw, of which fome be longer,others rounder, others of rhe colour of yellow wax, diuers of a crimfon red, greater for the moft part than rhe ref. There be alfo green Plums, and withall very long, of a fiveer and wleafanr tafte : moreouer, rhe pulpe or meate of fome is drier, and eafilier feparated from the ftone : of other-fome it is moifter, and cleaueth fafter : our common Damfon is knowne to all, and therefore not to be flood vpon. 
LIB. 3 .

Of the Hiftory of Plants.

1497

I Pruaus Dumeftica.

O) The Damiontree.

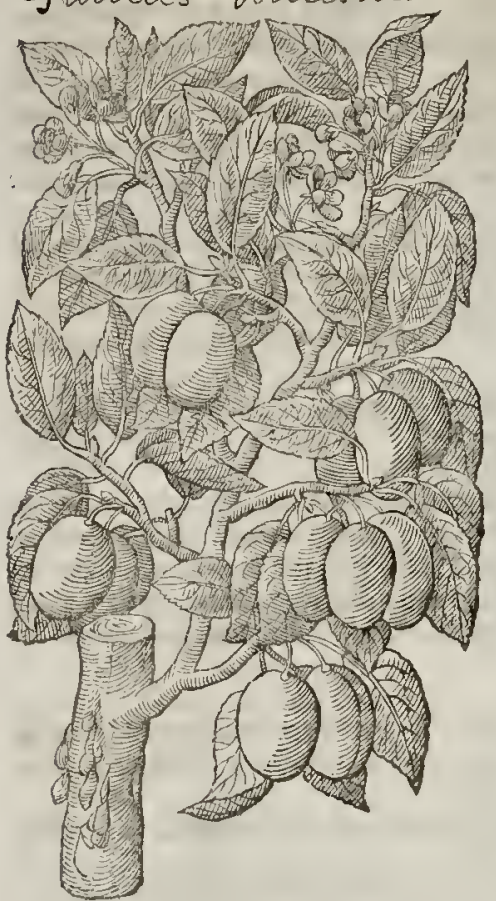

3 Prunes Ainygdalina.

The Almond Plum tree.

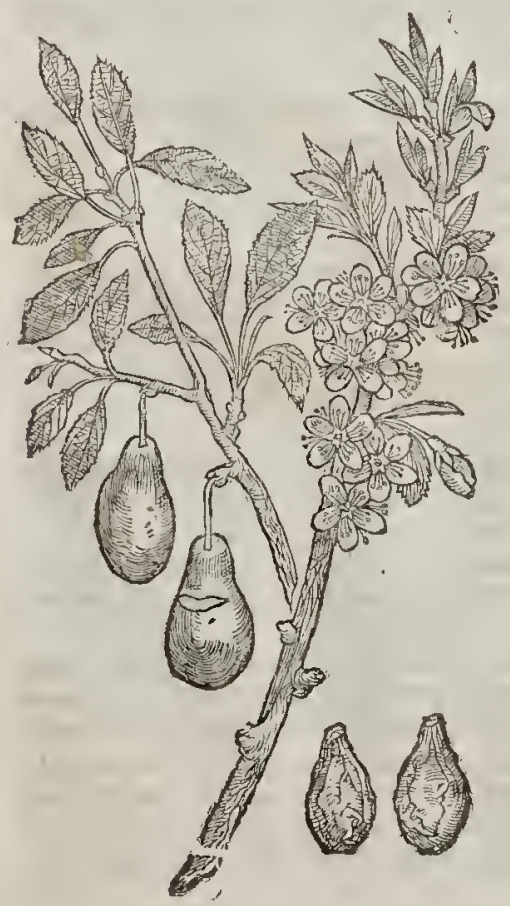

2 Prunus CMirobilana.

The Mirobalane Plum tree.

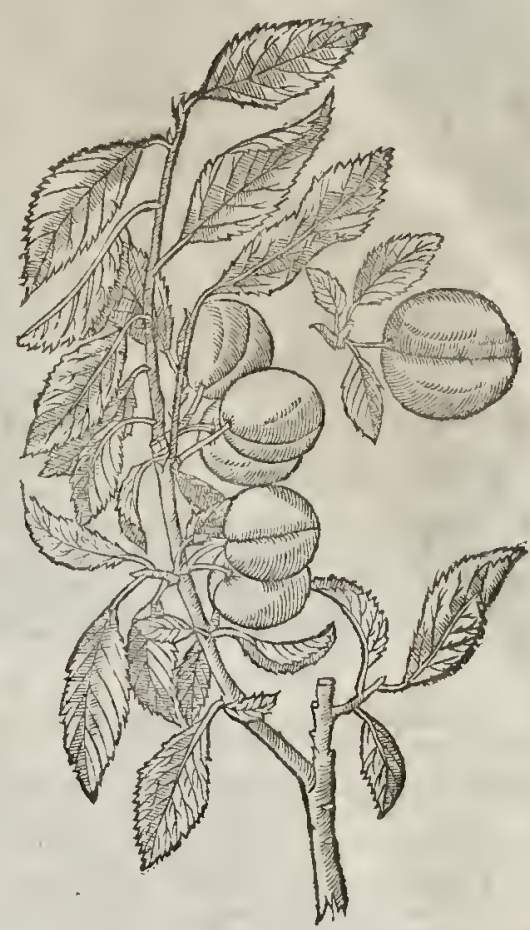

5 Prunus fylueftris:

The Sloe tree.

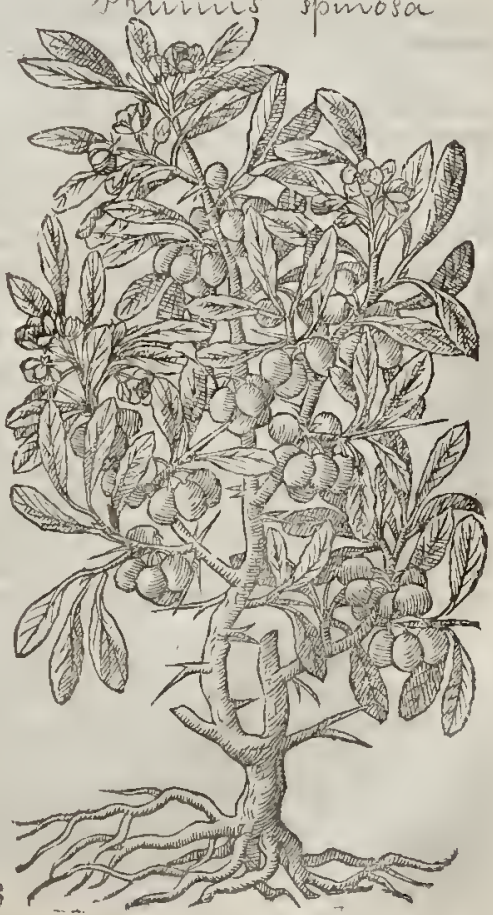

$\mathrm{kkkkk}$ 
2 The Mirobalan Plum tree groweth to the height of a great tree, charged with many great armes or boughes, whieh diude themfelues into fmall twiggy branches, by means whereofit yeeldeth agootly and pleafant thadow : the trunke or body is couered with a finer and thinner barke than any of the other Plum trees : the leaues do fomewhat refemble thofe of the Cherry tree barke are very tender, indented about the edges: the floures be white: the fruit is round, hanging they long foot-ftalkes pleafant to behold, greene in hebound, hanging vpon full ripe it glifereth like purple mix tafte : the ttone is fmall, or of a meane bigneffe : the : free for meate is full of iuice pleafant in yeare.

The A lmond Plum groweth vp to the height of a trce of a meane bigneffe : the branches are long, fmooth, and euen: the leaues are broad, fomthing long, and ribbed in diuers places, with fuall nerues running through the fame: the floures are white, fprinkled with a littledah of purp'e farcely to be perceiued : the fruit is long, hauing a cleft downe the middle, cf a browne red
colour, and of a pleafant tuftc.

4 The Damafeen Plum tree groweth likewife to a meane height, the branches very brittle: the leates of a deepe green colour: the fruit is round, of a blewin blacke colour : the ftone is like vnto that of the Cherry, wherein it difiereth from all other Plums.

5 The Bulleffe and the Sloc tree arewilde kindes of Plums, which do vary in their kind, euen as the greater and manured Plums do. Of the Bulleffe, fome are greater and of better tafte than others. Sloes are fome of onetalte, and fome of others, more fharpe; fome greater, and others le1 fer; the which to diftinguifh with long defcriptions were to finall purpofe, confidering they be all and euery of them knowne etren vnto the fimple $:$ therefore this thall fuffice for their feueral de-
fcriptions.

G The Place.

The Plum trees grow in all knowne countries of the world : they require a loofe ground, they alfpecially of the factilies, as we will forthwith declare.

The Plum trees are alfo many times graffed into trees of other kindes, and being fo ingraffed,
hey fociemparentis, fuccmm adoptionis, wt Plinius dicit, exbibent.

ficiomparentis, fuccmin adoptionis, vt Plinius dicit, exhrbent.

The greateft varietic of thele rare Plums are to be found in the ground of $M{ }^{r}$. Vincent Pointer of Twicknam, before remembred in the Chap. of Apples : although my felfe am not witlout fome
and thofe rare and delicate.

The wilde Plums grow in moft hedges through England.

$$
\text { 9f The Time. }
$$

The common and garden Plum trees dobloome in April : the leaues come forth prefently with then : the fruit is ripe in Sommer, fome fooner, fome later.

The Plo The Names.

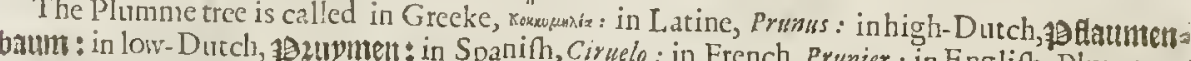

7 he furt is callet in Greele

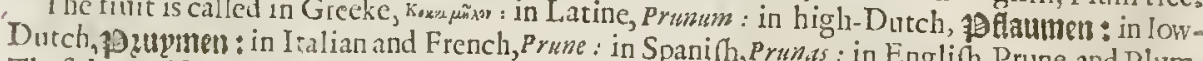
Thefe hauc alfo

Thuold Wricers haue

in Englih, Damfons, or Damashe Prunes : and in Syria neere vnto Damafcus, Damafena Pruna: or Plums. So in our a Dewe vfe rocall thofe that thofe that grow in Spain, Hifpanica, Spanim Prunes of How in Hungaric, Hungarica, or Pannonica, Plums Of Hungarie : fone, Gallic, Pruna, or French Prunes, of the country of France. Clearcus Peripateticus
faith, that they of Rhodes and Sicilia do call the Damaske Prunes Brabula.

$$
\text { 9. The Temperature and V crutues. }
$$

and coole, that be ripe and new gathered from the tree, what fort foeuer they are of, do moiften as Plumnes do very quickly rot, fo is alfo the iuice forment, and the fame nothing goot at all: for wife wife to caufe the neate to putrifie which is taken with them : onely they are good for thofe that would kecpe their bodies folubleand coole; for by their moifture and flipperineffe they do mol-
lifie the belly.

B Dried Plums, commonly called Prunes, are whol fomer, and more pleafant to the ftonack, they yeeld more nourithment, and better, and fuch as cannot eafily putrific. It is reported, faith $G$ alen in his booke of the faculties of Nourihments, that the ben doe grow in Damafcus acity of Syria, and next to thofe, they that grow in $S$ paine : but thefe doe nothing at all binde, yet diuers of the Damaske Danfon Prunes very much; for Damaske Damfon Prunes are more aftringent, but they firmelt firmth, inh is books of the faculties of fimple medicines, that they domanifefly loofe the belly, 
yet leffer than they that bee brought out of Spaine; being boiled with Mead or honied water, which hath a good quant itie of honey in it, they loofe the belly very much (as the fame Authour faith)although a man take them alone by thenfelues, and much more if the Mead be fupped after them. We moft commend thofe of Hungarie being long and fweet; yet more thofe of Morauia the chiefe and principall citie in times palt of the Prouince of the Marcomans: for the fe a fter they be dried, that the waterie humour may be confumed away, be moft pleafant to the tafte, and do ea fily without any trouble fo mollifie the belly, as that in that refpeet they go beyond Caflia and Manna, as Thomas Iordanus affirmeth.

The leaues of the Plum tree are good againft the fivelling of the Vuta, the throat, gums, \& ker- $C$ nels vnder the throat and iawes; they ftop the rheume and falling downe of humors, if the decocti. on thereofbe madein wine, and gargled in the mouth and throat. faith.

The gumme which commethour of the Plum. tree dorh glew and faften together,as Diofcurides D

Being drunke in wine it wafteth away the ftone, and healech Lichens in infants and young chil. E dren; if it be layed on with vineger, it worketh the fame effe fts that the gum of the Peach and cherzie tree doth.

The wilde Plums do ftay and binde the belly, and fo do the vnripe plummes of what fort foetuer, F whiles they are tharpe and fower, for then are they aftringent.

The inice of Sloes doth itop the belly, the lask and bloudy flix,the inordinat courfe of womens $G$ termes, and all orher iffites of blout in man or woman, and may very well be vfed in ftead of Acatia, which is a thornie tree growing in Agypt,very hard to be gotten, and of a decre price, and therfore the better for wantons; albeit our Plums of this countrey are equall vnto it in vertues.

\section{Cна Р. 127. Of Sebeften, or the AJfyrian Plum.}

Sebefterne, Myxa, five cryxara.

Affyrian Plums.

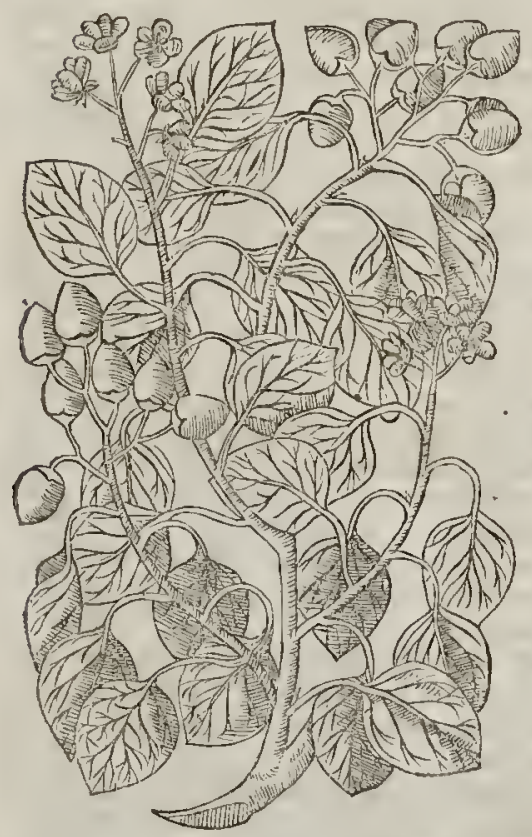

$$
\text { If The Defoription. }
$$

Ebeftines are alfo a kinde of Plums:the tree whereof is not vnlike to the Plum tree, fauing it groweth lower than the moft of the manured Plum trees; the leaues be harder and rounder; the floures grow at thetops of the branches confifting of fiue mall white leaues, with palc yellow in threds in the middle, like thofe of the Plum tree:after followeth the fruit like to litrle Plummes, faftened in lirtle skinny cups, which when they be ripe are of a greenin black colour, whercin is contained a fmall hard ftone. The fruit is fweet in tafte, the pulpe or meat is very rough and clammic.

$$
\text { If The Place. }
$$

The Sebeften trees grow plentifully in Syria and Egypt; they were in times paft forreine and ftrange in Iraly, now they grow almoft in euery garden, being firft brought thither in Plinie his time. Now do the Sebeften trees, faith he, in his 15.booke, 18 . chapter, begin to grow in Rome, among the Seruice trees.

$$
\text { T) The Time. }
$$

The time anfwereth the conmon Plums.

$$
\text { q } T \text { he Names. }
$$

Pliny calleth the tree $M y x a$, it may bee fufpeEted that this is the tree which Matron Puradus in his Atticke banket in Athences doth call inguzus, but we cannot certainely affirme it, and efpecially becaufe diuers haue diuerfly deemed thereof. The berryor fruit is named 
My xon and Myxarion, neither hame the Latines any other name. The Arabians and the A pothecaries do call it Sebefton : which is alfo made an Englifh name: we may call it the Affyrian Plum.

$$
\text { Tा The Temperature and Vertues. }
$$

A Sebeftens be very temperately cold and moit, and haue a thicke and clammie fubftance; therefore they nourith more than moft fruits do, but withall they eafily ftop the intrailes, and ftuffe vp the narrow paffages, and breed inflammations.

B They take atvay the ruggedneffe of the throat and lungs, and alfo quench thirft, being taken in a looch or licking medicine, or prepared any other kinde of way, or elfe taken by themfelues.

C The weight of tendrams, or of an ounce and a balfe of the pap or pulpe hereof being inwardly tan ken, doch loofe the belly.

D There is allo made of this fruit a purging Electuaric, but fuch an one as quickly mouldeth, and therefore it is not to be ved but when it is new made.

\section{С на Р. 128. Of the Indian Plums, or e Mirobalans.}

\section{eा $T$ he Kindes.}

THere be diters kinds of Mirobalans, as Chebula, Bellurnce, Emblica, \&c. They likewife grow vpor diters trees,and in countries far diftant one from anothcr, and Garcias the Portugall Pby fition is of opinion, that the fiue $k$ indes grow vpon fiue diuers trees.

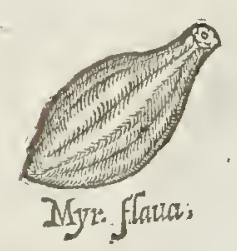

Dys wartom
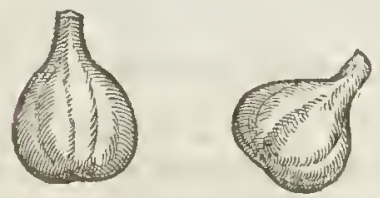

Mye bollerín.

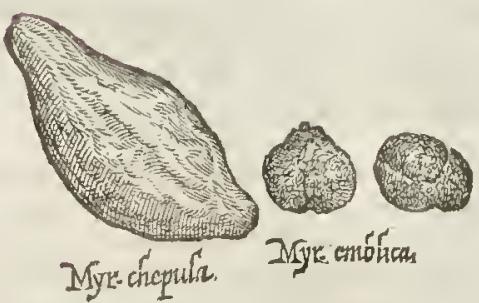

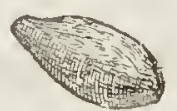

$I$ T The Defcription.

The firft of the Mirobalan trees, called Clitivle, is a thrubbie tree altogether wilde (which the Indians doe call Aretca:) in ftature not vnlikc to the Plum tree; the branches arc many and grow thicke together, whereon are fet leates like thofe of the Peach tree. The fruit is greaterthan any of the reft, fomw hat long, fathioned like a pcare.

2 This fecond kinde of Mirobalan, called Flatu, or Cutrina, which fome do call Aritiqui, but the common people of India, Arare, groweth vpon a tree of meane ftature, hauing ma . ny boughes ftanding finoly in order, and fet full of leates like vnto the Seruice tree.

3 The third kinde of Mirokalans, called Emblice, the Indians doe call $A$ miale, which grow vpon a trec of mean ftature, like the former, but the leates are very much iagged, in thape like the leaues of Ferne, but that they be fomewhat thicker : the Indians do not put the fruit hereof vnto phy ficall vfes, but occupie it for the thickening and tanning of their leather in ftead of Rhus, or Coriars Sumach, as alfo to make inkc and bletch for othcr purpores.

4 Mirobalani Bellirica, called of the Sata. ges Gotni, and Guti, groweth vp to a meane fature, garnifhed with leaucs like vnto Laurell or the Bay tree, but fomewar leffer, thinner,and of a pale greene colour.

5 The fift kinde of Mirobalans is called Indice, which the Indians do call Reqamale; ir groweth vpon a tree of meane ftature, or rather von a thrub or hedge plant, bearing leattes like the Willow, and a fruit eight fquare. There is a fift kinde, the tree whereof is not mentioned in Authors.

$$
\text { qT The Place and Time. }
$$

The laft foure kindes of Mirobalans do grow in the kingdome of Cambaia : they grow likewifc in Goa, Batecala, Malanor, alnd Dabul:the Kebula in B ifnager, Decan, Guzarate, and Bengala, $<$ many other places of the Eat Indies. The time agreeth with other fruits in thole countries.

$$
\text { The Names. }
$$

Thofe which we haue faid to be yellow, the inhabitants of thofe countrics whęre they grow doe 

call them Arare; tho fe that be blacke they call ReZemnale; the Bellerice, Gotim; the Chebute, Aretca; the
Emblice are called Aretiqui.
T The Temperature.

All the kindes of Mirobalans are in tafte aftringent and thatpe like voto the vnripe Sorbus of Setuice betties, and thetefore they are of complexion eold and dtic.

T The Veriues.

The Indians vfe them rather to bind than purge; but if they do vfe them for a purge, they vfe the $A^{\prime}$ decoction of them, and vfe them much conferued in fugar, and efpecially the Chebula; the yellow
and blacke be good that way likewife.

The yellow and Bell erica taken befote meat,ate good againft a laske, ot weake ftomacke, as $G$ arci- B as writeth.

The yellow and blacke, or Indice, and the Chebula, purge lightly, if two or thteedrams be taken, $C$ and draw fuperfluous humots from the head.

The yellow, as fome write, purge choier, Chebule flegme, Indica melanehole, and ftengthen the $D$ inw ard parts, but rofted in the embers, or otherwife watted, they drie more than they purge.

There are two fot ts efpecially brought into thefe parts of the world conferued, the chebula, and $E$ of them the beft are fomewhat long like a fmall Limon, with a hard rinde and black pith, of the taft of a conferued Wall-nut; and the Bellerice, which are round and leffer, and tenderer in earing.

Lobel writeth, that of them the Emblica do meanly coole, fone do drie in the firft degree, they F purge thc ftomacke of rotten flegme, they comfort the braine, the finewes, the heart, and liter, procure appetite, ftay vomite, and coole the heat of choler, helpe the vnderftanding, quench thirf, and the heate of the intrailes:the greateft and heauieft be $t$ hc beft.

They purge beft, and with leffer paine, if they be laid in water in the Sun vntill they fwell, \& fod $G$ on a foft fite, 8 aftet they have fod and be eold,pteferued in foure times to :nuch white honey, put
to them.

Garcias found the diftilled water to be right profitable againft the French difeafe, and fuch like $H$ infections.

The Bellerice are alfo of a milde opetation, and docomfort,and are cold in the firt degree, and I drie in the fecond:the others comeneere to the Emblice in operation.

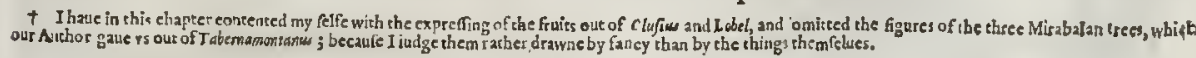

\section{Cн а P.129. Of the friube tree.}

Iuinbe Arabum, five Ziziphus Dodonai.

The Iniube tree.jhes vulgaris.

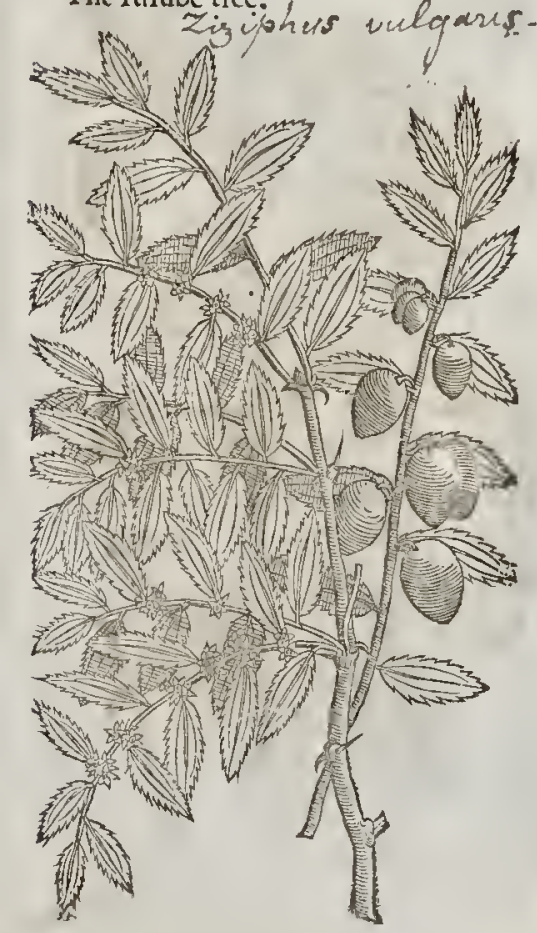

\section{T The Defcription.}

THe Iniube tree is not much leffer than $z i$. Ziphus candida, hauing a w teathed trunke of body, and a rough batke full of tifts or cranies, and itiffe branches, befer with ittong and hard prickles; from whence genw our inany lon's twigs, ot little ftalkes, halfe a foot or more in length, in thew like Ruthes, limmer, and ea bowing thentelues, and vety flendis like the twigges of Spartum : about which enme Jeaues one aboue another, which are fo new s: long, not very great, but hard and rougt lite is the leaues of $\bar{P}$ eruinca or Peruinckle; $\&$ amor $x$ thefe leaues eome forth pale and moffic little floures: after which fuceeed long red well tafted fweet berries as big as Oliues (of a meane quanticy)or lutrle Prunes, or fmal Plums, wh erin there are hard round ftones, or in which a fmall kernell is contained.

T) The Place.

There be now at this day Luinbetrees growing in very many places of I taly, wh hichin cimes paft were new ly brought thither out of Syrid, and that about Fliny his time, as he himfelfe hath written in his $17.600 k, 10$. chap.

$$
\text { 1 The Time }
$$

It floureth in A prill, at which time the feeds et itones ate to be fet ot fowne for incteafe.

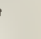

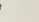

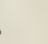


बा The $N$ ames.

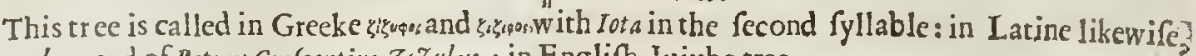
$Z$ izpphrs; and of Petras Crefcentius, Zizulus : in Englifh, Iniube tree.

The fruit or Plums are named in Greeke $\xi_{i \xi u p a,} \zeta_{1} \zeta_{i q \alpha}:$ Galen calleth them mpme, as cuicen plainely theweth in his 369 .chapter, intreating of the Iuiube, in which be fet downe thole things that are mentioned concerning S crica in Galens books of the faculties of Nourifhments:in Latine likewife $Z_{s z y p h a}$ and Serica $:$ in hops, Iuiwbe : in Englifh, luitsbes.

Iuiubes are temperate in heate and moifture.

T The Temperature.

वा The Vertues.

A The fruit of the Iuiube tree eaten is of hard digeftion, and nourineth very little but being taken in fyrrups, electuaries, and fuch like confections, ic appeafeth and mollifieth the roughneffe of the throat, the breft and lungs, and is good againit the cough, but exceeding good for the reines of the backe, and $\mathrm{kidneies}$ and bladder.

\section{Ch A P. 130. Of the Cherrie Tree. TT The Rindes.}

The antient Herbarifts hame fet down fonre kindes of Cherrie trees, the firft is great and wilde? the fecond tame or of the garden: the third, whofe fruit is foure: the fourth is that which is called in Latine Chamecerafus, or the dwarfe Cherrie tree. The later writers have found diuers forts more, fome bringing forth great fruit, others leffer, fome with white fruit, fome with blacke, others of the colour of blacke bloud, varying infinitely according to the climate and countrey where they. grow.

I Cerafus vulgaris.

The common Englifh Cherrie tree. Ojums eurasers. a.

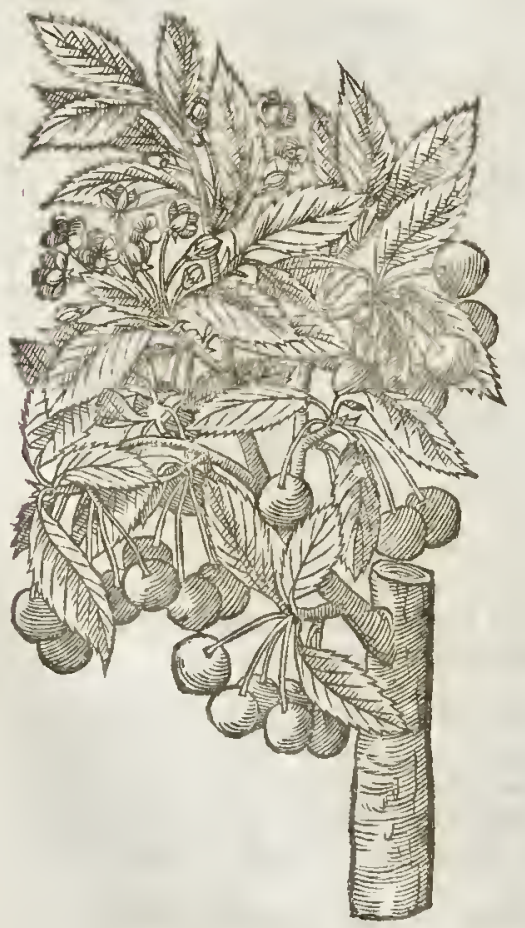

\section{Corafus Hipanica.} The Spanifh Cherrie tree?

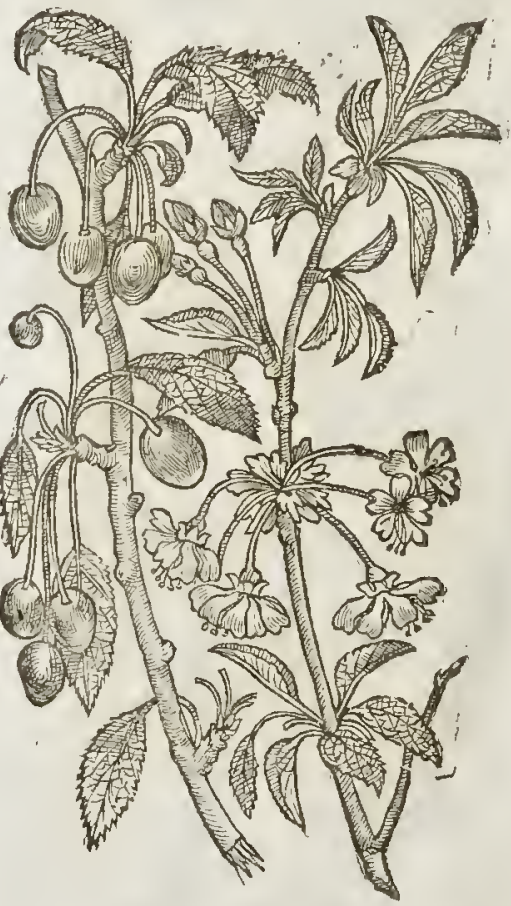


$\mathrm{L}_{\mathrm{IB} .3 .}$

\section{T The Defcription.}

I The Englifh Cherric tree groweth to an high and great tree, the body whereof is of a

1 meane bigneffe, which is parted aboue into very many boughes, with a barke fomewhat fmooth, and of a browne crimfon colour, tough and pliable : the fubftance or timber is alfo browne in the middle, and the outward part is fomewhat white. The leaues be great, broad, long, fet with veines or nerues, and fleightly nicked about the edges : the floures ate white, of a mean bignes, confifting of fiue leaues, and hauing certaine threds in the middle, of the like colour: the Cherries be round, hanging vpen long ftems or foot-ftalks, with a ftone in the midf which is couered with a pulpe or foft meat; the kernell thereof is not vnpleafant to the tafte, though fomervhat bitter.

2 The Flanders Cherry tree differech not from our Englifh Cherrie tree in ftature or forme of leaues or floures; the difference confifteth in this, that this tree bringeth forth his fruit fooner, and greater than the other: wherefore it nay be called in Latine, Cer afws precox, five Belgica.

5 Cerafes Serotina.

Late ripe Cherrie tree:
6 Cerafus vno pediculo plura.

The Clufter Cherrie tree.
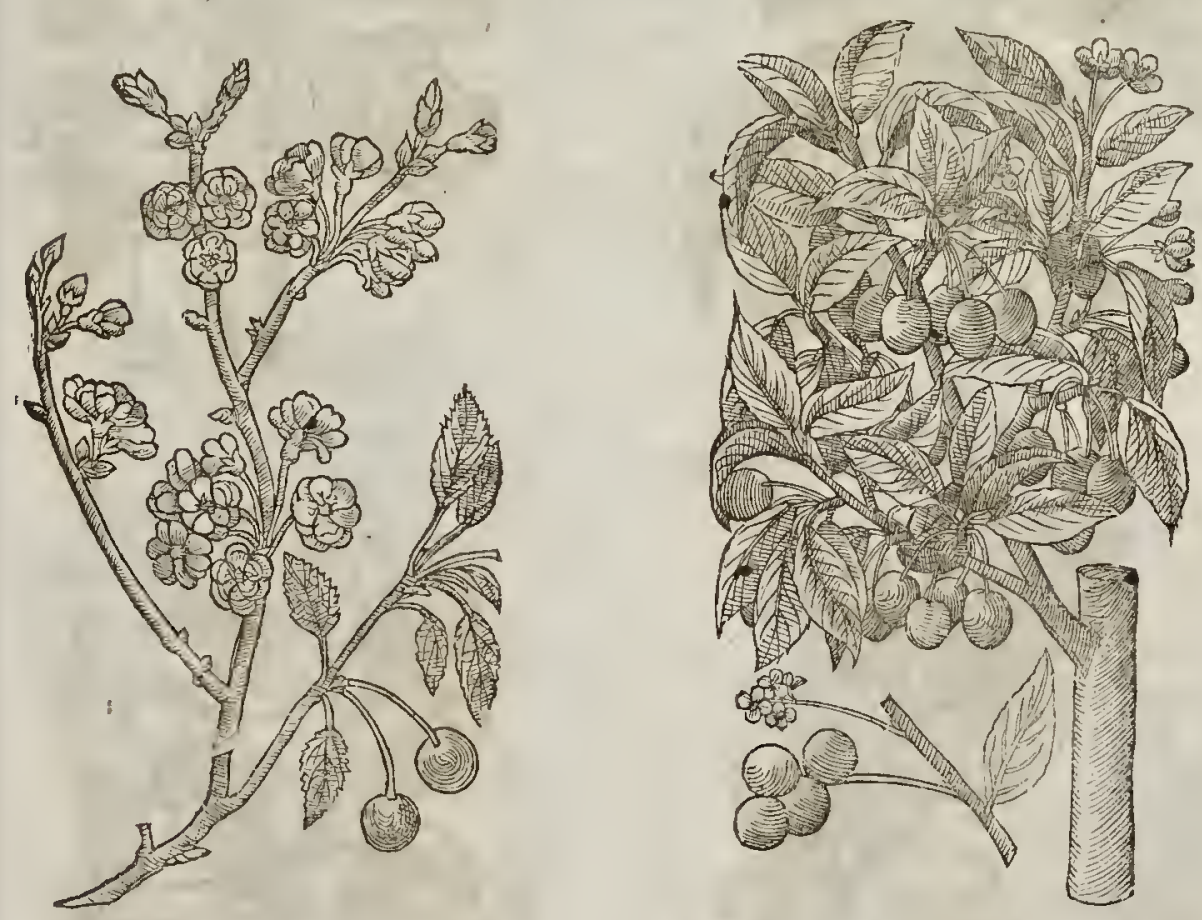

3 The Spanith Cherric tree groweth vp to the height of our common Cherrie tree: the wood or timber is foft and loofe, couered with a whitifh fcalie barke: the branches are knotrie, greater $\&$ fu!ler of fubftance than any other Cherry tree: the leaues are likewife greater and longer than any of the reft, in fhape like thofe of the Cheitnut tree:the floures are like the others in forme, but whiter of colour : the fruit is greater and longer than any, white for the moft part all oucr, except thofe that ftand in the hotteft place where the Sun hath fome reflexion againf a wall:they are alfo white within, and of a pleafant tafte.

4 The GAdfcoine Cherrie tree groweth very like to the Spanirh Cherry tree in ftature, floures, and leaues: it differeth in that it bringeth forth very great Cherries, long, tharpe pointed, with a certaine hollowneffe vpon one fide, and fpotted here and there with certaine prickles of purple colour as fruall as fand : the tafte is molt pleafant, and excelleth in beautie.

5 The late ripe Cherry tree gro weth vp like unto our wilde Englin Cherry tree, with the like leaues, 
7 Cerafos multiflora fructus cdens. The double foured Cherry tree bearing fruit.

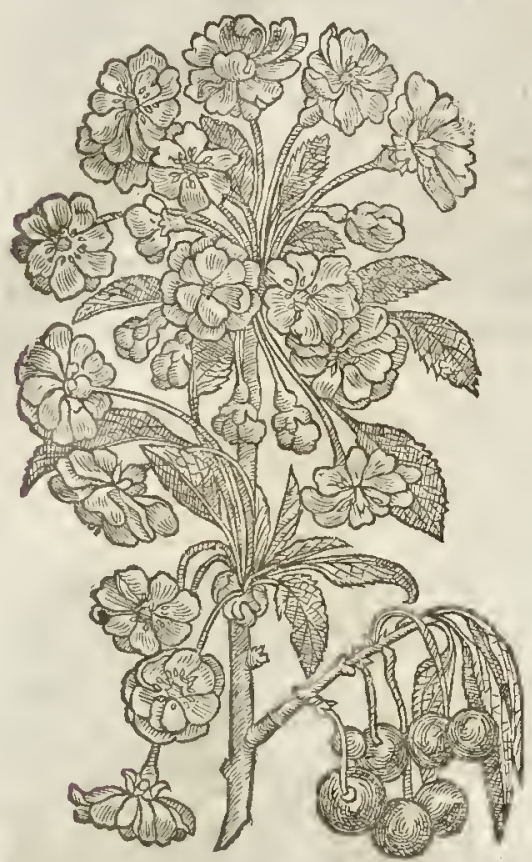

9 Cerafrs aniummigrado racemofa.

Birds Cherry, and blacke Grape Cherry tree. Jumms is 99 Padus.

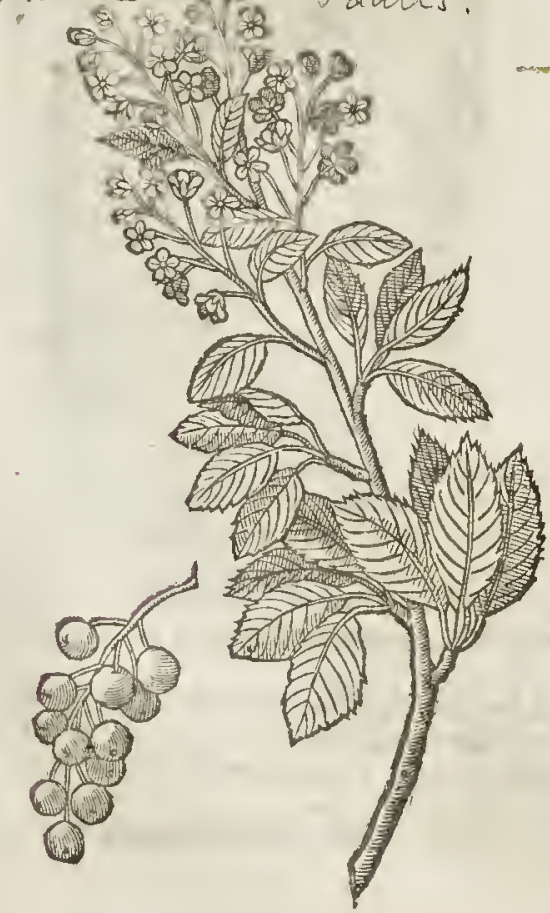

8 Cerafus multiflorapauciores fructusedens.

The doule floured barren Cherry tree.

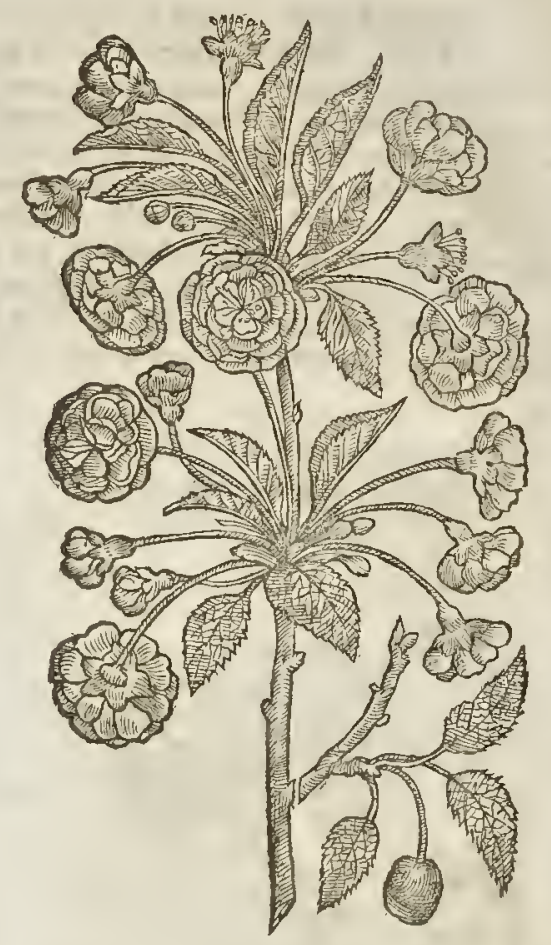

Io Cerafus racemolarubra.

Red Grape Cherry tree.

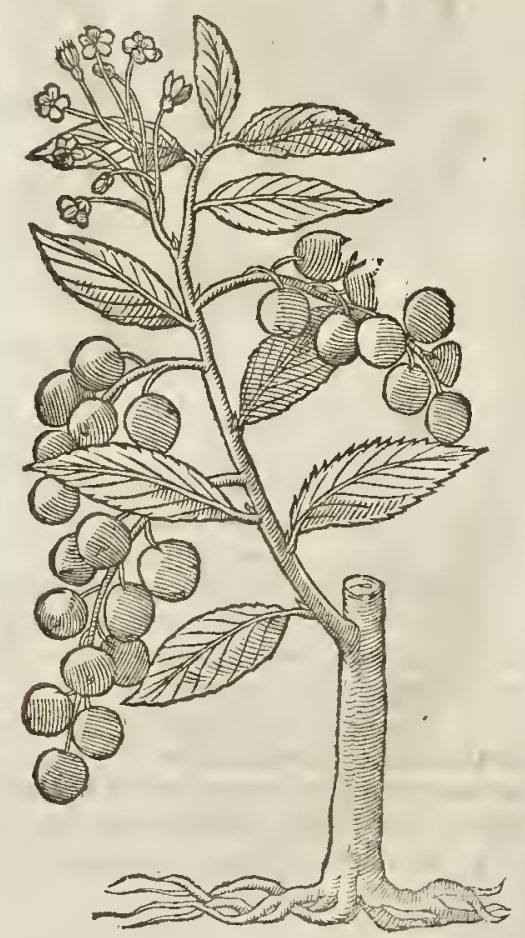


Jeaues, branches, and floures, fauing that they are fometimes onee doubled : the fruit is fmall, round, and of a darke bloudy colour when they be ripe, which tlie Freneh-men garher with their ftalkes, and hang them vp in their houfes in bunehes or handfulls againft winter, which the Phytitians do giue vito their patients in hot and burning feuers, being firft fteeped in a little warme water, that eaufech them to fwell and plumpe vp as full and frefh as when they did grow vpon the tree.

6 The Clufter Cherry-tree differeth not from the laftefcribed either in leates, branehes, or ftature : the floures are alfo like, but neuer commeth any one of them to be double. The fruit is round, red when they be ripe, and many growing vpon one ftem or footftalke in clufters, like as the Grapes do. The taite is not vnpleafant, al though fomewhat foure.

7 This Cherric-tree with double floures growes wp vnto a fmall tree, not vnlike to the eommon Cherrie-tree in each refpect, fauing that the flours are fomewhat doub'cd, that is to fay, three or foure times double; after which commeth fruit(though in fmall quantitie) like the other common Cherrie.

8 The double floured Cberric-tree growes vp like vnto an hedge buih, but not fo great nor high as any of the others; the leaues and branches differ not from the reft of the Cherrie-trees. The floures hereof are exceeding double, as are the floures of Marigolds, but of a white colour, and fmelling fomewhat like the Hawthorne floures; after which come feldome or neuer any' fruit, although fome Authors ha:te faid that it beareth fometimes fruit, which my felfe haue not at any time feen; notwith ftanding the tree hath growne in my garden many yeeres, and that in an exeellent good plaee by a bricke wall, where it hath the reflectioks of the South funne, fit for a tree that is not willing to beare frutit in our cold climat.

II Cerafus nigra.

The common blacke Cherry-tree OPums avium I. In.

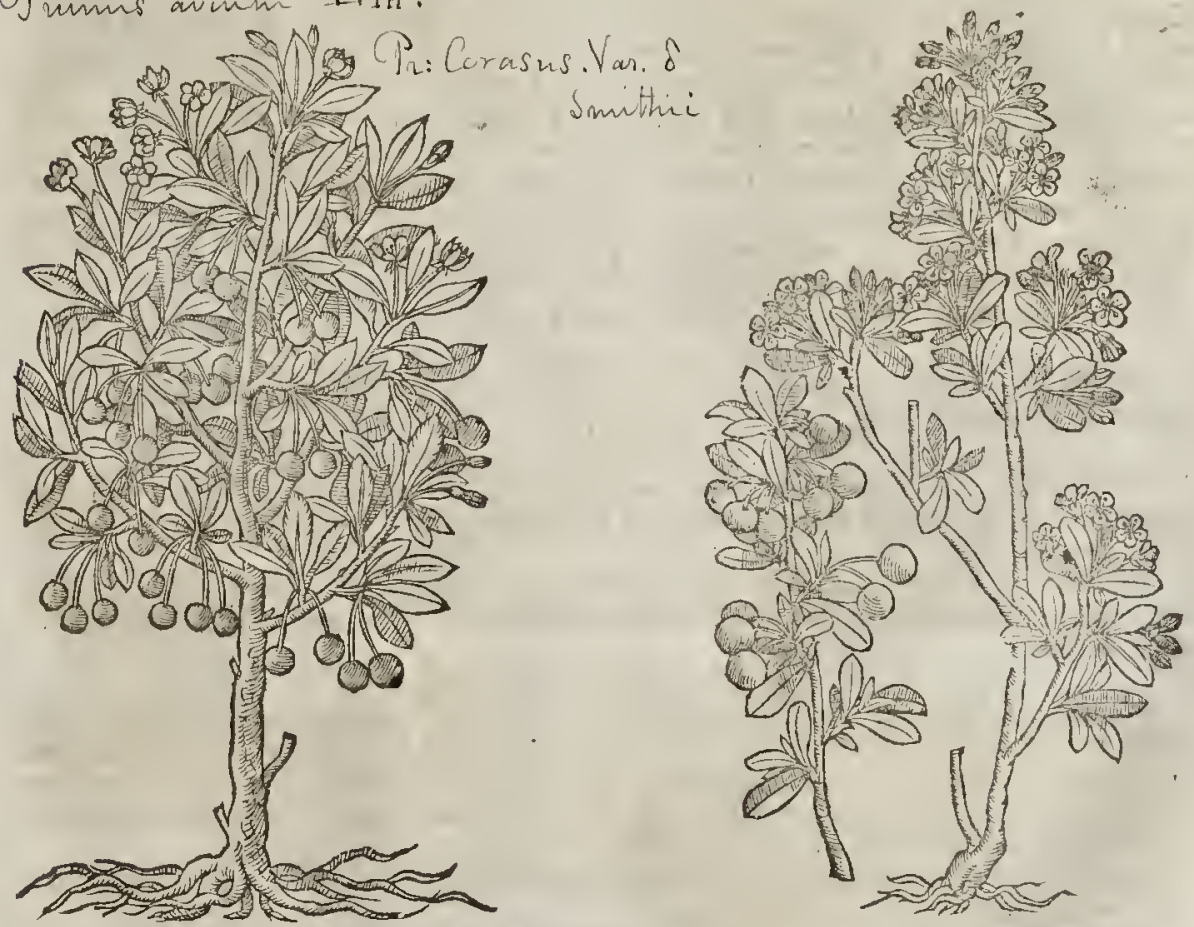

12 chamecerafus. The dwarfe Cherry-tree.

9 The Birds Cherry-tree, or the blacke, Cherry-tree, that bringeth forth very much fruitvpon one braneh (which better may be vndertood by fight of the figure, than by words) (prinueth vp like an hedge tree of fmall ftature, ir rroweth in the wilde woods. of Kent,and are there vfed for ftoekes to zraft other Cherries vpon, of better tafte, and more profit, as efpecially thofe ealled the Flanders Cherries: this wilde tree growes very plentifully in the North of England, efpeeially at a place called Heggdale, neer vnto Rofgill in Weftmerland, and in dituers other places about Crof bie Rauenfwaitla, and there called Herberrie-tree: it groweth likewife in Martome Parke, foure Ll111 miles 
miles from Blackebune, and in Haward neere thercunto; in Lancathire almoft in euery ledge: the leaues and branehes differ not from thofe of the wilde Cherry-tree: the floures grow alongft the fmall branches, confifting of fue fmall white leaues, with fome greenifh and yellow thrums in the middle:after which come the fruir, greene at the firft, blacke when they be ripe; and of the big-
neffe of Slocs; of an har $\mathrm{h}$ and vnplcafant tafte.

10 The other birds Cherry-tree differeth not from the former in any refpect, but in the colour of the berries; for as they are blacke; fo on the contrary, thefe are rod when they be ripe, wherein
they differ.

I I The common blacke Cherry-tree growes vp in fome places to a great fature : there is no difference betweene it and our common Cherry-tree, fauing that the frut hereof is very little in refpect of otber Cherries, and of a blacke colour.

12 The dwarfe Cherry-tree groweth very feldome to the height of three eubits: the trunke or body fmall, coured with a darke coloured blacke : whereupon do grow very limber and pliant twiggy tranches: the leaues are very fmall, not much vnlike to thofe of the Priuite bulh: rhe Roures are fmall and white:after which come Cherries of a deepe red eolourwhen they beripe, of tafte fomewhat tharpe, but not greatly vnpleafant : the branches laid downe in the earth, quickly take root, whereby it is greatly increafed.

My felfe with diuers others haue fundry other forts in our gardens, one called the Hart Cherry, the greater and the leffer; one of a great bigneffe, and molt pleafant in tafe, which we call Luke Irardes Cherry, becaufe be was the firt that brought the fame our of Iraly; another we haue called the Naples Cherry, becaufe it was firt brought, into thefe parts from Naples : the fruit is very gieat, tharpe pointed, fomewhat like a mans beart in thape, of a pleafant taitc,and of a deepe blackith colour when it is ripe, as it were of the colour of dricd bloud.

We haue another that bringeth forth Cherries alfo very greatb, igger than any Flanders Cherrie, of the colour of Iet, or burnithed horne, and of a molt pleafant taite, as witneffeth $M^{r}$. Bull, the Quecnes Maiefties Clockemaker, who did tafte of the fruit (the trec bearing onely one Cherry, which he didente; but my felfe neucr tafedo it) at the impreffion hereof. Webatrealfoanorher, called the Agriot Cherry, of a rea fonable gond talte. Another we have wirh fruit of a dun colour, tending to a watehet. We haue one of the dwarffe Cherries, that bringeth forth fruit as great as moft of our Elanders Cherries, whereas the common fort bath very fmall Cherries, and thofe of an harh tafte. Thefe and many forts more we hate in our London gardens, whereof towrite particularly would greatly enlarge our volume, and to fnall purpofe : therefore what lath been faid thall fuffice. $¥$ I muft here(as I haue formerly done, in Peares, Apples and other fuch fruites) refet you to my two friends $\mathrm{M}^{\mathrm{r}}$. Iohn Parkinjon, and $\mathrm{M}^{\mathrm{r}}$. Iohn $\mathrm{W}$. Men, the one to furnith you with the hitory, and the other with the things themfelues, if you dafire them. $\neq$

\section{The Time.}

The Cherrie-trees bloome in Aprill; fome bring forth their fruit fooner; fome later : the red Cherries be alwaies better than the blacke of their orwe kinde.

\section{The Names.}

The Cherry-tree is called in Greeke, xipxos: and alfo in Latine, Cerafus : in high-Duteh, rebenbaum : in low-Dutch, 流etienboome, and Crieckenboom: in French, Cerifier: in Englifh,
Cherry-tree.

The fruit or Cherries becalied in Greeke, ussina, and xupzos:and in Latine likewife, Cerafa:in Englirh, Cherries : the Latine and Englin names in their feuerall titles thall fuflice for the reft that might be faid.

9 The Temperatureand Vertues.

The beft and principall Cherries be thofe that are fomewhat fower: thofe little fweet ones which bewilde and foonet ripe be the wort: they containe bad juice, they very forn putrifie, and do ingender ill bloud, by reafon whereof they do not oncly breed wormes in the belly, but troublefone agues, and often peltilent feuers : and therefore in well gouerned common wealths it is earcfully prouided, that they thould not be fold in the markets in the plague time. B wife cold, and the iuice they make is not good.

C The Flanders or Kentifh Cherries that are through ripe, baue a better juice but watery, cold and moift:they quench thirf, they are good for an hot fomacke, and profitable for thofe that have the agte: they eafily defcend and make the body foluble : they nourith nothing at all.

D The late ripe Cherries which the French-men keep dried againft winter, and are by rhem ealled Morelle, and we after the fame name call them Morell Cherrics, are dry, and do fomewhat bind ; thefe being dried are pleafant to the tafte, and wholeforae for the fomacke, like as Prunes
be, and do top the belly. 


\section{1 B. 3. Of the Hiftory ot Plants.}

Generally all the kindes of Cherries are cold and noiftof temperature, although fome more $E$ cold and moite than orhers : the whieh being eaten before meat doe foften the belly very gently, they are vnwhol fome either vnto moift and rheumatieke bodies, or for vnhealthieand eold to-
maekes.

The common blaeke Cherrics do ftrengthen the ftomaek, and are wholefomer than the red Cher- F ries, the which being dried do ftop the laske.

The diftilled water of Cherries is good for thofe that are troubled with heate and inflammati- $G$ ons in their ftomackes, and preuaileth againft the falling frekneffe gituen mixed with wine:

Many excellent Tarts and other pleafant mears are made with Cherries, fugar, and other delicat $F$ fpices, where of to write were to fmall purpole.

The gum of the Cherrie tree taken with wine and water, is reported to helpe the ftone; it may do I good by making the paffages flippery, and by tempering \& alaying the fharpneffe of the humors and in this maner it is a remedy alfo for an old cough. Diof corides addetl, that it makerh one well coloured, cleareth the fight, and caufeth a good apperire ro nreat.

\section{Сан г. 13і: Of the Mulberrie tree.}

I Moris.

The Mulberrie tree.

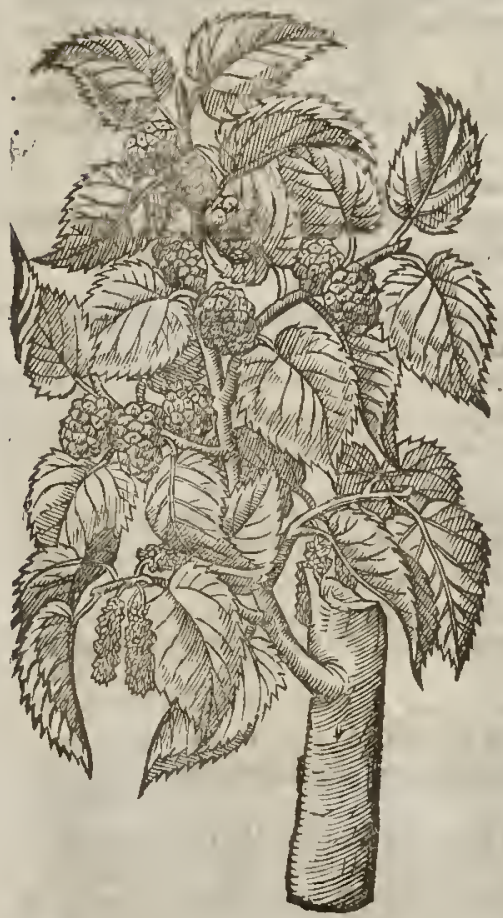

2 Morus alba.

The white Mulberric tree:

Tा The Defription.

1 The common Mulberie tree is high, and ful of boughes:the body wherof is many times great, the barke rugged; \&xthat of the rnot yellow :the leaues are broad and Tharp pointed, fomething hard, and nieked on the edges; in ftead of floures, are blowings or catkins, which are downie : the fruit is long, made vp of a number of litrle graines, like vnto a blackeBerrie, but thieker, longer, and mueh greater, at the firft greene, and when it is ripe blacke, yet is the
inice (whereof it is full) red : the root is parted many waies.

$$
\text { L11111 } 2
$$

2. The 
2 The white Mulberrie tree groweth vntill it be eome vnto a great and goodly ftature, almof as big as the former : the leaues are rounder, not fo tharpe pointed, nor fo deeply fnipt about the ed. ges, yer fometimes finuated ot deeply eut in on the fides, the fruit is like the former, but that it is white and fomewhat more tafting like wine.

$$
\text { Ti The Place. }
$$

The Mulberry trees grow plentifully in Italy and other hot regions, where they doe maintaine great woods and groues of them, that there Silkc wormes may feed thereon. The Mulberry tree is fitly fet by the flip; it nuay allo bc grafted or inoculated into many trees, being grafted in a white Poplar, it bringeth forth whitc Mulberics, as Beritus in his Gcoponickes reporteth. Thefegror in fundry gardens in England.

$$
\text { The Time. }
$$

Of all the tices in the Orchard the Mulberry dorh laft blome, and not before the cold weather is gone in May (therefore the old Writers were wont to eall it the wifelt tree) at which time the Silke wormies do feeme to reuiuc, as hauing then wherew ith to feed and nourifh themfelues, which all the winter before do lie like fmall graines or feeds, or tather like the dunging of a flem flie vpon a glaffe, or fone fuch thing, as knowing their proper time both to performe their duties for which they were ereated, and alfo when they may hauc wherewith to maintaine and preferue their owne bodies, vnto their bufinefle aforefaid.

The berries are ripe in Auguft and September. Hegefonder in Atbeneus affirmetl, that the Mul. berie trees in his time did not bring forth fruit in twentie years together, and that lo great a plague of the gout then raigned and raged fo generally, as not oncly men, but boies, wenches, eunuchs, and women were troubledwith that difeafe.

\section{This tree is bancd in Grecker ames.}

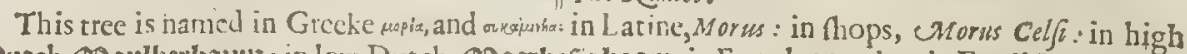
Dutch, ghatuetbaut : in low Dutch, 990 gtbefie boom: in French, Meurier : in Engligh,Mulberry
eree.

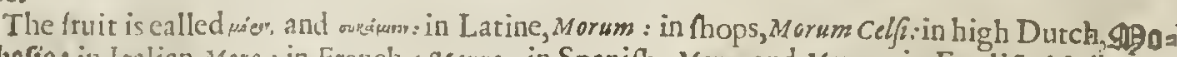
stbefie: in Iralian, Moro: in Frenel, erewre: in Spanih, Moras and Mores: in Englih, Mulberry.

\section{The Temperature and Vertues.}

A Mulberries being gathered before they be ripe, are cold and dry almof in the third degree, and do mightily binde; being dried they are good for the laske and blowdy flix; the pouder is ved in meat, and is drunke with wine and water.

B They ftay bleedings,and aifo the reds; they are good againf inflammations ot hot fwellings of the mouth and iawes, and for other inflammations newly beginning.

C The ripe and new gathered Mulberrics are likewife cold and be fulof iuiec, wh ich hath the tafte of wine, and is fomething drying, and not without a binding qualitie:and therefore it is alfo mixed with medicines for the mouth, and fuch as helpe the bot fwellings of the mouth, and almonds of the throar, for which infirmities it is fingular good.

D Of the iuice of the ripe berries is made a confection with fugar, called Diamorum : that is, after the manner of a fyrtup, which is exceeding good for the vlcers and hot fwellings of thc tongue, throat, and almonds, or Vuula of the throat, or any other malady arifing in thofe parts.

E Thefe Mulberries taken in meat, and al fo before meat, do very fpeedily pafie through the belly; by reafon of the moifture and flipperineffc of theit fubftance, and make a paffage for other meats, as Galen faith.

F They are good to quench thirf, they ftir vp an apperite to meat, they are not hurtfull to the fo: macke, but they nourin the body very little, being taken in the fecond place, or after meat, for al. though they be leffe hurtull than other like fruits,yet are they corrupted and putrified, vnleffe they fpeedily defeend.

$G$ The barke of the root is bitter, hot and drie, and hath a feouring facultic : the decotion hereof doth open the ftoppings of the liuer and fpleen, it purgeth the belly, and driueth forth wormes.

H The fame bark being fteped in vineger helpeth the tooth ache:of the fame effect is alfo the de. coction of the leates and barke, faith $D$ iofcorides, who fhewerh that about harueft time there iffueth out of the root a iuice, whieh the next day after is found to bchard, and that the fane is very

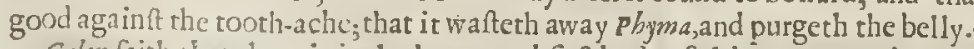
Galen faith, that therc is in the leaues and firft buds of this tree cettaine middle facultie, both
to binde and fcoure. 


\section{Снат. 132: Ofthe Sycomore tree.}

\section{Sycomorus.}

The Sycomore tree?

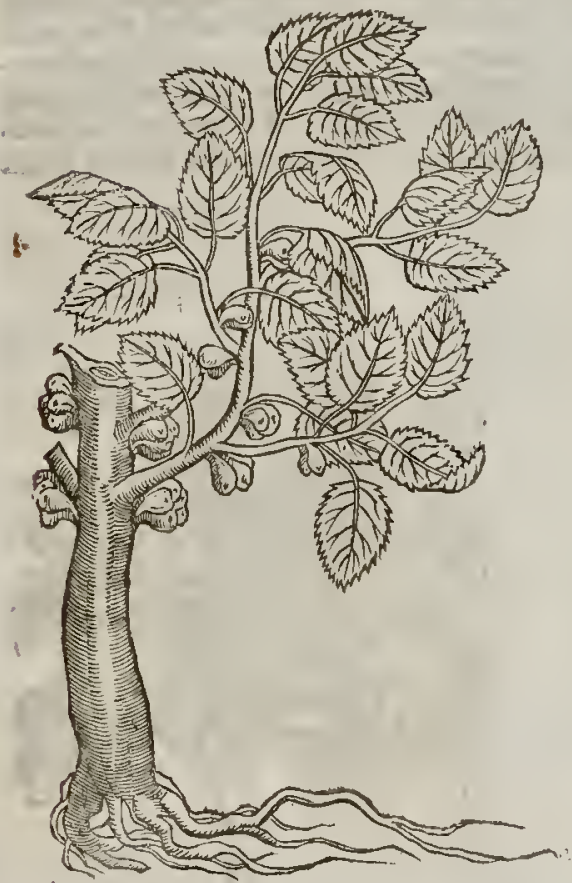

Q The Defcription.

$T^{\text {He }}$ sycomore tree is of no fmall 1 height, being very like to the mulberie tree in bigneffe $\& 2$ thew, as alfo in leafe: the fruit is as great as a Fig, and of the fame fathion, very like in ituce and tafte to the wilde Fig, but fiveeter, and without any grains or leeds within, which groweth not forth of the tender boughes, but out of the body and great old armes very fruitfully: this tree hatl in it plenty of milkie iuice, which fo foon as any part is broken or eut, doth iffue forth.

\section{T The Place.}

It groweth, as Diofcorides writeth, very plentifully in Caria and Rhodes, and in fundry places of Egypt, ds at the grear Cayre or Alkaire, and in places that doe not bring forth much wheat, in which it is an helpe, and fufficeth in ttead of bread \&c corne when there is fcarfitie of victuals. Galenwriteth, that he faw a plant of the Syeomore tree like to the wilde Fig tree, fruit and all.

\section{a) The Time.}

It bringeth forth fruit three or foure times in one yeare, and oftner if it be fcraped with an iron knife, or other like inftrument.

q The Names.

This tree is called in Gteeke, ovespusos, of the Fig tree and the Mulbery tree : in Latine, sycomorus : corneliss Cellus nameth it backward Morofycos: the Egyptians of orr time docall it Ficus PlsaraoWus, or Pharao his Fig tree, as witneffeth Bellonius : and it is likewife termed Ficus eAgyptia, Egyptian Fig trec,and alfo Morus Egyptia, or Egyptian Malberrie tree. We cal it Englifh, Sycomore tree af ter the Greek and Latine, and alfo Mulberry Fig tree, which is the right Sycomore tree, and not the great Maple,as we have faid in the chapter of the Maple.

The fruit is named in Greeke Sycomorom, and in Italian, Sycomzoro and Fico d' Egitto.

T The Tempcrature and Vertues.

The fruit of the Syeomore tree hath no harpneffe in it at all,as $G$ alen faith. It is fomwhat fweet in tafte, and is of temperature moift after a fort, and cold as be Mulberries.

It is good, faith Diofcorides, for the belly; but it is a's, 396 , that is, without any nourifhment, and $B$ troublefome to the ftomacke.

There iffueth forth of the barke of this tree in the beginning of the Spring, before the fruit ap- C peareth, a liquour,which being taken vp with a fpunge, or a little wooll, is dried, made vp into fine cakes,and kept in gallie pors : this mollifieth, elofeth wounds together, and diffolueth groffe humours.

It is both inwardly taken and outwardly applied againft the bitings of ferpents, hardneffe of the $D$ milt or f pleene, and paine of the tomacke proceed ing of a cold caufe : this liquor doth very quick-
ly putrifie.

$$
\text { LIIIIS CHAP }
$$




\section{CнA \\ 9i The Defoription.}

1 He garden Fig tree becommeth a tree of a meane ftature, hauing many branches full of white pith within, like Elderne pith, and large leaues of a darke greene colour, diuided into fundry fections or diufions. The fruit commeth out of the branches wi thout any foure at all that ener $l$ could perceitue, which fruit is in fhape like vnto Peares, of colour either whition, or fome. what red, or of a deep blew, full of fmall graines within, of a fweet and pleafant ta fte; which beeing broken before it be ripe, doth yeeld moft white milk, like vnto the kindes of Spurge, and the leaucs alfo beeing broken doe yeeld the like liquour; but when the Figges be ripe, the itice thercof is like
honic.

I Ficus.

The Figerec.

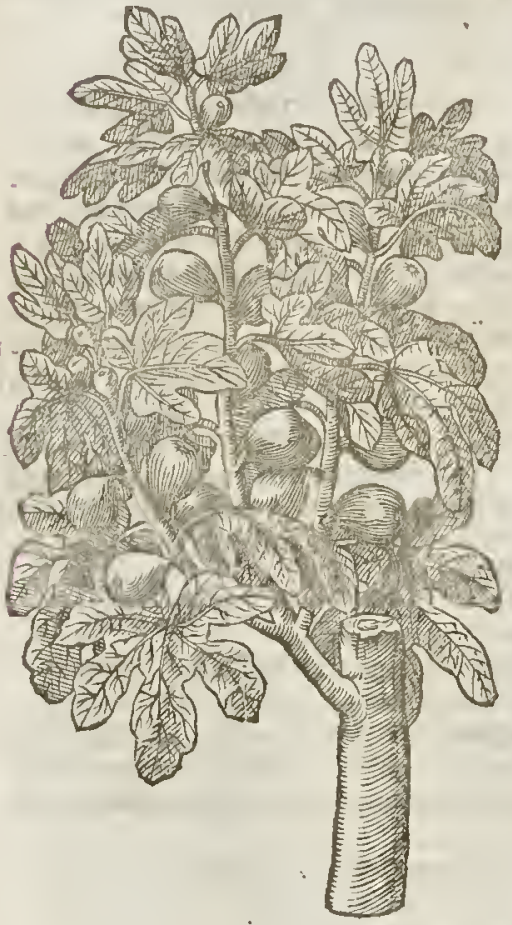

$\ddagger 2$ Chameficus. The dwarfe Fig tree.

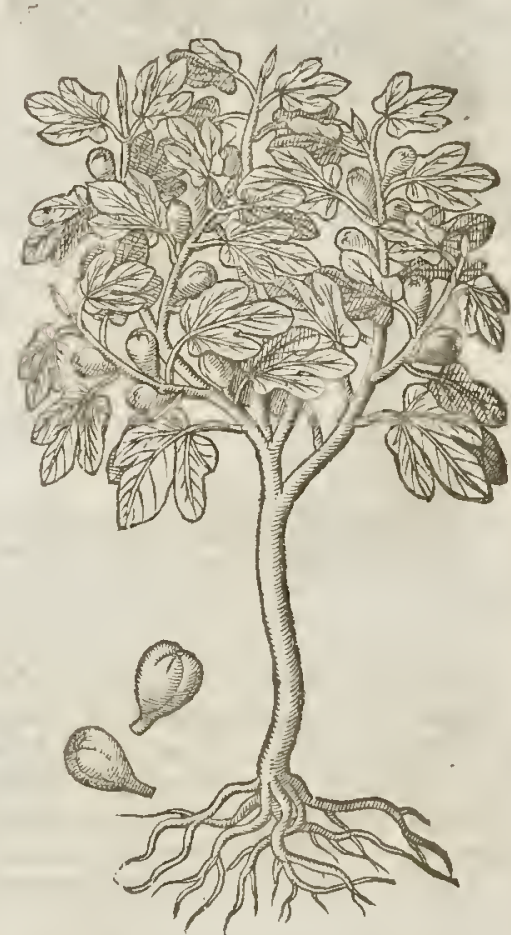

2. The dwarfe Fig-tree is like vnto the former in leaues and fruit, but it neuer growe thaboud the height of a man,and hath many fmall thoots comming from the roots, whereby it greatly in creareth.

There is allo ancther wilde kinde, whofe fruit is never ripe; Thoophrastus nameth it Erincos; $P$ ling Caprificus.

$$
\text { IT The Place. }
$$

The Fig trees do grow plentifully in Spain and Italy, and many other countries, as in England. where they beare fruit, but it neucr commeth to kindely maturitie, except the tree be planted under an hotwall, rwhereto neither North, nor Northeaft windes can come.

$$
\text { If The Time. }
$$

The dwarfe Fig treegroweth in my garden, and bringeth forth ripe and very great fruit in the monech of Auguft, of which rigs fundry perfons haue eaten at pleafure

In England the Fig irces pur ane forth their leaues vntill the end of $M$ av, where ofrentimes the fruit commeth forth before the leames appeare. 
T) The Names.

The Fig tree is called in Greeke, ouns and of diuers, for difference fake bewwecne it and the wild

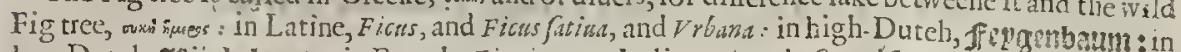

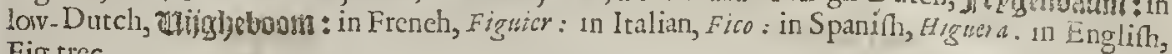
Fig trec.

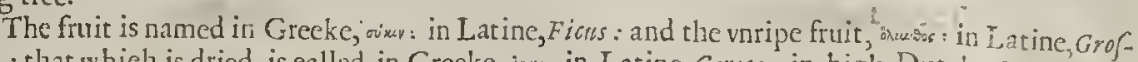

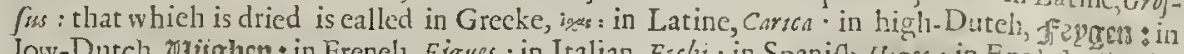
Iow-Dutch, đaigh)en : in Frencl, Figues : in Italian, Fachi: in Spaninh, Higos : in Englih, Fig:the

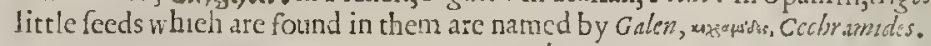

$$
\text { बा The Tempcrature. }
$$

The greene Figs new gathered are fomewhat warme and moif: the dry and ripe Figs are hot al. mot in the third degree, and withall fharpe and biting.

The leates alfo hame fome tharpneffe, with an opening power, but not fo frong as the iuice. I The Vertucs.

Thedry Figs do nourih better than the greene or new Figs; notwithfanding thay ingender not very good bloud, for fucli people as do feed much thereon doe beeome low tie.

Figs be gond for the throat and lungs, they mitigate the cough, and are good for them thar be thort winded : rhey ripen flegme, caufing the fame to be eafily fpet out, efpecially when they be fodden with Hyfop, and the deeotion drunke.

Figges famped with Salt, Rew, and the licrnels of Nuts withftand all poyson and corruption C of theaire. The Iring of Pontus, called Ghithridates, vfed this preferuatiue againt all venon and poyfon.

Figs ftamped and made into the forme of a plaifter with whear meale, the pouder of Fenugreek, and Lineteed, and the roots of marith Mallowes, applied warme, do foften and ripen impoftumes, phlegmons, all hor and angry fwellings and tumors behinde the eares : and if you adde thereto the roots of Lillies, it ripeneth and ireaketh Venerious impoftumes thar cone in the flanke, which impofume is ealled Bubo, by reafon of his lurking in fuch fecret places : in plaine Englinh termes they are ealled botehes.

Figs boiled in Wormwoodwine with fome Barly meale are very good to be applied as an impiaifer vpon the bellies of fuch as haue the droptic.

Dry Figges hauc power to foften, eonfume, and make thinne, and may be ved both outwardly and inwardly, whether it be to ripen or foften impoftumes, or to featter, diffolue, and confume them.

The leatres of the Fig tree dowafte and confume the KSings Euill, or fwelling kernells in the throat, and do mollific, wafte, and confume allother tumors, being finely pouned and laid rhereon: butalter my pract ife, being boiled with the roots of marih Mallowes vntill they be folt, and fo ineorporated together, and applied in forme of a plaifter.

The ruilky iuyce cither of rhe frgs or leaues is good againft all roughneffe of the stinne, lepries, fpreading fores, tetrurs, inall poeles, meafels, purhes, wheales, freekles, lenciles, and all other fpots, fcurnineffe, and deformitic of the body and face, being mixcá with Barley mealc and applied: ir dorl alfo takearvay warts and fuch like excrefcenees, if it be mingled with fome fartic or greafic thing.

The milke doth al focure the tooth-ache, if a little lint or cot ton be wet therein,and put into the hollowneffe of the tooth.

It openeth the veines of the hemorrhoids, and loofeneth the belly, being applied to the funda- $K$ ment.

Figs ftamped witl the pouder of Fenugrecke, and vineger, and applied plaifterwife, doecafe the intollerable paine of the liot gout, efpecially the gout of the feet.

The milke thereof pur into the wound proceeding of the biting of a mad dog, or any other venomous beaf, pieferueth the parts adioyning, taketh away the paine prefently, and curcth the liurt.

The greene and ripe Figs are good for thofe that be troubled with the ftone of the kidneyes, for they make the eonduits flipperie, and open them, and do alfo fomewhar elenfe : whereupon afrer the catimg of the fa: ue, ir hapnetl that mueh grauell and fand is conueyed fort?.

Dry or barrell Fige, ealled in Latine Carice, are a remedie for the belly, the cough, and for old infirmiries of the elief and lungs : they feoure the lidnies, and elenfe forth rhe fand, they mitigate rhe paine of the blactder, and eaufe wo nen with child to have the eafer deliuerance, if they feed therenf for certaine dayes together before their time.

niof corids faith , that the white liquor of the Fig tree, and iuiee of the Icaucs, docurdle milkeas $p$ renuet doth, and difinlue the nilke that is cluttered in the ftomacke, as do:l vineger.

It bringeth downe the menfes, if it be applied with the yoike of an egge, or with j el'ow war.

CHAP,

\section{D}

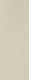

\section{${ }^{4}$}

(1)

\section{$\kappa$}

$J_{4}$ 


\section{C н а г.134. Of the prickly findian Fig tree.}

Ficus Indica. The Indian Fig tree.

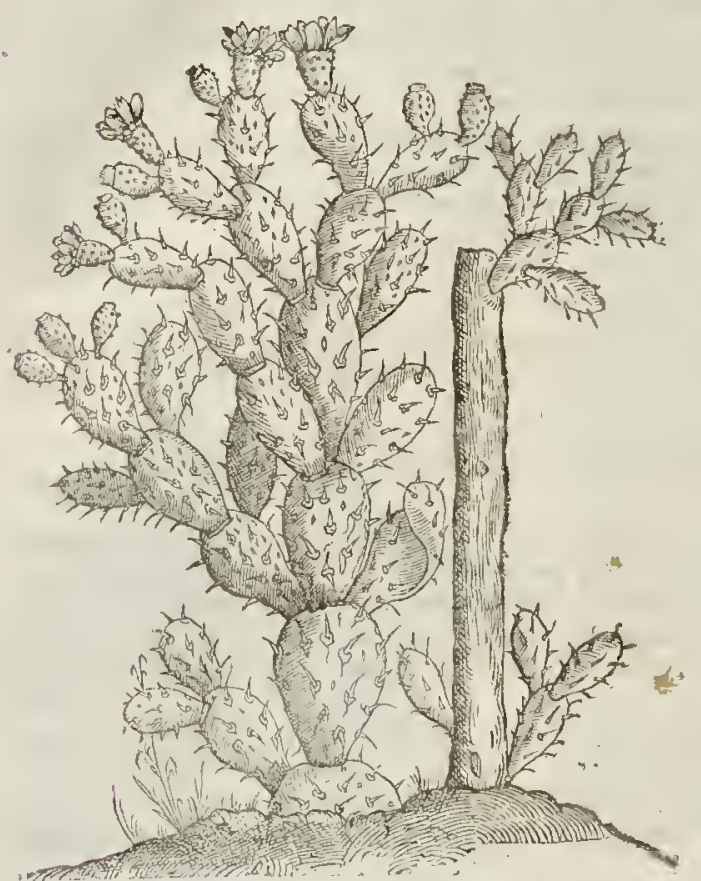

Frulzus.

The ftuit:

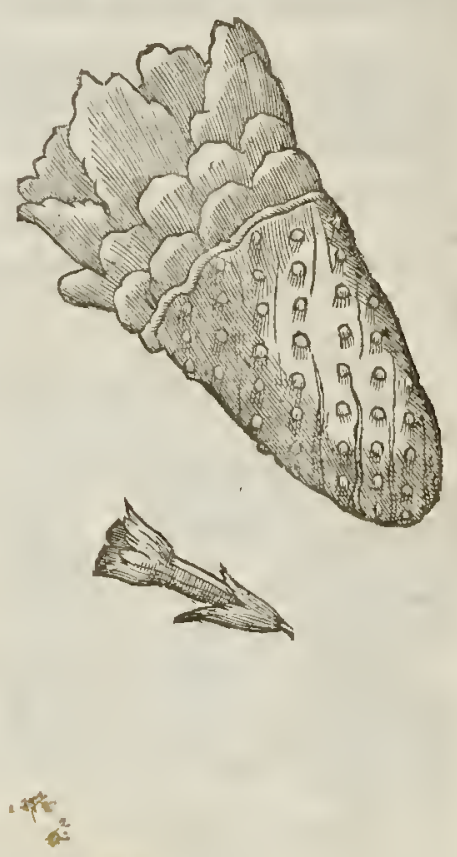

T) The Defcription.

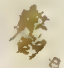

7 His ftrange and admirable plant, called Ficus Indica, feemes to be no other thing than a mul1 riplication of leaues, that is, a tree made of leaues, without body or boughes ; for the leafe fet in the ground doth in thort fpace take root,and bringeth out of it felfe other leaues, from which do grow others one a fter another, till fuch time as they come to the height of a tree, hauing alfo in the meane feafon boughes as it were comming from thofe leaues, fometimes more, other whiles fewer, as Nature lift to beftow, adding leafe vnto leafe, whereby it occupieth a great piece of ground : thefe leaues are long and broad, as thicke as a mans thumbe, of a deepe greene colour, fet full oflong, llender, tharpe, and whitith prickles : on the tops of which leaues come forth long floures not vnlike to thofe of the manured Pomegrenat tree, of a yellow colour : after which commeth the fruit like vnto the common Fig, narrow below, and bigger aboue, of a greene colour, and ftuffed full of a red pulpe and iuice, ftaining the hands of them that touch it, as do the Mulberries, with a bloudy or fanguine colour: the top of which Figs are inuironed with certaine fcaly leaues like a crowne, wherein are alfo contained fmall graines that are the feeds : the which being fowne, do bring forth plants round bodicd, like vnto the trunke of other trees, with leaues placed thercon like the other; which being fet in the ground bring forth trees of leaues, as we haue fhewed.

* Vpon this plant in fome parts of the Welt Indies grow certain excrefcences, which in continuance of time turn into Infects ; and thefe out-growings are that high prized Cochenele wherwith they dye colours in graine.

$$
\text { 9ा The Place. }
$$

This plang growcth in all the traft of the Eaft and Weft Indies, and alfo in the countrey Norembega, now called Virsinia, from whence it hath beene brought into Iraly, Spaine, England, and other countries: in Italy ir fometimes beareth fruit, but more often in Spaine, and neuer as yet in England, alchough I haue beftowed great pains and colt in keeping it from the iniury of our cold. slymat. 
It groweth alfoat S. Cruxand other places of Barbary, and alfo in an Inland of the Mediterranean fea, called Zante, about a day and nights failing with a meane winde from Petraffe a port in Morea, where my feruant William Mar/hall (before remembred) did fee not only great ftore of thofe trees made of leaues, but alfo diuers other round bodied plants of a woody fubftance from whence he brought me diucrs plants thercof in tubs of eartl $\mathrm{l}_{\mathrm{j}}$ very freth and greene, which flourithed in my garden at the imprefion hereof.

II The Tirise.

Thefe plants do grow greene and frefh both Winter and Sommer, by the relation of my forefaid feruant : notwithftanding they nut be very carefully kept in thefe countries from the extremitic of Winter.

This is thought to be the plant called of Pliny, Opuntisum; whercof he hath written, ib. 2 r:ea.17. in this manner: About Opuns is the herbe opuntia, to mans tafte fweet, and it is to be maruelled, that the ront fhould be made of the leaues, and that it thould fo grow. Opuns is a city necre vnto Phocis in Greece, as Paufanids, Strabo, and Pliny teftifie : but it is commonly called in Latine, Freus Indica : of the Indians, Tume, and Tunes, and ailo Anapallus, as teftificth Bellomus: in Euglifh, Indian Fig tree.

There is a certaine other deferibed for the Indian Fig tree, by $T$ heophraftus, lib. 4 . which Pliny, 3i6. I 2 . cap.5. doth eloquently expreffe almoft in the famewords, but turned into Latine, whereof we intend to fpeake in the next clapter.

9i The Temperature and Vertues.

We have no certaine infrution from the Antients, of the temperature or faculty of this plant, $A$ or of the fruit thereof : neither haue we any thing whereof to write of our owne knowledge, more than that we have heard reported of fuch as haue eaten liberally of the fruithereof, that it changed their vrine to the colour of bloud; who at the firft fight thereof ftood in great doubt of their life, thinking it liad been bloud, whereas it proued afterwards by experience to be nothing but the tincture or colour the vrine had taken from the iuice of the fruit, and that without all hurt or griefe at all.

It is reported of fome, that the inice of the fruit is excellent good againf vicers of long conti- B nuance.

$¥$ Cochenele is giuen alone, and mixed with other things; in maligne difeafes, as peftilent fe-C uers and the like, but with what fucceffe I know not. $\ddagger$

\section{$\mathrm{C}_{\mathrm{H}} \mathrm{A}$. 135. Of the arched Indian Figtree. 20 논 \\ II The Defeription.}

$\mathrm{T}$ Hís ratc and admirable tree is very great, Araight, and couered with a yellowith bark tending to tawny : the boughes and branches are many, very long, tough, and Hexible, growing very long in thort fpace, as do the twigs of Oziars, and thofe fo long and weake, that the ends thereof hang downe and touch the ground, where they take root and grow in fuch fort, that thofe twigs become great trees :and the fe being growne vp vnto the like greatneffe, doe caft their branches or twiggy tendrels vnto the earth, where they likewife take hold and root; by meanes wherof it conmeth to paffe, that of one tree is made a great wood or defart of trees, which the Indians do ife for conerture againft the extreme heate of the Sun, wherewith they are grieuoully vexed:fome likew ife vfe them for pleafure, cutting downe by a direct line a long walke, or as it were a vault, through the thickelt part, from which alfo they cut certaine loope-holes or windowes in fome places, to the end to receiue thereby the frefti coole aire that entreth thereat, as alfo for light, that they may fee the ir cattell that fced thereby, to auoid any danger that might happen vnto them either by the enemic or wilde beafts : from which vault or clofe walke doth rebound fuch an admirable echo or anfwering voice, if one of them fpeake vnto another aloud, that it doth refound of anfwer againe foure or fute times, according to the height of the voice, to which it doth anfwer, and that fo plainly, that it cannot beknowne from the voice it felfe: the firft or mother of this wood or defart of trees is hard to be knowne from the children, but by the greatneffe of the body, which three men can fcarfely fathom about : vpon the branches whereof grow leaues hard and wrinckled, in thape like thofe of the Quince tree, greene abouc, and of a whitifh hoary colour vnderneath, whereupon the Elephants delight to feed: among which leaues come forth the fruit, of the bignes of a mans thumbe, in thape like a fmall Fig, but of a fanguine or bloudy colour,and of a frreet taft, 
E.

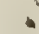

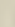

I The Place,

This wondrous tree groweth in diuers pla: ces of the Eaft Indies, efpecially neere vnto Goa, and alfo in Malaca : it is a franger in molt parts of theworld.

\section{- The Time.}

This tree keepeth his leaues green winter and Sommer.

9 T he Names.

This tree is called of thofe that hane tranelled, Ficus Indica, the Indian Fig; and $\mathbf{A r}$. bor Gea, of the place where it groweth in greateft plenty : we may call it in Englin, the atched Fig tree.

\# Such as defire to fee more of this Fig tree, may haue recourfe to Clufius his Exoticks, lib.1.cap. I. where he thewes it was mentioned by diuers antient Writers, as 9. Curtius, lib.9. Plin. lib. 1 2.ca.5. Strabo, lib.5.and Theophr. Hift.Plant. lib.4.cap.5. by the name of Ficus indica, $\neq$ $s$

\section{T) The Temperatureanavertues:}

We haue nothing to write of the temperature or vertues of this tree, of our owne knowledge : ncither hate wee receiued from others more, than that the fruit hereof is ge. nerally eaten, and that without any hurt at all, but rathergood, and alfo nourirhing.

\title{
C н а : 136 : \\ m \\ Of Adams Apple tree, or the Weft-Indian Plantaine.
}

\author{
If The Defription.
}

W

Hether this plant may be reckoned for a tree properly, or for an herby Plant, it is difputable, confidering the foft and herby fubftance whereofit is made; that is to fay, when it notwithftanding it may be cut downe with one ftroke of a fwd of the bignefie of a mans thigh, euen with as much eafe as the root of a Radih or caro of fword, or two or three cuts with a knife, threddy root rife immediately diuers Radih or Carrot of the like bigneffe : from a thicke fat times more, according to the foile where it growe of the length of three cubits and a halfe, fomeficient to sirap a childe in of two yeares it groweth, and of a cubit and more broad, ofbignes fuf colour, hauing a broad rio running thord, in thape like thofe of Mandrake, or an ouerworn green of the extreme hot fcorching Sun, or of their the middle thercof: which leates, whether by reafon that there is nothing thereof Sun, or of their orne nature, in Seprember are fo dry and withered, thefe leates rifeth v) a thicke tr or to be feene but onely the middle rib. From the middeft of off, as alfo thofe nexr the ground, by, whereon doth grow the like leaues, which the people do cut therwife would remaine alow and mafe vntill it come to a certaine heioht bafe plant. This manner of cutting they ve from time to time, the fruit. In the middeft of the top aboue the reach of the Elephant, which greedily feeketh after whereon dogrow diucrs apples in formeng the leates commeth forth a foft and fungous ftumpe, 
L13.3. Of the Hiftory of Plants.

with a thin rinde like that of the Fig, of a yellow colour when they be ripe: the pulpe or fubftance of the meate is like that of the Pompion, without either feeds, ftones, or kernels, in ta ft not greatly pereeiued at the firft, but prefently after ir pleafeth, and entifeth a man to eat liberally thereof, by a certaine entifing fweetnes it yeelds : in whieh fruit, if it be eut according to the length (faith niyne Author)oblique, tranfuerfe, or any other way what foever, may be feen the thape and forme of a eroffe, with a man fafned thereto. My felfe haue feene the fruit, and eut it in pieces, which was brought me from Aleppo in pickle ; the croffe I might pereeine, as the forme of a fpred-Egle in the root of Ferne; but the man lleaue to be fought for by thofe that haue better eyes and indgment than my felfe.

CMura serapionis. Adams Apple tree.

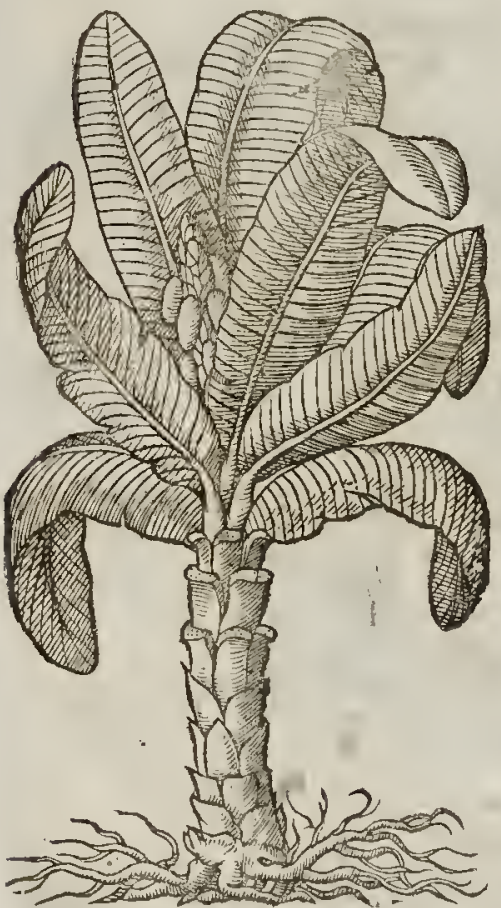

MuS Fructus. Adanis Apple.

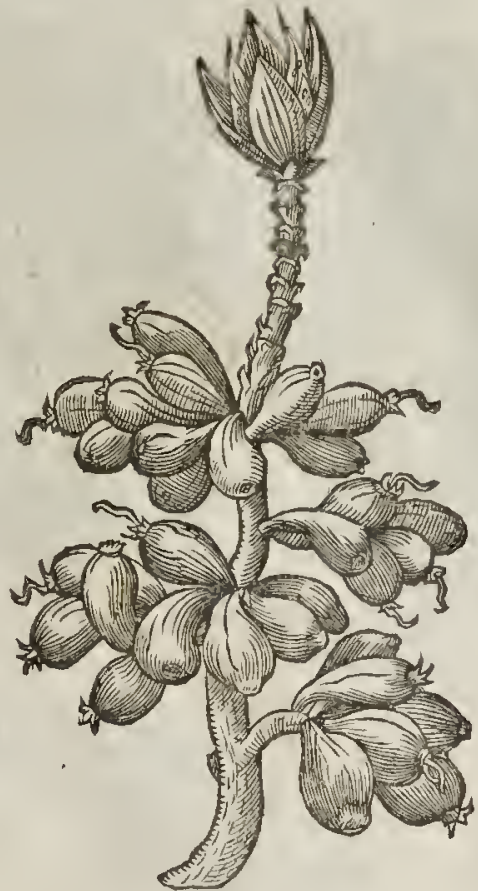

¥ Aprill 10. 1633. my much honored friend D. Argen: (now Preliuent of the Colledge of Phy fitions of London) gaue me a plant he receined from the Bermuda's : the length of the italke was fome two foot ; the thiekneffe thereof forne feutn inehes about, being crefted, and full of a foft pith, fo that one might eafily with a knife cut it afunder. It was crooked a little, or indented, fo that eaeh two or three inehes fpace it put forth a knot of fome halfe inch thickneffe, and fome inch in length, which incompafied it more than halfe about; and vpon each of thefe ioints or knots, in two rankes one aboue another, grew the fruit, fome twenty, nineteene, eighteene, \& 8 . more or leffe, at each knot: for the branch I had, eontained nine knots or diuifions, and vpon the loweft knot grew twenty, and vpon the vppermoft fifteene. The fruit which I recciued was not ripe, but greene, each of them was about the bigneffe of a large Beane; the length of them fone fitue inches, and the bredth fome ineh and halfe: they all hang their heads downewards, hauc rough or vneuen ends, and are fiue cornered; and if you turne the vpper fide downward, they fomewhat refemble a boat, as you may fee by one of them expreft by it felfe : the huske is as thicke as a Beanes, and will eafily thell off it : the pulpe is white and foft : the ftalke whereby it is falned to the knot is veric thort, and almoit as thieke as ones little finger. This ftalke with the fruit thereon I hanged up in my thop, were it beeame ripeabout the beginning of May, and lafted vntil lune : the pulp or neat was very foft and tender, and it did eate fomewhat like amM uske-Melon. I hate gituen vout the figure of thewbole branch, with the fruit thereon, which I drew as foone as I reeeined it, and it is marked with this figure I. The figure 2 . Theweth the thape of one particular fruit, with the lower 
fidevpwards. 3. The fame cut throtgh the middle long wayes. 4. The fame cut fide wayes: thaue been told (but how certaine it is I know not) that the floures which precede rhe fruit are bell-fafhioned, and of a blew colour. I could obferue no feed in the fruit; ir may be it was becaufe it had been cut from the ftocke fo long befo:e it came to maturitie. This Plant is found in many places of A fia, Africke, and America, efpecially in the hor regions: you may find frequent mention of it among ft the fea voyages to the Eaft and Weft Indies, by rhe name of Plantaines, or Platanus, Barnamas, Bonnanas, Bowanas, Dauanas, Poco, \& 6 . fome (as our Author bath faid) haue iudged it the forbidden fruit; other-fome, the Grapes brought to Mofes out of the Holy-land. \$

crufa fructus exactior Icon.

An exacter figure of the Plantaine fruit.

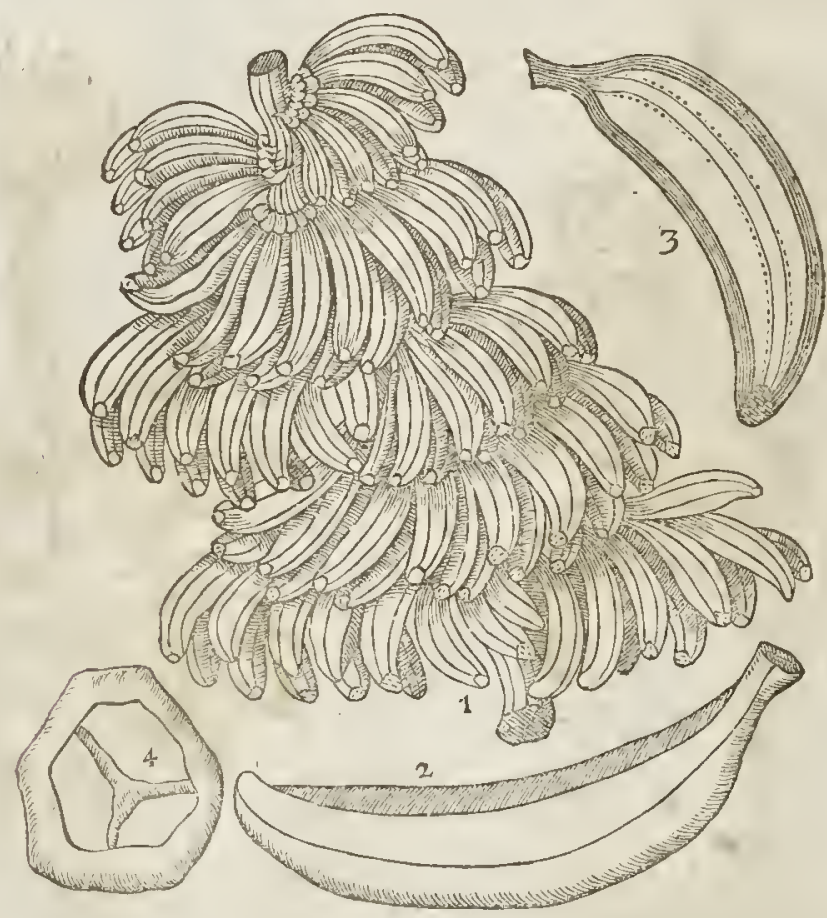

It The place:

This admirable tree groweth in Egypt, Cyprus, and Syria, neere vnto a chiefe city there called Alep, which we call A leppo; and alfo by Tripolis, not far from thence : it growerh alfo in Cana$\mathrm{ra}$, Decan, Guzarate, and Bengala, places of the Eaft Indies.

\section{T $\tau$ be $T$ ime.}

From the root of this tree thooteth forth yong fprings or thoots, which the people take vpand plant for the increafe in the Spring of the yeare. The leaues wither away in September, as is aboue faid.

\section{q) The Names.}

It is called Mufa by fuch as traucll to Aleppo : by the Arabians, Mufa Maum : in Syria, Croofe: The Grecians and Chriftians which inhabit Syria, and the Iewes alfo, fuppofe it to be that tree of whin? fruit Adam did tafte; which others thinke to be a ridiculous fable: of Pliny, opuntia.

It is called in the Eaft Indies (as at Malauar where it alfo groweth) Palan : in Malayo,Pican :and in thar part of Africa which we call Ginny, Bananas : in Englifh, Adams Apple tree.

\section{T The Temperature.}

Diofcorides and Serapio iudge, that it heateth in the end of the firft degree, and moiftneth in the ond of the fame.

$$
7 \text { The Vertues. }
$$

1. The fruir hereof yeeldeth but little nourifhment : it is good for the heare of the breaft, lungs, and bladder : it ftoppeth the liuer, and hutreth the ftomacke if too much of it be eaten, and pro- 
cureth lonfeneffe in the belly: whereupon it is requifit for fuch as are of a cold confitution, in the eating thereof to put vnto it a little Ginger or other fpice.

It is alfogood for the reines, or kidnies, and to provoke vrine: it nouriheth the enilde in the inc- B thers wombe, and ftirreth to generation.

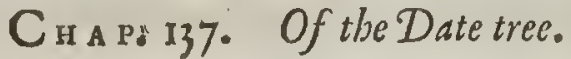

Palma.

The Date trec.

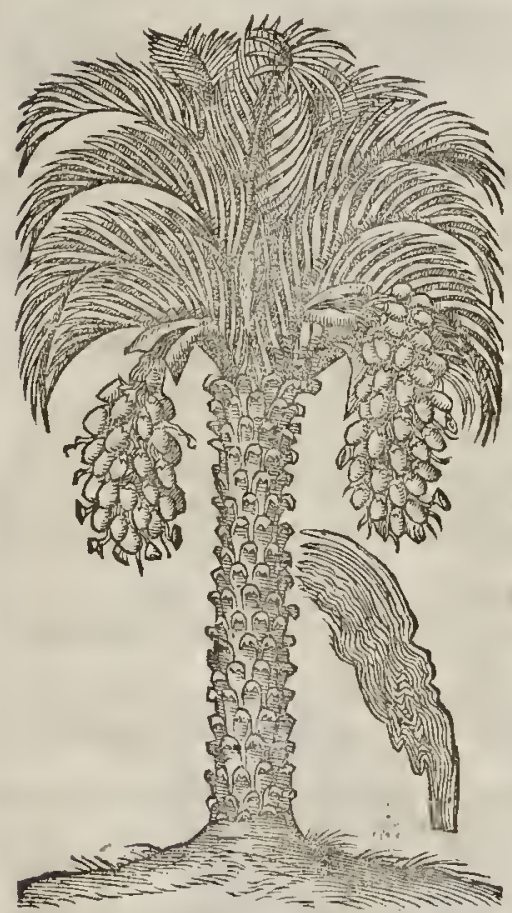

Palmarum frotion \& flores cum Elate. The fruit and floures of the Date tree.

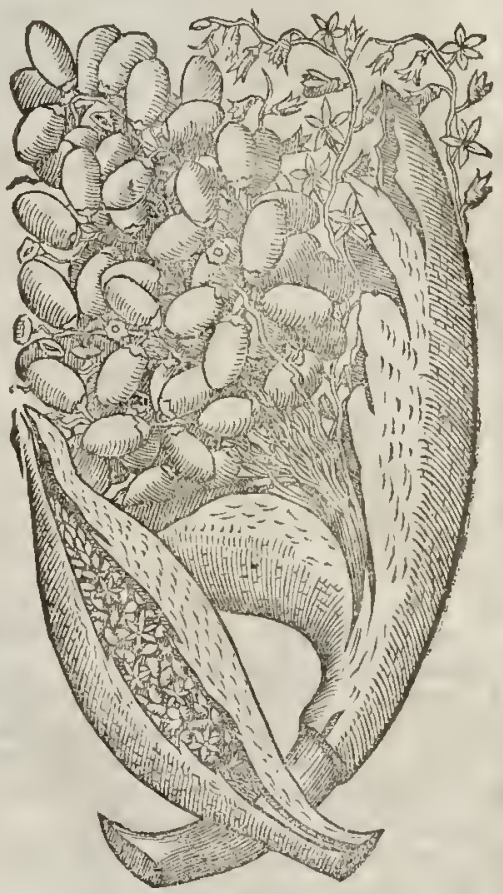

9 The Defcription.

$\mathrm{T}$

He Date tree groweth very great and high : the body or trunke thereof is rhicke, and contered with a fcaly rugged barke, caufed by the falling away of the leaucs : the boughes grow onely on the top, confifting of leaues fet vpon a wooddy middle rib like thofe of Reeds or Flags : the inner part of which rib or ftalke is fofr, light, hollow, and fpongic. Among the leanes come forth the floures included in a long skinny membrane, as it were a theath or hofe, like that which eouereth the Floure de-Luee before it be blowne, which being opened of it felfe, white floures ftart forth, ftanding vpon fhort and flender foot-ftalkes, which are faftened with certaine fmall filaments or threddy frings like vnto little branches: after which fpring out from the fane branehes the fruit or Dates, which be in fafhion long and round, in tafte fweer, and many times fomewhar harfh, of a yellowifh red colour; wherein is contained a long hard ftone, which is in ftead of kernell and feed; the which I haue planted many times in my Garden, and haue growne to the height of three foot: but the firft froft hath nipped them in fuch fort, that foone after they perirhed, notwithetanding my, induftrie by eouering them, or what elfe I could doe for their fuccour.

$$
\text { 4) The Place. }
$$

The Date trees grow plentifully in Afriea and Egypt; but thofe which are in Paleftina and $\mathrm{Mmm}$ nim Syring 
Syria be the beft:they grow likewife in moft places of the Eaft and Weft Indies, where there be di. uers forts, as well wilde, as tame or manured.

$$
\text { II The Time. }
$$

The Date tree is alwaies green, and floureth in the Spring time: the fruit is ripe in September, and being then gathered they are dried in the Sunne, that they may be the better both traniported into other countries far diftant, as alfo prefcrued from rotting at home.

$$
\text { of The Names. }
$$

The tree is called in Greeke, qoin : in Latine, Palma : in Englifh, Date tree.

The fruit is named in Grecke, Feideros savixum: that is to fay, Glans Palmarum, or the fruit of the Date

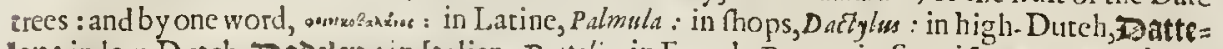
len: in low-Dutch, Dadelcu : in Italian, Dattoli : in French, Dattes : in Spaninh, Tamaras, and Dattiles : in Englifh, Date.

The cod or theath wherein the foures and Dates are wrapped, is called inim : and of fome, bipanar.

$$
\text { T) The Temperature and Vertses. }
$$

A All manner of Dares whatfocter are hard of digettion, and eat fe head-ache: the worfer fort be thofe rhat be dry and binding, as the Egyptian Dates; but the fott, moif, and fwcet ones are leffe hurrfull.

B The bloud which is ingendred of ( ) ates in mans body is altogether groffe, and fomewhat elammy: by thefe the liuer is very quickly ftopped, efpecially being inflamed and troubled with fome hard fwelling : fo is rhe fpleere likerile.

C The Dates which grow in colder regions, when rlicy cannot eome to perfect ripeneffe, if they be eaten too p!cutifully, do fill the body full ot raw humors, ingender wirde, and of times caufe the Ieprofie.

D The dricr forts of Dates, as Eicfcorides fititl, be good for thofe that feet bloud, for fuch as haue bad fomacks, and for thofeal fo rhar be troubled with the bloudy fix.

The beft Dates, ealled in Latine $C$ ryota are good for the roughneffe of the throat and lungs.

F There is made hereof borth by the eunning Confentoners and Conkes, diuers excellent eordiall, enmfortable, and mourihing medicir es, and that procure luft of the body rery mightily.

$G$ They doalfo refreth and refoe! 1 eh mo itrengrh as are entring into a confumption, for rhey ftrengthen the fecbleneffic of the liter ard fpleene, being made into eonuenient broths, and phyfi-
call medicises directed by a iearned Phylitian.

H Dry Dates do fop the be!!y, and fay vomiting, and the wambling of womens Aomaches rhat arewith ehilde, if they be ether eaten in meates or otherwife, or ftamped and applic d vnto the fomacke as a pectorall plaifter.

I The afhes of the Date ftones haue a binding qualitie,and emplaftick facultie, they heale puthes in the eyes, Staphylomata, and falling away of the haire of the eye lids, being applied together with Spikenard : with wine it keepeth proud flefh from grow ing in wounds.

K The boughes and leaues dncuidently binde, but efpeeially the hofe, rhat is to fay, the theath o: cafe of the floures: and there fore it is gond to vfe thefe foot as there is nced of binding.

L The leaues and branches of the Date tree do heale greene wounds and vleers, refrefin and cools hot inflam rations.

M Galen in his booke of Medieines acenrding to the kindes mentionerh a compofition ealled Dirpalma, which is to be ftirred with the bough of a Date tree in fead of a fpature or a thing to ftirre with, for no other caufe than rhat it may receitue thereby fome kinde of aftriction or binding force.

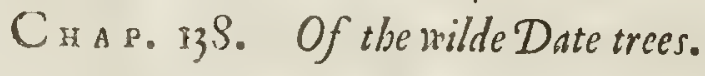 \\ 9 The $\mathrm{Defcription}$.}

I THeophraftus maketh this plane to be a kinde of Date tree, but low and of fmall growth, 1 feldome attaining aboue the height of a cubit: on rhe top whereof fhoot forth for fides whereof breakes forth a buth of threddy ftrings : among which rifeth vp fmall branches garnithed wirh eluters of whire fontes, in which before they be opened are ro be feene vnperfert Thapcs of leaues, elofely enmpaffed about with an in mumerable fort of thin skinny hulls; which utde fhapes with rhe foures are ferued vp and eaten at the feeond eour fe among orher iunkets, with a litele falt and pepper, being pleafant to the tafte. $\neq$ The ftalke is about the thicknes of ones 
I Palmites, fue Chamerriphes. The little wilde Date ttee.

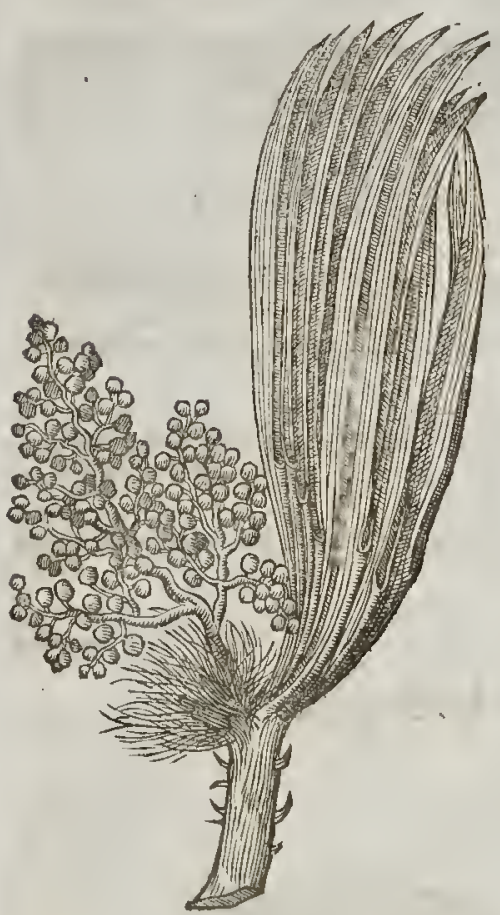

¥ Fruitus Palmadini.

The futit of the Cone-Date.

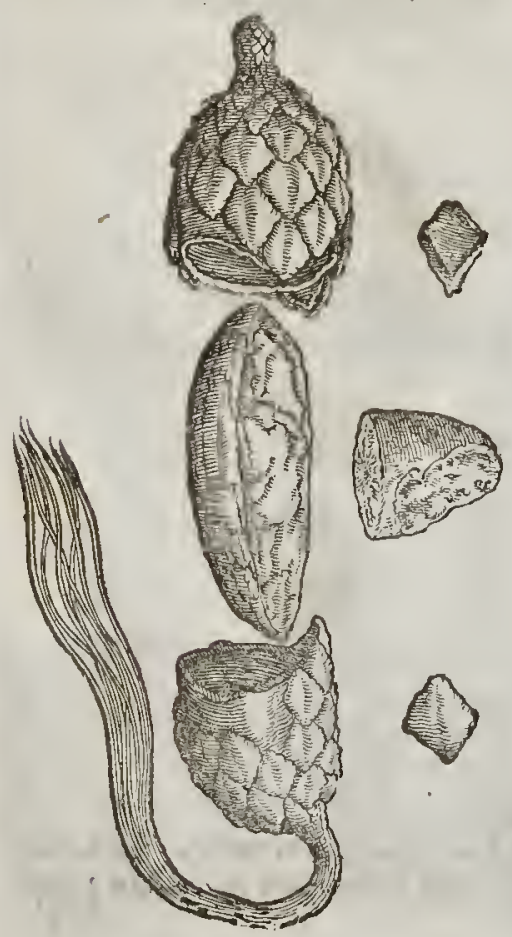

2 Palmaspinzs, fuse $\boldsymbol{P}$ alma conifera.

The wilde Date ttee bearing cones:

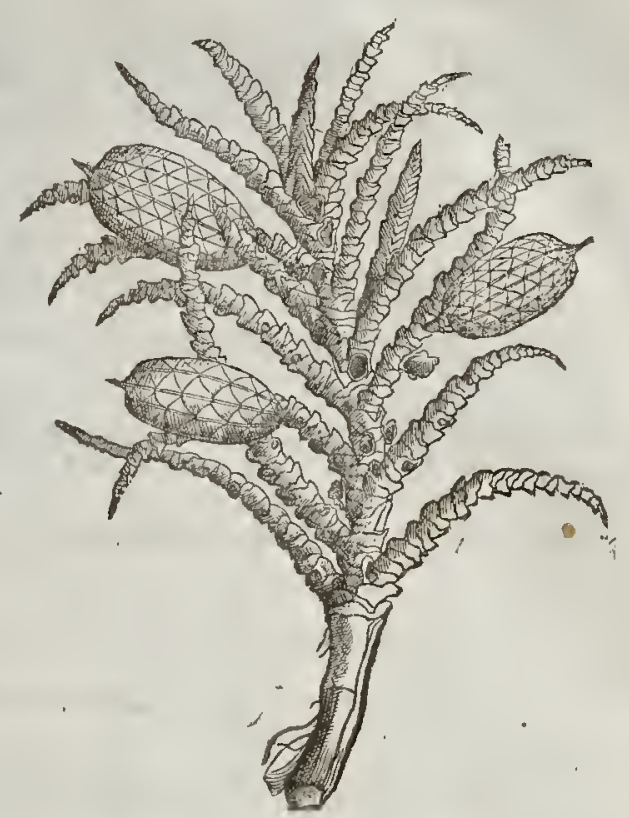

little finger, here and there fet with a fer crooked pricks: the leaues within fome handfull or two of the ftalke are cuit vp and made into little befomes, which ate fold in many glaffe fhops here in London.

2 The wilde Dare tree that brings forth cones or key-clogs, is of moft tratuellers into the Indies thought to be barren of Dates,except fometimes it yeelderh forth fome fmall berries like into Dates, but dry, and nothing worth. This tree gtoweth to the height and bignefle of a low ttee, the trunke or body whereof is foft, of a fungous or pithy futb. ftance, vnfit for building, as is the manured Date tree: the branch it felfe was btought vnto vs from the Indies, dry \& void ofleaues, wherefore we rnuft defcribe the leanes by teport of the bringer. Thebranehes (faith my Author) are couered ouer withlong flaggie leaues, hanging downe of a great length like thofe of the Date tree: the branches are alfo couered with a fealy or fcabbed barke, verie rough, one fcale or plate lying ouer another, as tiles vpon a houre : the fruit growes at the end of the bianches, not unlike a great pine Apple cone, cotered oter with a skinne like the Indian Nut : wherein is contained a hel, within which fhell lieth hid an acorn or long Mmmmm ?

kérnell 
lsencll of an inch long, and fometimes longer, very hard to be broken, in tafte like the Cheftnut which the faudge people do gratc and ftampe to pouder to make them bread.

4T The Place.

Thcoplyraftes faith the firft growes in Candy, but much more plentifully in Cilicia, and are now found in certaine piaces of Italy by the lea fide, and alfo in diuers parts of \$ paine.

The other hath been found by trauellers into the Welt Indies, from whence haue bin brought the saked brancheswith the fruit.

The time anfwereth that of the manured Date tree.
The

$$
\text { I The Names. }
$$

The little Date tree or wilde Date tree is named of Theophraftus, xauspipars: in Naples, Cephagliono. in Latine commonly Palmites. That which is found in the midft of the yong fprings, and is

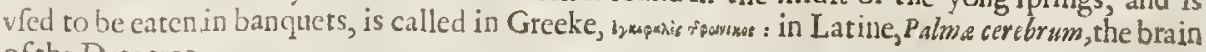
of the Date tree.

बा The Temperature and Vcrtues.

A. Gales fuppofeth that the brain of the Date tree confifteth of fundry parts, that is to fay, of a cer:taine waterie and warme fubftance, and of an earthy and cold; therefore it is moift and cold, with a certaine aftriction or binding qualitie.

B Beir taken as a meat it ingendreth raw humors and winde, and therefore it is good to be eatera with pepper and falt.

\section{A. 139. Of the drunken Datetree. Areca, fue Faufel. \\ The drunken Date tree.}

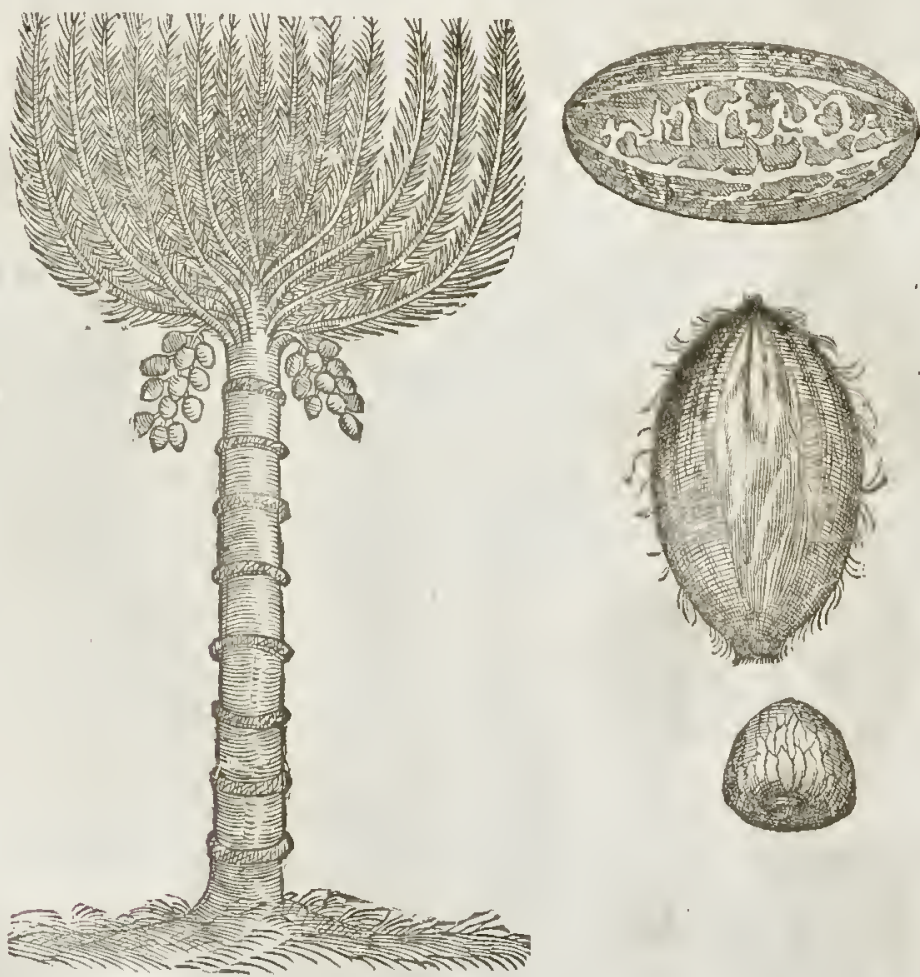

-1 The Defription?

He drunken Date tree, which Carolus Clufurs calleth $F_{\text {Aufel, }}$, is an Indian tree of a great bignes,

the timberwhereof is very foft and fpongious, exceeding fmooth and plaine vnto a great 
height, nor poffible to be climbed vp; and therefore the Indians fot. their eafier afeending $v p_{3}$ at fome diftances do tie round about the tree certaine wyths or ropes made of the barkes of trees, as may be perceiued by the figure, whereby very cafily they go vp and downe to gather the fruit at their pleafure. The top of the tree is duided into fundry branehes, in fubftanee like to the great cane; whercupon do grow faire flaggie leaues like thofe of the Palme or Date tree, whereo! doubtleffe this is a wilde kinde: from the bottome of which branehes commeth forth fruit un long bunches like traces of Onions, couered with a foft pulpe like vnto the Wall-nut, rough, and verie full of haire of a yellowifh colour, and like the dried Date when it is ripe: within which huske is contained fruir like vnto the Nutmeg, but greater, very hard, and ftriped oner with red and white veines, or finues.

$$
\text { 9t The Place, Time, and Names. }
$$

This Date tree, which the Arabians call Faufel, that is by interpretation, Auellawa Indicu, the Indian Nut or Filberd, $A$ uicen and Serapio call Filfel, and $F u f f l$. It growerh in the Ealt Indies in diuers and fundry places, as in Malauar, where vulgarly it is called PAC; and of the Nobles and Centlemen, Areca : which name is vfed amongft the Portugals which dwell in rhofe Indies : in Guzarate and Decan it is called Cupare : in Zeilan, Po.az : in Malaca, Ptran : in Cochin, Chacani : in Englifh, the drunken Date trec, which name we haue eoined from his qualitic,becaufe the fruit maketh thofe drunke that eate thereor.

- It is cold and dry in the fecond degree.

$$
\text { 9) The Tempcrature. }
$$

\section{TheVertues.}

The fruit of Area before it be ripe is reckoned amongt the ftupefactiue or aftonifhing medicines; for whofocuer eateth thereof waxeth drunke, becaufe ir doth exceedingly amafe and aftonifh the fenfes.

When the Indians are vexed with fome intolerable ache or paine, or muft of necefitic endure fome great rorment or tortrire, then do they take of this fruit,whereby the rigor of that pain which otherwife they fhould feele, is very much mitigated.

The iuice of the fruit of Areca doth ftrengthen the gums, faften the teeth, comfort the ftomack, tay vomiting and loofeneffe of the belly : it doth alfo purge the body from congealed or clorted bloud gathered within the fame.

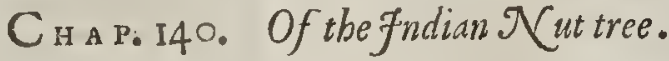

\section{वा The Defription.}

I THe Greeians haue not known, but the Arabians haule mentioned this Indian Nut tree, the body whereof is very great, fmooth and plaine, void of boughes or branches, of a great height; wherefore the Indians do wrap ropes about the body thereof, as they doe vpon the zrec laft defcribed, for their more eafe in gathering the fruit : the timber whereof is verie fpongic within, but hard without, a matter fit tomake their $C$ anoos and boats of: on the top of the tree grow the leaues like thofe of the Date tree, but broad, and fharpe at the point as thornes, whereof they vfe to make needles, bodkins, and fuch Itkc inftruments, wherewith they fow the failes of their fhips, and do fuch like bufineffe :ainong thefe leaues come forth clufters of floures like thofe of the Cheftnut tree, which turne into great fruit of a round forme, and fomwhat tharp at one end; in that end next vnto the tree is one hole, fomtimes two bored through : this Nut or fruit is w rapped in a couerture, confifting of a fubftance not vnlike to hempe before it be beaten foft : there is alfo a finer and gentler futffe next vnto the fhell, like vnto Flax before it be made foft : in the middle whereof is contained a great Nut eouered with a very hard hell, of a browne colour before it be polifhed, afterward of a blacke fhining colour like burnifhed horne : next vnto the thell vpon the infide there cleauch a white cornelly fub fance firme and follid, of the colour and tafte of a blanelied Almond : within the cauitic or hollownes thereof is contained a moft delectable liquor like vnto milke, and of a moft pleafant tafte.

2 We have no eerraine knowledge from thofe that hate trauclled into the Indies, of the tree which bearerh this litrle Indian Nut; neither bauc we any thing of our owne knowledge, more; than that we fee by experience that the fruit hereof is leffer, wherein confifteth the difference.

$\ddagger$ The orher, expreffed in the fame table with the former, by the name of ( Me henbethene, Clus $f-$ us receiued it by rhe fame name from Cortufus of Padua : yet ir doth not (as hee faith) well agree with the defcription; and he rather approtles of their opinion who refer tt to the Nux ?ng uentaric; $\mathrm{Mmmmm} 3$ 


\section{y of Plants:}

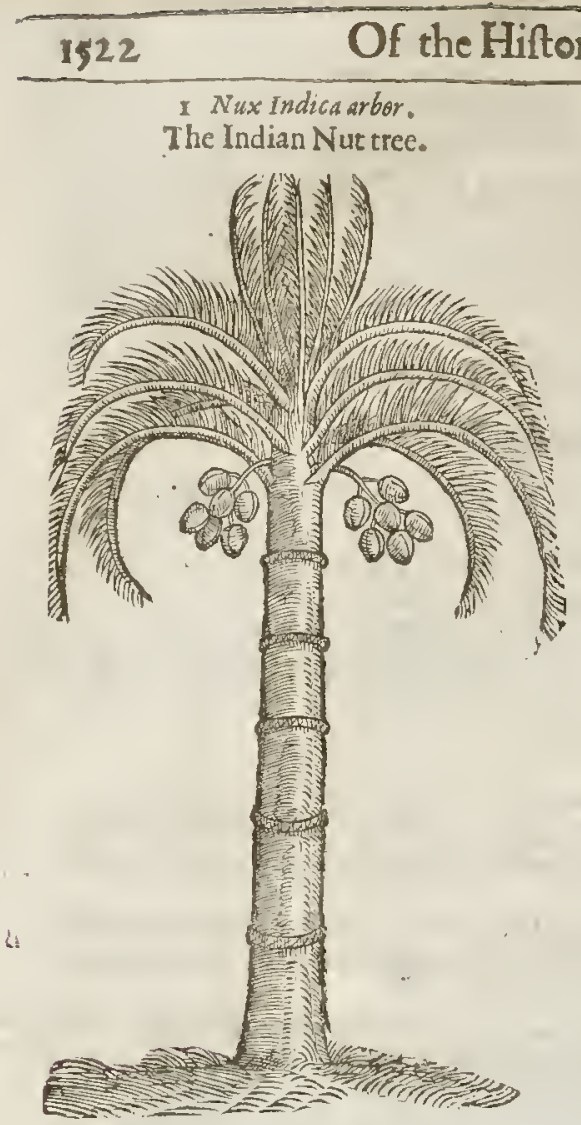

I Nux Indica arbor.

dian Nut tree.

2 Nucula Indica.

The little Indian Nut.

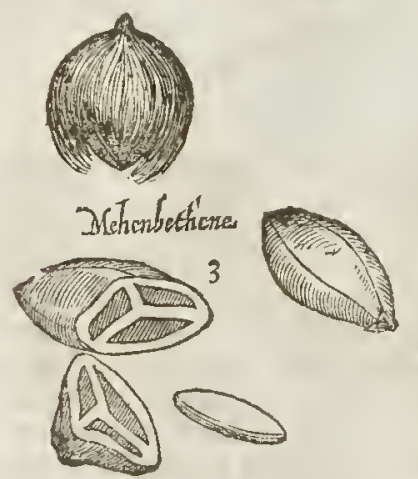

Nux Indica. The Indian Nut.
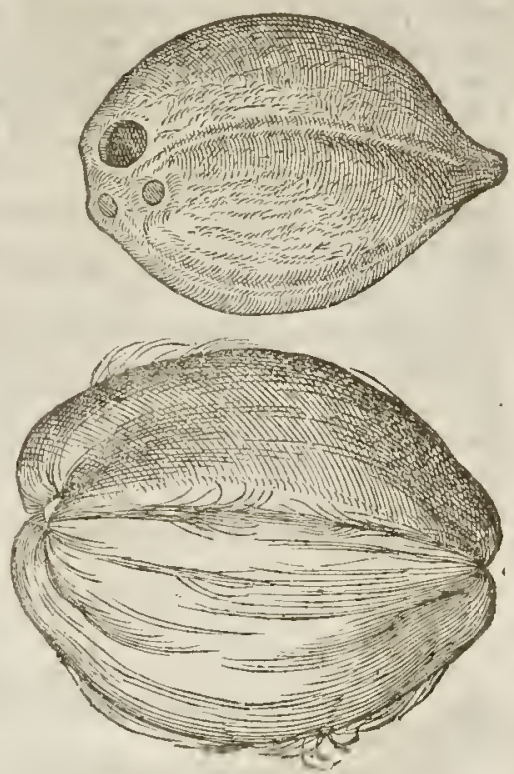

or Bex.It is fome inch long, of a triangular figure, with a hard and wooddy thel:which broken, fhewes three cells or partitions, in each whereof is contained a long kernell white and fweet. $\ddagger$

$$
\text { 9 The Place. }
$$

This Indian Nut groweth in fome places of Africa, and in the Eaft Indies,and in all the Inlands of the Weft Indies, efpecially in Hifpaniola, Cuba, and Saint Iohns Inland, and alfo vpon the continent by Carthagena,Nombre de Dios, and Panama, and in Virginia, otherwife called Norembega, part of the fame continent, for the moft part neere vnto the fea fide, and in moirt places, but it is feldome found in the v $\mathrm{p}$. landifh countries.

oT The Time.

It groweth greene Winter and Sommer.

The fruit is called in Latine, Nux Indica : of the Indians, Cocus : of the Portugals that dwell in
e Eat Indies, Cocco, the Eart Indies, Cocco, taken from the end, wherein are three holes reprefenting the head of a Mon-
kie: Serapio and $R$ hafis do call this tree Iaralnare, ideft, Arlorem Nuciferam, the tree bearing Nuts:
of Auicen, Glauci al hend: of the vulgar people mon among the Perfians and vulgar people, $M$ aro, and the fruit $N$ arel; which name $N a r e l$ is comand the greene fruit. Eleri : in Gea ir : it is called in Malauar, Tengamaran: the ripe fruit, Tenga ;

The diftilled liquor is called sula. and the Lanhan : in Malain, Triccan : and the Nur, Nihor.

It is of of The Temperature. of The Temperature. 


\section{18.3. Of the Hiftory of Plants.}

T The vertues and vfe.

The Indians do ve to cut the twigs and tendcr btanches toward the euening, at the ends whete- $\mathbf{A}$ of they haue bottle gourds, hollow canes, and fuch like things, fit to teceiue the water that droppeth from the branches thercof, wh ich pleafant liquior they drinke in ftead of wine; from the which is drawne a ftong and comfortable Aqua $V$ it $x$, which they ve in time of nced againft all mannet of fickneffes; of the branches and boughes they make their houfes; of the trunk or body of the tree, fhips and boates; of the hempon the outward part of the fruit,they make ropes and cables; and of the finer ftuffe, failes for their thips.

Likew ife they make of the thell of the Nut,cups to drinke in, which welikewife vfe in England, $\mathbf{B}$. gatnifhed with filuer for she fame purpotes. The kemell ferueth them for bread and mear; the milkie itlice doth ferue to conle and refrefh their wearied fpirits : o:rt of the kernel when it is ftamped, is preffed a molt precious oile, not onely good for meat, but alfo for medicine, wherewith they annoint their feeblc lims after their tedious trauell,by meanes whereof the ache and paine is mitigated, and other infirnities quite taken away ptocceding of othet caufes.

\section{Cна а. I41. Of the Dragon Tree.}

I Draco arbor.

The Dragon tree.

Bracaria Straio

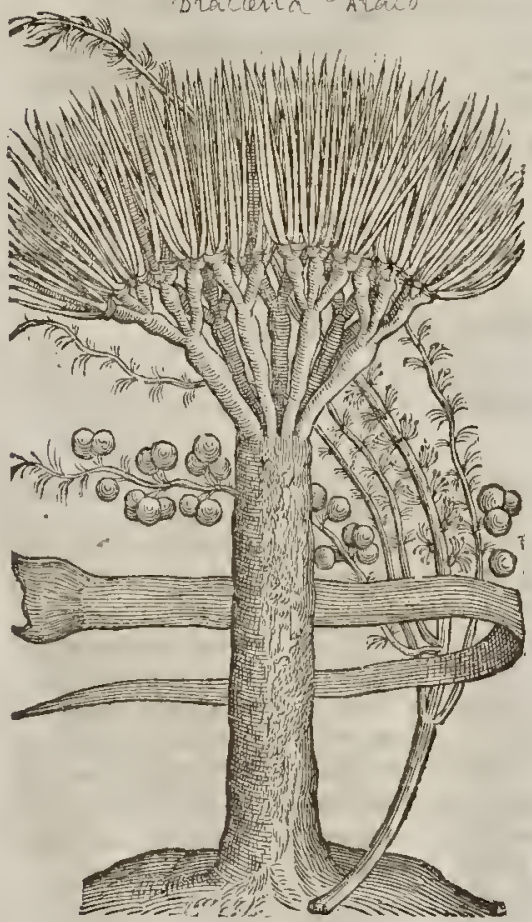

Draconis fructus:

'The Dtagon ttee fraic.'
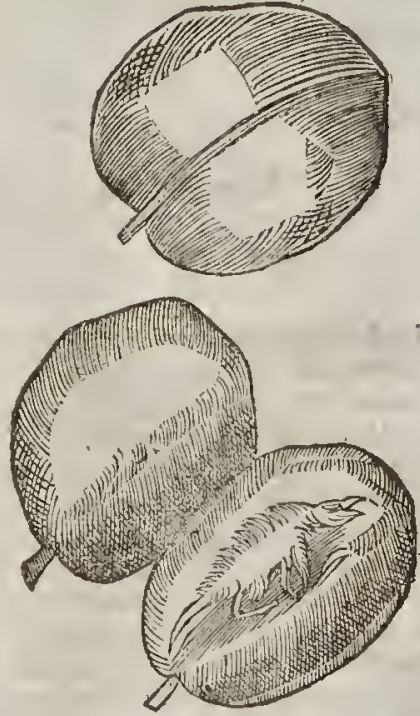
Low ifh colnur, round, light and bitter, courered with a threefold skin or filme, whercin is tobe feene, as Monardur and diuers other report, the forme of a Dragon, hauing a long necke or gaping mouth;

- the ridge or backearmed with tharpe prickles, like the Porcupine; it hath alfo a long taile, \& foure feet, very cafie tobe difcerned:the figure of it we hate fet forth vnto you according to the greatneffe rhercof, becaufe our words and mcaning may be the better vnderftood, and alfo the leafe of the tree in his full bignefle, becaurc it is impoffible to be cxpreffed in the figure: the trunke or bo. dy of the tree is couered with a rough barke, very thin, and eafie to be opened or wounded with any fmall toole or inftrument;which bcing fowounded in the Dog daies, bruifed or bored, doth yecld forth drops of a thicke red liquour, which of the name of the tree arc called Dragons teares, or $S \mathrm{an}$. guis Draconis, Dragons bloud : diuers haue doubted whether the liquour or gummic iuice were all one with Cinnalaris of Doforides (not meaning that Cinaber made of Quickfiluer)but the receined opinion is, they differ not, by rearon their qualitic and temperaturc worke the like effect.

\section{Th The Place.}

This trec groweth in an Ifland which the Portugals call Madera, and in one of the Canarie Iflands, called Infuls Portus Sarcti; and as it feemeth it was firf brought out of Africke, although fome are of a contrary opinion,and fay, that it was firft brought from Carthagena, in America, by.
the Bifhop of the fame Prouince.

$$
\text { T) The Time. }
$$

The time of his growing we haue touched in the defeription, where wee faid that it flourifheth and groweth grcenc all the yeare.

$$
\begin{aligned}
& \text { The names hape beenc fufficiently fpoken of in the defcription and in their feuerall titles. } \\
& \text { Tा The Temperature and Vertues. }
\end{aligned}
$$

A \#. The Sanguis D raconis which is thought to procecd from this trce hath an aftringent faculty, and is with good fucceffe vied in the ouermuch flowing of the courfes, in fluses, Dy fenteries, fpitting of bloud, faftening loofe tecth, and fuch other affcess which rcquire aftriction. B Smiths alfo vfe it to varnifh oucr their workes to giue them a fanguine colour, and keep them
from ruft. $\neq$

\section{C на Р. 142: Of the SajJafras, or eAgue tree.}

\section{If The Defcription:}

T

He Saffafras trce grows very great, much like wnto the Pine tree : the trunke or body is ftraight, vppermoft of the colour of a hes, of arcat height: it is coucred with a two fold grofferinde, the ny goodly branches, like thofe of the PaIme wood of a tawnie colour : on the top come forth mathofe of $\mathrm{Fic}$ tr thole of the Fig tree, of a fweet fmcll when they be grecne, but much fweeter when they be dry, de. clining to the fmell of Fenell,w ith much fweetneffe in taftc: they are greene Winter and Sommer, ncither bearing fruit nor floures, but is altogether barren as it is faid : the roots are grofle, conformable to the greatneffe of the tree, of a tawnie colour, difperfing themfelucs far abroad vnder the vpper cruft of the earch, by meanes whereof they arc often caft downe with meane blafts of winde. \# The wood of the tree is very ftrong, hard and brittle, it hatb not fo ftrong \& 8 pleafant fmell as that of the ront, neither is it in fuch vfe. The leaues are of two forts, fome long and fmooth, and not fnipt about the edges : othcr-fome, and thofe chicfely on the ends of the branches, arc decptaken from a little tree, which grew in the Garden of parts. I haue giuen the figure of a branch yeares agoc. $\ddagger$

I The Place.

This tree groweth in the moft parts of the Wcft Indies, efpecially about the cape of Florida Wingandico,and Virginia,otherwife named Norembega.

It flourifhcth and keepeth grcenc Winter and Sommer. 
SעSAfras.

The Saffafras tree.

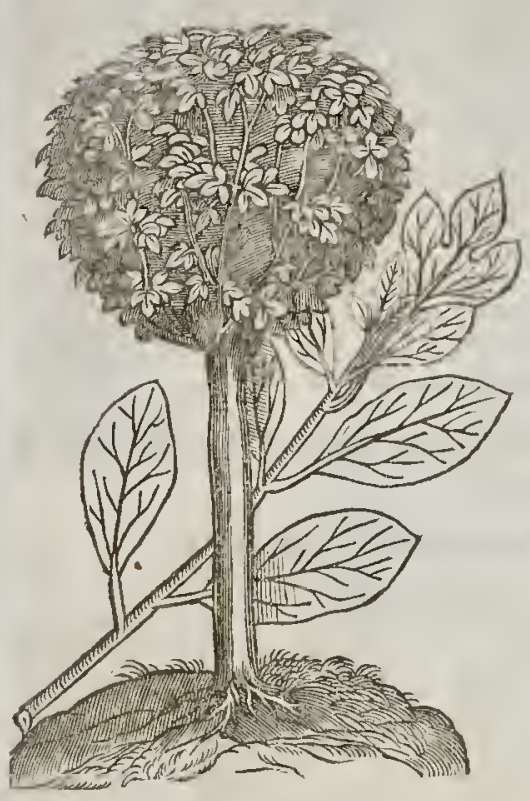

\section{The Names.}

The Spaniards and French men liaue named this tree, Saffafras: the Indians in their tonguc, Pautme: for want of an Englifh name we are contented to call it the Ague tree, of his vertue in healing the Ague.

$$
\text { T The Temperature. }
$$

The boughes and branches hereof are hor at dry in the fecond degree; the rinde is hotter, for that it entreth into the third degree of heare and drineffe, as is manifeftly pereeitued in the decoction.

$$
\text { of } T \text { he vertues. }
$$

The beft of all the tree is the root,and that $\mathrm{A}$ worketh the beft effect, the which hath the rinde eleauing very faft to the inner part, and is of colour tawnie, and much more fweet of fmell than all the tree and his branches.

The rinde tafteth of a more fweet fmell $B$ than the tree; and the waterbeing fod with the root is of greater and better effeets than any other patt of the tree, and is $n f$ a more fweet finell $l_{3}$ and therefore the Spaniards vfe it, for that it worketh bettet and gteater ef. feôts.

It is a tree that groweth neete vnto the fea; and in temperate places that haue not much drouth, nor moifture. There be mountaines growing full of them, and they caft forth moft fweet fmell, fo that at the beginning when they faw them firft, they thought they had been trees of Cinnamon, \& in part they were not deceiued : for that the rinde of this tree hath as fweet a fmell as Cinamon hath, and doth imitate it in colout and fharpneffe of tafte, and pleafantneffe of fmell: and fo the water that is made of it is of a moft fweet fmell and tafte,as the Cinamon is,and procuteth the fame works and effects as Cinamon doth.

The wood hereor eut in final pieces and boiled in water, to the colour of Claret wine, and drunk D for eertaine daies together, helpeth the dropfie, remoueth oppilation or ftopping of the liter, cuseth quotidian and tertian agues, and long feners.

The root of Saffa fras hatli power to comfore the liuer, and to free from oppilations, tncomfort $\mathrm{E}$ the weake and feeble ftomacke, to caufe good appetite, to confume windine ffe, the chiefe ft caufe of cruditic and indigention, ftay vomiting, and make fweet a ftinking breath.

It prouoketh veine,remourth the impediments that doe caufe barrenneffe, and maketh women F. apt to conceine.

\section{C н а . 143. Of the Storax tree.}

\section{If The Defcription.}

THe Storax tree groweth to the height and bigneffe of the Quince tree: the trunke or bodie is - conered with a barke or rinde like vnto the Biteh tree: the branches ate fmall and limmer, whereon do grow leaues like thofe of the Quince tree, greenifh aboue, and whitifh vndetneath: among which eome forth white floures, like thofe of the Orange tree, of an vnpleafant fmell: after commeth the fruit or berries, ftanding vpon long and flender foottalks, couered oner with a little woollineff, of the bigneffe of a bladder nut, and of the fame colour; whetein is contained fmall 
Styrax arbors.

The Storax tree.

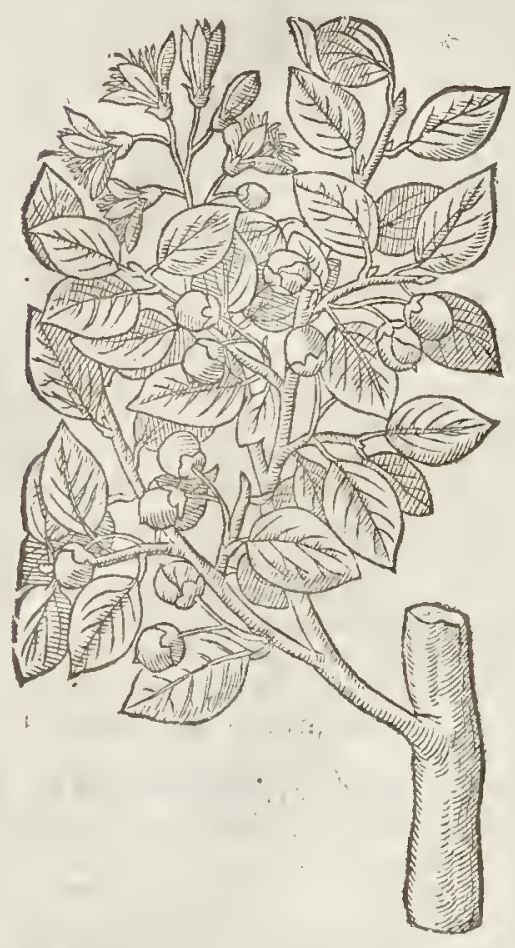

feed, whereunto alfo cleaue ecrtane gumnic teares, bearing the name of the tree, and whinch iffue from the trunk or body when it is wounded.

$$
\text { T The Place. }
$$

This tree groweth in duuers places of France, Italy and Spaine, where it bringeth forth litt!e or no gum at all : it groweth in Iud $x_{2,}$, Pamphylia, Syria, Pifidia, Sidon, and many other places of Iurie nt Paleftine, as alfo in diuers Inlands in the Mediterranean fea,namely Cyprus, Canily, Zant,and other places, where it bringerly forth his gummy liquour in full perfection of fweetneffe, and alfo in great plenty, where it is gathered and put into great Canes or Reeds, whereof as fome deeme it took the name Calamita; others deeme of the leames of Reeds wherein they wrap it : herenf I hate two fmall trees in my garden,
the which I raifed of feed.

$$
97 \text { be Time. }
$$

It floureth in May, and the frut is ripe in September.

\section{If The Names.}

This tree, as may be gathered by fome, was called styra.e, by reafon of that gum or ligutour which droppeth out of the fame, being like vnto the hot"niv pipes of Ife, that hang at the eatues of houfes in W inter, called Styria,or of the Canes or the learies of Reeds fpoken of before: in Latine, Storax Calamita: in Englifh, Storax, which is kept in Canes or the leanes of Reeds: there floweth from fome of thefe trees a certain gummie liquor, which neter groweth naturally hard, but remaineth alwaies thinne, which is called li: quid Sty rax, or Storax.

of The Temperature.

The gum of this tree is of an heating, mollifying, and concosting qualitie.

\section{T) The oritues.}

A. It helpeth the cough, the falling downe of rheumes ard humours into the chent, and hoarfneffe of the voice: it alfo helpeth the noile and found ing of the eares, pretaileth againft strumas, or the Kings euill, nodes on the nerwes, and hard fwellings proceeding of a co!d eaufe: it preuaileth alfo againft all cold poifons, as Hemlocks and furch like.

Of this gum there are made fundry eveellent perfumes, pomanders, fweet waters, fiveet bags; and fweet wathing balls, and diters other fweet chaines 2 bracelets, whereof to write were imper-
tinent to this hiftorie.

\section{Cн а P.144. Of the Sorrowfull tree or Fudian Mourner.

$$
\text { Tf The Defcription. }
$$

A Rbortrifi, the fad or forrow full tree waxeth as big as an Oliue rree, garnifhed with many good tiferous and fweet full of leaues like thofe of the Plum tree: among which come forth nom te odoHew nhew themfelues onely in the night time, and in the day rime looke withered and with a mourning cheere: the leates alfo at that time fhrinke in themfelues together, much like a tender plant that is froft bitten,very fadly lumping, lowring, and hanging downe the head, as though it loathed the light, and could not abide the heatenf the Sun. I hould but in vain lofe labour in repeating a foo. lin fanfie of the Poeticall Indians, who would make fooles beleene, that this tree was once a faire datghter of a great Lord or King,and that the. Sun was in lowe with her, with other toies which I 
Li B. 3. Of the Hiftory ol Plants.

Arbor triftis.

The forrow full tree.

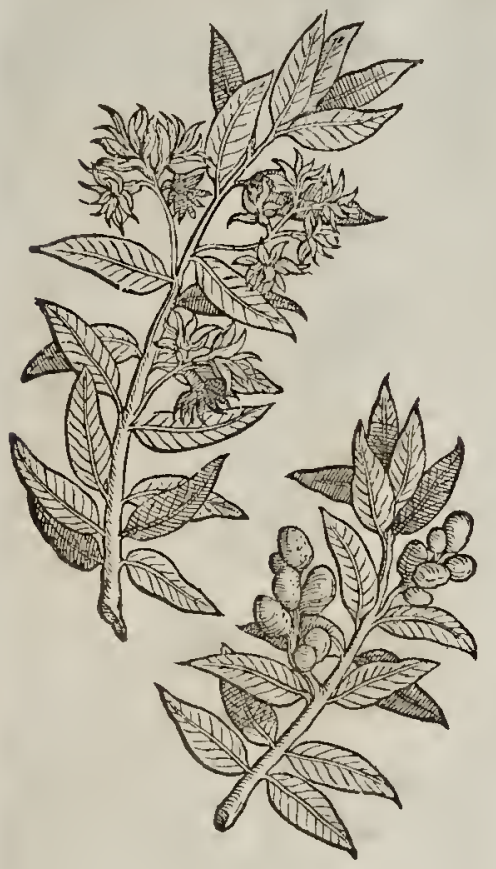

omit. $\neq$ The floures arewhite, fomewhat like thofe of Iafmine, but more double. ard they are of a very fweet fmell: there fueceed them many litile cods, eontaining fome in feeds a piece fomewhat like rhofe of Stramo. ninm. $\neq$

$$
\text { If The Place, Time, and Names. }
$$

This tree groweth in the Eaft Indies, efpecially in Goa, and Malayo : in Goa it is called $P_{\text {arizataco }}$ in Malayo, Singadi. in Decan, Pul: of rhe Arabians, Guart: and of the Periiansand Turkes, Gul: in Englifh, rbe Sad or Sorrowfu!l rree, or the Indi.n inourner. The time is fpecified in the defeription.

T The Temperature and Vertues.

We haue no ceartaine knowledge of the A temperature hereof, neucrtheleffewe tead that the Indians do colour their brothes and meates with the ftalkes of rhe floures hereof in flead of Saffron, or wharfocuer that they defire to haue of a yellow colour.

It is reported, that if a linnen eloth be ftee- B ped in the diftilled water of the floures; and . the eyes bathed and wafhed therewirh, belperh rhe itching and paine therof; and faietis the humours that fall downe ro the fame.

There is made of the fplinters of rhe wond certaine tooth-pickes, and many prerty toies for pleafure.

\section{A $\mathrm{A}$. 145. Of the Ballamtree.}

\section{TI The Kindes.}

$T^{\prime}$

Here be diuers forts of trees from which do flow Balfames, very different one from another, not

onely in forme, but alfo in fruit, liquour, a nd place of growing; the which toditzinguifh would require more time and trauell than either our fmall time wil afioord, or riches for our maintenanee todifcouer the fame in their naturall countries: which otherwife by report to fet downe certaine matter by incertainties, would difcredit the Author, and no profit fhall arife rhereby to the Rea der: notwithftanding we wil fet downe fo much as we haue found in the workes of fome tranellers, which beft agree with the truth of the hiftorie.

\section{If The Defcriptien.} Here be dimers trees growing in the Indies, whole fruits are called by the name of the fruit of the Balfam tree : among the reft this whofe figure we hatie fet forth vnto your view,we our felues haue feene and handled; and therefore the better able to deferibe it. It is a fruit very crooked,and hollowed like the palme of an hand, two inehes long, halfe an inch rhicke, coucred with a thieke fmooth rinde, of rhe colour of a drie Oken leafe; wheroin is contained a kernell (of the fame lengrh and thiekneffe, apr to fil the faid thell or rinde) of rhe fub tanee of an Almond; of the colour of athes, far, and oilie; of a good fmell, and very vnplea fant in rafte.

2 The wood we haue dry brought vnto vs from the Indies for our vfe in Phy fieke (a frnall de feription may ferue for a dry fticke) neuerrheleffe wee hauc other fruts brought from the Indics, whole figures are not fet forth, by realon rhey are not fo well knowne as defired; wherenf onc is of the bignes of a Wal-nur, fomewhat broad on rhe vpper fide, wirh a rough or rugged thell, ineuren, blaeke of colour, and full of a whire kernell, wirh mueh iuiee in it; of a pleafant tafte and fincll, like the oile of Mace: the whole futut is exceeding light,in refpect of the quantitie or bigneffe, cuen as 


1528 Of the Hiftorie of Plants. L18.3:

itwere a piece of Corke; which notwithftanding finketh to the bottome when it falleth into the water, like as doth a frone.

I Balfamifructus?

The fruit of the Balfam tree:

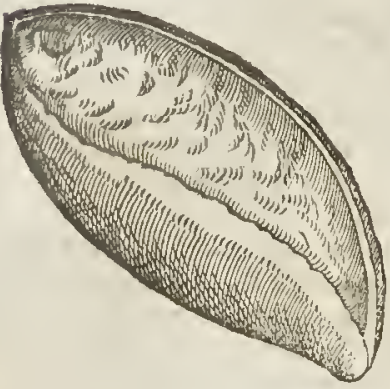

* 3 Balfansum Alpini cum Carpobalfanso. The Balfan irce with the fruit.

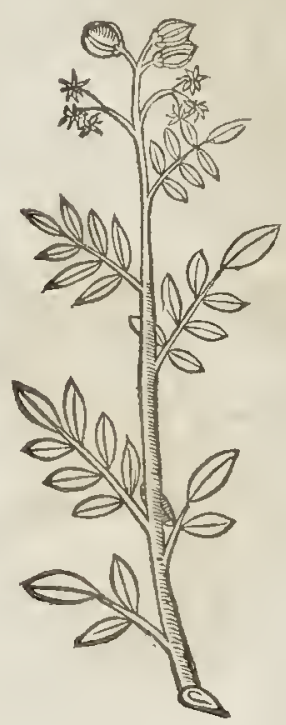

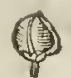

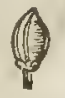

3. This tree, faith Garcias, that beareth the fruit Carpobalfamum, is alfo one of the Balfam trees:it groweth to the leighr and tigneffe of the Pomegranate rree, garnifhed with very many branches: whereon do grow leaues like thofe of Rue, but of colour whirer, alwaics growing greene : amongf which come forth floures, whereof we haue no certaintie: after which eommerh forth fruit like that of the Turpentine trec, which in fhoppes is called Carpobalfamum, of a pleafant fmell; but the liquour which flowerh from the wounded tree is much fweerer: which liquour of fome is called opobalfarmum.

F Proper Alpinus hath wrir a large Dialogue of rhe Balfam of the Antients, andalfo figured and deliuered the hiftorie thereof in his booke De Plant. AEgyptiscap. 4 4.whether I refer the curious I haue prefenred you wirh a Iip from his tree, and the Carpobalfamum fet forth by our $A$ uthor, which feemes to be of the fame planr. The leaues of this are like to thofe of Lentifcus, alswaies greene,and winged, growing three, fine, or feuen faftened to one foot-ftalke; the wood is gummie, reddifh, and well fmelling: the floures are fmall and white like thofe of Acatia, growing vfually rhree nigh to. gerher : the fruit is of the fhape and bigneffe of that of the Turpentine tree, containing yellow and well fmelling feeds, filledwith a yellowin moifture like honey, their tafte is bitterifh, \& fomwhat biting the tongue. $\neq$

Ot rhefe Balfam trees there is yet another fort : the fruit whereof is as itwere a kernell wirhour a thell, eouered wirh a thin skin ttraked with many veines, of a browne colour : the meat is firm and folid, like the kernell of the Indian Nut, of a white colour, and withont fmell, but of a grateful taft; and it is thoughr ro be hot in the firf degree, or in the beginning of the feeond.

There be diuers forrs more, which might be omitted becaufe of tedioufneffe:neuertheleffe 1 wil trouble you with tw o fpeeiall trees worthy the noting:there is, fairh my Author, in Ameriea a great tree of mon ftrous hugeneffe, befer with leaues and boughes euen to the ground; the rrunke wherof is conered with a twofold bark, the one thick like un to Corke, \& another thin nexr to the tree:from betweene which barks dorh flow (the vpper barke being wounded)a white Balfam like vnto teares 
or drops, of a moft fweet fauour, and fingular effeas, for one drop of this which thus difts 1 let. our of the tree, is worth a pound of that which is made by decotion : the fruit hereo! is imall in refpect of the others; it feldome exceedeth the bignes of a Peafe, of a bitter talte, inclofed in a nar¡Ow huske, of the length of a finger, fomething thin, and of a white colour; which the Indians do vfe againft head ache : which fruit of molt is that we hane before defcribed, called Carpobilfamum.

It is alfo written, that in the Ifland called Hijpaniola; there groweth a fmall tree, of the height of two men,without the indiftry of man, hauing ltalkes or ftens of the colour of athes; whereon do grow greenc leaues, tharpe at both ends, but more greene on the vpper fide than on the lower; hauing a middle rib fonewhat thicke and ftanding out; the foot-ftalkes whereon they grow are fomewhat reddith : among which leaues commeth fruit growing by clufters, as long as a mans hand, fingers and all : the ftones or graines in the fruit be few, and greene, but growing to redneffe motc and more as the fruit waxeth ripe. From the which is garhercd a juice after this manner:they take the young thootes and buds of the tree, and alfo the clunters of the fruit, which they bruife, and boile in water tothe thickeneffe of hory, which bcing ftrained, they keepe it for their vfes.

They vfe it againft wounds and vicers; it ftoppeth and ftancheth the bloud; maketh them cleane; bringeth vp the Refh, and healeth them mightily, and with better fucce the than true Balfame. The branches of the tree being cut, $\mathrm{caf}$ forth by drops a certaine cleare water, more worth than Aqm vite, mott wholefome agautit wounds, and all other difeafes proceeding from cold caufes, if it bedrunken fome few daies toscther.

$$
\text { of The place. }
$$

Thefe trecs grow in diters parts of the world, fome in $A g y p t$, and moft of thofe countries adiacent: thete groweth of them in the Ealt and $\mathrm{W}$ eft Indies; as trauellers in thofe parts report.

$$
\text { - The Time. }
$$

Thefe trees for the moft part keepe greene winter and Sommer.

$$
\text { T) The Names. }
$$

Balfame is called in Greeke, Bádonus: in Latine alfo Balfamums : of the'Arabians Balferi, Balefina, and $B e l \int_{a} x:$ in Italian, Balfamo : in French, Barme.

The liquor that floweth out of the tree when it is wounded, is called opobal famm : the wood Xylobalfamuss : the fruit Carpobalfannum: and the liquor which naturally floweth from the tree in Agypt Balfamum.

Balcame is hot and dry in the fecond degree, wirh aftrition.

$$
\text { at } T \text { be Vertues. }
$$

Naturall Balfame taken in a morning fafting, with a little Rofewater or wine, to the quantitie of fute or fix drops, helpeth thofe that be afthmatike, or fhort of winde: it preuaileth againft the paines of the bladder, and ftomacke, and comforteth the fame mightily; and alfo amendeth a ftinking breath; \& takes aw ay the thak ing fits of the quotidian rgue, if it be taken two or three times.

It helpetli confumprions, clenfeth the barren wombe, efpecially being annointed vpon a peffary, B or mother fuppofitorie, and vfcd.

The ftomacke being annointed therewith, digeftion is helped thereby; it alfo preferueth the nomacke from obfructions and windineffe; it helpeth the hardneffe of the fpleene; eaferh the griefes of the reines and belly, proceeding of cold caufes.

It alfo taketh aw ay all manner of aches, proceeding of cold caufes, if they be annointed therewith; but more fpeedily, if a linnen clnth be wet therein, and laid thereon: vfed in the fame manner, it diffoluetl hard tumors, called oedmain; and ftrengthneth the weake members.

The fame refrefheth the braine, and comfortcth the parts adioining, it helpetly the palfie, convulfions, and all griefes of the finewes, if they be annoirned therewith.

The maruellous effects that it workerh in new and greene wound, were heere too long to fet downe, and alfo fuperftuous ; confidering the skilfull Chirurgion whom it mont concerneth, doth know the vfe thereof, and as for the beggerly Quackfaluers, Runnagates, and knauifh Mountibanks, we are not willing to inftruct them in things fo far aboue their reach, capacitic and worthinetie.

\section{Сан аро46. Of a kinde of Balme, or Ballame Tree:}

\section{9) The Defcription.}

His tree which the people of the Indies do call crolli, groweth to the bigneffe of a great tree, hatuing a truike or body of a darke greene colour, fprinkled oucr with many afh coloured Nnnnn n. 
fpots : rhe branches are many, and of very great beautie; whereupon do grow leailes not vnlike to thofe of the thth-trec, confiting of many fmall leaues, fet vpon a middle rib; grow ing narrowet eucr towards tlie point, euery particular nne ja ged on the fides libe the teetl of a faw : which be. ing plucked troin the ftem, yecldeth forth a milhie juice, tough and clammie, fauouring like the bruifed leates of Fenell, and as ir femeth in tafte fomewhat aftringent: the floures grow in elufters vpon the twiggie brancles, like thofe of the Vine a little before the grapes be formed: afte: fo'loweth the frut or berries, fomewhat greater than Pepper cones, of at oilie fublance, grecne at the firn, and of a da ke reddih colour when they be ripe. \$ The firt nithe figures was taken fro $n$ a tree, only of three yeeres growth, bur the larter from a trce cone to bis full growth, as it is affirmed in Clifius his Car. Pofier. It diffets only in that the leaucs of the oid trees are not at all fuips or duided on the edges. $\ddagger$

I Molli,fise Molly Clifij, \& Lobely.

The Ballame tree of Clufius and Lobels defctiption.

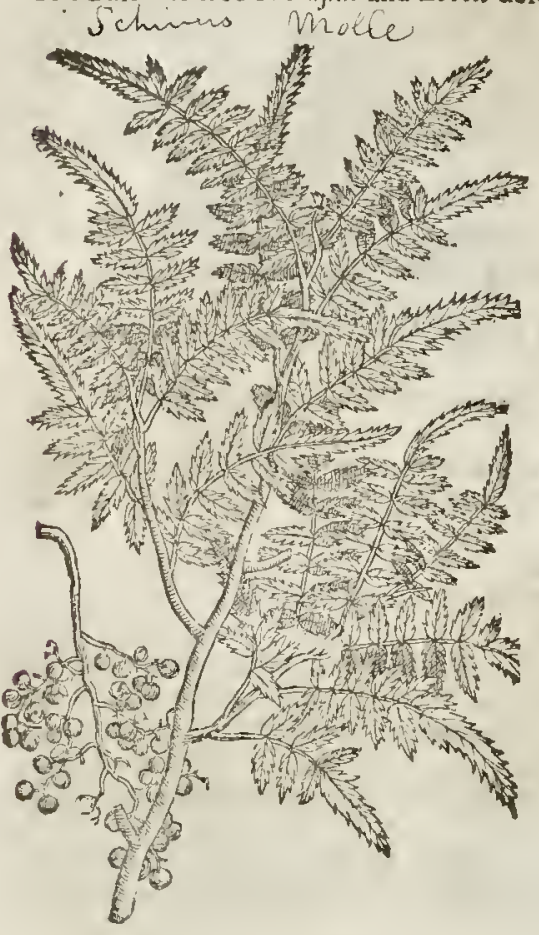

₹ Molic arboris adultat riwas. A beanch of the old tree of Molic.

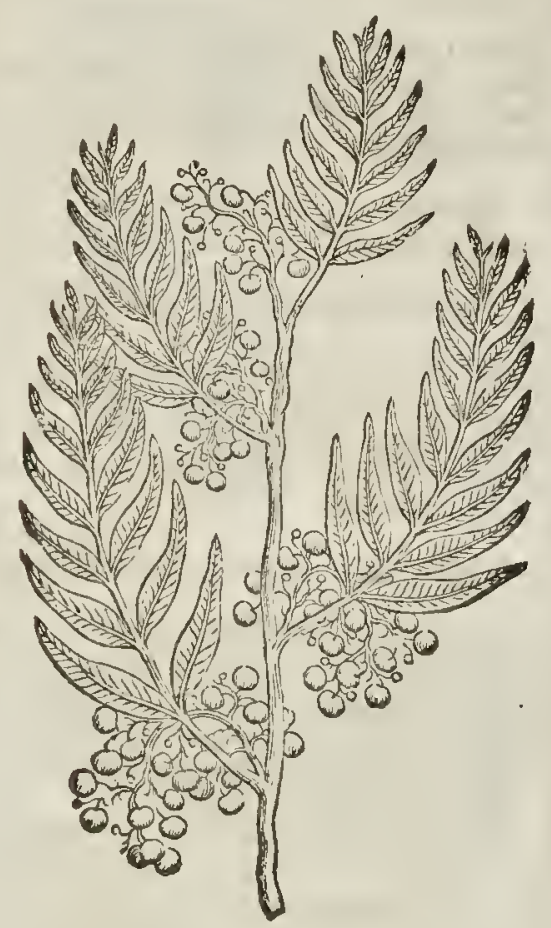

9] The Place.

This tree, faith a learned Phyfition called loh. Fragolus, doth grow in the King of Spaine his garden at Madryll, which was the firt that eter he did fee: fince whieh time, l bn Ferdinando Sccrktary vnto the forelaid king did thew vnto the faid Frayofus in his owne gardenatree fo large, and of fueh beautie, that he was neuer fatisfied with looking on it and meditating vpon the vertues thereof. Whiehwords I haue receiued from the hands of a famous learned man, called $\mathrm{M}^{5}$. L ince lot Bruwne, D' in Phylicke, and Phyfition to rhe Q:leenes Maieftic, at the imprefion hereof; faith. fully tranflated out of the Spanith tongue, withour adding or taking any thing away.

They grow plentifully in the vales and low grounds of Peru,as all affirme that have trauelled to the VVeft Iridies; as a' o thofe tlat hate defcibed the fingularities thereof. My felfewith diners othe:s, as namely Mr Nicholes Lue, a worthipfull Mereliant of the Cirie of I ondon ; andalfo a mot skifull A pothecary, $M^{r}$. Tames Garret, wh haue teceiued feeds herc of from the right Honohiscare in getting, as alfo for high Chamberlaine of England, wothy of triple tonour for the ft parts of rhew

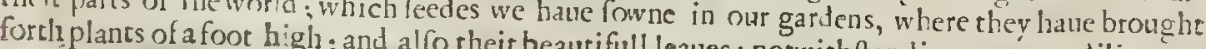
flants of a foot high; and alfo theit beautifull leaues: notwithltanding our care, dilicence, 
and induftry, they haue perifhed at the firft a pproch of winter, as not being ablc by rcaron of their tenderneffe to indure the cold of our Winter blafts.

ף The Time:

As touching the time of his flourihing;and bringing his fruit to maturitic, we haue as yet no ccrtaine knowledge, but is thought to bc greeneboth VVinter and Sommer.

\section{Tा The Names.}

This molt notable trce is called by the Indian name crolle: of fome, Molly, and Muelle, taken from his tender foftneffe, as fome hatue deemedit inay be called the Fennell tree, or one of the Balme, or Balfam trees.

If The Temperature.

This tree is thought to be of an aftringent or binding qualitie; whereby it appeares bcfides the hot temperature it hath, to be compounded of diuers other faculties.

\section{The Fertues.}

The Indians vfe to feeth the fruit or berries hereof in water, and by a fpeciall skill they have in $A$ the boiling,do make a moft wholefome wine or drinke, as alro a kind of vineger, and fometimes hony; which are very ftrange effects, thefe three things being fo contrary in tafte.

The lcaues boiled, and the decoction drunke, helpeth them of any difeafe procecding of a cold B caure.

The gum which iffueth from the tree, being white likc vnto Manna, diffolued in milke, taketh C away the web of the eies, and clearcth the fight,being wiped oucr with it.

The barke of this tree boiled, and the legs that be fwolne and full of paine, bathed and wathed D with the decoetion diuers timcs, taketh away both infirmities in fhort fpace.

This tree is of fuch eftimation among the Indians, that they workhip it as a god, according vnto E their fauage rites and ceremonies : much like as Pliny reporteth of Homers Moly, the moft renowned of all plants, which they had in old time in fuch eftimation and reucrence, that as it is recorded, the gods gate is the namc of Moly, and fowriteth oxid:

\section{Pacifer buic dederat forem cyllenius album, croly vocant Superi, migra radice tenetur.}

If any be defirous to lee morchcreof, they may reade a learned difcourfe of it fet forth in the $\mathrm{La}=\mathrm{F}$ tine tongue, by the learned Lobel, who liath at large written the hiftorie thereof, dedicated vnts the sight Honourable, the Lord Chamberlaine, at the Impredion hereof, faithfully ouerfeene and examined by the learned Phyfition before remembred, $\mathrm{M}^{r}$. Doctor Browne, and his cenfure voon the lame. ‡ Together with Lobels reply, who iudged this plant (and not without good reafon) to be a kinde of the true Balfam of the Antients, and not much different from that fet forth by Pro. Sper Alpinos, whereof $\mathrm{I}$ hauc made mention in the foregoing chapter. $\ddagger$

\section{Cна P. 147. Of the Canell, or Cinnamontree.}

If The Defription.

x Te tree which hath the Cinnamon for his barke is of the ftature of an Oline tree:hauing a body as thick as a mans thigh, from which the Cinnamon is taken; but that taken from the fmaller branches is much better : whichbranches or boughes are many, and very ftraight; wheron do grow beautifull leates, in fhape like thofe of the Orenge tree, and of the colour of the Bay leafe (not as is hath been reportcd) like vnto the leaues of flags or floure de-Luce:among thefe pleafant leaues and branches come forth many faire white floures, which turne into round blacke fruic or berries, of the bignefie of an Hafell Nut, or the Oliue berry, and of a blacke colour; out of which is preffed an oile, that hath no fmell at all vntiil it be rubbed and chafed betweene the bands: the זrunke or body with the greater armes or boughes of the tree are couered with a double or twofold barke, like that of $S u b e r$, the Corke tree : the innermoft whereof is the true and plcafant Cinnamon, which is taken from the tree, and caft vpon the ground in the heate of the Sunne; through the heate 
Cañelle folium, Bacillus, or Cortex.

The leafe, barke, and trunke of the Cin. namon tree.
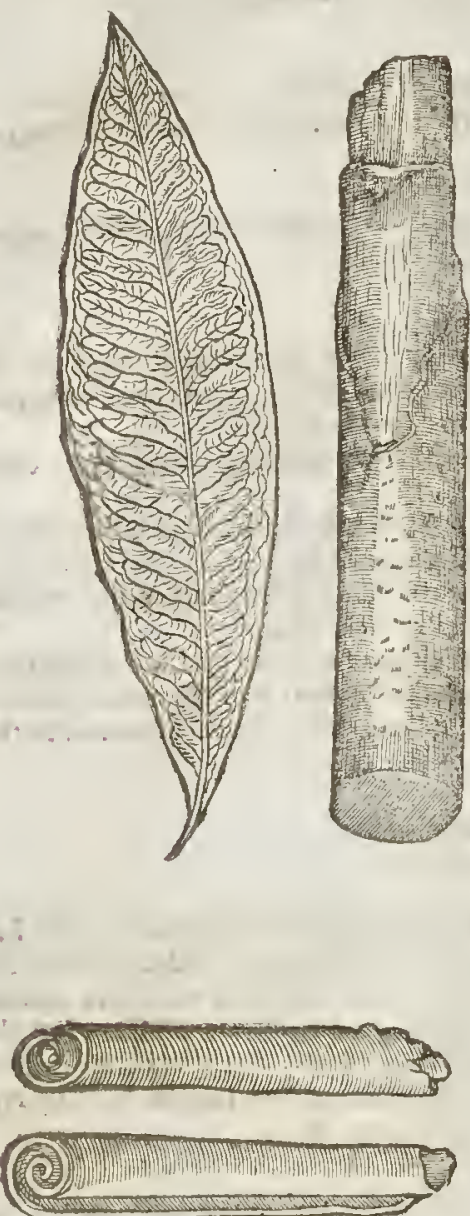

thereof it turneth and foldeth it felfe round togerher, as wee daily lee by viewing the thing it felfe : this tree being thus peeled recoucreth a new barke in the fpace of three yeares, and is then ready to be disbarked as afore. That Cinnamon which is of a palceolour hath nor been well dried in the Sunne: that of a faire browne colour is bef ; \& that which is blackith, hath been too much dri. ed,and alfo hath taken fome wet in the time of drying.

₹ 2 Befides the Cinnamon vulgarly knowne and vfed, there is another fort which alfo is commonly receiued for the Caffia of Diofcorides and the Antients. Now this differs from the former in that it is of a redder colour, of a mote hard, follit, and compace fubftance, commonly alfo thicker, \& if you chew it,more clammy and vifcous : the tafte and fmell are much like Cinnamon, yet not altogether fo ftrong as that of the beft Cinnamon. There is much controuerlie in late Wtiters concerning both the tuue Cinnamon, and Caffia of the Antients : the which I have not time nor fpace here to mention, much leffe to infift vfon: I haue obferued that both the Cinnamon and Caffia that we. baue are conered oner w ith a rough gtayinh barke, like that of an Oke or other fuch tree, which is cleane fcraped off, and taken away befote it be brought to vs. $\neq$

$$
\text { q. The Place. }
$$

The chiefent places where the trees doe grow that beare Cinnamon,are Zeilan, and Malanar : but thofe of Zeilan are the beft? they grow in other of the Molucea Ilands: as laoa, or Iau, the greater and the leffe, and alfo in Mindanoa, for the moft part vpon mountaines.

$$
\text { II The Time. }
$$

The Cinnamon tree groweth green winter and Sommer, as doall the other trees of the Molueeaes, and Eaft Indies for the moft

Pant : the boughes whereof are cut off at fea-
appointed the time. appointed the time.

There hath beene fome controtterfie among writers concerning the tree whofe bark is Caßia, and that tree that beareth Cinnamon, making them both one tree: but that opinion is not to be receiued: for there is a great difference berweene them, as there is betwixt an Oke, and a Cheitnut trec; for the tree whofe barke is caffia, is doubrleffe a baftard kinde of Canell, or Cinnamon: in thew it feriour.

$$
\text { Cinnamon is called in Italion conella in } 9 \text { The Names. }
$$

Zimmet coeslin: the Grecians, wanella: in Spanifh, Canola: in French, Camelle : in high Dutch? and as fone fay, 2 uerfra, others, 9 uer fe: in Ormus, Darchini (i.) lignure Chinense in Zeilan, Cuurde: in the Ifland laula they name it Cameas: tongtie frgnifieth Dilce lignum Chinenfe, the wood of China : in Malauar, Cais maiss, which in theit

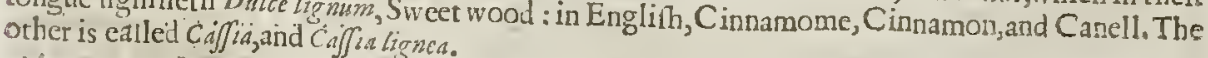

Diofcorides writeth that Cinnamon The Temperature and Vertues.

Diofcorides writeth, that Cinnamon hath power to warmac, and is of thinine parrs: is is alfo dric 
$\mathrm{L}_{1 \mathrm{~B}, 3 .} \quad$ Of the Hiftory of Plants.

and aftringent, it provoketh vrine, cleareth the eies, and maketh fweet breath.

The deeotion bringeth downe the menfes, preuaileth aganft the bitings of venomous beafts $\mathrm{B}$ the inflammation of the inteftines and reines.

The diftillcd water hereof is profitable to many, and for diuers infirmities, it comforte h the $C$ weake, cold, and feeble ftomacke, eafeth the paines and fretrings of the guts and intrailes proceeding of cold caufes, it amendeth the euill colour of the face, maketh fweet breath, \& giveth a moft pleafant taftevntodiuers forts of meats, and maketh the fame not onely more plea fant, but al fo more wholefome for any bodies of what eonftitution foeuer they be, notwithftanding the binding qualitie.

The oile drawne chimieally preuaileth againft the paines of the breft, eonforteth the ftonacke, D breaketh wirtdineffe, caufeth good digeftion, and being mixed with fome honie, taketh aw ay fpors from : the face, being annointed therewith.

The diftilled water of the floures of the tree, as Garcias the Lufitanian Phyfitionwriteth,excel- E leth far in fiveetneffeall other waters whatfoener, which is profitable for fuchuhingsas the barke it felfe is.

Out of the berries of this tree is drawn by expreffion, as out of the berries of the Oline tree, acer- $F$ taine oyle, or rather a kinde of fat like butter, without any fmell at all, exeept it bee made warme, and then it fmelleth as the Cinnanon doth, and is much vfed againft rhe coldneffe of the finewes all paines of the ioints, and alfo the paines and diftemperature of the ftomacke and breaft.

Tnwrite as the worthineffe of the fubiect requireth, would aske more time than we haue to be- $G$ ftow vpon any one plant; therefore thefe few thall fuffice, knowing that the thing is of great ufeamong many, and knowne to molt.

$\neq$ Caffiavfed in a larger quantitie ferueth well for the fame purpofes which Cinnamon H doth. $\neq$

\section{CHA P. 142. Of Gum Lacke and bis rotten tree.}

Lacca cum fuis bacillis.

Gum Lacke with his ftaffe or fticke.
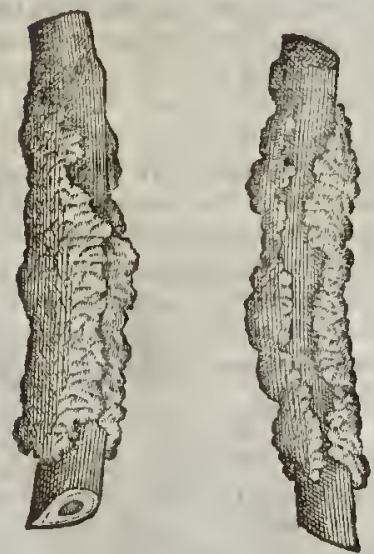

T) The Defcription.

The tree that bringeth forth thatexcremen: tal fub ttaneecalled Lacca,bothin the fhops of Europ and elfewhere, is ealled of the Arabians, Perfians and Turkes, Loc Sumutri, as who fhould fay, Lacca of Sumutra:fomewhich hate fotermed ic, haue thought that the firft pientie thereof came from Sumutra, but herein they haue erred, for the abundant ftore thereof eame from Pegu, where the inhabitants therof do eal it $L a c, \&$ others of the fame Prouince, Trec: the hiftory of which tree, aceording to that famous Herbarift Clufirs is as followeth. [There is in the eountrey of Pegu and Malabar, a great tree, whore leaues are like them of the Plum tree, has uing many fmall twiggiebranches; when the trunk or body of the tree waxeth old, it rotteth in fundry places, wherein do breed certain greac Ants or Pifmires, which eontinually work and labour in the time of Harueft and Sommer, againft the penurie of Winter : fueh is the diligenee of thofe Ants, or fuch is the nature of the tree wherein they harbour, or both, that they prouide for their winter food, a lumpe or maffe of fub tanee, which is of a crimfon colour, $0^{\circ}$ beaurifull and fo faire, as in the whole World the like is not feene, whieh ferueth nor onely to phy fieall, vies but is a perfeet and coltly eolour for Painters, ealled by vs, Indian Lack. The Pifmires (as I faid) worke out this colour, by fineking the fubftance or matter of Lacca from the tree, as Bees do niake honie and wax, by fucking the matter Nannan 3 
thereof from all herbes, trees, and floures, and the inhabi tants of that country, do as diligently feek for this Lacca, as we in Eng land and other countries fecke in rhe woods for honie; which Lacca after they haue found, they take from the tree, and dry it into a lump; among which fometimes there come ouer fome fticks and pieces of the tree with the wings of the Ants, which haue fallen among it,as we daily fee.

$\neq$ The Indian Lacke or Lake which is the rich colourvfed by Painters, is none of that which is vifed in fhops, nor here figured or defcribed by Clufin, wherefore our Aurhor was much miftaken in that he here confounds togerher things fo different; for this is of a refinous fubitance, and a faine red colour, and wholly vnfit for Painters, bur vfed alone and in compofition to make the beft hard fealing wax. The other feemes to be an artificiall thing, and is of an exquifite crim fon colour, butofwhat it is, or how made, I haue not as yet found any thing rhat carries any probabilitie of truth. $\ddagger$

$$
\text { II The Place. }
$$

The tree which beareth Lacca groweth in Zeilan and Malauar, and in other parts of the Eaff Indies.

Of the time we haue no certaine knowledge.

$$
\text { 9 The rime. }
$$

I The Names.

Indian Lacke is called in fhops Lacca : in Italian, Lachetta: Auicen calleth ir Lich: Paulus and

Diefcorides, as fome haue thoughr, Cancamum: the other names are expreffed in the defcription.
TT The Tempcyature and Vertues.

A Lack or Lacca is hot in the fecond degree, it comforteth rhe heart and liuer, openeth obfruct: ons, expelleth vrine, and preuaileth againft the dropfie.

B There is an artificiall Lack made of the fcrapings of Brafill and Saffron, which is vfed of Pain: ers,and not to be vled in Phyficke as the other naturall Lacca.

\section{Of the Indianleafe.}

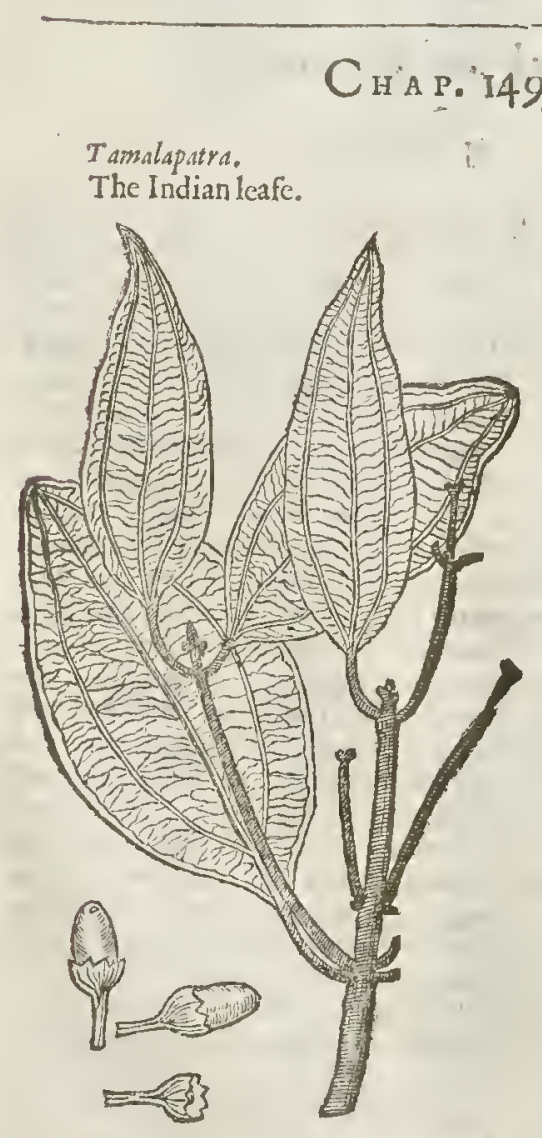

Tamalapatra.

The Indian leafe.

\section{The Defcription.}

T Amalapatra, or the Indian leafe grows vipon a great tree like the Orenge tree, with like leaues alfo, but broader, a little harp pointed; of a greene gliftering colour, and three fmall ribs running rhrough each leafe, after the man: ner of Ribwort, wherby ir is eafie to be known: it fmelleth fomewhat like vnto Cloues, but not fo ftrong as Spikenard or Mace (as fome hatue deemed) nor yet of fo fubtill and quick $a$ fent as Cinnamon. There was fent or added vnto this figure by Cortufus a certaine fruit like vnto a fmall Acorn, with this infeription, Frum ctus Canclle, the fruit of the Canell tree, which may be dotbted of, confidering the defcription of the forenamed tree holden generally of moft to be perfect.

$$
\text { 97 The Place. }
$$

The Indian leafe growerh not flecting vpor the water like vnto Lens paluftris, as Diofcerides and Pliny do fet downe, (though learned and painfull writers) but is the leafe of a grear tree, a branch whereof wee haue fet forth vnro your view, which groweth in Arabia and Cambaya, far from the water fide.

$$
\text { 9. The Time. }
$$

Or the time we haue no cerrain knowledge, but it is fuppofed to be green winter and fom. mer. 
T The Names.

Tamalapatra is called of the Indians in their mother tongue, efpecially of the Arabians, Cadeg: Indi, or La degi Indi, that is, Folium Indicum, or Indum, the Indian leafe : but the Mauritanians doe call it Tembul. The Latines and Grecians following forne of the Arabians, haue ealled it ckala bathrum.

$$
\text { I The Temperature and Vertues. }
$$

The Indian leafe is hot and dry in che fecond degrec,agreeing with Nardus in temperature, or as A others report with Mace : it prouoketh vrine mightily, warmeth and eomforteth the ftomacke, and helpeth digeftion.

It prevaileth againft the pin and web in the eyes, the inflamed and waterie eyes, and all other infirmities of the fame.

It is laid a mong eloathes, as well to keepe them from moths and other vermine, as alfo to gitue $C$ vnco them a fweet fmell.

\section{Cна в. 150. Of the Clone tree.}

\section{Caryophyllivericlufij.}

The true forme of the Clous tree.

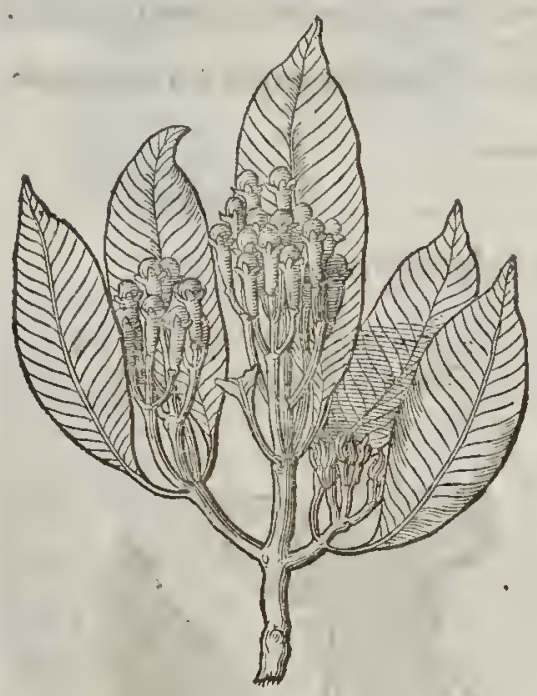

T The Diferiplion.

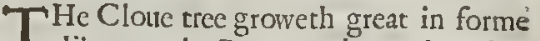
like vnto the Bay tree, the trunke or bodie whereof is eourered with a ruffet barke: the branehes are many, long, and very brittle, whereupon do grow leates like thofe of the Bay tree, but fomewhat narrower : among ft which come the floures, white at the firft, after of a greenifh colour, waxing of a darke ted colour in the end : whieh floures are the very eloues when they grow hard:after when they bedried in the Sunne they beeome of that dusky blaek colour which we dayly fee, wherein they eontinue. For thofe that wee have in eftimation are beaten downe to the ground before they be ripe, and are fuffered there to lie vpon the ground vntill they bee dried throughly, where there is neither graffe, weeds, nor any other herbes growing to hinder the fame, by reafon the tice draweth vnto it felfe for lis nouringment all the moifture of the earth a great eireuit round about, fo that nothing ean there grow for want of moifture, and therfore the niore conuenient for the drying of the Cloues. Con-

trariwife, that groffe kinde or Cloues which hath beene fuppofed to be the malc, are nothing elfe than fruit of the fame tree tatrying there vntill it fall downe of it felfe vnto the ground, where by reafon of his long lying, and meeting with fome raine in the mean feafon, it lofech the quick tafte that the others haure. Some haure ealled thefe Fufti, whereof we may Englifh them Fuffes. Some a firme that the floures hereof furpalfe all other foures in fivectneffe when they are greene; and hold the opinion, that the hardned floures are not the Clones themfelues, (as wee haue written) but thinke them rather to be the feat or huske wherein the floures doe grow : the greater number hold the former opinion. And further, that the trees are inerea fed w ithour labour, graffing, planting, or ocher induftrie, but by the falling of the fruit, which beare fruit within eight yeares after they be rifen vp, and fo continue bearing for an lundred yeares together, as the inliabitants of that colncrey do affirme.

T) The Place.

The Cloue tree groweth in fome few places of the Molucca Iflands, as in Zeilan, Iaua the greater and the leffe, and in diners other places. 


\section{-T The Time.}

The Clotes are gathcred from the fiftecnth of Septembet vnto the end of Februarie, not with hands, as we gather Apples, Cherries, and fucli like fruit, but by beating the tree, as Wall-nuts are
gotten, as we hate written in the defeription.

$$
\text { T) The Names. }
$$

The fruit hereof was vnknowne to the antient Grecians : of the later writers called Kapuiguraco : in Latine alfo Caryophyllus, and Claves : in French, Clou de Gyrofle: the Mauritanians, Char humfel: in

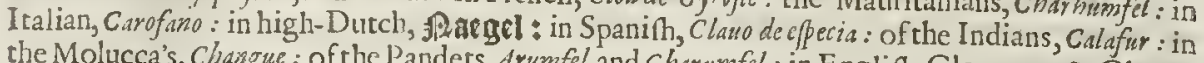
the Molucca's, Changue : of the Panders, Arumfel, and Charumfel: in Englin, Cloue tree, \& Cloues.

Cloues are lot and dry in the third degree.

$$
\text { IT The Temperature. }
$$

$$
\text { 91 The Vertues. }
$$

A Clones ftrengthen the ftomaeke, liuer, and heart, helpe digeftion, and prouoke vrine.

B The Portugall women that dwell in the Eaft Indies draw from the Cloues when they bee yec. greene, a eertaine liquor by diftillation, of a moft fragrant fmell, whicli eomforteth the heart,and
is of all cordials the moft effectuall. Cloues ftop the belly : the oile or water thercof dropped into the eyes, tharpens the fight, and
clenfeth away the cloud or web in the fame.

D The weight of foure drams of the pouder of Cloues taken in milke procureth the act of genera?

E There is extracted from the Cloues a certaine oile or rather thickebutter of a yellow eolour which being chafed in the hands fmelleth like the Cloues themfelues, wherewith the Indians do cure their wounds and other hurts, as we dowith Balfam. The vfe of Cloucs, not oncly in meat and medicine, but alfo in fweet pouder and fuch like, is
fufficiently knowne: therefore this thall fuffice.

t There were formerly three figuses in this chapter : wherefore I omitted two as inpeninent.

\section{Cна в. 15I. Of the $\mathcal{X}$ (utmegtree.}

I. Nux Mufcata rotunda, fine famina.

The round ot fergale Nutmeg.

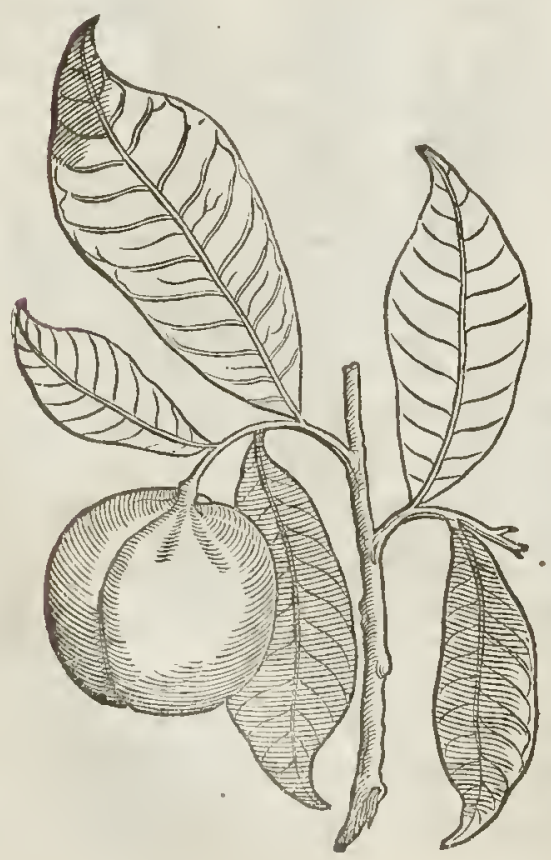

2 Nux Myristica oblonga, fue mas: The longin ot male Nutmeg.

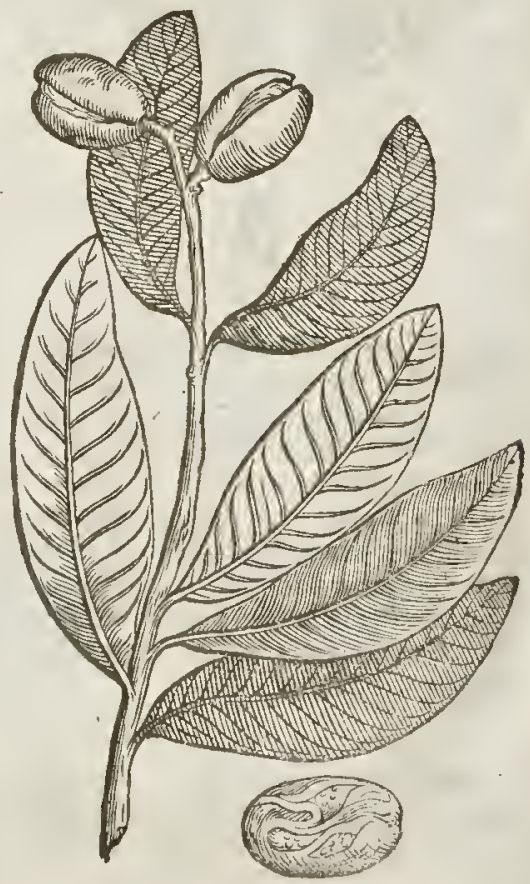


Li B. 3. Of the Hiftory of Plants.

Nux Mofchatacum fua Mac: The Nutmeg with his Maceabout him.

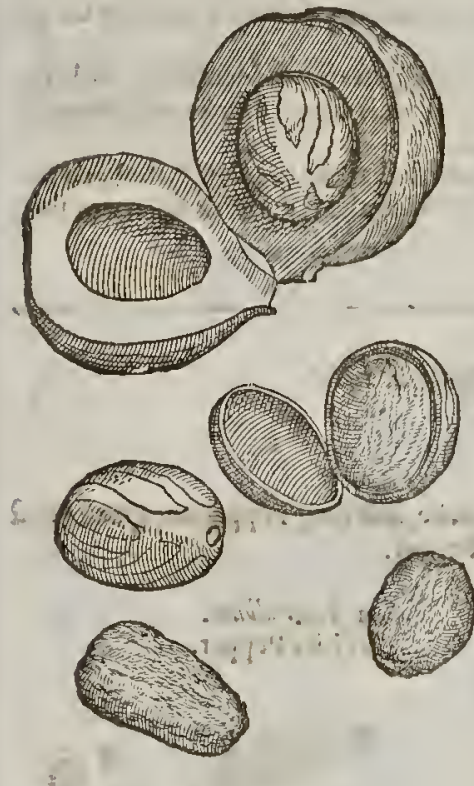

$$
\text { It the Defcription. ... " }
$$

i THetree that beateth ihe Nutmeg - and the Mace is in forme like to the Peare tree, but the leaues of it are like thofe of the Bay or Orenge tree, alwaies greene on the vpper fide, and more whitifh vnderneath; among which come forth the Nut and Mace as it were the floures. The Nut appeareth.firt, compaffed about with the Mace, as it were in the middle of a fingle rofe, which in proceffe of time doch wrapand inclofe the Nut round on euery fide : after commeth a huske like that of the Vall-nut, but of an harder fubftance, which inclofetly the Nut twith Lis Mace as the Wall-nut husk doth couerthe Nut, which in time of ripeneffe doth clcaue of it filfe as the Wall-nut huskedoth; and heweth his Mace, which then is of a perfeet crimfon colour, and maketh a moft gondly fhew, efpecially when the tree is well laden with fruit : after the Nut becommeth dry, the Mace likewife gapeth and forfaketh the Nut, cuen as the firtt huskeor comerture, and leaues it bareand raked, as we all do know ; at which time it getteth to it felfea kinde of darke yelIow colour, and lofeth that brauc crimfon dye which it had at the firft.

$\mp 2$ The tree which carricth the male Nutmeg (according to Clufiss) thus differs from the laft defcribed : the lcaues are like thofe of the former in thape, but much bigger, being fometimes a foot long, and three or furre inches broad; their common length is fenen or eight inches, and bredth two and a halfe:they are of a whitifh colour vnderneath, and greene and thining aboue. The Nuts a!fo grow at the very ends of the branches, functimes two or three together, and not onely one, as in the common kinde. The Nut it felfe is alfolarger and longer : the Mace that incompaffes it is of a more elegant colour, but not fo frong as that of the former.

I can fcarfe beleeue our Authors affertion in the foregoing defcription, that the Nut anpeareth firft, compafted abour with the Mace as it were in the nuiddeft of a fingle Rofe, 8cc. But I rarher thinke they all come forth together, the Nutmeg, Mace, the greene outward huske and all, iuftas we fee $W$ all-nuts do, and onely open themfelues when they come to full maturitie. In the third figure you may fee expreft the whole manner of the growing of the Nutmeg, together with both the forts of Nutmegs taken forth of their thells: $\neq$

$$
\text { 9. The Place. }
$$

The Nutmeg tree groweth in the Indies, in an Ifland efpecially called Banda,and in the Iflands of Molucca, and in Zeilan, though not fo good as the firt.

$$
4 \text { The Time. }
$$

The fruit is gathered in September in great aboundance, all things being common in thofe countries.

$$
\text { T) The Names. }
$$

The Nutmeg tree is called of the Grecians, Kupur mprsxs, of the Latines, Nux Mofohata, and Nux Myrifica : in Ttalian, Noce cMofcada : in Spanifh, Nue de efcetie : in French, Noix Mufade : in

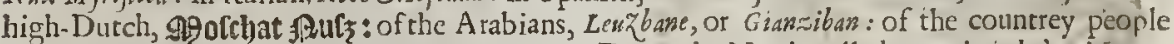
where they grow, $p_{\text {alla }}$ : The Maces, Bunapalla. In Decan the Nut is called lapatri, and the Maces, Iaifol: of Auicen,laufiband, (i.) Nux Bardenfis. The Maces he calleth Befbafe: in Englifh, Nutmeg.

$$
\text { बा The Temperature. }
$$

The Nutmeg,as the Mauritanians write, is hot and dry in the fecond degree complete, and fomwhataftringent.

Nutmeg's cauféd fweetbreath, and amend thole that do ftink, if they be much chewed and hol- $A$ den in the moutli. 
The Nutmeg is good againft freckles in the face, quickneth the fight, frengthens the belly and feeble liner; it raketh away the fwelling in rhe fpleene, ftayeth the laske, breaketh winde, and is good againft all cold difeares in the body:

C Nutmegs bruifed and boiled in Aqua vita vntill they hauc wafted and confumed the moifture, adding thereto of Rhodomel (that is, honey of Rofes) gently boiling them, being ftrained to the forme of a fyrrup, cure all paines proceeding of windie aud cold caufes, if three fpoonfulls be $\mathrm{g}$ uen falting for certaine dayes together.

D The fame bruifed and boyled in ftrong whitewine vntill three parts be fodden away, with the roots of Mother-wort added thereto in the boyling, and ftrained : this liquor drunke with fome fugar curcth all gripings of the belly proceeding of windinefie.

E As touching the choice, there is not any fo fimple but knoweth that the heauieft, fattef, and fulleft of iuice are the bef, which may eafily be found out by pricking the fame with a pinne or fuch like.

\section{Chар. 152. Of the Pepper Plant.}

\section{Th The Kindes.}

7 Herc be diuers forts of Pepper, that is to fay, white, blacke, and long Pepper, one greater and longer than the other; and al fo a kinde of Ethiopian Pepper.

I Pipernigrum.

Blacke Pepper.

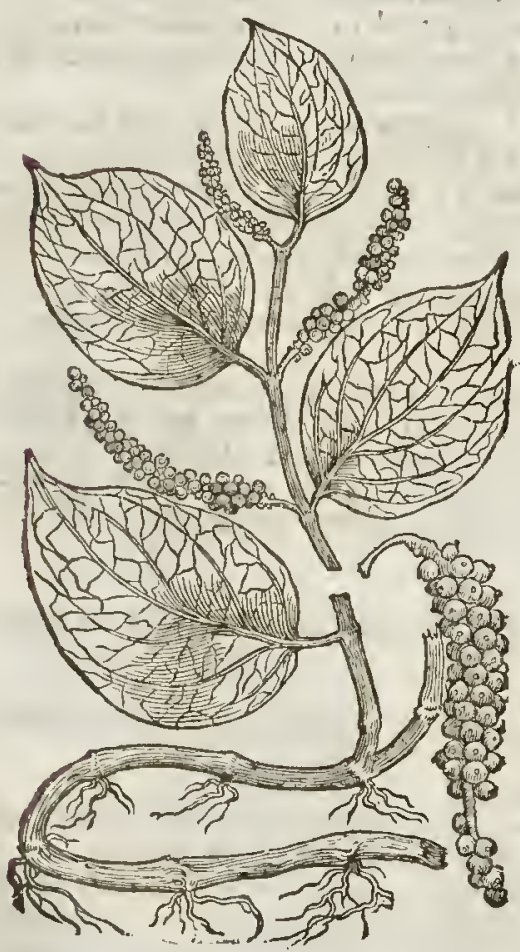

3 Piper album? White Peppet:

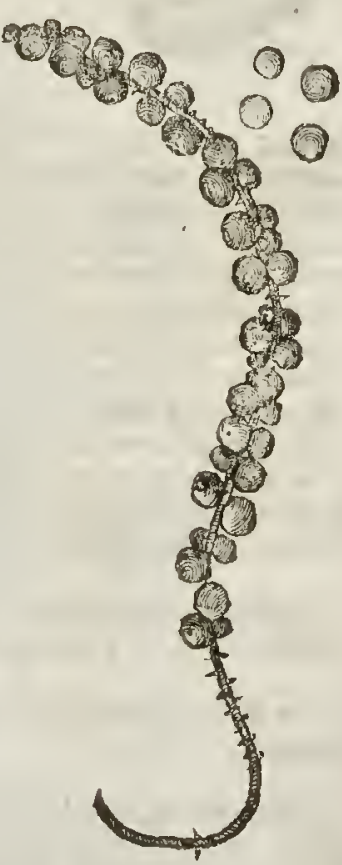

T The Defeription.

I He Plant that beareth the blacke Pepper groweth vp like a Vine among bulhes and brambles where it naturally groweth; but where it is manured it is fowneat the bottome of the tree Faufel and the Date trees, whereon it taketh hold, and clymbeth vp euen to the top, as doth the Vine, ramping and taking hold with his clafping tendrels of any other 


\section{Lip. 3. Of the Hiftory of Plants.}

thing it meeteth withall. The leaues are few in nu norr, $\ddagger$ groving at each io:ntone, firt? nno ve

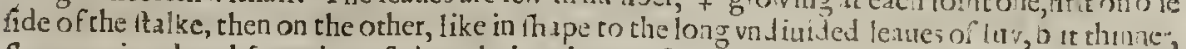
fharpe pointed, and fometimes fo broad, that they are foure inches o der, out mo t co n nonly wwo inehes brosd, and foure long, hauing alwaies fiue pretty large nerues runnmg a'o l zit then. The fruit gro v cluftering together vpon long falks, which come forth at the ioints a dainf the leaues, as youm $\mathrm{m}$ fer in the figure: the root (as one may conie.ture) is creeping; for the branches that lie on the ground do at their ioints put forth new fibres or roots. We are beho'den to clufues for this exa $\mathfrak{t}$ figure and defcription, which he made by certaine branches which were brought home by the Hollunders from the Eant Indies. The curious may fee more hereof in his Exoriekes and netes vpon Gurcias. ‡

$$
\begin{aligned}
& \text { t } 2 \text { Pipor longum. } \\
& \text { Long Pepper. }
\end{aligned}
$$

4 Piper etthiopicum, Gise Vitalonga. Pepper of Ethiopia.
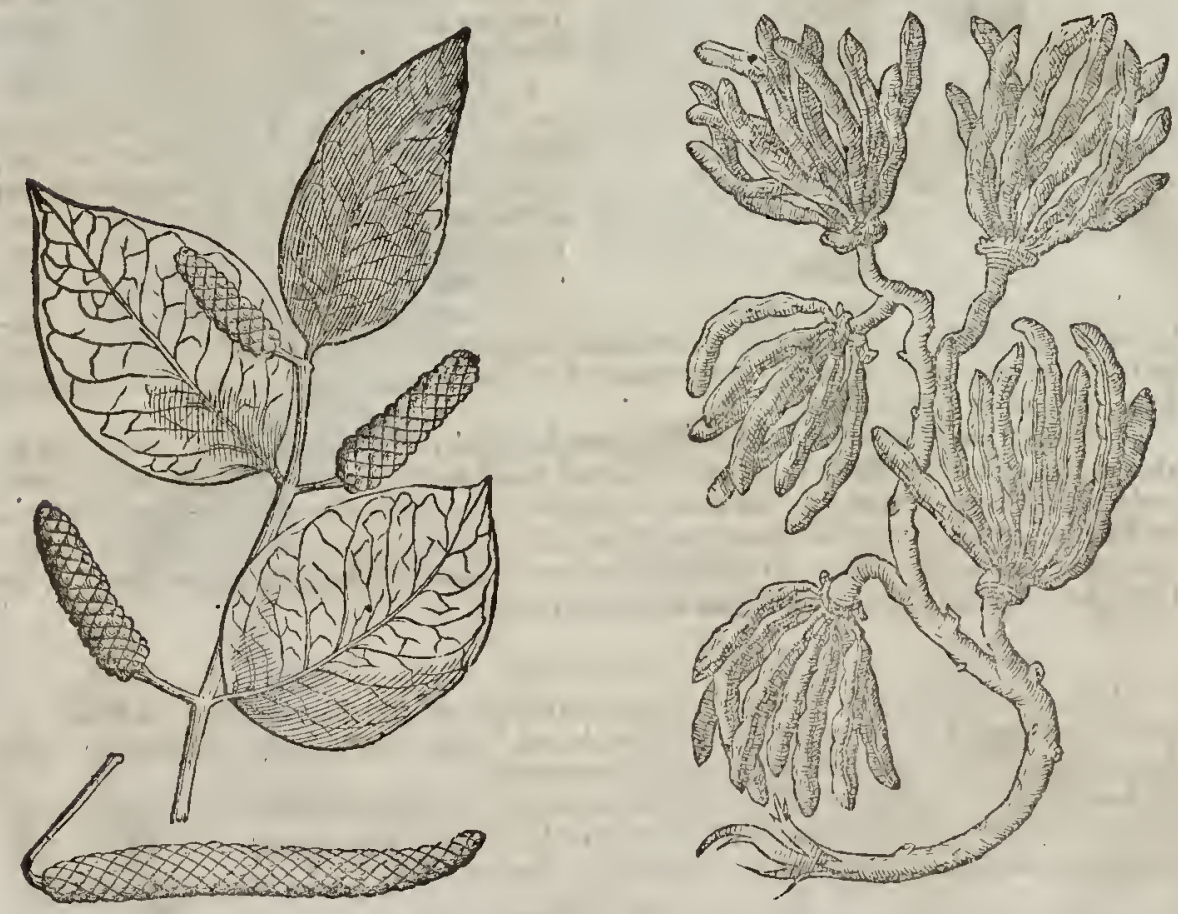

2 The Plant that brings white Pepper is not to be diftinguifhed from the other plant, but only by the co'our of the fruit, no more than a Vine that beareth blacke Grapes, from that which bringeth white : and of fome it is thought, that the felfe fame plant doth fometimes change it felfe from black to white, as diuers other plants do. $¥$ Neither luf us, nor any other elfe that 1 hate yer met with, haue deliuered vs any thing of certaine, of the plant whereon white Peppergro:ves: Clufous only hath given vs the manner how it growes vpon the falkes, as yout may fee it here expreff $\neq$.

There is alfo another kinde or Pepper, feldome brought into the fe parts of Europe, called piper Canarium - it is hollow within, light, and empty, but good to draw flegme from the head, to helpe the tooth-ache and cholericke affe ets.

3 The tree that beareth long Perper hath no finilitude at all with the plant that brings biacis and white Pepper : fome have deemed them to grisw all on one tree, which is not confonant to truth, for they grow in contuties fard difant one from another, and alfo that countrey where there is blacke Pepper hath not any of the Iong Pepper; and therefore G alen following Dioforid"s, ware tugerher both ower feen in this print. This tree, faith Monardes, is not great, yet of a wooddy fo'). feance, difper fing here and there bis clafping tendrels, wherewith it taketh ho'd of other trees and fuch other things as do grow neere vnto it. The branches are many and twigg ie, whereon growes the fruit, coufining of many graines growing vpon a flender foot-ftalke, thruft of compa at clofe 
$\neq 5$ Piper Caudatism. Tailed Pepper.

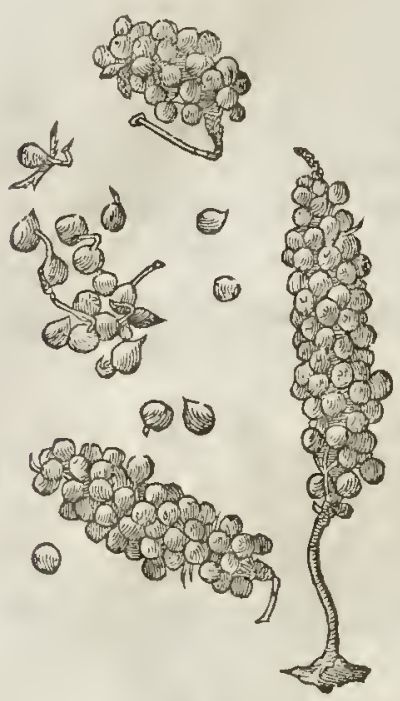

together, greene at the firft, and afreiward blackifh; in tafte fharper and hotter than common blacke Pepper, yet fweeter, and of better tafte. \# For this figure alfo I acknowledge my felte beholden to the learned and diligent chufiz ws, who caufed it to be drawne from a branch of fome foot inlength, that he recsiued from $D^{\text {r }}$. Lambert Hortenfines, who brought it from the Indies. The order of growing of the leaues, and fruit is like that of the blacke; but the joinrs ftand fomewhat thicker together, the leafe allo doth litcle differ from that of the blacke, onely it is thinner, of a lighter greene, and (as Clusizus thought) hath a fhorter loot-ftalke, the veines or nerues alfo were leffe imminent, more in number, and run from the middle rib to the fides, tather than along th the leare. $\neq$

4 This other kinde of Pepper broughe vnto vs from Athiopia, called of the country where it groweth, Piper Asthiopicum : in Mhops, Amomum, and alfo Longa Vita. It groweth vpon a fmall tree, in manner of an hedge buth, whereupon grow long cods in bunclies, a finger long, of a browne colour, vneuer, and bunehed or pert $\mathrm{vp}$ in diuers places, diuided into fue or fix lockers or eels, each where of containeth a round feed fomewhar long, leffer than the feeds of Prony, in tafte like common Pepper, or Cardemomum, whofe facultic and temperature it is thought,
haue, whereof we hold it a kinde.

5 Another kinde of Pepper is fometimes brought, which the Spaniards do call pimenta de rabo, that is, Pepper with a taile: it is like vnto Cubebes, round, full, form what rough, blacke of colour, and of a harpe quicke tafte, like the common Pepper, of a good fmell: it growetli by clufters vp. on fmall ftems or ftalkes, which fome have vnaduifedly taken for Amomum. The King of Portingal forbad this kinde of Pepper to bebrought ouer, for feare leaft the right Pepper fhould be the leffe eftecmed, and fo himfelfe hindered in the fale thereof.

$$
9 \text { The Place. }
$$

Blacke and white Pepper grow in the kingdome of Malauar, and that very good; in Malaca alfn, but not fogood; and alfo in the Iflands Sunde and Cude : there is great itore growing in the
kingdome of China, and fome in Cananor, but not much.

Pepper of Æthiopia groweth in America, in all the traet of the country where Nata and Carthago are fituated. The reft hath been fpoken of in their feuerall deferiptions. The white Pepper
is not fo common as the blacke, and is vfed there in ftead of falt.

The plant rifeth of The Time.

$$
\begin{aligned}
& \text { The plant } 1 \text { ifeth vp ut the firfe of the fpring; the fruit is gathered in Auguft. } \\
& \text { The Grecians Names. }
\end{aligned}
$$

The Grecians, who had beft knowledge of Pepper, do call it mimes : the Latines, Piper : the Ara猖effer : in Englinh, Pepper.

Thac of Erhiopia is called, Piper Ethiopicun, Amomum, Vit longa, and offome, Cat pomum whereof we hold it ro be a kinde. I recciued a branch hereof at heng, and of fome, Cardamomum, of London, called $\mathrm{M}^{\mathrm{T}}$. Stetien Bredwell, with his fruit alfo.

\section{a The Temperature.}

The Arabians and Perfian Phyfitians iudge, rhat Pepper is hot in the third degree.

But the Indian Phyfrians which for the moft part are Emperickes, hold that Pepper is cold,as almoft all other fpice,which are hot indecd:the long Pepper is hot alfo in the third degrec, and as
we have faid, is thought to be the beft of all the kindes.

A Diofcorides and others agrecing with him The'rertues. be put in medicaments for the eies. 
L I B. 3. Of the Hiftory of Plants.

all Pepper heateth, prouoketh vrine, digefteth, draweth, difperfeth, and clenfeth the dimneffe $B$ of the fight as Diof corides noteth.

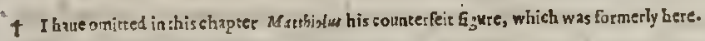

\section{Cha p. 153. Of baftard Pepper, called Betle, or Betre.}

Betle, fine Betre.

Baftard Pepper.

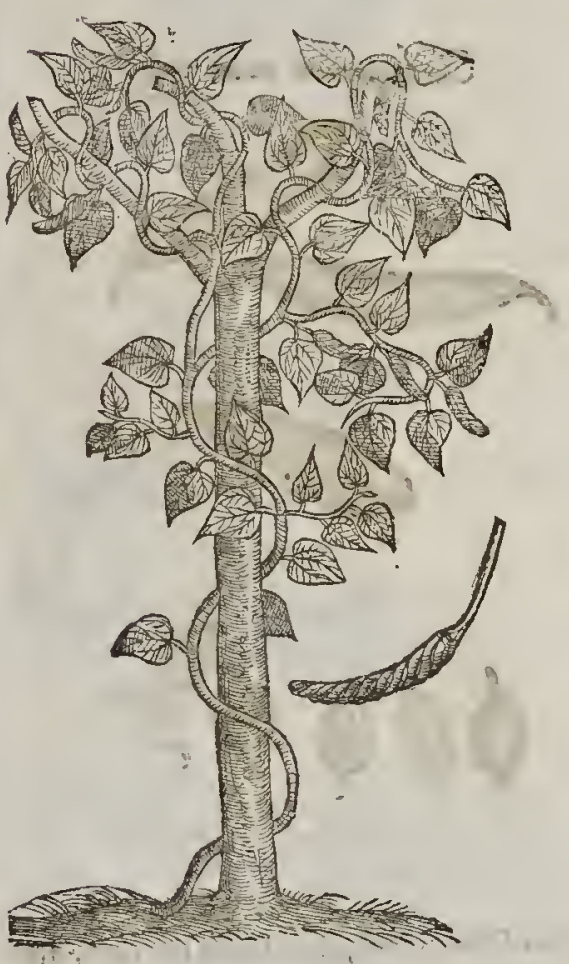

9) The Defription.

This plant climeth and rampeth vpontrees, buhes, or what foeuer elfe it meeteth withall, like vnto the Vine, or the blacke Pepper, whereof fome hold it for a kinde. The leaues arc like thofe of the greater Bindeweed, but fomewhat longer, of a duftic colour, with diuers veines or ribs running through the fane. The fruit groweth among the leates, very crookedly writhed, in thape like the taile of a Lyzard, of the tafte of pepper, yet very pleafant to the palate.

$$
7 \text { The Place. }
$$

It groweth among the Date trees, and Arcca, in moft of the Molucea Intands, efpecially in the marrifh grounds.

$$
\text { 9ा The Time. }
$$

The time anfivereth that of Pefper.

$$
\text { If The Names. }
$$

This hath been taken for the Indian leafe, but not properly : of moft it is called Tembul, and Tambul : in Malaurer Betre : in Decan, Guzarat, and Canam it is called $P$ an : in Molaio, Siri.

$$
\text { Qf The vfe and Temperature. }
$$

The leaues chewed in the mouth are of a bitter tafte, whereupon (faith Garcias) they put thereto fome Areca and with the lime made $O$. oyfter fhels, whereunto they alfo adde fome Amber Griece, Lignum wloes, and fuch like, which they ftanpe together, making it into a pafte, which they role vp into round balls, keepe dry for their vic, and carry the fame in their mouthes vntill by little and little it is confumed ; as when we carry fugar-Candy in our mouthes, or the iuice of Licorice; which is nor onely vnto the feely Indians meate, but alfo drinke in their tedious trauels, refrething their wearied fpirits; and helping memory: which is eftecmed among the Empericke Phyfitions, to be hot and dry in the fecond degree. $¥$ Garcias doth not affirme that the Indians eate it for meate, or in want of drinke, but that they eate it after meate, and that to giue the breath a pleafant fent, which they count a great grace, fo that if an inferiour perfon that hath not chewed Betre, or fome fuch thing, come to fpeak with any great man,lie holds his hand before his mouth left his breath fhould offend him.

\section{Cн А Р. 154.: Of Graines, or Graines of Paradife.}

\section{T) The Kindes.} Tere be diners forts of Graines, fome long, others Peare fáfhion; fonne greater; and others
leffer.

000000 9. The 
If The Defcription.

t $T^{H}$ He firft figure hereof fetteth forth vnto your view the cod whercin the hot fpice lieth, Ihich we call Graines: in thops, Grana Paradif $:$ it groweth, by the report of the Lear-
ned, :pon a low herby plant: the leatres are fome foure inches long, and three broad, with fomewhat a thicke middlerib, from which run tranfuerfe fibres; they much in thape refemble thofe of Cloues. The fruit is like a great cod or huske, in Thape like a Fig when it groweth vpon the tree, but of colout ruffet, thruft full of fmall feeds ot graines of a darke reddith colour (as the Figure fheweth which is diuided) of an exceeding hot talte.

Cardamomigenera.

The kindes or forts of Gtaines:
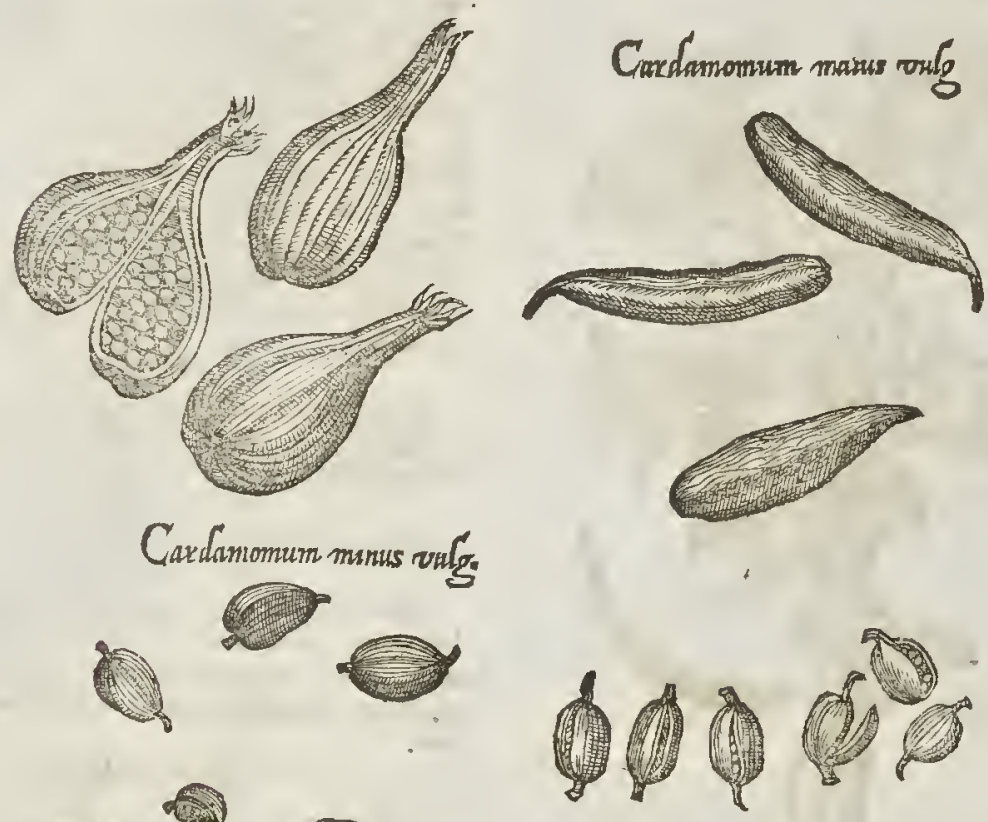

(2)
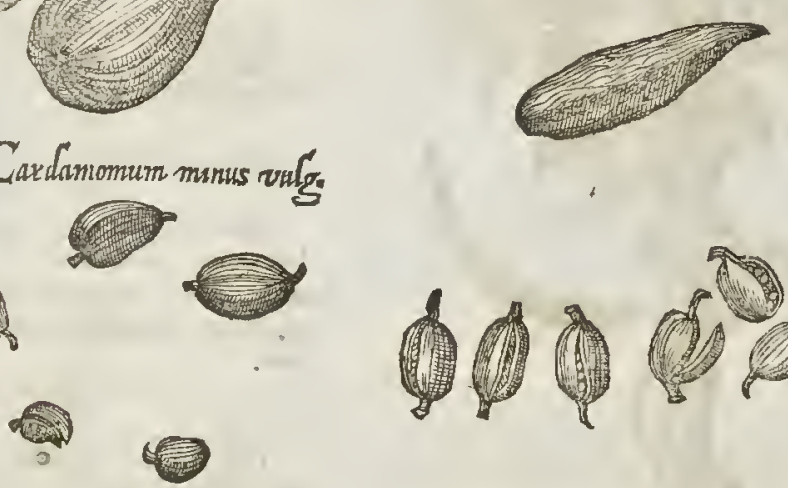
The orhet forts may be diftinguifhed by the fight of the picture, confidering the onely diffe-
rence confifts in forme.

Graines grow in Ginny, and the The Place. vnto Cananor; it groweth in Malauar, in Ioa, and in the Eaft Indies, from the pott of Calecute They fpring vp in May, being fowne $T$ T $T$ be $T$ ime.

$$
\text { Graines are called in Greeke, } 7 \mathrm{The} \text { Names. }
$$

Graines are called in Greeke, sassipus : in Latine, Cardamonsum : of the A rabians, Corrumeni : of It is called in Malauar, Etremelli, : in Zeilan, Encal : in Beng : the other, Saccolaa ceguer (i.) minus. chi. The firft and largeft fort are called of fome, Mileguetts and, Guzarat, and Decan, Hil, and ElsGraines of Paradice.

Auicenwriteth, that Saccolus Cardun The Temperature. with aftriction.

I The Vertues. A The Graines chewed in the mouth draw forth from the head and tomacke waterinh and pitui-
tous humors.

They alfo comfort and warme the weake, cold, and feeble ftomacke, helpe the ague, and rid the
Thang fits, being drunke with Sacke. 


\section{Cн а P. 155. Of Yucca or fucca.}

\section{Yucca, fuse Iucca Perisana. \\ The root whereof the bread Cafaua or Cazaula is made.}

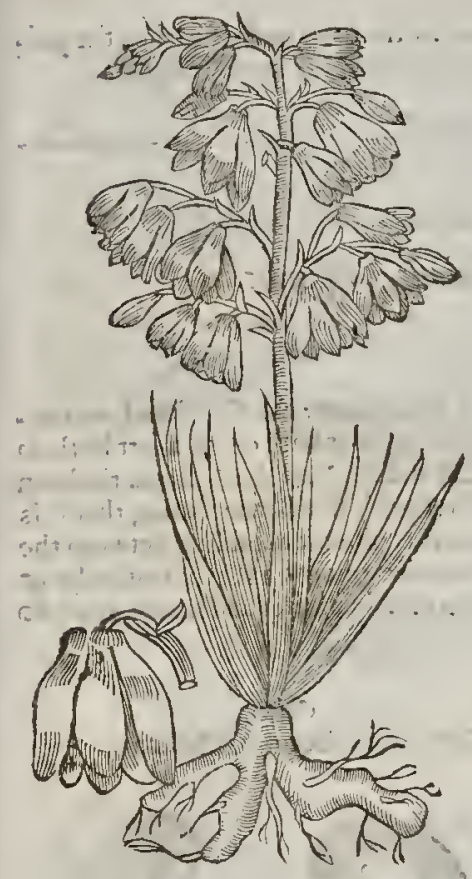

T The Defcription.

7 He Plant of whofe root the Indianbread called Cazauta is made, is a low herbé confifting onely of leaues and rocts: it hath neither ftalke, floures, nor fruit, that I can vn. derftand of others, or by experience of the plant it felfe, which hath giowne in my garden foure yeares together, and yet doth grow and profper exceedingly; neucrtheleffe without litalke, fruit, or floures, as aforefaid. It hath a very great root, thicke and tuberous, and verie knobby, full of iuice fomewhat fwect in tafte, bat of a pernicious qualitic, as faith my Author: from which root rifeth vp immediately forth of the ground very many leates ioyned vnto the head of the root in a round circle; the which are long, of the length of $\mathbf{a}$ cubit, hollowed like a gutter or trough, verié fmooth, and of a greene colour, like that of Woade: the edges of the leaues are tharpe like the edge of a knife, and of a browne co. lour : the point of the leafe is a prick as tharp as a ncedle, which hurteth thofe that vnaduifedly pafle by it: the leafe with aduifed cye viewed is like vnto a little wheriy, or fuch like boat : they are alfo very tough, hard to break, and not eafie tocut, except the knife be very Tharpe.

$\mp$ Lobel in the fecond part of his Aduer $\sqrt{a}$. ria largely defcribes and figures this plant $;$ and there hec affirmes hee wrot a defcription (the which he there fets downe) for our Author ; but he did not follow it, and therefore committed the fe crrours : Firft, in that hee faith it is the root whereof Cazatua bread was made; when as Lobel in his defeription faid he thought it to be Alia pecies ì Yucca Indica cx qua panis communis fit. Secondly, in that he fer downe the place out of the Hifforis Lugd. (who tooke it out of $T$ bezet) endeauouring by that meanes to confound it with that there mentioned, when as he had his from $\mathrm{M}^{\mathrm{r}}$. Edwa ards his man. And thirdly, (for which indeed he was moft blame-worthy, and wherein he moft fhewed his weakenefie) for that hee doth confound it with the as anibot or true $Y_{\text {wicca, }}$ which all affirme to hame a leafe like that of hemp, parted into feuen or more diuifions: and alfo in that he puts it to the Arachidnit of Thcophrafsers, when as lie denies it both floure and fruit; yetwithin fome few yeares after our Author lad fet fortli this Worke it floured in his garden.

This fome yeares puts forth a pretty ftiffe round ftalke fome three cubits high, diuided into divers vnequall branclics carrying many pretry large foures, fhaped fomewhat like thofe of Fritil: laria, but that they are natroiver at cheir bottomes: the leaues of the floure are fix : the colour on the infide white, but on the out fide of an ouerworne reddin colour from the falke to the middeft. of the leafe; fo that it is a foure of nogreat beautic, yet to beefteemed for the raritic. T faw it once floure in the garden of $M^{5}$. W. ilmot at Bow, but neuer fince, though it hath been kept for many yeares in fundry other gardens, as with $\mathrm{M}^{\mathrm{x}}$. Parkinfon and $\mathrm{M}^{*}$. Tuggy. This was firft written of by our Author; and fince by Lobel and $M^{*}$. Parkinfon, who keepe the fame name, as alfo Batubine, who to diftingnith it from the ocher calls it $Y$ ucca foligs Aloes. $\ddagger$

$$
\text { It The Place. }
$$

This plant groweth in all the tract of the Indies, from the Magellane fraights vnto the cape of Florida, and in mott of the Iflands of the Canibals, and others adioyning, from whence I bad that, plant brought me thar groweth in my garden, by a feruant of a learned and skilfull Apothecary of Excelter, named Mr.Tho. Edwards. 


\section{The Time.}

Ir keepeth greene both Winter and Sommer in my garden, without any couerture at all, not: withftanding the iniurie of our cold clymat.

$$
\text { Tा The Names. }
$$

It is reported vnto me by Trauellers, that the Indians do call it in fome parts, cranihot, but ge: erally $Y$ ucca and Incca : it is thought to be the plant called of $T$ heophraftus, Arachidna; and of Plixy,
Aracidna.

$$
\text { Tी The Temperature. }
$$

This plant is hot and dry in the firft degree, which is meant by the feces ordroffe, when the poi tonous iuice is preffed or ftrained forth, and is alfo dry in the middle of the fecond degree.

$$
\begin{aligned}
& \text { Ch A P. } 156 \text {. } \\
& \text { Of the fruit Anacardium, and Caious, or Caiocus. } \\
& \text { IT The Defcription. }
\end{aligned}
$$

He antient writers haue been very briefe in the hiftorie of Anacardinm : the Grecians haue rou? Thape and colour name of Araxs som, raking the name from the likeneffe it hath of an heart both in

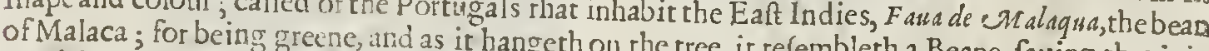
much bigger : bur w g the the is refembleth a Beane, fauing that is outw a d the butward rinde and the kernell, (whichis like an Almond) a certaine oile of a tharpecaufticke or Oliues and fuch like, to procurc appetite.

Anacardium.

The Beane of Malaca.

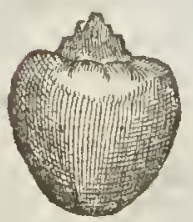

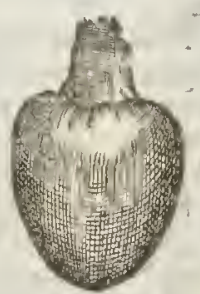

Caious.

The kidney Beane of Malaca.
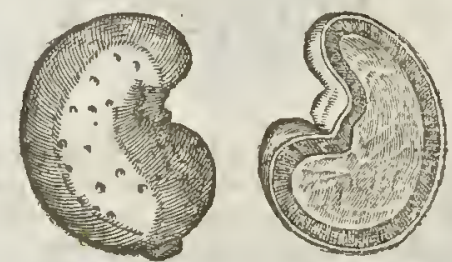

The other fruit groweth vpon a tree of the bignefie of a Peare tree : the leaues are much like to thole of the Oliue rree, but thicker and farter, of a feint greene colour : the floures are white, confi. fting of many fmall leaues much like rhe floures of the Cherry tree, but much doubled, without fmell : after commeth the fruit (according to Clufius, of the forme and magnitude of a goofe egge, tween whice; in the end whereof is a nut) in Thape like an Hares kidney, hating two rindes, beThe Beane is contained a molt hot and tharp oile like that of 4 Anacardirm, whereof it is a kind. ftickenur, where f the in telfe is no leffe pleafant and wholfome in eating, than the Piftacid, or Fiwherein is their chiefeft felicitie cate with great delight, affirming that it prouoketh Veneric, ter : neere vnto withe felicitie. The fruit is contained in long cods like thofe of Beans, but greafmell, fpongious within, and full of forth an excrefcence like vnto an apple, very yellow, of a gnod fweet in rafte ar theone and full of iuice, without any feeds, ftones, or graines at all, fomewhat hath bin repured of rome for narower than the other, Peare falhion, or like a little bottle, which Apple.

The firf growes in moft parrs of the Place. and Decan. The later in Brafile. 


\section{L13.3. Of the Hiftory of Plants.}

Theie rrees floure and flourifh Winter and

\section{The Timze.}

IT The Names.

Their names haue been touehed in their deferiptions. The firt is called Anacardium, of the like: neffe it hath with an beart: of the Arabians, Baludor : of the Indians, Bibo.

The feeond is called Caious, and is thus written, Caious, and Caims: of fome, Caiocus.

\section{- The Temperature and Vertues.}

The oile of the fruit is hot and dry in the fourth degree, it hath alfo a eanficke or corrofute qua- $A$ litic : it taketh away warts, brcaketh apoftumes, preuaileth againft lepric, alopecia, and eafeth the paine of the teeth, being put into the hollowneffe thereof.

The people of Malauar do ve the faid oile mingled with ehalke; to marke their eloathes or any $B$ other thing they defire to be coloured or marked, as we do vfe chalke, okar, and red marking ftones, but the ir eolour will not be taken forth againe by any manner of art what foener.

They alfo give the kernell fteeped in whay to them that be aftlmaticke or thort winded; and C when the fruit is yet green they ftieke the fame fo fteeped againft the wormes.

The Indians for their pleafure will giue the fruit vpon a thomenr fome other tharpe thing, and hold it in rhe flame of a candle, or any other flame, which there will burne with fuch eraekings, lightnings, and withall yeeld fo many ftrange eolours, that it is great pleafure to the beholders which haue nor feene the like before.

$$
\therefore
$$

\section{Cha Pa 157.}

\section{Of Fndian $\mathcal{M}$ orrice Bells, and diwers otber Fndian Fruits.}

\section{t I Lbouay Theueti.}

Indian Morrice Bels.
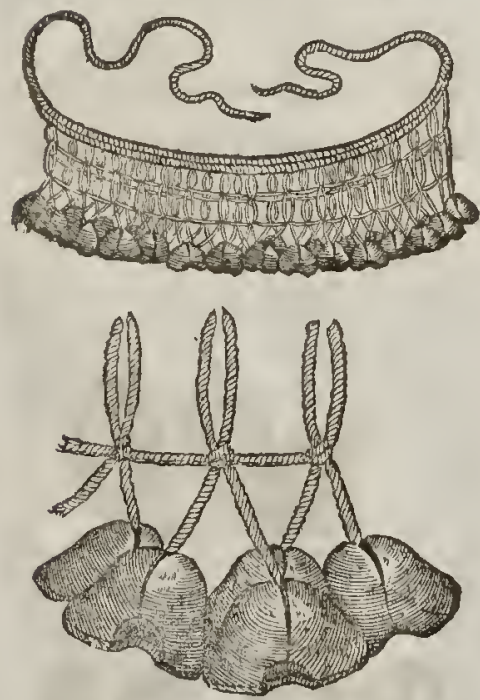

† 2 Fructus Higuero. Indian Morofcobels.
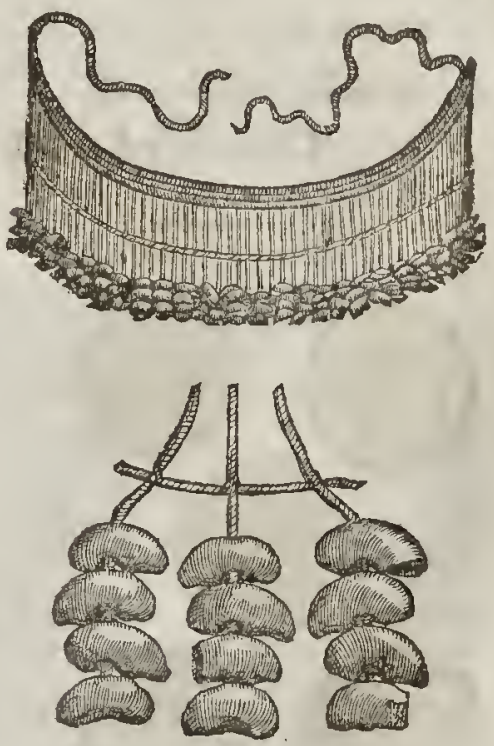

9 The Defription.

$T^{\text {His fruit groweth vpon a great tree of the bigneffe of a Peare tree, full of branches, garnifhed }}$ with many leares which are alwaies greene, three or foure fingers long, and in bredth two: when the branches are cut off there iffueth a milky iuice not inferiour to the fruit in his venomous 
qualitie. The trunke or body is couered with a grayi h barke : the timber is white and foft, not fic to make fire of, much leffe for any other vfe; for being cut and put to the fire to burne, it yeeldeth forth fuch a loath fome and horrible ftinke, that neither man nor beaft are able to endure it : wherefore the Indians hane no vfe thereof, but onely of the fruit, which in thape is like the Greeke letrer $\triangle$, of the bigneffe of a Cheftnut, and couered with a mott hard thell, wherein is contained a kernel of a moft venomous and poyfonfome qualitie, wherewith the men being angry with their wiues, do poyfon them, and likewife the women their husbands : they likewife vfe to diporanoint and invenome the ir arrowes therew ith, the more fpeedily to difpatch their enemies. Which kernell they take forth with fome contenient inftrument, leauing the fhell as whole as may be, not touching the kernell with their hands becaufe of its venomous qualitie, which would fpoile their hands, and fometimes take away their life alfo. In which thells they pur fome little fones,and tye them vpon Atrings (as you may percciue by the figure) which they dry in the Sunne, and after tye them about their legs, as we do bells, to fet forth their dances, and Morofco Marachina's, wherein they take great pleafure, by reafon they thinke themfelues to cxcell in thofe kindes of dances. Which ratling found doth much delight them, becaufe it fetteth forth the diftinction of founds, for they tune them and mix them with great ones and little ones, in fuch fort as we doe chimes or bells.

2 There is alfo another fort hereof, differing onely in forme; they are of the like venomous qualitie, and ved for the fame purpofe. ₹ The fruit of Higuerro is like that of a gourd in pulpe, and it may be eaten : the thape of the fruit is round, whereas the former is three cornered. $\neq$

$$
\text { The place. }
$$

Thefe do grow in moft parts of the Weft Indies, efpecially in fome of the Iflands of the Canio: bals, who vfe them in their dances more than any of the other Indians. ¥ You may fee thele vpon ftrings as they are here figured, amongft many other varieties, with $\mathrm{M}^{\mathrm{r}}$. Yohn Tradefcant at Soutb Lambeth. $\ddagger$

\section{T) The Time.}

We haue no certaine knowledge of the time of fouring ot bringing the fruit to maturitie.

$$
\text { T The Names and V/e. }
$$
fuffice.

We haue fufficiently fpoken of the names and wfe hereof, therefore what hath beene faid may

+ The figures were tranfgoled.

\section{$\mathrm{C}_{\text {на }}$ Р. 158 . Of the vomiting and purging $\mathcal{N}$ (uts.}

I Nuces vomice.

Vomiting Nuts.

\section{Nuces purgantes. Purging Nuts.}
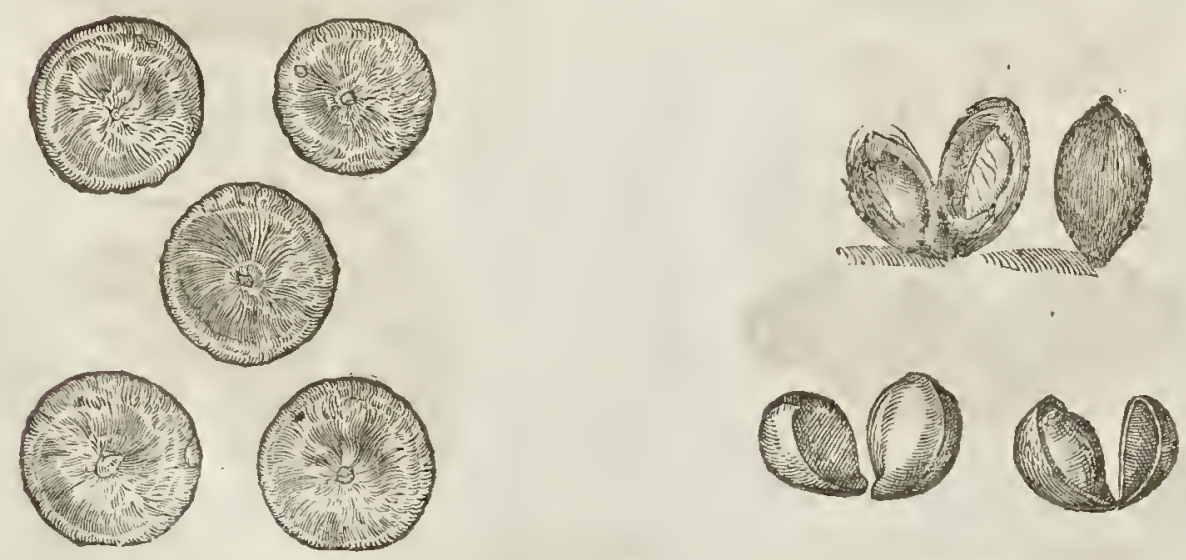


\section{The Defription.}

1 Nicen and Serapio make $N u x$ vomica, and 2 ux Metbl, to be one, whereabout rhete hath $A$ been much cauclling; yet the cafe is plaine, if the text be true, that the Thorne Apple is $N u x$ Methcl Of the ttee that beateth the fruit that is called in thops $N u x$ vomica, and Nux Methel,we hate no certaine knowledge : fome are of opinion, that the fruit is rhe root of an herbe, and not the nut of a tree : and therefore fince the cafe among the learned refeth doubt ful, we leaue the reft that might be faid to a further confideration. The fruit is round, flat, like a little cake, of a ruffet ouerworne colour, fat and firme, in tafte fweet, and of fuch an oily fubftanee, thar it is not poffible to ftampe it in a mortat to pow det; but when it is to be vfed, it muft be grated or fcraped with fome inftrument for that purpofe.

2 Thete be certaine Nuts brought from the Indies, called purging Nuts, of their qualitue in purging groffe and filthic humors, for want of good inftruction from thofe that haue trauelled the Indies, we can write nothing of the tree it telfe : the Nut is fomewhat long,ouall, or in thape like an egge, of a btowne colour : within the fhell is contained a kernell, in talte fweet, and of a purging facultie.

The Place and Time.

Thefe Nuts do grow in the delarts of Atabia,and in fome places of the Eaft Indies : we haue no certaine know ledge of their fpringing, or time of maturitie.

$$
\text { T The Names. }
$$

Auicen affirmeth the vomiting Nut to be of a poifonous qualitic, cold in the fourth degtee, ha uing a ftupifying nature, and btingeth deadly lleepe.

$$
\text { Th The Vertucs. }
$$

Of the Phyficall vertues of the vomitting Nuts we thinke it not neceffarie to write, becaufe the $A$. danger is great, and not to be giuen inward ly, but mixed with other compofitions, and thet very curiounly by the hands of a faithfull A porhecaric.

The pouder of the Nut mixed with fome flerh, and caft vnto erowes and other rauenous fow les, B doth kill and fo dull their fences at the leaf, that you may take them with your hands.

They make alfo an exeellent lallet, mixed with fome meat or butter, and laied in the garden $\mathbf{C}$, whete cats ve to fcrape to buric their exctements, fpoyling both the herbes and alfo feeds new fowne.

\section{C. А P. 159. Of divers forts of Indianfruits. \\ 9 The Kindes.}

Hefe fruits are of diuers forts and kinds, wher of we haue little knowledige, mote than the fruits themfelues, with the names of foms of them : thetefore it mall fuffice to fet forth vnto your view the forme onely, leauing vnto Time, and thofe that fhall fueced, to write of them at large, which in time may know that, that in this time of infancic is vnknowne.

\$ Vr Authour formetly in this Chapter fet forth diuets figutes of Indian fruits, and

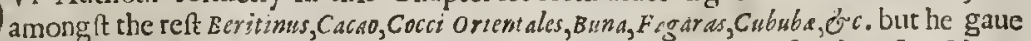
but onely threedefcriptions,and the fe either falfe or to no purpole; wherefore I haue omitted them, and in this chapter gituen you moft of thefe fruits which were formerly figured therin, together with an addition of fundry other out of Clufius his Exotielies, whofe figures I haue made vfe of, and here giuen you all thofe which came to my hands though nothing fo many as are fet forth in his Exotickes; neither, if I thould haue had the figures, nould the thortneffe of my time nor bigneffe of the booke(being already growne to fo large a volumr) fuffer mee ro hatue in ferted

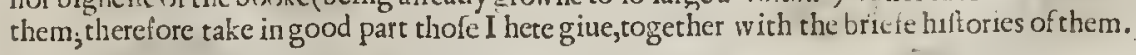

\section{T The Defcripion.}

I

$7 \mathrm{He}$ firft and one of the bet knowne of thefe fruts, are the $C$ abibs, called of the Arabian Phyfitions Cubil,e and 2 uabel; but of the vulgar 2 qubebochm $t_{1}$. in Iana where rhey pleatifu!ly grow, Cumuc: the other Indians, (he Malayans excepted)call them $\mathrm{Cu}=$ bs fini, not for that they grow in China, but becaufe the Chinois vfe to buy them in lana and Sunda, and fo catry them to the other potts of India. The plant which carrics this fruit hath leates 


\section{is 48 Of the Hiftory of Plants:}

I Cubibr. Cubibs.

2 Cocci Orientules, Cocculus Indi.
cubibe
$9 \%$

Cocci.

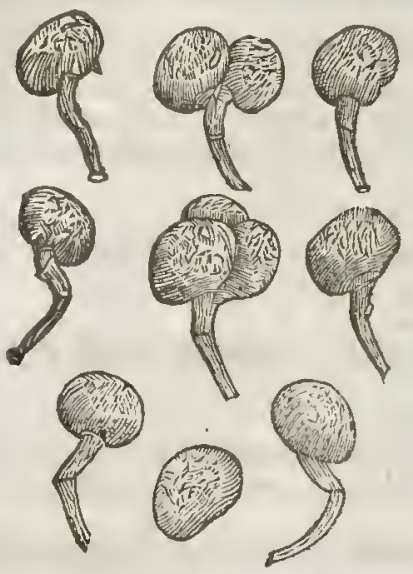

3 Fagard.

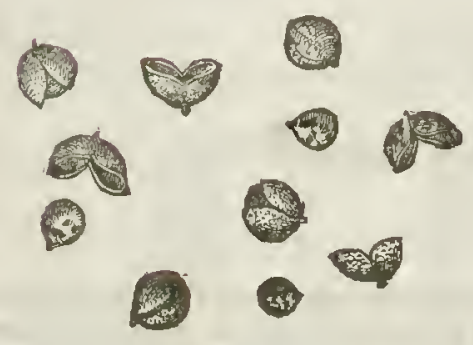

4 Mungo:

c

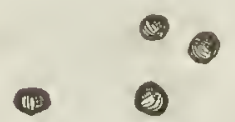

$58 u * a$

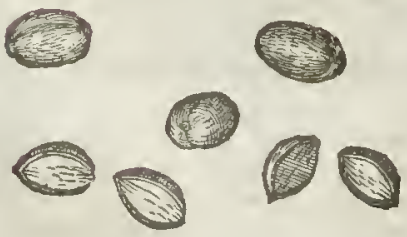

\$ 1 momum vcrum.

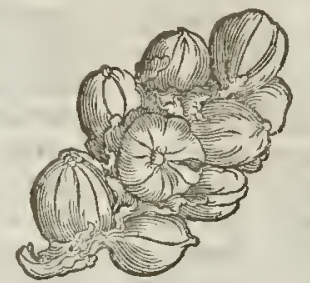

\$ Amormum purium.
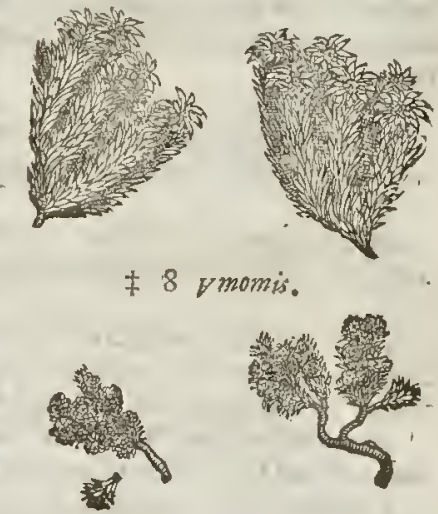

9 Beritinus.
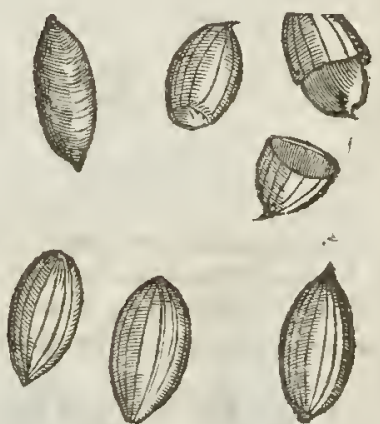

* ro Nuces infane. Mad Nuts:
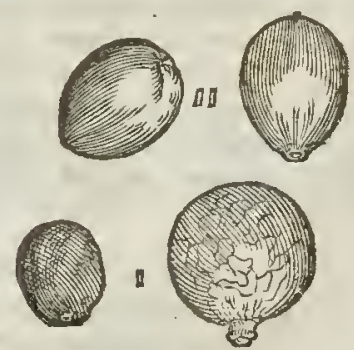
like thofe of pepper,but narrower, and it alfowindes about irees like as Iuy or Pepper doth : the fruit hangs in clufters, like as thofe we eall red Currans, and not clofe thruft together in bunches, as grapes: the fruit ar berries are of the bigneffe of Pepper eornes, wrinckled, and of a brownith colour: they are of a hot and biting a romat icke tafte, and of times hollow within, but if theybe not kollow, then haue they a pretty reddith fmooth round feed vnder their rough vtter huske; cach of thefe berries commonly hath a piece of his foot-ftalke adhering to it. It is reporred thar the Natines where it growes firft gently boile or fcald thefe berries beto e they fell them, thar fo toone els may haue them, by fowing the feeds. Some haue thought thefe to haue beene rbe Carpef fum of the Antienrs; and other-fome haue iudged them the feeds of $A g$ mots $C$ aftus, but both thefe opinions are erronious.

Thefe are hot and dry in the beginning of the third degree; wherefore they are good againft the $A$ cold and moift affects of the ftomaeke and flatuleneies: they helpe to clenfe the breaft of tough and thicke humours; they are good for the fplecne, for hourfneffe and cold affects of the wombe, ehewed with Malfieke, they draw mueh Alegnaticke matter from rlie head, rhey heat and comfort the braine. The Indians vfe them macerated in wine to exeite veneric.

2 The Plant whieh carries this fruit is vnknowne, but rhe terrie is well knowne in fhoppes by the name of Cocculis Indicusfome call them Corci Orientales : others, Caccula orientales: fome, as Cor. dus for one, thuke them the finit of Sol anum furiof fum : others intge rhem the fruit of a rithynale, or of a clemat is. Thefe berries arc of the bigneffe of Bay berries commonly round, and growing but one vpon a flalke; yet fometimes they are a little cornered, and grow rwo or three ciutering together : their outer coat or thell is hard, rough, and of a brownifh duskie colour : their inner fibftance is very oily, of a bitter tafte.

They are vfed with good fuceeffe to kill lice inchildrens heads, being made into pouder and fo $B$ ftrowed among ft the haire. They bate al fo another faculty whieh our Author formerly fet downe in the chapter of Alaternus ( $w$ here he confounded thefe with $F_{\text {ag ar as) }}$ in thefe words, which I haue there omitred, to inferr lece ;

In England we vee the fruit called cocculus Indi in pouder mixed with fower, hony, and erummes of bread to catch filli with, it being a numming, foporiferous, or fleeping medicine, caufeth rhe fifh to turne vp their bellies, as being fenceleffe for a time.

3 Fugara is a fruit of the bigneffe of a Chich-peafe, eouered with a thin eoat of a blackith afth colour,vnderwhich outer coat is a flender thell containing a follid kernell, involued in a thin and blacke filme. The whole fruit both in magnitude, forme, and eolour is fo like the Cocculus Indus laft deferibed, that at the firft fight one would take it tobe the fame. Anicen mentions this in his 266. Chap.after this manner. What is Fag ar b? It is a fruit like a Chich,hauing the feed of Mahatleb, and in rhe hollownefle is a blacke keruell as in Schehedinegi, and it is brought out of Sofale.

He places it among th thofe that heate and dry in the third degree, and commends it againt the cold neffe of the ftomacke and liuer, it helps eoncoetion, and bindes rhe belly.

4 This whieh Clufurs thinkes to be Mungo (whieh is v fed in the Eaft Indies about Guzarat and Deean for pronender for hor(es) is a finall frut of the bigneffe of Pepper, crcted, very like Coriander feed,but that it is bigger and blaeke, ir is of a hor tafte.

5 Buna is a fruit of the bigneffe of Fagara, or fomew hat bigger or longer, of a blackinh arh co: lour,couered with a thin skin, furrowed on both fides longwife, whereby it is eafily diuided into two parts, which containe each a kernell longith and fiat vpon one fide, of a yellowith colour, and acide tafte. They fay that in Alexandria they makea certaine very cooling drinke hereof. Rawwol fius in his isurnal feenes to deferibe this fruit by the name of Bume: and by the appellation, forme, and faculties; he thinkes it may be the Buncho of Auicen, and Buncha of Rhafis, to Almanfor. Clafurs.

6 This is a kind of Cardamome: and by diuers it is thought to be the true Amomum of the Antients, and to this purpofe Nicholas Marogna,a Phyfition of Verona harb written a treatifewhich is fet forth at the later end of Pona's defcriprion of Mount B. aldas, to w bieb I refer the eurious:thefe cods or berries(whether you pleafe to call them) grow thickeccluftering rogether, they are round, and eommonly of rhe bignefle of a elerry:the outer sk in is rough, fmoorher, whiter, and lefte crefted than that of rhe Cardamome: within this filme lye rhe feeds eluftering togerher, yet with a th in filme parted into three, the particular feeds are cornered, fomewhar moother and larger than thofe of Cardamomes, but of the fame aromaricke rafte, and of a browne colour. Their temperature and faculties may be referred to thofe of Cardamomes.

7. 8. This with the next enfuing are by Cluffus fet ford by the names I here gitie you them; shough(as he faith) neirher of them agree wirh the Amomum of Diof(cordes, they were only branches fet thicke with leates, hauing neither any obferuable fmell or tafte : they were fent to the learned and diligent Apothecaric Wralarandus Donrez of Lyons, from Ormul the famous Mart \& port town in the Perfian Bay.
9. Thofe that accompanied the renowned Sir Francis Drat. :
oyage about the World 
II Cacao, Small Cocoes.
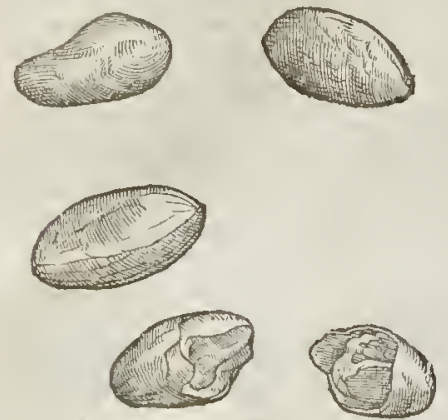

I2 Crcciopbora, Quince Dates:

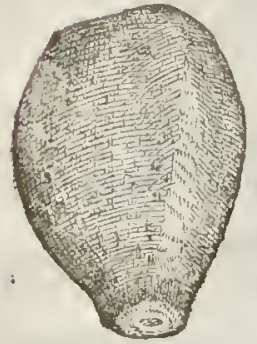

* 13 Baruce.Arara.Orakioria. Cropiot.

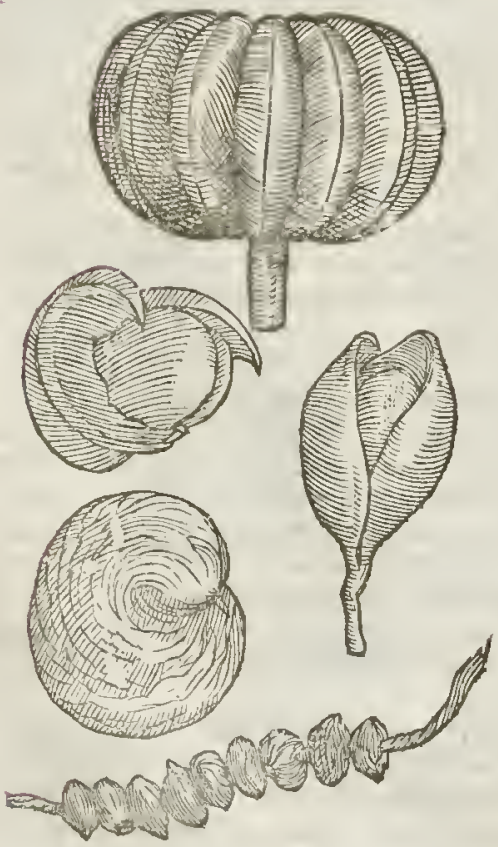

\& 14 Guapobanus. Tree Melon.

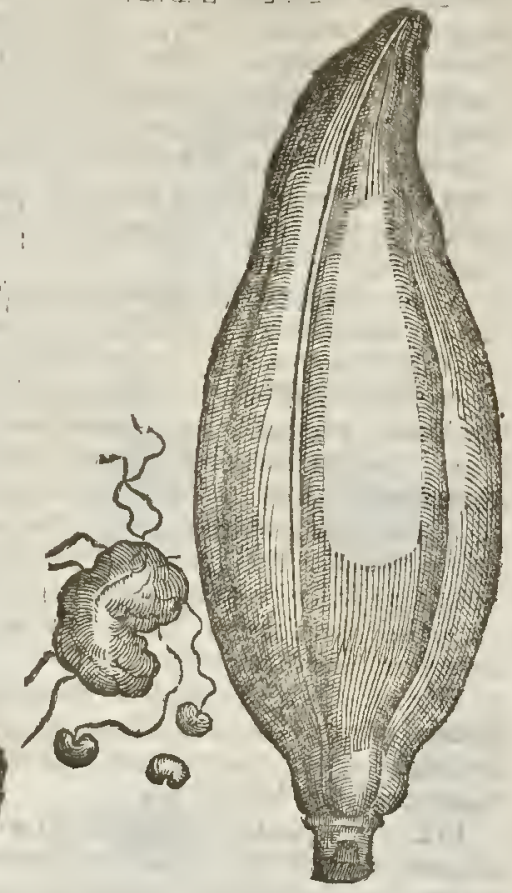

\$ 15 Anans: The Pinia, or Pine Thifle?

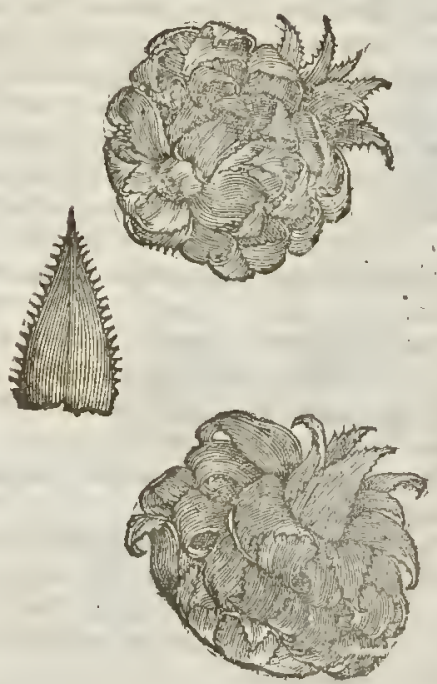


light vpon a certaine defert Illand, whetein grew many very tall rrees, and looking for fomething amongft thefe to refterh themfelues, among it othets they obferued fome bigger than Okes, hauing leates like thofe of the Bay tree, thicke and thining, not fnipt about the edges, their fruit was longith like to the fmall Acrornes of the Ilex ot Holme Oke, but without any eup; yet couered with a thin thell of an ath colour, and fomtimes blacke, hatung within it a longith white kerneli wrapped in a thin peeling, being without any manifeft tafte; They when they found it, thouglimuch oppreft wlth hunger,yet durft not tafte thereof, leaft it thould hate been poilonous : but afterwards comming to the Inand Beretina, not far from this, they found it to abound with rheferrees, $\&$ icarned that their fruit was not poifonous, but might be eaten. Wheruponafterwards they ingant of othervictuals, boiled fome as they do Peafe, and ground others into Houre, wherewith they made puldings. They found this tree alfo in the Moluccoes.

ro The firit exprafed in this table is the mad Plum, or as Clufuss had rather terme it the Mad

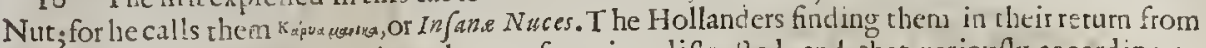
the Eaft Indies, ant eating the kernels, were for a time difracted, and that varionfly, aecording to the particular temperature of each that ate of them; as you may fee in Chifus Exot.li6. 2. Cap.26. This was ro:Ind, little more than two inehes about, with a thell not thieke, but fufficiently ftrong, brownith on the out fide, and not fmooth, but on the infide of a yellowifh colour and fmooth, conraining a membranous fone or kernel! couered with a black puip, in form and bignelle not much vnlike a Bullas or Sloe, hauing a large whire fpot on the lower part whereas it was faftened to the ftalke: vinder the oulpe lay the kerne!l, fomewhat hard, and of an afh colour: the font-falke was thort and commonly carried but one fruit, yet fometimes they obferued wo growing together:the tree wheron this fruit grew was of the bigneffe of a Cherry tree, hauing long and narrow leaues like thofe of the Peach tree: the orher fruit figured in the 2. place was of a brownifh yellow colour, fomwhat bigger, but not vnlike a fmall Nut, and inch long, and fomwhat more about, fmaller below, and bigger aboue, and as it were parted into foure, being very lard and follid. Of this fee mote in the fourteenth place.

II The Cacoa is a fruitwell knowne in diters parts of Ameriea; for they in fome places vfe it in ftead of money, and to make a drinke, of which, though bitter, they highly eiteeme: the trees which beare them aîebut fmall, hauing long and narrow leates, and willonely grow well in places madowed from the Sun. The fruir is like an Almond taken out of his husk, and it is courered with a thin blacke skin, wherein is contained a kernell obliquely diuided into two or three parts,btow nith, and diftinguifhed with ath coloured veines, of an aftringent and ungratefull tafte.

12 This which Clufius had from Cortujus, for the fruit of Edellium, is trought to be the Cuciof Pliny, and is the Cuciophera of Mattholus, and by that name our Author had it in this Chapter. The whole fruit is of the bigneffe of a $Q$ unce, and of the fame colour, with a fweet and fibrous flerh, vnder which is a nut of the bigneffe of a large Walnut or fomewhat more, al nott of a triangular form, bigger below, and finaller aboue, well fmelling, of a darke afh colour, with a very hard thell, which broken there is therein contained a hard kernell of the colour and hardneffe of maible, hauing a hollowneffe in the middle,as much as may containea Hafell Nat.

13 In this table are foure feuerall fruits defcribed by Clufins Exot.lib.2.c. 2. I. The fir?t is cal. led Baruce, and is faid to grow vpon a high tree in Guyana called Hura: it confffted of many Nurs of fome inch long, frongly faftened or knit together, each hauing a hard wooddy thell, falling into two parts, containing a round and fuooth kernell couered with an ath coloured filne.

They fay the natiues there $v$ fe this fruit to purge and vomite.

The feeond called Arara gtowes in Kaiana,but how, it is not knowne : it was fome inch long, co. ueted with a skin fuffieiently hard and blacke,faftened to a long and rugged falke that feemed to hauc catried more than one fruit:the kernell is blacke, and of the bignefle of a wilde Oliue.

The natiues vfe the decostion hereof towafn maligne vlcers, and they fay the kerncll will loofe $\mathbf{B}$ thebelly.

The third named orskoria is the fruit of a tree in Wiapoek, called Inrmwa, they vfe this to cure their wounds, dropoing the iniee of the fruit into them. This fruit is fiat almoft an inch broad, and two long, burwrithen like the cod of the true Cytifus, but much bigger, very wrinckled, of an ath colour, containing a fmooth feed.

The fouth ealled Cropiot is a fmall and thriuelled fruir,not much unlike the partieulat ioints of the Æishiopian pepper.

The fauages vfe to take it mixed among th their Tabaco to affwage head-ache:thete were diuers of them put vpon a tring (as you may fee in the figure) thebetter todry them.

14 This which by Clufus \& Lobel is thought to be the Guanabamis mentioned by Scaliger Exerc. 281. part.6.is a thicke fruit fome foot and halfelong, coucred with a thicke and hard rinde, freezed ouer with a foft downinaffe, like as a $Q$ rinee is, but of a greenibs eolour, with fome venes, ot rather furrowes cuaning alongt it, as in Melows:the lower end is Comewlat fharp: at the vppeten it is 
faftened to the boughes, with a firme, hard, and fibrous falke : this fruit containes a whitili pulfe, which the Ethiopians ve in burning feuers to quench the thirft, for it hath a pleafant tartneffe:this dried becomes friable, io that it may be brought into pouder with ones fingers, yet retainerh its aciditic:in this pulp lye feeds like little Kidneis, or the feeds of the true Anagyr is, of a black thining colour, with fome fibres comming out of their middles: thefe fowne brought forth a plant hauing leaucs like the Bay tree, but it dyed at the approch of Winter. Cluf.

is Ananas Piniaj, or Pine Thifle is a plant hauing leaues like the edizon aquaticum, or wate

\$ 16 Fabe Egyplie affinis.

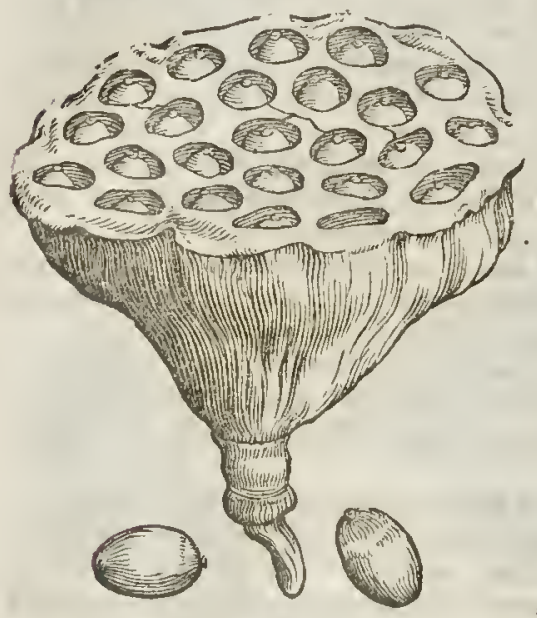

¥ i7 Coxce Cypote. Amygdala Peruane: Almonds of Peru.
\$19 Frutustetragenm. The fquare Coco.

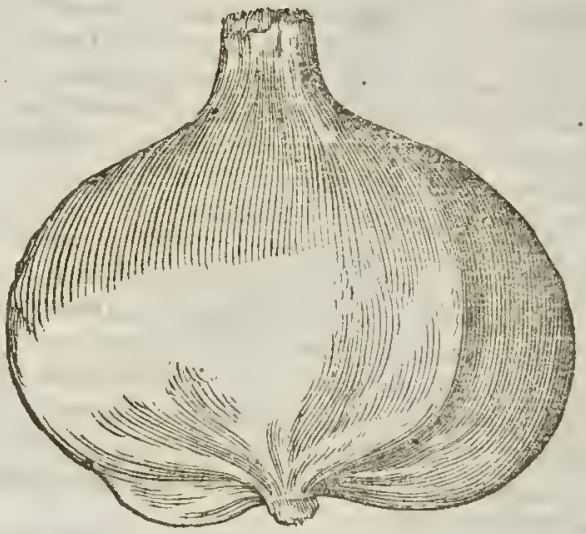

\# 20 Arboris laniferefiliqua. A cod of the wooll-bearing tree.
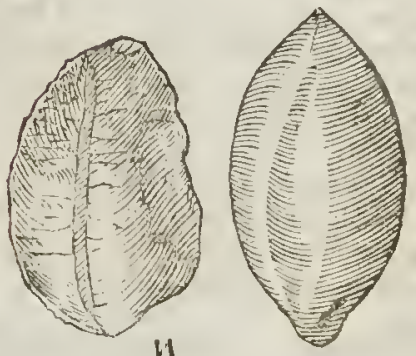

‡ 18 Buenas Noches:

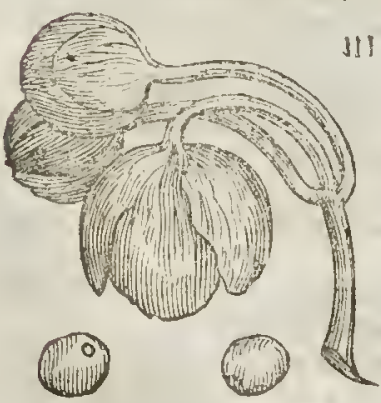

3I)

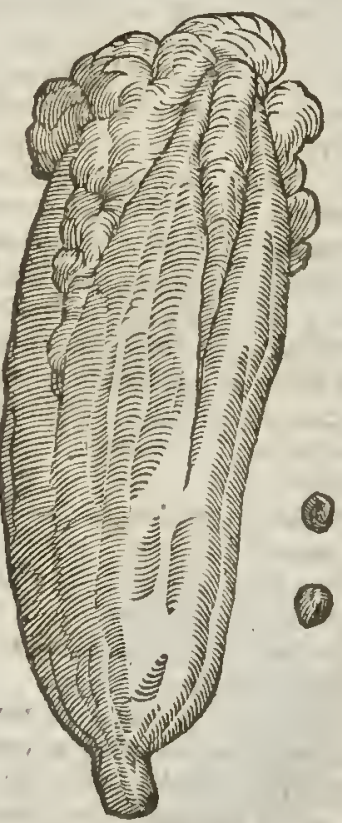

Sengreene, 
Sengreene, fomew hat tharpe and prickly about the ciges : the ftalke is round, carrying at the top therof one fruit of a yellowith colour when it is ripe, of the bignes of a Mclon, conered with a fealelike rinde: the fmell is gratefull, fo newhat like that of the Malocotone : at the top of the fruit, and fomerimes below it come forth fuch buds as you fee here prefented in the figure, which they fet in the ground and preferue the kind by in ftead of feed:the meac of this fruit is fweet \&very pleafant of rafte, \& yeelds gool no:trifhnent; there are certaine fruall fibres in the meat thereof, which chough they do not offend the mouch, yet hurt they the gums of firch as too frequently feed thereon.

16 The forme of this is fo newhut itrange, for it is like a large Poppy head cut off nigh the top: the fub ttancethereof was membranous and wrinckied, of a brownifh colour, very fmooth : the cir. cumference at the tor is about nine inches, and fo it growes fmalierand fmaller cuen to the 1talke, which feems to haue carried a floure whereto this fruit fitcceeded:the top of the fruit was etten, and in it were orderly placed 24.cauicies, in each whereof was contsined a little Nut like an Acorn,al. moft an inch long, and as miteh thick; the vpper part was of a brownifh colour, \& the kernel withid was rank and all mouldy. Cluf ius eutú learne neit her whence this eane, nor how i grew, but with a great deale of pro'bability thinks it m.ly be that which the Autients defcribed by the name of $F_{a b a}$ Egypia.

17 The former of thefe two Clufius receiued by the name of Coxco Cypote, that is the Nut Cypote: It is of a dusky brovne colour, mooth, and thining, but on the lower part of an afh colour, rough, which the P.inter did no: well expreffe in drawing the figurc. The :. hee reeciued by the name of Almentras del $P$ eru, (i.) Almonds of Peru:the fhell was like in colour and fubft ance to that of an almond, and the kerisell not valike neither in fubttance uor tafte:yet the forme of the hell was different, for it was triaugular, with a backe ftanding vp, and two tharp fides, and thefe vety rough

I8 This was the truit of a large kind of Convolvulus which the Spaniards called Bwenas noithes; or Goodnight, becaufe the Anoures ve to fade as foone as night eame. The feeds were of a footy colour as big as large Perfe, feing three of them contained in a skinny three cornered head. You may fee more hereof in Cluffiss, Exot, lib.2.cap. 18.

19 This is the figure of a fquare fruit which Clufs sus conieotures to baue been fome kind of Indian Nut or Coco: it was eouered witl a finooth rinde, was feuen inches long, and a foot and halfe about, bcing foure inches and a halfe from fquare to fquare.

20 A bout Bantam in the Eaft Ind ies growes a rall tree fending forth many branches, which are fet thicke with leaues long and narrow, bigger than thofe of Rofemary:it carries cods fix inches long, and fute about, cottered with a thin skin,wrinckled and tharp pointed, which open themfelu es from below into fue parts, and are full of a foft woolly or Cottony matter, wherewith they ftuffe curhions, pillowes and the like, and alfo fpin fome for certaine vfes: amongft the downe lye blacke feeds like thofe of Cotton,but leffe, and not faftened to the downe.

2I This which Cluf calls Palma faccifera, or the Bag Date,becaufe it carries the figure of an Hippocras bag, was found in a defart Ifland in the Antlantick ocean, by certaine Duteh mariners who obferued whole woods thereof :thefe bags were fome of them 22 . or more inches long, and fome feuen inehes broad in the broadeft place, itrongly woue with threds croffing one another, of a brownifh yellow colnur. Thefe fachels (as they report who cut them from the tree) wcre filled with fruit of the bigneffe of a Walnut huske and all:within thefe were others, as round as if they had bin torned, and fo hard that you could fearee breake them with a hammer:in the mid ft of thefe were white kernels, tafting at the firft fonewhat like pulfe, but afterwards bitter like a Lupiue.

22 The tree which carries this rough cod is very large, as I hane been told by diners: fome who faw it in Perfia, \&c otbers that obferued it in Mauritius Ifland.Clufus alfo notes that they hatic b in brought fron diuters places:the eod is fome three ine hes long, and fome two inches broad, of a du . skie red colour, and all rough and prickly: in thefe cods are contained one, two or more round nuts or feeds of a grayith ath colour, hauting a little fpot on one fide, where they are faftened to the cod they are exceeding hatd, and difficult tobreake, but broken they thew a white kenel very bitter and vnpleafant of tafte. I haue feen very many and haue fome of thefe,and fonc haue offered to fel them for Eatt Indian Beazor, whereto they haue fome fmall refemblanee, though norhing in facultie like then (if I may credit reporr,which I had rather do than make tryall) for I haue been told by fome that they are poifonous; and by others, that they ftrongly procure vomit.

' 3 The long end expreffed in this figure is called in the Eaft Indies (as Clufins was told) $\mathbb{F}_{a y e}$ $b_{a k},{ }_{\text {, ic }}$ w as round, the thickneffe of ones little finger, and fix inches long:the rinde was thick, $b$ lack, hard and wrinckled, and it contained a hard pulpe of a fowrifh tafte, which they affirm was eatable.

The other was a cod of fome inch and balfe longand fome inch broad, membranous, rougl,and of a brownith colnur, fharp pointed, and opening into two parts, and difinguifhed with a thin film in o foure cels, wherein were conrained fearlet Peare fafhioned little berries, hauting golden fpois efpecis"ly in the middles. This growes in Brafile, and as Clufurs was informed was called $D$ ahari.

24 In the recond place of the tenth figureand defeription in this chaptes you may finde the PpPp? lingle 
\# 2 r Palma faccifera. The Sachell Date.
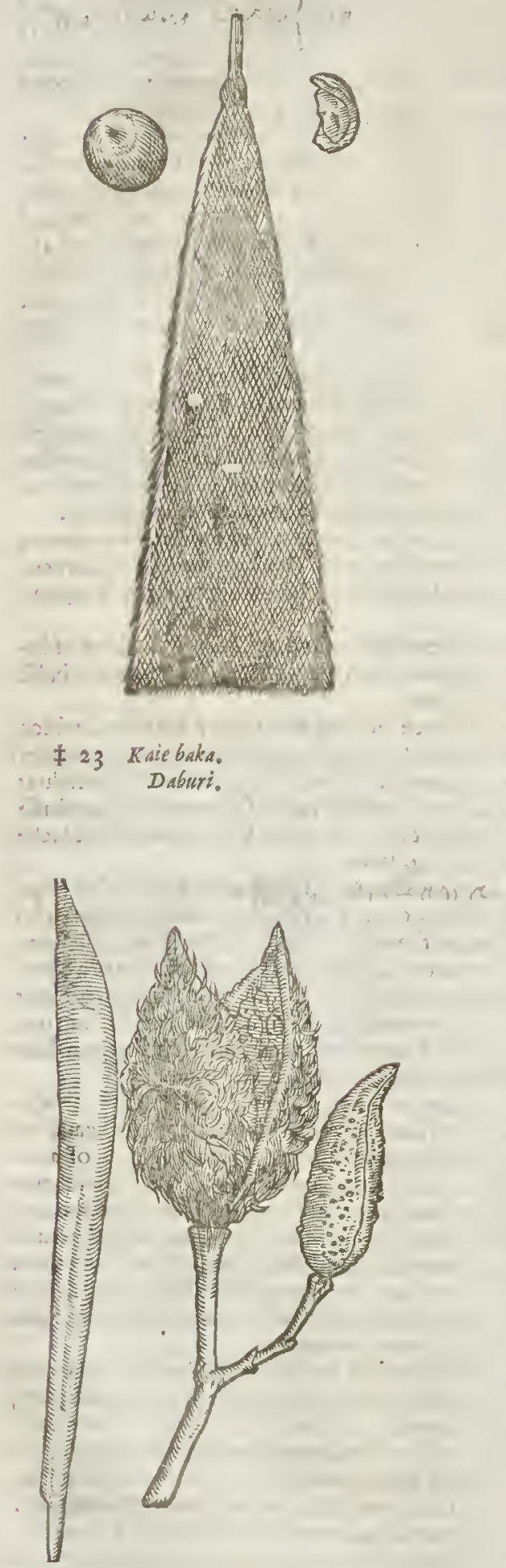

¥2 Lobus Echinatus. Beazor Nuts.

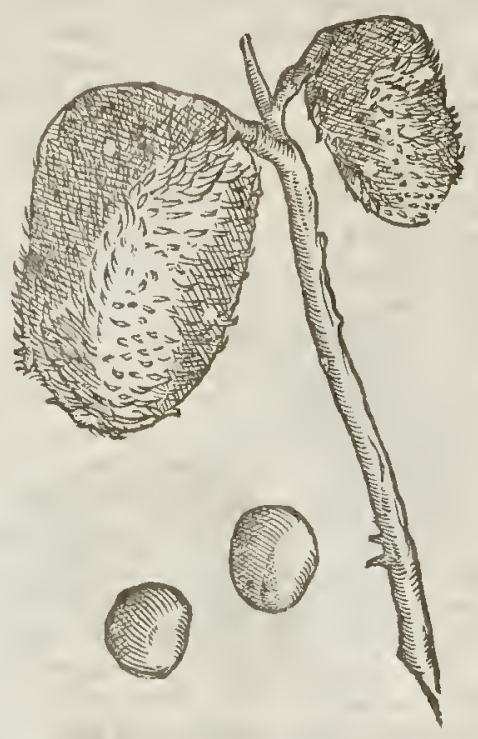

\$24 Nucula Indica racemora. 'TheIndian,or rather Ginny Nut.'

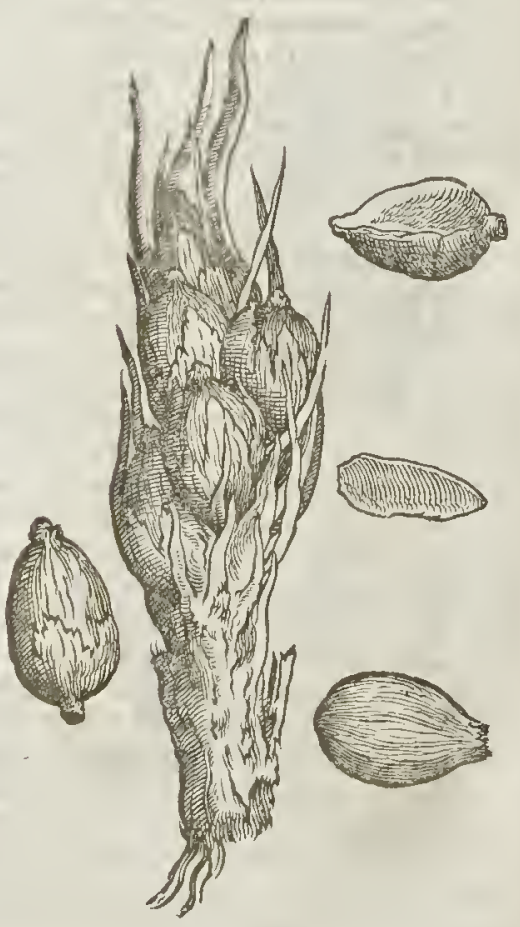


t5 25 Fructus (quamosia: Scalie ftuits.

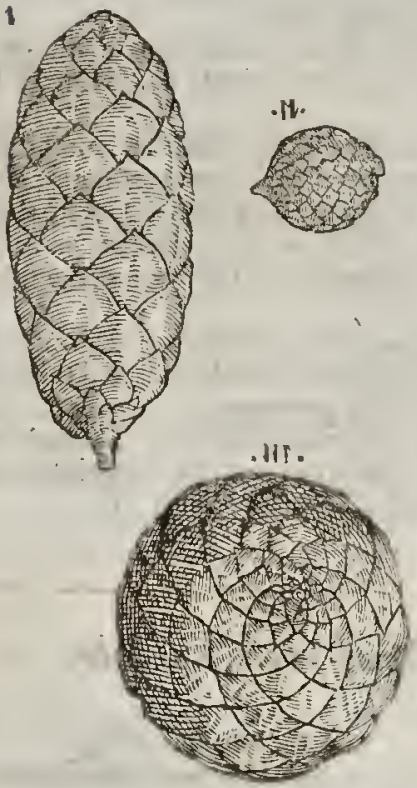

\$26 Fructus aly̆ Exotici.

Other ftrange fruits.

了.

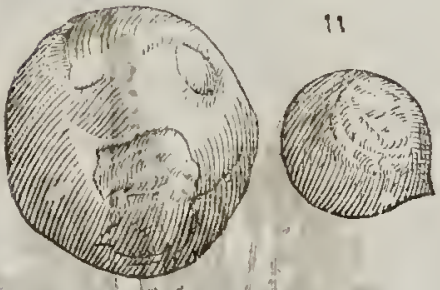

114.

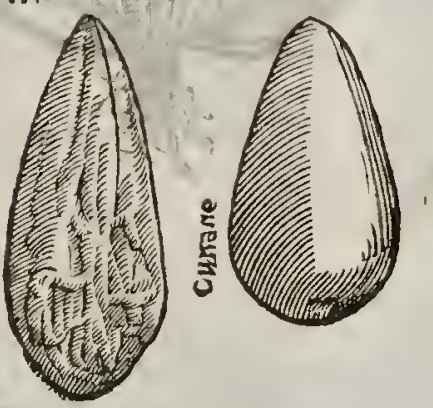

¥26 FruERus alÿ Exotici.

Other Arange fruits.
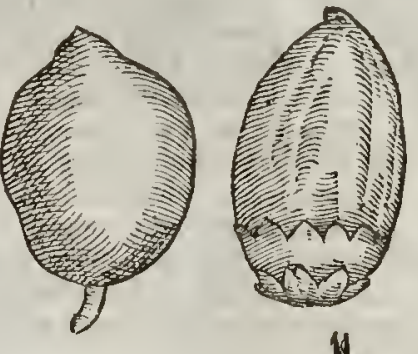

U

fingle Nut here figured, defcribed, \& fet forth but this figure better expreffes the manner of growing therof: for firt it prefents to the view the nuts in their outer husks growing clofe to. gether, then the fingle nuts in and out of their husks,and laftly their kemell : the fhell of this nut containes in it a certaine oilie fubftance, fomwhat refembling the oile of fweet almonds: the treewhereof this nut is the fruit growes in Ginny, and is much vfed by the people there, for they preffe a liquour forth of the leaues, or elfe boile them in water, \& $x$ his fertes them in fread of wine \& beare, or at leaft for a commondrink, of the fruit they make bread of a very fweet and pleafant tafte.

25 Thefe fcaily fruits are fet forth by Clinfius, Exot.l.2 c.3.The firft was three inches long and two inchesabout, and had in it a longifh hard follid kernell, with many veines difperfed ouer it,and fuchkernels are fomt imes polithed, whereby they become white, and then their blacke veines make a fine fhew, which hath giucn occa fion to fom e impoltoss to put them to faile for rare and precious ftones.

The fecond was fmall, round and feaily, and the failes turned their points downwards towards the ftalke.

The third was alfo feaily, of the bigneffe of a Walnut in his huske, with the fcailes very orderly placed, and of a brownith colour : it had a kernel which ratled in it when it was Thaken.

26 The firft of the two in the former table was brought from Ginny, it was of the bigneffe and thape of a plum, two inches long, and one and halfe broad, of a thicke fungous fubtance, fomewhat wrinckled, and blackin on the outfide, and within containing a certaine whitifh infiped friable pulpe, wherein lay a few fmall feeds.

The fecond was fome inch and balfe long, an inch thicke, coucred with an afh coloured sk in compoled within of many fibres almot like the huske of the Nut Faufell, at the lower end it ftood in a double cup, and it was tharp pointed epppp? 
at the vp per end:in this skin was contained a kernell, or rather nur,blacke, hard, and very wrinckled nor nuch vnlike to that of Fanfell, whereto I refer it as a kinde thereof. Thefe two are treated of by Clufies, Exot.126.2.0.23.

The firtt of the fecond table(wherein are contained foure figures) was of a round forme, yet a little flat on one fide, diftinguifhed vnder the blacke and thining coat wherewith it was couered, with furrowes running euery way, not vnlike to the Nut Faufell taken forth of his couer : the inner pulpewas hard and whirilh, firtt of a falt, and rhen of an aftringent tafte.

The fecond of thefe was an inch long, but rather the kernell of a fruit, than a fruit it felfe; it was round except at the one end, and all niter knobby (though the picture expreffe not fo much) there was alfo fome thew of a triangular forme at each end.

The third was two inches and a halfe long,and in rhe broadeft part fome inch and more broad:ir was fn newhat crooked, the backe high and rifing, the top narrow, and the lower part tharp pointed, of an afh colour, with thicke and eminent nerues running alongt tlise back from the top to the low er part, expreft with fuch art, as if they had been done by fome curious hand: it feemed to haue bin ensered ouer with another rinde, but it was worne off by the beating of the watues of the fea vpon the more.

The fruit Cumane figured in the fourth place of this table,was two inches long, and an inch broad at the head, and fo fmaller by litrle \& little, with a back ftanding out, fmooth, black, and Mining, hawing three holes at the top, one aboue, \& two below:they faid it grew vpon a mal tree called Morrenur, and was yet vnripe, but when it was ripe it would be as big again,and that the natiues where it rew (which was as I take it about Wiapock) roft it vpon the coles, and cate it againf theliead. a:he. Cluf fus fets forth thefe foure in his E,vot, . $2.6,22$, he deferibes Cunane cap.21. $\$$

\section{С на в.16о. Of Sun-Dew, Youth woort, Ros Solis.}

I. Ros Solis folio rotundo.

Sun-Dew with round leaues:

- Orosera rotrividitia

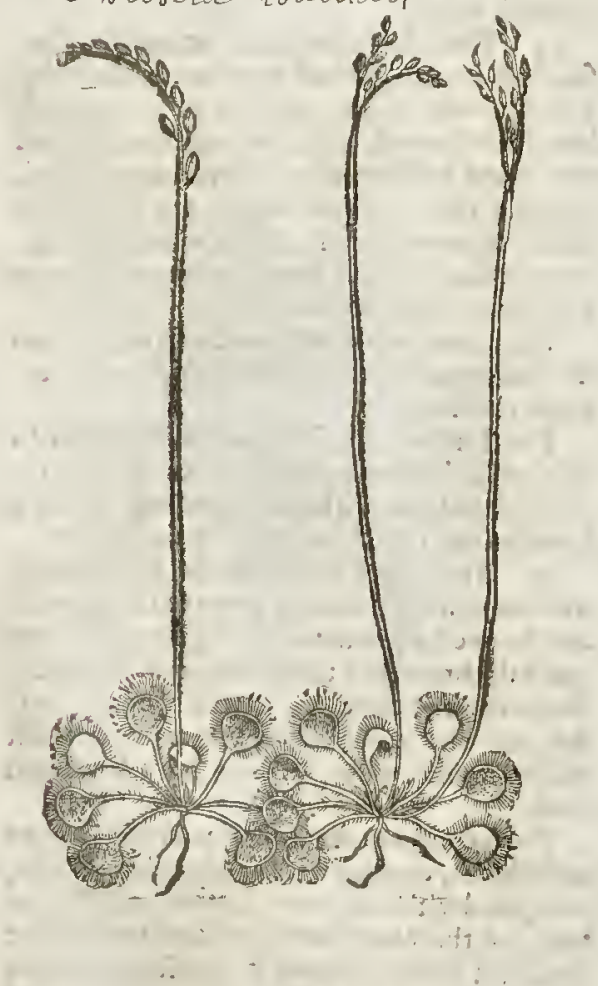

2 Ros Solis folio oblongo.

Sun-Dew with longith leaucs?
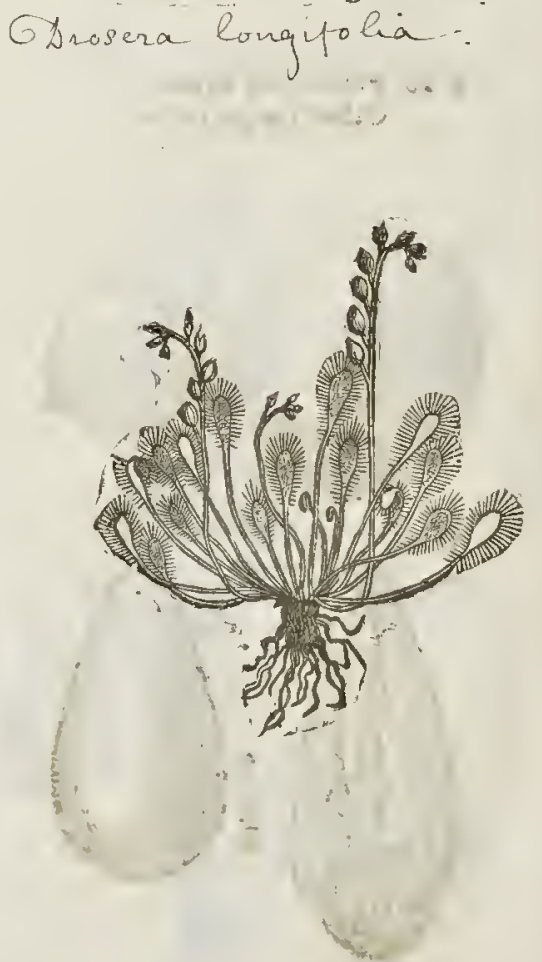


\section{IT The Defcription:}

I

Vn-Dew is a little hetb, and growcth vety low, it hath a few leaues Atanding vpon flende? ftems, very finall, fomething round, a little hollow, and like an eare picker, hairy and reddith as be alfo the ftcrus, hauing dew and moifture vpon them at the dricft time of the yeare, and when the Sun thineth hottef: euen at high noone and a moneth after there fpring vp little ftalks, a hand breadth high, on which ftand fimall whition floures: the roots ate very flender, and like vnto haires.

2 The fecond kinde is like vnto the fotmer, in ftalks and floures, but larget, and the leaucs are longer, and not fo round, wherein confifteth the difference.

$$
\text { T) The Place. }
$$

They grow in defart, fandic and funny places, but yet wateric, and feldomeother-whetc than 2 . mong the white marith mofle which groweth on the ground and alfo vpon bogs.

$$
\text { The Time. }
$$

Sun-Dew flouriheth in Sommer, it flourcth in May or Iunc : it is to be gathered when the wea. ther is moft dry and calme. The diftilled water herenf that is strawne forth with a glaffe ftill, is of 2 . glittering yellow co! our like gold, and coloureth filuct put therein like gold.

$$
\text { 9t The Names. }
$$

It is called in Latine, Ros Solis : of diuers, Nurella $:$ it is named of orher, Salf Ro/ $t$, of the dew which hangeth vpon it, when the Sun is at tlwe hottent: it is called in high Dutch, $\$$ ondaw, and Suioatw: in low Dutch, 2 Loopichectutt, which in Englifh fignificth Luftwoort, becaufe fhecpc and other cattell, if they do but oncly tafte of it, are ptonoked to luft. It is called in Englifh, Sun-Dew, Ros Solis, Youth-w oort: in the Worthern parts, Red Rot, becaufc it rotteth fhecpe; and in Yorkehire, Moore grafle.

It is a fearing or caufticke herbc, and very much biting, being hot and drie in the fourth degtee:"
T The Vertues.

The leaues being ftamped with fale do cxulccratc and raife bliftets, to what part of the body fo- A euer they be applied.

The latet Phy litions hatc thought this herbe to be a tarc and fin zular remedic for all thofe that B be in a confumption of the lungs,and efpecially the diftilled water the rcof : for as the herbe doth kecpant hoid faft the moifture and dew, and fo faft, that the cxtreme drying heatc of the Sun cane not confume and waftc aw ay the fame: fo likewife men thought that herew ith the naturall and radical humidity in mens bodies is prefetued and cherifhed. But the we therof doth other vife teach. and seafon theweth the contrarie : for fecing it is an extreme biting hetb, and thar the diftilled wa. ter is not altogether without this biting qualitie, it cannor be taken with fafety: for it hath alfo bin obferued, that they haue fooner perifhed that vfed the ditililed water hereof, than thofe that abfeai. ned from it, and hauc followed the right and ordinarie cour fe of diet.

Cattell of the female hinde are ftirred vp to luft by cating cuen of a fmall quantity: which thing $\mathbf{C}$ hath greatly increafed their vain opinion, without fence or seafon; fot it doth not moue nor prouoke cattcll to luft, for that it increaferh the fub ftanec of the feed, but becaufe through his fharp and biting gutulitic it ftirreth vp a defire to lutt, which before was dulled, and as it were afleepe.

It ttrengthmeth and nouritheth the body, efpecially if it be diftilled with wine, and that liquour $D$ made thereof whicli the common people do call Rofa Solis.

If any be defirous to hate the faid drinke effectiall for the purpofes aforefaid, let them lay the $\mathrm{E}_{0}$ leaues of Rofa Solis in the fpirit of wine, a dding thereto Cinnamon, Cloues, Maces, Ginger, Nut$\mathrm{meg} s$, Sugar, and a few graincs of Muske, fuffering it fo to ftand in a glaffe clofe ftopr from the aire; and fet in the Sun by the fpace of ten da ies, then ftraine the fame, and keep it for your vfc.

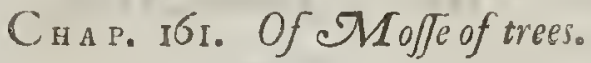

\section{G The Defcriptions}

T

Rec Moffc hath ceraine things like laires, made vp as ic were of a multitude of flendet learies, now and then ali to be iagged, hackt, and fincly carued, twifted and interlaced one in another, which clcauc faft to the barkes of rtees, hanging downc from thc bodies: one of this kinde is more

$$
\text { P PPPP } 3
$$


Mulcus quernus.

The Moffe of the Oke \& of other trees.

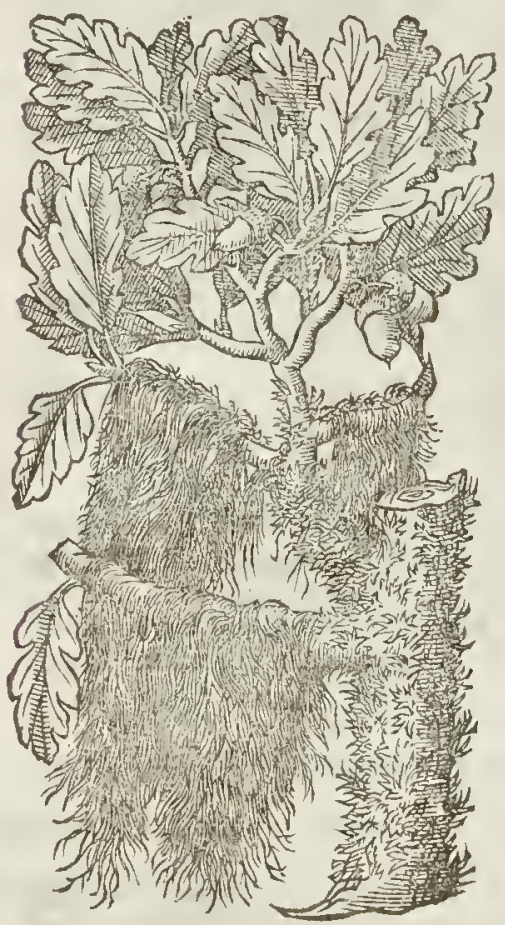

flender and thin, another more thicke, another fhorter, another longer; all of them for the moft being of a whitinh colour,yet of entimes there is a certainc one alfo which is blackc, but leffer and thinner : the moft commendable of them all, as Pliny faith, be thofe that are whitifh, then the red. difh, and laftly fuch as be blacke.

$$
\text { T) The Place. }
$$

This Moffe is found on the Oke tree, the white and blacke Poplar tree, the Oliue tree, the $B$ irch tree, the Apple tree, the Peare tree, rhe Pine tree, the wilde Pine tree, the Pitch tree, tre Firre tree, the Cedar tree, the Larch tree, \& on a great fort of other trees. The beft, as Diofcorides faith, is that of the Cedar tree, the next of the Poplar, in which kinde the white and the fweer fmelling Moffe is the chiefent theblackinh fort is of no account. Matthiolus writeth, that in Italy that Molfe is fweet which growerh on the Pine tree, the Pitch trce, the Fir tree, St the Larch tree, and the fiveeteft that of the Larch tree.

$$
\text { 9) The Time. }
$$
long.

Moffe vpon the trees continucth all the yeare

$$
\text { TT The rames. }
$$

It is called of the Grecians $\beta$ pron of the Latins, Mufeus : the Arabians and fome Apothecaries in other countries call it $V \int n e a:$ in bigh Dutch, 99 or 5 : in low Dutch, 990 fch : the French men, L "Moufch: the Italians, CHufgo : in Spanifh, Mufco de los arbures: in Englih, Moffe, trec Molfe, or Moffe of trees.

\section{The Tempcrature.}

Moffe is fomewhat cold and binding, which notwithftanding is more and leffe according vnto the nature and facultie of that tree on which it groweth, and efpecially of his barke : for it taketh vnto it felfe and alfo retaineth a certaine propertic of that barke, as of bis breeder of which hee is ingendred : therefore the Mofie which commeth of the Oke doth coole and very much binde, befides his owne and proper facultic, it receiteth alfo the extreme binding quality of the Ote barke
it felfe.

The Moffe which commeth of the Cedar trec, the Pine tree, the Pitch tree, the Fir tree, the Larch tree, and generally all the Rofine trees are binding, and do moreoner digeft and foften.

$$
\text { Tा The Vertues. }
$$

A Serapio faith, that the wirie in which Moffe hath been fteeped certain daies, bringeth found Ileep; treng theneth the ftomacke, faicth vomiting, and ftoppeth the belly.

$B$ Diofcordes writeth, that the decoction of Moffe is good for women to fit in, that are rroubled It is fit tobe vfed in compofitions which Ben, and with oilcs to thicken them withall.

C neffe; for which things that is bef of aich ferue for fiveet perfumes, and that take away wearifom:

\section{Снат. 162. Of ground sioffe.}

$$
\text { TI The Kindes. }
$$

Here groweth alfo on the fuperficiall or vppermoft part of the earth diuers Moffes, as alfo vpon rocks and tony plices, and marih grounds, differing in forme not a little.

I THecommon Moffe of The Defeription.

$$
\text { बा The Defcription. }
$$

1 but fpecially vpon the bottome of old and antient trees, but fpecially vpon fuch as grow in thadowie woods, and alfoat the bottom of thadowy 
I Mufausterrestris vulgaris.

Common ground Moffe.

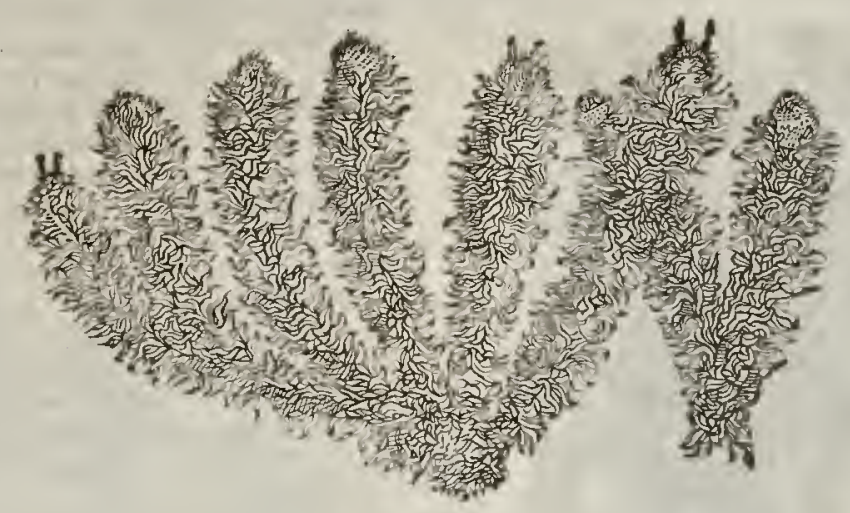

3 Murcus terreftris fopartius.

Beefomc ground Moffc.

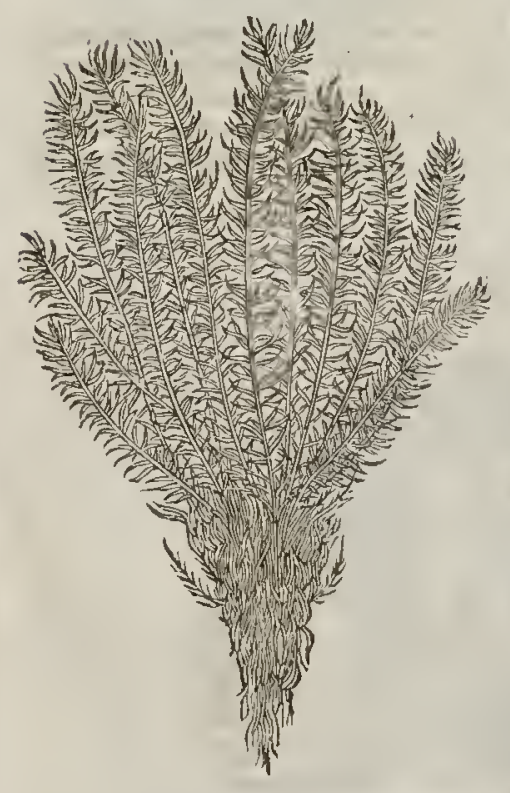

3. 4. Mufcus capillaris, fue Adiantham aureum maius of minus.

Goldilockes or golden Maiden-haire the bigger and leffe.

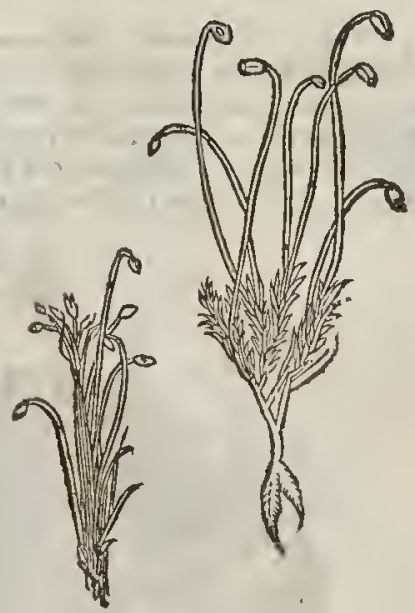

inclges ind ditclics, and fuch like plaacs : it is very well knowne by the foftneffe and length there: of, bcing a moffe moft common, and thercfore ncedeth not any further defeription.

2 Becfome Moffe, which feldome or neucr is foumd but in bogs and marith places, yet fone. times haue I found it in fhadowic dry ditches, where the Sun neucr fheweth his face: it groweth vp halfe a eubit high, eucry particular leafc confifing of an innumerable fort of bairy threds fet vpon a middle rib, of a thining blacke colour like that of Maiden-hairc, or the Capillare Moffe $A$. dinzthum anrewm, whereof it is a kinde.

3 This kinde of $M \circ f e$, called CMuras capillaris, is feldome found but vpon bogs and moorifh places, and alfo in fome thadow ie dry diteheswherc the Sun doth not come. I found it in great aboundance in a thadowie ditch vpon the left hand neere vnto a gate that leadech from Hampted heathis 


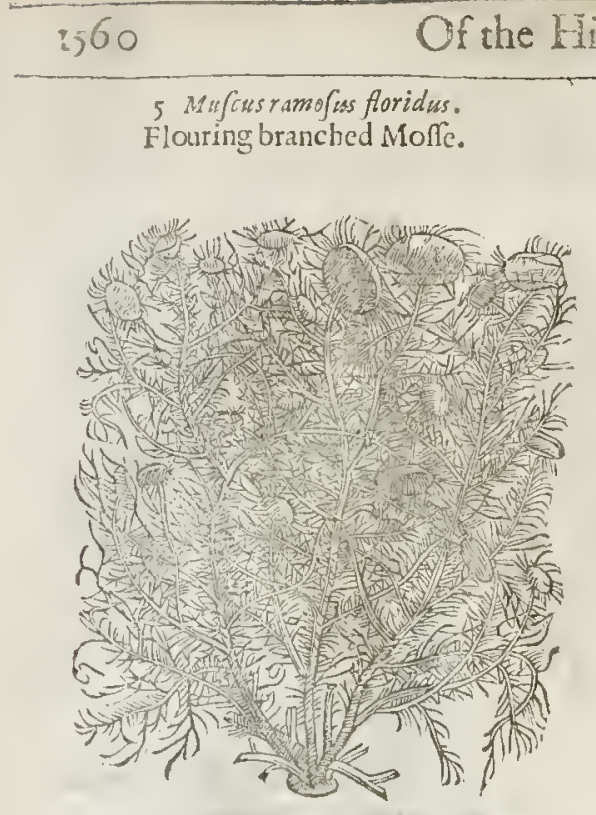

y of Plants.

L 1 в. 3.

heath toward Highgate; which place I haue thewed vnto diucrs expert Surgeons of London, in our wandering abtoad for our farther knowledge in Simples. This kind of Moffe, the ftalkes thereol are not aboue one handfuil high, coured with thort haires ftanding very thicke together, of an obfcure yeilow green colont ; rut of which ftalkes fpring vp fometimes very fine nalied ftems, fomewhac blacke, rpon the tops of which hang as it were littlc graines like wheat cornes. The roots ate vety flendet and matuellous fine.

$¥$ Of this wdianthum aureum there are threekindes, different onely in magnitude, and that the two bigger baue many hairie threds vpon their branches, when as the leaft hath onely three or foure clofe to the root; and this is the leaft of plants that I euct yet faiv grow. $\neq$

4 Of this there is alfo another kinde altogether leffet and lower. This kind of moffe groweth in moif places alfo, commonly in old moffic and torten trees, likewife vpon rncks, and ofrentimes in the chinks and crannies of ftone walls.

5 There is oftentines found vpon old Okes and Breches, and fuch like nuet-grnwn ttees, a kinde of Moffe haung many flender branches, which diuide themfelues into nther lefer branches; whereon are placed confufedly very many fmall threds like haircs, of a greenifh afh colout: vpon the ends of the tender branehes fnmetimes there crmmeth forth a foure in thape like unto a little buckler or hollow Mu hrom, of a whitifh colour tending to yellownes, and gatnifhed with
the like leaues of thofe vpon the lower branches.

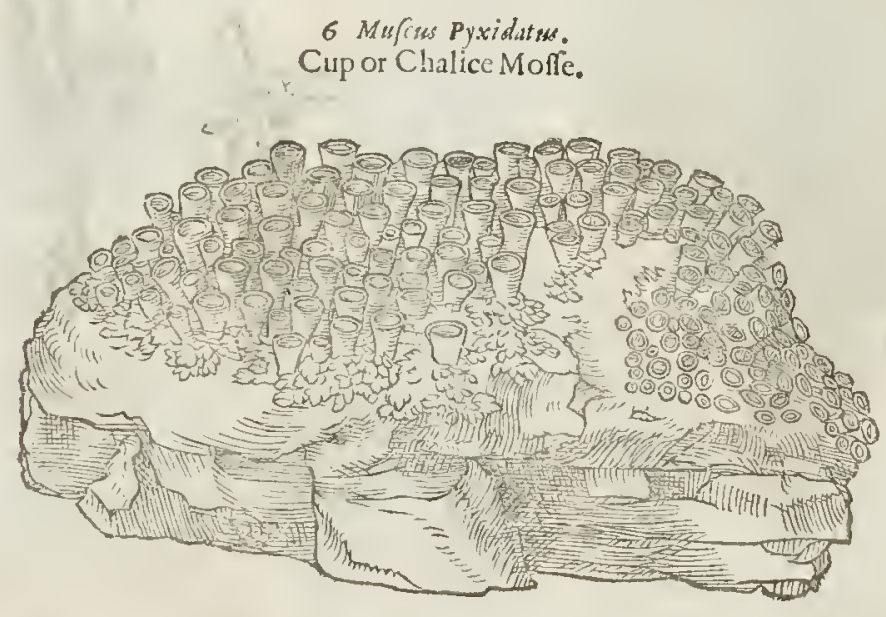

6. Of this Mone there is another kinde, which Lobel in his Dureh Herbal hath fet forsh vadet the titk of Mrfors P $\%$, wdatus, which I haue Englifhed, Cnp Moffe or Chalice Moffe: it grotveth in the molt barren dry and gratuelly ditcl bankes, creeping flat vpon the ground like vnto Liuerwort, butnf a yellowin twite colour: among which leates ftart vp here and there certaine little things fantoned like a little cup called a Beaker or Chalice, and of the fame colour and fubftance of the lower leaues, which vndoubtedly mav be taken for the floures : the pouder of which Moffe giuen tochildren in anv liquio: for certaine dayes together, is a moft certaine remedic againft that pe-
rillous malady called the Chin-cough? 7 There is likewife found in the finadowie places of high mountaines, and at the foot of old 
and rotten trees, a certaine kinde of Meffe in face and fhew not vnlike to that kinde of Otes ituse called Dryopteris. It creepeth vpon the ground, hauing diuers long branches, confifing of many fmall leaues, cuiery particular leafe madevp of fundry little leaues, fet vpon a middle rib oue oppo: fite to another.

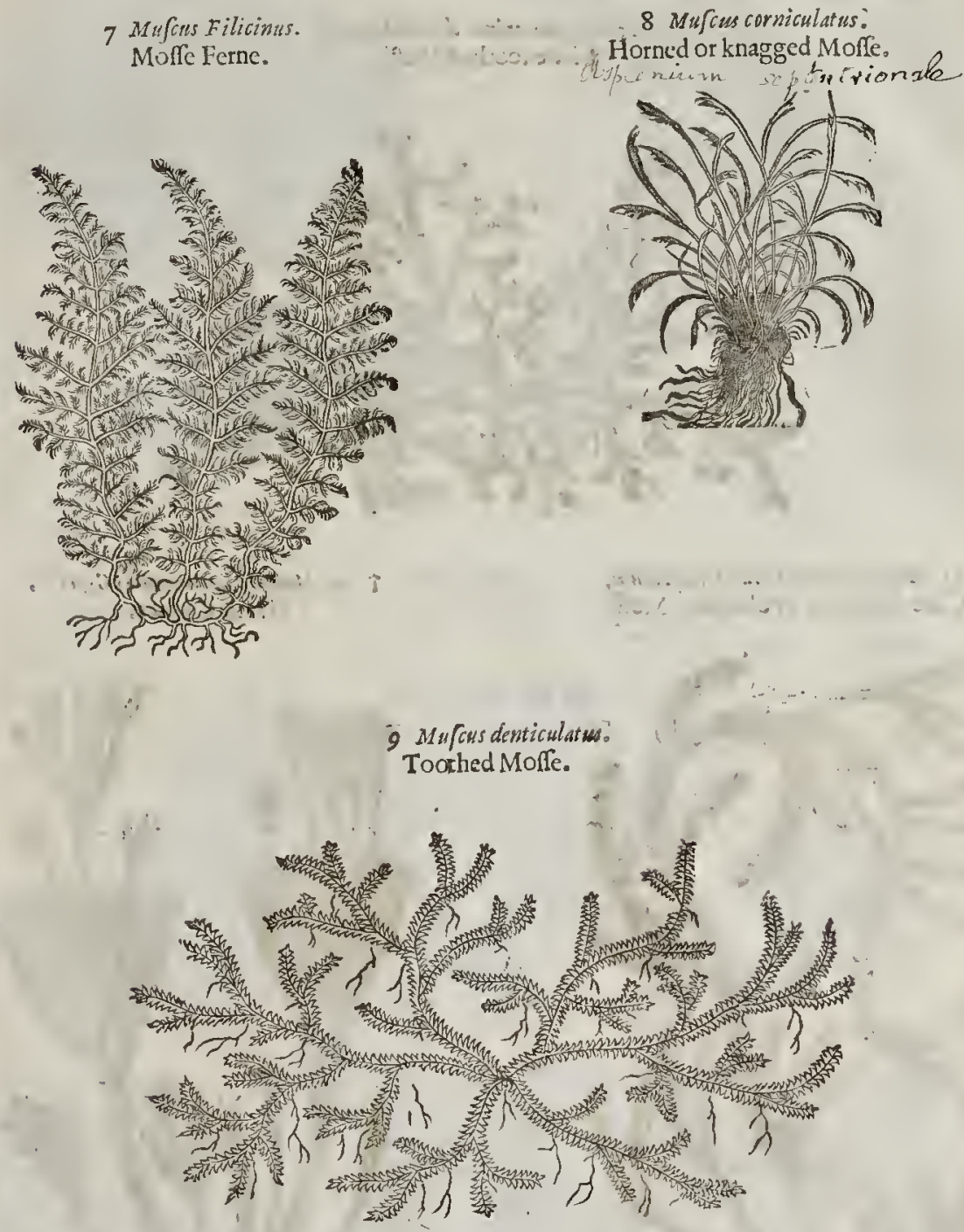

8 There is found vpon the tops of our moft barren mountaines, but efpecially were fea Coles are accuftomed to be digged, ftone to make iron of, and alfow where ore is gotten for tinne and lead, a certaine fmall plant: it rifeth forth of the ground with many bare and naked branches, diuiding th.enfelues at the top into fundry knags like the forked hornes of a Deere, cuery part whereof is of an oucrworne whitifh colour.

$\mp$ Our A tithor formerly gaue another figure and defcription of this plant, by the name of $\mathrm{Ho}$ 10,7 cumpetrestm, which I hate omitted, thinking this the better. Tragus, Lonicerus, and Baubine referre this to the Fernes and the laft of them calleth it Filix faxatilis corniculata: Pena and Lobel

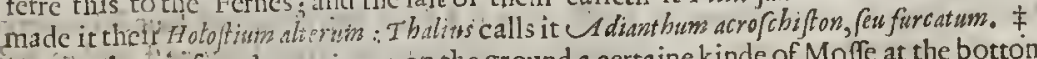
$\therefore$ 9. There is found creeping vpon the ground a certaine kinde of Moffe at the bottom of Hearls and Ling, and fuch like buthes growing vpon barren mountaines, confifting as it were of fcales made vp into a long ropeor cord, difperfing it felfe far abroad into fundry branches, thrufting out , dipering ir felfe far abroad into fundry banches there 
here and there certain roots like threds, which take hold vpon the vpper crult of the carth, whereby it is fent and difperfed farabtoad: the whole plant is of a yellowinh greene colour.

io This other kinde of Molle is found in the like places : it alfo difperfeth it felfe far abroad, and is altogether leffer than the precedent, wherein confifts the difference.

Io Mufrus minor denticulatus:

Little toothed Molfe.

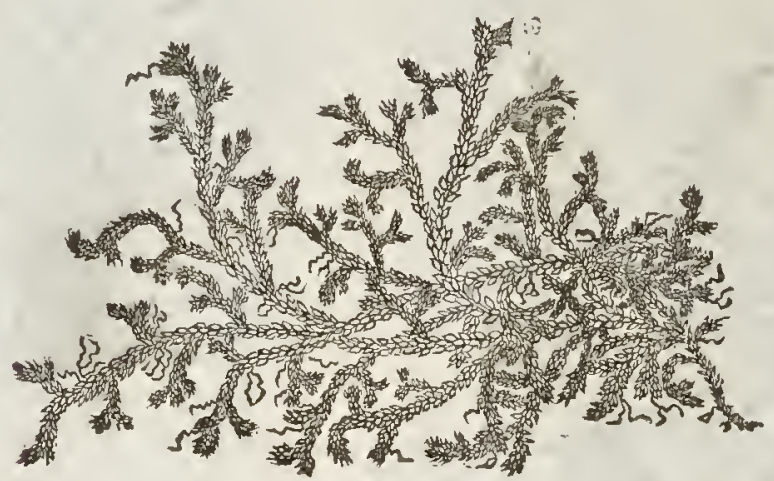

1 I Mufus clanatus, fine Lycopodium.

Club Moffe, or Wolfe claw Moffe.

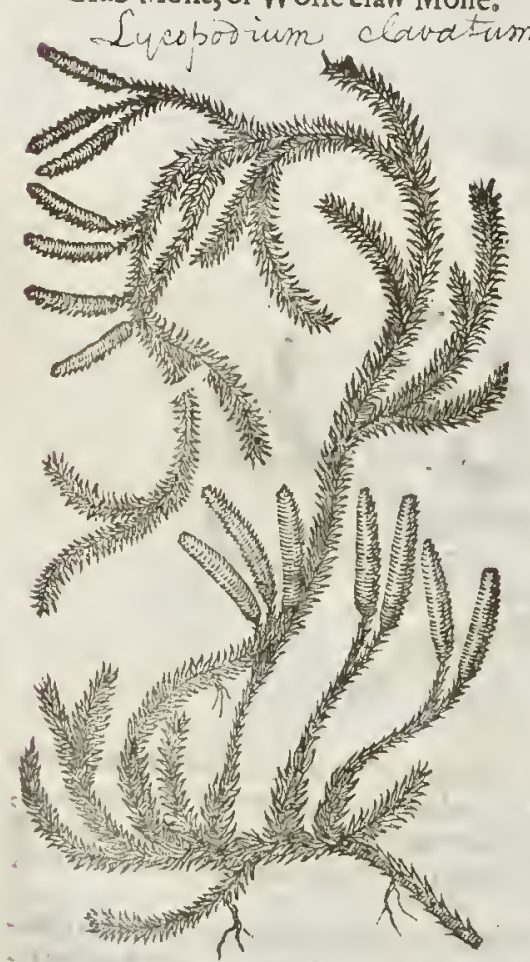

12 Mufcus clausarsfolÿs Cypreßi: Heath Cypres.

18 There is likewife anotherkinde of Moffe, which I baue not elfewhere found than vpon Hampled heath, neere vnto a little cottage, growing clofe vpon the ground amongt buthes and brakes, which I haue thewed vnto diuers Surgeons of London, that haue walked thither with me for their further knowledge in Simples, who haue gathered this kinde of Moffe, wherof fome haue 
LiB.3. Of the Hiftory of Plants.

$1 \leqslant 6\}$

I 3 Mufus excranio bumano.

Moffe growing vpon the skull of a man.

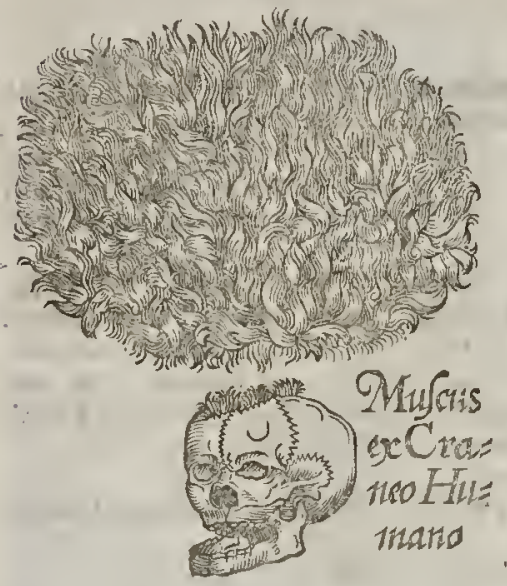

made them hat-banus, girdles, and alfo bands to tye fuch things as they hal before gathered, for the which purpofe it molt fitly lerued; fome pieces whereof are fix or eight foot long, confifting as it were of many lairie leaues fet vpon a tough ftring, very clofe couched and compait together, from which is alfo fent forth certaine other branclies like the firft : in fundry places there be fent down fine little ftrings, which fetue in ftead of roots, wherewith it is faftened to the vppet part of the earth, and taketh hold likervife vpon fuch things as grow next vnto it. Thete fpring alfo from the branches bare and naked ftalkes, on whicl grow certaine eares as it were like the catkins or blowings of the $\mathrm{Ha}$ fell tree, in thape like a little club or the reede Mace, fauing that it is much leffer, and of a yellow ith white colout, very well refeimbling the claw of a Wolfe, whereof it tooke his name; which knobby katkins are altogether barten, and bring forth neitlier feed not floure.

+ I4 Mrifous parvus ficllaris.

Sniall Heath Moffe.

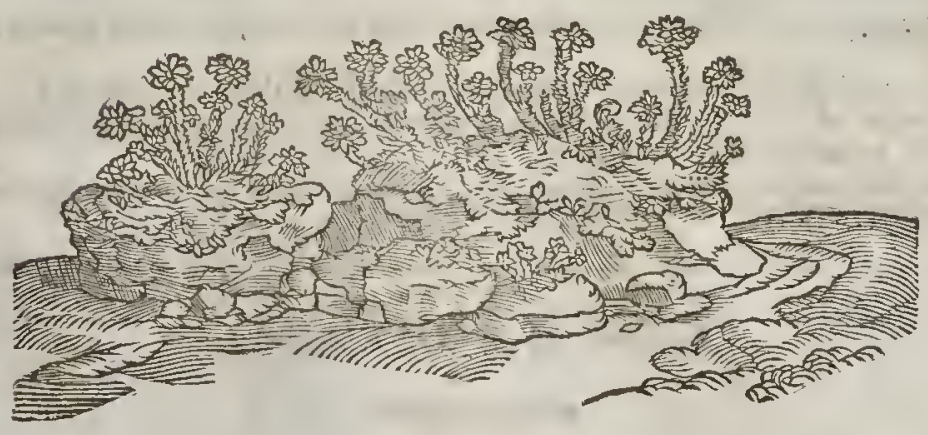

7. I2 This, whore figute in the former edition was by our Author vnfitly put for Lauandor Cotton (hauing more regard to the tit le of tie figure in Tabernamontanus, than to fee whether it were that which he theredefcribed) is no other than a kinde of Mufus clauatus, or Club-Mofle. It is thought to be the Selano mentioned by Pliny, lab.25. cap. I t. Tragus and fome others call it $S_{t-}$

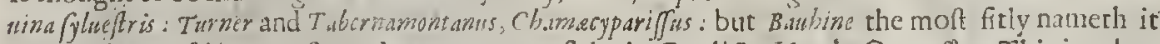
Mufus clawdus folys cypres: : and Turner not vnficly in Englifh, Heath Cyprefle. This is a low plant, and keepes greene $W$ intur and Sommer: the leates are like thofe of Cypreffe, bitter in tafte, but without fmell : it cartics fuch eares or cackins as the formet, and tho fe of a yellowith $\mathrm{co}$ lour : it is found growing in diuers wooddy mountainous places of Germanie, whlere they cail it noalo Sorutubanu, or wilde Sanine. $\neq$

13 This kinde of Molfe is found vpon the skulls or bare fcalps of men and women, lying long in charnell houfes or other places, where the bones of men and women are kept together : it groweth very thicke, white, like vnto the fhort mofe vpon the trunkes of old Okes : it is thoughe ro be a fingular remedic againft the falling Euill and the Chin-cough in children, if it be poudered, and then giuen in fweet wine for certaine daies together.

\pm I4 Vpondivers heathy places in the moneth of May is to be found growing a littie thort Moffe not much in thape different from the firft defcribed, but much leffe, and patted at the top

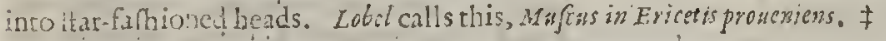


Their feterall deferiptions fet forth their naturall places of growing.

$$
\text { I The Time. }
$$

They fourith efpecially in the Sommer moneths.

\section{TI The Names.}

Goldilozke is called in high-Dutch, notoertodt, golden moedertodt, Jung orauben hat:

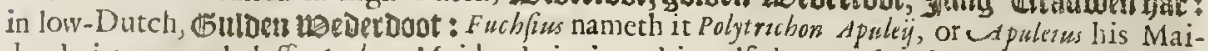
den-haire, neuertheleffe Apulezus Maiden-haire is nothing elfe but Diofcorides his Trichomases, called Englihh Maiden-haire; and for that caufe wee had rather it fhould be rermed Mufcus capillaris, or hairy Moffe. This is called in Englith, Goldilockes : it might alfo be termed Golden Moffe,or Hairy Moffe.

Wolfes claw is called of diuers Herbarifs in our age, CMufcus terreftris: in high-Dutch, 2Beet:

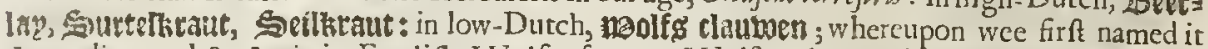
Lycopodiun, and Pes Lupi : in Englifh, Wolfes foot, or Wolfes claw, and likewife Club-Moffe. Molt thops of Germanie in former times did fallly terme it Spica celtica: but they did worfe, and were very much too blame, that vfed it in compound medicines in ftead of spicaceltica, or French Spikenard : as touching the reft, they are fufficiently fpoken of in their deferiptions.

The Temperature. cold.

The Mofles of the earth are dry and aftringent, of a binding qualitie, without any heate or

Goldilocks and the Wolfes clawes are temperate in heate and cold.

If The Vertues. A The Arabian Phy fitians do put Moffe among ft their cordiall medicines, as fortifying the fo-
macke, to ftay vomit, and to fop the laske. B Moffe boiled in Wine and drunke foppeth the fpitting of bloud, piffing of bloud, the termes,
and bloudy flix.

C Mofle made into pouder is good to ftanch the bleeding of greene and frefh wounds, and is a great helpe vnto the cure of the fame. D Wolfes claw prouoketh vrine, and as dieronymas Tragus reporteth, wanteth the fone, and dritueth
it forth.

E Being ftamped and boyled in wine and applied, it mitigateth the paine of the gout. F Floting wine, which is now become flimie, is reftored to his former goodneffe, if it be hanged

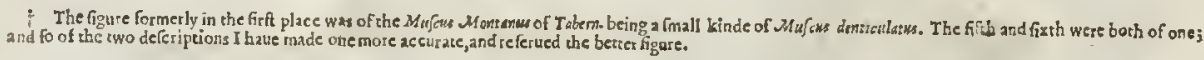

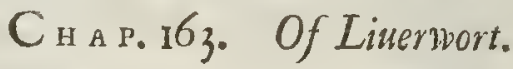

\section{If The Defcription.}

I Iuerwort is alfo a kinde of Moffe which fpreadeth it felfe abroad vpon the ground, ha-

Luing many vneuen or crumpled leaues lying one ouer anorher, as the feales of Fifhes

do, greene aboue, and browne vnderneath : among ft thefe grow vp frnall fhort falkes, fpred at the top like a biafing farre, and certaine fine little threds are fent downe, by which it cleaweth and fticketh faft vpon ftones, and wpon the ground, by which tt liucth and fouri/heth.

2 The fecond kinde of Liuerwort differeth not but in ftature, being altogether leffe, and more fmocth or euen : the floures on the tops of the flender fems are not fo much laid open like a far ; but the efpeciall difference confifterh in one chiefe point, that is to fay, this kinde being planted in a por, and fet in a garden aboute the ground, notwithftanding it fpitteth or cafteth round about the place great ftore of the fame fruit, where neuer any did grow before.

$\ddagger$ Of this fort which is fmall, and oftentimes found growing in moif gardens among Beares. eares, and fuch plants, when they are kept in pots, there are two varieties, one hauing little falkes fome inch long, with a farre-fathioned head at the top : the other hath the like tender ftalke,and a round head at the top thercof. $\ddagger$

3 This is found vpon rockes and fony places, as well neere vnto the fea, as further into the land : it groweth flat vpon the fones, and creepeth not far abroad as the ground Literwort doth, it only refech it felfe in fpots and tufts fet here and there, of a dufy ruffet colour aboue, and blackinh inderneath : among the crumpled leaues rife vp diuers fmall ftems, whereupon do grow little farlike floures of the colour of the leaues $:$ it is often found at the bottom of high trees gm:ving vinn 
LI B: 3 . Of the Hiftorie of Plants.

I Hepaticaterreftris. Ground Liuer-wort.

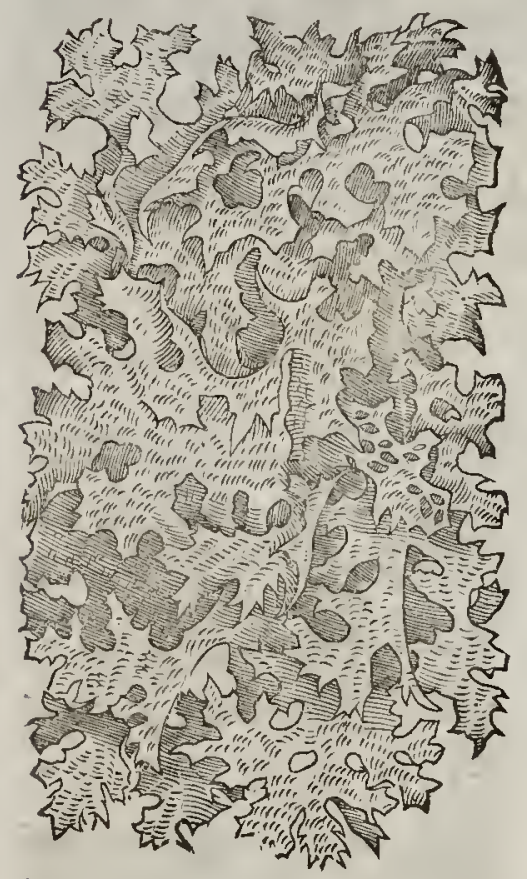

3 Hepatica petree. Stone Liuerwort.

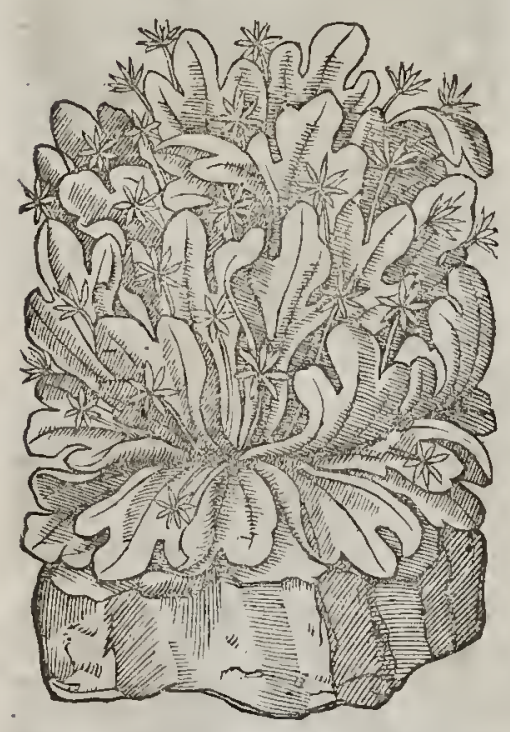

2 Hepaticaftellata o vmbellata. Small Liuer-wort with ftary and round heads.
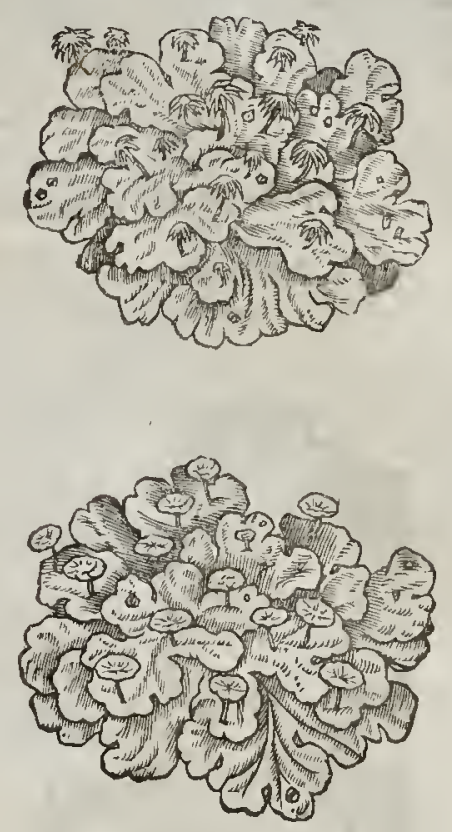

high mountaines, efpeciall in hadowie places.

$$
\text { बा The Place. }
$$

This is often found in fhadowy and moift places, on rocks and great ftones layd by the highway, and in other common paths where the Sun beams do feldome come, and where notraueller frequenteth.

$$
\text { Tा The Time. }
$$

It brings forth $h$ is bla ling ftars and leaues oftentimes in Iune and Iuly.

$$
\text { If The Names. }
$$

It is called of the Grecians, nery of the Latines, Lichen: and of fome, apuor, that is to fay, Mufus, or Moffe, as Diofcorid"s wicneffeth : it is named in hops Hepatica, yet there are alfo many other herbes named Hepatioc, or Liuer-worts, for difference whereof this may fitly becalled Hepatica petra, or Stone Liuer-wort, hauing taken that name from the Germanes, who call this Liuerwort. Stevn Lebetataut : and in low-Dutch, Steen Leteretupt: in Engli h, Liuerwort The Temperature.

This Stone Liuerwort is of temperature cold and dry, and fomew hat binding.

I The vertues.

It is fingular good againft the inflammations of the liuer, hot and tharpe agues, and tertrans which proceed of choler. 
Diofcorides teacherh, that Liuer-wort being applied to the placeftancherh bleeding, takes away all inflammations, and that it is good for a tetter or ring-worme, called in Greche, s'ck' and that it is a remedie for them that haue the yellow iaundice, euen that which commeth by the inflammation of the liuer; and that furthermore it quencheth the inflammarions of the tongue.

$$
\begin{gathered}
\mathrm{C}_{\text {на ал } 164 .} \\
\text { Of Lung-wort, or wood Liuer-port, and Oifter-greenc. }
\end{gathered}
$$

I Lichen arborum.

Tree Lung-wort.

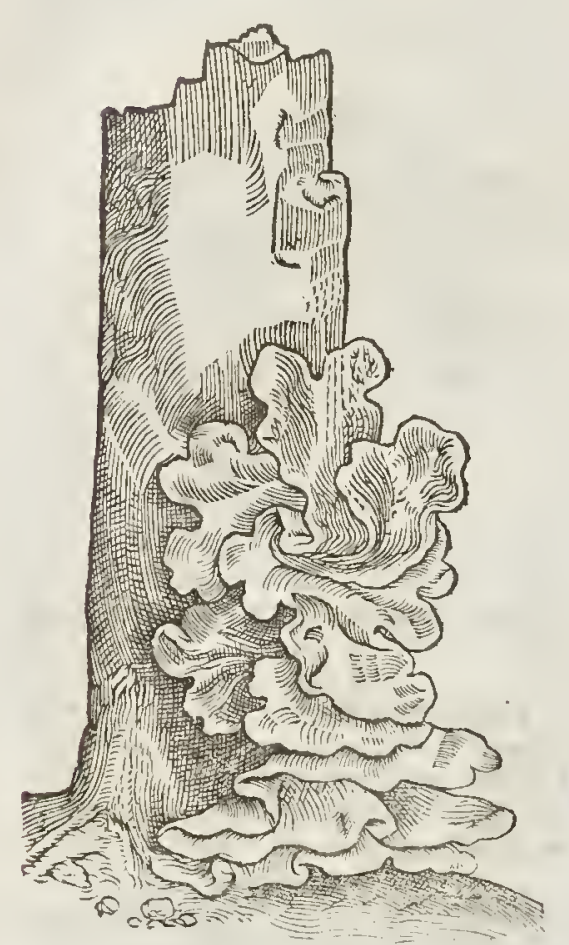

2 Lichen marinus.

Sea Lung-wort, or Oifter-greene.

$$
9 \text { The Defeription. }
$$

I T O Liuerwott there is ioyned Lung-wort, which is alfo another kinde of Moffe, drier, broader, of a larger fize, and fet with fcales : the leaues hereof are greater,and diuerlly folded one in another, not fo fmooth, but more wrinckled, rough and thicke almoft like a Fell or hide, and tough withall : on the vpper fide whitinh, and on the nether fide blackigh or dufty, it feemerh to be after a fort like to lungs or lights.

2 This kinde of fea Molle is an herby matter much like vnto Liuer-wort, altogether without ftalke or ftem, bearing many greene leaues, very vneuen or crumpled, and full of wrink les, and fomwhat broad, not much differing from leaues of crifpe or curled Lettuce : this groweth vpon rockes w ithin the bowels of the fea, but efpecially among oifers, and in greater plenty anong thofe Oifters which are called Wall-fleet Oifters : it is very well knowne enen to the pore Oifter-women which carry Oifters to fell vp and downe, who are greātly defirous of the faid moffe for the decking and beautifying of their Oifters, to make them fell the betrer. This moffe they doe call Oiftergreene.

$\neq 3$ The branches of this elegant plant are fome handfull or better high, fpred abroad on euerie fide, and only confifting of fundry fingle roundith leaues, wheteto are fafned fomtimes one, 


\section{B. 3. Of the Hiftory or Plants. \\ $1 ; 67$}

fometimes two or more fuch leaues, fo that the whole plant confifts of branches made vp of fuch round leaues, faftned together by diuers little \& veryfinal threds: the lower leaues which ftick faft to the rockes are of a brownifh colour, the other of a whitifh or a light greene colour, fmooth and fhining. This growes vpon rockes in diters parts of the Mediterranean. Clufsus fetteth it forth by the name of Lichen Karinus; and he receined it from Imperato by the name of Sertuleris : and Cortus fus had it from Corfica, by the title of Corallina latifolia and he called it opuntis marina; hauing reference to that mentioned by Thcophraft. lib.1. cap. 1 2. Hift. Plant. $\neq$

$\$ 3$ Lichen marinus rotundifolius. Round leatied Oifter-weed.

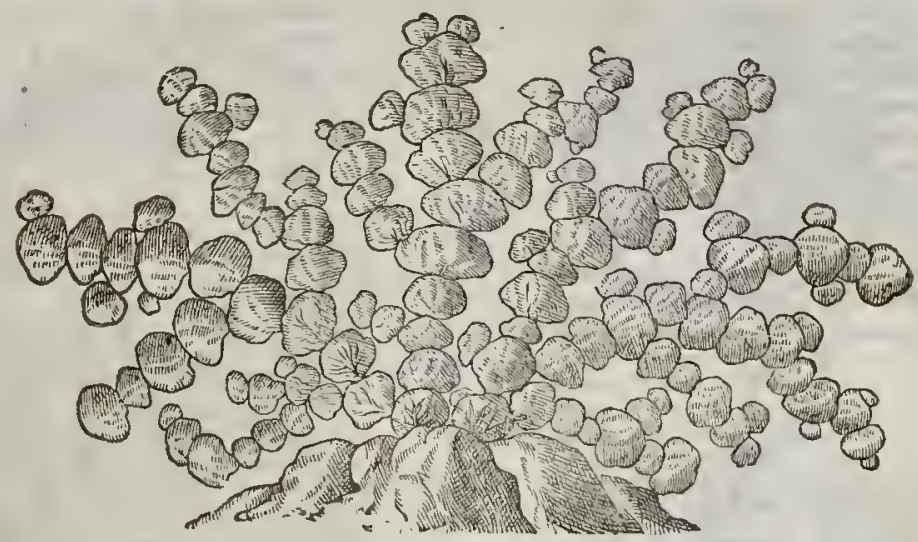

4 Quercus marina.

Sea Oke or Wracke.

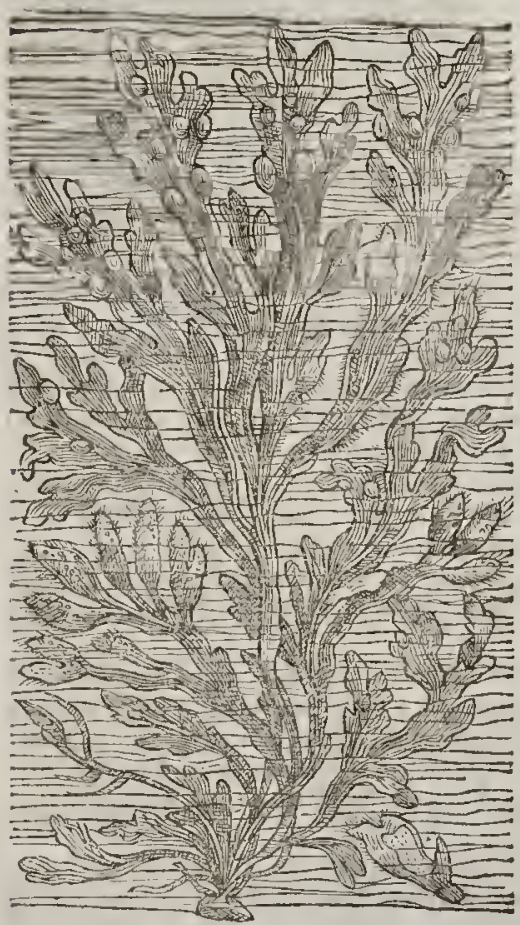

¥ 2 aerchs marine varietas. A varietic of the fea Oke or Wrack.

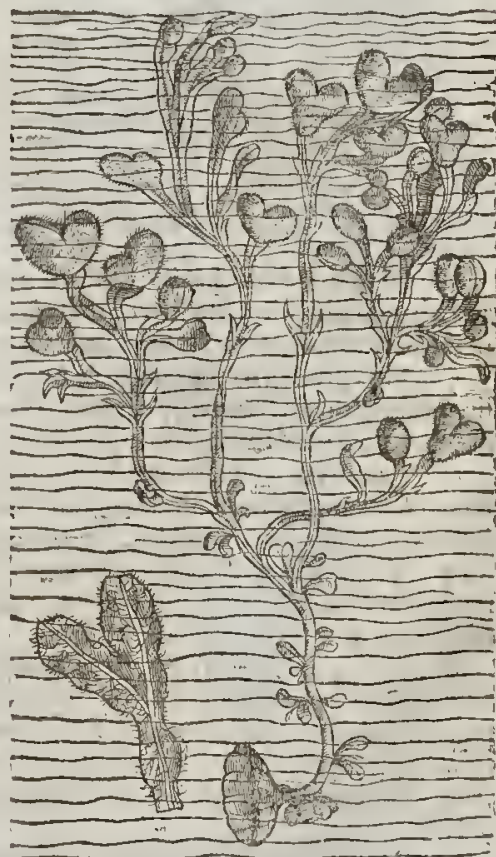

4 There is alfo another fort of fea Weed found vpon the drowned rockes, which arenaked and bare of water at eucry tyde. This fea Weed groweth vnto the rocke, faftned vnto the fame at one 
end, being a foft herby plant, very flipperie, infomuch that it is a hard matter to ftand vpon it with: out falling: it rampeth far abroad,and here and there is fet with certaine perft vp tubercles or bladders, full of winde, which giueth a crackewhen it is broken : the leafe it felfe doth fomewhat refemble the Oken leafe, whereof it tooke his name 2uercus marin, the fea Oke: of fome, Wracke, and Crow Gall. His vfe in phyficke hath not beene fet forth, and therefore this bare defcription may fuffice.

\section{\# 2 Quereus marina fecunda. Sea Thongs.}

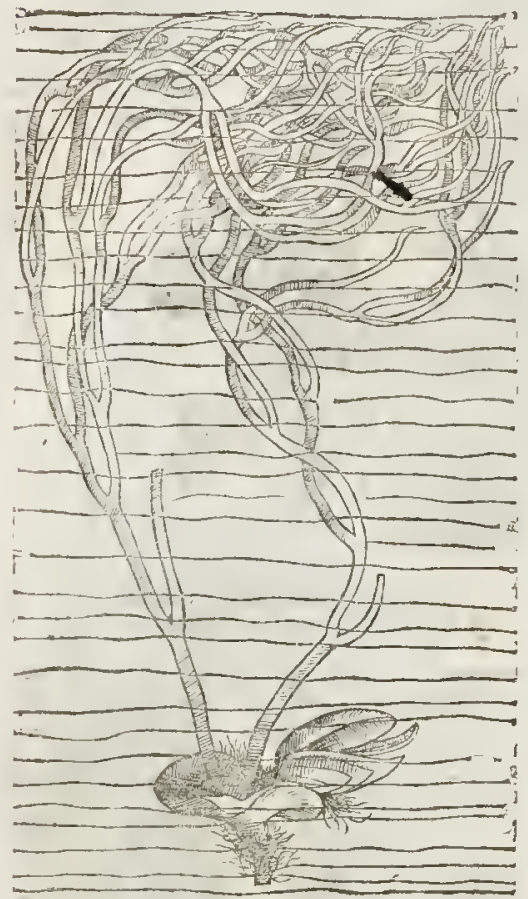

\# 6 2uercus marina tertia. The third fea Wracke.

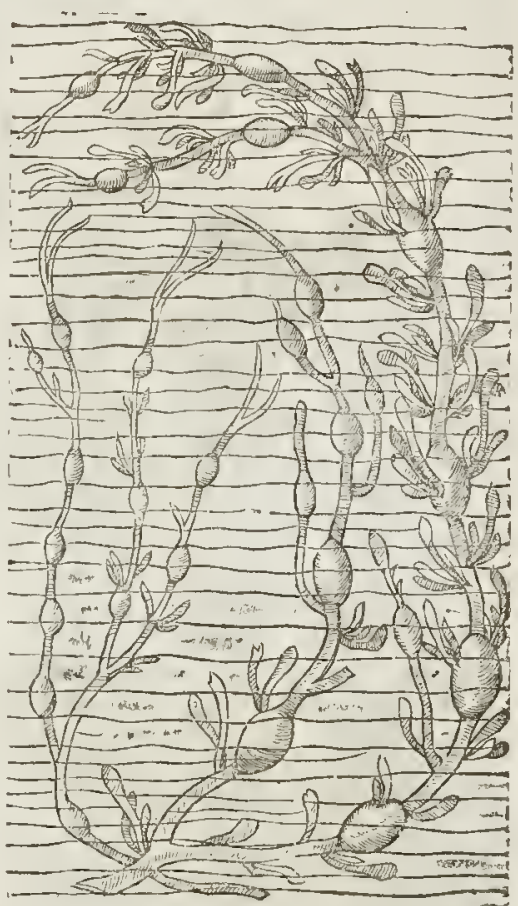

\# Of this 2uercus marina, or $F$ ucus, there are diucrs forts, whereof I willigine you the figures and a briefe hiftorie : the firft of thefe is onely a varietie of the laft defcribed, differing there-from in the narrowneffe of the leaues, and largeneffe of the fwolnebladders.

5 This growes to the length of fiue or fix foot, is fmooth and memb ranous, being fome lialfe fingers bredth, and variouny diuided, like wet parchment or leather cut into thongs: this hath no fwolne knots or bladders like as the former; and is the Fucus marinus (esundus of Dodoneus.

6 This Wracke or fea weed hath long and flat falkes like the former, but the falks are thicke fet with fwolne knots or bladders, out of which fometimes grow little leatres, in other refpects it is not vnlike the former kindes. Doton sus makes this his Fusus marinus 3.

7 The leates of this other W racke, which Dodonaus makes his Frous marinus quartas, are narrower, fmaller, and much diuided; and this hatheither none or very few of thofe fwollen bladders which fome of the former kindes have.

8 This, which Lobel calleth Alga marina, hath iointed blacke branched creeping roots of the thicknefe of ones finger, which end as it were in diuers eares, or hairy awnes, compofed of whitifh hairy threds fonewhat refembling Spikenard : from the to ps of thofe eares forth leaues, long, narrow, foft, and graffe-like, firft greene, but white when they are dry. It growes in the fea as the former. They vfe it in Italy and other hot countries to packevp glaffes with, to keepe them from breaking.

? Of this Tribe arediuers other plants; but I will onely giue you the hiftory of two more, which I firft obfcrued the laft yeare, going in company with diters London A pothecaries to finde Simples, as farre as Margate in the Ifland of Tenet; and whofe figures (not before extant that I know of) I firft gaue in my Ioumall or enumeration of fuch plants as we there and in orher places found. The firft of thefe by reafon of his various growth is by Bubine in his Prodromus difein- 
guifhed into two, and deferibed in the fecond and third places. The third he calls Fucus lomgis $\beta_{t-}$ mo, lates:mo, crafforme folio, and this is marked with the figure $\mathrm{r}$. The fecond hecalls Fucus arborens polyfchides; and this you may fee marked with the figure 2 . This fea Wced (as I haute faid) hath a various face, for fometines from a fibrous root, which commonly groweth to a pibblc flone, or faftened to a rocke, it fendeth forth a round ftalke feldome fo thicke as ones little finger,and about fomc halfe foot in length, at the top whereof growcs out a fingle leafe, fometimes an ell long, and then it is about the bredtly of ones hand, and it ends in a harpe point, fo that it very wcil refembles a two edged fword. Sometimes from the fame root come forth two fuch fanioned leares, but then commonly they are leffer. Otherwhiles at the top of the flalke it diuides it felfe ineo eight, nine, ten, twelue, nore or fewer parts, and that iuft at the top of the ftalke, and thefe neucr come to that length that the fingle leaues do. Now this I indge to be the Futus poiyf chides of Bumfine. That thefe two are not feuerall kindes I am certaine; for I have marked both thefe varieties from oneand the fame root, as you may fee them here cxpreft in the figure. At Margate wlere they grow they call them fea Girdles, and that name well befits the fingle one; and the linided one they may call Sea Hangers, for if you do hang the tops dow newards, they doe reafonable wcll refemble the old fathioned fword-hangers. Thus mucli for their thape : now for their colour, which is rot the fame in all; for fome arc more greene, and thefe can fearce be dried; other-fome are whition, and thefe do quickly dry, and then both in colour and fub ftance are fo like parcliment, that fuch as know them not would at the firft view take them to be nothing elfe. This is of a glutinous fub ftance, and a little faltifh tafte; and diuers hate told me they are good meate, being boiled tender, and fo eaten with butter, vineger, and pepper.

\section{\$ 2uerens matrina quatt: Iagged Sea Wrackc.}

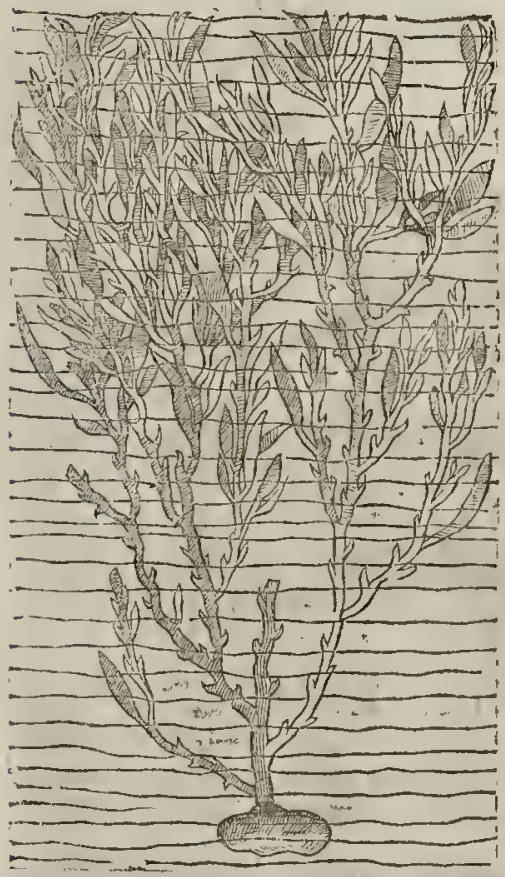

$\ddagger S$ Alga. Graffe Wracke.

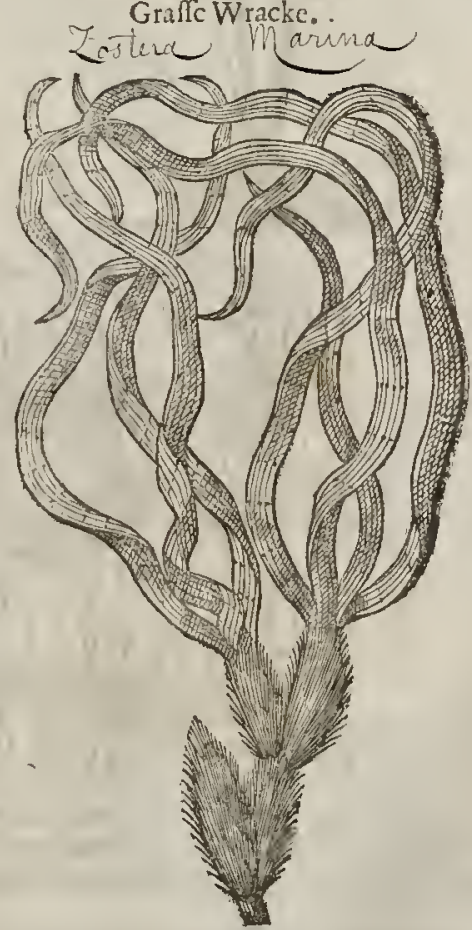

Io This which I gite you in the tenth place is not figured or deferibed by any that as yet haue met with; wherefore I gaue the figure and defeription in the forementioned Iournall, which I will here repeatc. This is a very fucculent and fungous plant, of the thickneffe of ones thumbe; it is of a dake yellowin colour, and buncheth forth on cuerie fide with many vnequall tuberofities or knots: wheretipon $\mathrm{M}^{\mathrm{r}}$. Thomas Hickes being in our companie did fitly name it Sea ragged Staffe. Wedid not oufetue it growing, but found one or two plants thercof fome foot long apicce. 
\$ Fucus phaganoides of poly chides. Sea Girdle and Hangers.

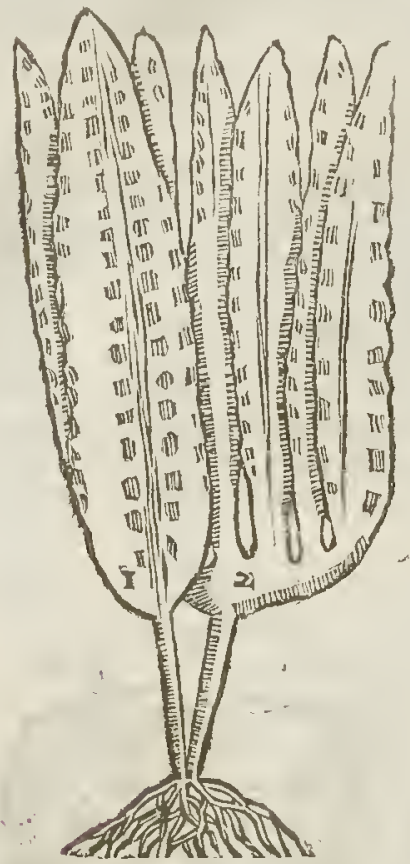

† Io Fucus pongiofus nodofus. Sea ragged Staffe:

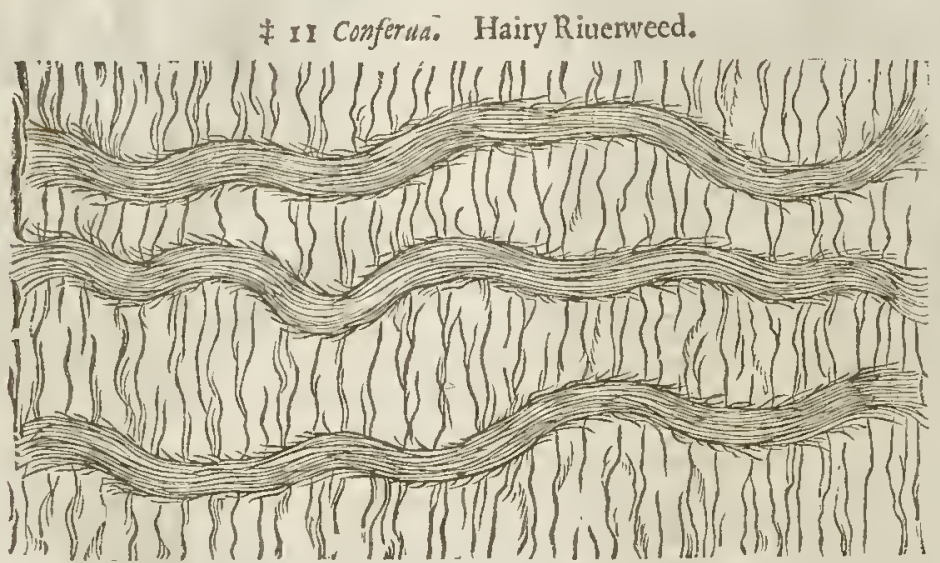

II In fome flow running waters is to be found this long greene hairy weed, which is thought to be the Conferua of $P$ liny : it is made vp onely of long hairy greene threds, thicke thrummed together without any particular thape or farhion, but only following the eurrent of the ftreame. $\neq$ बा The Place.

It groweth vpon the bodies of old Okes, Beech, and other wilde trees, in darke \& thick woods : it is oftentimes found growing vpon rocks, and alfo in other fhadowie places.

$$
\text { IT The T ime and Names. }
$$

It flouritheth efpecially in the Sommer moneths.

It taketh h is name Pulmonaria of the likeneffe of the forme which it hath with lungs or lights, called in Latine $P$ umones, of fome, Lichen: it is called in high-Duteh, lungenktaut:in low-Dutch Longhancrupt : in French, Herbe a Ponlman : in Englinh, Lung-wort, and wood Linerwort.

This feemeth to becold and dry. If The Temperature. 
I I B: 3 .

Of the Hiftoric of Plants.

$157 \mathrm{I}$

The Vertues:

It is reported that fhepheards and certaine horfelecehes dowith good fucceffe giuc the pouder $\mathbf{A}$ hereof with falt vnto their theepe and other cattell which be troubled with the cough, and be broken winded.

Lungwoort is much commended of the learned Phyfitions of our time againf the difeafes of $B$ the lungs,efpecially for the inflammations and vlcers of the fame, being brought into pouder, and drunkew itliwater.

It is likewife commended for bloudy and greene wounds, and for vicers in the fecret parts, and C. alfo to ftay the reds.

Moreouer, it ftoppeth the bloudy flix, and ocher flixes and feourings, either vpwards or downewards, efpecially if they proceed of eholer : it fayeth vomiting, as men fay, and it alfo ftoppeth the belly.

Oifter greene fried with egges and made in toa tanfie \& eaten, is a fingular remedy for to ftreng: $D$ then the weaknefle of the backe.

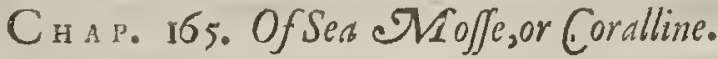

\section{ขा The Kindes.}

Here be diuers forts of Moffe, growing as well within the bowels of the fea, as vpon the rocks, diftinguifhed vader fundry titles.

I Mufcus marinus, fove Corallina alba. White Coralline, or fea Moffe.

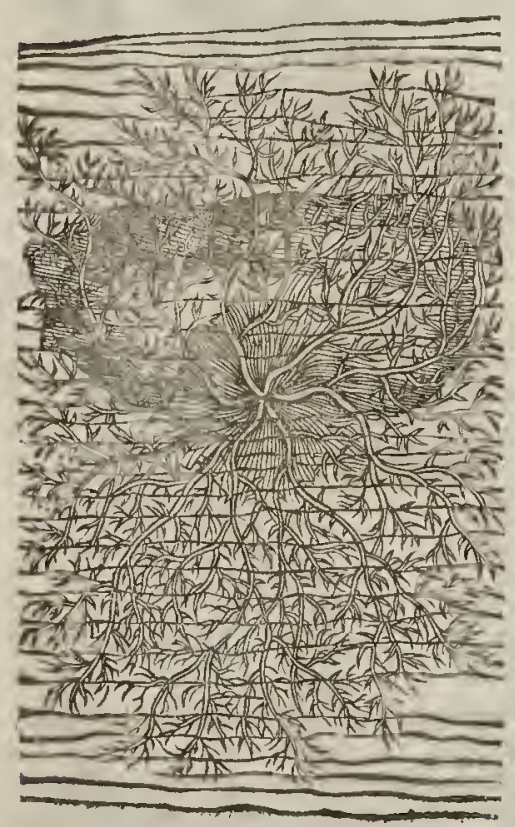

† 2 Mufus narinus albidus. White fea Moffe.

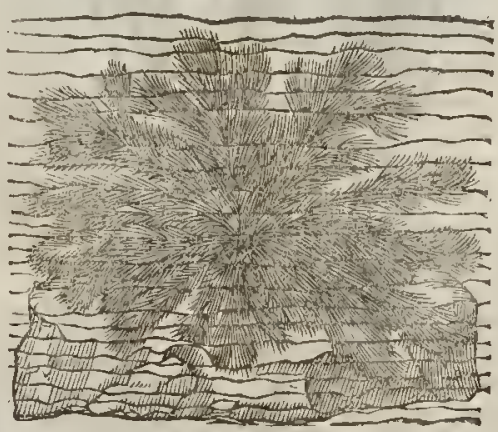

3 Corallina Anglica.

Englin Coralline.

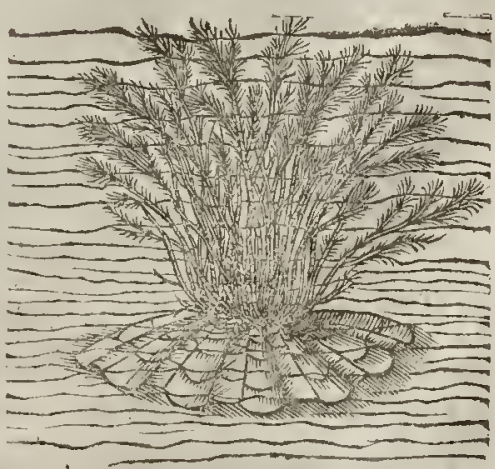




\section{T The Defcription.}

fubftance. 2 The fecond is much like vnto the former, yet not ftony, but more finely cut, and growing
more vpright,branehing it felfe into many diuifions at the top, growing very thieke together, and in great quantitic, ont of a picee of ftone, which is fafhioned like an hat or fmall ftonic head, wher-
by it is faftened vnto the roeks.

3 This third kinde of fea moffe is very well knowne in thops by the name Corallina, it yeeldeth forth a great number of thoots, in thap mueh like vnto Corall, being full of fmall branches difperfed here and there, diuerly varying his colour, according to the place where it is found, beeing in fome places red, in otherfome yellow, and of an herby colour; in fome gray, or of an afh colour, and
in otherfome very white.

4 The fourth kinde of Sea Moffe is fomewhat like the former, but finaller, and not fo plentiful where it groweth, profpering alwaies vpon fhels, as of Oyfters, Mufeles, and Seallops, as alfo vpon rolling fones, in the bottome of the water, whieh hatue tumbled downe from the high clifftes and rocks, notwithfanding the old prouerbe, that rolling ftones neuer gather Moffe.

4 Corallina minnims.

The fmalleft Coralline.
5 Mufous Corallinus, five Coralliza montana: Corall Moflé, or mountaine Coralline.
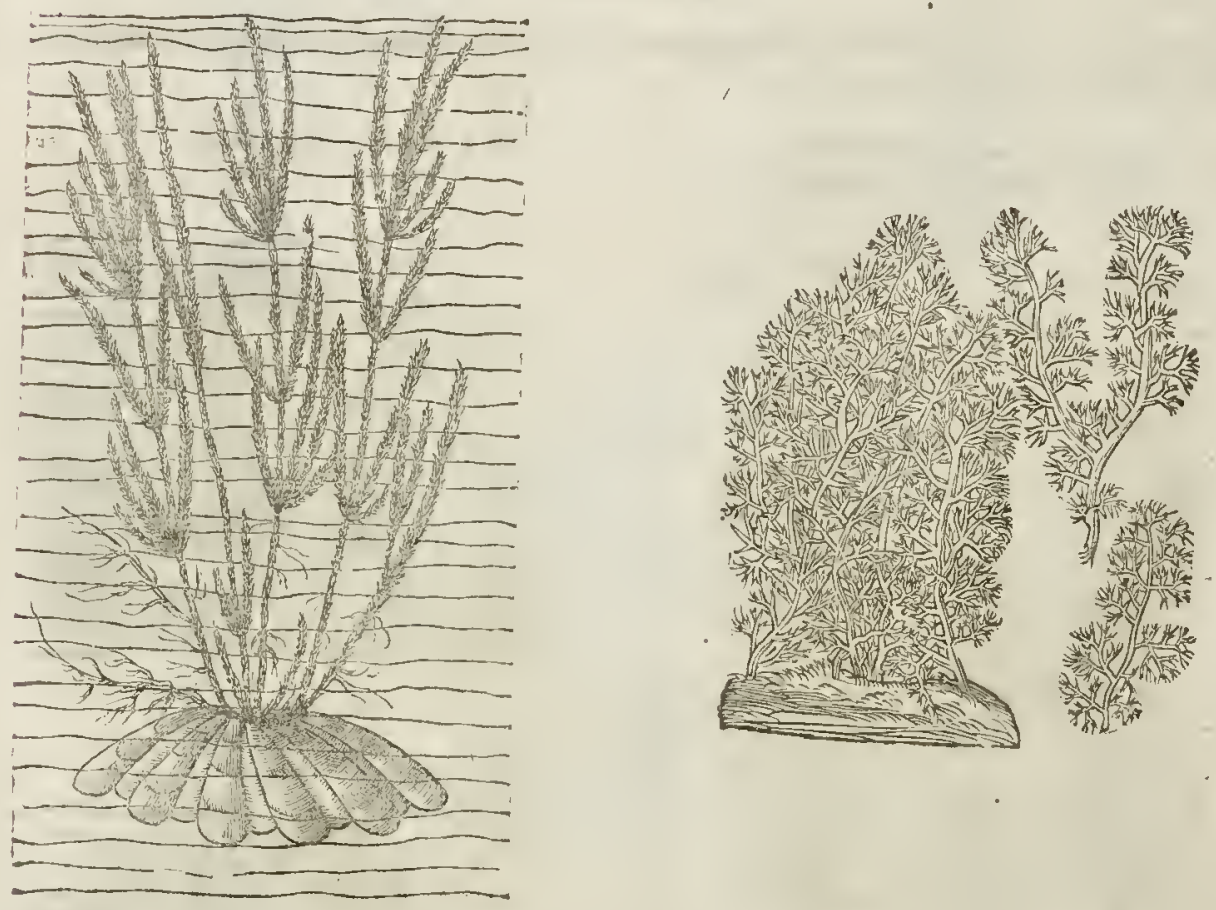

5 There is found vpon the rocks and mountaines of France,bordering vpon the Mediterranean fea, a eertaine kinde of Coralline, which in thefe parts hath not been found : it groweth in manner like vnto a braneh of Corall,but altogether leffer, of a mining red colour, and of a fony fubftance. \pm I know not what our Author meant by this defeription; but the plant which here is figured
out of Tallernomont anus hut of Talier namontanus (and by the fame title he hath it) is of a Moffe growing vpon Hampfead into very light whitedry fub tanee ending in little threddy ehiues : all the branehes are hollow, and of a atall. $\neq$

6 There is allo found von the rocks neere vnto Narbone in France, and not far from the fea, a 
6 Fscus marinus texuifolius.

Fenell Coralline, or Fenell Moffe.

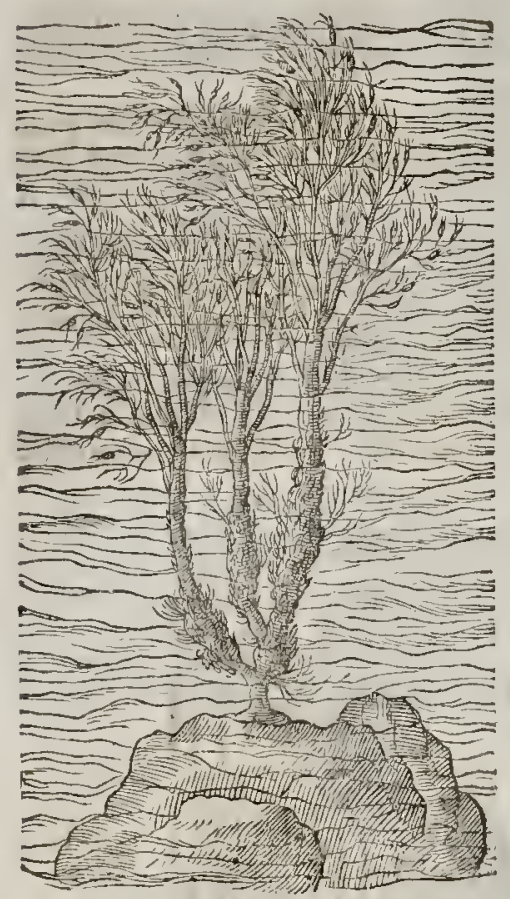

\section{\$ Fucustenuifolius alter.} Bulbous fea Fennell.

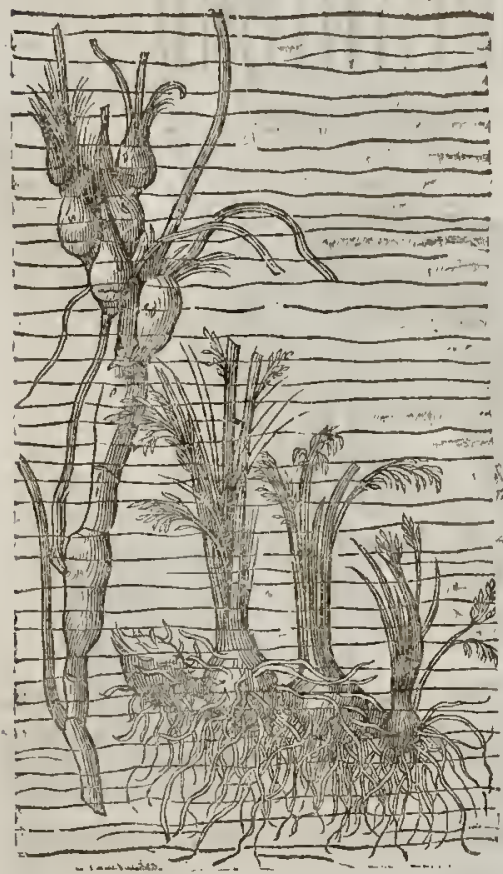

\$ Fucus ferulaceus. Ruplsea Fenell.

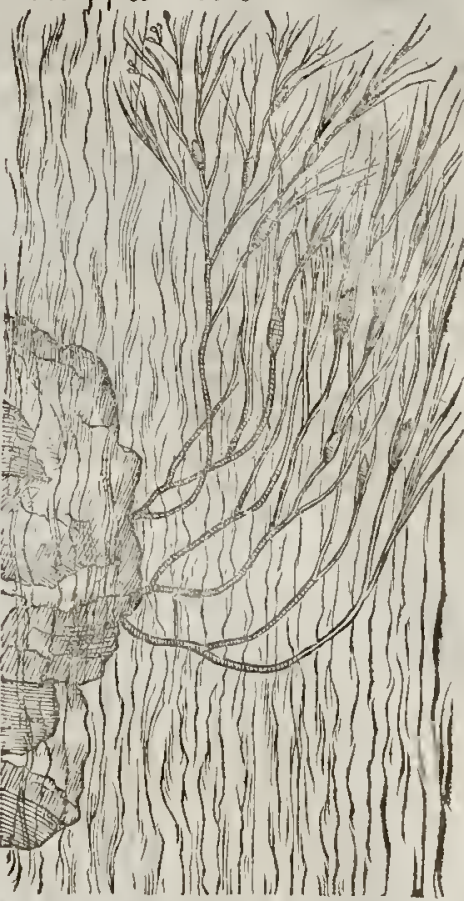

\section{\$ Mufous marinus Clufans.} Branched!Sea Moffe.

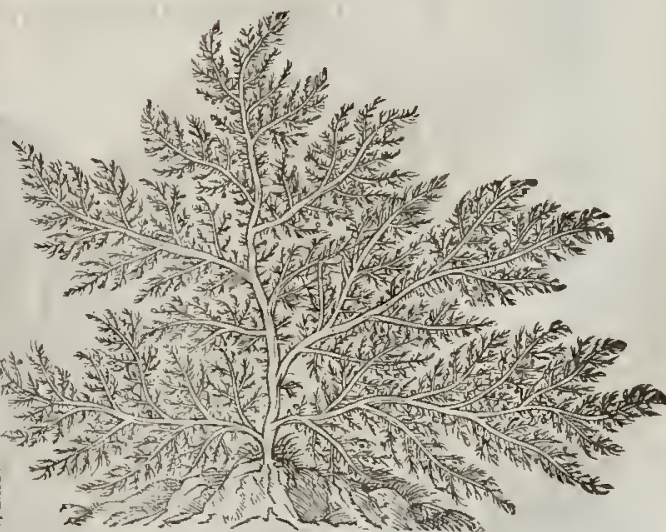


kinde of Coralline : it groweth vp to the forme of a fmall fhrub, branched diterfly; whercon doe grow fmall graffe-like leates, very finely eut or iagged, like vnto Fennel; yet are they of a ftony fubftance,as are the reft of the Corallines; of a darke ruffer colour.

¥ 7 This growes allo in the like plaees, hating many fmall long Fennell-like diuided leaues vpon ftalks fome foor long, with fome fwelling eminences here $\&$ there fet in the divifions of the leaues:this is by Lobel ealled by the name I here giue you it.

8 This alfo hath fine cut leates like thofe of Fennell,but mueh leffe \& fhorter, of a faire green colour : thefe grow vp from round euberous roors, whieh together with the fibres they fend forth are of a blackin colour : the ftalks alfo are tuberous and fwolne, as in other plants of this kind. It growes in the fea with the former. Dodonaus calls this Fucus marinus virenstenuifolizs.

9 This kinde of fea Moffe growes fome foure or more inches lorg, diuided into many branches, which are fubdiuided into fmaller, fet with leaues finely iagged, like thofe of Cammomill, at firft foft, flexible, and tranfparent, greene below, and purplifh aboue; being dried, it becommeth rough and fragile, like as Coralline. It growes in the Mediterranean fea.

10 This Sea Moffe is a low little exerefence, haung fomewhat broad eut leaues growing ma ny from one root : in the whole faee it refembles the moffe that grows vpon the branches of Okes and other trees, and is alfowhite and very like it, but much more brittle. This by Dodonaus is called Mufcus Marinustertius.

‡ 10 Mufus marinus 3. Dod Broad leafed Sea moffe.

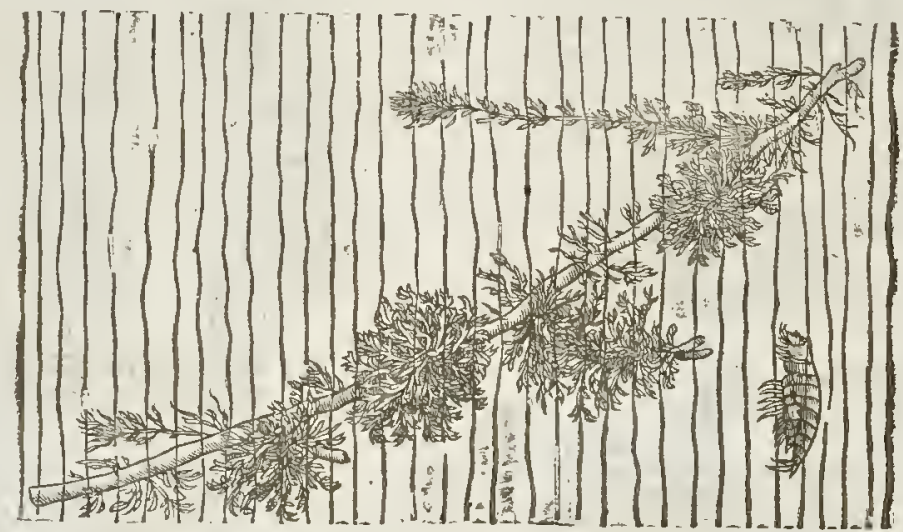

¥ I Abies marina Belgica, Cluf. Clufins his Sea Firr.

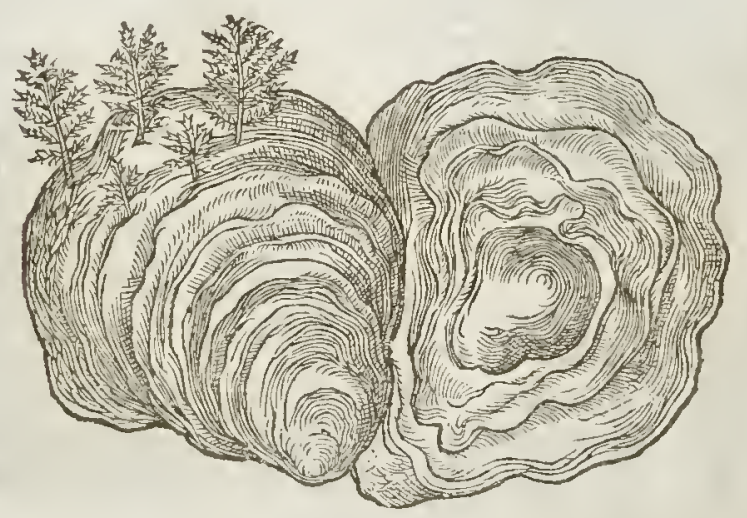

it Vpon the rocks and thels of fea fiftes are to be found diters fmall plants, hauing refemblanee to others that grow vpon the land; and Clufims faith, wpon the coaft of the Low countries he obfertued one whieh very mueh refembled the Fir-tree, hauing branehes growing orderly on both fides, but thofe very brittleand fmall, feldome exeeeding a handfull in height, and couered as it were with many fmall fcales. He obferued others that refembled Cypreffe rrees, and other branches that refembled Tameriske or heath. 
L1E. 3. Of the Hiftory of Plants.

T) The Place.

Thefe Moffes grow in the fea vpon the rocks, and are of tent imes found vpon Oifter fhels, Mus . kell thells, and vpon ttones : I found very great plenty thereof vnder Reculuers and Margate, in the Ille of Tharet;and in other places alongf the fands from thence vn to Douer.

$$
\text { I T The Time. }
$$

The time anfwereth the other Moffes, and are found at all timcs of the yeare.

$$
\text { The Names. }
$$

Sea Moffe is called in Greeke вpir smanov: in Latine, Mufcus marinus: of the A pothecaries, Italians, and French men, Corallins: in Spanifh, Malharquiana yerua: in high Dutch, 98 eetmo[z: in low Dutch,

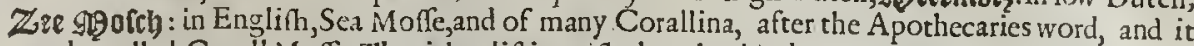
may be called Corall Mofle. The titles dittinguih the other kindes.

$$
\text { T The Temperature. }
$$

Corallina confitteth,as Galen faith, of an carthie and waterifh effence,both of them cold : for by his tafte it bindeth, and being applied to any hot infirmitic, it alfoeuidently cooleth : the earthic effence of th is Moffe hath in it alfo a certaine faltneffe, by realon whereof likewife it drieth mightily.

$$
\text { T) The Vertues. }
$$

Diofcorides commendeth it to be good for the gout which hath nced to be cooled.

The later Phy fitiohs haue found by experience, that it killeth wormes in the belly; it is given to $\mathrm{B}$ this purpofe to children in the weight of a dram or thereabouts.

That which cleaueth to Corall, and is of a reddifh colour, is of fome preferred and taken for the C beft : they count that which is whitinh, to be the worfer. Notwithftanding in the French Ocean, the Britain, the low countrey, or elfe in the Germane ocean fea, there is farce found any other than the whitith Coralline, which the nations neere adioyning do effectually vfe.

\section{Cнa p. 166. Of Corall.}

I. Corallium rubrum. Red Corall.

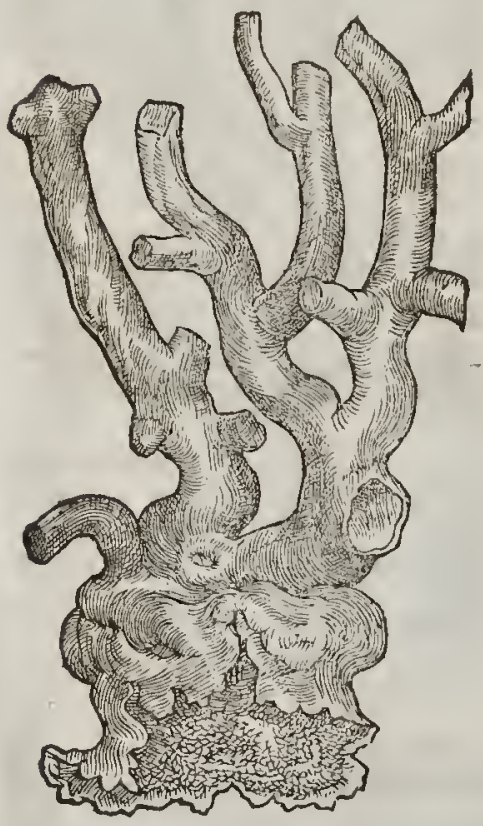

2 Corallium nigrum, froe Antiparbes. Blacke Corall.

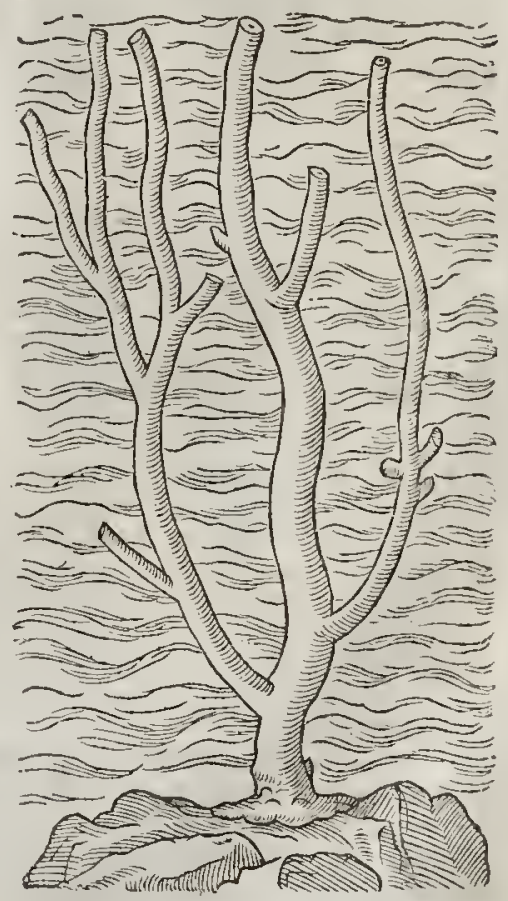

ब $T h e$ 
3 Corsllium album. White Corrall.
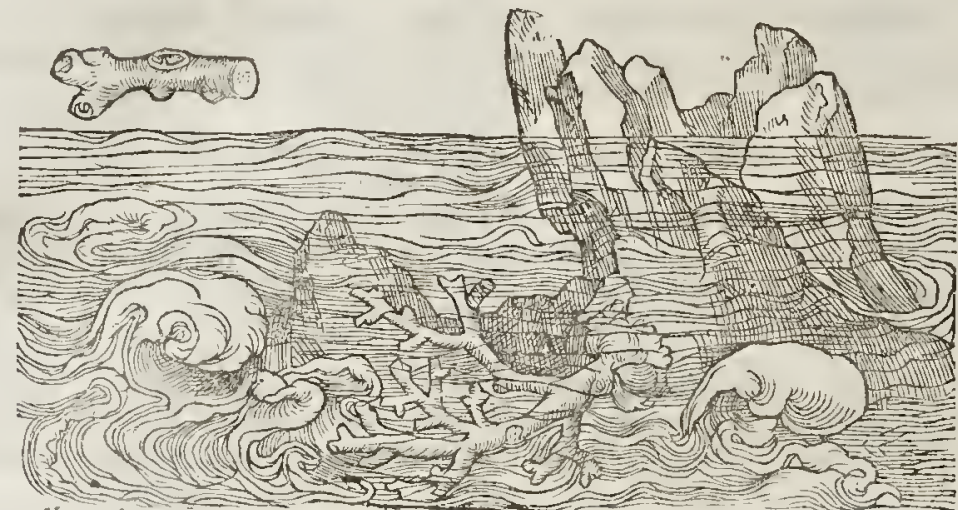

4 Corallium album alterum.

Theotherwhite or yellow Corrall;

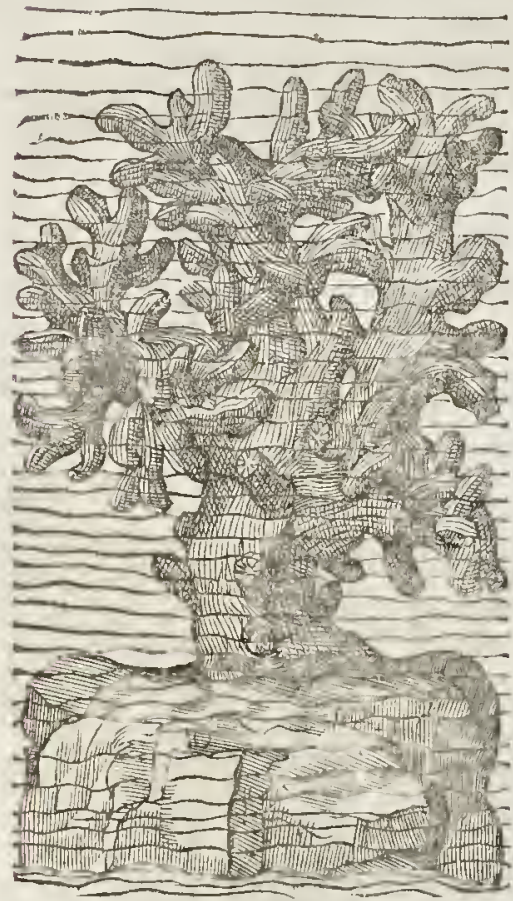

$\$ 5$ Coralloides albicans.

Whition bafard Corall.

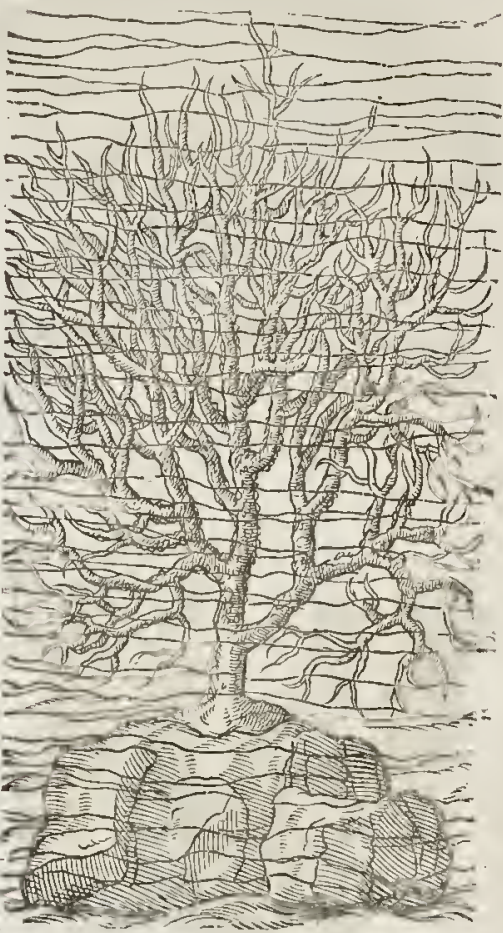

बा The Defiription.

1 Lthough Corrall be a matter or fubltance, euen as hard as ftones.yet I thinke it not aA miffe to place and infert it here next vnto the moffes, and the rather for that the $k$ indes thereof do fhew themfelues, as well in the mancr of their growing, as in their place and forme, like vnto the Moffes. This later age wherein we liue, hath found moe kindes hereof than euer were knowne or mentioned among the old writers. Some of thefe Corrals grow in the liken fit nf a fhrub, or ftony matter; others in a fraight forme, with crags and ioints, fucl as we fee by experi. ence: the which for that they are fo well knowne, and in fuch requeft for piny ficke, I will not ftand to defrrbe; only this remember, that there is fome Corrall of a pale yellow colour, as there be fome red, and fome white.

3 The blacke Corrall gruweth vpon the rocks neere to the fea about Mafilia, in manner of the former; herein differing from it, in that this is of a fhining blackecolour, and very finooth, grow. ing ve rather like a tree, than Iike a fhrub

3 The whitc Corrall is like to the former, growing vpon the rocks neere the fea, and in the Weft parts of England,about Saint Michacls mount; but the branches hereof are fmaller, and wore brittle, finelier difperfed into a number of branclies, of a white colour. 
$¥ 6$ Coralloides rubens.

Reddifh baftard Corall.

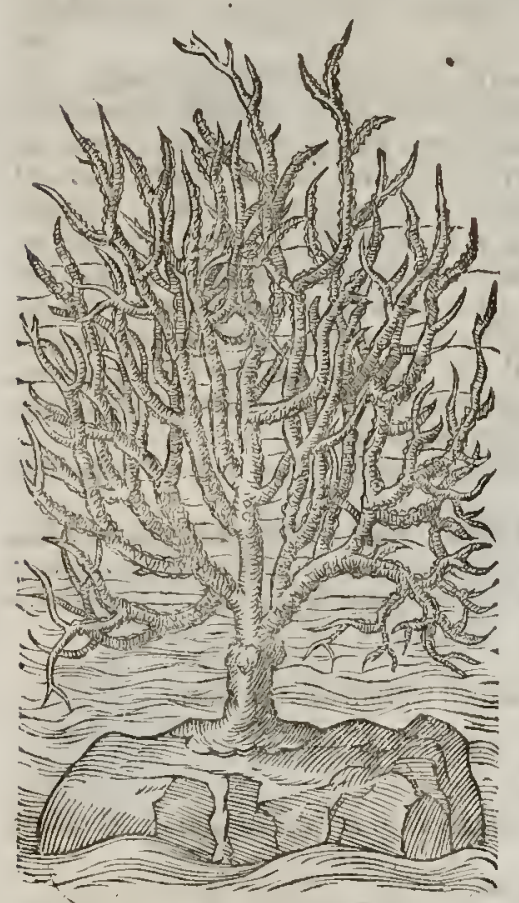

\$ spongia infundibuliforma.

Funnell falhioned Spunge.

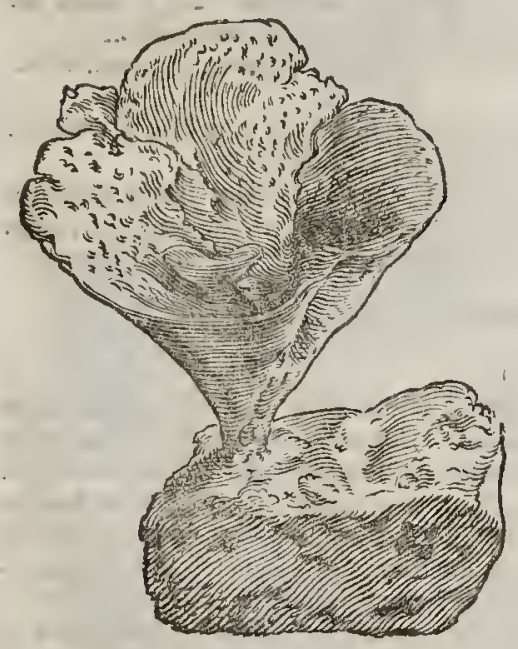

7 spongia marina alba. White Spunge.

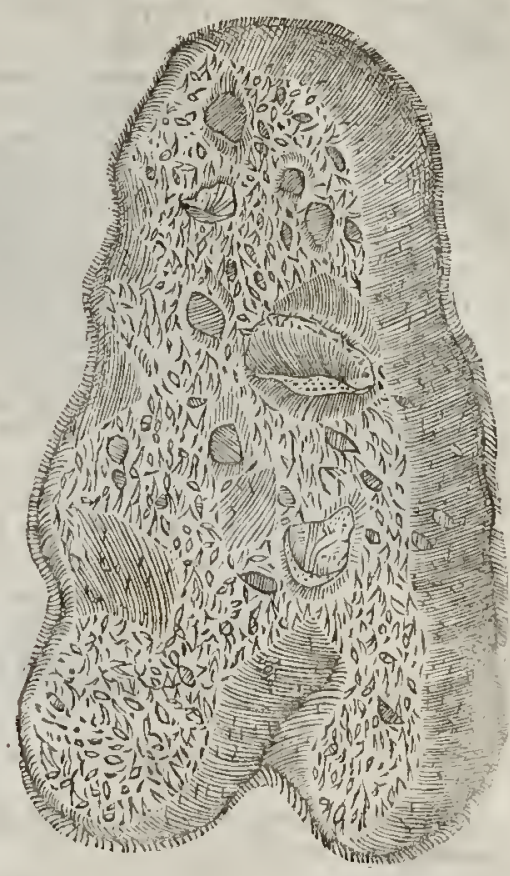

† spongia rumoro. Branched Spunge.

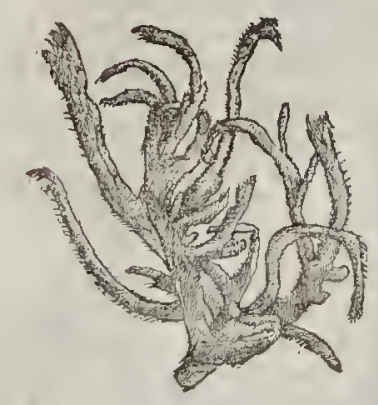

4 The fourth and laft groweth alfo vpon the Wefterne rocks of the fea, and in the place afore named, and varieth his colour, fomerimes waxing white, fomecimes yellow, and fomerimes red.

$\neq 5$ This growes vp with many branches fome two or three handfulls high; the inner part is a hard wooddy fubftance, which is couered ouer with a white and hard ftony matter, fo that it much refembleth white Corall, but that it is neither fo thicke, hard, nor fmooth, but is rough 
and bends cafily without breaking, which Corall will not do. Lobol calls this corallina alba, it growes in the Mediteranian fea, and vpon the Coafts of Spaine.

6 This in all refpects is like the laft defcribed, the colour excepted, which is a darkered, and therefore better refembles the red Corall. Clufus refers both thefe to the Quercus marina mentioned by Thcophrafius, Hift.plant.li6. $7 \cdot$ cap. $4: \neq$

7 There is found growing vpon the rockes neere vnto the fea, a certaine matter wrought together, of the fome or frotn of the lea, wh ich we call fpunges, after the Latine name, which may very fitly be inferted among the fea Moffes, whereof towrite at large would greatly increafe our volume, and little profit the reader, confidering we haften to an end, ard alfo that the vfe is fowell knowne vnto all: therefore thefu fow lines may ferue vntill a further confideration, or a fecond Edition. $¥$ Spunges are not like rhe Alcyonium, that is, an accidentall matter wrought together of the froth of the fea, as our Author affirmes, but rather of a nobler nature than plants, for they are faid to haue fence, and to contrat themlelues at the approach of ones hand that comes to cut them vp, or for feare of any orher harme-threatning object, and therefore by moft writers they are referred to the savera: which fome render Plantaniwalid, that is, fich as are neither abfolute plants, nor liung creatures, but participate of both: they grow of diuers thapes and colours vpon the Reckes in rhe Mediterranian,as alfo in the Archipelago, or Egean fea.

8 clufus obferued one yet adhering to the ftone whereon it grews whicl in fhape refembled a funnell, but in fubttance was like another Spunge.

9 There is alfo to be found vpon our Enslith coaft a fmall kinde of fpunge caft vp by the fea; and this is alfn of different thapes and colour, for the fhape it is alwaies diuided into fundry branches, but that after a different manner; and the colour is oft times brownil, and otherwhiles gray or white. Lobel makes it Conferme marina renus. +

$$
\text { q The Place. }
$$

The place of their growing is fufficiently fpoken of in their fenerall defcriptions.

The time andwereth the other kindes of fea Moffes.

$$
\text { T) The Names. }
$$

Corallium rubrum is called in Englifh, red Corrall. Corallum nigrum, blacke Corrall. Corallium slbum, white Corrall.

\section{The Temoerature.}

Corrall bindeth, and meanely cooleth : it cles firh the fcars and fpots of the eies, and is very effectuall againft the iffues of bloud, and ealcth the diffieultie of making water.

$$
\text { का The p'er'ues. }
$$

A Corrall drunke inwine or water, preferueth from the fpleene; and fome lang it about the neckes of fuch as haue the falling fickeneffe, and it is g 'uen in drinke for the fame purpofe.

B It is a foueraigne remedy to druc, to ftop, and ftay all iffues of bloud whatfoetier in man or wo: man, and the dy fentery.

C Burned Corrall drierh more than when it is vnburned, and being gituen to drinke in water, it helpeth the gripings of the belly, and the griefes of the ftone in the bladder.

D Corralldrunke in wine prouketh leepe : but if the patient hatue an ague, then it is with better fueceffe minifted in water, for the Corrall cooith, and rhe warer moiftneth the body, by reafon whereofit reftraineth the burning heate in agues, and repreffeth the vapours that hinder fleepe.

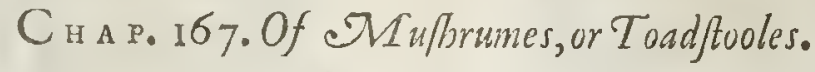

$$
\text { 9) The Kiades. }
$$

Ome Muthrumes grow forth of the earth; aher vpon the bodies of old trees, whicl differ $\circlearrowleft$ altogether in kindes. Many wantons that dwell neere the fea, and haue fin at will, are very defirous for change of diet to feed vpon the birds of the mountaines; and fuch as dwell vpon the hills or elumpion grounds, do longe after fea fifh; many that hate plenty of both, do bunger after the earthie excrefcences, called Murhrumes : whereof fome are very venomous and full of poifon, nchers not fo noifome; and neicher of them very wholefome neate; wherefore for the auoiding of rhe venomous qualitie of the one, and that the other which is leffe venomous may be difcerned from it, I hate thousht good to fet forth their pictures with their names and places of growth. $\neq$ Becaufe the booke is already grown too voluminous, I will only giue you the figures of fueh as my Author hath bere mehtioned, with fome few others, but not trouble youwith any more hiftory, yet difinguith betweene fuch as are catable, and thofe that be poyfonous, or at leaft nor to be eaten, for the firfe figured amongit the poy fonous ones, is that we call Ietves-eare, which hath nonovfonous facutic in it. Clufus (all whofe figures I could hate here gituen you) hath writcen a peculiar tract of thefe baftard plants, or excrefences, where fuch as defize it may finderhem fuificiently dilicourfed of. 
$18.3=$

Of the Hiftory of Plants.

I Furgi vinssotiffmi cfoulcnti. Common Mufhrums to be caten.
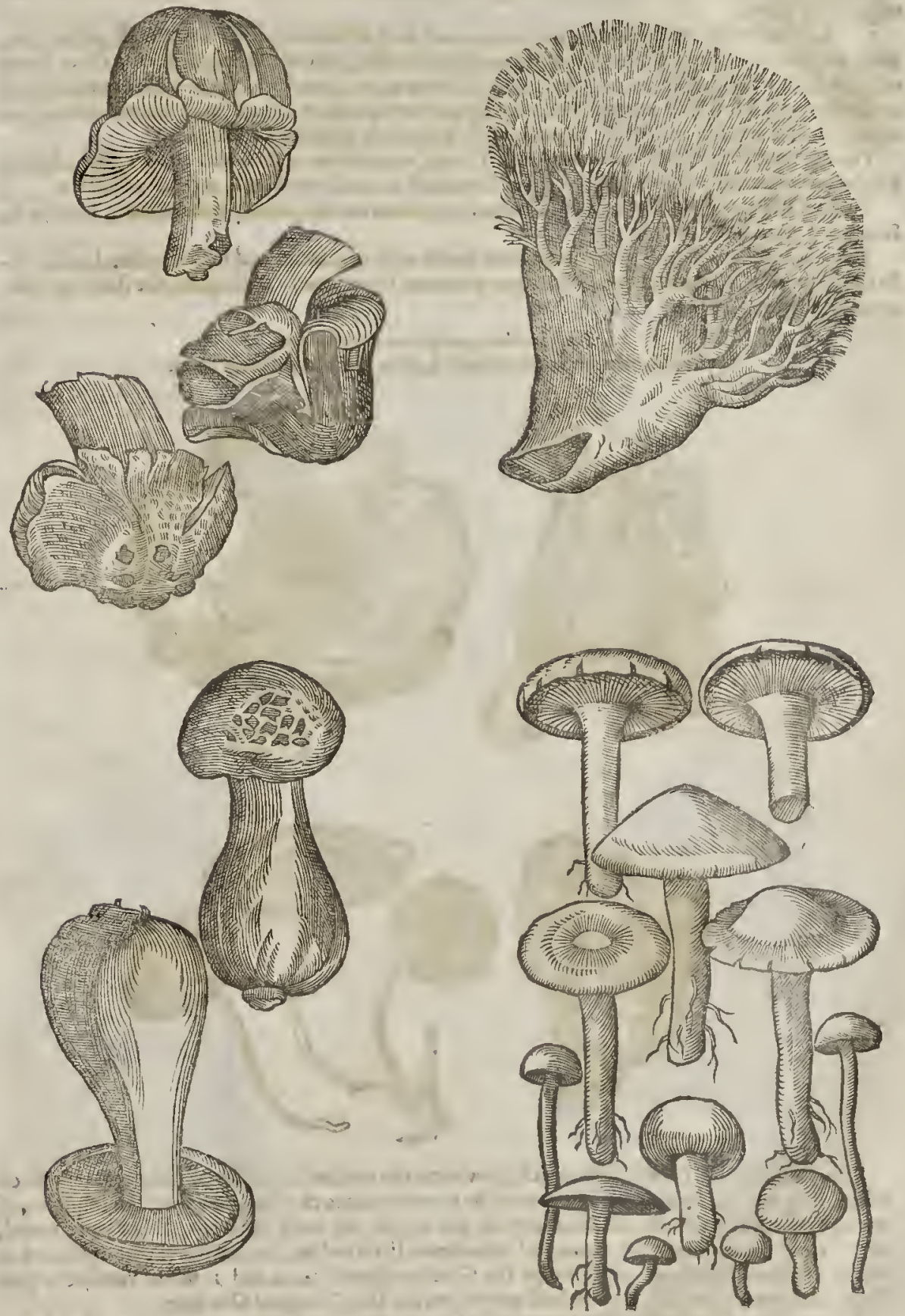

Rrtre 2

tate

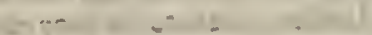

ax 
IT The Defoription.

I

Round Mufhrums grow vp in one night, ftanding vpan a ascke and round ftalke, like Ivntoa broad har or buckler, of a very white colour vnt i's begin to wither, at what tima it lofeth his fairew hite, declining to yellowneffe wise lower fide is fomewhat hollow, fet or decked with fine gutters, drawne along from the mids is centre to the circumference or round edge of the brim.

2 All Muhroms are wirhout pith,rib, or veirs : they differ not a little inbigneffe and colour, fome are great, and like a broad brimmed hat;others fmaller, about the bignefle of a filuer conne called a doller : moft of them are rad vnderneath; fome more, fome leffe; others little or norhing red at all:the vpper fide which bearch out, is either pale or whitifh, ot elfe of an ill fauored colour like afhes (they commonly call it Ath colour) or clfe it feemeth to be fomewhat yellow.

There is another kinde of Muhrums called Fungi parui lethales galerwulat : in Frglifh, deadly Muhrums, which are fafhioned like vnto an hood, and are molt venomous and full of poifon.

There is a kinde of Muhrum called Fungus Clypeiformis lathalis, that is alfo a deadly Munisum, Eafhioned like a little buckler.

There is another kinde of Muhrum, which is alfo molt venomous and full of poifon, bearine al. fo the hape of a buckler, being called Fungus vertenatus Clypeiformis : in Englith, the flinking vero. mous Muthtom.

\section{Fungitethales, aut filtem non ef culewti.}

Poyfon Mufrums, or at the leaft fuch as ate not vulgarly caten.
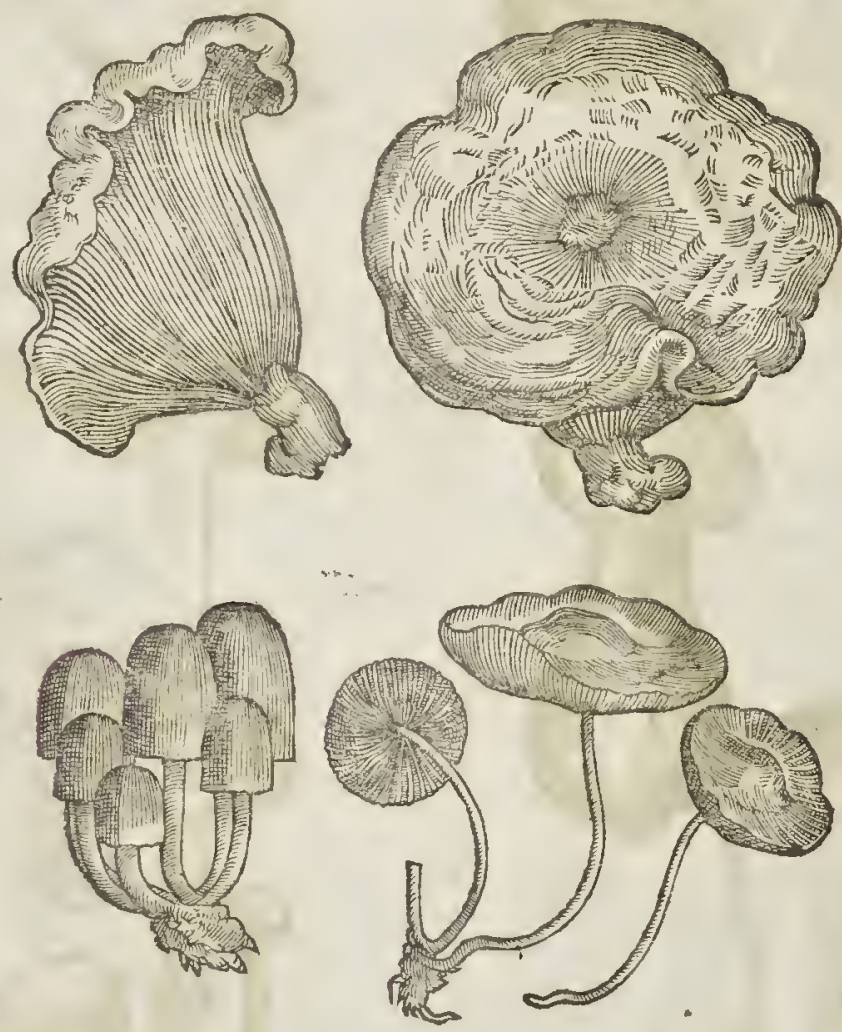

The Mufhrums or 'Toodftooles which grnw vpon the trunkes or bodies of old trees, very much refembling Awricula Isede, that is Iewes eare, do in continuance of time grow vnto the fubfance of wood, which the Foulers docall Touchwood, and are for the moft halfecirculed or halfe round, whofe vpper part is fomew hat plaine, and fomernme little hollow, but the lower part is plaited or purfed togerher. This kinde of Muhrum the Grecians do call rimpra, and is full of venome or poi. fon as the former, efpecially tbofe which grow vpon the Ilex, Oliue,and Oke trees.

There is likewife a kinde of Muntrum called Fungus Faxagtnofus, growing vp in moift and tha: dow ie woods, which is alfo venonnous, haming a thicke and tuberous falke, an handfull high, of a diskifh colour; the top where of is compat of many fmall diuifions, like vnto the hony combe. 
$L_{1 B} 3 . \quad$ Of the Hiftory of Plants.

Fungus fambucinus, five Awricula Iuda. Iewes eares.

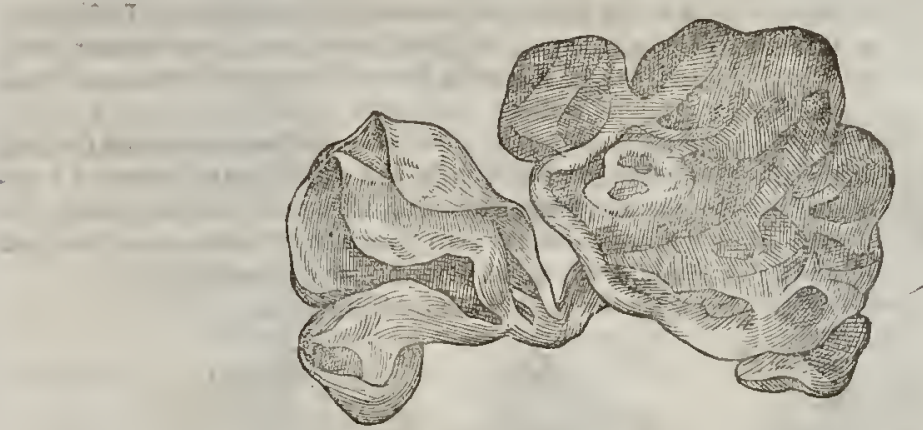

Furgi letbales, fue non cfoulenti.Poyfonous Murhrums.
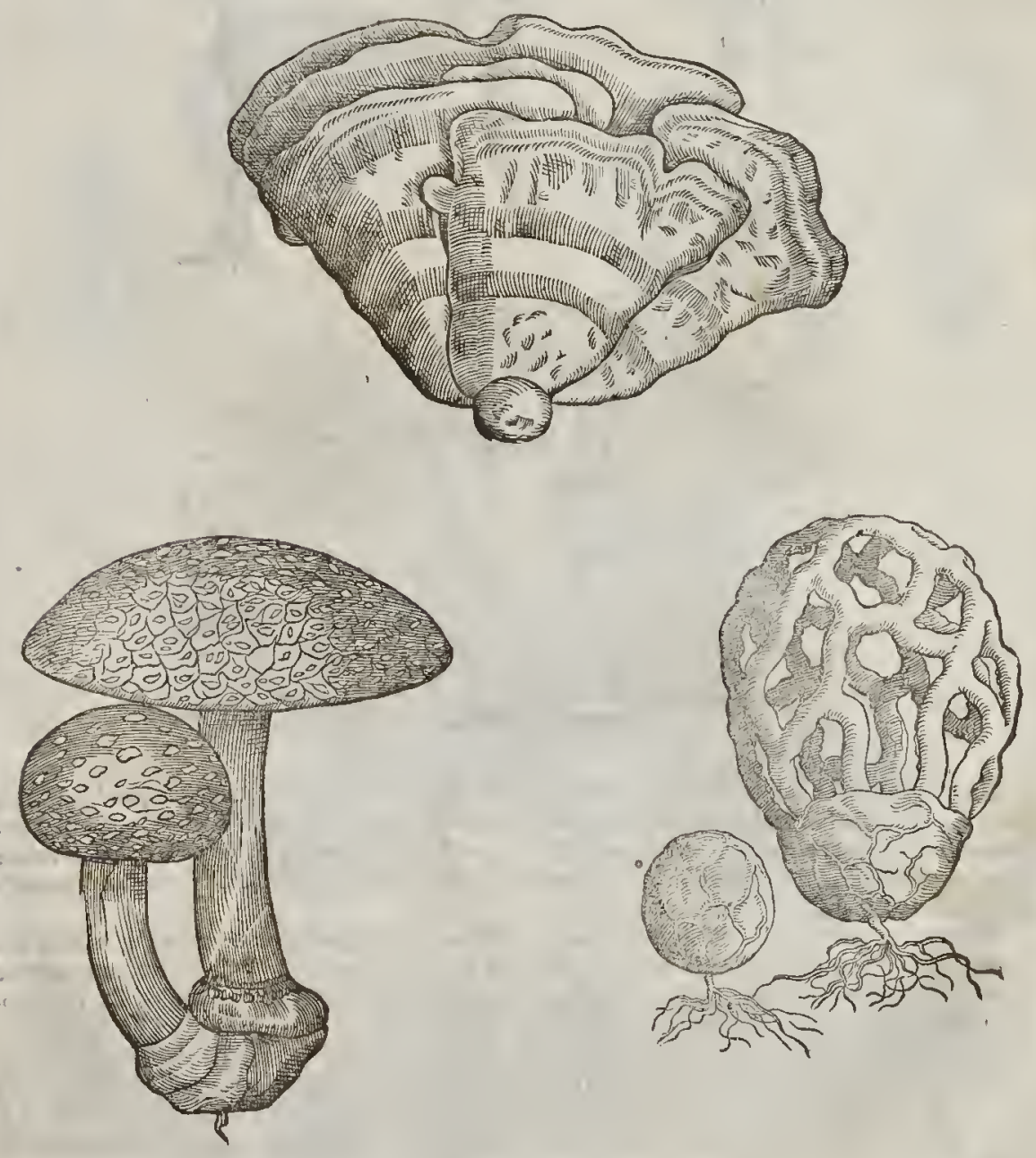

Rruts 
There is aifo found another, fet forth vnder the title Fungus sirilis penis arecti forma, which wee Englinh, pricke Muthrum, taken from his forme.

3 Fungrus orbicularis, or Lupi crepitus, fome do call it Luccrnarum fungus : in Englin, Fuffe balls, Puche Fulfe, and Bulfifts, with which in fome places of England they vfe to kill or fmolder their Bees, when they would driue the Hiues, and bereate the poore Bees of their mear,houfes, and liues: thefe are alfo vfed in fome places where neighbours dwell far a funder, to carry and referue fire from place to place, whereof it tooke the name, Lucernarum Fung us: in forme they are very round, ficking and cleauing vnto the ground, w ithout any ftalks or ftems; at the firft white, but afrerward of a duskifh colour, hauing no hole or breach in them, whereby a man may fee into them, which being troden vpon dobreath forth a moft thin and fine pouder, like vnto fmoke, very noifome and hurtfull vnto the eies, caufing a kinde of blindneffe, which is called Poor-blinde, or Sand-blinde.

Frngi lethales, five non efculenti. Poifonous Muhturums.
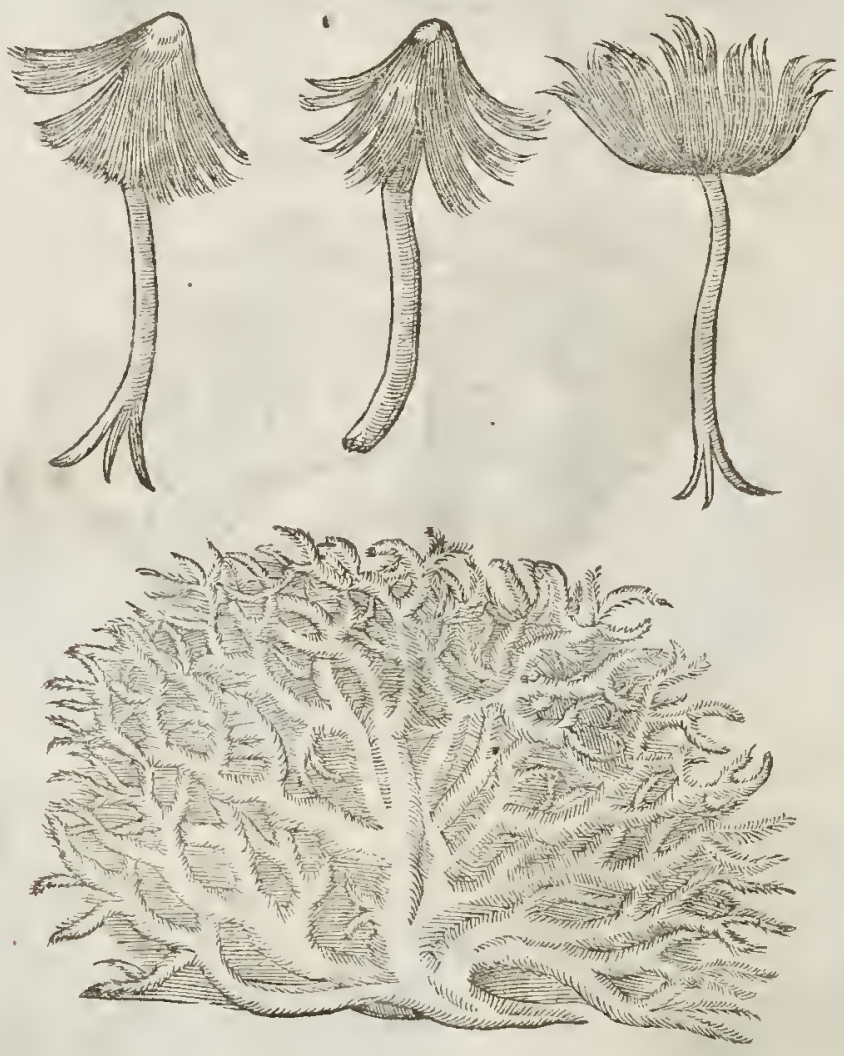

There is another kinde of $F u n g u s$, or Muthrum, which growerh in moift medowes, and by ditch fides, fiue or fix inches high, coured oner wirh a skin like a piece of theepes leather, of a rufiet coIour; which being taken aw ay there appeareth a long and white fumpe, in forme not much vnlike to an handle, mentioned in the ritle, or like vnto the white and tender ftalke of Aron, but greater:
this kinde is alfo full of venome and poifon.

There is likewife a kinde of Mufhrum, with a certaine round excrefcence, growing within the earth, vnder the vpper cruft or face of the fame, in dry and grauelly ground in Pannonia and the Prounces adioiningwhich do caufe the ground to fwel, and be full of hils like Mole-hils. The people where rhey grow, are confrained to dig them vp and caft them abroad like as we do Mole-hils. fpoiling rheir grounds, as Mole-hils are hurrfull vnto our foile ; thefe hate neither falks, leaules, fibres nor itrings annexed or faftened vnro them, and for the mott part are of a reddifh colour, but with in of a vhirint yellow: the Grecians haue called this tuberous excrefcence, Idna, and the La. tines $r$ rbera: the Spaniads do call rhem Turmas de ticra: in Englith wre may call them Spanith
Fuffebals.

$$
\text { TI The Place. }
$$

Mulhrums come vp about the roots of trees, in graffe places of medowes, and Ley Land newly 
Fungus fauizinofus.

Hony-combid Murhrome.

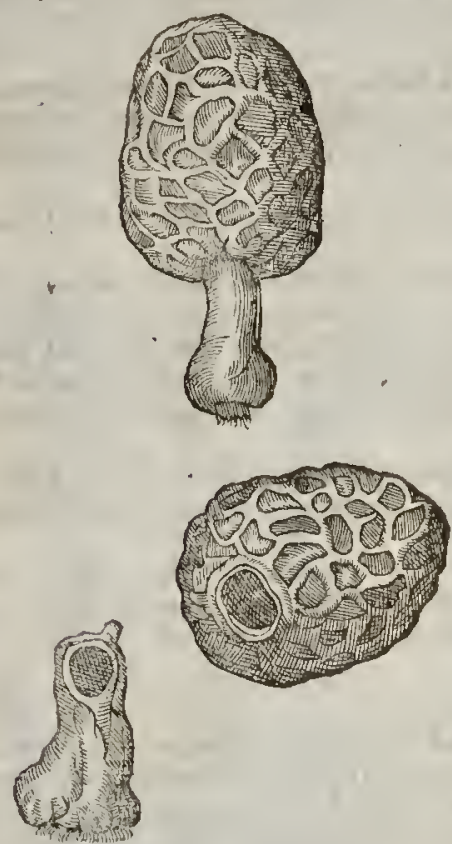

Fungus Virilis Pesis effigie. Pricke Mufhrom.

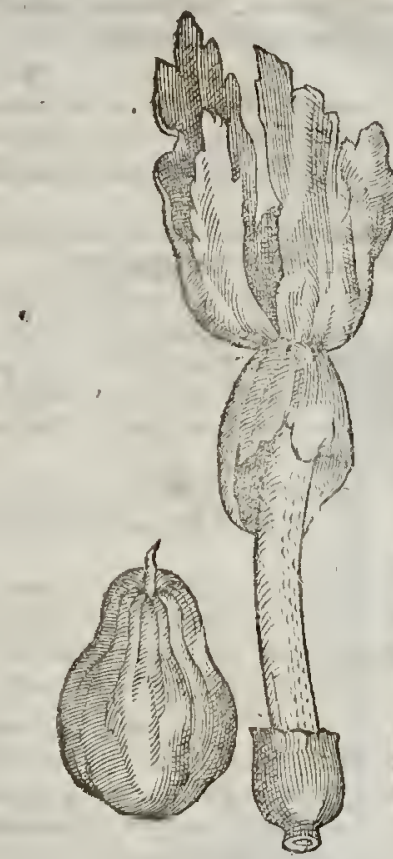

Tubera icres.

Fuffe-balls, or Puckfifts.

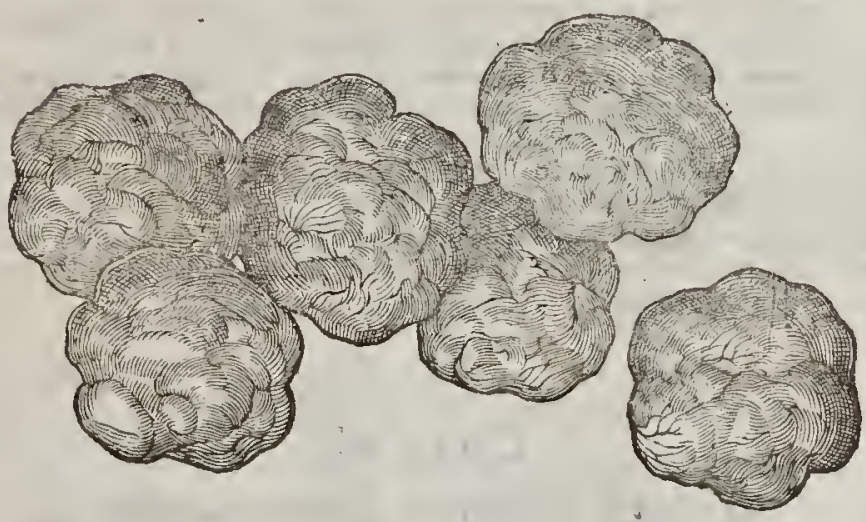

furued; inwoods alfowhere the ground is fandy, but yet dankin : they grow likewife our of wood, forth of the rotten bodics of trees, but they are vnprofitable and nothing worth. Poifonfome Mu1hroms, as Diofcurides faith, groweth where old rulty iron lieth, or rotren clouts, or neere to ferpents dens, or roots of trees that bring forth venomous fruic. Diuers efteene thore for the beft which grow in medowes, and vpon mountanes and hilly places, as Hor,ace faith, lib. fer. 2. fatyr.4,

$$
\begin{aligned}
& \text { paturacf, alijs male creditur. } \\
& \text { Natus op }
\end{aligned}
$$

The medow Muthroms are in kinde the bef; It is ill trufting any of the relt. 


\section{- The Time.}

Diuers come vp in Aprill, and lät not till May, for they flourith but whilef Aprill continues: others grow later, about Auguf, yet all of them after raine, and therefore they are tound one yere fooner, and another later. Muthroms, faith $\nu$ iny, grow in thoures of raine : they come of the flime of trees, as the fame Author affirmeth.

$$
\text { 9 The Names. }
$$

They are called in Latine, Fusgi : in Greeke, pimas : in Italian, Fong hi : in Spanifh, Hungos, Cuguminns: in French, Campmion, which word the low-Countrey men alfovfe, and call them $\mathbb{C a m}=$

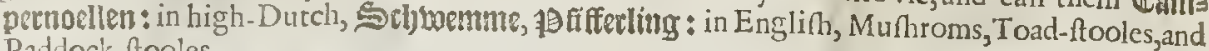
Paddock-ftooles.

The Mufhroms that come vp in Aprill are called in Latine of fome, spongiole : of the Italians, Prignoli : and in high-Dutch, 9 hoechel

They that are of a light red are called of fome Bolet;, among the later ones which rife and fall a: way in feuen dayes. The white, or thofe which be fomewhat yellow, are called in Latine, Suilli: which the later Phyfitions name Porcini, or Swine Mufhroms. Suilli, faith Pliny, are dried, being hanged vpon ruthes, which are thruft through them. The dry ones are in our age alfo eaten in Bohemia and Auftria : they that grow by the roots of Poplartrees are called of the Latines, Populne;, Ponlar Murhroms.

Puffes-fifts are commonly called in Latine, Lupi crepitus, or Wolfes fifts: in Italian, Vefcie de Lrpo: in Englifh, Puffes-filts, and Fufie-balls in the North. Pliny nameth them Pezica, as though he thould fay, fiat.

Tree Mulhroms becalled in Greeke, pumites : in Latine, Fungi arborum, and Fungi arborei : in Ens gifh, tree Muhtons, or Touch-wood : in high-Dutch alfo Schuemme. They are all thought to be poifonfome, being inwardly taken. Nicander writeth, that the Mufhroms of the Oliue tree, the Ilex tree, and of tic Oke tree bring death.

\section{of The Temperature and Vertues.}

A Galin afirmes, that they are all ve:y cold and moift, and therefore do approch vinto a venomous and nurthering facultie, and ingender a clammy, pituitous, and cold nutriment if they be eaten. Toconclude, few of then are good to be eaten, and moft of them do fuffocate and ftrangle the eater. Therefore I giue my aduice vnto thofe that lout fuch ftrange and new fangled meates, to beware of licking honey among thornes, left the fweetneffe of the one do not counteruaile,the tharp.
neffe and pricking of the other.

B Fuffe-balls are noway eaten : the pouder of them doth dry without biting : it is fitly applied to merigalls, kibed heeles, and fuch like.

C In diuers parts of England where people dwell farre from neighbours, they carry them kindled with fire, which lafterh long: whereupon they were called Lucernarum Fung $i$.

D The duft or pouler hereof is very dangerous for the eyes, for it hath been often feen, that diuers haue been pore-blinde cuer after, when fome fmall quantitie thereof hath been blowne into their eyes.

E The countrey people dovfe to kill or fmother Bceswith thefe Fuffe-balls, being fet on fire, for the which purpofe it fitly ferueth.

F $\ddagger$ The fungous excrefcence of the Elder, commonly called a Iewes eare, is much ved againft the inflammations and all other foreneffes of the throat, being bolled in milke, fteeped in beere, vineger, or any other conucnient liquor. $\neq$

\section{C н A P. 168 . Of great Tootb-wort, or Clownes Lung-wort. \\ T The Defcription.}

1 Here is often found among the Muthroms a certaine kinde of excrefcence confifting of be here inferted : it riferh fort and alfo in fubfance, hauing a the ground in forme like vnto orobanche, or the Broome-Rape, af alo offales like terth (whereof it tooke his name) of a dufty thining colour tending to purple. The ftalke rifeth vp in the midd le, garnithed with little gaping hollow foures like thofe of Satyrion; on the out fide of an ouerworne whirith colour : the whole plant refembleth a rude forme of that 
gellie, or flimie mattet, found in the fields, which we all the falling of farts : the toot is fmall and tender.

2 There is alfo another fort hereof found, not differing from the precedent : the chiefe diffe: tence confifteth in that, that this plant is altogether leffer; $\neq$ and hath a root diuerly diuaricared like Corall, white of colour, full of juice, and without any fibtes annexed theteto $\neq$; in othes refpects like.

I Dentaria maior Mathioli.

Great Toothwoort, or Lungwoort?

Sathrax squamaria

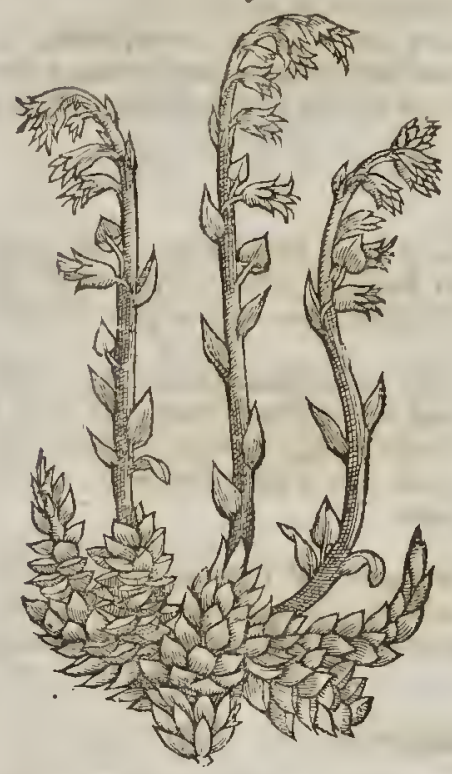

2 Dentaria minar. Little Lungw@ort. 


\section{IT The Defcription:}

I THe Saunders tree groweth to the bigneffe of the Walnut-tree, garnifhed with many goodly branches; whereon are fet leanes like thofe of the Lentiskc tree, alwaies greene; among which come forth very faire fioures, of a blew colour tending to blackneffe; after commeth the fruit of the bigneffc of a Cherry, greene ar the firlt, and blacke when it is ripe; wichout taftc, and ready to fall downc with cuery little blaft of winde : the timber or wood is of a white colour, and a very pleafant fmcll.

2 There is likewife auother which groweth very great, the floures. and fruit agree with the other of his kinde : the wood is of a yellowifh colour, wherein confifteth the difference.

$\neq 3$ The third fore which wee call Red -Saunders is a very hard and follid wood, hauing little or no fmell, the colour thercof is very red, it groweth not in thofe places where the other grow, neither is the forme of the tree defcribed by any that I know of, it is frequently ved to colous fauces, and for fuch like vfes. $\ddagger$

$$
\text { T The Place. }
$$

The white and yellow Saunders grow naturally, and that in great aboundance, in an Ifland callcd Timor, and alfo in the Eaft-Indies beyond the rituer Sanges or rather Ganges, which the Indians call Hunga, and alfo about Iaua, where it is of betrer odour than any that groweth elfewhere.

The red Saunders growes within the riter Ganges, efpecially about Tanafarim,and in the mar.: rifh grounds about Charamandell : Amecn, Serapio, and moft of the Mauritanians call it by a corrupt name, samlal: in Timor, Malaca, and in placcs neere adioyning, Chandama: in Decan and Guzarate, Scrumd. : in Latine, Sandalum and Santalim, ardding thereto for the colour album, falum, or Citrinman, aud rubrum, that is, white, ycllow, and red Saunders.

$$
\text { qI Thi Time. }
$$

Thefe trees which are the white and ycllow Saunders grow greene Winter and Sommer, and are not onc knowne from another, but by the Indians themfelues, who hate taken very certaine notes and markes of them, becaufe they may the more fpeedily diftinguifh them when the Mart commeth.

$$
\text { The Names. }
$$

Their names hate been fufficiently fpoken of in their defcriptions .

$$
\text { of The Temperature. }
$$

+ Yellow and whitc Saunders are hor in the third degree, and dry in the fecond. The redde Saunders arc not fo hot. $f$

\footnotetext{
A The Indians dovfe the decoction made in water, againft hot burning agues, and the ouermuch flow ing of the menfes, Erifipelas, the gout, and all inflammations, efpecially if it be mixed with the juicr of Nighthade, Hounlee'rc, or Purflane.

$B$ The whitc Saunders mixed with Rofe water, and the temples bathed therewith, ceafeth the paine of the megrim, and keepeth backe the flowing of humours to the eies.

C Luicen affirmeth it to be good for all pafions of the hart, and maketh it glad and merry, and thercfore good to be put in collifes, iellies, and all delicate meates which are made to ftrengthen and rcuiue the fpirits.

D $\neq$ Red Saunders hatc an aftrictite and ftrengthning facultie, but are not cordiall as the other two, they are vfed in diuers medicines and meates both for their facultie and pleafing red colour which they gite to them. $\neq$
}

\section{Cir A P.I70. Of Stony mood, or wood made Stones. T The Defcription.}

A Mong the wonders of England this is one of great admiration, and contrarie vnto mans reafon and canacitie, that there fhould be a kinde of wood alterable into thc hardneffe of a ftone called Stonie wood, or rather a kinde of water, which hardneth wood and other things, into the nature and matter of Rones. But we know that the workes of God are wonderfull, 
LIB.3.

Lignum Lapideum, fue in Lapides conwerfum. Stonie wool, or wood made ftones.

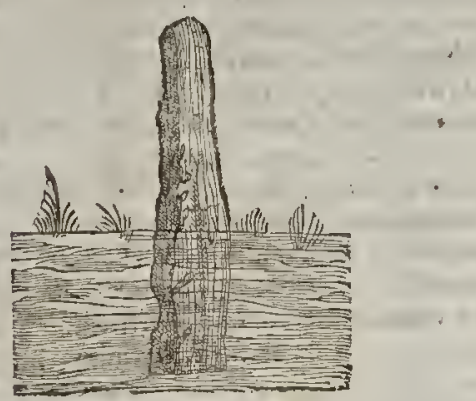

wonderfull, if we doe but nariowly feareh the leaft of them, whieh we dayly behold, mueti more if we turne our eyes vpon thofe that are feldome feene, and knowne but of a few, and that of fueh as haue painfully trauelled in the feerets of Nature. This ftrange alteration of nature is to be feene in fundty parts of England \& Wales, though the qualities of fome waters and carth,which ehange fueh things into ftone as do fall therein, or which are of purpofe for triall put into them. In the North part of England there is a Well neere vnto Knacsborough, whieh will eliange any thing into frone, whether it be woot, timber, leanes of trees, moffe, leather gloues, or fueh like. There be ditters places in Bedfordthire, Warwiek hire, and Wales, where there is ground
t part of the ftake which is within the ground of that qualitie, that if a ftake be drinen into it, that part of the ftake which is within the ground will be a firme and hard ftone, alid all thatwhieh is aboue the ground retaineth his former fub-
ftanee and nature. Alfo my feife being at Rougby (about fuch time as our fantalticke people did with great coneouirfe and multitudes repaire and runlieadlong vnto the facred Wells of Newnam $R c g$ is, in the edge of Warwickinire, as vnto the water of life, which could cureall difeafes) I wene from thenee nnto there Wells, where I found growing ouer the fame a faire Afh tree, whofe boughes did hang oucr the fpring of water, whereof fome that were feare and rotten, and fome that of purpore were broken off, fell into the water, and were all turned into ftones: Of thefe boughes or parts of the tree I brought into London, which when I had broken in pieces, therein might be feene, that the pith and all the reft was turned into ftones; yea many buds and flourings of the tree falling into the faid watet, were alfo turned into hard ftones, ftill retaining the fame ihane and fafhion that they were of before they were. in the water. I doubt not but if this water were proued about the hardning of fome Confe etions Pliy fieall, for the prefertation of them, or other fpecial ends, it would offer greater oceafion of admiration for the health and benefit of mankindc, than it dotl about fueh things as already hauc been expetimented, tending to very little purpofe.

\section{C на Р. I7.}

\section{Of the Goofe tree, Barnacle tree, or the tree bearing Geefe.}

Britannice Conchs anatifore.

The breed of Barnacles.
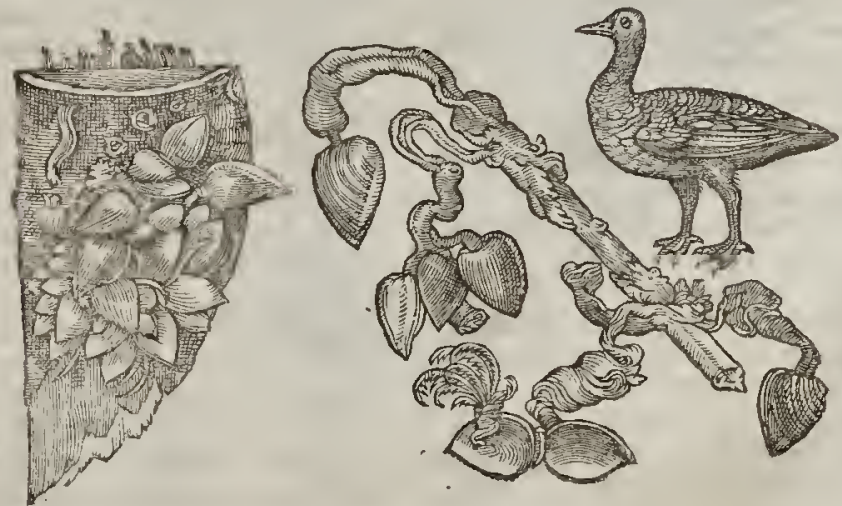


\section{The Defoription.}

$\mathrm{H}$ Auing traulled from the Graffes growing in the bottome of the fenny waters, thc Woods, and mountaines, euen vnto Libanus it felfe, and alfo the fea, and bowels of the fame, wee fame, ro end with one of rhe maruells of th is of rofer forth according ro the wh peculiar volume, bur alfo a deever fearch into the bowels of , would not only reçuire a large and fuffer me towade inro, my fufficiencie alfo onfided of nature, than my intended purpotewil vnto fome excellent men, learned in the fecrets of natur, leauing the hiftorie thereof rough hewen, fpace rake it as ir falleth out, the naked fects of nature, to be both fined and refined : in the mean North parts of Scotland and the Inlands a diath, though vnpolithed. There are found in the certaine thells of a whire colour tending to rufet, whele Orchades, certain trees whereon do grow which fhells in rime of maturitic dongen to ruffet, wherein are contained little liuing creatures: falling inro rhe warer do become fowen, and out of them grow thofe little liuing things, which Geefe; and in Lancafhire, tree Geefe : b which we call Barnakles; in the North of England, brant nothing. Thus much by the recle : but the other that do fall vpon the land perifh and come to which may very well aecord with ruth.

But what oureyes han in Laneathire called the Pile of Foulders, wryerein touched we fhall declare. There is a fmall Inand fhips, fome whereof have been caft rhirher wherein are found the broken pieces of old and bruifed branches of old and rotten trees, caft vp there likewife; whe, and alfo the trunks and bodies with the that in time breederh vnto certaine thels, in thap lite; whercon is found a certainc fpume or froth and of a whitill colour : wherein is cons, in thape like thofe of the Muskle, but tharper pointed, it were rogether, of a whitill colour, one end where in forme like a lace of filke finely wour as

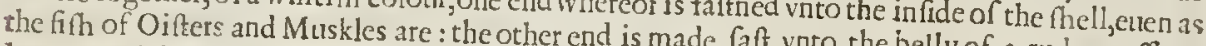
lumpe, which in time thell gapeth open, and the firft thing that append forme of a Bird: when it is perfeetly formed the lcgs of the bird hanging out, and as it groweth oreater it the forefaid lace or fring; next come tlic it is all come forrh, and hangeth onely by the bill tie, and falleth into the fea, where ir gathereth fearhers and frace after it commerh to full maturilard, and leffer than a Goofe, hauing blacke legs and bill or growerh to a fow le bigger than a Malfpotted in fich manner as is our Mag-Pie, called in fom or beake, and feathers blacke and white, Lancanire call by no orher name than a rree Goofe : ioyning do fo mucl abound therewith, thatee Goofe : which place aforefaid, and all thofe partsadhereof, if any doubr, may it pleafe then to repaire vnto bef is bought for three pence. For rhe truth monic of good witneffes.

Moreouer, it thould feeme that there is another fort hereof; the hiftorie of which is true and of mine owne knowledge : for trauclling vpon the fhore of our Englih coaft betweene Dourer and Rumney, I found rhe rrunke of an old rorten tree, Thermens iviues that were rhere artending their husch (with fomehelpe that I procured by Fiwater vpon dry land : vpon this rotren tree I found growing many thoufands of we drew out of the ders, in fhape like vnto puddings newly filled, before they be fodden whis of long crimfon bladfhining ; at the nerher end whereof did grow a but much whiter, refembling a thell fin rhat growerh wa fhioned fomewhat like a fmall Muskle, called a Lympit: many of thefe fhells I bronghr with won the rockes about Garnfey and Garfey, found in them liuing things wirhout formeng with me to London, which after I had opened I I found liuing things that were very naked in thape; in orhers which were neerer come toripenes fofr downe, the thell halfe open, and naked, in thape like a Bird: in orhers, the Birds conered with called Barnakles. I dare not abfolurely auouch ready to fall out, which no doubr were rhe Fowles concerning the tree thar beareth thofe buds a fortery circumftance of the firtt part of this hiftory, howbeit thar which I hate feene wirh mine a forefaid, burwill leate it to a further confideration; ly ailouch, and boldly pur downe for mine eyes, and handled wirh mine hands, I dare confidentmight be one of thofe beforementioned had been ouerturned, as manv orher rrees are; or rhat any trees falling into or fome violent wind Orchades, will of thenfelues beare the like fow les, by reafon of rhing into thofe feas abour the fo prcbable coniectures, and likely to be rruc, I may nor fon of rhofe feas and waters, thefe being to eoniure.

¥ The Barnakle, whofe fabulous breed my Author here fets downe, and diuers others haue 
a!ro delivered, were found by fome Hollanders to haue another originall, and that by egges, as other Birds hate : for they in their third voyage to finde out the North-Eaft paffage to China, and the Molueco's, about the eightieth degree and eleuen minutes of Northerly latitude, found two little! Itands, in the one of which they found aboundanee of thefe Geefe fitting vpon their egges, of which they got one Goofe, and tooke aw ay fixty egges, \&xe. Vide Pontani, recum do vrb. Amftelodsm. Hift.lib.2. cop 22 . Now the thells ont of which thefe birds were thought to fly, are a kinde

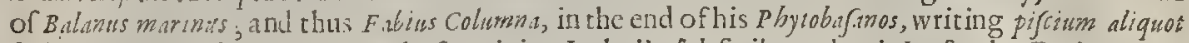
bifforia, iudiciotily proues: to whofe opinion I wholly fubferibe, and to it I refer the Curious. His

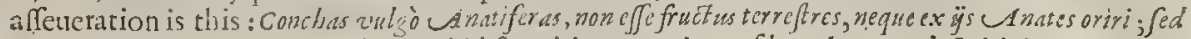
Balanimarina peciem. I could hauc faid fomthing more hercof, but thus mueh I thinke may ferue, together with that which Fódiss colimma hath written vpon this foint. $\neq$

$$
\text { if The Place. }
$$

The borders and rotten plankes whercon are found thefe fhels wherein is bred the Barnakle, are taken vp in a frnall Inand adioyning to Lancahire; halfe a mile from the maine land, called the pile of Foulders.

$$
\text { T. The Time. }
$$

They fpawne as it were in March and A prill; the Geefe are formed in May and Iune, and cone to fulncffe of fathers in the moneth after.

And thus hauing through Gods affitanee difcourfed fomewhat at large of Graffes, Herbes, Shrubs, Trees, and Moffes, and eertaine Exerefences of the earth, with other things moe, incident to the biftorie thereor, we conelude and end our prefent Volume, with this wonder of England. For the which Gods name be euer honored and praifed.

\section{FINIS.}

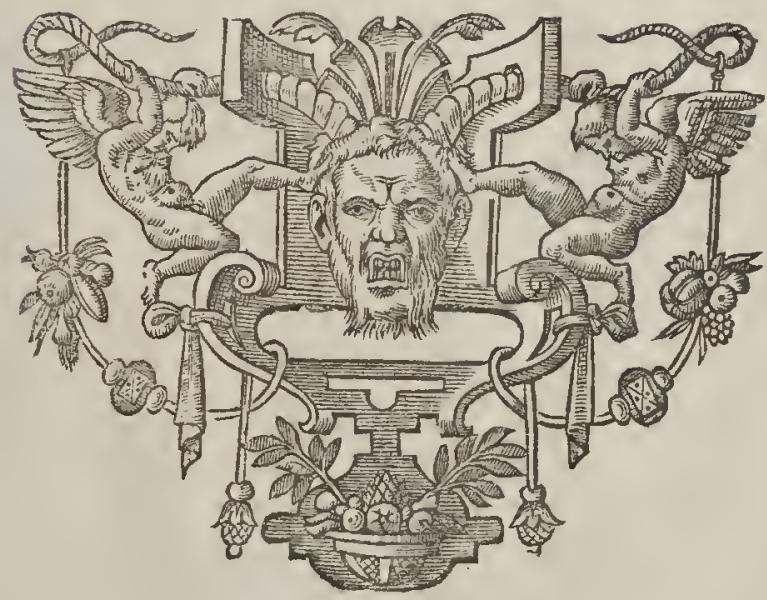




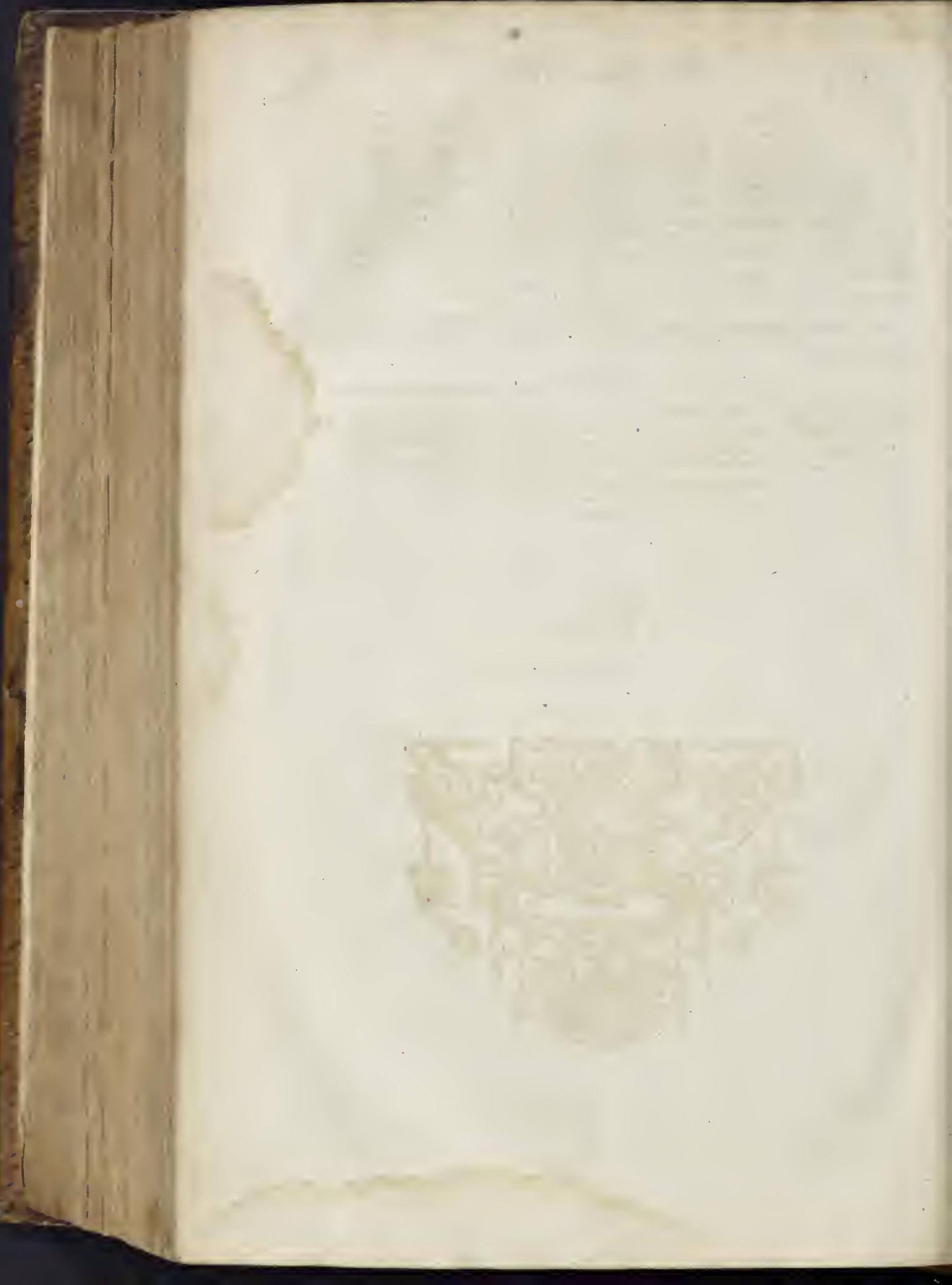




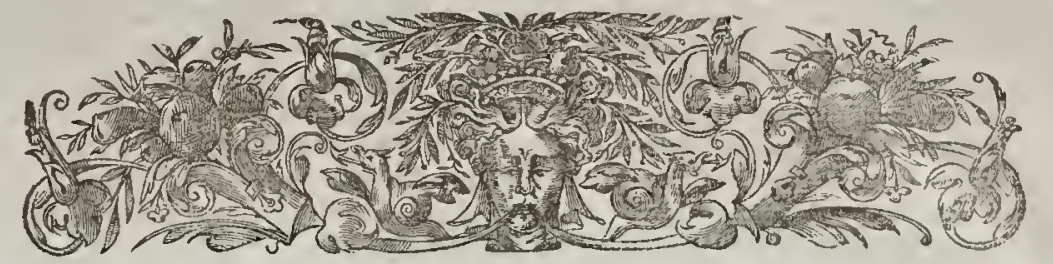

\section{A N A P PENDIX OR A D ITIO N OF certaine Plants onitted in the former Hiftorie.}

\section{The Preface.}

Meven Auing run through the Hiftoric of Plants gathered by $\mathrm{M}^{\mathrm{r}}$. Gerrard, and much enlarged the 2 20. fame both by the addition of many Figures and hiftories of Plants not formcrly contained in it,and by the amending and cncreafing the hiftoric of fundry of thofe which before were therein treated of; I finde that I haue forgotten diuers which I intended to haue added in their fitting places : the occafion hereor hath becne, my many bufineffes, the troublefomeneffe, and aboue all, the great cxpectation and liaft of the Worke, whereby I was forced to performe this task within the compaffe of a yeare. Now being conftant to my firit refolution, I here haure, as time would giue me leauc, and my memorie ferue, made a briefe collection and addition(thongh without method) of fucl as offered themfelues vnto me; and without doubt there are fundric others which are as fitting to be added as thofe; and I thould not haue been wanting, if time would have permitted me to haue entred into further confideration of them. In the meane time take in good part thofe that I haue here prefented to your view.

\section{Cна в. I. Of the Maracoc or Pafion-floure. 9ा The Defoription.}

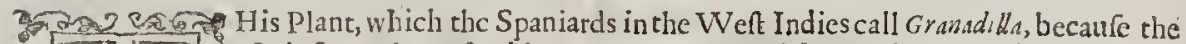
165. Fin fruit foncwhat refembles a Pomegranat, which in their tongue they tetm Gra-

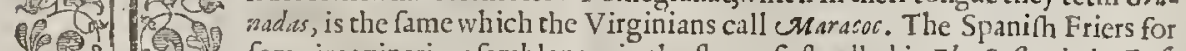

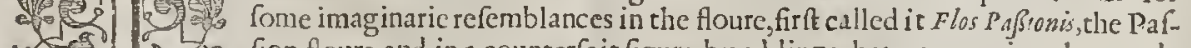

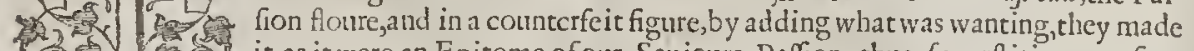
16 30 it as itwere an Epitome of our Sauinurs Paffion: thus fupertitious perfons

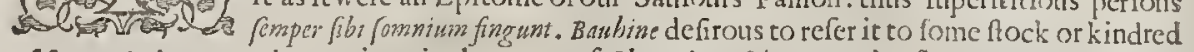
of formerly knowne plants, gitues it the name of Clematis trifolia : yet the floures and fruit pronounce it not properly bclonging to their Tribe; but Clemat is being a certaine genericke name to all wooddy winding plants, this as a fpecies may come vnder the denomination, though little in other refpeets participating with them. The roots of this are long, fomewhat like, yet thicker rian thofe of Surfaparills, running vp and downe, and putcing vp their heads in feuerall placcs:from thefe roots rife vp many long winding round italkes, which grow two, three, foure, or more yards high, according to the heate and feafonableneffe of the yeare and foile whereas they arc planted: von thefe ftalkes grow many leanes diuided into three parts, tharpe pointed, and fnipt about the edges : commonly out of the bofomes of each of the vppermolt leates there growerh a clafping tcadrcll and a floure : the floure growes von a little foot-ntalke fome two inclies long, and is of $a$ longith conered forme, with fiue little crooked hornes at the top, before fucl time as it open it felfe; but opened, this longifh head dinides it felfe into ten parts, and fuftaines the leatres of the ftoure, which are very many, long, tharpe pointed, narrow, and orderly fpred open one by another, fome lying traight, others crnoled : thefe leates are of colout whitinh, but thicke fpotted witla a Peach colour, and towards the bottome it hath a ring of a perfe et Peach colour. and aboue and bencath it a whice ciscle, which gite a grear grace to the floure; in the middeft wherenf rifes an vmbrane, which parts it felfe into foure or fiue crooked fpotted lorncs, with broadifh beals: from Seffer 2 


\section{2}

\section{An Appendix to}

the midft of thefe rifes another roundith head which carries thrce nailcs or hornes, biggeft at one, and fmalleft at their lower end : this floure with vs is neuer fucceeded by any fruit, but in the H'ct Indies, whereas it naturally growes, it beares a fruit, when it is ripe of the bigneffe and colour of Pomegranats, but it wants fuch a ring or crown about the top as they hatue; the rinde alfo is much thinner and tenderer, the pulpe is whitioh, and without tafte, but the liquor is fomwhat tart : they open them as thcy doegges, and the liquor is fupped off with great delight, both by the Indians and Spaniards, (as Monardus witnelleth) neither if they fup off many of them thall they find their ftomack oppreft, but rather their bellies are gently loofned. In this fruit are contained many fecds fomwhat like Peare kernells, but more cornered and rough.

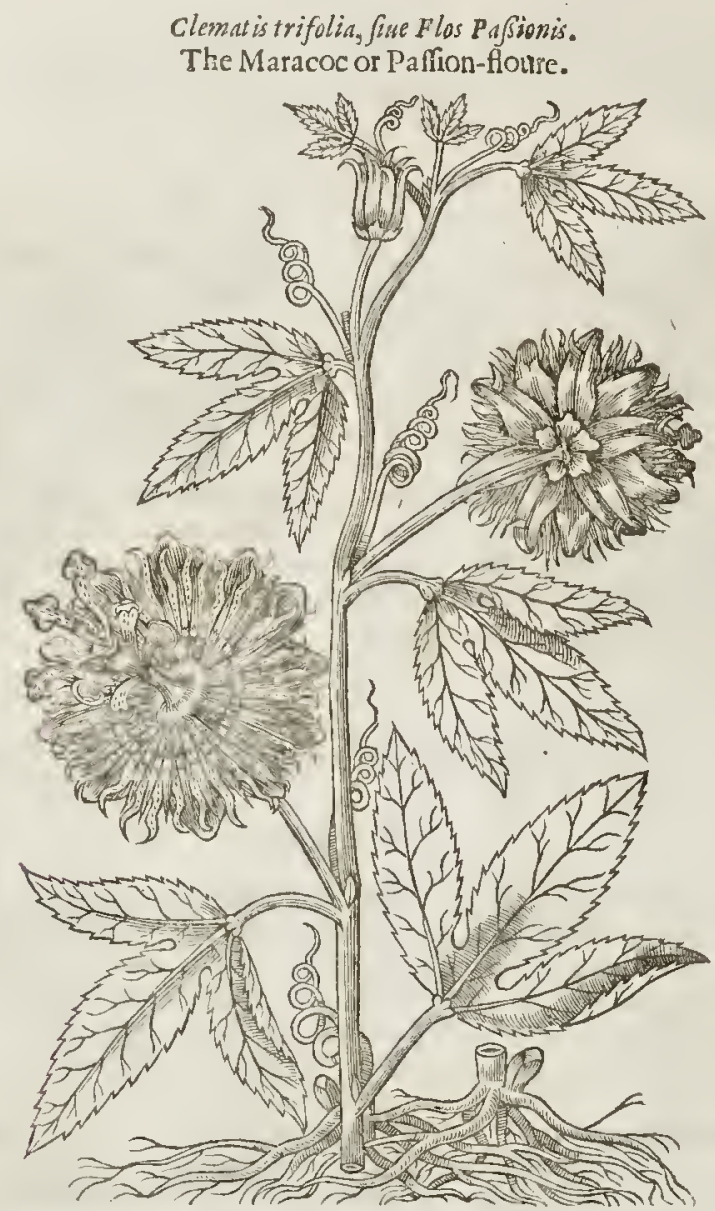

This growes wilde in moft of the hot countries of America, from whence it hath been brought into our Englith gardens, where it growes very well,but floures only in fome few places, and in hot and feafonable yeares : it is in good plenty growing with Mifreffe Tuggy at Weftminfter, where I hate fome yeares feene it beare a grear many floures.

\section{C н A. 2. Of Ribes orred Currans.}

\section{The Defcription.}

1 Te plant which carries the fruit which we commonly terme red Currans, is a thrubbie whice with of the bigneffe of a Goofeberry buh, bur withour prickles : the wood is foft and White, with a pretty large pith in the middle $:$ it is conered with a double barke, the vndermoft, being the thicker, is greene, and the vppermont, which fometimes chaps and pills off, is of a brownifh 
colour, and fmoots: the burke of the yongett fhoors is whition and rough : rhe leaues, which grow vpon foortalkes fome two inches long, are fomewhat like Vine leaues, bur fanaller by much, and lefie cornered, being cut into three, and fometimes, but feldomet, into fitle parts, fomwhat thicke, with many veines running ouer them, greener aboue than they are below : out of the branches in Spring time grow ftalkes hanying dow we fome fix inches in lengch, carrying many lirt! greenifh Aoures, which are fucceded by little red berries, cleare and fmooth, of tre bigneffe of the Whortle berries, of a pleafant tart tafe. Of chis kinde there is another, onely different from this in the fruit, whicl is try ice fobig as that of the common $k$ ind.

4he 2 The which beares the whice Currans is commonly ftraighter and bigger than the former : the leaues are lefter, the floures whiter, and fo alfo is the fruit, being cleare and tranfparent, with a little blachith rougli end.

I Ribes vulgaris fructu rubro. Riles Red Currans.

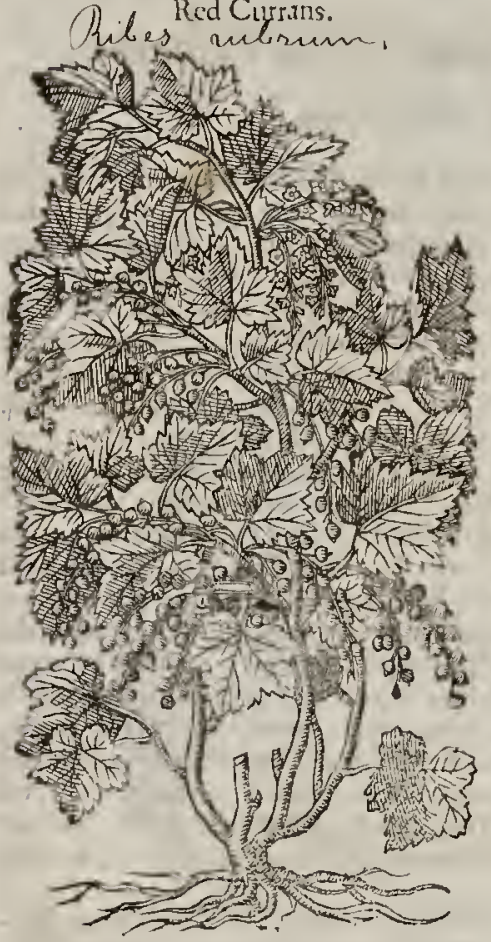

2 Ribes fruitualio.

Yhite Curians.

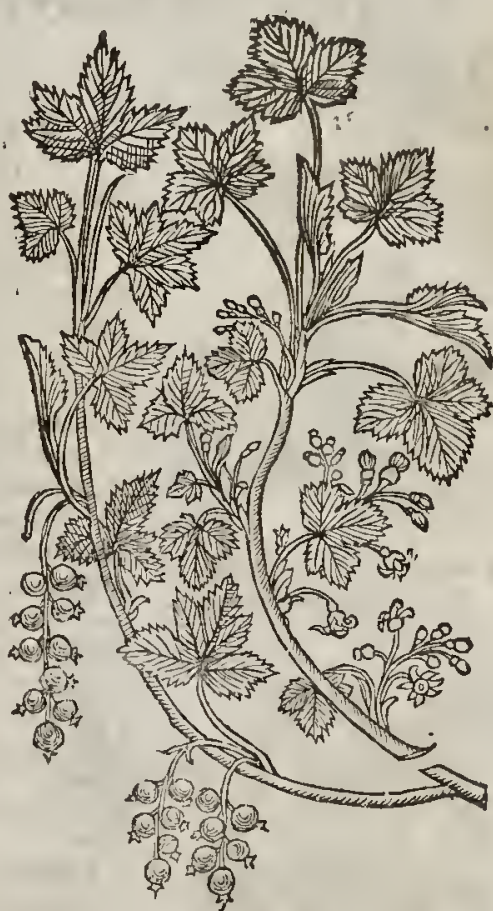

3 Befides thefe there is another, which differs little from the former in thape, yet grows fontwhat higher, and lach le ffet leaues : the floures are of a purplin green colour, and are fucceeded by fruic as big againe as the ordinary red, but of a linking and fomewhat loathing fatour : the leates alfo are not without this finking fnell.

$$
\text { 91 The Place, Time, and Nimes. }
$$

None of the fe grow wild with vs, but they are to be found plentifully growing in many garderis, efpecially' the two former, the red and the white.

The leates and floures come fortlx in the Spring, and the frut is ripe about Midfommer.

This plant is thought to hatre been vnknowne to the antient Greekes : fome thinke it the $R$ ibes of the Arabiin Serapio . Fuchfius, Mathiolus, and fome other deny it; notivith?tanding Dodonew affirms it : neither is the controuerfie eafily to be decided, becaufe the Author is briefe in the defcription thereof, neither haue we lis words but by the hand of a barbarous T tanflator. Howcter the fhops of late time take it (the faculties confenting thereto) for the true Ribes, and of the fruit hereof prepare their Rob de Ribes. Dodonsus ealls it Ribefum, groffularia rubra, or Groffulariatranfmarina; and they are diftinguifhed into three furts, Rubra, Alba, Nigra Ribefia, red, wh hite, and blacke

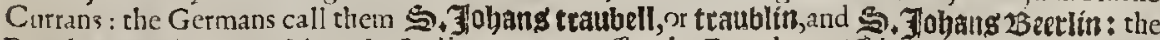

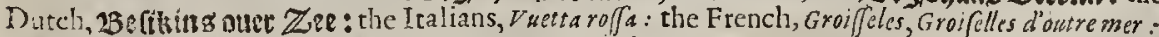
the Bohemians, 3 aboui $\Phi$. Jana : the Englif, Red Clitrans : yet mutt they not be confounded $\operatorname{SifRS} 3$ 
with thofe Currans whieh are btought from Zant, and the eontinent adioyning thereto, and which arevuIgarly fold by our Groeers; for they ate the truit of a fmall Vine,and differ much from thefe. The Temperature and $V$ crtues. A The berries of red Currans, as alfo of the white, are cold and dry in the end of the fecond degree,
and hate fome antiction, tosether with tenuitic of parts.

B They extinguifh and mitigate feueri h heates, repreffe eholet, temper the outer-hot bloud, refift putrefasion, queneh thir t, helpe the deiection of the apperite, ftay eholericke vonitings and feourings, and helpe the Dy fenteric proceeding of an hot eaufe.

C The inice of thefe boiled to the height of honey, either with or without fugar (whieh is ealled rob de Ribes) hath the fame qualities, and eonduees to the fame pirpofes.

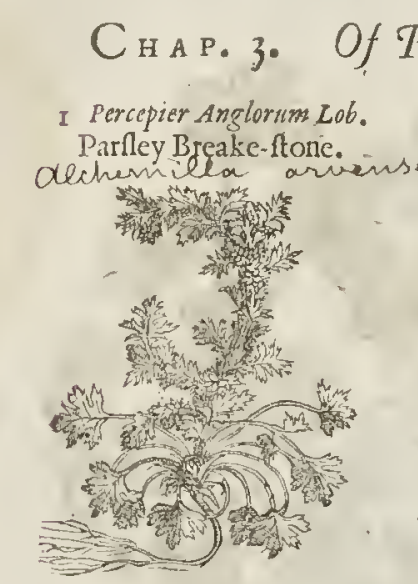

2 Polygoni Herniarie facie. Baftatd Rupture-wort.

D

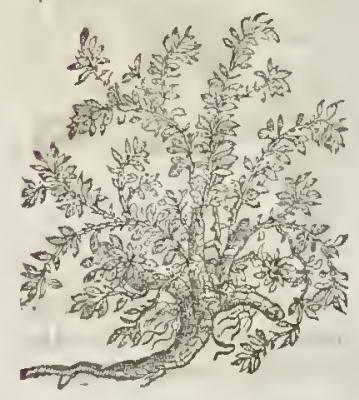

Parfley Breake-flone, and baftard Rupturemort.

If The Defoription. i 1 Thought it was not altogether incontenient to couple thefe iw o Plants together in_one Chapter; firft, tecaufe they are of one ftature; and fecondly, tak in cur of one and the fame Hiftory of Plants, to wit, the Aducrjaria of Pena and Lobel.

The firft of thefe, which the Authors of the Aduer faria fet forth by the name of Percepier, (and rather affert, than affirme to be the Scandix of the Anticnts) is by Tabernamontanins enlled Scendix minor:

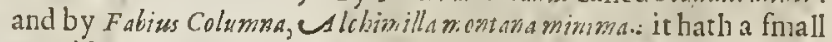
wooddy y ellowith fibrous toot, from which rife sp one, two, or more little flalks, feldome exceeding the height of an handfull, and thefe. are round and hairy, and wp on them grow little round inh leates, like the tender leaues of Cheruill, but hairy, and of a whitifh green coIour, faftned to the ftalkes with fhort foot-ftalkes, and hauing little eares at their fetting on : the lioures are fmall, greene, and five cotnered, many eluftering together at the fetring on of the leates: the feed is fmall, fmooth, and yellowith : the ftalks of this plant gtorr fomerimes vptight, and otherwhiles they lean on the ground $\mathrm{ir}$ is to be found vpon diturers dry and barren grounds, as in Hide Parke, Tuthill fields, \&e. It floures in May, and ripens the feed in Iune and Iuly. It feemes by the Authors of the Adurer /aria, that in the Wert eountrey about Briftow they eall this Herbe Pereepier; but our herbe women in Cheapfide know it by the name of Parfley Breakeftone.

This is hot and dry, and of fubtil parts : it vehemently and fpeedily moues vrine, and by fome is kept in piekle, and earen as a fallad.

The diftilled water is alfo conmended to be effectuall to moue vrine, and elenfe the kidnies of grauell.

2. The hiftorie of this, by the forementioned Authors, Aduerfo pag. 404. is thus fet fortli vnder this title, Polygonium Herniarie foligs e' facie, peramplaradice Aftra. galitidi : Neither (fay they) ought this to be defpifed by fueh as are ftudious of the knowledge of Plants; for it is very litrle knowne, being a very fmaill herbe lying along vpout the ground, and almoft oucrwhelmed or eouered with the graffe, hauing little branches icry full of oints : the little leates and feeds are whitin, and very like thofe of Herriaria or Rupture-wort : the whole plant is white, hauing a very fnall and moffie floute : the toot is larger than the fnialneffe of the plant feemetl to require, hard, branched, diuerfly turning and winding and therefore hard to be plucked vp: the tafte is dry and hottifh. It growes vpon a large Plaine in Proininee, betwec ne the eities Artes and Selon. Thus miveh Pennand Lobcl. I am deeeiued, if fome ferw yeares agone I was not fhewed this plant, gathered in fome part of this kingdome, but where, I am not able to affirme. 


\section{Cна р. 4. Of Heatb Spurge and Rocke Rufe}

\section{Tा The Defcription.}

7 Hefe Plants by right thould have followed the hiftorie of Thymelea, for in thape and facultie they are not much val ike it. The firtt is a low thrub, fending from one root many branehes of fome cubit long, and thefe bending, flexible, and couered with an outer blackifh barke, whieh eomprehends another within, tough, and which may be ditided into fine threds: the leaues are like thofe of Chanale a, yet leffer, horter and thicker, a litrle rough alfo, and growing about the branehes in a eertaine order: if you ehew then they are gummie, bitter at the firft,and afterwards hot and biting : the floures grow among the leaues, longith, yellowith, and di. uided at the end into foure little leaues : the fruit is faid to be like that of Thymalea, but of a blite. kifh eolour, the root is thicke and woodd ie. It growes frequently in the kingdome of Granadoand Valentia in Spaine, it floures in Mareh and Aprill. The Herbaritts there terme it Sanamunda, and the common people, evicrda-cruzby reafon of the purging faeultie.

I Sanamunda I. Clur.

Heath Spurge.

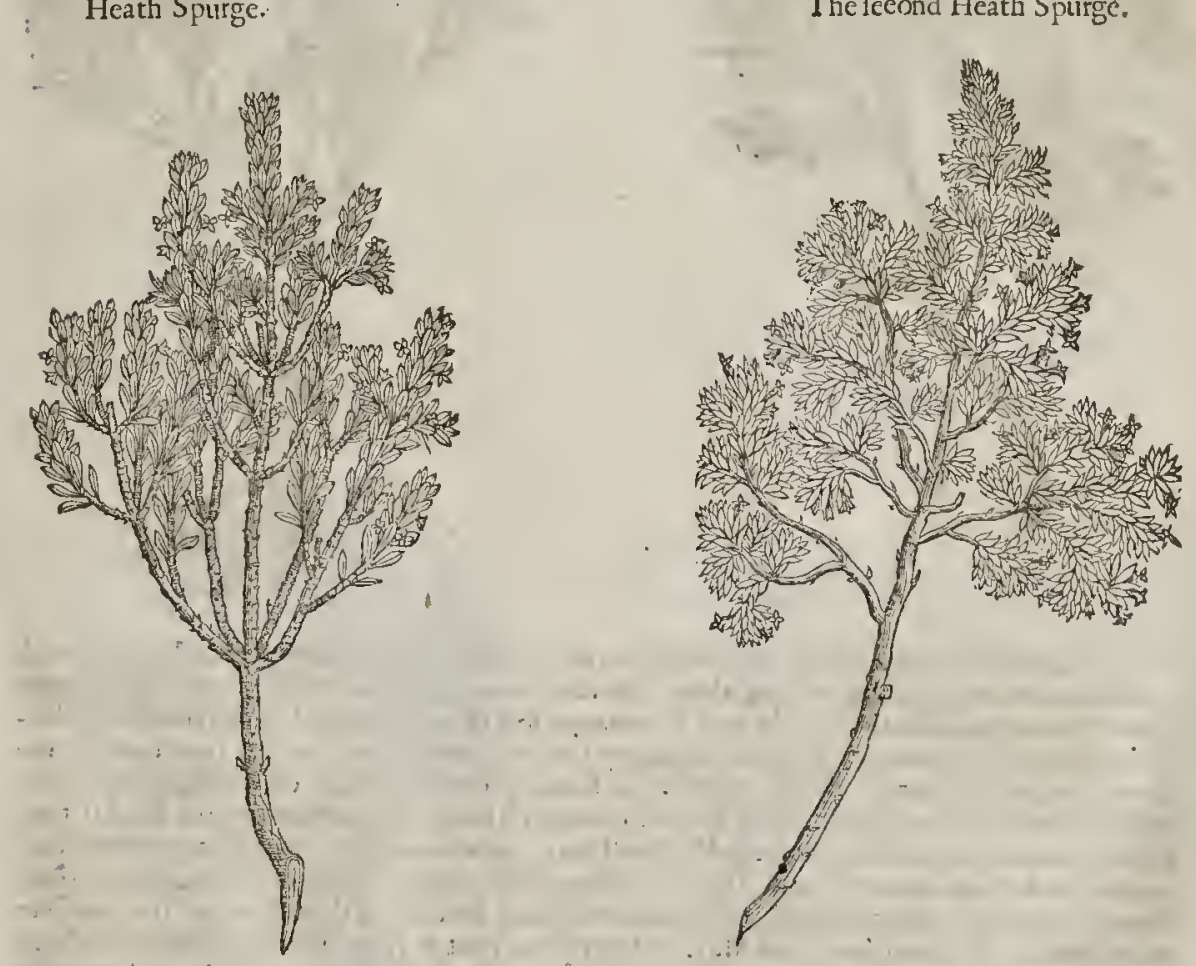

2 Smamunda z.Cluf. The feend Heath Spurge.

2 The other is a firub fome cub it high, haung tough fexible branehes eouered with a denfe and thiek barke, wh ieh, the outw ard rinde being taken away, ouer all the plant, but ehiefely next the root, may bedrawn into threds like Flax or Hemp : the vpper branehes are fer with thiek, ihort, fat, rough fharp pointed leaues, of fomwhat a faltin tafte at the firf, a fterwards of a hot \& biting tafte: the floures are many, little and yellow: the root is thicke and woodd ie like as that of the former this growes vpon the fea coaft of $S$ paine;andon the mountaines nigh Granado, where they call it $S$ anaznunda, and the eonmon people about Gibraltar eall it Burhalaga, and they only vfe it to heat their ouens with. It Houres in Februaric. "Angrisillara ealled this, Empetron: Cafalpinus, Cacoron, and in the Hiftoria Lugd it is the Cneoron nigrum Myconi: Sefamoides minus: Dalcchamp $\ddot{y}_{2}$ and Phacoides, Oribafij quibufdam. 
3 This is bigger than either of the two former, hauing whiter and more flexible branches, whofe barke is unmea furably tough and hard to breake : the vpper branches are many, and thofe very downie, and hanging downe their heads, fet thicke with little leaues like Stone-crop, and of the like hot or burning facultie: the floures are like thofe of the former; fometimes greenith, otherwhiles yellow : Clus fus did not obferue the fruit, but faith, it floured at the fame time with the former, and $\mathrm{grew}$ in all the fea coaft, from the Straits of Gibralter, to the Pyrenæan mountaines. $\mathrm{Ab}$ fon fus pantins called this Cneorov: Lobel and Tabernamontanus call it Erica Alexandrina.

3 SAmamunda 3.Cluf.

The third Heath Spurge.

Pafserina hirsuta.

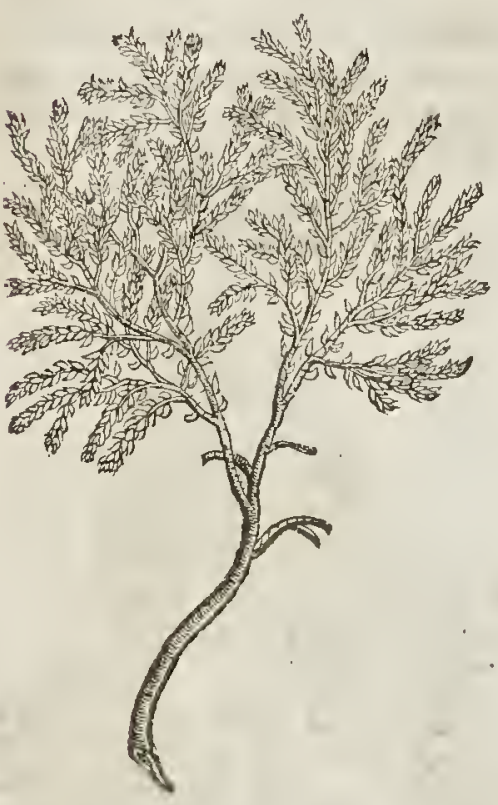

4 Cheoren eMattbioli. Rocke Rofe.

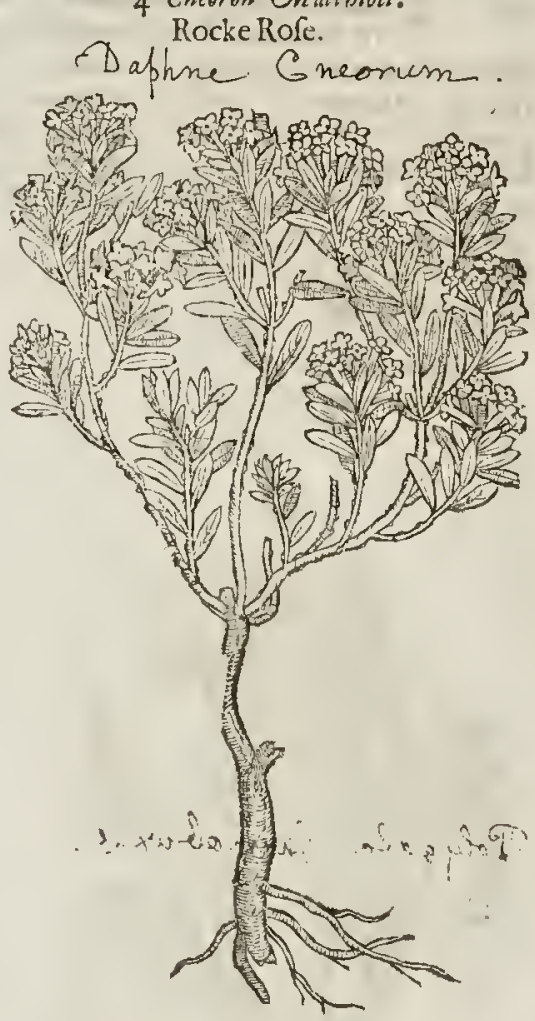

4 This alfo may not unfitly bee ioined to the former, for it hath many tender ficxible tough branches commonly leaning or lying along vpon the ground, vponwhich without order grow leaues greene, skinny, and like thofe of the true T hymelea; at firft of an ungratefull, and afterwards of a bitter tafte,yet hauing none or very little acrimony (as far as may be perceiued by their tafte: ) the floures grow vpon the tops of the branches fix feuen or more together, confifting of foure little leaues of a reddin purple colour, very beautifull and well fmelling, yet offending the head if they be long fmelt vnto : thefe are fucceeded by fmall berries, of colour white, containing a round feed, coured with an an coloured skin. The root is long, of the thickeneffe of ones little finger, fometimes blackirh,yet moft commonly yellowith, tough, and fmalleft at the top where the branches come forth. It floures in Aprill and May, and ripens the fruit in I une : it foures fometimes thrice in the yeare, and ripens the fruit twife; for Clufress affirmes that twife in one yeare he gathered ripe ber ries from one and the fame plant. It growes plentifully vpon the mountainous places of Auftria about Vienna; whither the countrey women bring the foures to the market in great plenty to fell them to deck vp houfes : it grows alfo in the dry medowes by Frank ford on the Mcene, where there is obferued a variety with white floures. Matthiolus would haue this tobe the Cneoron album of $T$ heophrafus : Cordus calls it $T$ hym elea minor : it is the Cneoron alterum Matthioli, and oleander fyl. Auifersize Myconi, in the Hift. Lugd.The Germans call it Stein 1 ofolin : and wee may call it Rocke Rofe, or dwarfe Oleander.

5 This plantby Eaubine is called Cneorum album folio olee argenteo mollt: and by Dalechampits, Cncorum album, which hath been thereafon I haue put it here yalthough afalpinus, Impcratus, and $P l_{\text {a- }}$ 
5 Cneorum album folys argenteis. White Rocke Rofe. convolucelus Cneoum

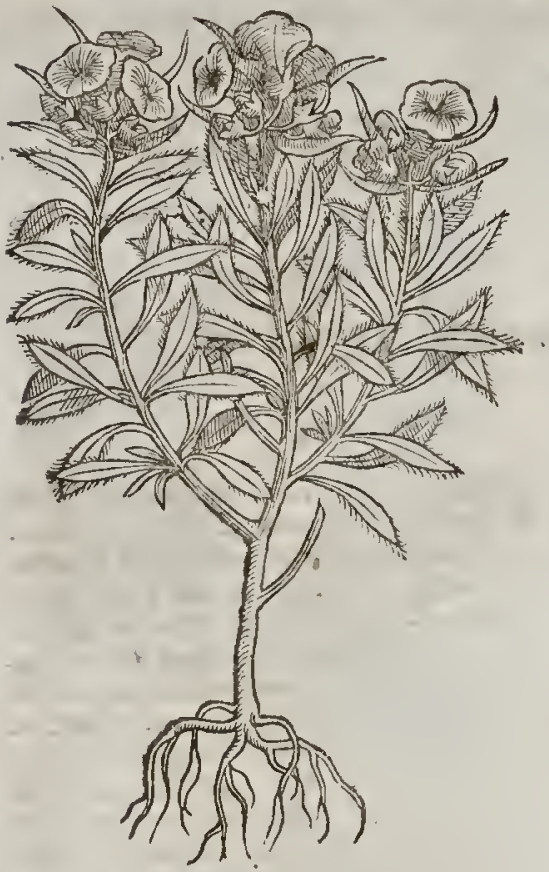

chamabuxus flore Colstes?

Baltard dwarfe box.

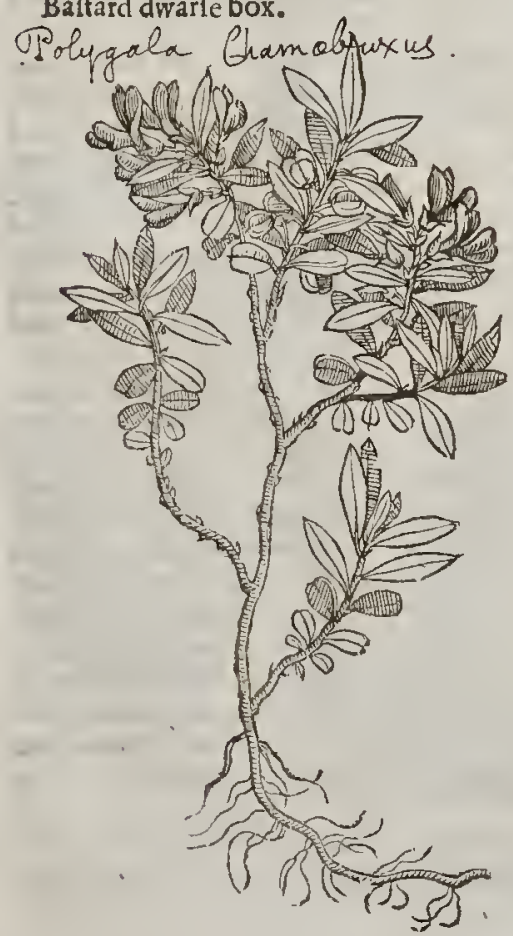

teau,who fent it to Clufius, would haue it to be and eal it Dorycnium: It is a fhrubby herb fending fromone root many fingle ntalkes fome halfe eubit or better high: the leaues which grow vpon the ftalkes without order, are like thofe of the Oliue, but fomewhat narrower, and cotered ouer with a foft fil. uer-like downineffe: at the top of the ftaiks grow many floures eluftering together ${ }_{3}$ of the thape of thofe of the leffer Bindeweed, but whire of colnur. This groweswilde in fome parts of Sicily, whence Cofilpinus calis it Dorychnium ex Sicilia.

\section{The Temperatureand Vertues.}

The three firf are very hot, and two fir $\mathbf{A}$ haue a trong purging facultic, for taken in the weight of a dram with the decoc:ion of Cicers they mightily purge by ftoole, both flegme, choller, and alfowaterith humours, and they are often $v$ fed for this purpofe by the Countrey people in fome parts of Spaine.

The faculties of the reft are not knowne, norwritten of by any as yet.

$$
\begin{gathered}
\text { Cha s. 5. Of Baftard } \\
\text { dwarfe Box. } \\
\text { I The Defription. }
\end{gathered}
$$

Tr His which Clufius fo: want of a name calls Anonymos fore Colutea : Gefner called Chamebuxus; to which $B$ aubine addes flore Coluter; and Befler in his hortus Eyftettenfis, agrecable to the name I haue giuen it in Englifh,ealls it Pfoudochamabuxus. It is a fmall plant hauing many ereping wooddy tough roots, here and there fending forth fmall fibers; from thefeariic many tough bending branches fome fpan long, hauing thicke tharpe pointed greene leause, almoft like thofe of Boxe, and thefe grow vpon the ftalks without any order, and when you firft chew them they are of an vngratefull tafe, afterwards bitter and hot; at the tops of the branches, docome forth amongft the leaues three or foure longifh floures, for the mot part without fmell; yet in fome places they fmell fweet, like as fome of the Narciffes, they confift of three leaues apiece; two whereof are white, and fpread abroad as wings, a whitifh little hood coucring their lowerends : the third is wrapt vp in forme of a pipe, with the end hollow \& crooked, and 
this is of a yellow colour, which by age oft times becomes wholly red : after thofe floures fueceed cods, broad and flat, little leffe than thofe of the broad leaued $\tau$ blaspi, and greene of colour, rough, and in each of thefe cods are commonly contained a couple of feed s, of the bignes of little Chichlings, of a blackith an colour, rough, and refembling a little dug.

This is fometimes found to vary, hauing the two winged leaues yellow or red, and the middle one yellow:

4) The Place.

It floures in Aprill and May, and ripens the feed in Iune; it growes vpon moft of the Auftrian and Stirian Alpes, and in diuers places of Hungarie. It is neither vfed in Phyficke, nor the facul :
ties thereof in medieine knowne.

\section{C н а P. 6. OfWinged Bindweed, or Qusmoclit}

2uamoclit, ive conuoluulus Pennatus. Winged Windeweed.

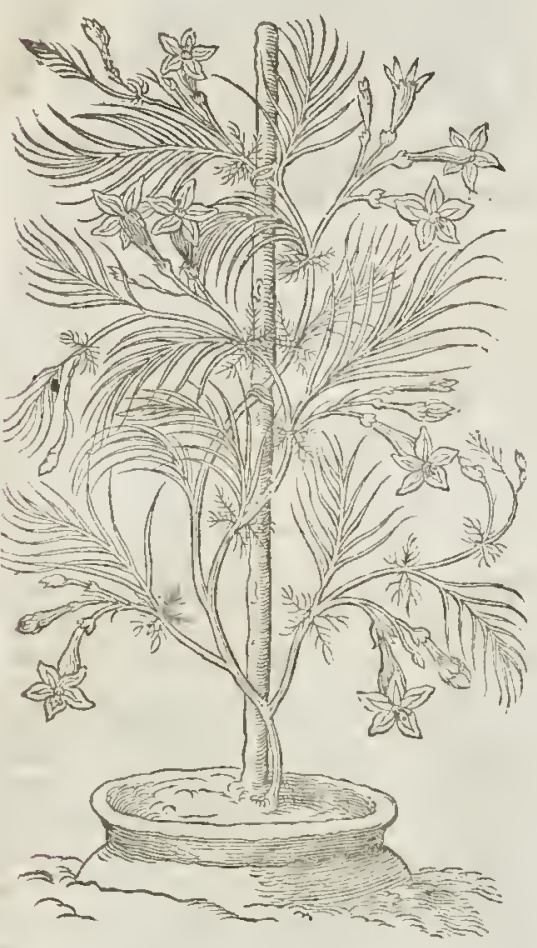

\section{The Defcription.}

7 He firft that wtit of and defcribed this plant was Cafalpinw, \& that by the name of Gelfinsinum rubryos alisrum : after him $C_{a}$ merarius gaue a defcription and figute therof in his Hortus Medicus, by the name of 2 uasioclit: and afterhim Fabias Colsmon both figured and defcribed it more accurately, whore defcription is put to the figure of it (we here give) in Cluf his Curipofteriores. It is fo tender a plant that it will not come to any perfect $\mathrm{i}$ on with vs, vnleffe in extraotdinary hot yeres, and by other artificiall helps, whetefote I will borrow the defcription thereof nut of Fabius Colunonia. This exoticke plant, faith he,cannor more fitly be referred to any kinde, than to the family of the convelusli, or Bindweeds, for in the nature andwhole habit it is almolt like them,excepting the tha pe of the winged lcaues : it is fored with leffe milk : the fours are long, hollow, but parted into fiue at the top, of a pleafing red colour, with ftreaked lines or folds, ftanding vpon long falkes one or two together comming out of the bofomes of the leaues at each ioint of the branches, and they haue in them fiue ycllowin pointalls then fueceeds a longin fruit feanding in a fcaly cup, ending in a harp poirtall, and co. uered with a tough skin,as that of the com. mon comvoluulus, but Itefer, hauing within it foure longifh blacke hard fecdes, of a biting
tafte. The leaues grow a lternately out of the ioints of the purple winding branches, being winged
and finely diuided, twife as fnall as the common $R$ hefeda, of a darke greene and finely diuided, twifeas fmall as the common $R$ hefeda, of a darke greene colour, but the young ones are yellowifh, firt hauing a few diuifions, but afterwards more, till they come to haue thirteen on a fide, and one at the top: but the lower ones are oft times forked : by reafon of the great plenty other fafhioned workes of Reeds, or the winding themfelues about artificiall hoops, croffings, or the eie of the beliolder, and is therefore kept in pots in beginning of the Spring growes vp in Iune, and the firtens of pleafure. The feed fowne in the Maple; ic foures in thend of Auguftand ripens the feed in the end of september fruit of the: 


\section{$\mathrm{C}_{\text {на а . }}$ 7. Of the fenfitive Herbe.}

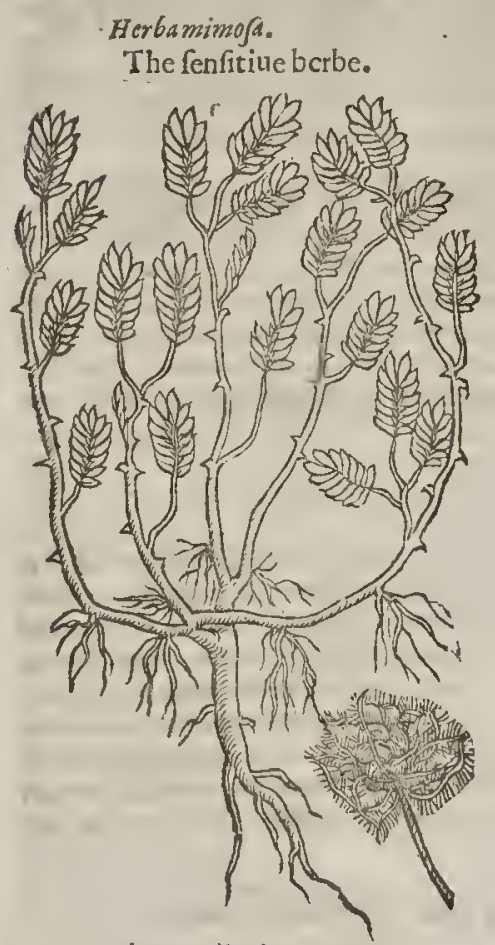

Eius exactioricon.

A perfect figure thereof.

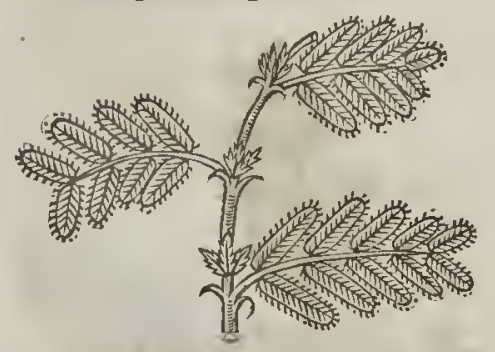

IT The Defcription.

$T^{H i s}$ which I here call the fenfitiue herbe, is that which Chriftopher a cofta fets forth by the name of Herba mimoofa, or the Mocking herbe, becaufc when one puts his hand thereto it forthwith feemes to wither and hang downe the leaues; but when you take it away againe it recoucrs the priftine greeneffe and vigor. I wil here gine you that which Acofta writes thereof, \& the figure \& hiftorie which Clufius gines in his notes vpon him; and alfo another figure better expreffing the leaues and manner of growing. There is found (faith Acoffa) in fome Gardens another plant fome fiue handfuls long, refting vpon the neighbouring fhrubs orwalls, hauing a flendet ftalke of a frech greene colour, not very round, fet at certaine fpaces with fmall and pricking thornes : the leanes are not vnlike the former, [That is, the Herba vius, which in condition is little different from this] being fomewhar leffer than thofe of the female Ferne. It loues to grow in moift and ftony places, and is called Herba mi. mofa, for the reafon formerly giuen. The nature hercof is much different from that of Arbor trifi is for euery night at Sun-fet it as itwerewithers and dries, fo that one would thinke it were dead, but at Sun-rife itreeouers the former vigor, and by how much the Sun growes hotter,by fo much it becomes the greener, and all the day it turnes the leaues to the Sun.

This plant hath the finell and tafte of Li- $A$ quorice, and the leates are commonly eaten by the Indians againft the cough, to clente the cheft, \& cleare the voice:it is alfo thought good againt the paines of the kidneies, and to heale greene wounds. Thus mueh $A$ coft $a$.

Now, faith Cluf frus, the leaues of many plants? efpecially pulfes, vfe to contradt or fhrinke vp their leaues in the night time. Now I recciued a dry plant, which was fent to me by the name of Herba mimo fa, by Iames Garret in the end of O Oto-
ber, 1599 , which hewrit he had of the right Honourable the Earle of Cumberland, who returning from Saint Iobn de Pserto rico in the Weft Ind ies, brought it put in a potwith fome earth, but could hot preferue it aline. But I caufed the figure of that dried plant to be expreffed as well as it might, fa to fit it to the defcription following; made alfo by the dried plant. This plant whieh was wholly drie and without leates had a fingle root, and that not thiek, but hard and wooddy, with few fibres, from whence arofe three or foure fhort ftalks, which fraight ditided themfelues into flender branches, which fpread themfelues round about vpoin the ground, at each ioint putting forth many long and flender fibres, like as in the branehes of the common Woodbinde, which lye vpon the ground: thefe branches were a eubit long, and fometines more, round, tough,with fome priekles, broader at their fetting on, as you may fee in the common bramble, yet leffer, fewer, \& leffe firme; thefc againe were dituded into other more flender branches fet with many litrle priekles, out of whofe ioints betwixt two little leaues grew forth foot-ftalks, bedeckr with their little leaues, which were many, fet in order, with other to anfwer to then on the other fide, but hauing no fingle leafe at the end: they were tender 8 . green, noc inlike the little ledues of $A c n c i n$, it thefe (at their firf eomming our)coue. red with a thin whitin hairines, as I garhered by a little branel retaining the foot-ftalkcand leaues rhereon (which he fent with the former) and it had alfo fome fibres comming forth thereof. He alfo alded to the former two little heads, whicls growing voon the fame plant, he writ he receited of the forcmentions 
forementioned right Honorable Earle with fome branches yet retaining the leaucs. Thefe little heads confined of many flender, narrow, and as it were prickly litcle leanes; amongft which lay hid round feeds, fmooth,blacke, and fomew hat fivoln in the middle : the floures I faw not, neither know I whether they were brought with the reft: but whether the leaues of this plant being green, $8 x$ yet grow ing on the grumnd, do wither at the approch of ones band, as Chriftopher $A$ Coftawrites, and for that caufe impoles the name thereon, they beft know who hawe feene the greene and yet growing plant : for the facultics you may hate recourfe to that which $A$ Cofta hath fet downe. Thus much Out of Clufius.

Novemb.7. 632 . I being w ith M. Iob Beft at the Trinity houfe in Ratcliffe; amon 5 other varie. cies, he thewed meadry plant hereof,wbich I hecdfully obfcrued, and carefully opening ont fome of the faireft leates, which (as allo the whole plant befides)were carelenly dried, I found the leaues grew vfually fome dozen or more on a foot-ftalke, iuft as many on one fide as on the other; $8 x$ they were conered oner with a little downines, which ftanding out on the ir edges made then look as if they had bin fnipt about the edges, which theywere not: alfo I found at euery ioint two little hoo. ked prickles, \& not two little lcaues or appendices at the fetting on of the foot-ftalks, but three or foure littic leates, as the rudinentof a yong branch, comming forth at the bofom of eacl footftalk:the longeft branch (as far as I remenber) was not aboue a fin long; I then drew as perfect a figinre as I could of the perfe steft branch thenf, duaw ing as rcers as I rny'c the lcaves to their ful bignedfe, rhe which I here prefent you wirhall. There are tw o figures formerly extant, the one this of

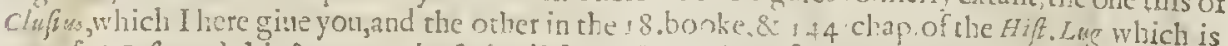
our of $A$ Cofta, and this fceems to be fo fardifferent fro is thit of Chums, that Bastine in lis Pmax:

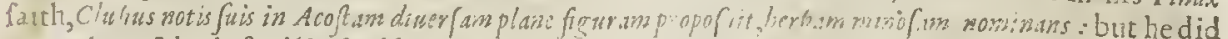
not wel confider ir, for it he had, he might hate found thic fo in nuch t fferent, thus far to agree; they boch make the branches prickly \& weak : the leaues many on one rib, one oppofite to another without an odde one at the end : but Clufins figures the leaures fo clofe together, that they feem but one leafe, and Acofar makes them too far a funder,and both of then mahe them too harp pointed, clur. made his be taken from a dried plant,and Acost a I itdg made his by the Id $x$ a thereofwhich he had in his memoric,and after this manner, if my iudgement faile menot, arc moft of the figures in lim expreft:but of this enotigh, if not too nueh.

\section{C п а P. 8. Of the Staffe tree, and euer-greene Primet.}

I Celaftrus Theoplorafi.

The ftaffe trec.

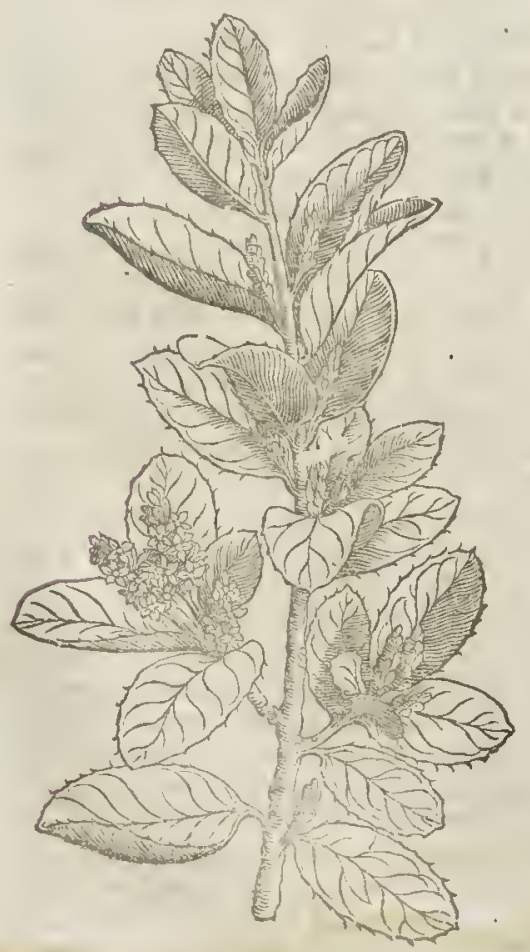

2 Pbillyria r.Clur. Clufius his I. Mocke-P'tiuet. 


\section{T) The Defoription.}

I

7 He hiftory and figure of this tree are fer forth in Clufizus his Cur poffer. and there it is afferted to be the xinuser, or wixaser of Theophraflus; for by diuers places in Theophraftus there collected, it is euident, that his Celaftus was euer greene, grew vpon very high and cold mountaines, yet might be tranfplanted into plaine and milder places, that it floured ex. ceeding late and could not perfect the fruit by reafon of the nigh approch of winter, and that it was fit for no other ve but to make ftates on for old men.

Now this tree growes but to a fmall height, hauing a firme and hard body, diuiding it felfe at the top into fundry branches, which being yonge arc couered with a greene barke, but waxing old with a brownifh one; it hath many leanes, growing alwaies one againft another, and thicke together, of a deepe fhining greene aboue, and lighter vnderneath, keeping their verdure both Wintet and Sonmer:they are of the bigneffe of thofe of Alaternus, not Inipt about the edges, but onely a little nickt, when they are yer yong; at the top of the tendereft branehes among the leaues, vpon footfalkes of fome inch long, grow fite or fix little floures confiting commonly of fue little leaues of a yellowifh greene colour, and thefe fhew themlelues in the end of Autumne, or the beginning of Winter, and alfo in the beginning of the Spring ; but if the Snmmer be enld and moift it thewes the buds of the foures in O trober ; the fruit growes on a thorr ftalke and is a berry of the bigneffe of the Myrtle, firt green, then red, of the colour of that of $A /$ aray us, ard laftly blacke when it is ithered : the fone within the berry is little,and as itwere three cornered, eonteining a kernell couered with a yellow filme. Where this growes wilde I know not, but it was firtt taken notice of in the publike Garden at the Vnitierfitie of Leyden, from whence it was brought into fome few gardens of this Kingdome.

2 The firft Phyllyria of Clufins, may fitly be refer'd to the rest of the fame tribe and name deferibed formerly in the 59 . chapter of the the third booke. It growes fornewhat taller than the Scarlet Oke, and hath branches of the thickneffe of ones thumbe or fomewhat more, and thofe couered with a greene barke marked with whitith fpots; the leaucs fomewhat refemble thofe of the Scarlet Oke, but greater, greener, thieker, fomew hat prickley about the edges, of an antingent tafte, but not ungratefull. The floure thereof clufius did not fee, the fruit is a little blacke berry, hanging downc out from the bofome of the leaues, and conteining a kernell or ftone therein. It growes wilde in many wilde places of Portugale, where they call it Azebo.

The temperature and vertues are refer'd to thofe fet downe in the formerly mentioned chapter.'

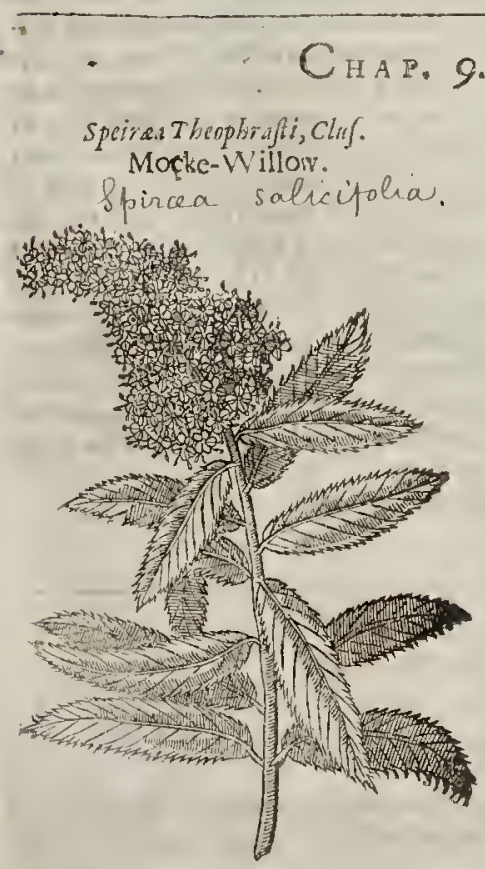

of Grockerlitlow.

(4) The Defcription:

THis Willow leaued thrub, which clufurs conicetures may be refer'd to the speires mentioned by Theophraftus, lib. r. cap, 23 . bift. plamt. I haue named in Englioh, Mocke-Willow, how fitly I know not; but if any will impofe a fittername I hall bewell pleafed therewith ; but to the thirg it felfe. It is a nurub, (Faith Clufirs) fome two enbits high, hauing lender branches cr twigs couc red ouer with a reddifh barke, whereon grow many leaues without order, long, narrow, like thofe of the Willow, finipt about the cdyes, of a light green aboue, and of a blewin greene viderneath, of a drying tafte conjoyned with fome bitternes. The tops of the branches for fome fingers leng th carry thicke fpikes of fmall foures cluftering together, and confifting of fiue leatues apiece, our of whofe midd le come forth many little threds of a whitifh red or fien colour, together with the floure, hauing no peculiar Tetet 
fmell, but fuch as is in the floure of the Oliue tree; thefe floures fading there fucceed fmall fiue cornered heads, which comming to full maturitie containe a fmall and yellowinh dutly feed : it foures in Iuly, and ripens the feed in the end of Augurt. Clufius had this plant from Fredericke Sebraims Phy fition to the Duke of Briga, and that from Briga in Silefia, and he (as I faid) rcfers it to the żrpais of Theophrafous, which he reckons amongft the fhrubs that carry fpike fafhioned flonres.

This is not ved in medicine, not the Temperature and faculties thereof as yet knowne.

\section{С н а т. Iо. Of the Strawberry-Bay.}

Ldrachne Theophraffi. The Sttawberry-Bay.

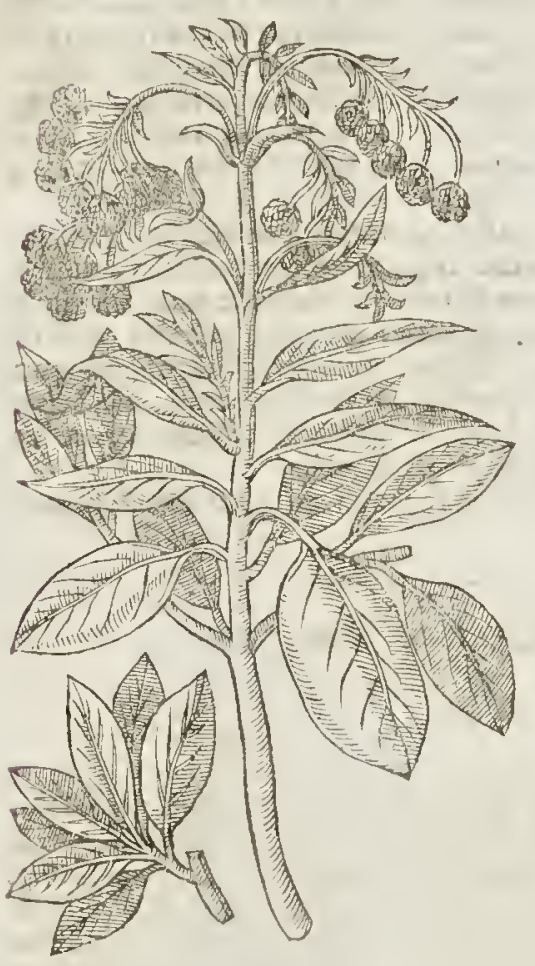

The Deforition.

THe figure and hiftory of rhis wete fent by Honoriss Bellus olt of Candy to Clufius, from whom $I$ haue it. It is that which $T$ beo. phraftus calls cadrachre ot (as molt of the printed bookes luaue it) Asdracbne, but the former feemes the righter, and is the better liked by Pling, lib.1:.Cap.22.At this day in Candy whete it plentifully growes, it is called $\mathcal{A}$ drach .I is rather a fhrub than a ttec, delighting in rockie and mountanous places, and keeping greene VVinter and Sommet, hauing leaues fo like thofe of Bayes, that they are diftinguithable only by the fmell, which thefe ate deftitute of. The barke of the bole and ail the branches is fo fmoorh, red and thining, that they thew like branches of Corall, this barke crackes or breakes off in Sommer, and pills off in thinne fleakes, at which time it is neither red nor hining but in a meane betweene yellow snd afhcolour. Ir hach floures twice in a yeere like as the Arbut m, or Strawberry tree, and that fo like it, that you can farfe know the one from the other; yet this differs from it in that it growes oixly 111 rhe mountaines, hath not the leaues jagged, neither a rough barke; the wood hereof is very hard, and fo brittle that it will notbend, and they vre it toburne and to make whorles for their womens fpindles. Theoplsraftses reckons vp this tree amongft thofe which die not when theit barkes are taken off, and are
alwes greene, and retaine their leaues at their tops all winter long : which to be fo Honorizs Bellers obferued. Bellonius alfo obferued this trec in many places of Syria.

The fruit in Temperature, as in Thape, is like that of the Stawbetry-ttee.

\section{Cua p.II. Of the Cherry-Bay. \\ If The Defcription.}

Hc Cherry-bay is one of the cuergreen trees : it rifes vp to an indifferent height, and is diuided into fundry branches, couered ouet with a fwart green barke:that of the yonger hoots is wholly 
green, the leaues alternateiy ingirt the branches, $\&$ they are long, fmooth, thiek, green, and thining, fnipt alfo lightly about the edges: when the tree is growne to fome height, at the tops of the bran ches amongtt the leaues of the former yeares growth,vpon a fprig of fome fingers length, it purs forth a great many little white floures, confinting of fiue leaues a piece, with many little chiues in them: thefe floures quickly fall away, and the fruit that fucceeds them is a berry of an ovall figure, of the bigneffe of a large Cherry or Damfon,and of the fame colour, and of a fireet and pleafant

Laurocerafi fles.

The Cherry-bay in floure.

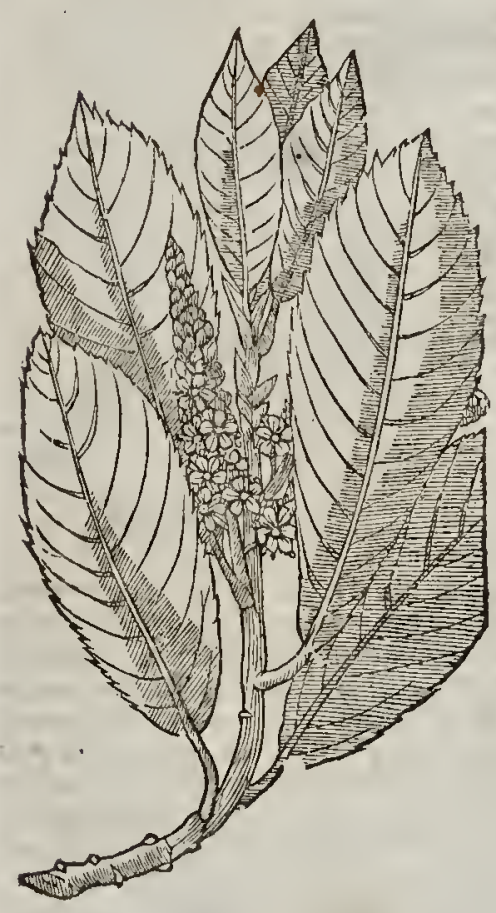

Lanrocerafi fructius.

The Cherry-bay with the fruit.

tafte, with a ftone in it like to a Cherry fone. This floures in May, and ripens the fruir in A uguft or September : it was firft fent to Cluffus from Conftantinople, and that by the name of Trabifoncurmals.r. Trape untina dactylus, the Date of Trapefon; but it hath noaffinitie with the Date. Dalechampius refers it to the fecond Lotus mentioned by Theophraftus, hift.plant. lib. 4.cup.4. but therewith it doth not agrec.Clufus and moft fince, cal it fitly Laurocerafus, or Ceraffes follio Laurino. It is now got into many of our choife Englifh gardens, where it is well refpected for the beauty of the leates and
their lafting or continuall greeneneffe. The fruit hereof is good to be eaten, but what phy ficall vertues the tree or leates thereof haue, it
is not yet knowne.

\section{ChA P. 12. Of the Euer-greene Thorne.}

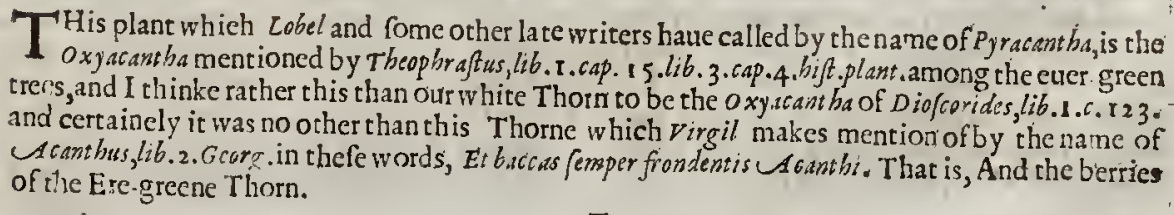

$\operatorname{Tetcta}$

This 


\section{$1604 \quad$ An Appendix to}

Oxyacanthat Theophrafti. The Euer-gteene Thorne.

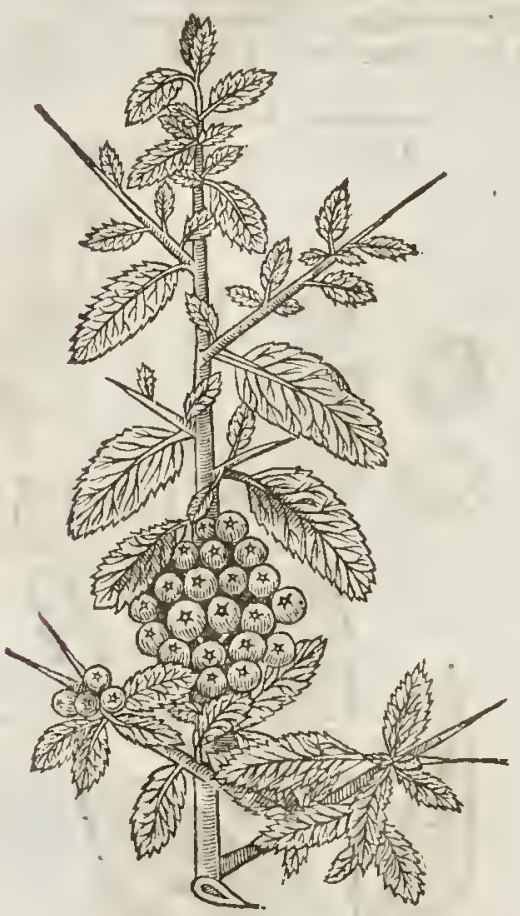

TT The Defcription.

$T$ His growes vp like a burh, nnleffe you keepe it with pruning, and rhen it will in time grow to the lieiglit of a fnal tree,as the Hawthorne, whereco it is of affinitie, lor the wood is white and bard, like ir, and conered ouer with the like barke; but the leaucs are fomwhat like thofe of the Damfon tree, lon. gith, fharp pointed, and fnipt about the ed. ges: \& they grow along the brarches, without any order,yet fomgtimes they heep this maner of growing : at each knot, wlere commonly there is a harpe prickle, growes out one of the larger leaues, which may be fome inch and halfe long, and tome thrce quarters of an inch broad:then rpon the prickle, and at the eomming out therof are three or foure, more or leffe,much imaller leaues: row thefe leatues are of a faise and fining green abouc, but paler vnderneath, and they kecponal rhe yeare: At the ends, and oft times in the mid. dles of the branches co me forth clufters or vimbels of litrle whition bluth colcured floures, confifting of fure leanes apiece, with fome little chiues in their middles: then follow clufters of berries, in thape, tafte, and bignefle like thofe of the Haw thorne, and of the fame, but mueh more orient and pleafing colour, and containing in them the like feed: now thefe berrics hang long vpon the tree, \& make a gallant fhew among the greene leaues, and chiefely then, when as the $A$ u. tumne blafts haue depriued other trees of their wonted verdure. Th is floures in May and Iune,and ripens the fruit in Scptember and October : it growes wilde in fundry places of Italy, and Prounec in Franee, but is kept in gardens with vs, where it is held in good eftecme for his euer greeneffe and pliableneffe to any worke or forme you defire to impore vpon him.

The fruit haue the fame faculties that are formerly attribured to Hawes, in the foregoing booke, $p a z \cdot 1328$. and therefore I will not here tepeat them.

\section{C н А . 13. Of the Egyptian $\mathcal{N}$ (ap,orgreat fuimbes tree. \\ Tा The Defcription.}

$\mathrm{T}$ His tree, which for his leaues and manner of growing I thinke may fitly be referr ed to the Iuiubes tree, is of two forts; that is, the one priekly, and the other not prickly, in other refpects they are both alike, fo that one figure and hiftorie may ferue for them both, which 1 will gite you out of Clufius, who receiued th is figure together with a defeription thereof from Honbrius Btllus, and alfo added therto that which Proper Alpin. hath written of it inhis 5. chap.de Plant. Af gypt. It grows to the height of an indifferent Peare-ttee, and the bodie and branches thereof are coucred with a whitin ah coloured barke : the leaues are like thofe of the Iuubes tree, two inches long, and one broad, with three nerucs running alongft them; of a deepe fhining greenc aboue, and more whitith vnderreath : and they grow alternately vpon the branches : and at their comming forth grow tufts of little white floures hanging vpon fingle long foot-ftalks : after thefe followes the fuit like vnto a fmall Apple, of the bignerfe for the moft part of a large Cherry, and fometimes as big as a VValnut, of a fweet tafte, containing therein a kernell or ftone like that of an Oliue. It beares fruit twife a yeare, for it hath ripe fruit both in the Spring and fall ; yet the vernall fruit feldom comes to good, 
oexopliation pinofa.

The gteat Iuiubes tree:

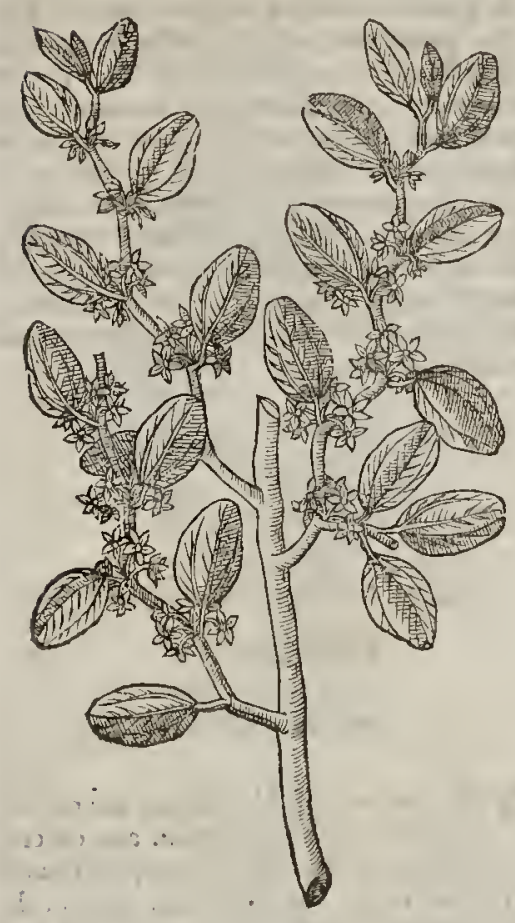

by reafon of the too much moifure of the fer. fon, whieh eaufes it to bceome worme-eaten. The Thorny kinde is deferibed by $A$ lpinss, who rightly iudges it the Connar us of Satheners, but the figure he giues is not very accurate. That whieh wants priekles growes (as well as the priekly one) in Egypr and Syria, as alfo in rlee ciry Rhetimo in Candy, whither it was brought out of Syria.

The hiftorie of both thefe trees is in serdpio by the name of $S$ adar : but he,aeeording to his etiftome eonfounds it with the Lot us of $D i$ ofcorides, from whieh it very mueh differs. Bello. nius in his fecond booke, and 79. ehap. of his Obfertiations, reekons vp 2Kapeca among the trees thar are alwaies greene: which is true, in thofe that grow in Egypt and Syria; but falfe in fuch as grow in Candy. That rree in Egype and Syria is called Nep, or Nap. Alpinses, ealls it Paliurus cuberner, or $\mathrm{Nab}$ ca Exyptionums, thinking it (as I formerly faid) the Connarus mentioned in the 14 . booke of Athereus his Deipnofophifts.

TI The Vertses out of Alpinss.

The fruit is of a cold and dry facultie, and the varipe ones are frequently vfed to ftrengthen the ftomacke, and itop lasks : the iuice of them being for this purpnfe eithet takenby the mouth, or injeeted by clyfter : of the fame fruic dried and maeerated in water, is made an infufion profitable againft the telaxation and vlcera- B tion of the guts.

The decoction or infufion of the ripedried fruir, is of a vety frequent vfe againft all peftilent feners : for they affirme that this fruit harb 5 wonder full efficacie againft venenate qualities, and putrifaction, and that it powerfully ttreng thens the heart.

Alfo the inice of the perfectly ripe fruit is very good to purge cholet fotth of the ftomacke and firft veiness : and they willingly vfe an in fufion made of them in all purride feuers to mitigate their heate or burning .

\section{Cha r. 14. Of the Perjan Plum.}

$$
\text { T The Defription. }
$$

I THis rree is thought by Clufrus (towhom I am beholden for the hiftoric and figure) to be rhe Pcrfea arbor menrioned by Pliny and Plut arch, but he fomewhat doubts whither it be that whieh is mentioned by T Teophraftus. Dtofcorides alfo, Galen and Strabo make menrion of the perfea arbor, and they all make it a tree alwaies greene, hating a longith fuir thut vp in the thell and eoat of an Almond: wirh which how this agrees you may fee by rhis defeription of Clufius.

This rree (fairh he) is like ro a Peare rree, fpreading ir felte far abroad, and being, alwaies green, hating branehes of a yellowith green eolour. The leaues are like thofe of the broadeft leatred Baytrec,greene aboue, and of a grayith eolour vnderneath, firm, hauing fome nerties running obliquely, of a good rafte and fmell,yer biring the tongue wirh a litrle afriction. The floures are like rlofe of the Bay, growing many thieke rogerher,and eonfift of fix fmall whitifh yellow leaties. The fruit at the firf is like a Plum, and afterwards ir becomes Peare farhioned, of a blacke colour,and pleafan t tafte : it hath in it a hearr fafhioned kernell, in tafte notvnlike a Chefnur,or fweet Almond. I found it flouring in the Spring,and I vnderftood the fruit was ripe in Autumne, by the relation of Sig: 


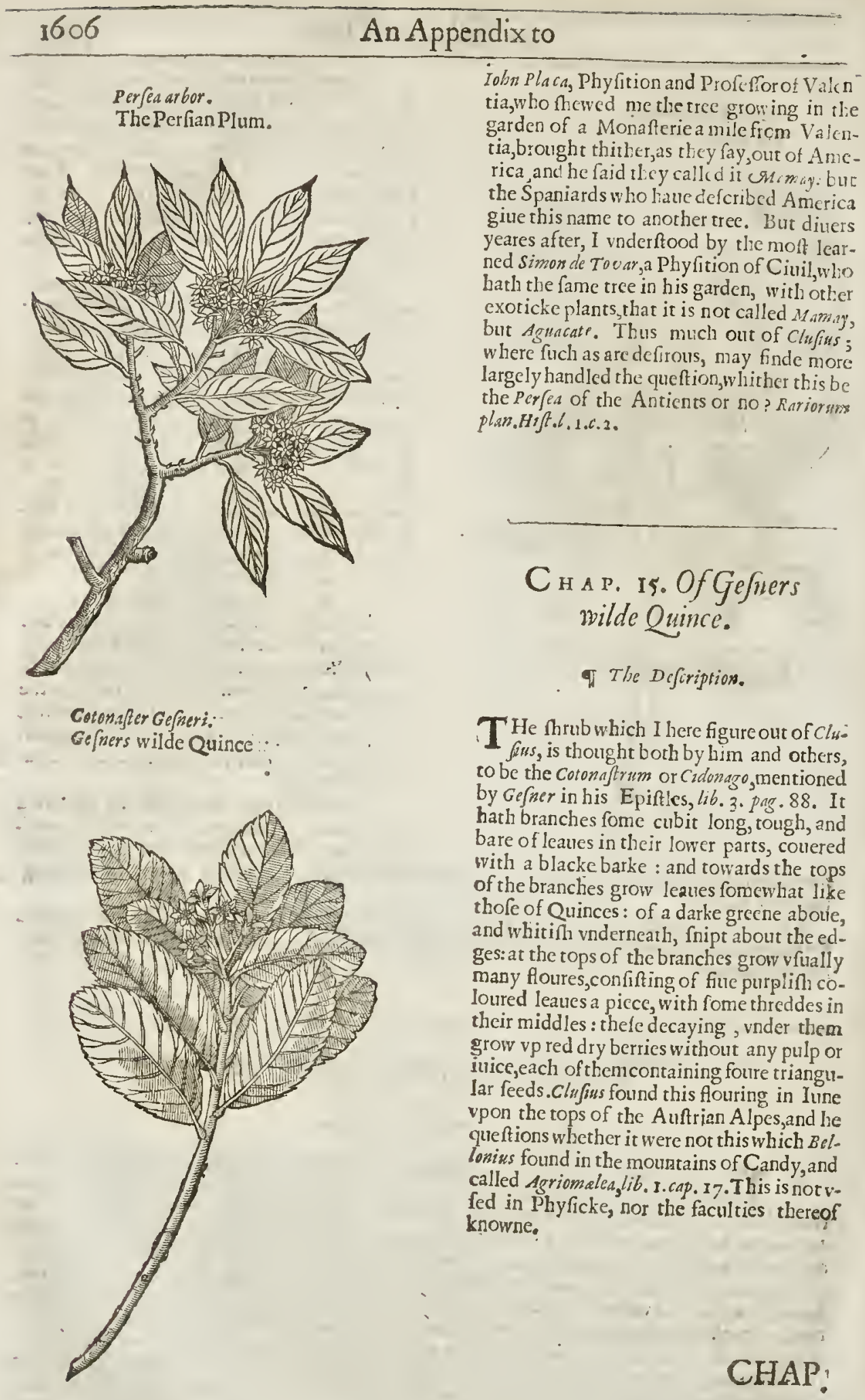




\section{$\mathrm{C}_{\text {HA P.16. Of Tamarindes. }}$}

Tamsarindus:

The Tamarinde:

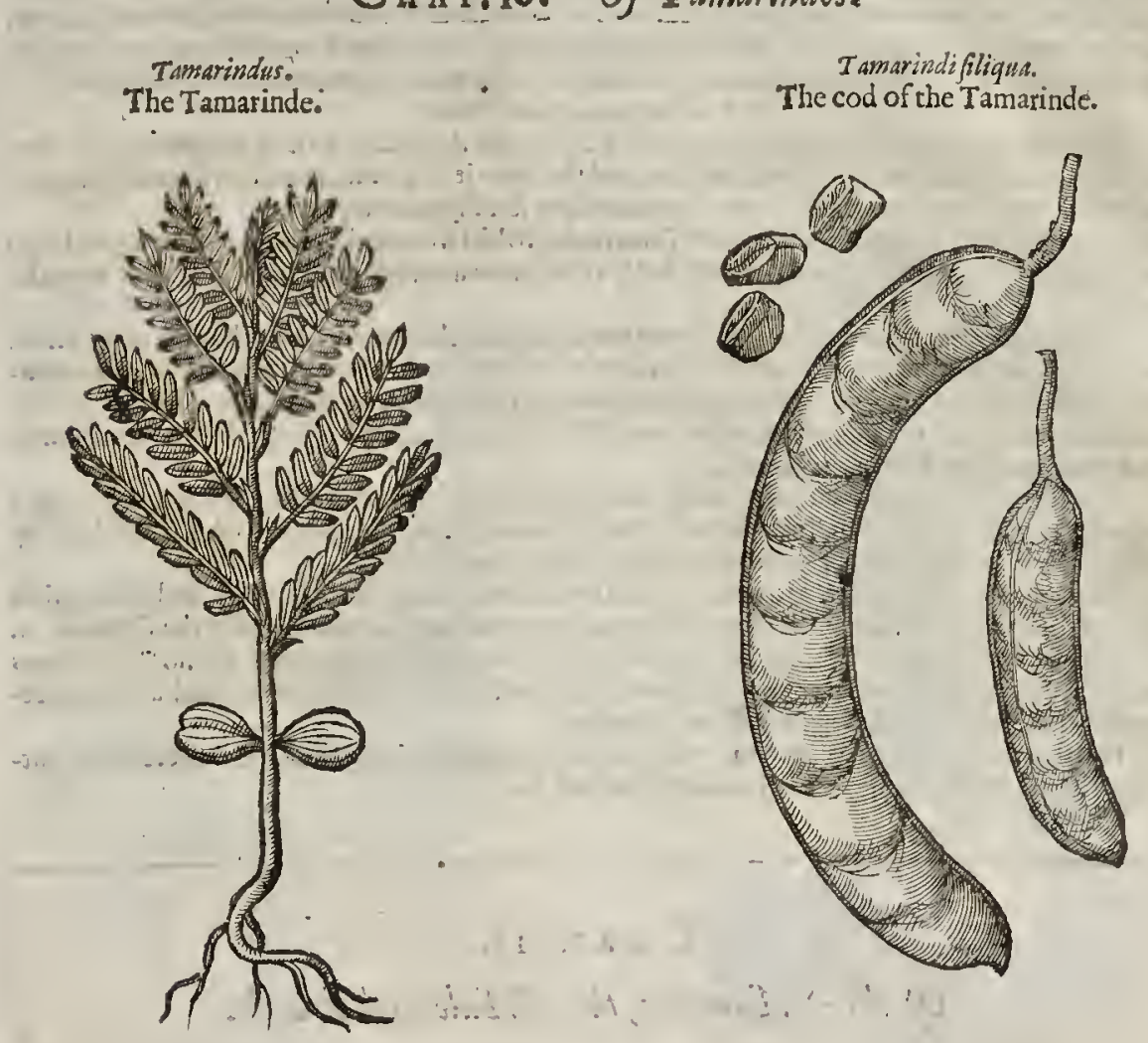

Tamarindifiliqua. The cod of the Tamarinde.

of The Defcription.

$T$

Amatinds, which at this day are a medicine frequently vfed, and vulgarly knowne in thops, were not knowne to the antient Greekes, but to fome of the later, as 1 a a uarits, and that by the name of oxyphenice, chat is, foure Dates, drawne as it may feeme from the Arabicke appellation, Tamarindi, that is, Indian Date : bur this name is vnproper, neither tree nor fruic being of any affinitie with the $D$ ate,vnleffe the Arabicke Tamar be a word vfed in compoition for fruits of many kindes, as the Greeke Män, the Latine exalum, and Apple with vs in Englith; for we call the Cone of the Pine, and excrefcence of the Oke leafe, by the name of Pine Apple, and Oke Apple. But how foener it be, it is no matter for the name, whether it be proper or no, if fo be that it ferue to diftinguith the thing from others, and we know what is denored by it. In Malauar they call it $P$ Pti : in Guzarat, Ambili, by which name it is knowne in moft parts of the Eaft Indies. This tree is thus defcribed by Proper wipinus, de Plant. efsypti,cap. 10. The Tamarind (faith he) is a tree of thebigneffe of a Plum tree, with many boughes and leaues like thofe of the Myrtle, many ftanding vpon one rib [one againft another, with a fingle one at the end :] it carrieth white fioures very like thole of the Orange tree : out of whofe middle comes forch foure white. and very flender threds : after thefe come thicke and large cods, at firft greene, but when they are ripe of an ath colour ; and within thefe are contained thicke, hard, brownifh, cornered feeds, and a blacke acide pulpe. Thefe trees grow in fome few gardens of Egypt, whither they laute bin brouglit our $n f$ -Arabia and Ethiopia. This plant hath this frange qualitie that the leates alwaies follow the Sun, and when it fets they all contrakt themfelues, and open out themfelues againe at the rifing chereof and there is obferued to be fuch force in this morion, that they clofely thut vp and hoid their cods (if any be on the tree) and then ar the rifing of the Sun they forgo: them againe. But I haue obferted this folding vp of the leates to be common to divers other Egyprian plants, as LA catid, Alrus, $A^{\prime} \sqrt{u s}$, and Seshriv. Thus muclo oit of Alpinus. 
The figure I here gine in the firft place, out of Lobel, is of a plant fome fix moneths old, arifen of a feed : and fuch by fowing of feeds I haue feene growing in the garden of my deceafed friend $\mathrm{M}^{x}$. Tuggy, but they ftill died at the firft approch of Winter. The other figure expreffes the cods, and fome of the feeds apart, taken forth of the cods : now the cods are neucr brought whole to vs, but the vtter rindes are taken off, and the ftrings or nerucs that runne along?t the cods : the pulpe and feeds in it are clofe thruft together, and fo are brought to vs in pots and fuch like veffels. T T be Temperature and Vertues.

A The fruit or pulpe of Tamarindes is cold and dry in the third degree : it is of good ve in cholericke difeafes, as burning Feuers, Tertians, and the like : it is a lenitiue and very gently purging medicine and therefore vfed to be put into medicines feruing to that purpofe.

B They vfe (faith Alpinus) the leaues of Tamarindes to kill wormes in young children; and alfo their infufion or decoetion to loofen the belly : the leaues are acide, and not vnpleafant vnto the tafte.

C The Arabians preferue the fmall and yet greene cods of this tree, as alfo the ripe ones, either with fugar, or the honey boiled out of the fruit of the Carob tree: they alfo mix the pulpewith fugar, which trauellers carry with them in their ioumies through the defart places of Africk, wherewith they being dry or ouerheared, may quench their thirk, coole and refrefn themfelmes, and alfo euacuate many hot humors by feoole.

D. In peftilent and all other burning putrid fcuers they drinke the water with fugar,wherein a good quantitic of Tamarinds hame been infufed; for it is a drinke very pleafant to fuch as are thlrfty by reafon of too much heate, for it powerfully cooles and quenches thirft.

E They are alfo vfed in all putrid feuers caufed by cholericke and aduft humors, and alfo againt the hot diftempers and inframmations of the liner and reines; and withall againft the Gonorrhxa.

F Some alfo commend them againft obftructions, the dropfie, iaundice, and the hot diftempers of the Spleene: they conduce allo to the cure of the itch, fab, leprofie, tetters, and all fuch vlcerations of the skin which proceed of adut humors. G They are not good for fuch as haue cold ftomacks, vnleffe their coldneffe be corrected by put-
ting to them Mace, Anife feeds, Squinanth, or fuch likc.

\title{
CHA. I7. \\ Of the Mamoera, the Male and Feinale.
}

\author{
IT The Defaription.
}

\section{T} Hehiftoric of thefe two trees, together with the figures I here giue you, are in the Cure Po: feriores of Cluf fus, from whence I will take as much as concernes their hiftory, and briefely.
heregine it you.

That of the Poet (faith he) is moft true, Non omnis fert omnia tellus : for I thinke there is no pro? uince to be found, which produces nor fone peculiar plant not grow ing in other rcgions, as they can teftifie who haue trauelled ouer forrein countries, efpccially if they haue applied themfelues to the obferuation of plants. A mong ft fuch I thinke I may reckon that honeft and courteous man $I 0 h n V$ an $V$ fele, who returning Out of that part of America called. Brafile, thewed me in the yeare 1607. a booke, wherein he in litely colours had expreft fome plants and liuing creatures : for as he told me, when he purpofed to tratell he learned to paint, that fo he might expreffe in colours, for his memoric and delight after he was returned home, fuch fingularities as he fhould obferue abroad. Now amongft thofe which hee in that booke had cxpreffed, I obferued two very fingular, and of a frange nature, whofe figures without any difficultie he beftowed vpon me, as alfo the fol.
lowing hiftorie. Thefe two trees, whofe figures you fee here expreft, are of the fame kinde, and differ only in fex;
for the one of them, to wit the male, is barren, and only carries floures, without any fruit ; but the
female onely fruit, female onely fruit, and that without floure: yet they fay they are fo louing, and of fuch a nature, that if they be fet far afunder, and the female haue not a male neere her, thee becomes barten, and beares no fruit: of which nature they alfo fay the Palme is.

Now the bole or trunke of that tree which beares the fruit is about two foot thicke, and it grow. eth fome nine foot high before it begin to beare fruit; but when it hath acquired a iuft magnitude then thall you fee the vpper part of the tree laden with fruit, and that it will be as it were thicke 


\section{the Hiftory of Plants.}

1609

girt about therewith for fome nine foot high more : the fruit is round and globe-fathioned, of the thape and magnitude of a fmall gonrd, hauing when it is ripe a yellowi ih pulpe, which the inhabitants vfe to eate to loofen their bellies :this fruit eontains many kernels of the bignes of a fmal peafe, blaeke and thining, of novfe that he could learne, but which were eaft arvay as vnneceffary: the leaues come forth amongt the fruit, growing vpon long foot-ftalkes, and they in thape mueh refemble the Plane tree or great Maple.

CMamoeramas.

The rnale Dug tree.

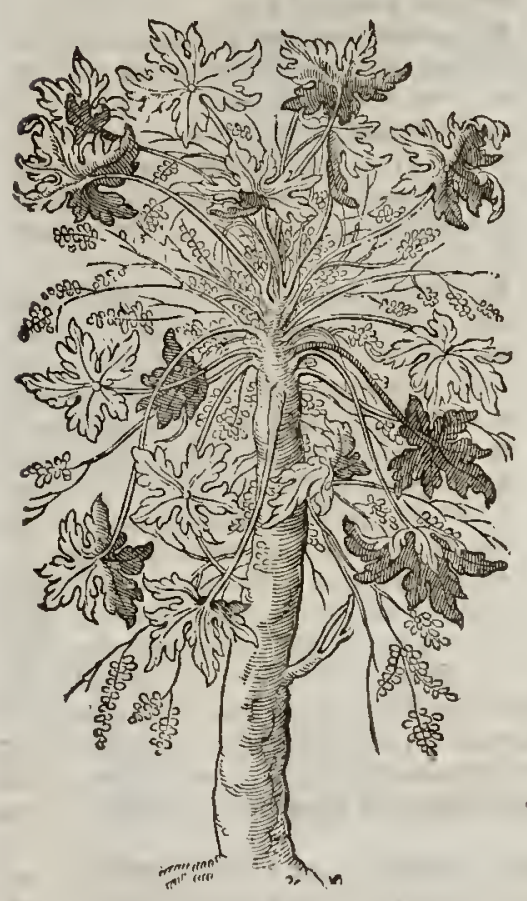

Mamoerafomina.

The female Dug tree.

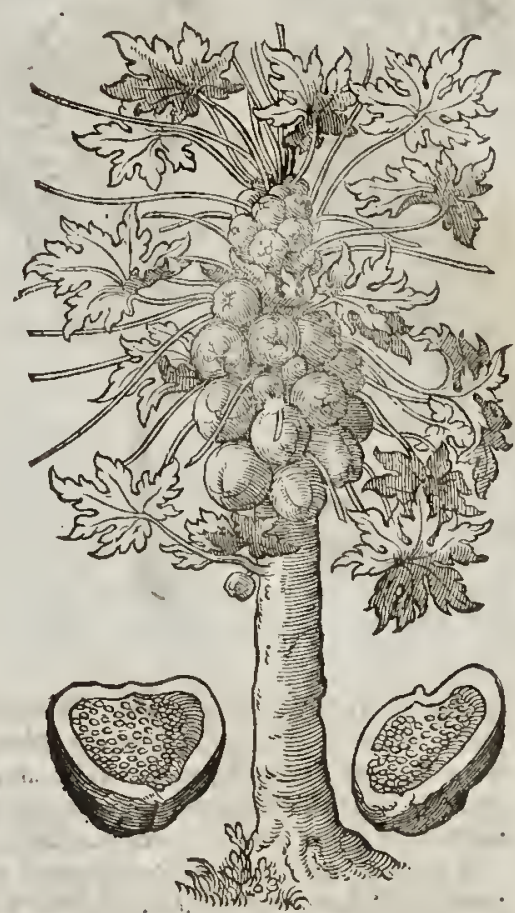

What name the Brafilians giue it he could not tell, but of the Portugals that dwelt there it was called $M$ amoera, and the fruit $M$ amaen, of the fimilitude I thinke they haue with dugs, whieh by the Spaniards are called Manzas and Tetas.

There is no differenee in the forme of the trunke or leaues of the male and female, but the male only earries floures hanging downe, eluftering together vpon long ftalks like to the floures of Elder, but of a whitifh yellow eolour, and thefe vnprofitable, as they affirme.

Both thefe trees grow in that part of Ameriea wherein is fe ituate the famous Bay called by the Portugals, Baya de todos los fanztos, lying about thirteene degrees diftant from the Equator towards the Antartieke pole.

\section{Chat. i8: Of the Cloue-Berry Tree.}

If The Defcription.

Muf alfo abftraet the hiftorie of this out of the Works of the learned and diligent Clufus, who fers it forth in his Exotieks, lib.I. cap. 57. in the next ehapter after Cloues.

I put (faith he) the defeription of this fruit next after the hiftorie of Clontes, both for the affinitie 


\section{0 \\ An Appendix to}

Amomum quorundam, fortè Garyophyllon Plinì. The Cloue-betry tree.

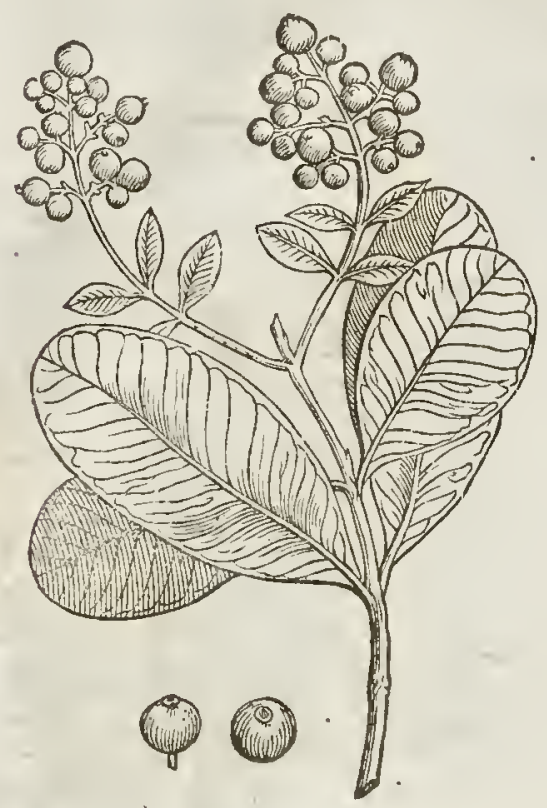

affinitic of fmell it hath with Cloues, as alfo for another caufe, which I will thew bereafter. Iames Gurret in the yeare $160 \mathrm{r}$ fent me from Lnatnn this round fruit, commonly bigger than Pcpper eornes, yee fome lefre, wrinkled, of a brownith colout, fuffieiently fragile; which opened, I found contained a feed round, black, which night be diuided into two parts, of ro leffe aromaticke tafte and fmell than the fruit it felfe, and in fome fort refembling that of Cloues : it growes in bunehes or clufters, as I coniectured by many berries which yet kept their falks. \& two or three whieh fucke to one little falke: to thefe were added leaues of one form, but of much diffcrent bignes, for fome of them were feuen inches long, and chree broad; fome onely five inehes long, and rwo and a half broad; others did nor exeeed 3 inches in length, and thele were not two inches broad; and fome a'fo were much leffe and narroiver than thefe,efpecially thofe that were found mixed with the berries, differing aecording to the place in the boughes or branches which they poffeft. I obferued none anong them which liad fnipt leaues, but fmooth, with many fmall veines running obliquely from the middle rib torhe frdes, with theis points now narrower, orherwhiles broader, and round in : they were of a brownifh anh colour, of a fufficient acride tafte : the branches which were added to the reft were flender, quadrangular, conered with a barke of an an colour,and thofe were they of a yeares growth; for thofe that were of an after grow th were brownifh, and they had yer remaining the prints where the leaues had growne, which for the moft part wcre one againt another, and thefe alfowere of an aeride tafte, as well as the leaues, and of novng ratefill fmell.

I receiued the fame fruit fome yeares before, but $w$ ithout the ftalks, and with this quention pro. pounded by him which fent it, An Amomum? And certainly the faculties of this fruit are not very much vnlike thofe which Diofcorides attributes to his Amomum; for it hath an heating aftrictiue and drying facultic, and I thinke it may performe thofe things whereto Diofcorides, Lib. I. Cap. 14. faith his is good; yet this wanteth fome notcs which he giues vnto his, as the leaues of Bryonie,
\&c.

But I more diligently confidering this Exotieke fruit, finde fome prime notes which do much moue me (for I will ingenuounly profeffe what I thinke) to iudge it the Garyoply/lon of pliny, for he, Hift.Nat. Lib. I 2. cap.7. after he hath treatcd of Pepper addes thefe words: [There is befides in the Indies a thing like to the Pepper corne, which is called Garyop byllon, but more great and fragil: they affirme it growes in an Indian groue; it is brought ouer for the fmels ake.] Though this defcription be briefe and fucein s, neither containes any faculties of the fruit it felfe, yet it hath manifent notes, which, compared with thofe which the fruit I here give you poffeffe, you fhal find them.very like; as comparing them to Pepper cornes, yet bigger and more fragile, as for the moft part thefe berries are : $t$ heir fmell is alfo very pleafing, and comming very neere to that of Cloues, and for the fmells fake only they were brought ouer in Plinies time. I found, this fruit being chewed made the breath to fmell well : and it is credible, that it would be good for many other purpo-
fes, if trial were made. 


\section{C н а P. 19. Of Guaiacum, or Indian Pock-mood。}

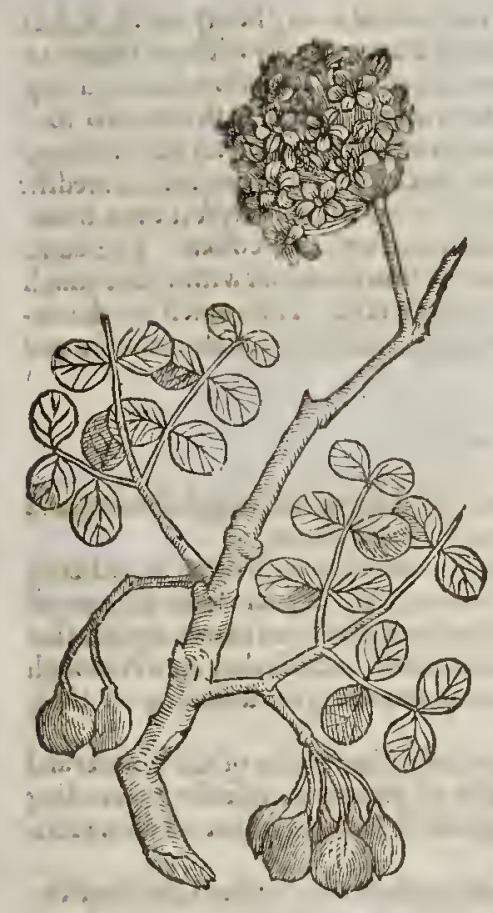

\section{Guaiaci arbor is ramulus. A btanch of the Guaiacum tree.}

\section{Tा The Defcriptit:}

Y Vaiaeum, which fome call Lignum SurIfum: others, Ligrum vite, is a well kown wood, though of a tree vnknown, or at leaft not eertainly knowne ; for this figure which I heregiue you out of Clufus, was. gotten, and the hittoric tramed as you thall heare by his own words, taken out of his scholia vpon the 2 I Chapter of Monardis." About the beginning (faith he) of the yeare i $60 \mathrm{r}$. I receined from Peter Garret a branch of a foot long, which he writ was giuen him by a eertaine Surgeon lately returned from Ameriea, for a braneh of the tree Guaiaem : which if it be a branch of the true Guaiacum, then hatl Nicolss Monardus fleightly enous het dow ne the hiftoric of this tree. I thus deferibed this branch whieh was fent me.

This branch was a foot long, very writhen, and diftinguifheu with many knots, fearfe at the lower end equalling the thicknefle of a writing pen or gonfe qui!, hauing an hard and yellowith wood, and a wrinkled barke 0 an afheolour: at the vpper end it was diuided into flender branches, whereof fome yet retained their leaties, and other fome the floures and the rudiment of the fruit : the leauses, or more truly the wings or foot-ftalkes of the leatues grew vpon flender branehes one againft another, each winged leafs luaning foure or fixe little leaues, alwaies growing by eouples one againft other, as in the Maftieke tree; and thefe were thickifh, round, and diftinginifhed with many veines, which by reafon of their drineffe (as I obferted) would eafily fall off, leating the foot talks naked, and onely retaining the markes whereas the leaues had beene. In the knots of the vpper branehes there grew as it were fwellings, out of which together grew fix, eight, ten, or more flender foot-ftalkes, fome ineh long, each earrying a floure not great, confinting of fix little leaucs (but whether white, yellow, or blew, I could not by reafon of the drineffe iudge:) out of the middle of the floure grew many little threds, and in fome the rudiment of the fruit began to appeare, hauing two ccls, almott fhaped like the feed-veffell of the co nmon Shepheards purfe.

Thus much Clufus, whoafterwards reeciued the fruit from two or three, but the moft perfeet from the learned A pothecaric Toh: Pon. of Verona: they are commonly parted into two parts or cels, yet he obferued one with three:he found longith ftones in them almoft like thofe of Enonyms, and they confifted of a v ry hard and hairy fubftanee like to that of the Date fones, eontaining a fmooth kernel of a yellowith colour.

Now will I giue you the deferiptions of ckonardus: then, what I haue obferted my felfe of this wood, which I mut confeffe is very little, yet which may giue fome light to the ignorant. Of this wood (faith exonardus) many haue written many waies, faying that it is either Ebonie, or a kinde of Box, or ealling it by fome other names. But as it is a new kinde of tree, not found in thefe regions, or any other of the whole world deferibed by the Antients, but only thofe of late clifeonered; fo this fhall be a new tree to vs : howeuet it be, it is a large tree of the bignes of the Ilex, ful of branches, hauing a great matrix or blaeki!h pith, the fubftance of the wood being harder than Ebonic: the barke is thicke, gummic or fat, and when therood is dry falleth eafily off: the leaues are fmal and hard : the floure yellow : thewhich is followed by a round follid fruit, eontaining in it feeds like thofe of the Medlar.

It growes plentifully in the Ifles of smito Domingo. 


\section{2 \\ An Appendix to}

Another kinde of rlis was afterwards found in the Ifland of S. Iohn de Puerto rico, neere to the former : it is alfo like the laft defcribed, but alrogether leffe, and almoft withour matrix or pith, fmelling ftronger, and being bitterer than rhe former, which being left, this is now in vfe, and of the wondrous effests it is ealled Lignmm fanct um ; neit her without defert, being (experience gituing teftimonie) it excells the orher : yer both their faculties are admirable in curing the French difeafe, and therefore the water or decostion of both of them are drunke, either mixed together,or feuerally, both for rhe eure of the forementioned difeafe, as alfo againft ditsers other affects, "Thus much for Momardus his defcription.

The wood which is now in vee with vs is of a large tree, whofe wood is very heauy, follid, and fit to turne into bow les or rhe like, and all that I hate yet feene hath been wholly without matrix or pith, and commonly it is of a daike brownifh colour, fomewhat inclining to yellow, liauing a ring of white ingirting ir next to the barke; I haue obferued a tree whofe diametre hath been two foot and a quarter, ro liaue had as litrle or leffe of this white wood as one whofe diameter was thirteene inehes; and rhis which was thirteene inches had only a white circle about it of one inch in bredth: I thinke the yonger rhe rree is, the bigger the white circle is : the beft wood is denfe, heauy, brownifh, leauing a quicke and biting tafte in the deco.tion, as alfo his fmell and colour. The barke of this wood is alfo denfe and heauy, of a hard fubfance and yellowith colour within, but rough and greenith, or elfe grayith withour, and of fomewhat a bitterin tafte. Thus much for the defription of the wood and his barke. Now let me fay fomewhat briefely of the temperature and
qualities.

\section{The Temperature and Irestues.}

A It is iudged to be hot and dry in the fecond degree: it hath a drying, attenuating, diffoluing, and clenfing facultic, as alfo ro moue fiveat, and refift contagion and putrefaction.

B The decoetion of the barke or wood of Guajacum, made either alone or with other ingredients, as thall be thought moft fit for rhe temper and age of the Patient, is of fingular vfe in the cure of the Frenich Poxes, and it is the moft antient and powerfull antidote that is yet known againft that difeafe: I forbeare to fpecifie any particular medicine made thereof, becaufe they are wel enough knowne to all to whom this knowledge belongs, and they are aboundantly fet downe by all thofe thar hate treated of that difeafe.

C It alfo conduceth to the cure of the dropfie, Athma, Epilepfie, the difeafes of the bladder and reines, paines of the ioints, flatulences, crudities, and laftly all chronicall difeafes proceeding from cold and moift caufes : for it oftentimes workes fingular effects whereas other medicines little prevaile.

D

It doth alfo open the obftuctions of the liuer and fpleene, warmes and comforts the ftomacke and all the intrals, and helps to free them of any groffe vifcous matter which may be apt to breed
difeafes in them.

$$
\begin{gathered}
\text { Сан а P. } 20 . \\
\text { Of the Guayaua, or Orange-Bay. } \\
\text { T The Defcription. }
\end{gathered}
$$

S Inson de Tourar fent Clufius a brancl of the tree which rhe Spaniards call Gwayduas, from which to drew rhis figure, and thus defcribes ir. This branch (fairh $\mathrm{Cls} / 3 \mathrm{ses}$ ) whofe vpper part together with the fruir I caufed robedrawne, was fome foot long, foure fquare, alternately fet witl leaues growing by couples, being foure inches long, and one and a halfe or two broad, of rhe forme of Bay leaues, very firme, haung a fwelling rib running alongth rhe lower fide, wirh veins running obliquely from thence to the fides, of an an or grayin colour beneath, but fmooth aboue, with the veines leffe appearing; which broken, though old, yet retained rhe fmell of Bay leates,and alfo after fome fort rhe tafte: the fruir was fnooth, yet fhriucled, becaufe peraduenture it was voripe, of the bigneffe of a mall apple, longifh, blackin on the out fide like a ripe plum, but within full of reddith pulpe, of an acide tafte; and in rhe middle were many whitifh feeds of the bigneffe of
Millet,or thofe thar are in Figs.

Nicolas CMondrdus (as he is turned into Latine by Clufurs) thus gives vs the hiftoric of Gunganas, in his fixry fourth Chapter. It is a tree, fairh he, of an indifferent bigneffe, and hath fpreading branches, the leafe of the Bay, and a white floure, like that of the Orange, yet forsewharbigger, 


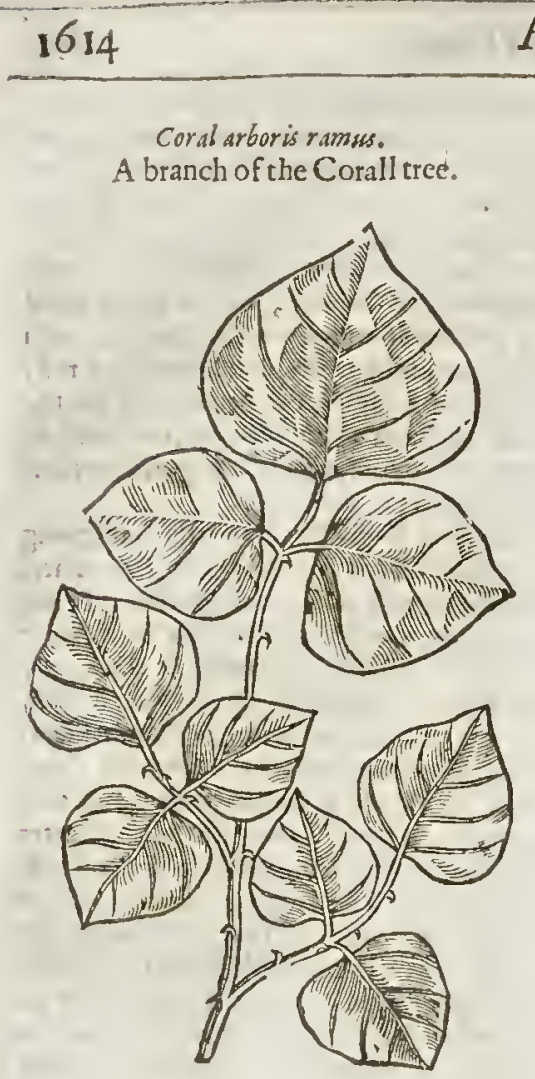

An Appendix to

reafon of his death who fent them me, which hapned Thortly after; y'et I hauc made the forme of the leaues wirh the manner as I coniectured they grow, to be delineared in the figure which I here give you. Whether Mat biolus in his laft edition of his Commentaries vpon Diofcorides would haue expreft this, by the Icon of his firft Acacia, whicti is prickly, and hath leaues refembling thofe of Lrtor Iuda, I know ror; but if he would haue expreffed this tree, the painter did not well play his
part.

After that Clufins had fet fo:th thus much of this tree in his Hift rariortm plant. the learned D. Caffameda a Phyfition alfo of Cinili certified me, faith he, that the fonres of this tree grow thicke together at the tops of the branches, ten, tweluc, or more hangiug vpon Thort foot-ftalkes, growing out of the fame place: whofe figure he alfo fent, but fo rudely drawne, that I could not thereby baue come to any knowledge of the foures, but that he therewith fent me two dried floures, by which I partly gathered their form. Now thefe flours were very narrow, 2 . inches long or more, confilting of three leaues, the vppermott of which much exceeded the 2 , narrow oncs on the fides both in length and breadth, and it was dourbIcd;but before the foure was opened it better refembled a horne or cod, than a floure, and in the middeft of the floure vnder the vpper leafe that was folded, but open at the top; there came forth a fmoth pointall, ditided at the top into nine parts or threds, who fe ends of what colour they were, as alfo the threds, I know not, becaufe I could not gather by the dry floure, whofe colour was quite decayed, and the picture it felf expreffed no feparation of the leates in the foure, no forme of threds, but onely the floures fhut, and refembling rather cods than foure, sand thofe of a deepe red colour. But if I could haue feen them frefher, I hould haue been able to haue giten a more exact defcription : wherefore let the reader take in good parr that which I haue here perfor-
med. Thus much clufius.

\section{C н}

If The Defcription.

Ome call this rma marian, and others haue thought it the Lenticula marina of Serapio, but they are deceiued, for his Lenticula marina defcribed in his 245. chapter, is nothing elfe than the Mufous marinas or Bryon tbalafion, defcribed by Dioforides, lib. $4 . \mathrm{cap} \cdot 99$. as any
that compares thefe two places together may plainely fee.

I The former of thefe hath many winding ftalkes, whcreon grow fhort branches fet thick wirl narrow leaues like thofe of Beluidere, or Befome flax, and annong thefe grow many skinny, hollow, empty round berries of the bigneffe and hape of Lentills, whence it takes the name : this growes
in diners places of the Mediterranian and Adriatickefeas.

2 This differs little from the former, but that the leaues are broader, fhorter, and fuipt about the edges. But this being in probabilitie the Sargazo of 1 cofta, you fhall here what he faies thercof. In that famous and no leffe to be feared nauigation del Sergazo (for fo they which faile into the Indies call all that fpace of the Ocean from the 18.to the 34.degree of Northerly latitude) is feen a decpe and fpatious fea couered with an herbe called Sarguazo, being a fpan long, wrapped with the tender branches as it were into balls, hauing narrow and tender leates fome halfe inch long, 
1 Lenticula marina angufifolia.

Narrow leaued Sea Lentill.

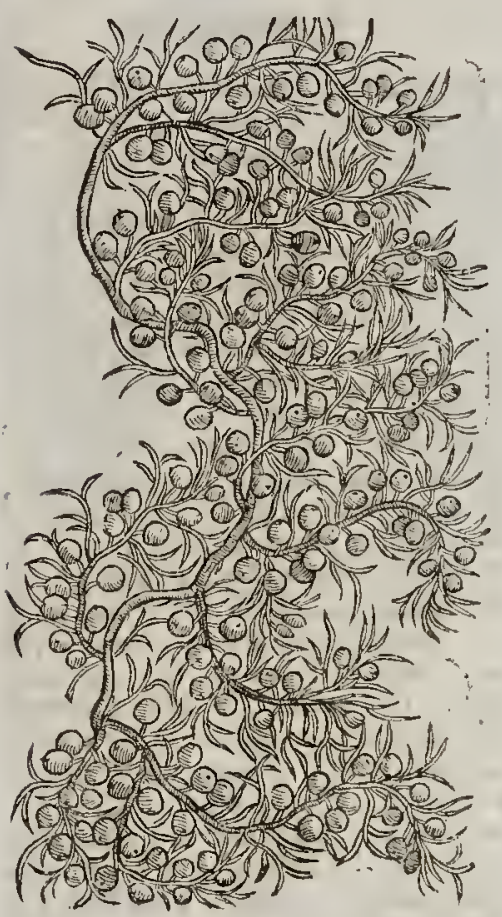

2. Lenticula marina ferratis folys: । Cut leaned Sea Lentill.

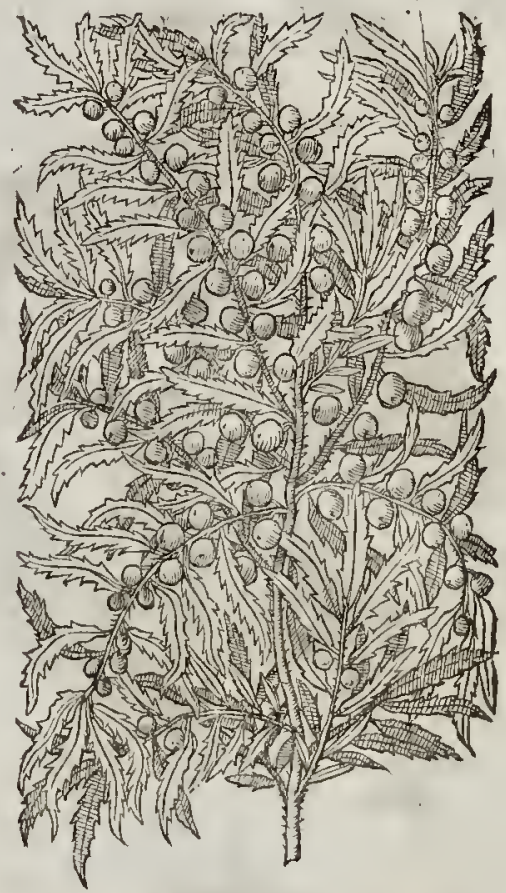

much fnipt about the edges, of colour reddin, of rafte infipide, or without any fenfible biting, but what is rather drawne from the falt water, than naturally inherent in the plant At the ferring on of cach leafe growes a feed round like a pepper come, of a whitih colour, and fometimes of white and red mixed, very tender when as it is firt drawne forth of thewater, but hard when it is dried, burby reafon of the thinneffe very fragile, and full of falt water : there is no root to be obfertred in this plant, but only the marks of the breaking off appeares; and it is likely it growes in the deepe and fandy bottome of the fea, and hath frall roots; yet fome are ofopinion that this herb is pluc ked vp and carried away by the rapide courfe of waters that fall out of many Inands into the Ocean. Now the Mafter of the fhip wherein I was did ftiffely maintaine this opinion; and in the failing here we were becalmed; but as far as euer wee could fee wee faw the fea wholly eouered with this plant, and fending down fome yong Sailers which thould driue the weeds from the fhip, and clenfe the water, we plainly faw round heapes there of rife vp from the bottom of the fea where by founding we eould finde no bottome.

* This plant piekled with falt and vineger hath the fame taft as Sampier, and may be vfed in ftead A thereof, and alfo eaten by fiteh as faile, in place of Capers. I willed it fhould be giuen newly taken forth of the fea, to Goats whych we earried in the fhip, and they fed vpon it greedily.

I found no faculties there of ; but one of the Sailers troubled with a diffieultic of making water, $B$. cafting out fand and groffe humors, ate thereof by chance both raw and boiled, onely for that the tafte thereof pleafed him : after a few daycs hee told to me that he found great good by the eating thereof, and he tooke fome of it with him, that fo he might vfe it when he came athore. Hitherto A Cofts. 
The Place.

It groweth in the deepeft ftreames of the Illyrian fea, whence the Fithcrmen draw it forth with hooks and other inftruments which they call Sperne. The whole plant, though dried,rerains
the faculties.

\begin{abstract}
THis elegant plant, which clufues re- crived from cortusus by the name of Myrioplyliam Pelagium, is thus defcrited by him: As much (faith hee) as I could conie Ature by the picture, this was fome cubit high, hauing a ftraight falke, fuffs. ciently llender, diuided' into many branches, or rather branched leaues, alrofof like thofe of Ferne, but far finer, bending their tops like the btanches of the Palme, of a yellowith colour : the top of the fa' $\mathrm{k}$ adomed with leffer leaues, cnded in $60 \mathrm{~s}$ tainc fcales or cloucs framed in to a head. which are found to containe no other ferd than tender plants already formed, in fhapc like to the old one: which falling, finke to the bottome of the fea, and there take roor and grow, and fo bccome of the fame magnitude as the old one from whence they came. The ftalke is faftned with moft flender and more than capillarie fibres, in ftead of a root, not vpon rocks and Oifter thells, as moft other fea planss are, but vpon fand or mud in the bottome. of the fea : this ftalke when it is drie is no lefie brittle thanglaffe or Coralline; bur greenc and yet growing it is as tough and flexible as Spartum or Matweed.
\end{abstract}

$$
\begin{aligned}
& \text { The Italian Fithermen callit Penachio delle } N i n f e \text {, and } P \text { alma de Nettuno . fome alfo, Scettro di Net: } \\
& \text { tuno. } \\
& \text { q The Virtues. }
\end{aligned}
$$
A They fay it is good againft the virulent bites of the Sea ferpents, and the venomous ftings or.
prickes of Fincs.

B Applied to fmall greenewound it cures them in the fpace of 24 houres.

C Cound fus writ, that he had made triall thereof for the killing and voiding of wormes, and that he found it to bc of no leffe efficacie than any Coralline, and that giuen in leffc quantitie.

\section{Cha p. 24. Of the Sea Fan.}

II The Defoription.

His elegant thrub groweth vpon the rnckes of the fea (where it is fometimes conered with the
water) in diuers places; for it hath been brought both from the Eaft and Wef Indies, and as
That been informed it is to be found in great plenty vpon the rocks at the Burmuda Ines, Cluffus
calls 
the Hiftory of Plants.

Frutex marinus reticulatus. Sea Fan.

calls it Frutex Marinis elegantißsmus, and

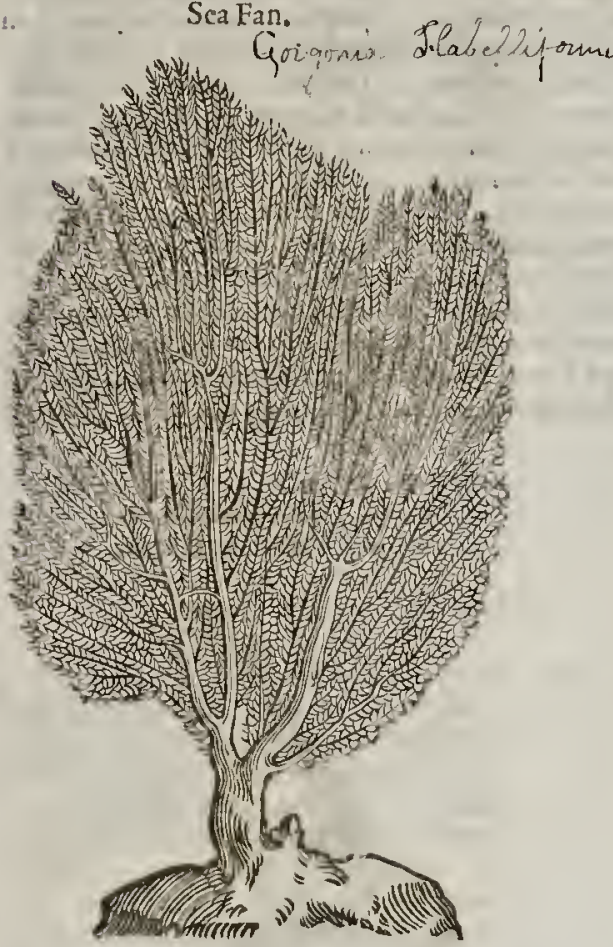

thinkes it may be referred to the $P$ alma $M a$ : rina of Theophraftus. Bubine hatls referred it to the Corallind's, calling it Corallina corticereticulato maculo o purpurraficnte. It growes vp fomtimes to the height of three foot, ha. uning a ftalke fome handfull or two high before it part into branches: then is it diuided in to three; foure, or more branches, which are fubdinided into infinite other leffer ftrings, which are finely interwouen and ioyned together as if they were netted, yet leauing fometimes bigger, othervhiles leffer holes: and thefe twiggy btanches be: come fmaller and fmaller, the farther they ate from the root, and end as ir were in fmal threds : thefe branches grow not vp on eterie fide, as in other plants, but flat one befides another, fo that the whole plant refembles a fan, or a cabbage leafe caten full of holes;yet fomtimes vpon the fides come forth other fuch fanne-like btanches, fome bigger, fome lefle, fometimes one or two, otherwhiles more. The inser fubftance of this Sea-Fan is a blackifh tough, and hatd wood, and it is all conered ouer with a rough Coral-like ftony matter, of a reddith or putplith colout, and this you may with your naile or a knife fcrspe of ffom the fmooth and blacke wood.

I know novfe of this, but it is kepr fot the beauty and raritie thereof, by many louers of fuch curiofities, amongft which for the tatenefe of the ftructure this may hold a prime place.

\section{Cha p. 25. Of China, and Baftard China. \\ If The Defcription.}

$\mathrm{T}$

His roorwhich is brought from the remoteft parts of the world, and is in frequentvfewith vs, hach notbeen knowne in Europe little aboue fourefeore and ten yeares: for Garsias $a b$ orta the Portugall Phy fition writes, That he came to the firft knowledge thereof in the Eaft Indies, in the yeare 1535 , and that by this meanes, as he relates it: It hapned (faith he) that about that time a merchant in the Ifle Dintold the noble gentleman $S^{r}$. Mart. Alfonfo de Soufa my Patron, by what meanes le was cured of the French Poxes, which was by a certaine root brought from China; whofe faculties he much extolled, becaufe fuch as vfed it needed notobferue fo ftrict a diet as was requifit in the vfe of Guajacum, but thould onely abftaine from Beefe, Porke, Finh, and crude fruits; but in China they do not abotaine from fin, for they are thete grear gluttons. When the report of this root was divulged abroad, euery man wonderfully defired to fee and vfe if, becaufe they did not well like of the ftrict dyet they were foreed ro obferue in the vfe of Guajacum. Befides, the inhabitants of thefe countries, by reafon of their idle life ate much giten to gluttony. About this time the China fhips arrine at Malaca, bringing a fmall quantitie of this root for their owne vfe. But this little was fought for with fuch earneftneffe, that they gaue an exceffue rate for it ; butafterwards the Chinois bringing a greater quantitie, the price fell, and it was fold verie cheape. From this time Guajacum began to be our of vfe, and banifhed the Indies, as a Spaniard that would famifh the Natiues. Thus much Gurcias concerning the firft vfe thereof in the Eaft Indies,

Vนиนиน 
I The China now in vec is a root of the largenefte of that of the ordinarie Flag, Iris paluftris, and nor much in fhape vnlike thereto, but rhar 15 wants the rings or circles that are imprinted in the other: the outer coat or skin of rhis root is thin, fometimes fmootb, otherwhile rugged, of a brownifli red colour, and not to be feparated from the fubftance of the root, which is of an indifferent firmeneffe, being not fo hard as wood, bur more follid than moft roots which are not of thrubs or trees : the colour is fomerimes white, with fome very fmall mixture of redneffe; otherwhiles it hath a greater mixture of red, and fonc are more red than white : it is almofe without taft, yet that it hath is dry, wirhout any bitterneffe or acrimonie at all. The beft is that which is indifferently ponderous, new, firme, not worme-earen, nor rorten, and which hath a good and frefh colour, and that either white, or mueh inclining thereto. The plant whofe root this is (if we may beleeuc Chrifopher A Cofta) harh many fmall prickly and Hexible branehes, not vnlike the Smilax appera, or the prickly Binde-weed : the biggeft of thefe exceedeth not the thickeneffe of ones little finger. The leates are of the bigneffe of thofe of the broad leaued Plantaine : the roots are as large as ones hand, fometimes lefte, follid, heauy, white, and alfo fometimes red, and many oft times growing together.

I China vulgaris officinaram. True China.

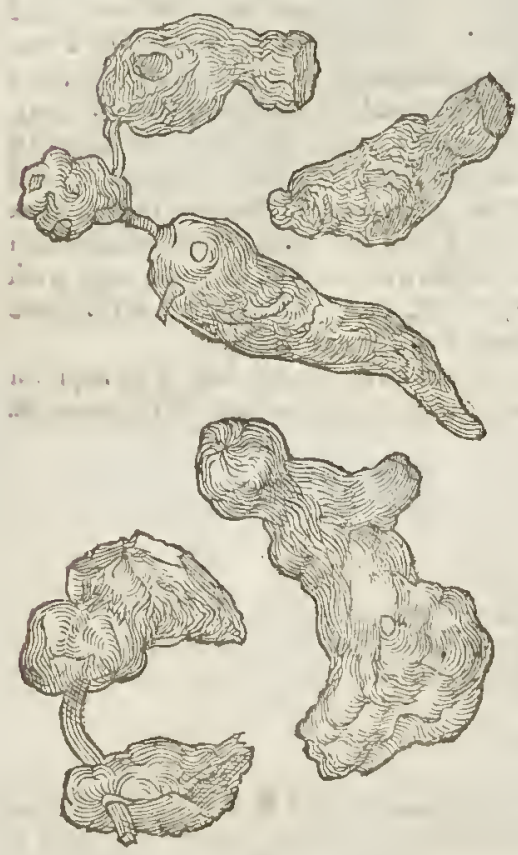

2 Pfezdo-Chins. Baftard Clina,

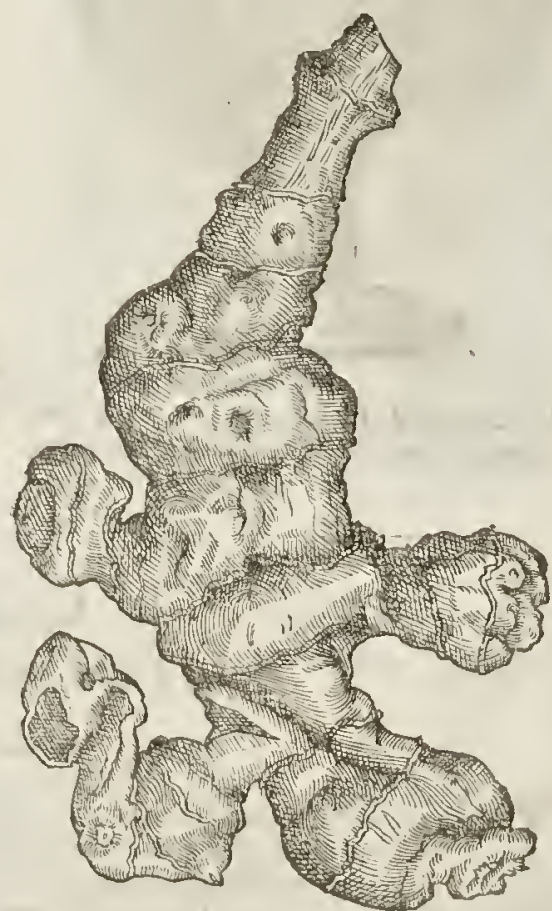

It groweth aboundantly in the territorie of China, and is alfo found in Malabar, Cochin, Cranganor, Coulan, Tanor, and other places.

The Chinois call it Lampat.n : in Deean they call it Lampatos : in Canarin, Bouti : the Arabians, Perfians, and Turks terme it Choph-China.

2 This other root, whofe figure you fee here expreft, was fent from London to Clufurs in the yeare $159 \mathrm{r}$, by Iames Gurret, being brought out of Wingandecaow, or Virginia, with rhis infcription, Chine pectes, A kinde of China. Clafus caufed this figure thereof to be drawne, and thus defcribeth it. This root (faith hee) was very knorty, and formed with our-growings, or bunches ftanding our, of a reddifh colour, and it yet rerained at the top fome parr of rhe Italke, being fomwhat like vnto that of swilax aper., or common rough Binde-weed, hard, wooddy, and full of veines, as the ftalks of $S$ mild ax apera . the fubftance of the root was alfo reddin, as theroot of the common Flagge, at the firft of a faltihl tafte, it bcing old, (for fo it was when I receiued it) 
and thendrying. Now I indge this the fame that the writer of the Virginian Hiftorie mentions in his chapter of roots, and faith, it was broughtinto England for Clina, thougln the Natiues knew novfe there of: but they vfe another root very like China, which they call $T$ finam, of which beeing cur, beaten, and preffed out with water, they draw a inice wherewith they make their bread. Thus much Clus fus, to whofe words I thinke it not amiffe to adde that which M'. Thomas Hariot (who was the writer of the Virginian lilttorie, here mentioned by Cluffius) hath fet downe concerning this thing.

T finaw (faith he) is a kinde of root much like vnto that which in England is called the China root, brought from the Eaft Indies. And we know not any thing to the contratie but that it may be of the fame kinde. Thefe roots gtow many together in great clufters, and doebring fortl a Brier ftalk, but the leafe in thape is far vnlike:which being flupported by the trees it groweth necereft vn. to,wil teach or clime to the top of the higheft. Ftom thefe roots whileft they be new or frefh, being chopr into fmall pieces and ftampt, is ftrained with water a ituice that maketh bread, and alfo beeing boiled, a very good fpoonemeat in manner of a gelly, and is much better in tafte, if it be tempered with oyle. This T fmav is not of that fort which by fone was caufed to be brought into England for the Clina roor; for it was difcouered fince, and is in vee as is aforefaid; but that which was brought hither is not yet knowne, neither by vs, nor by the inhabitants, to ferue for any vee or purpole, al though the roots in thape are very like. Thus much Hariot.

\section{The Temperatureand Vortucs.}

China is thought to be moderately hot and drie : the decoction thereof made alone or with o- A ther thing s, as the difeafe and Symptomes thal require, is mich commended by Garciar, for to cure the French pox, but chicfely that difeafe which is of fome ftanding: yet by moft it is iudged leffe porverfull than Guajacum, or Sarfaparilla.

It attenuares, moues fweat, and dries, and therefore refifts putrifaction : it itrengthens the liuer, B helpes the dropfie, cures maligne vlcers, fcabbes, and lepry. It is alfo commended in Confumptions.

The decodion of this root, faith Garcias, befides the difeafes which haue communitie with the $\mathrm{C}$ Poxe, conduces to the cure of the Palfie, Gout, Sciatica, fchirrous and cedematous tumours. It al. fo helps the Kings-cuill. It cureth the weakenefle of the ftomacke, the inucterate head-ache, the ftone and vlceration of the bladder; for many by the vfe of the decoction hereof baue beene cured, which formerly receitued help by no medicine.

\section{CHAn:26. Of Coftus.}

TI The Defoription.

Thur

His fimple medicine was briefely defcribed by Diofcorides, who mentions three kindes thereof, bur what part of a plant, whether root, wood, or fruit, he hath not expreft: but one may probable. $1 y$ conie eture it is a root, for that hewirites toward the end of the Chapter where he treats thereof, lib. I.cap. I 5.that it is adulterated by mixing therewith the roots of Helenism commagenum; now a root cannorwell be adulterated but with another. Alfo plirg, lit. I 2.cap. I 2 .calls it a root; but neither any of the antient or moderne Writers haue deliniated the plant, whofe roor fhould be this Coftus. Diojcorides makes three forts, as I hate faid : the Arabian being the beft; which was white, lighr, trong, and well fmelling : the Indian, wlich was large, light, and blacke: the Syrian, which was heauic of the colour ot Box, and ft rong fmelling. Now Plimy makes two kindes, the blacke, and the white, which he faith is the better; fo I iudge his blacke to be the Indian of Diofcorides, and his white, the Arabian. Much agreeable to the fe (but whether the fame or no, I do not determine) are the tworoors whofe figures there prefent to your view, and they are called by the names of Coffus dulcis (I thinke they thould hate faid odoratus) and coftus smarus.

I The firt of thefe, which rather from the fmell, rhantafte, is called fweet, is a pretty large root, ligh,, , whirc, and well fmelling, hauing the fmell of Orris, or a violet, but fomew hat more quick and prercing, efpecially if the roor be freth, and not tooold :it is oft times diuided at the top into two, three, or more parts, from whence feuerall italks laue growne, and you fhall fomtimes obferue vpon fome of them pieces of thefe ftalks fome two or three inches long, of the thickeneffe of ones 
litrlc finger,crefted, and filled with a foft pith, like as the ftalks of Elder, or morc like thofe of the Bur-docke : the tafte of the root is b itter, with fome acrimonic, which alfo Diofcorides requites in his, for he faith, the talte fhould be biting and hot ${ }_{3}$ thus much fot the fitt, being Coffus dulcis of the Thoppes.

I Coftus Indicus freodoratus. Indian or fweet fmelling Coftus.

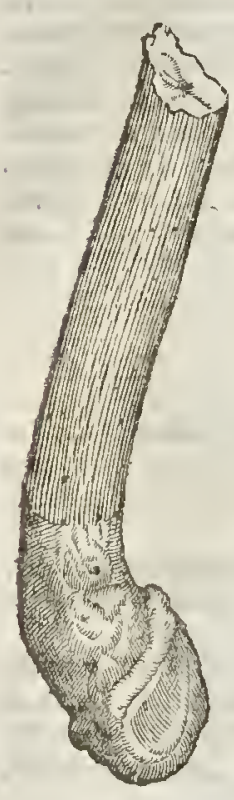

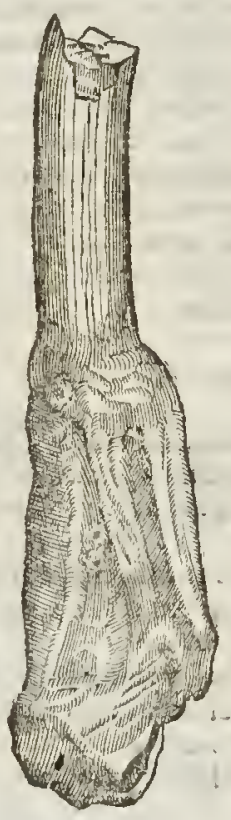

2 Cost us Officinarum Lobeliy. Bitter Coftus.
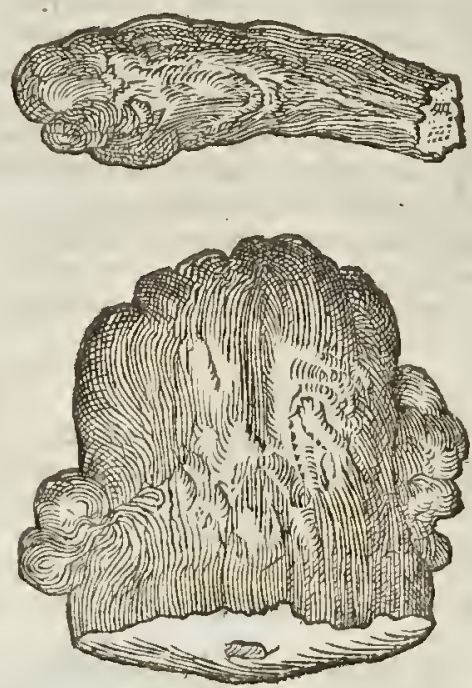

2 The fecond, which is the Cofus amarss, and it may be the Indian of Diofcorides, and Niger of $P$ liwy, is a root blacke both within and withour, light,yet very denfe. It fremes to be of fonie large root, for that it is brought ouer cut into large pieces, of the bigneffe of ones finger, fometimes bigger fometimes leffe, which it feemes is for the more conuenient drying theteof, fot a latge tont, vn leffe it be cut into pieces can fcarcely be wel dried:the tafte of this is bitcer, fomewhat clammy and ingrate : the fmell is little or none.

Thereare fome other toots which haue been fet forth by late writers for Coftus, but becaufe they are neither in vfe, knowne here with vs, nor more agreeablec to the defcriptions of the Antients, I haftening to an end, am willing to paffe them oner in filence.

$$
\text { TT The Temperature and Vertues out of the Antients. }
$$

A It hath a heating and attenuating facultie, and therefore was ved in oile to annoint the bodie againft the cold fits of A gues, the Sciatica, and when it was need full to dtaw any thing to the fuperficies of the body.

B It is alfo contenient to moute vrine, to procure the termes, to help ftrains, convulfions, or cramps and paines in the fides; and by reafon of the bitterneffe it kills wormes.

C It is good to be drunke againft the bite of the viper : againft paines of the cheft, and windineffe of the ftomacke taken in Wine with Wornte-wood: and it is ved to be put into fundrie Antidotes: 


\title{
Сна Р. 27. OfDrakes root, or Contra-yerus.
}

\author{
बा The Defcription.
}

Hat root whicli of late is knowne in fomc thops by the Spanifh name Contra-yerua, is the fame which Cluf fus hath fet forth by the ritle of D rakema radix : wherefore I will giue you the hiftoric of Clufuss, and thereto addc that which Monardus writes of the Contra-yerua. For though Babhinc, and the Author of the Hifforia Lug dunenfis fccme to make thefc diffcrent, yet I finde that both Clufus his figure and hiftorie cxastly agrec with the roots fent vs from Spainc by that title, wherefore I thall makc them one, till fome fhall thew mchow they differ: and Clufius feemes to be of this minde alfo, who defired but the degree of heatc which Morn.rdus gines thcle, and that is but the fecond degree : now thefe haut no tafte at the firft,vntill you haue chewed them a pretty while, and then you thall findc a manifeft heate and acrimonie in them, which clufius did allo obferue in his.

-In the ycare (faitl Clufuls) 158 r.thc generous Knight Sir Fraxicis D rake gaue me at London certain roots, with threc or foure Peruvian Beazor ftones, which in thc Autumne before (hauing finithed his voyagc, wherein paffing thc Straights of Magellan, hc had encompaffed the World he had broug ht with him, affirming them to bc of high cfteeme amongit the Peruvians : now for his fake that beftowed thcfe roots vpon mc, I haue giuen them the title Drik'na radsx, or Drakes root, and haue made them to be expreffed in a table, as you may here fec them. ?.
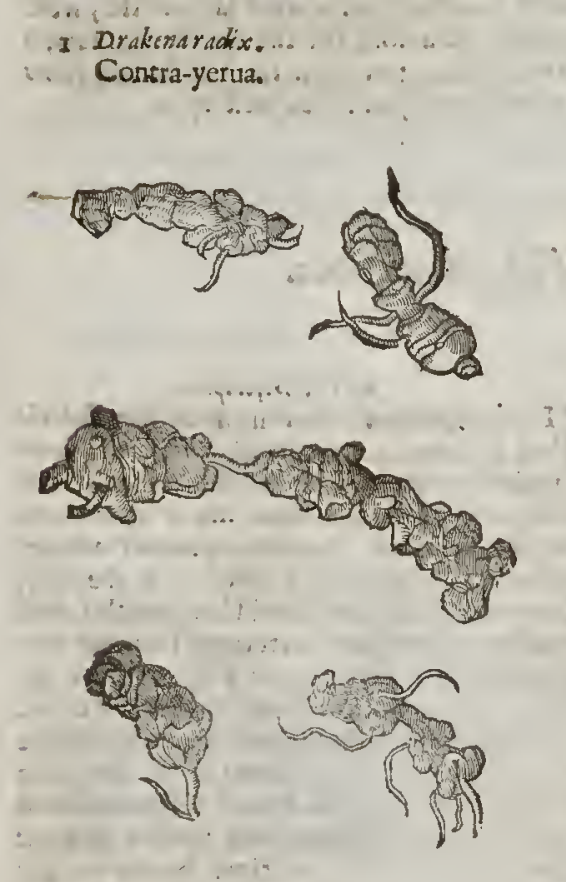

Thefe roots were for the mott part fome halfe inch thick, longith, now and then bunching out into knots and rnequall heads, and their tops lookcd as if thcy were compoled of thicke fales, almont like thofe of the Denturia emneaphyllos; blackifh withour,wrinckled, and hard. becaule dried: their inner part was white; they had lender fibres here and there growing out of theru, and fome more thicke and large, hard alfo and tough,at which hung other knots: I ob fcrucd no manifelt finel they had, but found them to haue a tafte fomcwhat aftringent, \& dry ing the tongue at the firft ; but being Jong chewed, they left a quicke and pleafing acrimonie in the mouth

It feemed ro have grcat affinitie with the Radis. S. Helane, whereof Nic. Monardus fpeakes in his booke of the Simpte Medicines btought from the Wctt Indies:but feeing N, Elot (who accompa. 
nied $S^{5}$.Fran.Drake in that voyage, faid, that the Spaniards in Peru had them in great requef, and they could not cafily be got of them, and that he had learned by them, that the lcaues were prefent poifon, but the root an antidote, and that not only againft the fame poifon, but alfo againft other and that it ftrengthned the heart and vitall faculties, if it were beaten to pouder, and taken in the moming in a little wine; and gituen in water, it mitigated the heat of Feuers. By reafon of thefe fa. culties it thould much agree with the Radix Contra-yerua, where of Cronardus writes in the fame booke : yet in thefe I required the aromaticke tafte and degree of heate, which he attributes vnto chicfe roots. Thus much clur.

A From Charcis a Prouince of Peru, faith Monard.are brought certaine roots very like the roots of Ir $\dot{x}$,but leffe,and hauing the fmell of Fig leaues. The Spaniards that liue in the Indies call them Contra-yerua,as if you thould lay an Antidote againft poifon;becaufe the pouder of them taken in white Wine is a molt prefent remedy againft all poifon of what kinde foetrer it be (only fublimate excepted, whofe malignitic is onely cxtınguifhed by the drinking of milke) it caufes them to bee caft v by vomite, or euacuated by fweat. They alfo fay that Philtres or anorous potions are caft forth by drinking this pouder. It alfo killeth wormes in the belly. The root chewed hath a ccrtain aromaticke tafte ioined with acrimony; wherefore it feemes hot in the fecond degree. Thus farre Monardses.

2 Clufus Exot.l. 4.C.II.being the next after Drakena radix, defcribes this root, whofe figure I giue you in the 2.place, \& that by the fame title as it is here fer forth. Thefe roats, faith he, feemed fon what like the Drakenaradix which were found in the great thip which brought backe the Viceroy from the Eaft Indies, and was taken by the Englith : for they were tuberous; and as much as one may gather by their forme, crept vpon the furface of the earth, hating vpon them many haires and fibres, and being of a footy colour, yet fomewhat inclining to yellow, dying the fpittle in chew ing them, and being bitter : they as yet retained foot-talks of the leaues, but of what farhion they were no man can eafily guefe. But it was likely they were of great vfe among the Indians, feeing that the Vice-roy brought them together with other precious medicines growing in the Eaft Indies, Iames Garret fent this to clufsus with the little plant dryed,w hafe figure you fecexpreft by it.

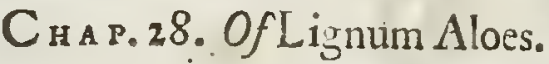

Lignum Aloes vulgare:

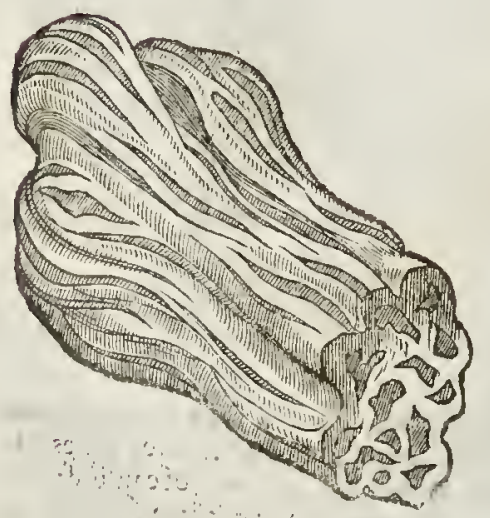

91 The Defription:

$T$ is a queftion whether the Agallochum defcri: bed in the 2 I.c.l. 1 of Diofcorides be the fame which the later Greeks and thops at this time call $X y$ loalo, or $L$ gnum Aloes, many make them the fame : ohers, towhofe opinion I adhere, make them differerent, yet hate, not the later, thew what Arallochum fhould bee, which I notwithetanding willdo; and though I doe noc now give you my arouments, yet I will point at the thing $3,8 x$ thew ofitucly my opinions of them.

The firft and beft of thefe is that which fome call Calumbar:orhers, Calurs ba, or Calambec: this is of high efteem in the Indics, \& feldom found bur among ft the Princes, and perfons of great cualitic; for it is fold oft times for the weight in gold; I haue not feen any therofbut in beads, it feenes to bea whiter wood than the ordinary. of a finergraine, not fo fubiect toros, and of a more fragrant finell, and but light.

The fecond fort, which is vually brought o: uer, and called in thops by the name of Lignum Aloes, is alfo a precions and odoriferous wood, efpecially burnt : the ftickes of this are com. monly knotcy \& vnfightly: fome parts of them being white, foft, and doted : otherforne, denfe, blackilt. 
blackifh,or rather i atermixt with blacke and white veines, but much more b lacke chan whice, and this put to the fire will fweat out an oily moifture, and burnt, yeeld a molt fragrane odour. This $I$ take to be the true Xylouloc of the late Greekes; and the Agalugen of Anicen; and that they call Palo \& Agula in the Indies.

The third is a wood of much leffe price than the former : and I coniccture it might well be fub. ftituted for $T$ hus : and this I take to be the Agallochum of Diofcurides; the Ligysm Aloes fylueftre of Garcias; and Agula brazu of Linfcosen. It is a firme and follid wood, fomewhat like that of the Cedar, not fubiect to rot or decay : the colourthereof is blackin, efpecially on the out-1ide; but on the in-fide it is oft times brownirh and fpeckled,containing alfo in it an oilie fubftance, and yeeld ing a fweet and pleafing fmell when it is burnt, but not like that of the two former : the tafte difoot this is bitterer than that of the former : and the wood(though denfe and follid)may be eafily eleft long-waies;it is alfo a farre handfomer and more fightly wood than the forner, hatuing nor many knots in it.

Garcias ab orta thus defcribes the tree that is the Lignum Aloes (I iudge it's that I haue fet forth in the fecond place:) it is (faith he) like an Oline tree, fumetimes larger: the fruit or floure I coild not yet fee, by reafon of the difficulties and dangers whic ha te to be indergone in the accirate obfer. uation of this tree (Tigers frequently there feeking their prey.) I had the branches with the leaues brougtrime from Malaca. Now they fay that the wood new eut downe hath no fragrant odour, nor till it be dried: neither the fmell to be diffufed ouer the whole marter of the wood, but in the lieart of the tree; for the barke is thicke, and the matter of the wood without fmell. Yet may I not denie, but the barke and woot putrifying that oilie and fat moifture, ray betake it felfe to the beart of the tree, and make it the more odoriferous : but there is nn need of purtifattion to get a finetl to the Lignum Aloes: for there are fundry fo expert and skilfull in the knowledge therrot, that they will indge of that which is new cut downe,whither it will be odoriferous or no. For in all forts of wood fome are better than otherfome:thus much out of Garciaj; where fuch as are defirous nay fee more vpon this fubicat.

Tा The Temperature and vertues.

It is of temperature moderate ly hot and dry, and alfo of fomcwhat fubtill parts. Chewed it A makes the breath fmell fweet; and burnt it is a rich perfume.

Taken inwardly it is good to helpe the ftomack that is too cold and moif, as alfo the weak liner. B

It is commended likewife in dyfenteries and pleurifies: and put allo into diuts Cordiall med i. C cinges and Antidotes as a prime ingredient.

\section{С на г. 29. Of Gedwar.}

I Gedwar aut, Geiduar.

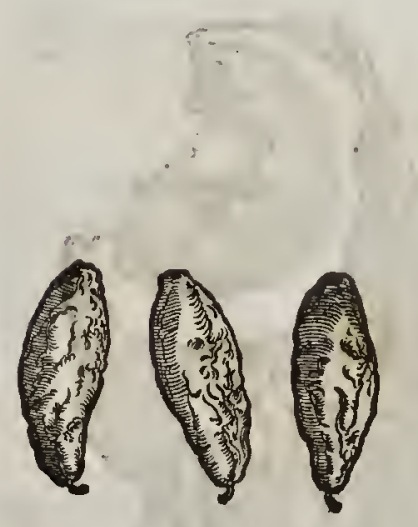

2 Zedoaria cxactior icon. A better figure of Zedoary?

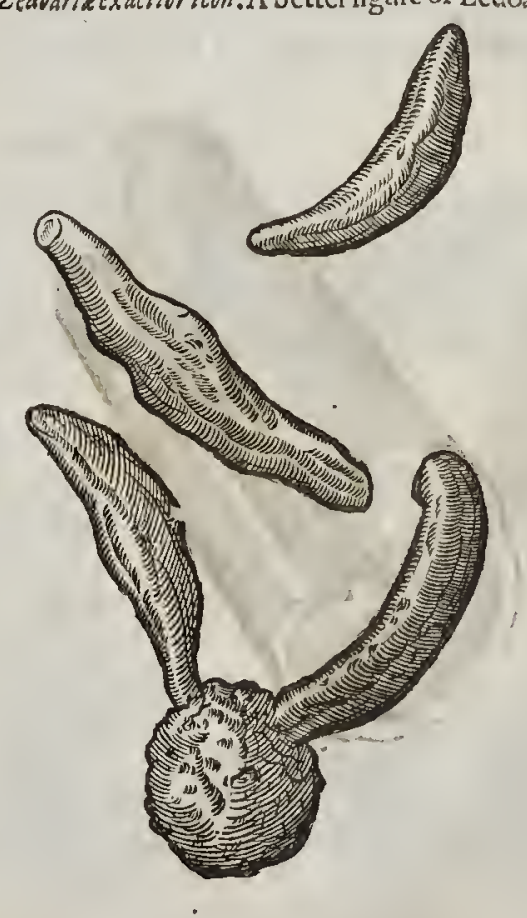


T) The Defoription.

- N vhe (hapter of Zedoaric(which I made the 28 . of the firtt booke) I might fitly haue given you

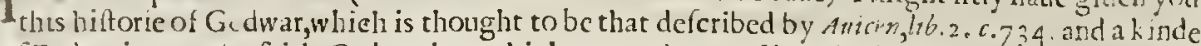
of Zedoarie: Garcias faith, Gedwar is at a high rate, and not eafily to be found, vnleffe with the Indian Mountibanks and juglers, which they call logues, which goc vp and downc the countrey like Rogues, and of thefe the Kings and Noblemen buy Geidnar : it is good for many things, but chiefely againft poifons, and the bites and Angs of venomous creatures. Now Cluf fars in bis suctarium at the end thereof gimes this figure, with the following hiftorie.

I. Becaufe Garcias, faith he, cap.42.l.1 . Aromatum hift. treating of Zec'oarie writes, that Anicon calls it Gedwar; and faith that it is of the magnitude of an Acorne, and almoft of the fame fhape, I in my notes at the end of that chapter affirmed that it was not krowne in Euroje, and hard tobe knowne. But in the yeare $1605,10 \mathrm{hn}$ Pona fent me from Verona together with otlier things two roots written on by the name of Gedwar verum. They were not much vnlike a longith Acorne, or (that I may more truly compare them) the fmaller bulbs of an A fphodil,or Anthora : the one of them was whole and not perithed: the other rotten and broken,yet both of them very hard and follid, of an aih colourwithout, but yellowin withinwhich tafted, feemed to poffeffe a hcating facultie and acrimonie.

But although I can affirm nothing of certaintie of this root, yet I made the figure of the wholler of them to be expreft in a table, that fo the forme might be conceitred in ones minde more eafily, than by a naked defctiption. Let the Studious thanke Pona for the knowledge hereof. Thus much Clufius.

2 In the 28 chapter of the firt booke I gatte the figure of Zodoarie out of Clufuss, hauing not at that time this figure of Lobel,which prefents to your view both the long and the round, with the manner how thcy grow together, being not feuerall roots, but patts of one and the fame.

\section{С нат: 30. Of Role-nrood.}

Apalatbus albicans torulo citree:

WhiteRofe-wood.
Apalatbus rubens. Reddifh Rofe-wood,
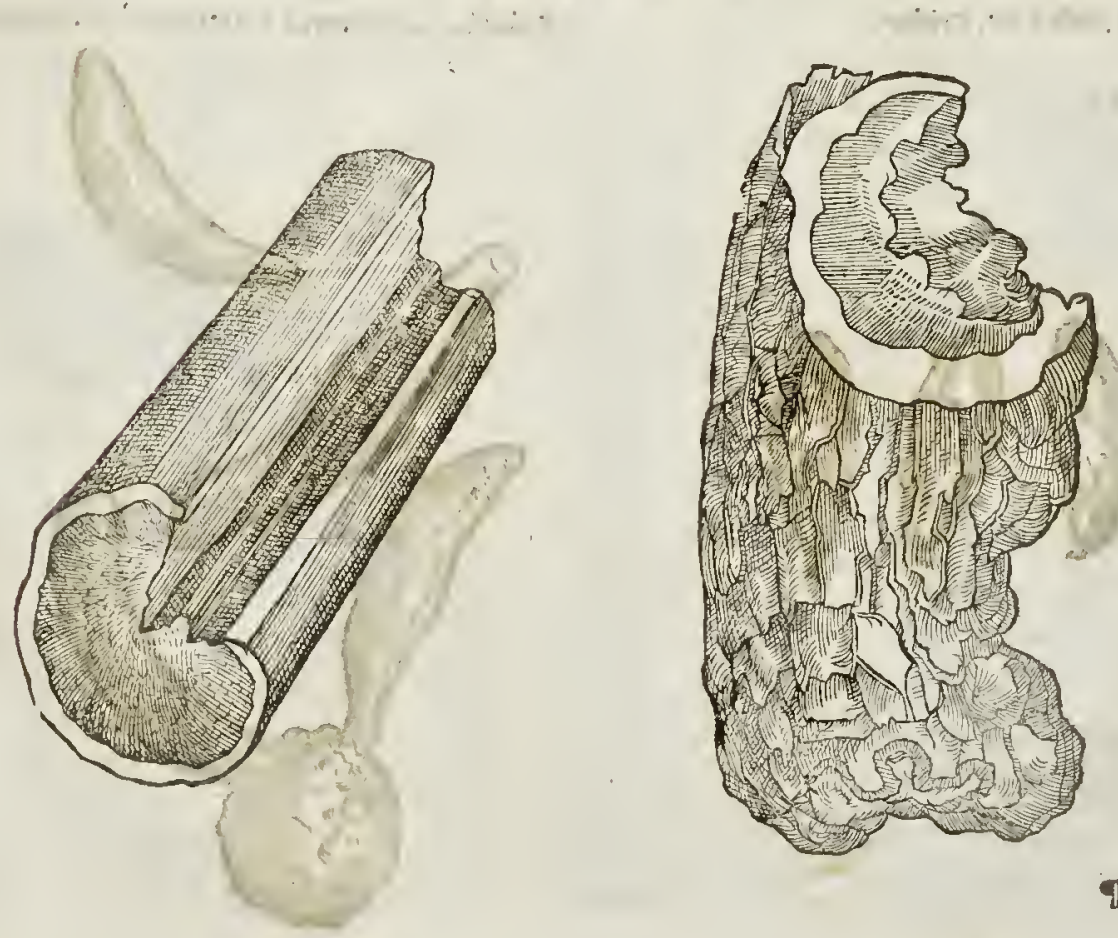
T) The Defcription.,

D th the fe as alfo fome other woods are referred to the $A \int p a l a t h w$ defcribed by Diofcoridis, $l . \mathrm{I}_{\text {. }}$. c.19.But rhe later of rhefe I take to be the better of the two forrs there menrioned. The firf of them is whirith without, haung a yellowith or eitrine coloured round in the middle : the tafte is hottifh, and fmell fomewhat like that of a white-Rofe.

The other harh alfo a fmall ring of white, next the rhicke and rugged barke, and the inner wool is of a reddith colour,very denfe; follid and firme, as alfoindifferent heauy : the fmell of this is alfo like that of a Rofe, whence rhey vulgarly eall it Ligrum Rhodism, Rofe-wood, rather than from Rhodes the place where the later of them is faid to grow.

\section{If The Faculties out of Diofcorides.}

It harh a heating facultie with a triction, whence the decoction thereof made in wine is conue: A nient to wafh the vleers of the mouth, and the cating vleers of the prituties and fuch vnclean fores as the $O$ zena (a ftinking veer in the nofe fo called.)

Put vp in a peffarie it drawes forrh the childe, the deco tion thereof ftayes the loofeneffe of the belly, and drunke it helpes the eafting vp of bloud, the difficulrie of making water, and windineffe.

A

T the end of this Appendix I haue thought good to giue you diuers deferiptions of Plants, which I receiued from my often mentioned friend $\mathrm{M}^{\mathrm{r}}$. Goodycr, which alfo were omitted in their fitting places, partly through hafte, and parrly. for that I reeciued fome of them after the prinring of thofe chapters wherein of righr rhey thould haue been inferted. They are moft of them of rare and not written of plants, wherefore more gratefull to the curious.

\section{Hieracium fellatum Boelj̄.}

THis plant is in round, hairy, fraked, branched falks, and long,rough,blun indented leaues like to Hieracism falcat um, but fearce a foot high : the floures are alfo yellow three times fmaller: which pat, there fucceed long crooked flender harpe pointed cods or huskes, neere an inch long, fpreading abroad,ftar-farhion,wherein a long feed is conrained:rhis hath no heads or woolly down like any of the reft, but onely rhe faid erooked coddes which doc ar the firft fpread abroad. The root is fmall, threddie, full of milkic iuice, as is alfo the whole plant and it perifheth when rhe feed is ripe.

\section{Hieracium medionigrum flore maiore Boeliy.}

This hath ar the firft fpreading von the ground many long, narrow, green, fmooth leates blunt: ly indented about the edges, like thofe of Hicracium falcatum, bur fmaller : amongft which rife vp rhree, foure, or more, (mall, fmooth, fraked round ftalks, diuided inro other branches, which grow longer than the ftalks themfelues leaning or trayling neere the ground:the floures grow on the tops of the ftalks, but one together,compofed of many pale yellow leaues, rhe middle of each floure being of a blackifh purple colour.

\section{Hieracium medio nigrum flore minore Bocly.}

This is alrogether like the laft before defcribed in ftalkes and leaucs: the flourcs are alfo of a blackith purple in the middle, but they are three times fmaller.

\section{Hicracium lanofum}

There groweth from one root three, foure or more round vpright fofr cortonic ftalks, of a reafonable bigneffe, two foot high, ditided into many branehes, efpeeially neere the rop, whereon groweth at eaels diuifion one broad tharpe pointed leafe, diuided inro corners, and very much erumpled, and alfo very foft cotronic and woolly, as is rhe whole plant $:$ rhe floures are fmall, double, of a palc yellow colour, , ery like thofe of $P$ ilofella repens, grow ing clufering very many rogether at the tops of the ftalkes and branches, forth of fmall round foft cottonie heads : thefe foure plants grew from 
feed which I receined from $\mathrm{M}^{\mathrm{r}}$. Coys, 1620 . and I made thefe defcriptions by the Plants the $22.0 \mathrm{f}$ Augurt, $162 x$.

$$
\begin{gathered}
\text { Blitumfpinofum: eft Beta Creticafemine aculeato Baubini CMatth. } \\
\text { pag. } 37 \mathrm{r} \text {. }
\end{gathered}
$$

This fendetl forth from one root many round greene ft trailing, ioynted, fmall branches, about a foot long : the leaucs are of a light greene colour, and grow at cuery ioint one, fomewhat like the leaues of great Sorrell,but they are round topped without barbes or eares below, or any manifeft tafte or fmell, very like the leaues of Beets, but much fmaller : the floures grow cluftering together abour the ioints, and at the tops of the branches fmall and greenifh, each floure containing fiue or fix very fmall blunt topped leaues, and a few duftic chiues in the middle: which paft, there eommeth great prickly thriuelled feed, growing enen clofe to the root,and vpwards on the ioints, eaeh feed having three fharpe priekes at the rop growing fide-waies, which indeed may be more properly ealled the huske;which huske in the in-fide is of a darke reddifh colour, and containeth one leed in forme like the feed of $F$ los Adonis, round at the lower end, and cornered towards the top, and tharp pointed,eouered oner with a darke yellowith skin; which skin pulled away, the kernell appeareth yellow on the outfide, and exceeding white withing and will with a light touch fall into very fruall pouder like meale.

\section{Geranï Betice Jpecies Bocliy.}

This hath at the beginning many broad leancs, indented about the edges, fomwhat diuided, like thofe of Geranium Cretıcum, but of a lighter greene colour, and fmaller : amongtt which grow vp many round hairy kneed trailing branehes, diuided into many other branches, bearing leaues like the former, but fmaller, and no more diuided. The floures are fmal like thofe of Geranum Mofchatum, but of a deeper reddin eolour,each floure hauing fiue fmall round topped leaues: after followeth fimall long hairie feed, growing at the lower end of a fharpe pointed beak like that of Geramism $M O f$ chatum: the whole plant perineth when the feed is ripe.

Boelius a Low-countrey man gathered the feeds hereof in Bxtica a part of Spaine,and imparted them to $\mathrm{M}^{\mathrm{r}}$. William Coys, a man very skilfull in the knowledge of Simples, who hath gotten plants thereof,and of infinite other ftrange herbes, and friendly gaue me feeds hereof,and of many other, Anno, 1620 .

\section{Antivrhinum minus fore Linaric luteum inforiptum.}

This hath at the firf many very fmall, round, fmooth branehes from one root, trayling on the ground, about foure or fue inelies long, fet with many fmall greene hort fharp pointed lestes, like thofe of Serpilhm, but that thefe are longer, fmooth, and three or foure growing oppofite one againf another: among ft which rife vp fite or fix, fometimes ten or twelue vpright round fmooth little ftalks a cubit high,dinided into branehes bearing fmall long fmooth greene leates, growing without order,as narrow as the vpper leaues of oenanthe Anguftifolia: at the toppes of the ftalks and branehes grow eluftering together fiue fix or more fmall yellow floures, flouring vpwards, leauing a long fpike of very fmall huskes, eaeh huske hauing a finall line or ehinke as though two huskes were ioined together, the one fide of the huske being a little longer than the other, wherein is eontained execeding fmall blackin feed. The root is very thort, fmall, and white, witl a few threds, and perifherh atwinter.

This plant is not written of that I can finde. I recciued feed thereof from $\mathrm{M}^{x}$. W William Coys often remenbred.

\section{Linaria minor aftiua.}

The ftalkes are round, fmooth, of a whitith greene colour, a foot high, weake, not able to ftand vpright : whereon grow long narrow fharpe pointed leaues, moft commonly bending or turning downewards. The foures grow in fpikes at the toppes of the branches, yet not very neere together,and are verie finall and yellow, with a fmall tayle : the feed of this plant is fmall, flat, and of a blackith gray eolour, inelofed in fmall round huskes, and you thall enmmonly haue at one time floures and ripe feed all on a falke. The whole plant is like to the common Linwia, but that it is a great deale leficr, and the floures are fix times as fmall, and perillo at W' inte: I alfo receited feeds thereof from $\mathrm{M}^{\mathrm{r}}$. William coys. 


\section{Scorpioides waltifloras Bö̈lÿ.}

This Plant is in cteeping branches and leaues like the conmon Scorpioidis buplesiri folio : the fioures are alfo alike, but a little bigger, and grow foure or fitue rogether on one foot-ftalke: the cods are rougher, and very much rurned sound, or folded one within anozher: in all things elfe alike.

\section{Scorpioides friliguacraffa Boeliy.}

This is alfo like the other in creeping branches and leaues: the flourcs are fomething bigger than any of the reft, and grow not aboue one or two tonerher on a foot-ttalk : the cods arc crooked, without any rough haire, yet finely ehcekquered, and feuten times bigger than any of the reft, fully as big as a grear Palner-worme, whcrein is the difference : the feed is almott round, yet extending fonewhat in length, almoft as big as fmall field Peafon, of a browne or yellowith colour. This al fo periheth when the feed is ripe.

Sept. 1. 1621 .

Silibum minus flore nut arate boelij.

This Thiftle is in falkes and leaucs much fmaller than our Ladies Thifle, that is to fay, The fta'kes are round, Araked, fo new hat woolly, with narrow skinny prickly edges three or fours foot high, diuided into many branches, whereon grow long leaues, deeply diuided, full of white milkclike ftreakes and tharpe prickles by the edges: the foures grow on the rops of the ftalks and branche, forth of fmall hcads, commonly turning downwards, of the big neffe of an Oliue, fer with very fmall llender marpe pricls, containing norbing but fmall purple chites, trreading abroad like thof of Itcen, with fome blewith chitues in the middle: the fecd followeth, inclofed in downe, and is fmall and grayih likc the fced of orher Thiftes, but it is as clammy as tsird-lime. The whole plant peritherh at Wintsr, and reneweth it felfe by rhe falling of his feed. I finde not this written

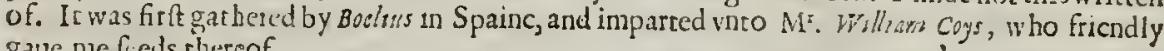
gave me feeds thereof.

Aracus maior Baticus Boelij.

It liath fmall weake foure fquare ftreaked trailing branches, two foot high, leffer, but like thofe of Eetches; whereon grow many leaues without order, and eucry feuerall lcafe is compofed of fix, feuen, or more fmall tharpe pointed leaues, like thofe of Lentils, fet on cach fide of a middle rib, which middle rib cndeth with clafping tcndrels : the floutes grow forth of the bofomes of the leaues, but one in a place, almoft without any foot-ftalkes at all, like thofe of Vetches, but of a whitifh colour, with purple ttrcakes, and of a deeper colour rending to purple towards the nailcs of the vpper couering leaues : after which follow the cods, which are litrle aboue an inch long, not fully fo big as thofe of the wildebcane, almoft round, and very hairy: where in is contained about 4 peafon, feldom round, moft commonly fomewhat flat, and fometimes corncred, nf a blackith co. lour, neere as big as field peafon, and of the tafte of Ferches: the whole herbe perilheth when the feed is ripe. This plant Boelines fent to Mr. Willam Coys, who hath carefully preferucd the fame kind ener fince, and friendly imparted fecds thercof to mc in $A m n o$ I $6_{2} 0$.

\section{Legumen pallidum Vlifipanenfe, Nanï Branciony.}

This plant is very like, both in ftalks, leaues, and cots, to $A$ Arscus matior Beticus, but the floures of this are of a pale yellow or Primrofe colour, and the whole herbe fraller, and nothing to hairy. It peritheth aifo when the feed is ripc. I receiued the feeds likewife from Mr. Coys.

\section{Ficia Indica frü̈u aibo. Pifum Indicum Gerardo.}

This Vetch differeth not in any thing at all, either in ftalkes, learcs, cods, falhion of the fontres, or colour thercof, fro nour conmon manured Vetch, but that it groweth higher, and the fruit is bigger and rounder, and of a very cleare white co'our, morc like to peafon than Veiches. Mir. Gerrardwas wont to call this Vetch by the name of P:fum Indicum, or Indian Peafe, gorten by hin af. ter the publihing of his Herball, as Mr. Coys reported to me. But the faid M'. Coys hath in ny indgment more properly named it vicia frutts albo which name I thought molt fir to call it by, onely adding Indica to it, from whence it is scportcd to haue been gotten. Isl.30. I $52 \mathrm{I}$.

Aftrao alus marines Lufatanicus Bocliy.

This hath fue, fix, or mote rond ftraked reddirh hairy ftalks or brunches, of a reafonable bigneffe, proceeding from one root, fomctimes creeping or leaning neere the gro thd, and fomerimes ftanding vpright, a cubit high, with many grcene leanes, fer by certaine dittances, our of order

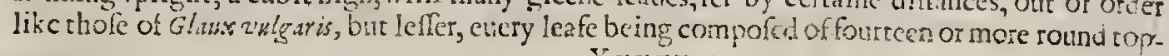

$$
\mathrm{XXXXX \times 2}
$$


ped leaues, a little hairy by the edges, fct on each fide of a long middle rib, which is about nine or ten inches in length, without tendrels : the floures grow forth of the bofomes of the leaues, neere the tops of the ftalkes, on long round ftreaked hairy foot-ftalkes, of a very pale yellow colour, like thole of Securidaca minor, but bigger, growing clofe together in fhort fpikes, which turne into fpikes of the length of two or three inches, containing. many fmall three cornered cods about an inch long, growing clofe together like thofe of Glaux wulgaris, each cod containing two rowes of fmall flat foure cornered feeds, three or foure in each row, of a darke yellowith or leadith colour, like to thofe of secaridaca minor, but three or foure times as big, of little talte : the root is fmall, llender, white, witli a few threds, and groweth downe right, and peritheth when the feed is ripe. I firft gathered feeds of this plant in the garden of my good friend M:. Iob. Parkinfon an A pothecary of London, 4 Ano 1616 .

\section{Fabavetcrum Ferratis folyis Boelï.}

This is like the other wilde Beane in ftalks, floures, cods, fruit, and clalping tendrels, but it differeth from it in that the leaues hereof (efpecially thofe that grow neere the tops of the ftalks) are notched or indented about the edges like the teeth of a faw. The root alfo peritheth when the feed is ripe. The feeds of this wilde Beane were gathered by Boelius a Low-country man, in Bæt ica a part of $\mathrm{Spaine}$, and by him fent to $\mathrm{M}^{\mathrm{r}}$. Willinn Coys, who carefully preferued them,and alfo imparted feeds thereof to me, in $A m n o 1620$. IHI. 31.1621 .

\section{Iifum maculatum Boelÿ.}

They are like to the fmall common field Peafon in ftalkes, leaues, and cods; the difference is, the floures are commonly fmaller, and of a whitith greene colour : the Peafon are of a darke gray colour, fpotted with blacke fpots in thew like to blacke Veluet; in tafte they are alfo like, but fomewhat harther. Thefe peafon I gathered in the gardèn of $\mathrm{M}^{\mathrm{r}}$. Iohn Parkinfon, a skilfull A pothecarie of London; and they were firft brought ant of Spaine by Boelins a low-Countrey man.

$$
\text { Lat byrus aftivus fore luteo. Iuly. 28. 162 t: }
$$

This is like Lathyris latiorefolio Lobclin, in Atalks, leaues, and branches, but fmaller: the ftalks are two or three foot long, made flat with two skins, with two excceding fmall leaues growing on the ftalks, one oppofite againft another: betweenewhich fpring vp flat foot-ftalks, an inch long, bearing two exceeding narrow tharpe pointed leaues, three inches long : betweene which grow the tendrels, diuided into many parts at the top,and raking hold therw irh:the floures ane fmal,and grow forth of the bofomes of the leaues, on each foot-ftalk one floure, wholly yellow, with purple ftrakes. After each floure followeth a mooth cod, almoft round, two inches long, wherein is contained fetren round Peafon, fomewhat rough, but after a curious manner, of the bigneffeand tafte of field Peafon, and of a darke fand colour.

\section{Latbyrus aftivus Beticus fore carulco Boclij.}

This is alfo like Lathyris latiore folio Lobeliy, but fmaller, yet greater than that with yellow flours, hauing alfo adioining to rhe flat ltalkes, two cared tharpe pointed leaues, and alfo two other flender Tharpe pointed leaues, about foure inches long, growing on a flat foor-ftalke beetweene them, an incli and a halfe long, and one tendrel between rhem diuided into two or three parts: the floures are large, and grow on long flender foure-fquare fooi-ftalkes, from the bofomes of the leaues, on each foot-ftalk one:the vpper great conering leafe being of a light blew, $8 x$ the lower fmaller leaues of a deep:r blew : whicin paft rhere come vp fhort flat cods, with two filmes, edges, or skins on the vper fide, like thofe of Eruilia Lobelij, containing within foure or fiue great flat cornered Peafon, bigger than field Peafon, of a datke fand colour.

\section{Lat hyres effivus cdulis Baticus fore albo Bocly.}

This is in flar skinny ftalks, leaues, foot. ftalks, and cods, ,vith two skins on the vpper fide, and in all things elfe like the faid $L$ at byrus with blew floures;only the floures of this are milk white : the fruit is allo like.

\section{Lathyrus afivus fore miniato.}

This is alfo in skimnic flat Palks and leaues like the faid Lathyrislatiore folio, but far fmaller, not three foot high : ir hath alfo fnall tharp pointed leates growing by couples on the ftalke, between which grow two leawes, about three inches long, on a flat foot-ftalk half an inch long:alfo between thofe leaues grow the tendrel sithe floures are coloured like red lead, bur not fo bright, grow ing on 
finooth thort foot-ftalks, one on a foot-ftalke : after which follow cods very like thofe of the com mon field peafon, but leffer,an inch and a halfe long, containing foure, fuce, or fixe cornered Peafon, of a fand colour, or darke obfeure yellow, as big as common field peafon, and of the fame tafte.

\section{Lat byrus paluftris Lufftanicus Boeliy}

Hath alfo flat skinnic ftalks like the faid Lathyrus latiore folio, but the paire of leates which grow on the ftalke ate exceeding fmall as are thofe of Lat hyrus flore lut co, and are indeed fcaree worthic to be called leates : the other paire of lcates are about rwo inches long, aboue halfe an nehe broad, and grow f: om betweene thofe fmall leates, on flat foot-ntalks, an inch long : betweene which leatres alfo grow the tendrels : the floures grow on foot-ftalks which are fite inches long, commonly two on a foot-ftalke, the great vpper courering leaues being of a bright red colour, and the vnder leatues ate fomewhat paler : after commeth flat cods, containung feten or eight fnall round peafon, no bigger. than a Pepper corne,gray and blacke, fpotted before rhey ate ripe, and when they are fully ripe of a blacke colour, in tafte like common Peafon : the ftalks, leaures, foot-ftalkes and coddes are fonw hat hairy and rough.

\section{Lathyrus aftivus dumetorum Baticus Boely}

Hath alfo flat skinnie ftalks likethe faid Lathyrus latiore folio, but fmaller, and in the manner of the growing of the leates altogether contratic. This hath alfo two fmall fharp pointed leaues, adioyning to the ftalke : betweene whieh groweth forth a flat middle rib with tendrels at the top, hauing on each fide(not one againft another) commonly rhree blunt topped leaues, fometimes three on the one fide, and rwo on the other, and fomerimes bur foure in all, about an inch and a halfe long: the floures grow on foot-ftalks, about two or three inches long,each foot-ftalk vfually bearing two floures, the great couering leafe being of a bright red colour; and the tw ovnder leatres of a blewinh purple colour : afterwhich follow fmooth cods, about two inches long, containing, fite, fixe, or feuen fmooth Peafon, of a browne Cheftnut colour, not round, but fomewhat flat, more long than broad, cfpecially thofe next both the ends of the cod, of the bigneffe and tafte of common field pea-
fon:

\section{Iuniperus fterilis.}

This thrub is in the manner of growing altogether like the Iuniper tree that beareth berries, on y the vpper part of the leates of the youngeft and tendereft bowes and branches are of a more reddifh greene colour: the floures grow forth of the bofoms of the leates, of a yellorvifh colour, which neuer exceed three in one row, the number alfo of each row of leaues : each foure is like to a fmall bud, more long than round, neuer growing to the length of a quarter of an inch, being nothing clfe but very fmall thort crudely chitues, very thieke and clofe thruft together, faftened to a very finall middle ftem, in the end turning into fmall duft, which flieth aw ay witl the winde, not nuch vnlike that of $\tau_{\text {axus }}$ fterilis : on rhis thrub is nemer found any fruit. I 5. Matij. I $62 \mathrm{I}$.

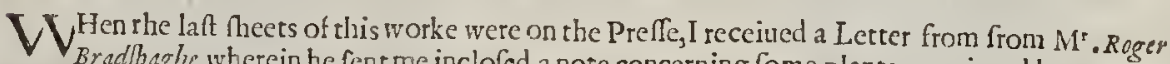
Bradhaghe, wherein he fent me inclofed a note concerning fome plants mentioned by our Author whieh I hatie thought fitting here to impart to the Reader : he writes not who it was that writ them, wherefore I cannot acquaint you with his name, but thanke him, though vnknowne, for his de. fire to manifeft the truth, and fatisfic our doubts in thefe particulars.

Beaure youwrite that Gerards Herbal is wpon a review, I hane thought good to put you in mind what I haue obferted touch ing fome plants which by him are affirmed ro grow in our Northern parts : firft the plant called $P$ irola, which he faith growerh in Lanfdale, thate made fearch for it the
fpace of twentie yeares, but no fuch is to be heard of.

Sea Campion wirh a red floure was told him groweth in Lancalhire: no fuch hath euer bin feen by fuch as dwell neere where they hould grow.

White Fox-gloues grow naturally in Lanfdale, faith he, it is very rare to fee one in Lanfdale.

Garden Rore he writes groweth about Leiland in Glouers field wilde : I haue leamed the truth from thofe to whom this Glouers field did belong,and I finde no fueh thing, only aboundanee of red wilde poppie, which the people call Corne-rofe is there feene.

White Whortics, as he faith, grow at Crosby in Weftmerland, and vpon Wendle hill in Lan. cafhire: I haue frught Crosbie very diligently for this plant and others which are faid to grow there, bur none could I finde, nor can I heare of any of the eounrey people in thefe parts, who day. ly are labouring vpon the mountains where the VVortle berries abound, that any white ones haue 
becn feene, fauing that thofe which Gerard calls red Whortcs, and they are of a very pale white green till they be full ripe, fo as when the ripe ones looke red, the vnripc ones looke white.

Cloud-berrie affuredly is nonther than Knout berric.

Heskets Prim-rofe groweth in Clap.dale. If $\mathrm{M}^{*}$. Hesket found it there it was fome extraordinary Juxurious floure, for now I am well affured no fuch is there to be feene, but ir is onely cherilhed in tour gardens.

Gerwd faith many of the e Northerne plants do grow in Cragge clofe. In the North cucry tow to and village necre any craggic ground botk with vs \& in Weftmerland haue clofes fo called, wherby Grards Cragge clofe is kept clofe from our knowledge.

\section{Chamanores, fut accinia subis. Knot, or Knour. berric, or Cloud-berrie.}

T

His Kirot, Kuout or Cloud-berric (for by all thefe names it is knowne to vs in the North, and taketh thefenames trom the ligh mountaines wherenn it growe:h, and is perhaps, as Gerard faith, one of the brambles, though without any prickles) hath rcors as fuall as packe thred, which creepe far abroad under the ground, of an ouerworne red coluur, he re and rlere tlirufting more faftly in to the moffic hi lockes tufts of finall threddie ftrings, and at certaine soints putring vp inall ftalks rather tough than woudy, halfe a foot high, fomthing reddin beiow : $\mathrm{cm}$ w bich do grow two or three leaues of d rea fonable tad green colour, with foot-ftalkes an inch leng, orealone anctler writhour order : the highelt is but little, and teldone well fpread open rle y ase tomerhirg megged, crifpie, full of nerues in euery part, notched about the edges, and with fene fouse gall cs a little deeper than the reft, whereby the whole leafe is lightly diuided into fite protions. On the top of the

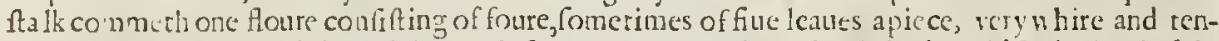
der,and rather crumpled than plaine, with fome few thort yellow threds in the midn : it it andeth in a little greene husk of fiue leaues, out of which when the flourc fades, conmeth the fruit, compored of diucrs graines like that of the bramble, as of eighr,ten or twelue, femetines of fewcr, and perhaps through fome nifchance but of three or two, fo ioined, as they maie frime refemblance of a heart, from whence (it may be) hath grown that ertour in Gerard of dividirg this plant into 2 kinds: the fruit is firft whirifh greene, after becommeth yellow, and reddifh on that fide next the Sun.

It groweth naturally in a blacke noift earth or moffe, whercof the countrie maketh a fewel we call Turfe,and that vpon the tops of wct fells and mountains among the Heath, moffe, and brake:as about Ing!ebornw in the Weft part of York-Thire, on Graygrcth al i k l fell on the edge of Lancafhire, on Stainmor fuch a lihe place in Weftmer land, and ofler fuch lihe high places.

The leates come forth in May, and in the beginning of Iure the foures : tl c fruit is rot ripe till late in Iuly.

The berries hate a harth and fomething vnpleafant tafte.

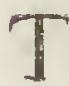

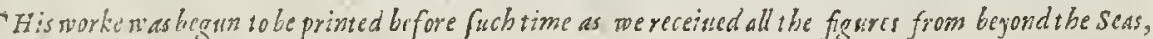
which wass the ocenfion I omitted thefe following in their fitting places but thinking it ret fit to omit them belang.

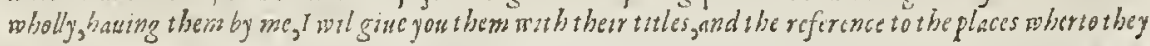

* In Augguft laft whiles this worke was in the Preffe, and drawirg to ar erd, I and Mr. William Broadwere at Chiffel-l. urtt with my oft mentioned fricnd $\mathrm{M}^{\mathrm{r}}$. Gcorge $B \mathrm{cw} / \mathrm{cs}$, and going ouer the heath there I obkerued this finall Spartum whofe figure I bere giue, and where of you hiall find mentiou, in the placenoted vnder the title of the figure; but it is not there deferibed, for that I laad not feen it, nor could finde the defeription therof in any Author, but in Durch, which I neither bad nor vnderftnod. Now this littlc Marweed hath fome fmall cresping ftringy roots:on which frow fomwhat thick heads, confifting of three or fourcleaues, as it were wrapt together in one skin, biggeft below, and fo growing fmaller vpwards, as in Schenanth, vntill they grow wp to the height of halfe an inch, then thele rufhie greene leaues (whereof the longent fearce exeeds two inches) breake out of thefe whitin skins wherein they were wrapped, and lye along von the ground, and among ft thefe growes vp a fmall grafie falke, fome handfull or betrer high, bending backe the top, which carries two rowes of fmall chaffie fecds.It is in the perfection about the beginning of Auguft.

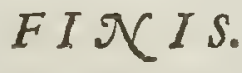


Cyperus Indicus, fose Curcuma.

Turmericke.

Pag. 3\}. Lib. \&, Cap. 3g

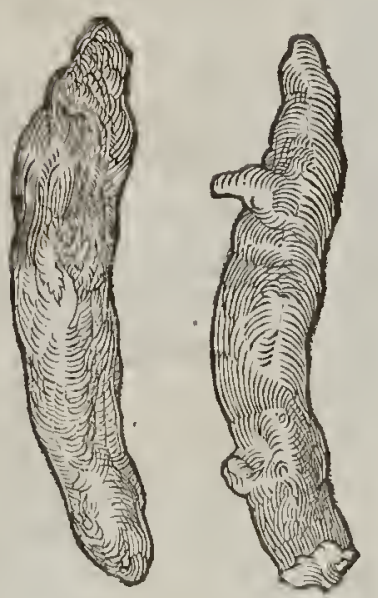

* Spartum noftras parvem Lobely.

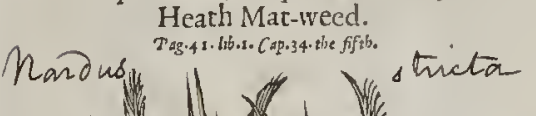
N N ven

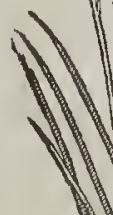

1

(t)

(I)

H

MI

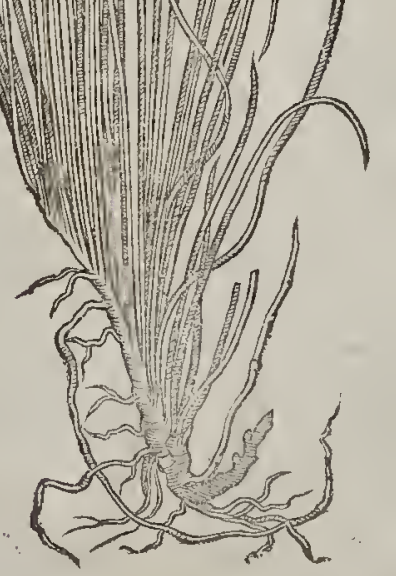

Iuncus minor capitulis Equifeti.

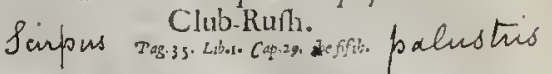

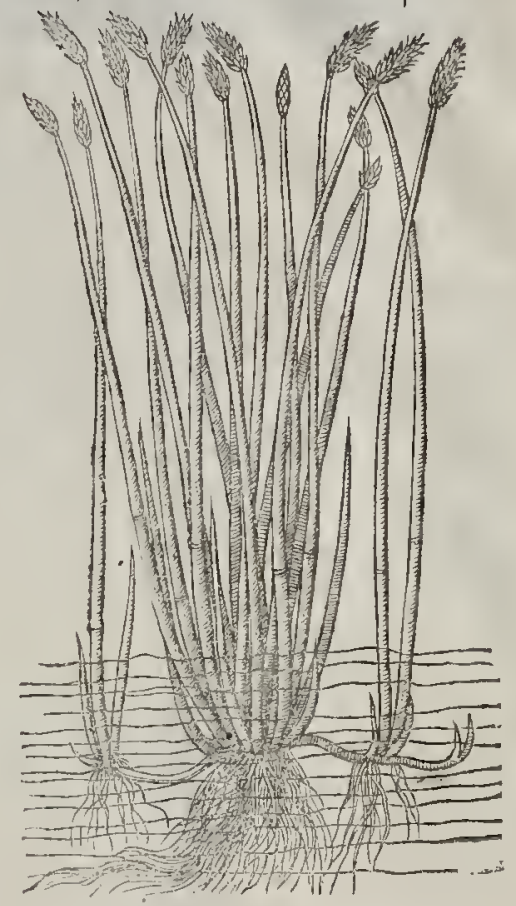

schanuthifores.

The floures of Camels Iay.

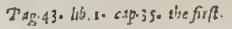

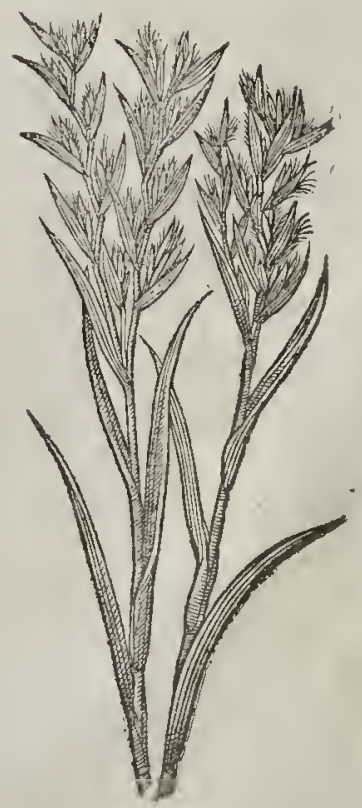




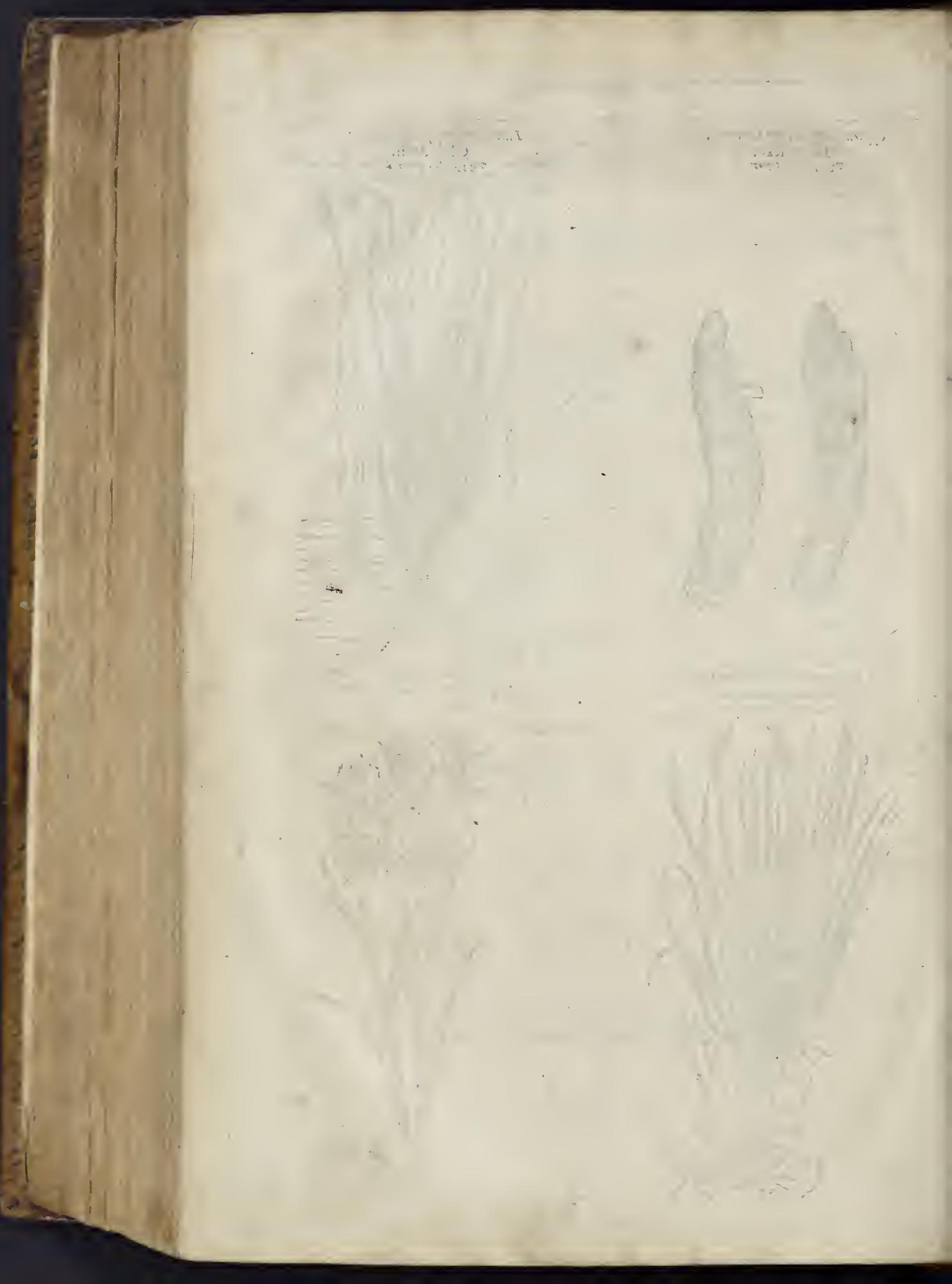




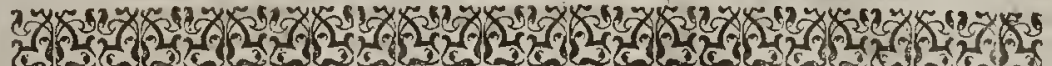

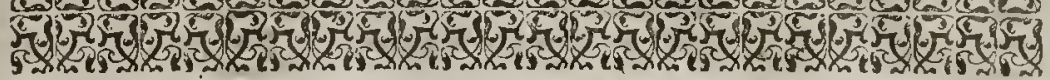 INDEX LAT:INVS STIRPIVM IN HOC opere defcriptarum necnon nomina quedam Greca. Arabica, Barbara, \&c.}

\section{A}

$A^{a}$ Biesmas.o fam. $\quad 1363$ Marina Belg.Clus. 1574 Abiga.

517 Abrotanum mas. of fam. eiss religua pec. $\quad 1106.1107$ Abinebium larifolism of tenuff. 1096 Anfriacsm. I098 Murinum. 1099 Album of a fgrpt. I IOI Inodormm of Abrotani fam. facie. I 102. Aburilon,

Acacia Diof Acanthes facions ofor $\begin{array}{r}1330.133^{2} \\ \quad 1147\end{array}$ Virgily. $\quad 1603$ Acanthism album or purpure wm. I I 4 . Acarna. $\quad 1175$ Accipitrima.

Acer mins of misus:

Acetoja.

Achillea.

Achras gr. Pyrus goluestris.

Acinos.

Pardalianches Matth. $\quad 762$

Pardaliasch. prim. Manh 8 x Batrachoides.

Pardalianch.Geftr.

Hiemale.

Eiss religue pec. Acorres Offic. 33. Paluft. 50. Verm intig. 63 ACtes, Plin, quibujatam Chrszophor. AEte gr.sambucks.

Aculcata,idest, Polyacantha.

Acas Mofchatr,ideft,Geranism.

Acsspafforis, id eft, Geranium vel pecten veneris.

Acutella,idest. Anonis.

Adiantum albsm.

Normm.1136.Verum. 1143. Auresm. $\therefore$ I559

Admirabilis Pernv. $\quad \therefore \quad 344$

Adonidisflos.

Ador, adorents fomer:

Adracla, vel Adracbne. = 1602 efgilops Narbon. $\quad 74$

Frima Nitth.75.Bromsoides. $\quad 77$ cAgopyrus, id ef, Fago-triticum.

iEgoceros,idest, Forum-gracum.

EEgyros,gr.Popelus.

Aeromels, ideft, $M$ iznn.

Afchinomerie.

etibiopis.

Agallochim.
Agaricus.

-1gerat:m.

Aglaophotis.

Agnis castus.

Agri Palma.

Agrifolium.

1339

Agrimonia.712. Syluest. $\quad 993$

Agriorigansm.

Aboviy.

fjuga, id est, Chamepitys.

Aizoon, vide Sedum.

Alabafritas. - $\quad 986$

Alaternws. $\quad 1398$

Albarnm. - 94

Album olus. $\quad, \quad 3$ II

Alcanna. $139^{6}$

Alees vulgaris.931: Egyt.937

Fruticoja.934. peregrima. 936

Alchermes. 1343

Alchimilla. 949. Montans.2594.

Alcibiadion, $\therefore 803$

Alectorolophos. $\quad 1071$

Alga. $\quad 1569$

Alifmaquorsud.443. Tragi, 649

CMath.742. Pratormm of Jyl.Col.

78. Diofcoridis. $\quad 787$

Alkall. 535

Alkekeng:i $\quad 342$

Alielnya. $\quad 1202$.

Alliaria. $\quad 796$

Alism.178.5yl.x79. Urfinmen. i6. Latsfolium.180. Alpinum.182

Alnses. 1477. Nigra. $\quad 1469$.

Aloe. $\quad 507$

Alopecuros.87. Mir. Anglica.ibi. Alfine einfóg pec. $611.612 . a d .617$.

Cruciatamarina. 622

Altercsm. 355.

Althat einfáspec.933. Lutca.935.

Alus Gallica. 807

Alypum. $\quad 506$

Abjum Galen.d Diof. $\quad 465$

Germanicum.Tab. 699.

Gules: quorsud. I 132 . Plin.1 I 25.

Fruticass. $\quad 1_{306}$

Amara dulcis. $\quad$, 350

Amaracus. 664

Amarartus purp. \& cirs spec. 322.

323.

Luteus.

Amarella Giesn.

Ambrofor.

Ambubeis,

Amburum.

Amellss Mosti

virgh.

Amedanis.
Ameos,idest, Ammi.

Anclancher, Lob.

Ammier eitus jpec.

Ammariacum.

Amomis.

inomum, Plin.

Germanicum.

Versm of purisus,

Qnorwidam.

Ampeloprafum.

Amygalus.

Peruana.

Amyrberid.

Anacardinsis.

Anagallis mas. of fam

Texuifol.er lutea.

Aguatica einfóspec.

Anagyris.

Ananas.

Anblatum, id est, Nidus auis.

Ancbufa Alcibiad.Lut. \&c.

Degener.

Andracline,gr.Porsulatea.

Androjace.

Androfemsm.

pec.varia a p. $37+$ ad: $3^{86 .}$

Ancthum. $\quad 1033$

Sylueftre veltortsofum. 1052

Angelica.

Anguria,idest, Cirrullus:

Anifum.

1035

Anoris. $\quad 1323$

Anonymos,Clus. $\quad 555$

Flore Coluter. $\quad 2597$

Anferina. 993

Antesphorbistm, II

Anthersis. $\quad 756$

Anthera. $\quad \$ 263$

Ambericus. 94

Antbora. $\quad 969$

Anthos, id oft, Flos Rofmarini.

Antbrifass. IOfo

Anibropomorphos, $\quad 352$

Anthylis alier lialo ! $\quad 623$

Lentifolia. 622

Marina. ib.

Montana Dal: 555

Ualeatina Clus. 566.

Leguminofiso 1240

Antipatises. $\quad 1575$

Ansiptbora, id eff, Antboran.

Antrirbinumeiufópec. $\quad 549$

Minss flore Linarre. $\quad 1628$

Tragi. 494

Aparine. I122

sphacis 


\section{Index Latinus.}

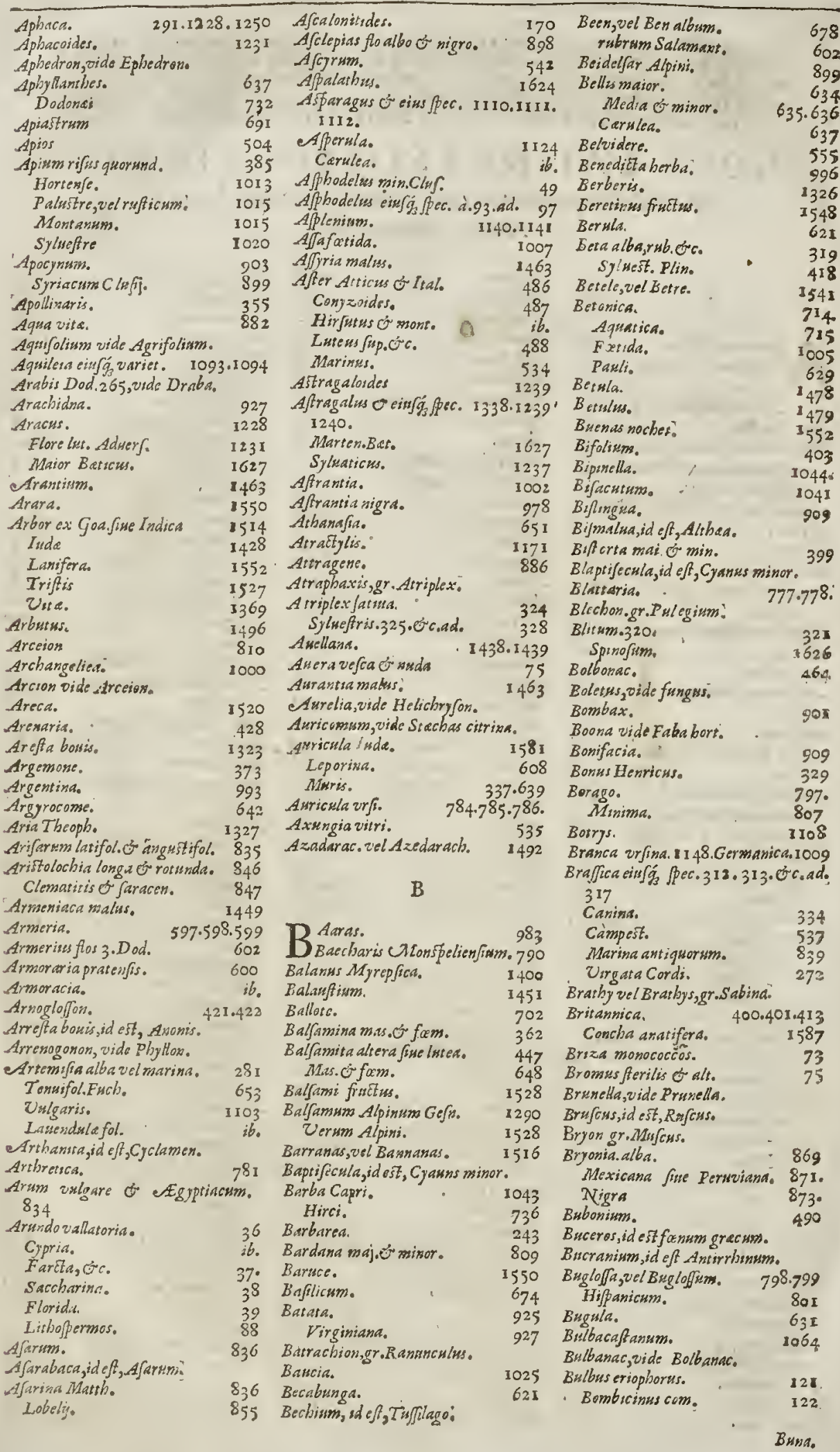




\section{Index Latinus.}

\begin{tabular}{|c|c|}
\hline Buna. & $154^{8}$ \\
\hline $\begin{array}{l}\text { Eundes fat. } \\
\text { Sjuestris. }\end{array}$ & $\begin{array}{l}235 \text {. } \\
\text { ibid. }\end{array}$ \\
\hline Bunism. & 1064 \\
\hline Bupisthalmsum. & 6.747 \\
\hline $\begin{array}{l}\text { Buplesurum angsitifol, Alp. } \\
\text { Angufifol. के latifol. }\end{array}$ & $\begin{array}{l}517 \\
608\end{array}$ \\
\hline Burfa paftoris. & 276 \\
\hline Brtomus. & 45 \\
\hline Buxus. & IfIO \\
\hline
\end{tabular}

\section{C.}

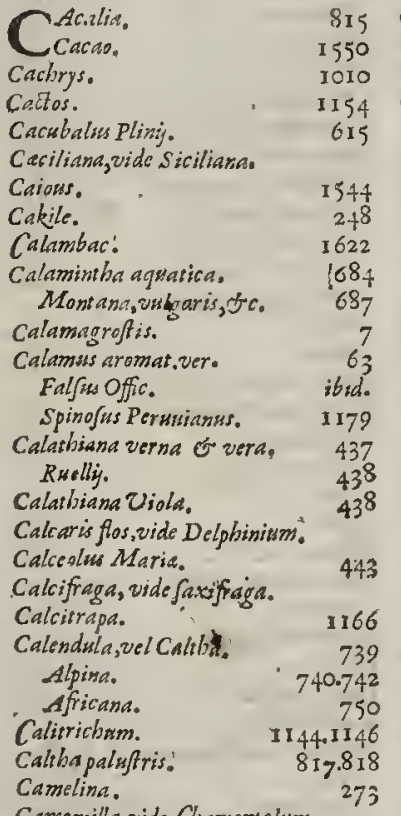

Camomilla, zide Clamemalum.

Campasa Carulea.

Companula.

450.451 .452

Carcartum.

Candela regia, vel Candelaria.

Canella.

Cannabina mas, of fam.

Cannab is mas, of fam. Spuria.

Sylueftris Diofcor.

\section{Cannacorts.}

Camtabrica.

Capillus veneris. II 4 j. I1 44.1146 Capnos, gr. Fumaria.

Capparis.

Leguminola.

Caprifolium, id eft, Periclymenищя.

Capficum.

Caput monaclis.

Gellinacezm.

$3^{64} \cdot 3^{65}$
291

1243

Cardamine einfófpec. $259 \cdot 260,60$.

Cardamomum.

Cardamum,gr.Naffurtium.

Cardiaca.

Cardurss acaulis.

Afoninss.

Benedictus.

Calcitrapa.

Chryfasthemus:

705
1158

\section{Ericcepisalus. \\ Fullonum. \\ Ferox:}

Globofiss.

Lanceatus.

Lactess $s_{2}$ ine Marite.

Mollis.

Mufcatus.

Perumianus.

Sperocepbalus.

Siellatus of folstitialis.

Vulgatifimus Viarun.

Carex Dod.

Carica.

Carlina. II 57.1158. Sylwefris. 1159

Carobe. 1429

Carota. $\quad 1028$

Carpentaris.

Carpe frum quor.

Carpinus.

Carpobalfamsim,

Carthamss.

Carub vide Carobe:

Carri, vel Carum.

Caryon,gr.Nux.

Caryophyllata einfós peco. 994.995.

Carjophyllins aromaticus. $\quad 1535$

Caryophy llws fios, co enss ßec. o varietat.a.p.588.sd. $597 *$ Syluestris.

Marinus.

Indicus.

Caryota vide Carota.

Caffia, vel Cajia Poetíca.

Poet.Lobel.

Lignea.

Nigra fise fistula.

CaJisa, vel Cafusha, vide Cuscuta.

Cafanea.

Equina, of Pernana.

Caftrangula.

Catanance.

grorundam.

Cataputia menor. Maior.

Gatsaric.

Cancafon, idef, Moly Indicum.

Cancalis einfóg foec.

Cauda equina, vide Equiferum.

Murris. 426. Uulpis.

Canlorapum.

Ceanotbos.

Cedrelaie.

Cedria.

Cedrus Libani.

Lycia.

Aliera.

Celastrus.

Celsis.

Cenchrys,gr.Mulium.

Centaurinm, vel Centaurea.

$$
\text { Magnum. }
$$

Parvim.

Centanroides.

Thaly

Centimorbis.

Cextrum galli.

Centsm capita.

Centummodia.
599.600

602

$75^{\circ}$

584

1293.

1532

I 43 I

I.

ibid.

717

425

4.1250

503

$49^{6}$

683

1021

87

318

1173

$135^{2}$

1353

1352

1369

1375

1600

1494

546

546
547

582

582
7 I 4

630

770

1162

565
Cestunculus.

Cepa, vel Cepe.

644

621

Cerafus einfg్g,pec, 1502.1503 , \%

ad. $\quad 1507$

Ceratonia, vel Ceratia. $\quad 1420$

Cerefoliam fativum of fo. 1038 Magrum. 1039

Ceress Peruwianus. $\quad 1179$

Cerinthe: 538

Cerras, vel Cerrus: $\quad 2345.1346$

Ceruicaria. $\quad 450$

Cestrummerionis. $\quad 46$

Ceterach. I I 40

Charefolism, vel Chereply llong gr. vide Cerefolats.

Chamealte,gr.Elulus.

Chamehalanus.

Chamaburus.

Chamabixus. 1597

Chamacerafas. $\quad 1505$

Chameciffos, id eff, Hedera terreft.

Chamacifus. 1284

Chamecypariflus. $\quad$ I 100

Chamadaphre. $\quad 895$

chamadrys. $\quad 6 ; 6$

Syluestris. $\quad 657$

Laci itiss fol. $\quad 527$

chamaficus. 1510

Chamefilix mar.Angl. 1143

Chamazenifta. I; 13

Chamairis. $\quad 56.57,58$.

Chamaitia. 1391

Chamsleonalbusa $\quad 1157$

Niger. 1150

Taberwamont. $\quad 1175$

Chamale Hce. 812

Chamalunum. $\quad 559$

Chamamalus. " 14

Chamamelum. $\quad 754.7$ is

sylueftre. $\quad 75$ ?

Chamamelfius. $\quad 145$

Chamamorus. $\quad \quad 1273.1630$

Chamenerion, Gefs. $\quad+7 \overline{7}$

Chamapericlywerum, I295

Chomapeace. $\quad 1293$

Cbamaprtys einfog spec. 525.526 .527 .

Chamsplatanss. 1425

Chamerriplies. $\quad 1519$

Chamerododendroni $\quad 1407$

Chamalaa. $\quad 1402$

Germanican $\quad 1403$

Chamefyce. $\quad 504$

363
Charanssa.

Chelidonia,vel Chelidonis minus.816
Maius.
1069

Chermes. 1342

Cherwa, vide Ricinus." 1618

Cberadoletbron, id eft, Xantbism.

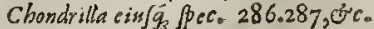
Ppecisertia Dod. $\quad 494$ Christophoriana. $\quad 969$ Chryfanthemum latifollum Alpinum. 742 Segetsm. $\quad 743$ Yalentinsm: Alpinum. 744 Secund.Clafisi. 744 Creticum of Befisum. 745 Perwoientm.

Litioresis 
Index Latinus:

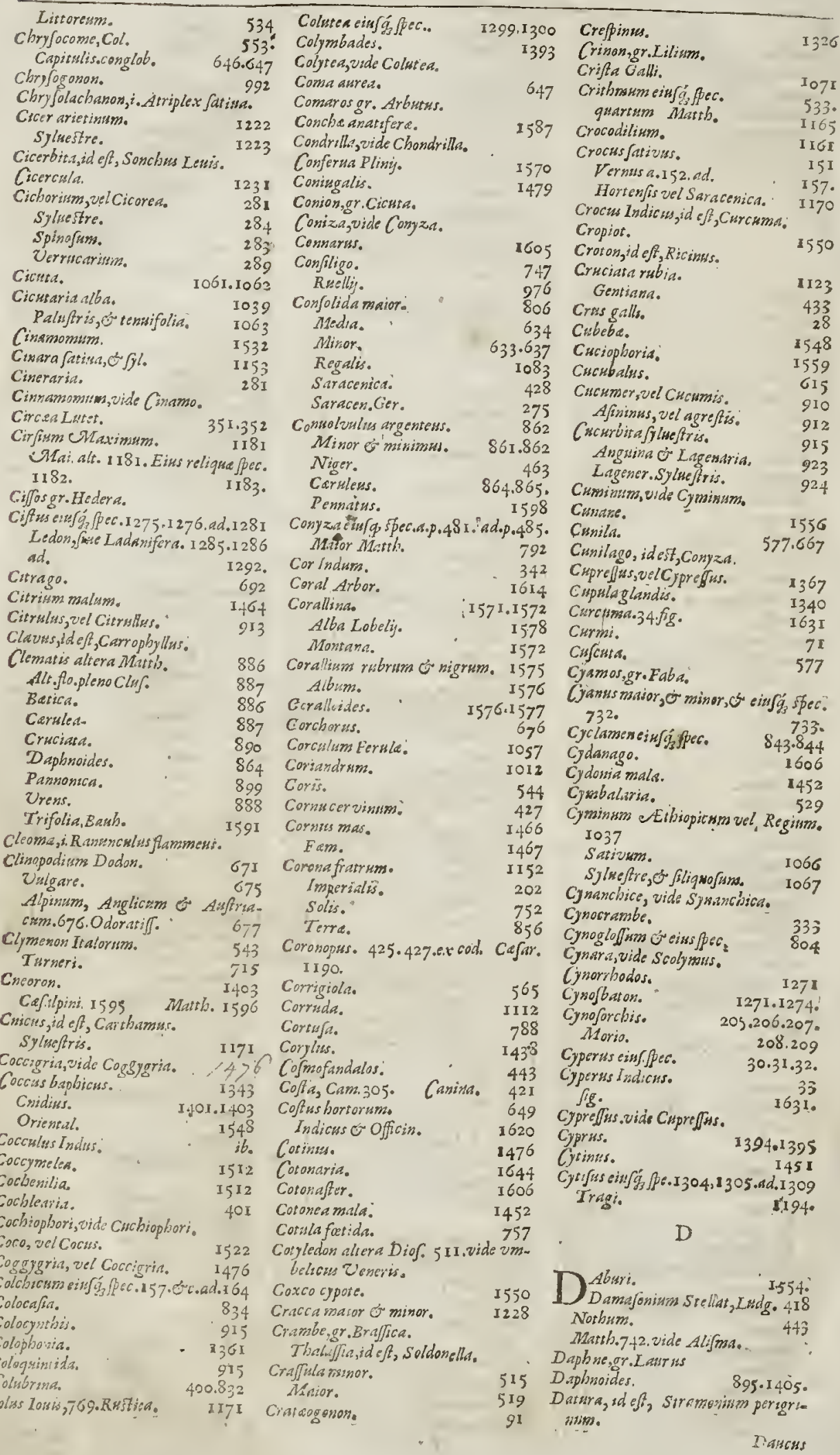


Index Latinus.

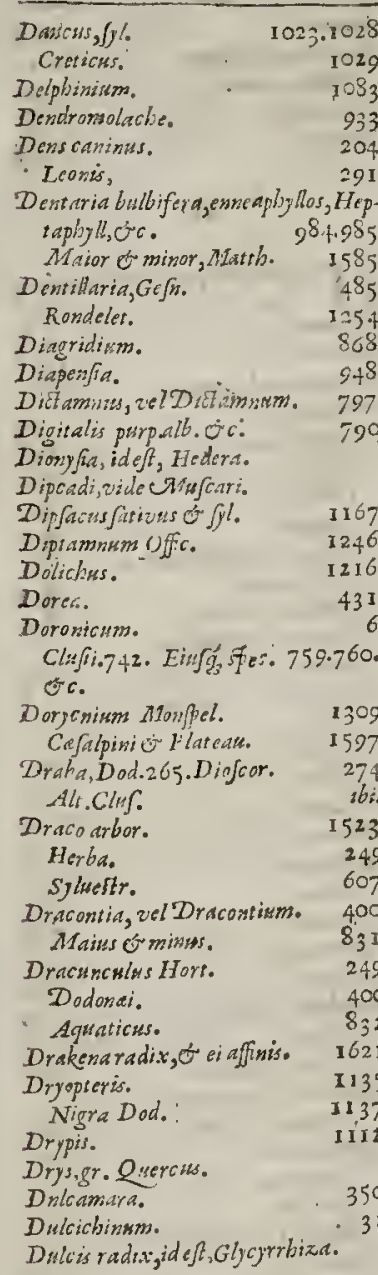

\section{E}

GBuitus.

Echiromelocattos.

Echisumpalustre.

German.fpinofrm Finch.

Vuloure.

Ilore Pulloci rubro.

iilsagnos Cordi.

Ilaphobofoum.

F.late, vide Palmia.

Elatcrism.

Elatime.

TertinTab.

Eleagroos Cordi, id est. Mgrtus. Brabamrica?.

Elelisphacos, idef, saltria.

Eliocryjwm.

Elsofelinsm,

Elephant is pediculas, i. Anacar dians.

Elleborastram, vide Helleboraster.

Elleborine.

Elleborms albes. vide Helleborks.

Empetrum.

Thasordes.

1177
337

337

799
802

ibi.

14.14

1025
Endinia, vide Cichorinm.

Enephyllon.

Enula campana.

Ephedra.

Ephemerum Marth.

Diolcoridis, Col.

Epilobion Gefneri:

Epilisism.

Epmedism.

Epimalis.

Epipatis.

Enftabe.

Epithynum.

Epithymbrum.

Epissticit.

Eqrapistm.

Egsiferum auf

cc. III3.11 it

1 II 5 .

Eranthemus, id eff, flos Adonis.

Errbinthos,gr.Cacer.

Erica of exrswaria pitc. $1=80.1381$.

co.ad.

Alexanarina, Lob. $\quad 1596$

Erigeros.

Mrrintsm:

Erinacea Clnfit.

Erifyseptron, id est, Cyperws.

Erizambac.

Ernangina, id eft, Orobanche.

Ereca fat ete fyl.

Nasturtorognat.

Murin. of agmat.

Murales Dal.

Peregr. Fue Cantab.

178.2790

281 .

$a_{321}$

Erucago espulit.

Errilia.

Erumm fativum Cords. Album fat. Fuch.ib. Syl. 1249

Eryngium of eiss fpec. 1162.1163. $116 \%$.

Vegorit. $\quad$ iIs6

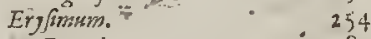

Cercale.

Eryshrodanum:

Efula.

Indics.

Euforbism, vide Esplorbirm.

3426 Enfragia, vide Euphrafia.

Enonymos Theoph.

Eupatoriums Mcfue.

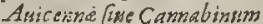

femis

Euphorbirm. Wulgare. ${ }_{1178}^{12}$

Euphragia fiue Euphrafia rabra,alt. Dod.g2. Carriex. 337 Albafise vuloaris. $\quad 663$

913 Esphrofinum.797 Eaphrofyne.663. Ezrala, vide Efula.

\section{F}

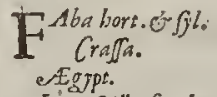

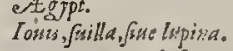

Fetcrumferreris foligs.

Fabago.

Fabersa.

569 Farara.

Fagi,vel Fugo-iritichm,
F̆gоругнй idem.

Fages.

Far.

Farrago.

Farfara,id eft, Tinfliago.

Farfarus.(i.) Populusa!ba.

Fafelise, id eft, Fab.s.

Fafoaliss, vide Phafealus.

Farfel.

Febrifuga.

Fel terre.

Ferram equinum.

Ferula:

Ferulago.

Festuca litalica.

Altere Dod.

Ficarie munor.

Ficus.

- Egypt.

Infermalis:

phireosis.

Iridica.

Indica Theopds:

Filigo.

Filicuta.

Petraia.

1444

69

68

1520

653

1235

1056

1056

73

75

816

1510

1509

$3 \pi^{2}$

1509

1512

1514

$642.6+4$

I 133

I 42

Frlipendula eirsga.pec. 1058.1059.

Filizs ante patrem,idef, Lyfomachis

fliguofa, gubufdam Colchicum, none. nellis T'iffllago.

Filis mas. 0 f $\alpha$ m.

Florida.

1128

Prmilarax.

Fiflici.

Fiftularia.

Unlgaris.

Flos Adonis.

Aphriranse.

Amaberualis.

Cretich, Confantinop, vel Hierof

lym.

Cucriti, vel Cornicis. $\quad 667$

Frsmextortm.

Pafjionis.

Regis.

Solismatior.

Solispyramidalit.

Minor.

Tisctoritus.

Fluida Gaze id aft Rhis $\quad 1317$

Foniculum marinum.

Vulgare.

Porcinum.

Fensm Bstgundiacum. $\quad 1189$

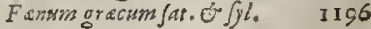

Folium Indrm. $\quad 1535$

Fontalis. $\quad 823$

Fontilapathrm Lob. $\quad 823$

Fraguria of Fraga. 997

1209 Frangula. $\quad 1460$

519 Fraxinelas. 1245

1552 Fraxisss.1471: Bribila, montana, vel fyluestris. $\quad 3473$

Frisillarid einfóg. 149.150

897 Frultse Indicioperigrinio1547. \&6.

519 ad. 1556

I 548 Frumintwin Amyleum.60. Turscam

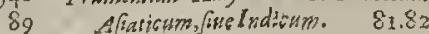




\section{Index Latinus:}

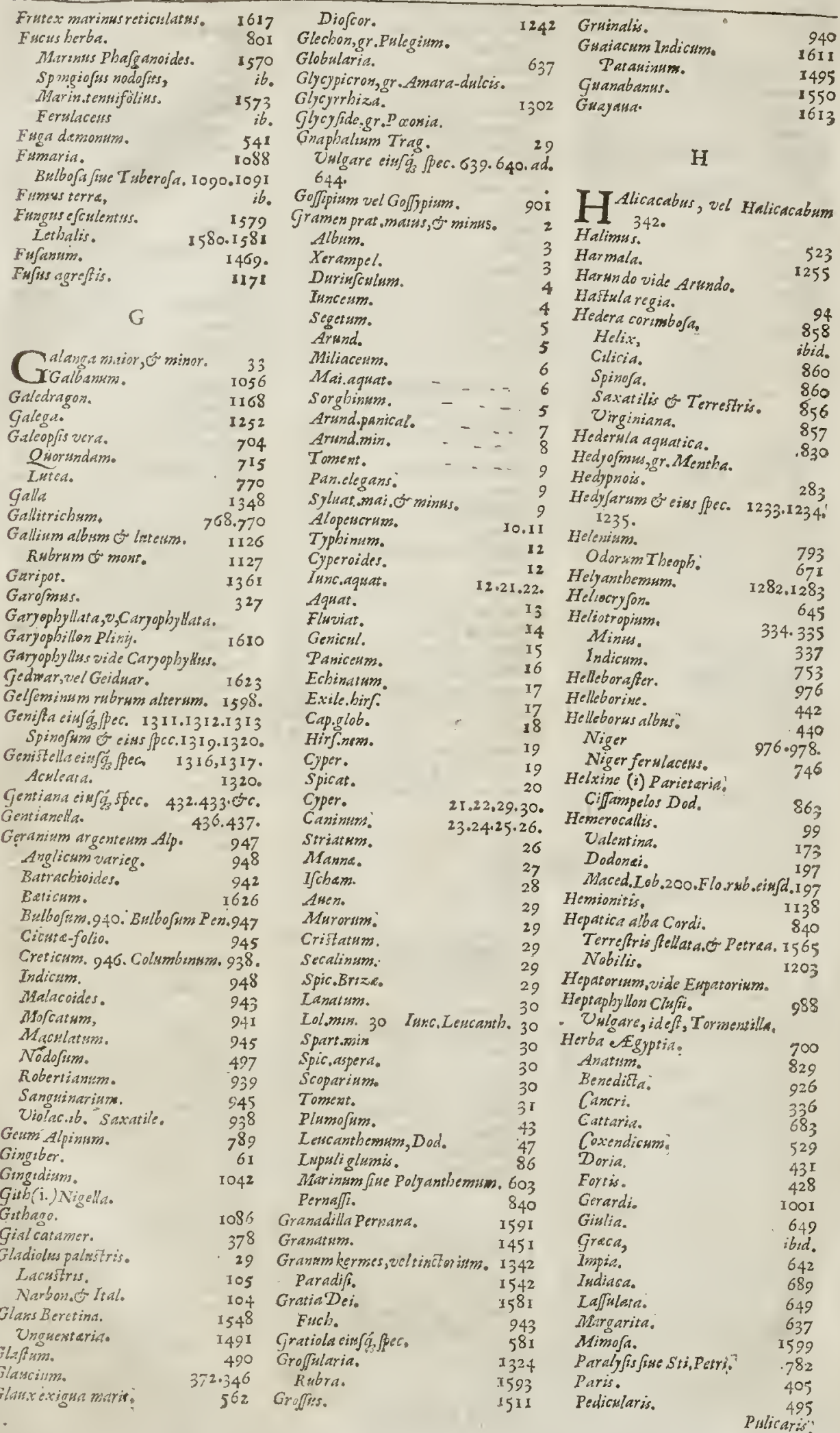




\section{Index Latinus.}

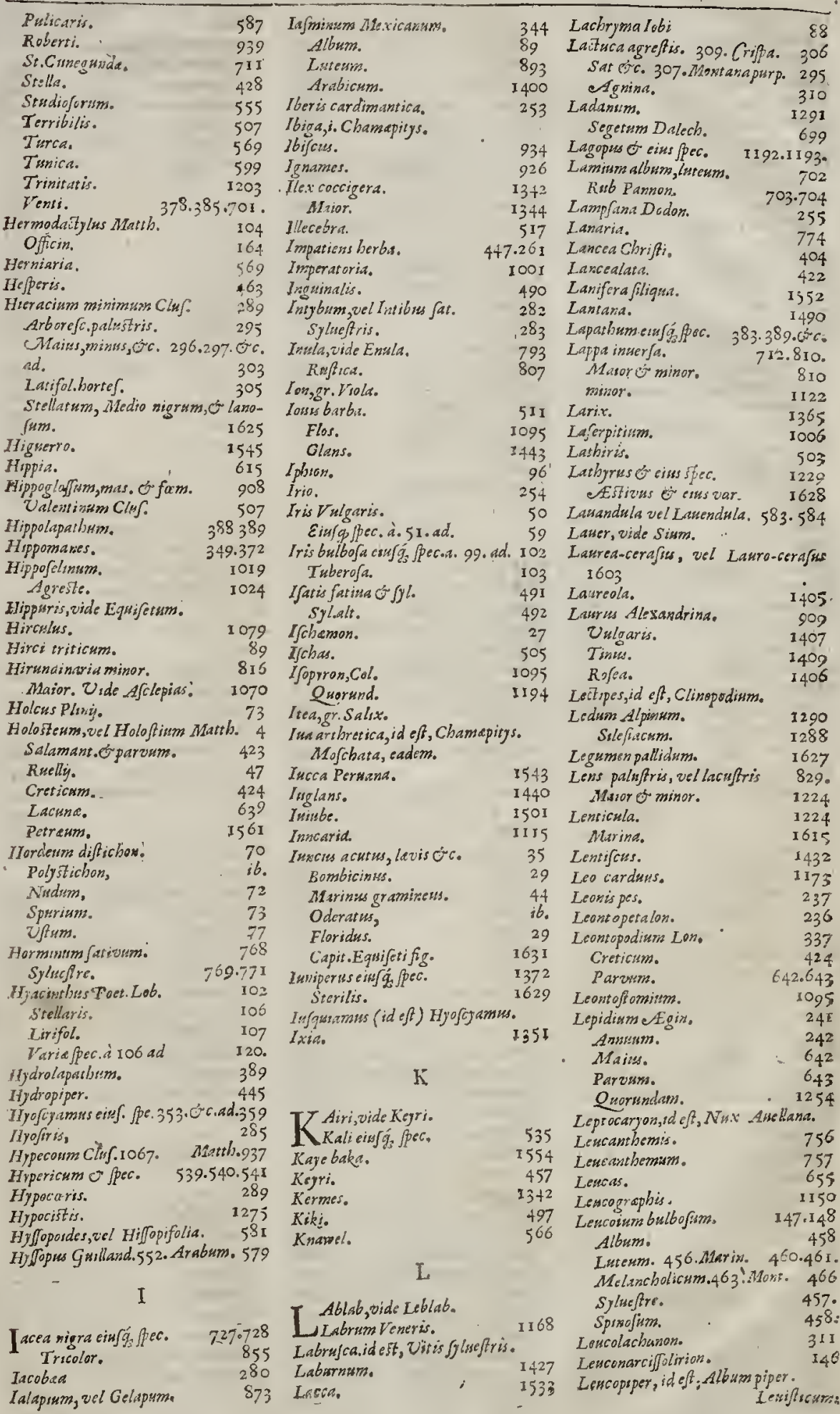




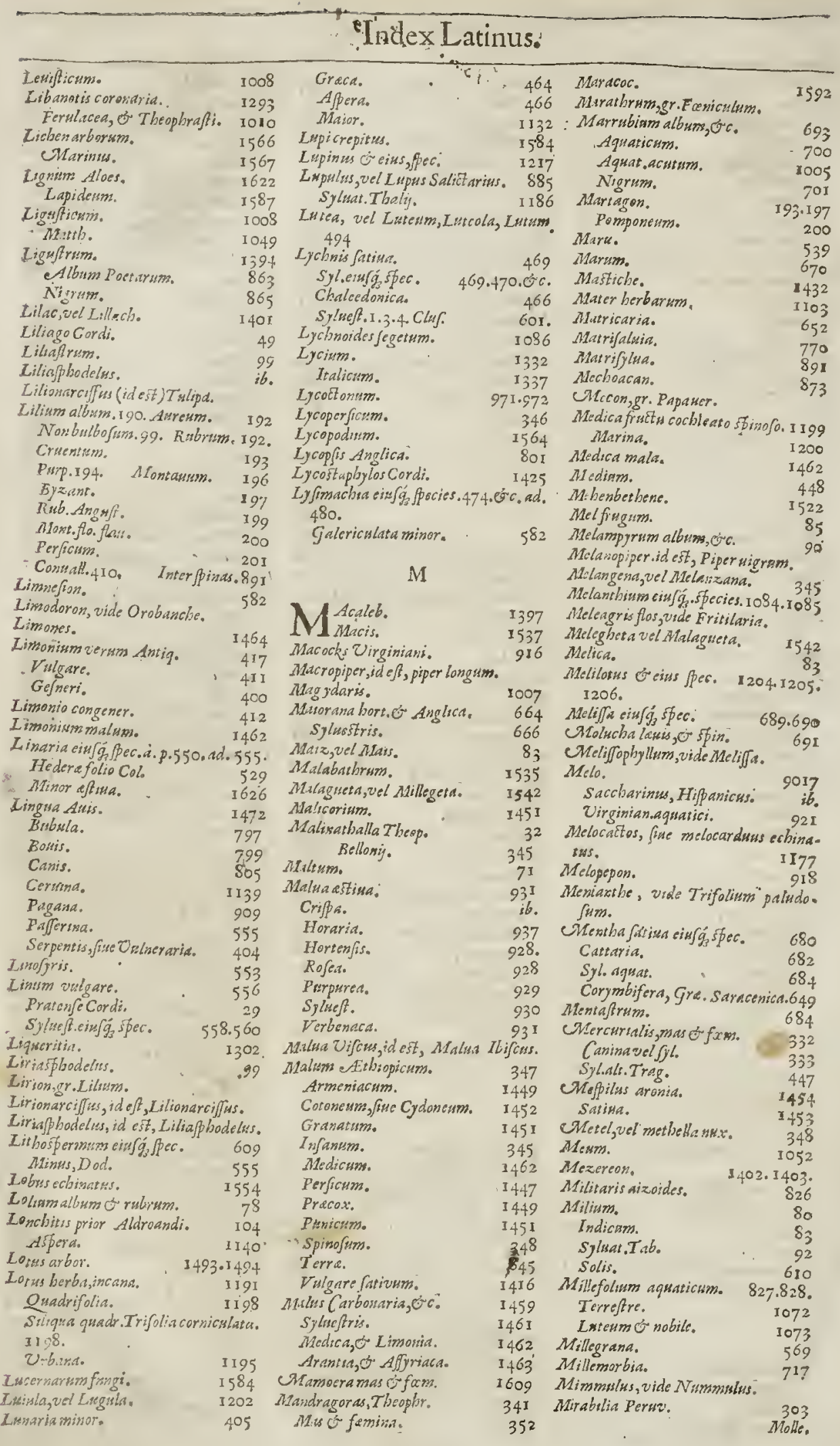


Index Latinus.

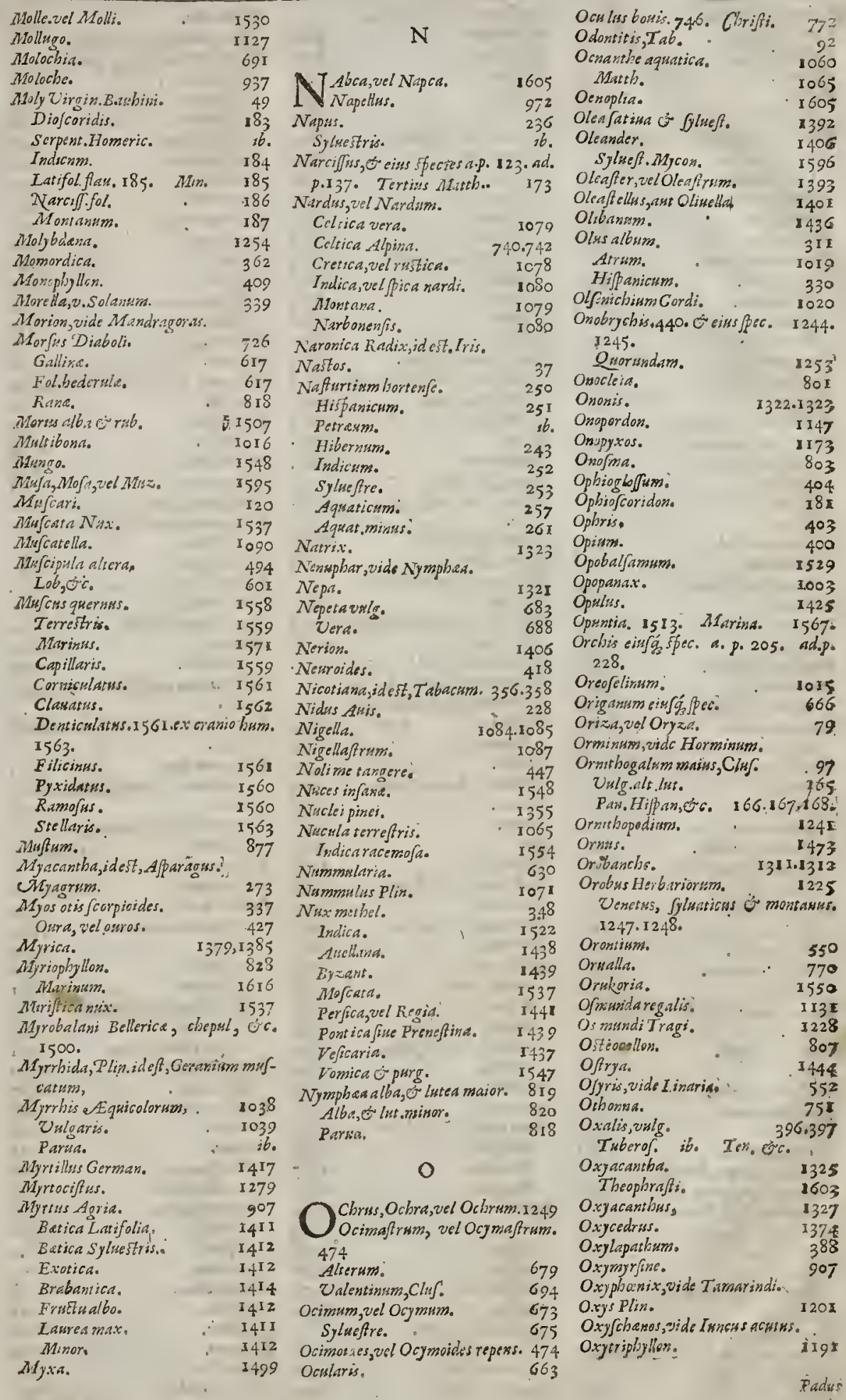




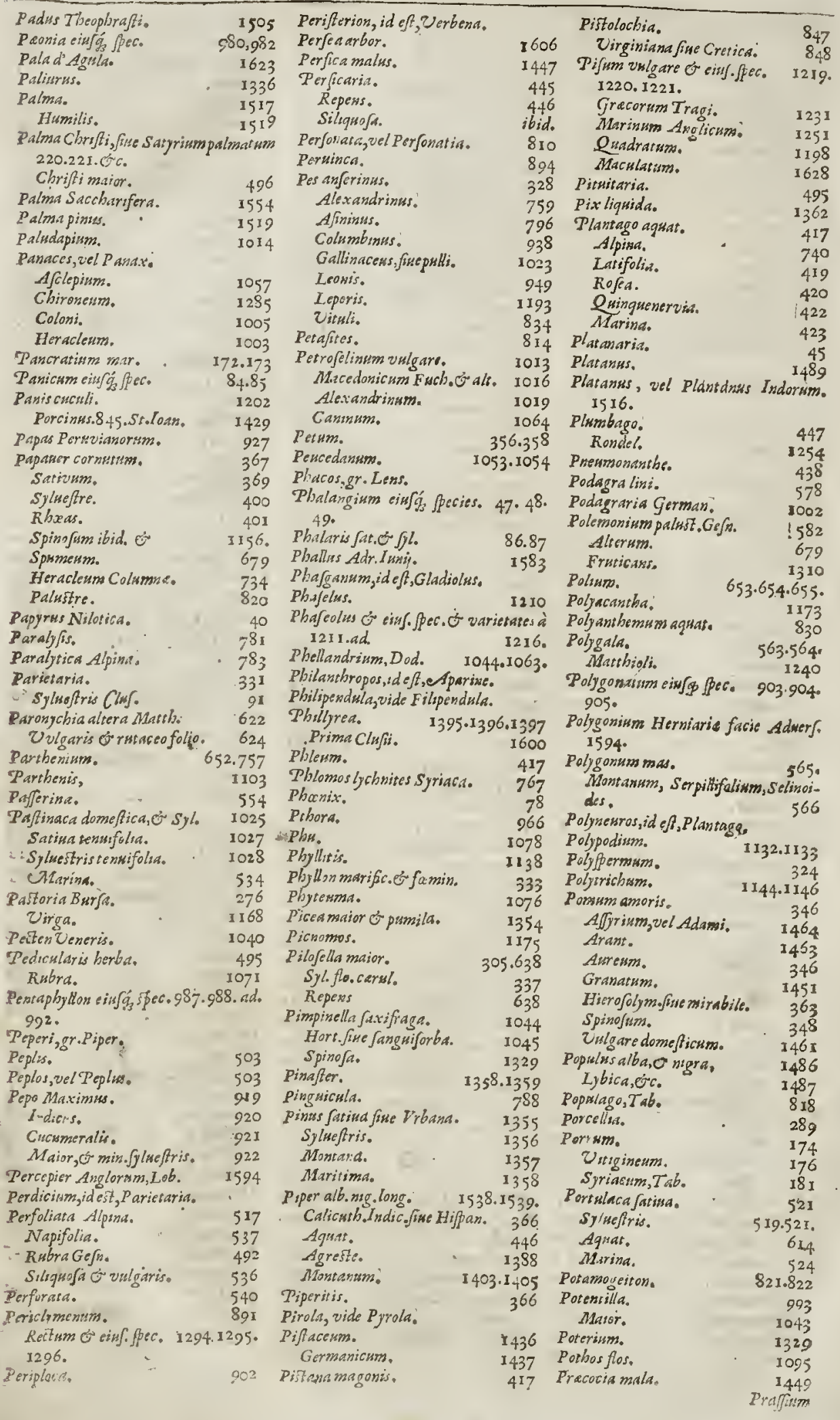




\section{Index Latinus.}

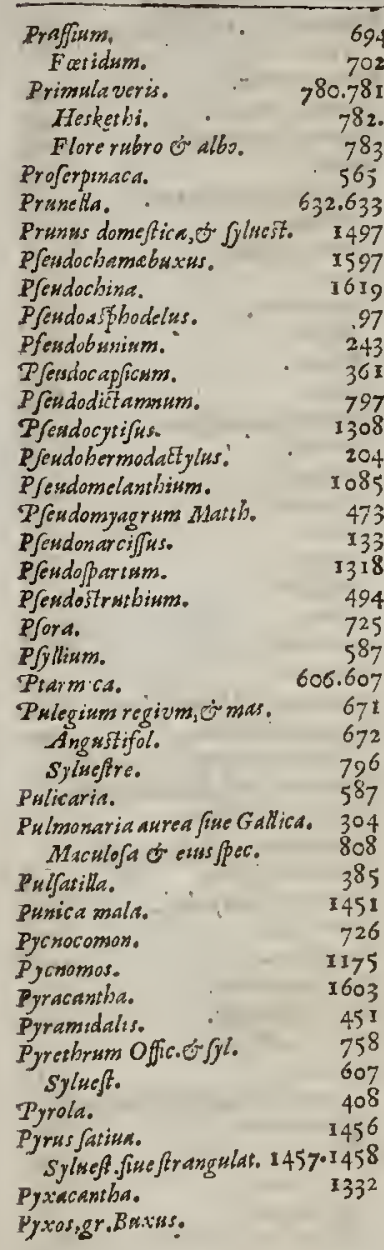

\section{Q}

$\mathrm{Q}$ madrifolium pheum. $\quad 1198$ Qsamoclit. $\quad 1598$ Osercus vulgaris. $\quad 1339.1340$ Marina of eiuspecies. I 567.1568 Quercula minor.

Minor.

657 Munor.
Quinquefolinm ejufgue jpec. $987.9^{88}$
$99^{2}$

Quinquenerwid.

$99^{2}$.

\section{R}

Q Abarbarum vide $\mathrm{k}$ ha. 391

Q Aladix cana . 1090.1091 . Chime. 1618

Drakena.1621, Rhodis. $\quad 532$ Scptbica.

Spiritus fanti.

$53^{2}$
302

1000 Ranunculus aquatilis. Aruenjes prat.0-Alpin. Bubofus of Illyricus.

829 Globojus, Lkifiam.
Monianus.Lut. . $\quad 956.964$

Nemarofusut. o Lalb. $\quad 384$ M.x. Anglows Multiplex, Coc. 557

Afraticus.

Flammens.

958.959

Palaftris.

961

Laifol.Cret.fol.Plantag. 952

Syluarum flo.ple $\pi$. $\quad 384$ Precox, parvus, Thalsetrifolio. 965.

Minimus Septent. Lob. ' 1090

Raphanus.

syluefris.

Aquaticus.

Rufticus.

syl.Offic.

Rapistrum.

Agrat.

Rapem $3370^{\circ}$

Rapim.237.Syl. $\quad 233.4+8$.

Genifte.

Repuncalns.

Rapuntium.

Reginaprati.

237.238 .

240

ib.

241

ib.

233

$8 \div 5$

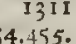

453.4 .55 .

I043

Rejeda.

Refura.

Resta bonis,id eft. Anonis.

Rha ciug $g_{3} \beta \in c$.

Colnjw. 1334

Catharticus, fuc folutivus. I 337

Rhodia radix.

Rhodium lignum, vide lignum shod ism. 1624

Rhododaphne.

Rbodora Pliss.

$R$ bus, vel Rboe coridria. syl.Plin.

Ribes, vel Ribefinm.

Ricizus.

Ritrovel Rutro.

Robur. $\quad 1340.134^{8}$

Rorella Roridd, vel Rosfolis. $\quad 1556$

Rofabortenfis ejasfpec, 1259.1260 . ad 1268. Syluestris, velcamina. I 2691270 Hiericontea. 1186 Celi,fue Mariana. . 468 Maric. $\quad 1386$

Rofea radin:

1386
532

Rofmarinam, vel Rofmarinus coronarimm of fluefre. $\quad 1292$

Rostrum crconie, vel Gruis, ideft Geraniars.

Porcinum.

291

Rubia einfáspec. $111 \$ .1119 .1120$. Cruciata.

I 123

R̈sbusIdens oे vulg. 1272

hepens fiucturafso. . $127 \mathrm{I}$.

Saxatilis.

Rumex.

Rufcus, vel $\mathrm{Ru}$ cum.

Rmiabort. of $f$ l.

Canina.

Capraria.

Muraria.

Pratenfis.

1273

388.390 .

907

1255

1256

1253

1144

Syluefris Hypericoides. $\quad 543$

\section{$S$}

Abdariffa.

Sabina foritis o baccifora. 396

bacrifcrs.1376 Seccarem. aliera.

Saccariam:

Sacerdotis crepida.

Saciaherba. $\quad 358$

Sagina pergula. $\quad \begin{array}{r}358 \\ 125\end{array}$

Sagitta, vel Sagittaria. . 416

Salicaria. $\quad 479$

Salicorria. 4535

Salinaris. $\quad 758$

Selurnca. 1078

Salix aquatica of valgaris. $\quad I_{3} 89$

Caprea. 1310

Humilis.

Marisa, ael Amarina. $\quad 1388$

Rojea. 1388

Silfaparilla. 13 Io

Saluia agreffir, nel Bofci. 75,66

Mavor of minor Horsenfit. 764

Alpina, Cretisa, Lindica. $\quad 765$

Abjunthites. $\quad 764$

Romana. $\quad 640$

Five. 1144

Sambor, vide Iafminum.

Sumbucuseing ga pecies. 1422.1423 1424.1425.

Sampfuchum.zel Sampluchus. 665

Saramundid. 996

Frima.2.3.Clafir. $\quad 5595.1596$

Sana fanti a Indorum, id eft, Tabacum.

Sardaracha Arabum.

Sanguinalis. $\cdot \begin{array}{r}1373 \\ 565\end{array}$

Sanguinaria. $\quad 428.565$.

Sanguiforba, vide Pimpinella.

Sangnis Praconis. 39

$\begin{array}{ll}\text { sanicula. } & 3988\end{array}$

Iraior. .. $\quad 949$

Angiftifolia." 783

Alpina Clus. Eboracenfis of grotiam ti.

Femina Fuch. $\quad 978$

788 1586 .

Santolivit.Dad. IIOg

Santonicum. 1100

Sap.t. $\quad 878$

Saponarit concana engl. 435

Vulgaris. 448.

Minor.Dal. $\quad 474$

Sarxifigon. $\quad 694$

Sarzaparilla, vide Salfaparilla.

Saffafras. $\quad 1525^{\circ}$

Sacureia. $\quad 575.576$

Satyrism erythron. quibugam. 204

Satyrii varia $\beta_{\text {ec }}$ a. p. 20 5, ad. 228. abortivssm,

Sanina, vide Sabina.

Saxifragn Antigrsormm. 604

Alba.

Alfonefolia. $\quad 567$

Aurea. $\quad 8+5$

Alba petraa. $\quad 842$

Anglicana of Pas $\quad 1047$

Magne Math. 605

Kubra,

1060 
Index Latinus:

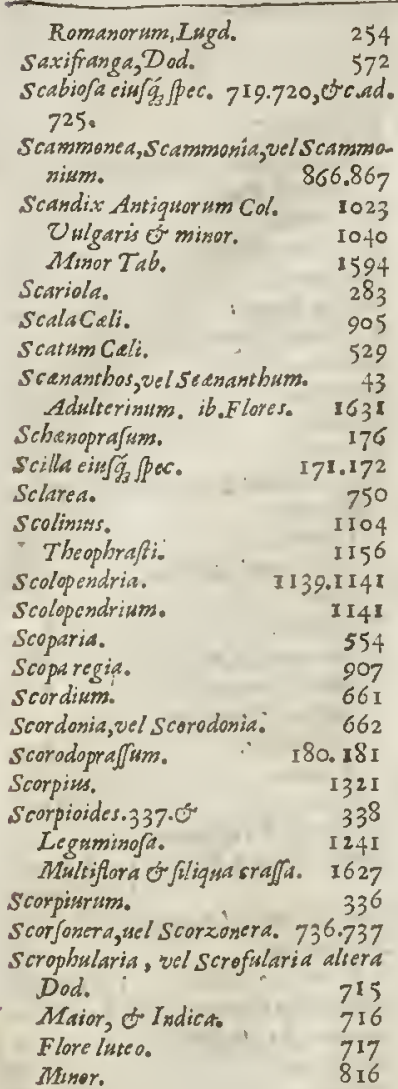

Scythica berba, vel radix, vide Radix.

Sebestena. I499.

secacul Arabum quibnfam Polygo. satum, aliys Sijer, aliys $\mathrm{P}$ astinaca marisa, aliys Eryngism marizum.

Secale.

Securidaca.

Sedsm mains.

Minus eiurfó șec. Aquatile.

Selago,Plis.

Selinum Siy folys.

mism, Cluf.

Semen contra.Vermes. IIOI

Semestina. $\quad$ II00

Sempersirum, vide Sedum matinum. 508.

Sena.

Senecievulg.

$129 \%$

Maior, ide St, Iacobad.

Serapias exifg.jpec. 222.223 .40 .

Serica.

Seriplium.

Seris.

Serpentaria.

Maior.

Serpentina, Matth.

Serpillum, vel serpyllum einfog sfoec. 570.571 .

Serratsila.

Sefamuades mag. \& tar.

CXitiss Scal.

Magnum Cordi.

493

507
976
CMinu Dal.

Sefamm Dod.

Verum.

Sefelipratenfe.

Crestcusn mai.e Mis.

Montanum or Majflienfe.

Peloponenje quorundam.

Athiopicum, fruter:

Sicslinna.

Sicla, idest,Beta.

Sideritis Alprna, Scordioides.

Heraclia Diof.

Angulifol.Vulgaris 6097

Prima Math.

Grouis odoris Thalif.

Secsuda, Diofcoridis.

Sigillum, B.Maria.

Salomonis.

silaus Cofalpini.

silermontanum,

silzge.

Siligua.

syluefris.

Siligraftrmm.

silphium.

Silybum.

Minus fore nat.

Sinapi album, fat.jyl.

Sion, vide Sism.

Sifarum Perкvianum. rulg.

Sifer.

Sifon.

Stfymbrim alt. Diof.

Sifyrrichism mai.eo minus.

Simm einj $\tilde{g}_{3} \int_{p}$ ec,

Minimsm Alp.

Terreftre, fen agrorum.

Smilax arbor.

Smilax appera.

Laris.

Hortenfis.

Peruviana.

Smyrnimm Creticum.

Sol Indranus.

Solanwm, vel Salatrum.339,340.342.

Odoriferum.

Powifersm.

Lignofum fruticofism, vel rubrum. 350.

Arborefcens.

Tetraphyllon.

Tuberofum efculentums.

soldanellamarina.

CHontana maior of minor.

Soler, vide Altizm folis.

Solidagofaracenica.

minor.

Mlaior:

Sonchus asper.

Lousis.

Leu.lat.erc.

Syluaticus, Tab.

Sophia Chirsirgorwm.

Sorbus.

Torminalis,

Sylueft. Math.
Sorghum.

Sparganium.

Sparrium.
1595
273

I 232

1049

1050.

$105 \mathrm{I}$

1062

I 42 I

$544^{\circ}$

696

699.

700

1005
1046

871

905

I 064

1048

66

1429

1428

366

1000

I150

1627

244.

925

1026

sbid.

1017

258

103

$56.257 .0 \% c$

$26 \mathrm{I}$

1018

$I_{344}$

859.860

$86 \mathrm{I}$

1216

859

1024

752

344

347

.

360

406

927
838

839

9

429

807

291

292

293.294.

255
1068

$x+71$
$i b i d$.

1473.

83

45
1314
Spartam Plin.einfógspec. 41.42.43?
I6jo. Spatula fortida.

Speculum Veneris

59

Speirea Theophrafti. $\quad 438$

Spelta.

1601

Spergula fo.albo, or rub. $\quad 69$ Marina. II 25

Spharocephalus. ibid.

spica.

I 152

Hortulana. 584

Nardi. 585.

Celrica. 1080.

Spicata. 1079

Spina alba fime peregrina? $\quad 822$. Aicida. $\quad \begin{aligned} & 1152 \\ & 1325\end{aligned}$ Appendix. '. 1327

Cerualis. I 1335

Cerui. 1338

Hirci. 1328

1337

Lutea.
Solstividis.

Spinachra. $\quad 1166$.

Sposdilium,vel Sphondylium 330

Spongia marina alba likm. 1009

Isfundibuli forma, 1577

Squamaria, id off, Dentariamaior.

Squilla,idest, Scilla.

Squinantbum, idefo, scananthos.

Stachys etujgáspec.

Aquatica, velpaluf. 695

Siaphis arria. $\quad 1005$

Sraphylinis. 495

Staplylodendrum $\quad 1028$

Stells leguminofa. $\quad 1437$

1240

Stellaria.

Aquatica.830.vide Alchimilla.

Sternutamentoria. $\quad 607$

Stabe. $\quad 725$

Argentea. $\quad 730$

Argent min.

Rofmarinifolio, c': $x$ Cod.Caf.73 I

Stechas. $\quad 585.586$

Cirrina. 646

Storax: 1526

Stramonia, vel Stramonium. $\quad 348$

Stratiotes agratile, vel Potamios, 826

Millefolism. $\quad 1074$

Strumaria. $\quad 810$

Strutbinm, vide Saponaria.

Strychnodendrom.

Strychnos,gr.Solansm;

$360^{\circ}$

Styrax.

1526

Suber.

Succifa.

sumach.

superba, Fuch.

Sycomorus.

1474

motum mains of tuberofum. 807

Parvam Boraginisfacie. $\quad i b i_{0}$.

- Maculofum fune fol. $\quad 809$

Synanchica. $\$ 120$

Syringa albaidf corulea. $\quad 1399$

Sygymrichion, vide Sifgnichism.

T.Tabacum 
TAbacks. Tartarsm.

Tamalapatra.

Tamarinds.

Tamarifous.

Tamm.

Tanacetim acutum alburs, 607

Vislgare o einspec. $\quad 650$

Pcrsuianum. . 750

sylueftre. $\quad 995$

Tapjus barbatru. $\quad \therefore \quad 773$

Taraxicon. $\quad \because \quad 20 \mathrm{I}$

Tarcon,vel Tarchor, - $\quad 249$

Tartonsalre. $\quad$ \&5 507

Tartarem. 883

Taivla, Datula, vide Datura." -

Taxus arbor." $\quad \$ 370$

Teda. $\quad 1358.1359$

Teleppirm Diof.quorund. 337 Unigare cinfg; pec. $\quad 519.520$

Tercbinthina Veneta. 1364.1434

Tercbintbus. " 1433

Terramerita, i. Curcuras.

Terre glans.

Malum fise Kapurm. $\quad \begin{array}{r}1237 \\ 45.849\end{array}$

Tertiola Cafalp." $\quad 1005$

Teficulus caininus.207 Varij. a. 205. ad 228.

Tetragonolobos.

Tetrabit.

AnguItifol.

Tescrium pratenfe.

Latifol Exynan ctuo

Thaliftrum fue Thalietrum. 1068

1251.

Thapfin. 1030.1301

Thap sus barbatus vide Tapfus bar.

Theriacaria. 495

Thanpt einf g pec.262.263, Grc.ad 27 I.

Crateve.

Thora Valdenfis.

Thuia, vel Thia.

Thus.

Thymbra St.Iulian:

Thymeleat.

Thymnm,vel Thymus durius o lati-

folism.

Creticsm.

Thyelium velThy felium $\quad 754$

Tigridis flos.

Tilia mas of fam.

Tinus, v.Tyкnks.

Tintiswabulam terra,i.Pyrola.

Tipha.

Tithymalus fyl.Lon.

465

965

1369

$+35$

1575

1403

(2)

4

122

$148_{3}$

Paralises, Heliofo.MYrrifol. dran.p.

ad.p. $\quad 497.505$

Tordilum,vel Tordylum. - 1050

Tormestilla. $\quad 992$

Toraboma. $\quad 329$

Trachelium. $\quad 450$

Tragacautha, Triggacanthum, 1328 . 1329.

Tragium Diof.Col. . " 1045

Tragon. : 1117

Trigopogon. : l 735

Tragopyron. $\quad 89$

Tragorchis. "210 Verbena co

Tragorigassm.668.Cluf. $\therefore 671$

Trafi. $\quad 32$

Tribulas aguaticus min 823, mat. 824 terrefris.

Trichonsanes.

II 46

Trifolism pratenge. - 1185

Maiks pirp. $\quad 1186$

Lut eum lupulinum of minus lut.ib. Afphaliexm, foue bitunsing fum 1187

Americum of Burgund. I 189

Salmantickm, ib.

Cordatum, of fliquofum mix. I 90

Lutesm filigua corrista. 1191

Paindofum. II94

Oderatum.

Cocbleatum.

Acetofum

Heparicym.

Siligua lunara Aipinum,

furm.

1207

Friglferm, ó stellatum. 1208

Frusicans. 1310

Triorcbis.

Triphyllon gr.Trifolikm.

Tripolimm.

Triffagi, vel Trixagó Palinfris.

Traticum esufgajpec.

Triticim amjloum.

Tomulentum.

Vaccisium:

Trolliusflos.

Tfinem.

1195

1199

1202

1203 0

310

310
218

Tulipa eiufor, varictates is.p. $137 . a d . p$. 146.

Trne vel Twras.

Turritis.

Turbith vel Thupesbsm. "415 Grif̧นm?.

Tafi'ago.

Alpist.

CMaror Matrit.

Tynass vide Latrus.

Typba, vide Tipha.

Sulara-V - 540

$V_{\text {Vaccoria, Vaccinimm flos, } 9 \text { urbuf- }}^{492}$ dum, Hyacinthus Botryoidesjalys Violapserpurea Martia.

Vaccinia, Uaccinium fruct us. 1395

Nigra ơ rubra. : $\quad 1415$ Alba, Panion, Vrfoco 1416 I417

Palufiria. I419

Nubis. I420.1630

Valeriana rubra, Dod. $\quad 678$ Hortenfis of fyl. 1075

Greca of Mexicina. $\quad 1076$

Answa, Alpina, latr. of anguft. 1077

veratrum album. $\quad 44 \mathrm{I}$

Nigrum. $\quad 977$

Nigrsm Dodor.

verbajculsm.

verbafomons

.774.775

Martuoli.

767

Sninirefoliss.

767
Verbena commsunis, facrd. $\quad .778$

Ferm.Trag: 254

Fytex. 515

vermiculat 523

Veronica fens.Fuchfiu.

Mas, reitas o.

Verrucaria, i. Tithymalus, vel Helio tropium minus.

Vefecara.

Vetonicas. 342

Viburnum $590^{\circ}$

Vicia or eims fpec. 1490

Indica $\quad$ I227.I228

Victorialis. $\quad 1627$

Yince $18 \dot{z}$

Vinceroxickm. $\quad \begin{array}{r}894 \\ \text { Vinum. }\end{array}$

Vinum. $\quad 878.879 .880$

Viola autwmalis fue calathiana. 438

449.

Aruenfis.

Damajc.

Nigrafise purp.

Casimafyl.

Luter.

Lusaris.

CMariass.

ititrosal.

Peregrina.

Palustris.

Pentaponia.

Tricolor, $C^{\circ}$ eins pers.

Violaria.

Viorna.

Tiperaria.

Virgaasred.

Pastozis.

Sangivines.

410

850.855

$85 \mathrm{I}$

456

464

$4+8$

463.

464

826

$440^{\circ}$

854

$852:$

886

736.737

429

1168

1467

Virgixea. $\quad 757$

Vifcagomaior.

Vifcarit. 601

VifCus, Vifoum. $\quad 1350$

Fifnaga. IO $4 \mathrm{I}$

Vira longa. 1539

Vitalba. $\quad 870.886$

Vitex. $\quad 5387$

Utis alba: : is 870

Fuch. $\quad 886$

Idea. $\quad$ I416.1417

Siliseftris, $\quad 871.886$

Vinifera. 875

Vitriola vel Vitraria i.Paripiatio.

Vitrum, Glafium.

Visurai, vide Viorsa.

Vlmaria.

Vlersus ciufáfpe. T 481,148

Umbilicusveneris. . 529

Marinus.

Visedo. 1496 .

Vrgmentariaglans. 'i $140 \mathrm{I}$

Vngula caballiza, i.THfilago.

Vinfoliums. $\quad 409$

Volubilis maior, minor, of nigra. 863

Volucrum matus, 89 .

Urceolaris, $33 \mathrm{I}$

Vrenaris.291. Urinalis 555

Urtica komena,yrens. 706

Mumor wrens. 707 
Nominum quorundam interpretatio.

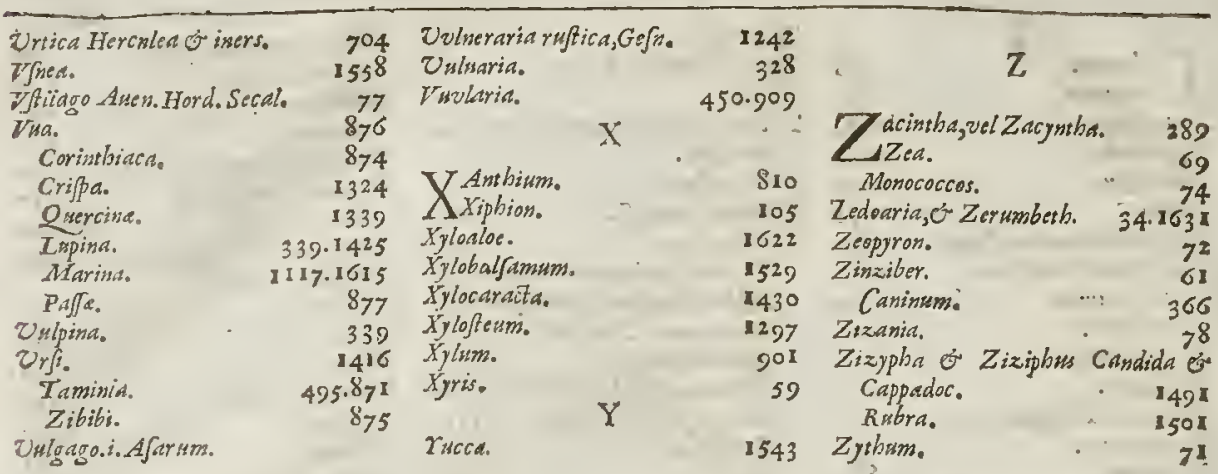

\section{NOMINVM ET OPINIONVM HAR- monia do confenfus.}

\section{A}

A

Bel,idest, Populus alba.

Abbel,i.Sauina.

Abrono Serapionis, i.Pijum cordatum.

Abrotanum femina, idest, Chamacypart] ${ }^{2 u s .}$

Abrugi,i.Pifum cordatum.

Acanophore, i.Iacea.

Acanthus Germanica, i. Sphondylium. Acenthium, i.Onopordon.

Acarwa Theoph.t.Scolymos.

Acetabulum, i.Cotyledon.

Acciptrina, i. Hiercczum, vel Sophia. Acinaria paluft is Gefaeri, i. Vaccinia - palufris.

-Acinus, i Clinopodium.

Achilleats. Millefolium.

Aconitum bace ifersm, id eft, Chriftophoriana.

Acowirum Pardalianches Dodonci, i.

Doronicum.

Acrocorion, i.Crocus vernus.

- Acstella,i.Refta bossis.

Acuspaftoris, i.Geraniam.

Adianthum album, id est Capillus ve.

neris.

Adiaselum albuns Plini, , idest, Ruta muraria.

Ador eft quoddam fiumentigenus. Ageratum,i.Balfanina munor.

Agnus caftus, i. Vitex.

Aoilenfa, Auetlan.

Aglaophotis,, Peonia.

Eqilops Pisiaj, id est, Cerris maior Lobel.

Agilops,i. Anenasterilis.

exgopogon Tragi, Ulmaria.

A Egeleshron oivtota bona.

Afchiromenen Plinit, i. noli metingere, vel potus berbat mimofin.

A:zoon,i.Semperuivism.

Aiwar,i. Chamepitys.

Alayeleti Auicensiesi.Medica.

Alacersus Dalefchampit, i. Pbillyera

Lobel.
Alectorolophos Plinii, i. Fiftularia, - Alieluia, $z$. Trifolism acetofum. Alchilel Serapionis, i.Polemonzum. Alcibiadion, i.Echinm.

Alchimelech, i. Melilorms.

Alfas Safa Anicerna,i.Medica. Algofarel Auicennc,i.Dancus. Alkakengi,i.Halicacabum. Alimonia, , T T ifolium aceso $\sqrt{u m}$. Alnam i. Puslegium.

Alnusrigra t. Frangula.

Altbar, i.Ibifcses.

Albucus, $i$. Ajphodelus albus.

Alsercum Plinir,i.Hyofcyamus.

Alphefera Arabsbus, id est, Bryonin

nigra.

Alfabarateia, i. Parthesinm.

Alcebran,i.Ezula.

Alfenefu, $i$. Abjintbium.

Aluefen, is Peucedanum.

Amaracus, i.Maiorana.

Amellus Virgilis, . Aster Aticus.

Imollis, i. Caltha palustris,

Ambubera, i.Cichorinm fyluestre.

Ampelos Plinii,i.Bryonia nigra.

Ansyrberis,i. Berberis.

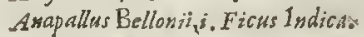

Answ, i.Prususs.

Anablatum Cordi, i. Dentaria maior

Marbioli.

Anblatum Dodonei, i.Nidus anis:

Anchufa, i.Buglofjum fylue stre.

Andirian Rhafis, $;$. Fabago.

Andration Auerrois, i. Pencedanum.

Androfemum Dodonei, i. Clymesnum

Italorwm.

Anetrmtorisofsm, i.Menm

Anguria,i.Pepo oblengus.

Anonis i. Reftabonis.

Apiastellum Apsleit,i.Bryonianigra.

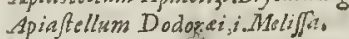

Aporinum Diof.i.Periploca.

Apolinaris, i.Hyofcyamus.

Apronia,i.Brionia nigra.

Aprus, $i$. Pifom rubrum.

Argentina, i Potentilla.

Aria Theophrasti, $i$. Sorbus Alpina Gefneri
Arcium,i.Eardana.

Argentrna,i.Olmaria.

Arthritica, i. Prumula veris.

Artemifra matrina, i.Cineratia

Arrbenogononi. Parictaria.

Armoracia, i.Rhaphanus rutticus.

Arornas, i.Isiniperus.

Arzi,i.Oriza.

Astruntia,i.Imperatoria.

Aferion $;$. Affer Atticus.

Astergis Rbafs, id eft; Azaradacls Anicenno.

Apalathus, i. Acatia Math.

Apleninm Jyluefire, i. Lonchitis.

Aplenium, Ceterach.

Astorca.i. Strechas.

Albanafa, i. Tanacetum.

Anlitica,i.Camamelum.

Auresum olus, i. Atriplex.

Anornus Perri Placentii,z. Frangula. Azabafer, i.Merm.

Azez,i.Lichen.

\section{B}

R Aaras,idest, Pronia:

B Baccaris,i.Conyza naior Math. Baccaris officinarum, i. Afarum. Bamia,i. Althea paluftris.

Baptifecula,i.Cianus.

Barbabirci,i.Tragopogon.

Bayba Touis, i. Scmperwrom?

Barba Aronji.Sempersizum.

Barbarea,i.P Sesdoburium:

Batis Plinii, i.Crithmm,

Bator, i.Terebistbss.

Bazari Chichen, j.Linum.

Bazara Cantona,i.Pflikm.

Becabunga, $i$. Anagallis aguatica.

Bechion, ?. I afjlago.

Bedoara arabibus, i.Spina alba.

Bedeguar Math. Syluar.s. Spina alba.

Bederangi, Meliffa.

Belridere Italica, iscoparia.

Beiahalalen, i. Aizoon.

Betonica Panli, Veronica:

Bibar, i Buphthalmon.

Bifaria,i.Dracunculus.

Bijacrum,i.Gingidism.

Bafatrakagi 


\section{Nominum quorundam interpretatio.}

Bafiatrabagi, id eff Tolygonutro. Bifnadvaisd eft I bi curs. Biflingua, id eff Hippogloffum. Bombexizid off Gofjopium. Botonaria, id eft Aphyllanthes. Boktomon, is Platanaria. Erancas vrina, id eft eAcantbus. Britannica, i. Biflorta guorurdam. Brafjoce Canimi;i. Cynocrambe. Eroeggin Plini, id eft Helxine Ciffampelos .

Brufcus, id ert Rufcus. Bulbus ag reftis, i. Colchioum. Bubonism, id eft Afeer Alticus. Buccinum, i. Confolida regalis Bugin, id eff, Cortex Berberis. Bsiomon Theoph.i.Iris palstrtris. Bulef, ideft Salix:

\section{C}

Achrys marinum, i.Crishmum. Cachrifera, id of, Libanotis. Cahade, id eft Polium. Cafal,i.Agrimonia: Caliabrina, sd eft Lonchicis: Calchoebrum, id est Fumerix. Calcifraga,i.Crishmsm. Caltha, ic eff Calexdula. Calcha Poetaram. 3. Calendwle. Calliurymom Gefn. "id eft Lilism cone vallistris.

Callitrican, i.Capillws Veneri.

Callion Plynty, Alkakengi.

Calichlarisjideft Hoofcyamen.

Calsegia jdeft Galanga.

Camphoratsm, Abrotankm magnsm

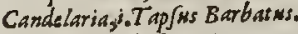

Canis Plinoid eft Vrtica.

Cancrm Anicenna, id eft Chelidenism minus.

Cantabrica Plini, ,. Rapunculm:

Cantabrica Turneri, id est CaryophylIus.

Capillaris,i.Capillus Veweris: Capros, ad est Emmaria.

Capnisis, idefs Eumaria.

Caprificus Plini, i.Ezula Tragi.

Curanful, . Caryopbyllos.

Cardensm, id ef P Peredobsnikm:

Cardopatism,sd est Carlina.

Cardrese fullonum, s. D ipfacus.

Carabia ACtuariy, id eff Ceratia frilquas

Ciarica, ideft Apios.

Carrabudion Stmeonis Serbi, Carmi.

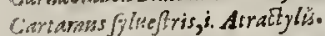

Carpensaria, $\mathrm{P}$.P feudobsinisurs.

Carjefwum, i.Cubebe.

Carpefimm Cialessi, i. Rafcus.

Carnabadion Simcosis Sethi, id eft $C_{A}$ rsims.

Cardel, id eft Sinapis.

Caflebar, i. Coritindrsm.

Cafflata MIattb. Syl. id eff, Hyofcyamess.

Cafusba,id est Cufoxta.

Caftoris rrifolitem, id est Trifolimm paludor $\mathrm{sm}$.

Corgyete, id est Pinpinells.

Caltrangula, siscrophwiariso
Calcitrapa Matchioli, idest Cardrus Stellatps.

Catef, i, Atriplex.

Cachrifera Rofmarinu, id est L bas. notis.

Cathfum,idest Abrotanum.

Cataputia maior, $i$ Ricinus:

Carcon Plini, i. Equifersm.

CaxdaV ilpism, i.Alopecurds.

Celiros, i.Gramenmanna.

Cacilians Plinig, id est Androfaram Dodo.

Centummorbia, i. Nummulatis.

Centrinm Galli,j.Horminnm.

Centunculus, i. Gnaphatum.

Cep ara, ed est Anagallis Aqraticis.

Ceratonia, i.Ceratiáfliqua.

Cercis Theop.id eft Arbor Inden

Cefis, id eft Daucus.

Gerka maior, $i$. Ricinus.

Ceraunia,i.Crafjula

Cersicaria,i. Trachelsim

Cichorikm verrweariwm, id est Hedyp nois.

Circea Gracis, i.MAndragora.

Cincinnalis, $i$.Capslus Feneris.

Crcerbira,isonchres:

Cnicus, i.Carthamks.

Crickm fupinam Cordi, id eft Cardinu benedictess.

Cricms fluestris, i. Atraltylis.

Carrego,i.Meliffa.

Cidromela,i.Malius Medica:

Cineraria,j.Iacobea Marima,

Charantia, so.Balfamina mas.

Chamaciffus, i. Hedera Terreftris.

Chamalesce,i.Tngrlago.

Chamapesce, id oft Rofmarinum fylue fre.

Chamexylon Pliny,j. Ginafalism:

Chamelea Germanica, id eft, Mezereors.

Chamedaphne, i. Lasriola.

Chamed aphre Pliny; id eft Vinca per vinca:

Chamepliam,i. Eryjirrum.

Chamerrbiphes,i. Palmires.

Chameleagnus, id eft Myrtus Brabartica.

Chamerops plinoi.Palma bsmilis: Charnuba, i.Ceratiafiliqua.

charfi,i.Apism.

Chaftara,i.Betonices

Chathe, i.Crowmer.

Chironia,i.Bryonia nigra:

Chitini, i.alihea.

Choeradoleshron, i.Xantbism

Chubece, CMalua.

Chiliod namis, i. Ben album.

Chryfolachanon Plini,j. Arriplex faivva.

Chrofenthemsm Pernviansm, i. Flos Solis.

Chryfoconoe Gefis j. Limarim.

Chryfogonon, i. Blastaria.

Chryforselis Aibensi, i.Malss lifedica. Cirrago,i.Melifas.

Clavrm Veneris, i. Nymphsa.

Clavicula j.Hedera Helin.

Clemetis Per egrina, i. Flammula Iowis $z z \approx z \approx \pi 2$
Clematis Daphnoides, idefl Yincaper. visca.

Clematis altera Matthol,j. Fiorna

Cleome Horati, i. Eryfimum.

Colabrina, i.Arsm EEgyptium.

Cocior, i. Fanicults.

Colocajia,i, Faba of Eg pria.

Columnaris,. Campana Laltefcems:

Colunibina Actmari, i. Uerbena.

Combul,i.Nardus.

Condif, i.Saposerin.

Condardum Plisii, i.Vaccariá.

Confolsda media Fuchjin, idef?, Bells: maior.

Conjolide media,i. Bugula:

Confolida minor Matrhioli, i.Prurella:

Confolida minor Rrellit, ide A Bellis ininor.

Conzambuch Turcor.j. Hemerocallis Valentind:

Contar as Athensi, i. Iniubaspecies inat ior.

Concordia, i. Agrinesis:

Conila, s.eMryrhis:

Confecratrix, i. Iris roff ass.

Coralloides Cordi, t. Dentaria Cirat thioli:

Corcorims Melochia, ideft Olus Indat cuns.

Corcorls Marcelli ver. id eft Anagal: mas.

Corydalis, i. Radix Cauna

CorIndum,i. Pijum Coraiatum

Coriziola Rhajss,i.Scrmomea.

Corona fratsom, $i$, Carduns Erioct: phaliss.

Corion, Coriandrum

Coronopus, ;.Cornu Cerai.

Corigrola, i. Centumnodia.

Corona nonachi,i. Dens Leonis:

Corona Regicip.Tomum fpinofrom:

Coroneole ${ }_{2}$.Lyfy machia.

Corydalizsm, s. Fsmavid.

Corylus, A Anellana.

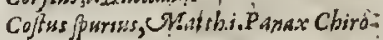
nism.

Coftus Hortor sm, Balfamita maior.

Costa Canina, $i$ : Qungmeneruia.

Corgdslopodium, s.Confol. Regalis. Corisus Dodo.s.Coscygria Plsriy.

Cot Axicenne, i. Ntedica:

Crepanella, id eft Dentillaria Rondele: siy.

Creta Misrina, j.Crithmsm.

Crinita, i.Capillus Veneris.

Cucullara, i.Ping nicula.

Csecurida, Dentillaria Rondelety.

Cuminurs CEtisopictum, i.Ammio.

Crsnilano, i.Conyza.

Cunegusnáis, berbaj, Eupatorismi $A * d$ comne.

Cusila Colsine the it Satarela.

Cunophuran,i.Nux Indica.

Guterder Anicenne,i. Saponaria.

Carcumas i. Yypersis Indus.

Curcas Clussi, inatinus

Cusbar, i.Corinndrum.

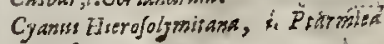
-12aftrirca, 


\section{Nominum quorundam interpretatio.}

Cyfo,idest, Hy foopus.

Cyminalis, ideft, Gextiser.

Cynanchernis, 3 .Cotrla faridd.

Cynofpaftus,i.P conia.

Cynoforchis i. Satyrium.

Cyrrocephaluw Apuleii, i deff, Antirrbirum.

Cynocephalus,i.Anotum.

Cynosbutos Diofe. ideft Rofafyluestris.

Cynosbutos Tragi,i.Oxyacawthus.

Cyrosbatos $k$ ue thiे, ${ }^{j}$. Rubses.

Cynosbatos Dalefe. $i$. Capparis.

Cyprus, i.Liguffrum.Lobeliy.

Crpru Dodid.Phillyrea.

\section{D}

$\mathrm{D}$ Amedrios, i.Chamedrys. Dasebalchil, i. Equifetum.

Darsch, Palma.

Darache mous, $z$.Mufa.

Datura, i.Stramonia perigrima,

Debonigi, i.Chamomilla.

DeEta,jo ef Beta.

Delphoniwm,i.Confolida Regalis.

Diapenfra,i. Saricmla.

Didar Arib,i.Vlmus.

Diritus Veneris, $i$. Nymphea.

Dilisideft I far is

Diocallia Apulei, i.Chomomelum.

Diofpiron, i. CMiliums folis.

Dioppir os P lini, i. Lacryma Iob.

Diofanshos Theop.i. Seperba Fuchjii.

Dochor, id est Paricurs.

Dolichus Thoopbr. id est Phafeolus Lobelis.

Dracoberba, i.Tarcon,

Dracufylmeftris,i.Psarmica.

Drofuitum,i.Haliabbi Anifum.

Drofion Cordi, 2 . Alcbizsills.

Drypis Guillandisi,i.Tragon. Mat.

Drypis Theop.i.Eryngism U Marinsm

Dryopteris Tragi, id eft Pteridion Cord:

Dryopteris,i.Adiantham sigrum.

Dryophonoss Plinii,ideft Arabis Dodan.

Dhlb Arab.i.Platasus.

Dulcamura,i.Amara.Dulcis.

Dulcifida,2.Peonia.

Dalcichion Grikandini, 1.Cypern dulcis Tragi.

Dumbebe,i.Endivia,

\section{E}

Chium Paluftre Cordi, i. Scorpion des Dodis"

Eghelo, Dodon. id eft Labisrnum Lo. beliy.

Eledgans M1at.i.Ziziphus alb. Lobel. Eleofelinam,i.Paludapirm

Ellifisplacos,i. Saluia.

Elkiageber,i.Rofnarimus."

Empetron Dod.i.Kali.

Enspetron Kandeletii,i. Crithmssm.

Empetron Tragi,i,berbaTurea.
Empetron, i.Herniaria.

Encephalus,i.Chamarrhipkes.

Enphbyllwow, Lobelii, i.Dentaria.

Enespbylisw, i.Lingra Serpentina.

Enneadymamen Gejneri, i.Gramex Par. wajf.

Ephetium,i.Ranunculus.

Euphrofynses $P$ linit, i.Borago.

Epilobion Gefn.i.Chawaneriwen Lobel

Epimetron,i.Epimedium.

Epipetron, Epimodism.

Eprpatfis Recertiormm, i. Helleborine.

Epipalfis Rondeletii, i. Hernintria. Eranthemum,i.Flos Adonis.

Ericoides, i.Euphrafia lutea, Dod. Eringium Vegetii, 3 . Acarna Theop. Eringium Guillan, i. Cardsus Siellatus Erinus, $i$.Cor coros Plinii -

Eruam fylueftre, i. Catanance.

Eryphion Apules,i.Rssa.

Eryfimsum Theop.i. Camelina.

Eryebrodanwm, i. Rubia tincterwm. Exspera,i.Verbera.

\section{F}

FArfara,i.Tufilago.

I Farfugimm,i.Tujilago.

Farfium Axicesne, ideft Thora Val. denfis.

Farfrugum,i.Caltisa palmstris.

Farasum,i. Tugilago.

Fardegeni,i.Origanam

FelTerre,i:Centasroum minus.

Faniculus Porcisks,j. Pescedanwn.

Fermlacoli, Thapfis.

Ferraria,i.Agrimosia.

Eerraria Lobelii, Serophularia.

Feftaca Plinit,i. Anena Sterilis.

Flammala Losis, id eft Clematis Peregrima.

Filicastrum,i.Ofmunda Regalis.

Filix. paluftris,i.Ofmurda Regalis.

Filax Florida, i. Ofmurada Regalis. Filix Latifolia Cordi,i. Ofmunda Re-
galis.

Ficaria, i.Chelidonium minus.

Flos Regirs, i.Confolsda Regalis.

Flos Ambarnalis,i. Polygala.

Fonralis, i.Potamegeston.

Folism Indam, id deft Gatcir.

Fuga Demonis, i. Hypericum

Fus us, i. Arraitylis.

Fumaria, Corydalis, i.Radis Cama.

G

Aledragon Plinit,i. Dipgacus. IGarofmus si. Airplex Olida. Gallitricum, i.Horminum.

Gelfeminum Indicums, i. Mijabilia $\overline{P e}$ ruziara.

Geniture, id eff, Anctum.

Genicularis, i, Plisu magnmm.

Gerecamshe, i. Bryosia nigra.

Gesm,i.Caryophyllats.

Giezar, i.Dancss.:

Giezar Aridras,o Belburen. Gith,i.Nigelle.
Githago Plinit,i.Lolijum.

Gladiolws Aquatilis,i. Inncus Floridius Globularia, Apholanthes.

Gloffograpbe, Amicenne,i. Fumaria. Gobjpinm,i.XYlon.

Granum Reginm CMefua, i.Ricmnsi Gramphena Plinii,i.Calendula.

Grofularia,i. Ribes,

Groffrlatia, , Ivia crijpa.

\section{H}

T. Abonog Arer,i.Chamanala, 1 Habal Nil Serapionis, i. ConvaIndus ceruless.

Halcalsmeg Aseroii, i. Faricsim.

Halgazar Aneroii, i. Paftisaca.

Halicacabum Vefica rism, id of Alke: kengi. Halscacabum Peregrinum, i. Pifum
Cordatum.

Hamefress,i. Chamsepitys.

Hanab. Alebaleb, i. Solanum.

Haraha, i. Crcurbiza.

Harbatum, i.Pescedansm.

Harenaria,s.Cornu Cermi.

Haronigi, id eft Deronicsm.

Hafmifen Syriacrm, id eff Convolunlm

Cersuless.

Haftsla Regia,i. Aphodelus albus.

Hafce, Thyawiss.

Handacocha Plinii, i. Trifolinms bicw: minofsm.

Hawr Arab.i.Populus alba.

Hebere, i.Xylaloc officisarum.

Herculania, Jiberbesa.

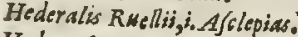

Hedera fpinofa, i.Smilax Afpera.'

Hedera Cilicia,so smilax eAfpera.

Helxine, i.Parietaria.

Helsce, i.Hedera Helix.

Hemen,i.Serpillum.

Hepatica alba Cord, i.Gramen Parnajti.

Herba Scythica,i.Glycyrrbiza vulg.

Herba Cafta,i.P eonia.

Herba Leonis,i.Palmea.

Herba Lucis,i. Chelidorium wains.

Herba Impetiginaria,i.Cbelidoniwm mains.

Herba Vulcani, i. Ranuncrlus.

Herba Scelerata,i.Ranwnculus.

Herba Vlceraria, $i$. Ranwnculus.

Herba Carfitich, i.Ransucslus.

Herba Dineotilie, Confolida Rega. lis.

Herba Stella, i. Cornu Cermi.

Herba Cancri,i.Helsotropinm.

Her ba Radioli Apslis, id eft Polypo dissm.

Herba Leonis Dodon. idest, Sgwilegia.

Herba S. Anthony,j. Dentillaria Rondelesij.

Herbu Coxendicnm, i.Cotgledon.

Herba Benedicta, i. Caryoghyllata.

Herba Fortis, ideft Solidago Sarace: tich.

Herba Taralyfos, i. Primula veris.

Herba Cinuellata, i. Fiolatricolor. 


\section{Nominum quorundam interpretacio,}

Herba Lafriata, id ef Balsemsita maior.

Herbe Pinnula, id est, Hjof cyamus.

Herba Tisca, Herniaria.

Herba Hungarica Dodon.i. Alcea.

Herba Simeonis Dodon. ideft, Alcea.

Herba Vrbana,i. Acantbus.

Herba Turica Gordoniy, id oft Ocymaltrum.

Herba Tunica Dodon, idef, Ceryoployllate. -

Horba Gallica Fracaftorij, i. Galega.

Herba Kintiralis, i.Sphondylitem.

Herba Sarda, id eft Kanunsulus aquaticus,

Herba Sacra,i. Tabaco.

Herba Sacra Agrippa,i. Melifa.

Hermodattyliss Dodon. id eft Culchicum.

Hermodalt. Italonsm, i. Iris tuberofa Lebel.

Heperis Clufi, i, Lencoism marinsm Lobeliy.

Iippia,i. Alfine.

Hirundinaria,i.eAfclepias.

Hortur Veneris, $t$. Cotyledon.

Horminsm Tridentinum, idef Colss Iouts.

Humadh, i.Lapathum.

Hunen, i. Irisbe.

Huniure, Irica.

Hydrofelinum,i. Paludapium"

Hydrofelinum Camerary, ideft Lauer maius.

Hoofcyamus Perkvianus, i.Tabaco.

Hoppogloffsm, Bonifacka,id eft Laurws Alex:

Hyofris Plini, i. Iacea nigra.

Hyophebalmon, $\hat{i}$. After Atticus:

Hy.pecoon Dodon, id eft Caminum gyl. weftre.

Hy pecoon Clufii,i. Alcea Voneta:

Hippofelinon, i. Olus atrum.

\section{I}

Arus,idef, Arum.

Iackiak, Anemone.

1afone, Campantala.

Infin,i.Enula.

Zanatri,i. Nux Mofcata.

Ibiga,i.Chamapitys.

Jezar Serapianis, i.Pastinaca:

Imperatrix, i. Mesm.

Inula Rufica Scribonz Largi,i.Conjo-

leda mitor.

Tugsinalis, i. Afer atricus.

Intybus, i. Cichorum.

Insis $F$, $b a$,i. Iy ofoymus.

Iosis Glars,, Cafanea.

Touis Flos, i. Lyclunis:

Jow is Arbor, . Quercus.

lorgir, $i$ Eruca.

Irio,i.Ery fomum.

Iuncus quadratus Celf, i. Cyporiss:

Tua Mufcaia,i, Chamapitys.

Infarti,s.Sambucus.

Ingriamus, i.H) of cytmus.

Ixopus Cordig. Chondrilla:

\section{K}

T广Antion,i. Centaurum.

Kanz,i.Amygdalus.

Kaper, i. Cappitris.

Kavroch.i.Chelidoniwm maius.

Kebikengi,i. Ranusculus.

Keiri,i.Lencoium.

Kemetri,i.Pyrus.

Kетит, i. Caminum.

Ken*e, i.Ligufrum.

Keruagh,i.Ricinus.

Kersegha, Ricinus.

Kermes, i.Coccus infeitoria.

Kulb,i. Dllium folis.

Kusbera Auerroi,ideft Coriuxdram:

Kusbor,i.Coriandrum.

\section{L}

T Abrufca,i. Bryonia nigra. Labrum Veneris, i.D ip acus.

Laburnum, i.Anagyris.

Lattarua,i.Tibymalus.

Latuca leporina, $i$. Soncbus.

Lattucelli, i. Sonchus.

LanataCordi, Aria Theoph.

Lancea Chrift t, ed eft, Lingua Serpentirs.

Lantana,i.Viburnum.

Lanaria, i. Radicula.

Lanceola,i.Quinguenerwit.

Laudata Nobilivtr, i. Veronica.

Latbyris, i.Cataputia.

Latbyrus,i.Pifum gliseftre.

Laner Lauacrum, Dip Dacus.

Laurus Alexandrina, id est, Hippoglofum.

Laurus rofen,i. Oteander.

Laurss fylueftris, id eft, Laurus Tines.

Laurentina Afathioli, i. Buguls.

Leo Columelle, i. Aguilegin.

Leontostomikm Gefneri, ideft, Agutlegin.

Leo Herbs Dodon.i. Aquilegin:

Lepidin Plinif, Piperitis.

Lefen Artbaur, i.Bugloform.

Leacacantba,3. Carlina.

Leucanthemum, i.Chamanclum.

Libadion Plini, i. Centasuresm.

Libanimm Apulei,i.Borago.

Limodoron Dodon, i. Orobmache.

Lingra awis, i. Fraxini femen.

Lingua Pagank, i. Hippoglofjum.

Liliago Cordi,i. Phalanginm Lobel.

Lifen,i. Plintago.

Lotus Urbane,i.Trifolism odoratum Lobely.

Longina, i. Loscistis.

Lichen, i.Hepatica officinarsm.

Lunaria Aribritica Gefneri, i. Auricu la Vrgto

Lsciola, i. Lingua ferpentina.

Lunaria Graca,i. Bolbon: $c$.

Lunaria manor Diofcor. id eft, Alysfon.

Lnpb Cordi,idracunculass.

Luinla, T, Trifolinm Acetof $1 \mathrm{~m}$.

$$
Z z z=x z 3 .
$$

Lycoftaphylos Cordi, id eft, Sambucus aguatica,

Lycopfos ${ }_{2}$. Buglosism fluestre.

Lycoperficum, i.Poma Amoris.

\section{M}

$\mathrm{M}$ Achla,id eft, Palma. Madon Plini, id eft, Bryonia alba.

Muhaleb Awicenne, idest, P fexdolign: frum.

Mabaleb, $i$ pecies pbillyrea.

MIgydaris Theophi. Laferpitins.

Milacocciffos, id est, Hedera Terre:fris.

Mislinatballa Theop, i. Mlala infanavel potius, Cyperus E/culentus.

Mulacciffus Cafari Bafti, Caliha pat: iufris.

Mlaluavifcus,i. Ibifcus:

Manss Mistu, .Quingrefolitm.

Atrana, i.Stramonia.

Murathrum, i. Feniculum.

Maru berba Dodon, id eft, Cerinth Plinit.

M.trinella,i,Pbu magnum:

Marmarites, i.Funarua.

Mirmorella,i.eAgrimonis:

Miftastes, i.Lajerpitium.

Alszan Pleni, i. Scabioja.

Mater Herbarkm, ir. Artemifia.

Muterflon, i. Iacea wigra.

Matrifaluia,i. Horminum.

ntar rifylua, i. Periclyme num.

Maurobebra Caput, id eft, Antirrbi: num.

Medum Diofcoridef, Viola Marin ana.

Medium Lobely, i.Iris martima Nar

bonenfis.

nI:lochua, i.Corcorus.

Ifelampodium, i.Helleborus niger:

Mel frugum Dioclis, i. Panicum.

Melampjrum,id est, Triticum Vaces. nsm.

Melajermum,i.Nigella.

Welich Arab. id eft, Trifolium fruticans.

Meleagris Flos, i.Frillillaria.

Melanthium, i. Nigella.

Melopinum, i. Pomum Spinolum.

Memiran Andr. Bellunenfss, i. Chelid maizs.

Memirefin Auicen.idem.

Mesd Hendi Arabibus, id eff, Scamona. ner.

Memitha Arabibus, id eft, Papaser Cornutum.

Memasylum, Arburus:

Menogenion, i.Peonia.

Mentha Saracenica, id of Bulfamila major.

Men, ideft Meum.

Memiren Serapionis, i. Chelidonimn minss.

Mechel, i. Stramonia.

Merzenius, i. Maiorana.

cefcatremfir, id eft, Dictame num.

Miple 


\section{Nominum quorundam interpretatio.}

Mille grana, i. Herriaria.

Menumbe Theop. id eft Trifolium prouftre.

Militaris, i. Millefoliwm.

Mista, i. Styrax.

Millemorbia,i.Scrophularia.

Mixa, i. Sebifter.

Molochin Serapionis, id eff, Corcoros Mutrhioli.

Molybdena, id est, Dentillaria Rondeleti\%.

Mosmordica, Balfemita mas.

Morgbani Syriacaz zd eft, Fabago Belrarum.

Mocbrs Dodon. id eft, Orobus Lo. bel.

Morella, i.Solunum Hortenfe.

Mula Herba Gaza,i.Ceterach. Mulsibona, i. Perrofelinsm.

Mumeiz, i.Sycomorus.

Mardlia Plin.Helnine.

Miophononon, Doronecum.

Myrtus fyluestris, i.Rufcrs.

Myrica,i.Tamarifces.

Myriophylurm, i. Viole aguatilis:

\section{N}

T Abatnabo, id eft, Hentha. Nanochach, i. Ammi.

Nard o Naron Arab, i.Rofa.

Nardus Cretica, i.P hu magnum.

Nardus Rufica Pliniy,ioideft, Conyza velpotirs Afarum.

Nirf.'Nafturtium.

Nirgol,i.Palma.

Naffurtism bibernum, i. Barbarea.

Neruphar,i. Nymphea.

Neottia, i.Nidus axis.

Nepa G.zze, i.Gessifa pinofa.

Nerism, ;.Olearder.

Nicophoron Plingy, i Smilax appera.

Nicojadina, Tabaco.

Nigellastrum,i,P feadomelaxtbium.

Nilofer, s.Nymphace.

Nil esuicenne, id oft, Convolvulus Corulews.

Nola Culinaria, i. Anemone.

Noli me tangere, $i$. Impatiens berba.

Noli me rangere, $i_{0}$ Cucumis fyimestris .

Nux Mrtel,i.Stramosia Fuch/ip.

Nis. Ueficaric, id of staphylodenidron.

Nywphea minima, i. Morfus Rana.

\section{O}

$\mathrm{O}$ Culus Clurifi,idest, Horminum fol.

Odontis, id eft. Dentillaria Rondelety.

Olualudia,i.Chamamalum.

Olea Bohemica, $i . Z$ iziphus alba.

Oleagnos,r.Chamelara.

Olenstellwm, Chamelan.

Olus ludracum, 3.Corcoros.

Olus album Dodon.i, Valeriana Cam-

pestres, vel Laituca agrima.

Oragra Vetcrum,i.Chamenerium.

Onzts Plisity. Origanum.

Ononis, i. Refta Byuis.
Orobrychis, id est, Gaput Gallinaceum.

Onobrychis Belgarum, i. Campanula Aritenfis.

Onofmi, id eft, Buglofim fylneftre.

Onopordon; id eft, Acanthism IKyrtcrin.

Ordelion Nicundri,i.Tordylion.

Ophris,i.Bifoliwm.

Ophioglofrum, id eft, Lingua ferpertis.

Oprentia Plesii, i. Ficus Indica.

Opfago,i Solanum fomniferum.

Orbicularis, i.Cyclamen.

Oruala, i.Hormunum.

Oreofelinum, $i . P$ etrofelinum.

Ornus, i. Fraxinus Bubula.

Orentism,tantirrbensm.

Ofira Cords,i.Ornus Tragi.

Osteocellon,i.Confolida masor

Ofrutium,i.Imperatoria.

Ofyris, t. Linaria.

Otbonsa,i.Flos Africanus.

Oxjacantba, i.Berberis.

O.tyacantbus i. Spira appendix, velpyracantba.

Oxys, Trifolism Acet ofism.

Oxymyrfine, i.Rufcus.

Oxy cocras Cordi, idest, Vacc inia par Inftris.

P

D Alwa Chrift; id est, Ricinus.

Palalia,i.C, ilamen.

Peder ata,i. Acantbus.

Panis Cuculi, ad eft, Trifolium Acetofum.

Pancratimm, i.Squilla.

Panis porcinus, $i-$-Cyclamen.

Papauer Spumeum, i. Ben album.

Paronychia Dsofcor. ideft. Ruta Mte rarive.

Pafferina, Ruelli, id eft, Morfus Gat lina.

Pedicularis berba,i.Staphy fagrie."

Pedincularia Marcelli, id eft, stapbisagria.

Feganou, i.Ruta fylueftris.

Pentadaltylon, i.Ricinus.

Peponella Gefceri, id eft, Pimpinella.

Perlaro, , Lot us arbor.

Perforata, i. Hypericon.

Ferdicion, i.Helxine.

Perifterzon,i.Scabiofa minima.

Perfonata,i.Bardana.

Pezica Plinit, funt fungispecies.

Pes ause, i. Ornithopodium.

Pes Leosis, i. Alchimilla.

Pes vituli, i, Arum.

Pes Leporinus, L.Lagopus.

Petrim America,i.Tabnco.

Petilius Flos,i.Flos africanus.

Pharnacerm, i. Coftus Spurius.

Thafg mon Theop.i.Gladiolus.

Phalangitis, Phalangism.

Phellos,i.Suber.

Phellandrium, i.Cisuraria palustris.

Phellandriwm Guillandini, i.Angelica.
Pharix,i.Lolinm.

Philomedium, i.Chelidonimm maiks.'

Pbileterissm, B. Bes album.

Pbleos,i.Sagittaria.

Phthirion,i.Pedicularis.

Phylateria,i.Polemonism

Pli.lyrea Dodon.i.Ligufrum.

Phyllon Theopbrafti, i. Mercurialis.

Philarthropos, i. Aparise.

Picnacomon Angnill,i.Rhejeda.

Pompinella pinofa Camacrariz, i, Poteria on Lobel.

Pinaftella, i.Peucedanum.

Piper aguaticum, i. Hydropiper.

Piper Calecuthism, Irdum, Brafilin: num, i.Capficums.

Piper agrefte, i.tritex.

Piflatu Sylmefris, id ofR NHx Veficas ria.

P.ftana, i. Sagittaria.

Plarta leonis,i. Alchimilla.

Prestmonanthe Lobeliz, i. Viola Calse" ibiana Dodonat.

Podagraria Germasica, id eft Herta Gerardi.

Polytricusa, i. Capillus Veneris.

Poltricum Fuchfis, id est eMufow capillaris.

Polygonatum, id efl, Sigillim Salomo: nis,

Polyganoides Dinfcoridis, id eff, Vinca perninca.

Polyantbemsm, i. Ranunculss egua: ticks.

Pologonum, i. Centumnodia.

Popeslago,i. Trffrlaga,zel Caltha palw.' ftris,

Potenillamaior, i. Vlmatia.

Pothos Coflei,i.Aguilegia.

Posbos Theophrasti,i.Aquilegia.

Proferpina herba, i.Chamomelum.

Protomediaji.Pimpinella.

Pfendorchis, B. Bifolitum.

P fendobsunium, i. Barbarea.

Pfesidocapficum, i. Strichnodendrox.

Pyrethrum Jyluestre, i.Ptarmica.

Pteridion Cordi, i.Dryopteris $T$ raoi.

Puffech,i.Pistacia.

Pnligaria, i.Conyza:

Q

Qtsemi,zd est,Nigetin,

$\mathbf{R}$

$\mathrm{R}$ Adix Naronic a, id est, lri:

R Ramel,i.Cilus.

Rapurn terra,, .Cyclamen.

Raginivisi, Fonicylum.

Raledialemen Haliabbs, id est, FumA ria.

Rigina prati,i.Vlmaria.

Rofa fatsina, i. Paonia.

Rofn lunonic, i.Lilium.

Rorastrum,i.Eryonia.

Rorella, i. Ros folis.

Rotula folis, i. Chancelum.

Rhododaphne,i.Oleander.

Rhododendron, i. Oleander?

Rhufclinum Apulei, i.Rewruculus! 


\section{Nominum quorundam interpretatio.}

Rina Maria, s. Aliarit. Rincus Marinus, i.Crielsmum. Rubus cerpinus, i.Smilux afpera. Rsme.t, id eft Lapabum. Ruta caprariatid eft Galega. Ruta palufris, idef Thalietrum.

\section{$S$} Abeteregi,jd eft Fumaria.
Sabaler, 2 .Sattreia. Sadeb, id eft Ruta. Sacra berba Agrippe, i. Saluia. Safforgel, i.Malus Cydonia Safarhe ramon, i.Sparganum. Salicaria, i. Lyfimachia. Salisuca. Gefracti, i. Nardus Celica. Salfirora, i. Ros folis.

Salicajtrism Plin.i. Amara dulcis. Salix Amorina, i. Salix bumilis.

Saliwaris,i.Pyrethrom.

Salsin vite, i. Rmia mariaric.

Salvia agrestis, idest scordiwm alte rum.

Salvia Romana, B. Baljansita maior. Salufandria, i. Nigelia.

Samalum Plinoi. Pulfatilla.

Samolum Plin. i. Anagallis Aqnatica. Samp fuchum, i, Amaracss.

Sangwis Herculis, id eft Helleboras al. bus.

Senguinaria,i,Cornu cerws.

Sanamunda.i.Caryophyllata gruibusdă.

Sarax, i.Filix.

Sardenia glans, i.Cafanea.

sauch,i. Malus Perfica.

Saxifragia lutea Fuchsi, id est Melilotus.

Saxifragia rubra,i. Pbilipendula.

Sagitta,i.Sagittaria.

Scammonea tenuis, i. Hel.rime Crffampeles.

Scandin, i. Pecten Veneris.

Scarlea, i.Horminum.

Scaumix Autrr.i.Nigella.

Scifima Gaza,i. Farus.

Schebederegi,i.Cannabis.

Scheiteregy,i.Fumaria.

Scoparia, i Ofyris.

Scolopendr $t_{a, i}$. Lingua coruind.

Scorodonia i. fcordism alterum, vel falvia agrestis.

scorpio Theophrasti, i. Genil/at firrofat. Scolymos Diofcor.i.Cinara. scilla, i.s quilla.

scuck Syrizca, i. Popaver Rhocas. Secatulnonardi,i. Sigillnm Salomo-

nis.
Selago Pliniy.jieft Sauina fylueftris

$$
\text { Iragi. }
$$

Seliem, i. Rapsm.

Seligonion, i. Peonit.

Sela:ton, $i$. Crocus vernus.

Seliga, . Nardws Celizca.

Sewinolis, Equifctum.

Sedmm maiks, i.jempervivum.

Seneffigi,i.Viola martia.

Serpentaria, i. Dracunculus.

Serisla Campana,i.'Melilotus.

Serapias massio. Orclios femira Treagi.
Seygar,i.Nux mofata.

Sida Theoph.i.Alchat paluftris.

Siderit is tertia Mazth.i. Ruta cassina Monfpelrenfirm.

Sidertis, i. Marrubiumagesaticum.

Siciliania Camerariy, 3 . Airdrofemsm Dodonci.

Siger Indi, id eft Paima.

Siringa cersilea Dodon, id est Lilac Mattbioli.

Siligsa deslcis, i. Ceratia filigna. Stlicula Varronis, $F_{0}$ nugrecam. Siliquaftrum Plini, i. Capjickm. Sigillum Marie, i. Bryonianiora. Sin, idest Ficus.

Sinasbariam, i. Mientha aquatica. Sinapt Perfocumi, tholapi.

Sifer.id est Sifarum.

Silaus Plini.Thifelinm.

Sifon Syriacum,i.Ammi.

Siftuiepteris Plin oi.Pompinellit. Siler Plin.iAlnus nigra.

Sithim,i.Larix.

Smilax levis, ideft Convolualus maior flo.albo.

Smyrhiza Plin.j. Myrrhis.

Sorbus aucuparia, id eft Fraxisus bubula.

Sorbus Alpina Gefnit. Aria Thecophrafti.

Sorbus fylueftris, id eft Fraxinus bubula.

Solanum rubrum,i.Capjierm.

Solanum lignofum Pliniy, id est Ana. radulcrs.

Solanum tesraphyllum, id eft Herb. Paris.

Solanzsm veficarism, s. Alkakengi.

Solatrwm, iosolasism borenfe.

solbaftrella,i.Pimpinclla.

Sefibio Theoph.i.Anemone.

sparganion Mathioli, id eft Platanaria.

Spina ackta, Oxyacantbus.

Spina adida, i. Oxiyacant ba.

Spinchirci,i.Tratgreantha.

Spina infeltoria, id eff, fhamnus folutivus.

Spina Indaica, i. Paliurzes.

SpireaTheoph.i.Viburnum.

sponfafolis, id eft Ros folss.

Sploacelus Dodon.i. Scordium alserum Lobeliz.

splyte, i.radix cava.

Spicata, sotamogeiton.

Staphylodendron Plin.i. Nux vefica. rice.

Statice Dalefcantp.i.Caryophyllus marinus Lobelii.

Stataria, Peucedanum.

Stellaria Horat. Astgrisi, i. Cardutus fellatus.

Strutbiopecris Cordi, i. Lenchitis.

Struthism, i. Saponaria.

Strumatria Galeni, i. Lappa minor.

Strangulatoria Asicconne, ideft Do rosicum.

Sucuram,i.Cicuta.

Succifa, i. Morfus Disboli.

Sursm Alticenno, r. Nigella.
Sympytam,i.Confolida maior.

Symphoniaca, i. Hyof cy.mmes.

Supercilism Veneris,i. I'sols agnat His." Supercilisssuterre, id eft, Capilius Vie. neris.

Su, i.Liguiritia,

\section{I}

7 Agetes Indica, id of Flos Afri: Tabaleb, i. Lens painftris.

Tamecnemssm Cords, i.Vaccaria

Tarifilon Auscenna, i. Trifolium bitis minofum.

Tatula Cluffi,i. Stramonia.

Tatoula Turcis, . Pomum pixofum,

Tamus.Dodon.i. Bryontis sigra.

Tayasacon, Dens Leonis.

Tarfa,i.Tamarifus.

Teda arbor, i.P ans fluestris.

Terzola,Baptiste Sardi, i. Eupatorima cannabinum.

Tetrabit, i.herba Indaica.

Terdina Paracelfr,i. Plou magnum.

Terpentaria, . Betonica Agwarica.

Tcliphano,i. Doronicum.

Thina, Larix.

Thut, Morrse.

Thria Theophrasti,i. Arbor vite.

Thyffelium, i. Aprem fyluestre.

Thymbra, i.Satureife..

Tornfol bobo, i. Heliotropiusm.

Topiaria,i. L Acanthes.

Trapezuntica Dactylus, id est Lamro: cerafus.

Tragtum,s.Fraxinella.

Tragium Germanicum, Atriplex ofida

Tremsula, i. Popsilus Ly bica.

Trufolism fibrinsm, id est Trifoliumpas Lisftre.

Trifolum cochleatum, Medica:

Trifolism frutscans, i.Polemonism.

Trifolikm Asphaltites, i. Trifolismbia tuminofism

Tuberterre, i. Cycldmen.

Turbath,i.Thapja.

Turbith Auiceuna,i. Tripoliwm.

Typhimm Theophrast.i.Tuffilage, is

\section{V.}

TEficariaperegrina, $;. P i \sqrt{H m}$ cory datum.

Veelgsita, Dod,i. Peirofelinum

Veratrams,i. Helleborrs.

Feratrum,nig. Diofis. Aftrantia rigra

Verbajcala, i.Primula veris.

Verdothel Haliah, .Ranusuculus.

ViEtoriola, s. Hippoglojfwin.

Vitss alba,i.Bryossa.

Viris Idert, Vaccinia.

Virga Jang wh ine Matthioli,, Cornus for minis.

Virga paftoris,i.Dipfacus.

Virali $\tau_{2} \dot{i}$.Craffula.

Vïralba, Viorna.

Titicella, i. Momord"ca.

Disctoricum 


\section{Nominum quorundam interpretatio.}

Fincetoxicum, i. Afclepits.

Viola rigra, $i$. Viola martia.

Uiola fummea, i. Viola tricolor.

Viperaria, i. Scorzonera.

Fifsuga, i. Girsoidirm.

Umbilicus Veneris, i. Coryledon.

Tusdo Plin. i. Arbutss.

Ungula caballina, i. Tufalago.

Ulticand, i. Solanem fornst sram.

Ulpienm Columella, i. Allism.

Urisaria, i.dens leanis.

Tfnew, $t$. Mufous.

Una Lapina Marcelli, i, Sambacus aquatica.

Uwa taminia, i. Bryonia sigra.

Vua lupina, i. Herba Paris.
Vua verja, i. Herba Paris.

Vus vslpis, i. Solasum bortenfe.

Vunlaria, i. Hippoglofins.

Trularia, i. Laurus Alexandrina.

Ivislaria Dodonei, i. Trachelium.

$\checkmark$ ulvarin, $i$. Atriplex olida.

Vulgago CALaceri,i. Afarkm.

Treata Caya, i. Stramonia.

\section{$\mathrm{X}$}

Y Aier, i. Alsiriem Libanat is.

A Xaniwm, $i$. Melasthitw.

Kylon, i. Goffipingr.

Xylocaratta, i. Ceretiajiligua.

Xjphinm, i. Gladiolus. rebet,i. Aretum.

\section{$\mathrm{Z}$}

Ahars Alicenna, id eft Antbylis Lobel.

Zairon, i. Olen.

Zarund, i. Ariftolochia.

Zarzaparilla, i. Sarja parilla.

Zerumbeth, i. Zedoaria.

Zizania, i. Lolum,

Zinziber cannsm, i. Cap frum

Ziziphus, t. Isisba.

Ziziphres alba, i. Eleagnus Matth.

Ziziphus alba Camerarii, i. Olea Boo berviea.

\section{[T-5)}

\section{A Table of fuch Englifi names as are attributed to the Herbes, Shrubs, and Trees mentioned in this Fiftorie.}

A

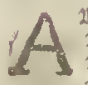

20 isective

Iicatiti

(iil), that to, sinallage

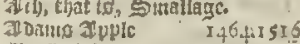

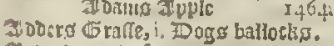

Aldoertoo:t, $i$. Snatie toeso.

3Loero tongue

alfric an 99 artsolo

Et: toptan apples

algoricke

Af grimonio

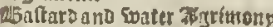

Jisnng eaftus

angue trec

alecolt, i, Coltmary.

All=goot, i. falfe 989ercurp.

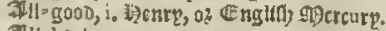
Inlisjeale

Birioofe, i. ground Jan

Zlisatoers, of Flycanoers 1005 . 1005

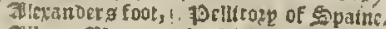

Aller of alocr, ano bitstatnocs, $\quad 1+60$

1477

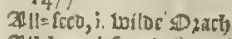

Dilritapa, i. 50000 soure1.

Jitnond eree

3itutond of $79 \mathrm{ert}$

Mlinono 10 juintres

Alkitengy, i. Souner Cherry.

Whanet, o: cortoe 1 buglofic

Anneed ano htg lindes

Zimb:oft, i. Dimu goog r hat

ancil coine

3 incetiolim," bean of

Zincrno:ce ano bta iatrocs, from 374 . to $3^{86}$

औurfe, on 3urfe feco

Nilec, ID: Dit

Xutglicanolyig sinneg

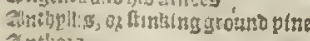

Aิnthoza

Blup'c end hto kinses.

Xinyle cithe ear th

Sipnis of lotie, or goisen siptict

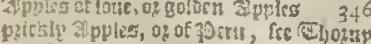
348

ateples of 3 erufalent

mas 7ipples

Intecritie

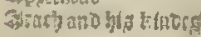

1035
1033

999
Irchatgel ono hitz sinocz

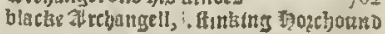

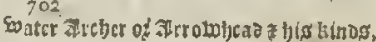

4 ró

Arbute tree, of Straboberrytres 1496

Aitcheo eree, 10oks basited figtree 1514

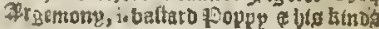

373.

Irifotocbla

Dronaticall reto

3ron

450 Attichokes

Irtmart, 1 . soatce 19 eppec

Flara bacca

\#iparagtsg and hts kindeg

alfpe tree, 03 aipen trec

J Ipbosal ano blo teros, from

and etes

개 bereg

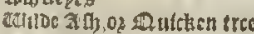

3 (t) $1150 \mathrm{otres}$

alfprdan atpple tree

3!Tyzion 10luin

3.veng ano lytg kindeg

Artich

สิxfer

Antropt

Athwo

a pgraue

\section{B}

$B^{2}$

a) 213aiomotne, 0213 alomony 532533 ASaftaro 4 Salomont

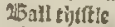

25 alme

batine of tht

25 alfantint

200line tree

גibalme 친

215 alfim (e) 1528

25allorice grafie, i. Dogg CUllons, 207

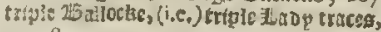

rsoret 25 allocko

abaneโwo:t, $j_{0}$ Soperfoozt

Comนanas

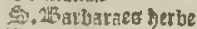

23 atbert buh ano big kinb

213 arice and thls titibocs

25 arnacie erec

ç6
25 arnacไcต, 02 tree gate

E. 15 armabeg tinte

25artinswoyt

$25 a$ afl and bfo binorc

'silbe 215 at

TED CDEs \$BaAt

colo 25 aff

25 aftar) Divarfe 2150

26atcblo ocs buttong

15 anmi and big kindes

$47^{2.95}$

45 itre and ljta kinber, $\quad 3_{407} \cdot I_{400}$

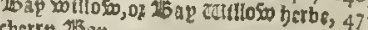

cherre $13 a$ e

sotloe $2 B$ op tree

Dzange 15 a

Tbeade tree

2 teane tres

NBeane ETape

tbeane ano jig hinoes

flat 15 eanc,i.

216 earbed tirafle

215eareg beech

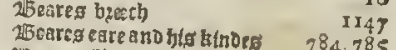

isearca (15arlce?

215earcirot

215 earefor

our llaoks 113 eottrabo

2 ibleso 215 elig.

In notan 99 ozrice belle

2ntumne $1 \mathrm{BB}$ ell: filoure

1587

1166

673

675

6,8

492 477 163

$1409^{\circ}$ 1613 1492 1429 217

Stenction, of Staple bolls

Sea bells

26 ellfionres

editioc tibell flomes

179

isaruet 4 bels

23 at ano bts thtroes

25 act) $t$ tre

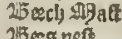

$28 \mathrm{sec}$ net

2t3 efom foreso

$554^{\circ}$

colto

215

Herttatu

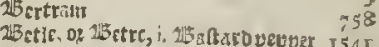

Sanis 3 setong and his zind

2isetone

218 to ater 21 etont

$215 i g, 0$, big 25 arle

719

Sig, o? big tisarlep

25 inderoeo anohts bitnoes, from $86 x$ to 865

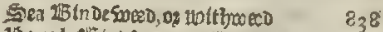

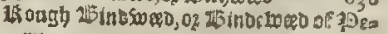

ri 859 


\section{A Table of Englifh names.}

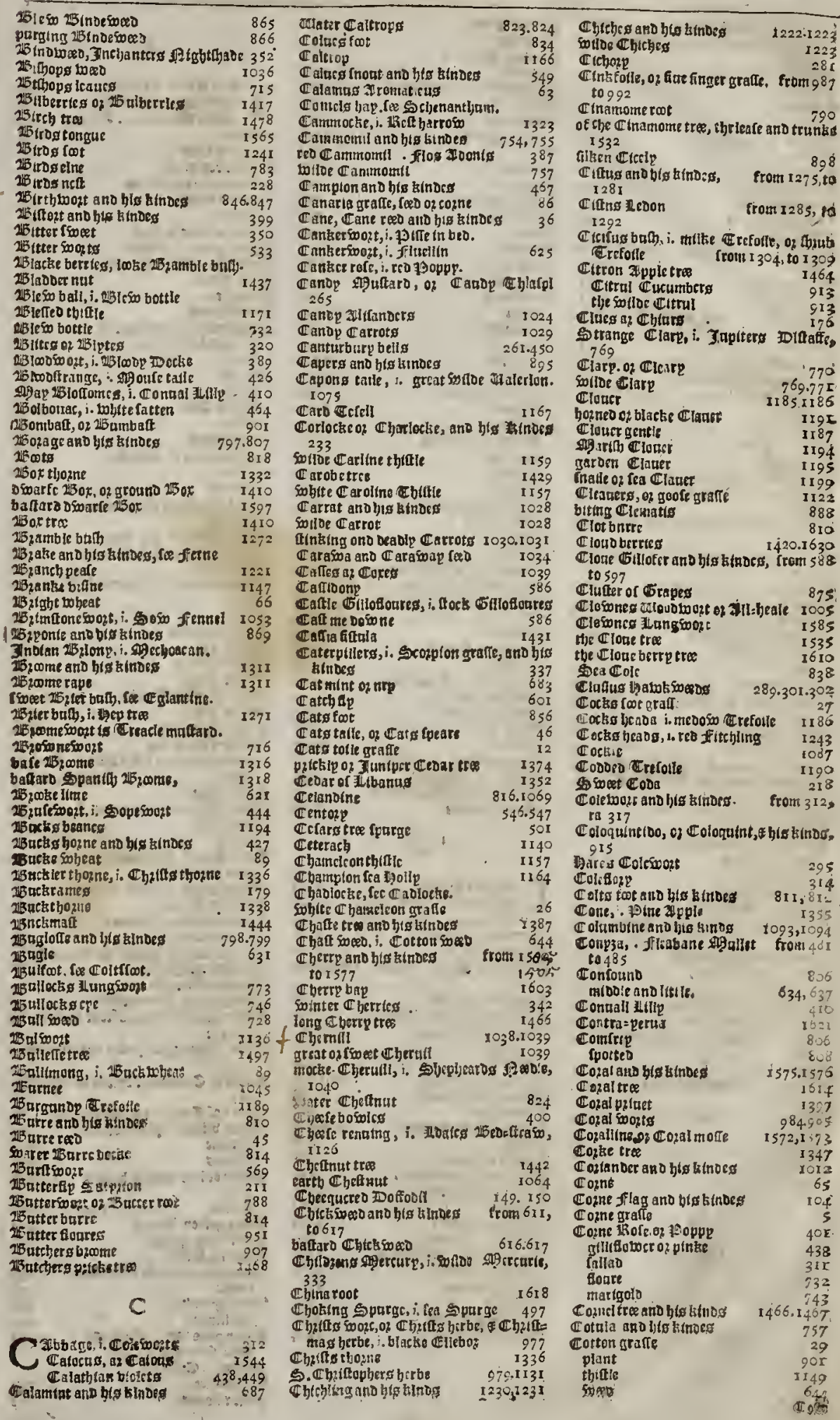


A Table of Englin Names.

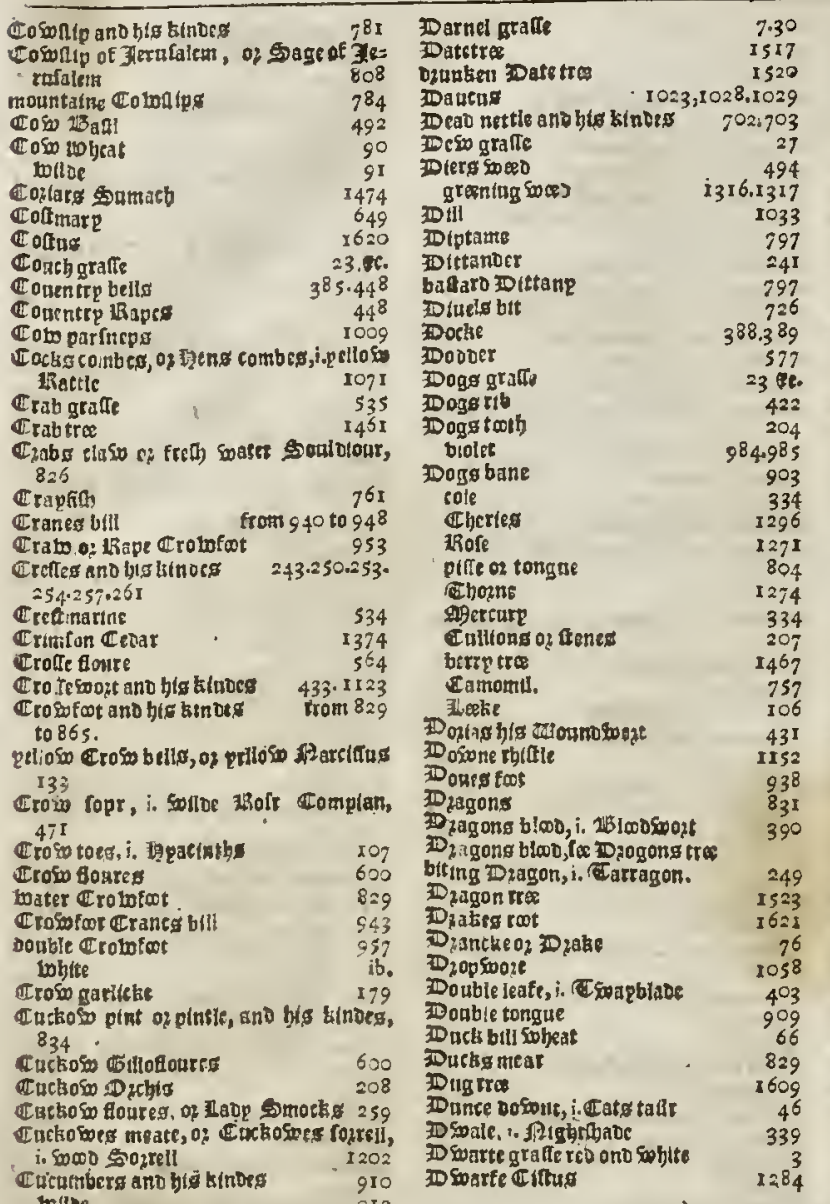

Inllos 912

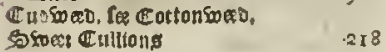

Eall nic to pout 855

Lacfes $\mathbb{C u t b i o n} \quad 602$

ब. 4. rage, i. Infmort 445

callions and cheir binoes, from 205, to 228

Camberiano

Cantm and bio kinteg $\quad$ I066

Sotloe I06?

Curans on finall rattongs 874

reo, 50hits, ano bloclae 1393

gaxben CPples, (1.) Zllauanoer Cotton

IIOQ

eppies tres $13^{67}$

Cquzefe grafe anobis kindes 12.19 .

$27.22,29,30$.

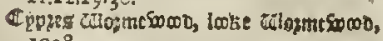
3098

Cypier iparge, to sparge 498

fieto erpurs 525

cepregs 5000 bjalie

I9

\section{D}

17 seforll and bis sindes from 223 to 137

Day 列

30. Ulinatiat filcure be ince

Dalmatian cap, i. \&ulp

70. anogitists

20 sncionat

\section{E}

D 3ferin $1 \phi_{2}$ inet

- Eglantine, i. Notut 25 tita EE grtatoate, i. 3lgt.trone

Egpptan caloum oo coo

egeptiantbozne

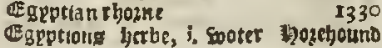
700

$\mathbb{E}_{\text {geptian }}$ fitg tra

Egeptran $\mathrm{NO}_{\text {Oulberte tra }}$

eloer ano bis biades

marifi)

Eline ano his ainors

Gelkboz, fa lisclicboze.

cieciampane

Enolu: ana his kinos:

Solido

Cagith slyercart

E*tingug ano bis thoeg.

Ers, 1. bitter Jherch

(Farthnut

(E) theopi in pepper

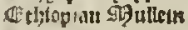

C'uplozbiam, gim gim thidie

बerch or cliozne

desos o: yeso tre

diencbrialt

eticr green 13 ziut

eurr grenthoune

$\begin{array}{r}1509 \\ 16 . \\ 142216 \\ 1425 \\ 1426 \\ 1481.1482 \\ 976- \\ 793 \\ 281.282 \\ 284 \\ 329 \\ 1162 \\ 1221 \\ 1064 \\ 1539 \\ 779 \\ 1178 \\ 1179 \\ 1370 \\ 663 \\ 1398 \\ 1604 \\ \hline\end{array}$

1396

1289

712

IIOI

$5 \circ 9$

ib.

1425

82

$6-$

1.282

284
329

329
1162

1221

1064

$\times 539$

$\operatorname{II} 78$

1179

663
1398

1398
1604

3 aहn?

F

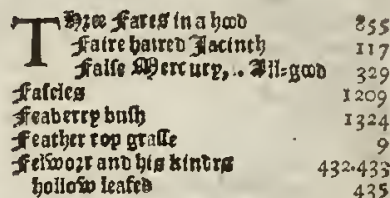

$\begin{array}{ll}\text { baftaro } & 435 \\ & 436\end{array}$

fentinel ano bif sinoes

fennel grant i. firtala 1056

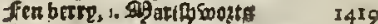

boin finnt 1058

(Fenmolom

fenap ftones:

fenpgreke ano big kluped 222

Ferne ano big kinoig ".

solil $\quad x_{132}$ I 28

prttp

blacke 9 be

Dlie

Domarfe fea

fleootrfois of ficutries

Fig trat

ofwarte

figson on, $i$, inall cetamoine

fitg beane

arches of bistife of fig tre

Inoian fistro toith the fruts

1131
1136

II 37

Jillbiro tra 1058

fir tres

fiftekenat tre

ivolfes sitis

sob fitchitus

215iter fitth

allibe fitteb of Witct

1143
652

1510

ib.

816

1217

1514

$148^{8}$

3 notan fitte

ftagereo sichts

medow ffine=tinge

pin ofe

Jíne tranto mage s

tolte,

Cozne filag

culloe flag ano bis sinoes

garoen flor

calloe

sinat, i. Claqan
from 987 to 992

Coab-flac 558 to 560

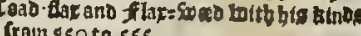

Caces toheat, i. toblte dabtat.

Iintulse fort

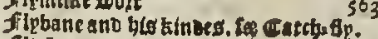

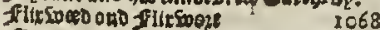

flosense hloure bo iace

fllotrgrathe os flotergrate.

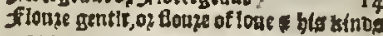
322.323

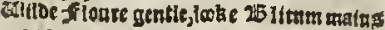
321

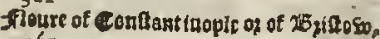
$4^{6} 7$

floure of Canop of of zerufaleth, ib:

flonte bilate, i, go alfe bolour . 323 Sutine 755

3oonis

Flourr beluce and blo sinders from 38 to 50

Fotn 9950102

3 volg goiloen filoure
fone fubing filoure

floturing is eeo

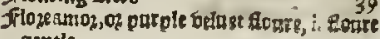
gentle

female finclin

322
625

bis kindeg 62 ?

Denry goos foo, j. 3 mbzofig Is

lokse Dke of $39 a$ adatif

Fols fort. i. Coltg foos.

iea fiolefort

Fowles tones 


\section{A Table of Englifh names.}

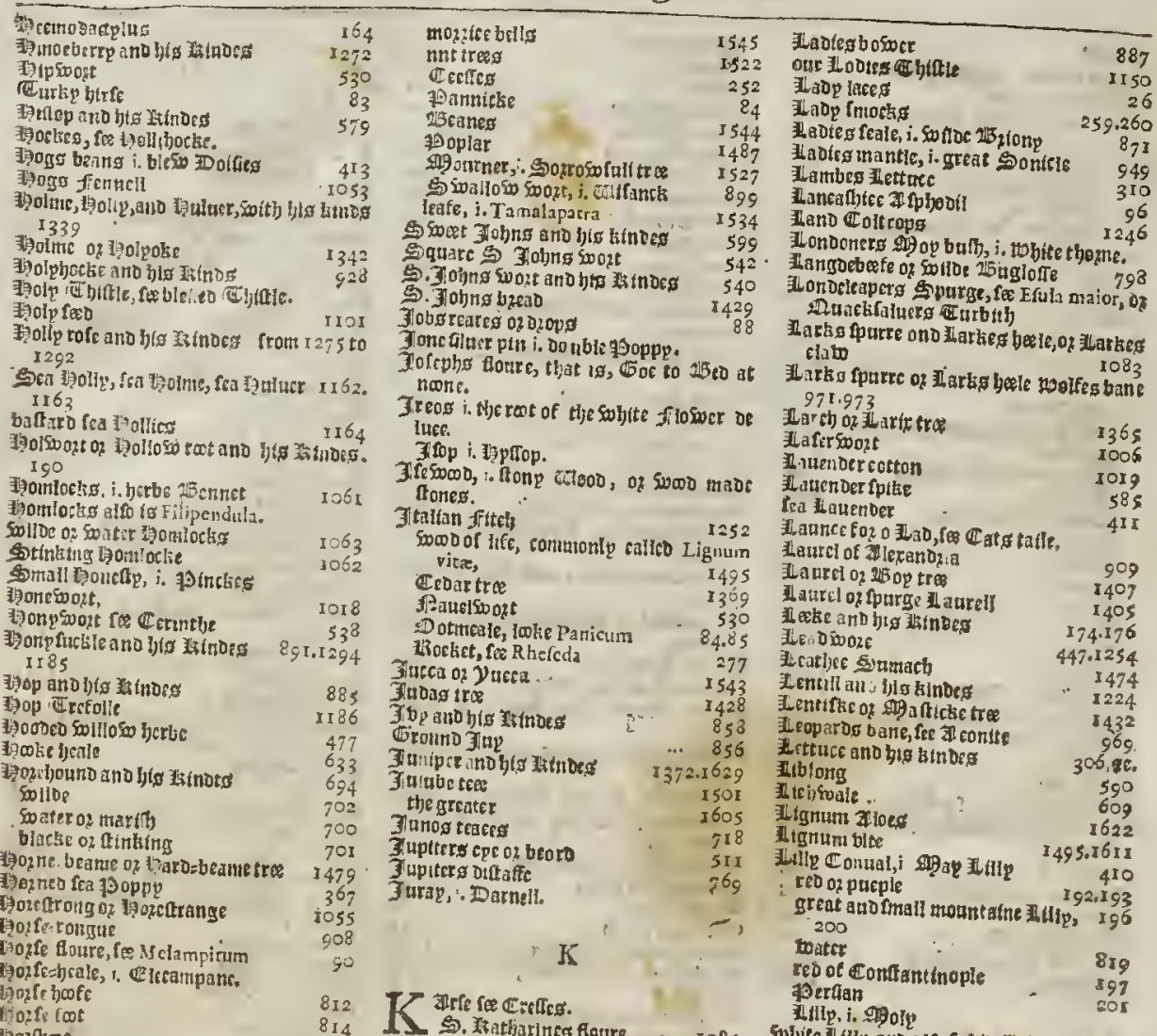

$\begin{array}{lr}812 \\ \text { finte foot } & 814 \\ \text { Hozhoe } & 1235\end{array}$

ijoxfetati, , i. Shancgtaffe, and big 1235 I I 3

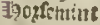

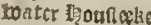

fei

gteat

3 outtos tongue os pir

Isontin-berte tra

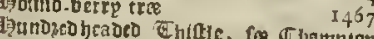

rea lyolly

Iequre fickle, $i$. 2 ic is bottle

Fuactnts, fis Jacinthy

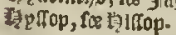

\section{I}

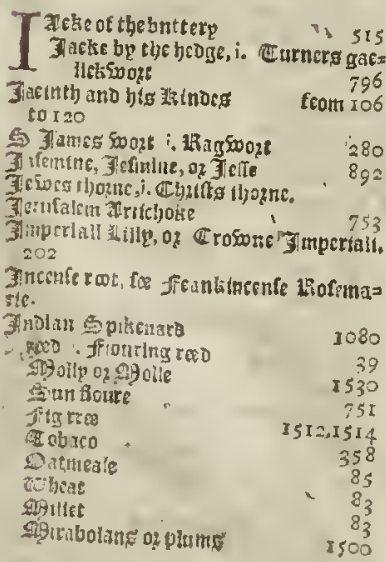

684

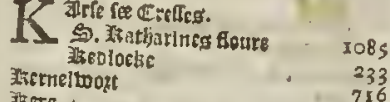

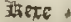

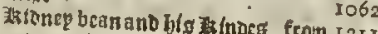

to 1216

titorep betine of 25 kaf

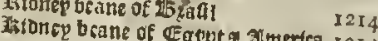

I3I

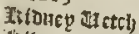

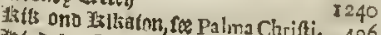

andelp Sontue, i. 26ertied Sauine.

1376

xinge fpeare

Xing $\mathbb{C o b}_{\mathrm{b}, \mathrm{i}}$ erototot

范pper nut

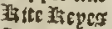

Gluer ik hap towo, fe gliut

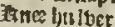

Truaptor ano

lunaptoco ano bis 1 is inderg

frage

Jincliolme

intses grolte

Anighte fpurre

in ights olitifotie

Itnights soter sencran

golo isnops, i. Crosofot.

tanot berty

knot rrafie

(565.) 567

finotty (cont) grafe

\section{L}

i. 90 \%

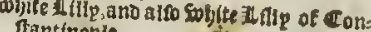
tantinopit

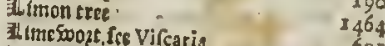

alunen of Zline tree ante gig $I_{4} 83$

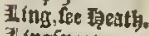

Uing soont.

Ilong Eurnep

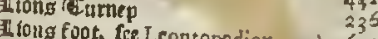

643 i $6_{42}$

743

Zlong leafe fee Zhtong tums?.

Ill iono foot o? pato

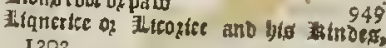

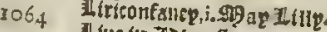

ILfue in Joleneffe
ithe long, i. Spanith so zpirs.

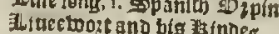

Sobjte

840
1567

noble Lituet5ogt, i. tharben fir ${ }^{1567}$ 1203

Lockeon Goulone
London feuftg

Inote tee 599

Lote tce

599
3493
1008

buttace

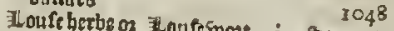

atre.

Il onfeponter

录 wofe to rtfe, i, Lyfimachis $\quad 154$

Ilo50 to 1 , 1. Lyfmachia $\quad 474$

Ilo5xp. I Zaur(c) 1405

Illesofie gratio 1405

Iung $500 \mathrm{ogt} \quad \div \quad 394.808 .1585$

rea 304.808.1585

icte 1566

zing floure

$43^{8}$
1217 He Ilodics fijwe, fer ont Hades

Itades $25 \mathrm{co}$ tros

Dur Lasieg haire

Zludotes combe

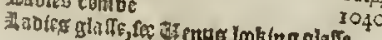

Lupines anohls extroes

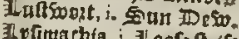
85

\section{7}

60

13

6

\section{8}

o8s anc 65 कon 585 II

454

7

tit
5 $4^{2}$

\%

65

5




\section{The Table of Englifh Names.}

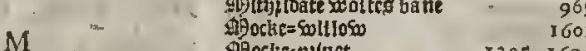

Sisociceppluet $\quad 1395.1600$

श्री olv oufotcerets Gattede 183,184

Molle Clufii \& Lobelii $153^{\circ}$

91900 opples

I009

II) 30 me

465

Magroare. 1007

\$2) atoenthatre and hy stutoeg 1143.3144 1146

common 99atombaite. 1466

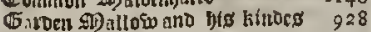

Che wilto gifallow.

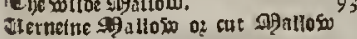

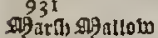

yelloto sifallo so

thentec \$i) allosw

Mamocta

\$IP an ozake and Ij/s binoe

9ipanna araffe

Sigule ano bits afnoce $\quad 1485$

Dig a rocorbe 2592

9Pargerites berbs 637

999) a tictome and bis kithocs 66

citioe 02 baftaro oz ge duno \$2 a rierome

(1503c5 99 arlerome

658

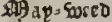

sit atozane fec 99 arleroute

$\begin{array}{lr}\text { S9 akicbate } & \text { 13 ro } \\ \text { 9i artetg } & 44.8\end{array}$

Sig atigolo and bls kinocs 739

70era 751 SHat(h) 817

$\$ 9$ attagons

\$3aruellous apples. $\quad 363$

ail aracli of perto 343

sigofterbopto 1001

25 tacke

819atictie ano bis the -

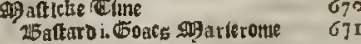

25attarb i. Eoact

gifatch $m 00$, , , 0 .

999atfeltoit 727

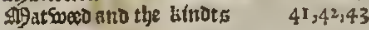

1630

\$) andocllite

1 inco

פijcat Sounach

oifebrath

gifeatiche fietcl

frood it

9head rotet

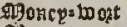

630

1132

goone ferne

1138. 1139

$\$ 20$ rice bells of 3 notis 3545

$9900 i e=g r a f t e$ is

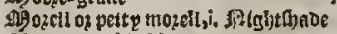

AHoftes ano hts klnoes 3558 , to 1563

Sisote fezm, i. Tolppoop

Sca mofrc,i, Clozalline

919other $=$ wo 0 ?

gifotber oferin

S9oufe care and hls almde $\quad 337,639$

99 oufe:tatic

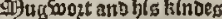

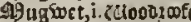

Hecttp 91 a

OHulbertc tras and bis Winoed 1127

Si) ulbertle figtree

sisulietne and bls kindes

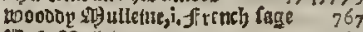

25a fe ghutleine

\$190th 9Pnllelthe 377

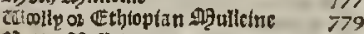

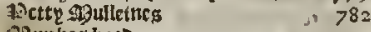

29) unkes bood 972

Iistubarbe

99uske $4 ., 94$

stielonts, 937

1 thots 41266

reteacle

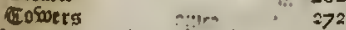

parrengrafte, i Scrophularia

99 uch good

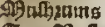

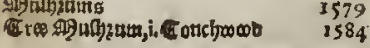

\$) groot varfinep

Eatiton, 57. Erefotic, 1185 , Esatte,

gipedia

9iselon thittie

gif elllore

gipelons

gercurtetrne

cutidor, 333 . englifis,

IiT)

Diucz to

Whitaro silecultrooob

STrSo 02 Siston

Di)

ditater 9 ill foite

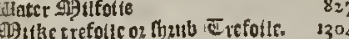

1243

9lillisoont ano blsklndes

vislactic and solste

\$Hillet

9i)

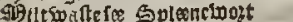

92) ituountainc

9i intandhts bindes 680

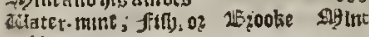
684

99oantatre mint

gllitrte and bis litnocs

1431

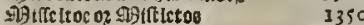

pitilyzoste mutato

1350
202
$3^{87}$

873

oog

453

1204

332

329
448

$44^{\circ}$
$14^{\circ}$

7

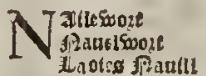

3Rauet gentic

1/2 a bes and his bilnocs

fitabe 50 ob bo $05050 x$

fitecksoed i. tempe

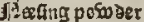

facmuphar, i eclater Iflly

fep fee बat atint

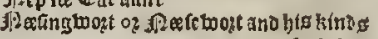

Pettie ano bls thitos

fiettle eree

Deato of blinde Rettic

Aecuer oping boznge

filcio oz tolloe

Eleeplug oz ocaole

1KicD

Inchanter.

rere

Potebeco, i. Yartow

706

700
1493

702

797

Jifoonc tive, fre to to bes at floone?

futs on byis bindes $1438,1437,1441$

$1522,: 547$

fAntmegcree

3notan flat

99adnats

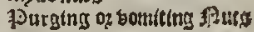

สงสter nuts
A leotlan, i.celaseco

Nigella and $y$ ts tinoe

P?option of whest

มุละสดส

- Culus Chrifi,i,woflde clare 772 Differlolt, $i, 25$ tfort Difiter grceue, i. Esea llung $=50025$

ID (i) and bls bitnog $\quad 1339$ ferme 135 Sf Jerutalem, of Coppatacta, op 1 bata blee 1 ic 8 featlet 134 \%

Geat bolme olse $\quad 348$

DDllander, 1 . 1hofe bap

Do lue tree and bls talmocs

1392,1393

Dline spurge 1402

Dneberte, i.berbe 19atid

Dne blade, i.one leafe

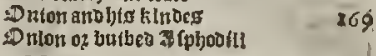

97

D) pen arte, . 99eolat

Dple,i.MParrith $\mathbb{E}$ IDer

D jacb and bis titnoes

Stinting

D zehanet, i. 3lketnet

Dichis anobits bittoes

to 228

Didengetro

Drengcbay

Dignn i tolloe 99 arierame? $\quad 3613$

Boats Dzgane

Diobanch

(17) zobug i.bitter is etch

$₫$ zplne and bis a inoes

131i, 2312

519.520

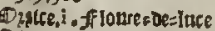

Dact

SDlmund the a to ater man,, tutaterforme

I 131

Jnolan פatmeale

Datsand his finocs

Die chiftle

Ditianolfi) likote

Ore congue, ind tefloes 746,747

Great Drcheale

979

$\triangle$ Dellpg

789

P

D \$Dction

Faodockic flooters 949

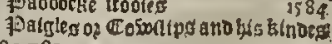
780,781

p)alnteongtaite

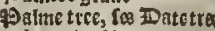

Palma Clarilli

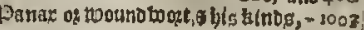
1005

Datuntcke ond bls stros $\quad 84,85$

Pamntcke grafie

Small soannick gratto

Donutics os

Papcr reeo

. 955

artielesues 549

oozomang parmacete; Sicphearos

Sinte

Pratling patn

19) artcly and his atrog

10 teake flone

785

783

parfolp pletc,i.knatort]

cutater ano bis atuds

26 a tard, 02 rco parthe

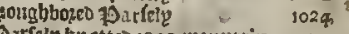

10 atfele tn otte 0,1022 , mountaiss, 1015 ,

beoge, 1022 ftorte, : 16, sol 10,1020

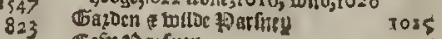

$\begin{array}{ll}\text { Cow } 19 \text { atrten } & 1000^{\circ}\end{array}$

âे वर्ष 


\section{A Table of Englifh Names:}

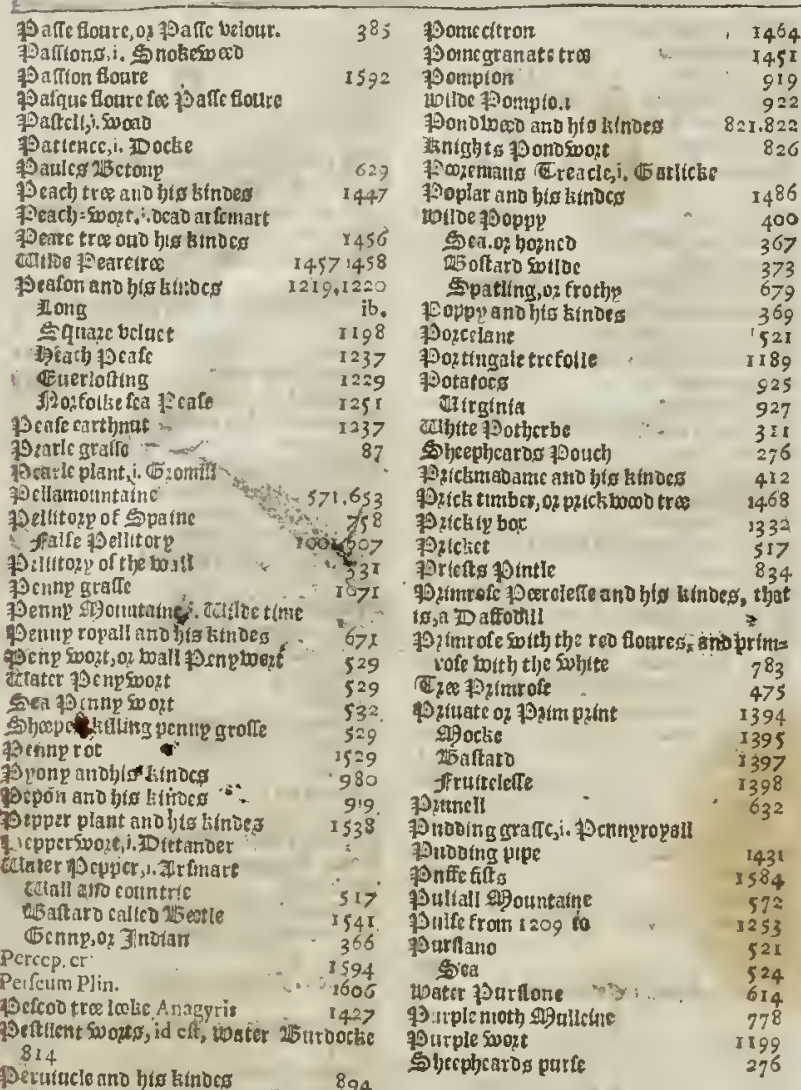

- detufucle ano bief hitnoes

23 iting, on purging 888

5. Pavters contio $\quad \cdots \cdots$ a $\quad 73$

30cttp Cottp - 542

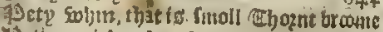

ashiraol bis figtra beorte

Diclicpnrfe i. Slicephearog purle

9 iglons grafte : Columbine

Digeone toot

19) Ho cone i, Cclitioe oat

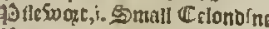

9 impernell ano bis kinoes

(10) atcr 9 impersell

Seo 19 linpernell

79 intics ano bis la1nocs $\quad 597.599$

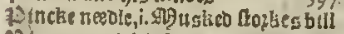

Pine tree ano his litnors I 55

to bite ano blesw $\mathrm{p}$ (pe

prite o, of pilte in beo

gittch tro

9j) ireb, o: ftinling tresfotle $\quad 1187$

Dialta Clauer 1200

plamatre anohis istnoes $4.19 \cdot 420.422$ 423.

toater ano bis latnocs

Sea 4 II

Sca 23 ucklyone 423

tolloc fea

a) lantaine a fruit

planctre

Dhatfe; 99 arfy eloc

93 lowmans fpictitoat

olunts ano bte liunoes

9. ack 5000

bocto zRof́mar

Dolerceio

90 oley ano his titnocs

7Polipody of the isali

90:tevosp of the Dke

901pvojp of the D tere 1233

938

$$
\text { (D) } 1
$$

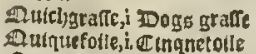

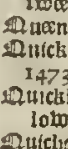 \\ Daince tra rocer.}

\section{$Q^{-}$}

\section{Q Quacfaluers f purge} in uacfiluers fetrbtti) Ditaker o 0 qualstug grate

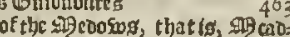

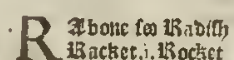

13 acker, 130 octo

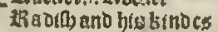

hote oz motutitoire

1haproost

1Ratfozt

inatong of the saune

zhampions atio hist

ZRamfong

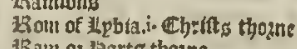

790

kBam of ligarts thoune

LRam Llaxotiue

I ́6. II. 499

1293

2 Somtpe

kîae ano bis binoes

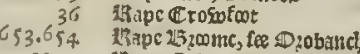

*⿻一𠃋十

318
3Rafpes $0 \%$, firambalcs ano bis binorgs
1452

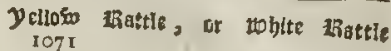

Lieo $13 a t t l e$, or thattle grate
zied $\mathbb{C}_{\text {olo }}$

1072

tReo Carons

Lato aro bis bindeg

3iscas moce, i.Catifarie

31

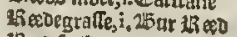

15 EO Swotloe

(chbogny of $p$ erp

Scroct, i.Calamus Aromsticis II

Sicost os fugar

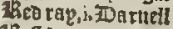

$3^{6.37}$

ziatt harzosio

Kinc in berrieg

39 ibsoogt ond big tofnocg

Ifiocket

inock 3riofe I595.1596

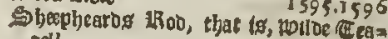
zell

130gation floure

Romanc 15 cames

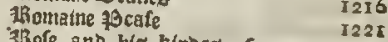

554

and bis kinoes, trom 1259

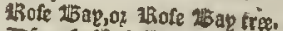

DWwarfe 1iofe 26 at

1406

Ziole Cloct

477.1407

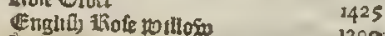

lisole 5ivodo 1390

Ros Inlis,i Sundocas I6

woilde 1Rofe

13 ofesoo2t, 62 roftroot $\quad 532$

Wo inter fee boliphocke

Compion

tolloc Tamplon $\quad 467$

$\begin{array}{ll}1311 \text { by } & 469 \\ & 387\end{array}$

180femarp ano his hinoss $\quad 1292$

thbire 180t 529

13eo tiot, Snnonaso . 1556

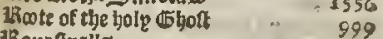

130unAusilig $122 \mathrm{~T}$

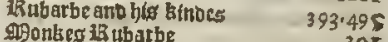

Igonker is ubatbe $39 \pi$

25attaro 23abarbe $39 \pi$

Englibh 25oftard Lis abarbe $\quad 3252$

The

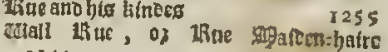
II 44

thafi seo grofic

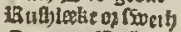

tis all oz sooter 1iud

559.1594

Sharpe og faro $18 n$

35

120

1Rah grain

TRall) p fea gratte

13pece

25 ge anto his kinoeg

\section{S}

Sifton ano his kinders from ISI th 157

Tiernall soffron $\mathrm{x} \leqslant 2,153 \mathrm{Fe}$

28aftoro Safton, ant bis tinecs

$$
1170
$$

tonde 25 attard

Sage onto his kitioes

II 1

Soge Ifofe ano big tiudes $764.7^{6} 5$

french Gagelooke Vcrbafcum Matthiols

767

5) age 92 ullen

कage of Jlerufalen

Sage of $15 \mathrm{ethlcm}$

ib:

ib.

mats and his binoes

Salomoug teale ano bis thindes 903.204

905

Salc swozt and bis bunoco looke sea

25tarte $\$$ aiteruant

135

562 


\section{A Table of Englifh Names.}

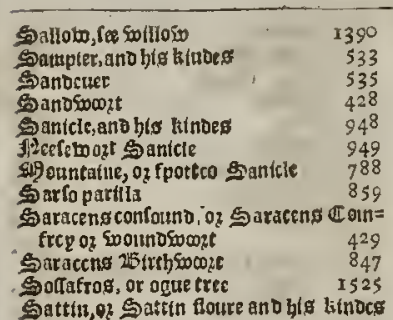

464

$4^{64}$. on ante bitnos from 205 to $: 28$ batorp ano hie kmoes $\quad 575.57^{6}$

Saain and bis kindes $\quad 1376$

Sostoce Sumath 1474

Sautortg tres

Sancerort

713

Englito $S$ arifrage

1047

213urnct Safifrare 1044

dabitc, and gol Din saxifuge $\quad 847$

Statifroge of the 3ucients. 604

Seabloug and big kinocs 7 Ig atto fo to 725

Silucr soblono

Small age สแอ bis tindeg

IoIs torat ttee

1526

Esmatl barog gmite 4 strakeografs

26

Garben Emilar 12 I Sakckowo and hits ktnoeg 399 banch

of Tizginta

Shake g 215 ustoff.

Snakics 5 ariiclie

Enaitc Clatat

Snopozogon and his thos,

Sineic to 0 ?t

399 tralwoberp anoblg tinoes 997

802 Strafoberty trec, of 3trbate tren

$18 \pi \quad 1496$

I 199 Gtratmberte bay

stabsont $i$, Evorotoret

Soulbierg 1 arrolv $\quad 1074$

bommer folcs atto bis kfubis 147

148

Sope: sopgt and ble tindeg

Dozbe tice ond bis limbes

corretl and bis kinoes

Sorrcll du Bois

Sorrominil tro

gotrom 1105

Sotrutcad ans biskinbeg 843.844

Douthifte anolyis sfuecs 292

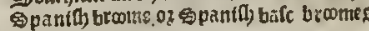

1314

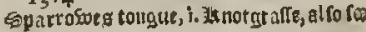

65aroms toad: 6ax

spetre for a uring

spearesuozt ano bis sinocs

gopeate Crosufoot

कuscort and bit kinuss $281.282 .23_{3}$

6untme euecory and hto btroca 286

287

notibe succo:

suthles, fis bonpfackics

stigar roco

Eagar cane

Eulphex \{popt, $i$, $12,0 \mathrm{~g}$ s fennelt

65 Suallo 20 ?

S5ont fortlo5io, j. Ea autc

Gunach

$13 \mathrm{cD}$ estumach

snin $\mathrm{s}_{8} 50$

Santoure

284

\% 527

5. 5ofnco-gadfe, that to snotgt affe

Gricistoous

$58 \%$

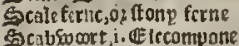

Scabwort, i. Eiccompone

especolncil lotke filnelien

expeltcorne ano his kinoco

E) cartolo

Ecatiet SDke

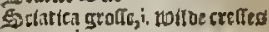

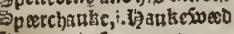

Sperage, i. afparagno

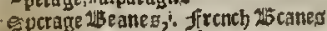

epicinall

isaftaro gpictinell

Sptoerfoust

opfted soater grafte

spitac ceptetre grafte

Lofe seicnica, Dames biolet.

Shcphearos Socrip

Scospton gratte and hig kinosf $337.33^{8}$

Scordium, i.water Eeznanber

âpigneli, i.,

toater opitke

Scurug=gralte, Spponeswot:

Scottib Ecaruic-gralie

Seo carte, i. Soldanella

Gea freather

Sea fran

ber inton

Sea lientll.

Sea splacgzade

Seo Dogn gratte

Sebeften, ol 3itettan plumune

selfe beale ano bits limoeg.

Sene bnil)

Uaftaro Sene, os senetro

Scugrenc

citater Sisugrene

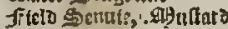

Senfitine berbe

gpiknaro

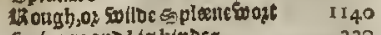

eqptnage ono bis kinocs 330

Spinod tre $\begin{array}{r}1468 \\ \text { I } 440 .\end{array}$

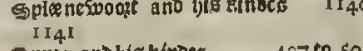

eputg anobistatnoes 497 to sos

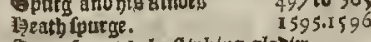

opurgswots,ioke ftinhing glabix

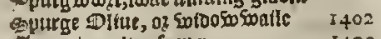
Eermotne altaclputs $\mathrm{I}_{403}$ eparge fax or mount atne sotoooso soatis 1404

I 404 murge zlatell

Qquill, ired Don

sintinanth

1405

I $>$ I

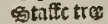

163

Serpenter ongue ro 300 erd tonguo

Seraptad ftoncs 222,223 (Fe.

Serutentro

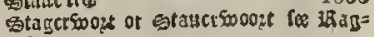

soost

Etandergraffe $i$. Dogs Gallions

zutioc socruice trie

Selamo peq, oz baftoto seato

Solanum, i.olit? pulfe

Gefett i, tharesowat

Gereli of $\mathbb{C} a n d p$

gifountatte getsalli, Nardus Celtica

Setfoitc,i.eojucntil

Eettergratie

Settre?

Setroall. 1076.1076.1077

\$) hadofo gzatfe. fee froografte

shane gralte, 1. Hogretatle

shascitout

sibepheazos neede

Shephearog vure, ferlo, of pouch 1040

Shberesgralte

Sickleswozt, fae 21 trtris

Silier mountainc

Glken Sumach

Statch costie

Gearchiont

Era ftar suogt

Etarre chille

stanes acre

Gtartoort, of Qhazewort anb hig \&indes

490491.492

tais of $115 \mathrm{cth}$ (et)em I 65

Qtarres of 3 erufalem. id eit, Jofephy foure

Stxchados ano bis tornoco

585

(5oloen Stęchas

646

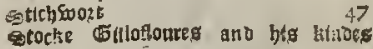
456

1209

ontone titurtin oest

Drouccop

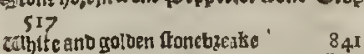

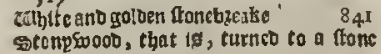

1587

stozks blll and hts bintigs 938.939

940

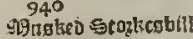

4tolate oto? treablit

941
945

sobirtiono:t

Sioc:tis

1907

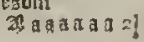

T. albaeano bis binpoto Tromatinue 1607

c I 379

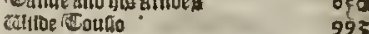

Eare aub hid binos $\quad 995$

Eirocuctlafing

Gieat Stide ditare 1230

Diofcorides bis utike tere $\quad 1242$

Clatragon

(Leafoli and bta binose II

Certible betbe 507

(4) ettet woost

Cetterberte, , 10 \&

obbitic and his kindes ri49.1150

Cbililc buon Rebittis and butets otbee

Goithe ceniftes

$\begin{array}{lr}\text { solfoe enifties } & \text { II } 7 \% \\ \text { chlafpy } & 262,263\end{array}$

$\begin{array}{rr}262,263 \\ \text { cholane ano bis binoes } & 1327\end{array}$

cultife onoute $\quad r 327$

Chorne bor: 1332

Chozne beoine ano blo tinbes 13 Ig

(1) i) zi:e Âlpple, or of pert 348

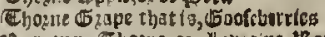

fourging (C) bome of 1 aratiae Haume

1337

ethozoso for or, og thozoto isafe $\quad 535$

(ethe lcafingratse $1: 85$

ch bie leauto literiogost 1203

(4.)intet 603

(1T)zoativo:t ano bts kfnocs $\quad 450$

Ebroughtort anobts kinbes $\quad 53^{6}$

Fie tme ano big tinbes

(Cine oz witoe derch 1228

toibe cture 579

Creping, o? ranniug fitme 570

20odocr, 02 laced atime 577

Dfuglie अine 574

Coadtole and bise titibess I $\$ 79$

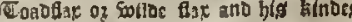

from 5 so to 558

Holntainets 599

Eormentil ono bigs kinoes

congebled

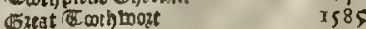

Cozches 774

(40uch ine $110 \mathrm{t} 261.447 .912$

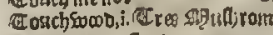

fosozing multars 272

Copswo:t, i. Shevineros parle

ilapp ertaces

Griplo ZigD̨ Grakes 


\section{A Table of Englifh Names.}

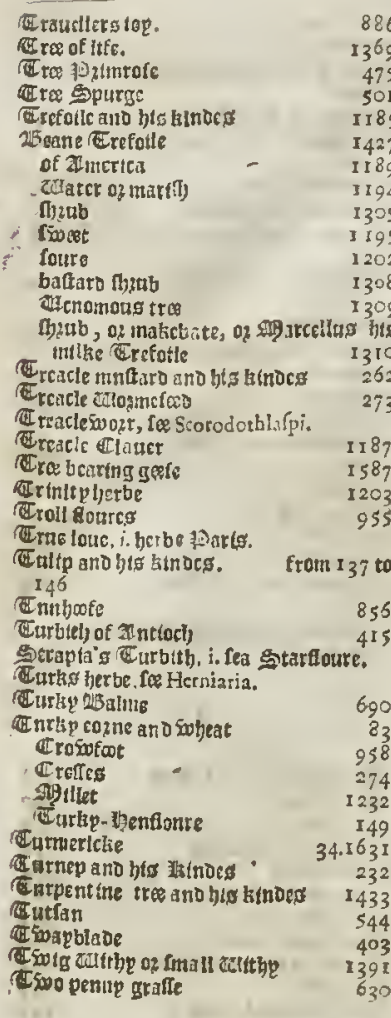

1. V

7 tertan ano ble kitroes tet जif eltuet floure oe lace IIfutce Sunach

\#tenus bafon, i. Eeafell batre, fx 9 g日 atmenhaire Tambe

Zl cobing glate

1040

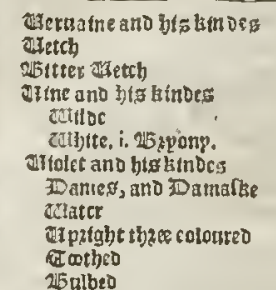

215 albed

2I perg 25 nglote on 3 J tpereherb

atirging bostor

Ap pight $\mathbb{D}$ ogge grate

\section{V}

W

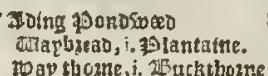

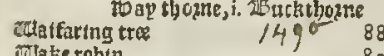
eclake robin cclall fionres

Utall $2 B$ artep of toapbennet colalnat

đali wort, i. Danewoze.

fes clartsont

(B)rabt clater grafle

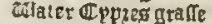

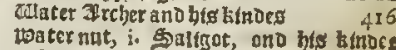
824

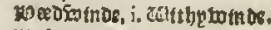

wo elcome to eur bonfs

ditclo, i. 万o pare foed

wheat ano bf 5 isinuce

Chige moneths

tobin and his bitroes

cibleken tres, i. tould 3ith.

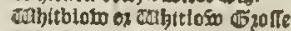

$717+78^{\circ}$
1227
1225
875
871
850
463
825
851
984
147
$73^{6}$
802
887
25

celbitio ozt. i. feuctfesion. cithite tot ono hts binoro, $i$. Solontons
feale. cubtt

i, water Etoer, of solioe extbozts

萑inder

marth

$43^{8}$

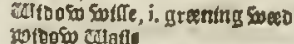

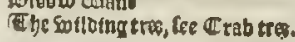

(ivest woiltams

Dillosid and bta kfnoes

5) woct, i. Ga aie

citiloso berbe

Winder rofe

xetnged culnoe inces

toltoe delnorticure

tot bestotios,

roit be

Dithe wind $c_{2}$, totthe and his kindeg.

oditch Elme I481.1582

Witich 非afell $\quad 1479,1482$

noas

HDobrafle

Docos thole grafe

491

a'coo Swaren, i Granbeed

to coblnde and hts binoes

biein, of Ladite bo5er.

bpright

22

tocodrcafe oz cetodorom

$89 x$

10000 made ftones

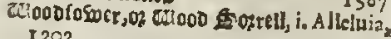
I 202

834 tioodraspeli

457 TO000 oz d5atlcke sage

73 aclooDop fitghthabe 662

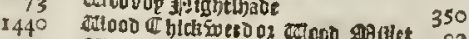

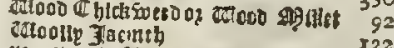

505 rooollen, $;$. .81) ullein.

6.13 toolfes bane ano bis tatnoes 969

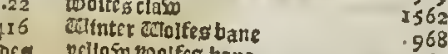

pellofw toolfcs bare

toolfcs falg

allozencgtalie, i. strenterop.

Englib, lee Camejine.

65.66 arozmeswood

69

3ait

II:I

15oman

Sea

1096

rog8

Inali leafeo gatoen, of Oconet 2099

Fozrein or baftaro

zetountosop, i. Eenfonno.

b6 3 intmos

826.1005 .1074

Yrrosis 1072

vose deine $\quad x_{370}$

Youth moa, i. Sanvesw 1479

Jaca, $\mathrm{i}$. Zucea.

ร̌tooatie 


\section{A Supplement or Appendix vnto the generall Table, and to the Table of Englis $\mathcal{X}$ (ames, gathered out of antient written. and printed Copies, and from the mouthes of plaine and fimple country people.}

\section{A}

A Riset is Doll-

Imen, Ameos:

3rgenstit, Percepies.

3ehs, Smmallage.

Alliaria, tn toutten coptes Cardiaca.

B

atomolu, Bienttan.

15alononte, Merim.

gatbluek, (5ential.

20 ct tored, Ixce nigra.

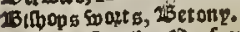

28 tros neft, wotloe forfinep.

1Bitros tengue, $\$$ ttrcthopst

S5oli, Chryfanthemum fegetum.

15iew ball, 151 esw bottle.

20its, $R$ anunculur globofus.

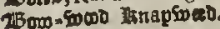

15 20 wone begle, 18 agle.

15 oof cuozt Conlolida minor.

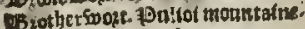

Di3 to wozt, VImaria.

237 be wozt, VImaria.

16ight, Cheledonia.

Tsaferwoet, sopelwozt.

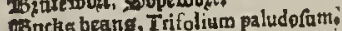

TB ackram, 4ron.

\section{C}

37todactse, Alliaria

Aartes, đrelles.

Catmint, Nept2.

Tenclefe, Toafootil.

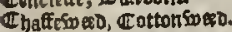

The racti of Chetueteli coas calies though

sottraip) Apium rifus

Charieg (ercacte, Allium.

Cqurchsogt, petmestoqail.

Etaerage, 3 rfmart.

Ilithe, the $1 B$ arte becke.

Clitherch, Gofe grafle os CItwerdi

UIits, Lapp?.

Cloae tongae, Elleborus niger.

Tocks foot, Colutntine.

Cocke fot, Cheledonia maior.

rofw fat, Tosw 15 afi.

at rialoic, the leter erentopg.

Croncberties, Vaccinia paluftris:

Citotobeli, pel!os Daffoli.

Crosm derries, Erica baccifera.

crowtent is Orchis, in limeotnelinte ano yotklbite.

crow rope, sopesongt.

CT tolo leksc, Hyacinthus Anglicus.

Eropsowa, I 1 cea nigra.

Coluet of at, Columbine.

Ealroge, 2 timatt.

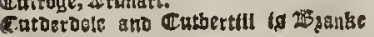
syane.

\section{D}

THinote, Crclamen

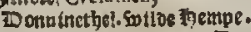

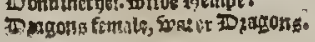

Toroptoopt, Filipendula.

Donccoosune, CatAasic.

DDwale is Aightheos

E

Dotetsoont. Dracontiuma"

Beteder Alliaria.

EIfesocte, Enula Campant.

Ea rty gall, great Centoge, of rathet

tmall.

etmali.

Efan, Erofesogt, zet nob out Cruciata,

\section{F}

The, white fildare Delute:

flametell, Cepea.

flaterell, Cepca.

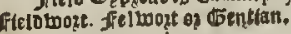

ffittswopt, Filago minor.

ffleadoclie, Petalites.

fleaswogt, Pfyllium.

forgec me not, Chamx pitys:

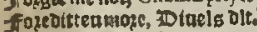

fraturole, Swater Dosagons.

frante, कptutte.

f relfer is the herbe that beatetb sotralis:

bertiss, Strabubertiex.

\section{G}

asingat metkets Ariftot, rotund a?

Baten tre oz đater tre (s Doge bertp trex.

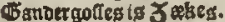

Gectobor, Aparine.

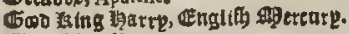

Gopiechitte, Igtmonte.

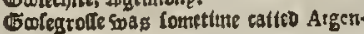
ina.

troofe bill A parine.

Earben Winger, Piperitis:

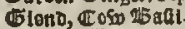

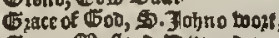

6.

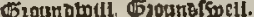

Franta needle, Geranium mufcatum

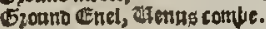

\section{H}

T. Thltens, elínte.

Hammersoot, pellitosy of the swall.

3arobow, 99aregolos.

lates epe, Lychnis fylueftri.

汸archell, Eroso leeke.

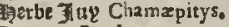

liserbetl, 1)enbanc.

Gethosw. Hedera terreftriz:

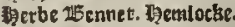

Herbe poter, Cosutp.

Herba martis, Martagon,

Hertelosole, Chamedryos,

Hertimort, Fraxinus.

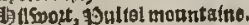

Hippia maior, common Đienpettsl.

Halg tope. Sollac Đeutpe.

joutrobcery, Solanum.

* orewore, Filago.

oufechtre, Ëtruander.

borfcheale etctampane.

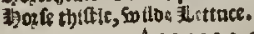

Hontto, ISathorlact.

3)

o?

altongt Politim.

furrobalc, Ambrofiz,

\section{I}

TAcea alba, woltoe of arthite Cani义?

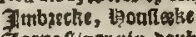

toane fituer pit Double fooppe:

K

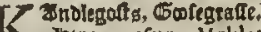

- Intings crosuthe Melilotus.

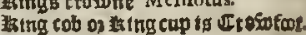

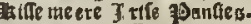

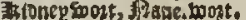

I

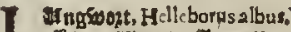

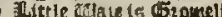

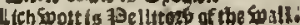

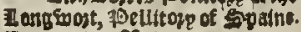

Ellip letce, goly.

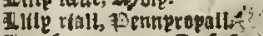

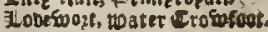

Illoufetwort. Stapbilacte.

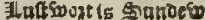

Ilpmgimort, Helleborus albus.

\section{M}

Ans 89 otherfoose Paima Grifti. mo biofiomes. (Conat Hitles: gitasololl. catite horeboand.

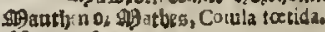

sip iteb, sintallage

giparcb betle, Cats taite.

sipertes 3rage

\$perecrop. Bumparat.

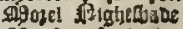

sil? surepeats, $O$ bus,

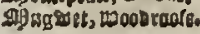

N

Tete. Iolliu

1) Befoise tralamint.

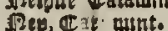

frofislaso, yetrom.

O

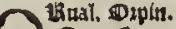

Bran C ucrats.

didrongac, Linglia bavis

p

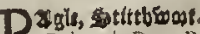
Palmo de Dieu, palana chrifti

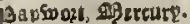

Patell, ato ato

Bopelton $\mathrm{H} \mathrm{l}$ ' bo tus niger.

Ferers faffe Tapfus barbatus's

- Peuter wozt, hosfes atte.

Fe unenta' $q$, 13 asalnte.

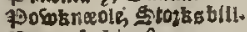

7 imrofs, Liguitrum.

9) patr, Gianen Leucanthemum: 


\section{A Table of obfolete and leffe vfed Englifh Names.}

\section{$2+\mathrm{R}$ \\ R}

Ing foat is toater erofofoot.

13 co kness is Hydropiper.

Hobin in the hofe is Lychnis fyl veltris.

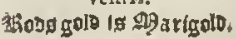

\section{$S$}

Ceabinozets Enula Campana.

Sea Docke to 2 bzanke bztinc

segrom is 13agionoze.

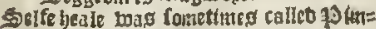
vernel.

G geep fliting to Cotyledon aquatica. EIscperougt is ilettrice.

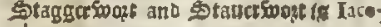

Stanttatch to \#ilfanbrt.

Stanocisoctis is $\$$ satprian.

S. SPartes fect is $\$$ os thitlie fech.

omall hanettp is bin's.

Sourenswost ts Ariftolochia,
Stthe plie ts Stozbs bHI.

Sorrbfalt Is Palma Cluifti.

Stob toont ts Oxys.

Sparros tongue tg Fnot grafie.

Sronnopt anb Stontioze ts Stchte

ccop.

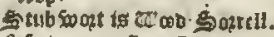

sonites grafie is thot graffe.

s.joine Earfe is thot gitaffe.

Sibichents Grotanorforlt.

Sofosions is 'T olumbine.

\section{I}

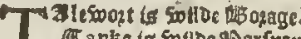

centre is solbe 9 sorfnep.

cetteriogent tg great cetanotne.

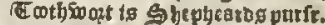

बatranetg Clymenum Italorum.

\section{W}

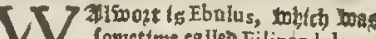
Cometine ealleb Filipendula

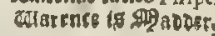

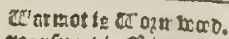
20ap actarbzeab te $\mathbf{P}$ antigo.

ฮatapirojt te H tpia major

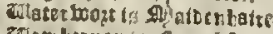

recephetnep io fietuerfic

E. bite 20 othen is gieat Dutfy

ach lide Satager is $\mathbb{T}$ ocki?

arstibe fitarting is $A f_{1} 1$ um.

tobise Golbsts great 3Datip.

te' 00 mat th to sanicle.

J7oob roswer is Oxps,

Caloebb? anse is F Faxinus。

topooncp is Ameos.

zuloifes thiste ts Chamaleon:

aclupesertrots Vaccisea.

topentet is Íbifsus.

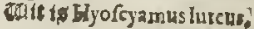

$$
\text { Y }
$$

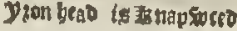

$Z$

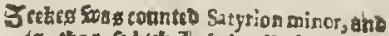

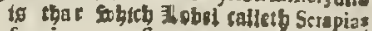
fcrmiza pratenfis. 
A Catalogue of the Brittih $\mathcal{X}$ ames of Plants, ent me by. $\therefore$ Mafter Robert Dauyes of Guifjaney in. Flint-Shire.

$\mathrm{A}^{x}$

Net. Dill,

Aurddanadl, Red Arehangcll Nettles. Aúrvanadl, vide $u$ wb yr ycber.

$$
\text { 2⿺辶 }
$$

B

Aradyl. Broome.

Banatlos. Furze.

Berwo yr Frengie. Crefies,

Berw yr drow. water Creffes.

Bedroen. a Birch eree.

Biattur. Beets,

Blaen yr rwrelb. Mereury.

Blaen y gwayn. Spearewort:

Bleidd dug. Wolfes bane

grialbv Mair. Cow flips.

Bravynen a Ruhh.

Bylwy. Cockle, or fieid Nigella

Bu/f gly Ddayar, Centoric..

Dam yr ebol. Folefoot.

- Cascangytbrel. Veraaine. cacammecj. Burre.

Calintyn y mél. Agrimonic. cancos hom. Knot gralfe. Camamilt. Camomil

crircb. Oats.

Cennin, Leckes:

Cesnix Pedr. Daffodil!

Gedor y Frach. Horíctaile.

cegid. Hemlocke."

celyren, Holly.

cbroernlys yr kirbir: Wood Sage? :

Clate yr ewie. Laurell.

Cloffleps. Gillofoures.

Clujhiev yr Derrovide Galledr.

Claft $\|_{y g}$ oden, Moure care.

Clasarlysy drapr. Brookelime.

coed Ceri. Seruice tree.

Comarch. Hempe.

Cower y laetb, Caliwlyn y mêl,

coed firin. Plun trees. : . I.

Corfent a Poole rced.

Crite y $B$ leiddiew, $\gamma$. Cacamboch.

Craitb vanas, Prunel or Stlfe healca

Crafanke y urix. Crowfoot.

Cribe fan Fraid. Becong

Cynglennydd. white Mullen.

Gyngony celioc. Setwell.

\section{D}

All g graed. Penny rogall:

Danadl, Nettles.

Danadien werr. White Archangell Netelsi Darit y Lew. Dandeleon.

Danadlen ddall. dead Nietele

C Bolgein yrardd. A Tarabaece, EfFev. Daracl Eidder. Iuy.

Eiddero y ddayar. Z ground Iuy;

Eidral

Eitbin yr ieir,, Hwb yr ycher.

Erienlys. 5 Iohns wort.

Erbis. Calsmint.

Eslunperfi, baftard Parfley
F

-A Beanes.

F Fenichy cwn. wild Cammomil. Fenich. Fenell.

Fetces. Fitches.

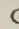

Alladr. Lungwort like Liuerw ore

T Garliec. Garlicke. Glefyny coed. Bugle.

Gladyn. Gladiol or Corne Flag.

Geleudrem, $\vee . L$ lyfie Emfras.

Gold Mair, Marigold.

Gruc. $\nabla . B a y a t l o s$

Grayanllys y dror. Brookelime

Grolydd rmall Chickweed.

Grolydd Mair. Pimpernell.

Gwenynddail. Grengnoc. Balme

$G$ reyddfyd.Woodbind or Honifuekle

Groden y Coed. Smooth Bindewood.

Grollt gwerrer. Venus haire.

Gwallty forwys. Maiden haire.

Gwayw yr Brembin. Daffodil.

Grenith. Wheat.

Gwinwyddex. Vine.

\section{b}

T. Tdy gramandi. Gromel.

Haidd. Barly.

Hefc aelfedoc. Water Torch, of Typba palufi. Hoceys. Mallowes.

Hockys y gors Marifh Mallowes.

Hwb yr y chen. Camock, or reft harrow

L.I

Laetb bron Mair. Sige of Ierufalegr

Llaulys. Sa audaere.

Llawenliys. Bor age,

Llewic ychwanath, v. yeafelen:

Llewic yr idr. Heribane.

Llewperd dûz. Acositum.

ZlyfeIvan. Mugwort.

Llyfie limydion, $\mathrm{v}$, Liffe fasa:

Liyfel levwelyn. Pauls Betony

Zlysey wernol. Celandine.

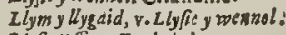

Zlyfee Effras. Eyebrighe

Liffe yr Crymmin, y. Gwylydd Mair.

Zlyfe Uiw, vide Dyars weed.

Llyje pen is Houflecke.

Llybe y gwaedlin. Yarrow or Milfoile

Llyfe Mair, vide Gold mair.

Llyge Amor. Floure gentle.

Llygaid y $D$ ydd. Daifies

Lij] feyr popdin, v. Daily grated.

Llyfec jrgat $t b$, v Erbix.

Ligfe y Bladdd, $\nabla$ o B leid dég.

th $l_{g}$ he y mocb. Nightflade.

I.lyjey cribev. Teafell.

Llyje Simion, v. Cas gan gutbrel.

Lly fie yr cyrob. Peliwinckle.

Llyfie Eva.
Zyraid y rar. Sal banke horoe:

Zlyriaidy mor.

L pryfer. Elme tree.

Zlwonlys. Siuruygrafte

A Afon Rafpis.

Matrcbalaz. Elecampane.

Marcb rbedyny derm, Polypoity, OKe Ferae

Maig. Turneps. 
March y rgal y gerddi, Artuchoke. Mefys. Strawberries.

Merigelly Iion. Fox gloues.

Meirs. Iuniper tree.

Moillioneny meircb. Right Trefoile

Minias. Mints.

Moron. Parfneps,

Moron y wes, wildePurfa ep:

$M w g$ y ddayar. Fumetory.

Mwffogl. Molfe.

Byrawydy bigail. Storks bill.

Nyddoes, Spinage.

N

Onatxyan A h tree. p

T) Aroes yr Arth. Beares breech

Pedere Mair. Crolfewort.

Perls y dwr, water Panfey.

Perfi Freggic. Smallarge.

Pbion ffrwoth, r. Mexic yelly lion.

Pidni y goc. Aron, or Cuckow pint.

l'ocrlys, v. y lấlys.

Paplys. a Poplar.

Prorf. y Bigail. Shepheards purfe.

Pysy ceirm. Tares.

R

Hedyu. Ferne.

Khedegab y dolw. v. Galladr. Rbis. Ric.

Rhofyra a Ror.

$S$

Aedsgmylle, v. Chrermlyr.

Sirodrmw. Sothernwood

Siacckedy melnydd, >.Cynfon Dwnoc: Siriar. Cherities.

Snoder Fair. Englifh Galingall.

Sozodly Crydd.v. Bliex yryinoteb.

Surany gó́. Wood Sorreli,

Surau Sorrcll.

$s_{y} f, \mathrm{r} . M e \int_{y} s_{4}$

\section{$\boldsymbol{T}$}

T Afody ki. Dogs tongue.

Tafod y neidr. Adders tongue. Tafod yr hydd. Harts tonguse.

Tafol. $\neq$ Dockr

Tafol Mair. Biftort.

Tagaradr, v. Hwb yr ycb:n.

Tefod yr eds. Birds tongue

Tafud yryels. Buglof:

relephiz. Orpin.

Tormata, Fulipenduls.

"ryat" v. Calinglyz y nél.

Traed y glomen. Columbine.

Triacly iglodian. Tormentilla.

Trazd y dryw. Parley Bacak Ptone, or fmal saxifrage

Triacly cymro. Germander.

Troed yr bedydd, Larke heel.

Wilfraev, r. Li, W

Himuion. Onioge
T. Bergfelen. Fleabane

$r$ benlas wexn, 7 . Claflgs:

$r$ bengaled. red Seabious.

I bealas, Blewbottle, or Curntloure.

$r$ bengorb. Herchound.

$\Upsilon$ clapilyes. Sabious.

$\Upsilon$ Dorfagl. med ow three leafed grafte:

$\Upsilon$ Droedrydd. Herbe Robert.

T Drwynfazor. Caliwlyn y wấl.

$\gamma$ Ddwy gennioc, herb Twopenec, or Monc w wath :

$\gamma$ Dorkwyd.wild tanfy or Silucrweed

$r$ dex bannoc, v. cyaffon Im jues,

$\gamma$ Dinboesh, Arfmatr.

$\gamma$ Ddayarlys. Peody.

$r$ Deddedige rent. Pilewort:

$\boldsymbol{Y}$ fendigedi. Tut fan or Parke leanes

$\boldsymbol{\gamma}$ Fabgon. Poppy.

$\boldsymbol{r} f y l f e x . r$ fronwys. fmall celandiac?

$r$ feidioc las, v. Llyfie Isan.

$\boldsymbol{r}$ fjddarlys. Prickmadam.

r fyddyg,n, v. Creitb on nit.

Y fyro fytb. Lly fiev pentx̂.

$\Upsilon$ gauri gocb. v. Buflly Ddayar:

$\Upsilon_{\text {gynga, v. Llyfe gr bidl. }}$

$\boldsymbol{\gamma}$ gleris. wilde Rofe, or Spargwort ${ }^{\top}$

$\Upsilon$ gâswenayn.Diuels bit.

$\boldsymbol{\gamma}_{\text {Byfog. a kinde of Spurge }}$

$\boldsymbol{\gamma}$ glaiarlys. $\boldsymbol{\gamma}$ grevlvs, Ground well

$\Upsilon$ gy/gadvr. Night thade or MordU.

$\boldsymbol{r}$ gingroen. Todeflax.

Y lew grynn d6/, Garden Orreh,

$\Upsilon$ Bew gwyxn gay us, wilde Orach

$\Upsilon$ Ulimlys, v.Lilyfee lino

$\Upsilon$ Uwynbidydd.Ribwort.

$\Upsilon$ Vindro.Doder.

$\Upsilon$ Uyfien yn bendizedic. Valerian.

$\tau$ Beḱadiys. Lunaria.

$\gamma$ Mor gelyn. Sea Holly

$\Upsilon$ Murlys, Pcllitory of the wall

$\Upsilon$ Pepicocb, r. red Poppt, or corne Rofe'

rrefarlys $\left\{\begin{array}{l}\text { Hit } 2 \text { Ariftolochia, }\left\{\begin{array}{l}\text { lone } \\ \text { geoz } \\ \text { bycbar }\end{array} \text { or Birthwort, }\right. \\ \text { or Hartwort, }\end{array}\right.$

Tr Alaw. Water Iilly.

Yrbën lydan,i.ffordd. Waybreadi;

r. Roblt. Rue, or herbe Grace.

rrvebelfa. Mifleltoc.

Yry galles Fraitb, our Ladies thiftle.

rry geallex Fendigedic. Card,Benedia

Yrboliacb. Clownes wort.

T/cal drain sponn Carline Thifle

$r f c a l l$ wilde Thiftles

really mocb. Sow thille.

Ifrol fair. Peters wall or fquare, S. Tohai wore

Y faw. Elder trees.

recoddaden. White the

$\Upsilon$ friab. Muftard.

$\gamma$ mernod. Wosmood.

$\gamma$ wermod weas, Feuerfen.

$x$ wirimydder

$\Upsilon$ winnydder d d , white Bryonic.

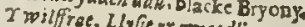

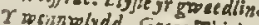

$\Upsilon$ weingolydd. Great Tbickureed 


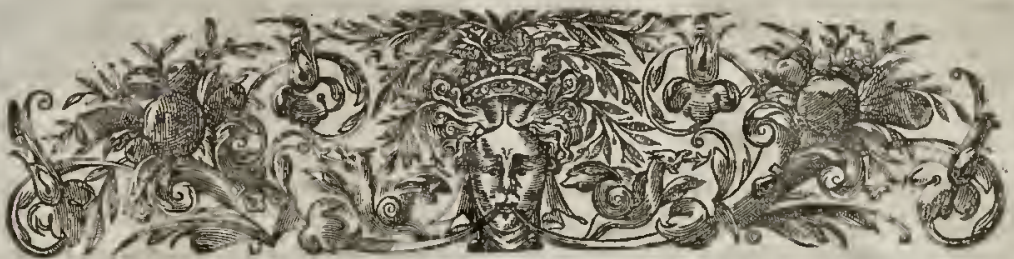

\section{A TABLE, VWHEREIN IS CONTAINED THE NATVRE AND VERTVES OF ALL THE Herbes, Trees, and Plants, defcribed in this prefent Herbal.}

\section{$A$}

C.

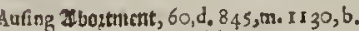
Agninft albosttuent, 766 , a

Aguint atelex, 71, e. 399, l. $756, b .1445, f_{0} \times 1529, d$. Againft 3 ches in the ioynts and fimbes, I $32, c_{0}$ I $64,6.28$ I b. I 209 . See Iaputs

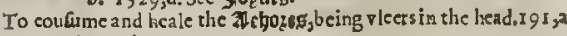
1197 , i. $1206, c_{0}$

3it of generation, vid. 115oblipand ilati.

Aganft the ftinging of 300 ers, fee eltipers and serpents.

To heale the Egilops, 74,a, 1361, h. 1368, d. I441, b.

Iffects of the breft, $783, i$. fee 15 , ealt.

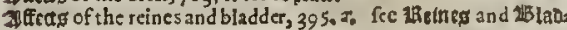
Der.

Iffects of the lungs, $306, e .78$ 3, i. fee II ungs:

To bring downe the afterbitth, 154, e. 653, a. 756, e. $796,9.870$,

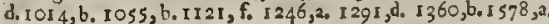
I 428 , b. fee Serondine

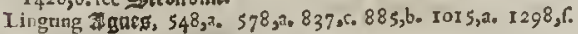
I $525, \mathrm{~d}$.

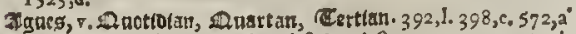
$572,2.637$ g. 653.g. $715, .756, f_{0} 853,1,855$, a. $924, c_{0} \cos 5, b$ 1367, g. I $455, x .1452$, d. I $506, e$.

3youes, and the cold tirs of them, $756, \mathrm{~d} .759, \mathrm{a}_{0}, 1002, \mathrm{c}_{0}, 1107, \mathrm{~d}$ 1257, $\mathrm{r}$. vid. कolating.

Ingnes, and the heare in them, $634, f .829,2.1326,4,1431,60$ 1586,7.

alketures, a cordial confeation, $1343, \mathrm{~b}$.

Ag:int the fwelling aed inflammation of the Alnonds of the throat, $231, c .331, d .456, b .509, f_{0}, 26,2.783$, h. $825,7.992$, f.

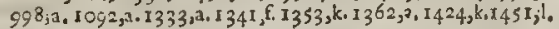
fec Inflammation.

A a ainft the milicious vicers of the 3imonos, $1015, b$

Ag ninft the 3tlopecte, 95, e. $5455^{3}$.

To cure the 3uphus, vide 990 opheso.

Zungina, v. Squinancis.

To helpe wrenches of the 3inkies, 132,5 .

Againt $S$ anthonites fire. 66 , f. $33 \mathrm{r}, \mathrm{b} \cdot 3390.0370, \mathrm{i} \cdot 395$, f. $5 \mathrm{II}, \mathrm{a}$.

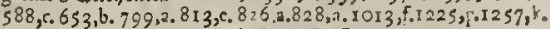
I 331, c. I $335,3.1393$, r. 1461 , b. fee Thifl anturatton.

$X$ astiootes againt poyfons, $233, f, 236, a, 407, b, 586, a .793, d$. 1029, त. 1257 , 11, fee 70 opron.

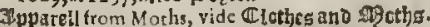

Tọ procure âtppetite, 245 , a. 308, d. $398, b .522,3.534, b .714$ co

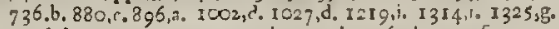
1326 , d. 1 393, , 1420 , ? 1424 , h. 1433 , b. 1465 , i. I 501 , f. 1507 , \% I 508 ,f. 1525, c. 1594,6 .

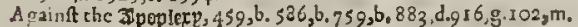
IOS8,F.I $448, \div 1484, r^{\circ}$

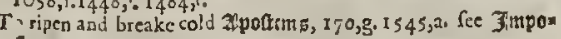
Sinne

In ripen and breake alpodtemis of the mouth and throa:, 580,2 ,

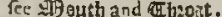

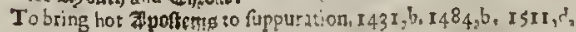

To breake inward anofem , $3,264,2.269, \cdots, 813, d$. Againft hidden cankrous 3ipoltams, $254, c_{0}$

To eure peftilentiail 2 poftems, fee $B u b o$ and $\mathbb{T}$ arbuncte To cure the Argema, 3 I0, b. 373,3.619, c I 195, a.

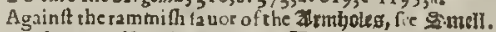

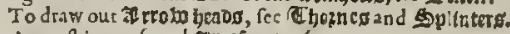
A gainf impoyfonsd artosect. $360 \cdot y_{*} \cdot 1007,1$.

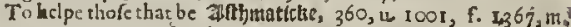

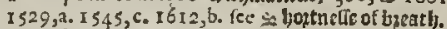

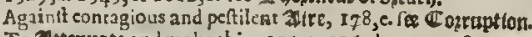

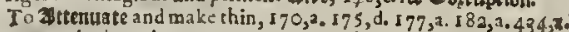

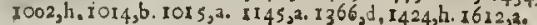

\section{B}

Gaint paine of the 18ackt. $8072^{\circ}$

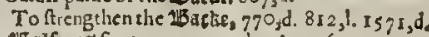
213 aifang for geene wounds, $x c \cdot 360,3.405$, a.

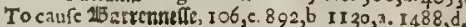
Againt 15 artenneffe, IS 25 , f. fec help Cenception. 113 athy for vicers and running fores, $1226, \mathrm{n}$. 21Bathy for members out of ioynr, gour, \& $2.1473, f$ Tohelpe 15 leare epes. Fee Eves.

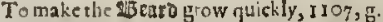

To fcoure a way the r. uruinefre of we 13 caro 19 , a.

Againf $2 B_{\text {ear }}$ motmes, $68 \mathrm{r}, \mathrm{e}$.

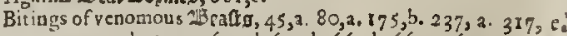
395, a. 434, d. 572, c. 619, d. $644, b .661, b 667,3.692,9.713, c_{\text {c }}$

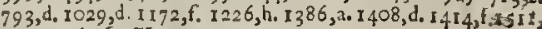
$\mathrm{m}, \mathrm{r} 533, \mathrm{~b}$, Ice đTenomous.

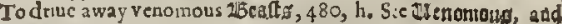
seruents.

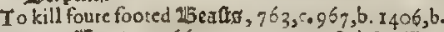

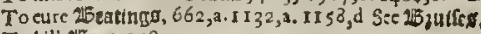

To kill $15 \leftleftarrows 8,1584$,

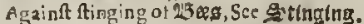

Tocaufe 213 exs to kecpe together, $602, \mathrm{c}$,

To helpe 2 Belchttmg

To loofe the 25 tlin gently, $62,1.174, a, 319, \pi .321,2.327, a .320^{\circ}$ a. $332,2.352$, e. $368, b .39 \mathrm{r}, \mathrm{g} .398, \mathrm{r} .527, \mathrm{e} .637, \mathrm{~b}$. $667, \mathrm{~h}$

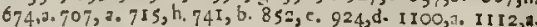

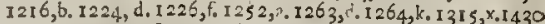
a. $1434, f_{0} 1445, f_{0} .1447$, d. $1498, \cdots .1500,6$ I I 06, , I I II, $\mathrm{K}_{\text {。 }}$ I 608, h.

To open and purge the Altclip mightily, 863, a. 816,1.925, bo

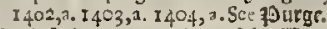

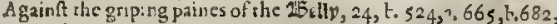

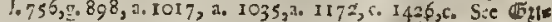
ping

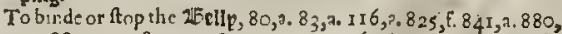
r. $884, \mathrm{e}, 1148$, , , 1128 , a. 1242,3 , I264, ko 1325 , , $1336, \mathrm{l}_{0}$

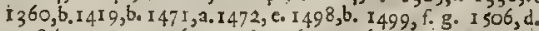
I $518, \mathrm{~b}$, I $521, \mathrm{c} .1536, \cdots$ I $558,1.16 \times 3,2,1625, \mathrm{~b}$. S:e fflle and Ilafse.

Todry a moirt 25eltp, 85 , b

Toftrengthen the $215611,1538,6$. 


\section{The Table of Vertues.}

To onen and breake 15 ilco, 870 , e. fee 15 otcheg

To reesine the 15 trth and giue it life, 766,2

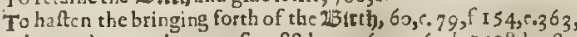
d. Ior $4, b$. I I 04, b. I I 2 I, f. I I 88, b. I 246 , a. I $360, b .1428, b$. Sec 30 dituerance and ctomen.

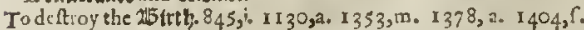
I $408, \mathrm{c}$.

Tobring forth the dead 15 irth. fee $\mathbb{C}$ btide.

To cure the 15 itt of a mad Dog, $28,2,66, a .334, b, 434, \mathrm{~d} .63 \mathrm{I}, \mathrm{f} .6 \mathrm{~g} 2$ h. 697 c. $702,3.810$, h.100 I, g. $1172, f .1426, e$. I $44 \mathrm{I}, \mathrm{g}$. I 446,11 .

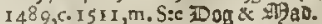

For 2 lialtincte of the face comming by ftroke or bitute, $5 I_{3} 2.239$

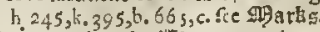

For tveund ot the 215 iadoct, I I 16,3

For vicers of the 115 tadoer, in I $6, d$. I $303, c$. I $619, c$

For paine of the 1 listadoer, 87 , a. 65 I d. 7 I 4, c. 8 I o, c. 877 , h. 932 , d $984, b, 1017, a, 155, b .161, a$. I $145, \mathrm{k} \cdot 1206, c, 1315, \mathrm{a}, 1356, \mathrm{c}$, I SI I, O. I 929,2 . I 12 ,

For the ftone in the 13 lavocr. fee stone

For inflammation of the QWI IaDder, $522, \mathrm{~d} .82 \mathrm{I}, \mathrm{d} .852,0$

Forftoppings of the 115 tab Der, $578, \mathrm{~d} .586, \mathrm{c} .66 \mathrm{I}, \mathrm{c}, 842$, a. $1024, \mathrm{~b}$ $1042, \mathrm{~b} \cdot 1045, \cdots 1053,2$.

Good forthe 151 ladoir, 622,d.626,d. I025,2.1041, b.106\$, c.1 I 12 b. 1303 c. 1502,7 . fec 31 infintuitice.

For 213 hafings, $935, \mathrm{~g}$. Ioo6, b.

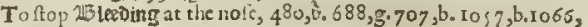
d. I I I 6, b. I $257, \mathrm{~m}$

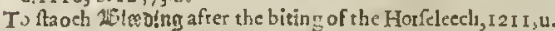

To ftop all kindes of 213 lewoing, $276, a .325, a, 355,2.396, b, 421$

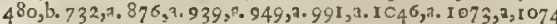
a. II 20 , b. I I 28 , a. I I 45, c. I I 50, a. I 240 , b. I $264, k, 7$. I 274,2 I $285, \mathrm{a}$, I $325, \mathrm{co}$ I $347, \mathrm{a}$. I $379, \mathrm{f} .1393$, f. I 471 , a, I 508, b. I $564 \mathrm{c}$

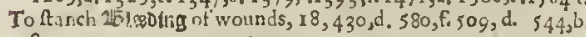
82, , c gol, co, I I $23, \mathrm{c} .1451, n$.

To take away 15 icmthcy, 557, d. 872 ,a.s:e fece

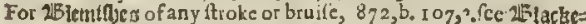
nefte be marke.

To raife a 1 Bufter, $816, \mathrm{~b}, \mathrm{~g} 63, \mathrm{a}$. I 557,2

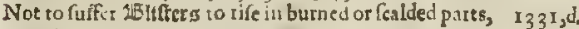
$1461, ?$

To increafe $101000,880, c, 125, b$

To diffolue and void cluttered 231000, and keepe it from congealing in the body, $251, e .434, c .447, a .527, c .574, a .632, b .645,9,565$

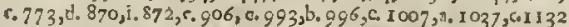
3. II 95, c. 1108,3 , I52I, c

To coolc and temper inflamed 25100,398, c. 522,c. $1263, g_{3}$ I 326 b. $1534, b$.

To clenfeor purge the $151000,39 \mathrm{I}, \mathrm{h} .574, \mathrm{c}, 629,1 \mathrm{i}, 766, \mathrm{~d} .885, \mathrm{~b}$ I0 89, b. 1167, c. I 432 , d.

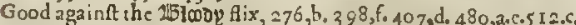
522, c. $557,1.649$ c. 774 b. 884 r. 932 c. 991 a. 993 a. $99^{8}$ a. 1046c.1073 2. I 224, b. 128 t a, 128 5 a.131 i d.1 368 a. 1443, 145 I n. 147 a. I 499 g. I 5 I 8 , d I 564 , b. Fie filic.

Againft fpirting of $151000,67, f .175$, d. $546, a .807$ a. 8102895 b $993 \mathrm{c} .1047 \mathrm{f} \cdot 1285$. $13^{6} 7 \mathrm{rr}$. $1388 \mathrm{a} .1373 \mathrm{k}$. I $443 \mathrm{cos} 446 \mathrm{r}$. 1451 g. 1452 c.I518 d. I524 2. I 64 to fce Spittina.

For thofe that pifte 201000 through the difeafes of the kidnies, 826 a. Pee 3 Dtfic.

To prouokc 250 otiqg luft, $557 \mathrm{f}, 772$ b. 1232 a. 1517 b. 1536 d. Sic ilnt.

To allay ouragious luft of the $213002,522 d, 926 \mathrm{~d}$. Sec Ulyatte.

To preferuethe 260 op from corruption, $88_{4} \mathrm{c}$.

To cooleand mo:ften the $1508 \%, 1264$ k. fectere

Tonourifl the 15000,026 ,

To make the $2500 \mathrm{p}$ weil colonred, 1367 , g. fee $\mathbb{C}$ olomted

To make the 150 D foluble 308 f. 317 e. 793 c. 798 b.805 c.877 c 911 e. 1089 c.15:7 a.

Totake away the raoke fracllof the $21500 v_{3}$ fce Smell.

To preferue dead 200 oic $5,96 \mathrm{k} .1353 \mathrm{C}$

To souer 2 Bones that are bare of fiefli, 1004 b. 1049 b:

Toglue together broken 15 ong $\$$ iu flort fpace, go6 c: i.433 k $1482 \mathrm{c}$

To draw out broken 18 ontes, 6o, c. $870 \mathrm{c}$ : $1055 \mathrm{f}$

To ripen and break $1150 t e b s 5,360$ v. $4092.870 \mathrm{c}$. I 007 a: to II a. To ripen and breakepeftilentiall abotebes, Igl c, roog a.k. $1172 \mathrm{f}$

How to make 15 seab light, and caufe it fooner to be leauened. 88 se

To comfortinecold we ale and feeble atingine, 33 b. 665 a: 692 .

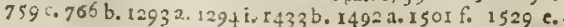

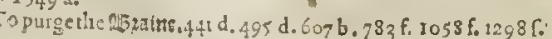

To warme and diy the 215 aine, 649 d. 759 e. 1086 d. $1294 i$ To cure 15 peating out in the wholc body. Yee 3 tch \& 5 cabs. Agrinft ftoppingot the 15 get, 245 b. 580 b. 11092 Againft painc of the 23 pet, $64 \mathrm{a} .779 \mathrm{~b}$. $\log 8 \mathrm{~h} .1257 \mathrm{~g} .1523 \mathrm{~d}$. To increafe milke in womens 15 zefts, fee 20 tlibe \& Parles.

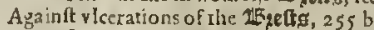

To ditTolue the hardne Te of womens $2 H_{\text {gents, }} \quad 28$ c. 527 b. $1226 \mathrm{~h}$.

To arw age great $\mathbf{2 5} z$ ftg and dry vp the milke, $88_{3} 1$.

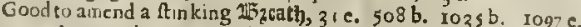
1177 h. 1294 d. 1433 c. 1465 g. I525 c. 1529 a.1533 a: 1537 I 54 I 2.1623 a

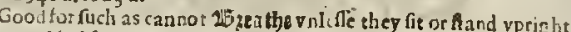
and hold their neckes ftraight vp. $688 \mathrm{~d} .692 \mathrm{~h}, 708 \mathrm{c} .793 \mathrm{a}$ IO24 d. II Oy a.

Good for thormetie of 14 ? 3 catly, I 74 d. 245 b. 350 5. 580 b. 657 a 725 a. $79^{2}$ C. 793 a. 813 d. 8499.874 b. $875 \mathrm{k} .8922$. $913 \mathrm{c}$

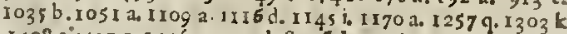
$1408 c_{0}^{\circ} 1437$ c. I 4460 0. 1511 b. See Shoumete.

Good ior tholc that arc 18 rosen or hurt intrardly.

For 15 josen winded catcll, $434 \mathrm{c}$.

For inward $11_{3}$ utfeg. $64, \mathrm{c}, \mathrm{h} .688 \mathrm{~d}, 715 \mathrm{i}, 782 \mathrm{a} .79 \div \mathrm{h} .807 \mathrm{a}, 849$ c. 870 i. 906 c. 1047 h. 112 I i. II 58 d.

Good for 2 is 7,56 h. 759 f. 849 c. $870 \mathrm{i} 906$ b. 1078 d. fee ffolls.

Toripea venereous $B$ uba's in the flanke or lbare, $60 \mathrm{c}, 490 \mathrm{a}$.

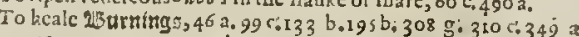

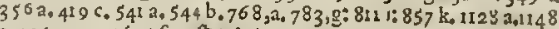
ה.1360a.1426 c: fec socaloing.

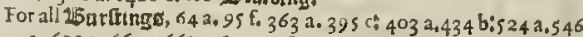
a, 632a.661 a.662 a.671 a. 483 a. 7.t4 a. 793 d: 507 a. 849 b。

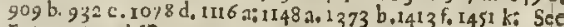
Eaberorele and lituptures.

\section{C}

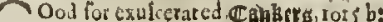

Good for the Canktrs in the cycs, called in Greckecarci. nomasa, $3: 7, k$.

Gond for the Canters in the mouth, 450 a: $451, b, 766$ c. $825, a$; $993 \mathrm{c:}$

To flay $\mathbb{C a n k e t s ~ f r o m ~ i n c r e a f i n g ~ o r ~ c r e e p i n g ~ f a r t h e r , ~} 79 \mathrm{~d} . \mathbf{J}_{37}$ b; Tocurc Cankers, $373 \mathrm{~d}$.

Good for Carbancles, 360 s.1369 d. i 393 c: $1441 \mathrm{~h}$ :

To ripen \& breake peftiTentiall Catbmites; $317 \mathrm{~d} .1226 \mathrm{~h}$ To take away Carbaneles. $1378 \mathrm{~d}$.

Againft the CatalepHc, 580 a. $820 \mathrm{~b}$

To cure Catartijeg, 175 c.360n. 370 6. 649 d"1053 b: 1333 a 1526 a. ree 15betineg:

To make a farc Carnation colour, $1419 \mathrm{~d}$ :

To knit together brokenbones in $\mathbb{C}$ attell,906 c.

To cure certainc difeafes of $\mathbb{C C}_{\text {attell, }} 705$ d:977, 1575

To cuic elattcil of the cough of the lung: $434, \mathrm{C} ; 774$ 15712.

Tohelpe tattell being chap-fallen, 3 e.

For Chips of the fundament, 1169 b. 1333 ai 1362 c. fec ffande. intent:

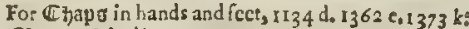

$\mathbb{C h a p s}$ of the lips, $7333 \cdots . \$ 444 \pi$.

To makc one Chatt, 821 e. $1388 \pi$

Good for the $\mathbb{C}$ bed, 586 a: 6942.756 F.779 e: 877 h: 1170 ating $1156 \mathrm{a} .1373$ b. $151 \mathrm{I} 0 ; 1620 \mathrm{c}$

Tocicnfe the Cheth of ill hilmors, 239 c:250 : 574 b. 694 a:714 7252.776 a.779 a: 791 b: 793 b:794i.833 3.8352 .881 d.1015 c. $11370: 1356$ d. Is II b.

To concof raw humois of the Chet, 245 b, 714 b;79t $t_{0}, 793$ b: 833 g. $1206 \mathrm{C.}_{4} 1408 \mathrm{c}$.

For eilyloblanes, 174 f.

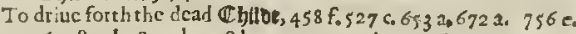
796 a. 80 r b. 87 o d. 1048 b. 2051 a. 1055 b. 1218 d. .1257 a:1.3782 $1625 \mathrm{a}$.

Tonourifh the $\mathbb{C}$ bilot in the wombe, rs17 b.

For the red rum and frets in Chtroter, fee Hams \& frets.

To repreffe $\mathbb{C}$ boler in the ftomacke, $1465 \mathrm{i} .1595 \mathrm{~b}$.

To purge fiboler, 868,1423 f.

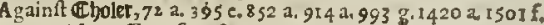

Cholertese pafiton, fee fiellony.

To dye Cleat b, 491 b. I2I I t. 1477 b.

To keepe Cloatheg from Moths,644 ai645a.t097 c, 1900 f: See Garments \& 8 if atbg. 


\section{The Table of Vertues.}

To abate the fwelling of the $\mathbb{C} 009.6 \mathrm{~s}$ d .

Good again ft Colo and hoarfencfic $360, n$. fec Goartineffe.

A gain it Colo difcafcs of she inward patts.434,e.44r,a.683,a. See aDifeares.

Goodagainft the Colonetre of the firewes. 891 , c. See St= nasues.

Good againft coloneffe in the ftomacke.34, d fee stomocke

Good for the Eelfactie palfion.1 007,9.2349, c

A temedy for the $\mathbb{E}$ olt ty=crill. $257, \mathrm{~h}$.

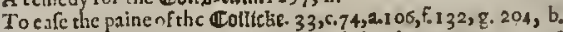
$360, x_{0} 3^{63}, a \cdot 3^{8} 7, a \cdot 407, c, 413,3 \cdot 497, b, 874, b .916, n \cdot 996,21048$

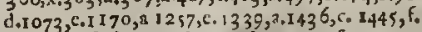

Good againft the coltitke and itone. 242, f. 7 56,a.79, 4, b. 1002, ho 1029, c.t152,2.

To reftorc colour decaicd. 31, e. 880, e. 121,1 .

To take away the bad colout somming of the yellow iaundise. $667, \mathrm{~d} .845, \mathrm{c}$.

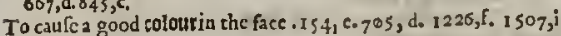
1533,5

To make a faire yellow colour. $1268, c$. I $338, c$

To make a decpe greene colour.1338, b.

To malour jellies, wises, and mears of a purple colour. 80 , $\Upsilon_{0} \cdot 33^{6}, \mathrm{e}$

To colour jellices, wines, and mears of a purple colour. 80 ,

To hindir (T) oneeption. 682, b.11 $41,7,1236, c$.

To helpe conevevtion. $79, \int .207, \mathrm{a} .332, \mathrm{~b} \cdot \mathrm{I} 029, \mathrm{~b}$.

To helpe coneotion in the ftomache $6,2, g 980, c .882,0.1001,8$ $1034,2.1049,5$

To heale the Conds lomasafec fiundaunent.

Good againft, or to helpe a confumption. $736,6.880, f .9365, \mathrm{~m}$. I $529, \mathrm{~b} .16$ I $9,6$.

A medicine for the confutmption of the backe. $\$ 07, \mathrm{c}$.

Good tor th ofe that are entring into a confumptlon. $1518, \mathrm{~g}$.

To cure the contradtion of finewes. $524,3.546,2.557, b, 615,2$.

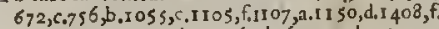

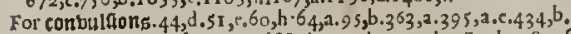
545, a. 572, b.665, f. 671, a. 688, d. 795, h. 705, d. $7^{8} 3$, b. 787 , $792, \mathrm{c}, 849, \mathrm{~b}, 883, \mathrm{a} .935, \mathrm{f} .1055$, h.

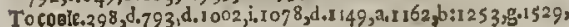
e.1620,b.

To cols and drie. $398,3.120 \mathrm{i}_{3} \mathrm{a}$.

Againft copraption of the nirc. 1373 , $1511, \mathrm{c}$.

To take a way eognes.196, r.5t2, b.1007, k.1 $392, c$.

$X$ A counterpoiton a gainft dea dly medicines, poifonous hearbes, biting and ftinging of venomous bcafts. 1257,0 .

Good againft the coumb 51 , d. 64, i.1 $32,2.232, c, 2 \$ 4, b .355, c .546$,

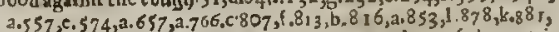

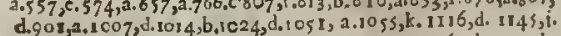

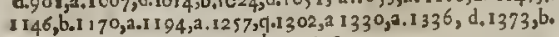
1443, e. $1446,0.1502,3.15$ I I , b, 0. 1526,2 .

Againt the chin-cough in young childten.631,d. 708 , c. 1373 , c. To prowoke the coutes, \& c. Sec flloures and estmes.

To ripen or belpe an old cough $95, \mathrm{~b}, 174, \mathrm{~d}_{1} 178, \mathrm{c} 239, \mathrm{c}, \mathrm{j} .33^{\mathrm{F}, \mathrm{a}} \mathrm{a}$ :

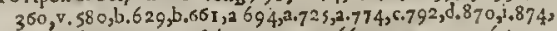

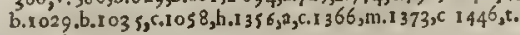
$1507, \mathrm{i}$.

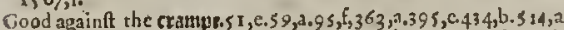
$54^{4}, 0,665, \mathrm{f}, 671, \mathrm{a}, 672, \mathrm{c}, 688, \mathrm{~d} 705, \mathrm{~b}, 71 \mathrm{~s}, \mathrm{~d}, 783, \mathrm{c} 793, \mathrm{~d} .849, \mathrm{~b}$

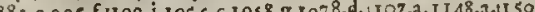

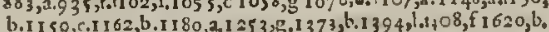

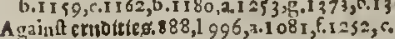

To glue together cuts made about the vaines fincwes and ten. duns.'3:, b.1 19 r ja. I116,a.1343,a.

\section{D}

$T^{2}$

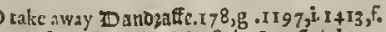
Agaiuft barkenette of the fightr. Sec 5 ight. To expcll rhe dead child e. $352, f_{0}, 74, a, 688, c, 6,64, b$. Sce chilloc.

Good againft Deafeneter. 17 , h. 3 Go,t. 16, h. 1172, b. 1408 , d

To feoure away , he otfoumitieg of tic skin.248,d.88, $3,0$. Sce frace and $\$$ ktt:

Tu caufe eafie and peedic aelturtance in clild de.bearing. $19 \mathrm{~g}, \mathrm{f}$. $694, b .705, c .1055,6.1511,0$. Sec $216 h$ th and somm.

Againft befficalty of making warct. $242,\{.3\}^{1}, a+\{27, \pi .623, a .645$,

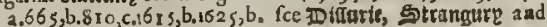
Uitine.

A 2 D locftitue.1224, d.

To helpe or make good oigrtion $31, c .24 t, a: 245,2.248, c .366, b$.

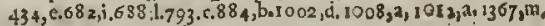
I $459, \mathrm{~d}, 1529, \mathrm{c}: 1533, \mathrm{~d} 1539, \mathrm{n}, \mathrm{T} 536,2$
Good againft Dimnete of the cies. $64,6.3$ ro,b.770, 4.83, , h. I o I I , ti $1098, k$

To eure old and cold olfeafes. $586, b .665, a .861, a .874, b, 880$, is 882 , n. I 008 , a. 10 , 8, d. I 257, u. I 53 t, b. 153 1, b. 16 I 2, c

A renedy for etsstinfte. $360, r \cdot 787,6,870, c, 1055, h$. Sce solutmming.

Good againt hot and tharpe ottlllat tons into the eres and other parts $355, a$.

To sure thebiting of a mad Dog. $170, \mathrm{c}, 466,3,7$ I $5, \mathrm{~d} 1226, h_{3,127} \mathrm{r}$ ? a. 124, , Sce 13 iting and $\$ 2$ ab.

aTokrepe bogs from growing grear.637, d.

$X$ To kill oogs 763 , d. 903 , 3 .

Good againtt the bitings of the fea Dargon. $1095, \mathrm{i}$

A gaínft orolwing together, or awry of Sinewes, $95, \mathrm{f}$.

To caufe troublefome and terrible Dzeames: 7 , e.177,a. $1225, \mathrm{k}$. Good again at melanelolicke beanes. $984, f$

To put away vene:eous ojeang, $82 \mathrm{l}$, h.

Ag unt the ozinete of the lungs. $629, \mathrm{~b}$.

To cuffe ozankennetre. $79,6.92,3.845$, i.1 $521, a$.

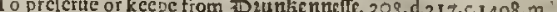

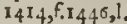

To helpe the orop: ptter, '.pifing by drops, or drop aftcr drop. 556,5 \$65, d.651, d.1061, 2.1460, E. 1ec 5trangurt.

To helpc thoic that are cotring into a opoptie. $64, h .657,665$, ba: $1257,9: 1388, \mathrm{~b}$.

An excelient purge for the Dzopfe. I $170, F^{\circ}$. $4^{26}$, f. Scc 10 urgatis ong.

Good sgainft the oloptie 31, a.34, d:59, b. $72, f .174$ d.178, c*360, xi $391, h .4$ I $9, a .441, a .497, b .529, b .532, b .548, c .582, c_{1} 649$, f. 6553

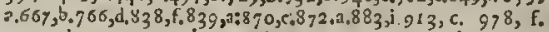

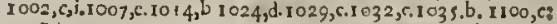

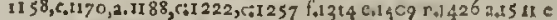
IS25 c I534,a.1608 f.16i2 c,16Tg b.

To curc the fores of the ougs. $898, \mathrm{~b}$.

Againft liot fwellings of the eugs 99 b.

Good for vlecrs of the ougg.36 3 i.939.

Tokecp downe maidens Dags.949

To driuc a way ottlinefle, fec melancholit

To ftay and cure 30 pientertes, $291,3,626,2,639$, e. 532 a 1349 c.I 52421623 c.fee $15 l o 000$ \& fitt.

To help the offtury or great pain tomake water. 32242 f $6 / 72$ I 89 c.fce ozop-pifte and trangary $\mathrm{E}$

Ood for mattering Eoreg. 732 a 858 c 885 c $1098 \mathrm{k} 133$ a $\Upsilon_{1} 3^{6}{ }^{6} b$

To mitigate or cure the pains of the eareg: $175 \mathrm{c} 305 \mathrm{c} 33 \mathrm{I}$ d 421 g 667f 709 C924a $1206 \mathrm{f} 1257$ i $1291 \mathrm{c} 140 \mathrm{~d} 1408 \mathrm{~d}$ 1988 c

Good for the noife ot humming in the eareg. I 75 c $308 \mathrm{c} 856 \mathrm{~s}^{\text {? }}$ $916 \mathrm{CtO13}$ i I $232 \mathrm{f} 1353 \mathrm{~g} 1526 \mathrm{z}$

To helpe iluc inuoluntarie cffufion of natural feed, 291 a

Huxtfull to theetes.177 2674 a

Good for the ele $\$ .663$ c 677 a $556 \mathrm{c} 1274$ b

Good for watering or runningeteg.66 d 428 a $550 \mathrm{c} 637 \mathrm{f} 68 \mathrm{Id}$ $694 \mathrm{~g} 8 \mathrm{rgh}$ I211 n $1264 \mathrm{r} 36 \mathrm{Ih} 148 \mathrm{gb} 535 \mathrm{~b}$

To ceafe the paine in fote reses and ftay the hot humour from tur ning into them $6_{7} \mathrm{i} 352 \mathrm{f}$ sogd $6777_{7} 6_{3} \mathrm{~b}_{772} \mathrm{c}_{7742} 899 \mathrm{~h}$ $1187 \mathrm{e} 1232 \mathrm{~d} 1263 \mathrm{Cr} 527 \mathrm{~b}$

To clente the tes from filmes. $509 \mathrm{~d} 772$ b $\$ 56 \mathrm{c}$

Good for to rake awas the inflamm2tion of the etegt373 a $378 \mathrm{C}$ 51 I 2512 c634a734a 74Id 772 c7742776b856e 9 i4 b 968 a ro43 $\mathrm{d} 33 \mathrm{I}$ b. fce 3 intamiatation.

How to preferuc the eqeg thut they bee not hurt with the fman!) pox or meafills i 549

To take away the rednclfe of the eres. 7226913 d.

To take a way the yellownefle of the eyes. $694 \mathrm{~g}$

To helpblack enes enmming bo blowes.73221211,0.1353 E.

Good for weeping wounds of etbosoce $63+$ b

A rcmedy againfthe Enterocele which is the falling of the blinde gut into the cods. 46 b $106 \mathrm{~d} 639$ \& 787 a $9 \$ 621204 \mathrm{~b}$ fee 15 nurm ttings and isuptureg,

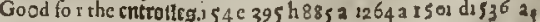

To clevie and fcoure the entratlg.8 33 a 1053 d

Againft the dif cafe Eshicles or night. Marc 984 f

Goodagain?t the Epilepfic-See fralitng Acknctic.

To eafe or affwage the inflam matio o called Ergfpelasi $G_{7}$ h $37:$ \& 829 b 2586 a.fee rnflammation.

To take away efeers t22 5 n.

Good again ft ercontations of thc conduirs of 2 be yard 284 b 1673 d

To wafte any etcrefence in any part of the body 792 , fec detrng. Good againt the exulectation of the priuy parts. $1402 \mathrm{~h}$. 


\section{F}

$T^{2}$

takeaway frechics and other fuch deformities of the fract

845 , i. $99^{8}$, d. 128 f. 1315 f $8134 \mathrm{t}$ h. I 378 b:1446 m.1482f. i 51 I h. fec freckles, $9902 p b$ bo:

To make the fif ace mooth, 67, k. 1 433,h, $1441 \mathrm{c}$ : ree Statt.

For rid ftaces, 360 t. 715 b. $912 \mathrm{f}, 1008 \mathrm{c}$.

For filling off of the haire, $1107, \mathrm{~g}$. fec atre:

Good againtt che fintling fi. knelle, I I $06 b_{0}, 204, c_{0} .45$ g. 44 , a 465 b. 485 b. 490, c. 574 c. 579, b. 586 b. 5972.623 b. 414 a: 738 b. 759 b. 763 c. 774 h. 787 g. 798 f. 849 f. 852 f. 870 c. 883 d. 916 g. 977 a. 984 c. 991 c. 1002 i. 1007 f, 1 cog c. 1035 d. I05 I $a_{1} 1055$ h: 1058 f, l. I061 b. 1162 b. 1188 c.1253 c. I 323 co 1367 l. 14322.1484 c.1507 g. $1578,2.1612 \mathrm{c}$ 。

Good for fuch a saue fralien from high places, 2 ₹ $\mathrm{e}, 350 \mathrm{~b}, 434 \mathrm{~b}$ 662 a: 792 c. 828 a. 896 f. 1002 c. I I 21 2. I1 22 a. I148 b, 1195 c: $1408 \mathrm{i}$. fec 115 sulfeg and $5 q$ that 5 .

Againt falliug of the nother, fee 2 hifother.

For the fraling of the Vvila, fee ctunla

For the difeafe cill!ed the fielloitp, 681 a. 688 d. I 419 b. I 451 d. For a fiellon, 95 c. 447 b. $1015 \mathrm{c}$.

To ripen and open fiellong, $67 \mathrm{~h}, 2$ soc.

For hol burning feuets, $284 \mathrm{a}_{4} 637 \mathrm{~b} 8142.853 \mathrm{~m} .1325 \mathrm{~b}, \mathrm{I}_{2} 6 \mathrm{~b}$ 1414 b. 14203414551.1608 a, fee beate.

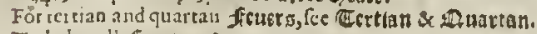
To helpe all fenctæ, 5 \& $2 \mathrm{c}$.

Fol the frenct hectique, $219 \mathrm{a}$ :

Toallay heate in a peftilont feucr, $853 \mathrm{mn}, 1465 \mathrm{j} .1608 \mathrm{~d}$

To cure wandring freacts, $1 ; 67 \mathrm{~g}$.

Againft peftilcnt fienerg, 589, b. 626 c. 725 f. 7412.814 a. 833 9922.1373 c. 160 , b. fee 70 eft lilent.

Againt ol: ficue:s, 429 b. $632 c$.

A gainf intermitting ffewerd, 8801. 1167 d. fee $\$$ guts

"To keepe figges from putrifying, $674 \mathrm{k}$.

For fiee in burnesand $f$ alds, 512 b.

For the fiftala in the eyeralled Egilops, fece egilops.

To open the narrow orifices of a fiftula, $\mathrm{I}_{42} 4 \mathrm{~m}$.

Good againft a faltalis, $37 \mathrm{~s} d, 839,3.856$ b. 10722,142413

For flltala's of the fundameni, ri6g b.

To hesle fitula $8,373 \mathrm{~d} .409 \mathrm{a} .719 \mathrm{E}$.

To mundifie fiftula' $\$, 44 \mathrm{I} c$.

To take away hardncfic in fiftula'g, $4416,506 \mathrm{~d}$

To kill tab), $506 \mathrm{c}$.

For thaking fitơ in a quotidian A gue, fee Dholbing.

For fts of an Ague, 395 a 428 b. 44 I c. Sec Ague.

For fils of a quartan Agtre, fee 2 Dattan.

Againit cold A gue fito, $5+5$ a. I057 d. fee Ilgue.

For kcrnels in the filank gi, fec Xernelg.

To purge tough fflegime by fiegc, 574 c. 653 c. $1009,6.10,92$ birizo a. II 97 b. I 482 d. I 501 f. Sic purgr.

Todraw raw ffleguraticle humors out of the head, $\quad 896 \mathrm{c}$ I501c.

To attenuate or make thin thicke and tough filegme, $\quad 880, \mathrm{c}$ $1001 \mathrm{f}$.

Toraife gently tougl and groffe fflegme fticking in the lungs and chett, 275 b. 66 i a.756 f. 794 i. 807 b. 207 b: It97 c, I2IOl. I3 2 a, c. Sce e beft \& 3 lung 5 .

To k: epe raw fileh) from corruption, 661 \&

Totake a way the fuper fluous ourgrowings of the ffeth, $1007 \mathrm{l}$.

Io confunte awdy pioud and fupcrivous filefls $536 \mathrm{c}, 1341 \mathrm{~h}$ Is $18 \mathrm{i}$.

Todriue away fileag, $485 d .588 d .1247 \mathrm{~d}$.

To driu: aw.ly filtes $480, c, h$.

To fay the filte, 3 71 1. 1081, d:79c $4: 12.787$ : $98+$ c.991 a: IIs a. 1339 c. I 34 T 6.7 45 5.

Goodagainftheblond fillo, 395 a 413 a: 419 b. 421 b: 679 a: 8202.

To top the bloudy filit, $116 \mathrm{~b}, 3 \$ 8 \mathrm{~b}, 39 \mathrm{r} \mathrm{c}, \mathrm{i}_{0}, 36 \mathrm{k}, 400 \mathrm{~b}, 63 \mathrm{~b}$ $661 f_{0}$, I $_{3}$ b. 787 c. 876 a. 88.4 a. 895 a. 935 d. 949 a.993 d. or 2 b. 1043 a. 1057 a. 1069 a. I1 I6b. II2I b. 1139 a II 50 a.1210g.

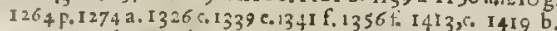
I $432 \mathrm{a}, 1436 \mathrm{c}_{0} 1445 \mathrm{~b}, \mathrm{c}_{0} \mathrm{I}_{452 \mathrm{~b}} \mathrm{I}_{459} \mathrm{~b}, 1466 \mathrm{~b}, 1475$ b. $1494 \mathrm{~b}$ isos a I571 c. 1578 b. 1594 b.

For heparicke fittres, 713 .

Io bring downe or protioke womens fliosoers, $31 \mathrm{~b}, \mathrm{~d}, 44$ a $60 \mathrm{c}$ : - 79 c, 154 c. I 70 r.178 c. 239 i. 2649.269 a.281 c. 317 g: 657 s

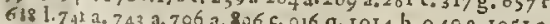
II $62 \mathrm{~b} .1188 \mathrm{a}, 1218 \mathrm{~d} .1246 \mathrm{a} .1294 \mathrm{k} \cdot 1367 \mathrm{~g}, 1378$ a. $1379 \mathrm{~b}$.

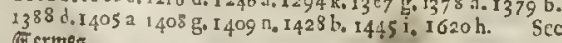

To fay ouermuch flowing of womens fflowors, $36.79 \mathrm{c:35}$ a

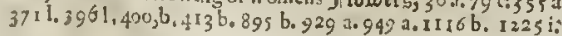

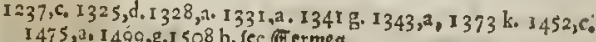
I $475,3,1499,25.1508$ b. Iec terme

Toftay the white fflue in women, fee nohites.

Againft the filut of the belly eanfed by the weakeneffe of the fto: macke, $1007 \mathrm{~g}$. $143^{6} \mathrm{c}$.

To ftop fitures of bloud, 766 d, 1072 a. I 1 I 6, b. $1293, \mathrm{a}, 1326, \mathrm{c}$ I 328 , a. I 34 I, f. I $392, a_{\text {. I }} 43$ 2, a, I $448, k$. I $452, c$. To ftop all fiuxes, $522 \mathrm{c}, 697, \mathrm{~b}$. $1237, \mathrm{~b}$. I $274, \mathrm{a}, 128 \mathrm{I}, 2.147 \mathrm{I}, \mathrm{a}$

To fupply want of $f(0 \mathrm{D}, 360, \mathrm{p}$.

T'okill floct $5,903 . \mathrm{a}$

Againft fractute of the head, 60,

firatares of titie bones, fee 218 2otien 2 to ones.

Good for frantiche perfons, $395, f .441,2.572,1, d, 798, d .1009$, 1055, h. I 388 , d.

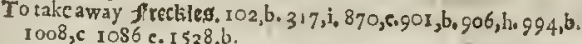

For the ffrenci) difeafe, fee Fregeh fooc

Jirenfie, fee frranticke.

fixter in children, 279,c.

Againft fretting of the guts, fcc do urs.

To dry and healc vp moift and maltgncylcers of the fandanene, To coole the licate of the ffunban arti, $852, b$.

$296, c, 807, k$.

For nfrs of the finnoanent, and the Cordylomat $a, 67,2,457, a .935$

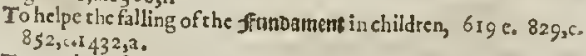

To curchard fwclings of the findanent

1.274, $6.1262, c$.

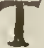

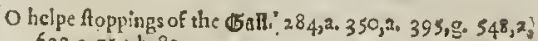
$632, c 714,6.837,5$. For Walls of the fundament, 1333,2

To ftay fpreading of Cbangteng, $\quad 79, \mathrm{~d} .877, \mathrm{l}$, i $218, \mathrm{c}, 121 \mathrm{~g}, \mathrm{ki}$ I 226, h. I 44 I. h. I 475 . d

Togiu a good fnell to $\mathbb{6}$ arments. \& preferue them from moths, I $109, c$ I 535 , $\therefore$ fec Cloatheg \& 9 pothg.

Hurt fill to Generation $681, \mathrm{~g}$.

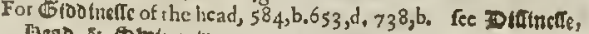
Beab, \& Dobotnutitng.

Todriue away Gruts,

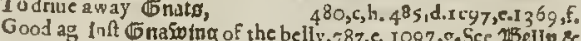
6) sping.

To take a way Ginatoingo of tbe ftomacke proeceding of hor cau. $[\mathrm{es}, 296, \mathrm{~b}$.

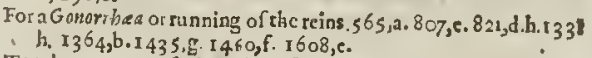

Totake away or cafcthe paine of the $\$ 5$ out, $102, \mathrm{a}, \mathrm{I} 64, \mathrm{~b}, \mathrm{I} 7 \mathrm{I}, \mathrm{h}$

$3 \mathrm{I} 7, \mathrm{f}, 355, \mathrm{~b} .37 \mathrm{I}, \mathrm{k} .41 \mathrm{I}, \mathrm{a}, \mathrm{c}, 458, \mathrm{e} .634, \mathrm{c}, 66 \mathrm{I}, \mathrm{c} .692, \mathrm{i}, 782, \mathrm{a}$

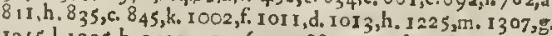

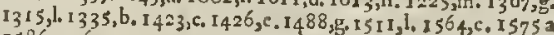
I586, , : 16 1 $19, \mathrm{c}$.

To purge Boutz humers, 164 , a. $497, \mathrm{~b}$,

For the hot $\mathbb{E}$ out, $5 I \mathrm{I}, \mathrm{b}, \mathrm{c}, 524, \mathrm{~b}$.

Anapproucd remedieagain the thout, 877, .

$532,6,6512$

Good againft tbe Goat in the hucklc bones, I yo7, a, fee Scia tita.

To helpe rhe Gout poffelling the feet, $488, \mathrm{~g}$.

$33 I, b l$

Todriue forth Wantell, 3r, a. $239, \mathrm{c} .243,2,33 \mathrm{I}, \mathrm{n} .682, \mathrm{~m} .708 \mathrm{k}$

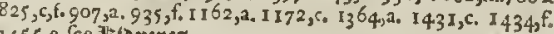
d 455 , c. fce latonepes.

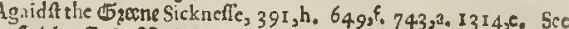
Sicknett: \& 99 atbs.

To mitigate $\mathbb{S}_{\text {ziping }}$ of the belly, $64, \mathrm{a} .80, \mathrm{~b} .174, \mathrm{~d} .373, \mathrm{c} .395$ ก. $485, a \cdot 546, a \cdot 572, b, 634, f, 649, r \cdot 916$, g. $1027, d \cdot 1029, b .1033$

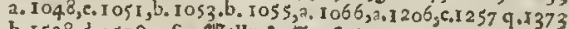

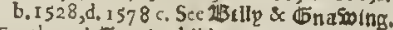

For the red Wut in children, $279 \mathrm{c}$.

Forfwellings in the $5 u m, 509$,

To ftrengthen the 6 tom $\$, 998, x_{0} .1451$, i.1 $521 \mathrm{c}$

Againft vlcers aud foreneffe of the (5ams, 825,a. 2078, e. 1333 at 1 $\$ 44$, , i.

Tolalc away heareis buirsing by t5umponot, $\quad I_{7} I_{2} k, 349,2$. $857, k$. 


\section{The Table of Vertues.}

Good aganft the roughnefe and freting of tbe 15 utg. $395, \mathrm{a}$. 932 , d. 1014, d.1049, c. I I $87,2.1453, k_{0} 1$ s3, c.

Againt the falling forth of the bint, called Saccus senty $y^{r} \mathrm{k} .490^{\circ}$ b.org.d.r 349.6 .

Agunft the vl.cration of the Bntp.522, f: $197, i_{1}, 1609, b$.

\section{H}

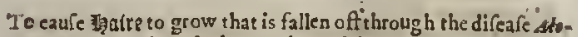
pecia.95,c.97, , .1 180, b. 2271, b.1 $44^{8}$, h.

To hinderthe growrh of foare. I $6,5,1211,50$

$X$ To elenfe the liatre fro an Nits and Liic, 644,2

To caufethe have to come in places that want it, through bur. ning, fealding, or otherw ife 73, a. 17 , , i. I $91, b .239,4.245, k$. 382 b.1081, f. I1 $45, \mathrm{~d}, 1146, \mathrm{e} 1177, \mathrm{~d}$.

Tu caure latire to wax yellow. 480,5776 , e.r $326, \mathrm{~d}$. $1494, \mathrm{e}$.

To caure thatre to full oft' $505, \mathrm{~b}, 858, \mathrm{~d} .876, c_{0}, 900, c_{.} 1089, \mathrm{f}$.

I I 36,44

To makethe 曻aite red, $1396, \mathrm{c}$.

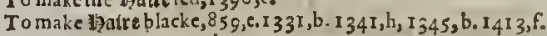
$1426, d, 147.5, c \cdot 149 \mathrm{I}, \mathrm{b}$.

To preferuc the

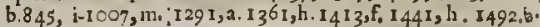
$1494 . \mathrm{c} .1528$, i

To leale the chaps of the bantos comming of cold, $67 . k$.

Tamake the hanos fmooth, ib.

Good to foften the 3atbutef of the fincwes and matrix, $191, d$ fee $\mathbb{N i}_{\mathrm{H}}$ actrt.

To wafte and confume arbmeffe of the Splecne, 64, e.250, e. fee spleste.

To diffolue or wate the broneffe of Tumors, $60, c_{4}$ See $S$ soels Itrgg, and fitumoz.

A remedy againt the poyfon of the fea 1 are. $787, \mathrm{~d} . \times 353 . \mathrm{m}$,

To rakeaway the 13 as of the eyc. $657, \mathrm{~b}, 845, \mathrm{~d}$.

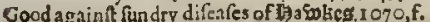

Tohelpe or eake away the theadeacbe $68, b 339.2 .359,1$. sog, $f$.

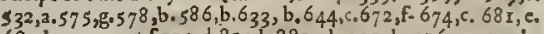

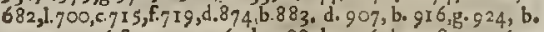

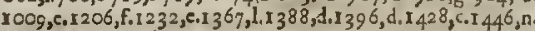
$1484, c_{1} 155 \mathrm{x}, \mathrm{e} .16 \mathrm{rg}, \mathrm{e}$.

Tocafe the intollerable paine of the J $_{\text {cab }}$ preceeding of heatc. $339,2,341, c .821$, d. 853,0

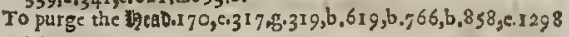
PI405,2.

Againft the wounds of the 1 heab. $356, a$

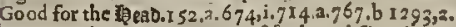

To purge the feab mightsly of foule and lim y humours. 378,2 , $637, c .663 .1 .816, b .845, \mathrm{~h}$.

To healefcabbed

To purge water and flegme out of the 媠eab by the mouth. $759, \mathrm{~d}$ 877 , l. I002.m 1 020,0.1433,g I 542,a.1549,2.

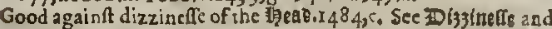
Stwinmittr.

To heale running vleers of the Feab. I $997, \mathrm{i}, \mathrm{I} 206, \mathrm{c}$. I226, $\mathrm{h}$.

1257,6 .
To ftreagthen inearing, 856,2 .

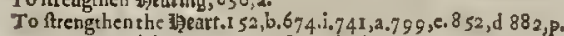
$1001, g .1406, d .1264$, a. I 501 , f, I 536, a, o. $1586, c$

To comfort the Ifeart. $64,9.441,2.590,2.661, \mathrm{e}, 686, \mathrm{~b}, 6,2, \mathrm{a}$ $741, a .797 . a 799, c .852, d .853,1.998, c .1023, d .1040, i_{1} 1043, b$. I $126,211263, \mathrm{~h} .1294, \mathrm{~h} .1465, \mathrm{j} \cdot 1501, \mathrm{f}$.

Good againt rhe trembling aod fhaking of the Heart. $584, \mathrm{~b}$ $741, c, 882,0.1047, i$ i. $264, i, a$. I $343, c$.

Good for the Bortt=6urning. $308,2.339,2876,2.1451$, d.

To take a way ligeate of the face, $, 999, \mathrm{t}$.

Totake avay the Beate of burnings and fealdings. $17 \mathrm{I}, \mathrm{k}$. $5 \mathrm{I} \mathrm{I}, \mathrm{b}$.

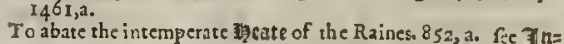
tammation.

To quencli the firie weate of the eies. fee eics and 3 ritammas tion.

To coolc the 1 eate of the intrailes, $588, a, 914, \mathrm{R} \cdot 1325, \mathrm{~g}, 1465,10$ $1501, f_{0.1516,2,}$

To coole the 1 irate of burning vlcers, $1394 . \mathrm{m}$.

To coole the Heate of the Liuer. $72, \mathrm{e}, 398, \mathrm{~b}, 852, \mathrm{a}, \mathrm{I} 325 \mathrm{~g}$

I $326, b$. Sec 1 incer.

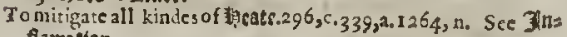
flamatton.

To refrelh or increafe inward and naturall Weatc. 880,c,882, $\mathrm{n}$

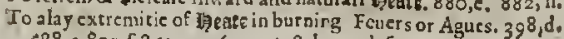

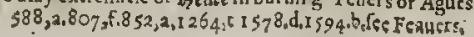

To alay and takeaway the eatc of yrine, $3^{2}, \mathrm{~b}, 1330$,

Good for the Meatiqae Feuer which is a Confunpticn, 219 ,

A remedy againft the veromous qualitics of igcmloctaes: $708, f$ Topenthe

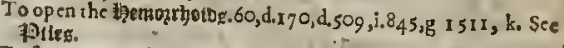

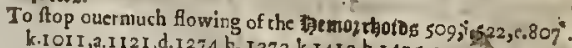
To cure the I 2 I, d, I 274 b. I 373 , 6,1413 b.1475,g.

To cure the hemo? thoidis, $363, r \cdot 805, a_{0} 1092 \mathrm{~g}$.

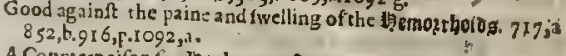

A Counterpoifon for henbane $708, \mathrm{~g}$

Good to tatten beng, 83,2

To caufe hents to lay cgges plentifully.709, e, $1253, \mathrm{~h}$

To cure

Good againft che lictiet. $395,4.572,2.68 \mathrm{I}, \mathrm{a} .849, \mathrm{~b}, 805,70 \mathrm{f}$

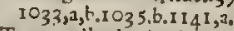

Tucure all aches in the ipg.'Sce onctatica

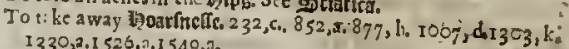
$1330,2.1526 .3 .1549,1$,

For ilinging of hopstse. 1257,0

To refrefha wearied $1902 f e$, and make him traucll the petter.

Againft ache and paine of the pucble=bene. $395,2.645,3.896, c$ $1257, d_{0}$." Ste sclatice.

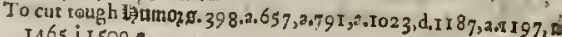
I465, i. I509.e

To putg: by fiege and vrine eholericke Inumo: $509,9,880, \mathrm{c}$

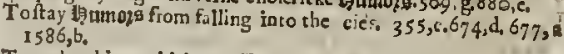

To make thinne, thicke grofe and fimy

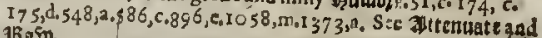

To digeft filt and pituitous thumozs. I089, g: I $303, \mathrm{I}$.

To concot and bring vp raw thwots that thick in the Chef

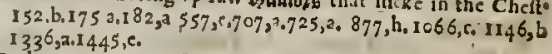

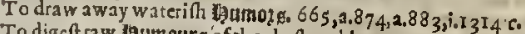
To digett raw lowmours of the eheft and lungs, $152,6,170,5.708,4$

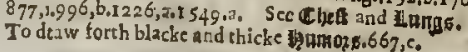

Good agtint a he yellow Taturbice $34,3,97,2,116$, d.1 $54,6,174$ $254, b .284, a .291, a .327, r .342, a, 350, a, 391,0,1,34, r_{1} 174$, $429, b .485,2.497 \cdot b .527 \cdot 2, d .534,25,8,0,556, b .578$, c. 421 ,

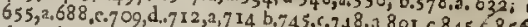

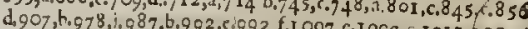

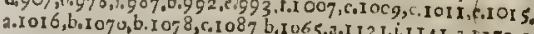
$1=22, r_{0} 1264,101299, c_{0} 1326,0,1366, c_{0} 1379$, $f_{1} 1$ I $41,7,1170 . c_{0}$

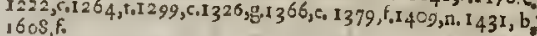

To curcthe blacke Jaundec. 13 i 3 \%

Good againft the old and long lasting fwellings of the Jafwes $1092, ?$. To affwage or heale the difeale called $f_{b}$ ris Sacer, or Wilde-firca
$805 . a .823, b$.

Againft vane Fi thagtrations. $343, \mathrm{~d}$

Good to limne flmageric wirb. 154 .

To take away the fwelling and paine ot hot 3 inpolthumes. $352 . \mathrm{g}$ $\sigma_{1} 5, a, 634, a .7$ I $8, b$.

To bring hard Jinp oftumes to maturarion or ripeneffe, $132, \mathrm{e}$ $557,0.935$. . Sce zipoftenieg.

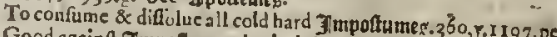
Good againft Impothumes in the ioints of the fingers, y. I $197, \mathrm{p}$ fislon.

To breake 3 mpottumes, 67, g. $68,3.87, \mathrm{c}, \mathrm{c}$.

To ripen and breake venerous 3 mpoftanic in the fank, $1,1, b$. $480, a .1351, b .2511$, d. fee 215 uboer.

To curcthe ditcafc called insperigo, ror $1, f$

Againtt the Tinfection of, the plague or peftilence, $495,6,597$, a

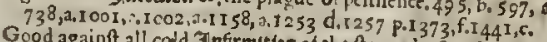

Good againft all cold Infirmitteg of the fom 2 cke, 877, h.I 408,8

Good for the 3 n firmitieg of the mother $757.2 .1209, \mathrm{~d} 1408$, ic

Againt ithe Zintirmtrieg of the hear $705,2.738 \mathrm{~b}$. Sec Heart. -

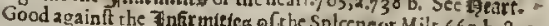

1 I $41,3 \cdot 1408$, g. I 608 , f. Sce spleme.

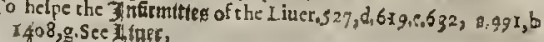

$\mathrm{B} b \mathrm{bbb} \mathrm{bb}$

rood 


\section{The Table of Vertues.}

Good for Finfirantetes of the kidries. $\$ 27, \mathrm{~d}, 619, \mathrm{c} .80 \mathrm{r}, \mathrm{c.} 859, \mathrm{~g}$.

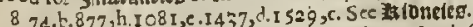

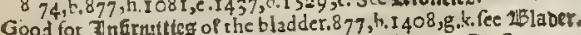

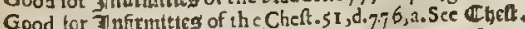

Good for 3 firtitteg of the Fundament, $68 \mathrm{I}$, d. See 3 fundoment. Good for 3 infinttteg of the Fundament, 81 , d. Sec 3 trivame Good againte neto ex.

Againf Tutrutter in the care?. 154 f

Agnot parts a dioyning. $876,3.1274$, 3. I 47 8, 2. . 508, b. Tec almono\%.

To help Fub ammattong o: the dogs.95, c.

Againf 3 infammattong newjy Gegur, 276, b. I394, m. I413, de $1460, g$. I $508, b$.

A remcdy againft the Jnfammation of rhe ftones. $95, \mathrm{c.355}$, $1211 \mathrm{c}$

Todifoluc 3 nfiammattong of the breaft, lunge, and rough arte. ric. $395, f .853,1.855, b .9 \pm 1, c, 1303, k$

To helpe or eale Inflammattums of the cics. $99, \mathrm{~b} .284, \mathrm{f}, 4 \mathrm{II}, \mathrm{b}$

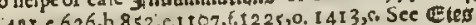

Good ig inft all inward 3 inflamusations. $306,0.637, \mathrm{~g} .92 \mathrm{I}, \mathrm{d}$ $1263,4,1420,3,1533$ b.

Agsint the Inflaminatlonet of the raires. $64,1.395, f .821$, d.

I $533, \mathrm{~b}, 1608, \mathrm{c}$. d. $2431,6 . \operatorname{Sec}$ Ltuct.

Good ror Fuflatumations of the fundamcnt. $490, b .807, k .1225,0$ $1257, \mathrm{r} \cdot 1349, \mathrm{~h}$.

To take away ot cure all Znfiammations. $37, c .66, b .250, c .5$ tó, $301, c .308 \mathrm{~g} .317, \mathrm{~d} .347,2.352, \mathrm{~g} .4+7,0.5$ I I $, 2.529, \mathrm{a} .719, \mathrm{a} .633, b$

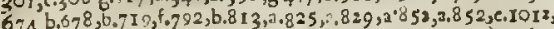

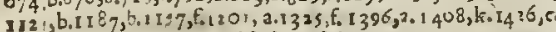
$1459,5.1400, c_{0} 1478, \mathrm{a} \cdot 1488$, h. I 518,1

$1459, r 014$ bers ow of 3 oint. $1,6, \mathrm{~d} .782, \mathrm{a} .794, \mathrm{~h} .845, \mathrm{k}, 876, \mathrm{e}$

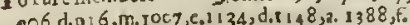

To eure the flaking of the Jothtg deslining to the palfie: See

Shabings. $1232, c, 1257, b_{0}: 233,5,1612, c$,

to frengthen the 3 oints 532,2

foaffwage or diffolue fwelliugs in the fotntg $770,6,635,6,1257, b$

Good for weeping wounds of the 3 ointo, $634, b$.

to helpe the long continuall paine of the 3 oint $\%, 861$, 2 .

Tdcurc the Jietitatter Sec soliatica.

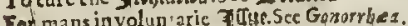

To tlay or Atop all Jutaeg of bloud. $355,6.421, b, 565, ? 631, b, 935$;

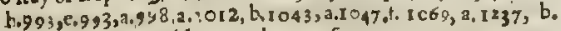

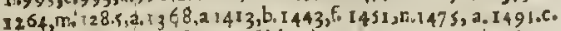
1264,968, b. See filureg of bloud.

Tobelad voon Jarag. $85, \mathrm{f}$.

To helpe the 3 schtng in the cornezs of; the eies, $509, f$

To take away the Fitebung of the eies, r043.d. $856, c .1527, b$.

To cure the 3teh ot the bod $.3,5, h_{0} 497,6.794,1.823,2.855, b$.

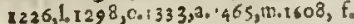

K

To take awsy the infinmation of the 3 etmets vader the cares, iawes, necke, arme.holesand finkes, $70+.2+121$ I, m. I $193, e$. $1499, \mathrm{C}$.

Toconfume or wafte away hard fwellings of the wernelo. 518 , a,

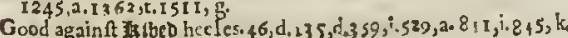
1225, F. . 226, l.1 $584, b$.

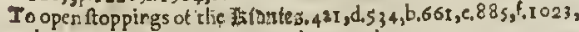
d. IO2r, 3. I045, a. I , 53,?.11 I 2, b، I 314, b. I 43 I,

To clenfe the Intonies. $239, \dot{e} .574, \mathrm{~b} .623,3.626, \mathrm{~d}$. 842,3 , IC3 3 ,

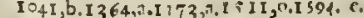

Good for the vlers ont

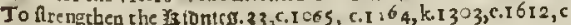

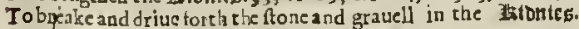
I 437, d. I 444, h. I s I I n. See Ditauel ind Sorone.

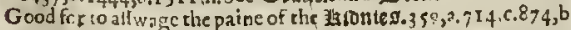

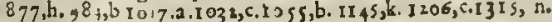
I $437, \mathrm{~d} \cdot 1474, \mathrm{~b}$ I $502, \mathrm{a}, 15 \cdot 7, \mathrm{~b}$.

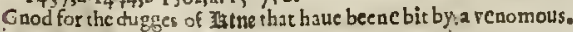
werme, or are chapt 78, ,

To foter the Hingsitath, $51 . g 5 c, e$.

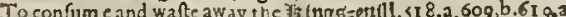

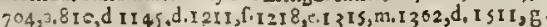
Is 26 , $a$. I ́́i

To difiolue and cure the isings eutl. $366,6,692, \mathrm{i}, 717,7.78$, h

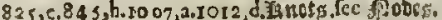

Ood for llamenefte i 80.2

Good againft the Ilagkse.36,2.395,a.6, 31, b.

Good fot thofe that ate roubled with a bot llaoke. $3^{6}, a^{2}$ 3 I I, $c, 8 \geq 0, a_{0}$ I $2^{26, c}$.

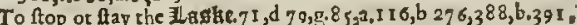
c.3,6,k.398,f,400,b.522, h. 541 , a. a 7 , b. 678 , b. 774, b. $783, d$ $876, a .881,5.88,1.891,2.935$, h. 993 , d.993,2.1012, b. I027, d.

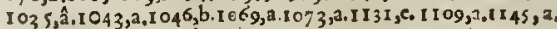

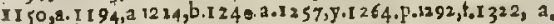

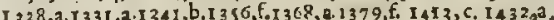

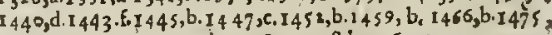
a 1491, c. $1494, c$. I 501 , b. I 5 c 8 , a. I $538, b$. I s 64 . a.

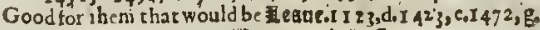

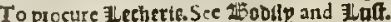

To take a way fwelling of the liletgr. 69 , a. I s 3 I,d.

Good againft the manginefic of the $\mathbb{L l}_{\mathrm{rgg}} 870, \mathrm{k}_{0} \mathrm{~T}_{4} 6 \mathrm{I}, \mathrm{b}$.

To helpe the old aehes and paine in the \#legs. $28 \mathrm{I}, \mathrm{b}$.

To eurc old and hithic v lecrșinthe 五egges. $700, \mathrm{~d}, 870, \mathrm{k}$

Tokill ll eopard $3.903,2$,

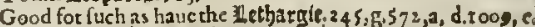
I 0 55, h. I I 80, c. I $388, \mathrm{~d}$

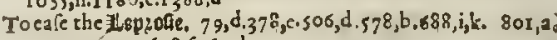
$876, c, 1545, a \cdot 1608, f_{0} 1619, b$.

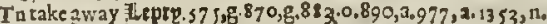
$1511, h_{\text {. }}$

Good againf Jenttld.248,e. $366,5 . i 608.4$

T'o take away Henttls in the face. I3 2, h. 360, t.g $_{2}$ I2, ith.

Tokill 3ice $495 . b 647, a .958, d, 1379, b .14,2, b .1549, b$.

Todriue Elice out ne the beard, head, and all other parts of the bo dy. $495, b, c$

Toheale \#- ichens (that is tecters or nirgwormes) in elildren or young infants, $1499, e$.

To prefrue and prolong the Ziffe of man, $882, \pi$.

For chaps of the Hing, fee efhap.

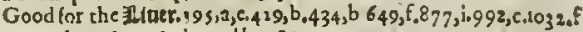
$1041, b .1\left[26,2.1162, b_{1} 1194^{\prime} b, 1485, a, 13 c 3 . c\right.$.

To coole the hor burning or inflammation of the Illiter. 284 , a.

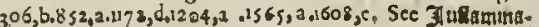
tion.

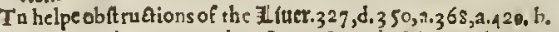
$434,5.442$ b. $527, a$ a' $534, b .548, a .578, a, d, 586, c 632, b, c .845, b$, $856, d .984, b .996, b, 1016, b .1095, a .1097, c .1167, b .1170, c_{0} 1232, c_{0}$ $1373, \mathrm{a} \cdot 1437, \mathrm{~d} .1447, \mathrm{~b}, 1472,5.1473, \mathrm{~b}, 1508, \mathrm{~g} \cdot 1525, \mathrm{~d} \cdot 1534, \mathrm{a}, 1612, \mathrm{~d}$ ree Estopptng

To mollifie and rake a way the hard fwellings of the 3 Liner. $242, \mathrm{C}$

Toftrengrhen the HLitut. $395, a .7$ I 3,a $1089, c_{1} 197, c, 1264, k_{0} 1501, f_{0}$

1 is $25, e, 1534,2.1536,1,1538 . b, 16,9, b, 1623, b$.

A good medicine sgainft Iloathing of mcat, $1097, b .1393,61408, \rho$ A ILonch for an old eouth \& itufin's of the Iur:ge, $667, \mathrm{c}$.

To ftay the Lunging of women with childe, 1451, e. fee tetomen.

Lot tong for cankers \& fores in childrens mouths,1:7 4 , i. fee swater

A medicine agairift the $\mathbf{H}$ ofofte eui'.44t,i.e.

To diflolue knotic and hard Itumpg in any part of the body. 96,6 . $702, b .863$, b.894,b.1012,b.10,8.h.

To curcthe Hanatictie perfon $958, b$

To equict the Hunaticke. $798, \mathrm{~d}$.

Good for the Hungs. $529, b .776,1.779, b .807,6.877, h .881$, d. 892

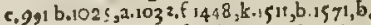

Toopen otrenoue ob trudions ot ftoppings of the lang 5.360 , h $586, c .653, c .849,1.916, g, 993, f, 1024, c .1257, q .1302,1.1428, b$ Againft deftillations vpon the Iungs $370_{2} \mathrm{~h}$

Toclenfe the linng $0.3^{2}, \mathrm{a} .1 \mathrm{7} 75, \mathrm{a} .574, \mathrm{~b} .6,2, \mathrm{~b}, 694$ a.807, c.

For the con [ump tion of the llange. I $54, c .629$. b 940, c, 1040,g I 148, a. I $303, k .1356$.c. I 437 , b. I 557, b.

To help the 1 ungs inflamed. $580, \mathrm{~b} .629, \mathrm{~b} .708, \mathrm{r} .852, \hat{2}$. $157 \mathrm{1}, \mathrm{b}$ Good againh the cough of the Inngs. $444,5.694, c$.

Gnod for the Hungs opprefled with taw cold lumors, i $52,6.667$

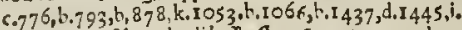

To proctuc or fir p bodily 1 aft. $108, c$, I $54, e .207, b, 248,6,25 \mathrm{I}, \mathrm{d}$ $707, c .752,2.770, c, 8$ I I , e.880, f.901, a. I023, e, 1026,a. 1029, b.

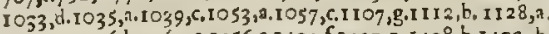
I I 54, c. I I 56, b. I I $63, c$, I $356, c .1434, f . I_{437}, c .143^{8}, b .1472,1$, See 13 oolle.

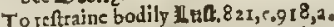

To eafe all Zurationg.37, b. $1620, \mathrm{~b}$.

M. A 


\section{The Table of Vertues:}

\section{M}

A Mcdicine againf 99 abmelle, 395,.572,

To take away Ninnente procciding of melancholy and the fpleene, $578,6.977,3$.

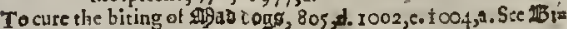
ttitg, 9 ad, nnd $\$ \mathrm{Dog}$.

To kill of aggots, $1369 . \mathrm{g}$

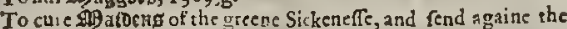

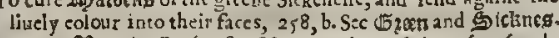
To cure Alfanginefe, $67, f .388, r_{0} 39 \mathrm{r}, \mathrm{h}, 506, \mathrm{~d} .536, \mathrm{c}, 6 \mathrm{I} s, \mathrm{~b}$ $794,1.1007, \div$. $444, \mathrm{~d} \cdot 1482, \mathrm{r}$.

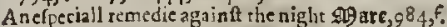

I'o tale a way blacke aud blew 90 ar bq proceeding of beating and bruifes, $373,6.870,-872, c .1035,1 \mathrm{ce}, 10,8, \mathrm{i}, \mathrm{I} 2 \mathrm{II}, \mathrm{m} .1218, \mathrm{c}$.

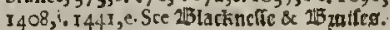

To take away sparters rentainirg afier fmall pox and mentels, 245, i. 1450, h. Is Ir, h,

Good for the 97 atrte, and to eafe the paines therc of, $395, a \cdot 42 \mathrm{r}$; 5. $485, r .577,6,653,718,4,726, d \cdot 766, a, 7^{8} 72,909, b \cdot 1004$, c. 1177 , $1291, \div 1294, \%$

To helpethe coldaeife and ftopping of the $\$$ inatrite, $3 \mathrm{I}, \mathrm{d} .377, \mathrm{~b}$.

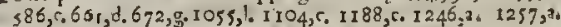
$1373, \mathrm{~b}, 1549,70$

To mollife and open the MPatrhi, I9, s, $586, c, 649,3.672$, ga II 97 , h. I 206, in. I $29 \mathrm{~g}$, d I 1426 , c.

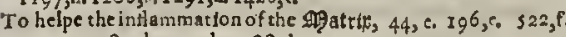
$557, \mathrm{n}_{1} 1081, \mathrm{~d}$, II $97, \mathrm{~h}, \mathrm{I} 388, \mathrm{~d}$.

To cure the fuffocation a nd fitrangling of the Intatrif, $\cos \mathrm{I}, 2$. I OSs, m. I I O4, c,See $\$$ DPother.

To bring the $\mathrm{MP}$ atritio ioto her right place againe, $1287, \mathrm{~b}$, $1341, g^{\circ}$

Toclenfe the sApatrix, $574, \mathrm{~b} .715,7$

Good for impoltumes of the $\mathbf{9 9}$ dititi, $8,8, \mathrm{~b}$

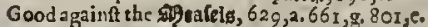

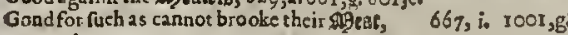
$1219, \mathrm{i}$.

To eafe the paine of the megrim, $359,2.360, r .584, a, 637, e .78$, 883 , d. 1073, , $1408,1,1586, b$.

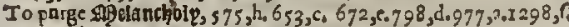
$1343, d$.

Good for a Afratachoip perion, $374, \mathrm{~d} .674,6.692,2.993, \mathrm{~g}$ $1343, \mathrm{e}$.

The Af ciltote plainet, 1206, b.

Toenre Meticerides, $\mathrm{x} 206, \mathrm{c}$

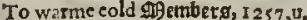

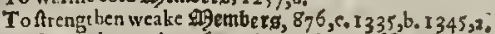

To ftrengthen and preferue the weakened sipemogle, $_{7} 66, \mathrm{~b}$ $1172, \mathrm{~b}$.

To comfort $919 \mathrm{mozp}, 41$ I , b, 663,c. $1294, \mathrm{c}$.

To ftop the ouernuch flowing of the itgenteg, Sae frioures and (Germes, 5 I, h.

To prouoke womens SPenfer, S:e fflosoerg and tetermes, SI, 64, b. ISII, त. I 533, 6.

To make one $99 \mathrm{etrp}, 152, \mathrm{a} .674, \mathrm{i}, 686, \mathrm{~b} .705, \mathrm{~d} .738, \mathrm{c} .797$, a $880, f_{0} 1047, i_{i} 1126,2_{0} 1343, s_{1}$

To keepe from 9 ertrgyalls, $\pi 388$, $\mathrm{g}$.

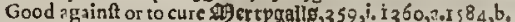

'To kill fig ice and Rats, 44T, e.

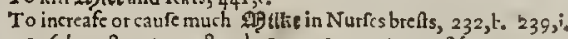
$296,6.308,2.524, \pi, 803$, b. 1033, a. I035, ?. I086, 2. I $242, ?$ $1307, \mathrm{~b} .1356, \mathrm{c}$.

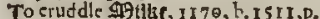

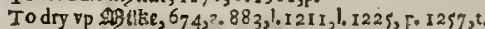

To hinder af tite from waxing foure and crud ling in the fomack, $68 \mathrm{i}, \mathrm{f}_{\mathrm{I}}$ I III,

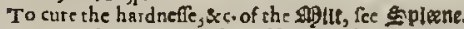

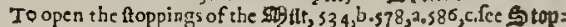
ping, Dbftr nation, ind Epieste.

Todraw mush moiture from the head, and elenie the braine, fee

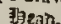

To dry vp ousermuch motatate of the ftomacke. $1242, \mathrm{a}, \mathrm{i} 393, \mathrm{c}$ $\mathrm{r} 4 \mathrm{r} 3, \mathrm{C}$

To bring downe the

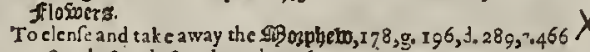
a. $821, \mathrm{~b} .833$, ,. $870,1.90$, h. I I 61 , a.

To takc a way the whice c. $1408, \mathrm{~d}$.

Tu take a way the blarke fig opphetw,519,?.833,b,979,e.
Againt the rifing and fuffocation of the $\$$ porther, $245, f_{0} 328$,

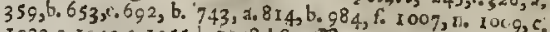

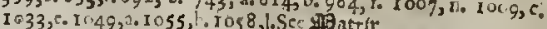

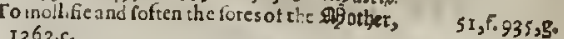

To helpe the falling downe of the $\$$ etber, $1432, \mathrm{a}$

To cie nic the Motber, $332, b .353, \mathrm{~m}$.

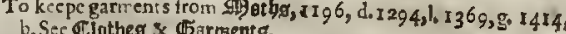

$T$ okill Mothes $13^{\varepsilon} g, \dot{s}$.

Againft the bicing of the 9 Q

To dry vp and hcalc the virulent vlcets of the 9190 oth, $\sigma_{32}, \mathrm{~d}_{10}$, 1. 1202,6 .

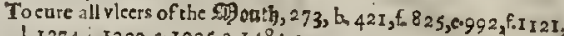
1.1274, $.1393,0.1395, x_{0} 1484$,

Agringt infammations of the $\$ 9$ outb, 400, r. $456, b .825$, c. 853 $m .876,2.998, a, 1274,2 \cdot 1331, b .1436, \cdot 2+41, k$

Anexcellent 9hanaricatine for old vieers and malignant Sores; 441, , I I I 5 , d, C e Micets.

Againf the Sigurtatne and other in firsities of Cattell, See Cats teth.

To helpe all \$purs, $1086, d$

To helpe the suffocatio by 1257,0 ,

\section{$N$}

TO Arengthen feature, 926 ,a.

To helpe the finding out of the paratl. I055, d:

"Ta take a way loofe fatiles on the fing ess or tocs, $877, \mathrm{l}$ To caufe ill faties to fall off, $557, \mathrm{~d}, 8 \mathrm{I} 6, \mathrm{~b}, 88_{3}, \mathrm{n}$. $963, \mathrm{a} \mathrm{I}_{3}$, d. $13{ }_{2}$,

"To heale the galled faecks of cattell, II $30, \mathrm{~b}$

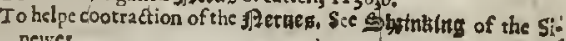
newe:.

Good for Afight sobeales, I $393, \mathrm{c}$

For Ringing of Petties, $_{708}$, h.

To caule foefing, fee osmeefing.

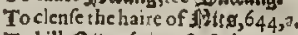

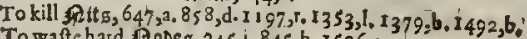

Towalte hard $\mathrm{f}$ ? 0 obe $\$, 245, \mathrm{i} .845, \mathrm{~h}, 1526,3$

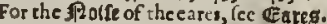

For fanching bleeding at the ßPofe, fee 1 llibleding

Tocaufs the figre to blecd, 1073, r,

Totake a way the difeafe of the Wrofe which is ealled Pulypus, fee Polypus.

To cure red fieric $\Re 0$ \& $2,912, f$ 'To cure the old fores and ricers which breed in the Hofthatis:

Againt f-ammetfe of the fect, hauds, and finewes, $\quad 892, \mathrm{Ca}$ 1148,5

How to enereafe aod ingender milke io \$farfise brefts,378,e, 560 $2, \mathrm{I}_{0} \mathrm{z}_{2}, \mathrm{~b}$

o

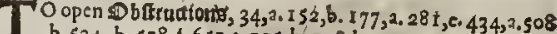
b. 534, b. $578,4.657$, a. 705, b. $778, b .925,2$. 1015,2010293 a. - ros 3, d. I I 45 , a. fee stopping

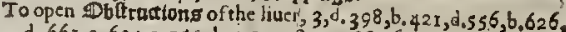
d. $661, c .694,2.714, b .791, a, 837, c .885,6,896,2.911, .993$ f. IOOI, e. IOI S, a, I023, d, I024, b, I08, b, II I I, $123^{6, d}$. 264, r. See Zliner and Stoppings.

Good againt Dbtrtuateng or ftoppings of the fpleene, $556, \mathrm{~b}$

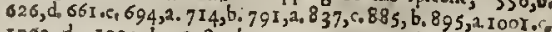

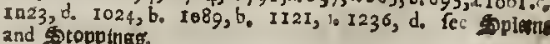

"Tn eure ar wafte 0 :demssa, viz; cold fwellings, $776, \mathrm{~b} .787, \mathrm{~g} .883$ 1. I 336, r. i $529, d, 16$ Ig,e.

A preclous $D$ ite to curedeepe wounds, thofe made through the body, or with any venomous weapons, nod allo prisks finewes; $54 \mathrm{I}, \mathrm{b}$.

An exeelient $D$ intment for members out of ioint, gout,and kibed hecles, 665 , ?.

$X$ Againf the danger proceeding of Opiyet, $567, a_{0} 787, \mathrm{~d}, 880$, had

To helpe IDptlattong or foppings of the liver, 393 , Shec Sothro atons.

Againf Dppreftion of the Cheft with raw aad cold humors, Sec

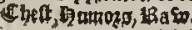
Bbbbbbi 2

tes 


\section{The Table of Vertues.}

To open Ditheer of fiflula's and iffues, fee filltalaes.

To curc the difeafe Ofeedo, fee Dearay.

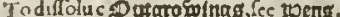

A gainf the 0 zenta, $76,2,1625,3$.

\section{p}

$\mathrm{T}^{\circ}$

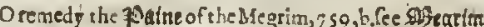

To affivage 19 atne. $71, \mathrm{e}, 310, \mathrm{~d}, 352, \mathrm{i} .355 \cdot 2 \cdot 370, \mathrm{~d}, 59, \mathrm{c}$ 557, h. 756, h. 872, e. 935 , a. 1033, d. I19s, b. $1292, \mathrm{e}$ $1394,1.1413, \mathrm{~d}, 1445, \mathrm{f}$.

For the \$atne of the gout, 359, b. $1195, b$. Fe Woth

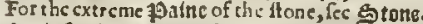

A gaint all 7 atneg of the ioynts, $637, a .874, b$

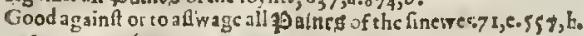
$6 \xi 1, c_{1} 0\{3, f$.

Againft Potre of the bladder, ioyned wheh heate and tharpncs of vifie, 201,1 .

Tohslpe the 10aines in the fidc, $47,2.64, a .661, a .694, a, 625.2$. $756,5.766, c, 849, b .870, i .935, b, 1017, a, 1058, h=1066, c .1159$ c. $1188,2.1257,9$

For Patnes of the Fundament, 421,8

For toafues prozeding of cold caufks, $245, \mathrm{~h}$

For Datutitin womens faec, $80 \mathrm{t}, \mathrm{d}$.

For forneing of the heart, fee heart.

To kecpe downe maidens $p$ aps, 949 ,

To cureforc 70 apg, $363, i_{0}, 80, b^{\circ}$.

To takc away hardne lle of the $¥$ Daps, $\{27,6$

To eure vlcers of the 30apd, fec Doge.

Goodfor feeblc toarts, $1106, k$

For the cholchicke 10alfion, fec fellont.

For Foation of the heart, $798, \mathrm{f}: 908, \mathrm{c}$

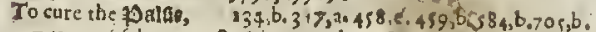
$759, a \cdot 766, b .792,2.896, \div$. 1055, b.h.158,g. 1180,2 . I $529, c_{0}$ 1619,6

To ftay or take a way che 79 earle of the eyc, $694,6,345, \mathrm{dat} 200, \mathrm{~d}$,

For 95 anane pcrfons, $6 \times 3, d .799, c^{\circ}$

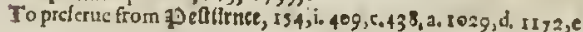
1253,5

To cxpel tb e poyfon of tbe 1960 thence, and caufe it to break fort in blifters ourwardly, $19, \mathrm{~h}$.

To bricake peltilent fores, $726,6,100 \%, k$. S:e 25otobs and tat boncleg.

To cure JPeftint earbuncles, $1002, b$.

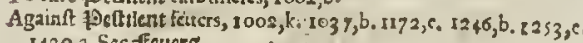
$1420, a$. Sce ffeucrs.

Good againft Pollcgmond, $829, b$, s s2, d

To diffolue 10 hleginong of thebreft, lunge, and sough Arterie, $1431, C$.

For 19 ingenfie, fee frantickes . . .

To confunc 1 'bymata, $12: 8, c_{0} 1336, c_{0}, 1508, h$.

Vetrifh or 9 9idures, $1374,1$.

Tocur: the 19lic d, $350, x .7 \pm 7, \mathrm{c} .774, \mathrm{~d} .817,4.87,6,6.1423, \mathrm{~d} . \mathrm{Sec}$ Hessorrboids.

To npen $\neq$ blieg of the fundament, $508, \mathrm{~b}$,

For piliting off of the haire, fee baite.

To takcaway potmpicg of the face, $913,59994, \mathrm{e}, 1315, \mathrm{f} 1445, \mathrm{~h}$,

For the 19 in in the eye, $856, f .5: c$ toeb.

Toopen the $19 / \mathrm{peg}, 377,3,79^{2}, 1$.

Remedy för thefe thint wotfe tu beo, 79,8

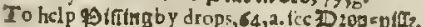

Good againft pitting bloud, $44, d .276, c .425, b .565,7_{1} .2$

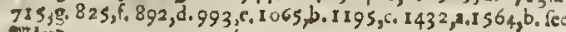
Triblob.

To caufe ons to piffr freely, $\quad$ I $4, c, 1045,2$. See prousk ธิtrine.

Good againft the plague, $8 \pm 4, b . \varepsilon_{3}$, , $.969, c .993, b$ 1001, 2 $1158, a$,

To draw renoms of the 10 lague from the heat and other ritall parts, $958,2,963, \mathrm{c}$.

Good for the 95 itentitie, $395, f, 653,6.708, e, 766, g .779,2.853,1$ ano 7 , d. Ios6, e. I $188, c_{1} 1303, \mathrm{~K}_{0} \mathrm{I}_{445}, \mathrm{c} .1623 \mathrm{z}^{\circ}$

Againft the fmall pocks. 629 2.66 I,g. $801, \mathrm{c} .1218, \mathrm{c}$

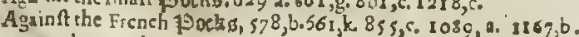
$1172 \mathrm{k}, 150 \mathrm{r}, \mathrm{h}$.

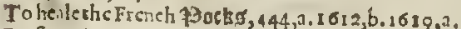

Preferuatues againt 7 popton, $688, c, 1$ ro $4, d$.

Good againt 7 Dogrfon, 49, b. 64, c. $254,5.359, k .273, c_{0} 407,3$

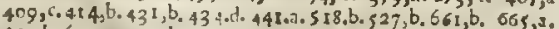
$667, h .694, c \cdot 712$, d. $715, d .726, e, 741,2,833$, i. $845, b .86 t, b$. $8,8,3,9,9,0.1001,2,1004, \cdots, 1014, b, 10029, d$ IIro, a. $1172, d$.

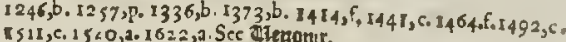

Againft cold joovfong, I77, a. $880, \mathrm{~h}, 882,0,1002,21,8366, f_{0}$ 1526,3.

Agninft the difeafe Polypusin the nofe. $13^{6} g: c$.

$400,2,833, c_{0} 1007,1$

A Gugular Popkleon, 512,1

To opea the Pooreg, 756 ,

Tohelpe the poif, 1086 , d.

A. PleicrattuE againt a cortupted or peftilent aire;

A fowernatiue againft the iafection of the Plingue, $661, \mathrm{~g}, 833$, 1078,20

Ag inft all renom and poyfon, $i$, $11, c, 1622, a$,

To pielerae grapes a whole yeaic, $877, \mathrm{~d}$.

Todraw out 39 itckles, fee teponts and Golinters.

To helpc the Ptiácise, $132 . \mathrm{g}$

Good againft the Dtifichs, $694,2,940, c_{1} 1040,8.1148, b, I_{356,}$ $1408, \mathrm{c}$

A Fultis for Twellings, $557.0 .62 \mathrm{t}, \mathrm{C}$

Tocurc Findtures made with Tharpe weapons, Bor, 8 .

Tofat ten forlilen, and eaufe them to lay great fore ot cgocs. Se

To curc the imples of the ficc, ree 7 imples.

To 1 ourge choler, $548, \mathrm{~b}, 564, \mathrm{~b} .598 .2 .922, \mathrm{a}, 1264, \mathrm{t} .1268$, b3 $1297, a$. $1364,2.1431, b$ I sor, d.

Tu joutge Choler and w. terifh humours mightily, $\rho x, b .344, z$ $307, a .783 .839, a .868, a, 900, b .1403, x .1404, a$.

To 19arge waterilh humors, s36, $3.839,9.872,2.874, \mathrm{a}, 9132$

1447 .

To pargr by fiege and virie, $60, \mathrm{i}, 350, \mathrm{~h}, 578, \mathrm{~b}, 870,2.883, \mathrm{i}$

To porge cholcr and tough phlegmeby ficge, $60, b, 41 \mathrm{r}, \mathrm{b}, 47 \mathrm{t}$, $494, \dot{a} \cdot 497,2.542,3.5,4, a, 580, c .845, a, 88$ s,b. 890,2 . 916,1

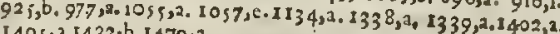
$140,3.1423,6.1470,2$

To florgethe belly; $382, a, 336,2,508, a, 560,7.578,58$,

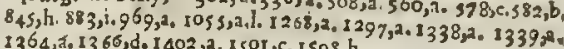
1364 ,

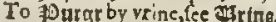

To Forge grofle hum or $3,414,4.896, c_{4}, 913,2,922,2,1367$,

To 70 rge tough phlegmaticke and rsw waterilh humors, 134 $164,2,310,6,332, m, 415,2 i, 582,2,666,2,870, b, 1180, h, I 501,4$
1397,2 .

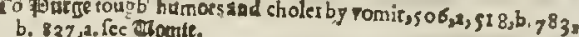

To parge the head of raw phlegmaticke humon, $39,2$.

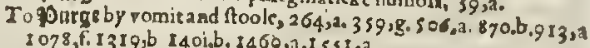

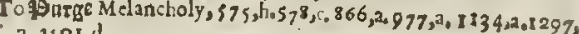
Fontgattong in the dropfic, $11, b .344,90,507,3,536,2,1402, c, 1403$ a
to $1404, d .1405, b$. $1423, f$.

For 3 ontanetie, 653,6

For the parples, $661.9,1199.7$.

Tudye jourple, fee $\mathbb{C}$ oloar

To take a way 30 albeg, $1107, c, 2225, \mathrm{pi}$

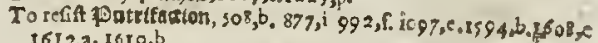
$1612, \mathrm{a} .1610, \mathrm{~b}$

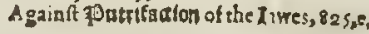

\section{Q}

A

Gainft do wartan Agues, $221,2242,6,89^{\circ} 6,3.99 i, c, 1089,6$ $1172, \mathrm{e} .1188 \mathrm{f}$.

To eurc 12 nattans, $542, f .575,8,718,6,838,6,977,1002, \mathrm{k}$ $1007, h, \log _{3}, \mathrm{~b}$.

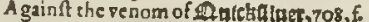

To cure 2 uotiblan Agues. $\{82, \mathrm{~d}$. 1 5 5,4 .

\section{$\mathrm{R}$}

Ood for the 13atnos, 844,7 . fee 3 toneprs

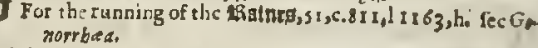

For obstruetions of the 13atnes, 578,3

To purgcor cleare the thaines, $2 s 4$, d.

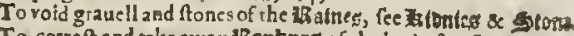

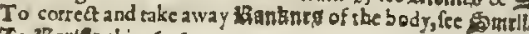

To 3 Barlie skin, $\sigma s \sigma, \sigma$. 


\section{The Table of Vertues.}

Tokill thats, 441, c.

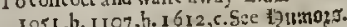

Todigeft and bing vp 1 Raswo humors lying in the cheft, .1145,

I $45, k$.

For thicandic of the face, $360, t_{0} 715, t_{0} .912, f_{0}, 999, f_{0} 1008, c$

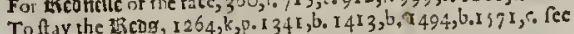
filowers \&

To procure tirf, fee silap.

Meftopattac to the brdy, i356,b. I 437, b.

Againft 1hbeumes, $2 \$ 4,1.359,1.370, \mathrm{r} .42 \mathrm{r}, 2.792, \mathrm{x} .813, \mathrm{~b}, 893$,

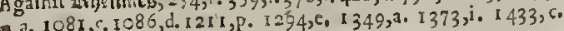
- $1499, \mathrm{c}$.

To puroc the

Todry sp IRlicutite, 101 $3, \mathrm{i} 108 \mathrm{r}, \mathrm{C}, 1294, \mathrm{c}$

For tie listers of the fundament, 60, d. fee fino antent.

For Ritfis in the hands and feet, 74, b.101 $1, f$

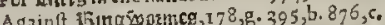

A

Againt liottentetic, 421, a. 49, . Totakcaway lioughn

$634, \mathrm{~d} .914, \mathrm{a} .1453,3^{\circ}$. For thoughlielle of the throat and bre A. $1356,1.1500, \mathrm{~b} .1502,1.1518$, 5 .

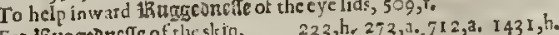
Fot things

$15 \mathrm{t}, \mathrm{h}$.

For thinuning of the eyes, fee Eres.

For thuming of the cares, fec Cartes.

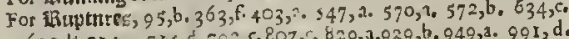
$692,10714, .7 \times 9$, d. $792,6.807,509,3.939, b, 949,3.991$,

I OI $1, e_{0}, 1055$, , I I $24, h_{0}$ II $45,1.119,5,5.1369, r_{0} 1482,5$

\section{$S$}

TT driue 2 way sabnetle, 66, b. 69, a. $798, c_{0} 799, r .880, f$ For 8 alt huno:s, $877, \mathrm{~h}_{0} 1303,1.1330,0,1453, \mathrm{k}$ An excellent Galue to cure wounds and old filthy vicers of aclegs, $360, b$.

Galut to eure Apoftems, tumore, greene wounds, old vlcers, buraine to cuse Aports of the head, $356, a$

An ex: cllent solat to incarnatc or bring wp fleth in decpe hollow An ex:erlent bolae to incarnate

wonnds and visto

Todifolue and dritcing

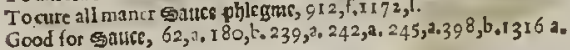
$1324, x$.

To curcfpreading eabs, 79, d. $506, d .1218, c$.

To heale reating

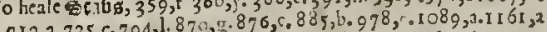
$712, a .725, c .794,1.87$, , $434, d .1444,3.1470, c_{0} 1619, b$.

I $298, \mathrm{r} .1393, \mathrm{~h} .1408, \mathrm{r} \cdot 1434, \mathrm{~d} .1444, \mathrm{~d} \cdot 1470, \mathrm{cos}$

Fne Encal te:ads in clitdren, 178 , d.

For acabo f ric bladder, $13035^{\circ}$

For fcabg of (hicep, $1218, \sigma .1444,0$

For fcabs of hecp,

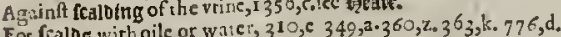

For fealog with oile or wate, $310, \mathrm{c}, 349, \mathrm{a} \cdot 360, \mathrm{k} .36, \mathrm{k}, 776, \mathrm{~d}$. fec 15 urnitig.

To take a w ay fcaleg. $1146, r, 1441, e$.

To take aw ay icales: $11,40,1 \mathrm{cs}, 849, \mathrm{r}, 8 \mathrm{72}, \mathrm{c}$.

Todraw forth feales, $\quad 363, \mathrm{k} .870, \mathrm{co} 87 \mathrm{I}, \mathrm{c} .958, \mathrm{~b}, \mathrm{k} 197, \mathrm{~m}$

I $291, \mathrm{~b}$.

Againft the statict, 60,h. $237, n, 242, \mathrm{c}, 245, \mathrm{~h} .250, \mathrm{c}_{2} 53,2,254$

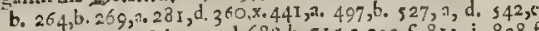
544, $54^{4}, \lambda_{2} 548$, b. 574, d.688, h. 71 5, c. 793, f. 8 ri, i, 838 , $85, c_{0} 872,5.935, f_{0} 1007, t_{0} 1055, c_{0} .1259$ e. $1180, g_{0} 1307, g$. $856, c_{0} 872,5.935,108,10,1619, x_{0} 1680, a_{0}$

I3II, d. 1319, c. 1488,

A gainft Scolopezders, fce $1 \mathrm{~b}$ earswothtus.

For the Scopbute, fec fearav

Againft rhe S:a fcompion, $68 \mathrm{r}, \mathrm{r}$

A g in

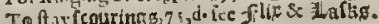

Forferatches, $53^{2, c}$

For rhe Scrophulic, iee lings entil.

To take 2 way fcurfe of the head, $37,6.66,6.1007 \mathrm{m.}$ it $46, \mathrm{c}, 1180$ b. 1197, r. I 226, 11.

To hetoc fcurutreffe or mangineffe, 67, f. fee sig anginefte.

To heale the dry licurfe, $8,90,3,1086, r$, I I $6, b$. I $373, \mathrm{~g}$. I $393, \mathrm{~h}$ r 44 I.C. $147^{2}, \mathrm{k}, 1.48,8, \mathrm{r}$,
Tocurerhe Scurap, $243, \mathrm{~b}, 250, \mathrm{~b}$, I s $8, \mathrm{a}, 402, \mathrm{a}, \mathrm{b}, \mathrm{c}: 621, \mathrm{a}$ $149 \mathrm{r}, \mathrm{a}$.

To dr.ue forth the feconbine, 1,91, f. $242, \mathrm{~d}, 352, f .574,2,662$ an $694, b .697, \cdots 74 \mathrm{r}, \mathrm{a}, 909,7.1001, \mathrm{co}$ 1 01 $9, \mathrm{~b}, \mathrm{x} 040, \mathrm{~g} \cdot 1048, \mathrm{~b}$ I $104, h .1257, a .1408$, g. lec Bftetbirth.

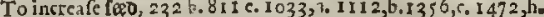

To ftay flowing of the feed in Dreams, or otherwits, $308, \mathrm{~h} .820,2$

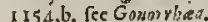

To deftioy naturall fab, $3^{n 8, h}, 3_{10}, e, 8,2, b$

To dry ip the fer, $709,6.1257, \mathrm{c}$

To reuiu c the fonces, $152,2.766$, b. 882, n. $1294, \mathrm{c}$

Tocure the Serpizo, $74, \mathrm{~h}$.

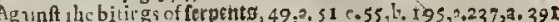
c. 400 a. $645,2.66 \mathrm{r}, \mathrm{b} .688,6.694, \mathrm{r} .748, \mathrm{~g} \cdot 715, \mathrm{~d} .725, \mathrm{c} .766, \mathrm{c}$ $796,6.803$ a.81 $0, c .849,3.880, b .898, x_{1}$ I0 $24, \mathrm{~d} .1026 \mathrm{~d} 1037$

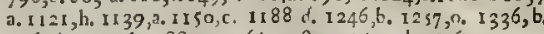
$1362, b .1373, f .1388, c .1406$ b. 1489, c. 1 15ng, d. I6 i 6.

To driuc away feepeuts $480, c \cdot 536,6,667,9,638, c_{0} 796, c, 803,3$ $1107,9.1257,0,1388$,

A zainftelic biting of the ferpent cerafes. 1.232, r.13: 3 ,

To helpe azalings of the ioynts inclinirg 10 a falfit; . $766, b_{0}$ I 1 as, $f$,

Fer the fbakings of an Agne, $458, c .688,7.849,1 ., 1001,6,5007, h$ $1465,11,1529, \cdots, 1542,6.1620, \cdots$

For liarunetre of the yeine, (ce lyate.

To allay harte humors, $807, \mathrm{f}$

Tokilland rot byave $429,5.789,7.1557$.

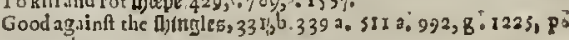
$1257, \mathrm{k}, 133 \mathrm{r}, \mathrm{c}, 1393, \mathrm{e}$

For broken Ghing 544 ,

For fotuertigs of A gues, fec fislings.

Againft thoptneffe of breath, 5 I d. 72 b. 245 b. $3952,5,546,2.574$; a. 870 l. 1055 a. $1055 k, 1058$ h. $1085, a .1146, b, 1246,2.1257$ d. fee 15 te atlj.

For the thot of envenomed darts and arrowes, Sic arrospeg and atiounos.

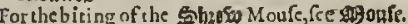

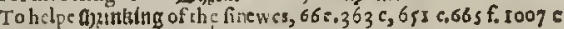
$105^{8} \mathrm{~g}, 1180 \mathrm{a}$.

For the falting đeknez. fee foallitu

Tobring dowae the defired ficlunes in women, fee flowers and atericg.

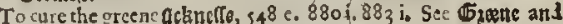
ingaidens.

For paine in the $00 c, 71$ c. 55 b. 3723.574 \&. 1078 a. $1445 i_{0} 1473$ b $14853.1620,0$.

To preferte the fight, $663 a_{1} 1032,3$

Totake away things which hind -r rhe $98 \mathrm{ght}, \quad \$ 48 \mathrm{~d}, 1070, \mathrm{a}_{0}$ IItgsa.

Good againft darkacfe of the Adjt, 62 a.310 a.317 a,61, c, 66, b. 674 d. 773 d.1436 b.1541 h.

To quiken the aght, $300 \mathrm{~b}, 360 \mathrm{r} .66, \mathrm{~b} .770 \mathrm{a} .8, \mathrm{~s} d .882, \mathrm{n}, 1008$ c, 1023 d.1043 d, 1045 .10702.1206d.1257 g. \$298 f, 1333 a 1353 f 3507 i. $3532 c_{0} 15332.1536 c_{0} 1538$ b.

Gcod for wounds, pricks, and hures of the auesucg. $36_{3} k, 121 \mathrm{~s}$ 15296.

For the loofneffe of the anseres, $916 n$;

To ftrengthen the atrewes, $317 \mathrm{k}, 548 \mathrm{~d}, 766 \mathrm{~b}, 1058 \mathrm{~g}, 1232 \mathrm{c}$ $1396 \mathrm{co} 14$ or d. I 5 or f. $1529 \mathrm{c}$.

Toftay the weeping of cut or lrurt aneiness $\quad 634$ b. rols d.

Toclenfe and amend the firtr of the face, 845 i, 12106,1445 hi 1460 e. fec jiaco.

To make the ftan faire and frooth, $912 \mathrm{a} .911601331 \mathrm{~b}, 140 \mathrm{~d}, \mathrm{~d}_{\mathrm{a}}$ 1445 h.1455 9 .

Toprocure fecue, 72 1.284a. 308 a,h. $310, d_{0} 34 \mathrm{I} a, 352 \mathrm{~h}, 355 \mathrm{cl}$

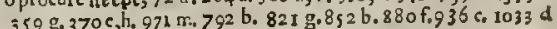
$126, c, 1578 \mathrm{c}$

To lhakc of heauy and drowfic Inepe, $\quad$ 152 a, $3002, \mathrm{~m}_{a}$ $1180 \mathrm{c}$.

To waken one out of a dead fleepe, 8820,1009, $1059 \mathrm{i}, 1180 \mathrm{~s}$ To eaufe dead thepe, $355 \mathrm{~d}$.

To e fmelling $1085 \mathrm{~d}$

To rctore fmell of the arme holes, $12 \$ 4$ d. 1156 b. 1177 b

For ranke tmell af the arme holes, $22 \$ 4$ d. 1456 b. 1177 , To drine awny frabes.
$849 \mathrm{~h}$. fec ferpents.

To caufe tnathe, 245 f. 441 d. 665 a, $674 f, 1405$ b

Toclenfe old filthy foges, $\quad 368 f .6292 .896 d_{9} 1049$ b is sith $\mathrm{h}$

For foese in the throat, fee exhyeat:

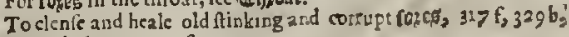
$50 g d, 620, a, 3055 f$

$\mathrm{Bbbbbbb} 3$

Te 


\section{The Table of Vertues.}

To confunc or walte aw ny pligge Sores. $725,6.726,6 \cdot 1172, f$. To drue away soztc5 6,2,g.738, c.797,a.799,6.1298,1

'To tak away $E$ ofto $743,6.1343, \mathrm{C}$

Totake away gounding in the eares, See Eates.

To reftore loff fpect vnto thofe that are $\mathrm{t} \mathrm{k} \mathrm{kn}$ with the dumbe paulfie and Apoplexy,4Ir, a.r I 80,d.1 294,e, r 448,i.

To inereafe goctine. See Sleeb.

Good againft spettitg of bloud.276,c.372,a.391,f.395, a, c 4I b. $421, b .522, c, 565, a .694,1.7$ I $5, g .766, c .884, a$ a $49, b, 1057, a$

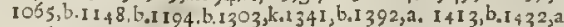
I 436, c. T $445, i_{0}$ Sec $21 B$ lowo.

To procure 5 itting 378,1 .

Aganft the birings of the Giptoer cilled Phalangium. $36, c, 49$ a I I 6, a. 3 r o, d. 545.a, IOI 5, c. 10,0 , g. I I 23,$20 ; 1257,0$. I $379, f$ $1434, b$.

To make the vitall sptits fiefli and liuely. $69^{2}$, f. $705, \mathrm{~d} .998, \mathrm{c}$. $1263,9,15+1,7$.

To cuole and refrethefainting Sptrtts.1523 6.

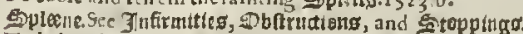

To helpe the Splesie if it be wafted $374, f$.

Remedies for thofe that hauc cuill Spleenes.55, l.317,b.955,a. $8,8, b, 805, a 1130, a \mathbf{1} 434, b$.

Againd the paine of the Splene 6, $4.325,0.572,6,8,6, c$.

To helpe the Expleent onercliarged with grofle bloud. 1097,d

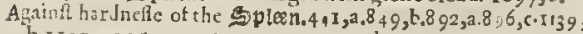
b I I 77, T. I $257, \mathrm{C} .1351, \mathrm{c} .1379,2,1500, \mathrm{~d}, \mathrm{I} 520 \mathrm{c}$

To open the ft oppings of the Splane $350, \mathrm{e} .527$, a. 548 , a. I too,

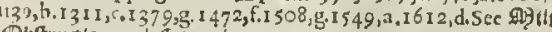
Qbitruaton, and Stapping.

To draw forth golinter fix.d in any pare of the bodr. $37.7,106$ $2.557, \mathrm{~m} \cdot 770, \mathrm{~b} .796, \mathrm{e.8} 49, \mathrm{c} .870, \mathrm{c}$. I o5s, f, see retoines.

To take away ot clenfe $\$$ pots in the face, I $32, h_{0} 289,1,366,6$.

$1045, c .1532, \mathrm{~d}$

To takeaway blacke and blicw spots of the face or any other

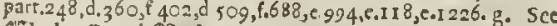
15 lachmete and 9 tatker.

Totakel iway Spoig of the ciescalled in Latis Albugines. I 195 , a

Tohelpe Squatts, $100=$ e. 1488 , h.fee falls, 28 zulfes.

Toenfe the Squinanct or Squince. $75, \mathrm{c} .490, \mathrm{e} .557, \mathrm{k} .852, \mathrm{f}$.

IOI 3 i. $1098, i$.

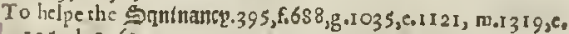
$1353 \mathrm{k} .1362, \mathrm{~s}$

A purewhite 5 tarth $835, \mathrm{e}$.

To eure the Sterch of the mourh 402,3

To rake away the $\Phi$ tench of the armeholesofec. Sumell.

Good for Stifenelte of the ioints. I394,1

Againt singting of bees and waspes. $682, \mathrm{n} \cdot 686, a 193^{2}, 2.1253$, $1257,0,1408, \mathrm{k}$

Againft Stinging of Nettles. 360.5 :

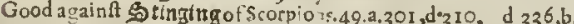
$337.2468,3.679, a-725$, d.852, f. $932, a .968, x, 1083, a .1$ I o , b, 1172 a I $257,0.1311$, b. I $465, y$

Good againft the stinting of the breath, 76,6 fee 18 zeath

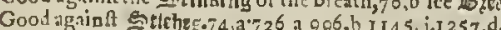

Totake away the Sticb in the fide with th paines thereof pre fently.766, g. I $351, \mathrm{c}$

To cur e the difeali Stomseace, 402 . a fec soctarute.

To dry and clen f the wemackt.508,3.682, i $1172, \mathrm{c} .1558,2$ 16 tg,c.1623. b.

To co afore a we.1ke and fecble Stomacke $51, \mathrm{~h}, 62,3,228,2$

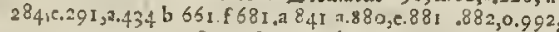

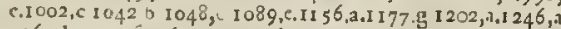

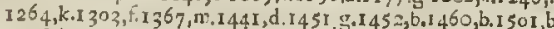
I5 $18,6,1521, c .1533$

Agvinft erudity or rawnefie of the Extentath $64: 9.366$ b.434, $682,1,806,7,1525, c_{1} 1540,3$.

Good for an hot Stomacke 28 , e. $304, c .306, b$.' $339, a, 398, b$. $\$ 22,9.852, c .876,1.91 \mathrm{I}, \mathrm{d} .921 \mathrm{I}, \mathrm{d} .998, \mathrm{~b} .1302, \mathrm{~d} .1326 . \mathrm{d} .1419, \mathrm{~b}$ $1420,2.1460, b .1506, c$.

Toeure or care paines and griefe of the Stonacta $360, n \cdot 388, b$. $672, \mathrm{~d} .793$ c. $877, \mathrm{~h} .1032, \mathrm{c} .108 \mathrm{I}$, c. I ros, e.1274, f. I $28 \mathrm{I}$, a.I 408 k. I $430, a 1433, b_{0}, 1529, a$

Todine aivay or diffolueall ventofties or windinefie of the Stonactie, $33,4,356, b, 1008,2,1529$ c. I 549 ?

ro zerme or heatc cold Stomacke.3, 3.51 h.1 78 .e.235 i. 242 a. 245 a.359. $2.366, b .682, \mathrm{~b} 692, \mathrm{~g}, 736, \mathrm{~b} .756, \mathrm{c} .773, \mathrm{~d}, 8 \mathrm{II}, \mathrm{g}$

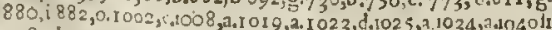

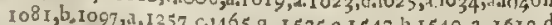
To purae the 5 som

To confunic or heipe wndnefre and fow cr belehings of the sto

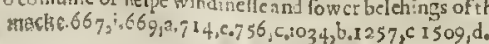

To heale the prine and ache of the stomatse, proceditg of clio, lct $279,3.308, a 391, c, 1097, a$.

Toclofe $v_{1}$, the rrouth of the ofematke, 1012,2 .

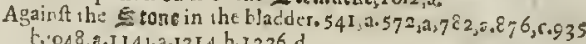
F, $048,2.1141, a, 1314$ h. $3336, d$.

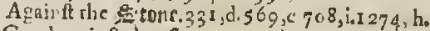

Good igaint the Stonc.254,d.258,b. $3^{8} 7, a \cdot 529, b .507 a, 6 c 0, b$ $610, a, 622, c .626, d .653, c .825, c .841, b, 842,2,859, g .907, a .935$ f. $936, b .984, c .993$, d.I $014, b, 1016, b .1023$, r. I 029, b.1032,c

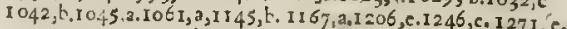

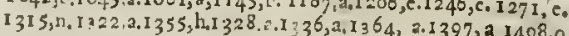

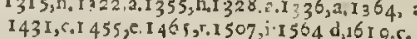

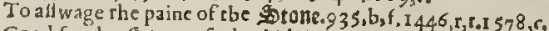

Good for the $S$ tonte of the kidnies $180 \mathrm{~d} .2=0, \mathrm{~d}, 28 \mathrm{r}, \mathrm{d}, 430$

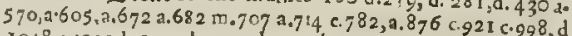
$1048, a .1222, b .1247$ b.1 74 h.13 I 4 h. I 356 c. 445 c. 921 c. $998, d$

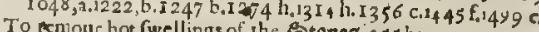
To emouc hot fwellings of the sitones. $355 \mathrm{~b}$ :

Toceafeand cure the burning heate and inflamanations of the Stones.279.b

To prouoke ro Stoole See 15 elip and 1 Parge

Good againft Stoppling 3 ot the Spleen.I-Z d 1016 \& 1155 b 120 f.13:4 b 1388 b $14: 4$ f 1445 i.1447 b.

Againt the ftopptnas of he Liuer and Gall.15 4 t 74 id 1070 its8b 1294 t 1314 b 1388 b 1434 f I $445 \mathrm{i}$.

To open topptngs of tic inward part;, $101421226 \mathrm{c} 1236 \mathrm{a}$ $129802366 \mathrm{~d} 14080$

Grodion ftesines. 37 b 1620 b:

Goodagaind ilic ftrangurte: $24 \mathrm{e} 60 \mathrm{~h} 64 \mathrm{~h} 242 \mathrm{f} 243$ a $4: 3$ a 485 a $5,2.7622$ d62: a 671 a 679 b $682 \mathrm{~m} 811$ i 842 a $45^{3} 32$ rorg b 1029 a 103721048 a 1051 a 1053 a Ito h 1141 a 1167

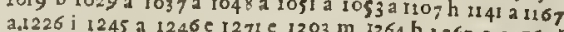
a.d226 i 1245 a 1246 e 127 t e $1303 \mathrm{~m} 5364$ b 1369 e $1376 \mathrm{c}$ ? 1445 i 1488 b

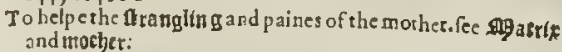

To recouer ftrength agnine 7366877 i 880 e 88211040 $1356 \mathrm{~b}$

To heilc ftripeg of the eyts. fee efex:

Againft Struma's or fwellings in the throat: ro6 c 279 b $896 \mathrm{c}$ e: Sec utingg eutli.

To fofen the Siruma's or fwellings of the throat $60 \mathrm{e}$ To diaw ftubs out of any part of the body: 13 a f. fee cTbonnes
and fplinters.

A remedy againt fuffing of the head through coldncte of the braines 1293 b;

A rcmedy againft ftafing of the Lungs. fee Hange

To aire the faftocation or the Matrix of Mother: See, Sthatrific

To heale frftatong:12 I1 0

To take away fun=burning $132 \mathrm{~d} 2892317$ i 466 a $557 \mathrm{~d} 845$,

870 e 872 a 912 h $594 \mathrm{e}: 226$.

To confume fuperfuans humo-s, 688 a togr fisere

Good againlt afurt t:r54d 852 f.

Topreferue one from Inrtetting: $1001 \mathrm{~g} 1097 \mathrm{~b}$

To eafe the difficultic of ftwalloswitg caufed of cold theume 580 a:

Io proulke f 5 weat $80 \mathrm{~b} 251 \mathrm{e}_{46} 6_{3}$ a 572 a $662 \mathrm{~b} 698$ a 725 e 756 g $759 f 799$ b 861 a 880 e 993 bioo2 e 1002 h I0Ire 1055 . 1158 a 11 g $2 \mathrm{C}_{1245} \mathrm{a} 1253 \mathrm{C} 1404 \mathrm{~b} \quad 1441 \mathrm{~m} 1465 \times 1612 \mathrm{~g}$

Toftay trocating $1264 k$ Goot againft or to diflolue hor fluellingg that are newly begun:
$66 \mathrm{c} 041$ a $1028 \mathrm{a}$.

To cure and diffolue all hard lswellings.7 b 250 c 494 b 557 h

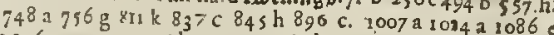

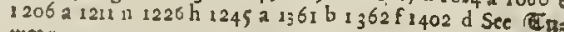
tho? 5 .

To walte and confume cold and old ftwellings.447 a $719 \mathrm{f} .748$

b 748 a 756 b 894 b yuo b 949 a roog a ror I 6 Ir 5021428,3 I $144 \mathrm{a}$.

To confume and takeaway hot floellingo: $72 f_{352}$ g 447 d. 557 d 615 a 626 a $924 b 93^{8}$ a 172 f 1393 e 1423 e 1484 b.

Totake away the hor fweltings of the uvula and Almonds in the

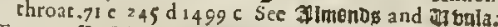

To open fluelithgo. 6- g

Towafte away hot fivelingg of the kernels in the Aanke, $883^{\circ}$ Sec Lernclds

Totake a way the rswelling in the fpleene. 242 c 639 e ross 2 $1538 \mathrm{~b}$

To allwage the fwelltig of the yard. I g6 e $1226, \pi$.

To fupple or waft aw y haid I5ociltngs of the fundament, $876 \mathrm{c}$ fee fiumbament.

To ripen hard fswelling gehind the ears.3 3516 t5i $d$ 


\section{The Table of Vertues.}

To mollific or watte away the hard 5 sealligg of the mother. $932, \mathrm{c} .12,6, \mathrm{n}$,

To curc frocling of the cliroat. $337, \mathrm{~b}_{0}$. $225, \mathrm{n}$.

Goud for hot ftorling of the iawes i 508 b.e.

To aliwag: fwothing of theftones.1 96 e.2. $29, \mathrm{c} .1066, \mathrm{~b}, 121 \mathrm{I}, \mathrm{k}$, I $; 88, \mathrm{c}$

A 88 , for fort fwetlinge. I 345 ,

Arcmedy for fort twellinger $5,2.621, \mathrm{~b}$

To take awaye froilutg of the ioints 74 a. $\{88, \mathrm{~b} .1066 \mathrm{~b}$

Aginit the hard fereltingt of the breafts and pappes $28, c .66,6$.

Good 25 gaint fiwtuming in the head called vertigo. $672,6.75$, b. 8.

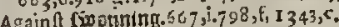

Againft fwotuning $5 e$ f $7.798,6$, I 343,4 ,

- Fenourse. $360, x \cdot 7,8, b .881,3$.

A good sarzup to foften the belly, and to purge Choller. $352,3$.

A $32, g^{\circ}$ feruines for many ex cellent purpofes. 807 , f.

A tystup er the infufion of Rofes will the lorec thereof. 1264.5

Epreup of the iuice of Rofes, $1264, x$.

\section{$\mathrm{T}$}

D light full to the tafte, $126_{3}, b_{0}, 455, c, 1533, c$

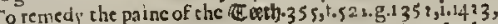
c. I 470, e $1475, h, 1489, h$, I 51 I g. I 545, a. See teroothathe. Toftop hollow teeth. $506, c$.

Good for teeth that are $f(t$ on edge or aftonied. $522, a, g$.

To taften loole tailj.400, c. $522,9.719,5.793, c .84925 .998,2,433,0$

Totanton

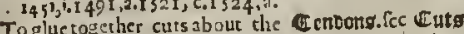

Toglue together cuts about the etemcs.95,a.1 77, b.185,a.245,c

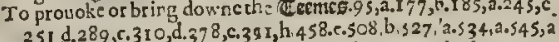
$572, a .653, a .661, \mathrm{a} .067, \mathrm{~b} .672, \mathrm{a} .68, \mathrm{~b}, \mathrm{~b} .688, \mathrm{c} .604, \mathrm{~b} 6,67,2.705$, c $756, c .774, c .792, a .84$, , d.907,b.909, a. $984, a, 100 t, c, 10, b, a$ 47 , b.I $708, a, 1086, a, 1087$, a, iI $04, b, I$ I $07, a$, I I 2 I, d.I I 58, c I 257,2 b.I $708, a+1086,2,1087$, ,a.1I

To ftay che oucrmuch flowing of womens terneg. $419, b .42 I, c$ $480, g .522, c .678, b .661, c .807$, hi 857 i.t. I $04^{6, c .10}, 12, a, 15243^{2}$

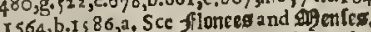

I 59 , c. 1 1 $188, F$, I $525, d$.

Good againft long and lingring tert tans. $1097, \mathrm{C}$.

Good for tertiants that proceed of choler. $349,8.969$, g. I $56,3,3$.

To take or feoure away tcttecs. $178.9 .250 . c_{0} 395,6.8012 .883,0$ $896, r, 900, c .978, \mathrm{c}, 11 ; 6, \mathrm{~b} .1 \mathrm{I} 61, a, 1360, \mathrm{~b}, 1393, \mathrm{~h} .1414, \mathrm{~d}, \mathrm{I} 446$ $896,5,900,6.978, \mathrm{C} 1156,5$.

To curc dingerous tettec $\$, 79, \mathrm{~d}$

Good ig ainft, or to helpe the fowle fpreading tettecs. $6: 9$, $x$

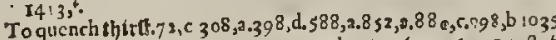

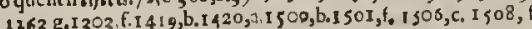
$1263,5.1303, d$

1394, 1608 , d. To quench

Todraw torth thoosne fixed in any part of the body. $557, \mathrm{~m}$ $619, ? .783, i .872, \mathrm{c}, 1058, \mathrm{~m} \mathrm{r} 246, \mathrm{~d}$ Sec sopltnters.

Tobreake or ripen impolhumes or tumors in thetheat.Scc 2 . poithunes.

Good for dife afes happening in the thyoat $.429, c .4 ; 0,3.10 ; 5, b$. $1122, \mathrm{~b}$.

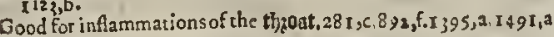

To calse aw ay the afperity or roughaeffe of the thy $0 a t .178, c, 779,2$ $798,1,133^{0,3}$

To helpethe thateses or griping paines of the bslly in women after their childing. $133 \mathrm{~g} \cdot 9^{8} 4^{\mathrm{a}}$.

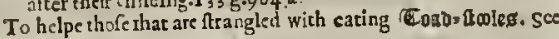
of utheame.

To take a way the Cornes of the eeter. fee Connco.

To take away the roughnes of the tongue in hot burning Aguesiee Lisonghnetie.

To curcthe difeafc of the Rougae called de Brann, which is rugedncfle, blackenelle, and drineffe with a fwelling $634, d$.

To caure feeled tooles to cut iron of ftone ridtout rurning the cdgr.6,39, $c$.

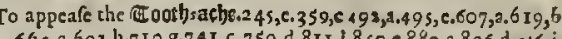

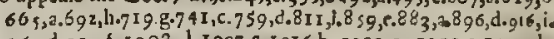

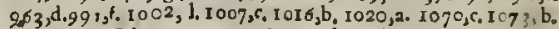
I I $50, \mathrm{a}, \mathrm{I} 158, \mathrm{~b} \cdot 1254, \mathrm{a} \cdot 1323, \mathrm{~b} \cdot 1353, \mathrm{~h}$. I $360, \mathrm{~d} \cdot 1379, \mathrm{~b}, 1508, \mathrm{~b}$; Sec (e)ert).

Againft the inflismm ations of the rentils. Sec \$1montos.

Good again the griping tomentô of the belly. fee tiselity and (b) zipings.

Good againf the tomments of the guts. See frats and tot jictse.

To caufe women to haue fpecdic teauell in ehilde-bearing. Sce Uibieth, Delitueeance, and adomen.

To cafe or helpe wonen that hauchard tranell in childe_besring and atcingreat extremity. $363, \mathrm{~d}$,

To helpca efeadellet from Merrigalls. 1388, .

A good oiatment for a wearied teanel les. 1 I 28.2

Gcod againt teembling and thakirg of the hearto fee Beact.

Good againit trembling of fincwes. $759, \mathrm{~b}$.

Good a gainft tutto2s. $356, a, 360, y$. Fee fwallingo:

Io takeaway the fwelling aud pain of hot tamozg. $529,2,678, \mathrm{~b}$. I 397, l. $1427, b$,

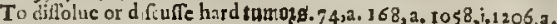
I 426, b. I I I I, g.1325,2.

To conlume. difsoluc, and drive a way cold tumos $8.66 \mathrm{~g}, \mathrm{c}, 682, \mathrm{k}$ $935 . g \cdot 1058, i_{1} 1107, k$.

Good againit the tuentng of the head called vcrigo fee wor 33 ts nette and lïsimnting.

To helpe the CEmpanp. 39 I.gsi $473, b$.

\section{$\mathrm{V}$}

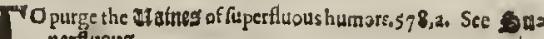
perturuoss.

Toglue rogether rifts gafhes, and cursabur the waints. feccits

To oper the Hatued of the Hxmorhoides. See Hewnog botbes.

To reprefie at apourg that hiuder Reepe. 1578,d,

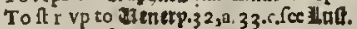

Good ag unft denecp. fee ILaf.

To helpe chofe that are b I cn vith ofrenomon, 5 beafts, 34 a.95, 8

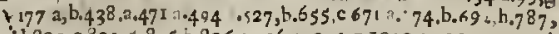

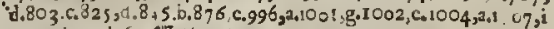
I 253 t.13 h. h.

Good aga with alenome. $54,1.738,0.793, \mathrm{~d}, 803, c, 825, \mathrm{~d}, 922, \mathrm{~b} .969$,

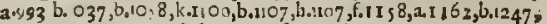
d.I $253, a \cdot 34^{1}, s_{0} 1408, d, 1455, y$. fice poylon.

To driuc away bensmong beats. 485, d. $655, c$

To driucaway aimtoatica or windincffe, $672, g 726, \mathrm{~d} .882,0,9,6$

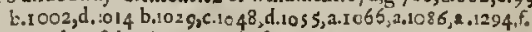

$1\{33$ d.1538,b. I612, c.1625, b. fec cettuthe.

Good for thofe that are bitten of aliperg, $619, \mathrm{~d} .738,2,810, d$ 849 , h, I 057, h.1 $123,2,1247, c, 1373$. F, 1 472, b. I 620, b

Tobe preferued from being bit of the wilpt. 833 , d.

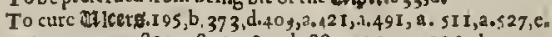
$630,2793, c, 813,3.836,2.855, b, 880,7,1024,1,106, b_{1}, 204, m$

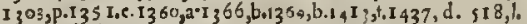

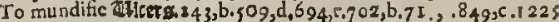
ก.T $226 . g .1446, \mathrm{~m}$

Tocarc Jilcers of great difficulty or hard to be cured. $360, y \cdot 527$.

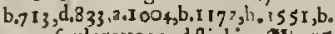

To cure foule rorcen and ftinking theers. $95, \mathrm{c} 28 \mathrm{r}, \mathrm{al} .359, \mathrm{co}$

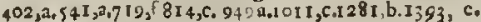

Tokeepe ulaleer from inflammation.6:5,9.700, d,

To dricrp moif virulent tileecg, ftay the humour, and heale

them, $31, f_{1} 1218$, k. 1362, d. 1378 , b. I489,d.1619,b

To alliwage and confume corrofute vlcers in any part of the body. I 225,p.1 226, h, $281, \mathrm{~b}$.

Good to clenfe maligne and corrofue bices $3.35,9,0.378$, d. 626 .2 661 a. $718, b .823, b_{0} 1315,0.1402,6.1433, k$.

Good for, or to eurchollow old and new blerrg.67, $1,188,2.191 \mathrm{~g}$

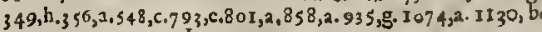
$1240, a$ I $2\{2, C . I \leqslant I\}, b$.

To appeafe the rage of ea nkernus blcers. $992, g$.

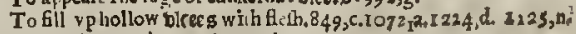
I 373, k.I 424, l. I 433 , i. I 439, b.

To curc vanomous bifers. $1218, \mathrm{c}, 1319, \theta_{4}$ 


\section{The Table of Vertues.}

For running thileers in the heads of poung Cbildren. Sie ats chores.

To beale vileerg of the fecret prets and fundament, $3 \mathrm{I}, \mathrm{f}, 1033, \mathrm{c}$ 939,0

To ftopblecding altect\$, $430 \mathrm{~d}$.

For aticers of the kidnies, 807 , 9 . 1116 , d

Good for allecte it the low out, 1 10

To heal and fill vp the Uitecrs growing in the eyes, 776, b. $1436, \mathrm{e}$.

Fot ruten dikers of the mouth, $458, b_{0}, 509, \Gamma_{0} 7 \mathrm{I} 9, \mathrm{~g} .825,6.1285$

b. : 303, i. I 306, a. I 50 ?, d

Tocute Uthers growing on the glandulous parl of the Yard, $3^{6} 3$,i.

For venomous inters of tic mouth, and almonds of therbroat,

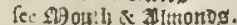

Fot Ificerations inthe priuities of man or woman, $965, \mathrm{c} .632, \mathrm{c}$ $12 \$ 5, b, 157:, 5$

For Milectatong of the mat ix, $363, i$,

Againft oticeration of the langs, $306, f, 63 \mathrm{I}, \mathrm{e} .69,2.907,6.9 \mathrm{eg}$ a $811, f$.

Tocure cilleatationd of the kidnies and bladder, $409, b .42 \mathrm{~cd}$ 949 a.

For the paine of an Income, 447,6

Gcod tor atc tinorzthanoing, I $436, \mathrm{~g}$, s sor.f.

An tinguent for wounds, 537, b. 805 b. 1 cos,

An cxes llcat Inguat to bring vp fleh in deepe wounds, 537 b. 649,

Toclevie the al oice, $3^{8}, x$

A gaint harihnelie of the tilofe, fe.

To t: $y$ Tistouts of bloud, $807, \mathrm{f}$. S e 15 loud.

To ptownke or caufe IIomit, 9 .g. 132,h. $174, c, 239, b$, , . 242, b

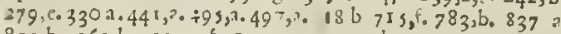
870, b. $969, b .1314$, f. I3 ;, u, 13 I 9, b. I4 5, a. $1408, k$ $\mathrm{I} 428$, ?

To reprefitoucrnuch Toniting of Choler, 145 , d. Ste ffello

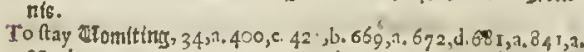
$883,1.993, \mathrm{~g}, 1012, \mathrm{a}, 1032, \mathrm{c} \cdot 14,9, \mathrm{~b} 1420,0433, \mathrm{~b}$. I $452, \mathrm{~b}$

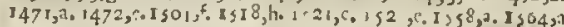
I $57 \mathrm{I}, \mathrm{C} . \mathrm{I} 594 \mathrm{~b}$.

For Jiomiting of loud, $572, a .631, b .68 \mathrm{r}, \mathrm{b}, 6 \mathrm{r}, \mathrm{d} 884, \mathrm{a},[09, \mathrm{l}, \mathrm{d}$ 1432 ,c. $1625, \mathrm{~b}$.

Tn thily Uenit in women with childe, 884,2 .

T'o ftay the defite of Jlomit at the f:a, $669, ? \cdot 108 \%, \mathrm{c}$

For Uipbraitings of the flomacke, $876, \mathrm{a}, \mathrm{d}$.

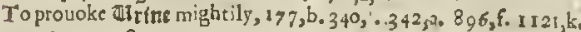
$1364,2.1378, a .1535, a+1594$,

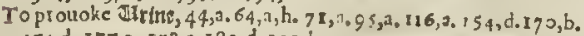

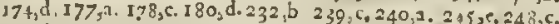
$258, \mathrm{~b} \cdot 284, \mathrm{a} .331, \mathrm{~d} \cdot 43 \mathrm{c}, \mathrm{a} 431,2,527, \mathrm{~d} .520, \mathrm{~b} .+32, \mathrm{a} 534, \mathrm{a}$. $541,3,545,3.565, d, 574, a \cdot 5+0, f_{0}, 5 \times 4, \ldots 60,3,62 \%, 4.849,7$. $655, b .661, a .962, a .665, a .667, b .672, \cdots, 674, a, 679, b, 688,6$ 705,c. $707,7.725, \mathrm{~b} .746,11,7,2, \mathrm{a} .794, \mathrm{~h} .814, \mathrm{~d}, 38, \mathrm{~d}, 841, \mathrm{~b}$

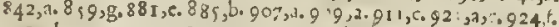

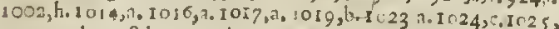

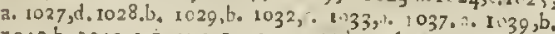

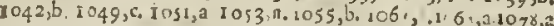

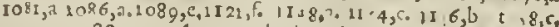
I 72 , c, I I 88,2, I $206, c_{0}, 12$ 6, h. I 2 I g, h I $220, b, 1226, f_{12}$,

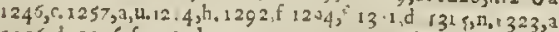

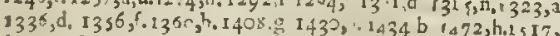

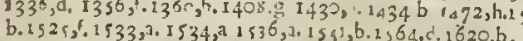

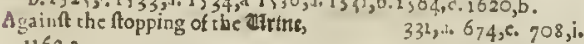
1262,9

To prou oke *if ritue gently, $534, \mathrm{~b}, 578,2 \cdot 1035, \mathrm{a}_{4} 1145, \mathrm{k}$. I $325, \mathrm{~b}$. $1341, c .1373,2.1397$, a.1433,k.1445, i. 146, Topurge much 1 tims out of them that haue the Droptic, igI, h,
$\checkmark 32,6$.

Io clewfe or purgathe atrine veficls of tougla and raw humouts,

To allay fiarpe IIttre, 342, a. 623,2,1445, f.

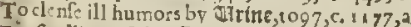

For fwelliag of the totula, $450, a, j 09, f, 707, b, 730, b, 8, n$ $802,6.1352, a .14=4.4 .1508, d$

For loofnetre of the citurala, $639, \mathrm{~d}_{1} 10,5, \mathrm{~d}_{0} 1508, \mathrm{~d}$

\section{WV}

1

helpe clidinbling of the ftomacke, $1032,5$. Toftig rctamblkng of womens ftomacks beiog with-chtid
To take nway ruggedatlarts, 963.3 .

Totake sway colatta in asy part of the body,290,d. $336 c_{i} 3 \pi, f$.

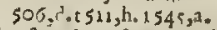

Fot tingiog of Culperfec Stinging

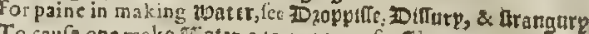
To czufe one make đ广 stet, 243,a.2:07,2. fec Uitur

For 1 thatering of the eyes, fe of tre.

To ameid cotiupt water at fea, $672, \mathrm{e}$

Goad Wuter 10 walh a fote throar,month, and ptiuities, $42 \mathrm{I}, \mathrm{f} .420$ c. $766, c .450,5.892,6.998, c .1274, \vdots 1395, a, 1625,3$.

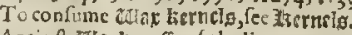

Agrint dateaticietfe of the liuer, 1204,2 . fee lutuer.

Toreftore ditcake perfons, $940, b$,

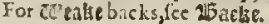

To canfe a traudler to fcele no curearifomntefte, $1104,2.1388, \%$.

To se moue co'carinette, $700, r, 756, h .880,1.892,11361,6, t 408 \mathrm{~d}$ $1523, b, 1558, \mathrm{r}$.

Totakeaway 100 bg of the eyes, $360,5.657$, b. $694, c_{0} 533, c_{0} 8.5, d$ $1187, c .1206, \mathrm{~d}, 121 \mathrm{I}, \mathrm{n}, 1303, \mathrm{~h}, \mathrm{t} 53 \mathrm{~h}, \mathrm{c}, \mathrm{t} 53 \mathrm{~s}, \mathrm{~b}, 1536, \mathrm{c}$

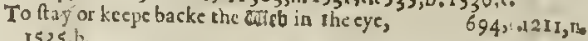
$1535, \mathrm{~b}$

Toltay ditaping in cut or hute finewcs, $\sigma_{34}, b_{0}, 1015, \mathrm{~d}$

Tobeautific yong đetenches faces, $391, \mathrm{~h}$.

Againft Eltang, $704,2.894, b .1024, d$

To confume, dilfolue,and take away cucts, $79, a .837, \mathrm{e} 1012, \mathrm{~d}$ I $225, \mathrm{n}$.

Againit right tobales, Ing $8, \mathrm{i}$, I $393, \mathrm{c}$.

To take away all ipheaic s, fic Doimpies \& fice.

To take away the paine of, and heale 10ljitio beg, 305, e. 6240 . $870, r, 1331,5$

Tottay or helpe the odtutes, $631, b .681, b .692, k$ 704, c. 8 I I l.

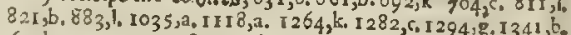

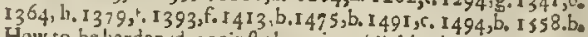
How to be lardened againtt the paine of to hlpping. $24^{8}$, d.

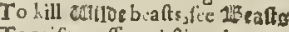

Toraife grofle and $\Omega$ imy hus ors our of the conduits of the swint. pipe, $1145, c$.

For toind in the bowts, $766 \mathrm{~d}, 1 \mathrm{cos}$ a.to1 9 b.1023 d.1025 c.1028 b $1032 c_{0} 1033 a_{1} 10353_{1} 1257 x_{0}$

For fiort wimeetncte, $674, \mathrm{c}$. gor, $a$.

Againft ritube in the ftomacke and colicke gut, $34, a, 71, c, 395,2$ :

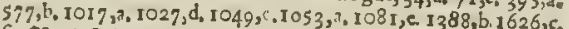
fee titentolities.

To breake, expell, and confume noinde, 170,b, x $78,5,974$, d. See dientociticis.

Tobreak ot waft the no indinete of the mattix, 940 , a.See 910 atri 'To keepetolin from fowring, I 75 , d. I I $30, \mathrm{~b}$.

Moderat ve of toine eommended, $88 \mathrm{r}$

To cấufe toint tafte well,1046, $\mathrm{d}_{\mathrm{g}}$..

To reftorefpirit in tofme, I $564, \mathrm{f}$.

Difference of toir:es, $8,8, a, b$.

To tempet or dlay them, $88 \mathrm{I}, 88_{2}$

For what perfons toutie is fittent, $88 \mathrm{r}, \mathrm{k}$

and for whom not, $88 \mathrm{r}, 1.884,4$.

Ciroiec of 203 mes, 879,9 .

Aga nft tuttcherafr, $1001, \mathrm{e}$.

Tokill ctolfeg, $, 903,2$.

Againft poyfon of roolfeg bane, $527, \mathrm{t}, 880, \mathrm{~h}, 1257,0$,

To clesfe tbe barren ratombe, and make it fit for conception I $\$ 29, b$.

Tn cure Auxes of the tulombe, 639, ,

Huttull to tomen with childe, $833, k$

To raife cclomen out of their fits, being ficke of the Mothet. See 9 9other.

Good for the ouermuch romiting of wionen with childh. fee tilo: initing.

For fwelings in ztomens brefts, $355, \mathrm{~b}$.

To makc odartm fruitfull, $683, b, 766,2$.

Tobting downe the naturall fickneffe of atomen, fee flosiner s \& germe:.

To iflolue the hardneffe of wtouneng brefts or pappes. See Leszatto.

Good for Ellomen with childe, I 455,d

To caufe cafie and fpeedy traucll to Cutumen that are with ehilde. $\$ 45, c .892, a, 909, a, 1029, b$, $1058, b$, 1095 , e. See 15 itth and IDelimetance.

Good fot Women newly deliuered, I 445,g.

In fay luft ing or longing in culomen with childe, 876,a,881.fo $S$ e longing.

Good for women not well clenfed after their deliuery $350,5.849$ : a. 984,201257 ,

To ftay the Flux of Woomens tetries, fec Eremon, 


\section{The Table of Vertues:}

To driuc for th cologmes, $793, \mathrm{c}, 866, \mathrm{a} .916, \mathrm{~h} .969, \mathrm{r} .978, \mathrm{k} .1012$, b. $1086, b$. I $353, \mathrm{n} .1367, \mathrm{~g}$.

To kill axtopines in jong children, 3, b. 34,a. 204,a.233.5. 242,g. 317, i. 359 ,d. 368, d. 522, b. $548,2.574$, b. 644, b. $649,8.705, b$.

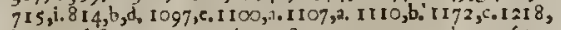
b.r. 1246, f. I 253, , . I 373 , k. I 378 , r. I 441 , c. I 447 , d.c. I $465 . y$. I 508, . I I $545, c .1575, \mathrm{~b}$. I $608, \mathrm{~b}, 1626, c .1620,6$, I 622.2.

To driue forth fae and round aclopmeg. $174, g .239 .9 .273,4.335$. d. 508, b. 651, b. 688. . I 1 I I, a.

To roid tolomes of the guts, $178, \mathrm{~d} .25 \mathrm{I}, \mathrm{d}, 360, \mathrm{x}_{0}, 580, \mathrm{c}, 647, \mathrm{a}_{\text {. }}$ I I 30 ,a. I I 58 .

To kill adormes in the eares, 688 , f 1353,8

Toclofe vp Eclound without perill of inflimmation, $639, c, 6,2 . \mathrm{c}$ k. 697, b. roo5.2. 1047, h. 1073,3 .

To cure đtound $8,24,7.18 .67,1.195, b .306, a .356,2,360 . y .563$, r. 373 .d. 407 d. $409,2.414$, b. 447 , d. $491,7.509$, d. $527.5 . r .537$ a $541,1.629 .1 .630,2.632, b .633, a, 635, a, 662, a .700, a .705$, d. 71 2.c. 71 a a 7 1 $8, f .839$, d. $938,3039,2.941, \cdots 943,7.949 .3$ 993 ,f. 1004, b. I024, a. 107 , b. I I 24, a. I I 26, a. I I 95, b. I 264 , 7. $1285, \mathrm{a} \quad 1433, \mathrm{f}_{0} \mathrm{i} 509, \mathrm{c}$.

To glue togetherand eure greene 10ownos. 3 ,b. 24, a. $28 \mathrm{x}, \cdots 329$, b. $363, a .403,3.480$, b. 546, b. 548, c. $799,2.807$, b. $906,2.936 . \mathrm{a}$

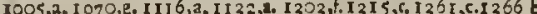
1436 , b. 1447,6 I $466, c_{0} 1482,6$. I 518 , l. I $571, r_{0} 1616, b$. To comfort and besle colound in finewy parts, ig $6,279, \mathrm{~d} .360, a$ 615,2 .

For ctionosin the hesd, 60 , f

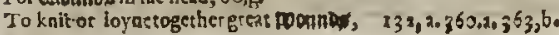
425,4
To keep geen catound s from inflimmation or fiery fwelling, $3^{5}$ h. $445.6 .557 \cdot 0.621 . c_{0} 7$ 1 8.b. 826.3.828.3.935,g,

Good ro foment or wath deepe and perrilous zdounba with. s4t.t.

To cure cetounon of the inw ard parts. 409 b. 54 r.b. $631, c, 633, b$

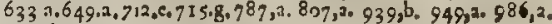

$993, \mathrm{~d}$. I I $21, c_{0}$
To ftanch the bleeding of toount $5,18.276, b$.

To heale and skiane rp colounos that are made in the head, 2,364 c $1393 \mathrm{C}$.

Good for poontos made with a renomed weapon, $541, b, 796, c$. 1007.1058 . k.I I 88.h.

Good for meunog of the dugs, 939 , 3.

For clound of the priuities. $939,3.993, \mathrm{~d}$.

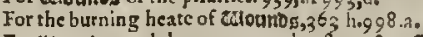

For toounds made by venomous beafte. Sec atentationd , sal 1 bealtg.

For Eituncts of the andes, 132

To take away rotinctiles, 870.0 .

\section{Y}

7 Ohelpe the fwellings, vicerations, and excorictions of the Yato, $349, \mathrm{~b} 1073, \mathrm{~d}$

To takeaway the $\mathcal{y}$ efloswterte of the skints: $\quad 356,2$. 845.e.

Toltay or helpe ycorting, 395,31682,1.1027,d,1033r. Gee entat: 


\section{Errata.}

Would him the courtegus Reader to take notice and amend there faults efcaped in theprin: ting, and topardon gther fuck literall faults as he may perhaps here and here ob ferue.

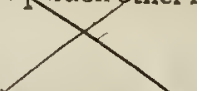

Faultsin Figurestranpofed.

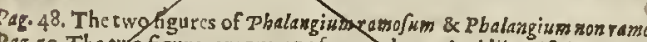

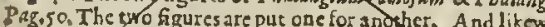

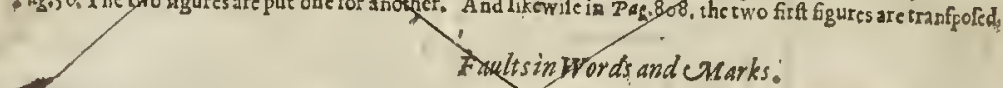

(5)

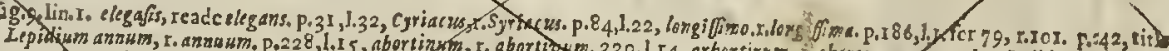

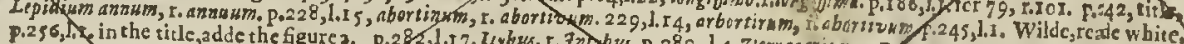

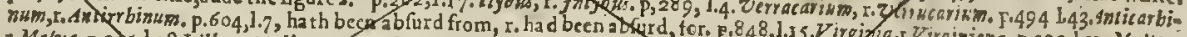

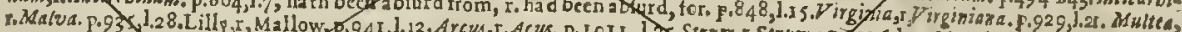

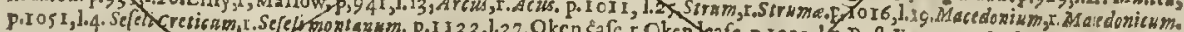

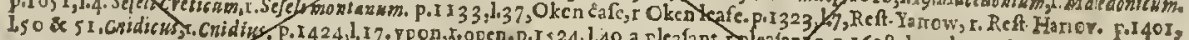

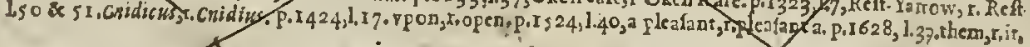

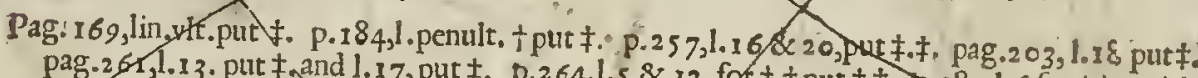

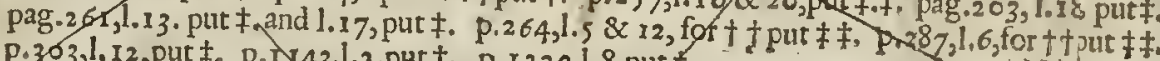

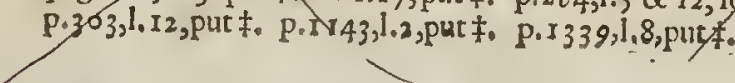

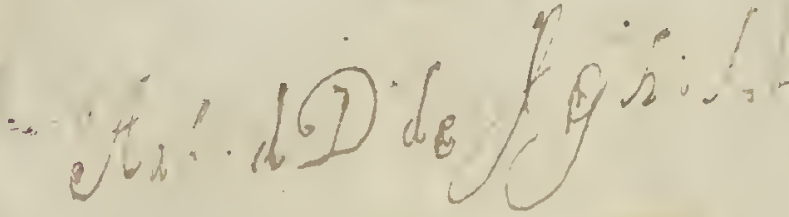





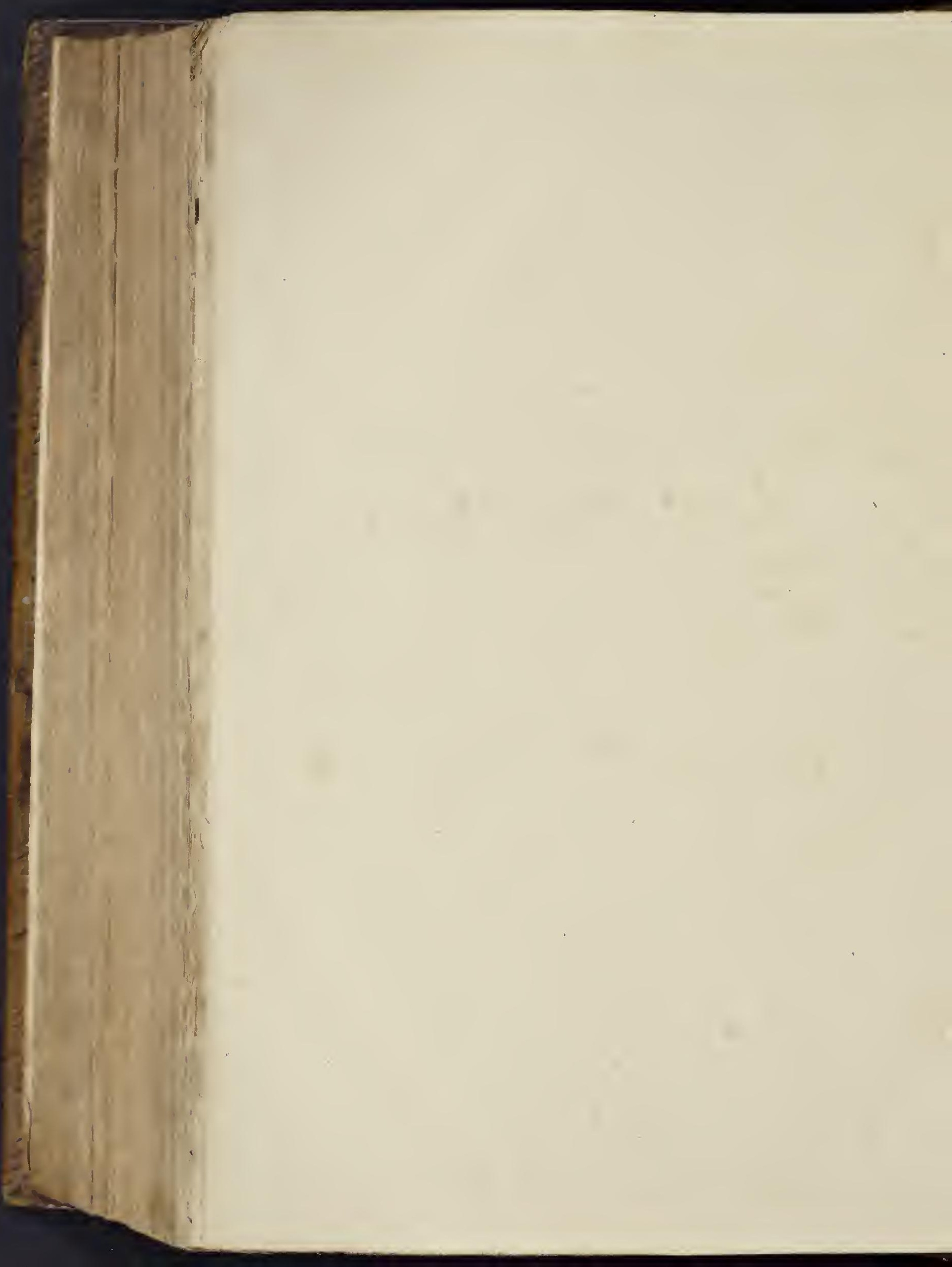



1.

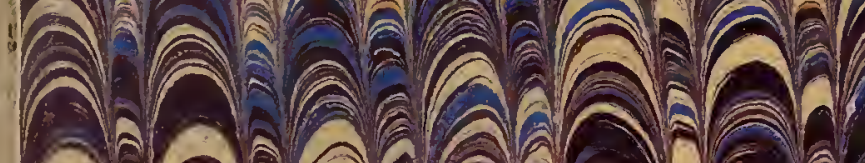

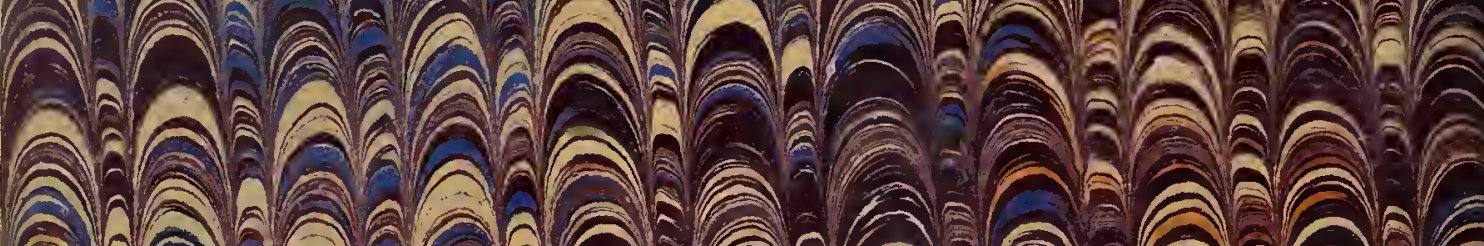

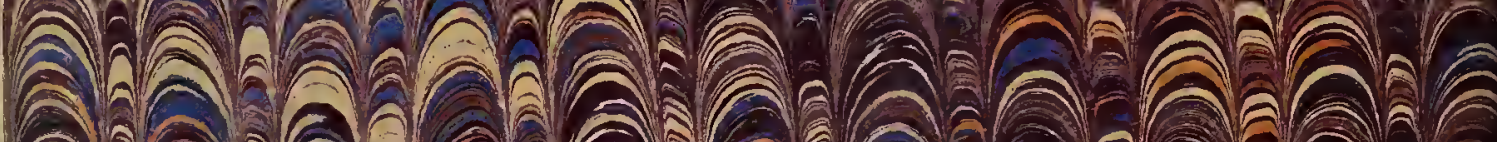

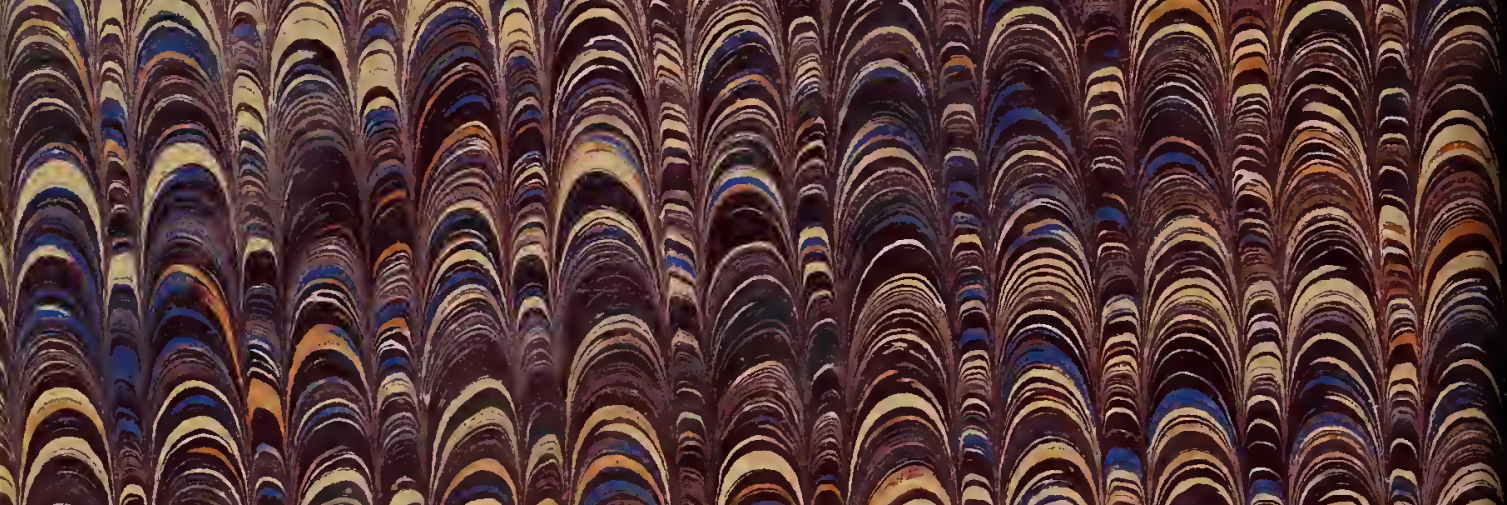

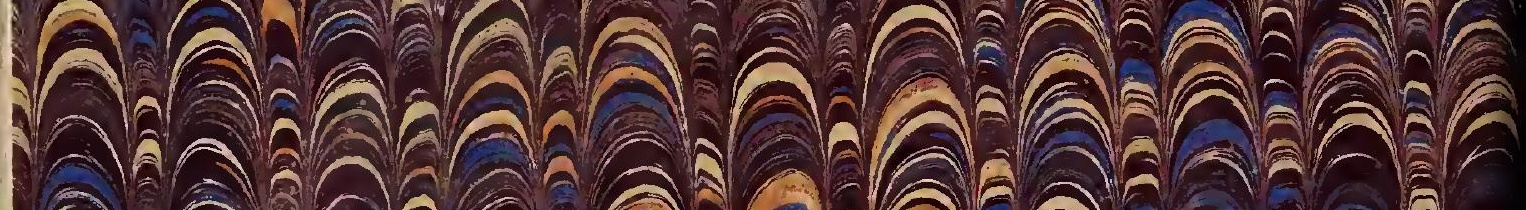

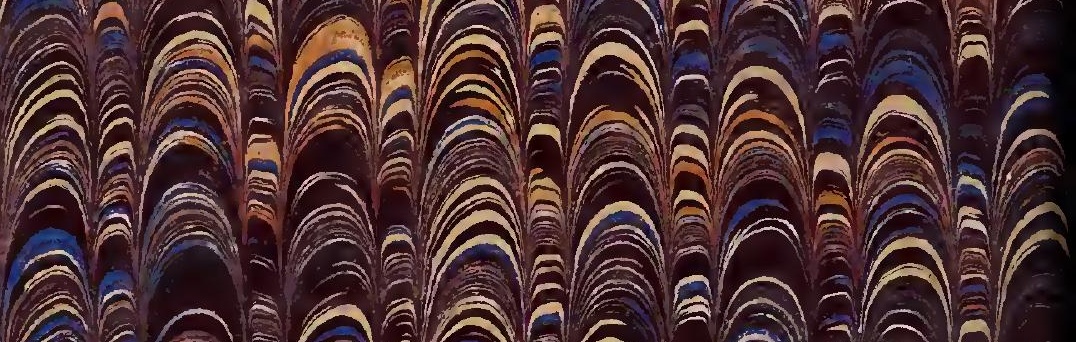

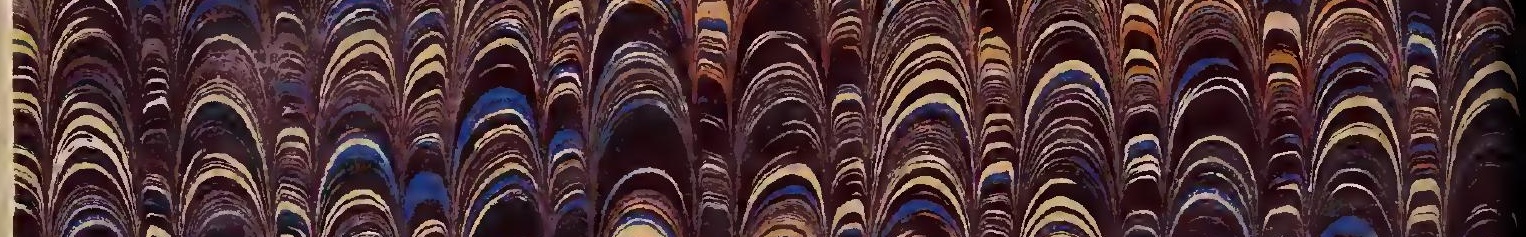

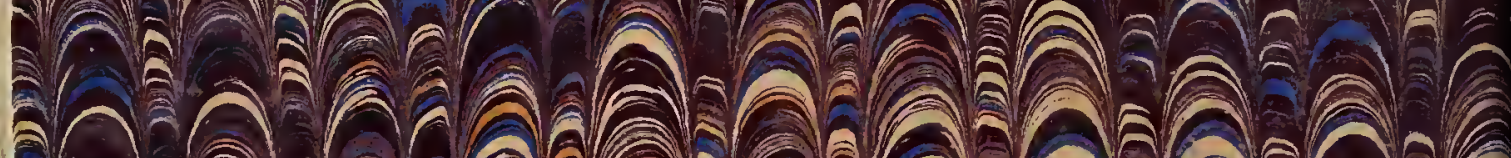

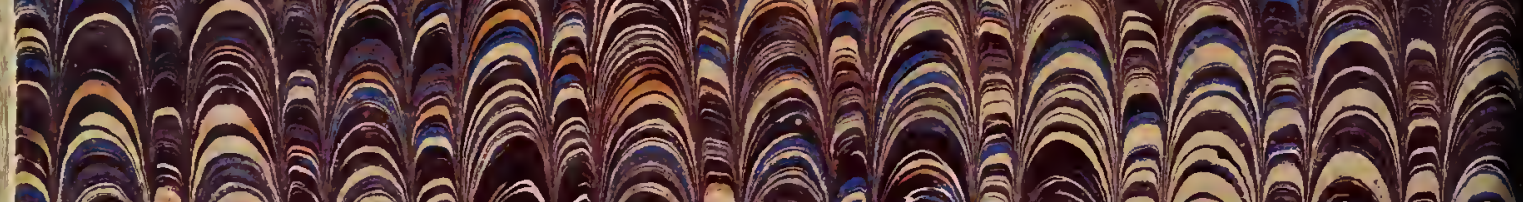

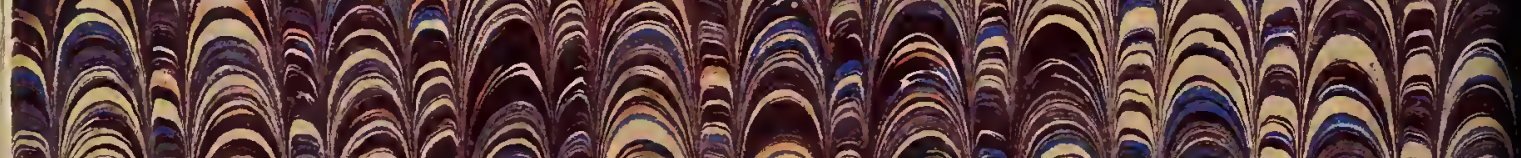

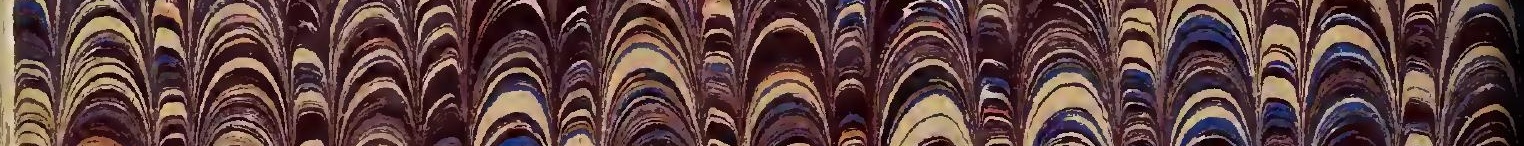

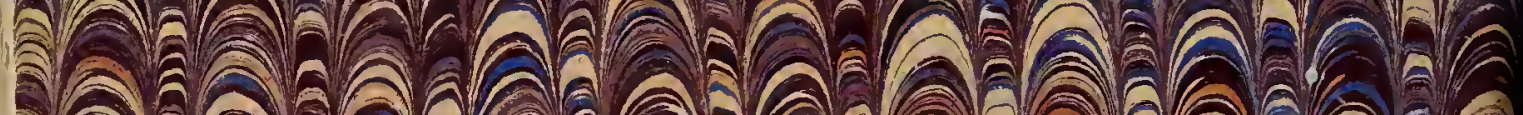

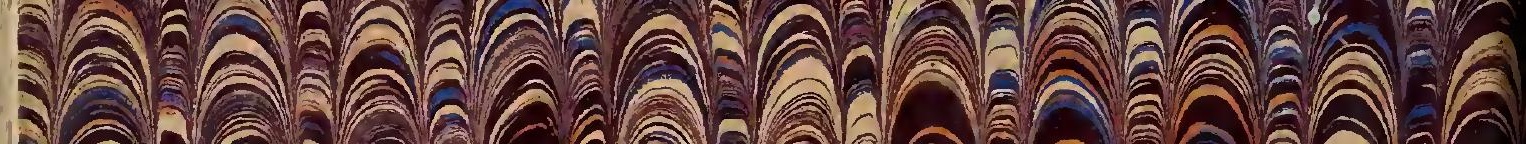

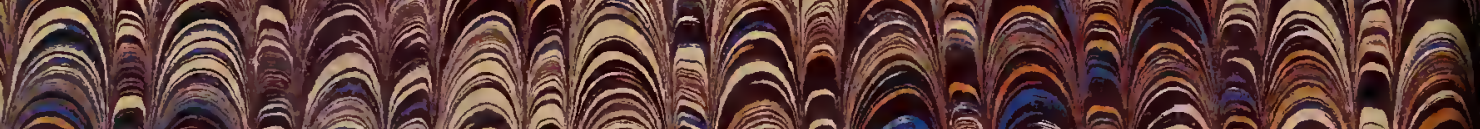

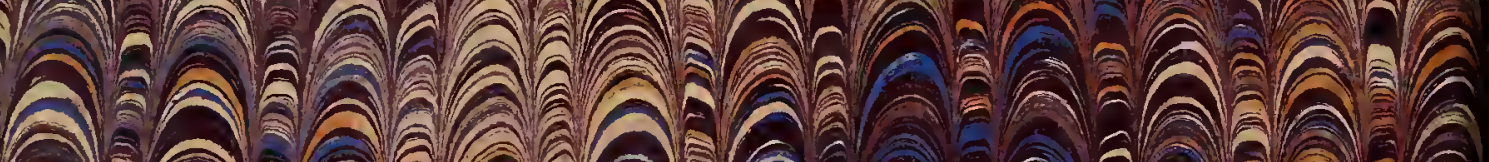

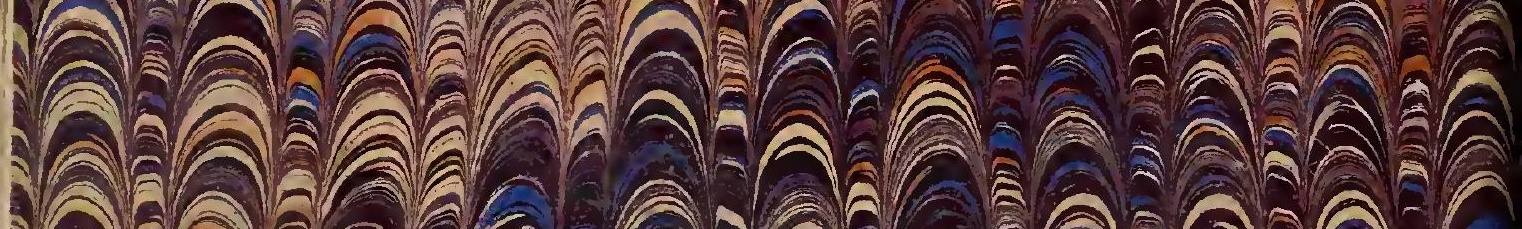

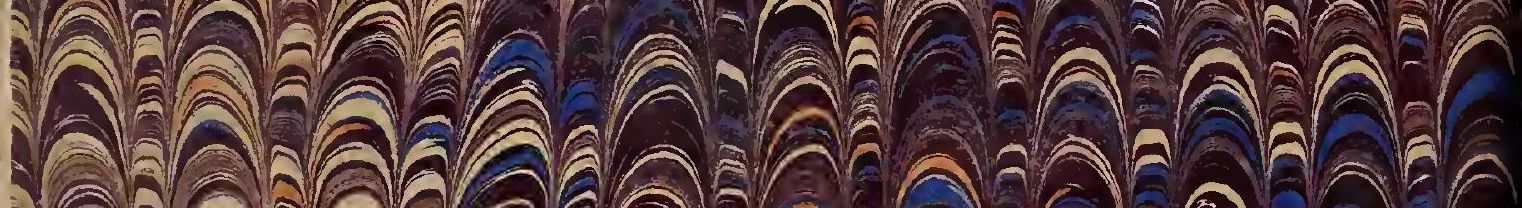

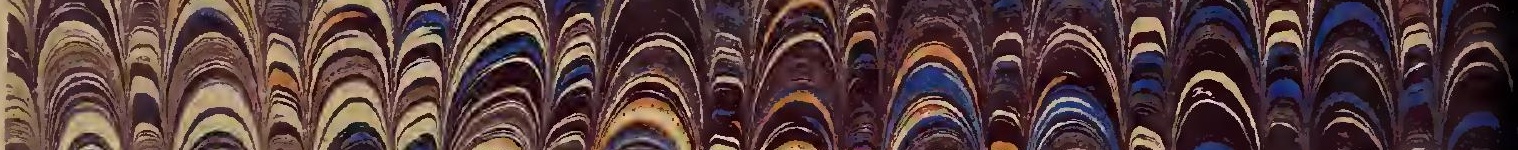




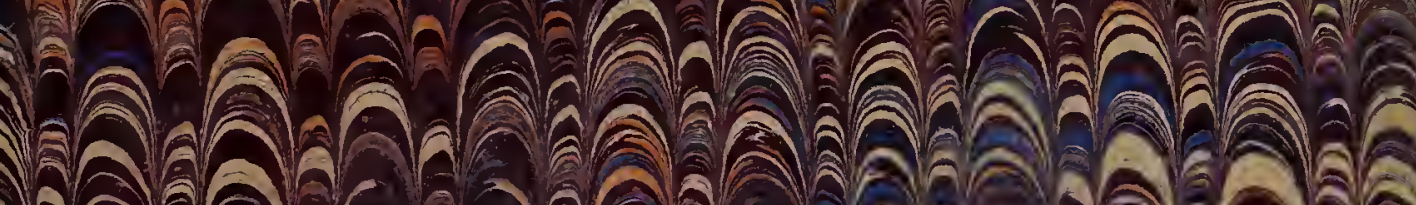
ลล.1. *a ล

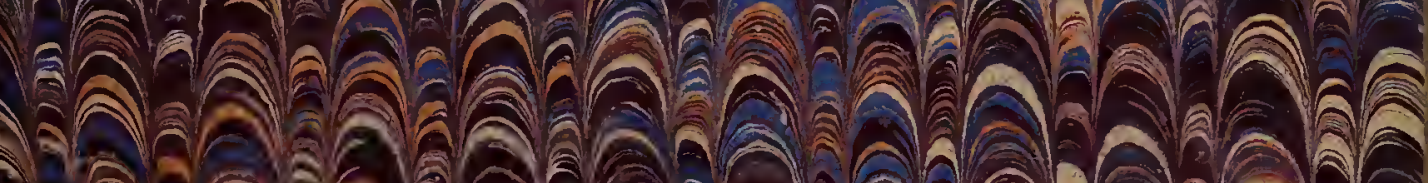

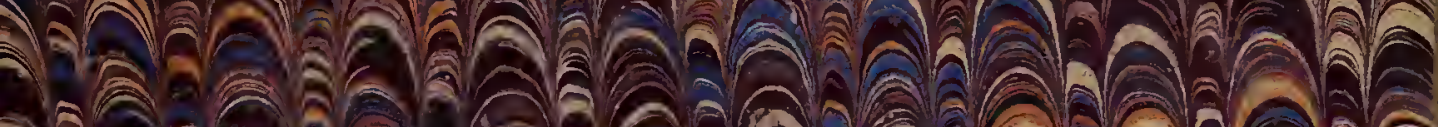

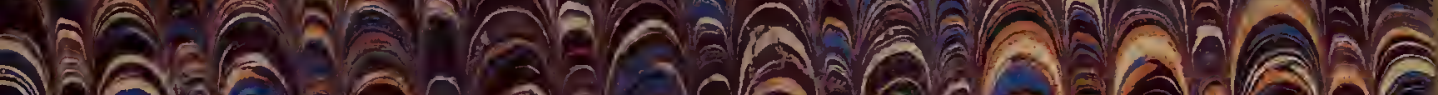
ลลว ล

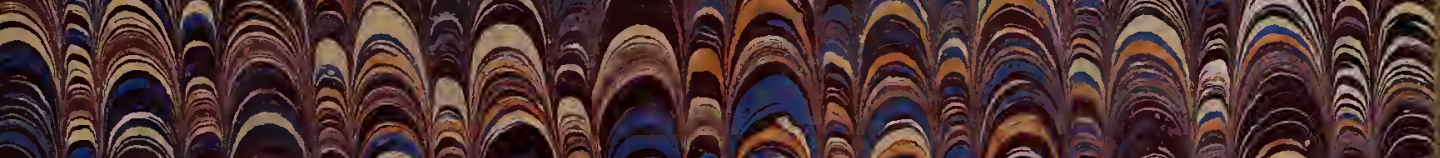
ละกล่

ล

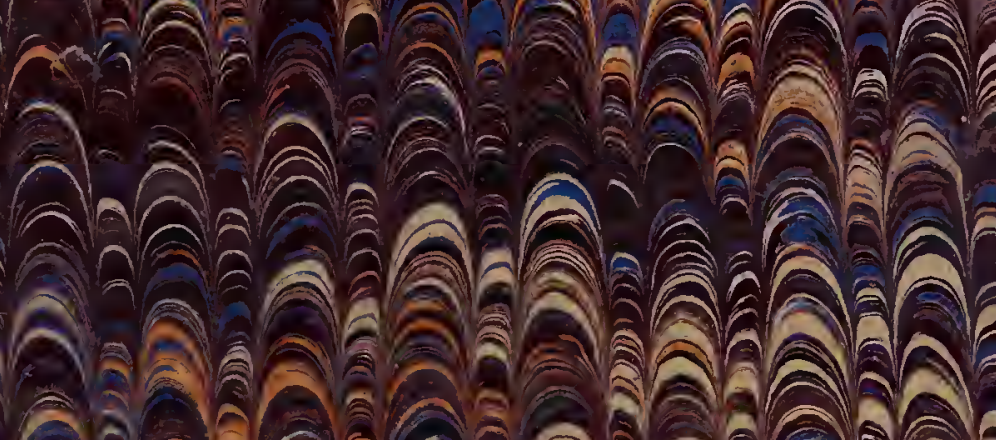

จ

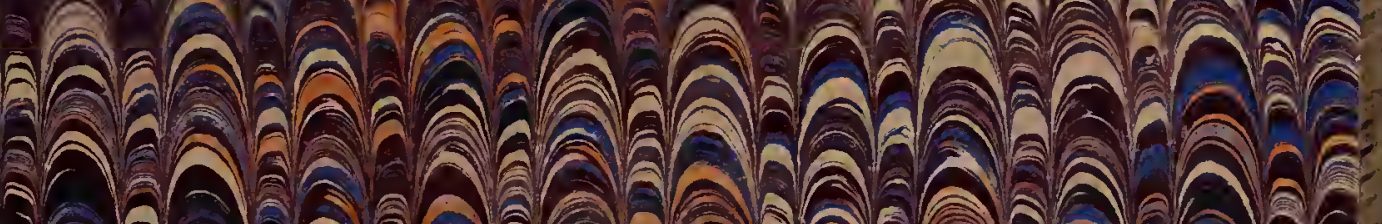

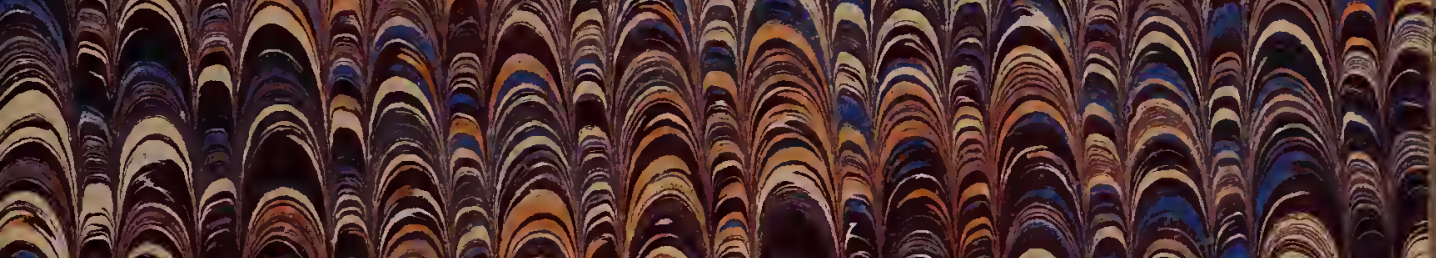

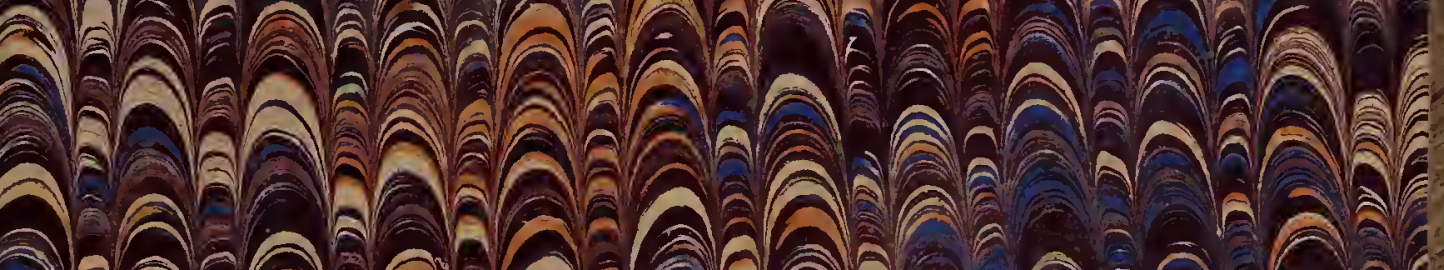

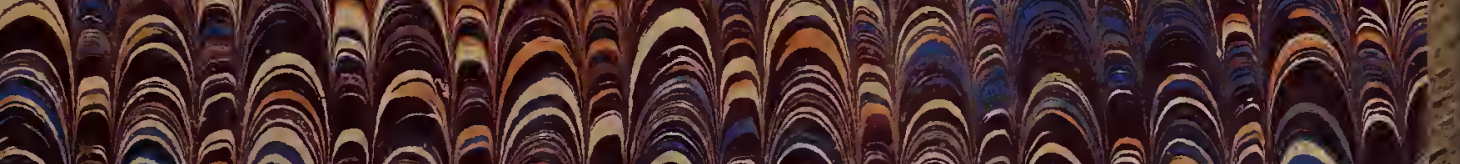

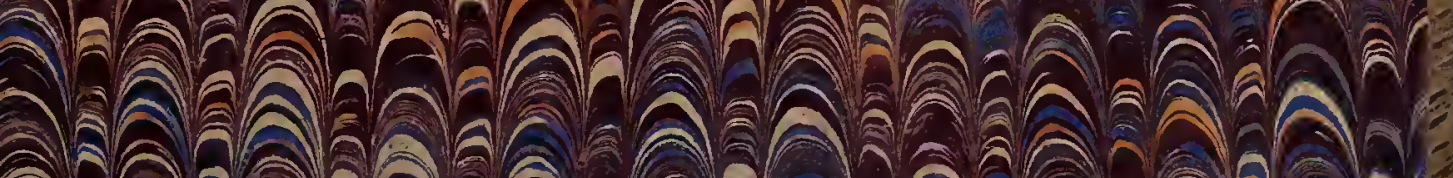

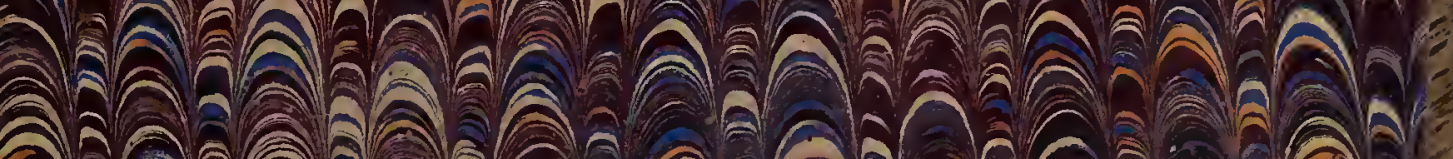

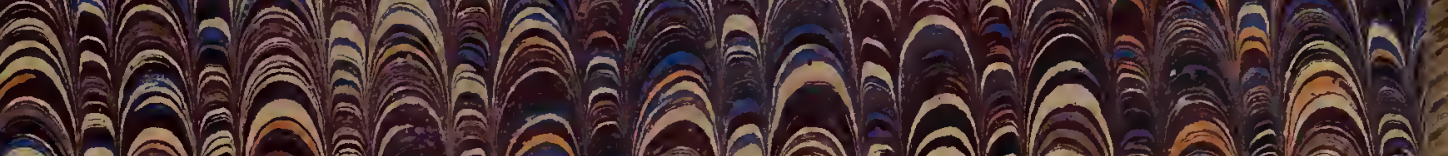

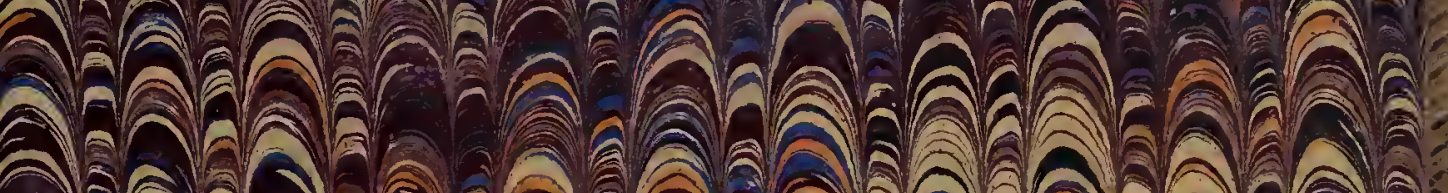

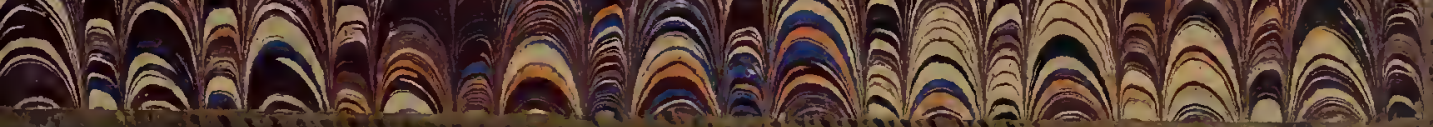




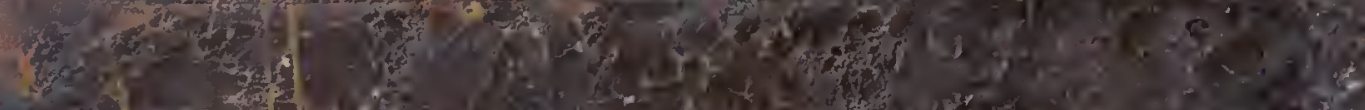

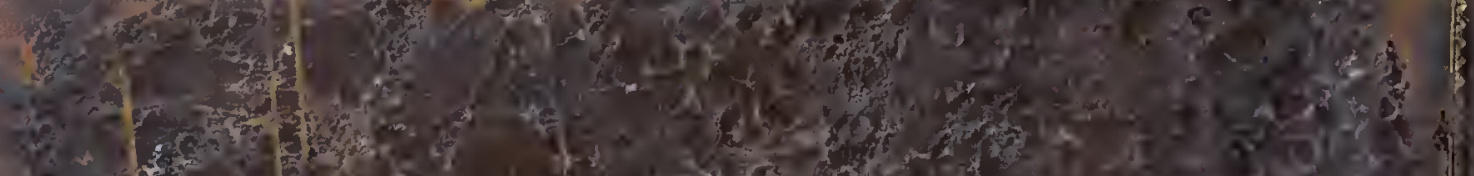

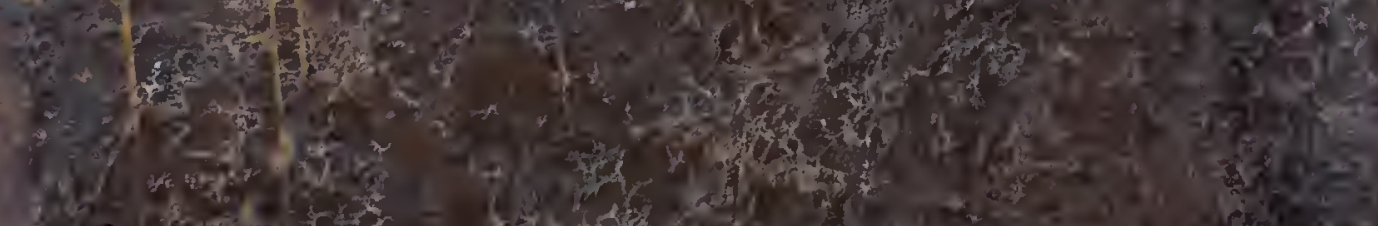

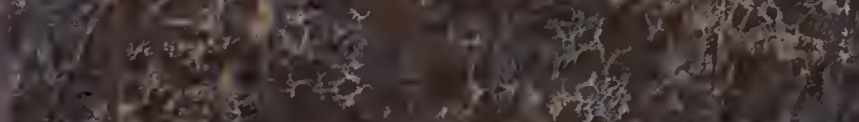

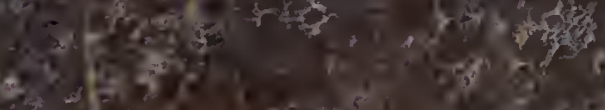

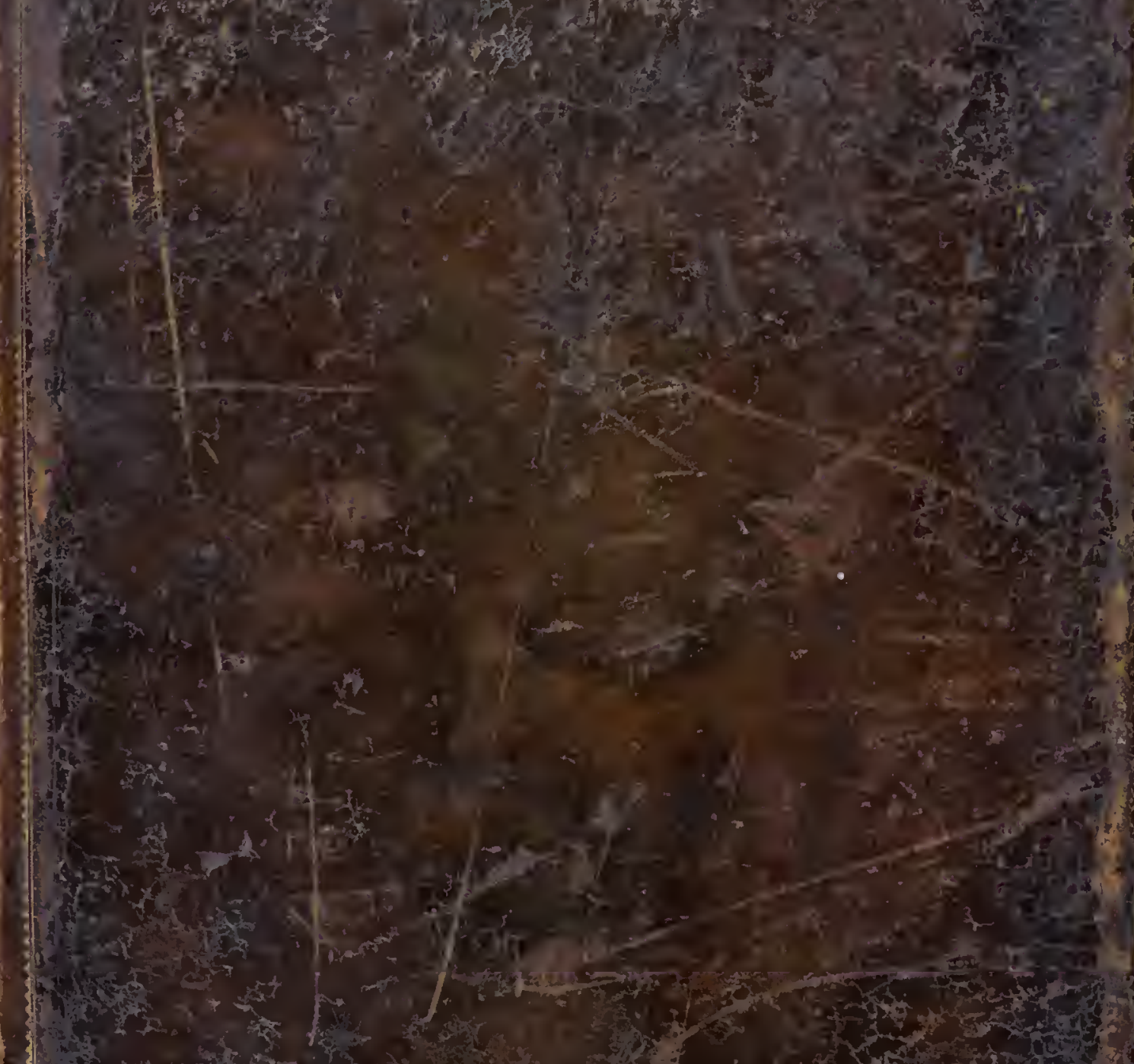




\section{ENGLISH (J. L.)}

cases containing 94 spes labels, and Introduction, I $886, \pm$ I $5 \mathrm{~s}$

FORBES and HEMSLEY - Enurneration of all the Plants known from China, Formosa, Hainan, Corea, the Luchu Archipelago, and the Island of Kongkong, with their Distribution and Synonymy, parts I to 5, with 9 plates and a map, 8vo, Linn. Soc., I 886-88 (pub i $8 \mathrm{~s}$ ), 1.2s $6 \mathrm{~d}$

FRIES (E.) Icones selecta Hymenomycetum nondum delineatarum, 2 series (complete), with 200 fine coloured plates, biography and portrait of the author, 2 vols, folio, new fine half morocco, Stockholm, i $86 \%-84, \ldots$ I I

GERARDE (John) The Herball or Generall Historie of Plantes, very much enlarged and amended by Thomas Johnson, Citizen and Apothecarye of London, with upwards of 2,000 fine old wood engravings of plants, I,630 pp of text, and indexes, with engraved title, complete and perfect, folio, newly bound in antique calf, red edges, $1633, \pm 5$

W. Wesley and Son, 28, Essex Street, Strand, London. 
description and 4 fine coloured plates, folio, half calf, I 847 (pub $£$ I I Is $6 a$ ), scarce, I $5 \mathrm{~S}$

- the same, with description, 4 most beautiful plates, finely coloured, elephant folio, new half morocco, $185 \mathrm{I}, 17 \mathrm{~s} 6 \mathrm{~d}$

$$
\text { A large-paper copy. }
$$

Filices Exotica ; or, Coloured Figures and Descriptions of Exotic Ferns, the drawings by Mr. Fitch, text and 100 fine coloured plates, royal 4to, cloth, i 859 (pub f,6 I Is), £, 4

HOOKER and ARNOTT-The Botany of Captrin Beechey's Voyage, comprising an account of the plants collected by Messis. Lay and Collie, 485 pp text, with 99 plates, 4 to, cloth, I $84 \mathrm{I}$, f $_{2} 2 \mathrm{~s}$

The places visited included Rio Janeiro, the coast of Chili, Easter, Ducie's, Elizabeth, and Pitcairn Islands in 1825 ; the Coral Islands of the Pacific, the Sandwich and Tahiti Islands, and Kamschatka in 1826 ; Macao, Loochoo, San Blas, Mexico, Chili, etc., in I827.

Natural History Book Circular, No. 100. 